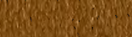

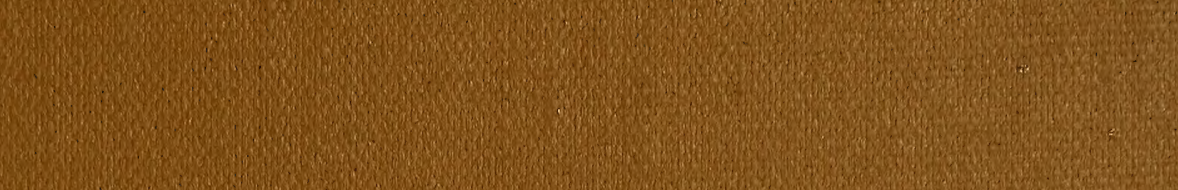











\section{STATISTICAL·GAZETTEER}

OF THE

\section{UNITED STATES OF AMERICA,}

FOUNDED ON AND COMPILED FROM

OFFICIAL FEDERAL AND STATE RETURNS,

AND THE

\section{SEVENTH NATIONAL CENSUS.}

BY

RICHARD SWATNSON FISHER, M.D.,

AUTHOR OF THE "BOOK OF THE WORLD;" THE "PROGRESS OF THE UNITED STATES ;" A " STATISTICAL ACCOUNT OF AMERICA," ETC., ETC.; ALSO, LITERARY EDITOR OF "COLTON'S AMERICAN ATLAS;" AND EDITOR OF THE "AMERICAN RAILWAY GUIDE."

\section{NEW YORK:}

P U B L I S E D BY J. H. COLTON,

No. 86 CEDAR STREET.

1853. 
Entered, according to Act of Congress, in the year 1853, by

$$
\text { J. H. COLTON, }
$$

in the Clerk's Office of the District Court of the United States for the Southern District of New York.

N. Y. Stereotype Assoctation, 201 William Street.
Pudney \& Russell, Printers, 79 John Street, N Y. 


\title{
EXPLANATION OF ABBREVIATIONS, ETC.
}

\author{
MADE USE OF IN THE PREPARATION OF THIS WORK.
}

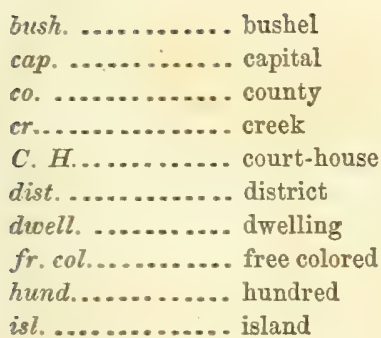

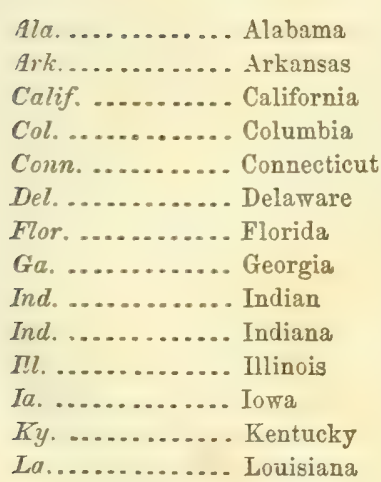

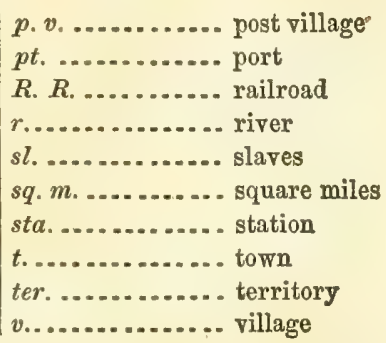

v............... village

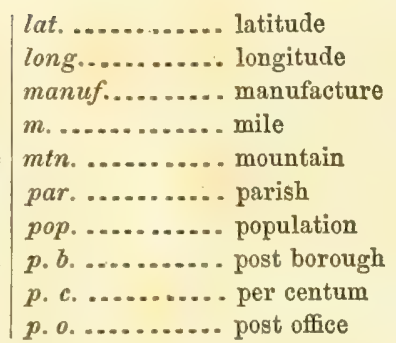

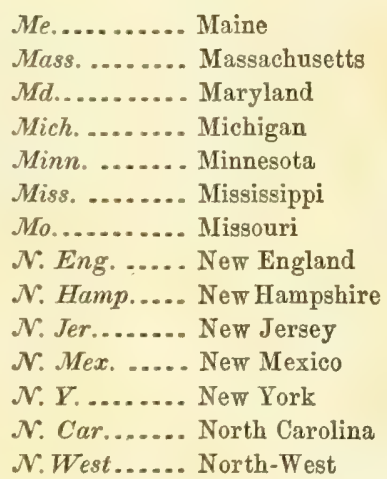

* * Where no date is affixed to statistics, they must be understood as referring to the year 1850 -the year of the statistical series used as the basis of the work.

** The distances of places from the capitals of the several States, unless otherwise expressed, are by direct lines. When distances are given by railroad, canal, post-road, or river, it is so expressed. 



\section{A STATISTICAL ACCOUNT}

\section{OF THE \\ UNITED STATES OF AMERICA.}

THE Cnited States, a confederacy of sovereign States, and the most influential republic of the world, occupies the middle portion of North America. This confederation, consisting originally of thirteen States, but now of thirty-one States, the federal district, and several territorial appendages, lies between the parallels of $24^{\circ}$ and $49^{\circ}$ north latitude, and the meridians of $10^{\circ}$ east and $48^{\circ}$ west from Washington, or $67^{\circ}$ and $125^{\circ}$ from Greenwich, extending from the Atlantic to the Pacific Ocean, and from the British colonies on the north, to the republic of Mexico and the great Gulf on the south. The whole extent of this boundary is now definitely settled by treaty.* The greatest width of this country, from east to west, is 2,900 miles, and the greatest depth, from north to south, 1,730 miles. Its area may be estimated at 3,260,000 square miles, including California, Texas, etc., recently acquired. It has a frontier of about 10,000 miles, of which 4,400 is sea-coast, and 1,500 lake-coast.

The territory of the United States is traversed by two principal chains of mountains, the Alleghanies on the east side, and the Rocky Mountains on the west. These divide the country into three distinct regions: the Atlantic slope, the valley of the Mississippi, and the declivity from the Rocky Mountains to the Pacific.

The Alleghayies are less a chain of mountains than a long plateau, crested with several chains of mountains or hills, separated from each other by wide and elevated valleys. East of the Hudson the mountains are chiefly granitic, with rounded summits, often covered at their tops with bogs and turf, and distributed in irregular groups without any marked direction. Some peaks of the Green Mountains, in Termont, and the White Mountains, in New Hampshire, rise to the height of 5,000 to 6,400 feet above the sea. After passing the Hudson, the structure of the mountains seems to change. In Pennsylvania and Virginia they assume the form of long parallel ridges, varying in height from 2,500 to 4,000 feet and occupying a breadth of one hundred miles. In North Carolina, the highest culmination is 6,476 feet; but in the northern part of Georgia and Alabama, where they terminate, they again lose the form of continuous chains, and break into groups of isolated mountains, touching at their base, some of which attain a considerable elevation.

The Roczy Mocntaiss are on a much grander scale than the Alleghanies. Their base is 300 miles in breadth, and their loftiest summits, covered with everlasting snow, rise to the height of 10 to 14,000 feet. These vast chains may be considered as a continuation of the Cordilleras of Mexico. They are distant from the Pacific Ocean from 5 to 600 miles, but between them and the coast several minor ranges intersect the country, of which the Maritime Range is the most conspicuous.

The immense valley included between these two ranges of mountains is intersected by the Mississippi River, which runs, from north to south, all through the United States. The country west of the Mississippi, with little exception, is yet a wilderness, inhabited by roving bands of Indians, and reyond the limits of the organized States the whites have scarcely a settlement; but the conntry east of that river is thickly populated, and in the highest state of cultivation. The most remarkable feature in the face of the country is the low plain, from 50 to 100 miles wide, which eztends along the Atlantic coast. Beyond this plain the land rises toward the interior till it terminates in the Alleghanies. The rest of the country east of the Mississippi is agreeably diversified

* The treaties relative tr, these boundaries are, 1. Treaty of Paris, 1793. 2. Treaty of London, 1794. 3. Louisiana Treaty, 1508. 4. Treaty of Ghent 1814. 5. Convention of London, 1818 and 1828. 6. Florida Treaty, 1819. 7. Treaty with Mexien. 13:. $\therefore$ Traaty with Iussia, 1524. 9. Ashburton Treaty, 1s42. 10. Texas Annexation Resolutions, 1845. 11. Oregon Irewit, 1516. 12. Treaty of Guadalupe, 1518. 
with hills and valleys, plains and mountains. The soil of the low country, except on the banks of creeks and rivers, is sandy, and comparatively unproductive; but the remainder has a strong, fertile soil, capable of supporting a dense population. The Pacific section is a highly varied country, abounding in wild and majestic scenery, and traversed by magnificent rivers. Much, however, of its interior is desert, and will probably never be inhabited by civilized man. The great California desert, indeed, is one of the dreariest regions of the world, the solitude being relieved only by a few oases in the neighborhood of streams, or on the borders of its numerous lakes; on these alone is there even an aboriginal population.

The shores of the United States are washed by three seas: the Atlantic Ocean, on the east, the Gulf of Mexico, on the south, and the Pacific Ocean, on the west. The principal bays and sounds on the Atlantic border are Passamaquoddy Bay, which lies between the State of Maine and the British province of New Brunswick; Massachusetts Bay, between Cape Ann and Cape Cod; Long Island Sound, between Long Island and the coast of Connecticut; Delaware Bay, which sets up between Cape May and Cape Henlopen, separating the States of New Jersey and Delaware; Chesapeake Bay, which communicates with the ocean between Cape Charles and Cape Henry, extending in a northern direction for 200 miles, through the States of Virginia and Maryland; Albemarle Sound, and Pamlico Sound, on the coast of North Carolina. There are no large bays or sounds on the coast of the Gulf of Mexico. On the Pacific coast, howerer, there are several excellent bays, but the principal and only one necessary to mention is the Bay of San Francisco, in the State of California. It is one of the finest bays in the world, and capable of containing the navies of all the European powers at one time.

With the exception of Michigan and Champlain, none of the great lakes of North America lie wholly within the territory of the United States; the rest are on the northern boundary, where they form a connected chain, extending through a distance of more than 1,200 miles. The first in the chain is Lake Superior, the largest body of fresh water on the globe. Few persons are really aware of the magnitude of these great lakes; they are truly inland seas, and navigation is as dangerous, and subjected to all the vicissitudes which are connected with the navigation of the Baltic, the Black Sea, or the Mediterranean. The following is a tabular statement of the extent of these freshwater seas, with the mean depth of their waters, and their elevation above the sea.

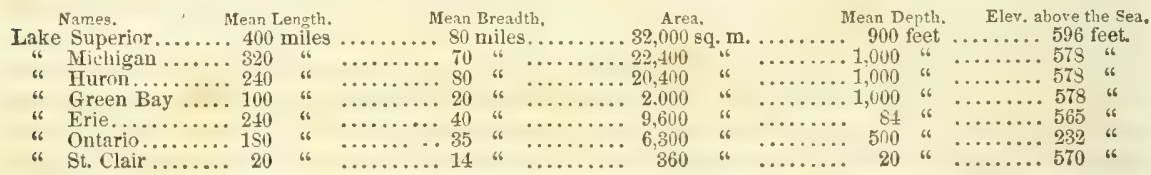

Lake Champlain, lying between Vermont and New York, is 128 miles long, and from 1 to 16 miles wide, and discharges its waters through the Sorel into the St. Lawrence. It is computed that the lakes contain above 14,000 cubic miles of water - a quantity more than five-sevenths of all the fresh water on the earth. The extent of country drained by the lakes, from the north-western angle of Superior to the St. Lawrence, including also the area of the lakes themselves, is estimated at 335,515 square miles.

The principal rivers of the United States may be divided into four classes. First, the Mississippi and its wide-spread branches, which drain the waters of the whole countryincluded between the Alleghany and Rocky Mountains; second, the rivers east of the Alleghany Mountains, which, rising from their eastern declivity, water the Atlantic plain, and hence flow into the ocean; third, the system of rivers flowing into the Gulf of Mexico, which may be subdivided into those flowing from the southern slope of the Alleghanies, and those having their source in the north-western highlands of Texas; and, fourth, those streams on the west of the Rocky Mountains, which flow into the Pacific Ocean.

The Mississippi rises west of Lake Superior, in latitude $47^{\circ} 47^{\prime}$ north, amid lakes and swamps, dreary and desolate beyond description; and after a south-east course of about 500 miles, reaches the Falls of the St. Anthony, where it descends perpendicularly 16 feet, and where are numerous rapids. From these falls it pursues at first a south-easterly, and then a southerly direction; and, after forming the boundary between Iowa, Missouri, and Arkansas, on the west, and Wisconsin, Illinois, Kentucky, Tennessee, and Mississippi, on the east, passes through Louisiana, and discharges itself through a delta of many mouths into the Gulf of Mexico. It is nearly 3,200 miles in length, and is navigable, with few obstructions, to the Falls of St. Anthony.

Its principal tributaries from the east are-1. The Wisconsin, which joins it between the parallels of $42^{\circ}$ and $43^{\circ}$ north latitude;-2. The Illinois, a navigable river, which joins it near latitude 
38040 north; -3 . The Ohio, which is itself formed by the junction of the Alleghany and Monongahela rivers at Pittsburg. It flows in a south-westerly direction for 945 miles, separating the north-western States from Virginia and Kentucky, and falls into the Mississippi in $37^{\circ}$ north latitude. The chief tributaries of the Ohio are the Wabash, the Cumberland, and the Tennessee, which last is formed of several streams from the western parts of Virginia and the Carolinas, which unite a little west of Knoxville, in the State of Tennessee, and runs at first south-west into Alabama, where it turns and runs north-west, through Tennessee into Kentucky, and joins the Ohio 10 miles below the mouth of the Cumberland; and-4. The Yazoo, which rises in the northern part of the State of Mississippi, and, running south-west, joins the Mississippi 100 miles above Natchez.

The tributaries from the west are-1. The Minnesota, or St. Peter's, which joins it about nine miles below the Falls of St, Anthony, after a south-east course of several hundred miles;-2. The Des Moines, which joins it near the parallel of $40^{\circ}$ north latitude, after a south-easterly course of more than 800 miles; -3 . The Missouri, which is formed by three branches, called Jefferson's, Madison's, and Gallatin's rivers, all of which rise and unite in the Rocky Mountains. The whole length, from the highest point of Jefferson's River, to the confluence with the Mississippi, is, by actual course, about 2,500 miles, and to the Gulf of Mexico nearly 4,000 miles; during the whole of which distance there is no cataract or considerable impediment to the navigation, except at Great Falls, which are above 2,000 miles from the Mississippi. At these falls the river descends, in the distance of 18 miles, 362 feet. The principal tributaries of the Missouri are the Yellow Stone, which rises in the Rocky Mountains, and joins it after a north-easterly course of 600 miles; the Nebraska, or Platte, which rises also in those mountains, and, after an easterly course of 800 miles, joins the Missouri in latitude $41^{\circ}$ north; and the Kansas, which joins it near latitude $39^{\circ}$ north, after an easterly course of more than 600 miles; -4 . The Arkansas, which rises in the Rocky Mountains, an'l pursuing a south-easterly course, forms, for some distance, the boundary between the Indian Territory and Texas; after which its course lies principally in the State of Arkansas, till it joins the Mississippi in $31^{\circ}$ north latitude. Its length is more than 1,300 miles;-5. The Red River, which also rises in the Rocky Mountains, below Sante Fé, and, after a south-easterly course of more than 1,000 miles, falls into the Mississippi in latitude $31^{\circ}$ north.

The principal rivers east of the Alleghanies are-1. The Connecticut, which rises in the highlands separating the United States from Canada, and running southerly, divides New Hampshire from Termont, and passing through Massachusetts and Connecticut, falls into Long Island Sound. It is narigable for sloops for fifty miles to Hartford, and by means of canals and other improvements, has been rendered passable for boats 250 miles farther; - 2. The Hudson, which rises west of Lake Champlain, and pursuing a southerly course of more than 300 miles, falls into the Bay of New Tork, after receiving numerous affluents. It is navigable for ships to Hudson, 130 miles, and for sloops and steamboats to Troy, 40 miles farther. It is connected with Lakes Champlain, Erie, and Ontario by means of canals from Albany, and with the Delaware by a canal from Rondout; 3. The Delaware, which rises in New York, and flowing southerly, separates Pennsylvania from New Fork and New Jersey, and falls into Delaware Bay, after a course of 300 miles. It is navigable for ships of the line 40 miles, to Philarlelphia, and for sloops 35 miles farther, to the head of the tide at Trenton Falls; -4. The Susquehanna, which also rises in New York, and, pursuing a southerly zig-zag course through Pennsylvania, falls into the head of Chesapeake Bay, near the north-east corner of Maryland. During the last 50 miles the navigation is obstructed by an almost continued series of rapids; -5 . The Potomac, which rises in the Alleghanies, and, after forming, during its Whole course, the boundary between Maryland and Virginia, falls into Chesapeake Bay. It is narigable for ships of the largest dimensions to Washington, the federal capital, about 200 miles from the ocean; but in the upper part of its course there are numerous obstacles, many of which, however, have been overcome by canals; -6. James River, which rises in the mountains, and falls into the southern part of Chesapeake Bay; and-7. The Savannah, which forms the dividing line between South Carolina and Georgia, and falls into the Atlantic in latitude $32^{\circ}$ north. It is navigatile for large ressels to Sarannah, 17 miles; and for boats to Augusta, 130 miles farther.

The principal rivers which rise south of the Alleghanies, and fall into the Gulf of Mexico, are1. The Apralachicola, which discharges itself into Apalachee Bay, in Florida. It is formed by the union of the Chattahoochee and Flint rivers, the former of which rises in the northern part of Gergia, and flowing south, receives the Flint at the south-west extremity of the State. During the latter part of its course, the Chattahoochee forms the boundary between Georgia and Alabama;2. The Mobile, which discharges itself into Mobile Bay. It is formed by two large rivers, the Alabarna and Tombighee, which unite near latitude $31^{\circ}$ north, after having pursued each a separate crurse of many hundred miles. There is another system of rivers flowing into the Gulf from the 


\section{UNITED STATES OF AMERICA.}

highlands of northern Texas, consisting of the Sabine, Trinity, Brazos, etc., which need only be mentioned here, as the geography of Texas will be minutely described elsewhere.

The rivers flowing from the Rocky Mountains to the Pacific, consist of-1. The Columbia, which rises near latitude $55^{\circ}$ north, and running south-west, falls into the ocean in latitude $46^{\circ} 15^{\prime}$, after a course of 1,500 miles. Its principal tributaries are Clark's River, Lewis' River, and the Multnomah or Willamette, all of which join it on its left bank. This river was discovered in 1792, and settlements were made in the neighborhood by Americans in 1810. The mouth of the river is obstructed by flats, but vessels of 300 tons can ascend to the distance of 125 miles, and large sloops farther;-2. The Sacramento and San Joaquin, emptying into the Bay of San Francisco;-3. The Buenaventura, rising in the coast range of the California Mountains, empties into Monterey Bay; -4. The Colorado, and River Gila (which separates Mexico from the United States), flow from the mountains near Santa Fé, and would, if not received by the Gulf of California, empty into the Pacific; they belong, however, to the same system of rivers.

The government of the United States is a federal democratic republic. It is based on the constitution of 1787 , and amendments thereto.

The electors of the most numerous branch of the several State Legislatures are qualified electors in the States respectively for all elective officers of the general government.

All legislative powers are vested in Congress, which consists of a Senate and House of Representatives.

The "House of Representatives" is composed of members chosen every second year by the people of the several States, and in number in accordance with the population of each, and in order to ascertain the number each State is entitled to, a census is taken every ten years, excluding from the enumeration for this object two-thirds of the slares, and all Indians not taxed. Each State is entitled to at least one representative. Vacancies are filled by intermediate elections. The House chooses its speaker and other officers. No person under twenty-five years of age, who has been less than seven years a citizen of the United States, and who is not a resident of the State electing him, is qualified for representative.

The constitution provided for a specific number of representatives from each State to compose the House until the ascertainment of the population under the census of 1790 ; but since then legislation has decennially fixed the number to be elected. From the 3d March, 1793, the apportionment was one representative to every 33,000 of the representative population; after 1803 , one to every 33,000 also; after 1813 , one to every 35,000 ; after 1823 , one to every 40,000 ; after 1833 , one to every 47,000 ; after 1843 , one to every 70,680 ; and after $3 \mathrm{~d}$ March, 1853,233 representatives to be divided pro rata to the several States. The following table shows the number of representatives to which each State has been entitled since the establishment of the government:

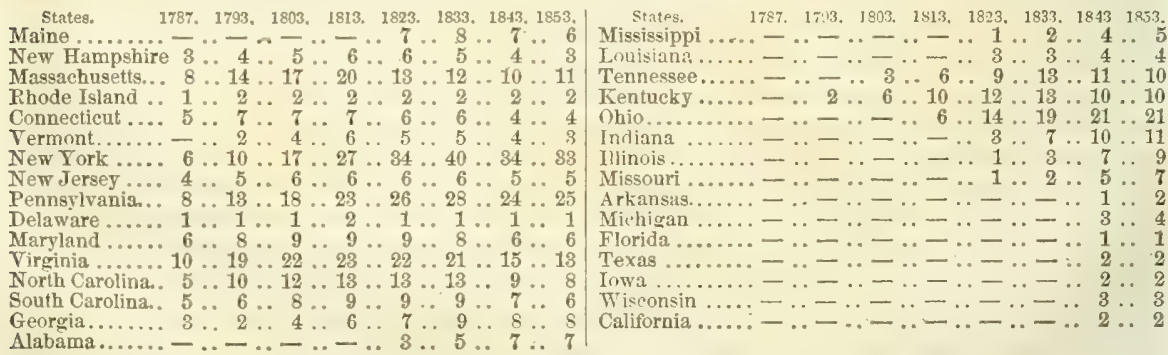

In addition to these representatives from States, the House admits a delegate from each organized Territory, who has the right to debate on subjects in which his Territory is interested, but can not vote. California has two members by a special t.

The "Senate" consists of two members from each State, elected by the Legislatures thereof respectively for six years. One-third the whole body is renewed biennially, and if vacancies happen, by resignation or otherwise, during the recess of the Legislature of any State, the executive of such State makes a temporary appointment until the next meeting of the Legislature, which fills such vacancy. Senators must be at least thirty years old, must have been citizens of the United States for nine years, and be residents of the State by which chosen. Each senator has one vote. The Vice-president of the United States is ex officio President of the Sentte, but a president pro tempore is elected by and from among the Senators, who, in the absence of the president, acts in his stead. 


\section{UNITED STATES OF AMERICA.}

The constitutional government went into operation on the 4 th March, 1789, but a quorum of the first Congress, which met at the city of New York, was not formed until the 6th April, nor was the first president of the United States inaugurated before the 30th April. The following is a complete list of sessions of Congress held up to the present time :

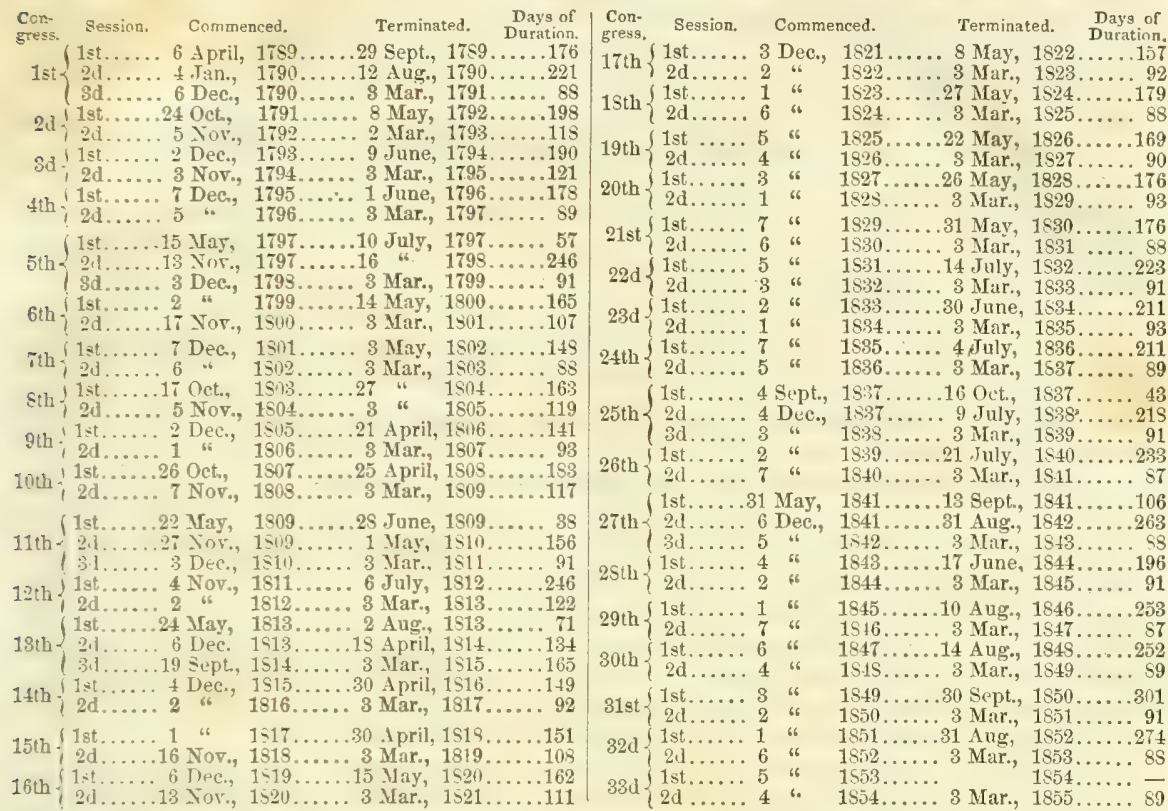

Besides its ordinary legislative capacity, the Senate is vested with certain judicial functions, and its members constitute a High Court of Impeachment. No person can be convicted by this court unless on the finding of a majority of Senators, nor does judgment extend further than to removal from office and disqualification. Representatives have the sole power of impeachment.

The Executive Power is vested in a President, who is elected by an Electoral College, chosen by popular rote, or by the Legislature of the State, the number of electors being equal to the number of Senutors and Representatives from the States to Congress. His term of office is four years, but he is eligithle for re-election indefinitely. The electors forming the college are themselves chosen in the manner prescribed by the laws of the several States. A majority of the aggregate number of votes given is necessary to the election of President and Vice-president, and if none of the candidates has such a majority, then the election of President is determined by the Fouse of Representatives, and that of the Vice-president by the Senate, from among the three candidates having the highest number of electoral votes, and in doing so, the vote is taken by States, the representatires of each State having only one rote, which must, of course, be determined by a majority of their number. To person can be President or Vice-president who is not a native-born citizen, of the age of thirty-five years, and who has been a resident of the United States for fourteen years. The President is commander-in-chief of the army and navy, and of the militia when in the service of the Lnion. With the concurrence of two-thirds of the Senate, he has the power to make treaties, appoint civil and military officers, levy war, conclude peace, and do all that rightly belongs to the executive power. He has a veto on all laws passed by Congress, but so qualified, that notwithstanding his disapproval, any bill becomes a law on its being afterward approved of by two-thirds of both houses of Congress. The President has a salary of $\$ 25,000$ per annum, and "the white house" at Washington for a residence during his official term. The Vice-president is ex-officio Presirlent of the Senate; and in case of the death, resignation, or other disability of the President, the powers and duties of that office devolve upon him for the remainder of the term for which the President had been elected. This provision of the constitution, for the first time since the foundation of the government, came into operation in 1841, on the demise of the late lamented General Harrian, who died 4th April, just one month after his inauguration, when John Tyler, the Vicepresirlent, succeeded. Vice-president Fillmore also succeeded President Taylor under this provi- 
sion. In case of the disability of the Vice-president, the President of the Senate pro tempore takes his place. The offices of President and Vice-president have been occupied by the following gentlemen since the adoption of the constitution:

Presidents.

Vice-presidents.

Terms of Office,

1. George Washington.............John Adams.................30th April, 1784, to 4th March, 1793

Do do do

3. John Adams .................... Thomas Jefferson ............. " " 1797 " " 1801

4. Thomas Jefferson ....................Aaron Burr .................... " " 1801 " "

5. Dn. do. ................Gerge Clinton $\ldots \ldots \ldots \ldots \ldots \ldots$ " " 1505 " " 1809

6. James Madison ........................ Do do (d. 20th Apr., 1812) " " 1809 "6 "6 1813

7. Do. do. .......................6. G6 1813 "6

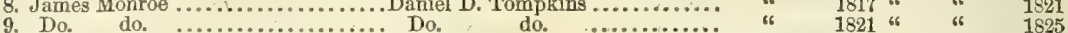

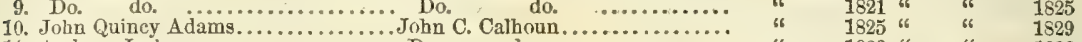

11. Andrew Jackson .................... Do. do. ................. "6 " 1829 " " " 1833

12. Do. do. ..................Martin Van Buren........... "6 "6 " 1838 " " 1837

13. Martin Van Buren.................. Richard M. Johnson ............ " " 1837 " 1841 "th April, 1841

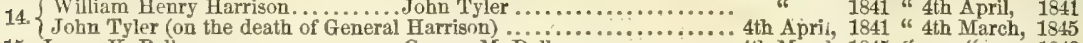

15. James K. Polk ................... George M. Dallas.................. 4th March, 1845 "6 "4

16. Zachary Taylor .................Millard Fillmore ............. " 1819 " 9th July, 1850

( Millard Fillmore (on the death of General Taylor).................. 9th July, 1850 " 4th March, 1858

17. Franklin Pierce ................... Wm. Rufus King (d.18 Ap., 185̌s). 4th March, 1853 " " " 1857

The administrative business of the nation is conducted by several officers, with the title of secretaries, etc., who form what is termed the "Cabinet." These are the Secretary of State, the Secretary of War, the Secretary of the Navy, the Secretary of the Treasury, the Postmaster-general, the Secretary of the Interior, and the Attorney-general-the last being the official law authority for advisement in administrative affairs. Each of these presides over a separate Department.

The "Department of State" was created by an act of Congress of the 15th of September, 1789; by a previous act of the 27 th of July, 1789, it was denominated the Department of Foreign Affairs. It embraced, until the establishment of the Department of the Interior in 1849, what in some other governments are styled the Department of Foreign Affairs and Home Department; but the duties now being divided, it confines its operations almost entirely to foreign matters, and hence its original title might with propriety and convenience be restored.

The Secretary of State conducts all treaties between the United States and foreign powers, and corresponds officially with the public ministers of the government at foreign courts, and with ministers of foreign powers, resident in the United States. He is intrusted with the publication of all treaties with foreign powers, preserves the originals of all treaties and of the public correspondence growing out of international intercourse; grants passports to American citizens visiting foreign states, etc. He has charge of the Great Seal of the United States, but can not affix it to any commission until signed by the President, nor to any instrument without authority of the President.

\section{Secretaries of State-Salary $\$ 6,000$ per Annum.}

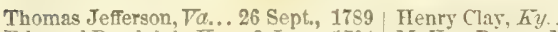

Edmund Randolph, $\overline{V a} . .2$ Jan., 1794 M. Van Buren, $\dot{N} \ddot{Y}$.

Timothy Pickering, $V \alpha . .4$ Feb., 1795 Ed. P. Livingston, La.

John Marshall, Fi..... 13 .Jay, 1Sin Louis M'Lane, Del....

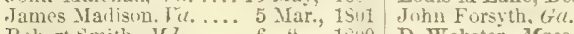

Polbert

James Minroe, Iit.

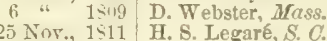

5 Mar., 1817 A. P. Upshur, Fa.

\begin{tabular}{|c|c|c|}
\hline Mar., & $1 S 25$ & John Nelson, Ma. . . . . . 29 Feb., \\
\hline $666^{6}$ & 1829 & J. C. Calhoun, $S . C \ldots \ldots 6$ Mar., \\
\hline Mar., & 1833 & J. M. Clayton, Del...... 6 " \\
\hline & & D. Webster, Mass. \\
\hline & 41 & Edward Everett.. \\
\hline 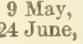 & $\begin{array}{l}1543 \\
1843\end{array}$ & Willam L. Marcy, $N . Y_{0} 5$ Mar., \\
\hline
\end{tabular}

This department has subject to it the Diplomatic Bureau, and the Consular Bureau. The United States are represented by Ministers Plenipotentiary at the Courts of Great Britain, France, Russia, Prussia, Spain, Mexico, Central America, Brazil, and Chili; by Commissioners at the court of Pekin, China, and at the Sandwich Islands; by a Minister Resident at the Sublime Porte, and to the Swiss Confederation, and at other courts by Chargés des Affaires; and United States' Consuls are stationed at all the important commercial ports in the world. Foreign Ministers accredited to the government of the United States are, Envoys Extraordinary and Ministers Plenipotentiary from Great Britain, Russia, the Argentine Republic, France, Spain, Chili, New Grenada, Brazil, Mexico, and Peru; Ministers Resident from Portugal, Prussia, and Belgium; and Chargés des Affiirs from Denmark, Austria, Holland, Sweden, Naples, Sardinia, Venezuela, and Nicaragua. Foreign Consuls from all commercial nations reside in the several Collection Districts of the Union

The "Department of the Interior" was established by an act of Congress of the 30th of March, 1849. The Secretary of the Interior is intrusted with the supervision and management of all matters connected with the public domain, Indian affairs, pensions, patents, public buildings, the census, the penitentiary of the District of Columbia, the expenditures of the Federal Judiciary, etc. Each of these interests is managed in a separate bureau or office, the immediate head of which is styled Commissioner, Superintendent, or Warden, as the case may be. 
Thomas H. Ewing, Ohio 6 Mar., 1S49 $\mid$ T. M.T. M.Kennon (dec.) 8 Aug., $1550 \mid$ Robert M.Clelland, Mich., 5 Mar., 1853 James A. Pearce (decl'd) 20 July, $1850 \mid$ Alex. H. H. Stuart, Va...10 Sept., $1850 \mid$

The "Department of the Treasury" was created by an act of Congress of the $2 \mathrm{~d}$ of September, 1789. The Secretary of the Treasury superintends all the fiscal concerns of the government, and upon his own responsibility recommends to Congress measures for improving the condition of the revenue. All public accounts are finally settled at this department; and for this purpose it is divided into the office of the Secretary, who has the general superintendence, the offices of the two Concrollers, the offices of the Six Auditors, the office of the Commissioner of Customs, the Treasurer's office, the Registrar's office, the Solicitor's office, and the office of the Coast Survey. Assisttant Treasurers' offices are also established at Boston, New York, Philadelphia, Charleston, New Orleans, and St. Louis.

\section{Secretaries of the Treasury-Salary $\$ 6,000$ per Annum.}

Alex. Hamilton, $N . Y . . .12$ Sept., $1789 \mid$ Richard Rush, $P a . . . . .7$ Mar., 1825 Walter Forward, $P a . . . .13$ Sept., 1841

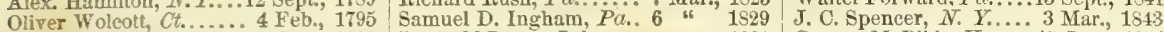
Sanuel Dexter, Jies.....31 Jan., 1502 , Louis M.Lane, Del...... 1531 George.M. Bibb, Ky.....15 June, 1s44

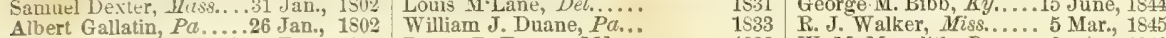
George W. Campbell, $\ddot{C}$ t. 9 Feb., 1814 Roger B. Taney, Mrd.... 1833 W. M. Meredith, Pa..... 6. " 1849 Alex.J. Dallas, Fa...... 6 Oct., 1814 Levi Troodbury, N. U... 7 Mar., 1833 Thos. Corwin, Ohio.....20 July, 1850 Wm. H. Crawford, Ga.. 5 Mar., 1817 Thomas Ewing, Ohio.... 5 " 1811 James Guthrie, $\mathbf{k} y . . . .5$ Mar., 1858

The "Department of War" was created by an act of Congress of the 7th of August, 1789, and at first embraced not only military, but also naval affairs. The Secretary of War superintends every branch of military affairs, and has under his immediate direction the Adjutant-general's office, the Quartermaster-general's Bureau, the Paymaster's Bureau, the Subsistence Bureau, the Medical Bureau, the Engineer Bureau, the Topographical Bureau, the Ordnance Bureau, etc.; and the department has the superintendence of the erection of fortifications, of making public surveys, and other important services.

\section{Secretaries of War-Salary \$6,000 per Annum.}

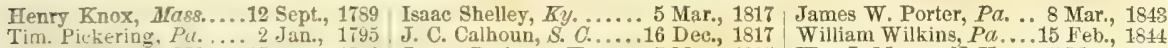

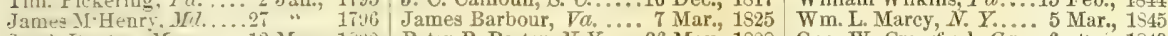

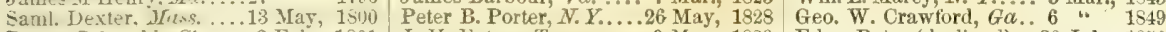
Roger Griswold, Ct..... 3 Feb., 1801 J. H. Eat on, Tenn. .... 9 Mar., 1829 Edm. Bates (declined) ..20 July, 1850

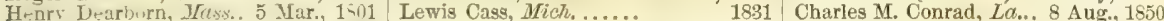
William Euitis

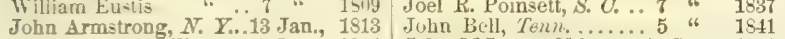
James Monroe, $\mathrm{Va} . . .27$ Sept., 1814 John M'Lean, Ohio.......13 Sept., 1841 Wm. H. Crawford, Ga... 2 Mar., 1815 J. C. Spencer, N. Y. ...12 Oct., 1841

The "Department of the Navy" was created by an act of Congress of the 30th of April, 1798, The Secretary of the $\mathcal{N}$ avy issues all orders to the naval forces and superintends naval affairs generally. Attached to the Department are-a Bureau of Docks and Navy Yards, a Bureau of Ordnance and Hydrography, a Bureau of Construction, Equipment, and Repairs, a Bureau of Provisions and Clothing, a Bureau of Medical and Surgical Instruments, etc.; and the National Observatory at Washington is under the control of the Navy Department. The ministerial duties of these several Bureaux were formerly exercised by a Board of Navy Commissioners.

\section{Secretaries of the Navy-Salary $\$ 6,000$ per Annum.}

George Cabot, Mas8..... 8 May, 1798 ; S. L. Southard, N. J. .... 9 Dec., 1823। T. W. Gilmer, Va......15 Feb., 1S14 Benjamin Stoddard, Mid.21 " 1793 John Branch, N. C...... 9 Mar., 1829 John Y. Mason, Va......14 Mar., $15+1$ Robert Smith. MId......26 Jan., 1802 Levi Woodbury, N. H... 1831 George Baneroft, DLass..10 "6 1945

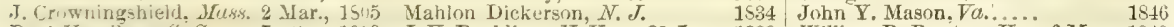

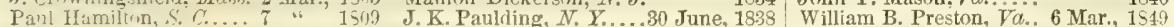
William. Jones, Pa......12 Jan., 1813 G. P. Balger, N. C...... 5 Mar., 1841 Wm. A. Graham, $N$. C...20 July, 1850 B.W. Crownings'd, MIass,19 Dec, 1814 Abel P. Upsliur, Va......13 Sept., 1841 J. C. Dobbin, N. C. .... 5 Mar., 1853 Smith Thompson, N. Y..30 Nov., 1818 David Henshaw, Mass...24 July, 1843

The "Department of the Post-office" was established under the authority of the Old Congress. The Postmaster-general has the chief direction of all postal arrangements with foreign states, as well as within the federal limits. The general business is managed by three Assistant Postmasterg-general, who preside respectively over the Contract office, the Appointment office, and the Inspection, etc., offices.

\section{Postmasters-general-Salary $\$ 6,000$ per Annum.}

Samuel Osgood, Mass...26 Sept., 1789 Timothy Pickering, $P$ a. 7 No\%., 1791 Ji, - ph His. r-ham, Gre. 2 Jan., 1795 Gileon Granger, Ct.....17 Mar., 1802 Reuben J. Meigs, Ohio.. "6 1814 Jishri M.Lean, Thio..... 9 Dec., 1823
William J. Barry, Ky... 9 Mar., 1829 Amos Kendall, $K y$....... 1 May, 1885 Francis Granger, $\ddot{N} . \dot{Y} .25$ " 6 Mar., 1841 Charles A. Wiekliffe, Ky.13 Stpl., 1511 Cave Johnson, Tenn. ... 5 Mar., 1845
Jacob Collamer, It..... 6 Mar., 1849

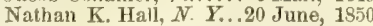
James Campbell, Tenn. 5 Mar., 1853 


\section{UNITED STATES OF AMERICA.}

The "Attorneys-general," who are considered as forming a part of the Cabinet, and who are the constitutional advisers and defendants of the government, are generally men of the greatest acquirements in their profession. The gentlemen who have held this office are enumerated in the annexed list:

\section{Attorneys-general-Salary $\$ 4,000$ per Annum.}

Edmund Randolph, Va..26 Sept., $1789 \mid$ William Wirt, Md......16 Dec., $1817 \mid$ John Y. Mas $\cap$ n, Va.... 5 Mar., 1845

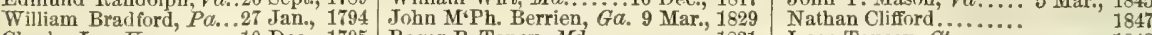

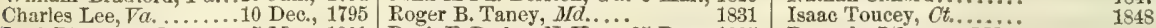

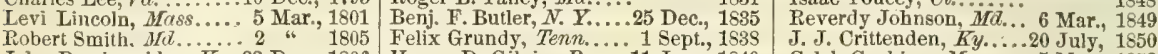

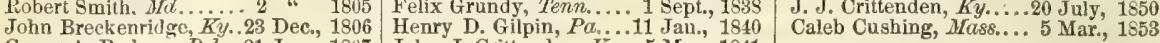
Crsar A. Rodney, Del...21 Jan., 1807 John J. Crittenden, Ky.. 5 Mar., 1841 William Pinckney, $M d . .11$ Dec., 1811 Hugh S. Legare, S. C....13 Sept., 1841 Richard Rush, Pa......10 Feb., 1814 John Nelson, Md....... 1 July, 1843

The judicial powers of the United States are vested in a Supreme Court, and in such other inferior courts as Congress may from time to time establish. The present judicial establishment consists of a Supreme Court, Circuit Courts, and District Courts.

The "Supreme Court," the highest judicial tribunal of the Union, is composed of a Chief-Justice and eight Associate Justices, the Attorney-general, a Reporter, and Clerk. This court is held in Washington, and has one session annually, commencing on the first Monday in December.

The Supreme Court has exclusive jurisdiction in all controversies of a civil nature where a State is a party, except between a State and its citizens, and except, also, between a State and citizens of other States or aliens-in which latter case it has original but not exclusive jurisdiction. It has exclusively all such jurisdiction of suits and proceedings against ambassadors or other public ministers, or their domestics or domestic servants, as a court of law can have or exercise consistently with the law of nations; and original, but not exclusive jurisdiction of all suits brought by ambassadors or other public ministers, in which a consul or a vice-consul is a party. It has appellate jurisdiction from final decrees and judgments of the circuit courts in cases where the matter in dispute, exclusive of costs, exceeds the sum or value of 2,000 dollars, and from final decrees and judgments of the highest courts of the several States in certain cases. It has power to issue writs of prohibition to the District Courts, when proceeding as Courts of Admiralty and maritime jurisdiction; and writs of mandamus in cases warranted by the principles and usages of law to any courts appointed or persons holding office under the authority of the United States. The trial of issues in fact in the Supreme Court in all actions at law against citizens of the United States is by jury,

A final judgment or decree in any suit, in the highest court of law or equity of a State in which a decision in the suit could be had, where is drawn in question the validity of a treaty or statute of, or any authority exercised under the United States, and the decision is against their validity; or where is drawn in question the validity of a statute of, or an authority exercised under any J tate, on the ground of their being repugnant to the constitution, treaties, or laws of the United Jtates, and the decision is in favor of their validity; or where is drawn in question the construction of any clause of the constitution, or of a treaty or statute of, or commission held under the United States, and the decision is against the title, right, privilege, or exemption, specially set up or claimed by either party, under such clause of the constitution, treaty, statute, or commission, may be re-examined, and reversed or affirmed, in the Supreme Court of the United States, upon a writ of error, the citation being signed by the Chief Justice, or Judge, or Chancellor of the court rendering or passing the judgnent or decree complained of, or by a Justice of the Supreme Court of the United States, in the same manner, and under the same regulations, and the writ has the same effect, as if the judgment or decree complained of had been rendered or passed in a Circuit Court; and the proceeding upon the reversal is also the same, except that the Supreme Court, instead of remanding the cause for a final decision, may, at their discretion, if the cause shall have been once remanded before, proceed to a final decision of the same, and award execution. But no other error can be assigned or regarded as a ground of reversal in any such case, than such as appears on the face of the record, and immediately respect the before-mentioned questions of validity or construction of the said constitution, treaties, statutes, commissions, or authorities, in dispute.

\section{Chief-Justices of the Supreme Cöurt-Salary $\$ 5,000$ per Annum.}

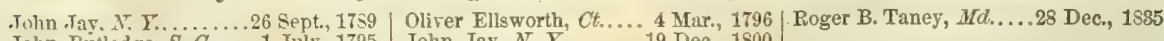
John Rutledge, $\dot{S} . \ldots \ldots .1$ July, 1795 John Jay, $N, Y \ldots \ldots . .19$ Dec., 1800

William Cushing, Mass..27 Jan., 1796 John Marshall, $\mathrm{Va} . . . .27$ Jan., 1501

The "Circuit Courts" are held by a Justice of the Supreme Court assigned to the Circuit and by the Judge of the District in which the Court sits conjointly. The United States is divided into 12 
UNITED STATES OF AMERICA.

nine judicial Circuits, in each of which a Court is held twice a year. The Circuits are as follows :

I. Maine, N. Hampshire, Massachusetts, and R. Island.

II. Vermont, Connecticut, and New York.

III. New Jersey and Pennsylvania.

IV. Delaware, Iraryland, and Virginia.

V. Alabama, Louisiana, and Kentucky.

VI. North Carolina, South Carolina, and Georgia.

VII. Ohio, Indiana, Illinois, and Michigan.

VIII. Kentucky, Tennessee, and Missouri.

IX. Mississippi and Arkansas.

The States of Florida, Texas, Iowa, Wisconsin and California have not yet been attached to any circuit; but the District Courts have the power of Circuit Courts. There is a local Circuit Court held in the District of Columbia by three judges specially appointed for that purpose. The ChiefJustice of that court sits also as District Judge of that District.

The Circuit Courts of the United States have original cognizance, concurrent with the courts of the several States, of all suits of a civil nature, at common law, or in equity, where the matter in dispute exceeds, exclusive of costs, the sum or value of 500 dollars, and the United States are plaintiffs or petitioners, or an alien is a party, or the suit is between a citizen of the State where the suit is brought and a citizen of another State. They have exclusive cognizance of all crimes and offenses cognizable under the authority of the United States (except where the laws of the Cnited States otherwise direct), and concurrent jurisdietion with the District Courts of the crimes aud offenses cognizable therein. But no person can be arrested in one district for trial in another, in any civil action, before a Circuit or District Court. No civil suit can be brought, before either of said courts, against an inhabitant of the United States, by any original process, in any other district than that whereof he is an inhabitant, or in which he shall be found at the time of serving the writ; and no District or Circuit Court has cognizance of any suit to recover the contents of any promissory note, or other chose in action, in favor of an assignee, unless a suit might have been prosecuted in such court to recover the said contents, if no assignment had been made, except in cases of foreign bills of exchange.

The Circuit Courts have appellate jurisdiction from final decrees and judgments of the District Courts, in all cases where the matter in dispute exceeds the sum or value of fifty dollars. They also have jurisdiction of certain cases, which may be removed into them before trial from the State courts. But no District Judge (sitting in the Circuit Court) can give a vote in any case of appeal, or error, from his own decision, but may assign the reasons of such his decision. The trial of issues in fact in the Circuit Courts, in all suits, except those of equity and of admiralty and maritime jurisdiction, is by jury.

The "District Courts" are held respectively by a district judge alone. Each State is one district for the purposes of holding District or Circuit Courts therein, with the exception of New York, Pennsylvania, Tirginia, Georgia, Florida, Mississippi, Louisiana, Arkansas, and California, each of which is divided into two districts, and of Alabama, Tennessee, and Iowa, each of which are divided into three districts. There are besides these, Territorial Courts, which are temporary, and lose that character whenever a Territory becomes a State.

Each court has a clerk, a public attorney or prosecutor, and a marshal-all of which are appointed by the President of the United States, with the exception of the clerks, who are appointed by the courts severally.

The District Courts of the United States have, exclusively of the courts of the several States, cognizance of all crimes and offenses that are cognizable under the authority of the United States, committed within their respective districts, or upon the high seas, where no other punishment than whipping, not exceeding thirty stripes, a fine not exceeding one hundred dollars, or a term of imprisonment not exceeding six months, is to be inflicted, and also have exclusive original cognizance of all civil causes of admiralty and maritime jurisdiction, including all seizures under the laws of impost, navigation, or trade, of the United States, where the seizures are made on waters which are navigable from the sea by vessels of ten or more tons' burthen, within their respective districts, as well as upon the high seas, saving to suitors, in all cases, the right of a common-law remedy, where the common law is competent to give it ; and also have exclusive original cognizance of all seizures on land, or other waters than as aforesaid, made, and of all suits for penalties and forfeitures incurred, under the laws of the United States. And they also have cognizance, concurreat with the courts of the several States, or their circuit courts, as the case may be, of all causes where an alien sues for a tort only in violation of the law of nations, or a treaty of the United States. They also have cognizance, concurrent as last mentioned, of all suits at common law, where the tniterl States sue, and the matter in dispute amounts, exclusive of costs, to the sum or value of one hundred dollars They also have jurisdiction, exclusively of the courts of the several States, of all suits against consuls or vice-consuls, except for offenses above the description aforesaid. 


\section{UNITED STATES OF AMERICA.}

The trial of issues in fact, in the District Courts, in all causes, except civil causes of admiralty and maritime jurisdiction, is by jury.

An act of the 18th of December, 1812, requires the district and territorial judges of the United States to reside within the districts and territories, respectively, for which they are appointed; and makes it unlawful for any judge, appointed under the authority of the United States, to exercise the profession or employment of counsel or attorney, or to be engaged in the practice of the law. And any person offending against the injunction or prohibition of this act. shall be deemed guilty of misdemeanor.

Appeals are allowed from the District to the Circuit Courts in cases where the matter in dispute, exclusive of costs, exceeds the sum in value of $\$ 50$, and from the Circuit Courts to the Supreme Court in cases where the matter in dispute exceeds the sum or value of $\$ 2,000$; and in some cases where the inconvenience of attending a court by a justice of the fupreme Court is very great, the District Courts are invested with Circuit Court powers.

The appointment of all judges of the United States is made by the President, by and with the advice of the Senate; and the judges hold their several offices during good behavior, and ean be removed only on impeachment. Their compensation is fixed by law, and can not be diminished during their period of office.

\section{GENERAL STATISTICS OF THE UNITED STATES.}

I. STATISTICS OF POPULATION, ETC., ETC.

1. Statement of the Extent, Population, Industry, and Wealth of each State and of the United States, on the 1st June, 1850.

\begin{tabular}{|c|c|c|c|c|c|c|c|c|c|}
\hline \multirow{3}{*}{ States and Territories. } & \multirow{3}{*}{$\begin{array}{l}\text { A rea in } \\
\text { Square } \\
\text { Miles. }\end{array}$} & \multicolumn{4}{|c|}{ Population. } & \multirow{3}{*}{$\begin{array}{l}\text { Populat'n } \\
\text { to : quare } \\
\text { Miles. }\end{array}$} & \multirow{3}{*}{$\begin{array}{c}\text { Manufac } \\
\text { turing Es } \\
\text { tablish'ts. }\end{array}$} & \multirow{3}{*}{$\begin{array}{l}\text { Farms in } \\
\text { Cultiva- } \\
\text { tion. }\end{array}$} & \multirow{3}{*}{$\begin{array}{l}\text { Cenaus } \\
\text { Valuation. }\end{array}$} \\
\hline & & \multirow{2}{*}{$\begin{array}{l}\text { TVhite } \\
\text { Persons. }\end{array}$} & \multicolumn{2}{|c|}{ Colored. } & \multirow[b]{2}{*}{ Total. } & & & & \\
\hline & & & Free. & slave. & & & & & \\
\hline Alabama .... & 50,722 & 426.486 & 2,293 & $3+2.592$ & 771.671 & 15.2 & 1,022 & 41,964 & $\$ 228,204,332$ \\
\hline Arkansas... & 52,198 & 162,189 & 608 & 47,100 & 209,897 & 4.0 & 271 & 17,758 & $89,841,025$ \\
\hline California & 188,981 & 272.306 & 33.201 & - & 308,507 & & - & - & $22.161,872$ \\
\hline Columbia Distriet . & 60 & 88,027 & 9,973 & 3,687 & 51,687 & 861.4 & 427 & 264 & $14,015,874$ \\
\hline Connecticut....... & 4,674 & 363,099 & 7,693 & - & 370.792 & 79.3 & 3,913 & 22,445 & $155,707,980$ \\
\hline Delaware......... & 2,130 & 71,169 & $18,0 \pi 3$ & 2,290 & 91.532 & 43.6 & 513 & 6,063 & $21,062,556$ \\
\hline Florida........... & 59,268 & 47,211 & 924 & 39,3019 & 87.444 & 1.4 & 121 & 4,304 & $22,862.270$ \\
\hline Georgia ........... & $5 S, 000$ & 521,572 & 2,931 & 381,652 & $906,1<5$ & 15.6 & 1,407 & 51,759 & $354,425,714$ \\
\hline Illinois ........... & 55,405 & 846.035 & 5,435 & - & 851.470 & 15.3 & 8,090 & 76.208 & $156,265,006$ \\
\hline Indiana $\ldots . . . . .$. & $\begin{array}{r}33,809 \\
187,171\end{array}$ & 977,625 & 10,788 & 一 & 988,416 & 29.2 & 4,326 & 93,896 & $202,650,264$ \\
\hline $\begin{array}{l}\text { Indian } T e r . . . . . . \\
\text { Iowa............. }\end{array}$ & 50,914 & 191.579 & 335 & - & 192,214 & 8.7 & 482 & 14,805 & 28.714 .688 \\
\hline Kentucky ....... & 37,630 & 761,417 & 10,007 & 210.981 & 982.405 & $\begin{array}{r}0.1 \\
26.0\end{array}$ & $\begin{array}{r}482 \\
3,471\end{array}$ & 74,777 & $\begin{array}{r}28.114,058 \\
301,628,456\end{array}$ \\
\hline Louisiana......... & 46,431 & 255,491 & 17,462 & 241,609 & 517,762 & 11.0 & 1,021 & 13,422 & $233,993.764$ \\
\hline Maine ............ & 30,000 & 581.813 & 1.356 & - & $5 \$ 3,169$ & 19.4 & $3,6 \mathrm{~S} 2$ & $46,76 \div$ & $122,7 \pi 7,571$ \\
\hline Maryland......... & 9,356 & 417,943 & 74.723 & 90,368 & 583,034 & 62.3 & 3,863 & 21,860 & 219,217364 \\
\hline Massachusetts..... & $\begin{array}{r}7,5010 \\
\end{array}$ & 955,450 & 9,064 & - & 994.514 & 126.1 & 9,637 & 34,235 & 572.342 .286 \\
\hline $\begin{array}{l}\text { Michigan .......... } \\
\text { Minnesnta Ter. }\end{array}$ & $56 ; 243$ & $395,(197$ & $\begin{array}{r}2,557 \\
39\end{array}$ & - & 397.654 & 7.0 & 1,979 & 34,089 & $59.787,255$ \\
\hline $\begin{array}{l}\text { Mimnesnta Ter. ... } \\
\text { Mississippi........ }\end{array}$ & $\begin{array}{l}83,000 \\
47,156\end{array}$ & $\begin{array}{r}6,038 \\
295.718\end{array}$ & $\begin{array}{r}39 \\
931\end{array}$ & $30 \overline{9,575}$ & $\begin{array}{r}6,0177 \\
606,526\end{array}$ & 12.8 & $\begin{array}{r}5 \\
866\end{array}$ & $\begin{array}{r}157 \\
3.960\end{array}$ & 22 \\
\hline Mlissouri.......... & 67.380 & 592,004 & 2,618 & 87,422 & 682,044 & 10.1 & 3,030 & 54,459 & $137,247,707$ \\
\hline Nebraska Ter..... & 136,700 & - & - & - & - & - & & & \\
\hline New Hampshire .. & $9,2 S 0$ & 317.456 & 520 & - & 317,976 & 34.2 & 3,301 & 29.229 & 103.652 .835 \\
\hline New Jersey ........ & 8,320 & 465,518 & 23,520 & 222 & 489.555 & 60.0 & 4,374 & 23,905 & $200,000,000$ \\
\hline New Mexico Ter... & 210.744 & 61.530 & 17 & 一 & 61,547 & .2 & - & - & $5,174.471$ \\
\hline New York......... & 46,000 & $3,048,325$ & 49,069 & $=$ & $3,097.394$ & 67.6 & 23.823 & 170.621 & $1,080,209,216$ \\
\hline North Carolina.... & 45,000 & 558,025 & 27,463 & 285.548 & $\$ 69,039$ & 19.3 & 2,523 & 56,916 & $226,500,472$ \\
\hline North-West Ter... & 587,564 & $10=510$ & & 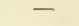 & & & & & \\
\hline Ohio ............ & 39,964 & $1,955,10 \mathrm{~s}$ & 25,319 & 一 & $1,980.427$ & 49.5 & 10,550 & 143,857 & $504,726.120$ \\
\hline Oregon Ter...... & 341,463 & $\begin{array}{r}18,155 \\
0.16\end{array}$ & 2616 & 一 & 13.294 & 0 & 51 & 1.164 & 5.063 .474 \\
\hline Pennsylvania ..... & $46,(100)$ & $2,255,463$ & 53.323 & - & $2,311,756$ & 50.2 & 22,036 & 127.577 & 722.456 .120 \\
\hline Rhode rsland. & $\begin{array}{r}1.360 \\
2+.500\end{array}$ & $\begin{array}{l}143.515 \\
274.567\end{array}$ & $\begin{array}{l}3.670 \\
8.956\end{array}$ & - & $\begin{array}{l}147.545 \\
669507\end{array}$ & $\begin{array}{r}108.0 \\
07.0\end{array}$ & 1,144 & 5.385 & 80.505 .794 \\
\hline T'tnnessee......... & 45.600 & 756.753 & 6,401 & 239,460 & $\begin{array}{r}665.006 \\
1,002,614\end{array}$ & 21.2 & $\begin{array}{l}1,413 \\
2,759\end{array}$ & $\begin{array}{l}29,709 \\
72,710\end{array}$ & $\begin{array}{l}285,206.694 \\
201,246.656\end{array}$ \\
\hline Texas..... & 237,321 & 154,034 & 397 & $5 \mathrm{~S}, 161$ & 212,592 & .8 & 8117 & 12,198 & $\begin{array}{r}201,240,050 \\
52,740,473\end{array}$ \\
\hline Utale Ter... & 157,923 & 11.330 & 24 & 26 & $11.3>0$ & .0 & 16 & 926 & 996,183 \\
\hline Vermont ........ & 10,212 & 313,402 & 718 & - & 311,120 & 30.0 & 1,835 & 29,657 & $92,205,049$ \\
\hline Virginia.. & 61,852 & 894,500 & 54,333 & 472,528 & $1,421,661$ & 23.1 & 4,433 & 77,013 & $430,7 \cup 1,082$ \\
\hline Washington Ter... & - & - & - & - & - & - & - & - & - \\
\hline Wisconsin ........ & 53,924 & 304,755 & 633 & - & 305,391 & 5.6 & 1,273 & 20,177 & $42.056,595$ \\
\hline
\end{tabular}




\section{UNITED STATES OF AMERICA.}

\section{Progressive Movement of Population.}

Colored Persons.

Decennial Increase.

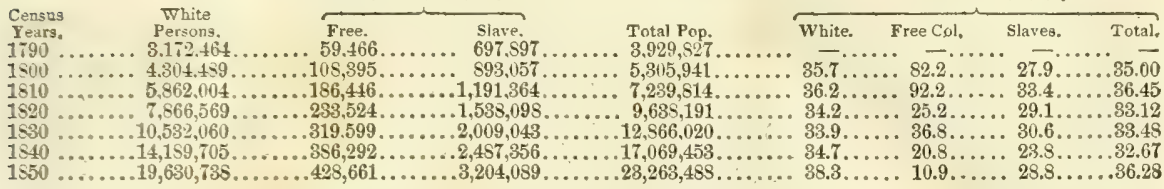

\section{Origin of the Free Population of 1850.}

Place of Origin

Maine.

Tow Hampshire...

Fermont ...........

Massacbusetts ......

Rhode Island.

Connecticut.

New York.

New Jersey ..........2.

Pennsylvania .....2,266,727

Delaware........... 104,316.

Maryland........... 5

England.

23,393 | Arkansas...............

A.-Native Population.

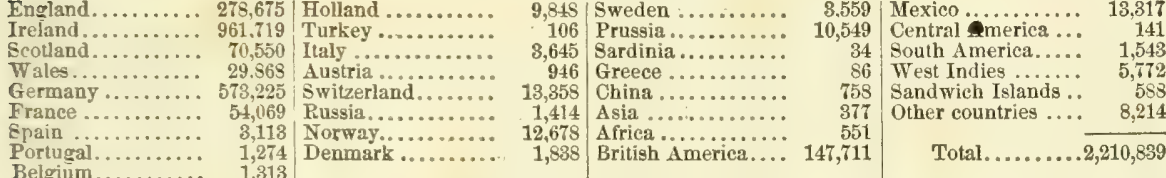

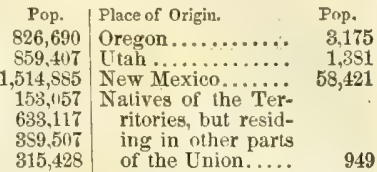

Total....... $\overline{17,737,578}$

C.-Origin Unknown. Total 39,154.

\section{Deaf and Dumb, Blind, Insane, and Idiotic, 1850.}

\section{A.-Absolute Number of each Class.}

White Persons.

$\overbrace{\text { Male. }}, 027 \ldots$ Fiem, $_{4,058}$

Deaf and Dumb....... 5,027 ..... 4,058

Blind ............... 4,519 ..... 8,478 .

Insane ............. $7.697 \ldots \ldots .7,459$

$8,276 \ldots . .5,954$

$B$ - Ratio of each Class to the aggregate Population.

Colored Persons.

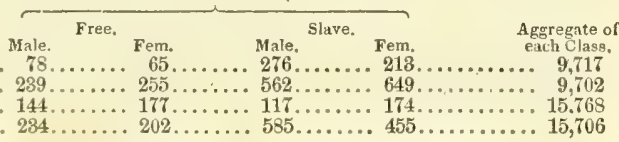

Culored Persons.

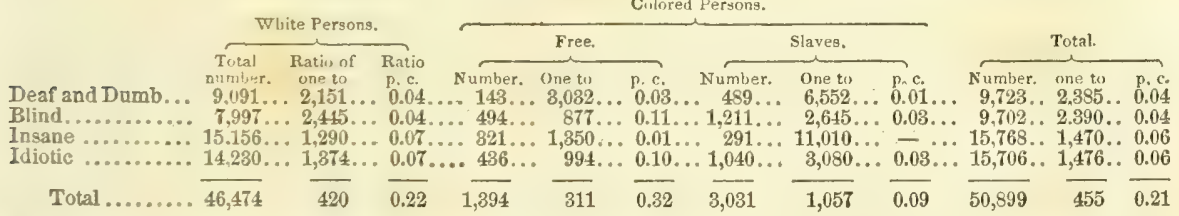

\section{Pauperism, 1850 .}

Number of paupers who received support within the year ending June 1st, 1850-native 66,434, and foreign 68,538 -total 134,972.

Number of paupers who were receiving support on the 1st June, 1850-native 13,473, and foreign 13,437 -total 50,353 .

Total cost of pauper support within the year specified $-\$ 2,954,806$.

The following exhibit shows the number and cost of paupers to each of the States, within the Jear 18:0 :

\begin{tabular}{|c|c|c|c|c|c|c|c|c|c|c|c|}
\hline$g^{*}$ ates. & Paupers. & Cost. & States. & Paupers. & Cort. & States. & Paupers. & Cost. & States. & Pau & Cost. \\
\hline a & & $\$ 151,664$ & Penn. & 11,551 & $\$ 232,133$ & Alabama.. & 363. & $\$ 17,559$ & Michigan & 1,190 & $\$ 27,556$ \\
\hline $\operatorname{atmp}$ & forot & 157,351 & Delaware & 697. & 17.730 & Miss.. & 260 . & 18,132 & Indiana & 1,182 . & 57,560 \\
\hline rm. . . & 3.654. & 120,462 & Maryland & $4,494 .$. & 71,668 & La. & 423. & 39,8116 & Illinois & 797. & 45,213 \\
\hline Fh. Island & $2.56 \% \ldots$ & 45.837 & N. Carolin & $1,931 \ldots$ & 60,085 & Arkansas & 105 . & 6,899 & Iow & 13 & 5,358 \\
\hline C & $2.337 \ldots$ & 324 & 8. Carolina & 1,642 . & 48,337 & Tennessee. & $1,005$. & 30,950 & Wisconsin. & 666. & 14,743 \\
\hline & 59.595. & 817,336 & Georgia . & $1,086$. & 27,820 & Kentucky. & 1,126 & 57.543 & & & \\
\hline Jerse & 9 & 10 & Florida. & 76 & 937 & Ohio ..... & & 95,250 & & & \\
\hline
\end{tabular}

\section{Criminal Stalistics.}

Whole number of persons convicted of crime within the year ending June 1, 1850-native 13,000, and foreign 14,000-total 27,000 .

- Whole number in prison on the 1st June of the same year-native 4,300, and foreign 2,460 total 6,700 . 
UNITED STATES OF AMERICA.

\section{II.-STATISTICS OF RELIGION.}

\section{Statistics of Churches.}

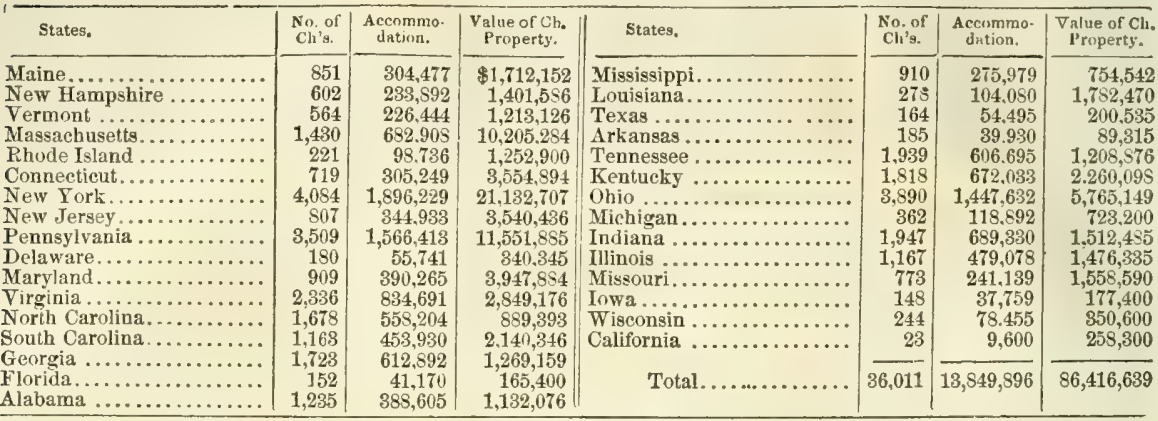

\section{Statistics of Religious Denominations.}

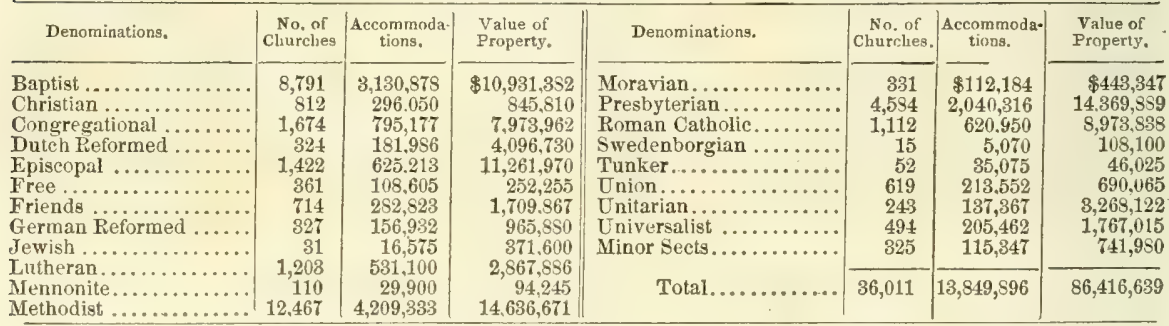

N. B. The above tables do not include the church statistics of the District of Columbia and the Territories.

III.-AGRICULTURAL STATISTICS.

1. A Statement showing the number of Acres of improved and unimproved Land, in Farms, the cash value thereof, and the average cash value per Acre, in each State and Territory.

\begin{tabular}{|c|c|c|c|c|c|}
\hline States and Territories. & $\begin{array}{l}\text { Acres of im- } \\
\text { proved land. }\end{array}$ & $\begin{array}{l}\text { Acres of unim. } \\
\text { proved land in } \\
\text { farms. }\end{array}$ & Total. & $\begin{array}{l}\text { Cash val. of land } \\
\text { improved and } \\
\text { unimproved. }\end{array}$ & $\begin{array}{l}\text { A verage } \\
\text { cash vaike } \\
\text { per acre. }\end{array}$ \\
\hline 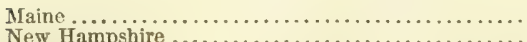 & 596 & & 393 & 361.748 & $\$ 12(14$ \\
\hline \multirow{2}{*}{ 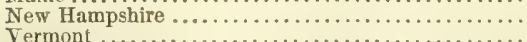 } & & & & & \\
\hline & 2 & 1, & 4 , & 7 & 15 \\
\hline \multirow{2}{*}{$\begin{array}{l}\text { Massachusetts } \ldots \ldots \ldots \ldots \ldots \ldots \ldots \ldots \ldots \ldots \ldots \ldots \\
\text { Rhode Island } \ldots \ldots \ldots \ldots \ldots \ldots \ldots \ldots \ldots\end{array}$} & 2 , & 1,22 & 3.3 & $109,076,347$ & 3250 \\
\hline & 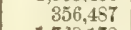 & 19 & & 2 & $30 \$ 2$ \\
\hline 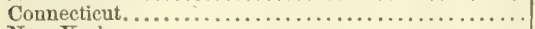 & 1,7 & & 2,8 & & 3050 \\
\hline \multirow{2}{*}{ 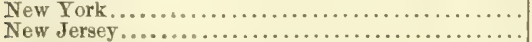 } & 12. & 6,71 & 19,1 & 12 & 2900 \\
\hline & & & 46 & 120.237 .511 & 4367 \\
\hline 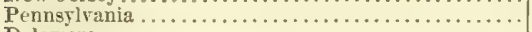 & 8,6 & $6,294,728$ & 14,92 & 99 & 2733 \\
\hline 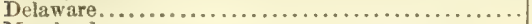 & & & & & 1975 \\
\hline 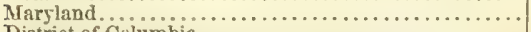 & 2,7 & 1,83 & 4,6 & 87 & 1551 \\
\hline 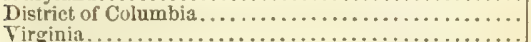 & & & & & 6303 \\
\hline \multirow{2}{*}{ 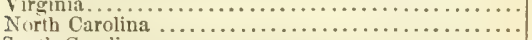 } & 10,36 & 15,79 & 26,1 & 216 & \\
\hline & & & & 6 & \\
\hline 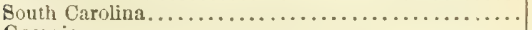 & & 1 & & & \\
\hline 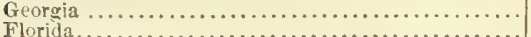 & 6, & 16 & & 95 & \\
\hline Alabama & & & & & \\
\hline 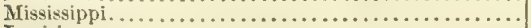 & & 7 & & & \\
\hline 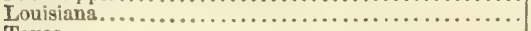 & & & 3 & 398 & 1371 \\
\hline \multirow{2}{*}{$\begin{array}{l}\text { Texas } \ldots \ldots \ldots \ldots \\
\text { Arkansas } \ldots \ldots \ldots \ldots \ldots \\
\end{array}$} & & 14 & 15 & 47 & 109 \\
\hline & & & & & 588 \\
\hline 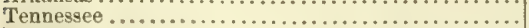 & & 849 & 13. & 12 & 516 \\
\hline 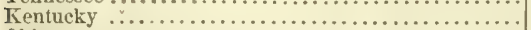 & 11,3 & 10,9 & & & \\
\hline Ohio Michigan & 9,5 & 8,1 & 17 , & 35 & \\
\hline 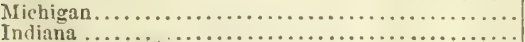 & & & & & \\
\hline \multirow{2}{*}{$\begin{array}{l}\text { Indiana } \\
\text { Illinois } \\
\ldots\end{array}$} & & & & 13 & \\
\hline & & 6.9 & 12 & & \\
\hline 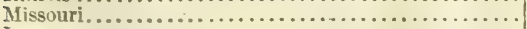 & 2,9 & 6.7 & & & 650 \\
\hline 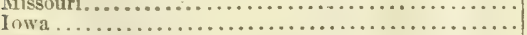 & & & & & \\
\hline 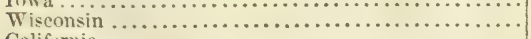 & 1,04 & 1,93 & $\begin{array}{l}2,9 \\
8,8\end{array}$ & 28. & \\
\hline \multirow{2}{*}{$\begin{array}{l}\text { Minnesota Territory } \ldots \ldots \ldots \ldots \ldots \ldots \ldots \ldots \ldots \ldots \ldots \\
\text { Oregon } \\
\text { do. }\end{array}$} & & 2 & & 8 & 561 \\
\hline & & 29 & & 2,8 & 658 \\
\hline Ulah do. & & & & & \\
\hline 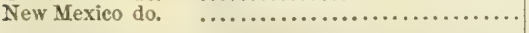 & 16 & & & 1,65 & \\
\hline & 622 & 184, & 300,0 & $3,270,7$ & av. 1079 \\
\hline
\end{tabular}


UNITED STATES OF AMERICA.

2. Statement of the Food Crops for the Year ending 1 st June, 1850.

\begin{tabular}{|c|c|c|c|c|c|c|c|c|c|c|}
\hline \multirow{2}{*}{$\begin{array}{l}\text { States and } \\
\text { Territuries. }\end{array}$} & \multirow{2}{*}{$\begin{array}{l}\text { Wheat, } \\
\text { bushels. }\end{array}$} & \multirow{2}{*}{$\begin{array}{c}\text { Rye, } \\
\text { busliels. }\end{array}$} & \multirow{2}{*}{$\begin{array}{l}\text { Ind. Corn, } \\
\text { bushels. }\end{array}$} & \multirow{2}{*}{$\begin{array}{l}\text { Oats, } \\
\text { buslrels. }\end{array}$} & \multirow{2}{*}{$\begin{array}{c}\text { Barley, } \\
\text { bushels. }\end{array}$} & \multirow{2}{*}{$\begin{array}{c}\text { B'k wheat, } \\
\text { bushels. }\end{array}$} & \multirow{2}{*}{$\begin{array}{l}\text { Rice, } \\
\text { pounds. }\end{array}$} & \multirow{2}{*}{$\begin{array}{l}\text { Peas and } \\
\text { Beans, } \\
\text { bushels. }\end{array}$} & \multicolumn{2}{|c|}{ Potatnes. } \\
\hline & & & & & & & & & $\begin{array}{l}\text { Irisls, } \\
\text { bushels. }\end{array}$ & $\begin{array}{l}\text { Swect, } \\
\text { bushele. }\end{array}$ \\
\hline Iaine & 296.259 & 102,916 & $1,750.056$ & $2,181,037$ & 151,731 & 104,523 & - & 205.5541 & $3,436,040$ & - \\
\hline New Hampshire. & 605 & 183.117 & $1,573.670$ & 973.351 & 70,256 & 65.265 & - & 70,856 & $4,304,919$ & - \\
\hline Termont....... & 535,955 & 176,283 & $2,032,396$ & $2,307,734$ & 42,150 & 209.319 & - & 104,649 & $4,951,014$ & - \\
\hline Massachusetts.. & 31,211 & 481,021 & $2,345,490$ & $1,165,146$ & 112.355 & 105,895 & - & 43,709 & $3,585,384$ & - \\
\hline Rhode Island... & 49 & 26,409 & 539.201 & $215,2 \div 2$ & 18.575 & 1.245 & - & 6,846 & 651,029 & \\
\hline Connecticat .... & 41.762 & 600.593 & $1,935,043$ & 1.258 .785 & 19,099 & 229,297 & - & 19,090 & $2,689.725$ & 80 \\
\hline New Jurk..... & $13,121.193$ & $4,145,152$ & $17,858,400$ & $26.552,814$ & $3,585.1159$ & $3,183,955$ & — & 741,636 & $15,398,362$ & 5,623 \\
\hline New Jerses & $1,601,190$ & $1,255.57 \mathrm{~s}$ & 8.759 .704 & $3,378,065$ & 6.492 & 878,934 & - & 14,174 & $3,207.236$ & 508.015 \\
\hline Pennsylvauia... & $15,367.691$ & $4,805,160$ & $19,835,214$ & $21,535.156$ & 165,554 & $2,193,692$ & - & 55,281 & 5.980 .732 & 52,172 \\
\hline Delaware ..... & 452.511 & 8.066 & $3.145,512$ & 601,518 & 56 & $S, 615$ & - & 4,120 & $240,5 \pm 2$ & 65.443 \\
\hline Marylani & $4,494.6511$ & 226.014 & $11.104,681$ & $2,242.151$ & 745 & 103,671 & - & 12,816 & 764,939 & 208,993 \\
\hline Dis of Columbia. & 17.37 & 5.509 & 65,230 & S. 134 & 75 & 378 & - & 7,754 & 29,292 & 3,497 \\
\hline Tirginia....... & 11.232 .616 & 455930 & $35,254,319$ & $10,179,045$ & 25.137 & $214, \$ 95$ & 17.154 & 521,581 & $1,316.933$ & $1,813,671$ \\
\hline North Carolina. & $2.130,102$ & 229.563 & $27,941,051$ & $4.052 .07 \mathrm{~S}$ & 2,735 & 16,704 & $5,465,868$ & $1,594,252$ & 620,818 & $5,095.709$ \\
\hline South Carolina.. & $1,066,277$ & 43,790 & $16,271,454$ & $2,322,155$ & 4,583 & 283 & $159,930,613$ & $1,026,900$ & 136,494 & $4,337.469$ \\
\hline Georgia....... & $1,085,531$ & 53.750 & $30,080.099$ & $3,520,044$ & 11,501 & 250 & $33,950,691$ & $1,142,011$ & 227,379 & $6,986,428$ \\
\hline ... & 1,027 & 1,152 & $1,996,809$ & 66,586 & - & 55 & $1,075,090$ & 135,359 & 7,825 & 757,226 \\
\hline Alabam & 294.114 & 17.261 & $25,754,04 \mathrm{~S}$ & $2,965.697$ & 3,958 & 315 & $2,311,252$ & $S 92,701$ & 246,001 & $5,475,204$ \\
\hline Mississippi & 137.990 & 9,606 & $22,446,552$ & $1,508.288$ & 229 & 1,121 & $2,719,556$ & $1,072,757$ & 231,452 & $4,741.795$ \\
\hline Louisiana. & 417 & 475 & 10.266 .373 & 89.687 & - & 8 & $4,425,349$ & 161,732 & 95.632 & $1,428,453$ \\
\hline Texas..... & $41,65.4$ & 3.1115 & $5,926,611$ & 178,883 & 4,776 & 59 & 87,916 & 179,332 & 93,548 & $1,323,170$ \\
\hline Arkansas.. & 199,639 & 8,047 & $\mathrm{~S}, 593,939$ & $656.1>3$ & 177 & 175 & 63,179 & 255,788 & 193,832 & 788,149 \\
\hline see. & 1.619 .351 & 89.163 & $52,276,223$ & $7.703,086$ & 2,737 & 19,427 & 258,854 & 869,321 & $1,067,844$ & $2,777,716$ \\
\hline Kentucky. & 522 & 415.073 & $58,675.591$ & $8,201,311$ & 95,343 & 16.097 & 5,688 & 202,574 & $1,492,487$ & $99 S, 184$ \\
\hline $\mathrm{Oh}$ & $14.4=7.351$ & $425.71 \mathrm{~s}$ & $59,078,695$ & $13,472,742$ & 354,358 & 6855,061 & - & 60,168 & $5,057,769$ & 187,941 \\
\hline $\mathrm{Mi}$ & $4,925,589$ & 105.571 & $5,6+1,420$ & $2,566,056$ & 75.219 & 472.917 & - & 74,254 & $2,359,897$ & 1,177 \\
\hline In & 6.214 .458 & 78.792 & $52,964,368$ & $5,655,014$ & 45,483 & 149,740 & - & 35,773 & $2,083,337$ & 201,711 \\
\hline IHI & $9,414.5 \div 5$ & 83.364 & $57,616,984$ & $10,087,241$ & 110,795 & 184,504 & - & 82.814 & $2,514,861$ & 157,483 \\
\hline ouri. & 2.951 .652 & 41.263 & 36.214 .537 & $5,275,079$ & 9,6831 & 23,641 & 700 & 46,017 & 939,006 & 385,505 \\
\hline Ior & $1.5311,5=1$ & 19.916 & 8.656 .799 & $1,521,345$ & 25.093 & 52,516 & 500 & 4,775 & 276,120 & 6,248 \\
\hline Tiscrnsir & $4,236,181$ & 81,253 & $1,935,979$ & $3,414,672$ & 209.692 & 79,578 & - & 20,657 & $1,402,077$ & 879 \\
\hline Califior & 17,328 & - & 12,2336 & - & 9,712 & - & - & 2,292 & 9.292 & 1,000 \\
\hline Terri & 1.401 & 125 & 16.725 & $30,5 \mathrm{~s} 2$ & 1,216 & 515 & - & 10,002 & 21,145 & 200 \\
\hline Oregon Territory & 211.493 & 106 & 2.918 & 65,146 & - & - & - & 6,566 & 91.326 & - \\
\hline Ctah Territnry.. & 107.702 & 210 & $9, \$ 99$ & 10,900 & 1,799 & 332 & - & 259 & 43,968 & 60 \\
\hline New Mex. Ter. & 196,516 & - & 365,411 & & 5 & 100 & - & 15,688 & 3 & 一 \\
\hline & & & & & & & & & & \\
\hline
\end{tabular}

3. Statcment of Live-Stock in the several States, for the year ending 1 st June, 1850.

\begin{tabular}{|c|c|c|c|c|c|c|c|c|}
\hline States and Territories. & Horses. & $\begin{array}{l}\text { Asses and } \\
\text { mules. }\end{array}$ & Milch cows. & $\begin{array}{c}\text { Working } \\
\text { oxen. }\end{array}$ & Other cattle. & Sheep, & Swine, & $\begin{array}{l}\text { Value of } \\
\text { live-stuck. }\end{array}$ \\
\hline Maine & 41,721 & 50 & 133,556 & $89, \$ 93$ & 125,890 & 451,577 & 54,598 & $\$ 9,705,726$ \\
\hline Jew Hampshire ... & 34.233 & 19 & 94,277 & 59,027 & 114.606 & 394,756 & 68,487 & $8,871.901$ \\
\hline Termont........... & 61.067 & 218 & 146,125 & 45,577 & 154.143 & $1,014,122$ & 66 & $12,643,228$ \\
\hline Iassar husetts $\ldots \ldots \ldots \ldots \ldots$. & 16 & 34 & 130,099 & 46,6 & 83,2 & 188 & 81,119 & $9,647,710$ \\
\hline Throrle Istand $\ldots \ldots \ldots \ldots \ldots$. & & 1 & 2 & 8.189 & 9,375 & 44,296 & 19,509 & $1,532,637$ \\
\hline$\ldots \cdots \cdots \cdots \cdots \cdots \cdots$ & 26 & 49 & 85, & 46.988 & 80,226 & 174,181 & 76,472 & $7,467,490$ \\
\hline lew York. & 447,014 & 963 & 931.821 & 178.909 & 767.406 & $3,453,241$ & $1,018,252$ & $73,570,499$ \\
\hline New Jersey. & 63.955 & 4,1159 & 118,736 & 12,070 & 80,455 & 160,488 & 250,370 & $10,679,291$ \\
\hline Pennsylvania. & $350.393^{\circ}$ & 2,259 & $53 \cap, 224$ & 61,527 & 562,195 & $1,822,357$ & $1,040,366$ & $41,500,053$ \\
\hline Delaware.... & 13.552 & 791 & 19,248 & 9,797 & 24,166 & 27.503 & 56,261 & $1,849,281$ \\
\hline Marylan 1 ... & 75,684 & 5,614 & $86, \$ 59$ & 34,135 & 98,595 & 177,9 & 352,911 & $7,997,684$ \\
\hline District of Colnmbia......... & 8 & 57 & 8 & 4 & 1 & 0 & 5 & 48 \\
\hline 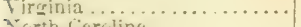 & 272.4 & 21,480 & 3 & 89, & 669 & 1,310 , & 1,83 & 35 \\
\hline Wrorth Carol & 148 & 9 & 2 & 37 & 42 & 5 & 1,8 & 47 \\
\hline$\cdots \cdots \cdots \cdots$ & 9 & $\begin{array}{r}.483 \\
7.470\end{array}$ & 1 & 20 & & 25 & 1, & 60,015 \\
\hline $\begin{array}{l}\text { Gerirgla ... } \\
\text { Florivila.... }\end{array}$ & 10 & $\begin{array}{r}58,369 \\
5,0112\end{array}$ & & $\begin{array}{r}73.256 \\
5.794\end{array}$ & & & $\begin{array}{r}2,168,617 \\
209,453\end{array}$ & 25 \\
\hline Alatuma & 128,001 & 59.995 & 227 & 66.961 & 433,263 & 371.880 & $1,904,540$ & $21,690,112$ \\
\hline Missiz-irrui . & 115 & 54,547 & 21 & 83.4 & 43 & 304,9 & $1,582,734$ & 3,662 \\
\hline Lruisiana.. & 89,514 & $44, \$ 49$ & 10อั.อั & 54,968 & 414 & 110,8 & 597,301 & 52,275 \\
\hline Texas. & 75.4 & 364 & 214.758 & 49,9 & 636,8 & 99,093 & 683.514 & $10,266,880$ \\
\hline Arl & 60,197 & 559 & 93,151 & 34,239 & 16 & 91,2 & 836,727 & 969 \\
\hline Ten & 270,636 & 75.3113 & 250.456 & 86.2 & 41 & 811. & $3,104,800$ & 29 \\
\hline $\mathrm{k}$ & 315.452 & 65,609 & 2 & 62, & 44 & 1,1 & 2,8 & 29 \\
\hline Thin & $4 f ?$ & 3,423 & 54 & 65 & 74 & $3,943,9$ & 1,96 & 1,741 \\
\hline Mrirhiga & 58 & 70 & 6 & $55 . ?$ & 119 & 746, & 47 & 8,734 \\
\hline Indiana & 314.299 & 6.599 & 284,5 & 40,2 & 35 & 1, 122, & 2.253 & $22,478,555$ \\
\hline $\begin{array}{l}\text { Illinnis } \\
\text { Miascuri }\end{array}$ & 267.653 & 10.5 & 294 & $\begin{array}{r}76, \\
710\end{array}$ & 54 & 89 & 1,91 & 258 \\
\hline $\begin{array}{l}\text { Mrascur } \\
\mathrm{I} r, \mathrm{k} a \mathrm{a}\end{array}$ & $\begin{array}{r}225.299 \\
25=86\end{array}$ & $\begin{array}{r}41,667 \\
754\end{array}$ & 230 & 112, & 44 & 76 & 1,702 , & 19,8 \\
\hline Wisen & 80,17 & $\begin{array}{l}104 \\
156\end{array}$ & $\begin{array}{l}40,8 \\
64,3\end{array}$ & $\begin{array}{l}21,8 \\
42,8\end{array}$ & $\begin{array}{l}69.0 \\
76.2\end{array}$ & $\begin{array}{l}149,960 \\
124,892\end{array}$ & $\begin{array}{l}823.246 \\
159.276\end{array}$ & $\begin{array}{l}3,659,275 \\
4,897,385\end{array}$ \\
\hline alif rnia.. & 21,719 & 1,666 & 4,280 & 4,780 & 253,599 & 17,574 & 2,776 & $\begin{array}{l}4,091,050 \\
3,351,058\end{array}$ \\
\hline linnesota $\mathrm{Te}$ & & & & & & & 784 & 92,959 \\
\hline regrin Terr & 8,046 & 420 & 9,427 & 8.114 & 24,188 & 15,382 & 30,235 & $1,876.189$ \\
\hline Etah Tarritrory .. & 2,429 & 325 & 4,861 & 5.266 & 2,489 & 3.262 & 914 & 546.968 \\
\hline New Mexico Ter & 5,079 & 8,654 & 10,685 & 12,257 & 10,085 & 377,271 & 7,314 & $1,494,629$ \\
\hline Aggregate ........... & $4,385.359$ & 559.229 & $6,892,044$ & $1,699,241$ & $10,268,856$ & $21,721.814$ & $30,316,608$ & $543.960,420$ \\
\hline
\end{tabular}


UNITED STATES OF AMERICA.

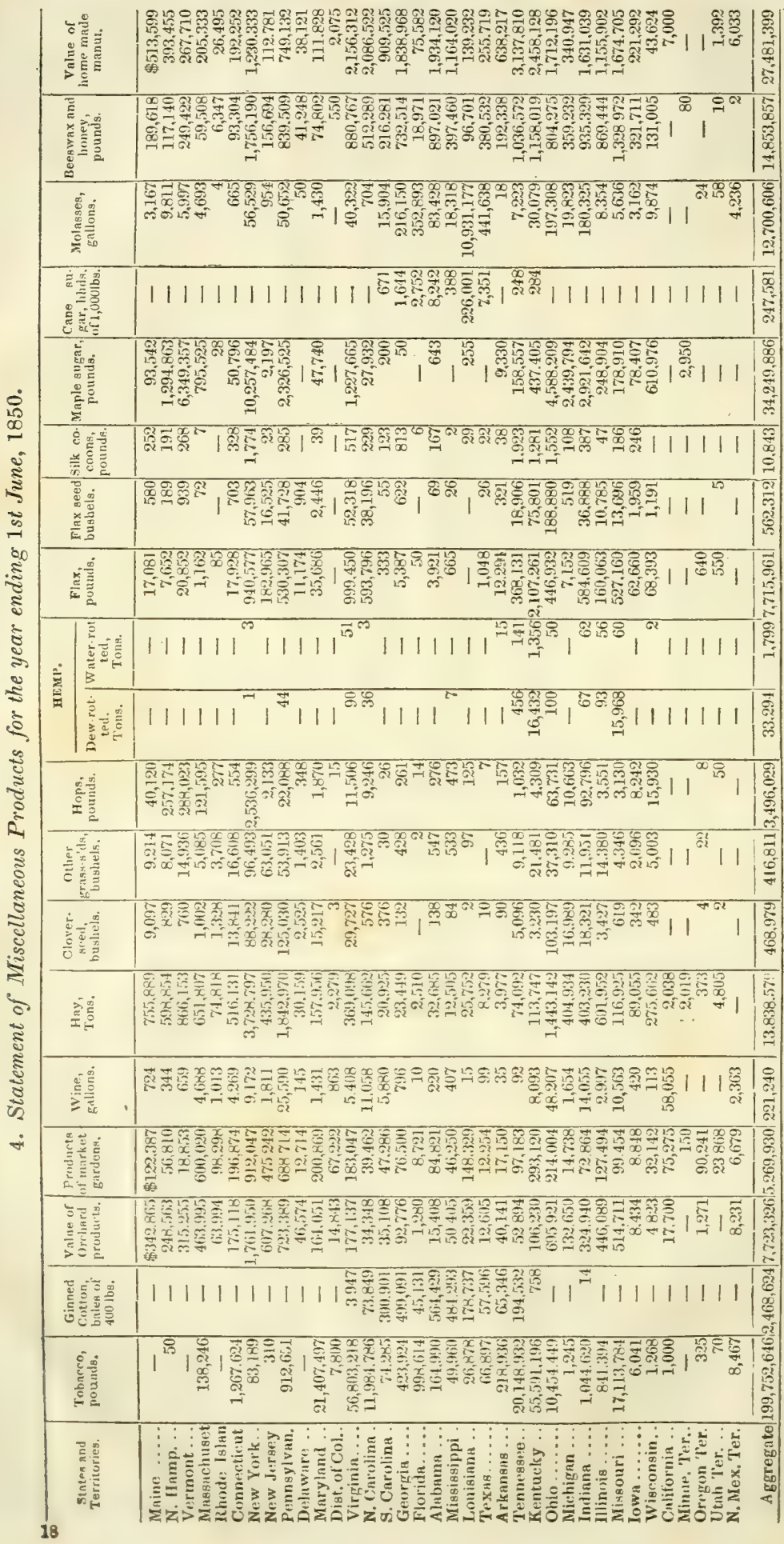


5. Statement of the Products of Animals for the year ending 1st June, 1850.

\begin{tabular}{|c|c|c|c|c|c|c|c|c|c|}
\hline $\begin{array}{l}\text { States and } \\
\text { Territuries. }\end{array}$ & $\begin{array}{l}\text { Wires., } \\
\text { pexnits. }\end{array}$ & $\begin{array}{l}\text { Butter, } \\
\text { pounds. }\end{array}$ & $\begin{array}{l}\text { Cheese, } \\
\text { pounds. }\end{array}$ & $\begin{array}{l}\text { Value of ani } \\
\text { mals slaught. }\end{array}$ & $\begin{array}{l}\text { States and } \\
\text { Terrritories. }\end{array}$ & $\begin{array}{l}\text { Wonol, } \\
\text { pounds, }\end{array}$ & $\begin{array}{l}\text { Butter, } \\
\text { pounds. }\end{array}$ & $\begin{array}{l}\text { Chrese, } \\
\text { pounds. }\end{array}$ & $\begin{array}{l}\text { Value of ani- } \\
\text { Irals slaught. }\end{array}$ \\
\hline Maine & $1,364,03 t$ & $9,2+3,811$ & $2,434,454$ & $\$ 1,646,773$ & Louisiana .... & 109,897 & 683,069 & 1,957 & $1,458,990$ \\
\hline N. Hampshire & $1.108,476$ & $6.977,056$ & 3196563 & $1,552.873$ & I'xus ...... & 131,374 & $2,326,556$ & 94,619 & $1,106,032$ \\
\hline Vermont.... & 3.400 .717 & $12,137,980$ & $8.720,834$ & 1.861 .336 & Arkansas.... & 182,595 & $1.854,239$ & 30,088 & $1,162,913$ \\
\hline Massachusr-tts & 855136 & $8,071.370$ & $7,08814 ?$ & $2,5001,924$ & Jennessee ... & $1,364,378$ & $8,139,585$ & 177.681 & $6,401,765$ \\
\hline Rhode Island. & 129,692 & 995670 & 316.56 & 667.486 & Kentucky .... & $2.297,403$ & $9,887,523$ & 213.954 & $6,462,598$ \\
\hline Connecticut.. & 497.454 & 5.498 .119 & $5,363,278$ & $2.202,266$ & Obio....... & $10,196,371$ & $34,449,379$ & $20.819,542$ & $7,439,243$ \\
\hline New Yurk... & $10,071.301$ & $79.766,094$ & $49,741.413$ & 13.573 .983 & Michigua. & 2,043283 & $7,065,878$ & $1,011.492$ & $1,328,327$ \\
\hline New Jersey. & 375.396 & $9,487,210$ & 365.756 & $2,638,552$ & Indiana ..... & $2.610,287$ & $12,881,535$ & 624,564 & $6,567,935$ \\
\hline Pennsylvania & 4481,520 & $39,878,418$ & $2,505.034$ & $8,219.481$ & Illinois...... & $2,150,113$ & $12,526.543$ & $1,278.2: 25$ & $4,972,286$ \\
\hline Delaware... & 57.763 & 1.055 .3 .8 & 3,187 & 373,665 & Mlissouri ..... & $1,627,164$ & $\tau, 834,359$ & 203572 & $3,367,106$ \\
\hline Maryland & 430.226 & $3,806,160$ & 3.975 & $1,954,800$ & lowa ........ & 373,898 & $2,171,188$ & 209,810 & 821,164 \\
\hline Dist. of Colum. & 525 & 14.872 & 1,500 & 9.038 & Wisconsin ... & 253,963 & $3,633,750$ & 400,283 & 920,178 \\
\hline Virginia ..... & 2.860 .765 & 11.089 .359 & 436,298 & $7,503,006$ & California .... & 5,520 & 705 & 150 & 100,173 \\
\hline N. Carolina. . & $4,70,738$ & $4,146: 29.5$ & 95,921 & 5767,856 & Minn. 'l'er. . & 85 & 1,100 & - & 2,840 \\
\hline S. Carolina ... & 487.233 & 2981,850 & 4,970 & $1,302,637$ & Oregon Terr. & 29.686 & 211,464 & 36,980 & 164,530 \\
\hline Georgiat..... & 990,019 & $4,640,559$ & 46.976 & $6,339,762$ & Utah Territury & 9,222 & 83,309 & 30,998 & 67.985 \\
\hline Florida & 23.245 & $3 \pi 1.498$ & 18,015 & 514,685 & New Mex.Ter. & 32,901 & 111 & 5848 & 82,125 \\
\hline Alabaina .. & 657.118 & $4,008.811$ & 31,412 & 4.823 .485 & & & & & \\
\hline Mississippi .... & 559,619 & $4,346,234$ & 21,191 & $3,636,582$ & Aggrega & 174 & 31 & & 109 \\
\hline
\end{tabular}

\section{Absolute and Relative Movement of Stock, Products, etc., 1840 and 1850.}

\begin{abstract}
Stuck, products, etc,
\end{abstract}
Inorses..............

Mileh enws,..........

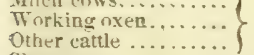

Shrep................

Swine $\ldots \ldots \ldots \ldots \ldots \ldots \ldots \ldots$

$\Pi_{\mathrm{n} n \mathrm{l}} \ldots \ldots \ldots \ldots \ldots \ldots$

Theat $\ldots \ldots \ldots \ldots \ldots$.

Iire..........................

Oats ............... 375531.575

Barley ............... 4.161 .504

Buck wheat.............. $7.291,743$

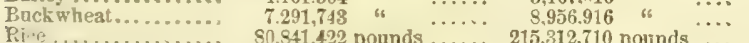

Tribace ...........

C.tton.................. 219.163,319

Sugar-rane ......... $15,110,509$

maple $\ldots . . .$.
".
water-rotted..

Flax..................

95,252 tons

10.219 .109 «

Polatnes-Irish $1,238,502$ pounds

Palathes-Irish ....... $108,298,060$ bushels

Wine ............. 124,734 gallong

Silk cocrnns......... 61,552 pounds

Value of home-made

manufactures....... $29,023,390$ dollars
1850 ,

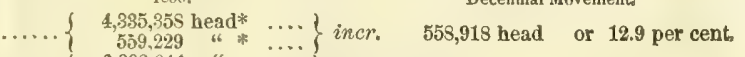
$6,392,041$ " $1.699,841$ "

$\begin{array}{rrr}1,699,241 & 6 & \ldots \\ 10,268,856 & \text { 4 } & \ldots .\end{array}$ (2) 21.721 .814 " $\quad .$. iner. $2,410,440$ " 30.316 .608 "... iner. 4.015 .315 "

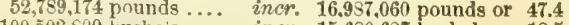
$100,503,899$ bushe's .... incr. $15.680,627$ bushels or 18.5 14.188639 " $\ldots$ decr. $4,456.928$ " or 23.9 $592,326,612$ " $\quad \ldots$ iner. $214,794.737$ " $146,567,579$ " incr. $23,496,538$ " or 19.9 $5,167,016$ " 6 iner $1,005.512$ "6 or 24.1 incr. $1.665,179$ " 6 or 22.8 iner. $184,471,283$ pounds or 166.3 der.r. $19,410.673$ " $\ldots \ldots$, 987.449 .6110 " $34 \ldots$ incr. $196,970,325$ " 34 or 24.9 $\ldots \ldots\left\{\begin{array}{rrr}34.249 .886 & \text { "... } & \ldots\end{array}\right\}$ incr. $126,720,077$ " $\quad$ or 81.6 247,5s1,400 "4 33,294 tons $\quad \cdots .$. 7.715 .961 " $13.53<.579$ tons $3,496,1129$ pounds .... iner. $2,257,527$ pounds or 182.2 $65.796,7,43$ bushels ..... ? $38,259,196$ « ....

96.506 gallons or 77.3 10,843 pisunds ..... decr. $\quad 50,709$ pounds or 82.3 $27,481,399$ dollars .... tecr, 1,541,981 dollars or $\quad 5.8$

68
66
66
66
66
66
66
66
66
66
66
6
66
6
66
86
66
66
66
66

\section{STATISTICS OF MANUFACTUREB:}

\section{General Statistics.}

The entire capital invested in the various manufactures in the United States on the 1st June, 18,0-not including any establishments producing less than the annual

value of $\$ 500$-amounted in round numbers to ...................... $\$ 530,000,000$

Value of raw material, fuel, etc., used during the preceding year............ $\$ 550,000,000$

Number of persons employed "6 " " "

Aggregate cost of labor " " " " "

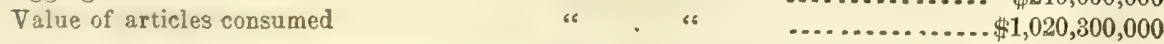

The total capital invested in manufactures in 1840 , was $\$ 267,726,579$, and hence the manufacturing capital of the Union has duplicated in the succeeding decade.

\footnotetext{
* In the census of 1850 , all horses, asses, and mules in cities are omitted, and those only or mainly employed in agricalture enumerated.
} 
UNITED STATES OF AMERICA.

\section{Statistics of the Principal Manufactures.}

\begin{tabular}{|c|c|c|c|c|c|c|c|c|c|c|}
\hline \multirow[b]{2}{*}{ BTATES, } & \multicolumn{5}{|c|}{ COTTON GOODS. } & \multicolumn{5}{|c|}{ WOOLEN GOODS. } \\
\hline & 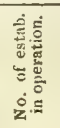 & 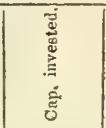 & 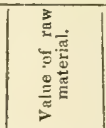 & 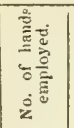 & 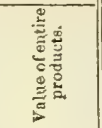 & 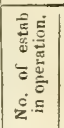 & 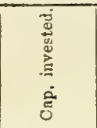 & 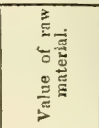 & 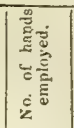 & 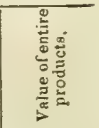 \\
\hline Iain & 12 & $\$ 3,329,700$ & $\$ 1,573,110$ & 3,739 & $92,596,356$ & 36 & $\$ 467,600$ & $\$ 495,940$ & 624 & $\$ 753,300$ \\
\hline & 44 & $10,950,500$ & $4,839,429$ & 12,122 & $8,830,619$ & 61 & $2,437,700$ & $1,267,329$ & 2127 & $2,127,745$ \\
\hline V & 9 & 202,500 & $\quad 114.415$ & $\begin{array}{r}241 \\
\end{array}$ & 196,100 & 72 & 886,300 & 830,684 & 1,393 & $1,579,161$ \\
\hline & 213 & $28,455,630$ & $11,289,309$ & 28,730 & $19,712,461$ & 119 & $9,089,342$ & $8,671,671$ & 11,130 & $12.770,56$ \\
\hline Rhod & 158 & $6,675,000$ & $3,484,579$ & 10.875 & 6,447,120 & 45 & $1,013,000$ & $1,463,900$ & 1,758 & $2,381,825$ \\
\hline & 128 & $4,219,100$ & $2,500,062$ & 6.186 & & 149 & $3,773,950$ & $3,325,709$ & 5,488 & 6,465 \\
\hline $\mathrm{Nev}$ & 86 & $4,176,920$ & ) $1,985,973$ & 6,320 & $3,591,989$ & 219 & $4,459,370$ & $3,838,292$ & 6,674 & 7,030 \\
\hline 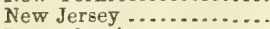 & 21 & $1,483.500$ & 666,645 & 1,712 & $1,109,524$ & 41 & 494,274 & 548,367 & 898 & $1,164,4$ \\
\hline & 208 & $4,528,925$ & $5,152,530$ & 7,663 & 5,3 & 380 & $3,005,064$ & $3,282,718$ & 5,726 & $5,321,8$ \\
\hline & 12 & 460.100 & ) $\quad 312.068$ & 838 & 538,439 & 8 & 148,500 & 204.172 & 140 & 251,0 \\
\hline & 24 & $2,236,000$ & $1,165,579$ & 3,022 & $2,120.504$ & 38 & 244.000 & 165,568 & 362 & 295,140 \\
\hline & 27 & $1,908,900$ & 828,375 & 2,963 & 1,486 & 121 & 392,640 & 488.899 & 668 & 841,013 \\
\hline $\mathrm{No}$ & 28 & $1,058,800$ & 531,903 & 1,619 & 831,342 & 1 & 18,000 & 13,950 & 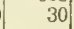 & 23,750 \\
\hline Sor & 18 & 857.200 & 295,971 & 1,019 & 748 & - & - & - & - & - \\
\hline Geo & 35 & $1,736,156$ & 900,419 & 2,272 & $2,135,044$ & 3 & 68,000 & 30,392 & 78 & 88,750 \\
\hline & - & 80,000 & 30,000 & 95 & 49,920 & - & - & - & - & - \\
\hline Ala & 12 & $65 \overline{1}, 900$ & 237,081 & 715 & 382,260 & - & - & - & - & - \\
\hline & 10 & 38,000 & 21,500 & 36 & 30,500 & - & - & - & - & - \\
\hline Lc & - & - & - & - & - & - & - & - & - & - \\
\hline Te & - & - & - & - & - & 1 & 8,000 & 10,000 & & 15,000 \\
\hline & 3 & 16.500 & 8,975 & 31 & 16.637 & - & - & - & - & - \\
\hline & 33 & 669,600 & 297,500 & 891 & 510,624 & 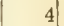 & 10,900 & 1,675 & 17 & 6,310 \\
\hline ky & 8 & 239,000 & 180,907 & 402 & 273,439 & 25 & 249,8 & 205,287 & 318 & 318,8 \\
\hline $\mathrm{Ob}$ & 8 & 297,000 & 237,060 & 401 & 394,700 & 130 & 870,220 & 578,423 & 1,201 & $1,111,027$ \\
\hline $\mathrm{Mi}$ & - & - & - & - & - & 15 & 94,000 & 43,402 & 129 & 90,242 \\
\hline & 2 & 43,000 & 28,220 & 95 & 44,200 & 33 & 171.545 & 120,486 & 246 & 205,802 \\
\hline Illi & - & - & - & - & - & 16 & 154,500 & 115,367 & 178 & 206,572 \\
\hline Mlis & 2 & 102,000 & 86,446 & 155 & 142,900 & 1) & 20,000 & 16,000 & 25 & 56,000 \\
\hline & - & - & - & - & - & i) & 10,000 & 3.500 & 7 & 13,000 \\
\hline & - & - & - & - & - & 9 & 31,225 & 32,630 & 25 & 87,992 \\
\hline $\mathrm{Ca}$ & - & - & - & - & - & - & & - & -1 & - \\
\hline District of Coltir & 1 & 85,000 & 67,000 & 144 & 100,000 & 1 & 700 & 1,630 & จ & 2,400 \\
\hline Total.. & 1.094 & $74,501,031$ & 34.835 .056 & 92,286 & $61.869,181$ & 1,559 & $28,118,650$ & $25,755,988$ & 39,252 & $43,207,555$ \\
\hline
\end{tabular}

MALT AND SPIPITUOUS LIQUORS.

\begin{tabular}{|c|c|c|c|c|c|c|c|c|c|c|c|c|}
\hline \multirow{2}{*}{ STATES. } & \multirow{2}{*}{$\begin{array}{c}\text { Capital in- } \\
\text { vested. }\end{array}$} & \multicolumn{7}{|c|}{ Quantities and kinds of grain, etc., consumed. } & \multirow{2}{*}{ 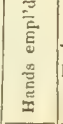 } & \multicolumn{3}{|c|}{ Quantities of liquor produced. } \\
\hline & & $\begin{array}{c}\text { Busbels of } \\
\text { barley, }\end{array}$ & $\begin{array}{c}\text { Bushels of } \\
\text { corr. }\end{array}$ & $\begin{array}{c}\text { Bushels of } \\
\text { rye. }\end{array}$ & $\begin{array}{l}\text { Busliels } \\
\text { of vats. }\end{array}$ & $\begin{array}{l}\text { Buslieis } \\
\text { of apples. }\end{array}$ & $\begin{array}{l}\text { Hids, if } \\
\text { mola's. } \\
\text { I }\end{array}$ & $\begin{array}{c}\text { Ton: } \\
\text { of } \\
\text { Lops s }\end{array}$ & & $\begin{array}{l}\text { Barrels of } \\
\text { ale, etc, }\end{array}$ & $\begin{array}{l}\text { sis of } \\
y \text { and } \\
\text { vines. }\end{array}$ & $\begin{array}{c}\text { Gallons of } \\
\text { rum. }\end{array}$ \\
\hline gine. & $\$ 17.000$ & - & - & - & - & - & 2,000 & -1 & 5 & - & - & 220,000 \\
\hline zon & 7,000 & 2,500 & - & - & - & - & - & 1 & 2 & 800 & - & - \\
\hline ssach & 457,500 & 80,000 & 19,400 & 26.600 & - & - & 55,130 & 29 & 131 & 25,800 & 120,000 & $3,786,000$ \\
\hline ode Is & 17,000 & 12,500 & - & - & $\rightarrow$ & 一 & - & 6. & 9 & 3,900 & - & - \\
\hline anec & 15,500 & - & 20,000 & 20,000 & - & - & 10 & 2 & $\Sigma 0$ & - & 130,000 & 1,200 \\
\hline Yo & $2,585,900$ & $2,062,250$ & $1,647,266$ & 990,067 & 6,707 & 60,940 & 24,500 & 581 & 1,380 & 644,700 & $9,231,700$ & $2,488,800$ \\
\hline Jer & 409,655 & 103,700 & 254,000 & 58,400 & - & 409,700 & - & 42 & 197 & 34.750 & $1,250.530$ & - \\
\hline$\cdots$ & $1,719,960$ & 550,105 & $1,483,555$ & 517,180 & 24,790 & 51,200 & 10 & 263 & 911 & 189,581 & $6,548,810$ & 1,500 \\
\hline$\cdots$ & 247,100 & 76,900 & 166,100 & 54,300 & 460 & - & - & 25 & $126^{\prime}$ & 26,380 & 787,400 & - \\
\hline$\cdots$ & 100,915 & 20,000 & 250,700 & 62,680 & 450 & - & - & 14 & 123 & 5,500 & 879,440 & - \\
\hline 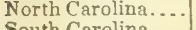 & 21,930 & - & 64,650 & 4,700 & - & - & - & - & 75 & - & 153,030 & - \\
\hline 1 & 3,475 & - & 18,100 & -1 & $1=$ & - & 一 & - & 33. & - & $\leq 3,900$ & 一 \\
\hline. & 7,150 & - & 20,150 & $2,500^{\circ}$ & 1,500 & - & - & - & 15 & - & 60,450 & - \\
\hline. & $\begin{array}{r}500 \\
8500\end{array}$ & $\overline{10,000}$ & - & - & - & - & 25 & - & 2. & - & - & 3,000 \\
\hline $\begin{array}{l}\text { Lo } \\
\text { Ke }\end{array}$ & $\begin{array}{r}8,500 \\
168,89=\end{array}$ & $\begin{array}{l}10,000 \\
65,650\end{array}$ & $=\overrightarrow{51}=0$ & - & - & $=-1$ & - & 10 & 8 & 3,000 & - & - \\
\hline e. & $\begin{array}{r}168.895 \\
66.125\end{array}$ & $\begin{array}{r}65,650 \\
3,000\end{array}$ & $\begin{array}{l}551,350 \\
258,400\end{array}$ & 30,520 & - & 5,000 & - & 18 & 274 & 19,500 & $1,491,745$ & - \\
\hline our & $\begin{array}{r}66.125 \\
298.900\end{array}$ & $\begin{array}{r}3,000 \\
124,440\end{array}$ & $\begin{array}{l}258,400 \\
309,200\end{array}$ & $\begin{array}{r}5,480 \\
24,900\end{array}$ & - & - & - & - & 159 & $\overline{44} 850$ & 657,000 & - \\
\hline 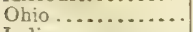 & $1,262,974$ & 330,950 & $3,588,140$ & $\begin{array}{r}24,900 \\
281,750\end{array}$ & 19.500 & - & - & $\begin{array}{r}31 \\
778\end{array}$ & $\begin{array}{r}179 \\
1,033\end{array}$ & $\begin{array}{l}44,800 \\
96,943 .\end{array}$ & $\begin{array}{r}939,400 \\
11,865,150\end{array}$ & - \\
\hline liana. & 334,950 & 118,150 & $1,417,990$ & 48,700 & 1,000 & - & - & 18 & 287 & 11,005 & $4,639,900$ & - \\
\hline nois & 303,400 & 98,000 & 703.500 & 48,700 & 2,200 & - & - & 30 & 274 & 27,925 & $2,315,000$ & - \\
\hline chigan & 139.425 & 32,030 & 212,300 & 19,150 & - & - & - & 16 & 98 & 10,320 & 690,900 & - \\
\hline Ti=en & 19.500 & - & 51,150 & 7,200 & - & - & - & - & 19 & - & 160,600 & - \\
\hline isconsi & 98.700 & 91,020 & 29,990 & 9,200 & - & - & - & 28 & 98 & 31,320 & 127,000 & - \\
\hline ew Mexi & 7,300 & 7 & 2,000 & 12,900 & - & - & - & - & 21 & - & 42,000 & - \\
\hline tah Terr & 3,000 & 1,000 & - & - & - & - & - & - & 3 & 300 & - & - \\
\hline Dist. of Columbia. & 12,000 & 5,000 & - & - & - & - & - & 2 & 1 & 1,350 & - & - \\
\hline
\end{tabular}


UNITED STATES OF AMERICA.

Statistics of the Principal Manufactures-(continued).

\begin{tabular}{|c|c|c|c|c|c|c|c|c|c|c|c|c|}
\hline \multirow[b]{2}{*}{ STATES. } & \multicolumn{4}{|c|}{ PIG IRON. } & \multicolumn{4}{|c|}{ CAST IRON. } & \multicolumn{4}{|c|}{ WROUGHT IRON. } \\
\hline & 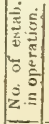 & 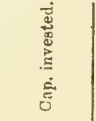 & 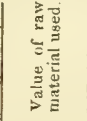 & 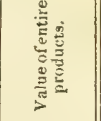 & 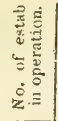 & 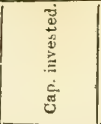 & 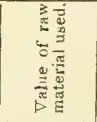 & 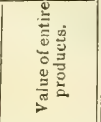 & 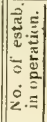 & 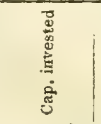 & 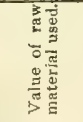 & 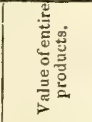 \\
\hline ain & 1 & $\$ 214,000$ & $\$ 14,939$ & $\$ 36.616$ & 25 & $\$ 150,100$ & $\$ 112,570$ & $\$ 265,000$ & $\rightarrow$ & & - & \\
\hline & 1 & 2.000 & 4.900 & 6,0 & 26 & 238 & 177,060 & 371,710 & 2 & $\$ 4,000$ & $\$ 5,600$ & $\$ 10,400$ \\
\hline & 6 & $\begin{array}{r}62,000 \\
469,000\end{array}$ & $\begin{array}{r}40.170 \\
185,741\end{array}$ & 295,123 & 68 & $1,499,050$ & $1,057,904$ & $\begin{array}{r}460,631 \\
2,235,635\end{array}$ & 6 & 610,300 & $\begin{array}{r}66,194 \\
221,194\end{array}$ & $\begin{array}{l}163,956 \\
428,320\end{array}$ \\
\hline & & & & & 20 & 428,500 & 258,267 & 728,705 & 1 & 208,000 & 111,750 & 222 \\
\hline & \begin{tabular}{|c|}
13 \\
1
\end{tabular} & 25,600 & 39.225 & 415,600 & 60 & 580,800 & 351.369 & 981,400 & 15) & 529 & 358,780 & 667 \\
\hline & 18 & 05,000 & $321.02 \pi$ & 597 & $32: 3$ & $4,622,452$ & $2,393,768$ & $5,921.980$ & 60 & 1,131 & 838,314 & 1,423 \\
\hline & 10 & 967,000 & 382,707 & 560,544 & 45 & 593.250 & 301,048 & 686,430 & 53 & 1,016 & 320,950 & 629 \\
\hline . & 150 & $5,570,425$ & $3,732,427$ & $6,071,513$ & 320 & $3,422,924$ & $2,8 \pi 2,467$ & $5,354.881$ & 131 & 7,620 & $5,485,391$ & 8,902 \\
\hline & $\overline{1 s}$ & 1420,000 & 560,725 & 1056.400 & 18 & $\begin{array}{l}373,500 \\
359,100\end{array}$ & $\begin{array}{r}153,852 \\
259\end{array}$ & 267,462 & 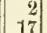 & $\begin{array}{r}15.000 \\
780.650\end{array}$ & $\begin{array}{r}19,500 \\
489511\end{array}$ & 55 \\
\hline & \begin{tabular}{|l|}
109 \\
29
\end{tabular} & $\begin{array}{r}1,420,001 \\
513,800\end{array}$ & $\begin{array}{l}200,, 20 \\
15,307\end{array}$ & $\begin{array}{r}1,006,400 \\
521,924\end{array}$ & $\begin{array}{l}10 \\
54\end{array}$ & $\begin{array}{l}359,100 \\
471,160\end{array}$ & $\begin{array}{l}209.190 \\
297.014\end{array}$ & $\begin{array}{l}650,000 \\
674,416\end{array}$ & $\left|\begin{array}{l}17 \\
39\end{array}\right|$ & $\begin{array}{l}780,650 \\
791,211\end{array}$ & $\begin{array}{l}439,511 \\
591,448\end{array}$ & $\begin{array}{r}771 \\
1.264\end{array}$ \\
\hline & 2 & 25,000 & 27,900 & 12,500 & 5 & 11, & 8.3 & 12. & 19 & 103,000 & 28,114 & $\begin{array}{r}1,204, y \\
66,9\end{array}$ \\
\hline & & $x^{2}$ & & & & & & 87,683 & & & & 00, \\
\hline & 3 & 26,000 & 25,540 & 57,300 & & 35,00 & 11.9 & 46,200 & 3 & 9,200 & 5,956 & 15,384 \\
\hline & - & & & & $F$ & & & & -1 & & & \\
\hline & 3 & 11,000 & 6,77 & 22,50 & 10 & 216,625 & 102,085 & 271. & 1 & 2,500 & 3,000 & 7,500 \\
\hline & - & - & 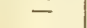 & - & 8 & & 50 & 117.400 & -1 & 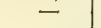 & - & -5 \\
\hline & - & - & - & - & 8) & 255 & 75 & 312,500 & - & - & - & - \\
\hline & - & - & - & 一 & 2 & 16,000 & 8,400 & 55,000 & - & - & - & - \\
\hline . & $\overline{23}$ & $1,02 \overline{1}, 400$ & $25 \overline{4} 900$ & $\overline{676,100}$ & 716 & 939.500 & 00005 & & -1 & $7 \overline{5} 050$ & $\overline{5}$ & - \\
\hline & 21 & 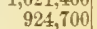 & 260,152 & Oro, & $\begin{array}{l}10 \\
20\end{array}$ & & $\begin{array}{r}90,035 \\
295,533\end{array}$ & $\begin{array}{l}264,325 \\
744,316\end{array}$ & 42 & $\begin{array}{l}755,050 \\
176,000\end{array}$ & 385,616 & $\begin{array}{l}670,618 \\
209700\end{array}$ \\
\hline & $35 !$ & $1,508,0$ & 630,0 & 1,255 & 183 & 2,06 & $1,199,790$ & 3,069 & 11 & 620,80 & 604,493 & $1,076,192$ \\
\hline & $x$ & 15.0 & 14,000 & 21. & 63 & 195 & & & & & - & - \\
\hline & 2 & 72,0 & 24.4 & 58. & 14 & 82 & 66 & 149 & 3 & 17,000 & 4,425 & 11,760 \\
\hline & 2 & 65,0 & 15 & (1), & 29 & & & & - & & & \\
\hline & 5 & 619,0 & 97,3 & 314,60 & 6 & 187. & 183 & 386,495 & 2 & 42,100 & 24,509 & 68,7 \\
\hline & - & & & & & & 2. & 8.500 & & $\rightarrow$ & & - \\
\hline & 1 & 15,000 & 8,251 & 27,000 & 15 & 116, & 86,9 & 216.195 & - & - & 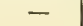 & - \\
\hline & - & 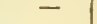 & - & & 1) & & & & - & - & - & - \\
\hline of $\mathrm{Col}$ & & - & & 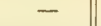 & 2 & 14,000 & 18,100 & 41,696 & 一 & - & - & - \\
\hline Total & $7 \pi, 1$ & 46,49 & 05.25 & 5,777 & 391 & 361 & 16.355 & 08,155 & 42 & 1058 & & \\
\hline
\end{tabular}

\section{INTERNAL IMPROVEMENTS.-RAILROADS, ETC.}

In no other particular can the prosperity of a country be more strikingly manifested than by the perfection of its roads and other means of internal communication. The system of railroads, canals, plank-roads, post-routes, river navigation, and telegraphs possessed by the United States, presents an indication of its advancement in power and civilization more wonderful than any other feature of its progress. In truth, the country in this respect occupies the first place among the nations of the world.

The primary design of nearly all the great lines of railway in the United States has been to connect the sea-coast with the distant interior; to effect which object it was necessary to cross the Alleghanies, which intersect every line of travel diverging to the West from the great commercial cities of the sea-board.

The following are some of the vast enterprises which have been undertaken to accomplish this great purpose, which have either been finished or are in such a state of progress as leaves no doubt of their being brought to a successful issue within a few years :

Fivst. The railroads connecting Portland, the commercial capital of Maine, with the British provinces, and through their public works, the St. Lawrence River and the lakes, with the Western States of the Union.

Second. The railroads from Boston westward, connecting at Albany with the roads of Central New York, and, by the more northern route, traversing New Hampshire and Vermont, continuing toward the West by the Ogdensburg Railroad, and bringing Montreal, the chief commercial city of Upper Canada, into eommunication with the capital of New England.

Third. The New York and Erie Railroad, extending from New York city to Lake Erie, and intended to form a part of a continuous line from the Hudson to the Mississippi-a project likely to be effected within the ensuing ten years.

Fourth. The Pennsylvania Central Railroad, from Philadelphia to Rittsburg, with numerous diverging branches, to points north and south of the general direction. This great route will reach St. Louis by a nearly due west course through Ohio, Indiana, and Mlinois. The Pennsylvania section will be completed abont the end of 1853 . 


\section{UNITED STATES OF AMERICA.}

Fifth. The Baltimore and Ohio Railroad, one of the most magnificent works of the day, passes from Baltimore, through Maryland and Virginia. to Wheeling, on the Ohio. At the latter point it will form a connection with the system of roads traversing the West and North-west.

Sixth. The roads proposed to be constructed under authority of Virginia, and already commenced, intended to establish communication between tide-water and the interior, and southwestern parts of that State, and to continue the same through Tennessee to the Mississippi.

Seventh. The several lines of railroad from Charleston and Savannah, penetrating South Carolina and Georgia, concentrating in north-eastern Alabama, and reaching the level region of the Mississippi by the valley of the Tennessee River. These roads, by their western continuation, will intersect lines running to every important point between the mountains and the Mississippi River.

Eighth. The Mobile and Ohio Railroad, from the Mexican gulf to the mouth of tho Ohio, and the Illinois Central Railroad to the lakes, a distance in a straight line of about 1,100 miles.

It will be seen at a glance that the leading idea in all these vast enterprises was to overcome the barrier presented by this chain of mountains, to a direct and unrestricted intercourse between the sea-board and the West, and to supply the want of those natural channels of commerce, navigable rivers, extending into the section we desire to reach. The enormous aggregate of expense of the numerous works specified above, undertaken with this one object, and their importance as public improvements, may be estimated from the following brief notice of the New York and Erie Railroad, which occupies the third place in our preceding enumeration: The longest continuous line of railroad in the world, and that in the construction of which the greatest natural obstacles have been overcome, is that which extends from the Hudson River, through the southern counties of New York, to Lake Erie. Its length is 469 miles, and it has branches of an additional length of 68 miles. Nearly its whole course is through a region of mountains. The bridges by which it is carried over the Delaware and Susquehanna rivers, and other streams, and the viaducts upon which it crosses the valleys that intercept its route, are among the noblest monuments of power and skill to be found in our country. The most of these works are of heavy masonry; but one of them is a wooden bridge, 187 feet in height, with one arch, the span of which is 275 feet. One of the viaducts is 1,200 feet long, and 110 feet high. 'The aggregate cost of this important work was $\$ 23,580,000$, and the expense of construction was $\$ 42,383$ per mile.

The following table presents, in a convenient form, some of the principal facts connected with railroads in the United States on the 1st January, 1852 and 1853.

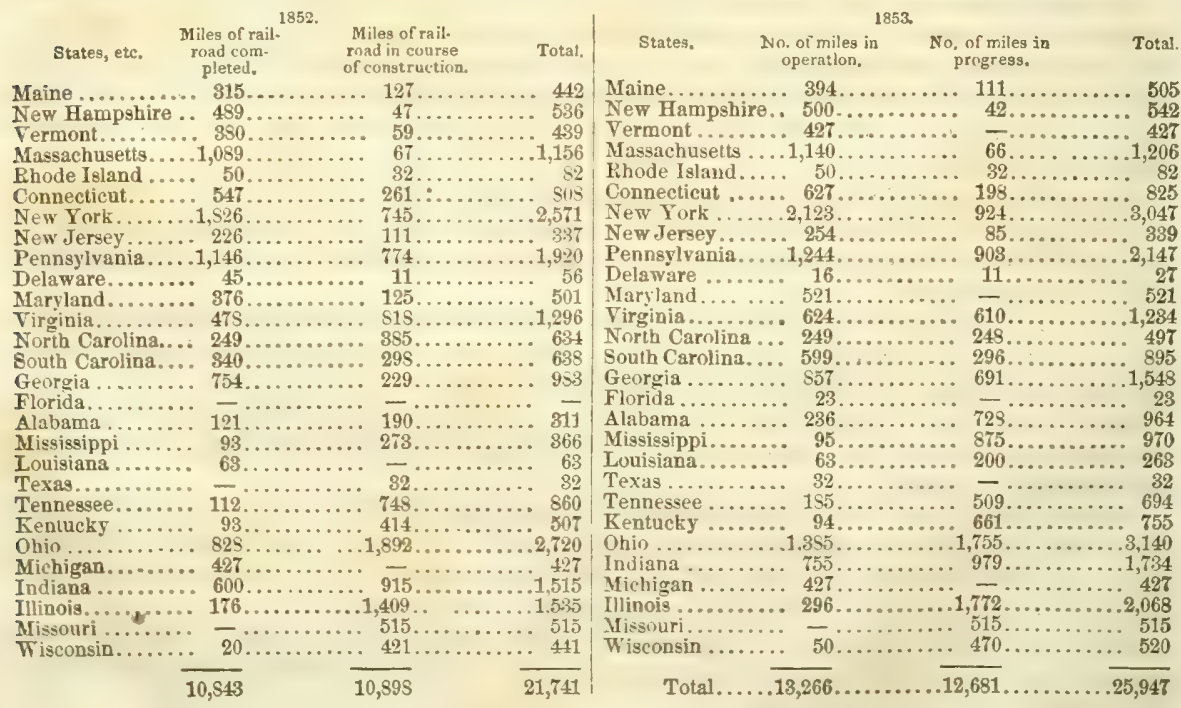

Measures are in progress for establishing railroads in California, with the object of connecting San Francisco with some of the principal towns of the State; and no doubt, ere the lapse of many years, that important division of the Union will be in possession of as large a proportion of these facilities for travel and business as her population and resources require. 


\section{UNITED STATES OF AMERICA.}

From the brief sketch of American railroads should not be excluded some mention of several projects which are not only closely connected with the interests of the United States, but possess something of national importance. The first of these, in point of vastness of design, is the enterprise of building a railroad from the Mississippi River to the Pacific Ocean. The routes proposed in this great work are almost as numerous as the persons who claim the merit of having first suggested and brought forward the scheme of thus completing the chain of railroad connection between the Atlantic and Pacific coasts of the Union. No scientific survey of any route west of the frontier of Missouri has been made, but it is not probable that any could be found that would bring the line of travel between the Mississippi and the ocean within the limit of 1,600 miles.

The natural obstacles to be overcome are the Rocky Mountains and the Sierra Nevada, the deserts between the Missouri and the former chain, and those of the great basin, the flying sands, and the want of timber. Further explorations may lead to the discovery of means to overcome these difficulties. Should the cost not exceed the average of Western roads, it would form no objection to the enterprise, since it would be only about $\$ 32,000,000$, or only twenty-five per cent. more than has been expended upon the Erie Railroad--less than fifty per cent. greater than the aggregate expenditure upon the Baltimore and Ohio Railroad, and not two-thirds of that incurred by the State of Massachusetts on her railroads. The only question, then, affecting the probability of the construction of the Pacific Railroad is that of practicability.

This can only be determined by thorough surveys of some or all of the routes proposed, from the valley of the Rio Grande, the Arkansas, the Missouri, and the Upper Mississippi. If this road were completed, and the route continued westward by steamship to Calcutta, it would reduce the time required for the circuit of the globe, by the American overland route, to 93 days, as follows : from New York to San Franciseo, 4 days; to Hong-Kong, 25 days ; to Calcutta, 6 days ; to Bombay, 13 days ; to England, 35 days; to New York, 10 days. Total, 93 days.

Another project for connecting, by the means of cheap and rapid conveyance, the two coasts of our confederacy, which deserves, as it has received, very great attention, is the proposition to build a railroad across the Isthmus of Tehuantepec, in Mexico. Its feasibility is established. The length of the road, according to the report of the surveyors, will be 166 miles from sea to sea; but only about 80 miles from the head of navigable water on either side.

The cost of the road, with all the necessary equipments, station-houses, etc., is estimated at $\$ 7,818,000$. The time expected to be required for its construction is three years. With this connecting link of communication completed, the voyage from New Orleans to San Francisco will be performed in eight or nine days.

For the purpose of comparison, the subjoined statement has been prepared, showing the number of miles of railroads, with their costs, according to the most generally received authorities in all the countries of Europe in which those improvements have been introduced:

\begin{tabular}{|c|c|c|c|}
\hline COUNTRIES. & Miles. & Aggregate cost. & Cost p. mile. \\
\hline 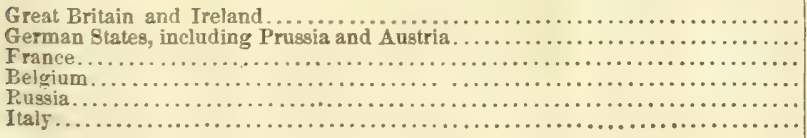 & $\begin{array}{r}6,390 \\
5,332 \\
1,018 \\
532 \\
200 \\
170\end{array}$ & $\begin{array}{r}\$ 1,218,000,000 \\
325,575,000 \\
238,9115,000 \\
46.288,000 \\
15,000,000 \\
15,000,000\end{array}$ & $\begin{array}{r}\$ 177,000 \\
61,000 \\
254,000 \\
49,000 \\
75,000 \\
88,000\end{array}$ \\
\hline & 14,142 & $1, \$ 59,068,000$ & 131,300 \\
\hline
\end{tabular}

By these statistics it is made to appear that the average cost of European railroads was $\$ 131,300$ per mile. The average cost of American railroads completed previous to the commencement of the present year was $\$ 34,307$ per mile. The excess of expenditure, therefore, in the construction of European roads over those in the United States, is $\$ 95,993$ per mile, or about 280 per cent. ; but it may be remarked that the average cost of construction in the United States of all the roads does not exceed $\$ 27,300$ per mile; so that the actual excess is $\$ 103,000$ per mile.

The foregoing statements develop the striking fact that the United States possess axtent of railroad nearly equal to that of the rest of the world combined; and, at our present rate of progression, we are likely, in a few years, far to exceed it. 


\section{UNITED STATES OF AMERICA.}

VI.-COMMERCIAL STATISTICS.

1. Statistical View of the Commerce of the United States, exhibiting the Value of Exports to and Imports from each Foreign Counlry, and the Tonnage of American and Foreign Vessels arriving from and departing to each foreign country, during the year ending June 30, 1850.

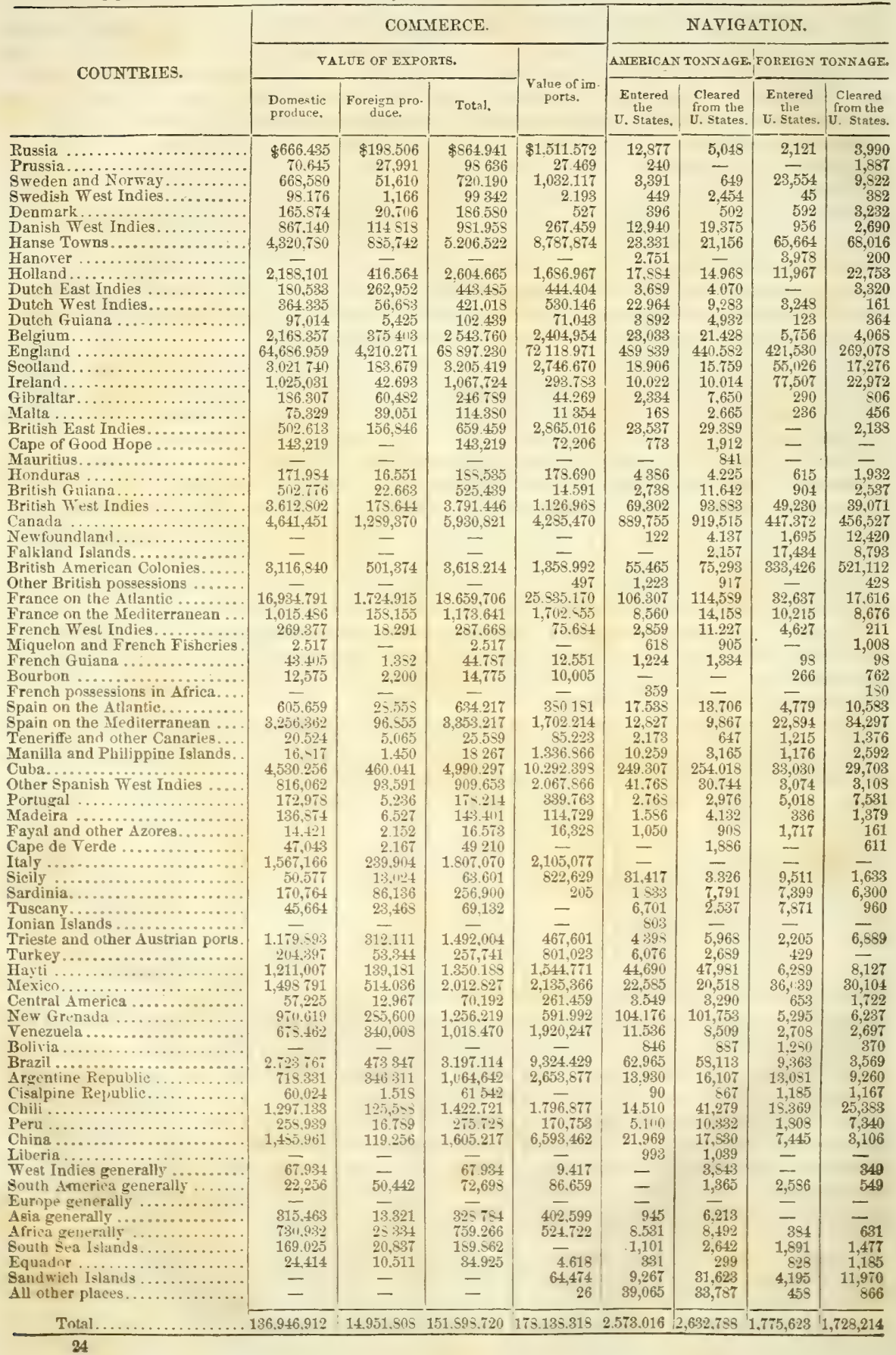


UNITED STATES OF AMERICA.

2. Slatement of the Commerce of each State, from July 1, 1849, to June 30, 1850.

\begin{tabular}{|c|c|c|c|c|c|c|c|c|c|c|}
\hline \multirow{3}{*}{ STATES, } & \multicolumn{7}{|c|}{ VALUE OF EXPORTS. } & \multicolumn{3}{|c|}{ VALUE OF IMPORTS. } \\
\hline & \multicolumn{3}{|c|}{ DOUESTIO PRODUCE. } & \multicolumn{3}{|c|}{ FOREIGN PBODUCE. } & \multirow{2}{*}{$\begin{array}{c}\text { Total of } \\
\text { American \& } \\
\text { fore ign } \\
\text { produce. }\end{array}$} & \multirow{2}{*}{$\begin{array}{c}\text { In } \begin{array}{c}\text { A merican } \\
\text { ressels. }\end{array} \\
\text {. }\end{array}$} & \multirow{2}{*}{$\begin{array}{c}\text { In Foreign } \\
\text { vessels. }\end{array}$} & \multirow{2}{*}{ Total. } \\
\hline & $\begin{array}{c}\text { In American } \\
\text { vessels. }\end{array}$ & $\begin{array}{c}\text { in Foreign } \\
\text { ressels. }\end{array}$ & Total. & $\begin{array}{c}\text { In } A \text { meri } \\
\text { can } \\
\text { vessels. }\end{array} \mid$ & $\left|\begin{array}{c}\text { In Foreign } \\
\text { vessels. }\end{array}\right|$ & Total. & & & & \\
\hline aine & $\$ 1,185.995$ & $\$ 400,820$ & $\$ 1,536.818$ & $\$ 14,564$ & $\$ 5,530$ & $\$ 20,094$ & $\$ 1,556.912$ & $\$ \$ 609.155$ & $\$ 247.256$ & $\$ 856,411$ \\
\hline N. Hami & $\begin{array}{r}11,100.835 \\
2,835\end{array}$ & 5,887 & $81,000.722$ & 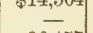 & $\begin{array}{r}\$ 0,000 \\
205\end{array}$ & $\begin{array}{r}\$ 20,034 \\
205\end{array}$ & $\begin{array}{r}P, 200.912 \\
8.927\end{array}$ & $\begin{array}{r}\$ 009.100 \\
19,962\end{array}$ & $\begin{array}{r}29.117 \\
29.1170\end{array}$ & 49,079 \\
\hline Tert & 404.749 & - & 404.749 & 26.157 & $=$ & 26,157 & 43,906 & $\mid \begin{array}{r}463,092 \\
\end{array}$ & - & 463.092 \\
\hline Massachus's. & 7.0011,111:3 & $1,253,370$ & $8,253.473$ & $1,898.497$ & 529,793 & $2,428,290$ & $10,680,763$ & $22,106,011$ & $8,268,678$ & $80,374,684$ \\
\hline Phode Island & 215.969 & 330 & 206.299 & 9,966 & - & 9,966 & 215265 & $\begin{array}{r}251,708 \\
251\end{array}$ & 6595 & 258.303 \\
\hline Conneetieut. & 241.262 & & 241.202 & & - & 668 & 241.980 & 311.927 & 60.463 & 372.390 \\
\hline New York... & $33.93 \pm, \pm 9$ & $7,568,391$ & $41,502,500$ & $7,086,68 \mathrm{i}$ & $4,123,302$ & $11,209,989$ & $52,712.789$ & $88,147,721$ & $22,975,803$ & $111,123,524$ \\
\hline New Jersey. & & 1.655 & 1.655 & - & - & & 1.655 & & 1,494 & 1,494 \\
\hline Pennsylvania & $3,48 \mathrm{~S}, 150$ & 621,314 & $4,049,464$ & 363,225 & 88,917 & 452,142 & $4,501,606$ & $10,795,462$ & $1,270,692$ & $12,066,154$ \\
\hline $\begin{array}{l}\text { Delaware ... } \\
\text { Maryland ... }\end{array}$ & $4,65 \overline{7,1} 195$ & $1,932,296$ & $6,559.481$ & 250.861 & 127,011 & $3 \bar{\pi} .872$ & $6,967,353$ & $5,529,682$ & 594,519 & $6,124,201$ \\
\hline Dist. of CoL.. & 72.175 & S.213 & 30,385 & & 12, & 200 & 80.588 & 59.219 & 600 & 59,819 \\
\hline Virgi & $2,365,241$ & $1,047,917$ & $3,413,155$ & $2, \pm 58$ & - & 2,488 & $3,415.646$ & 172.878 & 253.721 & 426.599 \\
\hline N. Carolina.. & 259.616 & 156.355 & 416.501 & 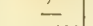 & - & $\rightarrow$ & & 179.249 & 144,443 & 323,692 \\
\hline 5. Carolina... & $6,467,201$ & 4.979 .691 & 11.446 .892 & 400 & 50 & 90 & $11.447,800$ & $1,313,65$ & 620,127 & $1,933.785$ \\
\hline Greor & $2.622,152$ & 4.929 .791 & 7.551 .943 & - & - & - & $7,551,943$ & 306.883 & 330081 . & 636.964 \\
\hline Tho & 1.113 .978 & 1.493 .990 & $2.607 .96 \mathrm{~S}$ & 15,656 & - & 15,656 & $2,623.624$ & 30241 & 65,468 & 95,709 \\
\hline na & 4.601.515 & $5,943,343$ & 10544.858 & & & & 10.544 .858 & 103,134 & 757,228 & 865,362 \\
\hline Loui & $20,927,751$ & $16,770,526$ & $37,698,277$ & 328.930 & 78,143 & 407,073 & $38,105,350$ & $8,107,929$ & $2,652,570$ & $10,760,499$ \\
\hline Missi & - & & & & & & & & & \\
\hline Tenn & - & - & - & - & 一 & - & - & 27.966 & - & 27.966 \\
\hline Missouri. & & & $\bar{n}$ & - & - & - & & 359643 & - & 359,643 \\
\hline Ohio ....... & 117.959 & 99,543 & 217,532 & - & 100 & 100 & 217,632 & 398.999 & 183.505 & 582,504 \\
\hline Kentuck & & $\overline{74} 513$ & 12004 & - & - & $=$ & & 190.987 & - & 190,987 \\
\hline int & 57,232 & 74.513 & 132.045 & - & 一 & 二 & 132.045 & 144.102 & $=$ & 144.102 \\
\hline & 1,232 & 16,437 & 17,649 & - & - & - & 17,699 & 7,783 & 7.922 & 15,705 \\
\hline $10 x$ & - & 24,955 & 24,958 & - & 一 & - & 24,958 & 14,652 & 10,998 & 25,650 \\
\hline Calif & - & - & - & - & - & - & - & - & - & - \\
\hline Oregon. & - & - & - & - & - & - & - & - & - & - \\
\hline
\end{tabular}

3. Statement of the Navigation of each State.

\begin{tabular}{|c|c|c|c|c|c|c|c|c|c|c|c|c|}
\hline \multirow{3}{*}{ TATES, } & \multicolumn{6}{|c|}{ TONNAGE ENTERED UNITED STATES. } & \multicolumn{6}{|c|}{ TONNAGE CLEARED FROM U. STATES. } \\
\hline & \multicolumn{2}{|c|}{ AMERICAN. } & \multicolumn{2}{|c|}{ FOREIGN. } & \multicolumn{2}{|c|}{ Total. } & \multicolumn{2}{|c|}{ AMERIOAN. } & \multicolumn{2}{|c|}{ Foreign. } & \multicolumn{2}{|c|}{ Total. } \\
\hline & No. & Tons. & No. & Tons. & No. & Tons. & No. & Tons. & No. & Tons. & No. & Tons. \\
\hline [aine & 253 & 53,309 & 1.040 & 89,577 & 293 & 143.186 & 585 & 111.123 & 1.046 & 91.014 & 1,631 & 202,187 \\
\hline 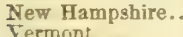 & 9 & 3.572 & 101 & & 110 & & & & 102 & & 107 & \\
\hline & 330 & 900 & 174 & 12. & 504 & & 322 & 81.073 & 20 & 1.783 & 342 & \\
\hline & 1.245 & 339.508 & 2,732 & 271. & 4,077 & 611. & 1,149 & 272,278 & 2,757 & 274.674 & 3,906 & 546,952 \\
\hline hode Is & 100 & 17.847 & 19 & 2,075 & 119 & 19 & 94 & 16. & 16 & 1.705 & 110 & 18,475 \\
\hline & 109 & 22.5 & 79 & 11.572 & 188 & & 87 & & & & 156 & \\
\hline & 4,137 & $1,502,290$ & 3,632 & 775.430 & 7,969 & $2,277,720$ & 3,610 & $1,411,557$ & 3,693 & 737.539 & 7,303 & $2,149.096$ \\
\hline $\mathrm{Fe}$ & $-\overline{3}_{52}$ & $\overline{100009}$ & 17 & $\begin{array}{r}1,601 \\
32,361\end{array}$ & 17 & $\begin{array}{r}1,601 \\
129,270\end{array}$ & 1 & 150 & 10 & 981 & 11 & 1.131 \\
\hline el: & -352 & 100,00 & -180 & 32,361 & -58 & 132,370 & 309 & 81,276 & 170 & 30.842 & 479 & 111 , \\
\hline Ma & 295 & $\mathbf{7 0 . 4 2 7}$ & 143 & 29,161 & 438 & 99,5 & 359 & 89,296 & 162 & 37, & 521 & 126.819 \\
\hline lumbia... & 7 & 1. & $0^{2}$ & $\begin{array}{r}154 \\
1877\end{array}$ & 9 & 1, & 8 & 1 & & 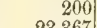 & 10 & 1,720 \\
\hline & 69. & & 88 & & 15 & & 187 & & 98 & & 255 & \\
\hline & 140 & 19,1 & 39 & & 188 & & 212 & & 62 & & 274 & \\
\hline & 163 & 52.7 & 142 & 44 & 305 & 96. & 205 & & 170 & & 375 & 125 \\
\hline Geer & 47 & 11,8 & 71 & 45,1 & 118 & 57. & 58 & 21, & 83 & 51 & 141 . & 72 \\
\hline & 56 & 7,5 & 39 & 10, & 95 & 17. & 60 & & 42 & & 10 & \\
\hline & & & 112 & & & & & & 10 & & & \\
\hline & 524 & 175,96 & $3 \pi 4$ & 174,884 & 898 & $850,85 \%$ & 493 & 211,80 & 356 & 158,13 & 84 & 369,9 \\
\hline & - & - & - & & & & - & - & - & & - & - \\
\hline & - & - & - & - & - & - & - & - & - & - & - & - \\
\hline & $\overline{17}$ & $\overline{10}$ & -70 & 10 & - & - & $T$ & - & - & - & - & \\
\hline Ohio & 178 & 21,628 & 136 & 18,243 & 314 & 39,871 & 137 & 15,485 & 131 & 18,322 & 268 & 33,807 \\
\hline & 97 & 7.254 & 394 & 49.709 & 491 & 56.963 & $\overline{112}$ & $\overline{7.982}$ & $\overline{390}$ & $4 \overline{6,719}$ & 502 & $\overline{54}$, \\
\hline & $1=$ & 6,690 & 4 & 648 & a? & 7,2 & . & 1,0 & (1) & 998 & 0 & 2,0 \\
\hline & & & 13 & & $=$ & 8. & & 5 & 12 & 3.017 & 15 & 3,6 \\
\hline & 140 & 47,950 & 3555 & 82,914 & 495 & 130,864 & 308 & 104,266 & 320 & 75,862 & 623 & 180,128 \\
\hline Oregrin... & - & - & - & - & - & - & - & - & - & - & - & - \\
\hline Total. & 8.412 & $2.573,016$ & 10,100 & $1,775,623$ & 18,512 & $4.348,639$. & 8,379 & $2,682,788$ & 9.816 & $1,728,214$ & 18.195 & $4,361,002$ \\
\hline
\end{tabular}


UNITED STATES OF AMERICA.

4. Statement exhibiting a condensed view of the Tonnage of the several Districts of the United States on the 30th of June, 1850.

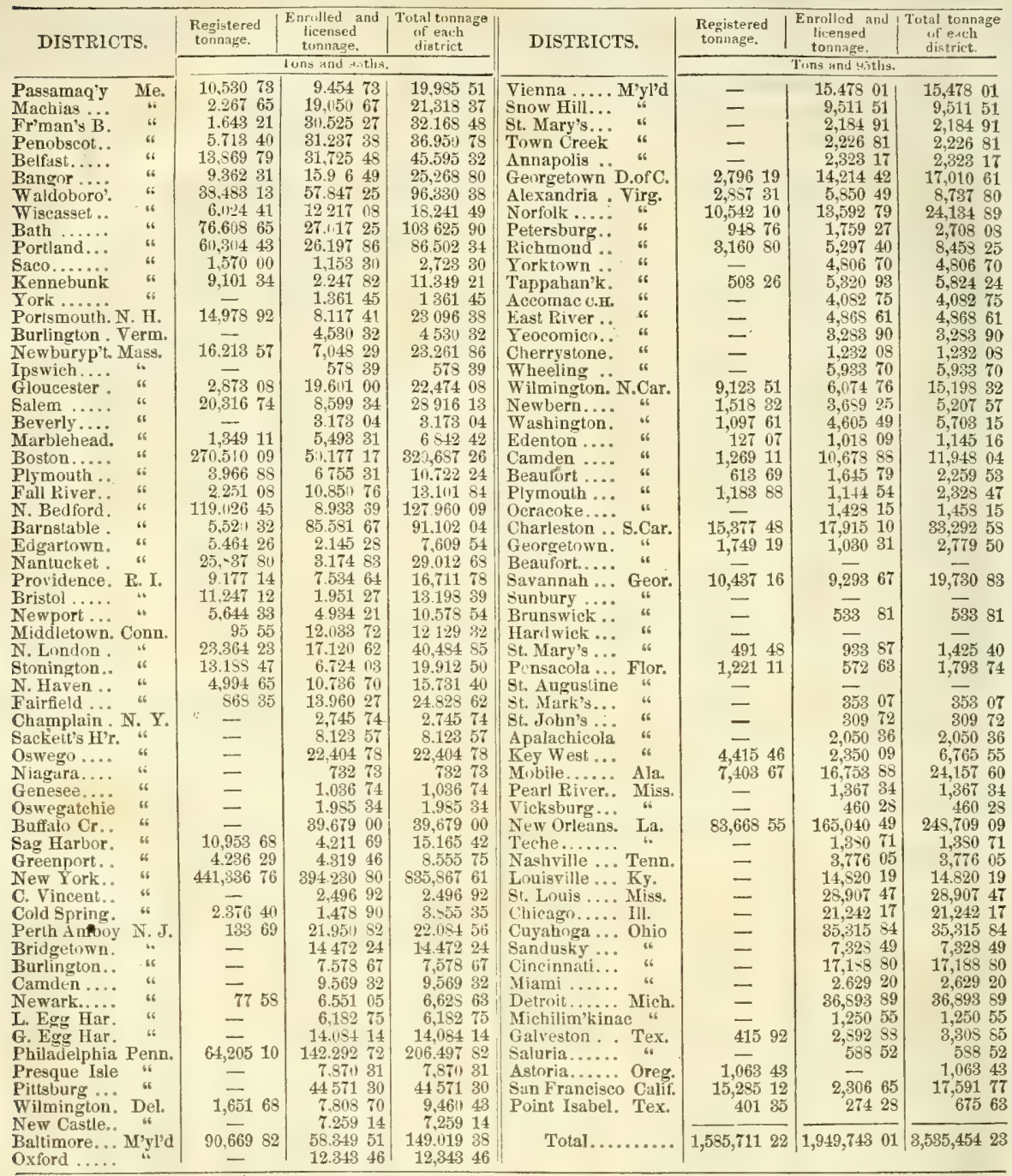

5. The general Statement of Tonnage Accounts from June 30, 1849, to June 30, 1850 .

\begin{tabular}{|c|c|c|c|c|c|}
\hline & $\begin{array}{c}\text { Regizter'd } \\
\text { tonnage. }\end{array}$ & $\begin{array}{l}\text { Aggregate } \\
\text { Lunnage. }\end{array}$ & & $\mid \begin{array}{c}\text { Reginter d } \\
\text { tonnage. }\end{array}$ & $\begin{array}{l}\text { Aggregate } \\
\text { tonnage. }\end{array}$ \\
\hline \multirow{6}{*}{ 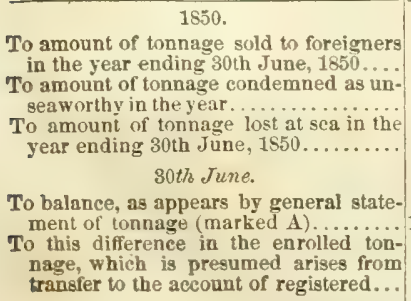 } & 13,467 & 13,467 & \multirow{6}{*}{ 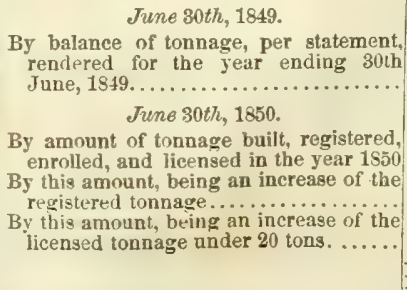 } & \multirow{2}{*}{$1,433,941$} & \multirow{2}{*}{$3,834,015$} \\
\hline & \multirow{2}{*}{$\begin{array}{r}4,666 \\
23,724\end{array}$} & 6,753 & & & \\
\hline & & $84, \pi 48$ & & 157,612 & 272,218 \\
\hline & \multirow{2}{*}{$1,585,711$} & \multirow{2}{*}{$3,535,454$} & & 31,016 & 31,016 \\
\hline & & & & - & 3,349 \\
\hline & - & 50,175 & & $\mid 1,627,06013$ & $3,640,599$ \\
\hline & & & & & \\
\hline
\end{tabular}




\section{UNITED STATES OF AMERICA.}

6. A comparative View of the registered and enrolled Tonnage of the United States, showing the Tonnage employed in the Whale Fishery; also, the proportion of the enrolled and licensed Tonnage employed in the Coasting Trade, Cod Fishery, Mackercl Fishery, and Whale Fishery, from 1815 to 1850 , inclusive.

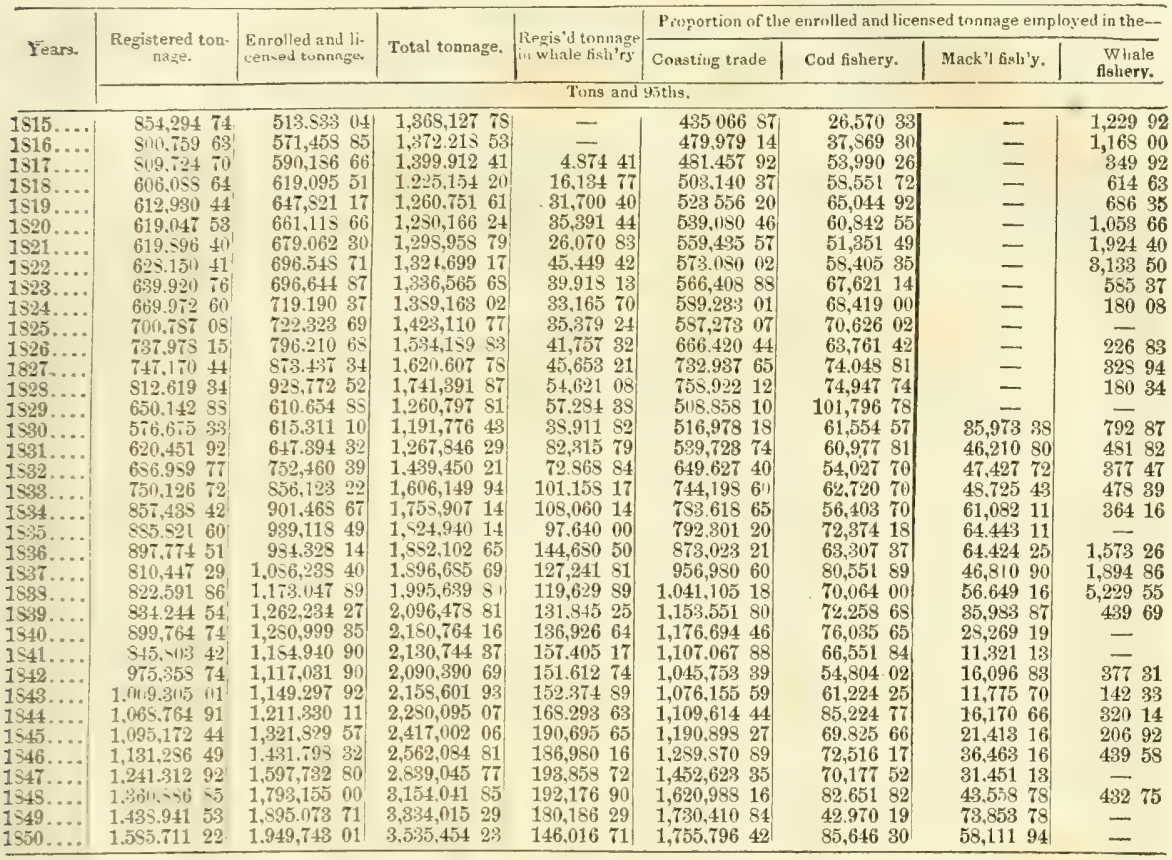

7. A Slatement of the Number of Vessels built in the several States, and the Aggregate Tonnage of each for the year ending 30th June, 1850.

\begin{tabular}{|c|c|c|c|c|c|c|c|}
\hline \multirow{2}{*}{ STd'TES. } & \multicolumn{5}{|c|}{ CLASS OF VESSELS. } & \multirow{2}{*}{ 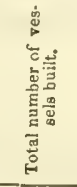 } & \multirow{2}{*}{ 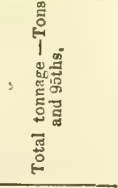 } \\
\hline & Ships. & Brigs. & Schooners. & $\begin{array}{l}\text { Sloops and } \\
\text { canal boats. }\end{array}$ & Steamers, & & \\
\hline 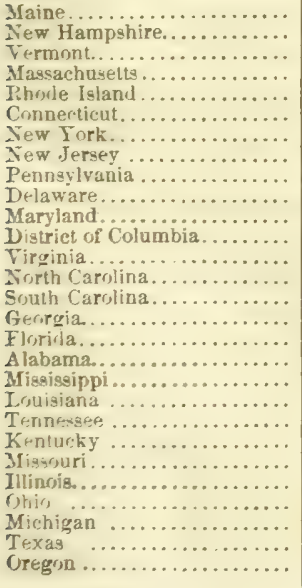 & $\begin{array}{r}127 \\
8 \\
-51 \\
5 \\
3 \\
26 \\
1 \\
7 \\
-16 \\
-1 \\
-1 \\
= \\
= \\
-1 \\
= \\
= \\
= \\
= \\
-\end{array}$ & 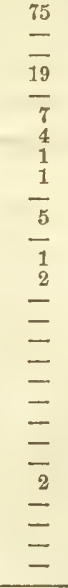 & $\begin{array}{r}115 \\
2 \\
46 \\
5 \\
27 \\
50 \\
35 \\
39 \\
12 \\
125 \\
\frac{27}{27} \\
23 \\
2 \\
2 \\
3 \\
16 \\
- \\
7 \\
4 \\
5 \\
2\end{array}$ & $\begin{array}{r}3 \\
- \\
3 \\
3 \\
9 \\
112 \\
17 \\
107 \\
3 \\
-8 \\
2 \\
- \\
- \\
- \\
8 \\
= \\
- \\
- \\
\end{array}$ & $\begin{array}{r}6 \\
1 \\
2 \\
1 \\
1 \\
82 \\
3 \\
31 \\
1 \\
4 \\
5 \\
5 \\
3 \\
- \\
4 \\
34 \\
5 \\
1 \\
16 \\
3 \\
-\end{array}$ & $\begin{array}{r}326 \\
10 \\
1 \\
121 \\
14 \\
47 \\
224 \\
57 \\
185 \\
16 \\
150 \\
8 \\
84 \\
83 \\
5 \\
2 \\
3 \\
24 \\
34 \\
5 \\
13 \\
31 \\
14 \\
1 \\
2\end{array}$ & 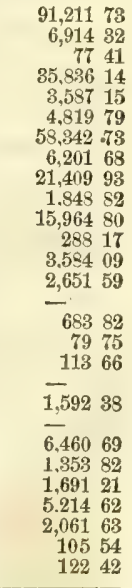 \\
\hline Trotal $\ldots \ldots \ldots \ldots \ldots$ & 247 & 117 & 547 & 290 & 159 & 1,860 & 272,21854 \\
\hline
\end{tabular}


UNITED STATES OF AMERICA.

8. Statement showing the Number and Class of Vessels built, and the Tonnage thereof, in the several States and T'erritories of the United States from 1815 to 1850 inclusive.

\begin{tabular}{|c|c|c|c|c|c|c|c|}
\hline \multirow{2}{*}{ YEARS. } & \multicolumn{5}{|c|}{ CLABS OF VEGSELS. } & \multirow{2}{*}{ 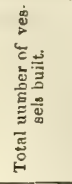 } & \multirow{2}{*}{ 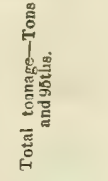 } \\
\hline & Ships. & Brigs. & Schnoners, & $\begin{array}{l}\text { Sloops and } \\
\text { canal boats. }\end{array}$ & Steamers. & & \\
\hline
\end{tabular}

VII. STATEMENT OF THE DUTIES, REVENUES, AND PUBLIC EXPENDITURES DURING THE YEARS ENDING 30Tн JUNE, 1849 AND 1850. RECETPTS.

From customs .......... $\$ 28,346,738,82$

From sales of public lands. 1,688,959 55

From miscellaneous sources $1,088,64913$

Total receipts.....\$31,074,34750 Avails of stocks, treasury

notes, etc., issued .......\$28,588,750 00

Balance in treasury 1st July,

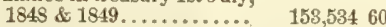

Total means ...... $\$ \overline{\$ 59,816,68210}$
EXPENDITURES.

$2,865,61588$

$7,972,83201$

$3,179,19266$

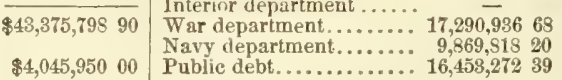

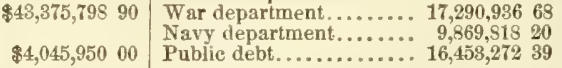

2,189,964 28 Total expenditures $\$ \overline{\$ 57,681,66782}$

$\overline{\$ 49,606,71315}$ Balances 1st July'49 \&'50 $\overline{\$ 2,184,96428}$
1850

$\$ 3,042,77007$ $4,839,59476$ $6,958,36024$ $3,400,52487$ $9,401,23916$ $9,401,239$
$7,923,313$
18 $7,437,36641$

$\$ 43,002,16869$ $\$ 6,604,54449$

VIII. STATEMENT OF THE PUBLIC DEBT 80 Tн NOVEMBER, 1850.

\begin{tabular}{|c|c|c|c|}
\hline DENOMINATION OF DEBT, & {$\left[\begin{array}{c}\text { Rate } \\
\text { per } \\
\text { cent. }\end{array}\right.$} & When redeemable. & Amount. \\
\hline 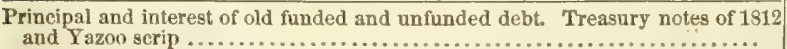 & - & On presentation & $\$ 119,58598$ \\
\hline Debt of the cities of the District of Columbia, assumed per act 30 th May, 1836 & 51 & $\$ 60,000$ per annum & 900,00000 \\
\hline Outstanding treasury notes issued previous to $22 \mathrm{~d} \mathrm{July}, 1346$, payable or fundable & - & On presentation & 189,01161 \\
\hline Outstanding treasury notes issued under act 26 th June, 1846 , payable or fundable & - & On presentation & 25.85000 \\
\hline Outstanding treasury notes issued under act 2 Sth Jan. 1847 , payable or fundable & - & On presentation & 44,70000 \\
\hline Btock issued for treasury notes 1837-1843, under act 2Sth Jan. $1847 \ldots \ldots \ldots \ldots$. & 6 & 1st January, 1868 & $154.3: 800$ \\
\hline 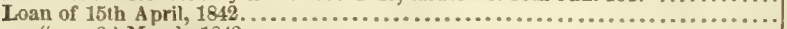 & 6 & 31 st Dec., 1862 & $8,198,68603$ \\
\hline 8 i March. 1843. & 5 & Ist July, 1853 & $6,468,28185$ \\
\hline $22 \mathrm{~d}$ July, 1846 . & 6 & 12th Nov., 1856 & $4,999.14946$ \\
\hline $2 S t h$. Tan., 1847 & 6 & 18t Jan., 1868 & $27,135,12200$ \\
\hline " 31st Mareh, 1848.. & 6 & 1st July, 1868 & $15,740,00000$ \\
\hline Mexican indemnity stock................. & 5 & 9th Aug, 1851 & 308,57392 \\
\hline
\end{tabular}


UNITED STATES OF AMERICA.

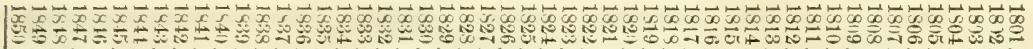

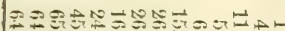

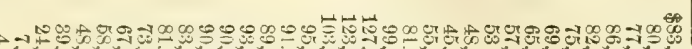

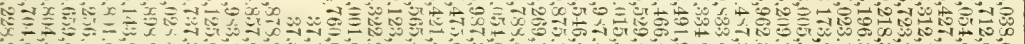

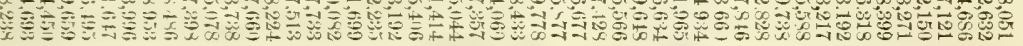

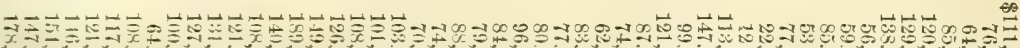
Fo

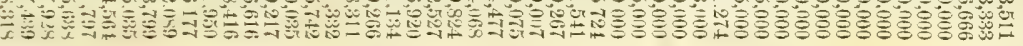

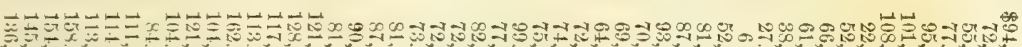

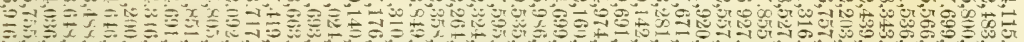

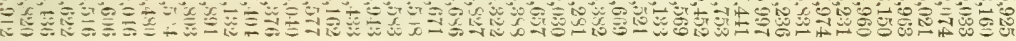

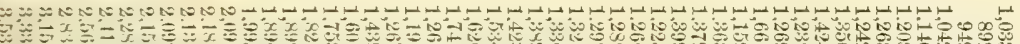

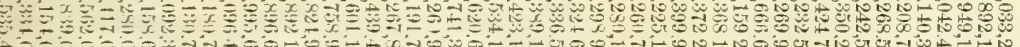

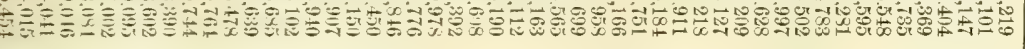

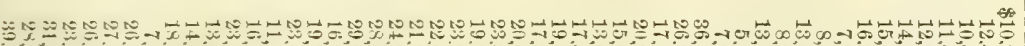
*

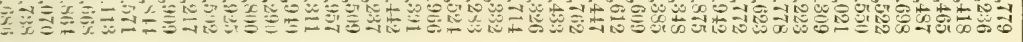

\section{He 000}

- I+

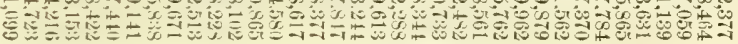

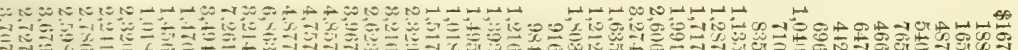
- o

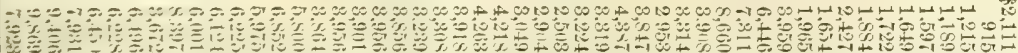
on

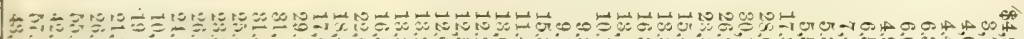

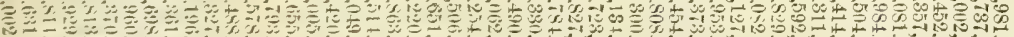

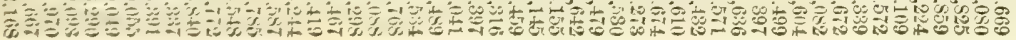




\section{STATISTICS OF COINAGE.}

\begin{tabular}{|c|c|c|c|c|c|c|c|c|}
\hline \multicolumn{3}{|c|}{$\begin{array}{l}\text { 1. Deposits for Coinage, at the } \\
\text { Mint of the United States and its } \\
\text { Branches, in the Year } 1850 .\end{array}$} & \multicolumn{6}{|c|}{$\begin{array}{l}\text { 2. Coinage of the Mint of the United } \\
\text { Stales and its Branches, in the } \\
\text { Year } 1850 \text {. }\end{array}$} \\
\hline \multirow{9}{*}{$\begin{array}{l}\text { Goln. } \\
\text { Coins of U.S., old stand. } \\
\text { Foreign Coins......... } \\
\text { Uniteu States Bullion.. } \\
\text { Foreign Bultion....... } \\
\text { Total of Guld ...... } \\
\text { sILvER. } \\
\text { United States Bullion.. } \\
\text { Foreign Bullion ........ } \\
\text { Foreign Coins........ } \\
\text { Total of Silver..... } \\
\text { Total ........... }\end{array}$} & & \multirow{7}{*}{$\$ 38,365,160$} & Denominations. & Pie & Value. & \multirow{2}{*}{$\mid \begin{array}{c}\text { Denominations. } \\
\text { Gold \& Copper } \\
\text { Colns ....... }\end{array}$} & Pieces. & Value. \\
\hline & $\begin{array}{r}99 \\
1,303\end{array}$ & & GoLD. & 81311261 & $\$ 26,2$ & & \multirow{2}{*}{$7,268,420$} & \multirow{2}{*}{$\$ 32,026,200$} \\
\hline & $36,938,8$ & & Eagles ....... & $\mid 348.951$ & $\begin{array}{r}0,48 \\
3,48\end{array}$ & \multirow{5}{*}{ 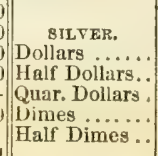 } & & \\
\hline & & & $\begin{array}{l}\text { Halt Eagles.. } \\
\text { Quar. Kagles }\end{array}$ & $\begin{array}{l}172,+32 \\
358,219\end{array}$ & $\begin{array}{ll}0 & 0 \\
12 & 50\end{array}$ & & \multirow{4}{*}{$\begin{array}{r}47,500 \\
2,683,000 \\
602,800 \\
2,411,500 \\
1,645,000 \\
\end{array}$} & \multirow{4}{*}{$\begin{array}{r}47,500 \\
1,341,500 \\
150,700 \\
244,150 \\
82,250 \\
\end{array}$} \\
\hline & $\$ 2$ & & \multirow{5}{*}{$\begin{array}{l}\text { Total Gold ... } \\
\text { copPer. } \\
\text { Cents....... } \\
\text { Half Cents... }\end{array}$} & & & & & \\
\hline & $1,526,596$ & & & \multirow{3}{*}{$\mid \begin{array}{r}2,701,764 \\
4,426,844 \\
39,812\end{array}$} & $\$ 31,981,7335 \times$ & & & \\
\hline & & & & & & & & \\
\hline & & $\$ 40,804,201$ & & & & Tot & 220 & $\$ 33,8$ \\
\hline & & & & 656 ] & $\$+4$, & & & \\
\hline
\end{tabular}

3. Coinage of the Mint of the United States, from 1792, including the Coinage of the Branch Mints, from the Commencement of their Operations, in 1838.

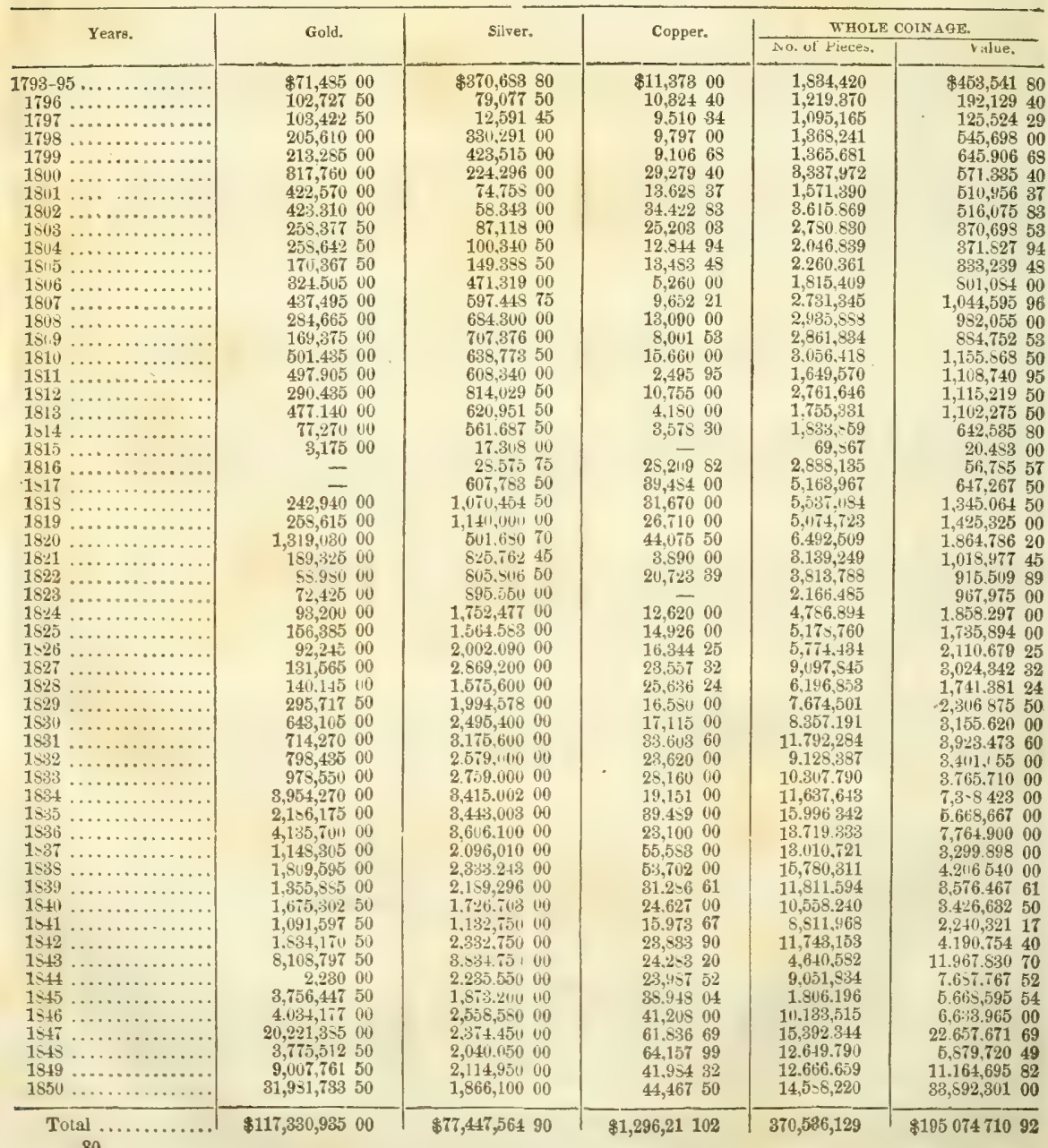




\title{
STATISTICAL GAZETTEER
}

\author{
OF THE

\section{UNITED STATES OF AMERICA.}

$A A R$

ACK

Alroxsbugg, p. v., Centre co., Penn.: on Eilk cr, $51 \mathrm{~m}$. N. W. Harrisburg. Pop. 226.

AARO's RUN, p. o., Montgomery co., Ky.: on a small tributary of Licking r., $49 \mathrm{~m}$. E. Frankfort.

A ввевүu.乃, p. จ., La Fayelte co., Miss. : 156 m. N. N.W. Jackson.

ABBETHLE district, S. Car. Situate W., and contains 960 sq. m. The Savannah washes its S. W. and the Saluda its N.E. borders, while numerous streams, tributary to these rivers, drain the interior. The surface is agreeably variegated by hill and dale, and a considerable part of the soil is rich and fertile. The products are chiefly Indian corn and cotton. Farms 1,814; manuf. 156; dwell. 2,391, and pop-wh. 12,698 , fr. col. 363, sl. 19,262-total, 32,818. Capital: Abberille. Public Works: Abberille Branch R. R.

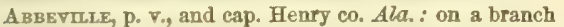
of Yattayabba cr., $86 \mathrm{~m} . \mathrm{S}$. W. Montgomery ; it contains a C. H. and other public buildings. The "Abbeville Banner" is issued weekly. Pop. 327.

A ввтFILLE, p. $v_{w}$ and cap. Abbeville dist., S. Car.: near the centre of the district, $90 \mathrm{~m}$. W. Columbia : it contains a C. H., a jail, an arsenal, a magazine, and several stores. The "Abbeville Banner", is issued weekly. A branch of the Greenville and Columbia R. R. terminates at this point. AвBeville, p. V., Vermillion par., La. : on W. side Vermillion r., 169 m. W. S. W. of Baton Rouge.

Abeerville, p. v., Medina co., Ohio: 109 m. N. E. Columbus.

Аввот, th, and p. 0., Piscataquis co., Me. : on Piscataquis T., 54 m. N. Augusta.

ABвotr's CrEeE, p. o., Davidson co., N.Oar. : on a cr. of the same name, $94 \mathrm{~m}$. W. Raleigh.

Аввоттsто wN, p. v., Adams co., Penn. : on Beaver cr., $42 \mathrm{~m}$. 8. 8. W. Harrisburg.

Aввоттвville, p. v., Darke co., Ohio: $94 \mathrm{~m}$. W. Columbug.

$\triangle$ BB'B VALLET, p. o., Tazewell co., Virg.: at the head of Tug fork of Sandy $\mathrm{r}_{\mathrm{n}}, 223 \mathrm{~m}$. W. S. W. Richmond.

Aberdezer, p. F., Monroe c0., Miss.: W. side Tombigbee $x$., $142 \mathrm{~m}$. N. E. Jackson. Two newspapers, the "Monroe Democrat," and the "Independent," are issued weekly.

ABERDEET, p. V., Brown co., Ohio: on Ohio r., opposite

Maysville, Ky., 86 m. 8. \&. W. Columbus. Pop. 807.

ABERTOII, p. V., Macon co., Ala.: on a head er, of Pea

r., $84 \mathrm{~m}$. E. S. E. Montgomery.

ABE SPRIXG, p. 0., Calhoun co., Flor. : 71 m. S. W. Tallahassee.

ABINGDor, p. p., Lake co., $I Z$.: on Des Plaines r., 208 m. X. E. Springfield.

ABmseDor, p.. ., Harford co., MId.: on W. side Bush cr., 87 m. N. N. E. Annapolis.

AsmGDOs, p. ₹., and cap. Washington co., Firg.: on a cr. of Holston x., $252 \mathrm{~m}$. W. S. W. Richmond. It contains the county buildings, several factories and stores, and about 300 dwellings. Two newspapers, the "Democrat" and "Virginian," are issued weekly.

Abington, p. v., Windham co., Conn.: S. of and near Mashamugit br. of Quinnebaug r., 42 m. E. N. E. Hart ford.

Abisetor, p. t., Wayne co., Ind.: on W. bank of E. fork of White r., $56 \mathrm{~m}$. E. Indianapolis.

ABINGron, to and p. v., Plymouth co, Mass, : on Old Colony R. R., $19 \mathrm{~m}$. S. Boston. The people are chiefly engaged in shoemaking. Pop. 5,269.

Abington, p. t., Montgomery co., Penn. : 94. m. E. Harrisburg.

Abington Centre, p. v., Lucerne co., Penns: (see WA. VERLY).

Aвогт, t. and p. v., Allen co., Ind.: on Aboite cr. of Little $\mathrm{r}_{0}, 96 \mathrm{~m}$. N. N. E. Indianapolis.

abrahamtown, p. vo, Marion co., Filor.

Abram's Plates, po o., Granville co., N. Oar.: $48 \mathrm{~m}$. N. Raleigh.

Авsсота, p.. ., Calhoun co., Mich. : 38 m. S. Lansing.

Assecum, p. v., Atlantic co., N. Jer.: on Absecum cr., 2 m. above the bay, and $61 \mathrm{~m} . \mathrm{S} . \mathrm{S}$. W. Trenton.

Aosdema, p. v., Knox co., Tenn.: on Bullrun er. of Clinch r., $153 \mathrm{~m}$. W. Nashville.

Academia, p. v., Juniata co., Penn.: $81 \mathrm{~m}$. W. Harrisburg.

Aсаремт, p. 0., Ontario co., $. N . Y_{0}: 180 \mathrm{~m}$. W. Albany. Accativk, p. v., Fairfax co., Virg.: 93 m. N. Richmond.

ACCDDET, p. v., Alleghany co., Md.: on Youghiogeny r., $2 \mathrm{~m}$. below Pennsylvania line, and $168 \mathrm{~m}$. W. N. W. Annapolis.

Accomac county, Virg. Situate on E. shore of Chesapeake Bay, and contains $480 \mathrm{sq} . \mathrm{m}$. Several islands in the adjacent waters belong to this county. Surface level, and soil mostly sandy. Corn and oats are the chief products, and some small quantity of cotton is grown. Farms 1,007; manuf. 17; dwell. 2,540, and pop.-wh. 9,742, fr. col. 3,161, sl. 4,98i-total, 17,890. Capital: Accomac C. $\mathbf{H}$.

Accomac Court-house, p. v., and cap. Accomac co, Virg : near the centre of the peninsula. so called DruMMONDSTOWN.

Accord, p. v., Ulster co., N. Y.: on Rondout cr., $64 \mathrm{~m}$. S. S. W. Albany.

Acror, p. v., Columbiana co., Ohio: 182 m. E. N. E. Ca lumbus.

AckworTH, p. $\nabla .$, Cobb co., Ga.: $92 \mathrm{~m}$. N. W. Milledgeville.

Ackwortr, t. and p. v., Sullivan co., N. Hamp.: on $\mathbf{N}$. side of Cold r., and $36 \mathrm{~m}$. W. Concord. Pop, 1,251. 
Aceuacranosck, t. and p. v., Passaic co., N. Jer.: at head of navigation of Passaic r., $61 \mathrm{~m}$. N. E. Trenton.

Aceunston, p. v., King William co., Firg.

ACrA, p. v., Greene co., N. Y.: $37 \mathrm{~m}$. S. S. W. Albany.

Acton, p. t., York co., Me.: near the head waters of Sal mon Falls r., $80 \mathrm{~m}$. S. W. Augusta. Pop. 1,359 。

Acton, t. and p. v., Middlesex co., Mass.: on N. of Stow r., $23 \mathrm{~m} . \mathrm{N}$. W. Boston. Pop, 1,605,

ACtON CORNer, p. O., York co., Me.: 83 m. S. W. Augusta.

ADA, t. and p. V., Kent co., Mich.: at the junction of Thorn Apple and Grand rivers, $48 \mathrm{~m}$. W. S. W. Lansing.

ADAIEs, p. v., Nachitoches par., La.: on a er. of Spanish Lake, 148 m. W. N. W. Baton Rouge.

ADAIR county, $K y$. Situate $\mathrm{S}$. centrally, and contains 440 sq. m. Drained by affluents of Green and Cumberland rivers. Surface hilly and broken; soil various, but of arerage fertility. Wheat, corn, oats, and tobacco are the principal products, and some cotton. Farms 1,010; manuf.19; dwell. 1,513, and pop.-wh. 2,28s, fr. col. 108, sl. 1,707-total, 9,898. Capital: Columbia.

ADATR county, Mo. Situate N. E., and contains $560 \mathrm{sq}$ m. Drained by the head waters of numerous rivers flow. ing to the Mississippi, and by Chariton r., which passes through it. Surface level, and chiefly prairie or bottoms: soils fertile. Farms 326 ; manuf. 5; dwell. 393 , and pop. -wh. 2,288, fr. col. 8, sl. 51-total, 2,342. Capital: Kirlssville.

ADATR county, $I \alpha$. Situate S. W., and contains $576 \mathrm{sq} . \mathrm{m}$. Taken from Pottowottamie in 1851.

Adarnsvinle, p. v., Cass co., Ga.: on N. W. of county, and $183 \mathrm{~m}$. N. W. Milledgeville.

Adatrovilue, p. v., Logan co., Ky.: on E. side Whippoorwill cr., $164 \mathrm{~m}$. W. S. W. Frankfort.

ADAMs county, $\pi l$. Situate W. on Mississippi r., and contains 760 sq. m. Drained by Bear cr. and several streams tributary to the Illinois. Surface level or undulatingchiefly prairie: soils very rich, producing wheat, Indian corn, oats, etc., abundantly, and some tobaceo. Farms 2,294; manuf. 118 ; dwell. 4,459, and pop.-Wh. 26,370, fr. col. 138-total, 26,508. Capital: Quincy.

ADAMs county, Ind. Situate N. E, and contains $336 \mathrm{sq}$. m. It is drained in the N. by St. Mary's r., and in the S. by the Wabash. Surface generally level, but near the riv. ers undulating, mostly covered with timber. Soil marly clay, and very fertile, producing large quantities of wheat, Indian corn, and hay; and horses, cattle, and hogs are exported. Farms 5i6; manuf. 11; dwell, 1,002, and pop.wh. 5,789, fr. col. 8-total, 5,797. Capital: Decatur.

ADAus county, $I a^{-}$- Situate $\mathrm{S}$. W., and contains $432 \mathrm{sq} . \mathrm{m}$. Taken from Pottowottamie in 1851.

ADAMs county, Mfiss. Situate S. W. on Mississippi r., and contains $44 \mathrm{~s} \mathrm{sq}$. m. Drained by the Homochito $\mathrm{r}$. and other streams. Surface moderately hilly, except in the neighborhood of the river, where there are extensive allavial tracts. Indian corn and cotton are the principal prom ducts. Farms 136; manuf. 15; dwell. 900, and pop.-wh. 3,952, fi. col. 255, sl. 14,415-total, 18,622. Capital: Washington. Public Works: Natchez and Malcolm R. R.

Adass county, Otio. Situate $\mathrm{S}$. on Ohio r, and contains $560 \mathrm{sq}$. m. Drained chiefly by Brush cr. Surface somewhat hilly, and the soils of average fertility. The principal products are wheat, Indian corn, and oats. Iron ore of fine quality is found in this county. Farms 1,509 ; manuf. 26 ; dwell 3,205 , and pop.-wh. 18,828, fr. col. 55-total, 18,853 . Capital: West Union.

Adars county, Penn. Situate S., and contains $528 \mathrm{sq}$. m. Drained by Conewaga cr. and the head waters of Monocacy $\mathbf{r}$. Surface uneven, and soils fertile. Wheat, Indian corn, and oats are the chief products. Farms 1,902; manuf. 124; dwell. 4,356, and pop.-wh. 25,426, fr. col. 555 -total, 25,981. Capital: Gettysbarg.

ADdus county, Wisc. Situate centrally, and contains
2,376 sq. m. Drained by tributaries of Wisconsin $r_{\text {. }}$ which runs through it. Surface undulating and. well wooded with a soil of great fertility. Farms -; dwell. 40, and pop. 187. Capital:

Adans, p. v., Irwin co., Ga.: $86 \mathrm{~m}$. s. Milledgeville.

ApaMs, t. and p. v., Berkshire co., Mass.: on Hoosic r., $191 \mathrm{~m} . \mathrm{N}: \mathrm{N}$. W. Boston. Pop, 6.172 .

AdAss, to and po v., Hillsdale eo., Mich. : $62 \mathrm{~m}$. S. Lansing. ADAMrs, p. v., Adams co., $I l_{*}: 84 \mathrm{~m}$. W. Springfleld.

ADAMs, t. and p. v., Jefferson co., N.Y.: on Sandy cr., 146 m. W.N. W. Albany. The Watertown and Rome R. R. runs by the village. Pop. of t. 3,106.

ADAMs, t. and p. v., Seneca co., Ohio: on a cr. of Sandusky r., $84 \mathrm{~m}$. N. Columbus. Pop. 1,416 .

ADAMs, p. v., and eap. Sauk co., Wisc.: on Baraboo r., 42 m. N. W. Madison.

ADAMs, p. v., Walworth co., Wisc.: 61 m. S. E. Madison. Adays Basiv, p. v., Mouroe co., N. Y.: on Erie Canal, $198 \mathrm{~m}$. W. Albany.

Adarsburg, p. vi; Westmoreland co., Penn.: on a cr. of Youghiogeny r., and near the Pennsylvania $R . R_{.}, 14 \hat{0}$ m. W. Harrisburg. Pop.'307.

ADAMsBurg, p. v., Gasconade co., Mo.: on Au Bøuf r., $36 \mathrm{~m}$. E. Jefferson City.

ADAMs' Centre, p. v., Jefferson c̀o, N. Y.: $144 \mathrm{~m}$. W. Albany.

ADAKs' Mruis, p. o., Pulaski co., Ky.: 81 m. \$. E. Frankfort.

ADAMs' MrLls, p. v., Muskingum co., Ohio: on Ohio Ca. nal, $61 \mathrm{~m}$. W. Columbus.

ADAMS' RuN, p. o., Colleton dist., S. Car.

A daxstown, p. v., Frederiek co., Ma.: on Monocacy r., $59 \mathrm{~m} . \mathrm{N}$. W. Annapolis

Adamstown, p. v., Lancaster co., Penn. : at the head of Conestoga cr., $43 \mathrm{~m}$. E. Harrisburg.

Ada ms vilue, p. v., Franklin co., Mass. : $79 \mathrm{~m}$. W. Boston. Ada Mrgvilue, p. V., Cass co., Mich.: on Christiana r., 68 m. S. W. Lansing.

Adaksvilie, p. v., Muskingum co., Ohio: 59 m. E. Columbus.

Adamsvicle, p. v., Crawford eo., Penn。: 216 m. N. W. Harrisburg,

ADAMSVILle, p. Y., Morgan co., Ky. : 98 m. E. Frankfort. AdaMsviLle, p. v., M'Nairy co., Tenn。: 119 m. S. W. Nashville.

ADANSFILLe, p. v., Newport co., R. I.

ADaMstule, p. v., Washington co., N. $Y_{0}: 48$ m. N. Albany.

Adario, p. v., Richland co., Ohio: 69 m. N. N. W. Columbus.

ADDISon county, Verm. Situate W. on Lake Champlain, and contains $724 \mathrm{sq}$. m. Drained by Otter er. and Mad and White rivers. Surface finely variegated by hill and dale. In the $\mathbf{E}$, it is mountainous, and the soils good, especially those near the lake and rivers. A beautiful white marble is quarried at Middlebury. Wheat, Indian corn, and potatoes are the chief products. Farms 2,292 ; manuf 157 ; dwell, 4,679, and pop.-wh. 25,426, fr. col. 108-total, 26,549. Capital: Middlebury. Public Works: Rutland and Burlington R. R.

ADDISON, p. v., Washington c0., Wisc. : 54 m. E. Madison. AdDison, p. v., Du Page co., $M l l .: 168$ m. N. W. Springfield.

Adpison, t. and p. v., Steuben co., N. Y.: on Canisteo r., 179 m. W. S. W. Albany. Pop. 3.721

AdDIsor, p. v., Gallia co., Ohio: on Ohio r., 89 m. S. E. Columbus.

Andrex, t. and p. v., Somerset co., Penn.; on the Youghiogeny r., $2 \mathrm{~m}$. from State line, and $13 \mathrm{~s} \mathrm{~m}$. W. S. W. Harris burg.

ADDISON, t. and p. vo, Addison co., Term. : near Lake Champlain, and $46 \mathrm{~m}$. W. N. W. Montpelier. Pop, 1,279 ADdrsos Ponst, p. 0., Washington co., Mife. 
ADEINE, p. r., Ogle co., $\Pi l .:$ on Leaf r., a tributary of Rock r., $17 ! \mathrm{m}$. N. Springficld.

AdexL, p. v., and cap. Dallas co., Ia.: on Raccoon er. of Des Moines r., $132 \mathrm{~m}$. W. Iowa City.

AdELPHT, p. T., Ross co., Ohia: on a cr. of Scioto r., 37 m. S. S. W. Columbus.

ADmoxDACK, p. v., Essex co., $N_{0} Y_{.:}$near the sources of Adironduck r., 1,800 feet above the ocean, and famous for the deposits of magnetic iron ore in its vicinity; $95 \mathrm{~m}$. ז. Y. IF. Albany.

ADRONDACK mountains, $N . \bar{Y}$ : a cluster of mountains S. W. of Lake Champlain. Mt. Marcy, one of the peaks, is 5,467 feet high, and there are others ranging from 3,000 to 5,000 feet. In general altitude they are little inferior to the White Jountains of New Hampshire, and, like them, abound with the most magnificent scenery.

ADRONDACK river, $N . Y_{.}$: oue of the head branches of the Hudson r., rising in the Adirondack mts. It is about 20 miles long, and flows through lakes Henderson and San. ford, which are 1,900 feet above the ocean.

ADMBALTX INLET, Oreg.: an inlet or natural canal of Puget's Sound, in the N. W. part of the Territory, and cmptring into the Straits of San Juan de Fuca.

ADOLPE, p. V., Chatham co., N. Car.

ADrux, p. v., and cap. Lenawee co., Mich. : at the junction of Beaver cr. and Raisin r., and on the Southern R. R., $86 \mathrm{~m}$. S. E. Lansing. It is a flourishing village, with several mills and factories. Two newspapers are issued, the "Watch-Tower," weekly, and the "Family Favorite," monthly. Pop. of t. $3,0 n 9$.

ADrTarce, p. v., Dutchess co., $\boldsymbol{N}_{0} \boldsymbol{Y}_{\text {: : }}$ on the Hopewell settlement, $79 \mathrm{~m}$. S. Albany.

AgAuEATCU mountain, $M e_{0}$ : three elevations in York co., $4 \mathrm{~m}$. from the sea, and a noted landmark. The highest summit has an elevation of 673 feet.
Agawau, p. v., Hampden co., Muss.: on W. side of' C'r: necticut r., $74 \mathrm{~m}$. W. Boston. It has several mills and fâttories.

Agevox Crex, p. v., Wapello co, Ia.: 61 m. S. W. Iowa City.

AGNeW's Mills, p. o., Venango co., Penn。: 168 m. N. W. Harrisburg.

At, p. V., and cap. Fulton co., Ohio: $132 \mathrm{~m}$. N. W. Co lumbus.

Am, t. and p. .., Lawrence co., Orio: on Symmes cr. 92 m. S. S. W. Columbus. Pop. 881.

AIKen, p. v., Barnwell dist., S. Car.: on S. side Shaw's cr. of Edisto r., $54 \mathrm{~m}$. S. W. Columbia, and on the line of the S. Car. R. R., 120 m. W. Charleston. Pop. 800 .

Aukin's Stork, p. o., Montgomery co., Ark. : 67 m. W. S. W. Little Rock.

Alr Mount, p. o., Clark co., Ala.: 102 m. W. S. W. Montgomery.

Akron, p. v., Erie co., $N_{0} Y_{0}$ : on Muddy er., 261 m. W Albany.

A kron, p. vo, and cap. Summit co., Ohio: on Little Cuyahoga $r$, at the junction of the Ohio and Erie, and Ohio and Pennsylvania Canals, and at the terminus of the Akron branch of Pittsburg and Cleveland $R . R$. The village has numero industrial establishments and considerable trade. Two newspapers, the "Summit Beacon," and the "Free Democratic Standard," are issued weekly. Pop. $3,226$.

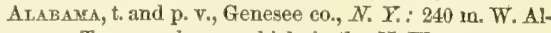
bany, on Tonawanda cr., which, in the N. W. part of the town, furmishes a feeder to the Erie Canal. Pop. 2,054.

AlABAMA river, Ala.: is formed by the union of the Coosa and Tallapoosa, and flowing S. W., it unites with Tombigbee r., forming Mobile r., $48 \mathrm{~m}$. above Mobile Bay. It affords, in connection with its branches, a great line of interior navigation.

\section{THE STATE OF ALABAMA.}

ALABAvi is bounded on the north by Tennessee, on the east by Georgia and Florida, on the south by Florida and the Gulf of Mexien, and on the west by Mississippi, and extends generally between latitudes $31^{\circ}$ and $35^{\circ}$ north, and longiturles $55^{\circ} 11^{\prime}$ and $55 \circ 31^{\prime}$ west from Greenwich, or $8005^{\prime}$ and $11029^{\prime}$ from Washington; a narrow strip, however, extends gouth berond the main body of the State betreen Florida and Mississippi, reaching the Gulf of Mexico, which it strikes in about 30 2 10'. Its length from north to south, excluding the strip of land above mentioned, is 228 miles, and its breadth varies from 146 miles on the north line to 210 on the south line; and the area of the State is 50,722 square miles.

The north-eastern part of Alabama, being traversed by several ridges of the Alleghanies, which terminate in this State, is decirledly mruntainous, bat presents nowhere any considerable elevations. South of this mountain region the surface has a general declivity toward the Gulf of Mexico, first descending gradually from mountains to high hills, and then Einking to a rast plain, scarcely broken except by gentle swells; and the more southern portion is a dead level, but little above the water surface of the ocean. The southern half of the State consists of extensive prairies and pine-barrens, interspersed with alluvial river bottoms of great fertility; and the lands of the centre and north are generally covered with a good if not a very rich and productive soil. In the valley of the Tennessee, which occupies so large an area in the northern part of the State, allurion is the prevailing formation; and the rich bottom-lands of this region are extensive, and form one of the richest agricultural districts within the limits of the State.

With the exception of the Tennessee, which takes a circular sweep through Northern Alabama, but receives no considerable tributary on its southern. side, all the rivers flow into the Gulf of Mexico; nearly the whole surface, indeed, is drain in into one single channel, the Mobile River, which by several large arms gathers up the watars of the wholo southern slope, except those of a comparatively small tract in tho south-east. The Chattahoochee although a large sfream, and Washing the eastern border for more than a hundred miles, receives only a few inconsiderable streams from this State; and the Choctawhatchee, Conecuh, and Perdido are, in point of size, secondary rivers. The Mobile, the great river of 1 laliama, is formed by the junction of two large rivers, the Alabama and Tombigbee, 50 miles above Mobile Bay. A f $-\mathrm{w}$ miles below its junction it gives out a large branch, called the Tensaw, which receives also an arm from the Alabama, and racheg Mobile Bay at Blakely. The Tombigbee, or Western Branch of the Mobile, is formed by the confluence of two large streams, the Tombigbee Proper from Mississippi, and the Black Warrior from Northern Alabama. It admits vessels drawing five or six feet of water to St. Stephens, 93 miles from the bay, and steamboats to Tuscaloosa, on the Black Warrir, 255 milas, and to Columbus, on the Tombigbee Proper, in Mississippi, about 300 miles. The length of this river, by its tortuous channel, is about $450 \mathrm{miles}$, and it is boatable almost to its sources. The Alabama, or Eastern Branch, is navigathe fror tessels rf six feet draft to Claiborne, 60 miles above its junetion with the Tumbigbee; 150 miles farther, to the mouth of the Cahawba, it has four or five feet of water, and to the junction of the Coosa and Tallapoosa, of which it is firras, it has in the shallowest parts three feet of water. Steamboats ascend it to Montgomery, 300 miles by the course of the river, and even to Wetumpka, on the Coosa, several miles above. The Coosa and Tallapoosa both have their rise in freorgia. The navigation of all these rivers, however, is interrupted during the season of low water in the summer months, and at best affords only a precarious means of transport for merchandise.

The sea-coast of Alabama extends only from the Perdido to the western line of the State, a distanee of some 60 milos, but it contains Mobile Bay, one of the largest and deepest basins on the Gulf, and the great outlet of the navigable wa- 


\section{ALABAMA.}

ters of the State. This fine sheet of water is about 30 miles long, and from three to 18 miles broad, and the main en trance has 15 feet of water at low tide, but vessels of more than eight or nine feet draft cannot approach nearer than 10 or 11 miles from Mobile City, except at high water. Smaller vessels may go hence to New Orleans by an inland channel through Pascagoula Sound, a long, narrow lagoon, lying between a range of low sand-islands and the mainland. Perdido Bay, on the south-eastern edge of the State, is of little consequence to commerce, and is, moreover, difficult of access, on account of the sand-bars and islands which block its entrance to the sea.

Alabama has great mineral resources. The whole central region is underlaid with vast beds of iron ore, or occupied by coal measures of great thickness and extent. The coal found here is of a highly bituminous eharacter, and well adapted for steamboats and factories, and being in juxtaposition with the iron ores, will greatly facilitate the progress of mining industry. The country in this region is also well wooded, fertile, and easily attained from all directions, and in the succession of events must eventually become of great importance to the whole South. Bloomeries and rolling mills, with other establishments for manufacturing iron, have already been erected, and the products of these have become both extensive and valuable. The principal seats of these operations are on the Cahawba and Coosa rivers. Besides coal and iron, Alabama yields lead ore, manganese, several descriptions of ochres, limestone, and marbles, and in the north-eastern section gold in considerable quantities has been collected. Lead ore, or galena, is found in the limestone formation, chiefly in Benton County: it is a pure sulphuret and granular, closely attached to the rock, and passes it in irregular bunches. The carbonate is also found, and in its neighborhood there are veins of calx spar and sulphate of barytes. Manganese ocours also in the limestone region, and has been used in the manufacture of chloride of lime. The ochres occur chiefly near Bucksville, and the red ochre found here is sufficiently rich to be used as an ore of iron. 'The marbles found in this State occur most plentifully on the Cahawba, and many of the beds afford specimens of great beauty: some are gray, with red veins; others are red and yellow, and specimens with greenish veins are not uncom. mon. There is also a buff-colored marble, filled with organic remains, and beds of white crystalline marble, clouded with red, occur. Black marble is also abundant. The compactness and thickness of these formations are such as to elicit a farorable opinion of their value, and cause them to be looked upon with great interest in connection with the industrial resources of the State. The resources of Alabama, however, have never been thoroughly examined; but there can be little doubt, taking the present knowledge of its mineral deposits as an index, that the researches now being instituted, will result in further and more valuable diselosures of a vast wealth of mineral within its borders, and be the means of placing the State in the first rank of mineral-producing districts.

The soil, climate, and vegetation of Alabama vary with the position and elevation of its several parts. In the north, where mountain is the prevailing feature, the soil is but moderately fertile, but in the intervales there is much that cannot be excelled. The climate is here moderate, and the regetation hardy: it is the region of the cereals, and a fine grazing country. The central parts of this State, less elevated and undulating, are well watered, and in the river-bottoms the land is extremely rich and productive. The valley of the Alabama is one of the most fertile regions of the Union. In the south the climate is very warm, the soils xich, but with great exceptions, and the principal grow ths of a tropical character. The sugar-cane has been found to succeed well in the extreme southern strip between Florida and Mississippi, and indigo was formerly raised in considerable quantities; rice, also, grows well in the alluvial bottoms near the Gulf; but cotton, which thrives throughout the State, is the great agricultural staple. The natural growths and animals are in no way different from those of the neighboring States on the Gulf of Mexico. The most common of aximals is the deer, and the country abounds in turkeys, partridges, geese, ducks, and various other species of smaller game; and fish in abundance may be taken in the rivers and bays.

Alabama was comprised within the limits of Georgia until 1502, when that State ceded her lands west of Chattahoochee river to the United States; and in 1817 Alabama was separated from Mississippi, and erected into a Territory; in 1820 it was admitted into the Union as an independent State. In 1810 the population was scarcely 10,000, but since then its growth has been extremely rapid, there having been a constant tide of immigration, chiefly planters, from the Atlantic States, In 1820 it contained 127,901 inhabitants; in $1830,309,527$; in $1840,590,756$; and in 1850, 771,671 , of which 426,507 were white persons, 2,272 free colored, and 342,892 slaves.

In 1850 the State was divided into two districts, the "Northern" and the "Southern." The Northern District comprised the counties of Benton, Blount, Cherokee, De Kalb, Fayette, Franklin, Ilancock, Jackson, Jefferson, Lauderdale, Lawrence, Lewistown, Madison, Marion, Marshall, Morgan, St. Clair, and Walker; and the Southern District, the eounties of Autauga, Baldwin, Barbour, Bibb, Butler, Chambers, Choctaw, Clarke, Coffee, Conecub, Coosa, Covington, Dale, Dallas, Green, Henry, Lowndes, Macon, Marengo, Mobile, Monroe, Montgomery, Perry, Pike, Pickens, Randolph, Russell, Shelby, Sumter, Talladega, Tallapoosa, Tuscaloosa, Wilcox, and Washington. The 18 counties in the north contained 214,666 inhabitants, of which 151,690 were whites, 495 free colored, and 62,481 slaves; and the 34 counties in the south, 557,005 , of which 274,817 were whites, 1,777 free colored, and 280,411 slaves. Deaf and dumb, in the whole State, 211; blind, 308; insane, 215, and idiotic, 505.

Alabama is principally engaged in agricultural pursuits; but it has also an increasing manufacturing interest, and a flourishing commerce. Its principal agricultural staples are cotton and sugar; and its chicf manufactures are coarse cotton fabrics, iron, machinery, agricultural implements, carriages, etc. The statistics of its various interests in 1850 were as follows:

Occupied Lands, etc.-Improved lands, 4,435,614 acres, and unimproved, 7,702,067 acres, valued at \$64,323,224. Number of farms, 41,964 Value of farming implements and machinery, $\$ 5,125,663$.

Live Stock.-Horses, 120,001; asses and mules, 59,895; milch cows, 227,291; working oxen, 66,961; other cattle, 483,263 ; sheep, 371,880 ; and swine, $1,904,540$-valued at $\$ 21,690,112$.

Products.-Wheat, 294,044 bushels; rye, 17,261; Indian corn, 28,754,01s; oats, 2,965,697; barley, 3,958; buckwheat, $31 \mathrm{~S}$; peas and beans, 892,701 ; Irish potatoes, 246,001 ; sweet potatoes, $5,475,204$ bushels ; rice, $2,311,252$ pounds; tobacco, 164,990 pounds; ginned cotton, 564,429 bales of 400 pounds; hay, 32,655 tons; clover seed, 138 bushels, and other grass seed, 547 ; hops, 276 pounds; water-rotted hemp, 70 tons; flax, 3,341 pounds ; flaxseed, 67 bushels; maple sugar, 613 pounds ; cane sugar, $5.2 \pm 2$ hogsheads of 1,000 pounds; molasses, 83.429 gallons; wine, 220 gallons ; ralue of products of orchard, $\$ 15,408$, and of market-gardens, $\$ S 1,821$; beeswax and honey, 897,021 pounds; silk cocoons, 167 pounds; rool, $65 i .115$ pounds; butter, $4,008,811$, and eheese, 81,412 pounds; and the value of animals slaughtered, $\$ 4, \$ 23,455$. Home-made manufactures were valued at $\$ 1,931,120$.

Manufactures_-Aggregate capital invested, $\$ 00,000,000$; value of raw material, fuel, etc., consumed, $\$ 00,000,000$; average number of hands employed, 00,000 -males, 00,000 , and females, 00,000 ; average monthly cost of male labor, 


\section{ALABAMA.}

$\$ 000,00$, and of female labor, $\$ 00,000$; annual valte of products, $\$ 00,000,000$. The whole number of manufacturing establishments, producing to the value of $\$ 500$ and upward annually, was 1,022-in the north, 341, and in the south, 681 ; and of these, 12 were cotton factories, using 5,208 bales of cotton; 10 were engaged in manufacturing eastings, 3 in the manufacture of pig-iron, and 1 in that of wrought iron. Capital employed in cotton factories, $\$ 651,900$; value of all raw material, \$23T.081; average number of hands -346 males, and 369 females; wages, per month-to males, $\$ 4,053$, and to females, $\$ 2,946$; ralue of products for the year, $\$ 352,260$, the products being $3,081,000$ yards sheeting, ete., and 790,000 lbs. rarn. Capital employed in cast-iron manufacture, $\$ 216,625$; value of raw material, $\$ 102,085 ;$ hands employed, 212. at arerage rages $\$ 30$ 05 per month; castings made, 1,915 tons; value of all products, $\$ 271,126$. The other departments of iron making-the manufactures of pig iron and wrought iron are comparatively insignificant; of the first, 522 tons were manufactured; and of the latter, 100 tons during the year. The remaining branches of the indastrial pursuita of dlabama are generally such as are required in an agricultural country. In Mobile, and some of the larger interior towns, however, there are large mechanic and machine shops, carriage factories, etc.

Foreign Commerce and Nitrigation-Exports.-Domestic produce, in American vessels, $\$ 4,601,515$, and in foreign ressels, $\$ 5,943.343$, or a total of $\$ 10,511,553$. Imports - in American vessels, $\$ 108,134$, and in foreign vessels, $\$ 757,228$, or a total of $\$ \$ 65,362$. Shipping employed in the foreign carrying trade: Entrances, 152 ressels, and 96,020 tons, with crews of 4,2S4 men, and 217 boys; of which, 40 vessels and 11,914 tons, with crews of 431 men and 13 boys, American; and, Clearances, 152 vessels, and 112,955 tons, with crews of 4,639 men and 281 boys-of which, 76 vessels, and 39,263 tons, with crews of 983 men and 41 boys, American. Mobile is the only port open to the foreign trade. Shipping omned within the state, 24,157 tons - of which, 1,405 tons, is registered "permanent," and 5,998 tons registered "temporary;" 16,003 tons is enrolled and licensed "permanent," and 751 tons is "licensed under 20 tons," The shipping narigated by steam is $12,02 \mathrm{~S}$ tons, chiefly employed on the rivers. During the year, three schooners of 113 tons were built. The following table will exhibit the movement of foreign commerce in this State, from 1818 to 1851 :

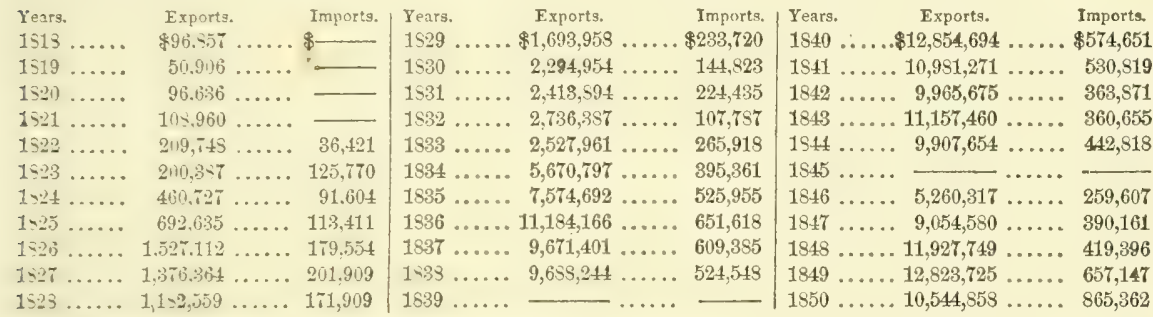

Internal Trate and Conmunication.-The greater part of Alabama as yet depends on wagons over common earth roads, for the transportation of its productions and supplies; and those places distant from the rivers and railroads are consequently almost isolated from the commercial world. The river navigation, however, is extensive, in its various courses measuring at least 2,000 miles. The great body of the products of the State find their way to Mobile, the commercial emporium; some are shipped by the Chattahoochee, for Apalachicola, and some-but in a smaller degree-by Tennessee Piver, to the Ohio, whence they are conveyed to New Orleans by the Mississippi, or by way of the Illinois Canal and the great lakes to a northern market. The cotton crop, passing in these various channels, may be estimated at one seventh the whole by the Chattahoochee, one sixteenth by the Tennessee, and the remainder by the system of rivers centering at Mobile Bay. The progress of the State in building railroads is as yet limited; the great line from Mobile to the Ohio River is completed within Alabama, and is progressing in Mississippi; the Tuscumbia and Decatur Railroad, now merged into the Charleston and Memphis Railroad, crosses the State in the north; the Alabama and Tennessee Rirer Railroad, 209 miles long. extends from Selma to Guntersville; the Montgomery and West Point Railroad is $86 \mathrm{miles}$ long, an'? there are several other important lines chartered, and some in progress: these have been of comparatively small benefit as yet, but when opened for commerce, and their exterior connections built, the effect they will have in stimulating production and consumption, will be felt in every direction-the latent mineral wealth of the State will be disentombed, the fine cotton lands on the rivers will be entered and cultivated, mechanio trades will be demanded everywhere, and the whole country will experience a beneficial change in its material welfare. Besides these avenues of commerce, Alabama has two canals, the "Muscle Shoals Canal," and the "Huntsvillo Canal " the former 35. miles long from Florence, along the morth bank of the Tennessee, and designed to overcome the obstruction caused by the shoals; and the latter extending from Triana on the Tennessee, 16 miles, to Huntsville.

Bunk:-In January, 15\% 0 , there was one bank in the State-the Bank of the State of Alabama-with branches at the principal points. Its aggregate condition, as published in the General Bank returns by the Federal Government, is exhibited in the following figures: Assets-loans and discounts, $\$ 2,116,591$; stocks, $\$ 71,018$; real estate, $\$ 152,601$; other investments, $\$ 1,229,201$; due by other banks, $\$ 928,209$; notes of other banks, 16,029 , and specie, $\$ 1,307,392 ;$ and liabilitis -rapital, $\$ 1,5(f), 000$; circulation, $\$ 2,553,563$; deposits, $\$ 1,216,319$; due other banks, $\$ 20,740$; and other liabilities, $\$ 395,124$.

Government. - The Constitution provides that every white male citizen of the United States twenty-one years of age, a resident of the State one year, and in the county, city, or town three months next preceding, may vote for the election of all constitutional officers. The executive power is vested in a Governor, who is chosen by a plurality of votes for two years; he must be at least thirty years of age, a citizen of the United States, and have resided in the State four years. The Gearal Asembly consists of a Senate and House of Representatives: the Senate of 33 members, elected for four years, rres half biennially, and the frouse of 100 members, elected for two years. The qualiflcations extend only to age and residence. The Assembly meets in Montgomery on the second Monday in November every second year, commencing 1827. The Judiciary consists of a Supreme Court, with a Chief Justice and two associate Justices, a Reporter, Attorney General, and Clerk; a Court of Chancery, with separate chancellors for the three districts of the State; nine Cireuit Courts, each with a Judge., Solicitor, etc.; County, or Probate Courts, etc. The judges of the Supreme and Chancery Courte are elected by joint vote of both houses of the legislature for six years 'Tbe Supreme Court has appellate juris 
diction only, and holds its sessions at the capital, annually, on the first Monday of January and June, for the hearing and determining points of law taken by appeal or writ of error from the Chancery, Cireuit, and Probate Courts. The volumes of reported decisions are 37 in number. For chancery legislation the State is divided into 3 Divisions and 87 Districts, in each of which at least one court is held annually. Circuit courts have jurisdiction in all civil and criminal cases in the State, and hold two sessions (spring and fall), in each connty annually. In Mobile county criminal jurisdiction has been transferred to the Special City court of Mobile, which holds three terms each year, and has concurrent jurisdiction with the Circuit Courts, except in real actions. The judges of probate are also clerks of the court and registers of deeds for their respective counties.

Alabama, under the law regulating the distribution of Representatives to Congress, has a delegation of seven members.

Finances.-On the 31 st December, 1849 , the foreign debt of the State amounted to $\$ 6,693,88898$, and the domestic debt to $\$ 1, \$ 45,22099$-total debt $\$ \$, 539,10997$. The annual liabilities of the State are-interest on debt $\$ 418,627 \mathbf{7 0}$, and the estimated current expenses of the government $\$ 97,67 \mathrm{~S}$ - total $\$ 516,30570$. The immediate means of the treasury on the 1st Nov., 1\$49, were-balauce from former dates $\$ 538,79244$, taxes for $1850 \$ 487,9 \$ 74$, and interest on $\$ 1,100$, $000 \mathrm{U}$. $\mathrm{S}$. 6 per cent. stock owned by the State $\$ 66,000$-total $\$ 1,092,77992$, from which deduct annual disbursements, and the balance will be $\$ 596,47422$, of which $\$ 438,016$ is the amount nf notes of the State bank in the treasury. The real balance then is $\$ 17,45822$, which sum is morever liable for $\$ 60,000$, appropriated for the rebuilding of the State House, burnt in Dec., 1849. The State has resources besides the U. S. stock, and the treasury balance above alluded to, amounting to $\$ 1,766,90764$, its interest in the State bank, etc., all which may be applied to the discharge of the public debt.

Religions Denominations.-The statisties of the principal denominations, according to their own returns in 1850 , were as follows: Presbyterians, 85 churches, 52 ministers, and 4,280 members; Protestant Episcopal, 19 churches, 23 ministers, and 718 members; Methodist Episcopal, 573 ministers, and 48,091 members; Baptists, 516 churches, 302 ministers, and 36,421 members; Roman Catholies, 11 churches, 20 ministers, and 9,000 members, etc. The Protestant Episcopal Church is under the Bishop of Alabama, and the Roman Catholic Church under the Bishop of Mobile, the see of the latter including also West Florida. Besides these, the minor churches are all more or less in existence.

Education.-Alabama has not been unmindful of the education of its citizens, and has many highly efficient educational establishments. Besides its primary and common schools, academies, ete., which are comparatively numerons, there are the University of Alabama, at Tuscaloosa, founded in 1838; La Grange College, founded in 1830; Spring Hill College, founded in 1830; Howard College, at Marion, founded in 1841, and others of various distinction. The University had in 1850, 9 teachers, 107 alumni, of which 16 were ministers, and 91 students-and a library of 7,123 volumes; the college at La Grange had 6 teachers, 111 alumni, and 70 students-and a library of 3,700 rolumes; the college at Spring Hill had 12 teachers and 70 students-and a library of 4,000 ; and Howard College had 5 teachers and 70 students $\rightarrow$ and a library of 2,450 volumes. At Marion is also located the Howard Theological Institution, under Baptist auspices, and there are Law and Medical Schools attached to the University.

Periodical Press.-The whole number of periodicals published in Alabama is 61, of which 21 are whig and 23 democratic in their policy, and 18 are devoted to literature, science, religion, ete. 6 are issued daily, 4 tri-weekly, 1 semiweekiy, 49 weekly, and 1 semi-monthly. The circulation of the daily papers is in the aggregate 9,177 copies; of the triweekly 550 copies; of the semi-weekly - copies; of the weekly 24,120 copies, and of the semi-monthly 750 copiesmaking in the aggregate about $4,230,441$ copies annually.

MoNTGomery is the State capital.

AtachuA county, Flor. Situate E. centrally, and contains about 1,800 sq. m. Surface varied, but mostly level, and drained by head sources of Santa Fé r. and other sireams. There are several lakes in the S. and E. portions, which communicate with St. John's r. Soil highly congenial to all Southern staples. Farms 233; dwell. 274, and pop.wh. 1,617, fr. col. 1, sl, 906-total, 2,524. Capital: Newnansville.

ALACHUA savannah, Flor.: situate N. W., in E. Flor., and comprises a flne savannah, about $50 \mathrm{~m}$. in circumference, without a tree or bush, but encireled with hills, corered with forests and orange groves on a very rich soil. The ancient Alachua Indian town stood on the borders of this savannah, but the Indians remored on account of the unhealthiness of the locality.

AlAIEDON, p. v., Ingham co., Mich.: on a cr. of Grand r., $12 \mathrm{~m}$. S. E. Lansing. Pop. 420.

Alamo, p. Y., Montgomery co, Ind.: on a branch of Sugar cr., $42 \mathrm{~m}$. W. N. W. Indianapolis.

AL.AMo, t. and p. v., Kalamazoo co, MFch, : on a cr. of Kalamazoo r., 46 m. W. S. W. Lansing.

Atamode, p. 0., Reynolds co., Mo.: 118 m. \$. S. E. Jefferson City.

A sumtchs, p. v., tauderdale co., Miss. : 92 m. E. Jackson.

Araxthes Grove, p. 0., Gentry co., Mo.: 161 m. N. W. Jefferson City.

AlapsHA, p. V., Lowndeg co., Ga.: $210 \mathrm{~m}$. S. Milledgeville.

AlAPAHA river, $G a .:$ a beanch of Suwannee r., rising in Dooly co., and haxing a S. E. and S. course to the junction n Hamilton co., Flor.: it is narigable for boats throughout its whole length of $112 \mathrm{~m}$.
AlAQUA, p. v., Walton, co., Flor. : on a cr. so called, 114 za. W. Tallahassee.

Alarka, p. v., Macon co., N. Car.: 276 m. W. S. W. Raleigh.

Alataмaнa river, Ga.: a navigable stream, formed by the union of the Ockmulgee and Oconee rivers. After a course of about $100 \mathrm{~m}$. from the junction, flowing in a gentle stream through forests and plains, it empties through sereral mouths into Alatamaha Sound, $60 \mathrm{~m}$. S. W. of Savannah, and thence passes to the Atlantic Ocean. It is navigable on both branches for about $300 \mathrm{~m}$. for boats of 30 tons. The bar at the mouth has 14 feet of water at low tide.

Alataraha sound, $G a$ : an arm of the Atlantic, which receives the Alatamaha $r$. It contains a number of beautiful islands, which are celebrated for the production of the long staple cotton called Sea Island cotton.

AlbA, p. v., Bradford co., Penn. : 108 m. N. by E. Harrisburg.

ALBANY county, $N . Y$. Situate N. centrally on IIudson r., and contains 515 sq. m. Drained by Normanskill, Namanskill, Haivankrauskill, and Coeyman's cr. : the Mo. hawk lies on the N. border. Surface uneven-in some places hilly : soils mostly sandy, but near the rivers highly fertile. Iron, limestone, ete., abound, and there are sulphur springs. Farms 2,903; manuf. 393 ; dwell. 12,747, and pop.-wh. 92,110, fr. col. 1,169-total, 93,279. Copital: Albany. Pubtio Workes: Champlain Canal; Albany and Schenectady R. R. ; Albany and Binghampton R. R.; extensive docks, etc.

AlBAxy, p. eity and cap. Albany co., $N$. $\boldsymbol{Y}_{*}$, and legislative capital of the State of New York: on W. side Iudson r., $376 \mathrm{~m}$. N. N. E. Washington, lat. $42039^{\prime} 03^{\prime \prime}$ N., long. 3० $16^{\prime} 59^{\prime \prime}$ E. from Washington, or $78^{\circ} 44^{\prime} 49^{\prime \prime} \mathrm{W}$. from 
Greenwich. Pop. 59,771. The portion of the eity on the river is built on a low flat, but beyond this the surface rises rapidly to an elevation of about 200 feet. The older part of the town is irregularly laid out, and several of the strects are narrow. The newer portions, however, are spacious and handsome, and contain fine shops and dwellinghouses. The public buildings, except the Exchange, are located on the heights, and have $\mathrm{a}$ commanding position, overlooking the vicinity. Among these, the Capitol, State House, and City Hall, are the most conspicuous. The Capitol is a large stone building, 115 feet long and 90 broad, fronting east on a fine park. It contains accommodations for the Senate and Assembly, the State Library, and numerous apartments for the use of the government. The State House, a fine marble building, is situate on the $\mathrm{E}$. Bide of the Park square, and accommodates the executive and administrative officers of the State; and the City Hall, an edifice of similar material, also on the same side of the Park, contains the municipal offices. The Exchange is a large granite building at the foot of State-street. The other public bnildings are the Albany Academy, the Medical College, the State Normal School, and numerous benevolent and literary institutions. The old State House, on the S. side of State-street, is now used as a depository for the geological colleetion made by the State surveyors. The cily contains between 60 and 70 churches, of various denominations, many of whieh are substantial and elegant structures; the streets are well lighted with gas, and water is supplied through iron pipes.

There are fire daily papers issued in Albany, namely, the "Argus" (dem.), the "Evening Journal" (whig), the "Atlas" (dem.), the "State P.egister" (whig), and the "Express" (neutral); and the four first of these issue also weekly editions. The "Knickerbocker," the "Dutchman," and the "Freeholder," are issued weekly; these are neutral in politics, and devoted chiefly to general news and literature. All these papers are ably conducted, and enjoy a side reputation.

The manufactures of Albany are extensive and various: it has numerous iron works, carriage factories, type founderies, oil-cloth factories, sawing and planing machines, malting houses, and has long been famous for its breweries The trade of the eity is also large, and its commercial conrections with the north and west give employment to thousands of its inhabitants, as merchants, store-keepers, laborers, ete.

Albany is the chief entrepot of a rast internal commerce its situation for such a purpose is unsurpassed. The Hudson washes its shores, and it has connection by canal with Iake Champlain, a long line of interior counties, and with the Great West through Buffalo. Railroads also extend hence to all points, and collect and distribute many million dollars' worth of property annually. The railroads centering at Albany are the Hudson River R. R., the Harlem Extension R. $\mathrm{P}_{\mathrm{s}}$, the Western, from Boston, several others from the direction of Canada, the great northern chain extending to Buffalo, and a line is about being built to Binghampton, on the Susquehannah, which will open to the eity the mineral treasures of Pennsylvania, and a large extent of fertile country intervening.

In the season of navigation, there are also several daily lines of steamers to and from New York, and on an average 3,000 or 4,000 persons are daily earried between the two places, while innumerable sloons, canal boats, and towboats transport millions of tons of merchandize and produce constituting the material of its vast commerce. Albany was originally a trading post of the Dutch, and dates as such from 1623. It was successively known as Beaverwyk and Wilhelmstadt; but after the capitulation, in 1661 it obtained the name of Albany, in honor of the Duke of Fork and Albany, the proprietary of the colony. In 1656 It was chartercd as a city.

AlBATY, p. v., Baker co, Ga. : on W. side of Flint r., 118 m. S. S. W. Milledgeville. A brageh of the Brunswick and Florida R. R. from Thomasville to this point is projected. Alsany, p. v., Whitesides co., $n b_{0}$ : on E. bank of Mis sissippi r., 188 m. N. N. W. Springfield.

Albany, p. T., Delaware eo., Ind.: on Mississinewa r.g $60 \mathrm{~m}$. N. E. Indianapolis.

Albany, t. and p. $\Theta_{\text {., Carroll con }}$ T. Hamp. : on Swift r., $52 \mathrm{~m}$. N. by E. Concord. Pop. 455.

ALbary, p. v., Caddo par. La.: 198 m. N. W. Baton Rouge.

Albany, p. v., and eap. Clinton co., Ky. : on Spring er. of Obey's $\mathrm{x}, 116 \mathrm{~m}$. S. Frankfort,

ALbasty, p. v., Green eo., Wiso. : 22 m. S. S. W. Madison

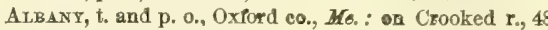
m. W. Augusta. Pop. 747.

Albany, p. v., Thesearawas eo., Chio: 80 m. E. by M. Columbus.

Albanx, p. v., Henry co., Tenn. : on S. fork of Obion r, $92 \mathrm{~m}$. W. Nashville.

Albaxy, to and p. o., Berks cø., Penn. : 5 e m. E. by N. Harrisburg.

Albavy, t. and p. v., Orleans co., Ferm. : 32 m. N. by E. Montpelier. Pop. 1,051.

Albavt, v., Linn co., Oreg. Ter.: on E. side of Willamette r., $20 \mathrm{~m}$. S. Salem.

Albemarle county, Firg. Situate centrally on the E. base of Blue Ridge, and contains 704 sq. m. Jarses $r$ washes its southern border, and the interior is chiefly drained by Albemarle r. and the head waters of the Rivanna. Surface diversified, and the soils good. Wheat, Indian corn, and tobaceo are the chief products. Farms 935 ; manuf. 102 ; dwell. 2,022, and pop.-wh. 11,876, fr. col. 586, sl. 13,338-total, 25,300. Capital; Charlotteville. Publio Works : Virginia Central R. R. and James River Canal.

Albemarle, p.v., Carroll co., Miss. : 87 m. N. by E. Jackson.

AlbeMarte, p. $\mathbf{\text { . }}$, and cap. Stanley co., $\mathbb{N}$. Oar.: $88 \mathrm{~m}$ W. by N. Raleigh.

Albemarle, p. v., Assumption par., La.: 46 m. S. by E Baton Rouge.

Albemarte sound, $N$. Car.: an arm of the Atlantic, extending $60 \mathrm{~m}$. inland, and is from 4 to $15 \mathrm{~m}$. wide, receiving the waters of Roanoke and Chowan rivers. It communicates with Chesapeake Bay by a canal through the Dismal Swamp, and with Pamlico Sound and the ocean, by narrow inlets.

A_bERTSOx'g, p. o., Duplin co., N.Car. : 69 m. S.E. Raleigh. AlbiA, p. v., and cap. Monroe co., Ia.: on a cr. of Des Moines r., $78 \mathrm{~m} . \mathrm{S}$. W. Iowa City.

Albion, p. v., and cap. Edwards co., $M l^{\circ}: 142$ m. S. F Springfield.

Albron, p. ₹., Providence co., R. I. : $18 \mathrm{~m}$. W. Proridence. Albion, p. v., and eap. Noble co., Ind.: on the N. side of Elkhart r., $120 \mathrm{~m}$. N. N. E. Indianapolis.

Alвion, to and p. o. Kennebec co, Me.: 21 m. N. E, Augusta. Pop. 1,604.

Alsior, t. and p. v., Dane co., Wisc. : $28 \mathrm{~m}$. S. E. Madison,

ALbion, t. and p. v., Calhoun co., Mieh. : at the junction of the forks of Kalamazoo r., and on the line of the Michigan Central R. R:, $96 \mathrm{~m}$. W. Detroit; it is a flourishing village, and has considerable trade. Pop. of $t, 1,666$.

Alsion, p. Y., and eap. Orleans co., N. Y.: or Erie canal, $217 \mathrm{~m}$. W. Albany. It contains a C. H., jail, and other co. buildings, and a convenient landing. The Rochester, Lockport, and Niagara Falls R. R. passes throngh the village. Three newspapers are issued weekly - the "Dem. ocrat," the "Republican," and the "American." Pop. 2,400. Axbros, t. and p. V., Ashland co., Ohio: $68 \mathrm{~m}$. N. by E. Colurabus.

Albror, p. v., Erie eo, Penn, : 214 m. W.N.W. Harrishurg. Alberght's, p. o., Des Moines co., Ia. ; 49 m. S. Iowa City. Albrightspille, p. v., Carbon co., Penn.: 70 m. N. E. Harrisburg. 
Albuguerque, p. v., Bernalillo co., $N$. Mox. : on E. side of Rio Grande, $76 \mathrm{~m}$. S. Santa Fé.

Andorgir, t. and p. v., Grand Isle co., Verm.: on the Vermont Central R. R. Pop. 1,568.

Alburgri peninsula, Ferm. : a triangalar tongue of land, projecting from Canada into Lake Champlain. The surface is low and level, and the soil fertile. The narrow waters dividing it from the mainland, are spanned by fine bridges to accommodate the railroads from the opposite shores, which here form a union.

Azburgh Springs, p. o., Grand Isle co., Term.: a famous mineral spring is found here, the waters of which are said to be efficacious in scrofulous affections.

Alcona county, Wich. Situatc N. E. on Lake Huron, and contains 682 sq. m. Drained by Au Sabje and Nenetau rivers and their tributaries. A new co. since 1550.

Alcove, p. o., Fond du Lac co., Wisc.: 80 m. N. E. Madison.

Alden, p. v., M'Henry co., $\Pi$. : 244 m. N. E. Springfeld. Aldex, t. and p. v. Erie co.. $N . F_{.}:$on a branch of Buffalo cr., $254 \mathrm{~m}$. W. Albany. Pop. 2,520.

Aldenville, p. v., Wayne co., Penn. : on a tributary of $\mathrm{N}$. branch of Lackawaxen cr., $121 \mathrm{~m}$. N. E. Harrisburg. It contains a large hemlock tannery, belonging to the daughter of the Hon. Zadock Pratt, which employs a capital of $\$ 200,000$, and tans annually 50,000 sides of sole-leather. Au extensive trade of lumber is carried on. Pop. about 450.

Alder Crenk, p. 0., uneida co., N. Y.: $106 \mathrm{~m}$. W. N. W. Albany.

AlDTE, p. v., Loudon co., Firg. : on a branch of Goose cr., $98 \mathrm{~m}$. N. Richmond.

Alert, p. v., Butler co., Ohio: 98 m. W. by S. Columbas.

Alexayder county, $\pi l$. Situate in the extreme S. on Mississippi r. at the junction of the Ohio, and contains 220 sq. m. Drained by creeks flowing into the Mississippi and Cash rivers. Surface various: in the N. W. are immense bottoms backed by high bluffs, and in the E. prairieg. The 8. portion is subject to overflow, and contains a large lake, called Horse-shoe Lake. Soils fertile and productive. Farms 202; manuf. 8 ; dwell. 455, and pop $\rightarrow$ wh. 2464 , fr col. 20-\$otal, 2,484. Capital: Thebes. Public Works: Illinois Central R. R., and extensive embankments.

Alexander county, $N$. Car. Situate N. W. centrally, and contains $420 \mathrm{sq}$. m. Drained by creeks tributary to Catawba and Tadkin rivers. Surface varied pleasantly; and soils of ordinary fertility. Farms 633 ; manuf. 4 ; dwell. 827, and pop.-wh. 653, fr. col. 24, sl. 543-total, 5,220. Capital: Taylorsville.

Alesander lake, Conn.: a small lake in Killingly township, one $\mathrm{m}$. long and half a $\mathrm{m}$. wide: called by the Indians Mashapaug. It is very deep.

AlexANDER, t. and p. v., Washington co., Me. : 126 m. E. by N. Augusta. Pop. 544.

Alesaxder, p. v., Burke co., Ga. : 92 m. E. Milledgeville.

Alexander, p. v., Putnam co., Firg.: 240 m. W. by N. Bichmond.

ALEXANDER, t. and p. v., Genesee co., $N$. $Y_{\text {.: }}$ on Buffalo and Rochester R. R., 293 m. W. Albany. Pop. 1,927.

Alexanderstille, p. Y., Montgomery co, Ohio: on the Miami eanal, $42 \mathrm{~m}$. W. S. W. Columbus.

Arexandria county, Firg. Situate N. E. on Potomac r. and contains about 40 sq. $m$. This conty, until 1846 , formed a portion of the District of Columbia. Surface uneven, and soils generally thin. Farms 94; manuf. 89; dwell. 1,484 , and pop.-wh. 7,213 , fr. col. 1,413 , sl. 1,352 -total, 10,005. Capital: Alexandria. Public Works: Chesapeake and Ohio Canal, and Orange and Alexandria R. R.

Arexardra, p. $\nabla_{\text {., }}$ and cap. Rapides par. La. : on Red r., below the lower rapids. It contains a $\mathrm{C}_{\text {. }} \mathbf{H}$., jail, and other co. buildings, and has considerable trade, being the great cotton depot of the Red $\mathbf{r}$. Two newspapers, the
"Red River Republican," and the "Western Democrat," are issued weekly.

Alexandria, p. V., Clark co., MIo.: on the S. side Des Moines r., $2 \mathrm{~m}$. from its mouth, and $180 \mathrm{~m}$. N. by E. Jefferson City.

Alexandria, t, and p. 0., Grafton co., N. Hamp.: $29 \mathrm{~m}$. N. W. Coneord.

ALEXANDRL, t. and p. $\nabla .$, Jefferson co., N. Y.: on st. Lawrence r., 166 m. N. W. Albany.

Alexandria, p. v., Licking co. 9hio: 33 m. E. N. E Columbus. Pop. 349.

Alexamdrta, p. .., Huntingdon co., Penn.: $86 \mathrm{~m}$. W. Harrisburg.

Arexandria, p. v.,De Kalb co., Tenn. : on a cr. of Cumberland r., 42 m. E. Nashville.

ALEXANDRIA, p. city, sea-port, and cap. Alexandria co., Virg.: on Potomac r., $106 \mathrm{~m}$. N. Pichmond. The river is here deep enough for tho largest ships. The port has considerable commerce. Tonnage in $1850,8,738$ tons. The Chesapeake and Ohio Canal terminates here-also the Alexandria and Orange R. R. The "Alexandria Gazette" is issued daily and tri-weekly, and the "Southern Church. man," an Episcopal paper, weekly. Pop. 8,795.

Alexardita, p. v., Benton co., Ala.: 5 m. S. W. Jacksonville, and $93 \mathrm{~m}$. N. by E. Montgomery.

AlexandriA, p. v., Madison co., Ind.: 42 m. N. N. E. Indianapolis.

Alexandria, p. $\mathrm{v}$., and cap. Campbell co., $\bar{y}$.: $5 \mathrm{~S} \mathrm{~m}$. N. N. E. Frankfort

Alexandria Centre, p. 0., Jefferson co, $N$. $Y .: 147 \mathrm{~m}$ N. W. Albany.

Alfixamidasa, p. vo, Mechlenburg co., $N$. Car.: $132 \mathrm{~m}$ W. S. W. Raleigh.

ALFONT, p. V., Madison co., Ind.: on Indianapolis and Bellefontaine P. R., 23 m. N. E. Indianapolis.

ALFORD, t. and p. v., Berhshire co., Mass.: on Green r., $112 \mathrm{~m}$. W. Boston.

Alfordstulle, p. v., Robeson co., $N$. Car.: 78 m. S. S. W. Raleigh.

AlFRED, to, p. v., and cap. York co., Me. : on Mousum r., $73 \mathrm{~m}$. S. W. Augusta.

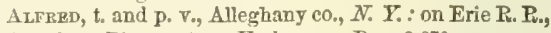
325 m. from Piermont, on Hudson r. Pop. 2,679.

Algiens, p. v., Jefferson par., La. : on the W. bank of the Mississippi, opposite New Orleans. The N. O. Opelousas and Texas P. R. has its E. terminus here. Belleville and Macdonough adjoin it; the whole neighborhood is well settled.

AlgANSEE, t. and p. V., Branch county, Mfich. : $75 \mathbf{m}, \mathrm{S}$. Lansing. Pop. 609.

Argova, t. and p. V., Winnebago county, Wisc.: $83 \mathbf{m}$. N. N. E. Madison. Pop. 702.

Atgorsc, t. and p v., St. Clair co., Mich. : 98 m. E. Lansing.

Algonede, p. 0., Houghton co, Mich.: 365 m. N. W.

Lansing.

Algoxqutn, p. v., M'Henry co., $\pi l$. : on Fox r., $168 \mathrm{~m}$. N. E. Springfield.

Almambra, p. v., Madison co., $T U$. (formerly LownyVILE) : $73 \mathrm{~m}$. S. S. W. Springfield.

AlIArce, $\nabla$. , Stark co., Ohio: at the intersection of the Cleveland and Pittsburg, and the Ohio and Pennsylvania R. Rs., $58 \mathrm{~m}$. from Cleveland, and 82 from Pittsburg.

ArmA, p. $v$., Stephenson $00 ., l_{0}: 6 \mathrm{~m}$. W. Pekitonica r., and $161 \mathrm{~N}$. Springfield.

Alisonid, p. Y., Franklin co., Tenn.: at the head waters of Duck $r$, and on the line of the Nashville and Chattanooga R. R., and also at the junction of the Mrinnville and Manchester R. R.

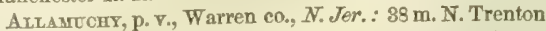
Allaidpale, p. v., Habersham co., Ga.: 98 m. N. Milledgeville.

Alratoona, p. v., Cass co., Ga. : on a cr. of Etowah r. and $108 \mathrm{~m}$. N. W. Milledgeville. The Western and Atlan- 
tic R. P. intersects it $32 \mathrm{~m}$. from Atlanta, and $100 \mathrm{~m}$. from Chattanonga.

Altegan county, Mizch. Situate W. on Lake Michigan, and contains 832 sq. m. Drained by Kalamazoo river and its tributaries, and Black $x$. Surface varied-elevated toward the E.: soils sandy, or sand mixed with clay, with rich alluvial valleys along the rivers. Timber abundant. Faras 270; manuf. 36 ; dwell. 997, and pop-wh. 5,120, fe. col. 5-total, 5,125. Capital: Allegan.

ALLEGAX, t., p. v., and eap. Allegan co., Mich. : on Kalamazoo r., at the head of navigation. The "Allegan Record" is published weekly.

ALLEGHANY county, Md. Situate extreme N. W., and contains $1,050 \mathrm{sq} . \mathrm{m}$. Drained by tributaries of $\mathrm{N}$. branch of Potomae $r$. and by Monongahela $r$. Surface mountainous, with broad valleys: soils fortile: coal and iron in profusion. Farms 892 ; manuf. 24 ; dwell. 3,850 , and pop.wh. 21,633, fr. col. 412, sl. 724-total, 22,769. Capital: Cumberland. Pubtio Works: Baltimore and Ohio R.R.; Chesapeake and Ohio Canal, and several railroads from Cumberland to coal mines.

ALLEgHANY county, $N$. $Y$. Situate S. W., and contains $1,185 \mathrm{sq.} \mathrm{m}$. Drained by Genesee r., which flows through the county. Surface finely variegated, the Genesee valley being bounded by ranges of table land, which extend $N$.

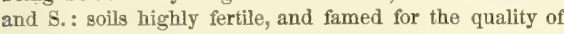
their cereal products. Bog iron abounds, and there is a spring from which Seneca oil is obtained. Farms 3,173; manuf. 291 ; dwell. 6,968, and pop.-wh. 37,683 , fr. col. 125total, 37,808. Capital: Angeliea. Public Works: Genesee Valley Canal; New York and Erie R. R.; Buffalo ard New York City R. R.

Alifegraxy county, Penn. Situate W., and contains 1,022 sq. m. Drained by Monongahela and Alleghany rivers, which, uniting near the centre of the county, form the Ohio r. Surface hilly and wooded, but fertile to a high degree. It is the centre of the $W$. iron region. Farms 3,729; manuf. 1,290; dwell. 22,551 , and pop.-wh. 134,827, fr. col. 3,463-total, 138,290. Capital: Pittsburg. Public Works: Pennsvlvania R. R.; Ohio and Pennsylvania R. R. ; Steubenville R. R.; Pennsylvania Canal, ete.

Aluegrary county, Virg. Situate centrally among the Alleghanies, and contains $520 \mathrm{sq} . \mathrm{m}$. Drained by the head waters of James r. Surface varied, and in some parts rugged; but in the valleys of the rivers the soils are rich and very productive. There are within the county several mineral springs and much picturesque scenery. The products are wheat and oats, with some tobacco. Farms 216; manuf. 10 ; dwell. 464, and pop.-wh. 2,763 , fr. col. 58, sl. 694 -total 8,515. Capital: Covington.

Aliegeaxr, t. and p. $\nabla$., Cattaraugus co., $N$. $Y$. (formerly Burtox): on the New Xork and Erie R. R., 408 m. W. N. W. New York.

Alteghaxy, p. city, Alleghany co., Penn. : opposite Pittsburg, of which it is a suburb. Three papers are published here-the "Enterprize," daily; "Freedom's Friend," daily and weekly; and the "News," weekly. Pop. 21,261.

Alugharr Brwge, p. v., M'Kean co, Penn.: $129 \mathrm{~m}$. N. W. Harrisburg.

ALLEGHANT mountains (called also, APPALLACEIAN) constitute a long range, varying from 50 to $200 \mathrm{~m}$. in breadth, and extend from Catskill Mountain in N. York, through Pennsylvania, Maryland, Virginia, N. Carolina, into Alabama. Their course is N. E. and S. W., parallel with the AtIantic Ocean, at a distance from it of from 60 to $150 \mathrm{~m}$. These mountains consist of a number of parallel ridges, known as the Blue Ridge, Laurel Mountain, Cumberland Mountain, etc., and vary in elevation from 600 to 2,500 feet, forming the great watershed between the Atlantic slope and the Mississippi valley. Extensive valleys or glades lie between the several ridges, in which is found much fine land, although generally of a rough and rugged aspect. They abound in rocks and mineral deposits, as iron, coal, etc.; and at their eastern base considerable gold has been collected.

ALLEGHANY river: a large stream, forming one of the great constituents of the Ohio r. : it rises on the W. side of the Alleghany mts. in Pennsylyania, about $30 \mathrm{~m}$. E. of Lake Erie, and, running first $\mathrm{N}$. W., into New York, then bending $\mathrm{S}$. W., re-entering Pennsylvania, through which it has a devious course to Pittsburg, where it is joined by $\mathrm{Mo}_{0}$ nongahela r., and the united streams constitute the Ohio. The Alleghany has a steady current, and is navigable for boats to Hamilton, $260 \mathrm{~m}$. above Pittsburg. Its banks are fertile, and for about $150 \mathrm{~m}$. from the junction have ridges of white oaks and chestnuts, with some patehes of poor pitch pines, interspersed wtth tracts of good land and low mead ows. The waters are always clear and limpid, whatever may be the state of the weather.

AllemaKeE county, $I \alpha$. Situate in N. E. corner, and contains $720 \mathrm{sq} . \mathrm{m}$. Drained by Upper Iowa, Yellow, and other rivers, tributaries of the Mississippi, which forms the E. border. Farms 2; dwell. 152, and pop. 777. Capital: Lansing.

Aldemance county, $N$. Car. Situate N. middle, and contains $576 \mathrm{sq}$. m. Watered by Haw $\mathrm{r}$. and its ereeks, Great Allamance, etc. Surface pleasantly varied, and soils of average fertility. Wheat, corn, oats, tobacco, and cotton are the chief products. Farms 923; manuf. 38; dwell. 1,516, and pop.-wh. 7,924 , fr. col. 324 , sl. 3,196-total 11,444. Capital: Graham.

Allemanck, p. v., Guilford co., $N$. Car.: on Great Allemance er., $66 \mathrm{~m}$. W. Raleigh.

Alter county, Ind. Situate N. E., and contains $672 \mathrm{sq}$. $m$. The county is well watered, and has numerous fine mill-streams. Little $r$. and Aboite r. rise in the W., and uniting, fall into the Wabash; and the St. Joseph's and St Mary's, from Ohio, unite at Fort Warne, and form the Mau mee, which falls into Lake Erie. These were formerly navigable at high water, but are now only used for milling Bee cr. Crooked er., and Cedar cr., afford also considerable power. Surface level, and well timbered. Soils excellent near the streams a sandy loam, and in the interior, clay, intermixed with marl. In the $\mathrm{N}$. W. are numerous oakopenings, or barrens. Farms 1,300; manuf. 127 ; dwell 3,097, and pop.-wh. 16,817, fr. col. 102-total, 16,919. Capital : Fort Wayne. Public Works: Wabash and Erie Canal : several railroads are projected.

ALLEN county, $K y$. Situate S. centrally, and contains 510 sq. m. Drained by numerous tributaries of Green r., which bounds it on the N. Surface level or unduleting, and soils of average fertility. The chief products are Indian corn, oats, wheat, and tobaceo, and some cotton Farms 740 ; manuf. 7 ; dwell. 1,249, and pop.-wh. 7,389, fr. col. 39, 8l. 1,314-total, 8,742. Capital: Scottsville. Public Works: Nashville and Lexington R. R.

AlLeN county, Ohio. Situate N. W., and contains 830 sq. m. Drained chiefly by the branches of Auglaize $r$. Surface elevated and rolling; soils very fertile. Wheat and Indian corn are the principal products. Timber is abundant. Farms 1,146; manuf. 50 ; dwell. 2,070 , and pop.wh. 12,085, fr. col. 24-total, 12,109. Capital: Lima. Public Works: Miami Canal, and Ohio and Indiana R. R.

Alrfy, t. and p. 0., Alleghany co., N. $Y_{0}: 216 \mathrm{~m}$. W. S. W. Albany. Pop. 355.

Axlen, p. v*, Cumberland co., Penn.: 28 m. S. W. Harrisburg.

Allex Centre, p. 0., Alleghany co., N. Y.:216 m. W. S. W. Albany.

Allen Centre, p. o., Union co., Ohio: 30 m. W. N. W. Columbus.

Allendale, v., Bergen co., N. Ter.: on Ramapo and Patterson R. R. $9 \mathrm{~m}$. N. Patterson.

ALLENDALE, p.v., Greene co., $\bar{K} y .: 71$ m. S.S. W. Frankfort. Allendale, p. v., Barnwell dist., S. Car. : 89 m. S. S. W. Columbia. 
Alien's, p. 0., Miami co., Ohio: 66 m. W. Columbus. Allen's Bridge, p. O., Marion dist., S. Car.: 80 m. E. Columbia

Allensburgr, p. 'v., Highland co., Ohio: 58 m. S. W. Columbus.

Allev's Fressh, p. o., Charles co., Md. : on the cr. of the same name, $42 \mathrm{~m}$. S. S. W. Annapolis.

AlleN's Grove, p. o., Walworth co, Wisc. : 49 m. S. E. Madison.

Allen's Grove, p. o., Scott co., Ia. : 46 m. E. Iowa City. AlLEx's HrL, p. o., Ontario co., $N$. Y.: $181 \mathrm{~m}$. W. AI-

bany.

Allen Sprivgs, p. .., Allen co., $\bar{k} y$.: near Sulphur fork of Big Barren r., 102 m. S. W. Frankfort.

Allen's Setrlement, p. o., Claiborne par., $L a$. ; at the head of Crow's cr., 193 m. N. E. Baton Rouge.

Allex's Station, p. 0., Hancock co., Tenn.: 194 m. E. Nashville.

Aцlenstown, t. and p. v., Merrimac co., $N$. Hamp. : on Suncook r., 10 m. S. E. Concord, Pop. 562.

Altenstule, p. v., Alleghany co., N. Y.: 218 m. W. Albany.

Allansviute, p. Y., Switzerland co., Ind.: 86 m. S. E. Indianapolis.

ALLEN8vilue, p. V., Todd co., $\bar{K} y$.: on Elk fork of Red r., a tributary of the Cumberland, $151 \mathrm{~m}$. S. W. Frankfort.

AllensviluE, p. V., Vinton co., Ohio: $46 \mathrm{~m}$. S. 8. E. Columbus.

Allenspilte, p. v., Mifflin co., Penn.: 42 m. N. W. Harrisburg.

Arlemton, p. $\nabla .$, Wilcox co., Ala. : on Pine Barren er., 49 m. S. W. Montgomery.

Aluentor, p. v., Washington co., R. I.: 28 m. S. S. W. Providence.

Allentown, p. $\nabla$. Monmouth co., N. Jer.: 12 m. E. by N. Trenton.

Altextows, p. T., Allen co., Ohio: $61 \mathrm{~m} . \mathrm{N}$. W. Columbus.

Allentown, p. v., and cap. Lehigh $\mathrm{co}_{*}$, Penn.: on S. side of Lehigh r., $78 \mathrm{~m}$. E. by N. Harrisburg. It is beautifully situate on an elevation in the midst of a well cultivated, pleasant, and populous country. It contains, besides the county buildings, a bank, several handsome churches, an academy, and eight schools, and a number of flourishing mills; and its trado is considerable. Six newspapers are published here-five weekly, and one semi-monthly: the "Lehigh Reporter" (neutral); the "Allentown Democrat;" the "Lehigh Patriot" (whig); the "Unabhongiger Republikaner" (dem.); and the "Friedensbothe" (neutral), are issued Weekly; and the "Youth's Friend," every second week. Pop. 3,780 .

Altigator, p. v., and cap. Columbia co., Flor. (formerly LATCASTEB): 97 m. E. S. E. Tallahassee.

AlligatoR, p. $\nabla_{*}$ Crittenden co, Ky.: $192 \mathrm{~m}$. W. Frankfort.

Altigator, p. V., St. Mary's par., La.: 52 m. B. S. W.

Baton Rouge.

Álisor, p. $v_{*}$ Logan co, $\bar{K}_{y}: 148$ m. S. W. Frankfort.

Alissorviule, p. v., Marion co., Ind.: on the Indianapolis and Peru R. P., $11 \mathrm{~m}$. N. Indiana.

Arlow AY, p. V., Wayne co., $N$. $Y_{*}:$ on the E. side of the outlet of Canandaigua Lake, $179 \mathrm{~m}$. W. Albany.

Allow Arstown, p. V., Salem co., $N$. Jer. : on Alloway's cr. of the Delaware, 60 m. S. S. W. Trenton.

Atrsborougr, p. V., Franklin co., Ala. : 169 m. N. W. Montgomery.

AlutRaNTE, p. $\nabla_{*}$, Wrilton co., Flor.: on Yellow Water

r., $146 \mathrm{~m}$. W. N. W. Tallahassee.

Armond, p. V., Portage co., Wisc. : $92 \mathrm{~m}$. N. Madison.

Alyoxd, t. and p. v., Alleghany co., $N$. $Y_{\text {.: }}$ on Canisteo r., and on the F. Y. and Erie R. E., $194 \mathrm{~m}$. W. Albany.

Alasoxt, t. and p. F., Lapeer co., Mich.; $61 \mathrm{~m}$. E. Lansing.

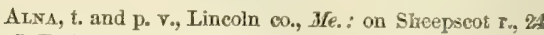
m. S. E. Angusta. Pop, 916.

Alpexa county, Mich. Situate N. E. on Lake Haron, and contains $576 \mathrm{sq} . \mathrm{m}$. : a new county since 1850.

Alpus, p. v., Greene co., Ohio: $55 \mathrm{~m}$. W. Columbus.

Alprove, p. v., Chattooga co., $G a_{0}: 152 \mathrm{~m}$. N. W. Milledgeville.

AlPine, p. V., Clark co, Ank.: $70 \mathrm{~m}$. S. W. Little Rock.

AlptNe Depôt, p. o., Morgan co., Firg.: on Baltimore and Ohio R. R., $149 \mathrm{~m}$. N. Richmond.

Alfs, p. o., Rensselaer co., $N . Y_{.: 21} \mathrm{~m}$. E. by S. Albany.

Areunia, p. v., Fayette co., Ind.: 60 m. E. by S. Indianapolis.

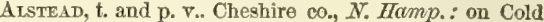
r., 39 m. E. Concord. Pop. 1,425,

Alston, p. v., Fairfleld dist, S. Car : $33 \mathrm{~m}$. N. Columbis. Altamont, p. v., and cap. Grundy co., Tenn. : centre of co., 72 m. E. S. E. Nashville.

Altayort, $\mathbf{V}_{*}$, Alleghany co., MId: a station on the Bal:timore and Ohio R. R., $224 \mathrm{~m}$. W. Baltimore.

Alta Sprongs, p. o., Limestone co., Tero: $126 \mathrm{~m} . \mathrm{N}$. Austin City.

Altay, p. ₹., Steuben co., N. $\bar{Y} .: 170 \mathrm{~m}$. W. Albany.

Althouse's st., Berks co., Penn.: on Philadelphia and

Reading R. R., 66 m. W. N. W. Philadelphia.

A zто, p. 0., Howard co., Ind.: $46 \mathrm{~m}$. N. Indianapolis.

Axto, t, and p. o., Fond du Lac co., Wisc : on E. branch

of Rock r., 61 m. N. N. W. Madison. Po?. 680.

Atro, p. v., Louisa co., Firg.: 46 m. N. W. Richmond.

Atton, t. and p. v., Kent co., Mich.: $58 \mathrm{~m}$. W. N. W. Lansing.

Atrox, t. and p. city, Madison co., $I l$. : on Mississippi $r$. $3 \mathrm{~m}$. above the mouth of the Missouri. It possesses great commercial advantages, and will probably become an important railroad terminus. Bituminous coal is abundant near the city. It is the largest place on the river above St. Louis. Shurtliff College and other institutions of a high character are located here; and there is also a weekly paper, the "Telegraph and Review," issued. The Chicago and Mississippi R. R. terminates here, and other Railroads are projected. Pop. 12,000.

Alton, p. v., Franklin co., Ohio: on a branch of Scioto r., $10 \mathrm{~m}$. W. Columbus.

Attor, p. v. and cap. Denton co., Tex. : between Hickory er. and Elm fork of Trinity r., 208 m. N. N. W. Austin City.

Altox, p. v., Penobscot co., Me.

Altos, t. and p. V., Belknap co., N. Hamp.; on a bay of Lake Winnepiseogee, $22 \mathrm{~m}$. N. N. E. Concord. The Cocheco R. R. passes through the village, $27 \mathrm{~m}$. N. W. from Dover. Pop. of t. 1,795.

AltoN, p. $\boldsymbol{V}_{*}$, Wayne co, $\boldsymbol{N} . \boldsymbol{Y}_{\text {.: }}$ on the Ridge Road, 169 m. W. Albany.

Altow Hru, p. o., Macon co., Tenn.: 216 m. E. S. E. Nashville.

AтroокA, p. V., Blair co., Penn.: on Penasylvania R. R., $131 \mathrm{~m}$. W. Harrisburg.

Alux Bark, p. o., Bedford co., Penn.: 86 m. W. S. W. Harrisburg.

Arou Creak, p. O., Delaware co., Ohio: on a cr. of the same name, tributary to the Scioto $r ., 23 \mathrm{~m} . \mathrm{N}$. Columbus.

Azdx Rock, p. 0., Alleghany co., Firg. : 149 m. W. Richmond.

Alcar Rrs, p. o., Monroe co., Ohio: on a cr. of the same name, flowing to the Ohio r., $106 \mathrm{~m}$. E. S. E. Columbas,

AzcM Sprovgs, p. 0., Rockbridge co., Tirg.: $111 \mathrm{~m}$. W. Richmond.

Atran, p. V., Jefierson co., Penn. : 122 m. W. N. W. Harrisburg.

AlvirA, p. V., Lycoming co., Penn.: 66 m. N. W. Harrishurg. 
Azviso, v., Santa Clara co., Culaf.: on Guadalupe r., 48 m. S. Vallego.

Axacerts, p. v., Wayne co., Firg.: 263 m. W. Riohmond.

AmagansetT, p. v., Suffolk co., $\mathcal{N}$. $Y$.: near tle E. extremity of Long Island, on the Atlantic, $181 \mathrm{~m}$. S. E. Albany.

fort.

Amands, t. and p. v., Fairfield co., Ohio: on Clear cr.,

$26 \mathrm{~m}$. S. E. Columbus. Pop, 1,536.

Amandavilite, p. vo, Elbert co, Ga, : 83 m. N. by E. Milledgoville.

Amazox, p. v., Madison co., Ia.: $131 \mathrm{~m}$. W. by S. Iowa City.

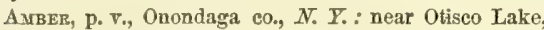
$126 \mathrm{~m}$. W. by N. Albany.

Amberson's Vallex, p. 0., Franklin co., Penn.: 58 m. W. by $\mathbf{S}$. Harrisburg.

A walet's Milus, p. o., Louisa co., Virg.: 46 m. W. N. W. Richmond.

A rвor, p. v., Lapeer co., Mich.: 73 m. E. by N. Lansing.

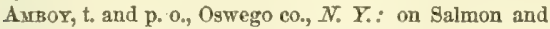
Scriba creeks, $123 \mathrm{~m}$. W. Albany. Pop. 1132.

Asroy, p. v., Ashtabula co., Ohio: 168 m. N. E. Columbus.

Amboy Cantre, p. o., Oswego co., N. $Y_{*}: 124 \mathrm{~m}$. W. Albany.

A MELIA eounty, Firg. Situate in the S. E, on Appomat. tox r., and contains 299 8q. m. Drained by the tributaries of the Appomattox. Surface level or undulating, and the soils originally rich and produotive. The staples are corn and tobacco. Farms 354 ; manuf. 5 ; dwell. 568, and pop. -wh. 2,794, fr. col. 157, sl. 6,819-total, 9,770. Capital. Amelia C. $\mathrm{H}$.

A melia, p. Y., Clermont co., Ohio: 109 m. B. W. Columbus.

Aurlia Island, Nassau co., Flor.: between St. Mary's Sound and Nassan r. Fernandina, a village at its $\mathrm{N}$, extremity, was formerly cap. of the co., and had considerable commerce, but is now almost deserted.

ArretI, p. V., and cap. Amelia co., Virg.: on Richmond and Danrille R. R., $36 \mathrm{~m}$. W. Richmond. It contains the usual county offices, and several factories.

AMENIA, t. and p. $\nabla_{.}$, Duchess co., N. $Y$.: on Housatonic r. The Harlem R. R. passes through it $89 \mathrm{~m}$. N. New York City, and in a valley between Taghkannic and Fishkill mts. $62 \mathrm{~m}, \mathrm{~S}$. by E. Albany. Marble, magnetic iron ore, and mineral springs are found in the township. Pop. 2.229.

Aventa UnIon, p. V., Duchess co., $N, Y_{.}: 67 \mathrm{~m}, 8$. by E. Albany.

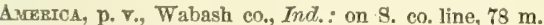
N. N. W. Indianapolis, A proposed R. R. from Kokomo to the Wabash, will interscet it.

Americas river (Rio de los Americanos), Califf: : a tributary of Sacramento r., famous for its golden sands. It rises in many branches on the W. slope of the Sierra Nera. da, and disembogues opposite Sacramento City.

A MERICUs, p. $\nabla$, and eap. Sumter $c \circ, G \alpha_{0}$ : on a cr, of

Flint $r_{n}$, and on the line of the South-western $R_{r} R_{*}, 91 \mathbf{m}$.

8. W. Milledgerille.

Arrerrots, p. v., Tippecanoe co., Ind.: on Wabash r. and canal, $61 \mathrm{~m} . \mathrm{N}$. N. W. Indianapolis.

AMrs, t. and p. 0., Montgomery co., $N . Y_{.}: 51 \mathrm{~m}$. W. N. W. Albany.

Arresburx, t. and p. v.. Essex co., Mass.: on $\mathbf{N}$. side Merrimac r., 37 m. N. E. Boston. Considerable manufactures, favored by an immense water-power, are carried on, and ressels of large tonnage are built on the Powow, a tributary of the Merrimac. The Eastern R. R. passes through the E. part of the town. Pop. 3,143.

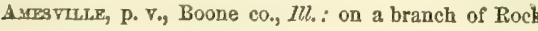

r., $178 \mathrm{~m}$. N. E. Springfield, and on the Galena and Chicago Union R, P.

Avesville, p. v., Ulster co., $N$. $\bar{Y}$.

AMesvule, p. r., Athens co., Ohio: 39 m. S. E. Columbus.

Axrenst county, Firg. Situate centrally at the base of Blue Ridge, and containg 418 sq. m. Drained by Pedlar

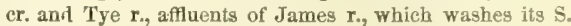
boundary. Surface elevated and much varied by hill and dale. Soils good, and very productive of wheat, Indian corn, oats, and tobaceo. Farms 728; dwell. 1,127, and pop. -wh. 6,353, fr. col. 393, sl. 5,953-total, 12,699. Capitasl: Amherst C. H. Public Works: James Piver Canal.

Amrerst, t. and p. V., Haneock con, Me.: 72 m. E. N. E. Augusta. Pop. 223.

AMmerest, t. and p. ₹., Hampshire co, Mass.: 73 m. W. Boston; is the seat of Amberst College, one of the best educational establishments in the Union. Pop. 3,115:2.

Armarst, t., p. v., and eap. Hillsboro' co., N. Hamp.: on Soulegan r., a branch of the Merrimac, 24 m. S. S. W. Concord. Pop. 1,613.

AMmers r, t. and p. v., Lorain co., Ohio: $108 \mathrm{~m}$. N. N. E. Columbus, and on the Cleveland and Sandusky R. P.1, 400 . Amuerst, p. v. and cap. Amherst co., Virg.: 84 m. W. Richmond, on Bufialo er, of James $r$.

Amicalola, p. v., Lumpkin co, Ga.: 92 m. N. W. Milledgeville.

A мrgsqiule, p. Y., Rappahannock co, Fing.: on S. side of Hedgeman's r., 86 m. N. N. W. Richmond.

Amrte river, Miss, and $L$ os. $_{*}$ : rises in Mississippi, and flows S. and S. E. $100 \mathrm{~m}$. to Lake Maurepas, uniting at Galveston with the Iberville.

A mrтz county, Miss. Situate S. W. on State line, and contains $860 \mathrm{sq} . \mathrm{m}$. Drained by the branches of Amit6 r. Surface, except near the streams, uneven, and the soil inferior. Cotton, Indian corn, and rice are the staple products. Farms 510; manuf. 1 ; dwell. 660, and pop.-wh. 3,641, fr. col. 3, sl. 6,050-total, 9,694. Capital: Liberty.

Amttsville, p. Y., Monongalia co., Virg.: 194 m. N. W. Richmond.

AurTx, t. and p. V., Aroostook co, Me.: 132 m. N. E. Atgusta. The monument at the sources of the St. Croix lies at the N. E. corner of the town. Pop. 256.

Amitr, p. V., Clark co., Ark.: 78 m. S. W. Little Roek

Amixx, p. Y., Johnson co., Ind. : 19 m. S. S. E. Indianapolis.

Anitr, p. $\nabla .$, Orange co, $\overrightarrow{V_{*}} Y_{.:}$on a branch of Willkill r., near S. State line, 98 m. \$. Albany.

Anrtr, p. Y., Washington eo., Penn.: 193 m. W. by S. Harrisburg.

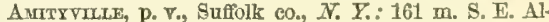
bany.

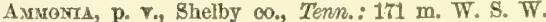
Nashville.

Amronoosuc (Upper) river, N. Hamp. : rises N. of White rats., and, passing N. E., approaches the Androscoggin r.; and thence turning $\mathrm{S}$. W., flows on to the Connecticut. Its length is about $50 \mathrm{~m}$., and the valley through which it flows from 7 to $8 \mathrm{~m}$. wide and $20 \mathrm{~m}$. long. The scenery of the neighboring couniry is beautiful.

Ammovoosuo (Lower) river, $N$. Elamp.: rises $W$. of the White mits, and, after a course of 50 miles, falls into the Connecticut, at Haverhill, by a mouth 100 yards wide. The valley of the river is about half a mile wide, and about 6 or $7 \mathrm{~m}$. from the Notch of the White mats. has a fall of some 50 feet, eut through a raass of stratified granite.

A мroskeaG, p. v., Hillsboro' co., $N$. Hamp.: 17 m. S. E. Concord, on Merrimac $r$, at the Falls, where the descent is 54 feet in a mile and a half, and around which there is a canal. The vil. has considerable manufaetures, and a newspaper, is issued weekly.

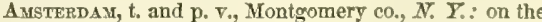
Mohawk r., $33 \mathrm{~m}$. W. Allany. The vil. is on the $\mathbf{N}$. side 
of the $r_{\text {., }}$ and a station on the Utica and Schenectady R. R. The "Intelligencer," a newspaper published here, is issued weekly. Pop. of t. 4,128.

AMsterdaAs, p. Y., Jefferson co., Ohio: $121 \mathrm{~m}$. E. by N.

Columbus.

ANsterdaxr, p. v., Cass co., Ind.: on the Wabash r., 68 m. N. W. Indianapolis,

Amsterdar, p. Y., Botetourt co., Firg.: 122 m. W. Richmond.

Aracostia, p. o., Washington $c_{0}, D_{0} C_{0}:$ on the cr. of the same name, 4 m. N. E. Washirgton.

AradARCo, p. v., Rusk co., Tex. : 268 m. N. E. Austin City ANanUAC, p. V., Liberty $\mathrm{co}_{2}, \mathrm{Tex}_{3}$ : on the E. side of Galreston Bay, $210 \mathrm{~m}$. E. by S. Austin City.

Analonink, p. V., Cherokee co., Texo. (formerly BranchTOWN): 184 m. N. E. Austin City.

Anamosa, p. v. and cap. Jones co, Ia. : 32 m. N. N. E Iowa City.

AN

ANAXDALE, p. v., Fairfax co., Firg.: $92 \mathrm{~m}$. N. Richmond.

ANAQUASSCOOK, p. v., Washington co., N. $Y_{0}: 33 \mathrm{~m} . \mathrm{N}$. by E. Albany.

Arastatia island, Flor.: situate on the $\mathrm{E}$, coast, and is $18 \mathrm{~m}$. long, and $1 \frac{1}{2}$ broad. At its $\mathrm{N}$. end, in lat. $29^{\circ} 50^{\prime}$, and long. $4^{\circ} 29^{\prime} \mathrm{W}$. from Washington, is a signal tower, well known to seamen.

ANCrext, p. o., Dane co., Wisc.

ANcrasr, t, and p. v., Columbia co, N. Y.: $49 \mathrm{~m}, \mathrm{~S} . \mathrm{E}$ Albany, on Ancram and Punch creeks, on the former of which are extensive iron works-iron ore, as also galena, being plentiful in the vicinity. Pop. 1,570.

ANORAM Lead-MINE, p.. ., Columbia co., N. Y.: on Punch cr., where there are considerable quantities of galena.

ANDalusrs, p. v. and cap. Covington $c_{0}, A l a .: 72 \mathrm{~m}$. s. Montgomery.

Axpalesia, p. v., Rock Island co., $M l .: 126 \mathrm{~m}$. N. W. Epringfteld.

Andaldsta, Bucks co., Penn.: $92 \mathrm{~m}$. E. Harrisburg.

ANDERSON county, $K y$. Situate N. centrally, and contains 240 sq. m. Drained by Salt r. and its creeks, and Kentucky r., which washes its E. border. Surface rariouschiefly undalatiog, and soils good, producing Indian corn, wheat, ete., and some small quantity of tobacco and cotton. Farms 420 ; mannf. 37 ; dwell. 8S3, and pop.-wh. 4,948, fr. col. 30, sl. 1,282-total, 6,260. Capital: Lawrenceburg.

ANDERSON district, S. Car. Situate N. W., and contains $780 \mathrm{sq} . \mathrm{m}$.; lying between the Savannah and Saluda, it is well drained by a number of the large tributaries of these rivers. The surface is undulating, and the soils very productive. The chief products are Indian corn, wheat, and tobacco, and an abundance of live stock is owned in the district. Farms 1,986; manuf. 66 ; dwell. 2,440, and pop. -Wh. 13,871, fr. col. 90, sl. 7,514-total, 21,475. Capital: Anderson. Pubtic Works: Anderson Branch of Greenville and Columbia R. R., etc.

ANDERSOx county, Tenn. Situate E. centrally, and contains $750 \mathrm{sq} . \mathrm{m}$. Drained by Clinch $\mathbf{r}$. and its creeks, and the head streams of the S. fork of Cumberland $r$. Surface uneven-sometimes hilly and broken, but soils of an average fertility, producing wheat, corn, oats, and tobacco. Farms 698; manup. 9; dwell. 1,091, and pop.-wh. 6,391, fr. col. 41, \&l, 506-total, 6,938. Capital: Clinton.

A sDERBon county, Tex. Situate N. E. centrally, between Trinity and Neches rivers, and contains about $800 \mathrm{sq} . \mathrm{m}$. Drained by Caddo, Broshy, Walnut, Harricane, Still's, and Ionic creeks of the Neches, and Cat-fish, Lake, Keacheye, and Parker's creeks of Trinity. Surface various, elevated in the middle, and sloping E. and W. Soils rich, and productive of sugar and cotton. Farms 206; dwell. 375, and pop.-Wh, 2,2S4, fir, col - , sl. 600-total, 2,854. Capital: Polestine.
ANDER80N, p. v., Clark co., $M l$. : $108 \mathrm{~m}$. W. Springfield. ANDERSON, t., p. v., and eap. Madison co, Ind. : on $\mathbb{S}_{\text {. }}$ side of White r., $36 \mathrm{~m}$. N. E. Indianapolis, and on the Indianapolis and Bellefontaine R. R., where it is intersected by the Richmond and Newcastle Extension R. R. The "Anderson Gazette" is issued weekly.

ANDERson, p. v., Warren co., N. Jer.: $56 \mathrm{~m}$. N. Trenton. ANDERson, p. v., Walker co., Ga.: 172 m. N. W. Milledgeville.

Andersoy, p. $\checkmark$. and cap. Anderson dist., S. Car. : 110 m. W. N. W. Columbus. A branch of Greenville and Columbia $R . R$. terminates here, and it is probable that a railroad will be built westward through Rabun Gap, toward the Tennessee lines. The "Anderson Gazette" is issued weekly, and the "Farmer and Planter" monthly,

ANDersor, p. v. and cap. Grimes co., Tex. : on Hollands cr. of the Navasota r., $132 \mathrm{~m}$. E. Austin City.

Andersonbuggh, p. v., Perry co., Penn.; 32 m. N. W. Harrisburg.

ANDERson River, p. o., Spencer co., Ind.: on a r. so called, flowing to the Ohio r., $122 \mathrm{~m} . \mathrm{S}$. S. W. Indianapolis. Andersow's Muls, p. 0., Butler co., Penn.: 168 m. W. Harrisburg.

ANDerson's Store, p. o., Caswell co, $N_{0}$ Car.: $68 \mathrm{~m} . \mathrm{N}$. W. Raleigh.

Anderson's Store, p. o., M'Nairy co., Tenn.: $118 \mathrm{~m} . \mathrm{W}$. S. W. Nashville

ANDERsox's StoBe, p. 0., Morgan co, Ohio: $58 \mathrm{~m}$. E. by \$. Columbus.

ANDERsonvilez, p. Y., Franklin co., Ind.: on a cr. of White Water r., $49 \mathrm{~m}$. E. by S. Indianapolis.

ANDERSONville, p. v., Anderson dist., S. Car.: on Seneca cr., at its junction with Savannah r., 120 m. W. by S. Columbia.

ANDes, $t_{0}$ and p. $\nabla_{0}$, Delaware co., $N . Y_{\text {.: }}$ on Papacton branch of Delaware r., $71 \mathrm{~m}$. S. S. W. Albany.

Andesvidize, p. V., Perry co., Penn.: 28 m. W. by N. Harrisburg.

Axdors, p. v., Philadelphia co., Penn。: 93 m. W. Harrisburg.

ANdover, p. v., Tolland co., Conn.: 18 m. E. Hartford.

ANDover, p. T., Henry co., $M l_{\text {: }}$ on N. side of Edward's r, $102 \mathrm{~m}$. N. N. W. Springfield.

ANDOVER, t. and p. 0., Oxford co, Me.; on Elis r., of the Androseoggin, $46 \mathrm{~m}$. W. N. W. Augusta. Pop. 701

Axpover, t, and p. o., Essex co., Mfass.: 21 m. N. Boston, on the S. W. side of Merrimae r. It is noted as the seat of a Theo. Seminary and other educational establishment3; and has numerous manufactures. Pop. 6,748.

$\Delta$ NDovere, t. and p. o., Merrimac co., N. Hamp.: on Blackwater r., 23 m. N. W. Concord, or by the Northern R. R., which passes through it, $28 \mathrm{~m}$. Pop. 1,220.

ANDovfr, p. v., Sussex co, N. Jer.: 27 m. N. Trenton.

ANDOVER, $t$, and $p_{0} v_{n}$, Alleghany co., $N$. $Y_{0}: 216 \mathrm{~m}$. W S. W. Albany, or 358 m. W. N. W. from New York by Erie $R_{0} R_{0}$, which passes through it. Pop. 1,476.

ANDo YER, t. and p. V., Ashtabula co., Ohio: $168 \mathrm{~m}$. N. E. Columbus. Pop. 963 .

ANDover, $t$, and p. v., Windsor co., Verm.: on the head waters of Williams' river, at the $\mathbf{E}$, base of the Green Mountains, $69 \mathrm{~m}$. S. Montpelier. Pop. 725 ,

A MDREW county, Mo. Situate N. W. on Missouri r., and contains 433 sq. m. Drained by Nodaway r. and the forks of Little Platter. Suriace level, mostly prairie, and the soils very productive. Farms 873 ; manuf. 5 ; dwell. 1,377, and pop.-wh. 8,758, fr. col. 13, sl. 662-total, 9,433. Capital: Sarannah.

ANDREW; p. v. and cap. Jackson co., Ia. : 5 m. N, of Macoquetais r., and $58 \mathrm{~m}$. E. N. E. Iowa City. A newspaper, the "Western Democrat," is issued weekly.

Andeew Chapel, p. 0, Madison con, Tenn.: $121 \mathrm{~m}$. W. by $S$. Jashville.

ANDREws, p. v., Morrow co., Ohio: $51 \mathrm{~m}$. N. Columbus. 
ANDBEws, p. o., Spottsylvania co., Firg.: 46 m. N. Richmond.

ANDRoscogene river, $M e_{0}:$ is formed by the junction of Magalloway r., and the outlet of Lake Umbagog, in New Hamp., in which State it has a $\mathrm{S}$. course of about $40 \mathrm{~m}$. After entering Maine, it takes a serpentine course, first, E., then $\mathbf{S}$., and finally E., for about $100 \mathrm{~m}$., when it runs over Pejepskeag Falk, and joins the Kennebee at Merry-meeting Bay, $6 \mathrm{~m}$. above Bath, and $18 \mathrm{~m}$. from the sea: its whole course is about $150 \mathrm{~m}$. The confluent streams from this bay is sometimes called the Sagadahock.

Axgetrc., t., p. $v_{.}$, and cap. Alleghany co., $N . Y_{0}:$ on Angelica cr, of Genesee r., 221 m. W. by S. Albany. It contains the county buildings, a bank, the "Alleghany County Bank," and several churehes; and a newspaper, the "Angelica Reporter," is issued weekly. Pop. 1,592.

ANGELINA county, Tew." Situate E. between Neches and Angelina rivers, and contains about 1,320 sq. m. Drained by Caney, King's, Buck, Shawnee, and other creeks of the Neches, and by Durazno, Poffer, and others of Angelina r. Surface beautifally varied-the watershed running parallel and near to Angelina r. Soils fertile, and produce cotton and sugar largely. Farms 88; dwell. 166, and pop.-wh. 945, fr. col. 24, sl. 196-total, 1,165. Capital: Marion.

Angelina river, Tera.: a considerable stream in E. Texas falling into Neches r. $2 \mathrm{~m}$, below Bevelport.

Angley's Beanch, p. o., Barnwell dist., S. Car. : $69 \mathrm{~m}$. S. by W. Columbia.

Axgota, t., p. v., and cap. Steuben co., Ind.: $142 \mathrm{~m} . \mathrm{N}$. N. E. Indianapolis.

Argold, p. v., Lake co., Ill. : 184 m. N. N. E. Springfield, and $6 \mathrm{~m}$. below the Wisconsin State line.

Añgold, p. v., Erie co., $N_{0} Y_{0}: 264 \mathrm{~m}$. W. Albany.

Angostura, p. v., Pike co., Ind.: about 180 m. S. S. W. Indianapolis.

Avgola, p. v., Sussex co., Del.

ANGola, p. 0, Onslow co., N. Car.: 92 m. B. E. Raleigh.

ANNAPOLIS Citr, port of entry and p. o.; co, seat., Anne Arundel co., and cap. of the State of Maryland; on W. side of Severn r., $3 \mathrm{~m}$. from its entrance into Chesapeake Bay, and distant $38 \mathrm{~m}$. E. N. E. of Washington, D. C. Lat. 380 $58^{\prime} 50^{\prime \prime} \mathrm{N}$., long. $76^{\circ} 29^{\prime} 26^{\prime \prime} \mathrm{W}$., from Greenwich, $0032^{\prime}$ $40^{\prime \prime} \mathrm{E}$. from Washington. In 1830 the population was 2,623, in 18402,792 , and in $18503,011-$ wh. 1,774, fr. col. 585, and sl. 652. The government removed from St. Mary's, the old capital, to Annapolis, then called Providence, 1689. Annapolis is regularly laid out, its strects diverging from the State House and Episcopal church, as from two principal centres. The State House is a substantial building; in this the old Congress held some of its sessions, and the Senate Chamber, in which Washington resigned his commission to that argust body, has been preserved unaltered. The State library contains about 25,000 volumes. The city has a markethouse, a bank (the Farmer's Bank of Maryland), a theatre, and about 420 dwellings, many of which are elegant and spacious. St. John'B College, formerly a branch of the University, is located here ; it was founded in 1784 , and in 1850 nad 6 professors, 30 students, 150 alumni, 8 of -whom were ministers, and a Library containing 3,292 volumes. The public press consists of two newrpapers, the "Maryland Republican," and the "Free Press," issued weekly, together circulating 1,200 copies. Shipping owned in the collection district of Annapolis, on the 1st June, 1850, was 2,323 tons, of which 336 was navigated by steam power. Some small manufactures are carried on, and the coasting trade hence is on a liberal scale. The city communicates with the interior lines of travel by the Annapolis and Elkridge $R . R$, $21 \mathrm{~m}$. in length, diverging from it in a N. W. direction to a junction with the Washington Branch R. R., at a point 18 m. from Baltimore, $22 \mathrm{~m}$, from Washington.

A.sinapolis, p. $\nabla .$, Jefferson co., Ohio: 122 m. E. by N. Columbus
Annapolis Junction, p. o., Anne Arundel co., $M d_{0}: 21$ m. N. W. Annapolis.

$\mathrm{ANN}_{\mathrm{NRBOR}}$ t., p. v., and eap. Washtenaw co., Mich.: on both sides of Huron $\mathrm{r}$, and on the line of Central $\mathrm{R}$. R. $37 \mathrm{~m}$. W. Detroit and $51 \mathrm{~m}$. E. S. E. Lansing. It is the seat of the University of Michigan, and an important point of in ternal trade. There is a bank here; and two newspapers, the "Michigan Argus" and the "Washtenaw Whig," are issued weekly. Pop. 4,870.

ANNe ArUNDEL county, Ma. Situate W. shore, and contains $678 \mathrm{sq} . \mathrm{m}$. Drained by creeks running to Patapsco, Severn, and West rivers. Surface is generally undulating, with some broken spots and swamps. Soils vary from sandy to clayèy loam; iron, copper, etc., abundant, and marl found in several parts. Tobacco is largely grown-in fact, is the principal staple. Farms 1,295; manuf. 156 ; dwell. 3,712 , and pop.-wh.16,542, fr. col. 4,602, sl. 11,249-total, 32,393. Cupital: Annapolis. Public Works: Annapolis and Elkridge R. R. In 1851 Howard co. was erected from Anne Arundel.

AnNaw ATKA, p. v., De Kalb co., Alla. : 150 m. N. N. W. Montgomery.

Ammisquar, p. v., Essex co., Mrass. : 32 m. N. W. Boston Annty Creek, p. v., McKean co., Penn.: on a cr. so named, $188 \mathrm{~m} . \mathrm{N}$. W. Harrisburg.

Ansvilize, t. and p. o., Lebanon co, Penn.: on Swatara cr., $18 \mathrm{~m}$. E. by N. Harrisburg.

Anselx, p. v., Gallia co., Ohio: 88 m. S. E. Columbus.

Assor county, $N$. Car. Situate S. on State line, and contains $760 \mathrm{sq} . \mathrm{m}$. Drained by Yadkin r. and tributaries. Surface somewhat uneven, and the soils of a good quality, prorlucing wheat, Indian corn, and cotton. Cotton is its great staple. Farms 675 ; manuf. 32 ; dwell. 1,166, and pop. -wh. 6,556, fr. col. 101, sl. 6,832-total, 13,499. Capital. Wadesboro.

Arson, t. and p. o., Somerset co, Me, : on W. bank of Kennebec r., 31 m. N. Augusta. Pop. 84S.

Axsoñ., p. v., New Haven co, Conn $n_{0}$ : on Naugatuck R. R., $16 \mathrm{~m}$. N. Bridgewater. A station on Naugatuck R. R., $16 \mathrm{~m}$. N. Bridgeport

AvTeSTOWN, p. .., Blair co., Penn. : 86 m. W. Harrisburg. AжтноNт, p. V., Delaware co., Ind. : 49 m. N. E. Indianapolis.

AvTHont's Creek, p. v., Greenbrier co., Firg.: on a cr. so called, $178 \mathrm{~m}$. W. Richmond.

ANтнокт's Nose: is the extreme point of a hill called the Klips, on the N. side of Mohawk r., and which forms a remarkable similitude to a magnificent proboseis, 300 or 400 feet in length.

ANTroNy's Nose: on the S. side of Breakneck Hill, on the $\mathrm{E}$. bank of the Hudson. It is a promontory of the Highlands, 877 feet above the river, having a resemblance to the human feature, indicated by its name. There is another similar formation below West Point, at the S. extremity of the Highlands.

Aктнолу Shonts, p. o., Elbert co., Ga.: 86 m. N. N E Milledgeville.

A.NTHONY"s VILLAge, p. V., Kent co., R. I.: 14 m, S. S. W. Providence.

ANTI Bark, p. o., Hïnds co., Ariss.

Antietay creek, MI.: a fine stream of the Potomac, running through Washington $\mathrm{co}, \mathrm{Md}$.

A NTIM county, Mfich. Situate N. W. on Lake Miehigan, and contains $618 \mathrm{sq} . \mathrm{m}$. A new eounty since 1850 .

Avтroch, p. v. Troop co., Ga.: $108 \mathrm{~m}$. W. Milledgeville. Aлтroch, p. v., Lake co., Ill.: $182 \mathrm{~m}$. N. N. E. Springfleld.

Awriocr, p. v., Contra Costa co., Calif. : 15 m. S. Vallejo, A мттосн, p. v., Picken co., Ala.: 106 m., W. N. W. Montgomery.

ANтाосH, p. v., Morroe co, Ohio. : 102 m. E. by S. Con lumbus. Pop. 107.

Axтосн, p, Y., Gibson co, Tenn。: 127 m. W. Nashville 
ANTKOCH, p. V., Ynrk dist., S. Car. : $47 \mathrm{~m}$. N. Columbia. Axtorn, p. T., Clark co., Ark. : on Antoin cr., 78 m. S. W. Little Rock.

ANTRLM, th and p. o., Shiawassee co., Mfich.: on Looking-glass r., 26 m. E. Lansing. Pop. 282,

ANTRLM, t. and p. o., Hillsborough co, $N$. Hamp. : on Contoocook r., 25 m. S. W. Concord. Pop. 1,143.

Antru, p. v., Guernsey co., Ohio. : 81 m. E. Columbus. Axtrom, p. v., Alleghany co., Penn.: 152 m. W. Harrisburg.

ANTwERP, t. and p. $0_{*}$, Jefferson co, $\mathcal{N}_{\text {. }} \bar{Y}_{.}$: on In$\operatorname{dian} r_{,}, 146 \mathrm{~m}$. N. W. Albany, The Watertown and Pots dam $R . R$. passes through it. Pop. 3,665.

ANTWERP, p. v., Paulding co., Ohio, : 122 m. N. W. Columbus.

A virt, p. F., Clarke co., Ark.: 8 m. S. W. Little Rock. AoNIA, p. Y., Wilkes co., Ga.: 58 m. N. N. E. Milledgeville.

Apollo, p. F., Armstrong co., Penn.: 152 m. W. by N. Harrisburg.

APPALACHICOLA river: is formed by the union of the Chattahoochee and Flint rivers, on the S. confines of Georgia; after which, flowing between E. and W. Florida, it falls into the Gulf of Mexico, E. of Cape Escondilla. It is wide and deep, the tide running up for $60 \mathrm{~m}$. The estuary (Apalache Bay) forms a fine harbor, but its entrance at low water is only 3 fathoms deep. The Appalachicola and its branches drain a basin having an area of nearly 20,000 sq. $m$.

Apratachrcora, p. v., port, and eap., Franklin co., Frlor.: on a bluff at the W. side of the entrance to Apalachicola $r$. $62 \mathrm{~m} . \mathrm{S}$. W. Tallahassee. The harbor is deep enough for large vessels, and the port has considerable coasting trade. The tonnage in 1850 was 2,050 tons, all navigated by steam, and chietly employed on the river. In the foreign trade 17,132 tons cleared, and 12,196 tons entered in the same year. A newspaper, the "Commercial Advertiser," is issued weekly. The village occupies a plot one mile square, and is regularly laid out. It contains the county buildings, and has numerous substantial warehouses and dwellings.

Appalacme, p. v., Tioga co., N. Y.: 138 m. W. S. W. Albany.

APPANoose county, Ia. Situate S. middle on State line, and contains $576 \mathrm{sq} . \mathrm{m}$. Drained by Chariton r. and branches. Surface undulating, chiefly prairie and soils fertile. Farms 153; manuf. 2 ; dwell. 521, and pop.-wh. 3,124, fr. col. 7-total, 8,131. Capital: Centreville.

Appersox's, p. o., Charles City co., Virg.: 22 m. S. E. Richmond.

Apple Creek, p. o., Cape Girardeau co., Mo.: on a cr. of the Mississippi so called, $15 \pi \mathrm{m}$. E. S. E. Jefferson City

Apple Creek, p. o., Wayne co, Ohio: on a cr, so called, $7 \mathrm{sm}$. N. E. Columbus.

Arple Grote, p. v., Tork co., Penn.: 32 m. S. E. Harrisburg.

Apple Grove, p. 0., Morgan co., $A l a_{*}: 146$ m. N. N. W. Montgomery.

Afple Grove, p. v., Polk co., Ind. : $112 \mathrm{~m}$. W. by N. W. Iowa City.

Apple Grove, p. V., Meigs co, Ohio: 85 m. S. E. Columbus.

Applator, p. v., Licking co., Otio : $41 \mathrm{~m}, \mathrm{E}$. by N. Columbus. Pop. 4?.

Applexox, p. v., Perry co. $I u_{0}$ : $111 \mathrm{~m}$. S. Springfield.

Appleton, p. v., Winnebago co., Wisc. : 82 m. N. by E. Madison.

Appixy county, $G a$. Situate 8. E., and contains 1,120 $\mathrm{m}$. Drained by Oemulgee and Alatamaha rivers in the $\mathrm{N}$., and the tributaries of Santilla $r$. in the S. Surface level, declining to S. E. : soils sand ș and light. Farras 313; dwell. 410, and pop.-wh. 2,521, fr. col. 24, sl. 404-total, 2,949. Capital: Holmesville.
Appung, p. v. and cap., Columbia co, $G a_{*}$ : on Great Kiokee cr., 63 m. E. by N. Milledgeville

Applisk, p. v., Jeferson co, N. Y.: 149 m. W. N. W. Albany.

Apromatrox county, Firg. Situate centrally between James and Appomattox rivers, and contains $320 \mathrm{sq} . \mathrm{m}$ Drained chiefly by Appomattox r. and several tributaries of James r. Surface level and soils of good quality. Farms 602 ; manuf. 10 ; dwell. 785 , and pop--wh. 4.210 , fr. col. 184 sl. 4,799-total, 9,198. Capital: Clover Hill.

Appomatтox river, Firg.: is a branch of James $x_{\text {, }}$, which it joins $60 \mathrm{~m}$, above its mouth, and is navigable to the falls $20 \mathrm{~m}$. above the junction; and, by means of a canal-boat. navigation is extended $80 \mathrm{~m}$. farther up.

APPOQUinimisa, hund., Newcastle co., De..: area 73,078 acres and pnp. 3,327.

Aguasco, p. v., Prince George's co., Md.: on W. side Patuxent r., 28 m. S. S. W. Annapolis.

AQUEDUCT, p. V., Westmorland co., Penn.: $128 \mathrm{~m}$. W. Harisburg.

Aquedect, sta., Dauphin co., Penn. on Pennsylvania R. R., $15 \mathrm{~m}$. E. Harrisburg.

Aquia, p. V., Stafford co., Virg.s: on N. side of cr. so caller, $4 \mathrm{~m}$. from its confluence with Potomac r., $61 \mathrm{~m}$. N. Ricbmond.

Aquid Creme Landivg, Stafford co., Firg.. : the N. terminus of the Richmond, Frederic, and Potomac R. R. Steamers from Washington connect the northern and southern lines of railroads-distance $55 \mathrm{~m}$.

AQuilis, p. v., Franklin co., Ga.: 89 m. N. N. E. Milledgeville.

Aquone. p. o., Macon co., N. Car.: 273 m. W. S. W. Raleigh.

Aransas, p. v., Refugio co, Tex. : $192 \mathrm{~m}$. S. Austin City. Ararat, p. o., Patrick co., Virg.: 174 m. S. W. Pichmond.

Arator, p. v., Pettis co., Mo.: on a cr. of south fork of Missouri r., $49 \mathrm{~m}$. W. Jefferson City.

ARBA, p. V., Randolph co., Fथ̈g.: $168 \mathrm{~m}$. N. W. Richmond.

ArBacoockeE, p. V., Randolph 'co., Ala.: 75 m. N. E. Montoromery.

Arbuckle, p. v., Mason co., Firg.: 162 m. W. by $\mathbf{N}$. Richmond.

Arcadia, p. v., Bienville par., La.: 177 m. N. W. Baton Pouge.

ArcsDrA, t, and p. v., Wayne $c_{*}, N . Y .:$ on Meed cr, $191 \mathrm{~m}$. W. Albany, The $\mathrm{v}$. lies on the Erie Canal.

Aroadra, p. v., Morgan co., $I l l$.: on N. eounty line, 36 Fo. W. Springfield.

Arcadort, p. v., Washington co., R. I.: 28 m. S. S. W Providence.

Arcadru, p. v., Madison co., Mo : on a cr, of St. Francois r., 106 m. S. E. Jefrerson City.

A rcadra, p. v.. Sullivan co, Tenn. : 121 m. E. Nashville.

Arcier, t. and p. o., Harrison co, Ohio: 99 m. E. N. E. Columbus. Pop. Sï.

Archubaid, p. o., Luzerno co., Penn. : 92 m. N. E. Harrisburg.

Arcota, p. V., Loudon co, Firg.: in S. E. extremity of co.. $92 \mathrm{~m}$. N. Richmond.

Arcol., p. v., Warren co., N. Car.: 49 m. N. N. E. Raleigh.

Arcola, p. v., Lake co., Ohio: 151 m. N. N. E. Columbus. The iron works of the village are extensive, and it is otherwise flourishing.

Areva, t. and p. v., Iowa co., Wiso.: on the S. side Wisconsin r., $31 \mathrm{~m}$. W. by N. Madison. Pop. 402.

Arexac county, Mrich. Situate E. on Saginaw Bay, and contains $504 \mathrm{sq}$. m. Drained by Rifle, Pine, and other streams. A new co. since 1550 .

Areadotsviule, p. Va, Adams co., Penn.: 42 m. S. S. W. Harrisburg. 
Arexzyllet, p. v., Cass cos, Iut.: on a cr. of Illinois r., $49 \mathrm{~m}$. W. Springfield.

Ararntrve, t. and p. o., Genesee co., Mich.: on Shiawassee r., $36 \mathrm{~m}$. E. Lansing. Pop. 436 .

Ar $\in$ o, p. v., Carroll co., Ill.: 152 m. N. N. W. Springfield. Areo, p. $v_{*}$, Hall co, Ga.: 98 m. N. Milledgeville.

Argo, p. F., Crawford co., Mo. : in the N. W. corner co., on a branch of Bourbease cr. of Maramee r., $54 \mathrm{~m}$. E. Jef ferson City.

bany.

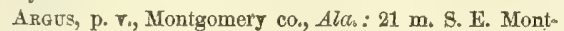
gomery.

Afgrte, t, and p. o., Penobscot co., Me. : on W. side Penobscot r., 69 m. N. E. Augusta. Pop، 338,

Argrux, p. v., Lafayette, co., Wisc. : on Peketonica r., $86 \mathrm{~m} . \mathrm{S}$. W. Madison.

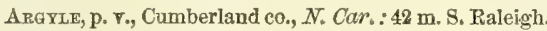
$\triangle R G Y L$, p. V., Jefferson co., MO.: 94 m. E. by S. Jefferson City.

ARgrLa, t. and p. v., Washington $c_{\diamond}, N_{0} Y_{*}$ : on Moses" kill, $33 \mathrm{~m}$. N. Albany. Pop. 3,274. A teld.

ArIEL, p. v., Marion dist, S. Car. : 80 m. E. Columbia.

Arrel, p. v., Wayne co., Penn.: 102 m. N. E. Harrisburg.

ARISPE, p. v., Bureau co., Ill.: $108 \mathrm{~m}$. N. Springfield.

ArK, p. V., De Kalb co, Ga. : 74 m. N. W. Milledgeville Azkadrlpura, p. vo and cap. Clark co., $A r k: 79 \mathrm{~m} . \mathrm{S}$ W. Little Roek.

A ersaxisas county, Ark. Situate E. on Arkansas r., near its entrance into the Mississippi r., and contains $960 \mathrm{sq} . \mathrm{m}$. Drained by a number of creeks, tributaries of Arkansas r. and of White r., which latter forms its N. E. border. Surface generally level, low, and subject to inundation. Westward it rises somewhat, and here commences "Grand Prairie," a fine, fertile country. Farms 153; dwell. 328, and pnp.-Wh. 1,695, fr. col. 12, sl. 1,598-total, 3,245. Capital Arkansas Post.
Althansas Post, p. v. and cap. Arkansás con, $A \eta \%$, on the N. side of Arkansas r, $52 \mathrm{~m}$, from its confluence with Mississippi $r$. It is the oldest town in the State, lawing been founded by the French in 1685 .

Ankassas river: one of the principal tributaries of the Mississippi $x$. It rises in the Rocky mts., near the sources of the Del Norte, about lat. $40^{\circ}$ N., and falls into the Mississippi, $400 \mathrm{~m}$. above Red r., in lat. 830 40'. Its wilole length is $2,170 \mathrm{~m}$., of which 1,980 are navigable. It sarpasses all the rivers of the middle region of the $U$. S. in the gracefulness and regularity of its windings, and the beauty and luxuriance of the cotton-wood groves that adorn its banks. In spring floods, steamboats can ascend it nearly to its source: the channel is broad, and the navigation is safe, unobstructed by rocks, shoals, or rapirls. The shores, as far W. as Little Rock, are unhealthy, large tracts on both sides being covered with lakes and stagnant pools. The country is a dead level, and there the drainage is imperfeet. On the Great Prairie, that commences inomediately above the port, and extends for $90 \mathrm{~m}$. up the country, the climate becomes more healthy, and this tract is thoroughly rentilated; but in the elosely-wooded bottnms the air is heavy and inelastic, and the mosquitos very troublesome. Still further up, the climate and country improve. Near the sources of the river, silver has been found; and the soil of the districts through which the river flows is so saturaterl with salt, that the waters are strongly impregnated and rendered unfit for drinking. Independent of the ton salino quality of the water, the rast proportion of red mold which is carried away by the current, produces a similar disqualifying effect as to its uses for general purposes. Arkankas River has been called the "Paradise of Savages," from the number of wild animals that are continually wandering along its banks.

AnTSANSAS (Little) river: a tributary of Arkansas r. It rises in the deep sand alluvial district, and crosses the traders' route from Missouri to Santa F'e, and falls into the Arkansas Proper, $1,700 \mathrm{~m}$. from its junction with the Mississippi r., in lat. $32^{\circ} 30^{\prime} \mathrm{N}$. , and long. $9 \mathrm{~S}^{\circ} \mathrm{W}$.

\section{THE STATE OF ARKANSAS.}

Arkansas is bounded on the north by Missouri, on the east by Tennessee and Mississippi, on the south by Lonisiana, and on the west by the Indian Territory and Texas; and extends generally between the latitudes $33^{\circ}$ and $36^{\circ} 30^{\prime}$ north, and the longitudes $89^{\circ} 30^{\prime}$ and $94^{\circ} 30^{\prime}$ west from Greenwieh, or $12{ }^{\circ} 23^{\prime}$ and $17^{\circ} 28^{\prime}$ west from Washingtor. Its length from north to south is 242 miles, and its breadth from east to west varies from 170 mules on the south line to 258 miles on the 36th parallel, where it is widest. The area of the State is $52,19 \mathrm{~s}$ square miles.

The surface of Arkansas presents great variations in its configuration. Along the Mississippi River, which demarks its boundary on the east, and for 30 to 50 miles inland, the country is low and widoly interspersed with lakes and swamps, and with inconsiderable exceptions, is annually overflowed by the floods of the Mississippi, Arkansas, and St. Francis.

In regard to the country west of the Mississippi, says Col. Long, it is proper to observe, that the broad ralley of the Lower Mississippi, which is terminated to the north by the hilly country, connected with a continuous rocky bar, or reef, traversing the beds both of the Mississippi and the Ohio, about 12 miles above their junction, and denominated the Grand Chain of those rivers respectively, and which stretches southward, interrupted by a single hill, or ridge, elerated more than a few feet above the reach of the highest floods; that this entire valley region, once probably an arm or estuary of the ocean, and inhabited by the mensters of the deep, but long since reelaimed by the immense alluvion precipitated over the Grand Chain, in cataracts incomparably more grand and stupendous than that of Niagara, and borne thither on the backs of countless floods, is one continued and almost boundless flat, broken only by a multiplicity of waterconrses, lagoons, and bayous, some of them tributary to tho Mississippi, and others supplied from it, and exhibits an aspect variegated rather than embellished by the inequalities just mentioned, together with countless swamps, slasbes, stagnant pools, ete. Across this valley there are as yet no passes by land secure from frequent and protracted interriaptions, occasioned by overflows from the rivers by which it is traversed, nor is there any encouraging prospect that roads ean be hereafter constructed to any tolerable adrantage, except in a very few instances.

The country through which the St. Francis River passes is one continuous swamp. The surface presents, in ordinary times, an alternating appearanee of lakes, bayous, cypress lands, and marshy ground: the lakes free from any growth of timber, except of cypress, growing in the water close to the banks, and the bayous, also free from timber, but freqnently Iying in broad and deep valleys, wooded not less thickly than the high ground, and containing comparatively little undergrowth. The valleys are in many cases inundated to the depth of 15 or 20 feet, or even more. The ponds are mostly filled with very large eypress trees, growing in the water, where its depth does not exceed 3 or 4 feet, except in time of overflow. The marshy gronnd is filled with trees of immense size, prineipally gum and sycamore, in the lower places, and white oak and hickory in those that are a little higher and dryer, having occasionally brakes of cane very thickly set, and frequently rising to the height of 20 and 30 feet, and of proportionate diameter.

Farther west the surface rises, and toward the centre of the State becomes moderately hilly, and farther west still it 


\section{ARKANSAS.}

rises into the Ozark Mountains. There are numerous and extensive prairies interspersed throughout, but much of the land is well wooded, and in many places it is covered with a heavy forest.

Of the highlands that hare been called the Ozark or Masserne Mountains, our knowledge is very imperfect. They consist of several low ridges, irregular in their direction, and seldom rising to an elevation of more than 1,500 or 2,000 feet. They appear to be composed chiefly of secondary rocks, limestones, clay slates, and sandstones, traversed in many places by dykes of greenstone, granite, and sienite. Those portions of this region which have been examined are found to be rich in metallic minerals, of which iron and lead, copper and zinc exist in great profusion. Coal and salt also abound; and there are valuable thermal and sulphurous springs. The Hot Springs of the Washita are remarkable for their high temperature, but are not powerfully impregnated with any mineral substances; they burst forth in great numbers and volume in a small valley lying between two lofty ridges of sandstone, and vary in temperature from $105^{\circ}$ to $1510 \mathrm{Fa} h$. There are said to be more than seventy of these springs, several rising from the bed of a small stream which flows through the valley, and others issuing from the bounding ridges, at various heights. The Washita oilstones, or noyaculites, so much esteemed, are found in this region.

The climate of Arkansas is temperate, but subject to sudden and frequent variations; and the whole country is exposed to the effect of the cold north winds which render the central portions of the United States so cheerless in the winter season. The same winds traverse southward to the equator, and are known in the Gulf of Mexico as the "northers," the terror of seamen navigating that sea. Yet in the spring, summer, and fall the seasons are highly propitious to agriculture, and here cotton, Indian corn, and, in fact, all the great staples of the conntry find the climate highly congenial. The soils vary from the most sterile to the most fertile, and on the margins of all the rivers the productiveness is unbounded. On most of these the soil is a rich alluvion deposited from the washings of the floods, deep and wide, covering millions of acres. Back from the rivers the soil becomes more and more sterile, and in many parts it is unfit for culture, either from scarcity of water or from metallic impreguation. The principal growths are pines, cypresses, sycamores, and oaks, according to the formation, and on the prairies, which are extensive, is that rank grass for which this description of land is so famous. On the whole, Arkansas has many advantages for agriculture, and it has many disadvantages. Where the Iatter, however, exist they are fully compensated for by the abundance of its minerals. It is also well stocked with wild animals, as the buffalo, deer, elk, beaver, otter, rabbit, raccoon, wild cat, catamount, wolf, bear, ete., which are valuable for their skins, and there is also a plentiful supply of wild turkeys, geese, quails, and other species of birds.

The State is traversed or washed by several of the largest rivers in America. The Mississippi bathes its eastern front for more than 350 miles by its windings, but affords no sites suitable for large towns in the present condition of the country. The Arkansas, one of the largest tributaries of the Mississippi, traverses the whole breadth of the State through its centre by a very tortuous course of about 1,530 miles, and is navigable during the greater part of the year far above its western limits. The Red River flows through the south-western corner, which is thus rendered accessible to steamboats. All the other rivers, some of which are of great magnitude, empty themselves into these three, affording navigable facilities to almost every quarter of the State. The St. Francis is a large and full river, rising in the eastern highlands of Missouri. Its channel, however, is much obstructed by numerous rafts or jams of fallen trees, and above and below the northern boundary its waters are dispersed in such a manner as to render the navigation intricate and difficult. The "Spread," as it is ealled by the inhabitants, extends for the space of about 50 miles, with a width in some parts of 20 miles, and is attributed to the earthquake of 1811, at which time a large tract of country sunk considerably below its former level, and the waters of the rivers were dissipated in numerous lakes and branches. The White River has its sources in the sonthwestern part "of the State, and passes into Missouri, whence it soon returns, reaching the Mississippi in a general Bouth-easterly course. Its length is not less than 600 miles; and although at present it is choked up in many places by accumulations of drift-wood, steamboats ascend it as far as Balerville, 260 miles, and on the removal of these obstructions will be able to ascend it 200 miles farther. The White River receives several large tributaries from Missouri, of which the Big Black, a navigable stream, is the principal; the Cache and Little Red River have their courses wholly within this State. The Arkansas receives no considerable tributary. The Washita, a noble river running through a fertile and beautiful region, drains nearly the whole southern part of the State: rising near the western border, it flows nearly parallel with the White Rirer and the Arkansas, first east, and then south-east, and is navigable upward of 350 miles from its mouth. The Little Missouri, the Saline, the Bayou Bartholomew, the Bayou Bøuff, and the Bayou Maçon, are its prineipal tributaries.

Arkansas formed a part of French Louisiana, and subsequently and until 1819, a portion of Missouri Territory. At the latter date it was erected into a separate territory, under its present name. In 1836 it was admitted into the Union as an independent State. The progress of its population was comparatively slow from 1820 to 1810 ; but since-as shown by the last census-the progress compares well with the most progressire of the States. In 1800 it contained only 1,052 inlabitants, chiefly settled near the mouth of the Arkansas River, and consisting of Frenchmen, whose progenitors settled Axkansas Post, the oldest white settlement of the country. In 1820 the population was 14,273 ; in 1830, 30,338; in $1810,97,5 i 4$, and in $1850,209,639$, of which 162,068 were white persons, 589 free colored persons, and 46,982 slaves. Deaf and dumb, 89 ; blind, 81 ; insane, 63 ; and idiotic, 102. The State $w a s$, at the latter date, divided into 51 counties, as follows : Arkansas, Ashley, Benton, Bradley, Carroll, Chicot, Clark, Conway, Crawford, Crittenden, Dallas, Desha, Drew, Frauklin. Fulton, Greene, Hempstead, Ifot Springs, Independence, Izarl. Jackson, Jefferson. Jubnson, Lafuyctte, Lawrence, Madison, Marion, Mississippi, Monroe, Montgomery, Newton, Perry, Philips, Pike, Poinsett, Polk, Pope, Prairie, Pulaski, Randolph, St. Francis, Saline, Scott, Searcy, Sevier, Union, Van Buren, Washington, Washita, White, and Yell.

Arkansas is almost wholly occupied in agricultural pursuits; its manufactures are merely in their inception, whether as to diversity or number of establishments; nor has it the advantage of a seaward commerce. The statistics afforded by the census of 1850 , and other official reports, exhibit the condition of the State to be as follows:

Occupied Lands, etc.-Improved lands, $7 \$ 1,531$ acres, and unimproved lands, 1,\$16,6S4 acres, valued at \$15,265,245. Number of farms, 17,758 . Value of farming implements and machinery, $\$ 1,601,296$.

Live Stock.-Horses, 60,197; asses and mules, 41,559 ; milch cows, 93,151; working oxen, 21,239; other cattle, 165,320; sheep, 91,256 ; swine, 836,727 -valued at $\$ 6,647,969$.

Products,-Wheat, 199,639 bushels ; rye, $\$, 047$; Indian corn, $8, \$ 93,939$; oats, 656,183 ; barley, 177 ; buckwheat, 175 ; peas and heans, 255,735 ; Irish potatoes, 193.532 ; street potatoes, iss.149 bushels; rice, 63,179 pounds : tolvaceo, 21 - 936 pounds; ginned cotton, 65,346 bales of 400 pounds; hay, 3,977 tons; clover seed, 90 bushels, and other grass seed, 436; hops, 157 pounds: water-rutted hemp, 15 tons ; flax, 12,291 pounds; flaxsced, 321 bushels; maple sugar, 9,330 pounds ; molasses, 


\section{ARKANSAS}

18 gallons; wine, 35 gallons; value of products of orchards, $\$ 40,141$, and of market-garden products, $\$ 17,150 ;$ beeswax and honey, 192,338 pounds; silk coccoons, 38 pounds; wool, 182,595 pounds ; butter, 1,5 $\$ 4,239$, and cheese, 30,088 pounds; and the value of animals slaughtered, $\$ 1,162,913$. Home-made manufactures were valued at $\$ 688,217$.

Manufactures.-Aggregate capital invested, $\$ 0,000,000$; value of raw material, fuel, ete., consumed, $\$ 000,000$; average number of hands employed, 0,000 ; males, 0,000 , and females, 000 ; average monthly cost of male labor, $\$ 00,000$, and of female labor, $\$ 0,000$; annual value of products, $\$ 000,000$. The whole number of manufacturing establishments, producing to the value of $\$ 500$ and upward annually, was 271 ; and of these three were cotton factories, employing $x$ capital of $\$ 16,500$, and using 170 bales of cotton annually, valued at $\$ 8,975$; hands employed, 13 males and 18 fernales; entire monthly cost of male labor, $\$ 190$, and of female labor, $\$ 106$; annual product, 81,200 pounds yarn, valued at $\$ 16,637$. The remaining and most numerous of the industrial pursuits of Arkansas, are those incident to all agricultural States, or such as are immediately needed, as carriage-makers, blacksmiths, tanners, etc. The distribution of manufactures in this State is very unequal; of the counties, 15 have no manufacturing establishments, 17 have less than five, 7 have five and less than ten, 7 have ten and less than fifteen, 2 have fifteen and less than twenty, and 3 have twenty and upward.

Commerce, Internal Commnication, etc.-Arkansas has no direct intercourse with foreign countries. Its export staples are carried to New Orleans for shipment, and most of its supplies are drawn from the same quarter. On all the great rivers steamboats ply regularly, and in sufficient numbers for the present wants of the population. Few of the roads are good, being chiefly earth tracks, almost impassable in wet weather. No railroads exist throughout the State, but there are several projected, and the spirit of enterprise appears to be alive on the subject. The initial point of the system projected is Helena, on the Mississippi, whence a direct line will be built to Little Rock, the capital, with an extension from that point to the Red River to meet the Texas roads pointing east, and another extension by way of Van Buren and Fort Smith, to be ultimately carried into the Indian territory, this latter being a part and parcel of the Great Southern Pacific Railroad. From these trunk lines branches will be built tapping the principal valleys, and giving to each section of the State facilities of direct railroad communication with the Mississippi rivers, and New Orleans the natural outlet of Arkansas products; a railroad is also projected from the main trunk west of White River northward through the fine agricultural and mineral region of Northern Arkansas and Southern Missouri.

Banks. - "No bank or banking institution shall be hereafter (1847) incorporated or established in this State." None are now in operation, and the old "State Bank" has for some time been in liquidation.

Government.-In accordance with the State Constitution, adopted 4th January, 1830, every free whito male citizen of the United States, 21 years old, and a citizen of Arkansas for six months next before the election, may vote in the district or county in which he resides. The Legislature consists of a Senate of 25 members, and a House of Representatives of 75 members. Senators must be at least 30 years of age, inhabitants of the State for one year before the olection, and of the district at the time, and are chosen for four years. Representatives must be at least 25 years of age, resident in their counties, and are chosen for two years. The governor is eleoted by a plurality of votes; he must be 30 years of agè, a native born citizen of the United States, and have resided in the State four years, and is chosen for four years (but is not eligible more than eight in any twelve years). His veto to any bill passed is negatived by a sulsequent majority vote of each house. In case of his disability or death, first the President of the Senate, and after him the Speaker of the Representatives, becomes governor to the end of the term. The Secretary of State, auditor, and treasurer, are elected by joint vote of the two houses. The Legislature meets at the Capital biennially.

Arkansas, under the law regulating the distribution of Representatives to Congress, has a delegation of two members.

The judiciary consists of a Supreme Court, which has a chief and two associate justices, an attorney, clerk, and reporter; six circuit courts, each with a judge and attorney, and county courts, etc. The Supreme Court has appellate jurisdiction only, except in particular cases pointed out by the Constitution. It holds two terms annually, in April and October, at the seat of government. The justices are elected by the General Assembly, by joint ballot, for eight years. Circuit courts have original juxisdiction over all criminal cases not expressly provided for otherwise by law, and exclusive original jurisdiction of all crimes amounting to felony at common law; and original jurisdiction of all civil cases which are not cognizable before justices of the peace; and in all matters of contract where the sum in controversy is over $\$ 100$. Two terms are held annually in each circuit. The judges and prosecuting attorneys are elected by the people, the former for four years, and the latter for two years. The justices of the peace in each county form a county court, and have exclusire jurisdiction in civil cases below $\$ 100$. The justices are elected in towns for two years.

Finances.-The whole revenue for the biennial period $1849-50$, amounted to $\$ 329,61551$, and the whole amount received into the treasury from all sources, was $\$ 495,19484$. The total paid out amounted to $\$ 433,97508$, leaving a balance of various accounts of $\$ 61,21976$. The State debt consists of bonds issued to the State Bank, and which are unredeemed; these consist of 6 per cents, amounting to $\$ 936,000$, due 1868 , and accumulated interest thereon. $\$$. 19,480 ; and 5 per cents., $\$ 39,000$, due 1857 , and interest, $\$ 17,06250$-or a total of debt and interest, $\$ 1,506,56250$, on which the annual accruing interest is $\$ 90,13180$. The total value of taxable property in the State in 1850 , was $\$ 31,995,885$, on which in that year a tax of $\$ 93,540$ was levied.

Religions Denominations.-The principal denominations in this State, acoording to statistics published by their own bodies in 1850, exhibited the following statements of their relative strength: Baptists, 6 associations, 78 churches, 49 ministers, and 2,509 members; Methodists, 60 traveling, 4 superannuated, and 153 local preachers, and 12,151 members; Roman Catholic, 7 churches, and 12 other stations, 6 ministers, and about 3,000 members; Protestant Episcopal, 2 clergy. The Roman Catholics are under the Bishop of Little Rock, and the Protestant Episcopalians under the missionary Bishop of Arkansas. The Presbyterians are numerous, but in consequence of the statistics of this denomination being included in synods, not co-extensive with the State, it is impossible to assess the apportionment due to Arkansas separately.

'Schoots and Education.-Although. Arkansas has had advantages to foster education equal to any others of the nem States, her improvident legislators have not improved them. There are but few common sehools in the State. In each township the 16 th section is given by Congress for the support of schools, and the revenue arising from leases of salt springs, and from estrays sold, forms part of the school fund. There are academies and high schools in Little Rock, Payetteville, Washington, Camden, and some other places. There is no State College, although Congress granted to the State seventy-two sections of land (2,592 acres) for the purpose of founding an institution of learning: this, by a law of the Legislature of 1849, and in atter defiance of the intentions of Congress, was distributed among the counties. The only effort to establish a college has been made by the Roman Catholies. In 1550 the Legislature granted them a charter 


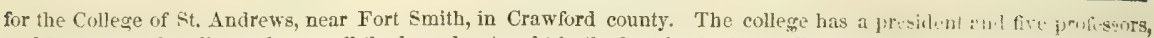
and its course of studies embraces all the branches taught in the best institutions. The Ecclesiastical Soninary is lncated on the college grounds, and is considered one of the finest edifices in the Union. St. Mary's Academy, for young ladics, at Little Rock, is also a Catholic institution.

Periodical Press.-In all the State there are but 14 periodicals-13 are issued weekly, and one at a period of two weoks. The aggregate circulation of the weekly papers is only 7,250 copies, or 377,000 copies annually. Of the whole number of papers, three are Whig in politics, and five Democratie, the remaining six being devoted to literature, religion, and rarious other subjects. Many single counties in Now York and Ohio contribute more to literature than the whole of this State.

"Arkansas, with all that nature has done for her, is far behind her neighbors in improvements, population, and general prosperity. It is a source of humiliation to make these acknowledgments; but the truth should be told, thongh the heavens fall." Such was the language of the Committee on Arkansas Railroads, at the New Orleans Convention, in 1851, and such must be the response of every intelligent resident of the State. With her increase of population, and reviving prosperity, however, it is to be hoped that so magnificent a State, one so richly endowed and so blessed with a propitious climate and soil, will take heed and redeem itself from the just opprobrium of the enlightened among them selves, and of the world that is observant of their progress.

LITTEE Rocr is the State capital.

ARKPORT, p. v., Steuben co., $N_{0}$..$:$ on Canisteo r., 218 m. W. by S. Albany.

Aekville, p. v., Delaware co., N. Y.: 57 m. S. W. Albany.

ARKWRIGHT, t. and p. v., Chautauque co., N. $Y_{.:}: 396 \mathrm{~m}$. W. by S. Albany. Pop. $1,2 \varsigma 3$.

ArLingtors, p. 0., Hancock co., Ohio: 83 m. N. N. W. Columbus.

ArlivgtoN, t. and p. v., Bennington co., Terms: on Green r. and Battenkill, 89 m. S. S. W. Montpelier. Fine marble abounds in the t. Pop. $1,0 s 4$.

ARLTRGTON, p. v., Bureau co., $Y l l_{0}: 110 \mathrm{~m}$. N. Springfield, Arrada, p. V., Macomb co., Mich.: on the N. branches of Clinton r., $84 \mathrm{~m}$. W. Lansing.

Armage, p. v., Indiana co., Penn. : in S. E. corner of co, $128 \mathrm{~m}$. W. Harrisburg.

ArmentA, p. vo, Scriven co., Ga.: 110 m. E. S. E. Milledgeville.

ArmesbuRG, p. F., Parke co, Ind.: on E. side of Vermillion $\mathrm{r} ., 66 \mathrm{~m}$. W. Indianapolis.

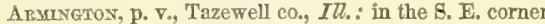
of co., $42 \mathrm{~m}$. N. by E. Springfield.

Armstrone county, Penn. Situate W. middle, and contains 575 sq. m. Drained by several tributaries of Alleghany r., which runs through it. Surface somewhat hilly, but agreeably diversifed. Soils of averago fertility, producing principally wheat and oats. Farms 1,612; manuf. 93 ; dwell. 5,052, and pop.-wh. 29,431 , fr. col. 129-total, 29,560. Capital: Kittaning.

ArMistrong, p. $\nabla_{\text {, }}$ Wabash co., Ill.: on a cr, of Wabash

r., $142 \mathrm{~m}$. S. E. Springfield.

Armstrong Acadearx, p. 0., Choctaw Nation, Ind. Ter.

Arartrone Muts, p. o., Belmont co., Ohio: $105 \mathrm{~m}$. E. Columbus.

ARMUCHEE, p. V., Floyd co., Ga, : on the W. side of Ar: muchee cr. of Oostanaula r., a tributary of Coosa r., $144 \mathrm{~m}$. N. W. Milledgeville.

ARNerTows, p. v., Burlington co., N. Jer.: 15 m. S. E. Trenton.

ARvartu, p. V., Brown co., Ohio: 82 m. S. S. W. Columbus. Pop. 61 .

Arxoldsiukg, v., Gilmer co., Firg.: $216 \mathrm{~m}$. W. by N. Richmond.

Apnoldtox, p. v., Ulster co., $N . \quad Y .: 58 \mathrm{~m} . \mathrm{S}$. Albany.

Arrordtox, p. $\nabla$. , Campbell co., Firg.: $102 \mathrm{~m}$. W. S. W Richmond.

ARNox, p. v., Wills co., $I l l .: 5$ m, from Indiana State line, and $146 \mathrm{~N}$. E. Springfield.

Aroosroor county, Me. Situate N. and N. E., and contains about $6,800 \mathrm{sq} . \mathrm{m}$. Drained by the Woolastook, Allagash, Aroostook of the St. John, and Mattawamkeag of the Penobscot. Numerous lakes and isolated hills are spread over the county. This is the largest county of the State, but is peopled only in its S. E. portion. Wheat, oats, and potatoes are the chief products. Farms 1,228; manuf. 59; dwell. 2,038, and pop.-wh. 12,529, fr. col, 6-total, 12,535. Capital: Houlton.

Aвоовтоок, p. v., Aroostook co., Me.

Aroosтоor river, Me.: rises in the N. part of the State, its head waters being separated from those of Penobscot $r$. by a stretch of highlands. Its course is circuitous, general$y$ easterly, until it falls into St. John's r. on the New Brunswick line, in lat. $400^{\circ} 05^{\prime} \mathrm{N}$. The lands on this river are fertile, and produce the finest qualities of grain and grasses. Its length is upward of $100 \mathrm{~m}$.

ArringtoN, p. V., Williamson, co., Tenn.: 18 m. S. Nashville.

ARrow ood, p. v., Spartanburg dist, S. Car. : 72 m. N. N. W. Columbia.

ARrow Rock, p. o., Saline co., Mo.: on 8. bank of Missouri $r_{.}, 54 \mathrm{~m}$. W. N. W. Jefferson City.

Arrowsmrths, p. o., Defiance co, Ohio: 104 m. N. W. Columbus.

Arsenat, p. O., Alleghany co., Penn,: 19 m. W. Harrisburg.

ARthUR6Burg, p. v., Duchess co., $N . Y_{*}: 76 \mathrm{~m}$. S. by E. Albany.

Arthurton, p. va, M'Henry co., IU.: 178 m. N. E. Springfield.

Artic, p. V., De Kalb co., Ind.: $122 \mathrm{~m}$. N. E. Indianapolis.

Assury, p. v., La Salle co., Ill.: in the N. E. part of the co., a mile W. of Rock r. and 184 m. N. N. E. Springfield.

AsBtry, p. ₹., Fayette co., Al $\alpha_{0}$ : on the E. side of Looxapatilla cr., $126 \mathrm{~m}$. N. W. Montgomery.

Asbury, p. v., Warren co., $N$. Jer.: $41 \mathrm{~m}$. N. Trenton.

Asbury, p. v., Perry co., Ohio: 47 m. E. S: E. Columbus.

Asвurr, p. v., Montgomery co., Tenn.: $52 \mathrm{~m}$. W. N W. Nashrille.

Assorx, p. v., Troup co., Ga.: $102 \mathrm{~m}$. W. Milledgeville. Ascension parish, $L a$. Situate S. W. of E. Dist., on both sides of Mississippi r., and contains $\angle 80 \mathrm{sq}$. $\mathrm{m}$. Drained TV. by tributaxies of Grand $\mathbf{r}$, and $\mathrm{E}$. by those of Amitié, etc. Surface low and level, subject to inundation, from which it is partially protected by levees or embankments. Oranges, figs, peaches, etc., grow in profusion: cotton and sugar are the staple products. Farms 157; dwell. 755, and pop.-wh. 3,339, fr. cal. 147, sl. 7,266-total, 10,752. Capital: Donaldsonville.

AscuTNEx mountain, Term.: situate in the towns of Windsor and Wethersfield. It is chiefly composed of granite, and is almost destitute of vegetation. Its elevation above the Connecticut $r$. is 3,116 , and above the ocean, 3,320 feet. Its ascent is steep and rugged.

Asmapoo Ferex, p. 0., Colleton dist., S. Car.: 108 m. S. E. Columbia.

Asmborover, p. v., and cap. Randolph co., N. Car.: 69 m. W. Paleigh.

Asmburstiss, t, and p. o., Worcester co., Mass.: a hilly 
district, drained by tributaries of the Connecticut and Merrimac, $45 \mathrm{~m}$. W. N. W. Boston. Pop. 1,s75.

Asiburnhay Depôt, p. 0., Worcester co., Mass.: on the Vermont and Massachusetts R. R., $11 \mathrm{~m}$. N. W. Fitchburg. Asmis, p. v., Coles co., Ill. : 74 E. Springfield.

Asmbx, t. and p. 0, Middlesex co., Mass, : 44 m. N. W.

Boston, on a branch of Nashua r. Pop. 1,218.

Ashibrsburg, p. v., Hopkins co, $K y_{*}: 122 \mathrm{~m}$. W. by S. Frankfort.

Asire county, N. Cas: Sitnate N. W. extreme, and contains 760 sq. m. Drained by New r. of the Great Kanawha, and other streams. Surface, an elevated plateau, between Blue Ridge and Stony Mountain: soils good. Farms 1,253; manuf. 3 ; dwell. 1,407, and pop.-wh. 8,096, fr. col. 56, sl. 5,951-total, 8,777. Capital: Jefferson.

Agr Creik, p. 0, Oktibbeha cr., Miss.: 107 m. N. E. Jackson.

AsHerx, p. o., Hancock co., Ohio: 70 m. N.W. Columbus, AsHFIELD, to and p. o., Franklin co, Mass.: in S. W. part of co., $162 \mathrm{~m}$. W. Boston.

AsmFord, t. and p. 0., Windham co., Conn.:29 m. E. Hartford. Pop. 1,291.

Astrord, t. and p. v., Cattaraugus co, $N_{0} \bar{Y}_{0}:$ on $\mathrm{S}_{\text {. side }}$ of Cattaraugus cr., $264 \mathrm{~m}$. W. by S. Albany. Pop. 1,65s,

Asm Grove, p. o., Green co., Mo.: $182 \mathrm{~m}$. S, by W. Jefferson City. field

Asr Grovk, p. o., Iroquois co., $I l l_{0}: 109 \mathrm{~m}, \mathrm{~N}$. E. Spring-

Asgruv, p. v., Washington co., Wisc.: $76 \mathrm{~m}$. E. by N. Madison.

AsHuaNd county, Ohio. Situate N. centrally, and contains 342 sq. m. It occupies the watershed between Lake Erie and the Ohio r. Drained in the $\mathrm{S}$. by the branches of Walhonding $\mathbf{r}$, and in the $\mathrm{N}$. by those of Vermillion and Black rivers. Surface rolling, and soils rich and productive. Farms 2,235; manuf. 71; dwell. 4,123, and pop. -wh. 23,789, fr. col. 3-total 23,792. Capital: Ashland. AsmLAND, p. V., Wapello co., Ia.: 61 m. S. S. W. Iowa City.

AsHuAND, p. $\nabla .$, Forsyth co., Ga.: 98 m. N. N. W. Milledgeville.

AsulaxD, Franklin co., Ky.: the late home of HENRY CLAY, the statesman of the Union; $1 \frac{1}{3} \mathrm{~m}$. S. E. Lexington. Asmaxd, p. ₹., Union co., Ky.: 169 m. W. Frankfort. Asmisis, to and p. V., Greene co., N. Y.: $44 \mathrm{~m} . \mathrm{S}$. W. Albany. Pop. 1,289.

Asmravd, p. v., Wayne co., Tenn, ; on the S. side of Buffalo r., $69 \mathrm{~m}$. S. W. Nashville.

Asmland, p. v., Middlesex eo, Mass.: 46 m. N. W. Boston. Pop, of $t_{6} 1,304$.

Asmu AND, p. Y., De Soto par., La. : 188 m. W. N. W. Baton

Rouge.

Asmlard, p. v., Bertie co., N. Car.: 89 m. E. by N. Raleigh.

AsHLAND, p. v., Henry co., Ind.: 22 m. E. by N. Indianapolis.

AsHLAND, p. v., and eap. Ashland co., Ohio: $72 \mathrm{~m} . \mathrm{N} . \mathrm{N}$. E. Columbus. Pop. of v. 1,264. The "Ashlander" (whig), and the "Ohio Union" (dem.), are published weekly.

Asmand, p. Y., Wayne, co, Penn.: 132 m. N. E. Harrisburg.

Asirand Furitace, p. v., Cambria co., Penn.: 94 m. W. Harrisburg.

Asmlex county, Ark. Situate S. E. on State line, and contains $660 \mathrm{sq} . \mathrm{m}$. Drained by creeks falling into the Bayou Bartholomew, on the E., and Spline and Wachita rivers on the W. Surface level prairie, and fertile. Farm 173; dwell. 269, and pop.-wh. 1,409, fr. col. 5, sl. 641-total, 2,058. Canital: Ashley C. H.

Bock

Asrreey, p. v., Carroll co., Ark.: 132 m. N. N. W. Little Asmlex, p. V., Pike co., Mo.: on a branch of Indian cr., 69 m. N. E. Jefferson City.
Asmlex, v., Delaware co., Ohio: on Cleveland, Columbus, and Cincinnati R. R., $31 \mathrm{~m}$. N, Columbus.

Ashlex Falls, p. v., Berkshire co., Mass.: $122 \mathrm{~m}$. W. Boston.

Ashlexville, p. v., Hampden co., Mass。: 86 m. W. Boston.

Ash Ridar, p. o., Brown co., Ohio: 84 m. B. S. W. Columbus.

AsH RIDGE, p. o., Pulaski co., $T$ IL. : $180 \mathrm{~m}$. S. Springfield, Asrr Run, p. o., Pendleton co., Ky.: 49 m. N. N. E. Frankfort.

Ast Spring, p. o., Harrison co., Tex.: 312 m. N.E. Austin City.

Asmtabula county, Ohio. Situate N. E. on Lake Erie, and contains $1,020 \mathrm{sq} . \mathrm{m}$. Drained by Conneaut $\mathrm{cr}$. and the Ashtabula and Grand rivers, which fall into Lake Erie, and by several creeks, affluents of Chenango cr., which flows toward the Ohio. Surface elevated and rolling, and soll generally fertile. Farms 2,243; manuf. 251; dwell. 5,306, and pop.-wh. 28,719, fr. col. 41-total 28,766. Capital: Jefferson. Public Works: Cleveland, Painesville, and Ashtabula R. R.

Ashíbula, t. and p. v., Ashtabula co., Otio: on Ashtabula r., near its entrance into Lake Erie, $171 \mathrm{~m} . \mathrm{N}$. E. Columbus. It is a place of commercial activity, both as a shipping port and railroad depôt, being on the line of the Lake Shore R. R.; and contains several fine warehouses and stores. T'wo newspapers, the "Sentinel" and the "Telegraph," are issued weekly. Pop. of v. 821, of t. 2,177.

Aszron, p. o., Dane co., Wisc.

Asmton, p. v., Clark co., Mo.: 130 m. N. N. E. Jefferson City.

Asmion's, p. o., Shelby co., Tex.: 182 m. E. by N. Austin City.

Asmton's Mruls, p. o., Frederick co., Firg.: 118 m. N. Richmond.

Ashuelot river, $N$. Hamp.: situate chiefly in Cheshire co. It has its source in a pond in Washington, and thence has a southerly course to Keene, where it receives a considerable tributary, and another joins it at Swanzey. From the latter point its course is $\mathrm{S}$. W. to the Connecticut, which it joins $3 \mathrm{~m}$. above the State line.

Ashymle, p. v., and eap. St. Clair co., Ala.: on S. side of Canoe cr. of Coosa r., $93 \mathrm{~m}$. N. Montgomery.

Ashvirle, p. v., Pickaway co., Ohio: 23 m. S. Columbus. AsHrilue, p. v., Holmes co., Miss.: $56 \mathrm{~m}$. N. Jackson. Ashricle, D. v., and cap. Buncombe co., N. Oar.: on French Broad r., $218 \mathrm{~m}$. W. Baleigh. Two newspapers, the "Ashrille Messenger" and the "Ashville News," both whig in politics, are published weekly.

Asww oon, v., Tensas par., La.: 102 m. N. N. W. Baton Rouge.

AsIIw0od, p. v., Maury co., Tenn.: 39 m. S. S. W. Nashville.

Aspen Grove, p. o., Pittsylvania co., Firg.: near Bannister $\mathrm{r}$. of the Dan, $102 \mathrm{~m}$. W. S. W. Richmond.

Aspen WALx, p. o, Charlotte co., Virg.: 46 m. S. W. Pichmond.

Assabet, p. o., Middlesex co., Mrass. : on the r. of same name, $33 \mathrm{~m}$. N. W. Boston.

Assumption parish, $L a$. Situate $\mathrm{S}$. W. of the State, and contains $396 \mathrm{sq} . \mathrm{m}$. Drained by Bayou La Fourche, and other streams. Surface low and marshy, subject to inundation. Soils rich and fertile, producing corn, cotton, and sugar. Farms 520; dwell. 926, and pop.-wh. 5,170, fr. col. 27, sl. 5,341-total 10,533. Capital: Napoleonville.

Assurption, p. v., and cap. Assumption par., La.: on W. side Bayou La Fourche, $38 \mathrm{~m}$. S. Baton Rouge.

Assyrta, p. v., Barry co., Mich.: 32 m. S. W. Lansing.

Astoria, p. v, Wright co, Mo : on a branch of Gascon. ade r., $84 \mathrm{~m}$. S. Jefferson City.

Astoris, p. v., Fulton co., IUl, : on a run of Sugar cr. $6 \mathrm{~m} . \mathrm{N}$. W. Illinois r. and $57 \mathrm{~m} . \mathrm{W} . \mathrm{N}$. W. Springfleld. 
Astoria, p. v., Queen's co.,, . Y. : on Fallett's Cove, a bay of the East r., near Hellgate, 132 m. S. Albany. Many New Fork merchants reside here, and are accommodated by regular steamboat navigation.

Astoria, p. v., Clatsop co., Oreg.: on S. side Columbia r., $8 \mathrm{~m}$. from its mouth. It is a port of entry, and was formerly a noted trading post, founded in 1811 by John $J$. Astor, the modern Croesus, and even at the present time is little more. There are many more eligible places than this for both foreign and internal commerce near the mouth of the river.

Asrutu, t. and p. o., Bradford co., Penn.: on the S. W. side of Susquehannah r., 98 m. E. N. E. Harrisburg. Wyalusing $\mathrm{F}$ alls are in this town.

Atchafalaya, p. v., Point Coupee par., La.: 42 m. N. W. Baton Rouge.

Atohafayala river, La.: an outlet of the Mississippi $\mathbf{r}$. from which it separates $2 \mathrm{~m}$. below the mouth of Red r., in $31020^{\prime} \mathrm{N}$. lat, and $900^{\circ} 40^{\prime} \mathrm{W}$. long., and hence has a course S., through Louisiana, upward of $147 \mathrm{~m}$. to the bay of the same name on the Gulf coast. It recerves in its course the Plaquemine, another outlet of the Mississippi. The navigation is obstructed by rafts.

Atchison county, MFo. Situate in N. W. corner of State, on Missouri r., and contains $580 \mathrm{sq} . \mathrm{m}$. Drained by the Nishnabatona, the Nodoway, and the head waters of Big and Little Tarkio rivers. Surface prairie, and exceedingly fertile. Farms 188; manuf. 5; dwell. 291, and pop.-wh. 1,641, fr. col. 7, sl. 30-total, 1,678. Oapital: Linden

Atrens county, Ohio. Situate S. E. on Ohio r., and contains $468 \mathrm{sq}$. m. Drained by Hocking $\mathrm{r}$. and its tributaries. Surface somewhat hilly and broken, but the soils are very fertile. Limestone, iron ore, and bituminous coal are abundant, and salt wells have been successfully operated in several districts. Farms 1,372; manuf. 60 ; dwell. 3,120, and pop.-wh. 18,119, fr. col, 96-total, 18,215. Capital : Athens. Public Works: Hocking Canal, Belpré R. R., etc.

ATHENs, p. vo, and cap. Izard co., $A_{r} k_{*}:$ on $\mathrm{N}$. side of White r., $94 \mathrm{~m} . \mathrm{N}$. Little Rock.

A thens, p. v., and cap. Limestone co., $A l a_{*}:$ on a cr. of Tennessee $\mathrm{r} ., 166 \mathrm{~m}$. N. Montgonery.

A Tirevs, p. v., and cap. Clark co., Ga.: on W. bank of Oconee r. $57 \mathrm{~m}$. N. Milledgeville. It is the seat of the University of Georgia, and is connected by R. R. with Savannah and Charleston. Four newspapers are published weekly - the "Athens Whig," the "Athens Banner" (dem.), the "Home of Mirth," and the "American Mechanic."

Atrens, p. Y., Menard co., Ill.: $3 \mathrm{~m}$. E. of Sangamon, $r$, and $11 \mathrm{~m} . \mathrm{N}$. Springfield.

ATHENs, p. т., Fayette co., $\bar{K} y_{0}$ : on a small branch of Kentucky r., 33 m. E. S. E. Frankfort.

Atrexs, p. o., Claiborne par., La.: 212 m. N. W. Baton Rouge.

Atmens, t. and p. F., Somerset co, Are.: on a tributary of Kennebec, r., 38 m. N. Augusta. Pop. 1,466.

Atuens, p. v., Monroe co., Miss. : on a small tributary of Little Tombigbee r., $152 \mathrm{~m}$. N. E. Jackson.

Atmens, t. and p. 0., Calhoun co., Mich.: on a tribatary of St. Joseph's r., 59 m. S. TV. Lansing. Pop, 532

Atrens, p. V., and cap. Gentry co., Mo.: $162 \mathrm{~m} . \mathrm{N} . \mathrm{W}$. Jefferson City.

Atriens, p. v., Clark co., Mo. : on S. W. side of Des Moines r., $140 \mathrm{~m}$. N. Jefferson City.

A thens, t, and p. v., Greene co., $N . Y_{2}:$ on W. side of Hudson r., opposite the eity of Hudson, between which there is a steam ferry, $36 \mathrm{~m}$. S. Albany. The $\mathrm{r}$. is a place of considerable business, and numerous sloops ply to and from N, Fork City; and the Albany and Troy steamboats make it a stopping place. Pop. 2,956.

Atmens, t., p. v., and eap. Athens co., Orio: on the N. bank of Hocking r., $62 \mathrm{~m}$. S. E. Columbus. It is the seat of the Ohio University, and contains numerous handsome buildings. The Cincinnati and Belpré R. R. passes through it. A branch of the State Bank is located jicre, and a newspaper, the "Athens Messenger," is issued weekly. Pop. of v. 899 , of $t, 2,361$.

Adirens, t. and p. v., Bradford co., Penn.; at the junction of Chemung $x$. with the Susquehanna, 121 m. N. Harrisburg. The North Branch Canal terminates here. Pop. of village 706 .

ATHENs, p. v., and cap. M·Minn co., Tenn.: on Eastanalla cr., and the East Tennessee and Georgia R. R., $58 \mathrm{~m}$. N. Dalton. A newspaper, the "Athens Post," is issued weekly.

Atuens, p. v., and eap. Henderson co., Texs. (formerly ALFRED): on a branch of Cedar cr., $222 \mathrm{~m}$. N. N. W. Austin City.

A thess, p. v., Caroline co., Firg.: 38 m. N. Richmond. Atmens, t, and p. o., Windham co., Vermo: $78 \mathrm{~m}$. $\mathrm{s}$. Montpelier.

Ammenstille, p. v., Greene co., Ill.: on Apple cr., in the N. E. corner of the co., $42 \mathrm{~m}$. S. W. Springfield.

Athensville, sta., Delaware co., Penn.: on Columbia R. R., 9 m. W. Philadelphia.

А тног, t. and p. o., Worcester co. Mrass. : on Miller's cr., $61 \mathrm{~m}$. W. N. W. Boston. Pop, 2,033.

AтHol, t. and p. o., Warren co., N. Y.: on a tributary of Hudson r., 62 m. N. N. W. Albany. Pop. 1,590.

Атног, Depot, p. o., Worcester co., Mass.: on the Vermont and Massachusetts R. R., $30 \mathrm{~m}$. W. Fitchburg and 88 from Boston.

Atkinson, t. and p. ₹., Piscataquis co., Me.: on S. side of Piscataquis r., 64 m. N. N. E. Augusta. Pop. 895.

Atkinson, t. and p. o., Rockingham co., N. Hamp.: 28 m. S. E. Concord。 Pop. 600.

Atkinson's Milis, p. o., Mifflin co., Penn.: $58 \mathrm{~m}$. W. N. W. Harrisburg.

Atrastio county, $N$. Jer. Situate S. E. on Atlantic Ocean, and contains 548 sq. m. Drained by Great and Little Egg Harbor rivers, and lined on the const by numerous low islands, forming shallow bays and inlets. Surface level, and soils light and sandy. Farms 327 ; manuf. 62 ; dwell. 1,5S4, and pop.-wh. S, 750 , fr. col. 210 , sl. 1-total, 8,961. Capital: May's Landing.

Aтlasta, p. v., De Kalb co., $G a_{0}:$ at the junction of the Georgia, Western, and Atlantic and the Mreon and Western railroads - an important dej. ôt of internal commerce. Distance to Augusta $171 \mathrm{~m}$. and to Charleston $308 \mathrm{~m}$; ; to Savannah $292 \mathrm{~m}$. ; to Montgomery, Ala., $175 \mathrm{~m}$.; to Chattanooga $104 \mathrm{~m}$; t to Nashville $291 \mathrm{~m}$., and to Knoxville $263 \mathrm{~m}$. by R. R. A newspaper, the "Atlanta Intelligencer," is issued weelily. Pop. 4,512

ATLAs, p. v., Pike co., $7 l$. : $63 \mathrm{~m}$. W. by S. Springfield, on the $\mathrm{E}$. side, near Snyeartee Slough, which is navigable for steamboats to this point in high flood.

Atsiox, p. v., Burlington co., N. Jer.

ATTALA county, Mfiss. Situate centrally, and contains 720 sq. m. Drained by the head branches of Pearl and numerous creeks of Big Black r. Surface undulating, and the soils fertile. Indian corn, rice, tobacco, and cotton are the chief products. Farms 1,336; manuf. 44; dwell. 1,431, and pop.-wh. 7,578 , fr. col. 9, sl. 3,412-total, 10,999. Capital: Kiosciusko.

Attalavilie, p. v., Attala co., Ariss. : 56 m. N. N. W. Jackson.

Atrapulges, p. v., Decatur co., Ga. : on W. side of Flint r., $172 \mathrm{~m}$. s. S. W. Milledgeville.

Atrics, p. V., Fountain co., Ind.: on the S. E. side of Wabash r., $66 \mathrm{~m} . \mathrm{N}$. W. Indianapolis.

Atric., p. v., Greene co., Wisc.: 38 m. S. W. Madison.

ATtICA, p. v., W yoming co., N. Y.: on Buffalo and Rochester I. R. $32 \mathrm{~m}$. E. Buffalo, and $258 \mathrm{~m}$. W. Albany. The village has considerable trade, and carries on manufactures of several kinds. A weekly newspaper, the "Wyoming County Mirror," is published here, and circulates about 800 copies. 
A trTCA, p. V., Seneea co., Ohio: in S. E. corner of co., 72 m. N. Columbus.

Atrics Centras, p. o., Wyoming co., N. Y.: $253 \mathrm{~m}$. W. Albany.

Aтrica, p.. ., Lenawee co., Mich.: 73 m. S. E. Lansing. Atrleborovgr, t. and p. o., Bristol co., Mass.: on Pawtucket r., 38 m. S. W. Boston. The Boston and Providence R. R. passes through the town. Pop. 4,200 .

A trleborough, p. v., Bucks co., Penn。: 21 m. N. N. E. Philadelphira and 100 E. Harrisburg.

AmLeBuRY, p. т., Duchess co., N. Y.: $58 \mathrm{~m}$. S. S. E. Albany.

Atwater, p. V., Portage con, Ohio: on Cleveland and Pittsburg R. R., 50 m. S. S. E. Cleveland and 115 m. E. N. E. Columbus.

ATwood, p. Y., De Kalb co., Ala.: 152 m. N. E. Montgomery.

A ubbelradBвe, p. o., Fulton co., Ired. : $8 \mathrm{~m}$. N. Indianapolis.

AUbuRr, p. v., Macon co.g Ala.: on Montgomery and West Point R. R., $60 \mathrm{~m}$. W. by N. Montgomery.

AєвUR, p. v., Gwinnett co., Ga. : 54 m. N. W. Milledgeville.

Auburs, p. v., Sanganoon co., $I l l_{.}$: on Sugar cr, $15 \mathrm{~m}$. S. by W. Springfield.

AuburN, p. T., and cap. De Kalb co., Ind. : on Eel r., 126 m. N. E. Indianapolis.

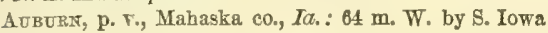
City.

A

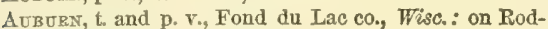
man r., 80 m. N. E. Madiron.

АUвURN, p. V., Cumberland co., Me.

AUBURN, p. .., Worcester co., Mass. : 42 m. W. Boston. AUBURr, p. T., Oakland co., Mich.: 78 m. E. by S. Lansing.

A UBणRN, p. v., Hinds co., Miss. : 24 m. W. by S. Jackson, A бовоR, p. $\nabla .$, Lincoln co., Mo.: $72 \mathrm{~m}$. N. E. Jefferson City.

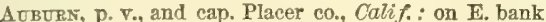
on the N. fork of American r., $6 \mathrm{~m}$. above its confluence with the $S$. fork

AUBURN, p. v., Rockingham co., N. Hamp. Pop. 810 .

AubuRN, p. ., and crp. Cayuga co., $N$. Y.: at the outlet of Owaseo Lake, and on the Rochester and Syracuse R. R., 174 m. W. Albany. It is the site of a State Prison, which occupies an area of $500,000 \mathrm{sq}$. ft., inclosed by a stone wall $4 \mathrm{ft}$. thick. The discipline of this prison is very strict, and the convicts are kept to hard labor. The Presbyterians have a theological seminary at Auburn, and there are also several flourishing academies. The "Journal" and the "Advertiser" are published daily; the "Cayuga New Era," the "Cayuga Chief," and the "Northern Christian Advocate," weekly, and the "Masonio Union," monthly. Numerous manufactures are carried on. Pop. 9,548.

Auburi, p. $\nabla$., Schuylkill co., Penn.: on Philadelphia and Reading R. R., 83 m. N. W. Philadelphia

AubuRx, t. and p. v., Geauga co., Ohio: on Chagrine r., $136 \mathrm{~m}$. N. E. Columbus.

A पвUR , p. ., Fauquier co., Firg.: 80 m. N. N. W. Richmond.

A गBURN, p. T., Cannon co, Tenn. : 47 m. W. S. W. Nashville.

Auburn Four Corners, p. o., Susquehanna co., Penn. : in S. E. part of co., $108 \mathrm{~m}$. N. E. Harrisburg.

Aucrlla, p. $\mathbf{v}$., Jefferson co., Flor.: on the $r$. of the same name, $26 \mathrm{~m}$. S. W. Tallahassee.

AUDRAT county, Mo. Situate E. middle, and contains $1,220 \mathrm{sq} . \mathrm{m}$. Drained by tributarieg of Salt $\mathrm{r}$. Surface level or undulating, and soils excellent, producing the cereals abundantly and some tobacco. Farms 417; manuf. 10; dwell. 498, and pop.-wh. 8,048 , fr. col. 1, sl. $457 \rightarrow$ total 3,506. Capital: Mexico.
Adouron county, Ia. Situate S. W., and contains 576 sq. m., taken from the Pottowottamie in 1851.

AUdUBON, p. т., Montgomery co., $I l l .: 42$ m. S. E. Springfipld.

A EDUBON, p. צ., Hardeman co., Tenn.: on a cr. of Big Hatchee r., 184 m. W. B. W. Nashville.

AUGERoNA, p. V., Jackson co., Virg: 218 m. W. N. W. Riehmond.

Avgratze county, Ohio. Situate N. W., and contains 396 sq. m. Drained by Auglaize r. and its tributaries. Surface undulating, and soil moderately fertile. Farms 1,393; manuf. 30 ; dwell. 2,020 , and pop.-wh. 11,251, fr. col. 87 total 11,338. Capital: Wapaukonnetta. Public Works: Miami Caual, etc.

Auglaize, p. v., Van Wert co., Ohio: on Little Auglaize r., $98 \mathrm{~m}$. W. N. W. Columbus.

AUGUSTA county, Virg. Situate centrally between Blue Ridge and Great North Mountain, and contains 860 sq. m Drained by the head waters of Shenandoah and James rivers. Surface picturesquely varied, and soils fertile. There are several medicinal springs in the county. Wheat Indian corn, and oats are the chief products, and cattle raising is much engaged in. Farms 1,264; manue. 181 dwell. 3,207, and pop.-wh. 19,024, fr. col. 533, sl. 5,053total 24,610. Oapital: Staunton. Public Works: Virginia Central R. R., ete

Augusta, p. Y., Benton co., Flor.: 160 m. S. E. Tallahassee.

Augusta, p. city, and cap. Richmond co, Ga.: on Savannah r., and at the intersection of the South Carolina, the Georgia, and the Burke County railroads. It is an important commereial point, and the depot of an extensive and fertile country, the produce of which, cotton, tobacco, etc., is sent down to Charleston, $137 \mathrm{~m}$., by $\mathrm{R}$. R., and to Savannah by the Savannah $r$. The city is well laid out, and has many spacious stores and dwellings. The public buildings are a City Hall, County Court House and Jail, a theatre, arsenal, hospital, and numerous churches. The "Sentinel" and "Constitutionalist" are published daily, and have also tri-weekly and weekly editions; the "Republic" is issued tri-weekly and weekly, and there are two monthly publications issued-the "Southern Medical Journal" and the "Southern Cultivator."

AUGUstA, p. Y., Jackson co., Ark. : 44 m. E. N. E. Little Rock.

Augusts, p. v., Hancock co., $I Z l_{\text {。 }}:$ in S. E. corner of co, $78 \mathrm{~m}$. W. by N. Springfield.

Augusta, p. v., Marion co., Ind. : in N. W. corner of co., $12 \mathrm{~m} . \mathrm{N}$. W. Indianapolis.

Avgusta, p. Vi, Des Moines co., Ia.: on the Chicagua or Skunk r., 61 m. S. S. E. Iowa City.

Augusta, p. v., Bracken co., Ky. : on the S. bank of the Ohio r., 66 m. N. E. Frankfort. It is the seat of Augusta College, a Methodist establishment, founded in 1825.

AUGUsta, t., p. city, and cap. Kennebec co., Me., and capital of the State of Maine: on both sides of Kennebec r., at the head of steamboat navigation, $43 \mathrm{~m}$. from the ocean. Lat. $44^{\circ} 18^{\prime} 43^{\prime \prime} \mathrm{N}$., and long. $69^{\circ} 50^{\prime} \mathrm{W}$. from G., or $7 \circ 12^{\prime}$ E. from W., and distant $595 \mathrm{~m}$. N. E. Washington. A fine bridge, 520 feet long, connects the two parts of the $\mathrm{v}_{\text {., }}$ which is regularly laid out, and rises gradually from the shores of the river. It contains the State House, Insane Hospital, the co. builđings, a U. S. Arsenal, and numerous churches and school-houses, many of which are elegant structures. The State House is located half a mile 8 . of the $\mathrm{r}$. The building is of white granite, and has spacious halls for the legislature and executive officers. Four newspapers are published weekly, the "Kennebec Journal" (whig), the "Age" (dem.), the "Maine Farmer" (agric.), and the "Gospel Banner." The Kennebec and Portland R. R. terminates here, connecting the $\mathrm{v}$. with Portland and other $\mathrm{New}$ England cities, and steambosts ply regularly between this place and the principal north Atlantic ports. Pop. 8,225 
Augusta, p. $\nabla .$, and cap. Perry co., Miss.: on Lenf cr,

a branch of Paseagoula r., 100 m. S. E. Jackson.

Augusta, p. v., St. Charles co., M10.: 80 m. E. by N. Jef-

ferson City.

Augusta, p. $\nabla$. , Sussex co., N. Jer.: $62 \mathrm{~m}$. N. Trenton.

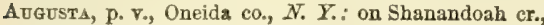

$90 \mathrm{~m}$. W. by N. Albany.

AUgUSTA, t. and p. v., Carroll co., Ohio: on a tributary of Sandy cr., 114 m. E. by N. Columbus. Pop.1,297.

Adgugta, t. and p. o., Northumberland co., Penn.: on

E. bank of Susquehanna r., $38 \mathrm{~m}$. N. Harrisburg.

Aumav's Hri, p. o., Montgomery co., $N$. Car.: 78 m. $\mathbf{s}$.

W. Raleigh.

Aurarta, p. T., Lumpkin co., Ga. : on a branch of Chatth hoochee r., $108 \mathrm{~m}$. N. W. Milledgeville. Gold is found in the vicinity, and hence its name.

Adrelia, p. v., Washington co., Ohio: in N. W. part of co., on Duck cr., 86 m. E. by S. Columbus.

Aureltus, to and p. v., Cayuga $c_{.,}, N$. $Y_{\text {. }}$ : between the outlets of Cayuga and Owasco lakes, $148 \mathrm{~m}$. W. Albany.

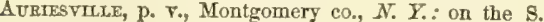
bank of the Mohawk, and on the Erie Canal, $42 \mathrm{~m}$. W. N. W. Albany.

AURora, p. V., Marshall co., Ala. : on a cr. of Locust fork of Black Warrior r., $121 \mathrm{~m}$. N. Montgomery.

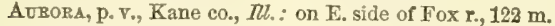
N. E. Springfield. The "Aurora Branch" of Galena and Chicago Union R. R. terminates here, and an extension continues the road to the Illinois $r$. at La Salle.

AURORA, p. V., Dearborn co., Ind.: on Ohio r., 108 m. 8.

E. Indianapolis. It is a place of considerable business and commercial activity. A newspaper, the "Western Commercial," is issued weekly.

AurorA, p. Y., Marshall co., $\bar{K} y .: 216$ m. W. by N. Frankfort

AurneA, t. and p. v., Hancock co.. Me. : 90 m. E. Augusta. AURorA, p. V., Cayuga co., N. $Y$ : on the $F$, bank of

Cayuga Lake, and a steamboat station on the Cayuga and Susquehanna route. Pop. 600.

Aurora, t. and p. v., Portage co., Ohio: in N. W. corner of co., 126 m. E. N. E. Columbus. Pop. 823.

AU SABLE river, $N . Y .:$ rises near the sourccs of Hudson r., and empties into Lake Champlain, in the S. part of Clinton co. It has two main branches, which unite at Au Sable

Forks village. Its falls afford extraordinary water-power. Immediately below the lower falls at Birmingham the river passes through a chasm for the distance of $2 \mathrm{~m}$., the walls of which are perpendicular rocks from 75 to 150 feet high, and from 50 to 65 apart at the top.

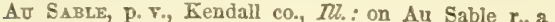
branch of the Illinois $\mathrm{r} ., 130 \mathrm{~m}$. N. E. Springfield.

Au Sable, y., Essex co., N. $\boldsymbol{Y}_{*}: 105 \mathrm{~m}$. N. Albany. The

"Au Sable Gazette" is publishod weekly.

At Sable Forks, p. o., Essex co., $N$. $Y$. : at the junction of the forks of Au Sable r., $126 \mathrm{~m}$. N. Albany.

Aosterlitz, p.V., Kent co., Mich. : $57 \mathrm{~m}$. W. by N. Lansing.

Austerlitz, to and p. v., Columbia $\mathrm{co}_{*}, N . \bar{Y}_{\mathrm{.}}$ : on Green r., a branch of the Elousatonic, 31 m. S. S. E. Albany. Pop. 1,874 .

Austris county, Tex. Situate S. E., centrally, on Brazos r., and contains about 1,100 sq. m. Drained by Caney, Piney, and Mill creeks from the W., and Fishpond Spring and others from the E., tributaries of Brazos $r$; slso by creeks of San Bernardo r., which bounds it W. Surface generally level, in the $\mathbf{N}$. undulating, and along the streams hearily timbered. The prairies are extensive and the soils very fertile. Farms 230; dwell. 432, and pop.-wh. 2,2S6, fr. col. 6, sl. 1,549-total 3,\$11. Capital: Bellville. Cits.

Austix, p. v., Ross co., Orio: 51 m. S. Columbus.

Austry, p. Y., and cap. Tunica co., Jiss.: $168 \mathrm{~m} . \mathbf{N}$. Jackson.
Austrs, p. city and cap. Travis co., Tex.: and capital of the State of Texas, on $\mathbb{N}$. side of Colorado r., about $200 \mathrm{~m}$ from the Gulf, and $1,420 \mathrm{~m} . \mathrm{S}$. W. Washington. It is as ye a mere village, but is rapidls improving. Pop. abont 1,500 T'wo newspapers, the "State Gazette," and the "South western American," are issued weekly.

Austinzurg, p. v., Ashtabula co., Ohio: on $\mathbb{N}$. side of Black r., 159 m. N. E. Columbus.

Austin's FeRry, p. o, Grainger co., Tenn.: 176 m. E Nashville.

A UBTTN's LAKE, p. 0., Kalamazoo c0, Mich. : 66 m. S. W Lansing.

Austinviluz, p. v., W the co., Firg.: on Cripple cr., 206 m. W. S. W. Richmond.

AUTAUgA county, Ala. Situate centrally on Alabama $r$. and contains 1,152 sq. m. Drained by Autauga, Mulberry, and other creeks of the Alabama; Ockmulgee cr. of $\mathrm{Ca}$ tawba r, etc. Surface varied-in places broken and rough. Soils of average fertility; very rich on the streams. Products corn and cotton. Farms 711; manuf. 61 ; dwell. 1,114, and pop.-wh. 6,274, fr. col. 19, sl. 8,730-total 15,023. Capital: Kingston. Public Works: Selma and Tennessee River $\mathrm{R}$. R.

Autaugatille, p. v., Autauga co, Ala.: 18 m. W. N. W. Montgomery.

$\Delta \nabla \mathrm{A}, \mathrm{v}$. v., Winnebago co., $M$. : $3 \mathrm{~m} . \mathrm{N}$, of Peketonica r., $172 \mathrm{~m}$. N. N. E. Springfleld.

AvA, p. v., Oneida co., N. Y.: $100 \mathrm{~m}$. W. N. W. Albany. AvALANCHE lake, $N$. $Y$.: a small body of water, between Mt. M'Intyre and Mt. M'Martin, in Essex co.: it is elevated 2,900 feet above tide, and is consequently the highest water in the State. It is tributary to the Hudson.

AverY, p. v., Monroe co., Ia. : 86 m. S. S. W. Iowa City. A veEY, p. V., Jo Daviess co., Ill.: 181 m. N. W. Spriagfleld.

Averysborougr, p. v., Cumberland co., $N$. Car. : on the E. side of Cape Fear r., $30 \mathrm{~m}$. S. Raleigh.

A trerr's Creek, p. o., Buncombe co., $N$. Car.: on a cr. 80 called, $228 \mathrm{~m}$. W. by $\mathrm{S}$. Raleigh.

AVERT's GORE, p. o., Franklin co., Term, : $52 \mathrm{~m}$. N. by W. Montpelier.

A vill, p. v., Noble co., Ind. : 118 m. N. by E. Indianapolis.

Amstox, p. v., Clinton co., $M l_{*}: 81 \mathrm{~m}$. S. Springfield. Atorelles parish, La. Situate E. of W. Dist., having the Wachita, Red River, and Bayou Atchafalaya on its E. border, and contains $1,200 \mathrm{sq}$. m. Drained by numerous tributaries of the border rivers. Surface low and swampy near the rivers, and subject to inundations; but in the W. more elevated, and the soils fertile, producing excellent cot. ton. Farms 393; manuf. 5; dwell. 792, and pop.-wh. 4,066, fr. col. 99, sl. 5,161-total 9,326. Capital: Marksville.

$\Lambda$ vo, p. ₹., Patrick co., Firg.: 162 m. B. W. Riehmond. A rocA, p. v., Livingston co., $M l_{*}$ : on $N$. fork of Vermillion r., 92 m. N. E. Springfield.

Avoca, p. v., Fond du Lac eo., Wisc.: 82 m. N. E. Madison.

Avoca, p. V., Jefferson co., Mo.: $89 \mathrm{~m}$. W. by S. Jefferson City.

Avoca, p. v., Steuben co., $N$. $\boldsymbol{Y}_{\text {.: }}$ on Conhocton r., 212 m. W. by S. Albany, and a station on the Buffalo, Corning and New York R. P.

Avor, t. and p. v., Hartford co., Conn.: $10 \mathrm{~m}$. W. of Hartford, and a station on New Haven and Northampton R. R., $37 \mathrm{~m}$, N. New Haven. Pop. 1,995.

Arox, p. ₹., St. Genevieve co, Mo.: 122 m. E. S. E. Jefferson City.

Arow, t. and p. ₹., Rock co., Wisc. : on Sugar cr., $86 \mathrm{~m}$ S. Madison. Pop. 555

Arox, t. and p. v., Franklin co., Me. : on Sandy r., $38 \mathrm{~m}$. N. W. Augusta.

Avor, t. and p. 0, Ionia $c_{2,}, M i c h .: 32 \mathrm{~m}$. W. N. W. Lansing. 
Aron, t. and p. r., Livingston co., $N . Y .: 162 \mathrm{~m}$. W. Albany. Pop. 2,807.

$\Delta$ vos, t. and p. v., Lorain co., Ohio: on Lake Erie, 114 m. N. N. E. Columbus.

Avondali, p. Y., Chester co., Penn. : 66 m. S. E. Harrisburg.

Avox LAkR, p. a, Lorain co., Ohio: 116 m. N. N. E. Columbus.

Axeville, p. ₹., Cattaraugus co., N. $Y_{.}: 218 \mathrm{~m}$. W. by

S. Albany.

A rersville, p. v., Deflance co., Ohio: 132 m. N. W.

Columbus.

A Yersticle, p. v., Stokes co., N. Car. : $112 \mathrm{~m}$. W. N. W.

Raleigh.

Arterres, p. 0., King William co., Firg.: 25 m. N. E.

Richmond.

Azalta, p. vo, Bartholomew co., Ind.: on E. side of E. fork of White r., $48 \mathrm{~m}$. S. S. E. Indianapolis.

Aztalan, p. v., Jefferson co., Wisc, : $27 \mathrm{~m}$. E. by S. Madison.

\section{B.}

BaBCock HILl, p. 0., Oneida co., N. Y.: $88 \mathrm{~m}$. W. N. W. Albany.

Babcocr's Grove, p. o., Du Page co., Ill.: 160 m. N. N. E. Springfield.

BabILON, p. V., Suffolk co., N. Y.: on Great South Bay, $142 \mathrm{~m}$. S. S. E. Albany-a pleasant and fashionable summer resort.

BACHELOR's GRotE, p. o., Rock co., Wisc.: $37 \mathrm{~m}$. S. bJ

E. Madison.

Bachilor's Hali, p. o., Pittsylvania co., Tirg.: $118 \mathrm{~m}$. W. S. W. Richmond.

Bachelo R's HoMk, p. o, Lee co., Tirg. : 296 m. W. by

S. Richmond.

Bachelor's Rimtreat, p. o., Pickens co., S. Car. : 119 m. N. W. Columbia.

Bachuax's Mrus, p. o., Carroll co., Mrd. : at the head of Big Pipe cr., 56 m. N. W. Annapolis.

BACK CREEK, Md.: a large cr. of Elk r., which, with the Chesapeake and Delaware Canal, forms a navigable passage across the neck of the peninsula.

Back Creek Vallex, p. o., Frederick co., Virg.: in the valley of Back cr., a tributary of Potomac r., $128 \mathrm{~m}$. N. by W. Richmond.

B $\triangle$ CK RIVEr, Md. : a large inlet of Chesapeake Bay, E. of Susquehanna $r$.

Bacon's Castle, p. 0., Surry co., Firg.: 51 m. S. E. Riehmond.

BAD AXE county, Wisc. Situate E. of Mississippi r., and contains $720 \mathrm{sq.} \mathrm{m.} \mathrm{Drained} \mathrm{by} \mathrm{Kickapoo,} \mathrm{Bad} \mathrm{Axe,} \mathrm{and}$ Raceoon rivers. Surface generally level, with large bottoms on the Mississippi: soils deep and rich. Erected since 1850 .

BAD AXE, p. $\nabla .$, Bad Axe co., Wisc.: on Bad Axe r., a tributary of the Mississippi, $98 \mathrm{~m}$. W. by N. Madison.

BADger, p. o., Fond du Lac co., Wisc.: $70 \mathrm{~m} . \overline{\mathrm{N}}$. E. Madison.

BaGdad, p. v., Smith co., Tenn.: 52 m. E. N. E. Nashville.

BAGDAD, p. r., Lafayette co., Mo. : 98 m. W. by N. Jefferson City.

Bahama Ceranner, or Gulf of Florida, the narrow sea Between the eoast of the United States and the Bahama Islands, $135 \mathrm{~m}$. long and 46 in mean breadth. The currents here are most violent, and ressels are frequently wrecked in passing through this strait.

Baireysbergir, p. v., Perry co., Penn.: on the line of the Pennsylvania R. R., $23 \mathrm{~m}$. W. by N. Harrisburg.

Barex"' Cresk, p. o., Osage co., Mo.: on a creek so called, falling into the Missouri r., 24 m. E. Jefferson City.
Bailex Creek, p. o., Tioga co., Penn.: 105 m. N. by W. Harrisburg.

Batley's Four Corners, p. o., Greene co., N. Y.: $38 \mathrm{~m}$ S. S. W. Albany.

BaIleyville, t. and p. v., Washington co., Me. : on St. Croix r., immediately $\mathrm{S}$. of the outlet of Schoodic Lakes, $126 \mathrm{~m}$. E. by N. Augusta. Por. 431.

Batnbrimge, p. v., Macon co., Ala.: $52 \mathrm{~m}$. E. Montgomery.

BAINBridge, p. v., and eap. Decatur co., Ga. : on E. side of Flint r., $160 \mathrm{~m}$. S. S. W. Milledgeville.

Bainbridge, p. v., Putnama co., Ind. : on Walnut fork of Eel r., $40 \mathrm{~m}$. W. Indianapolis.

BaINBRIDGE, p. v., Williamson co., $I l l$.: on a branch of Big Muddy r., 142 m. S. by E. Springfield.

BaINbridge, p. v., Christian co., Ky.: 170 m. W. S. W. Frankfort.

Baindridge, t. and p. v., Berrien co., Mich.: $102 \mathrm{~m}$. W. S. W. Lansing.

Baingridge, p. v., Ross co., Ohio: on S. side Paint cr., a tributary of the Scioto $r_{\text {. }}$, and near the falls, $54 \mathrm{~m}$. S. by W. Columbus. A branch of the Cincinnati. Hillsboro', and Parkersburg R. R. terminates here.

Baingridge, p. v., Lancaster co., Penn.: on the N. E. bank of Susquehanna r., $17 \mathrm{~m}$. S. E. Harrisburg.

Batnbeidge, $t$. and p. v., Chenango co.. N. $Y$. : on Susquehanna r., $96 \mathrm{~m}$. W. by S. Albany. Pop. 3,838.

Batnibridge, p. v., Robertson co, Tenn. : 23 m. N. by W. Nashville.

Bampdstown, p. v., Oglethorpe co., Ga.: 46 m. N. Milledgeville.

Batting Hollow, p. V., Suffolk co., N. Y.: 152 m. S. E. Albany.

BAKER county, Ga. Situate S. W., and contains 1,296 sq. m. Drained by Chickasawatchie or, and Ichawaynochaway r., tributaries of Flint r., which traverses it in a N. E. and S.W. direction. Surface various-mostly lerel, and the soil sandy, but productive for cotton. Farms 444; manuf. 12 ; dwell. 755 , and pop.-wh. 4,355 , fr. col. 0 , sl. 3,765-total 8,120. Capital: Newton.

BAKER's, p. o., Washington co., Ky. : 42 m. S. W. Frankfort.

BAKER'S, p. O., Champaign co., Otio: $58 \mathrm{~m}$. W. Columbus. BAKER's CorNers, p. o., Walworth co., Wisc. : $56 \mathrm{~m}$. E. by S. Madison.

BAKER's FALLS, $N_{0} Y_{0}:$ on Hudson r., 52 m. abote Albany. The descent is 76 feet in 60 rodo.

Bakersfied, t. and p. v., Franklin co., Term.: on a branch of Missisque r., $40 \mathrm{~m}$. N. by W. Montpelier. 1,523.

BAKER's IsLAND: a small island in the Atlantic, off the coast of Maine.

BAKER's IsLAND: a small island off the Massachusetts coast, $5 \mathrm{~m}$. E. N. E. Salem. There is a lighthouse on the N. end.

BAKER's RIVER, $N$. Hamp. : a considerable stream, formed of two branches - the N. branch from Moosheloc mts., and the $\mathrm{S}$. branch from the town of Orange; after their union, the river has a $\mathbf{S}$. E. course to the Pemegewaset $\mathrm{r}$., into which it falls.

BAKER's RUN, p. o., Hardy co., Virg.: on a cr. so called, $146 \mathrm{~m}$. N. W. Richmond.

Bakerstown, p. v., Alleghany co., Penn.: $162 \mathrm{~m}$. W. IIarrisburg.

Bakersville, p. v., Litchfield co., Conn.: $32 \mathrm{~m}$. W. Hartford.

Bakenstilue, p. v., Coshocton co., Ohio: 62 m. E. N. Et Columbus.

BAKERStrLle, p. v., Washington co, Mrd.: on the E. side Marsh cr., $94 \mathrm{~m}$. W. N. W. Annapolis.

Bakersville, p. v., Somerset co., Penn.: 128 m. W. S. W. Harrisburg.

Bakersville, p. v., Yancey co., N. Car.: on Cane or. of Nolichucky x, $193 \mathrm{~m}$. W. Raleigh. 
BuxDWn county, Ala. Situate S. W. on Mobile Bay, and contains 2,150 sq. m. Drained by numerous creeks and tributaries of the bay, Alabama r., and Perdido r. The coast on the Gulf of Mexico is lined by long sand islands, which also inclose Mobile Bay from the sea. Surface near the coast a sand plain, but the land rises inland. Soils, except on the streams, poor. Cotton is the chief product. Farms 121; manuf. 38; dwell. 397, and pop.-wh. 2,100, fr. col. 96, sl. 2,21s-total 4,414. Capital: Blakely. Public Works: Girard and Mobile R. R. (proposed).

BALDWIN county, $G a$. Situate centrally, and contains 329 sq. m. Drained by tributaries of Oconee r., which traverses from N. W. to S. E. Surface uneven, and the soil of arerage fertility-Indian corn and cotton being the chief products. Farms 240; manuf. 3; dwell. 647, and popwh. 3,522 fr. col. 24, sl. 4,602-total 8,148. Capital: Milledgeville. Public Works: Milledgeville and Gordon R. R., and Eatonton P. P.

Balcony Fails, p. 0., Rordibridge co., Türg.: $118 \mathrm{~m}$. W. Richmond, on James r., at the passage of the Blue Ridge, and the W. terminus of James River Canal. The river is here narrow, and crossed by a feeder dam, and the scenery highly picturesque.

Bald Creek, p. o., Yancey co., N. Car.: on a er. so ealled, $192 \mathrm{~m}$. W. Raleigh.

BALD EAgLe, p. o., Bath c0., Ky.: 58 m. E. Frankfort

BALD EAGLE, p. o., York co., Penn.: 32 m. S. by E. Harrisburg.

Bald Eagle Mountatis, Penn.: on the confines of Huntingdon and Centre counties, and N. E. of Juniata $r$, about $80 \mathrm{~m}$. W. Harrisburg. Bald Eagle, or Sinking Spring Valley, lies at the E. base on the edge of Bedford county, and is $5 \mathrm{~m}$. wide. It is remarkable for a phenomienon called the "Swallows" which absorb several large streams, and discharge them again after a subterranean passage of several miles.

Bald EAgle Rrver, Penn.: rises in Centre co., and runs N. E. to the W. branch of Susquehannah r. after a course of 60 miles.

Batd HeAd, Me.: a headland"on the S. W. side of TVells Bay, lat. $43^{\circ}$, and long. $80^{\circ} 85^{\prime}$ W. from Greenwich.

BALD HEAD, N. Car.: a cape at the S. W. end of Smith's island, at the mouth of Cape Fear r. A lighthouse is erected here, $24 \mathrm{~m} . \mathrm{N}$. N. W. from Frying-pan Shoal, lat. 380 51', and long. $78^{\circ} 18^{\prime} \mathrm{W}$. from Greenwich.

Bard Hilu, p. o., Muscogee co., Ga.: 96 m. W. S. W. Milledgeville.

BaLd Hill, p. o., Norfolk co., MFass.; 22 m. S. S. W. Boston.

Bald Mount, p. o., Lucerne co., Penn.: 82 m. N. N. E. Harrisburg.

Bald Mountatn, p. o., Oakland co., Mich.

BALDwIN, p. Y., Chemung co., N. Y.:156 m. W. S. W. Albany.

Baldwix, p. v., Butler co., Penn.: 173 m. W. N. W. Harrisburg.

BALDWINSTILE, p. V., Worcester co., Mfass, : on the line of the Vermont and Massachusetts R. R., $21 \mathrm{~m}$. W. Fitchburg, and 71 from Boston.

BALDWLSTILLE, p. v., Onondaga co., $N . Y$. : on the N. W. side of Oswego r., $138 \mathrm{~m}$. W. by N. Albany. A newspaper, the "Onondaga Gazette," is issued weekly. field.

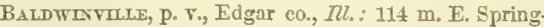

BaLIze, or North-east Pass of the delta of the Mississippi r., $100 \mathrm{~m}$. below New Orleans. It is the principal ship passage to and from the Gulf of Mexico.

Baltze, p. V., Plaquemine par., La.: on the pass of the same name, $155 \mathrm{~m}$. S. by E. Baton Rouge.

BaLlard county, $\bar{k} y$. Situate $W$. on the Ohio and Mississippi rivers, and contains $372 \mathrm{sq} . \mathrm{m}$. Drained by the Humphrey, Willow, and Mayfield creeks. Surface rugged, but soils fertile, producing grain in abundance, with tobaceo and some cotton. Farms 453; manuf. 7; dwell. 775, and pop.-wh. 4,628, fr. col. 26, sl. 842-total 5,496. Capital: Blandville. Putlic Works: Mobile and Ohio R. R

Ballard's Bridge, p. O., Chowan co., N. Car.: $138 \mathrm{~m}$. E. N. E. Raleigh.

Barlardsville, p. v., Oldham co, $K_{y}:$ on $\mathrm{S}_{\text {. E. }}$ line of co., $26 \mathrm{~m}$. W. N. W. Frankfort.

Ballardostilie, p. Y., Boone co., Virg.: on E. side of Guyandotte r., $252 \mathrm{~m}$. W. Kichmond.

Ballard Vale, p. 0., Essex co., Mlass.

Ballenger's, p. o., Tipton co., Ind. : 87 m. X. Indianapolis.

BALlEW's FERrX, p. o., Calcasieu par., La.; on E. side of Sabine r., $152 \mathrm{~m}$. W. by $\mathrm{S}$. Baton Rouge.

BaLl Ground, p. 0., Cherokee co., $G \alpha_{n} ; 104$ m. N. by W. Mrilledgeville.

Batl Play, p. 0., Monroe co., Tenn.: 158 m. E. by S. Nashville.

Barl's Pond, p. o., Fairfield eo. Conn.: $54 \mathrm{~m}$. S. W. Hartford.

Ballston Centre, p. v., Saratoga co., N. Y.:24 m. N. N. W. Albany.

BALLSTON SPA, p. v., and cap. Saratoga co., $N_{\text {. }} Y_{\text {.: }}$; on a small branch of Kayaderosseras cr., $27 \mathrm{~m}$. N. N. W. Albany. It is much celebrated for its mineral springs, and is the most fashionable summer resort in the Union. Railroads connect it with Troy, Schenectady, and Albany, southward, and with Whitehall, ete, northward. Tro newspapers, the "Ballston Democrat," and "Ballston Journal," are issued weekly.

Balistown, p. vo, Ripley co., Ind.: 56 m. S. E. Indianapolis.

Ballstille, p. т., Powhatan co., Tirg.: on Deep cr, of James r., $38 \mathrm{~m}$. W. Richmond.

BALTIMORE county, Md. Situate N. E., and contains 631 sq. m. Drained by Patapsco, Gwinn's, Jones, and Great Gunpowder Falls rivers. Surface uneven and varied. Soils thin and rocky, but fertile. Timber abundant, as also iron, copper, and other minerals, with building stone of various kinds. Farms 1,655 ; manuf. 2,569 ; dwell. 30,065 , and pop.-wh. 175,358 , fr. col. $28,5 \pi 0$, sl. 6,718-total 210,646 . Capital: Baltimore. Pullic Works: Baltimore and Ohio R. P. ; Philadelphia, Wilmington, and Baltimore R. R. ; Baltimore and Susquehanna R. R., with Westminster Brancn; and the Chesapeake and Ohio Canal, A R. R. also runs from Westchester, $\mathrm{Pa}$., direct to Baltimore (in progress).

Battivore City, sea-port, p. city, and cap. Baltimore co, $M d_{0}$ : on the $\mathrm{N}_{\text {. side Patapsco }}$., $14 \mathrm{~m}$. from its entrance into Chesapeake Bay, and $204 \mathrm{~m}$. from the Atlantic Ocean, by ship channel, and $28 \mathrm{~m}$. N. Annapolis; lat. $39^{\circ} 17^{\prime} 23^{\prime \prime}$, and long. $0^{\circ} 24^{\prime} \mathrm{E}$. Washington.

The city is pleasantly situated on a slightly undulating ground, and some of the elevations in the vicinity command fine riews. As laid out, it includes four miles square, and is built around the bay. The streets are regular and spacious, the buildings mostly of brick, and some of them exhibiting beautiful architectural combinations. Jones' Falls, a small stream from the $N$., divides the city into two parts, and over it are erected several handsome stone and wooden bridges.

The harbor of Baltimore is capacious and safe, and consists of an inner basin and an outer harbor-the latter at Fell's Point, and accessible to the largest ships. The entrance is commanded by Fort M'Henry.

The principal public buildings are the City Hall, the County Court House, the State Penitentiary, County Prison and House of Refuge, the Roman Catholic Cathedral, the finest in the Union, and numerous buildings deroted to collegiate, academic, and other literary and educational purposes. The monuments of Baltimore, and its numerous fountains, are distinguishing features in the adornments of the eity.

The population, in 1550 , amounted to 169,051 souls, of 
which 140,666 were whites, 25,442 fr. col., and 2,946 sl. The tutal value of real and personal estate was $\$ 30,237,960$, and the taxes raised, $\$ 617,994$, of which $\$ 381,509$ was eity $\operatorname{tax}$. Baltimore has 4 colleges, 67 academies and private schools, and 71 primary and public schools. The University, St. Mary's College, and Washington Medical College, are the principal collegiate institutions. There are 99 churches of all denominations, of which 6 are Baptist, 10 Episeopal, 3 German Reformed, 8 Lutheran, 42 Methodist, 4 Presbyterian, 8 Roman Catholic, and 8 others not specified. The public press consists of 6 daily, 4 tri-weekly, 10 weekly, 1 semi-monthly, and 2 monthly periodicals and newspapers; and of these 6 are religious, 1 agricultural, 1 musical, and 1 colonization; the remainder are devoted to politics and general news.

The industrial employments of the citizens are various and extensive. There are 2,243 establishments; the manufacturing eapital invested, $\$ 6,541,922$; males employed, 15,442 ; females employed, 5,044; raw material consumed, $\$ 9,414,244$; monthly cost of labor, $\$ 459,441$; annual products, $\$ 20,416,511$; of these establishments, 71 are blacksmith, 356 boot and shoe, 111 cabinet ware, 120 cigar, 238 clothing, 26 coach and earriage, 10 brass founding, 13 iron founding, 10 gunsmith, 12 machine, 10 piano-forte, 17 printing and publishing, 24 sail-making, 21 ship-building, 13 shipjoiner, 16 ship-smith, 31 silver-smith, ete., 19 stove, 15 weavers, 21 wheelwright, and 10 whitesmith-the remainder various, and of common interest.

As a commercial eity Baltimore ranks next to New Orleans among the southern ports. It has an immense inland trade, which will be greatly increased when the lines of communication are completed to a junction with those of Ohio and other western States. In 1850, the principal receipts from the interior for consumption and export, were : Cumberland coal, 146,645 tons, and anthracite, 160,000 tons ; wheat, $2,600,000$ bushels (about $1,750,000$ bushels taken by millers, and 850,000 bushels shipped); Indian corn, 3,000,000 bushels; oats, 450,000 bushels, and considerable lots of rye, barley, peas, and beans; beef, pork, and bacon; tobacco, 41, 533 hhds.; wool, 500,000 lbs., etc., ete.; the inspections of flour amounted to 896,592 barrels; of corn meal, to 46,000 barrels; and of rye flour, to 5,441 barrels; of leather, to 413,974 sides. Flour and tobacco, however, are the two great staples of Baltimore, and well has it been designated as " the greatest market for tobacco in the United States, and the principal flour market in the world." Its coastwise trade is also very extensive, and the shipping of Balttmore is found in every port from Passamaquoddy Bay to the Rio Grande ; the lumber of Maine, and the cotton and sugar of the Gulf States are brought here in vast quantities, as are also the various manufactures and merchandises of the intermediate Atlantic ports ; in $1850,25,000$ bales cotton were landed from southern ports, and $63,000,000$ feet of lumber from Bangor and other ports of Maine. The shipping owned in the collection district, of which Baltimore is the port, amounted on the 1st of June, 1850, to 140,019 tons, of which was registered 90,670 tons; enrolled and licensed 57,612 tons, and licensed under 20 tons 737 tons ; and of the enrolled and licensed tonnage, 13,115 tons, navigated by steam-power. In 1549-50, 66 vessels, of an aggregate burden of 11,683 tons, were built in the port district. The Baltimore clippers are pronounced to be the perfection of naval architecture; and they are no less fitted for trade than for privateering, in which eapacity they made a great figure in the last war with England.

Boston, New York, and New Orleans are the only seaboard ports of the Union, the foreign commerce of which exceeds that of Baltimore. In $1849-50$, the entrances amounted to 438 vessels and 99,598 tons, and the clearances to 521 vessels and 126,819 tons; and the value of merchandise imported was $\$ 6,121,201$, and of that exported, $\$ 6.967 .353$. The great bulk of the foreign commerce of Baltimore is earried on with the States of South America and the West India colonies, and the continent of Europe. With the British ports in Europe the connection is very limited.

There are 10 banks in Baltimore, with an aggregate eapital of $\$ 7,101,051$. The circulation in 1850 amounted to $\$ 2,073,578$, discounts to $\$ 10,925,106$, and deposits to $\$ 3,648, \$ 19$, and the amount of specie on hand to $\$ 2,113,755$. There are also a number of insurance companies and savings' institutions.

The eity is bountifully supplied with pure and wholesome water from public springs and fountains; these are inclosed by circular railings, and covered by small, open templets, consisting of columns supporting a dome, which are highly ornamental. The eity, however, derives its great supply from an elevated part of Jones' Falls, from which the wa ter is condueted through an aqueduct to a reservoir on Calvert-street, whence it is distributed in pipes.

The lines of travel diverging from Baltimore, are: the Baltimore and Philadelphia R. R., $97 \mathrm{~m}$. loug; the Baltimore and Susquehannah R. R., extending to Harrisburg, $\mathrm{Pa}$; and the Baltimore and Ohio R.R., with a branch R. R. to Washington; and lines of steamships or sail-ressels ply to Philadelphia, Norfolk, and other Atlantic ports. These great routes of communication unite the eity with every part of the Union, and insure a rapid and certain transit to its ever-increasing trade.

Baltimore was first laid out as a town in 1729 , and in 1765 it contained only 50 houses. It was chartered as a city in 1797. Since this period its inerease has been constant, and its prosperity material.

BALTIMoRe, p. v., Warren co., Ind.: on W. side of Wabash r., $72 \mathrm{~m}$. W. N. W. Indianapolis.

Baltimork, hund., Sussex co, Del. : facing on the ocean. Area 52,210 acres, and population 2,301.

Baltimoris, p. v., Fairfield co., Otio.: on both sides of Miami Canal, 20 m. E. S. E. Columbus. Pop. 492.

BALTIMORE, p. v., Barry co., Mitch.: $32 \mathrm{~m}$. W. by S. Lansing.

BANCROFT county, $I a$. Situate N. W., and contains 432 sq. m., taken from Pottowottomee in 1851.

BancRofт, p. v., Hampshire co., Mass.: 118 m. W Boston.

BANGOr, t., p. city, port of entry, and cap. Penobscot co., Me.: at the head of navigation on the Penobscot r., $30 \mathrm{~m}$. N. by E. from Belfast Bay, and 60 from the sea. Lat, $44^{\circ}$ $4 \tau^{\prime} 50^{\prime \prime}$ N., and long. $65^{\circ} 47^{\prime}$ W. from Greenwich. Pop. 14,432. Kenduskeag r. divides the eity into two parts, which are connected by bridges; a mile above the city it has a fall which affords mill-power. The harbor is spacious, and at tide is deep enough for the largest vessels. The principal staple of trade is timber. The Bangor Theolngical Seminary, and other good schools, are located here; and the periodical press consists of two daily papers, the "Mercury" and the "Whig and Courier," and four weekly papers, two of which are editions of the daily papers, and the others, the "Democrat" and the "Jeffersonian." Churches of all denominations are numerous. There is a $\mathrm{R}$. R. extending hence to Old Town, and another, the Kennebec and Penobseot R. R., will afford, when finished, a direct $R$. $R$. communication southward. Steamboats ply regularly to and from the river villages, and also to and from Boston and Portland. Banger was incorporated as a town in 1 171 , and was chartered as a city in 1884. Just above the city, a bridge, 1,320 feet long, spans the Penobseot, connecting Bangor with Orrington.

Bangor, t. and p. v., Franklin co, $N$. $Y$.: on a tributary of Salmon r, $152 \mathrm{~m}$. N. N. W. Albany. The Northern R. R. passes through it $63 \mathrm{~m}$. W. Rouse's Point, and $55 \mathrm{E}$. Ogdensburg. Pop. 2,160.

BANK Lick, p. o., Kenton co., $\kappa_{y}$ : 62 m. N. Frank fort.

Bankston, p. v., Choctaw co., Diss.: $82 \mathrm{~m}, \mathrm{~N}$. by E. Jackson. 
Banksville, p. v., Fairfield co., Conn.: $5 \mathrm{~s}$ m. S. W. Hartford.

Bankton, p. v., Saline co., IU.: between the middle and

S. forks of Saline er., $156 \mathrm{~m}$. S. S. E. Springfield.

Bannke, p. o., Kane co., $n l .: 159$ m. N. N. E. Springfield.

BAXNER, p. 0., Lafayette co., Miss. : 134 m. N. Jackson.

Bannerman, p. o., New Hanover co., N. Car.:110 m. S

by E. Raleigh.

bus.

Bantax, p. o., Clermont co., Ohio: $102 \mathrm{~m}$. S. W. Colum-

Bantay Fazis, p. o., Litchfield co., Conn.: $86 \mathrm{~m}$. W. Hartford.

Baptist Misston, p. o., Cherokee Nation, Ind. Ter.

Baptistown, p. v., Hunterdon co., N. Jer : 29 m. W. N.

W. Trenton.

Baptist Varley, p. o., Tazewell co., Virg.: $248 \mathrm{~m}$. W.

by $\mathrm{S}$. Richmond.

Baraboo, p. v., Sauk co., Wisc.: on S. side Baraboo r.

$33 \mathrm{~m}$. N. by W. Madison.

Barber's, p. 0., Columbia co., Flor.

Barber's Corners, p. o., Will co., $I l l .: 143 \mathrm{~m} . \mathrm{N} . \mathrm{N}$. E Springfield.

Barber's Creet, p. o. Jackson co., Ga.: 60 m. N. Milledgeville.

Barber's Cross Roads, p. o., Isle of Wight co., Firg. $64 \mathrm{~m}$. S. E. Richmond.

Barbersvmue. p. v., Jefferson co., Ind.: 76 m. S. E. Indianapolis.

BARBOUR county, Ala. Situated S. E. on Chattahoochee r., and contains $9 S 0 \mathrm{sq}$. m. Drained by numerous creeks of Chattahoochee $r$., the head waters of Choctawatchie $r$, and Pea $r$, which forms its W. border. Surface undulating, and the soils generally fertile. Corn and cotton are the staple products. Farms 1,325; manuf. 39 ; dwell. 2,306, and pop.-wh. 12,842 , fr. col. 10 ; sl. 10,780-total 23,632 . Capital: Clayton.

BARbour county, Firg. Situate N. W., and contains $380 \mathrm{sq} . \mathrm{m}$. Drained by the numerous creeks forming the E. fork of Monongahela $r$. Surface much diversified, somewhat rough, and soils rich, producing wheat, corn, oats, and tobacco abundantly. Maple sugar is made largely. Farms 1,075; dwell. 1,467, and pop.- wh. 8,671, fr. col. 221, sl. 118-total 9,005. Capital: Phillippa.

Barbour, p. Y., Choctaw co., Ala.: 118 m. W. Montgomery.

Batrour's Mrirs, p. o., Lycoming co., Penn.: $86 \mathrm{~m}$. N. by W. Harrisburg.

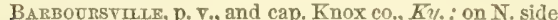
Cumberland r., 112 m. S. E. by S. Frankfort.

Barboursville, p. v., Cabell co., Tirg.: on N. bank of Guyandotte r., $260 \mathrm{~m}$. W. by N. Richmond.

Barbotrspille, p. v., Orange co., Virg.: 64 m. N. W.

Richmond, near the line of the Central R. R.

Barbourstrlle, p. v., Delaware co., $N . Y .: 96 \mathrm{~m}, \mathrm{~W} . \mathrm{S}$, W. Albany.

Barcelona, p. $\nabla .$, Chautauque co., $N . T$. : on Lake Erie, $298 \mathrm{~m}$. W. Albany, and on the Buffalo and State Line R, R. It is a port, and place of considerable business.

BARCLAY, p. Y., Whitesides co., III.

Barchatsvidue, p. v., Cumberland eo., $N_{0}$ Car

Bardstown, p. $\nabla_{\text {., }}$ and cap. Nelson con, Ky.: on E. side of Beech fork of Salt r., $42 \mathrm{~m}$. S. W. Frankfort. It is the site of St. Joseph's College, a Catholic institution.

Barestille, p. o., Monroe co., Ohio : 108 m. E. Columbus. Barertule, p. v., Lancaster co., Penn.

BARGatistown, g. v., Atlantic co., N. Jer.: $56 \mathrm{~m}$. S. by E. Trenton.

Barges, p. o., Butler co., Ala. : on Pine Barren er., 48 m. 8. W. Montgomery.

Barhavermie, p. v., New Kent co., Tirg.: 40 m. E. Richmond.

BAR Harbor, p. o, Hancock co, Me. : $98 \mathrm{~m}$. W. Augusta.
Barivg, t. and p. v., Washington co, Mre.: on st. Croíx r., $183 \mathrm{~m}$. E. by N. Angusta. The Calais and Baring R. R. $6 \mathrm{~m}$. long, connects it with Calais. Pop. 390.

Barker's Settleineant, p. v., Barbour co., Virg.: $172 \mathrm{~m}$. N. W. Richmond.

Barierstille, p. v., Saratoga e $0 ., N$. $Y$ :

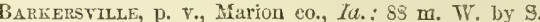
Iowa City.

Barkiramstead, t. and p. o., Litchfield co., Conn.: on a branch of Farmington r., 24 m. N. W. Hartford. Pop. 1,525. BABE RIVER, t. and p. o., Jeffersol co., Wisc. : $31 \mathrm{IL}$. E. Madison.

Barksdale, p. o., Halifax co., Firg.: on a er. of Roanoke r., $98 \mathrm{~m}$. S. W. Riehmond.

BARLow, t. and p y., Washington co, O7io: $78 \mathrm{~m}$. E. S. E. Columbus. Pop. 1,062.

BARNARD, t, and p. o., Windsor co., Verm. : on tributaries of White and Qteechee rivers, $83 \mathrm{~m}$. S. Montpelier. P.1,647. Barinardstille, $p_{0}$., Roane co, Tenn.: on S. side of Tennessee r., 124 m. E. by S. Nashville.

Barniorovgit, p. v., Gloucester co., $N$. Jer.

BARNEGAT, v., Dutchess co.,,.,$Y_{\text {.: }}$ on E. silde of Hudson r., $4 \mathrm{~m}$. S. of Poughkeepsie, and $78 \mathrm{~m}$. S. Albany. Noted for its lime.

Barmegat, p. v., Ocean co., N. Jer. : 56 m. S. E. Trenton, BARNEgAT BAY AND INLET, $N$. Jer. : a long, narrow bay, separated from the ocean by Island Beach and Squam Beach, and having its entrance southward by an inlet of the same name. It is $20 \mathrm{~m}$. long, and from 1 to $4 \mathrm{~m}$. wide, and receives several considerable creeks, of which Metedecunk $r_{\text {. }}$ at its $N$. extremity, is the largest.

Barnertille, p. v., Schoharie co., $N . Y_{.:}: 38 \mathrm{~m}$. W. by $\mathrm{S}$. Albany.

BarNes, p. 0., Richland co., Ohio.: $58 \mathrm{~m}$. N. by E. Columbus.

Bapnes' Copners, p. o., Lewis con, N. Y.: $123 \mathrm{~m} . \mathrm{N}$. W. Albany.

Barnes' Cross Roads, p. o., Dale co., Ala.: 90 m. S. E. Montgomery.

Barnesville, p. v., Pike co., Ala.: 42 m. S. S. E. Montgomery.

Barnesville, p. v., Montgomery co., Ga.: 78 m, S, E. Milledgeville.

Barsesvilie, p. va, Belmont co., Ohio: 96 m. E. by N. Columbus.

Barnet, t. and p. v., Caledonia co., Verm.: on W. side Connecticut r., $27 \mathrm{~m}$. E. Montpelier. The Connecticut and Passumpsic Rivers R. R. passes through it, $51 \mathrm{~m}$. N. of White River Junction, and $9 \mathrm{~m}$. S. St. Johnsbury. P. 2,521. Barneys, p. o., Philips co., Ark.

BarNiatis Island, $N . Y_{0}$ : the most northerly of the St. Lawrence $r$. islands, belonging to the United States.

Barninart's Mrlus, p. 0., Butler co., Penn.: $170 \mathrm{~m}$. W. by N. IIarrisburg.

BARN IsLAND (GREAT), $N$. $Y$.: lies in the East r. N. of Hell Gate, 147 m. S. by E. Albany, and is about $2 \mathrm{~m}$. in circuit. Litrile Bark Island lies to the N. E., and is separated from the above by a narrow channel called Little Hell Gate, and at the confluence of Harlem r. with East r.

Bardetable county, Mrass. Situate S. E., and contains about $335 \mathrm{sq} . \mathrm{m}$. This county includes the whole of Cape Cod, and is a sandy, unproductive region. Farms 789 ; manuf. 423; dwell. 6,532, and pop.-wh. 85,153 , fr. col. 123 -total 35,276. A great portion of the male inhabitants derive their living from the fisheries or other maratime employments. Capital: Barnstable.

Baristable, t., p. v., sea-port, and cap. Barnstable co., Mrass.: on Barnstable Bay, 62 m. S. E. Boston. Tonnage of the port 91,102 tons, chiefly employed in the flsheries. The iay opens on Cape Cod Bay, and at its bar has from 6 to 7 feet water. Pop. 4,902

BarNsteAd, t. and p. v., Belknap co., N. Hamp.: on Suncook r., 18 m, N. E. Concord. Pop. 11,\$48, 
BARswelt district, $S$. Cor . Situate S. W., and contains 1.160 sq. m., lying between the Savamah and the South Edisto rivers. Drained by tho Salkawatchie, and the tributaries of the two first named rivers. There are several stiplutur springs in the district. Surface undulating and inclining to the S. W.; and the soils fertile. Indian corn, rice, and cotton are the principal products. Farms 1,55s; manuf. S5; dwell. 2,460, and pop.-wh. 12,2S9, fr. col. 311 , sl. 14,00s-total 26,60s. Capital: Barawell. Public Works : South Carolina R. R.

Barswell, p. v., and cap. Barnwell dist., S. Car.: on Turkey cr., near Salkahatchie r., 57 m. S. S. W. Columbia.

Barracksville, p. v., Marion co., Firg.

BARRe, t, and p. v., Worcester co., HAss.: on Ware r., $56 \mathrm{~m}$. W. Boston. Two newspapers, the "Barre Patriot" and the "Barre Gazette," are issued weekly. Pop. 2,976.

BARre, t, and p. v., Washington co., Ferm.: on Onion r., $8 \mathrm{~m}$. S. by E. Montpelier. The town fnrnishes fino building granite: the State Ilouse at Montpelier is constructed of material furnished from its quarries. Pop. 1,85.

Barre Cextre, p. o., Orleans co., $N . Y .: 226 \mathrm{~m}$. W. Albany.

BARREN county, $\bar{K} y$. Situate $\mathbf{S}$. centrally, and contains 546 sq. m. Drained by the head waters of Big Barren, an arm of Green r. Surface uneven, and sometimes rolling, and soils of average fertility, producing largely tobacco and the cereals. Farms 1,813; manuf. 33; dwell. 2,607, and pop.-wh. 15,513, fr. col. 113, sl. 4,554-total 20,210. Capital: Glasgow. Public Works: Nashrille and Lexington $\mathrm{R} . \mathrm{R}$.

BARREN. p. 0., Harrison co., Ind. : $112 \mathrm{~m}$. S. Indianapolis.

Barren, p. o., Williamson co., Tenn. : 22 m. S. Nashville

Barren Creek Springs, p. o., Somerset co, Mld.: on N. side Barren cr. of the Nanticoke, 55 m. S. E. Annapolis.

Barren Grove, p. o., Bureau co.,,$l l .: 54$ m. N. Springfield.

Barren Hill, p. o., Montgomery co., Penn. : 92 m. E. Dy S. Harrisburg.

Barrex Hul, p. o., Henry co., Tenn.: 88 m. W. by N. Nashville.

Bareen Plate, p. 0., Robertson co., Tem. : 26 m. N. Nashville.

Barrex RIDGe, p. o., Vanzant co., Tex.: 258 m. N. N. E. Austin City.

BarReN rivers, (BIG and LITTLE), $\bar{k} y .:$ tributaries of Green r.

Bareftrstille, p. v., Lumpkin co., $G a_{*}$ : 106 m. N. W. Milledgeville.

Barreville; p. V., M'Henry co., $M$. : on W. side Fox r. $183 \mathrm{~m}$. N. E. Springfield.

Barrtngton, p. v., Cook co.. $I l_{*}$ : in N. W. part of co, $182 \mathrm{~m}$. N. E. Springfield.

Barrington, t. and p. v., Strafford co., N. Mamp.: 28 m. E. Concord. The "Devil's Den," a curious cave with several large chambers, exists ander this town-one of the chambers is 60 feet long, 10 to 15 feet high, and 8 wide. It has also numerous small lakes, the outlets of which afford water power. Pop. 1,754.

Barrington, t. and p. V., Yates co, $N$. $Y$.: on E. side of Crooked Lake, $176 \mathrm{~m}$. W. Albany. Pop, 1,556.

Barington, t. and p. v., Bristol co., R. $I .: 8$ m. E. S. E. Providence, Pop. 795.

BarR's Stoke, p. o., Macoupin co., Ill.: $42 \mathrm{~m}$. S. W. Springfield.

BARRr county, Mich. Situate W. centrally, and contains 576 sq. m. Drained by Thorn Apple r., a tributary of Grand r., and in the S. by streams flowing to the Kalamazoo. Surface undulating, well timbered, and soils fertile. Farms 738; manuf. 26 ; dwell. 1,037, and pop.-wh. 5,083, fr. col. 39-total 5,072. Capital: Hastings.

BARRT county, Mo. Situate S. W. on the State line, and contains $650 \mathrm{sq} . \mathrm{m}$. Drained E. by tributaries of White $\mathrm{r}$ and W. by the head waters of Neosho r. of the Arkansas.
Surface unslulating; in the W. and misldle bitly and brolien. Timber abundant. Farms 359 ; manuf. 2 ; 1 well. 511 and pop-wh. 3,317, fr. col. 0, 81. 150-total 8,467. Capital. Cassville.

Barre, t. and p. v., Schuylkill co., Penn.: on Deep cr. of the Susouchanna, $44 \mathrm{~m}$. N. E. IIarrisburg.

Barir, p. v., Pike co, Ill. : $75 \mathrm{~m}$. W. Springfield.

Barry, p. v., Lawrence co., Ark. : 113 m. N. N. E. Litlle linck.

Bulry, p. v., Frederick co., Mrd.: 62 m. W. N. W. Annapolis.

BARrT, p. v., Jackson co., Mich.: on Sandsione cr., and on the line of the Michigan Central R. R., $80 \mathrm{~m}$. S. Lansing.

BArry, p. v., Clay co, Mo.: 186 m. W. N. W. Jefferson City.

Barry, p. va, Cuyahoga co., Olio: 126 m. N. N. E. Columbus.

BAnrx's Bridae, p. 0., Lunenburg co., Virg.: $66 \mathrm{~m}$. S. W. Lichmond.

Barrytos, p. v., Choctaw co. (formerly cap. Washington co.), Ala.: on Oka Tappah cr. of Tombigbee r., $115 \mathrm{~m}$. W. S. W. Montgomery.

Barrytowx, p. v., Duchess co., $N$. $Y$.: on E. side of IIudson r., 45 m. S. Albany.

Barryville, p. v., Sullivan co., $N . Y_{.}: 95 \mathrm{~m}$. S. W. Albany.

BarrTvilie, p. v., Stark co., Ohio: 112 m. N. W. Columbus.

Bart, t. and p. o., Lancaster co., Penn : at the head of Octarara cr., 45 m. E. Ilarrisburg. Pop, 3,238 .

Barter Brook, p. o., Augusta co, Firg.: 99 m. W. Richmond.

BArtuoloyew county, Ind. Situate S., and contains 405 sq. m. The principal streams are Driftwood r., Flat Rock er., and Clifty cr, which have extensire bottoms. Surfice hilly and broken in the W., but elsewhere level or undulating. In the bottoms the soil is a rich alluvion mixed with disintegrated limestone and gravel; tho hilly parts have a clay soil. Every part of the county is well adapted to agriculture. Farms 1,219; manuf. 49 ; dwell. 2,149, and pop,-wh, 12,346, î, col. s2-total 12,42S. Cupital: Columbus. Pullic Works: Madison and Indianapolis R. R., and the Columbus and Jeffersonville $R$. $\mathrm{R}$.

Bartilolonew, p. o., Drew co., Ark.: on E. side Bayou Bartholomew, $104 \mathrm{~m}$. S. E. Little Rock.

Bartlfit, t. and p. v., Coos co, N. Hamp. : on Saco r., at the foot of the White mts., $65 \mathrm{~m} . \mathrm{N}$. E. Concord, P. 761.

Bartlets, p. v., Washington co., Ohio: $76 \mathrm{~m}$. S. E. Columbus.

Bartos, t. and p. $\nabla .$, Tioga co., $N$. $Y_{0}:$ on the Susquehanna and Chemung rivers, $125 \mathrm{~m}$. W. S. W. Albany.

Bartor, t. and p. v., Orleans co., Ferm.: on Barton r. $36 \mathrm{~m}$. N. E. Montpelier. Pop. 987.

Bartox, p. v., Lowndes co., Miss. : 128 m. N. E. Jackson.

Bartox, p. v., Washington co, Wisc.: $76 \mathrm{~m} . \mathrm{E} . \mathrm{N} . \mathrm{E}$ Madison.

Barton Hrul, p. o., Schoharie co., $N . \bar{Y}:: 38 \mathrm{~m}$. W. Albany.

Barton's CrekK, p. o., Dickson co, Tenn.: $42 \mathrm{~m}$. IV. Nashville.

Barton's Landive, p. o., Orleans co, $\overline{V e r m}$.

Bartonsville, p. v., Monroe co, Penn. : 112 m. N. E. Harrisburg.

Bartonstrule, p. V., Windham co., Term..: 92 m. S. Montpelier.

Basan, p. o., Meigs co., Ohio: 84 m. S. E. Columbus.

BAscobel, p. V., Jackson co., Ga.: 74 m. N. by W. Milledgeville.

Buscom, p. o., Seneca co., Ohio: 50 m. N. X.TF. Columbus.

BAsE LAKE, p. o., Washtenaw con, Mrich.: $46 \mathrm{~m}$. S. E Lansing. 
Basian's Gap, p. o., Morgan co., Ala.: $145 \mathrm{~m}$. N. by W. Nontgomery.

Basilav's Milis, p. 0., Johnson co., Ark.: $82 \mathrm{~m}$. W. by N. Little Rock.

BuSiI, p. v., Clark co., Ala.: $9 \mathrm{~s}$ m. S. W. Montgomery.

Basiy KNoв, p. 0., Johnson co., Mo.: 102 m. W. by N. Jefferson City.

Baskenridge, p. v., Somerset co., N. Jer.: $42 \mathrm{~m}$. N. by E. Trenton, memorable for the eapture of Gen. Lee by the

English in the Revolutionary War.

B ASNetTrille, p. V., Marion co., Virg.

BASs LAKE, p. o., Daze co., Wise.

Bass River Hotex, p. 0., Burlington co, $N$. Jer. : $57 \mathrm{~m}$. B. E. Trenton.

BAstior county, Texo. Situate S. W. on Colorado $x_{\text {s, and }}$ contains about $1,400 \mathrm{sq} . \mathrm{m}$. Drained by numerous creeks of the Colorado, which traverses the county from N. W. to S. E. Surface generally elevated and undulating-in the N. some low hills. The streams are fringed with heavy timber, between which are small and beautiful prairies. Soils a deep black mold mixed with sand. Indigo and wild grapes grow spontaneously; , and the lands are highly farorable for cotton. Farms 219 ; manuf. $9 ; d w e l l .377$, and pnp.-wh. 3,150, fr. col. 0, sl. 919-total 4,099. Cupitul; Bastrop.

Bastrop, p. v., and cap. Morehause par., La.: on W. side of Bayou Bartholomew, $162 \mathrm{~m}$. N. by W. Baton Rouge.

B $\triangle S T R O P$, p. v., and cap. Bastrop co., Tex.: on N. side Rio Colorado, $26 \mathrm{~m}$. E. S. E. Austin City. It is the centre of a rich agricultural country, and has great advantages as an interior commercial village.

Batatia, p. V., Kane co., $\Pi l l_{0}$ : on the Aurora branch of the Galena and Chicago Union R. R., $36 \mathrm{~m}$. W. Chicago, and $194 \mathrm{~m}$. N. N. E. Springfielel.

Batamia, t., p. v., and eap. Genesee eo., $\lambda^{r} . Y_{.}$: on Tonawanda cr., $226 \mathrm{~m}$. W. Albany. Sereral railroads terminate at and pass through the place; and there are two newspapers, the "Republican Adrocate" (whig), and the "Spirit of the Times" (dem.), issued weekly. It is a neat village, and has considerable trade. Pop. of t. 4.461.

Bataria, $t$ and p. T., Branch co., Afich.: on Southern Miehigan R. R., 60 m. S. Lansing. Pop. 724.

Batatia, p. v, and eap. Clermont co., Ofio : on the N. bank of the E. fork of Little Miami r., SS m. S. W. Columbus. The "Clermont Sun" (dem.), and the "Clermont Courier" (whig), are published weekly. The village has some manufactures.

Batavia Kill, p. 0., Delaware co, N. Y.: 77 m. S. W. Albany.

Batemax's Store, p. 0., Houston con, Ga.: 42 m. S. S. W. Milledgeville.

Batre county, Bro. Situate S. W. on State line, and contains 750 sq. m. Drained by tributaries of Osage r. Surface undulating-principally prairie, and soils very fertile. Timber plentiful on the rivers. Farns $472 ;$ dwell. 626 , and pop.-wh. 3,520, fr. col. 8, sl. 140-total 3,668. Capital: Batesville.

Batesvrle, p. $\nabla$, and cap. Independence co., Ark.: on lent bank of White r., is m. N. N. E. Little Rock.

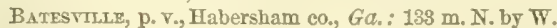
Milledgeville.

Batzstllue, p. v., Guernsey co., Ohio: 92 m. E. Columbus.

BatestilleE, p. v., and eap. Bates co. (formerly Harmony Mission), MYo.: on N. bank of Osage r., $126 \mathrm{~m}$. W. Jefferson City.

Batru connty, $K y$. Situate N. E., and contains 260 sq. m. Drained by Slate and other creeks, tributaries of Licking $\mathbf{r}$, which forms its E. Border. Surface occasionally hilly with much level or rolling lands; and the soils very fertice. The chicf products consist of the cereals and tobacco. Farms 1,01s; manuf. 23; dwell. 1,595, and pop.53 wh. 9,477 , fr. col. 102, sl. 2,535-totad 12,114. Cupital. Oringsville.

BATI county, Firg. Situate centrally among the Alleghanies, and contains $756 \mathrm{sq} . \mathrm{m}$. Watered by the head streams of James r., flowing E., and of Greenbrier, fowing W. to the Ohio. It is an elevated billy country, and contains a number of medicinal springs. Soils very fertile in the valleys, producing grain, and feeding thousands of cattle and sheep. Farms 261; manuf. 17; dwell. 410, and pop.-wh. 2,436, fr. col. 43, sl. 917-total 3,426. Capitul: Bath C. II.

BıtI, p. v., Franklin eo., Ind.: (see Miservil.te).

Baty, p. v., and cap. Mason eo., Ill.: on the L. bank of rllinois r., $38 \mathrm{~m}$. N. W. Springfield.

Batir, t., p. c., and sea-port, Lincoln co., Ife. on W. bank of Kennebee r., $12 \mathrm{~m}$. from the ocean, and $28 \mathrm{~S}$. Augusta. It is one of the prineipal cornmercial towns of the State, and is largely engaged in ship-building. Tonnage, 103,626 tons, of which 76,606 tons are employed in foreign commerce. A branch of the Kennebec and Portland R. R., $9 \mathrm{~m}$. long, connects the place with the general railroad sygtem of the U, S. Six newspapers are published lere-the "Northern Tribune" (whig), tri-weekly and weekly; the "Eastern Times" (dem.); the "Weekly Mirror" (neutral), and the "Sagadahock Reviers" (neutral), weekly; and the "Journal of Education," semi-montbly. Pop. 8,020 .

BatI, p. v., Beaufort co., N. Car.: on a cr. of Pamlico Sound, $12 \mathrm{~s}$ m. E. Raleigh.

Bati, t. and p. O., Grafton co., N. Bamp.: on Ammonoosue r., at its confluence with Connecticut r., $69 \mathrm{~m}$. N. N. E. Coneord. At the $\mathrm{v}$, the Ammonoosuc is crossed by a bridge 350 feet long. Pop. of t. 1,514.

Bati, t., 1. v., and cap. Steuben co., $N_{0} . I_{\text {: }}$ on the Conhocton r., 173 m. W. S. W. Albany. The "Steuben Courier" (whig), the "Farmer's Advocate," and "Steuben Democrat" (dem.), are published weekly. The village is an important station on the Buffalo, Corning, and New Fork City R. R., and has a large number of flourishing flour and saw mills. Pop, of t. 6,185 .

BATI, $t$ and p. v., Summit co., Ohio: on a cr. of Cuyahoga r., 108 m. N. E. Columbus. Pop. 1,400 .

Barri, p. v., Northampton co., Penn,: 90 m. E. N. E. Harrisburg.

Batu, p. V., and cap. Bath co., Firg.: 132 m. W. N. W. Tichmond. The village is noted for its medicinal springs: the Warm Spring at this place has a temperature of $96^{\circ}$ Fahr, and about $6 \mathrm{~m} . \mathrm{S}$. W. are hot springs, the temperature being $112^{\circ}$; these are much visited by invalids.

BatH Alux, p. v., Bath co., Virg.

Batil Spring, p. o., Decatur co., Tenn.

Batoy Rotge, EAst, parish, $L \alpha$. Situate on the E. bank of Mississippi r., and contains 2Ss sq. m. The lands are well drained by numerons streams, tributaries of Amitie r., which borders it E. Surface slightly elevated above flood mark. Soils productive of corn, cotton, and sugar. Farms 2s7, dwell. 1,044, and pop.-wh. 5,347, fr. col. 279, sl. 6,3ั5̆1 -total 11,977. Capital: Baton Rouge.

Baton Rouge, West, parish, La. Situate W. side of Mississippi, and contains 576 sq. m. Drained by creeks and bayoux falling into Bayou Atchafalaya, which borders it $\mathrm{S}$. and $\mathrm{W}$. Surface low, level, and subject to inundation, except along the streams where the land is slightly elevated. Cotton is the principal production. Farms 128; dwell. 392, and pop.-wh. 1,818, fr. col. 102, sl. 4,350-total 6,270. Capital: West Baton Rouge.

Batov Rouge, p. v., and cap. East Baton Rouge par., La. and cap, of the State of Louisiana: on E. bank of Lississippi r., $245 \mathrm{~m}$, from its mouth, and $1,120 \mathrm{~S}$. W. Washington. It is the site of an U.S. barracks, and contains the State House, the Louisiana Penitentiary, county offices, and otber handsome public and private dwellings. It is mostly built upon an elevated plain, some 25 or 30 feet above the river, the business portion being at the foot of the bluff. The 
"Baton Rouge Gazette," and "Democratic Adrocate," are published weekly. Pop. 1,262,

Baton Rovge, C. H., p. v., and cap. West Baton Rouge, $L a .:$ on the W. side of the Mississippi r., immediately opposite Baton Rouge.

Baror Rovgr, p. v., Chester disto, S. Car : $62 \mathrm{~m} . \mathrm{N} . \mathrm{Co}-$ lumbia.

BatraHatcnte river, $A l a$. and Miss.: a tributary of Tombigbee $\mathrm{r}_{\text {- }}$-it rises in Alabama, and after a course of $70 \mathrm{~m}$. disembogues in Monroe co., Miss.

B $\triangle T T E N$ KnLL, a tributary of the Hudson r. from Vermont. It has a course of about $50 \mathrm{~m}$, in which it furnishes many excellent mill sites, and falls into the Hudson below Fort Miller Bridge.

BATTENVLue, p. v., Washington co., N. Y.: 38 m. N. E. Albany.

Battleborotgh, p. V., Edgecomb co., N. Car, : 46 m. E. by N. Raleigh.

BatTle CREEK, p. v., Calhoun co., NECh.; at the junetion of Battle cr. and Kalamazoo r., $42 \mathrm{~m}$. S. W. Lansing. The Michigan Central R. R. intersects the v. $120 \mathrm{~m}$. W. Detroit. Battle Creek, p. o., Marion co, Tenn.

BATTLE CrEEK, Mich. : the largest branch of Kalamazoo r. It is about $40 \mathrm{~m}$. long, and furnishes many good mill sites.

Battlefield, p. 0., Lauderdale co., Afiss.: $88 \mathrm{~m}$. E. Jackson.

Battle Groond, p. o., Tippecanoe co., Ind.: on the W. side Tippecanoe r., $66 \mathrm{~m}$. N. W. Indianapolis. Famons as the seene of General Harrison's victory over the Indians.

Baunstows, p. v., Berks co., Fenn. : 52 m. E. by N. Harrisburg.

Barixgtos, p. o., Washington co., Penn.: $192 \mathrm{~m}$. W. Harrisburg.

Baxter's, p. 0., Muskingum co., Ohio:50 m.W. Columbus.

Bar, p. o., Pope co., Ill.: on Big Bay cr., 185 m. S. S. E. Springfield.

BAY HUNDRED, p. o., Talbot co., Md. : on E. side of Eastern Bay of the Chesapeake, $28 \mathrm{~m}$. S. E. Annapolis.

Bay Modnt, p. o., Greene co., Tenn.: 132 m. E. Nashvilie.

Barov Chicot, p. v., St. Landry par., La.: 66 m. W. N. TV. Baton Rouge.

Bıyou GouLA, p. v., Iberville par., $L a_{0}: 22 \mathrm{~m}$. W. by S. Baton Rouge.

Bayou Plekre, p. o., Caddo par., La.: 172 m. N. W. Baton Rouge.

Bayou Ramois, p. o., St. Mary's par., La.: 58 m. S. W. Baton Rouge.

BAYou Rouge, p. o., Aroyelles par., $L a_{0}: 58$ m. N. W. Baton Pouge.

Bar's Botrosr, p. o., Gallia co., Ohio: 98 m. S. E. Columbus. Pop. 1,302.

BAzETT, p. 0., Navarre co., Texo.: on the W. side of Trinity r., $210 \mathrm{~m}$. N. N. E. Austin City.

BazeTta, t. and p. v., Trumbull co., Ohio: $145 \mathrm{~m}$. N. E. Columbus.

Benci Branch, p. o., Beauiort dist., S. Car. : 112 m. S. Columbia.

Beaci Grote, p. 0., Lacerne co., Penn.: 102 m. N. E. Harrisburg.

Beaci Havev, p. vo, Lucerne co., Penn.: 98 m. N. E. IIarrisburg.

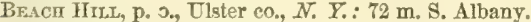

Beacri LaNd, p. 0., Chattooga co., Ga.: 162 m. N. W. Milledgeville.

Benle's Mrlis, p. o., Juniata co., Penn.: 34 m. W. Harrishurg.

Benctsville, p. v., Washington co., Penn. : 208 m. W. by 8. Harrishurg.

Braltstille, p. ., Monroe co., Ohio: 104 m. E. CoIumitras.

Benystrlig, p. v., Darke co., Ohio: $92 \mathrm{~m}$. W. Columbus.
Bean Blossox, p. o., Brown co., Ind. : on a cr. so called, $38 \mathrm{~m}$. S. Indianapolis.

Bean"s Station, p. o., Grainger co, Tenn.: 188 m. E. by N. Nashville.

Beantown, p. v., Charles co., MId.: 38 m. S. W. Annapolis.

Bear Branch, p. o., Duplin co., N. Car.: 52 m. S. S. E. Raleigh.

Bear Branch, p. o., Ohio co., Ind.: 86 m. S. E. Indianapolis.

Bear Creek, p. o., Jay co., Ind.: on a cr. so called, a tributary of Wabash r., $62 \mathrm{~m}$. E. N. E. Indianapolis.

BeAR CREeK, p. o., Montgomery co., Ill.; $46 \mathrm{~m}$. S. Springfield.

Bear Creek, p. o., Cedar co., Mo.: on a cr. so called, a tributary of Sac r. of the Ossage, $60 \mathrm{~m}$. S. W. Jefferson City.

BeAR Creek, p. o., Poweshrick co., Ia.: $46 \mathrm{~m}$. W. Iowa City.

Bear Creer, p. 0., Lucerne co., Penn.: 86 m. N. E. Harrisburg.

Bear Creek, p. o., Montgomery co., Ohio.: $82 \mathrm{~m}$. W. Columbus.

Bear Creek, p. o., Sauk co., Wisc.: 48 mo. W. by N. Madison.

Bear Crefex, p. 0., Piekens co., Ala.: 124 m. N. W. Montgomery.

Bear Creek, p. o., Sabine co., Texo, . 246 m. E. Austin City.

Beard's Bluff, p. o., Marshall co., Ala.: $132 \mathrm{mo}$. N. Montgomery.

Beardstown, p. v., and cap. Cass co., $I l l .:$ on E. side of the Illinois r., $48 \mathrm{~m}$. W. by N. Springfield.

Beardstown, p. v., Perry co., Tenn. : 78 m. S. W. Nashville.

Bear Gap, p. o., Northumberland co., Penn.: $72 \mathrm{~m} . \mathrm{N}$. Harrisburg.

Bearmont, p. O., Schuylkill co, Pemn.: 52 m. E. N. E. Harrisburg.

Bear Rayge, p. 0., Autauga co., Ala.: 28 m. N. W. Montgomery.

Bearsville, p. v., Ulster co., $N$. Y.: 69 m. S. S. E. Albany.

Beartown, p. v., Lancaster co., Penno: 48 m. S. E. Har risburg.

Bear WaLlow, p. o., Barren co., Ky.: 108 m. S. by W.

Frankfort.

Beaseley, p. o., Jefferson co., Flor.

Bratie's BlufF, p. o., Madison co., Miss.: $32 \mathrm{~m}$. N. by

E. Jackson.

Beattie"s Ford, p, o., Lincoln co., N. Car. : $142 \mathrm{~m}$. W. by S. Raleigh.

Beatty's BrIDge, p. o., Bladen co, N. Car.: $81 \mathrm{~m}$. $\mathrm{S}$. Raleigh.

Bbaty's Mrlls, p. 0., Marion co, Virg.

Beatrstown, p. v., Warren co., $N$. Jer : on Musconeteong er, at the W. base of Schooley's mt., $52 \mathrm{~m}$. N. Trenton.

Beaufort county, $N$. Car. Situate E. on Pamlico and Pungo rivers, and contains $670 \mathrm{sq} . \mathrm{m}$. Surface flat, and subject to inundation. Cotton and rice the staples. Farms 594: manuf. 73; dwell. 1,663, and pop, -wh. 7,668, fr. col. 904, sl. 5,249-total 13,516. Capital: Washington.

BEAUFORT distriet, $S$. Car. Situate in 3. W. corner of the State, and contains 1,120 sq. m. Facing S. E. on the Atlantic, and lying between the Savannah and Cambahee rivers, and drained by their tributaries and the Coosawatchie $\mathbf{r}$. The coast is lined with a number of islands, the largest of which are Hilton Head, St. Helena, and Port Royal, which form a number of canals and inlets. Surface low and marshy, and soil generally sandy. The chief products are Indian corn, rice, and cotton. Farme 842 ; manuf. 18: dwell. 1,355, and pop.-wh. 5,945, fr. col. 5s1, sl. 39,279 --total 38,805. Citpital: Coosariatehie.

Beaurozt, p. v., sea-port, and cap. Cartaret co., N. Car.: 
$\$ 26 \mathrm{~m}$. E. S. E. Raleigh. The harbor is spacious and safe and admits ressels drawing 14 feet water, entrance being had by Old Topsail Inlet, $11 \mathrm{~m} . \mathrm{N}$. W. Cape Lookont. The port has a good commerce, and the shipping belonging to the disirict in 1850 was 2,250 tons, chiefly coasters. On Bogue Point, at the entrance of the harbor, stands Fort Macon.

BEAUEORT, p. V., Franklin co., Mo.: 58 m. E. Jefferson City.

BEAUFORT, p. v., sea-port, and eap. Beaufort dist., S. Car.: on the W. side of Port Lioyal r., an inlet of the Ailantic, 16 $\mathrm{m}$. from the sea and $156 \mathrm{~S}$. Columbia. The harbor is good, but on account of a bar at the mouth, vessels of more than 11 feet draft are prevented entrance. It has little or no commerce, and the site is unhealthy.

Beaumont, p. o., Lucerne co., Perin.: 72 m. N. E. Harrisburig.

Beacmont, p. v., and cap. Jefferson co., Tex. : on the W. bank of Neches r., $28 \mathrm{~m}$. above its entrance into Sabine Bay, and 224 m. E. by S. Austin City.

Bedver county, Penn. Situate W., and contains $B S 2$ sq. $\mathrm{m}$. Drained by Beaver $\mathrm{r}$, and the Ohio, which flows through it. Surface uneven, sometimes billy, but soils fertile. Coal and iron are abundant. Farms 1,811; manuf, 186; dwell. 4,564, and pop.-wh. 26,444, fr. col. 245-total 26,689. Capital: Beaver, Public Works: Cleveland and Pittsburg R. R., Ohio and Pennsylvania R. R., Beaver and Erie Canal, ete.

Beatere, to and p. v., Pike co., Ohio: on the line of the Cincinnati, Hillsboro', and Parkersburg R. R., 62 m. S. by I. Columbus. Pop. 520 .

BeAver, p. v., Anderson co., Tex. : 216 m. N. E. Austin City,

Beater, po vo, and cap. Beaver co., Penn.: at the confluence of Big Beaver r. with the Ohio r., $30 \mathrm{~m}$., by the river course, below Pittsburg, and $157 \mathrm{~m}$. W. Harrisburg. Two newspapers, the "B. Argus," and the "Western Star" (whig), are issued weekly. Pop. 2,550.

BEAyer, po vo, Boone co, Ill.; on a cr. of Pock r., 164 m. N. by E. Springfield.

Bearer Brook, p. O., Sullivan co., N. Y.: $121 \mathrm{~m}$. S. S. W. Albany.

Beaver Creek, p. v., Bond co., Ill.: on Beaver cr, of Kaskaskia r., $72 \mathrm{~m}$. S. by E. Springfield.

Beaver Creek, p. 3., Pulashi co, Ind.: on a cr. of Tippecanoe r., $\mathrm{S} 1 \mathrm{~m}$. N. N. W. Indianapolis,

Bfater CreEK, p. O., Washington co, Mra.: on a cr. of Antietam r., $74 \mathrm{~m} . \mathrm{N}$. W. Annapolis.

BeAter Creek, p. 0, Campbell co., Firg: $98 \mathrm{~m}$. W. by S. Pichmond.

Beaver DaM, p. o., Kosciusko co., Ind. : 105 m. N. Indianapolis.

Beaver Dav, p. o., Union co., N. Car.: $116 \mathrm{~m} . \mathrm{S} . \mathrm{W}$. Ralerght

BeaYer Darr, p. o., Goochland co., Tirg.: $21 \mathrm{~m}$. W. Richmond.

Beater Das, p. o., Dodge co., Wisc. : 51 m. N. E. Madison.

Beaver Dars, p. o. Allen co., Ohio: 89 m. N. W. Columbus.

BeA ver DAM, p. o., Clark co., Miss. : $98 \mathrm{~m}$. E. by $\mathrm{S}$. Jackson.

BEATER DaM Depôt, p. o., Hanoter co., Firg.: on the line of the Virginia Central R. R., $\mathbf{4 0} \mathrm{m}$. (28 m, direct) N. W. Richmond.

Beater Day Forks, p. 0., Tipton co., Tenn.: $158 \mathrm{~m}$. W. S. W. Nashville.

Bearer Dax Spring8, p. o., Híckman co., Tenn.: 42 m. E. Tr. Nashville.

BeAfer Daus, p. o., Chemung co., $N$. $Y_{0}: 162 \mathrm{~m}$. W. S. W. Albany.

Deaver Istand. p. o., Yichilimackinac en., Mich.: 212 m. N. N. W. Lansing. The Beavers are a cluster of islands at the entrince of Lake Michigan. The lurgest, Big Beaver, contains about 25,0010 acres, and is now +11 pussession of a band of Mormons, under the direction of Strang, one of the most eminent advocates of the church.

Beaver Kill, p. o., Sullivan co., N. Y.: on a er. of same name, tributary to the Papacton Branch of Delaware r., 74 m. S. S. W. Albany.

Beaver Mradow, p. O., Chenango co., N. Y.: $101 \mathrm{~m}$. W. Albany,

Beater Meadows, p. 0., Carbon co., Fenn.: in the anthracite coal region of the Lehigh r., $78 \mathrm{~m}$. N. E. Harrisburg. Pop. 525.

Beaver P’onds, p. o., Montgomery co., Ky.: $60 \mathrm{~m}$. E. by S. Frankfort.

BeAver RIDgé, p. o., Knox c0., Tenn.: 153 m. E. by S. Nashville.

Beaver Ruin, p. 0., Union co., Ark.: 108 m. s. Little Rock.

Beaver Springs, p. o., Union co., Penn. : 82 m. N. W. Harrisburg.

Beavertown, p. Y., Union co., Penn。: $59 \mathrm{~m} . \mathrm{N}$. W. Harrisburg.

Beater Valley, p. o., Columbia co., Penn.: $57 \mathrm{~m}$. N. E. Harrisburg.

Becket, t. and p. v., Berkshire co., Mass.: on the Green mountain range, $104 \mathrm{~m}$. W. Boston. Pop. 1,223.

Becket's Store, p. o., Pickaway co., Ohio: $25 \mathrm{~m}$. S. Coumbus.

Bechetsvinte, p. v., Tallapoosa co., Ala.: 32 m. N. E. Iontgomery.

Beckifausville, p. v., Chester dist., S. Car.: on the W. side of Wateree r., $44 \mathrm{~m}$. N. Columbia.

Beckley, p. o., Raleigh co., Virg.: 267 m. W. Richmond.

BeChfille, p. v., Carroll co., Mifs. : 74 m. N. Jackson. Bedfore county, Penn. Situate S. middle, and contains $9 S 2 \mathrm{sq} . \mathrm{m}$. Drained by the bead waters of Raystown Braneh of Juniata r., and several tributaries of the $\mathrm{N}$. branch of Potomac r. Surface mountainous, with extensive and fertile valleys. Iron and bituminous coal abound. Farms 1.S75; manuf. 117; dwell. 3,896, and pop。 -wh. 22,637, fir col, 415-total 23,052. Capital: Bedford.

BEDFORD county, Tenn. Situate centrally, and contains 650 sq. m. Drained by Duck r. of the Tennessee and its ributary creeks. Surface finely variegated with hill and dale, with abundance of timber, and the soils generally fertile, Farms 9S6; manuf. 2s; dwell. 2,754, and pop.-Wh. 15,935, fr. col. 71, sl. 5,503-total 21,512. Cappital: Shelbyville. Public Works: Nashville and Chattanooga" R. IR. and branch to Shelbyville.

BEDFORD county, Virg. Situate at the $\mathbf{E}$. base of the Blue Ridge, between James and Staunton rivers, the interior being drained principally by creeks falling into the latter. It contains akout $600 \mathrm{sq} . \mathrm{m}$. Surface generally hilly, sometimes mountainous, and soils very fertile, producing Indian corn, oats, tobacco, etc., abundantly, The "Peaks of Otter" overlook it from the west. Farms 1,364; manuf. 16 ; dwell. 2,396, and pop.-wh. 15,556, fr. col. 463, sl. 10,061-total 26,080. Capital: Liberty. Public Works: Virginia and E. Tennessee R. R.

BEDFORD, p. v., and cap. Lawrence co., Ind. : between the $\mathrm{E}$. fork of $W$ hite $r$. and Salt $r_{0}, 3 \mathrm{~m}$. from the junction, and $64 \mathrm{~m} . \mathrm{S} . \mathrm{S}$. W. Indianapolis $\mathrm{R} . \mathrm{R}$.; is a place of some importance. The New Albany and Salem R. R. passscs through it N. and S., and the Cincinnati and St. Louis R. R. E. anil W. A branch of the State bank is lo ated here.

BEDFord, p. v., and cap. Trimble co., $K y_{.}: 38 \mathrm{~m} . \mathrm{N}$. W. Frankfort. A mile from the $\mathrm{v}$. is an Epsom salts spring surcharged with sulphur, and near it accommodatious are provided for invalid visitors.

BEDForo, t, and p. v., Calhoun co., Mich, : on Kalamazoo $r_{n,} 46 \mathrm{~m}$. S. W. Lansing. The Michigan Central R. R. pass es throuigh the S. part of the t., $124 \mathrm{~m}$. W. Detroit. P. 747 . 
BEDFORD, t, and p. $\mathrm{v}_{0}$, Middlesex co., Mass.: on Shawsheen r., $15 \mathrm{~m}$. N. W. Boston. Pop. 975 .

BEDFORD, t. and p. v., Hillsborough co., $N_{0}$ Hamp. : on Merrimac r., $18 \mathrm{~m}$. S. Concord. The t. has good waterpower and furnishes various minerals. Pop, 1,906.

BEDForr, p. Y, and cap. Westchegter co., N. Y.: $129 \mathrm{~m}$.

B. Albany. Pop. 3,209.

BEDFORD, t. and p. v., Cuyahoga co., Ohio: on Tinker"s

cr., 128 m. N. E. Columbus. Pop. 1,854.

Bedford, t., p. vo, and cap. Bedford co., Penn.: on Roystown branch of Juniata r, $94 \mathrm{~m}, \mathrm{~W}$. by S. Harrisburg. It is pleasantly situate in the midst of a mountain valley, and is celebrated for its mineral springs. Three newspapers, the "B. Gazette" (dem,), the "Jackson Democrat," and the "Democratic Inquirer" (whig), are published weekly. The accommodations for visitors are ample and superior.

Benford Station, p. o., Westchester co., $N . Y_{\text {.: }}$ on the

line of the Harlem R. R., $42 \mathrm{~m}$. N. New York City.

Bedr, p. o., Grimes co., Ter. : 132 m. E, Austin City.

Bee Braxch, p. o, Pettis co., Mo.: 66 m. W. by Ni Jefferson City.

Beеch BLuFF, p. O., Dallas co., Ark.: 64 m. S. E. Little Rock.

Befor Crefe, p. o., Clinton co., Penn.: 92 m. N. N. W.

Harrisburg.

BEECH Fork, p. o., Washington $c^{\circ}, \bar{K} y_{*}:$ on a creek of Salt r. so called, 45 m. S. W. Frankfort.

Beeci Grove, p. 0, Rush co., Ind. : 42 m. E. S. E. Indianapolis.

BeEch Grovk, p. 0., Philips co., Ark.: 89 m. E. by S. Little Rock.

Brech Grotre, p. o., Coffee co., Tenn. : 48 m. S. E. Nashville.

BEEOH IslaND, p. o., Edgefield dist., $S$. Car. : 58 m. W. Columbia.

BEECH LaND, p. o, Licking co., Ohio: 32 m. E. N. F.

Columbus.

BEECH LATD, p. 0., Union co., $A r k$, : $112 \mathrm{~m}$, S. S. E. Lit-

tle Rock.

Besch Woods, p. Oo, Warren co, Penn.: 184 m. N. W.

Harrisburg.

Beechy Mire, p. o, Union co, Ind.: 70 m. E. by S. In-

dianapolis.

BEEmrE, p. o., Clinton co., Mo. : on Smith's fork of Little

Platte r., 138 m. N. W. Jefferson City.

Befrumar, to and p. T., Duchess co., $N, Y_{*}$ : on Fishkill $r_{\text {, }}$

a tributary of Hudson r., 87 m. S. Albany. Pop. 1,585.

BezkMan's Mruts, p. o., Somerset co., N. Jer. : $22 \mathrm{~m}$. N.

by E. Trenton.

Begkmantows, t. and p. o, Clinton $c_{0}, N_{\text {. }} Y_{.}:$on Lake Champlain, $140 \mathrm{~m}$. N. Albany. In the W. part of the town are the lakes Chazy and Chateaugua, the sources of the $r$. of the same name. Pop. 3,384 .

Berlen's Statior, p. o., Marshall co, Virg.: 240 m. N.

W. Richmond.

BEE LnNe, p. o., Allegan co, AFich.: $60 \mathrm{~m}$. W. Lansing. Bemirerpille, p. v., Sussex co, N. Jer.: $73 \mathrm{~m}$. N. Trenton.

Bee PIDge, p. on, Knox co., Mo.: $112 \mathrm{~m}$. N. Jefferson City.

Befsley's Porst, p. o., Cape May co., N. Jer. : 92 m. \$. Trenton.

Beetowr, p. Y., Grant co., Wisc. : $69 \mathrm{~m}$. W. by S. Madison.

Beetree, p. o., Kershaw dist., S. Car.: 39 m. N. E. Columbia.

Beglex's, p. o, Perry co., Ky.: 122 m. 8. E. Frankfort.

Betate p. o., Richmond co., Ga.: on the line of the Georgia R. R., 11 m. W. Augusta, and 69 m. E. N. E. Milledgeville.

Bez-Arr, p. $\nabla$. , and cap. Harford co., Ma. : between Winter's and Binham's Runs, 89 m. N. Annapolis. A newspaper, the "Gazette," is issued weekly. The country in the vicinity comprises one of the finest agricultural districts of the State.

Belare, p. o., Lancaster dist., S. Corr.: 68 m. N. by E. Columbia.

Belcher, p. o.y Washington co., N. $\Gamma_{\text {: }} 42 \mathrm{~m}$. A. by $\mathrm{E}$. Albany.

Bruchertowr, t. and p. T., Hampshire co., Yas8.: $68 \mathrm{~m}$. W. by S. Boston.

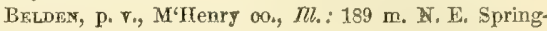
field.

BELEW's CREEk, p. or, Stokes co., N. Car. : 108 m. W. N. W. Raleigh.

BeLfAST, t., p. c., seaport, and cap. Waldo $\mathrm{cos}_{\text {, }}$ Me. : a the head of Belfast Bay, on the W. side of Penobscot r., 30 $\mathrm{m}$. from the ocean, and $37 \mathrm{~m}$. E. Augusta. The harbor is spacious, and sufficiently deep for the largest ressels. The prineipal exports are lumber and fish. Ship-builiting is extensively engaged in: in 1550,32 vessels, and 6,215 tons, were built. The shipping belonging to the district amounts to 45,595 tons, chiefly employed in the cossting trade, and the cod and mackerel fisheries. There are two newspapers published here, the "State Signal," and the "Republican Journal," both democratie, and issued weekly. It has regular communication by steamboat with the ports north and south. Pop, 5,052.

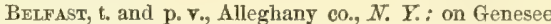
r., $233 \mathrm{~m}$. W. by S. Albany. The Genesee Valley Canal here leaves the river, and passes S. W. up the valley of Black er.

Belfast, p. v،, Clermont co., Ohio: 92 m. S. W. Columbus.

Belfast, p. v., Northampton co., Penn. : $89 \mathrm{~m}$. E. by N. Harrisburg.

Berfast, p. o., Marshall co., Tenn.: 56 m. S. Nashville.

BeLFord, p. o., Nash con, N. Car.: on Swift er., 46 m. E. by N. Paleigh.

Belgrade, t. and p. v., Kennebee co, Me.: 10 m. N. Augusta. The town is almost surrounded by beautiful lakes, the outlets of which, in their course to the Kennebec, furnish extensive mill-power, The Androseoggin and Kennebec R. R. traverses the eastern edge of the town; $67 \mathrm{~m}$. N.E. Portland, and 15 S. W. Waterville.

Belgrade Milus, p. v., Kennebec co., Me.: at, the outlet of one of the Iakes on the edge of the town of Belgrade 16 m. N. Augusta.

Bulg ap county, $N$. Hamp. Situate N. E., and contains 484 sq. m. Drained by Suncook and Winnipiseogee rivers, the Merrimac, and several creeks of Winnipiseogee Lake and Great Bay. Surface various, and soils moderately fertile. Farms 2,438; manuf. 163; dwell. 3,436, and pop.wh. 17,693, fr. col. 28 total 17,721. Capital: Gilford. Pub7ic Works: Boston, Concord, and Montreal R. R., and Cocheco Valley R. R.

Beli county, Tea. Situate centrally on Little r., of the Brazos, and contains about $900 \mathrm{sq}$. m. Surface well drained, and soils fertile. Erected since 1850.

BeLt, p. v., Highland co., Ohio: $59 \mathrm{~m}$. S. W. Columbts.

BeLr, p. v., and cap. Bell co., Text.: on Little r. of the Rio Brazos, 64 m. N. N. E. Austin City.

Bell AIr, p. v., Crawford co., $I l_{0}:$ on $\mathrm{N}$. fork of Embarras r., 104 m. E. S. E. Springfield.

Berl Are, p. o., Cooper co., Mo. : 84 m. W. by N. Jefferson City.

Bell Arr, p. o., Belmont co., Ohio: $114 \mathrm{~m}$. E. Columbus. Berl Brook, p. o., Greene co., Orio: $58 \mathrm{~m}$. W. by S. Columbas.

Belle Ceytre, p. o., Logan co., Ohio: $54 \mathrm{~m}$. N. W. Co lumbus.

Bellefontatne, p. v., Choctaw co, Aliss.: $112 \mathrm{~m}$. N. N E. Jackson.

Bellefortatie, p.. ., and cap. Logan co., Ohio: $52 \mathrm{~m}$. N. T. Columbus, It is an important entre, and has a flourisling busincss. Railroads pass through the village, 
N. and S., and E. and W. A newspaper, the "L. Gazette," is published weekly.

Bellefonte, p. v., and cap. Jackson co., Ala. : on Paint Rock cr. of the Tennessee r., 156 m. N. by E. Montgomery. A newspaper, the "Jackson County Democrat," is issued weekly.

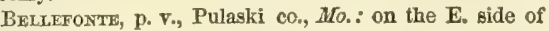
Gasconade r., 59 m. S. Jefferson City.

Bellefonte, p. v., and cap. Centre co., Penn. : on Spring cr. of Bald Eagle r, $68 \mathrm{~m}$. N. W. Harrisburg. It is extensively engaged in the iron trade, and has a connection by canal with West Branch Canal. Three newspapers, the "C. Berichter," and the "C. Demoerat" (dem.), and the "Democratic Whig," are issued weekly. Pop. 2,913.

Bellefountatr, p. V., Columbia co., Wisc.: 38 m. N. E. Madison.

Bellefotntat,, p. v., Mahaska co., Ia.: on the S. side of Des Moines r., $70 \mathrm{~m}$. W. S. W. Iowa City.

Belle Hayen, p. o., Accomac co., Virg.: 112 m. E. by N. Richmond.

Belle Isle, p. 0., Onondaga co., N. Y.: $136 \mathrm{~m} . \mathrm{W}$. by N. Albany.

Bellemont, p. V., Lancaster co., Penn, : 42 m. E. by S.

Harrisburg.

Bellemonte, p. v., St. Louis co., Mo.: 114 m. E. by N. Jefferson City.

Belle OMBre, p. จ., Ballard co., Ky.: 240 m. W. by S. Frankfort.

Belle Ponvt, p. 0., Boone co., Ia.: $132 \mathrm{~m}$. W. by N. Iowa City.

Belle Pont, p. O., Delaware co.g Ohio: $27 \mathrm{~m} . \mathrm{N}$. Columbus.

Belle Pratrie, p. Oa, Hamilton co, $I$. . 148 m. S. S. E. Springfield.

Belle River, p. o., St. Clair co., Mich. : 111 m. E. Lansing, on the r. so called, which falls into St. Clair r. after a course of upward of $50 \mathrm{~m}$.

Belle VernoN, p. o., Wyandott co., Ohio: $66 \mathrm{~m}$. N. by W. Columbus.

Belle Vervor, p. o., Fayette co, Penn.: 153 m. W. by S. Harrisburg.

Belleview, p, o. Talbot $c_{0}, G a_{0}: 87 \mathrm{~m}$. W. by S. Milledgeville.

Belleview, p. o., Rusk co., Tea. : 216 m. N. E. Austin City.

BELLETTEw, p. vo, Calhoun co., Ill.: on a beautiful prairie on the E. side of Bay cr., 69 m. W. S. W. Springfield.

Beluevnew, p. ₹., Christian co., Ky.: 174 m. W. by S Frankfort.

Berletrew, p. v., Lebanon co., Penn. : 33 m. E. by $\mathbb{N}$. Harrisburg.

Belleview, p. o., and cap. Bossier par., La.: on E. side of Lake Bodeau, 210 m. N. W. Baton Pouge.

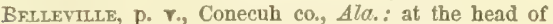
Murder cr, of Conecuh r., $78 \mathrm{~m}$. S. W. Montgomery.

Bellevilue, p. v., Desha co., Ark. : 118 m. S. E, Little Rock.

Bellevilue, p. V., Hendricks co., Ind. : 21 m. W. S. W Indianapolis.

Belleville, p. v., and cap. St. Clair co, $T U_{*}:$ on Pockland cr, $92 \mathrm{~m}$. S. by W. Springfield. The site is elevated, and the surrounding country highly fertile. Three newspapers are published here-the "I3. Advertiser" (dem.), the "Ze-itung," a German paper (dem.), and the "Illinois Fepublican" (whig). The village is one of the most flourishing of the interior.

Belletule, p. พ., Wayne co, Afich.: 76 m. X. S. E. Lansing.

Belleftrle, t. and p. $\nabla$. Essex co., $N$. Jer.: on W. side Passaic r., along which it extends $3 \mathrm{~m} . .57 \mathrm{~m}$. N. E. Trenton. It has fine milling facilities and considerable manufactures. Pop. 8,513 .
Belleville, p. v., Jefferson co., $N$. Y.: $168 \mathrm{~m}$. W. N. W. Albany. It is situate on the Sackett's Harbor Branch R. $\boldsymbol{P}_{\text {. }}$ Belleville, p. o., Richland co, Otvio: on the S. side of Clear fork of Walhonding r., $50 \mathrm{~m}$. N. by E. Columbus, and on the line of the Columbus and Lake Erie R. R., $47 \mathrm{~m} . \mathrm{N}$. Newark.

Bellevilde, p. Y., Mifflin co, Penn.: 62 m. N. W. Harrisburg.

Belleville, p. o., Roane co., Tonn.: 112 m. E. by $\mathbf{S}$. Nashville.

Belleville, p. V., Wood co., Virg. ; on E. side of Ohio r., $12 \mathrm{~m}$. S. Parkersburg, and 256 W. N. W. Pichmond.

Belleville Port, p. v., Essex co., Ma88.: 36 m. N. by E. Boston,

Believute, p. v., Huron co., Chio: 80 m. N. by E. Columbus.

BeLteVOE, t. and p. V., Eaton co., Mfich.: on Battle cr., 32 m. W. S. W. Lansing. Pop. 769.

Bellevok, p. v., Jackson co., Ia. : on W. bank of Mississippi $\mathrm{r}, 58 \mathrm{~m}$. N. E. Iowa City. It is a place of considerable commercual activity.

Bellffair Milis, p. 0., Stafford co., Virg.: $58 \mathrm{~m} . \mathbf{N}$. Richmond.

Bellingham, t. and p. ₹., Norfolk co., Mass. : on Charles r., 32 m. S. W. Boston. Pop. 1,281.

Bell Mount, p. o., Somerset co, Ma.: 76 m. S. E. Annapolis.

Bellows' Falis, p. v., Windham co., Term. : on the W. side of the Connecticut $r$, at the falls so called, $78 \mathrm{~m}$. $\mathrm{S}$. by E. Montpelier. There is a canal around the falls, which prolongs the navigation of the $r$. Much picturesque scenery surrounds the $\mathrm{v}$.; it is more celebrated, however, as a xailroad centre, than for any peculiar industry.

Beli Placi, p. o., Marshall co., $I l l .: 86 \mathrm{~m}$. N. by E Springfield.

BeLl PoINT, p. o., Giles co., Fing.: $182 \mathrm{~m}$. W. by $\$$. Richmond.

Bellport, p. $\nabla$. Suffolk co., $N . Y_{.}$: near Fire Place Bay, 138 m. S. S. E. Albany.

Belisburgi, p. v., Dickson co., Tenn.: on S. side of Harpeth r., a tributary of Cumberland r., $25 \mathrm{~m}$. W. Nashville.

Bell's Cross Roads, p. 0., Louisa co, Tirg. : 42 m. N. W. Richmond.

Bell's Landnge, p. o., Monroe co., Ala.: on E. side of Alabama r, $76 \mathrm{~m}$. S. W. Montgomery.

Bell's MINES, p. o., Crittenden co., Ky.: $192 \mathrm{~m}$. W. by $\mathrm{S}$. Frankfort.

Bell's Store, p. o., Fairfield dist., S. Car.: $37 \mathrm{~m} . \mathrm{N}$. Columbia.

Bell's Valley, p. o., Rockbridge co., Virg.: 11S m. W. by $\mathrm{N}$. Richmond.

Bell VALE, p. o., Orange co., N. Y.: 85 m. S. by W. Albany.

Bellville, p. v, Hamilton co., Flor.: 78 m. E. Tallahassee.

Beclville, p. v., and eap. Austin co., Teco: on Piney fork of Brazos r., 78 m. E. by S. Austin City.

Bemanr county, Ohio. Situate $\mathbf{E}$, on the Ohio r., and contains 586 sq. m. The interior is drained by Wheeling, M'Mahon's, and Captina creeks, and contains the sources of several of the tributaries of Muskingum $r$. Surface elevated, hilly, and broken, but soils good. Farms 2,552; manuf. 185; dwell. 5,823, and pop.-wh. 38,766, fr. col. 834 -total 34,600. Capital: St. Clairsville. Public Works: Central Ohio R. R.

Belmoxt, p. o., Sumter co., Ala. : $3 \mathrm{~m}$. W. Tombigbee $\mathbf{r}_{\bullet,}$ and $99 \mathrm{~W}$. by N. Montgomery.

Bецкомт, p. o., Pike co., Ill.: 69 m. W. by S. Springfield.

Belmort, p. o, Crawford co., Ark: 123 m. W. N. W. Little Pock

Belvont, p. o., Gonzales co., Tero. : 61 m. 8. Austin City. 
BeLvoNt, to and p. v., Waldo co., Me.: $33 \mathrm{~m} . \mathrm{E}$. by $\mathrm{N}$. Angusta.

Belmont, p. o., Panola co., Miss.: on N. W. side of Tallahatchie r., $119 \mathrm{~m}$. N. by E. Jackson.

Belmont, p. o., Belmont co., Ohio: 103 m. E. Columbus. Por. 105 .

Beturont, p. Y., Newberry dist., \&. Car, : on N. E. side of Little r., $57 \mathrm{~m}$. N. W. Columbia.

Belmont, p. v., Fayette co., Tenn.: on a head cr. of Loosahatehie r., $148 \mathrm{~m}$. W. S. W. Nashville.

BeLMoNT, p. O, Loudon co., Virg.: 111 m. N. Richmond.

BELoIT, $t_{\text {s. }}$ and $\mathrm{p}_{\text {. }} \mathrm{v}_{\text {e, }}$ Rock co., Wisc.: on both sides of Rock r., at the junction of Turtle cr., $42 \mathrm{~m}$. $\mathrm{S}$. by E. Madison. It has several mills, machine-shops, and a prosperous college, and numbers about 3,000 inhabitants. The "Beloit Journal" (whig) is issued weekly. A branch of the Galena and Chicago Union R. R. extends to Beloit. In the vicinity are many of those mounds which abound in the West. Pop. 2,730,

BELPRE, t. and p. v., Washington co., Ohio: on the Ohio r., opposite Parkersburg, $87 \mathrm{~m}$. E. S. E. Columbus. The t. occupies a beautiful meadow, as its French name implies. Blennerhasset Island, the rendezvous of Aaron Burr and his co-patriots, lies a little below the v. Belpré, from its position, will hereafter become an important railway centre -it is the point at which the Cincinnati, Hillsboro', and Parkersburg R. R. will meet with the North-western R. R., a branch of the Baltimore and Ohio R. R., by which a direct route from Cincinnati to Baltimore, $547 \mathrm{~m}$, long, will be effected. Pop, ${ }^{1}, 623$.

Beltspille, p. v., Prince George's co., Mfd.: on Washington branch of Baltimore and Ohio R. R., $27 \mathrm{~m} . \mathrm{W} . \mathrm{S} . \mathrm{W}$ Baltimore, and 18 W. by N. Annapolis.

Belvidere, p. $\nabla$. , and cap. Boone co., I Ul.: on N. branch of Kishwaukee r., and on the line of the Galena and Chicago Union R. R., $78 \mathrm{~m}$. W. Chicago, and $193 \mathrm{~m}$. N. N. E Springfield. It is a flourishing town of some $2,000 \mathrm{inhab}$ itants.

BeLVIDEeE, t. and p. צ., Lamoelle co., Verm. : on a branch of Lamoelle r., at the W. base of the Green mts., $33 \mathrm{~m}$. N. Montpelier. Pop 256.

BeLtroere, p.. ., and eap. Warren co., N. Jer.: on the E. side of Delaware r., $45 \mathrm{~m} . \mathrm{N} . \mathrm{N}$. W. Trenton, and on the Belvidere and Delaware R. R. It is destined to become an important entrepôt of commerce between Philadelphia and N. W. New Jersey. Two newspapers, the "Warren Journal" (dem.), and the "Warren Intelligencer" (whig), are issued weekly.

BEM, p. o., Greene co., Wisc.: 26 m. S. by W. Madison.

Bemax's Cross Roads, p. o., Sampson co., N. Car.: 62 m. S. E. Raleigh.

Besur Creek, p. 0., Cambria co., Penn.: 103 m. W. Harrisburg.

Bemus' Heights, p. v., Saratoga co., $N$. $Y$. : on W. side of Hudson r., $22 \mathrm{~m}$. N. Albany. Noted in history as the scene of warlike operations in the Revolutionary War.

Benвrook's Muls, p. o., Lzard co., Ark. : 87 m. N. Little Rock.

Benderstruck, p. v., Adams co., Penn.: 33 m. S. W. Harrisburg.

Bendy's Landing, p. o., Tyler co., Texo. : 194 m. E. by S. Austin City.

Benedict, p. ₹., Charles co., Md.: on W. side Patuxent r., $32 \mathrm{~m}$. S. by W. Annapolis.

Beneia, p. 0., Chickasaw co., MFiss, : 183 m. N. E. Jackson.

Beverold, p. T., Washington co., MId.: 46 m. N. W. Annapolis.

Benevola, p. T., Pickens co., Ala.: 117 m. W. N. W. Montgomery.

Benezette, p. o., Elk co., Penn。: 128 m. W. N. W. Harrisburg.
Benford's Store, p. o., Somerset co., Penn. : 123 m. W. by S. Harrisburg.

Bengat, t. and p. v., Clinton co,Mich. : on Stony cr. of Grand r., 18 m. N. W. Lansing. Pop. 143.

BENHADEN, p. o., Wakulla co., F'lor. : 26 m. S. W. Tallahassee.

BENICIA, p. v., and cap. Solano co., Calif.: on N. W. side of Suisun Bay, $4 \mathrm{~m}$. E. Vallejo.

BenNertsBUthe, p. v., Tompkins co., N. Y.:172 m. W. by S. Albany.

BENNETr's Cormers, p. o, Madison co., N. Y.: $110 \mathrm{~m}$. W. by $\mathrm{N}$. Albany.

BenNetT's Cornerg, p. o., Jackson co., Mich.: $85 \mathrm{~m}$. S. W. Lansing.

BenNetT's CREEK, p. ov, Steuben co., N. Y.: $209 \mathrm{~m}$. W. by S. Albany

BENiETT's Ferrx, p. o., Jackson co., Tenn. : 54 m. E. by N. Nashville,

BennetT's MrLis, p. o., Lewis co., Virg.: 187 m. N. W. Richmond.

BenNetT's River, p. o., Fulton co., Ark. : 113 m. N. Lit tle Rock.

Bennetts ville, p. v., St. Clair co.s, Ala. : 100 m. N. Mont gomery.

BenNetTstilite, p. จ., Chenango co., N. Y.: $101 \mathrm{~m} . \mathrm{W}$. Albany.

Bennetrsville, p. v., and cap. Marlborough dist., S. Oar.: 97 m. N. E. Columbia.

Bennetsprilie, p. v., Clark co., Ind.: $91 \mathrm{~m}$. \$. by E. Indianapolis.

Bennington county, Verm. Situate S. W. on the State line, and contains $612 \mathrm{sq}$. $\mathrm{m}$. Drained in the W. by Hoosic r. and Batten Kill, in the E. by West and Deerfield rivers. Surface traversed by mountains. Lead and iron abound, and also quarries of beautiful marble. Lands better adapted to grazing than tillage, although in the W. there are sereral fertile valleys. Farms 1,397 ; manuf. 147; dwell. 3,404, and pop.-wh. 18,512, fr. col. 77-total 18,589. Cap. ital: Manchester. Public Works: Western Vermont R. R.; Bennington Branch R. R. ; and the Bennington and New York R. P.

Bennivgton, p. v., Hillsborough co., $N_{0}$ Hamp.: $28 \mathrm{~m}$. S. W. Concord.

Bennington, p. v., Marion co., Ia.: on N. side of Des Moines r., $88 \mathrm{~m}$. W. by S. Iowa City.

BenNingtos, t, and p. v. Wyoming co, N. $Y_{0}$ : on Cayuga and Tonawanda creeks, $253 \mathrm{~m}$. W. Albany. P. 2,406. Bennington, p. v., Shiawassee co., Mich.: on N. side of Looking-glass r., $23 \mathrm{~m}$. N. E. Lansing.

Bennivgton, t. and p. v., Morrow co., Ohio: $38 \mathrm{~m}$. N. bJ E. Columbus. Pop. 1,265.

Benvivgton, p. V., Switzerland co., Ind.: 90 m. S. E Indianapolis.

Bennington, t. and p. v., Bennington co., Ferm.: on a branch of Hoosic r., $98 \mathrm{~m}$. S. by W. Montpelier. It has several mills, furnaces, and factories; and two newspapers, the "State Banner" (whig), and the "Yermont Gazette" (dem.), published weekly. A branch of the Western Vermont $\mathrm{R}$. R. comes to the $\mathrm{Y}$. from N. Bennington. P. 3,923,

Bennington Centre, p. o., Bennington co., Verm.: 99 m. S. by W. Montpelier.

BexsoN, p. v., Hamilton co., $N . Y_{.}$: on Saeandaga r., 52 m. N. W. Albany.

Benson, t. and p. vo, Rutland co., Term. : on lake Champlain, 54 m. S. W. Montpelier. Pop. 1,305.

Benson's Landing, p. o., Rutland co., Ferm.: $56 \mathrm{~m}$. S. W. Montpelier. The lake is here about a mile wide.

Bent Creek, p. o., Appomattox con, Vir.: $72 \mathrm{~m}$. W. by S. Richmond.

Bentivogito, p. o., Albemarle co., Firg.: 68 m. W. by N. Richmond.

Bentley's Corners, p. o., Jefferson co, $N . Y_{*}: 142 \mathrm{~m}$. N. W. Albany. 
Bentlex Creek, p. o., Bradford eo., Penn.: $113 \mathrm{~m}$. N. by E. Harrisburg.

Bestletrille, p. v., Washington eo., Penn.: $288 \mathrm{~m}$. W. by S. Harrisburg.

Berton county, Ala, Situate N. E., and contains $1,0 S 0$ sq. m. Drained by the head waters of Tallaponsa $r$, and several creeks of Consa r. Surface generally elevated, level, or undulating. Well wooded on the streams; and soils highly fertile, produeing wheat, Indian corn, and cotton. Gold is found within this county. Farms 1,227; manuf. 31; dwell. 8,198, and pop.-wh. 13,397, fr. col. 3, sl. 8,763total 17,163. Capital: Jacksonville.

BENTON county, Ark. Situate N. W. corner, and contains $1,020 \mathrm{sq} . \mathrm{m}$. Drained by the head streams of White and Illinois rivers, the latter a tributary of Arkansas $r$. Surface hilly and broken. Soils indifferent. Farms 295; manuf. 5; dwell. 572, and pop.-wh. 3,508, fr. col. 1, sl, 201 -total 3,710. Capital: Bentonville.

BeNTor county, Flor. Situate W. of E. Florida, on the gulf, being bounded E. by Withlacoochee r. Drained by a number of streams falling to the sea. Surface flat. Soils adapted to rice, cotton, and sugar. Farms S2; dwell. 113, and pop.-Wh. 604, fr. col. 0, sl. 322-total 926. Capital : Melendez.

Benton county, Ind. Situate N. W., and contains $360 \mathrm{sq}$. m. Big and Little Pine creeks, which fall into the Wabash and Sugar cr., a tributary of the Illinois, drain the greater part of the county. Surface level or undulating, and mostly prairie. Wheat, Indian eorn, and oats are the staple growths. Mt. Nebo and Mt. Gilboa, are noted mounds in the N. part of the county. Farms 149; dwell. 180, and pop.-wh. 1,144, fr. col. 0-total 1,144. Capital: Oxford.

BEsTON connty, To. Situate centrally, and contains 720 sq. $\mathrm{m}$. Drained by Cedar $r$. and its creeks. Surface level or undulating-prairie chiefly, and very productive. Farms 67; dwell. 121, and pop.-wh. 672, fr. col. 0-total 672 . Capital: Vinton.

Benton county, Minn. Situate E. side of Mississippi, and contains about $3,000 \mathrm{sq}$. m. Drained by numerous tributaries of the Mississippi. Surface varied, and many lakes. Timber of all kinds plentiful. Farms 20; manuf. 1; dwell. 71, and pop.-wh. 416, fr. col. 2-total 418. Capital: Sauk Rapids.

Bвxток county, Mo. Situate W. centrally, and contains 580 sq: $m$. Drained by Osage $r$. and its tributaries. Surface rolling-in some parts hilly and well timbered; prairie covers three-fourths of the whole. The soils are exceedingly fertile, and produce abundantly whent, Indian corn, and tobacco, with some cotton. Farms 510 ; manuf. 10 dwell. 789, and pop.-wh. 4,546, fr. col. 9, sl. 460-total, 5,115 . Capital: Warsaw.

Bextox county, Oreg. Situate W. between the Pacific Ocean and the Willamette $r_{\text {, }}$ and drained chiefly by Mary's r., and other tributaries of the Willamette. Mt. Snelling, near the centre of the co., is the loftiest eminence. Soils along the Willamette valley exccedingly fertile, and the waterpower afforded by that stream of great value. Contains 16,000 sq. m. Farms 110; manuf. 1; dwell. 149, and pop. - Wh. 810, fir. col. 4-total, 814. Capital: Marysville.

Berron county, Tenn. Situate N. W., and contains 380 вq. $\mathrm{m}$. Drained by Big Sandy and other creeks of Tennessee r., which lies on the E. border. Surface level or undulating, and solls generally fertile, producing abundantly grain and tobacco. Farms 706; manuf. 2; dwell. 984, and pop-wh. 5,931, fr. col. 21, sl. 363-total, 6,315. Capital . Camden. Public Works: several R. R's. are projected, centering at Camden; one from Nashville, one to Holly Spring8, and one westward, via Dresden, to the Mississippi.

Bextox, p. $\nabla_{\star}$, Lowndes co., Ala.: 28 m. S. W. Montgomery.

BeNtox, p. Y., and cap. Saline co., Ark. : on N. side of Ealine r. $_{2} 24 \mathrm{~m}$. S. W. Little Rock.
Bevtox, p. v., Elkhart co., Ind.: on N. E. side of Elkhart $r_{.}, 120 \mathrm{~m}$. N. Indianapolis.

Eenton, p. v., and eap. Franklin co., Ill.: on E. sile of Big Muddy r., 126 m. S. by E. Springfield. The "B. Stand ard" (whig) is issued weekly.

Bexton, p. T., and cap. Marshall co., $K y_{0}:$ on N. E. side Clark's r., 212 m. W. by S. Frankfort.

Benton, p. v., and cap. Yazoo co., Miss.: at the head of a cr. of Big Black r., $31 \mathrm{~m}$. N. by W. Jackson.

Benton, p. v., Washtenaw co., Mich.: 51 m. 8. E. Lansing.

Benton, p. v., and cap. Seott co., Mo. : $6 \mathrm{~m}$. W of Missis sippi r., and 168 m. S. E. Jefferson City.

Benton, t. and p. v., Grafton co., N. Hamp.: $59 \mathrm{~m} . \mathrm{N}$. by W. Concord. The Boston, Conenrd, and Montreal R. R. crosses the t. $73 \mathrm{~m}$. from Concord. Pop. 478

BENTON, t. and p. o., Yates co., N. Y: $192 \mathrm{~m} . \mathrm{W} . \mathrm{Al}$ bany. The p. 0 . is loeated at Bellona. Pop, $8, \pm 56$ 。

Benton, p. v., Holmes co., Ohio: $76 \mathrm{~m}$. N. E. Columbus. Benton, p. v., Columbia co., Penn. : $62 \mathrm{~m}$. N. by E. Harrisburg.

Benton, p. v., and cap. Polk co., Tenn. : on the N. E. side of Toceo $\mathrm{r}$., a little $\mathrm{E}$. of its junction witk the Hiwass e r. 138 m. E. S. E. Nashville.

Benton, p. v., Iowa co, Wisc. : $37 \mathrm{~m}$. W. Madison.

Benton Centre, p. o., Yates co., M. Y.: $194 \mathrm{~m}$. W Albany.

Bentox Ridge, p. o., Hancock co., Ohio: $70 \mathrm{~m} . \mathrm{N}$. W Columbus.

Benton's Port, p. o, Van Buren co., Ta.: on the E side Des Moines r., $66 \mathrm{~m}$. S. by W. Iowa City.

Bentonstilie, p. Y., Johnson 60., N. Car.: 21 m. S. E Raleigh.

Bentonville, p. v., Fayette co., Ind.: $54 \mathrm{~m}$. E. by S. Indianapolis.

Bentonvilue, p. v., Adams co., Ohio. : 76 m. S. by W. Columbus.

Bentonville, p. T., Coffee co., $A l a$ : 73 m. 8 . Mont gomery.

Bentonvilie, p. V., Warren co., Virg.: 102 m. N. by W. Richmond.

Bentonville, p. v., and cap. Benton co., Ark.: at the head of Sugar cr, of Neosho r., $156 \mathrm{~m}, \mathrm{~N}$. W. Little Rock. Benvenue, p. O., Dauphin co., Penn.: $18 \mathrm{~m}$. N. Harrisburg.

Benzinger, t. and p. o., Elk co., Penn。: 123 m. N. W. Harrisburg.

BEREA, p. vo, Cuyahoga co., Ohio: at the falls of E. branch of Rocky r., 118 m. N. E. Columbus. The Cleveland, Columbus, and Cincinnati R. R. passes through the village, $12 \mathrm{~m} . \mathrm{S} . \mathrm{W}$. Cleveland.

Berea, p. v., Granville co., N. Car.

Bergen county, N. Jer. Situate N. E on Hudson r., and contains 356 sq. m. Drained by Hackensack, Saddle, and Ramapo rivers: surface various. The Palisades, facing the Hudson, are in Bergen county. Soils moderately fertile, producing grain and potatoes. Farms 1,12s; manuf. 71: dwell. 2,606, and pop.-wh. 13,094, fr. col. 1,590, sl. 41 -total, 14,725. Capital: Hackensack. Public Works: Ramapo and Paterson R. R.

BERgex, t., p. v., and cap. Hudson co., N. Jer.: on Ber gen Hill, $48 \mathrm{~m} . \mathrm{N}$. E. Trenton. The $\mathrm{t}$. was setiled by the Danes as early as 1616. $\mathrm{PO}_{1}$. 2,758 .

BERGEN, t. and p. v., Genessee co., N. $Y_{.}:$on Black cr., $217 \mathrm{~m}$. W. Albany. The Buffalo and Rochester R. R. passes through the place.

Betgen Iron Works, p. 0., Ocean co., N. Jer.

BErgen Porvi, p. v., Hudson co., N. Jer .; the S. extremity of the co, between Newark Bay and the Kills.

Bergez's Store, p. o., Pittsylvania c0., Firg.: $122 \mathrm{~m}$. IV. S. W. Richmond.

Bergholtz, p. o., Ntagara co., N. Y.: $256 \mathrm{~m}$. W. Albany. BerEeler county, Firg. Situate N. E. on Potomac $\mathbf{r}_{\text {, }}$ 
and contains $390 \mathrm{sq} . \mathrm{m}$. Drained by Back cr. and other streams. Surfice uneren and hroken, and soil stubborn. Wheat, corn, and oats are the staple prodncts. Farms 570 ; manuf. $\mathrm{S1}$; dwell. 1,66s, and pop.-wh. 9,566 , fr. col. 249 , si. 1,956-total, 11,7i1. Capital: Martinsburgh. Public Wurks: Baltimore and Ohio R. R.

BerkJEr, to and p. v., Bristol co, Mass. : on Taunton r., 49 m. S. W. Buston. Pop. 908.

Berkley, p. v., Madison co., Ala.: 169 m. N. Montgomery.

Berkley, p. v., Washita co., Ark.: 72 m. S. by E. Little Rock.

Berkeler Spritgs, p. T., and cap. Morgan co., Tirg.

Berk6 county, Penn. Situate S. E., and contains 1,020 sq. m. Drained by tributaries of Schuylkill r., which passes through it, Surface diversified; mountains in N. W., and the soils generally fertile; coal and iron abundant. Agricultural staples, wheat, corn, and rye. Farms 4,780; manuf. 1,286; dwell. 12,931 , and pop.-wh. 76,576 , fr. col 55s-total, 77.129. Capital: Reading. Public Works: Philadelphia and Reading R. R.; Sehuylkill Navigation; and Union Canal.

Berkshrik county, Mass. Situate W. on State line, and contains $1,400 \mathrm{sq} . \mathrm{m}$. Drained by Housatonic and Hoosic rivers. Surface broken, being traversed by Green mis, soils moderately fertile, and capable of cultivation to the hill tops. Farms 2,897; manuf. 387 ; dwell. 8,638, and pop. - wh. 48,332, fr. col.1,259-total, 49,591. Capital : Lenox. Public Works: Housatonic R. R.; Western R. R.; Pittsfield and North Adams R. R.; Troy and Boston R. R., etc. Berkshibe, p. v., Kane co., IZl.: 163 m. N. E. Springfield.

Berkshtre, p. V., Tioga co., $N$ Y.: $142 \mathrm{~m} . \mathrm{W} . \mathrm{N} . \mathrm{W}$. Albany.

BertshIPE, t, and p. v., Delaware co, Ohio: $23 \mathrm{~m}$. N.by E. Columbus. Pop. 1,555.

Berksmire, p. v., Gwinnett co., Ga.: 75 m. N. W. Milledgeville.

Berkshme, t. and p. v., Franklin co., Term.: on Missisque r., 48 m. N. Montpelier. Pop. 1,955.

Benkshter T allex, p. v., Morris co., $N$. Jer. : on Rockaway r., $61 \mathrm{~m}$. N. Trenton.

BerleN, p. v., Sumter co., Ala, : 129 m. W. Montgomery. BerLa, p. v., Clinton co., Ind. : 40 m. N. W. Indianapolis. Berlta, t. and p. v., Hartford co., Conn.: $12 \mathrm{~m}$. S. W. Hartford. The New Haven, Hartford, and Springfield R. R. passes through the t., $25 \mathrm{~m}$. N. New Haven. Pop. 1,868 .

Berlex, t. and p. v., Marquette co., Wisc.: on Fox r., 78 m. N. N. E. Madison. Pop, 1,052

Berls, p. v., Sangamon co., Ill.: on the Sangamon and

Morgan R. R., $16 \mathrm{~m}$. W. Springfield.

Berurs, p.. ., Worcester co., Ma. : near the head of Trap cr., $78 \mathrm{~m}$. S. E. Annapolis

Beinin, t. and p. V., Worcester co., Mass. : on a branch of Assabet r., $32 \mathrm{~m}$. W. by N. Boston. Pop. 866 .

BeruT, p. v., Coos co., N. Hamp.: on a branch of $\Delta \mathrm{m}$ monoosuc r., $84 \mathrm{~m}$. N. Concord. The Atlantic and St. Lawrence $R$. R. passes through the town, $97 \mathrm{~m}$. N. W. Portland.

BERLN, t, and p. V., Rensselaer co, $N_{\text {. }} Y_{*}$ : on Little Hoosic r., 22 m. E. Albany. Pop. 205.

BerLIN, t. and p. v., Holmes co, Ohio: $74 \mathrm{~m}, \mathrm{~N}, \mathrm{E}$,

Columbus. Pop, 1,452.

Berutv, p. Y., Somerset co., Penn.: 117 m. W. S. W. Harrisburg.

BERLIN, p. $\nabla .$, Marshall co, Tenn. ; about $3 \mathrm{~m}$. S. Duck r. and $42 \mathrm{~S}$. Nashyille.

Berurv, p. v., Southampton co., Firg.: $51 \mathrm{~m}$. \$. by E. Pichmond.

Breler, t. and p. v., Washington co., Tem.: on Onion r., $4 \mathrm{~m}$. S. by W. Montpelier. The Vermont Central R. R traverses the $t$. above and below Montpelier. Pop. 1,507.

Berlta Centre, p. v., Mahoning co., Ohio: 129 m. N. E. Columbas.
Berlin Cross Roads, p. 0., Jackson co., Ohio: 65 m. S. S. E. Columbus.

Berlin Falls, p, 0., Coos con, N. Hamp.: on Androscoggin r., 87 in. N. by E. Coneord.

Berlintille, p. V., Erie co., Ohio: $97 \mathrm{~m}$. N. N. E. Columbus.

Bermodran, p. v., Adams co., Penn.: $21 \mathrm{~m}$. S. by W Harrisburg.

Bernadotie, p. v., Fulton co., $I l$. : on Spoon r., $57 \mathrm{~m}$ N. W. Harrisburg.

Bernalillo county, $N$. Mero. Situate centrally on the Rio Grande, by the tributaries of which it is drained. Farm 164; dwell. 1,654, and pop.-wh. 7,749, fr. col. 2-total, 7,751. Capital: Bernalillo.

BerNardstown, t. and p. .., Franklin co., Mass.: on W. side of Connecticut r., $76 \mathrm{~m}$. W. by N. Boston, The Brattleborough Branch of Vermont and Massachusetts $\mathrm{P} . \mathrm{P}$. and the Connecticut River $\mathrm{R}$. R. form a junction in this locality. Pop. 937

BerNe, to and po $\mathrm{v}_{0}$, Albany cos, $N_{0} \bar{Y}_{0}: 17 \mathrm{~m}$. W. Albany, on Fox's cr. of Schoharie cr. Pop. 3,441 .

Berne, p. V., Monroe co., Ohio: $108 \mathrm{~m}$. E. by S. Columbus.

Bernhard's Bax, p. v., Oswego co., N. Y.: 41 m. W. N. W Albany. Pop. 3,441.

Bervprlue, p. v., Berks co., Penn.: on W. side Schuylkill r., $51 \mathrm{~m}$. E. by N. Harrisburg.

BERRIEN county, Mich. Situate S. W. corner, and contains $576 \mathrm{sq} . \mathrm{m}$. Drained by Pawpaw, St. Joseph, and Galien rivers. Surface various: the valleys have a rich loamy soil, and timber grows heavily. Farms 690; manuf. 61 dwell. 2,126, and pop.-wh. 11,178, fr. col. 289-total, 11,417 Capital, Berrien Spring. Public Works: Central Michigan R. R.

Berrien Springs, p. v., and cap. Berrien co, Mich.

Berry, p. o., Dane co., Wisc.

Berryseurg, p. v., Dauphin co., Penn. $31 \mathrm{~m}$. N. Harrisburg.

Berry's Ferry, p. o., Livingston co., $\bar{K} y$. : on Ohio r., opposite Golconda, 209 m. W. by S. Frankfort.

BerRY's LICK, p. o., Butler co., Ky.: $182 \mathrm{~m}$. S. W. Frankfort.

Berry's Mili, p. o, Union co, $\bar{K} y .: 172 \mathrm{~m}$. W. by $\mathrm{s}$ Frankfort.

Berrysvilue, p. v., Knox co. Ind.: 97 m. S. W. Indiauapolis.

Berrytor, p. v., Cass co., $I l l_{*}$ : on a cr. of Sangamon r. 29 m. N. W. Springfield.

Berryvilue, p. v., and cap. Clarke co., Virg.: $111 \mathrm{~m} . \mathrm{N}$. by W. Richmond

Bershebs, p. Y., Henry co., Ga.: 66 m. W. by N. Milledgeville.

Bertie county, N. Car. Situate N. E. on Albemarle Sound, and contains $680 \mathrm{sq} . \mathrm{m}$. Drained by tributaries of Chowan and Roanoke rivers, the latter of which bounds it 9 Surface low and marshy, and the soils productive of Indian corn and cotton. The pineries are valuable for naval stores. Farms 542; manue. 50; dwell. 1,070, and pop.-wh. 5,314, fr. col. 313, sl. 7,194-total, 12,851. Capital: Windsor.

Bertrand, t. and p. $\nabla$. Berrien co., Mich.: on St. Joseph r., $9 S \mathrm{~m}$. S. W. Lansing.

Berwiok, p. v., Warren con, $I U$ : on W. fork of Spoon r., 83 m. N. W. Springfield.

Berwick, p. v., Sencea co., Ohio: 83 m. N. by W. Columbus.

Bermick, p. v., Columbia co., Penn.: on Susquehanna r., $63 \mathrm{~m}$. N. by E. Harrisburg. Pop. $4 \mathrm{~S} 6$.

Berzelia, p. v., Columbia co., Ga.: on the line of the Georgia R. R., 21 m. W. Augusta, and 68 m. E. by N. Milledgeville.

Bhistand, p. 0., Essex co, Virg.: 51 m. N. E. Riehmond.

Bethary, to and p. v., New Haven co., Conn.: on W. 
side of Connecticut r., 27 m. S. S. W. Hartford. Pop. 914.

Bethany, p. v., Pancla co., Ten. : 292 m. N. E. Austin City.

Bethavy, to and p. v., Genesee co., $N_{*} Y_{\text {: }}$ : on Little Tonawanda and Black creeks, $229 \mathrm{~m}$. W. Albany. The Buffalo and New York City R. R. passes through. P.1,904. Betratr, p. v., Butler co., Ohio. : 89 m. W. S. W. Columbus.

Bethany, p. v., and eap. Wayne co., Penn. : on Dyberry cr., 123 m. N. E. Harrisburg.

Betrant, p. v., Brooke co., Tirg.: $252 \mathrm{~m}$. N. W. Richmond.

Bethany, p. v., and cap. Harrison co., Mo. : on Big cr. of the W. fork of Grand r., $153 \mathrm{~m}$. N. W. Jefferson City.

Brthary Church, p. o., Iredell co, N. Car.: $117 \mathrm{~m}$. W. Raleigh.

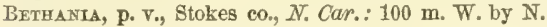
Raleigh.

Bethania, $\nabla$. , Lancaster co., Penn : 43 m. E. by S Harrisburg. Has a printing and book-binding establishment and other manufactures, and about 40 dwellings.

Bether, p. V., Fairfleld co., Conn.: 53 m. S. W. Hartford, and on the Danbury and Norwalk R. R., $19 \mathrm{~m} . \mathrm{N}$. Norwalk.

Bftres, p. v., Glynn co., Ga.: near the mouth of Alatamaha r., $153 \mathrm{~m}$. S. E. Milledgeville.

Bethel, p. v., Morgan co., Ill. : on the line of the Sangamon and Morgan R. R., $45 \mathrm{~m}$. W. Springfield.

Bethel, p. v., Bath co., Ky.: 69 m. E. Frankfort.

Bethe L, t. and p. $\nabla_{\text {., Oxford }} \mathrm{co}_{*}, \mathrm{Me} \mathrm{e}_{*}$ : on the Androscog. gin r., $48 \mathrm{~m}$. W. Augusta, and on the Atlantic and St. Lawrence R. R., 70 m. from Portland. Pop. 2,253 .

Bermel, p. v., Shelby co., Mo.: 92 m. N. Jefferson City.

Betere, p. v., Wayne co., Ind.: 69 m. E. Indianapolis.

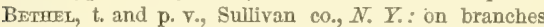
of Delaware r., $113 \mathrm{~m}$. S. W. Albany. Pop, 2,087.

Bether, p. ₹., Clermont co., Ohio: 86 m. S. W. Indianapolis.

Betane, p. v., Berks co., Penn. : 51 m. E. Harrisburg. Betriel, p. v*, York dist,, S. Car.: 79 m. N. Columbia. Bermer, t. and p. v., Windsor co., Term.: on White $\mathbf{r}_{*}$ $29 \mathrm{~m}$. S. by W. Montpelier. The t. contains a valuable soapstone quarry. The Vermont Central R. R. passes through the $t_{0}, 39 \mathrm{~m}$. from Windsor. Pop. 1,730 .

Betrel, p. v., Mercer co., Virg.: 208 m. W. Richmond. BetrifesdA, p. y., Williamson co., Tenn.: 24 m. S. Nashville.

Beтhleheq, t. and p. $\nabla_{*}$, Litehfield co., Conn.: $31 \mathrm{~m}$. W. Hartford. Pop. $\$ 15$.

Bethlehem, p. v., Sumter dist., S. Car.: 41 m. E. Columbia.

Betmlehear, p. v., Clarke co., Ind.: 87 m. S. S. E. Indianapolis.

BexrlemeM, t. and p. v., Grafton co., N. Hamp.: on Ammonoosuc r., $72 \mathrm{~m}$. N. by W. Concord. Pop. 952.

Bетеп енек, p. V., Gilmer co., Virg.: 213 m. W. N. W. Richmond.

Berhleney, t. and p. v., Hunterdon co., N. Jer. : $37 \mathrm{~m}$. N. by W. Trenton. Pop. $2, \pi 46$.

Bethlemer, p. v., Marshall co, Miss, : 168 m. N. Jackson.

Bethlfmer, t. and p. v., Albany co., N. $Y_{\text {: }}:$ on Normanskill, etc., 5 m. S. Albany. Pop. 4,102

Bethlemex, p. v., Columbus co., Ala.: $63 \mathrm{~m}$. E. by N. Montenmery.

Eetirlemfur. t. and p. F., Northampton co., Pennz. : on Lehigh r., at the mouth of Manokicy cr., $83 \mathrm{~m}$. E. by N. Harrisburg. Settled by the Moravians in 1741, and still one of their principal localities. Pop. 1,516.

BetmlemeM Cestre, p. v., Albany co., N. $Y_{\text {. }}$

BETHAoNT, p. $v_{1}$, Orange co., N. Car.: 46 m. N. W. Raleigh.
BeTtSpille, p. v., Seneca co., Ohio: on a branch of Sandusky r., 85 m. N. by W. Columbus.

Bevlat, p. o., Johnson co., N. Car.: 28 m. E. Raleigh. Bevans, p. v., Sussex co., $N$. Jer. : 89 m. N. Trenton. Beverly, p. v., Adams co., $M l .: 73$ m. W. Springfield.

Beveriy, p. v., Burlington co., $N$. Jer.

Beveruy, t., p. v., and sea-port, Essex co, Mass.: $16 \mathrm{~m}$, N. by E. Boston. It lies on the N. side of the bay, opposite Salem, with which it is connected by a bridge, 1,500 feet long, over which the Eastern R. R. passes. A railroad also extends hence to Gloucester. Shipping owned in the district 3,173 tons, all in the coasting trade. Pop. 5,376.

Beverly, p. v., Anson co., $N$. Car.: on Big Brown or. of Yadkin r., $87 \mathrm{~m}$. N. E. Raleigh.

Beverit, p. v., Washington co., Ohio: on N. side of Muskingum r., $7 \mathrm{~S} \mathrm{~m}$. E. S. E. Columbus.

Beverly, p. v., and cap. Randolph co., Firg.: on the E. fork of Monongahela r., $155 \mathrm{~m}$. W. N. W. Richmond. Beqerly Farms, p. o., Essex co., Mass.: $18 \mathrm{~m}, \mathrm{~N}$ by $\mathrm{E}$. Boston.

Bevis' TAYerN, p. o., Hamilton co., Ohio: $106 \mathrm{~m}$. S. W. Columbus.

BEWLEYTLLE, p. v., Breckenridge co., $K y_{0}: 112 \mathrm{~m}, \mathrm{~W}$. by S. Frankfort.

Bexar county, Tex. Situate W., and contains about $120,000 \mathrm{sq} . \mathrm{m}$. It extends from $28{ }^{\circ}$ to $36^{\circ} 30^{\prime}$, and embraces all the country from the organized counties to the $P \cos r$. All the great interior rivers of Texas have their sources within its territory. Surface in the S. part, undulating or rolling prairie, interspersed with oak-openings and groves. On the $N$. ranges of hills run $E$ and $W$., forming a watershed between the streams of the E. and S. W. Lime and sandstone abundant, and there are several mineral springs. Soil, a dark, sandy, calcareous loam, rich and productive The southern part is only occupied. Farms 117 ; manuf 13; divell. 1,204, and pop--wh. 5,635 , fr. col. 28 , sl. $389-$ total, 6,052. Capital: San Antonio.

Bexar, p. v., Marion co, Ala.: 150 m. N. W. Montgomery.

BrBB county. Ala. Situate centrally, and contains 864 sq. m. Drained by tributaries of Catawba $r$, which traverses the county centrally. Surface moderately undulating, and the soils, especially on the rivers, fertile. Products va rious, Indian corn and cotton being the principal. Farms 654 ; manuf. 13 ; dwell. 1,153 , and pop.-wh. 7,097 , fr. col 11, sl, 2,861-total 9,969. Capital: Centreville.

BIBB county, $G a$. Situate centrally, and contains $432 \mathrm{sq}$ m. Drained by Ockmulgee r. and its tributaries. Surface uneren. Soils generally sandy, but near the streams highly fertile, producing fine cotton. Farms $30 \mathrm{~S}$; manuf. 82 ; dwell. 1,234, and pop.-wh. 7,009, fr. col. 53, sl. 5,637-total, 12,699. Capital: Macon. Public Works: Central Georgia R. R.; Macon and Testern R. R. ; and South-western R. R. Brckter's Milcs, p. o., Russell co., Virg. : $267 \mathrm{~m}$. W. by S. Richmond.

BIDDEFORD, p. v., York co, Mo : on S. side of Saco r, at its mouth, 67 m. S. W. Augusta. The "Mereantile Advertiser" (whig), is issued weckly. The Portland, Saco, and Portsmouth R. R. passes through the $t ., 36 \mathrm{~m}$. from Portsmouth and 15 from Portland. Pop. 6,095.

BmWell's Barr, p. o., Butte co, Calif.: on middle fork of Feather r., $113 \mathrm{~m}$. N. by E. Vallejo.

Bienville parish, La. Situate N. W. of W. dist., having Lake Bisteneau for its W. border, and contains $1,080 \mathrm{sq} . \mathrm{m}$. Drained by Grand Bayou and the creeks Black Lake, Saline, and others, tributaries of Red r. Surface, a plateau somewhat elevated: soils fertile, producing excellent cotton. Farms 27i; manuf. 2; dwell. 571, and pop.-wh. 3,623, fr. col. 21, sl. 1,595-total, 5,539. Capital: Mount Lebanon.

Big BAR, p. o., Trinity co., Calif.

Big Barrex, p. O., Claiborne co., Tonn.: on N. side of Clinch r., 176 m. E. Nashville. 
Big Bester, p. o., Oakland co., Mich. : 59 m. E. Lansing.

Bre Bexd, p. o., Gilmore co., Firg.: 230 m. W. N. W. Richmond.

Brg Bexd, p. o., Venango co., Penn. : 157 m. W. N. W. Harrisburg.

Big Bexd, p. o., Waukesha co, Wisc.: 53 m. W. Madison.

Big Bend, p. 0., Aroyelles par, La. ; 78 m. N. W. Baton Rouge.

BIG BEND, p. o., Whitesides co., IZl.: on a peninsula of

Rock r., 189 m. N. Springfield.

Big Brook, p. o., Oneida co., $N . Y_{.}: 97 \mathrm{~m}$. W. by N. Albany.

Bigbт Fork, p. o, Momroe co, Miss.: 129 m. N. E. Jackson.

Bigbyville, p. v., Maury co., Tenn.: on a er. of Duck r., $47 \mathrm{~m}$. S. by W. Nashville.

Big Cane, p. 0., St. Landry par., La. : 58 m. W. Baton Rouge.

Big Cedar, p. o., Jackson co., Mo.: 128 m. W. by N. Jefferson City.

Big Clifwr, p. o., Hardin co., $\bar{K} y .: 67$ m. W. by $\mathrm{S}$. Frankfort.

Big Crekk, p. o., Philips co., Ark. : 82 m. E. S. E. Little Rock.

Bie Cresk, p. D., Fort Bend, Tex.: 158 m. E. by S. Austin City.

Big CReEK, p. o., Forsyth co., Ga.: 83 m. N. W. Milledgeville.

Big CrekE, p. o., Rapides par., $l \alpha .: 107 \mathrm{~m}$. N. W. Baton Rouge.

BIG CREeK, p. o., Johnson co., MO. : $83 \mathrm{~m}$. W. Jefferson City.

Erg Creek, p. o., Stokes co., N. Car.: $102 \mathrm{~m}$. W. by N. Paleigh.

Big Creer, p. o., Yallabusha co., Miss.: 107 m. N. by E. Jackson.

Brg Creek, p. o., Shelby co., Tenn. : on a cr. so called, 1 ริ $\mathrm{m}$. W. by S. Nashville.

Big Crrak, p. o., Edgeñeld dist., S. Car.: 53 m. W. Columbia.

Bigelow's Mirls, p. 0., La Porte co., Ind. : 131 m. N. W. Indianapolis.

Big Falis, p. o., Orange co., N. Car.: $31 \mathrm{~m} . \mathrm{W}$. by N. Raleigh.

Big Flatrs, t. and p. o., Chemung co., $\boldsymbol{N}$. $\boldsymbol{Y}$ : : on Chemung r. 193 m. W. S. W. Albany. The N. Y. and Erie P. R. passes through the t., $293 \mathrm{~m}$. from New York City, and $176 \mathrm{~m}$. from Dunkirk; also the navigable feeder of the Chemung Canal. Pop, 1,709.

Big Foot Pratrie, p. o., Walworth co., Wisc.

Big Grades, p. o., Russell co., Firg. : 287 m. W. by S. Richmond.

Big Hrul, p. o., Madison co., Ky.: 51 m. S. E. Frankfort.

Big Holiow, p. o., Greene co., $N$. $\boldsymbol{Y} .: 39$ m. S. W.

Albany.

Big Island, t. and p. v., Marion co., Ohio. : 48 m. N. by W. Columbus. Pop. 604.

Big Island, p. o., Bedford co., Virg., 113 m. W. by S. Pichmond.

Big LAurel, p. o., Yancey co., $N$. Car. : on a cr, so called, $219 \mathrm{~m}$. W. Raleigh.

BIG LIck, p. 0., Roanoke co., Firg.: 186 m. W. by S. Richmond.

Pig MeAdow, p. o., Grayson co, Virg. : 217 m. W. S. W. Pichmond.

Big Mills, p. o., Dorchester co., Md.: on Chicamacomico cr., 69 m. S. E. Annapolis.

BiG NंEck, p. O., Adams co., $I l_{*}: 89 \mathrm{~m}$. W. Springfield.

BIC, OAF, p. O., Kemper co., Miss.: 102 m. E. N. E. Jackson.
Bre Plain, p. o., Madison co., Ohio: 26 m. 8. W. Columbus.

Bug Pond, p. o., Fayette ca, Ala.: 133 m. N. W. Montgomery.

Big Pratrik, p. o, Wayne co, Ohio: 47 m. N. E. Columbus.

Big Readr, p. o., Edmondson co., Ky. : 108 m. S. W. Frankfort.

Big River Mrics, p. a, St, Frangois co, Mo.: 98 m. E. S. E. Jefferson City.

Big Rock, p. o., Kane co., $I u l_{.}$: on a cr, so called, a tributary of Rock r., 208 m. N. E. Springfield.

BIG SANDY river: rises in the Alleghany Mountains, near the head waters of the Tennessee and Cumberland rivers, and falls into the Obio between Virginia and Kentucky, being the boundary between these States for nearly $200 \mathrm{~m}$. It is navigable to the $\mathrm{W}$ ascioto Mountains. The $\mathrm{E}$. and W. branches join about $40 \mathrm{~m}$. above its entrance to the $\mathrm{Obio}$.

Big Skin Creek, p. o., Lewis co., Virg.: 187 m. W. N. W. Rickmond

Big Spring, p. o., Marshall co., Ala.: 143 m. N. Montgomery.

Big Spring, p. o., Pocahontas co., Virg.: $147 \mathrm{~m}$. W. by N. Richmond.

Brg Sphing, p. o., Breckenridge co., $K y_{*}: 85 \mathrm{~m}$. W. S. W. Franklin.

Big Spring, p. o., Cumberland co., Penn.: 42 m. N. E, Harrisburg.

Big Spring, p. o, Montgomery co, Mo.: $47 \mathrm{~m}, \mathrm{~N} . \mathrm{E}$ Jefferson City.

Brg Sprivg, p. o., Ottawa co., Mich.; $57 \mathrm{~m}$. W. by N. Lansing.

Brg Spring, p. o., Wilson con Tenn.: 29 m. E. Nashville. Big Spring, p. 0., Shelby co., $I U_{\text {. : }} 67$ m. S. E. Springfield.

Big Springs, p. os, La Porte con, Ind.: $128 \mathrm{~m} . \mathrm{N} . \mathrm{W}$. Indianapolis.

Brg Stream Ponnt, p. o., Yates co, $N_{0} Y_{*}: 187 \mathrm{~m}$. W. Albany.

Bнg SwaMr, p. o., Columbus co, $\lambda$. Car.: $11 \tau$ m. S. E. Raleigh.

Brg Tree Corners, p. o., Erie co, N. Y, 249 m. T. Albany.

Bic Woons, p. o., Calcasieu par, $L a,: 130$ m. W. Baton Rouge.

Brg Woods, 7. 0., Du Page co, $I l .: 193$ m. N. E. Springfield.

Brylerica, t. and p. v., Middlesex co., Mass. ; on Concord and Shawsheen r., $18 \mathrm{~m}$. N. W. Boston. The Middlesex Canal and Lowell and Boston R. R. pass through the $\mathrm{E}$. part of the town. Its manufactures are large, and its facilities for increasing them immense. Pop. 1,616.

BHLING's Grove, p. Os, Livingston co., $I l_{n}: 87 \mathrm{~m} . \mathrm{N}$. E. Springfieid.

Brleivasville, p. v., Union co., Ind.: 69 m. E. Indianapolis.

Buloxr, p. v., Harrison con, Miss. : on Point Caddo, of Biloxi Bay, 149 m. S. by E. Jackson. The "Sea-shore Sentinel" is issued weekly.

Brloxi, p. v., Newton co., Tex. : 232 m. E. Austin City.

Buvgram, t. and p. 0., Somerset co., Me. : on E. side of Kennebec r., $42 \mathrm{~m}$. N. Augusta. Pop. 752.

Brngram, to and p. v., Potter co, Penno: $169 \mathrm{~m} . \mathrm{N} . \mathrm{W}$. Harrisburg.

Binghampton, p. $\nabla$. , Lee co, $l l l_{0}: 132 \mathrm{~m} . \mathrm{N}$. by E. Springfield.

Bivendupton, p. v., and cap. Broome co., $N$. $Y$.: at the junction of the Chenango and Susquehanna $r$. It is one of the most important inland villages of the State. The New York and Erie R. R. passes through it, $225 \mathrm{~m}$. from New York City, and it is the S. terminus of the Chenango Canal. Railroads will also be built from this point to AJbany, Utica, and Syracuse. Four papers are published 
in the village--1 daily and 3 weekly. The $v$, is handsomely laid out, and has several fine buildings and bridges. Its trade with the surrounding country is very extensive, and is constantly increasing.

Brimley's Brmae, p. o., Lancaster co., Perm.: $87 \mathrm{~m}$. S. E. Harrisburg.

Brachardylle, p. v., Susquehanna co., Penn. : $13 \pm \mathrm{m}$. N. E. Harrisburg.

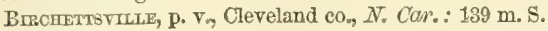
W. Raleigh.

Birce PoNd, p. o., Crawford co., Mo.: $53 \mathrm{~m}$. S. E. Jefferson City.

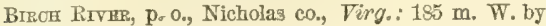
N. Pichmond

Brro, p. o., Hillsdalo co., Mich : $67 \mathrm{~m}$. S. Lansing.

BIRDSALr, to and p. o, Alleghany $\mathrm{CO}_{n}, N$. $Y .:$ on Black er., $231 \mathrm{~m}$. W. by S. Albany. Pop. 597.

Brrdsborougr, p. v., Berks co., Penn.: 62 m. E. by $\mathrm{N}$. Harrisburgh.

BIrD's Pun, p. o., Guernsey co., Ohio: $53 \mathrm{~m}$. E. N. E. Columbus.

Brrdsvilife, p. $\nabla_{n}$, Burke co, Ga.: $81 \mathrm{~m}$. E. Milledgeville.

BiRMngris, p. v., Jackson co., Ala.: 162 m. N. Montgomery.

Biramvgham, p. ₹., Pontotoc co,, Miss.: 158 m. N. N. E. Jackison.

BIRAINGHAM, p. v. Schuyler co., IZl : on the W. side of

Crooked cr. of Illinois $x ., 72 \mathrm{~m}$. N. W. Springfield.

Brrminghan, p. v., Van Buren co., Ia. : 57 m. S. by W.

Iowa City.

Birminghsy, p. v., Oakland co,, Afich.: $70 \mathrm{~m}$. E. by S.

Lansing. It lies on the Detroit and l'ontiae li, R.,13 m. from the former place.

Bimptrghav, p. v., Erie co., O7io: on W. side of Vermillion r., $96 \mathrm{~m}$. N. Columbus.

Birminghay, p. V., Huntingdon co, Penn, : on W. branch of Little Juniata r., $96 \mathrm{~m}$. N. W. by W. Harrisburg. Lead and iron abound in the vicinity.

Bisilop Hild, p. v., Henry co., Ill.: $95 \mathrm{~m}$. N. by W. Springfield.

Bisuropvthle, p. v., Sumter dist., S. Car.: 63 m. N. R. by E. Columbia.

Brssell, p. o., Calhoun co., Ill.: $60 \mathrm{~m}$. W. S. W. Springfleld.

Brsser's, p. on Geauga co, Ohio: 133 m. N. E. Colimbus.

Bringstrle, p. v., Spartanburg dist., S. Cus.: $\$ 9 \mathrm{~m}$. N. W. Columbia.

Buschighet, p. o., Kane co., Ilb. : 201 m. N. E. Springrfield.

Buack Birn, p. o., Newcastle co., Del. : 15 m. N. Dover. BLAck Brook, t. and p. o., Clinton co., $N . Y_{\text {. : on Saranac }}$ and $A u$ Sable r., and Black Br., $125 \mathrm{~m}$. N. Albany. P. 2,525.

Black Crtek, p. o, Scriven con Ga.: 111 m. E. by S. Milledgeville.

Black Cresk, p. o., Luzerne co., Penn.: 98 m. N. E. Unirishurs.

BLAcK CreEk, p. o., Sullivan co, Ind.: on a cr. of

Wabash r., so called, $88 \mathrm{~m}$. S. W. Indianapolis.

BuAcK Crent, p. On, Holmes con, Ohio: $69 \mathrm{~m}$. N. E. Cilumbuls.

Brack Creek, p. v., Alleghany co, $\lambda . Y_{*}$ : on a cr. so called, $229 \mathrm{~m}$. W. by S. Albazy.

Brack Creeks, p. O., Wayne co., N. Car.. 49 m. S. E. Tilluigh.

Black Earth, p. o., Dane co., Wisc.: on a river so called, $13 \mathrm{~m}$. W. Madison.

Black Face, p. 0., Nottoway co., Virg.: 47 m. S. W. Riclimond.

BLAckford county. Ind. Situate Y. E., and conteins 169 sq. In. surface lerel. but in some brarts gently undulatiner. and the soils are excellent for farming purpeses; wutere! 63 by the Salamonie and Lick rivers. Timber abundant Farms 306; manuf. 6.; dwell. 514, and pop.- -wh. 2,819, fr. col. 11-total, 2,\$60. Capital: Hartford

BuAcK Fosk, p. o, Hancock eo, $K y_{*}$ : on a cr. so called $114 \mathrm{~m}$. W. Frankfort.

BuAck Hawk county, Ia* Situate N. Ev centrally, and contains 756 sq. $m$. Drained by Cedar $x$, and its creeks. Surface undulating prairie, with some wood land. Farm 9 ; manuf. 1 ; dwell. 26, and pop.-wh. 135. fr. col. 0-total, 185-Capital: Cedar Falls:

Black HawK, p. O, Carroll co., Mhiss, ; on Abyaca cr. of Yazoo cr., 69 m. N. Jackson.

BuAck HAWE, p. o, Bearer oo, Penn。: 197 m. W. Harrisburg.

Blackerti (formerly Cost Mrars), p. o., Chesterfield co., $\nabla v r^{\prime} g_{0}: 12 \mathrm{~m}$. W. Riehmond.

Black HuL, p. o., Koufman co., Tex.: 210 m. N. N. E。 Austin City.

Blace Hole, p. o, Lycoming co, Penn.: $83 \mathrm{~m} . \mathrm{N}$. by

W. Harrisburg.

Black Horse, p. o., Chester co, Penn.: 64 m. S. E Harrisburg.

Buack Horst, p. 0, Middlesex co, $N_{0}$. Jer, : $27 \mathrm{~m}$ E. N. E. Trenton.

BLACK $J_{\triangle C K}$, p. 0, Fayette co, Tex.: at the head waters of Yavidad r., $62 \mathrm{~m}$. S. E. Austin City.

BLACK JACK. p. o., Scott co.g Ark.: 100 m. W. Little Rock.

BLACK JACK, p. o., De Soto par., $L a_{0}: 197$ m. N. W. Baton Rougre.

BLACE JACK GRove, p. o, Hopkins co., Tex, : $256 \mathrm{~m}$ N. N. E. Austin City.

BLACK LAKE, p. o., St. Lawrence co., $N . Y_{.}$: on a lake so called, $152 \mathrm{~m}, \mathrm{~N}$. E. Albany. Black Lake is a fine sheet of water, lying nearly parallel with the St. Lawrence $r$; at its $\mathrm{S}$, end it receives Indian $\mathrm{r}_{\text {, }}$ and at its $\mathrm{N}$. end empties into Osweghatchie r., at the mouth of which is Ogdensburg, the W. terminus of the Northern R. R.

Black LaND, p. 0., Tishemingo con, Miss.: 198 m. N. E. Jackson.

Black Lick, p. o., Indiana co, Penn.: $126 \mathrm{~m}$. W. by $\mathrm{N}$. Harrisburg.

Black Mirgo, p. o., Williamsburg dist., S. Car. : $77 \mathrm{~m}$ E. S. E. Columbia.

BLucr OAE, p. 0., Charleston dist., $S . C a{ }^{*} .:$ on an island so called of Santee r., 61 m. E. S. E. Columbia.

Bwack OAK Grovk, p. Oø, Hardeman co., Tenn. : $139 \mathrm{~m}$ S. W. Nashville.

BLACK OAK POLxt, p. O., Hickory $\mathrm{CO}_{2}, M 0 .: 68$ m. S. W Jefferson City.

Bцser river, $N$. $Y$ : : the third in size wholly within the State. It rises in Herkimer co., has a course of $108 . \mathrm{m}$, and empties into Blaok-river Bay, at the foot of Lake Ontario. At Leyden it falls 63 feet, whence to Carthage, $40 \mathrm{~m}$., the $r$. is navigable for boats, but below to its mouth navigation is obstructed by rapids. From the falls, at Leyden, the Black River Canal extends S, to the Erie Canal at Rome.

Brack Rrver, p. o., Jefferson co., N. Y.: 138 m. N. W. Albany.

Btack River, t. and p. v., Lordin co., Ohio: on Black r. and Lake Erie, $1 \cap 9$ m. N. N. E. Columbus, The r. has a good harbor and considerable trade. Pop. of t. 659.

Btack Rives Chapel, p. o. New Hanover co., $N_{\text {. }}$ Car.: $79 \mathrm{~m}$. \$. by E. Raleigh.

Black Rrver Falus, p. 0., La Crosse co., Wisc. : 118 m. N. W. Madison.

BLACK Rock, t. and p. o., Erie co., N. Y.: on Lake Erie, $233 \mathrm{~m}$. W. Albany. The city of Buffalo is surrounded on three sides by the town. Several islands in the Niagara $r$. belong to Black liock. Railroads extend hence to Niagara Falls and to Buffalo. Pop. 7,508 .

BLAck Rock, p. o., Rappahannock co., Virg.: 98 m. N. N. W. Richmond. 
Blacks AKD W WITES, p. 0., Nottoway, co., Virg.: $32 \mathrm{~m}$. S. W. Tichmond.

BzAck's BLufF, p. v., Wileox co., Ala.: on Alabama r., $73 \mathrm{~m} . \mathrm{s}$. W. Montgomery.

BLACKSBUEGH, p. v., Montgomery co., Tirg.: on a cr, of New r., 179 m. W. by S. Richmand.

Blacksmees, p. o., Marion eo., Viıg: 207 m. N. W. Richmond.

Brackstocks, p. o., Chester dist., S. Car.: on Charleston and South Carolina $\mathrm{R}_{*} \mathrm{P}_{\mathrm{w}} 41 \mathrm{~m}$. N. by W. Columbia.

BuAcK's Strore, p. o., Tippah co., Ifiss.: $171 \mathrm{~m}$. N. by E. Jackson.

Buackstone (or Pawtucket) river: rises in Mass., and disembogues into Providence r., where it furuishes immense hydraulic power, and bas been much used for manufacturing purposes. The Blackstone Canal, from Worcester to Providence, $45 \mathrm{~m}$, follows the valley of this r.: it was completed in 1829, and cost about $\$ 700,000$.

Buackstone, p. t., Worcester co., Mass. : 33 m. B. W. Boston. Pop, 4,42?.

Buack SwaMr, p. o., Sandusky co., Ohio: $92 \mathrm{~m} . \mathrm{N}$. by W. Columbus.

Buacksville, p. V., Monongalia co, Firg: near the State line, $217 \mathrm{~m} . \mathrm{N}$. W. Richmond.

Bracksvilue, p. v., Barnwell dist., $S_{0}$ Car.: on the line of the South Carolina R. R., $80 \mathrm{~m}$. from Charleston, and $49 \mathrm{~m}$. S. S. T. Columbia.

Black Walnut, p. o, Halifax co, Firg. : 100 m. S. W. Richmond.

BLACK WARror river, Ala. : is formed of two head branches, Locust fork, or E. Branck, and Malberry r., which rnite in $\mathrm{S}$. W. part of Jackson co. Below the junction the r. has a general S. and S. W. direction, $80 \mathrm{~m}$. to the Tombigbee r., which it meets in the S. of Greene co. Steamboats navigate to Tuscaloosa; and for boats there is sufficient water much farther. The whole length of the r. is about $160 \mathrm{~m}$.

Black Water, p. o., Sussex co., Firg.: 67 m. S. S. E. Pichmond.

Black Water, p。 o., Sussex co., Del。: $51 \mathrm{~m}$. S. Dover.

Black Water, p. o., Kemper co., Miss. : 104 m. E. N. E. Jackson.

Black Water, p. o., Morgan co., Ky.: 98 m. E. by S. Frankfort.

BLACKWELL's IsLAND: in Fast $\mathbf{r}_{\text {. }}$, between New York and Long Island. The City Penitentiary, Lunatic Asylum, etc., are located on the island.

BuAck Wolf, p. o., Winnebago co, Wisc.: on Winnebago Lake, 73 m. N. N. E. Madison.

Blackwood Town, p. vo, Camden co, $N$. Jer.: $37 \mathrm{~m}$. S. Trenton.

Bladen county, N. Car. Situate S. E. on Cape Fear r., and contains 1,080 sq. m. Surface low and swampy. Indian corn, rice, cotton, and tar are produced. Farms 496; manuf. 61 ; dwell. 1,005, and pop.-wh. 5,055, fr. col. 354, sl. 4,858-total, 9,767. Capital: Elizabeth.

Bladensidrg, p. $\vee_{4}$, Prince George's eo, Md.: on the Washington Branch R. R., $7 \mathrm{~m}$. from Washington, 38 from Baltimore, and $22 \mathrm{~m}$. W. Annapolis.

Bladenselte, p. o., Knox co., Ohio: 43 m. N. N. E. Columbus.

Bladon Spentgr, po o., Choctaw co., Ala. : $121 \mathrm{~m}$. W. by by $\mathbf{S}$. Montgomery.

Blain, p, o., Perry co., Penn. : 21 m. W. Harrisburg.

Blatwe, p. v.. Lawrence co., Ky.: on Blaine cr., 158 m. E. Frankfort.

Brann's Cross Roads, p. o., Grainger co., Tenn.:4 m. N. Holsten r., and $181 \mathrm{~m}$. E. Nashville.

Blare county, Penn. Situate centraliy, and contains 634 sc. $m$. Drained by head streams of Jumiata $r$. Surface mountainous, diversificd by extensive valleys: soils ordinarily fertile. Farms 826 ; manuf, 130 ; dwell. 3,718 , and pop. - wh. 21.517, ft. eol. 260-total, 21,777. Capitul: Holli- daysburg. Public Works: Pennsylyania Canal and R. R.

Blatr Furnace, p. o, Blair co., Penn: 87 m. W. by $\mathbb{N}$. Harrisburg.

Bualr's Ferrx, p. o., Roane co., Tenn : 108 m. E. by \$. Nashville.

Blatistown, p. v., Warren co., N. Jer.: 61 m. N. by W. Trenton. Pop. of t. $1,405$.

Blatrevilue, p. v., and cap. Union co., Ga.: on Notley cr., $118 \mathrm{~m}$. N. N. W. Milledgeville.

Buamevilu.e, p. v., Posey co, Ind.: on Big cr. of Wabash r., $117 \mathrm{~m}$. 5. W. Indianapolis.

Bla irsville, p. V., Indiana co., Penn. : on Kiskinimitas $r .$, and on the line of Pennsylvania $R, R .198 \mathrm{~m}$. from Harrisburg, and 58 from Pittsburg. Pop. 1,512.

Blarrsville, p. v., York dist., \&. Car.: $88 \mathrm{~m}$. N. by E. Columbia.

Blakeley, t. and p. v., Lucerne co, Penn : on Lackawannock r., $108 \mathrm{~m}$. N. E. Harrisburg.

Blakely, p. v., sea-port, and cap. Baldwin co, $A$. $q_{2}$ : on the E. side of T'ensaw r., opposite Mobile. The harbor admits vessels drawing 11 fect water, and is in many respects superior to that of Mobile.

BLAKELY, p. v., and eap. Early co., Ga.: 184 m. S. W. Milledgeville.

Blikely, po v., Stokes con, N. Car.: 109 m. W. by N. Raleigh.

Blakgseug, p. v., Wapello con, Ia.: $62 \mathrm{~m}$. S. W. Iowa City.

Blasc, p. o., Lucas eo, Ohio: $122 \mathrm{~m}$. N. N. W. Columbus.

Blanohe, p. o., Lafayette con, MO.: $93 \mathrm{~m}, \mathrm{~W}$. by $\mathrm{N}$. Jefferson City.

Blavohard, t. and p. V., Piscataquis $c_{0}, M e_{0}$ : on Piseataquis r., 57 m. N. Augusta. Pop. 192

Blaxcilaro Bridge, p. v., Hancock co., Ohio: on Blanchard cr., 87 m. N. by W. Columbus.

Blamenester, p. v., Clinton co., Ohio: on Cincinnati and Fillsborough $\mathrm{R} . \mathrm{R}_{\mathrm{*}}, 39 \mathrm{~m}$. from Cincinnati and $66 \mathrm{~m}$. S. W. Colambus.

Blandenstille, p. v., M'Donough co, $I l l$ : on Decker's cr., $83 \mathrm{~m}$. N. W. Springfield.

Blandville, p. v., and cap. Ballard co, $K y_{*} ;$ on N. side of Mayfields r., $243 \mathrm{~m}$. W. Frankfort.

BLANFORD, t. and p. V., Hampden co., Mass. : on branches of Westficld r., $96 \mathrm{~m}$. W. by S. Boston. Pop. 1.41s.

Blanket Hill, p. o., Armstrong co., Pems.: 123 m. W. Harrisburg.

Blavvelturlis, p. v., Rockland eo., $N_{*} Y_{.}$: on the line of the New York and Erie R. R., $4 \mathrm{~m}$. W. Plermont and $106 \mathrm{~m}$. \$. Albany.

Blawexbuggr, p. v., Somerset $\operatorname{co}_{*}, N$. Jer.: $16 \mathrm{~m}$.

N. N. E. Trenton.

Blecker, t. and p. o., Fulton co., $N_{0}$..$:$ on Garoga cr. and Stony cr: of Sacondaga r., $46 \mathrm{~m}$. N. W. Albauy. Garoga and Fish lakes are in this town. Pop. 511.

Bledsor county, Tenn. Situate S. E. centrally, and contains $520 \mathrm{sq.} \mathrm{m}$. Drained by Sequatdy r., its ereeks, the head waters of Coney fork of Cumberland $r_{\text {, }}$, and of Emery's r. of the Clinch. Considerable hills bound the valley of Sequatehy r., which runs through the county in a $N$. and S. direction. The grains, tobaceo, and cotton are produced. Farms 325; manuf. 2 ; dwell. 854, and pop.-wh. 5,042, fr. col. 90, sl. 827-total, 5,959. Capital: Pikeville.

Bledson's Landing, p. o., Crittenden $\mathrm{co}_{*}, A r k .: 131 \mathrm{~m}$. E. N. E. Little Rack.

Blendon, t. and p. V., Franklin co., Ohio: on Alum and Big Walnut cr., upper branches of Scioto $r_{.,} 10 \mathrm{~m}$. N. by E. Columbus. Pop. 1,323.

Bleninely, t. and p. v., Sehoharie co, $N$. $Y_{\text {.: }}$ on Schoharie r., $85 \mathrm{~m}$. S. W. Albany. Pop. 1,814

BLINK Bonny, p. 0, St. Lawrence co, $N . Y_{.}: 138 \mathrm{~m}$. N. E. Albany 
BLIsH's MrLls, p. O., Franklin con, MO. : 62 m. E. Jefferses City.

Buissfield, t. and p. v., Lenawee co., Mich. : on Raisin r., and on the line of the Erie and Kalamazoo R. R., $22 \mathrm{~m}$. from Toledo, and $7 \pm \mathrm{m}$. S. F. Lansing. Pop. 924

Butssvile, p. V., Marshall co, Ind. : $106 \mathrm{~m}$. N. Indianapolis.

Blissville, p. V, Jefferson co. Ill.: 108 m. S. by E. Springfield.

Blivex MHIs, p. 0., M'Henry co., $\pi u_{*}: 197$ m. N. F Springfield.

Block House, p. 0., Scott co., Firg.: 257 m. W. by S. Riehmond.

Brock Istaxd lieg in the Atlantic Ocean $14 \mathrm{~m}$. S. S. W. Judith Point. It constitutes the t. of New Shoreham, Newport co., $R$. $I$, and is $8 \mathrm{~m}$. long and from 2 to 4 broad. The surface is uneven and occasionally elevated, and the soils sandy and gravelly loam moderately fertile. There are several ponds on the island. Formerily it was noted for its fine cattle and dairies, but at the present time it is chiefly occupied by fishermen.

Blockrille, p. v., Chautauque eon, N. Y.: $283 \mathrm{~m}$. W. S. W. Albany.

Bloodget Mrus, p. o., Cortland co., N. Y.: $119 \mathrm{~m} . \mathrm{W}$. Albany.

Blood's Pornt, p. 0., De Kalb co., IU. : 212 m. N. by E. Springfield.

Bloony Ren, p. o., Bodford co., Penn.: on Raystown cr., 87 m. W. S. W. Harrisburg.

Bloos, p. o, Cook co., Ill. : $251 \mathrm{~m}$. N. E. Springfield.

Bloom, p. o., Rush co., Ind.: 33 m. E. by S. Indianapolis.

BloomfietD, t. and p. V., Hartford co., Conn.: on Wood r., 7 m. N. W. Hartford. Pop. 1,421.

Bloonfrield, p. V., and cap. Greene co, Ird.; оn the E. side of the W. fork of White r., $65 \mathrm{~m}$. S. W. Indianapolis.

Bloonfield, p. v., Edgar co, $I l l_{\text {。 }}$ : $152 \mathrm{~m}$. E. Springfield.

Bloomfield, p v., Kemper co., Afiss.: 93 m. E. N. E Jackison.

Bloomfleld, p. vo, and cap. Davis co., Ia.: $78 \mathrm{~m}$. S. W. Iowa City.

Bloomfreld, p. v., NeIson ca., $K y$ : 83 m. S. W. Frankfort.

Broomfield, t. and p. o, Somerset co., MLe.: on the Kennebee r., 29 m. N. Augusta. Pop. 1,801.

Bloomineld, p. v., and cap. Stoddart co., MFo.: $162 \mathrm{~m}$. S. E. Jeflerson City.

Bloommeld, t. and p. V., Essex co., N. Jer. : 49 m. N. E. Trenton. The $\mathrm{v}$. is one of the most flourishing of the State. Pop, of t. 3,355.

Bloomfleld, t. and p. v., Morrow co, Ohio: $51 \mathrm{~m}$. N. by

E. Columbus. Pop. 1,413.

Bloonfield, t. and p. v., Crawford co., Penm.: $197 \mathrm{~m}$. N. W. Harrisburg.

Broomrield, p. v., Loudon co., Firg.: on Goose cr., 102 m. N. by W. Richmond.

Broounfexd, t. and p. V., Essex co., Term : on W. side of Connecticut $\mathbf{r}$, and drained by branches of Nulhegan $\boldsymbol{r}_{\text {., }}$ $63 \mathrm{~m}$. N. E. Montpelier. Pop. 244.

Bloomined, t. and p. T., Walworth co., Wise. : in S. E. corner of co., $67 \mathrm{~m}$. S. E. Madison. Pop. 879

BLoomigrergi, p. v., Sullivan $c_{*}, N$. Y.: $82 \mathrm{~m}$. S.S. W. Albany.

Bloomingedegr, p. v., Fajette co, Ohio: on a branch of Paint cr., $31 \mathrm{~m}, \mathrm{~S}, \mathrm{~S}$. W. Columbus.

Blooumfale, p. v., Passaic co., N. Jer.: 68 m. N. E. Trenton.

Broommedare, p. V., Cabel co, Tirg. : $254 \mathrm{~m}$. W. by N. Richmond.

Bloommgdate, p. v., Dn Page $c_{\circ}, 17 .: 247$ m. N. E Springfield.

Bloovixgd ALF, p. r., Jefferson c0., O7rio: $102 \mathrm{~m}$. E. by N Columbus.
Broomate Grove, p. 0., Franklin co., Ind. : 62 m. E. by \$. Indianapolis.

Blooming Grove, t. and p. o, Orange co., $\mathcal{N}$. $Y$.: on Murderer's cr., $86 \mathrm{~m}$. S. Albany. Newburg Branch R. R traverses the N.W. part of the t., and on the S. E. is the Scunnecunk mt. Pop. 2,184.

Blooving Grove, p. o, Montgomery co, Tenn.: on a cr. so called, $49 \mathrm{~m}$. W. by N. Nashville.

Bloomnesport, p. 0., Randolph con, Ind.: 64 m. E. by N. Indianapolis,

Broomington, t. and p. $\nabla_{m}$ Winnebago co.. Wise. : $63 \mathrm{mo}$ S. E. Madison. Pop. 909 .

Bloniragton, p. $v_{-}$and eap. Monroe co. Ind. : on the line of the New Albany and Salem Extension R. R., $106 \mathrm{~m}$. from New Albany, and $46 \mathrm{~m}$. S. W. Indianapolis. The Indiana University is located here; and the newspapers published in the v. ore the "Reporter" and the "Herald," weekly, and the "Christian Record," monthly.

BloomingtoN, p. Y., Clinton co., Ohio: $57 \mathrm{~m}$. S. W. Columbus.

Bloomington, p. v., and cap. M'Lean co., $I l_{*}: 83 \mathrm{~m}$. N. E. Springfield. The Illinois Central $\mathcal{L}_{\text {. }} \mathrm{R}_{\text {., }}$, and the Chicago and Mississippi R. R. will intersect at this point.

Bloompgton, p. Y., Morgan co., Ky.: $102 \mathrm{~m}$. E。 Frankfort.

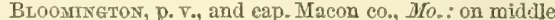
fork of Chariton r., and on the line of the Hannibal and Missouri R. R., $56 \mathrm{~m}$. N.Jefferson City.' The "Bloomington Gazette" is published weekly.

BloomugtoN. p. v., 'Tipton co., Tenn.: $161 \mathrm{~m}$. W. S. W. Nashville.

Blooming Vallex, p. o., Crawford co., Penn.: $197 \mathrm{~m}$.

N. W. Harrisburg.

Bloomigvllef, p, o., Erie co., Orio: $97 \mathrm{~m}$. N. by E. Columbus.

Bloonseuren, p. v., Halifax co., Firg.: on S. E. side of the Dan r., $117 \mathrm{~m}$. S. W. Richmond.

Bцoonsburen, p. v., and eap. Columbia co., Penn.: on the E. or main branch of Susquehanna r., $69 \mathrm{~m}$. N. by $\mathrm{E}_{\text {. }}$ Harrisburg. It is a thriving village on the North Branch Canal, and publishes two newspapers, the "Columbia Democrat," and the "Star of the North." Pop, 1,515.

Broouseurr, p. v., Warren co., $N$. Jer.: on Musconecong cr., $32 \mathrm{~m}$. N. by W. Trenton.

Broovrulle, p. v., Delaware co, $N . Y_{\text {.: }}$ on the W, side of the W. branch of Delaware r., $57 \mathrm{~m}$. S. W. Albany.

Bloomille, p.v., Will co., Ill. : on Rock cr., of Kankakee r., $240 \mathrm{~m}$. N. E. Springfield.

Bluourille, p. v., Seneca co, O7io: $73 \mathrm{~m} . \mathrm{N}$. Columbus.

Blossiurg, p. v., Tioga co., Penn. : 100 m. N. by W IIarrisburg. Bituminous coal, of excellent quality, abounds in the ricinity, and great facilities have been arranged for its transport to market by railroad and canal.

Blossou Hil, p. o., Caddo parish, La. : $235 \mathrm{~m} . \mathrm{N}$. W. Baton Rouge.

BlouNt county, Ala. Situate $\mathbb{N}$. centrally, and contains $940 \mathrm{sq}$. m. Drained by Locust and Mulberry forks of Black Warrior $r$. Surface varions-in the S. rolling and uneven, and in the $\mathbf{N}$. somewhat hilly: soils of average fertility. Wheat, Indian corn, and cotton are the staple growths Farms 758; manuf. 9; dwell. 1,197, and pop.-wh. 6,941, fr. col. 0, sl. 426-total, 7,367. Capital: Blountsville.

Brount county, Tenn. Situate E. on the State line, and contains $\$ 10 \mathrm{sq} . \mathrm{m}$. Drained by tributaries of Tennessee $\mathbf{r}$. which lies on the W. border. Surface uneven-broken and hilly on the E., and the soils generally fertile. Iron is found herein. The products are the grains, with some tobacco and cotton. Farms 976; manuf. 3S; dwell. 1,992, and pop. -wh. 11,1S3, fr. col. 115, sl, 1,084-total, 12,382. Capital: Maysville.

Blotyt's Chenk, p. o., Beaufort co, $N$. Car.: $92 \mathrm{~m}$ E. S. E. Raleigh. 
Bloust's Frert, p. O., Columbia co., Flor, : $63 \mathrm{~m}$. E. Tallahassee.

BlounT's Sprate, p. o., Blount co., Ala. : 119 m. N.

Montgomery.

Blountstown, p. v., Calhoun co., Flor.: 66 m. S. W.

Talkahassee.

Blountsymle, p. T., and cap. Blount $00_{.,}$Ala.: on a cr. of Malberry fork of Black Warrior r., $117 \mathrm{~m}$. N. Montgomery.

Blotxtstille, p. v., Henry co., Ind.: $52 \mathrm{~m}$. E. by N. Indianapnlis.

Bloentspilue, p. v., and cap. Sullivan co, Tenn.

BuUg Balt, p. 0., Cecil co., Ma. : 54 m. N. Ev Annapolis,

Brue Bart, p. o., Butler co., Ohio: 93 m. S. W. Columbus.

Bude Barl, p. o., Lancaster co., Penn: 42 m. S. E. Harrisburg.

Blue Bert, p. o., Montgomery co., Penn.: 91 m. E. Harrisburg.

Blue Creek, p. o., Adams co., Ohío: on a er. so called of Ohio r., 83 m. S. S. W. Columbus.

Buov Crenk, p. o, Habersham co., Ga.: 119 m. N. E. Milledgeville.

Blue Crefk, p. o., Pike co., Ala. : $37 \mathrm{~m}$. \$. Montgomery.

Blot Crees, p. o., Franklin co., Ind.: 64 m. E. S. E. Indianapolis.

Blue Ere, p. 0., Benton co., Ala.: 96 m. N. N. E. Montgomery.

BluE Grass, p. o., Scott co., Ia. : 49 m. E. Iowa City.

Bute Grass, p. 0., Fulton eo., Ind.: 87 m. N. Indianapolis.

Buxe Hrul, t. and p. o, Hancock co, Me, : on a bay formed between the mainland and Mt. Desert Island, $29 \mathrm{~m}$. S. E. Augusta. From a hill near the r. a most splendid view of the surrounding scenery is presented. Pop. 1,989.

Bute Hru, p. o, Williamson co, Tex: $31 \mathrm{~m}$. N. Austin City

Butre Hotse, p. 0., Colleton dist, S. Car. : 76 m. S. by W. Columbia.

Blue Lick, p. o., Franklin co., $A l a$. : 163 m. N. W. Montgonaery.

BLUE LICK, p. o., Clark co., Ind.: 91 m. S. S. E. Indianapolis.

Blue Lick Sprerge, p. o., Nicholas co., $K y$.: on S. side of Licking r., $61 \mathrm{~m}$. E. Frankfort.

Buof Moond, t. and p. o., Dane co., Wisc.: 21 m. W. S.W. Madison. Pop, 315 .

Bute Modrtatr, p. 0., Northumberland co., Penn.

BuUe PluM, p. o., Washington co, Tenn.: 198 m. E. Nashville.

Butz's Porrt, p. 0., Erittenden co., Ark. : 129 m. E. N. E. Little Rock.

Blug PoNd, p. O., Cherokee co., Ala. : 139 m. N. E. Montgomery.

Bute PInGE, or South Mountain: the eastern ridge of the Alleghany Mountains, which branches off from the main range in North Carolina, and crosses the States of Virginia, Maryland, etc., and extends to the highlands of the Fudson r. The Peaks of Otter, in Virginia, the highest part of the ridge, have an elevation of nearly 4,000 feet; and there are other peaks of not much less an altitude.

BLUE RDge, p. 0., Botetourt co., Virg.: $116 \mathrm{~m}$. W. Richmond.

Bute Ringe, p. o, Yancey co, N. Car.: 193 m. W. Raleigh.

Brof Rmge, p. o., Gilmer co., Ga.: 151 m. N. W. Mdledgeville.

Blut PIDge, p. o., Shelby co, Ind.: $29 \mathrm{~m}$. S. E. Indianapolis.

Bute Prver, p. o., Iowa co., Wisc. : 53 m. W. Madisnn.

Buog Rock, t. and p. o., Muskingum co., Ohio: on SLuskingum r., $56 \mathrm{~m}$. E. Columbus. Pop. 1,476.
BluE Rock, p. o, Chester co., Penn.: 68 m. S. E. Harrisburg.

Blue Sprivg, p. o., Morgan co., Ala.: $147 \mathrm{~m}$. N. Montgomery.

Blue Spring, p. o., Smyth co., Virg.: 210 m. W. S. W. Eichmond.

Blue Spring Grove, p. o., Barren co., Ky.: $86 \mathrm{~m}$ S. S. W. Frankfort. The Nashville and Lexington R. R will probably pass near this place.

Bute Springs, p. o., Jackson co, Mo. : $116 \mathrm{~m}$. W. Jefferson City. The Pacific R. R. from St. Louis will probably intersect this point.

Blue Stone, p. 0., Tazewell co., Virg.: $232 \mathrm{~m}$. W. Richmond.

Blue Sulphur Sprivgs, p. o., Greenbrier co, Virg. $180 \mathrm{~m}$. W. Pichmond. These springs are much frequented. by invalids; they are situate in a mountain valley, and are surrounded by grand and picturesque scenery.

Blue Wing, p. o., Granville co., N. Car.: $71 \mathrm{~m}$. N. by W. Raleigh.

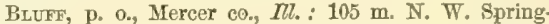
fleld.

BuufF, p. o., Sauk co,, Wisc.: 31 m. N. W. Madison.

BlufF Dale, p. o., Greene con, $7 \%$ : 87 m. W. S. W Springfield.

Buuff Dale, p. 0., Des Moines co., $I a .: 52$ m. S. by E. Iowa City.

Blurf PoINT, p. o., Yates co., N. Y.: 166 m. W Albany.

BLUfF Port, p. o., Sumpter co., Ala.: on the W. side of Tombigbee r., opposite the mouth of Black Warrior r., 92 m. W. Montgomery.

Bzukf Sprrat, p. o., Talladega co., Ala.: $74 \mathrm{~m} . \mathrm{N}$ Montgomery,

Blufe Sprivg, p. o., Talbot co., Ga.: 83 m. W. by S Milledgeville.

ButfF SpRING, p. o., Attala co., Miss.: on E. side of Big Black r., 69 m. N. N. E. Jackson.

BlufF SPRING, p. O., Johnson co., Mo. : $94 \mathrm{~m}$. W. Jefferson City.

Bluff Springs, p. 0., Gibson co., Tenn. : 137 m. W. by S. Nashville.

Blufktor, p. v., and cap. Wells co., Ind. : $82 \mathrm{~m}$. N. E. Indianapolis. The "Republican Bugle" and the "B. Banner" are published weekly.

ButFFTON, p. o., Beaufort dist, S. Car. : 116 m. \$. by W. Columbia.

Bluffor, p. v., Marquette co., Wisc. : 3 m. N. Green Lake, and $58 \mathrm{~m} . \mathrm{N}$. by E. Madison.

Butfeville, p. V., Carroll co, I I $l_{\circ}$ : on the E. side of Mississippi r., $223 \mathrm{~m}$. N. N. W. Springfield.

Buytife, p. o, Schuylkill co., Ponm.: 34 m. N. E. Harrisburg.

Blythevilue, p. v., Jasper co., Mo.: 159 m. S. W. Jefferson City.

Bonlsburg, p. v., Centre co., Penan : on Spring er., 69 m. N. W. Harrisburg:

Boardiar, p. v., Mahoning co., Okio: 131 m. N. E. Columbus.

BoARdtree, p. o., Cherokee co., Ga.: 100 m. N. W. Milledgeville.

Bodermuk, p. v., Giles co, Tenn.: 62 m. S. by W: Nashville.

Betia, p. v., Mercer co., Ohio: $97 \mathrm{~m}$. N. W. Columbus.

Betrf Pritie, p. o., Franklín par., La. $:$ on W. side of Cypress Lake, $108 \mathrm{~m}$. N W. Baton $\mathrm{K}$.

Bogaksville, p. v., unon dist, $S$. Car.: $_{0} 69 \mathrm{~m}, \mathrm{~N}$. by W. Columbia.

BogARD, p. o., Daviess co, Ind.: $89 \mathrm{~m}$. S. W. Indianapolis.

BngGr Depôt, p. o.. Chnetaw Yation, Tnri. Ter.

Bogrs Rux, p. 0., Stark co., Ind.: 100 m. N. N. W Indiannpolis. 
Botimg Spring, p. o., Fentress co, Tenn.: on N. side of Clear fork of New r., 61 m. E. Nashville.

Botlifg Springs, p. o., Benton co., Ala.: 110 m. N. by E.

Montgomery.

Bolling Sprengs, p. o., Cumberland co., Penn. : $22 \mathrm{~m}$.

W. Harrisburg.

Bomstow, p. v., Henderson co.s $N_{\text {. Car.: on a }}$ cr. of

French Broad r. so called, $228 \mathrm{~m}$. W. S. W. Raleigh.

Bors Blañ Island: in Lake Huron, S. E. Mackinaw. It is $10 \mathrm{~m}$. long and $3 \mathrm{~m}$. wide in its greatest breadth. A lighthouse has been erected on the E. point.

BOKE'S CREEK, p. O., Union co., Ohio: $32 \mathrm{~m}$. N. W. Columbus.

BoLAND's, p. o., Itawamba co., Miss. : on W. side of Little Tombigbee r., 169 m. N. E. Jackson.

Bolen's Mulis, p. o., Vinton con, Ohio: 58 m. S. E. Columbus.

Botigen, p. 0., Greene co., Ala.: $105 \mathrm{~m}$. W. by N. Montgomery.

Bolington, p. o., Loudon co., Virg.: $107 \mathrm{~m}$. N. Richmond.

Bolryar county, Miss. Situate W. on Mississippi r., and contains $720 \mathrm{sq.}$ m. Drained by Large and William's Bayoux, tributaries of Sunflower $r_{\text {., }}$ and has several lakes. Surface mostly level or undulating, and occasionally swampy; soils rich and productive. Indian corn and cotton are the principal staples. Farms 57; dwell. 95, and pop.-wh. 395, fr. col. 2, sl. 2,180-total, 2,577. Capital: Bolivar.

Bolivar, p. ., Jackson co., Ala.: on N. side of Big Raccoon er., $3 \mathrm{~m}$. distant, and $172 \mathrm{~m}$. N. Montgomery.

Boltrak, p. v., and cap. Poinsett co, $\Delta r \%$. : 108 m. N. E. Little Rock.

BOLIFAR, p. v., and cap. Boliver co., Miss.: on E. side of Mississippi r., $105 \mathrm{~m}$. N. N. W. Jackson.

Bolivar, p. v., and cap. Polk co., Mo.: on a tributary of Sac r. of the Osage, $89 \mathrm{~m}$. S. W. Jefferson City,

Bolrrar, t. and p. v., Alleghany co., $N_{.} Y_{.}$: on a tributary of Oswaye cr., $223 \mathrm{~m}$. W. by S. Albany. Pnp 712.

Bolrtar, p. v., Tuscarawas co., O7io: on W. side of Tuscarawas r. and on the Ohio Canal, $92 \mathrm{~m}$. N. E. Columbus.

Bolrvar, p. v., and cap. Hardeman co., Tenn.: on S. W. side of Big Hatchee r., 148 m. W. S. W. Nashrille.

Bolsten's Mruss, p. o., Cumberland co, $\mathbb{N e}$.: $54 \mathrm{~m}$. S. W. Augusta.

Bozton, t. and p. V., Tolland co., Conn.: on the line of the Providence, Hartford, and Fishkill R. R., 16 m. E.

Hartford, Pop. 607.

Bourox, p. v., Williamson co., Ill.: 218 m. S. by E. Springfield.

Bolton, t. and p. $\nabla .$, Worcester co., Mass.: betweén Concord and Nashua r., $29 \mathrm{~m}$. W. by N. Boston. P. 1,268,

Boltor, t. and p. v., Warren co., N. Y.: on Lake George, 57 m. N. Albany. Pop. 1,147.

Botsor, t. and p. V., Chittenden co., Verm.: on Onion r., in the valley of which the Termont Central R. R. runs, $17 \mathrm{~m} . \mathrm{X}$. W. Montpelier. The N. part of the tomn lies on the Green mts. Pop. 602.

BolTon's DEP6T, p. o., Hinds co., Miss.: on the line of Vicksburg, Jackson, and Brandon R. R., 27 m. from Vicksburg. and 19 W. Jackson.

Boltonvule, p. Y., Cobb co., Ga.: 108 m. N. W. Milledgeville.

Borr's Fori, p. 0., Lawrence co., Ky. : 114 m. E. Frankfort.

Bosriax, t. and p. o., Franklin co., $N$. $Y_{\text {.: }}$ on St. Regis, and Racket $r$. and several tributaries of Salmon $r$., $126 \mathrm{~m}$. N. N. W. Albany. Pop. 1,963.

Boy A Ts SpkIxiss, p. 0., White co., Tern.: $87 \mathrm{~m}$. E. by S, Nashrille.

Bonaparte, p. . , Du Page co., $I l l .: 288 \mathrm{~m}$. N. E. Springfield.

Bonaparte, p. T., Van Buren co., Ia.: on the E. side Des Moines r. $66 \mathrm{~m}$. S. Iuwa City.
Bor AQua, p. o., Hickman co., Tem.: 52 m. \&. W. Nashville.

BoND county, $7 u$. Situate S. centrally, and contains 360 sq. m. Drained by E. and W. forks of Shoal cr., Beaver $\mathrm{cr}_{.4}$ and other streams, affluents of the Kaskaskia. Surface level or undulating, chiefly prairie, intermixed with timber; soil exceedingly rich and productive. Farms 665 ; manuf 17; dwell. 1,076, and pop.-wh. 6,136, fr. col.8-total, 6,144. Cupital: Greenville. Pubtic Works: National Road.

Bond's VILLAGE, p. V., Hampden co, Mrass.: $82 \mathrm{~m}$. W. by S. Boston.

BoNDville, p. 0, Bennington co, Term.: 76 m. $\mathrm{S}$ Montpelier.

Bone Creek, p. o., Ritchie co., Virg.: $213 \mathrm{~m}$. W. N. W. Richmond.

BoNm YARD, p. o., Tishemingo co., Miss.: 206 m. N. E. Jackson.

Bormax, p. $v$, and cap. Fannin co., Tex. : on the W. side of Bois d'Are r., 267 m. N. by E. Austin City. A newspaper, the "B. Advertiser," is published weekly.

Boxнosnue, p. O., St. Louis co., Mro.: 90 m. E. Jefferson City.

Boxs, p. v., Washington Co., O7io: on E. side of Duck cr. of Ohi r., $90 \mathrm{~m}$. E. by S. Columbus,

BONNET CARRÉ (Square Bonnet, so ealled from a remarkable bend on the r.), p. v., and eap. St. John Baptist par., La. : on E. side Mississippi r., $37 \mathrm{~m}$. S. S. E. Baton Rouge.

Bonny Doos, p. o., Jefferson co., $G \dot{\alpha},: 5 S$ m. E. Milledgeville.

Bono, p. o., Lawrence co., Ind.: on the S. of the E. fork of White $\mathrm{r} ., 68 \mathrm{~m}$. S. Indianapolis. field.

Bonus PratrTe, p. o., Boone co, $I l l_{*}$ : on the E. side of Piskashaw cr., 269 m. N. by E. Springfield.

BOONE county, $n l$. Situate N. middle, and contains 432 sq.m. Drained by Rock r. and its tributaries. Surface level, with some wet prairies, and soils of exceeding richness; timber plentiful. Farms 597 ; manuf. 17 ; dwell. 1,352, and pop.-wh. 7,621, fr, col. 5--total, 7,626. Capital: Belvidere. Pubtic Works: Galena and Chicago Union R. R. and branch to Beloit.

BooNe county, Ind. Situate N. W. centrally, and contains $408 \mathrm{sq} . \mathrm{m}$. The prevailing soil is a black loam several feet deep, resting on a substratum of clay, and in some places of sand and gravel; it is very fertile. No part of the State is better timbered. The county is situated on the ridge or dividing swamps between White $r$. and the Wabash, and contains the sources of several fine streams, tributaries of these rivers. Farms 1,393; manuf. 28; dwell. 1,914, and pop.-wh, 11,611, fr. col. 20, total, 11,631. Capital: Lebanon. Pubtic Works: Indianapolis and Lafayette R. R.

BOoNe county, $I a$. Situate centrally, and contains 576 sq. m. Drained by Des Moines $r$. and tributaries. Surface level or undulating-prairie intermixed with woodland, and soils excellent. Dwell. 119, and pop. - Th. 735 , fr. col. $0-$ total 735. Capital: Booneville.

BooNe county, $K y$. Situate N. an Ohio r., and contains 312 sq. m. Drained by creeks flowing to the Ohio. Surface uneven, and soils not unproductive. Indian corm, wheat and tobacco are the chief products. Farms 982 ; manuf. 16 ; dwell. 1,615, and pop,-wh. 9,044, fr. col. 37, sl. 2,104-total 11.185. Capital: Burlington.

Boone county, Mo. Situate centrally on Missouri r., and contains $680 \mathrm{sq}$. m. Draíned by Rock, Femme, Cedar, and other creeks. Surface chiefly level prairie intermixed with woodland, and the soils fertile. The chief products, besides grain, are tobacco and hemp. Farms 1,376; manuf. 21 ; dwell. 1,924, and pop.-wh. 11,300, fr. col. 13, sl. 3,666-total 14,979. Capital: Columbia.

Booke county, Firg. Situate W., and contains $390 \mathrm{sq}$ m. Drained by the head waters of Little Coal cr., a tribu- 
tary of Great Kanawha r. Surface undulating, and soils fertile. Coal is abundant. Farms 361; manuf. 3 ; dwell. 495, and pop.-wh. 3,054 , ir. col. 0, sl. 183-total 3,237. Capitul: Boone C. H.

Boove, p. v., Ashe co., $N_{0}$ Car.: $172 \mathrm{~m}$. W. N. W. Raleigh.

Booxv's MrLLs, p. 0., Franklin co., Virg.: 136 m. W. by

S. Richmond.

Boone Fatley, p. O., Letcher co., Ky. : 169 m. E. by S.

Frankfurt.

Booneville, t. and p. v., Oneida co., N. Y.: on Black r., $93 \mathrm{~m}$. N. W. Albany. The Black River Canal passes through the town N. and S. centrally. Pop..3,306.

Boonevilie, p. $\nabla$., and cap. Boone co., Ia. : $98 \mathrm{~m}$. W. N. W Iowa City.

Boonevilue, p. r., and cap. Owsley co., Ky.: 75 m. E. by S. Frankfort.

Boonernle, p. v., and cap. Brazos co., Tex. : on Carters cr. of Navasota r., 137 m. E. by N. Austin City.

Boon Grovk, p. o., Porter co., Ind.: 128 m. N. W. Indianapolis.

Boovill, p. o, Johnson co., $N$. Car.: on a cr. of Neuse

r., $37 \mathrm{~m}$. S. E. Raleigh.

Boonsborough, p. V., Washington co., $M d_{*}: 73 \mathrm{~m}$. W.

N. W. Annapolis. The "Odd Fellow," a weekly newspaper, is published here.

Boonsborough, p. v., Washington co., Ark.: $147 \mathrm{~m}$. N. W. Little Rock.

Boon's CreeK, p. o., Washington co., Tenn.: on a cr. so called of Watauga r., $247 \mathrm{~m}$. E. Nashville.

Boor's HrLL, p. o, Lincoln co., Tenn.: 73 m. S. Nashrille.

Boox's Lick, p. o, Howard co., Mo.: $52 \mathrm{~m}$. N. W. Jefferson City.

Boonton, p. v., Morris co., N. Jer.: $41 \mathrm{~m}$. N. Trenton.

Booxtox's TAx YARD, p. o, Madison co., Virg.: $76 \mathrm{~m}$. N. W. Richmond.

Boonvilez, p. $\nabla .$, and cap. Scott co., Ark.: on Petite Jean cr. of Arkansas r., 147 m. W. N. W. Little Rock.

BooNvILLE. p. v., and cap. Warrick co., Ind.: $128 \mathrm{~m}$. S. S. W. Indianapolis.

Boonville, p. V., and cap. Cooper co., Mo. : on S. side of Missouri r., $52 \mathrm{~m} . \mathrm{N}$. W. Jefferson City. It is a place of considerable business, and here are published weekly the "B. Weekly Democrat," and the "B. Observer" (dem,)-the Iatter is also published semi-weekly. Numerous steamers make this a regular landing place.

Bоотнват, t. and p. $\mathbf{v}$., Lincoln co., Me: between Sheepscot and Damariseotta r., with the ocean on the S. $37 \mathrm{~m}$. S. by E. Augusta. It has a good harbor, and the inhabitants are largely engaged in the fisheries. Pop. $82,504$.

Boothevilte, p. V., Marion co, Firg.: 187 m. N. W. Richmond.

Bordeaux, p. v., Abbeville dist., S. Car.: $78 \mathrm{~m}$. W. Columbia.

Bordextown, p. v., Burlington co., $\lambda_{\text {. Jer.: on E. side }}$ of Delaware r., $8 \mathrm{~m} . \mathrm{S}$. by E. Trenton. The site is elevated some 60 feet above the river, and is remarkable for it beautiful scenery. Here Joseph Bonaparte resided while in America. The railroads connecting New York and Philadelphia pass through the v., and the Delaware and Raritan Canal has its W. outlet at this place.

Bordeter, p. 0., Union co., $K y_{.}: 161 \mathrm{~m}$. W. by s. Frankfort

Borland, p. v., Newton co., Ark. : on Buffalo fork of White r., $104 \mathrm{~m}$. N. N. W. Little Rock.

Borodro, p. o. (formerly Morzautille), p. v., Avoyelles par., La. : 82 m. N. W. Baton Rouge.

Borodno, p. o., Wayne co., Mich.: 82 m. E. 8. E. Lansing.

Borodrvo, p. v., Onondagea co., N. Y.: on Skaneateles lake, $127 \mathrm{~m}$. W. by N. Albany.

Bosc $\Delta$ WEN, to and p. V., Merrimac co., N. Hamp.: on W. side of Merrimac r. and Northern $R, R_{*}, 10 \mathrm{~m}$. N. Coneord. Black Water r. passes through the t., and affords fine mill sites. Pnj. 2,063.

Bosserman's Mruls, p. V., Perry co., Penn.: $20 \mathrm{~m}$. W. Harrisburg.

Bossier county, La. Situate N. W. between Red r. and Bayou Dorcheat, and contains 1,016 sq. m. Drained by Bayou and Lake Bodeau, and streams tributary to the border rivers. Surface low and marshy; soils rich, producing corn, cotton, and sugar. Farms 333; dwell. 478, and pon. —wh. 2,507, fr. col. 0, sl. 4,455-total 6,962. Capital: Belleview. The "great raft" of Red $r$. hies within this county.

Bosster Point, p. o., Bossier par., La.: $177 \mathrm{~m}$. N. W. Baton Rouge.

Bostick's Mrlls, p. o., Richmond co., N. Car.: $123 \mathrm{~m}$. S. W. by W. Raleigh.

Boston, p. v., Wayne co., Ind. : 65 m. E. Indianapolis.

Boston (formerly KaUTATINCHUNK), p. Y., Northampton co., Penn.: 87 m. E. by N. Harrisburg.

Boston, p. v., Yolo co., Calif.: on W. side of Sacra mento r., at the mouth of American r., 60 m. N. E. Vallejo. Boston, p. o., Nelson co., $k y .: 47$ m. S. W. Frankfort.

Boston, t. and p. V., Ionia co., Mich.: on S. side of Grand r., 39 m. W. by N. Lansing. Pop. 424

Bostox, p. o., Erie co., N. Y.: 247 m. W. Albany.

Boston, t. and p. v., Summit co., Ohio: on Cuyahoga r. of Lake Erie, and on the line of the Ohio Canal, $122 \mathrm{~m}$. N. N. E. Columbus. The v. is a busy place and has oonsiderable trade. Pop. 1,1S0.

Bostor, p. city, sea-port, and cap. Suffolk co., and capital of the State of Massachusetts : at the head of Massachusetts Bay, near the confluence of Charles and Mystie rivers. These streams are navigable only for a few miles, but uniting with Neponset and Weymouth rivers, form one of the noblest harbors of the world-land-locked, accessible to ships of the line, easily defended, and rarely obstructed by ice. It extends $14 \mathrm{~m}$. from Point Alderton to Medford; and from Chelsea to Hingham is at least $\mathrm{s} \mathrm{m}$. Wide, corering 75 sq. m., and would hold atl the shipping of the Union. The entrance for large vessels is very narrow, barely suffi. cient for two to sail abreast. It is defended by three fortresses, two of which, on George's and Castle islands, are on the largest scale, and constructed with all the improvements of modern science. The third, or Citadel, on Governor's island, is not yet completed. These will effectually command the entrance, and, when finished. make it impregnable. The harbor is well adapted to commerce. The peninsula and island of Boston is literally fringed with wharves and docks, while around the harbor and its affluents are clustered many cities and villages, into which Boston overflows, all of which have piers and landingplaces, viz. : Hingham, Hull, Quincy, Milton, Dorchester, Roxbury, Brookline, Brighton, Newton, Watertown, Cannbridge, Charlestown, Chelsea, Malden, Medford, and Som. erville. Lat. $42021^{\prime} 23^{\prime \prime} \mathrm{N}$., and long. $71001^{\prime} 09^{\prime \prime} \mathrm{W},-432$ m. N. E. Washington City.

The early settlers chose for their residence, in 1630, a peninsula, conneeted with the main by a narrow isthmus, occasionally overflowed, and divided at high tide into two islands. The entire tract contained 600 acres. It was called Shawmut or Trimountain, and derived its name from its springs and three.lofty hills. The spot was undoubtedly selected for pure water, facilities for eommerce, and security from wolves and Indians. Boston soon became an important sea-port, and at an early period became distinguished for her enterprise and commerce, and was peculiarly noted for her ship-building and fisheries. In $1 \vec{i}+1$ the pop. Was 17,000 . For more than half a century inom this period the growth of the city was checked by wars and the restrictive policy of England, and hence in 1790 the city contained only 18,088 inhabitants. Before the Revolution she was the first commercial eity on the coast; her reputation was identified with the country, and the colonists were generally 
known as Bostonians among the French and Canadians. But during that eventful struggle her citizens were compelled to abandon their firesides, and their commerce was literally ruined. Her sacrifice for the common cause was severe, and her reeovery slow. New York and Philadelphia consequently outstripped her. But since 1790 the eity has advanced rapidly. She embarked largely in the trade to India and China; in voyages to the North-west Coast, and in the fisheries, carrying trade, ete. ; and opened an extensive business with Russia, the Mediterranean, South America, Liverpool, and the British Colonies. When commerce was paralyzed by the embargo and war of 1812 , she commenced manufactures, which have since expanded into every variety of form. More recently her eitizens have taken a deep interest in railroads, and opened to the city an interior to which nature gave her no access.

A peninsula, less than one mile square, was soon found insufficient for Boston, and the State annexed to her Dorchester Point, a peninsula of 600 acres. To this, now ealled South Boston, she is united by four bridges. At a later period ferries were established to Noddles Island ( 660 acres), and this now forms a ward of the eity. Some hundred acres have also been reclaimed from the sea; but these narrow limits, about $3 \mathrm{sq} . \mathrm{m}$. in extent, proved inadequate, and have long been exceeded, and the population outside the chartered limits of Boston already equals the population within. As a metropolitan district, Boston, indeed, may be said to extend a circuit of nine miles round the Exchange, within which limits the population in 1850 was 269,874 .

The population of Boston proper, at successive decennial periods, has been as follows: in 1790 , it was 18,088 ; in 1800 , 24,987 ; in $1810,33,250$; in $1820,43,298$; in $1830,61,391$; in $1840,93,383$; and in $1850,138,788$.

As Boston grew in population and manufactures, the natural spring, which gave it the Indian name of Shawmut, gradually failed; and the water deteriorated, and the citizens were obliged to deepen the ancient wells from year to vear. It was at length necessary to resort to a foreign supply. In 1795 wooden pipes were laid by a company from Jamaica Pond, and as the demand increased, $10 \mathrm{in}$. fron pipes were substituted, This source having proved insufficient, a new aqueduct was constructed from Cochituat Lake, $20 \mathrm{~m}$. from the Exchange, and was opened in 1819. The menn elevation of the lake is 120 feet above the marsh level. The water is carried $14 \mathrm{~m}$. by a brick conduit of an elliptical form, 6 feet 4 in. by 5 feet, with a regular descent of 31-6 inches per mile, to a large reservoir in Brookline. Here a pond of 22 acres, and holding $100,000,000$ gallons, has been formed by closing the outlet of a valley. The reservoir is 123 feet above the sea. The water is carried over Charles r. by two parallel pipes $30 \mathrm{in}$. diameter. From Brookline, large iron pipes, carry the water to a granite reservoir on the summit of Beacon Hill, holding 2,500,000 gallons, and to another on Dorehester Heights, holding $6,000,000$ gallons. These are 120 feet above the sea, and the water is hence conducted through $70 \mathrm{~m}$. of pipe through the streets, and has generally been introduced into dwellings and stores. The head is suffieient to throw a 3 in. jet 92 feet high, from the fountain on the Common. The aqueduct is competent to supply $14,000,000$ gallons daily. East Boston is also supplied from this source, pipes being conducted over Charles and Mrstic rivers.

The city proper now is, and the suburbs soon will be, lighted with gas.

The principal public buillings in Boston and its vieinity, are Quincy Market, a granite structure, 500 by 35 feet; the State House, a large and commodious building; Faneuil Hall, an ancient brick edifice; the Massachusetts General Hospital, a large stone structure, at West Boston; the old State House; the Massachusetts Eye and Ear Infirmary; the Institute for the Blind at South Boston; the Orphan Asylum; the Farm Sehool; the City Hall, and Suffoll Court House, large granite buildings; the Registry of Deeds"
Offices; the Merchants' Exchange, of granite, also; the Atheneum, of free-stone; the Custom Ifouse; a Club Hisuse, of free-stone; 23 large Schocl-houses, costing $\$ 703,000 ; 41$ Primary School-houses; 3 Theatres; a Museum : and 2 large buildings of granite, used for coneerts und lectures. Boston has also erected an extensive Jail, of Quincy granite, and a spaeious Alms House, at Deer Island. At Tainsford's Island she has also the Quarantine Hospital, and the buildings hitherto used for jails and alms houses at West and South Boston. The eitizens of Boston have rarely been wanting in the cause of benevolence, and many of their institutions are richly endowed. Previous to 1845 , a single institution, the General Hospital and M.Lean Asylum, had received $\$ 640,942$; and the entire amount of donations to such public objects was ascertained to have been, prior to $1816, \$+\$, 942,659$.

Yery few of the ancient burial grounds are now used for interments; several have been planted, and contributo much to the ornament of the city. In 1881, Nount Auburn, in Cambridge, a spot romarkable for its natural benuties, was selected as a rural cemetery. It contains 118 acres, and during the last 18 years, 1,756 lots have been sold, realizing $\$ 175,000$. Roads and paths have been opened, a granite gateway and chapel built, and iron railing set round it; many tasteful monuments of marble have been erected, and it has become a place of frequent resort for the living as for the dead. At Forest Hill, Roxbury, is another beautiful cemetery, and others at Brighton and Wood Lawn. The cemetery of Mount Auburn is the first instance in America of a large tact having been chosen for its natural beauties, and improved by landseape gardening, to prepare it for the reception of the dead.

Boston is the commercial emporium of New England, and next to New York among the commereial cities of the Union. In 1850, the shipping owned in the district amounted to 320,687 tons. The foreign arrivals amounted to 2,877 vessels, of an aggregate burden of 478,859 tons; and the foreign clearances, 2,839 vessels, of 437,760 tons. The shipping built in the year $1849-50$, was 23,450 tons. The value of imports in 1849 was $\$ 24,117,175$; and of exports, $\$ 8,843,974$. Boston enjoys, also, a large local and coast-wise trade. Within the borders of Massachusetts are two eities with orer 30,000 inhabitants, ten with 10,000 to 20,000 , ten towns with 6,000 to 10,000 , twenty with 4,000 to $6 ; 000$. Between these and Boston an active commerce exists; and by her iron arms she reaches through this populous interior to the north and west, to Canada and the Mississippi. The coastwise importations in 1849 consisted in part of 269,818 bales of cotton, 262,632 tons anthracite, 987,988 barrels of flour, $3,002,593$ bushels of corn, 621,513 bushels of oats, rye, and shorts, 38,199 barrels turpentine, 663,530 sides of leather, 156,556 barrels of pork, 200,560 pigs of lead, etc. Large importations are also made, particularly from New Orleans, of beef, hemp, sugar, molasses, tobacco, and other articles. Vessels of all sizes, from 50 to 1,000 tons, are engaged in the coasting trade. The arrivals in $15 \pm 9$ were 6,100 vessels, which number does not include sloops and schooners, Iaden with wood, stone, and sundries, some thousands annually, that do not report at the custom house. By railroad the tonnage transported amounted to $1,167,129$ tons.

The trade of Boston with the West and South is immense; her manufactưres and imports are sent by railway and packets to the farthest limits of the country. Lines of packets run to all the seaboard cities, freighted with the cottons, boots, shoes, and other domestic goods, the produce of the State's industry. With California, also, Boston bas had large dealings: at least one fifth of the shipping that sails from Atlantic ports for "El Dorado," hails from Boston.

In 1650 , there were 29 banks in the citr, and the banking capital amounted to $\$ 21,460,000$. The amount deposited in Savings' Banks, was $\$ 3,977,799$ orned by 29,799 depositors. The stock capital of Boston insurance companies, was 
$\$ 5,4 \$ 3,000$. There were also in the city numerous mutual, and streral foreign insmance companies.

The assessed value of property in Buston is $\$ 179,525,000$, and the city detot to abuat $\$ 7,100,000$, ehiefly owing on account of the water-worlis. This debt is small compared with the wealth and resources of the city. The property of the city consists of the "Common," a beautiful park of 48 acres, encircled by an iron fence; the Public Garden, containing 14 acres, and several public squares and areas, embelished by fountains. These are all devoted to the health and recreation of the citizens. She owns also raluable property that may be sold; the whole is valued at $\$ 5,071,000$, and at the present time yields a revenue of $\$ 300,000$ annually. The expenses of the eity aro chiefly for her schools, street improvements, watch, and the support of correctional and humane institutions.

Some or the artificial structures which connect Boston with the main deserve notice. The Western Avenue, 7,000 feet long, leads from the old peninsula to Brookline, Roxbury, and Brighton; it is a solid structure of granite, filled in with earth, and cost $\$ 700,000$. Besides forming a wide carriage road, it creates a large water-power, and has redeemed many aeres from the harbor. West Boston Bridge and Causeway, 6,190 feet long, connects Boston with Cambridge; Canal Bridge is 2,796 feet long; Warren Bridge, 1,390 feet; Long Wharf, 1,800 feet long and 200 feet wide; Central Wharf, 1,379 feet long and 150 feet wide; India Wharf, 950 feet long. Along these wharves are continuous blocks of warehouses, 4 or 5 stories high, ant from 50 to 50 feet deep. Granite, Connecticut, and Lexis's wharves are of like size, and have ranges of large stone warehouses.

The sehools of Boston are frequently referred to as models of perfection. Their number and excellence, with her liberal patronage of education, have given the city the title of the Modern Athens, and their merit and importance cannot be overrated. In 1850, her primary schools had 11,376 scholars, her grammar schools 9,154 , and other schools 471 scholars. Boston has also a Latin and High School, in which the higher branches are taught with signal ability. All these schools are open free of charge to all. Without the chartered limits of the city are Harvard University, with its Law and Theological Sehools, a Baptist College, and many excellent schools and academies.

There are several public libraries in the city. The Atheneum Library, the Boston and Mereantile libraries, the Law Library, the State Library, and several libraries of Harvard University. These together contain upward of 150,000 volumes.

There are 80 periodicals and newspapers published in Boston, several of which are worked by steam presses, and have large circulations. These refer to almost every department of literature, religion, science, agriculture, banks, railroads, belles-lettres, statistics, history, medicine, law, education, etc.

The religions and charitable institutions of the city are also numerous. It has nearly 200 churches and places of worship. There is also a General Hospital, two Insane Hospitals, an Asylum for the Blind, an Eye and Ear Infirmary, a Lying-in-IIosnital, an Asylum for Orphan Girls, and a Farm School for Boys. Most of these are liberally endowed.

The United States have expended large sums in and around Boston on their fortresses and arsenal, extensive navy yard, dry dock, and rope walks, and stores of cannon, arms, and materiel, a Customs House, and hospitals for sick and infirm seamen. All these are situated in Boston Harbor, and are valued at $\$ 8,000,000$. The navy yard is second only to that of Norfolk.

Should Boston and her suburbs inerease for 25 jears at its present rate, its population will exceed 1,500,000. If we would seek for a solution of the growth of Boston in commerce, wealth, and population, we may have it not only in ita central position and admirable harbor, but in the enter- prise, intelligence, and frugality of her people. Her enterprise descends lineally from those bold ancestors who planted an empire in the wilderness. Their spirit sul their love of letters are inherited. These have guided its enterprise. But it is one thing to acquire and another to retain. The frugality of the people is the great sceret of accumulation. and hence Boston has risen to its present glorious positiori, which is every day becoming more and more enviable ana unapproachable.

Boston, p. v., Andrew co., Mo.: 163 m. N. W. Jeffersor City.

Boston, p. v., Williamson co., Tenn.: 23 m. S. Nashville.

Boston Conner, p. O., Berkshire co., Mass.: $126 \mathrm{~m}$. W. Boston.

Boston, p. v., and cap. Bowie cong Tex. : 297 m. N. E. Austin City.

Boston, p. v., Culpepper co., Virg.: 7.6 m. N. N. W. Richmond.

Boston, p. v., Thomas co., Ga.: $157 \mathrm{~m}$. S. Milledgeville,

Bost's Mrlis, p. o., Cabarras co., N. Car.: 103 m. W. by S. Paleigh.

Botanic Him, p. o., Nash co., N. Car.: 39 m. E. N. E. Raleigh,

Botaniok Garden, p. o., Perry co., Tenn.: 73 m. S. W. Nashville.

Botetourt county, Virg. Situate S. middle, W. of the Blue Ridge, and contains 950 sq. m. Drained by James r. and tributaries. Surface hilly- with extensive ralleys, and soil good, producing wheat, corn, and tobacco. Farms 712; manuf. 38; dwell. 1, 803 , and pop.-wh. 10,749, fr. col. 423, sl. 8,786-total 14,908, Capital: Fincastle.

Botetourt Springs, p. o., Roanoke co., Firg.: $137 \mathrm{~m}$. W. by S. Richmond.

Botheli.e, p. v., Fond du Lac co., Wise. : 68 m. N. by E. Madison.

Bouckville, p. o., Madison co, $N . Y_{.}$: on the line of the Chenango Canal, $90 \mathrm{~m}$. W. Albany.

Bound Broor, p. v., Somersei co., N. Jer.: 24 m. N. by E. Trenton.

Bountr Laxt, p. 0., Piekins dist., S. Car. : 113 m. N. W. Columbia.

Bodriox county, $\bar{K} y$. Situate N. E., centrally, and contains 230 sq. m. Drained by numerous ereeks, tributaries of S. fork of Licking $\mathrm{r}$. Surface rolling, rising toward the sea; and the soils highly productive. Wheat, rye, corn, and oats are the principal products. Farms 734 ; manuf. 34; dwell. 1,348, and pop.-wh. 7,15s, fr. col. 242, sl. 7,026total 14,426. Capital: Paris. Pubtio Works: Lexington and Maysville R. R.

BourBon, p. v., Marshall co., Ind.: 102 m. N. by W. Indianapolis.

Botrbonton, p. v., Boone co., Mo.: 38 m. N. W. Jefferson City".

Bourneville, p. v., Ross co., Ohio: on the N. W. side of Paint er., $49 \mathrm{~m}$. S. Columbus.

Bovins, p. v., Warren co., Mifse, : on the line of the Vicksburg, Jackson, and Brandon R. R., $36 \mathrm{~m}$. W. Jackson. Bovivs, t. and p. v., Delaware co., $N . Y .: 86 \mathrm{~m}$.W.S.W Albany.

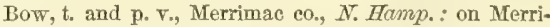
mac r., $7 \mathrm{~m}$. S. Concord. Bow Falls, of the Merrimac, are here overeome by a short canal.

Bow D $\Delta$ rk, p. o., Greene co., MIo. : 107 m. S. W. Jeferson City.

Bow Doxs, t, and p. v., Lincoln co., Me.: $23 \mathrm{~m}$. S. by W Augusta. Pop.1,85\%.

Bow doin Centre, p. 0., Lineoln co., Me. : 25 m. S. by W Augusta.

BowdorvuAm, t. and p. v., Lincoln co., Me.: on Kennebec r., $23 \mathrm{~m}$. S. Augusta. The lumber trade and shipbuilding are the principal occupations. Pop. 2,381.

Bowpor, p. v., Carroll co., Ga.: $113 \mathrm{~m}$. W. Milledgevilie 
Bowdon, p. v., Talladega co., Ala.: $62 \mathrm{~m}$. N. Montgomery.

BowEN's PratrIE, p. o., Jones co., Ia. : $41 \mathrm{~m}$. N. Iowa City.

Bowentwie, p. v., Carroll co., Ga. : 117 m. W. Milledgeville.

Bower, p. o., Clearfield co., Penn.: 108 m. W. N. W. Harrisburg.

Bower Bank, t. and p. o., Piscataquis co., Me.: on Sebec

Lake, 65 m. N. by E. Augusta. Pop. 17 .

Bower Hilu, p. O., Washington co., Penn.: $187 \mathrm{~m}$. W.

Harrisburg.

BowEr's, p. o., Southampton co., Virg.: $71 \mathrm{~m}$. S. by E. Richmond.

Bower's Mrlis, p. o., Lawrence co., Mo.: on Spring r., a branch of Neosho $r_{v}, 146 \mathrm{~m}$. S. W. Jefferson City.

Bowerstille, p. ve, Franklin co., Ga. : on a er, of the Middle fork of Broad r., $85 \mathrm{~m}$. N. Milledgeville.

Bowerstiule, p. v., Greene co., Ohio: 52 m. W. S. W. Columbus.

Bowre county, Tex. Situate in the N. E. corner, between Red r. and Sulphur Fork, and contains about $960 \mathrm{sq.m}$. Drained by numerous creeks running $\mathrm{N}$. and $\mathrm{S}$. from a central watershed. Surface elevated, undulating, and well timbered, with small and beautiful prairies between the streams; soils deep and fertile, producing excellent cotton and sugar. Farms 158; manuf. 5; dwell. 250, and pop.wh. 1,271, fr. col, 0, sl. 1,641-total 2,912. Capital: Bostor

Bow lesville, p. พ., Fluvanna co.. Firg. : $49 \mathrm{~m}$. W. by N. Richmond.

Bowline Green, p. v., Oglethorpe co., $G a .:$ on Athens Branch of Georgia R. R., $46 \mathrm{~m}$. N. Milledgeville.

Bowlivg Green, p. v., and cap. Clay co., Ind.: on Eel r. of the W. fork of White r., $48 \mathrm{~m}$. W. S. W. Indianapolis.

Bowling Green, p. v., Fayette co., Ill.: on the W. side of Beck's er. of Kaskaskia r., 56 m. S. E. Springfield.

Bowling Green, p. v., and cap. Warren co., Ky.: on the W. side of Big Barren r. of Green r., 122 m. S. W. Frankfort, and by $\mathrm{r}$. course to the Ohio, $180 \mathrm{~m}$. The $\mathrm{v}$. is accessible to steamboats of 200 tons, and has considerable trade, chiefly in tobaceo. The Nashville and Louisville R. R. wil pass through Bowling Green.

Bowling Grees, p. v., and cap. Pike co., Mo.: $74 \mathrm{~m}$. N. E. Jefferson City.

Bowling Greter, p. 0., Wood c0., Ohio: 52 m. N. W. Columbus.

Bowiling Green, p. v., and cap. Caroline co, Firg.: a ferv miles E. of Mlattapony r., $37 \mathrm{~m}$. N. Riehmond.

Bowlingsville, p. Y., Union dist., S. Cas*. : $67 \mathrm{~m}$. N. Columbia.

Bowaran's Creets, p. o., Wyoming co, Penn.: $98 \mathrm{~m}$. N. N. E. Harrisburg.

Bowrax's Mruss, p. o, Rockingham co., Firg. $106 \mathrm{~m}$.

N. W. Richmond.

Bownanstille, p. v., Lancaster co., Penn.

Bowse, t. and p. o., Kent co., AFich.: $48 \mathrm{~m}$. W. by N. Lansing. Pop. $2-20$.

Bowshersviute, p. v., Wyandott $\mathrm{co}_{0,}$ Ohio: $66 \mathrm{~m}$. N. by W. Columbus.

Boxsorougr, t. and p. T., Middlesex co, Mass, : between Concord and Nashua r., $25 \mathrm{~m}$. N. W. by N. Boston. P. 896 BoXFord, t. and p.v., Essex co., Mass. : $23 \mathrm{~m}$. N. Boston. Boxuex, p. v., Hamilton co., Inds: $31 \mathrm{~m}$. N. Indianapolis.

Boxvmue, p. v., Montgomery co., Ga. : on the W. side of Oconee r., near its junction with the Ocmulgee, $s 4 \mathrm{~m} . \mathrm{s}$. Milledgeville.

Bord's Creek, p. 0., Sevier co., Tenn. : on a cr. of Henry r. of the Tennessee, $183 \mathrm{~m}$. E. Nashville.

Bordstox's Mrurs, p. o., Kosciusko co., Ind.: 98 m. N. Indianapolis.

Bornstrule, p. v., Weakiy co., Tenn. : at the head wan ters of Obion $r_{n}, 108 \mathrm{~m}$. W. Nashville.
Bочртох, p. v., and cap. Mecklenburgh co., Virg.: 74 m. S. S. W. Richmond. Randolph Macon College, founded 1832 , is located about a mile to the west.

BoxeR's SETtlemeNt, p. o., Buchanan co., MFo : on E. fork of Platte r., $149 \mathrm{~m}$. W. N. W. Jefferson City

Boyerstown, p. v., Berks co, Penn.: 63 m. E. by N. Farrisburg.

Boxkiv's Depôt, p. o., Kershaw dist., S. Car. : on Camden Branch of the South Carolina R. R., 26 m. E. by $\mathbb{N}$. Columbia.

BOYLE county, $K y$. Situate centrally, and contains 226 sq. m. Drained by creeks of Salt and Kentucky rivers. Surface rolling, and solls very fertile, producing the grains and tobaceo. Farms 443; manuf. 53; dwell. 927, and pop. -wh. 5,389, fr. col. 313, sl. 3,421-total 9,126. Capital. Danville. Public Works: Nashville and Lexington R. R.

BoyLstox, t. and p. v., Worcester co., Mass.: on Nashua r., $39 \mathrm{~m}$. W. Boston. Pop. 918.

BOyLston Centre, p. O, Worcester c0., MFcoss.: $37 \mathrm{~m}$. W. Boston.

Bozratr, t. and p. o., New London co., Conn.: $32 \mathrm{~m}$. E. by S. Hartford. Pop. 867.

Bozrahplule, p. v., New London co., Conn。 : 30 m. E. by S. IIartford.

Braceville, t, and p. v., Trumbull co., Ohio : on Mahoning r., $133 \mathrm{~m}$. N. E. Columbus. Pop. 956

Bracken county, $K y$. Situate N. E. on the Obio $r_{\text {., and }}$ contains $21 \mathrm{~s}$ sq. $\mathrm{m}$. Drained by $\mathrm{N}$. fork of Licking and several creeks of the Obio. Surface hilly and broken; soils moderately productive. Farms 728 ; manuf. 21 ; dwell, 1,497, and pop.-wh. 7,948, fr. col. 115, sl. 840-total 8,903. Capital: Brookville.

Brackner, p. v., Susquehannah co, Penn. : 122 m. N. E. Harrisburg.

Braderville, p. v., Westmoreland co., Penn. : 162 m. W, Ifarrisburg.

Bradford county, Penn. Situate N. E. on State line, and contains 1,180 sq. $\mathrm{m}$. Drained by the Chemung and Susquehanna rivers and their tributaries, the Towauda, Wyalusing, and sugar. Surfice generally mountaincus, with exceptions along the rivers, and the soils highly prow ductive. Bituminons coal is found on the Towanda. Farms, 5,096; manuf. 562; dwell. 7,491, and pop,-wh. 42,684, fr, col. 197-total 42,331. Capital: Towanda, Pubtic Works: North Branch of Pennsylvania Canals; Williamsport and Elmira R. R.

BRADFORD, p. v., Harrison co., Ind.: $104 \mathrm{~m}$. S. Indianapolis.

BRAdFord, t. and p. V., Steuben co., N. Y.: 165 m. W. by S. Albany. Pop. 2,110

Bradford, to and p. y., Penobseot co., $\boldsymbol{Y e}_{0}: 68 \mathrm{~m} . \mathbf{N}$. E. Augusta.

Bradford, t. and p. v., Essex co., Mrass.: on Merrimac r., $28 \mathrm{~m}$. $\mathrm{Y}$. Boston. It is connected with IIaverhill by a brikge. ovet which the Boston and Maine $\mathrm{R}$. R. is carried, $32 \mathrm{~m}$, from Boston. The $\mathrm{t}$ is noted for its boot and shoe factories. Pop. 1,328.

BradFord, t. and p. F, Merrimac co, N. Homp.: on the Concord and Claremont R. R., $25 \mathrm{~m}$. from Concord. P 1,341 Branford, p. v., Orange co., Verm.: ou Connecticut r., $29 \mathrm{~m}$. E. by S. Montpelier. Two literary periodieals are published here, the "Vermont Family Gazette," weekly, and the "Green Mountain Gem," monthly. The Connecticut and Passumsic Rivers R. R. passes through the $t$, on the edge of the river.

BradFord, p. v., Coosa cc., Ala.: 28 m. N. Montgomery.

Bradford Cextre, p. o., Orange co., Term.: $27 \mathrm{~m}$. E. by S. Montpelier.

Bradford Ingtitete, p. o., Sumter dist., S. Car.: $42 \mathrm{~m}$. E. Columbia.

Bradford . Springs, p. o., Sumter dist., S. Car.: 42 m. E. Columbia. 
BRADFordvilie, p. v., Marion co., $K_{y}$ : on a cr, of Rolling fork of salt $x_{\text {. }} 47 \mathrm{~m}$. S. TI. Frank fort.

BradLEX county, Ark. Situate S. centrally, and contains \$80 sq. m. Drained by Wachita and Spline rivers and their tributaries. Surface rolling-chiefly prairie, and soils fertile. Farms 303; manuf. 1; dwell. 440, and pop.-wh. 2,601 ff. col. 2, sl. 1,226-total 3,829. Copital: Warren.

Bradery county, Tenn. Situate S. E. on State line, and contains $526 \mathrm{sq} . \mathrm{m}$. Drained by creeks of Hiwassee r. Surface mountainous, rugged, and except on the streams, of inferior fertility. Indian corn is the chief product, and some cotton and tobacco is also grown. Farms 856; manuf, 44; diwell. 1.955, and pop.-wh. 11,47s, fr. col. 37, sl. 741-total 12,259. Capital: Cleveland. Public Works: East Tennessee R. R., etc.

Bradley, p. o., Jackson co., Ill.: $128 \mathrm{~m}$. S. Springfleld.

BrADLEY, p. On, Allegan co, Mich.: $76 \mathrm{~m}$. W. by S Lansing.

Bradleyvule, p. ₹., Sumter dist., S. Car. : $57 \mathrm{~m}$. E. by S. Columbra.

BrıDshaw; p. o., Giles co., Tenn.: 63 m. S. by W. Nashville.

Bradr, to and p. o, Kalamazoo co., Mich.: on the head waters of Portage r., $69 \mathrm{~m}$. S. W. Lanoing, Pop. 57."

BPuDY's BEND, p. o., Armstrong co., Pern.: $146 \mathrm{~m}$. W. by N. Harrisburg.

Bradyvillz, p. v., Adams co., Ohio: 82 m. S. by W. Columbus.

Bradrvmie, p. T., Cannon co., Tenn. : 46 m. S. E. Nashwille.

BraGG's, p. o., Lowndes' co., Ala.: 31 m. S. W. Mon:gomery.

Braggvilte, p. V., Middlesex co, MFass.: 26 m. N. W. Boston.

BeATNARD's Brmger, p. O., Rensselaer co., $N . Y$.

BratNTrEe, t. and p. v., Norfolk e., MFass.: on the line of the Old Colony R. P., 10 m. S. Boston. 'The South Shore R. R. and the Fall River $R, R$. also diverge from this $t$. It has considerable manufactures, and some shipping engaged in the coasting trade and the fisheries. Braintree was the birth-place of the elder Adams. Pop. 2,969.

BratnTree, t, and p. v., Orange co., Verm.: at the head of White r., and on the line of the Vermont Central $R$. R. $16 \mathrm{~m}$. S. Montpelier. Pop. 1,228.

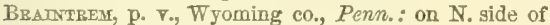
Susquehanna r., $102 \mathrm{~m}$. N. by E. Harrisburg.

Brakelervilue, p. v., Monroe co., Penn. : 105 m. E. N.E. Harrisburg.

BrAKE's Ruy, p. O., Hardy co., Virg.: $122 \mathrm{~m}$. N. W. Pichmond.

Bramay's Comiers, p. O., Schenectady co., N. Y.: 18 m. W. Albany.

BraNCE county, Mich. Situate S. middle on State line, and contains $576 \mathrm{sq} . \mathrm{m}$. Drained by several creeks of St. Joseph r. Surface rolling; wood and prairie, and the soils rich and loamy. Farms 1,442; manuf, 53 ; dwell. 2,800 , and pop.-wh. 12,456, fr. col. 16-total 12,472. Capital. Branch. Public Wortes: Michigan Southern R, R.

BeAvcH, p. T., and cap. Branch co., Mich.: on W. branch of Coldwater r., 63 m. S. by W. Lansing. The Michigan Southern R. R. passes a little S. of the $\mathrm{v}$., $95 \mathrm{~m}$. from Monroe.

Brancer Dalt, p. o., Schuylkill co., Penn.

Brasch Hrut, p. O., Clermont co., Ohio: $87 \mathrm{~m}$. S. W. Columbus.

Brancer Istard, p. o., Pickens dist., S. Car.: $124 \mathrm{~m}$. N. W. Columbia.

Braxcr Post, p. o., Yates co., N. Y.: at the head of the W. arm of Crooked Lake, $167 \mathrm{~m}$. W. Albany.

Braxchtown, p. v., Cherokee co., Tex.: 196 m. X. E. Aurtin City.

Bratcerviluse, p. 0., St. Clair co., Ala. : 78 m. N. Montgoraery.
Braxcm ville, p. v., Sussex co., N. Jor.: on Paulin's Kill, $62 \mathrm{~m}$. N. Trenton.

BRANCrville, p. v., Orangeburg dist., S. Car.: on W. side of Edisto r., $46 \mathrm{~m}$. S. by E. Columbia. At this point the Columbia Branch R. R. branches from the South Carolina R. R., 62 m. from Charleston.

Brafdiniburg, p. vo, and cap. Meade co., $K y$.

Brandon, p. v., and cap. Rankin co., Miss.: at the E. terminus of the Vicksburg, Jackson, and Brandon P. R. $14 \mathrm{~m}$. E. Jackson. The "B. Republican" (whig) is issted weekly. The railroad will be continued eastward to Selma, Ala.

Brandon, p. v., Knox co., Ohio: 39 m. N. E. Columbus. Brantox, t, and p. o., Oakland co., Mich.: $63 \mathrm{~m}$. E, Lansing. Pop. $8 \%$.

Brandon, t. and p. v., Futland co., Verm.: on Otter cr. of Lake Champlain, $42 \mathrm{~m}$. S. by W. Montpelier. The Fiutland and Burlington $R$. R. passes through it, $50 \mathrm{~m}$. S. Burlington. Two newspapers, the "Vermont Tribune" and the "Brandon Post," are issued weekly. Pop. 2,885 .

Brandonville, p. v., Preston co., Firg.: 177 m. N. W. Richmond.

Brand's IroN Works, p. o., Washington co., R. I.: 28 m. S. by W. Providence.

Bravdr, p. v., Miami co., Ohio: $72 \mathrm{~m}$. W. Columbus,

Brandt, t. and p. v., Erie co., N. Y.: on Lake Eric and Cattaraugus cr., $268 \mathrm{~m}$. W. Albany. Pop. 1028.

BraNdYWINE, p. v., Shelby co., Ind.: 23 m. S. E. Indianapolis.

Brandrwine, p. v., Prince George's co.g MId.: 36 m. S. W. Annapolis,

Bramdywine creek: rises in Pennsylvania, whence it fows S. into Delaware, and after uniting with Christina cr. it enters the Delaware, forming the harbor of Wilmington. It is navigable to Brandywine village, at which point there is 6 or 7 feet water at tide; and furnishes excellent mill sites, which are occupied by numerous flour mills.

Brandywine, hund., Newcastle county, Del. : between

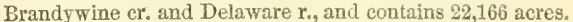
It has numerous flour and other mills. Pop. 3,492.

Brandpwine Manjor, p. o., Chester co., Penn.

Brandywire Milus, p. o., Summit eo., Ohio.

Brandywlak Springs, p. o., Neweasle, Del.

Bravrord, t. and p. v., New Haven co., Conn. : on Branford $\mathrm{r}$. of Long Island Sound, $43 \mathrm{~m}$. S. by W. Hartford. The New Haven and New London R. P. passes through the $\mathrm{t} .7 \mathrm{~m}$. E. New Haven. Pop. 1,425.

Brantingham, p. v., Lewis co., N. $Y .: 114 \mathrm{~m} . \mathrm{N}$. W. Albany.

Brasher's Falis, p. O., St. Lawrence co N. $_{0} Y_{0}:$ on Deer r., and near the line of the Northern R. R., $152 \mathrm{~m}$. N. W. Albany. The falls and rapids of the $r$, furnish extensive water-power.

Brasher's Iron Woriss, D. O., St. Iawrence $\mathrm{co}_{0}, N_{0}, \bar{Y}_{\text {. }}$, $161 \mathrm{~m}$. N. W. Albany.

Brashersville, p. v., Perry co., Ky. : 122 m. S. E. Frankfort.

Brassmown, p. v, Union co., Ga.: $142 \mathrm{~m}, \mathrm{~N}$. by W. Milledgeville.

BrattheBorovgh, t. and p. v., Windham co., Temn.: on the W. side of Connecticut r., $95 \mathrm{~m}$. S. by E. Montpelier. The Vermont and Nassachusetts R. R. and the Vermont Valley R. R. here form a junction, $69 \mathrm{~m}$. from Fitchburg, and 24 from Bellow's Falls. Manufactur's are extensire, and the $t$. one of the most flourishing in the State, Three newspapers are published liere, the "Eagle," semi-weekly, and the "Vermont Phoenix," and the "Windham County Democrat," weekly.

Bratrongville, p. v., Fork dist., S. Cay': $54 \mathrm{~m} . \mathrm{N}$. Columabia. Pop. 3,816 .

Braxtor county, Virg. Situate N. W., and contains $\$ 00$ sq. m. Drained by Elk and Littlo Kanawha rivers and their numerous tributaries. Surface hilly in the $\mathrm{S}$.- -in oth- 
er parts, broken and rough. Coal is found in the county. Soils moderately fertile, producing wheat, corn, and tobacco. Large quantities of sugar are made. Farms 408 ; manuf. 10 ; dwell. 679 , and pop.-wh. 4,123 , fr. col. 0 , sl. 89-total 4,212. Capital: Braxton C. H.

Braxton, p. v., and cap. Braxton co., Firg.: on Elk r. $189 \mathrm{~m}$. W. by N. Richmond.

BrazrL, p. v., Clay co., Ind. : 54 m. W. Indianapolis.

Brazoria county, Tex. Situate S. E. on the Gulf, and contains about $1,200 \mathrm{sq}$. m. Drained by the San Bernardo Brazos, and innumerable streams flowing into these and the Gulf of Mexico. Surface low and level : within $10 \mathrm{~m}$. of the coast the country is an open prairie-the residue is beautifully variegated, with woods of live-oak lining the streams. Soil, except near the coast, a deep black mold, and very productive. Farms 134; dwell, 296, and pop.-wh. 1,329, Ir. col. 5, sl. 3.507-total 4,841. Capital: Brazoria.

Brazoria, p. v., and cap. Brazoria co., Tex.: on W. side of Brazos r., $53 \mathrm{~m}$. from the Gulf, and $197 \mathrm{~m}$. S. E. Austin City.

Brazos county, Texo. Situate centrally on the forks of Brazos and Navasoto rivers, and contains 220 sq. m. Drained by streams falling from a central watershed to the border rivers. Surface elevated and undulating ; timber skirting the water-courses; soils exceedingly rich and productive of sugar and cotton, with the grains. Farms 47; dwell. s1, and pop.-wh. 466 , fr. col. 0, sl. 145 -total 614. Capital Booneville.

Brazos river, Tex. : one of the largest rivers of the State, emptying directly into the Gulf of Mexico. It rises in a vast number of tributaries in the hilly region of the $\mathrm{N}$. W., and has a general S. S. E. direction. In its lower course it is narigable for ships-higher up, for steamers and boats, Its largest confuents are Little $r_{0}$, Yegua $r_{v,}$ and the Narasoto $r$. : the two first from the W., and the latter from the $\mathrm{E}$.

Brazos Santlago, p. v., Cameron co., Tex. : a few miles N. of the mouth of the Rio Grande, and about $300 \mathrm{~m}$. S. Austin City.

Breakabeen, p. o., Schoharie co., $N . Y_{*}: 46 \mathrm{~m} . \mathrm{W}$ Albany.

Breakneck, p. v., Butler co, Penn.: 172 m. W. by N. Harrisburg.

Brean's Briogf, p. o., St. Martin's par., $L a$.

Breatmit county, $K y$. Situate E., and contains $680 \mathrm{sq}$. m. Drained by N. and middle forks of Kentucky. Surface hilly and broken-the N. and N. E. parts mountainous; and the soils, except on the rivers, indifferently productive. Bituminous coal is abundant. Farms 433; manuf. 15 ; dwell. 625 , and pop.-wh. 3,603, fr. col. 12, sl. $170-$ total 3.7S5. Capital: Jackson.

Breckentidge county, $K y$. Situate $\mathrm{N}$. W. on Ohio r. and contains $456 \mathrm{sq} . \mathrm{m}$. Drained by Rough cr. and its tributaries in the $\mathbf{S}$., and by Sinking and other ereeks of the Ohio in the $\mathrm{N}$. Surface uneven, but soils productive. Sinks oocur in this county. Farms 8S9; manuf, 18; dwell. 1,452, and pop.-wh. 8,616 , fr. col. 11, sl.1,966-total 10,593. Cupitul: Hardingsburg.

Brekdixg's, p. 0, Adair co., Ky.: 73 m. S. W. Frankfort.

Breese, p. 0., Greene co., $I U .: 46 \mathrm{~m}$. W. by S. Springfield.

Brentgstlle, p. v., Lehigh co., Penn.: $74 \mathrm{~m}$. E. by N. Harrishure.

Bremen, p. v., Cook co., $x l_{0}: 152 \mathrm{~m}$. N. E. Springfield. Brevex, p. o., Marshall co., Ind. : 106 m. N. by W. Indianapolis.

Brevex, p. 0., Mecklenburg co., $K y .:$ on the E. side of Pond cr, of Green r., 146 m. W. S. W. Frankfort.

Bremex, t. and p. v., Lincoln co., Me.: occupies a peninaula jutting into the Atlantic, $37 \mathrm{~m}$. S. by E. Augusta. It Is alnust slirroumlad by navigable waters. Pop. S91.

Breares, p. v., Fairfleld con Ohio: on Rush cr., $87 \mathrm{~m}$. S. E. Columbus.
Breven, p. v., St. Louis co., Mo.: 102 m. E. Jefiorson City.

Bremer county, Ia. Situate N. E., and contains $432 \mathrm{sq}$. m. Taken from Pottowattomie in 1851

Brenuam, p. v., and cap. Washington co., Tero. : on New Year's cr. of Brazos r., 84 m. E. Austin City.

Brennerstille, p. v., Preble co., Otio: $89 \mathrm{~m}$. W. Columbus.

Brentstille, p. v., and cap. Pince William co., Virg.: on a branch of Oecoquam r., $78 \mathrm{~m}$. N. Richmond.

Brentwood, t. and p. v., Rockingham co, N. Hamp.: on Exeter r., 33 m. S. E. Concord. Sulphate of iron is abundant in this locality. Pop. 923.

Brtssr, p. o., Monroe co., Mich.: on Lake Erie, at the mouth of Stoney cr., $86 \mathrm{~m}$. S. E. Lansing. The harbor facilities are very eligible for lake craft.

Brewer, t. and p. O., Penobscot co, Me.: on the E. side f Penobscot r., opposite Bangor, $57 \mathrm{~m}$. N. E. Augusta.

Brewer Centre, p. O., Penobscot con, Me.: 59 m. N. E. Augusta.

Brew erstille, p. v., Sumter co., $A l \alpha_{\bullet}$ : $105 \mathrm{~m}$. W. by N. Montgomery.

Brewersville, p. v., Jennings co., Ind.: 67 m. S. W. Indianapolis.

Brewerton, p. v., Onondaga co., N. Y.: $112 \mathrm{~m}$. W. by N. Albany.

Brawertor, p. v., Laurens dist., S. Car.: $61 \mathrm{~m}$. W. by N. Columbia.

Brewer Village, p. v., Penobseot co., Me.: opposite Bangor, 57 m. N. E. Augusta. Steamers call here reguarly.

Brewington, p. v., Sumter dist., \$. Car., : $53 \mathrm{~m}$. E. by $\mathbf{S}$. Columbia.

Brewster, t. and p. v., Barnstable co., Mass.: on Cape Cod Bay, 67 m. S. E. Boston. It has some manufactures, but the inhabitants are chiefly fishermen. Pop. 1,526

Brewster's Station, p. 0., Putnam co., N. Y.: $82 \mathrm{~m} . \mathbf{S}$. Albany.

Brtckerpilie, p. v., Lancaster co., Penn。: 28 m. E. S. E. Harrisburg.

Bricklaid, p. v., Lunenburgh co., Virg.: 66 m S. W. Richmond.

Brick Menting Ilouse, p. o., Cecil co., Ma. : 59 m. N.N.E. Annapolis.

Brick Store, p. o., Newton co., Ga.: 47 m. N. W. Millodgeville.

Brickstrle, p. v., Cuyahoga co., Ohio: on Cuyahoga cr., $118 \mathrm{~m}$. N. E. Columbus.

Brickvilue, p. v., Lawrence co., Ala.s: a little S. of Tennessee r., at Muscle Shoals, and 193 m. N. by W. Montgomery.

Bridesburg, p. Y., Philadelp\$ia co., Penn.: 91 m. E. Harrisburg.

Bridgr, p. 0., St. Francis eo., $\boldsymbol{A} r k$.

BrimgeborovgIr, p. v., Burlington co., N. Ter.

Bridge Crifek, p. o., Geauga co., Ohio: 128 m. N. E. Columbus.

BRIDGEForth's, p. o., Limestone co., $A l a$ : : $196 \mathrm{~m}$. N. by W. Montgomery.

Bridgemamptor, p. v., Suffolk con, $N . Y_{.:}$on the E. end of Long Island, on the Atlantic, $137 \mathrm{~m}$. S. E. Albany.

Brugeport, t. and p. city, Fairfield co., Conn.: on an arm of Long Island Sound, which receives Pequanock r., a fine mill stream, $78 \mathrm{~m}$. S. W. Hartford. The harbor is eligible for large steamboats and trading craft, and the city has extensive manufactures. The New York and New Haven $\mathrm{R}$. R. is here intersected by the Housatonic R. R. giving it access to the $\mathrm{E}$. and $\mathrm{W}$., and to the $\mathrm{N}$. The "Republican Standard" (whig) is published tri-weekly and weekly, and the "Republican Farmer" (dem.) weekly. Pop. 7,538

Brtbgeport, p. v., Huntingdon co, Penn.: 62 m. W. Harrisburg. 
Brmgkport, p. v., Marion co., Ind.: on National Road, $9 \mathrm{~m}$. W. Indianapolis.

BrIDQEPort, p. Y., Franklin co., Ky.: 5 m. from Frankfort.

Brmgerort, t. and p. V., Saginaw co., Mich.: on the S. side of Cass $r$. of the Saginaw, $61 \mathrm{~m}$. N. E. Lansing.

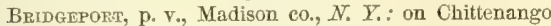
cr. of Oneida Lake, $105 \mathrm{~m}$. W. by N. Albany.

Bridgeport, p. v., Gloucester co., N. Jer. : 34 m. S. by W. Trenton.

Bridgerort, p. v., Belmont co., Ohéo: on the Ohio r. opposite Wheeling, $114 \mathrm{~m}$. E. Columbus. It will eventually be an important $R$. R. centre, where the lines from Pennsylvania and Virginia will connect with those of Ohio. The "Belmont Farmer," an agricultural paper, is issued month1y. Its trade is considerable, and it has some substantial warehouses.

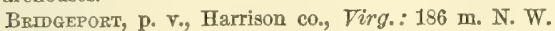
Richmond.

BrIDgeport, p. y., Brown co., Wisc. : on E. side of Fox r., $123 \mathrm{~m}$. N. E. Madison.

BrIDGEPORT, p. v., Jackson co., Ia.: on Makoqueta r., $57 \mathrm{~m}$. N. E. Iowa City.

Bridgeton, p. v., port, and cap Cumberland co., $N$. Jer.: on Cohansey cr, $20 \mathrm{~m}$. up, and $60 \mathrm{~m}$. S. Trenton. Sloops come up to the port, and the $\mathrm{v}$, has considerable business. Shipping owned in the district 14,472 tons. Two newspapers, the "Bridgeton Chronicle" and the "New Jersey Pioneer," are issued weekly. On the W. side of the cr. are extensive iron works. Pop. of $t, 2,446$.

Brtdgetos, p. v., Park co., Ind. : $61 \mathrm{~m}$. W. Indianapolis. Bridgeton, to and p. $\nabla_{*}$, Cumberland co., Me.: on Long Pond, $51 \mathrm{~m}$. S. W. Augusta. From this point there is a navigable communication to Portland through the Oxford and Cumberland Canal, Pop. 2,710.

Bridgeton, p. v., St. Louis con, Mo.: $13 \mathrm{~m}$. N. W. St, Louis and $101 \mathrm{~m}$. E. Jefferson City.

BRIDGetoN, p. v., Shelby co, Ala.: 62 m. N. N. W. Montgomery.

Brimgtown, p. v., Caroline co., Md.: 42 m. E. Annapolis.

Brtdge Valley, p. o., Bucks co., Penn.

Bridgeville, p. v., Dorchester co., Ma.

Bridgeville, p. V., Sussex co., Del.: on the S. side of

Nauticoke r., $38 \mathrm{~m}$. W. by S. Dover.

Bemgeville, p. v., Warren co., N. Jer. : on Pequest r., $43 \mathrm{~m}$. N. by W. Trenton.

Bridgeville, p. v., Sullivan co., N. Y.: 92 m. S. W. Albany.

Brmgefilue, p. v., Muskingum co., Ohio: 51 m. E. Columbas.

Bridgewater, p. v., Litchfield co., Conn.: 56 m. W. Hartford.

BRIDGew Ater, p. v., Washtenaw co, Mich.: on N. branch of Raisin r., $57 \mathrm{~m}$. S. E. Lansing.

BRIDGEWATER, t. and p. Y., Plymouth co., Mass.: on Taunton r., 29 m. S. Boston. Fall River R. R. passes through the t., and the Bridgewater Branch $R$. $R$, extends between South Abington and Bridgewater. It has numerolis manufactures. Pop. 2,790.

BrIDGEW ATER, t. and p. V., Grafton co., $N$. ITamp : between Pemegewasset $r$. and Newfound Lake, $36 \mathrm{~m} . \mathrm{N}$. by W. Concord. Pon. 664.

Bridgewater, p. t., Oneida co., $N$. $Y$.. on a cr. of Unadilla r., $75 \mathrm{~m}$. W. Albany. Pop. 1,308.

BRIDGEWATER, t. and p. Y., Williams co., Otivo: on the

St. Josephs of the Maumee, 188 m. N. W. Columbus. P.493 BRDGEW ATER, t. and p. Y., Aroostook co, Me. Pop. 119?. Bridgewater, p. v., Bucks co., Penn. : 103 m. E. by N. Harrisburg.

BRIDGWW ATER, p. ₹., Rockingham co., Virg.: 104 m. N. W. Richmond.

BrYDGEWATEE, p. $t$, Windsor con, Term.: on Water- queechy r., $46 \mathrm{~m}$. S. Montpelier. Soapstone is extensively quarried in this t., also iron. Killington Peak lies on the W. border. Pop, 1,311.

Brinle Creek, p. o., Grayson co., Virg.: 200 m. W. by S. Richmond.

Bripport, t, and p. o., Addison co, Term.: on Lake Champlain, opposite Crown Point, $41 \mathrm{~m}$. W. S. W. Montpelier. The waters of the t. are strongly impregnated with sulphate of magnesia. Pop. 1,393.

Brifr Creek, p. o., Wilkes co., N. Car.: $139 \mathrm{~m}$. W. by N. Raleigh.

Brier Creer, t. and p. o., Columbia co., Penn. : $69 \mathrm{~m}$. N. N. E. Harrisburg.

Brter Hull, p. o., St Lawrence co., N. Y.: 169 m. N. W. Albany.

Brigg's Mults, p. o., Ohio co., Ky. : $122 \mathrm{~m}$. W by $\mathrm{S}$. Frankfort.

Bright, p. o., Dearborn co., Ind.: 78 m. S. E. Indianapolis.

Brighton, t. and p. o., Essex co., Ferm.: on the Green Mountains near the Canada border, 52 m. N. E. Montpelier. St. Francis r. has its source in this loeality. Pop. 193.

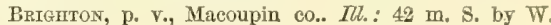
Springfield.

Brighton, p. v., Beaufort dist., S. Car.: 108 m. S. Columbia.

BrightoN, to and p. v., Washington co., $I a .:$ on the $S$. side of Skunk r., 35 m. S. by W. Iowa City.

Brighton, t. and p. v., Somerset co, Me.: $43 \mathrm{~m} . \mathrm{N}$ Augusta. Pop. 748 .

Brightow, t. and p. v., Livingston co., MFich. : 53 m. E. by S. Lansing. Pop. 1,015.

Brighton, t. and p. v., Middlesex co., Mass.: on Charles r., $5 \mathrm{~m}$. W. Boston, with which it communicates by R. R. The Boston cattle market is located here, and in 1549 the animals sold counted 46,465 beef cattle, 20,055 store cattle, $14 \$, 965$ sheep, and 80,120 swine, valued at $\$ 2,976,265$. A cemetery has been lately established. Assessed valuation $\$ 1,146,212$. Pop. 2,356.

Beightox, t. and p. v., Monroe co., $N_{.} Y_{\text {. : }}$ on the Erie Canal, $259 \mathrm{~m}$. from Albany. Pop. 3,117.

Brighton, v., Richmond co., $N . Y_{\text {. }}$ a a beantiful village and summer resort on Staten Island, $152 \mathrm{~m}$. S. Albany.

Brighton, t. and p. v., Loraine co., Ohio: on the W. branch of Black r., $86 \mathrm{~m}$. N. N. E. Columbus. Pop. 669.

Brighton, p. v., Beaver co., Penn.: on W. side Big Beaver $\mathrm{r}, 4 \mathrm{~m}$. from its mouth, and $193 \mathrm{~m}$. W. Harrisburg. It is connected with New Brighton by a fine bridge. The Ohio and Pennsylvania R. R. passes Brighton, $38 \mathrm{~m}$. from Pittsburg.

BrightoN, t. and p. v., Kenosha co. Wisc. : $11 \tau \mathrm{m}$. E. S. E. Madison. Pop. 810 .

BrightoN, $\nabla .$, Sacramento co., Calif.: on E. side of Sacramento r., $53 \mathrm{~m}$. N. W. Vallejo.

Bright Seat, p. Y., Anne Arundel co., MId.

Brigntsville, p. v., Marlborough dist., $S_{\text {. }}$ Car.: on Crooked cr. of Great Pedee $r ., 91 \mathrm{~m}$. N. E. Columbia.

Brimfield, p. 0., Peoria co, $I l l .: 46$ m: N. by W. Springfiela.

Bemfreld, t. and p. $\vee$., Hampden co, MFass. : on Chico pee and Quinnebaug r., $63 \mathrm{~m}$. W. S. W. Boston. P. 1,421. Brlmfield, t. and p. v., Portage co, Ohio: $118 \mathrm{~m}$. N. E Columbus Pop. 1,015.

Brindetowy, p. v., Burke co., N. Car.: on the E. side of Silver cr. of Catawba r., $168 \mathrm{~m}$. W. Raleigh.

Britrghan's Grope, p. o., Tippecanoe co., Ind.: $62 \mathrm{~m}$ N. W. Indianapolis.

Brivgrens, p. $v_{0}$ and cap. St. James par., $L a_{0}:$ on W. side of Mississippi r., $35 \mathrm{~m}$. S. Baton Ronge.

Brinklexpicte, p. v., Halifax eo., $N$. Car..: on rittle Fishing cr., $54 \mathrm{~m}$. N. E. Raleigh.

Brintox, p. v., Champaign co., Ohio: $52 \mathrm{~m}$. W. by $\mathbf{N}$. Columbus. 
Briscoe Ritn, P. o, Wood co., Virg.: 240 m. W. N. W. Richmond.

Bristersburgh, p. v., Fauquier co., Tirg. : 89 m. N. by W. Richmond.

Bristol county, Mfass. Situate S. E. on Buzzards' Bay, and contains $620 \mathrm{sq} . \mathrm{m}$. Drained by Taunton and other rivers. Coasts deeply indented. Surface level; soils modcrately fertile. Navigation and manufactures employ most of the inhabitants. Farms 2, 550; manuf. 562; dwell. 12,134, and pop.-wh. 74,760 , fr. col., 1,432-total 76,192 . Capitals: New Bedford and Taunton. Public Works: Boston and Providence R. R.; Fall River R. R.; Taunton and New Bedford P. R., etc.

Bristol county, $R, I$. Situate $E$. between Mt. Hope and Narraganset bays, and contains $96 \mathrm{sq}$. $\mathrm{m}$. Surface diversified: soils, a gravelly lnam and fertile. Farms 200 ; manuf 87; dwell. 1,167, and pop.-wh. 8,190, fr. col. 321-total 8,514. Oapital: Bristol.

Bristol, t. and p. v., Hartford co., Conn.: on branches of Farmington r., $14 \mathrm{~m}$. W. by $\mathrm{S}$. Hartford. It is distinguished for its manufacturing industry, and especially for its clocks, etc. Pop. 2,8S4.

Bristox, p. v., Kendall co., Ill.: on W. side Fox r., opposite Yorkville, $139 \mathrm{~m}$. N. N. E. Springfleld.

Bristox, p. v., Anne Arundel co., MId.: 29 m. N. N. W. Annapolis.

Bristor, t. and p. o., Lincoln co., Me. : on the E. side of Damariscolta $\mathrm{r}$. at its mouth, $30 \mathrm{~m}$. S. by $\mathrm{E}$. Augusta. It has a good harbor, and some shipping engaged in the coasting trade and fisheries. Pop. 2,910.

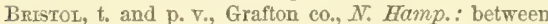
Pemegawasset $\mathrm{r}$. and Newfound Lake, $31 \mathrm{~m} . \mathrm{N}$. by W. Concord. Pop. 1,108.

BeIstol, t. and p. r., Ontario co., N. Y.: on Mudd cr., 182 m. W. Albany.

Bristol, t. and p. vo, Morgan co., Ohio : on Meigs er. of Mushingham r., 66 m. E. by S. Columbus. Pop, 1,725.

Biristor, t. and p. v., Bucks co., Penn.: on the W. bank of Delaware $r_{\text {., }}$ and the $\mathbf{E}$. terminus of the Delaware division of the Pennsylvania Canal, $108 \mathrm{~m}$. E. Harrisburg. Immense amounts of coal are deposited here and shipped to the E. A newspaper, the "B. Gazette," is published weekly. The Trenton and Philadelphia $R . R$. passes through Bristol, $19 \mathrm{~m}$. N. Philadelphia. Pop. 2,578.

Bristor, t., p. $v_{*}$, port, and cap. Bristol co., $R_{.} I_{0}$ : on the E. side of Narragansett Bay, $18 \mathrm{~m}$. S. by E. Providence. It has a good harbor, and is extensively engaged in coasting and the fisheries. The shipping owned in the district, 13,19s tons. The "Bristol Phoenix" is published weekly. Mit. Hope lies in this t, $2 \mathrm{~m}$. N. E. of the C. H., which is a flne elevation of about 300 feet. Here King Philip, chief of the Pequods, held his court; the view from the summit is extensive and highly interesting. Pop. 4,616.

Berstor, t. and p.. ., Addison co., Verm.: on the New Haven r., 50 m. S. W. Montpelier. The Green Mountains

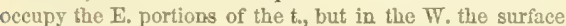
is level and fertile. Pop. 1,31.

Bristor, t. and p. r., Kenosha co., Wisc. : on Des Plaines r., 183 m. E. S. E. Madison. Pop. 1,225,

Bristol CeNtBe, p. o., Ontario co., N. Y.: $192 \mathrm{~m}$. W. Albany."

Bristoltille, p. v., Trumbull co., Ohio: on Grand r., $14 \mathrm{~m}$. X. E. Columbus.

Bristolvilie, p. v., Barry co., Mich.

Bristor, p. r., Elkhart co., Ind.: on the line of the Indiana Northern $\mathrm{K}_{.}$R., and S. of St. Joseph $\mathrm{r}_{\text {., }} 133 \mathrm{~m} . \mathrm{N}$. Indianapolis.

Berrion's NECL, p. 0, Marion dist., S. Car.: $112 \mathrm{~m}$. E. Columbia.

Brixtox, p. v., Alexandria co., Virg.: 98 m. N. Richmond.

Broadaliza, t. and p. ve, Fulton co, N. Y : $: 36 \mathrm{~m}$. N. W. Albany. Poje 2.tit.
Broad Broor, p. o, Hartford co., Conn.

BroAd CREEK, hund., Sussex co., Del. : between Broad er. and Nanticoke cr., and contains 60,860 acres. Pop. 2,712.

Brond Creez, p. o., Queen Anne co., $M I d$.

BroAdrord, p. \%., Smyth co., Firg.

Broatpilin, hund., Sussex co., Del. : in the N. E. part of the co., and contains 8,916 acres. Pop. 3,927.

Broad Mouvtaly, p. 0., Schuylkill co., Penn.

Broad Oaks, p. o., Pope co., Ill.; $272 \mathrm{~m}$. B. Springfield.

Broad R.rple, p. o., Marion co., Ind.: on a cr. of Broad r., $68 \mathrm{~m}$. N. E. Milledgeville.

BroAD river, Ga.: one of the W. branches of Savannah r., which it enters at Petersburg.

BrosD river, S. Car.: an arm of the Atlantic, between Port Royal Island and the main. Beaufort is situated on this river.

BroAD river, S. Car.: rises in North Carolina, and, receiving the Pacolet and Tiger rivers, unites with the Saluda, above Columbus, forming the Congaree.

BroAD river, p. o., Elbert eo., Ga.: on the NN. side of Broad r., $67 \mathrm{~m}$. N. E. Milledgeville.

Broad Top, p. o., Huntingdon co., Penn.: $74 \mathrm{~m}$. W. Harrisburg.

BroADWAY, p. o., Warren co., $N$. Jer. : on the line of the Morris Canal, $37 \mathrm{~m}$. N. by W. Trenton.

Broadwell, p. o., Harrison co., $\bar{y} y .: 82$ m. N. E. Trankfort.

Brock, p. o., Darke co., Ohio: $84 \mathrm{~m}$. W. Columbus.

Brockawayrille, p. v., Jefferson co., Penn。: $154 \mathrm{~m}$. W. N. W. Harrisburg.

BRocketT"8 BeIDGe, p. o., Fulton co., N. Y.: $73 \mathrm{~m}$. W. N. W. Albany.

Brockport, p. v., Monroe co., $N . \quad Y$.: on the Erie Canal, $217 \mathrm{~m} . \mathrm{W}$. Albany. It has some manufactures, and a weekly newspaper, the "B. Watchman."

Brock's Crossivg, p. o., St. Croix co., Wisc. : 212 m. N. W. Madison.

Brock's GaP, p. o., Rockingham co., Virg.: $102 \mathrm{~m}$. N. W. Richmond.

Broken Arrow, p. o., St. Clair co., Ala.: 108 m. N Montgomery.

BrokeN SWORD, p. o., Crawford co., OTio: $62 \mathrm{~m}$. N Columbus.

Bronsor, p. O., Huron co., Ohio : $78 \mathrm{~m}$. N. Columbus,

Bronson's Pratrie, p. o., Branch co., Mich.: 97 m. S. W. Lansing.

Brookdale, p. O, MיHenry co., Ill, : 273 m. N. N. E, Springfield.

Brooke county, Firg. Situate N. W., between the Ohio r. and the Pennsylvania State line, and contains 154 sq. m. Surface uneren, and soil fertile. Iron ore and bituminous coal are abundant. Farms 284; manuf. 29; dwell. 889, and pop,-wh. 4,923, fr. col. 100, sl. 31-total 5,054. Capital: Wellsburg. Putlic Workis: Pittsburg and Steubenville R. R.

BrootfFeld, t. and p. v., Fairfield co., Conn.; on Still r. a branch of Housatonie r., $42 \mathrm{~m}$. S. W. Hartford. The Housatonic R. R. passes through it, $29 \mathrm{~m}$. N. Bridgeport Pop. 1,360 .

BrookFIELD, p. v., Leo co., $\pi l_{\text {. : }} 196 \mathrm{~m}$. N. Springfield. BrookrIELD, t. and p. v., Worcester co., Mccss.: $58 \mathrm{~m}$. W. Boston.

BrookFIELD, t. and p. Y, Carroll co., N. Hamp.: $31 \mathrm{~m}$. N. E. Concord. Near the centre of the $t$. is a pond, the source of the W. branch of Salmon Fall $r$., and there is a still larger pond on the N. W., which empties into Winnipiseogee Lake. Pop. 552.

Brookfreld, p.y., Jackson co., Ia.: 58 m. N. E. Iowa City. Brookfiecd, p. V., Madison co., N. Y.: on Unadilla $r_{\text {. }}$ $58 \mathrm{~m}$. W. Albany. The tributaries of the Unadilla furnish fine mill sites.

BronkFELD, t. and $\mathrm{p}$ v., Trumbull co., Ohin: on a branch of Shenango er., 153 m. N. E. Columbus. P.1,451. 
Brookmierd, t. and p. v., Tioga co., Penn.: on Cowanesque cr. of Tiogn r., $142 \mathrm{~m}$. N. N. W. Harrisburg.

Broorfield, t. and p. T., Orange co., Term. : $19 \mathrm{~m}$. S. Montpelier. Several ponds in this to are sources of tributaries of White $r$. Marl is abundant. Pop. 1,6r2.

Brookfleld, t. and p. v., Waukesha co., Wisc.: on Fox r., 108 m. E. Madison. The Milwaukie and Mississippi R. R. passes through the t., $20 \mathrm{~m}$. W. Milwaukie. P. 1,939 。 Brookraver, p. V., Lawrence co., Miss.: on a head stream of Bogue Chitto, $76 \mathrm{~m}$. S. Jackson.

Brookhatex, t., Suffolk eo., N. Y. Pop. 8,597.

BrookuANDVute, p. v., Baltimore co., Ma.: on the line of the Westminster Branch R. R., $17 \mathrm{~m}$, from Battimore.

Brooking, p. t., Hancock co,, Me.: $62 \mathrm{~m}$. E. Augusta.

Bвоокцп, p. v., Clark co., Mo.: 138 m. N. E. Jefferson City.

Broozitve, p. v., Madison co., Ga.: on the W. side of the middle fork of Broad r., $71 \mathrm{~m}$. N. N. E. Milledgeville.

Brookitye, t. and p. v., Norfolk co., Mass.: $3 \mathrm{~m}$. W. by S. Boston. It is chiefly occupied by the aristocracy of Boston, who have country seats and rillas in this locality Pop. 2,516. It is reached by the Western Avenue and R.R Brookurve, p. T., Jackson par., La.: $156 \mathrm{~m}$. N. W. Baton Rouge.

BrookLINE, t. and p. 0., Hillsborough co., N. Hamp. : 38 m. S. by W. Concord. Pop. 718.

Brookznve, t. and p. v., Windham co., Verm. : $86 \mathrm{~m}$. S. Montpelier. Pop, 285.

BrookL YN, p. V., Conecuh co., Ald .: on the W. side of Conecuh r., $78 \mathrm{~m}$. S. by W. Montgomery.

Brookry , p. v., Campbell co., Ky.: 58 m. N. N. E. Frankfort.

BrookLYN, t., p. v., and cap. Windham co., Conn.: on Quinnebaug r., 38 m. E. by N. Hartford. Pop. 1,515.

BrookzyN, p. V., Schuyler co., Ill. : on W. side of Crooked cr., $97 \mathrm{~m}$. W. N. W. Springfield.

BrookcrN, p. т., Noxubee co., Miss.: 112 m. N. E. Jackson.

BrooxLYN, p. V., Jackson co., Mich.: on Groose cr. of the N. branch of Raisin r., 44 m. S. by E. Lansing.

BRookLYN, p. city, and cap. Kings co., N. Y.: on the W. end of Long Island, opposite New York City, $145 \mathrm{~m}$. S. Albany. Pop. in 1810, 4,402; in 1820, 7.175; in 1830, 15,396; in $1840,36,233$; and in $1850,96,838$. It is now the eighth, in regard to population, in the Union, and the segond in the State. Dwell., in $1850,10,197$. Value of real estate $\$ 32,010,711$, and of personal property $\$ 3,950,589$.

Brooklyn was originally built on very uneven ground, and still-although the grades have been greatly leveledretains many of the natural beanties for which it was so pre-eminent. The Heights of Brooklyn, seen from the New York side of the East River, are unrivalled as city scenery, and there are also, farther back, eminences which afford fine localities for residences. The streets are regularly laid out, and are from 60 to 100 feet wide; and on the whole, no other city of the Union has so many substantial and handsome public buildings. The City Hall is a fine marble structure, at the head of Fulton-street, and the banking houses, school-houses, and churches are elegant and commodious. It is the city of churches. The city is divided into eleven wards, and governed by a mayor and common council, and in its police arrangements is much superior to the neighboring city of NewYork. It is lighted throughout with gas, which has also been generally introduced into the dwellings of the rich; and there is a project on foot for introducing into the eity a supply of water from the $\mathrm{S}$. side of Long Island. At present, water is supplied from the public pumps or cisterns; and in ease of an extensive fire, there is not a sufficiency. The charter officers of the city are the mayor, comptroller, street commissioner, commissioner of repairs and supplies, collector of taxes, and chief of pohce; and for each ward an alderman and assistant alderwan, a supervisor, an assessor, a commissionter of exeise, and constable. These are elected by the citizens, and form respectively boards intrusted with the eity government. The city clerk, the attorney and. counselor, the health officer, the city treasurer, the sealer of weights and measures, the clerk of police and justices courts, the city surveyors, etc., are appointed by the common council. For police purposes, the eity is divided into four districts, each, except the first district (which has 48), having 32 policemen, under a captain and two assistant captains.

The commerce of Brooklyn is relatively large; but as the city is within the collection district of New York, no separate returns are made in the published accounts. The river front of the city is literally fringed with wharves, and backed by extensive warehouses, while the Atlantic Dock and its immense stores enhance the importance of its shipping facilities. The dock contains $42 \frac{1}{2}$ ares, and the pier front, facing on Buttermilk Channel, has a length of 3,000 feet. Bhips of the largest size enter it, and unload into the adjoining stores by means of patent cranes, worked by steam-power. Other dock facilities are about to be built beyond Red Hook. There are four banks in the city, two savings' institutions, and four fire insurance companies, with numerous other association\& for commercial and economical purposes. Its churches number 63, of which 11 are Episcopal, 7 Roman Catholic, 6 Baptist, 6 German Reformed, 5 Congregational, 7 Presbyterian, 11 Methodist Episcopal, and each one, African Methodist Episcopal, Universalist, Unitarian, Friends, Sailors' Bethel, Congregational Methodist, American Primitive Methodist, Protestant Methodist, Second Advent, and Reformed Presbyterian. The city contains thirteen school districts, which are under the superintendence of the Board of Education. It also constitutes one colored school district. The public schools are entirely free to children residing within the respective districts in which the schools are located. Each district contains a valuable district library, the use of the books being free to all the inhabitants of the district, both male and female. In the larger districts the libraries number between 3,000 and 4,900 volumes each. Academies and high schools for youth of both sexes are also very numerous, and are generally well and ably conducted. The Brooklyn Institute, Washington-street, is one of its highest institutions, and has connected with it a Youths' Free Library, and free lectures and concerts are given during the winter. Anong the benevolent institutions of the city, the most conspicuous are the City Hospital, Raymond-street, and the Dispensary in Pineapple-street.

In the east part of Brooklyn is the United States' Nary Yard, situate on the Wallabout. It covers some 40 acres, and contiguous thereto are mooring grounds, etc. The yard is inclosed on the land side by a high brick wall, and within are large ship-houses, timber sheds, store-houses, workshops, etc.; and an immense Dry Dock, the greatest work of the kind within the United States, has been lately completed. The Naval Hospital, half a mile east of the yard, occupies a commanding eminence, and is surrounded by a fine park and grounds, about $\$ 3$ acres in extent.

The Greenwood Cemetery, on Gowanus Heights, in the S. part of the city, is one of the most picturesque and beautiful burial-plots any where to be found. It occupies nearly 300 acres of land, and is laid out in avenues, embellished by shade trees and shrubbery. The surface is of every variety, interspersed with ponds and lakelets, and from its higher parts commands an extensive view of the harbor, and the scenery of the lower Hudson. Its monuments, erected in memory of the dead, some at the expense of the public or societies, and others in commemoration of private friendships or relations, are of every description, but chiefly of white marble, and finely sculptured. Altogether, it is the most extensive and most beautiful cemetery within the borders of the Union, and is an establishment of which the city may well be proud.

For so large a city, Brooklyn is but poorly represented by 
its press, a fact accounted for by its proximity to New York City, the literary as well as the commercial emporium of America. Four papers are published daily, the "B. Star," and the "B. Advertiser" (whig), the "Daily Freeman" (indep".), and the "B. Eagle" (dem.); and the papers published weekly are the "Long Island Star" (whig), and the "Independent" (temperance), and there is also a weekly edition of the "Eagle." The New York papers are delivered here to citizens at the same time as in New York; and as these generally contain more extended accounts of, and comments on current affairs, and are conducted with more skill and talent, they have a much larger circulation than the Brooklyn papers. The nearness of New York, indeed, affects every grade and profession in the same manner: few of the richer elasses purchase their goods or provisions in Brookiyn; and hence no department of life has the same vitality as it would have if the wealthy could be induced to purchase of their neighbor, instead of giving the profit of their custom to the traders of the neighboring city. In many respects, however, Brooklyn is only a suburb of the metropolis-a residence for business men, and not a mart of commerce.

Brooklyn is connected with New York by five ferries: Hamilton Avenue Ferry and South Ferry (Atlantic-street), run to Whitehall, in New York; Fulton Ferry, from foot of Fulton-street, Brooklyn, to Fulton-street, New York; Catharine Ferry, from foot of Maine-street, Brooklyn, to Catharine-street, New York; and Jackson Ferry, from foot of Jackson-street, Brooklyn, to foot of Governenr-street, New York. The steamboats on these ferries are all of the first class, and commodious for carriages and wagons as well as passengers. The fare on the three first is one cent for each passenger.

Brooklyn was the scene of stirring events at an early stage of the Revolutionary War. In August, 1776, this part of Long Island became the seat of strife, and the fortifications then thrown up by the patriots may still be seen, but are now undergoing the process of demolition to extend city improvements. The principal of these is Fort Green, which will hence be known as Washington Park, and which will be devoted to recreation and health. Near the Navy Yard is the tomb in which are deposited the remains of 11,000 Americans who perished in the prison ships moored in the bay during the Revolution. At the conclusion of peace, in 1788 , Brooklyn contained only 56 houses; nor was it until the period between 1820 and 1830 that it began to receive the overflowing population of New York. Since then it has rapidly increased, and in all probability the census of 1860 will find it a city of 200,000 souls. The only drawback, indeed, to its unlimited settlement, seems to be the want of a sufficient supply of water for so large a population as circumstances would indicate to be its destiny to contain.

BrookLrN, t. and p. จ., Cuyahoga co., Ohio: on a cr. of Cuyahoga r., $120 \mathrm{~m}$. N. E. Columbus. The Cleveland and Columbus R. R., and Cleveland and Sandusky R. R. pass through the t. immediately west of Cleveland. Pop. 6,375.

Brookstrn, t. and p. v., Susquehannah co, Penn.: 132 m. N. N. E. Harrisburg.

BrookLYN, p. v., Halifax co., Virg.: 97 m. S. W. Richmond.

Brooknear, p. $\nabla .$, Campbell co., Tirg.: on the N. side of Roanoke r, $92 \mathrm{~m}$. W. by S. Richmond.

Brooks, t. and p. o., Waldo co., Me.: $37 \mathrm{~m}$. E. by N. Augusta.

BROOK's Grove, p. 0., Livingston co., $N_{*} Y_{*}: 212 \mathrm{~m}, \mathrm{~W}$. Albany.

Brook's, p. o., 'Jasper co., Ind.: 96 m. N. W. Indianapolis.

Brook"s TAN YARD, p. o., Macon co., Tenn.: $49 \mathrm{~m}$. E. N. E. Nashville.

Brooksville, p. v., Blount co., dla.; on a er. of Tennessee $r_{\text {. }}, 128 \mathrm{~m}$. N. by W. Montgomery.
Brooksville, p. v., Randolph co., Ga.: 133 m. S. W Milledgeville.

Brooksvilue, t. and p. v., Hancock co, Me. : on E. side of Penobseot Bay, $49 \mathrm{~m}$. E. Augusta. The t. occupies a peninsula navigable on three sides. Pop. 1,383.

Brooksville, p. o., Albemarle co., Virg. : on the Virginia Central R. R., $81 \mathrm{~m}$. N. W. Richmond.

Brookville, p. o., Ogle co., $I l$. : on E. side of Elkhorn cr., $226 \mathrm{~m}$. N. Springfield,

Brookville, t., p. v., and cap. Franklin co., Ind. : between the forks of Whitewater $\mathrm{r}_{\text {, about }} 2 \mathrm{~m}$. N. of their junction, and $63 \mathrm{~m}$. E. S. E. Indianapolis. It also lics on the Whitewater Canal, $31 \mathrm{~m}$. from Lawrenceburg. Its manufactures are considerable. Two newspapers, the "Franklin Democrat" and the "Indiana American".(whig), are published weekly.

BrookvILLE, p. o., and cap. Bracken co., Ky. : 62 m. N. E. Frankfort.

Brookville, p. v., Montgomery co., Md.: on Reedy er. of Patuxent r., $37 \mathrm{~m}$. N. W. Annapolis.

Brookville, p. v., Noxubee co., Afiss.: 108 m. N. E. Jackson.

Brookville, p. v., Marion co., Mo. : on S. side of South

Fabius r., 93 m. N. by E. Jefferson City.

Brookville, p. v., Granville co., $N$. Car.: $47 \mathrm{~m} . \mathrm{N}$. Raleigh.

Brookville, p. ., Genessee co., N. Y.: $226 \mathrm{~m}$. W. Albany.

Beook ville, p. $\nabla_{1,}$ and eap. Jefferson co, Penn.: on $\mathrm{N}$. branch of Red Bank er. of Alleghany r., $156 \mathrm{~m}$. W. N. W. IIarrisburg. It is a flourishing village, and has two newspapers, the "Jeffersonian" (dem.) and the "Jefferson Star" (whig), issued weekly. Pop. 763.

Brookvilie, p. v., Jefferson co., Ia.: $92 \mathrm{~m}$. S. by W. Iowa City.

Broone county, $N . T$. Situate $\mathrm{S} . \mathrm{W}$. middle, and contains 627 sq. m. Drained by Susquehanna r. and its tributaries, Chenango, Tioughnioga, Nanticoke. Surface broken and hilly, with extensive and fertile valleys bordering the streams. Timber plentiful; salt and sulphur springs occur in several parts. Farms 2,497; manuf. 229; dwell. 5,651, and pop.-Wh. 30,211, fr. col. 419-total, 30,660. Capital: Binghampton. Prblic Works: Chenango Canal; New York and Erie R. R.; and several railroads to Albany, Utica, and Syracuse (in progress).

Broome CeNTre, p. o., Schoharie co., N. Y.: $28 \mathrm{~m}$. S. W. Albany.

Brotzmantille, p. v., Warren co, N. Jer.: on the E. side of Delaware $\mathrm{r}_{0}, 57 \mathrm{~m}, \mathrm{~N}$. by W. Trenton.

Browse, p. o., Berks co., Penn.: 54 m. E. N. E. Harrisburg.

Brower's Mruls, p. 0., Randolph co., N. Car.: $73 \mathrm{~m}$. W. Palcigh.

Browry county, $I l$. Situate W. on Illinois r., and contains $308 \mathrm{sq} . \mathrm{m}$. Drained by Crooked and M'Kee's creeks. Surface undulating prairie, with bottoms and bluffs along the Mlinois. Farms 818 ; manuf. 73 ; dwell. 1,853, and pop. -wh. 7,184, fi. col. 14 -total, 7,193. Capital: Mount Sterling.

Brown county, Ind. Situate S. centrally, and contains 320 sq. m. Surface hilly, with fertile valleys and rich bottoms. Timber abundant; corn and hemp grow well in the bottoms; wheat, oats, and grass on the bills. Drained by Salt cr. and its tributaries, and Bear Blossom er. Farms 535 ; manuf.; 5 ; dwell. 790, and pop.-wh. 4,827, fr. col. 19-total 4,816. Capital: Nashville.

Brown county, Ohio. Situate S. W. on Ohio r., and contains 468 sq. m. Drained by White Oak, Spaight, Eagle, and Red Oak creeks. Surface generally level-on the Ohio somewhat broken; soils fertile, producing fine crops of whent, Indian corn, oats, and tobacco. Farms 1, 843 ; manuf. 92; dwell. 4,83S, and pop.-wh. 26,52Q fr. col. 812-total 27.332. Capital: Georgetown. 
Brows county, Wisc. Situate N. E., at the head of Green Bay, and contains $472 \mathrm{sq} . \mathrm{m}$. Surface diversified, with woodland and prairie, and soil excellent. Farms 190; manuf. 27 ; dwell. 1,008, and pop.-wh. 6,173, fr. eol. 42total 6,215. Capital: De Pere.

BRoWNFIELD, to and p. v., Oxford co., Mfe.: on Saco r., 63 m. W. S. W. Augusta. Pop. 1,320.

Brow Nhela, t. and p. v., Lorain co., Ohio: on Vermillion r. of Lake Erie, $104 \mathrm{~m}$. N. by E. Columbus. P. $1,082$.

Browning, p. 0., Schuyler co., Ill.: 89 m. W. N. W. Springtield.

Browntngton, to and p. v., Orleans co., Term.: on Willoughby cr. of Barton r., $89 \mathrm{~m}$. N. N. E. Montpelier. The Connecticut and Passamsic Rivers R. R. passes through the t. Pop. 613 .

Beowningtox, p. v., Butler co., Penn.: 193 m.W. by N. Harrisburg.

Browningtoy Centre, p. v., Orleans co., Term. : $39 \mathrm{~m}$. N. N. E. Montpelier.

Brows's, p. 0., Fairfield dist., S. Car.: 29 m. N. Columbia.

Brown's Buufr, p. o., Sumter co., Ala.: on Tombigbee r., $108 \mathrm{~m} . \mathrm{W}$. by N. Montgomery.

Brownseorougr, p. v., Oldham co., Ky.: on the line of the Louisville and Frankfort R. R., $37 \mathrm{~m}$. N. W. Frankfort.

Brow ssbukg, p. v., Hendricks co., Ind.: 13 m. N. W. Indianapolis.

Brownsburg, p. v., Bucks co., Penn.: on W. side of Delaware r., $123 \mathrm{~m}$. W. Harrisburg.

- Browrsedra, p. v., Rockbridge co., Virg.: 106 m. W. by N. Riehmond.

Browa's CoRNer, p. 0., Kennebec co., Me.; 6 m. distant from Augusta.

Brown's CAVE, p. o., Albemarle co., Virg. : 71 m. W. by N. Richmond.

Brown's Grove, p. o., Hamilton co., Ohio: 186 m. S. W. Columbus.

Browv's Mruss, p. o., Washington co., Ohio: $99 \mathrm{~m}$. E. by $\mathrm{S}$. Columbus.

Brown's Milis, p. O, Burlington co, N. Jer.

Brown's Store, p. v., Warren co., Ohio: 82 m. S. W. Columbus.

Brownstown, p. v., Sevier co., Avk.: 133 m. W. S. W. Little Rock.

Brownstown, p. F., and cap. Jackson co., Ind. : on the E. side of a branch of E. fork of White r., $61 \mathrm{~m}$. S. Indianapolis. The "Jackson County Advocate" is published weekly.

Brownstown, t. and p. $\nabla_{\text {., }}$ Wayne co., Mich.: on Lake Erie and Detroit r., 82 m. E. S. E. Lansing. The $\nabla$. is located on a $\mathrm{cr}$. of the same name, $2 \mathrm{~m}$. from the lake. Pop. 1,017.

Brown's VALLEX, p. 0., Montgomery co., Ind. : $42 \mathrm{~m}$. W. by $\mathrm{N}$. Indianapolis.

Brownstilut, p. o., Talladega co., Ala. : 68 m. N. Montgomery.

Brownstille (formerly Grand Pratrie), p. v., and cap. Prairie co., Ark.

Beowssville, p. V., Union co., Ind.: on E. fork of White $r_{\text {. }}$, and on the line of the Junction R. R., $64 \mathrm{~m}$. E. by S. Indianapolis.

Browsspille, p. т., and cap. Edmonson co., Ky.: on the S. side of Green r., 102 m. B. W. Frankfort.

Brownstrue, p. v., Cameron co., Tex. : on the N. bank of the Rio Grande, somewhat below Matamoras, $326 \mathrm{~m}$. S. Austin City. It is a flourishing $\nabla$. , and has considerable commerce with the river towns. Fort Brown was located here, and gives name to the $\mathrm{r}$. The "Rio Grand Sentinel" and "American Flag" are weekly newspapers published here.

Brownstrle, $p$; v., Piscataquis con, Me : on Pleasant $r$. of the Piscataquis, $73 \mathrm{~m}$. N. E. Augusta.
BrownstrulE, p. v., Washington co., MLd.: $73 \mathrm{~m}$. N. W. Annapolis.

Browasville, p. v., Hinds co., Mfiss.

Brownsville, p. v., Saline co., Mo.: on N. side of Black r., $88 \mathrm{~m}$. W. by N. Jefferson City.

Brownsville, p. v., Granville co., N. Car.: on Grass cr. of Poanoke $\mathrm{r}_{*}, 49 \mathrm{~m}$. N. Paleigh.

Brownstille, p. v., Johnson co., Ark: : 86 m. W. N. W. Little Rock.

Browastille, p. v., Licking co., Ohio: 26 m. E. Columbus. Pop. 480.

Brownsvilue, p. v., Fayette co., Penn. : on the E. bank of Monongahela r., at the mouth of Redstone cr., $189 \mathrm{~m}$. W. Harrisburg. The National Road here crosses the $\mathrm{r}$. by a fine bridge. Three newspapers, the "B. Free Press" and the "B. Herald" (both whig), and the "Cumberland Presbyterian," are published weekly.

Brownsvilue, p. v., Marlborough dist., S. Car

Brownsville, p. v., and eap. Haywood co., Tenn.: 146 m. W. by S. Nashville. The line of the Mobile and Ohio $R$. R. will pass through or near this village.

Brownsville, p. v. Windsor co., Verm.; 48 m. S. Monte pelier.

Browntown, p. v., Bradford co., Penn.: 123 m. N. Harrisburg.

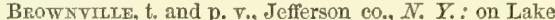
Ontario, N. of Black r., 148 m. N. E. Albany. The Cape Vincent Extension of the Watertown and Rome R. R. passes through the $v ., 76 \mathrm{~m}$. from Rome and $21 \mathrm{~m}$. from Cape Vincent. The lower falls of Black r. furnish extensive water-power, and below them the river is narigable from the lakes. Pop. 4,282.

Brownville, p. vo, Ogden co., Utah Ter.

BRUCETOWN, p. v., Frederick co., Virg.: 122 m. N. W. Richmond.

Bruceville, p. v., Knox co., Ind.: on the E. side Wabash, $4 \mathrm{~m}$. from the river and $92 \mathrm{~m}$. S. W. Indianapolis.

Bruceville, p. v., Carroll co., Md.: on Big Pipe cr., 59 m. N. W. Annapolis.

Bruck ville, p. V., Morgan co., $M l$ : $34 \mathrm{~m}$. W. by s. Springfield.

Bruin, p. o., Carter co., Ky.: 110 m. E. Frankfort.

Brors, p. o., Butler co., Penn.: $198 \mathrm{~m}$. W. Harrisburg.

Brutaton, p. v., King and Queen co., Virg.: 43 m. N. N. E. Richmond.

Brtin's Cross Roads, p. o., Parke co., Ind. : $69 \mathrm{~m}$. W. Indianapolis.

Bruly Landivg, p. o., West Baton Rouge par., $L a$.

Brumitexdvilue, p. v., Berks co., Penn.; 56 m. E. N. E.

Harrisburg.

BRUMAKEL's, p. o., Davidson co., N. Car.: 94 m. W. Raleigh. Pop. 169.

Brunersbuga, p. v., Defiance co., Ohio: 114 m. N. W. Columbus.

Brunerstown, p. v., Putnam co., Ind.: 44 m. W. by S. Indianapolis.

Beunswick county, $N$. Car. Situate S. E. corner, and contains $1,340 \mathrm{sq} . \mathrm{m}$. Drained by tributaries of Cape Fear r., which forms its E. border, and Waceamaw r. Surface flat and marshy, and soils indifferent. Rice and pine are the staples. Farms 385 ; manuf. 80 ; dwell. 771 , and pop. -wh. 3,651, fr. col. 319, sl. 3,302-total 7,272. Capital: Smithville.

Brunswiok county, Firg. Situate S. of Nottaway r., and contains $680 \mathrm{sq} . \mathrm{m}$. Drained by the head waters of Chowan r. Surface diversified, and soils of moderate fertility, pro. ducing abundantly Indian corn, oats, and tobaceo. Farms 655 ; manuf. 5 ; dwell. 1,051, and pop.-wh. 4,595, fr. col. 543, sl. 8.456-total 13,894. Capital: Lawrenceville.

Brunswick, p. v., port, and cap. Glynn co., Ga.: on the E. side of Turtle r., $168 \mathrm{~m}$. S. E. Milledgeville. Its harbor is spacious, safe, and is accounted the best $\mathrm{S}$. of Mason and Dixon's line. Ships drawing not more than 13 feet can 
pass the bar at low tide. The $\mathrm{v}$. is 13 ? $\mathrm{m}$, above the bar and $8 \mathrm{~m}$. above the lighthouse on St. Simon's Island. The shipping of the district in 1850 was 583 tons. The Brunswick Canal extends to the Alatamaha r. $12 \mathrm{~m}$., and it is proposed to build a railroad from Brunswick to Thomasville, with a branch to Tallahassee, and other branches from Troupville to Albany and from Thomasville to Bainbridge on Flint $\mathbf{r}$. These, when completed, will raise Brunswick to a high rank as a Southern port.

Brunswick, p. v., Peoria co., $M l .: 93 \mathrm{~m} . \mathrm{N}$. by W. Springfield.

Brunswick, t. and p. v., Cumberland co., Me. : on Androseoggin r., near its mouth, $29 \mathrm{~m}$. S. by W. Augusta. Lat. $43^{\circ} 53^{\prime} \mathrm{N}$. and $69^{\circ} 55^{\prime} 01^{\prime \prime} \mathrm{W}$. The r. furnishes a navigation for steamers and extensive mill-power. Large quantities of lumber are brought to this port from the borders of the Androscogoin, and a great deal is sawed at this point. A bridge connects it with Topsham, over which the Kennebec and Portland R. R. passes, $27 \mathrm{~m}$. from Portland, a branch of which $\mathrm{R}$. R. also runs to Bath, $9 \mathrm{~m}$. Bowdoin College, founded 1794, is located here, and has a medical school. Pop. 4,976.

BRUNSWICK, p. v., Chariton co., Mo.

BRunswick, t. and p. v., Medina co., Ohio: 104 m. N. E. Columbus. Pop. 1,417.

Brunswrok, t. and p. v., Essex co., Torm.: on Nulheghan r. and Paul's stream of the Connecticut, $54 \mathrm{~m}$. N. E. Montpelier. Two considerable ponds lie in the town, discharging their waters into the Connecticut. Pop. 119.

Brush Creer, p. o., Fandolph co., N. Cor?: $37 \mathrm{~m} . \mathrm{N}$. Raleigh.

Beusfi Creerk, p. o., Perry co., Ala.: $62 \mathrm{~m} . \mathrm{W}$. by N. Montgomery.

Bresil CReek, p. 0., Knox co., Ill.: 108 m. N. N. T. Springfield.

Brost, Hnt, p. o, Du Page co, $\Pi l_{2}: 282 \mathrm{~m}, \mathrm{~N} . \mathrm{E}$. Springfield.

Brushr.aND, p. o., Delaware co., $\boldsymbol{N}_{0} \boldsymbol{Y}_{\mathrm{.}}: 62 \mathrm{~m}$. S. W.

Albany.

Brosir Run, p. o., Washington co., Penn.: $203 \mathrm{~m} . \mathrm{W}$. Harrisburg.

Brusm Mriss, p. o., Franklin co., $\mathcal{N}$. $\boldsymbol{Y}$.: on the line of the Northern (Ogdensburg) R. R., $69 \mathrm{~m}$. from Rouse's

Point and 49 trom Ogdensburg; and $149 \mathrm{~m}$. N. N. W. Albany.

Brosh Vallex, p. o., Indiana co., Perm. : 142 m. W. by N. Harrisburg.

Brushrnle, p. v., Queen's co., $N . \quad I_{0}:$ on the line of the Long Island R. R., 14 m, from Brooklyn, and $145 \mathrm{~S}$ by E.

Albany.

Bresir Creek, p. o., Anderson dist., S. Cer': : $10 S \mathrm{~m}$.

N. W. Columbia.

Brushx Fuat, p. o., Watauga co., N. Car.

Brosiry Fork, p. o., Coles co., I l.: on Brushy fork of

Embarras r., 107 m. E. Springfield.

Brushy Prairie, p. 0, La Grange co., Ind. : 128 m.

N. by E. Indianapolis.

Bruynswick, p. Y., Ulster co., $N$. $\Gamma .: 74 \mathrm{~m}$. S. by W. Albany.

Bryar county, Ga. Situate S. E. on the Atlantic, and contains $472 \mathrm{sq}$. m. Drained by Cannouchee and Ogeechee rivers. Surface low and flat, with much swamp; soils light and sandy. Farms 209, dwell. 212, and pop.-wh. 1,164, fr. col. 15, sl, 2,245-total 3,424. Capital: Eden.

BeraN, p. v., Saline co., Mo.: on a cr. of Salt fork of Black r., $76 \mathrm{~m}$. W. by N. Jefferson City.

Bryax, p. ₹., and cap. Williams co., Ohio: on Lick cr. of Tiffin r., $132 \mathrm{~m} . \mathrm{N}$. W. Columbus. The "Family Visitor" (dem.) is published weekly.

BryaNsBurgE, p. $v_{*}$, Jefferson co, Ind.: on the E. of Big cr. 91 m. S. E. Indianapolis.

Bryantown, p. v., Charles co., JId. : 36 m. S. W. Annapolis
Bryanstrule, p. v., York co., Penn, : 22 m. 8. Harrig. burg.

Bryant's Creik, p. 0, Monroe co., Ind.: 48 m. S. W. Indianapolis.

Bryantsvili, p. v., Lawrence co., Ind. : 63 m. 8. by W. Indianapolis.

Bryantsviule, p. F., Garrard co, $K y_{.}: 42$ m. S. S. E. Frankfort.

Bucharar county, $I a$. Situate E. centrally, and contains 576 sq. m. Drained by Cedar and Wabesipinicon rivers. Surface rolling-chiefly prairie, and soils rich. Farms 45 ; manuf. 1; dwell. 74, and pop.-wh. 517, fr. col. 0-total 517. Capital: Independence.

Bucharar county, Mo. Situate N. W., on Missouri r. and contains $320 \mathrm{sq}$. m. Drained by Little Platte $r$, and its aflluents. Surface generally prairie, with some woodland. Soils excellent. Farms 1,258; manuf. 89; dwell. 2,030, and pop.-wh. 12,072, fr. col.11, sI. 902-total 12,975. Capital: Sparta.

Buctarar, p. v., Alleghany co., Penn. : $183 \mathrm{~m}$. W. by N. Harrisburg.

Buchanan, t. and p. v., Berrien co., Mich.: on the W. side of St. Joseph's r., 86 m. W. S. W. Lansing.

Buck, p. o., Laneaster co., Penn. : 42 m. S. E. Harrisburg.

Buckatonex, p. o., Clark co., Miss.: on Buckatoney r. $106 \mathrm{~m}$. E. by S. Jackson.

Buck Branch, p. o, De Kalb co., Ill.: on Somonauk cr., 212 m. N. E. Springfield.

Bucr Bridet, p, o., St. Lawrence con, $N$. $Y_{.:}$on Grasse r., 153 m. N. N. W. Albany.

Buck Creak, p. o., Tuscaloosa co., Alab. : 104 m. N. W. Montgomery.

BUоK CreEk, p. 0., Seriven co., Ga.: on a cr. so called of Savannah r., 114 m. E. by S. Milledgeville,

Buck CrefK, p. o., Greene co., Ind.: 69 m. S. S. W. Indianapolis.

Buck Ere, p. o., Laurens co., Ga.: on a cr. so called, 33 m. S. E. Milledgeville.

Buck Ere, p. o, Garrard co., $\not y_{*}: 44$ m. S. S. E. Frankfort.

Buck Ere, p. o, Putnam co, Ohio: 102 m. N. W. Columbus.

Buok Exe Cotrage, p. o., Perry co., Orio: 38 m. E. by 8. Columbus.

Buok Exe Furrace, p. o., Jackson co, Ohio: $66 \mathrm{~m}$. S. S. E, Columbus.

Buck Ere Town, p. o., Frederick co., Ma. : 63 m. N. W. Annapolis.

BUCKFIELD, t, and p. v., Oxford co., Me.: on a branch of the Androscoggin r., $31 \mathrm{~m}$. W. by S. Augusta. A branch of the Atantic and St. Lawrence $\mathrm{P}$. R., $13 \mathrm{~m}$. long, reache this place from Mechanic's Falls, 36 m. Portland, P. 1,659. BueK Grove, p. o, Rush co, Ind, : 38 m. E. S. E Indianapolis.

Buckganjox, p, o, Lewis co, Virg.: $194 \mathrm{~m}$. W. N. W. Richmond.

Buck HEAd, p. o., Morgan co., Ga. : on Oconee r., $27 \mathrm{~m}$. N. Milledgeville.

Buck HEAD, p. 0, Fairfield dist., S. Car.: 39 m. N. by W. Columbia.

BuOK HeAd Causex, p. o., Colleton dist., S. Car.: 106 m. S. by E. Columbia.

Buck Hoxtow, p, o., Franklin co., Term. : 42 m. N.N.W. Montpelier.

Bucshori, p. o., Winston co., Mifss. : $82 \mathrm{~m}$. N. E. Jackson.

Buckmorर, p. 0., Bromn co., $\Pi$. : 88 m. W. by N. Springfield.

Bucknorर, p. o., Carroll co., Ga. : 117 N. W. Milledgeville.

Brсқпора, p. o., Bienville par., La. : 187 m. N. W. Baton Rouge. 
Buckiory, p. o., Columbia co., Penn.: 73 m. N. by E. Harrisburg.

Buckwaudv county, Virg. Situate centrally, S. of James r., and contains $520 \mathrm{sq.m}$. Drained by tfibutaries of James r. Surface undulating and various, and the soils ordinarily fertile. The productions are wheat, Indian corn, oats, and tobacco, with some cotton. Farms 616 ; manuf. 5 ; dwell. 1,062, and pop.-wh. 5,426, fr. col. 250, sl. 8,161-total 18,837. Capital: Maysville. Pubtic Works: Richmond and Lynchburg $\mathrm{R}, \mathrm{R}$.

Buckivghar, t. and p. v., Bucks co., Penn. : 112 m. E. Harrisburg. The inhabitants are chiefly Quakers.

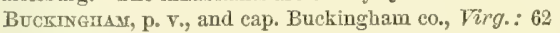
m. W. Richmond.

Bucklavd, t. and p. o., Franklin co., Mass.: on S. side of Deerfield $\mathbf{r}_{\mathbf{r}}, 91 \mathrm{~m}$. W. Boston. Pop, 1,056.

Buckland, p. o., Prince William co., Virg.: on the N. side of Occoquan r., $84 \mathrm{~m}$. N. by W. Richmond.

Bucklard, p. v., Hartford co., Conn.

BuckLix, p. v., Winnebago co., $M$. : $267 \mathrm{~m}$. N. Springfield.

Buck Porvt, p. o., Jackson co., Tenn.: 67 m. E. N. E Nashville.

BUCK Pratrie, p. o., Lawrence co, MO.: on N. side of Honey cr., $138 \mathrm{~m}$. S. W. Jefferson City.

Buchsar, p. v., Queens co., N. Y.: on Beaver Dam cr. $122 \mathrm{~m}$. S. by E. Albany.

Bucks county, Penn. Situate S. E. on Delaware r., and contains 546 sq. m. Drained by Neshaminy and Tohickon creeks, and the head waters of Perkiomen cr. Surface hilly, or rather rolling, but beautifully diversified, and soil of average fertility. Wheat and other grains are heavy crops. The county is noted for its pottery. Farms 4,707 ; manuf. 636; dwell. 9,757, and pop.-wh. 54,366, fr. col. 1,725 -total 56,091. Capital: Doylestown. Public Works: Norristown, Doylestown, and New Hope R. R.; Trenton and Philadelphia R. F。 ; and Delaware Division of Pennsylvania Canals.

Bucks, p. ₹., Columbiana co., Ohio: 123 m. N. E. Columbus.

Buckskin, p. o., Gibson co., Ind. : 112 m. S. W. Indianapolis.

Buchsport, t. and p. v., Harcoek co., Mre.: on E. side of the Penobscot r., $56 \mathrm{~m}$. E. by N. Augusta. It has a fine harbor and considerable trade, especially in lumber. A ferry is established on the river. Pop. $3,3 \$ 1$.

Beckspozt Centre, p. O., Haneock co., DLe.: 59 m. E. by N. Augusta.

Buckstown, p. V., Somerset co., Penn. : 108 m. W. by S. Harrisburg.

Buersville, p. v., Bucks co., Penn.: 112 m. E. TharrisBurg.

Buckgville, p. v., Horry dist., $S$. Car.: $113 \mathrm{~m} . \mathrm{E}$. Columbia.

BEck Tootr, p. o., Cattaraugas co., N. Y.: 256 m. W.S.W. Albany.

Bucrros, t., p.F., and cap. Crawford $\mathrm{co}_{n}$ Ohio: on the S. side of Sandusky r., $56 \mathrm{~m}$. N. Columbus, It is one of the most flourishing towns of the State, and has considerable srade, being central in a fine agricultural region. The "People's Forum" (dem.) is published weekly. The line of the $O$ hio and Indiana R. R. intersects it. Pop. 2,315.

Bute, p. v., Montgomery co., N. Y.: $52 \mathrm{~m}$. W. N. W. Allany.

BeErA Fista eounty, $I a$. Situate N. W, and contains $576 \mathrm{sq}$. m. Taken from Pottowattomie in 1851.

Buena. Vista, p. o., Carroll eo., Tenn.: 86 m. W. by \$. Nashville.

Bueva Vrsta, p. o., Prince George co., MId. : $32 \mathrm{~m}$. ธ. W. Annapolis.

Buena Vists, p. v., Atlantic co.,.$N$. Jer.: 49 m. S. S. E. Trenton.

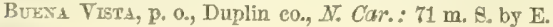
Pateigly.
Buexa Vista, p. 0., Jefferson co., Tind.: $76 \mathrm{~m}$. S. by E. Indianapolis.

Buena Vrsta, p. o., Washita co., Ark.: $\$ 2$ m. S. by W. Little Rock.

Buexa Vista, p. o.. IIarrison co., $k y$.: $41 \mathrm{~m}$. E. by $N$. Frankfort.

Buena Vista, p. o., Monroe co., Ala.: $71 \mathrm{~m}$. S. W. Montgomery.

Buena Vista, p. o., Stephenson co., $\pi l .: 273 \mathrm{~m} . \mathrm{N}$. Springfield.

Bueva Visxa, p. o., Platte co., Mo.: $156 \mathrm{~m}$. W. by N. Jefferson City.

Buena Vista, p. o., Chickasaw co., Miss. : 132 m. N. E. Jackson.

Buena Vxsta, p. o., Clinton co., Ia. : on the N. side of Wapsipinicon $r$. of the Mississippi, $42 \mathrm{~m}$. E. by N. Iowa City.

Buens Vista, p. 0, Shelby co, Tex.: 237 m. E. N. E. Austin City.

Buena Vista, p. 0., Greenville dist., S. Car. : 98 m N. W. Columbia.

Beena Vista, p. o., Marion co., $G a .: 78$ m. S. W. Milledgeville.

Buexa. Vista, p. o., Holmes con, Ohio: 68 m. N. E. Columbus.

Butina Vista, p. o., Portage co., Wisc. : $148 \mathrm{~m} . \mathrm{N}$ Madison.

Bunda Vista FurNace, p. o., Rockbridge co., Virg.: $113 \mathrm{~m}$. W. by N. Richmond.

Buena Vista Springs, p. o., Logan co, $\bar{k} y .: 144 \mathrm{~m}$. S. W. Frankfort.

Buffalo, p. v., Washita co., Art. : \$6 m. S. by W. Littlo Rock.

Buffalo, p. v., White co., Ind.: on the E. side of Tippecanoe $\mathrm{r}^{*}, 83 \mathrm{~m}$. N. W. Indianapolis.

Buffalo, p. $v_{\text {, }}$ and cap. Dallas co., $M \Gamma_{0}$ : $\$ 3$ m. S. by W Jefferson City.

Buffalo, post city, port of entry, and cap. Erie co. $N . I_{.}:$at the outlet of Lake Eric, and the head of Niagart r., $254 \mathrm{~m}$. W. Albany. The eity-lies on Buffalo cr., which falls into the lake, and ennstitutes its harbor. The distance to Albany by railroad is $525 \mathrm{~m}$., and by canal $364 \mathrm{~m}$. Lat. $42 \circ 53^{\prime}$ N., and long. $75^{\circ} 55^{\prime}$ W. Pop. in 1S10, 1S,213, and in $1850,42,260$.

Buffalo is the great entrepôt between the north-west and the states of the Atlanfic sea-board-the gate tlurough which the bulk of commercial material must pass for a matriet. Its position is unrivaled on the lakes, and from the advintages possessed by its port it has become the rundezvons for a yast tonnage employed on these western waters. Tho harbor is spacious and safe, tho creek having a elepth of 13 or 14 fect for a mile up), and being from 12 to 16 rods wide Its only obstruction is the sand and gravel at its mouth, driven in by gales of wind, but this defect has been obviated by the extension of a pier 1,500 feet long from the $S$. side of the entrance. This picr, which has a light-house at its end, operates as a breakwater, and, by confining the creek, has cleared its channel, so that vessels drawing $\$$ feet pass in without difficulty. The increasing commeree of the port, lowever, demands greater aceommodations, ano several valuable improvements are projected in the harbor.

The land on which the city is built rises by a rery gentle ascent two miles from the water, and from its higher parts affords fine riews of the neighboring scenery, the lake, the Niagara River, and Canada shore being within the view. The eity is laid out in broad and regular streets, which eontain numerous elegant stores, large warehouses, depôts of railroads, etc, and most of the dwellings are substantial and neat. There are three public squares, which add much to the salubrity and beauty of the eity. The public buildings are a court-hotse, jail, and other county uffices. two markets, the city offices, churches, bamts, ete. The Romun 
Catholic Cathedral, a new edifice, is one of the finest temples in America.

The city is divided into five wards, and is governed by a mayor and common council. The charter officers are a comptroller, treasurer, surveyor, etc., and in each ward are health inspectors, and other officers. The courts are the County Court, the Recorder's Court, and the Police and Justices' Courts. In the Fire Department there are nine engine companies, two hook and ladder, and a hose company. Water is supplied to the citizens through pipes, and the streets are lighted with gas. Among the benevolent institutions of the city, the most conspieuous are the Orphan Asylum, the City Hospital, the Hospital of the Sisters of Charity, the Female Orphan Asylum, and the Association for the Relief of the Poor. The eity is well supplied with common schools, open to all children, and has many highls efficient academies and private schools.

The Cniversity of Buffalo was chartered in 1846, and has a medical department. The Young Men's Association, established in 1835, is one of the best literary societies in the State, and has a fine library of 6,000 or 7,000 volumes, and a select cabinet of mineral and zoological specimens. During the winter, a series of lectures on literary and scientifie subjects are delirered by eminent professors. The German Young Men's Association is a similar institution, and has in its library nearly 2,000 rolumes, chiefly valuable works in the German language. The rooms of both these are amply supplied with periodicals and netrspapers.

The press of Buftalo consists of the "B. Commereial Advertiser," the oldest daily paper in the city : a tri-weekly edition is also issued ; the "Patriot and Journal," weekly; the "Western Literary Messenger," monthly; the "B. Medical Journal and Monthly Review ;" the B. Daily Courier," of which tri-weekly and weekly editions are also published; the "Morning Express," daily, tri-weekly, and weekly; the "B. Republic" daily and weekly; the "Daily Queen City ;" the "Evangelical Christian," semi-monthly; the "B. Christian Advocate;" the "Wool-Grower and Magazine of Agriculture and Horticulture," monthly; the "B. Pathfinder," weekly; and the following, which are German publications: "Der Weltburger," semi-weekly and weekIy ; the "B. Telegraph," weekly; and the "B. Democrat," daily and weekly.

There are in the city about 40 churches: 3 are Episcopal, 4 Presbyterian, 1 Associate Reformed Presbyterian (Scotch), 1 Reformed Presbyterian, 1 colored Presbyterian, 5 Methodist Episcopal, 4 Baptist, 1 Unitarian, 1 Universalist, 7 Roman Catholic, 1 Lutheran, and 7 or 8 German churches of various denominations.

The commerce carried on between Buffalo and Canada, in 1850 , amounted to $\$ 527,2 \% 0$, or which $\$ 220,196$ was the value of exports, and $\$ 307,074$ of imports; and the shipping employed in the transit of the merchandise reprasented by these values, was-American ressels cleared, 252 (29,696 tons), and entered, 246 (26,35̌2 tons); and British ressels cleared, 466 ( 73,897 tons), and entered, 473 ( 75,640 tons). Total clearances, 743 ressels (103,593 tons), and rotal entrances, $\tau 19$ vessels (101,992 tons). The value of imports from domestic lake ports, was $\$ 2,525,781$, and of exports, $\$ 11,501,737$. The arrivals, coastwise, numbered 3,555 vessels $(1,255,430$ tons), and the clearances, 3,599 ressels $(1,263,907$ tons). The value of merchandise delivered by the Erie Canal, was $\$ 41, \$ 59,270$, besides which the railroad from Albany delivered goods to the value of $\$ 6,041.456$. Forming the material of this commerce, we find the sugars of Louisiana, the cottons of Tennessee and Mississippi, the hemp of Kentucky, the furs of Missouri and the distant West, the copper of Lake Superior, the Iead of Wisconsin, the agricultural and forest products of all the States bordering on the lakes, the manufactures of Jew England and New York, and a small amount in bond and otherwise of Canadian products. The imports into Buffalo, in 1850 , from the Western States, consisted in part of 1,103,039 bar- rels of flour, $3,681,346$ bushels of wheat, $2,598,375$ bushels of Indian corn, $52,124,275$ feet boards and seantling, $19,988,962$ staves, $4,568,000$ shingles, 161,110 boxes and $3,15 \mathrm{~s}$ casks of eheese, 40,135 kegs and 2,203 barrels of butter, 53,567 bales of wool, 10,180 sheep, 46,44 S live and 7,420 slaughtered hogs, etc. The exports consisted of the prop erty landed at Buffalo from the Erie Canal, the Albany and Buffalo Railroad, and the manufactures and productions of the city itself; of these, castings, agricultural implements, furniture, dry goods, groceries, etc., formed the great bulk, but included was almost every thing that is known to commerce. (For a full account of the commerce of Buffit 2o, consult Andrewos' Report of the Trade and Commerce of the British Forth American Colonies with the Lnited. States, etc., presented. to the C.S. Senate [Dec. 23] in 1551.)

The shipping owned in the collection distriet of Bufialo, on the 30th June, 1850 , amounted to 39,679 tons, all of the class "permanent enrolled, and licensed," of which 23,0 ss tons were propelled by steam, and the whole engaged in the coasting trade. The number of vessels built in the year ending at the same date, was $7[1,730$ tons $]-1$ brig, 2 schooners, and 4 steamers.

Buffalo has 10 banks, and one savings' institution; also, including agencies, 44 fire, marine and life insurance companies.

The railroads uniting Buffalo with Canada, the Great West, and the States eastward, are magnificent works. Those pointing east, are the great line terminating at Albany, and. there connecting with the New England and Southern New York roads, and the narigation of the Hudson; and the several lines uniting with the New York and Erie R. R., known as the Buffalo and New Fork City P. R., and the Buffalo, Corning, and New York R. R. The West is reached by the Buffalo and State Line $R$. $R$., which connects with the system of roads in Ohio and the other lake States, and extends to the Mississippi River; and Canada will be reached by the Buffalo and Brandtford $R$. $R_{v}$, the Great Western R. R., and others now being constructed. Railroads also run to Niagara, Lewistown, etc. There are also several plank roads centering in Buffalo, and reaching back to the principal villages in the county.

Buffalo was founded in 1801 by the Holland Land Companv, bat for a long period it made little progress, since in 1814, when burned by the British, it did not contain more than 200 houses; nor was it until the Erie Canal opened a navigable passage from the lake to the Hudson Rirer, that it exhibited any uncommon rapidity of growth. Since that period, however, its prosperity has been unbounded, and its rise in the scale of importance as a commercial city has been such as its original founders could never have dreamed of. It now ranks as the fourth city of the State, and the twelfth of the United States, in respect of population, and in a commercial point of fiew is surpassed by only three or four of our sea-board ports.

Bufrato, p. t. Guernsey co., Ohio : on Buffalo fork of Seneer er. $69 \mathrm{~m}$. E. Columbus, Pop، \$34.

BcFfalo, t. and p. o., Washington eo., Penn。: $189 \mathrm{~m} . \mathrm{W}$ Harrisburg.

Beffalo, p. v., Perry co., Tenn.: on Buffalo r. of the Tennessee, $68 \mathrm{~m}$. W. S. W. Nashville.

Buffalo, p. v., Putnam co., Firg.: on the E. side of Grat Kanawha r. $25: 3 \mathrm{~m}$. W. by X. Ticbmond.

BcFrato, p. v., Henderson co., Texo.: on the N. bank of Trinity r., $216 \mathrm{~m}$. N. by E. Austin City.

Buffalo Crty, p. v., Marion $\mathrm{co}_{\text {.s }}$ Ark, : $101 \mathrm{~m}$. N. Little Rock.

Bufralo Cresk, p. o., Campbell co., Tenn.: on a cr. so called of the S. fork of Cumberland r., $132 \mathrm{~m}$. E. by $\mathrm{N}$. Nashville.

Beffalo Cross Roads, p. o., Union co., Penn.: $53 \mathrm{~m}$ N. br IT. Harrighirg.

Btfralo Ford, p. o., Wythe co., Tirg. : $205 \mathrm{~m}$. W. by S. Pichnonk. 
BufFalo Ford, p. o., Randolph co, $N_{\text {. }}$ Car. : $69 \mathrm{~m}$. W. Raleigh.

Buffalo Forge, p. o., Rockbridge co., Virg. : on Buffalo cr., $123 \mathrm{~m}$. W. Richmond.

Bufralo Grove, p. 0., Ogle co., $1 l_{\text {. }}$ : on Elkhorn cr., 227 m. N. Springfield.

Buffilo Heart, Sangamon co., Ill.: $23 \mathrm{~m}$. N. E. Springfield.

Buffalo Hril, p. o., Orange co., N. Car.: $42 \mathrm{~m}$. N. W. Raleigh.

Buffalo Latse, p. o., Marquette co., Wisc.: on the lake so called, $91 \mathrm{~m}$. N. Madison.

Buffalo PlanNs, p. o., Erie co, $N_{*} Y_{*}: 249 \mathrm{~m}$. W. Albany.

Bufralo Pratrte, p. v., Rock Island co., $M l_{\text {. : }} 180 \mathrm{~m}$. N. N. W. Springfield.

Buffalo Run, p. o., Centre co., Penn. : 67 m. W. N. W Harrisburg.

Buffalo Run, p. 0., Monroe co., Virg.: 168 m. W:

Richmond.

Buffalo Sperres, p. o., Amherst co., Firg.: $92 \mathrm{~m} . \mathrm{W}$.

Richmond.

BUFORD, p. v., Ohio co., Ky.: 124 m. W. S. W. Frankfort.

Buford, p. F., Highland co., Ohio : 73 m. S. W. Co lumbus.

Buford's, p. o., Bedford co., Virg.: $123 \mathrm{~m}$. W. Rich mond.

Buford's Bridge, p. o., Barnwell dist., S. Car. : on Salkawatchie r., $62 \mathrm{~m}$. S. Columbia.

Btggabo, p. o., Wilkes co., N. Car.: 136 m. W. by N. Paleigh.

Bug HAll, p. o, Macon co., Ala. : 84 m. E. S. E. Montgomery.

Bणlä, p. 0., Obion co., Tenn.: 164 m. W. Nashville.

Bulgen's Mruls, p. o., Coosa co., Ala. : $32 \mathrm{~m}$. N. Montgomery.

Bullbonus' Grove, p. o., Will co., $I l l .: 213$ m. N. E. Springfield.

Bulu CreeK, p. o., Wood co., Virg. : 243 m. W. N. W. Richmond.

Bulrton, p. o., Waukesha co, Wisc. : 86 m. E. Madison.

Buluir county, $\bar{K} y$. Situate N., and contains $248 \mathrm{sq} . \mathrm{m}$. Drained by Salt r., which traverses it from E. to W. Surface generally rolling, but in N. E. uneven; solls moderately fertile. Wheat, oats, and corn are the principal products. Some salt is made in the county. Farms 562; manuf. 14; dwell. 970 , and pop.-wh. 5,392, fr. col. 27, sl. 1,355-total 6,774. Capital: Shepherdsville. Public Works: Louisville and Nashville R. R. (projected).

Bull Mruss, p. o., Taney co., Mo.: on Bull cr., $137 \mathrm{~m}$. 8. by W. Jefferson City.

Bulzock county, Ga. Situate S. E., and contains 864 sq. m. Drained by tributaries of Ogeechee $\mathbf{r}_{\text {., }}$ which bounds the county N. E., and Connouchee r, which lies on the S. W. Surface low and sandy, and soils indifferent. Cotton is the chief product. Farms 412; manuf, 3 ; dwell. 477 , and pop.-wh. 2,840 , fr. col. 0, sl. 1,460-total 4,300. Capital: Statesboro'.

Bollock Creek, p. o., York dist., S. Car.: on a cr. so called of Broad r., $71 \mathrm{~m}$. N. by E. Columbia.

Bull Pun, p. o., Grainger o., Tenn. : on Bull Run cr. of Clinch r., 159 m. E. Nashville.

Bulv's Head, p. o., Duchess co., $N$. $Y$.

BLLI SW AMr, p. o., Orangeburg dist., $S$. Car.

Bulltown, p. V., Braxton co., Virg.: on Little Kanawha r., $188 \mathrm{~m}$. W. N. W. Richmond.

Bullville, p. v., Clange co, N. $Y$.: 94 m. \$. by W. Albany.

Buxcoms, p. 0., Pontotoc co., Miss. : 152 m. N. E. Jackson.

Burcoure county, $I \omega$. Situate N. W., and contains 720 घq. m. Taken from Pottowattomie in 1851.

Buncosme county, $N_{\text {. Car }}$. Situate W., between Blue
Pidge and Stony mts., and contains 900 sq. m. Drained by French Broad, a tributary of Tennessee r. Surface, an elevated table-land, with fine valleys, and a soil of good qual ity. Black $m t n, 6,476$ feet high, the loftiest summit of the Alleghanies, lies in the N. part of the county; and there is a warm spring in the 8. W. Grazing is the chief occupation, but considerable grain is produced. Farms 1,105 manuf. 19; dwell. 1,942, and pop.-wh. 11,601, fr. col. 107, sl. 1,717-total 13,425. Capital: Asherille.

Buncombe, p. v., Walton co., Ga. : $62 \mathrm{~m}$. N. W. Milledgreville.

Bundrsiuren, p. v., Geauga co., Ohio: 142 m. N. E Columbus.

Bunger's Miri, p. o., Greenbrier co., "Virg. : $163 \mathrm{~m}$. W Richmond.

Bunker Hilu, p. o., Macoupin co., Tu.: on the line of the Terre Haute and Alton R. R, $33 \mathrm{~m}$. S. Springfield.

Bunker Hrux, t. and p. v., Ingham co., Mich.: $22 \mathrm{~m}$

S. by E. Lansing, Pop. 374 .

Bunker His., p. o., Bucks co., Penn.: 102 m. E. by $\mathrm{N}$ Harrisburg:

Bunker Hrus, p. o., Bedford con, Firg.:116 m. W. by S Richmond.

Bunker's Hill, p. o., Catawba co., N. Car.: $142 \mathrm{~m}$. W Raleigh.

BuNKER's HrLx, p. v., Giles co., Tenn. : 67 m. \$. by W. Nashville.

Burbots (Bourbeuse), p. 0., Franklin co., Mo. : on a $\mathrm{er}$ so called, $54 \mathrm{~m}$. F. by S. Jefferson City.

Burbank, p. o., Wayne co., Ohio: $86 \mathrm{~m}$. N. E. Columbus.

Burchinlie, t. and p. o., St. Clair co., Mich.: $104 \mathrm{~m}$ E. by N. Lansing. Pop。 472 .

Bundett, p. Y., Tompkins co, $N$. $Y_{*}$ : on the E. side of Seneca Lake, $157 \mathrm{~m}$. W. by S. Albany.

Bureat county, Ill. Situate N. middle, and contain. $864 \mathrm{sq} . \mathrm{m}$. Drained by several tributaries of the Hinois r., which washes its S. E. border. Surface level or undulating-in some parts wet, and the soil is everywhere fertile Groves of timber and prairies are frequently met with Farms 741; manu.f. 20 ; dwell. 1,464, and pop.-wh. 8,831 fr. col. 10-total 8,841. Capital: Princeton. Public Works. Central R. R. ; Chicago and Rock Island R. R.; and Aurora Extension R. R.

Buraess" Store, p. o., Northumberland co, Firg.: 59 m. E. N. E. Richmond.

Burgetrstown, p. マ., Washington co., Penn.: $187 \mathrm{~m}$ W. Harrisburg:

Burke county, Ga. Situate E., between Savannah and Ogeechee r., and contains 950 sq. m. Drained by Brier and Beaver dam ereeks of the Savannah and Buckhead cr. of the Ogecchee. Surface varied, and soils of average fertility, producing largely of cotton, Indian corn, etc. Farms 712; manuf. 41; dwell. 1,017, and pop.-wh. 5,116, fr. col 152, sl. 10,832-total 16,100. Capitat: Waynesboro'. Pubtie Works: Burke County R. R. and Central Georgia R. R. Burke county, N. Vorr. Situate W. centrally, and contains 840 sq. m. Drained by Catawba r. Surface elevated, and in the N. W. mountainous. Wheat, corn, oats, and tobaceo are largely produced, and much attention is paid to live-stock. Farms 373; manuf. 22 ; dwell. 9S3, and pop.wh. 5,477, fr. col. 163, sl. 2,132-total, 7,772. Capital: Morgantown.

Burise, t. and p. o., Franklin co., $N . Y_{.}$: on Chateanguay r., $14 \mathrm{~S}$ m. N. Albany. The Northern (Ordenslurg) R. P. passes through the village, $49 \mathrm{~m}$. from Rouse's Point and 69 from Ogdensburg. Pop. 2,777.

Burke, t. and p. o., Caledonia co., Verm.: on branches of Passumsic r., 34 m. N. E. Montpelier. Burke Mountain in the $\mathrm{S} . \mathrm{E}$. of the town, is 3,500 feet high. Pop, 1,103.

RuRKe's Gardex, p. 0., Tazewell co., Firg.: $236 \mathrm{~m}$, W. Richmond.

Burkespille, p. o., and cap. Cumberland co, $K y$. : on the $\mathrm{N}$. side of Cumberland $\mathrm{r}_{*}, \mathbf{1 0 3} \mathrm{m}$. S. by W. Frankfort 
Burkesville, p. v., Prince Edward co., Virg.: $54 \mathrm{~m}$. W. by $\mathrm{S}$. Richmond.

BuRkeville, p. v., and cap. Newton co., Tex.: on Little Cow cr. of Sabine r., 232 m. E. by N. Austin City.

Burktтisvilie, p. v., Frederick co., Md.: $64 \mathrm{~m}$. N. W.

Annapolis.

Burettrsprule, p. v., Attala co., Miss. : 73 m. N. N. E.

Jackson.

BurLeson county, Tex. Situate centrally, on W. side of Brazos r., and contains about 1,100 sq. m. Drained by Cedar cr. of the Brazos, and by Davidson's, First, Second, and Third forks of Yegua cr., which forms its S. border. Surface undulating, rising to the N., and prairie interspersed with woodland. Soils famous for fertility. Farms 115; dwell. 224, and pop.-wh. 1,213, fr. col. 0, sl. 500-total 1,713. Capital: Caldwell.

Bunleson, p. v., Franklin co, Ala.: 169 m. N. W. Montgomery.

Burlargham, p. v., Panola co., Miss. : 153 m. N. N. E. Jackson.

BURLINGHaN, p. v., Sullivan co., $N$. $Y$.

Burlingram, p. v., Meigs con, Ohio: $78 \mathrm{~m}$. S. E. Com lumbus.

Borldxgtow county, $N$. Jer. Situate S., extending from the Delaware r. to the Atlantic. Drained by Assumpink, Crosswick's, Black's, Craft's, Assiscunk, Rancocus, and Pensaukin creeks of the Delaware, and Wading r. of Little Egg Harbor $r$. Surface level; soils various, from sand to loamy gravel and clay. Bog-iron ore and pine wood abundant; also marl. In Springfield there is a petrifying well. Farms 1.685; manuf. 452; dwell. 7,356, and pop.-wh. 21,194, fr. col. 2,009, sl. 0-total 23,203. Capital: Mount Holly. Puzlic Works: Camden and Amboy R. R. and Mount Holly Branch I. R.

Burlnigton, t. and p. v., Hartford co., Conn.: on Farmington $r_{\text {., }} 19 \mathrm{~m}$. W. Hartford. Pop. 1,161.

Burlivgton, p. v., East Baton Rouge par., La.: on 1 mitie r., $16 \mathrm{~m}$. N. E. Baton Rouge.

Bunlivaron, p. v., Carroll eo., Ind.: on S. side of Wild it r., ti m. N. by W. Intianapolis.

Bortington, p. o., Kane eo., $I l l .: 162$ m. N. N. E. Epringfield.

Burlingtox, p. city, and cap. Des Moines co, Ia.: on the W. bank of the Mississippi r., $248 \mathrm{~m}$. above St. Louis, and $62 \mathrm{~m}$. S. S. E. Iowa City. The land on which the city is built rises gradually from the river to hills, which form an amphitheatre around it. It has many fine public edifices, several mechanical and manufacturing establishments, and a large commerce. Three newspapers are published, the "Telegraph," tri-weekly and weekly; and the "B. Hawk Eye" (whig), and the "State Gazette" (dem.), weekly. One of the Pacific lines of railroad will probably have its E. terminus at this point. Burlington was formerIy the State capital; it was laid out in 1833, and in 1850 contained a population of 5,129 , being the largest city of the State.

Burlingron, p. v., and cap. Boone co., $\bar{K} y .: 57 \mathrm{~m}$. N. by E. Erankfort. "The "B. Advertiser" (whig) is published weekly.

Burlington, t. and p. o, Penobscot co, Mre.: $92 \mathrm{~m}$ N. E. Augusta. Pop. 451 .

Burlington, t. and p. v., Calhoun co., Mich.: on St. Joseph r., 49 m. S. S. W. Lansing. Pop. 811 .

Burlington, : and p. v., Middlesex co., Mass. : on Shawsheen r. $14 \mathrm{~m}$. N. W. Boston. Pop, 547.

Burlixgros, t., p. city, and port of entry, Burlington co., N. Jer.: on the E. side of the Delaware, opposite Bristol, $18 \mathrm{~m}$. S. by W. Trenton, and on the Camden and Amboy R. R., $16 \mathrm{~m}$. from Camden. The city is encircled 8 . and E. by a small stream, so as to form an island, which is connected with the main by bridges and causeways. Burlington was founted 16is, and incorporated 17st. The shipping of the district in 1550 amounted to 7,578 tons. It 85 has a newspiper, the " $\mathrm{B}$. Gazette," published weekly; and some manufactures and commerce. The official residence of the Protestant Episcopal Bishop of New Jersey is at Riverside in this city. Pop. 5,398.

Burlivgton, t. and p. v., Otsego co., N. $Y_{0}: 68 \mathrm{~m}, \mathrm{~W}$ Albany. Pop. 1,885.

BuRlingtos, p. v., and eap. Lawrence co., O7io: on the N. bank of Ohio $r_{\text {, }}$ at the extreme $\mathrm{S}$. point of the State $108 \mathrm{~m}$. S. by E. Columbus. It has various manufactures and several public buildings; and enjoys considerable commerce with the river towns. Pop. 2,529.

Burlington, t. and p. v., Bradford co., Penn. ; on Sugar cr., $102 \mathrm{~m}$. N. Harrisburg.

Burlifgton, t., p. eity, port of entry, and cap. Chittenden co., Term.: on Lake Champlain, 31 m. W. N. W. Montpelier. Lat $44017^{\prime}$, and long. $72036^{\prime} \mathrm{W}$. The village is situate on a bay, which, in the form of a regular curve, sets up a little on the E. side of the lake; on the S. the Ievel is low, but on the $\mathrm{N}$. rises to a high bluff, which, during the war of 1812, was strongly fortified. The streets cross each other $\mathbf{E}$. and $\mathrm{W}$. and $\mathrm{N}$. and $\mathrm{S}$., forming regular squares. Near the ceratre is a fine area on which the C. I is located. Many of the houses are handsome structures, generally surrounded by shrubbery, with gardens in the rear; and there are commodious stores and warehouses, It is the largest and most convenient place in the State, and has a constant connection with the railroads leading through New England to Canada and the Great West. The lake is here $10 \mathrm{~m}$. wide, and the harbor is protected from W. winds by a breakwater. The scenery on all sides is magnificent, combining lake and mountain views of great beauty and sublimity. The public buildings are the University of Vermont: it is an efficient and well-endowed institution, and has a medical department; the co. buildings, banks, churches, and several academic edifices. In the neighborhood are several flourishing manufacturing villages, chiefly on Winooski or Onion r. Three newspapers are published here, the "B. Sentinel" and "B. Free Press" daily and weekly, and the "Courier," weekly. The shipping owned in the district in 1850 amounted to 4,580 tons, of which 3,096 tons was navigated by steam. The elearances in the foreign trade in 1849-50, amounted to 342 vessels, measuring 82,856 tons, and the entrances to 404 vessels, measuring 99,435 tons. The collection district of Burlington comprises the whole lake shore of Vermont. Pop. of $t, 7,505$.

Burlingtow, p. !t., Racine co., Wisc. Pop. 1,629.

Burdiggton Flatis, p. o., Otsego co., N.Y.: on Whartons $\mathrm{cr}$. of Unadilla r., $72 \mathrm{~m}$. W. Albany.

Burnerstulue, p. V., Barbour co., Virg. : 178 m. N. W. Richmond.

BurNeTt, to and p. v., Dodge co., Wisc.: 86 m. N. E. Madison. Pop. 816.

Bornetr Corner, p. o., Dodge co., Wisc.: 89 m. N. E. Madison.

Burnett's Creer, p. o., White co., Ind. : $92 \mathrm{~m} . \mathrm{N}$. W. Indianapolis.

Burnhaur Village, p. v., Waldo co., Me.

Burning Spring, p. o., Wirt co, Firg. : 228 m. W. N. W. Richmond.

Burns, t. and p. v., Alleghany co., $N$. $Y_{\text {. : }}$ on Canaseraga cr. $217 \mathrm{~m}$. W. by S. Albany. The Buffalo and New York City R. R. passes through the village, $8 \mathrm{~m}$. from Hornellsville. Pop. 961.

Bcrxs, t. and p. $\nabla$. Shiawassee co., DFich.: on Shiawassee r., $34 \mathrm{~m}$. E. Lansing. Pop. 717.

Buexs, p. v., Henry co, IUl.: 182 m. N. by W. Springfield.

Brexside, p. o., Clearfield co., Penn.: $128 \mathrm{~m}$. W. by $\mathrm{N}$. Harrisburg.

Burs' Level, p. o., Cumberland eo., $N$. Car.

Btrnsville, p. v., and cap. Yancey co., $\Lambda_{\text {. }}$. Car. : $208 \mathrm{~m}$. W. Ralcigh. 
Burdeflle, p. v., MDonough co., $M l: 107 \mathrm{~m}, \mathrm{~N} . \mathrm{W}$. Springfield.

Burnsvifre, p. v., Dallas co., Alla. : $59 \mathrm{~m}$. W. Montgomery.

Burnt Cabins, p. o., Fulton co., Penn. : 74 m. W. S. W. Harrisburg.

Bunkt Cons, p. o., Monroe co., Ala.: 74 m. S. S. W.

Montgomery.

Bctrt Hills, p. o., Saratoga co., N. $Y .: 23$ m. N. Albany.

Btrnt Ordnarr, p. 0., James City co, Tirg. : 49 m. E. by Y. Richmond.

Burnt Prarre, p. o, White co., Ill.: 198 m. S. E. Springfield.

Bunxt Quanter, p. o., Dinwiddie co., Virg. : 38 m. S. S. W. Richmond.

Bernt Shop, p. o., Orange co., N. Car.

Bunnt Stand, p. o., Carroll co., Ga. : 112 m. N. W. Milledgeville.

Burntvule, p. v., Brunswick co., Virg. : 62 m. S. S. W. Richmond.

Bur OAK, p. o., Mercer co., MTo. : $152 \mathrm{~m}$. N. N. W. Jefferson City.

Burrilurnle, t. and p. v., Providence co., $R$. $I$. : on Branch r. of the Blackstone, $17 \mathrm{mo}$. N. W. Providence. It has excellent water-power and some manufactures. Pop. 3.533 .

Burr OAKs, t. and p. o., St. Joseph co., Mich. : on Prairie r., 74 m. S. S. W. Lansing. The Michigan Southern R. R. passes through this place, $110 \mathrm{~m}$. from Monroe, and $133 \mathrm{~m}$. from Chicago.

Burr's Ferry, p. o., Sabine par., La. : on the Sabine $\mathbf{r}_{\text {, }}$ $216 \mathrm{~m}$. N. W. by W. Baton Rouge.

Burk's Mrris, p. o., Jefferson co., $N_{*} Y_{*}: 138$ m. N. W. Albany.

Burrstule, p. v., Caroline co., Mrd.: 44 m. E. S. E. Annapolis.

Burrsthle, p. v., Russell co., Ala. : 73 m. E. Montgomery.

Burryilze, p. 0., Litchfield co., Conn.: on the line of the

Naugatuck R. R., $57 \mathrm{~m}$. from Bridgeport, and $23 \mathrm{~m}$. W. by

N. Hartford

Bursorvilete, p. v., Bucks co.g Penn。: 108 m. E. Harrisburg.

Burton, p. v., Adams co., Ill.: 126 m. W. Springfield.

Button, t. and p. v., Cattaraugus co., N. Y.: (see AlleGHANx). Pop. $1,037$.

Burtox, t. and p. v., Geanga co., Ohio : on Cuyahoga r.,

$141 \mathrm{~m}$. N. E. Columbus. Pop. 1,064.

Burtox's, p. O., Tishemingo co., Miss.: 206 m. N. E. Jackson.

Burton's Corners, p. o., Boone co., Ill.: $292 \mathrm{~m} . \mathrm{N}$. by

E. Springfield.

Butronsville, p. v., Montgomery co., $N . Y_{.}: 32 \mathrm{~m} . \mathrm{W}$. by N. Albany.

Burtonstule, p. v., Darien co., Ky.: 129 m. W. by S.

Frankfort.

Burtonton, p. V., Copiah co., Miss. : on Bayou Pierre,

$38 \mathrm{~m}$. S. W. Jackson.

Burtrille, p. v., M'Kean co., Penn.

Burwell's bay, p. o., Isle of Wight co., Virg. : on a bay of James r. so called, $68 \mathrm{~m}$. \$. E. Richmond.

Besbayville, p. v., Houston co, Ga. : 42 m. S. W. Milledgeville.

Busr Kill, p. o., Pike co, Penn. : 142 m, N. E. Harrisburg.

Bcsmall's Basn, p. 0, Monroe co., $N . Y_{.}:$on the Erie Canal, $256 \mathrm{~m}$. from Albany, and $108 \mathrm{~m}$. from Buffalo.

Busholistule, p. v., Greene co, $N_{0} Y_{*}: 43 \mathrm{~m} . \mathrm{S}$, by W. Albany.

Busm's Mrlus, p. o., Lewis co., Firg. : 194 m. W. N. W. Richmond.

BUst's STORE, p. 0., Laurel co., Ky.: at the head of the
S. fork of Rock Castle cr, of Cumberland r., $92 \mathrm{~m}$. S. S. F. Frankfort,

Bushvilite, p. v., Franklin co., Ga.: 99 m. N. by E. Milledgeville.

Bustwick, t., King"s co., $N_{0}, \boldsymbol{Y}_{0}$ : on Newtown cr., 149 m. S. by E. Albany. Pop. 3,739.

Bushy Creek, p. o., Williamson co, Tex. : $22 \mathrm{~m}$. N. Austin City.

Business Corner, p. o., Van Buren co., Ia.; 62 m. S. by W. Iowa City.

BuskrRK's BrIDGE, p. o, Washington con, $N_{0} Y_{0}:$ on Hoosic r., 24 m. N. E. Albany, and on the Troy and Boston R. R., $21 \mathrm{~m}$. from Troy,

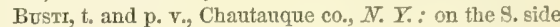
of Chautauque Lake, 283 m. W. S. W. Albany. P. 1,991.

Bustueton, p. o., Philadelphia co., Penn.: $93 \mathrm{~m}$. E. Harrisburg.

Bбтсне:'s Store, p. o., Randolph co., Virg.: $162 \mathrm{~m}$ W. N. W. Richmond.

Bute Creek, p. o., Marion co., Oreg. Ter.: on the creek so called, 23 m. N. E. Salem.

Buteville, p. v., Marion co., Oreg. Ter.: at the mouth of Bute cr., 18 m. N. E. Salem.

Butler county, $A l a$, Situate centrally in S. dist., and contains $964 \mathrm{sq} . \mathrm{m}$. Drained in the S. and $\mathrm{E}$. by tributaries of Conecuh r., and in the N. W. by ereeks of Alabama r. Surface undulating, and soils of average fertility. Corm and cotton are the chief products. Farms 553; manuf. 14; dwell. 1,210, and pop.-wh. 7,162, fr. col. 35, sl. 3,639-total 10,836. Capital: Greenville.

Butler county, Ia. Situate $\mathrm{N} . \mathrm{E}_{\mathrm{w}}$, and contains 576 sq. m. Taken from Pottowattomie in 1551.

ButLer county, $\bar{K} y$. Situate W. centrally, and contains 560 sq. m. Drained by tributaries of Green $r$, which runs through it. Surface irregular, and soils fertile, producing wheat, Indian corn, and tobacco. Farms 629; manuf. S; dwell. 897 , and pop.-wh. 5,056, fr. col. 18, sl. 6S1-total 5,75๊. Capital: Morgantown.

BUilfir county, Mo. Situate S. E. on State line, and contains 640 sq. m. Drained by St. François, Big Black, an 2 Little Black rivers. Surface prairie, and there is considerable marsh in the county. Solls very fertile. Farms 143 ; dwell. 265, and pop.-wh, 1,563, fr. col. 0, sl. 53-total 1,616. Capital: Butler C. I.

Butuer county, Ohio. Situate S. W. on State line, and contains $484 \mathrm{sq} . \mathrm{m}$. Drained by tributaries of Miami r., which traverses the county from $\mathrm{N}$. E. to S. W. Surface uneven. Soils of excellent quality, producing wheat, corn, and oats abundantly, and excellent timber. Farms 2,262; manuf. 269 ; dwell. 5,315, and pop.-wh. 30,429 , fr. col. 360 -total 30,789. Capital: Hamilton. Public Works: Miami Canal; Cincinnati, Hamilton, and Dayton R. R. : Hamilton, Eaton and Richmond R. R., ete.

Butler county, Penn. Situate W. centrally, and contains $824 \mathrm{sq} . \mathrm{m}$. Drained by tributaries of Alleghany and Bear rivers. Surface uneven, but the soils highly fertile. Wheat, Indian corn, buck wheat, ete., are the chief products. Iron is found. Farms 2,945; manuf. 14s; dwell. 5,251, and pop.-wh. 30,262, fr, col. 84-total 30,846. Capital: Butler. Public Works : Pennsylvania and Ohio R. R.

Butler, p. Y., De Kalb co, Ynd.: 122 m. N. E. Indianapolis.

BUTLER, p. V., Baltimore co., $I R$.

Butler, p. v., Richland co., Ohio: $52 \mathrm{~m}$. N. by E. Columbus.

Butler, t. and p. v., Wayne co., N. Y.: $159 \mathrm{~m}$. W b5 N. Albany. Pop. 2,272.

Butler, p. F., and cap. Choctaw co., Ala. : $112 \mathrm{~m}$. W. by S. Montgomery.

Butler, t., p. v., and eap. Butler co., Penn. : on Conequenessing er. of Beaver r., $162 \mathrm{~m}$. W. by $\mathrm{Y}$. I Iarrisburs. It is a handsome v., with some manifactures, and has three newspapers, the "Butler County Whig;" the "Democratic 
Herald," and the "Butier Democrat," issued weekly. Pop. 1,154 .

Butlek, p. v., Franklin par., La. : 117 m. W. Baton Rouge.

Butler, p. v., Milwaukie co., Wisc. : 146 m. E. Madison. Butler, p. v., Fulton co., Ky. : 264 m. W. S. W. Franlfort. ButLrR, p. v., Keokuk co., Ia. : $52 \mathrm{~m}$. S. W. Iowa City.

Butler, p. v., and cap. Dodge co., MFo.: $156 \mathrm{~m}$. N. by W. Jefferson City.

Butrer's Lavideg, p. o., Jackson co., Tenn.: on E. side of Cumberland r., $69 \mathrm{~m}$. E. N. E. Nashville.

Butlerstille, p. V., Anderson dist., S. Car.: $118 \mathrm{~m}$. W. by N. Columbia.

Butlertile, p. v., Butler co., Ala.: $116 \mathrm{~m}$. W. by N. Montgomery.

Butlervillue, p. v., Warren co., Ohio: 73 m. S. W. Columbus.

Butrahatchy, p. o., Monroe co., Miss. : on r. so called, 173 m. N. E. Jackson.

BuTTE county, Calif. Situate N. E. between Sacramento r. and the E. State line. Drained chiefly by Feather $\mathrm{r}$. and its branches, and also by numerous streams tributary directly to the Sacramento. The whole is included in the Gold Region, and has been very productive of that metal. Much of the soil, especially of the valleys, is rich and fertile, and well adapted to agricultural purposes. Pop. in 1550 , about 4,786 .

BetTe DES Morts lakes, Fise.: these lakes are expansions of the Neenah or Fox r. Great Butte des Morts lake, $4 \frac{1}{2} \mathrm{~m}$. above Lake Winnebsgo, is $3 \frac{1}{2} \mathrm{~m}$. long and from 1 to $2 \mathrm{~m}$. wide, and Little Butte des Morts lake, immediately below Winnebago rapids, is $41 \mathrm{~m}$. long and about a mile wide.

ButTe des Morts, $t$ and p. o., Winnebago co., Wisc.: on Fox r., 152 m. N. N. E. Madison. The town takes its name from some mounds within it, which tradition says are the resting place (Hitls of the Dead) of Indians slain in a great battle. These are now grown over with grass, and present much the same appearance as the ancient mounds so profusely scattered through the West.

Butteville, p. v., Sutter co., Calif.: on the E. side of Sacramento r., $76 \mathrm{~m}$. N. by E. Vallejo.

Butterfle, p. o., Oswego co., A. Y.: $111 \mathrm{~m}$. W. N. W. Albany.

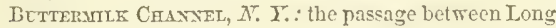
Island and Governor's Island, in the harbor of New York.

Buttermik Falis, p. 0., Orange co., $N$. $Y_{\text {.; }}$ on Hudson r., $84 \mathrm{~m}$. S. Albany. 'The falls from which the p. o. is named are $2 \mathrm{~m}$. below West Point, and consist of a beautiful and romantic cascade falling into the Hudson $r$.

Butrernot Ridge, p. o., Sandusky co., Ohio: $9 \mathrm{~S} \mathrm{~m}, \mathrm{~N}$. Columbus.

Butrernuts, t. and p. $\nabla$, Otsego co., $N$. $\bar{Y}$.: on Butternuts and Unadilla creeks, $82 \mathrm{~m}$. W. by S. Albany. The p. o. was formerly named Gilbertsville. Pop. 1,927.

BuTr's county, $G a$. Situate centrally, and contains $3 S 6$ sq. m. Drained by tributaries of Oekmulgee $\mathbf{x}$. Surface level and soils good. Cotton and Indian eorn are the principal products. Farms 391 ; manuf. 14; dwell. 642, and pop. -wh. 3,680, fr. col. 3, sl, 2,S05-total 6,488. Capital: Jackson.

Butzrown, p. $\nabla_{.}$, Northampton co., Penn.: 94 m. N. E. Harrisburg.

Brxtox, t. and p. T., Fork co., Yre.: on E. side of Saco r, $62 \mathrm{~m} . \mathrm{S}$. W. Augusta. The r, has here a fall of 80 feet, and furnishes excellent water-power. Pop. 2,995.

Butror Centef, p. O., York co., M.s.: 68 m. S. W, Augusta.

Buxcrspule, p. Y., Coosa co., Ala.: 81 m. N. Montgomery.

Buzzisd's Roost, p. o., Franklin co., Ala.: $18 \mathrm{~m}$. W. Tuseumbia, and 20\% $\mathrm{X}$. W. Montgomer. Qu
Brgerry, t. and p. o., Philadelphia co., Pennu: on Poquessing er., $98 \mathrm{~m}$. E. by $\mathrm{S}$. Harrisburg.

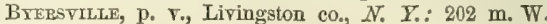
Albany.

Bresville, p. v., Guernsey co., Ohio: $79 \mathrm{~m}$. E. Columbus.

BxFieu, p. v., Essex co., Mass : on Parker r., which has falls, and furnishes good water-power, $28 \mathrm{~m}$. N. by E. Boston. Dummer Academy, founded by the lieutenantgovernor of that name in 1756 , is located here.

ByHarta, p. F., Marshall co., Miss. : 167 m. N. Jackson.

Brngton, p. o., Pike co., Ohio: $60 \mathrm{~m}$. S. Columbus.

Brlez's MrLu, p. o., Morgan co., Mo.: on a cr. of Osage r., 54 m. W. S. W. Jefferson City.

Brrkevilxe, p. v., Harrison co., Ind.: 113 m. S. Indianapolis.

Brron, p. v., La Porte co., Ind.: on the line of the Northern Indiana R. R., $128 \mathrm{~m}$. N. by W. Indianapolis.

Bxron, p. v., Greene co., Ohio: $52 \mathrm{~m}$. S. W. Columbus.

Brion, p. v., Ogle co., Ill.: on the W. side Roek r., 146 m. N. by E. Springfield.

Brron, p. v., Oxford co., Me. : $49 \mathrm{~m}$. W. by N. Augusta.

Brron, p. o., Shiawassee co, Mich.: on the E. side of Shiawassee r., $32 \mathrm{~m}$. E. by N. Lansing.

BrRoN, t. and p. v., Genessee co., N. Y.: on Black er. of Genessee $\mathrm{r}_{.}, 217 \mathrm{~m}$. W. Albany. There are several sulphur springs in the town. The Buffalo and Rochester R. R. passes through the village, $51 \mathrm{~m}$. from Buffalo. P. 1,566.

Broon, t. and p. v., Fond du Lac co., Wisc. : $106 \mathrm{~m}$. N. N. E. Madison, and $6 \mathrm{~m}$. S. of the base of Lake Winnebago. Pop. Ss2.

\section{C.}

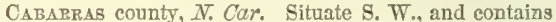
$432 \mathrm{sq} . \mathrm{m}$. Drained by the tributaries of Rochy $\mathrm{r}$. of the Yadkin. Surface hilly and somewhat broken; and soils of average fertility, producing wheat, Indian corn, and cotton largely. Farms S75; manuf. 41; dwell. 1,296, and pop-wh. 6,943, fr. col. 119, sl. 2,685-total 9,747 Capital: Concord.

CABELl county, Tirg. Situate W. on Ohio r., and contains $680 \mathrm{sq}$. m. Drained chiefly by the tributaries of Guyandotte $r$., which flows throughout it. Surface hilly and broken, and the soils indifferent. Wheat and Indian corn are the chief products. Coal is plentiful. Farms 498; manuf. 33 ; dwell. 976 , and pop.-wh. 5,904, fr. col. 6, sl. 389 -total 6,299. Capital: Cabell C. H. Public Works: Guyandotte R. R.

CaBelL C. H., p. v., and cap. Cabell co., Virg. : 273 m. W. Richmond.

CABIN Creek, p. o., Lewis co., $F y_{.}$: on a creek so called of the Ohio r., $86 \mathrm{~m}$. E. N. E. Frankfort.

Cabir Hill, p. 0., Delaware co, N. Y.: $63 \mathrm{~m} . \mathbf{S}$. W. Albany.

Cabiv Hill, p. o., Elkhart co., Ind.: 128 m. N. Indianapolis.

CABIV PoIvT, p. v., Surrey co, Firg.: near Chipoak cr. of James r., $38 \mathrm{~m}$. S. E. Richmond.

Cabotrilie (See Cmcopee).

САвот, t. and p. o., Caledonia co., Term.: $17 \mathrm{~m} . \mathrm{N} . \mathrm{E}$. Montpelier. Poj. 1,3506.

CACAPON Depôt, p. o., Morgan co., Virg.: on Great Cacapon er. of the Potomac, $146 \mathrm{~m}$. N. by W. Richmond, and by the Baltimore and Ohio R. R., $133 \mathrm{~m}$. from Baltimore.

Cacaporville, p. v., Hampshire co., Virg.: on Little Cacapon cr, $142 \mathrm{~m}$. N. by W. Richmond.

Cachomasso, p. o., Dallas co., Ark.: 53 m. S. Little Rock.

CADDo parish, La. Situate N. W. betwee Red r. and State line, and contains 1,036 sq. m. Tell drained by crecks and bayoux of Eed $r$. Lake Caddo occupies the 
whole centre of the county. Farms 305; dwell. 742, and pop.-wh. 3,687, fr. col. 39, sl. 5,208-total 8,884. Capital: Shreveport.

Cadno, p. v., Caddo par., La.: on Caddo Lake, $218 \mathrm{~m}$. N. W. Baton Rouge.

CADDo Cove, p. o., Montgomery co., Ark. : on Fourche Caddo, 78 m. W. S. W. Little Rock.

Cade's Cove, p. o., Blount co., Tenn. : on a cr. of Tennessee r., 173 m. E. S. E. Nashville.

Cadiz, p. F., Heary co., Ind:; on Duck or., $37 \mathrm{~m}$. E. by $\mathrm{N}$. Indianapolis.

CAdiz, t. and p. v., Greene co., Wisc. : 41 m. S. S. W. Madison. Pop. 459.

CADIZ, p. v., and cap. Trigg co., $K y$.: on Little r. of the Cumberland, $9 \mathrm{~m}$. above its confluence, $172 \mathrm{~m}$. W. S. W. Frankfort.

CADIZ, t., p. v., and cap. Harrison co., Ohio: $102 \mathrm{~m}$. E. by N. Columbus. It is a thriving village, has considerablo trade with the neighborhood, and has two newspapers, the "C. Republican" (whig), and the "C. Sentinel" (dem.), issued weekly. Pop. of v. 1,144, and t. 2,453.

Cadron, p. v., Conway co., Ark. : on the N. side of Arkansas r., where Cadron cr. enters it, $33 \mathrm{~m}$. N. N. W. Little Rock.

Cadwallader, p. o., Tuscarawas co, Ohio: $84 \mathrm{~m}$. E. by N. Columbus.

Cadrville, p. Y., Clinton co., $N$. $Y_{\text {.: }}$ on N. side of Saranac r., $7 \mathrm{~m}$. from its mouth at Plattsburg, and $136 \mathrm{~m}$. N. Albany.

Cageville, p. v., Haywood co, Tenn.: $162 \mathrm{~m}$. W. by S. Nashville.

CAHABA, p. . ., and cap. Dallas co., Ala. : on the W. bank of Alabama $r$, immediately below the confluence of the Cahaba r., 49 m. W. by S. Montgomery. It has considerable river trade, and is the centre of a fine agricultural country dependent on it for a market. The "Dallas Gazette" (dem.) is issued weekly.

CAH ABA river, $A l a$. : a large tributary of the Alabama r. which it joins at Cahaba v., $195 \mathrm{~m}$. above the confluence of the Alabama and Tombigbee. ville.

CAnss, p. o., Gwinnett co., Ga.: 78 m. N. W. Milledge-

Canrs, p. \%, Lancaster co, Penn. : $42 \mathrm{~m}$. \$. E. Harrisburg.

Cannspille, p. v., Wilson co., Tenn. : on a cr. of Stone's r., 31 m. E. by S. Nashville.

CATrtuck, p. v., New Hanover co., N. Car.: $103 \mathrm{~m}$. S. S. E. Raleigh.

CA IrA, p. V., Cumberland co., Virg.: on Willis r., $45 \mathrm{~m}$. above its confluence with James r., and 46 m. W. S, W. Richmond.

CAIR0, p. v., Decatur co., Ga.: at the head of Little r. of the Ocklockony, $156 \mathrm{~m}$. S. S. W. Milledgeville.

Carro, p. city, Alexander co., Ill.: on the extreme S. point of the State, at the confluence of the Ohio and Mississippi r., $176 \mathrm{~m}$. S. Springfield. It is destined to become an important commercial centre. The ground on which it is planned is low and liable to innndation, but by building levies round the river fronts this may be prevented. The city is the property of a company, and great pains have been taken to improve its natural facilities. The Central $R$. R. to Galena and Chicago commences here, and on the opposite side of the river the Mobile and ohio $R$. $R$. will terminateboth these great works are in progress.

Carro, p. v., Stark co., Ohio: 103 m. N. E. Columbus.

Carro, p. Ya, Henderson co., Ky.: $163 \mathrm{~m}$. W. by $\mathbf{S}$. Frankfort.

CAIPo, t. and p. V., Greene co., $N$. $Y .:$ on Catskill er. 26 m. \$. W. Albany. Pop. 2,881.

CAIro, p, v., Edgefield dist., S. Car. : 76 m. W. S. W. Colambia.

CALATs, $t$, and p. v., Washington co., Me. ; at the head of navigation of St. Croix r., 133 m. E. N. E. Augusta. It is connected with Baring by a railroad, and a bridge is throw over the St. Croix, below the lower falls of that $x_{\text {, }}$ connect ing it with the British territory. Extensive water-power is afforded by the river falls. The tide here rises 20 feet, and vessels of the largest class ascend to the lower village. It trade is chiefly in lumber. Three newspapers are printed in Calais-the "C. Advertiser" (whig), the "Frontier Journal" (dem.), and the "Sentinel" (whig)-all published weekly. Pop. 4,753.

Calars, p. t., Washington co., Verm.: on the head branches of Onion r., 9 m. N. N. E. Montpelier. P. 1.410 .

CALAIS, p.v., Monroe co., Ohio: $108 \mathrm{~m}$. E by S. Columbus.

Calavos, t. and p. o., Dodge co., Wisc. $:$ on a er, of Beaver Dam r., 34 m. N. E. Madison. Pop. 413.

Calapooya, p. v., Linn co, Oreg. Ter.: on a cr. of the same name, $39 \mathrm{~m}$. S. Salem. The er. falls into the Willamette r. at Albany.

Calaubrya, p. v., Rowan co., N. Car. : 108 m.W. Raleigh.

Cala veras river, Calif.: a tributary of the San Joaquin $r$. from the Sierra Nevada. The gold washings of this stream have been very productive.

Calaveras county, Calif. Situate centrally on E. State line. Drained by the Mokolumne, Calaveras, and severa of the branches of Stanislaus r. Surface eastward, mountainous-in the west, a plain declining to the San Joaquin r. Throughout it is rich in gold, and its agricultural capacities are ample. Pop. in 1850 about 16,884 .

CALCASIEU river, $L a_{0}$ : rises in Natehitoches parish, $S . W$ of Red r., and flows in a generally S. course to the Gulf of Mexico. Near its mouth it expands into a lake about 20 $\mathrm{m}$. long and from 1 to $10 \mathrm{~m}$. wide. The tide rises to the head of the lake, but both lake and river are too shallow for a certain navigation.

Calcastet parish, La. Situate S. W., between Sabine r. and Bayou Mermenteau, and contains 5,400 sq. m. Drained chiefly by Calcasieu r. and its numerous tributaries. Surface low, swampy, and containing several large lagoons. Cotton and sugar are the principal products. Farms 239 ; dwell. 548, and pop.-wh. 2,716, fx. col. 241, sl. 957-total 3,914. Capital: Lisbon.

Calcutra, p. ₹., Columbiana co., Ohio: 130 m. E. by S. Columbus. Pop. 147

CALDWEL county, $K y$. Situate W. on Tennessee $r_{\text {. }}$ and contains $586 \mathrm{sq}$. m. Drained by tributaries of the Tennessee and Cumberland, the latter of which runs through it, and by the Treadwater cr, of the Ohio $r$. Surface level or undulating, and soils fertile, producing largely of wheat, Indian corn, oats, and tobacco. Iron is found in the county. Farms 889 ; manuf. 85 ; dwell. 1,746, and pop.-wh. 9,809, fr. col. 132, sl. 3,107-total 13,048. Capital: Eddyville.

CALDWELI parish, La. Situate centrally in W. Dist., and contains $576 \mathrm{sq}$. m. Drained by Wachita r. and tributaries, Surface E. level and alluvial-W. finely varied with bill and dale. Farms 185; manuf. 1; dwell. 300, and pop.wh. 1,584, fr. col. 0, sl. 1,231-total 2,815. Capital: Columbia.

Caldwell county, Mo. Situate N. W. middle, and contains $432 \mathrm{sq}$. na. Surface level prairie. Drained by Shoal cr., the W. fork of Grand River, and other streams, Soil everywhere fertile. Farms 232; manuf 7 ; dwell. 359, and pop.-wh. 2,176, fr. col. 4, sl. 136-total 2,316. Capital: Kingston.

Caldwel county, $N$. Car. Situate N. W. at the E. base of the Blue Ridge, and contains $720 \mathrm{sq} . \mathrm{m}$. Drained by tributaries of Catawba r., which bounds it S., and by the head waters of Yadkin $r$. Surface elevated and hilly-in the W. mountainous. Soils fertile, and grain crops abundant. Farms 366; manuf. 8; dwell. 926, and pop.--wh. 5,006, fr. col. 108, sl. 1,208-total 8,317. Capital: Lenoir.

CAldwell county, Tex. Situate centrally on N. E. side of San Mareo of the Guadalupe r., and contains $682 \mathrm{so} . \mathrm{m}$ Drained by Plum and other creeks. Surface elevated and rolling-chiefly prairie, but in N.W. somewhat hilly. Farns 
51 ; dwell. 174, and pop.-wh. 1,054, fr. col. 1, sl. 274-total 1,329. Capital: Lockhart.

Catoweli, p. v., Orange co, N. Car.: 49 m. N. W. Raleigh.

Caldwel, t. and p. o., Essex co., $N$. Jer.: on Deep and Green Brooks of the Passaic r., $51 \mathrm{~m}$. N. N. W. Trenton, It has considerable manufactares. Pop. 2,476.

Calowell, t. and p. v., Warren co., $N . Y_{\text {.: }}$ at the head of Lake George, $49 \mathrm{~m}$. N. Albany. There is a regular steamboat communication between this village and the outlet of the lake near Ticonderoga. The ruins of Fort William Henry and Fort George are near this place, and are objects of interest to summer travelers, who resort to this neighborhood in great numbers. Poi). 752 .

Caldwell, p. v., and cap. Burleson co., Tex.: on Davidson's cr. of the Yegua, a tributary of Brazos r., 54 m. E. N. E. Austin City.

Candwell's, p. o., Washita par., $L a .: 148$ m. N. N. W. Baton Rouge.

Calpwell's Prateie, p. o., Racine co., Wisc.: $72 \mathrm{~m}$. E. S. E. Madison.

Caledoxra county, Form. Situate N. E. on Connecticut r. and contains $718 \mathrm{sq}$. m. Drained chiefly by Passumsic and Wells rivers, and contains also the head streams of Lamoille and Onion rivers. Surface finely varied, and in the W. hilly. A great portion of the county has good soils, producing wheat and other grain, and affording sustenanee to numerous cattle and sheep. Limestone and granite abound, and there are several sulphur springs. Farms 2.754; manuf. 215 ; dwell. 4,231, and pop.-wh. 23,081 , fr. col, 5-total 23,086. Capital: Danville, Public Forks: Connecticut and Passumsic Rivers R. R., etc.

Caledonia, p. v., Pulaski co., $I l l$. : on the Ohio $r_{.}, 18 \mathrm{~m}$. abore its junction with the Mississippi, and 163 S. Springfield.

Caledonia, t, and p. v., Pacine co., Wise.: on Root $r_{*}$ 87 m. E. S. E. Madison. Pop. 1,098.

Caledonta, p. F., Pusk co, Tex.: 233 m. N. E. Austin City.

Caleporta, p. Y., Lowndes co., Afiss.: on the S. side of Buttahatchee $\mathrm{r}$. of Little Tombigbee $\mathrm{r}$., $146 \mathrm{~m}$. N. E. Jackson.

Caredoxis, t. and p. o., Kent co., Hichs: on Thornapple $\mathrm{r} ., 44 \mathrm{~m}$. W. by N. Lansing. Pop. 99.

CALEdonIA, p. v., Washington co., MO. : on the S. side of Big r. of the Maramee r., 95 m. S. E. Jefferson City. The ncighborhood abounds in minerals.

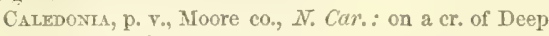
r., 61 m. W. S. W. Raleigh.

Caledonta, p. v., Marion co., Ohio: on the W. side of the W. branch of Whetstone r., $46 \mathrm{~m}$. N. Columbur.

Caledonla, p. v., Elk co., Penn. : 132 m. N. W. Harrisburg.

Caredorra, t. and p. $\nabla$. , Livingston co., N. $Y_{*}: 199 \mathrm{~m}$. $\pi$. Albany. The town is drained by tienessee r., and has a fertile soil. The Buffalo, Corning, and New York $R$. $R$. passes through it to a junction with the Canandaigua and Niagara Falls R. R. Pop. 1,804.

Caledonla, p. v., Heary co., Tenn.: 98 m. W. Nashville.

CatF IsLaND, a small island in Detroit r., near its mouth, and near Goose Island.

Calmoun county, Flor. Situate in W. Florida on the GuIf, and contains 1,280 sq. m. Drained by Chipola $x$., and the Appalachicola, which forms its E. border. Surface low, and in some parts swampy. Soils excellent. Farms 63; manuf. 1; dwell. 165; and pop.-wh. 886, fr. col. 38, sl. 458-total 1,377. Capital: St. Joseph. Pubtic Works: St. Joseph and Iola R. R.

CALHoun county, $I l$. Situate W. between the Illinois and Mississippi rivers, and contains $236 \mathrm{sq}$. m. Drained by Bay and other creeks. Surface elevated in the interior, and along the border rivers are high bluffs and extended alluvial bottoms. Farms 205 ; dwell. 600 , and pop.-wh. 3,230 , fr. col. 1-total 3,231. Capital: Hardin.

CALHOUN county, Wich. Situate S. centrally, and contains 720 sq. m. Drained by St. Joseph and Kalamazoo rivers. Surface undulating and finely lumbered; soils rieh and loamy. Sandstone is abundant on the Kalamazoo. Farms 1,724; manuf. 61 ; divell. 3,433 , and pop.-wh. 18,965; fr. col.197-total 19,162. Capital: Marshall. Public Works: Michigan Central R. R.

CALHOUN county, Tex. Situate S. W. on Matagorda and Espiritu Santo bays, and contains about $560 \mathrm{sq} . \mathrm{m}$. Matagorda island is included within this county. Drained by rivers and creeks falling into the adjacent bays. Surface low, and near the coast sandy; the soils of the interior are rich and productive. Farms 22; dwell. 182, and pop.-wh. St6, fr. col. 0, sl. 231-total 1,110. Cupital: Port Lavaca.

CAlHoux, p. .., Autauga co., Ala.: 22 m. N. W. Montgomery.

CaLrors, p. v., and cap. Gordon co., Ga. : on the line of the Western and Atlantic R. R., 80 m. from Atlanta, and 146 N. W. Milledgeville.

CAlmoux, p. v., Lumpkin co, Ga.: 137 m. N. N. W. Milledgeville.

Calmoun, p. v., La Fayette co., Ark.: $118 \mathrm{~m}$. S. by W. Little Rock.

CarHour, p. v., Henry co, MTo.: at the head of Tebo cr. of the Osage r., $79 \mathrm{~m}$. W. by S. Jefferson City.

Calnous, p. v., Daviess co., $\bar{K} y_{*}: 161 \mathrm{~m}$. W. by S. Frankfort.

Calnotw, p. v., Anderson dist., S. Car.: 103 m. N. W. Columbia.

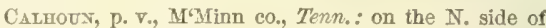
Hiwassee r., 126 m. E. S. E. Nashville.

CALHots, p. V., Richland co., IUl. : $102 \mathrm{~m}$. S. E. Springfield.

Carmoun's Mrrls, p. o., Abbeville dist., S. Car.: $92 \mathrm{~m}$. W. Columbia.

\section{THE STATE OF CALIFORNIA.}

C.Imorist neculyies all that portion of California Alta* westward of the followiug line, to mit-beginning at the intersection of 420 north latitude, and 1200 longitude west from Greenwich, or $42355^{\prime}$ from Washington; thence south in a direct course to 390 north latitude; thence south-east to where the Rio Colorado intersects the parallel of 350 north latitude and thence down the mid channel of that river to the boundary between the United States and Mexico. Within these limits the surface measures 185,981 square miles, or $120,947,840$ acres.

This grand division of California (the only part, indeed, to which the name properly applies) is traversed from N. to $\mathrm{S}$. by two principal ranges of mountains, called respectively Sierra Nevada, which divides the region from the great basin, and the Coast Range, running almost parallel to and at a short distance from the Pacific coast. The main feature of this reginn is the long, low, broad valley of the San Joaquin and sacramento rivers-the two valleys forming one--500 miles long and 50 miles broad. Lateral ranges, paralleI with the Sierra, make the structure of the country, and break it into a

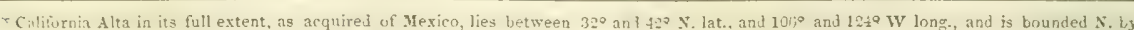

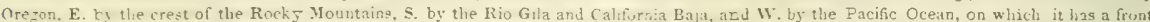
of tut $\mathrm{m}$. The area included within those limits is $418,691 \mathrm{sq} . \mathrm{m}$. This extensive tertitory 10 now divided into the State of California, Liah Territury, and in part) the Territury of New Mexico 


\section{CALIEORNIIA.}

surface of valless and mountains-the valleys a few hundreds, and the mountains 2,000 to 4,000 feet above the sea. These form greater masses and become more elevated in the north, where some peaks, as the Shasté, enter the regions of perpetual snows. The great valley is discriminated only by the names of the rivers that traverse it. It is a single geographical formation, lying between the two ranges, and stretching across the head of the Bay of San Francisco, with which a delta of 25 miles connects it. The two rivers rise at opposite ends of this long valley, receive numerons affluents-many of them bold rivers, becoming themselves navigable rivers-flow toward each other, meet half way, and enter the bay togetber in the region of tide water: making a continuous water line from one end to the other. The resources of this valley, mineral and agricultural, are immense, and perhaps no part of the world affords greater facilities for easy development. Gold and quicksilver are the most valuable of its mincral products. The soil and climate, though varying much with locality, are generally well suited for agriculture. Westward of the rivers, the soil is-chiefly dry and unproductive; but on the east side the country is well watered and luxuriantly fertile, being intersected by numerous fine streams, forming large and beautiful bottoms of rich land, wooded principally with white oaks. The foot hills of the Sierra, which limit the valley, make a woodland country, diversified with undulating grounds and pretty vales. Near the Tulare Lakes, and on the margins of the Sacramento and San Joaquin rivers, the surface is composed of level plains, gradually changing into undulating, and rolling toward the mountains. The region west of the Coast Range to the Pacific-the only portion inhabited before the discovery of gold-has long been the seat of numerous missions; and around these, generally situated in the most lovely vales, agriculture has converted the country into a perfect garden. All the cereals of temperate regions are eultivated, and the olive and grape thrive luxuriantly. Wheat is the first product of the north. The moisture of the coast seems particularly suited to the cultivation of roots, and to vegetables used for culinary purposes, which, in fack, grow to an exiraordinary size. Few localities, indeed, can produce in such perfection so great a variety of grains and fruits.

The coasts of California are generally precipitous and rugged; and in relation to their extent present few good harbors. The bays of San Diego, Monterey, and San Francisco, are the finest, and their capacities extensive. San Franciseo Bay is one of the most important in the world, not merely as a harbor, but also and mainly from the accessory advantages which belong to it-fertile and picturesque dependent country, general mildness of climate, connection with the great central valley, etc. When these advantages are taken into account, with its geographical position on the line of commurication with Asia, its importance rises superior to all contingencies. Its latitudinal position is that of Lisbon; its elimate that of Italy; bold shores and mountains give it grandeur; the extent and resources of its dependent country are the cynosure of the world. The bay is separated from the sea by low mountain ranges, and only a narrow gate, about a mile wide, affords an entrance. It is land-locked in every sense of the word, and protected on all sides from the weather. Passing through this narrow entrance, the bay opens to the right and left, extending in each direction about 35 miles, having a total length of 70 and a coast of 275 miles. It is dirided by projecting points and straits into three separate compartments, of which the northern two are called San Pablo and Suisson bays. The surface is much broken by numerous islands-some mere rocks, and others grass-covered, rising to the height of 300 to 800 feet. Directly fronting the entrance, mountains, a few miles from the shore, rise about 2,000 feet above the water, crowned by forests of lofty eypress, which are visible from the sea, and make a conspicuous landmark for vessels entering the bay. Bebind, the rugged peak of Mt. Diavolo, 3,770 feet high, overlooks the surrounding country of the bay and the San Joaquin.

The shore presents a varied character of rugged and broken hills, rolling and undulating land, and rich alluvial tracts, backed by fertile and wooded ranges, suitable for towns, villages, and farms, with which it is beginning to be overspread. Such is the bay and proximate country and shore of San Francisco. It is not a mere indentation of the coast, but a little sea to itself, connected with the ocean by a defensible gate. The head of the bay is about 40 miles distant from the sea, and there commences its connection with the noble valley of the San Joaquin and. Sacramento.

The climate of California is so remarkable in its periodieal changes, and for the long continuance of the wet and dry seasons, dividing as they do the year into about two equal parts, which have a most peculiar influence on the labor applied to agriculture and the products of the soll, and, in fact, connect themselves so inseparably with all the interests of the country, that it is deemed proper briefly to mention the causes which produce these changes, and which, it will be seen, must exercise an important and controlling influence on the commercial prosperity and resources of the country. It is a well-established theory, that the currents of the air under which the earth passes in its diurnal revolutions, follow the line of the sun's greatest attraction. These currents of air are drawn toward this line from great distances on each side of it, and, as the earth revolves from west to east, they blow from north-east and south-east, meeting, and, of course, causing a calm on the line. Thus, when the sun is directly, in common parlance, over the equator, in the month of March, these currents of air blow from some distance north of the Tropic of Cancer and south of the Tropic of Capricorn in an oblique direction toward this line of the sun's greatest attraction, and form what are known as the northeast and south-east trade-winds. As the earth in its path round the sun gradually brings the line of attraction north in summer, these currents of air are carried with it; so that about the middle of May the current from the north-east has extended as far the 38th or 39th degree of north latitude, and by the 20th of June, the period of the sun's greatest northern inclination, to the northern portions of California and the southern section of Oregon. These north-east winds, in their progress across the continent toward the Pacific Ocean, pass over the snow-capped ridges of the Rocky Mountains and the Sierra Nevada, and are, of course, deprived of all the moisture which can be extracted from them by the low temperature of those regions of eternal snow; and consequently no moisture can be precipitated from them, in the form of dew or rain, in a higher temperature than that to which they have been subjected. They therefore pass over the hills and plains of California, where the temperature is very high in summer, in a very dry state; and, so far from being charged with moisture, they absorb, like a sponge, all that the atmosphere and surface of the earth can. yield, until both become apparently perfectly dry. This process commences when the line of the sun's greatest attraction comes north in summer, bringing with it these vast atmospheric movements, which on their approach produce the dry season in California, which, governed by these laws, continues until some time after the sun repasses the equator in September; when, about the middle of November, the climate being relieved from these north-east currents of air, the south-west winds set in from the ocean, charged with moisture, the rains commence, and continue to fall-not constantly, as some persnns have represented, but with suffleient frequency to designate the period of their continuance-from about the middle of November until the middle of May, in the latitude of San Francisco-as the woet season. It follows, as a matter of course, that the dry season commences first and continues longest in the southern portions of the State, and that the climate of the northern part is influenced in a much less degree by the causes heretofore mentioned than any other section of the country. Consequently, we find, that as low down as latitude $39 \circ$, rains are sufficiently frequent 
CALIFORNIA.

in summer to render irrigation quite unnecessary to the perfect maturity of any crop which is suited to the soil and climate. There is an extensive ocean-current of cold water which comes from the northern regions of the Pacific, or, perhaps, from the Aretic, and flows along the coast of California. It comes charged with, and emits in its progress, cold air, which appears in the form of fog when it comes in contact with a higher temperature on the American coast-as the gulf stream of the Atlantic exhales vapor when it meets in any part of its progress a lower temperature. This current has not been surveyed, and, therefore, its source, temperature, velocity, width, and course, have not been accurately ascertained. It is believed by Lieutenant Maury, on what he considers sufficient evidence-and no higher authority can be cited-that this current comes from the coasts of China and Japan, flows northwardly to the peninsula of Kamtschatka, and, making a circuit to the eastward, strikes the American coast in about latitude $41^{\circ}$ or $42^{\circ}$, it passes thence southwardly, and finally loses itself in the tropies. Below latitude $39^{\circ}$, and west of the foot-hills of the Sierra Nevada, the forests of California are limited to some seattering groves of oak in the valleys and along the borders of the streams, and of red-wood on the ridges and on the gorges of the hills-sometimes extending into the plains. Some of the hills are covered with dwarf shrubs, which may be used as fuel. With these exceptions, the whole State presents a surface without trees or shrubbery. It is eovered, however, with various species of grass, and, for many miles from the coast, with wild oats, which in the valleys grow most luxuriantly. These grasses and oats mature and ripen early in the dry season, and soon cease to protect the soil from the scorching rays of the sun. As the summer advances, the moisture in the atmosphere and the earth, to a considerable depth, soon becomes exhausted, and the radiation of heat from the extensive naked plains and hill-sides is very great. The cold, dry currents of air from the north-east, after passing the Rocky Mountains and the Sierra Nevada, descend to the Facific, and absorb the moisture of the atmosphere to a great distance from the land. The cold air from the mountains and that which accompanies the great ocean-current from the north-west thus become united, and vast banks of fog are generated, which, when driven by the wind, have a penetrating or cutting effect on the human skin, much more uncomfortable than would be felt in the humid atmosphere of the Atlantic at a much lower temperature. As the sun rises from day to day, week after week, and month after month, in unclouded brightness during the dry season, and pours down its broken rays on the dry, unprotected surface of the country, the heat becomes so much greater inland than it is on the ocean, that an under-current of cold air, bringing the fog with it, rushes over the coast range of hills, and through their numerous passes, toward the interior. Every day, as the heat inland attains a sufficient temperature, the cold, dry wind from the ocean commences to blow. This is usually from 11 to 1 o'clock; and, as the day advances, the wind increases and continues to blow till late at night. When the vacuum is filled, or the equilibrium of the atmosphere restored, the wind ceases; a perfect calm prevails until about the same hour the following day, when the same process commences and progresses as before. And these phenomena are of daily occurrence, with few exceptions, throughout the dry season. These cold winds and fogs render the climate at San Francisco, and all along the coast of California, except the extreme southern portion of it, probably more uncomfortable to those not accustomed to it in summer than in winter. A few miles inland, where the heat of the sun modifies and softens the wind from the ocean, the climate is moderate and delightful. The heat, in the middle of the day, is not so great as to retard labor or render exercise in the open air uncomfortable. The nights are cool and pleasant. This description of climate prevails in all the valleys along the coast range, and extends throughout the country, north and south, as far eastward as the valley of the Sacramento and San Joaquin. In this vast plain, the sea-breeze loses its influence, and the degree of heat in the middle of the day, during the summer montlss, is much greater than is known on the Atlantic coast in the same latitudes. It is dry, however, and probably not more oppressive. On the foot-hills of the Sierra Nevada, and especially in the deep ravines of the streams, the thermometer frequently ranges from $110^{\circ}$ to $115^{\circ}$ in the shade, during three or four hours of the day, say from 11 to 3 o'clock. In the evening, as the sun declines, the radiation of heat ceases. The cool, dry atmosphere from the mountains spreads over the whole country, and renders the nights cool and invigorating.

The yalleys which are situated parallel to the coast range, and those which extend eastwardly in all directions among the hills toward the great plain of the Sacramento, are of surpassing fertility. They have a deep, black, alluvial soil, which has the appearance of having been deposited when they were corered with water. This idea is strengthened by the fact, that the rising grounds on the borders of these valleys, and many hills of moderate elevation, have a soil precisely like that of the adjoining plains. This soil is so porous that it remains perfectly unbroken by gullies, notwithstanding the great quantity of water which falls in it annually during the wet season. The land in the northern part of the State, on the Trinity and other rivers, and on the borders of Clear Lake, as far as it has been examined, is said to be remarkably fertile. The great valley of the Sacramento and San Joaquin has evidently been at some remote period the bed of a lake; and those rivers which drain it present the appearance of having cut their channels through the alluvial deposit after it had been formed. In fact, it is not possible that they could have been instrumental in forming the plain through which they pass. Their head-waters come from the extreme ends of the valley, north and south; and were it not for the supply of water received from the streams which flow into them from the Sierra Nevada, their beds would be almost, if not quite dry in the summer months. The soil is very rich, and, with a proper system of drainage and embankment, would undoubtedly be capable of produeing any crop, except sugar-cane, now cultivated in the Atlantic States of the Union. There are many beautiful valleys and rich hill-sides among the foot-hills of the Sierra Nevada, which, when the profits of labor in mining shall be reduced so as to cause its application to agriculture, will probably support a large population. There is said to be a rich belt of well-timbered and watered country extending the whole length of the gold region betwoen it and the Sierra Nevada, some twenty miles in width. There is no information sufficiently accurate respecting the eastern slope of the great snowy range, to enable us to form any opinion of its general character or soil. Some of its valleys have been visited by miners, who represent them as equal to any portion of the country to the westward of it. The great valley of the Colorado, situated between the Sierra Madre and the Sierra Nevada, is but little known. It is inhabited by numerous tribes of sarages, who manifest the most decided hostility toward the whites, and have hitherto prevented any explorations of their country, and do not permit emigrants to pass through it. Therefore, parties from Santa Fé, on their way to California, are compelled to make a circuit of near a thousand miles northward to the Salt Lake, or about the same distance southward by the route of the Gila. Although this valley is little known, there are indications that it is fertile and valuable. The name of the river "Colorado" is descriptive of its waters; they are as deeply colored as those of the Missouri or Red Rirer, while those of the Gila, which we know flows through barren lands, are clear. It would seem impossible for a large river to collect sediment enough in a sandy, barren soil, to eolor its waters so decply as to give it a name among those whe first discovered and have since visited its shores. The probability, therefore, is, that this river flows through an alluviai valley of great fertility, which has never been 


\section{CALIFORNIA.}

explored. This conjecture is strengthened by the fact that the Indians who inhabit it are hostile, and oppose, as far as they can, all persons who attempt to enter or explore it. This has been their uniform course of conduct respecting all portions of the continent which have been fertile, abounding in game and the spontaneous productions of the earth. As this valley is situated in the direct route from Santa Fé to California, its thorough exploration becomes a matter of very great importance, especially as it is highly probable that the elevated regions to the north of it, covered with snow during most of the year, will force the line of the great national railway to the Pacific through some portion of it. The soil situated west of the Sierra Nevada, and embracing the plain of the Sacramento and San Joaquin, covers an area, as nearly as can be estimated, of between fifty and sixty thousand square miles, and would, under a proper system of cultivation, be capable of supporting a population equal to that of Ohio or New York at the present time.

The climate and soil of California are well suited to the growth of wheat, barley, rye, and oats. The temperature along the coast is too cool for the successful culture of maize as a field crop. The fact that oats, the species which is cultivated in the Atlantic States, are annually self-sowed and produced on all the plains and hills along the coast, and as far inland as the sea-breeze has a marked influence on the climate, is sufficient proof that all the cereal grains may be successfully cultivated without the aid of irrigation. It is quite true that this ausiliary was extensively employed at the missions, and undoubtedly increased the product of all crops to which it was applied, as it will in any country on earth if skillfully used. This does not prove, however, that it was essentially necessury to the production of an ample reward to the husbandman. The experience of all the old inhabitants is sufficient evidence of this. If their imperfect mode of culture secured satisfactory returns, it is reasonable to presume that a more perfect system would produce greater results. There is abundant evidence to prove, that in the rich alluvial valleys, wheat and barley have produced from forty to sixty bushels from one bushel of seed, without irrigation. Irish potatoes; turnips, onions, in fact all the edible roots known and cultivated in the Atlantic States, are produced in great perfection. In all the valleys east of the coast range of hills, the climate is sufficiently warm to mature crops of Indian corn, rice, and probably tobacco. The cultivation of the grape has attracted much attention at the missions, among the residents of towns, and the rural population, and been attended with much success, wherever it has been attempted. The dry season secures the fruit from those diseases which are so fatal in the Atlantic States, and it attains very great perfection. The wine made from it is of excellent quality, very palatable, and can be produced in any quantity. The grapes are delicious, and produced with very little labor. When taken from the vines in bunches, and suspended in a dry room by the stems, they become partially dry, retain their flavor, and remain several weeks, perhaps months, without decay. Apples, pears, and peaches are cultivated with facility; and there is no reason to doubt that all the fruits of the Atlantic States can be produced in great plenty and perfection. The grasses are very luxuriant and nutritious, affording excellent pasture. The oats, which spring up the whole length of the sea-coast, and from forty to sixty miles inland, render the cultivation of that crop entirely unnecessary, and yield a very great quantitiy of nutritious food for horses, cattle, and sheep. The dry season matures, and I may say cures, these grasses and oats, so that they remain in an excellent state of preservation during the summer and autumn, and afford an ample supply of forage. While the whole surface of the country appears parched and vegetation destroyed, the numerous flocks and herds which roam over it continue in excellent condition. Although the mildness of the winter months and the fertility of the soil secure to Califormia very decided agricultural advantages, it is admitted that irrigation would be of very great importance, and necessarily increase the products of the soil in quantity and variety during the greater part of the dry season. It should therefore be encouraged by government, in the survey and disposition of the public lands, as far as practicable. The farmer derives some very important benefits from the dry season. His crops in harvest-time are never injured by rain; he can with perfect confidence permit them to remain in his fields as long after they have been gathered as his convenience may require; he has no fears that they will be injured by wet or unfayorable weather. Hence it is that many who have long been accustomed to that climate prefer it to the changeable weather east of the Rocky Mountains.

As already stated, the forests of California south of latitude $39 \circ$, and west of the foot-hills of the Sierra Nevada, are limaited to detatched, scattering groves of oak in the valleys, and of red-wood on the ridges and on the gorges of the hills. It can be of no practical use to speculate on the causes which have denuded so large an extent of country, further than to ascertain whether the soil is or is not favorable to the growth of forest trees. When the dry season sets in, the entire surface is covered with a luxuriant growth of grass and oats, which, as the summer advances, become perfectly dry. The remains of all dead trees and shrubs also become dry. These materials, therefore, are very combustible, and usually take fire in the latter part of summer and beginning of autumn, which commonly passes over the whole country, destroying in its course the young shrubs and trees. In fact, it seems to be the same process which has destroyed or prevented the growth of forest trees on the prairies of the Western States, and not any quality in the soil unfriendly to their growth. The absence of timber and the continuance of the dry season are apt to be regarded by farmers, on first going into the country, as irremediable defects, and as presenting obstacles almost insurmountable to the successful progress of agriculture. A little experience will modify these opinions. It is soon ascertained that the soil will produce abundantly without manure; that flocks and herds sustain themselves through the winter without being fed at the farmyard, and consequently no labor is necessary to provide forage for them; that ditches are easily dug, which present very good barriers for the protection of crops until live fences can be planted and have time to grow. Forest trees may be planted with little labor, and in very few years attain a sufficient size for building and fencing purposes. Time may be usefully employed in sowing various grain and root erops during the wet or winter season. There is no weather cold enough to destroy root crops, and therefore it is not necessary to gather them. They can be used or sold from the field where they grow. The labor, therefore, required in most of the old States to fell the forests, clear the land of rubbish, and prepare it for seed, may here be applied to other objects. All these things, together with the perfect security of all crops in harvest-time from injury by wet weather, are probably sufficient to meet any expense which may be ineurred in irrigation, or caused for a time by a scanty supply of timber. In the northern part of the State, above latitude $39^{\circ}$, and on the hills which rise from the great plain of the Sacramento and San Joaquin to the foot of the Sierra Nerada, the forests of timber are beautiful and extensive, and would, if brought into use, be sufficiently productive to supply the wants of the sonthern and western portions of the State.

The extent and value of the public lands suitable for agricultural purposes in California cannot be aseertained with any degree of accuracy until some very important preliminary questions shall have been settled. It is not known whether the Jesuits who founded the missions, or their successors, the Franciscans, ever did, or do now, hold any title from the Spanish crown to the lands which they occupied. Nor has any investigation been made to ascertain how far those titles, if they ever existed, have been invalidated by the acts of the priests or the decrees of the Mexican govern- 
CALIFORNIA.

ment. A supericial riew of the matter would be rers apt to lead to the supposition that the Jesuits, so celebrated for wisdom and foresight, would not fail to secure that which, at that time, would probably have been obtained by merely asking for it-a royal decree, granting to them all the lands they might require in that remote country for ecclesiastical purposes. There have been some intimations to that effect, but nothing is distinctly known. These missions embrace within their limits some of the most raluable lands in the State, and it is rery important that it should be ascertained whether they belong to the government or may be justly elaimed by individuals. Most of the land fit for cultivation south of latitude 390 , and west of the valley of the Sacramento and San Joaquin, is claimed under what purport to be grants from the Mexican government. On most of these grants the minerals and metals are reserved to the government; conditions were coupled with many of them which have not been complied with; in others, the boundaries described embrace two or three times às much land as the grant conveys. The Mexican law required all grants made by the prorincial government, with few exceptions, to be confirmed by the supreme government. The great distance which separate them, and the unfrequent or difficult means of commonication, made a compliance with the law so expensive and tardy that it came to be almost disregarded. There were other causes which led to this neglect. Prerious to the treaty with Mexico and the immigration of American eitizens to that country, land was not regarded as of much value, except for grazing purposes. There was room enough for all. Therefore, the claimants or proprietors did not molest one another, or inquire into the validity of titles. These extensive grants are described by natural boundaries, such as mountains, bays, and promontories, which, in many instances, wight allow of a variation of several miles in the establishment of a corner with chain and compass. By the treaty of Guadalupe Hidalgo, the United States purchased all the rights and interests of Mexico to and in California. This purchase not only embraced all the lands which had not been granted by Mexico, but all the reserved minerals and metals, and also reversionary rights which might accrue to Mexico from a want of compliance on the part of the grantees with the conditions of their grants, or a voant of perfection in the grants. The lands in the northern part of the State, abore 390 , have not been explored or granted. They are supposed to embrace an area of about twenty millions of acres, a large portion of which is doubtless valuable for its timber and soil. Comparatively fer grants hare been obtained in the great valley of the Sacramento and San Joaquin. This rast tract, therefore, containing, as is estimated, from twelve to fifteen millions of acres, belongs mostly to the government. South of this valley and west of the Colorado, within the limits of California, as indieated in her constitution, there are said to be extensire tracts of valuable unappropriated land; and, on investigation, it will probably appear that there are many of them in detached bodies which have not been granted.

The gold region of California is between 400 and 500 miles long, and from 40 to 50 miles broad, following the line of the Sierra Nerada. Further discoveries may, and probably will, increase the area. It embraces withiu its limits those extensive ranges of hills which rise on the eastern border of the plain of the Sacramento and San Joaquin and, extending eastwardly from 50 to 60 miles, they attain an elevation of about 4,000 feet, and terminate at the base of the main ridge of the Sierra Nevada. There are numerous streams which have their sources in the springs of the Sierra, and receive the water from its melting snows, and that which falls in rain during the wet season. These streams form rivers, which have cut their channels through the ranges of foot-hills westwardly to the plain, and disembogue into the Sacramento and San Joaquin. These rivers are from 10 to 15 , and probably some of them 20 miles apart. The principal formation, or substratum, in these hills, is talcose slate; the superstratum, sometimes penetrating to a great depth, is quartz; this, however, does not cover the entire face of the country, but extends in large bodies in various directions-is found in masses and small fragments on the surface, and seen along the ravines, and in the mountains overhanging the rivers, and in the hill-sides in its original beds. It crops out in the ralleys and on the tops of the hills, and forms a striking feature of the entire country over which it extends. From innumerable evidences and indications, it has come to be the universallr-admitted opinion, among the miners and intelligent men who have examined this region, that the gold, whether in detached particles and pieces, or in veins, voas created in combination with the quart?. Gold is not found on the surface of the country, presenting the appearance of having been thrown up and scattered in all directions by volcanic action. It is only found in particular localities, and attended by peculiar circumstances and indications. It is found in the bars and shoals of the rivers, in ravines, and in what are called the "dry diggings." The rivers, in forming their channels, or breaking their way through the hills, have come in contact with the quartz containing the gold veins, and by constant attrition cut the gold into fine flakes and dust; and it is found among the sand and gravel of their beds at those places where the swiftness of the current reduces it, in the dry season, to the narrowest possible limits, and where a wide margin is consequently left on each side, over which the water rushes, during the wet season, with great force. As the velocity of some streams is greater than that of others, so is the gold found in fine or coarse particles, apparently corresponding to the degree of attrition to which it has been exposed. The water from the hills and upper valleys, in finding its way to the rivers, has cut decp ravines, and, wherever it has come in contact with the quartz, has dissolved or crumbled it in pieces. In the dry season, these channels are mostly without water, and gold is found in the beds and margins of many of them in large quantities, but in a much coarser state than in the rivers, owing, undoubtedly, to the moderate flow and tempo-

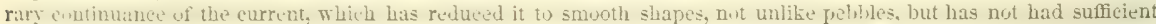
force to cut it into flakes or dust. The dry diggings are places where quartz containing gold has cropped out, and been disintegrated, crambled to fragments. pebbles, and dust lor the action of water and the atmosphere. The gold has been left as it was made, in all imaginable shapes-in pieces of all sizes, from one grain to several pounds in weight. The erideness that it was created in emmbinatinn with yuartz, are too numeruls and striking to admit of doubt or cavil they

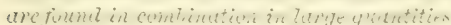

I very lare proportion of the pitees of gold fouml in these situations hare more or less quartz adhering to them. In mant specimens, they are so combined they cannot be separated without redncing the whole mass to pow der, and subjecting it to the action of quicksilver. This gold, not haring been exposed to the attrition of a strong current of water,

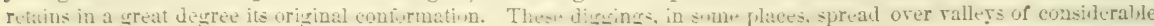
extent, which have the appearance of an alluvion, formed by washings from the adjoining hills, of decomposed quartz and slate earth and regetable matter. In addition to these fact, it is beyond doubt true that several vein-mines have been discovered in the quartz, from which numerous specimens have been taken, showing the minute connection between the gold and the rock, and indicating a value bitherto unknown in gold mining. These refns do not present the appearance of places where gold may have been lodged by some violent eruption. It is combined with the quartz in all imaginable forms and degrees of richness. The rivers present very striking, and it would seem, conclusive evidenee repreeting the quantity of goid remaining undiscovered in the quartz reins. It is not probalje that the goid 
CALIFORNIA

in the dry diggings and that in the rivers-the former in lumps, the latter in dust-were created by different jirece sws. That which is found in the rivers has undoubtedly been eut or worn from the veins in the rock, with which their currents have come in contact. All of them appear to be equally rich. This is shown by the fact that a laboring man may collect nearly as much in one river as he can in another. They intersect and cut through the gold region, running from east to west, at irregular distances of fifteen to twenty, and perhaps some of them thirty miles apart. Hence it appears that the gold veins are equally rich in all parts of that most remarkable section of country. Were it wanting, there are further proofs of this in the ravines and dry diggings, which uniformly confirm what nature so plainly shows in the rivers.

The quicksilver mines of California are believed to be numerous, extensive, and valuable. Hitherto this metal, so ngeful in the arts and mining, has been chiefly derived from Spain and Mexico, and its production been a monopoly. The best known mine in California is that near San Jose, which is elaimed by Mr. Forbes, of Tepic, in Mexico. The cinnabar ore which produce the mineral lies near the surface, is easily procured, and the mine is believed to have been remarkably productive. Discoveries of other like mines are reported in other parts of the State, but little is publicly known respecting them, the belief being, however, that quicksilver will be eventually found in sufficient quantities for all purposes of extensive mining operations, if not for export. It is, undoubtedly, a fortunate circumstance, that nature, in bestowing on this State such vast metallio wealth, has thus provided, almost in its immediate neighborhood, inexhaustible stores of the only agent by which gold can be successfully separated from its matrices, It is also believed that California is rich in silver, copper, iron, and coal. A silver mine has been discovered a short distance from Monterey, which affords a very rich ore, and has been productive in comparison to the labor bestowed in operating it. In the neighborhood of San Franciseo bituminous coal is abundant, and the indieations noted in many other seotions leave no doubt of the great extent of coal formation in the State. With regard to other metals, time and circumstances are required to develop our knowledge of them; but there can be but one opinion on the subject, that California is, in one part or other of its territory, bounteously supplied with all the more useful as well as the precious metals.

California offers a very interesting and but partially explored fleld of research to the botanist. Almost every variety of regetation, from the luxuriant productions of the tropies, to the stinted and scanty growth of the frozen regions, may be found in this country. The labors of Douglas and others have made known to the world many of the most valuable and remarkable species. Of these it is possible here to mention only a few. Of the pine and oak, there are several noble and useful varieties in different parts of the country. One of these, pinus Douglasie, first described by Douglas, is probably the grandest of the whole vegetable kingdom. It is found on the mountains about the Bay of San Francisco, and in some other sections of California, generally on elevated localities. Specimens of this tree occur of the height of 240 feet, the base of whose trunks have a circumference of nearly 60 feet. The trunk is quite destitute of branches, until above more than half the altitude, when they grow outward and upward in such a manner as to give the top the form of an inverted pyramid. From the ends of the branches hang the cones or seed-vessels, from 12 to 15 inches in length, and egg-shaped. The seeds are as large as a good sized bean, and furnish a common article of food to the Indians, who collect large quantities of them in the autumn, and pound them into a kind of cake, which is baked on heated stones. The wood is very fine-grained, and contains a great quantity of resin. The pinus Sabinii, $p$. Lambertiana, $p$. nobitis, and $p$. resinosa, are also fine species, though less in size than their gigantic relative. The former is, however, a large tree, being often found 110 feet high, and from 10 to 12 in diameter. Among the elevated plains of Upper California it grows quite plentifully, as also on the low hills, near the coast, where it attains a larger size. The natives frequently build their fires against these trees to save the trouble of collecting fuel; by this means, also, a sweet gum is made to exude from the trunk, which serves them for sugar. The white oak grows on the low and level parts of the country. It is not generally a large tree, being from 40 to 50 feet high, and from 2 to 3 feet in diameter at the base. The top is extremely thick and leafy, forming an almost impenetrable mass of boughs. It is in some places very abundant. The quercus navalis occupies the prairies, river banks, and lower hills, and is 4 or 5 feet in diameter, with branches of corresponding dimensions, extending horizontally from the trunk. The live oak ( $q$. virens) grows only on the highlands, It is from 2 to 5 feet in thickness, and from 60 to 70 in height. The maple, the ash, the beech, the chestnut, in several varieties, compose large portions of the forests. It is impossible to give a full description of the flowering shrubs and plants of California, so great is their variety and beauty. A species of raspberry (ribes speciosum) is one of the most elegant flowering shrubs of the country. It is exceedingly abundant in some localities, and, with its long crimson stamens, and its deep green leaves, presents an appearance truly lovely. The flowers bloom early in spring. In many places are found several species of mimutus, one of which is from 8 to 4 feet in height, and is a very showy plant. This country also has numerous species of phlox and heuchera, and innumerable quantities of epilo. bium, enothera, or primrose, pentstemon, papaver, or poppy, deiphinium, and salvia. A species of lily also grows here, the ronts of which are eaten by the natives. The Scilla esculenta grows along the whole coast; this is called by the natives "quamash," and the root forms a very common article of food. To prepare this for eating, a hole is made in the ground, and a number of stones placed in it, on which a fire is kindled and kept burning until they are made hot, when the fire is extinguished, and the roots, wrapped in straw, leaves, and moss, are placed upon them. They are well roasted in a few hours, and are then taken off and hung up to dry. This root is also sometimes pounded and made into cakes, which are preserved for future use; the taste is sweet, and rather agreeable, but if eaten too freely they are apt to produce diarrhea. This plant is most abundant on the banks of rivers and on lowlands by the margins of forests, in which localities are also found several species of pyrola, caprifolitum and lupinaiu, which sometimes cover an immense extent of land. The arbutrus is also abundant in similar situations. The large species (a.procera), is a fine shrub frequently attaining a growth which entitles it to be called a tree. The $a$. wva ursi is found in almost erery part of the colder sections of the country, and its berries are frequently eaten by the natives, and even by travelers. A very useful plant to the natives is the helonixs tenax, the fibres of which are stronger than any hemp. Cords made of this are used by the Indians for the purpose of snaring deer and other animals, and one the thickness of the little finger is so strong as not to be broken by the largest elk. The gooseberry grows in California, and bears plentifully. The sand-hills and moors are covered with a great variety of syngenesious plants, and on the more fertile and humid soil grows a gaudyfinwered currant-bush, and a pretty species of honeysuckle. Perhaps the most remarkable shrub here is the yedra, a poisonous plant, which, however, affects some particular constitations only. By contact with the skin, it produces tumors and riolent inflammation. It is a slender shrub, preferring coll and shady places, and bearing a trefoil crenated leaf. Two roots-the plants of which are very beautiful-are used by the natives for soap; these are called amole and samate. On the rocky coast of Monterey are immense collections of sea-weed, fucus pyriformis, which 
CALIFORNIA.

are said to have gathered there in such abundance as to have saved several vessels from splitting on the rocks, when driven on them by the tempest.

The animal kingdom in California is made up of most of the zoological varieties found east of the Rocky Mountains, and of some few species peculiar to the region itself. The black bear (ursus Americanus) is an inhabitant of many districts, and in its habits and appearanee differs little from its congener of the north; the barren-ground bear (ursus curctus) is of a lighter color, but in every other respect similar to the black bear; the grizzly bear (ursus feroxo) is also a denizen, and is the most formidable wild animal of the country. The Polar bear (ursus maritimus) is sometimes seen on the northern coast, but is evidently a stranger, borne down on floating ice from the higher latitudes. The raccoon (prooyon lotor), the American badger (meles salradoira), the glutton or wolverine (gulo luscus), the common weasel (inustela vulgaris), the ermine ( $m$. erminea), the mink, martin, and skunk, are found in various parts, and are valuable for their furs. In many parts wolves are very numerous. The species mostly seen are the common wolf (lupus Americanus), the gray wolf ( $l_{0}$ griseus), the dusky wolf $\left(l_{0}\right.$ nubilis), the black wolf $\left(l_{*}\right.$ ater), and the prairie wolf (canis latrans). Foxes are common, and of these two species exist, the red fox (canis fulvus) and the gray fox (c. cinerea-argentatus). Of the cat tribe there are several species, as the cougar or puma (felis concolor), the northern lynx ( $f$. canadensis), the banded Iynx (f. fasciata), and the red lynx (f. mufa). These inhabit mostly the dense forests and thickly-wooded sides of the monntains, preying on deer and other animals. In the Sacramento and San Joaquin rivers, as well as on many parts of the coast, the common hair seal ( $p$ hoca vitellina) is abundant, and follows the track of the salmon. The beaver (castor fiber) and the musk rat ( $f i b e r$ zebethicus) are also common, especially at the confluence of the Sacramento with the Bay. The quality of the far of these latter animals, however, is inferior to that obtained more to the north. The moose (comers alces) is found in all the woody and mountain regions, and near the coast, and the elk (corvus canadensis) roams through the valleys in immense herds. There are many other species of deer found in various parts, as the black-tailed deer (c.macrotis), the long-tailed or jumping deer (c. loucurus), etc.; and the prong-horned antelope $(a$. furcifer) is found in considerable numbers. The mountain sheep, or argali (ovis montana), inhabits the loftiest and coldest mountains; in its general appearance it resembles the large domestic sheep, but has horns out of all proportion to its body, and is covered with a coarse short hair, of a dingy brown color, which can scarcely be called wool. The pison (bos.Americanus) is seldom seen, but is not altogether unknown to the hunter. The sea otter (lutra morina) is abundant along the coast, and at the mouths of rivers, and the land otter ( $l$. Brafiliensis) is found in many parts of the country. Of rats, mice, marmots, hares, rabbits, and squirrels, there are numerous species in all parts of the country.

Among the feathered tribes of California, the first worthy of notice is the great vulture (sarcoramphos Californianus), second only to the huge condor of South America, and elosely allied to it in many respects. It is met with along the whole coast; it is solitary in its habits, rapacious, of enormous size, and singular in conformation and appearance, and seems to hold the same position in the scenery of this country as its European congener, the lammergeyer, in that of the Alps. It builds in the highest trees of the mountain forests, and only approaches the valleys in search of its carrion food. When full grown, it measures about 4 feet 8 inches from beak to end of the tail, and from 9 to 10 feet from tip to tip of its wings. Its color is brownish black, the bill and legs yellow, and its quills are much esteemed by the hunter for making tubes for his pipe. The turkey buzzard (cathartes aura) is also found here, but is not common, but the black vulture (cathartes atratus) is found in every part. The golden eagle (aquila chrysotus), the bald eagle (aquila leucocephaba), the osprey or fish-hawk (aquila hatioa), the black hawk or peregrine falcon (falco peregrinus), the jer-falcon (falco istandious), and several others of kindred species, but of lesser note, are found here, as the sparrow-hawk, the pigeonhawk, and the gos-hawk-the latter identical with the European species so celebrated in the royal sport of falconry. Owls of various species are found throughout the country; and among the birds common to the temperate region of the continent may be mentioned the shrike, the robin, the cat-bird, the thrush, the lark, the red-wing, the cross-bill, the raven, the magpie, the jay, the wood-pecker in numerous varieties and species. In some parts of the south the humming-bird is quite numerous, and swallows of every description-barn, eliff, and bank swallows-are as common as in any other section of the Union. There is probably no other country which produces so many varieties of grouse, or in so great numbers. The bays, inlets, and rivers are alive with water-fowl, and the low lands near the outlets of some of the streams in the Pacific coast actually swarm with geese, ducks, widgeons, teal, cranes, curlews, snipes, and various other waders and swimmers. The swan (cygnus buccinator') is the largest swimming bird of the country, and seems to differ nothing from the same species elsewhere. The white pelican ( $p$. onocrotalus ) is found on the coast, and large numbers frequent the bays and harbors. Off the coast, too, may be seen the mighty albatross ; specimens of enormous size are sometimes seen, measuring 4 feet in length and 10 or 12 across the wings.

The waters of California are replete with fish of every size and variety. The seas swarm densely, and the bays and rivers are alive with their peculiar denizens. The California Gulf produces great numbers of edible shell-flsh. The oyster, the pearl-shell, the muscle, several species of haliotis, all afford either food or articles of trade and ornament to the inhabitants. In California fish are generally little sought after, the productions of the earth being so numerous and plentiful; but in the colder regions of the north they afford the common, and sometimes the sole subsistence of the natives. In the Columbia, as well as in the San Joaquin and Sacramento rivers, and in almost every water-course having its outlet in the sea, the number of (salmo) salmon are almost incredible. On some of these rivers from two to three thousand are sometimes taken in a single day. The Indians sometimes eapture them with a kind of wicker basket similar to that used by the fishermen on the Atlantic coast for taking lobsters. This is done in the spring, when the fish are on their passage up the stream. They are also taken with the spear, which consists of a sharp piece of bone fastened to the end of a shaft of wood 12 or 15 feet in length, and which the Indians use with great dexterity, frequently securing salmon of from 20 to 30 pounds in wreight. The fish are dried or salted, and preserved for future use. They are also sometimes taken with only a small scoop net, fastened to the end of a pole. Douglas speaks of an individual measured by him which was 3 feet 5 inches long, and 10 inches broad, weighing 35 pounds. This size is not exaggerated, specimens nearly or quite as large having often been seen. Some of the streams also abound with very fine salmon-trout, and with a small trout nearly resembling the one which affords so much sport to the anglers of the older States. The sturgeon (accipenser transmontanus) sometimes attains great size in the large rivers, being from 8 to 10 feet in length, and weighing nearly 500 pounds. In general, however, this fish is of much smaller dimensions. It is principally found not far from the mouths of the rivers. In the Bay of Montercy is a species of mackerel (scomber colias) in great plenty, and easily taken. Here, as well as in most other parts of the coast, also swim schools of a small fish resembling, if not identical with, the sardine of Italy, familiar to epicures. These are sometimes seen in such immense numbers that the surface of the water for a great distance around resembles a living mass, being kept in 
constant commotion by their fins. Porpoises are very numerous in almost every bay on the whole coast, and in foul weather may always be seen playing their pranks on the waves, while far in the offing appears the spouting of the huge whale. The halibut, pilchard, skate, turbot, bonito, and many other species, are found in various parts of the sea-coast, The shell-fish are numerous and valuable, particularly in the gulf. 0 f these may be mentioned, oysters, which are often of large size and excellent flavor; muscles, several species of haliotis, patella, cardium, and turbo, besides the pearl oyster (mya margaritifena), the product of which, as an article of commerce, is well known. The pearls produced by these shell-fish are in this country of very fine water, though rather irregular in figure.

The estimates and ascertainments by census, of the population, resourees, and productions of California have hitherto been very incomplete, and in reference to the population returned by the federal census of 1850 , it can scarcely be considered as an approximation. The estimate made by General Douglass, of the State Senate, in the fall of the year 1850 , is perhaps more nearly accurate, and is given below for what it is worth. The population by the census of 1850 is that returned to the Legislature by the census agent. The returns of 1852 are those of a census instituted by the State authorities, and those which will be adopted by the U. S. census department in the official exhibit of the condition of the State. The following are the population returns referred to:

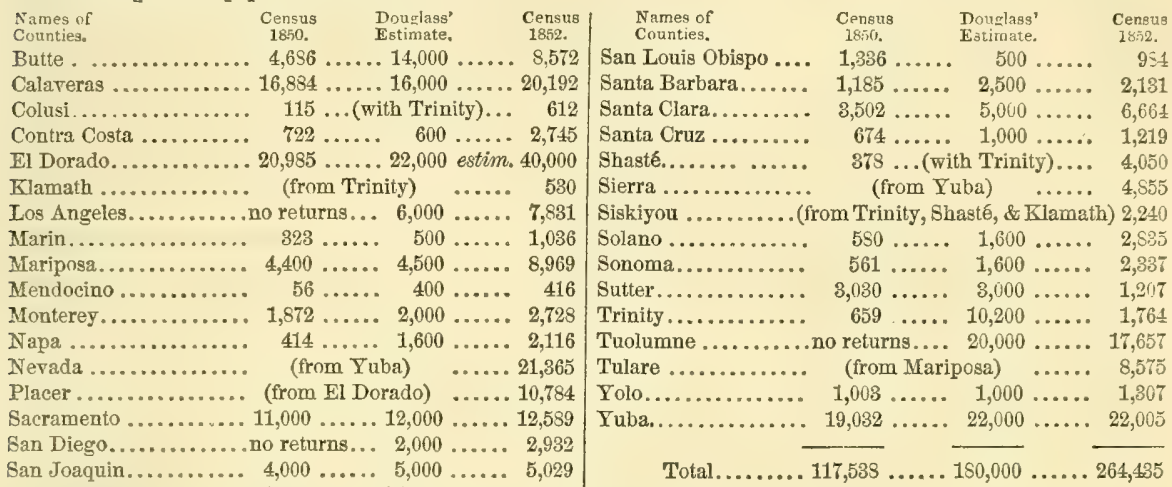

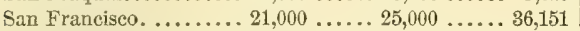

-Humbolt County, from Trinity, and San Beraardino County, from Los Angeles, are counties erected since 1852.

The following summary of the census of the State in 1852, is abstracted from the report of W. Van Voorhies, Secretary of State, to the governor, and dated 25th January, 1853: "Immediately after the adjournment of the last Legislature active measures were commenced, which have been prosecuted up to the present time, for the purpose of making a correct and complete exhibit of the population and resources of the State. This object, however, has been but imperfectly accomplished, in consequence, in some degree, of the intrinsic difficulties of so complicated and extensive an undertaking in a new and comparatively unknown country, but mainly owing to the mixed, unsettled, and fluctuating character of our population, the difficulty of thoroughly exploring the mountain counties, the hostile tribes of Indiuns infesting some sections, and the mistaken supposition on the part of many that the business of the census agent was in some way connected with taxation. Believing that the occasion of taking this census afforded an opportunity which might not be again soon enjoyed, of procuring interesting geographical, geological, mineralogical, and other information pertaining to the natural curiosities and features of the State, I embraced it, and instructed each of the census agents to collect whatever of notable objects might come within theix observation. These instructions not having been received by some of them until they were far advanced in their labor, were only carried out in a portion of the counties. A number of the counties, however, are represented in this particular and much useful and interesting intelligence collected on these subjects. Even from the imperfect showing which is thereby made, it will be seen that our State contains within her borders almost every variety of minerals and many most inviting fields of investigation to the natural philosopher, the antiquary, and the statesman.

"A large number of the most important counties having failed to furnish any information on these subjects, we are left to conclude that much of the most useful and interesting matter in this branch remains yet to be developed.

"Population.-It will be observed that the county of El Dorado has not been as yet returned, either as respects population or productions. This is admitted to be one of the most populous and productive counties of the State. The vote cast in this county at the late generaI election was, as appears from the returns on file in this office, 11,252; and fudging from the relation generally obtaining in this State between the vote and population, it should contain 40,000 inhabitants. This county cast a vote of 2,844 greater than any other county in the State. The county of San Francisco, with a population of 36,151 , casts 8,408 votes. The county of $\mathrm{Yuba}$, with a population of 20,005 , casts a vote of 4,276 . The county of Nevada, with a population of 21,865 , casts a vote of 5,474 . The county of Calaveras, with a population of 20,192 , casts a vote of 5,132 . The county of El Dorado, therefore, which cast a vote of 11,252 , I set down as containing a population of 40,000 ; which is, in fact, an under estimate, preserving the parallel exhibited in other counties between the number of rotes and inhabitants. Estimating the population of El Dorado at 40,000 , makes the entire population of the State 264,435. This appears from the actual returns of the census, with the exception of El Dorado County, and the data upon which I have based the estimate of that county are given above. There can be no doubt, however, that in consequence of the difficulties previously mentioned, not more than five-sixths of the whole population of the State has been taken. The reports of all the census agents who have made returns, set forth the fact of their inability to obtain the whole population of their respective counties; adding then one-sixth to the population returned and that estimated for EI Dorado County, gives the population of the State at 308,507 , which is believed to be about correct. Our entire popular vote at the late general election was 76,890 , according to the election returns on file in this office, estimating the population at four times the amount of the popular vote, which is below the ratio usually obtaining throughout this State, and far below that obtaining in other States of the Union, places our population at 307,560. This exhibit shows an 


\section{CALIFORNIA.}

increase in the course of two years, taking the actual returns of the census, of 99,435 , an annual increase of 49,717 , and an increase of 30 per cent. per annum; of the increase per cent. per annum, the United States, according to the lato census, was $3 \frac{1}{3}$, showing a difference of increase between the State of California and the other States of the Union of $26 \frac{1}{2}$ per cent. per annum. Taking, however, the estimated and more probable census of the State, namely, 308,507, and it gives an annual positive increase of 71,753 , an increase of 43 per cent. per annum, and a difference of inerease per cent. between California and other States of 391.

"This population is composed as follows:

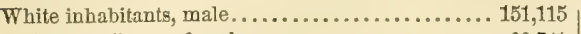

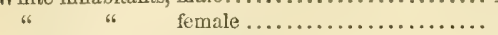

Citizens over 21 years of age . ............ 93,311

Negroes, male......................... 1,687

" female ........................ 253

" over 21 years of age................ 1,259

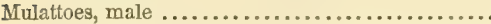

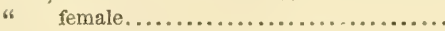

". over 21 years of age.................

Indians (domesticated), male.

female.

Indians over 21 years of age .............. 15,866

Foreign residents, male.................... 50,631

" " female $\ldots \ldots \ldots \ldots \ldots \ldots \ldots \ldots .4,360$

" over 21 years of age............... 39,444

TOTAL.

424 Citizens over 21 years of age ................ 93,344

98 Negroes .................................. 1,890

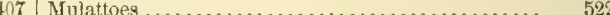

19,675 Indians (domesticated) . . . . . . . . . . . . . . . . 32,539

12,864 Foreign residents........................ 54,991

"In this estimate the county of $\mathrm{El}$ Dorado is not included, which will probably add to the whites 30,000 ; to the cilizens of the United States over 21 years of age 12,000 ; to the negroes 200 ; to the mulattoes 50 ; to the Indians 1,000 ; and to the foreign residents 5,000-making a final total of whites, 210,858 ; citizens over 21 years of age, 105,314; negroes, 2,090 ; mulattoes, 572 ; Indians (domesticated), 33,539; foreign residents, $59,991$.

"The counties of Nevada, Placer, and Yuba have reported 9,809 Chinese. The other counties have embraced them without discrimination under the general head of foreign residents, the number is believed to approximate 25,000 .

"Productions and Capital.-Under this head, I regret to state, that not only the county of El Dorado, entire, but that of Calaveras, also, in part, two of the most wealthy and productive of the State, have to be omitted, not having as yet been returned.

"A few of the counties have reported on the subjects of horticulture, manufactures, milling, farming, and farming utensils, separately, while the others have combined them under the general head of 'capital employed for other purposes.'

"The following items are not included under the general head above mentioned:

Capital employed in stock, farming, and gardening

$\$ 1,857,50200$

fruits and orchards.

366,91000

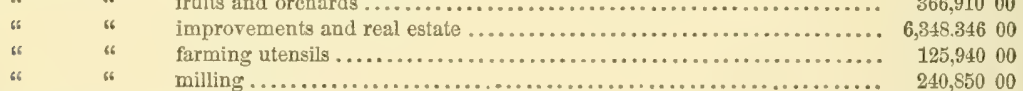

- making the total capital employed for purposes other than those specified under general heads $\$ 49,800,951 . \quad$ Estimate of El Dorado and Calaveras counties, $10,000,000$-making $\$ 59,800,981$.

"The articles of sheep, hogs, and poultry, although not specifically required by law, have been reported upon from twenty counties, and are as follows: sheep, 82,867 , at $\$ 12$ each- $\$ 994,404 ;$ hogs, 38,976, at $\$ 10$ each-389,760; poultry 96,230 , at $\$ 2$ each-192.460; total value, $\$ 1,576,624$.

"For the number of horses, mules, cows, beef cattle, work oxen, bushels of barley, oats, wheat, potatoes, corn, acres of land in cultivation, quartz-mills, capital invested in quartz mining, capital invested in Placer mining, capital invested in other mining, and capital employed for other purposes, reference is made to the statistics of different counties respectively.

"The following is the estimated value of the live-stock and agricultural products. These prices are given at an average much below the market value:

\begin{tabular}{|c|c|c|c|c|c|}
\hline Iorses..... at $\$ \$ 0 \ldots \ldots \ldots \ldots \ldots \ldots \ldots \ldots \ldots$ & - $\$ 1,9 \$ 3,19000$ & Barley...... at $\$ 140$ & $\begin{array}{l}\text { tura } \\
\text { bus }\end{array}$ & $\begin{array}{l}\text { oducts. } \\
\ldots \ldots \ldots\end{array}$ & $\$ 3,163,22700$ \\
\hline Mules...... at $50 \ldots . . . . . . . . . . .$. & 82890000 & Oats...... at 100 & 6 & & 100,49700 \\
\hline Cows...... at $50 \ldots \ldots \ldots \ldots \ldots \ldots$ & - $5,216,95000$ & Wheat...... at 240 & "6 & $\ldots \ldots$ & 652,23100 \\
\hline Beef cattle. at $25 \ldots \ldots \ldots \ldots \ldots \ldots$ & - $7,884,80000$ & Potutoes.... at 150 & " & ...... & $2,059,75500$ \\
\hline Tork oxen. at $50 \ldots \ldots \ldots \ldots \ldots \ldots \ldots \ldots$ & . $1,453,250 \quad 00$ & Curn........ at 250 & c6 & $\ldots \ldots \ldots$ & 156,33000 \\
\hline
\end{tabular}

The counties of Sonoma, Santa Cruz, Santa Clara, Sacramento, Napa, Mendocino, Los Angeles, and Contra

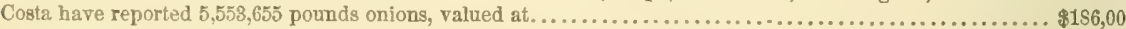

The counties of Yolo, Sierra, Santa Barbara, Santa Cruz, Santa Clara, and Monterey have reported $2,359,250$ cabbages, raluel at.

The counties of Sonoma. Santa Barbara, Santa Clara, and Monterey have reported 30,271 bush. of beans, value

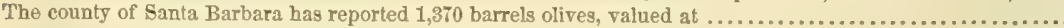

The counties of Santa Barbara and Santa Clara have reported 26,S11 grape vines, valued at ...............

The counties of Yolo, Sonoma, Sierra, Sacramento, and Mendocino have reported 490,990 lbs, turnips, valued ..

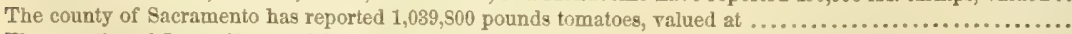

The counties of Santa Clara and Sacramento have reported $1,107,500$ pounds of carrots, valued at. ..........

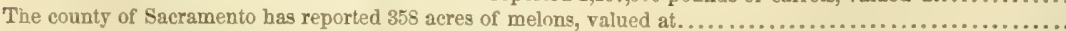

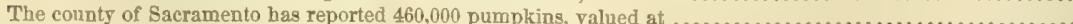

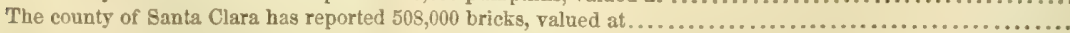

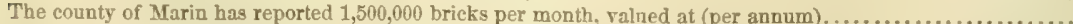

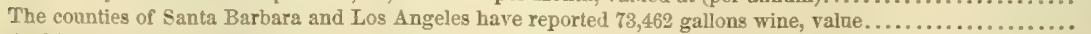

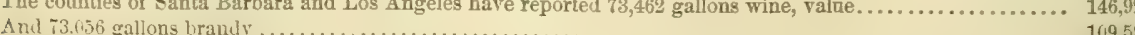

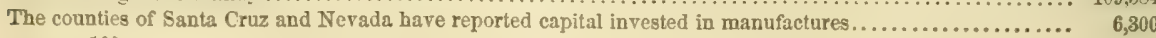


"Showing total capital and productions of the State as follows:

Total capital employed for purposes other than those specified under general heads, including estimates for El Dorado and Calaveras..

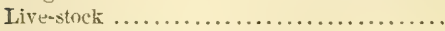
Agricultural products ...................

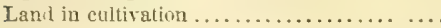
Estimate for El Dorado and Calaveras ........

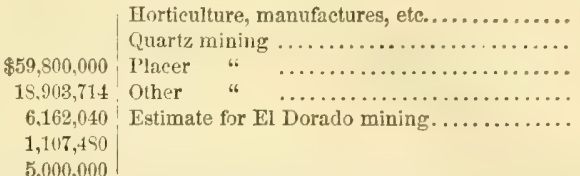

Horticulture, manufactures, etc............

$\$ 1,150,000$ $5,41,405$ $4,174,419$ 3.951 .623 $2,50,11,000$ $5,000,000$

"In the abore estimate it will be observed that the value of no land except that in actual cultivation is included.

6. With these facts now before us, it may not be uninteresting or devold of utility to take a comparative view of our position in reference to the other States of the Union.

"Horses.-In these we are in advance of ffteen of the States. MFutes.-In these we are in advance of twenty-six of the States. Milch Cons.-In these we are in advance of twelve of the States. Work Oxen.-In these we are in advance of eight of the States. Sheep.--In these, although having returns from only twenty counties, we are in advance of four States. Swine,-In these, although only twenty counties have reported, we are in advance of three States. $\bar{V}$ alue of Live-stock.-In this we surpass twenty-two of the States. Barley.-In this we are only equaled by one State, New York, We raise more than one-half as much of this article as is produced in the whole Union besides. Potutoes.-In this agaiu we stand next to New York, and raise one-fifth the quantity produced by the balance of the Union. Wheat.-In this we surpass ten of the States. Oats.-In this we cultivate more than three-fourths of our sister States. Indian Com. -We produce less of this than any State of the Union. Beans.-In this we surpass nine of the States, notwithstanding only five counties have reported the quantity produced. Hay.-In this, though not returned from more than one-half counties, we exceed nine of the States. Fruits.-In these we excel all the States in variety, and one-half in quantity produced. Ifining.- In this branch of industry we stand not only without a parallel, but without a competitor. Agriculture.-This important branch has been comparatively but little attended to in this State, and consequently in the value of cultivated land we are surpassed by all the States of the Union. The fact, however, that we excel most of them in the productions of the soil, shows the fertility and productiveness of our lands in a most favorable light. Trade.-Yolo, Trinity, Sutter, Santa Cruz, San Diego, Sacramento, and Nevada counties have reported merchandise to the amount of $\$ 1,000,000$. The remainder of the counties have included this item, with others, under the general head of 'Capital' employed for other purposes-in these, too, we surpass more than one-half the States. Minerals,-The many interesting geological developments made by the census, place our State far in advance of all her sisters in the variety and importance of these great handmaids of science and civilization. Many matters of interest are touched upon in the reports of the different agents, which, on account of their isolated character, could not be arranged under general heads and elassified. I have, therefore, endeavored to supply this defect by reference to them in this manner. It is needless to say the estimates submitted in this report are not claimed to be entirely accurate, but sufficiently so for practicable purposes. They will be found, I think, to present no exaggerated representation of our resources."

VALLET is the capital of the State; the Legislature of 1553 , however, sat at Benicia.

Catmorista, t. and p. o., Branch co., Mich.: 66 m. S. by W. Lansing.

Calmornia, p. v., Yallabasha co., Mifss. : 109 m. N. by E. Jackson.

Cartfornda, p. v., Clermont co., Ohio: $87 \mathrm{~m}$. S. W. Columbus.

CALIFORNIA, p. v., and cap. Moniteau co., MO.: $21 \mathrm{~m} . \mathrm{W}$. Jefferson City.

Califorisa, p. v., Floyd co,, Ga.: 145 m. N. W. Milledgeville.

Calin's FEREx, p. o., Lexington dist, $\mathcal{S}$. Car.

Caliaghan's, p. o., Alleghany co., Virg.: at the forks of the roads leading to the Hot and Sulphur Springs, $5 \mathrm{~m}$. W. of Covington, and $141 \mathrm{~m}$. W. Richmond.

Callaxds, p. o., Pittsylvania co., Tixg.: 122 m. W. S. W. Pichmond.

C.LLAWAT county, $F y$. Situate W. on S. border, and contains $450 \mathrm{sq} . \mathrm{m}$. Drained by Clark's and Blood rivers, Eributaries of the Tennessee, which lies on its E. border. Surface level, and soils moderately fertile. The products are wheat and Indian com, with some tobacco and cotton. Farms 933 ; manuf, 7 ; dwell, 1,191, and pop.-wh. 7.094, fr. col. 10, s1. 992-total 8,096. Capital: Murray.

C.ALLAWAT county, Mo. Situate centrally on Missouri $r$. and contains $640 \mathrm{sq}$. m. Drained by $\mathrm{Au}$ Vase and other creeks. Surface undulating, with good timber, and the soils fertile. Wheat, corn, and tobacco are the chief products. Farms 1,169; manuf. 33; dwell.1, 612, and pop.-wh. 9, 998 , f. col. 22, sL 8,907-total 13,527. Capitul: Fulton.

Callexsburg, p. o., Clarion co., Penn.: on the S. side of Clarion r., a tributary of Allegbany r., $152 \mathrm{~m} . \mathrm{W} . \mathrm{N}$. W. Harrisburg.

Callexsyrlze, p. v., Pendleton co., $K y_{0}: 49$ m. N. E. Erankfort.

Callicoox, p. v., Sullivan co, $N . Y_{*}$ : on the E. side of tis Delareare $r$, sf $\mathrm{m}$. S. W. Albany.
Callicoon Drpôt, p. o., Sullivan co., N. Y.: on the New York and Erie R. R., $141 \mathrm{~m}$. from New York, and 323 from Dunkirk.

CALN, p. O., Chester co., Penn.: 58 m. E. by S. Harrisburg.

Calio, p. o., Warren co., $N$. Jer.: 51 m. N. by W Trenton.

Calunet county, Wisc. Situate N. E. on Lake iFinuebago, and contains $821 \mathrm{sq}$. m. Drained ehiefly $\mathrm{h}_{\mathrm{T}}$ the head streams of Manitouwoc and Sheboygan rivers. Surface varied-in the centre traversed by a rocky rido; and timber abundant. Farms 125; manuf. 4; dwell. 55:, and pop.wh. 1,721, fr. col. 122-total 1,843. Capita?: Mauchester.

Calumet, p. o., Porter co., Ind. : on Calumet cr., $134 \mathrm{~m}$. N. N. W. Indianapolis.

Catumet Village, p. v., Fond du Lac co., Wisc.: on the S. E. side of Winnebago Lake, $88 \mathrm{~m}$. N. E. Madison.

CALUMIo riyer, Ind. : rises on the W. side of La Porte co, and runs W. nearly parallel with Lake Michigan, into Illinois; there a part of it empties into the lake, $15 \mathrm{~m} . \mathrm{N}$. E. of Chicago, and the other part returns directly E., parallel with its former course, and only 3 or $4 \mathrm{~m}$. N. of it, falling into the lake at its extreme southern bend. The name was derived from calumet, the Indian "pipe of peace." Its original name was Ken-no-mo-kong.

Caltary, p. v., Athens co., Ohio: $63 \mathrm{~m}$. S. E. Columbus. Calvert county, Mrd. Situate W. shore, and contains 239 sq. m. Drained by creeks filling into Chesapeake Bay and Patuxent $r$. Surface undulating, rising from the waters ; soil a fine mold, producing tobacco, corn, wheat, etc. Farms 431; dwell. 1,006, and pop.-Th. 3,630, fi. col. 1,430, sI. 4,4s6 -total 9,646. Capital: Prince Frederick.

Calvin, p. o., Huntingdon co., Penn.: 69 m. W. Harrisburg.

CAMAK, p. V., Warren co., Ga.: on the lics of the Georgia R. R., 47 m. from Augusta, and $45 \mathrm{E} . \mathrm{N}$. E. Milledge 
ville. A branch $R$. $R$. hence diverges to Warreaton, dis$\operatorname{tant} 4 \mathrm{~m}$.

Casratrone, p. Y., Clinton co., Ia.: on the W. side of the Mississippi r., $67 \mathrm{~m}$. E. by N. Iowa City. A railroad is projected to run hence to Iowa City.

Camargo, p. v., Lancaster co., Penn.: 46 m. E. S. E. Harrisburg.

Camargo, p. $\nabla .$, Lincaln co., Tenn.: 69 m. S. Nashville. Carargo, p. v., Mfonroe co., Miss. : 142 m. N. E. Jackson. Carrargo, p. v., Jefferson co, Ind.: 76 m. S. E. Indianapolis.

Casrargo, p. v., Montgomery co., Ky. : 62 m. E. by S. Frankfort.

CAMrria county, Penn. Situate W. centrally, and contains $720 \mathrm{sq} . \mathrm{m}$. Drained by W. branch of Susquehanna r., and the head waters of the Connemaugh. Surface rough and sometimes mountainous-the Alleghanies making its E. and Laurel Ridge its W. border. The soils are of average fertility. Farms 1,089; manuf. 126; dwell. 2,898, and pop.-wh. 17,645, fr. col. 128-total 17,773. Capital: Ebensburg. Prublic Works: Pennsylvania Canal and Pennsylvania $R$. R.

Cavbria, p. V., Lucerne co., Penn.: 67 m. N. E. Harrisburg.

Casrbria, p. v., Hillsdale co., Mrich.: 62 m. S. by W. Lansing.

Cambris, t. and p. v., Niagara co., N. $Y_{0}: 248 \mathrm{~m} . \mathrm{W}$. Albany. The Rochester, Lockport, and Niagara Falls R. R. passes through the t., $61 \mathrm{~m}$. from Rochester. Pop. 2,360.

CAMrBRtA, p. o., and cap. Wayne co., Ia.: $112 \mathrm{~m} . \mathrm{S}$. W. by W. Iowa City.

Cayibra Mruls, p. o., Hillsdale co., Mich.: $62 \mathrm{~m}$. S. by W. Tansing.

Cambridge, p. v., Dallas co., Ala. : 62 m. W. S. W. Montgomery.

CAMBRIDGE, p. $\nabla .$, Dane $c_{0}$, Wisc, : on the W. side of a stream flowing into Lake Koshkonong, 19 m. E. by S. Madison.

CAVBRtDGE, eity and p. o., Wayne co., Ind.: on the W. branch of White Water r., where it is erossed by the $\mathrm{Na}$. tional Road and the Indiana Central R. R., 52 m. E. Indianapolis. The White Water Canal has its northern terminus at Hagerstown, $7 \mathrm{~m}$. N. of Cambridge.

C. AMBridge, p. v., Ileury co., Ill.: $92 \mathrm{~m} . \mathrm{N} . \mathrm{N}$. W. Springfield.

CAMr.BRIDGE, p. V., and cap. Dorchester co., MYd: on the S. side of 'Choptank r., $12 \mathrm{~m}$. from Chesapeake Bay, and 37 II. S. E. Annapolis.

CAJrBRIDGE, t. and p. o., Somerset co., Me.:47 m. N. by E. Angusta. Pop. 633.

Cargridge, tiand p. O., Lenawee co., Mich.: 54 m. S. by E. Lainsing. Pop. 9:t,

Currerdeg, p. $\nabla$., Saline co., Mfo.: on the S. side of the Missouri r., 64 m. W. N. W. Jefferson City.

Caviridge, t., p. city, and cap. Middlesex co., Mass. $8 \mathrm{~m}$. N. W. Boston. The Observatory stands in lat. 42022 $4 S^{\prime \prime}$, and long. $71^{\circ} 0 \mathrm{~S}^{\prime}$ W. Cambridge is the seat of Harvard University, one of the most flourishing schools of the United States, founded 168s; and here is located Mount Auburn Cemetery, a spot remarkable for its natural beauties. The public buildings are at East Cambridge, at Lechmere's Point, a vo at the S. E. extremity of the to, which is connected with Boston and Charlestown by bridges. A newspaper, the " $\mathrm{C}$. Chronicle," is issued weekly. The t. is also connected with Boston by R.R. Pop. 15,215.

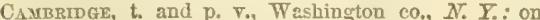
Hoosic r., $31 \mathrm{~m}$. N. N. E. Albany. Pop. 2,593.

Cambringe, t., p. $\nabla$. and eap. Guernsey co., Ohio: on the

E. bank of Wells er., $72 \mathrm{~m}$. E. Columbas. Pop. of t. 2,489.

Cavrbridge, p. v., Abbeville dist., $S$. Car.: $\tau 4 \mathrm{~m}$ W. by N. Columbia.

Caurrider, t. and p. o., Lamoille co, Termo: on Lamoille r., $31 \mathrm{~m}$. N. W. Montpelier. Pop. $1, \$ 40$. 102
Cambridge, p. V., Laneaster co., Penn.: 46 m. E. S. E. Harrisburg.

CAvmbider Port, p. o., Middlesex co., Mass. : 2 m. N.W. Boston. It is a place of considerable commerce, and several manufactures are established here. It has lately been incorporated with Cambridge City.

Canbemger Port, p. v., Windham co., Verm.: $93 \mathrm{~m} . \mathrm{s}$. Montpelier.

CAMOEN county, Ga. Situate s. E. corner, facing the Atlantic, and having for its S. boundary St. Mary's r., and contains 765 sq. m. Drained by Buffalo cr., Santilla r., and several streams tributaries of the St. Mary's. Surface low and sandy, with swamps. Rice and cotton are the principal products. Farms 235; manuf. 5; dwell, 642, and pop.wh. 2,069, fr. col. 4, sl. 4,246-total 6,319. Capital: Jeffersonton.

CAMDEN county, Mo. Situate centrally, and contains 480 sq. $m$. Drained by Osage $r$, and its tributaries. Surface level or undulating, with considerable woodland and a soil of great fertility. Farms 214; dwell, 860, and pop.-wh. 2,208, fr. col. 0, 8l. 130-total 2,338. Capital: Erie.

CAMDEN county, N. Jer. Situate W. middle, on Delaware $\mathrm{r}$, and contains $26 \mathrm{~s} \mathrm{sq} . \mathrm{m}$. Watered by creeks of the Delaware. Surface flat; soils moderately fertile. Farms 731 ; manuf 148 ; dwell. 4,090, and pop.-wh. 23,325 , fr. col. 2,097, sl. 0-total 25,422. Capital: Camden. Public Works: Camden and Amboy R. R.

CAMDEN county, N. Car. Situate N. E. between Pas quotank and North rivers, and contains $228 \mathrm{sq} . \mathrm{m}$. Surface low and marshy, and soils indifferent. Farms 579; manuf. 15 ; dwell. 770 , and pop.-wh. 3,572 , fr. col. 290 , sl. $2,187-$ total 6,049. Capital: Camden C. H.

CAMDEN, p. v., and eap. Wilcox con, Ala.: on a cr. of Alabama r., $63 \mathrm{~m}$. W. S. W. Montgomery.

Canmen, p. V., and cap. Benton co., Penn.: about $6 \mathrm{~m}$. W. of Tennessee $\mathbf{r}_{\text {, }}$ and $69 \mathrm{~W}$. Nashville. The Nashville and Mississippi R. R. will pass through this place.

CAMmen, p. V., and cap. Washita co., Ark.: on the W. side of Washita $r_{.}, 78 \mathrm{~m}$. S. by E. Little Rock.

Cander, p. v., Kent co, De ? : on the S. branch of Jones cr., $3 \mathrm{~m}$, s. by E. Dover.

CANOEN, p. v., Carroll co., Ind. : on the N. side of Passianong cr., $68 \mathrm{~m} . \mathrm{N}$. N. W. Indianapolis.

CAMDEN, p. O., Schuyler co., Ill. : on a tributary of Crooked cr., 84 m. W. N. W. Springfield.

CANDEX, t. and p. v., Waldo co., Me.: on the W. side of Penobscot bry, $36 \mathrm{~m}$. E. by S. Augusta. It has a good har bor and a number of vessels employed in the coasting trade and the fisheries. Lime is the principal staple, and is exported in large quantities. Ship-building is also an extensive employment at this port. Pop. 4,005.

CAMrDEX, p. ซ., Madison co., Miss.: on a cr. of Big Black r., $36 \mathrm{~m}$. N. by E. Jackson.

CaMDEN, t. and p. O., Hillsdale co., Mich.: on Little St. Joseph's r., 66 m. S. by W. Lansing. Pop. 594.

CaMDEN, p. v., Ray co., Mo.: on the N. side of the Missouri $\mathrm{r}_{\mathrm{a}}, 112 \mathrm{~m}$. W. N. W. Jefferson City, and by course of the r., $342 \mathrm{~m}$. abore St. Louis.

CAMmEx, p. $\nabla .$, and cap. Camden co., N. Car.: on the E. side of Pasquotank r., $147 \mathrm{~m} . \mathrm{E} . \mathrm{N}$. E. Raleigh. The tonnage of the district of which it is the port, amounted in 1 s5 0 to 11,913 tons.

CANDEN, t. and p. v., Oncida co., N. Y.: on Fish cr., 108 m. W. N. W. Albany. The Watertown and Rome R. R. passes through the village $18 \mathrm{~m}$. from Rome. Pop. 2,S20.

Cavdear, t., p. eity, port, and eap., Camden co., $N$. Jer. on the E. side of Delaware r., opposite Philadelphia, 5 s m. S. by W. Trenton. The city is united with Philadelphia by three ferries. The largest ships come up to the lower part of the city, and vessels of 150 tons to the central parts. The city has considerable manufactures and trade, and contains numerous fine public buildings, churehes, and school-houses. The Camden and Amboy R. R. has its terminus at this 
point, and there is also a railroad to Woodbury. Three newspapers are published here weekly, the "West Jerseyman" (whig), the "C. Phønix," and the "C. Democrat" (dem.) Pop. 9,618.

CAMDEN, p. v., Preble co., Ohio: on the W. side Seven Mile cr., $92 \mathrm{~m}$. W. by S. Columbus.

CAMDEN, p. v., and cap. Kershaw dist., S. Car.: on the E. side of Wateree r., $31 \mathrm{~m}$. N. E. Columbia. The river is navigable to this point for $\tau 0$ tons flat boats, but since the completion of the Camden Branch of the South Carolina R. R. the bulk of its commercial material has been conveyed by land. The village has some manufactures, and its public buildings are commodious and substantial. A newspaper, the " $C$. Journal," is issued semi-weekly. Camden is noted as the scene of two battles of the Revolution-the one fought 16th Aug., 1780, and the other 23d April, 1781. A monument, erected in honor of Baron De Kalb, and the foundation of which was laid by Lafayette in 1825 , stands at the end of De Kalb Street; it is of white marble, and the chief ornament of the village.

CAMIDEN, p. v., Benton co., Tenn.: $69 \mathrm{~m}$. W. Nashville.

CAMDEN MrLls, p. o., Rock Island co., Ill.: on Copper cr. of Rock r., $123 \mathrm{~m}$. N. W. by N. Springfield.

CAMDENVILLE, p. v., Anderson co., Ky.: 22 m. S. W. Frankfort.

CAMEL's RUMP, Term.: one of the highest peaks of the Green Mountains, $17 \mathrm{~m}$. W. Montpelier. Its elevation is 4,188 feet above the ser-level.

CAMERon county, Texo. Situate S. W. on Gulf of Mexico, and contains about $5,600 \mathrm{sq}$. m. It includes the Isla del Padre. Its principal settlements are on the Rio Grande. Farms 11; dwell. 1,554, and pop.-wh. 8,469, fr. col. 19, sl. 53 - total 8,511. In this enumeration Starr and Webb counties are also included. Capital: Santa Rita.

Cameron, t. and p. v., Steuben co., $N . Y_{\text {. }}$ : on the Crnisteo r., $216 \mathrm{~m}$. W. by S. Albany. The New York and Erie R. R. passes through the village, $324 \mathrm{~m}$. from New York City, and $145 \mathrm{~m}$. from Dunkirk. Pop. 1,701.

Cameron, p. v., Clinton co., Penn.: 78 m. N. W. Harrisburg.

Cameron, p. V., and eap. Milam co., Tex. : on the N. side of Little r. of the Brazos r., 64 m. N. E. Austin City.

Cameron's Mrus, p. o., Steuben co., N. Y.: $222 \mathrm{~m}$. W. by S. Albany.

Camlecs, t, and p. v., Onondago co, $N_{.}$. Y.: $128 \mathrm{~m}$. W. Albany. The Erie Canal traverses the northern part of the town, and the Rochester and Syracuse R. R. intersects the village, $7 \mathrm{~m}$. W. Syracuse. Pop. 3,106 .

CAMPBexl county, Ga. Situate N. W., and contains 388 sq. m. Drained by Chattahoochee $r$. and its creeks. Surface undulating, and soils of average fertility. Products wheat, Indian corn, and cotton. Farms 694; manuf. 18 ; dwell. 920, and pop.-wh. 5,718, fr.col. 7, sl. 1,507-total 7,232 Capital: Campbellton. Public Works: La Grange P. P

CAMPBelu county, Ky. Situate N. between the Ohio and Licking rivers, and contains $180 \mathrm{sq}$. m. Drained by creeks flowing into the border rivers. Surface uneven, and soils moderately productive. Wheat, oorn, and tobacco are the staple products. Farms 730 ; manuf. 12; dwell. 2,319, and pop.-wh. 12,871, fr, col. 79, sl. 177-total 13,127. Capital. Newport. Publio Works: Lexington and Cincinnati R. R. (projected).

Campbeli county, Tenn. Situate N. E., and contain 672 sq. m. Drained by Cumberland and New rivers, and Clinch r. washes its S. E, border. Surface uneven and hilly-in the N. W. mountainous. Soils, with some exeeptions, fertile, and productive of the cereals and some cotton. Farms 521; manuf. 14; dwell. 916, and pop.-wh. 5,653, fr. col. 97, sl. 318-total 6,068. Capital : Jacksboro'.

Cavpbell county, Firg. Situate $\mathrm{S}$. between James and Staunton rivers, and contains $576 \mathrm{sq} . \mathrm{m}$. Drained by Falling r., Otter cr., and other streams. Surface much broken, bat soil productive. Wheat, Indian corn, oats, and tobacco are the principal growths. Farms 758; manuf. 119 ; dwell. 2,203, and pop.-wh. 11,538, fr. col, 841, sl. 10,866-total 23,245. Capital: Campbell C. H, Pubtic Works: Virginia and East Tennessee R. R., etc.

CaMpbeli, p. v., Coles co., $M l_{0}$; on the W. side of Embarras r., $2 \mathrm{~m}$ from that stream, and $67 \mathrm{~m}$. E. S. E. Springfield.

CAMPBELL, p. v., Lawrence co., Ohio: $96 \mathrm{~m}$. S. by E. Columbus.

Cavapeli C. H., p. v., and cap. Campbell co., Firg.: 92 m. W. S. W. Richmond.

Campbelz's Bridge, p. o., Marion dist., S. Car.: 89 m. E. by N. Columbia.

CAMPBelisbdrgh, p. v., Henry co., Ky. : on the Louis ville and Cincinnati R. R., $30 \mathrm{~m}$. N. W. Frankfort.

Campbell's Corners, p. o., Oakland co., Mich.

Canpbell's Mills, p. o, Windham co, Conno: $38 \mathrm{~m}$.

E. N. E. Hartford.

Campeell's Post, p. v., Portage co., Ohio: 122 m. N. E. Columbus.

Cavpbelu's Rest, p. o., Sullivan co., Tenn. : 247 m. E. by N. Nashville.

Campreeli's Station, p. o., Knox co., Tenn.: on the N side of Tennessee r., $129 \mathrm{~m}$. E. Nashville.

CaMrbellstille, p. v., and cap. Taylor co., Ky.: $58 \mathrm{~m}$ S. by W. Frankfort.

Campeelisvilite, p. v., Giles co., Tenn. : on a cr. of Tennessee r., $59 \mathrm{~m}$. S. by W. Nashville.

CaMPBelutoN, p. v., Jackson co., Frlor.: on the W. side of Chipola r., $78 \mathrm{~m}$. W. N. W. Tallahassee.

Camprellton, p. v., and cap. Campbell co., Ga. : on both sides of Chattahoochee r., $93 \mathrm{~m}$. W. N. W. Milledgeville.

Campbellton, p. v., Itawamba co., Miss. : 173 m. N. E Jackson.

Campbelltown, p. v., Steuben co, $N . Y$. on E, side of Conhocton r., $174 \mathrm{~m}$. W. by S. Albany. The Buffalo, Corning, and New York R. R. passes through the village, $9 \mathrm{~m}$. from Corning.

Cavpbeletown, p. v., Lebanon co., Penn.: $15 \mathrm{~m}, \mathrm{E}$. Harrisburg.

Camprellyille, p. v., Duchess co., N. Y.:63 m. S. by E. Albany,

Campiellytlle, p. v., Sullivan co., Penn.: 87 m. N Harrisburg.

CaMP Call, p. o., Cleveland co., N. Car.: 153 m. S. W. Raleigh.

CAMP CrEeK, p. o., Koseiusko co., Ind.: 78 m. N. by E. Indianapolis.

Camp Creek, p. o., Jefferson co., Ark.: 52 m. S. by E Little Rock.

Camp Creek, p. o., Livingston co., Ky.: $198 \mathrm{~m}$. W. by $\mathrm{S}$ Frankfort.

Carrp Crefr, p. o., Greene co., Tenn.: on a cr. so called of Nolichucky r., $228 \mathrm{~m}$. E. Nashville.

Canpelio, p. o., Plymouth co., Mass.

CAMP Ground, p. v., Appling co., Ga.: 117 m. S. S. E Milledgeville.

Camp Hirl, p. o., Tallapoosa co., $A l a_{0}: 43 \mathrm{~m}$. N. F Montgomery.

Camp Izard, p. O., Marion co., Fllor.: 162 m. S. E. by E Tallahassee.

CaMr Milis, p. o., Floyd co., Virg.: 163 m. W. S. W Richmond.

Camponelzo, p. v., Spartanburgh dist., S. Car.: $73 \mathrm{~m}$ N. by W. Columbia.

Camp Point, p. o., Adams co., $\pi l_{0}: 61 \mathrm{~m} . \mathrm{W}$. by N. Springfield.

CaMr Ridge, p. o., Williamsburgh dist., S. Car.: $77 \mathrm{~m}$. E. by S. Columbia.

CaMP Spring, p. 0., Lawrence co., Ala. : 166 m. N. N. W. Montgomery.

Cамpт,, p. v., Nachitoches par., La.: on the N. E. side of Red r., $158 \mathrm{~m}$. N. W. Baton Rouge. 
Campton, t. and p. o., Grafton co., N. IIamp.; on Pemegemasset r., $44 \mathrm{~m} . \mathrm{N}$. by W. Concord. Pop, 1,439.

Campton Vilimage, p. v., Grafton co., N. Hamp. : $43 \mathrm{~m}$.

N. by W. Concord.

CAMrtown, p. v., Bradford co., Penn.: 112 m. N. Harrisburg.

Canptown, p. v., Essex co., $N$. Jer.: on Elizabeth $r_{\text {., }} 47$ m. N. N. W. Trenton, Considerable manufactures are carried on in this village. It derives its name from the fact of the encampment of the American army at this point during the Revolutionary war.

CaMPVILle, p. v., Tioga co., N. Y.: on the N. bank of Susquehanna r., $122 \mathrm{~m}$. W. S. W. Albany, and on the line of the New York and Erie R. R., 240 m, from New York and $229 \mathrm{~m}$. from Dunkirk.

CAMPrille, p. v., Litchfleld co., Conn.

CANA, p. o., Jennings co., Ind.: 57 m. S. E. Indianapolis.

CanaAN, p. vo, Marion co, Ala.: $153 \mathrm{~m}$ N. W. Montgomery.

CanaAr, to and p. v., Litehfield co, Conn.: on the E. side of Housatonic r., $42 \mathrm{~m}$. N. W. Hartford. The river between this and Salisbury has a fall of 60 feet, and affords extensive hydraulic power. Iron and lime are the chief manufactures. The Housatonic R. R. passes through Canaan, 73 m. N. of Bridgeport. Pop. 2,727.

CANAAX, p. v., Jefferson co., Ind.: about $2 \mathrm{~m}$. W. of Indian Kentucky r., 76 m. S. E. Irdianapolis.

CANAAN, to and p. v., Somerset co., Me.: on the E. side of Kennebec r., 27 m. N. by E. Augusta. Pop. 1,696.

Carasir, to and p. o., Grafton co., N. Hamp.: on Mascomy r., $33 \mathrm{~m} . \mathrm{N}$. W. Concord. Pop. 1,686.

CANuar, t. and p. v., Columbia co., $N_{0} Y_{*}: 22 \mathrm{~m} . \mathrm{S} . \mathrm{E}$. Albany. The Hudson and Berkshire R. R., and the Albany and West Stockbridge (western) R. R. traverse the t, and the latter touches the v., $33 \mathrm{~m}$. from Albany. Pop. 1,911.

CaraAN, t. and p. o., Wayne co., Ohio: 84 m. T. E. Columbus. Pop. 1,923.

Canaar, t. and p. o., Wayne co., Penn.: on branches of Lackawaxen cr., $143 \mathrm{~m}$. N. E. Harrisburg. The R. R. extending from Carbondale to Honesdale traverses the $t$. in its N. part.

Canaux, t. and p. o., Essex co, Verm.: in the N. E. corner of the State, $67 \mathrm{~m}$. N. E. Montpelier. Pop. 471.

Canaan Centre, p. vo, Columbia co., $N . Y_{0}: 24$ m. S. E. Albany.

Canaan Four Corners, p. v., Columbia co., $N_{*} Y_{0}: 23$ m. S. E. Albany.

CanaANville, p. v., Athens co., Ohio: 73 m. 8. E. Columbos.

Canada creek, $N . Y_{.}:$the W. and largest branch of the Nolowk r. It is about $60 \mathrm{~m}$. long, and in its course has several rapids and cascades, which afford views of much grandeur and interest.

Canadian, p. v., Mississippi co., Ark.: 142 m. N. E. Little Rock.

Canadice, t. and p. v., Ontario co., N. Y.: on Honeyoke Lake, $187 \mathrm{~m}$. W. Albany. Hemlock Lake bounds it on the W. side. The to contains mauch fine agricultural land. Pop. 1,069.

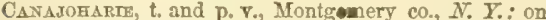
the S. side of Mohawk ro, $42 \mathrm{~m}$. W. Albany. The Erie Canal passes through the village. The "Montgomery County Union" (dem.), is issued weekly. Pop. 4,097.

CaYar, p. 0., Onondaga co., N. Y.: $122 \mathrm{~m}$. W. Albany.

Caral, t. and p. O., Venango co., Penn.: 197 m.W.N.W. Harrisburg.

Canal Doper, p. o., Tuscarawas co., Ohio: on the Ohio Canal, Sti m. E. by X. Columbus.

Canat Fulton, p. 0., Stark co., Ohio: on the E. side of Tuscarawas $\mathrm{r}$, and on the Ohio Canal, $96 \mathrm{~m}$. N. E. Columbus.

Canal Lethigritue, p. Y., Coshocton co, Ohio: on the 104
N. side of Tuscarawas r., and on the Ohio Canal, $66 \mathrm{~m}$. Ko by $\mathrm{N}$. Columbus.

Canal Winchester, p. v., Fairfleld co., Otio : on a branch of Little Waluut er., and on the Ohio Cunal, $14 \mathrm{~m}$. S. E. Columbus. Pop.i274.

CANAXDaigen lake, $N . Y .:$ a beautiful skeet of water situate centrally in Ontario co. Its length, from N. to S., is $14 \mathrm{~m}$., and its medial breadth alooul $1 \mathrm{~m}$. It discharces itself into the river of the same name at the $\mathrm{v}$, of Canandaigua.

CANANDATGUa river, $N_{0} Y_{*}:$ is formed from the waters discharged from the lake, and under various names winds its course to the Seneca, the common recipient of a cluster of small lakes.

Canandatgea, t., p. v., and cap. Ontario co., $N$. $Y$.: on the W. side of Canandaigua Lake, $177 \mathrm{~m}$. W. Albany. The v. is pleasantly situate at the outlet of the lake, and contains, besides the $c 0$. buildings, a number of substantial and elegant churches, stores, and dwellings. The "Ontario Repository" (whig), and the "Ontario Messenger" (dem.), are published weekly. The Rochester and Syracuse R. R. passes through the v. $29 \mathrm{~m}$. from Pochester, and it is the $\mathrm{N}$. terminus of the Canandaigua and Elmira R. R., and the E. terminus of the Canandaigua and Niagara Falls R. R. Pop. 6,212.

Canandaigua, p. o., Lenawee co., Mich.: on the W. side of Bear cr. of Raisin r., $64 \mathrm{~m}$. S. by E. Lansing. The Southern Michigan $R$. R. runs $4 \mathrm{~m}$. N. of the village.

Carasatga, p. o., Polk co.g Tenn. : 142 ma. E. S. E. Nashville.

Canastota, p. .., Madison co., N.Y.: on the Erie Canal, and the Utica and Syracuse R. R., $201 \mathrm{~m}$. from Albany.

CANDIA, t. and p. o., Rockingham co., $N$. Hamp.: on the height of land between the Merrimac $x_{\text {. }}$ and the ocean, 17 $\mathrm{m} . \mathrm{S} . \mathrm{E}$. Concord. The view from these heights is extensive, reaching on one side to the White Mountains, and on the other to the distant Atlantic. Pop. 1,482.

CANDOE, t. and p.. ., Tioga co., N. Y.: on Cottotong cr., $127 \mathrm{~m}$. W. by S. Albany. The v. lies on the Cayuga and Susquehanna R. R., 10 m. N. Owego. Pop. 3,483.

CANDOR, p. v., Washington co., Penn.: 192 m. W. Harrisburg.

CANEADEA, to and p. v., Alleghany co, $N_{0} Y_{n}$ : on the Genesee $r .227 \mathrm{~m}$. W. by S. Albany. The $\mathrm{r}$. is on the W. side of the river. Pop. $1.4 \pi 7$

CaNe Botrom, p. o., Lauderdale co., Tenn.: $162 \mathrm{~m} . \mathrm{W}$. by S. Nashville,

CAve Crerk, p. v., and cap. Butler co, Mo. : on the W. fork of the cr. so called, $154 \mathrm{~m}$. S. E. Jefferson City. Cane cr. is a tributary of Big Black Water $x$, which it joins a little below the Arkansas State line.

Cane Crees, p. o., Chatham co., N. Corr.: on a cr. of Cape Fear x. so called, $43 \mathrm{~m}$. W. by N. Raleigh.

Cane Creek, p. o., Lincoln co., Tenn. : on a cr. of Elk r. so called, $64 \mathrm{~m}$. S. by E. Nashville.

Cane Creer, p. o., Franklin co, Ala.: 174 m. N. W. Montgomery.

CANEMAH, v., Clackamas co., Oreg. : on E. side of Willamette r., $2 \mathrm{~m}$. above Oregon City, and $38 \mathrm{~m}$. N. by $\mathrm{E}$. Salem.

Cant Ponvt. p. 0., Troup co., Ga.: 112 m. Milledgeville. Cane Speirg, p. o., Bullitt co., Ky.: 51 m. W. S. W. Frankfort.

CANEx, p. v., Washita co., Ark. : 86 m. S. Little Rock. CANEx, p. v., Matagorda co., Teas.: on a stream so called, $147 \mathrm{~m}$. S. E. Austin City. The Caney empties into the Gulf at the N. E. end of Matagorda Bay.

Caney Branor, p. o., Greene co, Tenn.: 219 m. E. Nashville.

Caser Fork, p. o, Warren co., Tenn.: on Caney fork of Cumberland r., $55 \mathrm{~m}$. E. by S. Nashville.

CANEY SPRINe, p. o., Marshall co., Tenn。: $32 \mathrm{~m} . \mathbf{8}$. Nashville. 
CANExtille, p. v., Grayson co., Ky.: 98 m. W. S. W. Frankfort.

CaNFIELD, p. v., and cap. Mahoning co., Ohio: $132 \mathrm{~m}$. N. E. Columbus, The "Mahoning Index," a dem. paper, is issued weekly.

CanField's Corner, p. o., Tioga co., N. Y. : $134 \mathrm{~m}$. W. S. W. Albany.

CAIICELLO, p. จ., Rockbridge co., Virg.: 112 m. W. Richmond.

Cantsteo, t. and p. $\nabla .$, Steuben co., $N . Y$.: on Canisteo r., $185 \mathrm{~m}$. W. by S. Albany. The $\mathrm{v}$. on the $\mathrm{N}$. side of the r. is intersected by the New York and Erie R. R., $337 \mathrm{~m}$. from New York, and 132 from Dunkirk. The "Canisteo Express" is issued weekly. Pop. 2,030.

CANISTEo river, $N$. $Y .:$ rises in Alleghany co, and after a general S. E. course of $60 \mathrm{~m}$., falls into Tioga r., in the $t$. of Erwin, Steuben co. It is navigable for boats for about $40 \mathrm{~m}$., and is the recipient of numerous fine mill streams.

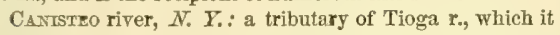
enters near the $\mathrm{v}$. of Painted Post. Its whole course is about $60 \mathrm{~m}$., and it is boatable for about $40 \mathrm{~m}$. ; and though in some parts no more than 4 rods wide, floats arks containing 1,000 bushels of grain, and opens fine facilities of intercourse with the Tioga and Susquehanna rivers.

Cannaday Gap, p. o., Floyd co., Firg. : at a pass of the mountains, $159 \mathrm{~m}$. W. S. W. Richmond.

Cannelton, p. v., Perry co., Ind.: on the Ohio r., 124 m. S. by W. Indianapolis. The neighborhood abounds in coal, from a particular species of which (cannel) the v. takes its name. It possesses great manufacturing advantages, and considerable capital has been invested in cotton and earthenware factories. Building material, fire clay, etc., are abundant. The "Economist," a weekly paper, is published here. Pop. about 700 .

CaNNON county, Tenn. Situate centrally, and contains $340 \mathrm{sq} . \mathrm{m}$. Drained by tributaries of Cumberland r. Surface mountainous, and soils generally fertile. Farms 877; manuf. 7; dwell. 1,326, and pop.-wh. 8,115, fr. col. 24, sl. 813-total 8,9s2. Capital: Woodbury.

Cannonsburgh, p. v., Kent co., Mich. : on a cr. of Grand r., $51 \mathrm{~m}$. W. N. W. Lansing.

Cannonsburgh, p. v., Greenup co., $K_{y} .: 72 \mathrm{~m}$. S. W. Frankfort.

Cannonsbuggr, p. $\vee$., Washington co., Penn. : on Chartier's cr., $18 \mathrm{~m}$. S. W. Pittsburg, and $182 \mathrm{~m}$. W. Harrisburg. Jefferson College, and a Theological Seminary are located here.

CannoN's FerRy, p. o., Sussex co., Del.: 89 m. S.

Dorer.

Cannon's Mrur, p. o., Columbiana co., Ohio: $126 \mathrm{~m}$.

E. N. E. Columbus.

Cannon's Store, p. o., Spartanburgh dist., S. Car.: 68

N. by W. Columbia.

Cannonstille, p. v., Delaware co., $N_{.}, Y .:$ on the N. side of Delaware r., $89 \mathrm{~m} . \mathrm{S}$. W. Albany.

Canoe Creek, p. 0., Burke co., N. Car.: 163 m. W. Raleigh.

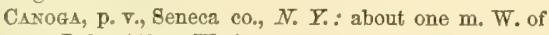
Cayuga Lake, $145 \mathrm{~m}$. W. Albany.

Carontod island, in Narraganset Bay, R. I.: $3 \mathrm{~m}$. W. Phode Island. It is $7 \mathrm{~m}$. long and a mile broad.

Canooches, p. o., Emanuel co., Ga. : on the r. so called, $79 \mathrm{~m}$. S. E. Milledgeville.

CArooche river, $G a_{0}$ : the W. and largest confluent of Ogeechee r. It is $100 \mathrm{~m}$. long, and navigable for $50 \mathrm{~m}$. to Cedar cr.

Canterbury, t. and p. v., Windham co., Conn.: on the W. side of Quinnebaug r., $41 \mathrm{~m}$. E. Hartford. Pop. 1,669.

Casterbury, p. o., Kent co., Del. : at the head of Mother Kill cr., $7 \mathrm{~m}$. S. by W. Dover.

Carterburg, t. and p. v., Merrimac co., N. Hamp. : on the E. side of the Merrimac r., $8 \mathrm{~m}$. N. Concord. In the S. E. part of the t, there is a Shaker's village. Pop. 1,614.
Canton, p. v., Smith co., Taos: 218 m. N. E. Austin City.

Canton, p. v., Wilcox co., Ala.: on the left bank of the Alabama r., 63 m. W. S. W. Montgomery.

Carton, p. v., Lawrence co., Ark. : on a cr. of Strawberry r., $109 \mathrm{~m}$. N. by E. Little Rock.

Canton, t. and p.v., Hartford co., Conn.: on Farmington r., $13 \mathrm{~m} . \mathrm{N}$. W. by W. Hartford. It has some manufactures. Pop. 1,994.

CANTON, p. V., and cap. Cherokee co., Ga.; on the N. side of the Etowah r., $113 \mathrm{~m} . \mathrm{N}$. W. Milledgeville.

CaNton, p. v., Washington co., Ind.: $77 \mathrm{~m}$. S. Indianapolis. The New Albany and Salem R. R. crosses the co. about a mile $\mathrm{S}$. of the village.

Canton, p. F., Fulton co., IUl.: on Big cr. of Spoon r., 47 m. N. N. W. Springfield.

Canton, p. V., Jackson co., Ia. : on the N. side of Makoqueta r., $47 \mathrm{~m}$. N. E. Iowa City.

CaNToN, p.r., Twigg co., Ky.: on the E. side of Cumberland r., $40 \mathrm{~m}$. from its mouth, and $194 \mathrm{~m}$. W. S. W. Frankfort. It is the place of shipment for the produce of a rich and productive back country.

Canton, t. and p. o., Oxford co., Me.: on Androscoggin r., $26 \mathrm{~m}$. W. by N. Augusta. Pop. 926.

Canton, p. v., and cap. Madison co., Miss. : between the forks of a cr. of Big Black r., 23 m. N. N. E. Jackson.

CANTON, t. and p. Y., Norfolk co., Mass. : on Neponset r., $14 \mathrm{~m}$. S. W. Boston. The Boston and Providence P. R. passes through the v., $14 \mathrm{~m}$. from Boston, and 29 from Providence. It has several iron, cotton, and woolen factories. Pop. 2,598.

Carton, p. v., Salem co., $N$. Jer.: on the W. branch of Stow cr., $61 \mathrm{~m}$. I. S. W. Trenton.

Canton, to, p. v., and cap. St. Lawrence co., $N_{0} Y_{\text {.: }}$ on Grasse $r$. of the st. Lawrence, $142 \mathrm{~m}$. N. W. Albany. At the v. a fine bridge is thrown over the stream, and the Watertown and Potsdam R. R. will cross the Grasse at this point. Pop. 4,685 .

CANTON, t., p. v., and cap. Stark co., Ohio: about 1 ? m. above the bifurcation of Nimishillen cr., $103 \mathrm{~m}$. N. E Columbus. Three newspapers, the "Ohio Repository" (whig), the "Stark County Democrat," and the "Ohio Staats Bote" (Germ. dem.), are published weekly. It is a very thriving place, being intersected by the Ohio and Pennsylvania $R$. R., Pop. of v. 2,604, and of t. 4,326.

Canton, t. and p. v., Bradford co., Penn。 : on Tonawanda r., $107 \mathrm{~m}$. N. by W. Harrisburg.

CArtos, p. v., Lewis co., Mo.: 108 m. N. N. E. Jefferson City.

Canton Centre, p. o., Hartford co., Conn.: 13 m. N. W. by W. Hartford.

Canton Mrlis, p. o., Oxford co., Me.: $27 \mathrm{~m}$. W. by N. Augusta.

Cantrele's Cross Roads, p. o., M.Minn co., Tenn. : 131 m. E. S. E. Nashville.

Cantwell's Bridge, p. o., Newcastle co, Del.: on the $\mathrm{N}$. side of Appoquinimink cr, $17 \mathrm{~m}$. N. by W. Dover.

CAPE ARAGo, Oreg. Ter.: a prominent headland. jutting into the Pacific Ocean, about $40 \mathrm{~m}$. $\mathrm{S}$. of the Umpqua $\mathbf{r}$.

CAPE AU GraY, p. O., Lincoln co, MFo.: on the W. side of the Mississippi r., 88 m. E. N. E. Jefferson City.

Cape Blanco, Oreg. Ter: : a headland on the Pacific coast, about $25 \mathrm{~m}$. N. of Cape Oxford.

CAPE CoD, Mass.: a projection from the mainland, in lat. $422^{\circ} 23^{\prime \prime} \mathrm{N}$., and long. $70^{\circ} 3^{\prime} 55^{\prime \prime} \mathrm{W}$. It is curred inward, something in the shape of a man's arm bent at the elbow and wrist, and is $65 \mathrm{~m}$. long, and from 1 to $20 \mathrm{~m}$. broad. It constitutes the $c 0$. of Barnstable.

Cape Disappointment, Oreg. Ter.: a headland at the entrance of the Columbia $\mathrm{r}$.

CAPE FARE, p. o., Taney co., MYo.: on White r., $138 \mathrm{~m}$. S. S. W. Jefferson City.

CAPE FEAR, N. Car.: the S. point of Smith's island, near 
the mouth of Cape Fear r., in lat. $33^{\circ} 48^{\prime} \mathrm{N}$., and long. $78^{\circ}$ $09^{\prime} \mathrm{Wr}$.

CAPE FEAR river, $N$. Car.: the best navigable river of the State. It has two branches: the N. W. branch, formed by the union of Deep and Haw rivers, from which, flowing about $100 \mathrm{~m}$, it receives the $\mathrm{N}$. E. branch, or Clarendon r., above Wilmington, and $34 \mathrm{~m}$. below it enters the Atlantic Ocean by two channels, one on each side of Smith's Island. Its channels have been deepened by embankments, and steamboats now navigate its waters to Fayetteville, $90 \mathrm{~m}$., at the lowest stage of the waters.

CAPE Forlwaither, Oreg. Ter.: a headland on the Pacific coast, about $10 \mathrm{~m}$. $\mathrm{N}$. of the month of Alseya $\mathbf{r}$.

CAPe Gtrardeau county, Mo. Situate S. E. on Mississippi r., and contains $860 \mathrm{sq} . \mathrm{m}$. Drained by White Water r. and other streams. Surface level, sometimes swampy, and studded with small lakes, Iron ore, useful clays, ete., are abundant. Wheat, Indian corn, oats, and tobacco are the chief products. Farms 1,019; manuf. 31; dwell. 2,108, and pop.-wh. 12,203, fr. col. 35, sl. 1,674-total 13,912 Capital: Jackson.

CAPE GIRARDEAU, t. and p. v., Cape Girardeau co., Mo. : on the W. side of Mississippi r., $168 \mathrm{~m}$. S. E. Jefferson City. It is the depôt of a great part of Sonthern Missouri. The "Western Eagle" (whig) is here published weekly.

CAPE Horv, Clarke co., Oreg.: a noted headland on the N. bank of Columbia r., in lat, $45^{\circ} 83^{\prime} 09^{\prime \prime} \mathrm{N}$., and long. $122^{\circ} 06^{\prime} 15^{\prime \prime} \mathrm{W}$.

Cafe Island, p. v., Cape May co., N. Jer. : at the extreme point of the State, $91 \mathrm{~m}$. S. Trenton. It is a place much resorted to by the fashionables in the summer season, for whom splendid boarding-houses and hotels are provided. The place affords great facilities for sea bathing and flishing.

CAPE LOOEOUT, Oreg. Ter.: a headland on the Pacific cosst, in lat, $45^{\circ} 08^{\prime} \mathrm{N}$.

CAPE MaY county, N. Jer. Situate S. point of State, and contains $240 \mathrm{sq} . \mathrm{m}$. Drained chiefly by creeks of Tuckahoe r., which demarks the N. border. Surface flat-in some places swampy. The coast is lined with long sand islands inclosing lagoons. Farmos 285; manuf. 4; dwell 1,218, and pop.-wh. 6.190, fr. col. 243, sl. 0-total 6,433. Capital: Cape May C. H.

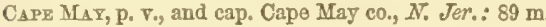
8. Trenton.

CAPE MAY : a promontory on the N. side of the entrance of Delaware Bay, $18 \mathrm{~m}$. N. of Cape Henlopen, and in lat. $35^{\circ} 5 r^{\prime} \mathrm{X}$., and long. $7 t^{\circ} 52^{\prime} \mathrm{T}$. There is a light-house on this point.

Cape Mespociro, Calif: : a bold headland of the Paciflo coast, in lat. $4{ }^{\prime} 21^{\prime} \mathrm{m}$. . .., and long. $121^{\circ} 35^{\prime} \mathrm{W}$. This is the most westerly point of the United States.

CAPE NedDick, p. O., York co, Mre.: on the headland so called, on the Atlantic Ocean, about $4 \mathrm{~m}$. above York IIarbor, and $81 \mathrm{~m}$. S. W. by S. Augusta. The cape is chiefly inhabited by fishermen.

CAPE OXFORD, Oreg. Ter.: a headland of considerable extent on the Pacifio coast, and by bending south, incloses a bay called Ewing Harbor. A city, named Port Oxford, has been founded here.

CAPE's Creek, p. o., Newton co, Mo.: on a cr. so called, $166 \mathrm{~m} . \mathrm{S}$. W. Jefferson City.

Cape Shoalwater, Oreg. Ter.: a headland on the N. side of the entrance of Shoalwater Bay.

CAPERILle, p. v., Northampton co., Tirg. : on Cape Charles, the S. point of the Chesapeake peninsula, $83 \mathrm{~m}$. E. by S. Richmond.

CAfe TLYCENT, t., p. F., and port of entry, Jefferson co., N. Y.: on the S. side of the St. Lawrence $r_{\text {r, }}$ opposite Wolf Island, $158 \mathrm{~m} . \mathrm{N}$. W. Albany. The $\mathrm{v}$. is an important commercial entrepot ; the Watertown and Rome R. R. termiantes lere, anil steamlwats ply regularly between this port and the principal lake ports of the Tnion and the Canadas. 106
The shipping owned in the district in 1850 amounted to 2,497 tons. Pop: 8,044

CAPOA BrIDGE, p. O., Hampshire co., Fỉrg.: 147 m. N. by W. Eichmond.

CAPON Springe, p. v., Hampshire co., Tirg.: 142 m. N. by $W$. Richmond. These springs are noted for their medicinal properties.

CAPTINa, p. V., Belmont co., Ohio: 105 m. E. Colnmbus.

Carawar, p. 0., Randolph co., N. Car.: 173 m. W. by S. Raleigh.

CARBon county, Penn. Situate E. middle, and contains 480 sq. m. Drained by tributaries of the Lehigh, which r. runs through it, Surface diversified, but in the N. W. and S. E. hilly and broken. Soils of moderate fertility. This is one of the first coal mining counties of the State. Farms 246 manuf. 158; dwell. 2,544, and pop.-wh. 15,656, fr. col. 30 -total 15,686. Capital: Mauch-Chunk. Public Works: Lehigh Navigation, and a number of railroads from MauchChunk to the mines.

Carbondate, p. v., Luzerne co., Penn.: on Lackawanna cr., $117 \mathrm{~m}$. N. E. Harrisburg. The celebrated Lackawanna coal is mined in this neighborhood, whence it is carried by $R$, $R$, to Honesdale, and thence by canal to Port Jervis, on the Delaware r., and by the Delaware and Hudson Canal to the Hudson $r$. There are also iron works in the vicinity. A mile W. of the T., Fall Brook has a cascade of $\$ 0$ feet descent.

CARDIF, p. 0., Onondaga co., N. Y.: $116 \mathrm{~m} . \mathrm{W}$. Albany.

CARDIFF, p. v., Warren co., Miss.: $31 \mathrm{~m}$. W. by $\mathrm{S}$. Jackson.

Cardivgtox, p. v., Morrow co., Ohio: on the Cleveland, Cokmbus, and Cincinnati $R . R ., 35 \mathrm{~m}$. N. Columbus.

Carey, p. Y., Wyandott co., Ohio: on the Finlay branch of the Mad River and Lake Erie R. Ro, $72 \mathrm{~m}$. N. N. W. Columbas.

Carifliz's Mrists, p. o., Perry co., Afiss.: on Tallahalla cr., 84 m. S. E. Jackson.

CABLINvrle, p. V., and cap. Macoupin co., IUt.: about 2 m. N. of Macoupin cr., and $41 \mathrm{~m}$. S. by W. Springfield. It is one of the most flourishing interior villages of the State, and an important station on the Sangamon and Alton R. R.

CARLisLe, p. v., Sullivan co., Ind.: about $1 \mathrm{~m}$. E. of Busseron $\mathrm{cr}$. of the Wabash, $86 \mathrm{~m} . \mathrm{S}$. W. Indianapolis. It is the principal $\mathrm{v}$. in the co., and has about 400 inhabitants,

Carltste, to and p. v., Middlesex co., Mass.: on the N. W. side of Concord $\mathrm{v}_{.}, 19 \mathrm{~m}, \mathrm{~N}$. W. Boston. Pop. 719 Carutsle, p. v., and cap. Nicholas co., Ky. : on a small cr. of Licking r., $51 \mathrm{~m}$. E. N. E. Frankfort.

Carlisle, p. V., Eaton co., Mich. : on a cr, of Big fork of Thornapple r., $26 \mathrm{~m}$. W. S. W. Lansing.

Cartisle, t. and p. v., Schoharie co, $N_{0}, Y_{0}: 37 \mathrm{~m}$. W Albany. The vicinity abounds with caverns. Pop. 1,81T Caristre, p. city, and cap. Cumberland co., Penn.: on the Cumberland Valley R. R., $22 \mathrm{~m}$. from Harrisburg. Lat. $40^{\circ} 12^{\prime} \mathrm{N}_{\text {. }}$ and long. $77^{\circ} 10^{\prime} \mathrm{W}$. Dickinson College is loeated here, and half a m. from the v, the United States' Barracks and Cavalry School. The v. has several manufactures, and a considerable trade with the neighboring districts. The periodical press consists of the "American Volunteer" (dem.), the "American Democrat" (dem.), and the "C. Herald" (whig), published weekly, and the "Monthly Friend." Pop. 4,579.

CARLISLE, t. and p. v., Lorain co., Ohio: on W. branch of Black r., 104 m. N. N. E. Columbus. Pop. 1512

Carlisle Sprtigs, p. o., Cumberland co, Penn.: $4 \mathrm{~m}$. N. Carlisle, and 21 W. by S. Harrisburg. The waters are sulphurous.

Carlochvile, p. v., Rutherford co., Tenn.: 81 m. S. E. Tashrille.

CARLOW, p. v., Hopkins co., $K y .:$ on Deer cr. of Green r., $163 \mathrm{~m}$. W. S. W. Frankfort. 
Carlotrstulie, p. v., Dallas co., Ala. : near Pine Barren cr. of the Alabama, $52 \mathrm{~m}$. W. by S. Montgomery.

Cariton, t, and p. v., Orleans co., $N . Y_{.}$: on Lake Erie, $221 \mathrm{~m}$. W. by N. Albany. The $\mathrm{v}$. is located on the $\mathbf{E}$. side of Oak Orchard e., about $2 \mathrm{~m}$. from the lake. Pop, 2,809.

Cariton, t. and p. O., Barry co., Mich.: on Little fork of Thornapple r., $35 \mathrm{~m}$. W. Lansing.

CARLTON's STORE, p. o., King and.Queen co., Virg.: 46 m. N. E. by E. Richmond.

CArLIIE, p. V., and cap. Clinton co., Ill.: on the W. side of the Kaskaskia r., $215 \mathrm{~m}$. from its mouth by its windings, and $87 \mathrm{~m}$. S. by E. Springfield. The railtroad from Vincennes across the State to Illinoistown, will probably intersect this point.

CARLYLE, p. v., Pickens co., Ala.: 118 m. N. W. Montgomery.

CARMIEL, p. $\nabla .$, Hamilton co., Ind. : 22 m. N. by E. Indianapolis.

CARMri, t. and p. o., Penobscot co., Me.: on Sowadabscook r., 46 m. N. E. Augusta. The Kennebec and Penobscot R. R. passes through the township. Pop, 1,228.

Carsires, t., p. v., and cap. Putnam co., N. $Y_{0}$ : on the W. side of Croton $\mathrm{r}, 78 \mathrm{~m}$. S. by E. Albany. There are several small lakes in the $t_{\text {., }}$ on one of which the $\mathrm{v}$. is pleasantly situate. Pop. 2,442.

CARMEL Hril, p. o., Chester dist., S. Car.: $71 \mathrm{~m} . \mathrm{N}$. Columbia.

CARMI, p. $o_{0}$ and cap. White co., $\Pi l_{0}$ : on the W. side of the Little Wabash r., $147 \mathrm{~m}$. S. E. Springfield.

Carmtarame's, p. o., Greene co., Penn.: $187 \mathrm{~m}$. W. by

S. Harrisburg.

Oarnent Pratrite, p. 0., Perry co., Ml.: 118 m. S. Springfield.

Carsestrille, p. v., and cap. Franklin co., Ga.: on Stephen's cr. of Broad r., $91 \mathrm{~m}$. N. by E. Milledgeville.

CARoLINE county, Mad. Situate E. shore on State line, and contains 310 sq. m. Drained by creeks of Choptank r., Marshy Hope cr., and other streams. Surface flat. Soils sandy, but improvable. Farms 730; dwell. 1,526, and pop. -wh. 6,096, fr. col. 2,788, sl. 808-total 9,692. Capital: Dentor.

CAROLINE county, Tirg. Situate E. between Rappahannock and North Anna, a tributary of Pamunky r., and contains $580 \mathrm{sq}$. m. Drained by head waters of Mattapony r. Surface hilly and broken, and soils various. The principal products are wheat, Indian corn, oats, and tobacco. Farms 715; manuf. 51; dwell. 903, and pop.-wh. 6,892, fr. col. 903, sl, 10,661-total 18,456. Capital: Bowling Green. Public Works: Frederick and Richmond R. R.

Carolina, p. v., Haywood co., Tenn.: 146 m. W. by S. Nashville.

Carolina Femate Corleger, p. 0., Anson co., N. Car.: 89 m. S. W. Raleigh.

CAROLTNE, to and p. V., Tompkins $c_{0}, N . Y_{0}$.: on the W. side of West Owego cr, $128 \mathrm{~m}$. W. Albany. The Cayuga and Susquehanna R. R. passes through the W. part of the t. Pop. 2,537.

Caroline Centre, p. o., Tompkins co., $N . Y .: 131 \mathrm{~m}$. W. Albany.

Caroune Mruts, p. o., Washington co., R. I.

Caroxdelet, p. O., St. Louis co., Mo.: on the W. side of the Mississippi, and $5 \frac{1}{2} \mathrm{~m}$. below St. Louis, and $108 \mathrm{~m}$. E. Jefferson City. It is an important $\mathrm{v}_{\text {, }}$ and contains about 800 inbabitants.

CARPentrer's Creek, p. o., Jasper co., Ind. : on the cr. so called, $93 \mathrm{~m} . \mathrm{N}$. W. Indianapolis.

CARPEATER's L LANDING, p. v., Gloucester co., N. Jer. : at the head of sloop navigation on Mantua er. of the Delaware, $7 \mathrm{~m}$. above its confluence, $44 \mathrm{~m}$. $\mathrm{s}$. W. Trenton. It has considerable trade in lumber and fire-wood. Pop. about 300.

Carpexters ville, p. vo, Putnam co., Ind. : on a branch of Bicr Raceoon cr., $35 \mathrm{~m}$. W. Indianapolis.

CARP RIYER, p. O., Marquette Co., Bfich,; on the $\mathbf{r}$ of same name, $292 \mathrm{~m} . \mathrm{N}$. W. Lansing. Carp r. is a smal stream emptying into Lake Superior, below Talcott Harbor

CARR, p. o., Jasper co., Ia.: 83 m. W. Iowa City.

CARribor, p. o., Aroostook co., Mre.

Carritunk, p. V., Somerset co., Me.: on the E. side of Kennebec r., $53 \mathrm{~m}$. N. by W. Augusta.

CARROLL county, Ar\%. Situate N. W. on State line, and contains $1,004 \mathrm{sq} . \mathrm{m}$. Drained by Creeks of White $\mathrm{r}$. Sur face level or undulating. Soils of average fertility. Farms 541; manuf 1; dwell. 686, and pop. -wh. 4,390, fr. col. 11 sl. 213-total 4,614. Capital: Carrollton.

CARzoll county, Ga. Situate N. W. on State line, and contains $760 \mathrm{sq}$. $\mathrm{m}$. Drained by Tallapoosa $\mathrm{r}$. and the tributaries of Chattahoochee r., which bounds it S. E. Surface elevated and broken, and the soil indifferent. Wheat, Indian corn, and cotton are the chief products. Farms 782 ; manuf. 16 ; dwell. 1,379, and pop.-wh. 8,252 , fr. col, 4 , sl. 1,101-total 9,357. Capital: Carrollton.

CABRoLl county, 10 . Situate $\mathrm{N}$. W. on Mississippi r. and contains 496 sq. m. Drained by Plum r. and several creeks. Surface undulating-prairie predominating. Near the Mississippi are several sloughs and lakes. Soil uniformly rich. Farms 482; manuf. 17; dwell. 814, and pop. -Wh. 4,583, fr. col, 3-total 4,556. Capital: Mount Carroll

CARROLI county, Ind. Situate N. N. W. middle, and contains $376 \mathrm{sq} . \mathrm{m}$. Surface generally level, but undulates on the Wabash, Tippecanoe, and Wild Cat, which are the principal streams. Mostly covered with timber. The soil is a rich loam. Farms 1,129; manuf. 79; dwell. 1909, and pop.-wh. 10,982, fr, col. 33-total 11,015. Capital: Delphi. Public Works: Wabash and Erie Canal.

Carroll county, $I a$. Situate W. and contains $576 \mathrm{sq} \mathrm{m}$. Taken from Pottowattomie in 1851.

Carrolu county, $\bar{K} y$. Situate N., at the confluence of Kentucky r. with the $O$ hio, and contains 142 sq.m. Drained by Kentucky r. and its creeks. Surface generally level, and the soils of an average fertility. Wheat, corn, and tobacco are the staple products. Farms 376 ; manuf. 17; dwell. 766, and pop.-wh. 4,552, fr. col. 25, sl. 949-total 5,526. Capjital: Carrollton.

Carroll parish, La. Situate N. E. of W. District, on Mississippi, and contains $720 \mathrm{sq} . \mathrm{m}$. Drained by Bayoux du Boeuf and Macon, and river Tensas-all tributaries of the Washita. Surface low and level; soils of great fertility. Farms 238; manuf, 10; dwell. 582, and pop.-wh. 2,336, fr. col. 10, sl. 6,443-total 8,789. Capital: Lake Providence.

CARBOLL county, MId situate $\mathrm{N}$. middle, and contains 462 sq. $\mathrm{m}$. Drained by streams flowing into Patapseo r., Chesapeake Bay, the Potomac, and Monocacy rivers. Parr's Ridge, a high watershed, divides the county, and diverts the course of the streams. Surface hilly and rocky; soils thin, but there is much good farm land. Grazing is much attended to: iron and copper abound, and there is fine timber. Farms 1,387; manuf. 124; dwell. 3,476, and pop.wh. 18,667, fi. col. 974 , si. 975-total 20,616. Capital: Westminster. Public Works: Baltimore and Ohio R. R. and Westminster Branch of Baltimore and Susquehanna R. R.

Carrolit county, Mfiss. Situate N. centrally, and contains $1,040 \mathrm{sq}, \mathrm{m}$. Drained by the branches of Yazoo and Big Black rivers. Surface various, but soils rich and productive. The principal products are Indian corn and cattle. Farms 986 ; manuf. 45 ; dwell. 1,441, and pop.wh. 8,661, fr. col, 18, sl. 8,812-total 18,491. Capital: Carrollton.

CARROLl county, Mo. Situate W. on Missouri r., having Grand $r$, on its E, border, and contains 670 sq. m. Drained by Waconda and Big creeks. Surface undulating, chiefly prairie Farms 388 ; manuf. 15 ; dwell. 770 , and pop.wh. 4,812, fr. col. 8, sl. 621-total 5,441. Capital: Carrollton. Carrolr county, $N$. Hamp. Situate E. middle, and contains 512 sq. m. Drained N. by Saco r., and S. and E. by creeks emptying into Lake Winnipiseogee. Surface raried; 
soils moderately fertile. Farms 2,805; manuf, 135; dwell. 3,724, and pop.-wh. 20,154, fr. col. 2-total 20,156. Capital: Ossipee. Public Works: Great Falls and Conway R. R.

CArroli county, Ohio. Situate E., and contains $432 \mathrm{sq}$. m. Drained by creeks tributary of Tuscarawas and Ohio rivers. Surface varied, and soils fertile, producing fine crops of wheat, oats, and Indian corn. Farms 1,926; manuf. 41; dwell. 3,068, and pop.-Wh. 17,633, fr. col. 52total 17,6s5. Capital: Carrollton. Public Works: Sandy and Bearer Canal; Carrollton Branch of Pittsburg and Cleveland R. R., etc.

Carroll county, Tenn. Situate W., and contains 960 sq. m. Drained by Big Sandy, and other creeks of Tennessee r., and Rutherford and S. forks of Obion r. Surface high, forming a watershed between the Tennessee and Mississippi rivers. Soils fertile. Farms 1,404; manuf. 24; dwell, 2,105, and pop.-wh. 12,814, fr. col. 18, sl. 8,135-total 15,967. Capital: Huntingdon. Public Works: Nashville and Mount Holly R. R. (projected).

Carrolt eounty, Virg. Situate S. middle, at the W. base of Blue Ridge, and contains 380 sq. m. Drained by creeks flowing into Great Kanawha $\mathbf{r}$. Surface elevated and hilly, and soils of great fertility. Wheat is the staple growth. The county has iron and coal mines, and sulphur springs. Farms 615 ; manuf. 11 ; dwell. 996, and pop.wh. 5, 726, fr. col. 29, sl. 154-total 5,909. Capital: Hillsville

Carroli, p. v., Carroll co., Ind.: on the W. side of the

Wabash r., $65 \mathrm{~m} . \mathrm{N}$. W. Indianapolis.

$\mathrm{C}_{\triangle \mathrm{BR} O L L}, \mathrm{t}$. and p. $\nabla_{0}$, Fairfield $\mathrm{co}_{\text {, }}$ Ohio: at the junction of the Ohio and Hocking Canals, $19 \mathrm{~m}$. S. E. Columbus.

Carroli, t. and p. o., Penobseot co., Me. Pop. 401.

Carroli, t. and p. o., Coos co., N. Hamp.: on the N. W. base of the White Mountains, $73 \mathrm{~m}$. N. Concord. P. 299.

$\mathrm{C}_{\triangle \mathrm{Br}} \mathrm{rl}$, t. and p. o., Chautauque co., $N . Y_{\text {. }}$ : on Conewango and Stillwater cr. $281 \mathrm{~m}$. W. by S. Albany. P. 1, $\$ 35$.

Carroll House, p. o., Coos co., N. Eump.: 73 m. N. Concord.

CARrolloville, p. V., Tishemingo co., Mriss. : $179 \mathrm{~m}$. N. E. by N. Jackson.

Carrollton, p. o., and cap. Pickens co., Ala.: on the W. side of Lublub cr. of Little Tombigbee $r, 122 \mathrm{~m}$. N. T. Montgomery. Two newspapers, the "Pickens Republican" (whig), and the "West Alabamian" (dem.), are published weekly.

Carrollton, p. v., and eap. Carroll co., Ark.: on the WV. side of Cruoked er. of White r., $123 \mathrm{~m}$. N. N. Wr. Little Tiock.

Carrollton, p. v., and cap. Carroll co, Ga. : $113 \mathrm{~m}$. W. N. W. Milledgeville.

Carroliton, p. v., and cap. Greene co, $M$.: on the borders of Spring Prairie, and about $6 \mathrm{~m}$. N. of Macoupin cr., $56 \mathrm{~m}$. S. W. Springfeld. The $\mathrm{r}$, is one of the most flourishing in the interior, and the country in the neighborhood rich and productive.

Carmollton, p. $\mathbf{v}_{\text {., }}$ and cap. Carroll co., $\bar{x} y_{.}:$on the Ohio r., at the mouth of Kentucky r., 86 m. N. N. W. Frankfort.

CARrollton, p. v., Jefferson par, $L a_{*}$; on the E. side of tha Mississippi r., $6 \mathrm{~m}$. from New Orleans, $74 \mathrm{~m}$. S. E Baton Rouge.

Carrollton, p. v., and cap. Carroll co., Miss.: on the S. side of Lig Sand er. of Lallabusha r., $\$ 2 \mathrm{~m}$. . . by E. Jackson.

CarrolltoN, p. v., and cap. Carroll co., MLo.: on the N. side of Wyaconda cr. of the Missouri r., $92 \mathrm{~m}$. W. N. W. Jefferson City.

Carrolltos, p. v., and cap. Carroll co., Ohio: a thriving v., $112 \mathrm{~m}$. E. by N. Columbus. A branch of the Cleveland and Pittsburg R. R. comes to this point. Two newspapers, the "Carroll Free Press" (whig), and the "Ohio Picayune" (dem.), are issued weekly.

Carrolltown, p. v., Cambria co., Penn。 : 105 m. W. by S. Harrisburg.
Carrollville, p. o., Wayne co., Tenn, : on the E. bank of Tennessee r., $86 \mathrm{~m}$. 8 . W. Nashville.

Carrebrille, p. Y., Cooper co., Mo.: 42 m. W. N. W. Jefferson City.

Carrstille, p. $\nabla$. , Isle of Wight co., Virg.: $59 \mathrm{~m}$. S. E. Richmond.

CArson lake, Utah Ter.: on the E. side of the Sierra Nevada, from which it derives its waters by the Carson $r$. It has no outlet.

CARgon river, Utah Ter.: a considerable stream rising in the Sierra Nevada, and falling into Carson Lake.

CARSON's creek, Calif.: a tributary of Stanislaus $\mathbf{r}$.

Carsonvile, p. v., Talbot co., Ga.: $86 \mathrm{~m}$. W. by S. Milledgeville.

CARTER county, $K y$. Sitnate N. E., and contains $710 \mathrm{sq}$. m. Drained by Big and Little Sandy rivers, and Tygat cr. Surface uneven, with extensive valleys and plains-in the W. hilly, and soils productive. Farms 654 ; manuf. 7 ; dwell. 944, and pop.-wh. 5,961, fr. col. 23, sl. 257-total 6,241. Capital: Grayson.

CABTER county, Tenn. Situate N. E., and contains 543 sq. m. Drained by Watauga $x$, and its tributaries. Surface an elevated table-land, rugged, and in the E. mountainous. Soils, especially in the valley of the Watauga, fertile and productive. Iron abounds. Farms 565; manuf. 47; dwell. 1,002, and pop.-wh. 5,911, fr. col. 32, sl. 353-total 6,296. Capital: Elizabethtown. Public Works: East Tennessee and Firginia R. R.

Carteret county, N. Car. Situate $\boldsymbol{S}$. E. on the Atlantic, and contains $4 S 0 \mathrm{sq} . \mathrm{m}$. The shore is beset by lagoons formed by sand-islands which line its whole front. Cape Lookout is its most prominent projection. Surface low and level; soils sandy, with extensive marshes. Products, Indian corn and naval stores. Farms 208; manuf. 19; dwell. 972 , and pop.-wh. 5,167, fr. col. 149, sl. 1,457-total 6,808. Capital: Beaufort.

CARTER'B, p. O., Jackson par., La. : 154 m. N. W. Baton Rouge.

Carter's Bridge, p. o., Albemarle co., Firg. : $74 \mathrm{~m}$. W. by N. Richmond.

Cartersburgh, $\nabla$, Hendricks $c_{0}$, Ind.: on the line of the Terre Haute and Richmond R. R., $17 \mathrm{~m}$. W. Indianapolis.

Carter's Station, p. o., Greene co., Tenn.: 223 m. E. Nashville.

CAkTeB's Stoke, p. o., Nicholas co., $K y .: 51$ m. E. Frankfort.

Carterstule (formerly AvBos), p. v., Oswego co, N. Y.: $116 \mathrm{~m}$. W. by N. Albany.

Carterstrlle, p. v., Cass co.9 Ga: 122 m. N. W. Milledgeville. The Western and Atlantic R. R. passes the v., $55 \mathrm{~m}$, from Atlanta.

Carterstille, p. v., Tishemingo co., Miss.: $182 \mathrm{~m}$. N. E. by N. Jackson.

Cartersmille, p. v., Darlington dist., S. Car.: $62 \mathrm{~m}$. E. N. E. Columbia.

Cartersville, p. v., Cumberland co., Firg.: on S. side of James $\mathrm{r}_{\text {, }}$ near the mouth of Willis cr., $37 \mathrm{~m}$. W. by $\mathrm{N}$. Richmond.

Cartirage, p. v., Tuscaloosa co., Ala.: on a cr. of Black Warrior r., $16 \mathrm{~m}$. S. Tuscaloosa, and $86 \mathrm{~m}$. N. W. Montgomery.

Carthage, p. v., Rush co., Ind.: on Blue r., $31 \mathrm{~m}$. E. Indianapolis. The Shelbyville and Knightstown R. P. passes through the village.

CARTIIAGE, p. Y., and cap. Panola co., Texo.: on a cr. of Sabine r., 256 m. N. E. Austin City.

CARTHAGE, p. v., and cap. Hancock co., $I l l_{\text {. : between }}$ Bear and Long creeks, $11 \mathrm{~m}$. E. of the Mississippi r. It is a properous $\mathrm{v}$, with a flne neighborhood. It is notorious as the scene of the murder of Joe Smith and his cempunions during the lato Mormon troubles, Coal is abundant for miley around. 
Carthage, p. v., Campbell co., Ky.: near the Ohio r., 62 m. N. N. E. Frankfort.

Carteage, $t$, and p. V., Franklin co., Me.: on Webb's r. of the Androscroggin, $33 \mathrm{~m}$. W. N. W. Augusta. Pop. 472 .

Cartrage, p. V., and cap. Leake co., Miss.: on the N. side of Pearl r., $47 \mathrm{~m}$. N. E. Jackson.

Carteage, p. v., and eap. Jasper eo., Mo : on the S。 side of Neosho r., $153 \mathrm{~m} . \mathrm{S}$. W. Jefferson City.

Carthage, p. v., and cap. Moore co., N. Car.: on the E. side of M'Lennon's or. of Deep r., from which it is distant $8 \mathrm{~m}$., and $51 \mathrm{~m} . \mathrm{s}$. W. Raleigh.

Carthage, p. v., Jefferson co., $N . Y_{.}:$on the $N$. E. side of Black r., $124 \mathrm{~m} . \mathrm{N}$. W. Albany. It has considerable iron works and several mills. The Long Falls furnish extensive water-power; above these the river is navigable 40 In. to the High Falls, where the Black River Canal commences, but below navigation is interrupted.

Carthage, p. $\nabla$. , Hamilton co., Ohio: on Mill cr., $8 \mathrm{~m}$. N. Cincinnati, and $94 \mathrm{~m}$. S. W. Columbus. The Miami Canal and the Cincinnati, Hamilton, and Dayton R. R. in tersects it at this point. Its central position in the county causes it to be a place of public meetings, and here the Hamilton County Agricultural Fairs are held.

CarThaGe, p. v., and cap. Smith co., Tenn.: on the N. bank of Cumberland r., opposite the confluence of the Caney Fork, $46 \mathrm{~m}$. E. Nashville.

Carthage (or Low Point) Landing, p. o., Duchess co., N. $Y .: 76 \mathrm{~m}, \mathrm{~S}$. Albany.

Carticay, p. v., Gilmer co., $G a_{0}:$ on the river so called, $132 \mathrm{~m}$. N. W. Milledgeville.

CARVER, $t$, and p. O., Plymouth co., MFass.: 41 m. S. E. Boston. Pop, 1,186 .

Carver's harbor, p. O., Waldo co, Me.

Carperspille, p. v., Bucks co., Penn.: 108 m. E. Harrisburg.

Carverton, p. v., Luzerne co., Penn.: 78 m. N. E. Harrisburg.

CARYstule, p. т., Champaign co., Ohio: $53 \mathrm{~m}$. W. by N. Columbus.

CASOADE, p. o., Dubuque co., Io, : on Fall r., a branch of Makoqueta r., 49 m., N. E. Iowa City.

CASCADE, p. o., Sheboygan co., Wisc.: $82 \mathrm{~m}$. N. E. by E. Madison.

CABCADE, p. o., Pittsylvania co., Tirg.: on a cr. of Roanoke r., $139 \mathrm{~m}$. S. W. Richmond.

Cascade La Portallue, Mfich.: on the S. shore of Lake Superior. It consists of a stream emerging from a cliff of the Pictured Rocks, 70 feet above the lake, in its escape into which it leaps to such a distance that boats pass dry and safe between it and the rocks. The cascade contributes a beauty to the sublimity with which the scene is invested.

Casco, p. v., Cumberland co., Mo.: on Crook'd er., $42 \mathrm{~m}$. W.S. W. Augusta. Pop. of t. 1,045 .

CAsco Bay, Cumberland co., Me.: an arm of the At lantic, which sets up between Cape Elizabeth and Cape Small Point, $20 \mathrm{~m}$. apart, and affords a good anchorage. About 800 small islands are scattered within its superfices, most of them habitable and productive.

CAsEY county, $K y$. Situate centrally, and contains 448 8q. m. Drained by head waters of Green and Salt rivers, and some creeks of Cumberland $r$. Surface uneven, and soils fertile. Salt springs abound. Wheat, corn, and tobacco, are staple products. Farms 758; manuf. 11; dwell. 1,005 and pop.-wh, 5,863, fr, col. 59, sl, 634-total 6,556. Capital: Liberty.

CAsex, p. v., Clarke co., IZl.: 97 m. E. Springfield.

Caservilize, p. v., Union co., Ky.: $178 \mathrm{~m}$. W. by S. Frankfort.

Cabher's Valley, p. o., Macon co., N. Car.: $263 \mathrm{~m}$. W. S. W. Raleigh.

Cash's NoB, p. o., Montgomery co., Ky.: $61 \mathrm{~m}$. E. by S. Frankfort.
Casmiown, p. v., Adams co., Penn.: on the Gettysburg and Chambersburg turnpike, $43 \mathrm{~m}$. S. W. Ilarrisburg.

Cagrville, p. o., Spartanburgh dist., S. Car.: $21 \mathrm{~m}$. N. W. Columbia.

$\mathrm{C}_{\triangle S B}$ conty, $G a$. Situate N. W., and contains $432 \mathrm{sq}$ m. Drained by Etowah $x$, and its tributaries. Surface elevated and hilly; soils generally fertile; on the atreams, a fine alluvion; wheat, Indian corn, and entton, are the chief products. Farms 601; manuf, 8 ; dwell. 1.702, and pop.-wh. 10,271, fr. col. 21, sl. 3,008-total 13,300. Capital: Cassville, Putlic Works: Macon and Western R. R. with Branch R. R. to Rome.

CAss county, $7 l \%$. Situate W. centrally, on the left bank of Illinois r., and contains $360 \mathrm{sq} . \mathrm{m}$. Drained by tributaries of Sangamon $r$., which borders the county on the $N$., and by Indian cr. Surface undulating; prairie and timber being equally distributed. Soils very fertile. Farms 606; manuf. 26 ; dwell. 1,169 , and pop. - wh. 7,248 , fr. col. 5total 7,253. Capital: Beardstown.

CAss county, Ind. Situate N. middle, and contains 376 sq. m. Surface generally level, but hilly or undulating near the Wabash and Eel rivers. All the S. part is heavily timbered bottom-land, while in the $\mathrm{N}$. prairie prevails. Considerable manufactures are carried on along the Wabash and other streams, which afford immense driving power. Iron ore, building stone, ete, are abundant. Farms 1.184; manuf. 108; dwell. 1,863, and pop.-wh. 10,959, fr. col. 62 total 11,021. Capital: Logansport. Public Works: Wabash and Erie Canal.

Cass county, $I \alpha$. Situate S. W., and contains $576 \mathrm{sq} . \mathrm{m}$, Taken from Pottowattomie in 1837.

Cass county, MFich. Situate S. W. on State line, and contains $504 \mathrm{sq}$. m. Drained by tributaries of St. Joseph $\mathrm{r}$. Surface gently undulating and diversified by prairie and timber groves. Soils exceedingly fertile. Farms 950 manuf. 21 ; dwell. 1,914, and pop.-wh. 10,518, fr. col. 389total 10,907. Capital: Cassopolis.

Cass county, Mo. Situate W. on the State line, and con. tains $670 \mathrm{sq} . \mathrm{m}$. Drained by the head waters of South Grand r. Surface level prairie, and soil excellent. Farms 729 ; manuf. 19 ; dwell. 933, and pop.-wh. 5,610, fr. col. 2, sl. 478-total 6,090. Capital: Harrisonville.

Cass county, Tex. Situate N. E. between Sulphur Fork of Red r., and Big Cypress $\mathrm{x}$. and Caddo lake. The watershed being near the $N$. border, the greater number and largest streams fall into the waters bounding it $\mathrm{S}$. Surface elerated, undulating, and well watered-timber abundant on the streams. Soils dark black mold mixed with clay. Farms 365; manuf. 10 ; dwell. 558, and pop.-wh. 3,059, fr. col. 0, sl. 1,902-total 4,991. Capital: Jefferson.

CAss, p. v., Tippecanoe co., Ind.: 63 m. N. W. Indianapolis

CAss, p. Y., Venango co., Penn. : 169 m. W. N. W. Harrisburg.

Cass, p. v., Du Page co., Ill.; about $3 \mathrm{~m} . \mathbf{N}$. of the Illinois r., and $158 \mathrm{~m}$. N. E. Springfield.

CA8s, p. .., Hillsdale con, Mich. : $59 \mathrm{~m}$. S. Lansing.

CAss, t. and p. v., Hancock co., Ohio: $84 \mathrm{~m}$. N. by W. Columbus. Pop. 621.

CAss, p. v., Franklin co., Ark.: $112 \mathrm{~m}$. N. W. Little Rock.

CASS, p. V., Lawrence co., Tenn.: $73 \mathrm{~m}$. S. by W. Nashville.

CASS river, Mich.: a large branch of Saginaw $r_{\text {., into }}$ which it discharges, about $20 \mathrm{~m}$. above its confluence. It passes through a rich interval, covered with a heary growth of beech and sugar tree. In high water it is boatable for 15 or 20 m., and in its whole course affords excellent mill sites.

Cassadaqa, p. v., Chautauque co., N. $Y_{\text {: }}$ : on the W. side of the lake so called, $276 \mathrm{~m}$. W. by S. Albany. Cassadaga lake and creek empty into the Conewango cr., a tributary of Alleghany $r$. 
fort.

CasbirT's Mruls, p. o., Morgan co., Kyy.: 89 m. E. Frank-

Cassorolis, p. v., and cap. Cass co., Mich, : on the N.W. border of Stone Lake, $89 \mathrm{~m}$. S. W. Lansing. bus.

Cusstowa, p. v., White co., Tenn.: $76 \mathrm{~m}$. E. Nashville.

CAssvitle, p. $\nabla$. , and cap. Cass co., $G a_{0}: 123 \mathrm{~m}$. N. W. Milledgeville. It is a thriving village, and has a weekly newspaper, the "C. Standard." The Western and Atlantic P. R. passes it on the S. W.

Cassrilde, p. v., Harrison co, Ohio: $98 \mathrm{~m}, \mathrm{E}$. by $\mathrm{N}$. Columbus.

CAssvilue, p. v., and cap. Barry co., Mo.: on Flat cr. of James r., a fork of the White r., 162 m. S. W. Jefferson City.

Casstrle, p, v., Oneida co, $N$. $Y_{\text {. }}$ : on Sauquoit cr, 76 m. W. by N. Albany.

Csssvicle, p. V., Huntingdon co., Penn.: 69 m. W. Harrisburg.

Cassville, t. and p. V., Grant co., Wisc. : on the E. side of Mississippi r., $84 \mathrm{~m}$. W. by S. Madison.

Cassville, p. v., Monongalia co., Firg.: 198 m. N. W. Richmond.

Casswert county, $N$. Car. Situate $N$. middle on the State line, and contains $482 \mathrm{sq} . \mathrm{m}$. Drained by tributaries of Dan $r$. Surface elevated and varied. Soils fertile. Wheat, corn, oats, and tobacco are largely produced, and the stock of cattle, etc., is ample. Farms 707 ; manuf. 56 ; dwell. 815 , and pop-wh. 7,081 , fr. col. 418, sl. 7,770 -total 15,269. Capital: Tanceyville.

Castalia, p. v.s Erie co., Ohio: 98 m. N. Columbus,

Castalian Springs, p. o., Sumner co., Tenn.: $33 \mathrm{~m}$. N. E. Nashville.

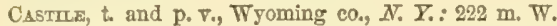
Albany. The Genessee r. flows through the E. part of the town, and in the N. part is Silver Lake. The village is located on the Buffalo and New York City R. R. Pop. 2,416. Castulr, p. V., Greene co., Penn.: 189 m. W. by S. Harrisburg.

Castre, p. F., Clinton co., Mo.: on a cr. of Platte $r_{.}$so called, 146 m. W. N. W. Jefferson City.

Castine, p. V., Darke co, Ohio: 81 m. W. Columbus.

Castive, t., p. v., sea-port, and cap. Hancock co., Me. on a peninsula on the $\mathrm{E}_{\text {. }}$ side of Penobscot Bay, opposite Belfast, $48 \mathrm{~m}$. E. Augusta. The town is almost surrounded by narigable waters. The village at the S. end of the peninsula has a good harbor, capable of receiving the largest ships. The site was occupied by the French as early as 1667, and it wos held by the British in the last war. It is the key to the Penobscot r., and might easily be fortified. The lumber and coasting trade employ its shipping, and much attention is paid to the fisheries. Pop. 1,261.

Castle Crajg, p. o., Campoell co., Firg.: 109 m. W. by

S. Richmond.

Castle Creek, p. o., Broome co., N. $\bar{X}$ : 112 m. \$. W.

Albany.

Castle Fin, p. V., York co, Penn. 41 m. S. by E, Harrisburg.

Castle Grove, p. 0., Jones co., Ia. : $42 \mathrm{~m}$. N. E. by E, Iowa City.

Castlearax's Ferro, p. o., Clarke co, Firg.: on Shenanduah r., $105 \mathrm{~m}, \mathrm{X}$. Wy $\mathrm{W}$. Iichmond.

Cistuemex's river, Pente: the E. branch of the Youghiogeny $r$. It is a rapid stream and has many falls and cascalles.

Castletox, t., Richmond co, $N$. $Y$.: on the N. end of Staten Island. Pop. 5,359.

C.strufosi, t, and p. 0., Barry co., Fich.: on the Bio Fork of Thoraapple cr. $42 \mathrm{~m}$. W. by $\mathrm{S}$. Lansing. In this town the river expands into large lakes, which cover a tenth of the town lands, Pop. 324
Castuftor, p. v., Renssellaer co., $N_{1}, Y_{\text {. }}$ : on the E. side of Hudson r., and on the line of the Hudson River R. R., 10 m. S. Albany.

Castleton, t. and p. v., Rutland co., Verm.: on Castleton r., 54 m. S. W. Montpelier. Lake Bombazine, $8 \mathrm{~m}$. long and less than $3 \mathrm{~m}$. broad, lies mostly in the town, and contains a beautiful island of 10 acres. The village is the seat of Castleton Medical College, a department of Middlebury College. The Saratoga and Castleton R. R. and the Rutland and Washington R. R. intersect at this point, and unite with the Vermont and Canada lines. P. 3.016.

Castor, p. o, Caldwell par., La.: 184 m. N. W. Baton Rouge.

Castorvilue, p. v., and cap. Medina $\mathrm{co}_{\text {, }}$ Texo.: on the W. side of the Rio San Antonio, 95 m. S. W. Austin City. The old Spanish military road crosses the $\mathbf{r}$. at this point. The inhabitants are chiefly Germans.

Caswelu, p. v., Lafayette co., Mfiss.: 153 m. N. by E. Jackson.

Cataroula parish, La. Situate E. centrally of W. Dist. and contains about $800 \mathrm{sq}$. m. Drained by tributaries of Red and Washita rivers. Surface F. flat, and subject to inundation - W. moderately hilly, and corered with pine timber. Soils fertile, producing Indian corn, potatoes, and cotton. Farms 358; manuf. 3 ; dwell. 655, and pop.wh. 3,5S5, fr. col. 19, sl. 3,378-total 6,982. Oapital: Harrisonburg.

CатанобlA river, $L a . ;$ a tributary of the Washita $\mathbf{r}$.

CatalPa Grote, p. o, Greene co, $\overline{K y} .: 76 \mathrm{~m}$. S. S. W. Frankfort.

CatatPa Grove, p. o., Marshall co, Temn. : 46 m. S. Nashville.

Catalpa Grove, p. V., Benton co., Ind.: 86 m. N. W. Indianapolis.

CAT-A-POODLE river, Oreg.: a tributary of Columbia $r$ from the N. E., emptying opposite the village of St. Helens. Cataracr, p. o., Otren co., Ind.: $52 \mathrm{~m}$. \$. W. Indianapolis.

Catasaugua, p. v., Lehigh co., Penn.: 73 m. E. by N. Harrisburg. Pop. 8S5.

Cataula, p. V., Harris co., Ga.: $114 \mathrm{~m}$. W. by $\mathrm{S}$. Milledgeville.

CAtA WBA county, N. Car. Situate centrally, and contains 430 sq. m. Drained by tributaries of Catawba r., which is its S. border. Farms 957 ; manuf. 3 ; dwell. 1,287, and pop. -Wh. 7,272, f. col. 21, sl. 1,569-total 8,862. Capital. Newton.

Catatrba, p. vo, Clarke co., Ohio: $48 \mathrm{~m}$. W. Columbus.

Catatiba, p. v., Botetourt co. Firg.: on a cr. so called, 133 m. W. Richmond.

Catawba Creek, p. o., Gaston co., N.Car.: 199 m. S. W. Raleigh.

Caratrba Sprivgs, p. $v_{0,}$ Lincoln co., $N_{0}$ Carn: on the W. side Catawba $r_{n}, 3 \mathrm{~m}$. distant, and $128 \mathrm{~m}$. W. by $\mathrm{S}$. Raleigh,

Catawba Frew, p. 0., Caldwell co., $N$. Car.: 153 m. W. Raleigh.

Catamiss 4 , t. and p. V., Columbia co., Penn.: on the Susquehanna, at the mouth of Catawissa cr., $53 \mathrm{~m}$. N. N. E. Harrisuurg. The Catawissa and Little Schuylkill R. R passes through the village. Pop. of $\mathrm{v} .565$.

Catamissa Valiex, p. o., Behuylkill co, Penn.: $58 \mathrm{~m}$ N. E. Harrisburg.

Catrigr Furvace, p. 0, Clarion co., Penn.: $156 \mathrm{~m}$. W. N. W. Harrisburg.

Catrantriss, to and p. v., Chemung co., $N_{0} \bar{Y}: 154 \mathrm{~m}$ W. by S. Albany. The $t$ is drained by Catharines and Cavuta creeks, Pop. 3,070.

Camuartse Lake, p. o, OnBlow co, $N$. Car.: 98 m. S. E. Raleigh.

C.Aтrcart, p. v., White co., Ind.: 82 m. N. N. W. Indianapolis.

Catuer's Crees, p. o., Henderson co., $N$. Car. 
Cathlanet, v., Pacific co., Oreg.: on the N. bank of Columbia ro, about $30 \mathrm{~m}$. from its mouth, and $86 \mathrm{~m} . \mathrm{N}$. Salem.

Catuetssirgh, p. 0., Greenup co., $\bar{K} y .:$ on the Ohio r., below the mouth of Big Sandy r., $133 \mathrm{~m}$. E. Frankfort.

CAxo, t. and p. v., Cayuga co., $N_{\text {. }} Y_{\text {.: }}$ on Seneca r., 142 m. W. Albany. Pop. 2,247.

Catos, t. and p. 0., Steuben co., N. Y.: $166 \mathrm{~m}$. W. S. W. Albany. Pop. 1,214.

Catonsvilu, p. v., Baltimore co., Md.: on the N. side of Patapsco r., $2 \mathrm{~m}$. distant, and $36 \mathrm{~m}$. N. N. W. Annapolis. Cato Springi, p. o., Rankin co, Míss.

CAtskill, t., p. V., and cap. Greene co., $N_{\text {. }} Y_{*}:$ on the W. side of Hadson $r .31 \mathrm{~m} . \mathrm{S}$. Albany, The $\mathrm{v}$, lies on both sides of Catskill cr, near its junction with the Hudson, and contains, besides the county buildings, several handsome churches, hotels, and stores. It has numerous manufactures, and is much engaged in the river trade. Two newspapers, the "C. Democrat," and the "Greene County Whig," are issued weekly. Pop. 5,454.

Catskill Mountains (Kaatsberg), $\lambda$. $Y$.: rise in Vlater co., and, extending through Greene and Schoharie counties, bend in a crescent form toward the Mohawk $r$. Round Top, the highest peak, measured by the barometer, is 3,804 feet above tide water; and a second peak is 3,718 feet. On the E. the mountains are precipitous, but on the W. side the descent is comparatively gentle. In these mountains, many of the wild animals indigenous to the State are still to be found. These mountains are frequently resorted to by summer tourists.

Cattaraugus county, $N$. $Y$. Situate $\mathrm{S}$. W., and contains $1,234 \mathrm{sq} . \mathrm{m}$. Drained by tributaries of Alleghany $\mathrm{r}$. and Cattaraugus cr.-the waters of the former being conveyed to the Gulf of Mexico, and of the latter to the Atlantic through St. Lawrence r. Surface elevated, well timbered, and the soils excellent, producing wheat, corn, ete., of the finest quality. Bog-iron ore, manganese, peat, marl, etc., are found in abundance; and near Freedom is an oil springthere are also saline and sulphar springs, Farms 3,655 ; manuf, 299; dwell: 6,750, and pop.-wh. 38,851, fr, col. 99total 38,950. Capital: Ellicottsville. Public Works: Genessee Valley Canal; New York and Erie R. R, etc.

CAUghdenox, p. V., Oswego co., N. Y. : $123 \mathrm{~m}$. W. N.W. Albany.

CAVE, p. on, Franklin co., $I U$.: in the S. E. part of the co., $138 \mathrm{~m}$. S. E. Springfield.

Cave, p. 0., White co., Tenn.: 78 m. E. Nashville.

CAVE IN Rock, p. 0., Hardin co, IUl. : on the Ohio r., 182 m. S. S. E. Springfield. The remarkable cave which gives name to this p. 0., is near the water's edge, and is partially filled at a high stage of the $r$. Its entrance is visible in passing up and down tho stream. A perpendicular shaft opens at some distance from its mouth, on ascending which the visitor finds a large number of chambers of various sizes, hung with stalactites. This is one of the greatest curiosities of the West.

Cavender's Creek, p. o., Lumpkin co., Ga.: $120 \mathrm{~m}$. N. N. W. Milledgeville.

Cavendish, t. and p. o., Windsor co., Term, : on Black r., $56 \mathrm{~m}$. 8. by E. Montpelier. The surface of the $t_{\text {. }}$ is exceedingly hilly, and the channel of the $r$. at the falls has been worn down some 100 feet. Considerable manufactures have been established on the streams. Pop. 1,576 ,

Cave Spring, p. 0., Floyd co., Ga.: a little to the W. of Cedar cr. of Coosa r., 145 m. N. W. Milledgeville.

Cate Spring, p. o., Scott co., Ky. : 18 m. N. E. Frankfort,

Cate Speing, p. 0., Wright co., Mlo.: $86 \mathrm{~m} . \mathrm{S}$. by W. Jefferson City.

Cave Sprnva, p. 0., Roanoke co, Virg.: on W. side of the Blue Ridge, $129 \mathrm{~m}$. W. Richmond.

Cavetown, p. $\nabla .$, Washington co., Md.: on Cave Branch of Beaver cr., $8 \mathrm{~m}$. from Hagerstown, and $86 \mathrm{~m} . \mathrm{N} . \mathrm{W}$. Annapolis.
Caruga county, $N$. $Y$. Situate W. centrally, and contains 648 sq. m. Drained by Skaneateles, Owasco, and Caruga lakes, their connections and creeks; also by severa streams emptying into Lake Ontario. Surfuce generally level, but much varied, and the soils productive. Gypsum abounds, and there are several sulphur, chalybeate, and saline springs in the county. Farms 4,228; manuf. 505 dwell. 9,259, and pop.-Wh. 54,924, fr. col. 534-total 55,458. Capitat: Auburn. Public Works: Erie Canal; Syracuse and Rochester R. R., ete.

CAYUGA, p. v., Hinds co., Miss.: on a small cr. of Big Black r., 83 m. 8. W. Jackson.

CAYukA, p. v., Jackson co., Dich. : 37 m. S. by E. Lansing.

Cayuga, p. v., Cayuga co., $N$. $Y_{\text {. }}$ : on the N. E. side of Cayuga Lake, $144 \mathrm{~m}$. W. Albany. The lake is here crossed by a bridge more than a mile long, over which the Roches ter and Syracuse R. R. passes, and a regular steamboat line runs from this $v$. to Ithaca, in connection with the Cayuga and Susquehanna R. R.

CAYugA lake, $\mathcal{N} . Y$.: lies between Seneca and Tompkins counties. It is about $40 \mathrm{~m}$. long, and from 1 to $33 \mathrm{~m}$. wide, and empties into Seneca $r$. It is very deep, and contains abundance of fine fish. A steamboat plies regularly from Cayuga Bridge to Ithaca, calling at the intermediate places.

CAYUTA, t, and p. 0., Chemung co., N. . $_{\text {: }}$ on Cayuta $\mathrm{cr}$. 142 m. W. S. W. Albany. Pop. 1,035.

Carotatille, p. Y., Tompkins co., $N$. $Y_{\text {.: }}$ on E. side of Cayuta Lake, 140 m. W. S. W. Albany.

Cazenovia, t, and p. v., Madison co., $N$. $Y$. : on Cazeno via Lake, $108 \mathrm{~m}$. W. Albany. It is a busy place, and has several manufactures. The "Madison County Whig". is issued weekly. Pop. 4,812.

CEcrl county, Md. Situate N. E., and contains $360 \mathrm{sq}$. m. Drained by Elk, North-east, and other rivers. Surface generally undulating; sometimes hilly and broken. Soils light and loamy, with a reddish clay subsoil. Rocks abundant, and iron, chromes, and other minerals found Timber sufficient for domestic purposes. Farms 1,208; manuf. 176; dwell. 3,056 , and pop-wh. 15,472, fr. col. 2,623, sl. 844-total 18,939. Capital: Elkton. Pubtic Works: Philadelphia, Wilmington, and Baltimore R. R.; Neweastle and Frenchtown R. R.; and Chesapeake and Delaware Canal.

CEOru, t. and p. o., Washington co., Penn.: on Muller's branch of Chartier's cr., $173 \mathrm{~m}$. W. Harrisburg. Pop. 1,2S7.

Cenuton, p. v., Cecil co., MIa.: on the N. of Sassafras r., $3 \mathrm{~m}$. distant, $48 \mathrm{~m}$. N. E. Annapolis.

Cedar county, Ia. Situate E., and contains $576 \mathrm{sq} . \mathrm{m}$. Drained by Cedar $r$. and its branches. Surface undulating and soils fertile. Farms 358 ; manuf. 4 ; dwell. 656 , and pop.-wh. 3,939, fr. col. 2-total 3,941, Capital: Tipton.

CEDAR county, Mo. Situate W., and contains 428 sq. m. Drained by the tributaries of Sac r. of the Osage. Surface level, with some woodland. Soils exceedingly fertile. Farms 347 ; manuf. 7 ; dwell. 561, and pop.-wh. 3,278, fr. col. 1, sl. 82-total 3,361. Capital: Fremont.

Cedar, p. v., Allen co., Ind. : at the confluence of Cedar cr. with Little St. Joseph r., 112 m. N. E. Indianapolis.

CEDAR, p. O., Livingston co., Mich.: 38 m. E. by S. Lansing.

Cedar Bayou, p. 0., Liberty co., Teso. : on a cr. so called, $172 \mathrm{~m}$. E. Austin City.

Cedar Blufr, p. v., Cherokee co., Ala. : 132 m. N. by

E. Montgomery. Formerly capital of the county.

Cedar Blufr, p. o., Ocktibbeha co., MFiss.: 107 m. N. E Jackson.

Cedar Blukt, p. o., Tazewell co., Firg. : $238 \mathrm{~m}$ W. by S. Richmond.

Crear Branch, p. o., Campbell co., Ga.: $91 \mathrm{~m}$. W. N.T. Milledgeville.

CEDASBURgH, to and p. $\nabla_{\text {., }}$ Washington co., Wisc.: : on the 
W. side of Cedar cr, of Milwaukie r., $74 \mathrm{~m}, \mathrm{E}$, by $\mathrm{N}$. Madison. Pop. 1,134.

Cemar Crfme, p. v., Sussex co, Del.: 27 m. \$. by E.

Dover. Cedar Creek hund. contains 72,090 acres.

Ceadr Cresk, p. o., Rutherford co., N. Car.: $173 \mathrm{~m}$.

W. S. W. Raleigh.

Creda Creer, p. o., Washington co., Wisc. : on the W. side of Cedar cr., $63 \mathrm{~m}$. E. by N. Madison.

CEDAB creek, Ind.: a tributary from the N. of Little St. Joseph $r$. It is an excellent mill stream, about $40 \mathrm{~m}$. in length.

CEDAR creek, Ind. : a branch of Kankakee r., the outlet of Cedar Lake.

CEDAR creek, Rockbridge co., Virg. : a tributary of James $r$. It is remarkable for the Natural Bridge that spans it $12 \mathrm{~m}$. $\mathrm{S}$. of Lexington. The $\mathbf{r}$. passes through a chasm which is 90 feet wide at the top, and the walls are 250 feet high, almost perpendicular. The bridge is a huge rock thrown across the ehasm at the top; it is 60 feet wide, and covered with earth and trees, forming a sublime spectacle when seen from the margins of the stream.

Cenar Creek, p. o., Barry co., Mich.: $42 \mathrm{~m}$. W. by S.

Iansing.

Cedar Cremk, p. o, Monmouth co., $N$. Jer.

CEDAR Crefer, p. o., Richland dist., S. Car.: on a cr. of

the Congaree r. so called, $17 \mathrm{~m}$. S. E. Columbia.

Cedar Cresk, p. o., Greene co., Tenn.: on Cedar cr, of the Nolichucky r., $221 \mathrm{~m}$. E. Nashville.

Cenar CBres, p. o., Frederick co., Virg.: 122 m. N. N.W.

Richmond.

Cedar Creek Mrris, p. o., Stephenson co., $I l l .: 156 \mathrm{~m}$.

N. Springfield.

Cedaf FAlis, p. $\nabla$. , and cap. Black Hawk co., Ia. : on

Cedar r., 73 m. N. W. Iowa City.

Cedar Falls, p. o., Randolph co., N. Car.: 66 m. W.

Raleigh.

CEDAR FAtis, p. o., Richland dist., S. Car": on Cedar cr. of Congaree r., $22 \mathrm{~m}$. \$. E. Columbia.

Cedar Ford, p. o., Grainger co., Tenn.: 179 m. E.

Nashville.

Cedar Grove, p. o., Jefferson co., Ala. : $92 \mathrm{~m}$. N. by W.

Nontgomery.

Cedar Grove, p. o., Sheboygan co., Wisc.: S. of Union

r. of the Sheboygan, $78 \mathrm{~m}$. F. by N. Madison.

CEDAB Grove, p. V., Franklin co., Ind. : on the E. sido

of White Water r., $88 \mathrm{~m}$. E. by S. Indianapolis.

Cedar Grove, p. 0., Orange con, N. Car.: $47 \mathrm{~m} . \mathrm{N} . \mathrm{W}$.

Raleigh.

Cedar Grove, p. 0., Wilson co, Tenn.: 33 m. E. Nashville.

CEDAR Grove, p. 0., Breckenridge co., Ky.: $89 \mathrm{~m}$.

W. by S. Frankfort.

CFDar Grove, p. o., Kauffman co, Ten, : on Cedar cr. of Trinity r., 226 m. N. N. E. Austin City.

Cedas Grove Muls, p. 0., Rockbridge co, Tirg. : 114 m. W. Richmond.

CEDAs Hrux, p. 0., Albany co., $N_{0}, Y_{0}$ : near the Hudson

r., $6 \mathrm{~m}$. S. Albany.

Cedar Hrit, p. o., Anson co., N. Car.: W. of the Yadkin $r ., 87 \mathrm{~m}$. S. W. Raleigh.

CEDAr island, Mich: a small island at the entrance of Detroit strail into Lake Erie.

Cedar Krx, p. o, Levy co., Flor.: 106 m. S. E. Tallahassee. The Cedar Keys consist of several small islands off the mouth of the Suwannee r., on the W. coast of the peninsula, and are inhabited by fishermen and wreckers.

CEDAR LAKE, p. 0., Lake co., Ind. : on the lake so called, $125 \mathrm{~m}$. N. W. Indianapolis. Cedar Lake is $8 \mathrm{~m}$. long, and three-fourths of a mile wide, and abounds in various descriptions of fish.

Cedar Lake, p. o., Brazoria co, Tero: on Cedar Lake Sayuu, on the s. W. part of the co, 155 m. 3. E. Austin City".
CeOAR LAKE, p, o, Calhoun cos, Jfich.: on a small collection of water so called, $42 \mathrm{~m}$. S. W. Lansing. The lake empties through a cr. of St. Joseph's r.

Cedar LAKE, p. o., Herkimer $c_{a}, N_{0}, Y_{0}:$ on a lake so called, 87 m. N. W. Albany.

OEDAR lake, Mich.: a small collection of water in the S. E. corner of Van Buren co., the waters of which are conducted into St. Joseph r. by a branch of Dowagiake r., which rises from it

Cedar Mount, p. o., Wythe co., Tirg.: $211 \mathrm{~m}$. W. by S. Richmond.

Cedar Platns, p. 0., Morgan co., Ala. : $148 \mathrm{~m}$. N. by W.

Montgomery.

Cendar Polnt, p. o., Page co., Virg.: 93 m. N. W. Richmond.

CEDAB RAPIDS, p. o, Linn $c_{0}, I a_{*}$ : at the rapids of Cedar r., \$3 m. N. by W. Iowa City.

Cedar Shoar, p. o., Chester dist., S. Car.: 61 m. N. W. Columbia.

Cedar Spriva, p. O., Benton co, Ala.: 99 m. N. N. E. Montgomery.

Cedar Sprivg, p. O., Wythe co., Firg.: 212 m. W. by S. Richmond.

Cemar Spring Asylum, p. o., Spartanburg dist., $S$. Car Cedar Sprligs, p. o., Spartanburg dist., S. Car.: $83 \mathrm{~m}$. N. W. Columbia.

Cedar SprLigs, p. o., Allen co, $k y_{0}: 122$ m. S. W. Frankfort.

Cedar Swavp, p. 0., Queens co. N. Y.: $122 \mathrm{~m}$. S. by E. Albany.

Cadoartows, p. v., Prulding co., $G a_{\text {. : }}$ between the forks of Cedar cr. of Coosa r., 132 m. W. N. W. Milledgeville. CEDAr TREE, p. o., Talladega co., Ala.: $61 \mathrm{~m}$. N. Mont gomery.

Cepar Valley, p. o., Wayne co., Ohio: 78 m. N. E. Columbus.

Cedartille, p. V., Cumberland co, $N$. Jer.: on Cedar cr., $4 \mathrm{~m}$. from Delaware Bay, and $62 \mathrm{~S}$. by W. Trenton, It has some manufactures and considerable trade in wood.

Cedarvilie, p. V., Herkimer co., N. Y.: $72 \mathrm{~m}$. W. by N. Albany.

Cedarvilte, p. v., Greene co., Ohio: on the line of the Columbus and Xenia R. R., $47 \mathrm{~m} . \mathrm{S}$. E. Columbus.

Cedarville, p. v., Washington co, Virg.: $246 \mathrm{~m}$ W. S. W. Richmond.

Cedron, p. v., Clermont co, Ohio: 86 m. S. W. Columbus, Celestive, p. V. Dubois con, Ind.: a few miles $\mathbf{S}$. of Patoka $\mathrm{r}$, and $95 \mathrm{~m}$. S. S. W. Indianapolis.

Cerria, p. Y., and cap. Mercer co, Olivo: on the W. side of the upper Wabash r., 94 m. W. N. W. Colnmbus. A newspaper, the "Western Standard" (dem.), is published weekly.

Celina, p. V., Jackson co., Tenn.: on the E. side of Cumberland r., $72 \mathrm{~m}$. E. N. E. Nashville.

Certrat, p. o., St. Louis co, Mo.: 92 m. E. Jefferson City.

Centrat, p. o., Columbia con, Penn.: $67 \mathrm{~m}$. N. by E. Harrisburg.

Cextral Brtder, p. o., Schoharie co., N. Y.: on Scho harie cr, of the Mohawk, $27 \mathrm{~m}$. W. Albany.

Central College, p. o., Franklin co, $N$. Y.: $133 \mathrm{~m}$ X. X. W. AlbanY.

Cextral Plisng, p. o., Fluvanna co, Firg.: 49 m. W. Richmoud.

Cevtrut Ponvt, p. O., Caroline co., Virg.: 37 m. N. Richmond.

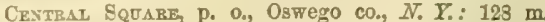
TI. T. T. Albany.

Centrat Vulage, p. V., Windham co, Conno: on the Norwich and Worcester R. R., 39 m. E. Hartford, $19 \mathrm{~m}$. from Norwich, and $40 \mathrm{~m}$. from Worcester.

Cevtre county, Penn. Situate centrally, and contains 1,480 sq. m. Drained by Bald Eagle, Penn's, and other 
creeks, and by the W. branch of Susquehanna $r$. Surface rocky and mountainous. Soils of a stubborn nature generally, but along the streams there is much that is highly fertile. Farms 1,043; manuf. 171; dwell. 3,936, and pop.wh. 23,112, fr. col. 248-total 23,355. Capital: Bellefonte. Centre, p. v., and cap. Cherokeo co, Ala.: $186 \mathrm{~m}$. N. by E. Montgomery.

Centre, p. v., Montgomery co., Ohio: 66 m. W. S. W. Columbus.

Centre, p. v., Talbot co., Ga.: $82 \mathrm{~m}$. W. by S. Milledgerille.

Centre, p. v., Cass co., Texo : 278 m. N. E. Austin City. Cenrre, p. v., Barren co., Ky.: 99 m. S. W. Frankfort.

Centee, t. and p. 0., Rock co, Wisc.: 47 m. S. by E. Madison. Pop. 626 .

Centre, p. v., Guilford co., $\mathcal{N}$. Car.: $69 \mathrm{~m}$. W. by N. Raleigh.

Centre, t. and p. 0., Perry co., Penn. : 36 m. N. W. Harrisburg. Pop. 1,208.

Centre Alarond, p. v., Alleghany co., N. Y.: $203 \mathrm{~m}$.

W. S. W. Albany.

Centre Baristead, p. $\nabla .$, Belknap co., N. Hamp.: on

Suncook r., $18 \mathrm{~m}$. N. E. by E. Concord.

CENTRE BeLPrí, p. v., Washington co., Ohio: on the

Ohio r., below Blennerhassett's Island, 86 m. E. S. E. Columbus.

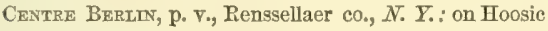

F., 19 m. E. Albany.

Centre Brwge, p. o., Bucks co., Penn.: 103 m. E. Harrisburg.

Centre Brook, p. o., Middlesex co., Conn. : 24 m. S. by E.

Fartford.

Centreburger, p. o., Knox co., Ohio: on the S. side of the

N. fork of Licking r., $33 \mathrm{~m}$. N. E. Columbus.

Centre Cambridge, p. v., Washington co., $N_{*} Y_{*}: 28 \mathrm{~m}$.

N. N. E. Albany.

Centrie CANistero, p. Y. Steuben co, $N_{0} Y_{0}:$ on the $S_{\text {. }}$

side of Canisteo r., 189 m. W. S. W. Albany.

Centre Conway, p. v., Carroll co., $N$. Hamp.: on Swift

r., $56 \mathrm{~m}$. N. E. Concord. The Great Falls and Conway

R. $R$. will pass near this village.

Centre Creek, p. o., Iron co, Utah Ter

Cenrtal CBoss, p. o., Essex co, Firg.: 62 m. N. E.

Richmond.

Centredate, p. O., Providence co., R. $I_{0}: 11 \mathrm{~m} . \mathrm{W}$.

Providence.

Centrafieid, p. $\nabla_{0,}$ Ontario co., $N, Y_{0}: 177 \mathrm{~m}, W$.

Albany.

Centrefrind, p. v., OIdham co, $\bar{K} y_{*}: 37 \mathrm{~m}$. N. W.

Erankfort.

Centremend, p. F., Highland co., Ohio: on the S. side of

Paint cr., $54 \mathrm{~m}$. S. W. Columbus.

Centre Groton, p. v., New London, co., Comn.: $43 \mathrm{~m}$.

E. E. Hartford.

Centre Gullford, p. v., Piscataquis co, Me.: $58 \mathrm{~m}$.

N. N. E. Augusta.

Centre Harbor, t. and p. v., Belknap co., N. Пamp.:

between Winnepisseogee Lake on the S., and Squam Lake on the N., $38 \mathrm{~m}$. N. Concord. Pop. 549.

Centre Hrut, p. o., Centre co., Penn.: 74 r. N. W.

Harrisburg.

Centae Hill, p. o., Stewart co., Ga.: 113 m. S. W. Milledgeville.

Centke Independerite, p. 0., Alleghany co., N. $Y .: 205$ m. W. S. W. Albany.

Crivtre Lebayon, p. v., York co., Me.: 84 m. S. W. Augusta.

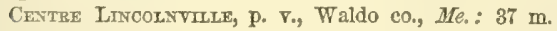

E. by S. Augusta

Centre Live, p. 0., Centre co., Penn.: 81 m. N. W.

IIarrisburg.

Centry Lisle, p. 0., Broome co., N. Y.: $113 \mathrm{~m}$. W. by S.

Albany.

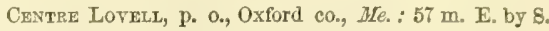
Augusta.

Centre Montvilue, p.., Waldo co,. Me.: $27 \mathrm{~m}$, E. by $\mathrm{N}$ Augusta.

Centre Morexand, p. v., Wyoming co., Penn.: $98 \mathrm{~m}$.

N. E. Harrisburg.

Centre Ossuppee, p. v., Carroll co., N. Hamp.: 42 mo

N. N. E. Concord.

Centre Polnt, p. v., Monroe co., $\bar{K} y_{*}: 118$ m. \$. 8 W

Frankfort.

Centre Porns, p. v., Sevier co., Ark,:147 m, W. S. W

Little Rock.

Centre Point, p. v., Iinn co., Ia. : on a cr. of Cedar $r$.

38 m. N. by W. Iowa City.

Centre Point, p. Y., Knox co., $I l l .: 78 \mathrm{~m} . \mathrm{N} . \mathrm{N} . \mathrm{W}$

Springfield.

Centre Port (now Ely Bluff), p. v., Dallas co, Ala.

on the E. side of Alabama r., 49 m. W. S. W. Montgomery.

Centeeport, p. v., Suffolk co., $N . Y_{.:}$on Great Cow Bay,

$118 \mathrm{~m}$. S. by E. Albany.

Centre Rnoge, p. v., Kemper co., Miss.: 91 m. E. N. E Jackson.

Centre Rutraxd, p. v., Rutland co., Term.: on Mill $r$ of Otter cr., $49 \mathrm{~m}$. S. by W. Montpelier.

Centre Sandwich, p. v., Carroll co., N. Hamp.: $46 \mathrm{~m}$. N. Concord.

Centre Simermax, p. v., Chautauque co., N. Y. : $293 \mathrm{~m}$ W. by S. Albany.

Centre Smoner, p. v., Kennebec co., Me.: 5 m. N. Augusta.

Centre Star, p. o., Lauderdale co, $A l a .: 194 \mathrm{~m}$. N. W. Montgomery.

Centre Strafrord, p. v., Strafford co., N. Hamp. : $21 \mathrm{~m}$.

E. Concord.

Centreton, p. $\nabla$. , Salem co., $N$. Jer.: 66 m. S. by W.

Trenton.

Centreton, p. $\nabla$., Huron co.g Ohio: $108 \mathrm{~m}$. N. by E. Columbus.

Chintretows, p. v., Dubuque co., Ia. : 66 m. N. E. Iowa City.

Centretown, p. v., Mercer co., Penn. : 197 m. W. N.W. Harrisburg

Centretown, p. v., Anderson dist., S. Car.: $118 \mathrm{~m}$

W. N. W. Columbia

Centre Valley, p. o., Lehigh co, Penn : 69 m. E. N. E Harrisburg.

Centre ValleY, p. O., Otsego co., N. Y.: 49 m. W. by N. Albany.

Centre Village, p. v., Camden co., Ga.: 168 m. S. E Milledgeville.

Centre Village, p. v.,Broome co., N. Y. : 117 m.W.S.W Albany.

Centreville, p. v., Montgomery co., Ark. : $72 \mathrm{~m}$. W. by S. Little Rock

Centrevilie, p. v., Leon co., Tex. : 126 m. N. E. Austin City.

Contrefirle, p. v., and cap. Bibb co., Ala, : on the E. side of Cahawba r., at the lower falls, $65 \mathrm{~m}$. N. W. Montgomery.

Centreville, p. v., Newcastle co., Del. : near the $\mathrm{N}$ State line, $39 \mathrm{~m}$. N. by W. Dorer.

Centreville, p. v., Leon co., Fllor.

Centrevilue, p. Y., Wilkes $\mathrm{Co}_{*}, G a_{0}:$ S. of Long cr, of Broad r., 51 m. N. E. Milledgeville.

Cratreville, p. $\mathrm{V}_{\text {a }}$ Columbia co, Wisc. : $61 \mathrm{~m}$. N. E, Madison.

Centreville, p. V., and cap. Wayne co., Ind. : on the E side of White Water r., $61 \mathrm{~m}$. E. by $\mathrm{N}$. Indianapolis. The Central Indiana $R$. R. passes through the $v$. about $11 \mathrm{~m}$. W Richmond.

Centreville, p. v., and cap. St. Joseph's co., AFich. : on the S. side of Prairie r. of St. Joseph's r., 78 m. S. W. Lansing. It is an improving town, and has a newspaper, 
the "St. Joseph's County Advertiser" (whig), published weekly. A branch of the University is located here.

Centreville, p. v., and cap. Appanoose co., Ia.: $76 \mathrm{~m}$.

8. W. Iowa City.

Cextreville, p. จ., Wabash co., $I l l .: 133$ m. S. E.

Springfield.

Centrevilue, p. T., Conway co., Ark. : 47 m. N. W. Little Rock

Centreville, p. v., Bourbon co., $\bar{K} y_{\text {. }}$ : $33 \mathrm{~m}$. E. Frankfort.

Centrevilue, p. V., St. Mary's par., La.: on the S. side of Bayou Teché, $51 \mathrm{~m}$. S. by W. Baton Rouge.

Centreville, p. v., and cap. Queen Anne co., Md.: at the head of Corsica cr., $25 \mathrm{~m}$. E. Annapolis.

Centreftllue, p. V., Barnstable co, Mass.: 63 m. S. Ev Boston.

Centreville, p. v., Amitie co., Miss.: 94 m. S. W. by S.

Jaekson.

Centreville, p. v., Moore co., N. Car.: 45 m. s. W.

Raleigh.

Ceivtrevilite, p. v., Hunterdon co., N. Jer.: 33 m. N.

Trenton.

Centreville, t. and p. V., Alleghany co., $N . Y_{0}:$ in the

$\mathrm{N}$. W. corner of the co., $228 \mathrm{~m}$. W. by S. Albany. P. 1,445.

Centeeville, p.v., Montgomery co., Ohio: $68 \mathrm{~m}$. W.S.W.

Columbus. Boilding stone is abundant in the neighborhood.

Centrefille, p. Y., Crawford co., Penn.: on a cr, of

Alleghany r., $157 \mathrm{~m}$. N. W. Harrisburg.

Centrevilule, p. v., Kent co., R. $I_{\text {. }}$ : on the E. side of

Patuxent r., $11 \mathrm{~m}$. 8 . S. W. Providence. The inhabitants are chiefly engaged in the manufacture of cotton goods. Pop. about 450 .

Cextreville, p. v., Laurens dist., S. Car. : $78 \mathrm{~m}$. N. W. Columbia.

Centrevitue, p. $\nabla .$, Hickman co., Tenn.: on the S. side of Duck r. of the Tennessee, $47 \mathrm{~m}$. S. W. Nashville. This v. was formerìy capital of the county.

Centrefille, p. v., Fairfax co., Firg.: on the N. branch of Occoquan cr., $84 \mathrm{~m}$. N. Richmond. It has some manufactures, and about 360 inhabitants.

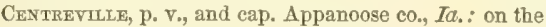

S. side of Cooper's cr. of Chariton r., $87 \mathrm{~m}$. S. W. Iowa City. Centre White Creet, p o., Washington co., N. Y.: 31 m. N. N. E. Albany.

Ceralvo, p. v., Carroll co., Afiss.: $71 \mathrm{~m}, \mathrm{~N}$. by $\mathrm{E}$. Jackson.

CERres, p. v., Alleghany co, $N_{0} Y_{0}:$ on a tributary of Alleghany r., $218 \mathrm{~m}$. W. S. W. Albany.

Ceresco, p. v., Calhoun co., Afich.: on the $\mathrm{N}$. side of Kalamazoo r., $39 \mathrm{~m}$. S.W. Lansing. The Michigan Central R. R. passes through the $\mathrm{v}, 5 \mathrm{~m}$. W. of Marshall.

Ceresco, t. and p. v., Fond du Lac co., Wisc. : on a cr. emptying into Green Lake, 65 m. N. E. Madison. P. 1,387. Cerro Gordo county, Ia. Situate W. middle, and con-

tains 576 sq. m. Taken from Pottowattomee in 1 s51. Cerro Gordo, p. v., and cap. Holmes co., Flor.

Cerro Gordo, p. v., Piatt co., $M u_{\text {. }}$ : on the S. side of the

N. fork of Sangamon r, $47 \mathrm{~m}$. E. N. E. Springfield.

CHAdD's Ford, p. o., Delaware co., Penn.: $162 \mathrm{~m}$. E. by S. Harrisburg.

Chagrin Falis, p. o., Cuyahoga co., Ohio: on Chagrin

r. of Lake Erie, 165 m. N. E. Columbus.

Chale BiufF, p. o., Greene co., Ark. : 143 m. N. E。 Little Rock.

Chatk Lever, p. o., Cumberland co., N. Car.: $39 \mathrm{~m} . \mathbf{8}$. Raleigh.

Chalk Lefei, p. o., St. Clair co., Mro.: $94 \mathrm{~m}$. W. by S. Jefferson City.

Crask Leter, p. o., Pittsylvania co., Jirg.: $108 \mathrm{~m}$.

S. W. Richmond.

CBate Letre, v, Benton co., Tenn.: on the W, side of

Tennessee $\mathrm{r}_{*}, 71 \mathrm{~m}$. W. by S. Nashville.
Chalk LeVel, p. o., Hopkins co., $\hbar y .: 171$ m. W. S. W. Frankfort.

Cralk ville, p. v., Chester dist., S. Car.: 87 m. N. W. Columbia.

Chanrers county, Ala. Situate E. on State line, and contains 720 sq. m. Drained by creeks of Chattahoochee and Tallapoosa rivers. Surface undulating, and soils generally fertile, producing wheat, corn, and cotton. Farms 1,342 ; manuf. 56 ; dwell. 2,138 , and pop.-wh. 12,784 , fr. col. 18, sl. 11,158-total 23,960. Capital: Chambers. Public Works: Montgomery and West Point R. R.

Chambers, p. vo, and cap. Chambers con, $A l_{0}$ : $68 \mathrm{~m}$. N. E. Montgomery.

Chambersburgh, p. v., Pike co., Ill. : on the W. side of M'Kee's cr. of the Illinois r., $53 \mathrm{~m}$. W. Springfield.

Chavbersburger, p. v., Clarke eo., Mo.: on Fox r. of the Mississippi, $136 \mathrm{~m}$. N. by E. Jefferson City.

Chambersibugh, p. v., Orange co., Ind.: at the head waters of Patoka cr., $84 \mathrm{~m}$. S. by W. Indianapolis.

Chambersburgh, p. v., Montgomery co., Ohio : on a branch of Miami r., $75 \mathrm{~m}$. \$. W. Columbus.

Chambersbureri, p. Yo, and cap. Franklin co., Penn. in the valley of Corecoheague r., a tributary of the Potomac, $44 \mathrm{~m} . \mathrm{S} . \mathrm{W}$. Harrisburg. It is one of the most flourishing places in the interior, has numerous manufactures, and considerable commerce. The Franklin R. R. extends hence to Hagerstown, $\mathrm{Md}$., $22 \mathrm{~m}$, and the Cumberland Valley R. R. to Harrisburg, $56 \mathrm{~m}$; ; the latter place forming a junction with the Pennsylvania $R$. R., ete. Five weekly newspapers are published here; the "Repository and Whig," the "Franklin Intelligencer" (whig), the "Valley Sentinel" (dem.), the "Valley Spirit" (dem.), and the "Messenger" (religious), Pop. 4,272.

Chaniber's Creek, p. o., Navarro co., Tex. : on a stream so called of Pecan er. of Trinity r., 148 m. N. N. E. Austin City.

Chamber's Milis, p. o., Buckingham co., Firg.: $56 \mathrm{~m}$, W. Richmond,

Chambersville, p. v., Dallas co., Ark.: $73 \mathrm{~m} . \mathrm{S}$, by W. Little Rock.

Chamblissburgh, p. v, Bedford co., Firg.: on a cr. of the Roanoke r., $126 \mathrm{~m}$. W. S. W. Richmond.

Champagnolie, p. v., Union co., Ark.: on the S. side of Washita r., $93 \mathrm{~m}$. S. Little Rock.

ChAMTPAIGN county, $I Z$. Situate E. middle, and contains 972 sq. m. Drained by the head streams of Sangamon, Kaskaskia, and Big Vermillion rivers. Surface undulating, with large prairies bordered by fine groves of timber. Soil excellent. Farms 273; dwell. 480, and pop.-wh. 2,647, fr. col. 2-total 2,649. Capital: Urbana. Public Works: Chicago Branch of Illinois Central R. R.

Champargin county, Ohio. Situate W. centrally, and contains $464 \mathrm{sq} . \mathrm{m}$. Drained by the head tributaries of Mad r. Surface generally level or undulating, in some places low and marshy. Prairie and timber well apportioned. Soils deep and rich, producing fine grain crops, Farms 1,677; manuf. 93; dwell. 3,437, and pop.-wh. 19,272, fr. col. 490-total 19,762. Capital: Urbana. Public Works: Mad Piver and Lake Erie R. P.

Ciasupion, t. and p. v., Trumbull co., Ohio: $177 \mathrm{~m}$. N. E. Columbus. Pop. 1,090 .

Crmasmion, t. and p. v., Jefferson co., $N . \quad Y$ : on the $\mathrm{S}$. side of Black r., $127 \mathrm{~m}$. N. W. Albany. Pop, 2 (n5.

Chanpion Soutu Road8, p. o., Jefferson co., N. Y.: 127 m. N. I. Albany.

Champlant lake, $N, Y$, and Verm.: this fine sheet of water lies between the States of New York and Vermont, and penetrates a fow miles beyond the line of the United States into Canada. Its length is about $140 \mathrm{~m}$., and it width from 1 mile to 10 miles. The direction of its length is nearly $\mathrm{N}$. and $\mathrm{S}$., and it contains a large number of small islands, most of which belong to Vermont. From Whitehall to Crown Point the lake is quite narrow, but at the 
latter point it begins to expand, and soon becomes three miles wide, still increasing in width northward, until near Burlington it attains its greatest spread. Steamboats of the first class, and vessels of 100 tons navigate the lake from end to end, and may pass the Sorel or Richlieu, its outlet to St. Johns, where steamboat navigation ceases. The lake is connected southward with the navigable waters of the Hudson by means of the Champlain Canal, 63 miles long. As the centre of the lake is approached, a large body of water presents itself to view, bordered by scenery of the most picturesque description. The headlands are seen to great advantage, and the vast range of mountains on either side is truly a scene of grandeur seldom witnessed. The highest peak of the Green Mountains, the Camel's Rump, is seen on the east, while the high range of mountains of Essex County loom boldly above the western horizon. This latter range of mountain peaks contains the highest land of the State of New Fork, and rises in some instances to the height of 5,000 feet and upward, the forests covering it swathed in clouds; streams leap from their sides, and cascades of great beauty foam from their crevices. The immediate shores of the lake have numerous indentations and bays of singular beauty; fish abound in the waters, and the angler nowhere else can so well enjoy the pleasures of the "gentle art" than here. Salmon, salmon-trout, sturgeon, pickerel, etc., of the finest flavor, abound through the whole length of this delightful lake.

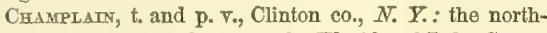
easternmost $t$. of the State, on the W. side of Lake Champlain, $153 \mathrm{~m}$. N. Albany. The v. on Chazy r., is intersected by the Northern R. R., 4 m. W. of Rouse's Point. P. 5,067.

Chavceroro, t. and p. v., York co., Penn.: on the S. W. fork of the Susquehanna r., 38 m. S. S. E. Harrisburg.

Crafoellorsville, p. V., Spottsylvania co., Virg.: S. of the Rappahannock r., $54 \mathrm{~m}$. N. by W. Richmond.

Centreery, p. O., Howard co., Ind.: $56 \mathrm{~m}$. N. Indianapolis.

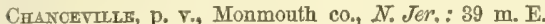
Trenton.

Chandlerspinte, p. T., Muskingum co., Ohio: $62 \mathrm{~m}$. E. by $\mathrm{N}$. Columbus.

Chandegevilu, p. v., Chester co., Penn. : 62 m. E. S. E.

Harrisburg.

Chanmahor, p. จ., Will co, $I l l .:$ on a tributary of Illinois r., $133 \mathrm{~m}$. N. E. Springfield.

Chavningrille, p. v., Dubuque ca, $I a_{0}: 69 \mathrm{~m}$. N. E. Iowa City.

Chantmly, p. o., Lincoln co., Mo. : 76 m. N. E. Jefferson City.

Chantmux, p. o., Fairfax con, Firg.: 92 m. N. Richmond.

Chapel Hill, p. $\vee$., Orange co., $N_{\text {. }}$ Car.: on New Hope r., a branch of Cape Fear r., $27 \mathrm{~m}$. N. W. Raleigh. The v. derives its chief importance from being the seat of the University of North Carolina. This institution was founded in 1789, and is well endowed. Permanent population, about 360 .

Chaper Hru, p. v., Monmouth $\mathrm{cos}_{\mathrm{s}} \boldsymbol{N}$. Jer.

Chapel Hill, p. т., Marshall co., Tenn. : on a cr. of Duck r., $37 \mathrm{~m} .8$, by E. Nashville.

Chapel Hrit, p. v., Perry co, Ohio: 52 m. E. by $\mathrm{S}$ Columbus.

Chapel Hrì, p. Y., Washington co., Tex, : 76 m. E. Austin City.

Chapel Hill, p. T., La Fayette co., Mo.: 98 m. W. by N. Jefferson City.

Chapelgburg, p. $\nabla .$, Cattarangus co., $N . Y .: 242 \mathrm{~m}$. W. by \$. Albany.

Chaptevilie, p. v., Ontario co., N. Y.: $172 \mathrm{~m}$. W. by N. Albany.

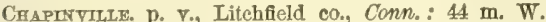
Hartford.

Chaplis, p. T., Nelson co., Ky.: 47 m. W. by S. Frankfort.
Chapurs, t. and p. v., Windham co., Conn.: on Naíchang r., 27 m. E. by N. Hartford. Pop. 799

Chapman, $t$, and p. o, Union co., Penn.: on Mahantango cr., 89 m. N. W. Harrisburg. Pop. 1,427.

Chapmantilie, p. v., Logan co., Virg.: $246 \mathrm{m.}$ W. Richmond.

Chappaqua, p. v., Westchester co., $\boldsymbol{N}_{.}, Y_{\text {. : }}$ on the line of the New York and Harlem Extension R. R. 97 m. S. by E. Albany.

Chappelu, p. v., Dallas co., Ark. : 59 m. S. Little Rock.

Crraptico, p. v., St. Mary's co., Mrd. : on the 8. side of Chaptico er., 47 m. S. by W. Annapolis. Chaptico er. is navigable to the village.

Chaptltepeo, p. v., Blount $c_{*}, A a_{*}: 122 \mathrm{~m} . \mathrm{N}$. by W. Montgomery.

Chapultepec, p. v., Benton co, Tenn.: 71 m. W. Nashville.

Chardor, p. v., and cap. Geauga co., Ohio: $180 \mathrm{~m} . \mathrm{N} . \mathrm{E}$. Columbus. It is a flourishing $\nabla$, and has two newspapers, the "Geauga Republican" (whig), and the "Free Democrat" (free soil), both published weekly. Pop. 1,622.

Charenton, p. v., St. Mary's par., $L a .: 54$ m. s. by W. Baton Rouge.

Charitow, p. $\nabla .$, Lucas co., Ia. : on the N. side of Chariton r. 103 m. S. W. Iowa City.

Chariton Mrlus, p. o., Adair co., Mo.: on Chariton r. $118 \mathrm{~m} . \mathrm{N}$. by W. Jefferson City.

Chablemowt, t. and p. o., Franklin co., Mass. : on Deelfield r., $93 \mathrm{~m} . \mathrm{W}$. Boston. The Greenfield and North Adams R. R. will traverse the $t$. E. and W., forming a section of the Troy and Boston line of railroads. Pop. 1,173.

Charlemont, p. v., Bedford co., Virg.: $118 \mathrm{~m}$. W. by S. Richmond.

Charltow county, Mo. Situate centrally on N. bank of Missouri $r_{\text {o, }}$ and contains 780 sq. m. Drained by Chariton r. and several tributaries of Grand r. Surface level or undulating prairie, and soil good. Farms 659 ; manuf. 24 ; dwell. 1,096, and pop.-wh. 5,688, fr. col. 4s, sl. 1,778-total 7,514. Capital: Keytesville.

Charles county, $\boldsymbol{M} d$. Situate W. shore, and contains 460 $\mathrm{sq}$. m. Drained by a number of creeks flowing to the Potomac and Patuxent rivers. Burface low and sandy. Soil indifferent and exhausted. Tobacco is the chief product but wheat, corn, etc., are grown extensively. Timber is various and abundant. Farms 709 ; manuf. 0 ; dwell. 1,335, and pop.-wh. 5,665, fr. col. 913, sl. 9,584-total 16,162 Capital: Port Tobaceo.

Charles river, R. $I .:$ has its source in' Warden's Pond, in S. Kingston, and empties into Pawcatuck r. at Westerly. Charles river, Mass.: rises on the borders of Hopkinton and Milford townships, and after a circuitous course, empties into Boston Harbor. It is navigable to Watertown, $7 \mathrm{~m}$. abore Boston.

Charles Crty county, Firg. Situate S. E. on a penin sula formed by James and Chickahominy rivers, and contains $208 \mathrm{sq}, \mathrm{m}$. Surface rolling, and soils sandy. Indian corn, wheat, and oats are the principal products. Farms 199 ; manuf, 6 ; dwell. 486 , and pop.-wh, 1,664, fr, col. 772 , sl. 2,764-total 5,200. Capital: Charles City C. H.

CHarles City C. $\mathrm{H}_{\text {, }}$ p. v., and cap. Charles City co. Virg.: on the N. side of James r., 33 m. E. by S. Richmond Canales River Village, p. v., Norfolk eo, Mas8. : on Charles r., 16 m. 8. W. Boston.

CHARLESTON district, S. Car. Situate S. E. on the Atlantic, between the Santee and Ashley rivers, and contains 1,520 sq. m. Drained by Cooper's r. and other streams. The surface is low and swampy, and produces abundantly rice and cotton, with some grain. Farms 652 ; manuf. 76 ; dwell. 5,213, and pop.-wh. 24,586, fr. col. 3,843, sl. 44,376total 72,805. Capital: Charleston. Public Works: Santee Canal, and South Carolina R. R.

Crarleston, p. v., Mississippi co., Mo.: 196 m. S. E. Jefferson City. 
Charleston, p. v., and cap. Coles co., $\pi$. : about $2 \mathrm{~m}$. W. of Embarras r., $82 \mathrm{~m}$. E. by S. S. Springfield. The Terre Haute and Alton R. r. will pass through this village.

Uharteston, t. and p. v., Penobscot co., Me.: $57 \mathrm{~m}$. N. E. Augusta. Pop. 1,283.

Charceston, t. and p. 0., Krlamazoo co., Mfich.: on the S. side of Kalamazoo r., $51 \mathrm{~m}$. S. W. Lansing. Pop. 846.

Charleston, p. v., and cap. Tallahatchie co, Mfiss.: on

Tillaboba cr. of Tallahatchie $\mathbf{r}, 114$ m. N. Jackson.

Charterton, p. V., Lee co., Icr.: on the bank of the Mississippi r, at the confluence of Sugar cr., $39 \mathrm{~m}$. S. by E. Iowa City, and about $6 \mathrm{~m} . \mathrm{S}$. W. Fort Madison. It is a place of some trade, and near the line of the proposed Dubuque and Keokuk R. P.

Cerarleston, t. and p. v., Montgomery co., $\boldsymbol{N}_{\text {. }} \boldsymbol{Y}_{0}:$ on the W. side of Schoharie cr., $31 \mathrm{~m}$. W. Albany. Pop. 2,216. Charleston, p. v., Tioga co., $N$. Y.: $134 \mathrm{~m}$. W. S. W. Albany.

Chapleston, p. city, port of entry, and cap. Charleston dist., $S . C(6)^{2}$, on a tongue of land formed by the meeting of Cooper and Ashley rivers in Charleston Harbor, $101 \mathrm{~m}$. S. E. Columbia. Lat. $32{ }^{\circ} 46^{\prime} 33^{\prime \prime}$ N., and long. $79057^{\prime} 27^{\prime \prime}$ W. from Greenwich, or $2 \circ 55^{\prime} 57^{\prime \prime}$ W. from Washington.

The bay, or Charleston Harbor, is a large estuary, with an average width of $2 \mathrm{~m}$., and extends about $7 \mathrm{~m}$. S. E. from Charleston to the Atlantic Ocean, which it enters between Sullivan's and Morrison's islands. Cooper and Ashley rivers are from 30 to 40 feet deep, the former being 1,400 , and the latter 2,100 yards wide opposite the city, and both are capable of accommodating the largest class of vessels. A sand-bar extends across the month of the harbor, but it has several channel entrances, the deepest of which, passing very close to Sulliran's Island, admits vessels drawing 16 feet water at high tide. The harbor is open to easterly winds, and vessels are much exposed during storms from that quarter-so much so, indeed, that they were at one time prohibited by law from lying at the wharves from the last of July to the middle of September. The fortifications protecting Charleston, are Fort Moultrie, on Sullivan's Island, Castle Pinckney, $2 \mathrm{~m}$. below the city, and Fort Johnson, about $4 \mathrm{~m}$. below.

The ground upon which Charleston is built is low, only clerated 8 or 9 feet above the level of the harbor at high tide, which here rises about 6 feet, flowing by the city with a strong current, and thus contributing to the salubrity of a location naturally unhealthy. The city has sereral times been inundated by the waters driven up the harbor by violent winds, and has from this cause at various times suffered considerable damage. The years $1699,1728,1752$, and 1797 are noted in the history of the city as periods of these derastating occurrences. The streets are laid out rectilineally, running east and west, from the rivers north and south, forming nearly square blocks. The width of the streets raries from 35 to 70 feet. Most of the buildings of the eity are of brick, and the drellings are in general of elegant construction. The streets are lined with the pride of India, while elegant villas, adorned with verandahs reaching from the ground to the tops of the houses, surrounded by green edges, and buried in the rich foliage of orange trees, magnolias, and palmettoes, give an air of wealth and elegance to the city. Charleston is divided into four wards, and is soverned by a mayor and 12 aldermen. Among the public buildings, are the City Hall, the Exchange, the District Court House, the jail, two arsenals, a theatre, the U.S. Custom House, the Halls of the College of Charleston, between 30 and 40 churches, several high schools, and buildings devoted to benevolent purposes, as the almis-houses, the orphan asylum. The Literary and Philosophical Society has a fine collection of objects of natural history, ctc.; the Academy of Fine Arts possesses some raluable paintings, and the City Library contains about 24, 000 volumes. The College of Charleston is one of the most flourishing institutions of the Sunthern States, and has an efficient staff, consisting of a president and six professors ; it was founded in $17 \$ 5$, and in 1850 had 70 students. The Medical College of the State of South Carolina was founded in 1833 ; in 1850 it had 8 professors and $15 \mathrm{~s}$ students. The list of free sehool pupils is 394 , and the average cost of instruction $\$ 10$ per annum; these are raluable schools, but are inadequate for so large a city. There is also a High School, founded in 1839, which averages from 130 to 150 pupils. It is endowed with $\$ 1,000$ a year for 100 years by the council. The number of grammar schools and academies, which are open only to pay scholars, are pretty numerous, and these are usually efficient institutions, a which the best classical and mathematical education can be had.

The public press of Charleston consists of four daily papers: the "Sun" (neutral), the "C. News" (dem.), the "C. Mercury" (dem.), and the "C. Courier" (neutral): of the latter a tri-weekly edition is also issued; four weekly papers, the "Southern Literary Gazette" the "Southern Baptist," the "Catholic Miscellany," and the "Southern Christian Advocate," three monthly periodicals, the "Gospel Messenger," the "School-Fellow" (educational), and the "Masonic Miscellany;" and one bi-monthly, the "Medical Journal." Many of these are publications exhibiting a ligh order of talent, and have circulations beyond the locality. The "Medical Journal" is a work of world-wide renown and has among its contributors the highest names among Southern physicians.

The city of Charleston is one of the most ancient in the Union, Its foundations were laid in 1672 . In 1677 it was called Oyster Point Town; in 1680 New Charlestown, and in 1682 New Charleston. It was chartered as a city in 1783. At an early period of its history it attracted a consiclerable population from Barbadoes, and received large accessions of French Huguenots. "On the spot," says Bancroft, "where opulenoe now crowds the wharves of the most prosperous mart on our Southern sea-board, among ancient groves that swept down the river's banks, and were covered with yellow jasmine which burdened the verdant zephyrs with its perfumes, the city was begun." Two centuries have nearly been completed since its foundation, and momentous have been the events and changes within that lapse of time. In 1731-we have it on the authority of an old historian-there were 690 houses in Charleston, 5 handsome churches, and that out of the city were to be found courtly, stately buildings, noble castles, etc. The advantages of the location were early appreciated, and it soon became a place of considerable trade. Its firs exports were staves, lumber, furs, and peltries, rice (first planted 1698), to which were added in 1747 indigo, in 1752 tobacco, and in 1790 cotton. At the present time its great exports are rice and cotton. Of cotton, the receipts from the interior in 1850 were 400,714 bales, and of sea-island, 17,991 bales, and the exports were 365,327 bales apland, and 16,437 bales sea-island; and the receipts of rice amounted to 147,690 barrels, and the exports to 181,417 barrels. The foreign commerce of Charleston, howerer, has not progressed equally with its oossting trade; and many reasons might be assigned for this, but none so weighty as the fault of its own inhabitants in preferring the employment of the shipping of other States, and neglecting its own facilities for ship-building. It has consequently become a tributary to Nortbern ports, and instead of reaping the benefits of a foreign navigation of its own, has been constantly heaping up the coffers of its Northern neighbors. At present, indeed, the great bulk of its staples are carried coastwise to New Tork, and thence shipped to foreign countries. In the year 1S $49-50$, ending $30 t h$ June, the clearances to foreign ports amounted only to 351 vessels (121,367 tons), and its direct entrances to only 308 vessels (96,619 tons), a proportion quite inadequate for the transportation of $s 0$ large a commercial material as that supplied from the back country, of which the wrt is the ont rutkt. The registered shipping 
of the port at this period consisted of 15,377 tons, and the shipping employed in the coasting trade, of 17,916 tons. The cosstwise trade of Charleston in comparison with this is immensely greater. In 1848 the arrivals were 63 steamships, 228 ships, 196 brigs, 398 schooners, 8 sloops, and 730 steamboats; and the clearances were 61 steamships, 163 ships, 177 brigs, 369 schoomers, 7 sloops, and 731 steamboats. At the same period, and of the above amount, the following were regular packets plying between Charleston and other ports of the Union: Boston, 6 vessels (1,371 tons); New York, 28 vessels (11,027 tons); Philadelphia, 13 vessels (2,950 tons); Providence, 2 vessels ( 346 tons) ; Baltimore, 6 vessels (600 tons); Wilmington, 4 vessels (1,538 tons); Savannah, 4 vessels ( 1,070 tons); and New Orleans, 7 vessels ( 1,627 tons) ; the remainder being made up of transient traders. Of this number, 5 were steamships, 11 ships, 9 barks, 21 brigs, 1 ketch, 26 schooners, and 8 steamboats. There are also engaged in the pilotage of the bar, 18 full branch pilots and 8 second branch pilots, employing 9 pilot boats, with an aggregate of about 400 tons.

There is at Charleston a Floating Dry Dock-one of the best of its kind in the Union; it is the balance dock of Gilbert, and was built in 1845 by James Marsh. Its length is 160 feet, its width 52 feet, and its depth 20 feet, and its capacity 1,500 tons. The operations of the dock are performed by a steam-engine.

The South Carolina $R . R$. is the great conduit of the commerce of Charleston to and from the interior. It extends from Charleston to Augusta, 136 miles, and has numerous connections (feeders), westward and northward, through which an immense amount of merchandise is carried to and fro. It has also the advantages of a canal 22 miles long, which connects the harbor with the Santee river, and by means of the railroads now building, it will have access to the Mississippi and Ohio rivers. Already its railroad facilities extend from Charleston to Nashville, Tenn., 598 miles, and to Montgomery, Ala., 482 miles.

Charleston has seven banks, with an aggregate capital of $\$ 9,500,000$, and five insurance companies, with capitals in the agregate amounting to $\$ 4,500,000$; also a provident iustitution for savings. The Bank of the State of South Carolina is the fiscal agent of the State, and holds, besides its capital of $\$ 1,123,357$, the deposits of the State funds.

The population of Charleston in 1790 was 16,359 ; in 1800 , is, 711 ; in $1810,24,711$; in $1820,24,780$; in $1830,30,289$; in $1840,29,261$, and $1850,42,985$. This is exclusive of St. Philip's parish, or the neck, which is, however, virtually a part of Charieston, and contains about 16,000 inhabitants.

Crarleston, p. v., Bradley co., Ten $\eta_{0}$ : on the S. side of the Hiwassee r., 123 m. E. S. E. Nashville. The East Tennessee and Georgia R. R. passes the $\nabla .40 \mathrm{~m}$. from Dalton.

Cilarzeston Four Cornters, p. o., Montgomery co., $N$. Y.: $32 \mathrm{~m}$. W. by N. Albany.

Crrarlestown, p. v., Franklin co., Arte: on Arkansas r., I08 m. W. N. W. Little Rock.

Cinarzfstown, t. and p. c., Middlesex co., Mfasis. : on a peninsula between Charles and Mystic rivers, and connected with Boston, etc., by bridges. The $c_{\text {. }}$ contains the Massachusetts State Prison, situated on Prison Point, the U.S. Nayy Yard, ete. Breed's Hill, where the noted battle was fought, 17th June, 1775 , lies immediately behind the $v_{*,}$ and this great event is commemorated by a granite obelisk (Bunker Hill Monument). The t. has considerable manufactures, trade, and commeree; and a newspaper, the "Bunker Hill Aurora," is here published weekly. Charlestown may be considered as a portion of the metropolitan district, of which Boston is the centre. Pop. 17,216.

CHARLESTOWN, p. $\nabla_{0}$, Cecil co., Mqd.: on the W. side of North-East r., 5 m. from Chesapeake Bay, and 49 m. N. E. Annapolis. The Pniladelphia, Wilmington, and Baltimore R. R. paeses near the $\mathrm{v}, 57 \mathrm{~m}$. from Philadelphia, and $\$ 1 \mathrm{~m}$. from Baltimore.

Charlegtows, p. $v_{.}$and cap. Clarke co., Ind.: on the
E. side of Pleasant Run of Silver cr., $3 \mathrm{~m}$. from the Ohio r., and $92 \mathrm{~m}$. B. S. E. Indianapolis.

Cinarlestown, t. and p. v., Sullivan co., $N$. Mamp.: on the E. side of Connecticut r., $45 \mathrm{~m}$. W. Concord. A bridge connects this $t$ with Springfield, Verm, and the Sullivan R. R. intersects the v. $8 \mathrm{~m}$. from Pollows Falls. Pop. $167 \mathrm{f}$.

Charlestown, p. v., Calumet co., Wisc.: 88 m. N. N. E. Madison.

Charlestown, t. and p. v., Portage co., Otio: on the N. side of the W. branch of Mahoning r., $154 \mathrm{~m}$. N. E. Columbus. Pop. 809 .

Charlestown, t. and p. v., Washington co., R. $I_{0}$ : on Charles $r$ of the Pawcatuck $r, 37 \mathrm{~m}$. 8 . S. W. Providence. Pop. 994.

Cuarlestown, p. v., and cap. Jefferson co., Tirg.: on the line of the Winchester and Potomac R. R., $10 \mathrm{~m}$. from Harper's Ferry, and $122 \mathrm{~m}$. N. Richmond.

CHARlevory county, Afich. Situate N. W. of Lower Peninsula, on Little Traverse Bay, and contains 534 sq. m. Erected since 1850.

Charloe, p. v., Paulding co., Ohio: 143 m. N. W. Columbus.

Chaplotte county, Firg. Situate S. middle, and contains $600 \mathrm{sq} . \mathrm{m}$. Drained by Roanoke $\mathrm{r}$. and its tributaries, Surface level, and soils fertile, producing wheat, Indian corn, oats, and tobacco. Farms 563; manuf. 6; dwell. 903 , and pop.-wh. 4,605, fr. col. 362, sl. 8,9S8-total 13,955. Capital: Charlotte C. H.

Charlotte, t. and $\mathrm{p}_{\text {. }}$ o., Washington co., MFe.: $131 \mathrm{~m}$ E. N. E. Augusta. Pop. 718.

Charlotte, p. v., and cap. Eaton co., Mich.: on the N, side of Battle cr. of the Kalamazoo $\mathrm{r}_{\text {., }}$ and $18 \mathrm{mo} \mathrm{S}$. W Lansing.

Crarlotte, p. v., and cap. Mecklenburoh co., N. Car. between Sugar and Little Sugar ereeks of Catawba r., 118 m.W.S.W. Raleigh, East of Charlotte there are rich gold mines, and at the $\mathrm{v}$. a branch mint has Iong been established for its coinage. The Charlotte and South Carolina $R, R$ has its $\mathrm{N}$., terminus at this point, and hence the $\mathrm{R}$. R. will be continued N. to Danville, Virg. Two newspapers are published weekly, the "Charlotte Journal" (whig), and the "Hornet's Nest" (dem.)! Pop. about 1,300.

Charlotte, p. V., Monroe co., N. $Y_{0}$ : on the W. bank of Genesee r. at its mouth, $7 \mathrm{~m}$. N. Rochester, and $194 \mathrm{~m}$ W. by N. Albany, (Sometimes called Port Genesce.) It has a convenient landing for steamboats navigating the $r$. and lake, and has regular steam communication with Canada and the principal lake ports.

Charlotte, t. and p. v., Chittenden co., Verm.: on the E. side of Lake Champlain, $31 \mathrm{~m}$. N. W. Montpelier. The Rutland and Burlington R. R. passes through the $\mathrm{y} .11 \mathrm{~m}$. from Burlington, and 109 from Bellow's Falls. It is one of the best farming t. in the State. Pop. 1,634.

Charlotwe, p.. ., and eap. Charlotte co., Virg. : $72 \mathrm{~m}$. W. S. W. Richmond. It contains the co. buildings, and has several mechanic shops. Pop, about 600 .

CiarlotTe, p. ., and cap. Dickson co., Tenn.: $33 \mathrm{~m}$. W. Nashrille. The Nashville and Mississippi R. R. will pass through the village.

Charlotte Centre, p. o., Chautauque co., $N$. $Y$.: on a branch of Conewango cr., $298 \mathrm{~m}$. W. by S. Albany.

Citarlotte Hali, p. v., St, Mary's co., MId.: at the head of Cool Springs cr., $39 \mathrm{~m}$. S. S. E. Annapolis, A noted college so called is located here; in 1850 it had 63 students. The $\mathrm{v}$. has about 120 permanent inhabitants.

Charlottesville, p. v., Hancock co., Ird.: on the F side of a branch of Blue r, $29 \mathrm{~m}$. E. Indianapolis. The Central Indiana R. R. passes through the village.

Charlotregville, p. V., and cap. Albemarle co., Vir.g. on Moore's cr. of Rivanna r., 63 m. N. W. Richmond. It derives its chief importance from being the site of the University of Virginia, which has a fine observatory, and is a most efficient institution. Three nerwspapers are pub- 
lished in the $\nabla$. , the "Virginia Adroeate" (whig), the "Jeffersonian Republican" (dem.), and the "Jefferson Monument" (lit.), all weekly. Pop. about 1,400.

Charlotiteville, p. v., Schoharie eo., $N . Y .: 42 \mathrm{~m}$. W. by S. Albany. Pop. 2,015.

Charlton, t. and p. o., Worcester co., Mass.: $49 \mathrm{~m}$. W. by $\mathrm{S}$. Boston.

Charlton, t. and p. v., Saratoga co., $N . X_{\text {. : on Aelplass }}$ cr. of Mohawk r., $21 \mathrm{~m}$. N. W. Albany. Pop. 1,902.

Charlton Depôt, p. o., Worcester co, Mass.: on the Western R. R., $57 \mathrm{~m}$. from Boston.

Charmerers river, Penn.: a small tributary of the Ohio r., which it joins $4 \mathrm{~m}$. below Pittsburg. It runs through the bituminous coal region of Washington co.

Chartiers, t. and p. o., Washington co., Penn.: on the N. side Chartier's or., $187 \mathrm{~m}$. W. by S. Harrisburg. There is abundance of coal in this locality, and on the cr. are a large number of saw and grist mills.

Chaseville, p. v., Murray co., Ga.: 163 m. N. W. Milledgeville.

Chasevilite, p. v., Benton co., Tenn.: on the W. side of Tennessee r., $69 \mathrm{~m}$. W. Nashville.

Chataty, p. v., Bradley co., Tenn.: 181 m. E. S. E. Nashville.

Chateadgax, t. and p. v., Franklin co., N.Y.: on the head tributaries of Chateaugay r., $157 \mathrm{~m}$. N. by W. Albany. The village lies on the Northern $R$. R., $45 \mathrm{~m}$. from Rouse's Point, and 73 from Ogdensburg. Pop. 3,696.

Chateaugar lake, $N$. $Y$.: this small lake, which is $4 \mathrm{~m}$. long, and about $2 \mathrm{~m}$. wide, lies in Beekmantown, in Clinton co. It abounds in fish, and has many secnes of beauty in its immediate neighborhood. Its surface is elevated 1,400 feet above the tide waters of Hudson $r$.

Chateavgar mountains, $N . Y_{\text {. }}$ a a range of hills commencing in Canada, and extending southward through the north-west part of Clinton into Franklin county. Some of the highest peaks are in Franklin, near Chateangay Lake.

Chateadgay river, $N_{0} Y_{0}$ : a stream flowing northward from Chateaugay Mountains into Canada, where it empties into the St. Lawrence River.

Chatrield, to and p. T., Crawford co., Ohio: $84 \mathrm{~m}$. N. Columbus. Pop. 1,356.

Cнатнам county, Gar. Situate S. E, on the Atlantic, between Savannah and Ogeechee rivers, and contains $420 \mathrm{sq}$. m. Surface very low, searcely above sea level-near the coast broken into islands by numerous inlets and canals. The chief products are rice and cotton. Farms 132 ; manuf 13; dwell. 1,915, and pop.-wh. 9,161, 年. col. 722, sl. 14,018 -total 23,901. Capital: Savannah. Public Works: Central Georgia R. T.

Chatriar county, $N$. Car. Situate centrally, and contains 858 sq. m. Drained by Haw r. and its tributaries. Surface elevated and varied. Soils clayey, and productive in wheat, corn, cotton, and tobaceo. Farms 1,633; manuf 4S; dwell. 2,210, and pop.-wh. 12,164, fr. col. 300 , sl. 5,985 -total 18,449. Capital: Pittsboro.

Cratrux, p. v., Sangamon co., $M$. . near the line of the Alton and Sangamon R. R., 24 m. S. S. W. Springfield.

Critinar, th and p. v., Barnstable co., Mrass. : on the S. E. point of Cape Cod, $78 \mathrm{~m}$. S. E. Boston. It has a good harbor, and an extensive coasting trade and fisheries. Salt is also manufactured. Fop. 2,467.

Ciratrax, to, Middlesex co., Conns.: on the Connecticut r., opposite Middletown, $16 \mathrm{~m}$. S. Hartford. It has considerable manufactures. Pop. 1,581.

ChathaM, t. and p. v., Columbia co., $N$. $Y$.: on Kinderhook cr., 16 m. S. E. Albany. Chatham Four Corners, a village in the $\mathrm{S}$. part of the town, is an important point, where several lines of $\mathrm{R}$. R. intersect or form a union. Pop. 3. S:9.9.

Cuntuly, t. and p. F., Morris en. . I. Ter.: on the Passaic r., $39 \mathrm{~m}$. N. N. E. Trenton. The river passes through the village. Pop. $2,469$.
Chathas, p. v., Chester co., Penn.: 63 m. E. S. E. Harrisburg.

Снатнам, p. v., Licking co., Olio : near the N. fork of Licking r., 39 m. E. N. E. Columbus.

Chatham Censtre, p. v., Columbia co., $N_{\text {. }} Y_{*}:$ on the line of the Western R. R., 20 m. S. E. Albany.

Chatham Centre, p. v., Medina co., Ohio: on the E. branch of Black r., $113 \mathrm{~m}$. N. N. E. Columbus.

Chateair Four Corners, p. v., Columbia co., N. Y.: on the S. part of the town of Chatham, $23 \mathrm{~m}$. S. E. Albany It is a village of great importance, being the point of intersection of the Albany and West Stockbridge $R$. R (western), the Hudson and Berkshire R. R., and the Harlem Extension R. R., ete.

Chatiam Hill, p. o., Smyth co., Virg.: 222 m. W. by S. Richmond.

Chatham Run, p. o., Clinton co., Penn. : 71 m. N. W. by N. Harrisburg.

Cirathair Vallex, p. o.,Tioga co, Penn.: 117 m. N. N.W. Harrisburg.

Chattamoochee, p. v., Gadsden co., Frlor: : on the E. side of Appalachicola r., immediatety below the union of Chattahoochee and Flint rivers.

Cnattahoochee river, $G a$, and $A l a . ;$ it has its rise in the Appalackee Mountains, and for a great part of its course forms the boundary line between Georgia and Alabams, forming ultimately the largest constituent of the Appalachicola $\mathrm{r}$. Steamboats ascend it to Columbus, and boating is carried much farther up.

Cinatranooga, p. v., Hamilton co., Tenn. : on the S. bank of Tennessee r., $112 \mathrm{~m}$. E. S. E. Nashville. At this point the Nashville and Chattanooga $R$. R. forms a junction with the Western and Atlantic R. R., $151 \mathrm{~m}$. from Nashville, and 311 from Augusta. A railroad is also in progress from hence to Charleston, on the East Tennessee and Georgia $R$. R. This point, indeed, is destined to become the entrepôt of an inmense inland commerce, reaching to the Atlantic sea-board on the one hrund and beyond the Mississippi and Ohio on the other. Two newspapers are published weekly, the "C. Gazette" (whig), and the "C. Advertiser" (dem.) Pop. about 3,000.

Chatrooga county, $G a$. Situate N. W., and contains $420 \mathrm{sq} . \mathrm{ma}$. Drained by Chattooga $r_{n}$, a branch of Coosa $r$ Surface elevated, hilly, and rugged, and the soils generall indifferent - on the streams fertile. Wheat, corn, and cotton are the chief products. Farms 419 ; manuf. 10 ; dwell. 869 , and pop.-wh. 5,131, fr. col. 4, sl. 1,680-total 6,815. Capital: Summerville.

Chattoogavile, p. vo, Chattooga co., Ga. : $148 \mathrm{~m} . \mathrm{N}$. W. Milledgeville.

Cradirost, p. $\nabla_{\text {., }}$ Jefferson co., $N . Y_{*}:$ at the head of Chaumont Bay, 149 m. N. W. Albany. It has unrivaled water-power and great facilities for lake commerce, its harbor being spacious and of easy access. It is also celebrated for its fisheries and for the quantity of blue limestone found in its vicinity. The Cape Vincent $R$. R. passes through the village, $86 \mathrm{~m}$. from Rome. Pop. about 400

CIIAgront bay, $N . \bar{Y} .:$ a fine open bay near the outlet of Lake Ontario. It is of an irregular shape, about $7 \mathrm{~m}$. long and $2 \mathrm{~m}$. wide, and receives Chaumont $r$. The fisheries of the bay are very valuable, and it abounds in all the descriptions found in the lake of which it is an arm.

Cancrons river, $N, Y_{i}$ : this stream rises in Jefferson County, and flows almost directly south, to its confluence witlı (haumont Bay. It is only 15 or $16 \mathrm{~m}$. in length, but affords abundance of hydraulic power.

Chauvcey, D. V., Athens con, Ohio : on the N. side of Hocking $\mathrm{r}$, and canal, $76 \mathrm{~m}$. S. E. Columbus.

Cractauque county, N. Y. Situate S. W. on Lake Erie, and contains 1,017 sq. m. Drained by Chautauque Lake, and a large number of streams flowing to Alleghany r. An elernter ridge traverses the cuunty 4 or $5 \mathrm{~m}$, distant from Lake Erie, forming the watershed. Surface finely varied, 
and the soils, even to the hill-tops, open to cultivation. Bog iron, copperas, alum, marl, etc., abound, and there ere sulphor springs and a hydrogen spring, which at Fredonia, Westfield, and Van Buren Harbor, are used to illuminatethe gas burning equal to coal gas. Farms 5,163; manuf. 510 ; dwell. 9,074 , and pop.-wh. 50,358, fr. col. $135-$ total 50,493. Capital: Mayville. Putblic Works: New Tork and Erie R. R., and Buffalo and State Line R. R.

Cinautauque Vallex, p. o., Alleghany co., N. Y.: 213 m. W. S. W. Albany.

Chautadque lake, $N_{.} Y_{*}$ : a most beautiful sheet of water in the county of the same name. It is $18 \mathrm{~m}$. in length, and varies in breadth from 1 to $3 \mathrm{~m}$., except near the middle, where it contracts to a few rods in width. It empties into Conewango cr. Its elevation is 726 feet above the surface of Lake Erie, and 1,291 above the ocean, being the most elevated lake in the Union on which steamboats ply.

Chautauque river, $N_{.} Y_{.}$: a tributary of Lake Erie, from the county of the same name. It flows through a deep ravine, and in its course furnishes excellent mill sites Cruzy, t. and p. v., Clinton co., N. Y.: on Chazy r., 146 $\mathrm{m} . \mathrm{N}$. Albany. The village is situate about $3 \mathrm{~m}$. W. of Lake Champlain, on which is also a village ealled Chazy Landing. Pop. 4,324.

Cheap Valley, p. o., Henry co., Tenn.; 89 m. W. by N. Nashville.

Chfat Brmge, p. 0., Preston co., Virg.: on Cheat r., $182 \mathrm{~m} . \mathrm{N}$. W. Richmond.

Cпеат river, Firg. : a large tributary of Honongahela r., from the mountain region of Randolph $c 0$.

Cheboygan county, Mich. Situate N. of Lower Peninsula, and contains $324 \mathrm{sq.} \mathrm{m}$. Erected since 1850.

CmEBoxgan river, Aich: the largest stream in the $\mathrm{N}$. part of the peninsula. It rises $\mathrm{N}$. W. of Saginaw Bay, flows in a $\mathrm{N}$. direction, and empties into the straits of Mackinac, opposite Bois Blanc Island. There are numerrous salt springs 12 or $15 \mathrm{~m}$. from its mouth.

Checkered Hotse, p. o., Oswego co., N. Y. (now KASOAG).

Crmectasville, p. v., Marion co., Tenn. : on the W. side of Sequatchy r., $94 \mathrm{~m}$. S. E. Nashville

Checktowaga, p. v., Erie co., N. Y.:246 m. W. Albany. Chersequakes, p. o., Middlesex co., N. Jer. : 34 m. N. E. Trenton.

Ceneraless, p. 0., Yam Hill co., Oreg. Ter.: on a r. of the same name, $28 \mathrm{~m}$. N. by W. Salem.

Crenalem river, Oreg.: a large $r$. from the $E_{\text {., formed }}$ by the union of the Skukumachuck and Newraukum rivers, and falling into Gray's Harbor.

CrmLMsford, t. and p. v., Middlesex co., Mass: : on the S. side of Merrimac r., $24 \mathrm{~m} . \mathrm{N}$. W. Boston. The town abounds in granite and limestone, and has several manufactures, among which are those of glass and iron. The Middlesex Canal passes through the town, and it has seyeral railroads on its borders, connecting it with the towns on all sides. Lowell was taken from Chelmsford in 1824. Pop, 2,095.

Crelsea, p. $\nabla .$, Mill co., $\pi u_{*}$ : 143 m. N. E. Springfield.

Chelsed, p. V., Washtenaw eo., Ifich.: 52 m. S. E. Lansing.

Chelsea, t, and p. $\nabla_{\text {, }}$ Suffolk $0 .$, Mass.: 3 m. N. E Boston. The Eastern R. R. passes through the town. It may be considered as a part of the Boston metropolitan district. It has considerable manufactures, and is on the whole a busy place. Chelsea has two newspapers, the "Telegraph" (whig), and the "Pioneer"-both published weekly. Pop. 6,701-in 1840 it had only a pop. of 2,390 .

CHelse., t., p.v., and cap. Orange co., Verm.: on a branch of White r., $22 \mathrm{~m}$. S. by E. Montpelier. The village contains the county buildings and about 80 dwellings. Pop. 1,958 .

ChEMUNG county, $" N$. $Y$. Situate S. W. middle, and contains 528 sq. m. Drained chicfly by Chemung r. and its tributary streams. Surface broken, hilly, and well timbered, with large river flats, Soils very productive. Farms 2,170; manuf. 321 ; dwell. 5,095, and pop.-wh. 28,537, fr. col. 28 -total 28,821. Capital: Elmira. Public Works: Che mung Canal; New York and Erie R. R.; Elmira and Williamsport R. R., etc.

Cnemure, p. v., M'Henry co., $I Z l_{0}$ : on the E. side of Piskashaw cr., 186 m. N. N. E. Springfield.

Chemung. t. and p. $\gamma_{*}$, Chemung con, $N_{0} \bar{Y}_{0}:$ on the $\mathrm{N}$. side of the Chemung r., $143 \mathrm{~m}$. W. S. W. Albany. The New York and Erie R. R. intersects the village $270 \mathrm{~m}$. from $\mathrm{Tew}$ York and 199 from Dunkirk. Pop. 2,672.

Cirfarong river, $N_{\text {. }} Y_{.}$: formed by the junction of Coschocton and Tioga rivers, in Steuben county, whence it flows in a S. E. direction through Chemung county and into the State of Pennsylvania, where it empties into the Susquehanna at the village of Athens. Its whole length is about $40 \mathrm{~m}$., and in high flood its rolume is sufficient to float down timber and produce to market. It is also used as the main feeder of the Chemung Canal.

Chenango county, $N$. $Y$. Situate W. centrally, and contains $792 \mathrm{sq}$. m. Drained by Chenango and Unadilla rivers and their tributary streams. Surface broken and hilly, but there are extensive and rich valleys, productive of all kinds of grain. Farms 4,406; manuf. 561; dwell. 7,572, and pop.-wh. 40,051, fr. col.280-total 40,311. Capitcal: Norwich. Prbtio Works: Chenango Canal, and Utica and Binghampton R. R. (projected).

Conenargo, t. and p. o., Lawrence co., Penn.: on the N. E. side of Beaver r., 193 m. W. by N. Harrisburg. Pop. 1,622 .

Chenango Forks, p. Y., Broome co, N. $Y$.: at the junetion of the Chenango and Tioughnioga rivers, and on the line of the Chenango Canal, $108 \mathrm{~m}$. W. S. W. Albany. It has considerable advantages for internal trade, etc. Pop. about 400. Pop. of Chenango t. 8,734.

Chenango river, $N . Y$. an important tributary of the Susquehanna r., which it joins at Binghampton, in Broome County. Its course is from Madison and Oneida counties, through Chenango and Broome counties for about $75 \mathrm{~m}$. and upon its banks are many flourishing villages. This river is navigable for boats and rafts $50 \mathrm{~m}$. above its mouth, and is used to a considerable extent to feed the Chanango Canal, which runs nearly parallel with it through its whole course.

Chenex's Grove, p. o., M'Lean co., $I l Z$.: on a head stream of the N. fork of Sangamon r., $72 \mathrm{~m}$. N. E. Springfield.

Cimenexvikre, p. $\nabla .$, Rapides par., $L a .:$ on the S. side of Bayou Teché, $81 \mathrm{~m}$. N. W. Baton Rouge.

Chexisgo, p. v., Cortland co., $N$. $Y$.: $114 \mathrm{~m}$. W. by S. Albany.

Chenuba, p. v., Lee co., Ga.: 117 m. S. T. Milledgeville Cheofee (Keowee), p. Y., Picken's dist., $S$. Car.: on a $\mathrm{r}$. so called, $127 \mathrm{~m}$. N. W. Columbia.

Cmepacher, p. vo, Providence co., $R$. $I$.: on the r. so called, $14 \mathrm{~m}$. W. by N. Providence.

Chequist, p. O., Davis co., Ia.: on Chequist er. of Des Moines r., $71 \mathrm{~m}$. S. W. Iowa City.

Cher.AW, p. v., Chesterfield dist., S. Car.: on the W. side of Great Pedee r., $89 \mathrm{~m} . \mathrm{N}$. E. Columbia. The r. is navigable to this point, and a great trade in cotton centres here. The "C. Gazette" (dem.) is issued weekly. Pop. 1,350.

Cheroree county, Ala. Situate N. E., near State line, and contains $756 \mathrm{sq}$. $\mathrm{m}$. Drained by Coosa $\mathrm{r}$. and its tributaries. Surface generally uneven and rough-in the W. hilly or mountainous. Gold is found at the base of the mountains. The soils are difficult of culture, and in sereral parts sterile. Corn and cotton are the staple growths. Farms 1,126; manuf. 15; dwell. 2,089, and pop.-Wh. 12,170, fr. col. 23, sl. 1,691-total 13,8\&4. Capital: Jefferson.

Cherokex county, $G a$. Situate N. W. centrally, and contains $523 \mathrm{sq}$. m. Drained by Etowah r. and its creeks. 
Surface elevated, hilly, and broken. Soils indifferent, exeept on the rivers, where they are very productive. Wheat and Indian corn are largely grown - cotton in small quantitics. Farms 1,000; manuf. 5; dwell. 1,970, and pop.-wh. 11,629, fr. col. 14, sl. 1,157-total 12,800. Capital: Canton.

Crerose county, $\mathrm{Ia}$. Situate W., and contains $576 \mathrm{sq}$. m. Taken from Pottowattomee in 1851.

Cherokee county, N. Car. Situate S. W. corner, and contains $1,200 \mathrm{sq} . \mathrm{m}$. Drained by the head waters of Hiwassee and Tennessee rivers. Surface elevated and hilly - on the N.W. and E. mountainous. Iron, gold, lead, and silver, also marbles of various hues and textures are found here. Soils excellent-on the hills producing fine grasses, and near the streams the several grains. Farms 459 ; manuf 5; dwell. 1,020, and pop.-wh. 6,493, fr. col. 8, sl. 337-total 6,835. Capital: Murphey.

CHERoke county, Tex. Situate E. eentrally between Neches and Angelina rivers, and contains about 740 sq. m. Drained by numerous tributaries of the border streams. Surface elevated, with a watershed running transversely N.W. and S. E. through the N. part of the county. Prairie predominates, but timber lines all the rivers. Farms 454 ; manuf, 8 ; dwell. 891, and pop.-wh. 5,359, fr. col. 1, sl. 1,283-total 6,673. Capital: Rusk.

Cherokes Nation, Ind.Ter. Situate between lat, $36^{\circ} 10^{\prime}$ and $37^{\circ} 02^{\prime} \mathrm{N}$, and extending from the Arkansas boundary to long. $100^{\circ}$ W. or about five degrees, and containing about $16,000 \mathrm{sq} . \mathrm{m}$. It is a fine agrieultural country, producing in abundance all the necessaries of subsistence, and is well watered by the Arkansas River and its numerous and wide-spreading arms. The Cherokees number about 28,000 souls, and are, perhaps, more advanced in civilization than any others of the immigrant tribes. They have large cultivated settlements, comfortable houses, numerous herds of cattle and sheep, and many fine horses, for which their extensive prairies afford an ample subsistance. They also manufacture salt from brine springs which exist extensively in their country, and to a considerable extent manufacture their own clothing and such agricultural implements, etc., as their necessities demand. They have of late years exported much of their surplus produets, bringing it down the rivers to New Orleans. The government of the Cherokees is based on a written constitution, and is republiean in form. They have an elective chief or governor, a general council, eleeted annually, and consisting of an upper and lower house, similar to the Senate and House of Representatives of the United States, and a judiciary, observing all the legal forms prescribed by the legislature. In fact, all the operations of the government are similar to those of other enlightened communities. They have adopted the English language to a great extent, and in their dress follow the fashions of Paris and New York. The United States supplies them with blacksmiths, wheelwrights, and wagonmakers, to teach them those useful mechanic trades; and they also receive a large annuity from the General frovernment on account of their lands east of the Mississippi River. Numerous missionaries are settled among them, and have been very successful in their endeavors to civilize and Christianize them; and their schools and churches are such as any enlightened nation might be proud of-more efficient, indeed, than several of the States of our Union can boast of; and their publie press is not inferior to that of Arkansas either in talent or respectability.

Cherokee HFights, p. o., Abbeville dist., S. Car. : $97 \mathrm{~m}$. W. Columbia.

CHerokeE IroN Works, p. o., Tork dist., S. Car, : $\$ 2$ m. N. Columbia.

Cherro, t. and p. o., Sullivan co., Penn. : 91 m. N. N. E. Harrisburg.

Cherry Crefe, t. and p. v., Chautauque co., $N$. $\Gamma_{\text {.: }}$ on Conewango cr., $268 \mathrm{~m}$. W. by S. Albany.

Cherrex Creek , p. o., Pontotoc co, Mfiss.: 146 m. N. N. E. Jackson.
Cherry Flat, p. o., Rutherford co., Tenn.: 39 m. S. E. Nashville.

Cinerrix Flate, p. o., Tioga co., Penn.: 107 m. N. by W. Harrisburg.

Cherrx Grove, p. o., Schuyler co., Mo.: on the S. side of Middle Fabius cr., $136 \mathrm{~m}$. N. Jefferson City.

Cherex Grove, p. o., Carroll co., Ill.: on the Galena and Dixon turnpike, $162 \mathrm{~m}$. N. by W. Springfield.

Cherry Hill, p. o., Brooke co., Virg. : ఇॅ็ m. N. W. Richmond.

Cherry Frul, p. v., Cecil co., Ma.: on the W. side of North-East ro, $4 \mathrm{~m}$. N. of Elkton, and $57 \mathrm{~N}$. E. Annapolis. It has a Methodist ehureh, a school-house, 2 or 3 stores, 22 dwellings, and about 100 inhabitants. The neighborhood is thickly settled, and within a eireuit of 2 miles there are 5 paper mills, 4 grist mills, a rolling mill, and 2 cotton facto ries, one of which employs 100 hands.

CHERRX Hirl, p. o., Washington co., Wisc.

Cherrey Hili, p. o., Chickasaw co., Misq.: 128 m. N. E. Jackson.

Cherry Hilt, p. o., Erie co., Penn.: 208 m. W. N. W. Harrisburg.

Cherry Lake, p. 0., Madison co., Flor. : $54 \mathrm{~m}$. E. by N. Tallahassee.

Cirerry Mills, p. o., Sullivan co., Penn.: 92 m. N. N. E. Harrisburg.

Cherry Ridge, p. 0., Wayne co., Penn.: 128 m. N. E. Harrisburg.

Cherry RIoge, p. o., Union par., $L a$. : 194 m. N. W. by

N. Baton Rouge.

CHERRY StONe (formerly HUNTLNGTON), p. v., Northampton co., Virg.

Cherry Tree, t. and p. o., Venango co., Penn. : $187 \mathrm{~m}$. W. N. W. Harrisburg.

Cherry Valley, to and p. $\nabla_{\text {. }}$ Otsego co., $N . Y_{0}:$ on Cherry Valley cr. of Susquehanna r., $38 \mathrm{~m}$. W. Albany. There is published in the $\mathrm{v}$. the " $\mathrm{C}$. $\mathrm{V}$. Gazette," a weekly newspaper. The Great Western Turnpike passes through the $t, 54 \mathrm{~m}$. from Albany. Pop. 4,206.

Cherry Vallex, p. O., Boone co, $I l l_{0}:$ on the W. side of Beaver cr. of Kishwaukee r., $168 \mathrm{~m}$. N. by E. Springfield. The Galena and Chicago Union R. R. intersects the ఛ. $85 \mathrm{~m}$. from Chicago.

Cherry Valiey, p. o., Wilson co., Tenn. : $41 \mathrm{~m}$. E. Nashville.

Cherry Vallex, t. and p. o., Ashtabula co., Otio: on Pymatuning cr. $197 \mathrm{~m}$. N. E. Columbus. Pop. 839.

Cegerryvilus, p. v., Northampton co., Penn. : $91 \mathrm{~m}$. E. N. E. Harrisburg.

Cherryvilte, p. V., Haywood co., Tenn.: on the S. branch of Forked Deer cr. of the Mississippi, $132 \mathrm{~m}$. W. by S. Nashville.

Cherrytille, p. v., Hunterdon co., N. Jer.: $39 \mathrm{~m} . \mathrm{N}$. by

W. Trenton.

CHES PPEAKE, p. v., Lawrence co., MOo.: 137 m. S. W. Jefferson City.

Cimesapeate Citry, p. v., Cecil co., Mrdo: at the confluence of Broad cr. and Back cr, of Elk r.,51 m. N. E. Annapolis. The Chesapeake and Delaware Canal has its W. terminus at this point

Cmrsapeake bay, Ma. and Firg.: is the largest arm of the sea within the limits of the Union. Its entrance is between Cape Charles and Cape Henry, in Virginia, $12 \mathrm{~m}$ apart, and it extends inland $270 \mathrm{~m}$., dividing Maryland into two unequal parts (and the lower part of the peninsula from the main body of Virginia). It is from 7 to $20 \mathrm{~m}$. broad, and generally as much as 9 fathoms deep. This great bay affords many commodious harbors, and a safe and easy navigation. Numerous fine rivers empty into it-the Susquehanna, at its north?rn termination, and the Potomac and James on its W. side; and besides these, it receives the waters of the Rappahannock, the Patuxent, the Patapsco, the Chester, the Elk, the Choptank, the Nanticoke, and 
numerous others. The area drained by these, its tributaries, has been estimated at $72,000 \mathrm{sq}, \mathrm{m}$. Baltimore is the chief commercial city within its circuit, but there are many others of minor importance which depend upon its waters for an outlet to the ocean. The fisheries of the Chesapeake are of immense value to the jnhabitants of its shores.

Chesmer's Store, p. o., Anderson co., Ky.: 18 m. S. W. Frankfort.

Cheshire county, $N$. Hamp. Situate S. W. comer, and contains $460 \mathrm{sq} . \mathrm{m}$. Drained centrally and W. by Ashnelot and other creeks of Connecticut r., which forms its W. border, and by Contoocook r. in the E. sections. Surface beautifully varied with bills and vales. Grand Monadnock, 3,718 feet high, lies in $\mathrm{S}$. W. Farms 2,805; manuf. 377 ; dwell. 5,302, and pop.-wh. 30,117, fr. col. 27-total 30,144. Capitul: Keene. Public Works: Cheshire R. R., Ashuclot $\mathrm{K}$. R., etc.

Cheseme, t. and p. F., New Haven co., Conn.: on Quinnipiak r., $22 \mathrm{~m}$. S. by W. Hartford. The $\mathrm{F}_{\text {. }}$ is the seat of an Episcopal academy, and is intersected by the New Haven and Northampton R. R., $15 \mathrm{~m}$. from New Haven. Pop.1,627.

Chesmre, t. and p. v. Berkshire co., Mass. : on Hoosic r., $110 \mathrm{~m}$. W. by N. Boston. Leather, boots, shoes, and glass are its chief manufactures, and it is noted for its fine cheese. The Pittsfield and North Adams R. R. passes through it. Pop. 1,297.

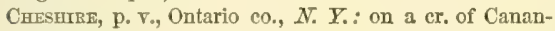
daigua Lake, $174 \mathrm{~m}$. W. Albany.

Cheshres, t. and p. v., Gallia co., Ohio: on the N. W. side of the Ohio r., $106 \mathrm{~m}$. S. S. E. Columbus. Pop. 1,410.

Chesnut Blofes, p. o., Dyer co., Tenn.: on the E. side of the S. branch of Forked Deer cr., $141 \mathrm{~m}$. W. by S. Nashville.

Chespux Crem, p. o., Autauga co., Ala.: an the cr. so called of Coosa r., $31 \mathrm{~m}$. N. by W. Montgomery.

Chesnut Flax, p. o., Walker co., Ga.: 186 m. N. W. Milledgeville.

Chusndt Grove, p. o., Shelby co., $K y_{\text {. }}: 23 \mathrm{~m}$. W. by N. Frankfort.

Chesnut Grovf, p. o., Lycoming co., Penn.: $78 \mathrm{~m}$. N. by W. Harrisburg.

Chesnut Grove, p. o., Chester dist., $S$. Car.: $56 \mathrm{~m} . \mathrm{N}$. Columbia.

Chesnut Groven, p. o, Davidson co., Tenn.: 18 m. W. Nashville.

Chasnot Grove, p. o., Pittsylvania co., Virg. : 123 m. W. S. W. Richmond.

Chesnot Hri, p. o., Perry co., Ala.: 62 m. W. N. W. Montgomery.

Chesput Hru, p. o, Calvert co., Md.: 22 m. S. by W. Annapolis.

Cheswot Hni, p. o., Hall co., Ga.: 84 m. N. N. W. Milledgeville.

Chesnut Hilly p. o., Walton co., Flor. : $126 \mathrm{~m}$. W. by N. Tallahassee.

Chesput Hrit, p. o., Washington co., Ind.: 83 m. S. Indianapolis.

Chesnut Hril, p. o., Strafford co., N. Hamp. : 33 m. E. Concord.

Cressur Hul, p. O, Philadelphia co., Penn.: $9 \mathrm{~m}$. W. Philadelphia, and $\$ 5 \mathrm{~m}$. E. Harrisburg. It is a highly healthy situation, and is resorted to by the Philadelphians in the summer season for recreation.

Chesmox Level, p. o., Lancaster co., Penn. : 47 m. \$. E. Harrisburg.

Ciregntit Ridge, p. o, Duchess co, N.Y.: $68 \mathrm{~m} . \mathrm{S}$, by E. Albany.

Chrbnut Ridge, p. o., Lincoln co., Tenn.: $\pi \mathrm{m}$. S. Nashville.

Caesrot Rmgi, p. o., Union co, Penn.: $43 \mathrm{~m}$. N. by W.

Harrisburg.

Cress Sprnggs, p. o., Cambria co., Penn.: 109 m. W.

Harrisburg.
Cuest, t. and p. o., Clearfield co., Penn.: on the W branch of the Susquehanna r., $108 \mathrm{~m}$. N. W. Harrisharg.

Chester county, Penn. Situato S. E., and contains 792 sq. m. Drained by Brandywine, Elk, Chester, and other creeks. Surface to the E. level or rolling - to the W. hilly and even mountainous. Soils generally fertile, producing large crops of grain. Farms 4,835; manuf. 1,086; dwell. 11,550, and pop.-wh. 61,209, fr. col. 5,229-total 66,438 Capital: West Chester. Public Works: Philadelphia and Columbia R. R.; West Chester Branch R. P. ; and a proposed R. R. from West Chester direct to Baitimore.

Cumster district, S. Oar. Situate N., botween Broad r. and the Wateree, and contains $480 \mathrm{sq}$. $\mathrm{m}$. Drained by the tributaries of those rivers. Surface pleasantly diversified by hill and dale, and the soils of middling quality. The staples are Indian corn and entton. Farms 844 ; manuf. 50 ; dwell. 1,541 , and pop.-wh, 8,005, fr. col. 146, sl. 9,887-total 13,038 . Capital: Chester.

Cenester, t. and p. v., Middlesex co., Conn.: on the E. side of Connecticut r., $27 \mathrm{~m}$. S. by E. Hartford. The $t$. is drained by Deep and other creeks, and has a small lake in its $\mathrm{N}$. part, which gives it considerable hydraulic power. The $\mathrm{v}$. is a neat and flowrishing place, with some manufactures. Pop. 992.

Cinester, t. and p. o., Dodge co, Wisc.: 72 m. N. E. Madison. Pop. 829 .

Cinester, p. v., Gwinnett co., Ga. : 73 m. N.W. Milledgerille.

Cirester, p. v., Wayne con, Ind.: 66 m. E. by N. Indianapolis.

Crester, p. v., and cap. Pandolph co., IUt.: on the Mis-

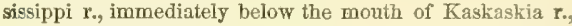
$132 \mathrm{~m}$. S. Springfield. It is a place of commercial importance, and the depot for the trade of an extensive back country. The $\mathrm{v}$. is Iocated on an elevated bottom at the foot of the bluffs, and has a good landing for steamboats. The "Chester Herald" is published weekly. Pop. about 1,300 .

Chester, t. and p.. ., Hampden co., Mass. : on branches of Deerfield r., $89 \mathrm{~m}$. W. Boston. It has some wool and cotton manufactures. The Western R. R. passes through the t. $119 \mathrm{~m}$. from Boston, and 81 from Albany. Pop. 1,521 .

Chester, t. and p. o., Eaton $\mathrm{Co}_{\text {, }}$ Mich. : on the Big fork of Thornapple r., 18 m. W. S. W. Lansing. Pop. 350,

CHester, t. and p. v., Rockingham co., N. Hamp.: on a branch of Exeter r., 22 m. S. S. E. Concord. Massabesic Pond, in the N.W. of the t., covers 1,500 acres. The $\mathrm{v}$. is a place of considerable business. Pop. 1,301.

Chester, t. and p. v., Morris co., $\lambda$. Jer.: on Black r., and several tributaries of the W. bank of the Paritan r. 38 m. N. Trenton. The $\mathrm{v}$, extends along the base of an isolated hill for more than a mile. Pop. 1,38t.

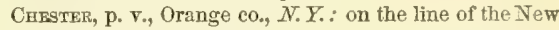
Fork and Erie R. R., 89 m. S. by W. Albany. The Newburg Branch R. R. diverges in this t. from the trunk line. Chester Village has long been known as a great lire-stock market. Pop. 1,642.

Chester, t. and p. ₹., Meigs co,, Ohio: $106 \mathrm{~m}$. S. E. Columbus. The $v_{0}$ is situate on Shade $r_{\text {. }}$ a tributary of the Ohio. Pop. of v. 190, and of $t 1,600$.

Chester, p. v., and eap. Delaware co., Penn.: on the W. side of Delaware $r, 84 \mathrm{~m}$. E. by S. Harrisburg. It is the oldest $\mathrm{v}$, in the State, having been founded long before Penn obtained his charter, and was, until 1701, called Upland. It contains the co. buildings, an Athenxum, and the dwellings are chiefly of brick or stone. Some of the original houses are still standing. The Philadelphia, Wilmington, and Baltimore R. R. passes through the $\mathrm{V}$., $15 \mathrm{~m}$. from Philadelphia. It has three newspapers, the "Delaware County Republican" (whig), the "Upland Vnion" (dem.), and the "C. Herald" (neutral), all published weekly. Pop. 2,097 . 
Chester, p. v., and cap. Chester dist., S. Car.: between

Broad and Wateree rivers, $59 \mathrm{~m}$. N. by W. Columbia.

Chester, p. v., Gibson co., Tenn.: 113 m. W. by S. Nashrille.

Chester, $t$, and p. 0. , Windsor co., Term.: on Williams r. of the Connecticut, 82 m. S. by E. Montpelier. The Rutland and Burlington R. R. intersects the v., $14 \mathrm{~m}$. from Bellow's Falls, and $106 \mathrm{~m}$. from Burlington. Pop. 2,008.

Chester river, Del. and MI.: a considerable stream of the eastern shore of Maryland, rising in Delaware, and flowing nearly S. W., dividing in its course the counties of Queen Anne and Kent, and falling into a large estuary of Chesapeake Bay, between Swan Point and Love Point. It is navigable to Charlestown, 30 miles.

Chester Cross Roads, p. o., Geauga co., Ohio: $165 \mathrm{~m}$. N. E. Columbus.

Chester Factories, p. o., Hampden co., Mass.: on the line of the Western R. R., $126 \mathrm{~m}$. from Boston.

CersterField district, S. Car. Situate N. E., between Great Pedee r. and Lyneh's cr., and contains 560 sq. m. Drained by creeks flowing to the limitary streams. Surface flat or rolling; and soils, except on the streams, sandy and of inferior fertility. The staples are Indian corn and cotton. Farms 518; manuf. 32 ; dwell. 1,263, and pop.-wh. 6,678, fr. col. 218, sl. 3,894 total 10,790. Capital: Chesterfield.

Cuesterfield county, Virg. Situate S. E., between the forks of James and Appomattox rivers, and contains 456 sq. $\mathrm{m}$. Swift cr. and other streams drain the interior. Surface somewhat broken, but soils of average fertility, producing wheat, Indian corn, oats, and tobaceo. There are valuable coal mines in the county. Farms 564; manuf. 30 ; dwell. 1,757, and pop,-wh. 8,405, fr. col. 468, sl. 8,616total 17,489. Capital: Chesterfield C. H. Public Works: Petersburg R. R.; Clover Hill R. R., etc.

Citesterfield, p. v, New London co., Conn.: on the E. side of a er. of Niantic r., $33 \mathrm{~m}$. S. by E. Hartford.

Chesterfreld, p. $\nabla_{\text {., Madison }} \mathrm{Co}_{\text {, }}$ Ind.: on the S. side of the W. fork of White r., $39 \mathrm{~m}$. N. E. Indianapolis.

Chrsterfield, p. vo, Macoupin co., $I l l_{0}:$ on the $\mathrm{N}$, side of Macoupin cr., and betreen it and Rock cr., $47 \mathrm{~m}$. S. S.W. Springfield.

Chesterfield, p. v., Grundy co., Tenn.: 73 m. s. E. Nashrille.

Chesterfield, to, Burlington co, $N$. Jer : on Crosswick's and Black creeks of Delaware r., which bounds it on the W. Pop, 4,514.

Chestekfiedd, p. vo, Madison par., La. : 149 m. N. Baton Rouge.

Cenesterfieid, t. and p. v., Hampshire co., Mrass. : on a branch of Westfield r., $91 \mathrm{~m}$. W. Boston. Pop. 1,014

Crestereneld, $t$ and p. v., Cheshire co., Y. Hetmp.: on the E. side of Connectient r., opposite Brattleboro', $49 \mathrm{~m}$. S. W. Concord. Spafford Lake, in the centre of the t., covers 526 acres, and emptics into the Connecticut. The $\mathrm{v}$. has a flourishing academy, founded in 1794. Pop. 1,680.

Chesterfieid, t. and p. v., Fulton co., Ohio: on the E. side of Tiffin $r_{t,}$ and on the N. State line, 104 m. N. N. W. Columbus. Pop. 53s.

Ciresterforcid C. H., p. v., and cap. Chesterfield co., Firg. : on the N. fork of Swift cr., $18 \mathrm{~m}$. S. W. Richmond.

Chesterfield C. H., p. V., and cap. Chesterfield dist., $S$. Car.: on the S. W. side of Thompson's cr. of the Great Pedee r., $97 \mathrm{~m}$. N. N. E. Columbia.

Cirsterfield Factory, p. o., Cheshire co., N. Hamp.: $51 \mathrm{~m} . \mathrm{S} . \mathrm{T}$. Concord.

Crester Hill, p. 0., Morgan co., Ohio: 82 m. E. S. E. Columlius

Chester Springs, p. V., Chester co., Penna : $65 \mathrm{~m}$. E. by

8. Harrisburg, A watering place frequently resorted to by summer visitors.

Cnestrerows, p. v.. port, and cap. Fent co.. JIR.: on a Ine and open plain on the $\mathrm{N}$. W. side of Chester $r, 80 \mathrm{~m}$. above its confluence with Chesapeake Baj, $31 \mathrm{~m}$. N. E. 122
Annapolis. The v. contains the C. H., the county prison, 1 Episcopal and 3 Methodist churches, a bank, and markethouse. It is the seat of Washington College, a branch of the University of Maryland, and it has also an academy, a ladies' boarding-school, and 2 primary schools. The "Kent News" is issued weekly. The government of the $\mathrm{v}$. is vested in 7 police commissioners, elected annually. Several steamboats and sloops ply regularly to and from Baltimore, and many of the inhabitants are employed in the bay fisheries. It was formerly a port of entry. Houses 200, and pop. 1,295 .

Chestertown, p. v., Warren co., N.Y.: between Hudson r. and Schroon r., $69 \mathrm{~m}$. N. Albany. Schroon Lake lies on the N. E. border of Chester $t$, and there are several small lakes within it, abounding in trout. Pop. of t. 1,850.

Chester Vinlage, p. V., Hampden con, Mass.: on the line of the Western R. R., $119 \mathrm{~m}$. from Boston, and 81 from Albany. It has some manufactures.

Chestervilite, t. and p. o., Franklin co., Me.: on Wilson's cr. of Sandy r. of the Kennebec, 17 m. N.W. Augusta. Pop. 1,142.

Chesterville, p. V., Chester co., Penn.: 63 m. E. by S. Harrisburg.

Chestervilue, p. v., Morrow co., Ohio: 46 m. N. E Columbus.

Chestervilue, p. v., Kent co., Mrd : in the N. part of the co., $53 \mathrm{~m}$. N. E. Annapolis.

Chesuncoor lake, $M e_{\text {. }}$ : a large sheet of water in Piscataquis $\mathrm{co}_{\text {, }}$ and through which the Penobscot $\mathrm{x}$. passes. It receives the Kahkoguamook and Umbazookskus rivers. This lake is about $25 \mathrm{~m}$. long and $3 \mathrm{~m}$. wide, and its central point is about $130 \mathrm{~m} . W . \mathrm{N} . \mathrm{W}$. Augusta. The country neighboring on the lake is very fertile and highly picturesque.

Cretnacmes lake, $L a$. : lies between Atehafalaya and Teche rivers, and receives its waters from the former at high water, discharging them at all seasons into it again, 15 $\mathrm{m}$. above its entrance to the Gulf. It is $40 \mathrm{~m}$. long, and from 1 to 6 wide, shallow, and surrounded by a low, marshy country, which is annually overflowed.

Cheriot, p. v., Hamilton co., Ohio: 123 m. S. W. Columbus.

Chew's Landing, p. v., Camden co., N. Jer.; on the N. side of Big Timber cr., 32 m. S. S. E. Trenton. The r. has considerable trade in wood and lumber.

Cheivsville, p. v., Washington co., Mrd.: $79 \mathrm{~m} . \mathrm{N}$. W. by W. Annapolis.

CrmCAGo, post eity, port of entry, and cap. Cook co.

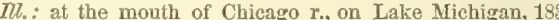
m. N. N. E. Springfield. Lat. $42 \circ 52^{\prime} 20^{\prime \prime}$ N., and long. $57035^{\prime} \mathrm{W}$. The main body of the r. sets back about $m$. into the city, then divides into two branches, both of which have a pretty uniform depth of 12 to 15 feet, all making a commodious and almost unlimited harbor for an immense amount of shipping which continually comes to, and goes from, this point. The eity borders on a wide, rich, and benutiful prairie, extending in different directions for many miles, and which is handsomely diversified by groves and strips of timber springing up at intervals along the banks on the lake shore, furnishing a diversified picture, which is greatly enhanced by gardens and villas, which, mixing with the scene, make it ore of enchanting loreliness. Though the site is very low and level, searcely five feet above the lake, there are no marshes or wet lands about the place, and the lake winds, by constantly agitating the waters, much like the tidal perturbations of sea-board rivers, have a good effect in promoting cleanliness and health to so large a city.

Chicago is one of the most substantial cities of the Great West. It extends along the lake shore for about a mile, and inland beyond the bifurcations of the river. The bar at the entrance bas been much reduced, and piers have been extended into the lake to prevent aceumulations of simul and drif. The depth is now sufficient, indeed, for the admission 
of the largest lake craft and steamers. Milwaukie is the only city of the Trest that has progressed at a more rapid rate within the past ten years. In 1830 Chicago was a mere trading post, and in 1840 it had only $4,4 \pi 0$ inhabitants. In 1850 its population amounted to 29,963 , being an increase of 25,493 within the decade, or at the rate of 570,31 per centum. The increase of Milwaukie, within the same period, was at the rate of $1,071.78$ per centum; of St. Louis, of 372.76 ; and of Cincinnati, of 149.11 per centum. Such facts are sufficient to show its present importance and its future prospects, which are attributable no less to the energy of the citizens of the place in prosecuting great public works, than to its position in relation to the route of travel, east and west. Fronting on the lake, it has direct shipping connection with all the ports of the States of the Union, north and west, and with Canada; and by means of the extensive lines of internal improvement, its commerce reaches from the Atlantic sea-board to the banks of the Mississippi. On all these great lines of travel and trade its commeree is brisk and ever increasing.

The internal improvements directly connecting Chicago with the great marts of commerce are, the Illinois and Michigan Canal, 100 miles long, which extends from the lake to the Illinois River at La Salle, and opens to the port the wide river country of the South and West, forming an outlet for the rich products of Kentucky, Missouri, Iowa, and Illinois, by the lakes; two lines of railroad round the bend of Lake Michigan, thence continuous tn the sea-board at Boston and New York, and also connecting with the Indiana and Ohio railroads; lines to the Mississippi Piver at Galena, Rock Island, and Quiney, Alton, and Cairo; a line along the shore to Milwaukie; and lines extending to Janesville, Madison, Fond du Lac, etc. Chiengo also reaches to the back country by means of numerous plank roads, which accommodate the producers of the neighborhood. Most of the lines of railroad have sufficiently progressed to insure their early completion; and to judge by the working of those portions now opened for traffie, the success of each enterprise will far exceed the anticipations of the most enthusiastic of their projectors. Chicago has felt their advantages; the internal trade of the State has quintupled itself within a few years, and eapital and population have sought a market so replete with facilities of trade and commerce as those centering at Chicago. In 1839, the total value of property in Chicago was assessed at $\$ 236,842$; in 1850 it was assessed at $\$ 8,562,717$, of which $\$ 6,804,262$ was real estate! At the latter period the commerce of the port was conducted through the agency of eight bankers and dealers in exchange, 109 wholesale, forwarding, commission, and produce houses, and 54 lumber dealers. During the year 1851, the arrivals at Chicago were as follows: steamers, 662; propellers, 183 ; schooners, 1,182 ; brigs, 230 ; barges, 13 . Total, 2,279 vessels, the aggregate burden of which was 958,600 tons. The following tables will exhibit the quantity of some of the leading exports and imports, by lake canal and railroad for the same year.

\begin{tabular}{|c|c|c|c|}
\hline \multirow[b]{3}{*}{ Barler .... bu, } & \multicolumn{3}{|c|}{ EXPORTS. } \\
\hline & Lake. & Canal. & Raiiroad. \\
\hline & 8,587 & 11,460 & - \\
\hline Beef......bbls. & 49,306 & 135 & - \\
\hline Beef.......tes. & 2,529 & - & - \\
\hline Butter.....lbs. & 10,424 & 75,117 & - \\
\hline Buff. robes "s & 7,215 & - & - \\
\hline Cattle.......No. & 448 & - & - \\
\hline Cheese....lbs. & 2,215 & $17 S, 737$ & - \\
\hline Coal......." " & - & $1,182,803$ & 909,749 \\
\hline Corn...... bu. & 221,317 & - & - \\
\hline Furs, etc. ppks. & 5,645 & - & - \\
\hline Flour.... bbls. & 71,723 & 683 & 一 \\
\hline Hams..... "6 & 1,934 & - & - \\
\hline IIams .. casks & 658 & - & - \\
\hline IIams... hhds. & 112 & - & - \\
\hline
\end{tabular}

Total.

19,997

49,441

2,829

85,441

7,215

418

181,052

$2,091,552$

$3,221.317$

5,645

72,406

1,984

$$
658
$$

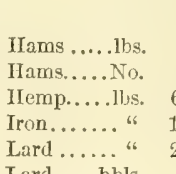

Tarl. oble

Lath.......pes.

Lead......lbs, 1,375,870

Lumber. . feet

Oats........bu. 767,059

Pot ashes.. "

Pork.....bbls.

Pork......tes.

Sh'lders .bbls

Slı'lders,hhds.

Sh'lders....No.

Sugar.....lbs

Sugar...hhds,

Sugar....bbls.

Timber .. C. ft

Wheat .... bu. 436, 508

Wool.......lbs. 1,086,944
Canto

\begin{tabular}{|c|c|c|c|}
\hline $\begin{array}{l}\text { Lithe. } \\
1,9554\end{array}$ & $\begin{array}{l}\text { Canal. } \\
700\end{array}$ & $\begin{array}{c}\text { Railroad. } \\
\text { - }\end{array}$ & Tital. \\
\hline 690 & - & - & $3,6 \%$ \\
\hline 635 & - & $\sim$ & 694,79 \\
\hline 40 & $1,035,579$ & $2,256,010$ & $8,451.1 !$ \\
\hline & - & - & $2: \%, 0$ \\
\hline & - & - & \\
\hline
\end{tabular}

$12,785,285 \quad 2,136,135 \quad 14,921,420$ $1,007-1,376,579$

$54,186,7 \pm 5 \quad 18,770,452 \quad 67,957,257$ 108 - $76 \pi, 197$

$\begin{array}{rlll}- & 114,366 & 8,000 & 122,366\end{array}$

$\begin{array}{llll}19.153 & 27 & - & 19,215\end{array}$

$459 \quad-\quad-\quad 489$

$\begin{array}{llll}1,020 & - & - & 1.026\end{array}$

$360 \quad-\quad-\quad 360$

$9,797 \quad-\quad 0 \quad 9,797$

311.312

7.512

437,660

$1,058,558$

\section{IMPORTS.}

Lake. Cannl. Railroad. \begin{tabular}{lrrrr} 
& Lake. & \multicolumn{1}{c}{ Cannl. } & Railroåd. & Total. \\
Bacon..... bs. & - & 434,716 & - & 434.716 \\
Barley ....bu. & 12,331 & 262 & 23,518 & 86.111
\end{tabular} Beef.....bbls. - $\quad 1,571 \quad-\quad 1,571$ Buff. robes.lbs. - $\quad 512.196 \quad$ - $\quad 519.196$ Corn......bu. - $2,352,362 \quad 295.003 \quad 2,647.463$ $\begin{array}{lllll}\text { Flour....bbls. } \quad \mathbf{6 , 6 3 0} & 5,819 & \mathbf{3 9 , 2 0 3} & \mathbf{5 1 , 6 5 2}\end{array}$ Hams.....lbs. - $1,086,933 \quad$ - $1,0 \leqslant 6,433$ Hemp.....lbs. - $1,035,643 \quad-\quad 1,035.619$ Hides....." - $487,306 \quad 361,070 \quad 848,5,6$ Lath ...pieces $27,583,475 \quad-\quad$ - $27,553, \frac{1}{2} \div 5$ Lard .....lbs. - $2,069,625 \quad$ - $2,069.625$ Lead....." - 1,402,135 - 1,402,135 Lumber .. feet 125,056,437 466,685 _ $\quad 125,523,122$ Oats......bu. - $\quad 181,293 \quad 152,555 \quad 334.148$ Pork.....bbls. $\quad-\quad 8,241 \quad-\quad 5,211$ Pork ....lbs. - - - 2,390,218 2,390,219 Shingles ..bu. $60,338,250 \quad-\quad \quad-\quad 60,385,250$ Sugar.....lbs. - $3,765,836 \quad-\quad 3,765,-46$ $\begin{array}{lllll}\text { Sugar...hhds. } & 2,563 \quad & - & - & 2,503\end{array}$ $\begin{array}{lllll}\text { Sugar.bls, bxs } & 2,854 & - & - & -\end{array}$ $\begin{array}{lllll}\text { Timber.C. feet } \quad 410,679 & \mathbf{1 5 2 , 2 9 7} \quad \mathbf{5} & \mathbf{5} 62,976\end{array}$ Tobacco...lbs. - $\quad 324,923 \quad-\quad 324,928$ $\begin{array}{llll}\text { Wheat ....bu. } \quad 26,084 & 67,972 & 274,021 & 388,077\end{array}$ Wood...cords $\quad 5,924 \quad 10,676 \quad 454 \quad 17,054$ Wool .....lbs. $\quad-\quad 520,026 \quad 211,930 \quad 731,956$

The above only represents a portion of the domestic commerce of Chicago, and even does not estimate that carried on by teams, which is commensurably large. The value of articles imported from Canada during the year, was $\$ 5, \$ 11$, and of exports from Chicago to Canada, \$116,185. The arrivals from Canada were $\tau$, and the clearances for the same destination, 13. The value of the whole domestic commerce for a series of vears, has been as follows:

Years. Imports. Exports.

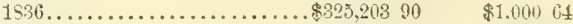

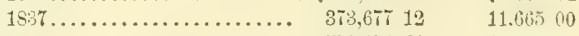

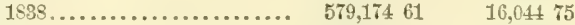

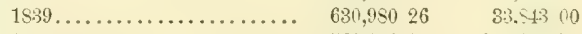

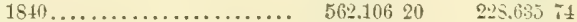

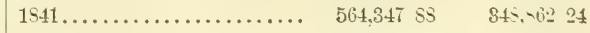

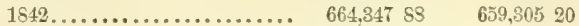

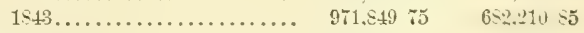
$1844 \ldots \ldots \ldots \ldots \ldots \ldots \ldots . . . \ldots 1,686,41600 \quad 785,50428$ $1545 \ldots \ldots \ldots \ldots \ldots \ldots \ldots .2 .144,45$ 73 $1.5+3.519$ S5

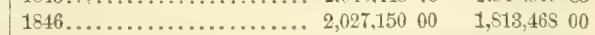

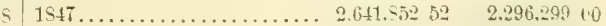

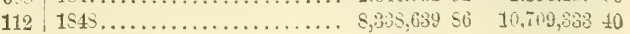


Chicago has five daily newspapers: the "C. Tribune" (indep"t.), the "C. Democrat" (dem.), the "C. Journal" (whig), the "Commercial Advertiser" (whig), and the "Argus," all of which also issue weekly editions; six weekly newspapers, the "New Covenant," and the "Western Citizen" (both Universalist), the "Gem of the Prairie" (lib.), the "Prairie Herald" (Presbyterian), the "Watchman of the Prairie" (Baptist), and the "Commercial Reporter;" one tri-weekly, the "Illinois State Gazette ;" one semi-monthly, the "North-western Medical Journal," and three monthly periodicals, the "Eclectic Review" (educat.), the "Prairie Farmer" (agric.), and the "North-western Journal of Homopathy."

Latrobe, an intelligent traveler, who visited Chicago in 1833, thus describes it: "This little mushroom town is situated on the verge of a level tract of country, for the greater part consisting of open prairie lands, at a point where a small river, whose sourees interlock-in the wet seasonwith those of the Illinois River, enters Lake Michigan. It, however, forms no harbor; and vessels must anchor in the open lake, which spreads to the horizon, on the north and east, in a sheet of uniform extent." The contrast between Chicago of 1833 and Chicago of the present day, is truly startling; and the writer of twenty years ago, had he been told that his "mushroom town" was so soon to become the focus of a commerce equal to that enjoyed by many of the States of Europe, would he have credited so unprecedented a fact, or would he not leve considered the prognostication the emanation of a crazy brain?

Chichesters, t. and p. v., Merrimac co., $N_{0}$. Hamp. : on Suncook r., $8 \mathrm{~m}$. E. Concord. Pop. 997.

Cuтckanomery, p. v., Hanover co., Virg.: on the r. of the same name, $s 1 \mathrm{~m}$. E. Richmond.

CHсканомеNY river, Virg.: a tributary of James $r$. from the N. W. It is about $60 \mathrm{~m} . \mathrm{long}_{\text {, }}$ and debouches $37 \mathrm{~m}$. above Point Comfort.

Cuckarraw Bend, p. o., Madison par., La.: $137 \mathrm{~m} . \mathrm{N}$. Baton Rouge.

Снichanadga, p. o., Hamilton co., Tenn.: on a cr. so called, $108 \mathrm{~m}$. S. E. Nashville.

CHoKas aw county, Ia. Situate N. E., and contains 576 sq. m. Taken from Pottowattomee in 1851 .

Crickasaw county, Miss. Situate N., and contains 972 sq. m. Drained by the Yallabusha, Ocktibbeha, ete. Surface undulating, and soils productive of Indian corn, cotton, and tobaceo. Farms 1,16ī; manuf. $29 ;$ dwell. 1, $01 \bar{i}$, and pop.-wh. 9,8s6, fr. col. 2, sl, 6,480-total 16,36s. Capital: Houston.

Cruckasaw, p. v., Mercer co., Ohio: 86 m. W. N. W. Columbus.

CHickasaminatome, p. v., Lee co., $G a .:$ on the cr. so called, a tributary of the Iehawaynochaway r. of Flint r., $123 \mathrm{~m}$. S. E. Milledgerille.

Cnickasaw Natrox, Ind. Ter. The Chickasaws are eettled in the Choctaw Territory. (See CHoctaws.)

Cmck's Springs, p. 0., Greenville dist., S. Car.: $92 \mathrm{~m}$. N. W. Columbia.

Cincopee (Cabotrllle), p. 4., Hampden co., MFass.: near the confluence of Chicopee $r$. with the Connectient, 4 $\mathrm{m}$. N. of Springfield and $80 \mathrm{~m}$. W. by S. Boston. It is one of the most enterprising manufucturing places in Jew England. A newspaper, the "C. Telegraph" (whig), is published weekly. Pop. \&,291.

Chicopee Falis, p. v., Hampden co. Mass.: at the falls of the Chicopee r., $2 \mathrm{~m}$. from its mouth, $80 \mathrm{~m}$. W. by $\mathrm{S}$. Boston. It has numerous factories. A branch of the Connecticut River R. R. extends from Cabotsrille to the Falls.

CrICOPEE river, MFass.: a tributary of the Connecticut $r$. into which it falls in the N. part of the town of Chicopee. In its course it receives the waters of Quaboag Pond and of Ware and Swift rivers.

Crincot county, Ark. Situate S. E. on Mississippi r., and contains S60 sq. m. Drained by Barou Macon, River de 124
Beuf, and Bayou Bartholomew. Surface low and levelsubject to inundation. Soils various - some very fertile, and some inferior. Cotton is the great staple. Farms 142; dwell. 226, and pop.-wh. 1,122, fr. col, 9, sl, 3,9s4-total 15,115. Capital: Columbia.

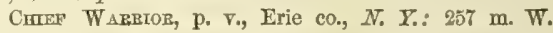
Albany.

Chikalate, p. v., Yell co., Ark. : on a branch of Petite Jean cr., 65 m. W. N. W. Little Rock.

Chmbstrle, p. vi, Yancey co., N. Car.: $216 \mathrm{~m} . \mathrm{W}$. Raleigh.

CHLHowere, p. v., Blount co., Tenn.: on the N. side of Little Tennessee r., $156 \mathrm{~m}$. E. by S. Nashville.

Crum, p. v., Miami co., Ind.: on the N. side of Eel r., 74 m. N. Indianapolis. The Goshen and Peru R. R. crosses the $\mathrm{x}$, at this point.

CHmI, p. F., Hancock co., Ilt. : 86 m. W. N. W. Springfield.

Cmer, t. and p. v., Monroe co., N. Y.: on the W. side of Black cr. of Genesee r., $206 \mathrm{~m}$. W. by N. Albany. The Buffalo and Rochester R. R. passes through the village 66 m. from Buffalo and $262 \mathrm{~m}$. from Albany. Pop. 2,247.

Cencr, p. v., Coshocton co., Ohio: 67 m. N. E. by E. Columbus.

Cimlitcothe, p. v., Wapello co., Ia.: on the $\mathbf{S}$. side of Des Moines r., 63 m. S. W. Iowa City.

ChrLlicotre, p. V., Peoria co., $I l l_{.}$: at the upper end of Prairie Lake, on its W. side, $80 \mathrm{~m}$. N. Springfield. It is a village of importance, and has considerable trade.

CпILlсотне, p. v., and cap. Livingston co., Mo.: on a fine prairie, $3 \mathrm{~m}$. N. of Grand $\mathrm{r} ., 118 \mathrm{~m}$. N. W. Jefferson City,

Chillicothe, p. city, and cap, Ross co., Ohio: on the W. side of the Scioto $r .37 \mathrm{~m}$. S. Columbus. In plan, this city somewhat resembles Philadelphia, being bounded $\mathrm{N}$ by Scioto r. and S. by Paint er., here about three-fourths of a mile apart. The principal streets follow the course of the Scioto, and these are crossed rectilineally by others extending from river to creek-the two main streets crossing each other in the middle of the city, and being each 99 feet wide. Water Street, which faces on the river, is $82 !$ feet wide, and the others 66 feet. The streets are lighted with gas. The city has numerous fine and substantial buildings, among which are the Court House, the markets, banking houses, hotels, and numerous churches and school-houses. The eity occupies the site of an aneient mound, but this has been leveled to make way for improvements. On the W. side of the eity is a hill rising abruptly to the height of 300 feet, from which there is an extensive and beautiful view of the eity and vicinity. Through the eity the Ohio Canal passes, and before long it will become connected in every direction by railroads now in course of construction. The city has two daily papers, the "Scioto Gazette" (whig), and the "Ancient Metropolis" (indep.), both of which also publish a weekly edition; and two weekly papers, the " $\mathrm{C}$. Advertiser" (dem.), and the "Ohio Correspondent" (indep.) As a place of manufactures and commerce, the city has a high rank among the inland towns, and is rapidly progressing in material prosperity. Chillicothe was formerly the State capital. Pop. in 1840, 3,977; in 1850, 7,093.

Cmillisedaedr, p. v., Northumberland co., Penn.

CHILIITECAUX, p. V., and cap. Dunklin co., Mo.: $192 \mathrm{~m}$. \$. E. Jefferson City.

CHrmark, t. and p. O., Dukes co., Mass. : in the S. W. part of Martha's Vineyard, $62 \mathrm{~m}$. 8 . by E. Boston. At the W. end of the town is Gay Flead, a noted headland on which is a light-house. There are some native Indians still residing on the neck leading to the Head. The $\mathrm{S}$. W. point of the town is known as Squebnocket. Pop. 747.

Chilo, p. v., Clermont co., Ohio: on the Ohio r., $100 \mathrm{~m}$. S. W. Columbus.

Chrutox"s Mrus, p. o., Walker co., Alos : 128 m. N. W. Jontgomery. 
Chutonvile, p v., Plymouth co., Mars.

Channer Pornt, p. o., Addison co., Verm.: on Lake Champlain, nearly opposite Crown Point, 52 m. W. by S. Montpelier.

Chnmex Rock, p. 0., Rutherford co., N. Car.: $192 \mathrm{~m}$. W. S. W. Raleigh.

Crura, t. and p. v., Kennebec co, Me.: on a beautiful lake which covers a great part of the town, and empties into a creek of Kennebec r., affording extensive $\mathrm{mmll}$ power. The village on the S. margin of the lake is a beautiful place. Several manufactures are carried on. Pop, 2,769.

Chena, to and p. v., St. Clair co., Mrich.: on the W. side of St. Clair r., $100 \mathrm{~m}$. E. Lansing. The village lies on Belle r., a tributary of the St. Clair. Pop. 1,037.

CharA, p. v., Lee co., IU.: 188 m. N. by E. Springfleld.

CHera, t. and p. ., Wyoming co., $N$. $Y$. : on Cattaraugu cr., $244 \mathrm{~m}$. W. Albany. Hydraulie power is abundant, and numerous mills are in operation. Pop. 1,961.

Chiva Grove, p. o, Pike co., Ala. : on the line of the Girard and Mobile R. R., 82 m. S. E. Montgomery.

Chiva Grove, p. 0., Pike co., Miss. : on the W. side of M'Gee's cr. of Bogue Chitto, 66 m. S. Jackson.

China Grove, p. o., Rowan co., N. Car.: 103 m. W. by S. Raleigh.

Chuna Grove, p. o., Williamsburg dist., S. Car.: on Cedar cr, of Black r., $92 \mathrm{~m}$. E. S. E. Columbia City.

Chura Grove, p. 0., Gonzales co., Tero. : 60 m. S. Austin

Crms HrLl, p. o., Gadsden co., Flor.: on Little r. of Ocklockony r., $20 \mathrm{~m}$. N. W. Taliahassee.

Camicaptr Grove, p. 0., Gwinnett co., Ga.: 64 m. N. W. Milledgeville.

Chincapisir, p. v., Duplin con, $N$. Car.: 69 m. S. E. Raleigh.

Chincoteague, p. o., Accomac co., Virg. : 122 m. E. N. E. Richmond.

CHonnibec, p. o, Talladega co., Ala : about 4 m. E. of Talladega, and $72 \mathrm{~m}$. N. by E. Montgomery.

Chipmax's Potri, p. o., Addison co., Verm.: on Lake Champlain, opposite Crown Point, $45 \mathrm{~m}$. W. S. W. Montpelier.

Chippewa county, Mich. Situate on the N. peninsula, occupying the E. extremity, and contains $2,376 \mathrm{sq} . \mathrm{m}$. Drained by several streams flowing to Lake Superior, Tah-qua-me-naw r. falling into the bay of the same name, and numerous rivers and creeks of St. Mary's r. and Lake Huron. Surface richly varied with much good farm land. Farms 17; manuf. 10 ; dwell. 187, and pop.-wh. 890 , fr. col. 8-total 898. Capital: Sault de St. Marie.

Chippewa couniy, Wisc. Situate N. W. on Mississippi r., and contains 2,740 sq. m. Drained by the Chippewa $r$. and other streams. In the $\mathrm{N}$. are many beautiful lakers. Surface much varied, but chiefly prairie. Timber abundant. Farms-; manuf. 3; dwell. 94, and pop.-wh. 614, fr. col. 0-total 614. Capital:

Crimpewa, t. and p. v., Beaver co., Penn.: $192 \mathrm{~m}$. W. Harrisburg.

CHIPPEWA, t. and p. v., Wayne co., Ohio: on the Chippewa r., $92 \mathrm{~m}$. N. E. Colurabus. The villoge lies on the N. bank of the river, about a mile from the W. border of the town. Pop, $2,637$.

Chiprew A, p. o., New Castle co., Del.

Chrppewa bay, $N$. $Y$.: on the E. side of St. Lawrence r. opposite St. Lawrence co. It contains a number of the "Thousand Islands."

CHIPPEWA river, Mich.: a branch of Pine r., which it joins near its mouth.

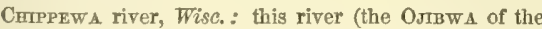
Indians) runs entirely across the State, having its rise on the borders of Michigan, near the sources of the Wisconsin, Montreal, etc., and running into the Mississippi $r$. near the foot of Lake Pepin. It is about 500 yards wide at its mouth. There are 14 rapids on the Chippewa-the priacipal one, called the "Falls," is about $75 \mathrm{~m}$. from its mouth, and has a descent of 24 feet in the distance of half a mile. A very large amount of pine lumber is annually sent down this river. Toward the sources of the stream and its branches there are many fine lakes, some of which have received names, and the principal are known as Lac Courtorielle, Lac Chetac, Lac du Flambeau, Tomahawk Lake, Red Cedar Lake, Rice Lake, etc. The Red Cedar Fork is the main branch of the Chippewa, entering it from the W., about $36 \mathrm{~m}$. above its mouth. About $60 \mathrm{~m}$. below Rice Lake, on this river, according to Schoolcraft, commences a series of rapids over horizontal layers of sandstone rock, which extend, with short intervals, down the river $24 \mathrm{~m}$. The remainder of the distance (about $50 \mathrm{~m}$.) to the junction is characterized by deep water, with a strong current; and at the junction is commanding and elevated, affording a fine view of a noble expanse of waters.

CurPPEW AYAN mountains. (See Rocky mountains.)

Cuittenango, p. $\nabla_{\text {, }}$ Madison $c o,, \mathcal{N}_{\text {. }} Y_{*}$ : on Chittenango cr, $112 \mathrm{~m}$. W. by N. Albany. The Syracuse and Utica R. R. passes near the village, and about a mile to the $\mathrm{N}$. the Erie Canal, with which a side cut connects it. It is a flourishing place, has some manufactures, considerable trade, and publishes the "Phenix" (dem.) weekly. Hydraulic cement is found in the neighborhood, and a mile $\mathrm{S}$. of the village is a valuable sulphur spring.

Chittenafgo Falis, p. o., Madison co., $N . Y_{.}$; on the river so called, $112 \mathrm{~m}$. W. by N. Albany.

Chitelisango river, $N$. $Y$. : rises in the town of Nelion, Madison co., and flows N. into Oneida Lake.

CHmTenden county, Verm. Situate N. W., on Lake Champlain, and contains 496 sq. m. Drained by Onion, Lamoille, and other rivers. Surface generally finely variegated, but mountainous in the $\mathbf{E}$; ; soils as various--here sandy, and there rich alluvion or clayey. Farms 1,908; manuf. 201; dwell. 4,805, and pop.-wh. 25,927, fr. col. 109 -total 29,036. Capital: Burlington. Public Works: Rutland and Burlington R. R.; Vermont Central R. R.; and Burlington Branch R. R.

Chimfenden, t. and p. v., Rutland co., Verm.: on the highlands of the Green Mountains, forming the watershed between Lake Champlain and the Connecticut r., $33 \mathrm{~m}$, S. by W. Montpelier. It is a rugged country and sparsely populated. Pop. 675.

CHocolate river, Mich a considerable stream of the Upper Peninsula, which has its rise in a small lake in the highlands N. E. of Menomonee $x_{0,}$ and running N. and N.E. discharges its waters on the S. border of Lake Superior.

Crocondt, t. and p. v., Susquebannah co., Penr.: on the N. line of the State, $126 \mathrm{~m}$. N. by E. Harrisburg.

Choctaw county, Ala. Situate S. W., and containg 861 sq. m. Drained by tributaries of Tombigbee $\mathrm{r}_{\text {. }}$ which forms the E. border. Surface level; soils fertile, producing corn and cotton. Farms 445; dwell. 760 , and pop.-wh, 4,620, fr. col. 0, sl. 3,769-total 8,389. Capital: Butler.

Choctaw county, Miss. Situate N. centrally, and contains $900 \mathrm{sq} . \mathrm{m}$. Drained by the head waters of Big Black r. and several creeks of the Yallabusha. Surface elevated and rolling, with abundance of timber; soils excellent. The products are chiefly Indian corn and cotton. Farms 1,132; manuf. 17 ; dwell. 1,405, and pop.-wh. 8,420 , fr. col 4, sl. 2,978-total 11,402. Capital: Greensboro.

Cuoctaw Agencx, p. o, Choctaw Nation, Ark.

Chootaw Agency, p. o., Oktibbeha co., Afiss. : on the E. side of Noxubee r., $100 \mathrm{~m}$. N. E. Jackson.

Chootaw Corner, p. o., Clarke co., Ala.: $84 \mathrm{~m}$. W. by $\mathrm{S}$. Montgomery.

Choctaw Nation, Ind.Ter.: is bounded N. by the Canada and Arkansas rivers, E. by the State of ATkansas, S. by Red River, and W. by the 100th meridian. The country in the $\mathrm{E}$, is mountainons, with large and fertile valleys-in the W. it is undulating and varied. The whole is ruell drained by numerous tributaries of the Arkansas and Red rivers, 
both of which are navigable for steamboats. The Choctaws are extensively engaged in agriculture, and have good houses and well-fenced fields, on which they raise corn and cotton in abundance, and they have good stocks of cattle, horses, and sheep. On the streams they have numerous saw and grist mills, and in several parts cotton gins; spinning and weaving are carried on in their principal settlements; and all their own blacksmithing, wagon-building, etc., are done by themselves under direction of mechanics furnished them by the United States' Government. The Choctaws are governed by a written constitution and laws; the nation is divided into four districts, each of which elects its own chief quartennially. The General Council, consisting of 40 membere, and chosen by the voters of each district, meets annually at the Couneil House, on the first Monday of October. This body frames all laws, but the chiefs have a veto, which the couneil can only overrule by a two-thirds vote. Their legislative business is transacted according to the usual forms of civilized societies, and the councilors are paid, during their sittings, $\$ 2$ from the national treasury. For judicial purposes, the nation is divided into districts, and trial by jury, and appeal to the higher courts are allowed. The military department is intrusted to a general elected by the people at large, and there are 32 captains in each district. The Council House, which is a large and commodious building, is located on the W. side of Kiameshi r., nearly equi-distant between the $\mathrm{N}$. and $\mathrm{S}$. lines of the national territory. The CHIOKAsAWs, who were their kinsmen on the E. side of the Mississippi, dwell with the Choctaws on the W. side, forming the fourth district of the nation. They are governed by the same laws, and have a proportional representation in the General Council. The two nations, however, receive their annuities from the United States separately, and are distinct in some other respects. Numerous missionaries are settled among both the Choctarrs and Chickasaws, and have succeeded well in their efforts to civilize them; so that these nations may now be considered as among the most intelligent of the Indian tribes.

Chorpees, p. v., Wells co., Ind. : $s t$ m. N. E. by N. Indianapolis,

Crioptaxk river, MId.: a large stream of the Eastern Shore, which rises in two main branches-one from Delaware, and flowing in a course generally S., empties through a large estuary into Chesapeake Bay, between Tighlman: Island on the $\mathrm{N}$. and Sharp's Island on the $\mathrm{S}$. It is narigable for sloops for nearly $40 \mathrm{~m}$. from its confluence with the bay.

Crrow ax county, N. Car. Situate on Albemarle Sound, between Chowan and Perquinons rivers, and contains 218 sq. m. Surface low and level, with swamps; soils sandy, but moderately fertile, producing corn and cotton. Farms 844; manuf. 28 ; dwell. 613, and pop.-wh. 2,914, fr. col.

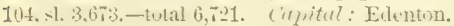

CrIoway river, N. Car, : is formed by the union of the Nottaway, Meherrin, and Blackwater rivers, which rise and have their courses principally in Virginia. It flows into Albemarle Sound, a little N. of the mouth of the Roanoke. It is navigable on the Meherrin branch for large ressels to Mrurfreesboro, near the Virginia State line.

Crmistray county, $I l l$. Situate centrally, and contains 560 sq. m. Drained by the South Fork and other tributaries of Sangamon r., which bounds it N. Surface chiefly uniulating pritie, with fronuent timber groves: anil sill everywhere fertile. Farms 434 ; manuf. 12 ; dwell. 555 , and pop. -wh. 3,202, fr. col. 0-total 3,202. Capital: Taylorsville. Public Works: Illinois Central R. R.

Curistiax county, $K y$. Situate W. on $\mathbf{S}$. border, and contains 540 sq. m. Drained by Little r. and W. fork of Red r., tributaries of the Cumberland. Surface generally level, and the soils varions-in the N. indifferent, but wel timbered, and in the $\mathrm{S}$. fertile, producing wheat, corn, and tobaceo. Iron and bituminous coal abundant. Farms 126
1,190; manuf. $7 \pi$; dwell. 1,965, and pop。-wh. 11,309 , fr col. 131, sl. 8,140-total 19,580. Capital : Hopkinsville. Public Works: A railroad from Nashville, Tenn., to Henderson, on the Ohio (projected.)

Christiana, p. v., New Castle co., Del. : on Christiana cr, $38 \mathrm{~m}$. N. Dover. The Philadelphia, Wilmington, and Baltimore $R_{0} R$. passes through the village. Its manufactures are comparatively large, and consist chiefly of flour, gunpawder, ete. The hund. of the same name cuntains 22,560 acres, and 3,902 inhabitants.

Cirristuaya, t. and p. o., Dane co., Wisc.: on the E. side of Rock cr., 20 m. E. S. E. Madison. Pop. 1,054.

Cimistiana river, Hich. $_{\text {. and }} I n d$. : a tributary of the St. Joseph $\mathrm{r}$. ; it rises in the E. part of Cass co., and flowing S. W. and S. passes into Indiana, where it joins the St. Joseph's at Elkhart village. It is a never-failing mill stream, and furnishes abundance of hydraulic power.

Christiansburge, p. v., Shelby co., $K y$.

Christiansburge, p. V., and eap. Montgomery co., Firg. $167 \mathrm{~m}$. W. S. W. Richmond. The Virginia and Tennessee R. R. will pass through this village.

Christiansburgir, p. v., Brown co., Ind.: on a branch of Salt cr., $46 \mathrm{~m}$. S. Indianapolis.

Christiarsitrere, p. v., Champaign co., Ohio: in the S. W. corner of the county, $57 \mathrm{~m}$. W. by N. Columbus.

Christiarsville, p. v., Mecklenburg co., Tirg.: $74 \mathrm{~m}$. S. W. Ríchmond.

Christarastille, p. v., Carroll co, Tenn.: $97 \mathrm{~m}$. W. by S. Nashville.

Cirristy's Fork, p. o., Morgan co., $K y$.

Cimistr's Prateie, p. o, Clay co, Ind.: 10 m. W. Bowling Green, and 59 W. S. W. Indianapolis.

Chuскатеск, p. ₹., Nansemond co., Virg. : on Chuckatuck cr., $8 \mathrm{~m}$, above its confluence in James r., and $62 \mathrm{~S} . \mathrm{E}$, Richmond. The village has several factories, and the river being navigable to this place, affords it considerable facilities.

Crnock Bexd, p. o., Jefferson co., Tenn. : on the N. side of Nolichucky r., $204 \mathrm{~m}$. E. Nashville.

Cridctanunda creek, $N, Y$.: rises in Fulton and Saratoga counties, and flows $\mathrm{S}$. into Montgomery co., where it empties into the Mohawk $r$. at the village of Amsterdam.

Cuvlafisise, p. c., Randolph co., Ala.: $76 \mathrm{~m}$. N. by E. Montgomery.

Criulasky, p. 0., Northumberland co., Penn.

Chultamoma, p. v., Marshall co., Miss.: $163 \mathrm{~m}$. N. by E. Jackson.

CutsentgeeE, p. 0., Macon co., Ala.: 42 m. E. by $\mathrm{S}$. Montgomery.

Chustervilue, p. vo, Lauderdale co., Afiss.: $88 \mathrm{~m} . \mathrm{E}$. Jackison.

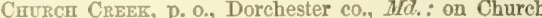
cr., $5 \mathrm{~m}$. from its confluence with Little Choptank r., and $41 \mathrm{~m}$. S. S. E. Annapolis.

Cnumer Grote, p. o, Knox co., Tenn.: $162 \mathrm{~m}$. E. Nashville.

Cirtroit Mili, p. o., Lowndes co., Ala.: $30 \mathrm{~m}$. W. S. W. Montgomery.

Cuubcr Hal, p. o., Luzerne co., Penn.: 88 m. N. N. E. Harrisburg.

CHurch Hri, p. o, Queen Anne con, Mrd: : at the head of South-East cr., $8 \mathrm{~m}$. from its confluence with Chester $\mathbf{r}$. $81 \mathrm{~m}$. E. by N. Annapolis, It has 3 churches, an academy, about 60 dwellings, and 250 inhabitants. The Episeopal church, built 1726 , is an old English structure of brick, large and massive, and capable of containing 1,000 persons, and has $a$ chancel and restry-room adjoining.

Crerere Huty, p. o., Christian c0., Ky. : 168 m. ธ. W. Frankfort.

Church Hrum p. O., Jefferson co., Afiss. : on the E. side of the Mississippi, about $3 \mathrm{~m}$. distant from the river, and 72 m. S. W. Jacksou.

Cercicr Hri, p. O., Trumbull co., Ohio: 148 m. N. E. Columbus. 
Chorch Hill, p. o., Halifax co., Virg. : near the confluence of Birch er. with Dan r., $110 \mathrm{~m}$. S. W. Richmond.

Churon's Store, p. O. Wilkes co., N. Carn: $146 \mathrm{~m}$. W. by N. Raleigh.

Churcetown, p. v., Lancaster co., Penn. : 48 m. E. by S. Harrisburg.

Churchtown, p. o., Columbia co., $N . Y_{\text {. : }} 48$ m. S. by E. Albany.

Crivronville, p. v., Monroe co., $N . \bar{Y} .:$ on the line of the Buffalo and Rochester R. R., $62 \mathrm{~m}$. from Buffalo, and 266 m. from Albany. It is a neat village of some 500 inhabit ants.

CHORCHVIr.E, p. V., Augusta co., Virg.: 94 m. W. by N.

\section{Richmond.}

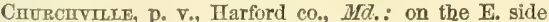
of Bynham's r., $46 \mathrm{~m}$. N. Annzpolis.

Crurdubsco, p. v., Franklin co., Ala.: 184 m. N. W. Montgomery.

Churubusco, p. $\mathrm{v}_{4}$, Anderson dist., S. Car.: $109 \mathrm{~m}$. W. N. W. Columbia.

Churubusco, p. v., Whitley co., Ind.: 109 m. N. N. E. Indianapolis.

Cicero, p. v., Hamilton co., Ind. : on Cicero cr. of White r., $26 \mathrm{~m}$. N. by E. Indianapolis. The Peru and Indianapolis $R . R$. passes a little eastward of the village.

CICERo, to and p. $\nabla .$, Onondaga $c_{0,}, N . Y_{.}:$on the S. W. side of Oneida Lake, $128 \mathrm{~m}$. W. by N. Albany. Chittenango $r$. flows along its $\mathbf{E}$. border. The village has about 500 inhabitants. Pop. 2,950.

Conclinati, post eity, port of entry, and cap. Hamilton co., Ohio: on the N. side of the Ohio r, directly opposite the mouth of Licking $r_{v}$, and distant by river course from Pittsburg $465 \mathrm{~m}$., from Louisville $132 \mathrm{~m}$., from the morth of Ohio r. $494 \mathrm{~m}$., and from New Orleans 1,447 m., and in direct line $113 \mathrm{~m}$. S.W. Columbus。 Lat. $39005^{\prime} 54^{\prime \prime} \mathrm{N}$., and long. $84^{\circ} 27^{\prime} \mathrm{W}$. from Greenwich, or $7 \circ 25^{\prime} \mathrm{W}$. from Washington. It is the largest inland city of the United States, and in point of population is only exceeded by Boston, New York, Philadelphia, Baltimore, and New Orleans. In 1800 it had about 750 inhabitants; in $1810,2,540$; in 1820 , 9,642 ; in $1830,24,831$; in $1840,46,338$; and in $1850,115,436$.

The city is located in a beautiful valley of about $12 \mathrm{~m}$, in circumference, surrounded by hills. This valley is divided almost centrally by the Ohio $\mathrm{r}$. It was first settled on the 24 th Dee., 1788 , by a party of men sent out under Mathias Denman and Robert Paterson, to improve a portion of the purchase made by the Hon. John Cleves Symmes. This purchase embraced a tract of 311,682 acres, lying between the Great and Little Miami rivers, and extending along the Ohio $x$. a distance of $37 \mathrm{~m}$. One square mile in each township was reserved for school purposes, and section 29 in each for the support of religious societies.

This party landed opposite the mouth of Licking r., and laid out a village called Losantiville, a name shortly afterward abandoned for that of Cincinnati. In Feb., 1789, another party, under Symmes himself, landed at North Bend, and there laid out what was intended to be a large city, to which they gave the name of Symmes. Soldiers were now sent out to protect the settlers at the Bend; but Fort Washington having been established, they were removed to Cincinnati subsequently, and the rivalry of the two places succumbed in favor of Cincinnati as the chief seat of business. The fort stood on what is now Arch-street, between Third and Fourth-streets, and east of Broadway. In 1790 General Harrison marched hence against the Indians, and in the next year General St. Clair started for the same place on his ill-fated expedition. The fort was successively commanded by Ziegler, Williamson, and Harrison, the latter of whom became subsequently President of the United States. In 1792 the first church was erected on what is now corner of Maine and Fourth-streets, and occupled by the First Presbyterian Church. In the rear of it are many graves of the pioneers. In 1793 , the first paper, called the "Sentinel of the North-west Territory," north of the Ohio r., was established at Cincinnati by William Maxwell. On the 11th Jan., 1794, a line of two keel boats, with bullet-proof covers and port-holes, and provided with eannon and small arms, was established between Cincinnati and Pittsburg, each making a trip once in four weeks. During this period, the town progressed but slowly, while idleness, drinking, and gambling prevailed in the army, and was to a great extent participated in by the citizens. The population at various periods is shown above. From 1800 to 1810 it progressed pretty rapidly, and considerable trade was carried on with New Orleans in keel boats, which returned laden with foreign goods. The passage to New Orleans then occupied about 25 days, and the return 65 . days. In 1819 the eity was incorporated, since which period its progress in population and material wealth has been uninterrupted and rapid in an astonishing degree, considering the difficulties it had to contend with before the establishment of steam navigation on the rivers and railroads throughout the country. It would be invidious to compare the early career of Cincinnati with that of Chicago, Milwaukie, and some others; they were founded under quite different auspices; the one in the midst of a country, bare of population, without a road, and scant of river facilities, and the others with every facility of travel perfected, and a tide of immigration unceasingly pouring upon them.

Cincinnati occupies the whole of the first bank of the river, ealled the Bottom, and the second, called the Hill, which is $\mathbf{1 0 8}$ feet above low water mark, and 60 feet above the first bank. The streets are so graded as to render the communication between the two parts easy, and many of them are adorned with fine edifices, and beautiful shade trees. It extends back to a third range of hills, a distance on Main-street of about two miles, and in the western part perhaps more, and along the Ohio about three miles. Excepting on the margin of the river, the city is regularly laid out in streets and alleys, crossing each other at right angles. The streets running E. and W., proceeding from the river, are denominated First, Second, etc., while those running N. and S. are named after the indigenous forest trees, as Walnut, Sycamore, etc. Main-street extends from the steamboat landing, on the river, directly north to the northern bounds of the eity. The streets are generally paved, and the foot-paths flagged. The city contains about 16,000 houses, 80 churches, many of them very fine edifices; 8 colleges, 4 medical schools, a law school, a female college, several female seminaries, 6 classical schools, a large number of finely-built public schools, 4 banks, with resources amounting to $\$ 3,968,371$; and 17 insurance companies, etc.; several public halls, the county and city courts, a mercantile exchange, and numerous libraries, and literary, philosophical and charitable institutions, an observatory, 4 theatres, a museum, gas-works, water-works, etc. In fact, it has all the appliances necessary for the physical, intellectual, and moral enjoyment of a large population; and in its manufactures, commerce, and general wealth, is pre-eminent among the cities of the world.

The manufactures of Cincinnati embrace almost every department of industrial employment. It would be impossible to enumerate them in the compass allowed to this article; but there are some industries that so distinguish the eity, that their enumeration is necessary. It has 6 distilleries; 140 bakeries; 12 bell and brass foundries: $\$ 2$ blacksmith shops; 10 boiler yards; 15 book-binderies; 37 booi and shoe factories; 31 breweries; 60 brick rards: 208 mason shops; 121 butchers' shops ; 2St earpenter and builuer shops; 24 carriage factories; 63 coopers' shops: 42 copper-plate printing establislments; 13 beef and tongue curing establishments : 4 cutleries; 32 daguerreotype establishments; 16 domestio liquor manufactories: 15 dye houses; 19 edge tool factories; 14 engraving establishments; 14 feed and flour mills; 44 founderies and engine shops; 136 furniture factories; 10 gilluing establishments; 2 glass 
works: 6 gunsmith shops; 40 hat factories; 14 ice-packing establishments; 5 iron rolling-mills ; 3 iron safe factories ; 5 iron railing factories; 10 lever lock factories ; 4 lithographic establishments; 7 looking-glass factories; 12 machinist shops; 5 marlle works; 6 mathematical and optical instrument factories; 10 upholsteries; 60 millineries ; 7 morocco leather factories; 6 musical instrument factories; 1 castor oil factory; 34 oil, lard, and stearine factories; 3 linseed oil mills; 72 paint and glazing shops ; 9 paper mills ; 14 patent medicine factories; 7 plane factories; 1 planing machine factory; 6 platform scale factories; 6 plow factories; 16 plumbing shops; 14 potteries; 33 pork, beef, and hamcuring factories (employing $2,450 \mathrm{hands}$, and producing anoually $\$ 5,760,000) ; 12$ publishing houses; 40 saddleries; 25 sash, blind, etc., factories; 22 sausage factories; 15 saw mills; 2 saw factories; 5 sheeting, etc., factories; 15 shirt and stock factories; 38 soap and candle factories; 7 steamboat building yards ; 3 stereotype founderies ; 22 stonecutting yards; 36 stone mason yards; 98 tailor establishments; 30 tanneries; 62 tobacco, cigar, and snuff factories; 30 turners' shops ; 2 type founderies; 26 vinegar factories; 42 wagon factories; 40 wine manufactories; 5 wire-working establishments; 38 whisky distilleries, etc. There are 180 several industries pursued, and the total number of all manufacturing and industrial establishments in the city was about 3,400 . The total number of hands employed, about 32,850 , and the annual value of products, $\$ 48,500,000$.

There are few cities of the Union so well furnished with facilities of locomotion. It has one of the finest rivers in the world fronting it, and railroads and canals stretching in every direction for thousands of miles. These form its great avenues of commerce. The Miami Canal, and the Ohio division of the Wabash and Erie Canal, connect the Ohio $x$. and Lake Erie, a distance of $251 \mathrm{~m}$. The principal completed railroads are, the Little Miami R. R. and its connections to Cleveland, $255 \mathrm{~m}$.; the Cincinnati, Hamilton, and Dayton, and its connections to Sandusky, $218 \mathrm{~m}$. ; the Cincinnati and Hillsboro' R. R. to Parkersburg, $179 \mathrm{~m}$. (now open to Hillsboro' $60 \mathrm{~m}$.); and a number of others completed, in progress, and projected, passing to every part of the State, and into all the neighboring States, and connecting Cincinnati with all the principal cities of the lakes, the sea-board, and the West and South. Cincinnati, in fact, is the chief centre of the railroad system of the West. It has direct railroad connection with every lakeport from Chicago to Niagara; with Albany, Boston, New York, Philadelphia, and Baltimore, and will soon have communieation with Charleston, Savannah, Mobile, New Orleans, and St. Lovis. Railroads are being constructed in all these directions, and when completed will build up Cincinnati, and make it a competitor for the wealth of commerce second to no other city of the world. It has already had the foretaste of its future, and is now stretching out its arms to gather in the vast, illimitable wealth with which nature has surrounded it. It has also telegraphs, giving it instantaneous communication with every larce city from Maine to Florida, and from the Atlantic to beyond the Mississippi.

The river trade is commensurate with the vast internal trade centering at this point, and with the manufacturing industry of the city. It is carried on chiefly in stemboats plying hence to Pittsburg and New Orleans, and the places intermediate. Its steamers also penetrate all the great rivers of the West-the tributaries of the great father of waters. The arrival of steamboats, in the year ending 31st Aug., 1850, numbered 3,698 ; of these $28 S$ were from New Orleans, 655 from Pittsburg, 214 from St. Louis, and 2,538 from other ports; and the departures amounted to $3,29 \mathrm{~S}$, of which 249 were for New Orleans, 547 for Pittsburg, 222 for St. Louis, and 2,274 for other ports. For the detailed statistics of the commerce of the port, for the year above named, the reader is referred to Hunt's Aferchants' Mragarine, for Oct. 1851. The shipping owned within the 125 district of Cincinnati, in 1850 , was 17,181 tons, of which 16,906 were navigated by steam-power.

The city is governed by a mayor, recorder, and 3 councilors for each of the wards into which it is divided. It has a separate judiciary, and also a commercial court, specially instituted to try causes arising between merchants. The amount of taxes collected for city purposes, for the year ending 20th March, 1851, was $\$ 438,345$, viz, : for general purposes, $\$ 130,172$; for interest on debt, $\$ 66,888$; for House of Refuge, $\$ 60,079$; for Poor-house, $\$ 51,268$; for support of watch, $\$ 40,053$; for support of common schools, $\$ 37,220$; and colored schools, $\$ 2,664$. The debt of the city at the same period, was $\$ 1,840,000$, and the value of its property amounted to $\$ 2,230,543$.

The newspaper and periodical press of Cincinnati consists of 8 daily papers, all of which issue weekly editions, and one a tri-weekly edition; of 22 weekly papers; of 1 semi-monthly, and 14 monthly periodicals. The daily papers are the "C. Gazette" (whig), the "C. Commercial" (indep"t.), the "C. Enquirer" (dem.), the "Chronicle and Atlas" (whig), the "C. Times" (indep"t.), the "Dispatch and Democrat" (dem.), the "Democratic Journal" (dem.), and the "Nonpareil." These circulate a weekly average of 2,000 to 22,000 copies each. The weekly papers are, "Cist's Weekly Advertiser" (commercial), the "Pictorial Advertiser," the "Columbian" (lit.), the "Price Current" (commercial), the "Western Police Gazette" "Life in Cincinnati," the "Screw-Driver," the "Warning Bell" (fireman's), the "Proclamation Reformer," the "Phonetic Advocate," the "Star of the West," the "Presbyterian of the West," the "Journal and Messenger" (relig.), the "Youth's Friend," the "Catholic Telegraph," the "Christian Age," the "Western Christian Advocate," the "Christian Apologist," the "Western Fountain" (temperance), the "Central Christian Herald," the "Wâhreet's Freund" (Grerm.), the "Der Deutshe Republikaner" (Germ.), the "Democratiches Wochenblatt" (Germ.), and the "Volksblatt" (Germ.) The "Sunday School Advocate" is published semi-monthly. The monthly periodicals are, the "Ladies' Repository," the "Templar's Magazine," the "Counterfeit Detector," the "Masonic Review," the "Western Lancet" (med.), the "Deutal Register," the "Law Yournal," the "Crisis" (liberty ?), the "Congress Hall," the "School Friend" (education), the "Eclectic Medical Journal," the "Golden Rule," the "United Presbyterian," and "Goodman's Counterfeit Detector." Thus it would appear that politics, religion, science, literature, etc., have their special advocates, and that all the great interests of the people has a special organ to herald their peculiarities to the world. Many of the above are conducted with great energy and talent, and have a circulation beyond their own locality.

At a short distance from the city, on the hills, in its back ground, are two beautiful villages, Mount Auburn and Walnut IIills, which are mostly occupied as country seats by persons doing business in Cincinnati. Walnut Hills is the seat of Lane Seminary, a theological institution under the New School Presbyterians. Four miles N. W. of the eity, are two fine cemeteries- "Spring Grove Cemetery," containing about 100 acres; and the "Wesleyan Cemetery," containing about 40 acres. Both are beautifully located, and have been greatly improved. For miles about Cincinnati the cultivation of the grape, for which the soil and climate are well adapted, is carried on extensively, and the vineyards form, perhaps, the most delightful portions of the scenery. The wine here produced is said to be equal to the wines of France, in flavor and body, and are now manufactured for commerce.

Crvcriati, p. T., Ralls co., Mo.: on the N. bank of Salt r., $78 \mathrm{~m}$. N. N. E. Jefferson City.

Crschisatr, p. v., Walker co., Tex.: on the S. W. side of Trinity r., $172 \mathrm{~m}$. E. by N. Austin City.

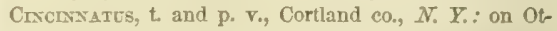
selic r., $108 \mathrm{~m}$. W. Albany. The village is a thriving 
settlement, and has several mills, tanneries, etc. Pop. 1,206 .

Crinaminsor, p. v., Burlington co., $N$. Jer.

CrRcletrle, p. v., and cap. Loudon co., Virg. : $112 \mathrm{~m}$. N. Richmond.

Circleville, t., p. v., and cap. Pickaway co., Ohio: on the E. branch of the Scioto r., 26 m. S. by E. Columbus. The village occupies the site of ancient fortifications, and has a fine fertile neighborhood. Its streets are laid out at right angles, and it has several circular and triangular areas devoted to public uses. The principal buildings are a handsome court-house, of brick, and in form octagonal, the market-house, the public offices, several handsome church edifices and school-houses, and the buildings belonging to the Ohio Canal, which passes through the village, and at this point crosses the river by a fine aqueduct. The railroad from Cincinnati to Wheeling also intersects it. Four periodicals are published here-the "C. Herald" (whig), the "C. Watchman" (dem.), the "Religious Telescope," and "Busy Martha" (religious.) In the village a considerable manufacturing business is engaged in, and the towu has several furnaces, tanneries, etc. As a commercial depot it occupies a place second to none of the interior towns, and its progress is onward. Pop. of v. 8,411 . - of t. 3,842 .

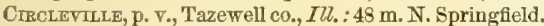

Crimco, p. O., Monroe co., Tenn. : on Citico er., 156 m. E. S. E. Nashville.

CrTY, p. o., Duchess co., N. $Y_{*}: 62 \mathrm{~m}$. S. by E. Albany.

CrrY island, N.Y.: an island in the East $r$., in the town of Pelham, Westchester County. It is $2 \mathrm{~m}$. long and about a mile wide.

CrTY PornT, p. . and port, Prince George co., Virg. : on the $S$. side of James r., on a point formed by the confluence of Appomattox r., $19 \mathrm{~m}$. S. E. Richmond. James $\mathrm{r}$. is navigable for large ships to this point, which is the port of Petersburg, with which city it is connected by a railroad $10 \mathrm{~m}$. long. Several lines of steam packets sail between this and New York, touching at Norfolk, etc.

Clackamas county, Oreg. Situate centrally, and contains 141,000 sq. m., but this area comprises a large unoccapied territory eastward. The county proper is of much less extent, and lies S. of Columbia r., and E. of Willamette $\mathbf{r}$. It is drained by Sandy r. of the Columbia, and the Clackamas and other tributaries of the Willamette $r$. The surface is generally level, and the soils of extraordinary fertility, covered with dense forests. Coal and iron exist in abundance, and building material is plentiful. Farms 150; manuf. 13; dwell. 368 , and pop.-wh. 1,836, fr. col. 23tatal 1,859. Capital: Oregon City.

Cratborne parish, La. Situate N. W., and contains $1,080 \mathrm{sq}$. $\mathrm{m}$. Drained $\mathrm{E}$. by the forks of Bayou D'Arbone, W. and S. W. by creeks of the Bayou Dorcheat and Black Lake cr. Surface varied, but generally level or rolling. Most of the parish consists of light pine land, but on the streams there are hard woods, and the soils are of good quality, suitable for cotton. Farms 554; manuf. 3 ; dwell. 842 , and pop.-wh. 4,949, fr. col. 0, sl. 2,522-total 7,471. Capital: Homer.

Clatborate county, Miss. Situate S. W., on Mississippi $r_{\text {., }}$ and contains $490 \mathrm{sq}$. m. Black $r$. washes its $N$. line, and it is drained chiefly by Bayou Pierre, and branches. Surface varied and uneven, and back from the streams the soils are light and sterile. Cotton and Indian corn are the chief products. Farms 310 ; manuf. 19 ; dwell. 659, and pop.wh. 3,449 , fr. col. 42, sl. 11,450-total 14,941. Capital: Port Gibson. Pubtic Works: Grand Gulf R. R.

Clatborne county, Tenn. Situate between Clinch r. and the $\mathrm{N}$. line of the State, and contains 580 sq. m. Drained by Powell's r. and numerous creeks of Clinch $r$. Mountain prevails in the $\mathrm{N}$. and $\mathrm{N}$. W., but the surface in other parts is pleasantly varied, and has extensive valleys. Iron is abundant. The principal agricultural products are corn, wheat, and oats, also pork. Farms 944 ; manuf. 24 ; dwell.
1,425, and pop.-wh. 8,609 , fr. col. 100, sl. 660-total 9,369. Capital: Tazewell.

Cramborne, p. v., and cap. Monroe co., Ala.: on the E. side of Alabama r., at the head of schooner navigation, 90 m. S. W. Montgomery.

Clarborie, p. v., Jasper co, Miss.: 72 m. E. S. E. Jackson.

Clanboenesville, p. v., Yazoo co., Miss.: on a cr. of Big Black r., $29 \mathrm{~m}$. N. W. Jackson.

Clarrvilue, p. v., Winnebago co, Wisc. : 88 m. N. E. by N. Madison.

Clapps, p. o., Guilford co., N. Car.: 78 m. W. N. W. Raleigh.

Clapptille, p. v., Worcester co., Mas8. : on the N. side of Westfleld $r_{\text {. }}$, and on the line of the Western $\mathrm{P} . \mathrm{R}_{\text {.., }} 9$ $\mathrm{m}$. W. from Worcester and $81 \mathrm{~m}$. W. by S. Boston.

Clars, t, and p. o., Potter co., Penn.: 132 m. N. W. Harrisburg.

Clare county, Mich. Situate centrally on Lower Peninsula, and contains 576 sq. m. Erected since 1850.

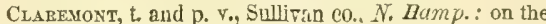
E. side of Connecticut r., $46 \mathrm{~m}$. W. by N. Concord. Iron and limestone are found in the town, and the village on Sugar er. has several manufactures; and a newspaper, the "National Eagle" (whig), is issued weekly. The town is connected with Concord by railroad. Pop. 3,606.

Charemont, p. v., Pickens co., S. Car.: 121 m. N. W Columbus.

Clarfarce, t. and p. v., Erie co., N. $Y$. : or the S. of Tonawanda cr., $244 \mathrm{~m}$. W. Albany. The Canandaigua and Niagara Falls R. R. passes through the town. Pop. 2,727.

Clarence, p. v., Greene co, Wisc. : $42 \mathrm{~m}$. S. by W. Madison.

ClaArence, t. and p. o, Calhoun co, Mfich.: $2 S \mathrm{~m}$ $\mathrm{S}$. by W. Lansing. Numerous lakelets are found in this town, and are the sources of streams flowing $\mathrm{S}$. toward the Kalamazoo r. and N. toward Black r. Pop. 483.

Clarence Cextre, p. o., Erie co., $N . Y: 242 \mathrm{~m} . \mathrm{W}$. Aibany.

Clarendon, p. v., Monroe co., Ark.: on the E. bank of White r., where it is formed by Cache r., $56 \mathrm{~m}$. E. Little Rock.

Clarendor, t, and p. v., Calhoun co., Mich.: on St. Joseph's $r ., 44 \mathrm{~m}$. S. by W. Lansing. The village lies on the N. bank of the river. Pop. 669 .

Clarendon, t. and p. Y., Orleans co., N. Y.: $218 \mathrm{~m}$. W. by $N$. Albany. The village contains about 250 inhabitants. Pop, 1,309.

Clarendon, p. v., Sumter dist., S. Car.

Clarendon, t. and p. v., Rutland $\mathrm{CO}_{i}$, Term. : on Otter cr., $58 \mathrm{~m}$. S. by W. Montpelier. The village lies on the Rutland and Burlington R. R., 6 m. S. Rutland, and the Western Vermont R. R. also passes through the town, 46 m. from North Bennington. Agriculture is the chief employment of the inhabitants. Pop, 147 .

Clarendon Springs, p. v., Rutland co., Term.: 55 m. S. by W. Montpelier. Here is a chalybeate spring, containing also corbonate of lime, which is resorted to by invalids for its medicinal properties.

Claridon, t. and p. v., Geauga co., Ohio: on Cuyahoga r., 146 m. N. E. Columbus, Pop. 1,006 .

Cuariox county, Penn. Situate N. W. centrally, and contains $5 \$ 0$ sq. m. Drained by Clarion and Toby's rivers and creeks of Alleghany r. and Red Bank r., the former of which washes its S. W. and the latter its S. borders. The $\mathrm{N}$. part of the co. is rough and uneven; in the $\mathrm{S}$. the surface is moderately undulating and fertile, with abundance of timber. It contains large deposits of iron ore, which are extensively worked. Farms 1,726; manuf. 246; dwell. 4,008, and pop.-wh. 23,448, fr. col. 117-total 23,565. Capitul : Clarion.

Cldruox, $t_{2}, p$ v., anil cap. Clarion co., Penn.: on the S. E, side of Clarion r, $152 \mathrm{~m}$. W. N. W. Harrisburg. The 
village is situate on the Susquebanna and Waterford turnpike, I m. E. of the river. Its site, previous to 1840 , was covered with pine woods; it is now one of the most important places of the interior, and has a population of about 1,200 inhabitants. Two newspapers are published in the town, the "C. Register" (whig), and the "C. Democrat"both weekly.

Clarion, p. v., Grundy co., Ill.: 126 m. N. N. E. Springfield.

Clajaon river (or Great Toby's er:), Penn.: an affluent of Alleghany r., from the N. E., and about $70 \mathrm{~m}$. long. It is navigable for boats for 50 or $60 \mathrm{~m}$., but is principally used to float down timber to Pittsburg, etc.

Cliark, p. o., Mercer co., Penn.: 204 m. W. N. W. Harrisburg.

CraRkE county, $A l a$. Situate S. W. between the Alaba$\mathrm{ma}$ and Tombigbee rivers, and contains 1,332 sq. m. The interior is drained by a large number of creeks falling into the border rivers. Surface uneven, but generally low. Soils indifferent, except on the streams, and there the lands are frequently inundated. Cotton and corn are the principal agrieultural products. Farms 456; manuf. 16 ; dwell 873, and pop.-wh. 4,901, fr. col. 9, sl. 4,876-total 9,786. Capital: Clarksville.

CLARKE county, Ark. Situate S. W. centrally, and contains $684 \mathrm{sq} . \mathrm{m}$. Drained by Washita $\mathrm{r}$., which runs on its E. border, and its numerous tributaries-one, the Little Miscouri $\mathrm{r}$., forming its $\mathrm{S}$. and W. borders. The surface is hilly and broken, and the soils, except on the marcins of the streams, sterile. The chief products are cotton and Indian corn, Farms 362 ; manuf, 2; dwell. 587, and pop.Wh. 3,113, fr. col. 7, sl. 875-total 3,995. Capital: Arkadelphia.

ClarkE county, $G a$. Situate N. centrally, and contains $414 \mathrm{sq} . \mathrm{m}$. Drained by the tributaries of Oconee $r$, which traverse it from $\mathrm{N}$. to $\mathrm{S}$. Surface elevated and undulating. Soils fertile, producing cotton, Indian corn, wheat, etc. abundantly. Farms 400; manuf. 55; dwell.1,024, and pop. 一wh. 5,515, fr. col. 15, sl. 5,589-total 11,119. Capital: Athens. Public Works: Athens Branch of Georgia R. R., extending from Union Point, $40 \mathrm{~m}$

CrARKe county, $I l l$. Situate $\mathrm{E}_{\text {, }}$ and contains $46 \mathrm{~s} \mathrm{sq} . \mathrm{m}$ Drained by Embarras r. and tributaries of Wabash $r$., which forms its E. border. Surface chiefly rolling prairie-in the E. somewhat hilly and broken. Soils fertile. Farms 636 ; manuf. 14; dwell. 1,621, and pop.-wh. 9,494, fr, col. 38 total 9,532. Capital: Marshall. Public Works: Terro Haute and Alton R. R.

Ciarke county, Inds situate on Ohio r., and contains 400 sq. m. Surface usually rolling, but nowhere hilly, except the Ohio bluffs, and the chain of "Knobs" on the W. and N. W. barders. Silver er. and Fourteen Mile cr. with some lesser streams, drain the soill, which are chiefly calcareons, and very productive. In the N. part of the co. are some wet lands, which are more fit for grasses than the cereals. Farms 1,048; manuf. 85 ; divell. 2,757, and pop.wh. 1ti.2fG. fr. col. 5-2-total 16. 22 . Cupitul : Charlestown. The Jeffersm ville an' Columlus I. R., and the Jew Albany and Salem R. R. traverse the county.

Clarke county, Ia. Situate S., and contains $432 \mathrm{sq} . \mathrm{m}$. Drained by the head waters of Chariton $r$, and numerous tributaries of Des Moines $\mathrm{r}$, of which White Breast cr. Otter er., Squaw cr., and South $r$, are the prineipal. The S.W. corner is drained by the head waters of Crooked Fork of Grand $\mathbf{r}$. Surface elevated, and in the middle of the co. forms the watershed between Des Moines aud Grand rivers. Soils fertile and deep. Farms - ; manuf. -; dwell. 14, and pop.-wh. 79, fr. col. 0-total 79. Capital:

CLARKE county, $K y$. Situate E. centrally, and contains 312 sq. m. Drained by Upper and Lower Howard creeks, and Three Mile cr., tributaries of Kentucky r., which forms the $\mathbf{S}$. line of the co. Surface generally level, and soils good, producing largely Indian corn, hemp, and tobacco, and immense numbers of live-stock are kept by the farmers. Farms 792; manuf. 17; dwell. 1,364, and pop.-wh. 7,709, fr. col. 134, sl. 4,840-total 12,683. Capital: Winchester. Public Works: Knoxville and Cincinnati R. R. Crarke county, Miss. Situate S. E., on the Alabama State line, and contains 756 sq. m. Drained by the Chickasawha and its numerous tributaries; it has immense waterpower. Surface generally level, and the soils of average fertility, with much that is the best, producing cotton and corn abundantly, with some rice. Farms 500; manuf. 7 ; dwell. 631, and pop.-wh. 3,823, fr. col. 6, sl. 1,648-total 5,497. Capital: Quitman. Public Works: Mobile and Ohio R. R.

ClaRkE county, Mo. Situate N. E., and contains 520 sq. $\mathrm{m}$. It is bounded on the E. by the Mississippi r., and on the N. E. by the Des Moines, and is drained chiefly by Fox and Wyaconda rivers and their tributaries. Surface moderately uneven, and eovered partially with timber. Soils fertile. Farms 425; manuf. 12; dwell. 805, and pop.-wh. 5,013, fr. col. 10, sl. 504 total 5,527. Oapital: Waterloo.

ClARKE county, Ohio. Situate toward S.W., and contains 412 sq. m. Drained by Mad r., Beaver cr., and Bucks cr., which afford extensive hydraulic power. Surface somewhat nneven. Soils fertile and well cultivated. Wheat, Indian corn, and \&ats are the staple grain crops. Cattle and sheep are raised in large numbers. Farms 1,398; manuf. 156; dwell. 3,753 , and pop.-wh. 21,855 , fr. col. 323 -total 22,178 . Capital: Springfield. Public Works: Mad River and Lake Erie R. R.; Little Miami R. R.; Springfield, Mount Vernon, and Pittsburg R. R.; Obio Central R. R., etc.

Clarke county, Oreg. Situate on the N. E. side of the Columbia r., and contains 40,000 sq. m. Cowlitz $x$. bounds it on the N. W., and receives, with the Columbia, the drain. age of the co. by a number of large streams. There are several isolated peaks in the co., as Mount St. Helens, and Cape Horn, the latter on the $\mathrm{N}$. bank of Columbia r. ; the surface, otherwise, is beautifully diversified, well wooded, and has fine soils. There are several small lakes near its W. border. Farms 7; manuf. 4; dwell. 95, and pop.-wh. 592, fr. col. 51-total 643 . Capital: Columbia City.

Clarke county, Firg. Situate N. E., and contains 230 sq. $m$. Drained by Opequan $r$. and tributaries of Shenandoah, which runs centrally through it. The surface is uneven, and on the E. mountainous, the Blue Ridge forming its E. border. Soils of good quality, producing wheat, corn, and oats largely. The mountain region forms excellent pasture for sheep and cattle. Farms 271; manuf. 48; dwell. 636 , and pop.-wh. 3,615 , fr. col. 123, sl. 3,614-total 7,352. Capital: Berryville.

Clarigs, t. and p. O., Coshocton co., Ottio: on White Woman's r., 62 m. N. E. Columbus. Pop. 839.

Clarksborovgir, p. v., Gloucester co., N. Jer.: $37 \mathrm{~m}$. S. 8. W. Trenton. Chiefly inhabited by the Quakers.

Clatrkgburgr, p. Y., Decatur co., Ind.: 43 m. E. S. I. Indianapolis.

Clarksburge, p. F., and cap. Lewis co., $K y .:$ on Salt Lick cr., $4 \mathrm{~m}$. S. of the Ohio r., and $91 \mathrm{~m}$. E. N. E. Frankfort.

Clatersourgir, p. v., Indiana co, Penn.: $126 \mathrm{~m}$. W. by N. Mlarrisburg.

Crarksbtrgr, p. v., Montgomery co., Ma.: on the E. side of Little Seneca cr., 52 m. W. N. W. Annapolis.

ClarksBUtgit, p. v., Erie co., $N$. $Y_{0}: 256$ m. W. Albany.

Crarksburgir, p. v., Monmouth co., N. Jer.: 16 m. E. Trenton.

Chatissbtrgir. p. r., Ross co., Ohio: on the N. line of county, $35 \mathrm{~m}$. S. by W. Columbus.

Clarksburge, p. ., and cap. Harrison co., Tirg.: on Monongahela r., $192 \mathrm{~m}$. N. W. Richmond. It is a thriving village, has two newspapers, the "Harrison Republican" (whig), and the "C. Demnerat," published weekly, and will shrtly have great commercial ficilities by tha forth-west 
ern $R . R$., which will pass through or near it. Pop. about 1,200 .

Clark's Corners, p. o., Ashtabula co., Ohio: $162 \mathrm{~m}$. N. E. Columbus. Pop. 1,454

Clare's Factory, p. o., Delaware co., $N . Y . ; 67$ m. S.W. Albany.

Clarkstielid, t. and p. v., Huron co., Ohio: on Vermillion r., $88 \mathrm{~m}$. N. by E. Columbus.

Clark's Fork, p. 0., York dist., S. Car:: $63 \mathrm{~m}$. N. Columbia.

ClaRK's ForK, p. o., Cooper co., Mo.: on Clark's Fork of Little Saline r., a tributary of the Missouri, $34 \mathrm{~m}$. W. N.W. Jefferson City.

Clark's Green, p. 0., Luzerne co., Penn.

Clark's Milrs, p. o., Moore co., $N_{\text {. }}$ Car.: on Lumber r., $61 \mathrm{~m}, \mathrm{~S}, \mathrm{~W}$. Raleigh.

Clark's Mrils, p. 0., Hempstead co., Ark.: 118 m. S.W. Little Rock.

Clark's Mizls, p. o., Washington co., Virg. : $252 \mathrm{~m}$. W. S. W. Richmond.

Clark's River, p. O., Callaway co., $K y$. : on the r. so called, $216 \mathrm{~m} . \mathrm{S}$. W. Frankfort.

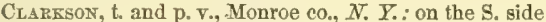
of Lake Ontario, and drained by Salmon and Sandy creeks, $210 \mathrm{~m}$. W. by N. Albany. The $\mathrm{v}$. situate on the Ridge Road, has several manufactures. Pop. of $t, 4,556$.

Clarigon, p. v., Columbiana co., Ohio: 123 m. N. E. Columbus.

Clarkgon Centre, p. v., Monroe co., N. Y.: $212 \mathrm{~m}$. Ti. by N. Albany.

Clarkston, p. v., Oakland co., Mich.: on a small lake forming one of the sources of the $\mathrm{N}$. branch of Rouge r., 59 m. F. Lansing.

Clarikstown, to, p. v., and cap. Rockland co., $N . Y$. : on the W. side of Fudson r., $102 \mathrm{~m}$. S. Albany. The t. contains a small lake (called Rockland Lake, so famous for its ice), which empties into Hackensack $r$. New City is the name of the village in which the co, buildings are located. Pop. 3,111 .

Clatikstrlie, p. $v_{*}$, and cap. Clarke $\mathrm{co}_{*}, A l \alpha_{*}$ : on the N. of Jackson's cr. of Tombigbee r., $96 \mathrm{~m}$. S. W. Montgomery.

CLARESVILLE, $p_{*} \mathrm{~V}_{*}$, and eap. Johnson co., Ark, : on a cr. of the Arkansas, $3 \mathrm{~m} . \mathrm{N}$. of that r., and $84 \mathrm{~m} . \mathrm{N}$. W. Little Rock.

Cuarkstiliz, p. v., and eap. Habersham co., Ga.: on Tugaloe r., a tributary of the Savannah, $113 \mathrm{~m}$. N. Milledgeville. It is a $\mathrm{v}$. of some 300 inhabitants.

Crarkstille, p. v., Anne Arundel co., Md.: 37 m. N.W. Annapolis.

Clarksville, p. v., Pike co., Mo. : on the W. bank of the Mississippi r., 88 m. N. E. Jefferson City.

Clarksvilue, p. v., Hunterdon co., N. Jer.: on spruce Run, at the E. base of Musconeteong Mountain, $42 \mathrm{~m}$. N. by W. Trenton. Iron and other ores are found in the whole district. The New Jersey Central R. R. passes through the v., $47 \mathrm{~m}$. from Elizabethport, and 17 from Easton.

Clarkspille, p. v., Albany co., N. $Y .: 6 \mathrm{~m}$. W. by $\mathrm{S}$. Albany.

Clarksville, p. v., Clinton co., Ohio: on Todd's cr. of the Little Miami r., $63 \mathrm{~m}$. $\mathrm{S}$. W. Columbus. It is a considerable $\nabla$. , and lies on the railkoad route from Cincinnati to Zanesville.

Clarkstrlie, p. v., Greene co., Penn.: at the junction of the N. and S. forks of Ten Mile cr. of the Monongahela r., $168 \mathrm{~m}$. W. by S. Harrisburg.

Clarkstille, p. v., and cap. Nontgomery co., Tenn. : on the $N$. side of Cumberland r., at the mouth of Red r., $40 \mathrm{~m}$. N. W. Nashville. It is a large and important $\mathrm{v}$., and has a large trade. There are published here the "Jeffersonian" (dem.), the "C. Chronicle" (whig), and the "Ledger" (whig), weekly, and the "Monthly Visitor" (literary). The R. R. from Nashville to Henderson, will pass through Clarksville.
Clarkstille, p. v., and cap. Red River co., Tex.: 886 m. N. E. Austin City.

Clarkatille, p. v., Mechlenburg co., Virg.: on the $\mathbf{S}$. side of Dan r., $92 \mathrm{~m} . \mathrm{s}$. W. Richmond.

Clarksvilt.e, p. v., Spartanburg dist., S. Car.: $73 \mathrm{~m}$. N. N. W. Columbia

Clarksville, p. v., Hamilton co., Ind.: 24 m. N. by E. Indianapolis.

Charksville, v., Clarke co., Ind.: on the $\mathbb{N}$. bank of the Obio r., about equi-distant between New Albany and Jeffersonville, $100 \mathrm{~m}$. S. by E. Indianapolis. Once a thriving village, Clarksville has been supplanted in business by its more enterprising neighbors.

Clarystille, p Y., Sullivan co., N. Y.: 90 m. S. 8. W. Albany.

Clatsop county, Oreg. Situate on the Pacific, immediately S. of Columbia r., and contains 6,000 sq. m. Drained $\mathrm{S}$. by Killamook r., flowing to the ocean, and the Tualatin r., a tributary of Willamette $r_{\text {., }}$ and in the N. W. by tributaries of the Columbia $r$. The surface is generally rolling but barely wooded. Coal has been found in sereral parts. Farms 24; manuf. 2; dwell. 91, and pop.-wh. 458, fr. col. 4-total 462. Capital: Astoria.

Cladselpille, p. v., Monroe co., Ala.: 86 m. S.W. Montgomery.

Cradgstille, p. v., Lehigh co., Penn.: 69 m. E. N. E. Harrisburg.

Craverack, t. and p. v., Columbia co., $N$. $Y_{\text {.: }}$ on Claperack er., $31 \mathrm{~m}$. S. by E. Albany. The $\mathrm{r}$. is about $4 \mathrm{~m}$. E. of Hudson City, and is intersected by the Hudson and Berkshire R. R. The Harlem Extension R. R. also traverses the t. in its E. part. Pop. 3,208.

Claverack river, $N . Y$. : rises in Columbia co., and runs into Kinderhook er., near its mouth. It is a good millstream.

Clay county, $17 l$. Situate S. centrally, and contains 468 sq. m. Drained by tributaries of Little Wabash $\mathbf{r}$. Surface level prairie, and soils fertile-wood along the streams. Farms 237; manuf, 6; dwell. 715, and pop.-wh. 4,268, fr. col. 21-total 4,289. Capital: Maysville. Pubtic Works: Cincinnati and St. Louis R. R.

Clax county, Ind. Situate W., and contains 360 sq. m. Eel r. and its tributaries drain the lands. Surface generally level. Soils good, and timber abundant. In the S. W. are some beautiful prairies. Coal and iron are found in all parts. Farms 829; manuf. 10; dwell. 1,326, and pop.wh. 7,926, fr. col. 1s - total 7,944. Capital: Bowling Green. Public Works: Terre Haute and Richmond R. R., and Wabash and Erie Canal.

CLAY county, $I a_{0}$ Situate N. W., and contains 576 sq. m. Taken from Pottowattomee co. in 1851

Cr.AY county, $K y$. Situate S. E., and contains 880 sq. m. Drained by Sturgeon, Sexton's, Goose, Red Bird, and other creeks of the $\mathbf{s}$. fork of Kentueky r. Surface generally undulating. Soils of average fertility. Salt springs and bituminous coal contribute much to the wealth of the county. Farms 511; manuf. 11; dwell. 782, and pop.-wh. 4,739, fr. col. 167, sl. 515-total 5,421. Capital: Manchester.

Clay county, Mo. Situate N. W., and contains 432 sq. m. Drained by Smith's Fork of Platte r., and by Fishing and other creeks of Missouri r., which bounds the co. on the S. Surface undulating, and soils of the most fertile description. The products are Indian corn, oats, and tobacco. Farms 944 ; manuf. 42 ; dwell. 1,352 , and pop.-wh. 7,555, fr. col. 5, sl. 2,742-total 10,332. Capital: Liberty.

Cuar, p. т., Yancey co., N. Car.: 204 m. W. Raleigh.

Clay, p. v., La Salle co., Ill.: 129 m. N. N. E. Springfleld.

CrAX, t. and p. o., Onondaga co., $N . Y_{0}:$ on the E. side of Oswego r., $128 \mathrm{~m}$. W. by N. Albany. The Oneida and Seneca rivers unite in this t., forming Oswego $r$. The p. 0 . is located in the $\mathrm{v}$. of Belgium. Pop, of t. 3,402. 
City.

Cray, p. v., St. Clair co., MO.: 98 m. W. S. W. Jefferson

City.

CIAT, p. T., Washington co., Ia.: $36 \mathrm{~m}$. S. by W. Iow a

Cist Hnu, p. o., Marengo co., Ala.: 89 m. E. Montgomery.

Cl.Aт Hrut, p. o., York dist., S. Car. : 66 m. N. CoJumbia.

Clay Lick, p. o., Owen co., Ky. : 23 m. N. Frankfort.

Cuat Poor, p. v., Kosciusko co., Ind. : on a small lake Which forms the head of a tributary of Tippecanoe r., $90 \mathrm{~m}$. N. by E. Indianapolis.

Craxstili.e, p. F., Marshall co., Ala. : on the N. side of the Tennessee r., $126 \mathrm{~m}$. N. Montgomery. The r. at this point has its extreme $\mathbf{S}$. bend.

Cuarspille, p. v., Boone co., Mo.: 28 m. N. by W. Jefferson City.

Claroville, p. Y., Washington co., Ind.: on Lost cr., 76 m. S. by W. Indianapolis.

Cuarspilue, p. v., Harrison co., Ky.: on the W. side of Ticking r., $48 \mathrm{~m}$. N. E. Frankfort

Cuarsville, p. v., Washington co., Penn.: 187 m. W. Harrisburg.

Clargville, p. ষ., Wood co., Tirg.: 240 m. W. N. W. Pichmond.

Chafstrute, p. V., Guernsey co., Ohio: in the S. W. part of the eo., $68 \mathrm{~m}$. E. Columbus.

Clayton county, Ia. Situate W. of Mississippi r., in the N. E., and contains 758 sq. m. Drained chiefly by Turkey cr. and its tributaries. Surface elevated, undulating, and about equally divided between prairie and woodland. Soils of exhaustless fertility. Farms 200 ; manuf. 12 ; dwell. 728, and pop.-wh. 3,8t1, fr. col. 2-total 3,s73. Capital: Garnavillo.

Clatton, p.. ., and cap. Barbour co., Ala. : on the high land forming the watershed between Pea $r$. and Chattahoochee r, 60 m. S. E. Montgomery.

Clarton, p. v., Berks co., Penn. : 58 m. E. N. E. Harrisburg.

Claiton, p. v., and cap. Rabun co., $G a .:$ in a hilly region, at the $\mathrm{S}$. base of the Blue Ridge, and about $3 \mathrm{~m} . \mathrm{N}$. of Tullalah r., a tributary of the Savannah $r_{*}, 122 \mathrm{~m}$. N. Milledgeville.

Cinfros, p. F., Adams co., Ill.: on the Quincy and Mount Sterling road, $72 \mathrm{~m}$. W. N. W. Springfleld.

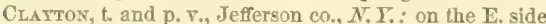
of St. Lawrence r., $153 \mathrm{~m}$. N. W. Albany. Chaumont r. and French er. drain the t. The v. lies immediately on the banks of the St. Lawrence. Pop. 4,191.

Clatton, p. v., Lenarree co, Mich.

Clayton, p. v., Montgomery co., Ohio: $74 \mathrm{~m}$. W. by S. Columbus.

Claytona, p. T.: Morgan co., Ohio: 66 m. E. S. E. Columbus.

Cuartontrle, p. v., Henderson co, $N$. Car.: on the W. side of French Broad r., $228 \mathrm{~m}$. W. S. W. Raleigh.

Cl.ar Till.ige, p. r.. Shelby co., $K \%$. : on the Louisville anil Frunkfirt post roarl. $12 \mathrm{~m}$. W. Frankfurt.

Clarmine, p. V., Oneida co., $\boldsymbol{N} . \boldsymbol{Y}_{\text {.: }}$ in the S. E. part of the co. io m. W. X. T. Albany.

Cratrille. n. v., Pruvidence co., R. I.

Clear Braxch, p. O., Washington co., Firg. : $254 \mathrm{~m}$.

T. S. T. Fichmond

Cleat Creer, p. o., Mechlenburg co., N. Car.: $122 \mathrm{~m}$. W. S. W. Rulpioln

Creal: Creer, p. o., Daviesg co., Mro.: on a cr. of Grand r. gn औ' 123 m. X. T. Tefferson City.

(1) An latie, I. I.: is one of a cluster of small lakes. Iring in the t. of Alexandria, Jefferson co.

Clear Creer. p. V., Chautauque co., $\boldsymbol{N}$ : $\boldsymbol{Y}_{\text {. }}$ : on Clear cr. of Conewango cr., 278 m. W. S. W. Albany.

Clfar Cretr, p. O, Greene co., Tenn. : 221 m. E. Nashville.
Crear Creek, to and p. 0., Fairfield co, Ohio: 29 m.S. by E. Columbas.

Cliear Creek Landirg, p. o., Alexander co., Ill, : on Clear er., in the N. W. part of the co.g $178 \mathrm{~m}$. S. Springfield.

Clearferd county, Penn. Situate W. centrally, and contains $1,425 \mathrm{sq}$. m. Drained by numerous creeks and tributaries of the W. branch of Susquebanna $r_{0}$, which traverses the county from $\mathrm{S}$. W. to $\mathrm{N}$. E. With some exceptions the surface is rough and the soils only moderately fertile. Some iron is produced. The agricultural staples are grain and some provisions. Farms 2,317; manuf. 122 ; dwell, 2,157, and pop.-wh. 12,482, fr. col. 104-total 12,556. Capital: Clearfield.

Clearfield, p. Y., and cap. Clearfield co., Penn.: on the S. side of the W. branch of Susquehanna r., $100 \mathrm{~m}$. N. W. Harrisburg. It is a flourishing place, and has a weekly newspaper, called the "Country Dollar" (dem.), which has a circulation of 700 copies.

Clearfigld Bridge, p. o., Clearfield co, Penn. : on Clearfield cr., $104 \mathrm{~m}$. N. W. Harrisburg. Clearfield cr. is a considerable tributary of the W. branch of the Susquehanna r., which it joins near the v, of Clearfield.

Clear Fork, p. o., Whitley co., $\bar{k} y_{.}:$on Clear er. of Cumberland r., 122 m. S. S. E. Frankfort.

CleAs Fork, p. o., Tazewell co., Firg.: on Clear Fork of Sandy r., $247 \mathrm{~m}$. W. by S. Richmond.

Crear Fork Mruz, p. o, Johnson co, Mo.: on Clear Fork of Black Water r., $76 \mathrm{~m}$. W. Jefferson City.

Clear Lake, p. 0., Fort Bend co., Tex.: $159 \mathrm{~m}$. S. F Austin City.

Clearuont, p. ₹., Warren co, Tem. : 56 m. S. E. Nashrille.

Clear Pont, p. 0., Hart co., $\bar{K} y_{.}: 93 \mathrm{~m}$. S. W. Frankfort.

Clear Sprive, p, 0., Greenville dist., $S$. Car.: $112 \mathrm{~m}$ N. W. Columbia,

Clear Sprtyg, p. o., Koseiusko co, Ind. : $95 \mathrm{~m}$. N. by E. Indianapolis.

Clear Sprtyg, p. o., Chickasaw co., Miss.

Cient Sperivg, p. o., Granger co., Tenn. : 183 m. E. Nashrille.

Clanp Sprixg, p. o., Washington co., MId.: at the F. base of North Mountain, $78 \mathrm{~m}$. N. W. Annapolis. The "Clear Spring Sentinel" (whig) is published at this place weekly.

Clearsyille, p. v., Bedford co., Penn.

Clear Water, p. o, Chippewa co., Wisc.: on the $\mathrm{N}$. side of L'Eau Claire cr. of the Chippewa r., $165 \mathrm{~m}$. N. Tr. Madison.

Cleaterand county, $N$. Car. Situate S. W., and contains $610 \mathrm{sq}$. m. Drained by tributaries of Broad r., which crosses the S. W. corner of the co.; these afford good water-power. Surface somewhat uneven. In the S. E. corner is King's MLountain, an isolated hill, noted as the scene of a famous battle. Farms 961; manuf. 13; dwell. 1,526, and pop.-wh. 8,592, fr. col. 57, sl. 1,717-total 10,396. Capital: Shelby.

Cleavelasd, p. v., and cap. Bradley co., Tenn.: on the East Tennessee and Georgia P. P., 123 m. S. E. Nashville, and $30 \mathrm{~m}$, from Dalton.

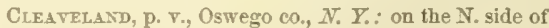
Oneida Lake, $122 \mathrm{~m}$. W. N. W. Albany. It is a busy village and has some manufactures.

Clesert, p. V., Hanoock co, Ohio: 81 m. N. N. W. Columbus.

Clemmonstule, p. ve, Davidson co., N. Car.: on the $\mathrm{E}$ side of Fadkin $r_{*}, 102 \mathrm{~m}$. W. by N. Raleigh.

Clestants, p. 0., Canawha co., Firg.: $238 \mathrm{~m}$. W. by N. Pichmond.

Clerront county, Orio. Situate S. W., and contains $4 \mathrm{St} \mathrm{kg} . \mathrm{m}$. Drained by the $\mathrm{E}$. fork of Little Miami r., and Stone Lick and other creeks tributary to it. The S. and S.W. 
parts of the county are drained by several creeks running to the Obio $\mathrm{r}$, which forms its borders in those directions. Along the Ohio the surface is hilly and broken; in other parts chiefly level, and occasionally wet; soils rich and fertile, and timber plentiful in the bottoms. Procucts wheat, corn, and tobacco, with pork and beef. Farms 2,098; manuf. 178; dwell. 5,437, and pop.-Wh. 30,044, fr. col. 411 -total 30,455. Capital: Batavia. Public Works: Cincinnati and Hillsboro' R. R., Little Miami R. R., ete.

Clzimont, p. vo, Richland co., I $l_{0}$ : 114 m. S. E. Springfield.

Clermont, t. and p. o., Columbia co., N. Y.: on the W. of Ancram cr., $38 \mathrm{~m}$. S. by E. Albany. The r. lies on the post road, between Albany and New York. Pop. 1,130.

Clermont, p. v., Marion co., Ind.: on Eagle cr., 9 m. W. N. W. Indianapolis.

Clermont Mtuls, p. o., Harford co, Md.

Clermontvilue, p. v., M'Kean co., Penn. : 182 m. N.W. Harrisburg.

Cleveland, p. city, port of entry, and cap. Cuyahoga co., Ohio: on Cuyahoga r., where it discharges into Lake Erie, $126 \mathrm{~m}$. N. N. E. Columbus. Lat. $41^{\circ} 31^{\prime} 07^{\prime \prime} \mathrm{N}$., and long. $81^{\circ}$ $45^{\prime} 5 \tau^{\prime \prime} \mathrm{W}$. Cleveland is the commercial emporium of northern. Ohio, and second only to Cincinnati in population and general progress. It possesses great facilities for the transit of goods and passengers: the Ohio Canal, extending to the Ohio r. at Portsmouth, $309 \mathrm{~m}$., has its northern terminus here, and another eanal, branching off from it at Akron, connects it with Pittsburg. It is connected with all the ports of Lake Erie by the lake shore chain of railroads extending from Niagara Falls to Milwaukie; with Pittsburg, by the Ohio and Pennsylvania R. R., and the Cleveland and Pittsburg R. R. ; and with Cincinnati by the Cleveland, Columbus, and Cincinnati R. R. : these, uniting with the various railroads running to the sea-board at Boston, New York, Philadelphia, Baltimore, ete., to the southward into Keniucky, Tennessee, etc., to Charleston, Savannah, Mobile, and New Orleans, and to the westward to and beyond the Mississippi r., give it access to every part of the settled portion of the Union, and serve as conduits of the vast commerce which centres at this point. And besides these great avenues, it has numerous plank and macadamized roads leading from it in all directions; and its telegraphic connections extend to every important city from the British Provinces to New Orleans, and from the Atlantic to the utmost western bounds of eivilization. Regular lines of steamboats ply to Dunkirk, to Buffalo, to Detroit, to Toledo, and Sandusky, and to the upper lake country.

Cleveland is one of those great cities of the West that have risen up as if by magic within the past twenty years. In 1830 the place contained less than 1,000 inhabitants; in 1840 it had 6,071, and in 1850 its population amounted to 17,034. It derives its name from General Moses Cleveland, an agent of the Connecticut Land Company, who accompanied the first surveying party upon the Connecticut Western Reserve. The place on which the eity now stands was surveyed under his direction in 1796. In 1799 there was but one family residing here, and even in 1825 there were under 500 persons within its limits. In 1814 Cleveland was incorporated as a village, and in 1836 it received a city charter.

The eity, except a small portion of it immediately on the river, is built on a gravelly plain, 80 feet above Lake Erie, of which it has a commanding prospect. The location is dry and healthy, and the view of the meanderings of the Cuyahoga r., and of the steamboat and lake eraft ever entering or leaving the harbor, or on the waters of the lake to the horizon, presents a fine picture of commercial activity. The country around is replete with rich scenery, and for miles around is under a high state of cultivation.

The plan of the city is rectangular, the stieets being usually 80 feet wide, except Main-street, running through the middle of the city which is 120 feet wide. Near the centre there is a public square of 10 acses, divided into four equal parts by intersecting streets, neatly inclosed and adorned with shade trees. The Court House fronts on this square. The city contains numerous well-built churches of all denominations, public institutions, schools, etc. Many of the private dwellings are expensive and tastent. The harbor is one of the best on the lake; it is formed by the mouth of the Cayahoga, and improved by a pier on each side, extending 425 yards into the lake, 200 feet apart, and faced with substantial masonry. The natural advantiges of the harbor are unsurpassed in the West. There is a light-house on the high bank of the lake, and another at the entrance to the harbor. The coast-wise commerce of Cleveland, in the year 1850, amounted in value to $\$ 13,886,531$, of which $\$ 7,030,957$ represented the imporis, and $\$ 6,855,556$ that of the exports. The shipping owned in the district was 35,315 tons, of which 9,994 tons were ravigated by steam-power. The shipping built within the year was 686 tons. Cleveland has also considerable commerce with Canada. The great bulk of its commercial material, however, is now conveyed on the railroads and canals, to and from the sea-board, etc., but the exact amount can not be ascertained.

Manufacturing, though in its infaney, is carried on to some extent. Most of the engines, and other equipments for the steamboats and railroads of the neighborhood, are manufactured at the Cuyahoga Steam Furnace; and there are also two large flouring mills here, one worked by stcam, and the other by the surplus water of the Ohio Canal. Of the ordinary mechanical trades there is a fair representation, and among them are several extensive establishments. The public schools of the city are numerous, and are tunder efficient management. The buildings are generally of brick; that on St. Clair-street is an ornament to the city. The course of instruction is graduated, and when the scholars are sufficiently advanced, they are promoted to the bigh school, in which they are instructed in several branchos of natural science. There are also many highly eficient private schools and seminaries; and the city has several literary associations and reading rooms. At the Lyceum lectures are delivered during the winter evening: There are three musical halls in the city. The public press of the city consists of three daily newspapers (which issue, also, weekly editions), and two weekly newspapers. The dailies are, the "C. Herald" (whig), the "C. Plaindealer" (dem.), and the "True Democrat" (free soil); and the Fieeklies are, the "C. Advertiser" (ncutral), and the "C. Germania" (Germ. dem.)

Ohio City, on the opposite side of the Cuyahoga r., is virtually a part of Cleveland; but it has a separate incorporation. It is in the same position as New Jork Cicy and Brooklyn, distinct corporations, with interests 2like. The municipal authorities of Cleveland consist of a mayor, and one alderman and three councilmen for each viard. The police arrangements of the city are excellent, and the cleanliness and order of the place are remarkable.

Cueves, p. vo, Hamilton con, Ohio: on the Mismi $x_{n}$ and about a mile from the $\mathrm{Obio}_{\text {, }}$ at North Bend, $113 \mathrm{~m}$. 3. W. Columbus. It is a thriving $\mathrm{v}$., and has about $\$ 00$ inhabite ants.

Clnfrord, p. v., Susquehanna co., Pernn. : 124 m. N. N. E. Harrisburg.

Clift Milis, p. 0., Fauquier co., Virg. : $82 \mathrm{~m}$. N. by W. Richmond.

Cumfon, p. Y., Madison co., Filor.

Cltfrt Creek, Ma.: a small stream in Jefferson co, which Palls into the Ohio i. a mile below Madison. It is remarkable for its cascades, at one oi which the rater falls over 100 feet within a short distanes. The da: $k$, deep gulf and rugged cliffs present much picturesoue scenery, ete.

Clifton, p. v., King George co., Virg.: 36 m. N. N. E. Richmond.

Curmon, p. v., Greene co, Ohiso: at the falls of the Little 
Miami r., 46 m. S. by W. Columbus. The v. enjoys inamense hydraulie power, and has several important manufactures. The country in the neighborhood is one of the finest agricuitural districts in the State. Pop. 252.

Clifror, p. $\nabla .$, Luzerne co., Penn. : 118 m. N. E. Harrisburg.

Cutron, p. r., Penobseot co., Me.

Cumrox, p. Y.. Monroe co., $N . Y_{\bullet}: 194 \mathrm{~m}$. W. by N. Albany.

Climton, p. v., Wayne co., Tenn.: 84 m. S. W. Nashville.

Clifton, p. V., Jefferson co., Mo. : on the W. bank of the

Mississippi r., $102 \mathrm{~m}$. E. by S. Jefferson City.

ClImTON Forge, p. v., Alleghany co., Firg.: 148 m.

W. by N. Richmond.

Clifton Minls, p. 0., Breckenridge co., $\not{K} y .: 90 \mathrm{~m}$.

W. by S. Frankfort.

CLIFTON PARK, t. and p. v., Saratoga co, $N . Y_{*}:$ on the

N. side of Mohawk r., $10 \mathrm{~m}$. S. of Balston Spa, and $22 \mathrm{~m}$. N. W. Albany. Pop, 2,868 .

Clistor Sprtigs, p. v., Ontario co., $N . \bar{Y} .:$ on the line of the Rochester and Syracuse R. R., $216 \mathrm{~m}$. W. Albany. The sulphur springs at this place have become celebrated for their medicinal properties, and are occasionally resorted to by invalids.

Clnit, p. Y., Decatur co., Ind. : on Clifty cr., 40 m. S. E. Indianapolis.

ClIFTY creek, Ind. : a tributary of White $r$., which it joins $8 \mathrm{~m}$. below Columbus. It is $50 \mathrm{~m}$. long. The Indian name of this stream was Es-the-nou-0-ne-ho-maque, or Cliff of Rocks River.

Crmax Pratrie, p. O., Kalamazoo co., Mich.: $52 \mathrm{~m}$. S. W. Lansing.

Cuncen river, Virg. and Tenn.: rises in Virginia and passes into Tennessee, and after a course of about $200 \mathrm{~m}$. unites with Holston $\mathrm{r}$. at Kingston, thus forming Tennessee r. It is navigable for boats throughout the greater part of its course.

Cline's Milus, p. o., Augusta co., Firg. : 104 m. W. N. W. Richmond.

Clnngmax, p. v., Cleaveland co., $N_{\text {. }}$ Car.: 159 m.W. S.W. Raleigh.

Cinison county, $\pi l$. Situate $\mathrm{S}$. W. centrally, and contains 468 sq. m. Drained by creeks of Kaskaskia r., which flows through it and forms the W. half of its S. border. Surface chiefly prairie with rich bottoms, and soils of extraordinary fertility, producing grains in abundance, and supporting much live stock. Farms 628; manuf. 8; dwell. 947, and pop.-wh. 5,002, fr. col. 137-total 5,139. Capital: Carlyle. Public Works: Cincinnati and St. Louis R. R.

Cunvon county, Ind. Situate N. W. centrally, and contains 432 sq. m. The streams are the middle and south forks of Wild Cat r., Sugar cr., and others. Surface, except near the Wild Cat r., level or undulating, and the whole, with the exception of some small prairies, is heavily timbered; soils alluvial with a clay substratum. Wheat is produced largely, and much attention is given to the raising of cattle and hogs. Farms 1,411; manuf. 21; dwell. 2,001, and pop,-wh, 11,845, fr. col. 24-total 11,869. Capital: Frankfort. Public Works: Lafayette and Indianapolis $\mathrm{R}$. R.

Cristox county, $I \alpha$. Situate $\mathrm{E}$. on Mississippi r., and contains $64 \mathrm{sq}$. m. The Wapsipinicon $\mathrm{r}$. forms its $\mathrm{S}$. border and also crosses the S. W. part of the coanty, and with its tributaries drains a large surface. The $\mathrm{N}$. is drained by tributaries of Makoqueta r., and the $\mathbf{E}$. by creeks of the Mississippi. Surface undulating, and about equally covered by wood and prairie; soils excellent, deep, and rich. Farms 306 ; manuf. 10 ; dwell. 499 , and pop.-wh. 2,802 , fr. col. 20-total 2,522. Capital: De Witt. Public Works: Lyons and Iowa City R. R., and Camanche and Iowa City R. R. (both projected as yet).
Cunvor county, $\bar{K} y$. Situate on the Tennessee State line, and contains 234 sq. m. Beaver, Otter, Little Indian, Obey's, and other creeks of Cumberland r, drain the interior. Surface diversified; soils fertile. The products are Indian corn, oats, wheat, tobacco, etc. Farms 499; manuf. 3 ; dwell. 774 , and pop.-wh. 4,591, fr. col, 36, sl. 262-total 4,889. Capital: Albany.

Cunvton county, Mich. Situate on lower peninsula centrally, and contains $576 \mathrm{sq}$. m. Drained by Maple r., Stoney cr., Looking-glass r. ; and other tributaries of Grand r. flow in a direction from E. to W. Grand r. crosses its S. W. corner. Surface level; soils usually good. Farms 614 ; manuf. 13 ; dwell. 946 , and pop.-wh. 5,100, fr. col. 2-total 5,102. Capital: De Witt.

Clinton county, Mo. Situate N. W., and contains 416 sq. m. Drained by Castile cr. and Smith's fork of Platte r., and by Shoal cr, of Grand r., with other streams tributary to the Missouri r. Surface level, two-thirds prairie; soils fertile, producing the grains, tobacco, etc. Farms 334 ; manuf. 0 ; dwell. 560, and pop.-wh. 8,346 , fr. col. 1, sl. 439 -total 8,786. Capital: Plattsburg.

Clinton county, N. $Y$. Situate N. E. corner of the State, on the W. shore of Lake Champlain S. of $45^{\circ} \mathrm{N}$. lat., and contains $938 \mathrm{sq}$. m. Drained by the Saranac, the Chazy, and the Au Sable, and other rivers, all of which empty into the lake, and in their courses afford extensire water privileges. There are sereral small lakes within the county, of which Chateaugay and Chazy lakes are the largest. The surface is beautifully diversified-in the $\mathrm{S}$. and W. hilly; soils of an average fertility, and much of the surface is yet covered with forest. Iron ore of an excellent quality is found in the S. W., and has been extensively worked; black marble exists near Plattsburg, and granite and gneiss are the prevailing rocks, except a narrow strip of limestone formation along the lake shore. There are sulphur and carbonic acid springs at Beekmantown. The products of the county are wheat, corn, and pork. Farms 2,095 ; manuf. 461 ; dwell. 6.713 , and pop.-wh. 39,935 , fr. col. 112-total 40,047. Capital: Plattsburg. Public Works: Northern R. R.; Plattsburg and Montreal R. P.; and Champlain and St. Lawrence $R$. R.

Clinton county, Ohio, Situate toward $\mathbf{S}$. W., and contains $430 \mathrm{sq}$. m. Drained by several forks and other tributaries of Little Miami r., which affords good water-power. Surface chiefly level or undulating; soils deep and fertile, with timber in sufficiency. The products are Indian corn, wheat, and grasses, which feed immense numbers of live stock. Salt is found in the S. W. district. Farms 1,366; manuf. 83 ; dwell. 3,245 , and pop.-wh. 18,247, fr. col. 591 -total 18,S8S. Capital : Wilmington. Public Warks : Cincinnati, Wilmington, and Zanesville R. R., etc.

Clnvtow county, Penn. Situate centrally in W., and contains 840 sq. m. Drained by oreeks and tributaries of the W. branch of Susquehanna r., which flows through its middle. Surface rugged and hilly-in the S. mountainous; soils of moderate fertility, and in some parts sterile. Iron and bituminous coal very abundant and extensively wrought. The agricultural products are wheat, oats, corn, ete. Farms 683 ; manuf. 149 ; dwell. 1,930, and pop.-wh. 11,055, fr. col. 152-total 11,207. Capital: Lock Haven. Public Works. Sunbury and Erie R. R.

Clanton, p. v., De Witt co., Texo: 80 m. \$. by E. Austin City.

Clantox, p. vo and cap. Van Buren con, Ark.: at the mouth of Archer's cr, of Little Red r., 60 m. N. by W. Little Pock.

Cunston, p. v., Henry co., Mo.: on the N. side of Big creek of the Osage r., $89 \mathrm{~m}$. W. by S. Jefferson City.

Clixtow, $t$, and p. o., Middlesex co., Conn. : on the $\mathrm{N}$. of Long Island Sound, $36 \mathrm{~m}$. S. S. E. Hartford, Pop. 1,344 .

Cunton, p. ₹., Greene co., Ala. : on a cr. of Little Tombigbee r., $98 \mathrm{~m}$. W. by $\mathrm{N}$. Montgomery. 
Cuntos, p. v., and cap. Jones co., Ga.: on Walnut cr. of the Ockmulgee r., $18 \mathrm{~m}$. W. Milledgeville.

Clizvton, p. v., Vermillion co., Ind.: on the W. side of Wabash $r$. and canal, $65 \mathrm{~m}$. W. by S. Indianapolis. It is a point from which considerable produce is shipped.

Clinton, p. v., and cap. De Witt co., $I l_{0}$ : on the N. side of Salt cr, of Sangamon r., 46 m. N. E. Springfield.

Clinton, p. v., Hickman co, $K y_{.}:$near the ecntre of the county, on the N. side of the Bayou Desha, $248 \mathrm{~m}$. W. S. W. Frankfort. It is probable that the line of the Mobile and Ohio R. R. will pass through or near this village.

Clinton, p. v., East Feliciana par., $L \alpha_{*}:$ on the E. side of Conute cr., $33 \mathrm{~m}$. N. E. Baton Rouge. The Clinton and Port Hudson R. R. terminates here, 24 m. from Port Hudson on the Mississippi r.

Cunntos, t. and p. v., Kennebec co., Mre.: on the E. side of the Kennebec r., $22 \mathrm{~m}$. N. by E. Augusta. The v. is situate on Sebastieook r., which runs through the t., and affords extensive water-power. Mills and manufactories of various kinds are numerous, Pop. of t, 1,743.

Clinton, p. ., Lenawee co., Mich.: on the E. side of the $\mathrm{N}$. branch of Raisin r., $53 \mathrm{~m}$. S. E. Lansing. It is a flourishing $\mathrm{v}$., and has some manufactures and milling, also an iron foundry, ete.

Cuaron, p. o., Hinds co., Miss. : on the line of the Vicksburg, Brandon, and Jackson R. R., $10 \mathrm{~m}$. W. Jackson. The Mississippi College, founded in 1830, is located here.

Crinton, $t_{\text {. }}$ and p. v., Rock co., Wisc. : on the S. of Turtle cr. of Rock r., $46 \mathrm{~m}$. S. E. Madison. The $\mathrm{v}$. is located on the post road, $10 \mathrm{~m}$. E. from Beloit. Pop. 1,176.

Cuñon, p. v., and cap. Sampson co., N. Car.: on a branch of Black r., 54 m. S. S. E. Raleigh.

Cuinton, p. v., Hunterdon co., N. Jer. : on the S. branch of Raritan r., $31 \mathrm{~m}$. N. by W. Trenton. It has an immense hydraulic power, and will become a manufacturing $\mathbf{v}$. of importance. The New Jersey Central R. R. passes it, 44 m. from Elizabethport and 20 from Easton.

Cinston, t., Duchess co., $N_{0} \bar{Y}_{\text {: }} 60 \mathrm{~m}$. S. by E. Albany. Pop. 1,795.

Clinton, p. $v_{*}$, Oneida co., $N . Y_{*}:$ on both sides of Oriskany cr., and on the line of the Chenango Canal, $86 \mathrm{~m}$. W. N. W. Albany. It is a flourishing $\mathrm{v}$., and has both manufactures and trade, for which its position on the river and canal peculiarly adapts it. It is noted for its fine seminaries, and about a mile W. of the $\mathrm{v}$. is Hamilton College, the buildings of which are conspicuously situate on an eminence.

Clinton, p. V., Worcester co., Mass. : on the N. side of Nashua r., and on the line of the Worcester and Nashua R. R., $16 \mathrm{~m}$. from Worcester and $30 \mathrm{~m}$. W. Boston.

Crrvton, t. and p.v., Summit co., Ohio: on Indian er. of Tuscarawas r. $97 \mathrm{~m}, \mathrm{~N}$. E. Columbus. The v. lies on the Ohio Canal, and is a place of considerable trade. Pop. 1,196 .

Cunton, p. v., Alleghany co., Penn.: 178 m. W. Harrisburg.

Cunvton, p. vo, and cap. Anderson co., Tenn.: on the

N. branch of Clinch $r$. of the Tennessee, $144 \mathrm{~m}$. E. Nashville.

Clnvton College, p. o., Smith co., Tenn.: 44 m. E. N. E. Nashville.

Clinton Conners, p. o., Duchess co., N. Y.: $62 \mathrm{~m}$. S. by E. Albany.

Cunvtondale, p. F., Ulister co., N. Y.: 64 m. S. by W. Albany.

Cuinton Fugnace, p. v., Clarion co., Penn.

Cunnton Hollow, p. o., Duchess eo., N. Y.: $63 \mathrm{~m}$.

8. by E. Albany.

Cunvton river, Mich: has its source in the numerous small lakes scattered over the central parts of Oakland co. and after collecting their waters, passes out of the county in a $\mathrm{N} . \mathrm{E}$. direction, and flowing thence $\mathrm{S}, \mathrm{E}$. and $\mathrm{E}$, discharges into the N. part of Lake St. Clair opposite the mouth of St. Clair r. It is about $50 \mathrm{~m}$. long. Its principal tributaries are North Fork, Stony cr., and Paint er., which discharge from the N. side, and Red r, on the S. side. It is boatable to lochester $20 \mathrm{~m}$, and after removing the bar at its mouth, vessels of the largest class can come to Mt Clemens, $6 \mathrm{~m}$. from the lake. In its course it waters a beautiful country and furnishes many mill sites.

Clintonville, p. v., Bourbon co, Ky. : 36 m. E. Frankfort. The line of the railroad from Knoxville to Covington will pass through or near to this village.

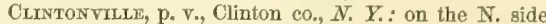
of Au Sable r., $10 \mathrm{~m}$. W. of Port Kent on Lake Champlain, and $100 \mathrm{~m}$. N. Albany. Immense deposits of iron ore exist at this point, and furnaces and rolling mills have long been in successful operation. The v. contains about 1,200 inhabitants.

Clintorville, p. v., Venango co., Penn.: 172 m.W.N.W. Harrisburg.

Clintonville, p. v., Greenbrier co., Virg.: 158 m. W. by N. Richmond.

Chintorrille, p. v., Franklin co., Ohio: on the Cleveland, Columbus, and Cincinnati R. R., $5 \mathrm{~m}$. N. Columbus, Curo, p. v., Wayne co., Ky. : 96 m. S. Frankfort.

Clio, p. v., Marlborough dist., S. Car : $87 \mathrm{~m}$. N. E. Columbia.

Curo, p. v., Greene co., Ohio: 59 m. W. S. W. Columbus.

Clock ville, p. v., Madison eo., N. Y.: $84 \mathrm{~m}$. W. by N. Albany.

Clokey, p. o., Washington co., Penn。: 190 m. W. Harrisburg.

Cloptox"s Mills, p. o., Putnam co., Ga. : on Little r.. a tributary of Oconee r., $13 \mathrm{~m} . \mathrm{N}$. W. Milledgeville. The Eatonton R. R. passes near by the mills.

Cloutiertulle, p. v., Nachitoches par., La.: on the E. side of old r., $127 \mathrm{~m} . \mathrm{N}$. W. Baton Rouge.

Clote, p. o., Sussex co., N. Jer.: 58 m. N. Trenton.

Cuove, p. o., Duchess co., $N$. $Y$.: on Clove Kill, a tributary of Fishkill, $80 \mathrm{~m}$. S. by E. Albany.

Clover, p. Y., Clermont co., Ohio: $92 \mathrm{~m}$. \$. W. Columbus.

Clover, p. T., Blair co., Penn.

Clover Bend, p. o., Lawrence co., Ark. : 102 m. N. N. E. Little Rock.

Clover Botton, p. o., Sullivan co., Tenn.: $214 \mathrm{~m}$.

E. by N. Nashville.

Clover Creek, p. o., Highland co., Virg.: on a cr. so called, $134 \mathrm{~m}$. W. N. W. Richmond.

Cloverdale, p. o, Putnam co., Ind. : on Doe cr., a tributary of Mill cr., $36 \mathrm{~m}$. W. S. W. Indianapolis.

Cloverdale, p. o., Botetourt con, Virg.: $186 \mathrm{~m}$. W. Richmond.

Cloverdale Hoteu, p. o., Bath co., Virg.: 122 m.W. N.W. Richmond.

Clover Garden, p. o., Orange co., N. Car. : $32 \mathrm{~m} . \mathrm{N}$. W. Raleigh.

Clover Green, p. o., Spottsylvania co., Virg. : $46 \mathrm{~m}$. N. by W. Richmond.

Clover Hul, p. o., Hunterdon co., N. Jer.: $32 \mathrm{~m}$. N. Trenton.

Clover firct, p. o., Blount co., Tenn. : 146 m. E. by S. Nashville.

Clovfr Milu, p. v., and eap. Appomattox co., Virg.: 70 m. W. by S. Richmond.

Clover Hili, p. v., Green co., Ky. : 69 m. S. W. Frankfort.

Clover LaND, t. and p. V., Clay co., Ind.: on the National Road, $58 \mathrm{~m}$. W. by S. Indianapolis.

Clover OrChard, p. o., Orange co., N. Car.: 36 m. N.W. Raleigh.

Clover Port, p. v., Breckenridge co., Ky.: on the S. side of the Ohio r., at the mouth of Clover cr., $100 \mathrm{~m}$. W. by S. Frankfort. It is an important point for shipping tobacco, and has about 750 inhabitants. There is fine coal in the 
vicinity, and $4 \mathrm{~m}$. in the interior are the White Sulphur, Breckenridge, and Tar Springs.

Clover Poet, p. v., Hardeman co., Tenn. : 143 m. S. W. Nashville.

Clovestule, p. v., Delaware co., $N . Y_{.}: 62 \mathrm{~m}$. S. W. Albany.

Cloyd's Creer, p. o., Blount co., Tenn.: 145 m. E. by S.

Nashville.

Chyattsvinle, p. o., Lowndes co., Ga. : 148 m. s.

Milledgeville.

ClyDE, p. ₹., Wayne eo., N. Y.: on the Clyde r., $158 \mathrm{~m}$. W. Albany. It has a large number of mills, factories, and mechanic shops ; and a newspaper, the " $\mathrm{C}$. Telegraph," is published weekly. The Erie Canal, and the Rochester and Syracuse (direet) R. R. pass through it.

ClyDE, p. v., Whitesides co., $M l .: 184 \mathrm{~m}$. N. Springfield.

CLYDE river, $N . Y$.: this stream is formed by the union of Flint and Mud ereeks in Wayne co., and flows E. 20 m., falling into Seneca river.

Clymar, t. and p. v., Dodge co., Wise. : 42 m. N. E. Madison. The $t_{\text {s }}$ is watered by several fine creeks falling into Rock river. Pop. 785 .

Clymer, t. and p. v., Chautauque co., N. Y.: on Broken Straw cr., 306 m. W. S. W. Albany. Pop, 1,127.

Clymer Centre, p. v., Chautauque co., N. Y.: 308 m. W. S. W. Albany.

Connova county, Miss. Situate N. W. on Mississippi r., and contains $828 \mathrm{sq} . \mathrm{m}$. Drained by Sunflower $r$, and its branches. Surface low and level, liable to inundation; soils very fertile, producing largely cotton and corn. Farms 161; manuf. 0 ; dwell. 260 , and pop.-wh. 1,387, fr. col. 2, sl. 1,391 -total 2,780. Capital: Delta.

Cost creek, Ind.: a fine mill stream, mostly in Fontaine co., about $45 \mathrm{~m}$. in length, and emptying into the Wabash, near the N. line of Parke co. An immense coal bank exists near its mouth, where it is crossed by the Wabash and Erie Canal.

Cosi Grove, p. O, Lawrence co., Ohio : on the W. bank of the Ohio r., $104 \mathrm{~m}$. S. S. E. Columbus.

Coal Hrum p. 0., Goochland co., Virg. : 14 m. N. W. Richmond.

Cont Mines, p. v., Chesterfield co., Virg. See BuackHЕTH.

Cosl Motntant, p. o., Forsyth co., Ga, : 98 m. N. N.W. Milledgeville.

Cost Post, p. r., Indiana co, Penn.: 124 m. W. by S. Harrishurg.

Coal River Marsheg, p. o., Raleigh co., $\sqrt{2} r g_{0}: 214 \mathrm{~m}$. W. Richmond.

Coal Run, p. o., Washington co., Orio: $86 \mathrm{~m}$. S. E. Columbus.

Costsyottr, p. v., Kanawha co., Tirg.: on the S. side

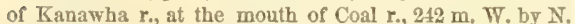
Richmond.

Coar Valley, p. o., Alleghany co., Penn.

Coate's Tavera, p. o., York dist., S. Car, : $72 \mathrm{~m} . \mathrm{N}$. Columbia.

Contesvilie, p. $\nabla_{.}$, Chester co., Penn.: on the $\mathrm{W}$. branch of Brandywine cr., $56 \mathrm{~m}$. E. S. E. Harrisburg. The v. has numerons manufactures, as paper, cotton, nails, etc.; and in its vicinity there is a noted chal rbeate spring.

Cobaltville, p. v., Middlesex co., Conn.

Совв county, $G a$. Situate N. W. centrally, and contains 520 sq. m. Drained in the N. by the head streams of Coosa r. and in the E. by the tributaries of Chattahoochee r. which traverses the E. border. Products chiefly cotton and Indian corn. Farms 931; manuf. 10; dwell. 1,918, and pop.-wh. 11,565, fr. col. 3, sl, 2,272-total 13,843. Capital: Marietta. Public Works: Western and Atlantic R. R.

Cobirssecostre waters, $M \epsilon_{*}$ : is a fine sheet of water, Iving W. of Hallowell, and connected with a number of smaller ponds. Its outlet is a $\mathrm{r}$. of the same name, which enters the Kennebec at Gardiner. These waters afford a great hydraulic power, an abundance of fish; and much delightfol scenery.

Coвb's Fork, p. o., Decatur co., Ind. : 62 m. S. E. by E. Indianapolis.

Совв's Mruss, p. o., Cherokee co., Ala.: 132 m. N. by E. Montgomery.

CoBkRLY's, p. o., Union co., Ohio : $37 \mathrm{~m} . \mathrm{N}$. W. by W. Columbus.

Совнам, p. ., Albemarle co., Virg.: $69 . \mathrm{m} . \mathrm{N}$. W. Richmond.

Cobleskint, t. and p. v., Schoharie co., $N_{.} Y .:$ on Cobleskill cr., $38 \mathrm{~m}$. W. Albany. In this t. there is a mill-stream issuing from a natural well, the depth of which has never been ascertained; it then enters a subterranean passage, and disappears for $7 \mathrm{~m}$., when it again rises and flows on the surface. Pop. 2,229.

Совясоок bay, Me.: a large bay, the recipient of a number of large ponds on the S. W. side of Eastport, in Passamaquoddy Bay.

CовтвN's Store, p. o., Mechlenburg co., N. Var.

Cocalico, p. v., Lancaster co., Penn.

Cochector, t. and p. $\nabla$., Sullivan co, $N . Y .:$ on the E. side of Delaware r., $76 \mathrm{~m} . \mathrm{S}$. W. Albany, and drained by Collicoon and Ten Mile creeks, tributaries of Delaware r. The Erie R. R. traverses the W. line of the $t_{n}$, and intersects the village, which lies on the Delaware, $141 \mathrm{~m}$. from New York.

CochesetT, p. o., Plymouth co., Mass.

Cochituate, p. Y., Middlesex co., Mauss.

Cochray's Cross Roads, p. o., Harris co., Ga.: $106 \mathrm{~m}$. W. by S. Milledgeville.

Cochran's Grove, p. o., Shelby co., Ill.: 58 m. E. S. E. Springfield.

Cocmean's Landing, p. o., Monroe co., Ohio: 110 m. E. by $\mathrm{S}$. Columbus.

Cochrat's Mruls, p. o., Pickens co., Ala. : $104 \mathrm{~m}$ W. N. W. Montgomery.

Cochraxsvilue, p. v., Chester co., Penn.: 54 m. E. S. E. Harrisburg.

Cochransville, p. v., Marshall co., Tenn. : $46 \mathrm{~m} . \mathrm{S}$. Nashville.

Cocirranton, p. v., Marion co., Ohio: 48 m. N. N. W. Columbus.

Cocke county, Tonn. Situate on the E. State line, and contains 374 sq. m. Smoky Mountains, one of the Alleghany ridges, bounds it on the E., and divides the State from North Carolina. Drained by French, Broad, and Big Pidgeon rivers, tributaries of Tennessee $r$., which runs along its $\mathrm{N}$. border. The surface is elevated and broken, and the soils thin. Indian corn is the chief product, and some beef and pork is produced for market. Farms 836; manuf. 85 ; dwell. 1,295, and pop.-wh. 7,502 , fr. col. 79 , sl. 719-total 8,300. Capital: Newport.

Cockntssville, p. v., Baltimore co., Md.: on the line of the Baltimore and Susquehanna R. R., $14 \mathrm{~m}$. N. Baltimore, and $40 \mathrm{~m}$. N. by W. Annapolis. A weekly paper, the "Baltimore County Advocate," is published at this place.

Cockrur, p. On, De Soto con, Jifs : 168 m. N. Jackson.

Codotngrille, p. v., Medina co., Ohio: 96 m. N. N. E. Columbus.

Conords, p. v., York co., Penn.: on Codorus er., $30 \mathrm{~m}$. $\mathrm{S}$. Harrisburg. Codorus cr. rises in Frederick co., Md., and after a circuitous course of $30 \mathrm{~m}$., enters the Susquehanna, near the v. of New Holland, in Penn.

Coel., p. 0., Livingston par., La. : 42 m. E. Baton Rouge. COE PIDGe, p. 0., Cuyahoga co., Ohio: 123 m. N. E Columbus.

Coesse, p. v., Whitley co., Ind.: on the S. of Eel r., 102 . m. N. N. E. Indianapolis.

Commans, t. and p. v., Albany co., $N_{0} Y_{*}:$ on the W. side of the Hudson r., $13 \mathrm{~m}$. S. Albany. Coeymans creek and other tributaries of the Hudson drain the $t$. The $\mathrm{v}$. 
contains several manufacturing establishments and extensive brick yards. The Albany steamboats stop here, and considerable trade is carried on by means of schooners and sloops navigating the Hudson. Pop. 3,050.

Comymans Hollow, p. F., Albany co., N. Y.: $19 \mathrm{~m} . \mathrm{S}$. Albany.

COFER, p. o., Hardin co., Ky. : $72 \mathrm{~m}$. W. by S. Frankfort. Coffadrliae, p. v., Neshoba co., Miss.; 69 m. N. E. Jackson.

COFFEe county, $A l a$. Situate S. E., and contains 1,008 sq. m. Drained by Pea $r$. and its branches. Surface level, but undulating-partially wooded; and soils rich and well drained. The agricultural staples are cotton and corn. Farms 604 ; manuf. 9; dwell. 893, and pop.-wh. 5,382, fr. col. 1, sl. 557-total 5,940. Capital: Wellborn.

COFFEE county, Tenn. Situate centrally, and contains 276 sq. m. Drained by the head waters of Duck cr. Surface undulating, inclining to the W., and the soils of average fertility. The principal products are Indian corn and wheat, with some tobaceo and cotton. Farms 485; manuf, 19; dwell. 1,179, and pop.-wh. 7,061, fr. col. 23, sl. 1,267 -total 8,851. Capital: Manchester. Public Works: M.Minnville Branch of the Nashville and Chattanooga R. R. Corres, p. v., Clay co., Ind.: 56 m. W. S. W. Indianapolis.

COFFen CORNer, p. 0., Coffee co., Ala.: 89 m. S. by E. Montgomery.

COFFee Crees, p. o, Porter co., Ind.; on the E. side of Coffee cr., about $2 \mathrm{~m}$. above its confluence with Calumic r., and not far from the line of Northern Indiana R. R., $136 \mathrm{~m}$. N. N. W. Indianapolis.

Coffee Landivg, p. 0., Hardin co., Tenn.: 107 m. S. W. Nashville.

Cofres Run, p. o., Huntingdon co., Penn.: 79 m. W. Harrisburg.

Coffervilue, p. v., Clark co., Ala.: on the $\mathbf{E}_{\text {. side of }}$

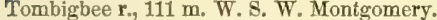

Coffeevilue, p. v., and cap. Yallabusha co., Miss. : on a creek of Yallabusha r., $116 \mathrm{~m}$. N. by E. Jackson. Pop. 600. The "Southern Appeal" (whig) is published weekly. Cofrin's Grove, p. 0., Delaware co., I $c_{*}: 55 \mathrm{~m} . \mathrm{N}$. Iowa City.

Cogrils, p. 0., MיMinn co., Tenn.: 132 m. E. S. E. Nashville.

Cogsweld, p. vo, M'Henry co., Ill.: 183 m. N. N. E. Springfield.

Corfasset, t. and p. v., Norfolk co., Mass. : facing N. E. on Massachusetts Bay, $16 \mathrm{~m}$. S. E. Boston. The coast is here rocky and dangerous; it has a considerable amount of shipping, chiefly engaged in coasting and in the fisheries, and the $\mathrm{v}$. is important as the E. terminus of the South Shore R. R., $11 \mathrm{~m}$. from Braintree. It has a flne summer climate, and the shore is a favorite resort for invalids and fashionables. Pop. 1,775.

Conoss, p. v., Albany co., $N_{*}, Y$. : on the S. W. side of Mohawk r., $8 \mathrm{~m}$. N. Albany, a little below the Falls, and near the jenction of the Champlain and Erie Canals. The water-power of the place is very extensive, and is used for various manufacturing purposes. It contains 7 ehurches, about 300 houses, and 2,600 inhabitants. A railroad is now in conrse of construction from Albany to this point to accommodate the manufacturing interest. The "Cohoes Cataract" (neutral) is published weekly. The name of this v. has lately been changed to that of Rockton.

Coноzs falls, $N$. $Y$.: immediately above Cohoes village, $2 \mathrm{~m}$. from the mouth of Mohawk r. The surrounding scenery is romantic, and when the $\mathbf{r}$ is full the falls present a grand appearance. Besides a rapid above and below the falls, the r., here from 300 to 400 feet broad, has a perpendicular fall of 70 feet. Half a mile below the falls is a bridge across the $r .800$ feet long, from which the view of the eatarast is seen to advantage. This fall is always an object of interest to travelers, and, if inferior to the gran- deur of Niagara, has much to attract and please in its varied scenery.

Condtitan Sprivg, p. o., Murray co, Ga. : at the base of Cohuttah Mountain, in the N. E. corner of the co., 164 m. N. N. W. Milledgeville. The spring is on the S. side of a small stream issuing from the mountain, which joins the Connesauga cr., $6 \mathrm{~m}$. below. This is one of the mast ralable mineral springs in this section of the country.

Corra, p. o., Carroll co, Miss. : $84 \mathrm{~m}$. N. by E. Jackson.

Corla, p. v., Washington co., $N . Y$.

CoINJook, p. Y., Currituck co., N. Car, : 160 m, E. N. E. Raleigh.

Coltsvilue, t, and po $v_{4}$, Mahoning co. Olio: in the N. E. corner of the co., 146 m. E. N. E. Columbus. Beaver $r$. and the Pennsylvania and Ohio Canal run through its S. W. portion.

Coker Crewk, p. o., Monroe co., Tenna. on the creek so called, 153 m. E. S. E. Nashville.

Cokesburgi, p. v., Hunterdon co., N. Jer.: $26 \mathrm{~m} . \mathrm{N}$. Trenton.

Cokesbury, p. v., Abbeville dist., S. Car. : on the W. side of and $2 \mathrm{~m}$. from Saluda $\mathrm{r}_{\text {., }}$ and on the line of the Greenrille and Columbia P. R., $94 \mathrm{~m}$. from Columbia. The Abbeville Branch $R$. R. diverges from the main road at this point

Colaparohek, p. 0., Monroe co., Ga.: 52 m. W. Milledgeville.

Colbrvilue, p, v., Clark co., Ky.: 39 m, E. \$, E. Frankfort.

Colchester, t. and p. v., New London co., Conn.: 21 m. S. S. E. Hartford. Surface uneven; soils of average fertility. Drained by Salmon $r$. in the N. W. and in the E. by head branches of Yantic $r$. The $v_{0}$ is pleasantly situated on the high ground near the eentre of the t., and is the site of Bacon Academy, founded in 1800 by the douation of $\$ 35,000$ from the gentleman whose name it perpetuates. The building is of brick, three stories kigh, 75 feet long and 84 wide. It usually has from 90 to 100 seholars. The $t$. is essentially an agricultural district, and has several saw and grist mills. Pop. 2,468.

Colcrester, t. and p. o., Chittenden co., Term, : on Lake Champlain, into which it projects in the form of $\mathrm{s}$ peninsula, forming on each side extensive bays. Lamoille r. runs through it and discharges into the lake. Winooski City, a flourishing manufacturing $\nabla$. , is partly within this t., the other part being on the opposite side of the river of the same name, which is spanned by a covered bridge The t. is traversed by the Vermont Central R. Pop, 2,575, Colchester, to and p. $0_{0}$, Delaware $c_{n}, N_{0} Y_{*}: 76 \mathrm{~m}$. S. W. Albany. The Papacton branch of Delaware $r$. forms the N. boundary of the t. and Beaver Kill drains it in the S. Pop. 2,184.

Cold Brook, p. o., Warren co., $M l l .: 88$ m. N. W. Springfield. The Peoria and Oquawka R. R. passes through the Ү. $23 \mathrm{~m}$. from Oquawka on the Mississippi r.

Coun Brook, p. v., Herkimer coa, $N_{\text {. }} Y_{\text {. : }}$ on a er, of same name, $76 \mathrm{~m} . \mathrm{N}$. W. Albany. There are several mills on the cr, and the $\mathrm{v}$. has about 300 inhabitants.

Colden, to and p. v., Erie co., $N . Y_{*}:$ on Cazenove cr. $28 \mathrm{~m}$. S. E. Buffalo and about $245 \mathrm{~W}$. Albany. There are several mills at the $\mathbf{v}$, or settlement. Pop. 1,314.

COLDENHAM, p. v., Orange co., $N . \quad Y: 74 \mathrm{~m} . \mathrm{S}$. Albany.

Colden lake, Essex co., N. $Y .:$ a short distance below Avalanche Lake, the waters of which it receires after a descent of 50 feet. It is one mile in length and half a mile wide, and has an elevation above the tide water of Hndson r. of 2,850 feet. It is a most romantic sheet of water, surrounded by high mountain peaks.

Coup Ruv, p. o., Cass co., $G a$.: on a cr. of Etowah r., $132 \mathrm{~m} . \mathrm{N}$. W. Milledgeville.

Cold Sprivg, p. o., Pottowattomee co., $\mathrm{Ta}_{.}: 212 \mathrm{~m}$. W by S. Iowa City. 
Cold Spring, p. v., Fairfield co., Conn.

Cold Sprivg, p. o., Shelby co., $7 l .: 52$ m. S. E. by E. Springfield.

Cold Sprixe, p. v., Harrison co., Ohio: 100 m. E. by N.

Columbus.

Colid Sprrag, p. v., Campbell e0, $K y_{*}: 62$ m. N. N. E.

Frankfort.

Cold Spring, p. o., Wilkinson co., Miss.: on the E. side of Homochitto r., $97 \mathrm{~m}$. S. W. Jaekson.

Cold Spring, p. v., Cape May co., $N$. Jer.: near the $\mathbf{s}$. extremity of the State, equidistant on three sides from the waters of the Atlantic, $84 \mathrm{~m}$. S. by E. Trenton. It is a v. of some 150 inhabitants.

Cold Spring, p. .., Putnam co, $N$. Y.: on the E. bank of the Hudson r., about a mile N. of West Point. It is romantically situated in the Highlands. The Hudson River R. R. passes through it, $54 \mathrm{~m}$. N. of New York City and 96 m. S. of Albany. The West Point Foundery, one of the most extensive iron founderies and machine shops in the Union, is located here. Pop. about 1,600.

Cold Spring, p. 0., Polk co., Tex.: 178 m. E. by N. Austin City.

Coun Sprtwe, p. o., Edgefield dist., S. Car.: $42 \mathrm{~m}$. W. Columbus.

Cold SPRING, t. and p. V., Jefferson co., Wisc.: on a branch of Rock r., 38 m. E. S. E. Madison. The Milwaukie and Mississippi R. R. passes through the S. part of the township. Polj, 568.

Cold Spring Harbor, p. v., Suffolk co, N. $Y_{\text {. }}$; at the head of the bay so called, $116 \mathrm{~m}$. S. by E. Albany. The bay sets up between Quecn's and Suffolk counties, being an arm of Orster Bay, and the v. lies around its head in the form of a crescent. It is a port of entry, has several ships engaged in whaling, and has a considerable coasting trade. Shipping owned in the district, 3,855 tons, of which 2,376 is registered tonnage. Its situation and scenery render it a desirable residence during the summer months. Pop. about 600 .

Cold Streas, p. v., Hampshire co., Virg.: on the E. side of Cacapon r., $134 \mathrm{~m} . \mathrm{N}$. N. W. Richmond. It has several factories and mills, worked by water-power supplied by the river, and has about 400 inhabitants.

Cold Water, t., p. v., and cap. Branch co., Jifich.: on Cold Water $r$ and its branches, $58 \mathrm{~m} . \mathrm{S} . \mathrm{S}, \mathrm{W}$. Lansing. It has numerous mills on its streams. The $\mathrm{v}$. is situate on the line of the Michigan Southern R. R., $92 \mathrm{~m}$. from Monroe and 156 from Chicago. The "C. Sentinel," a weekly newspaper, is published here. Pop. 2166.

Cold WATER, p. 0, Marshall co., Misso: $178 \mathrm{~m} . \mathrm{N}$. Jackson.

Cold WATER, p. 0., Elbert co., Ga.: on a cr, of Sarannah r. so called, 78 m. N. N. E. Milledgeville.

Cold Water, p. 0., Wayne co., Ohio: 86 m. N. E. Columbus.

Cold WATER, p. o., Mercer co., Ohio: $97 \mathrm{~m}$. W. N. W. Columbus.

CoLD WeLL, p. o., White co, Ark. : 13 m. N. N. E. Little Rock,

Cols county, MO. Situate centrally, and contains $440 \mathrm{sg}$ $m$. The Missouri $r$. washes the county on the $Y$. and the Osage r. on th: E.-the inturior being chitfly drained by Moreau cr. and its branches. Surface somewhat uneven; soils generally fertile. Farms 638; manuf. 28; dwell 9S4, and pop.-wh. 5,699, fr. col. 18, s]. 979-total 6,696. Cap itul: Marion. Puldic Wurks: Pacifle R. I.

Colebroor, t. and p. v., Litchfleld co, Conn. : on the W branch of Farmington r., $25 \mathrm{~m}$. $\mathrm{N}$. $\mathrm{T}$. II Iartford. Drained by Colebrook $r_{*}$, a tributary of the before named. Surface hilly, and sills gravelly, but gond grazing lands. It has some few manufactures. Pop. 1,364

Colebrook, t. and p. o., Coos co., $\boldsymbol{N}$. Hamp. : on the E. side of the Conneclicut $r, 106 \mathrm{~m}$. N. Concord. It is drained by the Mohawk and Beaver rivers, and has much fine intervale lands on the Connecticut. It is entirely agricultural in its industry. Pop. 908

Coterrook Date, $t$, and p. o., Berks co., Penn.: $67 \mathrm{~m}$. E. Harrisburg,

Coterrook River, p. o., Litchfield co., Conn.: on the r. so called, $27 \mathrm{~m}$. N. W. Hartford.

Cols CAMP, p. o., Benton co., Mo. : on Cole Camp cr., a tributary of Osage r., $58 \mathrm{~m}$. W. S. W. Jefferson City.

Cole CREEK or (Coal creek), p. o., Fountain co., Ind: 72 m. W. N. W. Indianapolis. Coal cr. is a fine mill stream, about $45 \mathrm{~m}$. in length, andenters the Wabash near the $\mathrm{N}$. line of Parke co., after passing through a splendid agricultural country. It has numerous tributaries from the $\mathbf{E}$. The best coal bank that has been found in the State is near the mouth of this stream, where the Wabash and Erie Canal crosses it.

Cole Crees, p. 0., Columbia co., Penn.: 67 m. N. E. Harrisburg.

Colmmax's Cross Roads, p. o, Edgefield dist, S. Car.

Colemansville, p. vo, Harrison co., Ky.: on the W. side of the W. branch of Licking r., $42 \mathrm{~m}$. E. N. E. Frankfort.

Colerann, to and p. v., Franklin co., Mrass. : on a branch of Deerfield r., which affords water-power, $92 \mathrm{~m}$. W. N. W. Boston. The surface is hilly, and furnishes fine grazing lands; the t. has also several important manufactures, consisting of cotton goods, iron castings, leather, hats, earthenware, and agricultural implements. It was first settled by a colony from the North of Ireland in 1736.

Colerans, p. v., Bertie co., N. Car.: on the W. bank of Chowan r., 143 m. E. N. E. Raleigh.

Colerativ, t. and v., Hamilton co., Ohio : on the E. side of Great Miami X., 100 m. S. W. Columbus. Pop. 3,125.

Coleraiv, to and p. Y., Belmont co., Ohio: on the N. side of Indian Wheeling cr., a tributary of Ohio r., $114 \mathrm{~m}$. E. by $\mathrm{N}$. Columbus. The surface is hilly, but the soils are rich and productive. Pop. 1,321.

Colerarv, to and p. v., Lancaster co., Penn.: 52 m. S. E. Harrisburg. It has several large manufacturing establishments, furnaces, ete.

Colerand Forge, p. o., Hunterdon co., Penn.: on Spruce cr., 83 m. W. Harrisburg.

Coles county, $\Pi l$. Situate E., and contains $864 \mathrm{sq.} m$. Drained by Kaskaskia and Embarras rivers, which furnish extensive mill power. Surface chiefly prairie, moderately undulating, and soils of excellent fertility. Farms 996 ; manuf. 0 ; dwell. 1,571, and pop.-wh. 9,299, fr. col. 36total 9,385. Capital: Charleston.

Colmbirage, p. v., Potter co., Penn。: 122 m. N. N. W. Harrisburg.

Colesiurgri, p. v., Delaware co, $I a_{*}:$ in the N. E. corner of $c 0 ., 67 \mathrm{~m}$. N. by E. Iowa City.

Cole's Mruis, p. o., Delaware co., Ohio.

Colesvin.ue, p. $\mathrm{Y}_{\text {, }}$ Stokes co, N.Car. $_{\text {: }}$ on the N. of Snow cr. of Roanoke r., $108 \mathrm{~m}$. N. W. Raleigh.

Colestille, p. v., Sussex co., N. Jer.: $62 \mathrm{~m}$. N. Trenton. Colesvilue, p. $\nabla_{*}$, Montgomery co., Md.: on one of the head streams of the Eastern Branch of Pototinae r., $29 \mathrm{~m}$. W. by N. Annapolis.

Colmstille, t, and p. $\nabla .$, Broome co., N. $Y_{*}:$ on the W. side of the Unadilla $r_{0}, 98 \mathrm{~m}$. S. W. Albany. Chiefly drained by creeks flowing into that stream. The surface is generally hilly; near the river, however, are alluvial flats of great fertility. Pop. 2,867.

Coleta, p. 0., Talladega co., Ala.: $74 \mathrm{~m}$. N. by E. Montgomery.

CollaMer, p. v., Copiah co., Miss. : 39 m. S.W.Jackson.

Collamer, p. v., Chester co., Penn.: 73 m. E. by \&. Harrisburg.

Collamre, p. v., Windham co., Comn。: $41 \mathrm{~m}$. E. by $\mathbb{N}$. IIartford.

Collamer, p. v., Cuyahoga co., Ohio: 120 m. N. N. W. Columbus.

Collasrs, p. v., Kane co, $I U$. : 155 m. N. N. E. Spring 
field. It lies on the edge of a beautiful prairie drained by a branch of Sycamore $r$.

Collaner, p. Y., Onondaga co., N. Y.: $112 \mathrm{~m}$. W. by N. Albany.

Collamer, p. v., Whitley eo., Ind.: 94 m. N. N. E. Indianapolis.

Collaver, p. v., Sauk co., Wisc.: on the N. side of Wisconsin r., $26 \mathrm{~m}$. N. W. Madison.

College Corner, p. v., Butler co., Ohio: in the N. W. corner of the co., and on the line of the Junction R. P. 102 m. W. by S. Columbus.

College Green, p. o., Cecil co., Ma.: 55 m. N. E. Annapolis.

College Hul, p. v., Lafayette co., Miss. : 149 m. N. N.E. Jackson.

Collegr Hili, p. v., Hamilton co., Ohio: 100 m. S. W. Columbus.

College Mound, p. o., Kauffman co., Tex. : 217 m. N. N. W. Austin City.

COLLEGE OF St. JAMES, p. o., Washington $e_{\star}$, DId, : $6 \mathrm{~m}$.

S. E. Hagerstown, 4 m. N. E. Williamsport, and 76 W. N.W. Annapolis. The college belongs to the Protestant Episcopal Church, and has a grammar-school attached to it. The college buildings, and the residences near them, make a goodly-sizer village. One of the main buildings was erected by General Ringgold, as his private mansion, nearly 60 years ago; the others have been erected since 1812 , when the institution was first opened. It was chartered in 1844. There are 5 resident professors, 3 lecturers, and several tutors, etc., and in 1850 it had 110 students. The annual expense for tuition, boarding, etc., is $\$ 225$. The enuntry in the neighborhood is fertile and healthful; the population, chiefly Germans, very industrious, frugal, and moral.

Collegriflue, p. v., Saline co., Arto.: 16 m. S. W. Little Rock.

Colletion district, S. Car. Situate S., and contains 2,100 sq. m. Drained by the Ashley, Edisto, Ashepoo, and Combahee rivers, the latter of which forms its S. W. border, and all fall into the Atlantic Ocean, which washes it on the S. E. Numerous islands line the coast, of which Edisto Island is the largest. Surface entirely level, and mostly swamp; soils productive of rice and cotton. Farms 888; manuf. 10; dwell. 1,515, and pop.-wh. 7,404, fr. col. 330, 8l. 31,771-total 39,505. Capital: Walterborough. Pubiic Works: South Carolina R. R

Colleton, p. v., Fayette co., Tenn. : 168 m. S.W. by W. Nashville.

Collettsville, p. v., Caldwell con, N. Car, : on the E side of Mulberry er, of New r., $157 \mathrm{~m}$. W. by N. Raleigh.

CoLuIER's, p. o.s Edgefield dist., S. Car.: 87 m. W. Columbia.

Collierstown, p. v., Rockbridge co., Tirg.: $117 \mathrm{~m}$. W. Richmond.

Colliersville, p. v., Shelby co., Tenn.: on the line of the Memphis and Charleston R. R., $31 \mathrm{~m}$. E. Memphis, and $176 \mathrm{~m}$. W. S. W. Nashville.

Colurs county, Tex. Situate N., and contains 860 sq. $\mathrm{m}$. Drained by numerous and wide-spreading tributaries of the Elm fork and of the $\mathrm{E}_{\mathrm{s}}$ fork (or Bois d'Are $\boldsymbol{r}_{\mathrm{s}}$ ) of Trinity r. Surface elevated and very diversified; soils excellent. Farms 218; manuf. 0; dwell, 311, and pop.-wh. 1,816, fr. col. 0, sl. 134-total 1,950. Capital: M'Kinney.

Collins, p. o., Manitouwoe co., Wise.

Corrins, p. o., Columbia co., Flor.

Colliws, t. and p. o., Erie co., $N_{0} Y_{0}$; on the $N_{\text {. side of }}$ Cattaraugus cr., $262 \mathrm{~m}$. W. Albany. Drained by creeks flowing into that stream and Lake Erie. The t. contains several factories and mills. Pop, 4,001.

Collin's Centre, po vo, Erie co., $N . Y .: 259 \mathrm{~m}$. W. Albany.

Colliv's Depôt, p. o., Hampton co., Mrass.

Collin's Setmement, p. o., Lewis co., Virg : $212 \mathrm{~m}$. W. N. W. Richmond.
Colinnsville, p. v., Hartford co., Conn.: on both sides of Farmington r., $14 \mathrm{~m}$. W. by N. Hartford. A branch of the New Haven and Northampton R. R. from Plainville, 11 m., terminates here. It is a flourishing $\mathrm{v}$., manufacturing chiefly axes and other edged tools. Pop. abont 1,500.

Coluingville, p. v., Madison co., Ill.: $80 \mathrm{~m}$. S. by W. Springfield, and about $10 \mathrm{~m}$. from Illinoistown, on the Mississippi $r$.

Collinsville, p. v., Lewis co., $N_{0}, Y_{0}:$ on the W. side of Black r., 102 m. N. W. Albany. Pop. about 200.

Collingville, p. v., Butler co., Otio : on the E. side of a branch of Miarni $\mathbf{r}, 89 \mathrm{~m}$. W. S. W. Columbus.

Collirene, p. 0., Lowndes co., Ala. : 27 m. S. W. Montgomery.

Collumstrlle, p.v., Lycoming co., Penn.: 78 m. N. N.W. Harrisburg.

Colly SwaMp, p. 0., Bladen co., N. Car.: on a cr. of South $\mathbf{r}$, so called, $184 \mathrm{~m}$. S. by E. Raleigh.

Coloma, p. v., Cherokee co., Alt.: 129 m. N. N. E. Montgomery.

CoLon, t. and p, 0., St. Joseph co, Mich.: on the S. of St. Joseph's r., 66 m. s. W. Lansing. The t. has several small lakes within it which supply numerous streams, and furnish immense water-power. Pop. 847.

Coloner's Fork, p. o., Picken's dist., S. Car.: on a branch of Tullulah r., $116 \mathrm{~m}$. N. W. Columbia.

Colory, p. o., Knox co., Mo.: 106 m. N. Jefferson City

Colorado county, Texe. Situate loward S., and contains $820 \mathrm{sq}, \mathrm{m}$. Drained centrally by affluents of Colorado r., which passes through it from N. to S.; on the E. by San Bernardo r., and on the W. by the head waters of Navidad r. Surface rolling; soils of the highest fertility, and suitable for cotton and sugar. Farms 116; manuf. 2; dwell. 283, and pop.-wh. 1,534, fr. col. 0, sl. 723-total 2,257. Capital: Columbus,

Colorado river, Utah and Nero Drex. Ter.: a vast river extending from its sources in the Rocky Mountains, near the head waters of the Columbia, the Missouri, Arkansas, and the Del Norte rivers, to the Gulf of California. Its tributaries are gathered from the Cordilleras, through a range of 6 degrees of latitude. Green $r$, which rises in a number of small lakes at the base of Fremont's Peak, in lat $43^{\circ}$, is its most northern constituent; farther south it receives the Yampa, the head waters of which almost interlock with those of the north fork of Platte $r_{\text {. }}$; the Uintah $\mathrm{r}_{\text {. }}$; the White r. ; Grand r., equal in volume to the Upper Colorado itself; the Navajo r.; the Yaquilla r.; the Rio Vergen, and others of considerable magnitude. The gencral course of the river is $\mathrm{S}$. and $\mathrm{S}$. W., receiving the largest and most voluminous of its constituents from the East Mountain country. In about lat. $38^{\circ}$ the Rio Gila meets it, and these two rivers enter the Gulf through a common estuary. The topography of the country through which the Colorado passes is as yet little known: but it is averred by those who have traversed the country, that the streams are navigable for hundreds of miles, and that the country is one well adapted to the support of a dense population, its agricultural capacities being equal to the finest lands of the States east of the Cordilleras. Along the banks of the river are found numerous ruins of cities, attributed to the Aztecs, and which in their architecture discover a high state of civilization in the builders. At the present day the whole region is a wilderness, inhabited only by the wild Indian.

COI.ORADO river, Tex.: one of the great rivers of the country, extending from its source in the Guadalupe Mountains, in an E. and S. E. direction to Matagorda Bay and the Gulf of Mexico, a distance of about 600 miles. It is navigable to Austin City for small steamboats, and is capable of great improvements in its whole length. At and near its mouth it is obstructed by rafts. About $8 \mathrm{~m}$. above Austin, a rocky ledge extends entirely across the stream, and obstructs navigation. The river has worn in this ledge 
many deep, narrow channels, through which the water rushes with the velocity of a mill-race. The current of the river is usually rapid throughout, and the waters quite limpid and pure, but when swollen by heavy rains, they sweep down immense volumes of red mud, sand, and silioions pebbles, from which fact the name Colorado has been derived. The country along the banks of this river is now thickly settled by farmers chiefly from Germany and other European States. The German settlements are models of economy and scientific farming.

Colosse, p. o., Oswego co., N. Y.: 128 m. W. N. W. Albany.

Colquit, p. v., Montgomery co., Ga. : 77 m.S. S. E. Milledgeville.

ColT's Neck, p. v., Monmouth co., N. Jer.: $32 \mathrm{~m}$. E Trenton. A place of considerable business.

\section{THE DISTRICT OF COLUMBIA.}

THE District of Columbia, the seat of the Government of the United States, originally occupied a square of ten miles, on both sides of Potomae River, and comprised portions of Virginia and Maryland, ceded to the United States for the use of the federal government. In 1846, however, that portion of the Territory south of the river was retroceded to Virginia, and hence the present territory lies altogether on its nortl bank, and contains only 60 square milc8.

The Maryland act of cession was passed on the $23 \mathrm{~d}$ December, 1788, and that of Firginia on the 3d December, 1789. Subsequent acts were passed by these States confirming the location.

This District was established in pursuance of a clause of the Constitution of 1789 (Sec. VII.-17), which declares that Congress shall have power " to exercise exclusive legislation, in all cases whatsoever, over such district (not exceeding ten miles square), as may by cession of particular States, and the acceptance of Congress, become the seat of the Government of the United States ;" and further, in pursuance of an Act of Congress, approved 16th July, 1790, which declared "that a district of territory, not exceeding ten miles square, to be located as hereafter directed, on the river Potomac, at some space between the mouths of the Eastern Branch and Conecocheague, be, and the same is hereby accepted, for the permanent seat of the Government of the United States; and that the President be authorized to appoint three Commissioners to survey, and by proper metes and bounds define and limit, a distriet of territory under the limitations above mentioned."

By a proclamation of the President, dated 30th March, 1791, the following were defined as the boundaries of the territory: "Beginning at Jones' Point, being the upper cape of Hunting Creek, in Virginia, and at an angle of 45 degrees west of the north, and running in a direct line ten miles for the first line; then beginning again at the same Jones' Point, and running another direct line, at a right angle with the first, across the Potomac, ten miles, for the second line; then from the terminations of the said first and second lines, running two other direct lines of ten miles each, the one crossing the Eastern Branch and the other the Potomac, and meeting each other in a point." The diagonal lines of this square run north and south, east and west, and, consequently, its angles are formed at the cardinal points.

The District of Columbia, as now demarked, contains only one county, that of Washington ; and in this are comprised the eities of Washington and Georgetown, and what are denominated the country parts. The statistical condition of this county, ete, in 1850, as exhibited in the census of that year, is as follows:

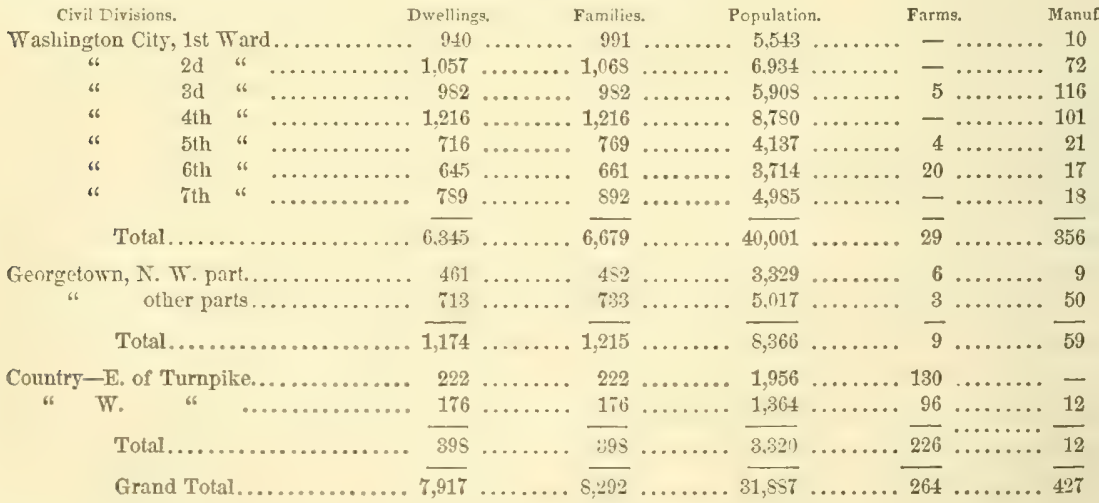

The following exhibits the caste and sexes of the population in the sereral civil divisions:

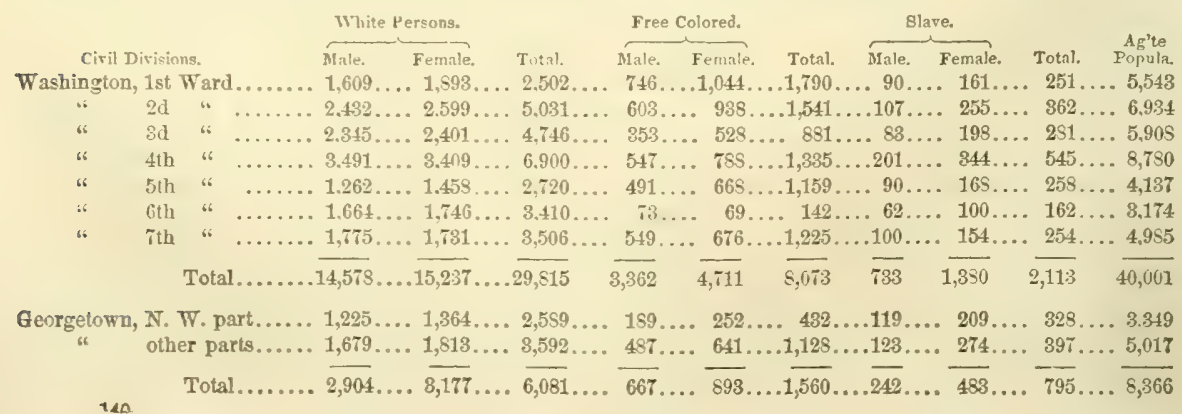


THE DISTRICT OF COLUMBIA.

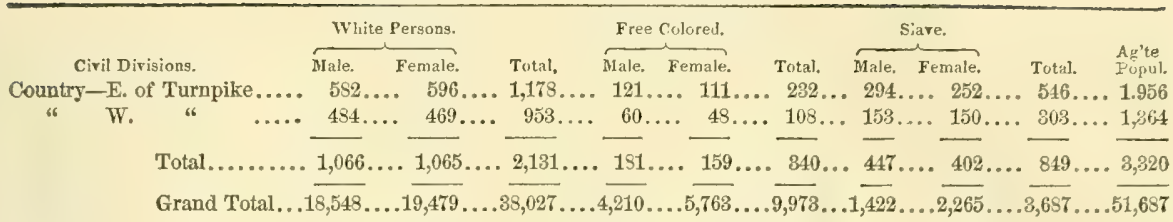

\section{DEOENNIAL MOYEMENT OF POPULATION.}

\begin{tabular}{|c|c|c|c|c|}
\hline $\begin{array}{l}\text { Date of } \\
\text { Census. }\end{array}$ & $\begin{array}{l}\text { White } \\
\text { Persons. }\end{array}$ & Free Col. & SIE & $\begin{array}{c}\text { Total } \\
\text { l'opula. }\end{array}$ \\
\hline 1500. & 10,066 & .. 783 & 4 & \\
\hline 181 & 16,079 & .. 2,849 & 5,395 & $\ldots$ \\
\hline 18 & 22,614 & ...... 4,049 & 6 & \\
\hline & 27 & ... 6,152 & & \\
\hline 184 & 30,657 & ... 8,361 & $\ldots$ & \\
\hline 1850. & 38,027 & . 9,973 & . 3,687 & 51,687 \\
\hline
\end{tabular}

or if the County of Alexandria be included in the returns for 1850-and such, for comparison with former returns, will be necessary-the figures are as follows:

45,240 11,386 5,069 61,695

The number of persons in the District suffering from physical infirmities was, in 1850, as follows:

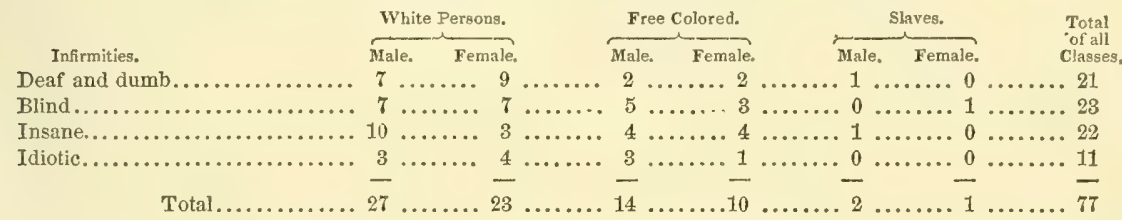

The employments of the District embrace almost every branch of national industry. Its manufactures and commerce are extensive, and its agriculture, though confined chiefly to the production of city-market products, is in a highly flourishing condition. In relation to these subjects, the census of 1850 supplies the following returns:

Occupied Lands, etc.-Improved lands, 16,267 acres, and unimproved lands, 11,187 acres, valued at $\$ 1,730,460$. Number of farms, 264. Value of farming implements and machinery, $\$ 40,320$.

Live-Stock.-Horses 824, asses and mules 57, milch cows 813, working oxen 104, other cattle 123, sheep 150, swine 1,685-valued in the aggregate at $\$ 71,643$.

Agricultural Products.- Wheat, 17,370 bushels; rye, 5,509; Indian corn, 65,230; oats, 8,134; barley, 75; buckwheat, 378 ; peas and beans, 7,754; Irish potatoes, 28,292 ; sweet potatoes, 3,497 bushels; tobacco, 7,800 pounds; hay, 2,279 tons; clover seed, 3 bushels; hops, 15 pounds; wine, 803 gallons; value of the products of orchards, $\$ 14,813$; and of market-gardens, $\$ 67,222$; beeswax and honey, 550 ; wool, 525 pounds; butter, 14,872 pounds; cheese, 1,500 pounds; and the value of animals slaughtered, $\$ 9,038$. Value of home-made manufactures, $\$ 2,075$.

Manufcctures.-Aggregate capital invested, $\$ 1,000,000$; value of raw material, fuel, etc., consumed, $\$ 1,000,000 ;$ average number of hands employed, 1,000; males 500, and females 500; average monthly cost of male labor, $\$ 10,000$, and of female labor, $\$ 5,000$; annual value of products, $\$ 1,000,000$. The whole number of manufacturing establishments, producing to the value of $\$ 500$ and upward annually, was 427 , and of these one was engaged in the manufacture of cotton goods, one in that of woolen goods, and two in making castings of iron-the remainder being distributed to a variety of handicrafts. The statistics of the specified manufactures were as follows:

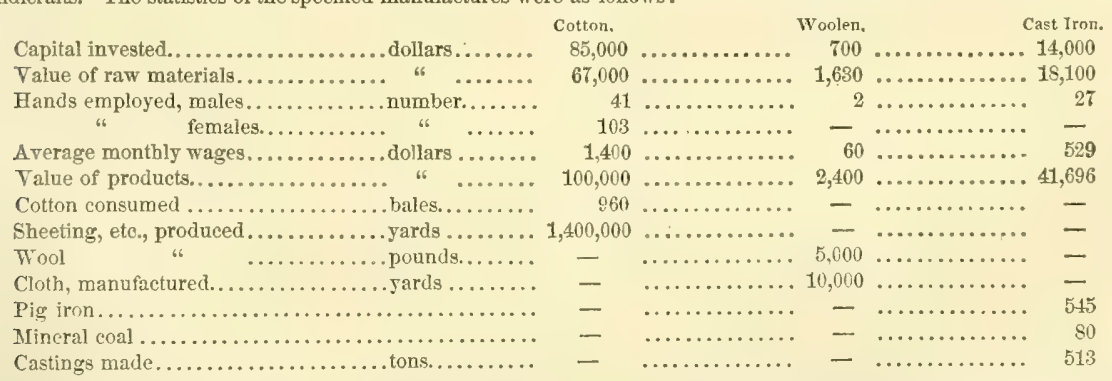

Commerce, Internal Communication, etc.-The foreign commerce of the District is limited. In the 5ear ending soth June, 1850, the exports and imports were as follows: Exports-domestic produce-in American vessels, $\$ 72,175 ;$ in foreign vessels, $\$ 8,213$ : total domestic produce, $\$ 80,385$; foreign produce-in American vessels, $\$ 200$ : total exports, $\$ S \cap, 583$. Imports-in American vessels, $\$ 59,219$; in foreign vessels, 600 : total, 59,519 -balance in favor of exports, $\$ 20,769$. The number of vessels entered during the year was nine, of an aggregate burden of 1,414 tons; and the number cleared. ten vessels, of 1,720 tons. Of the vessels cntered, two, and 154 tons, were foreign, and of those cleared, two, and 200 tons-the remainder being American. Georgetown is the only port. Alexandria, formerly a district city, has eight times the amount of foreign commerce, owing probably to its being the eastern terminus of the Chesapeake and Ohio Canal. 
The tonnage owned within the District is 17,010 tons, of which 2,796 is registered, and the remainder enrolled and licensed, and employed in the coasting trade and on the canal. The steam marine measures 1,949 tons. During the year 1819-50, there were built 8 sloops and canal boats of 288 tons burden.

The District is connected with the interior by numerous fine turnpikes, and by railroads diverging from the neighborhood on both sides of the Potomac, and also through that river and its several branches. The Chesapeake and Ohio Canal has its terminus at Georgetown, and extends to a western terminus at Cumberland, to which point and along the whole line of its route an active commerce with the Distriet is carried on. The railroads of the District are the Washington Branch R. R., connecting it with Baltimore, anã the West and South; and diverging from Alexandria, which is virtually a part of the metropolis, are the Orange and Alexandria R. R. (which connects at Gordonsville, its S. terminus, with the Virginia Central R. R.); and the Manassas Gap R.R., which extends into the heart of elevated valleys beyond the first ridge of the Alleghanies. These avenues open to the national capital a respectable sphere of commerce, and when completed will be the means of greatly enlarging the trade and general interests of the place.

Government, etc.-The government of the Distriet is vested solely in Congress. It has no representation, nor any voice in the election of federal officers. The only fundamental laws, beyond the Constitution of the United States, to which its governors are subject are those which were in force in Maryland at the period of the cession of the jurisdiction of that State in 17 SS.

WASUNGTON and GEORGETOWN are the cities of the District: these are described under their proper captions.

Columisia county, Flor. Situate N., and contains 2,400 sq. m. Drained E. by creeks of St. Mary's and St. John's rivers, and W. by tributaries of Suwanee r., which forms its boundary in that direction. It contains several small lakes and springs, the sources of its streams. Surface generally level, covered with pines, and iu many parts swampy. Okefinokee Swamp extends from Georgia into this county. The soils are sandy and mostly unfit for cultivation, but there are exceptions. Farms 475; manuf. 3; dwell. 569, and pop.-wh. 3,541, fr, col. 1, sl. 1,266-total 4,808. Capital: Alligator.

Columbra county, Ga. Situate E., and contains 580 sq. $\mathrm{m}$. Drained by Little $\mathrm{r}$. and other tributaries of Savannan r., which rise on its N. E. border. Surface undulating, and soils generally fertile. The chief products are cotton, Indian corn, and other grains. Gold is also a produetion of the county, but in no large quantities. Farms 459 ; manuf. 7; dwell. 751, and pop.-wh. 8,617, fr. col. 72, sl. 8,272total 11,961. Capital: Appling. Public Works: Georgia R. R.

Coldombia county, $N . Y$. Situate E. between Hudson r. and the State line of Massachusetts, and contains $624 \mathrm{sq} . \mathrm{m}$. Drained by Kinderhook, Claverac, Copake, and other creeks of Hudson $r$. Surface varied, chiefly consisting of two longitudinal valleys; soils highly fertile. Pine, hickory, oak, maple, elm, and chestnut are the principal forest trees. Iron, lead, manganese, zinc, marble, and other building stone are abundant. Mineral springs, sulphurous and chalybeate, are found in Lebanon and Stockport. The county has great facilities for commerce, and in manufactures has made great progress. Its agricultural products are the cereals, potatoes, butter, cheese, and wool. Farms 250 ; manuf. 208 ; dwell. 7,029 , and pnp.-wh. 41,771 , fr. col. 1,302-total 43,073. Capital: Hudson City. Public Works Fludson River R. R.; Harlem R. R.; Albany and West Stockbridge (western) R. R.; Hudson and Berkshire R. R.; Lebanon Springs R. R., ete.

Columbra county, Penn. Situate N. E. centrally, and contains 650 sq. m. Drained by Fishing, Cattawissa, Big Roaring, and other creeks of the E. branch of Susquehanna r., which traverses it from N. E. to S. W. Surface broken and uneven, wooded, and the soils generally fertile, producing the grains in great abundance. Iron and coal underlie the greater part of the county and have been worked successfully. Potter's earth is also found. Farms 1,179; manuf. 291; dwell. 2,924, and pop.-wh. 17,607, fr. col. 108 -total 17,710. Capitab: Bloomsburg. Public Works: North Branch Canal and Cattawissa R. R., etc.

Colomeris county, Wisc. Situate centrally, and contains 796 sq. m. Drained by the Neenah or Fox r. on the $N_{\text {., }}$ by Wisconsin $r$, on the W., and a branch of Rock $r$. on the S. E. The Neenah and Wisconsin here approximate each nther elosely, and their navigation is united by means of a canal eut through Winnebago portage. The surface is level prairie interspersed with groves, and the soils are exceedjugly fertile. Farms 833; manuf. 24; dwell. 1,853, and pop.-wh. 9,517, fr. col. 18 - total 9,565. Capital: Fort Winnebago, Public Works: Portage Canal.

Columbra, p. v., Henry co., $A l_{c}$. : on the E. side of Chattahoochee r., 100 m. S. E. Montgomery.

Columina, p. v., and eap. Chicot co., Ark.: on the isthmus between the Mississippi r. and Old Fiver Lake, 142 m. S. E. Little Rock. It is a pleasant v., with 7 or 8 stores, and about 300 inhabitants. The whole country round is one cluster of cotton plantations.

Columbia, t. and p. v., Tolland co., Conn.: 21 m. E. S.E. Hrartford. Drained by a branch of Willimantic r., which affords water-power. Surface uneven, and soils gravellywell adapted to grazing. It has but few manufactures. Pop. 2,041.

Columbia, p. v., Fayette co., Ind. : on Garrison's cr, of White Water $\mathrm{r}$, about $3 \mathrm{~m}$. W. of the latter, and $51 \mathrm{~m}$. E, S. E. Indianapolis.

Colomits, p. v., and cap. Whitley co., Ind.: on the N. W. side of Blue r., $105 \mathrm{~m}$. N. N. E. Indianapolis. It is a flourishing $\mathrm{v}$. and has aboat 600 inhabitants.

Colembia, p. v., Monroe co., $11 l_{*}: 97 \mathrm{~m}$. S. by W. Springfield, and $13 \mathrm{~m}$. S. of Illinoistown on the Mississippi r.

Columbia, $v_{v}$, Wapello con, $I a_{*}$ : on the $N$. side of Des Moines r., $61 \mathrm{~m}$. S. W. by W. Iowa City.

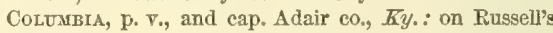
cr. of Green r., 79 m. S. S. E. Frankfort. Pop. 600 .

Cordmis , p. v., and cap. Caldwell par., $L a_{0}:$ on the W. side Wachita $r_{*}, 124 \mathrm{~m} . \mathrm{N}$. N. W. Baton Rouge. It contains the county C. H. and about 200 inhabitants.

Columbia, t. and p. v., Washington co., Me.: in the $\mathrm{S}$. part of the co, $112 \mathrm{~m}$. E. by N. Augusta. Pleasant River Bay sets up to its $\mathrm{S}$. border, and the river itself passes through the $t$., furnishing excellent mill sites. Its trade is considerable, particularly in lumber. The $\mathrm{v}$. is located at the head of tide water, on Pleasant $r$. Pop. of t. 1,140.

Colouria, t. and p. O., Jackson co., Mich.: on North Raisin $r_{0}, 45 \mathrm{~m}$. S. S. E. Lansing. The $t$, is well drained by numerous lakes and streams, and is one of the most flourishing in the county. Pop. 1,140.

Coldmiri, p. V., and cap. Boone co., DFo.: on the W. side of Hinckson's branch of Rochperce r., a tributary of Missouri r., 27 m. N. N. W. Jefferson City.

Colomis, p. v., and cap. Marion co., MFiss.: on the E. side of Pearl r., $77 \mathrm{~m}$. S. S. E. Jackson.

Colturia, p. v., and cap. Tyrrell co., $N$. Car.: on the E. side of Scoupernong cr., 3 or $4 \mathrm{~m}$. from its confluence with Albemarle Sound, and $168 \mathrm{~m}$. E. Raleigh.

Columisis, t. and p. o., Coos co., N. Hamp.: on the E. side of Connecticut r., $108 \mathrm{~m} \mathrm{~N}$. by W. Concord. The surface is uneven and mountainous, and has several rapid crecks flowing to the Connecticut. There are also several small ponds in the $t$, on the banks of one of which, Lime Pond, vast quantities of shells are found, from which lime is made. Pop. 762 .

Colcmist , to and p. v., Herkimer co., $N . \bar{Y}$. : about $10 \mathrm{~m}$. S. of the village of Herkimer, and $68 \mathrm{~m}$. W. N. W. Albany. 
The $t$. is drained by the head streams of the Unadilla and Susquehanna rivers, and by creeks flowing $\mathrm{N}$. to the Mohawk r. Pop. 2,001 .

Cotumbra, p. v., Warren co., N. Jer.: on the E. side of Delaware r., at the mouth of Paulin's Kill, 52 m. N. N. W. Trenton.

Condmats, t. and p. o., Familton co., Ohio: on the N. side of the Ohio and Little Miami r., $6 \mathrm{~m}$. E. Cincinnati and $96 \mathrm{~m} . \mathrm{S}$. W. Columbus. The Little Miami R. R. traverses its S. border in the valley of the river. Pop. 2,416.

Colunnia, p. v., Lancaster co., Penn.: on the E. bank of Susquehanna r., over which there is a bridge 5,690 feet long, resting on stone piers. It is eonnected with Havre de Grace by the Tide Water Canal, and the Philadelphia and Columbia $R_{0} R_{0}$ passes through it and branches off to the N. W., to a junction with the Lancaster and Harrisburg R. $R$. It has considerable trade with Baltimore and Philadelphia. The borough contains a town hall, jail, 13 church$\mathrm{es}$, and a number of other public buildings; and it is supplied with water, through pipes, from some springs in the vicinity. The "C. Spy" is published weekly. Pop. 4,340 .

Coldmata, p. eity, and cap. Richland dist., S. Car., and capital of the State: on the E. side of Congaree r., immediately below the confluence of its constituents, Broad and Saluda rivers, in lat. $33^{\circ} 57^{\prime}$, and long. $81^{\circ} 07^{\prime} \mathrm{W}$., $500 \mathrm{~m}$. $\mathrm{S}$. by W. Washington. The $\mathrm{r}$. is here open to light draft navigation. The city is built on an elevated plain of about 3 or 4 miles in extent- the descent sloping in all directions gradually. It was founded in 1787, and is laid out on the rectangular plan, the streets crossing each other at right angles, and 100 feet wide. The principal buildings are the State House, the county buildings, market house, banking houses, academies, and churches. The State House, in the central part of the city, is 170 feet long and 60 feet wide, two stories high. Columbia is also the seat of the South Carolina College, founded in 1804, and which, in 1850, had 8 professors and 195 students, and a library of 17,000 volumes. The college buildings are very extensive and of brick, surmounting one of which is a fine observatory, which possesses apparatus of great value. This institution is under the patronage of the State. The Southern Theological Seminary is also located here. It is a Presbyterian institution, and in 1850 it had 6 professors and 32 students, with a library of 4,600 volumes. The dwelling houses are chiefly of wood, but there are several built of brick in a style of elegance becoming the capital of the State. The city is supplied with pure water from springs, raised by steampower, and distributed through iron pipes. The high situation the city occupies contributes greatly to the health of the inhabitants, and also affords an extensive view of the surrounding scenery, which is chiefly a cotton and corn region, in the highest state of eulture.

Columbia has three daily and two weekly newspapersthe dailies are, the "State Rights Republican" (dem), the "South Carolinian" (dem.), and the "Telegraph" (indep.), the last two of which issue also tri-weekly and weekly editions; and the weeklies are the "Palmetto State Banner" (dem.), and the "South Carolina Temperance Advocate." The city has also considerable manufactures, which have been altogether initiated within the past decade, and its trade and commercial connection has greatly advanced since the completion of the lines of railroad diverging in all directions from this the chief railroad centre of the State, and when the system proposed for South Carolina shall have formed junctions with the lines of the surrounding States, tne commercial prosperity of this city will be indefinitely enhanced. The railroads now centering in Columbia are-the Columbia Branch of the South Carolina R. R.: the Charlotte and South Carolina R. R.; and the Greenville and Columbia R. R., with their branches and connections West and North. The design is to continue the last through Rabun Gay to Chattanooga, thus connecting this place di- rectly with the Ohio Valley railroads, and those extending to and beyond the Mississippi river. Pop. 4,600 .

Columbra, p. v., and cap. Maury co., Tenn.: on the S. side of Duck r., $39 \mathrm{~m}$. S. by W. Nashville, Jackson College, founded 1833, is located here, and in 1850 had 5 professors, 26 students, and a library of 2,500 volumes. Two newspapers, the "Tennessee Democrat" (dem.), and the "Maury Intelligencer" (whig), are published weekly; and the "Guardian" (literary), monthly. The public buildings are the $\mathrm{C}$. H. and county jail, and the village also contains several stores and about 1,600 inhabitants. The railroad from Nashville via Florence, etc., to Jackson and New Orleans, will pass through or near this place.

Columbis, p. V., Brazoria co., Teas: on the W. side of Brazos r., $38 \mathrm{~m}$. from the gulf, and $154 \mathrm{~m}$. S. E. Austin City. It is a flourishing village and exjoys considerable river trade. Pop. 360.

Columbia, p. o., Fluvanna co., Firg. : on the N. side of James $r$., where it is joined by the Rivanna $r_{.,} 49 \mathrm{~m}$.W.N.W. Richmond. Pop. 300.

Columbta Centee, p. o., Licking co., Ohio: 38 m. N. E. by $\mathbf{E}$. Columbus.

Columbia Citx, p. va, Clark co., Oreg. Ter, : on the $\mathrm{N}$. bank of Columbia $\mathrm{r}_{.}, 57 \mathrm{~m}$. N. Salem. It has good prospects of becoming one of the commercial places of future Oregon.

Columbia Cross Roads, p. o., Bradford co., Penn.: 122 m. N. by E. Harrisburg.

Columbia Furnace, p. F., Shenandoah co., Firg.: 112 m. N. W. Richmond.

Columbia (or Opegon) river, Oreg. Ter.: is the great river of the country, and the recipient of all the other rivers of the territory, having their origin eastward of the ccast range of mountains. Its $\mathrm{N}$. branch rises in the Rocky Mountains in about $50^{\circ} \mathrm{N}$. lat. and $116^{\circ} \mathrm{W}$. long., and thence pursues a N. route to near M'Gillivray's Pass. Here the river is 3,600 feet above the sea-level, and, receiving Canoe r., it then turns $S_{\text {. }}$, and in its course to Fort Colville it successively takes up the waters of numerous tributaries, the chief of which are the Kootanie, or Flat Bow, and Flat Head or Clark's rivers. The Columbia is thus far surrounded by high mountains, and often expands into a chain of lakes. At Colville its elevation is 2,049 feet above the sea, having fallen 556 feet in 220 miles. To the $\mathrm{S}$. of this point it tends to the W., receiving Spokan $r$. from the $\mathrm{E}$. thence it pursues a W. course for $60 \mathrm{~m}$., and bending to the $\mathrm{S}$., receives Okanagon $\mathrm{r}$., which has its source in a line of lakes extensirely susceptible of canoe navigation. The Columbia thence passes $\mathbf{S}$. until it reaches Wallawalla, in $45^{\circ} \mathrm{N}$. lat., and receives the Saptin or Lewis r.; here the elevation of the Columbia is 1,286 feet, and its width about 3,500 feet. It now takes its last turn to the W., receiving the Umatilla, Quisnel's, John Day's, and Chute rivers from the S., and Cathlatate's from the $\mathrm{N}$., and pursuing a rapid course for $80 \mathrm{~m}$., it passes the gorge of the Cascade Mountains in a series of falls and rapids, that form an insurmountable obstacle to the passage of boats, even in time of flood, and are overcome by portages. From this point there is still-water navigation for 40 miles, when rapids again interrupt free sailing, but hence to the ocean 120 miles, the river, though frequently obstrncted by bars, is open to vessels of less than 12 feet draft. In this part of its course it receives the Willamette $r$. from the S., and the Cowlitz from the $\mathrm{N}$. The Willamette is navigable for small vessels to within three miles of its falls. Within a distance of 20 miles from the ocean, the Columbia is greatly increased in width, and at its mouth, between Cape Disappointment and Cape Adams, its width is seven miles, but from each of these capes a sand-bar extends which renders the actual navigable channel contracted and narrow. The mouth of the Columbia was discovered by Captain Gray, of Boston, commander of ship Columbia, of 220 tons, on the 11th May, 1792 ; and on the strength of this discovery the 
United States based their right to the territory watered by its tributaries.

Colombiana county, Ohio. Situate E., and contains 740 sq. m. Drained by Little Beaver $r$, and its branches, and the Ohio $r$. washes its S. E. borders. Surface in the S. hilly and broken, with a light soil-in the $N$. and middle more level, with deep and productive soils. Limestone and water lime exist in all parts; salt springs in the $\mathrm{S}$., marl in the N., and iron ore and bituminous eoal in the central districts; live-stock is numerous; and the agricultural products very large; and coal and salt have long been produced in large quantities. Farms 2,388; manuf. 180; dwell. 5,834, and pop.-wh. 33,444, fr, col. 177-total 33,621. Capital: New Lisbon. Public Works: Ohio and Pennsylvania P. R.; Cleveland and Pittsburg $R_{\text {. }} R_{\text {., }}$ etc. ; and the Sandy and Beaver Canal.

Columblana, p. v., and cap. Shelby co., $A 2 \alpha_{0}: 7 \mathrm{~m} . \mathrm{W}$. of Coosa r., and $5 \mathrm{~s}$ m. N. by W. Montgomery.

Coldmbiara, p. v., Columbiana co., Ohio: on the line of the Ohio and Pennsylvania R. R., $59 \mathrm{~m}$. from Pittsburg and 132 m. E. N. E. Columbus. Pop. 600

Coldubian Grove, p. o, Lunenburgh co, Virg.: $66 \mathrm{~m}$. S. W. Richmond.

Coummous county, N. Car Situate S. E., and contains $530 \mathrm{sq} . \mathrm{m}$. Drained by Lumber $\mathrm{r}$, and its tributaries, and in the S, and $\mathrm{E}$, by White Marsh and Beaver creeks of Waccomaw r. Surface low, and somewhat marshy. Soils good with some exceptions, producing corn, potatoes, and rice. Farms 399 ; manuf. 5 ; dwell. 777 , and pop.-wh. 4,257, fr. col. 149, sl. 1,503-total 5,909. Capital: Whitesville. Public Works: Wilmington and Manchester R.R.

Coluarius, p. v., Hempstead co., Ark.: 122 m. S. W. Little Rock.

Colcumus, p. T., Columbia co., Flor.: on the E. side of Suwanee r., immediately below the confluence of Withlacoochee r., $64 \mathrm{~m}$. E. by S. Tallahassee.

Columorus, p. V., and cap. Muscogee co, Ga.: on the $\mathrm{E}$. side of Chattahoochee r., at the head of steam navigation, and immediately below the falls of the $r$., which have a descent of 111 feet in 3 miles, $118 \mathrm{~m}$. W. by S. Milledgeville. It is 175 miles above the junction with Flint $r$, and $275 \mathrm{~m}$. above Appalachicola Bay. Immediately below the falls the river has a width of only 118 yards, but soon expands to 250 yards wide. The site of the $\mathrm{r}$, is 60 feet above the ordinary height of the $r_{\text {. }}$ and covers 1,200 acres. Two streets running parallel with the $\mathrm{r}$. N. and $\mathrm{S}_{\text {. }}$ are 165 feet wide, and six others have a width of 132 feet; these are intersected at right angles by twelve other streets, which are 99 feet wide. It contains a $\mathrm{C}$. H., jail, several banks, a markethouse, numerous churches, and about 2,400 dwellings; and it also has several large cotton mills, and woolen factories and flouring mills. It is one of the great commercial centres of Georgia, and a depót of a large extent of rich cotton country. The Muscogee R. R. terminates here, and extends hence to Macon, connecting with the Central R.R. to Savanrah, and the Macon and Western R. R., etc., to Nashville and Knoxville, Tenn.; from Gerard, on the opposite side of the river, a railroad is about to be built to Mobile. The bridge over the $r$. at this point cost $\$ 30,000$. A large number of steamboats ply on the r., carrying cotton, ete., to the seaboard and New Orleans; at all seasons, boats drawing 5 feet of water can come up to this place. Columbus is a $\mathrm{v}$. of modern date, haring been laid out in 1428 ; its growth has been rapid-in 1840 it had 3,114 inhabitants, and in 1850 , about 8,000 . It has three newspapers, the " $\mathrm{C}$. Times" published tri-weekly and weekly, and the "C. Enquirer" and the "Southern Sentinel," pablished weekly.

Columisus, p. v., and cap. Bartholomew co., Ind. : on the $\mathrm{E}$. bank of the $\mathrm{E}$. fork of White r., immediately below the mouth of Flat Pock er., $41 \mathrm{~m}$. S. S. E. Indianapolis. Its sit nation is in flne one, on bigh ground overlooking the valleys of White r., Flat Tock cr., and Haw cr., which nearly surround it. The line of the Madison and Indianapolis $R, R$. passes through the v., and here also is the $N$. terminus of the Jeffersonville $R$. $R$. It is a place of considerable manufactures, and its trade and commerce, fostered by its ample facilities of transportation, are large and ever increasing. It has two newspapers, the "Spirit of the West" (whig) and the "C. Democrat," both issued weekly. Pop. about 4,500 .

Colunaus, p. v., Adams co., $M l_{0}$ : on the Quincy and Columbus R. R., $80 \mathrm{~m}$. W. by $\mathrm{N}$. Springfield, and $15 \mathrm{~m}$. from Quiney, on the Mississippi r.

CoLUMBus, p. v., and cap. Hickman co., $K y$ : on the Mississippi r., $25 \mathrm{~m}$. below the mouth of the Ohio r., and $252 \mathrm{~m}$. W. S. W. Frankfort.

Columbes, t. and p. v., St. Clair co., Mich.: on Belle r., $97 \mathrm{~m}$. E. Lansing. Pop. 3,077.

Columbus, p, city, and cap. Lowndes co, Miss.: at the head of steamboat navigation, and E. of Tombigbee r., 126 m. N. E. Jackson. The city is built on an elevated bank, 120 feet above the $r_{\text {. }}$ and contains, besides the court-house and other county buildings, 7 churches and several large warehouses. There is a bridge across the river which cost $\$ 50,000$. The trade centering here is large, the eity being the chief depot for the cotton, etc., of an extensive country and the inhabitants enjoy the benefit of a well-conducted paper, the "C. Democrat," which is published weekly. Pop. 8,000 .

Colunires, p. v., Johnson co., Mo.: on Black r., 92 m.W. by N. Jefferson City.

Colurbes, p. v., Burlington co, $N$. Jer. : $11 \mathrm{~m} . \mathrm{S}$. by E Trenton.

Columbus, t. and p. v., Chenango $c_{0}, N_{0} Y_{0}:$ on the W. side of Unadilla er., $80 \mathrm{~m}$. W. Albany. The $\mathrm{v}$. is a small agricultural settlement. Pop. of t. 1,381

Colvines, p. city, and cap. Franklin co., Ohio, and cap. of the State of Ohio: on the E. side of the Scioto $r$. just below the confluence of the Whetstone $\mathbf{r}_{\text {., }}$ in lat. $39^{\circ} 57^{\prime} \mathrm{N}$. and long. $83^{\circ} 03^{\prime} \mathrm{W} ., 396 \mathrm{~m}$. from Washington. Previous to 1512, when it was fixed on for the State capital, the site of the city was in the wilderness. In 1820 it contained 1,400 inhabitauts ; in $1830,2,439$; in $1840,6,048$; and in $1850,17,883$.

The land on which the eity is built rises gradually from the $r$., and the streets are laid ont at right angles. Broadstreet extends from the river along the National Road to the $\mathrm{E}$, of the city, and is 120 feet wide, and High-street, 100 feet wide, crosses Broad at the N. W. corner of the Public Square, of 10 acres, running N. and S. This is the principal business street. All other streets are 88 feet wide, and the alleys 33 feet wide. The public buildings are the Capitol or State House, the Penitentiary, asylums severally for the insane, the deaf and dumb, and the blind; several colleges, seminaries, and numerous churches of all denorninations. The old State House was destroyed by fire on the 1st Feb., 1852, and in ennsequence a great number of documents illustrating the history of the State were lost, never to be restored. The new State House is one of the most magnificent buildings in the Union. It is 304 feet long and 154 feet wide, covering an area of 55,936 square feet. The basement is 16 feet above the common surface; the height of blocking course is 62 feet, and to the top of the rotunda 157 feet, its diameter being 64 feet. The first floor contains 28 fire-proof rooms for the public offices; and the second floor coutains the Hall of Representatives, which is 84 feet long and 721 feet wide, the Senate Chamber 56 feet by 72 ; ; the Library, the U.S. Court room, and 26 committee rooms. The State Penitentiary is also a spacious and elegant edifice on the Scioto r., N.W. of the State House. It is a splendid building, of hewn limestone; the centre is 56 fect long, 4 stories high, and the two wings each 200 feet long and 8 stories bigh. The private dwellings are generally neat, substantial, and many of them elegant.

The avenues of travel and commerce connecting Columbus with other parts of the State and Union, are the National Road, a branch of the Ohio Canal. the Columbus and $\mathrm{Xenia}$ 
R. R., the Cleveland, Columbus, and Cincinnati R. R., the Central Ohio R. R., etc. The railroads are the creations of the last ten years, and have been the cause of the oxtraordiuary triplication of the polulation in that period. As a commercial depot, the city has eminent fitcilities-as a central position, in regard to every portion of the State, its location on one of the largest rivers, and its grand works of internal improvement. It has numerous and extensive manufactures, and, on the whole, is one of the most prosperous among western cities. There are published within the city two daily newspapers, both of which also issue tri-weekly and weekly editions; four weekly, one semi-montbly, two monthly, and one occasional. The dailies are the "Ohio State Journal" (whig), and the "Ohio Statesman" (dem.) The weeklies are the "Ohio Standard" (whig), the "Dollar," and "Swan's Elevator" (neutral), and "Der Westbote" (Germ.) The semi-monthly is the "Ohio Cultivator" (agric.) The monthlies are the "Wester"n Literary Magazine," and the "Ark;" and the "Conventional Reporter" is published occasionally.

Columbus, t. and p.o., Warren co., Penn.: 159 m. N.W.

Harrisburg. Iron is manufactured in this $t$. Pop. 1,422

Columbus, p. v., Polk co., Tenn. : on the N. bank of the Hiwassee r., 133 m. S. E. by E. Nashville.

Colcmbes, p. V., and cap. Colorado co. Tex. : on the W. bank of Colnrado r., $83 \mathrm{~m}$. in a direct line S. E. fiom Austin City. The $\mathrm{v}$. stands on a high bluff, forming part of a beautiful elevated prairie, surrounded by dense forests of cotton-wood, live-oak, etc. The population amounts to about 600 .

Columbus, t. and p. v., Columbia co., Wise.: on a branch of Rock r., 26 m. N. E. Madison. Pop. 960.

Columbus Crtr, p. v., Lonisa co., $I \alpha .:$ on the W. side of Towa r., about $2 \mathrm{~m}$. below the junction of Cedar $\mathrm{r}_{.}, 27 \mathrm{~m}$. S. by E. Iowa City.

Couvsi, p. v., and cap. Colusi co., Calif.: on the W. side of Sacramento r., in the S. E. corner of the co., $80 \mathrm{~m}$. T. by E. Vallejo.

Colusi county, Calif. Situate N. W., and contains $3,600 \mathrm{sq}, \mathrm{m}$. Drained by numerous tributaries of Sacramento r., which forms its E. border. Surface generally level-in the W. hilly and mountainous, being in that direction bounded by the coast range. Farms 00 ; manuf. 00 ; dwell. 000, and pop - wb. 0000, fr. col. 000-total 0000 . Capital: Colusi.

Colvin's Tavern, p. 0., Culpepper co., Virg.: $77 \mathrm{~m}$. N. N. W. Richmond.

Comat county, Tex. Situate S. W. centrally, and contains 760 sq. m. Drained centrally by creeks of the Rio Guadalupe, on the N. by Marten's Fork of Fio San Marcos, and in the S. W. by the Rio Cibolo, which bounds it in that direction. Surface mountainous, with the great Valley of the Guadalupe intervening. Soils generally rich, and well cultivated in the settlements. The inhabitants are chiefly Germans, whose habits of industry and thrift will be invaluable to the State. Farms 55; manuf. 8 ; dwell. 867 , and pop.-wh. 1,662, fr. col. 0, sl. 61-total 1,723. Capital: New Braunfels.

Coman's Welt, p. o., Sussex co., Virg.: 53 m. S. S. E. Pichmond. Formerly a noted watering place, it is now an almost deserted village.

Comrort's, p. o., Jones co., $N$. Car.: 98 m. S. E. Raleigh.

Comrach (Comac), p. v., Suffolk co, $N . Y$. : on the middle post road, $122 \mathrm{~m}$. S. S. E. Albany. It contains about 30 dwellings.

Commerce, t, and p. v., Oakland co., Mich, : $52 \mathrm{~m}$. E. by S. Angusta. It contains numerous small lakes, some of which empty into the Rouge $r$., and others through Clinton $r$. The $\checkmark$. is located on the S. side of Burt Lake. Pop. 1,428.

Commree, p. v., Tunica co, Miss. : on the E. bank of the Mississippi r., $168 \mathrm{~m}$. N. by W. Jackson. It was originally designed for a large eity, and the commercial mart of the back country, to reach which a railroad was com- menced, but abandoned. The place is now composed of a few dwellings.

Commerce, p. v., Sentt en., Mfo. : on the W. bank of the Mississippi, $12 \mathrm{~m}$. below Cape Girardeau, and $178 \mathrm{~m}$. S. E. Jeflerson City. Its name is a misnomer.

Commerce, p. V., Wilson co., Tenn. : on a er, of Cumberland r., $37 \mathrm{~m}$. E. Nashville.

Commetrabueg, p. v., Washington co., Penn. : $191 \mathrm{~m}$.W. Harrisburg.

Como, p. o., Whitesides co., $I l l$.: on the N. side of Rock r. at the point where Elk Horm $r$. has its confluence, $136 \mathrm{~m}$. N Springfield.

Coxo, p. o., Henry co., Tenn: $92 \mathrm{~m}$, W. by N. Nashville. Covo, p. o., De Soto co., Miss. : 167 m. N. Jackson.

Constook, t. and p. v., Kalamazoo co., Mich : on both sides of Kalamazoo $\mathrm{r}_{\mathrm{n}}, 34 \mathrm{~m} . \mathrm{S}$. W. by W. Lansing. It is a rich agricultural town. The $\mathrm{v}$. is situate on the $\mathrm{N}$. side of the r., and on the line of the Michigan Central R. P.., 137 $\mathrm{m}$. from Detroit, and $144 \mathrm{~m}$. from Chicago.

Comstock's Landing, p. 0., Washington co., $N . Y_{.: 57}$ T. N. by E. Albany.

ConchardeE, p. V., Talladega co., $A l a .: 61 \mathrm{~m} . \mathrm{N}$. Montgomery.

Concord, p. v., Sussex co., Del. : at the head of Broad er., a tributary of Nanticoke r., $38 \mathrm{~m}$. S. Dover.

Coxcord, p. v., Morgan co., Ill. : on the S. of Indian cr. $48 \mathrm{~m}$. W. Springfield.

Concorn, p. V., Baker co, Ga. : on the W. side of the Ichowaynochaway r., a tributary of Flint r., $132 \mathrm{~m}$. S. W Milledgeville. It lies on the Albany and Fort Gaines road.

Concord, t. and p. v., Jefferson co., Wisc.: on the S. of Rock r., 39 m. E. Madison.

Concord, p. v., Tippecanoe co., Ind.: on Wea cr. of Wabash r., $5 \mathrm{~m}$. N. W. Indianapolis.

Concord, p. v., Louisa co., Ta. : on the E. side of Iowar., $31 \mathrm{~m}$. S. by E. Iowa City.

Concord, p. V., Lewis co., $K y_{*}:$ on the S. bank of the Ohio $r$., 89 m. E. N. E. Frankfort. It contains a church, 7 stores, and 160 inhabitants.

Coxcord, t. and p. v., Somerset co., Me. : on the W. side of Kennebec r., 42 m. N. by W. Augusta. Pop. 550.

Corcoro, t., p. V., and one of the capitals of Middlesex co., Mass. : on both sides of Coneord $r, 17 \mathrm{~m}$. W. N. W. Boston. The $t$. has a soil of average fertility, and is well drained by the Assabet and Sudbury rivers, which here unite, forming Concord r. The v. contains a C. H., jail, several churches, and about 200 dwellings. Here, on the 19 th April, 1775, was made the first forcible resistance to the British power, and a handsome monument now marks the spot where the first blood of the Revolution was spilled. The monument is a granite obelisk, 25 fect high, with a square base $5_{\frac{1}{2}}$ feet in diameter, and about 3 feet high, with an appropriate inscription on a panel of Italian marble. Concord was the first inland settlement in the Colony of Massachusetts Bay, and was incorporated as early as 1635 . Its Indian name was Musketaquid. The General Court of the colony frequently held its sessions in this town, and in the year 1774 the Provincial Congress selected it as their place of meeting. The manufactures of Concord consist of cotton goods, satinets, and flannels; boots, shoes, hats, cabinet ware, agricultural implements, etc. Many of the establishments are on an extensive scale. The Fitchburg $\mathrm{R}, \mathrm{R}$. passes through the town $20 \mathrm{~m}$. from Boston and 30 from Fitchburg. Pop, 2,249.

Coxcord, t. and p. v., Jackson co., Mich.: on the head streams of Kalamazoo r., $36 \mathrm{~m}$. S. Lansing. The $\mathbf{r}$. is located on the stage route from Jackson to $T$ hite Pidgeon, $14 \mathrm{~m}$. from Jackson. The water-power of the neighborhood is immense, and in this $t$, are found some of the best farming lands of the co. A mile $\mathrm{S}$. of the $\mathrm{v}$. are several mincerl springs. Pop, 954.

Concord, p. v., Callaway co., Mo.: at the head of Aux Vases r. $31 \mathrm{~m}$. N. by E. Jefferson City. 
Coxicord, p. v., and cap. Cabarras co., $N$. Car.: on the W. side of Big Cold Water cr., a branch of Rocky r. of the Yadkin, $102 \mathrm{~m}$. W. S. W. Raleigh. It is a considerable v. of some 400 inhabitants.

Covcorv, t., p. v., and cap. Merrimac co., $N$. Hamp., and cap. of the State: it lies on both sides of the Merrimac $x$. , in lat. $43^{\circ} 12^{\prime} 29^{\prime \prime} \mathrm{N}$., and long. $71^{\circ} 29^{\prime} \mathrm{W} ., 474 \mathrm{~m}$. N. E. Washington. There are five ponds in the town, the largest of which are Turkey Pond in the S. W., and Long Pond in the N.W. sections, the outlet streams of which furnish extensive hydraulic power. The Contoocook r.joins the Merrimac on the $\mathrm{N}$. line of the $t$., and forms at the junction the celebrated "Duston's Island." The intervale lands of the Merrimac are very fertile, and highly cultivated. Soon after entering Concord, the r. passes over Sewell's Falls, and thence has no natural obstruction until it reaches the fall at the S. E. extremity of the t., where is a vast water-power Locks are here constructed, and boat navigation secured. The river is here about 100 yards wide, but during freshets the water rises 20 feet above the ordinary level, presenting to the eve a body of water a mile wide. There are handsome bridges spanning the river. There are three villages in the t., the principal of which, and the seat of its chief business, is on the W. side of the r., extending along it about $2 \mathrm{~m}$. The State House, Court House, State Prison, and other puthlic buildings are in this $\mathrm{v}$. The State House occupies a beautiful site in the centre, and is constructed of hewn granite. It is 126 feet in length, 49 feet in width, and with a projection in the centre of 4 feet on each front. The cost of the building was $\$ \$ 0,000$. The State Prison is atso a massive granite building, 70 by 36 feet, surrounded by a high stone wall. The second principal village is at Sewall's Falls, and the other in the F. part of the town.

Concord, originally called Penacook, was granted by Massachusetts to a company of settlers, 17th Jan., 1725, and the settlement was begun in the following year. In 1783 it was incorporated under the name of Rumford, which name was changed in 1765 to Concord. The population in 1775 was 1,052; in 1790, 1.747; in 1800, 2,052; in 1s10, 2,393 ; in $1820,2,835$; in $1830,3,727$; in $1840,4,897$; and in 1850 8,581 , its progress during the last decade having been stimulated by the development of its manufacturing facilities and the extension of the railroad system centering within it Concord is now, indeed, one of the chief seats of New Bngland industry. It has numerous large cotton factories, paper mills, boot and shoe shops, and a variety of other industrial establishments. Its neighborhood also abounds in granite, which is exported. In the t. are also potteries, fulling mills, ete. ; and in the publishing business Concord has long been remarkably successful. In 1550 four newspaper were published weekly, and one semi-monthly; the weekly papers were, the "N. H. Patriot and State Gazette" (dem.); the "N.H. Statesman" (whig); the "Independent Democrat" (free soil); and the "Congregational Journal" (relig.); and the semi-monthly, was the "Under-Current," a paper devoted to temperance.

Concord lies on the route of travel and commerce between Boston and Montreal, and Boston and the far TVest, an hence has become a principal centre of the New England system of railroads. It has also a rainroad connection with Portsmouth. The railroads centering here are, the Concord R. R., extending to Nashua and Boston; the Boston, Con cord, and Montreal R. R., extending to Haverhill on the Connecticut, and to Montreal; the Concord and Claremont R. R.; the Portsmouth and Concord R. R.; the Northerm New Hampshire R. R, extending to West Lebanon, on the Connecticut, and continued by the Vermont. New York, and Canada railroads to Rouse's Point, Montreal, Ogdensburg, Kingston, etc.

Coxcone, p. v., Franklin co., Ponn.: 61 m. W. by S. IIarrisburg.

Corcord, t. and p. v., Lake co., Ohio: $3 \mathrm{~m}$. S. of Painesville and 146 N. E. Columbus. The town is drained by several tributaries of Grand r., which afford excellent mill-sites. Pop. 1,031.

Concokd, p. v., Harrison co, Tero, : 266 m. N. E. Austin City.

Concorp, t. and p. o., Essex co., Verm.: on the N. W side of the Connecticut r., $37 \mathrm{~m}$. E. by N. Montpelier. It is drained in the N.W. by a branch of Passumsic r., and two ponds in the $\mathrm{S}$. E. part of the $t$, discharge their waters into Connecticut r., affording mill-sites. Concord is an excellent grazing country.

Corcoed, p. T., Appomattox co., Firg.: 82 m. W.S. W. Richmond, Pop, 1,152.

Coxcond river, Mass.: formed by the union of Assabet and Sudbury rivers at Concord, and after passing through the towns of Bedford, Bellerica, and Chelmsford, it falls into the Merrimac r., between Lowell and Tewkesbury. This $r$. furnishes the Middlesex Canal with most of its water.

Concordu parish, La. Situate W. of Mississippi $r_{n}$, and contains $750 \mathrm{sq} . \mathrm{m}$. The Tensas r. lies on its W. border, and Red r. on its $\mathbf{S}$. border. The surface is level, and except a few elevated strips, liable to inundation in times of high water. The solls are exceedingly fertile, and origiually were covered with a heavy forest growth. The chief product is cotton, of which a large amount is produced. Farms 148; manuf. 0 ; dwell. 219 , and pop. $\rightarrow$ wh. 823, fr. col. 1, sl, 6,931-total 7,758. Capital: Vidalia, Public Works : a R. R. projected from Vidalia to Shreveport.

Concondi, p. v., Bolivar co., Miss. : on Lake Concordia $121 \mathrm{~m}$. N. N. W. Jackson.

Concordi, p. V., Darke co., Ohio: on the E. side of the hearl stream of White Water r., $93 \mathrm{~m}$. W. Columbus.

Concordia, p. v., Fayette co, Tenn.: on Loosahatchie r., in the N. W. corner of the county, $167 \mathrm{~m}$. W. S. W. Nashville. It contains about 200 inhabitants.

Concordprile, p. v., Delawate co., Penn.: 79 m. E. by S. Harrisburg.

Conecocmeague river, $M d$. : a tributary of the Potomac r. from Pennsylvania. It empties itself at Williamsport.

Conecur county, Ala. Situate S. middle, and contains 1,476 sq. m. Drained by Escambia r., Burned Corn cr., Murder cr., and others, tributaries of Conecuh r., which passes from N. E. to S. W. in the S. part of the co. Surface low and generally level, and soils moderately fertile, producing cotton, coru, and some rice. Farms 498; manuf 12 ; dwell. 817 , and pop.-wh. 4,922, fr. col. 6, sl. 4,394 total 9,322. Capital: Sparta. Public Works: Gerard and Mobile R. P., ete.

CoNecurl river, Ala. and Flor.: rises in Alabama, and passes through Florida into Pensacola Bay. Two miles below the Florida line it receires the Escarnbia, the name of which it assumes, although the larger stream. It is navigable for more than 100 miles.

Conemadgir river, Penn.: rises in the Alleghany Mount ains, and runs W. N.W. into the Alleghany r., $29 \mathrm{~m} . \mathrm{N} . \mathrm{N} . \mathrm{E}$, Pittsburg. In the lower part of its course it takes the name of Kiskeminetas. It has salt-works on both its banks, $15 \mathrm{~m}$ N. E. Greensburg. The Pennsylvania Canal passes along its border from Johnstown till it enters into the Alleghany. Its length is about $150 \mathrm{~m}$.

Covercys, p. o., Pike co., Miss.: $86 \mathrm{~m}$. S. Jackson.

Cosestoga, t, and p. v., Lancaster co, Penn.: on Conestoga cr., $39 \mathrm{~m}$. S. E. Harrisburg.

Coxesus, t. and p. $\nabla$. ., Livingston co., $\boldsymbol{N}$. $\boldsymbol{Y}$.: between Conesus and Hemlock lakes, $195 \mathrm{~m}$. W. Albany. The Buffalo, Corning, and New York R. R. passes through the $t$ The $r$, is a small agricultural settlement in the midst of a fine fertile region. Pop. of t. 1,418.

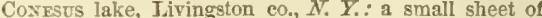
water about $9 \mathrm{~m}$. long and a mile in width. Its depth exceeds 300 feet : its waters are pure and cold, and contain ahundance of fish.

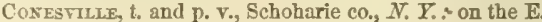


side of Schoharie cr., and drained by its tributaries. Distant 56 m. S. W. Albany. Pop. 1,552.

CoNewANGo, to and p. v., Cattaraugus co., $N$. $\boldsymbol{Y}_{*}$ : on the cr. so called, $272 \mathrm{~m}$. W. by S. Albany. Pop. 1,408 .

Conewargo creek, $N . Y$. : rises in Chautauque and Cattaraugus counties, and flows $\mathrm{S}$. into Alleghany r., receiving the outlet of Chautauque Lake and other tributaries. It affords good boat navigation in season of flood, and is a fine mill-stream.

CONGAREE river, S. Car.: is formed by the union of Broad and Saluda rivers, two fine streams which unite immediately above Columbia, the State capital. The Congaree receives no large affluents, but about 30 miles $\mathbf{S}$. E. of Columbia it is joined by the Wateree from the N. W., and thence the united streams take the name of Santee, a river flowing to the Atlantic Ocean, which it reaches in about $33^{\circ} 20^{\prime} \mathrm{N}$. lat.

Congress, t. and p. o., Wayne co., Ohio: in the N. W. corner of the co., $84 \mathrm{~m}$. N. E. by N. Columbus. In the E. Killbuek cr, and in theW. the Muddy Fork of Walhonding $r$. drain the surface, and afford fine mill-seats.

ConHoctor, t. and p. v., Steuben co., N. Y.: on Conhocton r., $185 \mathrm{~m}$. W. S.W. Albany. The Buffalo, Corning, and New York R. R. passes along the valley. Pop. 1,992.

Сомностом river, $N_{0} Y_{\text {. }}:$ a constitnent of the Chemung, about $55 \mathrm{~m}$. Long. It is navigable for rafts in high water, and at all seasons furnishes exterisive mill-power.

Corne, p. o., Licking co., Ohio: 33 m. N. E. Columbus. Conkrin, to and p. o., Broome co., N. Y.: on both sides of Susquehanna r., $103 \mathrm{~m} . \mathrm{S}$. W. Albany. The surface of the $t$. is hilly, but in the valley of the $r$. there are alluvial flats. The New York and Erie R. R. runs through the t. $220 \mathrm{~m}$. irom New York City. Pop. 2,232.

Conkliv Ceivtee, p. o., Broome co., N. Y.: 106 m. S.W. Albany.

ConNente, t. and p. Y., Ashtabula co., Ohio: the most N. E. town of the State, on Lake Erie, $173 \mathrm{~m}$. N. E. Columbus. Conneaut r. drains the whole surface, and at its mouth or harbor the village, a flourishing place, is eligibly situate for commerce, and owns many vessels engaged in the lake trade. The Cleveland, Painesville, and Ashtabula R.R. passes through it, connecting it with the sea-board and the far West by continuous chains of railroads. Conneaut has manufactures and considerable trade, and is destined to become an important commercial depot. The "C. Reporter" is published weekly. P. of v. 817-t. 2,694.

Conneattrinle, p. v., Crawford co., Penn.: on the line of the Beaver and Erie Canal, $98 \mathrm{~m}$. from Beaver, on the Ohio r., 38 m, from Erie, and 216 N. W. Harrisburg.

\section{THE STATE OF CONNECTICUT.}

Connecticut, lying between Massachusetts and Long Island Sound, and extending from Rhode Island to New York, is 90 miles in length from $\mathrm{E}$. to W., and in width, from N. to S., from 60 to 70 miles. It is situated between $41^{\circ}$ and $42^{\circ}$ $02^{\prime}$ latitudes $\mathrm{N}$., and between $71^{\circ} 40^{\prime}$ and $73^{\circ} 43^{\prime}$ longitudes W. from Greenwich, or $3^{\circ} 19^{\prime}$ and $5^{\circ} 22^{\prime} \mathrm{E}$. from Washington. The contents of its superfices is estimated at 4,674 square miles.

The aspect of the country is greatly diversified by hills and valleys. The hills are generally of a moderate size, and occur in quick succession, presenting to the traveler a beautiful and constantly-varying scenery. All the principal ranges are continuations of the mountains of the States lying northward. The Housatonic range enters the State in the northWest, and extends in a southerly direction along the Housatonic River to the coast; this is rather a succession of groups and eminences than a continuous range. The Green Mountain range, eoming from Vermont and Massachusetts, passes through the State from N. to S., and terminates at West Rock, a bluff 40 feet high, two miles N. W. of New Haven. Bethrcen this and the Connecticut River is the Mount Tom range, which, coming from Massachusetts, also traverses this State, and terminates at East Rock, $3 \pi 0$ feet high, a litile to the north-east of New Haven. The Blue Hills in Southington, a part of this range, have an elevation of 1,000 feet, and are said to be the highest land within the State. On the E. gide of the Connecticut is a fourth range, which crosses the river at Chatham and terminates at East Faven.

The principal valleys of the State are the Housatonic on the E., the Connecticut in the centre, and the Quinnebaug in the E. The Valley of the Connecticut varies in breadth from 10 to 16 miles, and extends northward from Middletown, having in this State a length of about 30 miles. This is a rich agricultural district. The valleys of the Quinnebaug and Housatonic have also fertile soil, and produce fine crops. The scenery of the valleys is magnificent, and the landscapes varied and romantic. Many of the surrounding hills are cultivated like gardens to the very summit, while others are bald, or only support a few stunted trees and shrubs. The Farmington Valley extends from New Haven N. through the the State between the Green Mountains and the Mount Tom range, and is from three to five miles wide. In the hilly parts of the State the soils are of moderate fertility, and are generally acknowledged to be better fitted for grazing than seed-farming.

Few of the streams are of much use to navigation, except in their lower courses. The principal is the Connecticut, which, coming from the $\mathrm{N}$., and pursuing a pretty direct southward course to Middletown, then suddenly turns to the south-east, and so flows on to the Sound. There is a bar at its mouth, but ressels drawing ten feet of water can go up to Middletown, and those drawing only eight feet to Hartford, 50 miles from the Sound. The navigation of the upper course of this river has been improved by means of locks and eanals, which secure boat navigation to the mouth of Well's River, in Vermont. The River Tunxis, or Farmington, is the principal tributary of the Connecticut in this State; it rises in the eastern slope of the Green Mountains, in Massachusetts, and runs to the S. as far as Farmington, where it abruptly changes its direction to the N., until, breaking through the trap range, here called the Talcott Mountains, it again flows southwardly, and joins the Connecticut opposite to East Windsor. The Housatonic rises in the western part of Massachusetts, and enters this State near the north-west corner, after which it runs in a southerly and south-easterly course to the Sound; the first part of its course is broken by cataracts, and its entrance is barred against large vessels; it has, however, a sloop navigation for a distance of 12 miles. The Thames, formed by the junction of the Quinnebaug, the Shetucket, and the Yantic at Norwich, empties itself into the Sound at New London, after a navigable course of 14 miles. All these streams and numerous smaller ones, are applicable as motive power, and, besides turning almost all the machinery of the State, are highly favorable to the fertility of the lands through which they pass. Scarcely is there a single square mile in all the country but has one or more sparkling, never-failing rills to refresh the soil and make it productive.

The whole coast of the State lies upon Long Island Sound, which is an extensive gulf or channel, being 140 miles in length and 25 miles wide in its broadest part. It is somewhat narrow at its Atlantic or eastern entrance, but expands in the middle; toward the west it gradually contracts, till it joins the harbor of New York by a narrow and crooked strait, called the East River. It admits of a free navigation throughout its whole extent for the largest ships, but in the western strait there was formerly a dangerous whirlpool, at a spot called Hell Gate, where the current is contracted by the rocky shores, and at certain seasons of the tide the navioationwas most hazardous. The obstructions, however, were removed by submarine 


\section{CONNECTICUT.}

blastings in 1552. The northern shore of the Sound is deeply penetrated by numerous bays and creets, affording excellent harbors. The harbor of New London is the best in the State-it is spacious, deep, and not liable to be frozen orer in winter. New Haven harbor has not sn great a depth. Stonington harbor is well protected by a breakwater, and the harbor of Bridgeport has similar improvements. These harbors form so many starting-points of travel or internal trade to the New England States and Canada.

Connecticut produces many valuable minerals. Iron ore of excellent quality and in great abundance, is found in various parts. The copper-mines of Bristol and Plymouth are regarded by many as the most profitable now worked in the United States, not excepting the mines of Lake Superior. The most distinguished scientific man of the State, Professor Silliman, has expressed the eonfident opinion that they extend from Bristol, in a southerly direetion, toward Hampden, for a distance of more than 30 miles, and that, if thoroughly worked, would be sufficient to give profitable employment to 30,000 miners. Aiready they furnish a large amount of ore. The Plymouth mines are equally rich. The vein here runs from east to west, with a vertical dip, cutting the geological formation of the mountain at right angles, and forming what is termed a rake vein. The working of this mine is only now being commenced, but there is erery indication that the code contained in the vein will yield a copper ore of as good quality and in as large a quantity as the mine now wrought at Bristol has ever produced. Copper also occurs at Granby, where it is found at the junction of the green-stone and new red sand-stone formations. Fine marbles, of different characters, are abundant; and free-stone, extensive quarries of which exist in the mountain regions, furnishes an excellent building material. Zine, cobalt, and manganese also occur, and plumbago and some other metals of minor importance have been discovered at various times and places. The mineral waters of Stafford have long been celebrated for their medicinal properties.

The soils of Connecticut are generally good, but in some parts better suited to grazing than corn-growing. The Valley of the Connecticut has a strong and fertile argillaceous loam, varying in different sections from a hard, stiff clay, to a light, sandy loam, according to the prevalence of argillaceous or silicious earth. In the eastern part of the State the prevailing soil is warm, strong, fertile, and excellent for grasses. The north-western part is in some places cold and sterile, but is generally a good grazing country. In the western part of the State are many fertile districts. The climate and vegetation correspond nearly with those of Massachusetts, the climate difering only in being a little more temperatc, and the season of growth in being earlier and somewhat more prolonged. The peach perfects its fruit in the southern portion of the State.

The first census of Connecticut, on which any relinnce can be placed, was that taken in 1756 , and exhibits the then population at 130,611; in 1774,18 years afterward, it was 197,556 ; and in 1782 it was found to have increased to an aggregate of 209,150 . The first United States' census, taken in 1790 , gives the total at that date at 238,141 , and from that period its decennial movements have been as exhibiled in the following table:

\begin{tabular}{|c|c|c|c|c|c|c|}
\hline \multirow{3}{*}{$\begin{array}{c}\text { Date of } \\
\text { Census. } \\
1790\end{array}$} & \multirow{2}{*}{$\begin{array}{l}\text { White } \\
\text { Persons. }\end{array}$} & \multicolumn{2}{|r|}{ Colored Yersons. } & \multirow{2}{*}{$\begin{array}{c}\text { Total } \\
\text { Popustion. }\end{array}$} & \multicolumn{2}{|r|}{ Intrease. } \\
\hline & & Free. & Slave. & & Numerical. & Percent. \\
\hline & 232.531 & 2,501 & 2,759 & 235,141 & $\cdots$ & $\ldots \ldots \ldots-$ \\
\hline 1800 & .. 241,721 & . . 5,930 & 951 & .. 251,002 & $\ldots 12,861$. & $\ldots \ldots \ldots 5.4$ \\
\hline 1810 & .. 255,279 & ......6, 6,453 & ... 810 & .. 262,042 . & 40 . & .4 .4 \\
\hline $1 \$ 20$ & 267,161 & 7,914 & 97 & . 275,202 . & .. 13,160 . & $\ldots 5.0$ \\
\hline 1830 & $.289,603$ & 8,047 & 25 & 297,675 & .. 22,473 . & 8.1 \\
\hline $1 S 40$ & . 301.S57 & .. 8,104 & $\ldots$ & $.809,97 \mathrm{~S}$ & .. 12,303 . & $\ldots 4.1$ \\
\hline 1850 & 363,305 & 7,486 & $\ldots$ & $.870,791$ & .. $60, \mathrm{~s} 13$. & .19 .6 \\
\hline
\end{tabular}

Of the total population in 1550, there were persons deaf and dumb, 359 ; blind, 152 ; insane, 462; and idiotic, 300 ; but in this enumeration are included those domiciled in the State hospitals, natives or residents of other States, sent into Connecticut for special purpose.

The State is divided into 8 counties and 14S townships, and contains 6 cities and 12 boroughs; the counties are Fairfield, Hartfleld, Litchfield, Middlesex, New Haven, New London, Tolland, and Windham; the cities are Bridgepcrt, Hartford, Middletown, New Haven, New London, and Norwich; and the boroughs are Danbury, Essex, Guilford, Litchfield, New Britain, Newtown, Norwalk, Southport, Stamford, Stonington, Waterbury, and Willimantic.

More equally in Connecticut than in any other State of the American Union, are the several great branohes of national industry distributed; and perhaps here, more than elsewhere, have the people a more direct interest in the prosperity of each. There are few large farms or manufactures, and as few persons who have not some ownership in a farm or workshop; and throughout the State the inbabitants are furmers in one season and manufacturers in another, economizing the seasons, and pursuing avocations suitable to each as it occurs. The statisties of the wealth and industry of the State in 1550 , as exhibited in the census, etc., of that year, were as follows:

Occupied Lands, etc.-Improved lands, 1,769,178 acres, and unimproved lands, 615,701 acres, valued at $\$ 72,726,422$.

Number of farms, 22,415 . Talue of farming implements and machinery, $\$ 1, \$ 92,541$.

Live Stock:-FIorses 26,579, asses and mules 49, milch cows 85,461, working oxen 46,958, other cattle 80,226, sheep 174,181, and swine 76,472 - valued in the aggregate at $\$ 7,467,490$.

Grain Crops.-Whent, 41,762 bushels; rye, 600,593 bushels; Indian corn, 1,935,848 bushels; oats, 1,158,788 bushels ; barley, 19,099 bushels; and buckwheat, 229,297 bushels.

Other Crops.-Tobacco, 1,267,624 pounds; peas and beans, 19,090 bushels; Irish potatoes, 2,6s9,725 bushels; sweet potatoes, 80 bushels; hay, 516,131 tons; clover-seed, 13,\$11 bushels; other grass-seed, 16,60s bushels; hops, $55 \pm$ pounds; flax, 17,928 pounds; flax-seed, 703 bushels; maple sugar, 50,796 pounds ; molasses, 665 gallons; wine, 4,269 gallnns, ete. The value of orchard products was $\$ 175,118$, and of market-garden products, $\$ 196,574$.

Products of Animals.-Wool, 497,454 pounds; butter, $6,498,119$ pounds; cheese, $5,363,277$ pounds; and the value of animals slaughtered during the year had been $\$ 2,202,266$. Silk eocoons were produced to the amount of 325 pounds, and beeswax and honey to that of 93,804 pounds.

Home-made Manufactures for the year ending 30th. June, 1850, were valued at $\$ 192,252$.

Manufactures.-Aggregate capital invested, $\$ 00,000,000$; value of raw material, fuel, etc., consumed, $\$ 0,000,000$; average number of hands employed, 00,000 - males, 00,000 , and females, 00,000 ; average monthly cost of male labor, $\$ 000,000$, and of female labor, $\$ 00,000$; annual value of products, $\$ 00,000,000$. The whole number of manufacturing establishments produeing to the ralue of $\$ 500$ and upward in 1550 , was 3,913 ; and of these $12 \$$ were cotton factories, 


\section{CONNECTICUT.}

149 woolen mills, and 91 iron houses, of which 60 manufactured castings, 18 pig iron, and 15 wrought iron. In the cotton manufictures the capital invested amounted to $\$ 4,219,100$; the cotton consumed in the year ending 30 th June, was 39,483 bales, and the value of all raw material, fuel, etc., was $\$ 2,500,062$; hands employed-2,708 males, and 3,478 females; monthly cost of male labor, $\$ 51,679$, and of female labor, $\$ 41,060$; products for the year, $51,750,700$ yards of sheeting, etc., and 950,000 pounds of yarn-the aggregate value of products, $\$ 4,257,522$. The capital invested in woolen manufactures was $\$ 3,778,950$; wool used, $9,414,100$ pounds; value of all raw material, fuel, etc., $\$ 3,325,709$; hands employed-males, 2,907 (cost per month, $\$ 70,141$ ), and females, $2,581(\$ 33,216)$; yards of eloth manufactured in the year, $9,408,777$, valued at $\$ 6,465,216$; and the following table will exhibit the state of the iron manufacturing interest:

\begin{tabular}{|c|c|c|c|c|}
\hline $\begin{array}{l}\text { Specifications. } \\
\text { Capital invested................... dollars ....... }\end{array}$ & $\begin{array}{l}\text { Pig Iron. } \\
225,600\end{array}$ & & $\begin{array}{l}\text { Cast 1ron. } \\
550,800\end{array}$ & $\begin{array}{l}\text { Wrought Irou. } \\
\text {.. } 529,500\end{array}$ \\
\hline Iron ore used ................... tons. . . . . . . & 35,400 & ..$\cdots \cdots$ & - & - \\
\hline Pig iron used $\ldots \ldots \ldots \ldots \ldots \ldots \ldots \ldots \ldots$. $6 \ldots \ldots \ldots$ & - & & 11,896 & $\ldots \ldots \ldots$ \\
\hline Blooms........................ & - & $\ldots \ldots \cdots$ & 一 & ........ \\
\hline 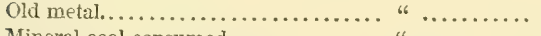 & - & .. & 337 & .. \\
\hline al coal consumed .............. " $\ldots \ldots \ldots \ldots$ & - & $\ldots$ & 7,592 & 5,062 \\
\hline sumed. ......... bushels....... & $2,870,000$ & . & 30,600 & . \\
\hline Talue of all raw material, etc.......... dellars........ & 299,225 & - & 351,369 & 355,750 \\
\hline Iands emplojed, males.............. number....... & 148 & . & 942 & 374 \\
\hline " females.......... " $6 \quad \ldots \ldots$. & $\longrightarrow$ & ........ & 7 & .. \\
\hline rage wages per month, males ..... dollars........ & 26.50 & $\cdots$ & 27.02 & 31.59 \\
\hline females.... " $6 \ldots \ldots$ & - & .............. & 8.00 & $\ldots$ \\
\hline $\begin{array}{l}\text { roducts in the year....................tons..... } \\
\text { nnual value of all products.......... dollars... }\end{array}$ & $\begin{array}{r}1,342 \\
415,600\end{array}$ & $\ldots \ldots \ldots \ldots \ldots$ & $\begin{array}{r}11,210 \\
981,400\end{array}$ & 6,325 \\
\hline
\end{tabular}

The total capital inrested in the iron manufacture is thus, $\$ 1,335,900$; the value of raw material, fuel, etc., $\$ 999,374$; and the annual value of products, $\$ 2,064,560$. The remaining employments of the aggregate number $(3,913)$ are various, and embrace all descriptions of hardware, cutlery, fire-arms, powder, paper, boots and shoes, and other manufactures. Connecticut, indeed, manufactures every article known to commerce and trade, from a needle or pin to the steam-engine and locumotive-together valued as before set down. The manufacturing industry of the State, however, is not all represented in the census, only estrblislments producing to the value of $\$ 500$ annually being those assessed; but it is well known that there are thousands of small shops throughout the conntry, which, though not noticed by the census, nevertheless, in the aggregate, own a large capital, and produce to a large annual amount-perhaps, indeed, these unnoticed establishments, if aggregated, would add one-third to the apparent extent of the manufacturing interest of the State.

Foreign Commerce,-The direct foreign commeree of Connecticut, although the State enjoys many peculiar facilities for engaging in such, is comparatively of small extent. The exports in the year ending 30th June, 1850, were valued at $\$ 241,930$, of which $\$ 66 \mathrm{~S}$ was the value of re-exports; and the imports were valued at $\$ 372,390$. This trade is chiefly with the British North American Provinces and the West India Islands. The shipping employed in carrying the merchandise abore represented, consisted of vessels entered 188 (34,152 tons), and vessels cleared $156(27,317$ tons). The amount of shipping owned in the State at the above named period was 113,085 tons, of which 42,511 tons was of the class registered, 68,188 tons enrolled and licensed, and the remainder vessels under 20 tons burden. Of the registered shipping, 11,483 tons were employed in the whale fisheries, and 31,028 tons in foreign commerce; and of the enrolled and licensed shipping, 5,249 tons were employed in the cod fisheries, and 571 tons in the mackerel fisheries; the remaining enrolled, etc., shipping being employed in the cnasting trade. The fisheries are carried on from the ports of New London and Stonington. The steam marine of the State, all of which is employed in coasting, amounted to 8,455 tons. The shipping built in the year was 3 ships, 7 brigs, 27 schooners, 9 sloops, and 1 steamer-in all, 4,819 tons. The following table will exhibit the movement of foreign commerce in the State from 1791 to 1850 :

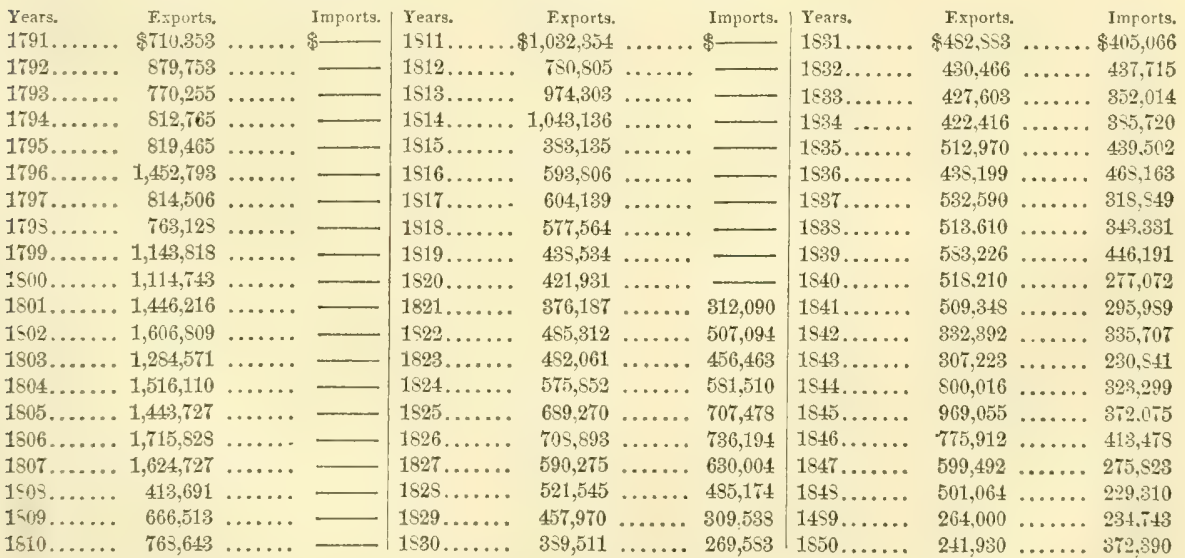

Internal Communication.-The lines of travel and transportation in Connecticut extend-east and west directly through the length of the State, having their termini at New York and at Boston, and-north and south, stretehing from the ports on Long Island Sound, across the country into Massachusetts, Maine, New Fampshire, and Vermont, and alimately to the Western States, and also into Canada. The connections thus formed extend sereral thousands of miles, 


\section{CONNECTICUT.}

and afford easy and expeditious routes of communication between the interior and sea-board. There are two lines of railroad running in a direction east and west-the line composed of the New York and New Haren R. R., and the New Haven and New London R. R., which, in connection with the Stonington R. R., and also with the Norwich and Worcester R. R., forms the Southern route between the two commercial centres, Boston and New York; and the Hartford, Providence, and Fishkill R. R., which will form a direct line through the middle section of the State, from Providence,

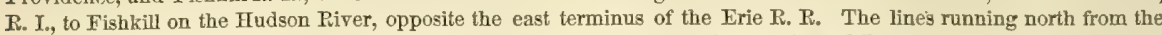
Sound ports are-the Norwich and Worcester R. R.; the New London, Willimantic, and Palmer R. R.: the New Haven, Hartford, and Springfield R. R.; the New Haven and Northampton R. R. (on the old canal route); the Naugatuck R. R.; the Housatonic P. R., and the Danbury and Norwalk R. R. There are also several additional railroads in progress or projected; one of which, and the most important, is that designed to effect an air line route between New York and Boston. The common and turnpike roads of the State are proverbially good and well kept. The only canal of any length the State ever possessed, the Farmington Canal, has been filled in, and now forms the bed of the New Haven and Northampton $\mathrm{R}$. P.

Banks, etc.-In April, 1850, there were in the State 41 banks and 2 branch banks, the condition of which at that date was as follows: Liabilities-capital. $\$ 9,907,503$; circulation, $\$ 5,258, \$ \$ 4$; deposits, $\$ 2,357,939$; due other banks, $\$ 168,765$; dividends unpaid, $\$ 37,372$; surplus fund, $\$ 753,654$; earnings since dividend, $\$ 304,396$, and other liabilities, $\$ 38,961$; and Assets-loans and discounts, $\$ 15,607,315$; real estate, $\$ 389,983$; other investments, $\$ 396,035$; due by other banks and brokers, $\$ 1,637,411$; notes of the banks, $\$ 215,349$; specie funds, $\$ 103,614$; specie, $\$ 640,622$, and expenses since dividend, $\$ 51,878$. Total of balance sheet, $\$ 19,122,207$. Connecticut had also 15 sarings' banks, in which $\$ 4,746,692$ was deposited by 32,966 individual depositors : the sums deposited in 1849-50 amounted to $\$ 1,051,300$, and the sums withdrawn to $\$ 719, \$ 98$. The aggregate expense of managing these institutions was $\$ 10,837$; and the dividends made on sums deposited ranged from 5 . to $7 \frac{1}{2}$ per centum. The securities on which the credits are based are loans on real and personal estate and stocks, and investments in bank stocks and bonds, etc. The Insurance Companies in the State comprised-8 general stock companies, with an aggregate of capitals amounting to $\$ 1,400,000 ; 11$ mutual general companies-capitals, $\$ 1,457,025 ; 6$ life mutual companies_capitals, $\$ 1,400,000 ; 2$ health companies-capitals, $\$ 203,175$; and 1 life and health company-capital, $\$ 100,000$.

Government.-The charter granted in 1662 , by Charles II., formed the basis of the government until 1818, when the present constitution was formed.

Every white male citizen of the United States, 21 jears of age, who has gained a settlement in the State, has resided six months in his town, is possessed of a freehold of $\$ 7$ a year in value, or has done military duty for one year, or has been excused therefrom, or has paid a State tax within the year, and who has a good morsl character, may rote at all elections on taking the oath. Every voter is eligible to any office, unless it be expressly excepted. The general election is held on the first Monday of April annually.

The legislature, styled the General Assembly, consists of a Senate and House of Representatives. The Senate is not to consist of less than 18 nor more than 28 members - senators are chosen by districts of equal population, and by a plurality of rotes, and in case any two candidates have an equal and highest rote, then the House of Representatires shall elect one of them. Representatives are chosen by towns, and in the same manner as senators; but in case of no candidate receiving a highest vote, the Senate chooses one as member from the two candidates having the highest. The legislature meets alternately at Hartford and New Haven, on the first Monday in May, yearly.

The Governor exercises the chief executive power. He must be at least 30 years of age and have been eleeted by a majority of votes, and in case there be no choice by the people, one of the two candidates having the highest vote is chosen by the General Assembly on joint ballot. The Governor has power to grant reprieves, except in eases of impeachment, but not pardons; and he may veto a bill, but a majority of both houses may pass it again, and it becomes law nevertheless. A Lieutenant-Governor (ex-officio President of Senate), Secretary of State, Treasurer, and Comptroller are chosen in the same manner as the Governor. All these officers are elected annually.

Connecticut, under the law relative to the distribution of representives, has four members in Congress.

The Judiciary of the State consists of a Supreme Court, a Superior Court, County Courts, ete. The Supreme Court consists of a ehief and four associate justices, and meets annually in each county. The Superior Court is held by one judge of the Superior Court semi-annually in each county. County Courts are held three times each year in the several counties by a judge elected annually by the legislature. Appeal lies from the County Courts to the Superior Court. Clerks of the County Courts are likewise clerks of the Superior Court and Supreme Court in their counties respectively. In all cases of libel, truth may be given in evidence. Sheriffs are chosen by the Assembly, and hold office for three years.

Finances, etc.-During the year ending 1st April, 1850, the total receipts into the public treasury amounted to $\$ 122,347$, and the expenditures to $\$ 118,392$, leaving a balance of $\$ 3,955$. The chief sources of income were, from taxes, $\$ 73,557 ;$ from dividends on bank stock, $\$ 37.053$, etc. The principal expenses were, the expenses of legislation, $\$ 25,956 ;$ salaries, $\$ 14,150$; contingent expenses of government, $\$ 15,399$ : judicial expenses, $\$ 19.002$, etc. Connecticut has no absolute debt. The contingent debt amounted to $\$ 5 s, 212$. The value of property belonging to the State otherwise than the School Fund, amounts to $\$ 106,000$.

Religious Denominations.-The statistics of the principal religious denominatinns, according to the returns made by ench in 1550, were as follows: The Congregationalists had 267 churches, 206 ministers, and 35,158 communicants; the Baptists had 111 churches, $\$ 9$ ministers, and 16.230 communieants: the Protestant Episenpalians had a bishop, and 106 ministers, and 9,360 communicants; the Episcopal Methodists had 148 ministers, and the other Methodist churches 8 ministers; the Presbyterians, 5 ministers; the Unitarians, 4 ministers; the Roman Catholies, a bishop and 9 priests; the Universalists, 14 preaehers; the Second Advent Church, 8 ministers; the Christians, par excellence, 5 ministers; the Free-Will Baptists, 1 minister; the Jews had 2 synagogues and 1 rabbi.

Educational Statistics. - The number of common school societies in the State on the 1st April, 1850, was 217; of school districts, 1,649, and of children between 4 and 16 years of age, 92,055. The value of the School Fund, 2d Septo, as appears from the biennial exhibit, was $\$ 2,076,60275$; and the amount of dividend for 1850 was $\$ 137,44951$, or $\$ 1$ 50 for every enumerated child. The returns do not give the number of teachers, or their wages, or the time during which schools are open, ' ut nly the information above indicated. The Legislature, at the session of 1849, appropriated $\$ 10,000$ for th. sta lishment of a State Aromal School, which is under the control of eight trustees, appointed by the General Assemh]y, one from each county. The collegiate establishments of the State are: Tale College, Trinity College, the Wesleyan University, and the Theological Institute. Yale College is one of the oldest, most richly endowed, and 
mast extensively useful institutions of learning in the United States. It was founded in 1701 by the gentleman whose name it perpetuates. In 1550 it had in the academical department 432 students, of which 93 were of the senior class, 91 of the junior class, 122 of the sophomore class, and 126 of the freshman class-total, 432 ; and the number of students in theology was 35 , in law 26 , in medicine 38 , and in plilosophy and the arts 21 -total in professions and the arts, 123 . Grand total, 555. From 1702 to 1850 , the number of graduates had been 5,932, of which 2,962 were living; and of the total 1,562 had been ministers of the gospel, of whom 724 were living in 1850 . The library of Yale College contains 49,000 volumes. Trinity College, an Episcopal institution, is located at Hartford. It was founded in 1824 , and in 1850 had 9 professors, 66 students, and a library of 9,000 volumes. Its alumni counted at the latter date 257 , of which 117 had taken holy orders. The Wesleyan University, at Middletown, was founded in 1831, and in 1850 had 8 professors, 125 students, and a library of 11,123 volumes. Since its commencement it had graduated 327 students, and of these 126 had gone into the ministry. At Hartford is the Theological Institution of Connecticut, an establishment under the Congregational churches, founded in 1S34. It had, in 1850, 3 instructors, 17 students, and a library of 5,000 volumes. Its alumni counted 151. There are, besides the above, a large number of acalemies, and other descriptions of private schools, which, for efficieney and cheapness, have few equals. There is also at Hartford the Connecticut Historical Society, which publishes its transactions at stated periods.

Craritable Institutions,-Connecticut, at an earlier period, and on a more extensive scale than any other of the States, commenced and completed institutions the object of which was the relief of those whom nature or accident had deprived of the use of senses or mental faculties. The principal of these institutions are the Retreat for the Insane, and the American Asylum for the Deaf and Dumb, both at Hartford; and to these may be added the State Prison at Wothersfield, conducted on pateraal and correctional, rather than vindictive, principles. The Retreat for the Insane was opened in 1824; on the 1st April, 1849, it contained 138 patients, and in 1849-50,135 were admitted, making 268 in all; and during the same year 125 were discharged, leaving in the retreat 143 . Of the patients discharged 64 were recovered, 24 improved, 7 not improved, and 30 died. The whole number of admissions, from the opening of the institution, had been 2,033. The terms of admission are $\$ 39$ a quarter for patients belonging to the State, and $\$ 4550$ for patients from other States, The American Asylum for the Deaf and Dumb was the first institution of the kind founded in the United States, and has been well endowed by individual, State, and Federal bounties. The number of students for the year ending 1 st May, 1850 , was 210 , and of these 20 were supported by friends, 32 by the State of Maine, 23 by New Hampshire, 19 by Vermont, 75 by Massachusetts, 7 by Rhode Island, 26 by Connecticut, and 8 by South Carolina. The annual cost is $\$ 100$, but in sickness extra necessaries are charged for; applicants for admission must be between 8 and 25 years of age, of good natural intellect, capable of forming and joining letters legibly and correctly, and of good moral character. During the year ending 31st March, 1850, there were discharged from the State Prison 48 convicts, and received 61 ; and at that date there remained in confinement 175, of which 163 were males and 12 females. The males are employed in making cabinet work, cutlery, and shoes; and the females in washing, cooking, making and mending clothing, and binding boots and shoes. The average number in confinement during the year was 160 . A small library has been purehased for the use of the prisoners, and it is a duty of the chaplain to give educational as well as religious instruction to the inmates, The institution is self-supporting, and the receipts for the year past show a balance in favor of the prison. A Reform School for Juvenile Offenders has also been lately established by the Legislature and individuals conjointly.

Periodical Press. - The whole number of periodicals and newspapers published in Connecticut, in 1850, was 51, of which 30 were political, and 21 literary, religious, scientific, etc. of the political papers, 20 were Whig and 10 Democratie in their teachings. Of the total, 8 were daily papers, 4 tri-weekly, 33 weekly, and 6 at other periods. The circulation of the daily papers amounted at each aggregate issue to 12,300 copies; of the tri-weeklies, to 1,600 copies; of the weeklies, to 34,810 copies ; and of all others, to 2,400 copies. The best known of the Connecticut periodicals, are-the "American Journal of Science," the "New Englander" (literary), the "Church Review" (religious), and the "Yale Literary Magazine" (literary) : a 1 of which are published from the New Haven press. The "Journal of Science" is under the editorial supervision of the celebrated Dr. Silliman, and has long stood at the head of scientific periodicals in America.

Connecticut consisted originally of two colonies: Hartford, settled by emigrants from Massachusetts in 1635, and New Haven, by emigrants from England in 1638. The two colonies were united under one government by a charter of Charles II, in 1662. In 1686 this charter was suspended by James II., and Andros, who had been appointed Governor of New England, was sent to assume the government. Repairing to Hartford, with a body of troops, he demanded the charter; the instrument was accordingly brought into the hall in the evening, with the intention of its being surrendered, but the lights were suddenly extinguished, and the charter was carried off and secreted by some of the colonists in the hollow of a tree, which is still in existence, and is to this day known as the Charter Oak. When Andros was deposed in 1689, the charter was resumed, and the govermment was administered under it until 1818, when the present constitution was formed and went into effect. Its principal provisions are referred to under another caption.

HARTFORD and NEW HAVEN are alternate capttals of the State.

Coxincticur river: this $\mathrm{r}$. has its sources in $N$. Hamp., and the mountainous tracts of Lower Canada. Its general course is from $\mathrm{N}$. to $\mathrm{S}$., and it is navigable for vessels of considerable burden for a distance of $50 \mathrm{~m}$. to Hartford, and to Middletown, about $30 \mathrm{~m}$. from the sea, for vessels of 12 feet draft. It is the Quoncktacut of the Indians, said to signify "Long River," or, as it is rendered by others, the "Piver of Pines." Its western branch forms the boundary line between the United States and Canada; and the main river, dividing Vermont and New Hampshire, crosses the western part of Massachusetts, passes through the central part of Connecticut, and after a fall of about 1,600 feet in its whole length of 410 miles, enters Long Island Sound in $41016^{\prime} \mathrm{N}$. lat. In its course it passes through a beautiful country, and by many very flourishing towns, among which may be mentioned Hanover, Haverhill, Walpole, and Charlestown, in New Hampshire; Windsor, Newbury, and
Brattleboro', in Vermont; Greenfield, Hadler, Northampton, and Springfield, in Massachusetts; and Hartford, Middletown, and Haddam, etc., in Connecticut. Its breadth, at the entrance into Vermont, is about 150 feet, but in its course of 60 miles it increases to a breadth of about 400 feet. In Connecticut and Massachusetts, its breadth raries from 500 to 1,100 feet. The canals and other improvements recently made to overcome the rapids and falls, have rendered it navigable for small boats which trade as far as Well's $r$ at a distance of $250 \mathrm{~m}$. above Hartford. The falls of most celebrity are Bellow's Falls, Queechy Falls, White River Falls, etc., in New Hampshire and Vermont; Montague and South Hadley Falls, in Massachusetts; and Enfield Falls, in Connecticut, at the last of which it meets tide water. The descent of the river, between Hanover, New Hampshire, and Enfield, Connecticut, is about 370 feet, of which 225 feet have been overcome by locks. 
The principal tributaries of this river are, in New Hampshire, the Upper and Lower Ammononsuc, Sugar, and Ashuelot rivers; in Vermont, Pasumsic, Wells, White, Queechy, Black, Williams, and West rivers; in Massachusetts, Miller"s, Deerfield, Chicopee, and Westfield rivers ; and in Connecticut, Farmington r. The banks of the Connecticut are in many places rough and precipitous, but there are other portions on both sides, extending from half a mile to 5 miles wide, and but slightly raised above the surface of the stream, which are annually overflowed, and consequently enriched, the soil of which is very fertile, and forms a large tract of meadow-land. From the beauty, utility, and length of this river, and also from its connection with the different towns and villages which lie on its banks, it forms one of the most distinguished features of New England. Large quantities of shad, of a superior quality, are taken annually, also some other fish; but the salmon, which formerly frequented it, have now disappeared.

Connell's Cross Roads, p. o., Bossier par., La. : $220 \mathrm{~m}$. N. W. Baton Rouge.

Connerrsville, p. v., Fayette co., Penn.: on the E. bank of Youghiogeny r., $168 \mathrm{ma}$.W. by S. Harrisburg. Pop. 600 .

CoNner's Milis, p. o., Cooper co., Mo.: 42 m. N. W. Jefferson City.

Connersyilue, p. v., Harrison co., Ky. : 42 m. E. N. E. Frankfort.

Connerspilue, p. v., and cap. Fayette co., Ind.: on the W. side of the W. branch of White Water r., $54 \mathrm{~m}$. E. by S. Indianapolis. It is an important place, being on the line of the White Water Canal, and of the Junction R. Pu., the first connecting it with the places $\mathrm{N}$. and $\mathbf{S}$., and the latter with those E. and W. of it. Two newspapers, the "White Water Valley" (whig), and the "Fayette and Union Chronicle" (dem.), are issued weekly. The $\nabla$. contains several large and substantial stores and warehouses, and is fully provided with churches and schools. The $\mathrm{C} . \mathrm{H}$. is one of the handsomest public buildings in the State. Pop. 2,200.

Cons's Creek, p. o., Shelby co., Ind.: on the cr. so called, $83 \mathrm{~m}$. . . E. Indianapolis. Conn's cr. is a good mill-stream, and a tributary of Flat Rock river.

Coxococheague, p. o., Washington co., Md. : on a cr. of Potomac r. so called, $9 \mathrm{~m}$. W. Hagerstown, and $79 \mathrm{~m}$. N. W. by W. Annapolis.

Covors, t. and p. o., Calhoun co., Mich.; $33 \mathrm{~m} . \mathrm{S}$. W. Lansing. The t. contains numerous ponds, and is drained chiefly by tributaries of Battle cr., which passes through its N. W. corner. Pop, 621 .

Coyotes, p. v., Harrison co., Ohio: on Conoten er. of Tuscarawas r., $98 \mathrm{~m}$. E. N. E. Columbus.

Coxquest, $t$. and p. v., Cayuga co., $N . Y_{.}$: on the N. side of Seneca r., which in the S. W. corner of the t. divides and forms Howland's Island. The surface is rolling. The v., $142 \mathrm{~m}$. W. by N. Albany, contains about 30 dwellings and 200 inhabitants. Pop. of t.1,863.

CONRad's Store, p. 0., Rockingham co., Virg.: $97 \mathrm{~m}$. N. W. Richmond.

Conshomon, p. ₹., Montgomery co., Penn.

Consolatiox, p. v., Shelby co., $K y .: 26 \mathrm{~m}$. W. Frankfort. Constabletrlue, p. v., Lewis $c_{0}, N_{0} Y_{*}:$ on a cr, of Black r., $98 \mathrm{~m}$. N. W. Albany.

Constantia, t. and p. $v_{n}$, Oswego co, $N . Y_{\text {. }}$ : on the N. side of Oneida Lake, $112 \mathrm{~m}$. W. N. W. Albany. It is drained by Scriba and other creeks flowing into the lake. The v. contains about 400 inhabitants. Pop. 2,495.

Constantita Centre, p. o., Oswego co., N.Y.: $110 \mathrm{~m}$. W. N. W. Albany.

Constantixe, to and p. v., St. Joseph co., Mrich. : on both sides of St. Joseph's r., $83 \mathrm{~m}$. S. W. Lansing. The r. is located on Fall cr., and is in a very flourishing condition, with considerable commerce and inland trade. Pop. of t. 1,494.

Constitution, p. v., Washington co., Ohio.

Content, p. O., Bulwer co., Miss.: $123 \mathrm{~m} . \mathrm{N} . \mathrm{N}$. W. Jackson.
Consentasa, p. o., Pitt co., N. Car.: on Contentria cr, a tributary of Neuse r., $74 \mathrm{~m}$. E. S. E. Raleigh.

Contoocook Village, p. v., Menimae co., N. Hamp. on Contooeook r., and on the line of the Concord and Claremont R. R., at the point of divergence of the Contoocook Valley R. R., $10 \mathrm{~m}$. from Concord. The water-power is here extensive, and a large manufacturing $\mathrm{v}$. has sprung up within a few years under the favoring influence of direet railroad connection with Boston and other parts of New England, etc. The Contoocook $\mathrm{r}$. is a tributary of the Merrimac $\mathrm{r}$., which it joins on the $\mathrm{N}$. line of Coneord,

Contra Costa county, Calif. Situate W., and contains $1,600 \mathrm{sq} . \mathrm{m}$. On the W. and N., San Francisco Bay and its tributary rivers demark its bounds and receive its drainage. Surface mountainous, with extensive valleys, the coast range passing through it. Farms 00 ; manuf. $00 ;$ dwell. 000 , and pop.-wh. 0,000, f. col. 00-total 0,000. Capital : Martinez.

Contreras, p. F., Butler co., Ohio: 94 m. W. S. W. Columbus.

Conventence, p. v., Fayette eo, Ohio: on the S. W. side of the N. Branch of Paint cr., $37 \mathrm{~m}$. S. by W. Columbus,

Convenient, p. v., Smith co., Tenn. : 49 m. E. by N. Nashville.

Convent, p. o., St. James par., La.: 37 m. S. S. E. Baton Rouge.

CoNwAY county, Ark. Situate centrally, and contains 1,860 sq. m. Drained by Cadron, Point Remove, and other creeks of Arkansas r., which washes its S. W. border. The surface is somewhat billy and broken, but the soils have an average productiveness, and yield good crops, Indian corn, etc. Farms 357; manuf. 3; dwell. 595, and pop.wh. 3,339, fr. col. 4, sl. 240-total 3,583. Capital: Lewisburg.

CoNwAY, t. and p. V., Franklin co, MFass, ; on the S. W. side of Deerfield r., $92 \mathrm{~m}$. W. by N. Boston. The p. o. lies near the eentre of the t. The manufactures of Conway consist of cotton and woolen goods, leather, cabinet ware, etc. It has fine farming lands. Pop. 1,831.

CoNwAY, t. and p. o., Aroostook co., Mre.: in the S. W. part of the con, $110 \mathrm{~m} . \mathrm{N}$. N. E. Augusta. The t. is drained by Muleneas cr., a tributary of Matawamkeng $r$., and by several streams tributaries of the Penobseot.

Conway, t. and p. $o_{n}$, Livingston $\mathrm{co}_{n}, \mathrm{M} F \mathrm{ch}_{0}:$ in the $\mathrm{N}$. W. corner of the co., $24 \mathrm{~m}$. E. Lansing.

Conway, t, and p. v., Carroll con, N. Hamp.: on Saco r., $56 \mathrm{~m} . \mathrm{N} . \mathrm{N} . \mathrm{W}$. Concord. Swift and Pequawkett rivers fall into the Saco within this $t$, and afford extensive millpower. The ordinary depth of the Saco is here about 2 feet, with a rapid current, broken by falls, but in season of flood it has heen known to rise 27 and even 30 feet in 24 hours. Magnesia and fuller's earth are abundant, and near the centre of the $t$. is a sulphur spring. The soils are very fertile. Conway village is a pleasant resort for travelers to the White Mountains, and will, before long, be connected with the railroads to Boston by the Great Falls and Conway R. R. Pop. 1,769 .

CONW A XBOROCGM, p. v., and cap. Horry dist., S. Car. : 108 m. E. by S. Columbia, on the W. side of Waccamaw r., which thus far is navigable for steamboats. The v. contains the county buildings and about 200 inhabitants, and has some trade with the neighboring settlements.

Coxyer's, p. o., Newton co., Ga. : on the line of the Georgia R. R., $141 \mathrm{~m}$. from Augusta and 30 from Atlanta, and $62 \mathrm{~m}, \mathrm{~N}$. W. Milledgeville.

Conyersville, p. v., Henry co., Tenn.: $89 \mathrm{~m} . \mathrm{W}$. Nashrille.

Conmegratr, p. v., Luzerne co., Penn.: 69 m. N. N. E. Harrisburg.

Cooch"s Bridge, p. o., New Castle co., Del.

Cook county, Illo Situate in the N. E., on Lake Michigan, and contains $856 \mathrm{sq}$. m. Drained by Calumic, Chicago, and Desplaines rivers. Surface low, level prairie, with 
imber groves and some swamps; rises from the lake shore. Soils fertile. Farms 1,S5̃ ; manuf. 227; dwell. 7,674, and pop.-Wh. 42,999, ir. col. 386-total 48,385. Cospital: Chieago. Public Works: Galena and Chicago Union R. R. ; Chieago and Rock Island R. R.; Aurora Extension R. R.; Chicago and Mississippi R. R.; Northern Indiana R. R.; Lake Shore R. R.; Chicago Branch of Central R. R., etc.; Nlinois and Michigan Canal ; and numerous plank roads.

Cook, p. v., Erie co., Penn. : 205 m. N. W. Harrisburg. Cooke county, Tex。 Situate N., and contains about 4,600 Bq. $m$. Drained by the head strearas of the Trinity and Brazos rivers, and by creeks falling into Red r., which bounds it on its N. side. Surface elevated and diversifled, chiefly prairie. Soils fertile. Farms 25 ; manuf. 0 ; dwell. 38, and pop.-wh. 219, fr. col. 0, sl. 1-total 220. Capital:

Cookestillek, p. v., Caddo, par., La.: 226 m. N. W. Baton Rouge.

Cоокнам, p. v., Fairfield dist., S. Car.: on the line of Charlotte and South Carolina R. R., $17 \mathrm{~m}$. N. Columbia. Coogsbukgr, p. v., Albany co., N. Y.: 26 m. S. W. Albany.

Coon's Corners, p. o, Erie co., Ohio: 99 m. N. Columbus. CoorservILIE, p. v., Crittenden co., Ky. : 208 m. W. by S.

Frankfort.

Cook's Law OfFIo, p. o., Elbert co., Ga.: 82 m. N.N.E. Milledgeville.

Cook's RUN, p. o., Clinton co, Penn.: 83 m. N. N. W.

Harrisburg.

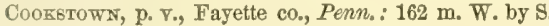

IIarrisburg.

Cookstown, p. v., Burlington co., N. Jer.

Coorsville, p. V., Anne Arundel co., Md.: at the

head of Cat-tail branch of Big Patuxent r., $42 \mathrm{~m} . \mathrm{N}$. W. Annapolis.

Cooksvilue, p. v., Rock co., Wisc. : on a branch of Cat-

fish r., $21 \mathrm{~m}$. S. S. E. Madison.

Cookstili., p. v., Noxubee co., Mfiss.: 112 m. E. N. E. Jackson.

Coolbadgh's, p. o., Monroe co., Penn.: 123 m. N. E. Harrisburg.

Cool Sprivg, p. o., Wilkinson co., Ga.: in the S. corner of the co., $32 \mathrm{~m}$. s. Milledgeville.

Coor Spring, p. o., Jefferson co., Penn. : 132 m. W. by N. Harrisburg.

Coolville, p. v., Athens eo., Ohio: on the W. side of Hocking $r$., near $4 \mathrm{~m}$. from its confluence with the Ohio $r$., $82 \mathrm{~m}$. S. E. Columbus.

Coor Well, p. o., Amherst con, Firg.: $100 \mathrm{~m}$. W. Richmond.

Coon Creek, p. o., Jasper co., Mo.: on the S. side of Coon er., a branch of Muddy cr. of Neosho r., $136 \mathrm{~m}$. S. W Jefferson City.

Coonewan, p. V., Pontotoc co., Miss. : 157 m. N. N. E. Jackson.

CooN Hilu, p. o., Santa Rosa co., Flor.: $165 \mathrm{~m} . \mathrm{W}$. Tallahassee.

Coon Praurie, p. 0., Crawford co., Wisc.: $76 \mathrm{~m}$. W. by N. Madison.

Coonvilue, p. v., Pottowattomee co., Ia.: $212 \mathrm{~m}$. W. Iowa City.

COOPER county, MO. Situate centrally, and contains 576 Bq. m. Drained by Black r., Rio a la Mine, and Saline and Monitean creeks, tributaries of Missouri r., which makes its N. boundary. Surface undulating, and soils very productive. Indian corn and tobacco are the principal agricultural staples, and live-stock is raised in large numbers. Farms 1,061; manuf. 79 ; dwell. 1,717, and pop.-wh. 9,837, fr. col. 22, 81, 3,091-total 12,950. Capital: Booneville. Publio Works: Pacific R. R.

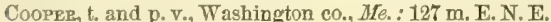
Augrusta. It is drained by two small lakes and several streams emptying into Cobscook Bay. The surface is ever and the soils productive. Pop. 562.

Cooper, p. v., Wayne co., Oltio : 78 m. N. E. Columbus. COOPER, t. and p. O., Kalamazoo co., Mich. : on both sides of Kalamazoo r., $56 \mathrm{~m}$. W. S. W. Lansing. Pop. 738.

COOPER river, S. Car.: unites with Ashley r. to form Charleston Harbor, entering it on the E. side of the city. A canal, $21 \mathrm{~m}$. long, unites Cooper with the Santee, and thus opens an extensive interior to Charleston.

COOPER"s, p. o., Franklin co, Virg.: 188 m. W. S. W. Richmond.

Coopersburg, p. v., Lehigh co., Penn。: 87 m. E. N. E. Harrisburg.

COOPEE's Gap, p. o., Rutherford co., N. Car, : $200 \mathrm{~m}$. W. by S. Raleigh.

Cooper's Mills, p. o., Lincoln co., Mre.; on the Kennebec r., 13 m. S. Augusta.

Coopez's Planss, p. V., Steuben co., $N_{0} Y_{0}$ : on the Buffalo, Corning, and New York R. R., $3 \mathrm{~m}$. from Painted Post and $168 \mathrm{~m}$. W. by S. Albany.

Cooperstown, p. v.y and cap. Otsego co., N. $Y_{0}$ : at the outlet of Otsego Lake, $58 \mathrm{~m}$. W. Albany. It is a neat and tastefully built village, and is surrounded by scenery not excelled by any in central New York for beauty. Three newspapers, the "Freeman's Journal" (dem.), the "Otsego Republican" (whig), and the "Otsego Democrat" (dem.), are published weekly. The manufacturing interest is considerable, cotton goods and paper being its staples. Pop. 1,400

Cooperstown, p. v., Brown co, Wisc. : on Benton cr. of West Twin r., 112 m. N. E. Madison, and equidistant between Manitouwoc and Green Bay.

Cooperstown, p. v., Venango co., Penn. : 103 m. N. W. Harrisburg.

Coopersville, p. v., Dearborn co., Ind.: 79 m. S. E.

Indianapolis.

Coopersville, p. v., Fentress co., Tenn. : 113 m. E. by N Nashville.

CoOperstilie, p. Y., Clinton co., N. Y.: $136 \mathrm{~m} . \mathbf{N}$. Albany.

Coopersvilux, p. v., Lancaster co., Penn.: 43 m. S. E. Harrisburg.

Coopersville, p. v., Union dist., S. Car. : $77 \mathrm{~m} . \mathrm{N}$. W. Columbia.

Coop's Cefeek, p. o., Marion co, Tenn : 100 m. S. E. Nashville.

Coos county, N. Hamp. Situate N., and contains 1.600 sq. m. Drained by tributaries of Connectieut $x$., and by the Androseoggin and Saco rivers, which flow into Maine. Much of the land is rough and broken, unfit for cultivation, but on the Connecticut, and other streams, the soil is fertile and productive. The White Mountains occupy the S. E part of the co. The climate is too severe for Indian corn, but all other grains and roots grow well. Farms 1,499; manuf, 69 ; dwell. 2,114, and pop. - wh. 11,819, fr, col. 4 total 11,853. Capital: Lancaster. Public Works: Atlantic and St. Lawrence R. R.

Coos $A$ county, $A l a$. Situate centrally, and contains 564 sq. m. Drained by Paint, Weoquatka, Hatehet, and Wowoka creeks of Coosa r., and by several creeks of Tallapoosa $x$. Surface hilly and broken. Soils fertile, with abundance of timber, cotton, Indian corn, wheat, with tobaceo and rice, are the products. Farms 1,130; manuf. 13; dwell. 1,725, and pop.-wh. 10,414, fr. col. 9, sl. 4,120-total 14,513. Capital: Roekford.

Coosa, p. v., Floyd co., Ga. : on the Coosa r., $146 \mathrm{~m}$. N. W. Milledgeville.

Coos a river, Ala, and Ga, rises in Georgia and runs through the N. W. part of that State into Alabama, and 8 $m$. below Wetumpka unites with the Tallapoosa $r$, to form the Alabama. The Coosa is navigable for steamboats to Wetumpka, and its whole course is about 240 miles

Coosawatchrr, p. v., and cap. Beaufort dist., S. Car.: on 
the W. bank of Coosawatchie r., near its confluence with Broad r., $97 \mathrm{~m}$. S. Columbia. It is a small v., being important solely as the county seat of justice.

CoosawatTeE, p. v., Murray co., Ga. : on the N. side of Coosawattee r., a constituent of the Coosa r., $142 \mathrm{~m}$. N. W. Milledgeville.

Copdke, t. and p. v., Columbia co., $N_{.} Y_{.}:$on the Massachusetts State line, $47 \mathrm{~m}$. 8 . by E. Albany. The E. part of the $t_{\text {. }}$ is hilly-in the W. are several small lakes and Ancram $r$. The $v$. lies near the Harlem R. R. Pop. 1,652.

Copase lake, Columbia co., $N_{.} \bar{Y}_{.}$: a beautiful sheet of water, about 600 acres in extent. Its shores bave a gentle declivity and are highly cultivated. The waters are remarkably clear, and the bottom of the lake is composed of white sand and gravel.

Copai, p. v., Haywood co., Tenn.: 146 m. W. by S. Nashville.

Copaxo, p. o., Refugio co., Ter.: on Aransas Bay, opposite to Aransas City Point, 162 m. S. by E. Austin City. It has a good harbor for small coasters and steamboats.

Copeland, p. o., Telfair co., Ga.: on the N. E. side of Okmulgee r., $78 \mathrm{~m}$. S. Milledgeville.

Copenhagen, p. v., Caldwell par., $L a .:$ on the W. side of and $2 \mathrm{~m}$. from Wachita $r, 116 \mathrm{~m}, \mathrm{~N}$. N. W. Baton Rouge.

Copenhager, p. v., Caldwell co., $N$. Car.: a few miles N. E. of the confluence of Lower cr. with the Catawba $x_{\text {, }}$ $162 \mathrm{~m}$. W. Raleigh.

Copenhlgen, p. $\nabla$. , Lewis co., $N_{\text {. }} \bar{Y}_{\text {.: }}$ on both sides of Deer cr., $120 \mathrm{~m}$. N. W. Albany. It is a flourishing $\mathrm{v}_{\text {., }}$ and engaged in manufactures. About half a mile below the $\mathrm{Y}$. on Deer cr., is a fall of 270 feet, nearly perpendicular.

Cope's Mriss, p. O., Jefferson co., Ohio: 123 m. E. by N. Columbus.

Copr, p. o., Johnson co., Ia. : on the N. side of Clear cr. of Iowa r., $10 \mathrm{~m}$. W. N. W. Iowa City.

Cortar county, Miss. Situate S. W. centrally, and contains $936 \mathrm{sq} . \mathrm{m}$. Drained by Bayou Pierre, the head streams of Homocbitto r., and tributaries of Pearl $\mathbf{r}_{\text {., which rans }}$ along its N. E. border. Surface flat and low. Soils various, chiefly sandy loam, producing cotton and corn. Farms 951; manuf. 21; dwell, 11,43, and pop.-wh. 6,303, fr. col. 11, sl. 5,490-total 11,794. Capital: Gallatin. Puttio Works: New Orleans and Jackson R. R.

Coprah Creer, p. o., Copiah co., Miss.: 29 m. S. Jackson.

Coplex, t. and p. $\nabla_{\text {. }}$ Summit co., Ohio: on the N. side of Wolf cr. of Tuscarawas r., $102 \mathrm{~m}$. N. E. Columbus, It has good water-power and numerous mills. Pop. 1,541.

Copopa, p. F., Lorain co., Ohio: on the E. side of Rocky r., 108 m. N. N. E. Columbus.

Copperas Creek, p, v., Fulton co, IZZ: on a er, of the Illinois r. so called, $49 \mathrm{~m} . \mathrm{N}$. N. W. Springfleld.

Copper Creer, p. 0., Mercer co, I $U_{\text {. }}$ : on Copper cr, of Illinois r., $122 \mathrm{~m}$. N. W. Springfield.

Copper CreEk, p. O., Jackson co, $I a$, on a cr. of Makoqueta r. so called, 64 m. N. E. Iowa City.

Copper Harbor, p. v., Houghton co., Mich, : at the N. E. extremity of Keweenaw Point, a peninsula projecting into Lake Superior, in about $11 \circ \mathrm{W}$. of $\mathrm{W}$ ashington, and to $47 \circ 30^{\circ}$ N. lat. The settlement has been formed as a depot for the mineral region in the neighborhood, and bas already risen to importance. It has a good harbor and other advantages as a commercial settlement. A railroad from Chicago is projected northward to the harbor, a direct distance of between 400 and 500 miles.

Copper PIDge, p. 0., Hancock co., Tenn. : 208 m. E. by N. Nashville.

Corat, p. o., M'Henry co., Ill.: about 4 m. \$, E, of Marengo, on the Galena and Chicago Union R. R., and $173 \mathrm{~m}$, N. N. E. Springfield.

Corav, p. Y., Suffolk co., N. $Y_{.: 122}$ m. S. E. Albany. It lies on the post road, between Smithtown and Riverhead.

Corbetsville, p. v., Broome co., $N_{0} Y_{\text {. : }} 10 S \mathrm{~m} . \mathrm{S} . \mathrm{W}$. Albany.
Cordatilie, p. v., Worcester co, Mass.

CordorA, p. v., Rock Island co, $I l_{\text {. }}$ : in the N. part of the co. and on the Mississippi r., $132 \mathrm{~m}$. N. by W. Springfield. Cordova, p. v., Grant co., Ky. : 38 m. N. N. E. Frankfort. Corfu, p. v., Genessee co., N. Y.: 228 m. W. Albany. Corrnna, t. and p. o., Penobscot co., Me.: 46 m. N. N. E. Augusta. The t. is watered by head branch of Sebasticonk river. Pop. 1,560 .

Corma Centre, p. o., Penobscot co., BHe. : 49 m. N. N. E. Augusta.

CoRrvtr, p. จ., Heard co., Ga.: on New r., a er. of Chattahaochee $\mathbf{r}, 108 \mathrm{~m}$. W. by N. Milledgeville.

Corintr, t. and p. o., Penobseot co., MFe.: on both sides of Kenduskeag stream, 55 m. N. E. Augusta. Pop. 1,600, Corivtr, t. and p. o., Saratoga co., $N$. $Y$.: on the S. W. side of Hudson r., $36 \mathrm{~m}$. N. Albany. The p. 0 . is situate at Jessup's Landing. Pop. of t. 1,501.

Corinth, p. v., Belmont co., Ohio : 110 m. E. Columbus. Condrre, t. and p. o., Orange co., Term.: $28 \mathrm{~m}$. S. E. Montpelier. The $t$. is drained by branches of Wait's r., which furnishes water-power, which is usod for milling purposes. Pop. 1,906

Cornise, t, and p. o., Sullivan co., N. Hamp.: on the E. side of Connecticut $r .47 \mathrm{~m}$. N. W. by W. Concord. The t. is connected with Windsor, Verm., by a bridge over the r. The surface is uneven, except on the $r$, but the soils are fertile. Along the streams flowing to the Connecticut there are numerous mills, etc. Pop, 1606 .

Cork, p. v., Ashtabula co., Ohio : 156 m. N. E. Columbus, Cork, p. v., Butts co., Ga.: $47 \mathrm{~m}$. W. by N. Milledgeville. Corner Gum, p. Y., Currituck co, N. Car.: $162 \mathrm{~m}$. E. by N. Raleigh.

Corners, p. O., Windsor co., Term. : 67 m. S. Montpelier. Corneriburg, p. V., Mahoning co., Ołio: 132 m. N. E. Columbus. It is a flourishing $v$, and has about 300 inhabitants.

Cornersvilue, p. v., Marshall co,, Mfiss. : 187 m. N. by E.

Jackson.

Cornersville, p. v., Giles co., Tenn. : in the N. E. corner of the co., $51 \mathrm{~m}$. S. Nashville.

CorN Grove, p. o., Benton co., Ala.: 97 m. N. N. E. Montgomery.

CornIE, p. ₹., Union co., Ark. : 108 m. S. Little Rock

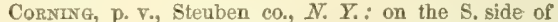
Chemung r., $166 \mathrm{~m}$. W. S. W. Albany. It has a large number of manufacturing establishments, and a newspaper, the "C. Journal" (whig), is issued weekly. The New York and Erie R. R., which passes through the $\mathbf{V}$., is here intersected by the Corning and Blossburg $\mathrm{R}$. R., which extends $\mathrm{S}$. to the bituminous coal region of Pennsylvania, and by the Buffalo, Corning, and New York R. R. Here, also, commences the navigable feeder of the Chemung Canal, which unites with the Erie Canal by means of Cayuga Lake and the Cayuga and Seneca Canal. Its coal trade is very extensive. Pop. 1,400.

Convish, p. v., York co., Me. : on the S. of Saco r. and its tributary, the Great Ossippee r., $66 \mathrm{~m}$. S. W. Augusta. Its soils are fertile and produce good wheat crops. Crockery and some other manufactures are engaged in.

Corvish Flat, p. o., Sullivan co., $N$. Hamp.: near the centre of the t., $49 \mathrm{~m} . \mathrm{N}$. W. by W. Concord.

Cornishrilue, p. v., Mercer co., Ky. : 29 m. S. Frankfort. Cornplanter, t, and p. O., Venango co., Penn. : $189 \mathrm{~m}$ N. W. Harrisburg.

Corsvule, t. and p. o., Somerset co., Me.: on the Wessaransett r., a stream of the Kennebeo r., 33 m. N. by E. Augusta.

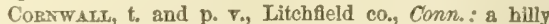
tract on the E. side of Connecticut $\mathbf{r}, 37 \mathrm{~m}$. W. by N. Hartford. The $\mathrm{v}$. lies about $2 \mathrm{~m}$. from the $\mathrm{r}$., and contains about 200 inhabitants. The Housatonic R. R. follows the valley oi the $r$. through the t., passing through the village of Cornwall Bridge, etc. Pop. 2,041 . 
CorNwal.t, t. and p. V., Orange co, $N, Y$ : on the W. side of Hudson r., St m. S. Albany. The surface of the $t$. is hilly, and in part mountain, having on the N. Butter Ifill and Crow's Nest, two noted peaks of the Highlands. This is a romantic region, and contains the site of many historic scenes. West Point is also in this town. The $\mathrm{v}$, is situate at the $\mathrm{N}$. termination of the Highlands, and contains about 240 inhabitants. Pop, 4,471.

Conntwali, p. v., Lebanon co., Penn.: 37 m. E. by N. Harrisburg.

Cornw Alt, t. and p. v., Addison co., Ferm. : on the W. side of Otter cr., $34 \mathrm{~m}$. S. W. Montpelier. In the S. part of the $t_{\text {. }}$ there are swamps covering a large surface. The Rutland and Burlington R. R. traverses N. E. along the valley of Otter creek. Pop. 1,155.

Cornwall Bridge, p. O, Litchfield con, Conn. : 41 m. W. Hartford, on the W. side of the Housatonic r., and on the line of Housatonic R. R.

CorNwali Hollow, p. o., Litchfield co., Conn. : 38 m. W. by N. Hartford.

Cornwallville, p. v., Greene co., $N . \quad Y .: 29$ m. S. W. Albany.

Corpus Christr, p. $\nabla_{\text {., }}$ and cap. Nueces co., Tero.: on the neck of the peninsula between Corpus Christi Bay and Nueces Bay, $198 \mathrm{~m}$. S. by E. Austin City. It is a place of considerable trade, and a regular line of steamships plies between it and New Orleans. Pop. 200.

Corsica, p. vi, Monroe co.g Ohio : 42 m. N. by E. Columbus.

Corsica, p. v., Jefferson co., Penn.: 132 m. W. N. W. Harrisburg.

Corsicara, p. v., and cap. Navarro co., Texe.: on the high prairie, between Pecan and Richland creeks of Trinity r., 122 m. N. N. E. Austin City. It has about 120 inhabitants, and the surrounding country is thickly settled by cotton planters.

CorTuAND county, N. $Y$. Situate centrally, and contains $500 \mathrm{sq} . \mathrm{m}$. Drained by Tioughnioga and Otzelic rivers, which afford extensive mill-power, and in flood are navigable for boats. Surface elevated, its N. boundary forming the watershed between Lake Ontario and the Susquehanna r. Soils a gravelly loam, intermingled with disintegrated lime and slate, and very fertile, yielding good crops of grain and grass. Timber is abundant. The manufactures are chiefly those of flour, lumber, cotton and woolen goods, leather, and potash. Farms 2,465 ; manuf. 202 ; dwell, 4,580, and pop.-wh. 25,104, fr. col. 36-total 25,140. Coppital: Cortland Village.

Cortuaxd, p. v., Kent co., Mich. : 54 m. W. by N. Lansing.

Cortland, p. v., Jackson co., Ind. : on the W. side of Driftwood r., or the E. fork of White r., $55 \mathrm{~m}$. S. by $\mathrm{E}$. Indianapolis.

Cortland, p. v., Newton co, Tex.: 247 m. E. by N. Austin City.

Cortuand Village, p. v., and eap. Cortland co, $N_{0} Y_{\text {.: }}$ on W. side of Tioughnioga r., $118 \mathrm{~m}$. W. Albany. It contains the co. buildings, several manufactures, and many of the houses are elegant structures. The neighborhood is highly cultivated. Pop. 1,600. The t. of Cortland has 7,758 inhabitants.

Corunna, p. V., and cap. Shiawassee co., Mich.: on the S. W. side of Shiawassee $r ., 27 \mathrm{~m}$. N. E. Lansing. The r. here furnishes a fine head of water, and works several mills. In the vicinity are found coal, lime, and sand fit for glass manufactures.

CorwrN, p. Y., Montgomery co., Ohio: 74 m. W. by S. Columbus.

Corypow, p. Y., and cap. Harrison co., Ind.: on a level bottom between the forks of Indian cr., $109 \mathrm{~m}$. S. Indianapolis, A newspaper, the "Harrison Gazette" (whig), is published weekly. As an inland v., Corydon has a respect able amount of trade, and a population of about 800 souls.
Conrdor, p. V., Henderson co., Ky.: $153 \mathrm{~m}$. W. Frankfort Conydon, p. vo, Warren co, Penn.: 173 m. N. W. Harrisburg.

Cosgrove Hall, p. o., Union co, Penn. : 43 m. N. N. W. Harrisburg.

Coshocton county, Ohio. Situate E. centrally, and contains 646 sq. m. Drained by Killbuck er, White-woman's er., or Walhonding r., and Tusearawas r., the two latter of which unite at Coshocton village, and form the Muskingum $r$. : these afford abundance of water-power. Surface uneven and hilly, but the hills are arable, and the soils everywhere fertile. Immense amounts of grain are cultivated, and the amount of live-stock is large. Salt, bituminous coal, iron ore, and lead ore are found in the co. Farms 2,736 ; manuf. 158 ; dwell. 4,325 , and pop.-wh. 25,630 , fr. col. 44-total 25,674. Capital: Coshocton. Public Works: Central Ohio R. R.; Ohio Canal; Walhonding Canal, etc.

Cosmocror, p. V., and cap. Coshoeton co, Ohio: on the E. side of Muskingum r., at the confluence of its constituents, the Walhonding and Tuscarawas rivers, $63 \mathrm{~m}$. E. by N.

Columbus. The $\mathrm{v}$, is laid out on four terraces, each 9 feet above the other, the first three being 400 feet wide, and the last about 1,000 feet; and the streets are at right angles with one another, dividing the $\mathrm{v}$. into 36 blocks of 400 feet square, and each block into 8 lots. The v., however, has expanded much beyond these original bounds, and the surrounding country is thickly settled. It contains a brick court house, several churches, mills, and factories, propelled by both steam and water. Two newspapers, the "C. Republicau" (whig) and the "C. Democrat" (dem.), are published week17, and the "Practical Preacher," a religious paper, is published semi-monthly. Pop. 850. The Walbonding and Ohio Canal form a junction on the opposite side of the river.

Cosmanes river, Calif: : rises from the Sierra Nevada, in El Dorado co., and passes thence in a direction W. S. W. into Sacramento co., in its lower part, dividing it from $\mathrm{Sm}$ Joaquin co., and then falling into San Joaquin $r_{0}, 12 \mathrm{~m}$. from its mouth.

Come Sans Dessent, p. o, Callaway co, Mo.: on the $\mathbb{N}$. bank of Missouri r., opposite the mouth of Osage $r_{*}, 11 \mathrm{~m}$ E. by N. Jefferson City. It is an old French settlement, and derives its name from its location on an isolated hill on the margin of the river.

Cotrle, p. O., Rapides par., La. : near Cotile Lake, $108 \mathrm{~m}$. W. N. W. Baton Rouge.

Coroma, p. v., Montgomery co., Aza.: on Cotoma cr., 12 m. S. Montgomery.

Cotosa, p. V., Walker co., Ga.: 182 m. N. W. Milledgeville.

Cotrage, p. o., Huntingdon co., Penn.: 63 m. W. Harrisburg.

Cotrage, p. o., Montgomery co., Mrd. : $36 \mathrm{~m}$. W. Annapolis. It is the $\mathrm{p}, 0$. for Leesborough, a v. on the Washington and Rockville turnpike, $9 \mathrm{~m}$, from the former. This ₹. has 3 churches-1 Catholic, 1 Episcopal, and 1 Methodist-and about 300 inhabitants : it has also 5 water mills and 1 steam saw mill.

Cottage Grove, p. o., Washington co., Minn. Ter.: 22 m. N. E. St. Paul.

Cotrage Grove, t. and p. 0., Dane co., Wisc. : $12 \mathrm{~m}$. $\mathrm{E}$. by $\mathbf{S}$. Madison. The $\mathrm{v}$. lies on a branch of Cat-fish $\mathrm{r}$. Pop. of the $t$, in 1850,785 .

Cottage Grove, p. o., Union co., Ind. : 68 m. E. by S. Indianapolis.

Cottage Hirl, p. o., Dupage co, $I l_{*}$ : on the line of the Galena and Chicago Union R. R., $16 \mathrm{~m}$. W. Chicago, and $162 \mathrm{~m}$. N. N. E. Springfield.

Cottage Hill, p. o., Lauderdale co., Tenn. : $158 \mathrm{~m}$. W. by S. Nashville.

Cottage HILI, p. o*, St. Joseph co., Ind.: $162 \mathrm{~m} . \mathbf{N}$. Indianapolis.

Cottage Howe, p. o., Harford co., Mrd.: on Deer cr., $8 \mathrm{~m}$. 
N. W. Bel-Air. The Great Rocks of Deer cr, $2 \mathrm{~m}$. W., are remarkable for their height and the romantic scenery of their vicinity. Iron ores and other minerals abound, and the neighboring lands are conceded to bo the best in the county.

Cottage Houre, p. o., Lincoln co., N. Car.: $142 \mathrm{~m}$, W. by N. Raleigh.

Cuttage Isx, p. o., La Fayette co., Wisc.: 49 m. S. W. Madison.

Cotrleville, p. o., St. Charles co., Mo.: on the N. side of Missouri r., $88 \mathrm{~m}$. E. by N. Jefferson City.

Cotron Gix Porr, p. o, Monroe co., Miss. : on the E. side of Tombigbee r., immediately below the junction of its E. and W. forks, and at the head of navigation, $152 \mathrm{~m}$.

N. E. Jackson.

Cotron Grove, p. o., Davidson co., N. Car.: $102 \mathrm{~m}$. W.

\section{Raleigh.}

Corton Grove, p. o., Pontotoc co., Miss. : 157 m. N. N. E. Jackson.

Cotton Grove, p. O., Madison co., Tenn.: 123 m. W. S.W. Nashrille.

Cortox Milu, p. o., Randolph co., Ga.: between Palala and Jumma creeks of Chattahoochee $r_{\text {., }}$ and on the line of the South-Western R. R., 12 m. from Fort Gaines, and 138 m. S. W. Milledgeville.

Соттол Plant, p. o., Tippah co., Miss. : 192 m. N. N. E. Jackson.

Cotton Plant, p. o., Rusk co., Tex.: 236 m. N. E. Austin City.

Cotton RImge, p. 0., Itawamba co., Miss. : 163 m. N. E. Jackson.

Cotton Vallex, p. 0., Macon co., Ala.: 33 m. E. Montgomery.

Cottonvilie, p. o., Marshall co., Ala.: $142 \mathrm{~m} . \mathrm{N}$. Montgomery.

CoTtonville, p. v., Jackson co., Ia. : between two creeks of Makoqueta r., and about $11 \mathrm{~m}$. N. of that stream; 50 m. N. E. Iowa City.

Cotros wood, p. v., Christian co., Ky.: 172 m. W. S. W. Frankfort.

Coтrorwoon creek, Shaste co., Calif.: a tributary of the Sacramento $r$. from the Coast Range of mountains.

Cotrrellvilte, t. and p. o., St. Clair co., Mich.: on the W. side of St. Clair r., $98 \mathrm{~m}$. E. Lansing. The $\mathrm{V}$., located on the immediate shore of the $r$., is a flourishing commercial and trading place, and a stopping place for steamboats navigating the river. Pop. of t. 913 .

Cotur, p.v., Barnstable co., Mass. : 62 m. E. S. E. Boston.

Coturt Port, p. V., Barnstable co., Mass. : 65 m. E. S. E. Boston.

Coulson's Mrui, p. o., Linn co., Mo. : on Little Yellow cr. of.Grand r., 92 m. N. N. W. Jefferson City.

Coulter's Store, p. o., Macon co, Mlo. : 89 m. N. by W. Jefferson City.

Cothterstille, p. v., Butler co., Penn.: 169 m. W. by N. Ifarrisburg.

Counciz Bend, p. o., Crittenden co, $A r K_{0}: 112 \mathrm{~m}$. E. by N. Little Rock.

Corncl Bucrfs, p. v., Pottowattomee co., Ia. : on the Missouri r., $216 \mathrm{~m}$. W. by $\mathrm{S}$. Iowa City. This is an important point in overland travel, being the last civilized settlement before entering the Indian country. Here the emigrant provides himself with his outfit, and, crossing over the Missouri, wends his way over the vast wilds. From Council Bluft's to Oregon City is $1,924 \mathrm{~m}$., and from C. B. to Sacramento City, $2,011 \mathrm{~m}$., the routes being those indicated by Horn's Overland Guide, published in 1852.

Council Hill. p. o., Joe Daviess co., Ill.: on the Galena and White Oak Spa road, $182 \mathrm{~m}$. N. N. W. Springfield, and about $s \mathrm{in}$. N. E. Galena.

Countsville, p. o., Lexington dist., S. Car.

Counxy LiNe, p. o., Tallapoosa co., Ala.: $37 \mathrm{~m}$. N. by E, Montgomery.
Country Line, p. o., Campbell co., Ga.: 88 m. W. N. W. Milledgeville.

Countx Line, p. o., Newton co., Mriss, : on the W. line of the co., $59 \mathrm{~m}, \mathrm{E}$. by N. Jackson.

County LiNe, p. o., Niagara co., N.Y.: 232 m. W. by N. Albany.

County Line, p. o., Davis co., N. Car.: $102 \mathrm{~m}$. W. by N. Raleigh.

Court Hili, p. o., Talladega co., $A l a .: 71 \mathrm{~m}, \mathrm{~N}$. by E. Montgomery.

Count House, p. o., Franklin co., Ala. : 187 m. N. W. Montgomery.

Courtuand, p. v., Lawrence co., Ala.: on the line of the Memphis and Charleston R. R., 172 m. N. N. W. Montgomery.

Courtuand, p. v., Shelby co., Tex。 : 246 m. E. N. E. Austin City.

Courtwright's Mills, p. o., Iroquois eo., $I b l .: 116 \mathrm{~m}$. N. E. by E. Springfield.

Coushattee Chrote, p. o., Nachitoches par., La.: $146 \mathrm{~m}$. N. W. Baton Rouge.

Cove, p.v., Shelby co, $\Delta l \alpha_{\text {. : }} 66 \mathrm{~m}$. N. by W. Montgomery. Cove, p. v., Polk co., Ark. : 118 m.W. S.W. Little Rock. Cove Creek, p. O., Benton co., Ala. : 96 m. N. N. E. Montgomery.

Cotentry, t. and p. v., Tolland co., Conn.: on the W. side of Willimantic r., and N. of Hop r., $17 \mathrm{~m}$. E. Hartford. The surface is uneven, and the soil a gravelly loam. The water-power afforded by the streams moves a number of mills and factories, chiefly woolen, cotton, paper, ete. Pop. 1,954.

CotenTRY, t. and p. v., Chenango co., N.Y. : $97 \mathrm{~m} . \mathrm{S}$. W. Arbany. The surface is hilly, and drained by Harper's and Kelsey's creeks, tributaries of the Susquehanna. The village contains about 250 inhabitants. Pop. 1,677.

Coventry, t. and p. o., Kent eo., R.I.: $13 \mathrm{~m} . \mathrm{S}$. T. Providence. The t. is watered by Flat $\mathrm{x}$ and the $\mathrm{S}$. branch of Pawtuxent r., which furaish extensive water-power, which is extensively used in manufactures of wool and cotton. $\mathrm{Po}_{1}, 2,820$.

Coventry, t. and p. v., Orleans co., Verm.: at the head of Lake Memphremagog, $46 \mathrm{~m}$. N. N. E. Montpelier. It is drained by Black and Barton rivers, which empty into this lake, and furnish good mill-power. The soil is generally a rich, deep loam, and very fertile. Pop. 867.

Cofentry ville, p. v., Chenango co., $N_{0} Y_{.}: 98 \mathrm{~m}$. S. W. Albany.

Covers, to and p. v., Seneca co., N. Y.: on the W. side of Caynga Lake, $152 \mathrm{~m}$. W. Albany. The surface is high and level, and is drained by numerous creeks falling into the lake. The $\mathrm{v}$. is a small agricult. settlement. P.2,253.

Covestrule, p. v., Albemarle co., Firg.: $72 \mathrm{~m}$. W. by N. Richmond. The Virginia Central R. R. passes through the village.

Confestlle, p. v., Monroe co., Penn. : 97 m. N. E. IIarrisburg.

Covervilite, p. v., Saratoga co., N. Y.: $28 \mathrm{~m} . \mathrm{N}$, by E. Albany.

Corractor county, $A 7 a$. Situate 8 , and contains 1,152 sq. m. Drained by Conecuh r. and Yellow Water r, and their tributary creeks. Surface low, but diversified, and soils not the most fertile. The products are cotton, corn, and rice, the latter in small quantity. Farms 188 ; manuf. 6 ; dwell. 503, and pop.-wh. 3,077, fr. col. 88, sl. 430-total 3,645. Capital: $\Lambda$ ndalusia.

Conngtov county, Mfiss. Situate S. centrally, and contains $486 \mathrm{sq}$. m. Drained by the head creeks of Leaf $\mathrm{r}$., a tributary of Pascagoula r. Surface level, and the soils light and sterile, but with great exceptions. Cotton, eorn, and potatoes are the chief products. Farms 272; manuf. 5; dwell. 313 , and pop.-wh. $2,22 \%$, fr. col. 2 , sl. 1,11 - total 3.338. Capitul: Williamsburg.

Covingtor, p. v., and cap. Newton co., Ga.: on the E. 
side of and $31 \mathrm{~m}$. from Fellow r., a constituent of the Okmulgee r., $54 \mathrm{~m}$. N. W. Milledgeville. The Georgia R. I. passes through the v. $130 \mathrm{~m}$. from Augusta, ant 41 m. from Atlanta. It is a considerable place, and contuins the $c 0$. offices, 4 churches, and many handsome buildings. It has also a respectable academy, and $2 \mathrm{~m}$. N., at Oxford, is Emory College, a Methodist institution.

Cotingtos, p. v., and eap. Fountain co., Ind.; on the E. side of Wabash r., $73 \mathrm{~m}$. W. by $\mathrm{N}$. Indianapolis. The Wabash and Erie Canal passes through the place, and since its completion in 1847, a great increase in the trade of the v. has resulted. A newspaper, the "People's Friend"(dem.), is published weekly. Pop. 1,600.

Covington, p. eity, Kenton co., Ky. : on the W. side of Licking $\mathrm{r}_{\text {, }}$ on the Ohio, opposite Cincinnati, $60 \mathrm{~m} . \mathrm{N}$. N. E. Frankfort. It is built on a beautiful plain, most of which is above high-water mark; and the streets are so arranged as to appear from the hills back of Cincinnati as a continuation of that eity. Newport lies on the opposite side of the Licking. It is connected with Cincinnati by a steam ferry. Covington is a highly flourishing place, and is destined to become a large city. It contains a city hall, 8 churches, a theological seminary, belonging to the Baptists; 70 or 80 stores, 35 tobacco factories, 3 rope-walks, a rolling-mill, and numerous other manufacturing establishments. About a mile back from the city is Linden Grove, a beautiful rural cemetery, and $4 \mathrm{~m}$. in the interior are Latonian Springs, a very fashionable and pleasant resort in the summer season. Two weekly newspapers, the "Democratic Union," and the "C. Journal" (whig), are published here; and also a monthly literary paper, called the "C. Gazette." From Covington, railroads are in course of construction to Louisville, Lexington, ete., which will form the connecting links between the systems of railroads already built, or being built on all sides S. of the Ohio, and those of Ohio and the other Western States. Pop. about 12,000.

Covirgton, p. v., Richmond co., N. Car.: on the W. side of Mountain cr. of Yadkin r., $72 \mathrm{~m}$. S. W. Raleigh.

Covington, p. v., and eap. St. Tammany par., $L a .:$ on the W. side of Bogue Fallia, a small stream emptying into Lake Pontehartrain, $64 \mathrm{~m}$. E. Baton Rouge.

Covingtov, t. and p. v., Wyoming co., N. Y.: $208 \mathrm{~m}$. W. Albany. Surface rolling, and drained by Allen's cr. The $\nabla$. is a small settlement of 25 or 30 dwellings.

Conisgton, p. Y., Miami co., Ohio: on the E. bank of Stillwater r., nearly opposite and a litlle $\mathrm{S}$. of the mouth of Greenville er., $71 \mathrm{~m}$. W. by N. Columbus. The site is 60 feet above the ordinary water level of the river, and the $\mathrm{r}$. contains several stores and mechanie shops, with about 600 inhabitants. Pop. in 1850451 .

Covivgton, p. v., Tinga co, Penn. : on a branch of Tioga cr., and on the line of the Corning and Blossburg $\mathrm{R} . \mathrm{P}$., 10 m. N. of Blossburg, and 107 N. by W. Harrisburg. Pop. 133.

Covington, p. v., and cap. Tipton co.,Tenn.: on a branch of Big Hatchee r., $18 \mathrm{~m}$. E. of the Mississippi, and 173 m. W. S. W. Nashville. It stands on a beautiful elevated country, and is surrounded with a highly cultivated and fertile region. It contains a neat court-house, about 120 baildings, and 600 inhabitants.

Covington, p. v., and cap. Alleghany co., Virg.: on the $\mathrm{N}$. side of James r., at the confluence of Jackson's and Pott's creeks, being the head of navigation. Its situation, in the midst of mountain scenery, is beautiful and healthy. The v. has several manufactures and mechanic trades, and is the commercial depôt for an extensive intramontane region. Pop. abont 500. The projected R. R. from Lynchburg to the Ohio $\mathrm{x}$. at Guyandotte, will pass through it.

Cowan's Ford, p. 0., Mechlenburgh co., N. Car.: 132 m. W. S. W. Paleigh.

Cow amstille, p. o, Rowan co., N. Car. : $102 \mathrm{~m}$.W. by \$. Raleigh.

Cowansvilue, p. v.. Armstrong co., Penn.: $152 \mathrm{~m}$. W. N. W. Harrisburg.
Cow bay, Queens co., $N_{0} Y_{\text {. }}$ : is an arm of Long Island Sound, extending inland about $5 \mathrm{~m}$., and navigable for steamboats. It is surrounded by highly cultivated farms and country villas. It is in the $t$. of North Hempstead.

Cow CReEk, p. 0., Saline co., Mo. : 72 m. N.W. Jefferson City.

Cow creek, Shaste co., Calif.: a tributary of the Sacramento r., from the Sierra Nevada.

Cowdersport, p. v., and cap. Potter co., Penn.: on the N. side of Alleghany r., $123 \mathrm{~m} . \mathrm{N} . \mathrm{N}$. W. Harrisburg. It is a thriving v., and has 300 inhabitants

Coweta county, $G a$. Situate W., and contains $532 \mathrm{sq} . \mathrm{m}$. Drained by Cedar cr. and New r. of Chattahoochee r., which forms its $\mathrm{N}$. W. border, and by tributaries of Flint r., which washes it on the E. border; surface uneven and wooded; soils generally good, producing largely cotton, Indian corn, and wheat, and some tobacco. Farms 911; manuf, 52; dwell 1,382, and pop.-wh. 8,202, fr. col. 18, sl, 5,415-total 13,635. Capital: Newnan. Public Works : La Grange R. R.

Cow harbor, Great and Little, Suffolk co., N. Y.: a large bay in Huntington $t$, communicating with Huntington Bay on the W., and separated from Long Island Sound by Eaton's Neck.

CowIKEe, p. v., Barbour co., Ala $:$ on Cowikee cr. of Chattahoochee r., 76 m. E. S. E. Montgomery.

Cowlesville, p. v., Wyoming $c_{*}, N_{*} Y_{*}: 223 \mathrm{~m}$. W Albany.

Cowlitz Farms, Pacific co., Oreg. Ter.: a fine agricultural settlement of the Puget's Sound Agricultural Society on the $W$. side of Cowlitz r., about $40 \mathrm{~m}$. from its mouth, and $120 \mathrm{~m}$. N. of Salem. The lands here are among the finest in the Territory, producing all the grains and vescetables of temperate climates. A good road leads hence directly N. to Puget's Sound and the port of Olympia.

Cowlixz river, Oreg. Ter.: a large tributary of the Columbia $\mathrm{r}$., from the $\mathrm{N}$. E., which in its main course forms the dividing line between Lewis and Clark counties. It is navigable to Cowlitz Farms, an establishment of the Puget's Sound Agrieuitural Company. It enters the Columbia about $48 \mathrm{~m}$. from its mouth.

Cow NEcK, Queens co., N. Y.: lies between Cow Bay on the W. and Hempstead Harbor on the E. It is $6 \mathrm{~m}$. long and $2 \frac{1}{2} \mathrm{~m}$. wide.

CowPEy Bratci, p. o., Barnwell dist., S. Car.

Cowpens, p. o., Spartanburgh dist., S. Car:: between Broad r. and Pacolet r., 93 m. N. N. W. Columbia. The locality is noted in history as the ground on which the "Battle of Cowpens" was fought, 11 th Jan., 1781 .

Cowper Hris, p. o., Robeson co., N. Car. : 88 m. S. by TY. Raleigh.

Cow Skiv, p. O., Ozark co, MLo.: 123 m. S. Jefferson City. Coxe's Creek, p. o., Bullitt co., $K y_{*}: 4 S$ m. W. by :. Frankfort.

Cossackie, t. and p. T., Greene $c_{*}, N . Y_{*}:$ on the W. side of Hudson r., $22 \mathrm{~m}$. S. Albany. On the W. the surface is somewhat hilly, in other parts level. It is drained by several creeks of the Hudson. The $\mathrm{v}$. is situate $1 \mathrm{~m}$. T. of the landing on the $r_{\text {. }}$; it contains 90 or 100 dwellings and about 600 inhabitants. Pop. 3,741

Coxsackie Landing, v., Greene co., $N . Y .: 22 \mathrm{~m} . \mathrm{S}$. Albany. Within the distance of a mile there are three landings at which stermboats stop several times a day during the season of navigation. It contains a number of stores, a ship yard, and dry dock, several brick yards, etc., and has a large river and inland trade, the former chiefly carried on by sloops. Pop. of the v. and neighborhood about 1,200 .

Cox's MrLus, p. o, Randolph co., N. crar.: $71 \mathrm{~m}$. W Raleigh.

Cox's Milts, p. o., Gilmer co., Virg. : 208 m. W. N. W. Richmond.

Cox's Murs, p. o., Wayne co., Ind.: 68 m. E. Indianapolis. 
Cox's SToke, p. o., Washington co., Tenn.: 236 m. E. Nashville.

Coxvitue, p. v., De Kalb co., $A . z_{0}: 151$ m. N. by E.

Mont gomery.

Cortevitue, p. v., Butler co., Penn.: 169 m. W. by N.

Harrisburg.

CozBx, p. v., Hamilton co., Tenn. : 109 m. S. E. Nashrille,

CrAB BotToM, p. o., Highland co., Virg.: on one of the head streams of Cow Pasture r., $120 \mathrm{~m}$. W. by N Riehmond.

Crab Hollow, p. o., Lincoln co., Ky.: 54 m. S. S. E. Frankfort.

Crab Hollow, p. O., Ray co., Mo.: $116 \mathrm{~m}$. W. by N. Jefferson City.

Crab Tree, p. o, Haywood co., N. Car.: $246 \mathrm{~m}$. W. by S. Raleigh.

Cracker's Neck, p. o., Greene co., Ga.

Craftskurg, t. and p. v., Orleans co., Verm.: $27 \mathrm{~m}$. N. by E. Montpelier. The $t$. is watered by Black $r$. of Lake Memphremagog and branches of Lamoille $r$. of Lake Champlain, both of which rise from the hills of this region. The $\mathrm{v}$, is on elevated ground, commands a fine prospect, and is a place of considerable business. In the centro of the $\nabla$. is a large public green, 80 by 24 rods in extent.

Cenaftsville, p. v., Elbert co., Ga.: 83 m. N. N. E. Milledgeville. Pop. of t. 1,223.

CraIg. p. o., Switzerland co., Ind.: $87 \mathrm{~m}$. S. E. Indianapolis.

Craig's Creek, p. o., Botetourt co., Virg.: on a cr. of James r. so called, $188 \mathrm{~m}$. W. Richmond.

Craigstille, p. o., Orange co., $N . Y .:$ on the line of the Newburgh Branch R. R., $16 \mathrm{~m}$. from Newburgh, and Ss $\mathrm{m}$. S. by W. Albany.

Crarn's Creek, p. o., Monroe co., N. Car.: on Crain's cr. of Lower Little r., a branch of Cape Fear r., $42 \mathrm{~m}$. S. W Raleigh.

Crarn's Conners, p. o., Herhimer co., $N . Y$.: $60 \mathrm{~m}$. W. by N. Albany.

Crainstinle, p. v., Hardeman co., Tenn.: on a branch of Big Hatchie $\mathbf{r}$, where it cuts the E. line of the co., 129 m. S. W. by W. Nashville,

Cranberry, p. v., Middlesex co., N. Jer.: on Cranberry Brook, a tributary of Millstone $\mathbf{r}_{*}, 16 \mathrm{~m}$. N. E. Trenton. The $\mathrm{v}$. contains several mills and about 400 inhabitants. It has a station on the Camden and Amboy R. R., $18 \mathrm{~m}$. from South Amboy.

Cranberry, p. v., Allen co., Ohio: 82 m. N. W. Columbus.

Cranberry, to and p. O., Venango co., Penn.: on the S. E. side of Alleghany r., $173 \mathrm{~m}$. W. N. W. Harrisburg. There are several furnaces in the t., and a pop. of nearly 2,000 . Cranberry Creek, p. 0. , Fulton $\mathrm{co}_{*}, N_{0}, Y_{*}$; on the cr. so called, $42 \mathrm{~m}$. N. W. Albany.

Ceanberry Forge, p. o., Watauga co, N. Car,: $168 \mathrm{~m}$. W. by N. Raleigh.

CraxberRy IsLes, t. and p. o., Hancock co., Mre.; on the Atlantic Ocean, 79 m. E. S. E. Augusta, These isles were attached to Mount Desert until 1830, when they were incorporated. They lie a few miles $\mathbf{E}$. by $\mathbf{8}$. of that island, and embrace Great and Little Cranberry, Sutton's and Baker's sslands. They afford good harbors, and are well located for the shore fishery. Pop. about 250. The p. o. is located on Great Cranberry Island. Pop. 283.

Cranberry Plaing, p. o., Carroll co., Virg.: 192 m. T. S. W. Richmond.

Crangerry Pratrie, p. o., Mercer co., Ohio: $89 \mathrm{~m}$. W. N. W. Columbus.

Crane Creek, p. o., Barry co., Mo: on a cr. so called, 189 m. S. W. Jefferson City.

Crane's Forge, p. 0., Assumption par., $L a .: 47 \mathrm{~m}$. S. Baton Rouge.

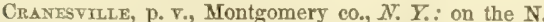
side of the Mohawk $r$ and on the line of the Ctica and Schenectady R. R., $23 \mathrm{~m}, \mathrm{~N}$. W. Albany.
Cranestille, p. v., Preston co., Virg.: 188 m. N. W. Richmond.

Craver county, N. Car. Situate S. E. and contains 930 sq. m. Drained by tributaries of Neuse r., which passes through the co., and enters a wide estuary which connects it with Pamlico Sound. Surface generally level-in some parts marshy. Soils fertile. Indian corn, potatoes, rice, and cotton are produced, and an immense amount of tar, pitch, and turpentine manufactured. Farms 38s; manuf. 67 ; dwell. 1,842, and pop.-wh. 7,222, fr. col. 1,536, sl. 5,951 -total 14,709. Capital: Newbern (New Berne).

Crapt's Mruxs, p. o., St. Lawrence co., $N . Y$.

Cravenstille, p. v., Daviess co, Mo.: on the N. E. side of Grand r., $136 \mathrm{~m}$. N. W. Jefferson City.

CrAWFord county, Penn. Situate in N.W., and contains 1,016 sq. m. Drained by French er, and its branches, and by Shenango cr. Oil cr., a tributary of the Alleghany r. affords bituminous oil, which is valuable in pharmacy. Surface moderately undulating and well wooded. Soils of average fertility. Iron ore is largely distributed throughout the co. The staple products are wheat; Indian corn, oats, and potatoes. There are several potteries in operation. Farms 4,070 ; manuf. 248 ; dwell. 6,592, and pop.-wh. 37,750, fr. col. 99-total 37,819. Capital: Meadville. Public Works: Beaver and Erie Canal, etc.

CraWfORD county, Ark. Situate N. W., and contains 960 sq. m. Drained by Lee's cr., Frog Bayou, and other tributaries of the Arkansas r., which forms its S. border Surface diversified by hills, rolling prairies, and alluvial bottoms, the latter well wooded and fertile. Indian corn is the chief product. Farms 499; manuf. 10; dwell. 1,247, and pop.-wh. 6,935, fr. col. 92, sl. 933--total 7,960. Capital: Van Buren. Public Workes: A railroad contemplated from the Mississippi r. to this point.

CRAWFORD county, Ga. Situate W. centrally, and contains $3 \$ 2 \mathrm{sq} . \mathrm{m}$. Drained chiefly by tributaries of Flint $\mathrm{r}_{\text {. }}$ which forms its S. W. border; the Echeconno, a tributary of Ocmulgee r., runs on its E. border. Surface generally level. Soils sandy, and not of average fertility. The chief products are cotton and Indian corn. Farms 445 ; manuf, 5.; dwell, 754, and pop.-wh. 4,342, fr. col. 13, sl. 4,629total 8,984. Capital: Knoxville. Public Works: Muscogee $\mathrm{R} . \mathrm{R}$.

CRAWFORD county, $I l l$. Situate S. E., on the W. side of Wabash r., and contains $468 \mathrm{sq}$. m. Drained by Embarras $\mathbf{r}$, and tributaries of the Wabash. Surface variedchiefly rich rolling prairie, producing largely, and feeding large amounts of live-stock. Farms 542; manuf. 0; dwell. 1.192, and pop.-wh. 7,118, fr, col. 17-total 7,185. Capital : Robinson.

CRAWFORD county, Inds Situate $\mathrm{S}$., and contains $320 \mathrm{sq}$ m. Surface uneven and broken, and the soil, except near the rivers, indifferent. Oaks and poplars are the prevailing timbers. Coal and iron abound in the W. districts. The Great Blue r. washes the E. borders, and Oil cr. drains the interior. Farms 540 ; manuf. 33 ; dwell. 1,027, and pop.wh. 6,523, fr. col. 1-total 6,524. Capital: Levenworth.

CRAwFord county, $I C$. Situate W., and contains 576 sq. m. Taken from Pottowattomee in 1851

CRAWFORD county, Mich. Situate N. centrally of Lower Peninsula, and contains 576 sq. m. Erected since 1850 .

CRAWFORD county, MO. Situate centrally, and contains $1,008 \mathrm{sq}$. m. Drained chiefly by Maramee $r$. and its numorous branches. Surface uneven and broken, with extensive bottoms. Soil of every description, from the most sterile to the most fertile. Iron is very abundant, and is extensively wrought. Farms 715; manuf. 9; dwell. 994, and pop.wh. 6,112, fr. col, 0, sl. 285-total 6,397. Capital: Steekville.

CrAWFORD county, Ohio. Situate toward the N. centrally, and contains $596 \mathrm{sq} . \mathrm{m}$. Drained by tributaries of Sandusky $r$., which also flows through it, and by the W. branch of Whetstone r. Surface elevated, and somewhat uneven- 
Well wooded. Soils fertile, and yield large grain-crops. Farms 1,210; manuf. 8; dwell. 3,070, and pop.-wh.18,167, fr. col.10-total 18,177. Capital: Bucyrus. Public Works: Cleveland, Cincinnati, and Columbus R. R.; Ohio and Indiana R. R., etc

CRAWFORD county, Wisc. Situate S. W., and contains $520 \mathrm{sq} . \mathrm{m}$. Drained by Kickapoo r, and its branches; the Mississippi $r$. Washes its W., and the Wisconsin $r$. its $\mathbf{S}$. borders, both of which receive several creeks. Surface chiefly undulating prairie. Soils rich and fertile. Timber is abundant. Farms 80 ; manuf. 11 (chiefly saw mills); dwell. 571, and pop.-wh. 2,45x, fr. col. 17-total 2,498. Capital: Prairie du Chien.

Crawford, t. and p. o., Orange co., N. $Y$. : on the S. E. side of Shawangunk r., $18 \mathrm{~m}$. W. Newburgh, and $77 \mathrm{~m}$. $\mathrm{S}$. by W. Albany. Surface hilly. The $\mathrm{v}$. is a small agricultural settlement. Pop. 1,912.

CrawFord, t. and p. o., Wyandott co., Ohio: to the W. of Sandusky r., a branch of which passes through its S. E. part, $67 \mathrm{~m} . \mathrm{N}$. by W. Columbia. It is traversed $\mathrm{N}$. and $\mathrm{S}$. by the Mad River and Lake Erie R. R., and the Findlay Branch diverges at the v. of Carey. Pop. 1,301.

Crawford's Cove, p. o., St. Clair co.n Ala.: $88 \mathrm{~m}$. N. by E. Montgomery.

Crawford Seminary, p. o., Quapaw Nation, Ind. Ter.: $150 \mathrm{~m}$. S. W. Jefferson City.

Cramford's Mrlus, p. o., Westmoreland co., Penn.: 144 m. W. Harrisburg

Crawfordstilie, p. v., and cap. Taliaferro co., $G a_{0}:$ between Ogeechee r. and Little r., the latter a tributary of the Savannah r., $37 \mathrm{~m}$. N. by E. Milledgeville. The Georgia R. R. passes through the place, $65 \mathrm{~m}$. from Augusta and $106 \mathrm{~m}$. from Atlanta. It contains the county offices, an academy, and about 200 inhabitants.

Crawfordstille, p. v., and cap. Montgomery co., Ind. : on the S. side of Sugar cr., a tributary of Wabash $\mathrm{r}, 46 \mathrm{~m}$. W. N. W. Indianapolis. The line of the New Albany and Salem R. R. passes through the v. N. and S., and thus connects it with the Ohio r. and with Lake Michigan, etc. I is important for its trade and commerce, and is the seat of Wabash College. Two newspapers, the "Montgomery Journal" (whig), and the "Montgomery Review" (dem.), are issued weekly. Pop. 2,400.

Cratfordsvile, p. Y., Washington con, $I a .: 28 \mathrm{~m}$. S. S. W. Iowa City.

Crawfordstrle, p. v., Spartanburgh dist., S. Car.: 103 m. N. W. Columbia.

Craptonvilez, p. v., Anderson dist., S. Car.: $118 \mathrm{~m}$. W. by N. Columbia.

Creachville, p. o., Johnson co., $N$. Car.: $31 \mathrm{~m} . \mathrm{S} . \mathrm{E}$. Raleigh.

Creagerstown, p. v., Frederick co, $M d$.: on N. side of Hunting cr., near its junction with the Monocacy r., $12 \mathrm{~m}$. N. of Frederick City, and $68 \mathrm{~m}$. N. W. Annapolis.

Creagir's Mruls, p. o., Wilcox co., Ala. : 69 m. W. S. W. Montgomery.

Creer Agency, p. o., Creek Nation, Ind. Ter.: at the confiuence of Verdegris $r$. with the Arkansas $r ., 3$ or $4 \mathrm{~m}$. W. of Fort Gibson on the Neosho r., 192 m. W. N. W. Iittle Rock.

Creek Natron, Ind. Ter. The Creeks occupy a large territory between that of the Cherokees, to the $\mathrm{N}$. and $\mathbf{E}$., and that of the Choctaws, on the S., extending W. to the 100th meridian. The Canadian r. separates the Creeks from the Choctaws, and the surface is chiefly drained by its N. fork, and by the Red or Pawnee fork of the Arkansas $r$. The soils are fertile, and large crops of the agricultural staples usual to the latitude are annually raised. Fort Gibson is supplied with provisions by the industry of this nation. They have large stocks of cattle and hogs, and are otherwise well provided. Their government is based on a written constitution; they select their own chief and representatives, the latter acting as the grand council of the nation. They have also a judiciary, observing all the legal forms of cive ilized nations, and in their schools and churches are not surpassed by the neighboring State of Arkansas. The missionaries have effected such improvements in their condition, indeed, that the civilization of the descendants of the present generation is secured, and by the aid of the mechanics and farmers, supplied to them by the General Government, they are taught the substantial industries needed in the State. On the whole, however, this nation is not 80 far advanced as either the Cherokees or Choctars - a fact which may be attributed to physical disabilities rather than to an inferior moral influence on the part of those charged with their welfare. Their country is not so well watered as that of either of the nations mentioned; nor are the incentives to industry, from their remote position from navigable channels, so great. The droughts of summer, and the piercing cold of the winter, are also drawbacks by which their interests suffer. The Seminoles are considered as a constituent part of the Creek Nation, and as such, inhabit the country between the forks of the Canadian $\mathbf{r}$. The Seminoles are more averse to labor than any other of the immigrant tribes, and hold slaves which they brought with them from Florida. So satisfied, however, are they with the country allotted them, that they are making strenuous endeavors to persuade the remnant of their tribe still in Florida to settle among them; and their endeavors have not been in vain, as, by a recent agreement with the chies who lately visited the seat of government to pay their respects to the President, they will remove forthwith. It is supposed that 300 of the nation still reside in the fastresses of the Florida peninsula. The number in the west of the Mississippi is estimated at 24,000 .

Creelsburgh, p. v., Russell co., $\overline{k y} .: 93$ m. S. by W. Frankfort.

Crescent, p. o., Lycoming co., Penn.: \$3 m. N. by W. Harrisburg.

Cresceivi City, p. v., Tuolumne co., Catif.: on the S. side of Tuolumne $\mathbf{r}, 16 \mathrm{~m}$. from its entrance into the San Joaquin r., and $81 \mathrm{~m}$. S. E. Vallejo.

Crete, p. o., Will co., $I l l .: 139$ m. N. E. Springfield.

Creve Coeur, p. 0., St. Louis co., Mo.: on Creve Coeur Lake, $92 \mathrm{~m}$. E. by N. Jefferson City. The lake communicates with Missouri $r$, through a short, narrow passage.

Crichton's Store, p. 0., Brunswick co., Virg.: $62 \mathrm{~m}$. S. by W. Richmond

Criglerstille, p. v., Madison co., Virg. : 76 m. N. N.W. Richmond,

Cripple Creer, p. o., Greenville dist., S. Car.: on a cr. of Reedy r., a tributary of the Saluda r. so called, $92 \mathrm{~m}$. N.W. Columbia.

Crippla DEer, p. o., Tishemingo co., Miss. : $212 \mathrm{~m}$. N. E. Jackson.

Crisp Pratrif, p. o., Dade co., Mo.: $106 \mathrm{~m}$. S.W. Jefferson City. It is located on a fine elevated prairie E. of Sac r., and drained by its branches.

Critrexdex county, $A r /$. Situate between the Mississippi and St. Francois rivers, and contains 1,950 sq. m. Drained by numerous creeks, sluices, and bayoux falling into the border rivers. Surface level, and subject to partial inundations. Soil, when sufficiently elevated for culture, highly fertile. Farms 192 ; manuf. 0 ; dwell. 360 , and pop.-Wh. 1, 842 , fr. col. 5, sl. 801 - total 2,648. Capital: Marion.

Crittenden county, $\bar{K} y$. Situate N. W. and contains $460 \mathrm{sq} . \mathrm{m}$. Drained by sereral streams, tributaries of the Ohio and the Cumberland, the former of which washes its $\mathrm{N}$. border, and the latter its $\mathrm{S}$. W. border. The surface is generally level or undulating, and the soils of an average productiveness, Indian corn, wheat, and oats are largely grown, and tobacco forms one of its great staples. Farms 662 ; manuf. 13 ; dwell. 978 , and pop.-wh. 5,474, fr. col. 29, sl. 848-total 6,351. Capital: Marion.

Critrender, p. V., Erie co., $N_{0} Y_{0}: 266 \mathrm{~m}$. W. Albany. 
Critmendex. p. v., Grant con, $\bar{k} y_{0}: 43$ m. N. by E.

Frankfort,

Crittevder, p. v., Howard co., Ind. : 49 m. N. Indianapolis.

Crittenden, p. v., Daviess co., Mo. : 136 m. N. W. Jefferson City.

Crockersville, p. o., Genesee co., Mich.: 49 m. N. E.

Lansing:

Crockerx Creer, to and p. o., Ottawa co., Mich.; on the N. side of Grand r., $8 \mathrm{~m}$. from its entrance into Lake Michigan. The p. o. is on Crockery er., which drains the E. half of the t. and affords water-power. Pop. 247.

CrocketT, p. V., and cap. Houston co., ?ex.: on the old military road between Bastrop and Nacogdoches, $163 \mathrm{~m}$. E. N. E. Austin City. The v. is beautifully situate on an elevated prairie, gradually declining to Trinity $r$. on the W., and Neches $r$. on the E., both of which receive the drainage of the country.

Crockert's Blufr, p. o., Arkansas co., Ark.: 94 m. S. E.

Little Rock.

Crocketssville, p. v., Breathitt co., Ky. : 102 m. E. S. E.

Frankfort.

Crogran, t, and p. o, Lewis co., $N$. $Y$.: on the E. side of Black r. and N. of Beaver cr., $112 \mathrm{~m}$. N. W. Albany. Surface hilly, and drained by tributaries of the Black river. Crognas, p. v., Putnam co, Ohio: 97 m. N. W. Columbus.

Crooked Crezk, p. o., Carroll co., Art.: on Crooked cr., a tributary of White r., $122 \mathrm{~m}$. N. N. W. Tittle Rock.

Crooked Cвerk, p. o., Steuben co., Ind.: on a branch of Fawn r. so called, 149 m. N. E. by N. Indianapolis.

Crookfid Creek, p. o., Monroe co., Mo.: on a cr, of Salt r. so called, $68 \mathrm{~m}$. N. by E. Jefferson City.

Crooked Cresk, p. o., Clinton co., Ill.: on Crooked cr. of Kaskaskia r., SS m. S. by E. Springfield.

Cronked Creer, p. o., Henry co., Ia.: on the er. so called, $35 \mathrm{~m}$. S. lowa City.

Crookfd Crerk, p. o., Stokes co., N. Car.: 108 m.

T. N. W. Raleigh.

Crooked Creek, p. o., Tioga co., Penn.: 114 m. N. N. E.

IIarrisburg.

Crooken Craek Furkace, p. o., Bullitt co. $\bar{k} y_{.}: 54 \mathrm{~m}$.

W. by S. Frankfort.

Crookpd Fork, p. o., Morgan co., Tenn.; on a fork of

Emery's r., a braneh of Temessee r. so called, $127 \mathrm{~m}$. E.

Nashville.

Crooked Hilu, p. o., Montgomery co., Penn. : \$3 m. E. IIarrisbura.

Crookfo lake, $N . Y$.: lies partly in Steuben and partly in Yates counties, It is $22 \mathrm{~m}$. long, N. and $\mathrm{S}$., and from 1 to $2 \mathrm{~m}$. wide-its surface 270 feet above Scneca Lake, with which it is connected by an outlet and canal. The waters are cold and transparent, and from 300 to 500 feet deep, abounding in salmon-trout, white-fish, pickerel, perch, sunfich, bass, and cat-fish. At Bluff Point, $9 \mathrm{~m}$. N. of the head of the lake, it is divided by a ligh promontory, jnto two arms-one extending to Penn-Ian, $13 \mathrm{~m}$., and the other to Branchport, $9 \mathrm{~m}$. A steamboat plies from Hammondsport, at the head of the lake, to Penn-Yan, and affords the passenger a fine view of the delightful scenery of the shores and neighborhood.

Cropwell, p. v., St. Clair co., Alla.: 100 m. N. Montgomery.

Crosbrvilus, p. v., Chester dist., S. Car.: on the S. side of Sandy r., $3 \mathrm{~m}$. from its confluence with Broad r., and 44 In. N. N.T. Columbia.

Cross Axcroon p. 0., Spartanburgh dist., S. Car. : between Tyger and Ennoree rivers, in the $\mathbf{S}$. E. corner of the co, 72 m. N. W. Columbia.

Crossaxtille, p. 0., Perry co, Olio: $47 \mathrm{~m}$. S. E. Columbus.

Cross Cremer Villagf, p. v., Washington $\mathrm{CO}_{4}$, Penn : on a cr. so called, 20s m. W. Harrisburg.
Cross Cux, p. o., Lawrence co., Penn.: 192 m. W. by N. Harrisburg.

Cross HrL, p. o., Laúrens dist., S. Car. : 63 m. W. N. W. Columbia.

Crossivgmule, p. v., Crawford co., Penn。: 204 m. N. W. by W. Harrisburg.

Cross Kers, p. o., Macon co., Ala. : $155 \mathrm{~m} . \mathrm{N}$. W. Montgomery.

Cross Kers, p. o., De Kalb co., Ga. : 86 m. N. W. Milledgeville.

Cross Kexs, p. o., Camden co., $N . J_{6 r} .: 37 \mathrm{~m}$, S. by W. Trenton.

Ceoss Kers, p. o., Union dist., $\mathcal{S}$. Car, : between Ennoree r. and Tyger r., in the S. W. corner of the co., $59 \mathrm{~m} . \mathrm{N}$. W. Columbia.

Cross Kers, p. o., Roane co., Tenn.: 138 m. E. by S. Nash rille.

Cross Kers, p. o., Rockingham co., Firg. : 93 m. N. W. Richmond.

Cross Krul Mruts, p. o., Berks co., Penn. : 57 m. E. N. E. Harrisburg.

Cross Plans, p. v., Ripley co., Ind. : on the Vevay State road, $10 \mathrm{~m}$. S. Versailles, and $73 \mathrm{~m}$. S. E. Indianapolis

Cross Plains, p. o., Robertson co., Tenn.: on the N. side of Sulphur Fork of Red r., a branch of the Cumberland, 26 m. N. Nashville.

Cross Platns, t. and p. v., Dane co., Wisc.: $12 \mathrm{~m}$. W. Madison, and watered by Black Earth r. and Sugar r., on the former of which the $\mathrm{V}$, is located. Pop. 339.

Cross Ridge, p. O., Tishemingo co., Miss.: 207 m. N. E. Jackson.

Cross River, p. o., Westehester co., N.Y.: on Cross r. or cr., a tributary of Croton r., $98 \mathrm{~m}$. S. by E. Albany.

Cross Roads, p. 0., Jackson co., Afiss. : 147 m. S. E. Jackson.

Cross Roads, p. o, Jefferson co, $\bar{k} y$.: 49 m. W. Frankfort.

Cross Roads, p. o., Madison co, Ohio : 28 m, S. E.

Columbus.

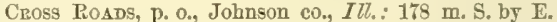
Springfield.

Cross Roads, p. o., Fanderburgh co., Ind. : 136 m. S. W.

Indianapolis.

Cross Roads, p. o., Tork co., Penn. : 37 m. S. by E.

Harrisburg.

Cross RoAds, p. o., Bedford con, Firg. : $10 \mathrm{Sm}$. W. by S.

Tiehmond.

Cross Roads, p. o, Franklin co., Ark.: 108 m. W. N.W.

Little Rock.

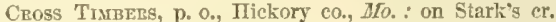

of Little Niangua r., a branch of Osage r., $66 \mathrm{~m} . \mathbf{S}$. W. Jefferson City.

Crossville, p. v., Lumpkin co., Ga.: 112 m. N. N. W. Milledgeville.

Crossvilue, p. v., Bledsoe co., Tenn. : 94 m. E. by S. Nashville.

Crosswick's, p. v., Burlington co., $N$. Jer.: on the high S. bank of Crosswick's cr., $S$ m. S. S. E. Trenton. It is chiefly a Quaker village, and contains about 300 inhabitants.

CrotoN, p. v., Hunterdon co., N. Jer.: $31 \mathrm{~m}$. N. by W.

Trenton.

Croton, p. v., Licking co., Ohio.

Crotos, p. v., Newago co., Mfich. : 87 m. N.W. Lansing. Crotoy, p. v., Delaware co., N. Y.: $72 \mathrm{~m}$. S.W. Albany. Crotor Falls, p. v., Westehester co., $N$. $Y_{\text {.: }}$ on Croton r., and on the line of the Farlem R. R., $51 \mathrm{~m}$. from New York, and 104 from Albany.

Croton Landisg, p. $\vee$., Westchester co., $N . I_{0}:$ on the N. side of Croton r., near its entrauce into Tappan Bay. The Fudison River R. R. passes the $\mathrm{v} .36 \mathrm{~m}$. from $\mathrm{New}$ York, and 114 from Albany; and steamboats make regalar stoppings here. It is a small but pleasant village. 
Croton river, $N, Y_{:}:$a fine stream, rising in Duchess and Putnam counties, flowing in a S. and S. W. direction through a part of Westchester co., and emptying into the Hudson r., about $2 \mathrm{~m}$, above the $\mathrm{v}$. of Sing Sing. Its length is about $45 \mathrm{~m}$. It takes its rise in several small lakes; its waters are very pure, and have for several years been directed through an aqueduct to New York, supplying that city with an abundance of water. The works built for the purpose of conducting the water, are among the most extensive in the world.

Crow Creer, p. o, Franklin co., Tenn.: on a cr. so called, 69 m. S. E. Nashville.

Crowder's Creek, p. o., Gaston co., $N$. Car. : on a cr. of Catawba r. so called, $142 \mathrm{~m}$. W. S. W. Raleigh.

Crow Mradows, p. o., Marshall co., Ind.: 108 m. N. by $\mathrm{W}$. Indianapolis.

Crown Pons, p. v., and cap. Lake co., Ind. : in the eentre of Robinson's Prairie, $14 \mathrm{~m}$. S. of Lake Michigan, and $139 \mathrm{~m} . \mathrm{N}$. W. Indianapolis. The $\mathrm{r}$. contains about 60 dwellings and 250 inhabitants.

Crown PoInt, t. and p. v., Essex co., $N$. $Y$.: on the W. side of Lake Champlain, $8 S \mathrm{~m}$. N. Albany. The W. part of the $t$, is mountain-in the E. and along the lake level, drained by Putnam's and some other streams. The v. on Putnam's cr. is only a small settlement. Crown Point was the site of important military operations during the old French and the Revolutionary wars. The ruins of the old fort of Crown Point are situate on a neck of land running into the lake in the N. E. part of the town, and are frequently visited by tourists as interesting objects connected with the national history. Pop. 2,379.

Crownsville, p. v., Anne Arundel co., Ma.

Crow's POND, p. o., Daviess co., Ky.: 182 m. W. by S.

Frankfort

Cromstrile, p. $\nabla$. , Spartanburg dist., $S$. Car.: on the N. side of Ennores r., $3 \mathrm{~m}$. distant, and $82 \mathrm{~m}, \mathrm{~N} . \mathrm{W}$. Columbia.

Croston, p. v., Jefferson co., Ohio.: 118 m. E. by N. Columbus.

Crovdor to and p. o., Sullivan co., $N$. Hamp.: $38 \mathrm{~m}$. N. N. W. Concord.

Crotidon Flat, p. o., Sullivan co., N. Wamp. : 39 m. W. N. W. Concord.

Crom Elsow, p. o., Duchess co., $N_{*} Y_{.}$: is a point $4 \mathrm{~m}$. N. of Poughkeepsie, and 60 m. S. Albany. Crum Elhow cr. is a tributary of the Hudson, which it reaches in the $t$. of Hjde Park: it is a good mill stream, on which are several mills and factories.

Cruso, p. o., Sereea co., N. Y.: 149 m. W. Albany.

Cristal Lake, p, o., M'Henry co, $I l l,:$ on the lake so

called, 183 m. N. N. E. Springfield.

COBA, p. v., Fulton co., 176. : 56 m. N. W. Springfield.

CuBA, p. v., Rutherford co., N. Car.: $186 \mathrm{~m}$. W. S. W.

Paleigh.

Cuba, p. v., Kent co., Mich. : 49 m. W. N. W. Lansing.

Curs, t. and p. v., Alleghany co., N. $Y, 226 \mathrm{~m}$. W. by 8

Albany. The land is elevated, and divides the sources of the Alleghany and Genesee rivers. In the $\mathrm{N}$. there is a small lake, and near the W. border is situate the Oil Spring Peservation. The $\mathrm{v}$. is situate on the line of the Genesee Valley Canal and the New York and Erie R. R. It is a flourishing place, with 1,000 inhabitants. Pop. 2,143.

CтвA, p. v., Clinton co., Ohio: 53 m. S. E. Columbus.

Cub Creek, p. 0., Charlotte co., Virg. : on a cr. of Roanoke r. so called, $84 \mathrm{~m}$. \$. W. Richmond.

Cuberatchee, p. $\nabla .$, Macon co., Ala. : on Cupiahatehee cr., 23 m. E. by S. Montgomery.

CoB HrLI, p. O., Baltimore co, $M d_{*}: 9 \mathrm{~m}$. from Baltimore.

Cuckooville, p. จ., Louisa co., Virg.: 48 m. N. W. Richmond.

Ctddebackville, p. o., Orange co., N. Y.: 92 m. S. S. W. Albany.
Cuddrhonk, p. v., Yallabusha co, Miss.: 118 m. N. by E. Jackson.

Cukro, p. v., and cap. De Witt co., Teso : on the E. bank of the Guadaloupe r., 89 m. S. by E. Austin City.

Cоцсноте, p. O., Polk co., Tenn. : $142 \mathrm{~m}$. \$. E. Nashville. Colloder, p. V., Monroe co., Ga.: 56 m. W. S. IT. Milledgeville.

Colloma, p. v., and cap. El Dorado co., Catif. : on the S. side of the S. fork of the American r., 100 m. F. N. E. Vallejo.

Culpepper county, Virg. Situate N. E., and contains 672 sq. m. Drained by Thornton $r$, and its branches, and Monntain cr, tributaries of Rappahannock $r$, which washes its N. E. border. Rapid Anna $x$, bounds it on the S. side Surface pleasantly diversified. Soils of average fertility producing grain and tobacco. Farms 504: manuf. 53. dwell. 1,084, and pop.-wh. 5,111, fr. col. 488, sl. 6,683total 12,2S2. Capital: Culpepper C.H. (Fairfax). Public Works: Orange and Alexandria R. R.

Culpepper C. H. (or Fairfax), p. V., and cap. Culpepper co., Firg.: Culpepper C. H. is the name of the P. O.-Fairfax the name of the village. It contains the usual co. buildings, several stores and mechanics' shops, and has about 300 inhabitants. It is situate $10 \mathrm{~m}$. N. of the Rappahannock r., and about $70 \mathrm{~m} . \mathrm{N}$. N. W. Richmond.

Culver Creek, p. o., Delaware co., Ohio.

Cumberland county, $I l l$. Situate S. E. centrally, and contains 324 sq. m. Drained by Embarras $r$, and its tributaries. Surface prairie, and very fertile. Farms 326 ; manuf. 0 ; dwell. 134, and pop.-wh. 3,720, fr. col. 0-total 3,720. Capital: Areenup. Public Works: Terre Haute and Alton R. R.; and the National Road.

Cumberland county, $\bar{K} y$. Situate $\mathrm{S}$. on the Tennessee State line, and contains 380 sq. m. Drained by creeks of Cumberland $r$., which flows through it from N. E. to S. W. Surface uneven and rugged. Soils moderately fertile, producing wheat, Indian corn, oats, and tobacco largely, and some cotton. Farms 607; manuf. 11; dwell. 942, and pop. -wh. 5,477, fr. col. 48 , sl. 1,485-total 7,005. Capital: Burkesville.

Cumberland county, $N_{\text {. }}$ Ter. Situate $S_{.,}$and contains 524 sq. m. Drained by Stow and Cohansey creeks, and Maurice and Tuckahoe rivers. Delaware Bay lies on its S. S. W. border, and for a mile or two back the country consists of a salt marsh. Surface level. Soil light, but of an average fertility. It contains iron ore and beds of marl, Glass and crockery are largely manufactured, and there are several extensive grist and saw mills. Farms SS4 manuf. 190 ; dwell. 3,281, and pop.-wh. 16,170, fr. col. 1,019, sl. 0-total 17,189. Capital: Bridgeton

Cumberland county, $N$. Car. Situate centrally, and contains $1,180 \mathrm{sq} . \mathrm{m}$. Drained by tributaries of Cape Fear $\mathbf{r}$, which passes through it in a general direction from $N$. to S., affording it a navigable channel to the sea. Surface undulating, with extensive valleys. Soils of average productiveness; Indian corn and cotton are its staples, and it has numerous cotton and other manufactures. Farms 959 ; manuf. 105; dwell. 2,531, and pop.-wh. 12,447, fr, col. 946 , sl. 7,217-total 20,610. Capital : Fayetterille.

Cumberlard county, Penn. Situate S. middle, and contains 544 sq. m. Drained by Conedogwinet er. and Yellow Breeches r., tributaries of Susquehanna $x$. The surface is moderately uneven, sometimes hilly, and the soils have an excellent fertility. Iron ore, clays, etc, abundant. The chief products are wheat, Indian corn, and oats, and there is much flour produced. Farms 1,842; manuf. 25s; dwell. 6,021, and pop.-wh. 33,370, fr. col. 957-total 34,327. Capital: Carlisle, Public Works : Cumberland Valley R. R., ete.

Comberlaxd county, Firg. Situate S. E. centrally, and contains 320 sq. m. Drained chiefly by Willis r. of James r., which bounds its $\mathbf{N}$. side, and creeks of Appomattox r., which runs on its S. E. border. Surface moderately hilly. Soils of average fertility, producing the grains and large 
quantities of tobreco. Farms 398; manuf. 9; dwell. 640, and pop.-wh. 3,083, fr. col. 839, sl. 6,329-total 9,751. Capital: Cumberland C. H.

Cesmberlavd, p. V., and cap. Alleghany co., Md.: on the N. bank of the Potomac r., at the mouth of Wills' cr., 146 ๓. W. N. W. Annapolis, and by R. R. from Baltimore, 179 $\mathrm{m}$. It is the centre of the vast mining region of Alleghany county, and an entrepôt on the great line of travel from the Atlantic to the Western States. The Baltimore and Ohio R. R. passes through it, and here commences the great National Road leading to the Mississippi river. The Chesapeake and Ohio Canal also terminates here. Besides these great works of internal improvement, there are diverging from Cumberland several lines of railroads connecting with the various mines of the Cumberland Coal and Iron Companies. The village contains a court-house, the eounty prison, a market-house, two banks, and several fine buildings, workshops, etc., connected with the public works; also, several handsome church edifices. Three newspapers are published here weekly, the "C. Civilian" (whig), the "Alleghanian" (dem.), and the "Unionist" (neutral)-each circulating from 400 to 500 copies of each issue. In 1850 , the population of Cumberland was 6,067 , of which 5,576 were white persons, 267 free colored persons, and 224 slaves, and hence it is the second town of Maryland in respect of population. In 1840 , the population was only 2,428 , the increase in the subsequent decade having been 149.8 per centum. The coal of this region is semi-bituminous, of excellent quality, and suitable for ocean steamships and a variety of other purposes to which the anthracite has hitherto been applied; it is brought to the markets of the East on the railroad and canal to Baltimore, and thence is tugged through the Chesapeake and Delaware Canal, and the Delaware and Raritan Canal, to the harbor of New York. The quantity of this mineral delivered in Baltimore in 1850 was 146,645 tons, and about 80,000 tons were deposited at Alexandria. The delivery at Baltimore in 1845 was only 16,000 tons; in $1846,18,393$ tons; in $1847,50,259$ tons; $1848,66,289$ tons; in 1849, 71,699 tons; and in 1850, as above related. In 1851, the delivery amounted to 163,855 tons, and is now increasing in a rapid ratio. The Coal Company have loaned money to the Baltimore and Ohio R. R. to furnish increased means of transportation, the want of which has alone been the cause of limiting the deposits. Cumberland coal contains 77 parts of carbon, 16 parts of volatile matter, and 7 parts of ashes. The Cumberland Coal and Iron Company is an amalgamation of the several companies before existing in that vioinity under various names: it was organized by the legislature of the State in 1852; and now holds about 12,000 acres of mineral lands, and has a working capital of about $\$ 5,000,000$.

Cumberlasd, p. v., Marion co., Ind.: on the National Road and the Indiana Central R. R., $10 \mathrm{~m}$. E. Indianapolis. It contains about 10 bouses and 175 inhabitants.

Coamberland, p. F., Fayette co., IIl.: on the National Road, 6 m. E. Vandalia, and 67 m. S. S. E. Springfield.

Conberland, t. and p. o., Cumberland $\mathrm{co}_{0}$, Afe.: on Casco Bay, 44 m. S. S. W. Augusta. The position gives it great commercial advantages. The Kennebec and Portland $R$. R. passes through the $\mathbf{S}$. part of the t., $9 \mathrm{~m}$. from Portland and 50 from Augusta. It has some manufactures and is engaged in the shore fisheries Pop. 1,626

CUMberland, p. v., Guernsey co., Ohio: on Buffalo fork of Will's cr., a branch of Muskingum r., $69 \mathrm{~m}$. E. Columbus. It has several mills and factories and about 450 inhabitants. Comberland, p. o., Grundy co., Tenn.: on a branch of Canev fork of Cumberland r., $79 \mathrm{~m}$. S. E. Nashville.

Conabreland, p. v., and cap. Cumberland co., Tirg.: on a high and healthy ridge between Willis $r$. and Appomattox r., $44 \mathrm{~m}$. W. by $\mathrm{S}$. Richmond. It contains about 180 inhabitants.

Cumberland bay, $N$. $\boldsymbol{Y}$ : : on the W. side of Lake Champlain, on the front of the $\mathrm{v}$. of Platlsburg-it is form162 ed by Cumberland Head, a peninsula stretching into the lake $4 \mathrm{~m}$, and is noted for a victory obtained by M.Donough over Downie, in the naval action of the 11th Sept., 1814. Cunberland Centre, p. O., Cumberland co., $M_{0}: 45 \mathrm{~m}$. S. S. W. Augusta.

Comberlavd Ford, p. o., Knox co., Ky.: on Cumberland r., $123 \mathrm{~m}$. S. E. Frankfort.

Cumberland Gap, p. o., Knox co., Ky. $:$ in the S. E. corner of co., $132 \mathrm{~m}$. S. E. Frankfort.

Cumberland Hilu, p. v., Providence co., $R$. $I_{\text {. }}:$ on the N. E. side of Blackstone $r_{0}, 16 \mathrm{~m} . \mathrm{N}$. by W. Providence.

Cunberland Iron Works, p. v., Stewart co., Tenn.: on the S. W. side of Cumberland r, $10 \mathrm{~m}, \mathrm{E} . \mathrm{S}, \mathrm{E}$. Dover and $54 \mathrm{~m}$. W. N. W. Nashville.

Cumberland river, $K y$. and Tenn.: a large river, the sources of which are found in the Cumberland Mountains, interlocking with those of Clinch and Kentucky rivers. It flows through Kentucky westwardly about 200 miles, enters the State of Tennessee, and meandering 120 miles, again enters Kentucky, through which its course is north-west to the Ohio river, into which it falls $11 \frac{1}{2}$ miles above the mouth of the Tennessee river, and 60 miles above the mouth of the Ohio river. Its entire length is about 600 miles, and it drains a territory equal to about 17,500 square miles; it is navigable for large steamboats and ressels to Nashville, 203 miles, and for boats of 15 tons 300 miles. At certain seasons of high water vessels of 400 tons may be brought down the river 400 miles to the $\mathrm{Ohio}$; and for half its length boats may navigate it at all seasons. The elevation of its sources are probably 1,200 feet above the level of the mouth of the river; it is the second river in size that falls into the Ohio, being inferior only to the Tennessee. Below Nashville, which lies on its south bank, the river is deep and narrow.

Cumberland Valley, t, and p. o., Bedford eo., Penn. between Evitt's Mountain and Will's Mountain, $108 \mathrm{~m}$ W. S. W. Harrisburg. Drained by Evitt's er., which runs through the valley.

Cumnsprlie, p. v., Hamilton co., Ohio: on the line of the Cincinnati, Hamilton, and Dayton R. R., $52 \mathrm{~m}$. from Cincinnati and $97 \mathrm{~m} . \mathrm{S} . \mathrm{W}$. Columbus. It lies on the W. side of Mill cr., and contains several flouring and grist mills and about 250 inhabitants.

Commis, p. V., and eap. Forsyth co, Ga.: on the W. side of and $6 \mathrm{~m}$. from Chattahoochee r., $94 \mathrm{~m}$. N. W. Milledgeville.

Cummestilite, p. v., Itawamba co., Miss. : 217 m. N. E. Jackson.

Cummtrgton, p. vo, Macoupin co, $I l l .: 33$ m. S. S. W. Springfield.

Coumtrator, t. and p. o., Hampshire co., Mass. : on both sides of Westfield r., $104 \mathrm{~m}$. W. Boston. Surface mountainous but excellent for grazing. Iron ore and soapstone abound. It has several manufactures, among which are cotton and wool. The $\mathrm{r}$, affords good water-power.

Commington West Viluage, p. т., Hampshire co., Mass.

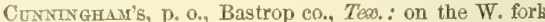
of Pin Oak cr., a tributary of the Colorado r., $45 \mathrm{~m}$. E. S. E. Austin City.

Cunntagrays's Store, p. o., Perrin co., N. Oar.: $62 \mathrm{~m}$. N. N. W. Raleigh.

Cordsvule, p. v., Buckingham co., Firg.: $62 \mathrm{~m}$. W. Richmond.

Cureton's Brider, p. 0., Henry co., Ala. : $100 \mathrm{~m}$. S. E. Montgomery.

CDRETON's STORE, p. 0., Lancaster dist., S. Car. ; $69 \mathrm{~m}$. N. N. E. Columbia.

Curria, p. V., Independenee co., Ark.: 87 m. N. by E Little Rock.

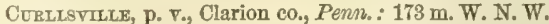
Harrisburg.

Cerriruck county, N. Car. Situate N. E. on Atlantic Ocean, and contains $576 \mathrm{sq} . \mathrm{m}$. It comprises the whole sea-coast from the Virginia line to Ocracoke Inlet, including 
Roanoke Island. Currituck Inlet separates it into two parts, and affords facilities for navigation. Surface flat, and in some instances swampy. Soils generally sandy. Farms 501; manuf. 0 ; dwell. 925, and pop.-wh.4,600, ir. col. 189, sl. 2,41i-total 7,236. Capital: Currituck C. H.

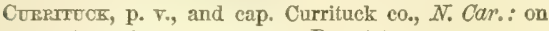
the TV. side of Currituck Sound. Pop. 687.

Corky's Milts, p. ๑., Washington co., Ga.

CurRY's Rus, p. o, Harrison co., Ky.: 44 m. N. E. Frankfort.

Cuntistrile, p. v., Berkshire co., Mass.: $126 \mathrm{~m}$. W.

Boston. It has several cotton mills, ete.

Cormingrule, p. V., Clearfield co., Penn. : on the N. side of Anderson's cr., near its junction with the W. branch of Susquehanna r., $102 \mathrm{~m}$. N. W. by W. Harrisburg.

Cesr, p. v., Clearfield co., Penn.: 107 m. N. W. by W. Harrisburg.

Crshing, t. and p. o., Lincoln co, Me.: on the W. side of St. George's r., opposite the peninsular t. of St. George, $3 S$ m. S. E. Augusta. This t. was settled by Irish emigrants as early as 1733 , and here was the celebrated stone fort erected by Major Burton. It has some commeree, and is much engaged in the shore fisheries. Pop. 805.

Cushingvule, p. v. Potter co., Penn.: 114 m. N. N. W. Harrisbarg.

Cussawago, t. and p. o., Crawford co., Penn.: $208 \mathrm{~m}$.

N. W. Harrisburg.

Crsseta, to and p. v., Chambers co., Ala.: on the Montgomert and West Point P. R., Ts $\mathrm{m}$. from Montgomery and 10 from West Point

Ctestard's, p. o., Crawford co., Penn.

Cotchogue, p. V., Suffolk co., $N_{\text {. }} Y_{0}$ : on the line of the Long Island R. R., $86 \mathrm{~m}$. from New York.

Cutmbert, p. v., and cap. Randolph co., Ga.: on the line of the South Western R. R., 143 m. S. W. Milledgeville.

CuTrer, to and p. o., Washington co., MYe. : on the Atlantic Ocean, $132 \mathrm{~m} . \mathrm{E}$. Augusta. It contains Little Machias Bay and Little r., and is bounded W. by Machias Bay, and has a good harbor ; considerable commerce is carried on, and the shore fishery is successfully pursued. 820. Cux OFF, p. o., Walton co., Ga.

Cut Orf, p. o., Drew co., Ark.: 126 m. S. E. Little Rock.

Cutrixgstule, p. v., Rutland co., Verm.: 63 m. S. by W. Montpelier.

Curanoga county, Ohio. Situate N. E. on Lake Erie, and contains $486 \mathrm{sq} . \mathrm{m}$. Drained chiefly by Cuyahoga and Rocky rivers, which empty into the lake, and afford large water-power, Surface level, declining toward the N. Soils everywhere of the highest fertility, producing the grains in abundance and grasses of the most nutritious quality. The climate is delightful. Farms 2,228; manuf. 162 ; dwell. 8,259, and pop.-wh. 47,745, fr. col. 351 -total 48,099. Capital: Cleveland. Public Works: Cleveland, Painesville, and Ashtabula R. R. ; Cleveland and Pittsburs R. R. ; Cleveland, Columbus, and Cincinnati R. R.; Cleveland and Sandusky R. R., ete., and the Ohio Canal.

Coxahoga Falis, p. v., Summit co., Otio: on the Cuyahoga r., at the falls, 109 m. N. E. Columbus. The r, here has its greatest bend toward the $\mathbf{S}$., and passes through a deep channel in the rocks, and by successive leaps falls in a short distance 240 feet, creating a great water-power. A considerable manufacturing village has here sprung up, the destiny of which is as yet only foreshadowed. The Pennsylvania and Ohio Canal passes through the place, and the Akron Branch R. R., uniting with the Cleveland and Pittsburg R. R. at Hudson, connects it with those two important commercial centres. Pop. about 3,000 . In the neighborhood bituminous coal is abundant, and is mined to a large extent.

Cстаноga rirer, Ohio: one of the most important rivers in northern Ohio. It rises in Geauga county, and runs southwardly through Portage county, where it gradually curves and courses through Summit and Cuyahoga counties, in a direction N. N. W. to Lake Erie, into which it falls at Cleveland. It is more than 60 miles long; it has numerons falls, and from its not being materially affected in its suppiy of water in the dry season, is exceedingly well adapted for mill and factory purposes. Along its banks several flourishing manufacturing villages have already sprung up, and there is every prospect of its becoming the focus of an immense manufacturing interest. The village at the great falls is destined to be a second Patterson or Lowell. The Ohio Canal runs along the valley of this stream about 35 miles to near Akron, and crosses it by an aqueduct at Boston, 23 miles S. of Cleveland. The mouth of the river, which has been improved and extended by piers, forms the harbor of Cleveland.

Cuxler, p. Y., Cortland co., $N_{\text {. }} Y_{\text {. : }}$ on the Tioughnioga r., $112 \mathrm{~m}$. W. Albany.

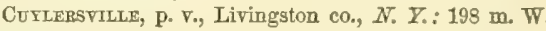
Albany.

Crnthrara, p. v., Posey co., Ind. : on Big cr. of Wabash r., $137 \mathrm{~m}$. S. W. Indianapolis.

Crathrana, p. v., and cap. Farrison co., Ky.: on the E. side of the S. fork of Licking r., $39 \mathrm{~m}$. E. N. E. Frankfort

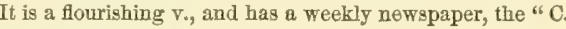
News" (dem.) Pop. 800.

Crnthlara, p. v., Pike co., Ohio: $62 \mathrm{~m}$. S. by W. Columbus. Pop. 134.

Crnthinana, p. v., Wapello co, Ia. : 66 m. S. W. Iowa City Cypress, p. o., Union co., Ky.: on Cypress cr., $173 \mathrm{~m}$. W. by S. Frankfort.

Crpress, p. o., Scott co., Mo. $:$ in the swamp region in the S. E. part of the co., $4 \mathrm{~m}$. W. of the Mississippi and $186 \mathrm{~m}$. S. E. Jefferson City.

Crpress Creek, p. o., Bladen co., ‥ Car.: 89 m. S. by E. Raleigh.

Cypress Crossing, p. 0., Newton co., Tex.: on Sabine r., 252 m. E. Austin City.

Crpress Grove, p. 0., New Hanover co., N. Car.: $97 \mathrm{~m}$ S. E. Raleigh.

Crpress InN, p. o, Wayne co., Tenn.: 81 m. S. S. W. Nashville.

Crkeston, p. Y., Lincoln co., Tenn.: 78 m. S. by E. Nashville.

\section{D.}

Dacusvilue, p. v., Pickens dist., S. Car. : 118 m. W. N. W. Columbia.

DADE county, Flor. Situate S., and contains about 3,840 sq. m. The drainage is very imperfect, and, except along the shores, the whole is a swamp. The Pay-hai-o-kee, or Everglades, is almost entirely within this county. These consist of an extensive grass meadow, covered fiom one to six feet deep with water, interspersed all over with islands of rich land and cypress swamps. These islands were safe retreats for the Seminoles during the war. The swamps are the abodes of alligators, serpents, and vermin of all kinds. The only really valuable land lies on the coast, and numerous small islands and kejs, with which it is lined. Farms 6 ; manuf. 2 ; dwell. 23, and pop.-wh. 147, fr. col.1, sl. 11-total 159. Oapital: Miami.

DADE county, $G a$. Situate N.W., and contains $240 \mathrm{sq}$. m. Drained chiefly by Lookout er. of the Tennessee $r$. Surface mountainous, with fertile valleys. Crops rarious, including Indian corn, wheat, cotton, tobacco, etc., but none in such preponderating quantity as to mark it as a principal staple. Farms 235; manuf. 4; dwell. 421, and pop.-wh. 2,532, fr. col. 0, sl. 148-total 2,680. Capital: Trenton. Public Works: Chattanooga and Nashville R. R.

DADE county, Mo. Situate S. W., and contains 504 sq. $m$. Drained by Sac $x$, and its tributaries. Surface undulating. Soils fertile. Farms 567; manuf. 13; dwell. 659, 
and pop.-wh. 3,976, fr. col. 1, sl. 269-total 4,246. Capital: Greenfield.

Dadeville, p. v., and cap. Tallapoosa co., $A l c_{0}: 45 \mathrm{~m}$. N. E. Montgomery, on a highland N. of Sandy cr., a tributary of Tallapoosa r., from which latter it is distant E. about $8 \mathrm{~m}$. It contains the usual co. buildings, and about 180 inhabitants.

Dadsvinle, p. v., Marion co., Tenn. : 87 m. S. E. Nashville.

Dagger's Sprive, p. o., Botetourt co., Tirg.: 109 m. W. Richmond.

DagGetT's Mrris, p. o., Tioga co., Penn. : 106 m. N. by W. Harrisburg.

Dagsborougr, hund. and p. v., Sussex co., Del. : on both sides of Pepper cr., which flows in a direction N. E. into

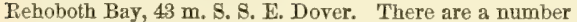
of grist and saw-mills on the r., and in the $\mathbf{v}$. are several stores, etc. The hund. contains 67,920 acres, and 2,512 inhabitants.

DAHLONEGA, p. vo, and cap. Lumpkin $\mathrm{co}_{0,} G a_{0}$ : on the E. side of Etowah r., and between that stream and Chestatee r., $112 \mathrm{~m} . \mathrm{N}$. N. W. Milledgeville. It is the eentral depôt of the Georgia gold field, and the site of a Branch Mint of the United States, at which gold only is coined. It contains also a court-house and other co. offices, several stores, and has 1,277 inhabitants. A newspaper, the "Mountain Signal," is published weekly.

DAHLONEGA, p. v., Wapello co., Ia. : about $4 \mathrm{~m}$. N. of Des Moines r., and $61 \mathrm{~m}$. S. W. Iowa City.

Datlex's Cross Roads, p. o., Lowndes co., Miss.: 112 m. N. E. Jackson.

DATngerfield, p. v., Titus co., Texa ; on Boggy cr. of Big Cypress, 262 m. N. E. Austin City.

DAIRY, p. o, Scotland co., Mo.: 134 m. N. Jefferson City.

Dáotä county, Minn. Situate S., and contains 16,400 8q. m., extending from the Mississippi to the Missouri. Its E, half is chiefly drained by the Minnesota r. and its tributaries, and its W. half by Sioux r. and the Tchan Sansan, or Riviere a Jaques. Innumerable small and larce lakes are interspersed throughout the co. The only part occupied by the whites is that immediately on the Mississippi $r$. Farms 00 ; manu?, 00 ; dwell. 78 , and pop,-wh. 582, fr col. 2-total 584. Capital: Fort Snelling.

DALE county, Ald. Situate S. E., and contains $860 \mathrm{sq} . \mathrm{m}$. Drained by the numerous tributaries of the Choctawatchie r., which traverses the co. from N. E. to $\mathrm{S}$. W. Surface level, with a barren soil, except the hummocks and swamps, which are exceedingly fertile. The products are cotton, corn, ete., with rice and sugar. Farms 697 ; manuf. 0 ; dwell. 928, and pop.-wh. 5,623, fr. col. 2, sl. 721-total 6,346. Capital: Newton.

DALE, p. o., Spencer co., Ind.: $128 \mathrm{~m}$. S. by W. Indianapolis.

DALE, p. o., Wyoming co., N. Y.: $221 \mathrm{~m}$. W. Albany.

Dale, p. o., Berks co., Penna: 61 m. E. Harrisburg.

Daleville, p. v., Lauderdale co., Ifiss. : on Ponta cr., 88 m. E. by N. Jackson.

Dalermle, p. $\mathbf{}$., Dale co., Ala.: on the E. side of a branch of Choctaw-Hatchee r., 80 m. S. S. E. Montgomery. It was formerly the capital of the county.

Daleville, p. v., Luzerne co., Penn.: 94 m. N. E. Harrisburg.

Daley's, p. o., Montgomery co., Tenns: 39 m. N. W. Nashville.

Daltas county, Ala. Situate S. centrally, and contains s72 sq. m. Drained by the Alabama r., which here receives the Cahawba and other streams. Surface nndulating, and soils, especially on the rivers, very fertile. Products, cotton, corn, and some rice. Farms 749 ; manuf. 32 ; dwell. 1,375 , and pop.-wh. 7,461 , fr. col. 8, sl. 22,258-total 29, $\pi 27$. Capital: Cahawba Public Works: Selma and Tennessee River R. R.; the Selma and Mississippi R. R.

Dall.as county, Ark. Situate between Saline and Wash164 ita rivers, and contains $792 \mathrm{sq} . \mathrm{m}$. Drained by creeks of the border rivers. Surface in some parts, hilly and uneven; in others, rolling or level-everywhere diversified, and plentifully wooded. Soils generally of an average fertility, and productive of corn and cotton. Farms 399 ; manuf. 9 ; dwell. 740, and pop.-wh. 4,333, fr. col. 2, sl, 2,542-total 6,877. Capitul: Princeton.

Dallas county, $I a$. Situate centrally, and contains 576 sq. m. Drained by Beaver, Raccoon, and other ereeks, tributaries of the Des Moines r. Surface chiefly rolling prairie, interspersed with timber. Soils excellent, being deep and rich. Farms 00 ; manuf, 00 ; dwell, 156, and pop. -wh. 854, fr. col. 0-total 854. Capital: Adell. Public Works: Council Bluffs R. R. (projected).

Datuas county, Mo. Situate S. W., and contains $576 \mathrm{sq}$. m. Niangua $r$, and Little Niangua r. and their creeks drain the whole co. Surface undulating, and oceasionally timbered. Soils indifferent, Iron ore abundant. Farms 361; manuf. 8 ; dwell. 597, and pop.-wh. 3,552, fr. col. 8, sl. 8stotal 3,618. Capital: Buffalo.

Dallas county, Tex. Situate N., and contains $920 \mathrm{sq} . \mathrm{m}$. Drained by the upper streams of Trinity $x_{\text {., }}$ which spread over the whole co. Surface elevated and level, chiefly prairie. Soils of excellent fertility. Farms 178; manuf. 1 ; dwell. 435, and pop.-wh. 2,536, fr. col. 0, sl. 207-total 2,743. Capital: Dallas.

Dallas, p. v., Pulaski co., Ky. : 82 m. S. by E. Frankfort.

Dalisa, p. vo, Madison par., La.: 132 m. N. Baton Rouge.

Darlas, p. ఛ., La Fayette co., Miss.: 147 m. N. N. W. Jackson.

Dallas, p. v., Greene co., Mo.: on the W. side of James r., the N. branch of White r., $129 \mathrm{~m}$. S. S. W. Jefferson City.

Dalias, p. vo, Highland co., Ohio: 66 m. S. S. W. Columbus.

Dallas, t. and p. O., Luzerne co., Penno: 98 m. N. E. Harrisburg.

Dallas, p. v., and cap. Dallas co., Texo: on the E. side of Trinity r., $192 \mathrm{~m}$. N. by E. Austin City. The "D. Her ald" (dem.) is the name of a weekly newspaper published in the village.

Dalluas, t. and p. o, Clinton co., Mrich.: $20 \mathrm{~m} . \mathrm{N}$. W. Lansing. Pop. 185.

Datras, p. v., Marshall eo, Virg.: 238 m. N. W. Richmond.

Dallas, p. v., Gaston co., N. Car.: 133 m. W. S. W. Raleigh.

DallabBubgr, p. $\nabla_{*}$, Owen co., $\bar{K} y_{0}: 32 \mathrm{~m} . \mathrm{N}$. by E. Frankfort.

Daliasburge, p. F., Warren eo., Ohio: $74 \mathrm{~m}$. S. W. Columbus.

Dallas Crty, p.. ., Hancock $c_{0}, I l l_{0}: 91 \mathrm{~m} . \mathrm{N}$. W. Springfield.

Dallastowry, p. v., York co., Penn. : 42 m. S. Harrisburg.

Dalmatia, p. v., Northumberland co., Penn.: $40 \mathrm{~m}$. N. Harrisburg.

Dalton, p. v., Wayne co., Ind.: on the W. side of Nettle cr., $56 \mathrm{~m}$. E. by N. Indianapolis.

Dalton, t. and p. o., Berkshire co, Mass.: on the line of the Western R. R., $108 \mathrm{~m}$. W. Boston. Drained by the E. branch of Housatonic r. It has several valuable manufactures. Pop. 1,029 .

Datros, to and p. $\mathrm{v}_{4}, \mathrm{Coos} \mathrm{CO}_{n}, \mathrm{~N}$. Hamp.: on the E. side of Connecticut r., $72 \mathrm{~m}$. N. by W. Concord. The Great or Fifteen Mile Falls commence in Dalton, and rush tumultuously along the $\mathrm{N}$. W. border. The $t$. is drained by John's $\mathbf{r}_{\text {., }}$ and other streams. In the W. and $\mathrm{S}$. the surface is hilly, and along the St. John's the majestic white pine abounds. The v. or settlement is located on the river bank. P. 750 .

Darton, p. v., Wayne co., Ohio : on the line of the Akron and Mrillersburg R. R., $80 \mathrm{~m}$. E. N. E. Columbus.

Datros, p. v., Murray co., Ga.: about 2 m. W. of Conasauga $r ., 14 \bar{m}$. N. W. Milledgerille. It is a new $\mathrm{v}$. which 
has sprung up under the benign influence of railways, and is one which will become a centre of population, commerce, and wealth. The Western and Atlantic R. R. passes through it $100 \mathrm{~m}$. from Atlanta, and $40 \mathrm{~m}$. from Chattanooga, and at this point is intersected by the East Tennessee and Georgia R. R. which runs $107 \mathrm{~m}$. to Knoxville. A newspaper, the "D. Times" (dem.), is issued weekly. The v. contains several fine buildings and shops belonging to the R. R. companies, and has about 600 inhabitants.

Damariscotta Miris, p. v., Lincoin co., Me. : at the out let of Damariscotta Pond, 26 m. S. S. E. Augusta.

Davariscotta river, Me $:$ this $r$, has its source in ponds in Jefferson and Noblesborough; its general course is southerly, between Neweastle, Edgecomb, and Boothbay on the W., and Bristol on the E. ; it is navigable for large shipping for $16 \mathrm{~m}$. Large quantities of timber are brought down the r., and numerous merchant vessels are annually built on this broad arm of the sea.

Damascoville, p. v., Columbiana co., Ohio: on the $\mathrm{N}$. line of the $c 0 ., 126 \mathrm{~m}$. N. E. by E. Columbus. It is a small village of about 200 inhabitants.

Damascus, t. and p. v., Henry co., Ohio: on the N. side of Maumee $x_{\text {., }}$ and of the Wabash and Erie Canal, $112 \mathrm{~m}$. N. N. W. Columbus. Pop. 233.

Damascus, to and p. v., Wayne co., Penn.: on the W. side of Delaware r., $128 \mathrm{~m}$. N. E. Harrisburg. The $\mathrm{v}$, on the r., which is here spanned by a bridge 500 feet long, is a small settlement of 30 or 40 dwellings.

Dakrasces, p. v., Spartanburg dist., S. Car. : 86 m. N. W. Columbia.

Damasous, p. vo, Montgomery co., Ma.: at the head of Seneca cr., $62 \mathrm{~m}$. N. W. Annapolis.

$D_{\text {AY river, }}$ N. Car. and Virg.: mostly in Virginia, the Dan uniting with Staunton $r$. forms the Roanoke. It has falls of 23 feet at Danville, but, by a canal around them, navigation is open for $100 \mathrm{~m}$. from its mouth.

Dara, t. and p. o., Worcester co., Mass. : $62 \mathrm{~m}$. W. Bosfon. A branch of Swift $x$. passes through the town. In the manufacture of palm-leaf hats there are numbers engaged -it is the principal manufacture. Pop. 842 .

Danborovgis, p. v., Bucks co., Penn.: 92 m. E. Harristurg, and about $3 \mathrm{~m}$. N. of Doylestown. It contains about 30 dwellings.

DANBJRGI, p. v., Wilkes co., Gan : on the S. side of Broad r., $12 \mathrm{~m}$. from its entrance into the Savannah r., and $68 \mathrm{~m}$. N. N. E. Milledgeville.

Danseter, to, p. b., and one of the capitals Fairfield co, Conn.: $48 \mathrm{~m}$. S. W. Hartford. Drained by a branch of Housatonie r., which furnishes good water-power. The borough is a pleasant village, built chiefly on one street. It contains 7 churches, and about 250 dwellings. The Danbury and Norwalk R. R. has its N. terminus at this point. The t. has several manufactures, and supports a newspaper, the "D. Times," which is published weekly. Danbury was captured and burned by the British in the revolutionary war, and large quantities of military stores seized-this occurred 26th April, 1777. In the battle the American general, Wooster, was killed. Pop. 5,964.

DANedri, p. V., and cap. Stokes co., N. Car.: $104 \mathrm{~m}$. N. W. by W. Raleigh.

DANBURY, t. and p. v., Grafton co., N. Hamps: in the $\mathrm{S}$. part of the $c_{0}, 29 \mathrm{~m} . \mathrm{N}$. W. Concord. The Northern R. R. passes through the t., $30 \mathrm{~m}$. from West Lebanon. P. 934 ,

DANBr, to and p. V., Tompkins co., $N . Y$. : about $8 \mathrm{~m} . \mathrm{S}$. Ithaca, and $184 \mathrm{~m}$. W. by S. Albany. The surface is hilly, and the soils a gravelly loam : drained by Cattotong er. and its tributaries. The $\mathrm{v}$. contains about 400 inhabitants. The Ł. has a large number of saw-mills. Pop. 2,411.

DANBr, t. and p. F., Rutland co., Verm.: near the head waters of Otter cr., $67 \mathrm{~m}$. S. by W. Montpelier. The surface is generaliy rongh, but the soils are bighly productive. The tr is noted for its butter and cheege. The Vermont Western R. L. passes through its S. E. corncr. Pop. 1,535.
DANBY, t. and p. o., Ionia co., Afich.: on Grand r., $18 \mathrm{~m}$. W. S. W. Lansing. Pop, 262.

DAMBY Four CorNers, p. o., Rutland co., Verm.: $66 \mathrm{~m}$ S. by W. Montpelier.

Daxorville, p. v., Haywood co., Tenn.: abeut $7 \mathrm{~m}$. S. of Big Hatchee r., 149 m. W. \$. W. Nashville.

DANDRIDGE, p. v., and cap. Jefferson co., Tenn, : on the N. side of French Broad r., 192 m. E. Nashville, It contains the usual co. buildings, sereral stores, and about 80 dwellings. It has a considerable trade in the vicinity.

DAXE county, Wisc. Situate S. centrally, and contains 1,285 sq. m. Drained by Black Earth, Blue Mound, and other tributaries of Wisconsin $r_{\text {., }}$ which washes its N. W. corner, and by Catfish r., Sugar r., and other affluents of Rock $r$. In its centre are the Four Lakes, renowned for their beauty. The level of Fourth Lake, above the Atlantic, is 788 feet, and above Lake Michigan, 210 feet. Surface generally rolling; hills and valleys succeeding each other; the hills seldom abrupt, and arable to their summits; the valleys well watered and seldom marshy. Soils generally black vegetable mold, sometimes loamy, and oceasionally clay mixed with sand. The underlying rocks are chiefly ealcareous. Farms 1,501; manuf. 87 ; dwell. 2,303, and pop.wh. 16,618, fr. col. 23-total 16,641. Capital : Madison, Pußlic Works: Milwaukee and Mississippi P. R.

DAre, t. and p. o., Dane co., Wisc. : $12 \mathrm{~m}$. N. N.W. Madison. Pop. 287.

Daniel's Mills, p. 0., Pierson co, N. Car, ; 53 m. N. N.W. Paleigh.

Daxielstille, p. v., and cap. Madison co., Ga.: on the high land between Oconee and Broad rivers, $74 \mathrm{~m}$. N. Milledgeville. It contains the usual co. offices, a jail, an academy, and about 25 or 30 stores and dwellings.

Danielsville, p. V., Dickson co., Tenn.:37 m. W. Nashville.

Danielsviluet, p. v., Spottsylvania co., Virg. : on one of the head branches of North Anna r, 49 m. N. N. W. Richmond. Gold is found in this region of country to a considerable extent.

Danielton, p. v., Beaufort dist., S. Cur. : 113 m. S. by W Columbia.

Dannemora, p. v., Clinton co., N. $Y_{*}$ : about $2 \mathrm{~m}$. N. of Saranae r., $10 \mathrm{~m}$. W. by N. Plattsburg, and $187 \mathrm{~m}$. N. Albany.

DANsville, p. V., Livingston co, $N_{.} Y_{*}$ : on Canaseraga r., a tributary of Genesee r. $195 \mathrm{~m}$. W. by S. Albany. Here are a succession of falls, within the distance of $1 \frac{1}{2} \mathrm{~m}$., affording a large power, and the $v$. contains several factories and mills, as paper-mills, flouring-mills, etc., and furnaces. Dansrille has three weekly newspapers, and one semi-monthly, viz., the "D. Herald" (whig), the "D. Courier" (dem.), the "D. Chronicle" (dem.), weeklies, and "Trembly's Advertiser," published semi-monthly. The Dansville Branch of the Genesee Valley Canal extends hence $11 \mathrm{~m}$. to the main canal, which it joins near the v. of Mt. Morris. Pop. 1,800. Daктом, p. v., Tishemingo co., Miss. : $195 \mathrm{~m} . \mathrm{N} . \mathrm{E}$ Jackson.

DANUBE, t. and p. v., Herkimer co., $N_{0} Y_{0}:$ on the $\mathrm{S}$. of the Mohawk r., $58 \mathrm{~m}$. W. N. W. Albany. The surface is undulating: soils sandy and calcareous loam: drained by Nowadaga cr. The Erie Canal, on which the $\mathrm{v}$. of Danube is located, passes through the N. part of the town, following the Valley of the Mohawk. Pop. 1,730.

Danters, t. and p. v., Essex co., Mrass.: 14 m. N. Boston. The soils are fertile and well cultivated. The principal $v$. is virtually a suburb of Salem, the streets being continuous. There is another $v$. in the $N$. part of the t.on on Beverly $r_{\text {o, }}$ at which numerous ships are annually built. Both these villages can be approached by ressels of considerable burden, and both have considerable trade and manufactures, principally in leather and its products. Pop. 8,110. The Salem and Lowell R. R. passes through the township.

DANville, p. v., and cap. Yell co, Ark.: on Petite Jean cr., $67 \mathrm{~m}$, W. N. W. Little Rock. 
Danvilue, p. v., Sumter co., $G a_{0}:$ on the W. bank of Flint r., 86 m. S. W. by S. Milledgeville.

Darvilie, p. $v_{\text {., }}$ and cap. Vermillion co., $I l l_{*}:$ on the N. bank of Big Vermillion r., immediately below the junction of its North and Salt Forks, $128 \mathrm{~m}$. E. by N. Springfleld. It is a large and flourishing place, and has two newspapers, the "D. Herald" (dem.), and the "D. Citizen" (whig), both issued weekly. Pop. 1,200. The surrounding country is fertile and populous.

Danville, p. v., and cap. Hendricks co., Ind.: on the W. side of the W. fork of White Lick cr., $20 \mathrm{~m}$. W. Indianapolis. The site of the $\mathrm{v}$. is elevated, and commands a fine prospect. It contains a handsome brick $\mathrm{C}$. $\mathrm{H}$. and other co. offices. Pop. 177. It was first settled in 1825. The "Advertiser" (whig) is published weekly.

Danville, p. v., and cap. Boyle co., $K y .:$ on a small cr. of Dick's r., about $3 \mathrm{~m}$. from its confluence, and $35 \mathrm{~m}$. S. by E. Frankfort. The line of the projected Nashville and Lexington $R$. $R$. passes through the $\mathrm{Y}$., making it an important trading place. It is the seat of the Centre College, and also of the Kentucky Deaf and Dumb Asylum. The college was founded in 1820, and in 1850 had a president and 7 professors, 363 alumni, and 152 students, with a library of nearly 6,000 volumes. The asylum had 60 inmates on the 1st Jan., 1851. Pop. about 1,600.

Danville, t. and p. v., Cumberland co., Me. : on the W side of Androscoggin r., $31 \mathrm{~m} . \mathrm{S}$. W. Augusta. It is chiefly devoted to agriculture. The Androscogrin and Kennebee R. R. here diverges from the Att. and St. Law. R.R. P. 1,696.

Danville, p. V., Tishemingo co., Miss.: $202 \mathrm{~m}$. N. E. Jackson.

Danville, p. V., and cap. Montgomery co., Mo. : on the E. of and about $3 \mathrm{~m}$. from the Loutre r., a tributary of the Missouri, $42 \mathrm{~m}$. N. E. by E. Jefferson City.

Danville, t. and p. o., Rockingham co., N. Hamp. : 30 m. S. E. Concord. Achusnut r. passes over the N. W. corner, and there are several ponds in the town. The surface is uneven, and the soils in most parts good. Pop. 1,614.

Danville, p. 0., Warren co., N. Jer,: $56 \mathrm{~m}$. N. by W. Tronton.

Danrille, p. v., Knox co., Ohio. : about $4 \mathrm{~m}$. W. of Walhonding r., and $52 \mathrm{~N}$. E. Columbus.

Danville, p. v., and cap. Montour co., Penn.: on the $N$. side of the N. branch of Susquehanna r., at the entrance of Mahoning cr., and on the line of the North Branch Division of the Pennsylvania Canal, 12 m. above Northumberland, and $30 \mathrm{~m} . \mathbf{N}$. by E. Harrisburg. A bridge here crosses the Susquehannar. The $\mathrm{v}$, contains several churches, stores, and about 3,300 inhabitants, and it has a considerable trade with the neighboring interior. Two newspapers, the "D. Democrat" (whig), and the "D. Intelligencer" (dem.), are issued weekly.

Dantilue, t., p. v., and cap. Caledonia co., Verm.: 24 $\mathrm{m} . \mathrm{N}$. E. Montpelier. The $\mathrm{v}$, is pleasantly situated near the centre of the $t$, and is surrounded by a fine farming country, well drained by tributaries of Passumsic $r$. which also afford mill-power. The t. has considerable manufactures; and a newspaper, the "North Star." Pop, 2,5i7.

Darvilue, p. v., Pittsylvania co., Firg.: on the N. side of Dan r., $128 \mathrm{~m} . \mathrm{S}$. W. by W. Richmond. The falls at this point, which is the head of boat navigation, afford great water-power, and this is extensively used for manufacturing and milling purposes. The v, is located on high ground, gradually rising from the river to a commanding eminence, from which the view of the vicinity is extensive and beautiful. Danville has become a place of extensive trade, and is a depot for the immense products of a wide country. It has large tobacco warehouses, numerous stores, and about 1,514 inhabitants, and here is published the "D. Register," a weekly newspaper. The Richmond and Danville $\mathrm{P}, \mathrm{R}$. has its $\mathrm{S}$. terminus at this point.

Danvilite, p. Y., Montgomery co., Tex. : $153 \mathrm{~m}, \mathrm{E}$. Austin City.
Darville, p. v., Des Moines co., Iat: about $4 \mathrm{~m}$. N. of Skunk r., and 57 m. S. by E. Iowa City. Pop. 1,087.

DAN WEBSTER, p. v., Henry co., Ind. : 48 m. E. by N. Indianapolis. The great statesman from whom the name of this $\mathrm{p} . \mathrm{o}$. is derived died on the 24th Oeto, 1852 .

Darbx, t. and p. v., Delaware co., Penn.; $87 \mathrm{~m}$. E. by S. Harrisburg. The v., on Darby cr., has about 360 inhabitants, most part of whom are Quakers. The $t$. is divided into Upper Darby and Lower Darby, and has 1,422 inhabitants.

DARBY, p. v., Franklin co., Ohio: $12 \mathrm{~m}$. W. Columbus, on the E. of Big Darby creek.

Darby Creer, p. o., Madison co., Ohio : on Big Darby cr., $16 \mathrm{~m}$. W. by N. Columbus.

Darby Platis, p. o., Union co., Ohio : near Big Darby r., $23 \mathrm{~m}$. N. W. Columbus.

DARBY's, p. o., Columbia co., Gro. : 76 m. E. N. E. Milledgeville.

Darbmville, p. v., Piekaway co., Ohio: on the W. side of Big Darby cr., $22 \mathrm{~m}$. S. by W. Columbus. Pop. about 400.

Dardanelle, p. v., Pope co., Ark.: on the S. bank of Arkansas r., $61 \mathrm{~m}$. W. N. W. Little Rock. Near this, on both sides the $r$., are rocky ridges, which are called the Dardanelles. Pop. 300.

DARIEN, t. and p. v., Fairfield co., Conn. : on Long Islaud Sound, $63 \mathrm{~m} . \mathrm{S}$. W. Hartford. The surface is undulating, and the soil excellent. The $\mathrm{v}$, is on a small stream which sets up from the Sound, and has some coasting trade with New York. It is also on the line of the New York and New Haren R. R. Pop. 1,454.

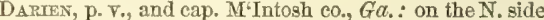
of Alatamaha r., $12 \mathrm{~m}$. above the bar at the entrance of the Sound, $156 \mathrm{~m}$. S. E. Milledgeville. The bar has 14 feet of water. The v. has progressed rapidly, and has the appearance of a place of considerable commerce. It is the natural port for all the country watered by the Alatamaha and branches, one of which, the Oconee, is navigable to Milledgeville; and the other, the Ocmulgee, to Macon. To Savannah and Charlesten, regular lines of steamboats are plied, and the coasting trade of the port is large. Pop. 550.

DaRIEN, t. and p. v., Genesee co., N. Y. : about $12 \mathrm{~m} . \mathrm{S} . \mathrm{W}$. Bataria, and $232 \mathrm{~m}$. W. Albany. The v. lies on the line of the Buffalo and New York City R. R., $27 \mathrm{~m}$. from Buffalo, and contains about 300 inhabitants. The $t$. is drained by Ellicott's cr. and other tributaries of Tonawanda r. Its surface is hilly, and soils clayey and calcareous.

DARIEN, to and p. v., Walworth co., Wisc.: 54 m. S. E. Madison. The surface is drained by Turtle cr. and its tributaries. The $\mathrm{v}$. is in a fine elevated tract to the $\mathrm{S}$. of the creek. Pop. of t. 1,013.

Darten Chatre, p. .., Geneseo co., N. Y.: on the line of the Buffalo and New York City R. R., 25 m. from Buffa. lo, and $284 \mathrm{~W}$. Albany.

Darien Depôt, p. o., Fairfield co., Conn.: on the line of the New York and New Haven R. R., 62 m. S.W. Hartford. DARK CoRNER, p. o., Campbell co., Ga.: 106 m.W. N. W. Milledgeville.

DARK Corver, p. o., De Soto co., AFiss. : $168 \mathrm{~m} . \mathrm{N}$ Jackson.

DARKE county, Ohio. Situate W. on Indiana State line, and contains $714 \mathrm{sq} . \mathrm{m}$. Drained by Stillwater, Greenville, and Panther creeks, tributaries of Miami r., and which afford large mill-power. Surface generally level. Soils fertile. It is an excellent grain county. Farms 2,151; manuf 10; dwell. 3,476, and pop.-Wh. 20,111, fr. col. 163 -total 20,2 it. Capitul: Greenville. Public Works: Bellefontaine and Indiana R. R.; Dayton and Greenville R. R. and its Extension, etc. Fort Recovery, in the N. W. of the county, was erected by General Wayne, 1795, on the spot where three years before General St. Clair had suffered his memorable defeat by the Indians.

Darke, p. o., Darke Co., Ohio: $98 \mathrm{~m}$. \$N. Columbus.

Darkesyille, p. v., Berkeley co., Virg.: on Sulphur 
Springs er., a branch of Opequan cr. of the Potomac r., 127 m. X. by $\Pi$. Richmond.

DarLingtor district, $S$. Oar. Situate E. centrally, and contains $1,050 \mathrm{sq} . \mathrm{m}$. Drained by Black and other creeks of Great Pedee r., which bounds it on the N. E., and by numerous affluents of Lynch's cr., which washes its S. W. border. Surface slightly undulating. Soils sandy and light, except on the margins of the streams, where it is very fertile. The chief products are cotton and Indian corn, with some wheat, oats, ete. Farms 857 ; manuf. 26 ; dwell. 1,313, and pop.-Wh. 6,750, fr. col. 39, sl. 10,041-total 16,830. Capital: Darlington C. H. Public Works: Wilmington and Manchester R. R.

Daritrgton, p. V., Montgomery co., Ind. : on the B. side of Sugar er. of Rock r., $42 \mathrm{~m}$. N. W. Indianapolis,

Darlington, p. v., St. Helena par., La.: 38 m. N. E. Baton Rouge.

DAmitngtoN, p. V., Harford co., Ma.: on the W. side of the Susquehanna r., about $2 \mathrm{~m}$. distant from it, and $49 \mathrm{~m}$. N. by E. Annapolis.

Daritngton, p. o., Beaver co., Penn.: on Little Beaver cr., $197 \mathrm{~m}$. W. by N. Harrisburg. It has about 400 inhabitants.

DARLIFGTON COURT-House, p. v., and cap. Darlington dist., S. Car.: on Swift er., a tributary of Black cr. of Great Pedee r., 69 m. E. N. E. Columbia. It is a v. of about 500 inhabitants, and lies about $3 \mathrm{~m}$. W. of Black creek.

Darlington Heights, p. o., Prince Edward co., Virg. : $61 \mathrm{~m}$. S. W. by W. Richmond.

Darnestown, p. v*, Montgomery con, $M d_{*}:$ on the S. side of Seneca cr., $51 \mathrm{~m}$. W. N. W. Annapolis.

Daretown, p. v., Butler co., Ohio: on the line of the Junetion R. R., 96 m. W. S. W. Columbus.

DARTFord, p. V., Marquette co., Wisc.: 52 m. N. by E. Madison.

D. Атто UTt, t. and p. ₹., BristoI co., IFass. : $52 \mathrm{~m}$. S. Boston. It has Buzzard's Bay on the S. E., and is penetrated by several inlets from it, one of which receives Aponiganset r., which is navigable to near the middle of the town. The manufacture of salt, ship-building, and the whale and coast fisheries, are the chief employments of the inhabitants. Pop. 3,563.

Darvill's, p. 0., Dinwiddie co., Firg.: $37 \mathrm{~m} . \mathrm{S}$. W. Richmond.

DARWIN, p. $\nabla .$, and cap. Clark co., $I l_{\mathrm{a}}$ : on the W. bank of Wabash $r_{\text {. }} 112 \mathrm{~m}$. E. S. E. Springfield. It is a flourishing place, and contains about 300 inhabitants.

Dapysaw, p. o., Jefferson co., Ark. : 49 m. S. by E. Jefferson City.

DAupHrr county, Penn. Situate S.E. centrally, and contains $608 \mathrm{sq}$. m. The Susquehanna washes the co. on the W. and S. W., and its tributaries, Mahantango, Powell's, and Swatara creeks, drain the interior. Surface rough, hilly, and in some parts mountainous. Soils generally fertile, producing all the grains abundantly, and tobacco. Iron and coal are mined in immense quantities, and there are several potteries in operation. The Dauphin co. coal is considered one of the best qualities in market. Farms 1,956; manuf. 253 ; dwell. 6,033 , and pop.-wh. 34,491 , fl: col. 1,263 -total 35,754. Capital: Harrisburg. Public Works: Pennsylvania Canal; Union Canal; Lancaster and Harrisburg R. R.; Pennsylvania R. R., ete.

DAUPHIN, p. v., Dauphin co., Penn.: on the E, side of Susquehanna r., $8 \mathrm{~m}$. N. Harrisburg. It is a thriving v. of 1,451 inhabitants. The line of the Main Division of the Pennsylvania Canal passes through it, $34 \mathrm{~m}$. from Columbia.

Davenport, p. V., and cap. Seott co., Ia.: on the W. side of the Mississippi r, opposite Rock Island, and 51 m. E. by \$. Iowa City. The site is $100 \mathrm{~m}$. below Galena, and 338 above St. Louis. A large amount of business is transacted here, and it is destined to become a place of importance, in connection with the railroad system of the West. It is now connected with Chicago by $\mathrm{R} . \mathrm{R}$., and a $\mathrm{R}$. $\mathrm{R}$. is projected hence to Council Blufis and the Pacific coast. It already supports two newspapers, the "D. Gazette" (whig), and the "Democratic Banner," both published weekly. Pop. 3,400.

DAvenport, t. and p. v., Delaware con, N. $Y_{0}: 57 \mathrm{~m}$. W. S. W. Albany. Surface billy, and soils argillaceous loam. Drained by Charlotte $r$. and its tributaries. The $\mathrm{v}$. lies on the $\mathrm{S}$. side of Charlotte r., and on the Catskill Post Road. Pop. 2,305.

Davenport Centre, p. v., Delaware co., $N$. $Y_{.}:$on the $\mathrm{S}$ side of Charlotte r., $61 \mathrm{~m}$. W. S. W. Albany.

DAvidson county, N. Car. Situate centrally, and contains $380 \mathrm{sq} . \mathrm{m}$. Drained by numerous ereeks of Yadkin r., which forms its W. and S. W. borders. Surface undulating. Soils fertile. Products, wheat and Indian com, with cotton and tobacco. Farms 1,231; manuf. 18; drell. 2,308, and pop.-wh. 12,139, ir. col. 189, sl. 2,992-total 15,320. Capital: Lexington.

DAVIDSoN county, Tenn. Situate centrally, and contains $720 \mathrm{sq} . \mathrm{m}$. Drained by numerous creeks of the Cumberland r., which passes through it from E. to W. Surface undulating, and agreeably varied. Soils fertile, and productive of all the grains, with cotton and tobacco in considerable quantities. Immense numbers of live-stock are owned in the co., and much live and salt provisions exported. Manufactures and commerce have also materially advanced of late years. Farms 1,384; manuf. 169 ; dwell. 4,257, and pop.-wh. 23, S58, fr. col. 848 , sl. 14,175-total 35,S51. Capital: Nashvilie. Puzlic Works: Nashrille and Chattanooga R. R.; Nashville and Cincinnati R. R.; Nashville and Louisville P. R.; Nashville and Ilenderson R. R.; Nashville and Mississippi R. R., ete.; and two railroads from Nashville to meet the Southern lines pointing toward the north.

Davinsor, p. v., Harrison co., Ind.: $112 \mathrm{~m} . \mathrm{S}$. by W. Indianapolis.

DArwsox, t. and p. v., Sullivan co., Penn. : 80 m. N. N. E. Harrisburg.

Datidson Centre, p. 0., Genesee co., Mich. : $56 \mathrm{~m}$. E. N. E. Lansing.

Davidsor College, p. o., Mecklenburgh co, $N_{\text {. }}$ Car.: in the $\mathrm{N}$. part of the co, between Roeky r. of the Yadkin and Davidson's cr. of Catawba r., 114 m. W. by S. Raleigh. It is located in an elevated and healthy region. The college that gives name to the p. 0 . was founded in 1835, and in 1850 had a president and 4 professors, and 60 students. Its alumni numbered 140 , of which 24 were ministers. The library has 5,000 rols. of well-selected books in all branches of learning.

Davioson's Rtrer, p. o., Henderson co., $N$. Car: : on the r. so called, one of the head streams of French Broad r., $234 \mathrm{~m}$. W. by S. Raleigh.

DAvidsonvilie, p. V., Anne Arundel co., MIC.: on the W. side of South r., at its head, $10 \mathrm{~m}$. W. Annapolis.

DAvmosville, p. v., Somerset co., Penn.: $117 \mathrm{~m}$. W. by S. Harrisburg.

DAvidsvulle, p. v., Franklin co., Tenn. : $7 \mathrm{~s}$ m. S. E. Nashville.

DAvie county, $N$. Car. Situate centrally, and contains $180 \mathrm{sq} . \mathrm{m}$. Drained wholly by creeks of Yadkin r., which lies on its E. border. Surface undulating. Soils fertile, producing cotton, tobacco, and the grains generally. Farms 404; manuf. 37 ; dwell. 1,027, and pop.-wh. 5,613, fr. col. 82, sl. 2,171-total 7,866. Capital: Mocksville.

DAviess county, Ind. Situate S. W., and contrins 420 sq. m. The forks of White $\mathbf{r}$. form its boundaries W. and S., and their many tributaries spread orer every part of the county. In the N. E. the surface is rolling and heavily timbered; the N. W. level, and interspersed with prairies and skirts of timber; the centre barrens, and the $\mathrm{S}$. and $\mathrm{E}$. undulating and heavily timbered. The soils are various, from sandy to pure clay. The bottoms of White r. are a rich black loam. Farms 1,221 ; manuf. 11; dwell. 1.503, and pop.-wh. 10,308, fr. col. 44-total 10,35\%. Capital: 
Washington. Public Works : Cincinnati and St. Louis R. R. ; and Wabash and Erie Canal.

DAVIESs county, $\bar{K} y$. Situate $N$. $W$., and contains 400 sq. $m$. Drained by creeks flowing $N$. into the Ohio $r_{\text {., }}$ which forms the boundary in that direction, and by creeks flowing $\mathrm{S}$. into Green r., which bounds the county S. Surface uneven. Soils ordinarily fertile, and producing the cereals, tobaceo, ete., in abundance. Farms 1,057 ; manuf. 18; dwell. 1,631, and pop.-wh. 9,423, fr. col. 50, sl. 2,880 total 12,353. Capital: Owensburgh.

Daviess county, Mo. Situate N. W., and contains 576 sq. m. Drained by Grand $r$. and its numerous and widespreading tributaries. Surface chiefly undulating prairie; and the soils everywhere fertile and productive. Indian corn and tobacco are largely grown-the other cereals to a less amount. Farms 342 ; manuf. 8 ; dwell. 784, and pop.wh. 5,056, fr. col. 1, sl. 241-total 5,298. Capital: Gallatin.

Davis county, Ia. Situate S. on the Missouri line, and contains 504 sq. m. Drained in the N. by Soap and Chequest creeks of Des Moines r., and in the S. by the head waters of Fox, Wyaconda, North Fabius, and other rivers flowing into the Mississippi. The surface is beautifulty diversified, chiefly undulating prairie, with frequent groves of timber. Soils of unsurpassed fertility. Farms 613; manuf. 11; dwell. 1,180, and pop.-wh. 7,257 , fr, col. 7total 7,264. Capital: Bloomfield.

DATIS county, $C$ tah Ter. Situate N. middle, and contains about 1,800 sq. mo. Drained by Weber $r_{\text {. }}$, the river Jordan, and other streams falling into the Great Salt Lake, which forms its $\mathrm{W}$. boundary. Surface hilly, with fertile valleys. Bear River mountains spread over its eastern sections. As a farming county it has excellent facilities. Farms 112 ; manuf. 1 ; dwell. 215 , and pop.-wh. 1,134, fr. col. 0-total 1,134. Capital: Farmington.

Davisborougr, p. v., Washington co., Ga.: on the line of the Central R. R., $122 \mathrm{~m}$. from Savannah, and $46 \mathrm{~m}$. E. by S. Milledgeville. It contains about 60 dwellings.

DAvIs' CREEK, p. 0., Washington co., Ia. : 17 m. S. Iowa City.

Daris' Creek, p. o., Dubois co., Ind.: on the cr. so called, $100 \mathrm{~m}$. S. S. W. Indianapolis.

Dafis' Crieer, p. o., Fayette co, Ala.: on the cr. so called, $134 \mathrm{~m}$. N. W. Montgomery.

Davis' Mruss, p. o., Barnwell dist., S. Car : 62 m. S. S.W. Columbia.

Davis' Mruls, p. o., Bedford co., Firg.: on Goose cr., a tributary of Reanoke r., $117 \mathrm{~m}$. W, by S. Richmond

DAvisonvile, p. v., Genesee co., Ifich. : 61 m. E. N. E. Lansing.

Davis' Stork, p. 0., Bedford co., Virg. : 108 m. W. by S. Richmond.

Daviston, p. v., Talbot co., Ga. : on the Macon and $C_{0}$ lumbus Turnpike, $79 \mathrm{~m}$, W. S. W. Milledgerille.

Davistown, p. v., Greene co., Penn.: 192 m. W. by S Harrisburg.

Da vigvilue, p. v., Bucks co., Penn. : 91 m. E. Harrisburg.

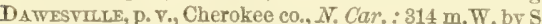
Raleigh.

DAwkIN's Mruls, p. 0., Jackson co., Ohio: $72 \mathrm{~m}$. S. by E. Columbus,

Dawson, p. v., Habersham co., Ga.: 128 m. N. Milledgeville.

DAwsonburge, p. v., Fremont co., $1 a_{0}: 224 \mathrm{~m}$. W. by S. Iowa City.

Dawson's, p. o., Alleghany co., Md. : on the N. W. side of the Potomac $\mathbf{r}_{0}, 11 \mathrm{~m}$. S. W. Cumberland.

$D_{A Y}, t_{0}$ and p. v., Saratoga co., N. Y.: in the N.W. corner of the co, $46 \mathrm{ma}$. N. by W. Albany. The surface is hilly, the Kayaderosseras Mountains extending across the town, and the most arable lands are those of the Sacandaga $\mathbf{r}$, which flows through it. The v. lies on the N. side of $r, P, 1,045$,

DaY's Landive, p. o., York co., Penn.: on the W. side of Susquehanna r, 31 m. S. S. E. Harrisburg
DAr's Store, p. o., Hopkins co., Ky. : 168 m. W. S. W. Frankfort.

DaysviLle, p. v., Og]e co., Ill.: $157 \mathrm{~m}$. N. Springfield. Dayeville, p. v., Todd co., Ky.: 152 m. S.W. Frankfort.

DaYTon, p. v., Marengo cos, $A l a_{r}:$ on a cr. of the Bogue Chickasaw, a tributary of Tombigbee $\mathbf{r}$, from the $\mathrm{E}_{n}, 81 \mathrm{~m}$. W. Montgomery.

Dayton, p. $v_{.,}$La Salle co., $I l l$. : on the W. side of Desplaines r., $6 \mathrm{~m}$. N. E. Ottawa, and $118 \mathrm{~m}$. N. by E. Springfield. It is a thriving $\mathrm{v}$., with about 250 inhabitants.

DAYтoN, p. v., Tippecanoe co., Ind. : on the W. side of the W. Fork of Ponceapichoux or Wild Cat $r ., 54 \mathrm{~m}$. N.W Indianapolis.

D $\triangle$ YToN, t. and p.. ., Cattaraugus co., $N . Y_{0}$ : on Conewango $\mathrm{cr}_{\text {. }}$ and drained by its tributaries. Surface undulating, and soils clay and gravelly loam. The v. lies on the line of the Erie R. R., $22 \mathrm{~m}$. from Dunkirk, and $262 \mathrm{~W} . \mathrm{S} . \mathrm{W}$. Albany. Pop. of t. 1,44s.

Dayton, t., p. eity, and cap. Montomery co., Ohio: at the confluence of the Mad and Miami rivers, in lat. $39044^{\prime}$ $\mathrm{N}$., and long. $84^{\circ} 11^{\prime} \mathrm{W}, 66 \mathrm{~m} . \mathrm{W} . \mathrm{S} . \mathrm{W}$. Columbus. It is one of those new centres of trade and commerce which have sprung up in the Great West with the progress of internal improvements, and which, during the decade ending with 1850, have been so wonderfully developed. The ground on which the city is built was originally purchased by John Cleve Symmes about the year 1795, and afterward it appears that Governor St. Clair and Jonathan Dayton, with several associates, contracted with Symmes for the purchase and settlement of so much of the original purchase as was included in the corporate limits of the present eity. The embryo town received the name of Dayton. Symmes being unable to meet his payments, the land reverted to the government, and afterward (in 1799), Daniel C. Cooper, of New Jersey, succeeded to the proprietorship. The town was then laid out upon a plan originaliy furnished by St. Clair with streets 100 feet wide, crossing each other at right angles. The town plot was divided into $280 \mathrm{lots}, 100$ feet front by 200 feet in depth; and upward of 50 out-lots of 10 acres each were laid off at the same time. But it was not till within the present century that the town had a tangible existence. In 1805 it was incorporated by the Legislature, and in 1806 the first brick dwelling was erected; and in 1810 it had only 383 inhabitants. Its progress, indced, seems to have been quite slow until the completion of the internal improvements connecting it with the commereial centres of the West were completed. In 1820 the inhabitants numbered 1,039 ; in $1530,2,954$; in $1840,6,067$; and in 1850, 10,977. In 1829 the Miami Canal, between Cincinnati and Dayton, was completed, and on the 25th January of that year a canal boat traversed the distance $(60$ miles $)$ between the two places. From this date the prosperity of Dayton commences, At a later period the cansal was opened to Lake Erie. The amount of tolls collected at the porl of Darton, in 1541, was $\$ 27,053$; in $1550, \$ 32,576$. There are also now upward of 250 miles of $\mathrm{M}$ 'Adam roads radiating from the city in all directions; and it is now eonnected, through the following railroads, with all the principal points of the Union: the Mad River and Erie R. R., $156 \mathrm{~m}$., terminating at Sandusky; the Cincinnati, Hamilton, and Dayton R. R., 60 m., terminating at Cincinnati; the Little Miami R. R., 84 m., at Springfield; the Dayton and Western R. R., $40 \mathrm{~m}$, at the State line; the Greenville and Miami

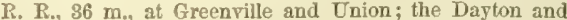
Michigan R.R., 140 m., at Toledo; and the Dayton and Xenia, $16 \mathrm{~m}$., at Xenia. These connect with lines reaching the length and breadth of the Enited States; and a continuous line of railroad is under contract from a point on the Ohio $x_{\text {., }}$ connecting with the Baltimore and Ohio $R_{\text {. }} \mathrm{R}_{\text {. to }}$ to Illinoistown, opposite St. Louis. The principal points on this road will be Columbus, Dayton, Indianapolis, Terre Haute, and St. Louis. The commerce on all the completed railroads is immense, but there is no immediate means of 
ascertaining its tonnage, description, or value. The commence of Dayton by canal, was in 1850 , as exhibited in the following table, which gives the amount of the principal articles received and shipped at the port in the year referred to.

$$
\text { Articles. }
$$

Ale and beer ............. bbls.

Flour

$$
\text { Arrived. }
$$

$31 \ldots$

Cleared.

$2,047$.

$4 \ldots 4,822$

$47 \ldots$

$9,381 \ldots$

$83 \ldots$

$1,831 \ldots$

$10,765 \ldots$

$89,953 \ldots$.

$18,359 \ldots$.

$840 \ldots$

Coke ........................ "

Oats .................... "

Seeds, grass, etc. ............ "

Seed, flax ................." "

Wheat .................. "

Butter .................. lbs

Burr blocks ............... "

Furniture and baggage ..... " "

Bacon and pork ............ "

Coffee ...................." "

Cotton, raw ..............." "

Cotton yarns ............." "

Candies ..................." "

Cut Stone ................. "

Crockery, foreign .......... "

Eggs ..................... "

Fruit, green ............. "

Feathers ................." "

Grindstones ............... " "

Gypsum.................. "6

Glassware ................ "6

Hemp ................. "

Hides and skins ..........." "

Ice ....................."

Iron, pig, etc. .............. *

Iron, cast ............... "

Lard ...................." "

Leather .................." "

Machinery ................ "

Merchandise ............. "

Mrolasses .................... "

Nails and spikes ........... "

Oil cake ................... "

Paper, Ohio ............... "

Powder, Ohio .............. "

Pot and pearl ashes ........." "

Sugar ................... "

Tallow .................. "

Tobacco.................. "

Tobacco, manufactured ...... "

Wool ...................." "

White lead ................ "

Sundries ...................

Hoop poles .............. num.

Hoge .................." "6

Staves, ete. .............. "

Shingles ................." "

Lath ................... "

Lumber ................. feet

Timber ....................

$9.568 \cdots$

$5,014 \ldots$.

$392 \ldots$.

$98,053 \ldots$

$107,585 \ldots$.

$11,022 \ldots$.

$279,170 \ldots$

$294,962 \ldots$.

$2,056 \ldots$.

$795 \ldots$

$16,387 \ldots$

$116,662 \ldots$

$\overline{11,729} \ldots$

$337 \ldots$

$62,066 \ldots$

$55,395 \ldots$

$163,113 \ldots$.

$11,938 \ldots$.

$9,105 \ldots$

$78,705 \ldots 1,696,000$

$1,774,712 \ldots . \quad 59,073$

$2,396,715 \ldots . \quad 43,069$

$1,653 \ldots . \quad 498,805$

$45,776 \ldots . \quad 38,059$

$89,333 \ldots . \quad 106,322$

$1,985,092 \ldots . \quad 330,744$

$357,352 \ldots . .13,000$

$388,369 \ldots . \quad 8,758$

… ... 3,167,176

$24,111 \ldots . .531,536$

$6,681 \ldots . \quad 15,222$

$7,717 \ldots . \quad 38,087$

$673,448 \ldots . \quad 9,562$

$358 \ldots . .121,713$

$16,311 \ldots . \quad 27,161$

$94,831 \ldots \quad 14,209$

$-\ldots .58,486$

$2,066,495 \ldots 1,219,938$

$851,110 \ldots \quad 72,974$

- ... 3,497

$1,657,758 \ldots . \quad 5,400$

$3,420,250 \ldots . \quad 116,250$

$1,140,200 \ldots 55,57,000$

$4,395,273 \ldots 298,466$

$117,741 \ldots . \quad 4,226$

The several locks of the canal afford considerable motive power within the limits of the eity; and in 1845 the Dayton Hydraulic Company constructed a hydraulic canal from a point at Mad r., $4 \mathrm{~m}$. above the city, by means of which the waters of a large and unfailing stream are brought through the place, the surplus water being discharged into the canal, and thence into the Miami r., below the eity. The whole of the power thus obtained is leased to manufacturers, and this addition of motive force is justly ranked as one of the chief sources of the prosperity now enjoyed by the city. A further inerease of hydraulic facilities is projected by conducting the waters of the Miami above the eity, through a canal, and discharging them into the same river below. Dayton surpasses all other western cities of its size in the variety and extent of its manufactories. Among the most notable and extensive are those for the manufacture of railroad cars on the largest scale; paper mills, which supply no small part of the West with wrapping, news, and book paper; foundries for stoves, hollow ware, etc., the annual value of these branches alone being at least $\$ 500,000$. There is no city in the West so largely engaged in the manufacture and export of linseed oil and oil-cake as Dayton. In $1850,184,000$ bushels of seed, valued at $\$ 163,343$, produced 294,500 gallons of oil, worth at 72 e. per gallon, $\$ 212,040$; and 8,680 tons of oil-cake, worth at $\$ 10$ per ton, $\$ 26,500$, the difference between the raw seed and manufactured articles being $\$ 75,492$, which represents the gross earnings of labor and capital employed. The amount of superfine flour manufactured annually in the city is equal to 125,000 barrels.

There are three chartered banks in the city: one a branch of the State Bank, one an independent bank, and one a free bank under the new law. The aggregate capital of these is $\$ 350,000$. Besides these, there are several private banks, which employ capital amounting to $\$ 200,000$, making the banking capital of the place $\$ 550,000$, a sum inadequate to the inoreasing wants of the manufacturing and commercial interests of the community.

The charter for a city government was granted by the Legislature in 1841. The city, for municipal purposes, is divided into six wards; and its affairs are managed by 12 councilmen, representing the several wards in a single body. The present revenue of the eity from taxes, licenses, ete., amounts to $\$ 20,000$, one-third of which is devoted to educational purposes. The public buildings, though neither so costly nor so perfect in architectural detail as those of the old and wealthy cities of the country, are neat and substantial. The Court House is one of the most elegant in the valley of the Ohio; its dimensions are 127 feet in length by 62 feet in breadth. It is built of hewn blocks of coarse but compact white marble, which abounds in the vicinity-the roof is of stone and the doors of solid iron, and the style of architecture that of the Parthenon, with slight improvements. The plan seems to be faultless, and the effect of the building imposing: its whole cost exceeded somewhat $\$ 100,000$. The streets of the city are lighted with gas, supplied by a company chartered for that purpose, as are the public buildings, and, as a general thing, also the stores. The gas is made from the bituminous coal found about the head waters of the Ohio, and affords a cheap and excellent light. Coke and tar are also obtained from the coal used in supplying the works.

There are two market-houses in the city. The principal one is 400 feet long, and paved with blocks of limestone; and a part of the second story of the building is occupied as a City Hall and Council Chamber. The markets exhibit the overflowing abundance of the valley, and prices are here about 20 per cent, below those of Cincinnati, and 40 or 50 per cent. below those of Boston and New York. As the population of the city increases, however, this disproportion in prices will, of course, be less.

Besides an excellent female academy and several private schools, there are six free schools in the city, which are conducted in the most admirable manner. Five of these are "common schools ;" the sixth is called the "High school," a popular college, into which the pupils from the other schools are admitted, when they have attained a prescribed advancement in the usual English studies, and sustain a good character. The principal literary institution is the 
Library Association, which has laid the foundation of a valuable library, having now upward of 2,000 volumes of selected works. The library is open to minors, under certain restrictions; and a course of lectures is usually delivered before the Association during the winter months, which is free to the citizens generally.

The periodical press of Dayton consists of four daily newspapers (all issuing likewise weekly editions), and one weekly paper: the dailies are, the "Western Empire" (whig), the "Transeript" (neutral), the "D. Journal" (dem.), and the "D. Gazette" (whig); and the weekly newspaper is the "D. Advertiser" (whig). In point of energy and talent, the Dayton press is not surpassed by the press of older and more realthy cities.

Daтrox, p. v., Rockingham co., Virg. : 102 m. N. W. Richmond.

DEad FALL, p. o., Abbeville dist., S. Car. : $\$ 9$ m. W. Columbia.

Dead Rrver, p. o., Somerset co., Me.: on Dead r. of the Kennebec, 63 m. S. by W. Augusta.

DeAD river, $M e_{0}$; the W. branch of Kennebec $r$. It rises near the boundary of Lower Canda, and after a course of $70 \mathrm{~m}$., falls into the Kennebec, $20 \mathrm{~m}$. below Moosehead Lake. It passes through a fertile and well wooded country.

Drack's Mrels, p. o., Caldwell co., N. Car.: $160 \mathrm{~m}$. W. by N. Paleigh.

DeAN, p. F., Owen co., Ind. : 49 m. S. W. Indianapolis.

Deax's Corners, p. 0., Saratoga co., N.Y.: 26 m. N. by E. Albany.

Deasspille, p. $\nabla$. , Oneida co., $N . Y_{0}:$ on the line of the Chenango Canal, $86 \mathrm{~m}$. W. by N. Albany. Pop. 200.

DEarborix county, Ind. Situate S. E. and contains 308 sq. m. Siluate on the Ohio $r$, and drained by its tributaries, the Great Miami, White Water, Laughery, and other streams. Surface generally undulating -in some parts hilly and broken. Soil fertile. Farms 1,520; manuf. 72; dwell. 3,549, and pop.-wh. 20,021, fr. col. 145-total 20,166. Capitul: Lawrenceburg. Public Works: White Water Canal; Lawrenceburg and Upper Mississippi R. R. ; and Cincinnati and St. Louis $\mathrm{R}$. R.

Dearborkyille, p. Y., Wayne co., Mrich.: on the S. side of Piver Rouge, $72 \mathrm{~m}$. E. S. E. Lansing. An arsenal of the United States is located here; it consists of 11 brick buildings arranged on the sides of a square 360 feet on each side. These buildings are connected by a continuous wall of heavy masonry, 12 feet high.

Deardorif's Mruls, p. o., Tuscaramas co., Ohio: on Tuscarawas $\mathbf{r}_{v}, 85 \mathrm{~m}$. E. N. E. Columbus.

De.itfisville, p. v., Nelson co., $\bar{y} y .: 46$ m. W. S. W. Frankfort.

DeAtoxstrice, p. va,Amelia co.,Virg.: 33 m. S.W. by W. Tichmond.

Deatertown, p. v., Morgan co., O7io: 52 m. E. by S. Columbus. It is pleasantly situate, and contains about 320 inhabitants.

Decatur county, $G a$. Situate S. W. comer of State, and contains siu sq. m. Drained ly Flint r., which runs through it, and the tributaries of Chattahoochee $r$., which forms its TV. border. Surface moderately uneven, and soils of arerage fertility. The chief products are cotton and corn, with some sugar, ete. Farms 411; manuf. 2; dwell. 898, and pop.-wh. 4,61S, fr. col. 5, sl. 3,639-total 8,262. Capital: Bainbridge. Putlic Works: Bainbriuge Branch of Drunswick and Florida R. R.

Decatur county, Ind. Situnte S. E., and contains 350 sq. m. Drained by Flat Rock, Clifty, and Sand creeks. Surface mostly level or undulating - on the streams somewhat hilly. The bottoms are rich, though small. In the E. and S. there is some flat, wetland. Farms 1,377; manuf. 39; dwell. 2,662, and pop.-wh. 14,951, fr. col. 156-total 15,107. Capital: Greensburg. Public Works: Lawrenceburg and Luper Mississinpi P. P.
Decatur county, $I a$. Situate $\mathrm{S}$. on Missouri line, and contains $540 \mathrm{sq} . \mathrm{m}$. Drained by the head waters of Welden r., and Crooked Fork of Grand r., which traverse the co. from N. to $\mathrm{S}$. Surface elevated and beautifully diversified, and the soils eminently fertile. Numerous Hungarians are settled at New Buda, in this county. Farms 46 ; manuf. 0 ; dwell. 145, and pop.-wh. 964, fr. col.1-total 965. Capital : Nine Eagles.

DEOATUR county, Tenn. Situate centrally on the W. side of Tennessee r., and contains $320 \mathrm{sq} . \mathrm{m}$. Drained by creeks of Tennessee $r$. Surface generally level or undulating, and soils good, producing largely of corn, wheat, etc., with some tobacco. Farms 443; manuf. 15; dwell. 941, and pop.white 5,263, free col. 17, slave 723-total 6,003. Capital : Decaturville.

Decatur, p. v., Morgan co., Ala. : on the S. bank of Tennessee r., $146 \mathrm{~m}$. N. by W. Montgomery. The Tuscumbia and Decatur R. R. has its E. terminus at this point; but this $R$. R. now forms a link in the great Memphis and Cherleston Route. The v, has considerable trade, and has a weekly newspaper, called the "Morgan Advertiser." Pop, about 700 .

DeCATUR, p. ₹., and cap. De Kalb co., Ga. : on the line of the Georgia R. R., $165 \mathrm{~m}$. from Augusta, and 6 from Atlanta, $82 \mathrm{~m}$. W. N. W. Milledgeville. It is pleasantly located in a fine hilly region, and is a $\mathrm{v}$. of considerable pretensions, Pop. 744.

Decatuk, p. Y., and cap. Macon co, Ill.: on the N. W. side of the N. fork of Sangamon r., $39 \mathrm{~m}$. E. by N. Springfield. It is situate on the edge of an extensive prairie, and in the midst of a fine agricultural region. It is one of the most thriving of the inland towns of the State; and its future, when the Central $R$. R. and other railroads intended to intersect it are finished, will be one of great prosperity. Its inhabitants number some 600 , and the immediate vicinity is thickly settled.

DeCATUR, p. $v_{\text {., }}$ and cap. Adams co., Ind, : on the W. side of St. Mary's r. of the Manmee, $96 \mathrm{~m}$. N. E. Indianapolis. It contains a C. H., jail, and the co. offices, about 120 dwellings, and 231 inhabitants. It has a weekly newspaper, the "D, Gazette" (whig)

Decatur, t. and p. o., Van Buren co, Mich.: on the $\mathrm{S}$. Branch of Pawpaw r., $80 \mathrm{~m}$. W. by S. Lansing. Pop. 386.

Deoatur, p. v., and cap. Newton co., Miss. : at the head streams of Chickasawha river, $64 \mathrm{~m}$. E. by $\mathrm{N}$. Jackson.

DECATUR, to and p. $\mathrm{v}_{0}$, Otsego co, $N . \bar{Y} .: 46 \mathrm{~m}$. W. Albany. Drained by Elk and other small streams. Surface elevated and hilly. Soil a sandy loam. The v, contains 28 dwellings and 200 inbabitants. Pop. of t. 927.

Decatur, p. v., Brown co., Ohio: between the forks of Eagle cr, $84 \mathrm{~m} . \mathrm{S}$. W. Columbus. It is a thriving $\mathrm{v}$., and has several flour, grist, and saw-mills on the neighboring streams. Pop. 171.

DECATUR, p. v., and cap. Meigs co., Tenn.: about $2 \mathrm{~m}$. S. T. of Tennessee r, and 117 E, S. E. Nashville. It contains the co. offices and about 180 inhabitants.

Decatur, t. and po o, Mifflin co, Penn.: in the mountains, $42 \mathrm{~m} . \mathrm{N}$. W. Harrisburg, and watered by Jack's cr. of the Juniata $r$. It is $14 \mathrm{~m}$. N. E. of Lewistown.

DEсATUR, t. and p. v., Greene co., Wisc.: $82 \mathrm{~m}$. S. Madison. The $\mathrm{y}$, lies on the W. side of Sugar r., a branch of Rock river. Pop, of t, 55s.

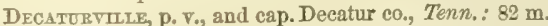
8. E. Nashville.

Droaturville, p. T., Washington co., Ohio: $78 \mathrm{~m} . \mathrm{S}$. E. Columbus.

Decker's Creek, p. o. Preston co., Firg.: on a cr. of Cheat $r$. so called, $183 \mathrm{~m}$. N. W. Richmond.

Deckertowa, p. o., Sussex co., N. Jer.: on the W. side of Wallkill r., $69 \mathrm{~m}$. N. Trenton. It has several stores, and about 160 inluabitants. The neighborhood is a fino limostone country. 
DeсоRAн, P. O., Winneshiek co., Ia.: $113 \mathrm{~m}$. N. by W. Iowa City.

DEDHAx, t., p. ., and cap. Norfolk co., Ma8s. : on Charles r., $13 \mathrm{~m}$. S. S. W. Boston. Neponset r. runs on its E. border, and a small stream runs from Charles $r$. into Neponset $\mathbf{r}$.these afford good water-power. The whole $t$. is well cultivated. The $r$. is pleasantly situated on Charles $r$., and contains about 200 dwellings, and the co. buildings. The Boston and Providence R. R. passes through the t., and gives off a branch R. R., $2 \mathrm{~m}$. long, to the village. Manufactures are carried on to some extent, and there are two newspapers published weekly, the "D. Gazette" (free soill), and the "Norfolk Democrat," Pop. 4,477.

DeED's CReek, p. o., Kasciusko co., Ind.: $100 \mathrm{~m}$. N. by E. Indianapolis.

DeEDstILLE, p. ४., Jefferson co., Ia.: $46 \mathrm{~m}$. S. by W. Iowa City.

Deep Crefk, p. ., Norfolk co., Virg.: at the N. terminus of the Dismal Swamp Canal, and on both sides of it, $87 \mathrm{~m}$. S. E. Richmond. It has a considerable trade, and exports cedar-wood and other products of the Swamp. Pop. about 160. The canal extends between Deep cr., a branch of Elizabeth r., $10 \mathrm{~m}$. from Norfolk, and Joyce's cr., forming thus a connection between Albemarle Sound and Hampton Roads-length 23 miles. It is fed by Lake Drummond, and the feeder, 3 m. Iong, $2 \frac{1}{2}$ feet deep, and 12 feet wide, is also navigable. The main canal is 40 feet wide and 6 feet deep, and has 5 stone locks on it, 100 feet by 22 feet.

DeEP Cut, p. o., Mercer co., Ohio: 94 m. W. N. W. Columbus.

Defprisur, p. $\nabla_{.}$, Renssalaer co., N.Y.; on the line of the Troy and Boston R. R., $7 \mathrm{~m}$. from Troy, and $13 \mathrm{~N}$. by E. Albany.

Deep River, p, v., Middlesex co., Conn: 33 m. S. by E. Hartford. It is situate at the confluence of Deep $\mathrm{r}$. with the Connecticut.

Defip Piver, p. o., Lake co., Ind.: on Deep r., a branch of Calumic r., $136 \mathrm{~m}$. N. W. Indianapolis.

DEEP RIVER, p. O., Poweshiek co., Ia.: 56 m. W. by N. Iowa City.

DeEp River, p. o., Guilford co., N. Car. : on the r. so called, a constituent of Cape Fear r., $72 \mathrm{~m}$. W. by $\mathrm{N}$. Raleigh.

DeEP river, $N$. Car.: one of the constituents of Cape Fear r. It has its sources in Guilford co., where it passes through Randolph into Moore and Chatham counties, in the last of which it joins the Haw, the principal branch, from which point it assumes the name of Cape Fear River.

DeEP WATER, p. o., Henry co., MOo : on the N. side of Deep Water cr., a tributary of Osage $r_{.,} 100 \mathrm{~m}$. W. by $\mathrm{S}$. Jefferson City,

DeEP W $\triangle$ TEER, p. O., Marshall co., Miss. : 167 m. N. by E. Jackson.

Deep Welu, p. o., Iredell co., N. Car. : 122 m. W. Raleigh.

Dexr Brook, p. o., Noxubee co., Miss.: 108 m. N. E. Jackson.

DeER CREek, p. v., Livingston co., Mich.: 29 m. S. E. Lansing.

Defe Creek, p. o., Mercer co., Penn.: 216 m. W. N. W. Harrisburg.

Deer Creex, p. o., Carroll co., Ind. : on a cr. of Wabash r. so called, $61 \mathrm{~m}$. N. by W. Indianapolis. Deer cr. is a fine mill-stream rising in the $\mathrm{S}$, part of Miami co, and running through Cass and Carroll counties to the Wabash, which it joins near Delphi.

Detr Creek, p. o., Issaquena co., Miss.: $49 \mathrm{~m} . \mathrm{N}$. W. Jackson.

DEERFTKLD, p. F., Randolph co., Ind.: on the S. bank of the Mississinewa r, $72 \mathrm{~m}$. E. N. E. Indianapolis.

DEERFIELD, $p_{0}$ v., Lake co,, $I l l$ : : equidistant between

Lake Michigan and Des Plaines r., 192 m. N. E. Springfield. DeERFIELd, p. va, Lenawee co., Jfich.: on the N. bank of Laisin r, $66 \mathrm{~m}$. \$. E. Lansing. The Michigan Southern
R. R. pasess through the village, $24 \mathrm{~m}$. from Monroe, and $224 \mathrm{~m}$. from Chicago.

DeERFIELD, t. and p. v., Franklin co., IFas8: $78 \mathrm{~m} . \mathrm{W}$. Boston. Drained by Deerfield r., which falls into the Con. necticut $\mathbf{r}$, here forming the $\mathrm{E}$. border of the town. The lands are very fertile, and afford the best meadows in the State. The v. is situated on a plain separated from the Connecticut by a chain of hills, and consists chiefly of one street. The town is almost wholly agricultural in its industry. Pop. 2,421

DEERFIELD, t. and p. v., Rockingham co., N. Hamp.: 10 m. S. E. Concord. Drained by Lamprey r., which runs throngh it. Surface uneven and soils difficult. Prop, 2.122.

DeErfield, $t$. and p. Y., Porlage co., Ohio: in the S. E. corner of the co. The $\mathrm{S}$. branch of Mahoning r. passes through the t. ; the $\mathrm{v}$. is located centrally. Pop. of t. 1,371.

DEerfield, p. v., Augusta co., Virg. : on Middle r., a branch of the S. fork of Shenandoah r, $108 \mathrm{~m}$. W. N. W. Richmond.

Deerfield, p. $\nabla_{*}$, Carroll par., La.: $156 \mathrm{~m}$. N. by W. Baton Rouge.

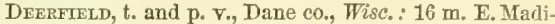
son. Drained by a fine mill-stream flowing into Lake Koshkonong. Surface level and soils rich. The $\mathrm{v}$. lies on the N. side of the creek. Pop. 639.

Drerfield Street, p. v., Cumberland co., N. Jer. : $55 \mathrm{~m}$. S. by W. Trenton. Pop. about 180 .

DeErfield Vinlage, p. v., Warren co., Ohio: on the N. bank of Little Miami r., $76 \mathrm{~m} . \mathrm{S}$. W. Columbus. It was founded in 1795 , but has never progressed on account of its liability to inundation, and its population does not now exceed 120 souls.

Deer Grove, p. o., Cook co., IIZ.: in the N. part of the co., on a cr. of Des Plaines r., $178 \mathrm{~m}$. N. E. Springfield.

DEERING, t. and p. o., Hillsborough co., N. Hamp. : $21 \mathrm{~m}$. S. W. Concord. Drained by Contoocook $r$. Surface diversified and soils of average fertility. Large quantities of brick are manufactured in this town. Pop. 1,890.

DeEr Isle, t. and p. o., Hancock co., Me. : $56 \mathrm{~m}$. E. by S. Augusta. The t. consists of an island on the $\mathrm{E}$, side of Penobscot Bay, and two or three small islands adjacent. These islands are fertile, and, having good harbors, are well situated for the shore fisheries and coasting. Pop. 3,037.

Deer Lick, p. o., Williams co., O7io : on a cr. of Maumec r. so called, $132 \mathrm{~m}$. N. W. Columbus.

DeEr PARK, p. V., La Salle co., IZl. : $6 \mathrm{~m}$. S. W. Ottame, and $109 \mathrm{~m}$. N. by E. Springfield.

Deer PARK, p. v., Suffolk co., $N_{0} Y_{.:}$on the line of the Long Island R. R., $37 \mathrm{~m}$. from Brooklyn, and $124 \mathrm{~m}$. S. S.W. Albany.

Deer Platn, p. o., Calhoun co., Ill.: in the S. extremity of the co, about $3 \mathrm{~m}$. N. of Milan, and $79 \mathrm{~m} . \mathrm{S} . \mathrm{S}$. TV. Springfield.

DeEr RTVER, p. o., Lewis co., $N_{0}, Y_{0}:$ on the r. so called, $112 \mathrm{~m}$. N. W. Albany.

Deersville, p. v., Harrison co., Ohio: 96 m. E. N. E. Columbus.

Defiarce county, Ohio. Situate N. W., and contoins 396 sq. $m$. Drained by the Maumee $r$. and its large and wide-spreading tributaries, St. Joseph's $r$., Tiffin $r$., and Blanchard's Fork. Surface uheven, with considerable level prairie, intermixed with wood and extensive bottoms. It is a fine grain county. Farms 296; manuf. 31 ; dwell. 1,237, and pop. -wh. 6,947, fr. col, 19-total 6,966. Capital. Deriance. Public Works: Miami Canal; and a R. R. from Fort Wayne to Maumee City, ete.

Defiarce, t., p. v., and eap. Deflance co., Ohio: at the confluence of the Au Glaize and Maumee rivers, on the line of the Wabash and Erie Canal, a few miles above the junction of the Miami Canal, and on that of the R. R., between Sandusky City and Fort Wayne, $114 \mathrm{~m} . \mathrm{N}$. W. Columbus It is thus most eligibly located for commeree at a poin where canals, railroads, and navigable rirers have a com- 
mon junction, and from which in every direction the avenues are uninterrupted. In the old Indian wars it was a poin of military importance. It contains the county buildings, offices, etc., has numerons saw, grist, and flour mills, \&e. Pop. of T. 890 .- -t. 1,281. Two newspapers, the "D. Democrat" (dem), and the "D. Banner" (whig), are issued weekly.

Defrietgville, p. v., Rensselaer co., $N$. $Y$.: 4 m. S. E. Albany. It contains 23 dwellings, and 130 inhabitants.

De GLAtze, p. o., Morehause par, La. : 167 m. N.W. by N. Baton Rouge.

DE KALB county, Ala. Situate N. E., and contains 720 sq. m. Drained by Big Will's cr. of Coosa r., and several creeks, tributaries of Tennessee $x$. The surface is generally hilly, except in the river valleys, in which the land is of extraordinary fertility. Indian corn and cotton, with tobacco, etc., are the chief products. Farms 616 ; manuf. 8 ; dwell. 1,254, and pop.-wh. 7,780, fr. col. 9, sl. 506-total 8,245 Capital: Lebanon. PublicWorks: Selma and Tennessee River R. R.

De KALB connty, Ga. Situate N. centrally, and contains $360 \mathrm{sq}$. m. Drained by branches of the Ocmulgee $\mathrm{r}$. and of the Chattahoochee r., the latter of which forms the N. W. border. Surface, an elevated table-land, and of a productive soil. Indian corn and wheat, with cotton and tobacco, form its staples. Farms 1,019; manuf. 45 ; dwell. 1,792, and pop.-Wh. 11,372, fr. col. 32, sl. 2,924 -total 14,328, Capitul: Decatur. Public Works: Georgia R. R.; Western and Atlantic R. R.; Macon and Western R. R.; La Grange R. R., etc.

KE KALB county, $Y l l$. Situate on the summit between the Illinois and Rock rivers, and contains $648 \mathrm{sq}$. m. Drained by Kishwaukee r., flowing N. W. to Rock r., and Fox r. and its branches, flowing $\mathrm{S}$. to the Illinois. Surface chiefly prairie, with groves of timber beautifully varying the scene Soils deep, dark, and rich. Farms 812 ; manuf. 4 ; dwell. 1.308, and pop.-wh. 7,539, fr. col. 1-total 7,510. Capital. Syeamore.

DE KALB county, Ind. Situate N. E., and contains 365 sq. m. Drained by St. Joseph's of the Maumee, and its several tributary ereeks. Surface undulating, and, with the exception of some wet prairies, heavily timbered. Soils excellent. Farms 831; manuf. 16 ; dwell. 1,421, and pop.wh. 8,241, fr. col. 10-total 8,251. Capital: Auburn.

DE KALB county, Mo. Situate N. W., and contains 432 sq. m. Drained by Blue and Grindstone creeks of Grand r., and by Castile and Livingston creeks, and the Third Fork of Platter. Surface, undulating prairie, varied with woodland. Soils fertile and productive. Farms 229 ; manuf.
1; dwell. 338, and pop.-wh. 2,008, fr, col. 2, sl. 65-total 2,075. Capital: Maysville.

De KaLB county, Tenn. Situate centrally, and contains $280 \mathrm{sq.} \mathrm{m}$. Drained by the tributaries of Caney Fork of Cumberland $\mathbf{r}$., which runs through the co. The N. part of the co. is hilly, but the S. and W. are level barrens, affording a plentiful subsistance for cattle. The grains, with cotton and tobacco, are produced; and there are some important manufactures. Farms 717 ; manuf. 24 ; dwell. 1,217, and pop.-wh. 7,335 , fr. col. 13, sl. 668-total 8,016 . Capital: Smithville.

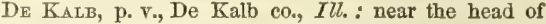
Sycamore $\mathrm{r}$., $152 \mathrm{~m}$. N. N. E. Springfield.

DE KALB, p. v., and eap. Kemper co., Miss. : about $2 \mathrm{~m}$. S. of Sacarnochee cr., and $97 \mathrm{~m}$, E. N. E. Jackson.

DE KALb, p. v., Buchanan co, Mo.: in the S. W. part of the co., 167 m. W. N. W. Jefferson City.

$D_{E} K_{A L B}, t$. and p. v., St. Lawrence co., $N . Y$.: on both sides of Oswegatchie r., $146 \mathrm{~m}$. N.W. Albany. The surface is hilly, and there is abundance of marble and iron ore. The $\mathrm{v}$. is situated on the E. side of the $r$., at the head of navigation, and contains about 40 dwellings. At the falls, immediately abore, there is immense water-power.

DE Kars, p. v., Gilmer co., Vüg.: on Little Kanawha r., $207 \mathrm{~m} . \mathrm{N}$. W. by W. Richmond.

DE KALB, p. v., Bowie con, Tex, : on Mud cr, of Red $r_{\text {. }}$ 297 m. N. E. Austin City.

DE KALB, p. v., Crawford co., Ohio: 66 m. N. by E. Columbus.

De Kalb Centre, p. 0., De Kalb co., IUl.: 148 m. N. N. E. Springfield.

Dekorra, t. and p. v., Columbia co., Wisc. : $26 \mathrm{~m} . \mathrm{N}_{\text {. }}$ Madison. Drained by the Wisconsin r., which runs through it. The $\mathrm{v}$. is situated on the S. E. side of the stream, and is well located for trade. Pop. of t. 661 .

Delafield, t. and p. .., Waukesha co., Wisc.: $49 \mathrm{~m} . \mathrm{E}$, Madison. Pop. 1,134,

DE Lafoey, p. V., Madison co. $N_{*}, Y_{*}: 104 \mathrm{~m}$. W. N. W. Albany.

DFiapalma, p. o., Brown county, Ohio: $82 \mathrm{~m}$. S. W. Columbus.

Delavai, p. v., Tazewell co., $I Z_{1}: 42 \mathrm{~m} . \mathrm{N}$. by E. Springfield.

Detapas, p. y., Cattaraugus co, $N . Y_{*}: 243 \mathrm{~m} . \mathrm{W}$. by $\mathrm{S}$. Albany. It is located on a tributary of Cattaraugus creek.

Delavax, t, and p. v., Waltyorth co., Wisc. : 49 m. S. E. Madison. Pop. 1,260.

\section{TIIE STATE OF DELAWARE.}

Delaware, next to Fhode Island, the smallest State of the Tnion, and, in point of population, much inferior to that State, lies between $3 S^{\circ} 28^{\prime}$ and $399^{\circ} 47^{\prime}$ latitudes N., and between $74^{\circ} 56^{\prime}$ and $75^{\circ} 46^{\prime}$ longitudes W. of Greenwich, or $1029^{\prime}$ and $2006^{\prime} \mathrm{E}$. of Washington. It is bounded on the N. by Pennsylyania (from which the are of a circle drawn with a radius of 12 miles from Newcastle as a centre, divides it), on the E. by Delaware Bay and the Atlantic Ocean, and on the S. and W. by Maryland. occupying the north-eastern portion of the peninsula between the bays Chesapeake and Delaware. The $\mathrm{N}$. and $\mathrm{W}$. and $\mathrm{S}$, boundaries were originally determined by Mason and Dixon, under whose name the lines are still known. The length of the State, N. and S., is about 92 miles, and its width varies from 36 miles in the S. to

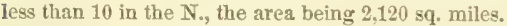

Nearly the whole of Delaware lies on the Atlantic plain. The northern part, however, to Christiana creek, belongs to the primary tract, and is hilly and somewhat rugged; but there are no hills exceeding 500 feet in height above the ocean. South of the creek above named, the surface is an almost perfect level, the general slope being toward the Delaware and the ocean. In the south-west the direction of the slope is toward Chesapeake Bay. A table-land, or low sandy ridge, nowhere more than 60 or 70 feet in height near its western boundary, passes through the State, and forms the watershed of the peninsula. This table-land abounds with swamps, in which most of the rivers and streams have their sources, some flowing west into the Chesapeake, and others east into the Delaware. At the southern extremity of the State is the Cypress Swamp, a morass 12 miles in length and 6 miles in width, including $\mathrm{an}$ area of 50,000 acres of land, the whole of which is a high and level basin, very wet, though undoubtedly the highest land between the sea and the bay. This swamp contains a great variety of trees and plants, and is infested by wild animals and roptiles. In the northern parts of the State, along the Delaware River and Baj, and for 8 or 10 miles inland, the soils are generally rich clays, in which the most useful agricultural staples can be easily reared; from thence to the swamps the soil is light and sandy, and of an inferior quality; and the central and southern parts have also a sandy soil, which gradually 


\section{DETATIRE.}

becomes more unproductive as the south is approached. Bog-iron ore is found in the swampy tracts iri the south, and has long been used for economical purposes; shell marl, highly valuable in agriculture, occurs, and in the north is found kaolin or porcelain clay, which has supplied the Philadelphia Works with that valuable earth.

The climate of the State is generally mild, and highly favorable to agrieultural pursuits. The northern portion has a salubrions atmosphere, but where the land is swampy, endemic sicknesses prevail to a considerable extent, The natural productions are similar to those of the middle region of the Atlantic States. Some large timber grows in the north, and throughout the State, in localities, woods of various kinds are found, and much has been exported at different periods.

All the rivers of Delaware are small, generally rising within the State, and flowing into the Delaware; the Brandywine, however, comes in from Pennsylvania, and the head waters of the Choptank and Nanticoke, which pass into Maryland, are within its limits. The streams are generally wide in proportion to their length, and navigable by gmall craft several miles from their mouths. The Brandywine (Brandewyne or Brandy River, of the Duteh) is, in the upper part of its course, a valuable mill-stream, but at Wilmington it receives Christiana Creek, and becomes navigable for large ships. Small vessels also go up the latter branch to Christiana Bridge. The Appoquinnimink River, Duck Creek, Jones' Creek, Mother or Murder Kill, Mispilion or Mospihon Creek, Broad Kill, Indian Creek, etes, are the other principal streams.

The eastern shore is washed by Delaware Bay; in all its length it has no good harbors, but generally presents long sandy beaches to the waves. To remedy this inconvenience, the General Government has constructed the Delawarc Breakwater, opposite the village of Lewestown, and above Cape Henlopen: it consists of two piers, one of which is designed to form a shelter from the fury of the waves, which roll in here with great violence, and the other to afford protection from the masses of floating ice brought down by the ebb tide. The breakwater proper is 2,743 feet long at the bottom, or 2,030 feet above high water, 75 feet wide at low water mark, and raised 15 feet above low, or 3 feet above high water mark. The ice-breaker is 1,710 feet in length at bottom, and 1,378 at top, of the same breadib as the breakwater, but only 9 feet in height. The whole work has cost nearly $\$ 3,000,000$. Rehoboth Bay, and the estuary, called Indian River, are the only arms of the sea extending inland: these, about 9 miles south of Cape Henlopen, are spacious but shallow basins, not admitting vessels of more than 6 feet draft. Cape False is the headland forming the south side of their common inlet from the ocean.

The first European settlers of Delaware were Swedes and Dutch, and their posterity still remain here, but have become merged in the more numerous body of other origins. There are a large number of blacks in the State, constituting onefourth of the whole population, but of these only a small portion is held in slavery. The first census of which there is any record, was that of 1652 , when there were about 3,000 inhabitants in the State; in 1700 the estimated number was 6,000 , and in 1750 it had risen to 25,000 . The flrst United States' census, taken in 1790 , gives the whole population at 59,096 , and from that period its decennial movements have been as follows:

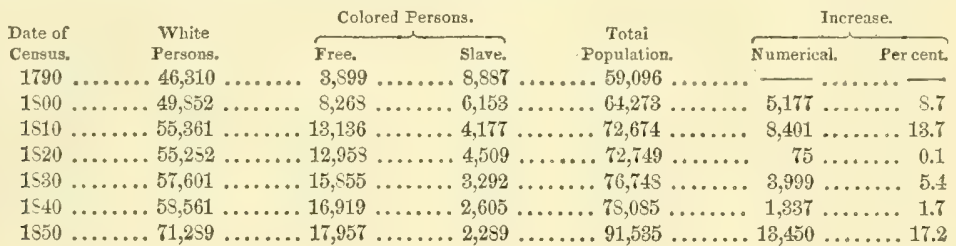

Of the total population, in 1850, there were persons deaf and dumb, 58; blind, 46; insane, 70; and idiotic, 101.

The State of Delaware is divided into 3 counties and 25 hundreds. The counties are Newcastle, in the north; Kent, in the middle; and Sussex, in the south. Newcastle County is subdivided into 9 hundreds, viz. : Appoquinnimink, Brandywine, Christiana, Mill Creek, Newcastle, Pencader, Red Lion, St. George's, and White Clay Creek, and contains an area of 271,490 acres. Kent County is subdivided into 6 hundreds, viz.: Dorer, Duck Creek, Little Creek, Mother or Miurder Kill, Milford, and Mispilion, and contains an area of 392,660 acres. And Sussex County is subdivided into 10 hundreds, viz.: Broad Kill, Broad Creek, Baltimore, Cedar Creek, Dagsborough, Indian River, Little Creek, Lewes and Rehobotl, Nanticoke, and North-West Fork, and contains an area of 636,100 acres.

Agriculture is the principal occupation of the inhabitants; but in the north, where there is abundance of water-power, manufactures have long been in existence, and are in a very flourishing condition. Commerce and trade are also extensive, and the whale fisheries have been prosecuted with success from Wilmington. The statistics of the wealth and industry of the State in 1850, as exhibited in the census, etc., of that year, were as follows:

Occupied Land8, otc.-Improved lands, 580,862 acres; and unimproved lands, 375,252 acres-valued together at the sum of $\$ 18,880,031$. Number of farms, 6,068 . Value of farming implements and machinery, $\$ 510,279$.

live-Stock.-Horses, 13,852 ; asses and mules, 791; milch cows, 19,248; worling oxen, 9,797; other cattle, 24,166 Bheep, 27,503; and swine, 56,261-valued in the aggregate at $\$ 1,849,281$.

Grain Crops.-Wheat, 482,251 bushels; rye, 8,066 bushels; Indian corn, 3,145,533 buslsels; oats, 604,518 bushels; barley, 56 bashels; and buckwheat, 8,015 bushels.

Other Crops.-Peas and beans, 4,120 bushels; Irish potatoes, 240,542 bushels; sweet potatoes, 65,443 bushels; hay, 30,159 tons; clover-seed, 2,525 bushels ; other grass-seed, 1,403 bushels; hops, 348 pounds; water-rotted hemp, o70 tons ; flax, 11,050 pounds; flax-seed, 858 bushels; molasses, 50 gallons; wine, 145 gallons, ete. The value of orchard products amounted to $\$ 46,574$; and the value of market-garden products, to $\$ 12,714$.

Products of Animats.-Wool, 57,765 pounds; butter, 1,055,308 pounds; cheese, 3,157 pounds; and the value of animals slaughtered in the year, $\$ 373,665$. Beeswax and honey were produced to the amount of 41,215 pounds.

Home-made manufactures, for the year ending 1st June, 1850, were valued at $\$ 38,121$

Manufactrures.-Aggregate capital invested in manufactures, $\$ 0,000,000$; value of raw material, fuel, ete., consumed, $\$ 0,000,000$; average number of hands employed, 00,000 -males, 00,000 , and females, 0,000 ; average monthly cost of labor-male, $\$ 000,000$, and female, $\$ 00,000$; annual value of manufactured articles produced, $\$ 0,000,000$. The wholc number of manufacturing establishments, producing to the value of $\$ 500$ and upward in 1550 , was 513 ; and of these, 12 were cotton factories, 8 woolen mills, 15 establishments engaged in manufacturing iron, viz. : 13 in manufacturing castings, and 2 wrought iron, and 16 tanneries. In the cotton manufactures, the cupital invested amounted to $\$ 460,000 ;$ the cotton con- 
DELAWARE.

sumed in the year, 4,730 bales of 400 pounds; and the value of all raw material, $\$ 312,068$; hands employed-male 413 and femalc 425 ; monthly cost of labor-male $\$ 6,326$, and female $\$ 4,926$; products for the year, 3,521,636 yards sheeting etc., and 533,000 pounds yarn, valued together at $\$ 538,439$. The capital invested in the voolen manufacture was $\$ 145,500$; wool consumed, 393,000 pounds; value of all raw material, $\$ 204,172$; average hands employed-male 122 , and female 15 ; monthly cost of labor-male $\$ 2,293$ and female $\$ 312$; annual products, 152,000 yards of cloth, etc., valued in the aggregate at $\$ 251,010$. In the manufacture of castings, the capital invested was $\$ 373,500$; the value of raw material, fuel, etc., $\$ 153,852$; hands employed, 250 , at average wages per month, $\$ 23.36$. Castings manufactured in the year, 3,630 tons; and value of entire products, $\$ 267,462$, of which $\$ 55,000$ was the value of articles other than castings. The capital invested in vrought iron manufactures, amounted to $\$ 15,000$; value of raw materials, $\$ 19,500$; hands employed, 50 males, at average monthly wages of $\$ 24.19$; tons of wrought iron made in the year preceding, 550 ; and value of entire products, $\$ 55,000$. In the tanneries, the capital employed amounted to $\$ 99,350$; the value of hides and skins used, $\$ 99,620$; hands employed, 108, costing monthly, $\$ 2,530$; number of skins tanned, 12,950, and of sides of leather, 52,100-together valued at $\$ 163,742$. The remaining employments of the aggregate number $(513)$ are various, but in the main consist of mills for flouring, grist-mills, saw-mills, gunpowder-mills, paper-mills, smitheries, etc.; and in the north are several machine-shops. Some salt is made from sea-water at Lewes and Rehoboth, and considerable ship-building is carried on at Wilmington.

Foreign Commerce.-The direct foreign commerce of Delaware is very inconsiderable, as the importations and exportations of the State are chiefly effected through Baltimore, New York, and Philadelphia, especially the latter port; the coasting trade, however, is extensive and active. During the year ending 30 th June, 1850, no direct imports or exports are recorded in the Treasury returns. The amount of shipping owned within the State at the above date amounted to 16,719 tons, of which 1,651 tons was of the class "registered," 14,689 tons of the class "licensed and enrolled," and 447 tons small licensed craft under 20 tons. The shipping sailed by steam-power amounted to 2,774 tons. There were built within the year 16 vessels, of an aggregate burden of 1,848 tons, viz. : 12 schooners, 8 sloops, and 1 steamer. The following table will exhibit the movement of foreign commerce in the State from 1791 to 1850 :

\begin{tabular}{|c|c|c|c|c|c|c|c|c|c|c|}
\hline ars. & Exports. & Imports. & Years. & Exports. & & Imports. & Years. & Exports. & & Imports, \\
\hline 791. & $\$ 119,879 \quad \ldots \ldots$ & & $1811 \ldots \ldots$ & $\begin{array}{r}\$ 88,632 \\
29,744\end{array}$ & ... & $\$$ & $\begin{array}{l}1831 . \\
1832 .\end{array}$ & $\begin{array}{r}\$ 81,514 \\
16,242\end{array}$ & $\ldots \ldots$ & $\begin{array}{r}\$ 21,656 \\
23,653\end{array}$ \\
\hline $792 \ldots \ldots \ldots$ & $\begin{array}{r}138,972 \quad \ldots \ldots \\
93,559 \quad \ldots \ldots\end{array}$ & & $\begin{array}{l}1812 \ldots \ldots \ldots \\
1513 \ldots \ldots\end{array}$ & $\begin{array}{r}29,44 \\
133,432\end{array}$ & & & 1888. & 45,911 & & $\begin{array}{r}20,000 \\
9,043\end{array}$ \\
\hline $94 .$. & 207,995 & & .... & 14,914 & & & 1834. & 51,945 & & 185,493 \\
\hline$\ldots$ & 158,041 & & .... & 105,102 & & & $1835 \ldots \ldots \ldots$ & 88,826 & & 10,611 \\
\hline $96 .$. & 201,142 & & $1816 \ldots \ldots \ldots$ & 56,217 & & & $18: 36 \ldots \ldots \ldots$ & 74,981 & & 107.063 \\
\hline ..... & $9 \$, 929$ & & $1817 \ldots \ldots \ldots$ & $44: 554$ & & & $1 \leqq 3 \pi \ldots \ldots \ldots$ & 40,333 & & 66,811 \\
\hline .... & 183,727 & & $1818 \ldots \ldots \ldots$ & 81,525 & & & $1838 \ldots \ldots$ & 36,544 & & 1,348 \\
\hline$\ldots$ & 297,065 . & & ........... & 29,829 & & & $9 \ldots \ldots \ldots$ & 8,630 & & none \\
\hline . & 418,695 & & $20 \ldots$ & 89,493 & & & $1810 \ldots$ & 37,001 & & 802 \\
\hline [S0 & 662,042 & & 1821. & 85,445 & & 80,997 & $18 t$ & $33,5 \$ 5$ & & 3,276 \\
\hline .. & $440,504 \ldots \ldots$ & & $522 .$. & 168.492 & & 216 & 184 & 58,655 & & 3,537 \\
\hline ..... & 428 & & .......... & 53,837 & & 24 & 18 & 95,682 & & $4,6 \$ 5$ \\
\hline . & 697,396 & & ........ & 18,964 & & & . & 126 & & 8,093 \\
\hline 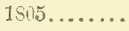 & 355,383 & & ......... & 31,656 & & 98 & $1 \mathrm{~s}-$ & 95 & & 2,274 \\
\hline . & 500,106 & & $1826 \ldots \ldots \ldots$ & 35,195 & & 10,009 & $1546 \ldots \ldots \ldots$ & $146,2 \geq 2$ & & 11,215 \\
\hline .... & 229,275 & & $1827 \ldots \ldots \ldots$ & 9,406 & & 3 & $1847 \ldots \ldots \ldots$ & 235,459 & & 12,722 \\
\hline & .... & & 18 & 29,396 & 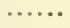 & & $1548 \ldots . . . .$. & 83,058 & & 490 \\
\hline & & & & & ... & & $1849 \ldots \ldots \ldots$ & 35,229 & & 1,400 \\
\hline 10 & 120,342 & & $1830 \ldots$ & 52,258 & & 26,574 & $1850 \ldots \ldots \ldots$ & none & & none \\
\hline
\end{tabular}

Internal Communication.-Except in the north, where the State is crossed by a canal and two railroads, the lines of travel are over ordinary turnpike and M'Adam roads. The Chesapeake and Delaware Canal is an important work, connecting those bays by a channel navigable for sea-going ressels; it extends from Delaware City, 46 miles below Philadelphia, to Back Creek, a navigable branch of Elk River, in Maryland, $13 \frac{1}{2}$ miles, and is 66 feet wide at the top and 10 feet deep, and it has two tide and two lift locks. The deep cut in this canal is 4 miles in length, through a hill 90 feet high. The work was complefed in 1829, at a cost of $\$ 2,250,000$. The Newcastle and Frenchtown R. R. extends also across the peninsula, between the Delaware and the Chesapeake, 16t miles, and, in connection with steamboats at each terminus, forms a convenient line of transportation between Philadelphia and Baltimore. The Philadelphia, Wilmington, and Baltimore R. R. crosses Delaware further north, and is the nearest land line between those cities, and the usual route taken by travelers between the Northern and Southern States. These are all the completed works of internal improvement within the State, but there are others projected and in progress, the object of which are prineipally to form a direct line from New York to Norfolk in Tirginia, and incidentally to afford accommodation to the agriculturalists of the sonthern sections.

Banks, etc.-On the 1st day of January, 1851, there were in Delaware six banks and three branch banks. The agcregate condition of these at that date was as follows: 7iut,ititic - capital, $\$ 1.293 .155$; circulation, $\$ \$ 3: 3,960$; deposits, $\$ 592.765$; other liabilities, $\$ 170.53$; and asset.s-loans and discounts, $\$ 2.284 .413$; stocks. $\$ 52,953$; real estate, $\$ 117,941$; other investments, $\$ 2,000$; other assets, $\$ 2 \$ 1,145$; specie funds, $\$ 51,022$, and specie, $\$ 159,778$.

Government.-The present constitution of Delaware gives the right of voting to all free white male citizens 21 years old, and who have resided in the State one year and in the county in which they offer to vote one month next before an election.

The legislature, styled the General Assembly, consists of a Senate and Innuse of Representatives. Senators, three from each county, must be at least 27 years old, possessed of 200 acres of freehold land in the county, or of an estate therein worth $\$ 1,000$, citizens and inhabitants of the State for three years, and for the last year of the county, and must bs chosen in counties for the term of four years. Representatives must be at least 24 years old, and have the same qualifcations as senators, exeept as regards the property qualification, and must be chosen for two years. The legislature meets at Dover on the first Monday in January biennially 


\section{DELAWARE.}

Delaware sends only one Representative to the Federal Congress.

The Governor (elected for four years by a plurality of votes) must be at least 30 years old, a citizen of the State for twelve years next before the first meeting of the legislature after his election, and an inhabitant for the last six years. The President of the Senate, the Speaker of the Representatives, and the Secretary of State are successively alternates to fill the office should it become vacant by death or disability of the Governor; but in case the office be filled by the Secretary of State, the General Assembly, at its next session, chooses a Governor ad interim. If the Governor elect die, decline, etc., the Governor in office continues until a new election is had. The Secretary of State is appointed by the Governor. The general elections are held on the second Tuesday of November.

The Judiciary consists of a Superior Court, Court of Chancery, Orphans' Court, etc. 'There are flve judges in the State, one of whom is Chancellor and President of the Orphans' Court, and of the other four, one is Chief Justice of the State, and three associate justices, one resident in each county. The Chief Justice and two of the associates form the Superior Court and Court of General Session, and all the judges, except the Chancellor, form the Court of Oyer and Terminer. The Court of Errors and Appeals is composed of three or more of the judges. The Orphans' Court consists of the Chancellor and the associate judge of the county. Judges are appointed and hold office during good behavior. The Register's Court is held by the Register, with appeal to the Superior Court, and all proceedings are in writing.

The constitution provides that no act of incorporation shall be passed without a two-third rote, unless it be the renewal of an existing incorporation; and all acts are to contain a power of revocation by the legislature. No act hereafter passed shall be in force longer than twenty years without a re-enactment of the legislature. No person belonging to the military, naval, or marine service of the United States can gain such a residence as will entitle him to vote by being stationed at any military or naval post in the State.

Finances, etc.-The government of Delaware is one of the least expensive in the Union. In 1850 the whole income amounted to only $\$ 31,86333$, and the expenditure to a sum $\$ 5,07141$ less than the income. The sources of income were-bank tax, $\$ 3,963$ 61; railroad tax, $\$ 2,500$; interest on loans, $\$ 5,14762$; bank dividends, $\$ 15,305$; retailers' licenses, etc., $\$ 4,35280$; fines, etc., $\$ 54981$, and sundries, $\$ 4549$. The expenditures were-executive, $\$ 3,33833$; legislature, $\$ 2,01097$; judiciary, $\$ 5,500$; school fund, $\$ 15,94762$, and balance, $\$ 5,07141$. The resources of the State are amply sufficient to meet all expenses of the government without recourse to personal or property tax. The invested capital of the State (including school moneys) amounts to $\$ 414,72583$, and the permanent annual income is as follows: dividends and interest on loans, $\$ 20,05264$; taxes on corporations, $\$ 5,725$; retailers' and tavern licenses, $\$ 4,3 \widetilde{2} 80$; fines and forfeitures, $\$ 54981$, and sundries, $\$ 1,07375$. The State is free from debt of any description.

Religious Denominations.-The statisties of the several religious denominations, as given by each severally, in 1850 , were as follows: the Protestant Episcopal had a bishop, 16 clergymen, 587 communicants; the Roman Catholics had 4 churches (at Brandywine, Delaware City, Newcastle, and Wilmington), and 3 priests; the Baptists (regular) had 1 church, 2 ordained and 2 licensed ministers, and 352 members; the Baptists (anti-mission) had 10 churches, 3 ordained and 3 licensed preachers, and 335 members; the Presbyterians (O. S.) belong to the Synod of Philadelphia and Presbytery of Newcastley and had 17 ministers and 1,276 members; the Presbyterians (N. S.) belong to the Synod of Pennsylvania and Presbytery of Wilmington, and had 15 clergy and 1,324 members; the Methodists have about 20 ministers, and are more numerous than any other single denomination; and there are also a considerable number of Quakers in the State.

Educational Statistios. - The number of free schools in the State in 1850, was 209, and of scholars attending them 13,288, divided as follows: Newcastle County, 72 schools and 4,969 scholars; Kent County, 55 schools and 3,876 scholars, and Sussex County, 82 schools and 4,443 scholars. The total amount paid for tuition was $\$ 38,46170$, viz.: in Newcastle, $\$ 17,29372$; in Kent, $\$ 10,96472$, and in Sussex, $\$ 10,20326$; and there was a sum charged for contingencies amounting to $\$ 5,74768$, making the annual cost, $\$ 44,20938$. The sources whence these moneys were derived are stated thus-from School Fund, $\$ 27,50733$, and from contribution and tax, $\$ 17,08956$. Besides these there are between 34 and 40 academies and grammar schools in the State. Delaware College, at Newark, was founded in 1833, and in 1850 had a president, 5 professors, and 30 students; its alumni at that period numbered 78 , of which 42 were in the ministry, and its library contained 7,000 volumes. St. Mary's College, at Wilmington, is under the sway of the Roman Catholics, and is, perhaps, the best literary institution of the State; in $1850 \mathrm{it} \mathrm{had} \mathrm{a} \mathrm{president} \mathrm{and} 3$ professors, and 107 students.

Periodical Press.-The whole number of newspapers published in Delaware in 1850 was 11, and of these 2 were issued tri-weekly, 1 semi-weekly, and 8 weekly (of the weekly, however, 3 are editions of the tri-weeklies and the semiweekly newspapers). The total circulation of each edition of the tri-weeklies was 1,900 , of the semi-weekly 1,000 , and of the weeklies 4,600 copies-in the aggregate equal to 12,300 copies weekly, or 639,600 copies annually.

Historical Sketch-Lord De la War, Governor of Virginia, appears to have been the first to enter the bay which thence took his name. This was in 1610 . The Duteh, from whom the names of its capes are derived, frequented it soon after, and had a post at Hoerenkill, but the precise date of their arrival is uncertain. The bay was by them called Nieuw Port May, or Godyn's Bay, and the river Zuyd Rivier, or South River. The Swedish W. I. Company, chartered in 1635 by Oxenstiern sent out in $1637 \mathrm{a}$ ship with a body of colonists under Peter Menewe or Minuits. In the following year Minuits seated himself on the Maniques, now Brandywine River, and there built Fort Christina. The Dutch, however, had never relinquished their elaim in this region, and in 1651 they built Fort Cassimir on the site of Newcastle. The subsequent settlements of the Swedes were mostly within the present limits of Pennsylvania, where New Gottenburg (Nya-Gœtheborg), the capital of New Sweden (Nya-Sveriga), was founded on the Island of Tinicum. In 1655 a small force from New Amsterdam reduced the Swedish settlements, which were incorporated with New Netherlands, and with that colony taken possession of by the English in 1664. The settlements on the Delaware, although this region fell within the chartered limits of Maryland, were attached to the province of New York until 1681, when they were purchased of the Duke of York by William Penn, who annexed them to Pennsylvania under the name of the Territories, or the Threa Loncer Connties on the Delaucare. They continued subordinate to that province, though with a distinct Iegislature, from 1701 until 1776 , when Delaware declared itself an independent State, and a constitution was framed by the inhabitants thereof. By this constitution the exective power was vested in a President and Privy Council, elected by the legislature. In 1792 a new constitution was framed, which was modified in 1802, in 1831, and in 1838; and it is now again proposed to alter the fundamental law. The principal provisions of the present constitution are given elsewhere. Delaware has hitherto been one of the least progressive of the American States, but within the last decade its population, material wealth, and general interestr have been developed in a very respectable ratio.

Dover is the capital of the State. 
DrLatwarze county, Ia. Situate N. E., and contains 576 sq. m. Drained by numerous tributaries of Makoqueta $r_{. s}$ which passes through the co. from $\mathrm{N}$. W. to S. E., furnishing excellent mill-power. Surface chiefly prairie, intermixed with timber groves. Soils of good quality, deep and productive. Farms 141; manuf. 3 ; dwell. 338 , and popwh. 1,759, fr. col, 0-total 1,759. Capital: Delhi.

DeraWARE county, Ind. Situate E., and containg 394 sq. $m$. Drained by White and Mississinewa rivers. Surface level or gently undulating, and mostly well timbered. Wheat and Indian corn are largely produced, and much attention is given to stock. Farms 1,084; manuf. 34; dwell. 1,874, and pop-wh. 10,839, fr. col. 4-total 10,843. Capital: Muncietown. Pullic Works: Indianapolis and Bellefontaine R. R.; Fort Wayne and Southern R. R.

DELAWARE county. $N . Y$. Situate toward the S. E., and contains 1,362 sq. m. Drained by the Mohawk or Delaware r. and its affluents. Surface greatly diversified by valleys and motuntains; the latter being extremely irregular, and broken by numerous streams. Soils generally of good. quality -in the valleys a rich deep mold, and on the hills a sandy loam, somelimes stony. Dense forests cover a great portion of the land. Grain and grass are produced abundantly, and grazing is much attended to, the butter produced being second only in quality to that of Oneida co. Lumber is floated to market on the Delaware and Susquehanna rivers. Farms 4,747; manuf. 433; dwell. 7,105, and popwh. 39,628, fr. col. 206-total 39,834. Capital: Delhi. Public Horks: New Fork and Erie R. R.

DeLAWARE county, Ohio. Situate centrally, and contains $612 \mathrm{sq} . \mathrm{m}$. Drained by Scioto and Whetstone riyers, and Alum and Big Walnut ereeks, which run from N. to S. through the co., and furnish extensive water-power. Surface rolling, and well supplied with timber. Soils generally of excellent fertility-wheat, Indian corn, potatoes, grasses, tobacco, etc., grow finely, and cattle, sheep, and swine are raised in large numbers. Farms 1,855; manuf. 95; dwell. 3,754, and pop-wh. 21,682, fr. col. 135-total 21,S17. Capitat: Delaware. Public Works: Cleveland, Columbus, and Cincinnati R. R.; Springfleld, Mount Vernon and Pittsburg R. R., etc.

Driatare county, Penn. Situate S. E. extreme, and contains $224 \mathrm{sq}$. m. Drained by Darby, Ridley, and Chester creeks of Delaware $\boldsymbol{r}$, which forms its S. E. borders. The surface is moderately undulating, and the soils very fertile and highly cultivated. Its agricultural products are wheat, Indian corn, and potatoes, besides which it furnishes an immense amount of regetables for the Philadelphia markets. It has a large trade, and its manufacturing interest is very extensive, embracing woolens, cotton goods, leather, crockery, and paper. Farms 1,376; manuf. 299; dwell. 4,118, and pop,- $\pi \mathrm{h} .23,120$, fr. col. 1.559-total 24,679 . Capital: Chester. Public Works: Philadelphia and Columbia R. R.; Philadelphia, Wilmington, and Baltimore R. R., ete.

DeLATARE, p. v., Jersey co., $I l$.: in the N. E. part of the co., $51 \mathrm{~m}$. S. W. Springfleld.

Delaware, p. 0., Ripley co., Ind.: $72 \mathrm{~m}$. 8. E. Indianapolis.

Dela IV ARE, p. O., Indian country, Nebr. Ter.

Delaware, t. and p. v., Pike co., Penn. on the W. side of Delaware r., $126 \mathrm{~m}$. N. E. Harrisburg. The $\mathrm{v}$. lies on the Delaware. The lands are drained by Dingman's cr. and Bushkill cr. Pop. 501.

DeLAWARE, t., p. v., and cap. Delaware co., Ohio: on the W. bank of the Oleatangy or Whetstone r., $22 \mathrm{~m}$. N. by W. Columbus. The r. contains a handsome $\mathrm{C}$. H. and other co. offices, 6 churches, several factories and mills, etc., and of late has become connected with the railway commerce of the State, by which it will rapidly increase in importance and wealth. It lies on the line of an $\mathrm{E}$. and $\mathrm{W}$. railroad, and has connections with the Cleveland, Columbus, and Cincisnati R. R., which runs $\mathrm{N}$. and $\mathrm{S}$. about $4 \mathrm{~m}$. to $1 \pi 6$ the eastward of the place. These connect it with the general system of western railroads, and hence with all the great centres of manufactures, trade, and commerce. The "Democratic Standard" (dem.), and the "Democratic Gazette" (whig), are issued weekly. Pop, of v. 2,075 - of t. 3,322 .

Delaw are bay: at the mouth of Delaware $\mathrm{r}$, is a large arm of the sea, $75 \mathrm{~m}$. Iong and 20 across its mouth, between Cape May on the $\mathbb{N}$. and Cape Henlopen on the $\mathrm{S}$. In the middle it is $30 \mathrm{~m}$. wide. The navigation is dangerous and difficult, being interrupted by many shoals. Below Port Penn, $70 \mathrm{~m}$. from the ocean, the bay has no safe natural barrier, nor is there one for several hundred m. s. from New York. To partially remedy this inconvenience, the United States Government have erected a magnificent breakwater within Cape Henlopen. The anchorage ground, or roadstead, is in a cove directly west of the Cape. The east or seaward end of the breakwater rests on the S. end of an extensive shoal, called the Shears, about $2 \mathrm{~m}$. N. of the Cape. (See Detaware, The State of).

DELAW ARE river: rises in two branches on the W. side of Catskill Mountains, in the State of New York-the Mohawks, or main branch, rises from a small lake near the borders of Schoharie County, in $42^{\circ} 45^{\prime} \mathrm{N}$. lat., at an elevation of 1, $\$ 86$ feet above tide water, and flows $\mathrm{S} . \mathrm{W}$. across Delaware County, nearly $50 \mathrm{~m}$. to the E. line of Broome County, within $10 \mathrm{~m}$. of the Susquehanna $\mathrm{x}_{\text {. }}$, and turning suddenly, it pursues a $\mathrm{S} . \mathrm{E}$. course of $5 \mathrm{~m}$, to the Pennsylvania line, in $42^{\circ}$ N. lat., $8 \mathrm{~m}$., below which it receives the Popacton branch from the S. E. This branch rises in Roxbury township, Delaware co, and pursues a S. W. course, about $50 \mathrm{~m}$ parallel with the main branch. From the junction of the two branches the river proceeds tn a winding course, $\mathrm{S}$. E. for $60 \mathrm{~m}$. to the N. W. corner of New Jersey, in $41024^{\prime} \mathrm{N}$. lat. at Carpenter's Point, and the mouth of Neversink $r$. It then turns to the S. W., along the base of the Kittaniug chain of mountains, $35 \mathrm{~m}$, when it passes this mountain by what is called the "Water Gap," which is considered a natural wonder. The distance through the mountain is about $2 \mathrm{~m}$., and the banks rise in a rugged and lofty wall, 1,600 feet high, precipitously from the water's edge, leaving at the S. E. entrance scarcely room for a road, overhung with immense masses of rock. The passage, however, widens toward the N. W., and the river contains some beautiful and fertile islands. Through this gap will be built a railroad, connecting the Wyoming coal-field of Pennsylvania with the Eastern markets. The view of the gap is highly picturesque, and the xiver here has great depth, From this point it pursues a $\mathbf{S}$. E., and then a $\mathbf{S}$. W. course to Easton, where it receives the Lehigh, a large tributary river, from the W. A little below, the river passes through South Mountain, and has a S. E. course to Trenton, $60 \mathrm{~m}$. below Easton, having in that distance 25 rapids, with a total fall of 165 feet. These rapids are navigable at high water. At Trenton is a fall that obstructs navigation, and below which it enters tide water. The river $\mathbf{S}$. of Trenton turns to the S. W., until near the bay, which enters the ocean in a S. E. direction. Five miles below Philadelphia, it receives the Schuylkill r., a large tributary from the N. W. The whole course of the $r$., from its source to the entrance into the bay, is about $300 \mathrm{~m}_{\text {, }}$ and to its entrance into the ocean, $375 \mathrm{~m}$. It is navigable for ships of the line to Philadelphia, by the course of the river and bay $120 \mathrm{~m}$. from the ocean, and $45 \mathrm{~m}$. from the entrance into the bay; and for sloops $35 \mathrm{~m}$. farther, or 155 from the ocean to Trenton. Above the falls, at Trenton, it is navigable for boats of 8 or 9 tons for $100 \mathrm{~m}$. The Delaware $\mathrm{r}$, is connected with the Hudson $\mathrm{r}$. and the bays of New York by the Delaware and Fudson Canal, by the Morris Canal, and by the Delaware and Raritan Canal. On these great works, a vast amount of coal from the Pennsylvania and Maryland mines is annually transported. There is also a canal from Delaware Citr, 42 miles below Philadelphia, to Back cr., a tributary of Elk r., which falls into Chesapeake Bay; this opens a 
navigable communication between Baltimore and Philadelphia, etc. Several bridges cross the Delaware, the lowest of which is at Trenton.

Delaw ARe Bridge, p. o., Sullivan co., $N . \bar{Y}$.

Deflatwark CrTx, p. F., Neweastle co., Del. : on the W. side of Delaware r., $28 \mathrm{~m}$. N. by W. Dover, and about $48 \mathrm{~m}$. below Philadelphia. The Chesapeake and Delaware Canal has its $\mathrm{E}$. terminus at this point, and the village has several warehouses, stores, and about 60 dwellings.

Delaware Grove, p. O., Mercer co., Penn.; 208 m. W. N. W. Harrisburg.

Delay, p, o., La Fayette con, Miss.: 142 m. N. by E, Jackson.

Delectable Hill, p. v., Pike co., Ind. : 100 m. S. W. Indianapolis.

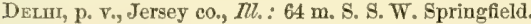

DELHX, p. V., and cap. Delaware co., Ia, : on a er. of Makoqueta r., $56 \mathrm{~m}$. N. by E. Iowa City. It is situated in the centro of the co., and about $3 \mathrm{~m}$. N. E. of Makoqueta river.

Dexim, $t_{n}, \mathrm{p} . \nabla .$, and eap. Delaware $\operatorname{co}, N . Y_{.}: 66 \mathrm{~m}$. W. S. W. Albany. The surface is somewhat broken by several tributaries of Delaware $r_{*}$, which here unite and form the Mohawks or W. branch of that river. The soil in the valleys is highly fertile. The $\mathrm{v}$. is pleasantly situate on a plain, W. of the Mohawhs, and contains about 800 inhabitants. It has a substantial court-house and jail, an incorporated acaderny, numerous factories, mills, and mechanic shops, and between 25 and 30 stores. Two newspapers are issued weekly, the "D. Express" (whig), and the "D. Gazette" (dem.) Delhi has a daily connection with Catskill and Kingston by stages. Pop, 2,969.

Dfirh, p. v., Winnebago co., Wisc.: 79 m. N. N. E. Madison.

Deim Centre, p. 0., Ingham co., Mich. : 7 m. S. Lansing.

Dellona, p. v., Sauk co., Wisc : on Dell cr. of Wisconsin r., $23 \mathrm{~m}$. N. W. Madison.

Delpri, p. v., and cap. Carroll co., Ind.: on the high $\mathrm{N}$. bank of Deer cr., one mile from its confluence with the Wabash r., and on the line of the Wabash and Erie Canal, $66 \mathrm{~m}$. N. W. Indianapolis. It contains a court-house and otber public offices, 5 churches, about 200 dwellings, and 1,200 inhabitants, and here are published the "Weekly Times" (dem.), and the "Delphi Journal" (whig), both issued weekly. It has an active canal business, and is a depôt of a very fertile, extensive, and rapidly-improving neighborhood.

Delper, p. V., Gasconade co., Mo.: on the N. side of Bourbeuse cr. of Maramec r., $42 \mathrm{~m}$. S. E. Jefferson City.

DELPH, t. and p. o., Hamilton co,, Otio: on the N. side of the Ohio r., between Cincinnati and South Bend, 1 c6 m. S. W. Columbus. The Cincinnati and St. Louis P. R. passes through it. Pop. 1,942.

Delphi, p. V., Onondaga co., $N . Y_{.}:$on the W. side of Limestone cr., a tributary of Chittenango cr., $21 \mathrm{~m}$. S. E. Syracuse, and 112 W. by N. Albany. It has abont 40 dwellings and 300 inlabitants.

Delpeos, p. v., Van Wert co., Ohio: on the Miami Canal, $96 \mathrm{~m}$. N. W. Columbas.

Delpiton, p. y., Fayette co., Ky.: 201 m. E. by S. Frankfort

Delrat, p. o., Upson county, Ga.: $72 \mathrm{~m}$. W. by S. Milledgeville.

Dexta county, Mich. Situate between Lake Michigan and the Menomonee r., and contains about 2,160 sq. m. Erected since 1550 .

Delta, p. v., Parke co., Ind. : 96 m. W. Indianapolis

DeLTA, t. and p. o., Eaton co, Mich.: 4 m. W. Lansing. Grand r. runs through the N. and E. parts of the t. P. 242.

Delta, p. V., Coahoma co., Miss.: on the E. bank of the Mississippi r. immediately below the Yazoo Bayou, $133 \mathrm{~m}$. 1. by W. Jackson.

Delta, p. V., Oneida co., N. $Y .:$ on the W. side of Mo- hawk r. and the Black River Canal, $96 \mathrm{~m}$.W. N.W. Albany It has several factories and mills, and about 300 inhabitants. Delta, p. v., Fulton co., Ohio: on a cr. of Maumee r., 122 m. N. N. W. Columbus.

Democracy, p. v., Knox eo, Ohio: on the line of the Springfield, Mount Vernon, and Pittsburg R. R., 46 m. N. E. Columbus.

Democraco, p. Y., Pike county, $K y_{0}: 153$ m. E. S. E. Frankfort.

Democrat, p. V., Buncombe eo., N. Car.: 238 m. W. Raleigh.

Demoorat, p. o., Iroquois county, Ill. : 123 m. N. E. Springfield.

Demopolis, p. v., Marengo co., Ala. : on the E. side of Tombigbee r., a little below the confluence of Black Warrior r., $92 \mathrm{~m}$. W. by $\mathrm{N}$ Montgomery. It is a flourishing $\mathrm{v}$., has considerable commerce, and a population of 800 souls.

Demos, p. v., Belmont co., Ohio: 114 m. E. Columbus.

Dempseytown, p.V., Venango co.,Penn.: 173 m.W. N.W. Harrisburg.

DENMARE, v., Iroquois co., $I$ ll. : $128 \mathrm{~m}$. N. E. Springfield. DeNMARK, p. v., Lee co., Ia. : about 3 m. S. of Skunk r. and $63 \mathrm{~S}$. by E. Iowa City.

Denmark, t, and p. o., Oxford co., Me.: on the N. side of Saco $x_{.}, 56 \mathrm{~m} . \mathrm{S} . \mathrm{W}$. Augusta. It is a fine wheat-growing section. Pop. 1,243.

DeNMARk, t. and p. v., Lewis co., $N . Y_{.:}$on the W. side of Black r., $126 \mathrm{~m}$. N. W. Albany, and drained chiefly by Deer cr. Surface somewhat hilly, and soil, rich loam, on a limestone basis. The v.lies on the river bank, and contains about 30 dwellings and 280 inhabitants. Pop. of t. 2.284.

Denmark, t, and p. 0, Ashtabula co, Ohio: 168 m. N. E. Columbus. Pop. 241.

Danmark, p. v., Madison co., Tenn.: on a cr. of Big Hatchie $\mathrm{r}_{\text {, }} 138 \mathrm{~m}$. W. S. W. Nashville.

Denning, p. v., Ulster co., N.Y.: 67 m. S. by W. Albany.

Dennis, t. and p. v., Barnstable co., Mass. : 64 m. S. E. Boston. The t. extends across Cape Cod. The $\mathrm{y}$. lies on Cape Cod Bay. Salt is here procured in large quantities by the evaporation of sea-water. The inhabitants own considerable tonnage, which is engaged in coasting and the shore fisheries. Pop. 3,257.

Dencis' Creek, p. o., Cape May co., $\mathcal{N}$, Jer. : on Dennis cr., a tributary of Delaware $\mathbf{r}, 69 \mathrm{~m}$. S. Trenton.

Dennis' Milus, p. o., St. Helena par., La. : 36 m. N. E Baton Rouge.

Dennisox's Conners, p. o., Herkimer co, $N, Y$ : $72 \mathrm{~m}$. N. E. Albany.

Demnisvilue, p. V., Amelia county, Virg. : 39 m. S. W. Pichmond.

Denny, p. o., Warren co, $I 7$. : $\$ 6 \mathrm{~m}$. N. W. Springfield. Dennysville, t. and p. o., Washington co., Me.: on the N. E. of Denny's river of Cobscook Bay, 181 m. E. by N. Augusta.

Denook, p. ₹., Waukesha co., Wisc. : $55 \mathrm{~m}$. E. Madison. Densontown, p. V., Rankin co., Aliss.

Dexr county, Mo. Situate S. E. centrally, and contains 576 sq. $m$. Drained in the $N$. by tributaries of Maramec $r_{\text {. }}$ and in the $\mathrm{S}$. the head waters of Current $\mathrm{r}$, all of which have their sources in a chain of hills, and traverse the eo. in an E. and W. direction. Organized since 155!)

DeNT, p. o., Hamilton co., Ohio: 100 m. S. W. by W Columbus.

Dexton county, Tex. Situate N., and contains $960 \mathrm{sq} . \mathrm{m}$. Drained by the upper streams of Trinity r., which here spread widely over the whole co. Surface clevated and well wooded. Soils of extraordinary fertility. Farms 81 : manuf. 0 ; dwell. 109, and pop.-wh. 631, fr. col. 0, sl. 10total 641. Capital: Alton.

Dextox, p. v., and cap. Caroline co., Ma.: on the F. side of Choptank r., $39 \mathrm{~m}$. E. by S. Annapolis. It is a place of considerable trade, and contains a substantial courthouse, three churches, a bank, etc. 
Denton Creek, p. v., Denton co., Tex.: on Denton

Fork of Trinity ro, $216 \mathrm{~m}$. N. by E. Austin City.

Denville, p. v., Morris co., N. Jer.: $48 \mathrm{~m}$. N. by E. Trenton.

Depanville, p. v., Jefferson co., $N_{0}, Y_{.}:$at the falls of Catfish cr., $158 \mathrm{~m}$. N. W. Albany. It contains several mills and about 30 dwellings.

De Perster, t. and p. $v_{\text {., }}$ St. Lawrence con, $N_{\text {. }} Y_{\text {. }}$; on the S. of Black Lake and Oswegatchie r, $152 \mathrm{~m} . \mathrm{N}$. W. Albany. The soils are excellent-surface undulating. The village is a small agricultural settlement, containing about 40 inhabitants.

De Prere, p. v., and eap. Brown co., Wisc.: on the E. side of the Neenah or Fox r., 112 m. N. N. E. Madison. It is situated at the De Piere rapids, which afford immense water-power. It is a village of great expectations.

Deposit, p. v., Delaware co., N. Y : on the N. side of Delaware r., 90 m. S. W. Albany. The New York and Erie $\mathrm{R}$. R. passes through the place, $187 \mathrm{~m}$. from New York and $282 \mathrm{~m}$. from Dunkirk. It has long been noted as a place of deposit for Iumber floated down the Delaware, and has otherwise an extensive and valuable trade. The population is now about 800 souls. The "D. Courier" is published weekly.

Derby, t. and p. v., New Haven co., Conn.: 36 m. S. S.W. Hartford. Drained by Naugatuck $r$. and other streams of the Housatonic r., which last washes its S. W. border. The principal village is situated at the head of sloop navigation, on the E. side of the Housatonic, just below the eonfluence of the Naugatuck, $12 \mathrm{~m}$. from the sound. It has considerable coasting trade. The $t$. has numerous manufactures, chiefly of wool and cotton. Pop. 3,524.

Dersx, t. and p. v., Orleans co., Verm. : $55 \mathrm{~m}$. N. by E. Montpelier. Lake Memphremagog bounds it on the W., and the interior is drained by Clyde r., which rises in Salem Pond, and affords water-power. The country is here well timbered and the lands fertile. Pop. 1, 50.

Derby LiNe, Orleans co., Verm.: $58 \mathrm{~m} . \mathrm{N}$. by E. Montpelier.

Derichson's Cross Roads, p. o., Worcester co, MId. : on the S. side of Aydelotte's Branch of Pocomoke r., $78 \mathrm{~m}$. S. E. Annapolis.

Derry, t. and p. r., Rockingham co., N. Hamp.: $28 \mathrm{~m}$. S. S. E. Concord. Its lands are well adapted to grazing, and it has some manufactures. The village is pleasantly

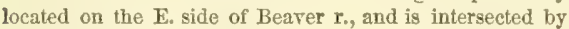
the Manchester and Lawrence R. R., 11 m. from Manchester. Pop. of t. 1,500.

DE RuYTER, t. and p. V., Madison con, N. Y.: $105 \mathrm{~m}$. W. Albany. Drained by the upper stream of Tioughninga $r$. Surface high and hilly, with soils clay and sandy loam. The $\mathrm{v}$, on the S. E. side of the r. has about 60 dwellings and 350 inhabitants. Pop. of t. 1,931.

UES ARC, p. o., Prairie, co, Ark.

Desria county, Ark. Situate S. E., and contains $612 \mathrm{sq}$ $\mathrm{m}$. The Arkansas and White rivers unite in this co., and fall into the Mississippi, which borders it on the E. Bayou Bartholomew also traverses the co, from $\mathrm{N}$. W. to $\mathrm{S}, \mathrm{E}_{\text {, }}$ besides which drainage is effected by a number of lakelets and creeks tributaries to the great streams above named. Surface low and level, subject to extensive inundations. Snils fertile, where susceptible of cultivation. Farms 118; manuf. 2 ; dwell. 350 , and pop,-wh. 1,670, fr. col. 56, sl. 1,169total 2,900. Capital: Napoleon.

Des Mones county, Ior. Situate S. E. on Mississippi r., and contains 384 sq. m. Drained by Flint cr. and other tributaries of the Mississippi. Skunk r. Washes the S. border, and has also several creeks from the interior. Surlace undulating, with high bluffs facing the Mississippi. Soils fertile. Farms 383 ; manuf. 28; dwell. 1,919, and popwh. 12,963, fr. col. 24-total 12,987. Capital: Burlington.

Des Morses lake, La Porte co., Ind. : a beautiful lake in the N. E. corner of the county, and is variously called Dis178 maugh or Dishamine, words corrupted from Des Moines, which signifies the Lake of the Monks.

Des Mornes river, $I a_{4}$ : rises in the Coteau des Prairies, and flows in a S. E. direction, through the S. part of tho State, and enters the Mississippi at the foot of Des Moines Rapids, on the boundary between Iowa and Missouri. In high stages of the water it is narigable 100 miles for steamboats, and for keel-boats in all seasons. It is the great interior river of the State, and ought, with propriety, to have given its name to it.

DE Sото parish, $L a$. Situate on W. border of State, between Red r. on the E., and Sabine r. on the W., and eontain $828 \mathrm{sq} . \mathrm{m}$. Drained by a number of streams tributary to the Sabine, and Bayou Pierre Lake. Surface much varied, but nowhere hilly. Bavou Pierre Lake, a large piece of water, occupies the N. E. corner of the co. Cotton and Indian corn are the chief products. Farms 427 ; manuf 9 ; dwell, 685 , and pop.-wh. 3,548 , fr. col. 25 , sl. 4,446total 8,019. Capital: Mansfield.

De Soro county, Miss. Situate N. W., and contains 840 sq. $m$. Drained by Cold-Water $r$, and other streams flowing W. into the Mississippi r., which washes its N.W. line. Surface low, but not swampy, or liable to overflows. Soils good, and productive of cotton, Indian corn, and potatoes Timber plentiful. Farms 1,257; manuf. 38; dwell. 1,614 and pop.-Wh. 9,457, fi. col. 2, sl. 9,553-total 19,062. Cospital: Hernando

DE SoTo, p. ₹., Jasper co., Mo.: on Drywood er., a branch of Marmiton cr. of Osage r., $135 \mathrm{~m}$. S. W. Jefferson City.

Des Peres, p. v., St. Louis co., Mo.: on the r. so called, 97 m. E. Jefferson City.

Desratauxville, p. v., Rapides par., La. : $107 \mathrm{~m} . \mathrm{N}$. W. Baton Rouge.

Detrort, p. V., Pike co., I $I \imath$ : : $76 \mathrm{~m}$. W. by S. Springfield.

Detroit, p. v., Marion co., Ala.: 153 m. N. W. Montgomery.

Detroit, p. o., Somerset co., Me.

Detrort, p. eity, and cap. Wayne co., Mich.: on the N.W bank of Detroit strait or river, $82 \mathrm{~m}$. E. S. E. Lansino; lat $42^{\circ} 24^{\prime} \mathrm{N}$., and long. $82^{\circ} 5 \mathrm{~S}^{\prime} \mathrm{W}-526 \mathrm{~m}$. from Washington. The eity extends along the river more than a mile and a hatf, the centre of it being about $7 \mathrm{~m}$. from Lake St. Clair and $15 \mathrm{~m}$. from Lake Erie. The original bed of the river opposite Detroit, and for a mile above and about three miles below, varies from 48 to 52 chains in width, averaging five-eighths of a mile-the width from the docks of Detroit to the opposite docks of Sandwich being about half a mile. The depth between the docks varies from 12 to 48 feet, averaging 32 feet; the descent from Lake St. Clair to Lake Erie is about 6 feet, or 3 inches per mile; and the velocity of the current in the deepest part of the channel opposite the city is $2 \frac{1}{2} \mathrm{~m}$, an hour. The stream is so deep and its current so strong and uniform, that it keeps itself clear, and its navigation is not affected as is that of the Mississippi with either rocks, sandbars, trees, or savoyers. Its current also carries along the ice with a slow and uniform motion, so that it is never dammed up in winter, while the St. Lawrence, at Montreal, is shallow and full of rocks, against which the ice lodges, and often forms a dam across the river and raises the water from 20 to 25 feet, overflowing its low banks for miles, and sweeping off and destroying large amounts of property. These peeuliarities of the river make Detroit a secure and accessible harbor in all seasons.

The plan of the city is rather uncouth, and labored with much mathematical ingenuity, better suited, it is acknowledged, to flatter the faney than to promote practical utility. Upon the river, and for 1,200 feet back, it is rectangular-io the rear of this triangular. The streets are spacious ; among the more noted are the eight avenues-Madison, Michigan Grand, and Washington Grand avenues, each 200 feet wide; Woodward, Monroe, Miami, Macomb, and Jefferson avenues, each 120 feet wide, and all, except Michigan, 
Monroe and Jefferson, terminating at one point, called the Grand Circus. The other streets are 60 feet wide, and generally eross at right angles. Atwater Street, upon the river, and Woodbridge Street, running parallel with it upon the declivity, are mostly occupied by stores and dealers in heavy merchandise. Woodward Arenue, leading from the river at right angles with Jefferson Avenue, through Campus Martius and the central part of the city, ranks as among the first business streets. The principal street running with the course of the river upon the summit of the declivity and through the central and most densely populated part of the eity is Jefferson Avenue. Upon this are most of the public and private offices loeated, as well as the dry goods and fancy stores generally. The Campus Martius is one of the most noted of the public squares-there are several others. The argillaceous nature of the soil renders the streets unpleasant in wet weather, but much has already been effected to abate this drawback by paving and sewerage.

The city is supplied with water from the Detroit River by means of a hydraulic establishment in the upper part of the city. The reservoir which contains the water is of cast iron, 60 seet diameter and 20 feet deep, secured by strong iron bolts and rivets; supported by a cireular brick building 62 feet is diameter, at an elevation of 47 feet from its foundation. It is inclosed with a frame building, standing on a brick foundation, 65 feet in diameter and 24 feet high, with a conical roof. The reservoir is supplied by means of a steam-engine, which works a forcing pump that is fixed sereral fiet below the surface of the river, and is found fully adequate to furnish an abundant supply of good and wholesome water to the whole city. Connected with these works there are said to be about $4 \mathrm{~m}$. of iron pipe and $10 \mathrm{~m}$. of tamarack $\operatorname{logs}$, and 50 hydrants or fire plugs, all of which cost the cily some $\$ 150,000$.

Detroit, although one of the most ancient settlements in North America, is, to every appearance, and in reality, of recent growth. Of the ancient style of the French buildings, scarcely a vestige remains. The eity is mostly built of wood, although there are a goodly number of substantial brick buildings. The most interesting of the public buildings are the old State House; the United States buildings (of polished limestone); the State buildings for the Supreme Court and public offices; the County Court House; the County Jail; the City Hall and market; and the Firemen's Hall. There are also 16 churehes in the city, many of which are worthy of special notice; of these 4 are Roman Catholic, 2 Episcopalian, 1 Presbyterian, 1 Scotch Presbyterian, 1 Congregational, 3 Methodist, 2 Baptist, 1 German Luth ran, and 1 Sailors' Bethel. The new Catholic Cathedral, or St. Peter's Church, is a large and substantial edifice, and being high, massive, and of good proportions, it has an imposing appearance. It is built of brick, and is 160 feet long and 81 feet wide. The coruer-stone was laid 29 th June, 1845, and it was consecrated 29th June, 1848. The Cathedral of St. Anne, known as the French Chureh, is 116 feet long by 60 feet wide. The First Presbyterian Church is also a good, substantial, and well-appearing brick edifice, with a portico and colonade in front, including which its length is 100 feet and its breadth 60 feet. In addition to these churehes there are several religious societies which meet in other public buildings.

Detroit has sereral extensive manufactories. It has five large steam saw-mills, which annually turn out upward of $9,000,000$ feet of lumber and 4,000,000 laths. These are situated directly on the river, and receive, without the trouble of land carriage, the lumber chiefly brought down f:om the northern parts of the State. Ship and boat building is also a very large and important branch of business. There are also three large foundries, with machine shops connected with them, which manufacture steam-engines, mill-irons, machinery of various kinds, stoves, plows, ete. These employ about 200 hands. There are also two boiler factories for the manufacture of boilers for steam-engines, and several machine-shops for working in iron and some in brass. There are likewise two pail factories, a sash factory, a stean flouring-mill, two tanneries, and five breweries. Cabinetmaking, and most other kinds of mechanical employments, are pursued to a considerable extent, and something is done at shoemaking, but much the largest portion of the boots and shoes worn in Michigan are made in Massachusetts, and most of the cabinet ware and coarse clothing comes from New York.

In addition to the retail trade there is a heary wholesale business done in Detroit, and the amount of it is annually increasing. Nearly all the merchants of the interior depend on Detroit to replenish their stock, and a large portion of them buy all their goods there.

The export and import trade of Detroit is immense. The imports coastwise, for 1848 , are estimated at $\$ 3,502,666$, and the exports at $\$ 2,781,192$, and the port has also a considerable trade with Canada, much of it illicit. The greater portinn of the agricultural products of the State are shipped from this port. The shipping belonging to or owned in the collection district are 39 steamers, 4 propellers, 1 barge, 8 brigs, 109 schooners, and 36 sloops-in the aggiegate, 23,619 tons. Regular lines of steamers sail and arrive daily to and from all parts, connecting here with the Michigan Central R. R., and with it forming a direct line from the north and east to Chicago and the Mississippi, and by this route thousands of emigrants travel annually, and millions of dollars'-worth of property are transported.

There are several charitable institutions in the city, and much attention has been paid to education. Among the charitable institutions, the orphan asylums stand pre-eminent, and reflect much credit on the inhabitants. There are also several scientific and literary societies, as the Historical Society, the State Literary Institute, the Medical Society, etc. Here, also, is one of the branches of the University, and 3 miles above the city is St. Philip"s College; Primary and Public Schools are numerous, and there sre a sufficient number of private and classical schools to supply all exigencies.

The periodical press of Detroit consists of 3 daily newspapers, 1 tri-weekly, 7 weeklies, and 2 monthlies; the dailies are, the "D. Free Press" (dem.), which has also a triweekly and weekly issue; the "D. Advertiser" (whig), which has also a weekly issue; and the "Daily Tribune;" the weeklies are the "Peninsular Freeman" (free soil); "Le Citoyen" (French); the "Western Adrocate" (whig); the "New Covenant" (relig.) ; and the "Michigan Christian Herald" (Baptist); and the monthlies are "Wellman's Miscellany" (lit.); and the "Michigan Farmer" (agric.) All these are conducted with an energy and talent surpassed only by the metropolitan press.

Detroit has 4 banks, the condition of which, on the 26th Dec. 1851, was as follows: liabilities-capital, \$761,223; deposits, $\$ 705,692$; circulation, $\$ 607,585$; due banks, $\$ 22, \$ 55$; and profits, $\$ 375,084$ : and resources-loans, $\$ 1,202.648$; specie, $\$ 150,244$; bank balances, $\$ 275,933$; real estate, $\$ 193,025$; and stocks, mortgages, etc., $\$ 650,000$. The Michigan State Bank had a capital of $\$ 151,57 \$$; the Farmers and Mechanics' Bank, $\$ 327,580$; the Peninsular Bank, $\$ 100,000$; and the Michigan Insurance Bank, $\$ 182,070$.

The present site of the city of Detroit, seems to have been risited by the French as early as 1610 . In 1720 the Fort Pontchartrain had been previously located bere. In 1759 the country fell into the hands of the English, and in $17 \mathrm{S3}$ became a part of the United Stales. In 1802 the rillage was incorporated; in 1305 it was destroyed by fire; in 1510 the ant of incorporation was repealed ; in 1812 the fort and town surrendered to the British, but were renceupied in 1513 ; in 1815 it was re-incorporated. Such is the chronology of its history. In 1810 it contained 770 inbabitants; in 1820 , 1,442 ; in $1830,2,222$; in $1840,9,192$; in $1815,13,065$; and in $1 \$ 50,21,019$. 
DETROT strait: this stream conducts the collected waters of lakes Superior, Michigan, Huron, and St. Clair, to Lake Erie. It is the largest stream of Michigan, and its local position makes it the most important. The word D'Etroit (Fr.) signifies strait, and, as applied to this stream, is a more appropriate appellation than the word river, and was first given to it by the French on its discovery. It is about $25 \mathrm{~m}$. long, and on an average, one and a tenth of a mile broad, and 36 feet deep. It moves with an equable current of about $2 \mathrm{~m}$. per hour. Its descent is 3 inches per mile, or 6 feet and 3 inches for its whole length. Its course is first south-westerly, and then southerly. In the winter season it closes with ice only after a continued succession of severely cold weather. If the temperature of the atmosphere moderates but for a few days, and that moderation even not above the freezing point, it will open by the action of its powerful current, which wears away the thickest ice in a short time. Hence the stream is not often long elosed. It has been known to remain one frozen bridge for six weeks, but it was a phenomenon in its history, rarely known, and then only in seasons of the greatest severity. It receives several inconsiderable streams from the American, and two or three from the Canadian shore. The most considerable is the Rouge. There are a number of islands that divertits waters, though they add to the beauty of its scenery. Amoug the largest are Grosse and Fighting islands. From some cause, there appears to have been a peculiar attraction to the banks of the Detroit more thau to any other stream in Michigan. The first settlements of the French were made on it, and the French travelers found three tribes of Indians equally tenacious in their attachment to it. From a gradunl accession, its banks on either side have been subdued and settled, so that in many places, for miles, it has the appearance of a continued village of a much older country than the recent State of Michigan. Like the lakes which it connects, it abounds with fine fish, the taking of which has become lucrative. The navigation of the strait is easy, and in the season of it, its waters are covered with steamboats and vessels of every description. The Detroit, although but a few miles in length, is one of the pleasantest and most beautiful streams in the United States. With banks of great fertility, covered with orchards of various fruit, with farms cultivated and productive, accompanied with incomparable ecenery, the prospect is rendered exceedingly delightful in passing up the strait.

Devereadx, p. T., Herkimer co., N. $Y_{*} .69 \mathrm{~m}, \mathrm{~N}$. W. by W. Albany.

Devereatx's Store, p. O., Haneock co, Ga.: 15 m. N. E. Milledgeville.

Devox, p. v., Henry county, The. : $12 \mathrm{~m}$. W. by N. Indianapolis.

DE MiTt county, $7 \%$. Situate centrally, and contains 46 sq. m. Drained by tributaries of the Sangamon $r$. Surface chiefly an elevated prairie, with a good portion of wood. Soils dark and rich. Farms 482; manuf. 1s; dwell. 881, and pop.-wh. 5,001, fr. col. 1-total 5,002. Capital: Clinton. Putlic Works: Illinois Central P. R.

DE WITr county, Tex. Situate S. W., and contains 680 sq. m. Drained chielly by the Guadalupe $r$ and its branches. Surface varied, but not hilly-a deep valley following the course of the Guadalupe, which traverses the co. from N. to S. "Soils very fertile, producing cotton, sugar, and the grains. Farms 10); manuf. $3 ;$ dwell. $28 \pi$, and nop - wh. 1,148, fr. col. 0, sl. 568-total 1,716. Capital: Cuero.

DE WITr, p. F., De Witt co., Mll: on the N. side of Salt cr. of Sangamon r., 5:3 m. E. N. E. Springfield.

DE WrTT, p. ve, and cap. Clinton co., Ia.: abou: $4 \mathrm{~m}$. N of Wapsipinicon r., and $49 \mathrm{~m}$. E. by N. Iowa City. P. 459 。

DE WrTT, to and p. v., Clinton eounty, Mich.: $2 \mathrm{~m}$. N. Lansing. The $\mathrm{v}$. is located on the $\mathrm{N}$. bank of Lookingglass $\mathrm{r}$. It is a flourishing place, and has a newspaper, the "Clinton Express," which is issued wakly. Pop. 706.

DE WrTt, p. v., Carroll co., Mfo. : on the N. bank of the 180
Missouri r., about $5 \mathrm{~m}$. W. of the mouth of Grand r., 81 m. N. W. Jefferson City.

DE Witr, $t$, and p. v., Onondaga co., $N_{\text {. }} Y_{\text {. }}$ : on bot 11 sides of Butternat er., and adjoining the city of Syracuse, $115 \mathrm{~m}$. W. Albany. The surface is vneven, and there is abundance of water-lime, which is largely quarried and exported. The $\nabla$. on the W. side of the cr. is a small agticultural settlement. Pop. of t. 3,3u2.

De Witrilile, p. v., Chantauque con, $N . Y_{.}: 286 \mathrm{~m}$. W. by S. Albany.

Dexter, t. and p. o., Penobscot co., Me.: on the watershed between Kennebec and Penobscot rivers, $49 \mathrm{~m}, \mathrm{~N}$. N. E. Augusta, The $\mathrm{v}$. is located at the outlet of a large pond of $5: 0$ acres, and has good hydraulic power. The soil of the $t_{\text {. }}$ is fertile, and produces excellent wheat. Pop. 1,918.

DexTER, p. ₹., Washtenat co., Mich. : on Mill cr., at its confluence with Huron r., $42 \mathrm{~m}$. E. S. E. Lansing. It is a thriving v., and has an abundance of water-power; and the Michigan Central R.R. passes through it $46 \mathrm{~m}$. from Detroit, and $236 \mathrm{~m}$. from Chicago.

DEXTER, p. v., Jefferson co., $N$. $Y_{0}:$ on the $\mathrm{N}$. side of Black r. at its mouth, $147 \mathrm{~m}$. N. W. Albany. It has an uninterrupted communication with Lake Ontario through Black River Bay, and piers have been constracted by the United States to improve its harbor. Within the $\mathbf{v}$, are several extensive mills and factories, worked by water-power; and the Watertown and Rome R. R. passes near it. Pop. 700.

Dianond Grote, p. o., Jasper co., Mo. : 146 m. S. W Jefferson City.

Diamond Grote, p. o., Brunswick co., Firg.: on the N. side of Meherrin r., 55 m. S. S. W. Richmond.

Diamond Hrlu, p. 0., Anson co., N. Car. : 104 m. S. W. Raleigh.

Diamond Hirl, p. o., Providence co., $R . T$.

DianA, t. and p. o., Lewis county, N. Y.: $124 \mathrm{~m}$. N. W Albany. Drained by Indian r., and the S. branch of Oswegatchie $r$. Surface hilly, and soil, sandy and gravelly loam, adapted to grass

Drana Miris, p. v., Buckingham co., Tirg.: $72 \mathrm{~m}$. W. Richmond.

Dias Cheek, p. v., Cape May county, N. Jer.:67 m. s. Trenton.

Dice ensonfille, p. V., Russell co., Tirg. : $267 \mathrm{~m}$. W. by S. Richmond.

Dickexsville, p. v., Grant co., Wise. : on the \$., and $2 \mathrm{~m}$. distant from Platte r., $69 \mathrm{~m}$. W. S.W. Madison. Lead is abundant in the neighborhood.

Diekivsox county, $I_{t}$. Situate N. W., and contains 432 sq. m. Taken from Pottowattomee in 1850 .

Dickivson, t. and p. v., Franklin county, $N_{0} Y_{0}: 142 \mathrm{~m}$. N. by W. Albany. Drained by Racket r. and the upper streams of St. Regis r. The N. part of the t. only is inhabited, the $\mathrm{S}$. being still a wilderness, abounding in lakes, and covered with dense forests. The $\mathrm{v}$. is on Deer $\mathrm{r}_{\mathrm{a}}$, a constituent of the St. Regis river. Pop. of t. 1,119.

Dickinson, to and p. o, Cumberland co., Penn。: $24 \mathrm{~m}$. S. W. Harrisburg. The country is hilly, and the soils calcareous. Iron ore abundant. Yellow Breeches cr. affords good water-power, and there are screral factories and mills along its banks; also several furnaces and forges. Population, 3,027

Dickisson, p. F., Franklin co., Virg.: 145 m. W. S. W. Pichmond.

Dickinsox's Stoke, p. o., Bedford county, Virg.: $117 \mathrm{~m}$. W. by S. Ricbmond.

DICKson county, Tenn. Situate eentrally, and contains 724 sq. $\mathrm{m}$. The co. lies on the watershed between the Cumberland and Tennessee rivers, the former of which forms its $\mathrm{N}$. E. line. The surface is varied, and the soils of arerage fertility, producing all the grains, with some tobacco and cotton. Timber abundant. Farms 467; manuf. 14; dwell. 10,680, and pop. - wh. 6,285, fr. col. 1, s1. 2,118total S,404. Coujutal : Charlotte. Putlic Trorks: Nashville 
and Henderson R. R.; and the Nashrille and Mississippi I. I.

Dicksov's Mrrus, p. o., Parke enunty, Ind. : $59 \mathrm{~m}$. W. Indianapolis.

Digmen, t., p. V., and port, Bristol co., Mass. : 38 m. S. Boston. Situated on the W. side of Taunton r., which is navigable to this place for small vessels. It has some manufactures, and considerable shipping is built and owned in the town. On the opposite side of the $r$, is "Dighton Rock," celebrated for an ancient inscription which has never been satisfactorily interpreted. Pop, 1,641.

Dille's Botros, p. 0., Belmont county, Ohio: $104 \mathrm{~m}$. E. Columbus,

Dillon, p. 0., Tazewell co., $M$. : about $3 \mathrm{~m}$. N. of Maçinaw er. of Sangamon r., 51 m. N. by E. Springfield.

Dillow's Run, p. o., Hampshire co., Virg. : 146 m. N.W. Pichmond.

Dilisborotgr, p. v., Dearborn co., Ind.: about $4 \mathrm{~m} . \mathrm{N}$. of Laughery cr., $79 \mathrm{~m}$. S. E. Indianapolis.

Dilisfurgir, p. v., York co., Penn.. 13 m. S. S. W. Harrisburg.

Dillworthtows, p. v., Chester co., Penn. : 69 m. E. S. E. Harrisburg.

Drumick, p. $\nabla$. , La Salle county, $I Z .: 123$ m. N. N. E. Springfield.

Drock, t. and p. v., Susquehanua co., Penn.: $113 \mathrm{~m}$. N. N. E. Harisburg.

Dingmansburg, v., Shelby co., Orio: 63 m. W. N. W. Columbus.

Dragmax's Ferry, p. o., Pike co., Penn. : on Dingmares cr. of the Delaware r., 123 m. N. E. Harrisburg.

Drisuore, t. and p. o., Shelhy co., Ohio: in the N. part of the co, $72 \mathrm{~m}$. W. N. W. Columbus.

DrNwidpre county, Virg. Situate S. E., and contains 616 Si. m. Drained by tributaries of Appomattox and Nottoway rivers, which bound it $\mathrm{N}$. and $\mathrm{S}$. respectively. Surface moderately uneren or rolling. Soils fertile naturally, but deteriorated. Tobacco, Indian corn, and wheat are the great staples. Mamufactures, trade, and commerce are in a flourishing condition. Farms 708; manuf. 71; dwell. 2,745, and pop.-wh. 10,985, ir. col. 3,253 , sl. 10,880-total 25,118 . Cayital: Dinwiddie C. H. Public Worles: Petersburg R. R.; South Side R. R., ete.

DinwIDDIE Cornt-House, p. . $_{\text {, }}$ and cap. Dinwiddie co, Firg.: on the N. side of Stoney er. of Nottoway r., $35 \mathrm{~m}$. S. by TV. Richmond.

Diswidde's TAK-YARD, p. 0., Campbell co., Virg. : 98 m. S. W. Riclimonu.

Dint Towr, p. v., Chattooga county, $G a .: 168 \mathrm{~m}$. N. W. Millowgeville.

IWMA SWAMP, Firg. and $\lambda^{\top}$. Car.: a large marshy tract of lind, commenving a litte S. of Norfolk in Virginia, and extending into North Carolina. It covers about 150,000 acres, and is $30 \mathrm{~m}$. long from $\mathrm{N}$. to $\mathrm{S}$., and $10 \mathrm{~m}$. wide. This tract is covered with trees, some of which are of enormons size, and between them is brashwood so thick as to be almost impervious. In the midst of the swamp is Lake Drummond, $15 \mathrm{~m}$. in eircumference. A navigable feeder, 3 m. long. from this lake, serves to supply the main trunk of the Dismal Swanjp Canal, which extends from Deep cr., a branch of Elizabeth r., $10 \mathrm{~m}$. from Norfolk to Joyce's cr. a branch of Pasquotank $r$., forming a connection between Albemarle Sound and Hampton Roads. This canal is 23 m. Iong, 40 feet wide, and 6 feet deep, and at intervals of a quarter of a mile it is 66 feet wide for turn-out stations. The sumnit level is 16 , feet above mid-tide in the Atlantic Ocean. There are 5 stone locks on it, 100 feet long by 22 feet wide. Cost $\$ 1,112,32: 3$.

Ditsey HrLL, p. o., Dubois co., Ind.: 104 m. S. S. W. Indianapolis.

Drvide, p. o., Marion county, $I a_{.}: 84 \mathrm{~m}$. W. by S. Iowa City.

Ditumat Crees, p. $\nabla$. Cumberland co., N. Jer.: on the cr. so called, which flows into Maurice Cove, of Delaware Bay, $69 \mathrm{~m}$. S. by W. Trenton. The cr. is navigable to the v. which contains about 180 inhabitants.

Drx Creek, p. o., Chickasaw co., Miss. , $12 \pi$ m. N. E. by N. Jackson.

Dixfield, t. and p. o., Oxford co., Me.: on the N. bank of Androscoggin $r, 81 \mathrm{~m}$. W. N. W. Augusta. It has a productive soil, well adapted to the growth of wheat. Pop. 1,180.

Dix Hrul, p. o., Suffolk co., $N_{*} Y_{*}: 124$ m. S. by E. Albany.

Dixmont, t. and p. v., Penobscot co., Me.: 39 m. N. E. Augusta. Surface undulating and the soil fertile. It is situated on the highland between the Kennebec and Penobseot, and drained by affluents of both rivers. It has considerable water-power and fine mill seats. Pop. 1,605.

Dixmont Milis, p. 0., Penobseot co., Me. : 36 m. N. E. Augusta.

Dixon, p. v., and cap. Lee co., $I U l_{\text {. : }}$ on the S. E. side of Rock r., $142 \mathrm{~m}$. N. by E. Springfield. The line of the Central R. R. crosses Rock r., at this point. Pop. 1,173.

DixoN's Milıs, p. o., Marengo co., Ala. : 92 m. W. by S.

Montgomery.

Drxos's Mruxs, p. o., Buchanan co., Mo. : 168 m.W.N.W. Jefferson City.

Drxon's Springs, p. 0., Smith co., Tenn.: about 3 m. N. of Cumberland x., and 41 m. N. E. by E. Nashville.

Dicksonville, p. o., Cole co., Mo.: $7 \mathrm{~m}$. W. Jefferson City.

Dixoxvilue, p. V., Lawrence co., Ind.: 63 m. S. by W. Indianapolis.

Doaksville, p. v., Choctaw Nation, Ind. Ter.

Doanesbtrifi, p. v., Putnam co., N. $Y_{*}:$ on the lime of the Harlem R. R., $55 \mathrm{~m}$, from New York and $98 \mathrm{~m}$. from Albany.

Dombin's Raxoh, p. o., Yuba co., Calif.: on the N. side of Tuba r., $112 \mathrm{~m}$. N. N. E. Vallejo.

Dовв's Ferry, p. v., Westchester co., $N$. $Y_{\text {. : }}$ on the E. bank of the Hudson r., $104 \mathrm{~m}$. S. Albany. Here is a good landing at which numerous regular steamboats touch daily, and there is a ferry across the river. It is a considerable $\mathbf{v}$, and has some manufactures and machine shops, which have been greatly advanced since the completion of the Hudson River R. R., which passes through it, $22 \mathrm{~m}$. from New York. This was an important point in the Revolutionary war.

Dockerर's Store, p. o., Richmond co., $N_{\text {. }}$ Car.: $92 \mathrm{~m}$. S. W. Raleigh.

Dodosville, p. v., M'Donough eo., $I l l .:$ on the S. line of the county, $62 \mathrm{~m}$. N. W. by W. Springfield.

DoDDrIDGe county, Firg. Situate N. W., and contains 720 sq. m. Drained by S. fork of Hugh's r., and by Midrle Island cr. and their affluents. Surface somewhat broken. Soils of average quality. Farms 240 ; manuf. 2 ; dwell. 525 , and pop.-wh. 2,719, fr. col. 0, sl. 31-total 2,750. Cupital: West Union. Public Works: North-Western R. R.

Dodge county, Mo. Situate N. on State line, and contains 252 sq. $m$. Drained by the constituents of Locust and Medicine creeks of Grand r. Surface level or undulating. Soils of good quality, and fertile. Farms 49 ; manuf. 0 ; dwell. 5T, and pop.-wh. 351, fr. col. 0, sl. 2-total 353. Capital: Butler.

DoDGE county, Wisc. Situate S. E. centrally, and contains 900 sq. m. Drained W. and S. by Rock and Benver Dam rivers, and $\mathrm{E}$. by streams falling into Lake Michigan. Surface beautifully diversified by hill and dale. Soils of extraordinary fertility. Farms 2,132; manuf. 28; dwell. 3.600, and pop.-wh. 19,128, fr, col. 10-total 19,138. Capitcel. Juneau. Public Works: Fond du Lac R. R.

Dodgeville, p. v., Iowa co., Wisc. : $62 \mathrm{~m}$. N. Mineral Point, and $46 \mathrm{~m}$. W. by S. Madison.

Dodgeville, p. v., Des Moines co, $I a_{0}: 59$ m. S. S. E Iowa City. 
Dodsorville, p. v., Jackson co.g Ala.: $145 \mathrm{~m} . \mathrm{N}$. Montgomery.

Dodsoxville, p. F., Highland co, Ohio: on the W. side of White Oak cr., $66 \mathrm{~m}$. S. W. by S. Columbus.

Dow Hilu, p. o., Highland co., Virg.: 126 m. W. N. W. Richmond.

Dot Rux, p. o., Chester co., Penn. : 69 m. E. S. E. Harrisburg.

Dogwood Neck, p. o., Horry dist., S. Car.: 114 m. E. by S. Columbia.

Dourvgtox, p. v., Bucks co., Penn. : 93 m. E. Harrisburg. Dorson, p. o., Clarke co., $I \ell$.: $106 \mathrm{~m}$. E. S. E. Springfield.

Domestre, p. o., Williams co., Ohio: 132 n. N. W. Columbus.

Dow, p. o., Sullivan co., Ind. : $82 \mathrm{~m}$. S. W. Indianapolis.

Donaldsox, p. Y., Schuylkill co., Penn.: $51 \mathrm{~m}$. N. E. Harrisburg.

DoNAlDsonvrlle, p. v., and cap. Ascension par, La.: on the S. W. side of the Mississippi r., immediately below the Bayou La Fourche, $27 \mathrm{~m}$. S. by E. Baton Rouge. It was formerly the State capital. The place is pleasantly situated, and has some fine buildings, among which are the C. H., Arsenal, U. S. Land Office, a college, etc. It has considerable trade and may be considered as the depot of the Bayou La Fourche country. Pop. 1,498.

Donegar, t. and p. o., Westmoreland co., Penn. : on the mountain valley between Laurel Hill and Chestnut Ridge, $138 \mathrm{~m}$. W. Harrisburg. Drained by tributaries of the Youghingheny and Kiskiminetas rivers, which afford water-power. Pop. 2,414.

Donmphax, p. vo, Ripley con, Mo.: 149 m. S. S. W. Jefferson City.

Doxnell's, p. o, Allen co., Ohio: $92 \mathrm{~m}$. N.W. Columbus. Dornellsville, p. v., Clark co., Ohio : $47 \mathrm{~m}$. W. by $\mathrm{S}$. Columbus. Pop. 196.

Dooux county, $G a$. Situate S. centrally, and contains $576 \mathrm{sq} . \mathrm{m}$. It occupies the height of land between Ocmulgee and Flint, and is drained by the tributaries of both rivers. Surface favorably diversified; soils generally fertile, but deteriorated by bad husbandry. Cotton is the principal product. Farms 663; manuf, 8 ; dwell. 962, and pop.-wh. 5,580, fr. col, 6, sl, 2,775-total 8,361. Capital: Drayton,

Door county, Wise. Situate N. E., and contains $432 \mathrm{sq}$. m. It occupies the N. part of the peninsula between Green Bay and Lake Michigan, and has its name from the fact of its being at the door or entrance of the interior navigable waters of the State. Capital: Gibralter. Organized sinco 1850 .

Door Crefr, p. o, Dane co., Wisc. : on a cr. so called flowing into Fourth Lake, $5 \mathrm{~m}$. N. Madison.

Doon prairie, La Porte co., Ind.: so named from the narrow gap in the timber at Door Village. It contains in all between 70 or $S 0 \mathrm{sq} . \mathrm{m}_{\text {., }}$ and is probably the richest and most beautiful prairie in the State.

Door Fillage, p. F., La Porte co., Ind.: about $4 \mathrm{~m}$.

S. W. La Porte, 128 m. N. W. by W. Indianapolis.

Dorcheat, p. o., Claiborne par, $L a_{\text {. }}$; on the large bayou of the same name, $210 \mathrm{~m}$. N. W. Baton Rouge. Bayou Dorcheat rises in Hempstend co., $A r k$, and passes S, into Louisiana, emptying jtself into Bisteneau Lake, of which it is the chief feeder.

Dorchester county, IId. Situate S. E. and contains 604 sq. m. Drained by tributaries of Choptank $r_{\text {, }}$, which bounds it on the $\mathrm{N}_{\text {., }}$ and of Nanticoke r., which makes its S. boundary. The Chesapeake washes its W. shore. Surface low and level-in parts swampy; soils varying from light and sandy to a stiff clay. Marl is abundant, and is used as a fertilizer. There is plenty of timber. Farms 1,049; manuf. 12 ; dwell. 2,705, and pop.-wh. 10,783, fr. col. 3,807, sl. 4,282 -total 1S,s7\%. Capital: Cambridge.

Dorchister, t. and p. T., Norfolk co., Mass.: 4 m. S.

Boston, and within the metropolitan district. It fronts on Dorchester Bay, in Boston Harbor, and extends between 189
Roxbury Brook and Neponset r, the latter of which furnishes great water-power as well as navigation. Vessels owned here are chiefly employed in the fisheries; it has also ex tensive manufactures. Few other localities have made such progress as this in wealth; in 1840 its assessed valuation was $\$ 1,691,245$; in $1850, \$ 7,199,750$. Pop. in $1840,4,875$, and in $1550,7,968$. The old Colony $R$. $R$. passes through the E. part of the town, and the Boston and Providence R. R. through the W. part.

Dorohester, p. v., Cumberland co., $N$. Jer.: $61 \mathrm{~m}$. S. by W. Trenton.

Dorohester, t, and p. o., Grafton co., N. Hamp. : $42 \mathrm{~m}$. N. N. W. Concord. It lies on the height of land between the Connecticut and Merrimac rivers, and is uneven and rocky, with fertile valleys. Mascomy and Baker's rivers are its primcipal streams. Pop. 711.

DORIO Arch (or Doric Rock), Mich.: is a name applied to an isolated mass of sandstone, which has the appearance of the work of art, consisting of four pillars supporting an entablature or stratum of stone covered with soil, and a handsome growth of pine and spruce trees, some of which are 50 or 60 feet in height. This curiosity is a projection of the Pictured Rocks on the southern shore of Lake Superior, and presents an interesting view to voyagers of the great lake.

Dormatstille, p. v., Albany co., $N$. $Y$.

Donnicktown, p. O., Monongalia co., Virg.: 203 m. N. W. Richmond.

Dorr, p.V., M·Henry co., IU. : 193 m. N. N. E. Springfield. Dorra NCE, p. Y., Stark co., $I U$, ; $92 \mathrm{~m}$. N. Springtield.

Dorkfille, p. Y., Washington co., $R . I_{.}: 33 \mathrm{~m}$. S. S. W. Providence.

Dorset, p. ., De Kalb co., $I U$.: on the E. side oi Big Indian cr., 138 m. N. N. E. Springfield.

Donser, p.v., Ashtabula co., Ohio: 168 m. N. E. Columbus DoRSET, $t$, and p, v., Bennington co., Verm. $\quad 77 \mathrm{~m}$. S. by W. Montpelier. Drained by Pawlet, Battenkill, and the head branches of Otter creek, which afford fine mill sites. Surface uneven. The Western Vermont R. R. passes through the town and village in $\mathrm{a}$. and $\mathrm{S}$. direction.

Dorser, p. o., Woodford co., Ky.: 16 m. S. E. Frankfort. Doty's Corner, p. Y, Steuben con, N. $Y_{\text {: }} 194$ m. W. Albany.

Dotryilie, p. v., Fond du Lae co., Wisc.: 64 m. N. E. Madison

DoubLE BRancmes, p. o., Lincoln co, Ga. : 73 m. N. E. Milledgeville.

Double Brafones, p. O., Anderson dist, S. Car. : $109 \mathrm{~m}$ W. N. W. Columbia.

Doubre Bridge, p. o., Lunenburgh co., Virg. : $67 \mathrm{~m}$ S. W. Richmond.

Double Brmges, p. o., Upson co.g Ga.: 68 m. W. Milledgeville.

Double Cabris, p. o., Henry co., Ga.: on Towathga er. $63 \mathrm{~m}$. W. N. W. Milledgeville.

Dotble OAK, p. o., Camden co, Mo.: 46 m. S. W. Jefferson City.

Double Prke Creek, p. o., Carroll co., MI. : $61 \mathrm{~m}$. N.W. Annapolis. Situate on a cr. of Monocacy r. so called.

Dotble Shoajs, p. o., Morgan co., Ga. : 35 m. N. by W. Milledgeville.

Double Sprivg, p. o., Benton co., Ark.: 157 m. N. W. Little Rock.

Double Sprivgs, p. o, Calaveras co., Calif. : on a small cr. of Calaveras $r_{.}, 76 \mathrm{~m}$. E. Vallejo.

Double SPRixgs, p. v., Oktibbeha co, Miss. : 106 m. N. E. Jackson.

Double Springs, p. o., Jackson co., Tenn. : 64 m, E, N. E. Nashville

Double WeLts, p.. ., Warren co, $G u_{0}:$ on the line of the Georgia R. R., 41 m. N. E. Milledgeville.

Doodsville, p. va, Pendleton co, $\overline{y_{2}}: 47$ m. N. E. Frankfort. 
DovgLass, t. and p. o, Worcester co, Mass. : 43 m. S. W. Boston. Drained by Mumford cr. of Blackstone $r_{\text {s, which }}$ affords good water-power. Iron ore is found, and in the $t$. there are considerable manufactures of cotton goods, boots, shoes, etc., and edge-tools. The country is fertile and highly cultivated. Pop. 1,878.

Douglass, p. v., Fayette co., Ia.: 84 m. N. by W. Iowa City.

Dovglass, p. v., Nacogdoches co., Tex.: on a cr. of Angelina $\mathrm{r}$, about $7 \mathrm{~m}$. from the latter, and $197 \mathrm{~m}$. E. N. E. Austin City.

Dotglass, t. and p. o., Montgomery co., Penn. : $68 \mathrm{~m}$. E. Harrisburg, Perkiomen and Swamp creeks drain the soils, which are fertile, and afford water-power for several mills and factories.

Douglassville, p. v., Berks co., Penn. : on the N. side of Schuylkill r., $18 \mathrm{~m}$. E. Harrisburg. The Philadelphia and Reading R.R. passes through the village, $44 \mathrm{~m}$. from Philadelphia and 48 from Reading.

Dorpuiv, p. v., Blount co., Ala.: 123. m. N. by W. Montgomery.

Doutxiet, p. 0., Anderson dist., S. Car. : 116 m.W. N.W. Columbia.

Dover, p. v., Baltimore co, MLd.

DOVER, p. $\mathrm{Y}_{*}$, Russell co., Allas : about $3 \mathrm{~m}$. W. Chattahoochie r., and $6 \mathrm{~m}$. N.W. Girard, $171 \mathrm{~m}$. E. Montgomery.

Dorer, p. v., Pope co., Ark. : on the E. bank of Illinois cr. of Arkansas r., $64 \mathrm{~m}$. N.W. Little Rock. It was formerly the co. capital.

Dover, hund., p. b., and eap. Kent co., Del., and capital of the State: on high ground, between the two principal branches of Jones' cr., $10 \mathrm{~m}$. above its entrance into Delaware Bay. Lat. $39^{\circ} 10^{\prime} \mathrm{N}$., and long. $75^{\circ} 30^{\prime} \mathrm{W} ., 114 \mathrm{~m}$. E. by N. Washington. The hundred contains 72,930 acres, and 3,932 inhabitants. The $\mathrm{b}$. is laid out regularly with wide streets, crossing each other at right angles. The State House stands on the $\mathbf{E}$. side of a large public place, and is an elegant building, and the buildings occupied by the co. offices occupy sites on the same square. It has 4 churches, a bank, an academy, 2 schools, several stores, about 120 dwellings, chiefly of brick, and between 600 and 700 inhabitants. A splendid monument, erected to the memory of Colonel John Haslett, who fell in the battle of Princeton, illustrates the patriotism of the citizens, and is the chief ornament of the place. The flour business is that distinzuishing Dover, and which is chiefly earried on with Philadelphia. A R. R., projected to run longitudinally through the State, will pass through the borough.

Dover, p. V., Bureau co., Ill.: 109 m. N. Springfield.

Dover, p. v., Mason co., Ky. : 76 m. E. N. E. Frankfort.

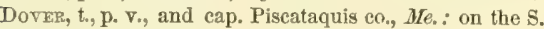
side of Piscataquis r., $59 \mathrm{~m} . \mathrm{N} . \mathrm{N}$. E. Augusta. The v, is located immediately on the banks of the stream. It has several mills; and a weekly newspaper, the "Piscataquis Observer," is published here. Pop. 1,927.

Dover, t. and p. o., Lenawee co., Mich.: watered by the S. branch of Raisin r., $61 \mathrm{~m}$. S. E. Lansing. The Michigan Southern $\mathrm{R}$. $R$. crosses the $t$. in an $\mathrm{E}$. direction, Pop. 1,223.

Dover, t. and p. v., Norfolk co., Drass. : on the S, and E. of Charles r., $16 \mathrm{~m}$. S. W. Boston. Drained by Trout and Nodnets brooks. Surface uneven, and much of it woodland. The $\mathrm{v}$. is located near the centre of the t., and is a pleasant place of about 200 inhabitants. The t. has about 631 inhabitanis.

Dover, p.v., La Fayette co, Mo. : 92 m.W. N.W. Jefferson City. It lies about $3 \mathrm{~m}$. $\mathrm{S}$. of the Missouri river.

Dover, t., p. vo, and cap. Strafford co., N. Iamp.: 38 $\mathrm{m}$. E. Concord. The $\mathrm{t}$, is drained by Cocheco and Black rivers, tributaries of the Piscataqua. It is the oldest $t$. in the State, having been settled in 1623. The $\mathrm{r}$, is built around the lower falls of Cocheco, where the descent is suddenly 32 feet, producing a vast water-power. These falls are at the head of tide, $12 \mathrm{~m}$. from the sea, and sloops can come up within a short distance of the mills. It has a courthouse, jail, etc., and numerous and extensive manufactures, but chiefly of cotton goods. It has also considerable shipping. The newspapers published here are the " $\mathrm{D}$. Enquirer" (whig), the "N. H. Gazette" (dem.), the "Morning Star" (whig), the "Myrile" (relig.), and the "Gospel Rill" (relig.), all issued weekly; and the "Cadets" Advocate" (temperance), issued monthly. The $\mathrm{v}$. is intersected by the Boston and Maine R. R.; and the Cocheco R. R. here diverges from it. On the whole, Dover is justly considered one of the most prosperous manufacturing towns of New England. Pop. 8,156.

DOVER, p. v., Morris co., N. Jer. : on both sides of Rockaway r., $47 \mathrm{~m}$. N. by E. Trenton. The two sections of the $\mathrm{v}$. are connected by bridges. Iron ore is abundant in the vicinity, and it has several large iron factories, ete. The Morris Canal descends into the valley in which it stands by an inclined plane and 4 locks; and at this point the Morris and Essex R. R. has its N. W. terminus, $44 \mathrm{~m}$. from Jersey City. Pop. about 400.

Dover, t. and p. o., Duchess co., N. Y.: $66 \mathrm{~m}$. S. by E. Albany. The p. o. is located at Dover Plains, and v. located on the Harlem R. R., $80 \mathrm{~m}$. from New York. The to abounds in marble and tron ore, and has several mills and factories. Pop. 2,147.

Dover, t. and p. v., Cuyahoga co., Ohio: on Lake Erie, $114 \mathrm{~m}$. N. N. E. Columbus. The v. is located about $3 \mathrm{~m}$. back from the lake. Pop. of t.1,112.

Dover, t. and p. v., York co., Penn.: on the E. side $r$ if Conewago cr., $18 \mathrm{~m}$. S. Harrisburg. The v. lies in the eentre of the $t, 10 \mathrm{~m} . \mathrm{N}$. W. York. The t. has several distilleries, tanneries, grist and saw mills, for which latter water is abundant.

Dover, p. V., and cap. Stewart co., Tenn.: on the S. W. side of Cumberland r, $61 \mathrm{~m}, \mathrm{~W} . \mathrm{N}$. W. Nashville. It contains the county offices, and about 400 inhabitants. The landing for steamers is one of the best on the river.

Dover, t. and p. v., Windham co., Term.: on the E. border of the Green Mountain range, $94 \mathrm{~m}$. S. Montpelier. Drained by West and Deerfield rivers, which have good mil sites. The soils are well adapted for grazing. The v. lies a little S. E. of the eentre of the town. Pop. of t. 709 .

Dover, p. v., Yazoo co., Miss. : 33 m. N.W. Jackson.

DOVER HurL, p. v., and cap. Martin co., Ind.: on the W. side of, and a mile end a half from the East Fork of White river, $79 \mathrm{~m} . \mathrm{S}$. W. Indianapolis. It contains a court-house and about 30 dwellings.

Dover Mrlus, p. o., Goochland co., Virg.: 17 m.W. by N Richmond.

Dovesville, p. v., Rockingham co., Virg. : $110 \mathrm{~m} . \mathrm{N}$. W Richmond.

Dowagiac, p. v., Cass co., Mich. : on a branch of Dowagiae r., $92 \mathrm{~m}$. S. W. Lansing. It lies also on the Michigan Central R. R., $178 \mathrm{~m}$. from Detroit, and 100 from Chicago.

Dow AgIac (Dowagiake) river, Mich.: takes its rise in the S. part of Van Buren and N. E. part of Cass counties, and passing over the northern, north-western, and western portions of the latter in a S.W. direction, into Berrien, enters the St. Joseph r. near the v. of Niles. It is upward of $30 \mathrm{~m}$. in length, and receives a number of tributaries, which, with the main stream, furnish excellent mill sites.

Doweltown, p. v., Surrey co., N. Car.: 132 m.W. N.W. Raleigh.

Downer's Grove, p. O., Du Page co., $I l l_{*}: 162 \mathrm{~m} . \mathrm{N}$. E. Springfield.

Downieville, p. v., and cap. Yuba co., Calif: : at the head of the North Fork of Yuba r., $137 \mathrm{~m}$. N. E. Vallejo. It is the head-quarters of one of the richest gold fields of the State.

Downivg's Mruls, p. o., Strafford co., N. Hamp.

Downivgsville, p. v., Grant county, $K y_{2}: 47$ m. N. N. E. Frankfort.

Downington, p.v., Meigs co., Otio: $69 \mathrm{~m}$. S. E. Columbus. 
Downingtown, p. v., Chester co., Penn. : on the W. side nf the E. branch of Brandywine cr., and on the line of the Philadelphia and Columbia R. R., $33 \mathrm{~m}$. from Philadelphia, and $74 \mathrm{~m}$, from Harrisburg. The dwellings, about 60 or 70 in number, are chiefly of stone, and it contains several mills and factories, stores, etc. It is surrounded by a fine and well-cultivated country. About $12 \mathrm{~m}$. below the $\mathrm{v}$., on the banks of the Brandywine cr., was fought the sanguinary battle of Brandywine, 11th September, 1777. A R.R., 22 m. long, is projected between Morristown and Downingtown.

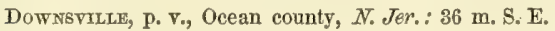
Trenton.

Doxlestown, t., p. v., and cap. Bucks co., Penn, : on the $\mathrm{N}$, side of Tacony er., $88 \mathrm{~m}$. E. Harrisburg. The borough is a flourishing place, has manufactures, and a good trade and about 1,005 inhabitants. There are published here 6 weekly newspapers, viz., the "D. Express," the "D. Democrat," and the "Independent Democrat," all democratic in principle; the "Morning Star," and the "Bucks County Intelligencer," both whig; and the "Olive-Branch," devoted to the temperance cause. The Norristown, Doylestown New Hope R. R. passes through the place. The $t$. is an excellent agricultural country, and is highly cultivated. Pop. 2,471.

Dorlestown, p. v., Paulding co., Ohio: 116 m. N. W. Columbus.

Dracur, t. and p. v., Middlesex co., Mass.; on the N. side of Merrimac r., opposite Lowell, 25 m. N. N. W. Boston. The two towns are connected by a bridge across the river. It is essentially an agricultural district, although Beaver r., which drains it, affords considerable water-power. Population, $3,5 \mathrm{~J} 3$

Drakestown, p. o., Morris co., $N$. Jer.: on Schooley's Mountain, $39 \mathrm{~m}$. N. by W. Trenton.

Deakesville, p. v., Morris co., N. Jer, : $42 \mathrm{~m}$. N. Trenton.

Drakesville, p. v., Davis co, I $a_{0}$ : on the N. side of Fox r., 78 m. S. W. Iowa City.

Dranesville, p. va, Fairfax con, Virg.: 96 m. N. Richmond. Situated about $6 \mathrm{~m}$. S. of the Potomac $r$., near the N. W. corner of the county.

Draper's Vallex, p. o., Pulaski co., Firg. : on the W. side of Kanawha r., about $2 \mathrm{~m}$. distant from that stream, and $193 \mathrm{~m}$. W. by S. Pichmond.

Drapersville, p. o., Mecklenburgh co*, Virg.: $92 \mathrm{~m}$, S. W. Richmond.

Draughtox"s Store, p. o., Sampson co., $N$. Cur.: $52 \mathrm{~m}$. S. by E, Raleigh.

Drawbridge, p. o, Sussex co, Det

Draxton, p. v., and cap. Dooly co., Ga. : on the S. side of Penalıatchee cr., $1 \frac{1}{2} \mathrm{~m}$. from its confluence with Flint r., and $8 t \mathrm{~m}$. S. S. W. Milledgeville.

Draytonsville, p. v., Uniou dist., S. Car.: 73 m. N. N.W. Columbia.

Dremersvilie, p. v., Schuylkill $\mathrm{co}_{*}$, Penn : 49 m. N. E. Harrisburg:

Disnnov's, p. o., Menry co., $\bar{K} y,: 25$ m. N. W. Frankfort.

Dresoex, p. v., Grundy co., $I l l$.: on the Illinois $r$., at the junction of the Desplaines and Kankakee rivers, the great constituents of the Illinois, and on the line of the canal, 128 $\mathrm{m} . \mathrm{N}$. E. Springfield. The $\mathrm{Y}$. is $52 \mathrm{~m}$. from Chicago by canal, and $45 \mathrm{~m}$. from Peru.

DresDeN, $t$, and p. 0 ., Lincoln co., Me.: on the E. bank of Kennebee r., $18 \mathrm{~m}$. S. Augusta. It is an agrieultural town, and has some river trade. Pop. 1,419.

Dresper, p. r., Muskingum co., Ohio: on Wakatomara cr., near its junction with Muskingum r., 51 m. E. by N. Columbus. A side-cut of the Ohio Canal reaches this place. Thus situate, it is highly favored for commerce, of which it has a considerable share, and it has also several factorits and mills, Pop, 1,445 .

Dresper, p. v., and cap. Weakly co., Tenn.: near the centre of the co., on one of the head branches of Obion r.,
$109 \mathrm{~m}$. T. by N. Nashville. It contains a court-hotse, ete. and about 395 inhabitants. The Nashville and Mississippi P. R. will probably intersect this $\mathrm{v}$. Two newspapers, the "D. Democrat," and the "Whig Mirror," are published weekly.

Dresdex MrLrs, p. o., Lincoln co., Me.: 19 m. S. Augusta. Dresserville, p. v., Cayuga county, $N . Y .: 141 \mathrm{~m} . \mathrm{W}$. Albany.

DREW county, Ark. Situate S. E., and contains $720 \mathrm{sq}$. $m$. The Bayou Bartholomew bounds it on the $\mathrm{E}$. and the Sabine $r$, on the W. side, the creeks falling into which drain the interior. A highland runs $\mathrm{N}$. and S. through the county, forming the watershed-the surface declining $\mathrm{E}$. and W. from its summit level. Tho soils are eminently productive, and the extent of forest moderate. Farms 277; manuf. 9 dwell 430 , and pop.-wh. 2,360 , fr. col. 0 , sl. 915-total 3,275 . Capital: Monticello.

Drew ERsbureh, p. v., Franklin co., Ind. : about 4 m. E. of the White Water r., and $76 \mathrm{~m}$. E. S. E. Indianapolis,

DRewrTstille, p. v., Southampton co., Virg. : $63 \mathrm{~m}$. S. S. E. Richmond.

Drewstille, p. v., Cheshire co., N. Hamp. : on the E. side of Connecticut r., at Bellow's Falls, $42 \mathrm{~m}$. W. Coneord. It has considerable manufactures.

Dripping Spring, p. v., Edmonson co., Ky.: $108 \mathrm{~m}$. W. Frankfort

Drownivg CreEK, p. o., Burke co., $N$. Car.: on a er. of Catawba r. so called, $148 \mathrm{~m}$. W. Raleigh.

Drowning ForK, p. o., M'Donough co., II. : on a er. so called, $73 \mathrm{~m}$. W. N.W. Springfield.

Drumon D's island, Dfich. : at the mouth of St. Mary's, 40 $\mathrm{m}$. long, has the best quality of secondary limestone, several harbors and fisheries, and a soil covered with pine and maple. The western extremity is the site of an ancient British fort.

Drýdrgh, p. v., Halifax co., Tirg. : 96 m. N. Richmond. Dry Creer, p. o., Kenton county, $K y .: 59$ m. N. N. E. Frankfort,

Dry Crees, p. 0., Covington county, Miss.: 62 m. S. E. Jackson.

Dry CrezT, p. o., Lancaster dist., S. Car .: 70 m. N. N. E. Columbia.

DryDEN, t, and p. o., Lapeer co., Mich.: 74 m. E. by N. Lansing. Pop. 1,131.

DerDEN, t. and p. v.. Tompkins county, $N . Y_{.}: 128 \mathrm{~m}$. W. by S. Albany. Surface undulating. Soil gravelly loam, and well watered and drained by Fall cr, and other small streams. The $\mathrm{r}$. is located on Virgil cr., and contains about 600 inhabitants. About half a mile W. of the place is a noted mineral spring, the waters of which are useful in rheumatic and cutaneous affections. Pop. of $t .5,122$.

DrY Fork, p: o., Bond co., Ill. : on Dry Fork of Shoal cr., a tributary of Kaskaskia r., 58 m. S. by E. Springfleld.

Dry Fork, p. o., Barren co, Ky.: 110 m. S. W. by S. Frankfort.

Dry Fork, p. o., Hamilton county, Olio: $102 \mathrm{~m} . \mathrm{S} . \mathrm{W}$. Columbus.

DRr Glaze, p. Y., Camden co, Mo, : on the Dry Au Glaize cr., a branch of Grand Au Glaize $x_{0}, 52 \mathrm{~m}$. S. S. W. Jefferson City.

Dry Hrun, p. o., Lauderdale co., Tenn. : 169 m. W. by S. Nashville.

Dry PoNds, p. o., Lincoln co., N. Car.: $146 \mathrm{~m}$. W. by $\mathrm{S}$. Raleigh.

Dry Rmge, p. 0., Drew co, Ar\%. : on the highland forming the watershed between Saline $\mathbf{r}$, and Bayou Bartholomew, $116 \mathrm{~m}$. S. E. Little Rock.

DRY Ridge, p. o., Somerset co., Penn。: $128 \mathrm{~m}$. W. S. W. Harrisburg.

DRY Ruge, p. o., Hamilton co., Ohio: 105 m. S. W. Columbus.

DRY Rळgen, p. on, Grant con, $K y$.: 42 m. N. N. E, Frankfort. 
Der Tics, p. o., Franklin co, Penn.: 50 m. W. S. W. ITarrisburg:

Dri Rus, p o., Tippah co, Mfiss. : $164 \mathrm{~m} . \mathrm{N}$. by E. Jackson.

Dry VAlLEY, p. o., White co., Tonn.: $84 \mathrm{~m}$. E. Nashville.

DrY Wood, p. O., Bates co., Mo. : on a er. of the Marmiton, a tributary of Osage r., $142 \mathrm{~m}$. W. S. W. Jefierson City.

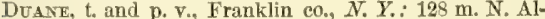
bany. Surface uneven and hilly, and the soil a fertile sandy loam. Watered by branches of Salmon r. and Deer creek. The $t$, is celebrated for its superior iron ores, which are capable of producing the finest steel for edge tools. The $\mathrm{v}$. lies on a branch of Salmon $\mathbf{r}_{\text {, }}$, and has several factories and mills; and there are also in the neighborhood furnaces, ete. Pop. of t. 222.

DUANESBURGH, t. and p. V., Scheneetady con, $N . Y_{0}: 22 \mathrm{~m}$. W. N. W. Albany. The $\mathrm{v}$. lies on a branch of Schohario cr. The surface of the $t$. is elevated and hilly, and watered by numerous creeks, which afford water-power, and has a soil of excellent fertility. Pop 3,464 .

Demsin, p. v., Fayette co, Ala.: 118 m. N. W. Montgomery.

Dublix, p. F., and cap. Laurens co., Ga.: on the W. side of Oconee r., $47 \mathrm{~m}$. S. S. E Milledgeville. It contains the co. offices, several stores, and about 70 dwellings.

Dublin, p. v., Wayne co., Ind. : on the National Road, 2 m. W. of Cambridge City, $50 \mathrm{~m}$. E. Indianapolis, Pop. 350. Debln, p. o., Harford co., Md.: 52 m. N. N. E. Annapolis.

Dublis, t. and p. o., Cheshire co., N. Hamp. : 34 m. S.W. Concord. Situated on the highlands between the Connecticut and Merrimac rivers. A considerable portion of Grand Monadnock lies within this town. It has good water-power and several factories and mills. The surface is better adapted to grazing than corn-growing. Pop. 1,088.

DUBLIN, p. v., Franklin co., Ohio: on the W. bank of Scinto r., $11 \mathrm{~m} . \mathrm{N}$. N. W. Columbus. The location is high and pleasant, and in the neighborhood there are several mills and factories. Pop. 247.

Dublen, p. o., Bucks co,, Penn, : 93 m. E. Harrisburg.

Dublin, p. $\nabla_{.}$, Graves co., $K y .:$ on a branch of Little Obion r., $20 \mathrm{~m}$. from the Mississippi r., and $238 \mathrm{~m}$. W. S. W. Frankfort.

Dublis Mrus, p. v., Bedford co., Penn.: $64 \mathrm{~m}$. W. by S. Harrisburg.

Dubors county, Ind. Situate S., and contains 432 sq. m. Drained by E. tork of White, the Patoka, and other streams, Surface generally level-in the N. E. rolling; soils of ordinary fertilits, but the bottoms are rich and fertile. Timber abundant. Corn and wheat are the staple products. Farms 794 ; manuf. 9 ; dwell. 1,146, and pop.-wh. 6,300, fr. col. 21 -total 6,321. Capital: Jasper.

DUBUQUE county, Ia, Situate N. E., aud contains 576 $\mathrm{sq}, \mathrm{m}$. Drained in the N. by Turkey cr., in the centre by Little Maeoqueta r., and S. by the N. fork of Macoqueta r. which, with other streams, falls into the Mississippi, which forms its E, border. Surface rough and uneven, but with much fertile land. Galena or lead ore is very abundan throughout the county, and mining forms the great interest of the inhabitants. Farms 755; manuf. 46 ; dwell. 1.952 and pop.-wh. 10,816, fr. col, 25-total 10,841. Capital. Dubuque. Pubtic Works: Dubuque and Iowa City R.R., ete.

Durcoue, p. .,., and eap. Dubuque co, Ia.: on the W. bank of the Mississippi $r, 424 \mathrm{~m}$. above St. Louis, and $72 \mathrm{~m}$ N. E. by N. Iowa City. It is built on a table area, or terrace, which extends along the r. for several miles, and the streets are laid out at right angles with each other. Dubuque was setkled by Canadian French as early as 1686 , for the purpose of trading with the Indians. Besides being the great mineral depot of the Iowa lead region, it is a place of much traffic, and interchanges largely with the vast interior, of which it is the chief outlet. Its chief export is
Iead, which is sent down the river in vast quantities. In the village are several wholesale stores, and one of the largest hotels of the West. The U. S. Land Office for the Northern District of Iowa, and the office of the Surveyor General of Iowa and Wisconsin, are located here. The population is now 4,071, and is rapidly increasing. There are four newspapers published in the village, the "Miner: Express" (dem.), the "D. Tribune" (whig), the "D. Telegraph" (whig), and the "Norwestliche Democrat" (German). Lead ore is found in abundance within the corporate limits of the vilage, and for miles around on every side.

Ducurss county, $N . \mathcal{Y}$. Situate $\mathrm{S}$. E., between IIudson r. and the Connecticut State line; and contains $765 \mathrm{sq} . \mathrm{m}$ Drained by Ten Mile, Fishkill, Wappenger's, and Crum Elbow creeks and their afluents. Surface diversified, but generally hilly, and intersected by two great longitudinal valleys. Some of the hills rise to the height of 1,700 feet Old Beacon, near Fishkill landing, 1,471 feet, and the Grand Sachem, or New Beacon, 1,6s5 feet above tide-water. The county abounds in minerals, of which iron, lead, and zino are the principal. Graphite is obtained near Fishkill, and marble, peat, and marl are found in all parts. Oak, chestnut, and hickory are the principal forest trees. The agricultural productions, besides the grains, are wool, butter, flax, and potatoes. The county has a large manufacturing interest, including almost every branch, and Poughkeepsie employs several large ships in the whaling business. Farms 3.208; manuf. 415; dwell. 9,562, and pop.-wh. 57,022, fr. col. 1,970-total 58,992. Capital: Poughkeepsie. Puðbic Works: Hudson River R. R.: Harlem R. R.; Providence, Hartford, and Fishkill R. P.. ete.

Duck Branch, p. o., Beaufort disto, S. Car. : 114 m. S. by TV. Columbia.

Duck Creek, p. o., Walker co., Ga.: 187 m. N. W. Milledgeville.

DUCK CreeK, p. 0., Dallas co., Tex.: on a cr. of Bois d'Are fork of Trinity r. so called, $189 \mathrm{~m}$. N. by W. Austin City.

Duck Creek, p. o., Trumbull co., Ohio: $146 \mathrm{~m}$. N. E. Columbus.

Duok Ceerk, hund, Kent co., Del. : between Duck cr and Little Duck er., extending from Delaware $r$, to the W. line of the State, and containing 65,080 acres. Its chief trade is in lumber. It has also several grist and other mills. Pop. 3,978.

Duck River, p. o., Hickman co., Tenn. : on Duck r., 51 m. S. W. Nashville.

Deck Sprivg, p. o., De Kalb co., Ala.: 182 m. N. by E. Montgomery.

Duduer, $t_{\text {. }}$ and p. $\mathbf{v}$., Worcester co., Mass.: on the W gide of Quinnebaug r., $49 \mathrm{~m} . \mathrm{S}$. W. Boston. It is a fine agricultural district, and has a considerable number of manufactures. Pop. 1,446.

Dudley, p. v., Polk con, Ia : on the S. side of Des Moines r., near the confluence of North r., $98 \mathrm{~m}$. W. by S. Iora Cits.

Dudley, t. and p. v., Hardin co., Ohio: on the Scioto r. $52 \mathrm{~m} . \mathrm{N} . \mathrm{N}$. W. Columbus, The v. lies on the N. side of the river. Pop. of $t .529$

Dudleytilly, p. V., Tallapoosa co., $A l a$ : on the E. co. line, and about $4 \mathrm{~m}$. S. of Tallapoosa r., $55 \mathrm{~m}$. N. E. Montgomery.

Dunlytows, p. v. Jackson co, Ind. : on the W. side of Fernon fork of Muscatatuk r., $64 \mathrm{~m}$. S. by E. Indianapolis.

Due West Corner, p. Y., Abbeville dist., S. Car. :115 m. W. by N. Columbia, A weekly newspaper, the "Erskine Miscellany," is published here, and circulates some 750 copies of each issue.

Duffiel.j's, p. o., Charles co, ifd.

DUfFiend's, p. o., Jefferson co., Virg.: $12 \tau \mathrm{m} . \mathrm{N}$. by W. Richmond. The line of the Baltimore and Ohio $P . R$ strikes this point $6 \mathrm{~m}$. W. of Harper's Ferry. 
Durt's Foris, p. v., Fayette co., Ohio: 29 m. S. W. Columbus,

DvGDEMoNA, p. v., Jackson par., $L a_{0}$ : on the r. so called, $147 \mathrm{~m}$. N. W. Baton Rouge. Dugdemona $r$, is a considerable stream rising in Bienville and Jackson parishes, and emptying into Catahoula Lake.

DUGGer's FerRY, p. o., Carter co., Tenn.: $254 \mathrm{~m}$. E, Nashyille.

DUG SPUR, p. o., Carroll co., Virg.: 188 m, W. S. W. Richmond.

Dugway, p. o., Oswego co., N. Y.: $136 \mathrm{~m} . \mathrm{N}$. W. Albany. DUEEDOM, p. 0., Graves co., Ky.: 247 m. W. S. W. Frankfort.

DukE's county, Mrass. Situate S. E. in the Atlantic Ocean, and corsisting of the islands of Martha's Vineyard, Chappequiddie, Elizabeth islands, and No Man's Land-the latter of which is the S. extremity of the State. These islands lie off and S. of Barnstable co. and Buzzard's Bay, and contain about 120 sq. m. Martha's Vineyard, the Indian Nope or Capawock, is $21 \mathrm{~m}$. long and $6 \mathrm{~m}$. in breadth. A large portion of the co. is woodland, but there is also sufficient grazing and grain land. The exports consist chiefly of wool and salt, with some grain, and many of the inhabitants are engaged in the fisheries and coasting trade. The first settlement of whites in the co. was in 1641 at Edgarton. Farms 265; manuf. 18; dwell. 771, and pop.wh. 4,487, fr. col. 53-total 4,540, Capital: Edgartou.

Dukes, p. O., Putnam co., Ohio: 98 m. N. W. Columbus, Dumas, p. v., Tippah county, Misis. : $171 \mathrm{~m}$. N. by E. Jackson.

Dumas Store, p. o., Richmond co., N. Car. : 79 m. S. W. Raleigh.

Dumbarton, t. and p. 0., Merrimac co, N. Hamp.: $10 \mathrm{~m}$. S. by W. Coneord. Surface elevated, but not hilly; soils fertile. Drained by several streams of Merrimac r., on which are several mills.

Dumbarton, p. v., Barnwell dist., S. Car.: 66 m. S. W. Columbia.

Dumbarton, p. v., Adams co., Ohio: on the E. side of Brush er, of the Ohio r., $72 \mathrm{~m}$. S. by W. Columbus.

Dumfres, p. v., Prince William co., Virg.: on the N. side of Quantico cr., a tributary of Potomac r., $69 \mathrm{~m}$. N. by E. Richmond. It is a thriving $v_{*}$, and has several factories and mills. The mouth of Quantico cr., $2 \mathrm{~s}$. below, is the best winter harbor in the Potomac, being seldom obstructed by jee.

DumMEar, t. and p. o., Coos co, N. Hamp.: $9 \mathrm{~S} \mathrm{~m}$. N. by W. Concord. Drained by tributaries of Androseog. gin and Connecticut rivers. It is a remote town and thinly setlled. Pop, 171.

Dexurerstown, t. and p. v., Windham "eo., Verm.: on the W. side of Connecticut r., $92 \mathrm{~m}$. S. by E. Montpelier. Drained by West $r_{\text {a, }}$ which is a fine mill stream. Surface hilly and rocgh, but adapted for grazing. This is one of the earliest settlements. Fort Dummer was founded in I625, and is a noted place in the Indian wars. Pop. 1,645。

Dumoxtrille, p. v., Fairfield co., Ohio: 28 m. S. E. Columbus.

Duncar, p. o. Wood co., Firg. : $253 \mathrm{~m}$. W. N. W. Richmond.

DuncaN, p. v., Cheborgan co. Mrch, ; $207 \mathrm{~m}$. N. Lansing.

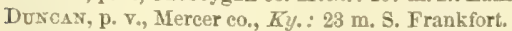

Duscaxion, p. v., Perry co., Penn.: on the line of the

Pennsylvania R. R., $16 \mathrm{~m}$. W. Harrisburg.

Duscan's Creek, p. 0., Cleveland co., N. Care: on a cr. of First Broad r. so ealled, $165 \mathrm{~m}$. W. by S. Raleigh.

Duncan's Falis, p. o., Muskingum co., Ohio: on the Muskingum r., $56 \mathrm{~m}$. E. Columbus. There is a dam across the stream at this point which affords a great head of water.

Dexcax's Minls, p. 0., Jasper c0., Mo.: 148 m. S. W. Jefferson City.

Dencarsville, p. T., Barnwell dist., S. Car, : $53 \mathrm{~m}$. S. by W. Columbia.
Dunoansvilue, p. v., Blair co., Penn.: on the line of the Alleghany Portage R. R., $4 \mathrm{~m}$. W. Hollidaysburg, and 141 m. by railroad from Harrisburg.

Duneanton, p. v., White co., Ill.: on Rectors fork of Saline cr., 148 m. S. E. Springfield.

Duncanvilue, p. v., Thomas co., Ga.: on the Thomasville and Tallahassee turnpike, $2 \mathrm{~m}$. N. of the Florida State line, and $168 \mathrm{~m} . \mathrm{S}$. by W. Milledgeville. The Florida Branch of the Brunswick and Florida R. R. will pass through this place.

Dundaff, p. $v_{.}$, Susquehanna co., Penn.: $122 \mathrm{~m}$. N. E. by N. Harrisburg. It has a glass-house, several stores, and 50 or 60 dwellings. Pop. about 300 .

DUNDAs, p. v., Calumet co., Wisc.: 96 m. N. N. E. Madison.

Dundee, p, $\mathrm{v} .$, Kane co., $M l .:$ on the W. side of Des Plaines r., about $4 \mathrm{~m}$. N. of Elgin, and $171 \mathrm{~m}$. N. E. Springfield.

DuNDEe, t. and p. v., Monroe co., Mich.: watered by Raisin $r$., which affords fine mill sites. The $v$. lies on the N. side of the stream, $18 \mathrm{~m}$. from Lake Erie and $68 \mathrm{~m}$. S. E. Lansing. It is one of the most flourishing villages of the interior, and has numerous mills \&c. Pop. 1,239.

DUNDEE, p. Y., Yates co., N. Y.: on Big Stream, a ereek falling into Seneca Lake, $158 \mathrm{~m}$. W. Albany. It has several important manufactories, as iron foundries, agricultural implement factories, etc., and contains about 1,000 inhabitants. A newspaper, the "D. Record," is published weekly. DUNDEE, p. T., Tuscarawas co., Ohio: $84 \mathrm{~m}$. E. N. E. Columbus.

Dunderrach, p. v., Robeson co., N. Car.: 81 m. S. S.W. Raleigh.

Dunganon, p. v., Columbiana co., Ohio: on the line of the Beaver Canal, $2 \mathrm{~m}$. E. of Hanover, and 122 E. N. E. Columbus.

Dunfax, p. o., M'Henry co., $I l l$. : on the E. side of Rush cr. of the N. branch of Kishwaukee $\mathrm{r}_{\text {., }} 194 \mathrm{~m}$. N. N. I. Springfield.

Dunkinsville, p. v., Adams co., Ohio: $78 \mathrm{~m}$. S. by W. Columbus.

DUNKIRK, p. v., Calvert co., $M d_{0}: 39$ m. S. by W. Annapolis.

DenkiRk, p. v., Chautauque co., $N$. Y.: on Lake Erie, $27 \mathrm{~S}$ m. W. Albany. It is the W. terminus of the New York and Erie R. R., and is intersected by the Buffalo and State Line $R$. $R$, which forms a link in the line of the Lake Shore R. R. from Buffalo to Monroe. It has rapidly progressed in every branch of industry since the completion of those great works, and is destined to become one of the great ports of the lakes. The harbor has been improved, and affords 12 feet of water on the bar. Steamboats arrive and depart hourly in connection with the railroads, and an extensive commerce is carried on, not only with domestie ports, but also with those of Canada. The "Chautauque Journal" (whig) is published weekly. From Dunkirk to New York City the distance is 469 miles. The harbor, formerly calted Chadwick's Bay, is capacious, accessible, secure, and capable of improvement to one of the best upon the lakes. Pop. 3,000 .

DuNkIRK, to and p. o., Dane co., Wisc.: $14 \mathrm{~m}$. S. E. Madison. The vo is loeated on the W. side of Catfish $\mathbf{r}_{\text {, }}$ which drains the t. Pop. 25s,

Dunkirk, p. v., Greenville dist., S. Car.: 106 m. N. W. by W. Columbia.

Duskrns county, $\mathbf{M 0}$. Situate between $36^{\circ}$ and $86^{\circ} 30^{\circ}$ $N$. lat., and occupying the $W$. half of the narrow strip projecting below the general line of the State into Arkansas, between the River St. Françis and the Mississippi River; it contains about $720 \mathrm{sq} . \mathrm{m}$. The greater portion is a swamp, abounding in ponds, lakes, and sluices unfit for cultivation; but there are some elevated prairies, perhaps to the extent of a fourth of the area of the county, situate principally in the N. W. and S. W. parts. White Water r. has :ts course 
through the swamps, forming swamp islands of various dimensions, ete. No part is fit for human habitation, yet we find that it has charms for some witless souls, as its statistics will show. Farms 76 ; manuf. 2 ; dwell. 215 , and pop.-wh. 1,205, fi. col. 11, sl. 13-total 1,229. Capital: Chilletecaux (probably the Indian name for chills and congh).

Duxiap, p. o., Hamilton co, Ohio: 102 m. S. W. Columbus.

Dunlap's PraTnIE, p. o., Cook co., IU.: 166 m. N. E. Springfield.

DENLAPSFILLE, p. $\nabla_{*}$ Union co, Ind.: on the W. side of the $\mathrm{E}$. fork of White Water $\mathbf{r}_{0}, 62 \mathrm{~m}$. E. by $\mathbf{S}$. Indianapolis. It contains a Presbyterian church, 3 stores, and 7 mechanic shops. Pop. 225.

Denlapstille, p. Y., Laurens dist., $S$. Car.: $73 \mathrm{~m}$. W. N. W. Columbia.

Diriterx, p. v., Warren co., Ohio: $71 \mathrm{~m}$. W. S. W. Columbus.

Duxmore, p. v., Luzerne co., Penn.: 91 m. N. E. Harrisburg.

Doxingstule, p. v., Washington co., Penn.: $187 \mathrm{~m}$. W. Harrisburg.

Dunnsmerge, p. v., Clinton co., Penn. : on the W. side of the W. branch of Susquehanna $r$. and opposite the mouth of Bald Eagle cr., 73 m. N. N. W. Harrisburg.

Dunn's Corners, p. o., Kennebec co., Me. : $10 \mathrm{~m}$. from Augusta.

DUNNSVILlE. p. v., Albany co., $N_{.} Y_{a}: 14 \mathrm{~m}$. W. N. W. Albany.

Dunnspille, p. v., Essex co., Tirg.: about $2 \mathrm{~m}$. W. of Rappahannock r., and $49 \mathrm{~m}$. N. E. Richmond.

Dunstable, t. and p. o., Middlesex co., Mass.: on the N. State line, $31 \mathrm{~m}$. N. W. Boston. Drained by Nashua and Salmon rivers; surface generally level and soils sandy. It has several mills and a sparse population of about 700 souls. Pop. 590 .

Duntonsviute, p. จ., Edgefield dist., $S$. Car.: $57 \mathrm{~m} . \mathrm{W}$. Columbia.

DU PAGE county, $I l l$. Situate N. E., and contains 342 sq. m. Drained by Du Page $r$. and other constitutents of Illinois r. Surface prairie and woodland intermingled; soils of great fertility, producing all the grains, etc. Farms 960 ; manuf. 18 ; dwell. 1,568, and pop.-wh. 9,287 , fr. col. 8-total 9,290. Capital: Naperville. Pullic Works: Galena and Chicago Union R. R. and Branches; Illinois and Michigan Canal, etc.

DU PAge, p. v., Will co., Ill.: 154 m. N. N. E. Springfield.

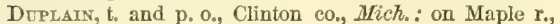
22 m. N. by E. Lansing. Pop. 419.

Duplix county, N. Car. Situate S. E. centrally, and contains $5 \pi 6 \mathrm{sq} . \mathrm{m}$. Drained by tributaries of North-East Cape Fear r., which passes through it. Surface low and level, with frequent swamps and marsh; soils fertile. Farms 923; manuf. 57 ; dwell. 1,419, and pop.-wh. 7,065, fr. col. 342, sl. 6,007-total 13,514. Capital: Kenansville. Public Works: Wilmington and Weldon R. P.

Dopont, p. V., Jefferson co., Ind.: on the line of the Madison and Indianapolis R. R., $14 \mathrm{~m}$. from Madison and $74 \mathrm{~m}$. from Indianapolis. It is a pleasant $\mathrm{v}_{\text {., }}$ and contains 2bout 60 houses, mostly built since 1847 .

Dtrree's OLd Store, p. 0., Charlotte co., Firg.: $73 \mathrm{~m}$. 8. W. by W. Richmond.

Dreuesne, p. V., Alleghany co, Penn. : 162 m. W. by N. Harrisburg.

Deocoir, p. 0., Perry co., Ill.: on a branch of Muddy cr., $133 \mathrm{~m}$. S. by E. Springfield.

Durand, p. v., Henry co. Ohio: $112 \mathrm{~m}$. N. W. Columbus.

Durango, p. $\nabla$. , Dubuque co, Ia. : on Little Makoqueta r., 71 m. N. N. E. Iowa City.

Durants Neck, p. o., Perquimans co., $N$. Car. : on the neck of land so called, formed between the Perquimans and Little rivers, and projecting into Albemarle Sound, $130 \mathrm{~m}$. E. by N. Paleigh.
Derbin's Corners, p. o., Williams co., Otio: 133 m. N. W. Columbus.

Dorelx, p. v., Bradford co., Penn.: $117 \mathrm{~m}$. N. Harrisburg Duritax, t, and p. V., Middlesex co., Conn.: $19 \mathrm{~m}$. S. Hartford. Drained by West r., a tributary of the Connecticut, which affords water-power. Surface uneven: soils fertile. The $v$, has a pleasant location on West $r$., near the centre of the town. Pop. 1,065 .

Durham, t. and p. o., Cumberland $\mathrm{con}_{n}, \mathrm{Me}_{\mathrm{e}}$ : on the S. W. side of Androscoggin r., $31 \mathrm{~m}$. S. by W. Augusta. It is a fine agricultural t., and has a prosperous river trade. A bridge over the river connects it with the opposite town of Lisbon. Pop. 1,894.

Durnam, t. and p. $\nabla$. , Strafford co., N. Hamp.: $32 \mathrm{~m}$ E. by S. Concord. Drained by tributaries of Piscataqua r., which afford water-power. The v. is on Oyster r., which is navigable for small craft. Granite is the chief export. In early times this town was the scene of many Indian barbarities. Pop. 1,499.

DURнам, p. v., Hancock co., $I l l .: 94$ m. W. N. W. Springfield.

DURHAM, t. and p. v., Greene co., N. Y.: 28 m. S. W. Albany. Surface hilly and broken; soils, clay and gravelly loam. The $\mathrm{r}$, stands on the Catskill $\mathrm{r}$., and has about 200 inhabitants, Pop, of t.2,600.

Durmax, t. and p. o., Bucks co., Penn.: on the W. side of Delaware r., $92 \mathrm{~m}$. E. by N. Harrisburg, and drained by Cooks or Durham er., which affords water-power. A singular and extensive cave is found in the limestone rock of this $t_{v}$, called the Devil's Hole, at the bottom of which is a basin of pure water 20 feet wide, which has a subterranean outlet. Pop. about 800 .

Durham Centre, p. o., Middlesex co., Conn.: $21 \mathrm{~m}$. S. Hartford.

DURHAM's CREeK, p. o, Beaufort co, $N$. Car. : on a cr. of Pamlico Sound so called, 98 m. E. by S. Raleigh.

Durhamille, p. v., Oneida co., $N$. $Y_{\text {.: }}$ on both sides of Oneida er., $106 \mathrm{~m}$. W. N. W. Albany. It is a v. of some 200 inhabitants.

Durhamrille, p. v., Lauderdale co., Tenn.: about $7 \mathrm{~m}$. N. of Big Hatchee r., and near the $\mathbf{E}$. line of the co., 153 m. W. by S. Nashville.

Durhautrile, p. v., Orange co., $N$. Car. : $42 \mathrm{~m}$. N. W. Raleigh.

Durlock, p. F., Lancaster co., Penn.: 36 m. E. S. E. Harrisburg:

Duroc, p. o., Benton co., M.o.: $67 \mathrm{~m}$. W. S. W. Jefferson City.

Durretsville, p. T., Richmond co, Firg. : 53 m. E. N. E. Richmond.

Dutch Creek, p. o., Washington co., Ia. : on a creek of Skunk r., 33 m. S. W. by S. Iowa City.

Dotcr Creek, p. o., Brown co.g Wisc.: on the cr. so called, $122 \mathrm{~m}$. N. N. E. Madison.

Dutch Neck, p. o., Mercer co., $N$. Jer.

Dutchville, p. v., Granville co., $N$. Car.: $42 \mathrm{~m} . \mathrm{N}$. Raleigh. Pop. 762.

Dutotsiurer, p. o, Monroe co, Penn.: on the W. side of Delaware $r_{*}$, to the $\mathrm{N}$. of the Water Gap, $106 \mathrm{~m}$. N. E. Harrisburg. It contains about 80 inhabitants.

DUvar county, Flor. Situate N. E., and contains 7.0 sq. m. Drained by tributaries of Nassau, St. John's, and St. Mary's rivers. Surface level, covered with pine, and the soils light but fertile, producing cotton and sugar. The plauters have easy access to market through the abovenamed rivers, which are all navigable, and no part of the county is more than 20 miles distant from one or the other. Farms 167; manuf. 5; dwell. 451, and pop.-wh. 2,38s, fr. col. 95, sl. 2,106-total 4,539. Capital: Jacksonville.

Durall's Bluff, p. o., Prairie co., $A v *$.

DUrBurs, t. and p. o., Plymouth co., Mass. : or Plymouth Harbor, $31 \mathrm{~m}$. S. S. E. Boston. Garnet's Point is within the town limits. The soil is sandy, but much of the land is 
fertile. It has some manufactures and about 2,679 inhabitants.

Dwigrit, p. v., Pope co., Ark. : on Illinois cr. of Arkansas r., 66 m. N. W. by W. Little Rock.

Dxcusburgh, p. v., Crittenden co., Ky. $: 192 \mathrm{~m}$. W. by S. Frankfort.

Drer county, Tenn. Situate N. W. on Mississippi r., and drained by Redfoot, Obion, and Forked Deer rivers; area 840 sq. m. The surface is rolling, well wooded, and the soils fertile. On the Mississippi ro, however, are extensive alluvial flats. The grains are the chief products, and some tobacco and cotton are grown. Farms 515; manuf. 7 ; dwell 824, and pop.-wh. 4,873, fr. col. 10, sl, 1,46s-total 6,351. Cotpital: Dyersburg, Public Works: Mobile and Ohio R. R.

Dyersburgh, p. v., and cap. Dyer co., Tenn.: on the N. side of the N. fork of Forked Deer cr., $146 \mathrm{~m}$. W. Nashville. It contains the co. offices and about 140 dwellings. Its trade with the neighborhood is considerable.

Drkman's, p. v., Putnam co., $N, Y:: 82 \mathrm{~m}$. S. by E. Albany.

Drsos's, p. o., Guernsey co., Ohio: $79 \mathrm{~m} . \mathrm{E}$. by N. Columbus.

\section{E.}

EAgre, p. $\nabla .$, Ia Salle co, $I l l_{*}$ : on the E. side of, and anout $2 \mathrm{~m}$. from Fermillion r. of the Illinois, $103 \mathrm{~m}$. N. N. E Springfield.

Eagle, p. 0., Warren county, Penn.: 168 m. N. W. Harrisburg.

EAGLE, t. and p. o., Clinton co., Mich.: $12 \mathrm{~m}$. W. by N.

Lansing. Grand $r$. and its branch, the Looking-glass $r$., How through the town, and furnish a vast mill-power.

EAgle, t. and p.v., Wyoming co., N. Y.: $226 \mathrm{~m}$. W. by S. Albany. Drained by head waters of Cattaraugus cr., etc Surface undulating. Soils argillaceous loam, well suited to grass and grain-heavily timbered. Pop. 1,381.

E.AGLe, t. and p. o., Hancock co., Ohio: $78 \mathrm{~m}$. N.W. by N. Columbus. Drained by Eagle and other creeks of Blanchard's fork of Maumee $\boldsymbol{x}$. Surface diversified. Soils dark loam, and on the streams well wooded. The creeks afford excellent water-power. Pup. 957.

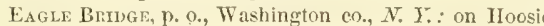
r., $26 \mathrm{~m}$. N. E. Albany. This is a great railroad centre, where the several lines leading $\mathrm{N}$. and $\mathrm{S}$., and $\mathrm{E}$. and W., meet anil form junctions.

Eagle Ci.jFfs, p. O., Monroe co., $I l l$. : on the bluffs of the Mississippi r., $6 \mathrm{~m}$. W. by N. Waterloo, and $109 \mathrm{~m}$. S. S. W. Springfield.

Eagle Creks, p. o., Bradley co., Ark.: on the cr. so called, $82 \mathrm{~m}$. S. E. Little Rock.

EAgle Creek, p. o., Benton co., Tenn.: on the cr. so called, $69 \mathrm{~m}$. W. Nashville.

EAGLF creck, Ind.: a fine mill-stream, rising in Boone co.; runs $\mathrm{S}$. about $40 \mathrm{~m}$, and empties into White $\mathrm{r}, 4 \mathrm{~m}$ below Inlianapolis. Its Indian name was Lau-anshinga paim-7onnock, or "Middle of the Valler," so called from the extensive bottoms, sometimes 4 or $5 \mathrm{~m}$, in width, through which it courses.

Eagle Errr, p. o., Bedford co., Firg.: 128 m. W. by S. Richmond.

Eagle Falts, p. o, Rockingham co., N. Car.: $86 \mathrm{~m}$ N. W. Raleigh.

Eagle Foundry, p. o., Huntingdon co., Penn.: $62 \mathrm{~m}$. W. ly X. IIarrisburg.

Eagle Furnace, p. o., Roane co., Tenn. : 134 m. E. by S. Nashrille.

EAgte Grove, p. 0., Elbert co., Ga.: 74 m. N. N. F. Milledgeville.

Eagle Harbor, p. .., Orleans county, $N_{0} Y_{*}: 220 \mathrm{~m}$ W. by $N$. Albany. It is a considerable village of 700 or 188
800 inhabitants, and lies on the Erie Canal, $57 \mathrm{~m}$. E. of Buffalo.

Eagle Harbor, p. v., Houghton co., Mich。 : on the N. side of Kew-y-wee-non Peninsula, about $15 \mathrm{~m}$. W. of Copper Harbor, and $360 \mathrm{~m}$. N. W. Lansing. This is a fine harbor opening to Lake Superior, and of late it has become a depot for the eopper miners of the neighborhood, from which they export their products and receive their supplies. Quite a village is already planted.

Eague Lake, p. o., Oakland co., Mfich: : on the borders of the lake so called, $55 \mathrm{~m}$. E. Lansing.

EAgLe LAKe, p. o., Colorado co., Tex. : on the E. side of the lake so called, $100 \mathrm{~m}$. E. S. E. Austin City. The lake is situated about $20 \mathrm{~m}$. S. S. E. Columbus, the co. seat.

Eagle Mills, p. o., Rensselaer co., $N, Y .: 26 \mathrm{~m}$. N. E. Albany.

Eagle Mrlls, p. o, Iredell co., N. Car.: $122 \mathrm{~m} . \mathrm{W}$. Raleigh.

Eagle Point, p. o., Ogle county, $I l l .: 160 \mathrm{~m} . \mathrm{N}$. by E. Springfield.

Eagle Riter, p. v., Houghton co., Mich.: about $360 \mathrm{~m}$. N. W. Lansing. The river itself is of trifling dimensions; but it has become the seat of vast mining operations. It empties into Lake Superior, about $8 \mathrm{~m}$.W. of Eagle Harbor. Eagle Rock, p. o., Wake co., N. Car.: 12 m. E. Raleigh, Eaglesmere, p. o., Sullivan co., Penn.: 81 m. N. by E. Harrisburg.

Eagle Town, p. v., Choctaw Nation, Ind. Ter.: on the W. side of Mountain Fork of Little r., an affluent of Red r., $158 \mathrm{~m}$. W. by S. Little Rock, Ark.

Eagle Town, p. v., Hamilton co., Ind. : on the E. branch of Eagle cr., $21 \mathrm{~m}$. N. by W. Indianapolis,

Eagle Village, p. v, Boone co, Inde: on the E. side of Eagle cr., and on the Michigan Road, 14 m. N. N. W. Indianapolis. There are several extensive mills on the cr., both above and below the place. Pop. about 200.

EAgLE VILLAGe, p. v., Wyoming county, N. Y.: $228 \mathrm{~m}$. W. by S. Albany.

Eagleville, p. v., Ashtabula co, Ohio: 162 m. N. E. Columbus, and about $4 \mathrm{~m}$. S. W. of Jefferson, the co. seat.

Eagleville, p. v., Williamson county, Tenn.: $27 \mathrm{~m} .5$. Nashville.

Eagleville, p. v., Tolland co., Conn.: on the New London, Willimantic, and Palmer R. R., 22 m. E. Elartford, and $36 \mathrm{~m}$. from New London.

Eagleville, p, va, Waukesha co., Wisc.: on the line of the Milwaukie and Mississippi R. R, 49 m, E. S. E. Madison, and $36 \mathrm{~m}$. from Milwaukit.

Earie's Furnace, p. o., Cass co., Ga.: $126 \mathrm{~m}$. N. W. Milledgeville.

Earlesville, p. v., Spartanburgh dist., S. Car.: $82 \mathrm{~m}$. N. N. W. Columbia.

EARlville, p. F., La Salle co, $I$ I . $_{0}$ : on the highland between Big and Little Indian creeks of Fox $r_{\text {s, }} 3 \mathrm{~m}$. from the N. co, line, and $133 \mathrm{~m}$. N. N. E. Springfleld.

Earlville, p. v., Madison eo., $N_{0} . Y_{\text {. }}: 76 \mathrm{~m}$. W. Albany, and on the Chenango Piver and Canal, $36 \mathrm{~m}$. from Utica, and 41 from Binghampton. It is a thriving place, has several warehouses and stores, and about 260 inhabitants.

Earlville, p. v., Berks co., Penn. : 63 m. E. Harrisburg. EARLY county, $G a$. Situate S. W., and contains $86 \pm$ sq. $m$. Drained in the E. by Spring cr. of Flint r., and in the W. by er. of Chattahoochee r., which runs along its W. border. Surface level and soils generally fertile, producing large crops of Indian corn and cotton, with some rice, sugar, ete. Farms 367 ; manuf. 11; dwell. 656, and pop.-wh. 3,716, fr. col. 1, sl. 3,529-total 7,246. Capital : Blakely.

EArly Grove, p. O., Marshall co., Miss. : $171 \mathrm{~m}$. N. by E. Jackson.

Eariy Grove, p. o., Lincoln co., N. Car.: 142 m. W. by S. Raleigh.

EARlYSVILLE, p. V., Albemarle co., Tirg.: 69 m.W.N.W. Richmond. 
EArprilur, p. v., Tpshur co, Tex, : 252 m. X. E. Austin. EAst AbtNgdoN, p. v., Plymouth co., Mass.: on Pembroke cr. of North r, 18 m. S. S. E. Buston.

East Altoy, p. v., Belhnap co., N. Itamp. ; 23 m. N. E. Concord.

EAst AND line of the Northern R, R., $25 \mathrm{~m}, \mathrm{~N} . \mathrm{N}, \mathrm{W}$. Concord.

EAST AUBURN, p. v., Cumberland co., Me.: on the W. side of Androseoggin r., 27 m. S. W. Augusta,

EAst Aurora, p. v., Erie co, N. Y.: 243 m. W. Albany. Situated on a branch of Buffalo creek.

EAst Aron, p. v., Livingston co., $N . Y_{*}: 196 \mathrm{~m}$. W. Albany. On the line of the Buffalo, Corning, and New York R. R., and about $2 \mathrm{~m}$. E. of Avon Springs. It is a $\mathrm{v}$. of some 400 inhabitants, and is surrounded by a highly-cultivated and thickly-settled country.

EAET BALDWIr, p. v., Cumberland co., Me: on the E. side of Saco r., $63 \mathrm{~m}, \mathrm{~S}$. W. Augusta.

East Bapitapd, p. v., Windsor co., Term. : 35 m. $\mathbb{S}$. Montpelier.

EAST BARrE, p. Ya, Huntingdon co, Penna : $\delta 9$ m.W. N.W. Harrisburg.

EAST BeXd, p. o, Surrey co., $N_{0}$ Car.: 112 m. W. by N. Raleigh.

East Bergen, p. $\nabla_{4}$, Genesee co., $N_{\text {. }}$. $_{\text {.: }}$ on the Buffalo and Rochester R. R., $59 \mathrm{~m}$. from Buffalo, and $269 \mathrm{~m}$. from Albany.

EASt Berksurre, p. v., Franklin co., Term.: on the N. W. side of Missisqui r., $51 \mathrm{~m} . \mathrm{N}$. by W. Montpelier.

East Berin, p. v., St. Clair co., Jfich.: 84 m. E. by N. Lansing.

East Berlin, p. t., Adams co., Penn.: 25 m. S. W. Harrisburg.

EAST Berse, p. V., Albany co., N. $Y_{\text {.: }} 16 \mathrm{~m}$. W. Albany. East Bethast, p. v., Genesee eo., N. Y.: $218 \mathrm{~m}$. W Albany.

Eaft Bethel, p. Va, Oxford co., Me.: on the N. side of Alder cr., an affluent of Androseoggin r., $46 \mathrm{~m}$. W. Augusta and, by the Atlantic and St. Lawrence R. R., $68 \mathrm{~m}$. from Portland.

East Bethel, p. v., Windsor county, Verm.: 29 m. s. Montpelier.

East Bethlehey, t. and p. o., Washington co, Penn.: $168 \mathrm{~m} . \mathrm{W}$. by S. Harrisburg. Monongahela r. and its tributary, Ten Mile cr., makes its boundary S. and E. There are several villages in the town. The surface is hilly, and the soil a rich loam. It has several factories, mills, and distilleries, and is crossed by the National Road.

East Bloomfield, t. and p. vo, Ontario con, $N_{.} Y_{*}: 184 \mathrm{~m}$. W. Albany. Drained by Mud ст. Surfuce undulating: soil clay and sandy loam. The $\mathrm{v}$, on the W. side of the cr. has several stores and about 450 inhabitants. Pop. of t. about 2,262 .

East Boston, p. O., Suffolk co., Mass.: (See Bostow.)

East Brewer, p. v., Penobseot co., Me.: about $7 \mathrm{~m} . \mathrm{E}$. Bangrer, and $71 \mathrm{~m}$. E. N. E. Augusta.

EAst Bretwster, p. Y., Barnstable co., Mass. : $79 \mathrm{~m}$. S. E Bostın.

EAST Bridgew ATER, t. and p. v., Plymonth co., Mass.: 22 m. S. Boston. Drained by a branch of Taunton $r_{2}$, which furnishes water-power. P, 2,545. It has several large factories, mills, and mechanic shops; and is connected with Boston by the Eridgewater Branch and the Old Colony R. R. EAst Brook, p. O., Lawrence co, Penn.: 182 m.W.N.W. Harrisburg,

EAST Brookfield, p. Y., Worcester co., Mass.: on the Western R. P., 53 m. W. by S. Boston.

EAST BrookfieLd, p. V., Orange co., Verm.: on a branch of White river.

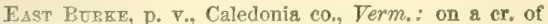
Pascat:msic: r.. $4 \mathrm{~m}$. N. E. Montpelier.

EAST Burniam, p. v., Waldo co., Me : on the N. E. side oî a small lake, 31 m. N. E. Augusta.
E.AST CaLAIs, p. v., Washington co., Verm.: 13 m. T. E. Montpelier.

East Camertidaz, po V., Middlesex co, Mass.: in the metropolitan district of Boston, and on the line of the Boston and Lowcll R. R. It is connected with Boston b- Canal Bridge, and by the viaduct of the Boston and Lowell R. R. over Clarles river. It contains a court-house, jail, and is a large and flourishing village. The former name of the place was Lechmere Point.

EAST OANERON, p. v., Steuben co., N.Y.: $184 \mathrm{~m}$. W. by S, Albany.

East Canaan, p. vo, Grafton co, N. Hamp. : $39 \mathrm{~m}$. N. W. by N. Concord.

East Car̃ani, p. va, Litchfield co., Conn.: $88 \mathrm{~m}$. W. N.W. Hartford.

East Canisteo, p. v., Steuben co., $N_{.} Y_{0}: 192 \mathrm{~m}$. W. ty $\mathrm{S}$. Albany. The v. lies on the Caristeo r., and the New York and Erie R. R., 337 m. from New York City, and 132 from. Dunkirk, now called Adtian.

EAST CARLETot, p. v., Orleans co., N. Y.: 228 m.W. by N. Albany. Situate on a branch of $\mathrm{Oak}=$ Orchard ereek.

East Centreville, p. v., Indiana co., Penn.: $123 \mathrm{~m}$, W. by N. Harrisburg.

East Charlemont, p. V., Franklin co., Mass.: on the N. side of Deerfield r., and on the line of the Greenfteld and North Adams R. R., $92 \mathrm{~m}$. W. by N. Boston.

East Charleston, p. v., Orleans co., Ferm, : on the N. side of Clyde r. of Lake Memphremagog, a few m. W. of the outlet of Seymour Lake, $51 \mathrm{~m}$. N. N. E. Montpelier. The line of railroad projected from Rouse's Point to the A tlantic and $\mathrm{St}$. Lawrence $\mathrm{R}$. $\mathrm{R}$. will intersect the village.

East Chathan, p. v., Columbia co., N. Y.: $19 \mathrm{~m}$. S. E. Albany. The Albany and West Stockbridge (western) R. R., and the Hudson and Berkshire R. R. intersect here.

East Cerster, p. v., Rockingham co., N. Hump. : 23 m. S. S. E. Concord.

EAST Chester, t. and p. v., Westchester co., $N . Y_{0}: 114$ m. S. Albany. Drained by Bronx and Hutchinson ereeks, affluents of Long Island Sound. Surface hilly and stony. Soil a fertile loam. The v., on the E. side of East Clrester cr., has a convenient harbor, and owns several sloops employed in trading with New York. The Harlem R. R., and the New York and New Maven R. R. pass through the town about $16 \mathrm{~m}$. from New York. There are in the town 91 farms, 7 manufacturing establishments, 268 dwellings, and 1,679 inhabitants.

EAst ChuNa, p. v., Wyoming county, N. Y.: $228 \mathrm{~m}$. W. Albany.

East Clarendon, p. v., Rutland co., Verms: 54 m. S. by W. Montpelier.

EAst Claridon, p. o., Geauga co., Ohio: on the E. branch of Cuyahoga r., $141 \mathrm{~m}$. N. E. Columbus.

East Clafesfield, Huron co, Ohio: on the right side of Vermillion r. of Lake Erie, 189 m. N. N. E. Columbus. East Clapkson, p. o, Monroe co., N. Y.: 212 m. W. by N. Albany.

East Cleveland, p. Y., Cuyahoga co., Ohio: about 4 m. E. by S. Cleveland, and $124 \mathrm{~m}$. N. E. Columbus.

East Cobbleskrl., p. v., Schoharie co., $N$. $Y .: 83 \mathrm{~m}, \mathrm{~W}$. Albany. Situated on the S. side of Cobbleskill er.

East Constable, p. o., Franklin co., $N$. $Y:$ : $154 \mathrm{~m}$. N. by W. Albany.

East Corinte, Penobscot co., Mre.: on a cr. of Eenduskeag $r$. of the Penobscot, $63 \mathrm{~m}$. N. E. Augusta.

East Corintr, p. v., Orange co., Verm。: on Wait's r. of the Connecticut, $22 \mathrm{~m}$. S. E. Montpelier.

East Craftsbury, p. v., Orleans county, Fem. : $81 \mathrm{~m}$. N. N. E. Montpelier.

East Creek, p. o., Cape May co., $N$. Jer.: 79 m. S. by E. Trenton.

East Cotchogue, p. v., Suffolk co., $N . Y_{\text {.: }}$ near the line of the Long Island R. R., $6 \mathrm{~m}$. W. of Greenport, and 129 m. S. E. by S. Albany. 
East Daris, p. v., Barnstable co., Moss. : 66 m. S. E. Boston.

East Dixfielio, p. v., Oxford con, Me.: 31 m. E. by N. Augusta.

East Dixмont, p. v., Penobscot co., Me.: 44 m. N. E. Augusta.

EAst Dorset, p. v., Bennington co., Term: on the line of the Western Vermont R. R., 74 m. S. by W. Montpelier.

East Douglass, p. v., Worcester co., Mass.: on Mum-

ford r., an affluent of Blackstone r., $38 \mathrm{~m}$. S.W. Boston.

EAst Dover, p. o., Piscataquis co., Me.: 71 m. N. N. E. Augusta.

East Duanesburgh, p. o., Schenectady co., $N_{0} Y_{.}: 21$ m. W. N. W. Albany.

East Durhas, p. 0., Greene co., N. Y.: 26 m. S. W. Albany.

East Eddington, p. v., Penobscot co., Me.: 72 m. N. E. Augusta.

EAst Eden, p. o., Erie co., N. Y.: 256 m. W. Albany.

East Eliziot, p. v., York co, Me. : on the line of the

Portsmouth, Saco, and Portland R. R., 99 m. S. S. W. Augusta.

East Étars, p. 0., Erie co., N. Y.: $263 \mathrm{~m}$. W. Albany.

EAst ExeTER, p. v., Monroe co., Mich.: on Stony cr. of Lake Erie, 73 m. S. E. Lansing.

East Fairfield, p. v., Columbiana co., Ohio: $136 \mathrm{~m}$.

E. N. E. Columbus.

East F AIRFIELD, p. v., Franklin co., Verm.: on an affluence of Missisqui r., 41 N. N. W. Montpelier.

East Falmotte, p. Y., Barnstable co., Mass.: at the head of an inlet of Fineyard Sound, $61 \mathrm{~m}$. S. S. E. Boston.

East Fishikrl, t., Duchess co., $N . Y_{0}: 72 \mathrm{~m}$. S. Albany. Drained by Fishkilt cr. Surface hilly in $\mathrm{S}_{0} ;$ in N. declining to plains. The t. contains 210 farms, 13 manufacturing establishments, 441 dwellings, and 2,610 inhabitants.

East Floreanck, p. 0., Oneida co., N. Y.: $108 \mathrm{~m} . \mathrm{W} . \mathrm{N} . \mathrm{W}$. Albany.

Eastrord, t. and p. v., Windham co., Conn.: $31 \mathrm{~m}$. E. by N. Hartford. Drained by Natchaug r., a tributary of Willimantic $r$. The $v$. is located between the forks of the r., and has several manufactures. Pop. 1128.

EAST Fork, p. o., Montgomery co., 7 on $_{0}$ : on the E. fork of Shoal er, an aftluent of the Kaskaskia r., $47 \mathrm{~m}$. S. S. E. Springfield.

East Fork, p. o., Macon co., Mo. : on the E. fork of Chariton r., $89 \mathrm{~m}$. N. by W. Jefferson City.

EAst Foxborovgh, p. ve, Norfolk co, Mrass.: near the line of the Boston and Providence R. R., $23 \mathrm{~m}$. S. by W. Boston.

East Fraxistin, p. v., Franklin co., Term.: 54 m. N. by W. Montpelier.

East Freedour, p. 0, Blair co., Penn. : 84 m. W. by N. Harrisburg.

EAST FreEtown, p. 0., Cortlandt county, N. Y.: $114 \mathrm{~m}$. TT. by $\therefore$ Albany.

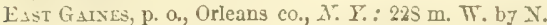
Albany.

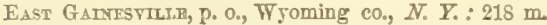
W. Albany.

EAst Galway, p. 0, Saratoga co., N. Y.: $2 \pi \mathrm{m} . \mathrm{N} . \mathrm{N} . \mathrm{W}$. Albany.

East Gexod, p. v., Cayuga county, $\lambda . Y_{0}: 137 \mathrm{~m} . \mathrm{W}$. Albany.

EAST Georgu, p. T., Franklin co., Verm.: on the line of the Vermont Central R. R., 48 m. N. W. Montpelier.

EAST Gervar, p. 0., Chenango $C_{2}, N . Y .: 100 \mathrm{~m}$. W. by S. Albany.

East Gervartown, p. V., Wayne co., Ind.: 56 m. E. Indianapolis.

East Glentrille, p. 0., Schenectady co., N. Y.: $19 \mathrm{~m}$. N. W. Albany.

East Graftox, p. 0., Rensselaer co., $N . Y_{0}: 21 \mathrm{~m} . \mathrm{N} . \mathrm{E}$. Albany.
East Granbr, p. v., Hartford county, Conn.: $14 \mathrm{~m}, \mathrm{~N}$. Hartford.

East Granville, p.v., Hampden con, $\mathbf{M a s 8}$ : on an affluent of Westfield r., $98 \mathrm{~m}$. W. by S. Boston.

East Greentush, p. v., Rensselaer county, $N_{0} Y_{*}: 6 \mathrm{~m}$. E. by $\mathrm{S}$. Albany. It contains about 30 dwellings.

East Greene, p. o., Chenango co., $N_{.}, Y_{.:} 99 \mathrm{~m} . \mathrm{W} . \mathrm{S} . \mathrm{W}$. Albany.

EAst Greevrilue, p. v., Stark co., Ohio: 100 m. N. E. Columbus.

East Greenwich, p. 0., Washington co., $N_{0}, Y_{0}: 34 \mathrm{~m}$. N. N. E. Albany.

East Greenwich, t., p. V., and cap. Kent co., R. I. : 12 m. S. Providence. Drained by Maskachug and Hunt's rivers, on which are numerous cotton and other manufactories. Surface rather rough and stony. Soils comparatively fertile, yielding good crops of corn, barley, and potatoes. The $t$, is also noted for its excellent fruit and cider. The harbor in front of the v., an arm of Narraganset Bay, is deep enough for vessels of 500 tons. A number of vessels are owned here, and the coasting trade and fisheries give employment to many of the inhabitants. Across the bay to Bristol is about 8 miles. The village is intersected by the Stonington and Providence R. R. Pop, of t, 2,358,

East Grove, p. o., Henry co., Ia.: $52 \mathrm{~m}$. S. Iowa City. East GroveraNd, p. O., Livingston co., $N_{0} Y_{*} ; 197 \mathrm{~m}$, W. Albany.

East GUILFord, p. Y., Chenango county, $N . Y_{0}: 84 \mathrm{~m}$. W. by S. Albany. Situate on the W. side of Unadilla cr., and contains about 30 dwellings.

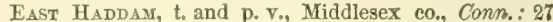
m. S. S. E. Hartford. Drained by tributaries of Connecticut $r$. which makes its W. border. Surface uneven and rocky. Soil fertile, and adapted to grazing. The v. of East Haddam lies on the $\mathrm{E}$. bank of the Connecticnt, a little below the mouth of Salmon r., $14 \mathrm{~m}$. from Long Island Sound. It is a thriving place, with a bank, etc. In the t. there are several other manufacturing villages-on Salmon $r$. axd its tributary, Moodus r. Pop. of t. 2,610.

Easthair, t. and p. v., Barnstable co., Mass. : 67 m. S. E. Boston. Situate on Cape Cod, about half way between the elbow and the Cape. Surface flat. Soil sandy and sterile. The inhabitants are chiefly engaged in coasting and the fisheries, and in the manufacture of salt, which is produced by the evaporation of sea-water. Pop. 845 .

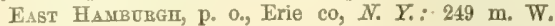
Albany.

East Hamion, p. O., Madison county, N. Y.: $82 \mathrm{~m}$. W. by N. Albany.

East Hampden, p. V., Penobscot co., Me.: on the W.

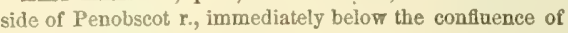
Sowadabscook r., $59 \mathrm{~m}$. N. E. Augusta.

EAst Hasrptoy, p. V., Middlesex co., Conn. : on Pine Brook, the outlet of Pocotopogue Pond, $17 \mathrm{~m}$. S. S. E. Hartford. The New York and Boston R. R. (direct line) will pass through the village.

East Hampton Lake, p. 0., Middlesex co., Conn. : 15 m. S. S. E. Hartford.

EAST HAMPtox, t. and p. v., Hampshire co., MFass.: 98 $\mathrm{m}$. W. by S. Boston. Drained by several tributaries of Connecticut $r$. Surface variegated, and soils alluvial and very productive. The v, is pleasantly situate on a fine millstream, and has several factories of cotton goods, boots and shoes, ete. Mt. Tom lies between this t. and the Connecticnt $r$. The line of the abandoned Hampshire and Hampden Canal passes through the $t_{\text {, }}$ and will be probably filled up and used as the bed of the New Haven and Northampton R. R. Pop. 1,342 .

East Hamprov, t. and p. V., Suffolk co, N. Y.: $135 \mathrm{~m}$. S. E. Albany. Occupies the extreme E. peninsula of Long Island, and includes Gardiner's and other small islands. Surface level; soil, sandy alluvion. Toward Montauk Point the land is rugged. On this noted point there is a 
light-house 140 feet high, the light of which can be seen $80 \mathrm{~m}$. from sea. A remnant of the Montauk Indians reside here on a conditional reservation of 1,000 acres. The $\mathrm{v}$. lies on a single street and contains about 400 inbabitants. There are in the $t, 168$ farms, 2 manufacturing establishments, 423 dwellings, and 2,122 inhabitants.

East Hanover, to and p. o., Lebanon co., Penn. : $21 \mathrm{~m}$. E. Harrisburg. It lies between the Blue Mountains and Swatara er., which gives it considerable water-power. It has several mills, ete., and about 2,600 inhabitants.

EAsT HARDWrok, p. ₹., Caledonia co., Verm.: on La Moille r., 24 m. N. E。 by N. Montpelier.

East Hantford, t. and p. v., Hartford co., Conn.: on the E. side of Connecticut r., opposite to Hartford, with which it is connected by a bridge, and the Providence, Hartford, and Fishkill R. $\mathrm{R}$. here crosses the $r$. The $t$, is drained chiefly by Hockanum r., which falls into the Connecticut, and affords extensive water-power. The land on the Connecticut is an alluvial meadow, very fertile; back of this it rises 15 or 20 feet to an extensive plain, and a causeway a mile long extends across the meadows to the bridge. The $\mathrm{v}$, is pleasantly located on the plain, mostly on one broad street, shaded by lofty elms and other trees, the former in rows down the middle and the latter on its sides. East Hartford has long been noted for its manufactures and has still a considerable amount. The first powdermill in the country was ereeted here in 1775 . The present population of the $t$. amounts to 2,497 souls.

EAST HARWICK, p. V., Barnstable co., Mass. : 72 m. S. E. Boston.

EAST HAven, t. and p. $\nabla .$, New Haven co., Conn.: on the E. side of New Haven Harbor, and on Long Island Sound, $37 \mathrm{~m}$. S. by W. Hartford; and separated from New Haven by Quinnipiac r., over which there are bridges and railroad viaducts. Farm r. also runs through the town. The surface is generally level, and the soil light and sandy or sandy loam-to the E., however, it is hilly, and the soil a gravelly loam. The $\mathrm{v}$, is pleasantly located and commands a fine prospect of Long Island Sound. It has some trade, and many of the inhabitants are engaged in coasting and fishing. The New Haven and New London R. R. passes through it. Population of the t. 1,673. A light-house stands on Five Mile Point, the E. side of the entrance to the harbor.

EAst HAVEN, t. and p. o., Essex co., Verm.: $46 \mathrm{~m}$. N. E. by E. Montpelier. Drained by Paul's stream on the E., and on the W. by Passumsic r. Surface mountainous and rugged, and but a small portion fit for cultivation. It is very sparsely settled. Pop. 94.

East Haverinll, p. v., Essex co., Mass.: on the N. side of Merrimac r, $32 \mathrm{~m}$. N. Boston.

EAst HAverhll, p. v., Grafton co., N. Hamp.; $13 \mathrm{~m}$. N. N. W. Concord.

East Hebron, p. $\nabla$., Oxford co., Me, : on a cr. of Little Androscoggin r., and on the line of the Buckfield Branch R. R., $81 \mathrm{~m}$. W. S. W. Augusta,

East Hempfield, t. and p. o., Lancaster co., Penn, : 32 m. E. S. E. Harrisburg. Drained by Little Conestoga r. Surface generally level, and soils fertile. There are several distilleries, mills, etc, in the town, and about 1,500 inhabitants. The Lancaster and Harrisburg R. R. passes through it, $5 \mathrm{~m}$. W. Laneaster.

East Herrick, p. o., Bradford co., Penn.: 108 m. N. by E. Harrisburg.

East Highgate, p. v., Franklin co., Ferm, : on the N. side of Missisqui r., $52 \mathrm{~m}$. N. N. W. Montpelier.

EAst Hilu, p. V., Alleghany co., $N_{0} Y_{*}: 203$ m. W. Albany. EAst HoMER, p. o., Cortlandt co, $N_{0} Y_{\text {: }} 117 \mathrm{~m}$. W. Albany.

East Houndsateld, p. o., Jefferson co., $N$. $Y$ : $143 \mathrm{~m}$, N. W. Albany.

EAST JAFFret, p. v., Cheshire co., N. IJamp.: $36 \mathrm{~m}$. S. W. Concord.
EAst JAYA, p. 0., Wyoming co, $N$. $Y .: 226 \mathrm{~m}$. W Albany.

EAST KENT, p. o, Litchfield co, Conn, : 11 m. W. by 8. Hartford.

EAst Krul, p. o., Greene co., $N_{0} Y_{0}: 40$ m. S. S. W. Albany.

East Kildively, p. Y, Windham co, Conn.: $46 \mathrm{~m}$. E. Hartford.

EAst Kingstow, t. aud p. v., Rockingbam co., N. ПIamp.: $37 \mathrm{~m}$. S. E. Concord. Drained by Pow-wow $r$. Soils fertile. It has several mills, tanneries, etc. The $\mathrm{r}$, is located on the Boston and Maine R. R. Pop. of t. 582 .

EAst KNox, p. o., Waldo co, Me. : 29 m. E. N. E. Augusta.

EAsT Kox, p. o., Wyoming co., $N$. $Y_{\text {.: }}$ on East Koy cr., $218 \mathrm{~m}$. W. Albany. The creek rises in Genesee co., and in Alleghany co. unites with West Koy cr., whence it flows into Genesee $r$. It is a good mill stream.

EAsT LaNDAFF, p. o., Grafton co, N. Hamp.: at the $\mathrm{S}_{0}$ base of Landaff Mountain, $94 \mathrm{~m}$. N. by W. Concord, The finest of iron ore abounds in this vicinity.

East Lansixg, p. o., Tompkins $c_{0, y}$ N. $Y_{\text {.: }} 136 \mathrm{~m}$. W. by S. Albany.

East La Porte, p. o., Haywood co., $N$. Car.: 240 m. W. Raleigh.

EAst LebaroN, p. v., Grafton co., $N$. Hamp.: at the N. end of Mascoma Pond, $46 \mathrm{~m}$. N. W. Concord. The Northern (N. H.) R. R. intersects the $\nabla ., 61 \mathrm{~m}$. by the route from Concord.

East Liee, p. o., Berkshire co., Mass. : 113 m. W. Boston. East Lempster, p. o., Sullivan co., N. Hamp. : 31 m. W. Concord.

East Leon, p. o., Cattaraugus co.g. N. $Y_{*}: 264$ m. W. by S. Albany.

East LewistoN, p. o., Mahoning co., Ohio: 137 m. N. E. Columbus.

East Lexington, p. $\nabla$., Middlesex co., DFass. : $9 \mathrm{~m}$. N.W. Boston. The Lexington and West Cambridge R. R. passes through the village.

EAst Liberty, p. o, Logan co, Ohio: $46 \mathrm{~m}, \mathrm{~N} . \mathrm{W}$. Columbus.

East Liberty, p. V., Allen co., Ind.: 104 m. N. E. Indianapolis.

East Liberty, v., Alleghany co., Penn.: on the Pennsylvania R. R., $5 \mathrm{~m}$. E. Pittsburg. It is a thriving place of some 600 inhabitants.

East Libertx, p. ., Fayette co., Penn.: on the \$. W. side of Youghiogeny r., $152 \mathrm{~m}$. W. by S. Harrisburg.

East LimingtoN, p. o, Fork co, Me.: 63 m. \$. W. Augusta.

East Luxe, p. v., Saratoga co., $N_{0}, Y_{.}: 19 \mathrm{~m} . \mathbf{N}$. by W. Albany.

East Livervore, t. and p. $\nabla .$, Kennebec co., $M e_{\text {e.: }}$ on the left bank of Androscoggin r., $21 \mathrm{~m}$. W. by N. Augusta. The Androscoggin R. R. passes through the v., about 16 m. from Leeds Station, its point of connection with the Androscoggin and Kenmebec R. R. Pop. of $t .592$.

EAst Livgrpool, p. V., Columbiana co., Orio: near the right bank of the Ohio r., $134 \mathrm{~m}$. E. N. E. Columbus. It is a well laid-out village, and contains several large warehouses, etc., being the principal depott of the flour from the numerous flouring-mills on Little Beaver $r$. The location is one of the pleasantest in the State-the land rises from the river, affording commanding sites in the more elevated parts.

East LoNg Mradow, p. v., Hampden co., Mfass. : $79 \mathrm{~m}$. W. S. W. Boston.

East Imax, p. V., Grafton county, N. Hamp.: $77 \mathrm{~m}$. W. N. W. Concord.

East Lxme, t. and p. v., New London co., Conn: $39 \mathrm{~m}$. S. E. Hartford. It has a number of ereeks falling into Long Island Sound, and on its $\mathrm{E}$. border is a deep inlet much frequented by fishermen, and in which large num- 
bers of fish are taken. The $\mathrm{v}$. lies about $6 \mathrm{~m}$. N. W. of New London, and is pleasantly situated on high land overlooking the sound. The $t$, is crossed in the $\mathrm{s}$. by the New Haven and New London R. R. Pop. 1,392.

East Macdoxovgri, p. o., Chenango co., N. Y.: $98 \mathrm{~m}$. W. by S. Albany.

EASt Machias, t. and p. v., Washington co., Mre. : $121 \mathrm{~m}$. E. N. E. Augusta. Drained by East Machias r., which, after receiving the waters of a large pond from the $\mathrm{E}$., falls into Machias r. and bay, at the S. extremity of the t. These afford immense water-power. The village, or settlement, lies on both sides of the river, and has several mills both above and below it. Pop. of t. 1,382.

EAst Madisor, p. ₹., Somerset eo, Me.: at the outlet of a large pond, $36 \mathrm{~m} . \mathrm{N}$. Augusta. It has several mills and about 80 inhabitants.

East Matne, p. o., Broome co., N. Y.: 118 m. W. S. W. Albany.

Eastmanstille, p. v., Fulton co, N. Y.: 41 m. N. W. Albany.

Eagt Marrox, p. o., Suffolk co., $N . Y$.

East Marion, p. Y., Livingston co., Mlich, : 34 m. E. S. E. Lansing.

East Marsfifield, p. ₹., Plymouth co., Mass.: $18 \mathrm{~m}$. S. E. Boston. It is pleasantly located about a mile back from South river.

East Menway, p. v., Norfolk co., Mass.: 20 m. S. W. Boston. The projected New Tork and Boston R. R. will pass through the village.

EAst Middueborotgh, p. Y., Plymouth co., Mrass.: $34 \mathrm{~m}$. S. by E. Bosinn.

East Mimblebury, p. v., Addison co, Term.: $30 \mathrm{~m}$. 8. W. Muntpelier.

EАSt Monmouth, p. V., Kennebee co., Me.: 13 m. S. W. Augusta.

East Monroe, p. v., Fighland co., Otio: on the W. side of Rattlesnake cr., a constituent of Paint cr., $51 \mathrm{~m}, \mathrm{~S} . \mathrm{W}$. by $\mathrm{S}$. Columbus.

EAST Montpedrer, to and p. vo, Washington co, Term. $6 \mathrm{~m}$. E. by N. Montpelier. The $\mathrm{v}$. is located on Onion r. by which the surface of the $t_{\text {. }}$ is drained. It is a fine agricultural recion, Pop, 1, 417 .

East Mostrilue, p. v, Waldo co., Me. : 30 m. E. N. E. Augusta.

EAST Mortorres, p. v., Suffolk co., N. Y.: 182 m. \$. S. E. Albany and about $62 \mathrm{~m}$. E. New York, on the S. side of Long Island.

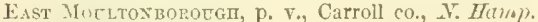
$89 \mathrm{~m} . \mathrm{N}$. by E. Concord.

EASt Nassau, p. o, Rensselaer co, N. $Y_{0}: 17 \mathrm{~m}, \mathrm{~S}, \mathrm{E}$. Albany.

East New Market, p. vo, Dorehester co., MMd.: about 8 m. E. of Choptank r., $39 \mathrm{~m}$. S. E. Annapolis.

EAst Netrport, p. v., Penobscot co., Me. : on a cr, of Sechasticuch r., 5.3 1n. N. E. Augusta.

East New Portland, p. v., Somerset co., Mre.: on Seven Mile Brook of Kennebec $r_{0}, 42 \mathrm{~m}$. N. N. W. Augusta.

EAST NeW Strakon, p. v., Kennebec co., Me.: 23 m. N. N. W. Anomsta.

EAST NEW VINEXARD, p. Y., Franklin co., Me.: $35 \mathrm{~m}$. N. N. W. Augusta.

EAST NETV YoRk, p. v., Kings co., N. Y.: $5 \mathrm{~m}$. from New York and $130 \mathrm{~m}$, S. Albany, This is a pleasant $\mathrm{Y}$, located on the tine of the Long Island F. R., and his within the past year or two been rapidly increased by the overflowing population of the adjoining cities, It has several promising manufacturing establishments.

EAST Northrort, p. v., Waldo co., Mfe.: on Belfast Bay, $42 \mathrm{~m}$. E. Augusta.

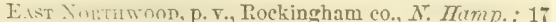
$\mathrm{m}$. I. by S. Concord.

Elst Jinetu Yarmoctu, p. v., Cumberland co., He. : 40 m. S. by Wr. Augusta.
East Nozwich, p. v., Queen's co., N. Y.: 126 m. S. Albany.

EAst Oedew, p. v., Lenawee co., Mich.: 71 m. \$. S. E. Lansing.

Easton, to and p. o., Fairfield co., Conn.:51 m. S. W. by s. Hartford. Drained by Saugatuck and Mill rivers, which run to Long Island Sound. It is entirely agricultural in its industry. Pop. 1,432.

Easton, p. v., and cap. Talbot co., Md.: on Treadhaven cr., $12 \mathrm{~m}$. from its confluence with the estuary of Choptank r., 27 m. E. S. E. Annapolis. Lat. $36^{\circ} 46^{\prime} 10^{\prime \prime}$ N., and long. $76^{\circ} 08^{\prime} \mathrm{W}$. It is the largest and most populous $\mathrm{v}$. of the eastern shore, and a place of considerable trade. It contains a C. H., a jail, a market-house, and 4 church ediflces; and it has two newspapers, the "E. Gazette" (whig) and the "E. Star" (dem.), both issued weekly. Pop. 1,413.

EAston, t. and p. v., Bristol co., Mas8.: 24 m. S. Boston. Drained by affluents of Taunton $\mathbf{r}$, on which are numerous establishments for cotton, wool, and iron manufactures. It is one of the most busy manufacturing towns in the State. The $v$. lies a little eastward of the centre of the $t$. P. 2,337.

EAstor, t. and p. v., Washington co., N. . $_{\text {. }}: 24 \mathrm{~m}$. N. by E. Albany. Drained by Battenkill and other creeks of Hudson r., which bounds it on the W. Surface diversified; soil, sandy and elayey loam. The $\mathbf{v}$. lies on the Troy and Whitehall turnpike, and contains between 300 and 400 inhabitants, The to has a pop. of 8,225 .

Easton, p. v., Wayne co., Ohio: $79 \mathrm{~m}$. N. E. Columbus.

EASTON, p. b., and cap. Northampton co. Penn.: on the W. side of Delaware $r$., where it receives the Lehigh $r$. $93 \mathrm{~m}$. E. N. E. Harrisburg. It is built on a point of land formed by the Delaware and Lehigh rirers and Bushkill cr. The streets are laid out along the cardinal points, crossing each other at right angles, and forming in the centre of the borough a square area, on which stands the court-honse. The part of the $\mathrm{v}$. on the Delaware is level, but considerably elevated above the river, and the ground rises gradually toward the W., to a considerable height. There are fine bridges and viaducts over all the streams abovementioned.

Easton is the entrepôt of a vast internal commerce botween the coal and iron fields of Pennsylvania and the Eastern markets, and will in time become an importan point in the line of travel from East to West, being situated at the most eligible pass between the two sections. Already it is the terminus of several lines of railroad and of three eanals, viz., the Morris Canal, the Lehigh Canal, and the Delaware Canal. Here terminates the New Jerser Central R. R., and also railroads coming from the western borders of Pennsylvania on Lake Erie, and from Pittsburg; and others are projected to Lake Ontario. The distance from New York to Frie via Easton, when the lines contemplated aro completed, will be 462 miles and to Pittsburg 423 .

As a business place Easton is one of the most prosperous towns of Pennsylvania. It will give some idea of the magnitude of its various interests, to state that there are within a radius of 3 miles of the place, 18 merchant and grist-mills, 6 saw-mills, 3 oil-mills, 3 tanneries, 5 founderies, 7 distilleries, 1 planing-mill and wire factory, 3 large blast furnaces, 2 cotton factories, and other smaller factories, all in full operation. At South Easton there is a vast waterpower, sufficient for a great inerease of manufactures; besides which the Lehigh $r$. has a fall of 200 feet between the Lehigh Water Gap and Easton, a distance of 25 miles, which would afford any additional water-power required.

The surrounding country is remarkable for the exquisite beauty of its natural scenery and its uncommon healthiness, as well is for its exceeding fertility and great ardvantages for manufactures, trade, and business. The excess of flour over and above the home consumption that is annually sent to market from Easton and its vicinity, excecds 117.110! barrels, and 50,000 barrels of corn meal. At Easton alone during 1851, there were manufactured 90,000 barrels of 
flour, 14,000 barrels of whiskey, 3,000 tons of pig metal, and 800 tons refined iron. Immense deposits of the finest kinds of iron ore have been found in the vicinity, and no section of the United States is more favorably adapted to the successful manufacture of iron. In short, the position and resources of Easton are so favorable, and its growth so rapid, that nothing but the opening of the lines of railroad now projected is wanting to enable it to take a position among the most prosperous of our inland cities.

The borough is well supplied with the means of education and religious instruction. It has numerous Sabbathschools and churches, and several primary and public schools, academies, etc.; and here is located Lafayette College, one of the best institutions of the State-manual labor forming a branch of its curriculum. This institution was founded in 1832 ; in 1550 it had a president, 7 professors, and 52 students ; its alumni counted 101, of which 30 were in the ministry, and its library contained 5,000 volumes.

The press of Easton consists of 8 weekly newspapers, viz. the "Northampton Correspondent" (dem.), "Der Democrat" (Germ. dem.), the "E. Whig," the "E. Sentinel"(dem.), the "Independent Democrat," the "Eastonian" (whig), the "Northampton Courier" (dem.), and the "Democrat and Argus" (dem.)-all issued weekly.

The population of Easton in 1820 was 2.370 ; in 1830 , 8,529 ; in $1450,4,865$, and in 1850 .

East Orange, p. 0., Delaware co., Ohio: on Alum cr., $15 \mathrm{~m}$. N. Columbus.

East Orange, p. v., Orange co., Verm.: 15 m. E. S. E. Montpelier.

East Orangeville, p. 0., Wyoming co., $N . Y_{.}: 218 \mathrm{~m}$. W. Albany.

EAst Orleans, p. v., Barnstable co., Mass. : 73 m. S. E. Boston.

East Orrington, p. v., Penobseot co, Me.: $68 \mathrm{~m}$. E. N. E. Augusta.

East Otтo, p. 0., Cattaraugus co., N. Y.: $24 \mathrm{~S}$ m. W. by \$. Albany.

East Pannted Post, p. o., Steuben co., N. Y.: $166 \mathrm{~m}$. W. S. W. Albany. By the Erie R. R. 295 m. from New Tork City.

East Palestine, p. v., Columbiana co., Ohio: $138 \mathrm{~m}$. E. N. E. Columbus.

East Palmira, p. o., Wayne co, N. Y.:168 m.W. by N. Albany.

EAST PARTSA, p. o., Oswego co., N. Y.: 122 m. W. N. W. Albany.

East Pargonfixeld, p. v., York co., Me.: $72 \mathrm{~m}$. S. W. Augusta.

East Pentbroke, p. v., Genesee co., N. Y.: $226 \mathrm{~m}$. W. Albany. The Puffalo and Rochester $R . R$, and the Canandaigua $R . R$. pass the village.

East Penk, t. and p. o., Carbon co., Penn.: $84 \mathrm{~m}$. E. by N. Harrisburg. Drained by Mahoning and Lizzard creeks of Lebigh r., which makes its E. border. The Blue Mountains traverse its $\mathrm{S}$. line, and through this, in the E. part of the $t_{\text {. }}$ is the Lehigh Water Gap. Iron ore and coal abound, and there are several furnaces, ete. Pop. about 1,700 .

East Peptipeli, p. v., Middlesex en., Mass. : 36 m. N.W Boston, near the line of the Worcester and Nashua $R_{n} R_{w}$

East Perv, p. v., Clinton co., $N$. $Y_{\text {. }}$ : on Little Au Sable r. of Lake Champlain, $126 \mathrm{~m}$. N. Albany.

East Phapesalia, p. v., Chenango co., N. Y.: $98 \mathrm{~m}$. W. by S. Albany.

East Pifrpoint, p. o, St. Lawrence co., N. Y.: $136 \mathrm{~m}$. N. W. by N. Albany.

Eusr Prke, p. Y., Wroming co., $N_{*} Y_{*}$ : on East Koy cr., $218 \mathrm{~m}$. W. Albany.

EAST Pitcairn, p. o., St. Lawrence county, N. Y.: 124 m. N. W. Albany.

East Pittsfiet. D, p. v., Somerset co., Me.: on a branch of Sebasticook r., 36 m. N. N. E. Augusta.
Ea8t Pittston, p. v., Kennebec co., Me. : 14 m. 8. S. E Augusta.

East Pratifield, p. v., Sullivan co., N. Hitmp.

East Plymoetir, p. v., Ashtabula co., Ohio: on Ashtabula cr., $172 \mathrm{~m}$. N. E. Columbus.

East Point, p. 0., De Kalb eo., Ga.: on the line of the Macon and Western R. R. $6 \mathrm{~m}$. E. of Atlanta, and the point from which the La Grange P. R. diverges. In a direct line it is distant $80 \mathrm{~m} . \mathrm{W} . \mathrm{N}$. W. Milledgeville.

East Poland, p. v., Cumberland co., Me.: on the line of the Atlantic and St. Lawrence R. R., $31 \mathrm{~m}$. from Portland, and $33 \mathrm{~m}$. S. W. Augusta.

EAstrort, t. and p. v., Washington county, Me.: $144 \mathrm{~m}$. E. by N. Augusta. The t. consists of Moose Island, $4 \mathrm{~m}$. long (2,150 acres), and several smaller islands, viz., Dudley's, Frederick, and Patmos, in Passamaquoddy Bay. The v. of Eastport (lat. $44^{\circ} 54^{\prime} \mathrm{N}$., and long. $66^{\circ} 56^{\prime} \mathrm{W}$.) is on Moose Island, which is connected with Dennysville and Perry by bridges, and with Lubec by a ferry, and is but a short distance from the British islands-Indian and Campo Bello. It has a fine harbor in Passamaquoddy Bay, and the tide is here rapid, and rises 25 feet. It has a large lumber trade, and its trade with the neighboring provinces has long been very flourishing. In the fisheries and coasting it has also a large number of vessels engaged. The tonnage of Passamaquoddy Bay in 1850 was 19,985 tons, of which 10,581 tons were registered, 9,153 tons enrolled and licensed, and 272 tons licensed and under 20 tons. Of the enrolled and licensed tonnage, 7,385 tons were engaged in the coasting trade, 1,316 in the cod fishery, and 482 in the mackerel fishery. The steam tonnage amounted to 213 tons registered, and 645 tons enrolled and licensed. During the year $1849-50,7,488$ tons of shipping were built, viz., 13 ships, 8 brigs, 15 schooners, and 3 steamers. Clearances to foreign ports, 746 (63,367 tons), and entrances, 720 ( 58,453 tons). Much of the shipping built here is sold and exported. The population of the t. in 1850 was 4.125. A United States' garrison is maintained at this station, which is the most easterly of the Union, and nearest to the British territory.

EASTPOET, p. r., Tishemingo co., Miss. : on left bank of Tennessee $r$., and immediately $W$. of the mouth of Bear $r$., 208 m. N. E. Jackson. The Memphis and Charleston R. R. passes through the $\mathrm{V}_{\text {., }}$ skirting the $\mathrm{r}$. from Tuscumbia to the Tennessee State line.

East Poultney, p. v., Rutland co., Verm.: 56 m. 8. S. W. Montpelier. It contains several mechanic shops and about 65 dwellings.

E.ASt PRinceton, p. v., Worcester co., Mass. : on a branch of Nashua r., 42 m. W. by N. Boston.

East Raisinville, p. v., Monroe co, Mich, : $76 \mathrm{~m}$. S. E. Lansing.

East RandolPh, p. o., Cattaraugus co., N. Y.: $234 \mathrm{~m}$. W. by S. Albany.

EAST RANDOXPH, p. v., Norfolk county, DLass.: 14 m. S. Boston.

East Randolph, p. v., Orange co., Verm. : on the Second Branch of White r., $23 \mathrm{~m}$. S. by E. Montpelier. The river here affords good water-power.

East Raymond, p. v., Cumberland co., Me. : 46 m. S. W. Augusta.

East Readfield, p. o., Kennebec co, Mre.: 7 m.W.N.W. Augusta, near the Androseoggin and Kennebec R. R.

East Richlaxd, p. v., Belmont county, Ohio: 112 m. E. Columbus.

East River, p. o., Mercer co., Virg.: 192 m. W. by $\mathbf{S}$. Richmond. East $\mathbf{r}$. is a tributary of Great Kanawha river.

East Rrver, p. o., Walton co., Flor.: on the r, so called, $132 \mathrm{~m}$. W. by N. Tallahassee.

East river, $N . Y_{0}$ : a strait between Long Island Sound and the harbor of New York. dividing Long Island from the mainland. It is about $15 \mathrm{~m}$. Iong, and navigable for the largest vessels. The noted pass, called Fell Gate, is situated opposite Barn Island, about $6 \mathrm{~m}$. from New York City. The 
fiterruptions to navigation in this channel have been removed, and the dangers which hitherto made it a scene of dread to the seaman, are among the things of the past, existing only in the legends of the forecastle.

East Rochester, p. V., Columbiana co., Ohio: $114 \mathrm{~m}$. E. N. E. Columbus, near the Cleveland and Pittsburg R. R., about $73 \mathrm{~m}$. from Cleveland.

East Rodmax, p. o., Jefferson co., $N . Y .: 123 \mathrm{~m}$. N. W. Albany.

East Roxbury, p. v., Washington county, Verm. : $13 \mathrm{~m}$. S. by W. Montpelier.

East Rumford, p. v., Oxford co., Me.: on the N. side of Androscoggin r., 42 m. W. N. W. Augusta.

East Rupert, p. v., Bennington county, Verm. : $77 \mathrm{~m}$. S. by W. Montpelier.

East Salem, p. o,, Washington co, $N$. $Y .: 40$ m, N. N. F Albany.

East Samtours, p. v., Essex co., Mass. : 37 m. N. by E. Boston.

East Sanborkton, Belknap co., N. Hamp. : near Great Bay, $21 \mathrm{~m} . \mathrm{N}$. Concord.

East Sand Lake, p. v., Rensselaer co, $N, Y_{*}: 14 \mathrm{~m} . \mathrm{E}$. Albany.

East Sandwroh, p. v., Barnstable co., Mass: on Cape

Cod Bay, 54 m. S. S. E. Boston.

East Sardy, p. 0., Venango co, Penn.: on Sandy cr., 174 m. W. N. W. Harrisburg.

East Sangerville, p. v., Piscataquis co, Me.: on the S. side of Piscataquis r., 63 m. N. N. E. Augusta.

EAsT SCHUYLER, p. O., Herkimer county, N. $Y_{0}: 71 \mathrm{~m}$. W. N. W. Albany.

East Scotr, p. o., Cortlandt co., $N_{.} Y_{0}: 122 \mathrm{~m}$. W. Albany. East Sharon, p. v., Potter co., Penn. : in the N. W. corner of the co., $132 \mathrm{~m}$. N. W. by N. Harrisburg.

East SharoN, p. v., Norfolk co., Mass.: 19 m. S. S. W. Boston.

East Sinarpsburgir, p. vo, Blair co., Penn.: 116 m. W. Harrisburg.

EAst SHEFFieI, D, p. v., Berkshire county, Mass. : $117 \mathrm{~m}$.

W. by S. Boston.

East Shelburne, p. V., Franklin county, Mass.: $83 \mathrm{~m}$.

W. N. W. Boston.

EASt Smelby, p. 0., Orleans co., $N . Y_{\text {.: }} 129 \mathrm{~m}$. W. by N. Albany.

East Sheldon, p. v., Franklin co., Verm.; on the \$. side of Missisqui r., $47 \mathrm{~m}$. N. N. W. Montpelier.

East Smithrield, p. v., Bradford co., Penn.: $108 \mathrm{~m} . \mathrm{N}$. Harrisburg.

East Sprnifinto, p. o., Otsego county, $\boldsymbol{N}_{0} \boldsymbol{Y} .: 54 \mathrm{~m}$, W. by N. Albany.

EAst Spetngfield, p. o., Jefferson co., Orio: $114 \mathrm{~m}$.

E. N. E. Columbus.

East Springmul, p. 0., Bradford co, Penn.: $10 \mathrm{~S}$ m. N. Harrisburg.

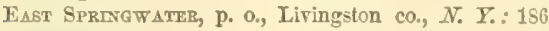
m. W. Albany.

EAst Standish, p. $\vee_{0}$, Cumberland co, Mre.: on the B. E. side of Sebago Pond, $55 \mathrm{~m}$. S. W. Augusta.

East Steruiri, p. Y., Wayne co., Penn.: 104 m. N. E. Harrisburg.

East Stonemax, p. ₹., Oxford co., Me.: 54 m. W. by S. Augusta.

East Stodgaton, p. ₹., Norfolk co., Mass.: on the line of the Fall River R. $\mathrm{R}_{\text {, }} 17 \mathrm{~m}$. $\mathrm{S}$. Boston, and $37 \mathrm{~m}$. from Fall River Village.

East Stroxg, p. v., Franklin co., Mre. : 37 m. N.W. by N. Aucusta.

EAst SuFfield, p. V., Hartford co., Conn.: on the W. side of Connecticut r., $13 \mathrm{~m}$. N. Hartford.

East SulutraN, p. v., Hancock co., $M e_{0}$ : $\$ 3$ m. E. by $N$. Augusta.

EAst Sulurvax, p. v., Cheshire co., N. Hamp.: $87 \mathrm{m.}$ W. S. W. Concord.
East Summer, p. v., Oxford co., $M e_{0}: 31 \mathrm{~m}$.W. Augusta. East Thetrord, p. v., Orange co., Verm. : on the W. side of Connecticut r., 37 m. S. E. by S. Montpelier. The Connecticut and Passumsic Rivers R. R. passes the village.

East Townsend, p. o., Huron co., Onio: 88 m. N. N. E. Columbus.

East Trenton, p. v., Hancock co, Me.: on the N. side of Mount Desert Island Sound, $73 \mathrm{~m}$. E. by N. Augusta.

EAst Troy, t, and p. Y., Walworth co., Wisc.: $66 \mathrm{~m}$. E. S. E. Madison. Drained by Honey er, of Fox r. and a number of small lakes. The $\mathrm{v}$. on the $\mathrm{N}$. side of Honey creek is a considerable settlement, and is conneeted with Milwaukie by a plank road. Pop, nf t, 1.818.

Esst Trox, p. 0., Bradford co., Penn.: $102 \mathrm{~m} . \mathrm{N}$. by W. Harrisburg.

Eists Tunner, p. v., Oxford co., MLe.: on the W. side of Androscoggin r., 24 m. W. S. W. Augusta.

East Union, p. v., Lincoln county, Me. : 31 m. E. S. E. Augusta.

East Union, t. and p. o., Wayne co., Ohio: $78 \mathrm{~m}$. N. E. Columbus. Drained by Apple cr., a constituent of Killbuck cr. Surface diversified: soil fertile. The Ohio and Pennsylvania $R$. R. runs along the N. line of the $t$. Pop.194.

EAst Unity, Sullivan co., N. Hamp.: on the S. branch of Sugar r., $31 \mathrm{~m}$. W. by N. Concord.

East VArior, p. v., Seneca co., N. $Y_{.}$: on the W. side of Cayuga Lake, $152 \mathrm{~m}$. W. Albany.

East Vassalboteugr, p. Y., Kennebec co., Me.: on the N. side of a large pond, $14 \mathrm{~m}$. N. E. Augusta.

Eastville, p. v, Randolph co., Ala : on Little Tallapoosa r., near the E. line of the State, 89 m. N. E. by N. Montgomery.

Eastvilie, p. v., Bath co., Ky.: $66 \mathrm{~m}$. E. Frankfort.

Eastville, p. v., and cap. Northampton co., Virg. : 86 $m$. E. Fichmond, on the $\mathrm{S}$. side of Kinc's cr., a small stream which enters by a broad estuary into Chesapeake Bay. It contains the co, offices and about 30 dwellings.

EAst VIRgK, p. o., Cortlandt county, $N . Y_{\text {. }}: 118 \mathrm{~m}$. W. Albany.

East Wakefield, p. v., Carroll co., N. Hamp.: $38 \mathrm{~m}$. N. E. Concord.

East W arehair, p. ₹., Plymouth co., Mass. : 42 m. S. S. E. Boston.

East Wasitivgtox, p. v., Sullivan co., N. Hamp. : $27 \mathrm{~m}$. E. by S. Concord.

East W Aterford, p. ₹., Juniata co., Penn. : on Tusearora cr., $47 \mathrm{~m}$. W. Harrisburg.

East Weare, p. v., Hillsbornugh co, $N$. Iamp.: on the S. side of Piseatiquay r., and on the line of the New IIampshire Central R. R., $14 \mathrm{~m}$. S. W. Concord, and $16 \mathrm{~m}$. from Manchester.

East Wrstroretand, p. v., Cheshire co., $N$. Hamp. : on the line of the Cheshire P. R., $46 \mathrm{~m}$. W. S. W. Coneord, 51 $\mathrm{m}$. from Fitchburg, and $14 \mathrm{~m}$. from Bellow's Falls.

East Westrulle, p. v., Mahoning en, Otrio: $137 \mathrm{~m}$. N. E. Columbas.

East Weryouth, p. V., Norfolk county, Mass. : on the shore of Yassaclusetts Bay, $11 \mathrm{~m}$.S. by E. Boston. The South Shore R. R. passes through the village, $7 \mathrm{~m}$, from Cohasset. and $15 \mathrm{~m}$. from Braintree.

East Whatelr, p. v., Franklin co., Mas8.: on the W. side of Connecticut r., $\$ 1 \mathrm{~m}$. W. by N. Boston.

East Wrutor, p. V., Franklin county, Me. : $27 \mathrm{~m} . \mathrm{N}$. W. Augusta.

EAst WrLtoN, p. T., Hillsborough co., N. IIamp. : $27 \mathrm{~m}$. S. S.W. Concord. The Nashua and Wilton R. R. terminates here, $15 \mathrm{~m}$. from Jashrille.

EAsr WImDinar, p. $\nabla_{\cdot,}$ Greene county, $N . Y_{0}: 32 \mathrm{~m}$. S. W. by S. Albany.

EAST WINDSOR, t. and p. v., Hartford co., Conn. : on the E, side of Connecticut r., 11 m. N. N. E. Hartford, Drained by Seantic r. and other streams, which furnish fine millpower. Surface level, and soil sandy or gravelly loam. 
The $\mathrm{r}$. is $1 \mathrm{~m}$. back from the Connecticut $r_{\text {, }}$ and is chiefty on one long street running parallel with the river. Here is located the Theological Institute of Connecticut, founded 1534. In 1850 it had 8 professors and 17 students, and a library of 5,000 volumes, and the number of its alumni counted 151. It has a farm and workshop for manual labor. The town has a goodly number of manufacturing and mechanical pursuits, and a population of 2,633 inhabitants.

East WrNdsor Hill, p. o., Hartford co., Conn. : 15 m. N. N. E. Hartford,

East Winturop, p. v., Kennebec co., Me.: 6 m. W. Augusta.

EАsт W овоR, p. v., Middlesex co., Maiss. : 9 m. N. N.W. Boston.

EAsт Woolwich, p. ₹., Lincoln county, MYe: $29 \mathrm{~m}$. S. Augusta.

East Worcester, p. v., Otsego county, N. $Y_{0}: 46 \mathrm{~m}$. W. Albany. Pop. about 200.

Earox county, Mich. Situate toward the S. centrally, and contains $576 \mathrm{sq} . \mathrm{m}$. Drained in the N. and E. by Grand r. and its tributaries; in the middle and west by Big Fork of Thornapple r.; and in the S. W. by Battle cr. of Kalamazoor. Surface uneven, and many of the streams are interrupted by falls and rapids, which make good mill-sites. The soils are everywhere fertile, and produce the best of wheat; and in many parts there are extensive forests. Farms 746 ; manuf. 48 ; dwell. 1,328 , and pop.-wh. 7,055, fr. col. 3-total 7,058. Capital: Charlotte.

EAToN, to and p. o., Eaton con, Mrich.: 16 m. S. W. Lansing. Drained by Battle cr. and the head waters of Thornapple r. Population 589. Charlotte, is located in this town

Eaton, to and p. o., Carroll co, N. Hamp.:51 m. N. E. Concord. Surface diversified. Soils middlingly fertile, and in the plains there is abundance of pine timber. Iron ore is found here. There are several large ponds in the town, some of which empty through Pigwacket $r$, into Swift $r$, on the $N_{\text {., }}$ and a larger one on the S. flows into Ossipee Lake. It is a purely agricultural region. Pop. 1,751.

EATON, t. and p. v., Madison co., N. Y.: 94 m. W. by N. Albany. Drained by the head streams of Chenanger. Surface rolling. Soil gravelly loam and clay, very fertile, producing the grains and grasses abundantly. The t. contains the co. seat, Morrisville, and also the v. and p. $o$. of Eaton, which lies to the $\mathrm{S}$. of the $\mathrm{t}$, on the W. side of the river. It has several factories and mills, and a population of about 500 inhabitants. Pop. of town 3,944 .

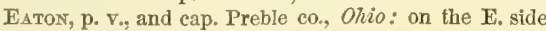
of St. Clair's or Seven Mile cr., which here has a fall of 20 feet in 80 rods, affording great water-power. It contains a court-house and other co, offices, several handsome churches, a considerable number of manufacturing establishments, stores, and warehouses, and has an extensive inland commerce. Its population numbers about $1,3: 2$ souls. Two newspapers, the "E. Register" (whig), and the "E. Democrat" are published weokly. The Cincinnati, Hamilton, and Eaton R. P. connecting ultimately with the Indiana Central R. R. at Richmond, intersects the v., and makes it an important station on one of the most important roads of the State.

E Hiarrisburg. Drained by Bowman's and other areeks of Susquehanna r., which makes its E. and N. E. boundaries. Surface mountainous. The "Knob," an eminence on the Susquehanna, rises 1,150 feet above its surface. The soils are of average fertility, and productive of grasses and grain. Pop. about 1,100 .

EAtoN, p. v., Gibson co., Tenn. : on the N. fork of Forked Deer er., 128 m. W. by S. Nashville.

Eaton, p. v., Cedar co., Mo.: 108 m. S.W. Jefferson City.

Eaton Cratre, p. o., Carroll co, N. Hamp.: 54 m. N. E. Concord.

EAton Rapios, t. and p. v., Eaton county Wich.: $12 \mathrm{~m}$.
S. S. W. Lansing. Drained by Grand r. The $\mathrm{v}$, is located at the rapids, called as above, and is a flourishing settlement. A newspaper, the "Eaton Democrat," is published weekly. Pop. of t. 1,525.

EAtorton, p. v., and cap. Putnam co., Ga.: to the E. of Little $\mathrm{r}_{\text {, }}$ a branch of the Oconee $\mathrm{r}_{\text {., }} 24 \mathrm{~m}$. N. by W. Milledgeville. It contains a court-house, and other co. offices, and about 600 inhabitants. The Eatonton R. R. to Milledgeville, when completed, will connect the v. with the Georgia and South Carolina R. R., and thus open up an avenue to the sea-board for an extensive agricultural country.

EATontown, p. v., Monmouth co., N. Jer. : on a branch of Swimming $\mathrm{r}_{\text {s }}, 36 \mathrm{~m}$. E. Trenton. It contains about 45 dwellings. The vicinity is a pleasant and fertile country, and has a commanding view of the $\Lambda$ tlantic, 4 or $5 \mathrm{~m}$, to the eastward.

EAtonville, p. v., Herkimer co., N. Y.: 64 m.W. N.W Albany.

Eat Pleine, p. o., Portage co., Wisc. : 108 m. N. by W Madison.

Ebenezer, p. V., Morgan county, Ga.: 37 m. N. N. W. Milledgeville.

Ebenezer, p. 0., Holmes county, Afiss. : 53 m. N. by E. Jackson.

Ebenezer, p. v., Fayette co., Tenn.: 159 m. W. S. W. Nashville.

Eibenezerville, p. v., York district, S. Car. : $76 \mathrm{~m}$. N. Columbia.

Emexsistran, p. b., and eap. Cambria co., Penn.: 103 m. W. by N. Harrisburg. It has a commanding site on the Alleghany Mountains, and contains a brick court-house and county offices, several stores, and about 600 inhabitants.

ECKFord, t. and p. v., Calhoun co., Mich.: 38 m. S. S.W. Lansing. The v. is on Beaver cf., a branch of Kalamazoo r., which is the principal drain of the township.

EckManstille, p. v., Adams co., Ohio: $76 \mathrm{~m}$. S. by W. Columbus.

Econour, p. v., Wayne co., Ind.: on the E. side of Martindale's fork of the E. branch of White Water $\mathrm{r}, 57 \mathrm{~m}$. E. by N. Indianapolis, Pop. 400 .

Economy, t. and p. v., Beaver co., Penn.: $182 \mathrm{~m} . \mathrm{W}$. by N. Harrisburg. It lies on the right bank of the Ohio $r_{\text {., and on }}$ the line of the Ohio and Pennsylvania R. R., $17 \mathrm{~m}$. below Pittsburg. The $\mathrm{v}$. is laid out on two streets parallel to the r., with others crossing at right angles. This settlement was made by George Rapp, a German, who with a number of his countrymen of the religious order of Harmonists, first settled in Butler co., Penn.; from thence they all removed to the Wabash, and built the village of New Harmony. At that time they numbered about 500 . New flarmony was purchased in 181.4 by Robert Owen, the Scotch Socialist, and Rapp and his followers established themselves at Economy. In 1832 a number of them seceded and joined Count Leon, who claimed to be a special messenger sent from heaven to establish a Zion in the West. They settled at Phillipsburg, opposite Beaver, but the society soon ceased to exist. The Harmonists hold their property in common. They have a good number of mills here, and are noted for their industry and sobriety. The population of Economy is about 1,400 . Rapp died in 1847.

Ecorce, t. and p. o., Wayne co, Mfich.: 76 m. E. S. E. Lansing. Drained by the Riviere Aux Ecorces, an affluent of Detroit Strait, which makes the E. border of the $t . P, 653$. Eddington, t. and p. v., Penobscot co., Ife. : $6 \mathrm{~m}$. N. E Bangor, and $71 \mathrm{~m}$. E. N. E. Augusta. The $\mathrm{v}$. is pleasantly located on the $\mathbf{E}$. side of Penobscot r., and has considerablo trading facilities. Pop. of to 606 .

Eddy Des Moines r., opposite the mouth of Gray's cr., $61 \mathrm{~m} . \mathrm{S}$.W. Iowa City.

Edprvicle, p. Y., Cattaraugus county, $N . T .: 252 \mathrm{~m}$. W. by. S. Albany.

Eddxpilue, p. v., and cap. Caldwell co., $\bar{K} y .:$ on the 
E. side of Cumberland r., $192 \mathrm{~m}$. W. S.W. Frankfort. It is a thriving village of about 600 inhabitants, and has considerable trade. Princeton, $\mathbf{1 4} \mathrm{m}$, to the $\mathrm{E}$., was the former county seat.

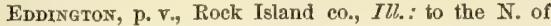
Copperas er., $124 \mathrm{~m}$. N. W. by N. Springfietd.

Eden, p. v., Bryan co., Ga. : 148 m. E. S. E. Milledgeville. EDEN, p. v., Hancock county, Ind. : on Sugar cr., $24 \mathrm{~m}$. E. N. E. Indianapolis.

EDEN, t. and p. o., Hancock co., Me. : oceupying the N. E. part of Mount Desert Island, $73 \mathrm{~m}$. E. Augusta. Surface uneven. Soil fertile. It is washed on three sides by Frenchman"s Bay and Mount Desert Sound, the latter of which separates it from the main. Several small islands of the coast in Frenchman's Bay belong to this town. With many fine harbors, it has comparatively extensive coasting trade, and great advantages for the shore fisheries, in which many of the inhabitants are engaged. It is noted, also, for its large crops of cranberries, amounting in some years to 1,000 bushels. Pop. 1,17.

Eden, p. v., Ingham co., Mich.

EDEN, t. and p. v., Erie co., N. Y.: 265 m. W. Albany. Drained by Cauquaga and Big Two Sisters' creeks, which flow to Lake Erie. Surface undulating; soil, a gravelly loam and clay. The $\mathrm{v}$. is on the S. side of Cauquaga $c x$., about $14 \mathrm{~m}$. S. Buffalo, Pop, of t.2,494.

Edex, t. and p. o., Fond du Lac co., Wisc. : 64 m. N. E. Madison. Drained by the head branches of Milwaulie $r$, which rise in this town, and also by streams falling into Winnebago Lake. Pop. 810

Enen, p. v., Trumbull con, Okio: $137 \mathrm{~m}$. N. E. Columbus, Located on a er. of the W. branch of Mahoning r., about 6 m. S. W. of Warren, the co. seat.

Enev, p. o., Randolph co., N. Car.: $73 \mathrm{~m}$. W. Raleigh.

EDEN, p. o., Laurens dist., S. Car. : $81 \mathrm{~m}$. N.W. Columbia

Edre, p. v., M.Kean co., Penn. : 161 m. N.W. Harrisburg.

IDEN, $t$, and p. v., Lamoille co., Term. : 31 m. N. by E. Montpelier. Drained by Greene r. and Wild Branch of Lamoille $r$. Surface mountainous, rocky, and cold, but good for grazing, and produces fine cattle and sheep. The $\mathrm{r}$. is pleasantly located near the centre. This $t$. was granted to "Colonel Seth Warner and his associates, our worthy friends, the officers and soldiers of his regiment, in the line of the Continental Army," 28th August, 1781. Pop, 66s,

EDENBURG, p.v., Cameron co., Tew. : $29 \mathrm{~s}$ m. S. Austin City EDEN BURg, p. V., Shenandoah co., Tirg.: $112 \mathrm{~m} . \mathrm{N}$. W Richmond.

EdRnfreld, p. v., Irwin co., $G a .: 119 \mathrm{~m}$. S. Milledgeville. EDEN'g Ridge, p. 0., Sullivan co., Tenn.: 240 m. E. by N Nashville.

Edenton, p. v., Clermont co., Ohio: 89 m. S. W. by S. Columbus,

Edenton, p. v., and cap. Chowan co., N. Car.: near the mouth of Chowan $r_{\text {, }}$, at the head of Edenton Bay, which sets up from Albemarle sound, $123 \mathrm{~m}$. E. N. E. Raleigh. It contains the co. offices, and has about 400 inhabitants. Considerable shipping is owned in the $\mathbf{v}$, and a newspaper, the "Albemarle Bulletin" (whig), is published weekly.

Edenton, p. v., St. Lawrence co, $N . Y_{\text {. }}: 146 \mathrm{~m}, \mathrm{~N}$. W. Albany.

Eden Vallex, p. o, Erie co., $N, Y_{.}: 267 \mathrm{~m}$. W. Albany.

Edenville, p.. ., Orange co., N. $Y .: 96$ m. S. S. W. Albany.

EDgar county, $I l l$. Situate F. midlle, and contains 612 sq. m. Drained by Big, Brulettes, and Cedar creeks, and Embarras r., all tributaries of the Wabash. Surface chiefly level or undulating: prairie interspersed with timber. Soils generally fertile, producing Indian corn, oats, wheat, etc. Farms 1.175; manuf. 88 ; dwell. 1,702, and pop,-wh. 10,641, fr. col. 51-total 10.622. Cupital: Paris. Putlic Works: Mississippi and Atlantic R. R.

Engar, p. $\nabla_{\bullet}$, St. John Baptist par., La.: 49 m. S. E. Baton Rouge.
EDGARTOWN, t., p. v., port of entry, and cap. Dukes co, Mfass.: on the E. portion of Martha's Vineyard, $73 \mathrm{~m}$. $\mathrm{S}$. by E. Boston. It includes also the fertile island of Chappequiddick, $5 \mathrm{~m}$. long and $2 \frac{1}{2} \mathrm{~m}$. wide, on the $\mathrm{S}$. E., on which are a remnant of the Indian tribe of the same name, Surface mostly level; soils sandy, but of average fertility. The v. (lat. $41^{\circ} 25^{\prime} \mathrm{N}$., and long. $70^{\circ} 25^{\prime} \mathrm{W}$.) is situate on the W. side of the harbor, and contains a C. H. and other county offices. A newspaper, the "Vineyard Gazette" (inclep.), is published weekly, The harbor is safe and accessible, and has a large interest in the whale fisheries and coasting trade. In the foreign trade, in 1849-50, five vessels $(1,223$ tons) were cleared, and seventy-two vessels (13,286 tons) were entered. The shipping owned in the collection district was 7,609 tons, of which 5,464 tons were registered, and of this 2.419 tons were employed in the whale fisheries; 1,956 tons were enrolled and licensed, and 189 tons were licensed (under 20 tons); of the enrolled and licensed shipping, 743 tons were employed in the cuasting trade, 953 in the cod fisheries, and 210 tons in the mackerel fisheries. The district of Edgartown comprises all of Martha's Vineyard and adjoining islands. Pop. 1,990 .

Edgeconbe county, $N$. Car. Situate E. centrally, and contains $492 \mathrm{sq} . \mathrm{m}$. Drained by Tar $\mathrm{r}$, and its tributaries; Fishing er. forms its $\mathrm{N}$. and part of the $\mathrm{E}$. border, and Tar r. the remainder to the E. line. Surface level. Soil modcrately fertile, adapted to cotton, and producing abundance of Indian corn, oats, wheat, ete. Timber abundant, and is exported. Farms 737 ; manuf. 14; dwell. 1,649, and pop. -wb. 8,365 , fi. col. 277, sl. 8,547-total 17,189. Capital: Tarboro'. Puটlic Works: Weldon and Wilmington R. R.

EDGecomb, t. and p. v., Lincoln co., Mre. : $29 \mathrm{~m}$. S. S. E. Augusta. The $t$. is situate between Damariseotta $\mathbf{r}$ : on the E. and Sheepscot r. on the W., being drained by their afluents. It has considerable shipping employed in the coasting trade and fisheries; and ship-building is here a considerable interest. Pop. 1,423.

EdGEFIELd district, S. Car. Situate toward the S. W., and contains $1,680 \mathrm{sq} . \mathrm{m}$. Drained ehiefly by tributaries of Savannah r., which makes its S. W. line, and of Saluda r., which washes its N. E. border. The head waters of South Edisto r. are also within the district. Surface moderately uneven. Soil not very fertile, but well adapted to cotton, corn, ete. It has also numerous productive establishments. Farms 2,030; manuf. 197; dwell. 3,019, and pop. -wh. 16,275, fr. col. 262, sl. 22,725-total 39,262. Copital: Edgefield Court-house. Pullic Works: South Carolina R. R.

Edgefrild C. II.,p. v., and cap. Elgefield dist., S. Car.. $64 \mathrm{~m}$. W. by S. Columbiit. It cuntains a C. II and other district uffices, and about 1,200 inbabitants. A newspaper, the "E. Advertiser" (dem.), is published weekly.

Edgefield, p. v., Pike co, $A l a .: 45$ m. S. E. Montgomery. Edge Hill, p. 0., King George co., Virg. : 54 m. N. N.E. Richmond.

Edge Hill, p. 0., Montgomery co., Penn.: 84 m. E. Harrisburg.

Edgemont, to and p. o., Delaware co., Penn.: $87 \mathrm{~m}$ E. S. E, Harrisburg. Drained by Ridley's cr. of Delaware r. It is a flne agricultural town, and contains about 800 inhahitants.

Edrva, p. Y., Scotland co., Mro. : on S. Fabius r., $123 \mathrm{~m}$. N. by E. Jefferson City.

Epixborougn, p. b., Erie co., Penn.: 207 m. N. W. Harrisburg. Pop. 500.

EntxbGrgin, p. v., Garrard county, $\bar{K}_{y}$.: $52 \mathrm{~m}$. S. E. Frankfort.

EDINBCrgh, p. v., Johnson co., Ind.: on the E. side of the $\mathrm{E}$. branch of White $\mathrm{r}$, about $2 \mathrm{~m}$. above the confluenec of Sugar r., and at the point where the Madison and Indianapolis $R$. $R$. crosses that stream, and the Shelbyville Lateral Branch R. R. connects with it, $30 \mathrm{~m}$. S. S. E. Indianapolis. It is a flourishing and important village, having 
extensive water-power, and being located in the midst of a fine agricultural region. It was first settled in 1S21, but until the completion of the Madison $R$. $R$. was of slow growth. It has now about 700 inhabitants.

Eonsburga, t. and p. 0., Penobscot co., $M e: 83 \mathrm{~m}$. N. E. Augusta. Drained by afflents of Penobscot $r$, which makes its E. boundary. The $\mathbf{t}$. is entirely agricultural and but sparsely settled. Pop. 98.

Edin bergir, p. v., Hillsdale $\mathrm{co}_{*}$, Mich.: $63 \mathrm{~m}$. S. by E. Lansing.

Edinburgh, p. v., Leake co,, Miss.: on the N. side of Pearl r., 58 m. N. F. Jackson.

Epinimgrir, t. and p. o., Saratoga co., N. $\boldsymbol{Y}_{.:}: 38 \mathrm{~m}$. N. by W. Albany. Drained by Sacondaga $r_{\text {. }}$; surface in the $E$. mountain, and in the W. undulating. "The river valley or flats of the Sacondaga is extensive, and its soil rich alluvion. The $\mathrm{r}$. is located on the left side of the $r$, and contains about 200 inhabitants. Pop, of $t, 1,536$.

Edivitrgr, t. and p. v., Portage co,, Ohio: 127 m. N. E. Columbus. Drained by one of the head streams of the W. branch of Mahoning r. Surface varied, and soils generally fertile, well adapted for grain growing. The $\mathrm{v}$. is pleasantly located in the centre of the t., $6 \mathrm{~m}$. S. E. Ravenna, and contains about 200 inhabitants. The t. has good waterpower, ete. Pop. 1,101.

Edinstrar, p. v., Lawrence co., Penn. : 200 m. W. N. W. Harrisburg.

EDINBU RGH, p. $\nabla .$, Mercer co., $N$. Jer.

Edinburgh Centre, p. o., Saratoga co., $N . Y .: 37 \mathrm{~m}$. N. by W. Albany.

Evisro, p. v., Lexington dist., S. Car. : on North Edisto r. $31 \mathrm{~m}$. S. Columbia.

Edrsto Mrlus, p. o., Edgefield dist., S. Car,: on South Edisto r., $58 \mathrm{~m}$. W. by S. Columbia.

EDisro river, $S$. Car.: has its rise in Edgefield district, in two main constituent rivers, the North and the South Edisto, which meet a little W. of Branchville, whence the course of the r. is E. and S. E. to the Atlantic Ocean, which it enters by two channels forming Edisto Island, about 12 $\mathrm{m}$. long and from 1 to $5 \mathrm{~m}$. wide. The Edisto is navigable for large boats for 100 miles.

EDMeston, t. and p. T., Otsego co., N. Y.: $74 \mathrm{~m}$. W. Albany. Drained by creeks of Unadilla $r$, which makes its W. border. Surface somewhat hilly; soil, sandy loam. The $\mathbf{v}$. on the right side of Oberton's er, contains about 80 inhabitants, and the $t$, about 1,885 inhabitants.

EDMoNdsow county, $\overline{K y}$. Situate W. centrally, and con tains $280 \mathrm{sq}$. m. Drained by tributaries of Green r., which passes through it from $\mathrm{E}$. to $\mathrm{W}$. There are several springs in the co., of which Dripping Spring is the most curious and best known. Surface diversified. Soils of average fertility producing all the grains abundantly, and tobacco, Jemp, etc. Farms 507; manuf. 4; dwell. 651, and pop.-wh. 3,753, fr. col. 10, sl.525-total 4,088. Capital: Brownsville. Public Works: Nashville and Louisville P. R.

Edvontor, p. $\nabla_{\text {., }}$ Barren county, $\bar{k} y .: 98$ m. S. S. W. Frankfort.

EDMond's, p. o., Brunswick co., Firg. : 57 m. S. by W. Richmond.

Ederville, p. v., Henderson county, N. Car.: $212 \mathrm{~m}$. W. by S. Paleigh.

Edrax, p. Y., Pocohontas co., Virg.: 146 m. W. by N. Richmond.

Edsallitile, p. v., Bradford co., Penn.: $112 \mathrm{~m}$. N. Harrisburg.

EDWARDs county, $I l l$. Situate toward S. E., and contains $216 \mathrm{sq}$. m. Drained by Little Wabash r. and Bonpas er. of Wabash r., the latter of which forms its E. boundary. The surface is level, mostly prairie, with well-wooded bottoms, and occasional groves of beautiful timber. Graingrowing is the chief business, but there are several mills, fanneries, etc. Farms 329 ; manuf. 7 ; dwell. 595, and pop. - wh. 3490 , fr. col. 81-total 3,524. Capital: Albion.
EDWARDg, t. and p. o., St. Lawrence co., $N . Y .: 144 \mathrm{~m}$. N. W. Albany. Drained by Oswegatchie $r$. Surface un even; soil, clayey loam. The grazing is cxcellent. The t contains iron ore, and has several factories and mills. Pop. $1, \cap 23$.

Edwardsburgh, p. v., Cass co., Mich. : 98 m. S. W Lansing. Situate on Beardstey's Lake and at the S. E corner of Beardsley's Prairie. The site is pleasant and the $\mathbf{r}$. is prosperous and increasing.

Edward's Dßrpô, p. O., Hinds co., Afiss.: on the line of the Vicksburg, Jackson, and Brandon R. P., $23 \mathrm{~m}$. W. Jackson.

EDWARD's Port, p. $\vee .$, Knox co., Ind. : on the right bank of the W. fork of White r., $18 \mathrm{~m}$. N. E. Vincennes and 87 m. S. W. Indianapolis.

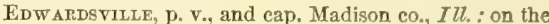
E. bank of the Cahokia r., $71 \mathrm{~m}$. $\mathrm{S}$. by W. Springfield. It contains the usual county buildings, several stores and factories, and about 400 inhabitants. It is located in an elerated and pleasant section and in the midst of a highly flourishing country. A newspaper, the "Madison Record," is puklished weekly.

Edwardsville, p. v., St. Lawrence co., $N$. $Y$.: on the right side of Oswegatchie r., $147 \mathrm{~m}$. N. W. Albany.

EDw ARDstille, p. v., Warren co., Ohio: in the S. E. of the county, $71 \mathrm{~m}$. S. W. Columbus.

Eex Prver, p. o., Allen co., Ind. : on the r, so called, 104 m. N. E. by N. Indianapolis. Eel r. (Sho-a-make, or "slippery fish") rises in the $\mathrm{N}$. W. corner of Allen co, and runs $100 \mathrm{~m}$. S. W. to Logansport, where it empties into the Wabash. Its course is rapid, its volume regular, and, for at least $60 \mathrm{~m}$., its average width is 150 to 180 feet. As a mill stream it is scarcely surpassed in the West.

EEL river, Ind. : a branch of White r., emptying into it at Point Commerce. It rises in Boone co., and runs first S. W. and then S. E. through Hendricks, Putnam, Clay, and Owen counties. It is $60 \mathrm{~m}$. long and about 160 feet wide, and affords good mill sites.

Eex river, Calif: : rises on the S. line of Trinity co. by several head streams, and in a course N. W. flows to the Pacific Ocean, which it enters a little S. of Humboldt Har bor. It is a small stream.

Eirfingram county, $G a$. Situate S. E., and contains 396 sq. m. It lies between Savannah $r$. and Ogeechee $r$, and is drained by creeks running to both. Surface level, and the soils very fertile. The staples are cotton, rice, and Indian corn, with some sugar, ete. Farms 308; manuf. 0 ; dwell. 355, and pop.-wh. 2,009, fr. col. 7, sl. 1,848-total 3,864. Capital: Springfield. Public Works: Central R.R. Effivgham county, $I l l$. Situate S. E. centrally, and contains $522 \mathrm{sq.} \mathrm{m}$. Drained chiefly by Little Wabash $r$. and its branches-in the W. by streams flowing to the Kaskaskia r. Surface gently undulating-chiefly prairie, but with abundance of timber. Soils fertile, but on the streams liable to floodings. Farms 391 ; manuf. 0 ; dwell. 712 , and pop.-wh. 3,792, fr. col. 7-total 3,799. Capital: Ewington. Public Works: Mississippi and Atlantic R. R.; National Road, etc.

Effirgham, t. and p. o., Carroll co, N. Hamp.: $41 \mathrm{~m}$. N. E. Concord. Drained by affluents of Ossipee lake and river; surface hilly. It is a fine grazing country, and has several tanneries and saw-mills. Yop, 1,252.

EmfinghaM, p. v., Darlington dist., $S$. Car.: on the $\mathrm{N}$. side of Lynch's cr. of Great Peedee $x ., 71 \mathrm{~m}$. E. by N. Columbia.

Effinghax Falle, p. v., Carroll co., $\mathcal{N}_{.}$Hamp. : $44 \mathrm{~m}$. N. E. Concord.

Efront, p. V., Monroe co., Penn.: 93 m. N. E. Harrisburg. EFtRd's Mrils, p. 0., Stanly co., $N$. Car. : 89 m. W. S.W. Raleigh.

EGg Harbor, Great, river and bay, $\lambda$. Jer.: the $r$. rises in Gloucester co, and flows $45 \mathrm{~m}$. into Great Egg Harbor Bay, which is about $5 \mathrm{~m}$. long and from 1 to $4 \mathrm{~m}$. broad. 
The $r$, is navigable for sloops over $25 \mathrm{~m}$. above May"s Landing, below which it flows through a marsh.

EGg HARBor, LitTLE, river and bay, $N$. Jer. : the r. rises in Burlington and Gloucester counties and flows to the bay. It is navigable for $25 \mathrm{~m}$., and is approached through $\mathrm{New}$ Inlet, which has a depth of water of from 15 to 18 feet.

Egrpt, p. v., Monroe co., N. Y.: $152 \mathrm{~m}$. W. by N. Albany. EGXPT, p. o., Effingham county, GO.. 183 m. E. S. E. Milledgeville.

EqXPt, p. O., Fayette county, Tenn.: 163 m. W. S. W. Nashville.

EgrPT, p. o., Colorado county, Tex.: 118 m. E. S. E. Austin City.

EGYPT, p. 0., Monroe co., Virg. : 173 m. W. Richmond. Elamsville, p. T., Patrick co., Virg.: 182 m. W. S. W. Richmond.

Er.BA, p. T., Washtenaw co., Mich. : 51 m. S. E. Lansing, Eliba, t. and p. v., Dodge connty, Wisc.: $28 \mathrm{~m}$. N. E. Madison. Pop, 1,548.

Euba, t. and p. Y., Genesee co., N. Y,: $222 \mathrm{~m}$. W. Albany. Drained by Oak Orchard cr. Surface undulating; soil, sandy and gravelly loam. The $v_{0}$ is on the left bank of the creek. Pop. of t. 1,772.

Elbert county, Ga. Situate N. E., and contains $560 \mathrm{sq}$. m. It has Savannah r. on the E., Broad r. on the S., and Light-wood cr. on the N., the two latter being affluents of the first. Drained by numerous creeks flowing to the Savannah. Surface hilly. Soil a productive red loam in the S. Staples-cotton, wheat, Indian corn, and other grains. Farms 804; manuf. 20 ; dwell. 1,177, and pop.wh. 6,676, fir. col. 16, sl. 6,267-total 12,959. Capital: Elberton.

Elberton, p. $\nabla .$, and cap. Elbert co., Ga. :73 m. N. by E. Milledgeville. It contains the county buildings, a church, several stores, and about 200 inhabitants.

Elbridge, p. v., Edgar co., $I l l$. : in the S. E. corner of the county, between Clear and Big creeks of Wabash $r$. $110 \mathrm{~m}$. E. by S. Springfield.

ELBRIDGE, t. and p. v., Onondaga co., N. Y.: $185 \mathrm{~m}$ W. by N. Albany. Drained by the outlet of Skaneateles Lake. Surface moderately uneven, and soils fertile. The Erie Canal passes through the $N$. part of the $t$. and the Rochester and Syracuse R. R. through its S. part. It contains several factories, a large number of fine mills and stores, and about 3,924 inhabitants.

Eu DARA, p. 0., Pike co., IZl.: 78 m. W. by S. Springfield.

Eldersburgh, p. T., Howard co., Mrd. : on the W. side of Cat-tail branch of Patuxent r., $31 \mathrm{~m}$. N. W. Annapolis.

Elderbville, p. v., Washington co., Penn.: 192 m. W. Harrisburg.

Elderton, p. r., Armstrong co., Penn.: on Plumb cr., $135 \mathrm{~m}$. W. N. W. Harrisburo.

Er Dorado county, Calif. Situate E. middle, and contains 1,600 sq. m. Drained by Middle and $\mathrm{S}$. forks of American r., and by Cosumnes r. and the N. fork of Mokelumne $r$. The E. part of the co. lies on the slope of the Sierra Nevada, and is a rough, volcanic region. In this part of the co, is Fremont's Lake, the source of the $\mathrm{S}$. fork of American r. ; it is $13 \mathrm{~m}$. long and $6 \mathrm{~m}$. wide. The W. part of the $c 0$. is a fine agricultural country. The whole co. is rich in gold, and it was at Sntter's Mill, a little W. of Culloma, the co. seat, that gold was first discovered. Farm 000 ; manuf. 00 ; dwell. 000 , and pop.-wh. 0,000 , fr. col. 0 -total 0,000. Capital: Culloms.

El Dorado, p. r., and cap. Union co., Ark.: in the midst of a fine elevated prairie, about $S \mathrm{~m}$. $\mathrm{S}$. of Washita $\mathrm{r}$. and $123 \mathrm{~m}$. S. by E. Little Rock. It is a considerable place and has a newspaper, "El D. Union" (whig), issued reekly.

Ex Dorado, p. v., Clark co., Mfo. : on the E. side of North Wyaconda r., $129 \mathrm{~m}$. N. Jefferson City.

Eu Dorado, p. 0., Culpepper co., Jirg. $: 73$ m. N. N.W. Richmond.

Eu Dorado, t. and p. 0., Fond du Lac co., Fire. : $67 \mathrm{~m}$.
N. E. by N. Madison. The v. lies about $8 \mathrm{~m} . \mathrm{N}$. W. of Fond du Lac.

Eldred, p. o., Wayne county, Penn.: 128 m. N. E. Harrisburg.

ELDRedvilie, p. va, Sullivan county, Penn.: 86 m. N. Harrisburg.

ELDRIDGe, p. v., Walker county, Ala. : 183 m. N. W. Montgomery.

Elevation, p. o., Johnson co., N. Car.: $31 \mathrm{~m}$. E. by S. Raleigh.

ELGTN, p. v., Kane co, Ill. : on the W. side of Fox r., 168 m. N. N. E. Springfield. The Galena and Chicago Union R. R. passes through the $\mathrm{v}, 42 \mathrm{~m}$. from Chicago. It is a place of considerable business, and has several mills, stores, ete., and about 700 inhabitants.

EIGIN, p. v., Cattaraugus co., $N . Y .: 233 \mathrm{~m}$. W. by $\mathrm{s}$. Albany.

ElrDA, p. V., Winnebago co., IIl.: on the S. line of the co., on a cr, of Rock r., $176 \mathrm{~m}$. N. by E. Springfield.

ELIJAH's CREFK, p. o., Boone co., Éy.: 51 m. N. by E. Frankfort.

Elmispont, p. v., Lyeoming co., Penn.: 69 m. N. by W Harrisburg.

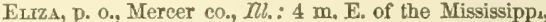
and $126 \mathrm{~N}$. W. Springfield.

ELIZ ABETH, p. v., and cap. Jackson co., Ark. : $84 \mathrm{~m}$. N. E. Little Rock. Situate on the left bank of White r., a little below the confluence of Big Black r., and at the head of steamboat navigation. It is well located for commerce, hav ing a splendid agricultural vicinage.

Eltzaretr, p. Y., Jo Daviess co., $M \eta_{0}$ : on the E. side of Apple r., a tributary of the Mississippi, $179 \mathrm{~m}$. N. by W. Springficld.

ELIZ.iBETI, p. Y., Ilarrison co., Ind.: on the S. fork of Buck er. $4 \mathrm{~m}$. from the $O$ hio $\mathrm{r}_{\text {., }}$ and $112 \mathrm{~m}$. S. by E. Indianapolis. It contains about 200 inhabitants.

ELIZABETH, t. and p. vo, Lawrence co., Ohio: $97 \mathrm{~m}$. S.S.E. Columbus. It is one of the first iron regions in the State, and has numerous furnaces in active operation. The Iron R. R. passes through the town from Ironton, on the Ohio, to a junction with the Scion Valley R. R.

ELIZABETH, t. and p. v., Alleghany co., Penns: between the Monongahela and Youghiogheny rivers, $162 \mathrm{~m}$. W. Harrisburg. Surface hilly; coal abundant. The $\mathrm{y}$. lies on the E. bank of Monongahela r., and by means of slackwater navigation, is reached by vessels of considerable burden, and many are built here. There are several factories and mills in Elizabeth, and a population of about 4,000.

ELIZABETI cape, Mre. : a celebrated headland, forming the western limits of Casco Bay. Near the point of the cape is a light-house, 50 fect high, in lat. $43^{\circ} 83^{\prime} \mathrm{N}_{\text {., }}$ and long. $70011 \mathrm{~s}$ W.

EI $61 \mathrm{so}$. m. It lies at the confuence of James $r$. with Chesapeake Bay, opposite to Cape Charles, and having Hampton Roads on its $\mathrm{S}$. border. It is one of the eight original counties into which Yirginia was divided in 1634. The surface is level, and the soils generally fertile. Farms 173; manuf. 12: dwell. 45\% 6 , and pop.-wh. 2,841 , fr. col. 97 , sl, 2,148total 4,5s6. Capital: Hampton.

EuTABetir CITY, p. v., and cap. Pasquotank co., N. Car.: on Pasquotank r., $20 \mathrm{~m}$. above its confluence with Albemarle Sound, and $173 \mathrm{~m}$. E. by N. Raleigh. Vessels drawing 7 feet water, come up to this place, and it has a communication with Hampton Roads through the Dismal Swamp Canal, a distance of about $52 \mathrm{~m}$. It contains the co. offices, several mereantile and trading houses, and about 800 inhabitants. Its exporis are staves, pine lumber, shingles, etc., chiefly to the West Indies, Three newspapers are published in the village, viz., the "Old North State" (whig), and the "Democratic Ploneer," issued weekly, and the "Baptist Messenger," issued semi-monthly.

Eizabetir islands, Duke co., Mass.: these islands lio 
between Buzzard's Bay and Vineyard Sound, and are 16 in number. The largest, Nashawa and Nashawenna, are inhabited. Gosnold, the discoverer of Cape Cod, wintered in one of these islands in 1602-3.

Eltzabeti Port, p. v., Essex co., N. Jer.: on Staten Island Sound, near its junction with Newark Bay, $89 \mathrm{~m}$. N. E. Trenton. It contains several manufacturing establishments, and about 140 dwellings, and is the $\mathbf{E}$. terminus of the New Jersey Central R. R., connecting with New York City by a steamboat route of $14 \mathrm{~m}$. The distance to Easton, Penn, is $64 \mathrm{~m}$.

Elizaretil river, Virg: rises in Princess Ann and Norfolk counties, and flows N. W. $25 \mathrm{~m}$. into a large estuary at the mouth of James r., forming a fine harbor at Norfolk. In conjunetion with the Dismal Swamp Canal and Pasquotank r., it forms a communication between Chesapeake Bay and Albemarle Sound.

Eutzabeth Town, p. v., and cap. Carter co., Tenn.: on the S. bank of Watauga r., a constituent of Holston, 257 m. E. Nashville. It contains a court-house and other co offices, and has sercral stores and about 200 inhabitants. In the vicinity there are several large iron-works.

Eltzabeth Town, p. v., and cap. Hardin co., Ill.: on the $\mathrm{N}$. bank of the Ohio $\mathrm{r}_{\text {, }}$ at the foot of Hurricane Island, $189 \mathrm{~m}$. S. S. E. Springfield. It contains the co. buildings, several stores, and 400 inhabitants. A short distance inland there are some iron furnaces.

EutabeTr Town, p. v., Bartholomew co, Ind. : a newlyformed village, on the line of the Madison and Indianapolis R. R., $35 \mathrm{~m}$. from Madison, and $55 \mathrm{~m}$. from Indianapolis. It contains about 40 dwellings.

ELIZABETH Town, p. va, and eap. Hardin co., $k y_{.}:$on the $\mathrm{N}$. side of Falley cr, a branch of Nolin's cr., $66 \mathrm{~m}$. S.W. Frankfort.

ElizaBeth Town, p. b., Essex co., N. Jer.: on Elizabeth cr., $2 \frac{1}{2} \mathrm{~m}$. from its entrance into staten Island Sound, $38 \mathrm{~m}$. N. E. Trenton. Lat. $40^{\circ} 38^{\prime} \mathrm{N}$., and long. $74^{\circ} 12^{\prime} \mathrm{W}$. The New Jersey R. R., and the New Jersey Central R. R. intersect at this point. It contains a court-house, jail, and about $400 \mathrm{dwellings}$, and has considerable manufactures. Vessels of 30 tons come up to the v., and of 300 tons to Elizabeth Port, 21 m. below. Pop. about 3,000 .

ElizABETE Town, t., p. v., and cap. Essex co., N. Y.: 98 m. N. by E. Albany. Drained by several branches of Boquet $r$. Surface mountainous in the W.; in the E. moderately uneven. The Clinton range of mountains rises on the $W$. border, some of the peaks being from 1,200 to 1,500 feet above the level of Lake Champlain. Iron ore of the finest quality abounds. The $v$. is on the left side of the $\mathbf{r}$, and contains a court-house, jail, etc., and about 70 dwellings. In the t. are several iron-works and a large number of saw-mills. Pop. 1,635.

Elizabeth Town, p. v., and eap. Bladen co., N. Car. : on the right bank of Cape Fear $r_{\text {., }} 40 \mathrm{~m}$, above Wilmington, and $78 \mathrm{~m}$. S. by E. Raleigh. It has considerable river trade, and is a thriving place. The principal buildings are the court-house, and other co. offices, and it has several stores, and about 600 inhabitants.

Elizabeth Town, p. v., Hamilton co, Ohio: on the right bank of White Water r., and on the line of the White Water Canal, 113 m. S. W. Columbus, It contains several stores, and about 200 inhabitants.

Elizabetr Town, p. v., Lancaster co., Penn.: in the forks of Coney cr., $33 \mathrm{~m}$. E. Harrisburg.

Elizabethvilee, p v., Dauphin co., Penn.: $28 \mathrm{~m}$. N. Harrisburg.

Elizaville, p. $\nabla$, Fleming co, $K y_{0}: 76$ m. E. by N. Frankfort.

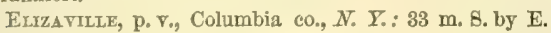
Albany.

ExK county, Penn. Situate W. centrally, and contains $860 \mathrm{sq} . \mathrm{m}$. Drained chiefly by the head waters of Clarion river-in the $\mathrm{E}$. by affiuents of the Susquehanna. The surface is elevated, somewhat rough, but the soils are of average fertility, and produce abundantly all the cereals and grasses. Farms 251; manuf. 50; dwell. 613, and pop. -wh. 3,529, fr. col. 2-total 3,531. Capital: Ridgeway. Pullic Works: Sunbury and Erie R. R.

ELk, p. o., Crawford county, Wisc.: $77 \mathrm{~m}$. W. by N. Madison

EL KADER, p. V., Clayton co., Ia.: on the 8. side of Turkey r., an affluent of the Mississippi, $81 \mathrm{~m}$. N. by E. Iowa City,

ElK Cries, t. and p. o., Erie co., Penn。 : $216 \mathrm{~m} . \mathrm{N}$. W. Harrisburg. Drained by Cussawaga cr., a branch of Elk cr., and a tributary of Conneaut r., on the last of which are salt springs. Surface hilly: soil, gravelly loam and pro ductive. It is a good agricultural town, and has about 1,800 inhabitants.

ElK Creek, p. 0., Grayson co., Tirg.: on the cr., a tributary of New r. so called, $216 \mathrm{~m}$. W. S. W. Richmond.

Eli Cross Roads, p. O., Ashe county, N. Car : $173 \mathrm{~m}$. W. by $\mathrm{N}$. Raleigh.

Elk Dale, p. o., Chester county, Penn. : 73 m. E. S. E. Harrisburg.

Elk FurNace, p. o, Nelson co, Firg. : 83 m. W. by N, Richmond.

ElK Garden, p. 0., Russell co., Firg.: 268 m. W. by $\$$ Richmond.

Erk Grove, p. o., Lafayette co., Mo.: 98 m. W. N. W. Jefferson City.

ELK Grove, p. O., Cook co., Ill.: to the E. of EIk cr. of Des Plaines r., $174 \mathrm{~m}$. N. E. by N. Springfield.

Elk Grove, p. o., Iowa county, Wisc.: $34 . \mathrm{m}$. W. by S. Madison.

ElKHART county, Ind. Situate N. middle, and contains 460 sq. m. Drained by St. Joseph's, Elkhart, and other streams. There are also several lakelets in the county. Surface undulating-one half timbered, and the residue prairie or oak-barrens. The prairies are remarkably fertile. Wheat and Indian corn are the staple growths; other grains and grass are produced in abundance. Iron is found, and at Meshawaka is largely manufactured. Farms 1,226; manuf. 70 ; dwell. 2,254, and pop.-wh. 12,674, fr. col. 16total 12,690. Cospital: Goshen. Public Works: Northern Indiana $\mathrm{R}$. $\mathrm{R}$., with branch to Goshen, and a $\mathrm{P}$. R. thence S. to Peru

ELKHART, p. v., Elkhart $\mathrm{co}_{\text {, }}$ Ind. : at the junction of Elkhart and St. Joseph's rivers, $131 \mathrm{~m}$. N. Indianapolis. It contains several mills, warehouses, stores, etc., and about 600 inhabitants, and is the business centre of a large section, ultimately to become an important place. The Indiana Northern R. R. intersects it $102 \mathrm{~m}$. from Chicago, and 146 from Monroe.

Elkhazt, p. v., Sheboygan co., Wisc. : 84 m. E. N. E. Madison.

ELKHART river, $I n d$, a fine mill-stream, an affluent of St. Joseph's $\mathbf{r}$. It has a permanent supply of water from springs and lakes, and for the last $40 \mathrm{~m}$. above its mouth its usual breadth is from 80 to 100 yards. The country through which it passes is one of the richest agricultural regions of the State.

Elkheart, p. v., Anderson county, Tex: 173 m. N. E. Austin City.

Elr Hrix, p. o., Amelia county, Firg. : $32 \mathrm{~m} . \mathrm{S}$ W. Richmond.

ELK HorN, p. v., Washington co., IIl.: at the head of Elkhorn er. of Kaskaskia r. $108 \mathrm{~m}$. S. Springfleld.

Eur HoRN, p. v., and cap. Walworth co., Wisc.: in the centre of the co., $49 \mathrm{~m}$. E. S. E. Madison. It contains the co. C. H., and other publie offices, and about 300 inhabitants. The trade at this point is considerable, and the $\mathrm{v}$. is connected with Racine on the lake by a plank road.

Elk HORN, p. o., Franklin co., $K y_{*}$ : on Elkhorn er, of Kentucky r., 12 m. N. by E. Frankfort.

EuK HorN, p. o., Montgomery co, MFo. $82 \mathrm{~m}$, N. E. Jefferson City. 
ELK Horn Grove, p. o., Carroll co., Tll.: on EIkhorn cr. of Rock r., $152 \mathrm{~m}$. N. Springfield.

Elk Lake, p. o., Susquehanna co., Penn.: 123 m. N. E. Harrisburg.

Elk Lavd, t. and p. o., Tioga co., Penn.: $122 \mathrm{~m}$. N. by W. Harrisburg. Drained by Cowanesque and Crooked creeks of Tioga r. Surface hilly; soil, grarel loam and clayheavily timbered. Pop. about 900 .

Elk Lick, t. and p. o., Somerset county, Penn.: $123 \mathrm{~m}$. W. S. W. Harrisburg. It has numerous mills, distilleries, etc., and is an excellent agricultural town. The Alleghany chain bounds it on the east, and it is drained by several branches of Youghiogeny $r$.

Erk Mrus, p. o., M'Donald co., Mo.: on Elk r. of the Neosho, near the W. line of the State, $194 \mathrm{~m}$. S. W. Jefferson City.

Elk Pont, p. v., Clayton co., Ia. : on Elk cr. of Turkey r., $72 \mathrm{~m}$. N. by E. Iowa City.

Euk Rmge, p. o., Giles co., Tenn. : 53 m. S. Nashville.

Euk Ridge Landing, p. v., Anne Arundel (Howard) co., $M_{0}$ : on the S. side of Patapsco r., $7 \mathrm{~m}$. above Baltimore, and at the head of tide-water. The Washington Branch R. R. diverges from the Baltimore and Ohio R. R., on the opposite side of the river, the former passing through the village. The viaduct over which the railroad crosses the stream, is 704 feet long and 59 feet above the surface of the water, resting on eight arches constructed of granite quarried in the neighborhood. The $\mathrm{v}$. has considerable manufactures, and, in fact, the whole vicinity is one scenc of mechanical industry. Pop. about 800 .

ElK River, p. v., Clinton co., $I a$. : on Elk r., a small affuent of the Mississippi, $69 \mathrm{~m}$. E. N. E. Iowa City.

ElK Rrver, p. 0., Franklin county, Tenn. : 69 m. S. S. E. Nashville. The $r$, from which this $p . o$. has its name, is a considerable tributary of the Tennessee $r$; it rises in the hilly region on the E. border of Franklin county, and thence passes through Lincoln and Giles counties, into Alabama, where it joins the Tennessee near the Muscle Shoals. It has a large number of affluents.

Eik river, Oreg. Ter. : a tributary of Umpqua r., which it joins at the $v$, of Elkton.

Erk river, $\boldsymbol{M}_{0}$ : rises in Pennsylvania, and flows by a broad estuary into the $N$. part of Chesapeake Bay. It is navigable for $15 \mathrm{~m}$. to Elkton.

Elk river, Ala.: an afluent of Tennessee $r_{\text {. }}$, which it enters a little above the Muscle Shoals.

ElK RuN, p. o., Fauquier co., Firg.: 92 na. N. by W. Richmond.

Erk Springs, p. o., Pike co., MFo.: on Elk Lick of Salt

r., $76 \mathrm{~m}$. N. E. Jefferson City.

Exқтол, p. v., Umpqua eo., Oreg. Ter.: at the confluence of Elk $r$. with the Umpqua, $93 \mathrm{~m}$. $\mathrm{s}$. Salem.

ElktoN, p. $v_{*}$, Crawford $c_{\circ}, T l_{n}$ : on the edge of a fine prairie, $10 \mathrm{~m}$. W. of Hutsonville, on the Wabash, and 108 m. E. S. E. Springfield.

ElkTox, p. v., and cap. Todd co., $\bar{K} y .:$ on Elk fork of Red r., a tributary of Cumberland $\mathbf{r}_{*}, 167 \mathrm{~m}$. W. S. W. Frankfort. It contains a court-house and other co, offices, and about 600 inhabitants.

Eliton, p. V., and cap. Cecil co., Ma. : at the forks of Elk r., $15 \mathrm{~m}$. above its confluence with Chesapenke Bar. at Turkey Point, $54 \mathrm{~m}$. N. E. Annapolis. It is a well-built place, with a court-house, co. prison, etc., and has 1,128 inhabitants. The Philadelphia, Wilmington, and Baltimore R. R. passes the town a little to the $\mathrm{N}$.

Elkton, p. V., Hickory co., Io. $_{*}$ : about $5 \mathrm{~m}$. T. of Pomme de Terre river, an affluent of Osage river, $83 \mathrm{~m} . \mathrm{S}$. W. Jefferson City.

EukтoN, p. v., Giles co., Tenn.: on Elk r. of tho Tennessee, $72 \mathrm{~m}$. S. Nashville. Pop. 200.

Elkton, p. v., Columbiana cr., Orio: on the N. bank of the middle fork of Little Beaver r., and on the line of the Sandy and Beaver Canal, 129 m. E. N. E. Columbus. It is 200 located on the W. side of the entrance of Elt Run, irsto the above-named river, and contains 160 inhabitants.

Elkville, p. v., Caldwell co., $N$. Car.: on Eik er., at its confluence with Yadkin r., $157 \mathrm{~m}$. W. by N. Raleigh.

Ellejay, p. v., and cap. Gilmer co., $G a_{0}$ : at the confluence of the Ellejay and Cottercay rivers, $143 \mathrm{~m}$. N. W. by N. Milledgeville. It contains a C. H. and other county buildings, and about 300 inhabitants.

Ellejay, p. v., Blount co., Tenn.: 156 m. E. by $\mathrm{S}$. Nashville.

Eluenborodgh, p. V., Grant co., Wisc. : on the E. side of Platte r., an affluent of the Mississippi, $68 \mathrm{~m}$. W. S. W Madison.

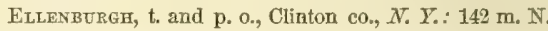
Albany. Drained by English and other creeks of Chateauguay $r$, which flows $\mathrm{N}$. into the St. Lawrence and the head streams of Chazy r. of Lake Champlain. Surface hilly but generally arable. Pop. 1,104.

Eluengowan, p. o., Baltimore co., $\boldsymbol{M} d$.

Ellenvilie, p. v., Ulster co., $N$. $Y$.: at the junction of Sand Bar and Good Beerkill creeks, 71 m. S. by W. Albany, and on the line of the Delaware and Hudson Canal. It contains three churches, an iron foundry, several stores, factories, and mills, and about 600 inhabitants; and a newspaper, the "E. Journal" (dem.), is issued weekly. In the vicinity is an old lead mine.

Elleroy, p. v., Stephenson county, $l l .: 173 \mathrm{~m} . \mathrm{N}$. Springfield.

Ellebslite, p. v., Harris co., Ga.: 106 m. W. S. W. Milledgeville.

Ellersle, p. v., Susquehanna co., Penn.: 129 m. N. E. Harrisburg.

Ellerr, t. and p. v., Chautauque $\cos , N$. $Y$ : $2 \pi \mathrm{s}$. W. by S. Albany. Drained chiefly by several crecks of Chautauque Lake, which forms its W. border. Surface undulating; soil, sandy and gravelly loam. The v, on the E. shore of the lake contains about 150 inlabitants. Pop. of the t. 2,504 .

Els Grove, p. o., Henry co, Tenn. $92 \mathrm{~m}$. W. by N. Nashville.

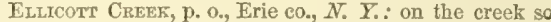
called, 259 m. W. Albany.

Ellicotr's Mrlss, p. V., Anne Arundel (Howard) co., MId. on Patapsco r., $12 \mathrm{~m}$. above Baltimore, and $31 \mathrm{~m}$. N. by W. Annapolis. The Baltimore and Ohio R. R. passes through the place. The whole vicinity is one scene of productive industry; and here is the greatest centre of flouring-nills in the Union. In 1850 the population amounted to 1,059 , of which number 196 were free colored persons. The "Howard Gazette" is published weekly. The vicinity for 10 or 12 $\mathrm{m}$. around has much grand scenery, and the lands in general are in a good state of eultivation.

Ellicotrsvil. $244 \mathrm{~m}$. W. by S. Albany. Drained by Great Valley cr. and its tributaries. Surface undulating; soil, sandy and gravelly loam. The $\mathrm{v}$. is located on the right side of the cr., which is an affiuent of Alleghany r.; it contains the county buildings, and about 800 inhabitants; and has three newspapers, the "Cattaraugus Whig," the "Cattaraugus Republican" (dem.), and the "Whig and Union," all published weekly. The $t$. is chiefly agricultural. Pop. 1,412.

Elingeton, t. and p. V., Tolland co., Conn.: $16 \mathrm{~m}$. N. E. Hartford. Drained by Broad Brook of Seantic r. and Hockanum $r$., the outlet of Snipsick Lake and an affluent of the Connecticut. Surface raried-on the E. hilly, and on the W. generally level; soils light and dry, and of average productiveness. The $\mathrm{v}$. is located at the cross roads, near the centre of the t., and contains about 60 dwellings. Pop. of the t. 1,355.

Ellisgrus, p. ₹., Outogamie co., Wisc. : 105 m. X. N. E. Madison.

Eltrigtor, t. and p. o., Chautauque co., $\boldsymbol{N}_{\text {. }} \boldsymbol{Y} .: 2 \% \mathrm{~m}$. W. by S. Albany. Drained by Clear cr. Surface undulat- 
ing; soil, sandy and gravelly loam. There are several tanneries and mills in the t., and about 2,001 inhabitants.

ELIINGTOOD's CORNER. p. V., Waldo co., Me.

ELliotr, t. and p. v., York county, $M \varepsilon_{*}: 100 \mathrm{~m}$. S. W. Augusta. Drained by creeks of Piscataqua r., which makes its S. W. border. Surface varied, and soil generally productive. There are several tanneries and mills in the t., and about 2,200 inhabitants.

Elitortsburge, p. v., Perry county, Penn.: $32 \mathrm{~m}$. W. Harrisburg.

Elliott's Cross Roads, p. o, Morgan co., Othio: $66 \mathrm{~m}$. E. S. E. Columbus.

Eluiotr's Cross Roads, p. o., Clinton co., Ky, : on the $\mathrm{S}$. line of the State, $110 \mathrm{~m}$. S. Frank fort.

Elliottstille, t. and p. o., Piscataquis co., Me.: $79 \mathrm{~m}$. N. by E. Augusta.

Elliottsville, p. v., Jefferson co., Ohio: on the right bank of the Ohio r., $126 \mathrm{~m}$. E. N. E. Columbus. It has sereral ponds and brooks emptying through sebec and Pleasant rivers into the Piscataquis. The $\mathrm{v}$. lies on Wilson's Brook, an affluent of Sebee Lake.

Ellis county, Texo. Situate N. centrally, and contains $800 \mathrm{sq} . \mathrm{m}$. Drained by the upper streams of Trinity r. Organized since 1850. Capital: Waxahachi.

Elurs island, $N . Y_{.}$: in the harbor of New York, opposite the mouth of Hudson $r$. It belongs to the United States, and is the site of Fort Gibson, now used as a naval store-house and powder magazine. It is also known as Gibbet Island, from the fact of its having been formerly the place for hanging or gibbeting pirates condemned to death.

ELLIS river, $M_{e}$ : a tributary of Androscoggin river.

Euts river, N. Hamp.: an affluent of the Saco from the White Mountains.

Ellisburgin, p. v., La Grange co., Ind. : 136 m. N. N. E. Indianapolis

Ellisbtrkgri, t. and p. v., Jefferson co., N. Y.: $136 \mathrm{~m}$. W. N. W. Albany. Drained by the branches of Sandy cr. an affluent of Lake Erie, which bounds it on the W. Surface level; soil, sandy loam. The $\mathbf{v}$. is located on Sandy cr. which affords extensive water-power, and has several mills, about 60 dwellings, and 400 inhabitants. The Watertown and Rome $R$. R. passes through the $\mathrm{E}$. part of the $t$., and at Pierrepont forms a junction with the Ellisburg and Sackett's Harbor R. R. Pop. 5,524,

Elissburgh, p. b., Potter co., Penn.: 126 m. N. by W. Harrisburg.

ELLISON, p. o., Wärren co., Ill.: $\$ 8 \mathrm{~m}$. N. W. Springfield.

Elliston, p. v., Madison co., Ky.: 48 m. S. E. Frankfort.

Ellistox, p. v., Onondaga con, N. $Y_{.}: 124 \mathrm{~m}$. W. by N. Albany.

Ellistown, p. ₹., Pontotoc co., Miss.: 155 m. N. E. Jackson.

Ellisvirle, p. v., Columbia co., Flor.: on the Santa Fé r. a tributary of Suwanee r., $112 \mathrm{~m}$. E. S. E. Tallahassee.

Ellisville, p. v., Bladen co., N. Car.: $73 \mathrm{~m}$. S. Raleigh.

Elissille, p. v., Fulton co., Ill.: on the E. side of Spoon $\mathbf{r}$. of the Illinois, $69 \mathrm{~m} . \mathrm{N}$. W. Springfield. There are several large mills on the river, both above and below the village.

Eluzsville, p. Y., and eap. Jones co., Miss. : on Tallahala er., a constituent of Pascagoula r., $78 \mathrm{~m}$. S. E. by E Jackson.

Ellisville, p. v., St. Louis co., MIo.: 88 m. E. by N. Jefferson City.

Eltisvilie, p. v., Louisa county, Firg.: 51 m. N. W. Pichmond.

Ellittsvilue, p. va, Monroe co., Ind.: 44 m. S. W. by S, Indianapolis. The New Albany and Salem R. R. intersects this place, $7 \mathrm{~m}$. N. W. Bloomington.

Eis.sworth, p. y., Litchfleld county, Conn.: $41 \mathrm{~m} \mathrm{~W}$. Hartford.

Elusworte, t., p. v., and cap. Hancock co., Me.: $71 \mathrm{~m}$. E. by N. Augusta. Drained by Union r., and there are several large ponds emptying into it. Surface varied. Soil fertile, adapted alike to grain growing and grazing. The $\mathbf{v}$. is situate at both sides of Union $\mathbf{r}$, at the head of tide water, and accessible to large vessels. The $r$. is here spanned by a bridge, conneeting the two sections of the $\mathrm{v}$, It contains a court-house, co. jail, and the co. offices, and about 600 inhabitants. Pop. of t. 4,009.

Ellsworth, p. va, Texas co., Mos: on Big Piney Fork of Gasconade r, $78 \mathrm{~m}$. S. by E. Jefferson City. Pop. 9:3.

ELLSWORTH, t. and p. v., Mahoning co, Ohio: $132 \mathrm{~m}$. N. E. Columbus. Drained by an affluent of Mahoning $r$. Surface diversifled, and soil of average fertility, well adapted to grass and grain. The $\mathbf{v}$, on the Canfield and Ravenna Turnpike, contains 150 inhabitants. The cheese and butter of this t. have long been noted in the markets.

Ellwood, p. v., Muhlenburgh co., $K y_{.}: 146$ m. W. S. W. Frankfort.

Ellwood's Bridge, p. o., Delaware co., $N . Y$.

ELa Bluff, p. O., Dallas con, Alan : $47 \mathrm{~m}$. W. Montgomery. Elixer, p. o, Salem co., N. Jer.: 57 m. S. S.W. Trenton.

Elm Grove, p. o., Marion co., $I \alpha_{0}:$ in the S. E. corner of the co, $77 \mathrm{~m}$. W. S, W. Iowa City.

Ely Grove, p. o., De Soto co., Miss. : $177 \mathrm{~m}$. N. Jackson. Eum Grove, p. o., Lewis county, Mfo.: 108 m. N. by E. Jefferson City.

ELM GRove, p. 0., Highland co., $I 7 l$.

Ely Hill, p. 0., Davidson co., Tenn.

Elurra, p. v., Stark co., $I l l_{\text {. }}$ : on the E. side of Spoon $r$. of the Illinois, $99 \mathrm{~m}$. N. Springfield.

Elmors, t., p. v., and eap. Chemung eo., N. Y.: $155 \mathrm{~m}$. W. by S. Albany. Drained by ereeks of Chemung r. Surface uneven; soil in the valleys and flats very fertile. The $v$. is located on the left side of Chemung $r$, at the entrance of Newton's cr., where is extensive water-power. It con-

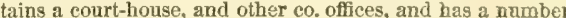
of manufacturing establishments, stores, warehouses, ete. It is also a great lumber market, and has a considerable trade. The Chemung Canal has its Southern terminus at this poin? and the New York and Erie R. R. passes throngh the $\mathrm{v}$, and $4 \mathrm{~m}$. W. of the $\mathrm{v}$. is tapped by the Canandaigua and Elmira R. R. Three newspapers are published here-the "E. Republican" (whig), the "E. Gazette" (free soil), and the "E. Couri r" (whig)-all issued weekly. Two bridge" cross th Chemung r., over one of which the R. R. passes, and over the other the turnpike. Pop. 6,212. The original nam of the t, was Con-e-wa-wah. It was settled in 1789 , and called "Newton," and in 1791, the $\mathrm{v}$. having been located by Moses De Witt, its name was ehanged to "Dewitts burg." In the last year the first frame-house was built, and the lands were sold to settlers at 18 pence per acre. The t. finally received its present title from some gentleman who named it after his wife. Pop. of t, 8,166.

Elmira, p. v., Fulton county, Ohio: 127 m. N. N. W. Columbus.

Ermore, t. and p. o., Lamoille co., Verm. : 16 m. N. by E. Montpelier. Drained in the $\mathrm{S}$. by branches of Onion r., and in the $\mathrm{N}$. by branches of the Lamoille. Surface elevated and rough; soils moderately fertile. The $r$, is located in the $N$. part of the $t$. on a branch of Lamoille $r$. The t. has several ponds, and contains iron ore. Pop. 504.

ELmoRe, p. o., Peoria co., $M l_{\text {。: }} 73 \mathrm{~m}$. N. Springfield.

Elur Point, p. o., Bond co., Ill. $:$ in the middle of Fork Prairie, between the forks of Shoal cr., an affluent of Kaskaskia r., $61 \mathrm{~m}$. S. by E. Springfield.

Elm Sprivgs, p. V., Washington co., Ark.: 144 m. N. W. Little Rock.

Eum True, p. o., Hancock co., $I l l .:$ on the edge of a fine prairie, $6 \mathrm{~m}$. E. S. E. Carthage, and $84 \mathrm{~m}$. W. N. W. Springfield.

ELM Woov, p. o., Peoria co., $I l l .:$ on Kiekapoo cr., 68 $\mathrm{m} . \mathrm{N}$. by W. Springfield.

Eum Wood, p. 0., Saline county, Mro.: $76 \mathrm{~m}$. W. N W Jefferson City. 
ELoN, p. o., Amherst co., Firg. : 92 m. W. Richmond. Errod, p. v., Ripley co., Ind.

Eutox, p. V., Cattaraugus co., N. Y.: $146 \mathrm{~m}$. W. by $\mathrm{s}$. Albany.

Eltox, p. v., Edgefield distriet, S. Car, : $64 \mathrm{~m}$. W. Columbia.

Elyria, t., p.v., and cap. Lorain co., Ohio: 108 m. N.N.E. Columbus. Drained by Black r. of Lake Erie, and its tributaries. Surface uneven; soils generally fertile. The v. is pleasantly located between the $\mathrm{E}$. and W. forks of Black r., which unite about half a mile N. of it, and each of which has a perpendicular fall of nearly 40 feet on the opposite sides of the v., affording extensive hydraulic power. The principal streets extend from one branch of the river to the other, and the buildings exhibit much neatness and taste It contains a court-house and other co. buildings, several furnaces, factories, and mills, and about 1,482 inhabitants; and two newspapers, the "E. Courier" (whig), and the "Lorain Argus" (dem.), are published weekly. The Lake Shore R. R. from Cleveland to Sandusky, passes through the village. Pop. of t. 2,658 .

Elysburge, p. vo, Northumberland co., Penn.: $54 \mathrm{~m}$. N. Harrisburg.

Elistan Frelds, p. o., Harrison co., Tex。: 270 m. N. E. Austin City.

ELYSIOM, p. $\nabla ., \mathrm{M}^{4}$ Henry co, $I l l_{0}:$ on the $\mathrm{S}$, side of Boon cr. of Fox r., $182 \mathrm{~m}$. N. N. E. Springfield.

Eirsvirle, p. v., Howard co., Afd.: on the Patapsco r. and on the line of the Baltimore and Ohio R. R., $21 \mathrm{~m}$. W Baltimore, and $40 \mathrm{~m} . \mathrm{N}$. W. Annapolis. It contains 1 cotton and 1 oakum factory, 1 chureli, 1 school, and 106 inhabitants. The houses are built of brick and stone. The vicinity is thickly seftled, and in a highly flourishing condition, both as respects its manufacturing and agricultural interests. The lands are fertile, and afford a considerable quantity of produce for market.

Elrton, p. v., and cap. Jefferson co., Ala.: at the head of Catoochee or Valley cr., 81 m. N. N. W. Montgomery. It contains a court-house and the co. jail and offices, and about 150 inhabitants. The country is elevated, and the lands famous for their fine cotton.

Eunvel county, Ga. Situate toward E. centrally, and contains $1,100 \mathrm{sq} . \mathrm{m}$. Drained by Cannouchee $r$, and other affluents of the Ogeechee, and by several head streams of Great Ohoopee r. of the Alatamaha. Surface level, and soils, except in the valless, sandy and of indifferent fertility. Farms 511; manuf. 0 ; dwell. 605, and pop.-wh. 3,591, fr col. 24, sl. 962-total 4,577. Capital: Swainshoro'.

Exauts, p. Y., Lehigh co., Penn : 76 m. E. N. E. Harrisburg. This is a Moravian village, at the foot of South Mountain, and is built in one street. It contains about 40 dwellings. The site was bequeathed by two brethren for the support and promotion of missions.

Evaus, p. o., Bedford county, Firg.: $123 \mathrm{~m}$. W. by S. Richmont.

Embarras Ponv, p. o., Edgar co., IU. : at the head of the E. fork of Embarras r., $93 \mathrm{~m}$. E. by S. Suringfield.

ExrBdex, t. and p. F., Somerset co., MYe.: 54 m. N. N. W Augusta. Drained by several affluents of Kennebec $\mathbf{r}_{\text {, }}$ Which makes its E. burder. The $r$. is loeated in the N. E. part of the town. Pop. of t. 971 .

Exbden Cextre, p. 0., Somerset co, Mre, $57 \mathrm{~m} . \mathrm{N} . \mathrm{N} . \mathrm{W}$. Augusta.

Eybreertur.e, p. v., Chester co., Penn.: $71 \mathrm{~m}$. E. by S. Harrisburg.

EMERatD Grove, p. 0., Rock co., Fisc. : 38 m. S. S. E. Madison.

EArERSON's TAN-Y $47 \mathrm{~m}$. W. Raleigh.

EMnery, p.v., Fulton co., Ohio: 128 m. N. N.W. Columbus.

Every's Mrlis, p. o., York co, Me.: on the S. branch of Mousam r., about $8 \mathrm{~m}$. below the pond from which the stream has its rise, and $82 \mathrm{~m}, \mathrm{~S}$. W. Augusta 202
Emasvinte, p. v., York county, Penn.: 37 m. S. by E. Harrisburg.

Eminenoe, p. v., Logan co., Ill.: in the N. E. part of the co., S. of Sugar cr, of Salt cr., an affiuent of the Sangamon, $37 \mathrm{~m}$. N. N. E. Springfield.

EMINENce, p. v., Henry co., Ky.: 23 m. N.W. Frankfort.

EMTNENCE, p. 0, Schoharie co., N. Y.

Eumance, p. v., and cap. Shannon co., Mo. : on the left bank of Current r., 98 m. S. S. E. Jefferson City. It contains a court-house, ete., and about 120 inhabitants.

Emrenton, p. v., Venango co., Penn.: 168 m. W. N. W. Harrisburg.

Erara, p. F., White co, $I l l_{0}$ : on the E. of Little Wabash r., $148 \mathrm{~m}$. S. E. Springfield.

Emare, p. 0., Lake co, $I l l$.: between Des Plaines $r$ and Lake Michigan, $8 \mathrm{~m}$. S. by W. Waukegan, and $199 \mathrm{~m}$. N. E. by N. Springfield.

Ennetr county, Ia. Situate N. W., and contains 432 sq. m. Taken from Pottowattomee in 1851.

Eмn:TT county, Mich. Situate N.W. extremity of Lower Peninsula, and contains $144 \mathrm{sq}$. m. A new co, since 1850.

EMnETT, to and p. 0., Calhoun co., Mich.: $43 \mathrm{~m} . \mathrm{S}$. W Lansing. Drained by Kalamazoo r. and its tributaries. The Michigan Central R. R. passes through the $t$ about $118 \mathrm{~m}$. from Detroit. Pop. 1,582.

EvnetT, to and p. v., Dodge co., Wisc.: 36 m. E. N. E. Madison. Pop. 1,207.

Emictrstilue, p. v., Randolph co., Ind.: on the $\mathrm{N}$. side of and about a mile from Mississinewa r., $64 \mathrm{~m}$. N. E. by $\mathrm{E}$. Indianapolis.

Eммrт, p. v., Wilkinson co., Gt\%: on the S. fork of Commissioner's er., an affluent of Oconee $r_{.,} 15 \mathrm{~m}$. S. Milledgeville. The Central R. R. passes through the v, $152 \mathrm{~m}$. from Savannah.

EmMtrsetrger, p. v., Frederick co., $M d$. : on the W. side of Flat r., a tributary of Tom's cr., and extending back almost to that stream, $73 \mathrm{~m}$. N. W. Annapolis. It has a churehes, several stores, and 812 inhabitants. In the vicinity the Roman Catholics have several celebrated religious and educational institutions. Mount St. Mary's College, 2 m. distant, is one of the best schools in the Union; it was founded in 1830, and had in 1850 a president, 24 professors and instructors, 137 alumni, and 126 students. Its library contains about 4,000 volumes. Mount St. Mary's Theologieal Seminary had a superior, and 8 professors, and 24 students. St. Joseph's Academy, about half a mile from the $\mathrm{v}$, is a female institution, conducted by the Sisters of Charity ; and near here is the Congregation of the Missions, from which so many sisters have been sent into the world to alleviate human suffering. Besides these there is St. Philomena's Asylum, attached to the Congregation of Missions for the Education of Orphan Girls, and served by four sisters; a Free School for girls, and other charities.

Exory, p. v., Washington co., Tirg.: 264 m. W. S. W. Richmond.

EvorT, p. va, Holmes co., Jfiss. : 56 m. N. by E. Jackson. EYORY IroN WORKs, p. O, Roan co, Tenn.: on Emory's r, a branch of Clinch r., $126 \mathrm{~m}$. E. by S. Nashville.

EurPIRE, p. o., Whitesides co., IU.: $188 \mathrm{~m}$. N. by W. Springfield.

Evrire Crty, p. v., Tuolumne co., Calif: : on the S. side of Tuolumne r., $85 \mathrm{~m}$. S. E. Vallejo.

EMPIRE IroN Works, p. o., Trigg co., Ky.: $197 \mathrm{~m} . \mathrm{S} . \mathrm{W}$. Frankfort.

ENDOR, p. 0., Will co., ILl.: 140 m. N. E. Springfleld.

ENERgY, p. o., Clark co., Afiss.: $98 \mathrm{~m}$. E. by S. Jackson. ExFELD, t. and p. V., IIartford co, Conn. : $16 \mathrm{~m}$. X. hy E. Hartford. Situate on the E. side of Connecticut r., over which is a bridge connecting it with Suffield, and also one in the S. part of the t, over which the Yow Haveu, IIarthirt, and Springfield R. R. passes from Windsor Locks to Warehouso Point. This railroad skirts the $r$, through the to, passing through Thompsonville. Scitico and Hazardville are other 
rillages in Enfield, Thompsonville is noted for its extensive carpet factories, and Hazardville for its powder mills. Pop. of town 4,460 .

Enfiexd, t. and p. o., Penobscot co., Me.: 92 m. N. E.

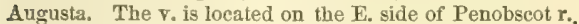
which forms the W. border of the town. A large pond lies on the E. border. Pop. 392.

ENTELd, t. and p. v., Hampshire co., Mass. : $66 \mathrm{~m}$. W. Boston. Drained by two branches of Swift $r$., a tributary of Chicopee r., which afford water-power. Surface diversiffed. Soil adapted best to grasses. There are considerable manufactures in the town, consisting of cotton and woolen goods, boots, shoes, etc. Pop 1, 36 .

ENfield, p. v., Halifax co., N. Car.: on the line of the Wilmington and Weldon R. R., $66 \mathrm{~m}$. N. E. Raleigh. It is a place of considerable business, and has 400 inhabitants.

ENTield, t. and p. v., Grafton co., N. $\operatorname{Hamp} .: 36 \mathrm{~m}$. N.W. Concord. Surface pleasantly diversified, and soil of average fertility. It contains several considerable ponds, the outlets of which afford water-power. The v. lies at the $\mathrm{S}$. end of Mascoma Pond, and there is a Shaker's village and settlement on the W. side of the same, which is characterized by the neatness and economy so usual with these sectarians. The seltlement embraces about 1,000 acres of land in a high state of cultivation. In the N. part of the $t$. is Enfield Station, on the line of the Northern $R$. R., which here crosses the t. $59 \mathrm{~m}$. from Concord. Pop. 1,742.

ErTield, t. and p. v., Tompkins county, $N$. $Y .: 143 \mathrm{~m}$. W. by S. Albany. Drained by creeks of Cayuga inlet, which afford water-power. Surface undulating; soil gravelly loam. The $\mathrm{v}$. contains about 30 dwellings. The t. is chiefly agricultural, and contains 2,117 inhabitants.

.ENFIELD, p. v., King William co., Virg.: 24 m. N. E. Richmond.

ENField Centre, p. Y., Tompkins county, $N . Y .: 145 \mathrm{~m}$. W. by S. Albany.

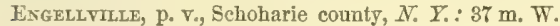
Albany.

Exglish Neighborhood, p. v., Bergen co., N. Jer. : $62 \mathrm{~m}$. N. E. Trenton. It contains 2 churches and about 40 dwellings. The distance from New York City is about 8 miles.

Exglish Pratrie, p. o., M'Henry co., $I Z$, : on the N. E. corner of the co., $198 \mathrm{~m}$. N. N. E. Springfield.

Exglish SETtLeMENT, p. Y., Marion county, Ia : on English cr., an affluent of Des Moines r., 103 m. W. s. W. Iowa City.

Exelishtown, p. v., Monmonth co., N. Jer.: on Matchaponix er., 27 m. E. Trenton. It contains several stores, about 40 dwellings, and 180 inhabitants. The country in the vicinity has a light and sandy soil.

Existille, p. v., Huntingdon co., Penn.: on Standing Stone er., $63 \mathrm{~m}$. W. by N. Harrisburg.

Exocr, t. and p. o., Noble county, Ohio: $84 \mathrm{~m}$. E. by S. Columbus. Drained by Duck cr. Surface varied, and soil generally fertile, well adapted to grain. Pop. 1,438.

Enoe Milus, p. o., Orange co., $N$. Car.: on Enoc r., an affluent of the Neuse, $31 \mathrm{~m} . \mathrm{N} . \mathrm{N}$. W. Raleigh.

Exon, p. o., Bureau co., $I l l_{\text {: : }} 113$ m. N. Springfield.

Exon, p. v., Macon co., Ala. : 81 m. E. Montgomery.

Exox, p. 0., Clark co., Ohio: 47 m. W. Columbus. P. 294.

ExoN Grove, p. o, Heard co., Ga.: $114 \mathrm{~m}$. W. by N. Milledgeville.

Enon VAlley, p. o., Lawrence co., Penn.: 159 m.W.N.W. Harrisburg.

Exoree, p. v., Spartanburgh dist., S. Car.: on Enoree r., an aftuent of Broad r., $86 \mathrm{~m}$. N. W. by N. Columbia.

ErosborgI, p. .., Franklin co., Ferm. : 44 m. N. by W. Montpelier. Drained by tributaries of Missisqui r., which flows through the N. part of the t., and affords good waterpower. Surface varied, and soil best adapted to grasses. The $\vee$. lieg about the centre, and contains 22 dwellings.

Erosburge Falis, p. 0., Franklin co, Verm.: 47 m. 2. by W. Montpelier.
ENTERPRISE, p. O., Orange co., Flor.: on the N. side of a lake or expansion of St. John's r, $226 \mathrm{~m}, \mathrm{~S}$. E. Taliahassee. Lat. $28^{\circ} 49^{\prime} \mathrm{N}$., and long. $81012^{\prime} \mathrm{W}$.

Enterprise, p. o., Wayne co., I $l_{.}$: on the E. side of EIm cr. of Little Wabash r., 112 m. \$. E. Springfield.

Exterprise, p. 0., Shiawassee co., Bich. : 27 m. N. E. Lansing.

ENTERPRise, p. V., M'Donald co., Mo. : on a branch of Elk r. of the Neosho, $182 \mathrm{~m}$. S. W. Jefferson City.

Enterprise, p. o., Lancaster co., Penn. : 42 m. E. S. E. Harrisburg.

Exterprise, p. v., Clark co., Dfis8.: on Chankey cr. of Chickasawa r., $92 \mathrm{~m}$. E. by S. Jackson.

ENterprise, p. v., Preble county, Ohio: $89 \mathrm{~m}$. W. by S. Columbus.

EoliA, p. o., Dane co., Wisc.: 22 m. N. E. Madison,

EPHratah, t. and p. v., Fulton co., N. $Y_{\text {. }} 46 \mathrm{~m}$. W. N.W. Albany. Drained by Garoga and Zimmerman's creeks, affluents of Mohawk $r$. The surface is uneven: soil, sandy loam. The $\mathrm{v}$. is located on the right bank of Garoga cr., and contains about 200 inhabitants. The t. has considerable water-power, and several factories and mills. Pop. 2,0s0.

Eрнгатан, t, and p. v., Lancaster county, Penn. : 33 m. E. by S. Harrisburg. The $\mathrm{v}$. was founded by a singular sect from Germany, the Tunkers or Dunkers. Most of the original peculiarities of the sect have disappeared, but they still live remarkable for the regularity of their lives, the simplicity of their manners, and the fervor of their devotion. Contention at law or with arms they regard as unchristian. Pop. about $1,979$.

Eppive, t. and p. v., Rockingham co, $\Lambda$. $H_{\text {csmp. }}: 27 \mathrm{~m}$. E. S. E. Concord. Drained by Lamprey $r$, which affords good water-power. Surface level, and soil generally of an average fertility. The $\mathrm{v}$. is located on the Portsmouth and Concord R. R., $19 \mathrm{~m}$. from Portsmouth, and $30 \mathrm{~m}$, from Concord. The t. has several tanneries, mills, etc., and 1,433 inbabitants. Pop. 1,663.

Epsom, t. and p. o., Merrimac co, N. Hamp. : $11 \mathrm{~m}$. E. by S. Concord. Drained by Suncook $r$. and its tributaries. Surface uneven; solls suitable for grass or grain. The v. lies on a creek of Suncook River. Pop. 1,365.

EQuality, p. v., and cap. Gallatin co., $I l$.: on the $\mathrm{N}$. side of the S. fork of Saline cr., an affluent of the Ohio r., 159 m. S. E. by S. Springfield. It contains a neat brick courthouse and other co. offices, several mechanic shops, stores, etc., and about 120 dwellings. In the neighborhood there are salt-works.

EQdality, p. V., Coosa county, Ala.: 32 m. N. by E. Montgomery.

Equalitx, p. V., Anderson dist., S. Car. : 119 m.W. N.W. Columbia.

Equator, p. o., tee co., $I \%$. : 136 m. N. by E. Springfield. Eoutwunk, sta, Delaware co., $N$. $Y$.: on the E. bank of Delaware r., and on the line of the New York and Erie R. R., $159 \mathrm{~m}$. from New York City. At present it contains little more than the railroad buildings and offices, and a hotel, but it has many adrantages that the future may develop.

Eoundork, p. V., Wayne co., Penn.: on the W. side of Delaware r., $189 \mathrm{~m}$. N. E. Harrisburg. It has several mills, and in the neighborhood are a large number of tanneries. Erasmus, p. O., Lincoln co., N. Car, : $146 \mathrm{~m}$. W. by S. Raleigh,

Ercildown, p. 0., Chester county, Penn.: 73 m. E. by S. Harrisburg.

Erie county, $N . Y$. Situate W., and contains $876 \mathrm{sq} . \mathrm{m}$. Surface generally level or undulating, except in the $\mathbb{S}_{*}$, where it is somewhat billy. Niagara $r$. and Lake Erie form its W. border, and Cattaraugus County' makes its S. line. Drained by Buffalo, Cayuga, Cazenovia, Seneca, Elicott's, Canquaga, and Tonewanda creeks. Farms 4,850; manuf. 688; dwell. 17,104, and pop.-wh. 100,214, and fr. col. 779total 100,993. Capital: Buffalo. Public Works: Erie 
Canal; Buffalo and Roehester R. P. ; Buffalo and Niagara Falls R. R. : Buffalo and State Line R. R. : Buffalo and New York City R. R.; Buffilo and Brantford R. R.; Buffalo, Corning, and New Iork R. R., etc., and numerous plank roads.

Eris county, Ohro, Situate N. on Lake Erie, and contains 324 sq. m. Drained by Huron and Fermillion rivers, and Pipe er, the latter emptying into Sandusky Bay, and the two first into the lake. Surface generally level, and soils fertile. A large commerce eentres in this co. Farms 1,021; manuf. 73 ; dwell. 3,362 , and pop--wh. 18,366, and fr. col. 202-total 18,563, Capital: Sandusky City. Public Works: Lake Shore R. R.; Sandusky and Toledo R. R.; Mad River and Lake Erie R. R.; Mansfield and Sandusky R. R., ete.

ERIE county, Penn. Situate in the N. W. corner of the State, facing on Lake Erie, and contains 720 sq. m. Drained by Conneaut, Elk, Walnut, and other creeks flowing into the Lake, and French cr. of the Alleghany r. Surface undulating; soils various, consisting of sandy losm, gravel, and clay in different proportions, and well adapted to grass. Farms 3,334 ; manuf. 255 ; dwell. 6,S25, and pop.-wh. 88,593, fr. col. 149-total 89,742 Capital: Erie. Public Workis: Erie and North-East R. R. ; Cleveland, Painesville, and Ashtabula R. R.; and Sunbury and Erie R. R.; also Beaver and Erie Canal. The two first of these form links in the great chain of railroads extending along the southern shore of Lake Erie.

E'RIE, p. v., Whitesides co., IIl.: on the N. side of Rock r., $122 \mathrm{~m}$. N. by W. Springfield.

Erie, p. o., Roan county, Tenn.: 129 m. E. by S. Nasbville.

Erre, t. and p. v., Mnnroe co., 1 rar.: 84 m. S E Lansing. Drained by Tance $r$, and Bay cr. The town is the sulutheasteramost in the State, and includes North Cape and several islunds. It contains a grod stone quarry. Pop, 1,144.

ERrE, p. v., and cap. Camden co., MIO.: on the S. side of Osage r., between the Little Niangua and Grand Au Glaize rivers, $45 \mathrm{~m}$. S. W. Jefferson City. It contains a courthouse, a jail, etc., and has a considerable river trade.

EkIE, p. b., port of entry, and cap. Erie co., Penn.: on Presque Isle Bay of Lake Frie, 215 m. N. W. by W. Harrisburg. Lat. $42^{\circ} 10^{\prime} \mathrm{N}$., and long, $80^{\circ} 08^{\prime} \mathrm{W}$. The borough extends along the bay for $3 \mathrm{~m}$., and from it $1 \mathrm{~m}$. The harbor of Erie is one of the best and safest on the Lake, with 8 or 10 feet of water on the bar, and the depth within it averages 20 feet. In extent it is about $6 \mathrm{sq}$. m. The borough contains the co. court-house, a jail, and other offices, churches of all denominations, schools and academies, a bank, numerous wholesale stores, commission and forwarding houses, and lumber yards; also foundries, mechanic shops, and manufacturing establishments of various kinds, Its pop. in 1. 41 was 3.412 ; in 1.50 it enntained 5.5 .11 : and in 15.2 . by estimate, 8,500. At the first period it had few facilities of internal communication-at the last, the line of railroads from Buffalo was completed, and also the line to Cleveland, thus extending its commercial highways to the extreme West and East of the Union. As yet, however, the pros. perity of the borough is only in its first grade of development. Its harbor is beine improwed: the line of eanul from Pitsbure is progressing to eompletion: at railruad is being built in connect it with the Eric I. I. and Xiew Yurk City; another from Erie, vict sunlury to Philadelyluia, in Pennsylvania; and still another to Pittsburg. These lines of travel and transportation will place it on a par with Buffalo, Dunkirk, Cleveland, Sandusky, etc., and make it, in a commercial point of view, one of the most important ports of Lake Erie. The lake commerce centering at this port is as yet comparatively small, and the shipping owned by the inbabitants in 1850 was only 7.570 tons, of which 5.350 tons were navigated by steam-power. Favoring circumstances now compel the fortunes of the place, and its rise will be rapid; and it is not improbable that when the census 204 enumeration of 1860 is taken, that Erie will count a popula tion of nearly 20,000 inhabitants. The newspaper press of Erie consists of a tri-weekly paper and 4 weekly papers: the tri-weekly is the "Erie Observer" (dem.), of which also is issued a weekly edition; the "E. Chronicle" (whig), the "E. Gazette" (whig), and the "Commercial Advertiser" (whig). Erie has long been a port, the position and local advantages of which were appreciated by the lake navigator, and it has as long been a harbor of refuge to the national vessels in war or storm. It was here that Perry, in the last war with Great Britain, fitted up his fleet; and in case of war again ensuing, no port on the lake has the same advantages for defense and safe harbor, Presque Isle being a natural breast-work, easily defended against the enemy.

$E_{R I E}$ lake: one of the flve great lakes of North America, between the United States and Canada. It lies between $41^{\circ} 22^{\prime}$ and $42^{\circ} 52^{\prime} \mathrm{N}$. lat., and between $780^{\circ} 5^{\prime}$ and $83023^{\prime}$ W. long., and has the States of Ohio, Pennsylvania, and New York on the S. and S. E. borders, and the fertile peninsula of Upper Canada on the N. Its shape is elliptical-its length $205 \mathrm{~m}$, and its breadth from 10 to $63 \mathrm{~m}$. It receives at its W. end, through the Detroit or strait, the discharge of water from the great upper lakes, and discharges its own waters through Niagara r., celebrated for its stupendous water-falls. Its surface is elevated $565 \mathrm{foct}$ abovn tide water at Albany, 52 feet below lakes Huron and Michigan, and 322 feet above the level of Lake Ontario. Its waters are shallower than those of the other great lakes the greatest depth that has been obtained by sounding is 270 feet, but its mean depth is not more than 120 feet. It receives from Canada but a few small streams, the principal of which is the Ouse, near its E. extremity. From Michigan it receives the Huron and Raisin; from Ohio, the Maumer Portage, Sandusky, Vermillion, Black, Cuyahoga, Grand Ashtabula, and Conneaut; from Pennsylvania, the Elik and other streams; and from New York, the Cattaraugus and Buffalo creeks. The rivers of Lake Erie have bars at their mouths, rarely affording more than 8 feet water. A little N. W. of sandusky Bay is a group of islands called Norih, Middle, and South Bass islands. In the N. part of South Bass Island is Put-in-Bay, which has 12 feet water, and atfords one of the best harbors on the lake, and is easily accessible. Into this harbor Commodore Perry brought his prizes after the battle of the 10th Sept., 1813. The best harbors on the south shore, aro the harbor of Sandusky, Ohio; Erie, Penn.; and Buffalo and Black Rock, N. York. Port Maitland, at the mouth of Grand or Ouse r., forms the best and almost the only harbor on the Caneda shore. Grand r., after a course of 100 miles, enters Lake Erie $40 \mathrm{~m}$. directly W. of its outlet. In consequence of its shallowness, a part of the lake is frozen over in winter, and navigation is for several months suspended. The importance of this lake for the purposes of commerce has been greatly increased by the canals and railroads, connecting its ports with the interior and the sea-board. The canals are the Welland, the Erie, the Ohio, the Miami, and the Wabash and Erie canals; and the principal railroads are-the line of railroads from Buffalo to Albany; the New York and Erie R. R., from Dunkirk to New York City; the Sunbury and Erie P. R., from Erie to Sunbury and Philadelphia; the Cleveland and Pittsburg R. R.; the Cleveland, Columbus, and Cincinnati R. R.; the line of railroads from Sandusky to Cincinnati; and the Southern Michigan R. R, from Toledo and Monroe to Chicago, etc.; and besides these, there is a continuous line of railroad from Niagara Falls, through Buffalo, Dunkirk, Erie, Cleveland, Sandusky, Toledo, etc., skirting the southern line of the lake from one end to the other, and connecting with the lines directing inland from these several ports. The business which is done on this lake by the aid of these channels is im. mense, and is constantly increasing. The following was the tunnage of the several collection districts on Lake Erio at two periods: 


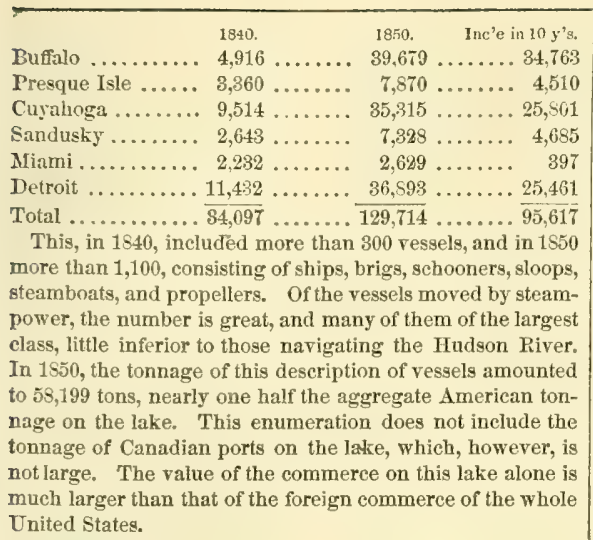

Erreville, p. v., Madison co, N. Y.: $102 \mathrm{~m}$. W. Albany. Pop. about 200

ERIN, p. v., Merriwether co, Ga.: on the N. line of the county, and about $6 \mathrm{~m}$. W. of Flint r., $78 \mathrm{~m}$. W. by $\mathrm{N}$. Milledgeville.

Erin, p. o., M'Henry co., $\pi l$. : $2 \mathrm{~m}$. N. of Woodstock, and 181 N. N. E. Springfield.

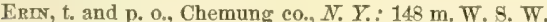
Albany. Drained by Cayuta cr. Surface hilly and broken, and soil gravelly loam of moderate fertility. It is almost entirely an agricultural town. Pop. 1,813.

ERTN, p. $\nabla .$, Chickasaw county, Miss.: 123 m. N. N. E. Jackson.

Erin, p. o, Jasper co., Tex. : on the E. side of Neches $r$. 233 m. E. Austin City. The Jasper and Beaumont Road intersects the place about $14 \mathrm{~m}$. above the $\mathrm{S}$. line of the co.

Erin Shadeg, p. o., Henrico co., Firg.

Errolt, t. and p. o., Coos co., N. Hamp. : 109 m. N. by E. Concord. Drained by Androseoggin r. and its tributaries. On the E. lies Lake Umbagog, which forms its boundary in that direction. The t. is entirely devoted to agriculture, and is very sparsely settled. Pon. ¿8.

Erving, t. and p. Y., Franklin co., Mass.: on the E. side of Connecticut r., $75 \mathrm{~m}$. W. by N. Boston. Drained chiefly by Miller's r. Surface diversified with fine meadows on the Connecticut. Its streams afford flne water-power, and it has considerable manufactures. The Vermont and Massa. chusetts $R$, R. traverses the $t$. on the $S$. and W. borders, following the valleys of the rivers. Pop. 449.

Erwinka, p. v., Bucks co., Penn.: on the right bank of Delaware River, $3 \pi$ m. N. Philadelphia, and $113 \mathrm{~m}$. E. Harrisburg.

Erwinspille, p. v., Cleveland county, $N$. Car. : $162 \mathrm{~m}$. W. S. W. Raleigh.

Erwinton, p. v., Barnwell dist., S. Car. : on the N. side of Briar er., an affluent of Savannah r., 73 m. S. S. W. Columbia.

Escambia county, $F$ lor. Situate in the extreme $W_{\text {., }}$ and contains 570 sq. m. Escambia r. and Pensacola Bay bound it on the E., and the Gulf of Mexico on the S., while the Perdido r. makes its W. line. Surface low and level near the sea, but rises to some height in the interior; it is drained by numerous tributaries of the border rivers. Soil generally poor, and covered with pines. Farms 34 ; manuf. 9; dwell. 563, and pop.-wh. 2,644, fr. col. 375, sl. 1,382-total 4.351. Capital: Pensacola. Public Works: Fort Gaines and Pensacola R. R.; Montgomery and Pensacola R. R.; Brunswick and Florida R. R., ete. (all projected).

Escambla river, $A l a$, and Flor.: rises in Monroe co, Alabama, and flows S. E. into Florida, where near the State line it unites with the Coneeuh, a larger river than itself, and thence flows S. into an arm of Pensacola Bay. From the junction this stream is properly the Conecuh.
Escomeag, p. v., Kent co., $R . I$.

Enculapia Sprixgs, p. v., Lewis co., Ky.: 92 m. E. by $\bar{~}$ Frankfort.

Egmond's Corners, p. o., Calhoun co., Bfich.: 58 m. S.W. Lansing.

Esom Hrut, p. o., Paulding co, Ga.: 118 m. N. N. W Milledgeville.

Esopus, t. and p. v., Ulster co., $N . Y_{0}: 57 \mathrm{~m}$. $\mathrm{S}$. by W. Albany. It has the Hudson $\mathbf{r}$, on the $\mathbf{E}$, and Pondout er. on the N.W. side. Surface uneven and broken; soil, sandy elay and gravelly loam. The $\mathrm{r}$. is located about $2 \mathrm{~m}$. W. of the landing on the Hudson, and contains about 30 dwellings. Pop, of $t$. 2,872.

Esperance, t. and p.. ., Schoharie co., $N_{0} Y_{*}: 30 \mathrm{~m}$. W. Albany. Drained by creeks of Schoharie $x .$, which bounds it on the E., and affords considerable water-power. The v. is located near the N. E, corner of the co, on the right bank of the river, and contains about 300 inbab. Pop. of t. 1,428.

Espy, p. v., Columbia co., Penn.: on the right bank of Susquehanna r., 62 m. N. by E. Harrisburg. Pop. about 200. Espyville, p. v., Crawford co., Penn.: 198 m. N. W. Harrisburg.

Essex county, Mass. Situate N. E., and contains $36 \mathrm{~S}$ sq. m. The Atlantic Ocean washes its E. line, and New Hampshire lies on its N. border. Drained by the Merrimac and Shawsheen rivers. Surface uneven and rough, but the soil in many parts good, and always well cultivated. It has an extensive coast, good harbors, an active commerce and fishing interest, and great wealth, and in manufactures is nne of the most productive in the State. Farms 2,816; manuf. 1,538; dwell. 18,578, and pop.-wh. 130,682, fr. col. 618-total 181,300. Capitals: Ipswich, Newburyport, and Salem, Public Works: Boston and Maine R. R, Eastern R. R.; Newburyport R. R.; Salem and Lawrence R. R., ete. Essex county, $N$. Jer. Situate toward the N. E., and contains $241 \mathrm{sq} . \mathrm{m}$. Drained by tributaries of the Passaie r., by the Rahway r., and some others. Two chains of hills pass through it, and make its surface uneven and rough; soils generally red shale. It has immense hydraulic power and extensive manufactures. Farms 1,745; manuf, 836 ; dwell. 10,964, and pop.-wh. 71,783 , fr. col. 2,161, and sl. $6-$ total 73,950. Capital: Newark, Putlie Works: Morris Canal ; Morris and Essex R. R.; New Jersey R. R., ete.

Essex county, $N$. $Y$. Situate N. E., and contains 1,79 sq. $m$. Surface hilly in the E., and mountainous in the W. Mount Marcy, the highest culmination, rises to the height of 5,467 feet above the level of the sea. Lake Champlain lies on its E. border, along which is some good Jand. It is one of the richest mining counties of the State, abounding in iron ores, copper, manganese, etc. Farms 1,572 ; manuf. 199; dwell. 5,321, and pop.-wh. 31,098, and fr. col. 50total 31,148. Capital: Elizabethtown. Public Works: Plattsburg and Whitehall R. P. (projected), etc.

Essex county, Term. Situate N. E. in the corner of the State, and contains 226 sq. m. Drained by streams of the Connecticut, St. Lawrence, and Lake Memphremagog. The Connecticut makes its E. line. Surface rough: soils generally poor, except in the river valleys. The county abounds in fine timber. Potatoes and oats are the chief products. Farms 602; manuf. 32 ; dwell, 546 , and pop.wh. 4,647, fr. col. 3-total 4,650. Capital: Guild Hall. Public Works: Atlantic and St. Lawrence R. R., etc.

Essex county, Firg. Situate E., and contains $2 S 0 \mathrm{sq} . \mathrm{m}$. Drained by tributaries of the Rappahannock $r$., which makes its N. E. border. Surface somewhat uneven: soil, except on the streams, sandy, and not of average fertility. Its products are the grains, with some cotton and tobacco. Farms 328; manuf. 17; dwell. 725, and pop.-wh. 3025 , fr. col. 419, sl. 6,762-total 10,2C6. Capital: Tappahannock.

Essex, p. b., Middlesex co., Conn.: on the W. side of Connecticut $r_{0}, 7 \mathrm{~m}$. from its mouth, and $31 \mathrm{~m} . \mathrm{S} . \mathrm{S} . \mathrm{E}$. Hartford. It is engaged in ship-building; and has a considerable coasting trade. Pop. aboui 1,000 . 
Essex, to and p. v., Essex co., Mass. : 27 m. N. E. Boston. Drained by Chebacco $r$. and other streams emptying into Squam Bay. The village lies near the centre of the town, and has about 350 inhabitants. Many small vessels are built in Essex, and numbers are employed in coasting and the fisheries. The manufactures of the town consist chiefly of boots and shoes, barrels, cordage, etc. Pop. 7,585 .

Essex, t. and p. o., Clinton co, Mich. : 23 m. N. by W. Lansing. Drained by creeks of Maple $r_{.,}$on which there are several salt-works. Pop, 410.

Essex, t, and p. v., Essex co, N. Y.: 108 m. N. by E. Albany. Drained by Boquet and other creeks of Lake Champlain, which makes its $\mathbf{E}$. border. The village is located on the lake shore, and has a good steamboat landing, etc. It is a place of considerable trade, with warehouses, stores, a ship-yard, and about 100 dwellings. The town is chiefly agricultural. Pop. 2.8\%1.

Essex, p. o., Fulton county, Ohio: 131 m. N. W. by N. Columbus.

Essex, t. and p. V., Chittenden co., Verm. : $31 \mathrm{~m}$.W. N.W. Montpelier. Drained in the S. by Onion r., and in the N. by Brown's r., a branch of Lamoille r. It has also several smaller streams. At Hubbell's Falls, on Onion r., are admirable mill-sites, at which considerable manufacturing operations are carried on. Surface varied by hill and dale: soil in the S. and W. sandy, and covered with pine-in other parts a sandy and clay loam, with hard. wood, and fertile. Along Onion r. are some tracts of beautiful intervale. The village near the centre contains about 20 dwellings. In the S. W. there is a new village, called Essex Junction, where the Burlington Branch diverges from the main line of the Vermont Central $R$. $R$. Pop, of t, 2,097 .

Estrulane Fornace, p. 0., Augusta co., Virg.: $105 \mathrm{~m}$ N. W. Richmoud.

Esterville, p. F., Atlantic co., $N$. Jer. : 51 m. S. by E. Trenton.

Estict county, $\bar{K} y$. Situate E. centrally, and contains $46 \mathrm{~S}$ 8q. m. Drained by creeks of Kentucky r., which flows through it in a north-west direction. The surface is rough and well-wooded, and the soils produce the usual staples of the State abundantly. Coal and iron are also staples, and are produced and worked successfully. Farms 604; manuf. 2 ; dwell. 934, and pop.-Wh. 5,568, fr. col. 6, sl. 411-total 5,985. Capital: Irvine.

Estrll's Mrurs, p, 0., Platte co, MYo.: 152 m. W. N. W. Jefferson City.

Estillville, p. V., and cap. Scott co., Virg. : on Mocassin cr. of the N. fork of Holston r., $292 \mathrm{~m}$. W. S. W. Riclimond. It contains a court-house and other co, offices, and about 40 dwellings.

Etmentdge, p. o., Jones co., $G a .: 29 \mathrm{~m}$. W. Milledgeville. ExxA, t. and p. v., Penobscot county, Me. : 49 m. N. E. Augusta. Drained by a branch of Sebasticook r. Surface diversified: soil of average fertility, producing excellent wheat. The village lies on the line of the Kennebec and Pembiecnt R. R. Pup. of t. stiz.

Erva, p. 0, Lapeer co., גiech. : 66 m. E. N. E. Lansing.

ETxA, p. Y., Tompkins county, $N$. $Y$.: on the right bank of Fall er., $181 \mathrm{~m}$. W. by S. Albany. It has about 250 inhalvitants.

Eтxa, t. and p. v., Licking co., Ohio: $16 \mathrm{~m}$. E. Columbus. Drained by S. fork of Licking $r$. The village is located on the National Road. Pop. of t.1,307.

Etna, p. o., Hanover co., Fing.

Etra Centre, p. o, Penobscot co., Me.: 47 m. N. E. Augusta.

Eтош Aн, p. 0., Cass cn., Ga.: on Etowah r, a constituent of the Coosa, $129 \mathrm{~m}$. N. W. Milledgeville.

Eтow An river, Ga.: one of the main constituents of Coosa r. It rises in Franklin co., and sweeps southerly through Cherokee and Cass counties, and into Flord co., where it unites with the Oostanaula r., forming together the Coosa, a river of 1 labama.
Etrers, p. on, York co., Penn.

EUBANk8, p. O., Columbia county, $G a_{*}$ : 69 m. E. N. E. Milledgeville.

EuchID, p. $\nabla$. , Onondaga co., $N . Y_{*}: \mathrm{S}$. of the outlet of Oneida Lake, $126 \mathrm{~m}$.W. by N. Albany.

Euchin, t. and p. v., Cuyahoga county, Ohio: $132 \mathrm{~m}$. N. E. by $\mathrm{N}$. Columbus. Drained by creeks falling into Lake Erie, which washes its N. limits. Surface broken, and much of the soil of only average fertility. The village is located on the line of the Cleveland, Painesville, and Ashtabula R. R. Pop, of $t, 1,447$.

Eufaula, p. v., Barbour co., Ala.: on the W. side of Chattahoochiee r., at the mouth of Eufaula cr., 73 m. E. S. E. Montgomery.

EuGENE, p. v., Vermillion co., Ind. : on the right bank of Big Vermillion r, about $3 \mathrm{~m}$. above its confluence with Wabash r., and $70 \mathrm{~m}$. W. by $\mathrm{N}$. Indianapolis. It has a town-hali and several stores, with a population numbering 300 souls.

Euharlex, p. v., Cass county, $G$ a. : 128 m. N. W. Milledgeville.

Evrogr, p. 0., Holmes county, Afiss.: 60 m. N. by E. Jackson.

Euphemra, p. o., Preble county, Ohio: $92 \mathrm{~m}$. W. by $\mathrm{S}$. Columbus.

Eurera, p. $v$, Trinity co, Oalif: on the E. side of the N. division of Humboldt's Bay, $180 \mathrm{~m}$. N. N. W. Vallejo.

Euners, p. v., Winnebago co., Wisc.: 78 m. N. N. E. Madison.

Eurefa Muls, p. o, Green co, Ohio: 53 m. W. S. W. Columbus,

Euтаw, p. v., and cap. Green con, Ala.: about 3 m. W. of Black Warrior r, and $96 \mathrm{~m}$. W. N. W. Montgomery. It contains a court-house and about 30 dwellings, and is situate in the midst of a fine elevated cotton region.

EuxAw, p. o., De Soto co., Miss. : $182 \mathrm{~m}$ N. Jackson.

Eutaw Springs, Charleston dist., $S$. Car. : a small affluent of Santee r., on the borders of which was fought the famous battle of Eutaw Springs, 8th September, 1781, between the Americans, under General Greene, and the British, under General Stewart. American loss, 555, and British loss, about 1,000 .

Evans, t. and p. v., Erie co., N. Y.: $281 \mathrm{~m}$. W. Albany. Drained by Little and Big Sisters' creeks, flowing into Lake Erie, which makes its W. border. Surface hilly: soil gravelly loam and clay, adapted to the growth of grain and the grasses. The village is located on the lake, and has a good landing. Pop. of the town 2,152.

Evaisiorge, p. b., Crawford county, Penn.: $208 \mathrm{~m}$. N. W. by W. Harrisburg.

Evaxisurgi, p. v., Coshocton co, Ohio: on the N. side of Tuscarawas $r$, and on the line of the Ohio Canal, $78 \mathrm{~m}$, E. N. E. Columbus. It has a fine commercial position, and contains several warehouses, stores, and about 120 dwellings. Pop. 800 .

Evaxs' Mruls, p. o, Chatham co, $N$. Car.: 29 m. W. Raleigh.

Eransport, p. v., Deflance co, Ohio: on the W. bank of Tiffin r., $122 \mathrm{~m}$. N. W. Columbus. Pop. 165.1

Exhssille, p. v., liock county, Wisc.: 32 m. S. S. E. Madison.

EFAsithLE, p. v., Washington co., Ark.: $149 \mathrm{~m} . \mathrm{W} . \mathrm{N} . \mathrm{W}$. Little Rock.

Evanswrle, p. city, and cap. Vanderburgh co., Ind.: on the high $\mathrm{N}$. bank of the Ohio r., $200 \mathrm{~m}$. from its mouth, and $144 \mathrm{~m}$. S. S. W. Indianapolis. It is the S. terminus of the Wabash and Erie Canal, and also of the Evansville and Illinois R. P.-two facts which make it an important point at which a large commerce must necessarily concentrate; it is by far the largest town and the greatest defôt for proul. uce. merchandize, and travelers on the whole line of the Ohio r., betwen Louisville and its mmuth, a distance of 400 miles. In 1550 the exports and imports of the port amounted 
to $\$ 7,000,000$, and the arrival and departures of steamboats to 5,395 . This was before the completion of the canal and railroad. It contains the courts and offices of the co., a branch of the State Bank, the U. S. Marine Hospital, a market house, with numerous churches, hotels, warehouses, stores, etc., and about 6,000 inhabitants. The public press of the city consists of two daily, one tri-weekly, and three weekly newspapers, two of the weeklies being editions of the dailies. The dailies are the "E. Journal," and the "F. Republican ;" the tri-weekly, the "Auzeizher " and the weeklies, the "Vanderburg Democrat," etc. The vast deposits of coal on the line of the canal will make Evansville, its terminus, one of the best points for fuel on the western waters.

Evansville, p. v., Jefferson co., $N, Y_{.}:$on the left side of Indian r., $135 \mathrm{~m} . \mathrm{N}$. W. Albany. There are large mills at this place and vicinity. The projected Watertown and Potsdam R. R. will intersect it.

Evasstiule, p. Y., Randolph co., IU..: on the E. side of Kaskaskia River, $1 \mathrm{~m}$. below Nine Mile cr., and $120 \mathrm{~m}$. S. Springfield.

Evansville. p. V., Preston co., Virg. : between Cheat and Valley rivers, $186 \mathrm{~m}$. N. W. Richmond.

Evenisg Silade, p. o., Lawrence county, Ark. : $123 \mathrm{~m}$. N. N. E. Little Rock.

Everett's Sprivg, p. o., Floyd county, G(6.: $142 \mathrm{~m}$. N.W. by $\mathrm{N}$. Milledgeville.

Evergreen, p. v., Conecuh con, Alc.: on an E. branch of Murder er. of Conceuh r., 73 m. S. S. W. Montgomery. The line of the Montgomery and Mobile R. R. will probably pass near or through this place.

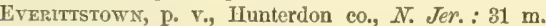
N. by W. Trenton.

Evenittsville, p. v., Wayne co, $N_{\text {. }} C a r .: 49$ m. S. E. Raleigh.

Eventon, p. V., Fajette county, Ind.: $5 \mathrm{~S}$ m. E. by S,

Indianapolis.

Ewixg, p. v., Ilocking co., Ohio: 42 m. S. E. Columbus.

EwING, p. o., Franklin co., 1 ll. : on Ewing's Fork of Big Muddy r., 135 m. S. S. E. Springfield.

Ewrxg's, p. o., Cumberland county, N. Jer.: $59 \mathrm{~m}$. S. Trenton.

EWINGToN, p. v., and cap. Effingham co., $I Z l .:$ on the W. side of Little Wabash r., $72 \mathrm{~m}$. S. E. Springfield. The National Road passes through the village. It has an elevated and pleasing site, and contains the co. offices, several stores, and about 60 dwellings.

Ewington, p. v., Gallia co., Ohio: $\$ 9$ m. S. E. Columbus. Excirange, p. 0, Warren co, N. Car.: 49 m. N. N. E. Ralcigh

Exciraxgevilue, p. v, Mercer county, Penzn.: $196 \mathrm{~m}$. W. N. W. Harrisburg.

ExeTer, p. v., Scott co., Ill.: on the S. side of Mauraiseterre cr. of Illinois $r, 47 \mathrm{~m}$. W. by S. Springfield. It has several large mills and abont 200 inhabitants. The site is one of the pleasantest in the State, and the surrounding country in a flourishing condition.

ExeTer, t. and p. v., Penobscot co., DTe-: 59 m. N. E. by N. Augusta. Drained in the N. and E. by Kenduskeag r., and in the S. by tributaries of the Sebasticook. Surface diversified : soil fertile, and productive of excellent wheat. The village lies a little $\mathrm{N}$. of the centre of the town, and is a small agricultural settlement. Pop. 1,S53.

ExETER, t., p. V., and cap. Rockingham co., N. Tump.: $32 \mathrm{~m}$. E. S. E. Concord. Drained by tributaries of Piscataqua r.; surface level, and soil various, but in general of average fertility. The village lies on Squamscot or Exeter $\boldsymbol{r}$, at the falls, at the head of tide water. Here is much valuable water-power, and ressels of considerable tonnage can approach to the foot of the falls. It contains a courthouse, a jail, and other co. buildings, several churches and schools, among which is Phillips" Academy, founded and endowed by John Phillips, LL.D, in 17S1, and at which many of the ablest jurors, statesmen, and literati of the Stato have received their early education. The town contains numerous manufacturing establishments, and has a newspaper, the "Exeter News-Letter," published weekly. The Boston and Maine R. R. passes through the place $50 \mathrm{~m}$. from Boston. Pop. of town 3,329 .

The settlement of Exeter was commenced in 1683 by Jobn Wheelwright and his companions, who formed themselves into a body politic, chose their own magistrates, and bound the people to obedience. Their laws were made in popular assemblies, and the combination thus entered into subsisted about three years.

Exerer, t. and p. v., Otsego con, $N \cdot \boldsymbol{Y}_{*}: 64 \mathrm{~m}, \mathrm{~W}$. by N. Albany. Drained by Butternut and Wharton's ereeks, and Canaderaga Lake lies on its N. E. line. Surface elevated and hilly; soil, calcareous mold, well adapted for graingrowing. The village, near the centre of the town, contains a ehureh and about 20 dwellings. Pop. of town 1,526 .

Exeter, t. and p. o., Monroe co., Afich.: 73 m. S. E. Lansing. Drained by Stoney cr. Soil well adapted to grain and grasses. Pop. 458 .

Exeter, t. and p.o., Luzerne co., Penn. : $97 \mathrm{~m}$. N. E. by N. Harrisburg. Surface uneven; soil excellent, Drained by Gardner's er. and Cascade Iiun, affuents of the Susquehanna $r$. Shawney Ridge passes through it; on the $\mathrm{E}$. side anthracite abounds. In the $\mathrm{S}$. part of this town the famous battle of Wyoming was fought in 1778. Campluell's "Gertrude of Wyoming" celebrates the horrors of the scene and circumstance. Pop. about 1,800.

Exeter, t. and p. v., Greene co., Wisc.: 21 m. S. S. W. Madison. The village is loeated on the W. side of Sugar cr., an affluent of Rock River. Pop. of t. 450

Ex:iler, t. and p. v., Washington county, R. I.: $22 \mathrm{~m}$. g. S. W. Providence. Drained by Wood r. and its branches. Surface diversified by hills and valleys; soil gravelly loam and productive. The streams furnish fine waterpower, which is extensively used for manufucturing purposes. The village is a small settlement east of the middlo of the town. Pop. of town 1,685.

Exeter Mills, p. 0, Penobscot co., DLe.: on Kenduskeag r., 62 m. N. E. by N. Augusta.

Experiuent Mills, p. o., Monroe county, Penn. : $105 \mathrm{~m}$ N. E. Harrisburg.

\section{F.}

Faber's Mills, p. V., Nelson co, Firg. : $\mathrm{s} 6 \mathrm{~m}$. W. by N. Richmond. There are here several mills and a small village of 15 or 20 dwellings.

F Adius, to and p.V., Onondaga co., $N . Y$. : $118 \mathrm{~m} . \mathrm{W}$. by $\mathrm{N}$ Albany. Surfuce hilly and broken; soil modcrately fertile, and good for grass, The v. lies a little E. of Tioughnioga r., about $15 \mathrm{~m}$. S. S. E. Syracuse.

FabiLs, p. o, Ilardy county, Firg. : 147 m. N. W Pichmond.

F $\triangle$ BIUS river, DI0. : rises on Appanoose and Davis coun ties of Iowa by several branches, the laroest of which are North, Middle, and South Fabius rivers, running in a direction from $\mathrm{N}$. W, to $\mathrm{S} . \mathrm{E}_{*}$, and uniting within a few miles of the Mississippi, into which their collected waters fall opposite Quincy, in the State of Illinois. The several branches have an average length of 100 miles, and form excellent mill-streams, but are navigable only for a slort distanco from their mouths.

Factitix, p. o., M'Minn co., Tenn.: 141 m. E. S. E. Nashville.

Factor's Fork, p. o., Wayne co., Tenn.: 95 m. S. W. Nashville.

Factory Hill, p. o., Nansemond co., Firg.: 82 m. S. E。 Richmond.

Factory Pornt, p. v., Bennington co, Femm: near the head waters of Green r., a branch of Battenkill, $91 \mathrm{~m}$. S. S. E 
Montpelier. The Western Vermont R. R. passes through Manchester, about a mile to the W. of the village.

Factoryville, p. v., Wyoming con, Penn.: on the left bank of Susquehanna r., $103 \mathrm{~m}$. N. N. E. Harrisburg.

Factoryville, p. v., Richmond co., $N$. $Y_{*}:$ on the $\mathbf{N}$. shore of Staten Island, $133 \mathrm{~m}$. $\mathrm{N}$. Albany. It contains the extensive works of the New York Dyeing and Printing Company, which gives employment to several hundred persons, and are the largest of the kind in the Union. Pop. of the $\mathrm{y}$. and neighborhood about 600. The North Shore Post-office is located here.

Factoryville, p. v., Tioga co., $N$. Y.: on Cayuta cr., 149 m. W. S. W. Albany. It contains several mills and factories, and about 50 dwellings. The Erie $R$. R. crosses the $c r$. a short distance below the village, $262 \mathrm{~m}$. from New York.

FaIr Bluff, p. v., Columbus co., $N$. Car : on the E. side of Lumber r., a branch of Little Peedee r., and at the point where the stream is crossed by the $\mathrm{S}$. line of the State, 109 m. S. Raleigh. The Wilmington and Manchester R. R. passes the village $63 \mathrm{~m}$. from Wilmington.

FaIrBURN, p. Y., Fayette county, Ga.: $77 \mathrm{~m}$. W. by N. Milledgeville. The "La Grange R. R." passes it $18 \mathrm{~m}$. from Atlanta, and 69 from West Point.

Fandone, p. v., Susquehanna co., Penn.: on a branch of Wyalusing er., 112 m. N. N. E. Farrisburg,

Fatr Dealuig, p. o., Marshall co, Ky.: 221 m. W. S. W. Frankfort.

Falrfax county, Firg. Situate N. E., having the Potomae r. and Alexandria co. in its N. E., and E., and S. E. borders, and contains $463 \mathrm{sq}$. m. Occoquan creek forms its S.W. line. Drained by numerous tributaries of the Potomac. Surface hilly and broken, and much of the soil sterile, but in the main adapted to grass and grains. Farms 610 ; manuf. 8 ; dwell. 1,380, and pop.-wh. 6,585, fr. col. 597, sl. 3,250total 10,652. Capital : Fairfax Court-house. Public Works: Orange and Alexandria R. R.; Manassas Gap R. R., etc

Falrfax, p. v., Culpepper co., Firg. (Seo Culpepper COURT-HOUSE)

Fairfax, t. and p. v., Franklin county, Ferm.: $37 \mathrm{~m}$. N. W. by N. Montpelier. Drained by Lamoille r. and its tributaries, which afford good water-power; the falls of the Lamoille r., which is here a large stream, are valuable for manufacturing purposes. Surface gencrally level; soils light, easily tilled, and tolerably fertile. The v. is located on the N. side of the Lamoille, opposite the mouth of Brown's river. Pop. of town 2,112 .

Fairfax, p. V., Monroe co., Ind.: on the right bank of Salt er., $51 \mathrm{~m}$. S. by W. Indianapolis. It is a flourishing place, with several mills, and about 800 inhabitants. The New Albans and salem I. L. passe's it about $2 \mathrm{~m}$. to the $W$

Falrfax Count-rouse, Fairfax co, Tirg. : at the head of Accatink r. $\$ 9 \mathrm{~m}$. N. Ricbmond. It contains the courtbouse, and other co. buildings, several stores and mechanic shops, and about 300 inhabitants; and a newspaper, the "Fairfax News," is issued weekly. The Orange and Alexandria R., li. runs 3 , of the v. ahout is m. distant.

FAtrField county, Conn. Situate S. W., and contains $630 \mathrm{sq}$. m. It is bounded by the Housatonic r., Long Island Sound, and the New York State line. It has $40 \mathrm{~m}$. of const on the Sound, and many good harbors. Drained by numerous tributaries of the Housatonic, and by Pequannock, Mill, Norwalk, Saugatuck, and other streams flowing into the Sound. The Housatonic is navigable to Derby. Surface agreeably diversified, and the soil strong. productive, and well cultivated. Farms 3,155 ; manuf, 482 ; dwell. 10,817, and pop.-wh. 58,370, fr. col. 1,4t5-total 59,75. Cilvituls: Fairfield and Danbury. Pullic Hork: Yew York and New Haven R. R.; Housatonic R. R.. ; Danbury and Norwalk R. R., ete.

F AIFFIEL county, Ohio. Situate ceutrally, and contains 520 sq. $m$. Surface elerated, sloping toward the Muskingum $r$. on one side, and the Scioto $r$. on the other. The land is generally level, interspersed occasionally with conical $20 \mathrm{~S}$ hills, and the soil is well adapted to grain culture. In the $\mathrm{S}$. the country is more hilly, and perhaps of less arerage fertility than in the $\mathrm{N}$. sections. The drainage is chiefly through the Hockhocking r. Farms 2,383; manuf. 162 dwell. 5,207, and pop.-wh. 29,984, and fr. col. 280-total 80,264. Capital: Lancaster. Public Works: Ohio Canal and Hocking Canal, which form a union at Carroll; Cincinnati, Stubenville, and Pittsburg R. R., etc., etc.

FAIRFIELd district, S. Car. Situate centrally, and contains $796 \mathrm{sq.} \mathrm{m}$. Drained by Little $\mathrm{r}$, and other affluents of Broad r., which makes its W. and S. W. border, and by

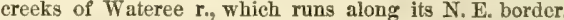
Surface declining southward, but generally level; soil light and fertile, produeing vast cotton crops, with some of the grains. Farms 675; manuf. 36 ; dwell, 1,252, and pop.wh. 7,076, fr. col. 82, sl. 14,246-total 21,404. Capital Winnsboro'. Putlic Works: Charlotte and South Carolina R. R.

Famfreld, p. v., Pickens co., Ala.: on the W. bank of Little Tombigbee r., $122 \mathrm{~m}$. W. N. W. Montgomery.

FAIRFIELD, t., p. V., port of entry, and cap. Fairfield co. Conn. : 56 m. S. W. Hartford. Drained by Mill r. and other streams falling into Long Island Sound, which bounds it on the S. Surface pleasantly undulating; soil fertile and well cultivated, producing grain and a large amount of garden vegetables. The to is divided into 3 parishes, Fairfield, Green's Farms, and Greenfield, which are also names of villages. The principal v. lies about $1 \frac{1}{2} \mathrm{~m}$. from Black Rock Harbor, which, next to that of New London, is one of the best on the Sound: it is built chiefly on one street, with a green or square in the centre, and contains a court-house, jail, and about 140 dwellings, and has several stores and mechanic shops. Greenfield is pleasantly situate in the N. W. part of the town, and is the scene of Dr. Dwight's fine poem of "Greenfield Hill." Fairfield is the port of entry of Fairfleld District, and in 1850 owned a tonnage of 24,829 tons, of which 868 tons were of permanent register, and the remainder enrolled and licensed, the latter engaged in the coasting trade. The foreign entrances in 1849-50 were 10 vessels, and 6,895 tons; and the clearances, 56 vessels, and 6,322 tons; and one ship of 239 tons was built in the same year. There is a light-bouse on Fairweather Island, a little E. of the entrance to the harbor. Pop. of $t$. 3.618. The Indian name of Fairfield was "Unquowa." The $\mathrm{v}$. was destroyed by Governor Tryon in 1779, as was also the v. of Green's Farms. The New York and New Iaven $\mathrm{P}, \mathrm{R}$. passes through it

Fatrfield, p. $\nabla_{*}$, Nelson $c_{0,}, \bar{y} y_{*}$; on a branch of Salt r. $86 \mathrm{~m}$. W. S. W. Frankfort.

FAIrFIELd, p. v., Franklin co., Ind.: on the E. side of the E. furk of White Water r., $66 \mathrm{~m}$. E. by S. Indianapolis, It is a flourishing $v_{\text {, }}$ and has about 200 inhabitants.

FaIrField, p. Y., and cap. Wayne co, $I U_{e}:$ on the borders of Hargraves Prairie, $126 \mathrm{~m}$. S. E. Springfield. It has a handsome brick court-house and other co. buildings, and contains several stores and about 250 inhabitants. Large quantities of castor-oil are manufactured here and in the neighborhood.

F Airfield, p. Y., and cap. Jefierson co., Ia. : on a branch of Big Cedar cr. of Skunk r., 49 m. S. S. W. Iowa City. It is the seat of a United States Land Office, and two newspapers, the "Iowa Sentinel" (dem.), and the "F. Ledger" (whig), are published weekly. The Dubuque and Keo kuk R. R., as projected, will make this village one of its stations. Pop. 1,200

Fairfield, t. and p. v., Somerset co., Me. : $22 \mathrm{~m} . \mathrm{N}$. by E. Augusta. Drained by several creeks of Kennebec r., which makes its $\mathrm{E}$. boundary, and is navigable for boals down to A ugusta, where it meets sloop navigation. Surface elevated and hilly: soil good, and adapted to grazing. The $\mathrm{v}$. is a small agricultural settlement, in the $\mathrm{S}$. part of the town, about $3 \mathrm{~m}$. W. of the Kennebec. Pop. of t. 2.452

Fargrield, t. and p. o., Lenawee co., Mfich.: in the 8 , 
part of the co., $74 \mathrm{~m} . \mathrm{S} . \mathrm{S}$. E. Lansing. It is drained by Bear cr. of Raisin r. Pıp. 132.

F AXRFIELD, to and p. v., Herkimer county, N. Y.: $73 \mathrm{~m}$. W. by N. Albany. Drained by W. Canada cr. Surface hilly and rough; soil clayey, fertile, and well adapted to grazing. The $\mathbf{v}$. contains 3 churches, an academy, several stores and mechanic shops, and about 300 inhabitants. Here was located the Western College of Physicians and Surgeons, founded 1812, but now discontinued. Pop. 1,646.

F AIRILLLD, p. v., Greene co., Otio: on the S. E. side of Mad r., and on the line of the Mad r. and Lake Erie R. R., $55 \mathrm{~m}$. W. by S. Columbus. It contains several mills and tanneries, various mechanie shops, and about 120 dwellings. The plain on which the $\mathrm{v}$. is located is circumscribed by a line of gentle hills.

Fatrfield, p. v., Adams co., Penn.: on the 8. side of Middle cr. of Monocacy r., $6 \mathrm{~m}$. W. of Gettysburg, and 43 m. S. W. Harrisburg.

FatrField, p. v., Bedford co., Tenn. : $47 \mathrm{~m}$. S. by E. Nashville.

FAIRFLLLD, p. v., Rockbridge co., Virg. : on a branch of South r., $99 \mathrm{~m}$. W. by N. Richmond. It contains about 130 inhabitants.

FATRFIELd, to and p. v., Franklin county, Verm. : $41 \mathrm{~m}$. N. N. W. Montpelier. Drained by Fairfield r., Black cr., ete., affluents of Missisqui r., and abounding in mill-sites. Surface uneven; soil fertile, and good for tillage, with extensive pasturage. The $\mathrm{v}$. on Fairfield $\mathbf{r}$. contains several mills and factories, and about 220 inhabitants. Population of town 2,591 .

FAIRFIELD, p. 0., Walworth county, Wisc.: 57 m. S. E. Madison.

FatrFiteld, p. v., Hyde county, $N$. Car. : 153 m. E. Raleigh.

Fairrield, p. v., Benton co., Mo. : on the left bank of Pomme de Terre r., a branch of the Osage, $73 \mathrm{~m}$. W. S. W. Jeũerson City.

Fatrfield Corners, p. O., Somerset co., Me. : on the W. bank of Kennebee r., 28 m. N. by E. Augusta.

FATR ForeEt, p. o., Desha co., Ark, : at the head of Abeel's cr., $73 \mathrm{~m}$. S. E. Little Rock.

Fatr Garden, p. 0., Sevier county, Tenn。: $179 \mathrm{~m}$. E. Nashville.

FaIR Grove, p. 0., Davidson co., N. Car.: $88 \mathrm{~m}$, W. Raleigh.

Fatr Haven, p. v., New Haven co., Conn.: on both sides of Quinnipiac r., and $37 \mathrm{~m}$. S. by W. Hartford. A bridge unites the two parts of the $\mathrm{v}_{\text {, }}$; also the viaduct of the New Haven and New London $R$. R., which passes through the place $2 \mathrm{~m}$. E. New Haven. It contains about 1,000 inhabitants, numbers of whom depend on the oyster trade and coast fishing for subsistence. A large portion of the oysters sold in New York are from Fair Haven.

FAIR HAveN, t, and p. v., Bristol co., Mass.: $51 \mathrm{~m}$. S. Boston, and immediately E. of New Bedford, from which it is separated by Acushnet r., over which is a bridge 3,960 feet in length. The v. contains several churches, a bank, etc., and has considerable shipping, chiefly engaged in the whale fisheries. In $1850,9,491 \mathrm{bls}$. sperm, and $14,145 \mathrm{bls}$. whale oil were brought into port by 13 ships. The Acushnet affords good water-power, and numerous mills and factom ries are Iocated on its banks. Pop. of town 4,304.

Fatr Haven, p. v., Preble co., Ohio: on an affluent of Miami r., $98 \mathrm{~m} . \mathrm{W}$. by S. Columbus. There are numerous mills in the vicinity, and the village contains about 45 dwellings and 250 inhabitants. The Four Mile Valley R. R. intersects the place.

FAIR HAVEN, t. and p. v., Rutland co., Verm. : $57 \mathrm{~m}$. S.W. by S. Montpelier. Drained by Castleton and Pultney rivers, which unite on the $\mathrm{S}$. border of the town, and about $13 \mathrm{~m}$. before entering East Bay of Lake Champlain. On Castleton r. are falls which produce a fine water-power. Surface diversified; soil fertile and well cultivated. Bom- bazine Lake makes the $\mathrm{E}$. boundary of the town. The $\mathrm{v}$. on the N. side of Castleton $r$, is intersected by the Saratoga and Washington R. R., $8 \mathrm{~m}$. E. of Whitehall. Pop. of $t .972$

FAIR HAVEN, p. v., Carroll co., Ill.: $152 \mathrm{~m}$. N. by W. Springfield. It is located on a fine elevated site at the sources of Little Plock river.

Fatr Hill, p. o., Cecil co., Md.: on the W. side of Big Elk r., $55 \mathrm{~m}$. N. E. Annapolis.

F AIR Mill, p. o., Marshall county, Virg. : $234 \mathrm{~m}, \mathrm{~N} . \mathrm{W}$. Richmond.

FAIR LAND, p. 0., Livingston co., MOo.: 116 m. N. W. Jefferson City.

FaIRLEe, t. and p. v., Orange co., Term.: 33 m. S. E. Montpelier. Drained chiefly by Fairlee Pond, the outlet of which empties into the Connecticut r., which forms its E. boundary. Surface monntainous, and the land rough and below the average fertility. Timbered chiefly with pine and hemlock. The v. lies on the Connecticut, and is intersected by the Connecticut and Passumsic River Ii. R., $22 \mathrm{~m}$. above White River Junction. A bridge across the river connects it with the town of Oxford. Pop..575.

Fatrmont, p. v., and cap. Marion co., Virg. : on the Monongahela r., $194 \mathrm{~m}$. N. W. Richmond. It is a thriving village, with considerable trade, and located at the point where the Baltimore and Ohio R. R. crosses the Monongahela. Pop. about 300. The "Democratic Banner," a weekly newspaper, is published here.

FaIR Mount, p. $v_{0}$, Onondaga co., $N_{0}$. $Y_{0}$ : immediatcly W. of the village of Geddes, on a stream emptying into Nine Mile cr. near its mouth, $124 \mathrm{~m}$. W. by N. Albany. The Rochester and Syracuse R. R. passes a little N. of the village. FatR Mount, p. o., Hunterdon co., $N$. Jer.

Fatr MounT, p. o., Miami co., Ohio: $66 \mathrm{~m}$. W. by N. Columbus.

FAIR MoUnt, p. o., Cass county, $G a .: 126$ m. N. W. Milledgeville.

Fair Modnt Springs, p. v., Luzerne co., Penn.: $77 \mathrm{~m}$. N. N. E: Harrisburg.

FATr Plax, p. 0., Hot Springs co., Ark: $37 \mathrm{~m} . \mathrm{S} . \mathrm{W}$. Little Rock.

Fatr Play, p. o., Morgan county, Ga. : 46 m. N. by W. Milledgeville.

Fair Play, p. v., Greene eo, Ind.: on the W. bank of the W. fork of White $r, 64 \mathrm{~m}, \mathrm{~S}$. W. Indianapolis, and on the line of the Wabash and Erie Canal. It contains about $40 \mathrm{dwellings}$, and has a thickly-settled neighborhood.

Fatr Play, p. o., Grant co., Wisc. : 67 m. S.W. Madison.

FAIr Play, p. 0., Benton county, Ala.: 97 m. N. E. Montgomery.

FAIR Plax, p. 0., Panola county, Tex. : 248 m. N. E. Austin City.

FaIR Pornt, p. o, Cooper county, Mo.: $47 \mathrm{~m}$. W. by N, Jefferson City.

FArrPort, p. F., Muscatine co., Ia. : on the right bank of the Mississippi r., $7 \mathrm{~m}$. E. by N. of Muscatine, and $40 \mathrm{~m}$. E. by S. Iowa City.

Fatrport, p. v., Chemung co., N. $Y_{.}$: on the Chemung Canal, at the junction of the feeder, $6 \mathrm{~m}$. N. Elmira, and 158 m.W. S. W. Albany. It contains several large warehouses, numerous stores and mechanics' shops, and 600 inhabitants.

FALRPORT, p. o., Lake co., Ohio: on the E. side of Grand r., at its confluence with Lake Erie, $145 \mathrm{~m}$. N. E. Columbus. It has a good harbor for lake craft, and is connected by a railroad $3 \mathrm{~m}$. with Painesville, of which it is the port. It has considerable business, and a population of about 250 inhahitants.

FAIRTON, p. v., Cumberland co., N. Jer.: at the union of Mill er. and Rattle-snake r., which flow into Cohansey er., 61 m. S. Trenton. It contains about 250 inhabitants. The vicinity is a fertile region, and has a fine bed of marl, which is used as a fertilizer.

FAIRvIEW, p. 0., Washington co. $M d_{0}: 91 \mathrm{~m}$. W. N. W Annapolis. 
Fatrview, p. v., Franklin county, Ga.: 95 m. N. E。 Milledgeville.

Falpview, p. v., Randolph co., Ind. : 67 m. E. by N. Indianapolis.

FAIRVIEW, p. v., Fulton county, $I l l .: 62 \mathrm{~m}$. N. N. W. Springfleld.

FAIRvIEW, p. o., Jones co., Ia.: $2 \mathrm{~m}$. S. of Anamosa, on Wapsipinicon r., 31 m. N. N. E. Iowa City.

Falrview, p. v., Todd county, Ky.: 161 m. S. W. Frankfort.

FAIrview, p. o., Concordia par., La.: $72 \mathrm{~m}$. N. N. W. Baton Rouge

FAIRVIEW, p. o., Pettis co., MO. : on Muddy er., a branch of Riviere a la Mine, $62 \mathrm{~m}$. W. Jefferson City.

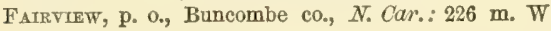
Raleigh.

FaIRview, p. v., Cattaraugus co., $N . Y .: 227 \mathrm{~m} . \mathrm{W}$. by S. Albany.

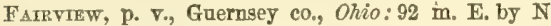
Columbus. Pop. 444.

FATRvuE, t. and p. v., Erie co., Penn. : 222 m. N. W Harrisburg. Drained by Elk and Walnut creeks of Lake Erie, which forms its N. boundary. Surface hilly: soil, a gravelly loam and fertile. The $v$. lies at the mouth of Walnut cr. on the lake, and is passed by the Cleveland, Painesville, and Ashtabula R. R. It is accessible to lake craft, and has some trade. The town has numerous mills, and 1,713 inhabitants.

Farrview, p. v., Greenville dist, $S$. Car.: 79 m. N. W. Columbia.

FAupyiew, p. v. Marion county, Tenn.: 98 m. S. E. Nashville.

FAmVIEW, p. V., Hancock co., Firg. : 264 m. N. W Richmond.

Fampiew Village, p. V., Montgomery co, Penn.: 93 m. E. Harrisburg.

Fatrville, p. v., Wayne co., $N$. $Y_{\text {.: }} 178 \mathrm{~m}$. W. by N. Albany. Pop. 240.

Fairville, p. v., Chester co., Penn. : 73 m. W. by $\mathrm{s}$ Harrisburg:

FAIR WAter, p. O., Fond du Lac co., Wisc.: on the W edge of the co., $52 \mathrm{~m}$. N. N. E. Madison.

Fairweather, p. o., Adams co., $I l_{*}: 79 \mathrm{~m} . \mathrm{W} \cdot$ by N. Springfield.

Farson's Depôr, p. o., Duplin co., $N$. Car.: on the line of the Wilmington and Weldon R. R., $64 \mathrm{~m}$. from Wilmington, and $9 S \mathrm{~m}$, from Weldon- $51 \mathrm{~m}$. S. E. Raleigh.

Falkland, p. ₹., Pitt co., $\boldsymbol{N}_{\text {. }}$ Car.: on a small affluent of Tar r., $66 \mathrm{~m}$. E. Raleigh.

Fallassburgr, p. V., Kent co, Mich: : $5 S 2$ m. W. N. TV. Lansing.

Fall Creer, p. o., Marion county, Ind. : on the cr, so called, X. by E. of Intianapulis.

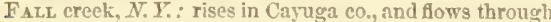

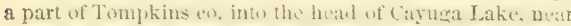
the $\mathrm{v}$. of Ithaca. This is a valuable and romantic stream, there being pieturestu tills affirting fine water-power.

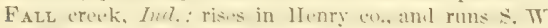
throum Malisom, II:milum, and Ilenry entunties, is m., into White $r$ above Indianapolis. It is one of the best millstreams of the state. It is the Indian "sursome-rathit-loc" or Silt-zecter, so called frum its fills mar I'enilleton, where it descends 25 feet in a mile, and at one place falls about 8 feet. Many of its water privileges are very valuable.

Fallea Thuber, p. o., Cambria co., Penn.

Faluing Bridge, p. o, Campbell co., Firg.: on Falling cr. of Roanoke r., $\$ 4$ m. W. S. W. Richmond.

Falutre Crefk, p. o., Wayne co., $N$. Car.: on a cr. of Neuse r. so called, 49 m. s. E. Raleigh.

Falling Mrum, p. o., Moore co.. N. Car.: 53 m. S. W. Raleigh.

Fallavg Sprivg, p. 0., Greenbrier co., Firg. : $156 \mathrm{~m}$. W. Richwond.
Falling Spring, p. O., Clark co, Miss.: 57 m. E. by S. Jackson.

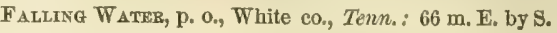
Nashville.

Falinge Waters, p. O., Berkeley co., Virg.: on the $\mathrm{S}_{.}$ bank of the Potomac r., $141 \mathrm{~m}$. N. N. W. Richmond.

Falx River, p. o., Columbia co., Wisc.: on Fall r., a tributary of Rock r., $33 \mathrm{~m}$. N. E. Madison.

FAll Rrver, t., p. v., and port of entry, Bristol co., Mass. : $16 \mathrm{~m}$. S. Boston. Drained by streams falling into Tauntou r, and Mount Hope Bay, a branch of Narraganset Bay. Surface elevated, rough, and uneven. The t. takes its name from Fall r., the outlet of Watuppa Pond, at the union of which with Taunton $r$. the great nanufacturng village of Fall River is located. This to without a parallel on the American Continent in regard to its combined facilities for navigation and hydraulic power. Fall r. rises $2 \mathrm{~m}$. E. of the $\mathrm{v}$. in Watuppa Pond, which is $11 \mathrm{~m}$. Iong and $1 \mathrm{~m}$. broad, originating in perennial springs. The descent of the r. to Taunton $r$. is 136 feet, and the volume of water constant and of sufficient power for the largest manufactures. The harbor on Taunton $r$. is safe and easy of access, aud of depth sufficient for the largest ships. It is one of the great nanufacturing centres of the State, and has extensive cotton mills, woolen factories, print-works, bleacheries, boot and shoe factories, foundries, etc., etc.; it has also several banks and insurance offices. In 1S49-50, the foreign entrances were 78 vessels $(12,739$ tons); and clearances, 37 vessels (5,479 tons). It has also a large coasting trade, and is engaged in the whale and other fisheries. The tonnage owned in the district in 1850 was 13,102 tons, of which 2,251 tons were registered, 10,748 enrolled and licensed, and $108 \mathrm{li}$ censed (under 20 tons). In the whale fisheries there were 928 tons employed, in coasting, 10,701 tons, and in the cod fishery, 47 tons; and the shipping propelled by steam amounted to 4,784 tons; and 1 ship, 3 schooners, and 1 steamer (in the agrgregate 1,254 tons), were built in the year next preceding. The port is connected with New York by a regular steam line, and with Boston by the Fall River R. R., etc. Two newspapers, the "Weekly News" (dem.), and the "F. R. Monitor," are issued weekly, circulating 700 to 800 copies each. Pop. in $1820,1,594$; in $1830,4,159$; in $1840,6,738$; and in $1850,11,522$.

Fall River, p. 0., Marshall co., Ala.: on an affluent of Tennessee r. so called, $133 \mathrm{~m}$. N. Montgomery.

FALLs county, Texo. Situate centrally on the Upper Brazos x., and contains about $940 \mathrm{sq}, \mathrm{m}$. Erected since 1550 .

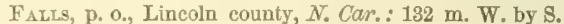
Raleigh.

FAlls, t. and p. o., Wyoming co, Penn.: 98 m. N. N. E. Harrisburg. Drained by Buttermilk. Falls er, of Susquenanna $r$, the latter of which makes the W. border of the $t$. Surface hilly; soil productive in grain, grass, ete., and there is abundance of timber. The er. has here a perpendicular fall of 30 feet, and affords immense hydraulic power

FALtsburGH, t. and p. v, Sullivan $\mathrm{cos}_{*}, N . Y_{\mathrm{s}}: 79 \mathrm{~m}$. S.W. Albany. Drained by Neversink $r$. and the head branches of Rondout cr. Surface hilly; soil gravelly loam, fertile, and well adapted for grain and grass. The v. is located on Neversink r., which here furnishes a fine water-power. It contains several mills, stores, etc., and about 200 inhabitants; and in the t. there are numerous others. Pop. of town 2,626.

Fallsiurgh, t. and p. o., Licking county, O7io: $43 \mathrm{~m}$. E. N. E. Columbus, Drained by a branch of Muskingum $r$, which affords great water-power. Surface diversiffed soil rich and fertile, producing fine wheat, etc. Pop. 1,206.

Farts Churcr, p. o., Fairfax county, Firg. : 134 m. N. Richmond.

Falisngton, p. 0., Bucks co., Penn.

Falts of BLANE, p. 0., Lawrence co, $K y$.: at the falls on Blane r., an affluent of Big Sandy r., $142 \mathrm{~m}$. E. by $\mathrm{S}$. Frankfort. 
Falts or Rovgr, p. $0_{0}$, Grayson co., $K y_{*}:$ at the falls of Rough cr., an affluent of Green r., $97 \mathrm{~m}$.W. S. W. Frankfort. Falds of St. Crolx, p. o., St. Croix co., Wisc. : on St. Croix r., $228 \mathrm{~m}$. N. W. Madison.

Fatrs of SchUrumlin, po o., Philadelphia co., Penn.: 91 m. E. Harrisburg.

Faliston, p. v., Hartford county, Md.: 46 m. N. N. E. Annapolis.

FALISTon, t, and p. o., Beaver co., Penn.: 194 m.W. by N. Harrisburg. Situate on the W. bank of Big Beaver r., which affords good water-power. It has several mills and factories.

Faltstown, p. v., Iredell county, $N$. Car.: $123 \mathrm{~m}$. W. Raleigh.

Falls Trutage, p. v., Litchfield co., Conno: on the E. side of Housatonic r., a little below the Falls, $41 \mathrm{~m}$. E. by N. IIartford. It contains sereral manufacturing establishments. The Housatonic R. $R$. passes through the place, 67 m. from Bridgeport.

FALMOUTI, p. $\nabla_{.,}$and cap. Pendleton co., $\bar{K}_{y} y_{0}:$ on the left bank of Licking r., which is joined by a main branch from the S. W. It contains a court-house and other co. buildings, several stores, and about 400 inhabitants. It has considerable river traffic

Falmoutr, t. and p. o., Cumberland co., $M e_{0}: 6 \mathrm{~m} . \mathrm{N}$. Portland, and $51 \mathrm{~m} .8$. W. Augusta. Drained by Presamscut r., its N.E. shere resting on Casco Bay. Surface level; soil generally fertile. It has a considerable amount of shipping employed in coasting and the fisheries. The Atlantic and $S_{t}$. Lawrence R. R., and the Portland and Kennebec R. R. pass through the town. Pop. 2,164

FALrovTI, p. v., Fayette county, Ind.: $46 \mathrm{~m}, \mathrm{E}$, by S. Indianapolis

Falmoctir, t. and p. o., Barnstable co., MIcoss.: $51 \mathrm{~m}$. $\mathrm{S}$. by E. Boston. It is situated on the $\mathrm{S}$. W. corner of Cape Cod, between Buzzard's Bay and Vineyard Sound. Surface level; soil light, but generally fertile. It has several good harbors, of which Wood's Hole, in the S. W., is the best, and has from 3 to 6 fathoms of water. It has considerable shipping employed in the coasting trade and the fisheries. There are numerous salt ponds, and the salt works of the town are very productive. Two streams furnish waterpower. On these are several mills and factories; but the great interest of the t. is on the seas. The villages are distinguished by their localities in North and West and East Falmouth, ete. Pop. of the t. 2,519.

FALrodTr, p. v., Laneaster co., Penn. : on the E. bank of Susquehanna r., where it receives Conewaga cr., and on the line of the Main Division of the Pennsylvania Canal, $13 \mathrm{~m}$. S. E. Harrisburg. It contains about 200 inhabitants.

FALMouth, p. V., Stafford co., Virg.: at the foot of the falls of Rappahannock r., $54 \mathrm{~m}$. N. Richmond. It lies nearly opposite Fredericksburg, with which eity it is connected by a bridge. It has a large number of flouring and other mills, various mechanic shops and stores, and about 600 inbabitants.

False Wasmta river, Ind. Ter.: a trib. of Red river.

FAnre, p. o., Choctaw co, Mfiss.: \$3 m. N. N. E. Jackson.

F Ax̃cy Bưfr, p. o., Glynn county, $G a_{0}: 167$ m. S. E. Milledgeville.

FA.XCX Faris, p. o., Graves co., Fy. : 214 m. W. S. W. Frankfort.

Fancy Grove, p. 0., Bedford co., Virg.: $118 \mathrm{~m}$.W. by $\mathrm{s}$. Pichmond.

Faxcy Hrus, p. o., Iredell county, N. Car.: 129 m. W. Raleigh.

FAsCY HIL, p. o., Murray county, Ga.: $166 \mathrm{~m} . \mathrm{N}$. W. Milledgeville.

Fancy Hil, p. 0., Rockbridge co., Virg. : 122 m. W. by N. Richmond.

F AnNettsburgir, p. b., Franklin co., Penn.: on the W. bank of Conecocheague r.,57 m.W. by S. Harrisburg. Coal and iron ores are abundant in this region.
FANNIN county, Texo. Situate $N_{0}$, and contains $960 \mathrm{sq}, \mathrm{m}$. The Red r. makes the N. boundary, and its tributaries, Bois d'Are r. and other streams, drain the northern and central parts of the county. The S. E. is drained by the N. fork of Sulphur $r_{n}$, and the S. W. by the head branches of the E. fork of Trinity $\mathbf{r}$. Surface level or undulating, except along the Red $\mathbf{r}$, the magins of which are traversed by ranges of low hills or bluffs. Dense forests overshadow the southern portion of the co.; the remainder, with the exception of the woody fringes of the streams, is open prairie, of which the soil is generally a deep black adhesive mold, and very fertile. Iron ore is abundant. Farms 381 ; manuf. 2 ; dwell. 548 , and pop.-wh. 3,260 , fr. col. 0, sl. 528 -total 3,788. Capital: Bonham.

Fardey, p. v., Culpepper co., Firg. : 73 m. N. N. W. Richmond.

Farlow's Grove, p. o., Mercer co., IIl.: on the N. side of Edward's r., an affluent of the Mississippi, $88 \mathrm{~m} . \mathrm{N}$. W. Springfield.

Farmer, p. o. Seneca $\mathrm{com}_{m} N_{0} \bar{Y}_{\mathrm{*}} \cdot$ in Farmersville, pleasant village about $2 \mathrm{~m}$. W. from Caytrga Lake, $153 \mathrm{~m}$. W. Albany.

FArmer, t. and p. o., Defiance co., Ohio: $132 \mathrm{~m}$. N. W. Columbus. Drained by tributaries of Maumee $r$. Surface diversified by hill and dale; soil a rich loam, producing grain and grass abundantly. Pop. $\$ 94$.

Farmer's, p. o., Merriwether co., Ga a: in Farmersville, a village $88 \mathrm{~m}$. W. by $\mathrm{S}$. Milledgeville.

Farmer's, p. o., Fleming county, $K y_{.}: 72$ m. E. by N. Frankfort.

Farmer's, p. o., York co., Penn.

Farmers and Mechanics' Mrlus, p. o., Jackson co., Ga.: $81 \mathrm{~m} . \mathrm{N}$. by W. Milledgeville.

Farmer's Brancu, p. o., Dallas co., Tex.: on a branch of Trinity r., $185 \mathrm{~m}$. N. by E. Austin City.

Farmersbergir, p. v., Clayton county, Ia. : $84 \mathrm{~m}$. N. Iowa City.

FARMer's CReEK, p. o., Lapeer co., Mich. : on a branch of Flint r. so called, $63 \mathrm{~m}$. E. by N. Lansing.

Farmer's Grove, p. o, Southampton co., Virg.: $67 \mathrm{~m}$. S. by E. Richmond.

Farmer's Grove, p. o., Greene co., Wisc.: 33 m.S.S.W" Madison.

Farmer's Hall, p. o., Knox county, $\pi l_{0}$ : about 6 m. W. by S. Knoxville, and $\$ 1 \mathrm{~m}$. N. N. W. Springfield.

Farmer's Hill, p. o., Duchess co., $N . Y$.

Farmer's Mills, p. o., Putnam co., N. Y.: 78 m. S. by E. Albany.

Farmer's Valley, p. o., M'Kean co., Penn.: $147 \mathrm{~m}$. N. W. Harrisburg.

Farmersville, p. v., Lowndes co., $A l a_{0}$ : on the Cahawba and Greenville Turnpike, $35 \mathrm{~m}$. S. W. Montgomery.

Farmersville, p. v., and cap. Union par., La.: on the N. side of Bayou d'Arbonne, $173 \mathrm{~m}$. N. W. Baton Rouge. It contains a court-house, jail, and about 200 inhabitants.

Fapiersvilue, p. V., Posey co., Ind.: about $3 \mathrm{~m}$. N. of Mount Vernon, and $151 \mathrm{~m}$. S. W. Indianapolis.

F ARIsersville, t, and p. v., Cattaraugus co, N. Y.: 229 m. W. by S. Albany. Situate on a watershed dividing the waters falling into Lake Ontario on the $\mathrm{N}_{\text {., }}$ into Lake Erie on the W., and into the Alleghany r. on the S., the waters of the latter ultimately falling into the Gulf of Mexico, and those of the former into the Atlantic Ocean through the St. Lawrence $x$. The v. contains about 200 inhabitants. Pop. of the t. 1,554.

Farmersvilise, p. v., Caldwell co., Ky. : 193 m.W.S. W. Frankfort.

Farmersville, p. v., Montgomery county, Ohio : $78 \mathrm{~m}$. W. by S. Columbus.

F ARMerstille, p. v., Dodge co., Wise. : on a branch of Rock r., 57 m. N. E. Madison.

Furs HrLt, p. o., Poinsett county, Ark, : 104 m. N. E, Little Rock 
Farmingdale, p. v., Queens co., N.Y.: on the line of the Long Island R. R., $31 \mathrm{~m}$. from New York City, and $137 \mathrm{~m}$. S. by E. Albany.

Farmixgham, p. v., Orleans co., N. $Y_{.}: 238 \mathrm{~m}$. W. by N. Albany.

Farmetetor, $t$. and p. o., Hartford county, Conn. : $9 \mathrm{~m}$. W. by S. Hartford. Drained by Tunxis or Farmington $r$. Surface hilly and varied; soil generally fertile, but light and sandy. Round Hill, near the village, rises abruptly to the height of 60 feet, and is nearly eircular in its form, covering about 12 acres. It is supposed to have been an island in a lake which covered all the present meadows. Farmington village is situate on an elevated plain, surrounded by hills; it lies on one principal street about $2 \mathrm{~m}$. long, beautifully shaded, and contains 2 churches, an academy, and about 130 dwellings. The New Haven and Northampton (Canal) R. R. passes through it $30 \mathrm{~m}$. from New Haven, and at Plainville gives off the Collinsville Braneh P. R. The Hartford, Providence, and Fishkill R. R. crosses the town E. and W. Unionville, Plainville, ete, are villages in Farmington. Pop. in t. 2,631.

Farmington, p. vo, Clark county, $G a_{*}$ : $49 \mathrm{~m}$. N. by W. Milledgerille.

Farmorgron, p. v., Rush county, Ind.: 37 m. E. S. E. Indianapolis.

Farmurgton, p. v., Fulton co., Ill.: on a branch of Copperas cr., $64 \mathrm{~m}$. N. by W. Springfield.

Farmington, p. v., Marion county, Tirg. : $206 \mathrm{~m} . \mathrm{N}$. W. Richmond.

Farmugrton, p. v., Van Buren co., Ia.: on the E. side of Des Moines r., opposite the mouth of Indian cr., $71 \mathrm{~m}$. S. by W. Iowa City.

Farutumgton, p. v., Graves co., $K y_{0}: 241$ m. W. S. W. Frankfort.

Farmington, tu, p. v., and eap. Franklin co., Me.: $32 \mathrm{~m}$. N. W. Augusta. Drained by Sandy r., a tributary of the Kennebec. Surface diversified; soil fertile, and producing good wheat and grass. The $\mathbf{v}$, is situate on Sandy $\mathbf{r}$, which affords water-power. There are several tanneries, potteries, etc., in the to, and 2,725 inhabitants. The "Chronicle," a weekly newspaper, is published here.

Farmivgton, t. and p. v., Oakland co., Mich.: $64 \mathrm{~m}$. E. by $\mathrm{S}$. Lansing. Drained by numerous affluents of the $\mathrm{N}$. branch of Rouge r. Surface diversified; soil deep and fertile-well wooded. The v. lies on Power's er., on which are numerous flour and saw mills. Pop. of $t, 1,844$

Faruington, p. v., Tishemingo co., Miss. : $205 \mathrm{~m}$. N. E. Jackson.

Farmington, p. v., and cap. St. Francois co., Mro.: at the head waters of St. Francois r., 114 m. E. S. E. Jefferson City. It contains a court-house, jail, several stores and mechanic shops, and about 400 inhabitants. It lies on the $\mathrm{E}$. confines of the great mineral region of the State.

Faritington, p. $\nabla .$, Davie co., N. Car.: on the W. side of Yadkin r., $104 \mathrm{~m}$. W. by N. Richmond.

F Armtsatow, t, and p. y., Strafford co., N. Hamp.: $33 \mathrm{~m}$. E. N. E. Concord. Drained by Cocheco r. Surface hilly, being traversed by the Blue Hills, or Frost Mountains, from the summit of which ships may be seen with the naked eye off the harbor of Portsmouth. Soils thin, but of average fertility. The principal village is situate at the $\mathrm{N}$. E side of, and about a $\mathrm{m}$. distant from the river, on which is the Dock, so named from its haring been used as such by the first settlers, who deposited their lumber here to be floated down the stream. Near this village is a remarkable rock, estimated to weigh 60 or 80 tons, so exactly poised on other rocks that it is caused to vibrate several inches by manual force. The Cocheco R. R. traverses the ralley of the river through the town, and the Great Falls and Comway R. R. crosses it in the E. Pon. in 155ๆ, 1,699.

Farmunetos, t. and p. o., Ontario co., N. T.: $182 \mathrm{~m}$. W. by X. Albany, Drained by Mud cr., a mill-stream emptying into Canandaignat outlet. Surbace level; soil, stiff 212 clay, and difficult of cultivation. Large tracts of waterlimestone are found here. Pop. 1,857.

Farmington, t. and p. o., Trumbull eo., Ohio: $146 \mathrm{~m}$. N. E. Columbus. Drained by head branches of Grand $r$. Surface hilly; soil excellent for grass, etc. Pop, 1,283.

Farmington, p. v., Fayette co., Penn.: 159 m. W. S. W. Harrisburg.

Faruington, p. v., Marshall county, Tenn.: $47 \mathrm{~m}, \mathrm{~S}$. Nashville.

Farmington, t. and p. o., Jefferson co., Wisc. : 23 m. E. Madison. Drained by Johnson's er., a tributary of Rock r. Surface varied and well timbered; soils rich and productive. Pop, 736 .

Farmin GToN, p. v., Ritchie co., Virg. : 228 m. W. N. W. Richmond.

Farmungton Falls, p. v., Franklin county, Me.: on the $\mathrm{N}$. side of Sandy r. of the Kennebec, opposite the mouth of Little Norridgewock r., $26 \mathrm{~m}$. N. W. Augusta.

Farm Ridge, p. O., La Salle co., $I l l .:$ about $2 \mathrm{~m}$. N. E. Vermillion $r$, of the Illinois, $97 \mathrm{~m}$, N. E. Springfield.

Farmville, p. v., Prince Edward co., Firg.: on the S. side of Appomattox r., and on the line of the South Side R. R., $52 \mathrm{~m}$. W. S. W. Richınond. It eortains two large tobacco warehouses, several extensive tobacco factories, various mechanie shops, and about 1,200 inhabitants. Boats navigate the river at all seasons to Petersburg, its natural port, and with which, and also with Richmond, it is now connected by railroad. The "Republican" (whig), a weekly newspaper, is published here.

Farmiar, p. v., Richmond county, Firg. : 53 m. N. E. Richmond.

Farivenstille, p.vo, Worcester co., Mrass. : on the Providence and Worcester R. R., 37 m. W. S. W. Boston.

Farrandsville, p. vo, Clinton co., Penn.: on the N. side of the West Branch of Susquehanna r., $74 \mathrm{~m}$. N. W. Harrisburg.

Farrell Place, p. v., Clinton county, N. Y.: $13 \pi \mathrm{m}$. N. Albany.

Farrionvilie, p. v., Pike county, Alo.: 43 m. S. E. Montgomery.

$F_{A B}$ RockawaY, v., Queens $c_{0}, N . Y_{0}:$ a fine summer retreat on the $\mathrm{S}$. side of Long Island. The $\mathrm{v}_{\text {, is located on }}$ a peninsula, between Jamaica Bay and the Atlantic, and contains a ehurch and about 40 dwellings. One $\mathrm{m}$. W. are the Marine Pavilion and Rock Hall, splendid boarding houses, which are resorted to by visitors seeking the benefit of a summer-marine residence.

FARRowsyille, p. v., Fauquier county, Firg.: $99 \mathrm{~m}$. X. X. W. Riehmond.

FAP WEST, p. o., Johnson co., Ind.: on the E. side of the West Fork of White r., $14 \mathrm{~m}$. S. by W. Indianapolis.

FAucetr"s Store, p. 0., Orange co., N. Car.:51 m. N.W. Raleigh.

Fausse Porsx, p. o., St. Martin's par, $L a$ : 42 m. S. by W. Baton Rouge.

FaUsse Riviere: a lake below Point Coupee, Louisiana, formerly the bed of the Mississippi, and until 1814 its principal channel. It is now filled up at both ends so as to be shut off from the new channel, and forms an extensive lake in the form of a horse-shoe. The banks are very fertile, and covered with fine farms.

Faverter, county, Firg. Situate N. E., and contains 720 sq. $m$. Drained by the branches of Rappahannock and Oecoquan rivers. Surface diversified by hills and valleys; s.mil mulerately proluctive. This is one of the best grain counties of the State, and has also large numbers of live stock. Farms 839 ; manuf. 62; dwell. 1,839, and pop.wh. 9.875 , fr. col. 613 , sl. 10,350-total 20,863. Capital: Warrenton. Pr'?i: Wonks; Orange and Alexandria R. I.; Warrenton Branch R. R.; Manassas Gap R. R., etc.

FAw: Grotr, t. and p. o., York co., Penn.: 42 m. S. E. Marrishurg. Drained by affluents of Murldy er., which makes its X. boundary, the $\$$. lime lying the Maryland state 
line. Surface hilly, and soil indifferent. There are several mills and factories in the town.

Fatrix Riter, to and p. o., St. Joseph's co., Mich.: $74 \mathrm{~m}$. S. E. Lansing. Drained by Fawn r., a tributary of St. Joseph's of the lake. The Southern Michigan R. R. passes through the N. W. corner of the town. Pop, 478.

FAYETTE county, Ala. Situate W. toward N., and contains 936 sq. m. Drained chiefly by Yellow cr., Looxapatilla r. and Sipsey r., tributaries of Tombigbee $r$. The E. part of the co. is drained by the head streams of several affluents of Black Warrior $r$. Surface undulating or level; soils fertile, producing cotton, corn, and the grains generally. Timber of various descriptions abundant, especially on the rivers. Farms 1,065 ; manuf. 24 ; dwell. 1,408, and pop.-Wh. $\$, 450$, fr. col. 10, sl. 1,221-total 9,6s1. Capital: Fayette.

FAYETTE county, $G a$. Situate centrally, and contains 280 sq. $\mathrm{m}$. Drained by the head tributaries of Flint $r$, which $r$. has its rise in the hills in the N. part of this co. In the S. the surface is level, but occasionally diversified. Soil rich and productive.- Cotton, Indian corn, whent, etc., are the principal staples. Farms 818 ; manuf. 6 ; dwell. 1,196, and pop.-wh. 6,740, fr. col. 4, sl. 1,965-total 8,709. Capital : Fayetteville. Pullio Worls: Macon and Western R. R.; La Grange R. R., ete.

F AYYTTE county, $M l$. Situate $S$. centrally, and contains G48 sq. m. Drained by affluents of Kaskaskia r., which runs through it, on which $\mathrm{r}$. the lands are subject to inundation, and frequently retain the waters in the hollows. Surface generally level, heing prairie and woodland intermixed: around Vandalia it is undulating. Farms 826 ; manuf. 4; dwell. 1,431, and pop.-wh. 8,027, fr. col. 48total 8,075. Capital: Vandảlia, Public Works: Illinois Central R. R. ; Mississippi and Atlantic R. R., etc.

FAXETr county, Ind. Situate E. middle, and contains 210 sq. m. Drained principally by W. fork of White Water r., which flows from $N$. to $S$. through the $c 0$, Surface rolling or level, with extensive bottoms densely timbered. Soil everywhere fertile. Pork, beef, and flour are the chief staples. Farms 956; manuf, 116; dwell. 1,818, and pop.wh. 10,145, fr. col. 72-total 10,217. Capital : Connersville. Public Works: White Water Canal; Junction R. R., ete.

FAYETTE county, $I \sigma$. Situate N. E., and contains 720 sq. $m$. Drained in the $N$. and middle by Turkey r. and its tributaries, and in the $\mathrm{S}$. by the head branches of Wapsipinicon r. Surface level prairie, intermixed with woodland. Soils deep and fertile. Farms 8; manuf. 0 ; dwell. 153, and pop,-wh. 825, fr. col. 0-total 825. Capital: West Union.

F $\triangle$ YYTTE county, $K y$. Situate centrally, and contains 280 sq. m. Drained by several affluents of Elkhorn r., a tributary of the Kentucky, which river also in part forms the S. E. border of the county. Surface elerated, inclining on all sides toward Kentucky $r$. Soils rich and fertile, producing immense grain crops, hemp and flax, tobacco, etc. The co. has also a large manufacturing interest. Farms 799 ; manuf. 156; dwell. 2,089, and pop,-wh.11,180, fr. col. 666, sl, 10,889-total 22,735. Capital: Lexington. Public Works : Lexington and Frankfort R. R. : and railroads (projected) to Covington and Maysville, on the Ohio R. R., and also to Nashville, Tenn., etc.

FAYETTE county, Ohio. Situate toward the S. W. centrally, and contains 416 sq. m. Drained by Rattle-snake cr., Paint cr., and Deer cr., their tributaries. Surface generally level; soils fertile. Farms 1,007; manuf. 29; dwell. 2,155, and pop.-wh. 12,456, fi. col. 270-total 12,726. Capital: Washington. Public Works: Cincinnati, Steubenville, and Pittsburg R. R., etc.

FaYzeTte county, Penn. Situate $\mathrm{S}$. W., and contains 824 sq. $m$. Drained by tributaries of Youghiogeny $r$, and the Monongahela, the latter $r$. forming the $\mathrm{W}$. boundary. The Laurel Mountain lies on the E. border, and renders the surface in that direction hilly and rough, but the soil is fertile and well cultivated. Coal and iron ore abound, and salt springs are found in several parts; there are also sul- phur springs, At the Ohiopile Falls the Youghiogeny descends 60 feet in the distance of a mile. The agricultural products consist chiefly of wheat, Indian corn, etc., and large quantities of bituminous coal are annually mined. Numerous furnaces, forges, and rolling mills are in operation, also glass factories and potteries, with several other staple manufacturing establishments. Farms 2,139; manuf. 232 ; dwell, 6,597, and pop.-wh. 37,443, fr, col. 1,669-total 59,112. Capital: Union Town.

F AXETTE county, Tex. Situate S. centrally, and contains $1,160 \mathrm{sq} . \mathrm{m}$. Drained chiefly by Colorado $\mathrm{r}$, and its tributaries-in the S. and S. W. by the head branches of Yavidard $r$. and Peach cr., the latter an affluent of Guadalupe r. Surface remarkably diversified-in the $\mathrm{E}$. undulating, in the middle hilly, alternating with broad plains, and in the W. level, inclining to the S. W. The prairies of this co, are not extensive, but are interspersed with islets of timber, and alternate with the forests of the numerous streams. Boil, a rich sandy loam, from 10 to 20 feet deep, and resting on a stratum of sand-stone. Gypsum, lignite, etc., are found in abundance. Farms 209 ; manuf. 6 ; dwell. 494, and pop.wh. 2,740, fir. col. 0, sl. 1,016-total 3,756. Capital: La Grange.

FAYetre county, Tenn. Situate S. W., and contains 576 sq. m. Drained by Loosahatchee and Wolf rivers and their affluents. Surface undulating, and consisting chiefly of prairie, but with extensive woodlands. Soils well adapted for general agriculture, producing wheat, Indian corn, oats, ctc., abundantly, cotton, and some tobacco. Large numbers of live-stock are also orvned in the co. Farms 1,172 manuf. 29 ; dwell. 1,951, and pop.-wh. 11,420, fr. col. 35 sl. 15,261-total 26,719. Capital: Somerville. Public Works: Memphis and Charleston R. R., with a branch to Somerville.

FAIETTE county, Virg. Situate W., and contains 920 sq. m. Drained by New r., a main constituent, and other tributaries of Great Kanawha r. Clear and Marsh Forks of Cool r. also rise in this co. Surface mountainous; soil sandy loam. On New r., $2 \mathrm{~m}$. from Fayetteville, is Long Point, which projects into the stream; its top consists of a flat rock of 2 acres in extent, and elevated 1.500 feet above the level of the water; and $6 \mathrm{~m}$. from the $\mathrm{v}$. is Hawh's Nest, or Marshall's Pillar, a naked, perpendicular rock, 1,100 feet high. There are several interesting remains of ancient fortifications in the vicinity. The agricultural staples are the grains and animal products, the hills being nine pasture lands. Farms 428; manuf. 7 ; dwell. 593, and pop.-wh. 3,782, fr. col.17, sl. 156-total 3,955. Capital: Fayetteville.

FATETTE, p. v., and cap. Fayette co., Ala.: on the W. side of, and about $2 \mathrm{~m}$. from, Sipsey $\mathrm{r}_{\text {o, }}$ an affiuent of the Tombigbee, $123 \mathrm{~m}$. N.W. Montgomery, It contains a courthouse, jail, and about 30 dwellings.

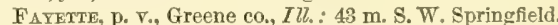

Faretre, t. and p. o., Kennebec co., Mre.: 18 m.W.N.W. Augusta. Drained by a branch of Sandy r., and in the $\mathrm{E}$. there are several large and beautiful ponds which empty into the Kennebee r. Surface rolling; soil adapted alike for grain and grass. The v. lies near the centre. Pop. 1,085,

FAYETTE, p. V., and cap. Jefferson co., Mfiss.: S. of Coles cr., an affluent of the Mississippi, $67 \mathrm{~m}$. S. W. Jackson.

FAyetre, p. v., and cap. Howard co., Mo.: on the W. side of Bonne Femme cr., an affluent of Missouri r., $49 \mathrm{~m}$, N. W. Jefferson City. It contains a court-house, co. jail, etc., and is the seat of a United States' land office, and of Fayette College, which in 1850 had 2 professors and 75 strdents. Pop. about 800. A newspaper, the "Missouri Dem. ocrat," is issued weekly.

FAYeTTE, t. and p. v., Seneca county, $N . Y .: 157 \mathrm{~m}$. W. Albany. Seneca Lake makes its W., and Cayuga Lake its E. boundaries; and several tributaries of Seneca r., which flows on its $\mathrm{N}$. border, drain the interior, and afford waterpower. Gypsum and limestone abound. The t. has several tanneries, mills, etc., and 3784 inhabitants. 
FAYYTTE, t. and p. o., Alleghany co., Penn.: $177 \mathrm{~m} . \mathrm{W}$. Harrisburg. Drained by branches of Chartier's cr. Surface hilly; soil a rich loam; coal and iron are abundant. The town has several mills.

FATETTE, p. Y., La Fayette county, Wisc. : $49 \mathrm{~m} . \mathrm{S} . \mathrm{W}$. Madison.

Fayette Corner, p. o., Fayette co., Tenn.: in the N. E. corner of the co., $129 \mathrm{~m}$. W. S. W. Nashville.

Fayette Springs, p. 0., Fayette county, Penn.: $167 \mathrm{~m}$. W. S. W. Harrisburg.

Fayetrevilue, p. V., Talladega co., Ala.: on the E. side of Coosa r., $49 \mathrm{~m}$. N. Montgomery. It is a thriving v., and has a considerable river trade and about 600 inhabitants.

FAYetTeVitice, p. v., and cap. Washington co., Ark.: on the left bank of White r., $146 \mathrm{~m}$. W. N. W. Little Rock. It contains a court-house, ete., a United States' land office, and several stores. Pop. about 450 .

FayetTeville, p. v., and cap. Fayette co., $G a_{0}$ : on a branch of Flint r., $78 \mathrm{~m}$. W. N. W. Milledgeville. It contains a court-house and other co. buildings, about 70 dwellings, and 300 inhabitants.

F AYETTEVILLE, p. v., and cap. Cumberland co, $N_{0}$. Car.: on the W. side of, and $1 \mathrm{~m}$. from, Cape Fear r., and at the head of uninterrupted boat navigation, $49 \mathrm{~m}$. S. Raleigh. Lat. $35008^{\prime} \mathrm{N}$., and long. $7905 \mathrm{~S}^{\prime} \mathrm{W}$. It is one of the large towns of the State, is regularly laid out with streets 100 feet wide, and has a court-house and other $c o$. buildings, three banks, and a United States' arsenal of construction. Its trade in flour, tobacco, and naval stores, is considerable. Three newspapers, the "North Carolinian" (dem.), the "F. Observer" (whig), and the "Communicator" (temperance), are published weekly, and have respectable circulations, Its manufactures are extensive, consisting of cotton mills, and flour, grist, saw, and oil mills, etc. Pop. in 1820, 3,532; in $1830,2,868$; in $1810,4,285$; and in $1850,5,312$.

F AYETTEVILLe, p. v., Onondaga co., $N . \quad Y$ : on both sides of Limestone cr., a branch of Butternut cr. of the Chittenango, the last of which falls into Oneida Lake, distant 112 m. W. Albany. The Erie Canal passes a listle N. of the village. It is a place of considerable trade, and has about 600 inhabitants.

F $\triangle$ YETTEVILLE, p. v., Bromu co., Ohio: on the E. fork of Little Miami r., 72 m. S. W. Columbus. Pop. 318.

Faymeteville, p. V., Franklin co., Penn.: on the Gettysburg and Chambersburg Turnpike, $46 \mathrm{~m}$. S.W. Harrisburg.

FATETteville, p. v., and cap. Lincoln co., Tenn. : on the N. bank of Elk r., an affluent of Tennessee r., 69. ma. S. by E. Nashville. It contains a court-house, several stores, and about 300 inhabitants, and has a newspaper, the "Lincoln Journal" (dem.), issued weekly.

Fayetrentlie, p. v., and cap. Fayette co., Firg.: about $2 \mathrm{~m}$. W. of New r., $203 \mathrm{~m}$. W. by N. Richmond. It contains a court-house, several stores, and about 300 inlabitants.

F a yetTeville, p. v., St. Clair co., $I l l$. : on the W. side of Kaskaskia r., 98 m. S. Springfield.

Fayetrevilite, p. v., Fayette county, Tex。 : $56 \mathrm{~m} . \mathrm{S} . \mathrm{E}$. Austin City.

Farettertlle, p. v., and cap. Windham co., Term.: on the W. side of West $\mathrm{r}$. of the Connecticut, $91 \mathrm{~m}$. S. Montpelier. It contains a court-house, jail, several mills and mechanic shops, and about 800 inhabitants.

FaYetTeville, p. v., Lawreace co., Ind. : 63 m. S. by W. Indianapolis.

FaxvmLE, p. v., Kane co., Ill.: on the W. side of Fox r., $5 \mathrm{~m}$. below Elgin, $162 \mathrm{~m}$. N. E. Springfield.

FeArIvg, t. and p. o., Washington co., Ohio: $88 \mathrm{~m}$. E.S. E Columbus. Drained by Duck r., which affords water-power; and the Muskingum r. makes a part of the $\mathrm{W}$. boundary. Surface hilly and broken; soil moderately fertile, and excellent for grazing.

FeARN's SPRIYGS, p. O., Winslow co., Ifiss. : 94 m. N. E. Jackson. The "F. Democrat" is published weekly.
Feasterville, p. v., Bucks county, Pem. : $97 \mathrm{m.E}$ Harrisburg.

FEAStervile, p. v Fairfield district, S. Car.: $83 \mathrm{~m} . \mathrm{N}$. Columbia.

Feather river, Calif.: an affluent of the Sacramento

Federalsburger, p. v., Caroline co., Ma. ; on the E. side of Marshy Hope cr., near the county line, $46 \mathrm{~m}$. E. S. E. Annapolis.

Frderal Store, p. o., Duchess co., $N . Y_{0}: 59 \mathrm{~m}$. S. by E Albany.

Federaltox, p. v., Athens co., Ohio: at the confinence of Federal cr. with Hocking r., $74 \mathrm{~m}$. S. E. Columbus.

Feeding Hilis, p. o., Hampden county, Mass.: $83 \mathrm{~m}$ W. by S. Boston.

Feed Spring, p. v., Harrison co., Ohio: 107 m. E. by N. Columbus.

FEE FEE, p. 0., St. Louis co., MFo.: $97 \mathrm{~m}$. E. Jefferson City. Situate about $3 \mathrm{~m}$. S. of Missouri river.

FeesedraIr, p. y., Brown county, Ohio: $87 \mathrm{~m}$. S. W. Columbus.

Felchtille, p. v., Windsor co., Fern. : 59 m. S. by E. Montpelier.

Feliciana parish, EASt, $L a$. Situate in the N.W. of the Eastern District, and contains $560 \mathrm{sq} . \mathrm{m}$. Drained by the upper branches of Amité r., and divided from West Feliciana by Thompson's cr. of the Mississippi. Surface elevated, inclining to the S., and somewhat rough. Soils eminently productive. Cotton is the great staple. Farms 361 ; manuf. 49 ; dwell. 712, and pop.-wh. 4,061, fr. col. 23, sl. 9,514total 13,598. Capital: Jackson. Prbblic Works: Clinton and Port Hudson R. R.

Filiciana parish, West, La. Situate N. W. of the Eastern District, and contains $350 \mathrm{sq} . \mathrm{m}$. The Mississippi r. makes its W. boundary, and Thompson's cr. demarks its E. line. Drained by Bayou Sara and numerous small bayoux and creeks falling into the Mississippi. Surface broken; soils rich and fertile. Cotton is the staple crop. Farms 234 manuf. 147 ; dwell. 599, and pop.-wh. 2,473 , fr. col. 106, sl. 10,666-total 13,245. Capital: St. Francisville. Public Works: West Feliciana R. R.

FELTCLANA, p. $\mathrm{v}$., Graves co., Ky.: on the $\mathrm{S}$. branch of Deshé r., 253 m. W. S. W. Frankfort.

Felicity, p. v., Clermont co, Ohio: about $31 \mathrm{~m}$. from Ohio r., $92 \mathrm{~m}$. S.W. Columbus. It contains several mechanic shops, stores, ete., and about 400 inhabitants. The country around is under the highest state of cultivation.

Feurx, p. O., Morgan Co, Mo.: on the Boonevillo and Versailles Turnpike, $41 \mathrm{~m}$. W. by S. Jefferson City.

Fellowshre, p. o., Burlington co., N. Jer.

Fellowstille, p. v., Preston co., Virg.: 181 m. N. W. Richmond.

Feltoxsviluz, p. v., Middlesex co., Mass.: on a branch of Concord r., $27 \mathrm{~m}$. W. Boston. It is a considerable maunfacturing village, and the terminus of the Laneaster and Sterling Branch R. R., 9 m. from South Acton, and 34 from Boston by the Fitchburg $\mathrm{R}$, $\mathrm{R}$.

FelT's Mills, p. o., Jefferson co., N. Y.: 136 m. N. W. Albany.

Feltville, p. v., Essex county, N. Jer.: 46 m. N. E. Trenton.

Fevine Osage, p. o., St. Charleg co., Mo.: 67 m. E. by N. Jefferson City.

FeNNer, t. and p. o., Madison co., N.Y.: 104 m.W. by N. Albany. Pop. $1,690$.

Fexinerstulle, p. v., Monroe co., Ponn.: 97 m. N. E. Harrisburg.

Fexamore, t. and p. o., Grant co., Wise.: $67 \mathrm{~m}$. W. Madison. Drained by Blue r., Trout cr., and other streams flowing $N$. into Wisconsin $r$. It is a large tract of fine prairie and woodland intermixed, with an abundance of water-power. Pop. 654 .

Fexs's Bridge, Jefferson co, $G a_{0}$ : on a branch of Ogeechee r., 3S m. E. Milledgeville. 
Fextox, p. v., St. Louis co., Mo.: on the S. side of Maramee r., 98 m. E. Jefferson City,

Fextoxvilue, p. v., Genesee co, Mich. : on the E. branch of Shiawassee r., $47 \mathrm{~m}$. E. Lansing.

FeNTrEss county, Tenn. Situate N. middle, and contains $420 \mathrm{sq}$. m. Drained in the W. by the forks of Obey's river, and in the $\mathbf{E}$. by creeks of the $\mathbf{S}$. fork of Cumberland river, which demarks its boundary in that direction. Surface hilly and broken; soils of average productiveness; timber abundant. Farms 499 ; manuf. 5 ; dwell. 707 , and pop.-wh. 4,305, fr. col, 1, sl, 148-total 4,454. Capital: Jamestown.

Fextriss, p. v., Guilford con, N. Car.: 74 m. W. N. W. Raleigh.

Ferdinand, p. v., Mercer county, Ill.: $71 \mathrm{~m} . \mathrm{N}$. W. Springtield.

Firdinand, p. v., Dubois co., Ind.: 110 m. S. by W. Indianapolis,

Ferguson's Corners, p. o. Tates co., N. $Y_{.}: 166 \mathrm{~m}$. W. by S. Albany.

Feronta, p. ₹., Telfair co., Ga, : $106 \mathrm{~m}$. S. Milledgeville.

FerRisburgin, t. and p. v., Addison co, Verm.: $32 \mathrm{~m}$. W Montpelier. Drained by Otter, Little Otter, and Lewis creeks, which afford water-power. Otter cr, is navigable to Vergennes, $8 \mathrm{~m}$. Lake Champlain bounds it on the W., and is here about $2 \mathrm{~m}$. wide. Basin Harbor, in this town, is deep and well protected, and is a place of considerable navigation and commercial importance. Large quantities of fish are taken annually from the lake and cured for market. The t. has some manufactures, and its agricultural products are large and valuable. The principal $v$. lies in the central part of the $t$., and there is a small $\mathrm{v}$. at Ferrisburgh Station, on the Rutland and Burlington R. P.2,075.

F ESSENDEN MIris, p. o., Rockingham co., N. Hamp.

Fetherolftstilles, p. 0., Berks co., Penns : 67 m. E. by $N$ Hartisburg.

FIATT, p. v., Fulton co., Ill.: 79 m. N. W. Springfield.

Fidde Pond, p. o., Barnwell dist., S. Car.: $72 \mathrm{~m}$. S. W. Columbia.

FidelirY, p. $\nabla .$, Miami county, Otio: $69 \mathrm{~m} . \mathrm{W}$. by N. Columbus.

FIfE, p. V., Jersey co., $I l_{0}$ : $59 \mathrm{~m}$. S. W. Springfield.

FIFE'S, p. O., Goochland co., Virg.: at the Cross Roads, $\mathrm{N}$. of James r., $33 \mathrm{~m}$. W. by N. Richmond.

Figirive island, Mich.: one of the largest islands in Detroit Strait, midway between lakes Erie and Huron, and below the confluence of the Rouge. It contains about $8 \mathrm{sq} . \mathrm{m}$.

Fillyore, p. o., Dubuque co., Ia. : $73 \mathrm{~m}$. N. E. Iowa City. FILLMORE, p. o, Alleghany co, $N, Y,: 214 \mathrm{~m}$. W. S. W. Albany.

FILLMORE, po $\nabla$, Porter county, Ind. : $181 \mathrm{~m}, \mathrm{~N}, \mathrm{~W}$. Indianapolis.

Fillmore, p. o, Washington co, Ohio: 84 m. E. S. E. Columbus,

Fillvore, p. o., Montgomery eo., $I l l_{\text {. : }}$ on a head branch of Hurricane cr. of Kaskaskia r., 51 m. S. by E. Springfield.

Fillarore, p. V., Putnam co., Ind : at the head of Deer cr. of Eel r., $32 \mathrm{~m}$. W. by S. Indianapolis.

Fncmore, p. o., Daviess county, Ky.: $134 \mathrm{~m}$. W. by $\mathrm{S}$. Frankfort.

Filcmone, p. o., Washington co., Wisc.: 63 m. E. N.E. Madison.

Fillmare, p. O., Randolph county, Virg.: 169 m. N. W. Richmond.

Firlmole, p. o., Monmouth co., N. Jer.: 29 m. E. Trenton. Frlwrore, p. v., Cleveland co, $N_{\text {. Car : }} 158 \mathrm{~m}$.W. by S. Raleigh.

FILlMORe, p. 0, Andrew county, Mo.: 177 m. W. N. W. Jefferson City.

Fillmore, po o, Centre county, Penn.:72 m. N.W. Harrisburg.

Finlmore City, p. o., and cap. Millard co, Utah Ter., and capital of the Territory.
FiLlMorE, p. o., Bledsoe eo., Tenn。: 104 m. E. by S. Nashville.

Fincastle, p. v., Brown county, Ohio: 73 m. \$. W. Columbus. Pop. 145

Fincastle, p. vo, Campbell co., Tenno: $159 \mathrm{~m}$, E, by $\mathrm{N}$. Nashville.

Fincastle, p. v., Putaam co., Ind.: 42 m. W. by $\mathrm{S}$. Indianapolis.

Fincastle, p. V., and cap. Botetourt co., Firg.: in the Valley of Cahawba er., an affluent of James r., $137 \mathrm{~m}$. W. Richmond. It contains a court-house and other co. buildings, four churches, various mills and mechanic shops, and about 800 inhabitants. Two newspapers, the "F. Democrat," and the "Valley Whig," are published weekly.

Finchvilue, p. v., Orange co., $N_{0} Y_{*}: 89 \mathrm{~m}$. $\mathrm{s}$. by W. Albany.

Fine Foris, p. o., Person con, N. Car.: $51 \mathrm{~m}, \mathrm{~N} . \mathrm{W}$. Raleigh.

Fine's Creek, p. o., Haywood co., N. Car.: on a cr. of Big Pidgeon so called, $248 \mathrm{~m}$. W. Raleigh. Big Pidgeon is an affluent of French Broad, and Tennessee rivers.

Fingersvillie, p. v., Spartanburgh dist., S. Car.: $76 \mathrm{~m}$. N. W. Columbia.

Finksiburge, p. v., Carroll co, Md. $:$ on the W. side of the N. branch of Patapsco r., 43 m. N. N. W. Annapolis,

Finley, t., p. v., and cap. Hancock county, Olizo: $81 \mathrm{~m}$. N. N. W. Columbus. Drained by Eagle and other creeks, affluents of Blanchard's Fork of Auglaize r., which runs E. to W. through it. Surface diversified; soils of average productiveness. The $\mathbf{v}$. lies on the S. side of Blanchard's Fort, and contains a court-house, jail, several stores and mechanic shops, and about 1,258 Populat. Three newspapers are published here, the "Democratic Courier," the "Hancock Whig," and the "Hancock Journal" (whig), all issued weekly. The Finley Branch R. R. extends hence E. by S., to Carey, on the Mad River and Lake Erie R. R., 16 miles. Pop. of t. 2,034

Finlex, p. v., Greene co., Mo. : on a branch of Finley cr, 57 m. S. S. W. Jefferson City.

Finleiville, p. v., Washington co., Penn.: $179 \mathrm{~m}, \mathrm{~W}$. Harrisburg.

Finnex Mris, p. o., Amelia co., Firg.: 38 m. s. W. Richmond.

FIRe islands, N.Y.: are a cluster of small islands in the Great South Bay of Long Island.

Fire-PLACE, p. v., Suffolk co., N. Y.: on the N. of Fireplace Bay, an arm of the Atlantic Ocean, 133 m. S. E. Albany.

Fire-PLAce bay, N. Y.: an indentation of Great South Bay of Long Island.

FIRE-STEE river, Mich.: a stream running into Lake Superior out of the Ontonagon. It has its source in the Porcupine Mountains of the Upper Peninsula.

First Fork, p. o., Clinton co., Penn.

Fisen's Cross RoADS, p. 0., Robertson co., Tenn.: $31 \mathrm{~m}$. N. W. Nashville.

Fisi Crefk, p. o., Steuben co., Ind.: near the S. line of the co, on Fish er., a tributary of St. Joseph r. of the Maumee, $136 \mathrm{~m}$. N. E. Indianapolis.

Fise Creek, po O., Marshall co, Firg.: on Fish cr., a tributary of Ohio r., $228 \mathrm{~m}$. N. W. Richmond.

Fish creek, $N . Y$. : the outlet of Saratoga Lake, and emptying into the Hudson $r$, at Schuylerville, where are located several mills and factories.

Fisu creek, $N . Y$.: rises in Lewis co., and empties into Wood's cr. in Oneida co. It is navigable for boats for a few miles from its mouth, and is a good mill-stream, on which are located several factories, etc.

Fismday, p. v., Wake co, $N_{\text {. }}$ Car. : $22 \mathrm{~m}$. S.W. Raleigh.

Frsmodr, p. v., Union dist., $S_{\text {. }}$ Car.: on the W. side of Broad r., 61 m. N. W. Columbia.

Fismer's, p. o., Catawba county, N. Car.: $148 \mathrm{~m}$. W Raleigh. 
Fishersburgh, p. o., Franklin county, Virg.: $145 \mathrm{~m}$. W. by $\mathrm{S}$. Richmond.

Fismer's island, $N . Y_{*}:$ lies off the E. end of Long Island, $14 \mathrm{~m}$. from shore. It is $8 \mathrm{~m}$. long and $1 \mathrm{~m}$. wide. The surface is varied, and soil very productive.

Fishersville, p. v., Windham co., Conn. : on French r., a branch of the Quinnebaug, $42 \mathrm{~m}$. E. by N. Hartford, It has considerable manufactures, and the $\mathrm{v}$. is intersected by the Norwich and Worcester R. R., $38 \mathrm{~m}$. N. from Norwich.

Fishersville, p. v., Merrimac county, N. Hamp. : at the junction of Contoocook and Merrimac rivers, $7 \mathrm{~m}$. N. N.W. Concord. The Northern R. R. passes through the v.

Fismersville, p. v., Augusta co., Firg. : on a small tributary of the S. Branch of Potomac r., $4 \mathrm{~m}$. E. by S. of Staunton, and $91 \mathrm{~m}$. W. N. W. Richmond.

Fisengrvule, p. Y., Jefferson county, $\bar{k} y_{*}$ : 51 m. W, Frankfort.

Fishervilue, p. v., Dauphin co., Penn

Fishimg Creek, p. o., Cape May co., N. Jer. : $76 \mathrm{~m}$. S. Trenton, Fishing cr. is a small stream about $5 \mathrm{~m}$, long, emptying into Delaware Bay.

Fishivg Creek, t. and p. o., Columbia co., Penn.: $68 \mathrm{~m}$. N. by E. Harrisburg. Drained by Fishing cr, of Susquehanna river. Surface mountainous; soil, clay and gravel. Pop. 1,114,

Fish House, v., Fulton co., $N$. $Y$. : on Sacandaga r., a branch of Hudson r., $67 \mathrm{~m} . \mathrm{N} . \mathrm{W}$. by N. Albany. It contains several stores, and about 40 dwellings. Sir William Johnson made the settlement at this point for the purpose of fishing and trading with the Indians.

FishkILl, t, and p. v., Duchess counts, $N . Y_{*}: 77 \mathrm{~m} . \mathrm{S}$. Albany. Drained by Fishkill and Wappinger's creeks of Hudson $x$. Surface diversified-in the S. mountainous: soil fertile. It has sereral convenient landings on the Fudson. Fishkill $\mathrm{v}$, lies on Fishkill cr., $5 \mathrm{~m}$. from Fishkill Landing, and contains about 1,000 inhabitants. There are several woolen and cotton factories, and numerous saw, flouring, and grist mills, and a newspaper, the "F. Standard," is issued weekly. Pop. 9,243. The Hudson River R. $\mathrm{P}$., and the Hartford, Providence, and Fishkill $\mathrm{P} . \mathrm{P}_{\text {. }}$ passes through this town.

Fishirill Layding, p. v., Duchess co., $N_{\text {. }} Y_{\text {. }}$ : at the mouth of Fishkill er., 79 m.S. Albany, and opposite Newburg, with which it is connected by a steam ferry. The creek has fine water-power, and along its banks are several extensive manufactories, as foundries, mechanic shops, etc. It contains about 1,400 inhabitants. The Hartford, Providence, and Fishkill R. R. has its W. terminus at this point, and connects, by means of the ferry, with the New York and Erie R. R., thus furnishing a link in the chain of railroads that run from the extremities of New England to and beyond the Mississippi r. and the great lakes.

Fismknt Plans, p. 0., Duchess $\mathrm{c}_{0}, N_{.} \bar{Y}_{0}:$ in the town of East Fishkill, 75 m. S. by E. Albany.

Fismkil mountains, Duchess county, $N$. $\boldsymbol{Y}$. (called, also, Matteawan Mountains): a continuation of the Highlands through which the IIudson r. passes-a range which enntinues N., under different names, to the Green Mountains of Vermont.

Fisnkilu (or Matteawan) creek, Duchess county, $N . Y$. rises in the centre of the co., and passing by the manufacturing villages of Glenheim, Matteawan, Fishkill, etc., empties into the Hudson r.

Fisir PoNd, p. v., Tallapoosa county, Ala.: $54 \mathrm{~m}$. N. E. Montgomery.

Frsu Port, p. 0., Rock Island co., $T U$. : on Rock r., $122 \mathrm{~m}$. N. X. W. suringfield.

Fism Trap, p. o., Baker county, Ga.: $146 \mathrm{~m} . \mathrm{S} . \mathrm{S} . \mathrm{W}$. Milledgeville.

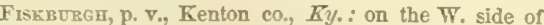
Licking r., 51 m. N. N. E. Frankfort.

Fisked AxE, p. o., Worcester co., Mrass.: $59 \mathrm{~m}, \mathrm{~W}, \mathrm{~S}, \mathrm{~W}$. Boston.
Fiskevilxe, p. v., Providence co., $R . I_{0}$ : on the $\mathrm{N}$. side of Pawtuxet $r_{a}, 11 \mathrm{~m}$. S. W. Providence. It is a place of considerable manufacturing industry.

Fisk's Cokvers, p. o., Winnebagu co., Wisc. : 87 m. N. E', Madison.

Frтсн, p. o., Cass co., Ind. : $71 \mathrm{~m} . \mathrm{N}$. by W. Indianapolis, Fitchioren, t. and p. v., Worcester county, Mass, : $42 \mathrm{~m}$. W. N.W. Boston. Drained by a large branch of Nashua $r$. and two smaller streams, which furnish immense waterpower, and on which are numerous large manufacturing establishments. Surface diversified and somewhat hilly; soil of average fertility. In the immediate vicinity of the $\mathrm{v}$. of Fitchburg is an immense quarry of excellent granite. The manufactures embrace woolen and cotton goods, paper, boots, ete. It is one of those towns of New England that have forced themaselves into prosperity by local advantages, and is now one of the chief centres of the railroad network of the country ; hence diverge the Fitchburg $\mathrm{R}$. R, to Boston, the Worcester and Fitchburg R. R. to Worcester, and the Vermont and Massachusetts R. R. to Greenfield-these, with their connections, extending to every part of the Union and the Canadas. The "Fitchburg Sentinel" is issued weekly. Population in $1 S 30,2,169$; in 1840, 2,604; and in $1850,5,009$.

FттснвияgIr, p. v., Dane co., Wisc.: 10 m. S. Madison.

Fitchillie, t. and p. v., Huron co., Ohio: 84 m. N. N. E. Columbus. Drained by a branch of Vermillion $r$. Surface diversified, and somewhat hilly; soil fertile, and well cultivated. The principal $v$. is situate on the $r$. near the centre of the t., and contains about 300 inhabitants. Fitchville was settled and is chiefly occupied by industrious emigrants from the New England States. Pop. 1,178.

Firz Hexny, p. v., Conway county, $A r k .: 41$ m. N. W. Little Rock.

Fitz Hexrs, p. o, Seneca county, Ohio: $\$ 1 \mathrm{~m} . \mathrm{N}$. Columbus.

Fitz Hexpx, p. 0, Westmoreland co., Penn. : $133 \mathrm{~m}$. W. Harrisburg.

Frrz Henry, p. 0., Ogle county, IUl.: 158 m. N. by E. Springfield.

Fitz Williar, t. and p. $v_{0}$, Cheshire co, $N$. Iamp.: 46 m. S. W. Concord. Drained by Priests and Camp Brooks, and there are several ponds of considerable size in the town. Surface hilly; soil rocky and stubborn; but there are considerable meadows which are very productive. Gap Mcuntain lies on the N. E. boundary, on which are found fine whetstones. The $\mathrm{v}$. lies near the centre, and is intersected hy the Cheshire R. R. Pop. of t. 1.45?.

Frve Corvers, p. 0., Cayuga county, $N . Y_{.:} 142 \mathrm{~m} . \mathrm{W}$, Albany.

FIVE Mile, p. o., Drown county, Ohio: 69 m. S. W. Columbus.

Frve Mret, p. v., Pickens dist., S. Car. : on a cr. so called, $122 \mathrm{~m}$. N. W. Columbia.

Frve Poists, p. o., Venango co., Penn.: 171 m.W. N. W Harrisburg.

Flackville, p. v., St. Lawrence co., $N . Y .: 152 \mathrm{~m} . \mathrm{N} . \mathrm{W}$ Albany.

Flage Spratg, p. 0., Campbell co., Ky. : 68 m. N. N. E Frankfort.

Flaggrows, p. ve, Somerset co., N. Jer.: 20 m. N. E. Trenton.

FlagstafF, p. o., Somerset co., Me.

FLANders, p. ., Morris co., N. Jer. : at the E. foot of Schooler's Mountain, $47 \mathrm{~m}$. $\mathrm{N}$. by $\mathbf{E}$. Trenton. It contains about 30 dwellings, and 160 inhabitants.

Flaxpers, p. T., Suffolk co., N. Y.: on the S. side of Little Peconic Bay, 133 m. S. S. E. Albany. It contains 15 or 20 dwellings.

Frat, p. o., Pike co., Ohio: $62 \mathrm{~m}$. S. Columbus.

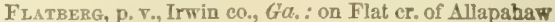
river, $102 \mathrm{~m}$. S. Milledgeville.

Fratbrook, p. 0., Columbia co., $N . Y$ 
Flatbroorvilie, p. v., Sussex co., N. Jer.: $78 \mathrm{m.} \mathrm{N}$. Trenton

F lateresa, $t$. and p. v., Kings county, $N . Y_{.}: 126 \mathrm{~m} . \mathrm{S}$. Albany. Surface diversifled, but generally level; soil, light loam and sand, well cultivated. The $\mathrm{v}$. is pleasantly situate on a plain, $4 \mathrm{~m}$. E. Brooklyn, and contains 3 churches, an academy, known as Erasmus Hall, an old and flourishing instifution, several stores, and about $80 \mathrm{~d}$ wellings. The pop. of the town, 3,176. Near the N.W. boundary of the town, the disastrous battle of Flatbush or Long Island was fought in 1776 .

Flat Creek, p. o, Montgomery co., $N$. $Y$.

Flat Creek, p. o., Lowndes county, Ga. : $146 \mathrm{~m}$. S. Milledgeville.

Frat Crefr, p. o, Bedford co, Tenn.; on a cr. of Duck river so called, $52 \mathrm{~m}$. S. S. E. Nashville.

Flat Heap lake, Oreg. Ter.: a considerable body of water at the W. side of the Rocky Mountains, in about lat. $47^{\circ} 30^{\prime} \mathrm{N}$., and the source of a main branch of Flat Head or Clarke's r., a tributary of the Columbia.

Fiat Head (or Clarke's) river, Oreg. Ter.: rises by several head streams on the W. side of the Rocky Mountains, and after a course of $260 \mathrm{~m}$., joins the Columbia r. above Fort Colville.

Flatlands, t. and p. v., Kings county, N. Y.: 128 m. S. Albany. This town includes Barren Island and several others lying off the sea-coast. Surface level; soil, sand and sandy loam. The village, about $6 \mathrm{~m}$. from Brooklyn, contains about 30 dwellings. Pop. of town 1,155.

Flat Lrck, p. on, Claiborne par., La. : on Flat Lick Bayou, a tributary of Bayou Dorcheat, $216 \mathrm{~m}$. N. W. Baton Rouge.

Flat Lrck, p. o., Knox co., Ky. : on a cr. so called, 103 m. S. E. Frankfort.

Flat River, p. o., Kent co, Mich.: on Flat r., a tributary of Grand r., 43 m.W.N.W. Lansing. Flat r. (or Co-cob-auquosh) rises in two small lakes in Mecosta co., flows through Montcalm, Ionia, and Kent counties, and discharges its waters into Grand r. in the t. of Lowell. It is 8 rods wide at its mouth, shallow, and the country on its borders is hilly and broken.

Flat Rock, p. o., Henry county, $G a_{0}$ : on the W. side of Ocmulgee r., $67 \mathrm{~m}$. W. N.W. Milledgeville,

Flat Rock, p. o., Shelby co., Ind.: on Flat Rock cr., a tributary of White $\mathrm{r} ., 33 \mathrm{~m}$. $\mathrm{s}$. E. Indianapolis.

Flat Rock, p. o., Bourbon county, $K y$. : on Elkhorn cr. an affluent of Kentucky r., 43 m. E. by S. Frankfort.

Flat Rock, p. 0., Cape Girardeau co., Mo.: 153 m. S.W. Jefferson City.

Flat Rock, p. o., Henderson county, N. Car.: on Flat Pock cr., a tributary of French Broad r., 217 m. W. S. W. Raleigh.

Flat Rock, p. o., Seneca co., Ohio: $79 \mathrm{~m}$. N. Columbus.

Fut Rock, p. on Kershaw dist., S. Cor,: $41 \mathrm{~m}$. N. N.W. Columbia.

Flat Rock, p. 0., Powhatan co.; Virg.: $23 \mathrm{~m}$. W. by $\mathrm{S}$. Richmond.

Frat Rock, p. 0., Crawford co., $I l l .: 115$ m. E. S. E. Springfield.

Flat Shoazs, p. o., Meriwether co., Ga.: on Flint r., 78 $\mathrm{m}$. W. Milledgeville.

FuAt Woods, p. o., Fayette co., Penn.: $159 \mathrm{~m}$. W. by S. Harrisburg.

Frat Woods, p. o., Braxton co.g Firg.: 192 m.W. N. W. Richmond.

Fiemtvilue, p. v., Luzerne county, Penn.: 97 m. N. E. Harrisburg.

FleETWOOD ACADEMY, p. o., King and Queen co., Virg.: 29 m. E. N. E. Richmond.

FLEMING county, $K y$. Situate N. E., and contains 480 вq. m. Drained by affluents of Licking $r_{\text {., }}$ which makes its S. W. boundary. Surface in the E. and S. mountainousotherwise undulating; soils calcareous and very fertile, un- derlined with limestone. Both agriculture and manufactures are here in a prosperous condition. Farms 1,211; manue. 96; dwell. 1,983, and pop.-wh. 11,628, fr. col. 147, sl. 2,139 -total 13,914. Capital: Flemingsburg. Public Works: Lexington and Maysville R. R.

Flemirg, p. v., Livingston co., Mich.: $37 \mathrm{~m}$. E. by S. Lansing.

FIEMING, to and p. v., Cayuga co., N. Y.: 113 m.W. by N. Albany. Drained by Owasco Lake, which makes its E. border. Surface undulating; soil, clay loam, and very productive. The $\mathrm{v}$, contains about 150 irhabitants, Pop. of town 1,198

Fleming, p. v., Centre county, Penn.: 63 m.N.W. Harrisburg.

Fleming"s, p. o., Shelby crunty, Ind.: 28 m. S. E. Indianapolis

Freming's, p. o., Weakley co., Tenn. : 118 m. W. by N, Nash ville.

FleMingsBdrar, p. v., and eap. Fleming county, $K y .:$ on Stockton Run, about $1 \mathrm{~m}$. from its confluence with Fleming er. of Licking r., $71 \mathrm{~m}$. E. by N. Frankfort. It contains a fine brick court-house, etc, and about 600 inhabitants.

Flemingsville, p. v., Tioga co., $N_{0} . Y_{.}$: about $5 \mathrm{~m}$. N: by E. Owego, and $98 \mathrm{~m} . \mathrm{W} . \mathrm{S} . \mathrm{W}$. Albany. It is a thriving village of 400 inhabitants.

Flemington, p. v., Wake co., N. Car.: $12 \mathrm{~m} . \mathrm{N}$. W. Raleigh.

Flemington, p. v., and cap. Hunterdon co., N. Jer.: in a mountain valley, $23 \mathrm{~m}$. N. by W. Trenton. It contains a stone court-house, under which is the co. jail; aboat 80 dwellings, and about 600 inhabitants. Two newspapers, the "Hunterdon County Democrat" (dem.), and the "Hunterdon County Gazette" (whig), are published weekly. A branch of the Belvidere Delaware $R$. R. will extend hence to Lambertville, on the Delaware.

Flimington, p. v., Marion co., Flor.: a few miles W. of Orange Lake, 109 m. S. E. Tallahassee.

FleToher, p. v., Miami co., Ohio: on a branch of Miami river, $61 \mathrm{~m} . \mathrm{W}$. by N. Columbus. It contains several mechanie shops, and about 250 inhabitants.

FiletCher, to and p. o., Franklin county, Verm.: $85 \mathrm{~m}$. N. N. W. Montpelier. Drained by branches of Lamoille and Missisqui rivers. Surface broken; soil indifferent. The $r$. lies on an affluent of Lamoille r. Pop. of t. 1,0St.

Flewellin's Cross Roads, p. o, De Soto co., Miss.

Fuicksville, p. v., Northampton co., Penn. : 79 m. N. E. Harrisburg.

Fusve, p. o., Cherokee Nation, Ind. Ter.: on Flint er., a branch of Illinois $r$. of the Arkansas, N. of Tah-le-quah.

Funv, t., p. v., and cap. Genesee co., Mich. : 46 m. E.N.E. Lansing. Drained by Flint $r$. and its tributaries, Surface diversified-chiefly prairie; soils rich and productive. The town has large water-power. The $v$. is situated on Flint r., and is a flourishing place of some 400 inhabitants, It contains a court-house, jail, etc., and has several factories, mechanic shops, and stores; and also two newspapers, the "F. Republican" (dem.), and the "Genesee Whig," both issued weekly. The United States" road passes through the village. Pop. of t. 3,304

FutNt, p. o, Steuben co., Ind. : 146 m. N. E. Indianapolis, Flint Creek, p. o., Ontario county, $N . Y_{.}:$on a cr. so called, $167 \mathrm{~m}$. W. Albany.

Futvt Creek, p. o., Harrison eo., Miss.: on a branch of Red cr. of Pascagoula r. so called, $118 \mathrm{~m}$. S. S. E. Jackson.

Funt Creek, p. o., Lake co., $1 l^{\prime}$ : : on a cr. so called, 183 m. N. E. Springfield. Lake Zurich, a beautiful sheet of water of 800 acres, lies immediately N. W. of the site.

Flint Gap, p. 0., Knox co., Tenn.: 168 m. W. Nashville. Finvt HiLl, p. o., St. Charles co, Mro, : on a small affluent of Riviere au Cuivre, $73 \mathrm{~m}$. E. N. E. Jefferson City.

Furvt Hill, p, o., Rappahannock county, Jirg. : $98 \mathrm{~m}$. N. N. W. Richmond.

Finnt Island, p. on, Mead county, $\bar{K} y_{0}: 89 \mathrm{~m}$. W. by $\mathrm{s}$. 
Frankfort. Flint Island lies in the Ohio r., on the Kentucky side, about $2 \mathrm{~m}$. below the $\mathrm{v}$. of Concordia.

Flint Ridge, p. o., Lancaster district, S. Car.: $67 \mathrm{~m}$. N. by E. Columbia.

Flisx river, Ga.: a constituent of Appalachicola r. It rises by several head branches on the S. slope of the Alleghany Mountains in Campbell and De Kalb counties, and has a course generally $\mathrm{S}$. for about $300 \mathrm{~m}$. to its confluence with Chattahoochee $r$, on the N. line of Florida, where it is 6 feet deep and 450 feet wide. Steamboats come up to Bainbridge, $50 \mathrm{~m}$. from its mouth.

FLINT river, Mich: : a principal branch of Saginaw r., which it joins $30 \mathrm{~m}$. from its mouth. It is about $100 \mathrm{~m}$. long, and affords, with its branches, immense water-power, and boats ascend it for a distance of $20 \mathrm{~m}$. from its mouth.

Flint Rock, p. o., Catawba co., N. Car.: on the S. side of Catawba r., $13 \mathrm{~s} \mathrm{~m}$. W. Raleigh.

Flynt's Mris, p. o., Washington county, Ohio: on Little Muskingum r, $97 \mathrm{~m}$. E. by S. Columbus.

Furnt Spring, p. 0., Bradley co., Tenn.: $131 \mathrm{~m} . \mathrm{S} . \mathrm{E}$. Nashville.

Fuintville, p. Y., Marion dist.y S. Car. : 126 m. E. by N. Columbia.

Flippos, p. o., Caroline co., Vïrg. : 46 m. N. Richmond. Flore, p. o., Smith co., Texo : 223 m. N. E. Austin City.

Florexce, p. v., and eap. Lauderdale co., Ala.; on the N. bank of Tennessee $r$. immediately below Muscle Shoals, $197 \mathrm{~m}$. N. W. Montgomery. Its site is a plain, 100 feet above the river, which is here navigable, when full, for steamboats. The streets are 100 feet wide, and laid off at right angles. It contains a court-house, jail, a United States Surveyor General's Office, ete., several mechanic shops and factories, numerous stores, and about 3,000 inhabitants. A newspaper, the "F. Gazette," is published weekly. It is eligibly situated for commerce, having a fine agricultural country around it, of which it is the natural market, being at the head of steamboat navigation. It will also become great railroad centre between the $\mathrm{N}$. and $\mathrm{S}$., and $\mathrm{E}$. and W. lines in those directions being in progress.
FLoReNoe, p. v., Stewart county, $G c_{0}$ : on the E. side of Chattahoochee $\mathrm{r}$., $127 \mathrm{~m}$. S. W. Milledgeville. It is a flourishing village, and has considerable river trade and a large conmereial connection with the interior. Pop. 600 .

Florence, p.v. Pike co, $I l_{\text {. }}$ : on the W. side of minois river, $54 \mathrm{~m}$. W. by S. Springfield.

Florence, p. v., Boone co., $\bar{K} y .: 61 \mathrm{~m}$. N. Frankfort.

Florence, p. v., Morgan co, Mo.: on the S. fork of Riviere a la Mine, $46 \mathrm{~m}$. W. Jefferson City.

Florence, to and p. on, St. Joseph's con, Mich.: $8 \mathrm{~m} . \mathrm{S} . \mathrm{W}$. Lansing. Drained by a tributary of St. Joseph's $\mathrm{x}$, which affords mill-power. Surface diversified; soil deep and rich, producing grain abundantly, and furnishing excellent pasture.

FLORENCE, t. and p. o., Oneida county, N. Y.: $112 \mathrm{~m}$. W. N.W. Albany. Drained by tributaries of Fish cr. Surface gently undulating; soil sandy loam. The $\mathrm{v}$. is near the centre, and contains about 20 dwellings. The Watertown and Rome R. R. touches upon the S. W. corner of the town. Pop. 2,575

Florexce, t. and p. $\nabla$. Erie co., Ohio: $97 \mathrm{~m}$. N. by E. Columbus. Drained by Vermillion and other creeks of Lake Erie. Surface rough; soil generally fertile. Iron ore is very abundant. The village, near the centre of the town, and also Birmingham, on the Vermillion, are both flourishing places. Pop. of t. 1,491.

Florence, p. $\nabla$. . Washington co., Penn.: in the N. W. part of the co., $192 \mathrm{~m}$. W. Harrisourg. It is a flourishing village of 600 inhabitants, and has a newspaper, the " $\mathrm{F}$. Enterprize," published weekly.

Florence, p. V., Switzeriand county, Ind.: $88 \mathrm{~m} . \mathrm{S} . \mathrm{E}$. Indianapolis.

Florence, p. v., Fremont county, $I a_{*}: 242$ m. W. S. W. Iowa City.

Florence, v., Louisa county, $1 a_{.}:$on the Iowa r., $46 \mathrm{~m}$. S. S.E. Iowa City. It was in this vicinity that Black Hawk, the celebrated Indian Chief resided until 1832, and here rest the remains of his ancestors.

FLoRID, p. o., Putnam co., Ill.: 122 m. N. by E.Springfield.

\section{THE STATE OF FLORIDA.}

Flortod, the most southerly of the Atlantic States, consists of a long, narrow strip on the northern shore of the Gulf of Mexico, extending from the Atlantic coast to the River Perdido, and of a vast peninsula, 320 miles in length, and about 150 miles broad, separating the Gulf of Mexico from the Atlantic Ocean. It lies generally between latitudes $25^{\circ}$ and $31^{\circ}$ north, and between longitudes $80^{\circ}$ and $87^{\circ} 45^{\prime}$ west from Greenwich, or $22^{\circ} 58^{\prime}$ and $10^{\circ} 43^{\prime}$ west from Washington, and comprises within its limits an area estimated at 53,756 square miles.

The southern portion of Florida, from about $280 \mathrm{~N}$. latitude, is an extensive marsh, which during the rainy season, between June and October, effectually prevents an overland passage from one shore to the other. North of this tract to Georgia, the surface of the country is generally a dead level, but in some parts it is undulating, and even presents some eminences worthy the name of hills. The face of the country, west of the neck of the peninsula, is somewhat more uneyen, but it contains no considerable elevations.

The Great Southern Marsh contains numerous tracts of pine land, prairies, and hummocks, and the more northerly part of the peninsula consists chiefly of fine forests, interspersed with hummocks, prairies, and marshes. The soil is generally sandy, except in the hummocks, in which it is clay, mixed with sand. These hummocks are scattered throughout the country, and vary in extent from a few acres to thousands, but forming in the aggregate only a small portion of the whole surface. They are covered with a growth of red, live, and water oak, dog-wood, magnolia and pine, and afford, when cleared, excellent arable land. The prairies, or savannahs, as they are here called, are sometimes pretty extensive, stretehing for several miles in length and breadth, and forming natural pastures. The barrens are overgrown with pine forests, with little underwood, and though the soil is generally indifferent, it is sometimes productive. The swamps or morasses, which form so conspicnous a feature in the country, are either formed by the inundations of the rivers, which, overflowing the high-wooded ridge that forms their banks, cover the lowlands in the rear with water, or they are produced by the drainage of the surrounding country; the latter, or pine-barren swamps, are overgrown with pine, eypress, and erpress knees; and the former, or river swamps, are covered with a heavy growth of various timber.

The rivers of Florida are numerous, and they afford raluable navigable channels. The St. John's rises in the Great Southern Marsh, and reaches the ocean after a northerly course of nearly 300 miles, in lat. $30^{\circ} 20^{\prime}$ north; for nearly 100 miles from its mouth it forms a wide, sluggish sheet of water, more resembling a lagoon than a river, and it is navigable to Lake Gurge, a little higher up, for ressels drawing s feet of water. Indian River is a long lagoon, having much the same character, and communicating with the ocean by Indian River Outlet. Charlotte and Amaxura are the principal rixers on the western side of the peninsula, the whole of which, south of the St. John's and Suwanee, contains only small strums. The suwanee is formed by the junction of the Withlacoochee and Little St. John's from Georgia, and reaches the Gulf at Yacasasa Bay; its bar has only 6 feet water at high tide. The Ocklockonee also rises in Georgia, and flows into Appalachicola Bay. The Appalachicola, formed on the frontier of Florida by the junction of the Chattahoochee and 


\section{FLORIDA.}

Flint rivers, falls into the bay of the same name, after a course of 75 miles, and is navigable for steamboats throuctout its whole length. The Choctawatchee, rising in Alabama, flows into the bay of its name, and the Escambia into Pensacola Bay. The St. Mary's forms in part the northern boundary, and is a fine navigable stream.

Florida has a sea-coast of more than 1,000 miles in Iength, but so much of it is rendered inaccessible by soundings, that it has few good harbors. West of Cape San Blas the shore is bold, but east of that point it begins to shallow. From Appalachee Bay to Tampa Bay the whole coast sends off shallow banks, and from Wacasasa Bay to the Amaxura there nre but six or seven feet of water six miles from shore; to the south of Carlos Bay the shores are bolder, On the eastern side there is no harbor south of San Angustine, and scarcely an inlet breaks the coast from tbat point to Cape Florida.

Snuth from the mainland, a chain of small rocky islands, named cayos or keys, extends to the westward, ending in a cluster of rocks and sand-banks, called the Tortugas, or Dry Tortugas. South of the bank upon which these keys rise, and separated from them by a navigable channel, is a long, narrow coral reef, known as the Florida Reef. The most important of these keys is Key West, a nautical corruption or free translation of Cayo Hueso (Bone Key), also called Thompson's Island. Long the haunt of smugglers and pirates, it is now a naval station of the first importance, and the seat of bands of wreckers, whose business is to assist vessels in distress; and a special court is here established to adjust salvages. The marine disasters occurring in this vicinity are frequent; the number of vessels which put into the port of Key West in distress, in 1850, and which had been ashore on the reef, was thirty, valued with their cargoes at $\$ 929,000$, and on these the salvage and charges amounted to $\$ 200,860$. This key is about six miles in length by two in breadth, with a large, well-she ered, and commodious harbor, which admits the largest vessels. The salt ponds, on the key, have of late years yielded con lerable quantities of salt, and are very valuable to those engaged in the manufacture. The Tortugas derive their name from the immense number of turtles that visit them and the adjacent keys and mainland for the purpose of depositing their eggs. The turtles here are of several kinds, and form an article of considerable traffic.

The whole of the peninsula is of diluvial formation. The substratum of the eastern part is clay mixed with sand, but that of the western is a kind of rotten limestone, which in many places is undermined by subterranean streams, forming numerous cavities in the ground, called "sinks." These sinks are inverted conical hollows, varying in size from a few yards to several acres, at the bottom of which running water often appears. The central district is the most productive; but even of this district a large portion is composed of poor pine-barrens, yet in the midst of these are found gentle eminences of fertile land, supporting a vigorous growth of oaks and hickories, while numerous rivulets of pure water flow through the country, or expand into beautiful lakes. Farther west the land is more generally poor. Thus it appears that but a comparatively small portion of Florida can be said to be available for cultivation, yet the warmth and humidity of the elimate compensate in a great measure for the stubborn nature of the soil, and give it a vegetation of great variety and luxuriance.

The productions, natural and agricultural, of Florida, are chiefly those which require a tropical sun to matare their fruits. It is not, however, merely in tropical products that Florida possesses advantages over every other State of the Inion: it is now established beyond a doubt that the Sea Istand, or long staple cotton (the production of which was formerly confined to a few small islands in South Carolina and Georgia) will grow luxuriantly even in the very centre of the peninsula. A fine quality of this staple has also been produced on the Suwanee, and in the very centre of the Alachua, as well as on the eastern coast. This important fact is no doubt attributable to the almost insular position of the State. The soils are also adapted to the successful cultivation of the coffee plant, also cocoa, the gugar-cane, cottons generally, Cubs and other tobaccoes, rice, indigo, arrow-root, Sisal hemp, New Zealand flax, etc., and the climate is suitable for the cochineal insect and silk-worm; corn, potatoes, turnips, and, in short, most of the vegetables known to the North or Suuth, find in one or other locality congenial soils. The fruits produced are too numerous to recount, and of the most delicate descriptions: oranges, lemons, limes, pine-apples, olives, grapes, etc., flourish luxuriantly, and if properly attendea to, would soon become valuable export staples. As matters stand at the present time, indeed, Florida supplies much of the tropical fruit found in the markets of our northern cities. It has every delicacy of vegetable culture, and at all seasons of the year; beets, onions, egg-plants, carrots, lettuce, celery, cauliflowers, etc., are produced with the most indifferent culture; and water-melons, cantelopes, pumpkins, cucumbers, and every thing that grows upon vines are in abundance and in great perfection. The driest seasons are relieved by heavy dews, and the sun that would bake the earth in other States, and wither the vegetation, is here so tempered by the prevailing moisture as to force the development of regetable life to the utmost, and envelop the earth in perennial verdure.

The climate of Florida has been spoken of, and justly, as one of the finest; and, aside from the miasms that arise from the swamps, as one of the most salubrious in the world. In the south the temperature scarcely changes the year round, and summer is only distinguished by the copionsness of its showers. No more delightful residence for invalids can be found than Key West, where the difference of the mean temperature of summer and winter is not more than 110 Falh. And what is said of Key West will equally apply to other portions of Southern Florida: Miami, on Key Biscayne Bay, has a climate at once placid and constant, and presents to the invalid of the North a desirable retreat from the rude blasts peculiar to that region; and were suitable accommodations prepared for their reception at the points indicated, numbers of those who now annually go to Cuba and the other West India Islands, would be induced to stop short on their voyage, and try the adrantages of so delightful a home climate. The average mean temperature of the State generally is about 730 , and in no place does the difference between summer and winter exceed 250 . The mean arerage quantity of rain during the year is 33 inches.

The grassy prairies of this country afford excellent pasturage, and have long been feeding grounds of the southern grazier; immense herds of cattle are constantly roaming over these, requiring no care from their owners, nor housing on account of the colds of winter; and in most parts of the State hoss thrive well and fatten without any other support than that which they derive from the abundant roots and mast of the country. And there is certainly no portion of the United Btates where game and fish are so abundant as in Florida. The fact that a large body of Indians supported themselves well for the space of seven years, while hunted themselves by an army of 6,000 men, is some evidence in proof of this assertion. It was common before the war for a good hunter to kill seven or eight deer of a day, and multitudes of these animals were slaughtered merely for their skins. The country abounds also in wild turkeys, partridges, geese, ducks, curlews, and various other species of smaller game. The whole coast is productive of the finest fish, and the oysters especially are of excellent flavor. Sheep-head, grouper, red-fish, mullet, green turtle, etc., are to be found in inexhaustible abındance at almost every point, both on the eastern and western coasts; and the numerous lakes, rivers, and ereeks of the interior teem with fresh-water fish, and the most delicious species of soft-shelled turtle, etc. On many parts of the coast sponges are found, and in this product the trade is constantlyincreasing. 
FLORIDA.

Wlorida contains 28 counties, the general statisties of which, and the capitals of each in 1850 , were as follows:

\begin{tabular}{|c|c|c|c|}
\hline :Counties. & Pop. & $\begin{array}{l}\text { Farms Manuf. } \\
\text { in cult. Estab. }\end{array}$ & Capitals. \\
\hline Alachua..... 274 & 2,524 & $\ldots 233 \ldots 0 \ldots$ & Newnanville \\
\hline Senton ...... 113 & 926 & $\ldots 82 \ldots 0$ & Melendez \\
\hline Calhoun ..... 165 & 1,377 & $\ldots 63 \ldots 1$ & St. Joseph \\
\hline Columbia .... 596 & 4,808 & $\ldots 475 \ldots 3$ & Alligator \\
\hline Dade ...... 23 & 159 & $6 \ldots 2$ & Miami \\
\hline Duval ....... 451 & 4,589 & $\ldots 167 \ldots 5$ & Jacksonville \\
\hline Escambia ... 563 & 4,351 & $\ldots 84 \ldots 9$ & Pensacola \\
\hline Franklin ....261 & 1,561 & $0 \ldots 0$ & Appalachicola \\
\hline Gadsden ... 6 6S4 & 8,783 & $\ldots 482 \ldots 0$ & Quincy \\
\hline Hamilton ... 301 . & 2,469 & $\ldots 205 \ldots 0$. & Jasper \\
\hline Hillsboro' . . 253 & 2,377 & $\ldots 120 \ldots 9$ & Tampa \\
\hline IIolmes ..... 267 & 1,644 & $\ldots 103 \ldots 0$ & Cerro Gordo \\
\hline Jackson .....5 560 & 6,639 & $\ldots 287 \ldots 0$ & Mariana \\
\hline Jefferson . ...520 .. & 7,718 & $\ldots 377 \ldots 7 \ldots$ & Monticello \\
\hline
\end{tabular}

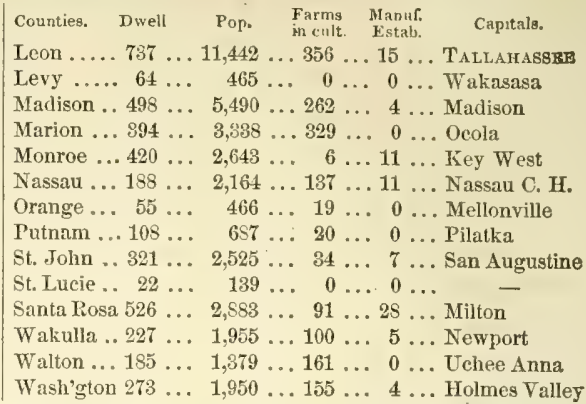

The whole number of dwellings in the State was, at the above date, 9,022, of families 9,107, and of inhabitants 87,401 , viz.: whites, 47,167-males, 25,674, and females, 21,493; free colored, 925-males, 420, and females, 505, and slaves, $39,309$. Of the whole population, the following classes and numbers of persons were blind, deaf and dumb, insane or idiotic: deaf and dumb-wh. 12, fr. col. 0, sl. 10-total 22 ; blind-wh. 12, fr. col. 2, sl. 12-total 26; insane-wh. 6, fr. col. 0, sl. 2-total 8; itiotic-wh. 29, fr. col. 1, sl. 7-total 37. The number of free persons born in the United States, was 45,320 ; of those born in foreign countries, 2,757 ; and of those whose country was unknown, 5S: the native population originated from-Maine 140, N. Hanp. 61, Verm. 55, Mass. 235, R. I. 66, Conn. 179, N. York 614, N. Jer. S3, Penn. 240, Del. 9, Md. 194, Dist. of Col. 33, Virg. 643, N. Car. 3,537, S. Car. 4,470, Geo. 11,816, Flonida 20,563, Ala. 2,340, Miss. 92, La. 146, Tex. 8, Ark. 5, Tenn. 112. Ky. 87, Ob. 58, Mich. 7, Ind. 14, Ill. 8, Mo. 7, Ia, 0, Wisc. 3, Calif. 0, and the Territories 0 ; and the foreign population was composed of natives of-England 300, Ireland 875, Scotland 182, Wales 11, Germany 307, France 67, Spain 70, Portugal 17, Belgium 4, Holland 8, Italy 40, Austria 8, Switzerland 7, Russia 2, Norway 17, Sweden 23, Denmark 21, Prussia 17, Asia 3, Africa 23, British America 97, Mexico 5, South America 3, West Indies 599, other countries 87.

And the following table will exhibit the decennial progress of the population since the first census of the State taken by the United States authorities:

\begin{tabular}{|c|c|c|c|c|c|c|c|}
\hline \multirow{2}{*}{$\begin{array}{c}\text { Cersus, } \\
\text { Year. }\end{array}$} & \multirow{2}{*}{$\begin{array}{l}\text { White } \\
\text { Persons. }\end{array}$} & \multicolumn{3}{|c|}{ Colored Persons. } & \multirow{2}{*}{$\begin{array}{l}\text { Totai } \\
\text { Population. }\end{array}$} & \multicolumn{2}{|c|}{ Decennial Increase. } \\
\hline & & Free. & Slave. & Total. & & Numerical. & $\mathrm{Pe}$ \\
\hline $1 S 30$ & 18.385 & 844 & 15,501 & & 34,730 . & - & 一 \\
\hline 1540 & 943 & 81 & & & 7 & 747 & 8 \\
\hline 1850 & 47,167 & 925 . & 89,309 & 40,234 & 87,401 & 32,924 . & 60.4 \\
\hline
\end{tabular}

The industry of Florida is devoted almost wholly to agriculture and commerce, the manufactures of the State as yet being of small account, and consisting of such branches only as those the position of the inhabitants immediately demands. None of the great national manufactures have yet been introduced, and henee manufactured goods of almost every description are imported from the Northern States and exchanged for the indigenous agricultural staples of the soil-an exchange creating a large commercial movement between the different sections of the Union, and in the interior of the State itself. The statistics of the wealth and industry of the State, as furnished by the census of 1850 , and other official returns, are as follows:

Occupied Lands, etc.-Improved lands, 349,049 acres, and unimproved Iands, 1,236,240 acres-valued in cash at $\$ 6,323,109$. Whole number of farms under cultivation, 4,304. Value of furming implements and machinery, \$65\$,795.

Live-Stoct:-Horses, 10,815; asses and mules, 5,002; milch cows, 72,576; working oxcn, 5,794; other cattle, 182,415; sheep, 23,311; and swine, 209,453-valued in the aggregate at $\$ 2,880,058$. (In 1840 there were 12,043 horses, mules, etc.; 118,080 neat-cattle of all kinds ; 7,198 sheep, and 92,650 hogs.)

Grain Crops.-Wheat, 1,027 bushels; rye, 1,152 bushels; Indian com, 1,996,869 bushels; oats, 66,556 bushels; barley, 0 bushels; and buckwheat, 55 bushels. (The crops of $1939-40$ were-wheat, 412 bushels; barley, 30 bushels; oats, 13,829 bushels; rye, 305 bushels ; buckwheat, 0 bushels; and Indian corn, 895,974 bushels.)

Other Crops,-Rice, 1,075,090 pounds; tobacco, 998,614 pounds; ginned cotton, 45,131 bales of 400 pounds; peas and beans, 135,359 bushels; Irish potatoes, $7, S 2 S$ bushels; sweet potatoes, 757,226 bushels; hay, 2,510 tons; elover-seed, 0 ; and other grass-seed, 2 bushels; hops, 14 pounds; hemp, dew-rotted, 0 tons, and water-rotted, 0 tons; flax, 50 pounds ; flax-seed, 0 buslrels; maple sugar, 0 pounds; cane sugar, 2,752 hogsheads of 1,000 pounds; molasses, 352,893 gallons: wine, 10 gallons, etc. The value of orchard products was $\$ 1,200$, and of market-garden products, $\$ 5,721$. The annexed table will exhibit the staple crops of 1540 and 1850 comparatively:

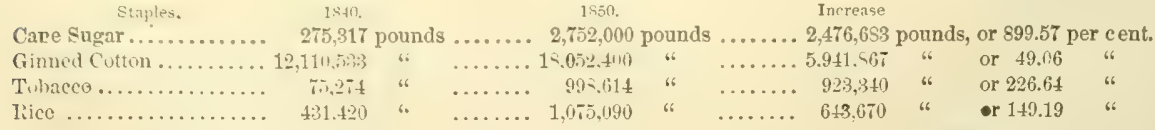

Products of Animals.-Wool, 29,247 (in 1840, 7.2S5) pounds; butter, 371.493 pounds ; cheese, 18.015 pounds ; and the value of animals slaughtered during the year had been $\$ 51 \pm, 655$. Silk cocoous were produced to the amount of 6 (in $\left.1510.124^{3}\right)$ pounds, and beeswax and honey, to that of 15,971 pounds.

Home-made manufactures for the year ending $30 \mathrm{th}$ June, 1850, were valued at $\$ 75,532$. (In 1840, $\$ 20,205$ ).

IIanufactures, - Aggregate capital invested, $\$ 1,209,107$; value of raw material, fuel, etc., used and consumed, $\$ 412,030$; arerage number of hands employed, 1,192 - males, 1,112 , and females, 80 ; average monthly cost of labor-male, $\$ 37,216$, and femall, s9.872 : anuual value of proiluets, $\$ 962.114$. The whole number of manufacturing establishments, producing to the annual value of $\$ 500$ and upward, was one hundred and twenty-one. 


\section{FLORIDA.}

Commerce, F Florida, in the year ending 30th June, 1550, exported to foreign countries to the value of $\$ 2,623,624$, of which amount $\$ 2,607,96 \mathrm{~S}$ represented domestic produce, and $\$ 15,656$ foreign merchandise re-exported. The proportion. of the total value of domestic produce carried in foreign bottoms, was $\$ 1,493,999$ - the remainder in national vessels. The foreign imports for the same year amounted in value to $\$ 95,709$, of which $\$ 30,241$ was carried in American, and $\$ 65,465$ in foreign vessels. The greatest portion of the exports are cleared from Appalachicola, which is also the outlet of Eastern Alabama, and South-western Georgia, whence produce is brought down the river in steamboats. The shipping entered at all the ports of the State amounted to 17,950 tons, of which was foreign 10,462 tons; and the shipping cleared, to 22,156, of which was foreign 12,134 tons. The tonaage owned in the several collection districts of the State, was as follows:

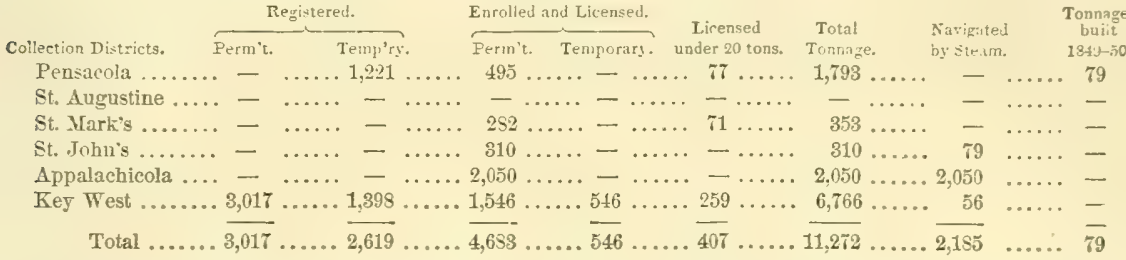

The coasting trade of Florida is immensely larger than its direct foreign trade, and employs a large tonnage both of steam and sail vessels. Of the cotton exported in $1851,70,547$ bales were sent direct to foreign ports, and 111,532 constwise, and so with other staples-which facts illustrate the course of Florida commerce. The statisties of the foreign commerce of the State for a series of years, exhibit the following movements:

\begin{tabular}{|c|c|c|c|c|c|c|c|c|}
\hline Years. & Imports. & Exports. & Years. & Implorts. & Exports. & Years. & Imports. & Expmise \\
\hline $1821 \ldots$ & $\$ 13,270$ & $\$$ & $18: 31$ & $\$ 115,710$ & $\$ 30,495$ & 1511. & $\$ 145,151$ & $\$ 36.629$ \\
\hline $1522 \ldots$ & 6,577 . & $1, \pi 77$ & 1532. & $306, \$ 45$ & $65, \pi 16$ & $1 \leqslant+2$. & $176,930$. & 33.251 \\
\hline $823 .$. & $4,808$. & 1,510 & 1533 & 85.356 & 61,505 & 1543 & 632 & $7611.6=5$ \\
\hline 624 . & 6,986 & 216 & 1534. & 135,798 & 223,525 & 1544 & 695 & 416 \\
\hline 1525 & 3,218 & 2,865 & 1835. & 98,173 & 61,710 & 1845 & 563 & 15 \\
\hline$\$ 26 \ldots \ldots$ & 16,590 & 200 & 1836. & $121, \pi 45$ & 71,662 & 1816 & 140,581 & 6. 143 \\
\hline 827 & $25 \pi, 994$. & 57,486 & $133 \pi$ & 305,514 & 90,054 & 1517 & $1+3,293$ & 1.510 \\
\hline 1523 & 168,292 & 60,321 & $1538 \ldots \ldots$ & 165,690 & 122,532 & 1843 & 64,267 & $1,896,683$ \\
\hline 1529 & 158,642 & 56,086 & 1839 & $2 \pi 9,233$ & 334.906 & 1549 & 63,211 & $2,51 \leq, 0$ \\
\hline 530 & $32,6 \mathrm{~S} 9$. & 7,570 & 1840 . & 190,728 & $1,858,850$ & 1850 & 95,709 & $6,623,624$ \\
\hline
\end{tabular}

Internal Communication.-Florida, beyond those provided by nature, has but few means of internal communication. In the south there are several military roads to depend on; and in the north, where greater progress has been made in the settlement of the country, there are some short railroads, and more progress has been made in opening inter-communication by ordinary roads. There are, however, several public works of great importance to the prosperity of the State projected ; one of which, the Ship Canal, or railroad across the neck of the peninsula, will be of vital importance to the commerce of the Gulf of Lexico; and the railroads from Savannah and Brunswick to Appalachicola, will also be tho means of opening up the southern parts of Georgia to the Floridian Gulf ports. There is also a railroad projected from some point on the St. Mary's River to Pensacola.

Government-The constitution of Florida provides that all free white male citizens, twenty-one years of age, who shall have resided in the State two years, and in the county six months next preceding, shall be eligible to rote at elections.

The Legislature, styled the General Assembly, consists of 2 Senate and House of Representatives. Representatives aro elected for one year, and senators for two years. Representation is apportioned every ten years according to population, three-fifths of the slaves being counted in the representative numbers. The general election takes place on the first Monday of October, and the Assembly meets biennially on the third Nonday in November.

The governor is elected by a plurality of votes for four years, and is ineligible for the four years next after. He must be at least thirty years of age, and have been ten years a citizen of the United States, or an inhabitant of Florida at the adoption of the constitution, and a resident thereof for flve years next before the election. The governor has a qualified veto on all legislative acts. In case of the disability or death of the governor, first, the President of the Senate, and second, the Speaker of the House of Representatives act in his stead for such part of the term as may be unexpired.

No officer in 2 banking company, while he serves in a bank, or for twelve months afterward, shall be eligible for the office of governor, senator, or representative; nor shall a duelisi or second in a duel hold any office under the State. The Secretary of State is elected by the Legislature for four years.

The Judiciary corsists of a Supreme Court, Cireuit Courts, and several courts of minor jurisdiction. The Supreme Court has appellate jurisdiction only, and is composed of a chief justice and two associate justices. It holds four sessions annually - one at Tallahassee, on the first Monday of January; one at Jacksonville, on the third Monday of February ; one at Tampa, on the first Monday of Mareh; and one at Mariana, on the third Monday of March. When one or two of the judges are disqualified from sitting in any cause, the vacancy is flled by a corresponding number of circuit judges. For the purpose of holding Circuit Courts, the State is divided into four circuits, viz., the Westerm, the Middle, the Eastern, and the Southern, to each of which there is one judge. The Circuit Courts have original common-law jurisdietion in all matters, civil and criminal, and also original equity jurisdiction, until a separate Chancery Court is established by the Legislature. The judges are now elected by concurrent rotes of the two houses of the General Assembly. An act was passed, however, in 1550-51, giving the election to the people, and limiting their term to six years; but this act has to be sanctioned by another Legistature before becoming law.

Respecting kanking, the constitution provides that "no bank charter shall be for more than thirty years, nor shall it ever be cxtended or renewed. The eapital of a bank shall not exceed $\$ 100,000$, nor shall a dividend be made exceeding 16 per cent. a year. Stockholders shall be individually liable for the debts of the bank, and no notes shall be issued for less than \$5." And, in relation to corporations, it further provides, that "no act of incorpontion shall be passed or altered except by the asscint of two-thiris of each hous", and by giving three months' notice." "The credit of the state shall not be pledged is aid of any corporation whatsoever." 
FLORIDA.

With regard to slavery, the same instrument says: "No law shall be passed to emancipate slaves, or to prohibit the immigration of persons bringing slaves with them; but free colored persons may be prevented from entering the State."

For an amendment of the constitution, two-thirds of each house must assent; the proposed alteration must then be published six months before the succeeding election, and then be again approved by a two-thirds rote in the succeeding General Assembly.

Florida, under the law-distributing congressional representation, has only one representative in Congress.

Finances, etc.-The assessed value of all real and personal property in the State in 1850 , was $\$ 22,784,837$; the value truly estimated, $\$ 2,862,270$. Florida has no public debt. The balance in the treasury for the year ending 1 st Nov., 1847 , was $\$ 3,75510$; and the receipts for the year ending 1st Nov., 1848, amounted to $\$ 56,83272$-making the resaurces for that year $\$ 60,587$ 82. The aggregate expenditures during the year were $\$ 59,25972$, leaving in the treasury, for future disbursement, $\$ 1,32310$. The average ordinary expenses of the government, however, is only about $\$ 45,000$ per annum.

Religious Denominations.-The statisties of the religions denominations of Florida, according to the census of 1859 , are as follows :

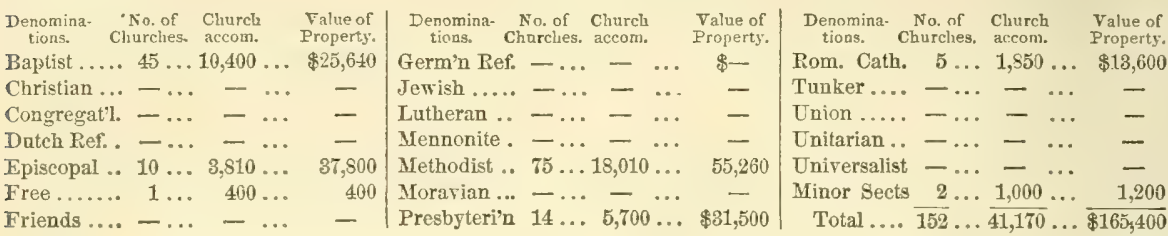

Florida is a diocese of the Protestant Episcopal Church; and it constitutes parts of the Roman Catholic dioceses of Savannah and Mobile-in the diocese of Savannah is included all of the State east of the Appalachicola, and in that of Mobile all west of that river.

Education.-Florida is as yet but ill provided with schools; it has no institutions in which a liberal education can be obtained, nor are the existing public schools or academies efficient in their organization. The State has ample means for the support of public schools from the proceeds of the lands designated by Congress for that purpose, and the State constitution makes it imperative on the Legislature to organize and provide for a system of public education. The pecaliar circumstances of the people, and the sparsity of the population, however, will, for a long time to come, present obstacles to the operation of any system devised, and more than apologize for any defleiencies that may be observed in the educational condition of the inhabitants. These matters must be left to time and favoring circumstances.

Periodical Press.-There are 11 newspapers published in the State, of which 10 are issued weekly, and 1 semi-weekly; and of these 5 are whig in politics, 3 democratic, 1 neutral, and two, the politics of which are not stated in the census. The semi-weekly paper has an average circulation of 200 at each issue, or 20,800 copies annually; and the 10 weekly papers an aggregate circulation of 5,550 , or 258,600 copies annually, maling the 309,400 copies the total anual issue. The papers having the largest circulations are, the "Commercial Advertiser" of Appalachicola, which is 1,500 copies weekly ; the "Sentinel," and "Floridian and Journal" of Tallahassee-the first having a weekly circulation of 1,300, and the Iatter of 800 , and the "Florida Republican," which issues 700 weekly; none of the others circulate more than 400 copies of each issue.

Hestorical SFetch.-The adventures of Narvaez, and the romantic wanderings of Ponce de Leon and De Soto, the buccaneering of the English, the wars waged with Oglethorpe by the Spaniards, and more recently, the long and bloody Indian wars, have given to Florida a greater historical interest than attaches to any other portion of the Union. But as one of the youngest sisters of our confederacy, but comparatively little is known of its geography, resources, and productions. Peninsulated from almost all intercourse with other States, it lies out of the great thoroughfare of travel; and while the commerce of the Great West sweeps around its shores, they are looked upon as so many dangerous reefs and rocks, threatening destruction to the mariner. In the foregoing sketch the aim has been to give an idea of the present actual state and condition of the country. Its history is briefly as follows:

Florida was discovered in 1496 by Cabot, and was visited by Ponce de Leon in 1512, who came in search of the spring of perpetual youth and beauty, and fabled mines of gold, the fame of which had filled all Europe. In 1562 we find the French and Spaniards contesting their respective rights to the soil. San Augustine was settled in 1564 , it being by forty Jears the oldest settlement in the United States. Pensacola was settled in 1596.

The archives cf the country during the Spanish rule having been carried away, it is difficult to judge to what extent the country was settlea previous to its cession to Great Britain. Remains of ancient settlements exist between the Suwanee and Chattahoochee rivers; the traces of old fortifications, roads, etc., are very distinct, and gun-barrels, pottery, ship-spikes, etc., are found; but the public opinion of the country is rather inclined to attribute these to the buccaneers, and the quantity of ship-spikes, etc., found, seem to render the opinion highly probable. It is presumable, therefore, from the known inertness of the Spanish character, and the slight progress made by them in the scttlement of new countries, that their settlements in Florida were of very little extent; and, with the exception of establishing a few missions, they never ventured far from the coast, and paid but little attention to the cultivation of the soil.

The cession to Great Britain was made in 1763: most of the Spaniards left the country, and it, soon began to prosper under the energetio impulse communicated by the Anglo-Saxon race. Efforts at settlement on a large scale were immediately undertaken, the gorermment favoring the enterprise by granting large tracts to settlers. Doctor Turnbull brought 1,500 families from the islands and shores of the Mediterranean, and located them at New Smyrna; and Lord Rolle, Governor Moultrie, Lord Beresford, and others established settlements; and on the breaking out of the Revolution, large numbers of royalists came into the country from Georgia and Carolina. In 1790 the exports of Florida reached 40,000 barrels of naval stores; and at this time one of the principal articles of eulture was indigo, which in the markets of London brought a higher price than that from any other country. The British possession of the country continued for but twenty years, but during that period more was effected in settling and improving the country than in the two bundred years of Spanish occupation.

But, unfortunately for Florida, in 1783 the province was retro-ceded to Spain, and the English population, which in $17 \pi 8$, in East Florida alone, numbered over 13,000 , principally len the country and went into the adjoining States. From 322 
this period to its cession to the Lnited States in 1521-a period of nearly forty years-it languished and atrugscled along with difficulty; cultivation was neglected, the English settlements having been allowed to go to ruin; and at no time during this period was the population in both the Floridas estimated at over 10,000, a large portion of whom lived in towns, or were hangers-on of government. - The Spanish population, to a considerable extent, left the country upon its cession, and immigration began to flow in rapidly; but the unsurveyed state of the country, the uncertainty of land-tifles, etc., militated against its settlement; and the fierce and turbulent Indian race, who had made it a battle-ground for over two hundred and fifty years, and who had never been conquered, and had no egress from their peninsular home, occupied the best lands, rendering it impossible to obtain them. But yet in spite of all these obstacles, a considerable population planted themselves in the country.

The territory was now beginning to reap the fruits of its American occupation, when in 1835 the desolating Seminole war broke out and continued for seven years, rendering all habitation out of the limits of the occupied parts insecure, and destroying all the improvements which had been undertaken. In 1842 this war terminated, and the Indians, after a struggle of nearly three hundred years, were forced to yield, and were nearly all transferred beyond the Mississippi. Thus the population of Florida had, up to 1842, undergone four entire revolutions, and after having been settled by the European race for two hundred and eighty years, was forced to begin anew the settlement of the country. Since this period, however, it has progressed with reasonable rapidity, and in 1815 it was admitted into the Union as an independent State. The few Indians now remaining, although they have given some temporary trouble to the inhabitants, have lately made up their minds to abandon their lomes, and will, before long, be domiciled with their brethren in the country beyond the limits of the white settlements, set apart for them by the beneficence of the Government, where alone they can be protected from utter annihilation.

TALTAHASSEE is the political capital of the State.

Florma, t. and p. 0., Hillsdale co., Mich. : $56 \mathrm{~m}$. S. by W. Lansing.

FlordoA, p. v., Monroe co., Mo.: on the S. side of the $\mathrm{N}$. fork of Fall r., $67 \mathrm{~m}$. N. by E. Jefferson City.

Florida, to and p. o., Berkshire county, Mass.: $106 \mathrm{~m}$, W. by $\mathrm{N}$. Boston. Drained by Cold $\mathrm{r}$. and other tributarics of Deerfield r., which have extensive water-power. Surface hilly; soil adapted to grass. Pop. 561.

Florma, p. v., Orange co., N. Y.: 94 m. S. by W. Albany. It has several mills and about 300 inhabitants.

Florida, p. v., Henry county, Ohio: on the N. side of Maumee r., and on the line of the Wabash and Erie Canal, $112 \mathrm{~m}$. N. N. W. Columbus. It is a flourishing place of 200 inhabitants.

Florida Bend, p. o., Aroyelles par., La.: $62 \mathrm{~m}$. N.W. Baton Rouge,

Flosis, p. v., Davis co., Ia : on a branch of Chequest cr. of Des Moines r., 67 m. S. S. W. Iowa City.

Frorisart, p. v., St. Louis county, Mo, : on Cold Water creek, a small stream of Missouri river, $106 \mathrm{~m}$. E. by N. Jefferson City.

Floukroys, p. o., Nacogdoches co, Tex, : 226 m. E. N. E. Austin City.

Flower CReEk, p. o., Pendleton county, Ky.: on a cr. of Licking r. so called, $57 \mathrm{~m}$. N. E. Fraukfort.

Flowerfieid, $t$, and p. o., St. Joseph's co., Mich. $: 78 \mathrm{~m}$. 8.W. Lansing. Drained by Rocky $r$ of St. Joseph $r_{*}$, which, with its tributaries, affords extensive mill-power. Surface dirersified; soil, a deep-black allurion, or vegetable mold. The $t$. contains several saw and flouring mills, but is as yet thinly populated. Pop .563.

FrowerT MoGND, p. o. Concordia parish, La.: $92 \mathrm{~m}$ N. N.W. Baton Rouge.

Floyd county, Ga. Sitante N. W., and contains 459 вq. m. Drained by the Oostanaula and Etowah rivers, uniting in the E. part of the county: these form the Coosa, which runs W. into the Alabama. Several minor streams, affuents of the rivers above named, also traverse the country. Surface hilly and broken; soil, exeept on the alluvial borders of the rivers, of indifferent quality. The crops of this $e_{0}$, are more various than in the S. counties, and consist chiefly of corn, wheat, etc., with a little cotton. Grazing is extensively practiced. Farms 397 ; manuf. 15; dwell. 866, and pop.-wh. 5,202, fr. col. 4, sl. 2,999-total 8,205. Capital : Rome. Public Works: Rome R. R.; Rome and Jacksonville R. R.

FLoYd county, Ind. Situate on Ohio r., and contains 144 sq. m. Drained by Silver and other creeks. A range, called the "Knobs," traverses the co, in a N, and $\mathrm{S}$, direction. These hills, from 1 to 3 miles wide, are eovered with the timber-oak and pine. Soil various-little first rate.
Corn and grasses are the chief products. Manufactures and ship-building are carried on extensively near the Ohio Farms 428; manuf. 106 : dwell. 2,448, and pop,-wh. 14,305, fr. col. 570-total 14,875. Capital: New Albany. Public Works: New Albany and Salem R. P

F Loxp county, $I a$. Situate $\mathrm{N}$. middle, and contains 576 q. m. Taken from Pottowattomee in 1851.

Froxd county, $\bar{K} y$. Situate $\mathrm{E}_{\text {s, }}$ and contains 960 sq. $\mathrm{m}$. Drained by Licking $r$., which rises in this county, and by numerous creeks of the W. fork of Big Sandy r. Surface considerably broken, well wooded, and along the streams fertile and productive. There are deposits of iron and coal, and also salt springs. Farms 365; manuf. 4; dwell. S62; and pop.-wh. 5,503, fr. col. 62, sl. 149-total 5,714. Capital: Prestonburg.

FLord county, Virg. Situate [S. middle, and contains 525 sq. m. Drained by $\mathrm{E}$. fork of New $\mathrm{r}_{\text {, }}$, and others, its tributary creeks. Surface mountain-ralley, bounded both E. and W. by ragged bills; soil adapted to grass, oats, etc. Farms 444; manuf. 16 ; dwell. 987, and pop.-wh. 6,000, fr. col. 15, sl. 448-total 6,458. Capital; Floyd Court-house (Jacksonville).

FLOYD, t. and p, v, Oneida co, $N . Y: 87 \mathrm{~m}$. W. N. W Albany. Drained by Nine Mile cr. of Mohawk r., which forms its S. boundary. Surface rolling; soil, clay marl, adapted to grass; along the Mohawk are rich alluvial flats. The $\mathrm{v}$. lies about the centre of the t., $6 \mathrm{~m}$. E. Rome. In the town are several woolen and cotton mills, etc. Pop. 1,495.

Floyd Court-house, p. o., Floyd co., Firg.: on the S. side of $\mathbf{E}$. fork of New r., $168 \mathrm{~m}$. W. S.W. Richmond. The village is called Jacksonville. . Pop. of v. 120 .

Floydsburgh, p. v., Oldham co., $\bar{K} y_{0}:$ on Floyd's cr, of Salt r., $34 \mathrm{~m}$. W. by N. Frankfort. Pop. 120.

Flord's Mruss, p. 0, Forry dist., S. Car. : 104 m. E. by S. Columbia.

FLUKE's, p. o., Botetourt co., Virg. : $147 \mathrm{~m}$. W. Richmond.

FluMe, p. o., Grafton co., N. Hamp.: on Pemigewasset river, $66 \mathrm{~m}$. N. by W. Concord. The country in the neishborhood is one of the wildest mountain-regions of the State, and is much visited by summer tourists.

Flushrvg, t. and p. O., Genesee co., Nfich. : 87 m. E. N. E. Lansing. Drained chiefly by Coal er, of Flint $r$. Surface level and elevated; soil of moderate fertility. Pop. 708.

Flushong, t. and p. v., Queens co., N. Y.: 124 m. S. by E. Albany. Drains into Long Island Sound, which bounds it on the N. Flushing Bay makes its W. and Little Neck Bay its E. border. Surface generally level-on the S. traversed by a stony ridge; soil a sandy loam, with some clay. It is a well-cultivated $t$, and produces a vast amount of market vegetables. The v. lies at the head of Flushing Bay, and contains a Roman Catholic, Episcopal, and 2 Vethodist 
churches, and 2 Friends' meeting-houses, about 20 stores, 200 dwellings, and 2.500 inhabitants. It is much frequented in the summer months, and steamboats ply regularly to and from New Tork City. St. Paul's College, an Episcopal seminary, is situated on College Point, about $2 \mathrm{~m}$. N. of the village, Two newspapers, the "Flushing Journal," and the "Plain Dealer," are issued weekly. Pop. of t. 5, \$76.

Flushive, ts and p.V., Belmont co., Otiio : $98 \mathrm{~m}$. E. by N. Columbus. Drained by Still-water cr, of Tuscarawas r. The v. contains various mechanic shops and stores, and about 200 inhabitants, many of whom are Quakers. Pop. of t. 1,912.

Frushing bay, $\boldsymbol{N}$. $Y_{\text {.: }}$ an arm of Long Island Sound. It is 3 mile long, and about 1 mile wide, and navigable to the village of Flushing for steamboats.

Flutanna county, Virg. Situate E. centrally, and contains 416 sq. $m$. Drained by affluents of Rivanna and James rivers, the first of which passes through the $c 0$. from $\mathrm{N}$. W. to S. E., and the last marks its S. border. Surface generally broken, but between the rivers there is a level tract of barren land. Soils indifferent, except on the rivers, where they are rich allurion, and very fertile. Gold is found in all parts of the co., and has been extensively gathered in the vicinity of Palmyra. Cotton and the cereals form the chief staples. Farms 454; manuf. 51; dwell. 878, and pop.-wh. 4,539, fr. col. 211, s1. 4,737-total 9,487. Capital: Palmyra,

Fluvand , p.v., Chautauque co, $N . Y .: 279 \mathrm{~m}$.W.S.W. Albany.

Fur CreeK, p. o., La Grange co., Ind. : 183 m. N. by E. Indianapolis.

Flt Creek, p. o., Otsego co., $N . Y_{.}: 49 \mathrm{~m}$. W. Albany.

Fly Mountain, p. o., Ulster county, $N$. $\boldsymbol{Y}$.: $53 \mathrm{~m}$. S. S.W. Albany.

FLYNN's Lick, p. o., Jackson co., Tenn.: on a tributary of Cumberland r. so called, $57 \mathrm{~m}$. E. by N. Nashville.

Focht's Forge, p. o., Schuylkill co., Penn.

Fogeesville, p. $v_{*}$, Lehigh co., Penn.: 73 m. E. N. E. Harrisburg. It has about 20 dwellings.

Fonda, v., and cap. Montgomery $\cos _{0}, N_{0} Y_{0}:$ on the $\mathrm{N}$. side of Mohawk r., $37 \mathrm{~m} . \mathrm{W} . \mathrm{N}$.W. Albany. The Utica and Schenectady R. R. passes through it. Its principal buildings are the court-house, jail, etc., and it has several extensive manufacturing establishments. A newspaper, the "F. Sentinel" (whig), is issued weekly. Pop. about 600.

Foxp DU LAC county, Wisc. Situate E. middle, and contains 964 sq. m. Drained in the W. by numerous streams falling into Winnebago Lake, and in the E. by streams flowing to Lake Michigan. The Sheboygan and Milwaukie rivers are the largest of these; the soils excellent, and wood plentiful; about one half the surface prairie, and there are some swamps and ponds. Farms 921 ; manuf. 16 ; dwell. 2,721, and pop.-wh. 14,465, fr. col. 3-total 14,468. Capital: Fund du Lae. Public Worlis: Fond du Lac and Chieago R. R., and others projected; also several plank-roads.

Fond de Lac p. v., and eap. Fond du Lac co., Wixe.: on a river of the same name, near its entrance into the lake, 66 m. N. E. Madison. It is a place of active trade, and steamboats run regularly between this and other places on the lake and the Neenah r. Pop. about 2,000. A newspaper, the "Fond du Lac Journal" (dem.), is issued weekly.

FOND DU LAc, a lake, Wisc. : this lake is from 30 tn $35 \mathrm{~m}$. long, and alrut in wide, and has a depth sufficient lor the purposes of navigation. The Neenah $r$. enters it near the middle on the W. shore, and leaves it at the N. W. angle by two channels, incksing Duty"s Island. ly which it is connected with Little Butte des Miforts Lake. These channuls are known as the Tinnebago liajicls. On the $\mathrm{Y}$. extromity the shore is low, having a narrow sabdy beach for an event of about $5 \mathrm{~m}$. On the E. side the slure presents remarkable features for an extent of $15 \mathrm{~m}$, in a wall composed of rocks laid together as if placed there by the hand of art. A similar wall pertains to portions of the W. shore, but with less coutinuty than is ohserved on the $\mathrm{E}$. In many respects the scenery resubles that of seucea Lake, in 2 . I. $2 \cdot 21$
Foriush, p. 0., Surrey co., N. Car.: 123 m. W. N. W. Raleigh.

Fordiam, p. v., Westchester co, $N_{1} Y_{0}:$ on the line of the Harlem R. R., $12 \mathrm{~m}$. N. New York City. The $\mathrm{r}$. contains about 70 dwellings, and is the seat of St. John's College, a Jesuit institution, and one of the most efficient schools of the United States. It was founded in 1841, and in 1850 had 16 professors and 65 students, and a library containing 12,600 volumes. Its alumni numbered 43 . It has also a preparatory school attached. This institution is not only for those of the Roman Catholic persuasion, but is open to all.

Fordstille, p. v., Marion co., Miss.: on the W. side and about $2 \mathrm{~m}$. distant from Pearl r., $82 \mathrm{~m}$. S. by E. Jackson.

Fordstille, p. v., Ohio county, $K y_{*}: 118 \mathrm{~m}, \mathrm{~W}$, by $\mathrm{S}_{\text {. }}$ Frankfort.

Forestburger, t. and p. v., Sullivan co, $N_{0} Y_{.}: 86 \mathrm{~m}$ S. S. W. Albany. Drained by Neversink r., which affords water-power. Surface hilly; soil gravelly loam; white and yellow pine abounds. The $\mathrm{v}$, contains about 20 dwellings Pop. of t. 715 .

Forfst Ciry, p. v., Tompkins county, $N_{*} Y_{*}: 134 \mathrm{~m}$. W. Albany.

Forest DaLe, p. o., Rutland co., Verm.

Forest Hill, p. o., Decatur county, Ind.: 49 m. S. E. Inclianapolis.

Forist Ullu, p. o., Union co., Penn.: 49 m. N. by E. Harrisburg.

Forest Lake, t. and p. 0., Susquehanna co., Penn. : 137 m. N. N. E. Harrisburg.

Forest Retreat, p. o., Nicholas co., $K y .:$ on the line of the Lexington and Maysville R, R., 49 m. E. N. E. Frankfort.

Forest ville, p. v., Wake co., $N_{\text {. }}$ Car.: on the line of the Gaston and Raleigh R. R., 16 m. N. Gaston.

Forestrille, p. v., Hartford co., Conn. : on the line of the Providence, Hartford, and Fishkill R. R., 15 m. W. S. W. IIartford.

Forestricle, p. V., Delaware co, Ohio: $47 \mathrm{~m}, \mathrm{~N}$. by W. Columbus.

Forge Virlage, p. .., Middlesex co., Mass. : on the line of Stony Brook R. R., $6 \mathrm{~m}$. E. by N. Groton, and $27 \mathrm{~m}$. N. W. Boston.

Forked DeEr river, Tenn. : rises by several large branches in Carroll and Henderson counties, which in Dyer and IIaywood counties collect themselves into two principal constituents, which form the main stream a little S. W. of Dyersburg, and run thence to the Mississippi r.; which is entered by several mouths forming a deltoid, composed of several islands. The average length of the streams is about 100 miles.

Forked Rrver, p. o., Monmouth co., $\boldsymbol{N}$. Jer.

Fork Irv, p. o., Dinwiddie co., Virg. : on the Petersburg and Farmville Turnpike, $27 \mathrm{~m}$. S S. W. Richmond.

ForKLAND, p. o, Greene county, Ala.: $103 \mathrm{~m}$. W. by N. Montgomery.

Fork Meetrig House, p. O., Baltimore co., Mrd.: on the S. side of Gunpowder Falls, 84 m. N. by E. Annapolis.

Fork Rmge, p. o., Marshall county, Virg. : 228 m. N.W. Richmond.

Forks of Buffalo, p. o., Marion co., Firg.: on Buffalo creek of Monongahela $r_{\text {., }} 208 \mathrm{~m}$. N. W. Richmond. The Baltimore and Ohio R. $\mathrm{R}$. follows the valley of this stream on its $\mathrm{N}$. side.

Forks of Elkhorx, p. o., Franklin co., $\bar{k} y$. ; on Elkhorn cr., $9 \mathrm{~m}$. E. by N. Frank fort.

Forks of Mary's PrVEr, p. o., Benton co., Oreg.: on St. Mary's r., 11 m. S. W. Salem.

Forks of Prgzon, p. o., Haywood co., $\lambda$. . Car.: on Big Pigeon $r_{\text {. }}$, where it bifurcates 9 m. E. S. E. Waynesville, and $246 \mathrm{~m}$. W. by S. Paleigh.

Forkston, p. v., Wyoming county, Penn?: 98 m. N. E. Harrisburg.

Fовкsvilue, p. 0., Lake co., IU. : 196 m. N. E. Springteld. 
Forasplte, p. v., Mechlenburgh county, Firg.: $78 \mathrm{~m}$. S. TV. Richmond.

Forkstrlek, p. จ., Wachita par., La. : 152 m. N. N. W. Baton Rouge.

Forktown, p.v., Somerset co., Md. : 66 m. S.E. Annapolis.

Fork UnioN, p. o., Fluvanna co., Virg. : 57 m. W. N.W. Fichmond.

Forney's, p. 0., Lincoln co., N. Car.: 143 m. W. by S. Paleigh.

Forrest Home, p. o., Cass county, Tew. : 308 m. N. E. Austin City.

Forsyru county, $G \alpha$. Situate N. centrally, and contains 288 sq. m. Drained by affluents of Chattahoochee $r$., which demarks its E, and S. E. borders, and of the Etowah, which runs through the $\mathrm{N}$. W. corner. Surface hilly, being traversed by the rugged watershed between the Etowah and Chattahoochee rivers. Soils, except on the streams, of inferior quality. Timber abundant, and of various sorts. Gold has been found in this co, to a considerable extent. The agricultural products are the grains, with some cotton and tobacco. Farms 765 ; manuf. 8 ; dwell. 1,384, and pop. -wh. 7,812, fir. col. 11, sl. 1,027-total 8,550. Capital: Cumming.

Fonsyth county, N. Car. Situate N. middle, and contains $396 \mathrm{sq} . \mathrm{m}$. Drained by affluents of Dan $\mathrm{r}$. in the $\mathrm{N}$. and of Yadkin $r$. in the S., the latter of which forms in more than half its length the W. boundary. Surface broken soil fertile. Farms 936 ; manuf. 80 ; dwell. 1,739, and pop. -wh. 9,663 , fr. col. 152, sl. 1,353-total 11,168, Capital: Winston.

Fonsytr, p. r., and cap. Monroe co., Ga.: on a branch of Ocmulgree $\mathrm{r}, 47 \mathrm{~m}$.W. Milledgeville. It has a fine courthouse, a jail, three churches, several mechanic shops, and numerous stores, and about 600 inhabitants. A newspaper, the "Bee," is issued weekly. The Macon and Western R. R. passes through the village, $24 \mathrm{~m}$. from Macon,

Forsytr, p. V., and eap. Taney co., Mo. : on the N. bank of White r., where it is joined by Swan cr., $142 \mathrm{~m}$. S. by W. Jefferson City. It contains the co, offices, several stores, and about 80 inhabitants. One of the best agricultural sections of the State, now fast filling up with an industrious population, lies about it. The canal has here two locks, and its summit level. It contains about 600 inhabitants.

Fort Adams, p. v., Wilkioson co., Miss.: on the E. side of the Mississippi r., opposite Red River Landing, 114 m. S. W. Jackson

ForT ADAus: a U. S. military post, Department No. 1 , Eastern Division, Newport, $R . I$. Lat. $41030^{\prime}$ N., and long. $71018^{\prime} \mathrm{W}$.

Fort Arcient, p. v., Warren co., Ohio: on the line of the Little Miami R. R., 41 m. from Cincinnati, and 63 m. S. W. Columbus.

ForT ANr, to and p. v., Washington county, $N . Y$.: $58 \mathrm{~m}$. N. by E. Albany. Drained by several creeks falling into Lake Champlain and Lake George, the latter of which marks its N. W. border. Surface mountainous, but much diversified; soils various-sand, clay, and alluvion. The village is situate on the Champlain Canal, and also on the line of the Saratoga and Washington $R . R$. The eanal has here three locks, and its summit level. It contains several stores, and about 600 inhabitants. Fort Ann, a celebrated stronghold in the French and Revolutionary wars, was erected at the head of boat navigation, on Wood's cr. in 1756. The t. has several forges, tanneries, mills, ete., aud 8,383 inhabitants.

Fori Argrle, Bryan co., Ga.: on the W. bank of Ogeechee $r$., opposite the W. terminus of the Savannah and Ogeechee Canal (now closed), $16 \mathrm{~m}$. W. Savannah. The fort was erected in 1733 to protect the settlers from the Spaniards: it is now in ruins.

Fort Atktnson, p. o., Clayton co, Ia.: $84 \mathrm{~m}$. N. by E. Iowa City.

Fort Atmenson, p. v., Jefferson co., Wisc.: on the S. side of Rock r., about $2 \mathrm{~m}$. above Koshkonong Lake, and 31 m. E. S. E. Madison.

Fort Batriridge, v., Russell co.g $A l \alpha_{0}$ : at the head of Cowikee cr., 51 m. E. by S. Montgomery. The Girard and Mobile R. R. will pass through this place.

Fort Barbour, p. o., Barbour co., Ala. : 69 m. S. E. Montgomery.

Fort Barrivgton Fierx, p. v., M'Intosh co, Ga.: on the Alatamaha r., 148 m. S. E. Milledgeville. Fort Barrington lies on the $\mathrm{E}$. side of the river, about $14 \mathrm{~m}$. above Darien, was built by the Carolinians in 1720 to intercept the escape of negroes to the Spanish settlement at San Augustine, in Florida.

Fort Bewd county, Tex. Situate S. E., and contains 820 sq. m. Drained by the Brazos r. and its tributaries, and in the $W$. by the San Bernardo, which in part makes its W. boundary. Surface a uniform level, furrowed by the great rivers, on which are dense growths of timber; three fourths of the county are open prairie. Soils, on the Brazos a chocolate-colored loam, 20 to 30 feet deep-on the prairies black mold, resting upon clay. The prairies afford excellent pasturage. Farms 109 ; manuf, 0 ; dwell. 199, and pop. -wh. 974, fr. col. 5, sl, 1,554-total 2,538. Capital: Richmond.

Foex Brount, p. o., Jackson co., Tenn.: on the N. side of Cumberland r., $57 \mathrm{~m}$. E. by N. Nashville.

Fort Brady: a U.S. military post, Department No. 2, Eastern Division, Sault St. Marie, Mich。Lat. $46^{\circ} 29^{\prime} 59^{\prime \prime} \mathrm{N}$., and long. $84^{\circ} 43^{\prime} \mathrm{W}$.

Fort Bridger, p. o., Nebraska Ter. : a noted Trading Post, $131 \mathrm{~m}$. beyond the South Pass of the Rocky Mountains, and 113 from Salt Lake City. It is on the best traveled route to the Mormon settlements and California, and is well known to emigrants as a hospitable resting place, where every thing needful for comfort and health can be obtained. Col. Bridger, the owner, has resided here since 1821.

ForT Brooke: a U. S. military post, Department No. 5 , Western Division, Tampa Bay, Flor. Lat. $27^{\circ} 57^{\prime}$ N., and long. $81^{\circ} 52^{\prime} \mathrm{W}$.

Font Browner, p. 0., Barbour co., Ala.: 72 m. S. E. Montgomery.

Fort Brown: a U. S. military post, Department No. 8 , Western Division, Brownsville, Tex, on the E. bank of the Rio Grande, opposite Matamoras

ForT CAPRON : a U. S. military post, Department No. 4 Eastern Division, St. Augustine, Flor. Lat, $299^{\circ} 50^{\prime} \mathrm{N}$., and $81027^{\prime} \mathrm{W}$.

Fort CASWELl: a U. S. military post, Department No. 4 , Eastern Division, Smithrille, $N$. Corr. Lat. $34^{\circ} 00^{\prime} \mathbf{N}$., and long. $75^{\circ} 05^{\prime} \mathrm{W}$.

Fort Clark, p. o, Alachua co., Flor, : 98 m. E. S. E. Tallahassee.

Fort Columbus: a U. S. military post, Department No. 3, Eastern Division, Governor's Island, New York Harbor, N.Y. Lat, $40^{\circ} 42^{\prime} \mathrm{N}$., and $74^{\circ} 02^{\prime} \mathrm{W}$.

Fort Constimution: a U.S. military post, Department No. 1, Eastern Division, Portsmouth, $N$. Hamp. Lat. $43^{\circ} 04^{\prime}$ N., and long. $70^{\circ} 49^{\prime} \mathrm{W}$.

Font Covington, t. and p. v., Franklin co., N. Y.: 156 m. N. by W. Albany. Drained by Salmon and its tributary rivers flowing to the St. Lawrence. Surface diversifled: soil, sand and clay loam, fertile. The v. lies on Salmon r. $5 \mathrm{~m}$. from its mouth, and contains several mills and stores, and about 800 inhabitants. The t. has extensive waterpower, and is eligibly located for manufactures, having rivers navigable to the St. Lawrence. Pop. 2,659.

Fort Croghax : a U. S. military post, Department No, 8, Western Division, Hamilton Creek, Austin, Tex.

Fort DADr, p. o., Benton co., Flor.: on the W. side of Withlacoochee r., $155 \mathrm{~m}$. S. E. Tallahassee. Between this and Fort Armstrong, on the opposite side of the r., is the site of the massicre of Mujor Dade and his companions by the Indians 
Fort Decatur, p. v., Macon co., Ala.: on the $\mathrm{S}$. side of Tallapoosa r., $29 \mathrm{~m}$. E. by N. Nontgomery. It is built on the site of an old fort, and is now a flourishing v., through which the Montgomery and West Point $\mathrm{R}$. R. passes.

Fort Defrarce, p. v., Caldwell co., N. Car.: $158 \mathrm{~m}$. W. Raleigh.

Fort Des Mornes, p. v, and eap. Polk co., Ia.: on the W. side of Des Moines r., $109 \mathrm{~m}$. W. Iowa City. It is a thriving trading town on the route of travel to Council Bluffs, and on the line of the projected railroad. It is a station at which overland emigrants can supply themselves with every necessary, there being here several extensive stores, hotels, etc.

Fort Duxcax, p. v., Kinney co.. Tex. : a U. S. military post, Department No. 8, Western Division, at Eagle Pass of the Rio Grand r., 224 m. S. W. Austin City. A flourishing town has been built at this point

FORT EDWARD, t. and p. v., Wushington co, $N . Y_{*}: 39$ m. N. by E. Albany. Drained by Moosekill and other streams of Hudson $\mathbf{r}$, which makes its W. boundary. Surface undulating; soil, clay and loam, very fertile. The $\mathrm{v}$. lies on the E. side of the Hudson, and on the line of the Champlain Canal and the Saratoga and Washington R. R., and contains about 600 inhabitants. Fort Miller lies at the $\mathrm{S}$. end of the town. The ruins of old Fort Edward, erected 1755, are still existing in the village: and a little $N$. is the scene of the barbarous murder of Jane $\mathrm{M}^{6} \mathrm{Crea}$ by the Indians in the Revolutionary War. There are in the town several mills and stores, and 2,328 inhabitants.

Fort Edward Centex, p. o., Washington co., N. Y. : 84 m. N. by E. Albany.

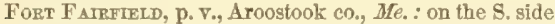
of Aroostook r., near the line of New Brunswick, $197 \mathrm{~m}$. N. E. Augusta.

Fort Fanning, p. o., Lery co., F lor.: formerly a U. S. military post, on the E. side of Suwannee r., $79 \mathrm{~m}$. S. E. Tallahassee.

Fort Gannes, p. $\nabla$. , Early co., Ga.: on the E. side of Chattahoochee r., 148 m. S. W. Milledgeville, and opposite Franklin, Ala. It is the terminus of the South Western R. P., and a railroad will be continued from this place in a $\mathrm{S}$. W. direction to Pensacola, $F$ lor. It is already a place of commercial importance, and has a good river trade.

Fort Ganves, p. v., Wahnatah co, Minn.: on the Mississippi $x$. immediately above the Sixth Rapids, $98 \mathrm{~m}$. N. W. by N. St. Paul.

Fort Gates: a U. S. military post, Department No. 8, Western Division, on Leon river, Texas.

Fon'T Gmsox, p. o., Cherokee Nation, Ind. Ter.: on the Arkansas r., at the confluence of Neosho or Grand r., and a U. S. military post, Department No. 7, Western Division. Lat. $35^{\circ} 48^{\prime} 04^{\prime \prime}$ N., and long. $95009^{\prime} \mathrm{W}$.

Fort Gramay: a U. S. military post, Department No. 8 Western Division, Jose Maria Village, Tex., on the E. side of Brazos r., 138 m. N. by E. Austin City.

Fort Gratiot: a U.S. military post, Department No. 2, Eastern Division, Mich. The $\mathbf{\Sigma}$. of Fort Gratiot is situate at the head of a rapid at the outlet of Lake Huron, the entrance of which is commanded by the fort. The fortifications were built in 1814, at the close of the war with Great Britain.

For' Hall, Oreg. Ter.: on Henry's r., a branch of

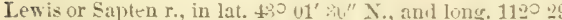
$54^{\prime \prime}$ W. A few miles $E$. is the junction of the Oregon and California routes, the former of which passes Fort Hall.

Fort Hamiton, p. v., Kings co., $N$. $Y$.: on the E. side of the Yarrows at the entrance of New Tork Marbor. Fort Hamilton, on the land, and Fort Lafayette or Diamond, in the channel, and on the W. side of the entrance Fort Richmond, command this important passage. The $\nabla$. is pleasantly located, overlooking a wide expanse of sea and the surrounding enuntry, and is much resorted to for summer

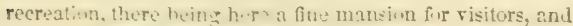
$-20$ much agreeable society. Steamboats ply regularly to and from New York, and stages run several times a day between this and Brooklyn. As a military post, Fort Hamilton belongs to Department No. 3, Eastern Division.

Fort Harlex, p. 0., Alachua co., Flor. : 106 m. E. S. E. Tallahassee.

Fort HeMbrex, p. V., Cherokee co, N. Car,: $294 \mathrm{~m}$ W. S. W. Raleigh.

Fort Hendresos, p. 0., Macon co., $A l a .: 46 \mathrm{~m}$. W. by $\mathrm{N}$ Montgomery.

ForT HILL, v., York dist., S. Car.: 89 m. N. Columbia.

ForT Hulu, p. 0., Lake co., Ill.: 187 m. N. E. by N. Springfield.

Fort How Ard: a U. S. military post, Department No. 2 , Eastern Division, Green Bay, Wisconsin.

Fort Holx, v., Macon co., Ala. : 38 m. W. Montgomery.

Fort Hurter, p. o, Montgomery co., $N . Y$.: on the $\mathrm{S}$. side of Mohawk r., and on the line of the Erie Canal, $31 \mathrm{~m}$ N. W. Albany, Here are the ruins of an old colonial fort.

ForT INdependence : a U. S. military post, Department No. 1, Eastern Division, Boston, Mass. Lat. $42^{\circ} 20^{\prime}$ N., and long. $71004^{\prime} \mathrm{W}$.

ForT IKGE: a U. S. military post, Department No. 8 , Western Division, on Leona river, Texas.

ForT JACKson: a U.S. military post, Department No. 5 , Western Division, New Orleans, Lovisiana.

Fort JkTFerson, p. v., Darke county, Otio: $87 \mathrm{~m}$. W. Columbus. Military fortifications formerly existed at this point. It is about $6 \mathrm{~m}$. S. by W. of Greenville.

Fort Jenn Lngs, p. o, Putnam co, Ohio: on the W side of Big au Glaize r., $97 \mathrm{~m}$. N. W. Columbus. The ruins of the old fort still remain.

Fonт Jessur, p. o., Sabine par., La. : between Red $r$. and Sabine r., 153 m. N. W. Baton Rouge.

Fort Johnson : a U. S. military post, Department No. 4 Eastern Division, Smithville, $N$. Car. Lat. $34^{\circ} 00^{\prime \prime}$ N., and long. $7 \mathrm{~S}^{\circ} 05^{\prime} \mathrm{W}$.

Fort Krannex, p. o, Indian Country, Nebr. Ter.: a post of the U. S., at which several companies of soldiers are usually stationed for the protection of the Indian frontier. Department No, 6, Western Division.

Font Kext, p. 0., Aroostook co., Me.: on the S. side of St. John r., at the confluence of Fish r., 218 m. N. by E. Augusta.

Fort Lafayette or Diaviond: a U. S. military post, Department No. 3, Eastern Division. At the Narrows of New Tork IIarbor, $\mathcal{N}$. $Y$. It lies in the channel, off Fort IIamilton.

Fort Larame, p. o, Nebr. Ter.: on the \$. side of Platte or Nebraska $r$, in lat, $42012^{\prime} 10^{\prime \prime} \mathrm{N}$, and long, $105^{\circ} 21^{\prime} 60^{\prime \prime}$ W. It is a U. S. military post, Department No. 6, Western Division.

Fort Lea venwortu, p. 0.: a U. S. military post, on the TV side of Missouri r, about $38 \mathrm{~m}$. above the mouth of Platte r. Lat. $39021^{\prime} 14^{\prime \prime} \mathrm{N}$., and long. $94044^{\prime} \mathrm{W}$. Here are extensive military works, defended by a company of dragoons and several companies of infantry. It is in the 6 th Military Department, Western Division.

Fort LINcoln : a U. S. military post, Department No. 8, Western Division, on Rio Seco, Tex.

Fore Litrleton, p. o., Fulton co., Penn. : $72 \mathrm{~m}$. W. by S. Harrisburg.

ForT Macktrac: a U. S. military post, Department No. 2, Eastern Division, Mackinac, Mich.

Fort Macor: a U. S. military post, Departmant No. 4, Easteru Division, Beaufort, $N$. Car.

Form Madisov, p. va, and cap. Lee co, Ia. : on the W. side of the Mississippi $\mathrm{r}$., $71 \mathrm{~m}$. S. S. E. Iowa City. The site of an old frontier fort, and only laid out as a village in 1835 . Fort Madison is now a place of considerable manufactures, commerre. and wealth. and in 1550 had 1,512 inhabitants. It contains a court-house, the county jail and offices, several handsome chureh's, the state penitentiary, and has many 
fine brick stores and dwellings. Its river trade is extensive, steamboats arriving and departing several times a day; and its trade with the interior is commensurately large. The village, indeed, is the natural outlet of one of the richest sections of the State. It is distant from Burlington $23 \mathrm{~m}$. by river. Two newspapers are published here, the "Iowa Statesman" and the "Whig and Register," both weekly. A branch of the Keokuk and Iowa City R. R. will probably be extended to Fort Madison.

Fort M'Henry: a U. S. military post, Department No. 8, Eastern Division, Baltimore, $\boldsymbol{M}$ d.

Fort M.Intosh: a U. S. military post, Department No. 8, Western Division, Laredo, Texas.

Fort M $\triangle$ rron : a U. S. military post, Departmeat No, 4 , Eastern Division, St. Augustine, Flor. Lat. $29050^{\prime} \mathrm{N}$., and long. $81027^{\prime} \mathrm{W}$.

Fort Martin Scotr: a U. S. military post, Department No. 8, Western Division, Fredericksburg, Texas.

Fort MEAde: a U. S. military post, Department No. 5, Western Divison, Tampa Bay, Flor. Lat. $27^{\circ} 57^{\prime}$ N., and long. $81^{\circ} 51^{\prime} \mathrm{W}$

Fort Merrilu; a U. S. military post, Department No. 8 , Western Division, Nueces River, Corpus Christi, Tex. Lat. $27^{\circ} 47^{\prime} 17^{\prime \prime} \mathrm{N}$., and Iong. $97^{\circ} 27^{\prime} 02^{\prime \prime} \mathrm{W}$.

Fort Mrferin: a U. S. military post, Department No. 3 , Eastern Division, near Philadelphia, Penn. Lat. $39 \circ 51^{\prime}$ N., and long. $75 \circ 12^{\prime} \mathrm{W}$

Forт MuI, p. o., York district, $S$ Car.: $81 \mathrm{~m} . \mathrm{N}$. Columbia.

Fort Mrrmer, p. $\nabla$., Washington co., $N$. $Y$.: on the E. bank of the Hudson $r_{0}, 34 \mathrm{~m} . \mathrm{N}$. by E. Albany. At this point the river has a fall of 20 feet, and a State dam, 8 feet high, is built for diverting the waters into the Champlain Canal, which passes through the village. There are several mills and stores here, and between 300 and 400 inhabitants.

Fort Mrtchelt, p. o, Russell co., Ala. : on the W. bank of Chattahoochee r., about $2 \mathrm{~m}$. above the confluence of Big Ochee creek, $73 \mathrm{~m}$. E. Montgomery.

Fort Monroe: a U. S. military post, Department No. 4 , Eastern Division, on Point Comfort, Virg. Lat. $37^{\circ} 02^{\prime} \mathrm{N}$, and long. $76 \circ 12^{\prime} \mathrm{W}$.

Font Montgomery, p. o, Cherokee co., N. Car.: $297 \mathrm{~m}$. W. S. W. Raleigh.

Fort Morgan : a U. S. military post, Department No. 5 , Western Divison, Mobile, Alabama.

Fort Moultriz: a U. S. military post, Department, No 4. Eastern Division, Charleston Harbor, S. Car. Lat. 320 $42^{\prime} \mathrm{N}$., and long. $79^{\circ} 56^{\prime} \mathrm{W}$.

Fort M'REA : a U. S. military post, Department No. 5 , Western Division, Pensacola, Flor. Lat. $30024^{\prime}$ N., and long. $83014^{\prime} \mathrm{W}$.

ForT Mrers: a U. S. military post, Department No. 5, Western Division, Tampa Bay, F'or. Lat. $27 \circ 57^{\prime}$ N., and long. $87052^{\prime} \mathrm{W}$.

Fort Niagara : a U. S. military post, Department No. 3 , Eastern Division, Youngstown, $N$. $Y$.

Fort Ontario: a U. S. military post, Department No. 3, Eastern Division, Ostrego, N. Y.

Fort Puse: a U. S. military post, Department No. 5, Western Divisiou, $L a$.

Fort PraIs, p. v., Montomery co, $N ., Y .:$ on the S. side of the Mohawk r.g and on the line of the Erie Canal, $48 \mathrm{~m}$. W. by $N$. Albany. It is a flourishing village, having several manufacturing establisbments and about 1,600 inhabitants. Fine stone is quarried in the vicinity. Two newspapers, the "Mohawk Valley Gazette" (whig) and the "Radii and Phœnix" (neutral), are issued weekly.

Fort Preble: a U.S. military post, Department No. 1 , Eastern Division, Portland, Me. Lat. $43038^{\prime} \mathrm{N}$., and long. $70018^{\prime} \mathrm{W}$.

Fort Prince, p. o., Spartanburgh dist., S. Car.

Fort Recoters, p. o., Nercer co, Otio: on a head branch of Wabash r., $97 \mathrm{~m}$. W. N. W. Columbus.
ForT RIPLEX: a U. S. military post., Department No, 6 Western Division, Minn. Ter.

Fort Scotr, p. o., Bates co, Mo.: and a U. S. military post, Department No. 5, Western Division. It is situate on Marmiton er, of Osage r., 146 m. W. .. W. Jefferson City,

Fort SeNeca, p. o., Seneca co., Ohio: $74 \mathrm{~m}$. N. by W. Columbus.

Forx Sumtr, p. V*, Crawford co, Ark: and a U. S. mi itary post, Department No. 7, Western Division. Situate on the W. line of the State, where it is crossed by Arkansas r., $181 \mathrm{~m}$. W. by N. Little Rock, It is proposed to build a R. R. from Little Rock to this point. The "Fort Smith Iferald" is published weekly.

Forr BNellive, p. v., and cap. Dacotah co, MFinn. a U. S. military post, Department No. 6, Western Division Situate at the confluence of Minnesota $r$, with the Mississippi. Lat. $44^{\circ} 53^{\prime} \mathrm{N}$., and long. $93008^{\prime}$ W. Within the jurisdiction of the fort there is a considerable village.

Font Sullivar: a U. S. military post, Department No.1, Eastern Division, Eastport, DIe. Lat. $44^{\circ} 44^{\prime}$ N., and long. $677^{\circ} 04^{\prime} \mathrm{W}$.

Fontsville, p. v., Saratoga co., N. Y. : 39 m. N. Albany. Fort Towson : a U. S. military post, Department No. 7 Western Division. Situate a little $\mathrm{N}$. of Red $r_{\text {., }}$ Choctaw Nation, Ind. Ter.

Fort Trumbull : a U. S. military post, Department No. 1, Eastern Division, New London, Conn. Lat. $41^{\circ} 22^{\prime} \mathrm{N}$. and long. $72 \circ 05^{\prime} \mathrm{W}$

Fort Vallex, p. v., Houston co, Ga.: 53 m. S. W. Milledgeville. At this point the Muscogee R. R. diverges from the South-Western R. R.

ForT W ARREN : a United States military post, Department No. 1, Eastern Division, Boston, Mass. : lat. $422^{\circ} 20^{\prime} \mathrm{N}$. and long. $7104^{\prime} \mathrm{W}$.

Fort Washington, p. v., Prince George's co., Ma. : a United States military post., Department No. 3, Eastern Di vision. The $\mathrm{v}$. is situate on the $\mathrm{E}$. side of the Potomac $r$., between Swan cr. and Piscataway $x ., 15 \mathrm{~m}$. S, of Washing. ton, $D . C$.

Fort W United States military post, Department No. 6, Western Division. Situate on False Washita river.

Fort Wayne, p. v., and cap. Allen co., Ind. : on a high bank, opposite to which, on the N., the St. Mary's and the St. Joseph unite and form the Maumee r., in lat. $41005^{\prime} \mathrm{N}$. and long. $85^{\circ} 09^{\prime}$ W., 103 m. N. N. E. Indianapolis, Here was the "Twightwee Village," or principal sect of the Miami, in their language called Ke-ki-omque, and here too was old Fort Wayne, built by General Wayne, Sept, 1794, and just below, on the opposite side of the Maumee, was fought the disastrous battle of $22 d$ Oet., 1790. At one time it was called "French Stores," as it was for a long time a trading post of that nation. Fort Wayne continued as a military post until 1819 , and until the removal of the Miamis and Pottowattomees in 1841, was resorted to by them for the disposal of their furs and to spend their annuities. It is now one of the most flourishing towns in the State, and contains about 6,000 inhabitants. In 1840 it did not contain more than 1,600 inhabitants. The Wabash and Erie Cana gives it access to the Wabash Valley and the Ohio r. on the one hand, and the Maumee Valley and Lake Erio on the other. Railroads, also, are being constructed to Lake Erie and central Ohio; also to Chicago, on Lake Michigan, and southward to the Ohio r. Several plank-roads also extend into the interior. The surrounding country is one of the best farming sections, and produces abundance of grain and provisions. With these advantages of travel and transport, it must become a centre of a vast commerce, and in time a populous eity, through which the products of a wide territory must pass for a market. It already contain extensive warehouses, stores, etc., the county buildings, a United States land office, a branch of the State Bank, etc. and has many substantial brick dwellings. All the principal 
religious denominations have churches in the place, and there are several first-rate academies and schools, among which may be mentioned the Methodist Female College, and a Catholie institution under the Sisters of Providence. Two newspapers, the "F. W. Sentinel" (dem.), and the "F. W. Times" (dem.), are issued weekly.

Fort Wrnnebago, p. v., and cap. Columbia co., Wisc. : at the portage between the Fox and Wisconsin rivers, $33 \mathrm{~m}$ $N$. Madison. It is one of the eligibly-situated trading towns in the State, and has now about 800 inhabitants. The fort Is abandoned as a military post.

Fort Wolcotr : a U.S. military post, Department No.1, Eastern Division, Newport, $R$. I.: lat. $41^{\circ} 30^{\prime} \mathrm{N}$., and long. 71018 ' W.

ForT WOOD : a U.S. military post, Department No. 3, Eastern Division, Bedlow's Island, Harbor of New York, N. Y. : lat. $40^{\circ} 42^{\prime} \mathrm{N}$., and $74^{\circ} 02^{\prime} \mathrm{W}$. long. This island fortification has for many years been the chief Recruiting Depôt of the United States army, and at various times it has had over a thousand men under drill and subject to draft. Between 3,000 and 4,000 recruits are annually passed through this "gateway to glory."

ForT WOoD : a U. S. military post, Department No. 5, Western Division, New Orleans, $L a$.

Forty ForT, p. O., Luzeme county, Penn.: 93 m. N. E. Harrisburg.

Forw ARDSTowr, p. v., Somerset county, Penn.: $123 \mathrm{~m}$ W. by S. Harrisburg.

Foster, t. and p. V., Providence co., R. I.: $18 \mathrm{~m} . \mathrm{W}$ Providence. Drained by head branches of the N. fork of Pawtuxet $r$, which afford water-power. Surface rough soil indifferent. The $\mathrm{v}$. is located in the N. part of the town. In the town there are several furnaces, cotton and woolen factories, and numerous mills. Pop. 1,932.

Foster, p. o., Bracken co., Ky.: 67 m. N. E. Frankfort

Foster Centri, p. v., Providence co., R.I.: $48 \mathrm{~m}$. W. Providence.

Fosterdade, p. v., Sullivan county, $N . Y .: 92 \mathrm{~m} . \mathrm{S} . \mathrm{W}$ Albany.

Fosteria, p. v., Blair co., Penn.: on the line of the Eastern Division of the Pennsylvania R. R., $128 \mathrm{~m}$. from Harrisburg.

Fostre's, p. 0., Tuscaloosa co, $A l \alpha_{.}$: on the W. of Black Warrior r., $93 \mathrm{~m} . \mathrm{N}$. W. Montgomery.

Foster?'s, p. o., Marion co., $I l l$. 78 m. S. S. E. Springrield,

Foster's Cross Roads, p. o, Bledsoe co., Tenn. : $95 \mathrm{~m}$.

E. S. E. Nasbville.

Foster's Fork, p. 0., Prince Edward co., Firg. : $62 \mathrm{~m}$, W. S. W. Richmond.

Foster's Mrr.s, p. o., Seneca co., Ohio: $93 \mathrm{~m}$. N. by W. Columbus.

Foster's Muls, p. o., Johnson county, Ind.: $29 \mathrm{~m} . \mathrm{S}$. Indianapolis.

Fostervilile, p. v., Cayuga county, $N . Y_{*}: 148 \mathrm{~m}$. W. by N. Albany.

Fostervilue, p. v., Rutherford co, Tenn.: on the line of the Nashville and Chattanooga R. R., $45 \mathrm{~m}$. S. E Nashville.

Foundervinue, p. v., Columbia co, Penn. : 77 m. N. N. E Harrisburg.

FountaIs county, Ind. Situate W. middle, and contains $390 \mathrm{sq} . \mathrm{m}$. Drained by Coal and Shawanee creeks, tributaries of Wabash r. Surface mostly level; on the S. and centre undulating, and variegated with forest and prairie. Soil a black loam, mixed with sand, and very productive; clays prevail in the S. Grain, flour, and pork are the staples. Coal and iron ore are abundant, and manufactures engage much attention. Farms 1,357; manuf. 103 ; dwell. 2,251, and pop.-wh. 13,201, fr. col. 52-total 13,253. Capital: Covington. Public Works: Wabash and Erie Canal.

Fountaix, p. v., Carroll county, Ind.: $62 \mathrm{~m} . \mathrm{N}$. W Indianapolis.
Fountain Dale, p. o., Adams co., Penn. : 89 II. \$. W. Harrisburg.

Founxatn Green, p. v., Hancock co., $I l l$. : on Decker's er., a branch of Crooked cr, of Illinois r., 84 ma. W. N. W. Springfield.

Fodntatn Green, p. v., Chester county, Penn.: 69 m. E, by S. Harrisburg.

Fountain Head, p. o., Sumner co., Tenn. : 31 II. N. N. E Nashville.

Fountain Hili, p. o., Ashley co., Ark. : 132 m. S. E. Little Rock.

Fountain Hill, p. 0., Greene co., N. Car. : 55 m. E. by S, Raleigh.

Fountain Inn, p. o., Greenville district, S. Car.: $81 \mathrm{~m}$. N. W. Columbia.

Fountary Run, p. o., Monroe co., Ky. : 114 m. S. S. E Frankfort.

Fountaty Sprivg, p. o., Wood county, Virg.: $249 \mathrm{~m}$. W. N. W. Richmond.

Fountain Spring, p. v., Sehuylkill co., Penn.: $48 \mathrm{~m}$. N. N. E. Harrisburg. On the line of the R. R. between Pottsville and Lewisburg.

Fountain Springs, p. o, Wapello co, $I a_{0}: 68 \mathrm{~m} . \mathrm{S}$. W Iowa City.

Fourche a Renault, p. o., Washington co., Mo. : on a cr. of Maramee r., 73 m. S. E. Jefferson City.

Fovrche Dusras, p. o., Randolph county, Ark.: on an affluent of Great Black river so called, $133 \mathrm{~m}$. N. N. E. Little Rock.

Four Corners, p. o., Huron co., Ohio: 89 m. N. by E. Columbus.

Four Mrte Braxcir, p. o., Barnwell dist., S. Car.: $72 \mathrm{~m}$. S. W. Columbia.

Four Mile Branch, p. o., Mouroe county, Tenn. : $157 \mathrm{~m}$. E. S. E. Nashville.

Four MILE Grove, p. o., Lee county, $\pi l_{*} ; 131$ m. N. by E. Springfield.

Forr Mrle Pramie, p. o, Van Zandt eo., Tex.: $212 \mathrm{~m}$. N. N. E. Austin City.

Four Mile Prairie, p. o., Fayette co., $I l l .: 63$ m. S. E. Springfield.

Fowler, t. and p. V., St. Lawrence e0., $N_{\text {. }}$ Y.: $137 \mathrm{~m}$. N. W. Albany, Drained by Oswegatchee $r$, and its tributaries. Surface uneven; soil, clay and sandy loam. The $\mathrm{v}$. lies on the $\mathrm{S}$. side of the river. There are several forges and furnaces, and numerous mills in the $t_{0,}$ and 1,897 inhabitants.

Fowler, t. and p. o, Trumbull co, Ohio: $146 \mathrm{~m}$. N. E Columbus. Drained by creeks of Chenango and Mahoning rivers. Pop, 1,089.

Fow LER's, p. 0., Brooke county, Virg.: 252 m. N. W Richmond.

Fow LeE's Mrlis, p. o., Geauga co., Ohio: $136 \hat{~ m . ~ N . ~ E . ~}$ Columbus.

Fowlerstille, p. o., Livingston co, $N . Y_{\text {. : a few miles }}$ W. of Genesee r., $204 \mathrm{~m}$. W. by N. Albany.

Fox county, $I a$. Situate W., and contains 576 sq. m. Taken from Pottowattomee in 185 1.

Fox, p. V., Davis county, $1 a_{0}: 77 \mathrm{~m}$. S. W. by S. Iowa City.

Fогвовобgн, t. and p. v., Norfolk county, MFass. : $23 \mathrm{~m}$ S. S. W. Boston. Drained by Rumford and Cocasset rivers of Taunton r., both of which furnish mill sites. Surface uneven; soils productive. The v. lies near the centre, on the $\mathrm{E}$. of a small pond. The $t$. has considerable manufactures, and 1,880 inhabitants. The Boston and Providence R. R. passes through the S. E. part of the town.

Fox Chase, p. o., Philadelphia county, Penna: $98 \mathrm{~m} . \mathrm{E}$ Harrisburg.

Fox Creek, p. o., St. Louis county, Mo.: $88 \mathrm{~m}$. E. Jefferson City.

Foxcroft, to and p. o., Piscataquis county, Me.: $78 \mathrm{~m}$ N. N. E. Augusta. Sebee Lake lies on its N. border, and 
Piscataquis r. on its S. border, the tributaries of which drain the interior. Pop. 1,132.

Fox Grove, p. o., Burke co., Ga.: 81 m. E. Milledgeville, For isles, Mrich. : two islands, situate a few miles $\mathrm{S}$. of Great Traverse Bay.

Fox Laks, p. o, Lake county, $I l l .: 187$ m. N. N. E. Springfield.

Fox river, $I U$. : a principal constituent of the Illinois $r$. It rises in Wisconsin, and after passing through a chain of small lakes near the dividing line of the State, enters Illinois and takes a southerly direction to the Illinois r., into which it falls at Ottawa.

Fox river, Wisc, (See N EeNAH river).

Fox Spring, p. o., Orerton co., Tenn. : 92 m. E. by N. Nashville.

Foxville, p. V., Fanquier co., Virg.: on Rappahannock r., $62 \mathrm{~m} . \mathrm{N} . \mathrm{N}$. W. Richmond. In the neighborhood is a fine slate quarry, and also a sulphur spring.

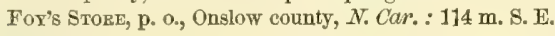
Raleigh.

Framinghax, t. and p. v., Middlesex co., Mass. : $21 \mathrm{~m}$. W. by S. Boston. Drained by Sudbury r., a branch of Concord r., on which are numerous factories and mills. It has also a number of ponds. Surface uneven ; soil fertile. Plumbage is found in the $t$. The $v$. lies on the $\mathrm{N}$. side of the river, and has considerable manufactures ; and a branch of the Boston and Worcester $R$. $R$, which runs through the S. part of the $t_{\text {, }}$, terminates here; and another branch terminates at Saxonville, a flourishing village to the N. E. of the principal village. The $t$, contains 4,285 inhabitants.

Francesvilue, p. v., Northampton co, $N$, Carr.: $82 \mathrm{~m}$. N. E. Raleigh.

Francr8co, p. o., Stokes co., N. Oar.: 108 m. W. N. W. Raleigh.

Fratciscoville, p. V., Jackson co., Jich.

Fravers Creer, p. o., Manitowoc co., Wisc.: 110 m. N. E. Madison.

Fratictstown, t. and p. v., Hillsborough co., N. Hamp. $24 \mathrm{~m} . \mathrm{S}$. W. Concord. Drained by Piscataquog river and its branches. Surface rough; soil generally stubborn; but there is much fertile intervale land. The v. is located on the S. E. side of a large pond, and has several mills and stores. Pop. of t. 1,114.

Francisville, p. v., Craw ford co., $G a$ : on the Knoxville and Talbotton Turnpike, $59 \mathrm{~m}$.W. S.W. Milledgeville.

Fravconta, to and p. v., Grafton co., N. Hamp.: $68 \mathrm{~m}$ N. by W. Concord. Drained chiefly by the S. branch of Lower Ammonoosue r, on which are extensive iron-work and numerous mills. A branch of Merrimac r. also has its rise in a pond, and flows $\mathrm{S}$. Mountain is the prevailing objection in the scenery. Profile Mountain, a bare, rugged summit, 1,000 feet high, when viewed from the N., presents a striking profile of the human countenance. The whole region is wild and picturesque. Iron ore, of fine quality, is found in the $t_{\text {.g }}$ and has been manufactured for the past fifty years. The village lies on the N. side of the Ammonoosuc branch. Pop, of t. 584

Franconra, p. v., Putnam co., Ohio : on the W. side of Big Auglaize $\mathrm{r}_{\iota}$, opposite the mouth of Blanchard's Fork, $108 \mathrm{~m}$. N. W. Columbus.

Franconia, t. and p. 0., Montgomery co., Penn. : $84 \mathrm{~m}$. E. Harrisburg. Drained by Indian, Pike, and Shippack creeks, and by the N. E. branch of Perkiomen cr. Surface level; soil red shale. It is an agricultural to, and has 1,268 inhabitants.

Fraskford, p. v., Pike co., Mo. : on a cr. of Salt r. of the Mississippi, $73 \mathrm{~m}$. N. E. Jefferson City.

Frankford, p. b., Philadelphia co., Penn. : on Tacony cr., $5 \mathrm{~m}$. N. E. Philadelphia, $97 \mathrm{~m}$. E. Harrisburg. It is a flourishing town, and has several factories and mills. Pop. 5,346. A newspaper, the "Frankford Herald" (neutral), is published weekly.

Frankrord, p. $\nabla .$, Greenbrier co., Virg. : on Thunder- gap er. of Greenbrier r., $162 \mathrm{~m}$.W. by N. Pichmond. Pop. about 200 .

Frankfort, p. v., Franklin co., $I l l_{0}$ : on Ewing's fork of Big Muddy r., 137 m. S. \$. E. Springfield. It has several mechanic shops and stores, and about 300 inhabitants.

Frankfort, p. v., and cap. Clinton co., Ind. : on the W. side of Prairie cr, of the $\$$. fork of Wild-cat r., $41 \mathrm{~m} . \mathrm{N} . \mathrm{N} . \mathrm{W}$. Indianapolis. It contains a court-house, a jail, 5 churches, and 8 or 10 stores. Pop. about 600 .

Frankfort, p. city, and eap. Franklin co., Ky., and cap. of the State: on the $\mathrm{E}$. side of Kentucky $\boldsymbol{r}_{.}, 62 \mathrm{~m}$. above its confluence with the Ohio r., in lat. $38014^{\prime} \mathrm{N}$., and long. $84^{\circ} 40^{\prime} \mathrm{W} .-551 \mathrm{~m}$. W. by S. Washington, $D$. $C$. The river, here eighty yards wide, winds through a deep limestone valley, on a plateau of which the eity is built, and opposite to and connected with it by a chain bridge, is South Frankfort, its suburb. Behind the eity the land rises abruptly 150 to 200 feet to the general level of the country, from which elevation the valley scene is extensive, and full of picture. Heavy rains frequently cause the river to rise 50 or 60 feet above its ordinary level. The river, the navigation of which has been improved by locks and dams, is regularly navigated to Frankfort by steamboats of considerable burden, and an extensive commeree, supported by a fine country neighboring on the banks of the Kentucky, centres at this point. The eity is also connected with the Ohio by a rail road to Louisville, and there is a railroad to Lexington, at which place other railroads diverge to the N. and N. E., and also to the $\mathrm{S}$., whence they are continued to the Atlantic cities, and to those of the Mississippi and Gulf of Mexico. Frank fort is a well-built and compact place: the streets are regular and wide, and many of the houses and public buildings of brick and white marble. Of the latter material, which is found abundantly in all this region, the State House is built: it is a splendid edifice, 86 by 54 feet, with a Ionic portico in front, and a lighted cupola on the top. The State Penitentiary is also located here, and among its other buildings are the court-house, the county jail, a market, etc. Its public press consists of 1 daily, 4 weekly, 1 semimonthly, and 1 monthly publications, viz., the "Commonwealth" (whig), daily and weekly; the "Old Guard ;" the "Kentucky Yeoman" (dem.), and the "Champion of Reform"-all weekly; the "Ecclesiastical Reformer," semimonthly; and the "Methodist Monthly Magazine," month1y. The manufactures of the city are various and extensive, and ships of considerable burden have been built here, and floated down the river to New Orleans. The city was founded in 1786, and was made the seat of government in 1792. In 1810 it had 1,099 inhabitants; in $1820,1,679$; in $1830,1,680$; in 1840, 1,917; and in $1850,4,372$

Frankfort, t. and p. v., Waldo co., $M_{e} .: 51 \mathrm{~m}$. E. N. E. Augusta. Drained by Marsh $r$, of the Penobscot, the latter forming the $\mathrm{E}$. boundary, and affording a navigable channel throughout the year. Marsh $r$ supplies good waterpower, and is the seat of numerous mills. The r. lies on Marsh Bay, which sets up from the Penobscot. The t. has an extensive lumber trade, and stores of various descriptions. Pop, 4,233.

FrankFort, t, and $\mathrm{p}, \mathrm{v}$, Herkimer co, $N . \bar{Y} .74 \mathrm{~m}$ W. by N. Albany. Drained by the Mobawk r., which makes its N. boundary. Surface billy and broken in the S.; in the $\mathrm{N}$. are rich alluvial flats. The $\mathrm{v}$. lies on the line of the Erie Canal, and contains about 600 inhabitants. The t. has several factories, mills, etc., and numerous stores. Pop. 3,028.

Frankfont, p. v., Ross co., Ohio: on the N. side of the N. fork of Paint er., $41 \mathrm{~m}$. $\mathbf{S}$. by W. Columbus. It has several mills and workshops, and about 400 inhabitants.

Frankfort, p. v., Hampshire co., Virg.: : on Patterson's er, of the N. branch of Potomac r., $151 \mathrm{~m} . \mathrm{N}$. N. W. Richmond. It contains several mechanic shops, about 85 dwellings, and 200 inhabitants. The Baltimore and Ohio R. R. runs near this village. 
Frankfort HiLl, p, o., Herkimer county, N. Y.: $75 \mathrm{~m}$. W. by N. Albany.

Frankfort Mreis, p. v., Waldo co., Me.: on Marsh r., at its mouth, 48 m. E. N. E. Augusta.

Frankfort Sprivgs, p. v., Beaver county, Penn. : $192 \mathrm{~m}$.

W. Harrisburg. It contains about 120 inhabitants, and has several stores and mechanic shops.

Fraxklns county, $A l a$. Situate N. W., and contrins 648 sq. m. Drained by Cedar, Bear, Little Bear, Spring, and other creeks, affluents of Tennessee r., which marks its N. boundary. Surface hilly and broken; solls generally of average productiveness. Cotton is the great agricultural staple. Farms 913 ; manuf. 28 ; dwell. 1,955 , and pop.-wh. 11,399, fr. col. 14, sl, 8,197-total 19,610. Capital: Russellville. Public Works: Memphis and Charleston R. R.

Fraskron county, Ark. Situate N. W., and contains 756 sq. m. Drained by creeks of Arkansas r., which divides it through the midule. Surface elevated, hilly, and broken; soil generally inferior, but on the river rich and fertile, producing cotton, tobaceo, and the grains. The hill-regions of the $\mathrm{N}$, and $\mathrm{S}$. are adapted to grazing. Iron ore, copper, and other minerals abound, and there is a plentiful supply of good timber for building, etc. Farms 454 ; manuf. 3 ; dwell. 617 , and pop.-wh. 3,497, fr. col. 3, sl. 429-total 3,929. Capital: Ozark.

Frankzin county, Flor. Situate S. of West Florida, and contains $324 \mathrm{sq}$. m. Drained by Appalachicola r., which forms in part the W. boundary, and empties through Appalachicola Bay into the Gulf of Mexico, which lies on its S. border. Surface low and wet, with many pouds and swamps; soil rich and fertile. The islands of St. George and St. Vincent, which inclose the bay, belong to this county. Farms 0; manuf. 0; dwell. 261, and pop.-wh.1,184, fr. col. 0, sl. 377-total 1,561. Capital: Appalachicola.

Franklix county, $G a$. Situate N. E., and contains $6 s 0$ sq. m. Drained in the N. E. by tributaries of Tugaloo r., which bounds it in that direction, and in the centre and S. W. by forks of Broad r. All these ultimately fall into Savannah r. Surface elevated and hilly; soils of arerage fertility, producing the grains and some cotton. Farms 1,305; manuf. 4 ; dwell. 1,546, and pop.-wh. 9,076 , fr. col. 55, sl. 2,382-total 11,513. Capital: Carnesville.

FraxkLts county, $I l l$. Situate $\mathrm{S}$., and contains 432 sq. $\mathbf{m}$. Drained by the forks of Big Muddy r., an affluent of the Mississippi. Surface diversified; soil of average productireness. Besides the grains, which form the staple crops, cotton and tobaceo have been grown with advantage. The greater portion of the co. is prairie, interspersed with timber groves; the substratum is limestone. Farms 577; manuf. 0 ; dwell. 971, and pop.-wh. 5,646, fr. col. 35 -total 5,6s1. Capital: Benton.

Frankur county, Ind. Situate S. W., and contains 400 sq. m. Drained by E. and W. branches of White Water $r$. and besides these are Salt, Pipe, Red Cedar Grove, and other creeks. Surface pleasantiy variegated, and soils of average fertility. Manufactures have made some progress. Indian mounds and other cartle works are found in several parts. Farms 1,739 ; manuf. 121; dwell. 3,256, and pop. - wh. 17,760, fr. col.208-total 17,968. Capital: Brookville. Public Works: White Water Canal.

Fraxkur county, $Y a$. Situate centrally, and contains 576 8q. m. Taken from Pottowattomee in 1551.

Fravkun county, $\bar{k} y$. Situate N. centrally, and contains 200 sq. m. Drained by Elkhorn and other creeks of Kentucky $r_{\text {, }}$ which runs through it. Surface hilly and somewhat broken. Soils fertile, and well adapted for the grains, tobacco, ete. It has also many manufactures and mechanic shops. Farms $\$ 50$ : manuf. 12 : Aw 11.1 .453 , and pop.-wh. 8,741, fr. col. 356, sl. 3,365-total 12,462. Capital: Frankfurt. Public Works: Louisville and Frankfort R. R. : and Lexington and Frankfort R. R.. etc.

FRAxhLix parish, $L \alpha$. Situate toward N. E. of Testern District, and contains $6 \mathrm{HS} \mathrm{s}$. $\mathrm{m}$. It lies betw een the bayoux 280
Macon and Bceuf, and is drained by afliuents of these streams. Surface diversified, elevated, and having several small lakes, or, rather, river expansions. Soils very fertile, and along the streams well wooded. Farms 283; manuf. 0 ; dwell. 346, and pop.-Wh. 1,664, fr, col. 14, sl. 1,573total 3,251. Capital: Winnsboro'.

Frankltn county, Me. Situate N.W., and contains 1,440 sq. m. Drained chiefly by Dead r. and Sandy r., both considerable tributaries of the Kennebee; in the N.W. Androscoggin has its rise, and passes S. into Lake Acquessuck, ete. There are numerous ponds in all parts of the county, the outlets of some of which furnish fine mill-sites. Surface undulating or hilly-in parts mountainous ; soils of a superior character, adapted alike to grain and grasses. Farms 2,521; manuf. 135 ; dwell. 3,487 , and pop.-wh. 20,007 , ir. col. 20-total 20,027. Capital: Phillips.

FrankLTN county, Mass. Situate toward N. W., and contains $650 \mathrm{sq} . \mathrm{m}$. Drained by Deerfield, and other tributaries of Connecticut $r$., which passes through it from the N. These streams afford immense water-power, which is used extensively for manufacturing purposes. Surface diversified by hill and valley-along the Connecticut are extensive meadows, and much of the soil is very fertile. It has also excellent pastures, on which are large numbers of live-stock. Farms 2,535; manuf. 2S5; dwell. 5,832, and pop.-wh. 30,779, fr. col. 88-total 30,867. Capital: Greenfield. Public Works: Vermont and Massachusetts R. R.; Connecticut River R. R.; Greenfield and North Adams R. R., ete.

FraxkLIN county, MFiss. Situate S. W., and contains $672 \mathrm{sq}$. m. Drained by Homochitto $\mathrm{r}$. and its branches, and also by the head streams of Amité $r$. Surface moderately uneren; soils not the best, except on the margius of the rivers. Pine barrens cover a large surface. Cotton, Indian corn, etc., are its staples. The streams are very favorable for mill purposes. Farms 330 ; manuf. 5; dwell. 447, and pop.-wh. 2,540, fr. col. 14, sl. 3,350-total 5,994. Capital: Meadville.

Fraxkun county, Mo. Situate E. middle, and contains 792 sq. m. Drained by Maramee $r$. and its principal tributary, the Bourbeuse; also by numerous smaller streams falling into Missouri r., which makes the N. boundary. Surface moderately uneven, and the soil of average fertility. This is a fine mineral region, abounding in lead, iron, etc., ores which are extensively mined and reduced. Farms 1,096 ; manuf. 32 ; dwell. 1,925 , and pop.-wh. 9,542 , fr. col. 20, sl. 1,459-total 11,021. Capital: Newport. Putlic Works: Pacific R. R.

Franklar county, $N$. $Y$. Situatetoward the N. E., and contains 1,527 sq. m. Surface generally mountainous, except in the $\mathrm{N}$. part, where there is considerable level or andulating lands. The soils are generally of a mixture of loam and sand, very productive. The interior is drained by the Saranac, running $\mathrm{E}$, to Lake Champlain, and the Chataugay, Salmon, Trout, Deer, St. Regis, and Racket rivers flowing to the St. Lawrence. Farms 1,647; manuf. 129 ; dwell. 4,233, and pop.-wh. 25, $\mathrm{C43}$, fr. col. 59-total 25,102. Capital: Malone. Public Works: the Northern (Ogdensburg) R. R.

Fraxkry county, N. Car. Situate N. middle, and contains 540 sq. m. Drained by affluents of $T_{a r} \mathbf{r}_{\text {, }}$, which runs through it; the principal of these are Swift and Fishing rivers, the latter making the N. E. boundary. Surface dirersified, but generally level; soils naturally fertile, and along the streams producing fine cotton and tobacco, and large crops of grain. Gold is found in several parts, and has been collected to a considerable amount. Farms 5Ss; manuf. 25 ; dwell. 1,155 , and pop.-wh. 5,684 , fr. col. 54 , sl. 5,507-total 11,713. Capital: Louisburgh, Public Works: Gaston and Raleigh R. R.

FrAYkL county, O7io. Situate centrally, and containg 529 sq. m. Drained by Whetstone (Olentangy) and Scinto rivers and their tributaries. Surface low and Ievel, some- 
tinzes wet; soil fertile, particularly on the streams, and well culivated, but in most parts better adapted to grazing than grain growing. Farms 2,666; manuf. 241; dwell. 6,701, and pop.-wh. 41,310 , fr. col, 1,600-total 42,910. Capital: Columbus, Pubtic Works: Ohio Canal; Columbus and Xenia R. R.; Cleveland and Columbus R. R.; Central Ohio R. P.; Columbus and Bellefontaine R. R., etc.

Franklis county, Penn. Situate S. middle, and contains 734 sq. m. Drained by the Conecocheague and Conedogwinit creehs and their branches, which furnish extensive water-power. It lies in the Kittatinny Valley-the great limestone valley of the State, and is traversed by South Mountain and Tuscarora or Cove Mountain. Iron ore is abundant, is extensively mined and reduced, and white marlle of a coarse texture exists, underlying the hilly regions. Farms 2,247 ; manuf. 455 ; dwell. 6,690 , and pop.wh. 37,956, fr. col. 1,948-total 39,904. Capital: Chambersburg. Public Works: Franklin R. R.

FrankLiv county, Tonn. Situate S. middle, and contains $756 \mathrm{sq}$. m. Drained by Elk r. and other streams. Surfaco hilly, being traversed by ofishoots of the Cumberland Mountains; soils generally fertile. It is a fine grazing county, and produces the finest of grains and some cotton. Its waterpower is considerable, and is used extensively for milling and manufacturing purposes. Farms 1,015; manuf. 67; dwell. 1,639, and pop.-wh. 10,096, fr. col. 49, sl. $3,623-$ total 13,768. Capital: Winchester. Public Works: Nashville and Chattanooga $R$. R., ete.

Frankur county, Verm. Situate N. W., and contains $5 \$ 6$ sq. m. Lake Champlain forms its W. boundary, and the Canada line its limit on the N. Surface hilly in the E., on the lake level; soil fertile, and adapted alike for grain and grazing. Drained by Missisqué r. and the Lamoille, which afford extensive water-power. At Swanton there are quarries of fine clouded marble, which are extensively wrought and the stone exported. Farms 2,172 ; manuf. 108; dwell. 4,\$27, and pop.-wh. 28,500, fr. col, 86-total 28,586. Capital: St. Albans. Putlic Works: Vermont Central R. R., ete.

Frankliv county, $\bar{\nabla} r g$. Situate S. middle, and contains 580 sq. m. Drained by Pig r., Blackwater r., Maggoty er., and other affluents of Roanoke r., which marks its $\mathrm{N}$. boundary. The Blue Ridge forms its W. limits, and is the source of all its streams. It is a fine agricultural county, and has a large amount of live-stock; and gold is found at the base of the hills and on the streams. Farms 1,299; manuf. 47 ; dwell. 2,024 , and pop.-wh. 11,638, fr. col. 66 , 8l. 5,726-total 17,430. Capital : Rocky Mount.

Franketw, t. and p. o., Gloucester co., $N$. Jer. : 44 m. S. Trenton. Drained by Raccoon cr., the sources of Maurice $r_{\text {. }}$ and by branches of Little Egg Harbor r. Surface level ; soil sandy, and covered with pines. It has several glasshouses, and some other manufactures. Pop. 2,984,

FrarkLIN, t, and p. v., Milwaukie county, Wisc.: $76 \mathrm{~m}$. E. by S. Madison. Drained by Root r., which empties into Lake Michigan at Racine. Surface level; soil deep and fertile, and well timbered. The $\mathrm{v}$. lies a little W. of the centre. Pop. of t. 1,246.

FraxkLIN, p. $\nabla$. . Henry co., Alcr.: on the W. side of Chattahoochee r., opposite Fort Gaines, 92 m. S. E. Montgomery. The South-western R. R. of Georgia terminates at Fort Gaines, and will be continued hence from Franklin to Pensacola.

Franklis, t. and p. v., New London co., Conn.: $82 \mathrm{~m}$. E. S. E. Hartford. Drained by Susquetonscut r., a branch of Yantic r., and Beaver Brook, all which afford waterpower. Ghelucket $r$, makes its N. E. boundary. Surface uneven; soil gravelly loam. The v. lies on the New London, Willimantic, and Palmer R. R., $20 \mathrm{~m}$. from New London. The t. has a number of mills and minor manufactures, but is chiefly devoted to agriculture and grazing. Pop. 895 .

Fraxklin, p. v., and eap. Johnson co., Ind.: on the E. side of Young"s cr. of Sugar cr., an affluent of the E. fork of White r., $20 \mathrm{~m}$. S. by E. Indianapolis. The Madison and Indianpolis R. $R$. passes through the $\nabla$., and the Martins. ville Branch $R$. $R$. diverges from this point. The $\mathrm{v}$. is situate on a high bluff, and contains a court-house and co. jail, several stores, and 1,800 inhabitants. It is the seat of Franklin College, a Baptist institution; and a newspaper the "F. Examiner" (dem.) is issued weekly.

Franklix, p. v., and cap. Heard co., Ga.: on the E. side of Chattahoochee $\mathrm{r}$, $112 \mathrm{~m}$. W. by N. Milledgeville. It contains a court-house, and about 30 dwellings.

Fraxklux, p. v., Morgan county, $I l l: 26 \mathrm{~m}$. W. S. W. Springfield.

FraNkLIV, p. v., and cap. Simpson co., $K y .:$ on the W. side of Drake's cr. of Barren r., $145 \mathrm{~m}$. $\mathrm{s}$. W. Nashville. It contains a court-house, jail, etc., and about 40 dwellings. The Louisville and Nashville Ii. R.will pass through or near this place.

FraxkliN, p. v., and cap. St. Mary's par., La. : on the W. side of Bayou Teché, $52 \mathrm{~m}$. S. S. W. Baton Rouge. It is a place of considerable business, and has some river and coast trade. Pop. about 600 .

FrankLir, t. and p. v., Hancock co., Me.: $91 \mathrm{~m}$. E. by N. Augusta. Drained by ponds and ereeks emptying into Taunton Bay, an arm of Frenchman's Bay, lying on the S. shore of the town. The v. lies near the head of the bay. Pop. of t. 736 .

Franklin, p. ., Holmes county, Miss. : on Big Cypress creek, $51 \mathrm{~m}$. N. Jackson.

Frankliv, p. v., Oakland co., Mich.: on a cr. of the N. branch of Rouge r., $66 \mathrm{~m}$. E. by S. Lansing.

Franklin, t. and p. o., Howard co., Mo. : $44 \mathrm{~m}$. N. W. Jefferson City. Drained by Bonne Femme r., a tributary of Missouri r., which makes its $\mathrm{S}$. boundary. There are two villages here, Old Franklin and New Franklin, the former lying on the N. bank of the Missouri, and the latter on Bonne Femme r., $2 \mathrm{~m}$. N, of it.

Fraxklin, t. and p. v., Norfolk co., Mass.: $27 \mathrm{~m}$. S. W. Boston. Drained by branches of Charles $r_{\text {. }}$, which marks its $\mathrm{N}$. boundary, and affords good water-power. The village is situate near the centre, and is intersected by the Norfolk County R. R. The t, has considerable manufactures, especially of straw bonnets, cotton goods, etc. Pop. of t. 1,818.

Franklis, p. v., and eap. Macon co., $N$. Car. : on the W. side of a S. branch of Tennessee r., $272 \mathrm{~m}$. W. S. W. Raleigh.

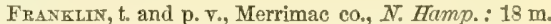
N. by W. Concord. Drained by Pemegewassett and Winnipiseogee rivers, which here unite and form Merrimac $r$. The village is situate on the Northern $R . R$, and here diverges the Bristol Branch $\mathrm{R}_{\text {. }} \mathrm{R}_{*}, 18 \mathrm{~m}$. long. The to has abundant water-power and some manufactures. Pop. 1,951.

FrANkLix, t. and p. v., Delaware co., $N_{0} Y_{.}: 71 \mathrm{~m}$. W. S.W. Albany. Drained by Oleout cr. and its tributaries, and affluents of Unadilla $r$. Surface broken; soil a reddish loam. The village lies on the $\mathbf{S}$. side of the creek, and contains about 600 inhabitants. The t. has numerous mills, and 3.057.inhabitants.

Franklis, t. and p. F., Warren co., Ohio: 72 m. W. S. W. Columbus. Drained by tributaries of Great Miami r., on the E. bank of which the village is located, and along which the Miami Canal runs. Pop. 2,5 14 .

Fraxkliv, p. b., and cap. Fenango co. Penn.: on the S. side of French cr., at its confluence with Alleghany r., $179 \mathrm{~m}$. W. N. W. Harrisburg. It contains a court-house, jail, etc., four churches, several forges, mills, and stores, and about 900 inhabitants. The creek is crossed by a bridge 200 feet long, and the Alleghany r. is navigable to this point for vessels of 60 or 80 tons during half the year. Two newspapers, the "Advocate and Journal" (neutral), and the "Venango Spectator" (dem.), are issued weelly. A canal is projected to Erie, and the Alleghany Valley R. R. will probably touch on this village. 
Frankin, p. p., Essex co., N. Ter.

Fravisun, p. v., and cap. Williamson co., Tenn.: on Harpeth $\mathrm{x}_{\text {., }} 19 \mathrm{~m}$. S. by W. Nashville. It contains a courthouse, ete., several stores, and about 60 dwellings, and has a newspaper, the "Western Review" (whig), published weekly. The Nashville and Florence R. $R$. passes through the village. Pop. of t. 2,305.

FrankLin, p. v., and cap. Robertson co, Tex.: on Mud cr, of Little Brazos r., 93 m. E. N. E. Austin City.

Frankidn, p. v., and eap. Pendleton co., Virg.: on the W. side of the S. branch of Potomac r., $124 \mathrm{~m}$. N. W. Richmond. It contains a court-house, and other county buildings, and about 200 inhabitants.

FBANELIN, t. and p. o., Franklin co., Term.: $54 \mathrm{~m}$. N. N. W. Montpelier. Drained by Roche's r. and branches of Missisqui $x$. Surface rough; soil moderately fertile and adapted to grazing. The village lies in the N. W. part of the t. Agriculture is the general pursuit, but there are several mills on the streams. Pop. 1,646 .

Fraxkuta, p. vo, Fulton co, Ark, : 118 m. N. Little Rock

Frankiti Centre, p. o., Lee co., Ia, : $69 \mathrm{~m}$. S. Iowa City.

Frakintin City, p. v., Norfolk co., Mass.: $28 \mathrm{~m}$. S. W. Boston.

Frankin College, p. o., Davidson co., Tenn.: near Nashville. This college was founded in 1845 , and had in $.850,5$ professors, 26 alumni, and So students, with a library of 8,000 volumes.

Fravklin Corners, p. o., Erie co., Penn.: 214 m. N. W. Harrisburg.

Franklindale, p. v., Bradford co., Penn.: $100 \mathrm{~m}$. N. Harrisburg.

Franklin Depôt, p. O., Southampton co., Virg. : $69 \mathrm{~m}$. S. S. E. Richmond.

Frankliv FuRvace, p. o., Franklin co., N. $T_{\text {. }}: 123 \mathrm{~m}$. N. Albany.

Fraxketi Furatace, p. o., Scioto co., Ohio: 93 m. S. by E. Columbus.

FraNkLty FurNace, po o., Sussex co., N. Ter : $67 \mathrm{~m} . \mathrm{N}$. Trenton.

Fraxkln Grove, p, o, Lee co., $I l l_{0}$ : at the head of Franklin cr. of Rock r. 142 m. N. Springfield.

Fravilin Milis, p. v., Portage co., Ohio: on Cuyahoga r., $115 \mathrm{~m}$. N. E. by N. Columbus. The falls at this point create a great water-power. The Ohio and Pennsylvania Canal passes through the rillage, which contains numerous mills, and among the dwellings are many fine buildings.

Franklin Springs, p. o., Franklin co., Ga.: between the forks of Broad r., $84 \mathrm{~m}$. N. Milledgerille.

Fraskitr Seuare, p. v., Columbiana co, Ofio: at the junction of Cherry and Middle forks of Little Beaver $r$, $114 \mathrm{~m} . \mathrm{E} . \mathrm{N} . \mathrm{E}$. Columbus, It contains several large mills and factories, and has about 800 inhabitants. The Ohio and Penusylvania R. R. passes through the village, $65 \mathrm{~m}$. from Pittsburg.

Fraskenvator, p. v., and cap. Washington par., $L \alpha_{n}$ : on the E. side of Bogue Chitto, $66 \mathrm{~m}, \mathrm{E}, \mathrm{N}$. E. Baton Rouge.

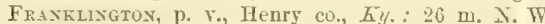
Frankfort.

Frankungtod, p. $v_{*}$, Franklin co, $N_{0}$ Car: : $87 \mathrm{~m}$, N. N. E. Raleigh.

Frankingtox, p. vo, Sehoharie county, $N_{0} Y_{0}: 43 \mathrm{~m}$. T.S. T. Aluany.

Franklixgtux, p. v., Fork co, Penn, : 15 m. S. S. W. Harrisburg.

Fraxeltstitie, p. v., Carroll co., .y.

Fraxklunvilue, p. v., Randolph co., N. Car.: $\pi 2 \mathrm{~m}$. W. Raleigls.

Fravintrvilue, p. v., Gloucester co., N. Jer.: $44 \mathrm{~m} . \mathrm{S}$. Trenton.

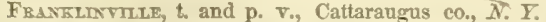
$2 s t \mathrm{~m}$. T. S. W. Albans. Drained by Ischua and Great Valley creeks. Surface undulating; soil, clay and loam. The r. lies in the X. E. part of the torn. Top of t. 1,706. 289
Frankstown, t. and p. b., Blair county, Penn.: $84 \mathrm{~m}$, W. by $N$. Harrisburg, Drained by creeks of Juniata $r$. Surface mountain and valley; soil generally good-in the valleys calcareous loam. The borough lies $2 \mathrm{~m}$. $\mathbb{N}$. Hollidaysburg, and contains about 450 inhabitants. The t. has several furnaces, etc., and 1,649 inhabitants.

Franksville, p. v., Claiborne par., La.: 208 m. N. W. Baton Rouge.

Franktown, p. v., Northampton co., Virg.: at the head of Naswadey cr., $182 \mathrm{~m}$. E. Raleigh.

Frantzdale, p. v., Ulster co., N. $Y_{*}: 58 \mathrm{~m} . \mathrm{S} . \mathrm{S} . \mathrm{W}$ Albany.

Frazer, p. 0., Chester county, Penn.: 71 m. E. S. E. Harrisburg.

Frazeysbergh, Muskingum county, Ohio: on the Ohio Canal, $58 \mathrm{~m} . \mathrm{W} . \mathrm{N} . \mathrm{W}$. Columbus.

FreAse's Store, p. o., Stark co., Ohio: 104 m. N. E Columbus.

Frederica, p. v., Kent co., Dela : on the N. side of Murderkill cr., $11 \mathrm{~m}$. S. Dover.

Frederica, p. v., Glynn co., Ga.: on the E. side of St Simon's Island, $168 \mathrm{~m}$. S. E. Milledgeville. Here are the ruins of a fort built by Gen. Oglethorpe in 1736. The village contains about 20 dwellings.

FreDERICK county, Mrd. Situate N. E., and contains 560 sa. m. Drained by Monocacy r. and Catoctin er., affluents of Potomac r. Surface undulating-in the W. South Mountain and its offshoots render it somewhat hilly and broken; soils various--in some parts decomposed slate, in others red shales, and in others of limestone formation. Its agricultural capacities are excellent, and it has extensive forests of oak, hickory, chestnut, locust, ash, etc. Its geology is of the primary era; its principal rocks quartz, sandstone, blue slate, dolomite, ete., and there is a fine white marble found in the county. Copper, iron, manganese ores, and barstes abound. Flouring mills, tanneries, smitheries, boot and shoe factories, woolen mills, etc., constitute its principa industrial establishments; of flouring mills there are 72 , and of tanneries 43. Farms 1,983; manuf. 245 ; dwell. 1,397 , and pop.-wh. 33,314 , fr. col. 3,760 , sl. 3,913-total 40,987 . Capital: Frederiek City. Public Works: Baltimore and Ohio R. R.; Frederick Branch R. R.

Frederick county, Firg. Situate N. E., and contains 480 sq. m. Drained by Opequan, Back, and Sleep cr., afflueuts of Potomac r. Surface diversified by hils and valleys, and soil of average productiveness-in some parts, especially along the rivers, very fertile. Iron ore, potters clay, etco, are abundant, and there are several extensive industrial establishments in various parts. The streams afford fine water-power, which is extensively used for milling purposes. Farms 1,025; manuf. 89; dwell. 2,325, and pop.wh. 12,769 , fr. col. 912, sl, 2,294-total 15,975. Capital: Winchester, Public Works: Wirchester and Potomac R. R. Frederick City, p. Y., and cap. Frederick co., Md.: on Carroll's cr., a tributary of Monocacy r. $68 \mathrm{~m}, \mathrm{~W} . \mathrm{N}$. W. Annapolis, Lat. $39^{\circ} 24^{\prime} \mathrm{N}$., and long. $77^{\circ} 18^{\prime} \mathrm{W}$. It is a well-built town, with regular, wide streets, and contains a court-house, a substantial building, the county jail, and other public offices; 17 churches, some of them spacious and of fine architecture; several literary and seientific institutions, and about 1,000 dwellings, mostly of brick or stone, and many of them elegant, and 6,025 inhabitants, of which 4,786 are white, 822 free colored, and 420 slaves. In regard of population it is the third town of the State, Baltimore and Cumberland only haring more inhabitants-in wealth and elegance it is second only to Baltimore. St. John's College, chartered in 1550 , and several other Poman Catholic institutions are loented in Frederick. The newspapers published here are the "Star" (literary), the "Banner of Liberty" (whig), the "Examiner" (whig), the "F. Herald" (whig), and the "Republican Citizen" (dem.), all issued weekly. The highway from Baltimore to Wheeling passes through Frederick, and a branch road connects it with the Balti- 
more and Ohio R. R. The valley of Monocacy r. is equally remarkable for its beauty, its rich agricultural resources, and its mineral wealth. Frederick is the depot of this district, and has a large commerce. Numerous manufactures are carried on, and also a large wholesale and retail trade.

Frederrok, p. T., Mahoning co., Ohio : on a branch of Mahoning r., $128 \mathrm{~m}$. N. E. Columbus.

Frederick, t. and p. v., Montgomery co., Penn.: $74 \mathrm{~m}$. E. by $\mathrm{N}$. Harrisburg.

Fredericksburgh, p. v, Washington co., Ind. : on Great Blue r., $88 \mathrm{~m}$. S. Indianapolis. It is a pleasant village of some 100 or 120 inhabitants.

Fredericksburgh, p. v., Wayne co., Ohio : on Salt cr., $96 \mathrm{~m}$. N. E. Columbus. It contains several mills and factories, numerous mechanic shops, and about 460 inhabitants.

Fredericksturgh, p. v., Osage co., Mo.

Fredericksburgh, p. v., Lebanon co., Penn. : $39 \mathrm{~m}$. E. by N. Harrisburg. Pop. 397.

Fredericksburgh, p. v., and cap. Gillespie co., Tex, : on Barron's cr. of Pedernales r., $73 \mathrm{~m}$. W. Austin City.

Fredericksburgh, p. b., Spottsylvania co., Virg. : on the S. W. side of Rappahannock $r$, below the falls and at the head of navigation, $110 \mathrm{~m}$. from its confluence with Chesapeake Bay, $60 \mathrm{~m}$. N. Richmond. Lat. $38^{\circ} 34^{\prime} \mathrm{N}$., and long. $77^{\circ} 3 \mathrm{~s}^{\prime} \mathrm{W}$. The city is surrounded by hills, and is laid out with great regularity. It has a court-house, jail, and public offices; several factories and mechanic shops, and numerous wholesale and retail stores. It exports immense amounts of tobacco, grain, and corn, and has a flourishing internal trade. It has one daily newspaper, the "Virginia Whig ;" two semi-weeklies, the "Democratic Recorder" (dem.), and the "F. News" (whig), both of which issued weekly editions; and one weekly, the "Christian Banner," a religious publication. The falls of the Rappahannock, in the vicinity, afford good water-power; and the city is supplied with excellent water from the river in pipes laid by a joint-stock company. The eity was named in honor of Prince Frederick, the father of George III. In 1830 it had 3,307 inhabitants; in $1840,3,974$; and in 1850 about 6,000 . The Richmond, Frederick, and Potomac R. R, passes through the city.

FreDERICKSHALx, p. V., Louisa co, Firg. : $31 \mathrm{~m}$. N. W. Richmond. The Virginia Central R. R. passes through the village.

Frederickstilte, p. $\nabla .$, Schuyler co, $I l_{*}$ : $176 \mathrm{~m}, \mathrm{~N}$. Springfield.

Fredertckton, p. v., Marion co., $I l_{0}$ : on Skillet fork of Little Wabash r., 93 m. S. S. E. Springfield.

FrederickTown, p. v., Washington $c_{*}, K_{y}:$ on Beech Fork, 43 m. S. W. Frankfört.

Frederichiows, p. v., Madison co., Mo. : on a branch of St. François r., 126 m. E. S. E. Jefferson City. Immense mining operations are carried on in the surrounding country.

TrederickTows, p. $\nabla .$, Knox co, Ohio: on Vernon r., $42 \mathrm{~m}$. N. N. E. Columbus. The Columbus and Lake Erie

R. R. passes through the village, $30 \mathrm{~m}$. from Newark. P. 712 Frederrokrows, p. $\nabla .$, Washington co, Penn.: $184 \mathrm{~m}$. W. Harrisburg.

Fredox, p. y., Sussex co., N. Jer.: 58 m. N. by W. Trenton.

Frigdonta, p. v., Chambers co., $A l \alpha_{0}:$ on a creek of Chattahoochee r., $71 \mathrm{~m}$. N. E. Nontgomery.

Friconis, p. v., Crawford co., Ind, : on a high bluff at the Iower end of the Horse Shoe Bend of the Ohio r., 106 $\mathrm{m} . \mathrm{S}$. by W. Indianapolis. It is about $4 \mathrm{~m}$. below Levenworth, and contains about 300 inhabitants.

Fredonts, p. v., Caldwell co., Ky. : on Livingston's cr. of Cumberland r., 192 m. W. S. W. Frankfort.

FredonIA, p. v., Washtenaw co., Mich.: 48 m. B. E. Lansing.

Fredonts, p. v., Pusk co., Tex, : 226 m. N. E. Austiu City. Frenowia, p. r., Chautauque co., $N$. Y.: on Canadaway cr. of Lake Erie, $3 \mathrm{~m}$. S. from Dunkirk and $273 \mathrm{~m}$. W. by $\mathrm{S}$. Albany. It contains several mills and factories, and about 1,200 inhabitants. The stores, hotels, streets, and public buildings are lighted by a "natural gas" issuing from the bed of the creek. Several lighthouses on the lake shore 2 re also lighted by the same earburetted hydrogen, which bums as brilliantly as coal or rosin gas. The "F. Courier" (whig) is published weekly. This is a pleasant and thrivingr village.

Fredonu, t, and p. o., Washington co., Wisc. : $76 \mathrm{mo}$ E. N. E. Madison. Drained by Milwaukie $r$, and its tributaries. Pop, 672.

FredonIA, p. v., Licking co., Ohio: 27 m. N. E. Columbus.

FredonIa, p. v., Williamson co., $I l_{0}$ : on the N. side of Big Muddy r., 136 m. S. S. E. Springfield.

Freponis, p. v., Montgomery co., Tenn.: on a ereek of Cumberland r., $34 \mathrm{~m}$. N. W. Nashville.

Fredonia, p. V., Macon county, Ga.: $76 \mathrm{~m}$. S. W. Milledgeville.

Free Bridge, p. o., Cass co., Ga.: on Etowah r., $122 \mathrm{~m}$. N. W. Milledgeville.

Freeburgh, p. v., Union co, Penn.: 49 m. N. N. W. Harrisburg.

Freedexsburgi, p. v., Schuylkill co., Penn.: 47 m. N. E. Harrisburg.

Freedom, p. v., Keokuk co., Ia. : 73 m. S. Iota City.

Freedon, p. v., Owen co., Ind.: on the W. fork of White r., 5 5 m. B. W. Indianapolis.

FreEdoM, p. V., Sauk county, Wisc.: on the N. side of Baraboo r., 38 m. N. W. Madison,

Frefadom, p. v., Carroll co., Md.: $51 \mathrm{~m}$. N. W. Annapolis, Freedom, p. vi, Lafayette co., Mo.: 86 m. W. N. W. Jefferson City.

FrEedom, t. and p. v., Waldo county, $M e_{*}: 27 \mathrm{~m}$. N. E. dugusta. Drained by a branch of Sebasticook $r$. Surface level; soll fertile. The village is ealled S. Freedom, and is a small agricultural settlement. Pop. of t,948.

Freedor, to and p. v., Carroll con, N. Hamp.: 46 m. N. N. E. Concord. Ossipee Lake borders it on the S., and receives its drainage. Surface uneven; soil of average fertility. The village is located at the outlet of the lake, on the N. side of Ossipee r. Pop. of t. 910.

Freedom, t. and p. o., Cattaraugus co., $N$. $Y .: 252 \mathrm{~m}$. W. by S. Albany, Drained by Clear and other creeks of Cattaraugus cr. Surface level; soil, gravelly loam, fertîle. Sandusky and Chelsea are villages in this t. Pop, in 1850, 1,652 .

Freedom, t. and p. o., Portage co, Ohio: $128 \mathrm{~m}$. N. E. Columbus, Drainage imperfect. Surface level, and in some parts wet; soil fertile. Pop. 996.

Freedom, p. b., Beaver co., Penn. : on the right bank of Ohio r., 2 m. E. of Beaver r. confluence, $182 \mathrm{~m}$. W. by N. Harrisburg. The Ohio and Pennsylvania R. R. passes through it, $23 \mathrm{~m}$. from Pittsburg. It is pleasantly situate on rising ground, and has many facilities for river commerce. Engines and boilers are made here, and steamboats of large size are built. Pop. about 600 .

Freedom, p. v., La Salle county, Il.: $192 \mathrm{~m}$. N. E. Springfield.

Freedom Platis, p. V., Duchess co., N. $Y_{*}: 67 \mathrm{~m} . \mathrm{S}_{*}$ Albany.

Freerold, t., p. v., and cap. Monmouth co., N. Jer. : $51 \mathrm{~m}$. E. by N. Trenton. Surface wet; soil, sandy loam and well cultivated. The village contains a court-house, county jail, and other public offices, several stores, and about 300 inhabitants. The Battle of Monmouth, a hard fight of the Revolution, occurred here $28 \mathrm{~h}$ June, 1778 . The village has three periodicals, the "Seminary Adrocate" (educational), the "People's Advocate" (dem.), and "Young America" (whig), all issued weekly. There are in the t. numerous distilleries, grist and saw mills, mechanic shops, etc., and 2,683 inhabitants.

FrвнноL, p. v., Greene co., $N . Y_{.}$: on Catskill cr., $26 \mathrm{~m}$, 
S. W. Albany. It contains about 30 dwellings and 200 inhabitants.

Freel, p. o., Polk co., Ia. : 113 m. W. Iowa City.

FrEELAND, p. o., Baltimore co., Mrd.

Freeland, p. o., Northumberland co., Penn.: $49 \mathrm{~m} . \mathrm{N}$. Harrisburg.

Frentand's, p. o., Muskingum co., Ohio: $72 \mathrm{~m}$. E. Columbus.

Freeman, t. and p. 0., Franklin co., Me.: 44 m. N. N.W. Augusta. Drained by a branch of Sandy r., on which also the village is located. Pop. 762.

Freemansburge, p. vo, Northampton co., Penn.: $87 \mathrm{~m}$. E. N. E. Harrisburg.

Freeman's Landing, p. o., Hancock co., Firg.: on the Ohio r., $264 \mathrm{~m}$. N. W. Richmond.

Freemantilute, p. v., Cherokee co, Ga.: $109 \mathrm{~m} . \mathrm{N}$. W. Milledgerille.

Friemanton, p. v., Effingham co., $I l l_{0}:$ on a branch of Little Wabash r., 71 m. 8. E. Springfleld.

FreEO, p. 0., Washita co., Ark.: 69 m. S. by E. Little Rock.

F r., $24 \mathrm{~m}$. E. S. E. Indianapolis.

Freeport, p. v., and cap. Stephenson $\mathrm{co}_{\text {, }}, I l l_{0}$ : on the S. side of Pecatonica r., $168 \mathrm{~m}$. N. Springfield. It is a flourishing village, and being neighbored by fine mineral as well as agricultural lands, must eventually become an important place. Two newspapers, the "F. Journal" (whig), and the "Prairie Democrat," are published weekly. The Galena Branch of the Central Illinois R. R. passes through the village, and is here intersected by the Galena and Chicago Union $R$. $R_{w}$, which lines connect it with Galena on the W., Chicago on the Ev, and Cairo on the S. of the State.

Frezport, to and p. o., Cumberland co., Mre.: $37 \mathrm{~m}$. S. S. W. Augusta, at the head of Casco Bay. The village is pleasantly situate, and has a small harbor, with some narigation and ship-building. The town is almost entirely agrieultural, and has 2,629 inhabitants.

Freeport, p. v., Harrison co., Ohio: on Big Stillwater cr. of Tuscarawas r., $94 \mathrm{~m}$. E. by N. Columbus. The Stillwater is boatable to this place, and at its mouth, $20 \mathrm{~m}$. distant, connects with the Ohio Canal. The village contains numerous warehouses, mechanic shops, stores, ete., and about 600 inhabitants. In the $t$. of the same name there are several flouring mills and other manufacturing establishments.

FreEPort, p. b., Armstrong co., Penn.: at the confluence of Buffalo cr. with Alleghany r., $152 \mathrm{~m}$. W. by N. Harrisburg. The Pennsylvania Canal passes this village, crossing the creek by an aqueduct. The village contains 6 or 7 churches, of various denominations, numerous mills, factories, and mechanic shops, and about 160 dwellings. Pop. about 800 .

Freeport, p. v., Wood county, Firg.: $252 \mathrm{~m} . \mathrm{N}$. W. Richmond.

Fremsrade, p. O., Middlesex co., Firg.: 49 m. E. by N. Richmond.

Fremstone county, Tex. Situate centrally on W. bank of Upper Frenchy r., and contains about $\$ 60$ sq. m. Erected since 1850. Capital: Freestone.

Freetown, t. and p. o., Bristol con, Mass.: 48 m. S. Boston. Drained by branches of Taunton r., which makes the $T$. boundary. Surface level; soil, light and sandy. The t. bas some manufactures, and the New Bedford and Taunton R. R. passes through it. Pop. 1, v1i

FreEToms, p. vo, Jackison co., Ind. : on a head branch of Salt cr., $58 \mathrm{~m}$. S. Indianapolis.

Freftown Corners, p. v., Courtlandt co., $N_{0} Y_{0}$ : on a creek of Tioughnioga r., $118 \mathrm{~m}$. W. Albany.

Frfe Union, p. o., Albemarle co., Tirg. : 69 m. W. N.W. Richmont.

Freisbergh, p. v., Colorado co., Texe. : on Peeper's cr., an aftuent of Cummin's er. of Colorado rog $80 \mathrm{~m}$. E. S. E. Austin City.
Fremont county, Ia. Situate in the S. W. comer of the State, and contains $496 \mathrm{sq}$. m. Drained chiefly by Nishnabatona r. and Keg cr., affluents of the Missouri r. Sure face an extended prairie, except near the Missouri, which marks its W. border, where the land is somewhat broken. The soils are fertile and among the best of the State. Farms 105; manuf, 0 ; dwell. 222, and pop.-wh. 1,244, fr. col. 0-total 1,244. Capital: Sidney.

Fremonr, p. vo, Pontotoc co., Miss: 156 m. N. N. E Jackson.

FrEmont, p. v., Steuben county, Ind.: $141 \mathrm{~m}$. N. N. E. Indianapolis,

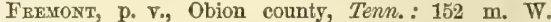
Nashville.

Fremont, p. v., Mahaska co., Ia.: on the highland between Big Cedar cr. and the S, fork of Skunk r., $57 \mathrm{~m}, \mathrm{~S} . \mathrm{W}$. Iowa City.

Fremont, p. v., Yolo co., Calif.: on the W. side of Sacramento r., opposite the mouth of Feather r., $62 \mathrm{~m}$. N. E Vallejo.

Frevort, p. v., and cap. Sandusky county, Ohio: on the W. bank of Sandusky r., $96 \mathrm{~m}$. N. by W. Columbus, To this point the $r$. is navigated by small steamers. The $v$. contains the court-house, etc., several warehouses, stores, and mechanic shops, and about 1,492 inhabitants, It is built on the site of old Fort Stonington. The eleveland, Norwalk, and Toledo R. R. intersects this place.

FrevoNT, p. o., Itawamba county, Aliss. : $172 \mathrm{~m} . \mathrm{N}$. E Jackson.

Fremowt, p. v., and cap. Cedar co., MFo.: on an elevated site between Cedar creek and Sac river, $105 \mathrm{~m}$. S. W. Jefferson City.

Frexont, p. o., Sullivan county, N. $Y .: 87 \mathrm{~m} . \mathrm{S} . \mathrm{W}$. Albany.

FremoNT, p. V., Shiawassee county, Mich.: 23 m. N. E. Lansing.

Fremont, p. 0., Brown county, Wisc. : 118 N. N. E. Madison.

Frexcr Broad, p. o., Buncombe co., N. Car.: on French Broad cr., $228 \mathrm{~m}$. W. Raleigh.

Frevcr Broad river, N. Car. and Tenn.: a constituent of Tennessee r. It rises by numerous head branches from the declivities of the Blue Ridge in Buncombe co., N. Car., and passing through a gap in the Stoney Mountains, enters Tennessee, and unites with Holston r., about $5 \mathrm{~m}$. above Knoxville. It is navigable for boats of 15 tons to Dandridge. Its chief branches are the Nolichucky $r$. in the N., and Big and Little Pidgeon rivers in the $\mathrm{S}$.

FrRich CAMP, p. 0., Choctaw co., Miss. : $74 \mathrm{~m}$. N. N. F. Jackson.

Frearch Creek, p. o., Knox county, $M l_{0}$ : on the cr. so calted, $79 \mathrm{~m} . \mathrm{N}$. N. W. Springfield.

Frexicr Creek, t, and p. v., Chautauque county, $N$. $Y$. the southernmost $t$. of the State, $298 \mathrm{~m}$. W. S. W. Albany Drained by French ereek. Surface hilly; soil moist sandy loam. The $r$, is located on the cr. near the centre, and contains about 20 dwellings. In the $t$. there are several mills. Pop. 725.

Frearcil Creek, t. and p. o., Mercer co., Penn.: $189 \mathrm{mo}$ W. N.W. Harrisburg. Drained by tributaries of Alleghany river, one of which, named as above, passes through the N. E. part of the $t$. Surface level; soil clay and loam, of moderate fertility. It has several tanneries and mills, and 1,126 in habitants.

Frexch Creak, p. o, Lewis co., Virg. : on a cr. of the E. fork of Monongahela r., $176 \mathrm{~m} . \mathrm{W} . \mathrm{N}$. W. Richmond. 'This is an agricultural settlenent, chieftr of New Encland peoyle, and contains about 80 scattered dwellings, various mechanic ehops, etc.

FrExch creek, $N$. Y. and Penn.: rises in Chautauque co. New York, and passes into Pennsylvania through Erie, Crew ford and Mercer counties into Fenango $\mathrm{CO}_{\text {, }}$ in which last it joins the Alleghany $r$, at the borough of Franklin, 
after a course of about 100 miles, for one half of which distance it is boatable.

Frexch Graxt, p. 0., Scioto co., Ohio: on the S. E. part of the co., near Ohio r., $95 \mathrm{~m}$. S. by E. Columbus.

Fresch Grove, p. o., Bureau co., Ill.: on a branch of Spoon r., 103 m. N. by W. Springfield. French Grove contains much fine timber, surrounded by rich rolling prairies.

French IstaNd, p. v., Spencer co., Ind.: on the Ohio r. at the head of French Island, $131 \mathrm{~m}$. S. by W. Indianapolis. It is a small v. of some 10 or 12 dwellings.

Freaver Lick, p. 0., Orange co., Ind.: 79 m. S. S. W. Indianapolis.

Frexchusy's bay, Me.: this important arm of the Atlantic is bounded W. by Baker's, one of the Cranberry islands, and $\mathbf{E}$. by a peninsula of the mainland, on the W. side of which is Musquito Harbor. The distance from Baker's Island to Skuttock Point is $10 \mathrm{~m}$., and its depth is $20 \mathrm{~m}$. It receives many valuable streams, and contains a number of excellent harbors and beautiful islands. It is easy of access, never obstructed by ice, and is one of the best retreats in a storm on the American coast.

Frevch Mouvtate, p. 0., Warren county, N. Y.: $68 \mathrm{~m}$. N. N. W. Albany.

Frexch's Corner, p. o., Kennebee co., Me.

French's Mriss, p. o., Bradford co., Penn.: $118 \mathrm{~m}$. N. by W. Harrisburg.

Frexchton, p. v., Lewis co., Virg. : 174 m. W. N. W. Ri.limond.

Frenchtown, p. O., Hunterdon county, N. Jer.: 29 m. N. by W. Trenton.

Erench Vrluage, p. v., St. Clair co., Ml. : about 6 m. E.

Illinoistown, and $90 \mathrm{~m}$. S. by W. Springfield.

Fravctintele, p. v., Clearfield co., Penn. : 108 m. N. W.

IIarrisburs.

FEnwsburgh, p. v., Chautauque co, $N . Y_{\text {.: }}$ on the E. side of Conewango cr., $274 \mathrm{~m}$. W. S. W. Albany.

Freysiusn, p. o., Montgomery co., N.Y.: 47 m. W. N.W. Albany.

Friar's Poivt, p. 0., Coahoma co., Miss. : 138 m. N. byW. Jackson.

FrICK's GaP, p. o., Walker county, Ga.: 187 m. N. W. Milledgeville.

Friedenstule, p. v., Lehigh co., Penn. : 77 m. E. N. E. Harrisburg.

Frinndereld, p. 0., Marion dist., S. Car. : $97 \mathrm{~m}$. H. N. E.

Columbia.

Friexd's, p. O., Chautauque co., $N . Y$.

FrIend's Grove, p. 0., Charlotte co., Virg. : 74 m. W. S.W. Richmond.

FrIENDShIP, p. v., Sumpter county, Ga.: 97 m. S. W. Milledgeville.

FrIendsme, p. 0., M'Donough co., $I l l .: 72 \mathrm{~m}$. W. N. W. Springfield.

Friendship, p. v., Anne Arundel co., Ma.

Friexdsur, p. v., Fond du Lac co., Wisc.: 61 m. N. E. Madison.

Friendehip, t. and p. o., Lincoln co., $M r_{0}: 36$ m. S. E. Augusta. Muscongar Bay bounds it on the W., and the Atlantic on the S., giving it considerable trading facilities. Several islands, off the coast, are included in the town. The village lies on a small estuary in the $\mathbf{S}$. E., and contains about 20 dwellings. Pop, of t.652.

Friendserp, p. V., Guilford con, N. Car.: 78 m. W. N.W. Raleigh.

Friendshre, t. and p. \%., Alleghany county, N. Y.: $218 \mathrm{~m}$. W. by S. Albany. Drained by Campan's cr. of Genesee r. Surface undulating; soil, argillaceous mold. The village, on the line of the New York and Erie R. R., is a flourishing place of some 500 inhabitants. Pop. of t.1,625.

Friendship, p. v., Sumter district, S. Car : 67 m. E. S. E. Columbia.

Ferexdsurp, p. o., Franklin co., Miss.: 78 m. S. S. W. Jackson.
Fetendship, p. o., Dyer co., Tenn.: $142 \mathrm{~m}$. W. Nashville. Frimidsiup, p. o., Scioto co., Ohio: $\delta 6 \mathrm{~m}$. S. Columibus. Friendstille, p. V., Wabash county, $I l_{0}$; $183 \mathrm{~m}$. S. E。 Springfield.

Friendsville, p. v., Blount county, Tenn. : 168 m. E. S. E. Nashville.

Friendsville, p. v., Susquehanna county, Penn. : $122 \mathrm{~m}$. N. N. E. Harrisburg.

Frismie's Mills, p. o., Warrick county, Ind.: on Little Pidgeon river, about $4 \mathrm{~m}$. from its mouth, $136 \mathrm{~m}$. S. by T. Indianapolis.

Frog Level, p. o., Newberry dist., S. Car.

Frontera, p. v., Socorro co., N. Mew.

Frontier, p. o., Clinton' co., N. Y.: 154 na. N. Albany.

Front Roxal, p. v., and cap. Warren co., Tirg.: on Happy er. of the Shenandoah r., about $1 \mathrm{~m}$. from its mouth. It is the present terminus of the Manassas Gap R. R., which, however, it is intended to extend to Harrisburg, in Rockingham co. It is a pleasantly situated village, and contains a court-house and other co, buildings, 2 churches, several stores and mechanic shops, mills, etc., and about 300 inhabitants.

Frostburgh, p. v., Alleghany co., Md.: on the National Road, $10 \mathrm{~m}$. W. Cumberland, and $156 \mathrm{~m}$. W. N. W. Annspolis. A railroad extends hence to Cumberland, which is chiefly used for the conveyance of the coal and iron of the Frostburg mining district to that point. Frostburg is one of the most elevated villages in the Union, being, according to Schriver, 1,792 feet above the level of Chesapeake Bay. It is the centre of a vast mining region.

Frozen Creer, p. 0., Breathitt co., Ky.: 102 m. S. E. Frankfort.

Fruit Hri, p. o, Christian con, $K y_{*}: 152$ m. W. S. W. Frankfort.

Frort Hrlt, p. o., Vigo co., Ind. : $78 \mathrm{~m}$. W. Indianapolis. Fruit Hill, p. o., Clearfield co., Penn.: 112 m. N. W. Harrisburg.

Frum Hrum p. o., Edgefield dist., S. Car.: $67 \mathrm{~m}$. W. by S. Columbia.

Frutr Frurs, p. F., Warren county, Ohio: 86 m. S. W. Columbus. The "Regenerator," a monthly periodical, is issued at this place.

Fryburge, p. v., Auglaize county, ohio: $78 \mathrm{~m}$. N. W. Columbus.

Frreburgh, t. and p. v., Oxford co., $M e_{\text {. : }} 63 \mathrm{~m} . \mathrm{W} . \mathrm{S} . \mathrm{W}$. Augusta. Drained by the Saco r., which passes through it. Surface varied; soll is generally light, but on the river very fertile. The village, on the E. side of Saco r., is situate on a beautiful plain surrounded by hills, and near it is "Lovell's Pond," celebrated in Indian warfare. Pop. 1,5»4.

Fryer's Bridge, p. o., Pike eo., Ala.: $49 \mathrm{~m}$. S. by E. Montgomery.

Fryek's Ponds, p. o., Burke county, $G a_{\text {. : }} 86 \mathrm{m.}$. Milledgeville.

FuLdo, p. v., Spencer county, Ind.: 122 m. S. by W. Indianapolis.

Fuller's Porvt, p. v., Coles co., Ill. : 75 m. E. by S. Springfield.

Fullerstille IroN Works, p. 0., St. Lawrence county, N. Y.: on a branch of Oswegatchie r., $131 \mathrm{~m} . \mathrm{N}$. W Albany. The works here are extensive, and the village contains about 400 in habitants.

Furton county, Ark. Situate N. middle, and contains $828 \mathrm{sq} . \mathrm{m}$. Drained in the $\mathbf{E}$, by the forks of Spring and Strawberry rivers, affluents of Big Black r., and in the W. by a large branch of White $r$. Surface diversified-in some parts broken; soils generally fertile. The streams afford many fine mill sites, and White $r$. is here navigable for boats of large size. Farms 220 ; manuf. 0 ; dwell. 2SS, and pop.-wh. 1,768, fr. col. 1, sl. 50-total 1,819. Capital: Pilot Hill.

FuLtor county, Ill, Situate toward the W. centrally, 1 and contains $56 \pm$ sq. m. Drained by Spoon r.. Copperas 
cr., and other afluents of Illinois r., which makes its E. and S. E. boundary. Surface undulating, and consisting of prairie and timber in about equal proportions; soil, a deep black mold, very fertile. Iron ore is abundant and has been successfully worked. Farms 1,942; manuf. 104; dwell. 3,811, and pop.-wh. 22,492, fr. col. 16-total 22,508. Capital: Lewistown.

Fultow county, Ind. Situate $\mathrm{N}$. centre, and contains 357 sq. m. Drained by the tributaries of the Tippecanoe, near which there is some hilly land, otherwise the surface is level or gently undulating. In the $\mathrm{N}$. $\mathrm{E}$. and $\mathrm{E}$, there are dense forests - in other parts prairies or barrens, with occasional groves. The timber lands are the best, being a deep black mold. Iron ore is abundant. Farms 777; manuf. 18; dwell. 1,0S5, and pop.-wh. 5,980, fr. col. 2-total 5,9S2. Capital: Rochester.

FulToN county, $K y$. Situate in $\mathrm{S} . \mathrm{W}$. corner of the State, and contains $180 \mathrm{sq} . \mathrm{m}$. Drained principally by Bayou Desha cr. and is bounded on the W. and N. W. by the Mississippi r. Surface generally level; soil rich and productive. In the W. part of the county there are several small lakes, which have their outlets into the Mississippi. The agricultural products are, tobacco, the cereals, and some cotton. Farms 361 ; manuf. 9 ; dwell. 5S6, and pop.wh. 3,499, fr. col. 4, sl. 943-total 4,446. Capital: Hickman. Public Works: Mobile and Ohio R. R.

Funton county, $N . Y$. Situate N. E. centrally, and contains $500 \mathrm{sq} . \mathrm{m}$. Drained by Sacandaga r. and East Canada cr. Surface hilly, approaching to mountain: soils of the valleys very fertile. Farms 1,861; manuf, 288; dwell. 8,736, and pop.-wh. 20,079, fr. col. 92-total 20,171. Capital: Jolnstown. Public Works: Etica and Schenectady R. R.; also Saratoga and Sackett's Harbor R. R. (projected), etc.

Fulton county, Orio. Situate N. W., and contains 432 sq. m. Drained chiefly by Tiffin $r$. and a number of other smaller tributaries of Maumee r. Surface moderately uneven and soils rich and fertile. Farms 826; manuf. 32 ; dwell. 1,355, and pop.-wh. 7,780 fr. col. 1-total 7,781. Capital: Dover. Public Works: Fort Wayne, Perrysburg, and Sandusky R. R., etc.

Fultox county, Penn. Situate S., and contains $4 \mathrm{~S} 0 \mathrm{sq} . \mathrm{m}$. Drained by affluents of the Potomac and Juniata rivers. Surface hilly, with fertile and extensive valleys. It is a fine grain and grazing country, and exports largely of its produce. It also yields iron, bituminous coal, potters clay, etc. Farms 581; manuf. 49; dwell. 1,383, and pop.-wh. 7,474, fr. col, 93-total 7,667. Capital: Harrisonville.

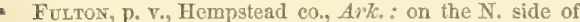
Red r., about $3 \mathrm{~m}$. E. of the confluence of Saline Bayou, 83 m. S. W Litlle Rock.

Fulton, p. v., Whitesides co., IUl.: on the E. side of Mississippi r., $144 \mathrm{~m}$. N. by W. Springfield.

Fulton, p. v., and cap. Itawamba co., Miss.: on the E. side of the E. fork of Tombigbee r., $168 \mathrm{~m}$. N. E. Jackson. It contains a court-house and about 30 dwellings.

Fultor, p. ₹., Barry co., Mich. $42 \mathrm{~m}$. W. by S. Lansing. Fulton, p. v., and cap. Callaway co., Mro.: on Aux Vases r. of Missouri r., $26 \mathrm{~m}$. N. E. Jefferson City. It contains a court-house and other county buildings, several stores, and about 600 inhabitants, with a thickly pojmlated neigliborhood. A weekly newspaper, the "Missouri Telegraph," is published here.

Fultos, p. o., Davie co., $\lambda_{\text {. Car. }}$ : on the W. side of Tadkin r., 98 m. W. by N. Raleigh.

Fultow, p. V., Oswego county, $N$. $\Gamma_{\text {.: }}$ on the $\mathrm{E}_{\text {, side }}$ Oswego r., $189 \mathrm{~m}$. W. N. W. Albany, and on the line of the Oswego Canal, $27 \mathrm{~m}$. from Syracuse and $11 \mathrm{~m}$. from Lake Ontario. The river here has a fall of 20 feet, which produces an immense hydraulic power, which propels severa flour and other mills. The "F. Patriot" is issued weekly It is a thriving and pleasant rillage, containing nurnerous stores and about 1,900 inhabitants.
Fultor, t. and p. v., Hamilton co., Ohio: $97 \mathrm{~m} . \mathrm{S} . \mathrm{W}$. Columbus. It extends along the Ohio $r_{0} 2 \frac{1}{2} \mathrm{~m}$., and back to the hill about half a mile, and is situate immediately above Cincinnati. The village, about a mile from the city, has extensive lumber yards, 11 steam saw mills, and 6 shipyards. As many as 40 to 50 steamboats are built here annually, besides barges, ships, etc. It has also a dry dock. The Little Miami R. R. passes through its principal street. The whole town is a scene of industry, and as a suburb of Cincinnati, it is one of its most important satellites. Pop. of t. in $1840,1,506$; in $1850,3,225$.

Fulton, p. v., Westmoreland co., Penn.: $147 \mathrm{~m}$. W. Harrisburg, Pop. 1,797.

Fuctov, p. v., Dallas co., $A 2 \alpha$. : 39 m. W. Montgomery. Fultow, p. v., Sumter dist., S. Car. : on the E. side of Santee r., 37 m. S. E. Columbia.

Fulton, p. v., Lauderdale co., Tenn.: on a bluff of the E. bank of Mississippi r., above the confluence of Big Hatchee r., $173 \mathrm{~m}$. W. by $\mathrm{S}$. Nashville. It has some river trade and about 40 dwellings.

Fultow, t. and p. v., Rock county, Wisc.: 42 m. S. E. Madison. Drained by Catfish and other affluents of Rock r., which winds through the town. The village is located at the confluence of Catfish and Rock rivers. Pop. $82 \varepsilon$.

Fuxtor, p. v., Fulton eo., Ind. : on the Logansport and Rochester turnpike, $80 \mathrm{~m}$. N. Indianapolis

Funton lakes, $N$. Y.: a chain of 8 lakes, lying partly in Herkimer and partly in Hamilton counties. They are connected by navigable outlets, forming the head branches of Moose $r$., which in Lewis county empties into Black river.

Fulton Centre, 1) v., Fulton co., $I l l:$ : on the E. side of Spoon r., opposite the village of Bernadotte, 54 m. N. W. Springfield.

Fultoninam, p. v., Schoharie co., $N$. $Y_{\text {.: }}$ on the W. side of Schoharie cr., $32 \mathrm{~m}$. W. by S. Albany.

Fultoniam, p. v., Muskingum co., Ohio: 56 m. E Columbus. It has several manufacturing establishments and mechanic shops, and about 600 inhabitants.

Fultonvilue, p. v., Montgomery co., $N$. $Y_{\text {.: }}$ on the $\mathrm{S}$ bank of Mohawk r. and on the Erie Canal, 37 m. W. N. W. Albany. The river is here crossed by a bridge. The village contains several stores and mechanic shops, a dry dock and boat-yard, and about 400 inhabitants; and has a news paper, the "Montgomery Whig," which is issued veekly. It is situate almost opposite to Fonda, the county-seat of justice.

Fultood's Store, 'p. o., Union co., $N$. Car.: $122 \mathrm{~m}$. W. S. W. Raleigh.

Fundx, bay of: this bay washes a part of the eastern shore of Maine, and is an important channel of commerce between the United States and British provinces of New Brunswick and Nova Scotia. It sets up round Cape Sable in lat, $43024^{\prime} \mathrm{N}$., and long. $65^{\circ} 39^{\prime} \mathrm{W}$, and crosses to the shure of Maine a little W. of Frenchman's Bay, from the mouth of which to the cape is about 150 miles. From Eastport to St. John's, N. B., is $60 \mathrm{~m}$., from St. John's to Annapolis $40 \mathrm{~m}$., and from thence to Halifax, overland, about $70 \mathrm{~m}$. The bay is divided near its head by Chignecto Cape. The N. W. part is called Chignecto Bay, and the S. E the Basin of Mines. From Eastport to the head of Chignecto Bay is $170 \mathrm{~m}$., to Windsor, at the head of the Basin of Mines, $150 \mathrm{~m}$, and from Windsor to Halifax $45 \mathrm{~m}$. The commerce of this bay is very considerable, and its fisheries are the most extensive and valuable in the world. The tides are supposed to rise higher in the Bay of Fundy than in any other part of the world, and their elevation increases in ascending; at Eastport they rise 25 feet, at $\mathrm{St}$. John's 30, at Cape Split 55, at Windsor 60, and at Cumberland 71. The islands within the bay are Grand Menan, and a cluster of small islands round it off. West Quoddy Head, and Campo Bello, near Eastport, and others-all belonging to the British. Isle de Haute contains beatiful specimens of asbestos. The rapidity of the tides, the at 
most persistent fogs, and the absence of good harbors between Eastport and St. John's, and from St. John's to Chignecto Cape, render the navigation dangerous and difficult. The tides herald their approach by a roaring turmoil, and overwhelm in their course all opposition, the first tide wave being from 8 to 10 feet in height. The harbor of St. John's is of easy access, safe, and of sufficient expanse and depth for a large fleet. It is located at the outlet of the great river of the same name, in lat. $45^{\circ} 20^{\circ} \mathrm{N}$., and long. $66^{\circ} \mathrm{W}$. Its chief export is lumber, and of this material it supplies by far the greatest quantity received in England.

Funkstown, p. v., Washington co., MI. : on the E. bank of Antietam er., $55 \mathrm{~m}$. W. N. W. Annapolis. It is a considerable village, and has 793 inhabitants.

Furvace, p. o., Erie co., Ohio.

Furnace, p. o., Berks co., Penn.

Furnace Village, p. V., Litchfield co, Conn.: on a creek of Salmon r., $44 \mathrm{~m}$. W. by N. Hartford. Here are extensive smelting works, famous for the production of a a fine quality of iron. The ore is obtained from a bed in the IF. part of the t, near the New York State line.

\section{G}

Gaвriel's Creek, p, o., Yancey co., $N$. Car.: $212 \mathrm{~m}$. W. Raleigh.

Gaddextille, p. v., Robeson co., $N$. Car. : 93 m. S. S.W. Raleigh.

GADDistows, p. V., Union co, Ga.: 133 m. N. by W. Milledgeville.

GAdFlx, p. o., Barry co., Mo. : 147 m. S. W. Jeferson City.

GADSDEN county, Flor. Situate centrally in W. District, and contains $1,150 \mathrm{sq} . \mathrm{m}$. It extends from the Georgia line to the Gulf of Mexico, and is inclosed on the $\mathbf{E}$. by Ocklockony r., and in the W. chiefly by Appalachicola r. Dog Island, off the coast, belongs to this county. Surface generally low and level-on the Appalachicola $r$. are hills or bluffs, and toward the $\mathrm{S}$. the lands are somewhat marshy; soils on the streams generally fertile, but in other parts there are extensive pine barrens and sandy wastes. Cotton, rice, sugar, and tobacco are grown. Farms 4S2; manuf. 0 ; dwell. 684, and pop.-wh. 3,900, fr. col. 4, sl. 4,879-total 8,783. Capital: Quincy.

GaDsDev, p. $V_{*}$, Cherokee co, Ala : 134 m. N. by E. Montgomery.

G $\triangle D 8 D E N$, p. F., Richland dist, S. Car.: on the N. E. side of Cedar er, of Congaree r., and on the line of the Columbia Branch R. R., 19 m. S. E. Columbia.

GAGE's LakkE, p. o., Lake county, $17 l_{n}: 192$ m. N. E. Springfield.

GAGE's PoINT, p. o., St. Francis co., Ark. : 91 m. E. N. E. Iittle Rock.

GaImanNa, p. v., Franklin co., Ohio.

GajLeY's MrLL, p. o., Hall eo, Ga.: 97 m. N. by W. Milledgeville,

Garnea's Store, p. o., Pike co., Ala. : about 4 m. E. Conecuh r. and $49 \mathrm{~S}$. by E. Montgomery.

GaINes, t. and p. v., Orleans co., $N . \bar{Y}$.: $224 \mathrm{~m}$. W. by N. Albany. Drained by branches of Oak Orchard cr. of Lake Ontario. Surface generally level; soil, clayey loam, very fertile. The $v$, is situate on the Ridge Road, and contains about 600 inhabitants. Pop, of t. 2,722. The Erie Canal passes through the S. portion of this town.

Gatres, t. and p. o., Tioga co., Penn.: 112 m. N. N. W. Harrisburg. Drained by Pine cr., an affluent of the W. branch of Susquehanna $r$. Surface diversified by hills and valleys; soils of moderate fertility. It constitutes a fine grazing country and has abundance of timber. Pop. 531.

Gatnes' BeND, p. 0., Hawkins co., Tenn. : 216 m. E. by N. Nashville.

Gatresborovgr, p. T., and cap. Jackson co., Tenn. : on the left bani of Cumberland r., $61 \mathrm{~m}$. E. N. E. Nashville. It contains a court-house and other public buildings, and about 800 inhabitants.

GAINESBOnodgH, p. v., Frederick co., Tirg.: on a branch of Back er, of Potomac r, $122 \mathrm{~m}$. N. N. W. Pichmond. I contains several mechanic shops and about 200 inhabitants.

Gaines' Cross Roaps, p. o., Rappahannock co., Virg.: 84 m. N. N. W. Richmond.

Gaines' Landine, p. 0., Chicot co., Ark. : 134 m. \$. E, Little Rock.

Gainestown, p. v., Clark county, Ala.: 106 m. S. W. Montgomery.

Gainesville, p. v., Sumter con, $A L a_{0}$ : on the W. side of Little Tombigbee r., at the mouth of Okanoxubee r., $112 \mathrm{~m}$. W. N. W. Montgomery. The "Republican Pilot and Sentinel" (dem.) is published weekly. Pop. about 600 .

Gainesville, p. v., and cap. Greene co., Ar\%.: about 17 m. W. of St. Francis r, and $137 \mathrm{~m}$. N. E. Little Pock. It is situate in the midst of a fine prairie country, and has a court-house, jail, etc., and about 200 inhabitants.

G.AInesvilue, p. v., and cap. Hall $c_{0,} G \%$ : on the left side and $3 \mathrm{~m}$. E. of Chattahoochee r., $92 \mathrm{~m}$. N. N. W. Milledgeville. It has a court-house, jail, etc., and has several stores and mechanic shops, with about 300 inhabitants.

Gatnesville, p. v., Hancock co, Df̈ss. : 129 m. S. S. E. Jackson. It is a flourishing village, and has a newspaper, the "Pine Knot" (disunion), a weekly issue.

GAINESVILLE, t. and p. v., Wyoming en, $N . Y_{.:} 218 \mathrm{~m}$ W. by S. Albany. Drained by Allen's and other creeks of Genesee r. Surface undulating, sometinaes hilly ; soil, clayey loam, and fertile, well adapted to grazing. The $v$., in the centre, contains several stores and about 45 dwellings. Pop. of t. 2,668. The Buffalo and New York City R. R. crosses the $t$, in the $\mathrm{N}$. E., $39 \mathrm{~m}$. from Hornellsville.

GaInesville, p. v., Allan county, Ky.: 124 m. S. W Frankfort.

Galeina, p. F., Floyd co., Ind.: on a branch of Indian cr., $96 \mathrm{~m}$. S. by E. Indianapolis.

Galena, p. city, and cap. Jo Daviess co., $I Z l$.: on both sides of Fever (properly Fêve or Bean, or, as some have it, Fevre, from a settler named Le Fevre) $r ., 6 \mathrm{~m}$. from- the Mississippi r., and $183 \mathrm{~m}$. N. by W. Springfield. It is the metropolis of the great lead region of northern Illinois and the commereial depôt of an extensive and fine country, the river being navigable to this point for the largest river steamers at all seasons. Its trade extends to all the towns on the Mississippi and Ohio rivers. The two parts of the city (the most densely populated part being on the W. side of the river), are connected by bridges; it contains a courthouse, jail, and other county buildings, several churches and schools, and has extensive manufactures, chiefiy consisting of such as are incident to the peculiar business of the place. Large quantities of copper are also smelted here, and there are numerous flour and saw mills. In 1551 it exported $33,082,190 \mathrm{lbs}$. of lead, valued at $\$ 1,417,851$, and among its other prineipal exports were flour, 39,335 barrels ; barley, 42,731 bushels; pork, 8,185 barrels; lard, 125,000 pounds; bacon, 312,568 pounds; butter, 87,618 pounds; eggs, 22,980 dozen; hides and skins, 9,826; horses, 800 ; cattle, 1,500 , etc., etc. It is also a great lumber market-in the same year it received $5,085,684$ feet Inmber, $2,470,500$ shingles, and timber and wood of other descriptions. GaIena has two daily papers, the "North-Western Gazette" (whig), and the "G. Jeffersonian".(dem.)-the first named has also tri-weekly and weekly issues, and the latter a weekly edition. The eity was first settled in 1526 , and was then an outpost of the wilderness, $300 \mathrm{~m}$. from the settlements. In 1840 it had 1.843 inhabitants, and in 1850 its population numbered about 6,500 , with a densely settled vieinity. The Galena Branch of the Mlinois Central R. R. passes through the city, and the Galena and Chicago Cnion R. P., gives it access to the lake ports and roads leading eastward. 
GALExa, p. v., Delaware co., Ohio: on Big Walnut er., 18 m. N. N. E. Columbus.

Gales, p. v., Sullivan county, N. Y.: 83 m. \&. S. W. Albany.

Gatesburger, p. v., Knox co., $I l l_{0}: 86 \mathrm{~m} . \mathrm{N} . \mathrm{N}$. W. Springfield. It is the seat of Knox College, founded in 1537 , and which, in 1850, had 5 professors, 25 alumni, and 49 students; and a library of 2,470 volumes. The v. contains several stores and about 600 inhabitants, and here are published two newspapers, the "G. News Letter" and the "North-Western Gazetteer," both weekIy issues. The Cenfral Military Track R. R. will here form a junetion with the Aurora Extension R. R.; and the Peoria and Oquaka R. R. will intersect the former a little S. of the $\mathrm{r}$.-these, together, forming direct communication between Chicago and two points on the Mississippi river.

Galesburger, p. v., Kalamazoo co., Mich.: on the N. side of Kalamazoo r., $52 \mathrm{~m}$. S. W. Lansing. It is a thriving $\mathrm{v}$., and has numerous mills and stores. The Michigan Central

R. R. intersects it $134 \mathrm{~m}$. W. from Detroit

Gale's FerRr, p. 0., New London co., Conn.

Galesville, p. Ya, Washington co., $N$. $Y$.: about a mile S. of Battenkill and $31 \mathrm{~m}$. N. N. E. Albany.

GaLION, p. v., Crawford co., Ohio : on the W. branch of Whetstone r., $54 \mathrm{~m}$. N. N. E. Columbus. It is a thriving village and an important railroad station on the Clereland, Columbus, and Cincinnati R. R., $79 \mathrm{~m}$. from Cleveland and $176 \mathrm{~m}$. from Cincinnati. Here also will be the $\mathrm{E}$, terminus of the Bellefontaine and Indiana R. R.

Gallagierville, p. V., Chester co., Penn.: on the line of the Philadelphia and Columbia R. R., $72 \mathrm{~m}$. E. by S. from Ilarrisburg.

Galiatis, p. v., Gallatin county, Ill.: $162 \mathrm{~m}$. S. S. E. Epringfield.

GALIATIN county, $I U$. Situate S. E., and contains 324 sq. m. Drained by Saline cr. and its tributaries. The Wabash and Ohio rivers bound it on the E., and above the mouth of the first mentioned there is a large island formed by the bifurcation of the stream. Surface undulating and chiefly prairie, with some swamps in the eastern section; soil chiefly sandy, resting on slate; and there are several salt springs. Farms 570; manuf. 17; dwell. 1,000, and pop. -wh. 5,109, fr, col. 339-total 5,448. Capital: Equality. Public Works: Alton and Nashville R. R. (projected).

Gallativ county, $\bar{K} y$. Situate $N$. middle, and contains $152 \mathrm{sq} . \mathrm{m}$. The Ohio r. makes its $N$. boundary, and Big Bone Lick on the N. E., and Eagle r., a branch of Kentucky $x_{*}$, on the $\mathrm{S}$. W., its boundaries in these directions. Surface undulating, and on the Ohio hilly; soils, fertile, producing good erops of the grains and tobacco. In every part of county fine timber is plentiful. Farms 414 ; manuf 11 ; dwell. 747, and pop.-wh. 4,399, fr. col. 34, sl. 704-total 5,137. Capital: Warsaw.

Gallatis, p. v., Parke co., Ind.: on the S. side of Big Pidgeon cr., $56 \mathrm{~m}$. W. S. W. Indianapolis. It has numerous mills, and both up and down the stream mills of all descriptions are in full operation.

Gallatin, p. v., and cap. Copiah co., Miss. : on the right side of Bayou Pierre r., $34 \mathrm{~m}, \mathrm{~s}$. S. W. Jackson. It has a court-house, etc., and about 400 inhabitants; and here is published the "G. Argus," a weekly newspaper. The country around is noted as a fine cotton growing region.

Galiatis, p. v., and cap. Daviess co., Mro.: on the W. side of and $1 \mathrm{~m}$. from the W. fork of Grand $\mathbf{r}$ of the Missouri, $187 \mathrm{~m}$. N. W. Jefferson City. It has a court-house, etc., and about 300 inhabitants.

Gariatix, p. v., and cap. Sumner co., Tenn. : about $8 \mathrm{~m}$. $\mathrm{N}$. of Cumberland r., $23 \mathrm{~m}$. N. E. Nashville. It contains a court-house, ete., several churches, academies, and seminaries, and about 1,200 inhabitants. A newspaper, the "Tenth Legion" (dem.). is issued weekly.

Gallatin river, $N . W . T e$ r. $_{0}$ one of the head streams of the Missouri r., rising from the E, slope of the Rocky 238
Mountains, near the sources of Yellow r. Its course is $\mathrm{N}_{\text {.g }}$ and uniting with Madison and Jefferson rivers, it constitutes the Missouri.

Gallatirviliz, p. v., Columbia co., N. Y.:42 m. S. by E. Albany. The $t$, of Gallatin is drained by Jansen's cr., is somewhat hilly, and has a soil of ordinary fertility; its pop. in 1850 was 1,586 .

Gatirs county, Ohio. Situate S., and contains 520 sq. m. Drained by Raceoon cr. and several smaller tributaries of the Ohio, which river washes its E. border. Surface generally hilly and broken, and the soil, excepting that of the Ohio bottoms, of inferior quality. The county was settled in 1790 by Frenchmen, and hence its name. Farms 1,190; manuf. 9 ; dwell. 2,975 , and pop.-wh. 15,365, fr. col. 1,198 total 17,063. Capital: Gallipolis.

Galita Furnaoe, p. o., Gallia co., Ohio: 79 m. S. S. E. Columbus.

Gallixee, p. o., Wayne co., Penn.: 122 m. N. E. Harrisburg. Originally a Moravian settlement.

GaLlmpolis, p. v., and cap. Gallia co., Otio : on the right bank of Ohio r., $88 \mathrm{~m}$. S. S. E. Columbus. The $\mathrm{v}$. is pleasantly situate on a high bank, 10 or 12 feet above the greatest floods; it contains a court-house, jail, 4 churches, mills and factories, numerous mechanic shops and stores; and among its dwellings are many handsome brick buildings. It has considerable river trade, and is a forwarding point for a great deal of produce. Its pop. in 1850 was 1,686. Two newspapers are published here, the " $\mathrm{G}$. Journal", (whig), and the "Gallia Courier" (neutral), both weekly issues. The $v$, dates from 181.0: the t. was settled in 1791 by Frenchmen, many of whose descendants still reside here. Pop. of t. 2,226 .

GAliowaY, p. v., La Salle co., IU.: on the S. W. side of Vermillion r. of the Illinois, $100 \mathrm{~m} . \mathrm{N}$. N. W. Springfield.

Gallupville, p. v., Schoharie co., N. Y.: on a branch of Schoharie er., $22 \mathrm{~m}$. W. Albany.

Gally Creek, p. 0., Pope co., Arǩ.: 76 m. W. N. W. Little Rock.

GalUs, p. o., Perry co., Ill.: on a cr. so called, $114 \mathrm{~m}$. S. Springfield.

Galpeston county, Tex, Situate S. E, and contains 620 sq. m. This county consists of two portions-mainlaud and insular. The mainland portion lies on the W, side of Galveston Bay, and is drained by Clear, Dickinson's, Highland, and other creeks running into it. The island of Galveston is $36 \mathrm{~m}$. long and about $2 \mathrm{~m}$. wide, and lies opposite the main, from which it is separated by West Bay. No portion of the surface is more than 20 feet above the level of the Gulf of Mexico, and with the exception of several small groves of live oak, the whole is open prairie; soils a black mold, resting on a layer of sand and comminuted shells, indicating the county to have been at no distant perjod the bed of the waters of the gulf. Farms 33 ; manuf. 38 ; dwell 727 , and pop.-wh. 3,755, fr. col. 30, sl. 714-total 4,529. Capital: Galveston. Public Works: Several railroads are projected which will make Galveston their seaward terminits.

GaLVESTON, p. city, port of entry, and cap. Galveston co., Tex. : near the E. end of Galveston Island, $200 \mathrm{~m}$. E. S. E. Austin City. Lat, $29016^{\prime} 37^{\prime \prime} \mathrm{N}$., and $94^{\circ} 49^{\prime} 41^{\prime \prime} \mathrm{W}$. It is the commercial emporium of Texas, and has the best and least difficult larbor on the whole coast. The clearances for foreign ports in 1850 were 9 vessels (2,924 tons), and the entrances, 10 vessels $(2,957$ tons). The tonnage of the district was 3,309 tons, of which 416 tons were registered, and 874 tons sailed by steam-power. The great bulk of its commerce is coastwise with New Orleans and New York, and the former port is connected with it by regular steamship lines. Railroads are now being built into the N. and N.W. interior, which will open up the country to settlement and a market. The city contains the court-house, a jail, and other co. buildings, several handsome churches, and many of the dwellings are elegant structures. It has numerous ware 
houses, wholesale and retail stores, and hotels; and here are published four newspapers, the " $G$. News" (neutral), and the "Civilian and Gazette" (dem.), tri-weekly issues; the "G. Journal" (whig), a semi-weekly; and the "G.Zeitung" (dem.), a weekly German paper. Galveston Island, on which the city stands, is about $36 \mathrm{~m}$. long, with an average width of $2 \mathrm{~m}$. The soil is good, being a black mold, about a foot deep, resting on sand and shells, and it has several ponds of good water. The air is cool and refreshing, and hence it has become a summer resort for invalids. Immense beds of oysters are found near its W. shore, and large quantities of fish are caught on all sides; wild geese, teal, brant, and other birds flock here to winter. This island was formerly a resort for pirates: the celebrated Lafitte had a fort here, the ruins of which are still seen about $2 \mathrm{~m}$. from its E. extremity on the W. shore. It is now in a state of excellent cultivation, and the residence of many wealthy farmers. The population of the city is now about 8,000 .

GaLwAY, t. and p. o., Saratoga co, N. Y.: 29 m. N. W. Albany. Drained by creeks flowing to the Mohawk and the Hudson. Surface undulating-in parts hilly; soil clayey loam, and well cultivated. The $\mathrm{v}_{0}$ is a small central settlement. The t. has numerous manufacturing establishments, fulling mills, woolen factories, tanneries, and grist and saw mills; also several stores. Pop. 2,155.

GaMbIER, p. v., Knox co., Ohio: on the N. side of Vernon r., $42 \mathrm{~m}$. N. E. Columbus. It is situate on a high and level ridge, encompassed on three sides by the river. It was laid out in 1526 in the centre of a tract of 4,000 acres belonging to Kenyon College, and was named after Lord Gambier, a prominent patron of that institution. It is now a flourishing r., but still derives its importance from the College. The buildings of Kenyon College are four in number, the principal building being an elegant Gothic edifice, of hewn stone, 190 feet long and four stories high. It was founded in 1826, by funds obtained in England, and is under the direction of the Episcopalians. In 1850 it had a president and five professors, 60 alumni, and 50 students, and its library contained 7,000 volumes. The theologieal department was founded in 1825, and has four professors and a library of 4,800 volumes. Here are published the "Western Episcopalian," a monthly religious periodical; the "Physlco-Medical Journal," a semi-monthly, and the "Universalist Adrocate," also a semi-monthly. The population of the $\mathrm{v}$. numbers between 400 and 500 souls.

GArBLE, p. o., Jefferson co., Ga.: $63 \mathrm{~m}$. E. Milledgeville.

GaMrie's, p. o., Alleghany county, Penn.: $158 \mathrm{~m}$. W. Harrisburg.

GANGES, p. 0., Richland county, Ohio: on the S. side of Black Fork of Walhonding r., $74 \mathrm{~m}$. N. N. E. Columbus.

GANSEVOoRT, p. v., Saratoga county, N. Y.: 36 m. N. by E. Albany. It is a station on the Saratoga and Washington R. R.

GAP, p. o., Walker county, $A l \alpha .: 135$ m. N. N. W. Montgomery.

GAP, p. O., Lancaster co., Penn.: at the E. fork of Mine Ridge, $51 \mathrm{~m}$. E. S. E. Harrisburg.

Gap Crvin, p. o., Ashe co., N. Car.: $132 \mathrm{~m}$. W. by $\mathbf{s}$. Raleigh.

GAP Cresk, p. o., Knox co., Tenn.: 168 m. E. Nashville. GAP GRove, p. o., Jo Daviess co., Ill.: $156 \mathrm{~m}$. N. by W. Springfield.

GaP MILLS, p. o., Baltimore co., MLd.

Gap Milis, p. 0., Monroe co., Virg. : 187 m.W. Richmond. $G_{\triangle R D E N} G_{R O V E}$, p. o., Decatur co., Ion: 126 m. W. S. W. Iowa City.

Garden Plats, p. 0., Thitesides co., $M l l_{0}: 143$ m. N. by W. Springfield.

GaRDinez, t. and p. $v_{0}$, Kennebec co., Mes: on the W. side of Kennebec r., $12 \mathrm{~m}$. S. by E. Augusta. The Cobbessecontee waters here enters the Kennebec and produces a water-power of great usefulness and extent. The mills here in operation are numerous, and supply immense quantities of sawn lumber for export. The village lies on the Kennebee, the site rising gently from the river, on the edge of which is the business portion. The "Kennebec Transeript" is published semi-weekly. In the v. are numerous well-built dwellings, a lyceum, several churches, with stores, mechanic shops, etc. Large vessels come up to this point to load, and steamboats, plying on the river, call regularly. The Kennebee and Portland $R$. $R_{\text {. passes }}$ through, touching the v. $7 \mathrm{~m}$. from Augusta, and 53 from Portland. Pop. in $1840,5,042$; in $1850,6,456$.

GARDINER's bay, N.Y.: at the E. end of Long Island. It is a considerable body of water, of a somewhat circular shape, $8 \mathrm{~m}$. in mean diameter, situate between the mainland and Gardiner's Island.

Garbiner's island, Suffolk co., N. $Y .:$ off the E. end of Long Island, from which it is distant some 8 or $4 \mathrm{~m}$, It is about $6 \mathrm{~m}$. long, and averages $2 \mathrm{~m}$. wide, forming the $\mathrm{E}$. boundary of Gardiner's Bay. Gardiner's Point is a long neck of land, projecting $N$. This island was settled in 1639 by Lyon Gardiner, a Scotchman; his descendants still own and occupy it.

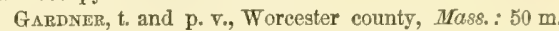
W. N. W. Boston. Drained by branches of Miller's river, which afford water-power. Surface uneven; soil of average quality. The $\mathbf{v}$. is on the Vermont and Massachusetts $R$. R. There are considerable manufactures in the town. Popalation 1,422.

GARDNER, p. v., Morgan county, Ohio: 67 m. E. S. E. Columbus.

GARDNER's BrIDGE, p. 0., Martin county, N. Car.: $92 \mathrm{~m}$. E. S. E. Raleigh.

Gardner's Mills, p. o., St, Clair county, Mo.: $97 \mathrm{~m}$. W. S. W. Jefferson City.

Gardnersville, p. v., Schoharie co., N. Y.: on Cobbleskill cr., $44 \mathrm{~m}$. W. Albany.

GARIS'S FERRY, p. o., Duvall co., F Zor.: 126 m. E. by S. Tallahassee.

Garland, t. and p. v., Penobscot co., Me. : 63 m. N. N. E. Augusta. Drained by the head branches of Kenduskeag $r$. Surface varied; soil fertile, and adapted to grain. The v. lies in the centre. Pop. of t. 1,200.

Garland's, p. o., Albemarle co., Virg. : 72 m. W. N. W. Richmond.

Garlandville, p. v., Jasper co., Miss. : at the head of Tallahala cr., $61 \mathrm{~m}$. E. by \$. Jackson.

Garmon's Milis, p. o., Cabarras eo., N. Car.: $104 \mathrm{~m}$. W. S. W. Raleigh.

GARNer's Ford, p. 0., Cleveland co., N. Car. : 159 m. W. S. W. Raleigh.

Garnetsville, p. vo, Mead co., $K y_{0}:$ on the S. bank of the Ohio r., $67 \mathrm{~m}$. W. by S. Frankfort.

Garoga, p. v., Fulton co., $N, Y_{.}$: on Faroge cr, of Mohawk r., $46 \mathrm{~m}$. W. N. W. Albany.

Garrard county, $5 y$. Situate centrally, and contains 312 sq. m. Drained by Paint Lick, Back, and Sugar ereeks, and

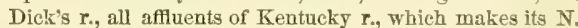
boundary. Sarface varied; soil very fertile. The principal productions are corn and tobaces Farms 666; manue, 21; dwell. 1,285, and pop.-wh. 7,036 , fr. col. 25, sl. 3,176-total 10,237. Capital: Lancaster. Public Works: Lexington and Huntsville R. R.

Garrattsville, p. V., Otsego co., $N$. $Y$.: on a branch of Unadilla r., $72 \mathrm{~m}$. W. Albany.

G.ARRETTSBURgh, p. v., Christian co., Ky.: 180 m.T.S.W. Frankfort.

Garrettssillle, p. v., Portage co., Ohio: 132 m. N. E. Columbus.

Garrettsville, p. v., Lycoming county, Penn.: $82 \mathrm{~m}$. N. N. W. Harrisburg.

Garrison's, p. o., Putnam county, $N . Y .:$ on the line of the Hudson River R. R., $82 \mathrm{~m}$. S. Albany.

GARRISONVILLE, p. F., Stafford county, Virg.: $59 \mathrm{~m} . \mathrm{N}$. Richmond. 
G $\triangle R R Y$ OWEN, p. o., Jackson county, Ian: $60 \mathrm{~m}$. N. E. Iowa City.

Garxbiurgh, p. v., Northampton con, $N$. Car.: at the junction of the Petersburg R. R., and the Seaboard and Roanoke R. R., 74 m. N. E. Raleigh.

Garigyille, p. v., Prince George co., Virg.: on a cr. of James r., 87 m. S. E. Richmond.

GASOONADE county, Mo. Situate E. of centre, and contains 539 sq. m. Drained by Bourbeuse cr. of the Mississippi $\mathbf{r}$. and Gasconade r., an affluent of the Missouri r., which forms its $\mathrm{N}$. line. Surface much broken, and soil, especially on the rivers, very fertile. It abounds in mineral wealth, iron ore, saltpetre and sulphur being everywhere found, and limestone plenty. Corn is the agricultural staple. Farms 553; manuf. 16 ; dwell. 950, and pop.-wh. 4, S81, fr. col. 0, sl. 112-total 4,996. Capital: Hermann. Pub'lic Works : Pacific R. R.

GASCONADE river, Mo. : rises in the S. parts of Texas and Wright counties by numerous head branches from the watershed dividing the streams flowing $\mathrm{S}$. to White $\mathbf{r}$., and those flowing N. to Missouri r. Its principal constituents are Piney, Robideaux, and Osage forks, all of which rise from the same highland. The length of the river is about $140 \mathrm{~m}$., through all which it affords immense water-power and passes through a rich mineral country to the Missouri which it enters about $100 \mathrm{~m}$, from its mouth.

Gas Factory, p. 0., Lincoln co., Tenn.: $69 \mathrm{~m}$. S. by E. Nashville.

Gaston county, N. Car. Situate s., and contains 808 sq. m. Drained by numerous affuents of the Catawbar., which forms its E. boundary. Surface moderately uneven; soil good. Cotton is the staple, though considerable wheat is grown. Farms 724 ; manuf. 10 ; dwell. 1,072, and pop.wh. 5,928, fr. col. 83, sl. 2,112-total 8,073. Capital: Dallas. Public Works: Charlotte and South Carolina R. R.

Gaston, p. v., Sumter co., Ala : on Kintabish cr. of Tombigbee $r_{0}, 110 \mathrm{~m}$. W. Montgomery.

Gaston, p. v., Northampton co., $N_{\text {. Car }}$ : on the N. side of Roanoke r., $66 \mathrm{~m}$. N. E. Raleigh. The Greenville and Roanoke R. R., and the Gaston and Raleigh R. R. connect at this point.

GastoN, p. V., Atchison county, MFo.: 218 m. N. W Jefferson City.

Gates county, N. Car. Situate N. E., and contains 813 sq. m. Drained by Cole's and other creeks, afluents of Chowan r., its W. boundary. Surface lerel, and soil productive and well-wooded. Cotton, corn, and potatoes are the leading products. Farms 490 ; manuf. 22 ; dwell. 850 , and pop.-wh. 4,15s, fr. col. 397, sl. 3,671-total 8,426. Capital: Gatesville.

G $\triangle$ TES, t. and p. o., Monroe co., N. Y.: 196 m. W. N. W. Albany. The Genesee r. makes its E. border. Surface un dulating; soil gravelly, sandy, and clayey loam. It is a fine farming distriet, and has several manufactures, mills, etc The $t$. is traversed by the railroads and canals leaving Tochester westward. Pop 2,005.

Gates, p. o., Newton co., Mro.: on the S. line of the co. $178 \mathrm{~m} . \mathrm{s}$. W. Jefferson City.

Gate's MrLls, p. v., Cuyahoga county, Ohio: on Chagrin river, $183 \mathrm{~m} . \mathrm{N} . \mathrm{N}$. E. Columbus.

Gatestille, p. v., and cap. Gates co., N. Car.: on Bennett's cr. of Chowan r., 113 m. N. E. Raleigh. It contains a court-house, several mechanic shops, and about 150 inhabitants.

Gadlex Bridge, p. v., Fayette co., Firg.: at the falls of Great Kanawha r., near the mouth of Gauley $\mathbf{r}_{2}, 218 \mathrm{~m}$. W. N. W. Richmond. The river is here 500 feet wide, and has a perpendicular fall of 22 feet. Navigation here ceases. The $\mathrm{r}$. has several flour and saw mills, stores, etc., and about 800 inhalitants.

GAOLEY river, Firg.: a tributary of Great Kanawha r. It rises from the Greenbrier Mountains, in Pocahontas co., snd flows W. into Nicholas $\mathrm{co}_{0}$, where it empties into the
Great Kanawha, a little above the falls. Its course is through a rich agricultural region.

Gavere, p. o., Columbiana eo., Ohio.

GaYHead, p. o., Greene co., N. Y.: 86 m. S.W. Albany.

GAY Hilu, p. o., Washington county, Teoo. : $68 \mathrm{~m}$. E. Austin City.

Gaylerstille, p. V., Cherokee co, $A 7 \alpha_{0}$ : on a branch of Little Will's creek, of Coosa river, 136 m. N. N. E Montgomery.

GAYLORD's BRIDGe, p.v., Litchfield co., Cmn.: on the Housatonic r. and R. R., $44 \mathrm{~m}$. W. by S. Hartford, and 42 m. from Bridgeport.

GAYsville, p. v., Windsor co., Ferm.: on White r., 34 m. S. by W. Montpelier.

Gearspille, p. v., White county, Tenn. : 82 m. E. S. E. Nashville.

Geatga county, Ohio. Situate N. E., and contains 594 sq. m. Drained by the heads of Cuyahoga and Chagrin rivers, which empty through Lake county into Lake Erie. Surface diversified; soils of good fertility, and timber abundant. Iron ore of a fine quality is found in this part of the state. Farms 1,006; manuf. 36; dwell. 3,240, and pop.-wh. 17,\$27, fr. col. 0-total 17,827. Capital : Chardon. Gebrart's, p. o., Somerset county, Penn.: $117 \mathrm{~m}$. W Harrisburg.

GeDDEs, p. v., Onondaga co., $N . Y_{.}$: at the S. W. end of Onondaga Lake, immediately $W$. of Syracuse. The $v$. is chiefly engaged in the manufacture of salt, of which, for the year ending 31st Dec., 1850, 259,448 bushels were produced, viz., 26,718 bushels coarse, and 232,710 bushels fine salt The Syracuse and Oswego R. R., and the Syracuse and Rochester R. R. pass through the village. Pop. about 800 . Geiger's Mruis, p. o., Berks county, Penn. : $62 \mathrm{~m}$. E Harrisburg.

Genegantslet, p. O., Chenango county, N. Y.: $105 \mathrm{~m}$. W. S. W. Albany.

General Wayne, p. O., Montgomery con, Penn.

GENESEE county, Mrich. Situate centrally, and contains $720 \mathrm{sq}$. m. Drained by numerous branches of Flint $\mathrm{r}$., whicl runs through the middle, and emptie through Saginaw $\mathbf{r}$. and bay into Lake Huron. Surface rolling; soil well adapted for grain and grass. On Flint r. very fine pine timber is abundant, and the county is well furnished with waterpower. Farms 1,255; manuf. 33; dwell. 2,25\%, and pop.wh. 12,003 fr. col. 28-total 12,031. Capital: Flint.

GENESEE county, $N . Y_{0}$. Situate W., and contains 473 sq. m. The surface level or gently undulating, and the soils chiefly sandy or gravelly loam, very fertile, and adapted equally to grass and to grain. Drained by Allen's, Black, and Tonawanda creeks. Iron ore, water-lime, and salt springs are found. Farms 2,574; manuf. 199; dwell. 5,014, and pop.-wh. 28,416, fr. col. 72-total 28,488. Capital: Batavia. Public Works: Buffalo and Rochester R. R. Canandaigua and Niagara Falls R. R.; Buffalo and New York City R. R.; Buffalo and New York R. R.; Batavia and Attica Branch R. R.

GeNrsee, to and p. v., Genesee co., Mich, : 52 m. E. N. E Lansing. Drained by Flint $\mathbf{r}$. The $\mathrm{v}$. is the seat of a U.S. Iand office. Pop. of t. 1,076.

GENESEE, t. and p. .., Waukesha co., Wisc.: $57 \mathrm{~m}$. E. by S. Lansing. Drained by affluents of Milwaukie $r$. The Milwaukie and Mississippi R. R. passes through the town 28 m. W. from Milwaukie. Pop, 1,290,

Geneseie Fork, p. 0., Potter co., Penn.: 183 m. N. N.W. Harrisburg.

GeNesue Grote, p. o., Whitesides co., $I l l .: 143 \mathrm{~m} . \mathrm{N}$. Springfield.

GENese river, $N, \overline{Y_{0}}:$ an affinent of Lake Ontario. It rises in Potter co. Penn., and passing into the State of NeTy York, pursues a northerly course to the lake. Its length is $145 \mathrm{~m}$., of which $125 \mathrm{~m}$. are in New York. At Tochester, within a distance of $3 \mathrm{~m}$., it descends by several falls and rapids $2: 26$ feet, affording an immense water-power. It is 
navigable $4 \mathrm{~m}$. to Carthagc, and above the falls is boatable for $20 \mathrm{~m}$. or more. The Genesee Valley Canal follows the course of this river, and is fed by it for a great distance. A railroad is also being construeted to follow in the same general direction, and the valley is crossed at four points by ruilroads traversing in an east and west direction. In the t. of Portage, Alleghany co., are three falls, one of 60 , one of 90 , and one of 110 feet, within a space of two miles, and along, the river, for three miles, are perpendicular walls of stone, 400 feet high, to which depth it has worn a channel in the solid rock. At this point it is crossed by one of the most splendid viaducts in the Union, over which is carried the Buffalo and New York City R. R. The Valley of the Genesee is the finest wheat country in the States, and is now thickly settled and in a high state of cultivation.

GenESEo, $p$ v., and cap. Henry co., I l. : on a cr. of Green r., $116 \mathrm{~m}$. N. N.W. Springfield. It has a court-house, ete., and about 200 inhabitants. The Chicago and Rock Island $R . R$. will pass through this village.

GEXESEO, t., p. ₹., and cap. Livingston co., N. Y. : $202 \mathrm{~m}$. W. Albany. Situate between Genesee r. and Conesus Lake, and drained by creeks flowing into them. Surface terraced and furrowed by valleys; soil rich and fertile. The village, on an elevated table, about $1 \mathrm{~m}$. E. of Genesee r., is well built, and has considerable trade. It contains a court-house jail, etc., an academy (formerly Livingston County High Schnol), numerous mechanic shops and stores, and about 1.700 inhabitants. The academy is a large three-story brick building. In this t. are situate the Wadsworth Farms, 10cated on the broad alluvial flats of the Genesee, and noted for their fertility and superior cultivation. Two newspapers, the "Livingston Republican" (whig), and the "Livingston Union" (whig), are issued weekly. Pop. of t. 2,953.

Gevera, p. v., Coffee county, Ala. : on Pea r., near its confluence with the Choctawhatchie river, 96 m. S. S. E. Montgomery.

Genev A, p. v., Ontario co., $N_{.} Y$.: on the N. W. corner of Seneca Lake, $159 \mathrm{~m}$. W. by N. Albany. It is one of the most beautiful villages of the State. The principal street runs parallel with the lake shore at an elevation of 100 feet, and from many of its residences terraced gardens extend to the banks of the lake. It has some manufactures, but is chiefly known as the seat of Genera College and its Medical School. The College was founded in 1828, and had in 18505 professors, 131 alumni, and 42 students, with a library of 5,400 volumes. The Medical Institute, a department of the College, was founded in 1835, and had 6 professors, 98 graduates, and 60 students. Besides the College libraries, there are two others in the village with cabinets of minerals, and ample supplies of philosophical apparatus. Three newspapers are published, viz., the "G. Courier" (whig), the "G. Gazette" (dem.), and the "Western Atlas" (dem.), all weekly issues. Pop. about 4,500.

GENEvA, t. and p. F., Ashtabula co, Ohio: $162 \mathrm{~m}$. N. E. Columbus. Drained by creeks of Lake Erie, which makes its N. boundary. Surface level; soil rich and deep. The v. lies on the line of the Cleveland, Painesville, and Ashtabula R. P., $54 \mathrm{~m}$. from Cleveland, Pop. of t. 1,358.

GGNErA, t, and p. 0., Walworth co., Wisc. : $58 \mathrm{~m} . \mathrm{S} . \mathrm{E}$ Madison. Drained by creeks of Fox $r$. and by Duck Lake The v. is located at the outlet of Geneva Lake, and has several mills, ete. Pop. of t. 1,583.

Gexeva, p. v., Kane co., $M l_{\text {. }}$ : on the W. side of Fox r. of the Illinois, $157 \mathrm{~m} . \mathrm{N}$. E. by N. Springfield. It is a new and rapidly-improving $\mathrm{v}$., and a point of commercial importanee, being the terminus of a branch of the Galena and Chicago Union R. R., $40 \mathrm{~m}$. from Chicago. A newspaper, the "Western Mercury," is issued weekly.

Gexeva BAr, p. o., Walworth co., Wisc. : on a bay on the N. W. side of Genera Lake, 56 m. 8. E. Madison

Gevod, p. o., De Kalb co,, $I l l_{\text {. : }}$ on Sycamore r., 164 m. N. N. E. Springfield.

GeroA, t. and p. 0., Livingston co., Mich. : 40 m. E. S. E.
Lansing. Drained by lakes and streams emptying into Huron river. Pop. of t.754.

Gexos, p. v., Christian county, Ky.: 172 m. W. S. W Frankfort.

Grivos, p. v., Walworth co., Wisc, ; $55 \mathrm{~m}$. 8. E. Madison. GeNoA, t. and p. v., Cayuga co, N. Y.: $143 \mathrm{~m}$. W. Aibany. Drained by Big Salmon cr. and its branches, and bounded W. by Cayuga Lake. The v. has several manufactures, etc., and about 250 inhabitants. Pop. of t. 2,5.3.

GenoA Cross Roads, p. o., Delaware co, Ohio: $17 \mathrm{~m}$, N. by E. Columbus.

GENTRY county, Mo. Situate N. W., and contains 797 sq. m. Drained by Little Platte r., West Fork of Grand r., and their branches. Surface diversified; soil of average fertility, well covered with timber, and well watered. Farms 444; manuf. 0 ; dwell. 708, and pop.-wh. 4,195, fr. col. 3 , sl. 50 -total 4,248. Capital: Athens.

Gentri Court-House, p. o., Gentry co., Mo.: on the E. side of the E. fork of Grand r., above the confluence of Scalp cr., $170 \mathrm{~m}$. N. W. Jefferson City.

Gentry ville, p. v., Spencer county, Ind. : $132 \mathrm{~m}$. S. S.W. Indianapolis.

Gentryyille, p. V., Gentry co., Mo.: on the E. side of the E. fork of Grand r., $166 \mathrm{~m}$. N. W. Jefferson City.

Gentspille, p. v., Abbeville dist., S. Car. : $92 \mathrm{~m}$. W. by N. Columbia.

Gentsville, p. v., Walton co., F'lor.: on a branch of Choctawatchie r., $100 \mathrm{~m}$. W. N. W. Tallahassee.

GEorgk lake, $N, Y_{\text {. }}$ : ealled, also, Lake Horicon. It lies chiefly between Warren and Washington counties, and is elevated 243 feet above the level of Hudson river. Length $36 \mathrm{~m}$.; breadth, from 2 to $3 \mathrm{~m}$., and surrounded by lofty and picturesque hills. Its surface enbosoms as many islets as there are days in the year-some of considerable size, and cultivated. Diamond Island is celebrated for its beautiful quartz crystals, A number of ruined forts are found on the shores of the Iake, which to the tourist recall recollections of troublous times. The bed of the lake is yellow sand, and the water is so pure and transparent that the bottom may be seen at the depth of thirty or forty feet, and myriads of fish sporting in the limpid element. The French eall it $L a c$ Sacrament, on account of the purity of its waters. Salmontrout, pike, pickerel, perch, silver and brook trout, etc., are taken in abundance. The lake has its outlet into Lake Champlain at Ticonderoga. A tourist, whose admiration of the scenery in the vicinity of Lake George is apparent, makes the following note of his impressions: "Time would fail us to enumerate the points of attraction on the way. The remains of Fort George and Fort William Henry at the head of the lake, must not be passed without a visit; neither must you leave the Lake House, till in the quiet hour of twilight, the old rusty gun has been fired, and you have heard the echo which is sent back from one mountain-top to another, till the sound seems to have died away, and then have it revive and reverberate again, as though another explosion had suddenly taken place. Every foot of the ground along the shore, and even the water itself, possesses vast interest. The bed of the lake is a handsome, yellowish sand, and the water is so pure and transparent as to render the bottom visible from thirty to forty feet. Here the delicious salmon-trout, that weigh from twelve to twenty pounds, are seen in their folicksome mood, sporting with each other, and inviting the bait of the angler." The Lake House is a noted traveler's rest in the village of Caldwell, a pleasant place situate at the base of the lake. Tourists reach this from Albany via railroad to Fort Edward, and thence by an excellent road through Glens Falls Fillage, etc. During the summer season a steamboat carries travelers from Caldwell to the head of the lake, where stages are in readiness to proceed on to the steamboat landing at Ticonderoga, on Lake Champlain.

George's Creek, p. o., Massae co., $I$ l.: on a branch of Great Bay cr. so called, 176 m. S. S. E. Springfield. 
George's CBeEk, p. o., Lawrence co., $K y .: 128$ m. E. Frankfort.

George's Mrris, p. o., Sullivan co., N. Hamp.

George's Store, p. O., Lincoln co., Tenn. : $73 \mathrm{~m}$. S. by E. Nashville.

Grorgesvinle, p. V., Franklin co., Ohio: on the E. side of Little Darby er., 13 m. S. W. Columbus.

Georgetown district, S. Car. Situate E., and contains

$6 S 3$ sq. m. Drained by Santee r., its S. boundary, Black, Great Pedee, and Waccamaw rivers-the last two emptying into Winjaw Bay, which lies wholly within it, Surface low and level. Though marshy in parts, it is very fertile. Rice is the great staple. Corn, potatoes, and cotton are grown largely. Farms 550; manuf. 6; dwell. 575, and pop. -wh. 2,193, fr. col. 201, sl. 18,253-total 20,647. Capital: Georgetown.

Georgetown, p. v., and cap. Sussex co., Del.: at the sources of Nanticoke and Indian rivers, $34 \mathrm{~m}$. S. by E. Dover. It contains a court-house, jail, etc., and about 400 inhabitants.

Georgetows, p. v., and cap. Williamson co., Tex. : on the S. fork of San Gabriel r., $32 \mathrm{~m}$. N. Austin City.

Georgetown, p. v., Fairfield co., Comn.: on the Danbury and Norwalk R. R., $56 \mathrm{~m}$. S. W. Hartford,

Georgetown, p. city and port of entry, Washington co., D. C.: a suburb of Washington, it is divided from that city by Rock cr. It is beautifully located on a range of hills rising above the Potomac, and stretching in undulating beauty along its borders. The heights of Georgetomn are lofty eminences, overlooking the city from the $N$. and $W$. Along these are many splendid villas and extensive gardens in the highest state of cultivation. Below reposes the city, and as far as the eje can reach, the silvery Potomac courses through a scene of exquisite beauty. The city presents many objects of attraction : its ancient college, a catholic institution; its nunnery ; its various literary institutions; its splendid aqueduct, and other noted edifices, are worthy of attention. The college is situate on the N. bank of the Potomac-it was originally an academy, founded in $17 \mathrm{~S} 9$ by the first Catholic bishop of the United States, and in 1r99 it was chartered as a college. In 1815 Congress raised it to the dignity of a university, and in 1851 a medical department was opened at Washington. The college buildings are spacious, and contain a fine library of $25,000 \mathrm{vol}-$ umes, an extensive philosophical apparatus, and a museum of natural history. The curriculum of studies occupies seven years. The nunnery, or Convent of the Tisitation, is situate on the heights, contiguous to the $\mathbf{E}$. margin of the river. The building appropriated for the ladies' academy is of brick, between 200 and 300 fect lung, and fol feet in breadth. These buildings occupy part of the side of an oblong square of five acres, a portion of which is laid out as a botanic garden. There are other edifices on the square, as the bishop's residence, an elegant chapel, the conrent, and charity schools. The whole is under the direction of the Sisters of the Tisitation. The aqueduct which convers the Chesapeake and Ohio Canal over the Potomac, is a stupumbus wirk: the piers, nire in number, and $\$ 6$ fict above high water, are of granite, and embedded 17 feet in the bottom of the river upon solid rock-its length is $1,416 \mathrm{fect}$, and the cost of construction was $\$ 2,000,000$. This aqueduct carries the canal to Alexandria. Oak Hill Cemetery; on the heirhts. is also worthy of nute: it was laid out in 1 y9 at the expense of W. W. Corcoran, Esq., the eminent banker, and is surrounded by a massive iron railing, with a gate-keeper's loige in the Jormen strle, and an elezant Gothic chapel. Georgetown was formerly a port of some note, and had considerable trade, and is even now a thriving and busy place. It is connected by canal and railroad with all parts of the Cnion. of late years many improvements hare been made in its streets, and many new buildings have been crected. The eity is also enraged in manufactures; in $\mathbf{1 5 5 0}$ it had 59 establishments in opcration. 212 among which was a rolling mill, a cotton factory, and numerous flouring mills. Two newspapers are published here, the "G. Advocate," tri-weekly, and the "Potomac Advocate," weekly. Its foreign commerce in 1849-50 employed 3,134 tons of shipping, viz.: elearances, 10 ressels (1,720 tons), and entrances, 9 vessels ( 1,414 tons). The shipping owned in the district amounted to 17,010 tons, of which 2,796 was registered tonnage, 12,763 enrolled and licensed tonnage, and 1,451 licensed. The steam shipping amounted to 1,949 tons; and 8 vessels (268 tons) were built during the year. The general statistics of the eity are as follows: dwellings 1,174 , families 1,215 , and population 8,366 , of which $6,0 S 1$ were white persons, 1,560 free persons of color, and 725 slaves. The population in 1810 was 4,985 ; in $1820,7,360$; in $1530,8,411$; in $1840,7,312$; and in 1850 , 8,366 .

GeoRgetown, p. ₹., Randolph co., Ga. : on the E. bank of Chattahoochee r., opposite the mouth of Eufaula cr., 139 m. S. W. Montgomery. It is a flourishing $\mathrm{v}$. , and has considerable river trade. Pop. 600.

Georgetown, p. V., and eap. Scott co., $K y_{.}:$on the $\mathrm{N}_{\text {. }}$ branch of Elkhorn er. of Kentucky r., $18 \mathrm{~m}$. E. by $\mathrm{N}$. Frankfort. It contains the court-house, etc., and is the seat of Georgetown College, founded in 1830, and under the direction of the Baptists. In 1850 it had 7 professors, 80 alumni, and 66 students; and a library of 650 volumes. The "Delphian Oracle" is a monthly literary magazine, published by the students, and in the $\mathrm{v}$. is also published the "G. Herald," a weekly newspaper. Pop. about 1.300 .

Geokgetowx, p. v., Floyd co., Ind.: on a branch of Indian cr., 102 m. S. by E. Indianapolis.

Georgetown, p. v., Vermillion co, $I Z$.: on the N. side of Little Vermillion r., 103 m. E. by N. Springfield.

Georgetown, t. and p. o, Lincoln co., Me. : $37 \mathrm{~m} . \mathrm{S}$. Augusta. It consists of two islands lying between the Kennebec and Sheepscot rivers and projecting into the Atlantic. It has good harbors, and the inhabitants are chiefly employed in coasting and fishing. Pop. 1,437. An unsuccessful attempt was made as early as 1607 to settle these islands. Georgrtow $v$, p. v., Copiah co., Mriss, : on the W. side of Pearl r., 26 m. S. by E. Jackson.

Georgetown, t. and p. v., Essex co., MIass.: 28 m. N. Boston. Drained by a branch of Parker's $x$. Surface diversifled; soils adapted to grass. The $\mathrm{v}$, is central, and has several manufacturing establishments. Pop. of t. 2,052 . The Newburyport R. R. passes through the N. part of the town.

GEORgetowr, t. and p. v., Madison co., N. Y. : $102 \mathrm{~m}$. T. by N. Albany. Drained by head branches of Otselic $r$. Surface hilly; soil, clayey loam. The v., on Otselic cr., contains sereral mills and about 400 inhabitants. Pop. of t. 1,411 .

Grorgetowr, p. v., and cap. Brown co., Otio: to the E. of White Oak er., $\$ 6 \mathrm{~m}$. S. S. W. Columbus. It has a courthouse, jail, 6 churches, numerous mechanic shops and stores, about 200 dwellings, chiefly of brick, and about 800 inbabitants. Two newspapers, the "Democratic Standard" and the "Democrat and Journal" are issued weekly.

Geomgetoms, p. v., Beaver co., Penn.: on the Ohio r., N. of Mill cr, $194 \mathrm{~m}$. W. Harrisburg. It contains about Di it inhillitants.

Georgetows, p. F., port of entry, and cap. Georgetomn dist., S. Car.: on the W. side of Winyaw Bay, at the confluence of Sampit cr., $106 \mathrm{~m}$. S. E. Columbia. Lat. $33021^{\prime}$ $N_{\text {, }}$ and long. $79017^{\prime} \mathrm{W}$. It contains a court-house, jail, 6 churches, a large number of stores and mechanic shops, and about 3,200 inhabitants. Two newspapers are published here, the "Winyaw Observer" (dem.), semi-weekly, and the "True Republican" (dem.), weekly. Its harbor is deep enough for ressels drawing 11 feet water; and the rivers flowing into Wingaw Bay, open to the port an extensive and fertile back country. It has an extensive coasting trade, and regular stuabers ply to and from Charleston and 
on the Great Pee Dee r. The entrances in 1850 from foreign countries were 2 vessels (297 tons), and the elearances to foreign countries 24 vessels $(3,655$ tons). Tonnage of the district 2,779 tons, of which 1,749 was registered and 1,030 enrolled and licensed.

GEORGETowx, p. v., Burlington county, N. Jer.: $27 \mathrm{~m}$. S. by E. Trenton.
Georgetown, p. v., and eap. Pettis co., MFo.: on Muddy cr. of Riviere a la Mine, $61 \mathrm{~m}$. W. by N. Jefferson City. It contains a court-house, etc., and about 200 inhabitants.

Georgetown, p. v., Lafayette co., Wisc.: $52 \mathrm{~m}$. S. W. Madison.

Georgetown Cross Roads, p. on, Kent co, Ma.: $45 \mathrm{~m}$ N. E. Annapolis.

\section{THE STATE OF GEORGIA.}

GEoRGIA is bounded on the north by Tennessee and North Carolina; on the north-east by South Carolina, from which Savannah River divides it; on the east by the Atlantic Ocean; on the sonth by Florida, and on the west by Alabamathe Chattahoochee River being the western boundary for more than half its length. It extends generally between latitudes $30^{\circ} 22^{\prime}$ and $35^{\circ} \mathrm{N}$., and longitudes $80^{\circ} 48^{\prime}$ and $84^{\circ} 41^{\prime} \mathrm{W}$. from Greenwich, or $3 \circ 46^{\prime}$ and $7^{\circ} 39^{\prime} \mathrm{W}$. from Washington. Its greatest length from north to south is 322 miles, and its greatest width from the east point of Tybee Island, at the month of Savannah River, to Florence, on Chattahoochee River, 224 miles; but from this point it gradually narrows northward, and on the parallel of $34^{\circ} 40^{\prime}$ does not measure more than 126 miles. The whole area of the State is $5 S, 000$ square miles.

No State in the Union presents a richer fleld for the geologist than Georgia. With a territory embracing the southern extremity of the great Atlantic chains of mountains, extending across them to the north-west into the valley of the Mississippi, ruuning to the south-west into the cretaceous slope of the Gulf of Mexico, and occupying along their eastern base a wide belt of territory, it contains most of the important geological formations. Commencing at the Atlantic Ocean and spreading out from 100 to 150 miles to the west, an extensive plain of a tertiary formation rises from the level of the sea, and gradually swells up to the height of about 500 feet, at a line passing near the head of navigation of the rivers Savannah, Ogeechee, Oconee, and Ocmulgee, where it meets a primary formation. Between the Gcmulgee and Flint rivers it leaves the primary formation to the right, and rests on the cretaceous from a point nearly midway between Macon and Knoxville, by a line running in a south-west direction to another point between Pataula Creek and Fort Gaines, on the Chattahoochee River. Bounded by the last mentioned line to the south-east, and by the southern edge of the primary, as indicated by the heads of navigation in the Flint and Chattahoochee rivers, the cretaceous forination extends from Alabama into Georgia, forming an acute triangle. The primary, or non-fossiliferous, bounded on the east by the tertiary and cretaceous formations as described above, crosses the State from north-east to south-west, with a width of 160 miles at the northern limit and of 100 miles at the southern. The Blue Ridge range of mountains passes near its western edge and forms the most elevated land of the State, varying in height from 1,200 to 4,000 feet. From this crest there is a gradual descent to the east ioy a series of parallel and undulating ridges, until the tertiary plain is reached. On the west the descent is much more precipitous. The western boundary of the primary is not very aceurately established, but is believed to be not far from a line running nearly north and south through the centre of Gilmer County, and continued in the same direction to near Canton, in Cass County, and thenee to the western base of the Allatoona Mountain, on the Etowah River, where it turns to the south-west, and passing near Van Wert, in Paulding County, and along the northern base of the Dugdown Mountain to the Alabama line. The north-western part of the State, bounded to the east and south by the western limit of the primary, consists of a transition, or older fossiliferous formation, except the extreme north-west corner, where the carboniferous occurs.

The coast is lined by a succession of low islands, intersected by numerons navigable channels, which afford good inland navigation all along the shore. They are generally separated from each other by wide bays or sounds, which bear their names and receive the waters of this section. The prineipal islands are Cabbage Island, Ossaba Island, St, Catharine's Island, Sapello Island, St. Simon's Island, Jekyll Island, Cumberland Island, ete. These are covered with rich plantations, and produce, as before stated, the long staple cotton ealled, from the place of its growth, sea-island cotton.

Along the southern line of the State, between the head branches of the Suwannee and the St. Mary's rivers, there is an extensive swamp, or series of swamps, covered with a thick growth of bay-trees, vines, and underwood, and in the wet season presenting the appearance of a wide lake containing islands of rich highland. This swamp extends over the border into Florida, and bears the Indian name of "Okefinoke" Several streams are lost in its morasses, aud others, head waters of rivers flowing to the Atlantic and Gulf of Mexico, take their rise from within its limits.

The great mineral region of Georgia is found in the primary and metamorphic formations of the spurs of the Alleghany Mountains, Through the northern portion of the State these pursue their course toward the south-west with similar features of parallelism and straightness peculiar to them further north; but their more broken eharacter, the greater ruggedness of their outline, and the impetuous nature of their streams, testify to different geological formations than the stratified shales and sandstones of which they are composed in Pennsylvania. It is in these out-liers of the main ridge that the metamorphic slates and quartz. rock are found. which are productive in gold ores; and frequently in near proximity to these are deposits of hematite iron ores of extraordinary extent. In the gneiss, also, are found veins of magnetic iron ore of great purity, as at Cane Creek, near Dahlonega. Specular ores, too, like those of the Iron Mountain in Missouri, are found in the vicinity of some of the hematite beds; and localities of the same ore are of frequent nccurrence down the course of Chattahoochee River. Another range of them, of much greater consequence, is found in the Allatoona hills, aiong the Etowah River. Here the broad, shallow stream, obstructed in its course, fal's over ledges of rock, producing good water power. On each side are seen, projecting from the hills, ledges of rough silicious rock, in strata of various degrees of thickness, dipping to the south of east. Beds of limestone are associated with these rocks and veins of sulphate of barytes, of great extent. On the south-eastern slope of this range of hills, talcose and mica slates, hornblende slate, green stone, and quartz veins containing gold, more abound. Through deep cuttings in these rocks, in one place 90 feet deep, the Western and Atlantic Pailroad passes. To the west and north-west an extensive limestone country commenees, about four miles from the river. Nearly the whole of Calss County is formed of this rock, and it spreads out into Floyd and Murray counties. Iron ores are found on both sides of the Etowah River. To the south-west they extend into Puulding County, and in the other direction through Cherokee County to its north-west comer; and so far as explored their runge is about 40 miles, and their course abont north-east and south-west. These ores, in their appearance and quality, resemble the best ores found in the Housatonic Valley. Numerous furnaces have 


\section{GEORGIA.}

been established in this region and are now in successful operation; the vast water-power, the abundance of timber, the cheapness of living, and the beauty of the climate being highly favorable characteristics of the region.

Georgia embraces every variety of soil, climate, and productions. While southern and middle Georgia are parched with heat, the more northerly climate among the mountains is moderate and even cold. The sky is of a deep blue, nor does a more lovely heaven smile upon Italy than that which favors this country. The cordon of islets which border the sea-coast has a light, sandy soil, but produces the finest staple, known to the world as sea-island cotton. In the south are the tide and swamp lands, producing immense crops of rice. The soil of this region varies as it is situated on the sea-shore or upon the large and small rivers. On the Savannah these lands are cultivated 20 miles from the brackish marsh up the river, and are the finest in the State; and next to these are the lands on the Alatamaha River, which in width are equal to those on the Savannah. They do not extend from the marshes up more than 16 milesbeyond, the freshets render them valueless, except for timber. Next come the tide lands of the Ogeechee, extending 10 miles up from the marshes, which produce rice, but are not well adapted to cotton. The tide lands of the Great Santilla are not as broad as the others, but are productive and fertile 20 miles up from the marshes, yielding good crops of rice and cotton, and are not so liable to inundation as those of other large streams. The inland swamps produce abundantly. Black-seed cotton is produced on the oak lands adjoining the inland swamps, though these lands are said to be of inferior quality. About 60 or 70 miles from the coast begin the pine lands, which are valuable chiefly for the immense quantity of timber annually yielded. Tar, pitch, and turpentine are also largely manufactured in this section. The middle region of the State contains land of a red, loamy soil, producing tobacco, cotton, and all the grains. It was once very productive, but owing to the exhausting system of cultiration adopted by the planters, it has become in many parts much impoverished, and large gullies and red barren hill sides often meet the eye in places where once abundant crops were produced. The planters, however, have become awake to the folly of a system so injurious to their best interests, and hill-side ditching, manuring, and a judicious rotation of crops, together with occasional rest to the land, is gradually restoring the soil. The institution of agricultural societies has also of late years stimulated emulation in this direction, and many of the great planters have set a good example to their neighbors by adopting the improvements which science has proved necessary to insure success in agrieultural operations. The lands in the south-western part of the State, between the Chattahnochee and Flint rivers, are in general fertile when first cleared, but are not very durable. Being of a light, Bandy soil they produce fine crops of cotton and sometimes sugar cane for a few years, and then become exhausted, when resort must be had to fertilizers. These lands, however, are cheaper in proportion to their fertility than any others in Georgia. In the north part of the State-that part kuown as Cherokee Georgia-the valleys are exceedingly rich, producing wheat, corn, potatoes, cte, and in some places cotton is extensively raised; but the crop is not so certain as in the lower regions. This, indeed, is peculiarly a grain country, while the mountains yield the more valuable minerals, and are exceedingly attractive as grazing lands. The land here is more costly than in any other part of the State, ranging from $\$ 10$ to $\$ 30$ per acre; while in the south-west lands of equal fertility cost not more than one-third those sumsthe difference being due to the greater durability of the northern soils. But Cherokee Georgia is not the place to raise cotton; it is to be the granary and work-shop of the State, and its fields will produce corn to feed the operatives who are to direct its water-power in manufacturing the cotton which the south produces, and in digging out from the bowels of the earth the minerals which are to regulate its inland eommerce.

Upward of fifty streams in the State of Georgia are enumerated as deserving and having the designation of rivers. A very cursory glance at the map will show that her water resources are immense. The streams of this state alone which pour the volume of their waters from the mountain springs into the bosom of the Atlantic Ocean and the Gulf of Mexico, would supply sufficient power, in the eligible sites, to manufacture all the cotton grown in the world, or to grind all the grain grown within the limits of the Union. The navigable rivers are the Savannab, the Alatamaha, the Oconee, the Ocmulgee, the St. Mary's, the Ogeechee, the Flint, the Chattahoochee, the Coosa, and various others. These bear down to the seaboard the productions of the interior, and are thronged by steamboats, sloops, and flat boats, laden with the material of a commeree valued at thirty-flve to forty million of dollars a year. If Georgia has not the best of harbors, she has a large number, equal to all the requirements of the coasting trade. Savannah, Darien, Brunswick, and St. Mary's have harbor accommodations for a large class of shipping, and are the centres of a considerable foreign trade. The great river of the State is the Sarannah, which rises by two principal branches in North Carolina, near the sources of the Tennessee and Hiwassee on the one side, and the Chattahoochee on the other, and after a course of about 300 miles, falls over the last chain of rock-hills into the great plain at Augusta, to which place, 250 miles from its mouth, it is navigable for steamers of light dran, and for large ships to Savannah, there being 18 or 19 feet water on the bar at low tide. Its principal tributaries are Brier Creek and Broad River. The Chattahoochee, rising near the southern branch of the Savannah, pursues at first a south-westerly course, but afterward turns to the south, and receiving Flint River on the Florida line, enters that State under the name of Appalachicola. It is navigable to the farls at Columbus, 300 miles from its mouth, for a great part of the year, and its whole length is about 500 miles. Flint River, above named, rises in the hilly country south of the Chattahoochee, and has a total length of 300 miles, of which 75 miles to the falls is open to navigation. The Oostanaula and Etowah, rising in the mountains of the north, unite their streams at Rome, in Floyd County, whence they pass directly west into Alabama, under the name of Coosa. The Alatamaha is formed by the junetion of the Oconee and the Oemulgee, which rise in the hilly region south of the Chattahoochee, and flow for about 250 miles nearly parallel to each other, where the latter bends round to the east, and unites its waters with those of the former-there are 121013 feet water on the bar of the Alatamaha at ebb-tide, and steamboats ascend the Ocmulgee to Macon, and the Oconee to Milledgeville, although there are some obstructions to their navigation. The Ogeechee has a course of about 200 miles, of which 40 miles are navigated by small vessels. The Santilla, or St. Illa, has a winding course, chiefiy through a low, swamp region, but is partially navigable for river craft. The St. Mary's River rises in a low ridge, near Okefinoke Swamp, and reaches the sea in Cumberland Sound; it has 18 feet of water on the bar at low tide, and sometimes as much as 28 feet in times of flood. The Allapaha and Withlacoochee, principa' constituents of Suwannee Iiver of Florida, and the Geklockonee liver, are considerable streams in the south part of the State, which empty into the Gulf of Mexico.

Mr. Stephens, one of Georgia's representatives in Congress, in a speech before that body, exhibited the physical, industrial, and mural combition of his state in the following glowing terins: "Georgia is the youngest of the old thirteen States that formed the Cnion. At that time she was the weakest of that fraternal band." * * * * * "Boston, New York, and Richmond were nearly as old as Georgia now is, when Oglethorpe first landed at Savannah. But notwithEtanding all this, I will not shrink from the compurisun, let it be instituted when o: where it may. Geurgia bas her beds 


\section{GEORGIA.}

of coal and iron; her lime, gypsum, and marl; her quarries of granite and marble. She has inexhaustible treasures of minerals, including gold, the most precious of metals. She has a soil and climate suitable for the growth and culture of every product known to husbandry and agriculture. A better country for wheat and corn, and all the cereal plants, to say nothing of cotton and tobacco, is not to be found in an equal space on this continent. There, too, grow the orange, the olive, the vine, and the fig, with forests of oak and pine sufficient to build and mast the navies of the world. \$he has mountains for grazing, rivers for commerce, and waterfalls for machinery of all kinds without number. Nor have these great natural advantages and resources been neglected. Young as she is, she is now the first cotton-growing State in the Union. She has, I believe, thirty-six cotton factories in operation, and a great many more hastening to completion-one of them has, or soon will have, ten thousand spindles, with two hundred looms, capable of turning out eight thousand yards of cloth per day. Her yarns are already finding their way to the markets of the North and foreign countries; and the day is not distant when she will take the lead in the manufacture as well as the production of this great staple. She has also her flour mills and paper mills-her forges, foundries, and furnaces, in full operation. Her exports exceed yeariy $\$ 35,000,000$ - equal to if not greater than those of all New England together. She has six hundred and fifty miles of railroad in operation, at a cost of $\$ 15,000,000$, and two hundred miles more in the course of construction. By her energy and enterprise she has scaled the mountain barriers, and opened the way for the steam-car from the southern Atlantic ports to the waters of the great valley of the West. But this is not all: she has four chartered. universities-nay, five, for she has one devoted exclusively to the edncation of her daughters. She was the first State, I believe, to establish a fernale college, which is now in a flourishing condition, and one of the brighest ornameuts of her character. She has four hundred young men pursuing a collegiate course-a greater number, I believe, than any State in the Union, in proportion to her white population. Go, then, and take your statisties if you wish-you will find not only all those things to be so; but I tell you also what you will not find, you will not find any body in that State begging bread or asking alms--you will find but few paupers-you will not find forty thousand beings, pinched with eold and hunger, demanding the right to labor, as I saw it stated to be the case not long since in the City of New York. And when you have got all the information you want, come and institute the comparison if you wish, with any State you please; make your own selection; I shall not shrink from it, nor will the people of that State shrink from it. Other gentlemen from the South ean speak for their own States- $I$ speak only for mine. And in her name, and in her behalf, as one of her respresentatives upon this floor, $I$ accept the gauntlet in advance, and $I$ have no fears of the result of a comparison of her statistics, socially, morally, politically, with any other state of equal population in this confederacy." * * * * * "That country has the greatest elements of prosperity where the same amount of human labor or exertion will procure the greatest amount of human comforts, and that people are the most prosperous, whether few or many, who, possessing those elements, control them by their energy, and industry, and economy for the accumulation of wealth. In these parliculars the people of Georgia are inferior to none in this or any other country. They have abundant reason to be content with their lot." ****** "The six hundred and fifty miles of railroad now in operation, to which I have alluded, were built by Georgia capital. One hundred and thirty-six miles, from Atlanta to Chattanooga, on the Tennessee River, which is one of the greatest monuments of the enterprise of the age, was built by the State. But her public debt is only a little over $\$ 1,800,000$, while that of the State of New York is over $\$ 20,000,000$, besides $\$ 14,000,000$ owed by the city alone; and the debt of Pennsylvania is $\$ 40,000,000$. The bonds of the State of Georgia are held mostly by her own people. You do not see them hawked about in Northern or foreign markets at a depreciation. But they, as well as the stocks and securities of the private companies, are held mostly by her own citizens, and are commanding premiums at home."

Georgia is divided into 94 counties, the general statisties of which, and the capital of each in 1850, was as follows:

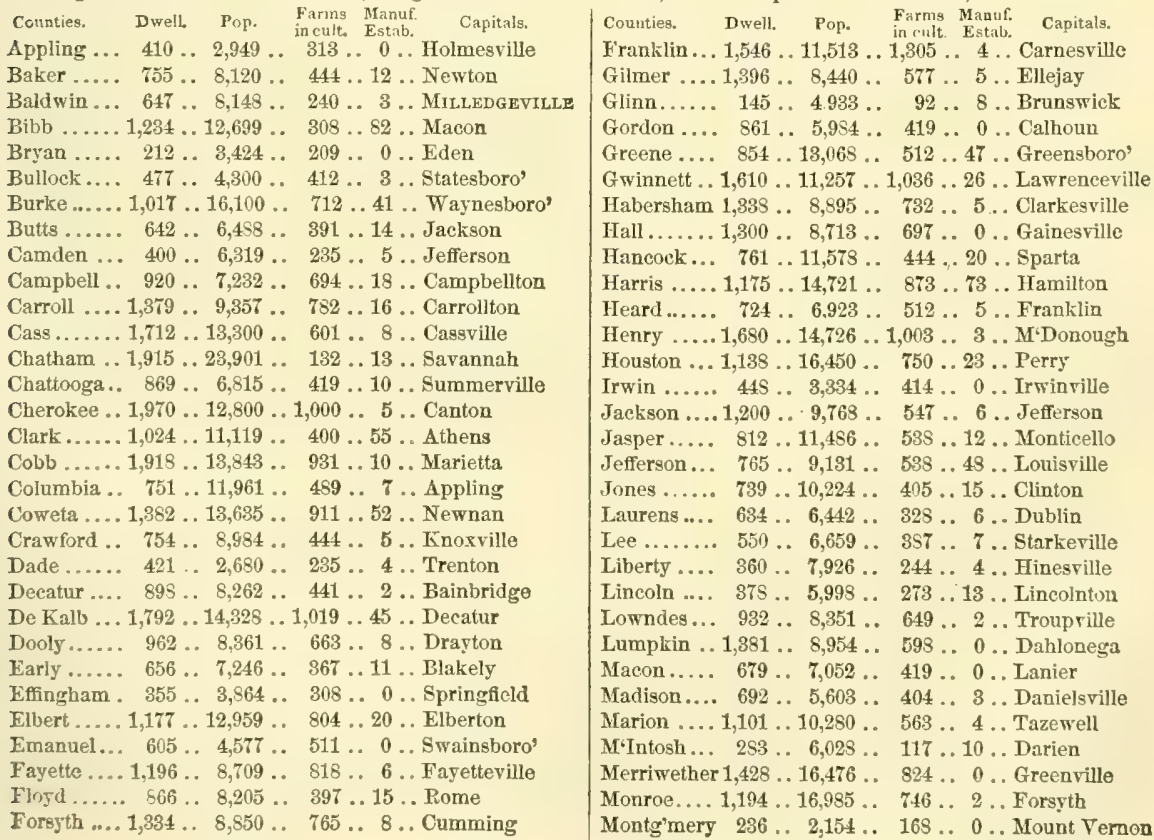


GEORGIA.

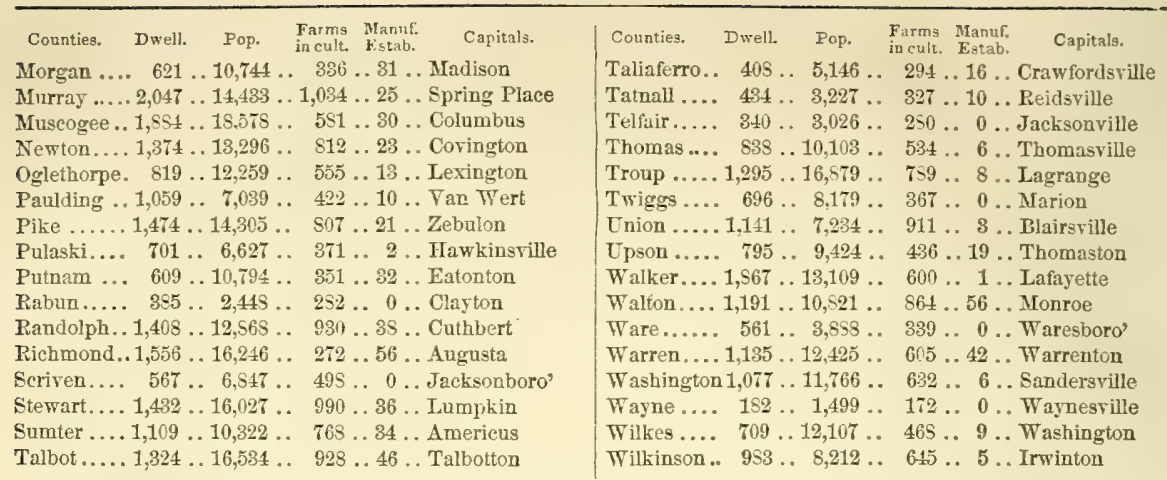

The whole number of dwellings in the State, at the above date, was 91,011 , of families 91,471 , and of inhabitants 905,999 , viz., whites 521,438 -males 266,096 , and females 255,342 ; free colored 2,880 -males 1,368 , and females, 1,512 ; and slaves 381,681. Of the whole population, there were: deaf and dumb-wh. 211, fr. col. 0, sl. 41; blind-wh. 224, fr. col. 5, sl. 80 ; insane-wh. 281, fr. col. 2, sl. 23; and idiotic-wh. 476, fr. col. 3, sl. 98. The number of free persons born in the United States was 517,995; the number of foreign birth was 5,907, and of birth unknown, 597; the native population originated as follows: Maine 178, New Hampshire 122, Vermont 186, Massachusetts 594, Rhode Island 138, Connecticut 712, New York 1,203, New Jersey 331, Pennsylvania 642, Delatware 117, Maryland 708, District of Columbia 72 , Virginia 7,331, North Carolina 37,522, South Carolina 52,154, Georgia 402,582, Florida 1,103, Alabama 31,154, Mississippi 184, Louisiana 42, Texas 25, Arkansas 25, Tennessee 8,211, Kentucky 455, Ohio 46, Michigan 3, Indiana 50, Ininois 41, Missouri 60, Iowa 1, Wisconsin 2, California 0 , and the Territories 0 ; and the foreign population was composed of persons fromEugland 679, Ireland 3,202, Scotland 367, Tales 13, Germany 947, France 177, Spain 13, Portugal 5, Belgium 11, Holland 11, Turkey 1, Italy 33, Austria 3, Switzerland 38, Russia S, Denmark 24, Norway 6, Sweden 11, Prussia 25, Greece 1, Asia 2, Afriea 18, British America 108, Mexico 8, South America 8, West Indies 95, and other countries 58.

The following table will exhibit the decennial progress of the population since the first census of the State, taken by the United States authorities:

\begin{tabular}{|c|c|c|c|c|c|c|c|}
\hline Censu & & & 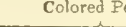 & tersons. & & Dec & Increase, \\
\hline Year. & Persons. & & & & on. & Numerical. & Percent. \\
\hline 1790 & 52 & 3 & & & 8. & - & \\
\hline 1800 & 101,678 & 1,0 & 59 & & 162 & 79.553 . & ..... 96.4 \\
\hline 1810 & 145,414 & . 1,8 & .105 & .10 & 3. & 90.382 . & .. 55.1 \\
\hline 1520 & 4 & 1 & $\ldots 14$ & 1 & 7 & 4. & .. \\
\hline 1830 & 290 & .2 & .. 21 & .22 & & .. 17 & $\ldots$ \\
\hline $1 S 40$ & ... 407,695 & .. 2 & .. 25 & $\ldots 22^{\circ}$ & . 6 & 174 & $\delta$ \\
\hline 1850 & .... 521,438 & ..... 2,580 & .. $3 S 1,681$ & .. 384,561 & 905,999 & 214.607 . & 31.0 \\
\hline
\end{tabular}

The statistics of the industry and wealth of Georgia, as furnished by the census of 1850 , and other official returas referring to that year, are as follows:

Occupied Lands, etc.-Improved lands, 6,378,479 acres; and unimproved lands, 16,442,900 acrcs-valued in cash at $\$ 95,753,445$. Namber of farms under cultivation, 51,759. Value of farming implements aud machinery, \$5,894,150.

Live-Stock.-Horses, 151,331; asses and mules, 57,3S9; milch cows, 331,223; working oxen, 73,2S6; other cattle, 690,016 ; sheep, 560,495 ; and swine, 2,168,617-valued in the aggregate at $\$ 25,728,416$. (In 1840 there were 157,510 horses, mules, etc.; 854,414 neat cattle of all kinds; 267,107 sheep, and $1,457,755$ swine.)

Grain Crops.-Wheat, 1,085.534 bushels; rye, 53,750 bushels; Indian corn, 30,050,090 bushels; oats, $3,820,044$ bushels ; barley, 11,501 bushels; and buckwheat, 250 bushels. (The crops of $1839-40$ were-wheat, 1,801,830 bushels; barley, 12,979 bushels ; oats, $1,610,030$ bushels ; rye, 60,698 bushels ; buckwheat, 111 bushels ; and Indian corn, $20,905,122$ bushels.)

Other Orops.-Rice, $35,950,691$ pounds; tobacco, 423,934 pounds; ginned cotton, 300,901 bales of 400 pounds; peas and beans, 1.142,011 bushels; potatoes-Irish, 227,379, and sweet, 6,9s6,428 bushels; hay, 23,449 tons; clover-seed, 132, and other grass-seed, 425 bushels; hops, 261 pounds; hemp-dew-rotted, 0 , and water-rotted; 0 tons; flax, 5,357 pounds; flaxseed, 622 bushels; maple sugar, 50 pounds; cane sugar, 1,641 hogsheads of 1,000 pounds; molaśses, 216,150 gallons; wine, 796 gallons, etc. The value of orchard products was $\$ 92,776$, and of market-garden products, $\$ 76,500$. The annexed table compares the crops of the great staples in $1 S 40$ and 1850:

\begin{tabular}{|c|c|c|c|c|c|c|c|}
\hline $\begin{array}{l}\text { Staץles. } \\
\text { ane Sugar ........... }\end{array}$ & $\begin{array}{l}1840 . \\
329,74 t \text { pounds }\end{array}$ & $\begin{array}{c}1850 \\
1,644,000\end{array}$ & ounds & $\begin{array}{c}\text { Movement. } \\
\text {.... incr. } 1,314,256\end{array}$ & & 010 & \\
\hline Ginned Cotton ........ & $168,392,396$ & ... $120,360,400$ & 66 & ....decr. $43,031,996$ & "6 & or 26.34 & 6 \\
\hline obaceo.............. & 162.594 & .. $\quad 423.934$ & " & .... iner. & "6 & or 160.25 & “6 \\
\hline Rice.............. & $12,384,732$ & .... 3S,950,691 & 66 & .... incr. $26,565,959$ & 66 & or 214.51 & $\$ 6$ \\
\hline
\end{tabular}

Products of Animals.-- Tool, 990,019 pounds (in 1540, 3i1.303); butter, 4.640 .559 pounds, and cheese, 46.976 pounds ; and the value of animals slaughtered in the year had been $\$ 6,299,762$. Silk cocoons were produced to the amount of $\$ 13$ pounds (in $1840,2,992 \frac{1}{2}$ ); and beeswax and honey, to that of 732,514 pounds.

Home-made maunfactures for the year cuding 30th June, 1850, were valued at $\$ 1, \$ 38,963$ (in 1840, $\$ 1,467,630)$.

MLunufuctuies.-Aggregate capital invested, $\$ 00,010.000$; value of raw material, fuel, etc., consumed, $\$ 0,000,000$, average number of hands employed, 00,000 - males, 00,000 . and females, $0.000 ;$ average montlily cost of labor-male, solin, 000 , and female, $\$ 00,000$; annual ralue of products, $\$ 00,000.000$. The whole number of manufacturing establishments, producing to the value of $\$ 500$ and upward in 1850, was 1,407, and of these 35 were eotton factories, 3 woolen factories, 140 tanneries, and 10 iron establisluments, of which 4 manufactured casting, 3 pig-iron, and 3 wrought ircm. 


\section{GEORGIA.}

The cotton manufactures employ a capital of $\$ 1,736,156$; the cotton consumed in the year ending 30 th June, 1550 , was 20,230 bales, and the value of all raw material, fuel, ete., was $\$ 900,419$; average hands cmployed-males $\$ 73$, and females 1,399 ; monthly cost of labor - male, $\$ 12,725$, and female, $\$ 10,352$; value of entire products, $\$ 2,135,044$, the products of the year haring been $7,209,292$ yards of sheeting, and 4,195,351 pounds of yarn.

The voolen manufactures have a capital invested amounting to $\$ 68,000$, and consume annually 153,816 pounds of wool ; value of all raw material, $\$ 30,392$; hands employed-males 40 , and females 38 ; monthly cost of labor-male $\$ 1,099$, and female, $\$ 5036$; cloth manufactured, 340,660 yards; value of the entire products, $\$ \$ 8,750$.

The tanneries employ a capital of $\$ 262,855$, and use annually 81,484 hides, and 21,705 skins, valued at $\$ 185,604$; hands employed, 402; monthly wages, or cost of labor, $\$ 7,107$; skins tanned, 21,705 , and sides of leather tanned, 162,968valued together at $\$ 361,586$.

The various iron manufactures are in accordance with the following statistics:

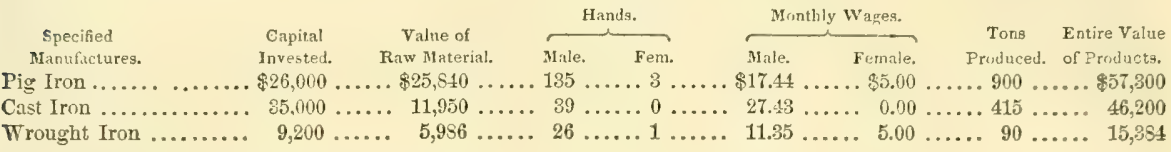

The total capital invested in the iron manufacture is thus $\$ 70,200$ : the value of raw material, fuel, etc., consumed, $\$ 43,776$; and the total value of products, $\$ 118,884$.

The branches of industry, others than those above enumerated, and forming the bulk of the manufactures of the State, consist chiefly of Mills of various descriptions, as saw and flouring mills, paper mills, boot and shoe shops, wheelwright shops, agricultural-implement manufacturers, ete., ete., which, taken together, and in connection with the national manufactures in which this State is engaged, constitute a very respectable manufacturing interest, and place Georgia in a proud position-first among its compeers of the Southern States.

Foreign Commerce. - Not more than a sixth of the commercial staples of Georgia are exported directly, or in shipping belonging to the State. The great bulk of its products are carried coastwise, and chiefly in northern vessels to northern ports, and thence trans-shipped to the foreign port; and even of the one-sixth, constituting the material of its direct foreign commerce, more than three-fifths is exported in vessels of foreign nations; besides, a large moiety of the products of Western Georgia is shipped at Appalachicola, in Florida. The exports to foreign countries, in the year ending 30 th June, 1850 , were valued at $\$ 7,551,943$, of which $\$ 4,929,791$ represents the value of merchandise carried in foreign bottoms; and the direct imports were valued at $\$ 636,964$, of which $\$ 330,081$ was the value of goods carried in foreign bottoms. The whole of the exports were of domestic origin. The total entries were 118 ( 57,017 tons), of which 71 (45,134 tons) were foreign; and the total clearances were 141 ( 72,563 tons), of which 83 (51,524 tons) were foreign. The whole of this commerce was done in the district of which Savannah is the port of entry. The amount of shipping owned in the State at the above-named period was 21,690 tons, distributed among the several collection districts as follows *

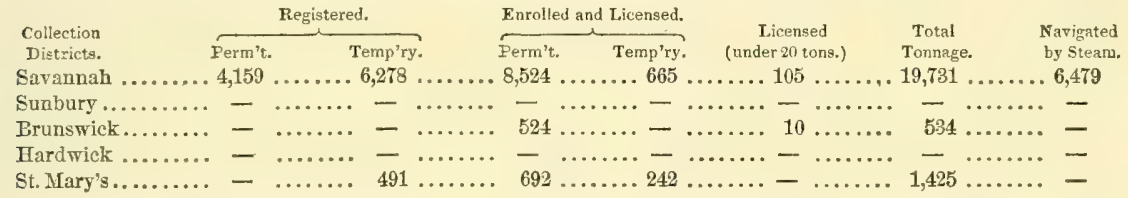

All the registered tonnage is employed in the foreign trade, and all the enrolled and licensed in the coasting trade: the vessels navigated by steam are of the latter classes. The number of vessels built in the year was $5-2$ schooners and 3 steamers-with a total burden of 684 tons. The statistics of the foreign commerce of Georgia for a series of years exhibit the following movements:

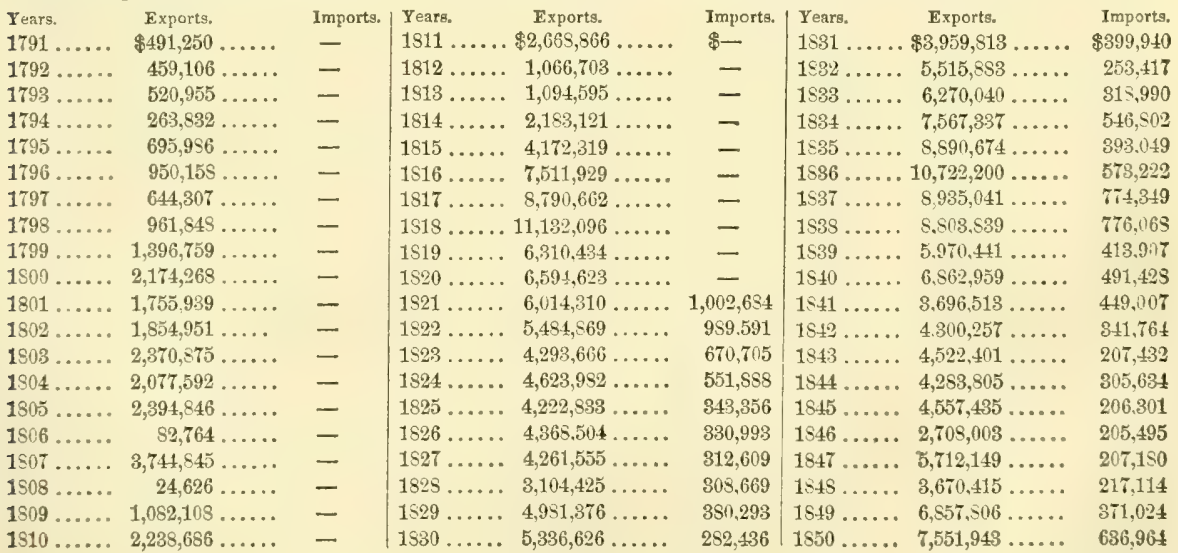

Intemal Communication.-The rivers of Georgia furnish in the aggregate a long line of narigable channels, which give the greater part of the interior a ready access by steamboat or batteaux to the Gulf and Atlantic seaboards. The names, length, etc., of the principal of these are given elsewhere. Georgia has also furnished itself with extensive and 
magnificent lines of internal improvements; her railways now in active operation have a length of 859 miles, and there are about 800 miles now in progress of construction, or for which charters have been obtained. The direction of the Georgia railways is generally between the seaboard and the interior; two lines, one from the port of Savannah and the other from that of Charleston, run south-west to a junction with the system of Tennessee railroads, terminating at Chattanooga, distant from the first-named place 432 miles, and from the latter 415 miles; and in their course give off several branches and connect with other railroads passing westward into Alabama, ete. Among the projected railroads the most important are those from Sarannah and Brunswick to the Flint River and the seaports of Florida. Georgia has also two short canals: the Savannah and Ogeechee Canal, 16 miles long, and the Brunswick Canal, 12 miles long; the former extends from Savannah to the Ogeechee River, but is now unused, and the latter from Brunswick to the Alatamaha Piver. The proportion of completed railroads to superficies in this State, in January, 1853, was as 1 mile of road to every $6 r_{\frac{1}{2}}$ square miles, and to the population as 1 mile of road to every 1,055 persons.

Banks, etc.-In December, 1850, there were in the State 11 banks and 10 branch banks, and their condition in the aggregate was as follows: liabitities-capital, $\$ 13,482,198$; circulation, $\$ 11,771,270$; deposits, $\$ 3,035,680$; due other banks, $\$ 3,035, \$ 93$, and other liabilities, $\$ 23,260$; and assets-loans and discounts, $\$ 23,312,330$; stocks, $\$ 963,611$; real estate, $\$ 338,429$; other investments, $\$ 236,205$; due by other banks, $\$ 5,020,998$; notes of other banks, $\$ 810,395 ;$;pecie funds, $\$ 306,909$, and specie $\$ 2,218,223$. The branch banks are branches of the Bank of the State of Georgia, the head-quarters of which is at Savannah.

Government.-Georgia's first constitution was made in 1777 ; a second in 1785, and the one on which the present government is based, in 1798. It has subsequently undergone numerous amendments. Every citizen of the State, 21 years old, who has paid all taxes demanded for one year, and has resided in the county for six months next before an election, has the right to vote.

The legislature is styled the General Assembly, and consists of a Senate and House of Representatives, the members of both of which are elected biennially. Representatives (130 in number) must be 21 years old and have been citizens of the State three years and of the United States seven years next before the election; senators ( 47 in number) are chosen in distriets, and must be 24 years old, and have been eitizens of the United States nine years. A census of the State is taken every seven years and representatives apportioned in accordance with its results.

The Governor is chief executive: he must be 30 years old, and have been a citizen of the United States twelve years and of the State six years, and be possessed of 500 acres of land, or $\$ 4,000$ in other property above all debts. He is elected for two years by a popular majority vote, or in case there be not a choice, then one of the two candidates having the highest number of votes shall be elected by joint ballot of the General Assembly. In case of the office becoming vacant, the chair is filled by the President of the Senate, and after him by the Speaker of the House. The governor may veto a bill, but two-thirds of both houses subsequently voting in favor of the rejected bill, makes it law nevertheless.

The executive officers of the govermment of the State are-a Secretary of State, a State Treasurer, a Comptrollergeneral, a Surveyor-general, and a State Librarian. The Keeper of the Penitentiary, Commissioner of the Deaf and Dumb, and State Printer, come under this head.

The Judiciary consists of a Supreme Court, Superior Courts, and courts of inferior jurisdiction. The Supreme Court, for the correction of errrors, consists of three judges, one of which is chief judge, elected by the General Assembly for such term as the law may provide, and are removable upon address of two-thirds of each house. The judges of the Superior Court are elected for six years, with jurisdiction exclusive in criminal cases and in land cases, and concurrent in all other civil cases. Justices of the inferior courts are elected by the people in districts. All judges have fixed salaries. The State is divided into thirteen circuits with a judge for each, viz, : Northern, Eastern, Southern, Western, Middle, Ocmulgee, Flint, Chattahoochee, Cherokee, Coweta, South-western, Macon, and Blue Ridge. Savannah and Augusta have special courts of Oyer and Terminer. Each county elects an "ordinary," who holds office for four years, and has the ordinary jurisdiction of a judge of probate. Sheriffs are appointed for two years, but not for two terms in succession.

On the institution of slavery, the constiution provides, that "There shall be no importation of slaves from Africa or any foreign place after October 1st, 1793, nor shall the legislature have power to free slaves without the owner's consent, or to prevent immigrants from bringing with them persons deemed slaves by any one of the United States. Slaves are protected in their persons, like free white persons, except in case of insurrection, and unless their "death should happen from accident in giving such slaves moderate correction." Amendments to the constitution, if passed by two-thirds of each house, shall be published six months before the next election of members of the General Assembly ; and if passed in the same manner at the first session thereafter, shall be adopted.

The militia of Georgia consists of 78,699 men of all grades and arms, of which 5,050 are commissioned officers, and 73,649 non-commissioned officers, musicians, and privates. Of the commissioned officers 89 are general officers, 91 general staff officers, 624 field offlcers, and 4,296 company officers.

The State benevolent institutions are an Asylum for the Deaf and Dumb, under the management of commissioners, and another for Lunatics, in the hands of trustees.

Finances, Debt, etc.-The balance in the treasury on the 20th Oetober, 1849 , amounted to $\$ 354,69752$, and the receipts into the treasury during the next fiscal year amounted to $\$ 355,2269 \mathrm{~S}$-total means for the year $\$ 709,924$ 50. Disbursements for the same period $\$ 355,44000$, and balance remaining $\$ 354,45450$; less unavailing for execution warrants $\$ 286,74600$, leaving an actual balance of $\$ 67,73850$. The public debt of the State amounted to $\$ 1,829,07222$, and the bonds have from 18 to 20 years to run. Of this sum $\$ \tau 2,000$ are in sterling bonds, sold to Messrs. Reid, Irving \& Co., of London, England, and the remainder Federal bonds. The semi-annual dividends, as well as the principal of the sterling bonds, are payable in London. The whole annual interest on the debt is $\$ 110,22333$. $\mathbf{A}$ committee of the legislatire appointed to examine the State accounts in 1551, recommended that the balance then in the treasury should be applied to the redemption of the sterling bonds, and the State has a sinking fund for the ultimate redemption of the whole debt as it becomes due. The chief sources of income are the general tax and a special tax on bank stock. The principal items of expenditure are the pay of the legislature biennially, about $\$ 65,000$, of the civil establishment, including judiciary, annually, about $\$ 45,000$; the support of the Deaf and Dumb Asylum, about $\$ 17,000$; printing, an annual average of about $\$ 6,000$, and miscellaneous expenses, about $\$ 12,000$ annually. The items of interest on and reduction of the debt are additional to these. The assessed value of taxable property in the State in 1850 was $\$ 335,116,225$.

Federal Representation.-Georgia, in acendance witb the present law regulating the distribution of members to the United States House of Representatives, occupies eight seats in that body. 
Religious Statistics.-The census of 1850 returns the several religious denominations, in reference to the churches, church accommodation, and church property of each, as follows:

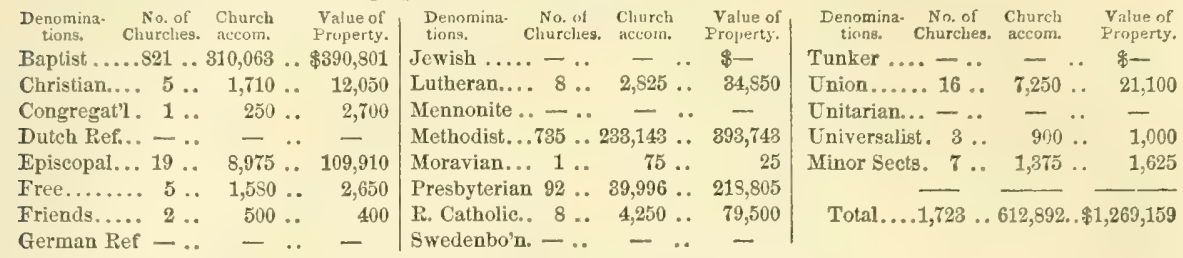

Georgia is a diocese of the Protestant Episcopal Church, and with all Florida east of Appalachicola Bay, forms the Roman Catholic diocese of Savanuah.

Education.-The State of Georgia in 1850 had 28 colleges or universities, 237 academies and high schools, and 822 common or primary schools. The chief collegiate institutions were, the University at Athens, founded in 1785, and in 1850 had 8 professors, 616 alumni, of which 65 were in the ministry, and 155 students, and a library of 13,600 volumes; Oglethorpe College, founded 1836, and located at Medway, had 6 professors, 83 alumni (13 ministers), 85 students, and a library of 4,500 volumes; Emory College, founded 1887 at Oxford, and belonging to the Methodists, had 5 professors, 138 alumni (16 ministers), 115 students, and 1,700 volumes; Mercer University, founded 1835 at Penfield, had 7 professors, 32 alumni (10 ministers), 71 students, and 3,400 volumes; and Wesleyan Female College at Macon, founded 1839 , had 8 professors, 156 alumni, and 198 students. The academies had 400 teachers and 14,296 students, and the common or primary schools 2,008 teachers and 24,000 schools.

Pauperism and Crime.-The whole number of persons who received support from the public funds within the year ending 1st June, 1850 , was 1,036, of whom 978 were native born and 58 foreigners; and the number of paupers at that date was 854-825 natives and 29 foreigners, Annual cost of support $\$ 27,820$. The whole number of persons convicted of erime in the year ending as above was 31, of whom 28 were natives and 3 foreign born; and the whole number in prison at that date was 92 . The State Penitentiary is located at Milledgeville.

Iristorical Sketch.-Georgia was the last settled of the old States; the Charter under which the colony was founded was granted in 1732 by George II.-in honor of whom it received its name-to the Trustees for the Establishing the Colony of Georgia. The double purpose of making the settlement was to relieve the distresses of the poor at home, and to secure the frontiers of the Carolinas from the Indians and Spaniards. In 1733 General Oglethorpe, one of the trustees, conducted the first colonists to the Savannah, and several bodies of Germans and Highlanders were soon afier brought over. The lands were held on a military tenure. The country was repeatedly traversed by the Spaniards from Florida, who considered the occupation of the English as an encroachment upon their domain. In 1752 the proprietary government was abolished, and Georgia beeame a royal colony. The original limits of the State included the territory now divided into the two thriving States of Alabama and Mississippi.

At the commencement of the Revolutionary War, Georgia was only in the infancy of her strength, and had just begun to enjoy peace and the advantages of a better system of government. The inhabitants knew the operation of the royal government only by its favorable contrast with that of the Trustees. Notwithstanding, the people did not hesitate to take part with their northern brethren. During the war that ensued, Georgia was overrun by the British troops, and the principal inhabitants were compelled to abandon their possessions and fly into the neighboring States. In proportion to their numbers, the exertions and losses of her citizens were as great as in any of the States.

After the war Georgia suffered on her frontiers from the incursions of the Creek Indians, whose hostility had been too often provoked by the whites. In 1790 a treaty was concluded with this nation, by which the boundaries of Georgia were established. In 1802 the Creeks ceded to the United States a large tract of country, which has since been ceded by the United States to Georgia, and forms the south-west corner of the State. Georgia possessed-as included within her limits - a claim to an immense body of Western land, of which in 1795 the Legislature sold a large portion, said to have contained 22,000,000 acres, to a company, by which it was again sold to individuals. In the succeeding year the Legislature declared the sale unconstitutional, and on the ground that it was obtained through bribery, they declared it to be roid, and ordered all the records to be burned. In 1802 Georgia ceded to the United States all the lands west of the Chattahoochee River, and of a certain line including the contested lands; and in 1814 Congress passed an act by which a compromise was made with the purchasers, who received a certain amount of public stock. The history of Georgis since this period records no territorial or government changes; but it is full of instruction, recording the gradual progress of a people in the arts, agriculture, manufactures, and commerce, from a small beginning to an elevation attained by few other members of the Confederation, in the escutcheon of which this State is one of the brightest stars.

Mruederume is the political capital of the State.

Gzorgia, t. and p. v., Franklin co, Verm.: $41 \mathrm{~m}$. N. W. Montpelier. Drained in the N. by creeks of Lake Champlain, which bounds it on the W., and in the S. by Lamoille r., which furnishes water-power. Along the lake the surface is level-otherwise somewhat hilly; soil in the $\mathbf{S}$. sand, and covered with pine growths. The v. lies on the Vermont Central R. $R_{v a}, 49 \mathrm{~m}$. from Montpelier. In the t. there are several tanneries and mills, but the industry of the inhabitants is chiefly devoted to agriculture. Pop. 2,686.

GrRMAN, t, and p. v., Chenango co., $N . Y_{.:} 106 \mathrm{~m}$. W. Albany. Drained by affluents of Otselic and Chenango rivers. Surface hilly; soil of moderate fertility and good for grazing. The $\mathrm{v}$. is situate near the centre, and is a small agricultural settlement. Pop. of t. 903.

Grevas, t. and p. 0., Darke co., Ohio: $94 \mathrm{~m}$. W. Colum- bus. Drained by tributaries of Greenville cr. of Miami r. Surface varied by bills; soil rich and fertile. Pop. 1,502. Germanis, p. v., Orange co., Firg.: 59 m. N. W. Richmond.

Germanno, p. o., Harrison co., Ohio: 112 m. E. N. E. Columbus.

German Settlement, p. o., Preston co., Firg. : a flourishing village and settlement, $188 \mathrm{~m}$. N. W. Richmond. It contains numerous mills, mechanic shops, ete., and about 600 inhabitants.

Gervanton, p. v., Stokes co., $N$. Car. : on Town fork of Dan r., $9 \mathrm{~S}$ m. W. N. W. Raleigh. It was, until 1S5t, capital of the county, and contains the old court-house, a jail, etc., several stores, and about 200 inhabitants.

Germantown, t. and p. o., Columbia co., N. Y. $35 \mathrm{~m}$ 
S. Albany. Drained by Hudson r., which is its W. boundary. Surface gently undulating; soil, clayey loam, and fertile. Pop. 1,022. There are several buildings, with stores, etc., on Hudson r., and the Hudson River R. R. passes through the town.

Germantown, p. v., Marion co., Ind.: on Fall cr., $15 \mathrm{~m}$. N. E. Indianapolis.

Gervantown, p. v., Mason co., Ky.: 69 m. E. N. E. Frankfort.

Germantown, p. T., Montgomery co., Ohio: in a beautiful valley near the junction of Big and Little Twin creeks of Miami r, and surrounded on the N. and E. by hills, 77 $\mathrm{m}$. W. S. W. Columbus. It is a thriving place with several manufactures and mechanic shops, and has about 2,000 inhabitants. It has a newspaper, the "Western Emporium," a weekly issue. It was settled by Germans from Pennsylvania.

Germantown, t. and p. v., Philadelphia co., Penn. : S9 m. E. by S. Harrisburg. Drained by Wissihicken and Wingohocking creeks. Surface hilly; soil, loam and alluvial bottoms. The r. lies $6 \mathrm{~m}$. N. W. of Philadelphia, and may be considered as one of its suburbs; it is principally built on one street about $3 \mathrm{~m}$. long, and contains numerous stores and mechanic shops. It is connected with Philadelphia by the Germantown Branch R. R. Germantown is noted as the scene of a great Revolutionary battle, fought in October, 1777 . The $t$, has several extensive manufacturing establishments, and in 1550 contained $\$, 304$ inhabitants. Germantown, p. V., Shelby eo., Tenn. : on the Memphis and Charlestown R. R, $17 \mathrm{~m}$. from Memphis and $182 \mathrm{~m}$. W.S. W. Nashrille.

Germantown, p. v., Fanquier co., Virg. : 72 m. N. N. W. Riclumond.

Gramantown, p. v., Clinton co., Ill.; $87 \mathrm{~m}$. S. by E. Springfield.

Graman Vallex, p. o., Morris county, N. Jer.: $53 \mathrm{~m}$. N. by E. Trenton.

Germanswille, p. Vo, Edgefield dist., S. Car. : on Cloud's cr. of Saluda r, 86 m. W. Columbia.

Gerratedstown, p. v., Berkeley county, Firg.: $189 \mathrm{~m}$. N. by W. Richmond.

GerRr, t. and p. v., Chautauque county, N. $Y_{0}: 278 \mathrm{~m}$. W. by S. Albany. Drained by Cassadaga er. and its tributaries. Surface undulating; soil gravelly loam, and well cultivated. It has a number of mills on the streams, but is essentially agricultural in its industry. Pop. 1,422.

Getrtsiburgit, p. v., Preble co., Otio: 93 m. W. by S. Culumbus.

Getrisbereir, p. b., and cap. Adams co., Penn. : on the heads of Monocacy r., $33 \mathrm{~m}$. S. S. W. Harrisburg. It contains a court-house, jail, etc., has several manufactures, and contains 2,180 inhabitants. The place is supplied with water by pipes from a neighboring spring. Here is located the Theological Seminary of the Lutheran Church. This institution was founded in 1825, and in 1850 had 2 professors, 226 alumni, and 26 students; and a library of 9,000 rolumes. Four periodicals are published in the borough, viz.: the "Adams Sentinel" (whig), the "Star and Banner" (whig), and the "Republican Compiler" (dem.), all weekly, issues, and the "Review" (whig), a monthly issue. Gettysburg is a place of considerable trade, and when connected with the system of railroads of the State will become a very important centre. It is surruunded by a fine agricultaral country. Pop. 2,15e.

GHENT, p. V., Carroll co, $K y_{0}:$ on the S. bank of the Ohio r., opposite Vevay, $37 \mathrm{~m}$. N. by W. Frankfort. It is a pleasant r., $_{\text {, and }}$ contains 3 churehes, a tobaceo manufactory, 7 stores, and about 400 inhabitants.

Gnexт, t. and p. v., Columbia co., $N . Y_{*}: 24$ m. S. by E. Albany. Drained by Clarerack er., on which are mills. Surface broken; soil gravelly loam. The v. contains about 800 inhabitants. The Harlem R. R, and also the Hudson and Berkshire R. R., pass through the t. Pop. 2,293.

250
Grolsox, p. v., Noxubee county, Afiss. : 95 m. E. N. E Jackson.

GHoLsonville, p. v., Brunswick co., Virg. : on the N. side of Meherin r., $58 \mathrm{~m}$. S. by W. Richmond.

Grbbon's Tavern, p. o., Delaware co., Penn.: $81 \mathrm{~m}$. E. S. E. Harrisburg.

Gribs's Cross Rosns, p. O., Cumberland co, N. Car.

GibBvilue, p. v., Sheboygan co., Wisc.: on the W. side of Onion r., a branch of Sheboygan r., 89 m. E. N. E. Madison.

GrmesonvilLE, p. v., Hocking co., Ohio: 47 m. S. E. Columbus.

Gibraltar, p. v., Wayne co., Mich.: on the W. bank of Detroit r., at its entrance into Lake Erie, $84 \mathrm{~m}$. S. E. Lansing. The harbor is good and has a light-house. The Gibraltar and Clinton Canal, terminating here, has never been finished, but affords a good head of water for manufacturing purposes. The $\mathrm{v}$. is small and not progressive.

GIBson county, Ind. Situate S. W., and contains 512 sq. $m$. Drained by the Patoka and other streams. The Wabash lies on its W. and White r. on its N. border. Surface agreeably undulating and generally well timbered; soil, loam and sand, and very productive. Farms 1,220; manuf. 23 ; dwell. 1,833, and pop.-wh. 10,554, fr. col. $217-$ total 10,771. Capital: Princeton. Public Works: Wabash and Erie Canal, and Evansville and Illinois R. R.

Grisor, t. and p. o., Susquehannah co., Penn.: $123 \mathrm{~m}$. N. N. E. Harrisburg. Drained by Tunkhannoe and Lackawannoc creeks. Surface hilly ; soil clay and gravel. It is almost wholly agricultural, and contains 1,344 inhabitants. Gmson, p. v., Pike co., Ohio: $61 \mathrm{~m}$. S. Columbus.

Gibson, p. v., Steuben county, $N . Y .: 184 \mathrm{~m}$. W. by $\mathrm{s}$. Albany.

Gibson's Welis, p. o., Gibson county, Tenn.: $123 \mathrm{~m}$. W. by S. Nashville.

GibsonviluE, p. v., Livingston county, $N . Y_{0}: 213 \mathrm{~m}$. W. by N. Albauy.

Gidley's Station, p. o., Jackson county, Mich.: $35 \mathrm{~m}$. S. by E. Lansing.

Gilbertsborougi, p. v., Limestone co., $\Delta l_{0}: 176 \mathrm{~m}$. N. by W. Montgomery.

Gilbert's Mills, p. o., Oswego county, $N . Y .: 148 \mathrm{~m}$. W. N. W. Albany.

GileERTSVILLE, p. v., Otsego con, N. Y.: on a branch of Unadilla r., $81 \mathrm{~m}$. W. by $\mathrm{S}$. Albany.

GiLBOA, t, and p. $\nabla_{0}$, Schoharie co., N. Y.:88 m. W. S.W. Albany. Drained by Schoharie cr. and its branches. Surface varied-in the W. hilly; soil rich and fertile. The $\mathrm{r}$. is located on Schoharie cr., and has several manufactures, mills, etc., and about 300 inhabitants. Blenheim is also a v. in this town. Pop. 3,024 .

GriboA, p. Y., Putnam co., Ohio: on the N. side of Blanchard's fork of Auglaize r., $87 \mathrm{~m} . \mathrm{N}$. W. Columbus.

GILBOA, p. o., Louisa co., Virg.: 58 m. N. W. Richmond. Gruchist's Bridge, p. 0., Marion dist., S. Car: $98 \mathrm{~m}$. E. Columbia.

Gromaigtrule, p. v., Dauphin co., Penn.

GILDER, p. v., Greenville dist., S. Car.: 112 m. N. W. Columbia.

GILeAd, p. o., Upshur county, Tex.: 248 m. N. E. Austin City.

Gilead, to and p. o., Oxford co., Me.: $59 \mathrm{~m}$. W. Augusta Drained by Androscoggin r., which runs from W. to E through it. Surface rough and hilly, and except on the river, fit only for grazing. The Atlantic and St. Lawrence R. P. traverses the S. bank of the Androscogoin. P. 859 .

Gread, p. v., Tolland co., Conn.: 16 m. E. S. E. Hartford. GILEAD, p. v., Miami co., Ind.: $89 \mathrm{~m}$. N. Indianapolis.

GILEad, p. v., Calhoun co., Ill.; on the E. side of the Mississippi, at the foot of the Bluffs, which are here about $2 \mathrm{~m}$. back from the river, $71 \mathrm{~m} . \mathrm{S}$. W. Springfleld.

GiuzAD, t. and p. o., Branch co., Mich.: $71 \mathrm{~m}$. S. s. W.

Lansing. Drained by Prairie and Fawn rivers of the St. 
Joseph's. Surface diversified; soil fertile and deep mold. It is one of the best farming sections of the State. P. 503.

Gilead, sta., Morrow co., Ohio: a station on the line of the Cleveland, Columbus, and Cincinnati R. R., $43 \mathrm{~m}$. from Columbus.

Gilead, p. V., Wood co., Ohio : on the S. side of Maumee river, opposite Providence, $108 \mathrm{~m}$. N. W. Columbus.

GrLes county, Firg. Situate S. W., and contains 59.1 8q. m. Drained by Sinking, Big and Little Stony, Walker's and Wolf creeks, branches of New r., a head of Kaunwha, and by heads of the James $r$. It is very elevated, being 2,000 feet above the ocean. Surface much broken, and in parts stony; soil on the numerous streams very rich. It is celebrated for its White and Grey Sulphur Springs. The grains are raised liberally, and tobacco and sugar to some extent. Farms 539; manuf. 0 ; dwell. 919, and pop.wh. 5,859, fr. col. 54, sl. 657-total 6,570. Capital: Giles Court-house (Parisburg).

Giles Court-House, p. o., and eap. Giles co., Firg. : in the $\mathrm{v}$. of Parisburg, on the left bank of New river, $182 \mathrm{~m}$. W. by S. Richmond. Immediately below the village the river passes through a gap of Peter's Mountain, a branch of the Great Alleghany Mountains.

GiLFond, t., p. v., and eap. Belknap co., N. Hcmp.: 26 m. N. by E. Concord. Drained by Gun-stock and Miies rivers, and the heads of Suncook r. Winnipiseogee Lake lies on its $\mathrm{N}$. burder, and on the S. E. part of the $t$. is Suncook Mountain. There are seven islands in the lake belonging to Gilford. The soil is generally productive and well cultivated. In the t. there are many mills and factories, chiefly of cotton goods. Pop. 2,425. The Boston, Concord, and Montreal R. R. passes through the E. part of the town.

Gilford Villagh, p. v., Belknap co., $N$. IIamp.: at the outlet of Winnipiseogee Lake, $25 \mathrm{~m}$. N. by E. Concord. It is a pleasant and thriving village.

GruI, t. and p. o., Franklin co, Mass.: 97 m. W. by N. Boston. The Connecticut $r$. forms its $\mathrm{E}$. and $\mathrm{S}$. boundaries, and along its banks are extensive meadows. Fall r., on the W. divides the t. from Greenfield. Surface mountainous, but generally fertile, and the people are chiefly engaged in farming. It has, however, several small manufactories. Pop. 754.

GILlelaNd CreEk, p. o., Travis co., Tew.: on a creek of Rio Colorado so called, $16 \mathrm{~m}$. E. S. E. Austin City.

GILLEsPre county, Texa, Situate centrally, and contains about 2,200 sq. m. Drained by Sandy cr., Pedernales r., and Rio Llano, affuents to the Colorado, which passes its N. E. corner. Surface much diversifled-parts hilly and rough, but most of it rolling or level; soil fertile, and well adapted to grain and pasturage. Farms 40 ; manuf. 7 ; dwell. 274, and pop.-wh. 1,285, fr. col. 0, sl. 5-total 2,240. Capital :

Fredericksburg.

GILLESPIEVILle, p. v., Ross county, Ohio: 49 m. S. Columbas.

Gill Hall, p. o., Alleghany county, Penn.: $171 \mathrm{~m}$. W. Ilarrisburo.

Grulrox's, p. o., Baker county, Ga. : on the E. side of a branch of Ichawaynochaway cr., $181 \mathrm{~m} . \mathrm{S}$. W. Milledgeville. GILIONStille, p. v., Beaufort dist., S. Car. : $120 \mathrm{~m} . \mathrm{S}$. Columbia.

Gill's Mruzs, p. o., Bath co., Ky. : 73 m. E. Frankfort. GILI's STORE, p. o, Lincoln county, Tenn.: $72 \mathrm{~m}$. S Nashville.

Gruisville, p. ve, Hall county, Ga. ; on Hudson's Fork of

Broad r., 93 m. N. N. W. Milledgeville.

GILMAN, t. and p. Oo, Hamilton eo, N. Y.: 72 m. N. N.W. Albany. This is a long, narrow township, extending $N$. from sacandaga $r$., nearly $40 \mathrm{~m}$. It has a number of lakes and streams, which afiord fine water-power. The surface is diversified-in the N. hilly, and most of it is yet a wilderness. Pop. 101.

Gimantion, t. and p. o., Belknap co., N. Hamp.: $19 \mathrm{~m}$.
N. by E. Concord. Drained by Suncook and Soucook rivers. Surface hilly; soil generally fertile. It is the seat of a flourishing academy, to which is attached "Gilmanton Theological Seminary." This seminary, founded in 1835, had in 18503 professors, 23 students, and 69 had completed their educational courses. The library contains 4,300 role. Pop. of t. 3,282.

Gimantown Iron-Works, p. v., Belknap county, ir $^{2}$ Mamp.: on a branch of Suncook river, $17 \mathrm{~m} . \mathrm{N}$. N. E. Concord.

Gilmer county, $G a$. Situate on N. line, and contains 793 sq. m. Drained by Toceo r., an affluent of Tennessee $r$, and Coosawattee, a head of Alabama r. Surface clevated and broken; soil good and well watered. Cotton, corn, wheat, and tobacco are the staples. Farms 57t; manuf. 5; dwell. 1,396, and pop.-wh. 8,236, fr. col, 4, sl. 200-total 8,440. Oapital: Ellijay.

Gilmer county, Firg. Situate N. W., and contains 611 sq. m. Drained by Little Kanawha $r$, and its numerous affluents. Surface diversified; soils good, Coal and salt springs are abundant in this portion of the State, and add much to the resources of the inhabitants. The cereals are likewise successfully cultivated. Farms 325; manuf. 2 ; dwell. 571, and pop.-wh. 3,403, fr. col. 0, sl. 72 - total 3,475. Capital: Glenville.

GILMER, p. v., Lake co., Ill.: equidistant between FoX and Desplaines rivers, $186 \mathrm{~m}$. N. E. Springfield. It stands on a fine elevated prairie, interspersed with groves of handsome timber.

GILMER, p. o., and eap. Upshur co., Tex. : on an upper branch of Little Cypress r., $153 \mathrm{~m}$. N. E. Austin City.

GILMER's Store, p. o., Guilford county, N. Car. : $83 \mathrm{~m}$. W. N. W. Raleigh.

Gruopolis, p. v., Robeson county, N. Car.: $112 \mathrm{~m} . \mathrm{S}$. Raleigh.

Ginsum, t. and p. v., Cheshire co., N. Hamp.: $39 \mathrm{~m}$. W. S. W. Concord. Drained by Ashuelot r., which furnishes water-power. The $\mathrm{v}$. on the N. side of the river bas considerable manufactures. Pop, of t. 666 .

Givger Hilu, p. o., Washington co., Penn. : $197 \mathrm{~m}$. W. by S. Harrisburg.

Ginsexe, p. o., Wyoming county, Tirg. : $246 \mathrm{~m}$.W. by N. Richmond.

Giv Town, p. v., Irwin county, Ga.: $117 \mathrm{~m} . \mathrm{S}$. by W. Milledgeville.

GTrard, p. v., Russell co, $A l \alpha .:$ on the W. side of Chattahoochee r., and opposite Columbus, $76 \mathrm{~m}$. E. Montgomery A railroad, in continuation of the Muscogee $\mathrm{R}$. $\mathrm{R}$. of Georgia, is projected from this point to Mobile.

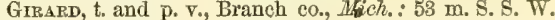
Lansing. Drained by Hog r. of the St. Joseph's, and there are several small lakes in the town. Surface level; soil rich. The village lies centrally on the S. side of the river, and is a small agrieultural settlement. Pop. of t. 934 .

Girard, p. v., Burke co., Ga.: 79 m. E. Milledgeville.

Girard, p. v., Trumbull county, Otio: $143 \mathrm{~m}$. N. E. Columbus.

GIRARD, t. and p. v., Erie county, Penn.: 221 m. N. W. Harrisburg, Drained by creeks of Lake Erie. Surface diversified; soils fertile. Lake Erie bounds it on the N. The $\mathrm{v}$. lies on the line of the Franklin Canal Company's R. R., 15 m. W. S. W. Erie, and the North Branch Canal crosses the township. Pop. of t. 2,918.

GLADDEN's Grove, p. o., Fairfield dist., S. Car. : $37 \mathrm{~m} . \mathrm{N}$. Columbia.

Giade Hrul, p. o., Franklin co., Firg.: 146 m. W. S.W. Richmond.

Glade Mruss, p. o, Butler co., Penn.: 178 m. W. N. W. Harrisburg.

Glade Mrnes, p. o., Hall co., Ga. : 106 m. N. N. W. Milledgeville.

Glade Run, p. o., Armstrong co., Penn. : 156 m.W.N.W. Harrisburg. 
Glade Spring, p. o., Harrison con, Tex. : $172 \mathrm{~m}$. N. E, Austin City.

Glames Cross Roads, p. o., Putnam co., Ga.: on a branch of Little r., $29 \mathrm{~m}$. N. W. Milledgeville.

Glade Spring, p. o., Washington co, Tirg. : on a cr, of Middle Fork of Holston r., $246 \mathrm{~m}$. W. S. W. Richmond. The Virginia and Tennessee R. R. will pass this point.

Gladeville, p. v., Preston co., Firg. : 173 m. N. W. Richmond.

GLADWIN county, Mich. Situate N. centrally of Lower Peninsula, and contains 576 sq. m. Drained by Tittibawassee $r$, an affluent of Saginaw $r$. Surface level or undulating; soil heavily timbered in part; the rest adapted to grass and grain - a good farming region. Set off since the year 1850.

Glady Creek, p. o, Randoiph co., Firg.: 158 m. N. W. Riehmond.

Giasco,p. $v_{*}$ Ulster con, $N_{.} Y_{*}$ : on the W. side of Hudson river, $43 \mathrm{~m}$. S. by W. Albany. Esopus cr. empties itself $3 \mathrm{~m}$. to the N. It has a good landing, and is noted for th: extent of its brick-yards. Pop, about 350 .

GLASGOW, p. v., Neweastle co., Del. : on Christian cr., $32 \mathrm{~m} . \mathrm{N}$. by W. Dover. The Newcastle and Frenchtown R. R. passes through it $11 \mathrm{~m}$. from Newcastle.

GLASGOW, p. v., and cap. Barren county, Ky.: a short distance E. of Beaver Branch of Big Barren r., $97 \mathrm{~m} . \mathrm{S}$. W. Frankfort. It contains a court-house, jail, ete., and about 200 inhabitants. The line of the Nashville and Lexington R. R., as projected, will pass through the village.

GLASGOW, p. F., Scott co., Ill. : $46 \mathrm{~m}$. W. S. W. Springfield. Glasgow, p. v., Jefferson county, $I \%$ : on a cr. of Big Cedar cr, 53 m. S. by W. Iowa City.

GLASGOW, p. v., Howard co., MO.: on the left bank of Missouri r., $58 \mathrm{~m} . \mathrm{N}$. W. Jefferson City. It is a thriving v., and has considerable river trade. Two newspapers, the "Howard County Banner," and the "G. Weekly Times," are published here. Pop. about 1,600.

Glasgow, p.v., Columbiana co., Ohio: 136 m. E. N. E。 Columbus.

Glassborougm, p. v., Gloucester county, $N$. Jer.: $43 \mathrm{~m}$. 5. by W. Trenton. It has several glass-houses and stores, and about 150 inhabitants.

Glass Creek, p. o., Barry coo, MFich.: 43 m. W. S. W Lansing.

Glass Viliage, p. v., Conway co., Ark.: on the W. side of Port Remove er., $52 \mathrm{~m}$. N. W. Little Rock.

Glastenbers, t. and p. v., Hartford co., Conn.: $8 \mathrm{~m}$. S IInrtford. Drained by creeks falling into Connecticut $r$. which makes its E. boundary. Surface rough; solil fertile. The $\mathrm{v}$, on Roaring Brook, about $2 \mathrm{~m}$. from Connecticut $r$, is engaged in manufactures. Pop. of t. 3,399.

GLEX, t. and p. o., Montgomery co, N. Y $: 36 \mathrm{~m}$. W. N. TY. Albany. Drained by Schoharie and other creeks of Mohawk $r$., which latter forms its N. boundary. Surface hilly; soil clayey loam. The Erie Canal traverses the Mohawh Valley, on which are the villages of Fultonville and Auriesville, l'op, of t, $8,043$.

GLEN, p. o., M'Kean co., Penn. : 144 m. N.W. Harrisbure Glevalts, p. on Marion county; $G a_{2}: 100 \mathrm{~m}$. W. S. TV Milledgeville. From this point streams flow in $E_{\text {., }}$ and $\mathrm{S}$., and $\mathrm{W}$. directions.

Glex Brook, p. o., Hart co., $K^{2} y$ : 81 m. S.W. Frankfort. GLENBURN, t. and p. o., Penobscot co., $M e_{.}$: $65 \mathrm{~m}$. N. E Augusta. Drained by Kenduskeag stream, which also affurels water-power. The r. is lectited on the lwrders of a limpe pond on the E, border of the town. Population of fuwn, y ,

GLexcos, p. r., Gallatin county, $K y_{0}: 42 \mathrm{~m}$. N. by E. Frankfirt.

Gifincoe, p. V., Bolivar co., Miss. : $112 \mathrm{~m}$. N. N. W. Jackson.

GLEN Cove, p. v., Queens co., N.Y.: at the head of Glen

Core an arm of Hempstead Harbor, $115 \mathrm{~m}$. $\$$. Albany. It 252 is a pleasant village, and is much resorted to in summer by the eitizens of New York, with which it is connected by regular steamboats.

GLendale, p. v., Berkshire co., Mass. : on the W. bank of the Housatonic $r$., where it is crossed by the Housatonic R. R., $118 \mathrm{~m}$. W. Boston.

GLEN DALE, p. o., Museatine co., Ia.: 39 m. E. S. E. Iowa City.

Glenfrinlas, p. v., Jefferson co., Mo.: on the right bank of Big r. of the Maramec, $88 \mathrm{~m}$. E. S. E. Jefferson City.

GleNHar, p. Y., Duchess co., $N . Y$. : on Fishkill er., about $3 \mathrm{~m}$. from Hudson r., $73 \mathrm{~m}$. S. Albany. This is a thriving village, chiefly engaged in the manufacture of iron, wool, etc., and containing about 800 inhabitants. It has immense water-power.

Glen Hope, p. o., Clearfield co., Penn. : $102 \mathrm{~m} . \mathrm{N}$. W. Harrisburg.

GLENMORE, p. v., Oneida co., $N$. $Y$.

GleNMORF, p. o., Buckingham county, Virg.: $61 \mathrm{~m}$. W. Richmond.

Glexn Grove, p. o., Fayette co., Ga.: \$8 m. W. N. W. Milledgeville.

Glinw Mruss, p. o., Culpepper co., Virg.: 73 m. N. N.W. Richmond.

Grenx's, p. o., Gloucester co., Virg. : 69 m. E. Richmond. Gless's, p. o., Clark county, $I a_{0}$ : 128 m. W. S. W. Iowa City.

Glenn's Fafis, p. v., Warren co., $N_{0}, Y_{\text {.: }}$ on the lef bank of the Hudson r., $41 \mathrm{~m}$. N. Albany. This is a great manufacturing v., and contains mills of all descriptions, furnaces, tanneries, etc., and about 2,500 inhabitants. Two newspapers, the "G. F. Clarion" (whig), and the "G. F. Republican" (dem.), are issued weekIy. The falls at this place have a total descent of 50 feet, and afford extensive water-power, by which a vast amount of machinery is moved. A bridge, 500 feet long, erosses the Hudson. Tho feeder of the Champlain Canal affords a navigable communication with the canal.

GlenN Springs, p. v., Spartanburgh dist., S. Car. : on Fair Forest cr., $78 \mathrm{~m}$. N. W. Columbia

Glevitille, p. v., Barbour co., Ala.: on Cowikee cr. of Chattahoochee r., 59 m. E. S. E. Montgomery.

Glex Rock, p. o., Tork co., Penn.

Glenpllte, t, and p. o, Schenectady co, $N . Y .: 22 \mathrm{~m}$. N.W. Albany. Drained by tributaries of Mohawk. $r$., which is its $\mathbf{S}$. boundary. Delplass er. crosses the E. part of the $t$. and falls into the Mohawk. The v. contains about twenty dwellings. The industry of the $t$, is chiefly devoted to agriculture. Pop. 3,409. The Utica and Schenectady R. R., and the Saratoga and Schenectady $\mathbf{R}$. R., traverse the Mohawk Falley through this town.

Glenville, p. v., Fairfield county, Conn.: 54 m. S. W Martford

Gi.ixim.t.F, p. v., and enp. Gilmer county, Firg.: on the S. side of Little Kanawha r., 20 S m. W. N. W. Richmond. GLEN W ALD, p. o., Sullivan county, N. Y.: 80 m. S. S.W. Albany.

Guenwood, p. v., Erie co., $N$. T.: 24S m.W. Albany. GLoBe, po o., Caldwell co., N. Car.: $169 \mathrm{~m}, \mathrm{~W}$. by $\mathrm{N}$. Raleigh.

GLOBE, p. O., Johnson co, MYO: $97 \mathrm{~m}$. W. Jefferson City. GLOtCESTER county, N. Jer. Situate S. W., and contains 2: 5 s.1. m. Irainet hy Great Egg IIarbor r., flowing into the Atlantic, Maurice r., flowing into Delaware Bay, and affuents of Delaware $x_{\text {. }}$ which lies on the W. Surface even: soil on the Delaware productive, and under fine cultiration, larocly supplying Philadelphia with fruit and vegetables; in the interior sandy, but well wooded with pine timber. Corn, rye, and lumber are leading exports. Farms 954: manuf. 141; dwell. 2,600, and pop. -wh. 15,035 fr. col. 620-total 15,65̃5. Capital: Woodbury. Publio WW 7. : Windbury branch R. R.

Grotcester county, Viry. Situate S. E. on Chesapeake 
Bay, and eontains $2 \pm 3 \mathrm{sq}$. m. Drnined by affluents of Plankitank and York rivers, between which it lies, and creeks of Mohjack Bay. Surface broken, except on the rivers, where the soil is very rich. Corn, wheat, and oats are the chief productions; there is also much good timber. Farms 578; manuf. 53; dwell. 1,000, and pop--wh. 4,290, fr. col. 6S0, sl. 5,557-total 10,527. Capital: Gloucester C. H.

GLOtCester, t. and p. v., Providence co, $R_{0} I_{0}: 14 \mathrm{~m}$. W. N. W. Providence. Drained by Chepachet and Pawtuxet rivers, which have good water-power. Surface uneren and rough; soil of average fertility, but best adapted to grazing. The t. has considerable manufactures, and Chepachet, ou the river so called, is a village of some celebrity for its productions. Pop. of t. 2,864.

Grotchster, t., p. v., and port of entry, Essex co., Mrass. $27 \mathrm{~m} . \mathrm{N}$. by $\mathrm{E}$. Boston. This is a maritime town, occupying the greater portion of Cape Ann, the N. boundary of Massachusetts Bay, and the inhabitants are chiefly employed in navigation, commerce, and the fisheries. Ii has a fine har bor, open at all seasons, and accessible to vessels of great burden. Lat. $42^{\circ} 36^{\prime} 44^{\prime \prime} \mathrm{N}$., and long. $70^{\circ} 40^{\prime} 19^{\prime \prime} \mathrm{W}$. The harbor and principal settlement lies on the $\mathrm{S}$. side of the peninsula. Sandy and Squam bays lie on the N. side, and afford harbors for small vessels. On Thrasher's Island are two light-houses. Gloucester has three newspapers, the " $G$. News" (indep.), and the "G. Telegraph" (whig), issued semiweekly, and the "Cape Ann Light" (whig), issued weekly. Pop, of t. 7,805 . The statistics of the foreign commerce of the district, of which Gloucester is port of entry, for the year ending 30 th June, 1550 , are as follows : Clearances, 177 (11,133 tons), of which 161 ( 8,259 tons) were foreign bottoms; and entrances, 178 (11,667 tons), of which 159 ( 8,180 tons) were for eign. The shipping owned in the district amounted to 22,474 tons, of which 2,873 tons were registered and engaged in foreign trade; 18,8s1 tons enrolled and licensed, of which 13,982 tons were employed in the cod fishery, and 4,599 tons in the mackerel fishery; and 720 tons licensed under 20 tons, of which 68 tons were employed in coasting and 652 tons in the cod fisheries; and the shipping built during the year was 26 schonners, of an aggregate burden of 1,996 tons.

Glodcester City, p. v., Camden co., N.Jer.: 30 m. S.W. Trenton.

Glotcester CodrT-HOUsE, p. V., and cap. Gloucester co. Tirg.: at the head of an arm of Mobjack Bay, $57 \mathrm{~m}$. E. S. E. Pichmond. It contains a court-house, jail, etc., 2 academies, and soout 200 inhabitants. Many wealthy people reside here, and the neighborhood is one of the richest in Virginia.

Gloucester Furnace, p.v., Atlantic co., N. Jer.: on a cr. of Little Egg Harbor r., $46 \mathrm{~m}$. S. E. Trenton. It has, besides the works from which it is named, several mills, ete., and about 400 inhabitants.

GLover, t. and p. o., Orleans co., Term.: 35 m. N. N. E. Montpelier. Drained by head branches of Black and Bar-

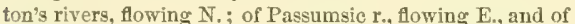
Lamoille $x$., flowing W. It lies on an elevated watershed. Surface hilly, and soil indifferent. Husbandry and agriculture are the chief occupations of the inhabitants. Pop. 1,137.

Grovesville, p. v., Fulton co., N. Y.: $42 \mathrm{~m}$. N. W. Albany. It contains extensive manufactures of buckskin gloves, mittens, moccasins, etc., and hence its appellative. Population about 400 .

GLymoxt, p. v, Charles co, Md. : on the Potomac r., $8 \mathrm{~m}$. below Fort Washington, and $48 \mathrm{~m} .8$. W. Annapolis.

GLTMPHilite, p. v. Newberry dist., S. Car. : $47 \mathrm{~m} . \mathrm{N}$.W.

\section{Columbia.}

GLYsy county, Ga. Situate S. E. on the Atlantic, and contains $389 \mathrm{sq.} \mathrm{m}$. Drained by Turtle r., Santilla r., which

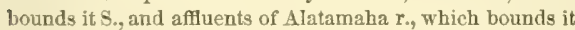
N. St. Simon's and Jykill islands belong to it. Surface low and level; soil fertile, and bears the best of cotton and rice. The islands produce the Sea Island cotton, so much valued, and the marshes an immense amount of rice. Farms
92; manui. 8 ; dwell. 145, and pop.-wh. 698, fr. col. 3 , El. 4,232-total 4,933. Capital : Brunswick.

Gradenituttex, p. v., Tuscarawas co., Ohio: on the E. bank of Tuscarawas r., $85 \mathrm{~m} . \mathrm{E} . \mathrm{N}$. E. Columbus. The Central Ohio R.R. will pass through the village. It was originally settled by the United Brethren, and contains a Moravian Church, several stores and mills, and about 260 inhabitants.

GoAT (or IRIs) island, $N, Y$ : lies in the Niagara $r$ at the Great Falls, the waters of which divide as they descend over the ledge into the abyss below. This island is approached from the American side by a bridge. Its extent is about 65 acres, and its periphery about a mile. It is still well timbered. The lower end of the island is a perpendicular bank of from 80 to 100 feet; thence to the water's edge, below the Falls, a sloping descent of about 100 feet more. From points on this part of the island, both the Falls are seen to advantage. Here has been erected a tower called Prospect Tower, with an observatory on the top, and a stair-case near by to descend to the water's edge,

GonвorD, p. 0., Washita county, Ark.: 88 m. S. S. W. Little Rock.

GODDARD, p. v., Rush county, Ind. : 43 m. E. S. E Indianapolis.

GoDFry, p. o., Madison county, Ill.: 71 m. S. S. W Springfield.

Goff's Corasers, p. o., Cumberland co., Mre.: 33 m. S.T. Augusta.

Gofr's Falis, sta., Hillsboro' co., N. Hamp.: on the Merrimae r, at the falls so called, $22 \mathrm{~m}$. S. Concord. The Concord $\mathrm{R}$. R. crosses the river at this point.

GorF's Mills, p. o., Steuben co., N. Y.: $192 \mathrm{~m}$. W. by S. Albany.

GoFFsTown, t. and p. v., Hillsborough co., 'N. Hamp.: $14 \mathrm{~m}$. S. Concord. Drained by Piscataquoag $\mathrm{r}$. and a tributary of Merrimac r., which afford water-power. The Merrimac runs along its E. border. Surface generally level, but diversified; soil fertile and well cultivated. Amoskeag Falls of the Merrimac are opposite this t. and have a descent of 48 feet in half a mile, around which is a canal. The t. has considerable manufactures, several villages, and 2,270 inhabitants. The New Hampshire Central $R, R$, crosses it in an $\mathrm{E}$, and W. direction.

Gofrstown Centre, p. T., Hillsborough co., $N$. Hamp. on the Piscataquoag $r$., and on the line of the New Itamp. shire Central R, R, $5 \mathrm{~m}$. from Manchester, and $15 \mathrm{~m}$. S. Concord.

Gogetvsville, p. v., Franklin co., Virg. : 134 m.W. S.W. Richmond.

Golansville, p. v., Caroline co., Virg.: 26 m. N. Richmond. It has several mills and mechanic shops, and about 150 inhabitants. In the vicinity there are several mineral springs.

Golconda, p. v., and eap. Pope co., $M$. : at the entrance of Lusk's cr. into Ohio r., 177 m. S. S. E. Springfield. It contains a brick court-house, ete., several stores, and about 300 inhabitants.

GOLDEN Grove, p. o., Greenville dist., S. Car.: on the E. side of Saluda r., $103 \mathrm{~m}$. W. N. W. Columbia. or br the route of the Greenville and Columbia R. R., which passes through it, $130 \mathrm{~m}$. from Columbia.

GoldeN Hixt, p. O., Dorchester co., MId. : 43 m. S. E. Annapolis.

Golden Hill, p. o, Wyoming co, Penn, : 97 m. N. N. E. Harrisburo.

Golden Hili, p. o., Chambers co., Ala. : 53 m. E. N. E. Montgomery.

GOLDEN LAKE, p. o., Waukesha co., Wisc.: $56 \mathrm{~m}$. E Madison.

Golden Pond, p. o., Trigg co, $K y_{.}: 197$ m. W. S. W. Frankfort.

Goldex's Bridger, p. v., Westchester co., $Y^{T}, \Gamma .: 98 \mathrm{~m}$. S. by E. Albany. 
Golder Sprixas, p. O, Anderson dist., S. Car.: on the W. side of Saluda r., 2 m. above Golden Grove, and $105 \mathrm{~m}$. W. N. W. Columbia.

Goldex VAllex, p. o, Rutherford co., $N_{\text {. }}$ Car.: $216 \mathrm{~m}$. W. S. W. Raleigh.

Gold Hul, p. 0., Meriwether county, Ga.: 94 m. W. Nilledgeville.

Gold Hill, p. 0., Rowan co., N. Car. : $106 \mathrm{~m}$. W. Raleigh. Gold Mine, p. o., Marion con, Ala.: 153 m. N. W. Montgomery.

Gold Mrne, p. o., Chesterfield dist., S. Car.: on the E. side of Ljnch's cr., 62 E. N. E. Columbia.

Gold Region, p. o., Moore co, $N$. Car.: $53 \mathrm{~m}$. S. W. Raleigh.

Goldsborough, p. v., Wayne co., $N_{\text {. }}$ Car.: on the N. side, and about $2 \mathrm{~m}$. from Neuse r., $51 \mathrm{~m}$. $\mathrm{S}$. E. Raleigh. It is a considerable $\mathrm{v}$., with a good trade, and has two periodicals, the "North Carolina Telegraph" (whig), and the "Patriot" (dem.), both weekly issues. It is an important station on the line of the Wilmington and Weldon $R . R$. also the E. initial point of the North Carolina R. R. ; and a railroad bence is projected to Newbern, one of the best ports of the State. Pop, about 700.

Goldsvilur, p. v., Cherokee co., Ga.: 118 m. N. W. Milledgeville.

Goldsvmle, p. v., Tallapoosa co, Ala.: 49 m. N. E. Montgomery.

GoLIAD county, Tex. Situate \$. E. centrally, and contains about 1,800 sq. m. Intersected by San Antonio r., and drained by its many branches, with the heads of Mission and Aransas rivers and affluents of the Guadaloupe. Surface moderately elevated, and gently undulating. Soil generally very good, and adapted to cotton growing. Some sugar may be raised, too. Farms 30 ; manuf. 0 ; dwell. 88, and pep.-wh. 435, fr. col. 0, sl. 213-total 643. Corpitul. Goliad.

GoLraD, p. v. and cap., Goliad co., Tex. : on a high roeky bluff on the S. bank of San Antonio r., 128 m. S. by E. Austin City. It is one of the oldest towas in Texas, dating from 1716, and was formerly a place of great importance, and, as its name implies, a place of strength. Its fortificatious were immense and considered by the Spaniards as impregnable, and are still in existence, though decayed, as are also most of the old buildings, which were of stone. On the opposite side of the river was an ancient mission. Goliad is now recovering from its demolished condition, and is again a flourishing place with considerable trade and general business.

Gonic, p. v., Strafford co., N. Hamp.: on the E. side of Cocheco r., $28 \mathrm{~m}$. E. Concord. It is a v. of considerable manufactures. The Cocheco R. R. passes through it, $8 \mathrm{~m}$. from Dover.

Gonzales county, Tex, Situate S. E. of centre, and contains $1.227 \mathrm{sq}$. m. Intersected by Guadalupe $\mathbf{r}$., and drained by San Marcos $r$. and Peach and Sandy crs., its affluents. Surface a rolling prairie in S,-in the N, more broken. Soi sandy loam, covered wilh a rich vegetable deposit, and adapted to cotton, grain, or grazing. Salt-springs are found on Salt fork of Sandy cr. Farms 123; manuf 0 ; dwell. 1S5, and pop.-wh. \$91, fr, col. 0, sl. 601-total 1,492. Capital Gonzales.

Govzares, p. o., and cap. Gonzales co., Tex.: on the $Y_{\text {. }}$ or left bank of Rio Guadalupe r., 62 m. S, S. E. Austin City. It is the centre of an extensive trade.

Goocmuand county, Firg. Situate E, centrally, and contains $273 \mathrm{sq}$. m. Drained by several affluents of the James $\mathrm{r}$. which forms its $\mathrm{S}$. boundary. Surface in the $\mathrm{S}$. rolling; elsewhere broken, affording many eligible mill sites. Soils various, and mostly long cultivated, though highly productive. Tobacen is the great agricultural staple, and coal is abundant, and the mines much worked. Gold has also been fount in consilerable quantities. Farms 405 ; manuf. 49; dwell. 876, and pop.-wh. 3,854, fr. col. 653, sl. 5,845- total, 10,352. Capital: Goochland C. H, Puzlic Works : James River Canal.

GoochlaND C. H., p. V., and cap. Goochland co., Firg.: on the $N$. side of James $r_{\text {., }}$ and on the line of the eanal, $25 \mathrm{~m}$. W. N. W. Richmond. It contains a court-house, jail, and about 40 dwellings.

Gooch's MrLis, p. o., Cooper co., Mo. : on Little Saline cr. of Missouri r., $34 \mathrm{~m}$. N. W. Jefferson City.

Goodall's, p. o., Hanover co., Virg. : $15 \mathrm{~m}$. N. Richmond. Good FIELD, p. v., Meigs co., Tenn.: 114 m. E. S. E.

Nashville.

Good Ground, p. v., Suffolk co., $N . Y_{.}: 129$ m. S. E.

Albany -a v. of some 8 or $10 \mathrm{~d}$ wellings, situate in the $t$ of Southampton.

Goop Hope, p. v., Milwaukie co., Wisc. : on the W. side

of Milwaukie r., $75 \mathrm{~m}$. E. by N. Madison.

Good Hope, p. o., Cumberland co., Penn.

GooD Hope, p. o., Walton county, Ga.: on a cr. of Appalachee r., 55 m. N. N. W. Milledgeville.

GoodnNG's Grove, p. o., Will con, Ill.: 138 m. N. E. Springfield.

GooD Intent, p. o., Washington county, Penn.: $182 \mathrm{~m}$.

W. by S. Harrisburg.

Good Luck, p. 0., Prince George's co., MI.: on the E. side of the W. branch of Patuxent r., 26 miles S. W. Annapolis.

GoodrtcI, p. v., Genesee co., Mich. : 49 m. E. N. E. Lansing.

Good's Precniot, p. o., Clark co, Ky.: 44 m. E. S. E. Frankfort.

Good Sprixe, p. o., Williamson co., Tenn.: 11 m. S. Nashville.

Good Springs, p. o., Mead co., $\bar{B} y_{0}: 76 \mathrm{~m}$. W. by S. Frankfort.

Good Spur, p. o., Carroll co., Virg.: 183 m. W. S. W Richmond.

Goodville, p. v., Lancaster co., Penn

GoodWATER, p. o., Coosa county, Ala.: $33 \mathrm{~m}$. N. by E. Montgomery.

GoodwIN"s Mruss, p. o., York county, Me.: 74 m. S. W. Augusta.

Goodwnsville, p. v., Dinwiddie county, Virg. : $42 \mathrm{~m}$

S. by W. Richmond.

Goose Creek, p. 0, Ritchie co, Virg.: 226 m. N. W. Richmond.

Goose Crefr, Tirg.: a branch of Roanoke $r$. It has its rise in the Blue Ridge, $5 \mathrm{~m}$. S. W. of the Peeks of Otter and after a course of more than $40 \mathrm{~m}$. enters the Roanoke in the 8. W. part of Campbell county.

Goose Pond, p. o., Oglethorpe co., Ga. : on a branch of Long cr, of Broad r., 69 m. N. N. E. Milledgeville.

Goose Rrver, p. o., Waldo co., Me. : $37 \mathrm{~m}$. E. Augusta Gordo, p. o, Pickens county, Ala.: $124 \mathrm{~m}$ N. W. Montgomery.

Gordox county, $G a$, Situate N. W., and contains 362 $\mathrm{sq} . \mathrm{m}$. Drained by Coosawattee $r$, and other head strearns of the Coosa $r$. Surface broken and cut up into many beautiful and fertile valleys. This is in the iron region, and possesses much undeveloped mineral wealth. Farms 419 manuf. 0 ; dwell. 861 , and pop.-wh. 5,156, fr. cal. 0, sl. 828 -total 5,984. Capital: Calhoun, Public Works: Allantic and Western R. R.

Gordor, p. v., Wilkinson county, Ga.: 17 m. s. by W. Milledgeville, The Milledgeville and Gordon R. R. di verges at this point from the Central Georgia $R . R ., 170 \mathrm{~m}$. from Savannah.

GordoN's SPRTNGs, p. v., Walker co., Ga.: 179 m. N. W. Milledgeville.

Gordonsvilue, p. v., Smith co., Tenn.: on the W. bank of Caney fork of Cumberland r., $49 \mathrm{~m}$. E. Nashville.

Gordossvile, p. v., Logan counly, $K y_{\text {. : }} 152$ m. S. W. Frankfort.

GoRdoxstule, p. v., Orange co., Virg. : at the E. base of 
Sonthwest Mountain, and at the heads of North Anna r., 56 m. N. W. Richmond. Within the last few years it has risen from the condition of a wayside store to that of a considerable village, and is destined to become an important commercial depôt. The Central Virginia R. R. passes through it, and is here joined by the Orange and Alexandria $R$. R., completed in 1852.

Gordonsvilie, p. v.,_Lancaster co., Penn. : 49 m. E. S. E. Harrisburg.

Gordonton, p. v., Pierson co., N. Car.: 51 m. N. W. Raleigh.

GorHar, t. and p. v., Cumberland co., Me.: 59 m. S. W. Augusta. Drained by Presumpscut $r$, which forms its E. border. Surface diversified; snil excellent and well cultirated. The v. lies on the York and Cumberland R. R., $10 \mathrm{~m}$. from Portland. The t. has a well-endowed academy and contains numerous mills and mechanic shops. Pop. 3,088.

Gorian, t. and p. o., Coos co., N. Hamp.; 81 m. N. by E. Concord. Drained by Peabody r. and other tributaries of the Androscoggin. Surface rough and broken-the S. being occupied by the White Mountains; soil indifferent and population sparse. The Atlantic and St. Lawrence R. R. passes through it, following the valley. 'Pop. 224,

Gorman, t. and p. v., Ontario co., N. Y.: $173 \mathrm{~m}$. W. by N. Albany. Drained by Flint cr. and creeks of Canandaigua Lake, which forms its W. boundary. Surface gently undulating; soil fertile and well cultivated. The $\mathrm{r}$. is located on the E. side of Flint cr.; and there are other villages, as Rushville, Gorham Centre, etc., in the town. Pop. 2,645.

Gormar, t. and p. 0., Fulton co., Ohio.: 136 m. N. W. Columbus. Drained by Tiffin r. and its branches. Surface uneren; soil fertile and productive. Pop. 906.

Goshen, p. o., Cherokee co., Ala.: 133 m. N. N. E. Montgomery.

Gosmex, t. and p. o., Addison co., Term.: 36 m. S. W. Montpelier. Drained by creeks of Great Trout Pond and Otter r. Surface mountainous; soil ordinary, but adapted to grasses. Iron ore and oxyde of magnesia abundant. Pop. 496.

Goshen, t. and p. 0., Litchfield co., Conn. : 34 m. W. by N. Hartford. Drained by affluents of Housatonic and Naugatuck rivers, which rise in this t. from several small ponds. Surface elevated and moderately uneven; soil excellent for grasses. It produces fine dairies, and has several manufactures. Pop. 1,457.

GosHeN, p. vo, Lincoln county, Ga.: 74 m. N. E. Milledgeville.

Goshes, p. v., and cap. Elkhart co., Ind.: on the E. side of Elkhart $\mathrm{r}_{n}, 126 \mathrm{~m}$. N. by $\mathbf{E}$. Indianapolis. It is a thriving v., and contains commodious county buildings, several halls for societies, large flouring and saw mills, numerous stores, about $200 \mathrm{dwellings,}$, and 1,200 inhabitants. It is well situate for a commercial depôt, and is connected by a branch with the Michigan, Southern, and Northern Indiana R. R. ; and a railroad is now in progress from Indianapolis via Peru to this point. The " $G$. Democrat" (dem.) is published weekly.

Goshex, t. and p. v., Hampshire county, Mass.: $92 \mathrm{~m}$. W. by N. Boston. Drained by heads of rivers falling into the Connecticut. Surface mountainous; soils indifferent, except for grasses. Lead, tin, emeralds, etc., are found. The v. lies near the centre. Pop. 512.

GoSHEN, t. and p. V., Sullivan co., N. Hamp.: $31 \mathrm{~m}$. W. by N. Concord. Drained by branches of Logan $r$, of the Connecticut. Surface varies; soil well adapted for cultivation. Sunapee Mountain lies in its S. E. part. The $\mathrm{v}$, is located centrally. Pop, of $\mathrm{t} 659$.

Gosmen, p. v., Cape May co., N. Jer.: on Goshen cr. 3 m. up from Delaware Bay, $73 \mathrm{~m}$. $\mathrm{s}$. Trenton.

Goshen, t., p. v., and one of the cap. Orange co., $N . Y$. : $84 \mathrm{~m}$. S. S. W. Albany. Drained by Wallkill cr. and other streams. Surface diversified-in some parts hilly; soil, rich lozin, overlying slate and limestone, and which produces excellent grass. The t, and neighborhood is noted for the superior quality of its milk and butter, which are daily carried into New York by railroad. The vo is located on a plain, and contains a court-house and other county buildings, situate on an elegant square, in which is a monument commemorative of those who fell in one of the battles of the Revolution, large hotels, extensive stores, and many of its dwellings are neat and tastefully built. It is a place of considerable business, and has about 1,200 inhabitants. The Erie R. R. passes through it, $45 \mathrm{~m}$. from Piermont. Goshen bas two semi-weekly newspapers, the "Banner of Liberty" and "Signs of the Times;" two weeklies, the "Independent Republican" (dem.) and "Democrat and Whig" (whig), and "Separate America" (abol.), the latter published quarterly. Pop. of t. 3,150 .

GOsHex, t. and p. v., Clermont co., Ohio: $82 \mathrm{~m} . \mathrm{S} . \mathrm{W}$. Columbus. Drained by affluents of Little Miami r., and possessed of a fine soil. The $\mathrm{v}$. contains numerous mills, mechanie shops, and about 700 inhabitants. The Cincinnati, Hillsboro', and Parkersburg R. R. passes through the t. and v., $32 \mathrm{~m}$. from Cincinnati. Pop. of $t_{4}, 397$.

Gosher, p. v., Oldham county, $ז y_{0}: 38$ m. W. N. W. Frankfort.

Gosmen, p. v., Lancaster county, Penn.: 53 m. E. S. L. Harrisburg.

Gosien HrLl, p. v., Union dist., S. Car. : between Ennoree and Tiger rivers, $51 \mathrm{~m}$. N. W. Columbia.

GosmeN Hili, v., Chesterfield dist., S. Car.: on Thompson's cr. of Great Pee Dee r., 82 m. N. E. Columbia.

Goshen Prarrie, p. o., Mercer co., MLo.: $147 \mathrm{~m}, \mathrm{~N}$. W. Jefferson City.

Goshenville, p. v., Chester co., Penn.: 69 m. E. S. E. Harrisburg.

Gosport, p. v., Clark county, $A l a$. : on the W. side of Alabama r, 98 m. S. W. Montgomery.

Gosport, p. v., Owen co., Ind.: on the right bank of the W. fork of White r., $37 \mathrm{~m}$. S. W. Indianapolis. It contaias several warehouses, stores, and mechanic shops, and about 600 inhabitants. It is an important location, and is intersected by two lines of railroad-the New Albany and Salem R. R. and the Evansville, Vincennes, and Indiana $P . R$. It was founded in 1818 by $\mathrm{E}$. Goss, from whom it is ramed, and in 1840 had less than 80 inhabitants-its growth to its present prosperous condition is owing chiefly to its railroad conneetions. The river here affords good mill sites, and is navigable for steamers.

Gotr's Cross Roads, p. o., Sullivan co., Tenn.: $252 \mathrm{~m}$. E. by N. Nashville.

GovLdsborougr, $t$. and p. v., Hancock co., Me. : $86 \mathrm{~m}$. E. Angusta. It occupies a large peninsula jutting into the Atlantic, between Gouldsborongh Harbor and Frenchman's Bay. Prospect Harbor, on the S. E., is easy of access and spacious; it has also other good harbors which afford it great facilities for navigation. The principal $v$. lies at the head of Gouldsborough Bay, on the W. side. The t. has some few manufactures, but its inhabitants are chiefly engaged in navigation and the fisheries. Pop. 1,399.

Gourdvine, p. v., Union co., N. Car.: 113 m. W. S. W. Raleigh.

Gouverneur, t. and p. o., St. Lawrence co., $N . Y .: 151$ m. N. W. Albany. Drained by Oswegatehie r. and its creeks. Surface generally level; soil various. The $v$. is located on the Oswegatchie, and contains about 300 inhabitants. The Watertown and Potsdam R. R. will intersect this t. Pop. of t. 2,783.

Goranstown, p. v., Baltimore county, $M_{d .:} 26 \mathrm{~m} . \mathrm{N}$. Annapolis.

Governor's BrIDGe, p. O., Anne Arundel co., MId.

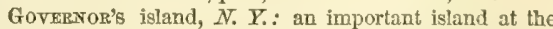
confluence of Hudson and East rivers, in New York Harbor, and which commands its entrance. It is strongly fortified. Castle William, Fort Columbus, and South Battery, are the names of the fortifications. 
Goternor:s Island, p. o., Macon co., N. Car.: $27 \mathrm{~m}$. W. by S. Raleigh.

Gow ANDA, p. v., Cattarangus co., N. Y.: $222 \mathrm{~m}$. W. by \$. Albany.

Gow Deysvilue, p. F., Union dist., S. Oar.: 73 m. N. W.

Columbia.

Gowen's Ferry, p. 0., Cedar co., 1a. : 23 m. E. by N.

Iowa City.

Gowensville, p. v., Greenville dist., S. Car.: $97 \mathrm{~m}$.

N. W. Columbia

GRACEIAM, p. v., Frederick co., Md: on the W. side of Monocacy r., 62 m. W. N. W. Annapolis.

GraDyptule, p. v., Adair co., Ky.: $76 \mathrm{~m} . \mathrm{s} . \mathrm{S} . \mathrm{W}$.

Frankfort.

Grafensberg, p. v., Adams co., Penn.: 49 m. S. S. W. Harrisburg.

Grafton county, N. Hamp. Situate W., and contains 1,437 sq. m. Drained by Ammonoosuck r. and other affluents of Connecticut r., its W. boundary, and the head waters of Merrimac and Saco rivers. Surface elevated and rough, with good mill streams; soil generally good, and adapted to grass or grain. Squam Lake, on its E. border, and Newfound Lake within it, are fine bodies of water and very attractive to strangers. Wool growing is successful and general. Farms 5,063 ; manuf. 424; dwell. 7, 598 , and pop. -wh. 42,316, fr. col. 27-total 42,343. Capital: Haverhill. Public Works: Northern (N. H.) R. R. ; Boston, Concord, and Montreal $\mathrm{R} . \mathrm{R}$.

Grafton, p. Y., Jersey co., $\Pi l_{0}$ : on the E. side of Mississippi r., $2 \mathrm{~m}$. below the confluence of the Illinois, $71 \mathrm{~m}$. $\mathrm{S}$. W. Springfield. It is situate on an elevated slope of land under the bluffs, and has a good steamboat landing. Pop. about 1,200 .

GrafToN, t. and p. v., Worcester con, Mrass.: 7 m. E. Worcester, 35 m. W. S. W. Boston. Drained by Blackstone $r$ and its tributaries, which afford excellent waterpower. Surface varied; soil excellent. The principal v. is located centrally, and there are others, as Farnumville on the S. and New England Village on the N. of it. The Boston and Worcester R. R. traverses the N. part of the $t_{\text {, }}$ the Grafton station being $39 \mathrm{~m}$. from Boston, and here diverges the Branch R. R. to Milbury on the Worcester and Providence $R$. P. ; and the Blackstone Canal passes through the S. W. corner. The t. has large manufactures, and 3,610 inhabitants,

Grafton, to and p. o., Grafton co., N. Homp. : 35 m. N.W. Coneord. Drained by Smith's r. of the Merrimac, which rises in several small ponds in this $t$. Surface hilly; soil rocky, but there is some good land. Glass Mountain, 150 feet perpendicular height, furnishes mica, or isinglass, an article of export. There are numerous mills on the streams, anl the inhabitants number 1,322 . The Northern Ners Hampshire R. R. passes through the t., $44 \mathrm{~m}$. by route from Concord.

Graktos, t. and p. o., Renssalaer co., $N . Y .: 16 \mathrm{~m}$. N. E. Albany, Drained by Poestenkill and other smaller creeks. Surface hilly and well timbered; soll, clay loam. There are several mills in the t., and a pop. of 2,197 souls.

Grafton, p. Y., Lorain co., Ohio : on the E. branch of Black r., $108 \mathrm{~m}$. N. N. E. Columbus. At this point the Cleveland, Norwalk, and Toledo R. R. diverges from the Cleveland, Columbus, and Cincinnati R. R., $25 \mathrm{~m}$. from Cleveland.

Grafton, t. and p. v., Windham co., Term.: $77 \mathrm{~m} . \mathrm{S}$. Montpelier. Drained by Saxton's and William's rivers. Surface uneven; soil generally fertile. The $v$, lies on the $\mathrm{N}$. side of Saxton's $\mathbf{r}$. The t. has some manufactures, and exports soapstone, which is abundant and of fine quality.

Graftos, p. v., Monroe $\mathrm{co}_{\text {., }}$ Wich. : $79 \mathrm{~m}$. S. E. Lansing.

Graftox, p. v., Washington co., Wisc, : on the W. side of Milwaukie r., $76 \mathrm{~m}$. E. N. E. Madison.

Granav, p. o, Jefferson co., Ind.: on Graham's fork of Muscackituck r., 66 m. S. E. Indianapolis.
Gratiam, p. v., and cap. Allamance co, N Car : about $4 \mathrm{~m}$. W. of Haw r. and $57 \mathrm{~m}$. W. N. W. Paleigh. The North Carolina $R$. R. passes the village, It contains a court-house, jail, etc., and about 300 inhabitants.

Grahan's Station, p. 0., Meigg co., Ohio: 84 m. S. E。 Columbus.

Grainan's Turn Out, p. o., Barnwell dist., S. Car.: on the line of the South Carolina R. R., $81 \mathrm{~m}$. from Charleston and $54 \mathrm{~m}$. S. S. W. Columbia.

Gramamsville, p. v., Sullivan co., $N_{0} Y_{0}: 68 \mathrm{~m} . \mathrm{S} . \mathrm{W}$. Albany.

Graharton, p. v., Clearfield co., Penn. : 105 m.W. N.W. Harrisburg.

Grahanivile, p. v., York county, Penn.: 32 m. S. E. Harrisburg.

GrahaMville, p. v., Beaufort disto, S. Car.: 116 m. S. Columbia.

Grampion Hrlus, p. o., Clearfield co., Penn.: $97 \mathrm{~m}$. W. N. W. Harrisburg.

GraNBY, t. and p. o., Essex co., Term.: 48 m. E. N. E. Montpelier. Drained by the heads of Paul's stream and of Moose $x$. Surface elevated, forming a watershed. It is an inhospitable country and thinly inhabited. Pop. about 200.

Gransy, t. and p. 0., Fartford co., Conn.: 162 m. N. N.W. Hartford. Drained by tributaries of Farmington r. Surface hilly and rough-Barn Door Hills rise 400 or 500 feet high: soil generally stubborn, but there is considerable good farming lands. The to has several pleasant villages and considerable manufactures. Pop. 2,498. This t. was taken from Simsbury in 1786, and contains the famous Simsbury copper mines-the Old State Prison of Connecticut. This odious place, unfit for the residence of the worst of criminals, is a pit or eavern more than 50 feet deep, dark, damp, and dismal, and in this infernal region the state convicts were immured; as such it was used for a period of 40 years, to the no small disgrace of our Puritan friends of the East.

GranBX, t. and p. $\mathbf{v}_{\bullet}$, Hampshire county, Mass. : $76 \mathrm{~m}$. W. by S. Boston. Drained by ereeks of Connecticut $r$. Surface in the N. hilly-Mt. Holyoke range bounding the $\mathrm{t}$. in that direction, and in the $\mathbf{S}$. diversified, with a fine soil. The mountainous parts are well wooded. It produces much garden stuff, which finds a market in Chicopee and Springfield; and it has several woolen factories, mills, etc. Pop. 1,035

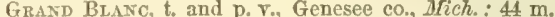
E. N. E. Lansing. Drained by Thread cr. of Flint r. and its affluents, Surface hilly; soil, deep black mold, well wooded and fertile. The $\mathbf{v}$. lies on the lef bank of the r., and is a considerable place.

Grand Butre, p. o., Panola co., Tex.: 272 m. N. E. Austin City.

Graxp Care, p. o., De Soto par., La.: on a er. of Sabine r. so called, $192 \mathrm{~m}$. N. W. Baton Pouge.

GraNd CANE, p. 0., Liberty county, Tex.: 196 m. E. Austin City.

Grand Coteat, p. vo, St. Landry par., La.: on the W. of Vermillion r., 55 m. W. Baton Rouge. Here is St. Charles College, a Roman Catholic institution, founded 1838; in 1850 it had 21 professors and 103 students. Its library contains 4,000 rolumes.

Grand Côte Prairie, p. o., Perry co., Ill.: on the prairie so called, $113 \mathrm{~m}$. $\mathbf{S}$. Springfield.

Graxd Detour, p. o., Ogle co., $I l l$ : on a peninsula formed by a great bend of Rock r., $142 \mathrm{~m}$. N. Springfield. It is a flourishing $\mathrm{r}$., with considerable manufactures and a good trade. Pop. about 600.

GraNd Ecorr, p. o., Natchitoches par., La.: on the S.W. side of Red $r_{0}$, at the entrance of Old $r_{.}, 144 \mathrm{~m} . \mathrm{N} . \mathrm{W}$. Baton Rouge.

Grand Falis, p. o., Newton co., Mo.: on the N. side of Neh-hah r., at the falls, $174 \mathrm{~m}$. $\mathrm{S}$. W. Jefferson City.

GraND GULF, p. v., Claiborne co., Jfiss.: on the E. bank 
of Mississippi r., $55 \mathrm{~m}$. W. S. W. Jackson. The river, by a remarkable bend here, forms what is denominated the Grand Gulf. It contains a town-hall, hospital, markethouse, theatre, etc., and has several manufacturing establishments and mechanic shops, numerous stores, and a population of about 1,200 . It enjoys a considerable trade in cotton, and supplies a wide neighborhood with provisions and merchandise.

Gramn Haver, p. Y., and cap. Ottawa co, Mich.; on the S. bank of Grand $r$, near its entrance into Lake Michigan. This is one of the best harbors on the W. side of the peninsula, and is a point made by steamers passing down the lake, and steamboats ply on the river as far as Grand Rapids. There is never less than 12 feet water on the bar, and opposite the harbor the depth varies from 15 to 30 feet, with a width of 65 rods. A light-house is erected at its mouth. The v. contains a court-house, etc., spacious warehouses, several steam saw and other mills, numerous stores, and is in a highly flourishing condition. In point of natural advantages, it has an excellent location; it is elevated 25 or 30 feet above the river, and is very healthy. Population about 900 .

Grand Istand, p. o., Erie co., $N . Y_{.}: 264 \mathrm{~m}$. W. by N. Albany. Grand Island forms a part of Tonawanda co, and is situate in Niagara r., equidistant between Black Rock and Niagara Falls, It is $9 \mathrm{~m}$. long, and in its broadest part $6 \mathrm{~m}$. wide, with an area of 17,381 acres. The land is level, well timbered, and very fertile. The river is deep, close in shore, and affords access to any part of the island. The $r$. of Whitehaven, at which the p. o. is kept, is located on its E. bank. This island was selected by M. M. Noah, on which to build a city and establish a colony of Jews, with the view of making it the "Ararat," or resting-place of that despised people. A monument, 15 feet high, with suitable inscriptions, was erected here by the projector in Sept., 1925, and is still standing. The undertaking was abandoned in consequence of the scheme having been non-approved of by the Rabbi of Europe.

Graxd IsLe county, Verm. Situated N. W., consisting principally of two islands in N. part of Lake Champlain, and contains $76 \mathrm{sq} . \mathrm{m}$. Surface gently elevated; soil highly productive and well tilled. Their flocks of sheep form no small part of their wealth. Farms 339 ; manuf. 8 ; dwell. 691, and pop.-wh. 4,142, fr. col. 3-total 4,145. Copital North Hero. Putlic Works: Vermont and Canada Railroad.

Grand IsLe, t. and p. v., Grand Isle co., Term.: $46 \mathrm{~m}$ N. W. Montpelier. The t, consists of the N. part of a laroe island of Lake Champlain so called, and has a fertile soil, producing the grains and fruits. Marble, limestone, and rock crystals abound. The $v_{0}$ is a small settlement in its centre. Pop. 666 .

GRAND LAKE, p. o., Chicot co., Ark.: on the W. side of the Mississippi r., near the S. E. corner of the State, $152 \mathrm{~m}$. S. E. Little Rock.

Grand lake, Me.: a large collection of water lying on the E. border of Maine, and partly in New Brunswick. It contains a large number of islands, and receives the waters of many small lakes and rivers, and is the chief source of St. Croix river.

Graxid LEDGE, p. o., Eaton co., Afich. : $12 \mathrm{~m}$.W. Lansing Here is a ledge of sandstone, 20 feet high, along the $\mathrm{N}$. bank of Grand r., and in the neighborhood, iron ore of fine quality is abundant.

Grand Marsir, p. O., Columbia co., Wiso. : 29 m. N. W. Madison.

Gramd Pranere, t. and p. o., Marion co, Ohio: $49 \mathrm{~m}$. N. N. W. Columbus. Drained by Scioto $\mathbf{r}$. Surface level; soil deep and black mold, very fertile. Pop. 474.

Grand Pratrie, p. o., Prairie co., Ark. : 31 m. E. N. E Litlle Pock.

Graxd Pratark, t, and p. o Marquette co., Wisc.: $49 \mathrm{~m}$. A. by E. Madison.
GRAND RaPIDs, p. T., and cap. Kent co., Mich.: on the S. bank of Grand r., at the rapids so called, $59 \mathrm{~m}$. W. N. W. Lansing. It contains a court-house, jail, ete. ; numerous mills and workshops, warehouses, stores, etc., and about 3,000 inhabitants. It is one of the most important places in Michigan, and has great conveniences for an extensive commerce, being the natural depôt of the country above. There are published in the village two newspapers, the "G. P. Inquirer" (dem.), and the "G. River Eagle" (whig). weekly issues. Building material of every description is found in the neighborhood, and salt springs within a few miles. It is approached to the foot of the rapids by lake steamers and other craft, and a canal is proposed to overcome the fall, which is here 15 feet, and by employing the entire volume of water, an immense hydraulic power ean be obtained. On the opposite side of the river are Indian mounds and burial places, and many remains of ancient habitations and corn fields. Pop. of v. 2,646, - of t. 3,149.

Grand Rapins, p. v., Portage co., Wisc.: on Tisconsin river, $98 \mathrm{~m}$. N. by W. Madison. The river in this $c 0$. is full of rapids and portages, affording water-power of great extent, which is used in many places for the transportation of lumber, large quantities of which are annually sent down to St. Louis. The pineries commence about $80 \mathrm{~m}$, above Fort Winnebago, and here a rwilroad, $2 \mathrm{~m}$. long, the flrst in Wisconsin, has been constructed to convey the logs from thie forest to the mills.

Grawd River, p. o, Caldwell co, Mo.: $123 \mathrm{~m}$. N. W. Jefferson City.

GraNd River, p. 0., Wayne county, Ia.; $112 \mathrm{~m}$. S. W. Iowa City.

Grand river, Utah Ter. : a large constituent of the Rio Colorado of California. It rises in the Rocky Mountains, in the neighborhood of Long's Peak and the "Parks," whence its course is generally W. S. W. to a junction with the main river, in about $38^{\circ} \mathrm{N}$. lat. In its upper course it has many rapids and falls.

GRAND river, Mich: the largest stream lying wholly within the State. It rises in Washtenaw and Hillsdale counties by two branches, which unite in Jackson co. From this point the river has a very serpentine eourse, but runs generally in a W. direction to Lake Michigan. It is about $270 \mathrm{~m}$. long, including its windings, and at its mouth, between 50 and 65 rods wide, and of sufficient depth to $2 \mathrm{~d}$ mit vessels of less than 12 feet draft. It is navioable 240 miles for batteaux, and receives in its course as its principal tributaries, Rouge, Flat, Maple, Looking-glass, and Red Cedar rivers, from the $\mathrm{N}$., and Thornapple $x$, from the $\mathrm{S}$, It is navigable for steamboats $40 \mathrm{~m}$. to the Great Rapids, below which it has nowhere less than 4 feet water. The river is subject to freshets, and the intervales in some places to inundations. At the Rapids it sometimes rises 15 feet, but at its mouth seldom more than a foot. Many flourishing villages are now located on the banks of Grand river.

Grand Saline, p. o., Cherokee Nation, Ind. Ter

Grand Spring, p. o., Dane co, Wisc.

Grand Traterse, p. o., Michilimackinae co., Mich.: 172 m. N. N. W. Lansing.

Grand Traverse bay: a considerable inlet of Lake Michigan, which sets up into the land in the N. W. part of Mackinac county.

Graxd Traverse islands, Mich.: a cluster of islands located at the entrance of Green Bay into Lake Michigan. They number ten or twelve, the largest of which are Pala. waton, Plum, Detroit, Brûle, ete

Grand VIEW, p. o., Edgar co., Ill.: at the head of Big cr. of Wabash r., 93 m. E. by S. Springfield. It is in the midst of a beautiful and fertile rolling prairie.

Graxd TIEw, p. r., Louisa co, $I c_{0}$ : about $2 \mathrm{~m}$. W. of Museatine Slough, $31 \mathrm{~m}$. S. S. E. Iowa City.

GRAND VIEW, t. and p. v., Washington co., Ohio: $106 \mathrm{~m}$. E. S. E. Columbus. Drained by creels of Olito r., which makes its S. E. border. Surfuce on the r. fertile bottoms, 
and in the uplands hilly, and fit only for grass. The v. lies on the Ohio, about $12 \mathrm{~m}$. above Newport. Pop. 1,154.

Grandvilxk, p. V., Kent co., Mich.: on the S. side of Grand r., at the confluence of Buck and Rush creeks, $63 \mathrm{~m}$. W. N. W. Lansing. The river is navigable for first-class steamers to this point. It contains several mills, factories, and mechanic shops, and ahout 600 inhabitants. Considerable water-power is furnished by the streams, and in the ricinity are extensive pineries, and within $3 \mathrm{~m}$. are salt springs and gypsum beds. It was settled in 1835 , and is now one of the most flourishing villages in the W. part of the State.

Granger county, Tenn. Situate N. E., and contains 354 sq. $m$. Drained by branches of Clinch r., its N., and Holston $\mathrm{r}$. its S. boundary, large tributaries of the Tennessee. Surface elevated in middle, and rough, but sloping toward the rivers, where it is more even and very fertile. The grains are the chief agricultural products. Farms 723; manuf. 34; dwell, 1,894, and pop.-wh. 11,170, fr. col. 165 , sl. 1,035-total 12,370. Capital: Rutledge.

Gratger, t. and p. o., Alleghany co., N. $Y .: 214 \mathrm{~m}$. W. Albany. Drained by affiuents of Genesee r, which flows through it. Surface undulating; soil sandy and clay loam. Pop. 1,301.

GRANGER, t, and p. $\nabla .$, Medina county, Ohio: $105 \mathrm{~m}$ N. E. Columbus. Drained by affluents of Cuyahoga and Rocky rivers, the surface forming a watershed between the waters of the two strearns. The $\mathrm{v}$. is situate in the centre. Pop. of $t .1,212$

Gravgersville, p. v., Macon county, Ga.: 79 m. S. W. Milledgeville.

GraNgervilie, p. v., Saratoga co., N. Y.: $24 \mathrm{~m} . \mathrm{N}$. Albany.

GraNtTE, p. 0., Knox county, IU.: $91 \mathrm{~m} . \mathrm{N}$. W. by W. Springfield.

Granitevilue, p. v., Edgefield dist., S. Car. : on the line of the South Carolina R. R., $11 \mathrm{~m}$. from Harrisburg, and 62 m. S. W. Columbia.

Graxt county, Ind. Situate N. E. middle, and contains 426 sq. m. Drained by Mississinewa $r$, an affluent of the Wabash, and its tributaries. Except on the borders of the chief streams, which are beautifully rolling, the county is quite level, and was originally timbered. Soils rich, and of a more than average fertility. Farms 900 ; manuf. 52 dwell. 1,884, and pop.-wh. 10,945, fr. col.147-total 11,092 Capital: Marion.

GraNt county, $\bar{K} y$. Situate $\mathrm{N}$., and contains 211 sq. m. Drained by Eagle cr, a branch of Kentucky r., and affluents of Licking $r$. and the Ohio. Surface diversified; soils rarious. Corn and tobacco are raised largely. Farms 730 manuf. 15; dwell. 1,081, and pop.-wh. 5,994, fr. col. 5, sl. 532-total 6,531. Capital: Williamstown. Public Works: Lexington and Corington $R$. R.

Grant county, Wise. Situate S. W. corner, and contains $1,122 \mathrm{sq} . \mathrm{m}$. The Wisconsin $\mathrm{r}$, bounds it $\mathrm{N}$, and on the $\mathrm{S}$. and $\mathrm{S}$. IT. the Mississippi. The interior is drained by Blue, Grant, Platte, and other rivers. The surface is considerably broken, but the soils are highly productive, and the whole county abounds in galens or lead ore, which is extensirely smelted. Farms 704; manuf. 75; dwell. 2,\$61, and pop.wh. 16.140, fr. col, 80-total 16,170. Capital: Lancoster. Pullic Wurks: Milwaukie and Mississiupi R. R.

Graxi, p. o, Grant co., Ind. : $54 \mathrm{~m}$. N. E. Indianapolis. GranthaN, t. and p. o, Sullivan eo, N. Hamp.: $38 \mathrm{~m}$. N. W. Concord. Drained by heads of Sugar r. of the Connecticut. Surface various. Corydon Mountain lies in the W. part, and in the E. there are low lands, adapted to tillage. It contains a noted mineral spring. The inhabitants are mostly farmers. Pop. 784.

Grantsiorougin, p. v., Campbell county, Tenn.: $157 \mathrm{~m}$. E. N. E. Nashville.

Gravt's CrFsk, p. O., Switzerland con, Ind, : at the mouth of a er. of Ohio $r$. so called, $57 \mathrm{~m}$. S. E. Indianapolis. 253
Grant's Lick, p. o., Campbell co., Ky. : on a cr. of Licke ing $\mathrm{r}$. so called, $57 \mathrm{~m}$. N.N. E. Frankfort,

GrANTSVILle, p. v., Alleghany co., Md. : on the National Road, $27 \mathrm{~m}$. W. Cumberland.

Granville county, N. Car. Situate on N. line, and contains $624 \mathrm{sq} . \mathrm{m}$. Drained by affluents of the Roanoke, and upper streams of Tar and Neuse rivers. Surface agreeably diversified, with some high land and considerable waterpower. Tobacco is the great staple. Cotton is raised extensively. Farms 1,074; manuf, 55; dwell. 2,093, and pop.-wh. 10,296 , fr. col. 1,088 , sl. 9,865 - total 21.249 Capital: Oxford. Public Works: Gaston and Raleigh Railroad.

Grarvilue, p. v., Delaware co., Ind.: on the left bank of Mississinewa r., $57 \mathrm{~m}$. N. E. Indianapolis. Pop. about 200. The Fort Wayne and Southern R.R., as projected, will pass near or through the village.

GrATVILle, $t$, and p. o., Washington co, N. Y.: $52 \mathrm{~m}$. N. N. E. Albany. Drained by Pawlet r. of Lake Champlain. Surface somewhat broken and uneven; soil clay loam, and fertile. The $\mathbf{v}$. is situate on Pawlet r., and on the line of the Rutland and Washington R.R.; it has several manufactures, and about 600 inhabitants. The t. has numerous mills, woolen factories, a pottery, etc., and 3,484 inhabitants.

Gratrille, t. and p. T., Licking county, Ohio: $27 \mathrm{~m}$ E. N. E. Columbus. Drained by W. fork of Licking river, which furnishes great water-power. Surface and soil adaptcd to agriculture. The $t$. was settled in 1805 by immigrants from Granville, Mass. The v. contains furnaces, mills, mechanic shops, and about 771 inhabitants, and about 1 mile $\mathrm{E}$, of the $\mathrm{v}$. is Granville College, a Baptist institution, founded in 1S31. In the academic department, in 1850, it had 5 professors, 60 alumni, and 35 students, with a library of 5,000 volumes; and in the theological department 2 prom fessors and 8 students, with a library of 800 volumes. The "Granville Intelligencer" is issued weekly. Population of t. 2,116 .

Grantrtle, t. and p. o., Bradford co., Penn. : $102 \mathrm{~m}$. N. Harrisburg. Drained by Tonawanda and other creeks of the N. branch of Susquehanna r. Surface varied; soil of moderate fertility. Pop. 797.

Granvilie, p. v., Jackson co., Tenn.: on the left bank of Cumberland r., $54 \mathrm{~m}$. E. by N. Nashville.

Grastrule, p. v., Monongalia co., Firg. : on Dunkard's cr. of Monongahela r., $202 \mathrm{~m}$. N.W. Richmond. It contain warehouses, mechanic shops, stores, etc., and about 200 inhabitauts.

Graxyitue, and p. vu, Addison county, Term. $23 \mathrm{~m}$ S. S.W. Montpelier-formerly known as Kingston. Drained by heads of White r., one of which falls 100 feet, 50 of which perpendicularly. Surface mountainous. The $\mathrm{v}$. is a seattered settlement on the E. side of the river. Population of $t .642$.

Graxtrlle, p. v., Putnam county, Ill.: 100 m. N. by E. Springfield.

Gratrultz t and p. V., Milwaukie co, Wisc.: $78 \mathrm{~m}$ E. W Y. Yutison. Drained by Milwaukie rirer and its branches, on one of which the $\mathrm{v}$. is located.

Grape Grote, p. o., Greene co, Ohio: 56 m.W. S. W. Columbus.

Geape Istaxt, p, o, Trler co., Firg.: on an island of Ohio $\mathrm{r}$. so called, $287 \mathrm{~m}$. N.W. Richmond.

Grape VINE, p. 0., Perty co., Ky。 : $108 \mathrm{~m}$. S. E. Frankfort. Grass Huls, p. o., Carroll county, Ky. : $34 \mathrm{~m}$. N. by W. Frankfort.

Grass LAKE, t. and p. 0., Jackson co, Mfich.: 40 m. S. S. E. Lansing. Drained by the E. branch of Grand $\mathbf{r}$., which has its source here in several small lakes. Surface elevated and varied; soil deep black mold. The p. 0 . is located in the $\mathrm{V}$ of Leoni, at the outlet of Grass Lake, and on the line of the Michigan Central R. R., which traverses the N. W. part of the town. Pop. 1,2S1 
Grass LaNd, p. o., Harrison co., Firg. : $200 \mathrm{~m}$. N. W. Richmond.

Grass river, $N_{0} Y_{0}$ : a tributary of St. Lawrence $r$. from New York. It rises in the S. E. part of St. Lawrence co., and flows in a $\mathrm{N}$. direction to the St. Lawrence, which it enters opposite to Cornwall Island, Canada.

Grass Vallex, p. v., Butte co., Calif: : on the middle fork of the Feather r., $173 \mathrm{~m}$. N. E. Vallejo. In the vicinity is one of the most productive gold-diggings in the State. Population 2,500.

Grassy Cove, p. o., Bledsoe co., Tenn.: 94 m. E. S. E. Nashville.

Grassy Creek, p. v., Pendleton co, $K y$ : on a cr. of Licking r. so called; $58 \mathrm{~m}$. N. E. Frankfort.

Grassy Creek, p. o., Yancey co., N. Car.: on a cr. of Nolichucky r. so called; $192 \mathrm{~m}$. W. Raleigh.

Grassy Pond, p. o., Spartanburgh dist., S. Car, : near the State line, 86 m. N. N. W. Columbia.

Grasst Vallex, p. v., Harrison co., Ind. : on the E. side of Indian cr., $4 \mathrm{~m}$. from the Ohio r., and $108 \mathrm{~m}$. S. Indianapolis.

Gratiot county, Mich. Situate centrally in Lower Peninsula, and contains $576 \mathrm{sq} . \mathrm{m}$. Drained by Pine $\mathrm{r}$, in the $\mathrm{N}$., waters of which flow into Lake Huron, and Maple r., which empties through Grand r. into Lake Michigan. Surface undulating, and well timbered with pine in the N.; soils adapted to grass and the grains. Unorganized in 1850 .

Gratiot, p. v., Muskingum co., Olizo: $42 \mathrm{~m}$. E. Columbus. Gratror, p. v., Lafayette co., Wisc.: on the Picaunica r., $49 \mathrm{~m} . \mathrm{S}$. W. Madison.

Gratis, t. and p. o., Preble co., Ohio: 84 m. W. S. W. Columbus. Drained by creeks flowing into Miami r. Surface diversified; soils light and fertile. It is a well cultivated country, and has 2,117 inhabitants.

Grattidude, p. o, Sussex co., N. Jer.: $69 \mathrm{~m}$. S. Trenton. Grattan, to and p. 0., Kent county, Mich: $57 \mathrm{~m} . \mathrm{N}$. W. Lansing. It is drained by numerous small lakes, which empty into creeks flowing to Grand $r$. Surface elerated and level; soil deep and fertile. The $t$. has abundance of fine timber. Pop, 648.

Gratz, p. v., Dauphin county, Penn.: $27 \mathrm{~m}$. N. by E. Harrisburg.

Grave Crees, p. o., Marshall Co., Tirg.: on a er, of Ohio r. 80 called, $235 \mathrm{~m}$. N. W. Pichmond.

Grater Hill, p. o., MeNairy co., Tenn.: 118 m. S. W. Nashville.

Graver Hru, p. o., Buckingham c0., Virg.: 54 m. W. Richmond.

Gravelix Hrul, p. o., Bladen co., N. Car.: 85 m. S. Pialeigh.

Gravelly Spring, p. o., Lauderdale co., Ala.: $178 \mathrm{~m}$. N. N. W. Montgomery.

Gratel Ridge, p. o., Bradley co., Ark. : 96 m. S. S. E. Little Rock.

Gravel Run, p. o., Washtenaw co., Mfich.: on an aftuent of Huron r. so called, $52 \mathrm{~m}$. S. E. Lansing.

Grated Spring, p. o., Frederick eo, Virg.: $126 \mathrm{~m}$. N. N. W. Richmond.

Graves county, $K y$. Situate $W$., and contains 540 sq.m. Drained by Mayfield $r$, and Little Obion $r_{\text {., }}$ affluents of Mississippi r., and in the E. by affluents of the Ohio. Surface generally level, and soil very productive of wheat, corn, and tobacco. Farms 1,279; manuf. 35; dwell. 1,694, and pop.-wh. 9,949, fr. col, 9, sl, 1,439-total 11,387. Capital: Mayfield.

GRaves, p. o., Hempstead county, Ark. : 108 m. S. W. Little Rock.

Graves, p. v., Caswell co., N. Car.: 66 m. N. W. Raleigh GraveseND, t. and p. v., Kings co., N. Y.: $8 \mathrm{~m}$, S. New York City. Drained by several creeks. The t. faces on the Atlantic, and includes "Coney Island," a place of resort for the citizens of New York in the bathing-season. Surface generally level, with extensive salt marshes and sandy hil- locks. The v, contains a Dutch Reformed Church, and about 20 dwellings. Pop. of the t, 1,064 .

Grates Ferex, p. o., Ohio co., Ky.: 181 m. W. 8. W. Frankfort.

Grave's Mrul, p. o., Madison co., Virg.: $76 \mathrm{~m}, \mathrm{~N}$. W. Richmond.

Gravesville, p. v., Herkimer co., $N_{0} Y_{0}: 71 \mathrm{~m} . \mathrm{W} . \mathrm{N} . \mathrm{W}$. Albany.

Grux, t, and p. o., Cumberland co., $M e_{0}: 46 \mathrm{~m}$. 8. W. $\Delta$ ugusta. Drained by branches of Presumpscut and North Farmouth rivers, and it contains a large part of Little Sebago Pond. It is a fine farming country, and has some manufactures. Pop, 1,788.

Gray Rock, p. o., Titus county, Tex.: 280 m. N. E. Austin City.

Graysburg, p. o., Greene co., Tenn. : 226 m. E. Nashville.

Gray's Creer, p. o., Cumberland co., N. Car.

Gray's Cross Roads, p. o., Randolph co., N. Car.: 98 m. W. Raleigh.

GraY's harbor, Oreg. Ter.: a fine bay in the N. W. of Oregon, into which the Chehalis r. empties. It is about 12 $\mathrm{m}$. deep, and in its widest part about $5 \mathrm{~m}$. The entrance is about $2 \frac{1}{2} \mathrm{~m}$. wide. This harbor takes its name from Capt. Gray, the celebrated discoverer of the Columbia $r$. and other important points, this among others, along the N. W coast.

GraYson county, $K y$. Situate W. centrally, and contains 651 sq. m. Nolin cr. on the S. E., and Rough cr. on the N. W., tributaries of Green $r$., with numerous affluents, drain it. Surface various, with some good mill-sites. Soil of average productiveness. Corn and tobacco are the leading productions. Farms \$24; manuf, 14; dwell. 1,065, and pop.-wh. 6,512, fr. col. 5, sl. 320-total 6,837. Capital: Litchfield. Public Works: Nashville and Louisville R. R.

Grayson county, Texo. Situate N. on Red r., and contains $956 \mathrm{sq} . \mathrm{m}$. Drained by Big Mineral, Little Mineral, Iron Ore creeks, and Choctaw Bayou in the $\mathrm{N}$., and in the S. by many head streams of Trinity r., which empties into Galveston Bay. Surface mostly undulating, with a few low hills on Red r. Soil on Red r. consists of a rich, black, friable mold, often very deep, and everywhere of almost incredible fertility: this is the cotton region. The interior is more sandy, and affords good grazing. Iron ore is abuudant, particularly on Choctaw Bayou. Farms 171; manuf. 0 dwell. 295, and pop,-wh. 1,722, fr. col. 0, sl. 186-tota 1,908. Capital: Sherman.

Grayson county, Virg. Situate W. on S. line, and contains $494 \mathrm{sq}$. m. Intersected by New r. (the upper portion of Great Kanawha r.), and drained by its branches and Laurel Fork, the head of Holston r. Surface very elevated -in parts mountainous, with productive valleys between, and abundance of water-power. A good grazing and farming county. Farms 604; manuf. 0 ; dwell. 1,001, and pop.wh. 6,142, fr. col. 36, sl. 499-total 6,677. Capital: Greenville.

Grayson, p. v., and eap. Carter co., $K y_{.}:$on the W. side of Little Sandy $\mathbf{r}_{\text {, }} 117 \mathrm{~m}$. E. by N. Frankfort. It has a court-house, two stores, and about 160 inhabitants.

Grayson, p. y., Crittenden co., Ark.: 110 m. E. N. E Little Rock.

Grarson C. H., p. o, and cap. Grayson co, Firg.: in the $\mathrm{v}$. of Greensville, on the right bank of New r., $198 \mathrm{~m}$. W. S. W. Richmond. The v, contains a court-house, jail, etc., several stores and mechanic shops, and about 200 inhabitants.

Grayson Springs, p. o., Grayson county, Ky.: 108 m. W. S. W. Frankfort.

Geatron Sulphur Sprixes, p. o., Carroll co., Firg.: $154 \mathrm{~m}$. W. S. W. Richmond.

Graysport, p. ., Yallabusha co., Miss.: on the S. side of Yallabusha r., $110 \mathrm{~m}$. N. N. E. Jackson.

Gray's Vallex, p. o., Tioga co., Penn. : 112 m. N. by W. Harrisburg. 
Graysville, p. o., Monroe co, Ohio: on a tributary cr. of the Muskingum, $96 \mathrm{~m}$. E. by S. Columbus.

Graysville, p. v., Herkimer co., $N_{0} Y_{0}: 73 \mathrm{~m}$. W. N. W.

Albany.

Graystille, p. v., Huntingdon county, Penn.: $79 \mathrm{~m}$ W. by N. Harrisburg.

Grayville, p. v., White county, $I l l .: 119$ m. S. E. Springfield.

Greast Creek, p. o., Floyd co., Firg.: 173 m. W. S. W. Richmond.

Greasy Crenk, p. o., Polk co., Tenn.: 144 m. E. S. E. Nashville.

Great Barrington, t. and p. v., Berkshire co., Mass. $118 \mathrm{~m}$. W. Boston. Drained by Housatonic r. and its branches. Surface, except in the valley of the river, uneven and hilly; soil generally fertile, and on the hills fine for grazing. Monument Mountain is a lofty eminence, and presents much wild and picturesque scenery. Iron ore and variegated marble abound. The $\mathbf{v}$. is situate on the $\mathbf{E}$. side of the river, and on the line of the Housatonic R. R., $55 \mathrm{~m}$. from Bridgeport. It is a considerable place, and has sevexal manufactures. $\operatorname{Van}$ Deusenville is a pleasant $v .2 \mathrm{~m}$. N. of the principal $\nabla$. Two newspapers are published in the t., the "Berkshire Courier" (whig) and the "Transcript" (whig), both weeklies. The manufactures consist of cotton and woolen goods, boots and shoes, hats, pig iron, tinware, etc. Pop. of $t, 3,263$.

Great bay, Rockingham con, $N$. Hamp. : in the S. E. part of the State. It is formed by the united waters of Swamscot, Winnicut, and Lamprey rivers, and its water pass N. E. through Little Bay, where Oyster r, unites with the current which passes into Piscataqua r. It is $4 \mathrm{~m}$. wide.

Great bay, Belknap co., N. Hamp.: an expansion of the outlet of Lake TWinnipiseogee, and discraryes its naters through Winnipiseogee $r$. into the Connecticut. Round and Long bays are situate between the lake and Great Bay, and there are two small bays in the river below

Great BeND, p. V., Jefferson co, $N_{*}$. $Y_{*}$ : at the great bend of Black r., $133 \mathrm{~m}$. N. W. Albany. It contains several mills and about 200 inhabitants. A bridge here crosses the Black river.

Great Bend, p. o., Meigs county, O7io: 92 m. S. S. E. Columbus.

Graat Bend, t. and p. $\nabla_{\text {, }}$ Susquehanna co, Penn. : 132 m. N. N. E. Harrisburg. Drained by aftiuents of Susquehanna r. Surface hilly; soil generally good, especially so in the rallers. The $v$ is situate on buth side of susquehanna $\mathbf{r}$, over which is a large covered bridge. The two parts of the $\nabla$. are about a mile apart. It contains several spacious stores and about 400 inhabitants. As a station on the New York and Erie R. R. it is important, for it is placed at a great convercing point of trale with nuny thriving turns in P'eunsylvania, and the Lesget's Gap Ii. I. rums hence into the Lackawanna coal and iron region. A large amount of business is done here, and the $r$. is rapidly filling up with an enterprising population. Pop. of the $t$. 1,150 .

Great Bridge, p. o., Norfolk co, Firg.: 72 m. S. E. Richmond.

Great Crossnge, p. o., Scott $\mathrm{co}_{2}, \bar{K} y$ : on Elbhorn er. $5 \mathrm{~m}, \mathrm{~W}$. of Georgetown and $16 \mathrm{~m}$. E. N. E. Frankfort. The Choetaw Acalemy was firmerly located here, which prom rided, uniler the superintendence of the War Deparment, for the education of Indians.

Great Falls, p. $\nabla .$, Strafford co., $N$. Ilamp. : on the W. side of Salmon r., at the fulls, $38 \mathrm{~m}$. E. Concord. This is a large and beautiful $v_{\text {., }}$ with extensive manufactures of cotton, etc., for which its immense water-power peculiarly adapts it. It lies at the point of junction of the Great Falls Branch of the Boston and Maine R. R., the Great Falls and Conway R. R., and the York and Cumberland R. R. Two newspapers are published here, the "G. F. Transeript" and the "G. F. Sketcher," both issued weekly. Pop. about 2,000 260
Great Milis, p. o., St. Mary's co., MId.; on a cr. of St. Mary's r., 53 m. S. Annapolis.

Great Okonagon lake and river, Oreg. Ter.: \& lone lake, or rather series of lakes, stretching between $48^{\circ}$ and $50^{\circ} \mathrm{N}$. lat., and forming the sources of the Okonagon r., a branch of the Columbia $r$., at the confluence with which is located Fort Okonagon, an establishment of the Hudson Bay Company.

Great Pee Dee river, S. Car.: a continuation of the Yadkin $r$. It rises under the latter name in Caldwell and Wilkes counties, N. Carolina, and continues thence in an-E. direction to the W. line of Forsyth county, when it abruptly turns S., and in a S. E. course passes over the border into S. Carolina, when it is called Great Pee Dee. Its principal affluents are Lynch's cr. and Little Pedee r., both consider able streams. Uniting with Waccamaw r. a little below Georgetown, it enters and forms Winyaw Bay, which com. municates with the Atlantic about $12 \mathrm{~m}$. below the union. This river is navigable for boats of 60 or 70 tons burden for $200 \mathrm{~m}$. Little Pee Dee r. enters it about $32 \mathrm{~m}$. up, and Lynch's cr. about $47 \mathrm{~m}$. up-both are boatable for a considerable distance.

Great Salt Lake county, Ttah. Situate on the $\mathbf{E}$ and S. shores of the Great Salt Lake, and comprises a district lying in the immediate vicinity. Surface low and level on the shore, but soon rises into mountains, which encircle the basin of the lake at no great distance. The soil is good, and, under cultivation, highly productive. Salt of a good quality, and in great quantities, is obtained from the lake; and on its shores the Mormons have settled, and emigrants for the Pacific shore here find refreshments and a halting place, before entering on the California desert. Farms 505; manuf 6 ; dwell. 1,238, and pop.-wh. 6,142, fr. col. 15total 6.15\%. Capitel: Great Salt Lake City.

Great Salt Lake Citr, p. city, and cap. Great Salt Lake co., Utah Ter. (See SaLt Lake Citx.) The precise name of this is "City of the Great Salt Lake."

GREAT SALT lake, Utah Ter.: a noted lake in the great California basin. It lies in lat. $41^{\circ} 10^{\prime} 42^{\prime \prime} \mathrm{N}$., and long. $112^{\circ} 21^{\prime} 05^{\prime \prime} \mathrm{W}$. (the astronomical position of an island in the lake). It communicates with Utah Lake through a strait called Jordan r., but has a somewhat lower level. Ctah Lake is fresh water, while Great Salt Lake is intensely salt, and its shores and bottom are incrusted with salt-the former for a width of several miles. The Mormons are settled in its neighborhood, and their original settlement and chief city, the City of the Great Salt Lake, is located on the E. side of Jordan $r$. The lake and its vicinity has been surveyed by Captain Stansbury, whose able report to Congress is a work of great interest and value. In the valley of this lake the most valuable lands of the Territory are located, and of these the Mormons have got possession.

Great Vallex, t. and p. o., Cattaraugus co., $N$. $Y .: 247$ m. Wr. by S. Albany. Drained by Great Valley, Tuniangu ant, and other creeks of Alleghany r. Surface somewhat broken, rising from the ralley of the Alleghany; soils, clay loam, and fi-rtile. The $r$ is a station on the Erie P. R., and is on the Reservation belonging to the Seneca Nation, now numbering about 700 . It commands the business of the valley, in which Ellicottville, is situate. Pop. 1,63S.

Great Works, p. V., Penobscot co., Me. : on the E. side of Penobscot r., at the confluence of Great Works stream, $74 \mathrm{~m} . \mathrm{N}$. E. Augusta. The stream so called is an important branch of the Penobseot, into which it falls opposite the Indian settement of Old Town; it has many mill sites, and along its banks considerable manufactures are carried on.

Greecr, t. and p. o., Monroe co., N. Y.: $203 \mathrm{~m}$. W. N.W Albany. Drained by creeks flowing through small bays tc Lake Ontario, which lies on its W. border, and Genesee $r$. lies on its E. boundary. Surface undulating; soil, gravelly, sandy, and clay loams. Charlotte and Adams Basin are post-offices in this $t$. Pop. 4,219.

Greeluxd Depôt, p. o., Rockingham co., N. Hamp. 
Greñ Baxk. p. o., Pocaliontas co., Firg. : on Deep er. of Greeubrier r., $146 \mathrm{~m}$. W. N. W. Richmond. It has several mills and mechanic shops, and about SU inhabitants.

Green Baxk, p. o., Burlington co., N. Jer.

Graex BAY, p. o, Des Moines county, Ia. : 67 m. S. E. Iowa City.

Green BAy, p. v., Brown eo., Wisc.: on the right bank of Neenab or Fox r., at the head of Green Bay, 124 In. N. E. by N. Madison. It occupies an important location, and has a good harbor; and its commerce is considerable. Many of its stores aad dwellings are large and elegant buildings, Fort Howard, on the W. side of the r., stands on a commanding eminence, and in the $\mathrm{v}$. is a U.S. lanil office. Pop. about 2,500. It is a place that must become, in the natural progress of events, a large commercial depôt. It was formerly the county capital.

Green bay, Wisc: : a large arm of Lake Michigan, extending inland from its N. W. corner for $100 \mathrm{~m}$., and having a breadth varying from 15 to $20 \mathrm{~m}$. Its direction is almost parallel with the western shore of the lake; at its entrance are the Grand Traverse Islands, extending in line about $30 \mathrm{~m}$. It is navigable to its head for vessels of 200 tons, and there communicates with Fox r, and the transterrene narigation of Wisconsin to the Mississippi $r$. The Menomonee, forming the N. E. boundary of the State, also cmapties into it.

Grennorougr, p. V., Oswego county, N. Y.: $136 \mathrm{~m}$ W. N. W. Albany.

Grefr Botrom, p. o., Shelby county, Tenn.: 193 m. W. S. W. Nashrille

Green Botrom, p. v., Cabell co., Firg. : 257 m. W. by N. Richmond.

GFEENBRIEs county, Virg. Situate W. centrally, aud contains 1,288 sq. $m$. Drained by Greenbrier r. in the $S$. and E., and W. by Meadow r., Cherry-tree $r_{\text {, }}$ and other heads of Gauley r., all which empty into the Great Kanawha, which furnishes numberless mill-sites. It lies W. of and at the foot of the Alleghany Mountains, and the surface is elevated and rough. There is much timber, and much maple sugar is made. Excellent pasturage abounds, and the lower parts are very fertile. Farms 603; manuf. 0; dwell. 1,419, and pop.-wh. 8,519 , fr. col. 156, sl. 1,317-total 10,022 Cupitul: Lewisburg. Pultic Works: Virginia Central R. R.

Geeinbeter, p. o., Northumberland co., Penn.: $57 \mathrm{~m}$.

\section{N. Harrisburg.}

GreENBrier river, Tirg.: a constituent of the Great Kanawha. It rises in Pocahontas county from the Great Alleghany Ridge, and passes in a general $\mathbf{S}$. W. course through Greenbrier county and into Monroe county, where it enters the Kanaw ha at its passage through Laurel Ridge.

Greenbrier Run, p. o., Doddridge co., Virg.: 212 m. W. N. W. Richmond.

Green Bud, p. o, Sussex county, Firg. : 43 m. S. E. Pichmond.

GreEN BUSH, p. v., Warren co., $I l l .:$ about $2 \mathrm{~m}$. N. of the W. fork of Spoon r., $77 \mathrm{~m}$. N. W. Springfield.

Greenbush, p. V., Polk co., Ia.: on North r, a branch of Des Moines r., 112 m. W. S. W. Iowa City.

Greenbubr, t. and p. o. Penobscot co.. Me. : $91 \mathrm{~m}$. N. E.

Augusta, Drained by Olamon and other affluents of Penobscot $r$. Surface varied; soil generally fertile. The $v$. opposite Aroyle is a pleasant and thriving place. Pop. of $t .417$.

GreENBUsh, p. v., Grant county, Ind.' 58 m. N. N. E. Indianapolis.

Greexbesh, to and p. o., Clinton co., Mich.: $22 \mathrm{~m}$. N. Lansing. Drained by Maple r, a branch of Grand. Surface elevated and level; soil, deep and fertile, with fine timber in abundance. Pop, 318.

Gezfriesh, p. o., Scott county, Miss.: 48 m. F. by N. Jackison.

Grementsi, t, and p. v., Renssalaer co., $N . Y_{0}:$ opposite Albany, on the E. side of Hudson r. Drained by several small creeks. Surface generally hilly; soil, clay loam, with sand and gravel. The land on the Hudson is level and very fertile. The $v$, contains several factories and stores, and about 1,200 inhabitants. There are several ferries to Albany, and the Hudson River R. R., and the Western (Albany and Stockbridge) $\mathbf{R}$. $\mathrm{R}_{\text {. }}$, have their terminus at East Albany, and there connect with the Troy and Greenbush R. R. Pop. 4,945,

Greenbusm, t. and p. v., Sheboygan co., Wisc. : $84 \mathrm{~m}$. N. E. Madison. Drained by Millet er. of Sheboygan r., on which also the $\mathrm{v}$. is located. A plank-road crosses the t, stretching from Sheboygan, on Lake Michigan, to Fond du Lac. Pop 634.

Green Castle, p. v., and cap., Putnam $\mathrm{co}_{\text {, }}$ Ind.: on a high table-land, $1 \mathrm{~m}$. E. side of Walnut fork of Eel r., 39 m. W. by $\mathrm{S}$. Indianapolis, lat. $39 \circ 40^{\prime} \mathrm{N}$, and long. $86{ }^{\circ} 4 \mathrm{~S}^{\prime}$ W. It was laid out in $181 \mathrm{~s}$, and contains a court-house, jail, and other county buildings, numerous mechanic shops, stores, etc., and is the seat of Indiana Asbury University. The university was founded by the Methodist denomination in 1637 , and in 1550 had a president, 8 professors, 120 alumni, and 120 students; and its 'sbrary contained 4,000 volumes. It has a law department. Besides this there are several first-rate schools in the $v$, and the usual number of free schools. The "G. Sentinel" (neutral), is issued weekly, Pop. about 2,000. Green Castle is on the line of the New Albany and Salem R. R., and also the Terre Haute and Richmond R. R., which intersecting it at this point, connects it with all parts of the State and United States. It is the commercial depôt of an extensive and fertile neighborhood.

Green Castle, p. v., Fairfield co., Ohio: 19 m. D. E. Columbus,

Green Castle, p. b., Franklin co., Penn.: on the E. of Conecocheague r., $62 \mathrm{~m}$. S. W. Harrisburg. It lies on the line of the Franklin R. R., equi-distant between Chambersburg and Hagerstown. It contains several manufacturing establishments, mechanic shops, stores, etc, and about 1,800 inhabitants. The "Conecocheague Herald" is issued weekly. It is surrounded by a fertile country.

Green Creek, p. o., Cape May co., $N_{\text {. Jer.: }} 71 \mathrm{~m} . \mathrm{S}$. Trenton.

Green Creek, t. and p. o., Sandusky co, Ohio.: $90 \mathrm{~m}$. N. Columbus. Drained by Green and other ereeks flowing into Sandusky Bay. Surface diversified, and soils well adapted to agriculture generally. The Mad River and Lake Erie R. R. (new line) is intersected in the E. part of this t. by the Cleveland, Norwalk, and Toledo R. P. 1,2s8,

Green Depôt, p. o., Kennebec co., Me.: on the Androscoggin and Kennebee R. R., $22 \mathrm{~m}, \mathrm{~S}$. W. Augusta, $41 \mathrm{~m}$. by route from Portland.

Greene county, Ark. Situate N. E. corner, and contains 959 sq. m. Drained by St. Francis r., its E. boundary, and Cache r., its W. boundary. Surface low and level, in parts marshy; soil fertile where capable of cultivation. Farms 345 ; manuf. 0 ; dwell. 436 , and pop.-wh. 2,530 , fr. col. 10 , sl. 53-total 2,593. Oapital: Gainesville.

Greene county, $G a$. Situate N. E. centrally, and contains 508 sq. m. Drained W. by Oconee r., and E. by Ogeehee $x$. and Little $r_{\text {, }}$ a branch of the Savannah. Surface elevated and swelling, and soil productive. There is good water-power, which is improved by mills and factories. Cotton is the staple. Farms 512; manuf. 47 ; dwell. 854, and pop.-wh. 4,744, fr. col. 58, sl. 266-total 13,068. Capital: Greensboro, Public Works: Georgia R. R., and Atheus Branch R. R.

GRERE county, Ind. Situate S. W., and contains 534 sq. m. The W. fork of White $r$. divides it almost equally, and it has other streams which afford mill-sites. Surface rather hilly $\mathrm{E}_{\text {, }}$, but level W.; soils, clay, variously mixed. The products are wheat, corn, and tobacco; lead, coal, and iron are abundant. Farms 1,227; manuf. 39; dwell. 2,089, and pop.wh, 12,238, and fr. col, 75-totsl 12,313. 
Capital: Bloomfield. Public Works: Wabash and Erie Canal; Vincennes and Indianapolis R. R., ete.

GREeNe county. $I l l$. Situate W., and contains $564 \mathrm{sq} . \mathrm{m}$. Drained by Apple and Macoupin ereeks, affluents of the Illinois r., which makes its $W$. line. Surface level, partly prairie and partly timbered; soil highly productive. This is in the coal region, and coal is abundant and easily obtained. Corn is the agricultural staple. Farms 1,155; manuf. 27 ; dwell. 2,024 , and pop.-wh. 12,389, fr. col. 50total 12,439. Capital: Carroliton.

GREENE county, Ia. Situate W. centrally, and contains $576 \mathrm{sq} . \mathrm{m}$. Drained by Raccoon r., a tributary of the Des Moines r. Unorganized in 1850 .

GrEeNE county, $\bar{K}_{y}$. Situate centrally, and contains 316 sq. m. Drained by Little Barren r., Russell r., and other head streams of Green r. Surface diversified and of moderate elevation; soils productive. Large numbers of cattle, sheep, and swine are raised. Tobacco is the great staple, but wheat and corn are produced largely. Manufactures are noticeable, for which the streams afford good facilities. Farms 791 ; manuf. 201 ; dwell. 1,105, and pop.-wh. 6,335, fr. col. 117, sl. 2,608-total 9,060. Capital: Greensburg. Public Works: Danville and Nashville R. R.

Greene county, Miss. Situate S. E., and contains 720 sq. m. Drained by Chickasawha r. and Leaf er., which uniting S. of it, form the Pascagonla. Surface low and generally even; soil, in parts unproductive, but covered mostly with forests of timber trees. Corn and potatoes, cotton and rice, are the prockuets. Farms 93; manue. 0; dwell. 217, and pop.-wh. 1,379, fr. col, 1, sl. 638-total 2,018. Capital: Leakesville, Pullic Works: Mobile and Ohio R. R.

Greene county, Mo. Situate S. W., and contains 1,157 sq. m. Drained by the heads of White $r$, which empties into the Mississippi, and branches of the Osage r., which runs into the Missouri, The surface is broken, a range of hills or mountains occupying the middle, and forming a watershed between the waters running $\mathrm{N}$, and $\mathrm{S}$. The soil fertile and well timbered. Farms $1,2 S 3$; manuf. 50 ; dwell. 2,046, and pop.-wh. 11,548, fr. col. 7, sl. 1,230-total 12,785. Capital: Springfield

Greeve county, $N, Y$, Situate $E$, centrally, and contains 583 sq. m. Drained by Catskill and Coxsackie ereeks, which flow into the Hudson r., which washes its E, border, and by the head branches of Schoharie cr., a tributary of Mohawk r. Surface diversified-in the S. and W. hilly and mountainous, and toward the N. E. more level. The mountains are sterile, but in the valleys there is much fine land. Iron ore, and many other minerals, are abundant throughout the county, as are marble, building stone, etc. Farms 2,672; manuf. 433; dwell. 5,745, and pop.-wh. 32,202, fr. col. 894 - total 33,126. Capital: Catskill. Public Works: Albany and Goshen R. P.

Greere county, N. Car. Situate E. centrally, and contains 182 sq. $m$. Drained by Mockasin $r$. and its affluents, which flow into the Neuse. Surface generally even; soil mostly productive. Corn and cotton are the leading crops. Rice is also raised. This is the pine region, and tar, pitch, and turpentine figure largely in the exports. Farms $3 \pi 2$; manuf. 87; dwell. 584, and pop.-wh. 3,259, fr. col. 116, sl. 3,244-total 6,619. Capital: Snow Hill.

Greene county, Olio. Situate S. W. centrally, and contains 384 sq. m. Drained in the N. W. by Mad r., and in other parts by the Little Miami and its aftuents. Surface level or undulating; soil fertile and well timbered. The numerous streams afford many water privileges, and all crops, especially of grain, are very large. Farms 1,626; manuf. 132; dwell. 3,760 , and pop.-wh. 21,460, fr. col, 456 -total 21,946. Capital: Xenia, Public Works: Little Miami R. R. ; Columbus and Xenia R. R.; Mad River and Lake Erie R. R.; Dayton and Xenia R. T., ete.

Greese county, Penn. Situate in S. W. comer, and contains $55 \mathrm{~s}$ sq. m. Drained E. by branches of Monongahela r., which is its $E$. boundary, and $W$. by afluents of the 262
Ohio. Surface mountainous, and water-power abundant soil very fertile, yielding great grain crops and supporting fine dairies. Timber plentiful, and much maple sugar made. Farms 1,789; manuf. 95; dwell. 3,777, and pop.wh. 21,600, fr. col. 476-total 22,136 Capital: Waynesburg.

GrEENE county, Tenn. Situate N. E., and contains 515 sq. m. Drained by Licking er. and Nolichucky $r$., heads of the Tennessee. Surface mountainous, with pleasant valleys; soils very productive of the grains, and adapted to sheep and cattle, which are raised in great numbers. Wheat and corn lead the products. Farms 1,346: manuf. 47; dwell. 2,933, and pop.-wh. 16,522, fr. col. 209, sl. 1,093total 17,824, Capital: Greenville. Public Works: East Tennessee and Virginia R. R.

Greene county, Virg. Situate E. centrally at foot of Blue Ridge, and contains $118 \mathrm{sq} . \mathrm{m}$. Drained by Conway r., a head of the Rappahannock, and Rivanna r., a branch of the James. Surface elevated and broken, with fine water-power; soil fertile, producing tobacco and the cereals abundantly. Farms 301; manuf. 24; dwell, 494, and pop. -wh. 2,667, fr. col. 34, sl., 1,699-total 4,400. Capital: Stannardsville.

GreEne county, Wisc. Situate S., and contains $592 \mathrm{sq} . \mathrm{m}$. Drained by Petitonica r. and Sugar cr., head waters of Rock r., which runs through Illinois into the Mississippi. Surface level; soils rich, with some prairie and good pasturage. The grains thrive abundantly. Lead mines are worked successfully, and copper is also found. Farms 763 ; manuf. 45; dwell, 1,4S1, and pop.-wh. 8,563, fr. col. 0-total 8,565. Capital: Monroe.

GrEene county, Alla. Situate W. middle, and contains 911 sq. m. Tombigbee r. forms its W. boundary, and the Black Warrior flows S. through the middle, by whose affluents it is drained. Surface varied, in parts hilly, in parts level meadow. Soil very fertile, producing heavy crops of cotton, the staple, and corn and some wheat. It has abundant water-power, and growing manufactures of flour, leather, cotton goods, and machinery. Farms 1,310; manuf. 71; dwell. 1,730, and pop.-wh. 9,265, fr. col. 49, sl. 22,127total 31,441. Capital : Eutaw.

Greene, t. and p. r., Kennebec co., Me. 24 m. S. W. Augusta, Drained by ponds and rivulets of Androseoggin r., which makes its E. border. Surface level; soil well adanted to grain producing. The $\mathbf{v}$. is a pleasant place on the E. bank of the Androscoggin. The Androseoggin and Kennebec R. R. passes through the town. Pop. 1,347.

Greene, p. v., Cape Girardeau co., Mo.: on Crooked cr., 116 m. S. E. Jefferson City.

Greene, $t$. and p. F., Chenango county, $N_{0} Y_{0}: 105 \mathrm{~m}$. W. S. W. Albany, Drained by Chenango $r$. and its tributaries. Surface hilly and broken; soil generally fertile. The $\mathrm{v}$, is situate on the line of the canal where it crosses the river, and contains numerous stores, mechanic shops, and about 800 inhabitants. Pop. of t. 3,781 .

Greene, p. o., Lancaster county, Penn.: $44 \mathrm{~m}$. E. by S. Harrisburg.

GrEene, p. o., Noble county, Ind.: 114 m. N. N. E. Indianapolis.

Greene's Store, p. o., Lawrence county, Ohio: $96 \mathrm{~m}$. S. S. E. Columbus.

GREeNFIeLD, p. v, and cap. Hancock co, Ind.: on the W. side of Brandywine or Swamp er., $20 \mathrm{~m}$. E. Indianapolis. It was settled in 1\$28, and contains a court-house and other co. buildings, and about 600 inhabitants. The National Road and the Indiana Central R. R. pass through it The "Spectator," a weekly newspaper, is published here.

GrEENFIELD, p. v., Greene co., $I l l$. : 43 m. S. W. Spring-

fleld. Pop. about 200 .

Grefnfield, p. v., and cap. Dade co., Mo.: about $1 \mathrm{~m}$ W. of Sac river, a branch of Osage river, $122 \mathrm{~m}, \mathrm{~s} . \mathrm{W}$ Jefferson City.

GrEexfeLD, t., p. o., and cap. Franklin co., Mass.: 90 m. T. by N. Boston. Drained by Greenfleld r, a branch 
or Deerfield $r$, which affords excellent water-power. Surface varied; soil fertile and well cultivated. The Connecticut $r_{\text {. }}$, the recipient of its waters, winds along its S. E. border. The $\mathrm{v}_{0}$ is pleasantly situate and well built; it has churehes of all denominations; several good academies and common schools, much trade, and is a manufacturing village of considerable celebrity, its manufactures consisting of eutlery, boots and shoes, eastings, guns, pistols, rifles, and iron work generally, harness, saddles, and a great variety of articles of domestic utility. Book publishing is also an ancient and valuable branch of business, and many works of lasting merit, especially on the subject of law, have issued from its press. It has three newspapers, the "Gazette and Courier" (whig), the "Franklin Demoerat" (dem.), and the "American Republic" (free soil), all issued weekly. Copper and iron ores are found in this town. Pop. 2,550.

GREENFIELD, t. and p. v., Hillsborough co., $N$. Hamp.: $2 \mathrm{~S} \mathrm{m.} \mathrm{S.} \mathrm{W.} \mathrm{Concord.} \mathrm{Drained} \mathrm{by} \mathrm{affuents} \mathrm{of} \mathrm{Contoocook}$ river, which flows along its $\mathrm{W}$. border. There are also several large ponds. Surface hilly and uneven; soil of moderate fertility; the hills afford good pasturage, and the ralleys and plains are favorable for grain. Crotchet and Lyndeborongh mountains are partly in this town. The $\mathrm{v}$. is situate almost centrally, and is a neat agricultural settlement, indicative of the staple industry of the town, which is almost wholly devoted to farming. Pop. of t. 716 .

Grenfield, p. v., Poinsett county, Ark.: 97 m. N. E. Litlle Rock.

Greenfreid, p. V., Highland county, Ohio: on the W. side of Paint cr., 49 m. S. S. W. Columbus. There are numerous manufacturing establishments in the vicinity, and the village, through which will pass the Cincinnati, Hillsboro, and Parkersburg R. R., is a flourishing place of some 900 or 1,000 inhabitants, with numerous stores and mechanie shops. A fine quality of limestone, suitable for building, is quarried near the village.

Greentield, t. and p. o., Erie co., Penn. : 204 m. N. W. Harrisburg. Drained by N. branch of Freneh cr. Surface diversified; soil fertile. Pop. 929.

Greenfield, p.v., Sullivan county, Tenn. : 248 m. E. by N. Nashville.

Greenfield, p. v., Nelson county, Virg.: 82 m. W. by N. Piehmond.

Grempreld, t. and p. v., Milwankie co., Wisc.: $72 \mathrm{~m}$. E. by S. Madison, Drained by ereeks of Milwaukie and Root rivers. Surface level; soil of great fertility, and deep. The $\mathbf{v}$. lies on the $\mathbf{N}$. branch of Root r., and contains about 200 inhabitants. A plank road, running S. W. from Milwaukie, passes through the town, intersecting the v. $8 \mathrm{~m}$. from Milwaukie. Pop. 1, 994 .

Gretanfield, t, and p. o., Hancock co., Me.: 96 m. N. E. Angusta. Drained by Olamon and Sunkhaze rivers, affluents of Penobscot r. Surface uneven; soil generally fertile. It is a fine grazing country, and is entirely deroted to firming. Pop. 305 .

Greentield Centre, p. v., Saratoga co., N. Y.: $32 \mathrm{~m}$. N. by W. Albany.

Greenfreld Hill, p. o., Fairfield county, Conn.: $66 \mathrm{~m}$. S. W. Hartford.

Greenfield Mills, p. o., Frederick eo., Ma. : on Monoeacy r., $6 \mathrm{~m}$. above its confluence with the Potomae, and 11 $\mathrm{m}$. S. of Frederiek City. There are 9 or 10 dwellings here, and about 60 inhabitants. The vicinity is thickly settled.

GreEnFord, p. F., Mahoning county, Ohio: 139 m. N. E. Columbus,

Green Grove, p. o., Luzerne co., Penn.: 87 m. N. E. Harrisburg.

GreEx Hill, p. o., Stewart county, Ga.: 126 m. S. W. Milledgeville.

GreEN Hill, p. o., Lauderdale co., $A l a_{0}$ : 181 m. N. N.W. Montgomery.

GRERN HILI, p. o., Columbiana co., Ohio: 181 m. N. E. Columbus.
Green Hill, p. o., Wilson county, Tenn.: 14 m. E. Nashville.

Green Hisl, p. o., Campbell co., Virg. : 97 m. W. S. W. Richmond.

Grees Hill, p. o., Rutherford county, N. Car.: $218 \mathrm{~m}$. W. S. W. Raleigh.

Green island, $N . Y$. : in the Hudson r., opposite Troy. It is about $2 \mathrm{~m}$. long and haif a mile wide. It is now used chiefly for railroad depôts.

GreEN LAKE, to and p. o., Marquette co., Wisc.: on the lake so called, $57 \mathrm{~m}$. N. by E. Madison. Pop. 725 .

Green Land, t. and p. o., Rockingham co., N. Hamp.: 39 m. E. S. E. Concord. Drained into Great Bay, which lies on the N. border. Surface level and low; soil fertile, producing fruit and vegetables largely for the markets of Portsmouth, from which it is distant $5 \mathrm{~m}$. The t. has several mills and stores, and 789 inhabitants.

Gresn Lraf, p. O., De Soto co., Mizss.: 159 m. N. by E. Jackson.

Green Level, p. o., Southampton county, Virg.: $62 \mathrm{~m}$. S. S. E. Richmond.

Green Level, p. o., Wake co., N. Car.

Green Meadow, p. O., Washington co., Tenn.: 240 m.E. Nashville.

Green Mount, p. o., Adams co., Penn.: 48 m. S. W. Marrisburg.

GREEN mountains, Verma: a northern range of the Alleghany Mountains, rising in Canada East, and passing in a direction $\mathrm{N}$. and $\mathrm{S}$. through Vermont, Massachusetts, and Connecticut, and terminating near New Haven, on Long Island Sound. Their verdant appearance originated their nomenclature, and also gave name to the State of Vermont. They decrease in height as they approach the S. Mansfield Mountain, the highest peak of the range, is 4,279 feet above the sea level; Camel's Rump, 4,190 feet; Killing. ton Peak, 3,67o feet; and Ascutney Mountain, 3,320 feet.

GREEN $\mathrm{O}_{\mathrm{AK}}$, to and p. o., Livingston co., Afich.: $47 \mathrm{~m}$. E. S. E. Lansing. Drained by the upper waters of Huron $\mathbf{r}$. and several lakes emptying into it. Surface level; soil deep and fertile. Timber is abundant. Pop. 941.

Grekvock, p. v., Crittenden co., $A r k_{*}$ : on the W. bank of Mississippi r., $136 \mathrm{~m}$. E. N. E. Little Rock.

Green Planis, p. o., Hancock co., Ill.: 93 m. W. N. W. Springfield.

Green Platrs, p. o., Northampton co., N. Car.: $81 \mathrm{~m}$. N. E. Raleigh.

Green Plasivs, p. o., St. Francis co, Ark.: 76 m. E. N. E. Little Rock.

Green Ponst, p. v., Kings co., $N . Y_{.}$: at the confluence of Newtown cr. with the East r., opposite New York City, and above Williamsburg. This is a new rillage, chiefly built up by persons doing business in New York, and who have their residences here. The improrements within a year or two have been great, and it has many substantial brick houses, ete. Pop. about 3,000 .

GREEN Pond, p. o., Union dist., S. Car.: 81 m. N. N. W. Columbia.

Greenport, p. v., Suffolk co., $N . Y_{.}$: near the end of the N. E. caudal extremity of Long Island, $124 \mathrm{~m}$. S. E. Albany, and by railroad $95 \mathrm{~m}$. from New York City. The steamboat route across the Sound to Stonington is $20 \mathrm{~m}$, It is a thriving village, with numerous mechanic shops, stores, etc., a weekly newspaper, the "Pepublican Watchman," and about 800 inhabitants. Several whaling vessels and numerous coasters are owned here. The harbor is deep, capscious, well sheltered, and seldom closed by ice; it is one of the best on the coast, and admits the largest class of shipping. Greenport, p. v., Cedar county, Mo.: 102 m. S. W. Jefferson City.

GreEN Rrver, p. o., Henry co., $I l l$ : on an affluent of Rock r. so called, $118 \mathrm{~m}$. N. N. W. Springfleld.

Greex River, p. o., Columbia county, N.Y.: 81 m. S. E. Albany. 
GrEen RIVEr, p. o., Windham co., Term. : on the W. side of the r. so called, $108 \mathrm{~m}$. S. Montpelier.

Grene River, p. o., Rutherford co., $N$. Car.: on the r. so called, 204 m. W. S. W. Raleigh.

Green RrFer, p. o., Hart co., Ky.: on the r. so called, $98 \mathrm{~m}$. S. W. Frankfort.

GREEN river, $K y .:$ a large tributary of Ohio r. It rises in the highlands of Lincoln County, and after a course generally W. and N. W., enters the Ohio r. $50 \mathrm{~m}$. above the mouth of Cumberland r., and $200 \mathrm{~m}$. below Louisville. It is 200 yards wide at its mouth, and is boatable for more than 200 miles.

Green's, p. o., Polk county, Texo. : 194 m. E. by N. Austin City.

Green's ButwF, p. o., Jefferson co., Tex.: on Neches r., 232 m. E. Austin City.

Greensborodge, p. ₹., Green county, Ala. : $79 \mathrm{~m}$. W. N. W. Montgomery. The vicinity is famous for its fine cotton.

Grennsborougr, p. v., and cap. Greene co., Ga. : on the Georgia R. R., $84 \mathrm{~m}$. from Augusta, and $87 \mathrm{~m}$. from Atlanta -36 m. N. Milledgeville.

Greensborotgr, p. v., Henry co., Ind. : on Duck cr. of Blue r., $36 \mathrm{~m}$. E. by N. Indianapolis. Pop. about 300 . The Fort Wayne and Southern R. P. will pass near or through this village.

Greensborough, p. v., Caroline co., Ma. : on the W. side of Choptank r., $43 \mathrm{~m}$. E. Annapolis,

Greensborougr, p. v., and cap. Choctaw co., Miss.: on one of the head branches of Big Black r., $93 \mathrm{~m} \mathrm{~N}$. N. E. Jackson. It contains a court-house, etc., and about 400 inhabitants. The vicinity is a fine cotton region, and is well settled.

Greensborough, p. V., and cap. Guilford co., N. Car.: between the $\mathrm{N}$. and $\mathrm{S}$. branches of Buffalo er. of Haw r., 75 m. W. N. W. Raleigh. It contains a court-house, jail, ete., several stores, and about 600 inhabitants. Two periodicals are published here-a weekly, the " $\mathrm{G}$. Patriot" (whig), and the "Common School Adrocate" (educat.), monthly. It is on the line of the North Carolina R. R., and the S. terminus of the Danville $\mathrm{R}$. R.

Grensiborotgri, p. $\nabla$. Greene co., Penn. : on the W. side of Monongahela $r, 168 \mathrm{~m}$. W. S. W. Harrisburg.

Greensb orough, t., Orleans co., Temm. : 29 m. N. E. by N. Montpelier. Drained by the heads of Lamoille $r$. Caspian and other lakes are in this $t_{\text {. }}$, the outlets of which afford water-power. Surface uneven; soil moderately fertile. The $\mathrm{v}$. on Lamoille $r$, is a small settlement, and has several mills. Pop. 1,008.

Gremssborougr, p. T., and cap. Decatur co., Ind.: on the heads of Sand er. $46 \mathrm{~m}$. S. E. Indianapolis. It was laid out in 1821, and contains a court-house, ete., numerous stores and mechanic shops, about 200 dwellings, and a population of 1,200. A newspaper, the "Clarion," is published weekly. The Lawrenceburg and Upper Mississippi R. R., and the Michigan Road pass through the village. The country is fine rolling prairie, and has a rich soil.

Grenssmorgh, p. v., and cap. Greene co., $K y_{0}:$ on the right bank of Greene $r_{\text {., }} 69 \mathrm{~m}$. S. S. W. Frank fort. It contains a court-house, jail, ete., and about 600 inhabitants. The Nashville and Lexington R. R. will probably pass through this rillage.

Greensburgir, p. $\nabla$. , and cap. St. Helena par., La. : on the W. side of Tickfau r., $42 \mathrm{~m}$. N. E. Baton Rouge. It has a court-house and other county buildings, a United States Land Office, and about 200 inhabitants. The Tickfau empties into Lake Maurepas.

Greessburgh, p. v., Greene county, $A r k$. : 147 m. N. E. Little Rock.

GreexsburgH, p. v., Trumbull co., Ohio: 156 m. N. E. Columbus. It contains several mills and mechanic shops, with stores, etc., and about $f 00$ inhabitants.

Grenssblrgi, p. b., and cap. Testmoreland co., Penn. 264
$146 \mathrm{~m}$. W. Harrisburg. It contains a court-house, jail, etc several churches of different denominations, several factories, numerous stores and mechanic shops, about $180 \mathrm{dwell}$ ings, and 1,050 inhabitants. Three newspapers are published in the borongh, viz.: the "Pennsylvania Argus" (dem.), the "Westmoreland Intelligencer" (whig), and the "Westmoreland Republic"-all weekly issues. It is an important depôt of internal trade, at which the Hempfield $R$. R. will form a junction with the Pennsylvania system of railroads.

Gremis's Corners, p. v., Oneida co., N. Y.: 96 m.W. N.W Albany. It is on the line of the Syracuse and Utica $R, R$, $19 \mathrm{~m}$. from Utica, and 34 from Syracuse.

Greensburgh Cross Roads, p. o., Sandusky co., Ohio. $92 \mathrm{~m}$. N. N. W. Columbus.

GreEv's Fork, p. o., Wayne co., Ind.: on a fork of White Water r. so called, $58 \mathrm{~m}$. E. by N. Indianapolis. The Newcastle and Richmond R. R, crosses the stream at this point. Greenspoer, p. v., St. Clair county, $A l a_{n}: 97$ m. N. Montgomery.

Green Spring, p. 0., Orange county, N.Car.; $47 \mathrm{~m}$. N.W. Raleigh.

Greer SpRing, p. o., Seneca county, Ohio: $84 \mathrm{~m} . \mathrm{N}$. Columbus.

Green Spring Rur, p. 0., Hampshire co., Firg.: $157 \mathrm{~m}$.

N. N. W. Pichmond

Greentor, p. Y., Lafayette co, Mo. : 106 m. W. N. W. Jefferson City,

Green Top, p. o., Schuyler co, Mo.: 137 m. N. N. W. Jefferson City.

Greentown, p. v., Stark county, Ohio: 106 m. N. E. Columbus.

Greentown, p. v., Howard co., Ind.: on Wild Cat cr., 49 m. N. by E. Indianapolis.

Greer Tree, p. o., Alleghanv county, Penn.: $173 \mathrm{~m} . \mathrm{W}$ Harrisburg.

GreENuP county, $K y$. Situate N. E. corner, and contains $339 \mathrm{sq} . \mathrm{m}$. Drained by Tygert's er. and Big and Little Sandy rivers, all which empty into the Ohio, which forms its N. and N. E. boundary, Big Sandy r. also separates the States of Virginia and Kentucky. Surface somewhat rough, except on the rivers, where the soil is very rich. The higher parts abound in coal and iron. Corn and wheat are easily raised. Farms 453 ; manuf. 20 ; dwell. 1,529, and pop.wh. 8,998 , fr. col. 50, sl. 606-total 9,654. Capital: Greenupsburg. Public Works: Maysville and Big Sandy R. R. Greenur, p. . $_{\text {. }}$ and cap. Greenup co. $K y_{0}:$ on the $\mathrm{S}$. bank of the Ohio r., at the mouth of Little Sandy r., $123 \mathrm{~m}$. E. by N. Frankfort. It is an important commercial point, and is intersected by the line of the Maysville and Big Sandy R. R. The . contains a court-house and other co. buildings, several groceries and stores, and between 400 and 500 inhabitants.

GReExur, p. v., Cumberland co., $I M$.: on the E. bank of Embarras r., 86 m. E. S. E. Springfield.

Greervale, p. o., Jo Daviess co., $I l l .: 176 \mathrm{~m}$. N. by W. Springfleld.

Grien VAluex, p. O., Bath co., Virg.: 133 m. W. by N. Richmond.

Green Vallex, p. o., Lafayette comnty, Mfiss. : $138 \mathrm{~m}$ N. by E. Jackson.

Greer Vrllage, p. v., Franklin co., Penn.

GreENTLLe distriet, S. Car. Situate N.T., and contains $793 \mathrm{sq} . \mathrm{m}$. Drained by Saluda $\mathrm{r}$. in the W.; and in the $\mathrm{E}$ by Ennoree r., both head streams of Congaree and Santee rivers. Surface elevated, and in the N. much broken, with many mill-streams. The soil is productive of all the grains, and cotton is much raised. Farms 1,068 ; manuf. 55 ; dwell. 2.851, and pop.-wh. 13,372, fr. col. 93, sl. 6,691-total 20,156 . Crpital: Greenville, Public Works: Greenville and Columbia R. R.

GREN FILLE county, Firg. Situate on S. line, and contains 443 sq. m. Drained S. by Meherrin r., and N. by Not 
taway r., its N. boundary, both which empty into the Chowan through North Carolina. Surface diversified, and soils of good fertility. Corn, cotton, and tobacco yield largely, and are staples. Farms 242 ; manuf. 3 ; dwell. 355 , and pop.wh. 1,731, fr. col. 123, sl. 3,755-total 5,639. Capital: Hicksford. Public Works: Greenville and Roanoke R. R.; Petersburg and Weldon R. R.

Greenville, p. v., and eap. Butler co., Ala.: on the W. side of Sepulgah r., $41 \mathrm{~m}$. S. S. W. Montgomery. It is a considerable village, and an important point in relation to the railway system of the State, being the point of junction of the Girard and Mobile R. R. and of the Montgomery and Mobile R. R.

Greenville, p. V., and cap. Merriwether co., $G a_{*}: 88$ m.W. Milledgeville. It contains a court-house, etc., several stores, and about 360 inhabitants.

GreEN ville, p. v., Floyd county, Ind.: $97 \mathrm{~m}$. S. by E. Indianapolis. It contains several stores, etc., and about 350 jnhabitants.

Greanville, p. . $_{\text {, }}$ and cap. Bond co, $I l l_{0}:$ on the E. fork of Shoal cr, of Kaskaskia r., 66 m. S. by E. Springfitd. It has a court-house, jail, ete., several mechanic shops and stores, and about 400 inhabitants. The "G. Journal" is published weekly, and the "Western Fountain," a Methodist periodical, semi-monthly

Graenville, p. v., and cap. Mecklenburgh co., $K y .:$ on an affluent of Green r., $147 \mathrm{~m}$. W. S. W. Frankfort. It contains a court-house and other co. buildings, and about 160 inhabitants. The vicinity is a fine farming region, and thickly settled with an industrious population.

Greenrale, p. v., and cap. Wayne co., Mo.: on the E. bank of St. François r., 140 m. S. E. Jefferson City. It con. tains a court-house, several stores, and about 300 inhab. itants.

Greenville, t. and p. o., Piscataquis co, Me.: $86 \mathrm{~m} . \mathrm{N}$. Augusta. Drained in the E. by Wilson's $r$. of the Sebec, and in the W. by streams running to Moosehead Jake, a S. arm of which penetrates into this town. Surface hilly; soils good for farming, and the industry of the inhabitants is chiefly devoted to agriculture. There is a small v. or settlement on the lake. Pop. of t. 326

Greeviville, p. v., and cap. Pitt co., N. Car..: on the S. side of Tar river, $35 \mathrm{~m}$. above its confluence with Pamlico Sound, $83 \mathrm{~m}$. E. by S. Raleigh. It contains a court-house, jail, etc., and about 400 inhabitants.

Greenville, p. v., Sussex county, N. Jer. : $51 \mathrm{~m} . \mathrm{N}$. Trenton.

GreknvmLe, p. v., Brown co., Wisc. : 129 m. N. E. by N. Madison.

GreENTILe, p. v., and cap. Hunt county, Tex.: 244 m. N. N. E. Austin City.

Greenville, to and p. v., Greene co., N. Y.: 23 m. S. W. Albany. Drained by Provost and Catskill creeks. Surface broken and hilly; soil clay loam and fertile in grass. The v. lies on Provost cr. Pop. of t. 2,242.

Grentrille, t., p. V., and cap. Darke co., Ohio: drained by several tributaries of Greenville cr. of the Miami $r$. Surface diversified; soil deep and rich, forming one of the finest farming towns in the State. The $\mathrm{v}$. is situate on the $\mathrm{S}$. side of Greenville er., and below the junction of Mud cr., \$1 m. W. by N. Columbus, and on the site of old Fort Greenville, where General Wayne concluded his treaty of peace with the Indians in 1795. It contains a handsome courthouse, a jail, several mechanic shops, manufacturing establishments and stores, and about 1,04t inhabitants. Two newspapers are published here, the "G. Journal" (whig), and the "Democratic Herald" (dem.), weekly issues. The Greenville and Miami R. R. passes through the $\mathrm{v}$., connecting it with Cincinnati and other Ohio cities, and with the railroad system centering at Indianapolis. Pop. of $t$. 3,416 .

Greenville, p. v., Providence co., R. I.: 9 m. W. N. W. Providence.
Greenvilus, p. v., New London co., Conn.; on the line of the Norwich and Worcester R. R., $1 \mathrm{~m}$. N. Norwich, and 36 S. E. Hartford.

Greinville, p. v., and cap. Greenville dist, S. Car.. near the head of Reedy $r$, of the Saluda, $106 \mathrm{~m}$. N. W. Columbia, or, by way of Greenville and Columbia R. R. $140 \mathrm{~m}$. from Columbia. It contains a court-house, jail, and district offices, 4 churches, a market-house, 2 academies, several mechanic shops, 21 stores of various deseriptions, and about 1,200 inhabitants. Two newspapers are publisher here, the "Southern Patriot," a tri-weekly, and the "G Mountaineer," a weekly.

Greenville, p. v., and cap. Greene co., Tenn.: about 4 m. N. W. Nolichucky r., and $222 \mathrm{~m}$. E. Nashville. It is pleasantly located on an elevated site, and contains the court-house, jail, etc., and many stores and mechanic shops, and here is published a newspaper, the "G. Spy" (dem.), a weekly issue. Near the $\mathrm{v}$. is Tusculum College, founded in 1843 ; in 1550 it had two professors and 136 students. Pop. about 700

Greesville, p. ve, Augusta con, $7 p^{*} g_{0}:$ on South $F_{*}$, an affluent of $\mathrm{S}$. branch of Shenandoah r., $95 \mathrm{~m}$. W. by $\mathrm{N}$. Richmond. It contains mills, mechanic shops, and factories driven by water-power, several stores, and about 300 inhabitants.

Greenviliz, p. o., Montealm co., Mich, : $46 \mathrm{~m}$. N. W. Lansing.

Greenville, p. v., and cap. Washington co., Miss.: on the E. bank of the Mississippi r., opposite Point Chicot, 91 m. N. W. Jackson. It contains a court-house, etc., and a few dwellings.

Greenwich, t, and p. V., Fairfield $\mathrm{CO}_{*}$, Conn.: the most south-western township in New England, 76 m. S. W. Hartford. Drained by Byram, Maharness, and other rivers, and hounded S. by Long Island Sound. Surface rough and uneven; soil generally fertile and productive. There are three several parishes and as many villages in the tom $n$. The New York and New Haven P. R. passes through it, and there are several good landing-places on the Sound. Many persons doing business in New York eity have their residences in this town, the growth of which has been rapid since the opening of the raitroad. Pop. in 1810, 3,921; in $1850,5,040$.

GREENWICH, t. and p. V., Hampshire co., Mass.: $66 \mathrm{~m}$. W. Boston. Drained by Swift $r$, of the Chicopee, which affords extensive water-power. The t. has some manufactures. The principal $\mathbf{v}$. is located centrally on Swift r., about $3 \mathbf{m}$. S. of Greenwich village. Pop. of $t .838$.

GreEnwror, t. and p. o., Cumberland co., $N$. Jor : $48 \mathrm{~m}$. S. S. W. Trenton. Drained by Newport, Stow, Cohansey, Mill, and Pine Mount creeks. Surface level; soil clay and loam, fertile and well cultivated. Pop. 1,158.

GrefiNwicer, t. and p. o., Washington co., N. Y.: $32 \mathrm{~m}$, N. by E. Albany. Drained by Battenkill and other creeks of Hudson r., which bounds it W. Surface uneven : soil a gravelly loam. There are numerous mills and factories in the t., and a newspaper, the "Union Journal" (whig), is issued weekly. The Champlain Canal passes along the Hudson. Pop. 3,803.

GREEN WICH, t. and p. V., Huron co., Ohio: $76 \mathrm{~m}$. N. N. E Columbus. Drained by branches of Vermillion r. Surface diversified; soils deep and fertile. The $\mathrm{v}$. is on the line of the Cleveland, Columbus, and Cincinnati R. R., $54 \mathrm{~m}$. from Cleveland, and is a place of considerable business. In the t, there are numerous mills and several manufacturing establishments, and 1,050 inhabitants.

Greenwich Village, p. V., Hampshire co., Mass, : on Swift r., $66 \mathrm{~m}$. W. Boston. It has some manufactures.

Grearwood, p. v., Johnson co., Ind.; on the line of the Madison and Indianapolis R. R., $10 \mathrm{~m}$. S. Indianapolis. The $\mathbf{v}$. contains several stores and about 350 inhabitants.

Greexwood, p. v., Marquette co., Wisc. : $61 \mathrm{~m}$. N. by E. Madison. 
GraeNwood, p. v., Caddo par., La.: 212 m. N. W. Baton Rouge.

Greenwood, p. v., De Kalb co, Ala.: $152 \mathrm{~m}$. N. by E. Montgomery.

GREENWOOD, t. and p. v., Oxford county, Me.: $46 \mathrm{~m}$. W. Augusta. Drained by ponds which are the sourees of Little Androseoggin r. The r., a small agricultural settlement, is situate in the S. part of the t. Agriculture, for which the soils are well adapted, is the chief employment of the inhabitants. Pop. 1,118.

GrEeN WOOD, p. o., Doddridge co., Virg.: 209 m. N. W. Riclimond.

Greenwood, p. v., Carroll co., Afiss.: $84 \mathrm{~m}$. N. by E. Jackson.

GReENw00D, p. v., McHenry co., $\pi l$. : $182 \mathrm{~m}$. N. by E. Springfield.

Greenwood, t. and p. o. Steuben co., $N . Y_{\text {.: }} 198 \mathrm{~m}$. W. by S. Albany. Drained by Bennett's and other creeks of Canisteo r. Surface hilly and fine for grazing. Pop. 1,155 .

Greenwood, p. v., Sumner co., Tenn.: $31 \mathrm{~m}$. N. by E Nashville.

Greenwood, t. and p. o., Columbia co., Penn.: $63 \mathrm{~m}$. N. N. E. Harrisburg. Drained by tributaries of Fishing cr. Surface diversified; soil good for grass and grain. There are several mills and factories in the t., and 1,326 inhabitauts.

GreENWOOD, p. V., Jackson co., F'lor.: 63 m. W. N. W. Tallahassee.

GreeNwOOD, p. v., Abbeville dist., S. Car.: 71 m. W.N. W. Columbia, or, by route of Greenville and Columbia $R$. R., $85 \mathrm{~m}$. from Columbia.

Greenw00D, v., Laurens disto, S. Car.: $77 \mathrm{~m} . \mathrm{N}$. W Columbia.

Greenwoon, p. v., Union county, Ga.: $142 \mathrm{~m}$. N. by W.

Milledgeville.

Greenwood Fursace, p. o., Huntingdon co., Penn. : 66 m. W. Harrisburg.

Gregory's Mill, p. o, Granville co, $N_{0}$. Car。: 49 m. N. Raleigh.

Greigsville, p. v., Livingston co., $N . Y$. : on the W. side of Genesee r., and on the line of the Genesee Valley Canal, $204 \mathrm{~m}$. W. by N. Albany.

Greigsville, p. v., Preston co., Virg.: $1 S 7$ m. N. W. Richmond.

GrenADA, $p, Y$, Yallabusha co, Afiss: on the $\mathrm{S}$, side of Yallabusha r., $100 \mathrm{~m}$. N. by E. Jackson. It is the seat of a United States Land Office, and has a newspaper, the " $G$. Republican" (whig), a weekly issue, Pop. about 400.

GLEY Rock, p. o., Hartford co., Md

Greysville, p. v., Sullivan co., Ind.: 84 m. W. S. W. Indianapolis.

Griffin, p. v., Pike county, Ga.: 63 m. W. N. W Milledgeville. It is situate on the Macon and Western $P$. R. $5 \mathrm{~s}$. from Macon, and $43 \mathrm{~m}$. from Atlanta. This rillage has become a point of much commerce, and is one of the most important railroad stations in the State.

GRIFFIN's p. O., Johnson county, Ark. : 86 W. N. W. Little Rock.

Griffinsedrgm, p. v., Culpepper co., Firg.: on a branch of Rappahannock r., $76 \mathrm{~m}$. X. V. T. Richmond.

Griffix's Creek, p. o., Benton co., Ala.: 94 m. N. by E. Montgomery.

Grifris's Mrlls, p. v., Erie co., $N$. $\Gamma_{\text {; ; }}$ on Cazenove cr., $246 \mathrm{~m}$. W. Albany. It has several saw and other mills, stores, etc., and about 30 dwellings.

Grifrin's Milis, p. o., Lowndes co., Ga.: $157 \mathrm{~m}$. S.

Milledgeville.

Griffitu's, p. 0., Nicholas co., Ky.: 53 m. E. Frankfort.

Griffitistille, p. v., Cabell co., Firg.: $24 \mathrm{~S}$ m. W. N. W. Fichmond.

Griggstows, p. F., Somerset co., $N_{0}$. Jer.: on the E. side of Millstone $\mathrm{r}, 28 \mathrm{~m}$. N. by E. Trenton. The Delaware 266 and Raritan Canal passes through it. It is a small $\mathrm{v}$. of some 12 or 15 dwellings.

Griggsville, p. v., Pike co., $I l l .: 58 \mathrm{~m}$. W. by S. Springfield. It is situate on the margin of a large undulating prairie, about $6 \mathrm{~m}$. W. of Naples, on the Illinois river.

Grnirs county, Tex. Situate E. centrally, and contains $1,288 \mathrm{sq} . \mathrm{m}$. Drained in the W. by affluents of Navasoto $\mathrm{r}$. which forms its W. boundary, and empties into the Brazos, which bounds it $\mathrm{S}$. W.; in the E. and S. by branches of the Trinity and head streams of the San Jacinto, both which empty into Galveston Bay. Surface in the N. hilly, but elsewhere undulating or level, with small prairies; soil of the bottoms a deep, rich, black mold of inexhaustible fertility-on the high land thin, and in the prairies af fords excellent grazing. On the streams are immense forests of valuable timber-pine in the W., oak, cedar, and ash in the E. Sulphur springs and iron ore are found. Farms 217; manuf. 0 ; dwell. 405, and pop.-wh. 12,328, fr. col. 0, sl. 1,680 - total 14,008, Capital: Anderson.

Grimesville, p. v., Grimes co., Tex.: 112 m. E. N. E. Austin City.

Grimville, p. v., Berks co., Penn. : 66 m. E. Harrisburg. Grindstone, p. o., Daviess county, Mo.: $142 \mathrm{~m}$. N. W. Jefferson City.

Grindstone Porvt, p. v., De Kalb co., Mo.: on Grindstone cr., $144 \mathrm{~m}$. N. W. Jefferson City.

Griswold, t. and p. o., New London co., Conn.: $39 \mathrm{~m}$. E. by S. Hartford. Drained by Pachaug r. and other streams tributaries of Quinebaug r. Jewett City, a place of considerable manufactures, is situate at the confluence of the Pachaug, and is intersected by the Norwich and Worcester R. R. The water-power of these streams is immense. Pop. of t. 2,065.

GRIswoLD, p. v., Hamilton county, $I U .: 138$ m. S. S. E. Springfield.

GRISWOLD's MrLis, p. o, Washington eo., N. Y.: $53 \mathrm{~m}$

\section{N. by E. Albany.}

Griswoldsyille, p. v., Jones co., Ga.: on the Central R. R., 24 m. S. W. Milledgeville.

Griswoldsville, p. V., Franklin county, Mass.: $77 \mathrm{~m}$.

W. by N. Boston.

Grogansville, p. v., Rockingham co, $N$. Car.: $89 \mathrm{~m}$. W. N.W. Raleigh

Groom's Corner, p. o., Saratoga co, $N$. $Y$.

Grooverville, p. v., Thomas co., Ga.: about $3 \mathrm{~m}$. W. of Ocilla r., $176 \mathrm{~m}$. S. S. W. Milledgeville.

Grosse Isle, p. o., Wayne county, Mich.: 80 m. S. E. Lansing. Grosse Isle, the largest island of Detroit Strait, is situate at its mouth and extends up the strait, interlocking with Fighting Island. It is $8 \mathrm{~m}$. long and from 1 to 2 broad, with a surface of about $12 \mathrm{sq} . \mathrm{m}$. It constitutes the t. of Monguagon.

Gross Tete, p. o., Iberville par., $L a$ : 36 m. S. Baton Rouge.

Grotow, t, and p. o., New London $\mathrm{co}_{0}$, Conn.: $39 \mathrm{~m}$. S. E. Hartford. It occupies a peninsula jutting toward Long Island Sound, and bounded E. by Mystic r, and W. by Thames r. It has a good harbor on Mystic r., and some whaling and other shipping is owned here. The New London and Stonington R. R, passes through the t. Surface hilly and rocky; soil indifferent, except along the Thames. There are several villages in the $t$. : Groton Bank, opposite New London; Portersville, on the Mystic ; Paguonuek, and Groton Centre. Old Fort Griswold, one of the fortiflcations of New London Harbor, is on Groton Heights, A monument is here erected to the memory of the defenders of New London, who fell in the attack of Arnold on that place in 1781. Pop. of t. 3,742.

Groton, to and p. v., Middlesex co., Mass.: 31 m. N. W. Boston. Drained by Nashua and Squanecook rivers, and it has a number of beautiful ponds. Surface diversiflel ; soils of extraordinary fertility. Groton is a t. of great wealth, and is the regidence of many of the first families of 
the State. At Groton Junction no less than six railroads form a union, diverging in every direction. Here are immense depots, warehouses, etc., and a considerable v. Groton Centre is about $3 \mathrm{~m}$. N. of this $\mathrm{r}$. The t. has considerable manufactures, mechanic and machine shops. Its population has greatly increased of late years: in 1540 it was 2,139 , and in $1850,2.515$.

Groton, L. and p. Y., Grafton county, N. Iramp. : $39 \mathrm{~m}$. N. N. W. Concord. Drained by Baker's r.; and it has several ponds. The river affords water-power. Surface diversiffed: soil fertile. There is a small $v$, in the $t$., and it has some small manufactures, but the people are chiefly agriculturists. Pop. of t. 776 .

Grotos, t. and p. v., Tompkins co., N. Y.: $129 \mathrm{~m}$. W. Albany. Drained by Fall and other creeks. Surface undulating; soil, gravelly loam, and fertile. The v., on a creek of Owasco Lake, contains several mills and manufacturing establishments, and has about 400 inhabitants. Pop. of $t .3,243$.

Grotox, p. o., Huron co., Ohio.

Grotos, t. and p. v., Caledonia county, Term. : $16 \mathrm{~m}$. E. Montpelier. Drained by Wills $r$. and its affluents. There are several large ponds in the t., at the outlets of which are fine mill-sites. Surface uneven; soil various, but generally good for grass. The v. is on Wills r., and has several mills. Pop. 595.

Groton Citr, p. v., Tompkins county, $N . Y .: 182 \mathrm{~m}$. W. Albany.

Grouse, p. O., Kane county, $I l l_{0}$ : on Sugar cr., $147 \mathrm{~m}$. N. N. E. Springfield.

Grout's ConNers, p. o., Franklin county, Mrass, : $75 \mathrm{~m}$. W. N. W. Boston. The Vermont and Massachusetts R.R. has a station here, and at this point forms a junction with the Brattleboro' Branch R. R., which diverges north, and the Amherst and Belchertown R. R., which goes south. There is a small $v$, here, with a tavern, ete.

Grove, p. o., Chatham co., N. Car.; $22 \mathrm{~m}$. W. Raleigh. Groye, t. and p. o., Alleghany co., N. Y.: $206 \mathrm{~m}$. W Albany. Drained by Cashaque and Canaseraga creeks Surface undulating; soil sandy loam. Pop. 1,154.

Grove CreEk, p. o., Jones co., I $a_{.}$: on a creek of Makoqueta r. so called, $44 \mathrm{~m}$. N. by E. Iowa City.

Grove Fars, p. o., Henderson co., Ill.: $98 \mathrm{~m}$. N. W. Springfield.

Grove Hili, p. o., Clark co., Ala.: 10 s. W. S. W. Montgomery.

Grove Hill, p. o., Warren co., $N$. Car.: on the N. side of Fishing cr., $47 \mathrm{~m}$. N. N. E. Raleigh.

Grove Hill, p. o., Page county, Virg.: $93 \mathrm{~m}$. N. W. Richmond.

Grove HiLl, p. o., Jackson parish, $L a_{0}$ : $152 \mathrm{~m} . \mathrm{N}$. W. Baton Rouge.

Groveland, p. v., Tazewell county, Ill.: $56 \mathrm{~m} . \mathrm{N}$. Springfield.

Groyeland, p. o., Essex co., Mrass.

Groteland, t. and p. O., Oakland co., Mich.: $67 \mathrm{~m} . \mathrm{E}$ Lansing. Drained by affluents of Clinton river. Surface mostly level. Timber is very abundant. Pop. 989.

Groveland, t. and p. vo, Livingston co., N. Y.: $201 \mathrm{~m}$. W. by N. Albany. Conesus Lake lies on the N. E. corner. Drained by Canaseraga cr. of Genesee r. Surface elevated and ridgy; soil, sand and clay loam. The Genesee Valley Canal passes through this to to Danville. Pop. 1,724.

Grovelard, p. o., Fulton county, Ohio: $127 \mathrm{~m}$. N. W. Columbus.

Groveland, p. v., Winnebago co, Wisc.: 91 m. N. N. E. Madison.

Groveland Centre, p. o., Livingston co., N. Y.: $204 \mathrm{~m}$. W. Albany:

Grove Level, p. o., Franklin county, Ga.: $98 \mathrm{~m} . \mathrm{N}$. Milledgeville,

Grore Mlodst, p. o., Dyer county, Tenn.: $151 \mathrm{~m} . \mathrm{W}$. Nashville.
Grovenor's Corners, p. o., Schoharie co., N. Y Grove Port, p. o., Franklin co., Ohio.

Grove's, p. o., Rush county, Ind.: $42 \mathrm{~m}$. E. by $\mathrm{S}$. Indianapolis.

Grovetor, p. v., Prince William co., Virg. : S5̆ m. N. Richmond.

Groveville, p. v., Mereer co., N. Jer.

GrubB's Mrlus, p. o., Putnam co., Ind. : $40 \mathrm{~m}$. W. by $\mathrm{S}$

Indianapolis.

Grub SPewass, p. o., Monroe co., Miss. 147 m. N. E. Jackson.

Grundy county, $I$. Situate N. E., and contains 324 sq. $m$. The Illinois $r$ divides the county, running from $\mathrm{E}$ to W.; the junction of Des Plaines and Kankakee rivers, which form it, being on its E. border. Surface undulating and prairie land; soils rich, without much timber. Waterpower abundant, and coal is found. Sulphur springs exist in S. part. Farms 217 ; manuf. 0; dwell. 543, and pop.wh. 3,021, fr. col. 2-total 3,023, Capital: Morris, Putzlic Works: Illinois and Michigan Canal; Chicago and Rock Island R. R.; Chicago and Mississippi R. R.

Grundy county, Ia. Situate centrally, and contains 504 sq. m. Drained by Black Hawk cr, and other affiuents of Cedar $r$. which empties into the Iowa and Mississippi. Surface generally rolling, and soil productive, with some good timber. Unorganized in 1550.

Grundy county, Mo. Situate N., and contains $451 \mathrm{sq} . \mathrm{m}$. Drained by E. fork of Grand r., Waldon r., and other affluents of Grand r., a branch of the Missouri. Surface mostly even, and soil rich prairie or good pasture ground. Farms 255 ; manuf. 5 ; dwell. 477 , and pop.-wh. 2,756 , fr. col. 1 , sl, 149-total 2,906. Capital: Trenton.

GUADALUPE county, Texo. Situate S, centrally, and contains $912 \mathrm{sq}$. m. Drained by Guadalupe r., which divides it about equally, and is a large and important stream; in the N. E. by San Mareo r., its N. E. boundary, and in the S. W. by Cibolo r., its S. W. boundary. Surface broken in the W., but generally a rolling prairie; soil on the rivers, the characteristic black mold of the region, inexhaustible in its fertility; between them sand is mixed with it, but it is very productive. Cotton and the grains are abundantly produced; sugar-cane is also cultivated. Iron ore abounds in N. and W., and deposites of lime, or chalk-beds, are near the streams. Sulphur springs are in the S., and the streams are bordered with heavy timber. Farms 101 manuf. 3 ; dwell. 216 , and pop.-wh. 1,171, fr. col. 5, sl. 335 -total 1,511. Capital: Seguin.

Guadalcre,p. v., Vietoria co., Tex..: on the Guadalupe river, $122 \mathrm{~m}$. S. S. E. Austin City.

GUADALUPE mountains, Tex.: a long range of hills lying between the Rio Puerco, or Pecos, and the heads of the Red, Brazos, Guadalupe, and Colorado rivers, which have their sources from its $\mathrm{E}$. slope. These mountains abound in minerals, as iron, gold, silver, and others, and are clothed in immense forests of the finest timber.

Guadalupe river, Texo: : one of the large rivers of the State, rising under the name of Gonzales $r$, from the $\mathrm{E}$ slope of the Guadalupe Mountains. It is noted for its singular blue color, but the water when placed in a glass appears quite limpid and pure. Its principal tributaries are the San Marco (a large stream), Peach and Sandy creeks. Its navigation is interrupted by a reef at its mouth. It falls into Esperitu Santo Bay.

Guernsey county, Otio. Situate E. centrally, and contains $656 \mathrm{sq}$. m. Drained by Wills cr. and branches of Muskingum r. Surface hilly, and soils moderately fertile. The cultivation of the grape has been successful on the slopes of its hills, which also afford fine pasturage as well as numerous water privileges. Bituminous coal is dug largely, and tobacco much cultivated. Farms 2.209; manuf 78 ; dwell. 5,079, and pop.-wh. 30,273 , fr. col. 165-total 80,438. Capital: Cambridge, Public Works: the Cincinnati and Wheeling R. R. 
Guest Station, p. o., Russell co., Virg. : 282 m.W. S.W. Richmond.

GuILDERLAND, t. and p. o., Albany county, N. Y.: $9 \mathrm{~m}$. W. N. W. Albany. Drained by Norman's Kill. Surface level; soil of average fertility. There are several mills and factories in the t., but agriculture is the chief occupation. Pop. 3,279

Githderlayd Cextre, p. o., Albany co., N. Y.: $12 \mathrm{~m}$. W. N. W. Albany.

Grildhald, to, p. v., and eap. Essex co., Term.: on the W. side of Connecticut r., 50 m. E. N. E. Montpelier. Two bridges here span the $r$. Several small streams, on which are mill-sites, drain the land. Surface, except near the river, uneven and rough. The v. on the Connecticut contains a court-house, jail, etc., and a number of substantia dwellings. The $t$, is essentially agricultural, and contains 501 inhabitants.

Gutlford county, N. Car. Situate N. in W. part, and contains $603 \mathrm{sq} . \mathrm{m}$. Drained by the heads of Haw and Deep rivers, by whose union Cape Fear $r$. is formed. Surface elevated and broken, with many mill streams; soils generally productive, adapted to grazing, and the culture of grain and cotton. Farms 1,658; manuf. 55; dwell. 3.045, and pop.-wh. 15,874, fr. col. 694, sl. 3,186-total 19,754. Capital: Greensboro. Pullic Works: N. Carolina P. F.

Gutlford, t. and p. v., New Haven co., Conn. : $36 \mathrm{~m}$. S. Hartford. Drained by Menunkatuc and other streams running to Long Island Sound, which faces its S. shore. Surface diversified; soil rich and fertile, being well cultivated. The borough of Guilford, incorporated in 1515 , is located about $2 \mathrm{~m}$. from the Sound, on an allurial plain, and near the Menunkatuc; its buildings are antiquated in appearance. Guilford Harbor is frequented by coasting and fishing vesscls. This $t$, is much frequented for sea bathing, for which it has good accommodations, and the seenery in the vicinity of Sachem's Head is wild and picturesque. Several manufactures are carried on in the t., but the people are generally employed in the fields or on the water. Pop. 2,650. The New Haven and New London R. R. passes through the E. part of the town.

Guilford, t. and p. v., Piseataquis co., Mfe.: 67 m. N. N. E. Augusta. Drained by affluents of Piscataquis $r$., which passes through its S. territory. Surface diversified; soil of excellent fertility. The $\mathrm{v}$. is pleasantly sited on the $\mathrm{N}$. side of Piscataquis r., and has several mills, ete. Pop. 834.

Geilford, t, and p. v, Chenango county, $N . Y: 87 \mathrm{~m}$. W. S. W. Albany. Drained by creeks of Unadilla $r$, which makes its E. boundary. Surface hilly and broken; soil, clay loam, and fertile. The $v$, contains several stores, and about 250 inhabitants; and in the t. there are several tanneries and numerous large mills. Pop. 2,612.

GuILFORD, t. and p. v., Medina co., Otio: $94 \mathrm{~m}$. N. E. by N. Columbus. Drained by Chippewa $\mathrm{r}$, and its branches, Surface diversified; soil deep and fertile, adapted to grain and grazing. The r. of Serille, at which the p. 1) is kept, is a flourishing place, with several mills, stores, ete., and about 600 inhabitants. Pop. of t. 1,807.

Gutlford, t. and p. v., Windham co, Verm.: $108 \mathrm{~m}$. S. by E. Montpelier. Drained by Green $r$. and several af fuents of Connecticut $\mathbf{r}$, which afford water-power. Surface diversifict: soil the hest. There is a mineral spring in this to, and also several mineral deposits. The principal v. is located centrally, and there is another flouring $v$. on Broad r. Guilford has several manufacturing establishments and 1.399 inhabitants.

Gritronen, n. Y.. Dearhorn co., Ind.: on the line of the Lawrenceburg and Lpper Mississippi R. R., $76 \mathrm{~m} . \mathrm{S} . \mathrm{E}$ Incianapolis.

Grrurord, p. v., Accomack co., Virg. : 112 m. E. by N. Richmond.

Gtruford Cextre, p. v., Chenango co., $N_{0}, Y_{0}: 89 \mathrm{~m}$. W. S. W. Albany.

Guilford Cextre, p. o., Windham co., Term. 265
Guinex's, sta, and p. o., Caroline co, Virg.: on the line of the Richmond, Frederick, and Potomac R. R., $12 \mathrm{~m}$. $\mathrm{s}$. of Fredericksburg and $4 \mathrm{~S} \mathrm{~m}$. N. of Richmond.

Gutonsvilue, p. v., Dearborn county, Ind.: 73 m. S. E. Indianapolis.

Gelf Mruxs, p. o., Montgomery co., Penn.: 88 m. E. Harrisburg.

Gulf Pratrie, p. v., Brazoria co., Tex.: 174 m. S. E Austin City.

Gulistan, p. o., Davidson co., Tenn.

GULley's Store, p. o., Johnson con, N. Car.

Gumborotgh, p. o., Sussex co., Del.: 42 m. S. Dover.

GUM Branch, p. 0, Darlington district, S. Car.: $7 \mathrm{~S}$ m.

E. N. E. Columbia.

GUM Creek, p. o., Dooley co., Ga. : on a cr. of Flint r. so called, $93 \mathrm{~m}$. S.W. Milledgerille.

Gux Grove, p. o., Union county, $K y .: 173 \mathrm{~m}$. W. by $\mathrm{s}$. Frankfort.

GoY LAKE, p. 0., Barry county, Mfich.: 40 m. W. S. W. Lansiug.

Gux Poxp, p. o, Baker county, Ga.: $14 \mathrm{~m}$. s. W. Milledgeville.

Guxr Spring, p. o., Louisa county, Virg.: $38 \mathrm{~m} . \mathrm{N}$. W. Richmond.

Gum Spring, p. 0., Smith county, Tex. : 218 m. N. E Austin City.

Gey Swass, p. o., Columbus co., N. Car.: on a er. of Lumber r, $112 \mathrm{~m}$. S. Raleigh.

Gux Sw AMP, p. 0., Marion dist., S.Car. : 66 m. N.W. by N. Columbia.

Gcy Tree, p. o., Chester county, Penn. : 61 m. E. S. E. Harrisburg.

GUNTER's Landing, p. v., Marshall co., Ala. : on the $\mathrm{S}$. side of Tennessee r., at its most southerly bend, $128 \mathrm{~m}$. N. Montgomery. It is one of the most inmportant points in the railroad system of the State, and here will terminate the Selma and Tennessee Piver R. P., and through it a general connection will be made with the railroads of Georgia and Alabama, and the North-west. At present it is a well known steamboat landing, and is connected with all the principal towns by lines of stages.

Guspavus, to and p. v., Trumbull co., Ohio: $157 \mathrm{~m}$. N. E Columbus. Drained by Pymatuning cr. of the Shenango Surface undulating; soil of excellent quality. The $\mathrm{v}$. is a flourishing agricultural settlement. Pop. 1,227.

Gustarts, p. o., Greene co., Tenn. : on the S. side of Lick cr, of Nolichucky r, $212 \mathrm{~m}$. E. Nashville.

Gustine, p. o., Adams county, Ohio: 81 m. S. S. W. Columbus.

Guthrie county, Ia. Situate S. W. centrally, and contains $432 \mathrm{sq}$. m. Drained by Upper Three r. and Raccoon river, branches of the Des Moines, which runs S. E. into the Mississippi. Unorganized in $\mathbf{1 8 5 0}$.

Gctirniesville, p. v., Chester co., Penn. : 59 m. E. S. E. Harrisburg.

Gethriestrlle, p. v., Tork dist., S. Car. : 66 m. N. by W. Columbia. It lies on the route of King's Mountain R. R., $10 \mathrm{~m}$. from Yorkville.

Getrexbtrigh, p. v., Clayton co., Ia : on the W. bank of the Mississippi r., about $\tau \mathrm{m}$. above the mouth of Turkey river, and $77 \mathrm{~m}$. N. by E. Iowa City.

Guraxdotre, p. v. Cabell co., Firg. : on the Ohio r., at the mouth of Guyandotte $r_{0}, 267 \mathrm{~m}$. W. by N. Richmond. It is one of the most important points of steamboat navigation in Western Yirginia, and the great stage route to Winchester commences here, A railroad is also projected to Covington and the east generally. It contains several extensive stores, various mechanic shops, and about 800 inhabitants. In the vicinity are found many relies of a former race of inhahitants, as bones, arrows, stone-axes, etc.

GUYANDOTTE river, Firg. : a large tributary of the Ohio, from Virginia, It rises in Wyoming co. from the Great Flat Top Nountain, and flowing in a N. N. W. direction, 
passes through Logan and Cabell counties into the Ohio $r$., $17 \mathrm{~m}$. above the mouth of Big sandy $\mathrm{r}$. It is about $200 \mathrm{~m}$. long. There are falls and rapids in this river, which furnish extensive water-power.

Guy's Mulus, p. o., Crawford co., Penn. : 208 m. N. W. Harrisburg.

GUYSvilte, p. v., Athens co., Orio: on the N. bank of Hockhocking r., $73 \mathrm{~m}$. S. E. Columbus.

GWYNNed, t. and p. 0., Montgomery co, Penn. : 86 m. E. Harrisburg. Drained by Wissahickon and Towamensing creeks, which afford mill-sites. Surface rolling; soil sandy loam. It has several mills and stores, and 1,571 inhabitants.

Girtwete county, Ga, Situate N. centrally, and contains $541 \mathrm{sq}$. m. Drained by branches of Chattahoochee $\mathrm{r}$. its N. W. boundary, which runs $\mathbf{8}$. W. into Appalachicola Bay, and by Yellow r. and other heads of Ocmulgee and Oconee rivers, which run S. E. into the Atlantic. Surface elevated and mountainous, being the watershed between the Gulf and the Atlantic. Soils good on the streams, and productive of wheat, corn, and cotton. Farms 1,036; manuf. 26 ; dwell. 1,610, and pop.-wh. 8,953, fr. col. 10, sl. 2,291-total 11,257. Capital: Lawrenceville.

Grpsum, p. o., Ontario county, $N . Y .: 178 \mathrm{~m}$. W. by N. Albany.

\section{H.}

Haberstram county, $G a$, Situate N. E., and contains 771 Bq. m. Drained N. E. by Savannah $r$. W. by Chattahoochee r. and its branches. Surface elevated and mountainous, with mill-streams, good pasturage, and considerable timber. Soils in lower parts very good; in higher, untillable; wheat and corn are the farming staples. This is in the mineral region, and the hills are rich in coal and iron, and gold is found. Farms 732; manuf. 5; dwell. 1,38s, and pop.-wh. 7,575, fr. col. 2, sl.1,218-total 8,895. Capital: Clarkesville.

Ha вolocartro, p. o., Hancock co., Miss. : 122 m. S. S. E. Jackson.

HACEENSACK, p. $\mathbf{v}$., and cap. Bergen co., N.Jer.: on the W. side of Hackensack r., $76 \mathrm{~m}$. N. E. Trenton, and $11 \mathrm{~m}$. N. by W. New York City. It contains a court-house and co. office, both of brick, 3 churches, 12 or 15 stores, and about 1, 1000 inhabitants. The $r$. is navigable for sloops up to this point, and the $\mathrm{v}$. has considerable trade with New York.

Hackersack, t, Bergen county, $N$. Jer.: 78 m. N. E. Trenton. It lies between Hudson and Hackensack rivers, and is a rich agricultural town, and has several manufactures. Pop. 3,456 .

Hackensack river, $\boldsymbol{N}$. Jer. : rises in Pockland Lake, and has a course of about $40 \mathrm{~m}$. to Newark Bay. In its upper course it is a fine mill-stream; at Hackensack $v$. it meets the tide, and thence flows through a level marsh to its confluence.

Hacketrstown, p. v., Warren county, $N$. Jer.: on the W. side of Musconetcong r., $44 \mathrm{~m}$. N. Trenton. The Morris Canal passes it a little to the W. It contains several mills and stores, and about 400 inhabitants.

Hackres's Cross Roads, p. o., Chatham co., N. Car.: $24 \mathrm{~m}$. W. Raleigh.

HADDAM, t, p. v., and one of the capitals of Middlesex co., Conn.: 23 m. S. by E. Hartford. Drained chiefly by streams flowing into the Connecticut $\mathbf{r}_{*}$, which makes its $\mathrm{E}$. boundary. Surface uneven and rough; the lands on the river, however, are smooth and fertile, though not altogether alluvial. Soils generally gravelly loam. There are immense quarries of freestone in the town, and large quantities are annually exported. The $\mathrm{v}$. contains a court-house, jail, ete. Pop. of t. 2,284.

HAddez's PoIrt, p. o., Charleston dist., S. Car.

Haddock's, p. o., Nassau county, Flor. : 172 m. E. by N. Tallahassee.
HaDdonfexted, p. V., Camden co., N. Jer.: on the S. of Cooper's er., 28 m. $\mathbf{S}$. $\mathbf{S}$. W. Trenton. It contains several mills, etc., and about 400 inhabitants.

HADEN's, p. o., Madison county, Ala.: $153 \mathrm{~m} . \mathrm{N}$. Montgomery.

HADENsville, p. v., Todd county, $K y .: 168$ m. S. W. Frankfort.

Hadensvilue, p. v., Goochland co, Firg. : 31 m. W. N.W. Richmond.

Hadley, t. and n. 0., Lapeer co., Mich.: 46 m. E. by N. Lansing. Drained by the heads of Farmer's cr. of Flint $r$. which rise from many small lakes and ponds. Surface generally level, but varied; soil, deep and rich vegetable mold. There are numerous water-mills in the town, and several stores. Pop. 846.

Hadlex, p. v., Will co., $I l_{\text {. : }} 148$ m. N. E. Springfield.

HAdlex, t. and p. v., Hampshire co, Mass. : 77 m. W. Boston. The Connecticut $r$. runs on its W. border, and is the recipient of two small mill-streams. It is connected with Northampton by a bridge 1,080 feet long. Hadley contains a large and fertile tract of alluvial meadow-in the E. part the land is elevated, and on the $\mathbf{S}$. border is Holyoke range. Tobacco and broom-corn are extensively grown. The v, is built on two parallel streets extending across a peninsula, formed by an abrupt bend of the river, and called respectively East and West Street-each about a mile long, and each having a separate Congregational church. Hopkins Academy, an old, well endowed, and flourishing institution, is situate between the two streets. Hadley has several manufactures, but is most celebrated for its manufacture of brooms, which are made by every farmer. Pop. of t. 1,986. Hadley was a retreat of the celebrated Gofie and Whalley, two of the judges who condemned Charles I. : they remained in seclusion bere for more than 15 years, when Whalley died; Goffe died and was buried in New Haven sereral years after.

HADLeY, t. and p. o., Saratoga co., N. Y.: $44 \mathrm{~m} . \mathrm{N}$. by W. Albany. Drained by Sacandaga $r$, which here enters the Hudson r., which latter makes its $\mathrm{E}$. boundary. Surface hilly; soil in general fertile-some only fit for grass. Hadley Falls, on the Hudson, a little above the confluence of the Sacandaga, afford extensive water-power. Timber is abundant, and in the t. there are numerous saw-mills, and there are also grist and other mills in operation. Pop. 1,012.

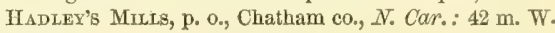
Raleigh.

Haderme, p. v., New London co, Conn.: on the E. side of Connecticut ro, $29 \mathrm{~m}$. S. S. E. Hartford. It has some manufactures.

HADNoT's, p. o., Carteret county, N. Car.: $122 \mathrm{~m}$. S. E. Raleigh.

HAErLem, p. v., New York co., $N . Y_{*}$ : on a plain on the S. side of Haerlem r, $\tau \frac{1}{2}$ m. N. N. E. City Hall. It forms a part of the twelfth ward of the City of New York, and is connected therewith by the Haerlem R. R. and several lines of stages. It has numerous and extensive manufacturing establishments, stores, and mechanic shops, and within the village, on the avenues leading to it, or in its vicinity, are many elegant residences, chiefly occupied by persons doing business in the city. On the opposite side of the river are several new suburban villages, which are rapidly filling up. Hagaman's Mrlls, p. v., Montgomery co, $N_{0} . Y_{.}: 32 \mathrm{~m}$. W. N. W. Albany. Here are several mills, and about 200 inhabitants.

HAGeR's Grove, p. o, Shelby county, BLo.: $87 \mathrm{~m} . \mathrm{N}$. Jefferson City.

Hagerstown, p. v., Wayne co., Ind.: on the W. side of the West Fork of White Water river, $52 \mathrm{~m}$. E. by $\mathrm{N}$. Indianapolis. It is a thriving $\mathrm{r}$. of 500 or $6: 0$ inhabitants. The White Water Canal has its $\mathbf{N}$. terminus here, and the village is also interseeted by the Richmond and Neweastle R. R.

Hagerstown, p. Y., and cap. Washington co., $M \alpha$ : : on 
the W. side of Antietam cr., $22 \mathrm{~m}$. above its confluence with the Potomac, and. $87 \mathrm{~m}$. W. N. W. Annapolis, Lat. $39037^{\prime} \mathrm{N}$., and long. $77^{\circ} 35^{\prime} \mathrm{W}$. The $\mathrm{v}$. is located in a fine and flourishing agricultural district, of which it is the centre, and is connected by the Franklin R. R. with the railroads of Pennsylvania. It is well built, with regular and wide streets, and contains a number of substantial public edifices, a court-house, jail, town hall, etc. It has seven newspapers, the "H. News" (neutral), the "Herald of Freedom" (whig), the "H. Mail" (dem.), the "People's Own" (neutral), the "Torchlight" (whig), the "Republican" (dem.), and the "Casket" (neutral)-all issued weekly. There are two banks in the $\mathrm{v}$. In 1850 it had 3,884 inhabitants, of which 435 were free persons of color and 183 slaves.

Hagerstown, p. v., Preble county, Olio: $84 \mathrm{~m}$. W. Columbus.

Hagerstille, p. v., Bucks county, Penn. : 87 m. E. Harrisburg.

HAGUE, p. v., Logan co., Ky.: 147 m. S. W. Frankfort.

$H_{\triangle G U E}, t$. and p. v., Warren co., N. Y.: $67 \mathrm{~m}$. N. Albany. Drained chiefly into Lake George, which lies on its E. border. Surface somewhat mountainous, and forming fine grazing fields. The v, overlooks Lake George, and is a small agricultural settlement. In the t. there are several saw and grist mills, and 717 inhabitants.

HAGUE, p. v., Westmoreland co., Virg.: 51 m. N. E. Richmond.

Hainesburgh, p. v., Warren co., N.Jer. : 41 m. N. N.W. Trenton.

HaIn Esvillex, p. v., Lake county, $I l l .: 192$ m. N. E. Springfield.

Hainesville, p. v., Clinton county, Mo.: $146 \mathrm{~m}$. N. W. Jefferson City.

Hainestille, p. v., Sussex co., N. Jer.: 62 m. N. by W. Trenton.

HALAWAKA, p. v., Chambers countr, Ala. : on the cr. so called, an affluent of Chattahoochee river, 74 m. E. N. E. Montgomery.

Haloron, p. o., Westmoreland co., Penn.: $147 \mathrm{~m}$. W. Harrisburg.

II ALCYONDALE, p. ve, Scriven co., $G a_{*}$ : on the left bank of the Ogeechee river, $112 \mathrm{~m}$. E. S. E. Milledgeville. The Central (Georgia) R. R. passes through it 50 miles from Savannah.

HAIE, p. o., Ogle co., $m_{0}: 152 \mathrm{~m}, \mathrm{~N}$. Springfield.

$H_{A L E}$ t. and p. o., Hardin county, Ohio: $54 \mathrm{~m} . \mathrm{N}$. W. Columbus. Drained by head streams of Scioto $r$. Surface raried; soil rich and productive. The Mad River and Lake Erie R. R. passes through its N. W. corner. Pop. 428.

HALE's EDDY, p. Y., Broome co., $N . Y_{0}$ : on the Delaware river, $92 \mathrm{~m}$. W. S. W. Albany. By route of the Erie R. R. (on which it has a station), it is distant from New York 182 miles, and from Dunkirk 287 miles.

Hale's Ford, p. O., Franklin co., Firg.: 188 m.W. S. W. Richmond.

Hale's Mrris, p. o., Fentress co., Tenn. : 106 m. E. by N. Nashville.

Halemsburgi, p. v., Lunenburg co., Firg. : 49 m. S. W. Riehmond.

Ifalf Dar, p. 0., Lake county, $1 l_{0}$ : on the W. side of Desplaines r., $185 \mathrm{~m}$. N. E. Springfield.

HALF Moox, t. and p. o., Saratoga co., $N, Y_{0} \cdot 18 \mathrm{~m}, \mathrm{~N}$. Albany. Hudson r. on the $\mathbf{E}$. forms its boundaries in that dircetion. Surface raried; soil sandy loam and clay. It has several mills and mechanic shops, and 10 or 12 stores. The Champlain Canal passes through it, and also the Rensselaer and Saratoga R. R., and the Albany Northern R. R. Pop. 2,78s.

HALF Moon, t. and p. o., Centre county, Penn.: $76 \mathrm{~m}$. W. N. W. Harrisburg, Drained by Bald Eagle cr, and Half Moon r., a branch of Spruce cr. Surface mountainous; soil in the vallers, calcareous losm. It is situate between two ridges of the Alleghanies. Iron ore, etc., is abundant, $2 \pi 0$ and there are several manufactories, mills, etc., in the town Pop. 1,519 .

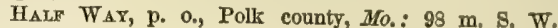
Jefferson City.

HALF-WAY House, p. v., York co., Yirg. : 47 m. E. S. F, Richmond.

HALF-WAY Pratrie, p. o., Monroe co., Ia. : 89 m. W. S. W. Iowa City.

HaLIFAX county, $N$. Car. Situate $N$. E, and contains $545 \mathrm{sq} . \mathrm{m}$. Drained by Roanoke $\mathrm{r}$, which forms its $\mathrm{N}$, and E. boundary, and Fishing cr., a branch of Tar r., which is its $\mathrm{S}$. boundary. The Roanoke is here navigable for large coasters, and makes marketing easy. Surface rolling or hilly. Soil good; in parts very productive. Cotton, corn, and tobacco are the leading crops. Lumber is also exported. Farms 868; manuf. 4; dwell, 1,759, and popwh. 5,763, fr. col. 1,872, sl. 8,954-total 16,589. Capital. Halifax. Public Works: Wilmington and Weldon R. R. Gaston and Raleigh R. R.

HALIFAX county, Firg. Situate on S. line centrally, and contains 765 sq. m. Drained by affluents of Roanoke $r$., which bounds it N. and N. E., and of Dan r., a branch of the Roanoke. Surface diversified with hill and valley, and covered in parts with fine pine timber. Soils generally productive. Tobacco is the staple. Corn and wheat are good crops. Farms 1,309; manuf. 21; dwell. 2,152, and pop.wh. 11,006, fi. col. 504, sl. 14,452-total 25,962. Capital Halifax C. H. Public Works: Richmond and Danville R. R.

HALTAX, t. and p. v., Plymouth co., Mass. : 27 m. S. by E. Boston, Drained by several ponds, the outlets of which afford water-power. Surface generally level; soil of average fertility. The v. is located centrally. Pop. of t. 784 .

Halifax, p. v., port, and cap. Halifax co., $N . C^{2} a r$, : on the left bank of Roanoke $\mathrm{r}_{.,}, \mathrm{m}$. below the great falls, and at the head of sloop navigation, $72 \mathrm{~m}$. N. E. Raleigh. It is laid out with great regularity, and contains a court-house, jail, etc., and is a place of considerable trade. It has a newspaper, the "Roanoke Republican" (whig), a weekly issue. The Wilmington and Weldon $R$. $R$. passes the $v$, and by means of a canal around the falls, the Roanoke is navigable for boats 130 miles above it.

HalfFax, to and p. v., Dauphin co., Penn.: $16 \mathrm{~m} . \mathrm{N}$. Harrisburg, Drained by several creeks which enter the Susquehanna on the W. border of the t. Surface mountainous; soil red shale. The $\mathrm{v}$. is on the $\mathbf{E}$. bank of Susquehanna r., and has about 400 inhabitants. The to has several grist, saw, and flour mills, and tanneries. Pop. 2,822 .

HALTFAx, p. v., and cap. Halifax co., Virg. : on the S. side of Bannister r., $87 \mathrm{~m}$. S. W. Richmond.

Halifax, t. and p. v., Windham co., Verm.: 106 m. S. Montpelier. Drained by Green and North rivers, both fine mill-streams. On a branch of North $r$. is a succession of cascades, extending 100 rods, with falls of 15 to 20 feet each. Surface elevated and uneven; soil fertile and well adapted to grazing. The principal $\mathrm{v}$. is situated toward the south. Pop. of t. 1,133.

Halifax, p. v., Wilson co., Tenn. : 23 m. E. Nashville.

HaLL county, $G a$. Situate N. E., and contains 651 sq. m. Drained by Chattahoochee $r_{\text {., }}$ which intersects the $\mathrm{N}$. half. Surface in the S. E. much broken by a range of hills or Inountains, in the $\mathrm{N}_{\text {. and }} \mathrm{W}$. more even, with some meadows. Soil on the rivers very fertile, yielding good crops of tobacco, whent, and corn; on the higher land is good grazing. It has mineral resources, though but partially dereloped. Farms 697 ; manuf. 0; dwell. 1,300, and pop.wh. 7,570, fr. col. 7, 81. 1,336-total 8,713. Capital : Gainesville.

HALI, p. o. Lawrence county, Mo.: 142 m. s. W. Jefferson City.

Haluetrsville, p. v., Lavacea co., Tex.: 87 m. S. E. Austin City. 
Halloca, p. v., Museogee co., Ga. : 118 m. W. S. W. Milledgeville.

Hallowes, t. and p. v., Kennebec county, $M_{e}: 2 \mathrm{~m}$. S. by W. Augusta, and facing on Kennebec r., which is here narigable. It is a good farming section, and has excellent mill-power. The $t$. lies on the river bank, with which the principal streets run parallel, and these are crossed at right angles by others which rise in grade to 200 feet back. from the stream. The business street on the river has numerous substantial brick warehouses and stores, and many of the dwellings are built with neatness and taste. Fessels drawing 9 feet water come up to the wharves, and regular steamboats ply between this place and Portland and Boston. It has also numerous vessels employed in the coasting trade. The principal exports are lumber, granite, etc.; the granite quarries have been worked for upward of 30 years, and yield a beautiful building stone of a light color and easily wrought. A newspaper, the "H. Gazelte," is issued weekly. Pop. of the t. 4,769. The Kennebec and Portland R. R. passes through the v., and has its present terminus at Augusta.

Hallowell Cross Roads, p. o., Kennebec co., Me.: $4 \mathrm{~m}$. W. by S. Augusta.

Hallsa's CвEkK, p. o., Nodaway co., Mo.: $192 \mathrm{~m}$. N. W. Jefferson City.

Halisborougr, p. V., Powhatan co., Firg.: 35 m. S. W. Frankfort.

Hall's Corners, p. v., Ontario county, $N$. $Y .: 166 \mathrm{~m}$. W. by N. Albany. The Canandaigua and Elmira $R, R$. passes through the v. $53 \mathrm{~m}$. from Elmira and 14 from Canandaigua.

HALL's Cornters, p. o., Allen co., Ind. : 101 m. N. E. Indianapolis.

Hall's Cross Roads, p. o., Harford co., Ma.: $47 \mathrm{~m}$. N. by E. Annapolis.

Hall's CRoss Roads, p. o., Franklin co., $N$. Car: : $37 \mathrm{~m}$. N. E. Raleigh.

IIALL's HiLL, p. O, Rutherford co., Tenn.: 29 m. S. E. Nashville.

Hall's Store, p. o., Sussex co., Del. : 53 m. S. Dover.

HaLL's stream, N. Hamp.: a small r. from the Highlands, forming the boundary between the United States and Canada, and is one of the sources of Connecticut $r$. By the trenty of 1842 , it is made a part of the boundary until it intersects the old line of 1784 , marked as $45^{\circ} \mathrm{N}$. lat, but which is not ascertained to be a little $\mathrm{N}$. of that parallel.

HaLl's Valuex, p. 0. Morgan co., Otio: $67 \mathrm{~m}$. E. by S. Columbus.

Hallsville, p. v., Boone county, Mo. : 31 m. N. N. W. Jefferson City.

Hallyville, p. v., Duplin co., $N$. Car... on the E. bank of North East Cape Fear r., 76 m. S. E. Raleigh.

HalLsville, p. v., Montgomery con, $N_{0} Y_{0}: 54 \mathrm{~m}$. W. N. W. Albany.

Hallsviliz, p. v., Ross county, Ohio: 38 m. S. by E. Columbus.

Halltown, p. V., Jefferson co., Tirg.: on the line of the Winchester and Potomac R. R., $7 \mathrm{~m}$. from Harper's Ferry, and $129 \mathrm{~m}$. N. N. E. Richmond.

Halselifille, p. v., Chester dist., $S$. Car.: $51 \mathrm{~m}$. N. Columbia.

HALSEY's, sta., Campbell co., Firg.: on the line of the Virginia and Tennessee R. R., 5 m. W. Lynchburg.

Halsex Valley, p. o., Tioga co., $N . Y_{.}: 132$ m. W. S. W. Albany.

Hambatgri's, p. o, Warren co., Firg.: 106 m. N. W. Pichmond.

Hamburg, p. V., St. Charles co., Mo.: 86 m. E. by N. Jefferson City.

Hamburg, p. V., Perry co., Ala. : a little to the W. of Cahawba r., $61 \mathrm{~m}$. W. N. W. Montgomery.

Hamburg, p. v., New London co., Conn. : 33 m. S. S. E. Hartford. It has considerable manufactures.
HamberG, p. v., Macon county, Ga.: $81 \mathrm{~m}$. S. W. Milledgeville.

HAMBURG, p. V., Clarke co., Ind. : on a branch of Silver cr., $97 \mathrm{~m}$. S. by E. Indianapolis. The Indianapolis and Madison R. R. passes it about a mile to the E., and the New Albany and Salem R. R. about $2 \mathrm{~m}$. to the W.

Hamburg, p. v., Calhoun $\mathrm{CO}_{*}, \mathrm{Il}$. : on the $\mathrm{E}_{\text {. }}$ side of the Mississippi r., $68 \mathrm{~m}$. S. W. Springfleld. It has a good landing, and contains several industrial establishments, stores, ete., and has a considerable trade. Pop. about 400 .

HАMвURG, p. Y., and cap. Ashley co., Ar7.. : 119 m. S. by E. Little Rock.

HАмвURG, p. F., Franklin co., Mis8, : 74 m. S. W. by $\mathrm{S}$ Jackson.

Hamburg, p. V., Preble county, O7io: 87 m. W. by $\$$ Columbus.

H AMBURG, t. and p. 0., Livingston co., JEch. : $40 \mathrm{~m}$. S. E. Lansing. Drained by numerous lakes and ponds emptying into Huron r. Surface level; soils fertile, but frequently wet. The $\mathrm{v}$. lies on the $\mathrm{S}$, or left side of the Huron. In the t. there are several mills, stores, etc., and 895 inhabitants.

Hamburg, p. Y., Sussex co., $N$. Jer. : near the E. bank of Wallkill r., $67 \mathrm{~m} . \mathrm{N}$. by E. Trenton. It has several mills, and about 200 inhabitants.

Hamburg, t, and p. v., Erie co, $N . \bar{Y}: 257 \mathrm{~m}$. W Albany. Drained by Cauquaga, Rush, and Smokes creeks of Lake Erie, which bounds it on the W. Surface undulating; soil a fertile calcareous loam. Hamburg, Hamburgon-the-Lake, and East Hamburg are villages in this t. It has numerous saw and grist mills, and is a fine agricultural country. On the lake are several convenient harbors for small craft. The Buffalo and State Line (Lake Shore) R. R. passes through it. Pop. of t. 5,219.

Hamburg, p. b., Berks eo., Penn.: near the Schuylkill water-gap of Blue Mountain, 58 m. E. N. E. Harrisburg. It is a place of considerable business, lying on the canal is of the Schuylkill, and having the Reading $R$. $R$. on the opposite side of the stream. Pop. 1,035.

Hamburg, p. v., Hardin county, Tenn.: 113 m. S. TV. Nashville.

II Amburg, v., Frederick co., $M a_{\text {. }}$ : at the base of Catoetin Mountain, $61 \mathrm{~m}$. N. W. Annapolis.

Hamburgh, p. v., Edgefield dist., S. Orr. : on the E. side of the Savannah r., $73 \mathrm{~m}$.W.S.W. Columbia, Augusta, $G u_{\text {. }}$ on the opposite side of the river, is connected by a bridge and viaduct. The South Carolina R. R. and the Georgia R. R. connect here, the one extending to Charleston $135 \mathrm{~m}$. and the other to Atlanta, $171 \mathrm{~m}$, and W. to Montgomery, Ala., and Nashville, Tenn. Regular steamboats also ply on the r. The V. consists of two parts; the lower town lies on the bank of the r., and is the business district, and the upper town stands on a height 60 or 70 feet above and back from the $r$, and has many commanding situations. It is regularly laid out, and contains many large stores and warehouses. It is a great cotton mart, and has a large interior trade; and a weekly newspaper, the "H. Republican" (dem.), is supported. Pop. about 3,000 .

HAMbURgh-oN-THE-LAEE, p. v., Erie co., $N . Y_{.}$: on the E. shore of Lake Erie, $257 \mathrm{~m}$. W. Albany. It is a considerable $v$, of about 300 inhabitants

HampeN, ta aud p. va, New Haven county, Comn. : $33 \mathrm{~m}$. S. S.W. Hartford. Drained by Mill r., which affords waterpower. Surface varies, the t, being located between two ranges of hills terminating at East and West Rocks, in the vicinity of New Haven. There are several villages, chiefly engaged in manufactures, Handen Plains, Centreville, Ives' Mount Carmel, etc., are on the line of the New Haven and Northampton R. R., and Whitneyville is located in the south-east, Pop. of t. 2,16s.

HAMDEN, $t$, and p. v., Delaware county, $N . Y .: 72 \mathrm{~m}$. W. S. W. Albany. Drained by W. branch of Delaware r. Surface mountainous and rugged; soil, except in the valley 
of the Delaware, not very fertile. The village, a small agricultural settlement, lies on the $\mathrm{N}$. bank of the river. The t. has several mills and stores, and 1,919 inhabitants.

Haver, p. v., Mason co., Ky. : 73 m. E. N. E. Frankfort.

Hamke'sviller, p. v., Brown co., Ohio: 84 m. S. S. W. Columbus.

Hamuton county, Flor. Situate N. on Georgia line, and contains $43 \pm$ sq. m. Drained by Allapahaw r., which runs through it; Suwannee r., which is its S. and E., and Withlacoochee r., its W. boundary. Surface low and level. Soll fertile, with some marshes, which favor the growing of rice, which, with cotton and corn, are the chief products. There are mineral springs in the $\mathrm{S}$. frequented by invalids. Farms 205; manuf. 0; dwell. 301, and pop.-wh. 1,775, fr. col. 9, s1. 655-total 2,469. Capital: Jasper.

Hamilton county, $I l l$. Situate S. E., and contains 436 sq. $m$. Drained by $N$. fork of Saline cr, an afflueat of the Ohio. Surface level or moderately elevated; soils of medium fertility, with marshes in parts. Corn, wheat, and oats are good crops ; tobacco is also cultivated. Farms 417 ; manuf. 0; dwell. 1,058, and pop.-wh. 6,310, fr. col. 52-total 6,362. Capital: M'Leansboro'.

HavizToN county, Ind. Situate centrally, and contains 412 sq. m. Drained by White r., a branch of the Wabash, and its afluents Cicero, Stoney, Coal, Fall, and other creeks. Surface level or undulating, and the soil excellent. Most of the co. Was originally heavily timbered. Wheat, corn, and pork are the chief products. Farms 1,261; manuf. 16 ; dwell. 2,159, and pop.-wh. 12,504, fr. col. 180-total 12,684. Capital: Noblesville. Public Works: Indianapolis and Peru R. R.

Havilion county, $\mathcal{N} . \bar{Y}$. Situate N.E., and contains 1,064 sq. m. Drained by Indian $\mathrm{r}_{\text {, }}$ a head, and Sacandaga $r$., a branch of Hudson $r$. on the E.; and W. and S, by Beaver r., emptying into Lake Ontario, and branches of tho Mohawk. Surface elevated and mountainous, sending numerous streams in all directions, and covered mostly with the primitive forests. It has numerous lakes: Long, Beaver, Piseco, Round, and Pleasant lakes are noted for majestic scenery and fine fishing. Around these, and on the streams, the soil is productive; its character is emineutly agricultural. Farms 201 ; manuf. 17 ; dwell. 407, and pop.wh. 2,186, fr. col, 2-total 2,188. Capital: Lake Pleasant. Public Horks: Saratoga and Sackett's Harbor R. R.

Hamilton county, Ohio. Situate in S. W. corner, and contains 404 sq. m. Drained by Mill er., and White Water, Miami, and Little Miami rivers, all affluents of the Ohio, which washes its $\mathrm{S}$. border. Surface made up on the Ohio of a series of terraces extending back for some distance, one above another, with moderate ascents between, and terminating in a beautiful variety of hills and wooded valleys. Soil exceeding productive, and under high cultivation. Wheat and corn are easily and abundantly grown. The culture of the grape is extensive, and has proved very successful, both in quantity and quality, the wines manufactured comparing favorably with those of France. The vineyards are among the most beautiful sights seen on the Ohio. Manufactures of every kind are carried on extensively, and its relations with Cincinnati and the Ohio make it one of the first counties of the State. Farms 2,502; manuf, 1,463; dwell. 21,021, and pop.-wh. 153,423, fr. col. 8,420 -total 156,S43. Capital: Cincinnati. Public Works: Little Miami R. R.; Cincinnati, Hamilton, and Dayton R. R.; Cineinnati, Hillsboro', and Parkersburg R. R.; Cincinnati and Marietta R. R.; Cincinnati, Wilmington, and Zanesville r. R. : Cinciunati and Daston (direct) P. R.; Ohio and Mississippi R. R.; White Water Canal; Miami Canal, etc.

Hanmox county, Tenn. Situate S. E., and contains 615 sq. $m$. The Tennessee intersects it from $\mathrm{N}$. to $\mathrm{S}_{\text {.g }}$ and its affluents, Sauda and Chickamauga creeks and Hiwassee river drain it. Surface in the E. broken or mountainous : in the W. more even. Soils generally fertile, and adapted to grass and the grains. Some cotton is raised, and much 272 pork fatted. Farms 633 ; manuf, 10 ; dwell. 1,590, and pop. —wh. 9,216, fr, col. 157, sl. 672-total 10,075. Capital: Harrison, Public Works: Western and Atlantic R. R.; Nashville and Chattanooga R. R.; and Chattanooga and Charleston R. R.

HAMrLTON, p. V., and cap. Harris co., Ga. : 101 m. W. S.W. Milledgeville. It is situate on the W. extremity of Oak Mountain, and contains a court-house, jail, cte-g several stores, and about 50 dwellings.

Haxmlton, p. v., Mahaska co., $I \alpha$. : on Des Moines r., 62 m. S. W. Iowa City.

HAMLtoN, p. v., Steuben co., Ind. : at the S. end of a small lake emptying into Fish cr. of St. Joseph's r., $186 \mathrm{~m}$. N. N. E. Indianapolis. There are large mills at the outlet of the lake.

Hamilion, p. o, Lafayette county, Wisc.: 51 m. S. W Madison.

Hamitox, p. V., Shelby co., Tex.: on the W. bank of Sabine r., 266 m. E. N. E. Austin.

Hamuton, p. ₹., Boone co., Ky. : 59 m, N. Frankfort.

Hamltow, p. v., and cap. Monroe co., Miss.: above the confluence of the Buttahatchie with Tombigbee r., $139 \mathrm{~m}$. N. E. Jackson.

Hamitow, to and p. o., Van Buren co., Mich.: $64 \mathrm{~m}$. W. S. W. Lansing. Drained by Dowagiac r., on which are extensive marshes. Surface level ; soil fertile. Pop. 372.

Hamoton, t. and p. o., Essex co., Mass. : 19 m. N. N. E. Boston. Drained by a branch of Ipswich river. Surface moderately uneven and diversiffed; soil generally productive. It has some maunfactures, Pop. 859.

Hameton, p. v., Martin co., N. Car.: on the left bank of Roanoke r., $92 \mathrm{~m}$. E. by N. Raleigh.

Hamltos, t. and p. v., Madison co., $N . \boldsymbol{Y}_{.}: 89 \mathrm{~m} . \mathrm{W}$. Albany. Drained by the heads of Chenango r. Surface uneven; soil, a fertile calcareous loam. The v, on Chenango r, contains numerous stores, mechanie shops, etc., and about 1,600 inhabitants. It supports a newspaper, the " $\mathrm{H}$. Reflector" (dem.) issued weekly. It is the seat of Madison University, and the Hamilton Library and Theological Institution, the latter being the original institution, but now a department of the former. It was founded 1819 , and in $1546 \mathrm{re}$ ceived a charter as a university. It is well endowed, and is in a highly prosperous condition. The University in 1850 had 9 professors, 127 students, 200 alumni, and a library of 7,000 volumes; and the Theological Institution had 4 professors, 32 students, and a library of 4,000 volumes. These institutions are both under the Baptists. Pop. of t. 3,599.

Hamrtos, p. v., and cap. Butler co., Ohio: on the E. bank of Great Miami r., $92 \mathrm{~m}$. W. S. W. Columbus, It is connected with Rossville, on the opposite side of the river, by a bridge. The $v$. has a court-house, jail, etc., numerous warehouses, stores, mills, factories, and mechanic shops, and as a commercial and railroad centre is one of the most important places within the State. Here a junction is formed between the several railroads from Indiana and the Cincinnati, Hamilton, and Dayton R. R.; and the Miami Canal passes through it. Pop. 3,207. Two newspapers are published here, the "H. Intelligencer" (whig), and the " $H$. Telegraph" (dem.), both weekly issues.

Havilton, p. v., Loudon co., Virg. : 116 m. N. Richmond. Hamitox Cross Roads, p. o., M'Minn co., Tenn. : 128 m. E. S. E. Nashville.

Hariltox Landing, p. o., Jackson co., Tenn.: $67 \mathrm{~m}$. E. N. E. Nashrille,

Hamiton Square, p. o., Mercer co., $N$. Jer.

Hamiltoxyille, y., Miffin co., Penn. : on the W. bank of Juniata $r_{\text {. }}$,and on the line of the Pennsylvania Canal, 52 m. W. by N. Harrisburg. It contains about 70 dwellings.

HaMLET, p. o. Chautauque county, N. Y.:279 m. W. by S. Albany.

HaxnkT, v, and sta, Providence co., $R . I .:$ on the line of the Providence and Worcester R. R., $15 \mathrm{~m} . \mathrm{N}$. by W. Providence. 
Haymelstow $\mathbf{x}, \mathbf{v}$, and sta., Burlington co., N. Jer. : on the Cumden and Amboy R. R., $68 \mathrm{~m}$. from New York City, and $19 \mathrm{~m}$. from Philadelphia.

MAммоск Grove, p. 0., Crawford co., Ga. : $56 \mathrm{~m}$. W. S.W. Milltedgeville.

HAmond, t. and p. v., St. Lawrence co., $N . Y_{\text {. }}: 154 \mathrm{~m}$. N. W. Albany, Situate between Black Lake and St, Lawrence $r$, and drained by their affluents. In the St. Lawrence, off the shore, are numbers of the Thousand Is!es. Surface generally level; soil a fertile sand and clay. The v. contrins about 200 inhabitants. In the to there are numerous mills and several stores, and 1,819 inhabitants.

Hamuod's, p. o., St. Joseph county, Ind. : $126 \mathrm{~m} . \mathrm{N}$. Indianapolis.

HAurond's Mrlus, p. o., Steuben $c_{, 5} \mathcal{N}$. $\boldsymbol{Y}_{\text {: }}$ on Conhocton r., $167 \mathrm{~m}$. W. S. W. Albany.

HAmrondsport, V., Steuben co., $N_{\text {. }} Y_{\text {. }}$ at the base of Crooked Lake, $\mathbf{1 7 4} \mathrm{m}$. W. Albuny. It contains large warehouses, severil mills, numerous stores, and about 800 inhabitants. A steamboat plies to Penn $Y$ an, $22 \mathrm{~m}$., and it communicates with Seneea Lake by Crooked Lake Canal.

Haunnd's Store, p. o., Auson co., N. Car.: $102 \mathrm{~m}$. S. W. Raleigh.

Hamrondrile, v. and sta, Columbiana co, Ohio: on the line of the Cleveland and Pittsburg R. R., $5 \mathrm{~m}$. from Wellsville, and $122 \mathrm{~m}$. E. N. E. Columbus.

Hammonton, p. V., Atlantic county, N. Jer.: $42 \mathrm{~m}$. S. Trenton.

HaMmonville, p. v., Hart county, $K y .: 79$ m. S. W. Frank fort.

Havorton, p. v., Chester county, Penn.: 62 m. E. S. E. Harrisburg.

IIAMPDEN county, Mass. Situate S. W., and contains 585 sq. $m$. The Connecticut divides it about equally in its $\mathbf{S}$. course, and it is drained by its affluents-W. by Westfield and Agawam rivers, and-E. by Ware and Chicopee; the Quinnebaug $r$. also rises in the E. Surface much diversified; in the W. rery hilly and broken, except on the streams; in the E. less broken, and pleasantly varied, and on the banks of the Connecticut a narrow strip of low, level meadows. These are unsurpassed in fertility and loveliness. Aside from them there is much prime land in both sections of the county. The $W$. has some timber; but the great business is manufactures-these, hitherto confined to Palmer, Westfield, Chicopee, and Springfield, now find the greatest power at Holyoke, where a dam across the Connecticut, built in 1849 , affords the best water-power in the State. There are cotton and woolen factories in Palmer and Chionpee; whip and eigar in Westfield; and raillroad car and locomotive in Springfield. Farms 2,616; manuf. 389 ; dwell. 9,0S3, and pop.-wh. 50,785, fr, col. 496-total 51,281. Capital: Springfield, Public Works: Western P. R.; Connecticut Piver R. R.; Chicopee Falls Branch R. P. ; New London, Willimantic, and Palmer R. R. ; Amherst and Belchertown R. R.; New Haven, Hartford, and Springfield R. R.; and New Haven and Northampton R. R. HArPder, t. and p. 0. Columbia co., Wisc. : 20 m. N. by E. Marlison. Drained by a head branch of Rnck r. Surface rolling; soil deep mold and well wooded. Pop. 439.

HAMPDEN, p. v., Marengo county, Ala. : 94 m. W. Montgomery.

Haupden, t. and p. v., Penobscot co., Me. : 59 m. E. N. E. Augusta. Drained by Sowadabscook r., which affords water-power, and the Penobscot river forms its E. boundary. Surface beautifully diversifled; soil fertile. The v, is situate at the confluence of the two rivers, $6 \mathrm{~m}$. below Bangor, and carries on an extensive trade in timber and agricultural produce. Pop. of t. 3,195.

IIAMPDEN, t. and p. o, Geauga co., Ohio: 147 m. N. E. Columbus. Drained by affluents of Grand river, which empties into Lake Erie. Surface elevated and diversified; soil rich and productive. The $\mathrm{v}$. is situate centrally, and is a small agricultural settlement. Pop. of t. 919 .
IIAMPDEN-Smnex Collage, p. o., Prince Edward county, Virg.: 62 m.W. S.W. Pichmond. The College was founded in $173 \%$, and in 185 ! had 6 profeesors, 1,510 alumni, 25 students, and a librury of 80,000 volumes. A preparatory acarlemy is attached to the College.

HAMPSHIRE county, Mas8. Situate W. centrally, and contains $583 \mathrm{sq}, \mathrm{m}$. Divided from N. to S. by the Connecticut river, and watered by its affluents, which afford much water-power. Surface much broken in the W.; in the E. hilly, and on the Connecticut $r$, a beautiful meadow, Soil in the middle rich meadow, producing great crops of corn, clover, hay, broom-eorn, and tobaceo; in the W. excellent grazing land, with fine dairies; and in the F. fine farms, except on the highest ground. Mount Tom and Mount Holyoke, with their adjacent ranges of hills, are well wooded, and much maple sugar is made. Small factories occupy most of the streams, and every kind of "Yankec notion" is produced. Much paper is made, and at Easthampton are the largest button factories in the United States. A rich lead anil silver mine, closed by accident, has been reopened in Southampton; zinc-blende is largely dug in Hatfield, and fine building stone is found in Pelbam. Farms 2,965; manuf. 319 ; dwell. 5,905, and pop,-wh. 35.45 , fr. col. 327 -total 35,732. Capital: Northampton. Pulslic Works: Connecticut River R. R.; Western R. R.; Amherst and Belchertown R. R.; New Haven and Northampton R. R.

Hampsime county, Firg. Situate N., and contains 838 sq. m. Drained by S, branch of the Potomae r., Great and Little Cacapon r., North r., Patterson's cr.; and other affluents of the Potomac r., which forms its N. boundary. It lies between the Blue Ridge and East Alleghany mountains, the latter intersecting the W. half. The surface is elevated and broken, affording many mill privileges, and excellent grazing. All the grains yield finely in the numerous valleys, and the mountains are well timbered, furnishing material for many saw-mills. Farms 1,063; manuf. 57; dwell. 2,035 , and pop.-wh. 12,389, fr. col. 214, sl. 1.433-total 14,036. Capital: Romney. Public Works: Baltimore and Ohio R. R.

HaMpshire, p. v., Kane county, Ill. : 172 m. N. N. E. Springfleld.

Hampsure, p. v., Lewis county, Tenn.: $58 \mathrm{~m} . \mathrm{S} . \mathrm{W}$. Nashville.

HaMpstead, p. v., Carroll co., Md.: 6 m. N. E. Westminster, and $55 \mathrm{~m} . \mathrm{N}$. W. Annapolis.

Haupstead, t, and p. v., Rockingham co, $N$. Mamp. : 32 m. S. S. E. Concord. Drained by ponds, the outlets of which empty into Merrimac r. Surface generally level; soil hard and fertile. Pop. of t. 789.

HaMPSTEAD, p. V., King George co., Virg.: 62 m. N N. E. Richmond.

Hamptor, t, and p. ₹., Windham co., Conn, : $85 \mathrm{~m} . \mathbf{E}$. Hartford. Drained by a branch of Shetncket $r$, which furnishes water-power. Surface diversified. and somewhat uneven; soil a gravelly loam--fertile. The v. lies on an elevation, and consists of one long street, with about 60 dwellings and other buildings. The $t$. has some manufuctures and several stores. Pop. 925. The New York and Boston (direct) R. R. passes through it.

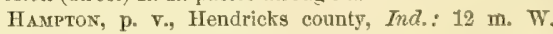
Indianapolis, and connected with that city by a plank-rond.

HamptoN, p. v., Rock Island co., $l l_{\text {. }}: 126$ m. N. N. E. Springfield.

II Aspton, t. and p. o., Saginaw co., Afich.: $61 \mathrm{~m} . \mathrm{N}$. E. Lansing. It lies on the E. side of Saginaw $r_{\text {, }}$ near its entrance to Saginaw Bay. Pop. 546.

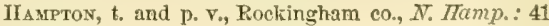
m. S. E. Concord. Faces S. E. on the Atlantic Ocean, and on its shore is a singular cliff, called the Boar's Head. The soil is fertile, and about a fifth of the surface is salt marsh. It has a good harbor, and is engaged in coasting and fishing. The Eastern R. R. passes through the $t .10 \mathrm{~m}$. S. Portsmouth. Pop. 1,197. 
H $_{\triangle M P T O N}$ t. and p. v., Washington co., N. Y.: $58 \mathrm{~m}$. N. by E. Albany. Drained by Poultney r., which separates it from Vermont. Surface diversified by hills and valleysthe valleys rich and productive. The $\mathrm{v}$, is a small agricultural settlement. In the t. there are several industrial establishments, and $\$ 99$ inhabitants.

Hamptos, p. v., Adams co., Penn.: 22 m. S. by W. Harrisburg.

Hampton, p. v., and eap. Elizabeth City co., Virg.: on the W. side of Hampton r., about a mile from its entrance into Hampton Roads, $74 \mathrm{~m}$. S. E. Fichmond. It contains a court-house, jail, ete., about 20 stores of varions descriptions, $150 \mathrm{~d}$ wellings, and 1,200 inhabitants.

HAMPTONBURgir, to and p. v., Orange co., N. Y.: $88 \mathrm{~m}$. S. S. W. Albany. Drained by Murderer's er. and Wallkill, the latter of which bounds it on the N. W. Surface undulating; soil a fertile clay loam. The p.o. is $4 \mathrm{~m}$. N. of Goshen. Pop. of t. 1,343.

HaMpton Falis, t. and p. o., Rockingham co., N. Hamp. $43 \mathrm{~m} . \mathrm{S}$. E. Concord. Situate immediately S. of Hampton, and divided from it by the $r$. from which it is named. In physical character, etc., it is similar in every respect to Hampton, from it was separated in 1702. Pop. 640.

HAMPTON roads, Virg.: a branch of Chesapeake Bay off the mouth of James r., between Old Point Comfort on the $\mathrm{N}$. and Willoughby Point on the $\mathrm{S}$. It has a sufficient depth of water for the largest ships of war, and is an important naval station. On Old Point Comfort is Fort Monroe, which mourts 335 guns, and on the opposite point is Fort Calho'm, which will mount 265 guns. The work at Old Point Comfort occupies an area of 56 acres, and including the ditch, 70 acres, and Fort Calhoun about 7 acres. These forts completely command the entrance to the roads.

Hamptonville, p. v., Surry county, $N$. Car.: $122 \mathrm{~m}$. W. N. W. Raleigh.

Hananer's Store, p. o, Randolph co., Ark.: $137 \mathrm{~m}$. N. N. E. Little Rock.

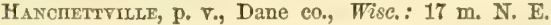
Madison.

I $\triangle$ NCOCK county, Ala. Situate N. W., and contains about 500 sq. $\mathrm{m}$. Drained by upper branches of the Black Warrior $r$. Surface moderately uneven, and soil generally good. Cors and cotton are the principal agricultural products. Farms 144; manuf. 1; dwell. 251, and pop. -wh. 1,4S0, fr. col. 0, sl. 62-total 1,542. Capital:

Haxcocs county, Ga. Situate E. centrally, and contains $4 S 1$ sq. m. Drained by branches of Ogeechee r., its E. bounilars, and of Oconee r., its N. W. bounilary. Surface diversified, with some moderate hills ; soil very productive. This is in the great cotton belt of Georgia, and attention is directed mainly to its cultivation. Farms 444 ; manuf. 20 ; dwell. 761 , and pop.-wh. 4,212, fr. col. 60, sl, 7,806-total 11.078. Onpital: Sparta.

HANCOCK county, $\pi l$. Situate $W$. and contains 731 sq. m. Drained E. by branches of Crooked cr., a tributary of the Illinois, and W. by affluents of the Mississippi, which divides it from Iowa and Missouri. Surface rolling: soil fertile, especially near the Mississippi: the E. has much prairie, and the county is deffeient in timber, thongh a belt of forest extends along the Mississippi. All the grains thrive, and manufactures are increasing. This will long be remembered as the closen seat of Joe Smith's adherents, and the field of the Mormon difficulties in 1\$46. Their halffinished temple remains to tell of the fanaticism and intolerance that in this, the 19th century, could array an otherwise noble penple against their brethren. because of their opinions on religion. Farms 1.167; manuf. 13 ; dwell 2.585. and pop. -wh. 14.fis:?, fr. col, 19--total 14,652. Cupital : Cartrage.

HAxcurk county, Ind. Situate E. centrally, and contains sos $s q . m$. Drained ly Blue $r$. and sugar and Brandywine creeks. Surface level or gently undulating, and generally timbered: snils rich, producing whent, corn, the srasecs, etc. in profusion. Farms 1,176; manuf. 36 ; dwel?. 1,655 , $27 t$ and pop.-wh. 9,595, fr. col. 108-total 9,698. Capital: Greenffeld. Public Works: Indiana Central R. R., Indianapolis and Bellefontaine R. R.

HANCook county, $I a$. Situate N. middle, and contains 576 sq. m. Drained by Boone r., a branch of the Des Moines, and the heads of Cedar and Iowa rivers. But little settled, and unorganized in 1850.

Harcock county, $K y$. Situate $\mathrm{N}$. in W. part, and coptains $158 \mathrm{sq}$. m. Drained by Black Fork cr. and Indian cr. affuents of the Ohio, which washes its whole $\mathrm{N}$. border. Surface considerably broken. Soil of average fertility. To bacen is cultivated. Large deposits of coal exist, and are wrought successfully; iron ore is also found. Farms 319 manuf. 15; dwell. 551, and pop.-wh. 3,216, fr. col. 15, sl. 622-total, 3,553. Capital: Hawesville.

Hancock county, Dre. Situate S. E., and contains 1,656 sq. m. Drained by Union $r$. and its branches. It has the Atlantic on the S., and Penobseot bay and river on the W., which furnish it with good harbors. The coast is covered with many islands, some large, and the fisheries form an important branch of trade. The surface is somewhat hilly; timber and water-power abundant, and lumber tho great export. Soil good; wool is grown, and many potatoes exported. Farms 2,271; manuf. 205; dwell. 5.550, and pop.-wh. 34,343, fr. col. 29-total 34,372. Capital : Castine.

HANCock county, Miss. Situate S., and contains 938 sq. m. Drained-E. by Wolf r., emptying into St. Louis Bry, and-W. by branches of Pearl r., its boundary toward Louisiana, a large navigable stream flowing into Lake Borgne. Surface rolling or low and level; soil mostly unproductive, with a growth of pine on much of it. Cotton and rice are the products. Farms 77 ; manuf. 11; dwell. 492. and pop.-wh. 2,444, fr. col. 12, sl. 1,216-total 3,672. Capetal: Shieldsboro.

HANcook eounty, Ohio. Situate N. W. centrally, and contains $525 \mathrm{sq}$. m. Drained by branches of Blanehard's Fork of Maumee r. and heads of Portage r., both of which flow into Lake Erie. Surface undulating ; soil very productive of all the grains, on which much pork is fittened. It is well wooded, and has several good mill streams. Farms 1,636; manuf. 35 ; dwell. 2,824, and pop.-wh. 16,725, fr. col. 26-total 16,751. Capital: Findlay. Public Works: Findlay Branch R. R.

Haxcock county; Tenn. Situate N. E., and contains 312 sq. m. Drained by Powells aud Clinch rivers, hends of the Tennessee. Mill-sites are numerous-and timber plenty and convenient. Surface much broken; snil fertile. Corn wheat, and tobacco are the chiep products. Farms 787 ; manuf. 17 ; dwell. 939, and pop.--wh. 5,448, fr. col. 10, sl. 202 -total 5,660. Capitab: Sneedsville.

HAxсOCK county, Virg. Situate in the extreme N., and contains 67 sq. m. Drained by affluents of the Ohio, which forms its $\mathrm{N}$. and $\mathrm{W}$. boundary. Surface uneven, favoring manufactures by the mill-sites it affords. Soils generally fertile, and adapted to grains and grazing. Biturininous coal is extensively forlnul. Farms 506 ; manuf. 26; dwell. 690, and pop.-wh. 4,140, fr, col. 7, sl. 3-total 4,150. Crapital . Haneock C. H.

Haxcock, t. and p. o., Hancock co., MFe: 77 m. E. by N Augusta. Drained by sevcral streams falling into Skilling and Taunton Bays, arms of Frenchman's Bay, and the S. E. part of the $t$, is a peninsula, bounded by these waters. The $\mathrm{y}$, is situate near the middle of the peninsula. Hancock has some navigation, and is much engaged in the shore fisheries. Top. of t, 962.

$\mathrm{H}_{\triangle \mathrm{ANCOCK}}, \mathrm{p}$. v., Washington co., Mfd.: on the $\mathrm{N}$. side of the Potomac r., $112 \mathrm{~m}$. N. W. Annapclis, and near the line of the Baltimore and Ohio R. R., $124 \mathrm{~m}$. from Baltimore. The Chesapeake and Ohio Canal also passes through it. It is the centre of a considerable trade, and has great facilities of transportation, which in the future may develop its destiny. 
Huycock, t. and p. v., Berkshire co., Mass.; $117 \mathrm{~m}$. W. Boston. The t. lies on the New York State Line, and is drained by branches of Kinderhook cr. and Housatonic $\mathbf{r}$. Surface mountainous; soil excellent for grass. It has numerous mills, mechanic shops, etc., and within the t. there is a Shaker settlement. Pop. 789.

Hancock, p. v., De Soto co., Miss. : 158 m. N. Jackson.

Havcock, t. and p. v., Hillsborough co., N. Hamp. : 29 m. S. W. Concord. Drained by branches of Contoocook r., which afford extensive water-power, and Long Pond, a considerable body of water, lies on the W. border. Surface uneven and mountainous; soil fertile, adapted to grazing, with considerable intervale. The t. has numerous small manufactures. Pop. 1,012.

H $_{\triangle \text { NCOCK, t. }}$ and p. v., Delaware co., N. Y.: $86 \mathrm{~m} . \mathrm{S}$. W. Albany. Drained by Papacton or E. branch of Delaware r., which last makes the S. W. border. Surface broken and hilly; soil in the v, rich and fertile. The v, lies on the New York and Erie R. R., 174 m. from New York City, and at the junction of the branches of the Delaware. It was formerly called "Chehocton," or union of streams, and is now a $\mathrm{y}$, of considerable trade, and has about 800 inhabitants. Pop. of t. 1,798.

HANCocK, t. and p. v., Addison co., Verm.: 29 m. S. S. W. Montpelier. Drained by head waters of Otter cr. and White r., flowing in different directions. Surface hilly, being situate on the Green Mountain range, and forming the dividing ridge between Lake Champlain and Connecticut river. It has a small central village, Pop. of t. 430 .

Hancock's Brmge, p. v., Salem county, N. Jer.: on Alloway's cr., $60 \mathrm{~m}$. S. S. W. Trenton. It contains a few stores, and about 200 inbabitants.

Hakoy, t. and p. o., Livingston co., Afich.: 24 m. E. S. E. Lansing. Drained by branches of Cedar r. Surface diversified by hills; soil fertile. It is a fine farming t., and has facilities for milling. Pop. $4 \$ 4$.

Haneyville, p. v., Lycoming co., Penn. : $77 \mathrm{~m}$. N. by W. Harrisburg.

HANFORD's Landing, p. o., Monroe co., $N_{0}, Y_{0}:$ on Genesee r., 198 m. W. N. W. Albany.

Flavging Rock, p. v., Lawrence co., Ohio: on the N. bank of Ohio :., $93 \mathrm{~m}$. S. S. E. Columbus, It is a principal shipping place for the iron of the region, and has several extensive iron manufactories. It is about $5 \mathrm{~m}$. below Ironton, which, on account of its being the terminus of the Iron $R$. P., will, of course, draw away the business of Hanging Rock. Its name is derived from a cliff of rocks about 400 feet high, which projects over the rear of the village. Pop. about 300 .

HANGING Rock, p. o. Kershaw dist., S. Car.: 24 m, N. N. E. Columbia.

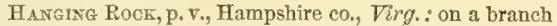
of Great Cacapon r., 187 m. N. W. Richmond. On the stream, both up and down, there are numerous mills.

Hannahatchie, p. v., Stewart co., Ga.: 117 m. S. W. Milledgeville.

Hanna's, p. o., Sumner co., Tenn.: 31 m. N. N. E. Nashville. The railroad between Nashville and Danville will intersect this point.

HANSA's Mills, p. o., Mahoning co., Ohio : 139 m. N. E. Columbus.

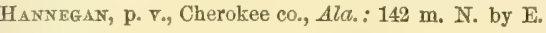
Montgomery.

Hanvegan, p. v., Atchison co, Mo.: on the E. side of Nishnabatona r., an affluent of the Missouri r., $218 \mathrm{~m} . \mathrm{N}$. W. Tefferson City.

Hasmegan, p. 0, Rush county, Ind.: 38 m. S. W. Indianapolis.

Haximal, p. v., Marion co., Mo.: on the W. bank of Mississippi r., $92 \mathrm{~m}$. N. E. by N. Jefferson City. It is a place of considerable enterprise and business, and has several large and commodious warehouses, stores, dwellings, ete. Population 2,230. The "Western Union" (whig), and the
"Missouri Courier" (dem.), are newspapers issued weekly. This is the Eastern initial point of the projected Hannibal and Joseph R. R.

Hanmibat, to and p. o., Oswego con, $N . \quad Y_{.}: 143 \mathrm{~m}$. W. N. W. Albany. Drained by several small creeks of Lake Ontario. Surface undulating; soil sandy loam and fertile. The $v$. is an agricultural settlement of some 35 or $\mathbf{4 0}$ dwellings. In the to are several mills, and 2,857 inhabitants.

Hannibal Centre, p. v., Oswego co., N. T.: $148 \mathrm{~m}$. W. N. W. Albany.

HANOVER county, Virg. Situate E. centrally, and contains 524 sq. m. Drained W. by South Anna r., which unites with North Anna to form Pamunky $r$, the last two bounding it $\mathrm{N}$. and flowing into York $\mathrm{r}_{\mathrm{o}}$, and $\mathrm{S}$. by Chickahominy $r$., a branch of the James. Surface uneven, and in parts hilly; soils very unequal, with much excellent corn and wheat land. Tobaceo is grown in parts. Noted historically as the birth-place of Patrick Henry, Wm. Henry Harrison, and Henry Clay, Farms 603; manuf, 32 ; dwell 1,327, and pop.-wh. 6,541, fr. col. 219, sl. 8,393-total 15,153. Capital: Hanover C. H. Public Works: Virginia Central R. R. ; Richmond, Frederick, and Potomac R. R., etc.

HANOVER, t. and p. o., Oxford co., Me. Pop. 366.

Havover, p. v., Jo Daviess co, Ill, : on Apple r., $173 \mathrm{~m}$. N. N. W. Springfield.

HaNover, v., Jefferson co., Ind.: on the high bluffs of the Ohio r., $6 \mathrm{~m}$. below Madison, and $\mathrm{S1 \textrm {S }}$. E. Indianapolis. Here is located Hanover College, founded 1829 ; in $1850 \mathrm{i}$ had a president, 9 professors, 120 alumni (of which 55 were ministers) 100 students, and a library of about 4,500 volumes. The $\mathrm{v}$. contains about 120 dwellings, and, including students, has about 800 inhabitants.

H ${ }_{\triangle \mathrm{NO}} \mathrm{VER}$, t. and p. o., Jackson co., Mich.: $41 \mathrm{~m}$. $\mathrm{S}$, Lansing. Drained by branches of Kalamazoo r. Pop. 931. Havover, t. and p. v., Plymouth co., MFass. : 22 m. S. S. E. Boston. Drained by Pembroke and other streams, which unite on the E. border of the t. to form North $r$; these afford fine water-power. It has considerable manufacturing establishments, and a population of 1,592 .

HANover, t. and p. v., Grafton co., N. Hamp.: $51 \mathrm{~m}$, N. W. Concord. Drained by streams falling into Connecticut $r_{\text {, }}$ over which is a bridge connecting it with Norwich. Surface pleasantly diversified; suils fertile. Moose Mountain, an elevated ridge, crosses the t. in a N. and S. direction. There are several islands in the Connecticut belonging to Hanover. The $\mathrm{v}$. is situate on a plain half a mile $\mathrm{E}$. of the $r$., and is a place of some consideration for its general industry and its great college. Dartmouth College was founded in 1769 , and has a medical department, founded 1797 , both of which are in high repute as seats of learning. In 1850 the college had 9 professors, 3,675 alumni, of which 785 had entered the ministry, 225 students, and a library of 22,400 volumes; and the medical school had 6 professors, 50 students, and 800 graduates. Many of the most distinguished statesmen, literati, and physicians of the Union claim this institution as their alma mater, and among these may be mentioned Daniel Webster, Franklin Pierce, Rufus Choate, Nathaniel Hawthorne, and other illustrious men, whose names are household words with their countrymen. The principal buildings of the $\mathrm{v}$, are erected round a square level area of 12 acres, and the remainder stand on different streets leading from the green in all directions. A montbly religious paper, the "Parents" Monitor," is published here. Pop, of t, 2,352

HANOVER, t, Burlington co., $N$. Jer.: $26 \mathrm{~m}$. S. E. Trienton. Drained by Black's and Crosswick's creeks, and a branch of Raucocus. Surface level; soil sandy loam and sand. It has several iron-works, distilleries, grist and saw mills. Pop. 2,247 .

Havover, t. and p. v., Morris co., N. Jer. : $47 \mathrm{~m}$. N. N. E. Trenton. Drained by Whppany and Parsipang rivers branches of Rockaway r., which runs on the $\mathrm{N}$. border of 
the t. Surface diversified, in the N.W. hilly ; soil, clay loam

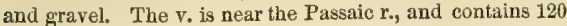
inhabitants. The t. has several iron-works and other manufactures, including woolen, cotton, paper, etc., and numerous grist and suw mills. Pop. 3,608 .

HANover, t. and p. v., Chautauque co., N.Y.: $267 \mathrm{~m}$. W. Albany. Drained chiefly by Silver cr., and Cattaraugus $r$ bounds it on the N., and on the N. W. Lake Erie. Surface broken and hilly; soil on the lake shore and on the streams very fertile. The $\mathrm{v}$. is a small settlement. This $\mathrm{t}$. is noted for its fine timber. It has considerable manufactures, and enjoys many water privileges for navigation and milling. The Buffalo and State Line R. R. passes through its N. W. part, and the New York and Erie R. R. through its S. portions. Pop. 5,144.

Hanover, t. and p. o., Licking co., Ohio: 41 m. E. N. E. Columbus, Drained by Licking $r$., which runs through it. Surface generally level; soil dark loam and sand, very fertile. The Ohio Canal runs along the valiey of the Lieking, and also the Steubenville and Indiana $\mathrm{R}$. $\mathrm{P}$., on the opposite side of the r. Pop. 1,157.

Hanover, p. b., Tork co., Penn.: on a branch of Conewago cr. of susquehanna $r, 31 \mathrm{~m}$. S. Harrisburg. It is a highly flourishing place with several manufactures, and has two newspapers, the "H. Spectator" and the "H. Gazette, both weekly issues. Pop. 1,240. A branch of the Baltimore and Susquehanna $\mathrm{R}$. $\mathrm{R}$. comes up to the borough.

Haxoyer, p. v., Coosa co., Ala. : 41 m. N. Montgomery.

Hanover, p. v., and cap. Hanover co., Virg. : near Pamunky r., and on the line of the Virginia Central R. R., 18 m. N. Richmond. It contains a court-house, jail, ete, and about 200 inhabitants.

Hanover Centre, p. v., Grafton co., N. Hamp. : $53 \mathrm{~m}$ N. W. Concord.

HANoter NecK, p. 0., Morris co., N. Jer.: 48 m. N. N. E. Trenton.

Hanoverton, p. v., Columbiana co., Ohio: on the line of the Sandy and Beaver Canal, $118 \mathrm{~m}$. N. E. Columbus. It contains warehouses, numerous stores, mills, etc, and about 800 inhabitants. A branch of the Cleveland and Pittsburg R. R., $1 \frac{1}{2} \mathrm{~m}$. long, comes up to the village.

Hansox, t, and p. v., Plymouth co, Mass. : 23 m. S. S. E. Boston. Drained by a branch of North $r$, and several ponds. It lies in the vicinity of extensive beds of iron ore, and manufactures largely ship anchors, nails, carriage springs, castings, ete. Pop. 1,217. The Old Colony R. R passes through Hanson, $12 \mathrm{~m}$, from Plymouth.

Hanson, p. v., Marion county, Mo.: $82 \mathrm{~m}$. N. N. E. Jeflerson City.

Hansonville, p. v., Russell co., Firg.: on the W. branch of Holston r., $263 \mathrm{~m}$. W. by S. Richmond.

HaP HazARD, p. o., Catahoula par., La. : $122 \mathrm{~m} . \mathbb{N}$. W. Baton Rouge.

Happy Vallex, p. o., Carter county, Tenn.: 259 m. E. Nashville.

Iraralsor, p. Y., Coweta co., Ga.: on the W. side of Flint r., is m. W. by N. Milledgeville.

HARBOR CREEK, t. and p. o, Erie co, Penn.: $216 \mathrm{~m}$. N. W. Harrisburg. Drained by several streams of Lake Erie, which forms its N. boundary. Surface broken; soil of average fertility. The p. o. is situate on the line of the Erie and North-east R. R., 7 m. from Erie. Pop. 2,093.

Harbor HiLr, Queens co., $N_{*} Y_{*}:$ the bighest point of land on Long Island, lying in the $t$ of North Hempstead. It is 319 feet above the Atlantic Ocean, from which it is visible 25 miles.

Hardemar county, Tenn. Situate S. W., and contains $912 \mathrm{sq}, \mathrm{m}$. Drained by Big Hatchie r., a tributary of Mississippi r., and its branches. Surface mostly level or slightly broken, with a light and sandy soil. There are good water privileges and some timber. Cotton is the staple, though the grains produce largely, and tobacco pays well. Farms 1,027 ; manuf. 64 ; dwell. 1,735 , and pop.-wh. 10,350, fr. 276 col. 38, sl. 7,108-total 17,496. Capital: Bolivar. Public Works: Memphis and Charieston $R, R$.

HARDIN county, 1 ll. Situate S., and contains 184 sq. m. Drained by Saline cr. and other affuents of Ohio r., which bounds it E. and S. Surface high and broken; soil fertile, with good pasturage. Lead and iron are abundant, Waterpower good. Farms 326 ; manuf, 0 ; dwell. 495, and pop.wh. 2,807, fr. col. 79-total 2,856. Capitul: Elizabethtown.

HARDIN county, Ia. Situate $N$. centrally, and contains $576 \mathrm{sq}$. $\mathrm{m}$. Intersected by the Iowa and drained by its affluents. Mostly unsettled. Unorganized in 1850.

HARDIN county, $K y$. Situate N. centrally, and contains 439 sq. m. Drained by Rolling Fork of Salt r. and Salt r., which bounds it N. E., and Nolin and Rough creeks, branches of Green r., all which flow into the Ohio. Surface much diversified ; soil fertile-wheat, corn, and tobacco are staples. Many sheep and cattle are raised. Farms 1,406; manuf. 50; dwell. 2,005, and pop.-wh. 12,023, fr. col. 43 , sl. 2,459-total 14,525. Capital: Elizabethtown. Public Works: Nashville and Louisville R. R.

HARDiN county, Ohio. Situate $N$. W. centrally, and contains $580 \mathrm{sq} . \mathrm{m}$. Drained centrally and S. by the Scioto $r$. and a branch of Miami r., and in the N. by Blanchard's fork of Maumee r., an affluent of Lake Erie. Surface elevated, but not much broken; soils fertile, and adapted to grain and grass, with good timber in parts. Farms 7S3; manuf. 26 ; dwell 1,402, and pop.-wh. 8,237 , fr. col, 14-total 8,251. Capital: Kenton. Public Works: Mad River and Lake Erie R. R.; Ohio and Indiana R. R., and Indianapolis and Bellefontaine R. R.

HARDIN county, Tenn. Situate S. W., and contains 1,043 sq. m. Drained by numerous creeks of Tennessee $r$., which flows through it from S. to W. Surface varied, with some low marshes; soil good and kind to the grains, which oonstitute the staples. Tobacco and cotton are raised in smalleo quantities. Farms 690 ; manuf. 19; dwell. 1,503, and pop. -wh. 9,040, fr. col. 31, sl. 1,257-total 10,328. Capital Savannah. Public Works: Memphis and Charleston R. R., and Nashville and Memphis R. R.

HARDIN, p. v., Shelby co., Ohio: on Frith cr., $68 \mathrm{~m}$ W. N. W. Columbus.

HARDIN, p. v, and eap. Calhoun co., $I l l_{*}:$ on the W. side of Illinois $\mathbf{r}, 66 \mathrm{~m}, \mathrm{~S}$. W. Springfield.

Hardw, p. o., Allemakee co., Ia. : $112 \mathrm{~m}$. N. Iowa City. Handingsburg, v., Dearborn eo., Ind.: on the W. side of Great Miami r., $2 \mathrm{~m}$. N. Lawrenceburg and $80 \mathrm{~m}$. S. E Indianapolis. It is also on the line of the White Water Canal.

Harding's Pont, p. r., Mississippi co, Ark. : $138 \mathrm{~m}$ N. E. Little Rock.

Hardingrille, p. vo, Gloucester $c 0, N$. Jer.: $38 \mathrm{~m}$. S. by W. Trenton.

II arminsburgu, p. F., Washington county, Ind.: $78 \mathrm{~m}$. S. by E. Indianapolis.

HardinsburgH, p. v., Montgomery county, $I U l .: 47 \mathrm{~m}$ S. by E. Springfield

Hardinsburgh, p. v., and cap. Breckenridge co., $\bar{k} y$. : about half a mile E. of Hardin's cr. and $93 \mathrm{~m}$. W. S. W.

Frankfort. It contains a court-house, jail, etc., and about 800 inhabitants.

I HaRDiN'B TAVERY, p. o., Albemarle co., Virg.: on the line of the Virginia Central R. K., $78 \mathrm{~m}$. W. N. W. Richmond.

HARDINSVILLE, p. $\nabla$., Shelby co., $K y_{.}:$on Benson cr. of Kentucky r., 9 m. W. S. W. Frank fort.

HaRDSTONex; p. o., Stewart county, Ga.: 114 m. S. W. Milledgeville.

IIARDWICE, t. and p. v., Worcester co., Mass. : $61 \mathrm{~m}$. W. Boston. Drained by branches of Ware $r$., which runs along its $\mathrm{S}$, border and furnishes water-power. Surface difersified; soil of ordinary fertility. The v., situate centrally, bis two churehes and about 250 inhabitants. Pop. of t. 1.681 . 
HARDWICK, t, and p. v., Caledonia co., Term.: $24 \mathrm{~m}$. N. N. E. Montpelier. Drained by Lamoille $r$, and its tributaries, which have extensive water-power. Surface rolling; soil productive. There are several sulphur springs in the $t$. The $v$, is on the N. bank of the Lamoille. Pop. of t. 1,402

H.ARDWICz, v. and port of entry, Bryan co., Ga.: $147 \mathrm{~m}$. S. E. Milludgeville. It is a port with commerce.

Hardwiclisville, p. v., Nelson co., Virg. : $88 \mathrm{~m}$. W. by N. Richmond.

HARDI county, Tirg. Situate N., and contains $1,16 \mathrm{~S}$ sq. m. Drained by North Branch of Potomac r., its N. W. boundary, South Branch of Potomac, which, with numerous branches, flows through the midale, and E. by Cacapon r. Surface mountainous, with the Alleghany ridge in the W., and Shenandoah and Branch mountains in the E. and $\$$., which, with the streams to which they give rise, afford the best of water-power and of timber; soil rich in the valleys, with good pasturage on the hills. Beef; pork, and wool are exported. Farms 723; manuf. 49; dwell. 1,327, and pop.-wh. 7.930 , fr. col. 353 , sl. 1,260-total 9,543. Capitul: Moorefield.

Harfolv county, $M$. Situate N. E., and contains 412 sq. m. It has the Susquehtmna for its N. E. boundary, Chcsapeake Bay its S. E., and Little Gunpowder r. its S. W., and is drained by their aftluents. Surface in the S. low and flat, with many arms of the bay; in the $\mathrm{N}$. elevated, stony, and hilly, with many fine water privileges; soil much diversified-in the $\mathrm{S}$. loam and clay predominate, and all parts are excellent grass lands. Deer cr., flowing into the Susquehanna, has perpendicular banks of stone from 200 to 300 feet high; limestone and granite are found, and rich iron ore is abundant. Farms 1,278; manuf. 72 ; dwell. 2,977, and pop.-wh. 14,418, fr. col. 2,777, sl, 2,166-total 19,356. Cupital: Bel-Air. Putlic Works: Philadelphia Wilmington, and Baltimore R. R.; Tidewater Canal; Philadetphia and Baltimore (direct) R. R.

HARFORD, t. and p. v., Cortlandt county, $N$. Y.: $124 \mathrm{~m}$. W. by S. Albany. Drained by East Owego cr. Surface uneven; sosl fertile, sand and clay loam. The $\mathrm{v}$. is a small settlement on the W. side of the creek. Pop. of t. 949 .

II $\triangle$ rford, t. and p. v., Susquehanna co., Penn. : $115 \mathrm{~m}$. N. N. E. Harrisburg. Drained by branches of Tunkhannock cr., which afford great water-power. Surface diversificd; soil aclupted to grass. The v. is a small but neat place. In the t. there are some manufactures and 1,302 inhabitants.

Hargave, p. v., Copiah county, Miss. : $37 \mathrm{~m}$. S. S. W. Jackson.

Iatgrove's Tavern, p. 0., Nansemond co., Virg.: $74 \mathrm{~m}$. S. E. Richmond.

HARkiNgtille, p. v., Auderson dista, S. Car.: 113 m. W. N. W. Columbia.

HArLaN counly, $\bar{K} y$. Situate S. E. corner, and contains $954 \mathrm{sq} . \mathrm{m}$. Drained by the head and many branches of Cumberland r., which runs througl it from N. E. to S. W. Cumberland Mountains form its S. E. border, and the surfuce is elevated and motintainous, with fine forests and abundant water-power; soil in the valleys productive and generally good pasturage. Farms 535; manuf. 0 ; dwell 65\%, and pop.-wh. 4.109, fr. col. 36, sl. 123-total 4,268. Cupitul: Harlan.

Harlax, p. v., Alien co., Ind.: 100 m. N. E. Indianapolis. $\mathrm{I}_{\mathrm{ARLAY}}$, p. v., and cap. Harlan co., $K y$. : on the Cumberland r., $118 \mathrm{~m}$. S. E. Frankfort. It contains a courthouse, jail, ete., and about 350 inhabitants.

Harlefstrle, p. v., Marion dist., S. Car. : on the W. side of Little Pee I)e r., 100 m. E. N. E. Columbia.

Hasces, p. o., Winnebago co., Ill.: on Willow er. of Kock r., 177 n. N. by E. Springfield.

Harcer. t. and p. v., Delaware co, Ohio: $18 \mathrm{~m}$. N. N. E. Colutalus. Drained by branches of Big Walnut and Big Lick orcks, Surfuce tevated and diversified; soil moler- ately fertile. The $\mathrm{v}$. is situate in the $\mathrm{S}$. W. part of the $t$. and is a small agricultural set*lement. Pop. 1,182.

HARLEM river, $N . Y_{0}$ : a strait connecting the East $r$ with Hudson $r$., and forming the N. boundary of New York county. Its western terminus has the name of spuyten Tuyvil cr. The whole is about $9 \mathrm{~m}$. long, and is crossed by several bridges, and also by High Bridge, or Croton Aqueduct, one of the finest works in the Union.

Harlem Spring, p. o., Carroll co., Ohio: 5 m. S. E. Carrollton and $108 \mathrm{~m}$. E. N. E. Columbus. There is a noted mineral spring at this place, said to have remedial properties.

Harlemville, p. v., Columbia co., $N_{0} Y_{2:}: 31 \mathrm{~m} . \mathrm{S}$. by E. Albany.

IArlensburgm, p. b., Lawrence county, Penn。: $193 \mathrm{~m}$. W. N. W. Harrisburg.

Harleysville, p. v., Montgomery co., Penn.: 81 m. E. Harrisburg.

Harlingen, p. v., Somerset county, N. Jer.: $16 \mathrm{~m} . \mathrm{N}$. Trenton.

Harmar, p. v., Washington co., Ohio: on the S. side of Muskingum r., opposite Marietta, and at its confluence with the Ohio, 88 m. E. S. E. Columbus. It is the site of old Fort Harmar, the first fort erected by Americans in Ohio, and is named after its commander. It is a flourishing place of about 1,200 inhabitants, and has several mills and mauufactories, for which it has abundance of water-power from the dam on the Muskingum; steamboats are also built here.

Ilarmarville, p. v., Alleghany co., Penn.: 177 m. W. IIarrisburg.

Ifarmonsbuger, p. b., Crawford co., Penn.: on Conneaut cr., at the N. end of Conneaut Lake, 212 m. W. N.W Harrisburg.

Haruony, p. v., Clay co., Ind. : 64 m. S.W. Indianapolis. HARMONX, 1. and p. o., Somerset co., Me.: $49 \mathrm{~m}$. N. by E. Augusta. Drained by Higgins' and Maine streams, whieh empty into Moose Pond, the source of a constituent of Sebasticook r. Surface diversified; soil fertile and adapted to wheat. The are two villages in the t. Pop, 1,107.

HARMONX, p. V., Washington co., Mo. : on Courtois or. of Maramee r., 83 m. S. E. Jefferson City.

Haruony, t. and p. v., Warren co., $N$. Jer. : $43 \mathrm{~m}$. N.W. Trenton. Drained by tributaries of Delaware $r$. Surface diversified; soil generally good. The Delaware forms the $W$. border of the $t$. The $v$. is a small seltlement of some 30 dwellings. Pop. of t. 1,564.

HaRMoNy, t. and p. v., Chautauque co., $N . Y_{.}: 288 \mathrm{~m}$. W. by S. Albany. Drained by Little Broken Straw cr., running $\mathbf{S}$. into Pennsylvania, and Goose cr. and other streams into Chautauque Lake, which lies on its N. E. border. Surface rolling; soil, sandy and gravelly Ioam. with some clay. The $\mathrm{v}$. is a small settlement on the lake. In the t. there are numerous saw and grist mills, tanneries, etc. Pop. 3,749.

Harmony, p. o., York dist., S. Car.: $77 \mathrm{~m}$. N. Columbia. Harmony, p. v., Keut en., $M$ l.

Hamonr, p. o., M.Henry eo., $\pi l_{0}: 172 \mathrm{~m}$. N. N. E. Springfield.

Harmont, p. o., Elbert county, Ga.: 8 T m. N. N. E. Milledgeville.

Harmony, p. v., Halifax co., Firg.: on an affluent of Dan r., 109 m. S. W. Richmond.

MARMoNy Grove, p. o., Jackson co., Ga. : $82 \mathrm{~m}$. N. by W. Milledgeville.

Haruoxy Vale, p. v., Sussex co., $N$. Jer. : $i \pm$ m. N. Trenton.

Hariagevilue, p. v., Cherokee co., $G a_{0}$ : on Etowah r., $186 \mathrm{~m}$. N. N. W. Milledgeville.

Harnedsville, p. v., Somerset county, Penn.: $11 \mathrm{sm}$ W. by S. Harrisburg.

IfARoLD, p. o., Montgomery co., Ark. : on Washita r., 59 m. W. by S. Little Rock.

Harpre's FerRy, p. V., Jefferson co, Firg.: at the confluence of the shumandoah and Potomac rivers, and where 
the united stream passes through the Blue Ridge, $122 \mathrm{~m}$. $\mathrm{N}$. by W. Richmond. Its scenery is most magnificent. The ఛ. contains several considerable manufactures, and has numerous large and well-stocked stores. A national armory is also located here, which has immense workshops, and in which are manufactured every variety of small arms and equipments. Among other products in 1850 were 9,600 percussion muskets and 10,836 muskets altered to percussion. The river is here spanned by a fine bridge nearly 800 feet long, and the Baltimore and Ohio R. R. passes through it, $82 \mathrm{~m}$. from Baltimore, and the Winchester and Potomac R. R. commences here. Along the N. bank of the r. the Chesapeake and Ohio Canal has its course. Pop. in $1850,1, \pi 47$.

HaRper's Frerry, p. o., Abbeville dist., S. Car.: on the Savannah r., $10 \mathrm{~S}$ m. W. by N. Columbia.

Harpersfield, t. and p. v., Delaware $\mathrm{co}_{*}, N . Y_{.}: 49 \mathrm{~m}$ W. S. W. Albany. Drained by Charlotte and Delaware rivers. Surface hilly and broken; soil a dark fertile loam, and well cultivated. The v. has about 260 inhabitants. There are in the $t$. several grist and saw mills, fulling mills, and tanneries. Pop. 1,604.

Harpersfield, t. and p. o., Ashtabula co., Ohio.: $162 \mathrm{~m}$. N. E. Columbus. Drained by Grand r., which runs through it. Surface diversified; soils rich and fertile. It has several mills and factories. Unionville, on the Cleveland, Painesville, and Ashtabula R. R., is the principal v. in the town. Pop. 1,279.

Harper's Home, p. o., Brunswick county, Virg.: $73 \mathrm{~m}$. S. S. W. Richmond.

Harper's Mills, p. o., Pendieton co., Tirg.: 132 m. N.W. Richmond.

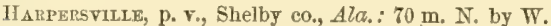
Montgomery.

ILarpenstille, p. v., Broome co., $N$. Y.: on the W. side of Susquehanna r., $103 \mathrm{~m}$. W. S. W. Albany. Pop. about 260.

H $\triangle$ RPETI, p. Y., Williamson co., Tenn.: 24 m. S. S. E. Nashrille.

Harrell's Store, p. o., New Hanover co.,. . Car.: 112 m. S. S. E. Raleigh.

Harrellsville, p. v., Hertford co., N. Car.: 102 m. N. E. Raleigh.

Harrietrstown, t. and p. o., Franklin co., N. Y.: 114 m. N. ly W. Albany. Drained by Lower Saranac Lake and several other lakes and ponds forming the sources of the Saranac and Racket rivers. Surface in the S. E. mountainous, otherwise varied; soil generally fertile, and timber is abundant. The $\mathbf{y}$, has several stores, and about 40 dwellings. The to is yet but sparsely settled and in a wilderness state. Pop. 157.

HarRIETtsville, p. v., Monroe co., Otio: 108 m. E. by S. Columbus.

IIArrixctos, p. Y., Cumberland co., N. Car.: $56 \mathrm{~m}$. S. liy Wr. Ralleigh.

Harringtos, t. and p. o., Washington co, Mre. $104 \mathrm{~m}$. E. Alugusta. The $t$ occupies two peninsulas, hatring Pitasant liver Bay un the E., and Narragatugus Bay on its W. side: and the rivers emptying into these, both of the sime nome. afford extmsive water-power. It has numerous mills, etc. Pop, 963.

I I ARrrs county, $G \alpha$. Sitnate W. centrally, and contains 414 s.4. m. I) rained by Long Canoe, Pine Mountain, and Mulherry creeks, atfluents of Chattahooche r., its IV. boundary. Pine Mountain crosses the N., and the surface is muels diversified. The soil is good, producing corn and the grains. Farms sis: manul. 73 ; dwell. 1.175 , and jup. -wh. 6,709, fr. col. 30, si. 7,982-total 14,721. Capital: II:milen.

HARris county, Tex. Situate S. E., and contains 1.656 sq. m. Iratined by Cedar Bayou, its E. bomdary: San Jacinto $r$., which flows through the $\mathrm{E}$, half, Spring cr., its briuch, antel X. line of county; Buffalo Bayon and its afflu$2 \pi$ ents, Sims, Brays, Horse Pen, White Oak, Hunting, Green's, and Carpenter's bayoux, and by Clear er., on its S. border, all of which empty into Galveston Bay. It is finely situated for the transportation of its products, having Galveston Bay in the S. E. and several large rivers: the San Jacinto navigable $40 \mathrm{~m}$., Buffalo Bayou 30 , and Cedar cr, 20, all deep streams, with scarcely perceptible currents, The streams are lined with forests, but most of the county is open prairie, with a rolling surface in the $N$. The soil just on the coast is of moderate fertility, but in the middle and N. consists of a deep black mold, with a substratum of shells, and the E. has some of the best land in East Texas. It timber is very valuable, consisting of pine on San Jacinto $r$, and Buffalo Bayou, and elsewhere of magnolia, eypress, cedar, and several kinds of oak. Rotten limestone and beds of clay abound in the N. Cotton is the great staple, bat all the grains yield largely, and sugar is suceessfully cultivated. In the S. E. was fought the famous Battle of Sau Jacinto. Farms 197; manuf. 42; dwell. 834 , and pop.wh. 3,756, fr. col. 7, sl, 905-total 4,668. Capital: Houston. Public Works: Houston and Galveston R. R., and Buffalo Bayou, Brazos, and Colorado R. R.

Harris, p. v., Louisa co., Virg.: 47 m. N. W. Richmond. Harrisburgin, p. v., Fayette co., $I n d_{.}: 50$ m. E. by S. Indianapolis.

Harrisburgh, p. y., Pontotoc co., Miss. : 149 m. N. N.E. Jackson.

II Arrisburgh, p. v., Mecklenburgh co., $N_{0}$ Car.: $127 \mathrm{~m}$. W. S. W. Raleigh.

Harrisirger, p. v., Abbeville dist., S. Car.: 103 m. W. by N. Columbia.

HArRisiurgh, t. and p. o., Lewis co., N. Y.: $124 \mathrm{~m}$. N. W. Albany. Drained by creeks, affuents of Black r., which afford water-power. Surface generally level; soil a brown loam. There are several mills and stores in the t. Pop. 1,367.

Harrisburge, p. city, and eap. Dauphin co., Penn., and capital of the State of Pennsylvania : on the E. bank of Susquehanna r., in lat. $40^{\circ} 16^{\prime} \mathrm{N}$., and long. $76^{\circ} 50^{\prime} \mathrm{W}$., 110 $\mathrm{m}$. N. Washington. The river though voluminous is not navigable here, except for rafts, which descend the current; but it is accessible from all parts by canal or railroad, and is a very flourishing interior market. The city is built on elevated ground, and commands a varied and pleasant prospect of the surrounding country. The public buildings are the State capitol, the court-house, the county prison, a Masonic Hall, the Laneasterian school, churches of all denominations, some built at great expense, schoolhouses, etc. The Capitol, or State house, is an imposing structure, consisting of a main building and two wings, each adorned with a portico and Ionic pillars; the central edifice is $1 S 0$ feet wide, 80 feet deep, and 108 feet from the ground to the top of the dome, and the whole is surrounded by an open area, adorned with two walks and an iron railing. Harrisburg has considerable manufactures and most of the mechanic arts; its commerce is extensive. The press of Ifarrisurg ecmsists of 1 daily newspaper and 7 published weekly; the daily is the "H. American" (whig), of which there is also a weekly edition, and the weeklies are the "Vaterland Vechter" (whig), the "Democratic Cnion" (dem.), the "Pennsylvania Telegraph" (whig), the "Keystone" (dem.), the "Church Advocate" (relig.), and the "Pensylvarta Intelligencer" (whig). Water is supplied to the city through iron pipes from a reservoir on Mount Airy, into which it is elevated from the Susquehanna. The eity is lighted with gas, and in its general police is one of the best conducted communities in the Union. Pop. in 1820 about 3.000 ; in $1830,4,807$; in $1540,5,980$, and in $1850,8,173$ Harrisburg bridge, over the Susquehanna, is a fine covered structure, extending to an island and thence to the opposite bank, 2, s 6 feet long, 40 feet wide, and 50 feet above the river, and below is the bridge of the Cumberland Valley R. R., also a substantial structure. 
Harrisburgh, p. v., Franklin co, Ohio: on Darby er., $14 \mathrm{~m}$. S. W. Columbus.

Hakris' Cross Roads, p. o., Franklin co., N. Car. : $35 \mathrm{~m}$. N. E. Raleigh.

HArris' Ferre, p. o., Washington co., Oreg. : on the Tualatin r., an affluent of the Willamette, $36 \mathrm{~m}$. N. by W. Salem.

Harris Hill, p. o., Erie co., N. Y.: 258 m. W. Albany.

Harris' Lot, p. o., Charles county, Mal.: $47 \mathrm{~m}$. S. W. Annapolis.

Harrison county, Ind. Situate S, and contains $446 \mathrm{so}$ m. Drained by Blue r. and Indian and Buck crecks, all affluents of the Ohio, which forms its S, E., S., and S. W. boumlary: Surface rolling-in parts broken; soil good-on the streatuns very productive, and occasionally barren, with thin soil. Sink-holes and caves occur in several parts. Corn, wheat, and pork are the staple products. Farms 1,650 ; manuf. 19 ; dwell. 2,645, and pop.-wh. 15,206, fr. col. 80 - total 15,286. Capital: Corydon.

Harrisor county, la. Situate W., and contain $496 \mathrm{sq} . \mathrm{m}$. Drained by Little Sioux, Soldier, and Boyer's river's, afluents of the Missouri, which forms its W. boundary. Unorganized in 1550 .

HARrison county, $\bar{K} y$. Situate N., in E. part, and contains $316 \mathrm{sq}$. m. Licking $\mathrm{r}$., a branch of Ohio r., crosses its N. E. corner, and its branches drain it. Surface diversified, affording good water-power. Soil very fertile, producing great crops of the grains, on which catlle, hogs, and shoep are raised in large numbers. Farms 1,130; manuf. 54; dwell. 1,753, and pop.-wh. 9,739, fr. col. 140, sl. 3,155total 13,06t. Capital: Cynthiana. Pullic Works: Lexingtum and Covington R. R.; and Frankfort and Covington R. R.

ILARRISON county, MFiss. Situate $\mathbf{S}_{\text {., }}$ and contains 1,064 sq. $m$. Drained by Wolf and Biloxi rivers in the S., and in the N. by Red and Black ereeks, aftuents of Pascagoula $r$. Surface mostly level, and in parts marshy; soil light and sandy, of moderate fertility, and covered with a growth of pine. Cotton is the export. Farms 84 ; manuf. 19 ; dwell. 727, and pop.-wh. 3,378 , fr. col. 56, sl, 1,441-total 4,875 . Capitul: Mississippi City.

Harrisun county, Mo. Situate N., and contains 792 sq. $m$. It lies between E. and W. forks of Grand $r$, a tributary of the Missouri, and is drained by their branches. Surface various, and soil generally fertile and well wooded. Farms 141; manuf. 0 ; dwell. 387 , and pop.-wh. 2,434, fr. col. 0, sl. 13-total 2,447. Capital: Bethany.

HARrtson county, Ohio. Situate E. centrally, and contains $412 \mathrm{sq} . \mathrm{m}$. Drained W. by branches of Tuscarawas r., a head of Muskingum r., and E. by several small streams flowing E. into the Ohio. Surface very uneven, giving rise to numerous mill-streams and good water-power. Soil very productive, and finely adapted to grain and grazing. Beef, pork, and wool are largcly raised, and manufactures are extensive. Farms 1,668; manuf. 74; dwell. 3,526, and pop.-wh. 19,570, fr. col.257-total 20,157. Capitul: Cadiz. Public Works. Ohio Central R. R.

HArrison county, Tex. Situate N. E., and contains 1,082 sq. m. Drained by Duffon's cr., Potter's er., Eight Mile cr. and other afluents of sabine r., its S. W. boundary, and Little and Big Cypress rivers, the latter its N. boundary, with Ferry and Caddo lakes, by the affluents of which the $\mathrm{N}$. is drained. The streams are small, but swift: surface almost level, with a gentle slope to the S. E., and, except a few prairies in the W., covered with a dense forest of huge pines, cypresses, elms, hickories, and oaks. Soll, except a few sandy ridges in the $\mathrm{N}$. W., very productive, consisting of rich black mold, with a substratum of red loam. Cotton yields great crops, and wheat as good or better. Excellent coal is found on the Sabiner. Farms 521 ; manuf. 13 ; dwell. 972, and pop.-wh. 5,604, fr. col. 5, sl. 6,213-total 11,522. Cupitul: Marshall.

U.Aezisox county, Virg. Sítuate N. W., and contains 459 sq. m. Drained by W. fork of Monongahela river and its branches, Surface elevated and broken, with fine millstreams; soil very fertile. Alt the grains thrive, and much attention is paid to raising cattle and fattening pork. Maple sugar and tobaceo are among the products. Farms 1,093; manur. 34 ; dwell. 1,566, and pop.-wh. 11,214, fr. col. 26, sl. 458-total 11,728. Capitul: Clarksburg. Public Work8: North-western R. R.

Hatrison, p. v., Winnebago co, $I l_{\text {. }}$ : on the S. of Peckatonica r., $152 \mathrm{~m}$. N. Springfield.

II Arison, t. and p. o., Cumberland county, DIe. : 51 m. W. S. W. Augusta. It has Crontied r. on the E., and on the W. Long I'ond, or Bay of Naples. It is connected with Portland by Sebago Lake and the canal. Surface various; soil fertile, and adapted to wheat. Pop. 1,416.

IIArrison, p. O., Washtenaw con, Mich.

IIArrtson, t. and po o., Westchester co., $N_{0} \Gamma_{0}: 138 \mathrm{~m}$. S. by E. Albany. Drained by Blind Brook and Mamaroneck cr., which run S. inte Long Island Sound. Surface level, but diversified; soil loam, and well cultivated. The p. o. is $26 \mathrm{~m}$. from New Tork City, and the $\mathrm{t}$, is intersected by the New York and New IIaven R. R. Pop. 1,261.

If ARRISON, p. v., flamilton co, Ohio: on the E. side of White Water r., and on the canal, $105 \mathrm{~m}$. W. S. W. Columbus. It is a flourishing v., with several mechanio shops, stores, ete, and about 700 inhabitants. A portion of the $\mathrm{v}$ is within the limits of Indiana, its main street being in the dividing line of the two states.

Harrison, p. v., and cap. Hamilton co., Tenn.: on the left or S. bank of Tennessee r., 117 m. E. S. E. Nashville. It contains a court-house, jail, ete., and about 400 inhabitants. The projected railroad from Charleston to Chattanooga passes through this place.

Harrisonuurgi, p. v., and cap. Catahoula par., $L a$ : on the W. side of Washita r., $97 \mathrm{~m}$. N. N.W. Batou Rouge. It contains a court-house, jail, ete., and about 200 inhabitants.

Harrisoxburgir, p. v., and cap. Rockingham co., Virg.: $110 \mathrm{~m}, \mathrm{~N} . \mathrm{W}$. Richmoad. It contains a court-house, jail, etc., and has numerous stores, being the trading centro of a large region of country. Two newspapers are publishea here, the "Rockingham Register" (dem.), and the "Harrisonburg Republican" (whig), both weekly issues. Pop. about 1,400 . It is intended that the Manassas Gap $R$. $R$ shall be carried from its present terminus at Front Royal, southward through Harrisonburgh.

Harison City, p. v., Westmoreland co., Penn.: 149 m. W. Harrisburg.

Harrison's Mills, p. O., Crawford co., Mo.: on the E. side of Maramec r, $62 \mathrm{~m}$. S. E. Jefferson City.

Harrison Square, p. v., Norfolk con, MIass. : on the line of the Old Colony R, R, $4 \mathrm{~m}$. from Boston.

Harrison Vallex, p. o., Potter co., Penn.: 131 m. N.W. Harrisburg.

Harrisomville, p. v., and cap. Monroe co, $I l l .:$ on the E. bank of the Mississippi $r_{,}, 112$ m. S. S. W. Springfield, It contains the county offices and several stores. Herculaneum lies on the opposite side of the river.

Harrisonville, p. v., Shelby county, $\bar{k} y$. : 27 m. W. Frankfort.

Harrisonville, p. V., and cap. Cass co, Mo. : on a fork of Grand river of the Osage, 115 miles W. Jefierson City. It contains a court-house, jail, ete, and about 150 iuhabitants.

Harrisonville, p. v., Baltimore co, Mru. : on the Uniontown Turnpike, $7 \mathrm{~m}$. W. Baltimore, and $29 \mathrm{~m}$. N. by W. Annapolis.

HARrisonvrLLE, p. v., Gloucester county, $N$. Jer. : $44 \mathrm{~m}$. S. by W. Trenton

IARErsoxvilie, p. V., Meigs county, Ohio.: $\$ 2 \mathrm{~m}$. S. E. Columbus.

Harrisontille, p. v., Fulton co., Penn.: 65 m. W. by $\mathbf{S}$. Harrisburg.

II ARlistows, p. v., Washington eo., Iml.: on the line 
of the New Albany and Salem R. R., $80 \mathrm{~m}$. from the former place, and $79 \mathrm{~m}$. S. Indianapolis.

Haristille, p. o., Marquette county, Wisc. : $52 \mathrm{~m} . \mathrm{N}$. Madison.

Harkisville, p. v., Montgomery county, $N$. Car.: $86 \mathrm{~m}$. W. S. W. Raleigh.

Harristille, p. v., Cheshire co., N. Hamp.: $78 \mathrm{~m} . \mathrm{S} . \mathrm{W}$. Coneord.

HARRISVILLE, p.v., Harrison co., Ohio: in the S. E. corner of the county, $110 \mathrm{~m}$. E. by N. Columbus.

Harrisville, p. v., Butler co., Penn. : 179 m. W. N. W. Harrisburg.

Harrisville, p. V., Brunswick co., Virg.: $51 \mathrm{~m}$. S. by W. Richmond.

Harrodsburgh, p. v., Monroe co., Ind. : 54 m. S. S. W. Indianapolis.

Harrodsburgh, p. $\nabla_{\text {., }}$ and cap. Mercer co., $K_{y .:}$ on a branch of Salt r., $29 \mathrm{~m}$. S. Frankfort. It contains a courthouse, jail, etc., several stores and mechanic shops, and 1,481 inhabitants. Bacon College is located here; it was founded in 1:36, and in 1550 had 5 professors, 75 students, and a library of 1.200 volumes. In the vicinity is a noted mineral spring, which is much resorted to by invalids.

Hark Hul, p. o., Marshall co., Miss. : 173 m. N. by E. Jackson.

Harimaransville, p. O., Montgomery co., Ohio: $74 \mathrm{~m}$.

W. S. W. Columbus.

Harr county, $K y$. Situate W. centrally, and contains 404 sq. m. Intersected by Green r, and bounded N. W. by Nolin cr., its branch. Surface mostly level, and soil productire. Tobacco is the great staple. Farms 829; manuf. 12 ; dwell. 1,212, and pop.-wh. 7,740 , fr. col. 52, sl. $1,301-$ total 9,098. Capital: Mumfordsville. Public Works: Danville and Nashville R. R.

Hartfuld, p. v., Chautauque co., N. Y.: 282 m. W. by S. Albany.

Hartford county, Conn. Situate N. centrally, and contains $727 \mathrm{sq}$. $\mathrm{m}$. Intersected from $\mathrm{N}$. to $\mathrm{S}$. by the Connecticut, and drained by its affluents, Farmington and Mill rivers on the W., and on the E. Poduuk, scantic, and other smull streams. Surface much diversified, from alluvial meadows, annually overflowed, to high rocky hills; soils also various, but generally very fertile, and under admirable cultivation. In the $\mathbf{E}$. are unsurpassed farms and dairies, in the middle the delightfus and invaluable meadows of the Comnecticut basin, and on the W. streams, land almost as good. The facilities for manufactures are great, and all improved. Tho articles made embrace almost every thing in use; but for value and quality, those best known are carpets, powder, axes, clocks, tinware, and iron castings. For commerce and transportation, it has the Connecticut navigable through it, and railroads in every dircetion. It embraces one capital of the State and the penitentiary in its limits, besides munificent benevolent and literary establishments. In the S. W is a copper mine of great extent and exceedingly rich ore. Irou is alsu formd, Farms 3.950 ; manuf. 734 : (1wehl. $11.31 \mathrm{~s}$, and pop,-wh. 65,756, fr. col. 1,210-total 69,966. Capital Hartford. Public Works: Farmington Canal (litlle used);

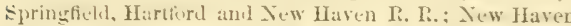
and Northampton (or Canal) R. R. ; Hartford, Providence and Fishkill R. R. ; Collinsville Branch R, R.

H $\triangle$ RTFuRd, p. city, and cap. Hartford co., Conn., and one of the callytals of the siate: on the W. side of Connecticut $r$. at the head of ship navigation, $50 \mathrm{~m}$. from its mouth, in lat. $41^{\circ} 45^{\prime} 59^{\prime \prime}$ N., and long. $72^{\circ} 40^{\prime} 45^{\prime \prime}$ W. $395 \mathrm{~m}$. N. E. Washington. The site of the city rises gradually from the $r_{\text {. }}$ and on the $\mathbf{S}$. and W. is considerably elevated. The compact part is more than a mile in length and about threefourths of a mile wide; and the streets are arranged with great regularity Little r., which crosses the city in its $\mathrm{S}$. part, furnishes a valuable water-power; bridges cross this and also the Connecticut $\boldsymbol{x}$., those over the latter connecting it with Eist Hartford. The most couspicuous publie build200
Ings are the State House, the City Hall, Trinity College, the American Asylum, the Retreat for the Insane, the Wadsworth Atheneum, numerous elegant churches, an arsenal, the market-houses, etc. There are 5 Congregational churches, 3 Episcopalian, 2 Baptist, 3 Episcopal Methodist, 1 Protestant Methodist, 1 Roman Catholic, 2 Second Advent, 1 Presbyterian, 1 Unitarian, 1 Universalist, and 1 Jew's Synagogue-in all 24 churches. Trinity (formerly Washington) College was founded in 1824, and in $1850 \mathrm{had}$ a president, $s$ professors, 300 alumni, of which 130 were in the ministry, and 80 students, and a library of 12,000 rolumes. It is under the control of the Episcopalians. The Antrican Asylum for the Deaf and Dumb was established by the late Rev. Thomas H. Gallaudet, and was the first institution of the kind in the United States; it has extensive buildings in the W. part of the city, and is the most flouristring and valuable asylum in the Union. The Retreat for the Insane is a little $\mathrm{S}$. of the eity, and, like the asylum, is a well-conducted and successful institution. Hartford has numerous academies and schools, which reflect great credit on the city; and it lias a public press not surpassed for morality and intelligence; it has 2 daily papers, of which weekly editions are also published, 6 weeklies, and 2 monthlies. The dailies are the "H. Courant" (whig), and the "H. Times" (dem.); the weeklies, the "H. Courier" (whig), the "Republican" (F. S.), the "New England Fountain" (temperance), and the "Christian Secretary" (Bapt.), the "Calendar" (Episc.), and the "Religious Herald" (Congr.), devoted to religious subjects. Hartford is also celebrated for its extensive book business. As a manufacturing city, Hartford stands high, and contains numerous lumber yards, machine shops, fire-arm manufactories, boot and shoe factories, and a variety of handicrafts; and as a place of commerce, it has many advantages, its natural market being the valley of the Connecticut, It is also a depôt of interior trade and railroad traffic, being in the centre of the State and intersected by railrouds from every direction. Steamboats also ply regularly to New $\mathbf{Y}$ ork. Pop. in 1810, 3,955; in $1520,4,725$; in $1530,7,076$; in $1510,9,463$; and in 1550 , 17.966. The Indian name of the site of Hartford was "Suckeag." In 1633 the Dutch built a fort here, and in 1635 , the Dutch having relinquished their claims to the English, Hartford was permanently settled by emigrants from Massachusetts under charge of Rev. Mr. Hooker. It was incorporated as it city in 1754 , and is now governed by a mayor and municipal officers.

HALTFORD, p. v., Forsyth co, Ga.: 103 m. N. N. W. Milledgeville.

Han'TFord, p. v., Ohio co., Ind.: on Loughery cr. $82 \mathrm{~m}$. S. E. Indianapolis. It contains about $50 \mathrm{~d}$ wellings, and 300 inhabitants.

HARTFORD, p. v., Knox county, $\Pi$.: 85 m. N. N. W. Springfield.

HARTFORD, p. $\nabla_{\text {., }}$ and cap. Ohio co., $K y$. : on the S. side of Rough cr. of Green r., $125 \mathrm{~m}$. W. S. W. Frankfort. It contains a court-house, jail, etc., and about 400 inhabitants.

Hartford, t. and p. o., Oxford county, $M e_{.}: 31 \mathrm{~m}$. W. Augusta. Drained by ponds and small streams emptying into Androscoggin r. It is a fine agricultural township, with a varied surface, and a soil well adapted for wheat and grass, The prineipal $\mathrm{v}$. is locuted centrally, and there are also North and suuth villages of the same name. Pop. of t. 1,293 .

HARTFORD, t. and p. T., Washington co., N. Y.: $47 \mathrm{~m}$. N. by E. Albany. Drained by branches of Wood cr. Surface hilly; soil sandy and clay loam. The v., situate on the old N. post road, contains 200 inhabitants. Pop. of t. 2,051.

Hartford, t. and p. 0., Trumbull co., Ohio: $156 \mathrm{~m}$. N. E. Columbus. Drained by affluents of Shenango creek. Surface diversiffed; soil fertile and well cultivated. Building stone is abunilant. Pop. 1.2.5.

HARTFold, t. and p. T., Windsor co., Ferm. : 43 m. S. S. E. Montpelier. Drained by White and Waterqueechy rivers; 
and the Connecticut, into which they fall, lies on the E. border. Surface somewhat uneven; soils generally fertile, and on the rivers rich, warm, and very productive. The principal $v$. lies at the mouth of White $r$, and there are in the t. the villages of West Hartford, Woodstock, White River Village, and Queechy Valley, the three first of which lie on White $r$, and the Vermont Central $R$. $R$. The $t$, has considerabie manufactures. Pop. 2,159.

Hartford, t. and p. v., Washington co, Wisc.: $54 \mathrm{~m}$. E. N. E. . $\downarrow$ adison. Drained by Rock r., which rises in this t. from a large porrl. Surface elevated and level; soil rich and fertile. The village is $\mathrm{S}$. of the river, and is a small agricultural settlement. Pop. of t. 1,008.

Hartiegig, p. o., Mercer co., Penn.: 203 m. W. N. W. Harrisburg.

Harthand, p. v., McHenry co., $I l l .: 180$ m. N. N. E. Springfield.

Hartland, t. and p. v., Somerset co., Me.: $43 \mathrm{~m}$. N. by E. Augusta. Drained by Sebasticook $\mathbf{r}_{*}$, and Moose Pond lies on its N. border. Surface elevated and rolling; soil adapted to grain and grass. There is a small v. toward the south part. Pop. of t. 960 .

Haptland, t. and p. v., Hartord co., Conn. : 23 m. N. W. Hartford. Drained by branches of Farmington r., and has considerable water-power. Surface mountainous; soil somewhat rocky, but fertile in grass. The principal $\mathrm{v}$. is situate in the S. E., and there is a v. called West Hartland. The $t$. has several mills, and carries on some mechanical business. Pop. 818 .

Hartland, t. and p. $\nabla_{\text {., Livingston }} \mathrm{co}$, Mich. : $43 \mathrm{~m}$. E. by S. Lansing. Drained by the heads of Shiawassee and Huron rivers. Surface elevated, but not broken, and forming the watershed between streams flowing $N$. and $S$, to the rivers named above. It is an excellent farming country, producing wheat, corn, etc., and has fine grazing tracts. Pop. of t. 996.

HARTLANn, t. and p. $\nabla .$, Niagara co., N. Y.: $244 \mathrm{~m}$. W. by N. Albany. Drained by Johnson's and Eighteen Mile creeks, flowing into Lake Ontario. Surface level; soil saudy and calcareous loam. The p. o. is a small agricultural village on the N. side of Johnson's creek. Pop. of t. 3,028.

HarTLAND, t. and p. O., Huron co., Ohio: $59 \mathrm{~m}$. N. by E. Columbus. Drained by a branch of Vermillion r. of Lake Erie, Surface level; soil sandy loam and fertile. It is a fine agricultural town and has 1,176 inhabitants. Pop. 1,024.

HaRTLAND, t. and p. v., Windsor co, Verm. : 51 m. S. S. E. Montpelier. Drained by Waterqueechy $r$. and Lull's brook, both affluents of Connecticut, which makes the E. border. The t. has immense water-power and numerous manufactures. Surface diversified; soil generally productive, and there are meadows on the Connecticut. The v. is lucated on the line of the Vermont Central R. R., $4 \mathrm{~m}$. above Windsor, and $4 \mathrm{~m}$. N. of it is the village of North Hartland. Pop. of $t .2,063$.

Hartuand, p. v., Waukesha cuunty, Wisc: $51 \mathrm{~m}$. E. Madison.

Hartleton, p. v., Union co., Penn. : 48 m, N. W. by N. Harrisburg.

HART LOT, p. o., Onondaga co., N. Y.: $122 \mathrm{~m} . \mathrm{W}$. by N. Albany.

HART's Grove, t. and p. o., Ashtabula $\mathrm{co}_{3}$, Ohio: $156 \mathrm{~m}$. N. E. Columbus, Drained by affluents of Grand river. Surface level; soil productive. Pop. 822.

Hartshopav, p. v., Orange co., N. Car.: $47 \mathrm{~m} . \mathrm{N} . \mathrm{W}$. Raleigh.

Harts Location, p. o., Coos co., N. Hamp. : $92 \mathrm{~m} . \mathrm{N}$. Coneord.

Haft's Milis, p. o., Ripley co., Ind. : on Laughery cr., 74 m. S. E. Indianapolis.

Hartstows, p. v., Crawford co, Penn. : 212 m. W. N. W. Harrisburg.

Hart's Village, p. V., Dutchess co., N. Y.: $56 \mathrm{~m} . \mathrm{S}$, Albany.
Hartstrule, p. v., Bartholomew co., Ind. : on Clifty cr., $42 \mathrm{~m}$. S. S. E. Indianapolis.

Hartsvilux, p. v., Berkshire co., Mass. : 109 m.W. by S. Boston. The shakers have a settlement in this neighborhood.

Harteville, p. Y., and cap. Wright eo., Mo.: on Wood's Fork of Gasconade $.0,94 \mathrm{~m}$. S. by W. Jefferson City.

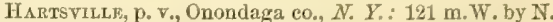
Albany. It contains several factories, tc., and 20 inhabitants.

Hartstrle, p. v., Bucks county, Penn. : 94 m. E. Harrisburg.

HARTSviLle, p.v., Darlington dist., S. Car : 73 m. E. by N. Columbia.

Hartsvilue, p. o., Sumner co., Tenn.: on the N. side of Cumberland r., 37 m. E. N. E. Nashville. Pop. about 400.

Hartville, p. v., Stark county, Ohio: 106 m. N. E. Columbus.

Hartwellfille, p. Y., Shiawassee eo, Drich. : 23 m. N. E. Lansing.

HARTwIoK, to and p. v., Otsego county, N. Y.: $66 \mathrm{~m}$. W. Albany. Drained by Otsego er. and Susquehanna $r$. Surface hilly; soil, fertile sandy loam. The $\mathrm{v}$. in the valley of Otsego er, contains several factories and stores, and about 400 inhabitants. The t. has also considerable manufactures, and 2,352 inhabitants.

Hartwick Seminary, p. o., Otsego co., N. Y.: on Susquebanna r., $62 \mathrm{~m} . \mathrm{W}$. Albany. Here is also a $\mathrm{\gamma}$ of some 20 or 25 dwellings. Hartwick Seminary is a literary and theological institution, under care of the Lutherans; it was founded in 1816 , and endowed with a fund amounting to $\$ 80,000$, by John Christopher Hartwick. In 1850 it had 2 professors, 5 students. and 52 persons had been educated at the institution since its foundation. Its library contains 1,250 volumes.

Hartwood, p. v., Stafford co., Firg. : 67 m. N. by W. Richmond.

HARTwood, p. v., Autauga co., Ala.: $42 \mathrm{~m} . \mathrm{W} . \mathrm{N} . \mathrm{W}$. Montgomery.

HARVARD, to and p. v., Worcester county, Mass. : $32 \mathrm{~m}$. W. N. W. Boston. Drained by Stony river, which has its souree in a pond in this t., and which falls into Nashua r., which makes its $W$. border. The $\mathrm{v}$. is situate centrally, and contains two churches, etc. In the N. E. part of the t. there is a Shaker's village; a good varicty of monumental slate is found here. Pop. of t. 1,632. The Worcester and Nashua R. R. intersects Harvard, $25 \mathrm{~m}$. from Worcester.

Harvard, p. v., Delaware co., N. Y.

Harvex's, p. o., Greene co., Penn. :189 m. W. S. W. Harrisburg.

Haevexsburgh, p. v., Warren co., Ohio: $\tau$ m. S. W. Columbus.

Harvey's Five Ponts, p. o., Westmoreland co., Penn.

Harvey's Polnt, p. o., Polk co., Ia. : on a creek of Deg Moines r., $102 \mathrm{~m}$. W. Iowa City.

HarveY's Store, p. o., Charlotte co., Virg.: $81 \mathrm{~m}$. S. W. Richmond.

Harveystilie, p. v., Luzerne co, Penn.: 86 m. N. E. by $\mathrm{N}$. Harrisburg.

HARwich, t. and p. v., Barnstable co., Mrass.: $72 \mathrm{~m}$. S. E. Boston. Drained by Herring $r$, the outlet of Long Pond, and affording great water-power. Its S. shore is washed by the Atlantic. Surface and soil low and sandr, as in other parts of the peninsula. The $\mathrm{v}$. is located centrally, and there are also $\mathrm{S}$, and $\mathrm{W}$. villages. The inhabitants are engaged in the salt manufactures, and also in narigation and the fisheries. Pop. of t. 3,25s.

HARTICII Port, p. v., Barnstable co., Mriss. : $55 \mathrm{~m}$. S. E. Boston. It has a good harbor fur coasters und fishing smacks.

Harwrnton, $t$, and p. v., Litchfield co., Conn. : $23 \mathrm{~m}$. W. Hartford. Drained by Lead $r$, and other tributaries of Naugatuck r., which lust bounds it on the W. and furnishes $2 \$ 1$ 
mill-sites. Surface elevated and rough, and the soil well adapted to grass. The v. contains 2 churches and about 35 habitations. The t, has numerous grist and saw mills and 1,176 inhabitants.

Hasbrovek, p. o., Sullivan county, N. Y.: 84 m. S. W. Albany.

HASkellville, p. v., Lawrence co., Ohio: 73 m. S. S. E.

Columbus.

HASEeNvILLe, p. v., Steuben co., N. Y.: $203 \mathrm{~m}$. W. by $\mathrm{s}$. Albany.

Haskinstille, p. v., Greene co., $\bar{k} y .: 73$ m. S. S. W. Frankfort.

Hastixgs, t., p. v., and cap. Barry co., Mich.: $33 \mathrm{~m} . \mathrm{W}$. Lansing. Drained by Thorn-apple $r$. and its affluents, which afford extensive water-power. Surface varied; soil rich and productive. The $\mathrm{v}$, lies on the $\mathrm{S}$. or left bank of the Thorn-apple, and contains a court-house, jail, ete., and has sereral industrial establishments. The t. has numerous mills, stores, ete. Pop. 554.

Hastixgs, t. and p. o., Oswego co., N. Y.: $128 \mathrm{~m}$. W. N. W. Albany. Drained by Salmon er. on the N., and on the $\mathrm{S}$. by creeks flowing into Oneida Lake and its outlets. Surface level; soil mostly a sandy loam. It has numerous mills, etc., and a pop. of 2,927 souls.

Hastings, p. V., Rockland co., Ohio: $62 \mathrm{~m}$. N. by E. Columbus,

Hastings Cevtre, p. v., Oswego co., $N . Y .: 128 \mathrm{~m}$. W. N. W. Albany.

Hastivgs-UPON-Hudson, p. v., Westehester co., $N$. $Y$.: on the E. side of Hudson r., $113 \mathrm{~m}$. S. Albany. It lies on the Hudson River R. R., $21 \mathrm{~m}$. by route from New York City Hall. The landing on the river is good, and the v. contains several factories, stores, etc. Pop. about 400.

Hastixgsville, p. v., Columbiana co., Ohio: $127 \mathrm{~m}$.

E. N. E. Columbus.

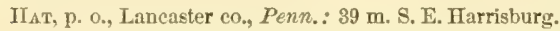
Hatborotgi, p. v., Montgomery co., Penn.: near Pennypack er., $97 \mathrm{~m}$. E. Harrisburg. Pop. about 200.

Hatchex:'s, p. o., Talladega county, Ala : $62 \mathrm{~m}$. N. Miontgomery.

Hatcir TurNpike, p. o., Tippah co., Mfiss.: $192 \mathrm{~m}$. N. N. E. Jackson.

Hat Creek, p. 0., Campbell co., Virg.: 92 m. W. by S. Richmond.

HATFIELD, t. and p. vo, Hampshire co, MFa8s. : $76 \mathrm{~m} . \mathrm{E}$. Boston. Drained by Mill r., which falls into the Connecticut on the W. border, and over which is a brilge to Hadley. Surface diversified, with extensive meadows on the river; soil everywhere fertile. Zine blende is extensively deposited, and there are other minerals. The $v$, lies on the W. side of the Connecticut, and the Connecticut River R. R. has a statim a little back, which is fast rising into a place of eonsideration. Pop. of t. 1,041.

Mar Grove, p. o., Warren county, $\Pi_{0}: 82 \mathrm{~m} . \mathbf{N}$. W. Epringfield.

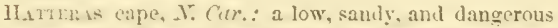
cape on the $s$. W. end of an island compreser of sand and rocks which incloses Pamlico Sound, lat $35015^{\prime}$ N., and long. $\quad 15=30^{\prime} \mathrm{W}$. It is the mariner's dread, and has been the seene of numerous shipw recks.

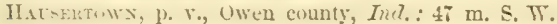
Indianapolis

HaYaris, p. v., Greene county, $A l a$, : 21 m. N. W. Montgomery.

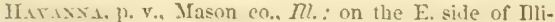
nois r., $42 \mathrm{~m}$. N. W. Springfield. Spoon $r$, enters the Illinois immediately opposite. The village has a convenient landing, and is situate on a sandy ridge 50 feet above the highest thouls. It is the chief shipping ylace for the county.

Haraswa, p. v., Chemung co., $\boldsymbol{N}$. $Y$.: on a creek of Geneca Lake, abont $3 \mathrm{~m}$. from its inlet and $154 \mathrm{~m}$. W. by $\mathrm{S}$, Albany. The Chemung Canal, and also the Canandaigua and Emira Ii. Ii. patss through the villige. It has about $2 \times 2$
800 inhabitants, and contains several flourishing manufacturing establishments and yards for boat building, and two newspapers are published here, the "H. Journal" (whig), and the "H. Republican" (indep.), both weekly issues.

Hatenstille, p. v., Bradford county, Penn.; 107 m. N. Harrisburg.

HAVERford, t. and p. o., Delaware co., Penn.: $86 \mathrm{~m}$. E. Harrisburg. Drained by Darby and Cobb's creeks-the former its W. boundary. Surface hilly; soil sandy loam, fertile, and well cultivated. It has several considerablo cotton and woolen factories, mills, etc. Pop. 1,317.

HAVERHIL, t. and p. v., Essex co., Mass.: 29 m. N. by W. Boston. Situate between Merrimac r. and the N. line of the State, and at the head of navigation. It is conneeted with Bradford by several bridges from 800 to 1,000 feet long. The $\mathbf{v}$. contains several large manufactories, mechanic shops, etc., and ressels of 100 tons come up to it; and it has two weekly newspapers, the "Essex Gazette" (whig), and the "Essex Banner" (dem.) There are also several other villages, with manufactures, etc. This $t$ is one of the first manufacturing places of the State, and is distinguished alike for the variety and quantity of its productions. The Boston and Maine R. R. passes through it. Pop. 5,877.

HAVERHILI, t., p. v., and cap. Grafton co., N. Hamp.: $67 \mathrm{~m}$. N. N. E. Concord. Drained by Hazen and Oliverian brooks, flowing into the Connecticut, which makes its W. boundary. Surface, except on the meadows, elevated; soil excellent for general farming. Granite suitable for millstones, and beds of iron ore are found in this town. The $\mathrm{y}$. called Haverhill Corner, is situate in the $\mathrm{S}$. W. angle, and is built around an oblong square. It contains a courthouse, jail, etc., and about 80 dwellings; and has a newspaper, the "Democratic Republican," issued weckly. North Haverhill, in the N. W., is another village: it is built on a street a mile long, straight, and very level. The Boston, Concord, and Montreal R. R. passes through the town. Pop. 2,405.

Haverilll Centre, p. o., Grafton co., N. Hamp.: $69 \mathrm{~m}$. N. N. E. Concord.

HAVERSTRAw, to and p. v., Rockland co., N. Y.: $92 \mathrm{~m} . \mathrm{S}$. Albany. Drained by several smalk creeks flowing into Irudson $r_{\text {, }}$, which bounds it on the $E_{*,}$ and on which are several convenient landings, also Stony Point, an important military post in the Revolutionary War. Surface hilly and mountainous, being covered by the Dunderberg-the valleys are fertile, consisting of clar-loam soll. The $\mathbf{v}$, on the W. side of the Hudson has several large brick-fields, shipbuilding yards, and about 600 inhabitants, and carries on a considerable river trade, chiefly with New York City. The river opposite the $t$. of Haverstraw is wide and expands into a fine bay, which, under the name of Haverstraw Bay, extends from Teller's Point to Verplank's Point, a distance of $6 \mathrm{~m}$, and is from 2 to $3 \mathrm{~m}$. wide. The t. has considerable manufactures, as iron, paper, ete., and numerous mills. Pop. 5, S58.

Havilayd Holiow, p. o., Putnam co., N. $Y .: 78 \mathrm{~m}$. S. by E. Albany.

Havilandsyille, po vo, Harrison co., Ky. : 38 m. N. E. Frankfort.

HAVRe de Grace, p. v. and port, Ilarford $\mathrm{co}_{2}, M d_{\text {.: }}$ on the W. side of Susquehama $r_{\text {, }}$ at its confluence in Chesapeake Bay, $63 \mathrm{~m}$. X. X. E. Annapolis. The Baltimore ant Philadelphia R. R. passes through it, and here is the terminus of the Tidewater Canal. The $\mathrm{v}$. itself is small but well built, and contains sereral warehouses, stores, ctc. It is principally noted as a commercial and trading port; it has also some manufuetures, and in the fishing season has many engaged in that line of business. The "Harford Madisonian" is published weekly. Pop. 1,336. In 1514 Havre was sacked and burned by the British under Admiral Cockhurn.

MAT"ESTILLE, p. Y, and eap. Haneock co., Ky.: on the S. side of Ohio r., at the mouth of Lead cr., $107 \mathrm{~m}$. W. 
Frankfort. It contains a court-house, jail, etc., 13 stores, several mechanic shops, and about 600 inhabitants. It derives consideration from its extensive mines, which supply steamboats navigating the river with excellent coal.

HAWFIELD, p. o., Orange co., $N$. Car.: $37 \mathrm{~m} . \mathrm{N}$. W. Raleigh.

HaW KesviLle, p. o., Franklin co, Tenn.: $81 \mathrm{~m}$. S. E. Nashville.

HAwk EYE, p. v., Des Moines co, Ia. : 55 m. S. by E。 Iowa City.

$\mathrm{H}_{\mathrm{AW} \text { KINS }}$ county, Tenn. Situate N. E., and contains 712 sq. m. Drained by Clinch r., which bounds it N. W., Holston r., which passes through it from N. E. to S. W., and their branches, all affluents of the Tennessee. Surface broken, and soil mostly fertile. It has good water-power, which is used. Corn and wheat are the staples, and many swine and beeves are falted. Farms 735 ; manuf. 21 ; dwell. 2,019, and pop.-wh. 11,578, fr. col. 107, sl. 1,690-total 13,370. Capitul : Rogersville. Public Works: East Tennesse and Virginia R. R.

HAW EINS LANDLX, p. 0., Ashley co., Ark. : 127 m. S. S. E. Little Rock.

Hawkrnsvinte, va, Tuolumne co., Calif.: on the N. side of Tuolumne r., $112 \mathrm{~m}$. S. E. Vallejo.

Hawkmsville, p. v., and eap. Pulaski en., Ga. : on the W. bank of Ocmulgee r., $58 \mathrm{~m}$. S. by W. Milledgeville. It contains a court-house, jail, ete., and has about 400 inhabitants. A considerable amount of produce is shipped from this point. HawkTrsville, p. V., Sussex co., Virg. : 44 m. S. by E. Richmond.

HAWK PoINT, p. o, Lincoln county, Mo.: on a cr. of Au Cuivre r., 62 m. E. N. E. Jefferson City.

HAWLEY, t. and p. v., Franklin co., Mass. : $96 \mathrm{~m}$.W. by N. Boston. Drained by branches of Deerfield r., which afford water-power. Surface elevated and rough; soil of average fertility, and well suited for grass. Iron ore abounds-also building stone, etc. The $\mathrm{v}$. is located centrally. Population of $\mathrm{t} .881$.

Hawley, p. o., Wayne co., Penn. : 57 m. S. W. Harrisburg. HAwlex's Store, p. o., Sampson county, N. Car. : $57 \mathrm{~m}$. S. S. E. Raleigh.

Hawleyton, p. v., Broome co., N. Y.: $112 \mathrm{~m}$. W. S. W. Albany.

Hawlexville, p. v., Fairfield co., Conn.: on a cr. of Housatonic r., and on the line of the Housatonic R. R., $43 \mathrm{~m}$. S. W. IIartford, and by railroad $23 \mathrm{~m}$. from Bridgeport.

Haw PATch, p. o., La Grange co., Ind. : 123 m. N. by E. Indianapolis.

HAW river, $N$. Car.: one of the constituents of Cape Fear river. It rises in Rockingham and Guilford counties, and in Chatham co. unites with Deep ro, which, together, under the name of Cape Fear r., empty into the Atlantic Ocean.

Hawsburgh, p. v., Rappahannock county, Virg.: $94 \mathrm{~m}$. N. W. by N. Richmond.

HATthorN, p. v., Montgomery co., Ala.

Haydevvili.e, p. v., Hampshire co., Mass. : on Mill r. of the Connecticut, $87 \mathrm{~m}$. W. Boston. It is a manufacturing $\mathrm{v}$. of abrut 500 inhabitants, and is much celebrated for its gold pens, which are sold throughout the Union.

Haydensville, p. O., - - e., Calif;

HAYDON's, p. o., Owen co., Ky.: $31 \mathrm{~m}$. N. Frankfort.

HAYES' STORR, p: 0., Gloucester county, Virg. : 48 m. E. Richmond.

Hayesvirle, p. v., Ashland co., Ohio: 66 m. N. N. E. Columbus.

Hayesville, p. v., Chester county, Penn.: $64 \mathrm{~m}$. E. by S. IIarrisburg.

HaYrield, to and p. o., Crawford county, Penn.: $207 \mathrm{~m}$. W. N. W. Harrisburg. Drained by tributaries of French creek, which makes its E. boundary. Surface rough; soil average. Pop. 1,581.

Hay Market, p. v., Prince William co., Firg. : $92 \mathrm{~m}$. I. Ly W. Richmond.
HaY Meadow, p. 0., Wilkes co., N. Car. : 144 m.W. by $\mathrm{N}$. Raleigh.

HA YNE's, p. o., Grainger co., Tenn. : 188 m. E. Nashrille. Haynesville, p. 0., Aronstook co., Me.: on the E. side of Mattawamkeag $r_{.}$, a branch of Penobseot r., $136 \mathrm{~m}$. N. E. Augusta.

HAYNESVILLE, p. v., York district, S. Car. : $71 \mathrm{~m} . \mathrm{N}$. Columbia.

Haynesville, p. $v_{n}$, and cap. Lowndes $c_{0}, A_{2} a_{0}:$ on Big Swamp er, of Alabama r, $22 \mathrm{~m}$. S. W. Montgomery. It contains a court-house, etc., and about 400 inhabitants.

HaYNestille, p. y., Houston county, Ga. : $5 \pi \mathrm{m}$. S. S.W. Milledgeville.

HAYS county, Tew. Situate centrally, and contains 964 sq. $m$. Drained in the N. and E. by Pedernales $r$, and other affluents of Colorado $r$., and in the $\mathrm{S}$. by IBlanco $\mathrm{r}$. of San Marco r., a branch of the Guadalupe. Surface elevated, with bold eminences and deep ravines in the $\mathrm{S}$. ; in the $\mathrm{N}$. less broken, with fine alluvial bottoms. Soil on the Pedernales, equal to any in the State; the rest is thinner, but gives good crops of corn and cotton. Native indigo grows in abundance, and sugar-cane is cultivated. Limestone is everywhere; beds of marl are frequent, and iron ore abounds. Timber forests skirt every stream, and waterpower is always near. Farms 22; manuf. 3 ; dwell. 41, and pop.-wh. 259, fr. col, 0, sl. 128-total 387. Capital : San Marco.

Hax's Creek, p. o., Carroll co., Mfiss.: on a cr. of Big Black r. so called, $\$ 1 \mathrm{~m}$. N. N. E. Jackson.

Hax's Spring, p. o., Jefferson county, Ky. : $47 \mathrm{~m}$. W. Frankfort.

Hay Stack, p. o., Surrey co., N. Car.: 123 m. W. N. W. Raleigh.

HaYsville, p. v., Dubois co., Ind.: on the S. side of the E. fork of White r., $95 \mathrm{~m} . \mathrm{S}, \mathrm{S}, \mathrm{W}$. Indianapolis. Pop. 200. Haysville, v. and sta., Alleghany co., Penn.: on the line of the Ohio and Pennsylvania R. R., $10 \mathrm{~m}$. N.W. Pittsburg. HaYsville, p. v., Marion county, $K y_{.}: 42 \mathrm{~m}$. S. by W. Frankfort.

Hayter's Gap, p. o., Washington co., Virg. : 253 m. W. S. W. Richmond.

Haywood county, N. Car. Situate S. W., and contains 956 sq. m. Drained by Big Pigeon r., a branch of Nolichucky r., and head of the Tennessee. Surface very high and broken in parts, affording excellent mill-streams. Soil productive, with fine pasturage and good timber. Many cattle are raised. Farms 653 ; manuf. 0 ; dwell. 1,110, and pop.-wh. 5,931, fr. col. 15, sl. 418, Indians 710-total 7,074 . Capital: Waynesville.

HaYwood county, Tenn situate W., and contains 506 sq. m. Drained S. by Big Hatchie river, N. by S. fork of Forked Deer r., both affluents of the Mississippi. Surface level, or gently undulating; soil very fertile; cotton is the staple; tobacco and corn come next, and much pork is fatted. Farms 967 ; manuf. 13 ; dwell. 1,454 , and pop.wh. 8,713, fr. col. 45, sl. 8,498-total 17,269. Capital: Brownesville.

HAYwood, p. v., Chatham co., $N$. Car, : at the confluence of Haw and Deep rivers of Cape Fear r., $27 \mathrm{~m}$. W. S. W. Raleigh.

Hazard Forge, p. 0., Hardy co., Virg.: 154 m. N. W. Richmond.

Hazardville, p. v., Hartford county, Conn.: $16 \mathrm{~m} . \mathrm{T}$. Hartford. It contains 58 bouses, 2 stores, 2 churches, a school-house, and Lyceum; and in the immediate vicinity are the extensive mills of the Hazard Powder Company.

Hazer Bortom, po o., Barry county, Mo : $157 \mathrm{~m} . \mathrm{S} . \mathrm{W}$. Jefferson City.

Hazel Frat, p. o., Shelby county, Tenn。: $176 \mathrm{~m}$. W. S.TF. Nashville.

HAZEL Greex, t. and p. 0., Grant co., Wisc. : $66 \mathrm{~m}$. S. W. Madison. Drained by Sinsinewa and other affluents of the Mississippi river Surface rugged i soil not the most fertile. 
Lead ore is found in abundance. The $\mathrm{r}$, is situate on the

Galena and Platteville Turnpike. Pop. of t. 654.

Hazel Green, p. o., Madison co., Ala. : 187 m. N. by W.

Montgomery.

Hazer Grein, p. o., Morgan co., $\overline{\text { y. }}$ : 88 m. E. by $\mathrm{S}$.

Frankfort.

HAZEL Grove, p. o., Saline county, Mo. : 68 m. W. N.W. Jefferson City.

HazeltoN, p. v., Luzerne county, Penn.: 79 m. N. E.

Harrisburg. It is a noted mining village, and is connected with the Lehigh navigation by a railroad. Beaver Meadow is a few miles $\mathrm{S}$. of Hazelton.

HAzELWOOD, p. o., Ballard co., $K y$. : 242 m. W. S. W. Frankfort.

Hazlew ood, p. v., Chester district, $S . C a r$. : 46 m. N. Columbia.

HazLewood, p. o., Wright co., Mo.: 104 m. S. by W. Jefferson City.

Headeey's Mriss, p. 0, Fountain county, Ind.: $67 \mathrm{~m}$. W. N. W. Indianapolis.

Head of Barren, p. o., Claiborne county, Tenn.: $173 \mathrm{~m}$.

E. by N. Nashville.

Head of Clinch, p. o., Tazewell county, Virg.: $229 \mathrm{~m}$. W. by S. Richmond.

Head of Paint, p. o., Morgan co., $K y .:$ at the head of

Paint cr. of Big Sandy r., 109 m. E. by S. Frankfort.

Hzad of Sassafras, p. $v_{*}$, Kent eo., $M d_{\text {. }}:$ at the head of the river so called, $18 \mathrm{~m}$. from its confluence with Chesapeake Bay, and 55 m. N. E. Annapolis.

Head Quarters, p. o., Nicholas co., $K y_{0}: 55$ m. E. N. F Frankfort.

Heding Sprixag, p. o., Davidson co.g $N$. Car. : $92 \mathrm{~m}$.W. Raleigh.

Heard county, $G a$. Situate W. centrally, and contains $267 \mathrm{sq} . \mathrm{m}$. Drained by Chattahonchee river, which passes through its $\mathrm{E}$. half. Surface mostly even, with good millsites; soils very productive ; cotton is the staple production. Farms 512; manuf. 5; dwell. 724, and pop.-wh. 4,520, fr. col. 3, sl. 2,40-total 6,923, Capital: Franklin.

Mrarnville, p. v., Putnam co., $G a .: 27 \mathrm{~m}$. N. by W. Milledgeville.

Heart Prairie, p. o. Walworth co., Wisc, : 46 m. E. S. E. Madison.

Heartw filville, p. vo, Bennington co., Verm. : $95 \mathrm{~m}$. S. by W. Montpelier.

IIfatir, t. and p. v., Franklin county, Muse.: $95 \mathrm{~m}$. W. N. W. Boston. Drained by branches of Deerficld $r_{n}$, one of which affords water-power. Surface mountainous; soil adapted to grazing. There is a central village. Population Sus.

Heati's Criek, p. o., Pettis co., Mo.: on a creek of Riviere a la Mine so called, $60 \mathrm{~m}$. W. N. W. Jefferson City. Heathoville, p. v., Halifax co., N. Car, : $73 \mathrm{~m}$. N. E. Raleigh.

IE.ıTisvml.f. p. v., and cap. Yorthumberland co., Firg.: near the head of Coan r., $63 \mathrm{~m}$. E. N. E, Richmond. It contains a court-house, jail, etc., and has several industrial estaklishments, and about 360 inhabitants.

IIEBBardsyrux, p. v, Henderson co, $\bar{H}_{3}: 137 \mathrm{~m}$. W. by $\mathbf{S}$. Frankfort.

IIEBEARDSYiLle, p. v., Athens co, Orio: $63 \mathrm{~m}$. S. S. E. Columbus.

Herrox, t. and p. T., Tolland co, Conn, : 19 m. 8. E. Hartford. Drained by Hop r, a branch of Willimantic r., which forms its $\mathrm{N}$. border, and in the S, the nutlet of North Pond affords water-power. Surface hilly and uneven; soil semerally of an average fertility, and good grazing land. The $v$, has 2 handsome churches, and about 40 neat dwellings; and besides the principal $\mathrm{v}$. there are several others. The t. has considerable manufactures (iron, cotton, paper, leather, etc.), and 1,345 inhabitants.

Herrov, p. v., Washington county, Ga. : $16 \mathrm{~m} . \mathrm{S}$. E. Milledgeville.
Hebkon, p. V., Porter co, Ind. : 119 m. N. N. W. Indianapolis.

Hввros, p. v., MeHenry eo., I Springfleld.

Hebron, t. and p. o., Oxford co., Me.: 37 m. W. S. W. Augusta. Drained by a braneh of Androsenggin $\bar{x}$. Surface diversified; soil genetally fertile. The $v$, is located about 2 m. W. of Buckfield Branch R. R., which passes through the east part of the town. Pop. of $t .839$.

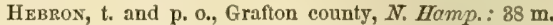
N. N. W. Concord. Drained by creeks emptying into Newfoundland Lake, which occupies a third of the area of the town. Surface diversifled; soil generally fertile. The v. is located on a stream near the head and west of the lake. Pop. of t. 565.

Hebrov, t. and p. v., Washington co., $N$. $Y$.: $44 \mathrm{~m}$. N. N. E. Albany. Drained by Black cr. Surface hilly and diversified; soil sandy loam and fertile. The v. is a small settlement $\mathrm{N}$, of Black $\mathrm{r}$., and contains about 70 inhabitants. In the $t$. there are some small manufactures. Pop. 2,5 48.

Hesron, t. and p. o., Potter co., Penn.: 127 m. N. W. Harrisburg. Drained by the head branches of Alleghany $r$. Surface somewhat broken; soil generally productive-on the whole a good farming section.

Hebron, p. v., Licking co, Ohio: on the Ohio Canal, 27 m. E. Columbus.

HebroN, p. v., Tyler county, Firg.: 239 m. W. N. W. Richmond.

Hechtown, p. v., Northampton co., Penn. : 95 m. E. N. E. Harrisburg.

Hecla, p. o., Carroll county, Tenn.: $97 \mathrm{~m}$. W. by $\mathbf{S}$. Nashville.

HeclA Works, p. v., Oneida co., N. $Y_{.}: 94 \mathrm{~m}$. W. N. W. Albany.

Hector, $t$, and p. v., Tompkins co., $N . Y .: 153 \mathrm{~m}$. W. by S. Albany. Drained by streams flowing in opposite directions into Cayuga and Seneca lakes, the latter of which forms its W. border. Surface elevated and undulating; soil fertile, aud adapted to grass. Hector is a small agricultural village, and there are several others, as Mecklenburg, N. Hector, Logan, Reynolds, Burdett, etc., in the town. Pop. of t. 6,056.

Hector, t. and p. o., Potter co, Penn. : 118 m. N. N. W. Harrisburg.

Hector, p. v., Jay co., Ind. : 73 m. E. N. E. Indianapolis, Hedgersville, p. v., Berkeley co., Vïrg. : 137 m. N. by W. Riclimond.

Hemlensiorgi, p. v., Adams co., Penn. : 24 m. S. W. Harrisburg.

Helderberg mountains, $N$. $Y_{0}:$ the $N$. portion of the Katsberg mountains, extending through Albany and Schoharie counties. They are 400 or 500 feet high, preeipitous, and consisting of limestone based on graywacke. Caverns and fossil remains occur in the calcareous formations.

HeLeva, p. V., and cap. Philips co., Ark.: on the W. side of the Mississippi, $97 \mathrm{~m}$. E. Little Rock. It contains a courthouse, jail, etc., a U. S. land office, numerous stores, and has three newspapers, the "Southern Shield" (whig), and the "True Issue" (State-rights), published weekly, and the "Bulletin" a monthly issue. It has a large trade with the back country and the settlements on St. Frances $r_{\text {., from }}$ which it receives considerable cotton for shipment. There is a very fine range of hills immediately back of the village, the only ones seen along the river for some distance; and on this account the country is not so liable to be flouded. Helena is thought to be well located for a terminus of a railroad to the Pacific, and as such was highly recommended to the New Orleans Convention of 1852. Pop. 677.

Helexa, p. o., Peoria co., $I l l$. : $76 \mathrm{~m}$. N. Springfield.

Helfina, p. v., Mason co., $K y$ : 78 m. N. E. Frankfort.

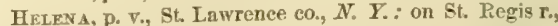
$155 \mathrm{~m} . \mathrm{N}$. N. W. Albany. It has several mills, and abous 200 inhabitants.

HeleNA, v. and sta, Newberry dist., S. Car. : on the line 
of the Greenville and Columbia R. R., $48 \mathrm{~m}$. W. N. W. Columbia. The Laurens $\mathrm{R}$. $\mathrm{R}$. here diverges from the main track to Laurens C. $\mathrm{H}$.

Helexs, p. o., Iowa co., Fisc.: on the S. side of Wisconsin r., $38 \mathrm{~m}$. W. Madison. The Milwaukie and Mississippi R. R. will pass through this village.

Helextille, p. v., Jefferson co., Wisc.: $48 \mathrm{~m}$, E. by $\$$. Madison.

Heluar, t. and p. o., York co., Penn.: 21 m. S. E, Harrisburg. Drained by Codorus and Grist creeks of Susquehanna r., which forms its $\mathrm{E}$. boundary. A bridge crosses the river at Wrightsville 5.690 feet long. Pop. 1,622.

Hell Gate, or Helle Gatt, $N . Y .:$ a passage between the East r. and Long Island Sound, formed by the approximation of Great Barn and Long Island, $7 \mathrm{~m}$. N. E. New York City. Jlelle Gutt means Eust Gute, and has no reference to the locality usually meant by its synonym. The rocks and eddies that formerly rendered its passage dangerous to navigation have been removed, and the largest ships can now go through without fear of injury.

Hellen, p. v., Elk co., Penn. : 142 m. N. W. Harrisburg.

Hellertown, p. v., Northampton county, Penn.: $94 \mathrm{~m}$ E. N. E. Harrisburg.

IIetton, p. .., Ashe connty, $N$. Cur: 173 m, W. by N. Raleigh.

Heltorvinie, p. v., Lawrence co., Indi: on Leatherwood er., $57 \mathrm{~m}$. S. Indiauapolis.

Hearlo, p. o., Whitesides countv, $m$.: $142 \mathrm{~m} . \mathrm{N}$. by W. Springfield.

Hem lock Lake, p. o., Livingston $\mathrm{co}_{\text {es }} N . \boldsymbol{X}_{0} ;$ on the W. side of the lake so called, $192 \mathrm{~m}$. W. Albany. Hemlock Lake is $6 \mathrm{~m}$. long and $1 \mathrm{~m}$. wide, and discharges its waters into the outlet of Honeoye Lake.

HrMviNgFord, $v$., Clinton co., $N . \quad Y:$ on the line of the Plattsburg and Montreal R. R., $26 \mathrm{~m}$. N. Plattsburg.

Hampeield, p. v., Lancaster county, Penn.. $29 \mathrm{~m}$. S. E. IIarrisburg.

Hemphill's Store, p. o., Mecklenburgh co., N. Car. : 124 m. W. S. W. Raleigh.

Henpstead county, $A r k$. Situate S. W., and contains 1,304 sq. m. Drained by Saline Bayou, and other affuents of Red r., its S. W. boundary, and by affluents of Little Missouri r., its N. E. boundary, and a branch of Wachita r. Surface level or slightly rolling, and well wooded; soils of moderate fertility, producing the grains and some cotton Farms 550; manuf. 8; dwell. 855, and pop.-wh. 5,180, fr. col. 32, sl. 2,460-total 7,672. Capital: Washington.

Hempstead, t. and p. v., Queens eo., N. Y.: $128 \mathrm{~m}$. S. Albany. Surface level; soil sand and sandy loam, requiring good cultivation. Hempstead Plains are a tract of some 15,000 acres, lying in a state of nature and common to the town. The village is situate on the $\mathbf{S}$. margin of these plains, and contains 1,600 inhabitants. It has numerous stnres, mechanic shops, etc., and a newspaper, the "H. Enquirer," is published weekly. Several islands belong to this to, and Rockaway Beach on the Atlantic, a place of resort for fashion in the summer season. Much garden produce is brought from this t. to New York. Pop. 8,811, A branch of the Long Island R. R., $3 \mathrm{~m}$. long, extends to Hempstead village

Hempstead Branch, p. $\nabla_{\text {., Queens }}$ co, $_{\text {, }}$. $Y$.: at the divergence of Hempstead Branch R. R. from the Long Island R. R., $20 \mathrm{~m}$. from Brooklyn.

Hen Bx, p. o., Montgomery co., Ohio: $69 \mathrm{~m}$. W. by $\mathrm{s}$. Columbus.

Hendersow county, $I Z l$. Situate W. toward the N., and contains 389 sq. m. Drained by Henderson's r. and Elison's and Honey ereeks, affluents of the Mississippi, its W. boundary. Surface generally level; soil productive, a part well timbered and part prairie. Farms 420 ; manuf. 27 ; dwell. 820, and pop.-wh. 4,610, fr. col. 2-total 4,612. Capital: Oquatwk. Pullic Wurks: Oquawka and Peoria R. R.

HENDERSON county, $K y$. Situate N. W., and contains
562 sq. m. Drained by affluents of Green r., its B. E boundary, and smaller affluents of the Ohio, its N. boundary. Surface various, with good mill streams; soil fitile. Tobaceo is the staple. Wheat and corn yield largely, and pork is an export. Farms 1,037; manuf. 44; dwell. 1,337, and pop.- wh. 7,654 , fr. col. 120, sl. 4,397-total 12,171. Capital: Henderson. Public Works: Nashville and Henderson R. R.

Hendersor county, N. Car. Situate W., and contains 422 sq. m. Drained by numerous heads of French Broad r., a branch of Nolichucky r., a head of the Tennessee. Surface broken and mountainous, having on the E. and $\mathrm{S}$. ranges of high hills separating the Atlantic streams from the affluents of the Obio; soil fertile and finely adapted to grazing. Farms 413; manuf. 1; dwell. 931, and pop.-wh. 5,892, fr. col. 37, sl. 921-total 6,\$5z. Capital: Hendersonville.

HeNDERsoN county, Tenn. Situate W., and contains 914 sq. m. Drained E. by Beech $x_{\text {, }}$, and other affluents of Tennessee r., and W. by heads of Big Hatchee and Forked Deer rivers, affluents of the Mississippi. Surface level, and soil fertile. The grains flourish, cotton is grown largely, and much pork fattened. Farms 973; manuf. 25 ; dwell. 1,798, and pop.-wh. 10,571, fr, col. 1, sl. 2,592-total 13,164. Oapitul: Lexington.

Hexderson county, Tex. Situate N. E. centrally, and contains $1,189 \mathrm{sq.} \mathrm{m}$. Drained by Cedar, Walnut, and Otter creeks, affiuents of Trinity $r_{\text {., its }} W$. boundary, and Kickapoo, Flat, and Caddo creeks, branches of Neches r., its E. boundary. Surface level or undulating; soil on the Trinity rich loam, on the Neches more sandy, and between "hickory uplands," which are exceedingly fertile and easily cultivated. Much of the county is a forest of fize timber, black walnut, hickory, oak, and pine. Trinity $r$, is boatable part of the year. Iron ore exists in large quantities, and siliciffed or petrified trees, so hard as to be used for flints, are found projecting from the ground or lying on the surface. Cotton and corn give large returns, and wild grapes abound on every stream. Farms 106; manuf. 0; dwell. 192, and pop.-wh. 1,155, fr. col. 1, sl. 81-total 1,237. Capital: Athens.

Henderson, p. y., Knox co., Ill.: $93 \mathrm{~m}$. N. W. Springfield.

Henderson, p. v., and cap. Henderson co, $K y_{0}$ : on the S. bank of Ohio ro, $148 \mathrm{~m}$. W. by S. Frankfort. It is a prizcipal shipping port for the tobacco, corn, etc., of the Green $r$. country, and it has also a considerable supply of coal and iron in its vicinity. It contains a court-house, 7 churches, 5 schools, 18 or 20 stores, 5 or 6 large tobacco factories, and about 1,800 inhabitants. Two newspapers, the "South Kentuckian" (whig), and the "Democratic Banner" (dem.), are published weekly.

Mexperson, p. v., Granville co., N. Car.: on the line of the Gaston and Raleigh R. R., $45 \mathrm{~m}$. N. Raleigh.

HeNDerson, to and p. v., Jefferson co, $N$. Y.: $143 \mathrm{~m}$. N.W. Albany. Drained by Stony and Little Stony creeks of Lake Ontario, on which the t. fronts. Surface Ievel; soil sandy loam. Several considerable islands in the lake belong to this $t$., and the W. part of the mainland is peninsular. The $v$. called Henderson Harbor, at the head of Hungry Bay, is a port, and has consilerable trading facilities; it has a good landing, and contains about 20 dwellings. The prineipal $\mathrm{v}$. lies $3 \mathrm{~m}$. back on Stony er., and is double the size of the former place. The t. bas several mills, etc., but is almost wholly agricultural. Pop. 2,239. The Ellisburg and Sackets Harbor R. R, runs along the E. end of the township.

HeNDERson, p. o., Houston co., Ga. : 51 m. S. S. W. Milledgeville.

Henderson, p. v., Mercer co., Pena . 189 m. W. N. W. Harrisburg.

Hendersor, p. v., and cap. Rusk co., Tex, : at the head of Big Shawnee cr., a constituent of Angelina r., $256 \mathrm{~m}$. N. E. Austin City. It is a considerable v., and has three 
newspapers, the "Texas Whig," the "IEgis of Truth," and the "Flag of the Union." Pop. about s00.

Henderson's MriLs, p. o., Greene co., Tenn. : $218 \mathrm{~m}$. E. Nashville.

HeNDzirsonvizle, p. v., and cap. Henderson co., N. Car.: on Mud cr. of French Broad r., 218 m. W. S. W. Raleigh. It contains a court-house, ete., several stores, and about 300 inhabitants.

Hendersonvilue, p. v., Sumner co., Tenn. : about 1 mile $\mathrm{N}$, of Cumberland r., $16 \mathrm{~m}$. N. E. Nashville.

HeNdrensville, p. v., Henry county, $\bar{k} y .: 26$ m. N. W. Frankfort.

HENDRIOK's county, Ind. Situate centrally, and contains $3 S 7$ sq. m. Drained by Eel r., and White Lick and Mad creeks, head waters of White $\mathrm{r}$. In the $\mathrm{S}$. and $\mathrm{N}$. W. the surface is undulating, elsewhere the county is level. More than half the soil is a rich loam mixed with sand. The staple products are wheat, corn, and pork. Farms 1,444; manuf. 10 ; dwell. 2,390, and pop.-wh. 14,047, fr. col. 36total 14,083. Capital: Danville. Public Works: Terre Haute and Richmond R. R.

Hendrick's, sta., Putnam co., Ind.: on the line of the Terre Haute and Richmond R. R., $44 \mathrm{~m}$. W. Indianapolis.

HeNDRYoK's p. o., Yazoo co., Miss. : $32 \mathrm{~m}$. N.W. Jackson. HENDRICK's MilLs, p。 o., Russell county, Virg.: 268 m. W. by S. Richmond.

HeNDRICK's Store, p. o., Bedford county, Firg. : $131 \mathrm{~m}$. W. by S. Richmond.

Hendricksvilue, p. ఛ., De Kalb co., Ala. : 152 m. N. by E. Montgomery.

HENDRYSBURGI, p. V*, Belmont co., Olio: $94 \mathrm{~m}$. E. Columbus.

HeNLopen cape, Del.: the S. W. point at the entrance of Delaware Bay, $18 \mathrm{~m}$. S. W. from Cape May, the opposite point, A lighthouse is located here. Lat. $86^{\circ} 47^{\prime} \mathrm{N}$., and lon. $75 \circ 6^{\prime} \mathrm{W}$.

Henly's Store, p. 0., Franklin co., $G a_{0}: 100 \mathrm{~m}$. N. Milledgeville.

Hennepix, p. V., and cap. Putnam co., Ill.: on the E. bank of the Illinois r., at its great bend, $102 \mathrm{~m}$. N. Springfield. It has an elevated and pleasant position, the ground rising gently from the river. It contains a court-house, jail, etc., numerous stores and mechanic shops, and about 430 inhabitants. Steambuats ascend to this point at a moderate stage of the water.

Hensiker, to and p. v., Merrimac co., N. Hamp.: $13 \mathrm{~m}$. W. by S. Concord. Drained by Contoocook r., which affords water-power. In the W. part of the to is Long Pond, which discharges itself into the Contoocook. Surface hilly soil moderately fertile. There are several villages in the $t$, the principal $\mathrm{v}$. near the centre. The New IIampshire Central R. R. and the Contoocook Valley R. R. cross each other in passing through Henniker. Pop. 1,696.

Hexvisg's p. 0, Gibson county, Tenn.: $122 \mathrm{~m}$. W. Nashville.

Henrico county, Firg. Situate E., and contains $268 \mathrm{sq}$. $\mathrm{m}$. Drained by affiuents of James $\mathrm{r}_{\text {., }}$ which bounds it S., and by Chickahominy r., its N. E. boundary, Surface undulating or broken, and much diversified; soil good, producing the cereals and tobacso; but the chief wealth of the $c 0$, arises from its vast mineral resources, its extensive commerce and growing manufactures. The great natural product of the earth is bituminous coal, deposits of which extend over a large part of it, and which is much sought after for its superior quality. The mines are deep, and widely wrought, and the quantity of coal annually brought up and exported, very great. Lying along the noble James r., at the head of navigation for the largest ressels, it has a fine situation for commanding the transportation of the products of the immense and fertile region of which it is the outlet. Ships from its ports visit all quarters of the world, loaded with corn, flour, wheat, tobacco, and coal. The falls of James $r$. furnish the best of water-power, with scarcely 286 a limit to its extent. This has been used in part, and hero are the largest flouring establishments in the State, and the best cotton and woolen factories. Though not a great agricultural county, its situation and other natural advantages make it one of the most important in the State. Farm 454 ; manuf. 230 ; dwell. 5,317 , and pop.-wh. 23,500 , fr. col. 3,663, sl. 16,109-total 43,572. Capital: Richmond. Publio Works: James River Canal; Richmond, Frederick and Potomac R. R.; Virginia Central R. R., etc.

Henrio"s Fork, p. o., Gilmer co., Virg. : 222 m. W. N. W. Richmond.

HENRIETTA, t. and p. 0., Jackson co., Mich. : 26 m. S. S. E. Lansing. Drained by Portage cr. of Grand $r$. There are several ponds in the t., and a considerable portion is marshy. Pop. 832.

Henreetta, t. and p. v., Monroe county, N. Y.: $193 \mathrm{~m}$. W. by N. Albany. Drained by tributaries of Genesee $r$, which marks the W. border, and of Irondequoit cr. Surface olling; soil sand and clayey loam, very fertile. The r. contains about 200 inhabitants. The industry of the to is deroted almost wholly to agriculture. Pop. 2,513.

Henfietta, t. and p. o., Lorain co., Ohio: $97 \mathrm{~m}$. N. N. E. Columbus. Drained by Vermillion r. and other streams, which run northward to Lake Erie. Surface diversifled; soil generally fertile. The $\mathrm{v}$. is located on the old post road. Pop. of t. 1,042 .

Henrietta, p. o., Montgomery co., Tenn.: 47 m. N. W. Nashville.

HeNRY county, Ala. Situate in S. E. corner, and contains $952 \mathrm{sq}$. $\mathrm{m}$. Drained W. by head of Choctawatchie $\mathrm{r}$., S. by heads of Chipola r., a tributary of Appalachicola r., and E. by affluents of Chattahnochee r., which forms its $\mathbf{E}$. boundary. Surface varied, affording water-power, to work up the pine timber that covers much of it. Cotton is the staple. Farms 671; manuf. 0; dwell. 1,142, and pop,-wh. 6,775, fr. col. 1, sl. 2,242-total 9,0:9. Capital: Abbeville. Public Works: Fori Gaines and Pensacola R. R.

Henry county, Ga. Situate N. W. centrally, and contains $357 \mathrm{sq} . \mathrm{m}$. A head of Ockmulgee r. druins it N. E. and a branch its S. part. Surface diversified, and soils very productive of ectton and the grains. Farms 1,003; manuf. 3; dwell. 1,680, and pop.-wh. 9,743, fr. col. 14, sl, 4,969total 14,726. Capital: MeDonough. Public Works : Macon and Western R. R

HENRY county, $l l l$. Situate N. W., and contains 804 sq. m. Drained by Spoon r., an aftluent of Illinois r., and Edwards $\mathrm{r}$. of the Mississippi in the S., and in the N. by Green r., a branch of Rock r., which bounds it N. W. Surface undulating or level; soil of great fertility, the river bottoms especially, and makes this a great farming county. Farms 281; manuf. 0 ; dwell. 772 , and pop.-wh. 3,807, fr. col. 0 total 3.807. Capital: Morristown. Pullic Works: Chicago and Rock Island $\mathrm{R}, \mathrm{R}$.

Hexry county, Ind. Situate E. middle, and contains 413 sq. m. Drained by Blue $r$. and Falls cr. Surface level or undulating, and, with the exception of a small extent of prairie in the $\mathrm{N}$., the land was originally well timbered. Wheat and corn are the chief staples, and a Jarge amount of stock is raised. Farms 1,$666 ;$ manuf. 124; dwell. 3,064 ; and pop.-wh. 17,380, fr. col. 225-total 17,605. Capital. Newcastle. Pullic Works: Indiana Central R. R. ; Richmond and Newcastle R. I.

IIEXRY county, Ia. Situate S. E., and contains $432 \mathrm{sq} . \mathrm{m}$. Drained by Chicagua or Skunk r., an affluent of Mississippi r., and its branches. Surface elevated, with good mill seats and a few prairies; soil highly productive of all the grains and grasses. Farms 947; manuf. 26; dwell. 1,545, and pop.-wh. 8,695, fr. col. 12-total 9,707. Capital: Mount I'leasant.

HENRY county, $K y$. Situate $\mathrm{N}$. in E. part, and contains 268 sq. m. Drained by Little Kentucky r., an affluent of Ohio $r_{\text {., in the }} W_{\text {., }}$ and $E$. by branches of Kentucky r., its E. boundary. Surface diversified; solls very fertile. To- 
bacco is the staple, but corn and wheat are largely grown, and many swine fattened. Farms 1,029; manuf. 75; dwell. 1,48S, and pop.-wh. 8,376, fr. col. 53, sl. 3,013-total 11,442. Capital: New Castle. Public Works: Louisville and Frankfort R. R., and Lovisville and Covington R. R.

Hesri county, Mo. Situate W. centrally, and contains 755 sq. m. Drained by South Grand r., a branch of Osage r., and its affluents Big Thibeau r., Honey, Tebo, and Deepwater creeks. Surface varied, with considerable high land and much good timber; soil well adapted to grazing and grain growing. Farms 385 ; manuf. 11 ; dwell. 561, and pop.-wh. 3,377, fr. col. 3, sl. 672-total 4,052, Capital: Clinton.

HENRY county, Ohio. Situate N. W., and contains $516 \mathrm{sq.}$ m. Maumee r. crosses it from W. to E., and its branches drain it. Surface level or undulating, and soil fertile. Farms 307 ; manuf. 15 ; dwell. 610 , and pop.-wh. 8,435 , fr. col. 0 total 3,435. Capital: Napoleon. Public Works: Wabash and Erie Canal; Fort Wayne, Perrysburg, and Sandusky R: $R$.

Hever county, Tenn. Situate N. W., and contains 828 sq. m. Bounded E. by Big Sandy r., an affluent of Tennes-

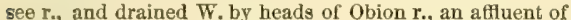
the Mississippi. Surface level, and soil remarkably fertile. Tobacco is the leading staple; wheat is a good crop, cotton is grown and many swine fatted. Farms 1,475; manuf. 51 ; dwell. 2,245, and pop.-wh. 13,392, fr. col. 20, sl. 4,821-total 15,233. Capital: Paris. Public Works: Nashvillo and Mississippi R. R.

HENry county, Firg. Situate $\mathrm{S}$. centrally, and contains 355 sq. m. Drained by branches of Smith's $r$. and other affluents of Dan r., a branch of the Roanoke. Surface broken, affording good water privileges; soil highly prodnetive. Tobaceo is the staple. Farms 52S; manuf. 41; dwell. 986, and pop.-wh. 5,324, fr. col. 208, sl. 3,340-total 8,572. Cipital: Martinsville.

Hexkx, p. V., Marshall county, $I l l .:$ on the W. side of Illinois r., $92 \mathrm{~m}$. N. by E. Springfield.

Hexry, p. o., Spartanburgh dist., S. Car. : 98 m. N. W. Columbia.

Hexry, p. o., Lawrence county, Tenn.: 79 S. S. W. Nashville.

Hesey, p. o., Sussex county, Virg.: 47 m. S. \$. E. Pichmond.

Hexry cape, Firg.: on the S. side of the entrance to Chesapeake Bay, $12 \mathrm{~m}$. S. of Cape Charles, the opposite point. Lat, $36^{\circ} 55^{\prime} \mathrm{N}_{\text {., }}$ and lon. $760^{\circ} 21^{\prime} \mathrm{W}$.

Hevry Clay Factort, p. O., New Castle co., Del.

Henry's Cross Roads, p. o., Sevier co, Tenn.: $177 \mathrm{~m}$.

E. Nashville.

Hexrystille, p. צ., Monroe county, Penn.: $97 \mathrm{~m}$. N. E. Harrisburg.

Henryvili,e, v, and sta., Clarke co., Ind.: on the line of the Jeffersonville R. R., $19 \mathrm{~m}$. N. Jefferson, and $88 \mathrm{~m}$. $\mathrm{S}$. Indianapolis.

Hrpburv, t. and p. 0., Lycoming county, Penn.: $74 \mathrm{~m}$ N. by W. Harrisburg. Lyeoming and Loyalsock creeks bound it W. and E. Surface billy and mountainous; soi slate and gravel. The t. has numerous mills and several manufacturing establishments, Pop. 1,701.

Herbert, p. o., Kemper co., Misss.: 86 m. E. N. E. Jackison

Herculaneum, p. v., Jefferson co., Mo. : on the W. bank of Mississippi r., $23 \mathrm{~m}$. below St. Louis, and $102 \mathrm{~m}$. E. by $\mathrm{S}$. Jefferson City. It is a thriving $v_{\text {. }}$, and one of the chief shipping ports of the Missouri lead region. There are several shot towers and factories in the vicinity. Pop. about 600.

Hereford, p. ఛ., Baltimore co, Ma.: $48 \mathrm{~m}$. N. by W. Annaprolis.

Hereford, t. and p. o., Berks en., Penn.: $72 \mathrm{~m}$. E. by N. Harrisburg. Drained by the branches of Perkiomen cr. Surface diversified. Shoub's Mountain being on the N. E. boundary; soil generally fertile. There are several manufactures and numerous mills in the town, and 1,417 inhabitants.

HeakTORD's, p. O., Mason co., Firg. : on the E, side of Ohio r., 263 m. W. N. W. Richmond.

Herkimer county, $N . Y$. Situate E. centrally, and contains 1,370 sq. m. Drained N. by heads of Oswegatchie $r_{.}$ an affluent of St. Lawrence $r_{\text {. }}$ Beaver $r_{\text {. }}$ Moose $r$. Independence and Otter creeks, branches of Black r., which flows into Lake Ontario, and S. by East and West Canada creeks, affluents of Mohawk r., which passes through it. Surface much broken. The Adirondack Mountains occupy the E., crossing the Mohawk at Little Falls, and the Chateaugay and Otsquaga ranges cover much of the co, with high hills. Soil on the Mohawk very rich; in the $N$. are extensive forests and the best of grazing, the co. being noted for its fine cattle and large dairies. It is well timbered, and the N. abounds in pine and hemlock. It also has great facilities for manufactures in W. Canada cr., which falls 23 feet per mile, and the Little Falls of the Mohawk, which descends 42 feet in three-quarters of a mile. The last are celebrated for their beauty, the river bed lying 300 to 400 feet below the banks it has cut through. Minerals of almost every kind are found, iron ore, lead, limestone, and gypsum, being the most useful, and others, noted the world over for the perfection and beauty of their crystals. Its staples are agricultural, butter, cheese, wool, and cattle. Farms 2,723; manuf. 277; dwell. 6,664, and pop.-wh. 33,062, fr. col. 152 - total 38.214. Capital: Herkimer. Public Works: Erie Canal; Utica and Schenectady R. R.; Mohawk Valley R. R.; Saratoga and Sackett's Harbor R. R.

Herkimer, t., p. v., and cap. Herkimer co., $N_{0} Y_{0}: 66 \mathrm{~m}$ W. N. W. Albany. Drained by West Canada and othe creeks of Mohawk r., which last runs along the $\$$. border. Surface level in the $\mathbf{S}$., being occupied by extensive alluvia flats-in the $\mathbf{N}$. it is somewhat hilly; soil generally fertile. The v. on the $\mathrm{N}$. bank of the Mohawk contains the courthouse, jail, etc, and has about 1,200 inhabitants, The " $\mathrm{H}$ Democrat" is issued weekly. In the t. there are flouring and other mills, tanneries, stores, ete. Pop. 2,602.

Hermax, t. and p. o., Dodge co., Wisc. . 58 m. E. N. E. Madison. Drained by affluents of Rock $r$. It is a fine tgricultural section, and is connected with Milwaukie by a plank-road.

Hermane, p. o., Ripley county, Ind.: 68 m. S. E Indianapolis. A small German settlement.

Hermann, p. v., and cap. Gasconade co., Mo.: on the $\mathrm{S}$. bank of Missouri r., $42 \mathrm{~m}$. E. by N. Jefferson City. It contains the county buildings and several stores, and is chiefly inhabited by Germans. It is a place which, in the progress of events, must become of commereial importance. The "H. Wochenblatt" (dem.) is published weekly, and the "Licht Freund" (rationalist), monthly. Population 943. In this vicinity, the cultivation of the vine is a prominent business : at least 200 acres of land are now deroted to this department of industry, and the quantity of wine manufactured has averaged, for the last fow years, 18,000 to 20,000 gallons.

Heriatage, p. o., Point Coupee par., $L a_{*}$ : $42 \mathrm{~m}$. N. T Baton Rouge.

Hermtaee, p. v., Floyd co., Ga. : near the Oostanaula r $142 \mathrm{~m}$. N. W. Milledgeville.

IIemmrage, p. o., Decatur co., Tenn.: 81 m. W. S. W Nashville.

Hermitage, p. v., Coles county, $1 l l .: 62$ m. E. by $\mathbf{S}$ Springfield.

Herutuge, v. and sta, Suffolk co., $N$. $Y$.: on the line of the Long Island $\mathrm{R} . \mathrm{R} ., 89 \mathrm{~m}$, from Brooklyn and $6 \mathrm{~m}$ from Greenport.

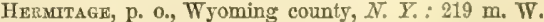
Albany.

Hermiage, p. o., Mercer co., Penn. : 207 m. W. N. TV Harrisburg. 
Hermitage, p. v., Augusta co., Tirg.: 107 m. W. N. W Richmoud,

Hermitage, p. Fo, Hickory co., Mo.: on the E. side of Pomme de Terre r., $75 \mathrm{~m}$. S. W. Jefferson City.

Hermon, t. and p. o., Penobscot co., Me.: 55 m. N. E. Augusta, Drained on the N. W. by a branch of Kenduskeag $r_{\text {. }}$, and in the $\mathrm{S}$. by Sowadabscook $r_{\text {., }}$ which passes through several large ponds. Surface elevated and rolling; soil moderately productive. Pop. 1,374.

IIERxon, t. and p. o., St, Lawrence co., $N . Y_{\text {: }} 136 \mathrm{~m}$. N. N. W. Albany. Drained by smail affluents of Grass and Oswegatehie rivers. Surface rolling; soil clay-loam, adaptto grazing. Timber very abundant, and iron, etc., exists in large quantities. Pop. 1,692. The Watertown and Potsdam R. R. will run on the W. border of Hermon.

Hernando, p. v., and cap. De Soto co., Mfiss. : on the N. of Coldwater $\mathrm{r}_{\text {, }}$ and about $20 \mathrm{~m}$, E. of Mississippi r., 168 m. N. Jackson. It contains a court-house, several stores, and about 400 inhabitants; and a newspaper, the "People's Press" (dem.), is issued weekly. A railroad has been projeeted hence to Commerce, on the Mississippi river.

Herod, p. o, Bartholomew co., Ind.: 40 m. S. S. E. Indianapolis.

Herrick, t. and p. o., Bradford county, Penn.: $112 \mathrm{~m}$. N. N. E. Frarrisburg.

Herrivg, p. o., Allen co, Ohio: 86 m. N. W. Columbus. Herriottsville, p. v., Alleghany eo., Penn.: $173 \mathrm{~m} . \mathrm{W}$. Harrisburg:

IIErrodtowa, p. v., Randolph co., Ga.: 134 m. S. W. Milledgeville.

Hertrord county, $N$. Car. Situate N. E., and contains 339 sq. m. Drained by Meherrin r., and other affluents of Chowan $r_{n}$, which is its E. boundary. Surface low and level, with a good growth of pine; soil moderatcly fertile. Much lumber is exported. Farms 378 ; manuf. 20 ; dwell. 631, and pop.-wh. 3,553, fr. col. 573, sl. 3,716-total 8,142. Cupitul: Murfreesboro'.

Hertford, p. v., and eap. Perquimans co., N. Car.: on the S. bank of Perquimans $r$., near its entrance into the bay of the same name, $132 \mathrm{~m}$. E. N. E. Raleigh. It contains a court-house, etc., and has about 200 inhabitants. Perquimans Bay is an arm of Albemarle Sound, and admits the navigation of vessels of censiderable burden.

Hess Rosd, p. o., Niagara co, $N . Y_{.}: 272 \mathrm{~m}$. W. by N. Albany.

Hessville, p. v., Nontgomery co., N. Y.: 42 m.W. N.W Albany.

Hester, p. v., Marion county. $M F_{0}: 87 \mathrm{~m}$. N. by E. Jeffurson City.

Hrinick's, p. o., York county, Penn.: $35 \mathrm{~m} . \mathrm{S}$, by E Harrisburg.

IIeuvelton, p. v., St. Lawrence co., $N . Y$. : on the N, or right bank of Cswegatehie $r, 7 \mathrm{~m}$. above Ogdensburg and $152 \mathrm{~m}$. N. N. W. Albany. It contains several mills, stores, ete., and about 300 inhabitants.

HEVENER's STORE, p. O., Highland county, Virg.: $136 \mathrm{~m}$.

W. N. Wr. lichmond.

Hewri, p. v., Boone county, Virg.: $242 \mathrm{~m}$. W. by N.

Richmond.

Hibernia, p. o., Clark county, Ind. : 92 m, S. S. E. Indiannpolis,

Mrmernia, p. T., Callaway co., Mo.: on the N. side of Missouri r., opposite Jefferson City.

Hiblrasia, p. o., Bullex co., Penn.: 173 m. W. N. W. Harrisburg.

Hibernia, p. o., Duval co., Flor.: 163 m. E. Tallahassee

Hiberia, p. v., Franklin co., Ohio: on the E. side of

Big Wainut cr., $8 \mathrm{~m}$. E. Columbus.

II brraia, p. o., Duchess co., $N$. $Y$.

Hicletson's Cross Roads, p. 0., Morgan co., Ohio: $63 \mathrm{~m}$.

E. S. L. Columbrus.

HekMax county, Ky

sq. m. bisunded W. by Mississippi r., and drained by Little $2 s s$
Obion $r_{\text {, }}$ and other of its affluents, Surface diversified, and soil generally very fertile. The staple is tobacen, but corn and the other grains are large crops, and swine are raised in large numbers. Farms 546; manuf. 9 ; dwell. 656 , and pop.-wh. 3,932, fr. col. 18, sl. 841-total 4,791. Capital. Columbus. Putlic Works: Mobile and Ohio R. R.

HickMan county, Tenn. Situate W. centrally, and contains $596 \mathrm{sq}, \mathrm{m}$. Intersected by Duck r., a tributary of the Tennessee, and drained by its numerous branches. Surface varied, and soil productive of tobaceo, the grains, and some cotton, and supporting great numbers of swine. Farms 778; manuf, 16 ; dwell. 1,296 , and pop.-wh. 7,559 , fr. col. 22, sl, 1,816-total 9,397. Capital: Vernon.

Hickman (formerly Mrlus Point), p. v., and cap. Fulton county, $K y_{\text {. }}:$ on the E. bank of the Mississippi r., $266 \mathrm{~m}$. W. S. W. Frank fort. It contains a court-house, jail, etc., several forwarding and commission houses, 14 or 15 stores, and a large tobacco stemmery. It is the shipping port of a large and fertile agricultural district; and here is published the "H. News Letter" (neutral), a weekly issue. Pop. about 600. Hrekman's Bend, p. o., Mississippi co., Ark. : $126 \mathrm{~m}$. N. E. Little Rock.

Hickory county, Mo. Situate W. centrally, and contains 396 sq. m. Drained by Little Pomme de Terre r., and other aftluents of the Osage. Surface undulating or prairie; suil very good, well timbered, and adapted to grazing. Farms 190; manuf. 6 ; dwell. 364, and pop.-wh. 2,143, fr. col. 1, sl. 185-total 2,329. Capital: Hermitage.

Hickory, p. o., Carroll county, Ohio: 106 m. E. N. E. Columbus.

Hickory, p. v., Washington county, Penn.: $192 \mathrm{~m}$. W. Harrisburg.

HickoRy, p. v., Lake co., $I l l_{\text {. : }} 202 \mathrm{~m}$. N. E. Springfield.

Hiokory BARReN, p. o., Greene co., Mo. : 104 m. S. W. Jefferson City.

Hickory CorNers, p. o, Barry co, Mfich。 : 42 m.W.S.W. Lansing.

Hickory Corners, p. o., Niagara co., N. $Y$.: $248 \mathrm{~m}$ W. by N. Albany.

Hickozg Criek, p. o., Audrain co., Mo.: on a cr, of Au Cuivre r. so ealled, 52 m. N. E. by N. Jefferson City.

Hickory Creek, p. o., Coffee county, Tenn.: $67 \mathrm{~m}$. S. E. Nashville.

Hickory Creek, p. o., Fayette co., Ill.: on the creek of Kaskaskia r. so called, 68 m. S. S. E. Springfield.

H ickory Fist, p. o., Cherokee co., Ga. : 108 m. N. N.W. Milledgeville.

Hichory Fuat, p. o., Simpson co, Ky.: 132 m. 8. W. Frank fort.

Hrckory Flat, p. o., Tippah co., Miss. : 164 m. N. N. E. Jackson.

Hrokony Fork, p. 0., Gloucester county, Virg.: $48 \mathrm{~m}$. E. by S. Richmond.

Hickory Ground, p. o., Norfolk co., Virr.: 93 m. S. E. Richmond.

Hrekory Grove, p. o., Montgomery co., Ala.: 24 m. \$. Montgomery.

Hickory Grove, p. o., Crawford co., Ga.: 49 m.W. S.W. Milledgeville

Hickory Grotz, p. O., Jackson county, Mich.: 38 m. S. Lansing.

Hzokory Grove, p. o., Oktibbeha co., Miss. : 118 m. N.E. Jackson.

Hickory Grove, p. 0., Warren co., Mo.; 60 m. E. by N Jefferson City.

Hickory Grove, p. o., Jackson county, Ia. : $63 \mathrm{~m}$. N. E. Iowa City.

Hrakory Grovk, p. o., York dist, S. Car, : 77 m. N. Columbia.

Hickory Head, p. o., Lancaster dist., S. Car.: $59 \mathrm{~m}$, N. by E. Columbia.

IIICkony Hill, p. o., Marion co., 1ll.: 96 m. S. S. E, Springfleld. 
Hickory Hill, D. O., Chester eo., Penn. : 67 m. E. by S.

Harrisburs.

Hickory IILL, p. v., Cole county, Mo.: $17 \mathrm{~m}$. \$. W. Jefferson City.

Fickory Hiz,, p. 0., Beaufort dist., S. Car. : 105 m. S.

Columbia.

Hroxorx Hinl, p. o., Cass county, Tex..: 288 m. N. E.

Austin City.

Hickory Lever, p. o., Talladega co., $A l \alpha_{*}: 92 \mathrm{~m}, \mathrm{~N}$, by E.

Alontgomery.

Hrckorx Lever, p. o., Carroll co., Ga.: 114 m. W. N. W. Milledgeville.

Hickory Platn, p. o., Prairie co., Arte.: 38 m. E. S. E.

Little Rock.

Hrckory Platis, p. o., Tishemingo co., Miss. : $196 \mathrm{~m}$.

N. E. Jackson.

Hickory Polst, p. o., M'Donough co, $I l l,: 76 \mathrm{~m}$. N.W. Springfield.

HiCKoRY PoINT, p. o., Lake co., Ind. : $136 \mathrm{~m} . \mathrm{N}$. W. Indianapolis.

Hickory Run, p. o., Carbon co., Penn. : 67 m. N. E. Harrisburg:

HickoRY TAveri, p. 0., Harford co., Md, : 47 m, N. N. E. Annapolis.

Hickory Withe, p. o., Fayette county, Tenn. : $161 \mathrm{~m}$. W. S.W. Nashville.

HicksbugGu, p. v., Dorchester co., MId.: $67 \mathrm{~m} . \mathrm{S} . \mathrm{E}$. Annapolis.

Hicksford, p. .., and cap. Greenville co., Virg.: on the right bank of Meherrin r., $62 \mathrm{~m}$. S. Pichmond. It contain a court-house, jail, ete., and has about 150 inhabitants. The Petersburg R. R. passes near the $v_{\text {, }}$, and here forms a junction with the Grecnville and Roanoke R. R., which at Gaston connects with the Raleigh $\mathrm{P}$. R., ete.

HicksmIRVILle, p. v., Schuylkill co., Penn.

Hick's MrLLs, p. O., De Kalb co., Ill.; on Sycamore r., $162 \mathrm{~m}$. N. by E. Springfield.

Hicssqule, p. v., Rutherford county, $N$. Car.: $192 \mathrm{~m}$ W. S. W. Raleigh.

Hicksville, t. and p. v., Defiance county, Otio: $128 \mathrm{~m}$. N. W. Columbus. Drained by affluents of Maumee river. Surface varied, but mostly level; soil sandy loam or alluvion. The $r$. is a small agricultural settlement. Population of t. 507 .

Hick vilue, p. v., Oakland co., Mich.: $56 \mathrm{~m} . \mathrm{E}$. by S. Lansing.

Hico, p. 0., Carroll co., Tenn. : 89 m.W. by S. Nashville.

Higganur, p. v., Middlesex co., Conn.: on the E. side of Connecticut r., $21 \mathrm{~m}$. S. by E. Hartford. It has a convenient landing.

Hig GINS, p. o., Fayette co., $I l l$. : 58 m. S. S. E. Springfield.

HIGGIN's FERRY, p. v., Edgefield dist., S. Car. : on Saluda river, $44 \mathrm{~m}$. W. by N. Columbia.

Higginsport, p. v., Brown co, Ohio: on the N. bank of the Ohio r., at the mouth of White Oak er., $91 \mathrm{~m} . \mathrm{S} . \mathrm{s}$. W. Columbus. It is a considerable v., containing 536 inhabitants, and has several mills and stores, and enjoys some river trade.

Higginstille, p. v., Oneida co., N. I.: $98 \mathrm{~m} . \mathrm{N}$. W. Albany.

Higernstilue, p. v., Vermillion co., Ill.: 112 m. E. N. E. Springfield.

HiggrNstille, p. v., Hampshire county, Tirg.: $162 \mathrm{~m}$. N. W. Richmond.

HigH BloE, p. o., Jackson co., Mo.: $126 \mathrm{~m}$. W. by N. Jefferson City.

Hrgr FALIs, p. F., Ulster co., $N . Y_{0}:$ at the high falls of Rondout er., $116 \mathrm{~m}$. S. by W. Albany, It contains several extensive mills, 6 stores, and 60 or 70 dwellings. About half a mile below the falls is a celebrated sulphur spring. The Delaware and Hudson Canal follows the valley of Rondout creek.

HighGate, t. and p.. . Franklin countv, Term.: $53 \mathrm{~m}$.
N. N. W. Montpelier. Drained by Missisqui r. in the 6. and Rock r. in the N., and situate on Missisqui Bay, an arm of Lake Champlain. The t. has fine water-power. Surface diversified; soil sandy loam. Bog-iron ore is found bere The $\mathrm{v}$. is located at the 8 . extremity of the bay, and is a small but pleasant settlement. Pop. of t. 2,6553.

Higigate Spring, p. o., Franklin county, Verm. : $55 \mathrm{~m}$. N. N. W. Montpelier.

Higir Grove, p. o., Nelson county, $k y .: 47$ m. 8 . W. Frankfort.

HIGII HrL, p. o., Montgomery co., Mo.: 54 m. N. E. Jefferson City.

Hrgh Hill, p. 0., Muskingum co., Ohio: $57 \mathrm{~m}$. E. by N Columbus.

Highland county, Ohio. Situate S., and contains 468 sq. m. Drained by Paint and Rattlesnake creeks of the Scioto r., Brush and White Oak creeks of Ohio r., and E fork of Little Miami. Surface high and rolling, and soil very fertile. It has fine water privileges, and some timber, is an excellent farming co., and exports wool and pork. Farms 2,323 ; manuf. 151 ; dwell, 4,477, and pop.-wh. 24,952 , fr. col. 829-total 25,781. Capital: Hillsboro'. Public Works. Cincinnati, Hillsboro', and Parkersburg R. R.

HIGHLAND county, Virg. Situate centrally, and contains $436 \mathrm{sq} . \mathrm{m}$. Drained by heads of $\mathrm{S}$. fork of Potomac $\mathrm{r}$. in the N.; in the S. by Cow Pasture r., and other heads of James river. Surface elevated, the county lying between the Alleghany and Shenandoah Mts., but a fine table-land of great fertility, producing the grains abundantly and feeding many cattle and sheep. Farms 389 ; manuf. 7; dwell. 651, and pop.-wh. 3,853, fr. col. 10, sl. 364-total 4,22t. Capital. Monterey.

HighlaND, p. v., Vermillion co., Ind. : on the W. side of Wabash $\mathrm{r}, 64 \mathrm{~m}$. W. Indianapolis.

Highland, $\mathrm{v}_{*}$, Clay co., Ind.: on the line of the Terre Haute and Richmond R. R., 55 m. W. S. W. Indianapolis, and $12 \mathrm{~m}$. from Terre Haute.

HrgmLavd, p. o., Tishemingo co, Miss.: $197 \mathrm{~m}$. N. E. Jackson,

HrgmaAND, p. v., Madison co, $I l l_{*}: 78 \mathrm{~m}$. $\mathrm{S}$. Springfield.

Higriand, p. o., Shelby county, Ala. : 68 m. N. by W. Montgomery.

HIGHLAND, t. and p. O., Oakland co., Mich. : 48 m. E. by $S$. Lansing. It lies on the high land forming the shed between the Shiawassee and Huron rivers. Pop. 851.

Hrghland, p. v., Ritchie county, Firg. : 238 m. N. W. Richmond.

Higurasd, p. v., Highland co., Ohio : on Lee's cr., $53 \mathrm{~m}$ W. Columbus.

HIGHLAND, p. o., Bath co., Ky. : 62 m. E. Frankfort.

Hightand, p. o, Bradford co., Penn. : $113 \mathrm{~m}$. N. Harrisburg.

IIIGHLAND, p. V., Jackson co., Tenn. : on the W. or right side of Cumberland $r, 66 \mathrm{~m}$. E. N. E. Nashville.

HrghLAND, p. o., Iowa county, Wisc, : $42 \mathrm{~m}$. W. by $\mathrm{S}$. Madison.

HignLAND, p. o., Jackson co., Mo.: on the W. side of Little Blue r., $128 \mathrm{~m}$. W. by N. Jefferson City.

Higilland Grove, p. o., Greenville dist., S. Car.: 112 m. N. W. Columbia.

HigILAND Grove, p. o., Harford co, MI.: $62 \mathrm{~m} . \mathrm{N}$. Annapolis.

Hrgmlavd Mruls, p. v., Orange co., $N, \bar{Y}: 90 \mathrm{~m} . \mathrm{S}$. by W. Albany. Here are several mills and stores, and about 30 dwellings.

Hignlaxd Mruls, p. o., Morgan county, Firg.: $152 \mathrm{~m}$. N. N. W. Richmond.

Highlands (Matteawan or Fishkill Mountains), $N . \quad Y$. See Fishizilu Mountains.

High MaRKET, p. y., Lewis co, $N . Y_{0}: 117 \mathrm{~m} . \mathrm{N}$. W. Albany

Higr Pise, p. o., Randolph county, Ala.: 86 m. N. E. Montgomery. 
High Porvt, p. o., Mercer co., Ill.: on Edwards $r_{\text {. }}, 114$

m. N. W. Springfield.

Higir PoIst, p. o., Cole co., Mo.

Highland Pramie, p. o., M'Henry county, $I l_{*}$ : $194 \mathrm{~m}$.

N. N. E. Springfield.

Higr Riwge, p. o., Fairfield county, Conn.: $47 \mathrm{~m} . \mathrm{S}$. W. Hartford.

Higr SHodis, p. o., Morgan co, Ga.: on the Appalachee $r$, at the rapid so called, $49 \mathrm{~m}$. N. N. W. Milledgeville.

High Shoars, p. o., Rutherferd county, N. Car.: $159 \mathrm{~m}$. W. S. W. Raleigh.

High Sprre, p. v., Dauphin co., Penn. : on the line of the Pennsylvania R. R., 6 m. S. E. Harrisburg.

Higr Sprivg, p. 0., Greene co., MFo.: 113 m. S. W. Jefferson City.

Hightow ER, p. 0., Forsyth co., Ga.: 112 m. N. W. Milledgeville.

Higutowers, p. o., Caswell co., N. Car.: $63 \mathrm{~m} . \mathrm{N} . \mathrm{W}$. Raleigh.

Higntstown, p. vo, Mercer co., N. J.: 19 m. E. Trenton. The Camden and Amboy R. R., $22 \mathrm{~m}$. from South Amboy, and $41 \mathrm{~m}$. from Camden, passes through it. It has a newspaper, the "Village Record," a weekly issue. Population about 400.

High VIEW, p. o., Frederick co. Virg. : 137 m. N. N. W. Richmond.

Higrville, p. O., Lancaster co., Penn. : 47 m. S. E. Harrisburg.

Hrgmwar, p. o., Greenville dist., S. Car. : 107 m. N. W. Columbia.

Huleam, p. 0., Overton co., Tenn.: 73 m. E. by N. Nashville.

Hri, t. and p. vo, Grafton co., N. Hamp.: 28 m. N. N.W. Concord. Drained hy Smith's r., which on the E. border empties into the Pemigewasset. Surface uneven and hillyRagged Mountain lying on its S. boundary; soil generally fertile. 'The $\mathrm{v}$. is located in the $\mathrm{S}$. E., and is built on one street, and by a bridge connected with Sanbornton. The Bristol Branch R. R. passes through Hill. Pop. 951.

HrLabeE, p. V., Talladega co., Ala.: $67 \mathrm{~m}$. N. by E. Montgomery.

Hillegas, p. o., Montgomery county, Penn.: $81 \mathrm{~m} . \mathrm{E}$ Harrisburg.

Hillerman, p. o., Massac co., I ll. : on the N. bank of the Ohio r., 155 m. S. S. E. Springfield.

HuL Grove, p. O., Darke co., Ohio: $87 \mathrm{~m}$. W. Columbus. HILL GROvE, p. O., Pittsylvania co., Firg.: 122 m.W. S.W. Tichmond.

Hrum inovse, p. o., Lake co., Ohio: 147 m. N. E. Columbus. Hilltay's Store, p. o., Marshall co., Ala.

Hilllard's, p. 0., Shelby county, Tex.: 255 m. E. N. E. Austin City.

Hirliardstox, p. v., Nash co., N. Car. : 52 m. E. N. E Raleigh.

Hilliardstille, p. т., Henry county, Ala.: 97 m. S. E. Montgomery.

Hrisboro' county, Flor. Situate S. on Tr. side of the peninsula, and contains about $3,200 \mathrm{sq}$. $\mathrm{m}$. It has the Gulf of Mexico for its W. boundary; in the N.W. Tampa or Espiritu Santo Bay, a large inlet of the Gulf, into which flow Hillsboro $r_{\text {., Alafia }} \mathrm{r}_{\text {., Indian }} \mathrm{r}_{\text {, }}$ and Manatee $\mathrm{r}_{\mathrm{s}}$; and in the S. W. Charlotte Harbor, another inlet, which receives Pease cr, and other streams. It covers a large extent of territory as yet unsettled, where nature exhibits some of her greatest productions in the majestic forests of cedar, magnolia, and cypress that cover it. The surface is various, parts being marshy, with impenetrable swamps, and parts fine rolling cotton lands. Soil, where cultivated, very fertile, and generally heavily timbered. The productions embrace figs, cranges, and pomegranates. Tampa Bay affords a fine harbor. Farms 120; manuf. 9; divell. 253, and pop.-wh. 1,711, fr. col. 6, sl. 660-total 2,377. Capital: Tampa 290
HuLSBOROUGH county, N. Hamp. Situate 8 , and cuntains 844 sq. m. Drained W. by Contoocook r., N. by Piscataquog r., S. by Souhegan r., and Nashua $r_{\text {, }}$ all tributaries of the Merrimac, which flows S. through the E. part of the co. Surface uneven and broken. Much of the soil is fertile, and most finely adapted to grazing and grain-growing. Its streams afford great water-power, especially the Merrimac, on which are many large cotton and woolen factories, and thriving manufacturing cities and villages. Among these, Manchester and Nashua stand first. and have advantages hardly surpassed in New England. Farms 3,675; manuf. 399 ; dwell. 9,939, and pop.-wh. 57,359, fr col. 118-total 57,477. Capital: Amherst. Public Works Nashua and Lowell R. R.; Concord R. R.; Nashua and Worcester R. R.; Peterboro' and Shirley R. R.; Wilton R. R. ; Contoocook Valley R. R. ; New Hampshire Central R. R., ete.

Hrwsborodgr, p. v., Lawrence co., $A l_{\text {t.: }}$ : on the Memphis and Charleston R. R, $172 \mathrm{~m}$. N. N.W. Montgomery.

Hrisвorovgh, p. v., Union county, Ark. : $11 \mathrm{r}$ m. S. Little Rock.

HпisвовобGH, p. v., Oneida county, $N . Y_{.}: 96 \mathrm{~m} . \mathrm{N}$. W. Albany.

HILSBOR6రGH, p. v., Jasper county, Ga.: 26 m.W. N.W. Milledgeville.

Hrisborotge, p. v., Fountain county, Ind.: on the E. fork of Coal cr., $56 \mathrm{~m}, \mathrm{~W} . \mathrm{N}$. W. Indianapolis. It contains about 20 dwellings.

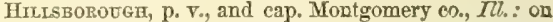
the E. of the Middle Fork of Shoal cr., 47 m. S. S. E. Springfield. It contains a court-house, jail, etc., several stores and mechanic shops, and about 600 inhabitants. The Terre Haute and Alton $\mathrm{R}$. $\mathrm{R}$. will pass through the village.

Hilisborovgr, p. v., Henry county, $I a$. : $49 \mathrm{~m}$. S Iowa City.

FIlusBorotgr, p. F., Fleming county, $K y_{\text {: }}: 74 \mathrm{~m}$. E。 Frankfort.

HilisBorotgr, p. Y., and cap. Scott co., Afiss: : on a small branch of Pearl r., $41 \mathrm{~m}$. E. by N. Jackson. It contains a court-house and several stores and mechanic shops, and about 500 inhabitants. The North Carolina R. R. passes through it.

Hulsborotge, p. v., Caroline co., Md.: on the E. side of Tuckahoe er., $55 \mathrm{~m}$. E. Annapolis.

Hillsiozocarn, p. v, and cap. Jefferson co., Mo.: on the high land between Big r. and the Mississippi, 92 m. E. S. E. Jefferson City. It contains a court-house, jail, etc., and has several stores.

HILSBOROugH, p. V., and eap. Orange county, N. Car.: on Eno r. of the Neuse, $42 \mathrm{~m}$. N. W. Raleigh. It contains a court-house, jail, ete., has sereral stores and mechanic shops, and publishes two newspapers, the "Recorder" (whig), and the "Democrat" (dem.), both weekly issues. Pop. about 600 .

Hiltsborougr, t, and p. v., Hillsborough co., N. Hamp. $21 \mathrm{~m} . \mathrm{W} . \mathrm{S} . \mathrm{W}$. Concord. Drained by Contoocook and Hillsborough rivers, which supply water-power. Surface uneven and hilly; soil of moderate fertility. The $\mathrm{v}$, has considerable manufactures, and in the $t$, are numerous industrial establishments, as mills, factories, mechanic shops, etc. Population 1.655 .

Filibiorotgr, p. vo, and cap. Highland eo., Ohio: 61 m. S. S. W. Columbus. It contains a court-house, jail, ete., several mechanic shops and stores, and in 1650 had 1,392 inhabitants. Two newspapers are published here, the " $\mathrm{H}$. Gazette" (dem.), and the "Highland News" (whig), both weekly issues. Hillsborough is a principal station on the Cincinnati, Hillsborough, and Parkersburg R. R., and as such must become the depôt for a wide and fertile country. It is $60 \mathrm{~m}$. by railroad route from Cincinnati.

HIIrsBorough, p. v., Washington co., Penn. : on the National Road, 173 m. W. Harrisburg. Pop. about 200. The site is 1,002 feet above the Ohio r. at Wheeling. 
Hrusborotgr, p. v., Coffee county, Tenn.: 67 m. S. E. Nashville.

Hrisborotgh, p. v, and eap. Washington con, Oreg.: on a branch of Tualatin $r ., 42 \mathrm{~m}$. N. Salem, and $14 \mathrm{~m}$. W. Portland.

Hrisboroder, p. v., Loudon cn., Firg. : 128 m. N. by W. Pichmond. It contains several mills and stores, and about 200 inhabitants.

Hulsborodgr Bridge, p. O., Hillsborough co., N. Hamp. : on the $\mathrm{N}$. side of Contoocook r., which is here crossed by a bridge, $20 \mathrm{~m}$.W. S.W. Concord. The Contoocook Valley R. R. has its present terminus at this point.

Hrlisborodger Centre, p. o., Hillsborough county, $N$. Hamp.: 23 m. W. S. W. Concord.

Hul's Corkers, p. o., Penobscot co., Me.

Hrisdate county, Wich. Situate S., and contains 608 sq. m. Drained S. by heads of St. Joseph's r., flowing into Maumee r., and N. by heads of St. Joseph's r., emptying into Lake Michigan. Surface undulating, with occasional marshes, and some of the highest land in the peninsula ; soil a black, sandy loam, and very productive of grain, but less adapted to grazing. In the $\mathrm{N}$. are "oak openings," but the rest of the co. was originally timbered heavily. Fine building sandstone is plenty in parts, and iron ore is found. Its streams have many fine mill-seats. Farms 1,411; manuf. 45 ; dwell. 2,965, and pop.-wh. 16,158, fr. col. 6-total 16,159. Capital: Hillsdale. Pubtic Works: Michigan Southern R. P.

HrilsdalE, t., p. V., and cap. Hillsdale co., Mich. ; on the outlet of St. Joseph or Bourbese Lake, $55 \mathrm{~m}$. S. Lansing, and on the line of the Michigan Southern R. R., and about 70 miles from Monroe and Toledo. It is eligibly situate as a manufacturing place, having a large water-power, and as a centre of trade has many advantages. The v. contains a court-house, jail, ete., and about 600 inhabitants. Two newspapers are published here, the "H. Gazette" (dem.), and "H. Standard" (whig), both weekly issues. Pop. of t. 1,067.

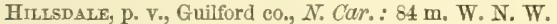
Raleigh.

Hilisdale, t. and p. v., Columbia co., N. Y.: 32 m. S. S. E. Albany. Drained by Ancram and Copake creeks. Surface hilly and mountainous, containing Taghkannac Mountain ; soil gravelly loam and clay. The village, sometimes called the "Turnpike," contains 2 churches and several stores, and 25 to 30 dwellings. The Housatonic Station, on the Harlem R. R., is $18 \mathrm{~m}$. from Chatham Four Corners. Pop. 2,123.

HrL's Grove, p. o., M'Donough co., Il\%. : 76 m.W. N.W. Springfield.

Hul's Grove, p. 0., Sullivan co., Penn. : S5 m. N. by E. Harrisburg.

Hrul's MrLs, p. o., Cook county, Ill.: 167 m. N. E. Springfield.

Hizl's Store, p. o., Randolph co., $\boldsymbol{N}$. Car.: 78 m. W. Paleigh.

HuLl's VALLEx, p. o., Williamson co., Tenn.

Hill's VIEw, p. o., Westmoreland co., Penn. : 128 m.W. Harrisburg.

Hillspilie, p. T., and eap. Carroll co., Virg.: on a cr. of New river, $203 \mathrm{~m}$.W. S. W. Richmond. It contains the co. offices, and about 200 inhabitants.

Hrlustrlle, p. v., Lawrence co., Penn.: 197 m.W. N.W. Harrisburg.

Hruc Top, p. v., Wagne county, Penn.: 147 m. N. E. Harrisburg.

Hrlltown, t. and p. v., Bucks county, Penn.: 86 m. E. Harrisburg. Drained by branches of Nishaminy river. Pop. 2,108.

HrLocheE, p. o., Washington co., Ark.: 143 m. N. W. Little Rock.

HrLtos, p. ., Monroe county, Ky.: 114 m. S. S. W. Frank fort.

Hiltow's, p. o., Sullivan county, Tonn. : on the Holston, 243 m. E. Nashville.
Hnockley, ts and p. o., Medina county, Ohio: $108 \mathrm{~m}$. N. E. by N. Columbus. Drained by Rock r., which affords numerous mill-sites. Surface elevated and broken; soil fertile, adapted alike to grain and grass. Iron ores, coal, and red sandstone abound. Pop, 1,416.

HrNDs county, Miss. Situate W. centrally, and contains 851 sq. m. Drained by affluents of Pearl r., its E. boundary, and of Big Black r., its N. W. boundary, and S. by Tallaha cr., which flows into the Mississippi. Surface level or rolling; soil very fertile, and admirably fltted for cotton growing. Cotton is the great staple, corn yields well, and some rice is made. Jackson, the capital of the State, is in its $\mathrm{E}$. part, on the Pearl r. Farms 852 ; manuf. 3 ; dwell. 1,656, and pop.-wh. 8,690 , fr. col. 25, sl. 16,625-total 25,340 . Capital: Jackson, Public Works: Vicksburg, Jackson, and Brandon R. R.; Raymond Branch R. R.; New Orlears, Jackson, and Northern R. R.

Hivos, p. o., Brazoria co., Texe. : on the W. side of Oyster cr., $162 \mathrm{~m}$. S. E. Austin City.

HivpsburgH, p. Y., Orleans co., $\mathcal{N}$. Y.: 216 m. W. N. W. Albany.

Hixesburgi, t. and p. v., Chittenden co., Verm. : $24 \mathrm{~m}$. W. by N. Montpelier. Drained by Platte $r$ and Lewis or. Surface uneven; soil fertile, well adapted to grass. The v. is on Platte r., and is built on one street. Some manufactures are carried on in the $t_{\text {n, }}$ and there are facilities for their increase. Pop. 1,837 .

Hises' Mruls, p. o., Ohio county, Ky. : 131 m. W. S. W. Frankfort.

Hineston, p. o., Rapides parish, La.: $116 \mathrm{~m}$. N. W. Baton Rouge.

Hivesville, p. v., and cap. Liberty co., Ga. : on the pine land S. of Taylor's cr., $130 \mathrm{~m}$. S. E. Milledgeville. It coutains about half a dozen dwellings.

Hrrghar, t. and p. v., Plymouth co., Mass.: 13 m. S. E. Boston. Situate on the S. side of Boston Bay. Surface broken; soil in parts fertile, but not generally so. The $\mathrm{v}_{\text {. is }}$ located at the head of an arm of the bay, and on the line of the South Shore R. R. It is a place of considerable trade, and is much employed in coasting and the fisheries. In the t. there are several manufactures. Pop. 3,952.

Hinklesbureh, p. v., Oldham co., Ky. : 38 m. W. N. W. Frankfort.

Hixkleton, p. o., Lancaster co., Penn.: on the N. side of Conestoga cr., 41 m. E. S. E. Harrisburg.

Hinmansville, p. v, Oswego co., N. Y.: $132 \mathrm{~m}$. N. W. Albany.

Hissdale, t. and p. v., Berkshire co., Mass. : 108 m. W. Boston. Drained by several creeks, affluents of Housatonic river. Surface elevated; soil generally good, and well adapted to grass. The $\mathrm{v}$, is a small central settlement. In the t. there are several manufactories. Pop. 1,253. The Western R. R. passes through the t, and has a station a little $\mathrm{W}$. of the village.

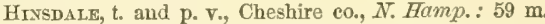
S. W. by W. Concord. Situate in the extreme S. W. comer of the State. Drained by Ashuelot $r$. and its branches, and small streams falling into Connecticut $r$, which is its W. houndary. A range of hills, from 800 to 900 feet high, crosses the t. E, and W. Surface, with this exception, moderately uneven; soil fertile and well cultivated. The Ashuelot R. R. passes through it. Pop. 1,903 .

HINSDALE, t. and p. v., Cattaraugus co., N. I. : $284 \mathrm{~m}$. W. by S. Albany. Drained by Ischua and Olean creeks, and contains a small lake called the Reservoir. Surface hilly and somewhat broken; soil well adapted to grass. The v. is situate on the Genesee Valley Canal and on the New York and Erie R. R., and contains several mills, me chanic shops, stores, etc., and about 500 inhabitants. It is eligibly situate for a considerable trading town, and has unusual facilities for expansion. Pop. of t. 1,302.

Hixtox's Grove, p. o., Piclens co., Ala. : 126 m. N. WV. Montgomery. 
Hrray, t. and p. o., Oxford con, Me. : 65 m. S. W. Augusta. Drained by Saco $r_{*}$, which runs through it and affords immense water-power. Surface diversified; soil of average fertility. Pop. 1,210.

Hrram, t. and p. v., Portage co., Ohio: $132 \mathrm{~m}$. N. E. Columbus. Drained by Cuyahoga r. and its affluents, and also by some head branches of Mahoning river. Surface clevated; soil rich and fertile. The $\mathrm{r}$. is central, and on a branch of Mahoning river. Pop. of t. 1,106.

Hrramburgir, p. v., Morgan co, Ohio: 66 m. E. S. E. Columbus.

Hrтchсоскville, p. \%., Litehfield co., Conn. : on the W. branch of Farmington r., $21 \mathrm{~m}$. N. W. Hartford. It contains several shops and stores, and about 250 inhabitants.

Hitesvilie, pa F., Coles county, Ill.: 88 m. E. S. E. Springfield.

Hiw $\triangle$ sseE river, $G a$, and Tenn.: rises in Union county, Georgia, and flowing into Tennessee enters the Tennessee r., $12 \mathrm{~m}$. S. W. Washington.

Hrx's Fegry, p. 0., Randolph co., Ark. : at the crossing of Current r., $146 \mathrm{~m}$. N. N. E. Little Rock.

Hizerville, p. v., Oneida county, $N . Y_{*}: 97 \mathrm{~m} . \mathrm{N} . \mathrm{W}$. Albany.

Hoadjer, p. 0., Racine county, Wisc.: $76 \mathrm{~m}$. E. by S. Madison.

HoAG's Corner, p, o., Rensselaer county, N. Y.: $12 \mathrm{~m}$. E. by S. Albany.

Hoвart, p. v., Delaware co., $N_{\text {. }} Y_{\text {.: }}$ on the head waters of Delaware r., $51 \mathrm{~m}$. W. S. W. Albany, It contains several mills, stores, etc., and about 300 inbabitants,

Hobart, p. v., Lake co., Ind. : on Deep r. of the Culumet, $128 \mathrm{~m}$. N. W. Indianapolis.

Hobieville, p. v., Greene county, Ind.: $77 \mathrm{~m}$. S. W. Indianapolis.

Hobbieville, p. v., Alleghany co, $N_{\text {. }}$ Y.: 214 m. W. by S. Albany.

Hobвyvmle, p. v., Spartanburgh dist., S. Car.: $97 \mathrm{~m}$. N. W. Columbia.

Hовокем, p. Y., Hudson co, $N$. Jer.: on the W. bank of the Hudson r., $62 \mathrm{~m}$. N. E. Trenton. It lies immediately opposite New York City, with which it is connected by three ferries. Within the past few years it has become a large $v$. chiefly inhabited by persons doing business in the neighboring metropolis. The Elysian Fields lie immediately $N$. of the $y_{3}$ and are a famous holiday resort in the summer and fall seasons.

Hookaxux, p. v., Hartford co., Conn.

Hockanum, v., Hampshire eo., Mass.: on the E. side of Connecticut $r$, and at the base of Mount Holyoke, $83 \mathrm{~m}$. W. Boston. There is at this point a horse ferry across the $r$. The v. contains a tavern, and abrout a dozen dwellings.

HоскпоскING river, Ohio: rises in Fairfield $\mathrm{cos}_{2}$ and after a course of about $80 \mathrm{~m}$. through a hilly country, enters the Obio at Hocking Port in the t. of Troy. Its name in the Delaware language means a bottle. It is navigable for small erait to Athens; $7 \mathrm{~m}$. $\mathbf{N}$. $\mathrm{W}$. of Lancaster it falls over a ledge of rock 40 feet perpendicular, and above the falls resembles "a bottle" in shape, whence its name. The country through which it passes is wild and picturesque, and along its banks numerous ancient motunds and fortifications are found. The lower valley abounds in yellow pine; The Hocking Canal follows the valley of this river.

Hookisg county, Ohio. Situate S. centrally, and contains 361 sq. m. Drained by Salt cr. and Hocking $r$. and its branches. Surfuce considerably broken, with a few high hills; soil fertile, producing large crops of grain and some tobnceo, and furnishing excellent grazing. Grain and pork are the chief exports. Farms 1,130 ; manut. 15 ; dwell. 2,367, and pop.-wh. 14,002, fr. col. 117-total 14,119. Cupitul: Logan. Pullic Works: Hocking Canal.

Hocking Port, p. v., Athens co., Ohio: at the entrance of Big Hockhocking r. into the Ohio, $88 \mathrm{~m}$. south-east Columbus.
HODGDON, t. and p. o, Aroostook co., Me. : $153 \mathrm{~m}$. N. E. Augusta. Situate on the E. line of the State, and drained by branches of Meduxnekeag river, which empties in the St. John at Woodstock, N. B. Surface diversified; soil excellent for wheat and grass. Pop. S62.

Hodgdon's Mulls, p. o, Lincoln co, Me.: 28 m. \$. E. Augusta.

Hodgenstille, p. Y., La Rue county, $\bar{K} y .: 64$ m. S. W. Frankfort.

Hodge's Beid, p. o., Fort Bend co., Tex. : 146 m. E. S. E. Austin City.

HoFrman's Ferix, p. o., Schenectady co, $N . Y_{.:} 18 \mathrm{~m}$. N. W. Albany.

Hoffran's Gate, p. o, Columbia county, $N_{0}, Y_{.}: 29 \mathrm{~m}$. S. S. E. Albany.

Hogansbureir, p. v., Franklin co, $\boldsymbol{N}_{\text {. }} \boldsymbol{Y}$. : on St. Regis r., $2 \mathrm{~m}$. from its entrance into the St. Lawrence, and $153 \mathrm{~m}$. N. N. W. Albany. It has several large mills and stores, and about 300 inhabitants. Steamboats pass up the $r$. from the St. Lawrence to this point.

Hogansville, p. v., Du Buque co, $I a_{*}: 60$ m. N. N. E. Iowa City.

Hoganstille, p. v., Troup co., Ga.: on Yellow Jacket cr. of Chattahoochee r., $100 \mathrm{~m}$. W. by N. Milledgeville. The Lagrange R. R. passes through it $59 \mathrm{~m}$. from Atlanta.

Hog Cresk, p. o., Allen county, Orio: $81 \mathrm{~m}$. N. W. Columbus.

Hogestown, p. v., Cumberland co., Penn.: 9 m. S. W. Harrisburg.

Hogle's Creek, p. 0., St. Clair co., Mro. : on a cr, of Osage r. so called, 82 m. W. S. W. Jeffersou City.

Hog Mountain, p. o., Hall co., Ga. : ou the S. W. part of the $c_{0}, 89 \mathrm{~m}$. N. N. W. Milledgeville.

HoHenlindev, p. v., Chickasaw county, Miss. : $128 \mathrm{~m}$. N. N. E. Jackson.

Holcomb, p. v., Burke co., Ga. : on the N. side of Ogeechce r., $64 \mathrm{~m}$. E. S. E. Milledgeville. It is a station of the Contral R. F., $100 \mathrm{~m}$. from Savannah, and $91 \mathrm{~m}$. from Nacon.

HoLDEN, t, and p. 0, Worcester con, Mass. $43 \mathrm{~m} . \mathrm{W}$ Boston. Drained by Blackstone and Nashua rivers, which have immense water-power. Surface somewhat uneven: soil, except on the rivers, indifferent. The manufactures of the town are considerable. Pop. 1,933.

Holdermax's Grove, p. o., Kendall co., $1 l_{*}$ : $128 \mathrm{~m}$ N. N. E. Springfield.

Holdersess, t. and p. v., Grafton co., N. Hamp. : $37 \mathrm{~m}$ N. Concord. Drained by tributaries of Merrimae r., which lies on its W. side; and Squam Lake lies on its E. border, and affords by its outlets, which flow into Pemigewasset, excellent water-power. It has several mills and factories, and 1,744 inhabitants. The Boston, Concord, and Montrea R. R. passes through the $S$. W. corner, $45 \mathrm{~m}$. by route from Concord.

II hlierness Centre, Y., Grafton co., 1. Hamp. : $36 \mathrm{m.}$ N. Concord.

Hollaxd, t. and p. o, Hampden county, Mass.: $63 \mathrm{~m}$. W. S. W. Boston. Drained by head branches of Quinnebaug $r$. It is a small town, with some manufactures. Pop. of t. 489 .

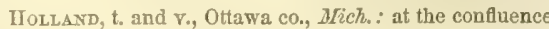
of Black $r$. with the estuary so called, $76 \mathrm{~m}$. W. Lansing. It has good harborage, and the $\mathrm{v}$. is a thriving place of some 400 inhabitants, The "Hollander," a weekly newspaper, is published. Pop. of t. 1,829.

Hollavd, t. and p. v., Erie co., N. $Y_{0}: 237 \mathrm{~m}$. W. Albany. Drained by Seneca and Cazenova creeks. Surface high and rolling; soil moist clay and sandy loam. The village consists of about 25 dwellings. Pop. of $t .1,315$.

Hollaxd, p. o., Venango county, Pem.: $197 \mathrm{~m} . \mathrm{N}$. W. Harrisburg.

Hollaxi, t. and p. o., Orleans co., Term. : 59 m. N. N. E. Montpelier. Situate on the Canada border. Draired bs streams flowing $\mathrm{N}$. into Lake Massawippi, S. inio Seymour 
Lake, and W. into Lake Memphremagog, the waters of all which are ultimately discharged through St. Francis r. into the St. Lawrence. Surface elevated, and has several ponds, the sources of the streams indicated; soil fertile. Pop. 669.

Holland Patent, p. v., Oneida county, N. Y.: $81 \mathrm{~m}$. W. N. W. Albany. It contains 2 churches, an endowed academy, and about 860 inhabitants.

Holland's, p. o., Laurens district, S. Car.: $63 \mathrm{~m} . \mathrm{N} . \mathrm{W}$. Columbia.

Holley, p. v., Orleans co., N. Y.: on Sandy cr., $216 \mathrm{~m}$. W. N. W. Albany. The Erie Canal and the Rochester, Lockport, and Niagara Falls R. R. here cross the creek. It is an active trading place of between 350 and 400 inhabitants.

Hollibarsbergi, p. b., and cap. Blair co., Penn. : on Beaver Dam er., $83 \mathrm{~m}$. W. N. W. direct, or by railroad 137 $\mathrm{m}$. from Harrisburg. It is a place of considerable trade, and has some manufactures. The Alleghany Portage R.R. commences here and passes over the Alleghanies, uniting the two sections of the Pennsylvania Canal, and also the eastern and western divisions of the Pennsylvania $R$. R. Hollidaysburgh has four newspapers, the "Democratic Standard" (dem.), the "H. Register" (whig), the "Shield" (relig.), and the "Blair County Whig," all weekly issues. Pop. in $1840,1,896$, and in $1850,2,417$.

Holliday's Cove, p. o., Hancock county, Virg. : $276 \mathrm{~m}$. N. W. Richmond.

Hollmarsville, p. v., Dooly co, $G a a_{0}$ : on the $\mathrm{E}$. bank of Flint r., $112 \mathrm{~m}$. S. S. W. Milledgeville.

Hollingsw ORTH, p. Y., Habersham co., Ga.: on a branch of Hudson's fork of Broad r., 94 m. N. by W. Milledgeville.

Hollis, t. and p. v., York co., $M e_{0}$ : 69 m. S. W. Augusta. Drained by affluents of Saco r.y which is its E. border, and Ossippee r. runs along its N. border. Surface diversified; soil generally fertile, with some fine meadows. The rivers afford excellent mill-sites. The v. lies on Saco r., opposite Buxton, with which it is connected by a bridge. The York and Cumberland $R$. $R$. crosses the t. and r. a little to the N. Lumber is extensively manufactured, and there are potLeries ete. Pop. of t. 2,683.

Hollrs, p. v., Peoria co., Ill. : 54 m. S. by E. Springfield.

Hollis, t. and p. o., Hillsboro' co., N. Hamp. : $35 \mathrm{~m} . \mathrm{S}$.

Concord. Drained by Nashua and its tributaries, and ponds and other streams of Merrimac river. There is much fine farming land in the to, which is well cultivated, The v. lies centrally. Pop. of t. 1,293.

Hollis Centre, p. o., York county, Me.: 71 m. S. W. Augusta.

Holuister's Milis, p. 0., Holt co, Mo.: 204 m. N. W. Jefferson City.

Holliston, t. and p. v., Middlesex co., Mass.: $25 \mathrm{~m}$. W. S. W. Boston. Drained by a branch of Charles river. The v. is situate centrally, and there is a station on the Milford Branch $R$. $R$. The t. has considerable manufactures.

Pop. 2,428.

Hollow Creek, p. o., Lexington disto, S. Car.: on a creek of Saluda r. so called, $27 \mathrm{~m}$. W. Columbia. Population 1,912 .

Hollow SqUARE, p. o., Greene co., Ala. : 98 m.W. N.W. Montgomery.

Holly Criek, p. o., Murray co, Ga.: on a creek of Oostanaula r. st; called, $147 \mathrm{~m}$. N. W. Milledgeville.

Holly Grove, p. o., Walker co., Ala.: 139 m. N. W. Montgomery.

Holly Grove, p. o., Stewart eo, Ga.: 126 m. S. W. Milledgeville.

Holiy HrLl, p. o., Charleston dist., S. Oar.

Holiy Poist, D. O., Drew county, Ark.; 97 m. S. S. E. Littie Rock.

Holly Retreat, p. o., Wilkinson co., Miss.: $108 \mathrm{~m}$. S. WV. Jackson.

Holly Sprixg, p. v., Wake co., $N$. Cur.: 16 m. N. N.W. Raleigh.
Holly Spring, p. o., Dallas co.n Ark. : 64 m. S. by W. Little Rock.

Holly Sprivgs, p. V., and cap. Marshall co., Miss.: on an elevated site or watershed dividing the streams, $168 \mathrm{~m}$. N. by E. Jackson. It contains a court-house, jail, several stores. and about 600 inhahitants. Its success is prospective, but there is every reason to believe that it will shortly become a great railroad and business centre, as it lies on the routes of several projected lines of important roads. Two newspapers, the "H. S. Gazette" (whig), and the "Jacksonian" (dem.), are issued weekly. Pop. about 600.

HolMDEL, p. v., Monmouth co., N. Jer.: 33 m. E. by N. Trenton. It is a small $v$. on an affluent of Navesink $r_{\text {. }}$ and contains about 20 dwellings.

HolMes county, Flor. Situate N. W., and contains 732 sq. $\mathrm{m}$. Choctawatchie $\mathrm{r}$. runs $\mathrm{S}$. through it, and it is drained by its branches. Surface mostly even, with some considerable elevations; soil on the sireams fertile, and much covered with pine. Cotton is the staple. Farms 103 manuf. 0 ; dwell. 267 , and pop.-wh. 1.481, fr. col. 0, sl. 163 -total 1,644. Oapital: Cerro Gordo.

HOLMES county, Jfiss. Situate N. centrally, and contains s76 sq. m. Yazoo r. bounds it W., and Big Black r. E., by branches of which it is drained. Surface various, and soils excellent. It possesses much good water-power, a part of which is improved, and raises large numbers of cattle and swine. The principal business is the eulture of cotton, for which the soil is very favorable. Farms 640 ; manuf. 21 ; dwell. 995, and pop.-wh. 5,537, fr. col. 4, sl. 8,377-total 13,918. Capital: Lexington.

HoLmes county, Ohio. Situate E. centrally, and contains $439 \mathrm{sq} . \mathrm{m}$. Surface diversifled, and in parts broken; soils of excellent quality, equally adapted to grass and grain. It has numerous manufactories, and raises many cattle, sheep, and swine. Farms 2,171; manuf. 122; dwell. 3,436, and pop.-wh. 20,448, fr. col. 4-total 20,452. Capital: Millersburg. Public Works: Millersburg Extension of the Akron and Hudson R. R.; Ohio and Pennsylvania R. R.

Holmes' BaY, p. o., Washington co., Me.

Holmesburgh, p. v., Philadelphia co., Penn.: on Pennypack cr., $96 \mathrm{~m}$. E. Harrisburg, and $9 \mathrm{~m}$. N. Philadelphia The er. is navigable to Lewis' Mill, in the neighborhood. Pop. about 400 . There is a mill here erected 1697 , and built of stone.

Holmes' Hole, p. v., Dukes co., Mass, : on the W. side of the bay so called, $69 \mathrm{~m} . \mathrm{S}$. S. E. Boston. The village has about 400 inhabitants. Holmes' Hole is an important harbor on the N. side of Martha's Vineyard, deep enough for the largest class of vessels, and secure. It is much resorted to by mariners when the winds are unfavorable to rounding Cape Cod, and as a port of refuge it has no superior. The inhabitants have a number of ressels, chiefly employed in coasting and the fisheries.

Holmes' Valley, p. V., and cap. Washington co., Flor.: $94 \mathrm{~m}$. W. Tallahassee. Situate on Holmes' creek, which empties through Choctawatchie r. into the bay of the same name. It has a court-house and about 60 inhabitants.

Holviesville, p. v., and cap. Appling co., $G a_{0}:$ on a branch of Little Santilla river, 107 miles S. E. Milledgeville. It contains a court-house, jail, etc., and about 160 in habitants.

Holimesvilie, p. V., Aroyelles par., La.: on the W. bank of Bayou Téche, $78 \mathrm{~m}$. N. W. Baton Rouge.

Holsestille, p. V., and eap. Pike co., Miss.: on the W. side of Bogue Chitto r., $72 \mathrm{~m}$. S. Jackson. It has a courthouse, and contains about 600 inhabitants. The "Temperance Banner" is a weekly newspaper, published here,

Holmesvilie, p. v., Holmes county, Ohio: $71 \mathrm{~m} . \mathrm{N}$. E. Columbus.

HolstoN, p. v., Washington co., Virg. ; on Holston r., 279 m. W. S. W. Richmond.

Holston Springs, p. Y., Scott co., Firg. : 292 m.W. S.W. Richmond. 
Hoxston Valiti, p. o., Sullivan co.. Tenn. : 253 m. E. Nashville.

HoLt county, Mo: Situate N.W., and contains $442 \mathrm{sq.m}$. Drained by Nodaway r., which bounds it E., and Big and Little Tarkio rivers, all affluents of Missouri r., which is its W. boundary. Surface off the rivers, level or rolling; on the Missouri are bluffs or high grounds. Soil productive, and well adapted to grazing. Farms 305 ; manuf. 5 ; dwell. 614, and pop.-wh. 3,S27, fr. col. 8, sl. 127-total 3,957. Capital: Oregon.

Holt's StoRe, p. o., Orange co., N. Car.: 47 m. N. W. Raleigh.

HoLy Neok, p. o., Nansemond co., Virg.: 76 m. \$. E. Richmond.

HoLyoke, t. and p. v., Hampden co, Mass.: $92 \mathrm{~m} . \mathrm{W}$. Boston. Taken from N. part of West Springfield, and formerly called Ireland Parish. Drained by several creeks flowing to Westfield $\mathrm{r}_{\text {., }}$ and the Connecticut forms its $\mathrm{E}$. boundary. Surface, except on the Connecticut, hilly; soil generaily fertile. The $\mathrm{v}$. is situate opposite South Hadley Falls, and dates back only a few years. It is intended to make it a large manufacturing place, and for this purpose a dam has been thrown across the river, securing to it an immense water-power. The v. will be built up by Boston capital, and already between four and five million dollars are invested in the enterprise. The manufactures are chiefly cotton, and there is also a very extensive machine shop here, at which the mill machinery is built. The "Hampden Freeman" (whig), is issued weekly. Pop. of t. 3,245.

Holxorse mountain, Hampshire co., Dloss. : a range of mountains, terminating in a high peak on the E. side of Connecticut river, opposite Mount Tom, and is, in fact, the same range as the latter, broken through by the Conneeticut. Its greatest elevation is about 1,000 feet. Its faces on tho river, and toward the $\mathrm{N}$. are very steep and precipitous, and generally well wooded.

Homasassa, p. v., Benton co., Flor.: at the head of the river so called, $158 \mathrm{~m}$. S. E. Tallahassee.

Hove, p. o., Indiana county, Penna: $123 \mathrm{~m} . \mathrm{W} . \mathrm{N} . \mathrm{W}$. Harrisburg.

HoME, p. v., Jefferson co., Ind.: 86 m. S. E. Indianapolis,

Hose, p. O., Van Buren county, Ia. : 73 m. S. by W. Iowa City.

Hover, p. o., Champaign county, Ill.: 90 m. E. N. E. Springfield.

HoMer, t. and p. v., Calhoun county, Mich. : $42 \mathrm{~m}$. S. by W. Lansing. Drained by S. branch of Kalamazoo x., which has large water-power. Surface generally levelsometimes marshy; soil fertile. The $\mathrm{v}$. is a thriving settlement on the r., and has about 300 inhabitants. Pop. of t. 929

HoMer, t. and p. v., Cortlandt county, N. Y.: $122 \mathrm{~m}$. W. Albany. Drained by Tioughnioga er. and its tributaries. Surface level; soil sandy and clay loam. The v. on the W. bank of the creek has numerous mills, factories, and mechanic shops, with stores, etc., and a population of 1,600 souls. The "Cortlandt County Whig" is published weekly. The $t$. is also largely engaged in manufactures. : Pop. 3,836 . Hoxer, p. 0., Potter con, Penn. : 187 m. N.W.Harrisburg.

HoMrer, p. v., Licking co., Ohio: on the N. fork of Licking river, $31 \mathrm{~m} . \mathrm{N}$. E. Columbus. It contains several mills, mechanic shops, stores, etc., and about 400 inhabitants.

HoNER, p. v, and cap. Claiborne par., $L a$ : on the E. side of Bayou Dorcheat, 194 m. N. W. Baton Rouge.

HoMrevtau. p, p. v., Medina county, Ohio: 84 m. N. N. E. Columbus,

Hove Sprivg, p. o., Holmes co., Flor.: $10 S$ m. W. N.W. Tallahassee.

HoYeWOOD, p. O., Seott county, Mriss.: 42 m. E. N. E. Jackson.

Hommener Crese, p. 0., Buncombe co., N. Car, : $282 \mathrm{~m}$. W. Paleigh.

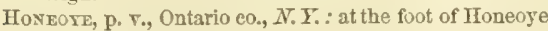
Lake, $159 \mathrm{~m}$. WT. by N. Albany. It has several mills and 291 workshops, and about 200 inhabitants. Honeoye Lake is about $5 \mathrm{~m}$. long and $1 \mathrm{~m}$. wide, and is a beautiful sheet of water.

Honeoye Falis, p. v., Monroe co., $N_{*}, Y_{*}:$ on Honenye cr., $192 \mathrm{~m}$. W. by N. Albany. The cr. has here a fall of 100 feet in $2 \mathrm{~m}$., of which 30 feet is a perpendicular fall in the centre of the village. $I t$ is the seat of numerous industrial establishments, furnaces, woolen factories, flouring mills, ete, and contains about 1,400 inhabitants. In the ricinity there is abundance of fine building stone.

Honesdale, p. b., and former cap. Wayne co., Penn. at the confluence of Dyberry and Lackawaxen creeks, 127 m. N. E. Harrisburg. It is the junction point of several railroads and canals, and may be considered as the W. terminus of the Delaware and Hudson Canal. It is a comparatively new place-in 1840 it contained 1.086 inhabitants, and in $1850,2,263$. Two newspapers are published here, the "Wayne County Herald" (whig), and the "H. Democrat" (dem.), both weekly issues. The borough has some important manufactures.

Honey Brook, t. and p. o.g Chester co., Penn.: $54 \mathrm{~m}$. E. by S. Harrisburg. Drained by branches of Brandywino river. Surface generally level; soil sandy loam. There are several mills, tanneries, stores, etc., in the $t$. Pop. 1,929 .

Honey Creek, p. o., M'Donald co., Mo.: in the S. W. corner of the State, $196 \mathrm{~m}$. S. W. Jefferson City.

HoNex CREek, p. o., Walworth co., Wisc. : on Honey or. of Fox river, $62 \mathrm{~m}$. E. S. E. Madison.

HoNex Cut, p. o., Baldwin co., Ala.: 156 m. S. S. W. Montgomery.

Honex Grove, p. o, Fannin co., Tex.: on Honey Grove cr. of Bois d'Are r., 294 m. N. N. E. Austin City.

Honey Point, p. 0., Macoupin co., Ill.: 47 m. S. by W. Springfield.

HoNer Town, p. v., Dale county, Ala.: 97 m. S. S. E, Montgomery.

Honeyvili,e, p. v., Page co., Firg.: on Shenandoah r., $96 \mathrm{~m}$. N. W. Richmond.

Hood"s Mruts, p. v., Carroll co., Ind. : on the W. branch of Patapseo r., and on the line of the Baltimore and Ohio R. P., $35 \mathrm{~m}$. W. Baltimore, and $36 \mathrm{~m}$. N. W. Annapolis.

Iloodsville, p. v., Marion county, Virg. : 208 m. N. W. Richmond.

Hooker, p. o., Hunt county, Texs: 255 m. N. N. E. Austip City.

Hookenstows, p. v., Greene con, N. Car.: on the W. side of Contentnea cr. of Neuse r., 68 m. E. S. E. Raleigh.

Hoorestown, p. v., Beaver co., Penn.: on a branch of Mill cr., $212 \mathrm{~m}$. W. Harrisburg. Pop. about 250.

Hookser, t. and p. v., Merrimac co., N. Hamp.: $11 \mathrm{~m}$. S. by E. Concord. Drained by Merrimae r., which runs through it, and has within the $t$ a descent of 16 feet in 18 rods, around which is a canal a quarter of a mile long. The $\mathrm{v}$. is situate on the W. side of the r., and on the line of the Concord $R, R, 9 \mathrm{~m}$. 5 . Concord. In the t, there are several large cotton and other manufactures, and there is plenty of power for their expansion. Pop. 1,503.

Hookвтоws, p. v., Baltimore county, MId.: $81 \mathrm{~N}$. by W. Annapolis.

Housu K, p. v., Greene county, Wisc.: 33 m. s. by W. Madison.

Hoosick, t. and p. o., Rensselaer co., N. Y.: 24 m. N. E. Albany. Drained by Hoosick $r$. and its tributaries. Surface Ailly; soil clay, sand, and loam, with some gravel, well adspted to grazing. The t. has several extensive mills and factories. In Hoosick the various railroads from Albany and Troy to Rutland, etc., north, and to Boston, etc., east, forn juetions. The Troy and Boston R. R. passes through an immense tunnel, driven through the Hoosick Mountains, in the south part of the town. Pop. 3,724.

Hoosick Falis, p. v., Rensselaer co., N. $Y_{0}:$ on both sides of Hoosick r., $26 \mathrm{~m}$. N. E. Albany. The r. here has a fall of 40 feet, affording immense water-power. The manu- 
factures carried on are considerable, and the $\mathrm{v}$, contains at least 600 inbabitants.

Hoostck mountain, Mass.: lies in Berkshire co., and is the source of a branch of Hoosick $r$. Its elevation is from 1,500 to 2,000 feet from its base. The Troy and Boston $R$. $R$ will pass through a tunnel in this mountain.

Hoosick (or Hoosack) river: rises from two heads, one having its sourees in Berkshire co., Mass., and the othor in the mountain tracts of Bennington co., Verm.; these unite near Hoosick Falls in New York, and the single stream meets the Hudson at Schaghticoke, $15 \mathrm{~m}$. N. Troy. This stream in many places is exceedingly rapid, and affords immense water-power.

Hoosier Grove, p. o., Linn co., Ia. : 14 m. N. Iowa City. Hoosige Grove, p. v., Greene co., Wisc. : $43 \mathrm{~m}$. S. by W. Madison.

Hootensville, p. v., Upson co., $G a_{\text {. : }}$ on the E. side of Flint r., 63 m. W. by S. Milledgeville

Hoover Hrul, p. o., Randolph co., $N$. Car.: $72 \mathrm{~m}$. W. Raleigh.

Hoover's Pornt, p. o., Macoupin co., $I$ l.

HopalkA, p. v., Leake co., Miss. : 58 m. N. E. Jackson.

Hope, p. o., Stewart county, Tenn.: 65 m. W. N. W. Nashrille.

Hopk, p. V., Pickens county, Alas.: on Lubbub cr. of Tombigbee r., 138 m. N. W. Montgomery.

Hope, p. V., Bartholomew co., Ind.: on the S. side of Haw cr., $37 \mathrm{~m}$. S. S. E. Indianapolis. It was originally settled by the Moravians, and now contains about 300 inhabitants.

Hope, t. and p. V., Waldo county, Me.: 81 m. E. S. E. Augusta. Drained by St. George's $r$. and its tributaries, and there are several small ponds in the town. Surface flat and soil sandy, but not unfertile. The village is in the E. part. Pop. of t. 1,107.

Hope, t. and p. จ., Warren co., N. Jer.: 51 m. N. N. W. Trenton. Drained by Beaver and other creeks, affluent of Delaware r. The $\mathrm{v}$. is on a branch of Beaver, and contains about 300 inhabitants. Pop, of t. 1,756.

HoPE, t. and p. v., Hamilton co., $N_{0} Y_{.}: 52 \mathrm{~m}$. N. W. Albany. Drained by Sacandaga $r$ and its tributaries, Stomy creek, etc. Surface varied; soil, except on the rivers, no very fertile. Hope village lies on the $\mathbf{E}$. side of Sacandaga river, below the confluence of Stony cr. Pop. of t. 789 .

Hope, p. v., Franklin co., Ohio: 17 m. N. E. Columbus.

Hop Ceatre, p. v., Hamilton co., $N_{.} Y_{*}:$ on the E. side of Sacandaga r., 55 m. N. W. Albany.

Hopedale, p. v., Harrison co., Ohio: 102 m. E. by N. Columbus.

Hopedale COMMUNTTY settlement, Worcester co., Mass. : contains a population of 180 souls. The association owns 500 acres of land, and earries on a dozen different branches of industry. It is represented to be in a flourishing and harmonious condition.

Hope Falls, p. 0., Hamilton county, N. $\boldsymbol{Y}_{\text {. } ~}: 53 \mathrm{~m}$. N. E. Albany.

Hope FarM, p. o., Louisa county, Ia.: 36 m. S. S. E. Torva Citv.

Hope Hild, p. o., Pike co., Jfiss. : 78 m. S. Jackson.

Hope Hill, p. o., Gibson county, Tenn.: $122 \mathrm{~m}$.W. by S. Nashville.

Hope Mrtz, p. o., Maury county, Tenn. : 42 m. S. by W. Nashville.

Hope Mruts, p. o., Page co., Virg.: on Shenandoah r., $100 \mathrm{~m} . \mathrm{N} . \mathrm{W}$. Richmond.

Hope Station, p. o., Lexington dist., S.Car. : on the line of the Greenville and Columbia R. R., $29 \mathrm{~m}$. from Columbia.

HopewEll, p. v., Mahaska county, Ia.: 64 m. W. S. W. Iowa City.

Hopewru, p. v., Greene county, Ala. : 93 m. W. N. W. Montgromery.

Hopewent, p. V., Crawford co., Ga.: 49 m. W. S. W. Milledgeville.
Hopewelu, p. o., Chickasaw co., MFiss. : 108 m. N. N. E. Jackson,

Hopewwlt, t. and p. o., Mercer co., N. Jer.: $16 \mathrm{~m} . \mathrm{N}$ Trenton. Drained by tributaries of Raritan river. Surface moderately uneven; soil good for wheat and grass. The t. has several grist, saw, and oil mills. etc. and 3.696 inhabitants.

HoPewril, t. and p. v., Ontario county, $N . Y .: 172 \mathrm{~m}$ W. by N. Albany. Drained chiefly by tributaries of Canandaigua outlet. Surface rolling; soil, elay loam. The v. is a station on the Canandaisua and Eimira R. R.. 8 miles E. by S. of the formor pluce. The t. has some manufactures. Pop. 1,923.

Hopewell, p. v., Mecklenburg county, N. Car.: $127 \mathrm{~m}$. W. S. W. Raleigh.

Hopewelu, t. and p. o., Muskingum $\mathrm{co}_{.}$, Ohio: $45 \mathrm{~m} . \mathrm{E}$. Columbus. Drained by Licking creek and its tributaries. Surface diversified; soil sandy loam and alluvion. The village is on the National Road, and contains about 150 inhabitants. Pop. of t. 2,388.

Hopewell, p. v., Macon co., Ill.: $42 \mathrm{~m}$. E. Springfield. Hopew elz, t. and p. v., Bedford county, Penn. : 83 m.W. Harrisburg. Drained by Raystown branch of Juniata river and its tributaries. Surface mountainous; soil, chiefly calcareous loam. Bituminous coal is abundant. Pop.1,392.

Hopew El, p. v., Jennings co., Ind. : on a cr. of Muscatatuk r., $66 \mathrm{~m}$. S. S. E. Indianapolis.

Hopewel, p. v., York district, S. Car.: $86 \mathrm{~m} . \mathrm{N}$. Columbia.

Hopewel, p. o., Upshur county, Tex. : 248 m. N. E. Austin City.

Hopewell Coxton-Woriss, p. o., Chester co., Penn.: 67 $\mathrm{m}$. E. S. E. Harrisburg.

Hopewell Cross RoADs, p. o., Harford co, Md, : on the main road between Baltimore and Philadelphia, where it is crossed by the Havre de Grace road, $4 \mathrm{~m}$. W. of Susquehanna $r$., and $6 \mathrm{~m} . \mathrm{N} . \mathrm{W}$. Havre de Grace. Large droves of cattle for the Eastern market pass this point.

Hopkivs county, $K y$. Situate W., and contains 628 sq. m. Drained by Green r., its N. E. boundary, Deer and Otter creeks, and Pond $r$., its branches, the last forming its E. boundary, and S. by Clear er., an affluent of the Ohio. Surface moderately uneven; soil very good, and in parts timbered. Tobacco is the staple, corn and wheat yield well, and much pork is raised. Farms 1,354; manuf. 10 dwell. 1,788, and pop.-wh. 10,199, fr. col. 50, sl. 2,192total 13,441. Capital: Madisonville. Public Works: Nashville and Henderson $R . R$.

Hopkins county, Tex. Situate N. E., and contains 1,064 sq. m. Drained N. by the S. fork of Sulphur r. and White Oak Bayou, affluents of Red r., and S. by heads of Lake Fork of Sabine r. Surface slightly uneven, and in the N. prairie; soil mostly very fertile, generally covered with a dense growth of timber, and when cleared gives great returns of cotton and corn. Farms 221; manuf. 0 ; dwell. 435, and pop.-wh. 2,469, fr. col. 0 ; sl. 154 -total 2,623. Capitad. Tarrant.

Hoptens' Grove, p. o., Polk co., Ian: a little E. of Des Moines $x_{0}, 117 \mathrm{~m}$. W. Iowa City.

Hopkins' TURN OtT, p. o., Richland dist., $S . C^{\prime}(b)$. : on the Columbia Branch of the South Carolina R. R., $11 \mathrm{~m}$, S. E. Columbia.

Hopkinsville, p. v., and eap. Christian co., $\bar{K}$. : on Little $r_{0}, 168 \mathrm{~m}$. S. W. Frankfort. It contains a court-house, jail, etc., 7 or 8 churches, several academies, numerous stores and mechanic shops, and about 1,800 inhabitants; and it bas two newspapers, the "People's Press" (dem.), and the "Green River Whig," both weekly issues. It lies on the proposed railroad line from Nashville to Henderson.

Hopkinsville, p. v., Warren co, Ohio: about a mile E. of the Little Miami R. R., $76 \mathrm{~m}, \mathrm{~S} . \mathrm{W}$. Columbus. It contains about 250 inhabitants.

Hopkivtow, t. and p. v., Middlesex co, Miss. : $27 \mathrm{~m}$ 
W. S. W. Boston. Drained by branches of Charles and Mill rivers, which have some mill-sites. Surface rough ; soil indifferent, but well cultivated. The Boston and Worcester R. R. runs on its $\mathrm{N}$. border. Hopkinton mineral springs are much visited in the summer, and are said to be remedial. The $\mathrm{v}$. is situate centrally. Pop. of t. 2,802.

Hopkinton, t. and p. v., Merrimae co., N. Hamp.: $7 \mathrm{~m}$. W. Concord. Drained by Contoocook $r$, and its branches, Warner and Blackwater rivers. Surface diversified; soil on the rivers fertile. The principal v. contains the county jail. Contoocookville and West Hopkinton are flourishing villages on the $\mathrm{W}$. side of Contoocook $\mathrm{r}$. and on the line of the Contoocook Valley R. R. The Concord and Claremont R. R. also passes through the town. Immense water-power is furnished by the rivers, and manufactories have been esestablished in all the villages. Pop. of t. 2,169.

Hopkinton, t. and p. v., St. Lawreuce con, N. Y.: $140 \mathrm{~m}$. N. N. W. Albany. Drained by the Racket and St. Regis rivers. Surface in the S. hilly and sterile, and in the N. level and fertile. The t. is about $35 \mathrm{~m}$. Iong from $\mathrm{N}$. to S., and about $8 \mathrm{~m}$. wide; but is searcely inhabited in the $\mathrm{S}$. part. The $\mathrm{v}$, in the $\mathrm{N}$. part of the t. contains about 200 inhabitants. In the t. there are numerous grist and saw mills, tanneries, etc. Pop. 1,470.

HopkINTON, t. and p. v., Washington co., R. 1. : $32 \mathrm{~m}$ s. W. Providence. Drained by Wood r. and other affiuents of Charles and Paweatuck rivers, which afford valuable water-power. Surface low and level; soil fertile, adapted to grain and grazing. The t. has cotton, woolen, and iron manufactures. The celebrated Brand's Iron Works are on Wood river. Hopkinton City is a flourishing v. on a branch of Charles r., in the S. part of the town. Pop. 2,478. Pawcatuck $r$, has productive fisheries of shad and alewives.

Hoppere's Mrus, p. o., Henderson co., $I l l$. : 98 m. N. W. Springfield.

Horicos, t. and p. v., Warren county, $N . Y_{.: 67} \mathrm{~m} . \mathrm{N}$. Albany. Drained by numerous lake creeks. Brandt Lake is wholly within this to, and Schroon Lake partly so-both have their outlets in the Schronn r., which bounds it on the W. Surface hilly and mountainous; soil indifferent, except on the alluvials of the streams. The v. lies in the S. part, and is a small agricultural settlement. Pop. of t. 1,152.

Hortcon, p. V., Dodge co., Wisc. : on Rock r., 49 m. N. E. Madison.

Ногмввоок, p. O., Bradford county, Penn.: $109 \mathrm{~m}, \mathrm{~N}$. Harrisburg.

Horney, t. and p. v., Steuben con, $N, Y: 164 \mathrm{~m}$. W. by S. Albany. Drained by creeks of Conhocton rivers. Surface somewhat hilly; soil of average fertility. Pop. 1,314.

HorNerfsvilue, t. and p. v., Steuben co., N. Y.: $196 \mathrm{~m}$. W. by S. Albany. Draned by Canisteo $r$ and its tributaries. Surface hilly and broken, but mostly arable. The v. lies on the Canisteo $\mathbf{r}_{\text {, }}$ on the line of the New York and Erie R.R., and at the point where the Buffalo and New York City R. R. diverges. There are large workshops here, several stores, and about 1,200 inhabitants. Pop. of t. 2,687 .

Hornerstown, p. v., Ocean co., $N_{*}$ Jer.: 39 m. S. E. Trenton.

HorNer's Nest, p. O, Meeklenburgh co., N. Car. : $133 \mathrm{~m}$. W. S. W. Raleigh.

Horssionovgr, p. ., Chesterfield dist., S. Car.: $79 \mathrm{~m}$ N. E. Columbia.

HorN town, p. v., Accomac co., Firg.: 112 m. E. by N. Richmond.

HORRY district, $S$. Car. Situate E, and contains 1,071 sq. m. Lies on the Atlantic Ocean, which is its S. E. boundary, and drained by Waccamaw r., which crosses the county from N. E. to S. W., and branches of Little Pee Dee r., which forms its W. boundary. Surface low and level; soil of moderate fertility, consisting in parts of marshes well adapted to rice growing. Corn, rice, and cotton are staples. 296
Farms 731; manuf. 7; dwell. 980, and pop.-wh. 5,521, fro col. 50, sl. 2,075-total 7,646. Capital: Conwaysboro,'

Horse Creek, p. o., Lexington dist., S. Car.

Horse Creek, p. o., Dade county, MIO.: $128 \mathrm{~m}$. \$. W. Jefferson City.

Horse CreEk, p. o., Will county, Itl.: 123 m. N. E. Springfield.

Horse Creis, p. o., Greene county, Tenn.: 226 m. E. Nashville.

Horse Creek, p. o., Rutherford co., N. Car.: $185 \mathrm{~m}$. W. S. W. Raleigh.

Horse Head, p. o., Johnson co., Ark.: on a creek of Arkansas r. so ealled, $91 \mathrm{~m}$. W. N. W. Little Rock.

Horse HeAD, p. o., Macon county, Ga: 76 m. \$. W. Milledgeville.

Horse Head, p. o., Prince George's co., MMd.

Horse Pasture, p. o., Hemry co., Virg.: 148 m.W. S.W. Richmond.

Horse Pen, p. o., Choctaw co., Afiss.: $97 \mathrm{~m} . \mathrm{N} . \mathrm{N} . \mathrm{E}$. Jackson.

IIORSE Shom, p. o., Pickens dist., S. Car.: on a fork of Tugaloo r., 144 W. N. W. Columbia.

Horse Shoe Bend, p. o., Tallapoosa co., Alat : on the Tallapoosa river, at the bend so called, $42 \mathrm{~m}$. N. E. Montgomery.

Horse Shoe Bottom, p. o., Russell co., Ky. : on the S. side of Cumberland r., $87 \mathrm{~m}$. S. Frankfort.

Horsenar, t. and p.. ., Montgomery co., Penn.: $97 \mathrm{~m}$. E. Harrisburg. Drained by Neshaminy and Pennypack creeks. Surface level; soil calcareous loam. The v. cailed IIorseham Square, in the centre of the t., has a Friend"s meeting-house, and about a dozen dwellings. Pop. of t. 1,209 .

Horsex's Cross Roads, p. o., Sussex co., Del. : $37 \mathrm{~m}$. S. Dover.

Hortox's VALlex, p. o., Russell county, Virg. : $278 \mathrm{~m}$. W. S. W. Richmond.

Hortonville, p. v., Brown co., Wisc.: 118 m. N. N. E. Madison.

Hosexsack, p. o., Lehigh co., Penn.: 82 m. E. N. E. Harrisburg.

Hoskinsville, p. v., Morgan co., Ohio: 69 m. E. by S, Columbus.

Hotchistssville, p. o., Litchfleld co., Conn.: between the branches of Pamperang $\mathbf{r}$., $32 \mathrm{~m}$. W. S. W. Hartford. It is a small manufacturing village of some 300 inhabitants.

Hotel, p. o., Bertie co., N. ear. : 101 m. E. Paleigh.

Hot House, p. oa, Gilmer county, Ga.: $137 \mathrm{~m} . \mathrm{N}$. W. Milledgevilie.

Hot Sprivgs county, Ark. Situate S. centrally, and contains 969 sq. m. Drained centrally and W. by Washita r., and $E_{\text {e }}$ by Saline $r_{\text {, a }}$ branch of the Washita, and the $E_{\text {. }}$ line of the co. Surface high and broken, with level river bottoms; soils fertile, excellent corn land, and the best of pasturage. Cattle and grain are the staples. It contains vast deposites of coal and celebrated hot mineral springs. Farms 320 ; manuf. 10 ; dwell. 579, and pop.-wh. 3,237, fr. col. 11, sl, 361-total 3,609. Capital : Rockporto Public Works : Little Rock and Shreveport R. R.

Нот Sprixgs, p. v., and former cap. Hot Springs co., Ark : $47 \mathrm{~m}$. W. S. W. Little Rock. It is a v. of some 200 inhabitants. Here are a large number of hot springs breasing from the W. side of a mountain, and flowing into a small er. of the Washita r., which is $6 \mathrm{~m}$. S. of the Springs. The temperature of the several springs vary from $110^{\circ}$ to $150^{\circ}$ Fahr. About $3 \mathrm{~m}$. N. E. are the chalybeate springs, the waters of which are cold; and in Montgomery co. about $30 \mathrm{~m}$. W. by N., are also sulphur springs. The whole neighborhood is of volcanic formation, and affords fine scenery, which, in conjunction with the remedial properties of the waters, have a happy effect on the broken-down constitution.

Hot SpRIYGs, p. v., Bath co., Virg.: 128 m. W. N. W. 
Richmond. Here is a fashionable watering-place, with erery accommodation for travel or sojourn. Dr. Rogers's analysis of 64 cubic inches of the water gives the solid matters contained therein as follows-carbonate of lime, 4.82 grains; sulphate of lime, 1.52 ; sulphate of soda, 0.92 ; sulphate of magnesia, 0.57 ; muriate of soda, 0.37 ; and silica, 0.05 . There are six baths, and the hot pool or bath ranges from $100^{\circ}$ to $107^{\circ} \mathrm{Fahr}$. There is a hot spout for ladies, and one for gentlemen, of the temperature of $106^{\circ}$ Fahr., with a fall of about 5 feet. The efficacy of these spouts in cases of local physical derangement is well established-their curative properties being much more rapid in action than if not thermal.

Hovck's Store, p. o., Carroll co., Md.

HovGH's STORE, p. o., Jasper co., Miss. : 66 m. E. by S. Jackson.

Houghton county, Mich. Situate on the Upper Peninsula, in the extreme $\mathrm{N}$., and contains $1,910 \mathrm{sq}$. m. It consists principally of a large peninsula, extending N. E. into Lake Superior, between which and the $\mathbf{5}$. part lies a large bay, bearing the same name-Keewaiwona Bay. It has many small streams flowing into the bay, and lake-on the E. side Yellow Dog, Pine, Huron, Sturgeon, Russell's, and Tobacen rivers; on the N. and W., Lower Montreal, Eagle, Salmon Trout, Elm, Misery, and Sleeping rivers. Surface much diversified, parts being rough and rocky, and parts cut up by numerous inlets of the lake. It has many lakes or ponds, the largest of which, Portage Lake, extends across the peninsula to a mile of the $\mathrm{N}$. W. coast, over which the Indians and hunters carry their canoes-whence the name. The agricultural resources of the co. have been little examined as yet. It has much good timber and waterpower. But its chief wealth is in its minerals, principally copper. Here, in immense masses, the purest and best of copper is found. The mines are of indefinite extent, and of surprising richness, and the amount exported is immense, though but a small part is yet wrought. Farms 18 ; manuf. 5 ; dwell. 116, and pop.-wh. 707, fr. col. 1-total 708. Capital: Eagle River. Public Works: Green Bay and Copper Harbor P.R.

HodgITONVILE, p. v., Windham co, Verm.: 93 m. S. Montpelier.

Houlks, p. O., Chickasaw co., Miss. : 123 m. N. N. E. Jackson.

Houltow, t., p. v., and cap. Aroostook co., Me.; $163 \mathrm{~m}$. N. E. Augusta. It lies on the New Brunswick boundary. Drained by Meduxnekeag $\mathbf{r}_{\text {. }}$ a branch of the St. John. Surface elevated and level; soil generally fertile. The $\mathbf{v}$. is located on the E. bank of the r., and about a mile $N_{\text {. is the }}$ old United States barracks. Stages from Bangor run daily, Pop. 1,453-in 1810 it was 1,597-decrease consequent on the abandonment of the garrison.

Houma, p. v., and cap. Terre Bonne par., La. : on Bayou Terre Bonne, $6 \pm$ m. S. S. E. Baton Rouge.

Housatonio, p. v., Berkshire co., Mass.: on the W. side of Housatonie r., and on the line of the Housatonic R. R., $90 \mathrm{~m}$. from Bridgeport.

Hocsatonic river, Mass, and Conn. : rises by two branches in the towns of Lanesboro' and Windsor, Berkshire co., Mass., and these meet at Pittsfield, where the river forms; it then passes $S_{\text {., }}$ and enters Connecticut, and meets the tide $14 \mathrm{~m}$. above its entrance into Long Island Sound. Its sources are more than 1,000 feet above the ocean; and in its course of 150 miles it affords numerous mill sites, and has on its banks many pleasant villages and seats of manufacturing industry. The volume of water is not ordinarily large, but in seasons of flood its valley is inundated, and the soil fertilized by the alluvion deposited by the waters. The scenery is everywhere beautiful; in some places it is enchanting. At Canaan there is a fall of 60 feet perpendicular. The name of the river, an Indian appellative, signifies "over the mountains."

Hoube Creek, p. O., Irwin co, $G a_{0}:$ on a cr. of Ockmulgee x. Bo called, $88 \mathrm{~m}$. S. Milledgeville,
HoUSE's SPRINGS, p. o., Jefferson co., Jro.: about $2 \mathrm{~m}$. En Big $\mathbf{r}$, and $87 \mathrm{~m}$. E. by S. Jefferson City.

IIougeVILLE, p. V., Lewis co., N. Y.: 105 m. N. W. Albuny. Hodston county, $G a$. Situate S. W. centrally, and contains 549 sq. m. Bounded E. by Ockmulgee $\mathrm{r}_{\text {., and drained }}$ by its affiuents Big Indian and Mossy creeks and Echeconno r. Surface various; soils very fertile and productive of corn, wheat, and cotton. Farms 750; manuf. 23; dwell. 1,13S, and pop.-wh. 6,512, fr. col. 14, sl. 9,921-total 16,450. Capital: Perry. Public Works: South-Western R, R., and Muscogee R. R.

Houstox county, Tex. Situate E. centrally, and contains 1,362 sq. m. It lies between Neches r. on the E. and Trinity r. on the W., and is drained by Elkhart cr., Hurricane Bayou, Carigo, Lost, Negro, Wright's, and White Rock creeks of the latter, and San Pedro, Walnut, and Connor's creeks, and Cochino Bayou of the former. Surface level, or gently undulating; soil on the Trinity of the best in the State, on the Neches rather lighter and more sandy. Hickory uplands eover much of the co., and afford rich corn and cotton lands. Petrified trees are frequently met with, and iron ore of good quality is found. Cotton is the staple. Farms 192; manuf. 0; dwell. 357, and pop.-wh. 2,036, fr. col. 12, sl. 673-total 2,721. Capital : Crockett.

Houstov, p. v., Heard co., Ga.; $113 \mathrm{~m}$. W. by N. Milledgeville.

Houston, p. o., Jackson co., Ind. : on a branch of Salt cr., $51 \mathrm{~m}$. S. Indianapolis.

Houston, p. ve, Adams county, $I Z l_{0}: 78 \mathrm{~m}$. W. N. W. Springfield.

Houston, p. v., Marion co., Mo.: a little N. of South Fabius r., $96 \mathrm{~m}$. N. by E. Jefferson City.

Houston, p. 0., and cap. Chickasaw co., Miss.: on the head of Chuckaluckee er. of Tombigbee r., $127 \mathrm{~m} . \mathrm{N}$. E. Jackson. It contains a court-house, jail, ete., and about 600 inhabitants; and three newspapers are published here, the "Southern Argus" (state rights), the "Sonthern Patriot" (whig), and the "Chickasaw Republican" (dem.), all weekly issues. Houston is a thriving $\mathrm{v}$., and has a fine neighborhood.

Houstow, p. v., Shelby county, Ohic: 71 m. W. N. W. Columbus.

Houston, p. o., Alleghany county, Penn.: $173 \mathrm{~m}$. W. Harrisburg.

Houston, p. v., Wayne co., Tenn.: on Indian er. of Tennessee r., 85 m. S. S. W. Nashville.

Houston, p. v., and enp. Harris co., Tex.: on Buffalo Bayou, at the head of steam navigation and directly opposite White Oak Bayou, 158 m. E. S. E. Austin City. It was commenced in October, 1636, and in November the old capitol was founded, and in the May following Congress held its first session in that building. In front of the city is a fine wharf 500 feet long, affording ample accommodation for its business. This wharf is flanked by two cotton presseg, erected by individual enterprise. The public buildings are Episcopal, Presbyterian, Baptist, Catholic, and Methodist churches, each denomination one, a good market-house, and a jail. Regular stages run twice a week for Austin and San Antonio, and for Nacogdoches and the Sabine. There is a very large country business transacted, and several of its merchants have acquired large fortunes. The heavy business is done chiefly on Main Street, which faces the wharves on the bayou. There are in the city 16 large firms that advance capital to planters, and are reimbursed by the next crops. There are also many engaged in the grocery and provision business, and several extensive commission merchants, druggists, warehousemen, etc. Houston possesses superior advantages for manufacturing, and may at some future time become important in that branch of industry. At present all her manufactured articles are purchased from the North and carried in steamboats up the bayou. There are five newspapers published here, the "Morning Star" (dem.), tri-weekly, and the "Telegraph and Texas Register" (dem.), the "Houston Gazette" (dem) 
the "Commercial Advertiser" (whig), and the "Wesleyan Banner" (relig.), all weekly issues. It is proposed to build a branch railroad, $50 \mathrm{~m}$. long, from this point to the Brazos Valley, where it will form a junction with the Red River and Galveston R. R. Pop, 6,000. Houston takes its name from Gen. Sam Houston, leader of the Texan army during the revolution-her first president as an independent state, and one of her present senators-a man, a soldier, and a statesman, worthy of the highest honors that the people can confer.

Houston, p. v., and eap. Texas co., Mo.: $97 \mathrm{~m}$. S. by E. Jefierson City.

Hotston, p. v., Bourbon co., Ky. : 37 m. E. Frankfort.

Houston's Store, p. 0., Morgan co., Ala. : 152 m. N. N.W. Montgomery.

Hotstonvilue, p. v., Iredell co., N. Car.: $127 \mathrm{~m} . \mathrm{W}$ Raleigh.

HowARD county, Ind. Situate N. centrally, and contains 296 sq. m. Drained by Wild Cat cr. and its branches, a tributary of Wabash $\mathbf{r}$. Surface level or slightly undulating, and soil uniformly rich. Timber is abundant, and corn, wheat, and the grasses grow finely. This county lies wholly on the Miami Reserves, and is not fully settled. Farms 746 ; manuf. 26 ; dwell. 1,190, and pop.-wh. 6,615, fr. col. 42-total 6,667. Capital: Kokomo (or Cocomo). Pullic Horks: Indianapolis and Peru R. P.; Andersontown and Logansport R. R.

How $\triangle R D$ county, $I a$. Situate N. E, and contains 432 sq. $m$. Drained by Upper Iowa $r$, and heads of Turkey $r_{\text {., }}$ both affluents of the Mississippi. Unorganized in 1850 .

HOW ARD county, MId. Situate centrally on W. shore, and contains 226 sq. m. It lies between Patapsco and Patuxent rivers, and is drained by their affluents. Surface undulating, and intersected by numerous creeks, which afford good water-power; soil mostly productive, with some waste land. This county was a part of Anne Arundel in 1850, and the census of that comprises both. Capital: Ellicott's Mills. Public Works: Baltimore and Ohio R. R.

How ARD county, MFo. Situate N. eentrally, and contains $453 \mathrm{sq} . \mathrm{m}$. Bounded S. and S.W. by the Missouri, and drained by Great Manitou and Bonne Femme rivers, its affluents. Surface varied, with some hills, and considerable water-power; soil excellent, yielding fine crops of corn and wheat, and some tobacco; it is admirably adapted to grazing. Farmo 1,105; manuf. 35; dwell. 1,685, and pop-wh. 9,040, fr. col. 39, sl, 4,890. Capital: Fayette.

HOW AED, p. v., Parke CO., Ind. : on Mill cr., near its entrance into the Wabash, and at the point where it is crossed by the Canal, $68 \mathrm{~m}$. W. N. W. Indianapolis.

How $A R D$, t. and p. Y., Steuben co., $N_{0} Y_{*}: 185 \mathrm{~m} . \mathrm{W}$. Albany. Drained by creeks of Canisteo and Conhocton rirers. Surface undulating; soil clay-loam and fertile. The $\mathrm{v}$. contains about 250 inhabitants. Pop. of t, 3,244.

Hotrasd, t. and p. o., Centre co., Penn. : $82 \mathrm{~m}$. N. W. Harrisburg. Drained by Bald Eagle cr. and its tributaries, and by Marsh and Beach creeks. Surface mountainous, the main ridge of the Alleghanies passing through it Pop. 1,527 .

HOW ARD's, p. o., Waukesha county, Wisc. : $62 \mathrm{~m}$. E. Madison.

How ARD's, st., Bibb co., Ga : on the Macon and Western

R. R, 6 m. W. by N. Macon.

How ARD's Grove, p. o., Sheboygan co., Wisc: $92 \mathrm{~m}$.

N. E. Madison.

How $A R D$ 's PoIst, p. O., Fayette co., $I l_{0}$ : on the National Rond, $69 \mathrm{~m}$. S. E. Springfield.

Howard's VALLEX, p. 0., Windham co., Conno: $27 \mathrm{~m}$. E. by N. Hartford.

Howardstilix, p. T., Stephenson co., IU.: $177 \mathrm{~m} . \mathrm{N}$. Springfield.

Howardsvinle, p. v., Albemarle county, Firg.: $76 \mathrm{~m}$. W. N. W. Richmond.

HoweLz, t., p. V., and cap. Livingston co., Afich.: $30 \mathrm{~m}$. 298
E. S. E. Lansing. Drained by the heads of Shiawassee and Cedar rivers. The $\mathrm{v}$, is situate on the Grand River Turnpike; it contains the county buildings, several stores and mills, and about 400 inhabitants; and has a news. paper, the "Livingston Courier," published weekly.

How ELL's DEPốT, p. o., Orange co., $N$. $Y$.

Howell's Sprivgs, p. o., Hardin co., $K y .: 69$ m.W. S.W. Frankfort.

Howelisville, p. v., Robeson county, N. Car.: $77 \mathrm{~m}$ S. by W. Raleigh.

Howellsville, p. v., Delaware co, Penna: 87 m. E. S. E. Harrisburg.

HowelL Works, p. ₹., Monmouth co., N. Jer. : on Manasquan r., $37 \mathrm{~m}$. E. by $\mathrm{S}$. Trenton. Here are extensive iron works, and a number of dwellings and stores for the workers.

Howe's, p. o., Concordia par., La.: 87 m. N. N. W Baton Rouge.

Howland, t. and p. o., Penobscot co., Me. : 86 m. N. N. E Angusta. Drained by Piscataquis r. and its tributaries, the Penobscot forming the $\mathbf{E}$. boundary. Surface varies, with wide intervales on the rivers. The $\mathrm{v}$. lies on the W. side of the Penobscot, opposite Enfield. Pop. 214.

How LAND, t. and p. v., Trumbull co., Ohio: 143 m. N. E. Culumbus. Drained by Mahoning and Mosquito rivers, the latter of which runs from $\mathrm{N}$. to $\mathrm{S}$. through the town. Surface diversified; soils of average fertility. The $\mathrm{v}$. lies

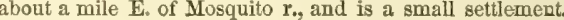
Pop. of t. 919

Howlet Hiri, p. o., Onondaga county, N. Y.: $126 \mathrm{~m}$. W. N. W. Albany.

Horsville, p. v., Loudon co., Firg.: on Kittoctan er., $126 \mathrm{~m}$. N. Richmond. It contains several flouring mills, etc. HebBard, t. and p. o., Trumbull co., Ohio: $151 \mathrm{~m}$. N. E. Columbus, Drained by tributaries of Shenango $r$. It is a fire agricultural township, and contains 1,272 inhabitants.

HUBbard's CokNers, p. O., Madison co., N. Y.: $94 \mathrm{~m}$. W. by N. Albany.

Hubbardetox, t. and p. v., Worcester co., Mass.: $51 \mathrm{~m}$. W. by N. Boston, Drained by Ware r, and its tributaries, on which are fine mill-sites. Surface various; soil indifferent, but well cultivated. The v. contains about 400 inhabitants. Pop. of t. 1,827.

HubbardToN, t. and p. o., Rutland co., Term. : $53 \mathrm{~m}$, S. S. W. Montpelier. Drained by Hubbardton $\mathrm{cr}$. and several streams of Bombazine Lake, all which empty into Castleton r. of Lake Champlain, and also by creeks of Onion river. Surface uneven and rough-in some parts mountainous, and soil indifferent, but good for grass. The $\mathrm{v}$. is central. Pop. of t. 701

Hubbleton, p. 0., Jefferson co, Wisc. : $37 \mathrm{~m}$. E. Madison. Hublergeurgh, p. v., Centre county, Penn.: 88 m. N. W. Harrisburg.

Huddleston, p. v., Pike county, Ark.: 97 m. W. . W. Little Rock.

Huddieston, p. o., Rapides parish, La.: $102 \mathrm{~m}$. N. W. Baton Rouge.

Huddeston Cross Rosds, p. o., Wilson co., Tenn.: 26 m. E. Nashville.

Hrodox county, $N$. Jer. Situate N. E., and contains 66 sq. m. Drained by Hackensack $r$. and Passaic r., both emptying into Newark Bay, and the latter its W. as the Hudson is its $\mathrm{E}$. boundary. Surface diversified, with high land in the N., and in the S. swamps; soil good. In the W. near the Passaic, is an old copper-mine, called the Stuyvesant Mine, which was wrought as early as 1731 . The $\mathrm{E}$. portion is fast changing into a suburb of the great metropolis opposite it. Farms 254; manuf. 52; dwell. 2,861, and pop.-wh. 21,319, fr. col. 500, sl. 2-total 21,821. Capital: North Bergen. Public Works : New Jersey R. R.; Union R. R., and Morris Canal.

Hunson, p. v., La Porte co., Ind.: 133 m. N. by W. Indianapolis. The Indiana Northern R.R. passes through it 
HUDSON, p. v., M'Clean co., $\Pi l$ : 66 m. N. E. Springfeld.

Hudsos, t. and p. o., Lenawee co., Jfich.: $60 \mathrm{~m}$. S. by E. Lansing, Drained by Bear cr., Tiffin's cr., which affords extensive water-power. The v, lies on its W. bank, and is intersected by the Michigan Southern R. R., $54 \mathrm{~m}$. from Mouroe. Pop. of t. 1,511.

Hudsox, t. and p. v., Hillsborough co., N. Tump.: $34 \mathrm{~m}$. S. by E. Concord. Drains into the Merrimac, which makes its W. border, and over which is a bridge to Little's Station. Surface level and fertile on the streams, but otherwise hilly and broken. The $\mathrm{v}$. lies on the outlet of a small pond centrally. Pop. of t. 1,812.

Hudsor, p. city, port, and cap. Columbia co., N. Y.: at the head of ship navigation, and on the E. side of Hudson river, 29 m. S. Albany. Lat. $42^{\circ} 14^{\prime}$ N., and long. $73^{\circ} 46^{\prime}$ W. $815 \mathrm{~m} . \mathrm{N}$. E. Washington. Fronting on the river, opposite Athens, is a promontory, rising 60 feet above the water, which has been formed into a promenade, commanding an extensive view, and on either side of this is a spacious bay, with sufficient depth of water for the largest shipping. The eity is regularly laid out, and the streets, with the exception of those near the shore, cross each other at right angles. The main street extends S. E. for more than a mile, to Prospect Hill, 200 feet high, to which the ground rises. On the $\mathrm{N}$. side of this street, toward its upper end, is a public square, and there is another, on which the court-house stands, in the S. part of the cily; this building is 116 feet long, the central part 40 by 60 feet, and the height 60 feet, surmounted by a dome, and entered by a portico of 6 Ionic columns, and the wings are 34 feet front, 40 feet deep, and two stories high. There are numerous churches in the city, many of them handsome and substantial structures, and also several highly efficient institutions of learning. The Hudson Lunatic Asylum is situate on State-street, facing the court-house on the $\mathrm{S}_{\text {., }}$ and is a very useful and flourishing institution. Hudson is supplied with water by a company from a spring at the foot of Eecraft's Mountain. Formerly the city had a large West India trade, but this has been superseded by the whale-fishing business, in which it has several ships engaged. Its river trade is very considerable, and it is the market for a large back country. It has several steamboats, barges, etc., employed, and the New Tork and Albany steamers usually make this a stoppingplace; a steam ferry connects it with Athens. The Hudson River R. R. passes through it, and the Hudson and Berkshire $\mathrm{R}, \mathrm{R}$. connects it with the Western $\mathrm{R}$. $\mathrm{R}$., and thence with Nerr England. With regard to its manufactures, Hudson has great facilities from the water-power in its neighborhood; some of its manufacturing establishmentsnumbering 77 in all - are extensive and valuable. It has 1 daily paper, 5 weeklies, and 1 semi-monthly; the "Morning Star" (neutral), is issued daily ; the "Columbia Republican" (whig), the "H. Gazette" (dem.), the "Democratic Freeman" (free soil), the "Washingtonian" (temp.), and the "Columbia County Journal" (whig), are weeklies; and the semi-monthly is the "Rural Republican" (literary). The number of houses in the city in 1850 was 832 , and the inhabitants 6,214 . Fudson was settled in 1783 by Thomas Jenkins and others, chiefly Quakers from Massachusetts and Rhode Island. In 1785 it was chartered as a eity.

Hedsor, t. and p. v., Summit co., Ohio: 117 m. N. E. Columbus. Drained by numerous ereeks flowing in several directions to the Cuyahoga $r$. Surface elevated and rolling; soil clay loam, very fertile in grass and grain. The village is pleasantly located on a plain, from which the ground rises toward the $\mathrm{N}$. It contains several stores, and about 600 inhabitants. The Cleveland and Pittsburg R. R. passes through it $26 \mathrm{~m}$. from Cleveland, and from it diverges the Akron Branch R. R. Hudson is the seat of the Western Peserve College, founded in 1526, and which is under Presbyterian supervision: it has a theological department. The College has 8 professors, and in 1850 had 181 alumni and $5 i$ students, with a library of 8,000 rolumes; and the theological department had 8 professors and 14 students. The periodicals published here are the "Ohio Observer" (relig.), and the "Family Visitor" (literary)-the first a weekly and the latter a semi-monthly issue. The $t$, is chiefly agricultural. Pop. of t. 1,457.

Hudson, p. o., Franklin co., Ga.: on Hudson's Fork of Broad $r_{s}, 83 \mathrm{~m}$. N. Milledgeville.

HudsoN (or North) river, $N . Y$. : one of the most important rivers of the United States, though in length and volume of water it is much less than many others. It was discovered in 1609 by IIendrich Hudson, whose name it bears, and it is supposed that he explored it as far as Albany. The Hudson rises by two main branches in the mountains TV. of lakes Champlain and George; the E. or Sebroon branch passes through Schroon Lake, and the other branch rises farther W. by various head streams, the two uniting in the S. part of Warren co., about $40 \mathrm{~m}$. from their respective sources. After a course of $15 \mathrm{~m}$. $\mathrm{S}$, the Hudson receives Sacandaga river; it then runs E. by S. 15 m. to Hadley's Falls, and thence $20 \mathrm{~m}$. N. by E. to Glen's Falls; it then flows $\mathrm{S} .40 \mathrm{~m}$., and receives from the W. its principal tributary, the Mohawk. Its fall in this distance is 147 feet; thence running a little W. of S. $156 \mathrm{~m}$., it enters the ocean at Sandy Hook. The whole length of the river from its sources to its entrance into New York Bay, is a little over $300 \mathrm{~m}$; and so straight is the river between Albany and New York, that the distance by water is less than that by land. The influence of the tide is felt a little above Albany, though it properly does not flow so far. It is navigable for large ships $118 \mathrm{~m}$. above New York, to Hudson, and for sloops and large steamers to Albany, $145 \mathrm{~m}$. Sloops and steamboats proceed $6 \mathrm{~m}$. farther to Troy, and sloops, by a dam and lock, to Waterford, $8 \mathrm{~m}$. abore Albany. Through a considerable part of its course its banks are elevated, particularly on the W. side, and in some parts are high, rocky, and precipitous. The Hudson River R. R. skirts its E. shore, and often is carried into the river on embankments. No part of the Union presents more picturesque scenery than the banks of the Hudson, and the passage through the Highlands, $53 \mathrm{~m}$. above New York City, is grand-here the mountains, over 1,400 feet high, come down to the very margin of the stream. New York owes much of its preeminent advantages to this noble river; being connected with the great western lakes by the Erie Canal and several lines of railroad, and with Lake Champlain and Canada also by both canal and railroad, and with Delaware $\mathrm{r}$. and the coal region of Pennsylvania-by the Delaware and Hudson Canal, it becomes the main trunk of an inmense commerce; it forms, indeed, one of the great connecting links of the chain which binds the East and West, and bears upon its bosom in the noblest steamers the world ever saw, and in a vast number of other craft, the traveler and the merchandise to and from the American metropolis. As might have been expected, its banks are lined by many large and flourishing eities and villages, the principal of which on the E. side, are Troy, Hudson, Poughkeepsie, and New York; and on the W. side, Albany, Catskill, and Newburg. Its waters were the theatre of the first successful attempt to apply steam to the propelling of vessels, and the very first to witness the application of caloric to the same purposes. The one dates from 1808, and immortalizes the names of Fuiton and Livingston, and the latter from January, 1853, immortalizing the name of Ericsson. Little did those who saw the commencement of the era of steam navigation dream of the extent of its application to the purpose of commerce; and as little may the lookers-on of to-day foresee the vastness of tho project just initiated by the later discovery.

Hudsonvirre, p. v., Breckenridge co., Fy.: on the N. side of Rough cr., $91 \mathrm{~m}$. W. S. W. Frankfort.

Hudsonville, p. v., Marshall co, Miss, : 176 m. N. by E, Jackson.

IYUFF's CreEK, p. 0., Logan county, Firg.: $217 \mathrm{~m}$. W Richmond. 
HugGin's CReEK, p. o., M'Nairy county, Tenn. : $122 \mathrm{~m}$. S. W. Nashville.

Hugmesville, p. v., Lycoming co, Penn. : on Muncy cr. $67 \mathrm{~m}$. N. Harrisburg.

Hughesvilie, p. v., Loudon co., Vèrg. : $114 \mathrm{~m}$. N. by W. Richmond.

Hugnsoxville, p. v., Duehess co., $N . Y$. : $76 \mathrm{~m}$. S. Albany. It contains about 35 dwellings.

Huguexot, p. v., Orange county, N. Y.: 92 m. S. S. W. Albany.

Hudmerton, p. v., Orleans co., $N$. $Y$.: on the line of the Erie Canal, $214 \mathrm{~m}$. W. by N. Albany. It contains several stores and about 300 inhabitants.

Hult, t. and p. V., Plymouth co., Mass.: 11 m. E. S. E. Boston--occupies a long, narrow peninsula, forming the S. E. boundary of Boston Harbor. The village is situate on Nantasket Head. Salt is manufactured in the town. Population 253.

Hulls, p. o., Athens co., Ohio: 68 m. S. E. Columbus.

Hull's Corners, p. o., Oswego co, $N . Y,: 146 \mathrm{~m}$. W. N.W Albany.

Ifuld's Mills, p. o., Duchess co., N. Y.: 51 m. S. Albany, Hulmesville, p. v., Bucks co., Penn. : 107 m. E. S. E. Harrisburg.

Humansvilux, p. v., Polk co., Mo. : 97 m. S.W. Jefferson City.

Hомводрт county, Ia. Situate N. W. centrally, and contains $576 \mathrm{sq} . \mathrm{m}$. Drained by several head streams of Des Moines $r$. Unorganized in 1850 .

Huмвоцрт, v., Trinity co., Calif. : on the E. side of Humboldt IIarbor, opposite its entrance to the Pacific ocean, and about $200 \mathrm{~m} . \mathrm{N} . \mathrm{N} . \mathrm{W}$. Vallejo. There is a v. called West Humboldt at the $\mathrm{N}$. of the entrance to the bay. These are small and uncertain settlements.

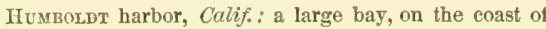
California, the entrance of which is in lat. $40041^{\prime} \mathrm{N}$. It was discorered in 1850 by the gold hunters, and it is said that a considerable quantity of gold has been collected in its neighborhnod. Some settlements have been made on its shores.

Humboxpt lake, Utah Ter.: a large lake in the California desert, in about lat, $40^{\circ} 15^{\prime} \mathrm{N}$., and long. $115^{\circ} 20^{\prime}$ W., and the recipient of Humboldt $\mathbf{r}$. It has no outlet.

IIrmbold mountains, Utah Ter.: a chain of hills so called, extending between the 118th and 119th meridian, and from about $39 \circ$ to $41^{\circ} 41^{\prime}$ N. lat. 'The Humboldt $r$, has its sources in the W. slope of this range.

HUMBOLDT river, Utah Ter.: a river rising about 1180 W. long., in the Humboldt River mountains. It has a tortuous course S. and W. until it falls into Humboldt Lake. The valley of this river is the route usually pursued by the overland emigration between the Salt Lake and California.

IUME, t. and p. v., Alleghany county, $N . Y_{.:}: 217 \mathrm{~m}$. W. Albany. Drained by tributaries of Genesee r., which passes through it. Surface undulating; soil clay loam, very fertile. Hume is a small agricultural village. Pop. of $t_{\text {. }}$ 2,478 .

Humlity, p. o, Pulaski county, Firg.: $192 \mathrm{~m}$. W. by S. livelimond.

IIvmezstown, p. b., Dauphin co., Penn.: on Swatara cr., 9 m. E. IIarrisburg. Pop. 620.

Humpurets county, Tenn. Situate N. W., and contains 519 sq. m. Bounded W. by Tennessee $\mathbf{r}_{\text {., }}$ and drained by its affluents, Turkey cr., Richland er., Bay cr., Duek r., etc. Surface mostly even, with good mill seats. Soil very good. Corn is the staple, but fine wheat is raised, and many hogs fattened. Farms 679: manuf. 16: dwe], 919. and pop-wh. 5.304, fr. col. 21, sl. 1,097-total 6,422. Capital: Waverley. Pulic Work: Nashville and Mississippi $\mathbf{R} . \mathrm{R}$

HunphreY's Vilya, p. 0., Holmes co., Ohio: 74 m. N. E Colunibus.

Heyphreystule, p. y., New Haven co, Conn.: on Naugatuck r., $6 \mathrm{~m}$. from its confluence with the Housatonic', and $37 \mathrm{~S}$. W. Hartford. It has considerable manufactures, 800 also iron and copper works, several stores, and about 400 inhubitants.

Humlock's Crewk, p. o., Luzerne co., Penn.: 87 m. N. E Harrisburg.

Hungary, sta., Hanover county, Firg.: on the line of be Richmond, Frederick, and Potomac R. R., $8 \mathrm{~m}, \mathrm{~N}$. Richmond.

Hunc county, Tero. Situate N. E., and contains 976 sq. m. Drained by heads of S. fork of Sulphur $\mathrm{r}_{\text {., }}$ and heads of the Sahine. Surface undulating, or hills of small elevation and gentle slope, and generally densely wooded; soil a rich loam in the river bottoms, which comprise a large part of the co, and though more sandy or clayey between them yet always very productive. The timber common to this region abounds, and on the streams are found the best of grapes in great quantities. It is well adapted to the staple of this quarter (eotton), and grows fine crops of corn Farms 93; manuf. 0; dwell. 268, and pop.-wh. 1,477. fr. col. 2, sl. 41-total 1,520. Capital: Greenville.

Hunter, p. v., Belmont co., Otio : 106 m. E. Columbus. Hunter, p. v., Boone county, Ill.; $187 \mathrm{~m}$. N. by E. Springfield.

HuNter, t. and p. v., Greene co., N. Y. : 38 m. S. S. W. Albany. Drained by heads of Schoharie cr. Surface mountainous, lying on the principal range of the Kaatsbergg. Round Top, their highest peak, is 3,804 feet above the Hudson river. Soil sterile, except in some exceptional valleys, and along the streams. Wood, timber, and bark are exported. The $\mathrm{v}$. is on Schoharie cr., and contains a number of mills, etc., and about 400 inhabitants. Pop. of t. 1,849 .

Hunterdon county, $\mathcal{N}_{\text {. Jer. Situate N.W., and contains }}$ 484 sq. m. Drained by Musconetoung r. and other affluents of Delaware r., its S. W. boundary, and E. by Raritan r. which empties into the Atlantic. Surface in the $\mathrm{N}$. high and broken ; in the $\mathrm{S}$. much more even; soil mostly fertile, producing fine crops of all the grains, and affording excellent pasturage. It has considerable water-power, and couvenient markets by land or water. Farms 2,486 ; manuf 309 ; dwell. 5,167, and pop-wh. 28,212, fr. col. 769 , sl. 8 total 28,959. Capital: Flemington. Public Works: Belvidere Delaware R. R.; Flemington Branch R. R.; New Jersey Central R. R.

Hunter's Cave, p. 0., Greene co, Penn. : 188 m.W. S.W IIarrisburg.

Hunterslaxd, p. o, Schoharie co., $N . Y .: 28 \mathrm{~m}$. W. by $\mathbf{S}$. Albany.

Huntenstown, p. v., Adams co., Pem. : 28 m. S. W. Harrisburg.

Huntersvilte, p. v., Lycoming co., Penn.

Hunterstille, p. v., and cap. Pocahontas co., Firg. : on Knapp's or. of Greenbrier r., 154 m. W. N. W. Richmond. The site is 1,800 feet above the level of the Atlantic Ocean and in the vicinity are several mineral springs. The $\mathrm{v}$ contains a C. H., jail, etc., and has several stores and about 200 inhabitants.

Hunterstilie, p. va, Hardin county, Ohio: $63 \mathrm{~m}$. N. W. Columbus. Pop. 84

Huntingburgh, p. v., Dubois co., Ind.: 107 m. S. S. W. Indianapolis. Pop. 250 .

Huntine Creek, p. o., Accomack co., Tirg. : $106 \mathrm{~m}$. E. Richmond.

Huntingdor county, Penn. Situate S. centrally, and contains $754 \mathrm{sq}$. m. Drained by Raystown Branch and other affluents of Juniata $r_{\text {, }}$ which crosses the N. part from E. to W. Surface much varied; parts are mountainous, but there are many beautiful valleys, which are exceedingly fertile. A part is too rough for cultivation, but abounds in fine timber and numerous mill streams. The lower lands produce excellent crops of wheat, rye, corn, buckwheat and oats, and the higher afford the best of grazing. The dairies are fine, and beef, pork, and wool, staples. Iron ore and bituminous coal are abundant; lead, salt, and alum 
sre found. Farms 1,415; manuf. 93 ; dwell. 4,298, and pop.-wh. 24,461, fr. col. 325-total 24,7s6. Capital: Huntingdon. Prulic Works: Pennsylvania Canal; Pennsylvani:a R. R.

Huntingdox, p. b., and cap. Huntingdon co., Penn: on the W. side of Frankstown branch of Juniata r, at its entrance into the latter, $61 \mathrm{~m}$, direct, or by railroad $97 \mathrm{~m}$. W. N. W. Harrisburg. It contains a court-house, jail, etc., and has considerable manufactures and a good trade. The "H. Globe" (dem.) and the "H. Journal" (whig) are issued weekly. The Pennsylvania Canal and R. R. pass through the borough. Pop. in 1840, 1,045-in 1850, 1,479.

Huntivgdon, p. y., and eap. Carroll co., Tenn.: on the S. fork of Obion r., $90 \mathrm{~m}$. W. by S. Nashville. It contains a court-house and other county buildings, several stores, and about 300 inhabitants. The neighborhood is one of the finest agricultural regions of the State, beautifully diversified, well watered, and rich and deep soil.

Huntingdon Vallex, p. o., Montgomery co., Penn.: 88 m. E. by S. Harrisburg.

Huntington county, Ind. Situate N. E., and contains 884 sq. m. Drained by Wabash r., and Little r., and Salamonie r., its branches. Surface level or undulating; soils a mixture of clay and sand, deep, and very fertile. Forest land predominates. Wheat, corn, beef, and pork are the leading products. Farms 782 ; manuf. 32 ; dwell. 1,356, and pop-wh. 7,S47, fr. col. 3-total 7,850. Capital: Huntington. Public Works: Wabash and Erie Canal; Wabash Talley R. R.

Huntisgton, t. and p. v., Fairfield co., Conn. : 44 m. S.W. Hartford. Drained by several creeks of Housatonic r., which makes the E. border, and is crossed by several bridges. Surface somewhat uneven; soils generally fertile. The $\mathrm{v}$. is located centrally, about equi-distant between the Housatonic and the Naugatuck Railroads. The manufactures of the town consist of woolen goods, paper, leather, etc. Pop. of t. 1,301.

Huntricton, p. v., and cap. Huntington co., Ind.: at the mouth of Flint cr., on Little r., $2 \mathrm{~m}$. above its entrance into the Wabash, and on the line of the canal, 81 m. N. N. E. Indianapolis. It contains a court-house, jail, etc., about 160 dwellings, and 800 inhabitants, and has two newspapers, the "Herald" (whig) and the "Age" (dem.), both weekly issues. It is the shipping place of a large and fertile back country.

Huxtington, t. and p. F., Suffolk co., N.Y.: 124 m. S. S. E. Albany. This t. stretches across Long Island, and embraces Oak Island beach, which here divides Great South Bay from the Atlantic Ocean. In the $\mathrm{N}$. the shores are deeply indented by several bays-in the $\mathrm{S}$, the land is drained by numerous small streams flowing into Great South Bay. Surface generally level-toward the N., however, it is somewhat hilly; soils various, none very fertile, but usually under the highest state of cultivation, The $\mathrm{v}$. is situatc at the head of Huntington Harbor, a continuation of Huntington Bay, and contains about 600 inhabitants. There are three newspapers published in the town, the "Long Islander," the "Suffolk Democrat," and the "Eastern State Journal," all issued weekly. The manufactures of Huntington are considerable. Pop. 7,481.

Huntumgton, t. and p. v., Lorain co., Ohio: 86 m. N. N. E. Columbus. Drained by the W. branch of Black r. Surface elevated and rolling; soil clay loam, very fertile. The $\mathrm{v}$. is central, and is a smail farming settlement. Pop. of t. 1,173.

Huntixgton, p. v., Laurens dist., S. Car. : $66 \mathrm{~m} . \mathrm{N}$. W. Columbia.

IUntington, t. and p. v., Chittenden co., Verm. : $19 \mathrm{~m}$. W. Montpelier. Drained by Huntington r., a branch of the Onion. Surface mountainous; soil generally adapted to grass. The t. contains Camel's Rump, one of the highest peaks of the Green Mountains. The $\mathrm{v}$. is situate on the W. side of the r., which here affords water-power. Pop. of township 885 .
IUUNTingtown, p. v., Calvert co., MId.: on the S. side of a cr. so called, $81 \mathrm{~m}$. S. Annapolis.

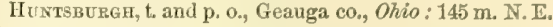
Columbus. Drained by the head-waters of Cuyahoga $r$. Surface elevated and rolling; soil fertile. Pop. 1,007.

Hunt's Hollow, p. v., Livingston co., N. Y. : $212 \mathrm{~m}$. W. Albany. Pop. about 200.

Huni's Store, p. o., Guilford county, N. Car.: $77 \mathrm{~m}$. W. N. W. Raleigh.

Huntsvilue, p. v., and eap. Madison co., Ala. : on Indian er. of Tennessee $\mathrm{r}, 10 \mathrm{~m}$. from the confluence, and $167 \mathrm{~m}$. $\mathrm{N}$. by W. Montgomery. It is the seat of a U. S. land office; and contains a court-house, jail, ete., a bank, several handsome churches, and has two newspapers, the "Democrat" (dem.) and the "Southern Star," both weeklies. It has considerable business, and promises to become one of the most flourishing towns of the State. The Memphis and Charleston R. R. will pass through it, and others in a N. and S. direction will connect with that important line. A canal extends hence to Triana, on the Tennessee, $16 \mathrm{~m}$. Pop. 6,000. Huntsville, p. vo, and cap. Madison county, Ark.: on War Eagle cr. of White r., 123 m. N. W. Little Rock. It has a court-house, etc., and about 100 inhabitants.

IIUntsville, p. v., Paulding $\mathrm{co}_{\mathrm{m}}, G a_{*}: 116 \mathrm{~m}, \mathrm{~W} . \mathrm{N}$. W. Milledgeville.

Huntspilie, p. v., Choclaw co, Miss. : 83 m. N. N. E. Jackson.

Huntsvilue, p. v., Schuyler co, $I I_{0}: 67$ m. W. N. W. Springfield.

Huntsvilie, p. v., and cap. Randolph co., Mo. : on the E. side of East Chariton r., $64 \mathrm{~m}$. N. by W. Jefferson City. It contains a court-house, jail, etc, and has several stores. Pop. 300.

Hontsville, p. V., Yadkin (formerly Surry) county, N. Car.: on the W. bank of Yadkin r., 108 m. W. N. W. Raleigh.

Huntsville, v, and sta., Wake co., N. Car.: on the line of the Gaston and Raleigh R. R., 9 m. N. Raleigh.

Huntsville, p. v., Luzerne co., Penn.: 107 m. N. E. Harrisburg.

Huntsville, p. v., Laurens dist., S. Car. : 58 m. N. W. Columbia.

Huntsville, p. v., and cap. Walker co, Texo : on Harmon's cr. of Trinity r., $143 \mathrm{~m}$. E. by N. Austiu City. It is one of the progressive settlements of Texas, and is surrounded by a thickly peopled and well cultivated country. The v. contains a court-house, etc., and several large stores, Two newspapers, the "Texas Presbyterian" (relig.), and the "H. Item," are published weekly. It is proposed to erect at this place a Female College, under charge of the Methodists, and other foundations are spoken of which, if completed, will make Huntsville a great seat of learning. Pop. about 600 .

Huntsville, p. v., Madison en., Ind.: on the N. side of Fall cr. of White r., a little above Pendleton, and about 26 $\mathrm{m}, \mathrm{N}$. E. Indianapolis. It is named after the families that first settled here.

Huntsville, p. ve, Lngan co., O7io: on Cherokee-mans cr., 49 m. W. N. W. Columbus. The Mad River and Lake Erie R. R. passes through it $9 \mathrm{~S} \mathrm{~m}$. from Sandusky.

Hun tsvielet, p. v., and cap. Scott co., Tenn.

HurLeY, t. and p. v., Ulster co., N. Y.: $4 \pi \mathrm{m}, \mathrm{S} . \mathrm{S}$. W. Albany. Drained by Esopus cr. Surface hilly ; soil fertile Joam, underlaid with limestone. The v. on Esopus er. is a small agricultural settlement, and contains 30 or $35 \mathrm{dwell}$ ings. Pop. of t, 2,008.

Hukox county, Jich. Situate E. between Saginaw Bay and Lake Huron, and contains $859 \mathrm{sq} . \mathrm{m}$. Draineil by Pinnebog and Willow rivers, flowing N., Zappopoie r. flowing E., and other small streams. Surface mostly lerel soil of moderate fertility, without stone, but marshy in places. It is well timbered with beech,-maple, pine, and tamarack, the last two supplying great numbers of spars. 
Lumber is the greatest export, the county being little settled. Farms 18; manuf. 0 ; dwell. 52, and pop. - wh. 210 , fr. col. 0 -total 210. Capital:

FluroN county, Ohio. Situate N. centrally, and contains $764 \mathrm{sq} . \mathrm{m}$. Drained by Huron and Vermillion rivers and their branches. Surface rolling or level; soil very fertile and finely adapted to grain and grass. Wheat and corn are leading crops, and great numbers of cattle, sheep, and swine are fed. Farms 2,414; manuf. 256; dwell. 4,619, and pop.-Wh. 26,167, fr, col. 36-total 26,203. Capital: Newark. Public Works: Cleveland, Columbus, and Cincinnati R.R.; Sandusky and Newark R. R.; Cleveland, Norwalk, and Toledo R. R.

Ifurov, to and p. o., Wayne co., Mich.: $72 \mathrm{~m}$. S. E. Lansing. Drained by Huron r., which affords water-power and navigation. In the $\mathrm{S} . \mathrm{W}$. there are swamps, but the general surface is elevated and fertile. Pop. 482.

Hurov, p. v., Des Moines co., Ia. : on the W. bank of the Mississippi, $58 \mathrm{~m}$. S. E. Iowa Gity.

Huros, t. and p. v., Wayne co., $N_{0}, Y_{.}: 159 \mathrm{~m}$. W. N. W. Albany. Drained by streams falling into Lake Ontario through East, Port, and Sodus Bays, which lie in this town. Surface level; soil gravelly and sandy loam. The villages are Huron and Port Glasgow. Pop. of t. 1,966.

Hurox, to and p. v., Erie co, Ohio: 100 m. N. N. E. Columbus. Drained by Huron r. and other affluents of Lake Erie. Surface level; soil sandy alluvion. The v. is located at the mouth of Huron r., and has a good harbor. It contains numerous warehouses, stores, commission-houses, etc., and about 800 inhabitants ; and is intersected by the Junction (Lake Shore) R. R. Pop. of t. 1,397.

Huron isles, Mich.: on the S. shore of Lake Superior, E. of Kew-y-wee-non Bay.

Huron lake: one of the five great lakes of North America. It lies between Lake Superior on the N. W., Michigan on the N. W. and W., and Erie and Ontario on the S. and S. E. ; and in regard to its astronomical position, lies between $43^{\circ} 5^{\prime}$ and $46^{\circ} 15^{\prime} \mathrm{N}$. lat., and between $79030^{\prime}$ and $84^{\circ} 50^{\prime} \mathrm{W}$. lon. Its length is $260 \mathrm{~m}$, - - along the coast of its W. shore it is $360 \mathrm{~m}$.; and its greatest breadth is $160 \mathrm{~m}$., but exclusive of the bay on the N. E., it is only about $90 \mathrm{~m}$. ; and its circumference is about $1,100 \mathrm{~m}$. Its principal indentations are, Saganaw Bay, extending into Michigan, and two others, one immediately N. of the Manitou Islands, and the other S. E. of them. The latter, called Georgian Bay, is about $170 \mathrm{~m}$. long and $70 \mathrm{~m}$, broad, and is not far from one-fourth the whole size of the lake. Manitou, or Great Spirit Islands, extend from a peninsula in the S. E. part, through its N. part-and with Drummond's Island, separate another sheet of water from the main lake $80 \mathrm{~m}$. long and $20 \mathrm{~m}$. wide. The boundary between the United States and Canada passes along the main Huron $225 \mathrm{~m}$, and between Lesser Manitou and Drummond's Island by what is called the Niddle Passage, and curves round to the $\mathrm{N}$. and W. 25 $m$. to the entrance of St. Mary's r. The elevation of the surface of the lake is 596 feet above the ocean, or less than that of Lake Superior by 45 feet, or than that of Lake Michigan by 4 feet. The greatest depth toward the W. shore is at least 1,000 feet, and its mean depth 900 feet, or about 300 feet below the level of the Atiantic. The largest of the Manitou Islands, called Great Manitoulin, is $90 \mathrm{~m}$. long, aud in its widest part nearly $30 \mathrm{~m}$. broad. The islands of Lake IIuron are said to amount in number to 82,000 . It receives the waters of Lake Superior by St. Mary's r., and thase of Lake Michigan by the Straits of Michilimackinac; and discharges its own waters by the Strait of St. Clair. Lake Nipissing empties into it through Francis r., and Lake Simcoe by Serern r. The Huron is subject to violent storms, which render its narigation dangerous. It has, however, fine harbors, and in process of time cities and a crowded population will vitalize its shores.

Hefon river, Mith : a considerable stream of the Inper Peninsula, having its source in the Porcupine Mountains, 302 from which it flows N. E., and discharges its waters into Lake Superior. It is navigable for crnoes.

HURon river, $\mathrm{Mich}$ : one of the most considerable streams watering the $\mathrm{E}$. part of the lower peninsula. It rises from many heads in Oakland and Livingston counties, and flows in a S. W. course to the $\mathrm{N}$. boundary of Washtenaw county, where it expands into Portage Lake. It then contracts and passes S. for a few miles, and then, pursuing a S. E. direction through Washtenaw and Wayne counties, enters Lake Erie a few miles below the mouth of Detroit $\mathbf{r}$. It has few tributaries in its lower course. The Huron is a beautiful transparent stream, passing alternately through rich bottoms, openings, plains, and sloping woodlands. Its length, by its meanderings, is about 90 miles.

Huron river, Ohio: rises in Richland co., and flows through Huron and Erie counties into Lake Erie at Ifuron. It is navigable by a crooked channel six or seven miles from its mouth, and has a canal along its border to Milan. It affords good water-power.

HURRICANE, p. 0., Conway county, Ark.: $47 \mathrm{~m}$. N. W. Little Rock.

HURricave, p. v., Montgomery co., Ill.: 57 m. S. S. E. Springfield.

HURRICANE, p. o., Franklin par., La.: 118 m. N. N. W. Baton Rouge.

Hurricave, p. o., Spartanburg dist., S. Car. : $103 \mathrm{~m}$. N. W. Columbia.

HuRricane CReEK, p. o., Lauderdale co., Miss.: 92 m. E. Jackson.

Hurricane Creek, p. o., Saline co., Ark.: 28 m. S. W Little Rock.

Herricane Crese, p. o., Henderson co., Tenn.: $112 \mathrm{~m}$ W. S. W. Nashville.

Herricane Grove, p. o., Grant county, Wisc.: 3 m. E. of Grant river.

Herricane Hinu, p. o., Lafayette co., Ark.: 118 m. S.W. Little Rock, 73 m. W. S. W. Madison.

Hurt's Cross Roads, p. o., Maury county, Tenn. : $36 \mathrm{~m}$. \$. Nashville.

HurT's MrLls, p. o., Harrison county, Ind. : $112 \mathrm{~m} . \mathrm{S}$. Indianapolis.

Huss AW, p. O., Carroll co.,Ark. : 132 m. N. W.Little Rock. Hustisrokd, p. v., Dodge county, Wisc. : 48 m. N. E. Madison.

Hustonthlue, p. F., Lincoln co., Ky.: 51 m. S. S. E. Frankfort.

Hutsoxpilize, p. v., Crawford co., Ill.: on the W. bank of Wabash r., 114 m. E. S. E. Springficld.

Hбттом's Fork, p. o., Wilkes county, $G a_{\text {. : }} 54$ m. N. N. E. Milledgeville.

Hutronsvilue, p. v., Randolph coounty, Firg.: $162 \mathrm{~m}$. W.N.W. Richmond.

Hranns, p. v., Barnstable co., Mrass. : 5 m. S. Barnstable Court-house, and 6 m m. S. S. E. Boston. It contains 2 churches and 120 inhabitants.

HYansis Port, p. v., Barnstable co., Mfass. : 65 m. S. S. E. Boston. The v, has a good harbor, with a breakwater constructed by the United States, and is a refuge for windbound ressels.

Hyatrspown, p. v., Montgomery co, $\boldsymbol{M} d_{0}$ : on the N.W. line of the co., $62 \mathrm{~m} . \mathrm{W} . \mathrm{N}$. W. Annapolis.

Hrattsville, p.v., Miami co., Ohio: on the Miami Canal, $62 \mathrm{~m}$. W. Columbus. It has several stores, and about 250 inhabitants.

Hrco, p. o., Halifax co., Virg.: 93 m. S. W. Richmond.

Hrco FALts, p. o., Halifax co., Firg.: on Hyeo cr., $98 \mathrm{~m}$. S. W. Richmond.

HrDE county, 1. Car. Situate E., and contains 809 sq. m. It has Pamlico Sound on the E. and S., and Pungo r. (or bay) on the $W$., and is drained by small creeks flowing into these. Surface low, level, and frequently marshy; soil moderately productive, with a heavy growth of pine. Corn is the chief crop-lumber the export. Farms 293; manuf. 
6 ; dwell. 923 , and pop.-wh. 4,798, fr. col. 211, sl. $2,627-$ total 7,636. Capital: Swan Quarter.

HYDE, p. V., Warren co., N. Y.: 58 m. N. W. Albany.

FrDe PARK, p. v., Grundy county, Ill.: 129 m. N. E. Springtield.

HyDE PARK, v, and sta, Queen's co., $N . Y$.: on the line of the Long Island R. R., $17 \mathrm{~m}$, from Brooklyn.

HYDes PARk, t, and p. T., Duchess co., $N_{0} Y_{0}: 61 \mathrm{~m} . \mathrm{S}$. Albany. Drained by Crum Elbow er., and bounded W. by Hudson r. Surface uneven; soil gravelly loam and clay; on the river very fertile. The v. is situate on the $\mathbf{E}$. side of Hudson $\mathrm{x}$., and has commodious landings and a horse-ferry across the river. It is a considerable place, with stores, mechanic shops, etc., and carries on a trade with New York City, with which it is connected by the Hudson River R. R. and steamboats. Pop. of t. 2,426.

Hyde PARK, p. Y., Luzerne co., Penn.: 113 m. N. E. Harrisburg.

Hrde PARE, v., Halifax county, N. Car. : 64 m. N. N. E. Raleigh.

HTDE PARK, to, p. V., and cap. Lamoille co., Verm. : $26 \mathrm{~m}$. N. Montpelier. Drained by numerous tributaries of Lamoille river, which afford water-power. Surface hilly ; soil fertile, and easy of cultivation. The v. contains a courthouse, jail, etc. Agriculture is the sole occupation. Population of t. 1,107.

Hydesburgin, p. v., Ralls co., Mo.: on a cr. of Salt r., 82 m. N. N. E. Jefferson City.

Hyde Setriement, p. v., Broome co., N. Y.: on the W. side of Tioughnioga cr., $113 \mathrm{~m}$.W. S. W. Albany.

Hrdevilie, p. v., Rutland co., Verm. : on the line of the Saratoga and Washington R. R., $3 \mathrm{~m}$. from Castleton, and 57 m. S. S. W. Montpelier.

HrdraUlic Mills, p. o., Albemarle county, Firg.: $73 \mathrm{~m}$. W. N. W. Richmond.

HXgEIA, p. O., Hamilton county, Ohio: 100 m. S. W. Columbus.

Hyndevtule, p. v., Schoharie co., $N_{*} Y_{*}:$ on Cobbleskill creek, $39 \mathrm{~m}$. W. Albany.

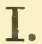

InRRiA, p. Y., Miller co., MO : about $2 \mathrm{~m}$. W. of Tavern cr. of Osage r., $32 \mathrm{~m}$. S. by W. Jefferson City.
Imeris, p. v., Morrow co., Ohio: on the line of the Cincinnati, Cleveland, and Columbus R. R., $50 \mathrm{~m}$. N. by E. Columbus and $85 \mathrm{~m}$. from Cleveland.

IbERviLLe parish, $L a$. Situate 8 . E. centrally, and contains $239 \mathrm{sq} . \mathrm{m}$. It lies on both sides of the Mississippi, and has Iberville and Amite rivers on its E., and Atchafolaya and Grand rivers on the W. Surface level and very low; soil very fertile on the rivers, where it is principally cultivated. Corn produces good crops, but cotton and su gar are the staples, of which large amounts are made and exported. Farms 219 ; manuf. 10; dwell. 698, and prip.wh, 3,568, fr. col. 104, s1. 8,542-total 12,214. Capital. Iberville.

Ibertille (or Bayou Manchae), $\alpha_{0}$ : an outlet of the Mississippi, about $15 \mathrm{~m}$. below Baton Rouge, and uviting it with Amité r., which flows into Lake Maurepas. It is nar. igable for small vessels in time of flood.

IBERVILLE, p. V., and eap. Iberville par., La.: on the E. bank of the Mississippi, $23 \mathrm{~m}$. S. S. E. Baton Rouge. It contains besides the county buildings, a fine hotel, serera stores and private dwellings, and is surrounded by a tract of excellent cotton and sugar land.

ICE's FerRx, p. o., Monongalia co., Firg.: 199 m. N. W. Richmond.

ICHEPUOKESA ASA, p. O., Hillsboro' co., F' lor. : on Hillsboro' r., 213 m. S. E. Tallahassee.

Iokesburair, p. v., Perry co., Penns: on a branch of the Susquehanna r., 29 m. N. W. Harrisburg.

IDA county, Ia. Situate N. W., and contains $432 \mathrm{sq} . \mathrm{m}$. Drained by Little Sioux r., an affluent of the Missouri, and its branches. Unorganized in 1850 .

IDA, t. and p. 0., Monroe co., Miéch. : 69 m. S. E. Lansing. It has a rolling surface, a fertile soil, mostly sandy loam, and excellent pastures. The Michigan Southern $R$. $R$. passes through the $\mathrm{N}$., and Ida sta. is $13 \mathrm{~m}$. from Monroe. Pop. of t. 345 .

IJAMSVILLE, p. V., Frederick co., Mrd. : on the N. side of Bush cr., $6 \mathrm{~m}$. from Monocacy r. and $51 \mathrm{~m}$. N.W. Annapolis. The Baltimore and Ohio R. R. passes through the v, 54 m. from Baltimore.

Ilchester Mills, p. v., Howard co., MMd.: on S. side of Patapseo r., $24 \mathrm{~m}, \mathrm{~N}$. W. Annapolis. The Baltimore and Ohio R. R. passes this $\mathrm{v} .13 \mathrm{~m}$. from Baltimore. There aro extensive flouriug mills at this place.

ILION, p. 0., Herkimer county, $N_{0} Y_{0}: 69 \mathrm{~m} . \mathrm{W} . \mathrm{N} . \mathrm{W}$. Albany.

\section{THE STATE OF ILLINOIS.}

ILLINoTs lies between latitudes $87^{\circ} 00^{\prime}$ and $42^{\circ} 39^{\prime} \mathrm{N}$., and between longitudes $37^{\circ} 49^{\prime}$ and $91^{\circ} 28^{\prime} \mathrm{W}$. from Greenwich, or $100^{\circ} 7^{\prime}$ and $14^{\circ} 26^{\prime}$ W. from Washington. It is bounded N. by Wisconsin; N. E. by Lake Michigan; E. by Indianathe Wabash River forming the boundary in half its length; $\mathbf{S}$. by the Ohio River, which separates Illinois from Fentucky, and W. by the Mississippi River, which flows between this State and the states of Wisconsin and Iowa.* The extreme length of Inlinois, on the meridian of Cairo City, is 378 miles, and its greatest breadth, which occurs on the parallel of Danville, is 212 miles; but the average length and breadth are much less. The periphery of the State measures 1,160 miles, the whole of which, with the exception of 305 miles, is formed by navigable waters; and its superficial land area is estimated at 55,405 square miles.

As a plysical section Illinois necupies the lower part of that inclined plane of which Lake Michigan and both its shores are the higher sections, and which is extended into and embraces the much greater part of Indiana. Down this plane, in a very nearly south-western direction, flow the Wabash and its confluents, the Kaskaskia, the Illinois aud its confluents, and the Rock and Wisconsin rivers. The lowest section of the plane is also the extreme southern angle of Illinois, at the mouth of the Ohio River, about 340 feet above tide-water in the Gulf of Mexico. Thongh the State of Illinois does contain some low hilly sections, as a whole, it may be regarded as a gently inclining plane in the direction of its rivers as already indicated. Without including minute parts, the extreme arable elevation may be safely stated at 800 feet above tide-water, and the mean height at 550 feet.

In some former period, observes Mr. Schooleraft, there has been an obstruction in the channel of the Mississippi, at or near Grand Tower, producing a stagnation of the current at an elevation of about 130 feet above the present ordinary

- The Act of Congress admitting this State into the Union prescribes the boundaries as follows: Beginning at the mouth of the Wabasil Iiver, thence up the inidule of the main cirannel thereof to the point where a line drawn due north of Vincennes last crosses that strean, thence due north to the north-iveat corner of the State of Indiana, thence east with the boundary line of the same State to the middle of Lake Yichizan, thence dise north along the middle of said lake to north latitude $40^{\circ} 30^{\prime}$, thence west to the middle of the Mississippi River, thence down the midjle of the main channel thereof to the mouth of the Ohio River, thence up the latter stream along its northern or right shore to the place of beginning. 
Water-mark. This appears evident from the general elevation and direetion of the hills, which for several hundred miles above are separated by a valley from 20 to 25 miles wide, that deeply embosomis the current of the Mississippi.

Wherever these hills exhibit rocky and abrupt fronts, a series of water-lines are distinctly visible, and preserve a remarkable parallelism, uniformly presenting their greatest depression toward the sourees of the river; and, at Grand Tower, these water-]ines are elevated about one hundred feet above the summit of the stratum, in which petrifactions of the madrepora and various fossil organic remains are deposited. Here the rocks of dark-colored limestone, which pervade the country to a great extent, by their projections toward each other, indicate that they have, at a remote period, been disunited, if not by some convulsion of nature, by the incessant action of the water upon a secondary formation, and that a passage has been effected through them, giving vent to the stagnant waters on the prairie lands above, and opening for the Mississippi its present channel.

Next to Louisiana and Delaware, Illinois is the most level State in the Union. A small tract in the southern part of the State is hilly, and the northern portion is also somewhat broken. There are, likewise, considerable elevations along the Illinois River, and the bluffs of the Mississippi in some places might pass almost for mountains. But by far the greater portion of the State is either distributed in vast plains, or in barrens, that are gently rolling like the waves of the sea after a storm.

The largest prairie in Illinois is denominated the Grand Prairie. Onder this general name is embraced the country lying between the waters falling into the Mississippi, and those which enter the Wabash rivers. It does not consist of one vast tract, but is made up of continuous tracts with points of timber projecting inward, and long arms of prairie extending between. The southern points of the Grand Prairie are formed in Jackson County, and extend in a north-eastern course, varying in width from one to twelve miles through Perry, Washington, Jefferson, Marion, Fayette, Effingham, Coles, Champaign, and Iroquois counties, where it becomes connected with the prairies that project eastward from tho Illinois River. A large arm lies in Marion County, between the waters of Crooked Creek and the east fork of the KasLaskia River, where the Vincennes road passes through. This part alone is frequently called the Grand Prairie.

Much the largest part of the Grand Prairie is gently undulating, rich, and fertile land; but of the southern portion, considerable tracts are flat, and of rather inferior soil. No insurmountable obstacle exists to its future population. No portion of it is more than six or eight miles distant from timber; and coal in abundance is found in most parts. Those who have witnessed the changes produced upon a prairie surface within twenty or thirty years, consider these extensive prairies as offering no serious impediment to the future growth of the State.

Dr. Beck, in his Gazetteer of Mrissouri, published in 1823, describes the uplands of St. Louis County as generally prairio; but almost all of that tract of country thus described is now covered with a young growth of fine thrifty timber, and it would be difficult to find an acre of prairie in the county. This important change has been produced by keepiug the fires out of the prairies.

The first improvements are usually made on that part of the prairie which adjoins the timber; and thus we may see, at the commencement, a range of farms circumseribing the entire prairie. The burning of the prairies is then stopped through the whole distance of the cireuit in the neighborhond of these farms, to prevent injury to the fences and other improrements. This is done by plowing two or three furrows all round the settlement. In a short time the timber aprings up spontaneously on all the parts not burned, and the groves and forests commence a gradual encroachment on the adjacent prairies; by-and-by you will see another tier of farms springing up on the outside of the first, and farther out on the prairie; and thus farm succeeds farm, as the timber grows up, until the entire prairie is occupied.Illinois in 1837 .

Illinois possesses immense advantages for internal navigation. Its north-eastern corner for fifty miles is washed by the waters of Lake Michigan, which open a communication with the whole lake-country of the North. The Mississippi Iivor forms its western border, and the Ohio and Wabash rivers demark its southern and eastern limits, together forming a natural water highway of unexampled extent. The rivers which have their courses within the limits of the State are Rock, Illinois, Kaskaskia, and Big Muddy, affuents of the Mississippi; the Embarras and Little Wabash, tributaries of the Wabash, and the Saline and Cash rivers, which empty into the Ohio. The Illinois is much the largest of these ; it is formed by the union of the Kankakee and Des Plaines, and in its course of 500 miles toward the Mississippi receives Fox and Spoon rivers, Crooked Creek, and several other streams from the north, and the Vermillion, Mackinaw, Sangamon, and others from the south. The current of the Illinois is in general gentle, with a wide, deep bed-in some places opening into broad and lake-like expanses. Rock River rises in Wisconsin, and has a course of 300 miles; it is navigable for some distance, but in its upper course is impeded by several rapids. The Kaskaskia rises in the eastern part of the State and pursues a direction nearly parallel to that of the Illinois and Rock rivers, and after a course of 300 miles renches the Mississippi in latitude $35^{\circ}$ north. The Big Mluddy is also a considerable stream. The rivers flowing to the Ohio and Wabash are generally of less volume than the smaller class of rivers flowing toward the Mississippi, but several are navigable, and all contribute much to the wealth of the country by the abundance of water-power they supply for mechanical purposes.

The northern portion of Illinois is inexhanstibly rich in minerals, while coal, secondary limestone, and sandstone are found in almost every part. Iron ore is also widely distributed. The minerals most common to the north-western section are lead and copper. The lead diggings extend over a vast tract and into the adjoining States, and are, doubtless, the most productive of any hitherto known. Silver has also been found in this region intermixed with galena. Tho coal of Illinois is bituminous, and is spread over a large extent of country; it is found in the ravines and bluffs of the Mississippi, and large veins were struck in excavating the canal below Ottawa. The great coal region, however, extends from central Iowa to northern Kentucky, across the State. Building stones of almost every deseription are quarried. Sulplur and chalybeate springs exist in several parts of the State, and there are salt springs in Gallatin, Jackson, Fermillion, and other counties. Immense boulders of granite are frequentiy seen upon the surface.

The soils of Illinois, though of such various character, are all highly fertile and productive. In the bottoms, or alluvial borders of the rivers, the soil is chiefly formed from the deposits of the waters during food. In some cases the mold so furmed is twenty-five feet and upward in depth, and of inexhaustible fertility. One-sixth of the alluvial land, however, is unfit for present cultivation, although it is productive in timber. A tract called the "American Bottom," extending along the Mississippi for 90 miles and about 5 miles in avernge width, is of this formation. About the French towns it has been cultivated, and produced Indian corn every year, without manuring, for a century and a half. The prairie lands, although not so productive, are yet not inferior for many agricultural purposes, and are preferred, where wood is to be hal, on account of their superiur salubrity. The barrens, or oak openings, have frequently a thin soil. In the 
north there are tracts somewhat stony, yet in every other part the plough may pass over millions of acres without meeting so much as a pebble to impede its course.

Illinois, extending as it does over five and a half degrees of latitude, must possess some variety in its climate, and the level surface that characterizes it, exposes it alike to sun and storm. The winters are everywhere severe, and the summers hot and prolonged. The climate is also subject to sudden changes, especially from November to May, and below the parallel of $40^{\circ}$ the summer heat is extremely enervating. The prevailing winds are the south-west, which blow for three-fourths of the year. The north and north-westerly prevail in the winter months. On the whole, however, the climate is favorable to out-door occupations, the proportion of clear and cloudy days being as 245 of the former to 120 of the latter. Vegetation commences with April, and the first killing frost occurs from the 1st to the 15 th Beptember. The general salubrity of Mlinois is well attested, and few suffer from endemic diseases, except those who are imprudent or scttle near swamps and other sources of miasms.

In general Illinois is well supplied with timber, and were it equally distributed through the State, there would be no part wanting. The kinds of timber most abundant are oaks of various species, black and white walnut, ash of several kinds, elm, sugar maple, honey locust, hackberry, linden, hickory, cotton wood, pecaun, mulberry, buckeye, sycamore, wild cherry, box elder, sassafras, and persimmon. In the southern and eastern parts of the State, yellow poplar and beech are the peculiar growths, and near the Ohio are clumps of yellow pine and cedar. The under growths are redbud, pawpaw, sumac, plum, crab-apple, grape-vines, dog-wood, spice-bush, green-brier, hazel, etc. The alluvial soil of the rivers produces cotton-wood and sycamore timber of amazing size. Many valuable medicinal plants are found in overy part of the State.

The wild animals found in Mlinois are similar to those existing in other parts of the Great West, but many snecies have become extinct. Of wolves the species still found are the gray wolf (canis lupus), the black wolf (canis lycaon), and the common prairie wolf (canis latrans). The latter is most common, and is found in considerable numbers. Panthers and wild cats are less frequently seen, but occasionally do mischief. The buffalo no longer roams on the prairies, and the deer and bear have retreated from the settlements. Foxes, raccoons, opossums, gophars, and squirrels, however, are numerous, as are muskrats, otters, and occasonally beavers about the rivers and lakes; but all these are being destroyed rapidly, and in a few years the trapper and hunter will have to move westward for sport and prey. Dncks, geese, swans, and many other aquatic birds visit the waters in spring time, and the small lakes and sloughs are often hiterally covered with the prairie fowl, and partridges are also abundant. The bee is found in the trees of every forest, and few States can boast of such variety and abundance of fish as are here found in the rivers and lakes.

Illinois is divided into 99 counties, the general statistics of which and the capitals of each in 1850 were as follows:

Cornties. Dwell. Pop. Farms Manuf, Capitals. Adams. .... 4,459 ..26,508 . 2,294 .. 118 .. Quincy Alexander... $455 \ldots 2,454 \ldots 202 \ldots 8$... Thebes Bond ...... 1,076 .. 6,144 .. 665 .. 17 .. Greenville Boone .... 1,352 .. 7,626 .. 897 . 17 .. Belvidere Brown ..... 1,353 .. 7,193 .. 815 .. 73 .. M't Sterling Bureau .... . 1,464 .. 8,841 .. 741 .. 20 .. Princeton Calhoun .... 600 .. 3,231 .. 205 .. 0 .. Hardin

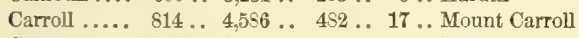
Cass ....... 1,169 .. 7,253 .. 606 .. 26 .. Beardstown Champaign . $4 S 0 \ldots 2,649 \ldots 273 \ldots 0.0$.. Urbana

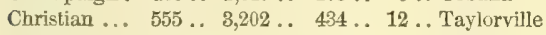
Clarke..... 1,621 .. 9,532 .. 636 .. 14 .. Marshall

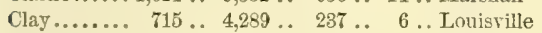
Chinton ..... 947 .. 5,139 .. $628 \ldots$ \& .. Cariyle Coles ...... 1571 .. 9,835 .. 996 .. 0 .. Charleston Cook . . . . . 7,674 . 43,385 . . 1,857 .. 227 .. Chicago Craw ford ... 1,192 .. $7,135 \ldots$.. $542 \ldots \quad 0$.. Robinson

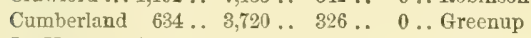
De Kalb.... 1,303 . . 7,540 . . 812 .. 4 . . Sycamore

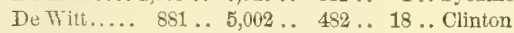
Du Page ... 1,563 .. 9,290 .. 960 .. 18 .. Naperville Edgar.... . 1,702 . . 10,692 . 1,175 .. 38 . . Paris Edwards ... $595 \ldots 3,524 \ldots 329$.. 7 ... Albion Effingham.. 712 .. $8,799 \ldots 391 \ldots$.. 0 .. Ewington Fayeite ... 1,481 .. $5,075 \ldots$.. $826 \ldots$... 4 Vandalia Franklin ... 971 .. 5,681 .. 577 .. 0 ... Benton Fulton .... 3,811 . 22,508 . 1,942 . 104 .. Lewiston Gallatin .... 1,000 .. 5,418 .. $570 \ldots 17 \ldots$ Shawneetown Green $. . .2,024$. . 12,429 . 1,155 .. 27 . . Carrollton Gruady .... 543 . 53,023 .. $327 \ldots 7$.. 7 Morris Hamilton ... 1,058 .. 6,362 . $417 \ldots$.. 0 .. M'Leansboro' Hancock . . 2, 2,585 . . 14,652 . 1,167 . . 43 . . Carthage Hardin .... $485 \ldots 2,857 \ldots 326 \ldots 0$.. Elizabethtown Henderson. . $805 \ldots$ 4,612 .. $420 \ldots 27 \ldots$ Oquawka Henry..... $772 \ldots 8,807 \ldots 281 \ldots 0 .$. Cambridge

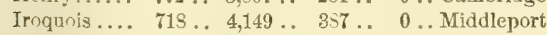
Jackson . . . . 1,039 . 5, 562 .. 604 .. 23 .. Murphrysboro Jasper . . . 589 . . 3,220 .. 233 .. 0 .. Newton

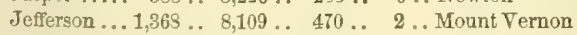
Jersey ...... 1,222 . . 7,354 . . 645 .. 44 . Jerseyville Jo Laviess. . 3,431 . 18,604 . 1,370 . 279 . Galena

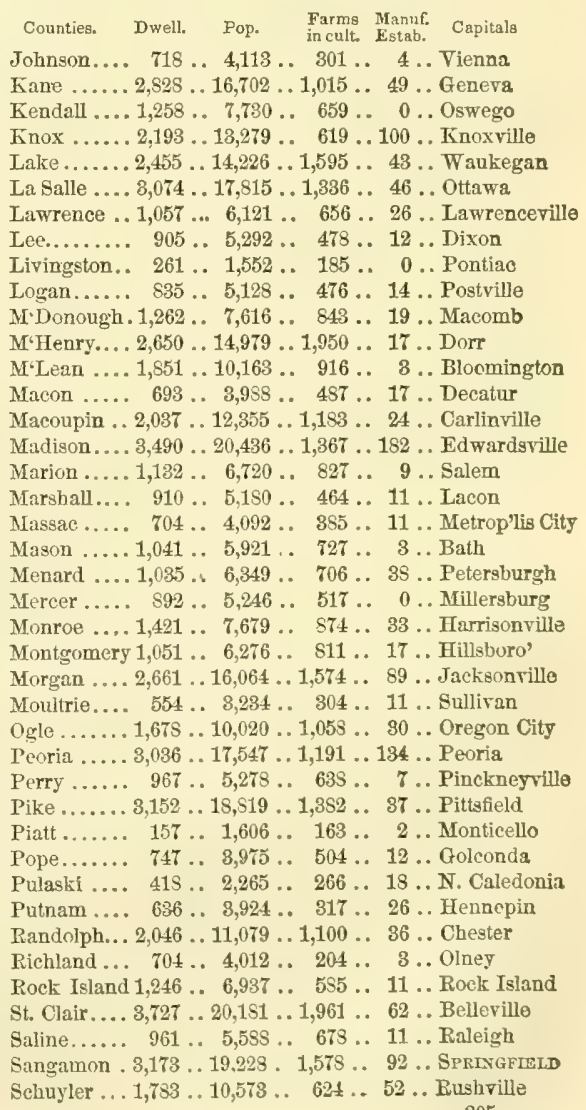

305 
ILLINOIS.

\begin{tabular}{|c|c|c|c|}
\hline Counties. & $\begin{array}{l}\text { Farms } \\
\text { in cult. }\end{array}$ & $\begin{array}{l}\text { Manuf. Capitals. } \\
\text { Estab. }\end{array}$ & $\begin{array}{l}\text { Farms Mranuf. Capitale. } \\
\text { in cult. Estab. }\end{array}$ \\
\hline & $1,300 \ldots 7,914 \ldots 712 \ldots$ & . 54 .. Winchester & Washington. 1,258 .. 6,953 .. 829 .. 9 .. Nashville \\
\hline Shelb & $1,411 \ldots 7,807 \ldots 834 \ldots$ & 7 .. Shelbyville & Wayne .... 1,209 .. 6,825 .. 492 .. 6 . Fairfield \\
\hline Stark .... & .. $594 \ldots 3,710 \ldots 343 \ldots$ & - 23 .. Toulon & White ..... 1,537 .. 8,925 .. 1,101 .. 22 .. Carmi \\
\hline Stephensor & a. $1,950 \ldots 11,666 \ldots 1,179 \ldots$ & . 75 .. Freeport & Whitesides.. $923 \ldots 5,361 \ldots 404 \ldots 24 \ldots$ Su .. $\quad 4$ ling \\
\hline Tazewell . & . . $1,991 \ldots 12,052 \ldots 1,110 \ldots$ & . 76 .. Fremont & . . 2,796 .. 16,703 . 1,200 .. 94 . . Joliet \\
\hline Enion.... & $. .1,259 \ldots 7,615 \ldots 810 \ldots$ & 21 ... Jonesboro' & Williamson. 1,195 .. $7,216 \ldots 752 \ldots 10 \ldots$ Marion \\
\hline Vermillion & .. 1,985 . . 11,492 . . 1,269 .. & . 15 .. Danville & Winnebago $1,979 \ldots 11,773 \ldots 919 \ldots 62 \ldots$ Rockford \\
\hline $\begin{array}{l}\text { Wabash .. } \\
\text { Warren ... }\end{array}$ & 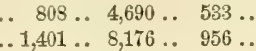 & $\begin{array}{l}9 \text {. . Mount Carmel } \\
42 \text {.. Monmouth }\end{array}$ & Woodford .. $747 \ldots 5,416 \ldots 506$.. 14 .. Metamora \\
\hline
\end{tabular}

The whole number of dwellings in the State was, at the above date, 146,544; of families, 149,153; and of inhabitants, 851,470 , viz. : whites, 846,104-males 445,644, and females 400,460; free colored, 5,366-males 2,756, and females 2,610. Of the whole population, there were, deaf and dumb-wh. 473, fr. col. 2-total 475; $37 i n d-w h$. 253, fr. col. 4-total 257; insane-wh. 246, fr. col. 3-total 249 ; and idiotic-wh. 368, fr. col. 2-total 371 . The number of free persons born in tho United States was 736,931 ; the number of foreign birth, 110,593, and of birth unknown, 3,947; the native population originated as follows: Maine 3,693, N. Hamp. 4,288, Verm. 1,381, Mass. 9,230, R. I. 1,051, Conn. 6,899, N. York 67,180, N. Jer. 6,848, Penn. 37,979, Del. 1,397, Md. 6,898, Dist, of Col. 226, Virg. 24,697, N. Car. 13,851, S. Car. 4,162, Ga. 1,341, Flor. 28, Ala. 1,335, Miss. 490, La.480, Tex. 63, Ark. 727, Tenn. 32,303, Ky.49,508, Ohio 64,219, Mich. 2,153, Ind. 30,953, Illinois 243,618, Mo. 7,288, Ta. 1,511, Wisc. 1,095, Calif. 3, Territories 16. And the foreign population was composed of persons from-England 18,62s, Ireland 27,786, Scotland 4,661, Wales 572, Germany 38,160, France 3,396, Spain 70, Portugal 42, Belgium 33, Holland 220, Italy 43, Austria 65, Switzerland 1,635, Russia 27, Denmark 93, Norway 2,415, Sweden 1,123, Prussia 286, Greece 4, China 1, Asia 2, Africa 11, British America 10,699, Mexico 30, South America 12, West Indies 75 , Sandwich Islands 9, and other countries 495.

The following table will exhibit the decennial progress of the population since the first eensus of the State taken by the United States authorities:

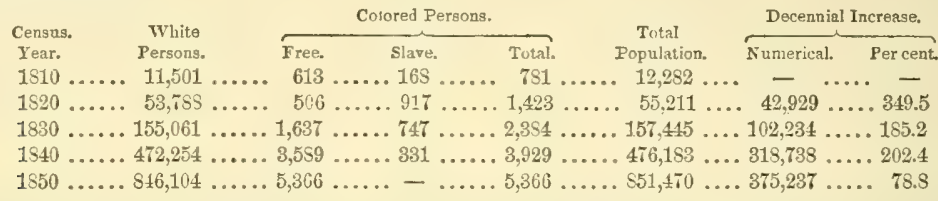

The statistics of the wealth and industry of Illinois, as furnished by the general census of 1850 and other official returns referring to that year, are as follows:

Occupied Lands, etc.-Improved lands, 5,039,545 acres, and unimproved lands, 6,997,867 acres-together valued in cash at $\$ 96,133,290$. Number of farms under cultivation, 76,208 . Value of farming implements and machinery, $\$ 6,405,561$.

Live Stock.-Horses, 267,653; asses and mules, 10,573; milch cows, 294,671; working oxen, 76,156; other cattle, $\mathbf{5 1 1 , 2 0 9}$; sheep, 894,043 ; swine, $1,915,910$ - ralued in the aggregate at $\$ 24,209,253$. In 1840 there were in the State 199,235 horses, mules, etc. ; 626,274 neat cattle; 395,672 sheep, and 1,495,254 swine.

Grain Crops.-Wheat, $9,414,575$ bushels ; rye, 83,364 bushels; Indian corn, $57,646,984$ bushels; oats, $10,087,241$ bushels ; barley, 110,795 bushels; and buekwheat, 184,504 bushels. The crops of $1839-40$ consisted of-wheat, $3,385,393$ bushels; barley, $\$ 2,251$ bushels; oats, 4,95\$,00S bushels; rye, $\$ 3,197$ bushels; buckwheat, $57, \$ 3 t$ bushels; and Indian corn, $22,63 t, 211$ bushels.

Other Crops.-Rice, 0 pounds; tobacco, 841,394 pounds; ginned cotton, 1 bale of 400 pounds ; peas and beans, 82,814 bushels; potatoes-Irish, 2,514,561, and sweet, 157.433 bushels; hay, 601,952 tons ; clover-seed, 3,427 , and other grass-seeds, 14,350 bushels; hops, 3,551 pounds; hemp-dew-rotted, 142, and water-rotted, 141 tons; flax, 160,063 pounds; flax-seed, 10,7 85 bushels; sugar-maple, 24S,904 pounds, and cane, 0 hogsheads of 1,000 pounds; molasses, 8,354 gallons; wine, 2,997 gallons, etc. The ralue of orchard products was $\$ 446,0 \leq 9$, and of markel-garden product8, $\$ 12 \overline{7}, 494$. The following table compares some of the principal staples at the two periods, 1840 and 1850:

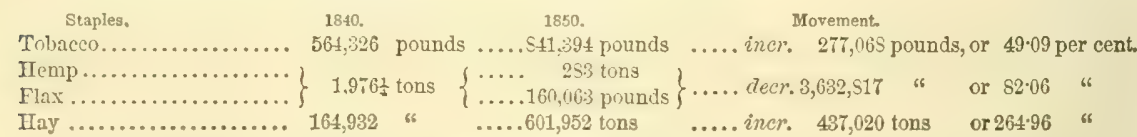

Products of Animals.- Wool, $2.150,113$ (in 1s39-40, 050,007 ) pounds; butter, 12,525,513 pounds; and cheese, 1,278,225 pounds. Value of animals slaughtered in the year $1549-50, \$ 4,972,256$. Silk cocoons were produced to the amount of 47 (in 1839-40,1,150) pounds; and beestrax and honey, to that of 869,411 pounds.

Ifmme-mate Honufuctures for the year ending $30 t h$ June, 1550 , were valued at $\$ 1,155,902$. In $1 \$ 39-40$, the value is set down at $\$ 993,567$.

Ifunufictures.-Agregate capital invested, $\$ 00,000,000$; ralue of raw matcrials, fuel, ete., consumed, $\$ 0,000,000$; average number of hands, 00,000 - males, 0,000 , and females, 0,000 ; average monthly cost of labor-male, 00,000, and female, $\$ 0,000$; annual value of products, $\$ 00,000,000$. The whole number of manufacturing establishments producing ti) the value of $\$ 50$, and upward in 1554 , was 3,199, and of these- 0 were cotton factories, 16 woolen factories, 96 tanneries, and 31 iron manufactories, of which 29 made castings, 2 pig iron, and 0 wrought iron.

The wooten manufactures employ a capital of $\$ 154.500$; and consume annually 396,964 pounds of wool; value of all raw material, fuel, etc., consumed, $\$ 115,367$; hands employed-males 124 , and females 54 ; monthly cost of labor-male, \$2.72:, and female, $\$ 676$; cloth manufactured, 306,995 yards, and yarn, 137,000 pounds; value of entire products, $\$ 206,572$.

The tinneries have a capital of $\$ 155,373$; value of hides and skins used, $\$ 122,907$; male hands emplojed, 240 ; montbly cost of labor, $\$ 5,145$; sides of leather tanned, 101,650, and of skins, 21,575 ; value of products, $\$ 241,028$. 


\section{ILLINOIS.}

The iron manufactures, under the three separate heads as given in the census, are exhibited as follows-in the manufacture of pig iron the capital invested amounts to $\$ 65,000$; ore consumed, 5,500 tons, and coke and charcoal, $170,(600$ bushels; value of all raw material, $\$ 15,500$; hands employed, 150 ; monthly cost of labor $\$ 3,310$; pig iron produced, 2,700 tons; value of entire products, $\$ 70,200$; - and in the manufacture of cast iran, $\$ 260,400$ is invested; material consumed -pig iron 4.S1s tons, old metal 50 tons, mineral coal 1,412 tons, and coke and charcoal 12.500 bushels-valued in the aggregate at $\$ 172,330$; hands employed, 332 , at average monthly wages $\$ 2850$; castings made, 4,160 tons; and other products to the value of $\$ 89,250$; total value of products, $\$ 441,1 \mathrm{S5}$. According to the census no vronght iron is manufactured in the State. The total capital invested in the manufacture of iron is thus $\$ 325,400$; the value of raw material, fuel, etc., consumed, $\$ 187,830$; the annual cost of labor, $\$ 153,264$; and the value of products, $\$ 511,385$.

The manufactures, otherwise than those enumerated, consist chiefly of the various trades and mechanic arts which usually exist in agricultural States, as saw, grist, oil, flour, and other mills; wheelwright shops; agricultural implement factories, etc., etc., which, taken together and in connection with the staple manufactures above detailed, exhibit a very respectable condition of the country in relation to this branch of industry.

Foreign Commerce.-The direct foreign commerce of Illinois is chiefly with the British provinces. The exports, all of domestic origin, for the year ending 30 th June, 1850 , were valued at $\$ 17,669$; and the imports at $\$ 15,705$. Of the exports only $\$ 1,232$, and of the imports $\$ 7,783$, were the values of goods carried in American bottoms. This represents the commerce of the collection district, of which Chicago is the port of entry, the ports on the Mississippi being in the district of New Orleans. The total entries were 22 ( 7,338 tons), of which 4 ( 648 tons) were foreign; and the total clearances were 9 (2,041 tons), of which 5 (998 tons) were foreign. The shipping owned in the district of Chicago on the 30th June, 1830, amounted to 21,242 tons, all "permanent register," and engaged in the coasting trade, and of this 649 tons was nari-

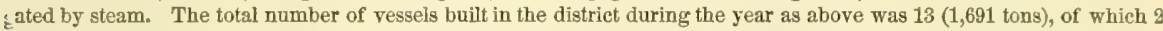
were brigs, 7 schooners, 3 sloops, and 1 steamer. The statistics of the foreign commerce for several years exhibit the following-exports in $1 \$ 47 \$ 52,100$, in $184 \$ \$ 11,835$, in $1849 \$ 88,417$, and in $1850 \$ 17,669$; and imports in $1847 \$ 266$, in 1843 $\$ 4,365$, in $1849 \$ 9,766$, and in $1850 \$ 15,705$.

Internal and Coasting Trade.-The means of internal communication in Illinois, except in one or two favored localities, are as yet very limited. Some of her interior rivers are navigable, and a cordon of navigable water almost insulates the State ; but until access to these be facilitated by railroads, their use to commerce must be comparatively small. Nevertheless, there are few ports that equal Chieago in its commerce, and Alton on the Mississippi is fast rising into importance, gor is Galena to be left unnamed in the list of commercial places. At these ports, as well as those on the Illinois River and Canal, a vast amount of business is transacted-that of Chicago with the East, and that of Galena, Alton, etc., chiefly with the South. The interests of the two sections are partially blended by the canal, which opens the lakes to the South and West, and will be completely united, when the vast system of railroads in course of construction is brought into action. The length of railroad now in operation within the State is 287 miles; the length in progress is 1,822 miles; and the length projected and surveyed about 600 miles. The principal points from and to which the several lines extend are-Chicago, where at least seven lines centre; Alton, which is the terminus of three lines; Galena, which is connected with Chicago on the east, and Cairo on the south; Cairo, where the great central railroad connects with the Mobile and Ohio railroad; Rock Island, the west terminus of the Chicago and Rock Island Railroad; and on the Indiana line, Vincennes, Terre Haute, ete., from which latter places the principal east and west lines pass, uniting the system of Illinois with those of Indiana, Ohio, ete. All the lines referred to will be completed within the next three years, and by that time Illinois will have fairly entered upon that great commercial destiny that awaits her eareer. The proportion of completed railroads to superficies in this State in January, 1853, was as 1 mile of road to every $19 \mathrm{l}$ square miles, and to the population as 1 mile of road to every 2,971 persons.

Banks, etc.-The condition of the State bank of Illinois on the 1st January, 1851, was as follows: assets-debts of all kinds due, $\$ 706,89057$; real estate at cost, $\$ 747,57505$; Illinois State bonds, $\$ 17,50154$, and interest, $\$ 20,24048$; Illinois State scrip, $\$ 14,55520$, and coupons, $\$ 4,750.36$; sundry stocks, $\$ 9,67499$; due by other banks and bankers, $\$ 18,35893$; broken bank notes, $\$ 12,801$; specie, $\$ 36,66685$; total, $\$ 1,675,55494$; and liabilities other than to stockholders-bonds of the bank outstanding, $\$ 184,000$; interest on same to date, $\$ 49,560$; due to other banks and individuals, $\$ 1,65289$; and notes and certificates outstanding, $\$ 215,97 \mathrm{~S} 01$; total, $\$ 445,19090$. All other banks in operation at the present time, 16 or 17 in number, are organized under the Free Banking Law of the State, and the notes are considered to be well secured, having government bonds and stocks as their basis.

Government.-The first constitution of Illinois is dated 26th August, 1818. The constitution on which the government is based at the present time was adopted in convention 31st August, 1847, and accepted by the people 7th March, 1848. It provides that every white male citizen, 21 years old, resident in the State for one year, may vote for all elective offices.

The legislature is termed the General Assembly, and consists of a Senate and House of Representatives; the Senate composed of 25 members, elected for four years, one-half every two years; and the House of Representatives composed of 75 members, elected for two years. Members of both houses must be citizens of the United States-senators must be 30 years old, and have been resident in the State for 5 years; and representatives must be 25 , and have resided in the State 3 rears. These numbers may be increased when the population amounts to $1,000,000$, but the number of representatives must never exceed 100. Pay of members $\$ 2$ a day for 42 days, and $\$ 1$ a day afterward. In forming senatorial or representative districts, the number of white inhabitants is only to be regarded.

The Governor is elected quadrennially by a plurality of votes. He must be 35 years old, a citizen of the United States and a resident of the State for the 10 years next preceding. The Governor must reside at the seat of government, and is not eligible for re-election at a consecutive term. A majority of the members elected to both houses may nullify the Governor's veto on any act of the legislature. The Lieutenant-Governor is required to have the same qualifications as the Governor; and in case of the death or disability of the chief executive, the Lieutenant-Governor acts in his stead, and he is also ex-nfficio President of the Senate.

The judiciary consists of a Supreme Court, Circuit Courts, and County Courts. The State is divided into three grand judicial divisions, each of which elects a judge for nine years, who must be 35 years of age, a citizen of the United States, and resident in the State five vears; and the three judges compose the Supreme Court, the jurisdiction of which is original in cases relating to the revenue, cases of mandamus and habeas corpus, and in some impeachments-in all other cases appellate. One of the judges is elected every three years. This court holds one session in each division annually ; the terms are : 1st division, at Mount Vernon, on the second Monday in November; 2d division, at Springfield, on the third Monday in December, and 3d division, at Ottawa, on the first Monday in Fetruary. There are fifteen judicial circuits, each 
of which elects a judge for six years, who must be 30 years of age, and otherwise qualified as are judges of the Supreme Court. Judges are not eligible to any other office during their term, nor for one year after. Cook County has a Jistric Court of Common Pleas. Each county elects a judge for four years, who holds a county court for the transaction of county and probate business, with limited civil and criminal jurisdiction.

Among the provisions of the Constitution are the following: no State bank can be created nor revived; acta creating banks must be submitted to the people and receive a majority of votes in their favor to become law; stockbolders are individually liable to the amount of their shares; corporations not for banking purposes may be established under general laws; slavery and lotteries are prohibited; duelling is a disqualification for office; colored persons, free or slave, are not permitted to come into the State.

To alter the Constitution, the amendments must be passed by a two-thirds vote of the whole number of members elected to both houses, published and referred to the next legislature, and if passed again by a majority, then they must be submitted to the people, whose approval by a majority vote makes them law.

The calling of a convention to amend the Constitution, if recommended by a two-thirds vote of the legislature, is submitted to the people, and if a majority of votes are in its favor, the convention shall be called by the succeeding legislature. Amendments can be proposed to but one article of the Constitution at one session.

The militia of Illinois, according to the Army Register for 1851, consists of 170,359 men of all arms, of which 4,618 are commissioned officers, and 165,741 non-commissioned officers, musicians, and privates. Of the commissioned officers 30 are general officers, 99 general staff officers, 1,297 field officers, and 3,192 compauy officers.

The principal State benevolent institution is the Asylum for the Deaf and Dumb at Springfield. This institution was opened in January, 1846. The number of pupils in January, 1849, was 60 , of whom 26 were females; and 10 were from Missouri and 1 from Iowa-the remainder from Illinois. The annual session commences the first Thursday in October.

Finances, Public Debt, etc.-The receipts into the treasury for the two years ending 30th November, 1850, were $\$ 402,17927$, of which $\$ 394,10353$ was derived from taxes, and $\$ 8,07574$ from all other sources; and the expenditures for the same period amounted to $\$ 326,12627$, of which $\$ 137,19616$ was ordinary expenses of the government, $\$ 78,43690$ special appropriations and expenditures, $\$ 4,61898$ interest on funds due deaf and dumb asylum, $\$ 105,69808$ issued to school commissioners, and $\$ 17615$ interest paid on old warrants. The receipts for the two years exceeded the disbursements $\$ 76,053$. The amount of interest fund tax received for the same period was $\$ 296,32689$, and the amount of interest paid was $\$ 263,03450$. The whole amount of real and personal estate subject to taxation in 1849 was $\$ 105,432,752$, upon which the State tax was $\$ 612,428$, but which netted only $\$ 578,76331$. In 1850 the value of taxable property amount ed to $\$ 114,782,645$ (true or estimated valuation according to the census $\$ 156,595,006$ ). The aggregate of the public debt on the 1st January, 1851 , was $\$ 16,627,50991$; of this $\$ 5,734,48148$ was state debt proper, and $\$ 7,843,02843$ the canal debt. These two debts are explained as follows:

\section{STATE DEBT.}

Principal debt funded under act of $1847 \ldots \ldots \$ 5,590,56536$ Interest on same to same date .......... 1,020,278 18

Arrears of interest funded ............ 1,945,485 27

Unfunded internal improvement

bonds.................. $\$ 180,00000$

Other kinds of indebtedness..... 144,680 00

Interest on last two amounts. .... $173,261 \quad 40$

Wiggins loan, princ'l and interest 142,00000

Liquidation bonds........... 150,000 00

From which deduct interest paid from mill

and a half tax, bouds surreadered, and sale

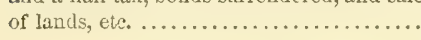

$\$ 9,346,27021$

$\frac{561,7 S 3 \text { T3 }}{\$ \$, 784,4814 S}$
CANAL DEBT.

Principal debt, exclusive of $\$ 1,600,000$ loan.. $\$ 7,079,11708$ Balance due on canal loan of $\$ 1,600,000 \ldots \ldots \quad 1,033,00000$

$\$ 8,112,11708$

From which deduct:

Interest paid from mill and a

half $\operatorname{tax} \ldots \ldots \ldots \ldots \ldots \ldots . . . \ldots 255,81851$

Bonds and scrip redeemed and

interest.............. 13,270 $14 \quad 269,0 \$ 865$

Total canal debt............ \$7,813,028 48 AGGREGATE DEIT.

State debt proper..................\$8,784,481 48 Canal debt.................... $7,813,02843$

Total debt...............\$16,627,509 91

Foderal Representation.-Illinois, in aceordance with the law regulating the distribution of members to the United States House of Representatives, occupies nine seats in that body.

Educction,-Illinois has large funds devoted to school purposes. On the 29th December, 1850 , the permanent funds applicable to the support of common schools amounted to $\$ 790,12066$; and the university fund amounted to $\$ 90,58958$, and the seminary fund to $\$ 58,75872$-together making a total of $\$ 939,79896$. The whole of this sum has been borrowed by the State, which pays six per cent. interest on the amount. The interest on the common school fund is $\$ 47,40723$, which is divided among the several counties in proportion to the number of white children under 21 years of age. In 66 counties that made returns for the year 1850 , there were 2,641 organized districts and school-houses, of which 1,370 were loghouses, 925 frame, 139 brick, and 37 stone, and of the whole number 106 contained more than one room. There were school libraries in 108 districts. The total amount of public moneys paid out for teachers' wages during the year was $\$ 149, \$ 7109$; amount, other than, public moneys, $\$ 81, \$ 4120$-total cost of teaching, exclusive of buildings, repairs, etc., $\$ 230,71229$. The principal colleges in the State are, Illinois College, at Jacksonville, founded in 1829 , and in 1850 it had 7 professors, 93 alumni, 34 students, and a library of 3,000 volumes; Shurtleff College, at Upper Alton (Baptist), founded in 1S35, and in 1850 it had 6 professors, 3 alumni, and 13 students, with a library of 1,600 volumes; M'Kendree College, at Lebanon (Methodist), founded in 1835, and in 1850 it had 4 professors, 33 alumni, 57 students, and a library of 1,700 volumes; Knox College, at Galesburg, founded in 1837, and in 1850 it had 5 professors, 16 alumni, 59 students, and a library of 3,000 volumes. Shurtleff College has connected with it a theological seminary ; and at Chicago is located the Rush Medical School, founded 1842, and in 1850 it had 6 professors, 70 students, and 16 graduates.

Pubtic Libraries.-One State Library of 4,000 volumes, 2 social libraries of 2,821 volumes, 4 college libraries of 8,120 volumes, 2 student's libraries of 625 volumes, 2 academic libraries of 2,000 volumes, and 16 public school libraries of 2,850 volumes-total 27 libraries, and 19,916 volumes.

Periodical Press, etc.-The whole number of newspapers and other periodicals published within the State 1s 119 , of which 73 are political, viz. : 39 whig and 36 democratic, and 43 are devoted to literature, science, religion, etc.; and 10 are published daily, 4 tri-weekly, 94 weekly, and 11 at other perious. The daily papers have an aggregate average 
cireulation of 3.580 copies, the tri-weekly of 1,650 enpies, the weekly of 69,472 enpies, and those published at other porion of 14,625 copies. Of the eleven periodicals published at other periods, as above, 2 are semi-monthlies, 7 monthlies, 1 quarterly, and one is issued eight times a year.

Religions Denominations, - The statistics of the several religious denominations in 1850 are exhibited in the following table:

\begin{tabular}{|c|c|c|c|c|c|c|c|c|}
\hline $\begin{array}{l}\text { Denmmina- No. of } \\
\text { ticus. Churches. }\end{array}$ & $\begin{array}{l}\text { Clinrch } \\
\text { accom. }\end{array}$ & $\begin{array}{l}\text { Value of } \\
\text { Eroperty. }\end{array}$ & $\begin{array}{l}\text { Denomina. No. of } \\
\text { tions. Churclies }\end{array}$ & $\begin{array}{l}\text { Church } \\
\text { accoun. }\end{array}$ & $\begin{array}{l}\text { Value of } \\
\text { Froperty. }\end{array}$ & $\begin{array}{l}\text { Denomilas- } \\
\text { No of } \\
\text { tiuns. }\end{array}$ & $\begin{array}{l}\text { Cliurrh } \\
\text { aceorn. }\end{array}$ & 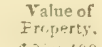 \\
\hline aptist......265 .. & 91,620 . & $\$ 204,095$ & German Ref. 2 . & 150 . & $\$ 310$ & R. Catbolic.. 5S .. & 29,000 & 40 \\
\hline ristian.... $67 \ldots$ & $30,754 \ldots$ & 42,950 & Jewish ...... - & 一 & - & Swedenbor'n. 1 & 140 & \\
\hline gat'l. 46 & $15,576 \ldots$ & 89,250 & Lutheran.... 40 & 16,440 & 40,120 & Tunker...... 4.. & 1,225 & \\
\hline ef. & $875 \ldots$ & 2,700 & Mennonite... - & - & - & $31 .$. & 8,875 & 32, \\
\hline copal & 14,000 & 78,850 & Methodist....3s9 & 6,474 & 327,290 & Unitarian & 1.500 & \\
\hline$\ldots 2 \ldots$ & $750 \ldots$ & 6,400 & Moravian.... 2 & 400 & 350 & Universalist. 4 .. & 1,300 & 11,4 \\
\hline iends ..... 6 . & 1,550 & 2,840 & Presbyterian.198 & 81,529 & 895,130 & Minor Sects.. 17 .. & 6,890 & \\
\hline
\end{tabular}

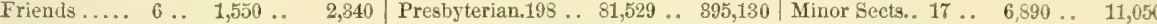

Making a total of 1,167 churches, having accommodation for 636,475 persons, and valued at $\$ 1,476,335$. The State constitutes the Protestant Episcopal diocese of Illinois and the Roman Catholic diocese of Chicago.

Pauperism, -The whole number of paupers who received support within the year ending June 1st, 1850, was 797 , of which number 376 were native born and 411 foreign; and at the date specified the number of paupers on the list.was 434 , of which 279 were native and 155 foreign born. The cost of supporting these had been during the year $\$ 45,213$.

Historical Sketch.-The name which now pertains exclusively to this State was, during a great part of the last century, bestowed upon all that rast country which lies north-west of the Ohio, and was derived from the River Illinois, which in the indigenous langunge signifies the River of Men. The first settlements were made by the French, and were the consequence of the enterprise of La Salle in search of the Mississippi. This traveler set out from Canada in 1670, and passing across the lakes to Michigan, descended the Illinois River. After examining the country, with which he was greatly pleased, he returned to Canada, leaving Chev. de Tonte in command of a small fort he had built and named Crêvecoeur. While in Canada he procured a number of volunteers to unite in the scheme of forming a settlement on the Mississippi in the Illinois country. They reached their destination in 1678, and founded the villages of Kaskaskia, Caholia, and several others of less note; here La Salle left his colony, while he descended the Mississippi to its mouth. Soon after this settlement, many enterprising persons explored the country in search of mineral wealth, and after the establishment of a colony at the mouth of the Mississippi, Iberville, the French governor, in company with others, undertook a similar expedition. At the beginning of the eighteenth century the settlements in Illinois are represented to have been in a flourishing condition. Kaskaskia had become a considerable town before any great progress had been made in the settlements on the Lower Mississippi; and one who calculated the future by what the present exhibited would have seeu little reason to foretell the rapid growth of Louisiana and the decline of Illinois, which afterward occurred. The descriptions given of Illinois by French writers were of the most captivating kind-its beautiful scenery, its fertile prairies, ils supposed (now realized) mineral wealth, were painted in glowing colors, and a new paradise was opened to Frenchmen on the banks of the Illinois; and to add to the attractions of the country, a monastery of Jesuits was established at Kaskaskia; the settlers, however, soon degenerated, and assimilated by degrees their manners to those of the Indians among whom they resided. Of these savages, their number and varieties, at the epoch of the first settlements, and soil, are not well ascertained. From the beginning to the middle of the 18th century, we hear little of the settlers; as the colonies of France and England extended, disontes arose respecting the boundaries, which had never been sufficiently defined. The French, anticipating a struggle for the preservation of their American possessions as early as 1749 , strengthened themselves by Eortifications on the lakes, on the Ohio, the Wabash, and Illinois, and in other parts of the Valley of the Mississippi, to which they laid claim. The British, on the other hand, claimed the country on the Ohio and the neighboring streams by virtue of the charters they had granted. The Ohio Company, which was formed soon after, produced hostilities hetween the two aations. At the elose of the war, which gave to Britain the province of Canada, the whole of the French claim to the Ilinois country was also ceded to Great Britain. During its continuance as a British dependency, nothing of importance seems to have occurred. Few or no additions were made to the settlements at Kaskaskia and the other French ports, the inhabitants of which were but little removed in seale of civilization above the Indians. At the peace of 1783, the Illinois country fell to the United States, and the whole territory, north-west of the Ohio River, was claimed by Virginia and other States as included in their charters. At the instance of Congress, a liberal cession of these claims was made to the General Government, and by the ordinance of 1781 a territorial government was establishcd over the whole region. Ohio was made a separate territory in 1799 , and in 1802 was admitted into the Union as a State, while the 5 cmainder of the territory retained its territorial attributes under the name of Indiana. In 1809 this territory was again divided, the eastern portion retaining the name of Indiana, and the western taking that of Illinois. Indiana was admitted ats a State in 1516, and Illinois, within its present limits, in 151s, since which period the progress of the country in popufation, general industry and wenlth, has been still onward, and at the present day it has grander works of internal improvement than many of the States that at the era of the Revolution were flourishing and populous communities.

SPRINGriden is the politieal capital of the State, and has been such since 1840. Kaskaskia and Vandalia were successively the metropolitan cities.

Irtixo:s Citr, p. v., Rock Island co., Ill.: $2 \mathrm{~m}$. frou the : Srissibsuni $x$; ; $12.4 \mathrm{~m}$ N. N. WT. Springfietd.

Illiwors river, Ind. Ter: : an affluent of the Arkansas. It rises in Benton and Tashington counties, $A r k$, anu after receiving several tributaries in its course, falls into Arkansas $\overrightarrow{\mathrm{z}}$.. about $\mathrm{m}$. above the confluence of Canadian $\mathrm{r}$. Along its lower course there are numerous salt springs.

Iliswas river, IZl.: one of the largest affluents of the Mississippi $\mathbf{r}$. It is formed by the union of Des Plaines and Kankakee rivers, which onme together at Kankakee village. The Thex Pluines rises in $W$ ixennsin, a few miles above the foundiry of Illinois, and ubrut $6 \mathrm{~m}$. from Lake Michigan.
It runs a $\mathrm{S}$. course orer a bed of limestone, and through a fertile country. Groves of timber are found on its banks, and are interspersed through the vast prairie region. In many places along its banks rock is abundant, and in some measure comapensates the comparative seareity of timber for buildings and fences. This $r$. is frequently written $A u x$ Plaines or O'Plane. The Kankakee rises in the N. part of Indiana, near the $S$, bend of St. Joseph's $r$, and runs a westerly course into Illinois, where it receives the Iroquois, and forms a junction with the Des Plaines in section 85 , township $34 \mathrm{~N}$., and range $\mathrm{S} \mathrm{E}$. from the third principal meridian. If ere is a large body of fine timber. but along 
the river itself there is very little. It is a rapid stream, and runs through a limestone bed. (See Kankanee r.) The Illinois, formed by these two main constituents, is the largest navigable river within the State. From the junction it runs nearly a W. course for part of the distance over the Grand Rapids to Ottowa, at the mouth of Fox r., receiving Au Sable from the $\mathrm{N}$. and Little cr., or Mazon, from the $\mathrm{S}$. Along this line, and especially at Marseilles, there is immense water-power, but no convenient navigation. The canal runs on the $N$. side, parallel with its bank. At Ottowa the $r$, is deep, and there is a convenient basin harbor for large steamboats, which ascend to this point in a high stage of the waters. The Lower Rapids, at a low stage of water, however, interrupt navigation between Ottowa and La Salle, where the Illinois and Michigan Canal terminates. The junction of the canal with the r., where have been constructed commodious basins for both eanal and steamboats, and it being the crossing place of the Central R. R., makes La Salle a business place of pre-eminent importance to the State. A short distance above, the Illinois receives Vermillion $x$, from the $S$, and Little Vermillion from the $N_{\text {., }}$ and about $6 \mathrm{~m}$. above Hennepin it curves to the S., and then to the $\mathrm{S}$. W., receiving Bureau and several smaller streams, and then expands into the beautiful sheet of water known as Peoria Lake. Three miles below Peoria the Illinois receives the Kickapoo cr. from the $N$., and the same distance below Pekin comes in Mackinaw from the W. Copperas er. enters from the E. part of Fulton co., where for many miles the $W$. bank of the $\mathbf{r}$. below the bluffs is a low, swampy region, interspersed with strips of land elevated above high water, the most conspicuous of which is Bailey's Island, or Liverpool, handsomely situated above the highest flood. Near Havanna, on the E. side, is a lagoon or slough, which in former times was frequently mistaken for the main stream, and directly opposite that village Spoon r. comes in from the $\mathbb{N}$. E. Pursuing the course of the $\mathbf{r}$. downward the mouth of Otter cr., from the W., is passed, and one or two other trifling streams, and at the N. W. corner of Cass co. the Sangamon $r$. flows in. Sugar cr, eomes in from the W., near the bluffs of which is located Schuyler City. Six miles below Beardstown, Crook cr. enters from the W., and a few miles farther down, Indian er., which loses itself in the inundated bottoms before its waters enter the Illinois. M.Kee's cr., from the W., enters the Illinois $2 \mathrm{~m}$. below Naples, and $2 \mathrm{~m}$. below that, from the E., the Mauvaise Terre. Passing Big and Little Blue rivers, two maguificent streams from the W., the Sandy, from the S. W. part of Scott co, enters the r. Macoupin cr., Otter, Raccoor, and other creeks, enter the r. farther down. At Naples the Illinois tarns to a more southerly course, which it pursues till within $6 \mathrm{~m}$. of the Mississippi, where it bends to the S. E., and finally to an E. course, where its waters unite with that river behind a cluster of islands. The parting of the channels of the Mississippi and rllinois rivers for steamboat navigation is at Grafton, $2 \mathrm{~m}$. below its mouth.

ImL.iystown, p. v., Monmuuth co., N. Jer.

INOEPENDENCE county, $A \gamma k$. Situate N. E. centrally, and contains 1,007 sq. m. Big Black $r$. bounds it on the $\mathrm{E}_{\text {., }}$ and White $\mathbf{r}$. flows through from W. to E., and their affuents drain it. Surface mostly rolling. and soil highly productive.
Cotton and tobacco are grown, but it is best adapted to grain and grass, which yield finely, and feed many cattle and hogs. On the rivers are the best of ash and cypress forests. Farms 694; manuf. 10; dwell. 1,159, and popwh. 6,927 , fr. col. 12 , sl. 828-total 7,767. Capitat: Batesville.

INDEPENDENCE, p. v., Warren co., Ind. : on the W. side of Wabash r., $63 \mathrm{~m}$. N. W. Indianapolis. A plank-road runs hence to Oxford, Benton co.

INDEPENDENCE, p. O., Grayson co., Firg. : 217 m.W. S.W Richmond,

INDEPENDENCE, p. v, and cap. Kenton $c 0_{\text {, }}, K_{y}$ : $51 \mathrm{~m}$. N. N. E. Frankfort. It contains a court-house, jail, several stores, and about 30 dwellings. It is $10 \mathrm{~m}$. from Covington. Pop. 250.

INDEPENDENCE, p. v., and cap. Jackson co., Mo.: about $4 \mathrm{~m}$. S. of Missouri r., and $129 \mathrm{~m}$. W. by N. Jefferson City. It has a court-house, jail, ete., several extensive stores, and about 800 inhabitants. There are two newspapers published here, the "Missouri Commonwealth," issued semi-weekly, and "Occidental Messenger," weekly. This is a great rendezvous of overland emigration to the Pacifle, and a point through which the Pacific R. R. will be carried. It business, which is immense, is chiefly connected with emigration, and here many of the emigrants obtain the bulk of their supplies. It has also some Indian trade.

INDEPENDENCE, t. and p. v., Alleghany co., N.Y.: $203 \mathrm{~m}$. W. by S. Albany. Drained by Independence and Cryder's creeks, heads of Genesee river. Surface elerated and rolling; soil clayey loam, and superior for grass-growing. A farming t., which makes some woolen goods. In the v. are several stores and mills. Pop. of t. 1,701.

INDEPENDENCE, t. and p. o., Cuyahoga co., Ohio: $117 \mathrm{~m}$. N. E. by N. Columbus. Drained by the Cuyahoga and its branches. Surface diversified; soils rich and fertile. The Ohio Canal passes through the v., about $9 \mathrm{~m}$. S. Cleveland. Pop. 1,455 .

INDEPANDENCE, sta., Richland Co., Ohio: on the Sandusky, Mansfield, and Newark R. R., $76 \mathrm{~m}$. from Sandusky, and 41 from Newark.

IXDEPENDENCE, p. v., Washington co., Penn.: $173 \mathrm{~m}$. T. Harrisburg.

INDEPENDENCE, p. o, Autauga county, $A l \alpha .: 23 \mathrm{~m}$. N.W. Montgomery.

INDEPENDENCE, p. $\mathrm{v}$., Washington $\mathrm{con}$, Tex. : about $8 \mathrm{~m}$. W. of Brazos r., 81 m. E. Austin City. It has a high situation in $\mathrm{La}$ Bahia prairie, $10 \mathrm{~m}$. from Washington, with extensive berds of coal in its ricinity.

INDHPBNDENCE, p. O., M.Lean county, $I l l .: 76 \mathrm{~m}$. N. E. Springfield.

INDFPENDENCE, p. Y., and cap. Buchanan Co., I $\%$.: on the E. side of Wabsipinicon r., $59 \mathrm{~m}$. N. N. E. Iowa City. It has a court-house, etc., and about 30 dwellings.

IndePendenoe HiL, p. o., Prince William co., Virg.: 81 m. N. Riehmond.

INDEPENDENCE river, $N_{0} \bar{Y}_{0}:$ an affuent of Black $r$. It rises in Hamilton co., and flows W. to its confluence with the Black, about $2 \mathrm{~m}$. E. of Martinsburg.

IxDESviLLE, p. v., Surry co., N. Car.: 127 m. W. N. W. Raluigh.

\section{THE STATE OF INDIANA.}

INDLAXA lies in the form of a parallelogram between Ohio and Illinois, and extends from Michigan, on the north, to the Ohio River, on the south. Geographically, it is situated between the latitudes $37^{\circ} 51^{\prime}$ and $41^{\circ} 46^{\prime}$ north, and between the Iongitudes $85^{\circ} 49^{\prime} 30^{\prime \prime}$ and $88^{\circ} 2^{\prime} 30^{\prime \prime}$ west from Greenwich, or $8047^{\prime} 30^{\prime \prime}$ and $110^{\circ} 0^{\prime} 30^{\prime \prime}$ from Washington. Its extreme length from north to south is 276 miles, and its greatest width 176 miles; but its average length is only about

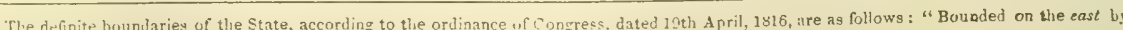
the the river Obio. from the month of the Great Miami to the mouth of the river Wabash; on the west by a line drawn along the midale of the Wabas. from its mouth to a point where a due north line, drawn from the town of Vincennes, would last touch the north-western sliore of the said river, and from thence by a due north line untit the same shall intersect an east and weat line dratwn through a point ten miles north of the soutlieru extreme of I.ake Michigan; on the north by the said east and west line, "etc,, to beginning 
242 miles, and its average breadth not more than 153 miles; and within these limits the area of its superficics is 38,809 square miles.

The general features of Indiana are those which pertain to all countries where mountain, in the strict sense of the word, is wanting; for if we except the river-hills and the accumulations of sand on the southern shore of Lake Michigan, no portion of the country has any continuous or definite elevation which even a forid imagination could dignify by such a term, and all of mountain that really appears is a few isolated "knobs," which serve only to diversify the scenery. Nearly two-thirds of the State is level, or at most, undulating, and a most singular feature of the country is the absence of any watershed or dividing ridge, such as almost every geographical region presents, from which the waters flow in different directions; still, however, the country has continuous slopes of great extent, and the difference in elevation of the highest land and the Ohio River at the Falls is nearly 600 feet, and a considerable difference is observed (about 70 feet) between the levels on the Ohio, at the Falls, and at the mouth of the Wabash, the latter being the lowest.

The river-hills, of which previous mention has been made, extend at various distances from, and parallel to, the conrses of the Ohio and other streams, and inclose what are termed the bottom-lands, which are chiefly covered with a rich alluvial soil, and thickly set with forests. These hills, along the Ohio River, are generally as high as the highest levels of the interior, often of a rugged and broken aspect, and where torn through by the tributaries of the Ohio, present much imposing scenery. Behind these a table-land spreads out and forms what with propriety may be termed the interior of the country; and now every thing is changed. Instead of the bottoms, with their mighty forests, the most various landscape appears; here are extensive groves of oak, ash, and other trees-there vast prairies, sea-like in their dimensions, and with untroubled surface; here the land undulates or rolls, as if formed into billows, by the dalliance of sofn winds, and oceasionally hills, rising from 100 to 300 feet high, remind us of a tempest-tossed sea, when the wares aceumulate in their might. There is such a marked difference between the several parts of the country, however, that no general description could embrace its topography, and hence it is necessary to detail its principal characteristics and its divisions as indicated by nature. 1. The Ohio Valley, including that of the White Water, contains some 5,000 square miles. This is a limestone region; it was originally clothed with heavy forests; and the soil in the bottoms, hill-tops, and sides is very rich. The hills are abrupt and broken, and the numerous tributaries of the Ohio River break through them in every direction. Many of these streams in dry weather show only the marks where the torrents have disappeared almost as soon as the storms which occasioned them. Of this division of the State, about two-thirds is good farming land, and the residue either too hilly or the soil too poor for profitable culture. The poorest part is in the flats at the heads of the streams. 2. The White River Valley extends from the Wabash centrally through the State to the Ohio line, and covers about 9,000 square miles of surface. It is almost uniformly level and heavily timbered, except in the western parts, where there are some prairies and barrens, and ranges of low rugged hills. The whole valley is destitute of rock, and the soils are of the richest kind, with little that is unprofitable. Most of the streams are clear and never-failing, and water-power is generally abundant. 3. The Wabash Valley is the largest division, and embraces an area of upward of 12,000 square miles. It interlocks with the valley of the White River, and the eastern portion resembles it. It is equally fertile, but more broken. The middle part of the valley has abundant water-power, but in the upper and lower parts it is less plentiful. From the river-hills, on the Ohio, to the Wabash, the surface is an inclined plane, and it is not a little curious to find streams, the head waters of which are near the borders of the Ohio Valley, traversing toward the Wabash, a river so much farther distant from their sources. 4. The north part of the State, watered by the St. Joseph's and the Kankakee, is much similar in its general character to the Wabash country, but is, perhaps, more swampy, and uear the lake the country has extensive sand-hills, which are covered only with stunted and shriveled pines and burr-oaks.

Indiana has numerous fine rivers, but for navigable purposes few of them except the Ohio, Wabash, White, etc., are at all eligible; most of them, however, afford valuable water-power. The Ohio, the final reservoir of the principal watercourses of the State, borders the whole country on the south, from the mouth of the Miami to that of the Wabash, a distance, by the river's course, of 380 miles. Between these two points few streams of any volume empty into it, and none exceed 30 or 40 yards in width at their mouths. Laughery, Indian Kentucky, Sirver, Indian, Blue, Anderson, Big Pigeon, Little Pigeon, etc., are the principal. The White Water joins the Miami six miles above its entrance into the Ohio. The Wabash, which rises in Ohio, runs first north, then north-west, then west, then south-west, then south, and again southwest, making the whole distance to its junction with the ohio, upward of 600 miles, of which more than one half is navigable. Its principal tributaries are: from the south and east, the Salamonie, Mississinewa, Wild Cat, Sugar or Rock, Raccoon, White, and Patoka rivers; and from the west and north, Little Wabash and Embarras rivers in Itinois, Termillion in both States, and in Indiana altogether, Tippecanoe, Eel, and Little rivers. White River, the most important of these, empties into the Wabash, 100 miles above its mouth; the West Fork, its longest branch, rises in Randolph County, near the Ohio line, and runs in a south-west direction, receiving in its course Eel River, Fall Creek, ete. ; and the East Fork, the principal tributaries of which are Salt Creek, the Muscatatuck, Sand Creek, Clifty, Flat Rock, and Sugar creeks, rises in Ripley County, and has a western course to its junction with the West Fork-the two forming White River proper-about fffty miles from its entrance into the Wabash. The St. Joseph's and St. Mary's form the Marmee, which passes to Ohio and Lake Erie. Another St. Joseph's and its tributaries, the Elkhart, etc., pass through the northern tier of counties, and ultimately fall into Lake Michigan. The Kankakee, the principal branch of the Illinois River, rises near South Bend, and runs sluggishly through the north-western counties for 100 miles, and in its course receives Yellow River, a stream about 50 miles long; extensive marshes everywhere bound its course. Deep and Calumic rivers lie near and south of Lake Michigan, and in some places are only soparated from it by banks of sand. The Iroquois or Pickamink rises south of the Kankakee, and runs nearly parallel to it for 50 miles, and joins it in Illinois.

Besides Lake Michigan, on the northern border, there are numerous other but small lakes in different parts of the State, principally to the north of the Wabash River. Several of them have no outlets; they are generally clear, howevers and have sandy shores and bottoms, They seldom exceed a few acres in extent, though some at the head of Tippecanoe Iiver and Turkey Creek, and near La Porte, cover several hundred acres. Mexancukkee Lake, a beautiful sheet of water, in Marshall County, is three miles long and half as broad; and Beaver Lake, six miles long and three miles wide, covers 10,000 acres. All these lakes abound in fish, and form in the surrounding scene objects which attract the gaze of the traveler.

The concluding chapter of the Peport of D. D. Owen on the Geology of Indiana, thus sums up the results of his reconnoissance on that topic: "Three geolrgical formalions exist in Indiana. 1st, a bituminous coal formation, occupying that portion of the State west of the second principal meridian; $2 \mathrm{~d}$, a limestone formation (similar to the mountain limestone of European geologists), prevailing in the counties east of that meridian; 3d, a diluvium, consisting of deposits of clay, 
sand, gravel, and boulders, overlying, and in many places covering up, the two other formations to a greater or less de yth, particularly in the northern part of the State. Now, as in this country no perfect seams of bituminous cual are fuund associated with calcareous deposits, similur to those of Middle and Eastern Indiana, the geologist can conficently predict that it is a waste of time and labor to search for coal in any part of the State east of this second meridian-for instance, as has been done in the neighborhood of the black bituminous aluminous slate, stretching north in a narrow band, commencing at New Albany, in Floyd County, and extending through part of Clarke, Scott, Jenninga, Bartholomew, Decatur, and probably beneath the diluvium in a northerly direction toward Elkhart. If we were to speculate, from geological observations, on the future condition of Indiana, we should say that the western counties are destined to become one day the chief manufacturing counties; since, with a few exceptions, all large manufacturing towns and districts are situated on the coal formation. The freestones of this formation being soft and fissile, owing to the existence of mica disseminated in layers through their substance, and to the ferruginous cement which unites their particles, being liable to undergo alterations by the action of the atmosphere upon it, a careful selection by the builder is always necessary. In several places, particularly toward the base of the formation, or near its eastern boundary, as at Attica, Williamsport, on Pine Creek, and near the French Lick, with a little care, freestone, white and fine grained, and excellently suited for architectural purposes, may be readily obtained. In character and geographical position it resembles the celebrated Seotch freestone, of which the new town of Edinburgh, and a portion of the town of Glasgow are built. At New Harmony there is a quarry of freestone, yielding roek that has stood the test of twenty years, yet it is by no means equal to the strata above alluded to in our eastern counties. A freestone of a very fine grain and white color is quarried at the French Lick, west of Paoli; it is manufactured into whetstones, that answer admirably for putting a fine edge on tools, and for polishing; they are exported to all parts of the United States. Good grindstones are also manufactured from a similar stratum of these freestones, of a coarser grain. The eastern boundary or base of the coal formation is the most likely place to afford salt water; for we find the most productive salt wells throughout the Western country occupying in the inferior members of the coal formation. Thus, should symptoms of salt water make their appearance in the counties of Perry, Spencer, Dubois, Martin, Daviess, Greene, Owen, Clay, Putnam, Montgomery, or Tippecanoe, the encouragement to make a search would be greater than if found elsewhere in the State. Salt, however, is not, strictly speaking, constant in its geological position. In Europe it usually occurs in the new red sandstone, a formation higher and of more recent origin than the bituminous coal formation; while on the Holston, a tributary of the Tennessee River, there is a fine salt deposit, surrounded by gypsum or plaster of Paris, lying on the grauwacke formation. Two or three salt wells have been sunk in the knobs east of Bloomington, through the silicious beds belonging to the sub-carboniferous group. The salt is of excellent quality; but the water has hitherto proved too weak to afford a fair profit. The boring after salt is, in truth, at all times attended with considerable uncertainty. Quantities of argillaceous iron ore-from which in Great Britain 600,000 tons of jron are annually obtained-oceur in some of the clay slates of the bituminous coal formation of Indiana. Some of the clay slates answer well for fire-brick; that now excavated near Troy is to be manufactured into fire-brick for sale-an important article of commerce in a country where steam-engines are so extensively used, and indispensable where furnace operations are carried on to any extent. Some of our clays in the coal formation answer well for the manufacturing of stone-ware and gray pottery-ware: such wares are now manufactured from them at Troy. Since I first called the attention of the proprietors to the deposit of the hydrated brown oxide of iron, near the Falls of Eel River, examinations have been made by digging in four or five different places; ore has been struck in all of them; many tons have been thrown up, and the prospects are so encouraging that the proprietors of the Falls are now endeavoring to form a company, to erect a furnace, and commence, on an extensive scale, smelting the ore. Sandstone being the predominating rock in the coal formation, and the greatest part of the soil of those western counties being formed from its disintegration, we find it generally of a sandy character. The dip and position of the various beds belonging to coal measures are generally constant, unless where, from the protrusions of basalt or greenstone, those volcanic disturbances, called by the miners 'fautts,' 'troubles,' or ' dykes,' have disturbed the regularity of position. If, then, the general dip and order of succession of the strata can be ascertained, and these should appear to be free from faults or material undulation, a pretty correct estimate might be formed of the depth of the various seams of eoal and other strata in different parts of the coal-fields of Indiana. Most of the limestones in the oolitic series-that is, those occurring in the counties of Crawford, Orange, Lawrence, Monroe, Owen, and Putnam-make good building materials. The encrinital limestones in Harrison, Washington, Jackson, Bartholomew, and Morgan counties, are also very suitable for that purpose; but the silicious strata, or sand rocks, in these counties, are generally soft and crumbling, and by no means durable. The only use that the black bituminous aluminous slate, occurring in the sub-carboniferous group, can be put to, is for the manufacture of alum. The sub-carboniferous group affords a water-lime, which appears to be a compound chiefly of limestone and clay, with some bituminous matter. It is associated with the black bituminous aluminous slate above mentioned. Some of the limestone in its neighborhood-for instance, those rocks which are excavated at the top of the hill behind Madison-contain green earth, and some are impregnated with bitumen and sulphuret of iron. In making a selection of building materials in such strata, care should be taken not to use any such unless their durability has been well tested, for they are generally liable to decay. The fossiliferous limestones of East Indiana, namely, those found in Jefferson, Switzerland, Dearborn, Ripley, Franklin, Fayette, and Union counties, are durable rocks, and some of them make beautiful marbles. The sub-carboniferous formation of Indiana is identical with the formation occurring in Middle Tennessee, in which the enormous deposits of the hydrated brown oxide of iron, constituting so much of the mineral wealth of that State, are found. The deposits of this kind of ore in Indiana, however, although found in the same formation, are not associated with exactly the same strata. In Tennessee they are in the silicious strata, just above the encrinital limestone: those at present discovered in Indiana are either resting on the oolitic series of limestone, or near the bituminous aluminous slate. The soil in Crawford, Lawrence, Orange, Monroe, Owen, and Putnam counties, being formed chiefly from the oolitic limestones, has a calcareous character, and is admirably adapted for the growth of grasses. Clay will be found to predominate in the soil of the counties of Floyd, Clark, Scott, Jennings, and parts of Bartholomew, Decatur, Shelby, Johnson, Marion, and Hancock, because the soil of these counties is underlayed by clay slates. Hence we find the beech-tree, which delights in a clayey soil, there growing luxuriantly. The soil of Jefferson, Switzerland, Dearborn, Ripley, Franklin, Fayette, Union, and parts of Decatur and Rush, being formed upon alternating strata of clay and limestone, must partake chiefly of these two earths. This soil is also well adapted to the growth of grasses. The soil of the north-western counties appears to be a siliceo-calcareuus sand, resting upon a clay bottom; this I conceive to be the reason why it is so much more productive than its external appearance promises. These points, however, I intend more fully to verify by analysis so soon as I can get samples 
INDIANA.

of all the various soils. As yet, my opinion has been formed chiefly from ocular observation, and reasoning from general principles. The water in the north-western counties is strongly impregnated with carbonic acid; this, acting as a solvent upon limestone and the protoxide of iron, dissolves them whenever it meets them in its passage to the surface. And thus we find these waters, often highly charged with these two ingredients, forming calcareous and chalybeate springs. As they lose very soon, by exposure to the air, the excess of carbonic acid, which acts as a solvent of these ingredients-and as iron is brought also by the same exposure to air to a higher degree of oxidation, and therefore to a more insoluble form-these two causes acting together, soon produce deposits of calcareous tufas and bog-iron ore, so frequently found in that country. The quantity of bog-iron ore is therefore continually on the increase. The greater part of Indiana must have been, at some period of the earth's history, covered by an ocean, for most of the fossils in the limestones are of a marine origin. None of the precious metals will ever be found in Indiana, unless in minute portions in boulders, or in small quantities in combination with other metals, because the primitive and grauwactic formations, in which alone productive mines of gold and silver ore occur, do not exist in Indiana. It is true that, in some rare instances, silver is found as a sulphuret and as red silver ore in such formations as exist in the Western country; but I have seen no symptoms of any such in our State. The same may be said of bismuth, tin ore, and native arsenic. The only metals which we need look for are iron, lead, antimony, manganese, zinc, cobalt, and possibly some varieties of copper and arsenic ores. It is not likely that anthracite coal will ever be found in Indiana, because that mineral is usually found in the primitive and grauwacke formations. Several detached pieees of native copper have been found in the State, one weighing five pounds; but, from the nature of the ore, its occurring in washed gravels, and only in isolated pieces, I have reason to believe that they do not originate in the State. I may add, that the Kupferschiefer of the German miners yields, at the mines of Mansfield, in. Thuringia, an abundant supply of copper ore. This copper slate, as found at the bottom of the new red sandstone forkation, which overlies the bituminous coal formation, and copper ores, have been found in the carbonifurous and mountain limestone'; there is, therefore, a possibility of discovering workable copper ore in the formations of Indiana. The fertility of the soil of Indiana is universally admitted, yet few are aware that it arises mainly from its geological position. It is well known to geologists that that soil is the most productive which has been derived from the destruction of the greatest variety of different rocks; for thus only is produced the due mixture of gravel, sand, clay, and limestone, necessary to form a good medium for the retention and transmission of nutritive fluids, be they liquid or æriform, to the roots of plants. Now, Indiana is situated near the middle of the Great Valley of north-western America, and far distant from the primitive range of mountains; and her soil is accordingly formed from the destruction of a vast variety of rocks, both crystalline and sedimentary, which have been minutely divided and intimately blended together by the action of air and water. It has all the elements, therefore, of extraordinary fertility."

The forests of Indiana contain all the trees natural to the soil and elimate of the whole central region of the United States; oaks and beech-trees, however, preponderate; they are found in almost every portion of the State, and probably count two-thirds of the whole number of its forest trees. Next in order are the sugar-tree, hickory, ash, walnut, poplar, elm, sycamore, cherry, hackberry, linden, coffee-tree, honey locust, and white maple, which are as widely diffused as the oak and beech. The black locust is abundant near the Ohio River, but is not found in the interior; the chestnut is only found in the neighborhood of the upper course of the east fork of White River; the pine is only found on the "knobs," near the Ohio, and on the sand-hills near Lake Michigan, while the tamarack is found only in the swamps of the Kankakee. The cypress, catalpa, and pecan, are chiefly found in the counties on both sides of the White River, below the junction of the forks; and cotton-wood is rare, except on the bottoms of the southern streams. Of the smaller trees and undergrowths, the principal are the dogwood, pawpaw, spear, plum, and thorn, and the persimmon and crabapple. Many of the forest trees attain magnificent dimensions, and in numerous instances the oak, sycamore, walnut, aud poplar have been found, measuring from five to seven feet in diameter, and more than 120 and 130 feet in height. The indigenous fruit trees found in Indiana comprise the wild plum, hawthorn, persimmon, pawpaw, wild chenry, mulberry, crab-apple, etc. These are found intermingling with forest trees, or bordering the prairies and barrens. Cranberries aro abundant in the north, and wild grapes, blackberries, gooseberries, and strawberries of excellent flavor grow spontaneously, and giving assurance that the corresponding domestic fruits can be cultivated with success. Walnuts, hickory nuts, and hazel nuts, are unusually abundant, and generally oak and beech mast is found in such quantities as to contribute lurgely both to feeding and fattening hogs.

Indiana is divided into 91 counties, the general statisties of which and the capitals of each in 1850 were as follows:

Counties, Dwell. Pop. Farms Manf. Capitals, Adams........1,002.. 5,797.. 574.. 11.. Decatur Allen .........3,097..16,919..1,300..127...Fort Wayne Bartholomew .2,149..12,428..1,249. . 49.. Columbus Benton ....... 180.. 1,144.. 149.. 0.. Oxford Blackford.... 514.. 2,860.. 306.. 6..Hartford Boone ........1,914..11,631..1,393.. 28..Lebanon Brown....... 790.. 4,846.. 535.. 5.. Nashville Carroll .......1,909..11,015..1,129.. 79..Delphi Cass..........1,863..11,021..1,134..108.. Logansport Clark ........2,757..15,828..1,048.. 88..Charlestown Clay ..........1,326.. 7,944.. 829.. 10...Bowling Green Clinton .......2,001..11,869..1,411.. 21..Frankfort Crawford .... 1,027. .6,524. 540.. 33.. Levenworth Daviess .......1,803..10,352..1.221.. 11... Washington Dearborn ... . 3,549 . .20,166 . 1,520 .. 72. Lawrenceburg Decatur......2,662..15,107..1,377.. 39..Greensburg De Kalb ......1,421.. 8,251.. 831.. 16. Auburn Delaware .....1,874..10,843..1,084.. 34.. Muncietown Dubois .......1,146..6,321.. 794.. 9..Jasper Elkhart......2,254,.12,690..1,226.. 70..Goshen Fayette .......1,818..10,217.. 956..116..Connersville Floyd ........2,448.,14,875.. 428..106.. New Albany
Counties. Dwell. Pop. Farms Manf. Capitals. Fountain......2,251..13,253..1,357..103..Covington Franklin.....3,286..17,968..1,739..121..Brookville Fulton ........1,085.. 5,982. . 777.. 13.. Rochester Gibson ......1,833..10,771...1,220.. 23...Princeton Grant........1,884..11,092..9900.. 52.. Marion Greene ......2,089..12,313..1,227.. 39..Bloomfield Hamilton ... . .2,159..12,684.. 1,261.. 16.. Noblesville Hancock ..... . 1,685. . 9,698..1,176.. 36. Greenfield Harrison ......2,645..15,286.. 1,650.. 19. . Corydon Hendricks. . . . 2,390 . 14,083. 1,444. .110.. Danville Henry ........3,064...17,605..1,666. 124..Newcastle Howard ...... 1,190.. 6,65\%,. 746.. 26...Kokomo Huntington ...1,356.. 7,850.. 782. . 32..Huntington Jackson.......1,956 ..11,047..1,173.. 18..Brownstown Jasper ... . . . . 592 . . 3,540. . 343.. 4.. Rensselaer Jay ..........1,179.. 7,047.. 876.. 9..Portland Jefferson ....4,092. .23,916..1,396..138...Madison Jennings......2,064..12,096..1,208.. 78. . Vernon Johnson . . . . .2,067. .12,101. .1,153. . 25. . Franklin Knox....... 1,969,.11,084. 961. 37. Vincennes Kosciusko . . . 1,783. . 10,243. .1,127. . 21. . Warsaw La Grange. ...1,479 . 8,387. 1,062. . 64. . La Grange 
INDIANA.

\begin{tabular}{|c|c|}
\hline 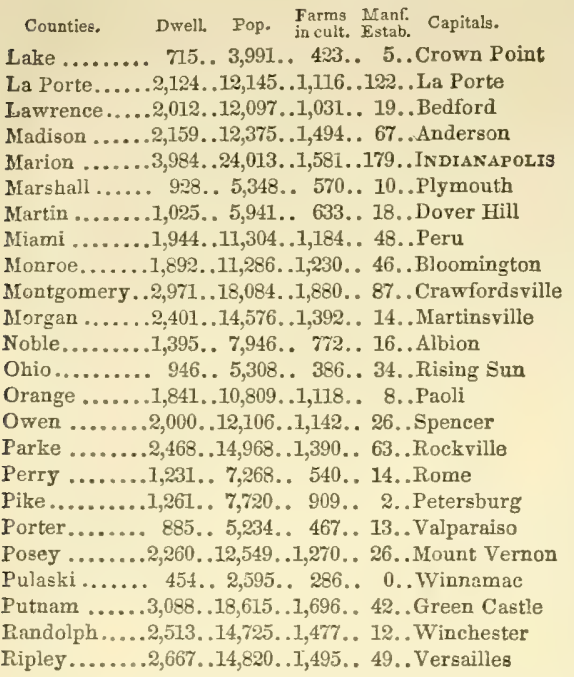 & 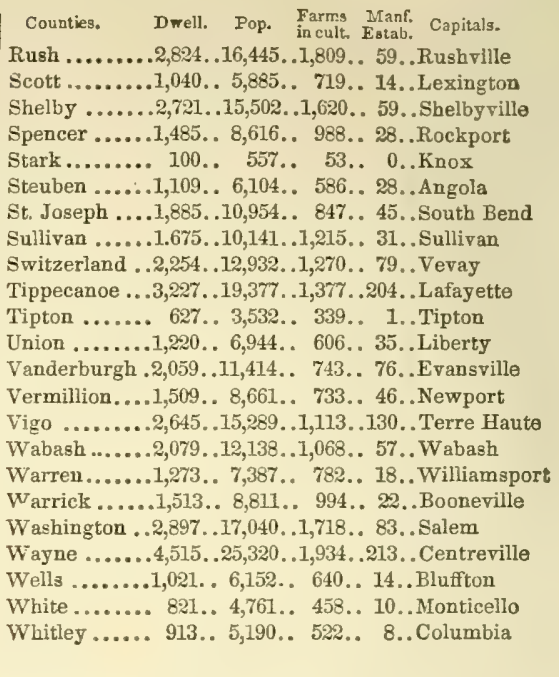 \\
\hline
\end{tabular}

The whole number of dwellings in the State was, at the above date, $170,17 \mathrm{~S}$; of families 171,564 , and of inhabitants 9S5,416, viz.: whites 977,605-males 506,400, and females 471,205; free col.10,755-males 5,472, and females 5,316. Of the whole population, there were deaf and dwmb-wh. 514, fr. col.4-total 51s; blind-wh. 340, fr. col. 9-total 349; insanewh. 569, fr. col. 10-total 579; and idiotic-wh. 906, fr. col.13-total 919. The number of froe persons born in the United States was 931.392 , the number of foreign birth 54,426 , and of birth unknown 2,598 ; the native population originated as follows: Maine 976, N. Hamp. 886, Verm. 3,1S3, Mass. 2,67s, R. I. 438, Conn. 2,455, N. York 24,310, N. Jer. 7,837, Penn. 41,245, Del. 2,737, Md. 10,177, Dist. of Col. 227, Virg. 41,819, N. Car. 33,175, S. Car. 4,069, Ga. 761, Flor. 21, Ala. 395, Miss. 2S7, La. 321, Tex, 44, Ark. 151, Tenn. 12,731, Ky. 68,651, Ohio 120,193, Mich. 1,\$17, Indiana 541,079, Ill. 4,173, Mo. 1,006, Ia. 407, Wisc. 99, Calif. 0, Territories 11 ; and the foreign population was composed of persons from-England 5,a50, IreIand 12,787, Scotland 1,341, Wales 169, Germany 28,584, France 2,279, Spain 3, Portugal 6, Belgium 86, Holland 43, Italy 6, Austria 17, Switzerland 724, Russia 6, Denmark 10, Norway 18, Sweden 16, Prussia 740, Asia 4, Africa 4, Brit. America 1,S7S, Mexico 31, Cent. America 0, S. America 4, West Indies 12, and other countries 108.

The following table will show the decennial progress of the population since the first census of the State taken by the United States authorities:

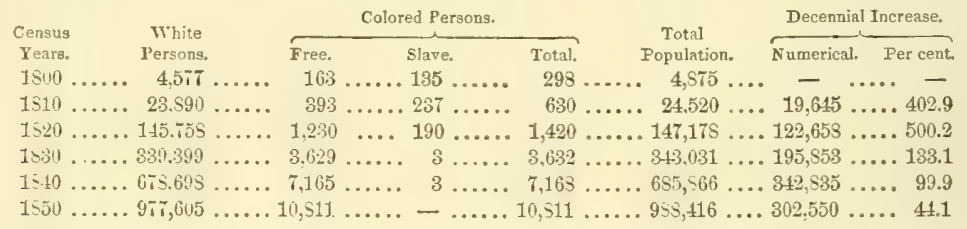

The statistical returns of the industry and wealth of Indiana, as furnished by the census of 1850 , and other official documents referring to that period, are as follows:

Occupied Lands, etc.-Improved lands 5,046,543 acres, and unimprored lands 7,746,579 acres-valued in cash at $\$ 136,355,173$. Number of farms under cultivation 93,896 . Value of farming implements and machinery $\$ 6,704,144$.

Live-Stock-Horses, 314,299 ; asses and mules, 6,599 ; milch cows, 234,554 ; working oxen, 40,221 ; other cattle 389,891 ; sheep, $1,122,493$; swine, $2,263,776$-total value of live-stock, $\$ 22,475,555$. In 1840 there were in the State 241,036 horses, mules, etc., 619,980 neat cattle of all descriptions, 675,952 sheep, 1,623,606 swine, etc.

Grain Crops.-Wheat, 6,214,453 bushels; rye, 7S,792 bushels; Indian corn, 52,964,363 bushels; oats, $5,655,014$ bushels;

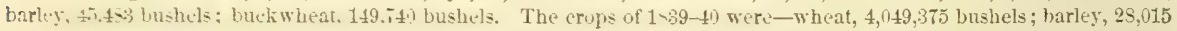
bushels; oats, 5,981,605 bushels; rye, 129,621 bushels; buckwheat, 49,019 bushels, and Indian corn, $25,155,887$ bushels.

Other Crops.-Tobacco, 1,044,620 pounds : ginned cotton, 14 bales of 400 pounds each; peas and beans, 35,773 bushels; potatoes-Irish, 2,0\$3,397, and sweet, 201,711 bushels; hay, 403,230 tons; elover-seed, 18,329 bushels; other grass-seed, 11.951 bushels; hops, 92,796 pounds; hemp-dew-rotted, 341 , and water-rotted, 1,071 tons; flax, 581,469 pounds; flaxBusd, $36,8 s 5$ bushels; maple sugar, $2,921,642$ pounds; molasses, 150,325 gallons; wine, 14,055 gallons, ete. The value of crchard prouluets was $\$ 324,94 \%$, and of market-garden products $\$ 72,564$. In comparing the principal erops of 1840 and 1550 , the following results are shown:

1810 .
Staples,
1850 .

Tobacco............... 1,820,306 pounds .... 1,011,62s pounds .... decr. $\quad 775,656$ pounds, or 42.61 per cent.

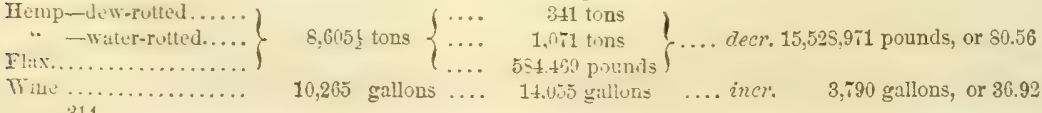


INDIANA.

Products of Animals.-Wool, 2,610,287 (in 1840, 1,237,919) pounds; butter, 12,8s1,585 pounds, and cheese, 624,564 pounds; and the value of animals slaughtered in the year had been $\$ 6,567,935$. Silk cocons were produced to the amount of 357 (in 1840, 379) pounds; and beeswax and boney to that of 935,329 pounds.

Home-made Manufactures for the year ending 30th June, 1850, were produced to the value of $\$ 1,631,039$.

Mun ufictures-Aggregate capital invested, $\$ 7,235,220$; value of raw material, fuel, etc., consumed, $\$ 6,229,113$; average number of hands employed, 27,312 -males, 24,137 , and females, 3,205 ; average monthly cost of labor, $\$ 600,000-$ male, $\$ 520,000$, and female, $\$ 50,000$-total value of products for the year, $\$ 19,199,651$. The whole number of manufacturing establishments in the State in 1850 , producing to the value of $\$ 500$ and upward, was 4,326 , and of these 2 were cotton factories, 83 woolen factories, 358 tanneries, and 19 iron manufactories, viz.: 14 for castings, 2 for pig iron, and 3 for wrought iron.

The cotton manufactures employ a capital of $\$ 43,000$; the cotton consumed during the year ending 1 st June, 1850 , was 675 bales; and the value of all raw material, fuel, etc., was $\$ 28,220$; average hands--males, 38 , and females, 57 ; monthly cost of labor-male, $\$ 495$, and female, $\$ 3 \$ 6$; entire value of products, among which were 300,000 pounds yarn, $\$ 44,200$.

The woolen manufactures had a capital of $\$ 171,545$, wool consumed, 413,350 pounds, and value of all raw material, fuel, ete., $\$ 120,486$; hands-males, 189 , and females, 57 ; monthly cost of labor-male, $\$ 4,122$, and female, $\$ 630$; products of the year, 285,500 yards of eloth and 104,000 pounds of yarn-valued at $\$ 205,802$.

In tanneries the capital employed, $\$ 514,897$; value of raw material, $\$ 405,838$; hands-male, 836 , and female, 2 monthly cost of labor-male, $\$ 15,199$, and female, $\$ 14$; products-skins, 57,070 , and sides of leather, $283,098-$ valued at $\$ 714,513$.

The condition of the iron manufactures is exhibited in the annexed tabular form:

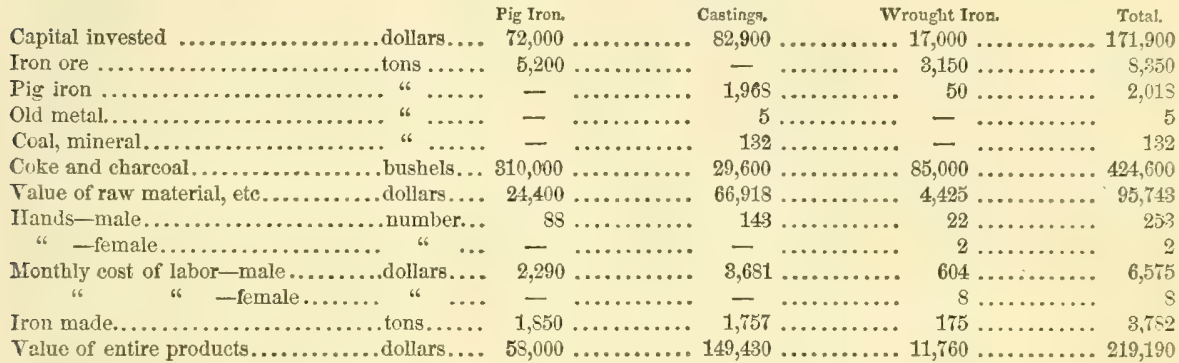

Indiana has also a large number of flour, grist, oil, saw, and other mills, asheries, etc., and the numerous trades and handicrafts, which constitute the aggregate of its manufacturing industry. Among its principal manufacturing plaecs may be named Madison, Indianapolis, New Albany, Cannelton, etc.-the last destined to become, at no distant day, the seat of a vast industry.

Inland Communication.-Indiana has no direct foreign commerce, but it has a vast domestic and inter-state trade by means of its navigable waters and magnificent systems of canals and railroads, and besides it is well supplied with plank, M:Adam, and other roads, which facilitate travel and transportation. The State has (January, 1853), within its borders 454 miles of canal and 929 miles of railroad completed. The canals are, the Wabash and Erie Canal, extending from Evansville, on the Ohio, to Toledo, on Lake Erie, 467 miles, of which 379 miles are in Indiana ; and the White Water Canal, extending from Lawrenceville, on the Ohio, via Cambridge, on the National Road, to Hagerstown, 75 miles. The principal railroads of the State eentre at Indianapolis, radiating in all directions, and forming links in the great national system which is rapidly springing into existence. There is also a large number of railroads in course of construction, the most important of which are, the Cincinnati and St. Louis Railroad, the Lawrenceburg and Upper Mississippi Railroad, the upper portions of the New Albany and Salem Railroad, and the Fort Wayne and Southern Railroad. These will be opened within a year or two, and there are others already projected that must be built within a very short space of time.

Brtuks, etc.-There are in Indiana 1 bank and 13 branch banks, the same being the State Bank of Indiana, at Indianapolis, and its several branches at Bedford, Evansville, Fort Wayne, Indianapolis, Lafayette, Lawrenceburg, Madison, Michigan City, New Albany, Richmond, South Bend, Terre Haute, and Vincennes. The aggregate condition of these institutions in November, 1850 , was as follows-liabritities: capital, $\$ 2,082,958$; circulation, $\$ 3,422,455$; deposits, $\$ 630,335$; due other banks, $\$ 112,175$; and assets-loans and discounts, $\$ 4,395,099$; real estate, $\$ 364,233$; other investments, $\$ 108,485$; due by other banks, $\$ \$ 15,062$; notes of other banks, $\$ 221, \$ 42$; specie, $\$ 1,197,830$. The constitutional provisions respecting banking in this State are: that no banks shall be established except under a general law, and the stockholuers shall be individually responsible for the debts of the corporation, in addition to their stock, to an amount equal thereto, and every bank must close banking operations within twenty years from its organization and promptly close its business. There are, besides the above-named banks, several others organized under the general banking law, but these have only lateły been established, and have not yet published any returns. Their circulating notes are secured by pledge of public stocks.

Government, etc.-The first constitution of Indiana is dated 29th June, 1816; the constitution on which the present State government is based was done in convention 10th February, 1851; ratified by the people 4th August, and went into operation 1st November of the same year. It provides as follows:

Every white male citizen of the United States, 21 years old, resident in the State six months next preceding an elcetion, and every white male of foreign birth, 21 years old, resident in the United States one year, and in the State six months next preceding an election, who shall have duly declared his intention to become a citizen of the United States, may vote. No negro or mulatto can vote. All elections by the people are by ballot, and all elections by the General Assembly riva roce. All general elections are held on the second Tuesday in October.

The: Generul Assembly consists of a Senate and HIouse of Representatives. The senate, not exceeding 50 members, and representatives, 100 members, are chosen in their respective districts-the former for four years (half every two years), 
INDIANA.

and the latter for two years. They must be citizens of the United States, residents of the State for the two years next preceding their election, and for one year of the district from which they are chosen. The sessions of the General Assembly are biennial, commeneing on the Thursday next after the first Monday of January; and no session ean be prolonged beyond sixty-one days, and no special session beyond forty days. Representation is apportioned according to a census of all white males over 21 years of age, taken every six years. "In all cases where a general law is applicable, general and not special laws shall be passed."

The Governor and Lieutenant-Governor are chosen for four years by a plurality of votes; they must be severally 30 years of age, and residents of the United States and of the State for the five years next preceding their election. The gubernatorial term commences on the second Monday of January. The Lieutenant-Governor is ext-officio President of the Senate; and in case of the removal or death of the Governor, he first, and after him such person as the General Assembly may appoint, shall act as Governor. The Governor is not eligible more than four years in any period of eight years. The Governor has power to grant pardons for all offenses, except in cases of treason and impeachment; and he may veto a bill, but, if afterward passed by a majority of those elected to each house of the General Assembly, it becomes a law nevertheless.

The administrative officers of the government are a Secretary of State, a State Auditor, and a State Treasurer, elected biennially by the people, and no one is eligible to either of these offices more than four out of any six years.

The officers elected by the people in each county are a Clerk of the Cireuit Court, an Auditor, a Recorder, a Treasurer, a Sheriff, a Coroner, and a Surveyor-the three first for four years and the others for two years, and none are eligible for more than two out of any three consecutive terms. All county officers must be residents for one year of the places from which they are chosen; and they and all town officers must reside in their precincts.

The Judiciary consists of a Supreme Court, Circuit Court, and Courts of Common Pleas, for the counties of Tippecanoe and Marion. These consist of not less than three nor more than five justices, chosen from districts by the people at large, for six years. At present it has three, of whom one is chief judge. A clerk of this court is chosen by the people for four years. The Supreme Court has appellate and such original jurisdiction as the General Assembly may confer. The State is divided into thirteen circuits, and each Circuit Court has a judge elected by the people of the circuit for six years, and he must reside therein. A prosecuting attorney is also elected for each circuit for two years. The Courts of Common Pleas for Tippecanoe and Marion counties are Special Courts, and have each one judge. Justices of peace are elected by the people of each township for four years. The Constitution provides, in this connection, for the establishment of tribunals of conciliation, the decisions of which are obligatory on those voluntarily submitting thereto; for commissioners to revise and simplify practice, and to ondify the laws; that any voter of good moral character may be admitted to practice law in all the courts of the State; that the Assembly may modify or abolish the Grand Jury system; that no person shall be an incompetent witness in consequence of his opinions on matters of religion; that in all criminal cases the juries may determine the law and the facts; that no man's property shall be taken without just compensation is first awarded and tendered.

Respecting colored people, it is provided that no negro or mulatto shall come into or settle in the State; all contracts made with such shall be void, and all persons employing them shall be punished by a fine of $\$ 10$ to $\$ 500$, and the proceeds of such fines shall be appropriated for the colonization of those negroes and mulattoes, and their descendants, in the State, at the adoption of the Constitution, and who are willing to emigrate.

Amendments to the Constitution are to be passed on by a majority of one Legislature, and referred to the next; and if passed by a like majority, then the amendments proposed are submitted to the people for ratification or rejection.

The militia of Indiana has not been reported to the U. S. authorities since 1332, since which period the population of the State has nearly trebled. At that time it consisted of 53,913 men of all grades and arms, and at present probably numbers 150,000 men.

Indiana has several benevolent institutions, among which the principal are the Asylum for the Deaf and Dumb, the Institution for the Blind, and the Hospital for the Insane at Indianapolis. At the Asylum all the Deaf and Dumb of the State, between the ages of 10 and 30 , are entitled to education without charge for board or tuition; and at the Institute the same privileges are granted, but except in extraordinary cases, applicants over 21 years of age are not admissable. The IIospital for the Insane, in the year ending 30th October, 1550 , admitted 58 ( 31 males and 27 females); 54 were discharged ( 26 males and 28 females); and at the end of the year 80 ( 40 males and 40 females) were left under treatment. This last institution was opened for the reception of patients (part of the buildings only being erected) in December, 184s. From that time to 30 th October, 1549 , there were 104 admitted, of whom 20 recovered, 4 improved, and 4 died, leaving 76 in the hospital, which, added to the 58 admitted in 1819-50, makes a total of 162 since the opening of the institution.

Finances, Delts, etc.-The balance in the Treasury on the 31 st October amounted to $\$ 428,94119$, and the receipts for the fiscal sear 1550 were $\$ 1,432,44278$ - total revenue $\$ 1,561,3 \$ 397$; and the expenditures for the same period amounted to $\$ 1,518,53404$, leaving a balance for future draft of $\$ 347,84993$. The chief sources of income are-permanent revenue, $\$ 455.630$; state prison, $\$ 11,145$; common school fund, $\$ 55,863$; university fund, $\$ 9,479$; bank tax, $\$ 1,984$; saline tax, $\$ 4.999$; Wabash and Erie Canal (by trustees), $\$ \$ 57,149$, etc. And the principal expenditures were on account of-Legislature, $\$ 31,010$; Executive, $\$ 5,578$; Judiciary, $\$ 19,706$; public printing, $\$ 11,522$; state prison, $\$ 3,606$; treasury notes cancelled, $\$ 141,575$; interest on treasury notes, $\$ 59,428$; interest on public debt, $\$ 188,595$; Wabash and Erie Canal (by trustees), $\$ 324,953$; deaf and dumb, $\$ 27,979 ;$ blind, $\$ 11,781$; insane, $\$ 32,501$; university fund, $\$ 14,382$; saline fund, $\$ \tau, 765 ;$ bank tax fund, $\$ 3,624$, ete.

Prior to 1847 the State owed on her foreign debt-principal $\$ 11,0 \pm 8,000$, and interest $\$ 3,326,640$-total $\$ 14,374,610$. In accordance with the acts of the Legislature of 19 th January, 1846, and 27th January, 1817, proposals were made to the bond holders that they should complete the Wabash and Erie Canal, and take the State's interest in it for one half this debt, and the State would issue new certificates for the other half, upon which she would pay interest at the rate of 4 per cent. per annum, until January, 1553 , and after that time 5 per cent., and issue certificates for one half the arrears of interest, upon which she would pay interest at the rate of $2 \frac{1}{2}$ per cent. per annum after January, 1S53. In this $2 \frac{1}{2}$ per cent. stock is also included 1 per cent. per annum upon the principal, which gives the holder of the old bond, when surrendered, 5 per cent, per anuum upon the new 5 per cent. stock, from the dividend day next preceding his surrender of the old bonds. On the 5th August, 1550 , there had been surrendered of the old bonds, and new certificates taken of principal $\$ 9,513,1(1)$, leaving then outstanling of her old bonds of principal, $\$ 1,730,72750$. The liabilities of the State and Canal, at the dato last mentioned, may be thus stated:

Stute Delst.--State's half principal of bonds surrendered, $\$ 4,751,500$; State's half interest on bonds with 1 per cent. of 316 
INDIANA.

principal with half of coupons added, $\$ 1,736,72750$-total foreign debt, $\$ 6,518,22750$. To which add domegtic debt $\$ 257,295$. Aggregate debt, $\$ 6,775,52250$.

Stute und Cunul Stock:-The amount of the several stocks iesued under the act for liquidating the public debt, up to 5 th August, 1550 , is as follows: 5 per cent. State stock, $\$ 4,731,500 ; 2$ t per cent. State stock, $\$ 1,736,72750 ; 5$ per cent. preferred Oanal stock, $\$ 4,079,500 ; 5$ per cent, deferred Canal stock, $\$ 702,000 ; 2 \frac{1}{2}$ per cent, special preferred Canal stock, $\$ 1,216,250 ; 2 \frac{1}{2}$ per cent. special deferred Canal stock, $\$ 207,400$-total stock issued to 5th August, $1850, \$ 12,723,37750$; of which amount deduct for 21 per cent. Stats stock redeemed, $\$ 20,000$, and the total outstanding is reduced to $\$ 12,708,3 \pi 750$. The State is paying interest only on the 5 per cent. State stock, at the rate of 4 per cent. ; after 1853 the rate will be 5 per cent.; and after 1853 also the $2 \frac{1}{2}$ per cent. State stock will draw interest at that rate. The remaining stocks are thrown upon the Canal, and their redemption, principal and interest, depends upon the receipts from the Canal, in accordance with the provisions of the acts heretofore referred to.

In $1839-40$ the State issued $\$ 1,500,000$ treasury notes to pay off her internal improvement liabilities, but these liaring been made receivable for all State dues, have now been almost all returned to the treasury. The State also issued bonds for the State Bank eapital, and treasury notes to pay the bank a debt which the State owed it. But these treasury notes were based upon a sinking fund belonging to the State, and held by the bank, which institution attends to the bonds issued for its capital, and also to the redemption of the notes based upon the sinking furad. The means held by the bauk are considered ample for these purposes.

The assessed value of personal and real estate in Indiana in 1850 was $\$ 152,870,399$, but the true or estimated value amounted to no less a sum than $\$ 202,650,264$.

Federal Representation.-Indiana, in accordance with the law apportioning federal representation, sends eleven representatives to Congress.

Religions Denominations.-The statisties of the several religious denominations in 1850 were as follows:

\begin{tabular}{|c|c|c|c|c|c|c|c|c|}
\hline $\begin{array}{cc}\text { Denomina. } & \text { No. of } \\
\text { tions. } & \text { Churclies. }\end{array}$ & $\begin{array}{l}\text { Church } \\
\text { accom. }\end{array}$ & $\begin{array}{l}\text { Value of } \\
\text { Property. }\end{array}$ & $\begin{array}{cc}\text { Denomina- } & \text { No. of } \\
\text { tions. } & \text { Churohes. }\end{array}$ & $\begin{array}{l}\text { Church } \\
\text { accom. }\end{array}$ & $\begin{array}{l}\text { Value of } \\
\text { Property. }\end{array}$ & $\begin{array}{cc}\text { Denomina- } & \text { No. of } \\
\text { tions. } & \text { "Clurches. }\end{array}$ & $\begin{array}{l}\text { Clurch } \\
\text { accom. }\end{array}$ & $\begin{array}{l}\text { Value n! } \\
\text { Property. }\end{array}$ \\
\hline Baptist... & 186,333 & $\$ 211,585$ & Jewish ..... - . & $-\ldots$ & $\$-$ & Tunker.... 5 .. & 3,000 & $\$ 8.1110$ \\
\hline Christian....182 .. & 64,266 . & 88,640 & Lutheran... 60 & $18,000 \ldots$ & 36,825 & Union ..... 5 & 1,250 & 2,350 \\
\hline Dutch Ref .. 4 .. & 1,025 & 1,650 & Methodist ...745 . & $256,872 \ldots$ & $4 S 2,460$ & Universalist.. 15 & 5,050 & 17,800 \\
\hline Episcopal .. 24 .. & 7,300 & 74,000 & Moravian.... 53 .. & $17,400 \ldots$ & 20,800 & Minor Sects . 12 & 2,822 & 4,025 \\
\hline Free....... 10 & 2,750 & 5,700 & Presbyterian 267 .. & $103,432 \ldots$ & 324,170 & & & \\
\hline
\end{tabular}

Friends .... $85,43,015$

German Ref, 2 ..

$450 \ldots$

3,500

Indiana constitutes a diocese of the Protestant Episcopal church, and also the Roman Catholic diocese of Vincennes.

Education.-Indiana has endowed her common schools and oolleges more liberally than any others of the New States. The constitution provides that " the common school fund shall consist of the congressional township fund, and the lands belonging thereto, of the surplus revenue, saline, and bank tax funds, the fund to be derived from the sale of county seminaries, and money and property heretofore held for such seminaries, all fines, forfeitures, and escheats, and lands not otherwise specially granted, including the net proceeds of the sales of the swamp lands granted to the State by the Act of Congress of September 2Sth, 1S50. The principal of the fund may be increased, but shall never be diminished, and its income shall be devoted solely to the support of common schools." The value of these several funds and incomes is stated by Governor Wright in his Message of December 2, 1851, to be $\$ 4,664,279$; and in addition to this sum, the school fund will be constantly augmented by the receipt of fines and forfeitures, and the profits of the sinking fund. The schools of the State are under the supervision of a Superintendent of Public Instruction, who is elected by the people, and holds office for two years. From the report of this officer, it appears that there were in 1851 about 400,000 between the ages of 5 and 21 years. The number of common schools was 5,599 , and the number of children attending school was $225,318$.

Indiana has also a large number of high schools and academies; and among her collegiate establishments the followIng are the most conspicuous: the Indiana State University, at Bloomington, founded in 1816; Hanover College, founded in 1829 ; W abash College, founded in 1881, and Indiana Ashbury University, at Green Castle, founded in 1837. At Hanover is also the Indiana Theological Seminary (Presbyterian), a department of Hanover College. The Universities have each a law department; and there are medical schools at La Porte and Indianapolis-at the first place the Indiana Medical College, and at the latter, the Indiana Central Medical College, both highly-flourishing institutions.

Libraries.One State library $(7,000$ volumes); four social libraries $(10,700)$; six college libraries (17,300); four students libraries $(4,890)$; one public school library (200)-total, sixteen libraries and 40,000 volumes.

Periodicat Press.-.The public press consists of 121 periodical publications, of which 79 are political-43 whig, and 36 democratic-and 42 are devoted to literature, science, religion, ete. Of the whole number, 9 are published daily, 2 triweekly, 109 weekly, and 1 monthly. The average circulation of the dailies, at each issue, is 8,984 ; of the tri-Treeklies, 1,500 ; of the weeklies, 49,734 ; and of the monthly, about 2,000 copies.

Pauperism and Crime.-The whole number of paupers who received support from the public funds within the year ending June 1st, 1550 , was 1,182, of which 860 were natives, and 322 foreigners; and the whole number of paupers at the date referred to was 583 , of which number 446 were natives, and 137 foreigners-costs to the publie for the year $\$ 57,560$. The whole number of convicts in the State Prison on the 30th November, 1550, was 142, and the number received during the following official year was 103, and during the same period there were discharged-by expiration of sentence, 21 ; by escape, 8 ; by pardon, 16 ; by order of court, 1 ; by death, 7 -total 53 ; and bence there were in prison on the 30 th November, 1851, 192 convicts, of which 8 were committed for life, 1 for 36 years, and 96 for less than 2 years; and 151 are committed for offenses against property, and 39 for offenses against the person. The State Prison is situate at Jeffersonville.

Historical Slcetch.-Indiana originally constituted a part of "New France," and subsequently of the "Territory NorthWest of the Ohio Piver." The exact period of its first settlement is not ascertained. It appears, however, that about 1690 the French Indians visited the site of Vincennes, at that time occupied by the Indian village of Appecaughke, and in 1702 a party of the same nation descended the Wabash, and established several posts on its banks, and among others Vincennes. The tribes inhabiting the country at that time, either from intestine feuds, or inability; made little opposition to the new-comers. The colonists at Vincennes, insulated, as it were, from the rest of mankind, and buried in the midst of the wilderness, gradually approximated the manners and customs of the Indians by whom they were sur- 
rounded, and formed marrages with their women, joined in their hunting parties, and subsisted more by the chase than by the proceeds of their agriculture. Of their simple annals they have left no records, for until 1763, when the country was ceded to England, we hear nothing of them. By the treaty of cession, the settlers were confirmed in their posses sions; but immigration did not reach the country till some time afterward. During the Revolutionary War they displayed their hereditary animosity to the English, and seized the first opportunity to join with the people; and in 1778 a Spanish resident gave such information respecting the strength and position of the British forces stationed at Vincennes, that by his directions General Clarke easily obtained possession, which, however, he did not long retain. By the treaty of 1753 , the country was included in the United States, and again the settlers were conflrmed in their possessions. In 1783 an Indian war broke out, which caused great distress among them, but they did not suffer to the same extent as the Americans, against whom vengeance was directed without merey; but by the attack of General Wilkinson in 1791 at the mouth of the Tippecanoe, and by the subsequent victories of General Wayne, a dangerous confederacy was broken up, and the tribes obliged to submit, when the district began to enjoy that repose of which it had for many years been deprived. By the treaty of Greenville in 1795 the United States obtained several eligible parcels of land, for which, as a compensation, they paid the Indians sums of money and sundry goods. Other cessions were made at subsequent periods; but notwithstanding these, a part of the Indians still remained hostile, and, excited and exasperated by the eloquence of Tecumseh, a leader of the Shawnees, and one of the most extraordinary men that ever appeared among them, several of the tribes united in resistance to the increasing power of the whites; and depredation had been committed to such an extent that in 1811 the government determined to exert its power. A force of regulars and militia was concentrated at Vincennes, and placed under the command of William Henry Harrison, then Governor. On the 6th November of the same year, the Governor appeared before Prophetstown, or Tippecanoe, on the Wabash, and demanded restitution of the property the Indians had carried off. After a conference, it was agreed that hostilities should not commence until next morning, that an amicable arrangement might be made, but in violation of this armistice, the Americans were attacked before daybreak by a large body of savages. Governor Harrison, however, knowing the character of the enemy, had so dis. posed his troops as to be able immediately to arrange them in order of battle; and therefore, though taken by surprise the Americans received their insidious enemy in a state of preparation. The combat, though short, was unusually severe; the Indians fought with desperate courage, but the precision of action on the part of the troops was such that the fate of the battle was soon decided, and the Indians driven in all directions, leaving forty of their number on the field, while their whole loss was not less than one hundred and fifty; nor was the American loss less in proportion. After the action, Governor Harrison having burned the town, and laid waste the surrounding settlements, returned to Vincen nes, and not long afterward the tribes sued for pence. The war with England in 1812 gave a fresh impetus to Indian hostility. Seduced into the service of England, the Indians, after committing great cruelties and excesses, received full retribution from the Americans; their villages were destroyed, and their whole country laid waste. During the latter part of the war with England, Indiana enjoyed comparative repose, and after the conclusion of peace in 1815 , the Indians ceased to molest or trouble the settlers. They are now wholly removed from the State. Until 1801 the territory now included in Indiana remained a portion of the Territory North-West of the Ohio; in that year it was erected into a separate territorial government, and at that time included all the territory West and North of the Ohio boundary. In December, 1315, the territorial legislature petitioned Congress for admission into the Union, and the privilege of forming a State Constitution. A bill for these purposes passed Congress in April,1516; a State Constitution (dated 29th June, 1516) was framed by a convention of delegates called for that special purpose; and the same having been acceptable to the federal legislature, Indiana was, in accordance with the law before mentioned, admitted in the December following, and became an independent member of that Union of which she is now so bright an ornament. The constitution formed at this period has since been revised, and in 1851 it was set aside by the adoption of a new constitution more consonant with the altered condition of the affairs and policy of the country.

IndanAPOLX, near the centre of the State, is the political capital ; Corydon was capital until 10th January, 1820.

Irdiaxa county, Penn. Situate W. centrally, and contains $753 \mathrm{sq} . \mathrm{m}$. Bounded S. by Kiskiminitas or Connemaugh river, and drained by its aftuents, and by $\mathrm{Ma}$ honing cr. and other streams-all branches of Alleghany river. Surface uneven; soil generally a sandy or clayey loam, and very productive. Its crops of wheat are very large, as are most grains, and it is especially fitted for grazing and dairies. It has much good water-power and mineral resources-cosl and salt particularly, which are very productive. Iron ore is found in the $N$. Farms 2,496; manuf. 75; dwell. 4,644, and pop.-wh. 26,916, fr. col. 254-total 27,170. Capital: Indiana. Pullic Works: Pennsylvania I. F. and Cauil.

Irdina, p. b., and cap. Indiana county, Penn.: $122 \mathrm{~m}$. W. N. W. Harrisburg. It contains a court-house, jail, etc., and about $1,4 n$ inhabitants. It has several large stores, 2 hotels, 2 flourishing academies, and several manufactories and fine churches. Three weelly newspapers are priated here. Pop. 968

Ixprisapous, p. city, and cap. Marion co., Ind., and eap. of the State of Indiana: near the geographical centre of the State, and on the E. side of the W. fork of White r., in lat. $39 \circ 55^{\prime} \mathrm{N}$., and long. $86^{\circ} 05^{\prime} \mathrm{W} .-573 \mathrm{~m}$. W. by N. Washington. The cily is located on a beautiful, fertile, and extensive plain just below the mouth of Fall cr. In the ordinance of Congress, authorizing the formation of a State constitution, 4 sections, or 2,560 acres of land, were donated for the permanent seat of government: commissioners wero 318 appointed in 1820 to make the selection, and in 1821 the city was laid out-in the October of which year 314 lots, central in the old plot of the city, were sold for $\$ 35,596$; lots which then sold for $\$ 200$ or $\$ 300$, now readily realize from $\$ \$, 000$ to $\$ 10,000$. At the period referred to the site was covered by dense forests, and for 40 or 50 miles around the country still remained in its pristine condition of an untouched wilderness. The original town plot was a mile square, but like all progressive cities, Indianapolis has overstepped its artificial limits, and extended itself on all sides, The streets are at right angles with each other. Washington, through which the National Road passes, the principal street of the eity, is 120 feet wide; Circle-street 80 feet, and others 90 feet; the alleys, E, and $W$., are 30 feet wide, those $N$. and S. 15 feet. The lots in the full lots are $97 \frac{1}{2}$ feet by 195 , bat on the diagonal streets and in the central blocks, touching Circle-street, the lots contain about a fourth of an acre each. On the 1st January, 1825, the public offices of the State were removed from Corydon, the former capital, to Indianapolis, and the permanent seat of government established here; but the Legislature held its sessions in the county court house until December, 1834, when the State House, an elegant building, 180 feet by 80 , was completed, at a cost of about $\$ 60,000$ : it is on the model of the Parthenon at Athens. The Governor's House is near the centre of the city, and is a fine four-fronted building, standing on a natural mound 60 feet high, and circumseribed by Circle-street; and from this also diverge four diagonal streets in the di- 
rection of the several corners of the city plot. The State House, governor's residence, and the State offices, were built by the proceeds of the sales of lots in the donation, as the Congressional grant was called. The other public buildings are its spacious market-houses, its many elegant and substantial churches, its fine hotels, its depots, bridges, etc. No city of its size in the Union, indeed, has so many publie accommodations; it is also a place of considerable manufactures, trade, and general businees, being the centre of a vast system of railroads from every direction. From the Ohio River comes the Lawrenceburg and Upper Mississippi R. R., the Madison and Indianapolis $R . R_{v}$, the Jeffersonville $R$. R., and a branch from the Evansville and Illinois R. R.; from the Wabash r. the Terre Haute and Richmond P. R., the Lafayette R. R., the Peru and Indianapolis R. R., and the Fort Wayne and Southern R. R.; and from the State of Ohio, the Indianapolis and Bellefontaine R. R., the Indiana Central R. R., etc. All these roads centering in the "railroad city of the West," bring to it an immense amount of business and travel, and will ultimately make this one of the most prosperous cities of the north middle section of the Union; most, if not all of these, connect with each other on the Union Track and Depot, constructed at the joint expense of the several companies, and are but as so many links in the chain of intercommunication between the North and South, and the East and West, connecting as they do, at their exterior termini, with the railroads of the Union generally.

The newspapers published in Indianapolis are the "Indiana State Journal" (whig), daily and weekly; the "Indiana State Sentinel" (dem.), tri-weekly; the "Indiana Statesman," weekly; the "Family Visitor" (temp.), weekly; the "Locomotive" (neutral), weekly; the "Home Miscellany" (iterary), weekly; the "Volkblatt," and "Suabia P. Organ" (Germ, dem.), both weekly. In reference to education, Indianapolis has made ample provision; it has 14 public schools, open to all, and numerous academies, seminaries, and classical schools. The Indiana Central Medical College was founded in 1849, and in 1851 had 49 studeuts, and $10 \mathrm{had}$ graduated: the lectures comraenced $28 \mathrm{th}$ Oct., 1850. There is a United States land office at Indianapolis. The general statistics of the city embrace about 90 drygoods stores, 30 groceries, 22 warehouses, 120 mechanic shops, 4 breweries, and about two-fifths of the dwellings are of more than one story in height, and about one sixth are of brick, the others being frame dwellings. In 1830 the inhabitants numbered 1,085, in 18402,692 , and in 18508,034 .

Irdianapolis, p. v., Mahaska co., Ia.: on the E. side of N. fork of Skunk r., 49 m. W. S. W. Iowa City.

INDIAN CreEK, p. O., Jackson county, Ga. : $82 \mathrm{~m}$. N. by W. Milledgeville.

Indiax Creet, p. o., Monroe co, Mo. : on a cr. of Salt r. so called, $73 \mathrm{~m}$. N. N. E. Jefferson City.

Indrax Creek, p. o., Monroe co., Firg.: near a branch of New r. so called, $169 \mathrm{~m}$. W. Richmond.

Indian Creek, p. o., Monroe co, Ind. : near a branch of Salt $\mathbf{r}$. so called, $57 \mathrm{~m}$. S. S. W. Indianapolis.

Indian Crees, p. o., Kent co., Brich.: 62 m. W. N. W. Lansing.

INDiAn Cresik, p. 0., Pike county, Ala.: 43 m. S. E. Montgomery.

INDIAN Grote, p. $\nabla .$, Livingston co., $M l_{0}: 85 \mathrm{~m}$. N. E. Springfield.
INDIAN HILL, p. o., Abbeville dist., S.Car, : 87 m. W. by N. Columbia.

INDIAY KEY, p. o., Dade county, Flor.: on one of the Florida Keys so called, 453 m. S. E. by S. Tallahassee. This key contains some 7 or 8 acres of rich alluvial soil, and is based on coral rock, as are most of the neighboring keys. It lies about equidistant between Florida Cape and Key West, and has a very equable and salubrious climate. Here is a small village, with a fine hotel, etc., for the accommodation of visitors.

Indian lake, Hamilton co., N. $Y .:$ a small lake in a wild and mountainous region. It is $4 \mathrm{~m}$. long and about a milo wide, and abounds in various descriptions of fish.

INDia Moond, p. o., Stewart co., Tenn。: 66 m.W. N.W. Nashville.

IndianolA, p. v., Warren county, Ia.: $3 \mathrm{~m}$. S. Prairie branch of Des Moines r., $107 \mathrm{~m}$. W. by \$. Iowa City.

INdianola, p. 0., Vermillion county, IU. : 107 E. N. E. Springfield.

IndianouA, p. v., Calhoun co, Texs: on Matagorda Bay, 142 m. S. S. E. Aurstin City. It has a good landing, several large stores, and about 300 inhabitants.

INDIAY ORCHARD, sta., Hampden co., Mass. : on Western R. R., 6 m. E. Springfield, 92 m. from Boston.

Indian Pratrie, p. v., Van Buren county, Iq.: $79 \mathrm{~m}$. S. S. W. Iowa City.

Indian Rrver, hund., Sussex co., Del.: $47 \mathrm{~m}$. S. b5 E. Dover. Situate on Indian $r$. and Rehoboth Bay, and approached from the Atlantic through an inlet so called. Ares 54,420 acres. It has some trade, but is chiefly a mauufaoturing district. Pop. 1,822.

INDIAN RIVER, p. o., St. Iucie co., Flor.: 309 m. 8. E. Tallahassee.

Indis RIVer, p. o., Washington co., Me.: near a cr. so called, $114 \mathrm{E}$. by N. Augusta.

Indiax RIVER, p. o., Lewis co., N. $Y .: 108 \mathrm{~m}$. N. W. Albany.

INDIAN river, $N$. $Y$. : a tributary of Oswegatchie $r$. It rises in Lewis county, and passes through Jefferson into St. Lawrence co., where it enters Black Lake, through which it flows to the Oswegatchie, and thence to the St Lawrence.

INDIAN river, F'lor: : a long lagoon on the $\mathrm{E}$. side of the peninsula, running nearly parallel with the coast line. It is about $120 \mathrm{~m}$. long, and varies much in breadth, frequently expanding into lakes 3 or 4 miles wide, and again contract ing to less than 50 yards. Its depth varies likewise, and it is not safe to navigate a sloop of more than 6 feet draft. The stream empties into the Atlantic through Indian River out let. Along its shores are excellent sugar lands.

INDIAN river, or stream, $N$. Hamp.: the principal head stream of Connecticut $x$. It rises in the highlands on the $\mathrm{N}$. line of the State, and after a S. W. course of about $30 \mathrm{~m}$. unites with the eastern constituent of the Connecticut, which has its source in the lake of the same name.

Indiax Springs, p. y., Butts co., Ga. : 46 m. W. N. W. Milledgeville. Here are, near a branch of the Ocmulgee, sulphur springs of great efficacy in curing diseases of the skin, rheumatism, etc., and rouch visited. The $\mathrm{v}$. has a large hotel, some substantial houses, three stores, and 200 inhabitants.

\section{THE INDIAN TERRITORY.}

THE INDIAN TERRITORY is an extensive country bordering on Missouri, Arkansas, and Texas, and situate generally between latitudes $33^{\circ} 40^{\prime}$ and $39^{\circ} 30^{\prime}$ north, and between longitudes $94^{\circ}$ and $100^{\circ}$ west from Greenwich, or $1 r^{\circ}$ and $23^{\circ}$ west from Washington. It is about 420 miles from north to south, and about 350 miles from east to west; but within this compass is included only the Indian Territory proper, or that extending from the Kansas to the Red River, and from the the west lines of Missouri and Arkansas to the old line of Texas. Beyond these limits the allotment of territory has been gradually going on, and the Indian settlements now range as far north as the Missouri River, across the proposed limits of Nebraska, and are stated in the census of 1850 to contain in the aggregate an area of 187,171 square miles.

This Territory was set apart by Congress for the pernanent residence of the Indian tribes transported from the settled 
States, and here they are secured a residence from the encroachments of the white races. They live under governments of their own, and many of the tribes have made great advances in civilization. The mumber of Indians resident in the Territory is computed at about 120,000 , four-fifths of which number has been transported from the countries east of the Mississippi. The most numerous tribes are the Cherokees, the Creeks, the Pawnees, the Choctaws, the Osages, and the Seminoles. The other tribes are numerically small.

Those tribes which have made most progress in civilization are the Ohoctanos, who have a written constitution and laws, their legislative, executive, and judicial officers, their schools, churches, and all the ordinary appliances of civilized societies; the Creeks, who, though not so far progressed in intelligence and industry, yet have made good advance, and have also a written constitution, recognizing a chief and council of the nation, and the Cherokees, who are, perhaps, on the whole, more eivilized than either of the above. These nations are deseribed in their proper alphabetical order. The other transported tribes are also improving under the efforts of the missionary and schoolmaster. They occupy various determined seetions of the Territory, and are not allowed to interfere with each others' governments. They have each their own laws, and are considered as so many distinct nations. The indigenous tribes bave not, as a general thing, advanced in the same degree as their brethren from the East. Some tribes, however, are settling into habits of industry. The barbarism of the Indian, indeed, is passing away, and the symbols of eivilization are becoming every day more apparent. Of late years considerable quantities of cotton, peltry, and other staples of the Territory have been brought down to New Orleans, and there is every prospect of this branch of commerce becoming permanent and extensive. The Indians have also a competent knowledge of many useful manufactures, such as the manufacture of domestic cloths, agricultural implements, wagons, ete., and as builders are equal to the most ingenious among their white brethren. In fact, they now manufacture almost every thing necessary to their comfort.

A proposition is on foot, adrocated by the Indians themselves, to petition Congress for the removal of all the Indian tribes within the United States to the lands at the base of the Rocky Mountains, and there secure to them a permanent residence; and also to constitute them a State of the Union, with Senators and Representatives in Congress. This elevation will doubtless be effected at no distant period, but at present few persons acquainted with the Indian charact er under its present circumstances, would be found to advocate such a proceeding. The next generation will be fitted by education and civilized habits to take part in the affairs of a confederation of which they may have become a member.

INdian Town, p. $\nabla .$, Currituck co., N. Car.: on North r., 143 m. E. N. E. Raleigh.

Irdiar Town, p. v., Bureau county, Ih.: $123 \mathrm{m.} \mathrm{N}$. Springfield.

Indiantown, p. v., Williamsburg dist., S. Car.: $86 \mathrm{~m}$. E. S. E. Columbia. It contains several stores, 20 dwellings, and 120 inhabitants.

INDIAN VALRer, p. o., Floyd co., Firg, : 161 m. W. 8. W. Richmond.

Indrar VIlLAGe, p. O., Wachita par., La. : 139 m. N. N.W. Baton Rouge.

Indteo HEAD, p. o., Coffee co., Ala.: 63 m. S. S. E. Montgomery.

INDUSTRY, t. and p. v., Franklin co., Mre. : on the N. side of Sandy $\mathrm{r}_{\text {., }} \mathrm{a}$ branch of the Kennebec, $29 \mathrm{~m}$. N. N. W. Augusta. The t. is fertile, with fine grazing land, and a large pond in the $\mathrm{N}$. furnishing water-power. The $\mathrm{v}$. is near the pond, has several mechanic shops, two churches, a hotel, and 200 inhabitants. Pop. of t. 1,041.

Industry, p. 0., Beaver co., Penn.: $187 \mathrm{~m}$. W. by N. Harrisburg.

Ixdustry, p. 0., Austin co., Tex. : on W. fork of Mill cr., 74 m. E. S. E. Austin City.

INGHux county, Mich. Situate 8 . centrally, and contains 564 sq. m. Drained N. by Cedar r., and W. by Portage r., which form Grand r., and flow into Lake Michigan. Surface mostly level, and well timbered with beech and sugar maple; the "openings" are more uneven and chiefly in the S.; soil very good, and, like the adjacent country, excellent grain and grass land. It has good water privileges, and there are indications of bituminous coal. Farms 991; manue. 32 ; dwell. 1,583, and pop.-wh, 8,606 , fr. col, 25total 8.631. Cit\}ital: Lansing.

INGHAN, t. and p. v., Ingham co, Dhich.: $17 \mathrm{~m}$. S. E. Lansing. A branch of Cedar $\mathrm{r}$. flows on its $\mathrm{E}$. border, which is mostly level and well timbered. Pop. 754.

IrgRAy's Cross RoADs, p. O, Lauderdale county, Alas: $159 \mathrm{~m} . \mathrm{N} . \mathrm{N}$. W. Montgomery.

\section{THE STATE OF IOIVA.}

Iow, the fourth of those magnificent States carved out of that vast territory acquired of France in 1803 , is situate generally between the latitudes $40^{\circ} 35^{\prime}$ and $433^{\circ} 30^{\prime}$ north, and between longitudes $900^{\circ} 18^{\prime}$ and $96^{\circ} 53^{\prime}$ west of Greenwich, or $18^{\circ} 16^{\prime}$ and $19{ }^{\circ} 51^{\prime}$ west of Washington; and is bounded north by Minnesota Territory, east by the Mississippi River, which separates it from Wisconsin and Ilinois, south by the State of Missouri, and west by Missouri River and its tribu 820 Columbus.

InManstilie, p. o., Rock county, Wisc.: 37 m. S. E. adison.

Institute, p. o., Randolph co., $N_{0}$ Car.: $68 \mathrm{~m} . \mathrm{W}$. aleigh.

Intercourse, p. o., sumter co., Ala.: $114 \mathrm{~m}$. W. by $\mathbf{N}$.

Intercotrese, p. v., Lancaster co., Penn.: 43 m. E. S. E.

IN vernisss, p. o., Columbiana co., Ohio: 126 m. E. N. E. Columbus,

IoNI, p. o., Anderson co., Tex. : equidistant from Trinity Neches rivers, 159 m. N. E. Austin City.

IONT A county, $M i c h$. Situate W. centrally, and contains . Drained by Grand r., which crosses it from $\mathrm{E}$. W. and its branches Maple and Flat rivers, and Lake, soil, black sandy loam, and on the streams alluvial bottoms of great fertility-generally timbered with oak, ash, and maple, free from stone, and excellent for grazing; good building stone is found on Grand $x$. Farms 601; manuf apital: Ionia.

t., p. v., and cap. Ionia countr, Mnch: $28 \mathrm{~m}$. W. N. W. Lansing, The t. lies on both sides of Grand $r$. Prairie er. in the N.; has a rich alluvial soil, and plenty of timber, and raises many cattle and sheep. The village is on the right bank of Grand $r$., at the head of boat navigation, and contains a court-bouse, jail, etc., a U. S. land office, and about 500 inhabitants. Population of t. $7 \pi 4$.

IOSEO county, Mich. Situate E. on Saginaw Bay, and contains $549 \mathrm{sq} . \mathrm{m}$. Drained N. by Au Sable r., and $\mathrm{S}$. by Augrais r. Surface broken, and in paris covered with swamps. Timber of all kinds is abundant, and lumber the chief export of this yet unsettled county. Unorganized in 1850 . 
IOWA.

tary the Tehankasndati or Big sinux Iiver, which divides it from the old North-West Territory.* Its width from nogth to snuth is 196 miles, and its greatest length from east to west 307 miles; included within which limits is an area of 50,914 square miles.

Situate nearly midway betwecn the two great oceans; bounded on both sides by the great rivers of the continent, and watered by innumerable smaller streams; possessing a fertite soil, inexhaustible mineral resources, a healthful climate, a free constitution, and a hardy and industrious population, the State of Iowa has commenced its eareer with prospects of far more than ordinary brilliancy. In extent of boundary, it is one of the largest in the Union, and it may safely be prophesied, that with these great advantages, it is destined at no distant day to rank among the first in point of wealth. and political importance, as it already exceeds its compeers in rapidity of growth.

The general face of the country is that of a high, rolling prairie watered by magnificent streams, and on the river courses skirted with woodland. An idea prevails at the East that the prairies are uniformly level. This is by no means the case. Sometimes, indeed, they spread out in boundless plains; but the high or upland prairies, which are much the most beautiful, as well as the best adapted to cultiration, present a series of graceful undulations not unlike the swell of the sea, from which they derive the appellation "rolling."-Sargent, $184 \mathrm{~S}$.

The chlef rivers of the State are: the Mississippi, which winds along its enstern border for nearly 450 miles, and the Missouri, which bounds it on the west from the mouth of Big Sioux River to the parallel of $40^{\circ} 86^{\prime} \mathrm{N}$. lat., a distance of more than 300 miles, both furnishing an almost unprecedented extent of external navigation, and their banks affording many eligible sites for commercial cities. Besides these magnificent streams, Iowa has many large interior navigable rivers, the most prominent of which are the Des Moines, extending through and dividing the State into two nearly equal sections, Skunk River, the Iowa, from which the State has its name, Wapsipinicon River, the Makoqueta, the Turkey River, the Upper Iowa River, and others flowing into the Mississippi, and numerous fine streams affluents of the Missouri. The Des Moines passes diagonally from north-west to south-east, and reaches the Mississippi at the foot of the lower rapids in the south-east corner of the State-the whole distance from the point where it strikes the northern boundary line of Iowa to its confluence being over 400 miles. It is this river-represented as being one of the most beautiful of all the noble rivers of the great West-that the State has undertaken, with the aid of a grant of lands made by Congress, to render navigable for steamboats of a medium class up to Eort Des Moines, a distance of over 200 miles from its mouth. It passes through the great coal fields and through a country scarcely equaled for its agricultural capacities. The stream is said to be peculiarly adapted to improvement in accordance with the plan proposed-a succession of substantial locks and dams creating slack-water-from the fact of its having rock bottom and high banks, which are not subject ts overflow. The Iowa, Skunk, ete, are rivers secondary in magnitude to the Des Moines, but they are of inestimable local value, being navigable into the interior for distances varying from 20 to 60 miles, and by their numerous affluent streams, furnishing to the settler hydraulie power sufficient for all the varied wants of a large manufacturing State. Most of these rivers pass over lime or sand-rock beds, and are generally skirted with fine timber. Limestone, indeed, is distributed abundantly over a great portion of the State.

Iowa is numbered as one of the great mineral producing States of the Union. Its lead mines in the north-east, and of which Dubuque is the centre, have been worked for a long period, and have been very productive in proportion to the number engaged in mining. The lead mines of Lowa are continuous of those of Illinois and Wisconsin. A review of the resources and capabilities of this country, says Doctor Owen, induces me to say, with confidence, that 10,000 laborers and miners could find profitable employment within its confines. The lead mines alone afford as much of that metal as the whole of Europe, excepting Great Britain, and their capabilities are mnbounded. Zine occurs in fissures, along with the lead; it is chiefly in the form of electric calamine, and is found in cellular masses; in some "diggings" this mineral is found in a state of carbonate, and in others as a sulphuret. Iron ore is abundantly distributed, but as yet no large amount has been converted into metal. In reference to the coal deposits, the geologist above quoted remarks, that between Johnson and Iowa counties an uplift of carboniferous sandstone is encountered which is probahly near the eastern limits of the Des Moines coal-field. The Iowa River meanders near the east margin of this deposit, but the seams presented on the river bluff are of inferior quality. It is umoard of two hundred miles in the direction of the valley of the Des Moines across the great coal-field; westwardly it extends from the Des Moines River, nearly across the State. The entire area of this field in lowa alone can not be less than 20,000 square miles-in all, embracing a country equal in extent to more than one half the State of Indiana. He estimates the beds of coal at 100 feet in thickness; and lying near the surface, they must be capable of being worked easily, and at small expense. Copper is also found in this State.

But Iowa mainly owes its prosperity to its agricultural resources. Its flne prairies are easily converted to cnltivation, and its natural pastures afford peculiar facilities for the rearing of eattle and sheep-farming; wool-growing, indeed, has become one of the staple employments of the settlers, and the raising of hogs for market has become no less a profitable occupation. The sheep and hog are here fed with little or no trouble, the natural productions of the earth affording 3 plentiful subsistence. For all agricultural purposes, indeed, Iowa is perhaps as fine a region as ever the sun eherished by its beams. It is demonstrated by actual survey that no State in the Union has a less quantity of inferior land. The timber lands are less extensive than the prairies, but the growths are so distributed as to negative any objection that might be interposed on this account. Compared to the lifetime of labor it takes to open a farm in the woods, the facility with which one can be established on the prairie is most striking and gratifying to the settler; and as sufficient timber for ail ordinary purposes is always within reasonable distance, the comparative absence of forests is not so important as it otherwise would be, and artificial groves of that useful and ornamental tree, the locust, ean be easily and quickly raised. Nothing can exceed the beauty of a prairie cottage, surrounded by its grove of locust, and, wherever met with,

* The of east of the middle of the mouth of the main channel of the Des Moines River; thence up the middle of the main channel of the said Des Moines Riror to a point on said river where the northern boundary line of the State of Missouri, as establisled by the constitution of that State, adopted June 12th, 1820, crosses the said middle of the man channel of the said Des Moines River; thence westwardly along the said northern boundery line of the Stnte of Missouri, as established at the time aforesaid, until an extension of said line intersects the midale of the main cliannel of the Mireouri River; thence up the middle of the main channel of the said Missouri River, to a point opposite the midale of the main channel of the $\mathrm{Li} z$ inux River, until it is intersected by the parallel of forty three degrees and thirty minutes north latitude; thence east, along said parallel of forty three degrees and thirty minutes, until said marallel intersects the middle of the main channel of the Mississipp1 Rurer; thence down the middle of the main channel of said Mississippi River to the place of beginning:" 
it marks the abode of taste and comfort. In riding over the State, however, the chief characteristic observed is its evenness-the monotony of its very beauty and fertility becomes tiresome.

In point of salubrity, Iowa is not surpassed by any of the new States. It is not exempt from the diseases incidental to rich and uncultivated regions, but from the openness of the country it is less liable to the scourge of malaria than ordinary. Take it altogether, it is a most attractive country for the immigrant. The salubrity of the climate, however, depends much on locality. The thermometer does not range so widely here as in similar latitudes east of the Alleghanies; it is exempt, too, from those easterly winds so searching and baneful in their effects on the pulmonic invalid. Along the low bottom-lands of the rivers, which are occasionally subject to inundation, there will be liability and predisposition to bilious affections, fevers, etc.; but upon the uplands and rolling prairies the air is buoyant and free from all baneful influences. Periodic breezes blow over these elevated portions of the country as regularly and refreshing as from the ocean between the tropics, tempering the extremes incidental to the latitude.

Iowa is divided into 49 counties, the general statisties of which and the capitals of each in 1850 were as follow:

\begin{tabular}{|c|c|c|}
\hline Counties." & Pop. & $\begin{array}{l}\text { Farms Manuf. Capitals. } \\
\text { in cult. Estab. }\end{array}$ \\
\hline Allamakee.... 152... & $777 \ldots$ & $2 \ldots 0 \ldots$ Postville \\
\hline Appanoose ... 521... & $3,131 \ldots$ & 153... 2...Centreville \\
\hline Benton ........ 121... & $672 \ldots$ & $67 \ldots 0 .$. Vinton \\
\hline Black Hawk.. $26 . .$. & . $135 \ldots$ & $9 \ldots 1 \ldots-$ \\
\hline Boone........ 119... & . $735 \ldots$ & 0... 0...Booneville \\
\hline Buchanan..... $74 \ldots$ & . $517 \ldots$ & $45 \ldots$.....Independ'nce \\
\hline Cedar........ 686... & $3,941 \ldots$ & $358 . . .4$...Tipton \\
\hline Clark ......... & $79 \ldots$ & $0 \ldots 0 \ldots-$ \\
\hline Claytoz...... $728 .$. & $3,873 \ldots$ & $200 \ldots .12 \ldots$ Garnavillo \\
\hline Clinton....... 499... & $2,822$. & $306 \ldots 10 \ldots$ De Witt \\
\hline Dallas..... & $854 \ldots$ & $0 \ldots$ 0...Adell \\
\hline Davis .........1,180... & $7,264 \ldots$ & $613 \ldots 11 \ldots$... Bloomfield \\
\hline Decatur....... 145... & $965 \ldots$ & $46 \ldots$. 0 .. Nine Eagles \\
\hline Delaware.... 338... & $1,759 \ldots$ & $141 \ldots 3 \ldots$ Delhi \\
\hline Des Moines .. 1,919... & $12,987 \ldots$ & $383 \ldots 23 . .$. Burlington \\
\hline Dubuque... & $10,841 \ldots$ & $755 \ldots 46 \ldots$. Dubuque \\
\hline Fayette ... & $825 \ldots$ & $8 \ldots 0 \ldots$ West Union \\
\hline Fremont.. & $1,244 \ldots$ & 105... 0...Sidney \\
\hline $.1,545 \ldots$ & $8,707 \ldots$ & $947 \ldots 26 \ldots$. Mt. Pleasant \\
\hline Iowa. & - $822 \ldots$ & $70 \ldots$.....Marengo \\
\hline Jackson .. & $7,210 \ldots$ & $703 \ldots 10 \ldots$ Andrew \\
\hline Jasper..... & $1,280 \ldots$ & $150 \ldots 0 .$. Newton \\
\hline Jefierson ......I,649... & $9,904 \ldots$ & $1,067 \ldots 54 \ldots$ Fairfield \\
\hline Johnson. & $4,472 \ldots$ & $377 \ldots .19 \ldots$ Iowa CitX \\
\hline Jones & $007 \ldots$ & $225 \ldots .3 \ldots$. Anamosa \\
\hline
\end{tabular}

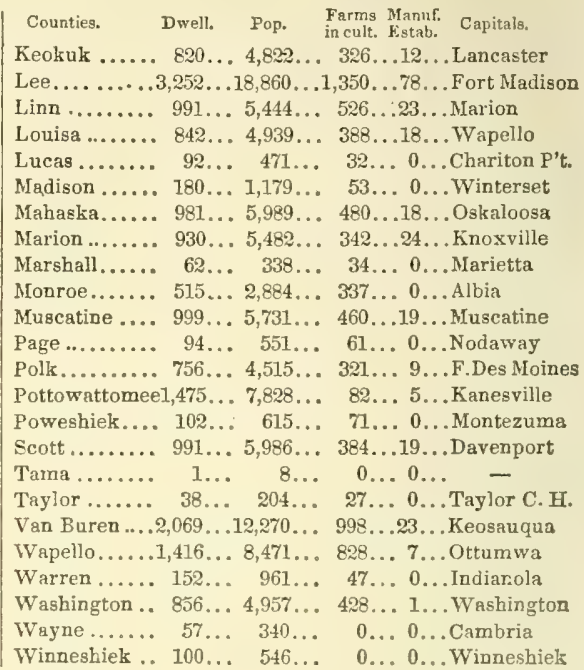

Since the census of 1850 was taken, Pottowattomee county has been divided into the following named counties: Adair, Adams, Audubon, Bancroft, Bremer, Buena Vista. Buncombe, Butler, Carroll, Cass, Cerro Gordo, Cherokee, Chickasaw, Clay, Crawford, Dickinson, Emmett, Floyd, Fox, Franklin, Greene, Grundy, Guthrie, Hancock, Hardin, Harrison, Howard, Humboldt, Ida, Kossuth, Manona, Mills, Mitchell, Montgomery, O'Brien, Oceola, Palo Alto, Plymouth, Pocahontas, Risley, Sac, Shelby, Sioux, Union, Wahkou, Winnebago, Worth, Wright, and Yell.

The whole number of dwellings in the State was, at the above date, 82,962 , of families 38,517 , and of inhabitants 192,214, viz. : whites 191,879-males 100,885 , and females 90,994 , free colored 895 -males 168 , and females 167 . Of the whole porulation, there were deaf and dumh-wh. 51, fr. col. 0-total 51; Uind-wh. 47, fr. col. 0-total 47; insane-wh. 40, fr. col. 0-total 40; and idiotic-wh. 93, fr. col, 0-total 93. The number of free persons born in the United States was 170,020 , the number of foreign birth 21,232 , and of births unknown 362 ; the native population originated as follows: Me. 713 , N. Hamp. 580, Verm. 1,645, Mass. 1,251, R. I. 256, Conn. 1,090, N. Y. 8,134, N. Jer. 1,199, Penn. 14,744, Del. 539, Md. 1,Ss8, Dist. of Col. 70, Virg. 7,861, N. Car. 2,589, S. Car. 676, Ga. 119, Flor. 51, Ala. 180, Miss. 185, La. 133, Tex. 10, Ark. 168, Tenn, 4,274, Ky. 8,994, Oh. 30,713, Mich. 521, Ind. 19,925, Ill. 7,217, Mo. 8,807, Ionoa 50,330, Wisc. 692, Calif. 8 , Territories 185; and the foreign population was composed of persons from-England 3,755, Ireland 4,858, Scotland 712, Wales 352, Germany 7,152, France 882, Spain 1, Portugal S, Belgium 4, Iolland 1,108, Italy 1, Austria 13, Switzerland 175, Russia 41, Denmark 19, Norway 36, Sweden 331, Prussia 88, Greece 1, Asia 2, British America 1,756, Mexico 16, Cent. America 0 , Sonth America 1, West Indies 14, and other countries 124.

The following table will show the decennial progress of the population since the first census taken by the United States authorities:

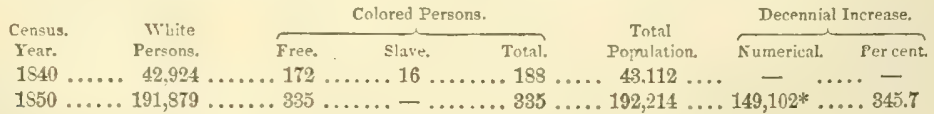

* A census of this State was taken in the latter part of the year 1552; the population of the counties was as follows: Allamakee 2,000, Appanoose 4,243, Benton 1,237, Black Hawk 315, Boone 1,024, Bremer 20:3, Buclianan 1,023, Butler 73, Cedar 4,871. Clark 549, Clay ton 6,318, Clinton 3,822, Dallas 1,216, Davis 7,553, Decatur 1,184, Delaware 2,615, Des ALoines 12,525, Dubuque 12,500, Fayette 2,055, Fremont 2,044, Guthrie 300, Henry 9,6R3, Iowa 1,323, Jackson 8,231, Jasper 1,974, Jefferson 10,225, Johnson 5,788, Jones 4,201, Keokuk 5,306, Lee 20,360, Linn 6,890, Louisa 6,476, Lucas 1,046, Madison 1,832, Mahaska 7,479, Marion 6,289, Marshall 710, Mills 1,453, Monroe 3,430, Muscatine 6,812, Page 636, Polk 5,939, Pottowattomee 5,0.77, Poweshiek 915, Ringgold 250, Risley 122, Scott 8, tis., Story 211, Tama 262, Tay lor 47., Crion 7y, Van Buren 12,753, Wapello 8,888, Warren 1,488, Waslington 5,851, Wayne 794, Winneshiek 1,523, Yell 250 . 
IOWA.

The statistics of the industry and wealth of Iowa, as ascertained by the census of 1850 , and in accordance with other public documents referring to the same period, were as follows:

Occupied Lands, etc.-Improved lands, 824,682 acres, and unimproved lands, 1,911,392 acres-valned in cash at $\$ 16,657,567$; number of farms under cultivation, 14,805; value of farming implements and machinery, $\$ 1,172,869$.

Iive-Stock.-Horses, 38,536; asses and mules, 754; milch cows, 45,704; working oxen, 21,892; other cattle, 69,025; sheep, 149,960 ; and swine, 323,247 -valued in the aggregate at $\$ 3,689,275$. In 1840 there were-horses, mules, etc. 10,794 ; neat cattle, 38,549 ; sheep, 15,354 ; and swine, 104.899 .

Grain Crops.-Wheat, 1,530,581 bushels; rye, 19,916 bushels; Indian corn, 8,656,799 bushels; oats, $1,524,345$ bushels; barley, 25,093 bushels; and buckwheat, 52,516 bushels. The crops of $1839-40$ consisted of wheat, 151,693 bushels ; barley, $72 S$ bushels; oats, 216,355 bushels; rye, 3,792 bushels; buckwheat, 6,212 bushels ; and Indian corn, 1,406,241 bushels.

Other Crops.-Rice, 500 pounds; tobaceo, 6,041 pounds; peas and beans, 4,775 bushels; potatoes-Irish, 276,120, and sweet, 6,243 bushels; hay, 89,055 tons ; clover-seed, 342, and other grass seed, 2,096 bushels; hops, 8,242 pounds; hemp -dew-rotted, 0, and water-rotted, 0 tons; flax, 62,553 pounds; flax-seed, 1,959 bushels; maple sugar, 78,407 pounds; molasses, 8,162 gallons; wine, 420 gallons, ete. The value of orchard products was $\$ 8,43 \pm$, and of market-garden products, $\$ 8, \$ 48$.

Products of Animals.-Wool, 873,898 (in 1840,23,089) pounds; butter, 2,171,183 pounds; and cheese, 209,840 pounds ; and the value of animals slaughtered during the year had been $\$ 521,164$. Silk cocoons were produced to the amount of 246 pounds; and beeswax and honey, to that of 321,711 pounds.

Home-made manufactures for the year ending 1st June, 1850, were valued at $\$ 221,292$ (in 1840, at $\$ 25,966$ ).

Branufactures.-Aggregate capital invested, $\$ 000,000$; value of raw material, fuel, etc., consumed, $\$ 000,000 ;$ average hands employed, 00,000 - males 00,000 , and females 000 ; average monthly cost of labor-male $\$ 00,000$, and female $\$ 0,000$; annual value of products, $\$ 000,000$. The whole number of manufacturing establishments producing to the value of $\$ 500$ and upward, in 1850, was $4 \$ 2$; and of these, 1 was a woolen factory, 14 were tanneries, and 3 were for the manufacture of cast iron. The balance of the manufactures and handicrafts, making up the sum of the establishments, consist of such as minister to the immediate wants of agricultural communities.

The rooolen manufacture employed a capital of $\$ 10,000$; wool consumed, 14,500 pounds; value of all raw material, $\$ 3,500$; hands employed, 7 ; monthly cost of labor, $\$ 78$; entire annual value of products, $\$ 13,000$; cloth produced, 14,000 yards.

The tanneries employed a capital of $\$ 20,350$; value of raw material consumed, $\$ 10,745$; average hands, 28 ; monthly onst of labor, $\$ 513$; number of skins tanned, 850 , and of sides tanned, 10,680 ; value of products, $\$ 21,520$.

In the manufacture of cast iron, $\$ 5,500$ invested; pig iron, 81 tons, and coke and charcoal, 200 bushels-valued at $\$ 2,524$-consumed; average hands, 17 ; monthly cost of Labor, $\$ 550$; castings made, 71 tons; value of entire products, $\$ 8,500$.

These summaries of the different national manufactures are relatively small; but they are a germ which the immense water-power of the country and the spirit of the people will soon foster into interests of magnitude and importance.

Commerce and Internal Communication.-Iowa has no direct trade with foreign countries, but its trade with the Atlantic and Gulf ports is comparatively extensive, its exports consisting principally of the products of agrieulture and the mines, and its imports of the manufactures of Europe and the Eastern States, groceries, wine, ete. The shipping ports are Keokuk, Fort Madison, Burlington, Muscatine City, Davenport, Lyons, Bellevue, Dubuque, etc., at all which places a busy trade is carried on with the interior. The annual value of the commerce of Keokuk, at the month of Des Moines River, though a city numbering less than seven years' existence, amounts to between five and six million dollars, and at the other ports the value of the import and export trade is little less in value. Keokuk is the entrepôt and depót of the whole valley of the Des Moines - a region in which more than half the population and agricultural wealth of the State is concentrated; and when the contemplated improvements in the navigation of the river are completed, it must of necessity become one of the most important of Western commercial cities. The exports from Dubuque consist ehiefly of lead. Keokuk, Davenport, Lyons, and Dubuque will shortly be connected with the interior by railroads, and hence their commerce will be indefinitely enlarged, and the interests of the whole State be developed by the increased facilities these highways will afford to transportation. Most of the railroads will centre at Iowa City, from which point a grand trunk railroad will be carried westward to Council Blufs, on the Missouri, and thence, in the progress of events, to the Pacific Ocean. None of these roads are completed; but, perhaps, as a means of developing the wealth of the interior, these lines are of inferior importance to the grand project of opening the channel of the Des Moines to steam navigation, as before alladed to: it will thus become the channel through which the greater part of the commerce of the country will pass, and along its barks will rise up cities and towns, equal in magnitude and wealth, to those on the Illinois or the Hudson-in fact, it will become as important to Iowa as those rivers are to the States through which they have their courses. Through Iowa will also pass a link of the great chain of North and South railroads, connecting St. Louis with the extreme settlements of Minnesota, etc. That portion of this chain within Missouri is already provided for, and will have the aid of the State to build it, and the same policy in relation to State aid will probably be pursued in Iowa.

Banking. - The constitution provides that "no corporation with banking privileges shall be created; and all persons or associations shall be prohibited by law from banking or creating paper to circulate as money."

Goxernment.-The constitution, the basis of the present government of Iowa, was adopted 3d August, 1816. Its principal provisions are as follows:

Every white male citizen of the United States, twenty-one years of age, insane and infamous persons excepted, having resided in the State six months and in the county in which he claims to vote thirty days, is allowed the right of suffrage. The general election is held biennially on first Monday in August.

The Legislature is styled the General Assembly, and consists of a Senate of 30 members, and a House of Representatives of 69 members. The number of representatives is not to exceed 72 , and senators not less than a third, nor moro than a half of that number. Senators are chosen for four years, one half every two years, and must be 25 years of age ; and representatives are chosen for two years - both senators and representatives must have been resident in the State at least one year next before the election. The governor's veto to any act of the Legislature is nullified by a subsequent two-thirds rote of both houses in favor of the rejected law. No member of either house is eligible to any office oreated or the emoluments of which have been increased during his term of service. No person holding any Iucrative office under the State or United States, is eligible to a seat in the House of Representatives. No law shall embrace more than one object and that shall be expressed in its title. No divorce shall be granted by the Legislature. A census of the State is taken every two years, and after each enumeration members are apportioned among the several counties according to 
IOWA.

the number of white inhabitants in each. The Legislature meets at Iowa City biennially on the first Jlonday of De. ceraber.

The governor is chosen for four years by a plurality of votes; he must be at least 30 years of age, and have resided in the State two years next preceding. In case of disability of the governor, his place is occupied by the Secretary of State, and after him by the President of the Senate and Speaker of the House of Representatives. The chief adninistrative offleers are a Secretary of State, a State Auditor, and a State Treasurer, chosen by the people each for two years.

The Judiciary consists of a Supreme Court, Circuit Courts, and courts of local jurisdiction. The Supreme Court consists of a chief and two associate justices, elected by joint vote of the General Assembly for six year's, and until their successors are elected and qualified. Any two of the judges form a quorum. The court holds a session each year in each of the five Supreme Court distriets into which the State is divided. This court bas appellate jurisdiction only in all chancery cases, and corrects errors at law under restrietions provided by the Legislature. The Supreme Court has a reporter. For the purpose of holding District Courts, the State is divided into six districts. The judges of this court are elected by the voters of their district for five years, and until their successors are elected and qualified; a prosecuting attorney and clerk of the District Court are elected each for two years by the voters of each county. Each county also elects a judge of probate, etc. Justices of the peace have jurisdiction in civil cases where the amount in controversy does not exceed $\$ 100$, and by consent of parties when it is below $\$ 500$.

Among the special provisions of the constitution are the following: No State debt shall be created exceeding $\$ 100,000$ except in case of war or insurrection, unless authorized by a special law which shall provide for the payment of the interest and of the principal within 20 years, which law shall be irrepealable, and before going into effect must be submitted to the people at a general election, having been published in at least one newspaper in each judicial district for three months preceding, and be approved by a majority of the voters. Corporations other than for banking purposes may be organized under general laws with certain resolutions. The State shall never become a stockholder in any corporation.

Finances, Putlic Debt, etc-On the 30 th November, 1550$)$, the funded debt of the State amounted to $\$ 79,442$, on which the annual interest was $\$ 5,304$; to this should be added auditor's warrants unpaid, $\$ 10,771$-total debt, $\$ 90,313$. The expenditures for the two years ending at the above period amounted to $\$ 75,410$, namely-expenses of legislature, $\$ 7,45 S$; executive, $\$ 11,200$; judiciary, $\$ 18,979$; public buildings at Iowa City, $\$ 3,200$; interest, $\$ 11,692$; and public printing, $\$ 8,028$. The revenue is derived from taxes upon real and personal property, which, according to the assessors' returns for 1850 , was valued at $\$ 22,623,384$, being $\$ 4,114,567$ more than in 1849 . The levy for State purposes was $2 \frac{1}{2}$ mills on the dollar-the tax for 1849 was $\$ 4 \pi, 296$, and for $1550 \$ \$ 5655$. The following are the various objects of taxation in $1550-$ polls, 332,259 ; land, $3,752,168$ acres- $\$ 13,277,483$; town lots, etc., $\$ 3,610,516$; capital employed in merchandise, $\$ 887,237$; mills, manufactories, distilleries, carding machines, and tan yards, with stock, ete., $\$ 432,238$; horses orer two years old, $38,585-\$ 1,460,475$; mules and asses over a year old, $305-\$ 15,591$; neat eattle over two years old, $99,406-\$ 1,106,055$; sheep over six months old, 140,599— $\$ 155,765$; hogs six months old, 206,452-\$202,397; pleasure carriages, 3,922$\$ 151,904$; watches, $3,577-\$ 43,702$; piano fortes, $55-\$ \$, 135$; capital, stocks, and profits in any incorporated or unincorporated company, $\$ 13,107$; boats and vessels, $\$ 15,059$; all other personal property over $\$ 100-\$ 207,554$; gold and sifver coin and bank notes in actual possession, $\$ 233,371$; claims for money or other consideration, $\$ 470, \$ 58$; annuities, $\$ 981$; notes, mortgages, etc., $\$ 105,956$; miscellaneous property, $\$ 90,809-$ total, $\$ 22,623,334$.

Federal Representation.-Iowa, in conformity with the law regulating the apportionment of members to the United. Statcs House of Representatives, occupies two seats in that body.

Religious Denominations. -The statistics of the several religious denominations in 1550 were as follows:

\begin{tabular}{|c|c|c|c|c|c|c|c|c|}
\hline $\begin{array}{l}\text { No of } \\
\text { Churclies. }\end{array}$ & $\begin{array}{l}\text { Church } \\
\text { atcom. }\end{array}$ & Property. & $\begin{array}{l}\text { Dennmina- } \begin{array}{c}\text { No of } \\
\text { tiuns, }\end{array} \text { Churclies. }\end{array}$ & $\begin{array}{l}\text { Cliurih } \\
\text { atcom. }\end{array}$ & $\begin{array}{l}\text { Value of } \\
\text { Property. }\end{array}$ & 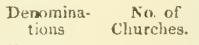 & & \\
\hline Baptist ... & 3,497 & $\$ 19,550$ & Jewish ..... - & 一 & $\$$ & Tunker...... - & - & $\$-$ \\
\hline an .... 8 & & & $\operatorname{ran} . . . .4$ & 1,000 & & $n \ldots \ldots .2$ & 450 & 7,10 \\
\hline t'l... 14 & & & $\ldots-\ldots$ & 一 & - & an.... - & 一 & - \\
\hline f... - & - & - & t.... $50 \ldots$ & 12,1 & 43, & salist.. 1 & 200 & 1,60 \\
\hline$\ldots 4 \ldots$ & 670 & 5,00 & $\ldots 2 \ldots$ & 500 & & bects... - & - & - \\
\hline .. - & - & & ian 24 & 5 & & & 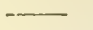 & \\
\hline .... 5 & 1,550 & & olic... 1i & 3,990 & 1) & 148 &, 759 & 7,40 \\
\hline erman Ref. . I & $200 \ldots$ & 800 & Swedenbor'g - & - & - & & & \\
\hline
\end{tabular}

The total number of churches in the State is 145 , in which is provided accommodation for 37,759 persons, and the value of church property is $\$ 177,400$. Yowa constitutes a diocese of the Protestant Episcopal Church, and is included in the Roman Catholic diocese of Dubuque.

Educatiom.-A superintendent of public instruction is chosen by the people for three years. All lands granted by Congress to this State, nll escheated estates, and such per centage as may be granted by Congress on the sale of the Public Lands in Iowa, constitute a perpetual fund, the interest of which, and the rents of the unsold lands, are applicable to the support of common schools. It is the duty of the Legislature to provide a schnol in each school district for at least three months in each year; and all moneys received from exemption from military duty and for fines imposed by the courts, are appropriated to such schools, or for the establishment of school libraries. The moneys arising from the sale or lease of public lands granted for the support of a University remain a perpetual fund to maintain such an institution. The school fund amounts to about $\$ 260,000$.

Libraries.-One State library, containing 2,500 volumes; and 4 public school libraries, containing 160 rolumes-total 5 libraries, and 2,660 volumes.

Public Press.-The public press of Iowa consists of 32 periodicals and newspapers, of which 24 are devoted to politics (12 whig and 12 democratic), and 8 to literature, religion, science, etc. One of these is published tri-weekly, and circulates 1,200 copies at each issue; 28 are weekly issues, with an aggregate circulation of 18,390 copies, and there are issued at other periods-1 semi-monthly, and 2 monthly, circulating 4,050 copies. The tri-wreekly and 3 weekly papers are published at Burlington, 4 weeklies at Dubuque, 2 weeklies and 1 monthly at Mount Pleasant, 1 weekly at Andrew, 2 at Fairfield, 2 at Iowa City, 2 at Fort Madison, 1 at Keokuk, 1 at Wapello, 1 at Oskaloosa, 2 at Muscatine, 2 at Fort Des Moines, 2 at Davenport, 1 at Keosauqua, 2 at Ottumwa, 1 semi-monthly at Kanesville, and 1 monthly at Tipton.

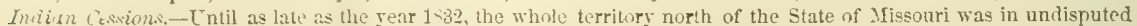
possession of the Indians. By a treaty made in 1830, the Sacs and Foxes, who were then the principal tribes, had ceded 
to the United States the best of their lands east of the Mississippi River. Their unwillingness to leave the ceded territory, in compliance with the treaty, led to the "Black Hawk War," which resulted in the total defeat of the Indians at the Battle of the Bad Axe, in Wisconsin, on the $2 d$ of August, 1582. In the September following, partly as an indemnity for the expenses of the war, and partly to secure the future safety and tranquillity of the invaded frontier, a slip of country on the west of the Mississippi, extending nearly 300 miles north of Missouri, and about 50 miles in width (now commrnly called the Black Harki jurchase), was ceded to the United States, and in June, 1583, the settlement of Iowa by the white man was commenced.

Further purchases were made successively in the years 1836 and 1837; and in 1842, by a treaty concluded by Governor Chambers, an immense tract of land, containing some 15,000,000 acres, was purehased of the Sacs and Fozes for the sum of $\$ 1,000,000$. This tract, known as the "new purchase," now contains some of the finest counties in the Btate, though a large part of it was occupied by the Indians until October in 1845.

The Pottowattomies, who inhabited the south-western corner of the State, and the Winnebagoes, who occupied the "neutral ground," a strip of country on the northern borders, have been peaceably removed within the past few years, and the Indian title thus became extinct in the whole country lying within the established limits of the State of Iowa. I fargent.

Historical Sketch, - Iowa was originally a part of the French province of Louisiana, which was purchased by the United States in 1803. The first white settlements were made in 1686, at Dubuque, by Frenchmen, who built a fort at that point and commenced a trade with the Indians, which was the sole dependence of the place for more than 2 century and a half. It is here that the great lead mines of the State were first diseovered, but at a later period. The territory now comprised within the State was a part of the Missouri Territory from 1804 to 1821, but after that was placed saccessively under the jurisdiction of Michigan and Wisconsin territories. In June, 1838, it was erected into the separate Territorial Government of Iowa; under which was also included all that portion of the present Territory of Minnesota west of the Mississippi Piver, and on the $3 d$ December, 1846, it was admitted into the Union as an independent State.

Iows CrTy, on the left bank of Iowa River, is the political eapital of the State; previous to May, 1839, Burlington, on the Mississippi, was the seat of government.

Iow a county, Ia. Situate S. E. centrally, and contains 576 sq. m. Iowa r. passes E. through the N., and its branch, English r., through the S. Surface rolling; soil fertile, and adapted to grain. Good timber on the streams, and some prairie between. Farms 70 ; manuf, 2 ; dwell. 143, and pop.-wh. 822, fr. col. 0-total 822. Capital: Marengo. Pullic Works: Council Bluffs R. R.

Low A county, Wise. Situate S. W., and contains 752 sq. m. Bounded $\mathrm{N}$. by Wisconsin r., and drained $\mathrm{N}$. by its afiluents, $S$. by heads of Peckatonica r., a branch of Rock r. Surface considerably broken, and inclining $\mathrm{N}$. and E. from a ridge or watershed crossing the county; soil very productive, with a basis of limestone. The chief wealth consists in its great mineral deposites; of these lead and copper are the principal, and great quantities of them are dug. Zine and ikon are also found. Farms $470 ;$ manuf. 24 ; dwell. 1,S46, and pop.-wh. 9,502, fr. col. 25-total 9,530. Capital: Mineral Point. Public Works: Milwaukie and Mississippi R. R., and Mineral Point R. R.

Iow A, p. T., Perry co., $l l l$. : on a branch of Little Muddy cr., $129 \mathrm{~m}$. S. by E. Springfield.

Iow A CrTy, p. v., and cap. Johnson eo., Ia., and cap. of the State of Iowa: on the E. bank of Inwa r., $52 \mathrm{~m}$. from the Mississippi r., $63 \mathrm{~m}$. from Burlington, $51 \mathrm{~m}$. from Davenport, and 71$) \mathrm{m}$. from Dubuque-from Washington, D. C., 1,455 m. The river is navigable to this place at all stages of the water, and regular steamboats from the Mississippi ascend it daily. The surface consists of a succession of plateaux rising from the margin of the $\mathbf{r}$., the first plain, about 100 yards wide, being deroted to a public promenade; the second plateanx is about 12 feet, and the third about 30 feet above the promenade, and on these the eity is built. The principal avenues run along the brows of these eminences, and are intersected centrally by Iowa Avenue, a magnificent street, on which stands the State House, an elegant building of bird's-eye marble, a richly variegated species of limestone; it is 100 feet long and 60 feet wide, and is built in the Greco-doric style, surmounted by a dome resting on 22 Corinthian columns. The avenues are 160 feet wide. Iowa City, as the capital of a wealthy State, is well situated, being easy of access from all points, and is capable of every species of improvement for manufacturing, mechanical operations, trade, and commerce. Already it is being made the centre of communication from all the principal ports of the Mississippi toward Council Blufis and the Pacific -in which direction railroads will soon be built.. Above the eity the river affords immense water-power, and has been improved by the erection of several extensive mills. It is the seat of a U. S. land office; and here, also, is an elegant county court-house, a jail, several substantial church buildings, and here will be located the State University recently chartered by the General Assembly of the State. The nerrspapers published here are the "Iowa Republican" (whig), and the "Iowa Capital Reporter" (dem.), both weekly issues. The site of the city previous to 1839 was in the wilderness: in that year it was selected by the legislature as the seat of government. Pop. 2,262.

Iow A river, $I a_{0}$ : a considerable affluent of the Mississippi. It riscs in Hancock county, and passes in an E. S. E. and E. direction through Franklin, Hardin, Marshall, Tama, Iowa, and Johnson counties, in the latter of which it suddenly turns to the S., and on entering Louisa county, again changes its direction S. E., and disembogues into the Mississippi by two mouths, forming a delta, the sides of which are about six miles in length; the upper fork is the main stream, and empties opposite Edward's r. of Illinois, and the other, called the Iowa Slough, is the lower fork. The river is navigable for light draft steamers at all seasons, and for boats much farther up. Its whole length is 300 miles Red Cedar r., its main branch, enters at Fredonia, and at certain seasons is navigable for keel-boats 100 miles from its mouth. The Iowa is a fine clear stream, and affords in its course innumerable mill seats and eligible city sites.

Iowaville, p. Y., Van Buren county, $I a_{0}$ : on the $\mathrm{N}$. side of Des Moines r., $61 \mathrm{~m}$. S. S. W. Iowa City. It has several large stores, 3 mills, 50 houses, and about 300 inhabitants.

IPswich, t., p. V., and cap. Essex co., Mass.: on Ipswich r., $25 \mathrm{~m}$. N. N. E. Boston. The t, has an uneven surface and a productive soil. The v. lies on both sides of the $r$, which is passed by a stone bridge, $2 \mathrm{~m}$. from its mouth. It has a court-house, jail, a noted female seminary, a bank, several commercial houses, and about 1,000 inhabitants. On the r., just above, are large factories. The $r$ is navigable, and the port had in 1850,578 tons shipping, mostly in the coasting trade. The Eastern R. R. passes through the v. 25 m. from Boston. The "Ipswich Clarion," a semi-monthly literary, is published here. Pop. of t. 3,349.

IRA, t. and p. V., St. Clair county, Mfich.: $93 \mathrm{~m}$. E. by $\mathrm{S}$. Lansing. It lies on the N. shore of Lake St. Clair, and is drained by Swan and Lautries rivers. Soil fertile, and surface undulating, and well covered with pine timber. Pop: of t. 597 .

IEA, t. and p. v., Cayuga co., N. $Y .: 141 \mathrm{~m} . \mathbb{T} . \mathrm{N} . \pi$. Albany. Little Sodus cr. touches the N., but the streame are small. Surface level, and soil very fertile. Farming is 
the chief pursuit. The $\mathbf{v}$. has a hotel and several stores. Pop. of t. 2,110.

IRA, t, and p. v., Rutland co., Verm.: on Castleton r., 54 m. S. S. W. Montpelier. The t, is rough and fitter for grazing. The $\mathrm{r}$. has a church, 2 or 3 stores, and 20 houses. The Troy, Whitehall, and Castleton R. R. crosses the N. of the town. Pop. of t. 40 \%

Ir $\triangle$ ввUвян, t., p. v., and cap. Orleans co., Verm. : $42 \mathrm{~m}$. N. N. W. Montpelier. Surface of the t. gently broken, and soil productive. Drained by Black r., which flow's into Lake Memphremagog. The $\mathrm{v}$. is on the river, and contains a court-house, jail, 2 stores, and a few houses. The "Orleans Gezette" (whig), is published here weekly. Pop. of $t .1,034$.

Irkodul county, $N$. Car. Situate W. centrally, and eontains 685 sq. m. Bounded S. W. by Catawba r., a head of Santee $r_{\text {, and drained }} \mathrm{N}$, and $\mathbf{E}$. by numerous affluents of Yadkin r. Surface broken and hilly, affording excellent water-power; soil very productive of wheat, corn, and cotton, which are the leading staples, and furnishes fine posturage. It has some good timber. Farms 1,096 ; manuf. 29 , âwell. 1,834, and pop. -wh. 10,547, fr. col. 30 , sl. 4,142 -total 1t,719. Capitul: Statesvile.

IRRLAND, p. o., Hampden co., Mass. : $82 \mathrm{~m}$. W. by S. Boston.

IRELAND, p. o., Lewis county, Virg.: 189 m. W. N. W.

Lichmond.

Ireland Cormerg, p. o., Albany co., $N$. $Y$.

IrIsi Grove, p. 0., Atchison co., Mro.: $214 \mathrm{~m} . \mathrm{N}$. W. Jefferson City.

Irigh Ripple, p. o., Lawrence county, Penn.: $159 \mathrm{~m}$ W. N. W. Harrisburg.

InoN county, Utah Ter. Situate S., stretching E. and W. across the Territory between latitudes $37^{\circ} 30^{\prime}$ and $35030^{\circ}$. Surface much varied, and where best known, well wooded and abounding in bituminous coal, salt, and gypsum. Farms 54; manuf. 2; dwell. S6, and pop.-wh. 360, fr. col. 1-total 360. Capital:

Iron Criank, p. o., Washtenaw co., Mich. : 43 m. S. E. Lansing.

IRONDEQUOTT, t. and p. v., Monroe co, $N_{*} Y_{*}: 139 \mathrm{~m}$. W. N. W. Albany. Genesee r. bounds it on the W., Lake Ontario N., and W. Irondequoit Bay. Surface level, with sand-hills in the E., and soil productive. It has some commerce, and is a resort for fishing. Pop. 2,397.

Irondequort bay, Monroe co., $N . Y$ : an arm of Lake Ontario, $6 \mathrm{~m}$. deep and $1 \mathrm{~m}$. wide. A creek of the same name, which affords numerous mill-sites, falls into the bay. Fish of various descriptions are taken here in abundance.

Iron Frryace, p. o., Scioto co., Ohio: $53 \mathrm{~m}$. S. by E. Columbus.

Inon Motntats, p. o., St. Francis co., Mo.: 93 m. S. E. Jefferson City. The celebrated Iron Mountain lies on the E. extreme of the Ozark Mountains, is $1 \frac{1}{\mathrm{~m}} \mathrm{~m}$ long, $1 \mathrm{~m}$. brosd, and 444 feet high. The top is solid ore, a micaceous oxide of iron of superior quality, yielding 60 per cent. of metal, and in the crude state is used to manufacture edge tools. The amount that may be made is immense, and is हलn to be brought into universal use by a railroad from St. Louis.

Irow RrDge, p. F., Dodge co., Wisc.: $51 \mathrm{~m}$. N. E. by E. Madison.

IroNtun, p. v., Lawrence co., Ohio: on the Ohio $r$., near the mouth of Stormes' cr., $97 \mathrm{~m}$. S. S. E. Columbus. It is a fine little village of rapid growth, the terminus of the Iron R. R., and the shipping port for the iron of a rich and extensive mining region. It has a fine depôt, several large stores and warehouses, and a large trade. The "Ironton Register" (neutral), is published here weekly.

IRONwOOD BLOFr, p. o., Itawamba county, Afiss.: $179 \mathrm{~m}$. N. N. E. Jackson.

Iroevors county, Ill. Situate N. E., and contains 1.399 8q. m. Drained by Sugar cr., Iroquois r, and other branches 326 of Kankakee $\mathbf{r}$, which flows on its $\mathrm{N}$. border, and soon into the Illinois, Surface mostly low and level, with many swamps and marshes, and some prairie; soils usually prom ductive, raising good crops of corn, and feeding numbers of eattle and swine. Farms 357; manuf. 0; dwell. 718 , and pop.-wh. 4,072, fr. col. 77-total 4,149. Capital. Middleport.

IroevoIs, p. v., Iroquois co., $I l l .:$ on the Iroquois r., 131 m. E. N. E. Springfield. It contains a large hotel, several fine stores, and two mills.

IRville, p. v., Muskingum co., Ohio: about $2 \mathrm{~m}$. from the Ohio Canal, $45 \mathrm{~m}$. E. by $\mathrm{N}$. Columbus. It has several stores, and 200 inbabitants.

IrviNe, p. v., and cap. Estill co., $K y_{.}:$on the N. side of Kentucky r., $57 \mathrm{~m}$. S. E. Frankfort. It has a fine location, and contains the court-house, jail, etc., about 40 dwellings, and 300 inhabitants.

IrviNe, p. o., Warren county, Penn.: $171 \mathrm{~m}$. N. W. Harrisburg.

IrVLNE'S STORE, p. o., Weakly co, Tenn. : 92 m. W. by N. Nashville.

IrvLng, p. v., Chautauque co., $N_{0} T_{.}$: on Lake Erie, at the mouth of Cattaraugus cr., $205 \mathrm{~m}$. W. by S. Albany. It has a good landing, and several stores and dwellings.

Irving, p. o., Barry co., Mich.: $44 \mathrm{~m}$. W. by S. Lansing.

Irting College, p. o., Warren co., Tenn.: 58 m. S. E. Nashville.

Irwis county, $G a$. Situate $\mathbf{S}$. centrally, and contains 2,064 sq. m. Drained by Ocmulgee r., its N. E. line, and heads of Santilla (or St. Illa) r., streams flowing into the $\Delta$ tlantic, and Little r., New r., Allapahaw r., and their branches, heads of Suwanee r., emptying into the Gulf. Surface diversified, with no great elevations, and much low land; soil productive of the grains, on which many cattle and hogs are raised, and cotton. Timber is abundant, pine particularly. Farms 414; manuf. 0; dwell. 448, and pop.wh. 2,883, fr, col. 1, sl. 450-total 3,331 Capital: Irwinsville. Public Works: Savannah and Pensacola R. R.

Irwin's Cross RoADs, p. O., Washington co., Ga.: 26 m. S. E. Nilledgeville.

InwIrsvilue, p. v., and cap. Irwin co., Ga.: about $3 \mathrm{~m}$. E. Allapahaw $\mathrm{r}_{\text {, }} 102 \mathrm{~m}$. S. by W. Milledgeville. It has a court-house, jail, etc., a few stores, and 20 dwellings.

IRwirtor, p. Y., and eap. Wilkinson co., Ga.: about $6 \mathrm{~m}$. W. Oconee $r_{s,} 19 \mathrm{~m}$. S. Milledgeville. It has a court-house, jail, academy, three churches, and 160 inhabitants.

ISABELYA county, Afich, Situate centrally on Lower Peninsula, and contains 576 sq. m. Drained by Salt, Chippewa, and Pine rivers, affluents of the Saginaw. A new county, unorganized in 1550 .

Iscrud a river, $N . Y .:$ an affuent of Oil cr., from Cattaraugus co., and which, through that river, empties into the Alleghany at Olean.

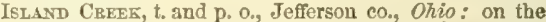
Ohio r., 126 m. E. N. E. Columbus, Drained by Island cr. Surface uneven, and soil very fertile, and excellent grazing. Wool is largely grown. Pop. 1,997.

Island Ford, p. o., Rutherford county, N. Car.: $202 \mathrm{~m}$. W. by S. Raleigh.

IsLAxD Grove, sta., Morgan co., Ill.: on the Sangamon and Morgan R. R., $19 \mathrm{~m}$. from Springfleld.

IsLe AU Crats, $N . Y .:$ an island of the St. Lawrence, of which there is another on the British side of the same name, between which the dividing line of the two countries passes. The one on the American side of the line belongs to the t. of Louisville, St. Lawrence co.

IsLE AU GALLOP, $N_{0} Y_{0}:$ an island of the St, Lawrence, and a part of the t. of Lisbon, in St. Lawrence co.

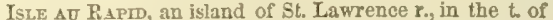
Madrid, St. Lawrence co.

Islebonotgr, t. and p. v., Waldo co., Me. : in Penobseot Bay, $47 \mathrm{~m}$. E. Augusta It is composed of a large, and several small islands near it, which have a fertile soil, with 
fine harbors, much frequented by fishermen and coasters. Fishing is the chief pursuit. Pop. of t. 984.

Isle Brevillie, p. 0., Natchitoches par., La. : 159 m. N.W. Batun Rouge.

IsLE OF SHOALs; a cluster of islands in the Atlantic, $8 \mathrm{~m}$. from Portsmouth Harbor, and called Hog, Duek, Btar, Smutty Nose, Londoner, White, and Malaga. They constitute the t. of Gosport, and are chiefly composed of rocks. Several of the islands have been connected with each other by sea walls, and their harbors otherwise improved. The inlabitants are fishermen, and besides supplying the Portsmouth market, salt large quantities for export. Pop. 103.

ISLE OF WIGET county, Virg. Situate S. E., and contains 352 sq. m. Bounded W. by Black r., a head of Chowan r., and $\mathbf{N}$. E. by James r. Surface various, with some good mill seats; soil mostly fertile. Corn is the staple. Sweet potatoes are much grown, and many hogs fattened. It has fine peach orchards, and its peach brandy is much noted. Farms 629 ; manuf. 13; dwell, 1,200, and pop.-wh, 4,724, fr. col. 1,234, si. 3,395-total 9,853. Capital: Smithfield. Public Works: Norfolk and Petersburg R. R.; Seaboard and Roanoke R. R.

IsLrP, t. and p. v., Suffolk co., N. Y.: on the Atlantic, 129 m. S. S. E. Albany. The surface is level, and soil sandy and mostly productive, with few streams. The v. contains two churches, and several stores and dwellings. Pop. of t.2,602.

Isxer, p. o., Choctaw county, Ala.: $122 \mathrm{~m}$. W. by S. Montgomery.

Isorx's Store, p. o., Maury co., Tenn.: 33 m. s. S. W. Nashville.

IspainaN, p. o., Fayette enunty, Tenn.: 163 m. S. W. Nashville.

IsRaEL's river, Coos co., N. Hamp.: a noted tributary of the Connecticut $r$. formed by the caseades and falls from the summit of Mt. Adams and Mt. Jefferson, and meeting the Connecticut at Lancaster. It is a beautiful stream, and along its banks is much picturesque seenery.

IsGaqUENA county, Mfiss. Situate W. centrally, and contains 964 sq. m. Xazoo r. is on its E. border, and the Mississippi its W. boundary; between these are Sunflower $r$., Williams bayou, and other streams. Surface low and even; goil highly productive. Cotton is the staple. Farms 75 ; manuf. 0 ; dwell. 110, and pop-wh. 366, fr. col. 7, sl. 4,105total 4,478. Capital: Tallula.

Italy Hill, p. 0., Yates co., N. Y.: 173 m. W. Albany.

ITaLX Howlow, p. o., Yates county, N. Y.: $176 \mathrm{~m}$. W. Albany.

Itasca county, Minn. Situate N. E. part of the Territory, and extent not ascertained. It lies on the $\mathrm{N}$. line of the U.S., and has on the N. a chain of lakes and rivers, extending from Lake of the Woods to Lake Superior, the last forming its $\mathrm{E}$. boundary. It is bounded $\mathrm{S}$. by Ramsey and Washington counties, and W. by the Mississippi r. and Pembina co. It embraces a large territory, hardly settled at all by white men, and little known, except by hunters and the natives, between whom a lively trade is kept up in furs, the only important product of the oo. Many streams afford fine fishing and facilitate travel, most of which have one or more lakes emptying into them. The largest of these are Mississippi r. and its lakes, Cass, and Winnibigoshish. Flowing E. into Lake Superior are Embarras r. East Swan r., Second Embarras r., and Cloquet ro, branches of St. Louis r.-a large stream-Knife r., Gooseberry r., Baptism r., etc. Farms 36 ; manuf. 0 ; dwell. 23, and pop. -wh. 97.

ITAsCA LAKE, MFinn. Ter, : a small lake, the source of the head stream of the Mississippi r. Lat. $47^{\circ} 10^{\prime} \mathrm{N}$., and long. $95^{\circ} 54^{\prime} \mathrm{W} .-3,160 \mathrm{~m}$. above the Gulf of Mexico. It is a beautiful lake, lying among the hills, surrounded by pines. Its outlet is 10 or 12 feet wide, and from 12 to 18 inches deep. It was discovered by Schoolcraft, July 13, 1832.

ITAWAMBB county, Mrss. Situate N. E., and contains 949 sq. m. Drained by several head streams of Tombigbee $\mathbf{r}$. Surfice level or undulating; soil mostly very productive.
Cotton is the staple, and corn but little inferior in its yield, Farms 1,499; manuf, 6 ; dwell. 1,862, and pop.-wh. 11,395 fr. col. 6, sl. 2,127-total 13,528, Capital: Fulton. Public Works: Mobile and Ohio R. R.

ITHACA, t., p. v., and cap. Tompkins co, $N_{0}, Y_{0}: 134 \mathrm{~m}$, W. Albany, Drained by Fall, Six Mile, and Cascadilla creeks, which fail into Cayuga Lake, The v. is situated on a plain, $1 \frac{1}{3} \mathrm{~m}$. S. of the lake, and on both sides of Cayuga inlet, which is navigable for large canal boats. The alluvial flat, on which the city is chiefly located, is inclosed on three sides by hills, which rise gradually to the height of 500 feet, and a part of the $v$. lies on the hill overlooking the beautiful lake in its front. The streets are at right angles, forming square blocks; its buildings are usually neat and commodious, and most of the thoroughfares are ornamented with shade trees. In available hydraulic power applicable to manufactures Ithaca is second to no other village in the State, and it is already engaged largely in industrial pursuits. The streams before named, in descending from the hills, have numerous falls. Fall cr. descends 438 feet in the course of a mile, having three successive falls of 70,50 , and 116 feet, the latter a grand cataract, and in an unbroken sheet, and other falls in the vicinity of the place are almost co-equal in extent and grandeur with these. The manufactures of the place comprise extensive cotton and woolen mills, flouring mills, iron works, machine shops, plaster mills, paper mills, and a variety of other industrial cstablishments. Its commercial advantages are also great. Southwoard the Cayuga and Susquehanna R. R. gives it access to the iron and coal fields of Pennsylvania, and at Owego it unites with the New Fork and Erie R. R., forming a direct route to New York City; and Northward through Cayuga Lake and Seneca Caual it communicates with the Erie Canal and the central chain of railroads extending between Albany and Buffalo. The prineipal exports south are plaster, flour, etc., which are exchanged for the coal, iron, etc., of that region. Iihace has two newspapers, the "I. Chronicle" (whig), issued daily and weekly, and the "I. Journal" (dem.), issued weekly. The v. was planned in 1800 by Simeon De Witt, and in 1821 it was incorporated. Pop. in 1830, 3,324; in 1840, 5,650; and in 1850, 6,909.

IтпACA, p. o., Darke county, Okio: 87 m. W. N. W. Columbus.

Ive's, sta., Hampden t., New Haven co., Conn.: on the New Haven and Northampton R. R., $7 \mathrm{~m}$, from New Haven. IVE's Grove, p. vo, Racine co., Wisc.: 79 m. E. S. E. Madison. A plank road passes $W$. through this village 11 m. from Racine.

Ire's Store, p. o., Princess Anne co., Tirg.: 94 m. S. E. Richmond.

Ivr, p. O., Tancey co, N. Car. : $206 \mathrm{~m}$. W. Raleigh.

Irx IsLaND, p. 0., Edgefield dist., S. Car.: 78 m. W. S. W. Columbia.

Ivy LoG, p. v., Union county, Ga.: 147 m. N. N. W. Milledgeville.

Ivy Mruls, p. vo, Delaware co., Penn.: $\$ 3$ m. E. by S. IIarrisburg.

IxoNIA, t. and p. v, Jefferson c0., Wisc, : on Rock r, 41 m. E. by N. Madison. The t. has a rolling surface, well timbered, and fine water-power. The soil is very rich, with prime grass lands. The v. lies on the left bank of Rock $\mathbf{r}$, and contains several stores and mills, and about 250 inhabitants. The plank road from Milwaukee to Madison passes through the town. Pop. of $t, 1,113$.

IzARD county, Ark. Situate N. centrally, and contains $841 \mathrm{sq}, \mathrm{m}$. Drained by White r., which runs through the county from N. W. to $\mathrm{S}, \mathrm{E}_{\text {, }}$, and its branchos Pine er. Buffalo fork, etc. Surface somewhat elevated, but pretty even; soil very fertile and excellent for grass and grain The pine is very abundant. Cattle and swine are raised in large numbers. Farms 832 ; manuf. 7 ; dwell. 496 , and pop.-wh. 3,017, fr. col. 0, sl. 196-total 8,218. Capital: Athens. 


\section{$\mathrm{J}$.}

$J_{\text {ACLNTo, p. v., and cap. Tishemingo co., Miss. : } 191 \mathrm{~m} .}$ N. N. E. Jackson. It contains a court-house, jail, etc., several stores and shops, and about 150 inhabitants. The "North Mississippi Union," a weekly paper, is published in this rillage.

JACKsborovgr, p. v., and eap. Campbell co., Tenn.: 148 m. E. by N. Nashville. It has a court-house, jail, a few stores and dwellings, and 100 inhabitants.

JaCE's CREEK, p. 0., Henderson county, Tenn.: $102 \mathrm{~m}$. W. S. W. Nashville.

JACk's Forks, p. o., Texas co., Mo.: on a branch of Current $r$, so called, $106 \mathrm{~m}$. S. S. E. Jefferson City.

J sq. m. Tennessee r. runs S. W. through the E. part, and Raccoon er. and other branches drain it. Surface various, with considerable low land; soil very fertile. Cotton and corn are the great staples. Wheat grows well, and many hogs are raised. Farms $\$ 56$; manuf. 4 ; dwell. 2,000 , and pop.-wh. 11,756, fr. col. 40, sl. 2,292--total 14,088. Capital: Bellefonte. Public Works: Memphis and Charleston R. R.; Nashville and Chattanooga R. R.

JACKsoN county, Ark. Situate N. E., and contains 679 sq. $m$. It lies between Big Black and White rivers on the W., and Cache r., a branch of White r., on the E. Surface mostly undulating or level; soil fine and well adapted to grazing, Corn is the staple, and large numbers of eattle and swine are raised. It has a great deal of excellent ash and cypress timber on its streams. Farms 232; manuf. 4 dwell. 447, and pop,-wh. 2,517, fr. col. 6, sl. 563-total 8,0s6. Capital: Elizabeth.

$J_{\triangle C K s o N}$ county, Flor. Situate N. W., and contains 929 sq. m. Appalachicola r. forms its E. boundary, and Chipola $r$, a branch of it, with its affluents, drains it. Surface level, with slight hills; soil generally fertile, on the streams very rich. Cotton is the great staple. Corn and wheat are good crops, and many cattle and swine are kept. Farms 287 manuf. 0 ; dwell. 560, and pop.-wh. 3,075 , fr. col, 30 , sl. 3,534-total 6,639. Capital : Mariana.

JACIsox county, $G a$. Situate N. E. centrally, and contains $523 \mathrm{sq.} \mathrm{m.} \mathrm{Drained} \mathrm{by} \mathrm{North} \mathrm{and} \mathrm{Allen's} \mathrm{forks} \mathrm{and}$ Appalachee r, head streams of Oconee r. Surface broken and elevated, with good meadows and water-power; soil fertile, and well adapted to grass. Cotton grows well Farms 547 ; manuf. 6 ; dwell. 1,200 , and pop.-wh. 6,808 , fr. col. 19, sl. 2,941-total 9,768. Capitaz: Jefferson.

JAcrsos county, II\%. Situate S. W., and contains $5 S 3$ sq. m. Drained by branches of Big Muddy r., a navigable stream crossing it S. W. to the Mississippi, which is its S.W. boundary. Surface rolling or slightly broken, with much timber and some prairie and swamp land; soil very fertile, with excellent grazing. On Big Muddy $\mathrm{r}$, are salt springs and immense deposits of coal. Copper is found. Farm 604 ; manuf, 28 ; dwell. 1,088, and pop.-wh. 5,829, fr. col 83-total 5,862. Capital: Murphysboros. Public Works. Illinois Central R. P.

$J_{\triangle C E S O N}$ county, Ind. Situate $\mathrm{S}$. centrally, and contains 524 sq. m. Drained by Driftwood, White, Salt, and Muscatatuck creeks, all fine mill streams. Surface level or undulating, with some "knobs" in the N. The bottoms are large and rich, and the soil generally sandy clay. Most of the county is well timbered. All the grains yicld great crops, and much beef and pork is fattened. Indian mounds are found in the N. Farms 1,173; manuf. 18; dwell. 1,965, and pop.-wh. 10,837, fr. col. 210-total 11,017. Oapital. Brownstown. Public Works: Jeffersonville R. R.

JAcrsor county, $I a$. Situate E., and contains $643 \mathrm{sq} . \mathrm{m}$. Drained by Macoquetais $r$. and its branches, affluents of the Mississippi, its E. boundary. Surface diversified, in parts broken; soil good and well timbered, produeing the cereals in abundance. This county is rich in minerals. It lies opposite the Galena lead district, and is abundantly supplied with lead, iron ore, copper, zine, and gypsum. Farms 703 ; manuf. 10; dwell. 1,277, and pop.-wh. 7,201 , fr. col. 9-total 7,210. Capitel: Andrew.

$J_{A O K S O N}$ parish, La. Situate N. centrally, and contains 927 sq. m. Drained by Dugdemona r. and branches $W$. and E. by branches of Wachita r., all affuents of Red r. Surface undulating, and covered mostly with a heavy growth of oak, hickory, sassafras, and poplar; soil on the river bottoms very fertile, and well adapted to cotton, which is the staple production. Farms 290 ; manuf. 6 ; dwell. 622 , and pop.-wh. 3,406, fr, col, 2, sl, 2,15s-total 5,566. Capital: Vernon.

JAoKson county, Mrich. Situate S. centrally, and contains $\tau 20 \mathrm{sq} . \mathrm{m}$. Drained $\mathrm{N}$. and W. by Portage r., a head of Grand r., and heads of Kalamazoo r., both flowing into Lake Michigan, and S. E. by heads of Raisin r., flowing into Lake Lrie. Surface undulating, with few hiils; soil a rich, sandy loam, bearing great grain crops and grass. I has good water-power, abundance of limestone and marl, fine building stone, and some coal. Farms 2,250; manuf. 95; dwell. 3,540 , and pop.-wh. 19,346 , fr. col. 85-total 19,431. Capital: Jackson. Pullic Works: Michigan Central R. R.

JACEson county, Miss. Situate S on the Gulf, and contains $1,243 \mathrm{sq}$. m. Drained by numerous branches of Pascagoula $r$., which crosses it from $\mathrm{N}$. to $\mathrm{S}_{\text {, }}$ and empties into Pascagoula Bay. Surface level and much of it wooded with pine; soil of moderate fertility. Corn is the staple, and many eattle and swine are raised. Farms 212 ; manuf. 8; dwell. 410, and pop.-wh. 2,273, fr. col. 100, sl. 820total 3,198. Capital: Jackson C. H.

$J_{A C K S O N}$ county, $\lambda$ fo. Situate W., and contains $7 \mathrm{S9}$ sq. m. Drained by Big and Little Blue rivers, affuents of the Missouri, its $\mathrm{N}$. boundary. Surface elevated and somewhat undulating; soil excellent, particularly for grain and grass, Corn is the agricultural staple. Large numbers of cattie, hogs, and sheep are raised on its fine pastures and abundant mast. It is well timbered and has good water-power. Farms 958; manuf. 78 ; dwell. 1,719, and pop.-wh. 10,992, fr. col. 39, sl. 2,969-total 14,000. Capital: Independence. Public Works : Pacific R. R.

$J_{A C K s o N}$ county, $N$. Car. Situate S. W., and contrins 834 sq. m. Drained by Tuckassege r., a head of the Tennessee $r$, and its affluents. Surface broken and mountainous. Soil very productive, yielding large crops of all the grains, and affording excellent pasture. Corn and pork are staples. Erected since 1850

JACKSON county, Ohio. Situate 8., and contains 3S4 sq. m. Drained by Raccoon and Symmes creeks, and Little Scioto, affluents of Ohio r., and Salt er., a branch of Scioto $r$. Surface somewhat broken, and soils highly productive of the grains and grass. Coal and iron ore are abundant. Corn, wheat, wool, and pork are farming staples. Farms 1,164; manuf. 14; dwell. 2,120, and pop.wh. 12,330, fr. col. 391-total 12,721. Capital: Jackson. Public Works: Cincinnati, Hillsboro', and Parkersburs R. R. : Scioto and Hocking Valley R. R.

J $\triangle$ CKSON county, Tenn. Situate N. centrally, and contains $369 \mathrm{sq}=\mathrm{m}$. Drained by small affluents of Cumberland r., which crosses it from N.E. to S. W., and is boatable at all seasons. Surface diversified, but not rough, with some water-power; soils fine. Tobacco and all the grains grow well, and many sheep and swine are raised. Farms 1,211; manuf. 4; dwell. 2,325 , and pop. -wh. 14,000 , fr. col. 115, sl. 1,558-total 15,673. Capital: Gainesboro',

JACEsON county, Tex. Situate S. near the Gulf, and contains 854 sq. m. Drained by Arenosa bayou W., Carancua bayou $E$., but mostly by Lavacca and Navidad rivers, which are navigable for vessels of light draft, and their branches. Surface a rolling prairie, wholly destitute of stone. The streams are lined with forests, the rest of the county is open; soil a deep black mold lying over red 
loam, and very rich. Corn and entton yicld enormously, and most esculents flourish. Indigo is raised abundantly. Cattle are an important staple, requiring little attention, and grazing on the prairies the year round. Farms 73 ; manuf 0 ; dwell. 114, and pop.-Wh. 627, fr. col. 30, sl. 339-total 996. Capital: Texana.

JACKson county, Virg. Situate N. W., and contains 412 sq. m. Drained E. by branches of Little Kanawha r., and W. by Big Mill, Big and Little Sandy creeks, aftluents of Ohio $r$., which bounds it N. W. Surface varied, with good mill seats; soil very good, adapted to grain growing and grazing. Corn, wheat, and pork are staples. Farms 602 ; manuf, 16 ; dwell. 1,034, and pop.-wh. 6,450, fr. col. 11, sl. 53-total 6,511. Oapital: Ripley (Jackson C. H.)

JACksox, p. v., Clarke co., Ala.: on the left bank of Tombigbee r., $112 \mathrm{~m}$. S. W. by W. Montgomery.

JACksor, p. V., Stephenson co., Ill.: on a branch of Peckatnnica r., $171 \mathrm{~m}$. N. Springfield.

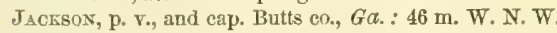
Milledgeville. It lies about $8 \mathrm{~m}$. W. of Ocmulgee r., and contains a court-house, jail, an academy, several churches and stores, and about 200 inhabitants.

JAcksoN, p. o., Elkhart county, Ind.: $87 \mathrm{~m}$. N. by E. Indianapolis.

JAcksor, p. $\nabla$. and cap. Breathitt co., $K y .:$ on the $\mathbf{N}$. fork of Kentucky r., 92 m. E. S. E. Frankfort. It is a pretty village, containing the county buildings, and has valuable salt works in the vicinity.

JACKSON, p. v., and cap. East Feliciana par., La. : on the E. side of Thompson's cr., $26 \mathrm{~m}$. N. Baton Rouge. Here is located Centenary College, founded in 1839, with 7 instructors, 40 alumni, 94 students, and 5,000 volumes in its

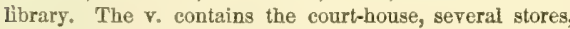
and about 1,000 inhabitants.

JACKsox, t. and p. $\mathrm{v}$., Waldo co., Me. : on a branch of Marsh r., 37 m. N. E. Augusta. It has a fine soil, producing superior wheat. Pop. of t. 833.

JAckson, t., p. v., and cap. Jackson co., Mich. : on Grand r., $82 \mathrm{~m}$. \$. by E. Lansing. The t. is drained by Grand and Portage rivers, affording excellent water-power, and has a rich soil adapted to grass or grain. Coal and abundance of white sandstone and limestone are found. The v. is on Grand r., where the falls furnish abundant water-power, and is extensively engaged in manufuctures of flour, leather, iron ware, machinery, etc. It contains a court-house, jail, the State penitentiary, a branch of the university, and several banks. Its situation and facilities for transportation and travel give it a large trade with the interior and the East. The Michigan Central R. R. passes through the $\mathrm{v}$. $76 \mathrm{~m}$. from Detroit. Two newspapers, the "American Citizen" (whig), and the "Jackson Patriot" (dem.), are published weekly. Pop, of t. 4,147.

JACKsor, p. v., and cap. Hinds co., MFiss., and capital of the State of Mississippi : on the W. bank of Pearl r., in lat. $82023^{\prime} \mathrm{N}$., and long. $90^{\circ} 08^{\prime}$ W. $-1,035 \mathrm{~m}$. W. S. W. W ashington. The site is level, and about a quarter of a mile from the river. The v., regularly laid off, contains a handsome State house, the governor's house, the State penitentiary, a U.S. land office, etc., several mechanic shops, about 40 stores of various descriptions, and 3,000 inhabitants. Three newspapers are published bere, viz., the "Mississippian" (dem.), the "Flag of the Union" (whig), and the "Hinds Gazette" (whig), all weekly issues. The Vicksburg, Jackson, and Brandon P. R. passes through Jackson, as will also the New Orleans, Jackson, and Northern P. R., ete.

JAcksoN C. H., p. $\nabla$. , and cap. Jackson co., MFiss.: on Cedar er., near Pascagoula r., 139 m. S. E. Jackson. It contains a court-house, jail, hotel, and a few houses.

$J_{\triangle O K B O N,}$ t. and p. V., Washington co., $N$. Y.: on $\mathrm{S}$. side of Batten IrIll, $86 \mathrm{~m}$. N. N. E. Albany, The t. has a varied surfaoe, a soil of moderate fertility, and considerable water-power. The Rutland and Washington R. R. crosses the E. part. 'The v. contains an academy, severul stores, and 300 inhabitants. Pop. of t. 2,129.

JACksos, p. v., and cap. Cape Girardeau co., Mo.: on Hubbes' cr. of Whitewater r., $12 \mathrm{~m}$. from the Mississippi, $162 \mathrm{~m} . \mathrm{S}$. E. by E. Jefferson City. It conlains a court-house, jail, etc., a U.S. land office, and about 600 inhabitants. The "Southern Democrat" is published weekly.

JAOKsos, t. and p. v., Coos co., N. Ilamp.: at the E. base of White Mountains, $64 \mathrm{~m}$. N. N. E. Concord. Drained by Ellis's r., a branch of Saco r., affording water-power. Surface very rugged; soil good. The $\mathrm{v}$. lies near the E. branch of Ellis's r. Pop. of t. 539.

JACksox, p. v., and cap. Northampton co., N. Car. : about $5 \mathrm{~m}$. N. Roanoke r., $84 \mathrm{~m}$. N. E. Raleigh. It contains the court-house, and a few stores and dwellings.

JAcksor, t., Jackson co., Ohio: 56 m. S. 8. E. Columbus. A fine grazing town. Drained by Salt creek. Pop. 717.

JAcksoN, p. v., and cap. Jackson co., Ohio : on a brauch of the Scioto, $65 \mathrm{~m}$. S. S. E. Columbus. It contains a courthouse, jail, several stores and small mills, and 480 inhabitants. The Iron R. R. will connect here with the Scioto and Hocking Valley R. R. The "Jackson Standard" (whig), and "Jackson Union" (dem.), are issued here weekly.

JACrson, t. and p. v., Susquehanna co., Penn.: on head of Tunkhannock cr., $185 \mathrm{~m}$. N. E. by N. Harrisburg. Surface rough, and soil good pasture. The $\mathrm{v}$. has 3 stores and 25 houses.

JACKsoN, p. v., and cap. Madison co., Tenn. : on Forked Deer r., 118 m. W. S. W. Nashville. It contains a courthouse, jail, 3 churches, 12 stores, and 600 inhabitants.

JAcksor C. H., p. v., and cap. Jackson co., Firg. : on Big Mill cr. of Ohio r., $241 \mathrm{~m}$. W. N. W. Richmond. It contains, besides a court-house and jail, several stores and mills, an academy, and 250 inhabitants.

JACKsoN, p. o., Louisa county, Firg.: 45 m. N. W. Richmond.

JACKsoN, p. v., and cap. Calaveras co., Calif. : at the junction of $\mathrm{N}$. and S. forks of Mokelumne r., $106 \mathrm{~m}$. E. by N. Vallejo. It contains a court-house, several stores, and 600 inhabitants. The washings in the vicinity are very rich in gold, and the soil excellent.

JACKsonborough, p. v., and cap. Seriven co., Ga. : on Brier cr., 104 m. E. hy S. Milledgeville. It contains a courthouse, jail, high school, several stores, and 150 inbabitants. JACKs,onborodge, p. v., Butler co., Ohio : 83 m. W. S.W. Columbus.

JACKsoN Brook, p. 0., Washington co., Me.: $123 \mathrm{~m}$. E. N. E. Augusta.

JAcksonвuRgI, p. F., Wayne county, Ind.: 73 m. E. Indianapolis.

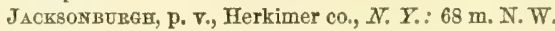
Albany.

$J_{\text {ACKson Corners, p. }}$., Duchess co., $N . Y_{*}: 43 \mathrm{~m} . \mathrm{S}$. Albany.

JACKSON CreEk, p. $\nabla$. , Will co., $M l_{.}$: on an aftluent of Illinois r. so called, $139 \mathrm{~m}$. N. E. Springfield.

JACKsoN FURNACE, p. v., Jackson co, Ohio: near the Little Scioto $\mathrm{r}, 77 \mathrm{~m}$. S. by E. Columbus.

JAckson HaนL, p. v., Franklin co., Penn. : 56 m. W. S. W Harrisburg.

Jackson Hax, p. o., Lancaster dist., $S . C a r$ : : $5 \$ \mathrm{~m}$. N. N. E. Columbia.

Jackson Hill, p. o., Davidson co., $N$. Cars : 96 m. W. Raleigh.

JACKsoN HrLl, p. 0., Spartanburgh dist., $S$. Car. : $\$ 9 \mathrm{~m}$. N. N. W. Columbia.

JACKSON POINT, p. o., Folt co., Mro. : 203 m. W. N. W. Jefferson City.

JACKson Port, p, o, Jackson co., Arz.: $97 \mathrm{~m}$. N. N. E. Little Rock.

Jackson's Casrp, p. o., Tallapoosa co., $A l \alpha_{*}:$ N. E Montgomery. 
JACKson's CREEK, p. o., Fairfleld distu, S. Car.: $28 \mathrm{~m}$. N. by W. Columbia.

JAOKgon's Ferrx, p. o., Wythe co., Firg. : near New r., 195 m. W. S. W. Richmond.

JACKsox's MiLls, p. v., Lenawee co., Mich. : 59 m. S.S.E. Lansing.

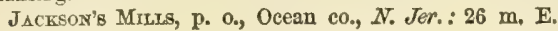
Trenton.

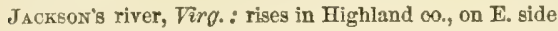
of Alleghany Mountains, and flows S. to Covington, then E. to its junetion with Cowpasture r., which two form the James. It has a very rapid descent, and furnishes much water-power.

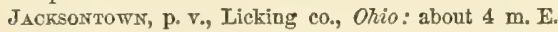
of the Ohio Canal, $29 \mathrm{~m}$. E. Columbus. It has several stores and 300 inhabitants.

$J_{\text {ACEson VALrex, p. }}$., Susquehanna co., Penn.: 132 m. N. E. by N. Harrisburg.

JACKSONVILLE, p. vo, and cap. Benton co., Ala.: on Chocoloche cr. of Coosa r., $102 \mathrm{~m}$. N. N. E. Montgomery. It contains a court-house, jail, several large stores, a few manufactories of farming implements, and 350 inhabitants. The "Republican" (dem.) is issued weekJy.

$J_{\text {ACKSONVILLE, }}$ p. v., and cap. Duvall co., Flor.: on the left bank of St. John's r., about $20 \mathrm{~m}$. from its mouth, 162 m. E. Tallahassee. The St. John's, here $1 \mathrm{~m}$. wide, furnishes access to the interior and the $\mathrm{N}$. coast, carrying hence heavy cargoes of cotton, and bringing hither many invalids attracted by the mildness of the climate. It contains a courthouse, jail, academy, and several stores and dwellings.

$J_{A C K S O N V I L L E,}$, . v., and cap. Telfair co., $G a_{0}:$ on the left bank of Ocmulgee r., $94 \mathrm{~m}$. S. by E. Milledgeville. It contains a court-house, jail, academy, and about 100 inhabitants.

J ACKSONTILLE, p. v., and cap. Morgan co., $I U .: 30 \mathrm{~m}$. W. Springfield. It is near Mauvaiseterre cr., surrounded by rich prairie, and is one of the most flourishing villages in the State. It has extensive manufactures of flour, cotton goods, leather, machinery, etc., a court-house, jail, several excellent high schools, and 2,000 inhabitants. Illinois College, founded in 1830 , has a fine location here, 6 instructors, 94 graduates, of whom 35 are ministers, 32 students, and a library of 2,500 volumes. The State institutions for the deaf and dumb, the insane, and the blind are pleasantly located and in successful operation in the outskirts of the village. The Sangamon and Morgan R. R. passes the $\mathrm{v} .33 \mathrm{~m}$. from Springfleld, and 21 from Naples. The "Morgan Journal" (whig) publishes weekly and tri-weekly editions.

JACh8ON wlLLE, p. V., Switzeriand c0., Ind.: 82 m. S. E.

Indianapolis

JACKsenville, p. v., Burlington county, $N$. Jer.: on

Assincunk cr., $10 \mathrm{~m}$. S. Trenton.

JACESONYLLE, p. Y., Tomplins co., $N . Y_{*}: 149 \mathrm{~m}$. W. Albiany

TACK, Nimle, p. v., Darke co., Ohio: $81 \mathrm{~m}$. W. by N. Columbus.

JAcksonvule, p. จ., Lohigh co., Penn.: 79 m. E. N. E. Harrisburg

JACESON VILLE, p. v., Windham co., Verm. : $1.05 \mathrm{~m}$ S. by W. Montpelier. It contains several stores and 200 inhabitants.

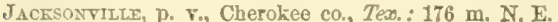
Austin City.

JACKSOFFILIE, p. 0., Bourbon county, $K y_{0}: 43 \mathrm{~m}, \mathrm{E}$, Frankfort.

JACESONvILlE, p. v., Tuolumne co., Calif.: on Tuolumne r., near the junction of Rattlesnake cr., 98 m. E. S. E. Vallejo. It is the centre of a rich gold district, and has severall st res and 500 inhabitants.

$J_{\triangle C E}$ 's ReEF, p. V., Onondaga co., $N_{0} Y_{.}: 141 \mathrm{~m} . \mathrm{W}$. by N. Albany.

J Harrisurg. 830
J $\triangle$ OOBSBURGH, p. V., Belmont county, Ohio: $107 \mathrm{~m} . \mathrm{E}_{\text {。 }}$ Columbus. A village of about 300 inhabitants.

JACOBSBURgi, p. v., Northampton co.g Penn.: 94 m. E. N. E. Harrisburg. Here is a bloomery forge making 50 tons iron per annum, and a few dwellings.

$J_{\Lambda C O B ' s}$ Fork, p. 0., Catawba co., N. Car.: $124 \mathrm{~m}$. W. Raleigh.

JACоBsтоW Trenton.

JAFFrEY, t. and p. v., Cheshire $c_{0}, N$. Hamp. : at the head of Contoocook ro, $37 \mathrm{~m}$. S. W. by S. Concord. It lies 8. E. of Monadnock Mountain, has a fine soil for grass, several ponds, affording excellent mill streams, a mineral spring furnishing yellow ocher, and small factories for cotton and woolen goods. The v. has a high school, a hotel, several stores, and 200 inhabitants. Pop. of t. 1,497.

JAKE's Pratrie, p. V., Gasconade county, MOo.: near Bourbeuse cr., 43 m. S. E. Jefferson City.

J AKE's RuN, p. o., Monongalia co, Virg.: $191 \mathrm{~m}$. N. W. Richmond.

JALAPA, p. v., Grant co., Ind. : on Mississinewa r., $63 \mathrm{~m}$. N. N. E. Indianapolis.

JALAPA, p. o., M·Minn co., Tenn.: 126 m, E. S. E。 Nashville.

$J_{A T, A P A}$, p. O., Greene co, $I l l_{0}: 43 \mathrm{~m} . \mathrm{S}$. W. Springfield.

$J_{A M A I C A}, t$, and p. v., Queens co, $N$. $Y .: 137 \mathrm{~m}$. S. Albany. Surface level, with slight hills in the N.; soil a sandy loam, and mostly fertile, with extensive salt meadows in the S., producing large crops of grass. Jamaica Bay occupies the $\mathbf{S}$, and the Union Race-course is in the W. part, $8 \mathrm{~m}$. from Brooklyn. The $\mathrm{v}$. is on the Long Island R. R., $11 \mathrm{~m}$. from Brooklyn, and contains the county clerk's and surrogate's offices, an academy, a female seminary, 6 churches, 6 hotels, 20 stores, several manufactories, an extensive repair shop for the railroad, and about 1,900 inhabitants. Two weekly papers are published, the "Long Island Farmer" (whig), and the "Long Island Democrat." Pop. of t. 4,247 .

Jamaica, t. and p. v., Windham eo., Term.: $86 \mathrm{~m}$. S. by W. Montpelier. Drained by West r., which affords fine water-power. Surface uneven, and soil mostly good. Limestone is abundant. The $\mathrm{v}$, is on a branch of the river, has valuable mills, several stores, and 450 inhabitants. Pop. of t. 1,606 .

$J_{\text {AMATOA, }}$ p. 0., Middlesex county, $\nabla 2 r g .: 51 \mathrm{~m}$. E. Richmond.

Javaroa Prank, p. V., Norfolk co., Mrass.: on the Boston and Providence R. R., $3 \frac{1}{2}$ m. S. W. Boston. Jamaica Pond, $5 \mathrm{~m}$. from the Exchange in Boston, supplied that city with water through $40 \mathrm{~m}$. of pipe, from 1795 to Oct., 1S48, when the Cochituate Aqueduct was opened. The v. is a beautiful suburb of the city, containing many splendid private residences and fine schools, and has some trade and manufactures.

JAMres CtTY county, Virg. Situate E., and contains 113 sq. m. It has James r. on the S., Chickahominy r., its branch, on the W., and York r. on the N. E. Surface generally level, and soil mostly fertile. Corn and whent are the staples. In this county was the first permanent settlement made by the English in America, Jamestown, its site, lying in the S. on James $r$. This town is noted now only for it monuments; but Williamsburg, $8 \mathrm{~m}$. distant, was long the capital of the colony, and is the seat of William and Mary College, the oldest, save Harvard, in the U. S., and widely distinguished for the elegance and refinement of its society. Farms 129; manuf, 0; dwell. 396, and pop.-wh. 1,489, fr. col. 668, sl. 1,868-total 4,020. Capital: Williamsburg.

JAMES river, Mo.: with its branches, drain most of Greene county, and then by a $\mathrm{S}$. course empties through Stone connty into White river.

JAms river, Virg. : the most important river of the Stato, and having its course wholly within it. It rises in the 11 - 
Ieghanies, and is formed by the union of Cowpasture and Jackson's rivers. North $\mathbf{r}$. joins it at the passage of the Blue Ridge, and it is afterward joined by the Rivanna and $\Delta$ ppomattox, the latter of which is its largest affuent. James r. is upward of $500 \mathrm{~m}$. long, and enters IIampton Foads near the mouth of Chesapeake Bay. Lyachłurg and Richmond are on this river. Above Richmond the navigation has been improved by the James River Canal, which is now completed to Balcony Falls. This river and it improved navigation form the outlet of a country abounding in tobacco, wheat, corn, hemp, coal, etc. Below Richmond the navigation is open to large vessels -120 ton ships come up to Rocket's, just below; 250 tons to Warwick, and to Jamestown a 40 gun man-of-war. On Harrison's bar there is 15 feet water at low tide.

J $\triangle$ MESEUTRGM, p. $\nabla .$, Middlesex co., N. Jer. : N. E. Trenton, Javres' Crezes, p. v., Huntingdon co., Penn. : on an afQuent of the Juniata so called, $67 \mathrm{~m}$. W. Harrisburg.

JAures' Cross RodDs, p. O., Washington co., Tenn.: 244 m. E. Nashville.

JANres' Fork, p. 0., Crawford co., Ark. : on a branch of Poteau r. so called, $124 \mathrm{~m}$. W. N. W. Little Rock.

J AMrES $^{\prime}$ Mím., p. o., Monroe co., $I l l_{0}: 112$ m. S. S. W. Springfield.

JAMFSON's, p. o., Owen co., Ky. : 22 m. N. Frankfort.

JAMesport, p. v., Suffolk co., $N$. $Y$.: about $2 \mathrm{~m}$. from Great Peconic Bay, $134 \mathrm{~m}$. S. E. by S. Albany. It is on the Long Island R. R., $16 \mathrm{~m}$. from Greenport.

Jamestown, r., Tuolumne co., Calif.: on the Tuolumne r., above the junction of Rattlesnake cr., 29 m. E. S. E. Yallejo.

JAwestows, t. and p. r., Boone co., Ind.\$26 m.W. N.W Indianapolis.

Javistown, p. o., Clinton county, Ill.: 85 m. S. by E. Springfield.

JAMESTown, p. $\nabla$. , and cap. Russell co., Ky. : about $5 \mathrm{~m}$. N. of Cumberland r., $83 \mathrm{~m}$. S. Frankfort. It contains the county buildings, several stores, and 200 inhabitants.

JAvRstown, p. o., Moniteau co., Mfo. : W. Jefferson City. JAXEstown, p. v., Chautauque county, $N . Y .: 281 \mathrm{~m}$. W. by S. Albany. It is near the S. E. end of Chautauque lake, or Conewango cr., its outlet, which furnishes fine waterpower. The lake is crossed to Maysville, $21 \mathrm{~m}$., by steamboats. The $\mathrm{v}$. has numerous and valuable manufactures of ftour, woolens, cabinet ware, leather, iron ware, and agricultural implements. It contains 6 churches, a bank, an aeademy, 25 stores, and about 2,000 inhabitants.

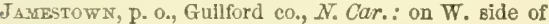
Deep r., $\$ 1 \mathrm{~m}$. W. by N. Raleigh.

JAMESTOWN, V., Firg. : on the N. bank of James r., $46 \mathrm{~m}$. E. S. E. Richmond. Fere, $32 \mathrm{~m}$. abore the mouth of James r., was the flrst permanent English settlement in America, made in 1607. Historical associations have made it classical ground, which business does not disturb. The only remains of the first settlement are the ivy-covered ruins of a church and the moss-grown stones in the churchyard.

JAMRSTOWN, p. v., Greene co., Ohio: on Cowar's cr. of the Little Miami, $41 \mathrm{~m}$. S. W. by W. Columbus. It contains 3 churehes, several mills, a high school, 6 stores, and about 400 inhabitants.

JaMestown, p. v., Mercer co., Penn. : on Shenango er., $214 \mathrm{~m}$. N. W. by W. Harrisburg. It contains several stores and mills, and 300 inhabitants.

$J_{\text {Aurgstown, p. o., Mliseogee }}$ o., Ga.: 115 m. W. S. W. Milledgeville.

$J_{\triangle \text { XVosTown, p. }}$., and eap. Fentress co., Tenn. : $126 \mathrm{~m}$. E. by N. Nashville. It lies at the foot of Cumberland Mountain, and contains the county buildings and a few stores and dwellings. "ै

$J_{A M E S T O W N}$ t. and p. v., Newport co., R. $I_{0}:$ in Narragansett Pay, $22 \mathrm{~m}$. S. Providence. The t. comprises Conoricut Isind, and has a rich soil, adapted to grass and corn. A fine farming t., $1 \mathrm{~m}$. W. from Newport and $1 \mathrm{~m}$. E. South Kingston, with ferries to both places. Pop. of t. 353

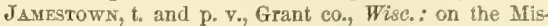
sissippi, $74 \mathrm{~m}$. W. S. W. Madison. The t. is well drained by affluents of the Mississippi, affording good mill-sites, is uneven, and very fertile. The $\mathrm{v}$, is small and on the river. Pop. of t. 622 .

Jamesville, p. v., Onondaga co., $N_{\text {. }} Y_{\text {: : }}$ on the W. side of Butternut cr., which furnishes water-power, $124 \mathrm{~m}$. W. by N. Albany. It contains 4 churches, 2 hotels, 6 mills for flour and gypsum, and 450 inhabitants.

$\Im_{\triangle M I B O N}$ 's, sta, Orangeburg dist., S. Car.: on the Columbia Branch of the S. Carolina $\mathrm{R}, \mathrm{R}, 7 \mathrm{~m}$. N. Orangeburg, $43 \mathrm{~m}$. S. Columbia.

$J_{\text {ANELET, }}$. o., Lewis county, Virg.: $187 \mathrm{~m}$. W. N. W. Richmond.

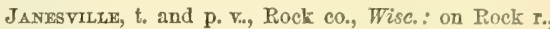
$34 \mathrm{~m}$. S. S. E. Madison. The t. has a rich and highly cultivated soil and even surface. The v. occupies both sides of Rock r. back to the bluffs, which are 100 feet high, and has several large mills on the excellent sites the falls here afford. The court-house occupies a bold eminence, overlooking a jail, several large stores, and many fine dwellings. Its trade is extensive and rapidly increasing. A railroad to Chicago is commenced. Two weeklies, the "Janesville Gazette" (whig), and "Rock County Badger" (dem.), are published. Pop. 3,419 .

Jarratrs, p. v., Sussex co., Virg. : on Nottaway r., 43 m. S. Richmond, The Petersburg R. R. passes through the v. $31 \mathrm{~m}$. from Petersburg and $83 \mathrm{~m}$. from Weldon.

J ARRETTS Ford, p. o., Kanawha county, Firg.: $219 \mathrm{~m}$. W. by N. Richmond.

JARRetTsville, p. v., Harford co., MYd.: near Deer cr., $45 \mathrm{~m}$. N. Annapolis.

J $\triangle$ SPER county, $G a$. Situate N. centrally, and contains 369 sq. m. Drained by affluents of Ocmulgee r., its $\mathrm{W}$. boundary, and E. by heads of Oconee r. Surface various; soils very fertile. Cotton is the staple, for which the country is admirably adapted, raising very large crops of excellent quality. Corn and wheat yield well. It has some waterpower. Farms 588; manuf. 12 ; dwell. 812, and pop.-wh. 4,323, fr. col. 29, sl, 7,134-total 11,4\$6. Capital: Monticello.

$J_{A S P E R}$ county, $I l l$. Situate S. E., and contains $456 \mathrm{sq} . \mathrm{m}$. Drained by Embarras and heads of Little Wabash r., both branches of Wabash r. Surface low and level, and in parts marshy; soil wet and not sufficiently drained. This done it would be very productive. Much of it is prairie, and part well timbered. Corn is chiefly grown. Farms 253; manuf. 0 ; dwell, 588, and pop.-wh. 3,206, and fr. col. 14total 3,220. Capital: Newton.

JASPER county, Ind. Situate N. W., and contains 973 sq. m. Drained by Kankakee r., its N. boundary, and Pickamink, or Iroquois $\mathbf{r}_{\text {, }}$ its branch, with their affluents. Beaver Lake, in the $\mathbf{N}$. W., is the largest sheet of water in the State, and abounds in excellent fish. Surface level, mostly wet or dry prairie, interspersed with groves or oak openings. Much of the land is fertile, and well adapted to grazing. Wheat, corn, and oats are the cereal staples. Farms 343 ; manuf. 4; dwell. 592, and pop.-wh. 3,539, fr. col. 1-total 3,540. Capital: Renselaer.

$J_{\triangle A P E R}$ county, $I \sigma .0$ Situate E. centrally, and contains $743 \mathrm{sq}$. m. Drained by N. and S. forks of Chicagua, or Skunk r., which runs S. E. to the Mississippi. Surface lerel or undulating; soil mostly prairie and very fertile. Good timber on the streams, which furnish some water-power. This region is a fine farming and grazing country. Farms 150 ; manuf. 0 ; dwell. 214 , and pop.-wh. 1,250, fr. col 0total 1,280. Capital: Newton. Public Works: Council Bluffs R. R.

$J_{A S P E R}$ county, Miss. Situate S. E. centrally, and contains 661 sq. m. Drained by Bogue Hume, Tallahala, and Leaf creeks, and branches of Chickasawha r., all flowing 
through Pascagoula $r$. into the Gulf. Surface level with moderate hills; soil productive. Cotton is the staple, corn a good crop, and large numbers of cattle and hogs are fatted. Its many streams furnish considerable water-power. Farms 540; manuf. 9 ; dwell. 674, and pop.-wh. 4,296, fir. col. 1, sl. 1,857-total 6,184. Capital: Paulding.

J ISPER county, Mo. Situate 8. W., and contains 1,179 sq. m. Drained N, by Big Dry Wood, Dry Wood, Clear, and Horse creeks, flowing $N$. into Osage $\mathrm{r}_{\text {, and }} \mathrm{S}$. by $\mathrm{N}$. and S. forks of Spring r., Centre cr., and other affluents of Neosho r., which runs into the Arkansas. Surface elevated and broken in parts, but mostly undulating; soil highly productive. Corn is the chief crop, but all the cereals thrive, and there is excellent pasturage. Cattle and hogs are raised in great numbers. Farms 408; manuf. 8; dwell. 664, and pop.-wh. 4,009, fr. col, 1, sl. 213-total 4,223. Capital: Carthage.

JASPER county, Tex. Situate E. near Sabine r., and contains $8 \$ 2$ sq. m. Drained N. by Angelina r., and other affluents of Neches r., which forms its W. boundary, and with its branches drains most of the county. Surface undulating in the $\mathrm{S}_{\text {, }}$ in the N. hilly; soil on the Angelina and Neches, which overflow their banks, a rich alluvial bottom of great fertility, producing heavy crops of corn, cotton, and sugar. Back of this the soil is sandy and much less fertile. The county is well timbered, and the Angelina and Neches, large navigable streams, make exportation easy and markets convenient. Farms 123; manuf. 6 ; dwell. 192 , and pop.-wh. 1,226, fr. col. 0, sl. 541-total 1,767. Capital: Jasper.

$J_{A S P E B}, p_{.}$.., and cap. Walker co, Ala.: $116 \mathrm{~m} . \mathrm{N} . \mathrm{N}$.W. Montgomery.

J ASPRE, p. Y, and cap. Newton co, Ark. : 104 m. N. N. W Little Rock. It contains a court-house and a few dwellings.

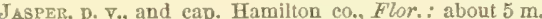
E. of Allapahais r., $S 1$ m. E. by N. Tallahassee. It contains a court-house and a fow stores and dwellings.

JAGPKR, p. $v_{\text {., }}$ and cap. Dubois co., Ind.: on the right bank of Patoka cr., $101 \mathrm{~m}$. S. S. W. Indianapolis. It contains a court-house, jail, hotel, several stores, and 400 inhabitints.

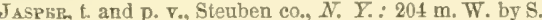
Albany. The t. has an undulating surface and loamy goil, well fitted for grazing, and is drained by Benneti's and Tuscarora creeks. It is a farming t. and has a pop. of 1,749.

J SSPER, p. r., Pike co, Otio: on the Scioto $\mathrm{r}$. and Ohio Canal, $61 \mathrm{~m}$. S. Columbus. Pop. 84 .

J $\triangle$ SPER, p. v., and eap. Marion co., Tenn.: on Sequatehy r., $92 \mathrm{~m} . \mathrm{S}$. E. Nashville. It is a small v. containing the county buildings.

JASPER, p. v., and eap. Jasper co., Tex.. on the W. bank of Sandy cr., a branch of the Neches, $124 \mathrm{~m}$. E. by N. Austin City. It occupies the centre of an extensive plain, and contains a court-house, 3 stores, hotel, and 200 inhabitinis.

$J_{A T T,}$ p. o, Rapides par., $L a .: 117 \mathrm{~m}$. ․ W. Baton Rouge. JATTON, p. 0., Grant county, Ind.: $64 \mathrm{~m}$. N. N. E. Intlianapulis.

$\mathrm{J}_{\mathrm{AT} A}$, t. and p. 0. W Wroming county, $N . Y_{0}: 244 \mathrm{~m} . \mathrm{W}$. Albany. Drained by Seneca cr., which has a few mill sites. Surfice rolling; soil clayey loam, adapted to grass. Farming is the chief business. Pop. 2.245 .

JAVA, p. v., Lucas co., Ohio: $117 \mathrm{~m}$. N. N. W. Columbus. JAVA VILlage, p. v., Wyoming co., $N_{\text {. }} Y_{\text {. }}$ : on Seneca cr. $245 \mathrm{~m}$. W. Albany. It contains a church, hotel, several mills: and 2 io inhabitants.

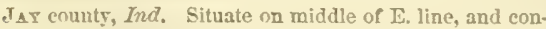
tains $362 \mathrm{sq}$. m. Drained by Wabash r., and Salamonie r., its branch, with their affluents. Surface rolling or level; solls everywhere very productive, with plenty of timber. It is a fine srazing region. Corn, wheat, and pork are the staples. Farms si6: manuf. 9: dwell. 1.179. and pop. -wh. 7,017, fr. col. 30-total 7,047. Capital: Portland.

382
$J_{\Delta Y}$, t. and p. v., Essex co., N. $\Gamma_{\text {. }} 116$ m. N. Albany. Drained by Au Sable r., which furnishes water-power. Surface mountainous, the Adirondack Mountains being in the E. part. On the Au Sable are rich flats. The $\mathrm{y}$. is on the E. branch of the Au Sable, and contains a hotel, s churches, a forge, several mills, and 500 inhabitants. Pop. of t. 2,685 .

$J_{A X}, t$. and p. v., Orleans co., Verm.: on N. line of the State, $51 \mathrm{~m}$. N. Montpelier. Drained by branches of Missisqui r., affording water-power. Surface very rugged. In the S. W. is Jay's Peak; soil fertile. Pop. of t. 371.

$J_{A Y}$, t., Franklin co., $M_{\theta}$ : on the Androscoggin, $27 \mathrm{~m}$. W. N. W. Augusta. A fine farming town. Pop. 1,733.

JAY BRIDGe, p. v., Franklin co., Me. : on the Androscoge gin, $26 \mathrm{~m}$. W. N. W. Augnsta. It contains several stores and mills, and is surrounded by a fine wheat and grazing region. Pop. 450.

JAY C. H., p. o., and eap. Jay co., Ind.: on the N. side of Salamonie r., $73 \mathrm{~m}$. N. E. by E. Indianapolis. It contains a court-house, jail, academy, several stores, and about 400 inhabitants. Formerly called Portland.

JAYNeSvilte, p. V., Covington co., Miss. : $44 \mathrm{~m}$. S. E Jackson.

JEANeretr's, p. 0., St. Mary's par., La.: 53 m. S. S. W. Baton Rouge.

Jesisvilue, p. v., Luzerne county, Penn.: 93 m. N. E. Harrisburg,

JEDDO, p. v., Orleans county, $N . Y_{0}: 241 \mathrm{~m} . \mathrm{W}$. by $\mathrm{N}$. Albany.

JeDpo, p. v., Jefferson county, Ohio: 123 m. E. N. E. Columbus.

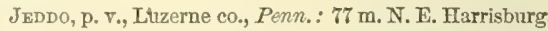
JEFFERSON county, Ala. Situate N. centrally, and contains 916 sq. m. Drained by Locust Fork and its affluents, flowing into Black Warrior $r$, which touches its W. border, and by heads of Cahawba r., a branch of Alabama r., in the E. Surface somewhat broken; soil excellent generally. Cotton, wheat, corn, and other grains yield largely, and there is much good pasturage. Coal is abundant in this part of the State. Farms 752; manuf. 4; dwell. 1,140, and pop.-wh. 6,714, fr. col. 8, sl. 2,267-total 8,959. Cupital. Elyton.

JEFFERson county, Ark. Situate S. E. centrally, and contains 1.293 sq. m. Drained by Saline r. and Bayou Bartholomew, flowing S, into Red r., and the Arkansas r., which crosses the county, running S. E. Surface varied, and geeerally well wooded, with good mill streams; snil very prom ductive, particularly of cotton and corn, and well fitted for raising esttle and swine, of which many are fatted. Farms 817 ; manuf. 9; dwell. 595, and pop.-wh. 3,197, fr. col. 16 sl. 2,621-total 5,834. Capital: Pine Bluff

JefFErsox county, Flor. Situate N. oentrally, and contains $45 \mathrm{~s} \mathrm{sq} . \mathrm{m}$. It extends from Georgia to the Gulf, and and is bounded E. by Oscilla r., emptying into Appalachee Bay. Lake Mickasukie lies on its N. W. border, and gives rise to a large stream, which in a mile or two disappears in one of the "sinks" common in parts of this State. Surface even, and soil fertile. Cotton is the staple. Corn does well, and some rice and sugar are made. Farms 377 manue. 7 ; dwell. 520 , and pop.-wh. 2,775 , fr. col. 5 , sh. 4,938. Capital: Monticello.

JEFFERSoN county, $G a$. Situate E. centrally, and contains $627 \mathrm{sq} . \mathrm{m}$. Drained N. by Briar cr., an affuent of Sarannah r., and S. by Ogeechee r. and its branches. Surface moderately uneven, with good mill streams; soil very productive, and good pasture in parts. Cotton is the great promlict of the county, of which a very large amount is grown. Corn is a good crop. Farms 538; manuf. 45 ; dwell. 765 , and pop.-wh. 3,717 , fr. col. 47 , sl. 5,367-total 9,121. Capital: Louisville. Public Works: Georgia Central R. R.

JEFFERSON county, $I l l$. Situate S, centrally, and contains 576 sq. m. Drained by heads of Big Muddy r., an affluent 
of Mississippi r., and branches of Little Wabash $r$. of the Ohio. Surface undulating, timbered in part with much prairie; soil of moderate fertility, and adapted flnely to grazing. Corn is the cereal staple, and beef and pork are leading products. Farms 470; manuf 2; dwell. 1,368, and pop.-wh. 8,083, fr. col, 26-total 8,109. Capital: Mfount Ternon.

JefFrRson county, Ind. Situate $8 . \mathrm{E}_{\text {. }}$ on the Ohio, and contains $857 \mathrm{sq} . \mathrm{m}$. Drained by heads of Museatatuk r. fowing $W$. into White r., and Indian Kentucky $r$, and other small streams, affluents of Ohio $r$. Except on the Ohio the surface is generally level, but at Hart's Falls, near Hanover, and the falls of Clifty, near Madison, the seenery is grand and beautiful. Bottom lands are rich, sandy loam, and the adjacent hills are very fertile. Uplands chiefly covered with beech and fitted for grass. Corn, wheat, beef, pork, and wonl are staples. It has good water-power, and its manufacture are important and increasing. Farms 1,396; manuf. 138; dwell. 4,092, and pop.-wh. 23,348, fr. col. 568 -total 28,916. Capital: Madison. Public Works: Indianapolis and Madison R. R.

JEFFERSON county, $I a$. Situate S. E., and contains 432 sq. m. Drained by Big Cedar er. and other affluents of Skunk r., which crosses its N. E, border. 'Surface diversifier, furnishing much excellent water-power; soil very fertile, bearing heavy crops of corn and wheat, and affording fine pasture. Cattle and grain are farming staples. Good coal is found. Farms 1,067; manuf. 54; dwell. 1,649, and pop.-wh. 9,903, fr. col. 1-total 9,904. Capitul : Fairfleld. Public Works: Dubuque and Keokuk R. R.

JEFFERsoN county, $K y$. Situate N. centrally, and contains $479 \mathrm{sq} . \mathrm{m}$. Drained by Floyd's fork and Pond er. of Salt r., and Mill cr., Harrod's cr., and other small affluents of Ohio r., which forms its W. boundary. Surface diversified, and soil very productive. It lies on the Ohio, above and below the falls or rapids, which have been avoided by a ship canal around them, affording easy navigation at all seasons and abundance of excellent water-power. Limestone is abundant, and fine crops of wheat and corn are grown, and large numbers of cattle, sheep, and hogs are fatted. Though a good farming county, its great interests are commerce and manufactures, the Ohio supplying ample facilities for both, which centre in Louisville, the largest city in the State, and one of the most important in the Great West. The manufactures embrace almost every thing wanted in the West, and a large tract of country on both sides of the Ohio exports its various products from this point. Farms 857 ; manuf. 614 ; dwell. 7,690, and pop.wh. 47,329 , fr. col. 1,591, sl, 10,911-total 59,831. Capital: Louisville, Public Works: Louisville and Portland Canal; Louisville and Frankfort R. R.; and Nashville and Louisville R. R. ; Louisville and Covington R. R., etc.

JEFFERSon parish, $L a$. Situate S. E., and contains 376 sq. m. Drained by Mississippi r., which crosses the N. part, and numerous bayoux running into the bays and lakes around the country. There are Lake Pontchartrain on the N., Catouche, Washa, and Little lakes on the W., and Barrataria Bay on the $\mathrm{S}$. Surface $1 \mathrm{nw}$, and much of it covered with swamps; scil immediately on the rivers exceedingly fertile, but much is untillable back of them, though furnishing great quantities of fine timber. Sugar is the great staple. Corn thrives abundantly and some riee is grown. Farms 81; manuf. 54; dwell. 8,825, and pop.-wh. 18,021, fr. col. 874, sl. 6,196-total 25,091. Capital: Lafayette City. Public Works: New Orleans, Jackson, and Northern P. R.

JEFFBesoN county, Miss. Situate S. W., and contains 513 sq. m. Drained by small affluents of Mississippi r., which forms its $W$. boundary. Surface moderately uneven, with numerous mill seats; soil in the W. very fertile, in the E. lighter, with a good growth of pine. Cotton is the staple -its culture commands almost exclusive attention, and gives immense returns. Farms 239; manuf. 7; dwell. 514, and pop.-wh. 2,657, fr. col, 43, sl. 10,493-total 13,193.
Capital: Fayctte. Public Works: Natchez and Malo colm R. R.

Jerferson county, Mo. Situate E. on the Mississippi, and contains $639 \mathrm{sq} . \mathrm{m}$. Drained W. by Big r., a branch of Maumee $r$., which runs on and near its $\mathrm{N}$. border into the Mississippi, and E. by Isle au Bois, Plattin, Joachin, and other small crecks. Surface moderately elevated ard broken, with low land in parts; soil yery good, affording fine grazing and large crops of corn and wheat. Much pork is made. It is rich in minerals; lead mines are numerous and inexhaustible; iron and copper are found, and mineral springs abundant. It has water-power, and makes large quantities of shot. Farms 704; manuf. 12; dwell. 1,119 , and pop.-wh, 6,407 , fr. enl 9, sl. 512-total 6,923 . Capital: Hillsboro', Public Works; Iron Mountain R. R.

JEFFERson county, $N$. $Y$.: Situate along E, shore of Lake Ontario, and contains $1,125 \mathrm{sq} . \mathrm{m}$. Bounded N. W. by St Lawrence r., and drained by Indian $r$. flowing $N$. into it and Black r., Chaumont, Stoney, and Sandy creeks, flowing into the lake. Surface for $10 \mathrm{~m}$. back from the lake, leve or undulating; it then slopes to the $\mathbf{S}$. E., and becomes broken and hilly. Most of the county is of the transition formation, consisting of Potsdam sandstone and varieties of limestone and shale. Bog, specular, and spaltic jron ores, tremolite, fluor spar, green malachite, heavy spar, peat, ete, are found. Soil a rich sandy loam, very productive. In the N. W. great crops of wheat are raised; in the S. E. is excellent grazing, and the swamps produce many cranberries for export. Farming is the chief pursuit; large dairies are kept, thousands of cattle and swine sent to market, much flax raised, and many sheep sheared. Its manufactures are extensive, chiefly of flour, lumber, iron, leather, potash, and woolen goods. Its commerce and shipping are large, and interior communication good and improving. Sackett's Harbor is one of the best on the lake, and the water-power on Black r. immense. Farms 5,490; manuf. 630 ; dwel? 11,926, and pop.-wh. 67,971, fr. col. 182-total 65,153. Capital: Watertown. Public Works: Watertown and Rome R. R.; Sackett's Harbor R. R.; Watertown and Potsdam R. R.

JafFErson county, Ohio. Situate E. on Ohio $r$, and contains $362 \mathrm{sq} . \mathrm{m}$. Drained by Yellow, Cross, Short, and Wells creeks, affluents of the Ohio, its E. boundary. Surface considerably broken, with numerous good mill streams soil very productive, equally adapted to grain and grass. Wheat, corn, and oats are farming staples, and much attention is paid to wool growing. Its manufactures are important, chiefly flour, leather, and woolen goods. Its lumber is valuable, and coal and iron are abundant. Farms $1, \$ 1$. manuf. 381; dwell. 5,191, and pop.-wh. 28.526, fr. col. 608 -total 29,132. Capital: Steubenville. Putlic Works. Steubenville and Indiana R. R.; Wellsville and Wheeling Railrond.

JEFFErson county, Penn. Situate W. centrally, and contains 479 sq. m. Drained by Mahoning and Bank ereks, flowing W. into Alleghany r. Surface broken and hills, affording many fine mill seats; soil good, with beautiful and very fertile valleys, and generally excellent pasturage. The grains yield abundantly, and there is good timber. Iron ore and coal exist in all parts in profusion. Farms 1,170 ; manuf. 222 ; dwell. 2,253, and pop.-wh. 13,421, fr. col. 97-total 13,57S. Capitul: Brookville.

Jefrerson county, Tenn. Situate N. E.. and contains 410 sq. m. It lies between Holston and Nolichucky rivers, and is drained by their branches. Surface rough and broken, well wooded, and abundantly supplied with water-power soil fertile. Corn and wheat are staples. A great nian hogs are raised. It has several manufactures of importance flour, leather, liquors, powder, woolen goods, ete. Farms 904 ; manuf. 72 ; dwell. 1,975 , and pop.-wh. 11,469 , fr. col. 107, sl. 1,628-total 13,204. Capital: Dandridge. Public Works: East Tennessee and Tirginia R. R.

JEFrerson county, Texe. Situate S. E., and contains 2,017 
sq. m. It is bounded S. by the Gulf of Mexico, and E. by Subine $r$, and lake. Drained by Neches $r$, which runs through the county into Sabine lake, its branches Pin Island bayou and Big Sandy cr., Cypress, Adams, and Cow bayous, affluents of Sabine r., and Taylor's bayou, of Sabine lake. Surface almost uniformly level, and, except a strip of timber land across the N., an open prairie, with many large swamps; soil on the Neches, in the N. E. and in the N. W., a black mold over yellow clay and sand, and very fertile-the rest fit only for grazing. The swamps are finely adapted to rice growing. Cotton and corn are the staples as yet, the county being little settled. The Neches and Sabine are large streams; the latter has a good harbor near its mouth, and Adam's, Cypress, and Cow bayous are navigable for boats of light draft. Farms 91 ; manuf. 4 ; dwell. 259, and pop.-wh. 1,504 , fr. col. 63 , sl. 269-total 1,836. Capital: Beaumont.

Jefrerson county, Firg. Situate N. E., and contains 221 sq. m. Drained by Opequan and Shenandoah rivers, branches of the Potomac, which bounds it N. E. Surface broken-in parts mountainous, with abundance of fine water-power; soil excellent, among the best grain and grazing land and the most valuable, taking the county through, in the State. Its scenery is very fine, that on the Shenandoah having no superior in the world for beauty or majesty. Its crops of wheat, corn, rye, oats, and potatoes are equally good, and all superior for yield and quality. For grazing, it is admirably fitted, and sheep and swine are reared in great numbers. Its manufactures are various and extensive, exclusive of the great U. S. armory, at Harper's Ferry. Farms 447 ; manuf. 165 ; dwell. 1,960 , and pop.-wh. 10,476, fr. col. 540, sl. 4,311-total 15,357. Capital: Charlestown. Public Works: Baltimore and Ohio R. R.; Winchester and Potomac R. $\mathrm{P}_{\mathrm{v}}$

JEFFERSON county, Wisc. Situate S. E., and contains 576 sq. m. Drained by Rock r., which crosses the county diagonally, and Bearer Dam r., and other of its branches. Koshkonong lake, through which Rock r. flows, is in the S. W. corner, and it has several fine ponds, which, with the streams, supply abundance of water-power. Surface varied, parts are hilly and rough, and parts quite marshy; soil fertile, very productive on Rock $\mathrm{r}$. and the streams generally, and most is heavily timbered, there being little prairie. Grain and grass thrive equally, and this is a fine farming county. Manufactures are increasing, and already of much importance. Farms 952; manuf. 74; dwell. 2,934, and pop. -wh. 15,314, fr, col. 3-total 15,317. Capital: Jeffersom. Pullic Horks: Milwaukie and Mississippi R. R.

JuFferson, p. V., and cap. Jackson county, Ga.: $79 \mathrm{~m}$. N. by W. Milledgeville. It contains a court-house, an academy, and a few stores.

JeFFERSON, p. v., Clinton co., Ind.: 4 m. W. Frankfort, 42 m. N. N. If. Indianapolis.

JefFerson, p. V., Cook co., Ill.: on N. branch of Chicago r., $179 \mathrm{~m}$. N. N. E. Springfield.

JeFFersox, th and p. v., Lincoln co., Me.: at the head of Damariscotta r., 18 m. E. S. F. Augusta. The t. embraces a large part of Damariscotta Pond, and has many mill streams, which are used to saw great quantities of lumber. It has a good soil and several manufactories of leather and woolens. Pop. of t. 2,228.

JFFFERSON, p. v., Frederick co, Mrd.: about $4 \mathrm{~m}$. from the Potomac, $77 \mathrm{~m}$. W. N. W. Annapolis. It lies between Catoctin er. and mountain, and has several stores and 350 inhabitants.

Jefrersox, to and p. v., Coos co., 2. Hamp.: 79 m. N. Concord. Drained by Israel's $r$. and its branches, which furnish water-power. John's r. rises in Pondicherry Pond, in the S. W. corner. Surface mountainous; soil in the lower parts fertile, and generally good pasture. The $v$. has 3 stores and a few dwellings, Pop. of t. 629 .

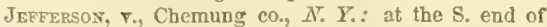
Seneca like, $165 \mathrm{~m}$. W. Nlbany. It has a fine landing, and 334 a steamboat plies daily to Geneva, at the other end of the lake, which never freezes over. It contains several hotels, stores, and warehouses, 9 flour, plaster, and lumber mills and 1,000 inhabitants. The Canandaigua and Elmira R. R. passes the $\mathrm{v} .21 \mathrm{~m}$. from Elmira. Two papers are published, the "American Standard" and "Corona Borealis,"

JEFFERSON, t. and p.. ., Schoharie co., $N . \quad Y .: \Delta 7 \mathrm{~m}$. W. by S. Albany. Surface mountainous, the high hills forming the watershed between the affluents of the Hudson and Delaware; soil unproductive, except in the valleys. Farming and grazing form the chief business. Pop. of town 1,749 .

Jefrerson, p.. ., and cap. Ashe co., $N$. Car.: about $2 \mathrm{~m}$. W. of New r., 158 W. N. W. Raleigh. It contains, besides a court-house and jail, several stores and 200 inhabitants.

JEFFERSON, p. v., and cap. Ashtabula co., Ohio: on a branch of Grand $r_{0}, 164 \mathrm{~m}$. N. E. by N. Columbus. The $t_{\text {, }}$ is slightly uneven, and has a fertile soil. The $\mathrm{v}$. is about 10 m. S. of Lake Erie, and contains a fine court-house, jail, an academy, and several stores. Pop. of t. 625.

Jefferson, t. and p. v., Greene county, Penn.: on Mononguhela $r ., 177 \mathrm{~m}$. W. by S. Harrisburg. The t. has a rolling surface, rich soil, and fine water-power. The v. is on Ten Mile cr., near its mouth, and contains an academy, a dozen stores, 3 mills, and 600 inhabitants.

Jefrerson, p. v., Rutherford co., Tenn.: 24 m. S. E. Nashville.

Jefferson, p. v., Cass co., Tex.: between Big Cypress r. and Black Cypress cr., about $4 \mathrm{~m}$. above their confluence, $249 \mathrm{~m}$. N. E. Austin City. The land around it is among the best for cotton and corn in the State.

Jefrarson, p. O., Powhatan co., Virg.: 26 m. W. by N. Richmond.

Jefferson, p. o., Marengo county, Ala.: $87 \mathrm{~m}$. W. Montgomery.

JeFFERsox, t., p. V., and cap. Jefferson co, Wisc. : on Rock r., $81 \mathrm{~m}$. E. by S. Madison. The v. lies a little above the junction of Crawfish $r$, and by a dam across Pock $r$. has abundant water-power, which is largely used in manufacturing. It has a good trade, several large stores, and 800 inhabitants, Pop. of t. 1,610.

Jefrerson Barracks, p. v., St. Louis co., Mo.: on the Mississippi, 11 m. 5. St. Louis, 104 m. E. Jefferson City. This is a U. S. military post, and contains a few stores and dwellings.

JEFFERSON Citr, p. o., and cap. Cole co., Mo., and cap. of the State of Missouri: on the S. bank of Missouri r., opposite the mouth of Cedar cr., and $137 \mathrm{~m}$. from its entrance into the Mississippi r.-lat. $35^{\circ} 36^{\prime} \mathrm{N}$., and long. $92^{\circ} 0 \mathrm{~S}^{\prime} \mathrm{W}$. $-950 \mathrm{~m}$. W. Washington. The site is elevated and uneven, and furnishes many beautiful building locations. It coutaing the State House, Governor's House, a large and elegant mansion, the State Penitentiary, etc., and has several extensive mercantile houses, stores, and mechanic shops, equal to the demands of the locality. Two newspapers are published here, the "Metropolitan," and "Jefferson Enquirer" (dem.), both weekly issues. Population about 2,600.

JefFerson Furwace, p. v., Clarion co., Penn.: $161 \mathrm{~m}$. W. N. W. Harrisburg. Here is a furnace producing 1,000 tons iron per annum.

JEFFErSox Muts, p. 0., Jefferson co., Mfo.: 96 m. E. S. E. Jeffersnn City.

JEFFERSON Mrlus, p. v., Coos co., N. Hamp. : on Israel's r., $81 \mathrm{~m} . \mathrm{N}$. Concord.

JaFersonton, p. v., and cap. Camden co., Ga.: on the S. side of Santilla river, at the head of navigation, $177 \mathrm{~m}$. S. E. by S. Milledgeville. It has a court-house and jail, several large stores, and 800 inhabitants.

Jefrersontow, p. v., Culpepper co., Firg.: 74 m. N. N.W. Richmond. It contains several stores and 350 inhabitants. Lee's Sulphur Springs are in the vicinity.

JhFFersoxtown, p. v., Jefferson county, $\overline{4} y .: 39 \mathrm{~m}$. W Frankfort. 
Jefrerson VALLEY, p. o., Westchester co, N. Y. : 104 m. S. Albany.

JeFPERSoNville, p. v., Sullivan county, $N_{0} Y_{0}: 87 \mathrm{~m}$. S. S. W. Albany.

JefFersonvilie, p. v., Clark co., Ind.: at the head of the falls on the Ohio, $103 \mathrm{~m}$. S. by E. Indianapolis. It lies on elevated ground, has a flne landing, and is the site of the State Prison. Steamboats are built here, and it has great facilities for trade and commerce, lying opposite Louisville, and being connected by railroad with the interior. It contains a United States land office, several large stores and warehouses, and about 3,000 inhabitants. The Jeffersonville $R$. R. terminates here

JEFFER ONville, p. o., Twiggs co., Ga. $: 27 \mathrm{~m}$. S. by W. Milledgeville.

JefFarsonvilue, p. v., Fayette co., Ohio: 35 m. S. W. Columbus.

Jefrersonville, p. v., Montgomery co., Penn. : near the Schuylkill, $87 \mathrm{~m}$. E. by S. Harrishurg.

JeFTERSONVILLe, p. v., Lamoille co., Term, : on Lamoille river, $29 \mathrm{~m} . \mathrm{N}$. N. W. Montpelier. It has small manufactories, sereral stores, and 350 inhabitants.

Jefrress' Store, p. o., Nottoway co., Virg.: 45 m. S. W. Richmond.

JeFrRY's CreEk, p. o., Marion dist., S. Car. : on a branch of Grent Pedee r. so called, $79 \mathrm{~m}$. E. Columbia.

Jelloway, p. V., Knox connty, Ohio: $41 \mathrm{~m}$. N. E. Columbus.

JeNA, p. o., Tuscaloosa co., Ala. : 102 m. N. W. by W. Montgomery.

JENKIN's BRIDGe, p. v., St. Clair co, Mo.: on Warblow cr. of the Osage, $\$ 6 \mathrm{~m} . \mathrm{S}$. W. by W. Jefferson City.

JeNKin's Store, p. o., Union co., N. Car. : 99 m.W.S.W. Raleigh.

JeNkrNtown, p. v., Montgomery county, Penn. : 85 m. E. Harrisburg.

Jenner's Cross Roads, p. v., Somersetco., Penn. : $117 \mathrm{~m}$. W. Harrisburg.

Jearierstulue, p. v., Chester co., Penn.: 69 m. E. by S. Harrisburg. It contains several stores, and about 300 inhabitants.

JENNINGs county, Ind. Situate S. E., and contains $35 \mathrm{~S}$ sq. m. Drained by Vernon and Graham forks of Muscatatuck r., Sand cr., and their numerous branches, all flowing W. into White $r$. Surface rugged and broken, with several beech flats. Soil of good fertility near the streams; the beech flats at their heads are used only for grazing. It has good water-power, abundance of excellent timber, fine limestone-quarries, much used for building, and a millstonequarry. Corn, wheat, and pork are farming staples. Farms 1,208; manuf. 78; dwell. 2,064, and pop.-wh. 11,773, fr. col. 323 - total 12,096. Capital: Vernon, Pullic Works: Madison and Indianapolis R. R.

JeNings, p. 0., Franklin county, Ind. : 66 m. E. S. E. Indianapolis.

JENings, p. 0., Hamilton county, Flor.: $69 \mathrm{~m}$. E. Tallahassee.

Jenving's Gap, p. o., Augusta co., Firg.: on E. sỉde of Shenandoah mountains, $123 \mathrm{~m}$.W. N.W. Richmond. North river, a branch of the James, rises here, and branches of the Shenandoah in the vicinity.

JenNtNG's Ordinarx, p. O., Nottoway co., Tirg.: $45 \mathrm{~m}$. S. W. Richmond, on the Richmond and Danville R. R., 50 m. from Richmond (by ears).

JENAY LIND, p. Oi, Chatham county, N. Car.: $46 \mathrm{~m} . \mathrm{W}$. Raleigh.

JENYY Lind, p. 0., Sebastian county, Ark. : $123 \cdot \mathrm{m}$. W. Little Pock.

Jericho, p. v., Perry co., Ala. : near Catawba r., $61 \mathrm{~m}$. N. W. by W. Montgomery.

JERTCHO, p. $\nabla_{\text {., Queens }} c_{0 .}, N_{.} Y_{\text {. }}$ about $2 \mathrm{~m}$. from the Sound and Long Island R. R., $129 \mathrm{~m}$. S. S. E. Albany. It has 2 hotels, several stores, and 300 inhabitants.
Jericero, p. o., Wayne co., N. Car.: $41 \mathrm{~m}$. S. E. Raleigh. J LRICLO, t. and p. v., Chittenden con, Terma : on N, side of Onion r., $26 \mathrm{~m} . \mathrm{N}$. W. by W. Montpelier. Drained N. by Brown's $r$ of the Lamoille, which affords good waterpower. Surface moderately uneven; and soil good: pasture on the hills, and fine meadows on the streams. The Vermont Central R. R. passes through the 8.W. part. The v. is

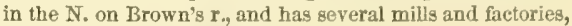
and 500 inhabitants. Pop, of t. 1,839.

Jericho, p. v., Kane co., 1ll.: near Big Rock cr. of Fox river, $149 \mathrm{~m}$. N. N. E. Springfield.

Jericho Centre, p. v., Chittenden county, Verm. : $22 \mathrm{~m}$. N.W. by W. Montpelier. It contains a hotel, soveral stores, and 40 dwellings.

JERSIGAN, p. 0., Orange county, F'lor.: 228 m. S. E. Tallahassee.

JEROME, t. and p. v., Union co., Ohio: on Big Darby cr., $15 \mathrm{~m} . \mathrm{N}$. W. Columbus. The t. has a rolling surface and fertile soil, with some mill-power. The $\mathrm{v}$, has a few stores and 200 inhabitants. Pop. of t. 1,249.

Jerome, p. v., Howard $\mathrm{co}_{*}$, Ind $d_{0}$ : on the N. side Wild Cat cr., $46 \mathrm{~m}$. N. by E. Indianapolis.

Jebomesville, p.v., Ashland county, Ohio: on Walhonding r., $68 \mathrm{~m}$. N. N. E. Columbus.

$J_{\text {ERSEY county, }} I l l$. Situate W. centrally, and contains 320 sq. m. Drained N. by Macoupin er., W. by Illinois r. $\mathrm{S}$. by the Mississippi, and by their affluents. Surface generally level; soil very productive of corn and wheat, and excellent grazing land. On the Mississippi are bluffs, 100 or 200 feet high, of alternate limestone and sandstone strata and through the county coal is found just below the surface. There is some prairie, but timber is plenty. Farms 645 manuf. 44; dwell, 1,222, and pop.-wh. 7,300, fr. col. 51total 7,354. Capital: Jerseyville.

Jersey, t. and p. v., Licking eounty, Ohio: 17 m. N. E. Columbus. The t. has a rich soil and some water-power. Pop. 1,230 .

JHRSE, p. v., Oakland oo., Mich. : 56 m. E. Lansing.

JERSEY CITY, p. city, and p. of entry, Hudson co., N. J.: on the W. bank of Hudson river, opposite the eity of New York, and connected with it by steam ferries. Incorporated in 1820, and in 1851 the v. of Harsimus, Pavonia, ete., were annexed. The streets run at right angles along and from the river front. There are several important manufactories here, as soap, glass, iron, pottery, ropes, starch, etc., and ship-building, and it has good wharves. The Cunard Steamships' Dock is here, and much business is created by the Morris Canal and the railroads terminating at this point. Southern and Western travel from New York City properly commences at Jersey City. Pop. of the city proper, 6,856 , or with its recent accessions, 11,473 .

Jersey Prairie, p. 0. , Cass $c_{0}, I U_{0}: 31 \mathrm{~m}$. W. by $\mathrm{N}$. Springfield.

Jerser Settrement, p. O., Davidson co., N. Car. : $92 \mathrm{~m}$. W. Raleigh.

Jersex Shore, p. b., Lycoming co, Penn.: on N. side of W. branch of Susquehanna r., $73 \mathrm{~m}$. N. by W. Harrisburg. It lies in a great coal and iron region, and has a large trade, some small manufactories, a dozen stores, and 725 inhabitants. A furnace and forge is $4 \mathrm{~m}$. distant. The Pennsylvania Canal passes through the $\mathrm{b} .53 \mathrm{~m}$. from Northumberland. The "Jersey Shore Republican" (dem.) is issued weekly.

Jerseytown, p. v., Montour co., Penn. : $56 \mathrm{~m}$. N. by E. Harrisburg. It contains two stores, a high school, and 200 inhabitants.

JERSEXVILLi, p. v., and cap. Jersey county, $I l_{\circ}: 59 \mathrm{~m}$ S. W. by S. Springfield. Situate near Jersey Prairie, and contains a court-house, jail, several stores, and 200 inhabitants.

Jeresaler, t. and p. v., Yates co., $N_{.} . Y_{.}$: on the W. side of Crooked Lake, $157 \mathrm{~m}$. W. Albany. Surface somewhat hilly; soil a fertile loam, yielding good grass and grain. 
Farming is the chief occupation. The v. has two hotels, a high school, several stores, and 400 inhabitants. Population of $t .2,912$.

Jrexester, p. v., and cap. Southampton co., Virg.: on the N. side of Nottoway r., $62 \mathrm{~m}$. S. by E. Richmond. It contains a court-house, jail, two hotels, and a few houses and stores.

Jerusatim, p. o., Davie co., N. Car.: 106 m.W. by N. Raleigh.

Jerusaleir, p. v., Monroe county, Ohio: 97 m. E. by S. Columbus.

Jirusalem Mrlus, p. o., Harford co., Md.: on E. side of Little Gunpowder Falls, $41 \mathrm{~m}$. N. by E. Annapolis.

Jercsalem Soutin, p. v., Queens eo., N. Y.: $137 \mathrm{~m}$. S. Albany-a small village settled by Friends.

JeSPAMINE county, $K y$. Situate $N$. centrally, and contains 154 sq. m. Bounded S. E., S., and S. W. by Kentucky r., and drained by IIickman and Jessamine creeks. Surface uneven, affording fine mill-seats; soil very good, equally for grain and grass. Large numbers of sheep and swine are raised. Farms 651; manuf. 67 ; dwell. 1,093, and pop -wh. 6,289, fr. col. 135, sl. 3,825-total 10,249. Capital: Nicholasville. Public Works: Lexington and Danville I. R.

Jesse's STORe, p. 0., Shelby co., Ky. : W. Fraukfort.

Jnssur's CrT, sta., Anne Arundel co., Md. : on Washington Branch R. R., 14 m. from Baltimore.

JETERSthlik, p. o., Amelia co., Virg.: 41 m. W. S. W. Richmond.

JETETT, t. and p. V., Greene county, $N . Y .: 32 \mathrm{~m} . \mathrm{S} . \mathrm{W}$. Albany. Drained by heads of Schoharie er. Surface uneven, and soil mostly fertile. Fanning is largely carried on. The r. has a hotel and several dwellings. Population of t. 1,451.

Jewett Centrk, p. v., Greene co., N. Y.: 35 m. S. W. Albany.

Jewert Citr, p. v., New London co, Conn.: on the E, side of Quinnebaug r., at the junction of the Patchaug, $38 \mathrm{~m}$. E. S. E. Ilartford. The rivers have a large fall here, which furnishes abundance of water-power. The $r$. has several large cotton factories, a bank, academy, machine-shop, and 1.500 inhabitants. Its trade is considerable. On the Norwich and Worcester R. R., $16 \mathrm{~m}$, from Norwich.

Jus Tows, p. o., Monongalia co., Firg.: 209 m. N. W. Tichmond.

JoAnya Furnace, p. v., Berks county, Penn.: $53 \mathrm{~m}$. E. Harrisburg. A furnace of 1,000 tons capacity is located liere.

Jore, p. o., Oregon co., Mo. : 103 m. S. S. E. Jefferson City.

Jonstown, p. v., Burlington co., N. Jer.: 12 m. S. S. E. Trenton.

Jo DAviess county, $I l l$. situate $\mathrm{N}$. W. corner, and contains 594 sq. m. Drained by Sinsinewa, Fevre, Small Pox, Applc, Rush, and Plum rivers, affluents of the Mississippi, its $\mathrm{W}$, boundary. Surface undulating and in parts broken; soil generally very good. A good farming county, with some water-power, but its minerals engross almost exclusive attention. It is in the heart of the great lead region of N. W. Illinois, S. W. Wisconsin, and E. Iowa, and its lead mines are apparently inexhaustible, the amount exported from Galena in 1851 being more than $33,000,000$ pounds. Copper of excellent quality is abundant; considerable silver, and even gold, has been found; and limestone, freestrome, and sandstone exist through the county. Farms 1,370; manuf. 279 : dwell. 3,431 , and pop.-wh. 18,336, fr. col. 218 -total 15,604. Capital: Galena. Public Works: Central Illinis R. P.

JomN"s, p. o., Liberty county, Tex.: $171 \mathrm{~m} . \mathrm{E} . \mathrm{S} . \mathrm{E}$. Austin City.

Jorry"s river, N. Hamp.: rises in Jefferson, Coos co., and flows N. W. into the Connecticut. Bordered by forests of huge pines.
JoHNsBUReIr, t. and p. v., Warren co., $N_{0}, Y_{0}:$ on W. side of Hudson r., $68 \mathrm{~m}$. N. by W. Albany. Drained by affluents of the Hudson, which furnish many mill-sites. Surface mountainous; soil a light sandy loam adapted to grass. The v. contains 2 hotels, 4 stores, and 800 inhabitants. Pop. of t. 1,503 .

Jornson county, Ark. Situate N. W., and contains 979 sq. m. Drained by Horse Head, Great Pine, Caney creek, ete., affluents of the Arkansas, which crosses the S. of the county. Surface uneven, and in parts hilly; soil fertile on the streams, and generally excellent pasture. Corn, cattle, and pork are staples, and good cotton is raised. Farms 526; manuf. 24 ; dwell. 777 , and pop.-wh. 4,4S9, fr. col. 7 , sl. 731 -total 5,227. Capital: Clarksville.

Johsson county, $I l l$. Situate $\mathrm{S}_{\text {., }}$ and contains $326 \mathrm{sq} . \mathrm{m}$. Drained by Cedar, Big Bay, and Cash creeks, affluents of the Ohio. Surface mostly level, with low land and ponds in the $\mathrm{S}_{\text {. }}$, soil sandy and well timbered. Corn and pork are the leading products. Sulphur springs are found. Farms 301; manuf. 4; dwell. 718, and pop.-wh. 4,096, fr. col. 17-total 4,113. Capital: Vienna.

JoHsson county, Ind. Situate centrally, and contains $321 \mathrm{sq}$. m. It lies between the upper portions of $\mathrm{E}$. and W. forks of White $\mathbf{r}$., and is drained by their branches, Sugar, Young's, Indian, and other creeks. Surface varied, in the S. W. hilly, S. and S. E. undulating, in other parts level. It has no waste land, but a rich loamy soil, generally covered with excellent timber. The staples are grain and pork. Tobacco is also raised. Farms 1,153; manuf. 25; dwell. 2,067 , and pop.-wh. 12,086, fr. col. 15-total 12,101. Capital: Franklin. Public Works: Madison and Indianapolis R. R. ; Martinsville Branch R. R.

Jornson county, $I \alpha$. Situate E., and contains $584 \mathrm{sq} . \mathrm{m}$. Drained by Iowa r., Clear and Old Man's creeks, and in the N. E. by Cedar $r_{v}$, all branches of the Iowa. Surface dirersified, with some prairie; soil very fertile. The Iowa is navigable part of the year, and furnishes excellent waterpower above Iowa City. It has quarries of fine building stone, beautifully variegated, and known as "bird's-eyo marble." Farms 377 ; manuf. 19; dwell. 799, and pop.wh. 4,450, fr. col. 22-total 4,472. Capital: Iowa City. Public Works: Lyons and Iowa City R. R.; Camanche and Iowa City R. R.; Davenport and Council Bluffs R. R.; Dubuque and Keokuk R. R., ete.

Jorrson county, $K y$. Situate N. E., and contains 379 sq. m. Drained by W. fork of Big Sandy r. and Big Paint cr. Surface elevated and uneven; soil well adapted to grazing. Cattle and hogs are the leading products. Farms 504; manuf, 5; dwell. 608, and pop.-wh. 3,843, fr. col. 0 , sl, 30-total 8,873. Capital: Painesville.

Jomsson county, Mo. Situate W. centrally, and contains 809 sq. m. Drained by Black Water r., flowing into Missouri r., and Panther r., a branch of the Osage. Surface slightly broken, with excellent timber and gond mill streams; soil fine, generally, and superior for grazing. Corn and pork are the staples, and some tobacco is grown. Farms 750 ; manuf. 25 ; dwell. 1,030, and pop.-wh. 6,573, fr. colo 12, sl. 879-total 7,464. Capitul: Warrensburg.

Jornsor county, Tenn. Situate in N. E. corner, and contains $312 \mathrm{sq}$. m. Drained by Watauga $\mathbf{r}$. and its branches, affluents of Holston $r$. It lies between mountain ridges and is much broken in parts, but has a rich soil in the valleys and fine grazing. It has good water-power and considerable iron ore. Farms 325; manuf, 42; dwell. 565, and pop.-wh. 3,455, fr. col. 14, sl. 206-total 3,705. Capital: Taylorsville.

Jorsson, t. and p. v., Lamoillo co., Verm. : on the Iamoille, $29 \mathrm{~m}$. N. by W. Montpelier. Surface uneven and well wooded with hemlock, spruce, and oak; soil largely alluvial and very fertile; back of the streams chiefly fitted for grazing. The $\mathrm{v}$. is in the $\mathrm{S}$., on the Lamoille, and has several mills and 300 inhabitants. Soapstone is found. Pop. of to 1,381 . 
Jorssox, p. o., Floyd county, Ga.: 149 m. N. W. Milleylgeville,

Jorissis, p. o., Mr.Donough county, $I l l .: 6 \$ \mathrm{~m} . \mathrm{N}$. W. Springfield,

Jorrisox, p. 0., Washington county, Mo.: 78 m. S. E. Jefferson City.

Joussonsurgin, p. v., Warren co., N. Jer.: about $4 \mathrm{~m}$. from Pequnst r., $51 \mathrm{~m}$. N. by W. Trenton. It has several mills anil about 310 inlıabitants.

Jorssox"s, p. o., Montgomery co., Tenn.: 51 m. N.W. Nashvilie.

Johrsov's, sta., Barnwell dist., S. Car.: on S. Carolina

R. R., $22 \mathrm{~m}$. from Augusta and 115 from Charleston.

Johnsonsbergh, p. v., Wyoming co., N. Y.: 236 m. W. Alloany.

Johngon's Coragrs, p. v., Summit co, Ohio: $111 \mathrm{~m}$. N. E. Columbirs,

JorNsox's Creek, p. v., Jeffersnn co., Wise. : on a branch of Rock r. so called, $81 \mathrm{~m}$. E. Madison.

Jomsiox's Creek, p. r., Niagara co, $N$. $Y$.: on a creck so called, flowing into Lake Ontario, $249 \mathrm{~m}$. W. by $\mathrm{N}$. Albany.

JoHnsox's Forks, p. o., Morgan co., Ky.: 93 m. E. S. E. Frankfort.

Johnson'g Mrims, p. o., Pitt co., $N$. Car.: on Swift er. an affluent of the Neuse, $59 \mathrm{~m}$. E. S. E. Raleigh

Jonxsox"s Mruis, p. o., Clark co., Ill.; on N. fork of Embarras r., 101 m. E. S. E. Springfield.

Jorinson's Sprivgs, p. o., Goochland co., Fïrg.: $27 \mathrm{~m}$. W. N. W. Rielımond.

Jornsontows, p. o., Northampton co., Firg.: on the Eastern Shore, $94 \mathrm{~m}$. E. by S. Pichmond.

Jornsonville, sta., Rensselaer co., $N . Y_{*}$ : on the Troy and Boston R. R., $16 \mathrm{~m}$. from Troy.

Jorrsonville, p. o., Cumberland co., N. Car. : $44 \mathrm{~m}$. S. S. W. Raleigh.

JomssoxrILLe, p. v., Trumbull co., Ohio: 117 m. N. E. Columbus.

Jomssorvilie, p. o., Williamsburgh dist., $S_{\text {. Car. : near }}$ Black r., $91 \mathrm{~m}$. E. S. E. Columbia.

Jomistox county, $N$. Car. Situate E. centrally, and contains $664 \mathrm{sq} . \mathrm{m}$. Drained by Moceasin and Little rivers, and Swift, Middle, and Black creeks, all affluents of the Neuse, which crosses the county in its 8. E. course. Surface uneven and broken, with numerons mill-seats; soil of average fertility. Cotton and corn, beef and pork are leading products. Farms 1,002; manuf. 102; dwell, 1,704, and pop.-wh. 8,900, fr. col. 163, sl. 4,663-total 13,726. Capital: Smithfield. Public Works; N. Carolina Central R. R.

Johnston, p. o., Poinsett county, Ark. : 112 m. N. E. Little Rock.

Jomistonviliz, p. o., Monroe co., Ga.: $51 \mathrm{~m}$. W. by N. Milledgeville.

Johsstows, t. and p. v., Barry co., Mïch.: 38 m. W. S.W. Lansing. The t. has an uneven surface and good soil, is well timbered, and has several ponds, the sources of affluents of Thorn-apple r. on the N., and $\mathrm{S}$. of the Kalamazoo. The $\mathrm{v}$, has a few houses and stores. Pop. of t. 450.

Jokrstown, t., p. v., and cap. Fulton co., $N . Y_{.}: 39 \mathrm{~m}$, N. W. Albany. Drained by Cayuduta and Garoga creeks of the Mohawk. Surface hilly, and soil a fertile loam. Noted for the manufacture of buckskin gloves, mittens, and moceasins. The v. is on Cayuduta, or Little Canada cr., $4 \mathrm{~m}$, N. of Mohawk r, and the Utica and Schenectady R. R. It has some water-power, and manufactures carriages, arms, leather, and various kinds of machinery. It has a courthouse and jail, the oldest in the State, the county clerk's office, a bank, an academy, 7 churches, 6 hotels, 20 stores, and 1.500 inhabitants. There is a sulphur spring near here, The "F. County Democrat" (dem.), and "F. County Republican" (whig), are published weekly. Population of town 6,131 .
Jornstown, p. Y., Licking co., Ohio: 21 m. N. E. Columbus. It crintains 3 churches, several large stores, a high school, and 357 inbabitants.

JoHnstown, p. b., Cambria co., Penn. : at the junction of Stony cr. and Kiskiminitas $\mathbf{r}$, $114 \mathrm{~m}$. W. by N. Harrisburg. It is regularly laid out, has good water-power, some manufactures, and 2,000 inhabitants. There are 4 furnaces near here, with an aggregate capacity of 7,000 tons. The Pennsylvania Canal and P. R. pass through the borough $85 \mathrm{~m}$. from Pitssburg. Two newspapers, the "Echo" (dem.), and "Valley Wreath" (whig), are published weekly.

JoHNstown, to and n. v., Rock con, Wisc, 34 m. S. E. Madison. The town has an undulating surface, and a soil adapted to grain. Fine limestone is quarried in this vicinity. The $\mathbf{v}$. has several stores and workshops. Population of town 1,571 .

Johnstown Centre, p. v., Rock co., Wisc.: 38 m. S. E. Madison.

Jomsstilu, p. v., Montgomery co., Ohio: $51 \mathrm{~m} . \mathrm{W}$. by 8. Columbus.

JoHNswille, p. v., Frederick co, M1d.; near Sam's cr., 52 $\mathrm{m}$. N. W. Annapolis. The $\mathrm{V}$. is not large, but surrounded by excellent farms:

JoLret, p.v., and cap. Will co., Ill.: on the O'Plain r., 148 m. N. E. by N. Springfield, The r. affords valuable watcrpower, which is used for several factories and mills. Tho principal buildings are a court-house, jail, an academy, several fine hotels and churches, and large warehouses. The Illinois and Michigan Canal passes through the v., and the Chicago and Rock Island R. I. $40 \mathrm{~m}$. from Chicago. The "Joliet Signal" (dem.), and the "True Democrat" (whig), are published weekly. Pop. about 2,700.

JoLLY, t. and p. v., Washington co, Ohio: 79 m. E. S. E. Columbus. Pop. of t. 1,015.

Jollitown, p. v., Greene co., Penn.: 189 m. W. by s. Harrisburg.

JoNATHAN's ĆREEK, p. o., Haywood co., $N$. Car.: near a branch of Big Pigeon r. so called, $249 \mathrm{~m}$. W. Ralejgh.

JoXes county, $G c$. Situate N. centrally, and contains 316 sq. m. Drained by Walnut and Falling creeks, affluents of Ocmulgee river, which touches its W. border. Surface somewhat broken, affording fine mill-streams; soil very fertile, produeing large cotton crops, a good yield of wheat and com, and good pasturage. It has important minufactories of flour and iron ware. Farms 405; manut, 15; dwell. 739 , and pop.-wh. 3,899 , fr. col. 46 , sl. 6,279-total 10,224. Capital : Clinton. Public Works: Central Georgia R. R.

JoNes county, $I \alpha$. Situate E. centrally, and contains 576 sq. m. Drained by Makoqueta $r$. and its branches, Fall $r$. and Bear cr., and Wapsipinicon $r$ and its branches, Talnut and Buffalo creeks. Surface level or undulating. It has a fine sril for grain and grass, plenty of timber, and gond water-power. The grains form the staple exports. Farms 225 ; manuf. 3 ; dwell. 559, and pop.-wh. 3,006, fr. col. 1total 3,007. Capital: Anamosa. Public Works: Dubuque and Keokuk P. R.

Jones county, Miss. Situate S. En, and contains $788 \mathrm{sq.} \mathrm{m.}$ Drained hy Bogue Hume, Tallaha, and Leaf creeks, affluvents of Pascagoula $r$. Surface slightly uneven, and soil of moderate fertility. Corn, cattle, and swine are the chief products, Farms 274; manuf. 0; dwell. 319, and pop.wh. 1,S87, fr. col. 3, sl. 274-total 2,164. Capital: Ellisville.

JONES county, N. Car. Situate S. E., and contains 329 sq. m. Drained by Trent r., which flows E. into the Neuse. Surface level, and much of it Iow and marshy ; soil, in parts, very fertile-in others, waste, irreclaimable land. Cotton is the chief product; corn is a large crop, and the marshes produce rice. Farms 240; manuf. 14; dwell. 440, and pop. -wh. 2,139, fr. col. 142, sl. 2,757-total 5,03S. Capital: Trenton. 
Jonks, p. o., Panola county, Texo. : 296 m. E. N. E.

Austin City.

Joxis' BuvfF, p. v., Sumter co., Ala.: on the right bank of Tombigbee r., $108 \mathrm{~m}$. W. by N. Montgomery.

JoNesborougr, p. v., Grant co., Ind. : on Mississinewa r.

54 m. N. N. E. Indianapolis.

JoNesborough, p. Y., Jefferson co., Ala.: 79 m. N. N. W. Montgomery.

JoNesborodgh, p. v., Fayette co., Ga. : 76 m. W. N. W. Milledgeville. The Macon and Western R. R. passes through the $\mathrm{v}, 79 \mathrm{~m}$. from Macon, and 22 from Atlanta.

Jonesborovar, p. v., and cap. Union county, $l l l .: 167 \mathrm{~m}$.

S. by E. Springficld. It contains a court-house, jail, a few large stores, and 300 inhabitants. The "J. Gazette" (dem.) is issued weekly.

JoNEsBoroUGH, t. and p.., , Washington co., Me. : at the head of Englishman's Bay, 114 miles E. by N. Angusta Chandler's r. flows through the t., affording water-power, at the mouth of which the $\mathrm{v}$, lies. Pop. of t. 466.

JoNEsBorotgr, p. v., Saline co., MOo. : on Salt fork of La Mine $x_{\bullet}, 61 \mathrm{~m}$. W. N. W. Jefferson City.

JoNesBorough, p. v., and cap. Washington co, Tenn.: 239 m. E. by N. Nashville. It contains a court-house, jail, two academies, and about 500 inhabitants.

JoNesBorovgr, p. v., Brunswick county, Virg.: $52 \mathrm{~m}$.

S. W. by S. Richmond.

Jones' Creek, p. 0., Randolph co., Ill.: on the er. so called, and near the Mississippi, $137 \mathrm{~m}$. S. Springfielu.

Jones' Crees, p. o., Liberty county, Ga.: 76 m. S. E. Milledgeville.

Joxies' Mruss, p. 0., Yallabusha co., MFiss. : 109 m. N. N. E. Jackson.

JoNes' Mruts, p. o., M'Nairy co., Tenn. : 123 m. S. W. Nashville.

JoNes' Mrtss, p. o., Merriwether county, Ga: 83 m. W. Milledgeville.

Jones' Mitus, p. v., Westmoreland co., Penn. : $147 \mathrm{m.W}$ Harrisburg.

JoNes' Nurserx, p. 0., Clark county, Ky. : 51 m. E. S. E. Frankfort.

JoNESPOET, t. and p. $o_{*}$, Washington county, $\mathcal{F e}_{*}: 112 \mathrm{~m}$. E. by N. Augusta. It has an excellent harbor, and is engaged in ship-building, the fisheries, and coasting trade. Pop. 826

JONEs's, sta, Hamilton co., Ohio : on the Cincinnati, Hamilton, and Dayton $\mathrm{R}, \mathrm{R}, 20 \mathrm{~m}$. from Cincinnati.

Joxes's Swrrer, sta., Morgan co., $I U_{*}$ : on the Sangamon and Morgan R. R., 39 m. from Springfield,

Jones' TAN-YanD, p. o, Calloway co, Mfo.: 34 m. N. E. Jefferson City.

Jonestown, p. v., Lebanon co., Penn.: at the junction of Great and Little Swatara creeks, 24 m. E. N. E. Harrisburg. It contains several stores, and 616 inhabitants. Near the $\mathrm{v}$. is a forge producing annually 150 tons of bars.

Josiesville, p. V., Hillsdale co., Mich. : on E. side of St. Joseph $r$. of Lake Michigan, $49 \mathrm{~m}$. S. Lansing. There is fine water-power here and extensive mills, manufacturing flour, woolens, coarse cottons, and machinery. It has a considerable amount of trade. The Michigan Southern R. R. passes through the village $75 \mathrm{~m}$. from Monroe. The "Jonesville Telegraph" (neutral) is published weekly, and the "Union S. S. Visitor" (religious), semi-monthly. Population 565 .

Joxestule, p. v., Saratoga co., N. Y.: 17 m. N. by W. Albany.

JoNesville, p. o., Tadkin co., $N$. Car.: on the S. side of Farkin r., $122 \mathrm{~m}$. W. S. W. Raleigh.

Joxestrlle, p. v., Monroe co., Ohio: near Sunfish creck, $110 \mathrm{~m}$. E. by S. Columbia.

Joxespiule, p. v., Union district, S. Car, : abont $3 \mathrm{~m}$, from

Pacolet r., 69 m. N. N. W. Columbia.

Josesvilie, p. v., Harrison county, Tex. : 241 m. N. E. Austin City.

JoNestule, p. V., Chittenden co., Term. on N. side of
Onion r., $19 \mathrm{~m}$. W. N. W. Montpelier, on the line of the Vermont Central R. R., 23 m. from Burlington.

JoNesviLLe, p. v., and cap. Lee co, Firg. : on a branch of Powell's r., about $6 \mathrm{~m}$. from the Cumberland mountains, $316 \mathrm{~m}$. W. by $\mathrm{S}$. Richmond. It contains a court-house, jail, a few stores, and 300 inhabitants.

JopPA, sta., Plymouth county, Mass.: on Bridgewater Branch of Old Colony R. R., $26 \mathrm{~m}$. from Boston.

JordAN, p. v., Onondaga co., $N . Y_{.}:$on the outlet of Skencateles Lake, $141 \mathrm{~m}$. W. by N. Albany. It contains 4 churches, 6 hotels, 15 stores, several flouring and saw mills, and manufactories of wooden ware. The Erie Canal passes through the v. $19 \mathrm{~m}$. W. Syracuse. Pop. of v. 1,500.

JoRDAN's Mruss, p. o., Orangeburgh dist., S. Car. : on a branch of South Edisto r., $37 \mathrm{~m}$. S. by W. Columbia.

JORDAN's PRAIRIE, p. o., Jefferson co., $n l$. : 108 m. S. S. E. Springfield.

JORDAN's SALTNE, p. v., and cap. Tanzandt county, Tex. : near the Sabine r. $197 \mathrm{~m}$. N. E. Austin City. It contains a court-house, a few stores, and 150 inhabitants. In the vicinity are salt springs of much value, and excellent pasture land.

Jorday's Store, p. o., Williamson co.,Tenn.: 26 m. S.W. Nashville.

JoRdan's Vallex, p. o, Rutherford co, Tenn.: $26 \mathrm{~m}$. S. E. Nashrille,

JoRDAVVILLE, p. v., Herkimer co., N. Y.: 131 m.W. N.W. Albany.

Josco, t. and p. v., Livingston co., Mich.: 37 m. E. S. E. Lansing. Drained by heads of Cedar r. Surface undulat. ing; soil sandy loam. A farming town. Pop. of $t, 645$.

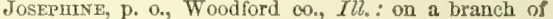
Mackinac er, 76 m. N. N. E. Springfield,

Jox, p. จ., Wayne co., N. Y.: 182 m. W. by N. Albany.

JoYner"s Depôr, p. v., Edgecombe c., $N$. Car.: $46 \mathrm{~m}$.

E. by N. Raleigh. The sta. is on the Wilmington and Weldon

R. R., $38 \mathrm{~m}$. from Weldon, and 126 from Wilmington.

JuDA, p. v., Greene county, Wisc.: 34 m. S. by W. Madison.

Julfa DeAx, p. o., Davidson co., Tenn.

Juliann Furnace, Centre co, Penn.: $72 \mathrm{~m} . \mathrm{N} . \mathrm{W}$.

Harrisburg. The furnace produces 1,400 tons of iron annually.

JULIAN's GAP, p. 0., Hamilton co., Tenn.: 112 m. S. E. Nashville.

JuLIUstows, p. v., Burlington co., N. Jer. : 15 m. S.S. E. Trenton.

Junction, p. o., Du Page co., IU.: $165 \mathrm{~m}$. N. N. E. Springfield. On the line of the Galena and Chícago Tnion $\mathrm{R} . \mathrm{R}$. $30 \mathrm{~m}$. from Chicago, and here the branches diverge to Aurora and Geneva.

Junction, sta., Providence co, $R$. $I$.: on the Stonington R. R., $5 \mathrm{~m}$. S. Providence.

Jincrios, sta. New Haven co., Conn.: on the E. bank of Housatonic r., at the divergence of Naugatuck R. R. from the New Tork and New Haven Tailroad, $9 \mathrm{~m}$. from Bridgeport.

Junction, p. o., Rensselaer co., N. $Y_{.:} 14 \mathrm{~m}$. N. by E. Albany.

Junctiox, sta., Chemung co., $N_{0}, Y_{\text {.: }}$ at the jumetion of the Canandaigua and Elmira R. P. with the Erie R. R., 4 m. W. Elmira.

Junction, p. o., Contra Costa co., Calif.

Junctiox, p. 0., Iuba co., Calif: : on Yuba r., 127 m. N. E. Vallejo.

Junction, p. V., Paulding $\mathrm{co}$, O7io : at the junction of Miami Canal with the Wabash and Erie Canal, $112 \mathrm{~m}$. N. W. Columbus.

Jurction, p. vo, Hanover co., Virg.: on $\mathrm{N}$. side of South Anna r., at the junction of the Virginia Central $P . R$. and the Richmond, Frederick, and Potomac R. R., $23 \mathrm{~m}$. by the latter from Richmond.

Junction, str., Greenville co., Firg. : on the Petersburg 
R. R., $20 \mathrm{~m}$. N. Weldon. The Greenrille and Ronnoke R. R. diverges hence and connects with the Gaston and Raleigh P. R.

Junction Stork, p. o., Botetourt co., Firg.: 129 m. W. Richmond.

JUNEAu, p. v., and cap. Dodge con, Wisc.: on a branch of Beaver Dam r., 39 m. E. N. E. Madison. It contains the court-house, a few stores, and 150 inhabitants.

Juniata county, Penn. Situate S. centrally, and contains 326 sq. m. Drained by Juniata $r$. and Licking and Tuscarora creeks, affluents of the Susquehanna, which its E. border touches. Surface broken and mountainous; soil very fertile in the valleys and very, good, producing great crops of wheat, rye, corn, and buckwheat, and affording the best of grazing. This is an excellent farming and dairy county, and great numbers of eattle and sheep feed on its fine pastures. Much pork is fatted also, and it is not wanting in deposits of coal and iron. Farms 832 ; manuf. 58; dwell. 2,16S, and pop.-wh. 12,904, fr. col. 125-total 13,029 . Capital: Mifflintown. Public Worles: Pennsylvania R. R. and Canal.

JuNLata river, Penn. : formed by the junction of Frankstown and Rayetown branches, and flows E, to the Susque hanna, $15 \mathrm{~m}$. above Harrisburg. The Pennsylvania Canal and $R$. R. pass along its banks.

Juniata, t. and p. v., Perry co., Penn.: on S. side of Juniata r., $26 \mathrm{~m}$. N. W. Harrisburg. Drained by Buffalo and Raccoon creeks. Surface broken; soil in the valleys very rich. It has fine water-power, and manufactures flour, leather, and iron. The Pennsylvania R. R. crosses the N. part. Pop. of t. 3,21 .

Jeniata Crossings, p. v., Bedford co, Penn.: $86 \mathrm{~m}$. W. S. W. Harrisburg.

JUNIOR, p. v., Scioto co., Ohio : about $3 \mathrm{~m}$. from the Ohio, $92 \mathrm{~m}$. S. by E. Columbus.

JUNrUs, t. and p. v., Seneca co., $N . \bar{Y} .: 165 \mathrm{~m}$. W. by N. Albany. Surface rolling; soil a rich loam, producing fine wheat. It has little water-power, and farming is the chief occupation. The v. has several stores and 200 inhabitanta. Pop. of t. 1,516.

Juso, p. o., Henderson co., Tenn.: 95 m. W. S. W. Nashville.

Justus' Mrurs, p. o., Hempstead co., Ark. : 116 m. S. W. Little Pook.

JrkuL island, $G a_{0}$ : at the mouth of Turtle and Little Santilla rivers, and on the S. E. coast of Glynn co. It produces the best of sea-island cotton.

\section{K.}

KaATERSknL, $N$. $Y$ : an affluent of Catskill cr. It has its sources from two ponds, each a mile and a half in circumference, in the town of Hunter, west of the Mfountain House, on Catskill Mountain. Two miles from the housc are a succession of beautiful and romantic water-falls-the flrst bring a descent of 175 feet-the sectnd, immediately following, 85 feet more; making the whole descent 260 feet, then plunging through a dark chasm, from which it takes a meandering course to Catskill creek.

КавLето ws, p. O., Jefferson co., Virg. : 128 m. N. by W. Riclimond.

Kalama river, Oreg. Ter. : a tributary of Columbia r., which it meets about $12 \mathrm{~m}$, above the mouth of Cowlitz r.

Kalamazoo county, Bich. Situate S. W., and contains $576 \mathrm{sq}$. m. Drained by Kalamazoo r. in the N. and by Four Mile, Bear, and Gull creeks. Surface level, or slightly undulating; soil, a black loam of extraordinary fertility. It has much heavy timber, beech, maple, ash, and black walnut, and a small part is prairie. It is an excellent farming and grazing co., producing all the grains in the greatest profusion, and is hardly less adapted to manufacturing, having an abundance of the best water-power. Bog-iron ore is extensively found. Farms 1,098; manuf. 51 ; dwell 2,387, and pop.-wh. 18,070, fr. col. 109-total 18,179. Capital: Kalamazoo. Pullic Works : Michigan Central R. R.

Kalayazoo, t., p. v., and cap. Kalamazoo eo., HFich. : 51 m. W. S. W. Lansing. Drained by Kalamazoo r. and several small tributaries. Surface moderately level, thickly wooded, and rich and productive. The $\mathrm{v}$. lies on the W. bank of the Kalamazoo r., and on the line of the Michigan Central R. R. The principal buildings are the court-house, jail, Huron Literary Institute, and a branch of the University of Michigan. Pop. 2,507. This is a very thriving, commercial, and manufacturing town, and is surrounded by a rich farming district. There are two papers published weekly, the "Kalamazoo Gazette" (dem.), and "Michigan Telegraph" (whig). There is here an U. S. land office, Pop. of t. 3,281.

Kalamazoo river, Mich.: it has its sources in Hillsdale and Jackson counties, and with its affluents drains also Calhoun, Eaton, Barry, Kalamazoo, and Allegan counties. Its course is circuitous, with a length of $200 \mathrm{~m}$., generally W. N. W., emptying into Lake Michigan only $98 \mathrm{~m}$, in a direct line from its source, and $41 \mathrm{~m}$. N. of St. Joseph's r. This river, with its tributaries, affords extensive mill-power, and flows through farming districts of unsurpassed fertility. It is navigable for vessels of 50 tons to Allegan, $38 \mathrm{~m}$. from the mouth, where there is 6 or 7 feet of water on the bar, Fhen the stream pours its least amount into the lake.

Kalamo, t. and p. o., Eaton co., Dfich.: 24 m. W. S. W. Lansing. Drained by the Big Fork of Thorn-apple river. Pop. 429.

Kalapooxa, v., Linn eo., Oreg. Ter. : on Kalapooya er., which falls into the Willamette at Albany.

Kalcaska county, Mich. Situate N.W. on Lower Peninsula, and contains $576 \mathrm{sq}$. m. Drained by Manistee river, emptying into Lake Michigan, and Grand Traverse $\mathbf{r}_{\text {., into }}$ Grand Traverse Bay. Erected since 1850.

Katida, p. v., and cap. Putnam co., Ohio: on the E. bank of Ottawa r., $92 \mathrm{~m} . \mathrm{N}$. W. Columbus. It contains a courthouse and jail, and supports one newspaper, the "K. Venture" (dem.), a weekly issue.

Kanawra county, Virg. Situate N. W., and contains $1,218 \mathrm{sq} . \mathrm{m}$. Intersected by Great Kanawha r., and drained by its affluents in the N., Elk r., Pocataligo r., and Sycamore, Sandy, and Big Sandy creeks; in the S., by Coal and Little Coal rivers, and Paint and Cabin creeks. It has a broken surface, and an ordinary soil, but great mineral resources; these consist principally of bituminous coal, of which six or seven million bushels are dug annually, and salt springs, which are very numerous and rich, the salt made from their waters exceeding two million bushcls per year. It has, besides, good water-power on the numerous branches of Great Kanawha $r .$, which is here a large navigable stream. Farms 777 ; manuf. 110 ; dwell. 2,110 , and pop.-Wh. 12,002, fr. col. 211, sl. 3,140-total 15,358. Capital: Kanawha. Public Works: Covington and Ohio R. R.; Improvements in the Kanawha river by James River Canal Company.

Kayawia Court-House, p. va, and cap. Kanawha co, Virg. : on the N. bank of Great Kanawha r., at the junctiou with Elk r., about $6 \mathrm{~m}$. above its confluence with Ohio r., 228 m. W. by N. Richmond. Is pleasantly situated, with an extended front on the river, which is here navigable for steamboats at low water. Also called CHARLEsToN. It contains a court-house, jail, etc., numerous stores, several steam and water mills-saw and flour-and about 170 dwellings.

Kanawha SaLINE, p. o., Kanawha co., Firg. : on the N.W. side of Great Kanawha r., $223 \mathrm{~m}$. W. by N. Richmond. It derives its name from the salt business pursued in its vicinity, and is a place of growing importance.

Kanawina river, Virg.: it has its source in Ashe co., $\mathrm{N}$. Carolina, where it reccives the waters of a number of mill. streams, and passing into Virginia, it drains Grayson, Carroll, Wythe, Pulaski, Montgomery, Giles, Monroe, Mercer, Greenbrier, Fayette, Nicholas, Kanawha, Putnam, and $\mathrm{Ma}_{2}$ 
son counties: taking a circuitous course, with many meauderings, nearly 300 miles, it empties into the Ohio $\mathrm{r}_{\text {. at Point }}$ Pleasant, in lat. $38^{\circ} 52^{\prime} \mathrm{N} ., 174 \mathrm{~m}$. N. by W. of its source, and $252 \mathrm{~m}$. below Pittsburg. At Point Pleasant, $66 \mathrm{~m}$. above the mouth, are the Kanawha Salt-works, where the river is nearly 500 feet wide. The salt district extends $15 \mathrm{~m}$. on the river, where the salt water is obtained by boring 300 to 500 feet through rock formation, tubing being passed down to exelude fresh water from the sides, and through which the brine rises to a level with the river. Steam-power is used for raising it still higher, and the bituminous coal of the same vieinity is used to effect evaporation. There are on this river and its tributaries five veins of common bituminous coal and two of cannel, all capable of being worked, and all above the level of the river. The largest is said to have an aggregate thickness of 24 feet. The cannel-coal is said to be equal to any of this kind in the world. About $100 \mathrm{~m}$. from the mouth are the Great Falls, where there is a single perpendicular descent of 50 feet. The principal affluents are the Elk, Coal, and Greenbrier rivers; the other tributaries are numerous, and aflord very extensive waterpowers.

Kaxe county, $I l l$. Situate N.E., and contains 513 sq. m. Drained by Fox r., a branch of the Illinois, which flows $\mathrm{S}$. through the E. part. Surface level or rolling; soil of great fertilits, and well cultivated-a superior farming eor. On the branches of Fox r. is fine water-power and timber, and limestone is abundant. Farms 1,015; manuf. 49; dwell. 2,S28, and pop.-wh. 16,696, fr. col. 6-total 16, 002 . Capital: Geneva, Pullic Works: Gatena and Chicago Lnion R. R.; St. Charles Branch R. R.; Aurora Branch R. R. and its extension.

KANe, D. 0, Greene co, Ill.: 53 m. S. W. Springfield.

Kavesvnue, p. v., and cap. Pottowattomee co., $I u_{*}: 6$ $\mathrm{m}, \mathrm{N}$. from Fort Croghan, and $4 \mathrm{~m}$. E. from Missouri r., 224 m. NT. by $\mathrm{S}$. Lowa City. This place Nas settled and huilt $\mathrm{b}$ the Mormons, and is an intermediate station for the overland emigration to Great Salt Lake Valiey. The "Frontier Guardian" (whig), is yullishod weetly. Pop. about 1.200.

Kaveviluz, p. 0., Kane county, Ill.: 150 m. N. N. W. Springfield.

ThLKAKEE river, $I l l .:$ its source is in St. Joseph's en. Indiana. This river, with its tribularies, drains the N. W. part of the State of Indiana, and Iroquois and Mill counties, in Illinois, and uniting with the Des Plaines river, their waters form the Illinois river. The principal tributary is the Iroquis river. On the s. side of the Kinkakee, in Illinois, are extensive fields of bituminous coal, and on the upper portion of the river are beds of iron ore. This river forms the northern boundary of the coal region of Illinois, $\mathrm{E}$. of the Illinois $r$. A company has heen chiartered fur the ingrolument of the river, to render it navigable by a system of dams and locks, which at some future day will probably open for 150 miles as buatiful is country as theru is in the If est. The prairie country is interspersed with groves and barrens, and on the F, side there are somie sand-rideres. The river wits diseorered by the French at an early period.

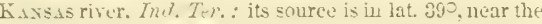
E. Lase of the Iiveky Mountains, and pursues at generally eastern course to the Missouri river, at the point where the Trest boundary of the State of Missouri leaves the Missouri river. Its whole course is about $1,200 \mathrm{~m}$., and navigable $900 \mathrm{~m}$. Its width at its mouth is 340 yards.

KAvzas, p. 0., Jackson co., MFo.: on the S. side of the Missouri r., $135 \mathrm{~m}$. W. by N. Jefferson City.

Kaposia, v., Dacotah co., Minn. Ter.: on the W. side of the Mississippi r., about $6 \mathrm{~m}$. below St. Paul. It is a fine site for a town, but as yet is little more than an Inulian settlement.

Kafitracs, p.. ., Clearfield co., Penn.: on the X. bank of the W. branch of the Susquehanna r., $92 \mathrm{~m} . \mathrm{W}$. N. W. Harrisburg. Coal, iron, and salt are produced in the vicinity.
KAsEY's, p. o., Bedford county, Firg.: 123 m. W. by \$. Richmond.

Kaskaskia, p. v., and eap. Pandolph co., Ill.: on Kaskaskia r., $10 \mathrm{~m}$. above its confluence with the Nississippi $\mathbf{r}$. and on a neck of land between the two, $127 \mathrm{~m}$. S. S. W. springfield. This town is one of the oldest in the Valley of the Mississippi, having been settled by the French in 1653, and in 1763, when ceded to the English, had some 130 families. It is beautifully situate in a lovely country. It contains a brick court-house and county jail, and also a nunnery and Catholic church, and a U.S. land office. Pop about 1,000

KASKASKIA river, $7 l l .:$ its source is in Champaign co., and runs in its general course S. S. W., draining with its numerous but small afluents the counties of Piatt, Moujtrie, Coles, Shelby, Montgomery, Fayette, Bond, Marion, Clinton, Washington, Madison, St. Clair, Monroe, and Randolph. The navigation of this river has been improved by the labor applied under the direction of the Board of Pablic Works, the drift-wood and other obstructions being remored from the channel, and sloping timber cut from the banks. In high water the river is navigable for $150 \mathrm{~m}$. to Vandalia, and some seasons to Shelbyville. At Vandalia the river is spunned by a substintial bridge for the National Road. The country drained by this river is very fertile, and varied by suitable proportions of prairie and timber-belts and groves. The source is $153 \mathrm{~m}$. N. X. E. from the mouth in a direct line, ancl its length in full, $300 \mathrm{~m}$.

Kasoag, p. v., Oswego county, $N . Y_{.}: 152 \mathrm{~m} . \mathrm{W} . \mathrm{N}$. W. Albany.

Kataidin Irox Works, p. O., Piscataquis co., Meo.: 96 m. N. N. E. Aususta, near Katuhdin Mountain, which rise 5,300 feet above the sea lovel, and affords a vastly grand and beautiful view. This mountain may be seen from Bangor, 70 miles distant, and is particularly noted for its steep acclivities, and its isolation in the district.

FitTli Ville, p. u., bruome cu., A. $\xi:: 121$ m. W. S. W. Albany.

KatFus county, Tex. Situate N. E. centraliy, and curtains 1,10S sq. m. Drained by E. and W. fork of Trinity r., its S. W. boundary, Ferry's and Lacy's forks of Cedar cr., its branch, and nany suall afluents, and in the X. E. by heads of Sabine $r$. Surface undulating, with some considerable elerations in the N., and good timber on the streams; soil a sandy loam, and mostly very productiveadapted to corn and cotton. Here is also excellent grazing in many parts. Its streams are not large, but some of them furnish good mill-seats. Farms 94; manuf. 0; dwell. 170,

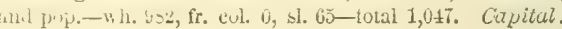
Tiautianan C. If.

Kavfuray C. H., p. v., and eap. Kaufman co., Tex,: on the unper watero of Cedar cr., $150 \mathrm{~m}$. N. N. E. Austin.

Kackadia, p. v., Browne co., Wisc, : 112 m. N. N. E. Aradison. At the rapids so called, and on the W. side of the Fox or Neenuh river.

Kautatiscirunk, p. o., Northampton co., Penn.: 84 m. N. E. by E. Harrisburg.

Krarsage mountain, Merrimac co, N. Hamp, : about 20 m. N. W. Concord. Elevation, 2,461 feet above sea level.

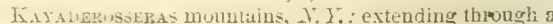
yart of Wirren, Saratogid, and Fulton counties, in a $\mathrm{S} . \mathrm{W}$. direction. Their greatest elevations are in the northern portions, which rise 800 to 1,200 feet above tide level; they gradually subside to the Moharvk Valley.

KEARSARge mountain, N. Hamp.: a mountain in Merrimac co. Its sumuit, composed of naked granite rock, is 2,463 feet above the sea, and affords, on a clear day, an extensive and interesting view of the country. Its slopes are ccred with a heavy growth of timber.

Kreapsty, p. 0., Genesee co., Mich.: about 40 m. W. N.W. Lansing.

Keגтспг, p. o., De Soto par., La.: 176 m. N. W. Baton Ruuge. 
Krannertille, v., Jefferson co., Firg.: on the line of the Baltimore and Ohio R. IR, $93 \mathrm{~m}$. from Baltimore, and 126 m. N. N. W. Richmond.

Keaton's SHOALs, p. o., Baker co., Ga. ;147 m. S. W. by S. Milledgeville.

Kеск's Chс rсH, p. o, Martin co, Ind. : 76 m. S. S. W. Indianapolis.

KeedrsvileE, p. v., Washington $\mathrm{co}_{*}, M_{2}$. on Antietam cr., $75 \mathrm{~m}$. N. W. by W. Annapolis.

Keefer's Store, p. O, Franklin co., Penn.: about $50 \mathrm{~m}$. S. W. Harrisburg

Keelersburger, p. 0., Wyoming co., Penn. : 48 N. N. E. Harrisburg.

Keelersville, p. v., Van Buren county, Mich.: $88 \mathrm{~m}$. W. S. W. Lansing.

KEENE, p. T., Jessamine co., $\overline{k y}$.: 26 m. S. E. Frankfort The line of the Lexington and Danville R. R. passes through the village.

KEExe, p. t., and eap. Cheshire co., $N$. ITamp. : $43 \mathrm{~m}$ S. W. Concord. Drained by Ashuelot r. and its tributaries, which flows through it, and affords excellent water-power. Surface diversified; soil rich, fertile, and well cultivated. At Feene the Ashuelot R. R. forms a junction with the Cheshire R. R. The $\mathrm{r}$. on the W. side of Ashuelot $r$. is beautifully situated, and contains many pleasant residences; and its wide streets are well shaded by ornamental trees. The court-house and jail are here. The $\mathrm{v}$. supports very considerable commercial and manufacturing interests; and has 3 newspapers, the "Spirit of the Times" (whig), "N. H. Sentinel" (whig), and "Cheshire Republican and Farmer" (dem.), all weekly issues. Pop. of t. 3,392 .

Krext, t. and p. V., Essex co., N. Y.: 112 m. N. by W. Albany. Drained by Ausable r. and its tributaries, which empty into Lake Champlain. Here are also numerous small lakes, from which several of the heads of the Hudson river have their sources. Surface mountainous, being traversed by the Adirondack range; and here it has its loftiest culminations, Mount Marey, Mount M'Intire, and Mount M'Martin. Soils along the rivers and in the valleys are fertile, but in other parts the rugged face of the country forbids cultivation. The v., a small agricultural settlement, lies on the E. side of the Ausable. Iron ore and other minerals abound in all this region. Pop. of t. 795 .

Kefive, t. and p. v., Coshocton co., Ohio : 63 m. E. N. E. Columbus. Drained by Mill cr., an afluent of Wallonding $r$. Surface elevated and rolling; soil deep, rich, and productive. The $\mathrm{v}$ lies on the $\mathrm{E}$. side of the cr., and is a small agricuitural settlement of about 200 inhabitants. Population of t. 1,079 .

Keeneville, p. o., Wayne co., $I l l .: 116 \mathrm{~m} . \mathrm{S}$. W. by S. Springfield

Keener's Setrueuent, p. 0., Cortlandt co., N. Y. : $125 \mathrm{~m}$. W. Albany.

Keensvilue, p. o., Union co., Penn. : 36 m. N. by W. Harrisburg.

KeEseville, p. T., Essex county, $N$. $Y$.: on both sides of Ausable r., 4 m. from Lake Champlain, 123 m. N. by E. Albany. There is here an extensive water-power, used by a number of thriving manufactories of iron and other products. It supports a paper, the "Essex Co. Republican" (whig), which is issued weekly. Pop. about 1,800 .

KenzletowN, p. V., Rockingham co., Virg.: 85 m. N.W. Richmond.

Kertis, p. o., Morgan county, Ohio: $88 \mathrm{~m}$. E. by S. Columbus.

Kritussurgh, p, v., Mercer co., IZl,: on the Mississippi at the confluence of Pope r., $112 \mathrm{~m}$. N. W. Springfield. It is a thriving v., and was onec the county seat.

Keitu's Cross Poads, p. o., Kent co., Del.

Kelderstille, p. v., Monroe co., Penn.: $95 \mathrm{~m}$. N. E. Harrislururg.

Kellertow N, p, v., Wilkinson co, Mis8. : 108 m. S. W Jackson.
Kellex's MrLls, p. o, Lawrence co., Ohio: 96 m. S. S. E. Columbus.

Kellogasville, p. V., Cayuga co., $N$. $\boldsymbol{Y}_{\text {.: }}$ between lakes Owasco and Skaneateles, $2 \mathrm{~m}$. W. of the latter and $138 \mathrm{~m}$. W. Albany.

Kelloggsville, p. V., Ashtabula co, Ohio: on the $\mathbf{N}$. side of Ashtabula cr., $172 \mathrm{~m}$. N. E. Columbus.

Kelley's Creek, p. o., St. Clair co, Ala, : 96 m. N. Montgomery.

Kelly's Ferry, p. o, Meigs co., Tenn.: on the Tennessee $r_{*}, 117 \mathrm{~m}$. E. S. E. Nashville.

Kelly'g Sprixgs, p. O , Talladega county, Ala.: $78 \mathrm{~m}$. N. by E. Montgomery.

Krluysville, p. v., Delaware county, Penn.: $83 \mathrm{~m}$. S. E. by E. Harrisburg.

Kellysville, p. o., Culpepper co, Virg.: 73 m. N. W. by N. Richmond.

Ketso, t. and p. Y., Dearborn co., Ind.: 71 m. S. E. Indianapolis. Drained by the upper branches of Tanner's cr. and affluents of White Water river. Surface somewhat broken; soils of average fertility, and productive. Pop. of t. 1,712.

Kextix Grove, p. o., Wake co., N. Car.: $10 \mathrm{~m} . \mathrm{N}$. Raleigh.

Kembespinle, p. v., Chester co., Penn.: 59 m. E. S. E. Harrisburg.

Krmper county, Miss. Situate on E. line, and contains $745 \mathrm{sq} . \mathrm{m}$. Drained E. by heads of Suquinochee r., flowing into Tombigbee r.; S. by heads of Chickasawha r., and W. by lieads of Pearl r. Surface elevated and somewhat uneven, with several good mill streams; soil very fertile. Cotton is the great staple, and its culture is almost exclusive. Corn thrives well, and great numbers of cattle and stwine are reared. Farms 730; manuf. 1; dwell. 1,249, and pop.-wh. 7,138, fr. col. 1, sl. 5,878-total 12,517. Capital De Kalb, Putite Works: Mobile and Obio R. R

KEMP, p. on, Kaufman county, Tex.: 183 m. N. N. E Austin City.

Kemp's Creek, p. o., Benton co., Ala.: 95 m. N. by E. Montgomery.

Kempsvillz, p. v., Princess Anne co., Firg. : on a branch of Elizabeth r, and at the head of tide-water, $88 \mathrm{~m}$. S. E Richmond. It contains several stores and. about 300 inhabitants.

Kenansvilue, p. v., and eap. Duplin co., $N$. Car.: on the $\mathrm{E}$. side of Grove er., $71 \mathrm{~m}, \mathrm{~S}$. E. Raleigh. The v. contains the court-house and about 150 inhabitants.

KExdal county, $1 l l$. Situate N. E., and contains 32 sq. m. Drained by Fox r., which erosses the N. W., and in the S. E. by Au Sable r., a small branch of Des Plaines r. Surface level or undulating; soil fertile, and much of it prairie, with timber on a few streams. It has considerable water-power and large deposits of coal. Farms 659 ; manuf 0 ; dwell. 1,258, and pop.-wh. 7,724, fr. col. 6-total 7,730 Capital: Oswego," Public Works: Aurora Extension R. R.

KENDALL, t. and p. v., Orleans co., $N$. $Y$.: $232 \mathrm{~m}$.W. by $\mathrm{N}$ Albany. Drained by Sandy and other creeks. Surface nearly level, with a gradual ascent from Lake Ontario, which forms the $\mathrm{N}$. boundary; soil sandy and gravelly loam, and well tilled. Pop. 2,289.

Kexdall, p. o., Beaver co, Penn.: 184 m. W. by N. Harrisburg.

KeNDALL, p. 0., Kendall county, Ill.: 123 m. N. N. E. Springfield.

Kendalu Creek, p. o., M'Kean co., Penn. : 151 m. N. W IIarrisburg

Kendalt, Mills, p. o., Orleans county, $N . Y_{0}: 229 \mathrm{~m}$. W. by N. Albany.

KExdall's Milcs, p. o., Somerset co., Me.: on the W. bank of Kennebec $r, 20 \mathrm{~m}$. N. by E. Augusta.

Kindall's Store, p. o., Stanley co., $N$. Car. : $67 \mathrm{~m}$. W. S. W. Raleigh.

KeNdaluvillu, p. v., Noble co, Ind.: on Little Cedar 
cr. and on the line of the Fort Wayne and Lima plaukroad, $126 \mathrm{~m}$. N. N. E. Indianapolis.

KridDetcK's SPGR, p. o., Patrick county, Firg. : 168 m. W. S. W. Richmond.

Kendeskeag stream, Me.: a tributary of the Penobscot r., which it joins at Bangor. It furnishes a large and valuable water-power.

KanNebec county, Me. Situate S. W. centrally, and contains 1,109 sq. m. Drained by Kennebec and Sebasticook rivers, and their affluents, and W. by the Androseoggin. Surface undulating, without being hilly, and soil highly productive. It has many ponds, which, with their streams and the Kennebec, afford immense water-power. It abounds in fine timber, and the Iumber trade is of great importance. The Kennebec is a large navigable stream, and its commercial facilities fine. Wheat, corn, oats, and barley yield well, and its pastures feed great numbers of cattle and sheep. The great export is potatoes, of which immense quantities are raised and sent to all parts of the Union. Farms 5,256; manuf. 331; dwell. 10,162, and pop.-wh. 62,379, fr. col.142-total 62,521. Capital: Augusta. Publie Works: Androscoggin and Kennebee R. R.; Androscoggin R. R.; Portland and Kennebee R. R.

KENNEBEc, t. and p. v., Kennebec co., Me.: 5 m.W. S.W. Augusta. About one-third the surface is covered by lakes; soil rich and well cultivated. The principal $v$. lies on the N. E. corner.

KENNBBEO river, MTe : one of the most important river of New England. Its principal source is at the outlet of Moosehead lake, but its more remote source is that of Dead r., which empties into Kennebec r., $20 \mathrm{~m}$. below the outlet. The source of Dead $\mathbf{r}$. is in the N. W. part of Franklin county, within $5 \mathrm{~m}$. of Chaudiere $r$. which flows into the St. Lawrence. The general course of Kennebec r. is S. by E., making several considerable curves, and draining with its tributaries, Somerset, Franklin, and Kennebec, and portions of Penobscot and Waldo counties, and traversing Lincoln. Its length from its remotest source is about $200 \mathrm{~m}$. It is navigable for boats $60 \mathrm{~m}$. to Waterville, for sloops to Augusta, $42 \mathrm{~m}$, and for ships to Bath, $12 \mathrm{~m}$. from its mouth. Its largest tributary is the Androscoggin, flowing in $18 \mathrm{~m}$. from its mouth. The confluent stream is sometimes called the Sagadahock. At Waterville, and other places ahove, are very valuable water-powers. The whole fall of the river is more than 1,000 feet, affording, with its tributaries, incalculable hydraulic power. The river is closed by ice generally for four months of the winter season, except below Bath, where the salt water usually keeps the port open at all seasons. The principal towns on the river are Bath, Hallowell, Augusta, Waterville, and Norridgewock, It flows through a fertile country and bears an extensive trade.

KENNEBUNK, to and p. v., York co., Me.: $66 \mathrm{~m}$. S. S. W Augusta. Drained chiefly by Mousum r., on which and on the Kennebunk there are several mills and factories. The $v$. is on the S. W. side of Mousum r., and at the entrance of the Kennebec into the Atlantic there is a good harbor. It is a port of entry, and has some shipping employed in the fisheries and coasting trade. Formerly it had an extensive trade with the West Indies, and many fine ships are still built in the town. Pop. 2,650.

Kennfiunk Depôt, p. o., York co, Me. : on the N. bank of Mousum r., and on the Portland, Saco, and Portsmouth R. R., 60 m. S. S. W. Augusta.

KENNEBUNKPORT, to and p. v., York co., Me.: $62 \mathrm{~m}$. S. S. W. Augusta, on the N. E. side of Kennebec r. and opposite to Kennebunk, with which its chief interests are connected. It has considerable shipping, and many of the inhabitants are engaged in coasting and the flsheries. Granite, much resembling that of Quincy, is abundant, and furnishes a staple of export. This $t$. and Kennebunk were in former times among the most active and busy shipping places in $\mathrm{Maine}$, but their trade has immensely diminished. Pop. of t. 2, $\ddot{0} 0 b^{\circ}$.
KeNnEDY's, p. 0., Brunswick oo., Virg. : 68 m. S. S. W. Bichmond.

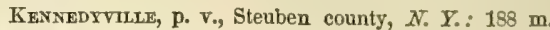
W. by S. Albany. The v. lies on the Bufialo, Corning, and New York R. R., 24 m. from Corning. It contains several stores and workshops, and about 260 inhabitants.

Kennemer, p. o., Marshall county, Ala.: 136 m. N. Montgomery.

Kennetis Square, p. v., Chester county, Penn, $71 \mathrm{~m}$. E. S. E. Harrisburg. It contains a Quakers' meeting-house and about a score of dwellings.

Kennow, p. o, Belmont county, Ohio: 89 m. E. by N. Columbus.

Kexmonsiurgir, p. o., Guernsey co., Ohio: 85 m. E. by N. Columbus.

Kenosha county, Wisc. Situate S. E. corner, and oontains 282 sq. m. Drained by Fox and Des Plaines (or $O^{\prime}$ Plain) rivers, which flow $\mathrm{S}$. into Illinois $x$. Surface gently undulating; soil a fertile prairie for the most part, and very productive of the grains and grasses. Its stock is very fine and dairies large. There is some timber on the streams, but where wanting, the lake supplies lumber and coal. Limestone is quarried on the rivers. Farms 914; manuf. 51 ; dwell. 1,912, and pop.-wh. 10,714, fr. col. 18-total 10,732. Capital: Kenosha.

Kenosha, p. v., and cap. Kenosha co, Wisc. : on Lake Michigan, 89 m. E. S. E. Madison, 10 m. S. Racine. Has an excellent harbor, and commands the trade of one of the finest farming districts in the world, the prairies of the county being of the richest and most beautiful character of the West. Tro small creeks empty into the lake, one above and the other below the port. Kenosha was formerly called Southport. The location is very desirable and pleasant: its shipping interests are likely to improve. Pop. 3,460 .

Kensico, p. v., Westehester co., $N_{*}, \boldsymbol{Y}_{\text {: }}$ : on the Harlem R. R., $125 \mathrm{~m}$. by route from Albany.

Kensington, p. Y., Hartford co., Conn.: on a S. branch of Little r., 14 m. S. \$. W. Hartford. The New Haven, Hartford, and Springfield R. R. passes it about a mile to the east. The v. has several manufactures, etc.

Kensington, p. v., Oakland co., Mich.: on Woodruff cr., a branch of Huron r., $46 \mathrm{~m}$. W. S. W. Lansing, A thriving v., surrounded by a rich farming district, and it has several flourishing mills and about 200 inhabitants.

KensingtoN, t. and p. $\nabla$., Rockingham co., N. Hamp. : $36 \mathrm{~m}$. S. E. Concord. Surface is nearly level and almost without streams. The $\mathrm{v}$. has sereral stores. Pop. of t. 700 .

Kensington, t. and p. v., Philadelphia co, Penn.: $96 \mathrm{~m}$. E. by S. Harrisburg, Although under a separate government, Kensington is in reality a part of Philadelphia and a suburb of thai city. It is situate $\mathrm{N}$. E. on the Delaware, and contains a large number of industrial establishments for the manufacture of cotton and woolen goods, etc., and has also manufactures of iron, glass, etc. Ship-building is also extensively carried on. It has a large wholesale and retail trade, Dwellings 7,555 , families 9,066, and pop. 46,776 .

KeNт county, Del. Situate centrally, and contains 614 sq. m. Drained by Duck, Little, Jones, Motherkill, and Mispillion creeks, emptying into Delaware Bay, and Nanticoke and Choptank rivers, flowing into Chęsapeake Bay. Surface moderately uneven; soil mostly very productive. Corn, wheat, rye, and oats are the chief crops, and great numbers of cattle and sheep are reared. It has some water-power, and exports considerable lumber. Farms 1,655 ; manuf. 121 ; dwell. 3,873 , and pop.-wh. 16,119, fr. col. 6,350, sl. 847-total 22,816. Capital: Dover. Public Work : a projected railroad from New York to Norfolk (air line).

Kext county, $M d$. Situate N. E, and contains $272 \mathrm{sq}, \mathrm{m}$, It has Sassafras $r$. on the $N$., Chesapeake Bay on the W., and Chester $r$, on the $S$., and a few creeks flowing into these. Surface high and rolling; soil fertile. Corn, wheat, 
oats, and sweet potatoes are the leading products of the soil. Marl and lime, from shell beds, are abundant. It bas sone mill-seats and considerable manufactures. Farms 667 ; manuf. 35; dwell. 1,584, and pop.-wh. 5,616, fr. col. 8,143, sl. 2,627-total 11,386. Capital: Chestertown.

KEXT county, Mrich. Situate $\mathrm{S}$. W., and contains 576 sq. m. Drained by Grand $r$., which crosses it, running to the W., and its branches, Rouge and Thorn-apple rivers. Surface rolling, except on Grand r., where it is hilly; soil a rich vegetable loam. It is equally adapted to grain or grass, and produces great crops. The W. is well timbered with black walnut, beech, and sugar maple, and on Rouge r. are valuable pine forests. It has immense water-power, especially on Grand $x$. Limestone and superior gypsum are abundant, and salt springs are found. Farms 847; manuf. 67 ; dwell. 2,251, and pop.-wh. 11,982, fr. col. 34total 12,016. Capital: Grand Rapids.

KEN county, $R$. I. Situate W. centrally, and contains $186 \mathrm{sq} . \mathrm{m}$. Drained by Pawtuxet and Flat rivers. Surface uneven and rough, with level tracts in the E.; soil a sandy or gravelly loam, and of great fertility. Its pastures are excellent, and many sheep are reared. It has fine orchards and gardens, known in all the markets around. The streams are small, but afford much water-power, and its manufactures of wool and cotton are extensive. Narraganset Bay lies E. of it, and its coasting trade and fisheries are valuable. Farms 688 ; manuf. 90 ; dwell. 2,625, and pop. -wh. 14,821, fr. col. 247-total 15,068. Capital: East Greenwich. Public Works: Providence and Stonington R. R. ; Hartford, Providence, and Fishhill R. R.

Kert, t. and p. v., Litehfield co., Conn. : 41 m. W. by $\mathrm{S}$. Hartford. Drained by the Housatonic r. and several of its affluents, all which afford excellent water-power. Surface generally mountainous, with fine valleys and intervales; soll in the mountains gravelly and hard-in the valleys calcareous loarn, and fertile. The $\mathrm{v}$. lies on the line of the Fousatonic R. R. and on the E. side of the river, which is here spanned by a bridge. In the to there are extensive deposits of iron ore and several furnaces, ete. Pop. 1, S49.
Kenr, p. 0., Stephenson co., $\Pi_{0}: 184$ m. N. Springfield.

Kext, t. and p. v., Putnam co.g N. Y.: 84 m. S. Albany. Drained by head branches of Croton $r$. Surface generally hilly-in the N. mountainous. Pop. 1,557.

Kent, p. o., Indiana co., Penn.: about $118 \mathrm{~m}$. W. by $\mathrm{N}$. Harrisburg.

Krevt, p. ఛ., Jefferson county, Ind.: 78 m. \$. S. E. Indianapolis.

KENT island, $M d .:$ the largest and most important island of Chesapeake Bay, containing $42 \mathrm{sq} . \mathrm{m}$. of surface. The first settlement within the present limits of the State was made on this island by Claiborne, and here is the scene of many interesting events in the early colonial history of the State. It lies opposite Annapolis.

Kenton county, $\bar{K} y$. Situate in most $\mathbf{N}$. point, and contains $145 \mathrm{sq}$. m. Drained by affluents of Licking r., its $\mathbf{E}$. boundary, and Ohio r., its N. boundary. Surface moder. ately uneven; soil fertile, admirably adapted to grain-growing and grazing. Tobacco, corn, wheat, and pork are the farming staples. It has much fine water-power and extensive manufactures. The N. is quite level, is under high cultivation, and densely populated, being a kind of dependency of Cincinnati, which is just opposite Covington, the largest town in the county. Farms 656; manuf. 109 ; dwell. 2,854, and pop.-wh. 16,116, fr. col. 92, sl. 830-total 17,088. Cap. ital: Independence. Putlic Works: Nashville and Cor ington $\mathrm{R}, \mathrm{R}$. ; Covington and Ohio R. R.; Lexington and Covington R. R., ete.

Kenton, p. v., and eap. Hardin co., Ohio: on the N. side of Scioto r., 56 m. N. W. by W. Columbus. The Mad River and Lake Erie R. R. passes through the v., $78 \mathrm{~m}$. from Sandusky. Two papers are issued here weekly, the "K. Republican" (whig), and "K. Herald" (dem.) This is the business centre of an excellent farming district. Population of $\mathrm{v} .1,065$.

Kentontown, p. v., Harrison co, Ky. : 54 m. N. E. by E Frankfort.

Kext's HiLl, p. v, Kennebec co, Mfo. : 13 m. W. N. W. Augusta.

\section{THE STATE OF KENTUCKY.}

KeNTUCKY is separated from Ohio, Indiana, and Mlnois by the Ohio River, which demarks its north boundary; and from Missouri by the Mississippi River, its western boundary. The east boundary is formed chiefly by Big Sandy River and the Cumberland Mountains, which separate it from Virginia, and on the south the boundary is co-terminus with the north boundary of Tennessee. The State lies generally between the latitudes $36^{\circ} 30^{\prime}$ and $39^{\circ} 12^{\prime} \mathrm{N}$., and between the longitudes $82^{\circ} 02^{\prime}$ and $89^{\circ} 40^{\prime} \mathrm{W}$. from Greenwich, or $5^{\circ} 00^{\prime}$ and $12 \circ 35^{\prime} \mathrm{W}$. from Washington. Its greatest length on the parallel of Cairo, in Illinois, is 365 miles, and its greatest width on the meridian of North Bend, in Ohio, is 168 miles; but the irregularity of its outline in some parts narrows its width to 40 miles, as on the east line of Graves County, and its length varies as much as 100 miles from a maximum. The estimated land area of the State is 37,680 square miles.

The face of the country may be generally described as level or moderately uneven. The levels, however, are not like a carpet, but are interspersed with small risings and declivities, which make a scene of varying interest. In the south-east the Cumberland Mountains, which form the boundary toward Virginia, except from this character; but even here no great elevations are attained, yet they give to that portion of the country a rugged and mountainous aspect, and their numerous spurs or offshoots, projecting quite into the middle of the State, render the surface of the whole eastern division somewhat broken and hilly. Farther westward the country becomes undulating, abounding in bold features, although the hills are much less abrupt than in the east, and gradually sink down with more rounded forms and gentler acchivities, until merged into the almost level plains of the Cumberland, Tennessee, and Mississippi rivers, Along the Ohio, and extending from 10 to 20 miles in different places from it, are the Ohis Hills, parallel with that beautiful strean. These hills are often high, generally gracefully rounded and conical, with narrow vales and bottoms around their bases, and gire to the country through which they extend a rough appearance; they are covered with lofty forests, and have often a good soil on their sides and summits; and the alluvial bottoms between them and the Ohio, and along the streams which fall into that river, are of the richest description.

In the genlogy of Kentucky the blue limestone occupies a conspicuous place; it forms the surface rock in a large part of the State, and is used for building purposes. Among the cliffs of the Kentueky River is found an excellent marble, capable of a fine polish. The cliff limestone is the base of the Ohio Falls at Louisville; the slate or shale is very common, bituminous, and supports combustion, and contains iron pyrites and ores, giving rise to mineral springs. The sand or freestone extends from Danville to Louisville, etc., and is used in the arts, and even for grindstones. The cavernous limestone, as its name imports, gives rise to many caves, the most famous of which is the Mammoth Cave (see MAuroth CAve). The limestone region, indeed, abounds in caverns, sinks, and subterranean water-courses. Sereral of the cares are of extraordinary dimensions, but the one above'mentioned is the most spacious and best known. The sinks or sinkholes are cavities or depressions on the surface of the ground, resembling those of Florida, already described, but of infe- 


\section{KENTUCKY}

rior extent; they are commonly in the shape of inverted cones, 60 or 70 feet in depth, and from 60 to 300 feet in eircumference at the top. Their sides and bottoms are generally covered with willows and aquatic productions, and the ear cat often distinguish the sound of waters flowing under them. It is believed that these sinks are perforations in the bed of limestone below the soil, which have eaused the earth to sink. Sometimes the ground has been opened, and disclosed a subterranean stream of water at the bottom of these cavities. The conglomerate or pudding-stone consists of quartz pebbles, rounded and united with fine sand by a kind of natural cement: it underiles the coal formation. The coal-beds of Kentucky are continuous of those of the Mllinois and Ohio; they cover 10,000 or 12,000 square miles, and are very accessible, but hitherto the quantity of coal mined has not been to any great amount-not more than five or six million bushels a year. Iron is equally abundant in the State, and it, too, is comparatively neglected, but from its deposits being mainly on or near navigable streams, it must inevitably become a source of future wealth to the country. An estimate of the quantity embraced has been fixed at $35,000,000$ tons. Small quantities of lead are also traced in Kentucky, and silver ore has lately been discovered near the Cumberland Falls. Salt springs abound in the sandstone formation, and have become very productive. Saltpetre-earth, or nitrate of lime, gypsum, or plaster of Paris, are found in the eaves. Mineral springs are numerous, embracing sulphur, saline, chalybeate, etc. The salt springs received the name of "licks" from the early settlers, on account of their being the favorite resorts of the wild animals, which were fond of licking the efflorescences so abundant around them. The name is also applied to the sulphureted fountains which occur in various places.

The most productive soil of Kentucky is that of the blue limestone formation; and in the neighborhood of Lexington and toward the Ohio, the country based on that route is said to be the ghrden of the State. The line demarking this region passes from the Ohio round the heads of Licking and Kentucky rivers, Dick's River, and down Great Green River to the Ohio; and in this great compass of above 100 miles square is found one of the most fertile and extraordinary countries on which the sun has ever shone. The soil is of a loose, deep, and black mold, without sand-on first-rate lands, from two to three feet deep, and exceedingly luxuriant in all its productions. It is well watered by fine springs and streams, and its beautiful climate and the salubrity of the country ure unequaled, the winter, even, being seldom so inclement as to render the bousing of eattle necessary. In a state of nature, nearly the whole surface of this region was covered with a dense forest of majestic trees, and a close undergrowth of gigantic reeds, forming what in the country are called canebrakes. In the southern part, however, on the head waters of Green River and its tributaries, is an extensive tract, thinly wooded, and covered in summer with high grass growing amid scattered and stunted oaks: struck with the contrast this region presented to the luxuriant forests of the neighboring districts, the first settlers gave the country the unpromising name of "barrens." As a general thing, the term is by no means appropriate. There are, indeed, portions of the barrens, which are known as the $k n o b s$, that are too sterile and rugged to admit of cultivation; but the soil is generally productive, atthough not of the first quality, and is well suited for grazing. There are also tracts in the mountain regions and portions of land on the Ohio Hills too much broken for general agriculture; but as a whole, Kentucky has as great a proportion of the best soils as any other of her sister States, and from the splendor of its climate, has many advantages possessed by few other regions.

The country in general may be considered as well timbered, producing large trees of many kinds, and to be exceeded by no country in variety. Perhaps among its forest growths none is more valuable to the settler than the sugar-tree, which grows in all parts, and furnishes every family with a plenty of excellent sugar; and the honey-locust, so euriously surrounded by large thorny spikes, bears long pods in the form of peas, having a sweet flayor, and from which domestic beer is made. 'The coffee-tree, greatly resembling the black oak, grows large, and also bears a pod in which is inclozed coffee. The pawpaw bears a fine fruit like a cucumber in shape and size, and of a sweet taste. The cane, on which cattle feed and grow fat, in general grnws from three to twelve feet high, is of a hard substance, with joints at eight or ten inches distance along the stalk, from which proceed leaves resembling the willow. There are many cane-brakes, so thick and tall that it is difficult to pass through them. Where no cane grows there is an abundance of wild rye, clover, and buffalo-grass covering vast tracts, and affording excellent pasture for cattle; and the fields are covered with wild herbage not common to other countries. Here is seen the finest crown imperial in the world, the cardinal flower, so much extolled for its scarlet color; and all the year, except the short winter mouths, the plains and valleys are adorned with a variety of flowers of the most admirable beauty. Here is also found the tulip-bearing laurel-tree, or magnolia, which is very fragrant, and continues to blossom and seed for several months together.

Among the agricultural staples of Kentucky, hemp and flax are the most conspicuous. Tobacco is also extensively grown; and the Indian corn and wheat of this State are large crops and excellent in quality. The first-named--hemp, flax, and tobacco-are, however, the great staples. The hemp crop of Kentucky is five-eighths of the whole yield of the United States-that of dew-rotted hemp is two-thirds, and that of water-rotted hemp is seven-twelfths of the whole of the respective descriptions; four-sevenths of the crop of flax is grown in Kentucky; and the tobacco crop yields more than a fourth of the aggregate of that production. Its wheat crop is surpassed in quantity by only ten States; its Indian corn crop is surpassed only by that of Ohio; only two States have larger crops of oats; only six produce more wool; only four a larger abundance of market-garden products; only seven more butter; only two more beeswax and honey ; and only one exceeds it in its home-made manufactures. The cash value of its farms makes it fourth in the list of States in point of agricultural wealth, and only three other States possess a greater wealth in live-stock, and one other equals it in the latter respect. And yet, with all this vast amount of wealth and production, not one-half of its surface was under cultivation in $1849-50$, to which period the above returns refer.

Nature has been most bountiful to this State in its noble rivers and useful streams. Beside the great peripheral waters, the Ohio, Mississippi, etc., several large and important water-courses traverse the interior, and, with the single exception of the Upper Cumberland, these flow in a uniform direction from south-east to north-west; and while the Ohio is the recipient of all the great rivers of the State, the Mississippi only receives a few inconsiderable streams of trifling use as avenues of commerce. The Sandy, Licking, Kentucky, and Cumberland rise in the same region in the mountains of the south-east. The Kentrecky is a rapid stream, running, like the other rivers of the State, in a deep channel with a rocky bed and generally perpendicular banks; it flows through a rich and highly cultivated country, and in high stages of the water is navigable for steamboats to Frankfort, 60 miles, and for flat boats about 100 miles further. The Licking, which also flows through a rich region of country, enters the Ohio, opposite Cincinnati, and affords boat navigation for about 80 miles. Salt River rises in the centre of the State; it has a great volume of water in proportion to the length of its eourse, and is navigable for boats for 100 miles. It receives from the south a large tributary, called the Rolling Fork. Green River, likewise, rises in the centre of the State, and takes a westerly course, until having received the Big Barren River 


\section{KENTUCKY.}

from the south, it turns to the north-west; it has a gentle current, with great depth of water. Steamboats go up to Bowling Green, on the Big Barren, 180 miles, and flat boats ascend nearly to the heads of the river. The Cumberland has its sources and its mouth in Kentucky, but the greater part of its course is in Tennessee. Rising on the western declivity of the Cumberland Mountains, it passes into the latter, and returning worth, enters the Ohio in the former State Its course is about 600 miles long, and steamboats go up to Nashville, Tenn., 200 miles, and in high stages of water even to Burkesville, in Kentucky. The Tennessee, being separated from the Cumberland by the mountains of that name, has no portion of its head waters in Kentucky, but it enters the State about 70 miles above its mouth, and admits steamboats to Florence, in Ala., a distance of about 300 miles. The navigation of several of these rivers has been improved by locks, ete., and in some the obstructions are overcome by canals and railroads.

Kentucky is divided into 100 counties, the general statistics of which and the capitals of each in 1850 were as follows:

Counties. Dwell. Pop. Farmg Hanuf. Capitala. Adair ........1,513..9,898.,1,010.. 19..Columbia Allen........1,249..8,742.. $740 \ldots 7 .$. Scottsville Anderson ..... \$83..6,260.. 420.. 37..Lawrenceburg Ballard....... 775. 5,496.. 4\$3 . 7... Blandvillø Barren ........2,667. .20,240..1,813. . 83..Glasgow Bath .........1,595..12,115..1,015.. 23. . Owingsville Boone........1,615..11,185.. 982 . 16..Burlington

Bourbon ......1,34S..14,466.. $734 . .34 .$. Paris Boyle......... 927.. 9,116.. 443. 53.. Danville Bracken...... 1,437.. 8,903.. 728.. 21..Brookville Breathitt ..... 625.. 3,785,. 433.. 15..Jackson Breckenridge ..1,452,.10,593. . 8s9.. 18...IIardinsburg Bullitt.......9970.6,774.. 562.. 14..Shepherdsville Butler ........ 897.. 5,755.. 629.. 8...Morgantown Caldwell.......1,746..13,048.. 859 . 85...Eddyrille Callaway ......1,191.. 8,096. . 933.. 7.. Wadesboro' Campbell .....2,319..13,127.. 730.. 12.. Newport Carroll ........ 766.. 5,526.. 376.. 17..Carrollton Carter.........944.. 6,241.. 654.. 7..Grayson Casey.........1,005 . 6,556. . 75 S.. 11... Liberty Christian . . . . . 1,965. .19,550 . 1,190.. 77... Hopkinsville Clark........1,364..12,683.. 792.. 17.. Winchester Clay ......... $752 \ldots 5,421 . .511 . .11 .$. Manchester Clinton........ 774.. 4,889. 499.. 3... Albany Crittenden..... 975, 6,351 .662, 13..Marion Cumberland.... 942.. 7,005.. 607.. 11..Burkesville. Daviess .......1,631..12,353...1,057.. 18... Owensboro' Edmonson..... 651.. 4,088.. 507.. 4..Brownsville Estill .......... 934.. 5,955.. 604.. 2..Irvine Fayette.......2,089..22,735 . 799..156..Lexington Fleming......1,983.13,914,.1,211..96..Flemingsburg Floyd......... 862.. 5,714.. 365.. 4...Prestonburgh Franklili......1,453..12,462..850.. 62..FRANEFORT Fulton........ 556. 4,446.. 361,. 9..Hickman Gallatin....... $747 . .5,187 . .4414 . .11 .$. Warsaw Garrard........1,255. .10,237.. 666.. 21..Lancaster Grant ........1,081..6,531. 730.. 15.. Williamstown Graves ........1,694..11,397..1,279.. 35... Mayfleld Grayson.......1,065. . 6,837.. 824.. 14..Litchfield Green ........1,105. 9,060. .791. . 20..Greensburgh Greenup.......1,529.. 9,654. . 453.. 20.. Greenup Hancock ...... 551.. 3,553.. 319.. 15..Hawesville Hardin . . . . . 2,005 . 14,525 ..1,406. . 50.. Elizabethtown Harlan .......6687.. 4,268,. 535.. 0.. IIarlan Harrison .....1,753..13,064..1,130.. 54..Cynthiana Hart .........1,212 . 9,093. 829.. 12 . Munfordsville Henderson ....1,337:.12,171..1,037.. 44..Henderson Henry........1,438, 11,442,.1,029 . 75. . New Castle Hickman ...... 6556. 4,791. 546. 9..Columbus Hopkins.......1,738. .12,441..1,354.. 10... Madisonville

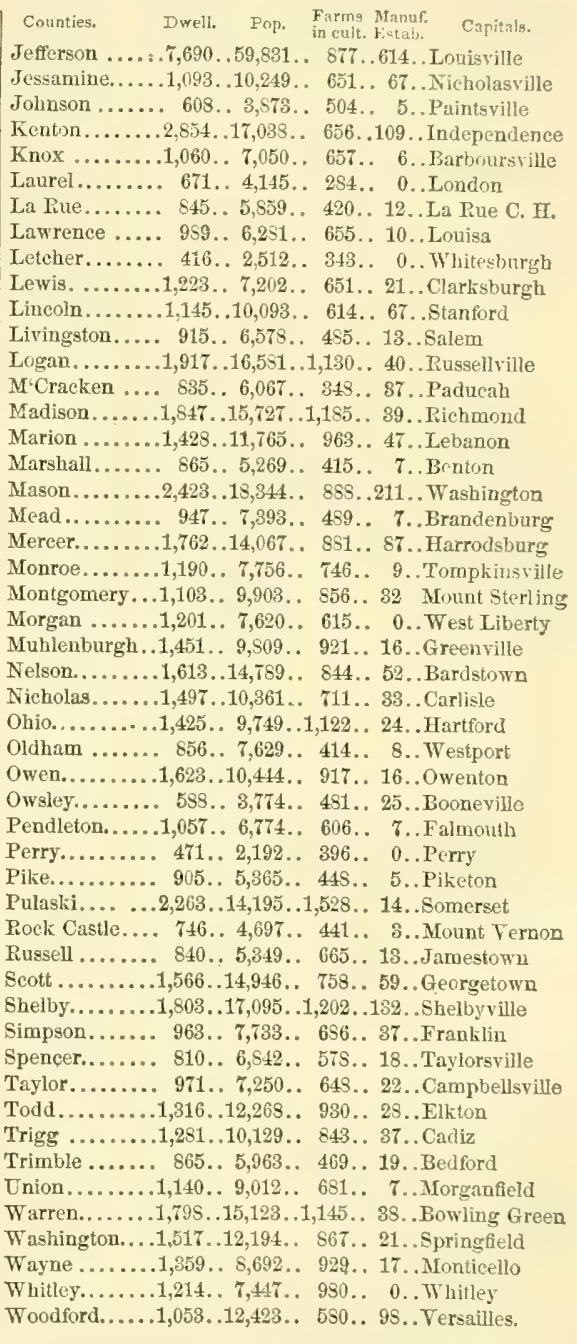

The whole number of dwellings in the State was, at the above date, 180,769; of families, 132,920 ; and of inhabitants, 982,405 ; viz., whites $761,6 S 8$ - males $392, \$ 40$, and females $365, \$ 49$; free colored 9,736 - males 4,771, females 4.965 , and slares 210,981. Of the whole population there were, deaf and dumb-wh. 4S5, fr. col. 4, sl. 50-tistal 539; ulind-wl. 421, fr. col. 19, sl. 90-total 530; insane-wh. 488, fr. col. 3, sl. 16-total 507, and idiotic-wh. 749, fr. col. 20, sl. S0-total 819. The number of free persons born in the United States was 740,881, the number of foreign birth 29,189, and of birth unknown 1,854; the native population originated as follows: Me. 227, N. Hamp. 225, Verm. 277, Mass. 665, R. I. 226, Conn. 448, N. Y. 2,851, N. Jer. 1,249, Penn. 7,491, Del. 507, Md. 6,470, Dist. of Col. 176, Virg. 54,694, N. Car. 14,279, 8. Car. 8,164, Ga. 892, Flor. 30, Ala. 792, Miss. 657, La. 671, Tex. 71, Ark. 271, Tenn. 23,623, Kentucky 601,764, Oh. 9,9S5̌, Mich. 59, Ind. 5, 898, Ill. 1.649, Mo. 1,467, Ia, 59, Wise. 11, Territories 8 ; and the forcign population was composed of persons from-England 2,505, Ireland 9,466, Scotland 653, Wales 171, Germany 13,607, France 1,116, Spain 21, Portugal 


\section{KENTUCKY.}

5, Belgium 27, Holland 35, Italy 143, Austria 12, Switzerland 279, Russia 70, Denmark 7, Norway 18, Sweden 20, Prussia 19S, Sardinia 1, Greece 1, Asia 3, Africa 4, British America 275, Mexico 42, Central America 1, South America 2, West Indies 41, and other countries 133.

The following table will show the decennial progress of the population since the first census of the State taken by tho United States authorities:

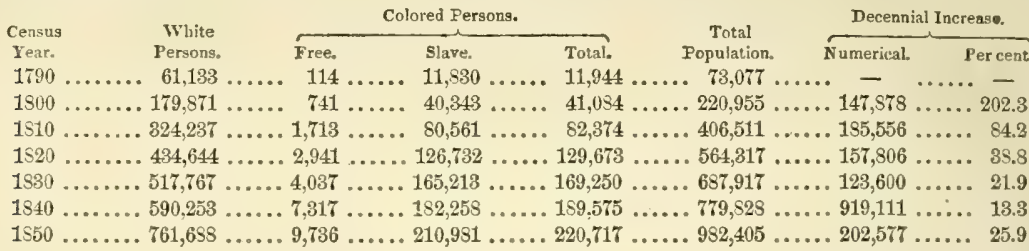

The statistics of the wealth, industry, productions, and institutions of the State, according to the census of 1850 , and other official returns referring to the same period of time, are as follows:

Occupied Lands, etc.-Improved lands, 11,368,270 acres, and unimproved lands, 10,972,478 acres-valued in cash at $\$ 154,330,262$; whole number of farms under cultivation, 74,777 ; value of farming implements and machinery, $\$ 5,169,037$.

Live Stock,-Horses, 315,652; asses and mules, 65,609; mileh cows, 247,475; working oxen, 62,074; other cattle, 442,763 ; sheep, 1,102,121; and swine, 2,861,168-valued in the aggregate at $\$ 29,591,387$. In 1840 there were in the State $395, \mathrm{S53}$ horses, mules, ete. ; 757,093 neat eattle of all kinds; 1,008,240 sheep; and 2,310,533 hogs.

Grain Crops.-Wheat, $2,140,822$ bushels ; rye, 415,073 bushels; Indian corn, $58,675,591$ bushels; oats, $8,201,311$ bushels ; barley, 95,343 bushels; and buckwheat, 16,097 bushels. In 1840 the crops were as follows-wheat, 4,803,152 bushels; barley, 17,491 bushels; oats, 7,155,974 bushels; rye, 1,321,373 bushels; buckwheat, S,169 bushels; Indian corn, 39,847,120 bushels.

Other Crops.-Rice, $5,6 \mathrm{SS}$ (in 1S40, 16,376) pounds; tobacco, $55,501,196$ pounds; ginned cotton, 755 bales of 400 pounds ; peas and beans, 202,574 bushels ; potatoes-Irish, 1,492,487 bushels, and sweet, 995,184 bushels; hay, 113,655 tons; cloverseed, 3,230, and other grass-seed, 21,451 bushels ; hops, 5,304 pounds; hemp-dew-rotted, 40,986, and water-rotted, 14,756 tons; flax, 7,793,123 pounds; flax-seed, 75,579 bushels; maple sugar, 437,345 pounds; cane-sugar, 284 hogsheads of 1,000 pounds; molasses, 40,047 gallons; wine, 8,093 gallons, etc. The value of orchard products was $\$ 106,160$, and of marketgarden products, $\$ 293,120$. The annexed form will exhibit the staple crops of $1 \$ 40$ and 1850 comparatively :
Staples.
1840
1850 .
Morement.

Tobaceo............. 58,436,909 pounds .... $55,501,196$ pounds .... incr. $2,064,287$ pounds, or 3.86 per centw

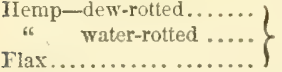

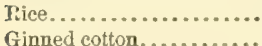

$\left\{\begin{array}{cc}\cdots & 40,936 \text { tons } \\ \cdots & 14,756 \text { " } \\ \ldots & 7,793,123 \text { pounds }\end{array}\right\}$

$9,992 \div$ tons

16,376 pounds $\ldots . \quad 5,688$ "6

$691,456 \quad$ "6 $\quad \ldots . .303,200$ :

$\{\ldots$ iner. $110,352,640$

.... decr. $\quad 10,688$ " $\quad 650$ " 65

Products of Animals.-Wool, $2,297,403$ (in 1840, 1,786,847) pounds; butter, 9,877,86s pounds; sheese, 213,784 pounds; and the value of animals slaughtered during the year had been $\$ 6,459,318$. Silk cocoons were produced to the amount of 1,301 (in 1840, 737 ) pounds; and beeswax and honey to that of 1,156,939 pounds.

Home-made Manufactures for the year ending 1st June, 1850, were produced to the value of $\$ 2,456,338$. In 1840 the aame class of goods were valued at $\$ 2,622,462$

MTanufactures.-Aggregate capital invested, $\$ 00,000,000$; value of raw material, fuel, etc., used and consumed, $\$ 00,000,000$; average number of hands employed, 00,000 -males 0,000 , and females 000 ; arerage mosthly cost of labor - male $\$ 000,000$, and female $\$ 0,000$; total value of products during the year, $\$ 00,000,000$. The whole number of manufacturing establishments producing to the annual value of $\$ 500$ and upward was 3,471 ; and of these $S$ were cotton factories, 25 woolen factories, 275 tanneries, and 45 iron works -20 for the manufacture of castings, 21 for pig iron, and 4 for wrought iron.

The cotton manufacture employs a capital amounting to $\$ 289,000$; value of all raw material, fuel, ete., consumed, $\$ 1 \$ 0,907$; average hands employed-males 181 , and females 221 ; entire wages per month to-males $\$ 2,707$, and fernales $\$ 2,070$; value of entire products during the year, $\$ 273,439$. The annual quantity of cotton consumed was 3,760 bales, and the products consisted of $1,008,000$ yards of sheeting, etc., and 725,000 prounds of yarn. Mineral coal used, 720 tons.

The voolen manufactures employ a capital of $\$ 249,820$; value of raw material consumed, $\$ 205,287$; arerage hands employed-males 256, and females 62 ; monthly cost of labor-male $\$ 3,919$, and female $\$ 659$; value of annual products, $\$ 318,819$. The quantity of wool consumed was 673,900 pounds, and there were produced in the year 878,034 yards of cloth.

The capital invested in the tannemies amounts to $\$ 763,455$; the value of raw material used was, in $1849-50, \$ 537,147 ;$ the arerage number of hands employed-males 877 , and females $2 ;$ at a monthly cost of labor-male $\$ 14,417$, and female $\$ 9$; skins tanned, 69,350; and sides tanned, 392,400-together valued at $\$ 985,267$.

The iron interest is in accordance with the following schedule referring to the year $1549-50$ :

\begin{tabular}{|c|c|c|c|c|c|c|c|}
\hline $\begin{array}{l}\text { Specitications. } \\
\text { Capital invested .................. dollars.... }\end{array}$ & $\begin{array}{l}\text { Pig Iron. } \\
924,700\end{array}$ & & $\begin{array}{l}\text { Cast Iron } \\
502,200\end{array}$ & & $\begin{array}{l}\text { Wrouglit Iron. } \\
\mathbf{1 7 6 , 0 0 0}\end{array}$ & & $\begin{array}{l}\text { Total, } \\
602,900\end{array}$ \\
\hline Ore used...................... tons ..... & 72,010 & .... & - $\quad-$ & -... & .. - $\quad$. & $\cdots$ & $\tau 2.010$ \\
\hline Pig iron used................." " ..... & - & . & 9,731 & .... & 2,000 . & .... & 11,731 \\
\hline luoms used................... " $\ldots \ldots$. & - & .......... & - & & 1,600 . & ... & 1,600 \\
\hline ral coal used............... " $\ldots$ & - & $\ldots \ldots \ldots \ldots$ & 2.649 & $\ldots \ldots \ldots$ & - & $\cdots$ & 2.649 \\
\hline oke and charcoal used............ bushels.. & 76,269 & $\ldots$ & 482,750 & & 0,000 & & $\$ 9,019$ \\
\hline alue of all raw material, fuel, etc. . dollars... & 60159 & & 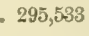 & & 00 . & & \\
\hline
\end{tabular}


KENTUCKY.

\begin{tabular}{|c|c|c|c|c|}
\hline Slecif & Pig Iron. & st Iron. & Wrought Iron. & \\
\hline nployed-males ...........number .. & $1,845 \ldots \ldots \ldots \ldots$ & $558 \ldots$ & $193 \ldots$ & 2,586 \\
\hline females......... " & $10 \ldots \ldots \ldots$ & $20 \ldots$ & - $\ldots$ & 30 \\
\hline Monthly cost of labor-male....... dollars.... & 37,355 . & 13,589 . & $5,867 \ldots$ & 57,111 \\
\hline remale..... " 6 ... & 47 & 83 . & - . & 131) \\
\hline produced.....................tons ...... & $24,245 \ldots$ & $5,888 \ldots$ & $8,070 \ldots$ & 33,203 \\
\hline $\begin{array}{l}\text { Value of other products..... } \\
\text { "s entire products .... }\end{array}$ & $\begin{array}{r}10,000 \ldots \ldots \ldots \ldots \\
604,037 \ldots \ldots \ldots\end{array}$ & $-\ldots$ & $-\overline{9, \pi 00} \ldots$ & $\begin{array}{l}10,000 \\
645,053\end{array}$ \\
\hline
\end{tabular}

The industrial establishments of Kentucky, comprised in the aggregate number, as before given, and not specially referred to, consist of the handicrafts usually found in agricultural countries, and several which may be considered peculiar to this State, as tobacco factories, rope-walks, bagging factories, ete., in which the great staples of the country are worked up and made ready for the market.

Foreign Commerce. - The internal position of Kentucky almost precludes it from a direct intercourse with foreign countries-its natural port is New Orleans, in the direction of which all its great rivers point, and from that port chiefly are its products and staples shipped, although a considerable quantity finds its way to the Atlantic ports via the Illinois River and Canal to Chicago, and thence by the great lakes to Dunkirk and Buffalo, and from those points to New York, ete., by railroad, canal, and river. Its exports in some measure are also sent via the Ohio River and Pittsburg. But if Kentucky does not export its merchandise directly, the offieial returns for a number of years have noticed direct exports, of which the following are the values-1837, $\$ 17,782 ; 1838, \$ 8,932 ; 1839, \$ 0 ; 1840, \$ 2,241 ; 1841, \$ 0 ; 1842, \$ 17,306 ; 1843$, $\$ 5,145 ; 1811, \$ 25,627 ; 1815, \$ 17,469 ; 1846, \$ 32,958 ; 1847, \$ 26,956 ; 1818, \$ 25,971 ; 1 \$ 49, \$ 19,738 ;$ and $1550, \$ 190,937$. The shipping owned in the collection district of Louisville in 1850 amounted to 14,820 tons - the whole navigated by steam power, and employed in river navigation. Thirty-four steamboats were built in the State during the year ending 30 th June, 1850 , and these had an aggregate burden of 6,461 tons.

Internal Communication.-Kentucky is bountifully supplied with navigable waters, and in all its great rivers important improvements have been made by locks, dams, and canals. The principal of these are the works on the Kentucky, Green, Licking, and Big Sandy Rivers; and the Portland and Louisville Canal, overeoming the falls of the Ohio at Louisville, properly belongs to this State. This work, although less than three miles in length, is one of the most important improvements in the West; it is 50 feet wide at the top, and admits the passage of the largest river steamers. The fall between the two points at which it joins the river is $22 \frac{1}{2}$ feet, which is overcome by four locks. Almost the whole line is excavated out of solid limestone, and was completed in 1833 at a cost of about $\$ 1,200,000$. The cost of the improvements on the four interior rivers above mentioned amounted to $\$ 2,133,580$. Kentucky has also an excellent system of turnpikes, and recently has commenced to build plank-roads. With regard to railroads, as yet about 130 miles only have been completed; but there are several vitally important works of this description in a state of forwardness, and which will he completed within the next two years. Of these the principal are the Kentucky portion of the Mobile and Ohis R. R., the Nashville and Henderson R. R., the Louisville and Nashville R. R., the Covington and Lexington R. R., the Maysville and Lexington R. R., and several others pointing to the south and south-east, to the Gulf of Mexico and the ports of the Atlantic; and the Maysville and Big Sandy R. R., which will connect with the lines terminating at Richmond, Petersburg, and Norfolk in Virginia. Upward of 600 miles of these projected lines are now (January, 185s) in process of construction, and a considerable length of the whole contemplated has been surveyed and partially located. The several railroads named (and others, no doubt, there are), when in full steam, will have a mighty effeet on the interests of the State, even as local channels of trade; but when their importance to the North and South, being links in the great chains in those directions, is considered, their very existence becomes the lever of all connection between the two divisions of the Union. In this point of view, Kentucky to the West of the mountains, and New Jersey to the East, are on a par, both essential to the building up of a national system of roads to connect the extremes of the country. The influence of these roads, even in the prospective, is well illustrated in the rapid advance in the value of property. In 1845 the assessment roll amounted to $\$ 228,458,161$; in 1850 it amounted to $\$ 299,331,465 ;$ and in 1851 it had increased to $\$ 31 ;, 0 \$ 2,604$; or in the latter year, which was one of great projects in matters of internal improvement, the increase amounted to $\$ 17,751,139$, or about 6 per cent. Such facts as these are lessons applicable to every State and to every individual who has at heart the advancement of his country in wealth and prosperity.

Banks, etc,-In January, 1851, Kentucky had 5 banks and 21 branch banks; the Bank of Kentucky (Louisville), has branches at Bowling Green, Dansville, Frankfort, Greenburg, Fopkinsville, Lexington, and Maysville; the Farmers? Bank of Kentucky (Frankfort) has branches at Covington, Henderson, Maysville, Mount Sterling, Princeton, and Somerset; the Northern Bank of Kentucky (Lexington), has branches at Covington, Louisville, Paris, and Richmond; the Southern Bunk of Kentucky (Russellville), has branches at Hickman, Owensboro, and Smithland; and the Bante of Louisville has branches at Paducah and Flemingsburgh. There are also other banks at Paducah, Covington, and Newport. At the date above referred to the aggregate statistics of all the banks and branehes then existing, were as follows: Liabilitiescapital $\$ 7,586,927$, circulation $\$ 7,613,075$, deposits $\$ 2,323,607$, and due other banks $\$ 1,256,589$; and assets-loans and discounts $\$ 12,506,305$, stoeks $\$ 694,962$, real estate $\$ 419,070$, other investments $\$ 440,127$, due by other banks $\$ 2,451,155$, notes of other banks $\$ 550,879$, and specie $\$ 2,791,351$.

Government, etc.-The present constitution of Kentucky was adopted in convention on the 11th June, 1850, and was subsequently ratified by the people by a vote of 71,563 in favor to 20,302 against it. The first State constitution was framed in 1790 , and a second in 1799

Every free white male citizen, 21 years of age, resident in the State two years, or in the county, town, or city one year next preceding the election, has the right of suffrage, but he shall have been for 60 days a resident of the preeinct in which be offers his vote. The general election is held on the 1st Monday of August. All votes are given viva voce.

The Legislature consists of a Senate and House of Representatives. Senators, thirty-eight in number, are chosen in single districts, one-half the number biennially, and at the time of election must be citizens of the United States, thirty years of age, and resident in the State six years, and in the district one year next preceding the election; and representalives, one hundred in number, are chosen from single districts for two years, and must be twenty-four years of age, and resident of the State for two years-the last year of the district. Representation depends on the number of qualified voters. In 1857, and every eight years thereafter, a census is to be taken, and representation apportioned accordingly, The sessions of the Legislature are biennial, commeneing 1st November (odd years). No session is to continue more than 


\section{KENTUCKY.}

sixty days, unless prolongation is agreed upon by two-thirds of all the members elected to both branches of the Legislature. Teachers of religion, and persons holding offices of profit under the State or the United States, are ineligible; and members during their term, and for a year thereafter, can not be appointed or elected, except by the people, to any civil office of profit in the State created, or the pay attached to which is increased during such term; nor are collectors of the public moneys eligible, unless six months before the election their accounts are closed and settled. The Legislature ean not grant divorces, or change of names, or sales of estates of persons under legal disabilities, nor change the venue in any criminal or penal prosecution by special legislation, but by general laws shall confer such powers upon the courts.

The govemor and lieutenant-governor are chosen quadrennially by a plurality of votes; they must be thirty-five years of age, citizens of the United States, and inhabitants of the State for the six years next preceding the election. The governor is not eligible for two consecutive terms: he enters upon office the fifth Tuesday after the general election, and continues in office until his successor has taken the oath of office. He grants pardons, etc., and may veto a bill, but a majority of all the members elect of both houses negatives his objections, and the bill becomes law. The lieutenantgovernor is enofficio President of the Senate, with the right to debate and vote, and when there is a tie to throw a casting vote; and if the office of governor become vacant he, and after him the Speaker of the Senate, shall act as governor if the vacancy occur after the first two years of the gubernatorial term-if before, the people fill the vacancy.

The administrative officers of the government are-a Secretary of State, appointed by the governor; and the people elect a State Treasurer for two years,'and an Auditor of Public Accounts, a Register of the Land Office, an Attorney. general, and other inferior officers for four years.

The Judiciary consists of a Court of Appeals, Circuit Courts, and County Courts. At Louisville there is a separate Chancery Court. The Court of Appeals has appellate jurisdiction only; the judges are elected for eight years by the people in districts, one every two years, and the judge having the shortest period to serve is chief justice. The judges must have been eight years practicing lawyers, and must be resident citizens, etc. Any three of the judges may constitute a court for the transaction of business. Circuit courts are established in each county, and for the election of judges of these courts the State is divided into twelve judicial eireuits, each of which elects a judge to serve for six years. There is also a County Court in each county, consisting of a presiding judge and two associates, elected for four years, any two of whom may transact business. There are also in each county two justices of the peace, to hold offlce for four years. Attorneys for the Commonwealth, clerks of courts, surveyors, coroners, jailers, and assessors are elected in their several circuits, districts, or counties, and their terms of office are the same as that of the presiding judge of the circuits, districts, etc. Each county elects a sheriff for two years, and each justice's district a constable.

"A commission to revise and arrange the statute law of the State, and another to prepare a code of practice, civil and criminal, shall be appointed by the Assembly at its first session."

Regarding slavery, the constitution provides that no laws shall be passed for the emancipation of slaves without the consent of their owners, or without paying the owners, prior to emancipation, a full equivalent, and providing for their romoval from the State. Owners of slaves may emancipate them, saving the rights of creditors. Immigrants to the State nay bring their slares with them, but slaves are not allowed to be introduced as merchandise, nor under any circumstances slares imported into the Union since. January 1st, 17\$9. Masters must treat their slaves humanely, or the slaves shall be sold. Slaves shall not have the right of an inquest by the Grand Jury, but shall not be deprived of an impartial trial by a petit jury. Free negrocs or mulattoes coming into or refusing to leave the State, are deemed guilty of felony, and may lye sent to the Penitentiary.

To amend the constitution, a majority of the members elect of each house must, within the first twenty days of a regular session, vote to lay the matter before the people, and at the next general election a majority of those entitled to rote for representatives, must vote therefor; the Assembly, at its next regular session, must pass a vote to lay the matter again before the people, and the majority of all the rotes, as before, must be given therefor, and then at its next session, the Assembly shall appoint an election for members to compose the convention, which shall consist of as many members as there may he in the House of Representatives, and no more-such convention to meet within three months after election for the re-adopting, amending, or changing the constitution.

The State militia of Kentucky, according to a return of 1851 , consists of $\$ 1,840$ men of all arms, of which 4,505 are commissioned officers, and 77,035 non-commissioned officers, musicians, artificers, and privates. Of the commissioned officers 43 are general officers, 145 general staff officers, 1,658 field officers, and 3,459 company officers. According to the constitution, all free white, able-bodied male persons in the State, between 18 and 45 years of age, except such as are by law exempt, compose the militia of the State, and elect thcir own officers.

The principal State institutions for the relicf of the unfortunate are-the Lunatic Asylum, at Lexingten, which, on the 1st January, 1850, had 366 inmates; the Deaf and Dumb Asylum, at Danville, which had at the same date 48 pupils; and the Institution for the Blind, at Louisville, which had 35 pupils. $\Lambda$ second Lunatic Asylum, at Hopkinsville, is nearly completed.

Finances, Public DeJt, etc-The ordinary receipts into the treasury for the year ending 10th October, 1851, amounted to $\$ 738,24552$, and the ordinary expenditures for the same year to $\$ 783,65340$-excess of income (ineluding balance from 1850), \$4,592 12. The value of taxable property in 1851 was $\$ 317,0 \$ 2,604$-increase since $1850, \$ 17,751,139$. The rate of taxation is 17 cents on every $\$ 100$ worth of property (10 cents for the ordinary expenses, 5 cents for the sinking fund, and 2 cents for the school fund). The objects of taxation are-general: land, 19,845,672 acres, ralued at $\$ 116.477,116$; town lots, 84.357 - $\$ 35,742,374$; slaves, 196,188 - $\$ 65,656,217$; horses, 332,998 - $\$ 12,658.510 ;$ mules, 49,694 $\$ 2.264,909$; jennies, 2,476-\$174,953; stores, $3,718-\$ 9.362,457$; surplue cash, bonds, etc., $\$ 39,092,992$; and specific: carriages and barouches, 3,465 - tax $\$ 1$ each; buggies, 4.679 -tax 50 cents each; pianos, 1.533 -tax $\$ 1$ each; gold spectacles, 1,4:2-tax 50 conts each; gold watches, $6,943-\operatorname{tax} \$ 1$ each; silver lerer watches, $3,05 \$$ - tax 50 cents each; studs, jacks, and bulls, 2,857 -taxed $\$ 5,636$. Total white males over 21 years old who pay a poll tax for county purposes, 157.410 .

The public debt has been chiefly contracted for the purposes of internal improvement. In 1529 so economically had the government been administered, that there was a surplus in the treasury of some $\$ 200,000$. This was distributed among the counties, and applied to internal improrements; and stimulated by the resulting benefits and the "new impulse" which had seized upon the adjoining states, Kentucky, in 1835 , borrowed $\$ 1,000,000$, to be expended also on turnpike roads, of which the country was then woefully deficient; other sums were subsequently borrowed, to be applied in the same way, forturnpikes, for railroads, and for locking, and damming, and creating slackwater navigation in the Kentucky, Green, and Licking rivers. For these purposes, also, a large share of the school fund was appropriated, for which the State now pays interest. The entire debt on the 1st January, 1552, was $\$ 5,726,30780$, composed as follows: debt to 


\section{KENTUCKY.}

individuals, $\$ 4,247,53740$; to Southern Bark of Kentucky for stock, $\$ 150,000$; to what is known as the Craddock Fund, $\$ 2,900$; and to Board of Education, $\$ 1,32 t, 77040$. To pay the interest and principal of this debt, the State has a sinking fund, the receipts into which, in 1551 , were $\$ 531,04451$, and the expenditures were $\$ 506,445$ 06-excess of receipts, $\$ 24,58948$. The sourees of income to this fund are-a tax from banks and dividends on stocks in the same, premiums on State bonds, dividends on stocks in turnpike-roads, dividends for slackwater improvements, of 5 cents on $\$ 100$ worth of property listed for taxation, tax on brokers and insurance companies, excess of ordinary revenue at the end of each fiscal year over $\$ 5,000$. The interest on the State debt has been punctually paid and some portion of the principalKentucky stocks are always held at a large premium in the markets.

Federal Representation.-Kentucky, in accordance with the ratio of apportionment adopted by the act of 23d May, 1S50, sends 10 representatives to the national legislature.

Erlucation.-The sehool fund in December, 1851, amounted to $\$ 1,400,270$, consisting of State and bank stock, and besides this the 2 per cent. tax, before named, is devoted to school purposes. The common schools are under a superintendent of public instruction, elected by the people for four years. According to his exhibit at the above date 99 cruniti-s and 5 cities and towns had made reports; the number of children reported as attending the district schools was 186,111,

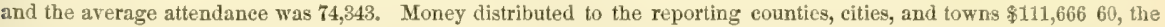
same having been paid from the interest on the permanent fund and 2 per cent, tax. These statisties embrace only the schools connected with the State system; the number of children in the State between the ages of 5 and 16 years was 205,755 , many of whom are doubtlessly attending the numerous private schools and academies which exist in every part of the State. The principal collegiate institutions in the State are-Transylvania University, at Lexington, founded 179S -in 1850 it had 7 professors, 610 alumni, and 40 students, and its library contained 14,000 volumes; St. Joseph's College, at Bardstown, founded 1829 (Catholic)-in 1850 it had 15 professors, 196 alumni, 155 students, and a library of 5,000 rolumes; the Center College, at Danville, founded 1820-in 1850 it had 7 professors, 363 alumni, and 152 students, and 5,500 volumes in its library; Augusta College (Methodist), at Augusta, founded 1S25-in 1850 it had 4 professors, 60 alumxi, 51 students, and a library of 2,500 volumes; Georgetown College (Baptist), at Georgetown, founded 1840-in 1850 it had 7 professors, 80 alumni, and 66 students, and a library of 6,500 volumes; Bacon College, at Harrodsburg, founded 1836in 1850 it had 5 professors and 75 students, and its library contained 1,200 volumes; Western Military Institute, at Drennun Springs, founded 1847 -in 1550 it had 10 professors and 150 students, and a library of 1,000 rolumes; and shclby College, at Shelbyville-in 1850 it had 4 professors and 93 students, and a library of 4,000 volumes; the Western Baptist Theological Institution, at Corington, was founded in 1540, and in 1550 had 4 professors and 18 students, and a librery of 2,000 volumes. There is a law school attached to the University at Lexington, and another to that of Louisville-both have 3 professors, and the former had in 185075 students and the latter 52 students. Medical schoois are also attached to these universities-that attached to Transylvania University was founded 1818, and in 1850 had 7 professors, 214 students, and 1,351 graduates, and that to Lonisville University, founded 1837, 7 professors, 376 students, and 53 graduates. The law and medieal schools of the University of Louisville are its most flourishing and important departments.

Putlic Libraries.-One State library, 9,000 volumes; one social library, 3,500 volumes; ten college libraries, 37,150 volumes; ten students' libraries, 7,190 volumes; three academic and professional libraries, 4,000 volumes; one library of scientific and historical society, 1,500 volumes; one public school library, 1,100 volumes; total, 27 libraries, 63,410 volumes.

Periodical Press.-The whole number of periodicals published in Kentucky in 1850 was 64 , of which 27 were newspapers devoted to whig and 12 devoted to democratic principles, the remainder being devoted to neutral politics, literature, religion, etc. Of the total number, 9 are published daily, and circulate at each issue an aggregate of 28,163 copies; 5 tri-weekly (1,356 copies); 4 semi-weeklies (4,000 copies); 41 weokly (21,412 copies); 1 semi-monthly (5,000 copies); and 7 monthly (5,150 copies). The monthly publications are-the "Methodist Monthly," at Frankfort; the "Baptist Review," the "Ciceronian Magazine," the "Examiner," and the "Medieal Journal," at Louisville; the "Gazette," at Covington, and the "Delphian Oracle," at Georgetown College. The principal daily newspapers arethe "Democrat," "Journal," "Advertiser," "Courier," "Journal of Commerce," published at Louisville. Daily papers also published at Covington, Lexington, and Frankfort.

Religious Denominations.-The statisties of the several religious denominations in 1850 , according to the census of that year, were as follows:

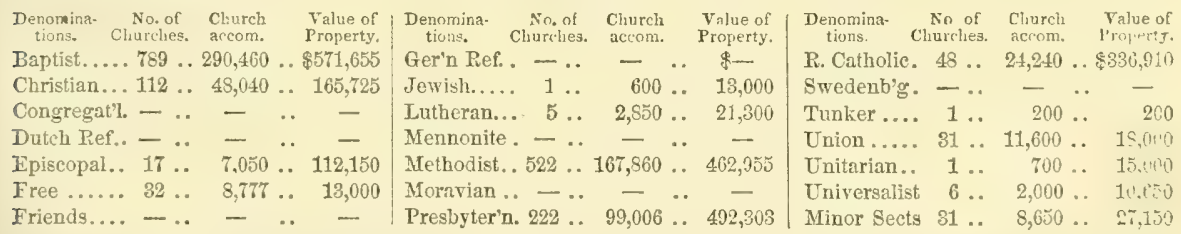

Niaking a total of 1,818 churches, having acemmodation for 672,033 persons, and church property valued in cash at $\$ 2,259,998$; or 1 church, accommodating 370 persons, to every 540 inhabitants, and ralued as property at $\$ 1,243$. Kentucky is a diocese of the Protestant Espiscopal Church, and also constitutes the Roman Catholic diocese of Louisville.

Punperian and Crime.-The whole number of paupers who received support within the year ending 1 st Jume. 1: T), was 1,126, of which number 971 were native born, and 155 foreigners; and the whole number on the pauper list at that date was 777, of which 690 were natives and 87 foreigners. Cost of support for the year, 857,513 . The whole number of convicts in the State Penitentiary, on the 1st December, 1S50, was 159-16 more than were inearcerated at the same period of the year 1849 .

Thistorical S7:tch.- It was not until the middle of the eighteenth century that the white man's foot-print was traced in Kentucky. The region was one great hunting-ground and battle-field for the savages of the North and South. Among the earliest American explorers were Boono and Knox, and these, after incredible perils, returned to Virginia and Carolina, spreading everywhere the fame of the backwoods. Then came Bullitt, Harrod, and Henderson. The foundation of Booneshoro' was laid lyy Daniel himself, who haul brought to the banks of the Kentucky the first white women-lus wife and daughter. Kenton, Calloway, and Logan arrired next. Kentucky was now made a county of Tirginia, and in 177 the first court was held at Harrodsburg. 


\section{KENTUCKY.}

A review of the political history of Kentucky presents but few prominent landmarks. The war of the Revolution closed, but left the Kentuckian in constant danger of Indian outrage. The citizens assembled at Danville, which became afterward famous for conventions west of the mountains, and soon came to the conclusion that the government at Richmond was too far distant to be relied upon for the means of defending the scanty settlements from the savage. Two other conventions at Danville recommended a peaceable and constitutional separation from Virginia. The third convention sent a petition to Richmond, and in 1736 an act was passed complying with the desires of Kentucky; but from several causes the separation was not completed, chiefly from a disinclination of the people to bind themselves to the old confederation, and for some time after this period the Kentuckian sought to obtain an independent nationality. A fourth convention at Danville only served to inflame more and more the minds of the people against the Central Government, and a report having become current that Mr. Jay had ceded the navigation of the Mississippi River to Spain, the usmost ill-feeling was the consequence. A fifth convention met, and on petition, a delegate to Congress was allowed by Virginia ; but the Constitution having been adopted, Congress turned over to the new government all action upon the claims of Kentucky. The whole State was again in ferment at this delay, and at this early period the refusal of Congress was attributed by able minds to the jealousy of New England of any increase of Southern power, and this jealousy was expected to continue under the new government.

Taking advantage of this state of things in the West, Spain proposed clandestinely through her minister peculiar commercial farors and facilities to Kentucky if she would erect herself into an independent government. These propositions had the effect of disturbing the public mind, and the risk of a severance from the Union was imminent. But a sixth and seventh eonvention were held at Danville; and though party politics ran high in the debates, constitutional measures at length prevailed, and an address to Congress was moved and voted. Two more conventions were subsequently held, and the question was determined by Kentucky becoming a separate territory in 1790 , and its admission into the Union on the 1st June, 1792.

Indian wars continued frequent on the frontiers, and complaints of the inefficiency of the federal powers were again heard. The whisky tax also became oppressive, and the American policy toward the French Republic was denounced in every cabin. Enthusiasm was at its height, and the agents of the mad minister Genet were received in triumph throughout the West. It was even proposed to raise troops in Kentucky to make a descent on New Orleans. Democratic clubs were extending everywhere, and even the governor did not scruple to write to the Secretary of State, "I shall feel but little inelination in restraining or preventing my fellow-citizens, ete., to gratify or remove the fears of a minister of a prince who openly withholds from us an invaluable right, and who secretly instigates against us a savage and cruel enemy." The old idea of independence was again mooted, but the storm passed over.

In the ten or twelve years which succeeded, and which included the period of negotiation for the navigation of the Mississippi, and then for the purchase of Louisiana, Kentucky was again destined to be agitated to her very centre. The treaty of 1795 with Spain gave to the United States the right of deposit at New Orleans, and the freedom of the river. Pending the negotiations, the Governor of Louisiana had approached some leading Kentuckians, with the view of a different treaty, but action on these premises was stayed by federal interference, and the faithlessness of the Spaniard was soon made evident. Seven years now passed in comparative quiet and prosperity, when the whole nation was excited by the intelligence that the Spaniards had violated the treaty by a denial of the right secured by the treaty of 1795 , and it became known that even Louisiana itself had been retroceded to France.

The purchase of Louisiana by the United States woula forever have composed the turbulent elements of the West but for the appearance there, at that period, of a man whose genius was of the most profound character, whose popularity had been wide, but whose career and ambition had been prematurely arrested. Aaron Burr was prepared for any great and desperate enterprise, and the West seemed to promise the widest fleld for his abilities. What the designs of Burr really were, has never, perhaps, been fully divulged. The probability is, they have been exaggerated; nor can any faith be placed in Eaton's story about the assassination of the President, the corruption of the navy, and the violent overthrow of Congress. Thirty years after this, when on his deathbed, Burr solemnly denied these treasonable designs. The policy, if not the ambition or virtue, of Burr was opposed to such a course. The material that he could rely on was entirely in the West; and within the bounds of a not very clearly ascertained national policy or duty at that period, an army of adventurers might be found to precipitate themselves upon the Spanish colonies of the South-west, and entirely revolutionize them. The success of the citizen Genet, a few years before, evinced this, but now tho times were even riper, as the Spanish troops, in the first heart-burnings of Spain after the cession to Bonaparte, had been ordered to our frontier, and an American army, under Gen. Wilkiuson, was ready to check their advance. War with Spain was daily expected.

This Southern empire, or republic, which loomed up so magnificently in the mind of Burr, was not intended to dispossess Spain; only/a part-it is difficult to say how much-of the territory lately purchased by our own government, was to be included, certainly New Orleans. The result of these transactions, however, belong to general history, and hence, in this connection, may be passed over in silence. Suffice it to say, that Burr was tried for treason, but though acquitted, the stain of the imputation cast on his patriotism has never been effaced; and to our own times, and in every school, his treason and its consequences are held before the youth of our land as a warning to their ambition. The lesson thus taught, however, seems to have little effect, else the extension of the area of freedom would still be more limited than it is found to be; in fact, the dream of Burr has become a real existence; and what he coveted-Louisiana, Texas, New Mexico, and California-are parts and parcels of the Union. Burr's great fault, then, appears to be, that he was in adrance of the times in which he lived.

Kentucky tnok an active part in the war of 1812. When the United States proclaimed against Great Britain, the war was hailed with acclamation, and supported with zeal by the inhabitants. When the nervs of the surrender of General Huil reached the State, it excited no feelings but those of a warmer enthusiasm in the cause. The whole quota of the State, consisting of upward of 5,000 men, was composed of volunteers, and was called into active service. In addition to these a force of mounted volunteers was raised, and at one time upward of 7,000 Kentuckians are said to have been in the field. So universal was the desire to share in the dungers and glories of the war, that the executive authority was obliged to interpose, to limit the numbers. During this period the chair of the State government was filled by Isaac Shelby, a hero of the Revolutionary War, who, at an advanced age, manifested the same enterprise and bravery that had gained him an honorable distinction in the battle of King's Mountain. At the battle of Frenchtown, and the barbarous massacre that followed it, many of the best eitizens of Kentucky were destroyed; and the impetuous, but ill-regulated, courage of her militia at the unfortnnate attempt to relieve Fort Meigs, proved fatal to a large body of her troops.

Since the termination of this war by the treaty of 1515 , the history of Kentucky is undisturbed by any stirring events. 
Its progress has been rapid, and the development of the country in agriculture and other national industries has oceupied the minds of the people in preference to warfare and strife. True, the war with Mexico was engaged in by many of its best citizens, but the scene of action was too far distant to affect the fortunes of the State. This happy termination of the feuds and fights of the first periods of its history, has resulted in Kentucky becoming one of the wealthiost and most prosperous States of the Union, and in many respects she stands conspicuous as an example of wisdom and patriotism for the instruction of future political communities.

Frankfort, on the Kentucky River, is the political capital of the State.

KExTUCKr river, $K y_{0}:$ one of the largest and most important tributaries of the Ohio River, from which the State derives its name, has three principal sources, by the north, middle, and south forks, which unite in Owsley co. The mast remote source is that of the north fork in Letcher co., but all three are in the Cumberland Mountains. The length of the river to the junction is $260 \mathrm{~m}$., and in a direct line only $108 \mathrm{~m}$; its general course being $\mathrm{N}$. W. The navigation of this river has been improved by a system of dams and locks, creating slackwater, and affording a least depth of six feet to the confluence of the forks. There are 17 dams and 17 locks, giving a rise of 20 to 25 feet each. The locks are 178 feet long, and 38 feet wide, allowing boats of heavy tonnage to pass. The whole ascent is 216 feet. For beauty and grandeur of scenery, the river is not surpassed by any in America, excepting the Hudson. For a great part of its course it runs through a deep channel in lime-rock, as it were worn by attrition. Coal is found in its banks at several localities, and a species of marble is found which is capable of a fine polish.

Kentuckrville, p. o., Susquehanna co., Penn.: $120 \mathrm{~m}$. N. N. E. Harrisburg.

Kkxтох, p. o., Jackson co., $A r k_{*}: 67$ m. N. E. Little Rock. KEokuK county, Ia. Situate S. E. centrally, and contains $576 \mathrm{sq} . \mathrm{m}$. Drained by N. and S. forks of Skunk r., which unite in the S. E., and in the N. by S. fork of English r., a branch of Iowa $r$. Surface rolling or almost level Soil a sandy loam of great fertility, producing all the cereals in abundance, and feeding large dairies. It has excellent water-power. Farms 326; manuf. 12; dwell. 820, and pop. -wh. 4,822, fr. col. 0-total 4,822 Capital: Lancaster.

K FоKUK, p. . $_{\text {, Lee co., I }}$. : on W. bank of Mississippi $r$. (at the foot of the Lower Rapids), $3 \mathrm{~m}$. above the confluence of Des Moines r., $86 \mathrm{~m}$. S. by E. Iowa City. It has a good landing and levee. The main body of the town is built back upon the bluff, which is nearly level. It stands upon a basis of limestone rock, of the finest quality, affording inexhaustible supplies for building. The settlement of this place was originally owing to the existence of the "Lower Rapids" of the Mississippi $r$, at the foot of which it is situated. These are eleven miles in length, running over a limestone bed. The fall in that distance is 24 feet. Hence, at low water, steamboats are compelled to here discharge their freight, towing it over the rapids with lighters. A company has been incorporated to build a canal around these rapids, sufficient to pass large steamers. The water of the canal will also be used for machinery. The locality of Keokuk, at the confluence of the Des Moines r., makes it the depôt, and entrepot of the fertile valley of the Des Moines, which contains more than half the population and agricultural wealth of the State. Pop., in 1810, was about 150 ; in 1815,$460 ; 1850,2,773 ; 1852,3,963$. The town contains 2 steam flour-mills, 3 steam saw-mills, 2 large foundries, between 80 and 90 stores, several hotels, a good market, and steam-ferry. The number of steamboat arrivals in 1851 and 1852, was 1,590. Here is the Medical Department of the State University, which is well endowed, and has 7 professorships. There are 6 churches, 1 hospital, 3 academies, 3 public schools, 3 select schools. The newspapers are "The Keokuk Dispatch" (dem.), "Whig and Register" (whig), a medical journal, and a temp. newspaper.

Keosateru, p. v., and cap. Van Buren co., Ia.: on the N. or left bank of Des Moines r., $60 \mathrm{~m}$. S. S. W. of Iowa city. It contains the C. H., jail, etc., numerous stores, and about. 60 inhabitants; and is a place of shipment for a fer- tile and extensive district of country. The "K. Jeffersonian" (dem.) is published weekly.

Kepner's p. o, Schuylkill co., Penn.: 63 m. N. E. Has risburg.

Kernersville, p. o., Forsyth co., N. Car.: 94 m. W. N.W. Raleigh.

KeRneysville, p. o., Jefferson co, Firg. : 122 m. N. by W. Richmond.

KerR's CreEk, p. o, Rockbridge county, Firg.: $112 \mathrm{~m}$. W. by N. Richmond.

KERR's Store, p. 0., Clarion co., Penn. : 144 m. N. W. by W. Harrisburg.

Kerser's, p. 0., Elk co., Penn.: 118 m. N. W. Harrisburg.

Kersinaw district, S. Car. Situate N. E., and contains 883 sq. m. Lynch's cr, a branch of Great Pedee r., forms its N. E. line, into which Little Lynch cr. flows. Wateree r. flows $\mathrm{B}$. through the W., and has many small tributaries, Surface diversiffed; soil on the streams of great fertility, the higher lands are somewhat sandy, but are all productive. Corn is the chief agricultural product. It has good pastures, on which are fed large numbers of cattle and sheep. Its water-power is large and important. Farms 383; manuf 21 ; dwell. 92S, and pop.-wh. 4,631, fr. col. 214 , sl. 9,578total 14,473. Capital: Camden, Public Works: Camden Branch R. R.

Kesslen's, p. o., Northampton county, Penn, : $94 \mathrm{~m}$ N. E. by E. Harrisburg.

KEsw ICK DEpôs, p. 0, Albemarle county, Virg.: $63 \mathrm{~m}$, N. E. by E. Richmond, on the line of the Virginia Central R. R., 7 m. E. Charlottesville.

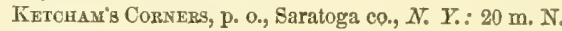
Albany.

Ketrle Creek, p. o., Potter co., Penn.: $95 \mathrm{~m} . \mathrm{N} . \mathrm{N} . \mathrm{W}$ Harrisburg.

Kettle Creek, p. o., Monmouth co, $N$. Jer.: on the creek so called, $36 \mathrm{~m}$. E. S. E. Trenton.

KEWANNA, p. o., Fulton co., Ind. : $80 \mathrm{~m}$. N. Indianapolis. KEWAsKU., p. O., Washington co., Wisc, : $63 \mathrm{~m}$. E. N. E. Madison.

KrWAUNEe county, Wisc. Situate N. E., and contains $342 \mathrm{sq} . \mathrm{m}$. It lies on the neck of the peninsula between Green Bay and Lake Michigan, and is drained by East and West Twin rivers, Scarboro' r., and other small streams. Surface uneven, and covered with heavy timber: soil little cultivated as yet. The county is but partially settled, and the timber business is the chief pursuit. Unorganized in 1850. Capital: Kewaunee.

KEWAUNEe, v., p. t., and cap. Kewaunee co., Wisc.: on the W. side of Lake Michigan, 137 m. N. E. Madison.

Kewenaw Peninsula, Mich.: a part of Houghton co, projecting into Lake Superior from its southern shore. Its length is about 43 miles, with an avernge width of 15 miles. It is surrounded on the N. W., N., and E. by the lake, on the S. by Kewenaw Bay, and on the S. W. by Portage lake, leaving an isthmus, which is but a mile across, and is used as a portage by the Indians and traders, with whom it has been the custom, when arriving here, to transport on their backs their peltries and cannes to the opposite shore. The peninsula is drained by a great number of small streams, which afford ample hydraulic power; and the same may be said of the whole coast of the mineral district of the trap rock elevations, extending from Kewenaw Point to Presque Isle river. The principal harbors are the Copper, Eagle, and Carp rivers, Kewenaw Bay, and Ontonagon river, which has a depth of six feet over the bar at the en- 
trance. The prst-ofleces are, Algonquin, Kewenaw Bay, Forhi-West Mins, Untonagon, and Peninsula. The soil of the peninsula is rich, and very favorable for cereals, as the climate is comparatively mild, on account of the moderating effect of a litge body of water on three sides. At Fort Wilkins the meteorological observations instituted by order of the General Government, proved the mean temperature to be two degrees milder than at Fort Brady, although the latter post is 60 miles farther south. The Hon. Truman Smith, who spent a season in examinations of the mining country, pronounces it to be decidedly more favorable for agrieulture than large portions of New England, including the northern part of Connecticut. Corn, potatoes, and summex and winter grains have yielded fair returns. The principal mining operations are for copper and iron, though gold, silver, lead, and other metals are found. The greater part of the copper is obtained pure in its native state, some containing a portion of silver. Masses are frequently raised of many hundred weight, and often give great labor in their removal from the deep shafts. The shipments of native copper and ore for the year 1850 were equal to 4,000 tons of copper, and for 1851 equal to the consumption of the Cnited States, or about 6,000 tons. The iron mines have been worked very extensively the past two years, and there are some 30 organized companies engaged in active operations in the viciuity of the cclebrated iron mountains. The metal produced is remarkable for malleability, and peculiarly adapted to boiler plate and wire. By an act of the General Government passed Sept. 26th, 1850, the mineral lands of fhis whole region were thrown into the market with the rights of pre-emption as to occupants of other public lands; and to occupants and lessees the privilege of purchasing one full section and no more, at the minimum price of $\$ 250$ per acre. The State of Michigan sent to the Washington National Monument a block of native copper 3 feet long, 1 f feet wide, and 2 feet 'deep, polished, and bearing this inseription :

ERON
M I C H I G A N,
"AN EMBLEM OF IIER TRUST IN TUE UNION."

KEWEXAw Bar, p. o., Houghton county, Mich.: on Lake Superior, 386 m. N. N. W. Lansing. Kewenaw (or Kew-y-wee-non) Bay is an indentation of Lake Superior, on its southern shore. It is an inlet extending into the T Pper Peninsula, dividing a peninsula of the same name on the $\mathrm{N}$. from the mainland on the opposite side.

Kex Pont, p. o., Nrommoth co., $\lambda$. Jer, : on a core of Raritan Bay, 32 m. E. N. E. Trenton. Great efforts have been made of late years to bring this place into notice, and with some sucess. It is cligibly situated for a port, and has excellent water accommodation. The southern route of railroad to Norfolk it is intended shall commence here, and it is also the N. terminus of a plank road to Trentou and Philadelphia. Steamboats run regularly to and from New York City-distance in a direct line, 24 miles.

Keysidrem, p. 0, Logan co, $K y,: 156$ m. S. W. Frankfort. Kessburem, p. o., Pike county, $I l l: 77 \mathrm{~m}$. W. S. W. Springfield.

Kerser's Bridge, p. o., Alleghany co., MId.: $176 \mathrm{~m}$. W. N. W. Annapolis

Kexsport, p. v., Clinton co., $I Z$. : on the W. bank of Taskaskia r., ol n. s. by E. Springtieli.

Ker Stone, p. o., Perry county, Penn.: 23 m. W. IIrrisburg.

Kessrone, p. V., Jackson co., Otio: on a branch of Raccoon cr., 69 m. S. S. E. Columbus. Here are extensive iron works.

Krasville, p. v., Charlotte co., Firg. : $66 \mathrm{~m}$. S. W. by W. Richmond.
KeYTEBFillen, p. v., and cap. Chariton co, Mfo.: on the E. side of Muscle Fork of Chariton r., near its confluence and about $15 \mathrm{~m}$. from the Missouri $\mathbf{r}_{0,}, 74 \mathrm{~m}$. N. W. Jefferson City.

KEY WEST, p. v., port of entry, and cap. Monroe co. Flor.: on the island so called, about $480 \mathrm{~m}$. in a direct S. S. W. line from Tallahassee. Lat, $24032^{\prime} \mathrm{N}$., and long. $81047^{\prime} 30^{\prime \prime} \mathrm{W}$. The island is $4 \mathrm{~m}$. long by $1 \mathrm{~m}$. in its widest part, and, including the salt pond, contains 197 acres. It is of coral formation, with little available soil, and very low and flat, nowhere 20 feet above the sea. Dogwood, Madeirawood, mangrove, and some other species, cover the unoecupied parts, and the cocoa-nut, orange, and guava, flourish luxuriantly where they can find soil sufficient. The key was granted by the Spanish crown, some 40 years ago, to John P. Salas, and in Dec., 1521, it was purchased of him by Col. Simonton, who took possession in person on the $22 \mathrm{~d}$ Jan., 1832, and in the following April he ereeted thereon the first small house. In April, 1823, a custom-house was established here, and it was made a station for the Gulf squadron. In 1832 it was made a military post, but the barracks were not completed until 1845. The buildings are large, airy, and commodious, and are placed on three sides of a quadrangle, the open side being toward the sea. Mrs. Mallory, mother of Senator Mallory, was the first white female that settled on the island. This was in 1523, and for a long time she was without a single companion of her sex. As pioneer matron of the place she was prosented with a choice lot of land, on which she has erected a mansion, and now occupies it as a boarding-house. John IIalleck, now a printer in Washington City, was the first white child born on the key--this was in Aug. 1829. From these small and recent beginnings, Key West has grown to be an important and prosperous place of about 2,000 inhabitants. It is the largest town in Florida, and in 1850 contained a court-house, jail, the latter a substantial stone building, 30 feet square, the U. S. District Court, which has cognizance of all wrecks and disasters, the State Circuit Court, the Marine Hospital, etc., and had 26 stores, 10 warehouses, 4 look-out cupolas, 4 churches, 11 wharves, and 650 dwellings. The Marine In spital is 100 feet by 45 , in the shape of the letter $\mathrm{H}$; it is a handsome building, well ventilated, and commodious. The churches are Episcopal, Baptist, Methodist, and Roman Catholic-small but neat buildings. There are 4 private schools, and 1 county school-the latter open free to the fatherless only. Fort Taylor is situate at the N. W. angle of the island, within the main entrance to the harbor; it is built on an artificial island, made by the deposit of many thousand tons of stone. It stands about 1,000 feet from the shore, and is 700 feet long in the rear, and 250 deep. The front facade is 253 feet within the bastions, the curtains being of the same length as the front. It is very substantially built, and has cost abont $\$ 1,500,000$. The harbor is capacious, safe, and easy of access. It may be enlarged by several different channels, the principal one being at the N. W. angle of the island-ships of 22 feet draft can enter there with safety. It is the only port admitting such between Pensacola and Hampton Roads. The principal business of Key West is wrecking, but numbers are employed in fishing, sponging, salt making, and other similar oceupations. Wrecking is a business peculiar to the reefs, and a matter of the highest importance. (On this subject, see "Hunt's Merchants" Magazine," for Jan., 1852.) Sponges abound on the reef, and the people are making a profitable business in gathering them, A large portion of the population comes from the Bahama Islands, and are called couch-men, from their skill in diving, and the part of the city this class inhabits is called Couchtown. Many of the leading merchants are from New England. The position of Key West is important; it is the $\bar{K} e y$ of the United States to the Florida Pass and the Gulf of Mexico; and hence it has been strongly fortified. The light-house stands on the highest ground of the island, and can be seen 16 miles at sea; and there is a 
light-ship anchored on the reef at the W. entrance of the harbor. There is also a substantial iron lighthouse on Sancly Ley, 11 m. S. S. W. At the E. part of the island there is a natural salt pond, from which 30,000 bushels of salt are annually manufictured. The steamers to Havanna and the Isthmus touch here regularly, and afford an opportunity for visiting it, and conveying to its sunny shores and fine climate the invalid of the North. In 1850, 66 vessels $(3,723$ tons) cleared, and 65 vessels (5,379 tons) entered the port. Shipping owned by residents, 6,766 tons, of which 4,415 was registered tonnage. Of the remaining tonnage, 27 vessels ( 1,539 tons) were wreckers, and 8 vessels ( 720 tons) were engaged in coasting and the fisheries.

KeZar Falls, p. 0., York co., Bre.: 91 m. s. s. W. Augusta.

K̈тсеA

KIckspoo, p. O., Anderson county, Tew. : 156 m. N. E. Austin City,

FIDDrILle, p, o., Clark county, $E y$.: 44 m. E. by S. Frankfort.

Kmrox, p, v., Cherokee Nation, Ind. Ter, : on the W. side of Sullivan er., $17 \mathrm{~m}$. above its confluence with the Arkansas. Dwight mission station is located here, and also a flourishing schnol for the education of Indian youth. The stream is navigable for keel boats.

Kingor, p. v., Coweta co., Ga.: on a branch of Flint r., $76 \mathrm{~m} . \mathrm{N}$. W. Milledgeville.

Krlgare, p. v., Carroll co.,Oh.: 107 m. E, N. E. Columbus. KILLA vook river, Oreg. Ter.: a stream emptying into the Pacific Ocean, in $45^{\circ} 36^{\prime} \mathrm{N}$. lat. Its sources are almost interlocked with those of Tualatin and of the Willamette.

Krlbourne, p. o., Delaware co., Ohio:21 m. N. Columbus. KrulbUck, p. 0., Cattaraugus co., $N$. $Y_{0}: 258 \mathrm{~m}$. W. by S. Albany.

Krulbuck, p. o., Ogle co., $\pi l_{\text {. : }} 163$ m. N. N. E. Springfield. Killbuck, t. and p. o., Holmes co., Oh.: 64 m. N. E. Columbus. Drained by Killbuck and its tributary creeks, which are fine mill-streams. Surface diversified; soil deep and fertile. Oxford, on the $\mathrm{E}$. side of Killbuck, is the principal village. Pop. of t. 1,215 .

Killiax's MrdLs, p. 0., Jincoln co., N. Car, : 134 W. by S. Raleigh.

Krucselu, t. and p. v., Windham county, Conn.: $44 \mathrm{~m}$. E. by N. IIartford. Drained by Quinnebang r. and its branches, which afford valuable mill-power. Surface uneven and rough; soil generally adapted to grass-on the streams, very fertile. There are, besides the principal $\mathrm{v}$., several others, at which extensive manufactures are carried on. The Norwich and Worcester R. R. skirts the Quinnebaug in this t., and the Fiew Fork and Boston (direct) R. R. will pass through its $N$. part. The manufactures of the $t$. consist chiefly of cotton goods, but there are also numerous handicrafts of minor importance. The "Windham County Telegraph" (whig), is issued weekly. Pop. of t. 4,545 .

Kullivgtos Peak, Term.: one of the highest culminations of the Green Mountains. It is located in the S. part of Sherburne township, and has an elevation of 2,924 feet above tille-water.

Krulivgwortr, t. and p. o., Middlesex co., Conn.: $32 \mathrm{~m}$. 8. by E. Hartford. Drained by Hammonasset and Menuketesuck rivers, which empty into Long Island Sound. Surface uneven-in the N. rough; soil sandy and gravelly loam. It is a good farming to, and has excellent dairies. Pop. 1,104.

Kmwariock, t. and p. v., Piscataquís co., Me.: $94 \mathrm{~m}$. N. N. E. Augtasta. Drained by Piscataquis r., and several of its affluents, one of which is the outlet of Otter Pond. Surface and soil adapted to grazing. The $\mathrm{v}$. lies on the $\mathbf{S}$. side of the Piscataquis, and has several mills, etc. Pop. of t. 322.

Krumarvock, p. v., Lancaster co., Virg..: on Chesapeake Bay, $54 \mathrm{~m}$. E. by N. Richmond. It contains about 200 inhabitants. The vicinity is a fine timber region.

Krluichaes, p. o., Choctaw county, Mfiss. : 65 m. N. E. Jarisson.
Kumbali's Laspisg, De Soto par., $L a$.: on the $\mathrm{S}$. end of Bayou Piere Lake, $176 \mathrm{~m}$. N. W. Baton Rouge.

Krmberlux, p. 0., Giles county, Virg.: 192 m. T. by g. Richmond.

Kmmberton, p. v., Chester county, Penn.: 68 m. E. by S. Harrisburg.

Kimboltos, p. o., Guernsey county, Oh: $88 \mathrm{~m}$. E. by $N$. Columbus.

Ktmulga, p. o., Talladega co., Ala.: on the Coosa r., 88 m. W. Montgomery.

Kincannon's FerRy, p. o., Meigs county, Tenn. : $120 \mathrm{~m}$. E. S. E. Nashville.

Kincsra, sta., Burlington co., N. Jer..: on the Camden and Amboy R. R., $4 \mathrm{~m}$. W. of Bordentown.

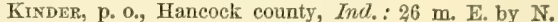
Indianapolis.

Kindermook, p. v., Van Buren co., Ar\%. : on the N. side of Little Rock r., $58 \mathrm{~m}$. N. Little Rock.

KinderirooK, p. v., Pike county, Ill.: 77 m. W. S. W. Springfield.

KINDERHOOK, t. and p. o., Branch county, Mich: $68 \mathrm{~m}$. S. S. W. Lansing. There are several small lakes in this town. Pop. $35 \overline{6}$.

KINDERHOOK, t. and p. v., Columbia co., N. Y.: $16 \mathrm{~m}$. S. Albany. Drained chiefly by Kinderhook cr., an affluent of the Hudson and its numerous tributaries, one of which is the outlet of Fish Lake, and all afford extensive water-power. Surface beautifully diversified; soil sandy loam and clay, and highly cultivated. The village, $5 \mathrm{~m}$. E. of the Hudson r., and $\mathrm{N}$. of the creek, contains about 1,500 inhabitants, and has numerous stores, etc. ; and a newspaper, the " $K$. Sentinel" (dem.), is published weekly. About $2 \mathrm{~m}$. S. of the village is Lindenwald, the residence of the venerable Martin Van Buren, ex-president of the United States; and there are several other villages. The manufactures of the t. are considerable. Pop. 3,972 .

KINDERHOOK, p. o., Lincoln co., Tenn.: 62 m. S. by E. Nashville.

KINDERHOOK, p. o., Washington county, Firg.: $248 \mathrm{~m}$. W. by S. Richmond.

KIng AND QueEn county, Firg. Situate E, and contains 337 sq. m. Mattapony river forms its W. boundary, and Piankitank r. its. S.E. Surface agreeably diversified, and in parts quite hilly. Soil generally fertile. Dragon Swamp, an the head of the Piankitank, has been drained, and affords a large tract of diluvial soil of great depth and almost meredible fertility. The crops of corn grown on the same spot, year after year, are unsurpassed in the Union. The staples of the co. are corn and wheat. Farms 502; manuf. 6; dwell. 892, and pop.-wh. 4,094, fr. col. 461, sl. 5,764total 10,319. Capital: King and Queen C. H.

King and Queen Court-rouse, p. v., and cap. King and Queen co., Virg. : 33 m. E. N. E. Richmond. It is situate on a plain about $1 \mathrm{~m}$. from Mattapony $\mathbf{r}_{\text {., }}$ and contains a court-house, the co. jail, and about 70 or 80 inhabitants.

King Creek, p. o., Barnwell dist, S. Car. : $86 \mathrm{~m}$. S. by W. Columbia.

KingFirLd, t. and p. o., Franklin county, Me.: $48 \mathrm{~m}$. N. by W. Augusta. Drained by Seven Mile Brook, an affiluent of Kennebee $r$. Surface generally hilly-in the W is Mount Abraham, a considerable elevation, from which the stream has its source; soil of average fertility. The $\mathrm{v}$. is a small setllement in the $\mathrm{S}$. E. corner. It is a fine grazing country. Pop. of t. 662

KING George county, Vïrg. Situate N. E., and contains 217 sq. m. It has Rappahannock river on the $\mathrm{S}$. W., and Potomac r. on the N. E., lying between them, and drained by small creeks flowing into them. Surface broken, and in parts marshy; soil of average fertility ; corn and wheat are the staples. It has good timber. Farms 279 ; manuf. 8; dwell. 526, and pop.-wh. 2,303, fr. col. 265, sl. 3,403-total 5,971. Capital: King George C. H.

Kinc Geurg i CourT-Irouse, p. Tn, and cap. King George 
co., Firg.: about $2 \mathrm{~m}$. from Rappahannock river, $51 \mathrm{~m}$. N. by E. Richmond. It contains a court-house, jail, ete., and about 100 inliabitants.

Kivg of Prussia, p. o., Montgomery co., Penn.: 84 m. E. Harrisburg.

Kivgs county, $N, \bar{Y}$. Situate on the W. end of Long Island, and contains $76 \mathrm{sq}$. $\mathrm{m}$. It has East r., Wallabout, Gowanus, and New York bays on the W., and the Atlantic and Jamaica Bay on the $S$. Its streams are all small. Newtown cr., emptying into East $r_{\text {., }}$ is the largest. Surface near East r. billy; $\mathrm{S}$. is a sandy plain. Farious ores of iron, porcelain clay, and peat are found in small quantities. Soil the best on the island, and under high cultivation. Its gardens are objects of great attention, and its fruit, especially grapes, very superior. Butter, potatoes, fruit, and market vegetables are the principal farming products. The great interests of the co. are manufacturing and commercial, and centre mostly in Brooklyn and Williamsburg. The chief manufactures are distilled liquors, cordage, iron ware, oils, oil-cloths, flour, leather, glass, etc. For particulars of these, and its commerce and ship-building, see BrookLYy and Wintiansiurg. Farms 363; manuf, 576; dwell. 15,809, and pop.-wh. 134,\$9S, fr. col. 3,984-total 138,882. Capital: Brooklyn, Pullic Works: Long Island R. R.

KrvG', p. o., Barbour county, Ala.: about 65 m. S. E. Montgomery.

Kings Benor, p. o., Franklin county, Ga.: $104 \mathrm{~m} . \mathrm{N}$. Milledgeville.

Ktrgsberry, t. and p. o., Piscataquis county, Me.: $59 \mathrm{~m}$. N. by W. Augusta. Drained by the heads of Piscataquis liver, one of which rises from small lakes in the S. W. part of the $t_{\text {. }}$ and the other from two others at the base of Russell Mount, in the N. E. Surface diversifled; soil well adapted to grazing and wheat-growing. Pop. of t. 181.

EIxgsborotgir, p. v., Fulton co., N. I.: $44 \mathrm{~m}$. N. W. Albany. It is a flourishing $\mathrm{v}$. of some 400 inhabitants.

Kings Bridge, p. V., New York co., N. Y.: 121 m. S, Albany. The p. o. is at the bridge so called, which crosses Spuyten Tuyvil creek, the dividing line between New York island and Westchester county.

KnvgsiuRY, p. $\nabla$. , Whitesides county, $I l l .: 12 \mathrm{~m}$. from Albany, and $133 \mathrm{~m} . \mathrm{N} . \mathrm{N}$. W. Springfield.

Kingsburx, p. o., Cumberland co., N.Car.: 43 m. S. by W. Raleigh.

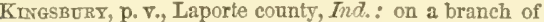
Kankakee river, $122 \mathrm{~m}$. N. by W. Indianapolis, and $6 \mathrm{~m}$. from Laporte.

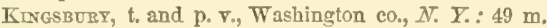
N. by E. Albany. Drained by Wood cr., which empties into Lake Champlain; also by the Hudson r. on the S. W. angle. Surface generally level; soil sand, clay, and sandy loam, well cultivated and productive. The village contains about 25 dwellings. The v. of Sandy Hill, the county seat of justice and scene of B. F. Butler's "Stated Preachings," is also in this town. Pop. 3,032.

KIrg's Creek, p. 0., Cald well co., N. Car. : 165 m. W. by N. Raleigh.

Kungsessng, p. t. and v., Philadelphia co., Penn.: $89 \mathrm{~m}$. E. by S. Harrisburg, and $7 \mathrm{~m}$. S. W. Philadelphia City. Schuylkill on the E., and Darby er. on the TV., bound it in those directions; both flow into the Delaware on its S. border; surface level; soil alluvial, and highly cultivated. In the Delaware are several islands belonging to the $t_{\text {. }}$ one of which, Mud Island, is the site of Old Fort Miftlin, noted for its protracted resistance to the British in 1777. On the Schuylkill is the botanical garden founded by the naturalist Bartram. Pop of t. 1,178.

Krygs Ferry, p. v., Cayuga co., N.Y.: 136 m.W. Albany. It contains about 40 dwellings.

Krvas Gap, p. v., Harris county, Gav: $97 \mathrm{~m}$. W. by s. Milledgeville.

Kivgsiex's, p. o., Crawford co., Penn. : 197 m. N.W. by.W. Harrisburg.
Kave's MruLs, p. 0., Kane county, $7 l .: 158$ m. N. N. F. Springfield.

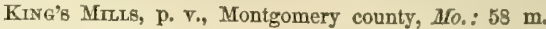
N. E. by E. Jefferson City.

King's Mountate, p. v., Lincoln co, N. Car., $156 \mathrm{~m}$. W. by S. Raleigh. In the neighborhood of this mountain is the scene of the celebrated battle of the 7th Oct., 1780, in which the British were defeated and compelled to surrender to the American militia.

King's Porvt, p. v., Dade county, Mo.: 131 m. S. W. Jefferson City.

Kingspom, p. v., Sullivan co., Tenn. : above the junction of the forks of Holston r., $236 \mathrm{~m}$. E. by N. Nashville. Contains several stores and about 30 dwellings.

King's Rrver, p. o., Carroll co., Ark.; on the r. so called, $144 \mathrm{~m}$. N. W. Little Rock.

Krig's Setrtlextent, p. o., Chenango co, $N . Y .: 97 \mathrm{~m}$. W. Albany.

Kingston, p. ., and cap. Autauga co., Ala.: on the W. side Autauga cr., $22 \mathrm{~m}$. N. W. Montgomery. The courthouse is here, and a few dwellings.

Kragston, p. v., Cass co., Ga.: on a branch of the Coosa r., $136 \mathrm{~m} . \mathrm{N}$. W. Milledgeville. The Western and Atlantic R. R. passes through the $\mathrm{v} . ;$ and here is the eastern terminus of Rome R. P., which is to be continued to Jacksonville, Ala., where it will connect the Selma and Tennessee River Railroad.

Kixgston, p. v., De Kalb co., Ill.: on Sycamore cr., 168 m. N. N. E. Springfield.

Etngston, p. o, Madison county, $\bar{k} y .: 48 \mathrm{~m}$, S. E Frankfort,

Kungston, p. v., Somerset co., Ma. : at the head waters of Anuemesix r., 74 m. S. S. E. Annapolis.

Krygston, t. and p. v., Plymouth co., Mass.: 32 m. S. S. E. Boston. Drained by Jones r. and its branches, which have their sources in several ponds, and empty into a branch of Plymouth Harbor. The harbor, in common with that of Duxbury, lies within the Gurnet, which forms the $\mathrm{N}$ boundary of Plymouth Harbor. Surface level; soil thin, sandy, and barren. Monk's Hill, on the borders of Plymouth, cormmands extensive views in every direction. The v., on Jones r., has an elevated site, and contains 3 churches and 50 or 60 dwellings, many of them neat and substantial. The t. has many vessels engaged in the cod and mackerel fisheries; and has also several factories and commercial houses, Pop. 1,593. The Old Colony R. R. passes through the town.

Knvgston, p. F., and cap. Caldwell co., Mo.: $123 \mathrm{~m}$. N. W. by W. Jefferson City.

KugGson, t. and p. V., Rockingham co., 2 . IIamp. : 85 m. S. S. E. Concord. Drained by two large ponds, the outlets of which unite and empty into the Merrimac; the largest, Great Pond, contains about 300 acres, and a wooded island of about 12 acres. Surface diversified, with several low hills; soil a fertile loam. Pop. of t. 1,192.

Engstox, p. v., Middlesex co., $N$. Jer.: on Millstone r., $15 \mathrm{~m}$. N. E. by N. Trenton, on the line of the New Jersey P. R. and the Delaware and Raritan Canal. Part of the v. lics in Somerset co. It contains several industrial estab lishments, stores, etc., and about 60 dwellings.

Kntgstos, t., p. v., and cap. Ulster co., $N_{.} Y_{\text {.: }} 58 \mathrm{~m}$ S. by W. Albany, Drained by Esopus cr. and its tributaries, and the Hudson $r$. makes its E. boundary. Surface somewhat uneven; soil sandy loam, overlying limestone

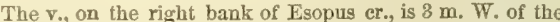
landing on the Hudson. It contains the court-house, jail, numerous stores, factories, and here are printed 3 newspapers, the "Ulster Republican," the "Democratic Journal," and the Ulster Democrat." Kingston, originally called Esopus, was early settled by the Dutch. Here was held the first convention of the State Representatives, which formed the old constitution-this was in April, 1777. On the $16 \mathrm{th}$ day of Oct following, the British army burnt the village. 
Gen. Vaughan was marching to the relief of Gen. Burgoyne, who was compelled to surrender to the American army the day following at Bemus' Heights. Kingston is now a flourishing town, with very considerable commercial and manufacturing interests. Pop. 10,236.

Kingstor, p. v., Ross county, Ohio: 34 m. S. by E. Columbus.

Kingston, p. o., Cumberland co, N. Car.: 50 m. S. by W. Raleigh.

Kingstor, t. and p. v., Luzerne co., Penn。: 81 m. N. N.E. Harrisburg. Drained into Susquehanna $r$., which forms its S. E. border. Surface uneven; soil generally fertile. The $v_{\text {.g }}$ formerly called Wyoming, is situate on the N. bank of the river, and is the shipping place of the coal mined in the neighborhood. It contains several stores, and about 80 dwellings. The railroad surveyed along the Susquebanna will pass through Kingston. The t. has some manufactures and mines. Pop. 2,306.

Kingston, p. v., Marquette co., Wisc.: on a branch of Neenah $\mathbf{r}_{\text {, }}$, into which it empties at the head of Puckawa Lake, $47 \mathrm{~m}$. N. by E. Madison.

Kungston, p. v., and cap. Washington co., $R$. I.: pleasantly situate, $27 \mathrm{~m}$. S. by W. Providence. It contains a court house, church, and about 30 dwellings,

Krigston, p. v., and cap. Roane co., Tenn. : on the point formed by the junction of Tennessee and Clinch rivers, 128 m. E. by S. Nashville. It contains the court-house, jail, and several stores.

Ktrgeton, p. o., Decatur county, Ind.: 54 m. S. E. Indianapolis.

Kingston Centre, p. 0., Delaware co., Ohio: $24 \mathrm{~m}$. N. by E. Columbus.

Kingston Mrans, p. v., Peoria co., Ill. : on the bluff near Illinois r., $52 \mathrm{~m}$. N. E. Springfield.

KINGstown, ., Talbot county, Md.: on the W. side of Choptank r., 34 m. E. S. E. Annapolis.

KINGSTREE, p. V., and cap. Williamsburgh dist., S. Car.: on the N. E. side of Black r., $73 \mathrm{~m}$. E. S. E. Columbia

Kingsville, t. and p. F., Ashtabula county, Ohio: on Conneaut r., $172 \mathrm{~m}$. N. E. Columbus. The to is bounded on the N. by Lake Erie, and is traversed by Conneaut $r$. Surface somewhat broken; soils rich and fertile. The v. is situate at the westernmost bend of the Connerut, and about $2 \mathrm{~m}$. S. of the line of the Cleveland and Erie R. R. Population of t. 1,494.

Krngstille, p. v., Clarion co, Penn.: 152 m. W. N. W. Harrisburg.

Kingspille, p. o., Talledega co., Ala.: N.E. Montgomery.

KING Willtam county, Virg. Situate E. centrally, and contains 235 sq. m. It lies between Mattapony r. and $\mathrm{Pa}$ munky r., which, uniting at the S. end of the county, form York r. Surface uneven, and pleasantly varied; soil genorally good, with many very fine plantations. Corn and wheat are the staples; some cotton and tobacco are raised. It has several good mill-streams. Farms 385; manuf. 10; dwell. 625, and pop.-wh, 2,702, fr. col. 346, sl. 5,731-total 8.779. Capital: King William C. H.

KIXG WrLttaM, C. H., p. v., and cap. King William co., Virg. : $24 \mathrm{~m}$. N. E. by E. Richmond. It contains a handsome court-house, a clerk's office, and co. jail, all of brick, handsomely inclosed with iron railing, and shaded by locust trees.

KrNGWOOD, t. and p. o., Hunterdon co., N. Jer.: $29 \mathrm{~m}$, $\mathrm{N}$. W. Trenton. Drained by Loakatong $\mathrm{r}$. Surface hilly; soil the red shale, clay, and loam, peculiar to this Statefertile; The $t$, contains several thriving villages. Population 1,799 .

KrngwOoD, p. v., and cap. Preston co., Firg.: $174 \mathrm{~m}$. N. W. by N. Richmond.

KnNmead, p. o., St. Francois co., Mo.: $11 \mathrm{~S}$ m. S. E. by E. Jefferson City.

KrNLOcK, p. 0., Lawrence co, $A d_{0}: 169$ m. N. N. W. Montgomery.
Krntock, p. o., Panola co., Tex, : 240 m. N. E. by E. Austin.

Kinnard, p. o, Hancock county, Ind.: about $20 \mathrm{~m}$. W. Indianapolis.

KinNard's Store, p. o., Maury co., Tenn.

Kinse, p. v., Du Page county, $I U .: 165$ m. N. N. E. Springfield.

Kinney's Four Corners, p. o., Oswego co., N. Y.: 154 m. W. N. W. Albany.

Kinniconick, p. o., Lewis county, Ky.: 98 m. N. E. Frankfort.

Krisedue, p. 0., Westmoreland co., Virg.: 57 m. N. E. Richmond.

Kinsman, t. and p. v., Trumbull co., Ohio: 156 m. N. E. Columbus. Drained by Pymatuning cr., an affluent of She. nango cr. in Pennsylrania. Surface diversified; soil deep, dark mold, and fertile. The $\mathrm{v}$. lies on the left bank of the creek. Pop. of t. 1,005.

Krnston, p. v., and eap. Lenoir co., N. Car.: on the N. side of Neuse r., $73 \mathrm{~m}$. S. E. by E. Raleigh. It contains the court-house, jail, and several stores.

Kintabish, p. o., Sumter co., Ala.: on Kintabish er, a tributary of Tombigbee r., $11 \mathrm{~s} \mathrm{~m} . \mathrm{W}$. Montgomery.

KINZER"8, p. o. and sta., Lancaster co., Penn.: on the Columbia and Philadelphia R. R., 52 m. E. S. E. Harrisburg.

Kinzus, t. and p. v., Warren co., Penn.: 158 m. N. W. Harrisburg. Drained by Kinzua er. of Alleghany r., which makes its $\mathrm{N}$. boundary, and supplies an immense waterpower-which operates a large number of saw and other mills. Surface very diversified; soil of average fertility. Pop. 431.

Kromatia, p. o., Red River co., Tex.: 263 m. N. E. by N. Austin.

Kirby, p. 0., Greene county, Penn.: 178 m. W. \$. W. Harrisburg.

Kirkersvilue, p. v, Licking co, Ohio: on the 8. side of a branch of Licking r., $21 \mathrm{~m}$. E. Columbus. It contains several stores, and about 250 inhabitants.

Kirkland, t. and p. v., Penobscot co., Me.: 68 m. N. E. Augusta. Drained by streams, affluents of Pushaw Lake, the latter emptying through the river of the same name into the Penobscot, which it reaches opposite the village of Old Town. Surface level; soil generally fertile. There is a emall $v$. in the centre. Pop. of t. 717.

KMRKLAND, t. and p. Os, Oneida co, N.Y.: 92 m.W. by N. Albany. Drained by Oriskany cr. Surface diversified by hills and fertile valleys; soil rich calcareous loam. The Chenango Canal passes through the t. about $10 \mathrm{~m} . \mathrm{S}$. W. of Ttica. There are several flourishing villages in the town which have considerable manufactures, and the town generally is engaged in a variety of handicrafts. Pop. of t. 8,421 . Krrkiard, p. o., Cabarras co., N. Car. . 112 m. W. by S. Raleigh.

KrRE's CROSS ROADs, p. o., Clinton county, Ind.: $30 \mathrm{~m}$. N. N. W. Indianapolis.

Kirk's Ferry, p. o., Tensas parish, La.: $102 \mathrm{~m}$. N. Baton Rouge.

Kirk"s Mruts, p. o., Lancaster co., Penn. : 47 m. E. S. E. Harrisburg.

Kirkstille, p. V., Madison county, Ky.: 49 m. S. E. Frankfort.

Krrksville, p. v., and cap. Adair county, Mro.: $112 \mathrm{~m}$. N. by W. Jefferson City.

KtRKVILLE, p. o., Butler county, Ala.: 33 m. S. S. W. Montgomery.

KIRKVILIE, p. v., Wapello county, Ia.: 63 m. S. W. Iowa City.

KirkVILLE, p. v., Onondaga county, $N . Y_{0}$ : on the Erie Canal and Syracuse and Utica R. P., $119 \mathrm{~m} . \mathrm{W}$. by N. Albany, by route of canal $15 \mathrm{~s} \mathrm{~m}$. and by railroad $137 \mathrm{~m}$. from Albany. It contains several stores and about 300 inhabitants. 
KIRkwoop, p. v., Broome co., $N_{\text {. }} Y_{\text {.: }} 118 \mathrm{~m}$. W. S. W. Albany. The v. lies on the New York and Erie R. R., 216 m. from New York City.

Kirsey's Cross RoaDs, p. o., Edgefield dist., S. Car : 67 m. W. Columbia.

KrrTLAND, t. and p. v., Lake county, Ohio: $138 \mathrm{~m}$. N. E. by N. Columbus, about $8 \mathrm{~m}$. from Lake Erie. Here the Mormons erected their first temple, which, since their leaving, has been used as a normal schoel. A tributary of Chagrine $r$. traverses the town. Soil rich and productive. Pop. 1,598.

Krshago-quillas, p. o., Mifflin co., Penn。: $46 \mathrm{~m}$. N. W Harrisburg.

Kiskatov, p. o., Greene co., N. $Y .: 43 \mathrm{~m}$. S. W. Albany

Kiskiminitas, t. and p. v., Armstrong co., Penn. : $142 \mathrm{~m}$.

W. by N. Harrisburg. Drained chiefly by affuents of the Kiskiminitas, or Conemaugh r., which forms its S. W. border, and Crooked er. makes its N. border. Salt is manufactured here. The Pennsylvania Canal has its course through the town. Mills of various descriptions are found on its streams. Pop. 2,503.

KisWaUkeE, p. F., Winnebago co., $I l l .: 163$ m. N. N. E. Springfield. A thriving town on Rock $r$. at the junction of Kiswaukee river.

Kitching's Minis, p, o., Orangeburgh dist., S. Car.: 43 m. S. Columbia.

Kittanlvg, t., p. b., and eap. Armstrong eo., Penn. : 152 m. W. by N. Harrisburg. Drained by several creeks of Alleghany r. and its tributaries, Crooked, Cowanshannock, and other creeks--the Alleghany making its W. and Crooked cr, its S. boundary. Surface hilly ; soil a fertile, gravelly loam. The $\mathrm{b}$. is situate on the Alleghany in the $\mathrm{N}$. W. corner of the t., and contains a court-house, jail, etc., a number of stores, tanneries, and workshops, and about 800 inhabitants. Two newspapers are published here, the "Armstrong Democrat" (dem.), and the "Free Press" (whig), both weekly issues. The Alleghany Valley R. R, will pass through Kittaning. Pop. 1,017.

KıтterI, t. and p. v., York co, Me.: 104 m. S. S. W Augusta. On the N. E. side of Piscatiqua r, opposite Portsmouth, and having its E. front on the Atlantic. It is the S. W. extremity of the State. Its coasts are deeply indented, and Spruce cr., or inlet, affords convenient harbors for the coasters and fishing vessels frequenting them. Shipbuilding is carricd on at Kittery to some extent, and ou Badger's Island, with which connection is madt: by a bridge, is lociter a U.S. nary yard. A bridge also connects it with Portsmouth. This t. was settled at an early date, and formerly enjoyed considerable trade with the West Indies. The Portsmouth, Saco, and Portland R, R. crosses the river here. Pop. of t. 2,706.

Kicckxersville, p. o., Northampton co., Penn.: $94 \mathrm{~m}$. N. E. by E. Harrisburg.

Klunesvilue, p. 0., Henderson county, N. Jer.: $35 \mathrm{~m}$ N. by W. Trentun.

Kinfesvilue, p. 0., Berks co., Penn.: 55 m. E. by N. Harrisburg.

Krap of ReEds, p. o, Granville co., N. Car,: $35 \mathrm{~m} . \mathrm{N}$. Raleigh.

Krapp"s, sta, St. Lawrence co, $N, T:$ on the Northern (Ogdensburg) R. R., $28 \mathrm{~m}$. E. Ogdensburg and $85 \mathrm{~m}$. W. Rouse's Point.

KNAPS, p. 0., Carter co., Ky.: 113 m. E. by N. Frankfort.

KNigIr's, sta., Lenawee co., Mich.: on the Erie and Kolamazuo R. R., 20 m. from Toledo and 12 from Adrian.

KNigutstows, p. v., Flenry co., Ind.: on a high bluff Tr. sile of Blue r., $33 \mathrm{~m}$. E. Indianapolis. The National Road and Central Indiana R. R. pass through it, and are her' tanped by the Knightstown and Shelbyville R. R., and this print will also be the terminus of the fort Wayne and Southern $\mathbf{R}$. $\mathbf{R}$. This is a flourishing $\mathbf{v}$, with extensive water-power. and is situate in the midst of a fine agricultural region. It contaius about siv inhabitants; but is des350 tined to become a place of great commercial importance and the centre of a large local trade.

Knightsville, p. v., Providence co., R. I. : 5 m. S. W. Providence. It is a small manufacturing village. The Hartford, P'rovidence, and Fishkill $R$. . R. will pass a little to the E. of it.

Кхов, p. o., Tazewell county, Virg. : 283 m. W. S. W. Richmond.

Knob Creex, p. o., Barren co., $\bar{y} y .: 108$ m. S. S. W Frankfort.

Ћ ков Fоr., p. Oa, Wetzel co, Virg.: 219 m. W. N. W Richmond.

Кмов Lick, p. o., Daviess co., $K y .: 133 \mathrm{~m}$. W. by $\mathrm{S}$ Frankfort.

KNoвnoster, p. Y., Johnson co, Mo. : $75 \mathrm{~m}$. W. by $\mathrm{N}$ Jefferson City.

Knottsymle, p. o., Daviess eo., $K_{y} .: 132 \mathrm{~m}$. W. by $\mathrm{S}$. Frankfort.

KNowersville, p. o., Albany county, $N . Y .: 14 \mathrm{~m} . \mathrm{W}$ Albany.

KNowlesvilie, p. v., Orleans co, $N . Y$ : on the Erie Cand, $246 \mathrm{~m}$. W. by N. Albany. It contains several warehouses, stores, and about 80 dwellings.

KNowlton, t. and p. o., Warren eo., N. Jer.: $49 \mathrm{~m}$, N. N. W. Trenton. Drained by Paulin's Kill, Beaver Brook, and Shawpocussing creeks. Surface hilly and varied; soil on the hills slaty, and in the valleys calcareous loam. Blue Mountain lies on its N. boundary, where is the Water Gap of the Delaware, and through which the connection will be made between the Belvidere Delaware $R, R$, and Cobb's Gap R. R. The v. lies on the S. side of Paulin's Kill, at its confuence with the Delaware, opposite the village of Columbia, and on the line of the Belvidere Delaware $R . R$. The Morris and Essex R. $\mathrm{R}$, will also form a junction at this point. Pop. of t. 1,355.

KNox county, $I l l$. Situate N. W. centrally, and contains 720 sq. m. Drained prineipally by Spoon r. and its W. branch, affluents of the Illinois. Surface level or undulating; soil a very rich prairie over most of the county. It has excellent timber on several of its streams. It is well calculated for grain crops and has the best of pasture. Corn and wheat are the leading staples, and much beef and pork is sent to market. Farms 619; manuf. 100 ; dwell, 2,193, and pop.-wh. 13,221, fr. col. 58-total 13,279. Capital: Knoxville. Pubtic Works: Oquawka and Peoria $\mathrm{R}$, $\mathrm{R}$, ete

Krox county, Ind. Situate S. W., and contains 496 sq. m. It lies between Wabash $\mathbf{r}$, on the W., its branch, White r., on the $S_{\text {s. }}$ and W. fork of White $\mathbf{r}$. on the $\mathrm{E}$. Surface undulating, with some river hills. It has rich prairies, and the timbered lands, which ocenpy a large share of the county, are mostly productive. Here are some sandy barrens and swamps, and the bottoms are subject to inundution. Corn and whent are most raised. Tobaceo is grown. It is a very fine grazing county, and eattle, wool, and especially pork, are much exported. Farms 961; manuf, 37 ; dwell, 1,969, and pop,-wh. 10.546, fr. col. 538 -total 11,084. Capital: Vincennes. Public Works: Evansville and Illinois R. R.; Cincinnati and St. Louis R. R., etc.

K wox county, $\bar{K} y$. Situate in S. E. corner, and contains 665 sq. m. Drained by Richland and Stinking ereeks, and other affluents of Cumberland r., which crosses the county. Surface uneven-in parts mountainous; soil in the valleys fertile and generally good gruzing land. It has many mill streams. Corn is the chief product, and great numbers of hogs are kept. Farms 657; manuf. 6; dwell, 1, (60, and pop.-wh. 6,239, fr. col. 199, sl. 612-total 7,050. Capital: Barboursville.

K Nox county, MIo. Situate N. E., and contains 513 sq. m. Drained by North, Middle, and South Fabius rivers and their branches, and $\mathrm{S}$. W. by N. fork of Salt $\mathbf{r}$. Surface gently uneven; soil excellent. The streams are skirted with valuable timber, and the bottoms very productive. Corn 
and cattle are the principal exports. Numerous mill-seats are found on the rivers. Farms 303 ; manuf. 7 ; dwell. 127 , and pop.-wh. 2,626, fr. col. 2, sl. 266-total 2,894. Capital: Edina.

Krox county, Ohio. Situate centrally, and contains 523 sq. m. Drained by Vernon, Walhonding, and N. branch of Licking rivers, afluents of Muskingum $\mathbf{r}$., which, with their branches, afford abundant water-power. Surface slightly broken in E. part, in the W. level or undulating; soil a vegetable loam in the W., and generally very productive. It is an excellent farming county, and immense quantities of wheat and corn are sent to the East. The dairy is of much importance, and large flocks of sheep are everywhere kept. Pork is also a very large export. It has superior facilities for manufactures, which are large and rapidly increasing, and great conveniences for reaching distant markets. Farms 2,268; manuf, 117 ; dwell. 4,s53, and pop.-wh. 28,S11, fr, col. 62-total 28,873. Capital: Mount Vernon. Public Works: Springfield, Mount Vernon, and Pittsburg R. R.; Mansfield and Sandusky City R. R.; Columbus and Lake Erie R. R., etc.

Krox county, Tenn. Situate N. E., and contains 445 sq. m. Drained by Holston, Nolichucky, French Broad, and Clinch rivers, all branches of Tennessee $r$., and affording fine water privileges. Surface broken and mountainous ; soil fertile, especially in the numerous beautiful valleys. Corn and wheat are very large crops, and the staples. The grazing is excellent, and many cattle, horses, sheep, and swine are reared. The manufactures of the co. are important and growing, consisting of flour, leather, iron, oils, liquors, paper, earthenware, etc. Farms 1,403; manuf. 67 ; dwell. 2.S04, and pop,-wh. 16,337, fr. col. 225, sl. 2,195-total 15,755. Capital: Knoxville, Putlic Works: Georgia and E. Tennessee R. R.; E. Tennessee and Virginia R. R.; Knoxville and Cincinnati R. R.; Blue Ridge R. R., ete.

Krox, t. and p. v., Albany co, N. Y.: 22 m. W. Albany. Drained by Bozrakill and a tributary of Foxes cr. Surface rough and hilly-the t. being partly covered by the Helderberg series of limestone; soil of average fertility. The $\mathrm{v}$. (Knoxville) contains about 200 inhabitants. The t. has numerous mills and tanneries, and 2,021 inhabitants.

Krox, p. v., and cap. Stark co., Ind.: on the S. side of Yellow r.. 108 m. N. by W. Indianapolis.

Krox, p. y., Knox co., Ohio: 38 m. N. E. Columbus.

Krox, t. and p. v., Waldo county, Me.: 31 m. E. N. E. Augusta. Drained by branches of Sebasticook $r$; surface somewhat hilly; soil rich, and fine grass land. The y. lies toward the N. W. Pop. of t. 1,102.

Krox Centre, p. V., Waldo co, Me.: 81 m. E. N. E. Augusta.

Krox Corners, p. o., Oneida co., N. Y.: 98 m.W. N.W. Albany.

Kroxville, p. v., Greene co., Ala.: $98 \mathrm{~m}$. N. W. by W. Montgomery.

Kroxville, p. v., and cap. Crawford co., Ga.: on an affluent of Flint $\mathbf{r}, 58 \mathrm{~m}$. S. W. by W. Milledgeville. It contains a court-house, jail, etc., and about 40 dwellings

Kroxvitie, p. o., Franklin county, Miss.: 78 m. S. W. Jackson.

Kroxville, p. v., and cap. Knox co., $I l l$ : near Haw cr., $83 \mathrm{~m}$. N. N. W. Springfield. Beautifully located on high rolling prairie, contains about 350 inhabitants. The courthouse is here. The "K. Journal" is published weekly.

KNoxville, p. v., and cap. Marion co., Ia. : on an elevation between White Breast r. and English cr., $81 \mathrm{~m}$. W. S. W. Iowa City.

Kroxville, v., Frederick $c_{0}, M d_{*}$ : on the lines of Chesapeake and Ohio Canal and of the Baltimore and Ohio R. P. $79 \mathrm{~m}$. W. Baltimore.

Kyoxville, p. v., Ray co., Mo.: 117 m. N. W. by W. Jefferson City.

Kroxville, p. v., Jefferson co., Ohio : $4 \mathrm{~m}$. from Ohio $\mathrm{r}$. and $126 \mathrm{~m}$. E. by N. Columbus; contains several stores. The $\mathrm{t}$, of Knox contains several villages, is bounded on the $\mathrm{E}$. by the Ohio r., and has 1,902 inbabitants.

Knoxville, p. o, Tioga co., Penn.: 115 m. N. by W. Harrisburg.

Knoxville, p. eity, and eap. Knox co, Tenn.: on the N. bank of Holston r., at the head of navigation, and about $4 \mathrm{~m}$. below the confluence of French Broad river, $157 \mathrm{~m}$. E. Nashville. Lat. $35059^{\prime} \mathrm{N}$., and long. $83054^{\prime} \mathrm{W}$. The city is most eligibly situate for an extensive inland trade. being at the navigable head of a great river, and on the line of intercommunication E. and W. nearly through the middie zone of the Union, and at a point whence will diverge N. and S. lines of railroad, extending on the one hand to Cincinnati, and on the other to the chief ports of the southern Atlantic States and Gulf of Mexico. Here, indeed, a junction is formed by three great railroads-the East Tennessee and Georgia R. R., connecting $\mathrm{S}$. with lines to Charleston and Savannah, and S. W. with those to Memaphis and the Gulf cities; the Knoxville and Ohio R. P. terminating at Covington on the Ohio; and the East Tennessee and Virginia R. R., which, connecting with the Virginia and Tennessee R. R. on the State line, and the latter uniting at Lynchburg with the railroads to Petersburg and Norfolk, Richmond and Alexandria, reaches directly to the great seaboard marts, which will take the vast productions of the interior, and return in exchange the manufactures and produets of the outer world. The city itself is regularly laid out, and handsomely built. It contains a fine court-house, a jail, and other county buildings. It is also the seat of East Tennessee College, founded 1792. This is a very efficient and flourishing institution. In 1850 it had a president, 5 professors, 122 alumni, and 57 students; and its library contained 4,500 volumes. A preparatory department is attached to the college, which has usually from 70 to 80 scholars. The public press of Knoxville consists of 5 periodicals, viz.: 1 semi-weekly and 4 weekly papers; the semi-weekly is the " $K$. Register" (whig), of which also a weekly edition is issued; and the weeklies are the "K. Whig" (whig), the "Plebeian," (dem.), the "Methodist Episcopalian" (relig.), and the "Holston Christian Advocate" (relig.) The city has already a good trade with the neighborhood, and contains wholesale and retail stores, churches of several denominations, two academies, and several primary schools. The present population is over 2,000 .

Kokomo, p. v., and cap. Howard co., Ind. : on Wild Cat cr., $53 \mathrm{~m}$. N. Indianapolis. The site of an Indian $\mathrm{v}$. by the same name. The Indianapolis and Peru $R$. $R$. and the New Castle and Logansport P. R. intersect each other at this point. It is the centre of a fine farming region, and must become the depot of a considerable internal traffic. Pop, about 600 .

Kooskooskif river, Oreg. Ter. : a tributary of Lewis, or Snake r. It rises in the Rocky Mountains, and flowing W. falls into Lewis $r$. in about $46^{\circ}$ lat, and $117^{\circ}$ long. The Presbyterians have missions on this stream.

Kootanre (Kutunaha, or Flat Bow) river, Oreg. Ter. . a large affluent of Columbia $r$. It has its sources in the Rocky Mountains in about $510 \mathrm{~N}$. lat. In its first part it flows along the base of the mountains to $48^{\circ}$, and then bends W., and passing through Flat Bow Lake enters the Columbia above the British line. At its extreme $\mathrm{S}$. bend is Fort Kootanie, a settlement of the Hudson Bay Company.

Koro, p. o., Winnebago county, Wisc. : 79 m. N. N. E. Madison.

Kontright, t. and p. $\nabla .$, Delaware county, $N . Y .: 58 \mathrm{~m}$ W. by S. Albany. Drained by tributaries of the Delaware $\mathbf{r}$. Surface hilly and mountainous; soil fertile loam. The $\mathrm{v}$. is situate centrally. South Kortright and Bloomville are other villages. Pop. of t. 2,181.

Koscrusso county. Ind. Situate $\mathrm{N}$. centrally, and contains 579 sq. m. Drained by Tippecanoe and Eel rivers and their branches, flowing $\mathrm{S}$. W. into the Wabash, and Tur-

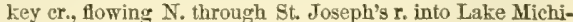


gan. Surface undulating. Soil fertile, and timber abundant. In the $\mathrm{N}$. are some wet prairies, and several lakes or ponds abounding in fish. It has many ponds that feed fine mill-streams, and afford much water-power. Corn and wheat are leading staples. Great numbers of hogs are fattened. Farms 1,127; manuf. 21; dwell.1,783, and pop-wh. 10,242; fr. col. 1-total 10,213. Cupital: Warsaw. Putlic Works: Goshen, Warsaw, and Peru R. R.

Koscrusco, p. v., and cap. Attala co., Miss.: on the W. side of Yockonockony r., 61 m. N. N. E. Jackson. There are 3 papers issued here weekly - the "Cbronicle" (whig), "Attala Democrat" (dem.), "Sentinel and Pilot" (dem.) The r. contains a court-house, etc., several stores, and 400 inhabitants.

Koskonone, t. and p. O., Jefferson eo., Wisc.: $32 \mathrm{~m}$. E. S. E. Madison. Within this town lies Lake Koskonong, through which Rock r. flows. Several tributaries also pour into the lake and $r$. within its limits. Pop. 1,512.

Kossutr county, Ia. Situate $\mathbb{N}$. centrally, and contains $576 \mathrm{sq}$. m. Drained by Boone r. and other heads of Des Moines r. Erected since 1850.

Kossutr, p. o., Jackson co., Tenn.: 73 m. E. N. E. Nashville.

Kossuth, p. o., Des Moines co, Ia.: 56 m. S. E. Iowa City, Kosstit, p. o., Racine county, Wisc.: $59 \mathrm{~m}$. E. by $\mathbf{S}$. Madison.

Kossutr, p. o., Boone county, III.: $185 \mathrm{~m}$. N. by E. Springfield.

KosstrH, p. o, Auglaize county, Onio: $78 \mathrm{~m} . \mathrm{N}$. W Columbus, Pop. 76.

Kossuth, p. o., Washington county, Ind.: 83 m. S. Indianapolis.

Kossure, p. 0a, Cherokee county, Ga.: $117 \mathrm{~m}$. N. W Milledgeville.

Kossuta, p. o., Washington co., Me.: 112 m. W. by $\mathrm{N}$. Augusta.

Kossuth, p. o., Clarion co., Penn.: 148 m. W. N. W. Harrisburg.

KowaITGA, p. o., Tallapoosa county, Ala.: 43 m. N. E. Montgomery.

Kown's river, Oreg. Ter.: a small r. emptying into the Pacific Ocean above Cape Arago.

Kratzerevilue, p. 0., Union co., Penn.: 48 m. N. by W. Harrisburg.

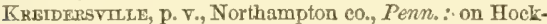
endocque cr. of Lehigh r., $79 \mathrm{~m}$. N. E. by E. Harrisburg.

Kresgeviluz, p. o., Monroe county, Penn.: 79 m. N. E.

Harrisburg.

Kнон's Muru, p. o., Carroll co., Mrd.: 63 m. N. N. W. Annapolis.

Kulpsvilie, p. O*, Montgomery county, Penn.: $83 \mathrm{~m}$. E.

Harrisburg.

Kunkletows, p. o, Monroe county, Penn.: $88 \mathrm{~m} . \mathrm{N} . \mathrm{E}$ Harrisburg

Krтzтошк, p. b., Berks co, Penn.: on a branch of Maiden cr., $59 \mathrm{~m}$. E. by N. Harrisburc. It contains several stores, mechanic shops, ete, and has 642 inhabitants.

KYGER, p. Y., Gallia county, Otio: 83 miles S. E. by S Columbus.

Krsertas, p. 0., Ulster county, $N . \boldsymbol{Y}_{.:} 68 \mathrm{~m}$. S. by W. Albany.

Krservit., p. o., Livingston county, $N$. $Y .: 214 \mathrm{~m}$. W. Albany.

Irte Rrver, p. o, Ogle county, $\Pi l .: 14 S$ miles N. by E Springfield.

\section{L.}

Inbanus, p. o, Robertson county, Tenn.: N. by W. Nashville.

LAcer, p. v., De Kalb co., $\Pi l_{*}$ : about 2 m. S. of Sycamore r., 166 m. N. by E. Springfield. 358
Lacex Sprivgr, p. v., Rockingham county, Firg.: $98 \mathrm{~m}$. N. W. Richmond.

Lacex's Spring, p. o., Morgan co., 1 la.: about $2 \mathrm{~m} . \mathrm{N}$. from Tennessee r., $143 \mathrm{~m}$. N. by W. Montgomery.

Lacervilte, p. v., Wyoming co., Penn. : 89 m. N. N. E. Harrisburg.

Laoervilie, p. v., Harrison co., Ohio: 104 m. E. by N. Columbus.

LACKAWACK, p. v., Ulster co., $N$. $Y$.: on a branch of Rondout cr., 68 m. S. S. W. Albany.

Lackawanka, t. and p. 0., Luzerne co., Penn.: $96 \mathrm{~m}$. N. E. by N. Harrisburg. Drained by Lackawanna r. Iron ore is dug. The $\mathrm{N}$. branch division of the Pennsylvania canal crosses the t. $73 \mathrm{~m}$, from Northumberland. Pop. 511

LACKAW ANNA river, Penn. : a tributary of Susquehanna $r$. It rises in Wayne and Susquehanna counties, and pursues a course $\mathrm{S}$. and $\mathrm{S}$. W. $30 \mathrm{~m}$. to its confluence. It affords extensive and valuable water-power.

LACEAWANNod mountains, Penn.: these mountains run between the sources of Lackawaxen and Lackawannoc rivers, One of their W. peaks is called Moosack Mountain, and is traversed by the railroad from Carbondale to Honesdale.

LACKAwatmi river, Penn.: a tributary of Delaware r. It rises chiefly in Wayne co., and flows through a deep valley, receiving Dyberry, Middle, and Waullenpaupack creeks, and enters the Delaware in Pike co., where is a dam across the Delaware to supply the Delaware and Hudson Canal water, and to enable the boats to cross the river. This canal follows the course of the Lackawaxen $25 \mathrm{~m}$. to the mouth of Dyberry creek at Honesdale, whence is a railroad to the Lackawanna coal mines, 16 miles distant

Lackawasent, p. т. and sta., Pike co., Penn.: on the Delaware r., $124 \mathrm{~m}$. N. E. by E. Harrisburg. Drained by Lackawaxen $r$. and other streams flowing into the Delaware. Surface ragged and heavily timbered; soil productive. The $\nabla$. is at the junction of the Lackawaxen and Delaware, the latter being dammed, and affording great water-power for the lumber mills and iron works, which constitute its chief business. The Delaware and Hudson Canal crosseg the Delaware here in an aqueduct supported by an iron wire suspension bridge, and proceeds up the valley of the Lackawaxen, which the Erie R. R. here crosses on two bridges. The sta. is $121 \mathrm{~m}$. from New York. Pop. of $t, 2,060$.

LAckenuTE, p. O., Polk co., Oreg. Ter.: on the branch of the Willamette so called, $18 \mathrm{~m}$. S. W. Salem.

LA Clate, p. v., De Kalb county, $I l l .: 136$ m. N. by E. Springfield.

LA ClEDE county, MO, Situate S. centrally, and contains 703 sq. m. Drained E. and S. E. by Gasconade r. and its branch, Osage Fork; N. and N. W. by Dry Auglaize cr. and Niangua r., branches of Osage $r$.; all flowing $\mathrm{N}$. into the Missouri. Surface quite elevated and rolling, with some hills. Soil very productive. A very fine farming and graging co, with good timber, rich bottoms, and a sufficiency of water-power. Corn and wheat are the staple cereals. Cattle and hogs are exported in large numbers. Farms 233 ; manuf. 2 ; dwell. 385 ; and pop.-wh. 2,357 , fr. col. 1 , sl. 140-total 2,498. Capital: Wiota.

LACON, p. $\nabla_{.}$, and cap. Marshall co., $M l_{*}:$ on the left bank of the Illinois r., $79 \mathrm{~m}$. N. by E. Springfield. It has a favorable position for trade and manufactures, and contains the county buildings, a high school, several stores, and 500 inhabitants. The "Lacon Herald" (dem.), and "Mlinois Gazette" (whig), are published weekly.

LacoNa, p. o., Jefferson co., $K y .: 49 \mathrm{~m}$. W. Frankfort.

LAcossa, p. v., Harrison co., Ind.: about $2 \mathrm{~m}$. from the Ohio r., $117 \mathrm{~m}$. 8. Indianapolis.

LaconIA, p. 0., Desha co., Ark.: 87 m. S. E. Little Rock, LAo our Parle, p. 0., Dakotah co., Minn. Ter.: $197 \mathrm{~m}$. W. St. Paul. This is a trading post on the Minnesota or St. Peter's $r$, which here expands to a considerable body of water, called by the French, Lac qui Parle (lake that 
talks), from the remarkable echoes produced by its rugged shores.

LA CRosss county, Wise. Situate W. centrally, and contains about 3,450 sq. m. Drained by Mountain, Black, and $\mathrm{L}_{\alpha}$ Crosse rivers, and their many branches, affluents of the Mississippi, which is its S. W. boundary. This co. covers a large territory, as yet little settled. It has fine large streams, lined with vast forests of valuable pine timber, which is in great demand, and furnishes the chief trade of the county. The surface is much varied, and the rivers afford excellent water-power. The soil is very fertile, and there is little prairie. That portion of La Crosse county lying $\mathrm{N}$. of the N. line of township No. 9 , has lately been erected into a separate county, under the name of Jackson. Capital: La Crosse (Prairie La Crosse).

LA CRosse, p. v., La Crosse co., Wisc, : on the left bank of the Mississippi, at the mouth of La Crosse river, 108 miles N. W. by W. Madison. It has a good landing, and contains several stores, and 300 inhabitants.

LACY, p. 0., Drew co., Ark: 77 miles S. S. E. Little Pock. Lacy's Hill, p. o, Pickens co., Allı.: $112 \mathrm{~m}$. W. N. W. Montgomery.

I_ADD's, sta., Erie co., Ohio: on the Sandusky, Mansfield, and Newark R. R., $8 \mathrm{~m}$. from Sandusky.

LaDDSBURgII, p. 0., Bradford co., Penn. ; 106 m. N. by E. Harrisburg.

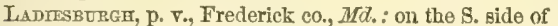
Sam's cr., $58 \mathrm{~m}$. N. W. Annapolis.

LuAdigA, p. o., Benton co., Ala..: on a branch of Coosa r., 112 m. N. N. E. Montgomery.

LADOGA, p. v., Montgomery co., Ind.: on N. side of Big Iaccoon cr., $34 \mathrm{~m}$. W. by N. Indianapolis.

L_dosox's, station, Charleston dist., \&. Car.: on the South Carolina R. R., 17 m. Prom Charleston.

Li F ARgerthle, p. v., Jefferson co., $N . \quad Y$.: on Chamount r., near its head, $158 \mathrm{~m}$. N. W. Albany.

L. Faretre county, Ark. Situate s. W. corner, and contains 1,664 sq. m. Drained W. by Red r., and Sulphur fork of Red r., and E. by bayous Bodeau and Dorcheat, affluents of Red r. Surface gently uneven, with some hills, on the rivers, and a few swamps. Soil on the streams of exceeding fertility; back of these it is sandy and less productive. Cotton is raised in immense quantities on the river plantations, and constitutes the almost sole object of cultivation and export. Corn produces well, and there is some good pasture. Farms 177; manuf. 2; dwell. 349, and pop. -wh. 1,900, fr. col. 0, sl. 8,320-total 5,220. Capital: Lewisville.

$\mathrm{I}_{\mathrm{A}} \mathrm{F}_{\text {AYETTE }}$ parish, $L a$. Situate $\mathrm{S}$. W., and contains 376 sq. m. Drained by Vermillion r., which flows through it $\mathrm{S}$. into Vermillion Bay and the Gulf of Mexico. Surface low and level, with frequent swamps. Soil of great fertility, where not too wet for cultivation. Cotton and sugar are the staple products, of which great amounts are exported. Corn grows luxuriantly, and yields finely. Some rice is raised in the swamps. Farms 441; manuf. 0 ; dwell. 630 , and pop.-Wh. 3,390 , fr. col. 160, sl. 3,170-total 6,720. Capitct: Vermillionsville.

$L_{\Delta} F_{A Y F T T E}$ county, Miss. Situate $N_{\text {., }}$ and contains 785 sq. $\mathrm{m}$. Drained by Tallahatchie and Yocanapatafa rivers, and Olackatuffa cr., affluents of Yazoo r. Surfaco level or gently rolling. Soil generally very productive, and affords fine pasturage. Cotton is the great staple. Corn yields finely, and is extensively exported, and cattle and hogs are raised in large numbers. It has good facilities for manufacturing, which is a growing interest in the co. Farms 1,044; manuf. 49 ; dwell. 1,382, and pop.-wh. 8,346, fr. col. 4, sl. 5,719total 14,069. Capital: Oxford. Public Works: Mississippi Central R. R.

LA FAYETTE county, DO. Situate N. W., and contains $652 \mathrm{sq} . \mathrm{m}$. Drained by Dan's fork and Salt fork of Black r. flowing $\mathrm{E}_{*}$, and Big Synbar and Big Terre Bean creeks

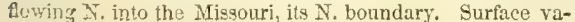

ried; hills and broken ground in the $\mathrm{S}$, and gentle swells in the N. Soil of great fertility, adapted to grain and grass. Corn and wheat are the cereal staples. Great numbers of sheep and swine are fed on its fine pastures and abundant mast, and pork is an important export. It has fine waterpower, the use of which is extensive and rapidly increasing. Farms 895 ; manuf. 67 ; dwell. 1,459, and pop.-wh. 9,005, fr. col. 70, sl, 4,615-total 13,690. Capital: Lexington. Public Works: Pacific R. R.

LA FAYETTE county, Wisc, Situate S. W., and contains 681 sq. m. Drained by Otter cr., Pecatonica and Wassemon rivers, affluents of Rock rlver, and Fevre river, an affluent of the Mississippi. Surface broken and hilly, with a little prairie. Soil of good quality, and adapted to grazing or grain, but the great interest of the $\mathrm{co}_{\text {. }}$ is mining. It lies on the $\mathrm{S}$. line of the State, and in the rich mining district around Galena and Dubuque, the former of which is the outlet of its wealth. This consists chiefly of almost inexhauslible deposits of rich galena or lead ore, the working of which is the principal pursuit, and less extensive but valuable copper and iron ores, with some silver. It has several mineral springs, good water privileges, and some timber. Farms 399 ; manuf. 21; dwell. 2,076, and pop-wh. 11,527, fr. col 14-total 11,541. Capital: Shullsburg. Public Works: Milwaukie and Mississippi R. R.

LA FAYETTE, p. v., and cap. Walker county, Ga. : $172 \mathrm{~m}$. N. W. Milledgeville. It contains a court-house, jail, two academies, a dozen stores, and 500 inhabitants.

LA FAYETTE, p. v., Stark co., 112. : on middle branch of Spoon r., 96 m. N. by W. Springfield.

IA FAYerre, p. V., and cap. Tippecanoe co., Ind.: on the E. bank of Wabash r., at the head of steamboat navigation, 58 miles N. W. Indianapolis. Lat. $40025^{\prime} \mathrm{N}$., and long. $86 \circ 49^{\prime} \mathrm{W} . ;$ it is the centre of railroad, canal, and plankroad trafic of great amount, and has several important manufactures. It contains about 40 dry goods stores, 13 clothing stores, 26 groceries, etc. About a dozen warehouses, and a variety of minor sales stores; also foundries, packinghouses, paper-mills, printing establishments, etc. It has also a large flouring business; three newspapers are published here, the "L. Courier" (dem.), daily and weekly, the "L. Journal" (whig), daily and weekly, and the "Wabash Atlas," weekly. The means of education are ample, and there are churches of all the leading denominations. A branch of the State bank is located at La Fayette, and two other banks have been established under the new law of the State. The Wabash and Erie Canal passes through the v., and intersecting it the New Albany and Salcm Extension R. R. ; and here also the La Fayette and Indianapolis R. R. forms a connection with the foregoing. Plank-roads extend hence to Oxford, Frankfort, Crawfordsville, etc. The situation of La Fayette is a very fine one; the ground rising grad. ually from the river, and the neighboring hills presenting much delightful scenery. It is also surrounded by an extensive body of land, which can not be excelled in fertility, and it abounds with streams, which afford much valuable waterpower. Pop. about 6,000 .

LA FaYeTte, p. v., Linn co., I $a_{0}$ : on a branch of Cedar $r$., $32 \mathrm{~m}$. N. by W. Iowa City.

LA FayetTe, p. 0., Christian co., Ky.: 192 m. S.W. by W. Frank fort.

La Fayetre, p. o., Grafton county, $N$. Hamp.: $66 \mathrm{~m}$. N. by W. Concord,

La FayetTe, p. y., Sussex co., N. Jer.: on Paulinskill r., $58 \mathrm{~m}$. N. Trenton. It contains a furnace, mill, several stores, and 100 inhabitants.

La FaYnetTe, t. and p. o., Onondaga. co., $N . I_{.}: 126 \mathrm{~m}$. W. by N. Albany. Drained E. by Butternut cr., and W. by Onondaga er., which furnish power for several flouring, saw, and grist mills. Surface hilly ; soil a clayey loam, and very productive. In the $N$. W. is a large Indian Reservation, through which the proposed railroad from Binghampton to Syracuse is to pass. Pop. 2,592. 
La Fayette, p. v., Madison co, Ohio: on Deer er., $22 \mathrm{~m}$. W. Columbus, Pop. 147.

La FAyetre, t. and p. o., M'Kean co., Penn.: $142 \mathrm{~m}$ N. W. Harrisburg. Drained by branches of Alleghany $r$. Surface broken, and soil adapted to grass. Pop. 928.

LA Fayetre, p. v., and cap. Macon co., Tenn. : on Long creek, a head of Greene r., 47 m. E. N. E. Nashville. It contains a court-house, jail, a half dozen stores, and 200 inhabitants.

LA FAxetTe, p. 0., Montgomery county, Firg. : $149 \mathrm{~m}$. W. by S. Richmond.

LA FAretre, t, and p. o., Walworth co., Wisc.: $55 \mathrm{~m}$. E. S. E. Madison. The t. has a varied surface, fertile soil and fine mill streams flowing into Fox r. A plank-road passes through to Racine. Pop. of $t .1,008$.

LA FAтETTE, p. v., and cap. Yam Hill cn., Oreg. Ter. at the falls just below the junction of the $\mathrm{N}$. and $\mathrm{S}$. forks of Yam Hill r., $24 \mathrm{~m}$. N. N. W. Salem. The Yam Hill r. is navigable for batteaux to within $3 \mathrm{~m}$. of this place, and empties into the Willamette $r_{\text {., about }} 22 \mathrm{~m}$. above the mouth of Tualatin river.

LA FAYETTE CrTY, p. o, and cap. Jefferson par, $L a$.: on the left bank of the Mississippi, 71 m. S.E. byE. Baton Rouge It is a continuation of New Orleans, and was consolidated under the same municipal government in 1S52. The New Orleans and Carrolton R. R. passes through it, and several ferries cross the river. In 1850 four papers were published, the "State Republican" (whig), and "Statesman" (dem.), semi-weekly; the "Spectator" (whig), weekly; and "German Courier" (dem.), daily. Pop. 14,190.

LA FAyeTte HrL, p. o., Fluvanna county, Firg.: $49 \mathrm{~m}$. W. N. W. Richmond.

La FaxetTe Springs, p, o., La Fajette co., Mfiss. : $135 \mathrm{~m}$ N. N. E. Jackson.

LA FAyetrevilce, p. o, Duchess county, $N_{0} Y_{0}: 47 \mathrm{~m}$ S. by E. Albany.

La FonTalNe, p. o., Harlan co., $K y_{0}: 129$ m. S. S. E. Frankfort.

LA Fontatre, p. o., Wabash co, Ind.: $76 \mathrm{~m}$. N. by E. Indianapolis.

LA Fodrohe INTErIor parish, $L a$. Situate 8. E., and contains 1,337 sq. m. Drained by Bayou La Fourche, which flows S. E. through the length of the co., and Bayou Blue, its $\mathrm{S} . \mathrm{W}$. boundary, both connecting the Mississippi with the Gulf. Along the E. border are Allemande, Washa, and Little lakes, and Barrataria Bay, connected by rivers, and emptying into the Gulf, and smaller ones in the interior. Surface low and level, much of it too wet for tillage. Soil of great productiveness, yielding heavy crops of cotton and sugar, which are the great staples, and universally cultivated. Corn thrives very well, and some rice is grown Farms 235; manuf. 4 ; dwell. 938, and pop $\rightarrow$ wh. 5,143, fr col. 22, sl. 4,363-total 9,533. Capital: Thibodeauxville.

LA Fourche river, $L a_{0}:$ an outlet of the Mississippi, which leaves the river above Donaldsonville, and after a S. E. course of $90 \mathrm{~m}$. falls into the Gulf of Mexico.

LAGADA, p. o., Wilson co., Tenn.: 22 m. E. Nashville.

La Graxge county, Ind. Situate N. E., and contuins 396 sq. m. Drained by Fawn, Pigeon, and Little Elkhart rivers, branches of St. Joseph's of Lake Nichigan; with these are connected many ponds, which feed fine mill streams, and afford excellent water-power. Surface mostly level; abou two-thirds of the county are barrens or oak-openings; the rest is mostly well timbered, and a little prairie. Soil in the openings, a sandy loam; in the forest-lands clay preponderates-everywhere good, and adapted to grain or grass. The openings produce wheat in profusion-the prairie corn, and the wooded parts grass and oats. The produce of all the grains is large, and great numbers of cattle, horses, and swine are raised for market. Farms 1,062; manuf. 64; dwell. 1,479, and pop,-wh. 8,369 , fr. col. 18-total 5,387 . Capitul: La Grange.

LA Grange, p, v., Franklin co, Ala, : 171 m. N. N. W. 360
Montgomery. It occupies a commanding eminence. La Grange College, founded in 1830, is located here. In 1850 it had 5 instructors, 140 alumni, 96 students, and a library of 4,000 volumes.

LA Grange, p. v., and eap. Troup co., $G a$. : on a small branch of Chattahoochie r., $109 \mathrm{~m}$. W. Milledgeville. The $\mathrm{v}$. contains a court-house, jail, 2 academies, several stores, and 600 inhabitants, It is on the La Grange R. R., $15 \mathrm{~m}$. from West Point. The "Citizens' Reporter" is published weekly.

LA GraNGE, p. v., and cap. La Grange co., Ind. : $131 \mathrm{~m}$. N. by E. Indianapolis. It contains a court-house, academy, several large stores, and 500 inhabitants. A plank-road leads hence $12 \mathrm{~m}$, to the $\mathrm{N}$. Indian $\mathrm{P}$. $\mathrm{P}$.

LA Graxge, p. o., Monroe co., Ia.: near Cedar er., 87 W. S. W. Iowa City.

LA Grange, p. v., Oldham county, $\overline{\boldsymbol{K}} y .: 30 \mathrm{~m}$. N. W. Frankfort. The $v$, is on the Louisville and Frankfort $R . R$., $33 \mathrm{~m}$. from Louisville, and is the site of a Masonic College, under the supervision of the Grand Lodge of the State.

LA GraNge, t. and p. o., Penobseot co., Me. : 78 m. N.E. Angusta. Drained by Birch and Pushaw rivers, branches of the Penobseot. Soil good, and well timbered. Lumbering is the chief business. Pop. 482.

LA Graxige, t. and p. v., Cass county, Mich.: $92 \mathrm{~m}$ S.W. by W. Lansing. Drained by affluents of St. Joseph's river, affording good mill-seats. Surface level, well timbered in parts, with prairie in the centre. Soil, superior wheat land. Pop. of t. 1,327.

LA Graxge, p. v., Lewis co., Mo, : on the Mississippi, at the mouth of Wyaconda r., 104 m. N. N. E. Jefferson City. A landing-place, with a few stores.

LA Gratige, p. o., Wyoming county, $N$. $Y .: 224 \mathrm{~m}$. W. Albany.

LA Grange, sta., Erie co., N. $Y_{.:}$on Buffalo and Stato Line R. R., 29 m. from Buffalo.

LA Grange, p. o., Randolph co., $N_{\text {. }}$ Car.: on E, side of Ultarie r., $\$ 2$ m. W. by N. Paleigh.

LA GrANGF, t. and p. 0., Lorain co., Ohio: $97 \mathrm{~m}$. N. N. E. Columbus, Drained by E. and W. branches of Black r., which afford water-power. Surface varied, and soil adapted to grain. The Cleveland, Columbus, and Cincinuati $\mathrm{R} . \mathrm{R}$. passes through it, $29 \mathrm{~m}$. from Cleveland. Pop. 1,402.

LA Gravge, p. 0., Wyoning co., Penn.: 97 m. N. E. by N. Harrisburg.

LA GRANGE, p. $\mathbf{Y}_{\text {, }}$ Fayette co., Tenn.: on the N. side of Wolf er., 181 m. W. S. W. Nashville. The Memphis and Charleston $\mathrm{R}, \mathrm{R}$, passes through this place, which contains an academy, several stores, and 500 inhabitants.

La Grangr, p. va, and cap. Fayeste county, Tex.: $58 \mathrm{~m}$ E. S. E. Austin City. It is pleasantly situated on the lef bank of the Colorado, about $100 \mathrm{~m}$. above its mouth, and contains a court-house, jail, academy, and 700 inhabitants. In the vicinity are quarries of a fine-grained sandstone, and dense forests of pine and cedar, affording the best of building materials in immense quantities.

LA. Gravge, t. and p. o., Walworth co, Wisc.: $44 \mathrm{~m}$. E. S. E. Madison. The t, has an elevated surface, several ponds, and a good soil, producing grain, ete. Pop. 966.

LA Grange BLUFF, p. v., Brown co, Ill.: on the right bank of the Illinois, $47 \mathrm{~m}$. W. by N. Springfield.

LA Grew Springs, p. o, Arkansas co, Ark.: 59 m. S. E. Little Rock.

LAcro, p. V., Wabash county, Ind.: on the $\mathrm{N}$. side of Wabash r. $78 \mathrm{~m}, \mathrm{~N} . \mathrm{N}$. E. Indianapolis. The Salamonie r. here joins the Wabash; the Erie and Wabash Canal passes through the $v_{\text {a, }}$ and plank-roads lead to Marion and Manchester. It has a large trade, and growing manufactures, and 700 inhabitants. The "Indiana Eagle" (dem.) is published weekly.

LA HARPE, p. Vo, Hancoek co, $\Pi_{0}: 87 \mathrm{~m}$. W. N. W. Springfleld.

Lairaska, p. o., Bucks co., Penn. : 98 m. E. Harrisburg. 
LAING's, p. o., Mouroe county, Ohio: 103 m. E. by S. Columbus.

Laixgsburgin, p. 0., Shiawassee co., Mfich.: $31 \mathrm{~m}$. N. E. Lansing.

Lairdstzlle, p. v., Oneida co., N. Y.: $96 \mathrm{~m} . \mathrm{W} . \mathrm{N}$. W. Albany.

Latrdstille, p. o., Lycoming county, Penn.: $74 \mathrm{~m} . \mathrm{N}$. Harrisburg.

LAkE county, $17 l$. Situate N. E. corner, and contains 468 sq. m. Fox $r$. passes $\mathrm{S}$. on or near the W. border, and through Pistakee lake in the N. W. corner, and Des Plaines (or OPlain) r. passes $\mathrm{S}$. through the E., parallel to the shore of Lake Michigan, its E. boundary. It has numerous smaller lakes or ponds, and in the E. several swamps. Surface level or gently undulating; soil very feriile, and much of it prairie, adapted to grain or grass, raising heavy crops of wheat, corm, buckwheat, oats, and potatoes, and feeding great herds of eattle and swine. The dairies are large, and very profitable; pork is a large export, and wool beginning to be. Its lake trade is important, markets convenient, water-power plenty, and is being brought into use. Farms 1,595; manuf, 43 ; dwell. 2,455 , and pop.-wh. 14,187, fr. col. 39-total 14,226. Capital: Waukegan.

LATKE county, Ind. Situate N. W. corner, and contains 469 sq. m. Kankakee $r$. bounds it S., and Lake Michigan $N_{\text {. }}$, and their affluents Calumic, Cedar, and Eagle rivers, etc., drain it. Surface diversified-rgenerally somewhat broken; soil various, on the lake shore sand-hills, covered with dwarf pine and cedar ; farther $\mathrm{S}$. is a rich alluvial tract, and S. of that a sandy loam, and on Kankakee r. large marshes. The central parts are excellent grazing; the $\mathrm{S}$. grows an abundance of grain. A large part is prairie and marl is plentiful. Farms 423; manuf. 5; dwell. 715, and pop.-wh. 3,990, fr. col. 1-total 3,991. Capital: Crown Point. Public Works: Northern Indiana R. R.; Central Michigan R. R.

LAKE county, Wich. Situate W. middle, on Lower Peninsula, and contains 576 sq. m. Drained by Notipecagon or Marquette, and Memoosie rivers, and a branch of Manistee $r$., affluents of Lake Michigan. Its bottoms are well timbered with oak and pine, and the soil is said to be very productive. It is thinly settled, and has been organized since $15 \% 0$.

LAKE county, Ohio. Situate N. E, on Lake Erie, and contains $221 \mathrm{sq} . \mathrm{m}$. Drained by Chagrine and Grand rivers and their branches. Surface rolling, and soil exceeding fertile. Corn and wheat are the leading crops. The other grains thrive well, and the grazing is of the best. Great numbers of cattle and hogs are raised for the Eastern markets, and the growth of wool is very heavy. It has good commercial facilities, and very important manufactures of lumber, flour, leather, iron, liquors, etc. Farms 1,449; manuf. 250 ; dwell. 2,700, and pop.-wh. 14,616, fr. col. 38-total 14,65็. Capital:Painesville. Public Works: Cleveland, Painesville, and Ashtabula R. R.

LAEE, p. 0., Washington county, $N . Y_{.}: 35 \mathrm{~m} . \mathrm{N}$. by E. Albany.

LAKE, t. and p. o., Luzerne county, Pennn: $84 \mathrm{~m}$. N. E. by N., Harrisburg. Surface rough. Bowman's Mountains are in the N., and Harvey's Lake in the E., which furnishes a good mill-stream. Grazing is chiefly attended to. Pop. 730.

LATE, t. and p. O., Stark county, Ohio: $105 \mathrm{~m} . \mathrm{N}$. E. Columbus. Pop. 1,732.

LAKE, sta., Lake co., Ind. : on the Michigan Central R.R., $20 \mathrm{~m}$. W. of Michigan City.

LAKE CARRAWAY, p. o., Carroll par., La.: 151 m. N. by W. Baton linuge.

Iake Ciramplatn (see Champlatn lake).

Laje Charres, p. 0., Calcasieu par., La.: $129 \mathrm{~m} . \mathrm{W}$. Baton Rouge.

LAKE COMfort, p. o., Hyde co., N. Car. : 138 m. E. by $\mathrm{S}$. Raleigh.
Laxe Creek, p. o., Lamar co, Tex.: on an affluent of Sulphur er. so called, 251 m. N. E. by N. Austin City.

Lake Drummond, p. 0., Norfolk co., Virg. : 85 m. S. E. Richmond.

Lane Erte (see Erie lake)

LAKe Grimrix, p. o., Marion en., Flor.: at the head of Oclawaha r., 1SY m. S. E. by E. Tallahassee.

Lake Huron (see Huron lake).

LAkELAND, p. o. and sta., Suffolk co, N. Y.:129 m. S. S. E.

Albany. The station is $49 \mathrm{~m}$. from Brooklyn on the Long Island R. R.

Lake Laxding, p. o., Hyde co., N. Car. : 152 m. E. by S. Raleigh.

Lake Maria, p. v., Marquetta co., Wisco: near the lake of that name, $46 \mathrm{~m}$. N. by E. Madison.

LAKe Miomigan (see Michigan lake).

LAKE Mutus, t. and p. o., Jefferson co., Wise. : $23 \mathrm{~m}$. E. Madison. The $t$, has a fine soil for the grains, good waterpower, and rapidly increasing manufactures. Pop. 884.

LAEE OF THE Desert, Dfich. and Wisc. : an inconsiderable lakelet, about half-way between the mouths of the Montreal and Menomonee rivers, through the former of which it empties into Lake Superior. The boundary line between the Upper Peninsula and the State of Wisconsin passes through its waters.

LAKE ONTARIo (see ONTARIo lake).

Lake Pleasant, t. and p. v., Hamilton co., N. Y.: $65 \mathrm{~m}$. N. W. by N. Albany. Drained by Sacandaga, Cedar, and Jessup's rivers, branches of the Hudson. It extends some $50 \mathrm{~m}$. N. and $\mathrm{S}$, and is mostly a wilderness dotted with beautiful lakes, the largest of which are Round Lake, Lake Emmons, and Lake Pleasant, on the W. shore of which latter is the small village of that name. It affords unsurpassed facilities for hunting and fishing, and is much resorted to for those purposes. Pop. 305 .

LAKEPORT, p. v., Madison co., N. Y.: $112 \mathrm{~m} . \mathrm{W}$. by N. Albany.

Lake Providence, p. v., Carroll par., La.: on the right bank of the Mississippi, $156 \mathrm{~m}$. N. Baton Rouge. It contains a court-house, jail, hospital, several stores and warehouses, and 600 inhabitants. Cotton is shipped in large quantities, and a considerable trade with the interior is carried on. Two newspapers are published here, "Le Republicain" (whig) and the "Carroll Watchman," both weekly issues. The lake consists of an ancient bed of the Mississippi r., which has taken a different course, and in the north and south part the entrance from the river is entirely closed. Its outlet to the $\mathrm{S}$. forms Tensas $\mathrm{r}$. This $\mathrm{v}$, is selected as one of the points from which the Louisiana and Texas R. R ought to commence.

LAKE RIDGE, p. o., Tompkins co., N. Y.: 149 m. W. by S. Albany.

LaKe St, Cratr, Mich.; between Canada and Michigan. It is by far the smallest of the chain of lakes connecting Lake Superior with the Gulf of St. Lawrence. Lat. $42{ }^{\circ} 52$ $\mathrm{N}$, and long $82^{\circ} 25^{\prime} \mathrm{W}$. It is $24 \mathrm{~m}$. long, and in circumference $90 \mathrm{~m}$., and 20 feet deep. Its banks are alluvial, elevated 20 feet above the water, and have an undulating surface. Its principal tributary streams are the Clinton $r$ from the W., and the rivers Chenal, Ecarte, and Thames from Canada. It is a beautiful lake, with clear and transparent waters.

LAKESVILIE, p. ₹., Dorehester co., Mrd.: S. of Little Choptank r., $41 \mathrm{~m}$. S. E. Annapolis.

LAKE SUPERIOR (see SUPERIor lake).

LAKE SWAMP, p. o., ITorry dist., S. Car.: about $4 \mathrm{~m}$. S. of Lumber r., 107 m. E. by N. Columbiء.

LAKETON, p. v., Wabash co., Ind. : about $1 \mathrm{~m}$. W. of Eel r., $88 \mathrm{~m}$. N. by E. Indianapolis.

LAKE VIEW, p. v., Dane co., Wisc.: 6 m. S. by E. Malison. The Milwaukie and Mississippi R. R. will pass through it.

LAKE VIllage, p. v. and sta, Belknap co., N. Hamp. : on an arm of Winnepiseogee Lake, $25 \mathrm{~m}$. N. by E. Concord. 
It is on the Boston, Concord, and Montreal R. I., $29 \mathrm{~m}$. from Concord.

Lakevilie, p. v., Litchfield co., Conn.

LAKEVILL, p. v., Oakland county, Afich.: $71 \mathrm{~m} . \mathrm{E}$. Lansing.

LAKEVILLE, sta., Ashland county, Ohio: on the Ohio and Pennsylvania R. R., $16 \mathrm{~m}$. W. of Wooster. At or near this point, the Springfield, Mount Vernon, and Pittsburg R. R. will intersect the line and form its best and most direct connection with Cincinnati.

Laireville, p. v., Livingston co., $N$. $Y$.: at the N. end of Conesus Lake, $209 \mathrm{~m}$. W. by N. Albany. The Buffalo, Corning, and New York R. R. passes near it.

Lakeville, p. o., St. Joseph county, Ind.: $118 \mathrm{~m} . \mathrm{N}$. Indianapolis.

Lake Wacoaraw, sta., Columbus co., N. Car.: $32 \mathrm{~m}$ W. of Wilmington, on the Wilmington and Manchester R. P.

LAKE Z ZRICH, p. v., Lake county, Ill. : 188 m. N. N. E. Springfield. It is a thriving $\mathrm{v}$, on the borders of a pond so called.

LAMAR county Tex. Situate N. E. on Red r., and contains 1,189 sq. m. Drained N. by Sander's and Upper and Lower Pine creeks of Red r., and \$. by N. fork of Sulphur r. and its affluents, Brigham's, Crockett's, Honey, Hickory, Sandy, Mulberry creeks, etc. Surface diversified, with hills in the $\mathrm{S}$. and a wide belt of river bottom in the $\mathrm{N}$.; soil of great fertility, that on Red $x$, yields almost incredible crops of corn and cotton, and is never failing. The other portions afiord excellent grazing, and good returns of potatoes and grain. Most of the county is heavily timbered with oak, walnut, ash, elm, and cedar. Cotton is the staple. Farms 409 ; manuf. 7; dwell. 497, and pop. $\rightarrow$ wh. 2,593, fr. col. 0 , sl. 1,(IS5-total. 3,973. Cupital: Paris.

LAMAR, p. o., Marshall county, Miss. : 179 m. N. by E. Jackson.

LANar, p. o., Randolph county, Ala: : $77 \mathrm{~m}$. N. N. E. Montgomery.

LAvar, p. v., Refugio co., Tex. : on the N. side of the enrrance into Aransas Bay, $154 \mathrm{~m}$. S. by E. Austin City. It has a favorable position for commerce, having a fine harbor in its vicinity and a limited trade on the coast. Pop. 500.

Laviar, p. v., Lake co., Ill. : $197 \mathrm{~m}$. N. N. E. Springfield.

Lamar, to and p. o., Clinton co., Penn.: $67 \mathrm{~m} . \mathrm{N}$. N. W. Harrisburg. Drained by Big Fishing and Cedar creeks. Surface rugged, with valleys of rich loam. It is well supplied with water-power, and has large flouring and saw mills and extensive iron-works.

Lamartive, p. o., Clarion co., Penn.: 107 m. W. N. W. Harrisburg.

Lavartine, p. o., Washita co., Ark. : 86 m. S. S. W. Little Rock.

Larartine, p. o., Giles county, Tenn.: 69 m. S. by W. Nashville.

Lamartine, p. o., Carroll co., Ohio: 103 m. E. N. E. Columbus.

Lassartine, p. o., Benton eounty, Ala.: 98 m. N. N. E. Montgomery.

Lamartine, to and p. o., Fond du Lac co., Wise. : $66 \mathrm{~m}$. N. E. Matison. It has an even surface, with some waterpower and some low land. Pop. 518.

Laxasco, v., Vanderburg co., Ind.: on the N. side of Ohio r., at the confluences of Little cr., and immediately W. of Evansville. It is a new village founded by Law, $\mathrm{M}^{\mathrm{C}} \mathrm{Call}$, and scott, and is named from the first letters of the several names - La-ma-sco - of those gentlemen. Its prosperity will be developed with that of Evansville.

LAMBertsville, to and p. v., Hunterdon county, N. Jer. : on the E. bank of Delaware r., $14 \mathrm{~m} . \mathrm{N}$. W. by N. Trenton. It has a favorable situation for trade and manufactures, which are prosecuted extensively. The Belvidere Delaware R. R. passes the v. $17 \mathrm{~m}$. from Trenton. A literary weekly, the "Delaware Valley Diarist," is published. Pop. of t. 1,417 .
Lambertvilue, p. O., Monroe co., Mich : 78 m. వ. E。 Lansing.

LAMBURGH, p. v., Iroquois co., Ill. : on the right bank of Kankakee r., 132 m. N. E. Springfield.

LA Mrse, p. o., Cooper co., Moo: on the river so called, about $4 \mathrm{~m}$. S. of the Missouri, $44 \mathrm{~m}$. N. W. Jefferson City.

LA MiNe river, Mo.: a tributary of the Missouri. It rises in Lafayette and Johnson counties, and flowing E. enters the above river 5 or $6 \mathrm{~m}$. above Booneville. It receives the Blackwater about $20 \mathrm{~m}$. from its confluence with the Missouri. These rivers are navigable for keel boats for a considerable distance.

Lamington, p. o., Russell county, $A l a$.: 68 miles E. Montgomery.

LA Mrka, p. o., Belmont co., Ohio : $102 \mathrm{~m}$. E. Columbus.

LAmorile county, Verm. Situate N. W., and contains 454 sq. m. Drained by Lamoille $r$. and its branches, and S. by Waterbury r., a branch of Onion r., both affluents of Lake Champlain. Surface broken and mountainous. The Green Mountains pass through the co. The Mansfield Mountains, a branch of the Green Mountain range, lies in the 8 ., and are among the highest in the State-one summit is 4,279, and another 3,933 feet high. The face of the co. is not prepossessing, being much scarred by rough and rocky elevations, but it has many fertile valleys and much fine pasture. Corn and wheat yield well, but oats and potatoes much better, and grazing is the chief business. The produce of the dairy, live stock, beef, and wool, are the leading exports. The rugged hills are well grown with timber, and the maple furnishes abundance of sugar for consumption and export. The hills are also the sonrces of many streams, which furnish much water-power for its valuable manufactures of leather, woolen goods, and "Yankee notions." Farms 1,082; manuf. 42; dwell. 2,022, and pop.-wh. 10,869, fr. col. 3-total 10,872. Capital: Hyde Park.

LAMoILLE, p. v., Bureau co, Ill. : on a tributary of Illinois $\mathrm{r}$, $128 \mathrm{~m}$. N. Springfield.

LAxorLle river, Term.: a considerable stream rising in Long Pond, on the N. W. border of Caledonia county, whence its course is $\mathrm{W}$. by $\mathrm{N}$. to Lake Champlain, into which it falls, $12 \mathrm{~m}$. N. Burlington. It has numerous tributaries, and its falls produce an immense and valuabie water-power.

LA MorTe, p. V., Jackson co., I $\alpha_{0}: 61 \mathrm{~m}$. N. E. Iowa City.

Lampeter, t. and p. o., Lancaster county, Penn.: $37 \mathrm{~m}$. E. S. E.'Harrisburg. Drained by Mill and Pecquea creeks and Conestoga $r_{n}$ which furnish good water privileges. Surface uneven, and soil fertile and highly cultirated. Leather and woolen goods are made. Pop. 3,556.

Lampsvinie, p. v., Belmont county, Ohio: 108 miles E. Columbus.

LArson's, p. o. and sta., Onondaga co., N. $Y$.: about $1 \mathrm{~m}$. W. of Oswego $\mathrm{r}_{0}, 141 \mathrm{~m}$. W. by N. Albany. The sta. is $18 \mathrm{~m}$. S. of Oswego, on the Oswego and Syracuse R. R.

LAN $\triangle R K$, p. o, Bradley county, Ark.: $69 \mathrm{~m}$. S. by E. Little Rock.

Laveaster county, Penn. Situate S. E., and coutains 933 sq. m. Drained by Conestoga, Pecquea, Conewango, and other creeks, affluents of the Susquehanna, which forms its S. W. boundary. Surface much diversiffed; parts very hilly, and parts with only an agreeable variety of hill and valley; affording much of the most delightful scenery to be found in the Union, particularly on the banks of the Susquehanna. Soil of excellent quality, equally adapted to grass and grain, and under a superior cultivation. Corn, wheat, rye, and oats, produce great crops-the cereal staples. The dairies are large, widely known, and very profttable; beef and pork are important exports, and wool is sheared to a large amount. The streams afford unlimited water-power, which is all employed in manufactures of iron, flour, lumber, woolen and cotton goods, leather, liquors, earthenware, ete. Iron, flour, and lumber, furnaces and mills, employ a large capital, and form a leading interest with the citizens. 
Farms 5,629; manuf. 1,146; dwell. 17,138, and pop.-wh. 95,318, fr. col. 3,626-total 98,944. Capital: Lancaster. Public Works: Philadelphia and Columbia R. R.; Columbia Branch R. R.; Harrisburg and Lancaster R. R.; Tidewater Canal, etc.

LAXCASTER district, S. Cor. Situated N. centrally, and contains 562 sq. m. Bounded W. by Catawba r., E. by Lynch's cr., and drained by their affluents. Surface elerated, and somewhat broken. Soils mostly very fertile. Cotton is the staple product, and very large crops are raised. Corn is the chief cereal, and wheat of a good quality is considerably raised. It has several good water privileges, and some manufactures. Farms 550 ; manuf. 203; dwell. 1,096, and pop.-wh. 5,861, fr. col. 113, sl. 5,014 - total 10,988. Capital: Lancaster.

Lancaster county, Firg. Situate E., at the mouth of Rappahannock r., and contains $96 \mathrm{sq}$. m. The Rappahannock forms its S. W. boundary, and several small creeks flow through the co. into it-among them, Carter's cr., noted for its excellent oysters. Surface varied, with no great elevation. Soil of average fertility, producing chiefly corn and oats. It has good timber, pine and oak in abundance. Farms 299; manuf. 4; dwell. 426, and pop,-wh. 1,805, fr. col. 263, sl. 2,640-total 4,708. Capital: Lancaster Court-house.

LANCASTER, p. ., Cass county, $I l l: ; 21 \mathrm{~m} . \mathrm{W} . \mathrm{N} . \mathrm{W}$. Springfield.

I.ANCASTER, p. v., Jefferson county, Ind.: $72 \mathrm{~m}$. S. S. E. Indianapolis. It lies within $2 \mathrm{~m}$. of the Madison and Indianapolis R. R.

LANCAster, p. v., and cap. Garrard co., Ky. : about $3 \mathrm{~m}$. E. of Dick's r., $42 \mathrm{~m}$. S. S. E. Frankfort. It contains a courthouse, jail, 2 academies, several stores, and 600 inhabitants.

LANCASTER, to and p. v., Worcester co., Mass. : $33 \mathrm{~m}$. W. by N. Boston. Drained by Nashua $\mathbf{r}$, and its W. branch -large streams, which supply fine water-power. Surface much raried - parts are quite hilly, while the rivers are borclered with extensive alluvial meadows; soil generally of superior quality, equally fitted for grass or grain. For farming its facilities are great, and none of them overlooked, and ior manufacturing little inferior. The articles made are numerous and steadily increasing in amount; among them are cotton and woolen goods, boots and shoes, leather, hats, combs, mechanic's tools, cabinet ware, etc. The Worcester and Nashua R. R. passes through the town along the river, and the sta. is $19 \mathrm{~m}$. N. of Worcester. The village is on a plain, at the junction of the two branches of the river, surrounded by hills, and contains an academy, a bank, and several stores. Pop. of t. 1,6s8.

Laticaster, p. v., and cap. Schuyler co., Mo.: $133 \mathrm{~m}$. N. by W. Jefferson City. It contains, a court-house, and several stores and dwellings.

LANOASTER, t., p. v., and eap. Coos co., N. Hamp.: on the Connecticut $\mathrm{r}_{\text {, }}$ along which the $\mathrm{t}$. extends about $10 \mathrm{~m}$. $88 \mathrm{~m}$. N. Concord. Drained by Israel's r. and its branches, which afford good water-power. Surface level, and soil very fertile along the Connecticut; the E. parts are too rugged for tillage, but furnish excellent pasture. The v, extends $N$. from Israel's $\mathbf{r}$, which has several dams on it, about $1 \mathrm{~m}$. from the Connecticut, and contains a courthouse, jail, 2 banks, an academy, and several stores and mills. The "Coos County Democrat" is published here weekly. Pop. of t. 1,559.

I AvOAStER, t., p. v., and sta., Erie co., N. Y.: $258 \mathrm{~m}$. W. by N. Albany. Drained by Ellticott's, Cayuga, and Seneca creeks, on which are several large mills. Surface undulating; soil a rich loam, yielding fine crops of grass and grain. The Buffalo and Rochester R. R. and Buffalo and New York City R. R. cross the township, and the sta. is $10 \mathrm{~m}$. from Buffalo. The $\mathrm{v}$. is on Cayuga cr., and contains? hotels, several mills and stores, and 800 inlabitants. Pop. of t. 3,791

LaYCAETER, p. v., and cap. Fairfield co., Ohio: on the upper part of Hocking r., $27 \mathrm{~m}$. S. E. Columbus. It is well laid out on both sides of the $r$, and contains a court-honse and jail, several large flouring and other mills, extensive machine shops, and many elegant stores. It enjoys a large trade with the surrounding country, and is the outlet of its produce, which here reaches the Hocking Canal $9 \mathrm{~m}$. from its junction with the Ohio Canal. The "Ohio Eagle" (dem.), and "L. Gazette" (whig), both publish daily and weekly editions, and the "L. Telegraph" (dem.), is published weekly. The Wilmington and Zanesville R. R. passes through it. Pop. 3,483.

Lanoaster, t., p. eity, and eap. Lancaster co., Penn.: on the right side of, and $1 \frac{1}{\mathrm{~m}} \mathrm{~m}$. from, Conestoga cr, $18 \mathrm{~m}$. from its confluence with the Susquehanna, and 34 miles E. S. E. Harrisburg. Lat. $40^{\circ} 02^{\prime} 36^{\prime \prime} \mathrm{N}$., and long. $76^{\circ} 20^{\prime} 33^{\prime \prime} \mathrm{W}$ $109 \mathrm{~m}$. N. N. E. Washington. It is a comfortable eity, with wide streets crossing each other at right angles, well paved, and lighted with gas. The city is divided into four wards. Many of the dwellings have an antique appearance, but generally are well built of brick and stone; and the inhabitants are supplied with water by means of an artificial basin and conducting pipes. The court-house is a handsome structure. Pop. in 1810, 5,407; in 1820, 6,663; in 1830, 7,704 ; in 1840, 8,417; and in 1850, 12,365. Previous to 1812 it was the eapital of the State; it was originally chartered as a borough in 1754 , and was incorporated as a city in 1818 . Lancaster is venerable on account of its associations with the past, and remarkable for its modern progress. It has ever been a place of trade, and a main entrepot of the commerce between the sea-board and interior. The rapid increase of the city in later days is owing chiefly to its railroad connections, and the consequent development of the vicinity on account of the increased facilities of travel and transportation. The lines connecting at this point, 70 miles from Philadelphia, and 37 from Harrisburg by route, are the Philadelphia and Columbia R. R., and the Lancaster and Harrisburg $\mathrm{R}_{\text {. R. }}$; forming portions of the great east and west line across the State. The improvements of Conestoga cr. are also available to Lancaster. Numerous manufactures are carried on in the town and eity; it has two large cottors mills, 1 steam furnace, 1 rolling mill, and three forges-the latter using water-power-and a large variety of mechanic shops. Stores of every description are numerous, and have a. large wholesale and retail trade; and the large number of hotels and taverns are evidence of the prosperous condition of the country trade, which requires such accommodation. There are four banks in Lancaster; and there are, besides the manufactures above-named, numerous distilleries, breweries, potteries, printing establishments, binderies, etc. It is also well supplied with churches and schools-one of the latter, a well-endowed institution, and formerly known as Franklin College, founded chiefly by Germans in 1787 ; and has several libraries, and other literary institutions. The public press of the city consists of nine weekly newspapers and one monthly; the latter being the "American Law Journal." The newspapers are, the "Union and Tribune," the "Folks' Friend," the "Examiner and Herald," the "L. Gazette," and the "American Press and Republican" (all whig); the "Lancasterian" and "L. Intelligencer" (both dem.), the "Saturday Express" (temperance), and the " $\mathrm{Co}$ lumbia Spy." The city is surrounded by a very fertile, highly cultivated, and populous country.

LANCASTER, p. v., and cap. Keokuk county, $I c_{*}:$ between Skunk river and its N. fork, $39 \mathrm{~m}$. S. W. Iowa City. It contains a court-house, several stores, and about 800 inhabitants.

LANCASTER, t., p. v., and cap. Grant county, Wisc.: $69 \mathrm{~m}$. W. S. W. Madison. Drained by a branch of Grant r., which has considerable fall. Surface uneven, and soil well adapted to wheat. It is in the mineral region, and has lead veins in the S. part. The v. contains a court-house, high school, several stores, and 300 inhabitants. The "Grant County Herald" (whig) is published weekly. Pop. of t. 1,682. 
Laxcaster, p. ., Smith co., Tenn.: on W. side of Caney fork of Cumberland r., $51 \mathrm{~m}$. E. by S. Nashville.

LANCASTER C. H., p. v., and eap. Laneaster dist., S. Car.: on a small branch of Catawaba r., $48 \mathrm{~m}$. N. by E. Columbia. It contains a court-house, jail, 2 academies, several stores, and 200 inhabitants.

LANCASTER C. H., p. v., and cap. Lancaster co., Virg.: $53 \mathrm{~m}$. E. by N. Pichmond. It contains a court-house and several dwellings.

LAVDAFF, t. and p. o., Grafton county, N. Hamp.: $57 \mathrm{~m}$. N. hy W. Concord. Drained by branches of Ammonoosuc $r$. Surface much broken. Landaff Mountain is in the E. Soil in the lower parts very fertile. Iron ore is found in the north. Pop. 948.

Landiesville, p. o., Lawrence co., Ala.: 157 m.N.N.W. Montgomery.

LANDGRove, t. and p. o., Bennington co., Verm.: $72 \mathrm{~m}$. S. by W. Montpelier. Drained by West r. Surface elevated, and generally too rough for cultivation. Pop. 337.

Landisidrgir, p. v., Perry co., Penn。: 23 m. W. by N. Harrisburg. It contains several stores, and a furnace of 1,100 tons annual capacity.

Landisville, p. o., Lancaster co., Pern.: 26 m. E. by S. Harrisłurg.

Lam of Pronise, p. o., Princess Anne co., Firg.: $102 \mathrm{~m}$. S. E. Richmond.

Lavdsnown, p. o., Prince William co., Virg.: 84 m. N. Richmond.

IAsnsford, p. o., Chester dist., S. Oar.: 2 m.W. Catawba river, $49 \mathrm{~m}$. N. Columbia.

LANE connty, Oreg. Situate S., and contains a large area of perhaps $50,000 \mathrm{sq}$. m. It has Linn $c 0$. on the N., Umpqua co. on the W., between it and the Pacific, and an unorganized region, attached to Umpqua co., on the $\mathrm{S}$. The Cascade range of mountains, which run parallel to the ocean through the territory, crosses the W. part of the co. separating the waters of its streams. West of this range it is drained by Long Tom, Coast, Middle, and M-Kenie's forks, head streams of Willamette $r$., which flows N. into the Columbia, and E. by Fall r, and its branches, pursuing a N. course, and emptying into the Columbia far to the $\mathrm{E}$. of the Willamette. It has fine streams, skirted with noble forests of gigantic growth, and is mostly in possession of the red man. Of its soil and products under cultivation, little is known, it being scarcely settled, and but just organized.

LANE, p. o., Elkhart county, Ind.: $127 \mathrm{~m}$. N. by E. Indianapolis.

L.AVFFIEL, p. v., Traywod m., Tenn.: on S. bank of Forked Deer r., $141 \mathrm{~m}$. W. by 8. Nashville.

LaNesBoro', t. and p. v., Berkshire co., Drass.: $114 \mathrm{~m}$, $\pi$. Wy X. Boston. It consists chiefly of a valley of great fertility, through which flow several heads of Housatonic and IIoosic rivers. The higher parts are excellent grazing land, and the lower highly cultivated and very productive farms. Wool is a heary export; limestone is abundant, and beautiful marble and graphic slate are found. In the S. is a pond much resorted to by fishing parties, and through the E. passes the Pittsfield and North $\Lambda$ dams R. R., East Lanesboro' Station being $6 \mathrm{~m}$. N. of Pittsfield. The $\mathrm{r}$, contains an acadeny and several stores. The new State Prison has recently been located here, Pop. 1,226.

LAxesborolgir, D. O., Anson co. T. Car. : on Lone cr. of Fucky r., 1it m. S. W. by W. Raleigh.

Laxesborotgri, p. r., Susquehanna co., Penn.; on the E. side of Cannewacta cr., $132 \mathrm{~m}$. N. E. by N. Harrisburg. It contains 2 hotels, several mills and tanneries, and 500 inhabitants. The Erie R. R. passes over the $r$. on a tresslo bridge, 450 feet long, and 70 feet above the creek.

L.NiE's Creek, p. O., Lnion co., .1. Cur.: on a branch of Rocky r., $112 \mathrm{~m}$. S. W. by W. Raleigh.

Luxi's Pratrie, p. o., Osage county, Mo.: $36 \mathrm{~m} . \mathrm{S}$. E. Jefferson City.

L.LVESYlLE, p. F., Harrison county, Ind.: $103 \mathrm{~m} . \mathrm{S}$.
Indianapolis. A plank-road passes through from Corydon to New Albany.

Lanesvilie, sta, Marion co., Ind.: on the Indianapolis and Bellefontaine R. $\mathrm{R} v, 9 \mathrm{~m}$. from Indiauapolis.

LanfSVIlle, p. v., FInyd co., $K y_{0}:$ on the W. fork of Big Sandy r., 162 m. E. S. E. Frankfort.

Lanesville, p. O., King William co., Tirg. : 26 m. N. N. E. Richmond.

L.argdos, p. v., Du Page county, Ill.: 164 m. N. N. E. Springfield.

LANGDON, to and p. o., Sullivan co., $N_{\text {. }}$ Hamp.: $41 \mathrm{~m}$. W. by S. Concord. Drained by Cold r. Surface various; soil fertile and well timbered. A farming and grazing town. Pop. $5 \pi 5$.

LANGDON's, sta., Jackson co., Ind.: on the Jeffersonville R. R., $25 \mathrm{~m}$. S. of Columbus.

Lavgharme's Taveri, p. o., Cumberland co., Virg.: 41 m. W. Richmond.

Langlex, p. o., Fairfax co., Virg.: $89 \mathrm{~m}$. N. Richmond.

Laxgsidry, p. o., Camden co., Ga. : near Little St. Illa river, $166 \mathrm{~m}$. S. E. by S. Milledgeville.

Lavgston, p. o., Jackson county, Ala.: about $\tau \mathrm{m}$. E Tennessee r., $145 \mathrm{~m}$. N. by E. Montgomery.

Langstille, p. v., Meigs county, Ohio: $73 \mathrm{~m}$. S. F Columbus.

LAYGuILle, p. o., St. Franȩois co., Ark. : near the branch of St. Francis r. so called, $82 \mathrm{~m}$. E. by N. Little Rock.

Lanier, p. F., and cap. Macon co., Ga.: about $3 \mathrm{~m}$. W. Flint river, $69 \mathrm{~m}$. S. W. Milledgeville. It contains a courthouse, jail, and 150 inhabitants.

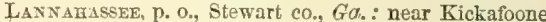
cr. of Flint r., $107 \mathrm{~m}$. S. W. Milledgeville.

Lansing, p. v., Outagamie co., Wisc.: 122 m. N. N. E Madison.

Lansing, t., p. city, and cap. Ingham co., Mich., and cap, of the State of Michigan: on the right or N. bank of Grand river, in a direct line, $4 S 3 \mathrm{~m} . \mathrm{N}$. W. by W. Washington, Lat. $42 \circ 43^{\prime} \mathrm{N}$., and long. $84^{\circ} 29^{\prime} \mathrm{W}$. The $t$. is drained by Grand river, which in the centre receives Cedar r. from the E., and has also several minor streams, all affording an immense hydraulic power. Grand $r$. is here narigable for batteaux; the surface is level, and the soils rich and produetive, yielding the grains and esculent vegetables abuutantly. The city was commenced in 1817 , and on the 25 th December of that year became the permanent seat of the State government; previous to that it was a wilderness, without an inhabitant, It is now a place of considerable pretension, and is future is predestined to be one of prosperity. The streets and squares are well arranged, and its public buildings projected on a scale of more than ordinary elegance. The State House, a large and handsome edifice, surrounded by an inclosed park, is situate on an eminence 50 feet above the river, and overlooking a beautiful region of woodland and intervale. It contains, besides, several steam and water mills for flouring and sawing, and has two fine hotels, about 250 dwellings, and 10 or 12 wholesale and retail stores. Two newspapers, the "Michigan State Journal" (dem.), issned weekly, and the "Primitive Exponnder" (whig), semi-weekly. Pop, of t. 1,226 .

Lassisg, p. vo, and cap. Allemakee co., Ia. : on the right bank of the Miseissippi, $113 \mathrm{~m}$. N. by E. Iowa City. It has a landing on the river, and contains a few stores and dwellings.

Lavsng burg, t. and p. v., Rensselaer $00, N . Y: 0 \mathrm{~m}$ N. by E. Albany. Drained by creeks of Hudson r., which on the W. forms its boundary. Surface near the river level, in the $\mathbf{E}$. somewhat hilly; soil gravelly and clay loam. The village, at the head of sloop navigation, on the Hudson, is a flourishing place, and with streets interseeting at right angles, and contains many substantial and neat buildings. It has 9 churches, numerous stores, wholesale and retail, hotels, groceries, etc., a bank, and several extensive and important manufactures, among which are those 
of fire-arms, brushes, iron and copper ware, oil foor-cloth, ete., and also plaster, flour, and other mills ; it is noted, also, for its malt. Three newspapers are published in the $v$., the "L. Democrat," and the "L. Gazette," both issued weekly, and the "Golden Tiule," a monthly issue. The v. has also sereral schools and a good academy. Several sloops, ete., are owned here, and are employed on the river. The State Dam, between here and Troy, 1,100 feet long and 9 feet high, forms a spacious basin, and by means of a lock enables vessels to come up to this place; and a briclge across the IIudson connects it with Waterford; and the Troy and Boston R. R. passes through it, connecting it with the railroads to the North and South. Pop. in 1840, 3,330, and in $1850,5,752$, of which about 4,300 are in the village. It is one of the most improving villages of the State, and with its present facilities of water and land travel and transportation, must continue to rise in the scale of importance.

Laxsixgfille, p. v., Tompkins co., $N . Y .: 146 \mathrm{~m}$. W. Albany.

LAONA, p. v., Chautauque county, $N_{\text {. }} Y_{\text {. : }}$ on Canadawa creek, $298 \mathrm{~m}$. W. Albany. It is a thriving village, containing several mills and 500 inhabitants.

LaONA, p. v., Winnebago co., Ill. : $192 \mathrm{~m}$. N. Springfield.

LAPEER county, Bfich. Situate S. E., and contains 720 sq. $m$. Drained by Flint $r$, and its branches flowing into Saginaw r. and bay, and Mill cr., Belle r, and N. branch of Clinton r., flowing into. St. Clair r. and lake. Surface gently undulating. The soil is mostly oak-openings; the $\mathrm{N}$. is well wooded with oak, elm, beech, maple, and pinethe last abundant on Flint $\mathbf{r}$., and of excellent quality. Soil on the streams very fertile, and superior for tillage. There is much first-rate pasture between them. Cattle, pork, and grain are the staples. There are many small streams in the co.; all are fine mill-streams, and the water-power is of great value. Farms 625 ; manuf. 45; dwell. 1,286, and pop.-wh. 7,007, fr. col. 22-total 7,029. Capital: Lapeer.

LAPERr, t. and p. o., Cortlandt county, N. Y.: $122 \mathrm{~m}$. W. by \$. Albany. Drained by Tioughnioga ereek and branches. Surface uneven, and soil clayey loam, admirably edapted to grain-growing, which is the chief business. Incorporated in 1845. Pop. 822.

IAPEER, t., p. v., and cap. Lapeer county, Afich.: $66 \mathrm{~m}$. E. by N. Lansing. Drained by Flint $r$, and its branches, which afford much superior water-power. Surface rolling, and soil very fertile. The $\mathrm{v}$. is at the junetion of Farmer's cr. with Flint r., and has abundant water-power in its vicinity. It cnrtains a court-house and jail, an academy, several flouring and other mills, and growing manufactures. The "L. County Demoerat" is published weekly. Pop. of t. 1,467.

Lapiansville, p. v., Kent co., $\Delta F i c h .: 47 \mathrm{~m}$, W. by N. Lansing.

LAPLAND, p. o., Buncombe county, N. Car.: $245 \mathrm{~m}$. W Raleigh.

LA PorNte county, Wisc. Situate N. W., and contains about 4,400 sq. $m$. Drained S. W. by St. Croix r. and its numerous tributaries, S. E. by heads of Chippewa r., all affluents of the Mississippi, and N. by St, Lnuis r., Mashkeg r., Burnt Wood r., and smaller streams flowing N. into Lake Superior, its N. boundary. With its streams are counected many large ponds, affording excellent fish, and much of the $\mathrm{co}$, is covered with swamps. The chief products are fish, game, and furs, and the inhatbitants Indians, bunters, and trappers, with a few traders. Farms 5; manuf. 1; dwell. 74, and pop.-wh. 4S3, fi. col. 6-total 489. Capital: La Pointe.

LA Porste, p. v., La Pointe en., Wisc. : on S. end of Madeline Island, $2 \$ 6 \mathrm{~m}$. N. by W. Madison.

Lapomba, p. o., La Fayette co., Afiss.: 129 m. N. by E. Jackson.

LA PorTe county, Ind. Situate N. W., and contains 552 Bq. m. Drained by Kankakee $r$. and its affluents, Calimuc river and Trail er., the last emptying into Lake Miehignn, where the co. touches the lake in the $\lambda$. W. Suriace undu- lating-prairies, groves, and ponds varying the scenery with sand-hills near the lake, and marshes on the Isankakee. Except near the lake and in the $\delta_{\text {, }}$ the soil is very productive, raising large crops of the grains, and much of it is excellent grazing land. Corn, whear, cattle, and bogs are the farming exports. Its ponds and streams furnish fine water-power, and it enjoys a good share of the lake trade. Farms 1,116; manuf, 122; dwell. 2,124, and pop.wh. 12,070, fr. col. 75-total 12,145. Capital: La Porte. Public Works: Northern Indiana R. P.; New Albany and Salem Extension R. R.; Michigan Central R. R.

LA Porte, p. o, Warren county, Penn.: 166 m. N. W. Harrisburg.

La Porte, p. vo, and cap. La Porte con, Ind.: $12 \mathrm{~S} \mathrm{~m}$. $\mathrm{N}$. by W. Indianapolis. It lies near several ponds on the edge of a prairie, and contains a court-house and jail, 3 bank, an academy and several high schools, and bas an extensive trade in grain and live-stock, with 2,000 inhabitants. The Indiana Medical College is located here, and in 1850 had 7 instructors, 19 alumni, and 104 studenls. The Northern Indiana R. R. passes the v. $58 \mathrm{~m}$. from Chicago. The " $\mathrm{L}$, County Whig" is published weekly.

LA Porte, p. 0, Lorain county, Ohio: 98 m. N. N. E. Columbus.

Lappon's Cross Roads, p. o., Washington co., MFO.: 84 $\mathrm{m} . \mathrm{N}$. W. by W. Annapolis.

Laputa, p. o., Franklin co., $K y_{0}: 8 \mathrm{~m}$. W. Frankfort.

Laredo, p. vo, and cap. Webb co., Texo : on the left bank of the Rio Grande, $227 \mathrm{~m}$. S. W. by W. Austin City. This was an old Spanish settlement of much importance, but through its border position, has lost its superiority. It is surrounded by a fine grazing region, and is rising again as a place of trade. It has steamboat communication with the Gulf cities, is a U.S. military post, and contains a courthouse and 500 inhabitants.

Larissa, p. o., Cherokee county, Tex.: 183 m. E. N. E. Austin City.

LARIINsburg, p. v., Clay county, Ill. : 69 m. S. E. Springfietd.

LARKIN's Fork, p. o., Jackson co., Ala..; on a branch of Tennessee r. so called, $166 \mathrm{~m}$. N. Montgomery.

Larkinsville, p. v., Jackson county, Ala.: $155 \mathrm{~m} . \mathbb{N}$. Montgomery. It contains an academy and 150 ivhabitants. LARNEd's CoRners, p. o., Ontario county, N. Y.: $179 \mathrm{~m}$. W. by N. Albany,

Larome, p. o., Somerset co., Me.: $4 i \mathrm{~m}$. N. Augusta.

Larrabee's Poinr, p. v., Addison co., Vemm.: on the E. side of Lake Champlain, near the entrance of Lake Geurge, $43 \mathrm{~m} . \mathrm{S}, \mathrm{W}$. Montpelier.

Larrx's Crees, p. o, Lycoming county, Penn.: $72 \mathrm{~m}$. N. IIarrisburs.

LA RuE county, $K y$. Situate centrally, and contains 218 sq. m. Drained by Rolling Fork of Salt r., an affuent of the Ohio, and S. fork of Nolin er., in affluent of Green r. Surface various; soil fertile, and grazing excellent. Corn, wheat, and tobacco are staple products. Many hogs, horses, and cattle are raised and exported. Farms 420; manuf. 12; dwell. 845 , and pop.-wl. 5,177, fr. col. 10, sl. 672-total 5,S59. Capital: La Rue.

LA SAlLe county, $17 \%$. Situate N. E., and contains 994 sq. m. Illinois $r$. crosses the middle, and its branclus drain it; N., Fox $r$. and its affluents, Indian and Somonauk creeks; S. Vermillion r. Surface undulating; soil very productive. Much of the co. is dry prairie, and deficient in timber, All the grains produce Iargely, and, with live stock, beef, and pork, constitute the farmers' staples. It has abundance of fine mill streams, and manufictures extensively. Beds of excellent coal yield fuel in abundance for consumption and export. Farms 1,836; manuf. 46; dwell. 8,074, and pop.-wh. 17.799, fr. col. 16-total 17.\$15. Cat,ital: Ottawa. Pullic Works: Illinois and Miehigan Canal; Chicago and Roet Istand R. li.; A urwra Extension R. R.; Illinois Central R. R., ete. 
LA SALLY, t. and p. o., Monroe co., $\not F i c h$, on Lake Erie, $75 \mathrm{~m}$. S. E. Lansing. Drained by Otter cr. and Aux Vases r., small streams, entering the lake. Surface level, and soil somewhat sandy, but finely adapted to wheat and grass. Pop. 1,106.

IA SALLF, p. V., La Salle co., $I Z$. : on the right bank of Illinois $\mathrm{r} ., 86 \mathrm{~m}$. N. by E. Springfield. It is at the junction of the Hlinois and Michigan Canal with the Illinois $\mathrm{r}, 1 \mathrm{~m}$. above Peru. The $r$. is navigable for the largest steamboats, and immense quantities of grain are shipped from this point by $r$, and canal. Huge warehouses line the river bank, and the dwellings occupy the high bluffs a little back. It is chiefly a commercial place, and fast increasing in importance and population. Pop. about 3,000 .

LA SAlle, p. V., Calhoun co., Tero.: on the S. W. shore of Matagorda Bay, 147 m. S. S. E. Austin City. It is a landing place for steamers, and has a small consting trade.

LA SAlle, p. On, Niagara county, N. Y.: $298 \mathrm{~m}$. W. by N. Albany.

Las CASAS, p. v., Rutherford co., Tenn.: 27 m. E. S. E. Nashville.

LABSELLSTILLE, p. v., Fulton co., N..$:$ on a branch of the Mohawk, $52 \mathrm{~m} . \mathrm{N}$. W. by W. Albany.

Lassiter's Mrlis, p. o., Randolph co, $N$. Car. : $71 \mathrm{~m}$. W. Raleigh.

Las Vegas, p. v., San Miguel co., $N$. Mex. : on Gallinas r., a branch of the Pecos, $45 \mathrm{~m}$. (direct) E. by S. Santa Fé. It is on the great route from Fort Leavenworth to Santa FE, and in a sandy valley, made productive by artificial irrigation from the Gallinos, which is a small and sluggish stream. It is well laid out, and mostly built of adobes, or sun-dried bricks. A considerable trade centres here, and it contains several mercantile houses, and about 1,000 inhabitants.

Lamnrop, p. o., Susquehanna co., Penn. : 116 m. N. N. E. IIarrisburg.

Iatoniax Springs, v., Kenton county, Ky.: $4 \mathrm{~m} . \mathrm{S}$. Covington. It is a fashionable watering-place, and is much resorted to in the summer season.

Latrobe, sta., Westmoreland co., Penn. : on W. division of Pennsylvania R. R., $42 \mathrm{~m}$. from Pittsburg.

Lattas, p. o., Ross co., Ohio: $44 \mathrm{~m}$. S. by W. Columbus.

LAtBacir, p. o., Northampton co., Penn. : 83 m. E. N. E. IIarrisburg.

LAUDERDALE county, Ala. Situate N. W., and contains $653 \mathrm{sq} . \mathrm{m}$. It lies between Tennessee $\mathbf{r}$. on the $\mathrm{S}$. and W. and the State of Tennessee on the $\mathrm{N}$., and is drained by Elk r., Blue Water and Cypress creeks, and other affluents of the Tennessee. Surface undulating or slightly broken soil very fertile. Cotton is the staple, of which great crops are raised. Corn grows about as well, and whent yields largely. The pastures are very good, and great numbers of swine are fattened. It has a large supply of water-power, and important and growing manufactures. The Muscle Shoals in the $\mathrm{S}$. $\mathrm{E}$. obstruct the navigation of the Tennes. see, but a long canal has been built around them, and markets are easily accessible. Farms 1.180 ; manuf. 32 ; dwell. 1,86s; and pop.-wh. 10,097, fr. col. 60, sl, 6,015total 17,112. Capital: Florence. Public Works: Musele Shoals Canal, $35 \frac{1}{2} \mathrm{~m}$. long.

LAtderdale county, Miss. Situate E. middle, and contains 703 sq. m. Drained by Chankey, Octibbeha, and Backalony creeks, heads of Chickasawha r., and E. by small aftuents of Tombigbee r. Surface varied; soil of average fertility, producing cotton, corn, and oats, and furnishing mast and grazing for many swine and cattle. It has a good growth of pine forest, and a few good mill streams. Farms 922 ; manuf. 31 ; dwell. 1,008 ; and pop.wh. 5,029, fr. col. 27, sl. 2,661-total 8,717. Capital. Marion.

LAUDERdate county, Tenn. Situate W. middle, and contains $474 \mathrm{sq}$. m. Drained by Forked Deer r. N., and Big Hatchie r. S., affluents of the Mississippi, its W. boundary. Surface pleasantly diversifled, with some low 366 land; soils various, and mostly of great fertility. Corn, cotton, and tobaceo are the agricultural staples. Swine aro fatted in great numbers. It has considerable water power, which is fast coming into use. Farms 287; manuf. 4; dwell. 568, and pop.-wh. 3,397 , fr. col. 6, sl, 1,766-total 5,169. Capital: Ripley,

LAUDERDALE FACTORY, p. v., Lauderdale county, Ala.: $181 \mathrm{~m}$. N. N. W. Montgomery. There is an extensive cotton factory, and a growing v. of 400 inhabitants.

Lauderdale Sprikgs, p. o., Lauderdale co., Miss, : $77 \mathrm{~m}$. E. Jackson.

LAUGHERY ereek, Ind. : an affluent of Ohio r., which it joins $2 \mathrm{~m}$. below Aurora. It is a large and valuable mill stream, and is navigable for flat boats nearly $40 \mathrm{~m}$. from its mouth. It rises in the S. E. corner of Decatar co., and runs through Ripley, Ohio, and Dearborn counties. Captain Langhery"s company was massacred by the Indians on this $\mathrm{cr}$., and hence its name.

Laughlintown, p. v., Westmoreland co., Penn. : $118 \mathrm{~m}$. W. Harrisburg, A charcoal furnace, of 1,400 tons annual capacity, is moved by a small stream near it.

LAURA, p. o., Miami co., Ohio : $69 \mathrm{~m}$. W. Oolumbus.

Ladrame, p. o., Tippecanoe county, Ind.: $65 \mathrm{~m} . \mathrm{N}$. W. Indianapolis.

I.AUReL county, $\bar{K} y$. Situate S. E, and contains $355 \mathrm{sq} . \mathrm{m}$ Drained by Rockcastle and Laurel creeks, branches of Cumberland $\mathrm{r}$. Surface uneven; soil good, better adapted to grazing than grain. Corn is the chief cereal. Attention is mostly directed to the rearing of cattle, horses, and swine, and large numbers are sent to market. Farms 284 manuf. 0 ; dwell. 671 , and pop.-wh. 3,946 , fr. col. 7 , sl. 192-total 4,145. Capital: London. Public Works: Knoxville and Ohio R. R.

Laures, p. F., Sussex county, Del. : on Broad cr. of Nanticoke r., $39 \mathrm{~m}$. S. Dover.

LAUREL, p. o., Franklin co., Ind. : on the W. branch of White Water r., $52 \mathrm{~m}$. E. S. E. Indianapolis. The v. (called Laurel City) is on the Whitewater Canal, and has considerable manufactures, and a large trade, with 600 inhabitanis

LAUres, p. o., Clermont county, Ohio: $86 \mathrm{~m} . \mathrm{S}$. W. Columbus.

LAUREL, p. o., Waslington co., Virg.: on a branch of $\mathrm{S}$. fork of Holston r., $246 \mathrm{~m}$. W. by S. Richmond.

LAUrel, p. o., Marion co., Mo.: $82 \mathrm{~m}$. N. N. E. Jefferson City.

Lauter mountains, Penn., Firg., and Tenn.: a ridge of the Alleghanies, west of the main chain. They extend from Pennsylvania across Virginia to Kentucky, and under the name of Cumberland mountains, divide the two latter States, and cross Tennessee, terminating near its $\mathbf{S}$. border.

LaUrel Bravci, p. o., Henrico co., Virg.

LAUREL Citr, v., Franklin co,, Ind. : on the Whitewater Canal, 14 m. N. W. Brookville.

Latred Creek, p. 0., Fayette co., Tenn.: 151 m. W. S.W. Nashville.

LaUrel FActory, p. ₹., Prince George's con, Md.: on the right bank of Big Patuxent r., $21 \mathrm{~m}$. W. N. W. Annapolis The Washington Branch R. In passes the $v ., 22 \mathrm{~m}$. from Baltimore.

LAURel Fork. p. 0., Bath co., $K y$. : on a er. of Licking r. so called, $66 \mathrm{~m}$. E. Frankfort.

Latrel Gap, p. o., Greene co, Tenn.: on W. side of Lick cr., 219 m. E. Nashville.

Latrel Grove, p. o., Pittsyltania co., Virg. : 118 m. S. W. by W. Richmond

I.AUBer Hill, p. 0., Marengo co., Ala. : on Beaver cr. of Tombigbee r., $82 \mathrm{~m}$. W. by $\mathrm{S}$. Montgomery.

Latrex Hri, p. O., Carroll co., Ga. : about $2 \mathrm{~m}$. S. Tallapoosa r., $122 \mathrm{~m}$. W. by N. Milledgeville.

Laurec Hru, p. 0., Richmond co., N. Car.: near Shoe Heel Swamp, $77 \mathrm{~m}$. S. W. by S. RaJeigh.

Láveer Hru, p. 0., Lunenburg co., Virg. : 54 m. S. W. Richmond. 
Lutrec Hrr., sta., West Feliciana par., La.: 36 m. N. by W. Baton Rouge. The West Feliciana R. R. passes here, 12 miles from Bayou Sara.

LAUReL Mriss, p. o., Rappahannock county, Virg.: $86 \mathrm{~m}$. N. N. W. Richmond.

Laurex Point, p. o., Monongalia county, Firg.: $107 \mathrm{~m}$. N. W. by W. Richmond.

Iadrel Springs. p. o, Ashe co., N. Car.: at the west base of the Blue Ridge, $165 \mathrm{~m}$. W. N. W. Raleigh.

Laurelville, p. v., Westmoreland co, Penn. : $184 \mathrm{~m}$. W. Harrisburg.

LAOREXS county, Ga. Situate S. E. centrally, and contains 763 sq. m. Intersected by Oconee r., and drained by its affluents, Big, Cool Spring, Palmetto, and Mercer's creeks, and north fork of Litile Ocmulgee $r$. Surface considerably broken; soil excellent. Cotton and corn are the staples. It is a fine grazing county, and raises great numbers of cattle and hogs, and has superior dairies. Its water-power is plentiful. Farms 328 ; manuf. 6; dwell. 634, and pop.-wh. 3,459, fr. col. 9, sl. 2,974-total 6,442. Capital: Dublin.

LAURENS district, S. Car. Situate N. W., and contains 926 sq. m. Bounded S. W. by Saluda r., and N. E. by Ennoree r., a branch of Broad r., and drained by their affluents, Reedy and Redburn rivers, and Duncan's cr., all flowing into the Santee. Surface much diversified; in parts hilly; soil of great fertility-producing fine grass, great crops of corn and wheat, and an immense yield of cotton. Cotton is the great staple. Many cattle and sheep are reared, and great quantities of pork fatted. It has superior and abundant water-power, and limestone and marl are extensively found. Its manufactures are large, and much capital is invested in making woolen and cotton goods, leather, Iumber, flour, etc. Farms 1,603; manuf. 141; dwell. 2,132, and pop. -wh. 11,371, fr. col. 83, sl. 11,953-total 23,407. Capital: Laurensville. Public Works: Laurens R. R.

Labreans, t. and p. o., Otsego co., N.Y.: $71 \mathrm{~m}$. W. Albany. Drained by Otsego cr. Surface hilly; soil a rich sandy loam. Farming is very profitable, and the leading interest. Iron ore is found. The r. called Laurensville is on the er., and contains two hotels, a foundry, several stores, and 500 inhabitants. Pop. of t. 2,168.

Latrenstite, p. v., and eap. Laurens dist., S. Car: near the head of Little r., $63 \mathrm{~m}$. W. N. W. Columbia. It stands on high land, and contains a court-house, jail, 3 academies, 15 stores, and 700 inhabitants. The "L. Herald" is published weekly. The p. o. is Laurens $\mathrm{C} . \mathrm{H}$. The Laurens $R$. R. extends hence to Helena, on the Greenville and Columbia R. R.

Latrexs Hinl, p. o., Laurens co., Ga.: near Rocky cr., 39 m. S. Milledgeville.

I iavretra, p. O., Sauk co., Wisc.: 38 m. N. W. Madison.

Lausamse, t. and p. o., Carbon co., Penn.: on the W. side of Lehigh r., $72 \mathrm{~m}$. N. E. Harrisburg. Surface mountainous, and soil unpropitious for farming. It is rich in coal, and the Beaver Meadow mine lies within it. A canal follows the Lehigh, with which several railroads connect the mines.

IATACCA county, Texas. Situate S. E. centrally, and contains 1,064 sq. mo. Drained by Lavacen r., its branches, Frmither's, Clark's, Supple Jack, and Big and Little Brushy creeks, Navidarl $r$, and its branches, Upper and Lower Rocky, Nixon's, and Sandy creeks. Surface mostly undulating, intersected in places by ravines, generally of no great depth; soil a rich black mold near the stream, with a substratum of reddish loam, which, mixed, are of a chocolate color, indicative of, and peculiar to, the finest lands in the State. Back of the rivers is more sandy, but scarcely less fertile. The streams are skirted with heavy timber; between them are a few prairies, Corn and cotton yield enormously, and most other crops are heavy. The grazing is peculiarly fine, and horses and eattle, requiring little or no attention, are reared in great numbers for the eastern markets and exportation. Indigo is easily raised, and peachos, figs, and melons are abundant. Farms 139; manuf. 0; dwell. 203, and pop.-wh. 1,139, fr. col. 0, sl. 432-total 1,571. Dapital: Petersburg.

Lavanstrule, p. Y., Somerset co., Penn.: $117 \mathrm{~m}$. W. by S. Harrisburg.

Latona, p. 0., Lueas co., Oh.: $112 \mathrm{~m}$. N. N.W. Columbus.

LAWN RIDGE, p. o., Marshall county, $I I_{0}: 87 \mathrm{~m}$, north Springfield.

LAWRENCE county, $A l a$. Situate N. W., and contains 758 sq. m. Bounded N. by Tennessee r., and drained by its affluents, and S. by head streams of Black Warrior r. Surface much diversified; in the $\mathrm{S}$. elevated and broken, in the $\mathrm{N}$. less broken, with some marshes; soil of great fertility. Cotton and corn are the leading and almost exclusive staples. The annual yield of each is very large-among the highest in the State. Large numbers of cattle, and especially of swine, are fattened for consumption and export. It has many mill streams and growing manufactures, and excellent facilities for marketing its staples. Farms 930 ; manuf. 24 ; dwell. 1,469, and pop.-wh. 8,343 , fr. col. 63, sl. 6,852-total 15,258. Capital: Moulton. Public Works: Memphis and Charleston R. R.

LAWRENCE county, Ark. Situate N. E., and contains 1,363 sq. m. Big Black r., a branch of White r., runs $\mathrm{S}$. through the $\mathrm{E}$. of the co., and the W. is drained by its affluents, Spring and Strawberry rivers, with their branches, Cache r., another branch of White r., is its E. boundary. Surface in the E. low and level; generally undulating, or slightly broken; soil fertile, adapted equally to grass or grain, and producing superior qualities of both. Corn is the staple. It is an excellent wheat region, and produces good crops of nearly every thing planted. The streams are heavily timbered with pine, ash, and oak, and the forests furnish mast for vast herds of swine. The Big Black is navigable through the co. Farms 601; manuf. 0; dwell. 800, and pop.-wh. 4,882, fr. col. 4, sl. 388-total 5,274. Capital: Smithville.

LAWRENCE county, $I l$. Situate S. E., and contains 354 sq. m. Drained by Embarras $r$. and its branches, and Bompas and Fox creeks, affluents of Wabash r., its E. boundary. Surface undulating or level; soils various; in the $\mathrm{N}$. E. are large swamps, on the Embarras r. rich bottoms, and W. large prairies, with good timber on the streams. Much of the co. is fine land, and in good cultivation. Corn, wheat, beef, and pork are staples. Farms 656; manuf, 26; dwell. 1,057, and pop.-Wh. 5,843, fr. col. 278-total 6,121. Capital: Lawrenceville. Public Works: Cincinnati and St. Louis Railroad.

LAWREXCE county, Ind. Situate S. centrally, and contains 438 sq. m. Intersected by E. fork of White r., and drained by its branches, Indian, Salt, Ieatherwood, and Guthrie's creeks. Surface generally rolling, with some hilly and broken land; soil excellent, and timber abundant. Corn, wheat, pork, cattle, and horses are the chief exports, pork being a very large one. Limestone is found in abundance. Tarms 1,031; manuf. 19; dwell. 2,012, and pop.-wh. 12,003, fr. col. 94-total 12,097. Capital: Bedford. Public Works: New Albany and Salem R. R.

LaWrence county, $K y$. Situate N. E., and contains 442 sq. m. Bounded E. by Big Sandy r., and drained E. by its branches, Westfork and Blanes creeks, and W. by heads of Little Sandy r., flowing N. into the Ohio. Surface moderately billy; soil of great productiveness. Corn is the staple grain; wheat, oats, and rye yield well. This $c 0$. is abundantly supplied with excellent pastures, and grazing is a leading interest. Its cattle and swine are superior, and reared in large numbers for $\mathrm{N}$. and E. markets. Horses of a fine breed are also sent to Virginia and Maryland. It has good salt springs. Farms 65̃ ; manuf. 10; dwell. 989, and pop.-wh. 6,143, fr. col. 1, sl. 137-total 6,251. Capital: Louisa.

LATREENCE county, Miss. Situate S. W., and contains 786 sq. m. Pearl r. passes S. through the co., and its affluents drain it; E., Silver and White Sand creeks, W., Babala cr., 
Fair r., Falling cr., and heads of Bogue Chitto. Surface mostly uncen, without being rough ; soil fertile. Cotton is the leading prodnet; corn and potatses give good returns, and rice is cultivated. Cattle and swine are raised largely. It has good mill streams, and some pine timber. Farms 458 ; manuf. 12 ; divell. 613 , and pop.-wh. 3,549 , fr. col. 0 , sl. 2,929-total 6,473. Capital: Monticello.

LAWRENCE county, MIo. Situate S. W., and eontains 573 sq. m. Drained by Spring r., Centre cr., and Neh-hah $x$. flowing W. and into Arkansas r., and by heads of Sac r. flowing $\mathrm{N}$. into the Osage. The Ozark mountains lie on its E. border, and the surface is much broken, giving rise to many streams and good water-power. The streams are small, but skirted with timber, and, in the lower parts, rich bottoms. The soil is well fitted for grazing, and parts are excellent grain land. Cattle and corn are the staples. Farms 4,107; manuf. 5; dwell. 743 , and pop.-wh. 4,607, fr. col. 4, sl. 245-total 4,559. Cupital: Mount Vernon.

LAWRENoE county, Ohio. Contains an area of $430 \mathrm{sq} . \mathrm{m}$., and is the most S. county in the State. Bounded S. E. and S. by the Ohio, and drained by its affluents, Storm's cr. Symmes cr., and Indian Guyandotte $r$. Surface hilly and broken; soil very produetive, and excellent grazing land. Corn, wheat, and oats yield fine crops, and great numbers of cattle and sheep are reared. Live stock, wool, and pork, are leading agricultural exports. A fine farming co., with plenty of mill-seats, but the great interest is mining the extensive deposits of iron ore and coal that are here so abundant, and manufacturing the iron into castings of all kinds. These employ a large capital and many laborers, and the exports of coal, and pig and cast iron, are very large. Excellent stoneware is made from clay found here. Farms 251; manuf. 29; dwell. 2,553, and pop. - wh. 14,920, fr. col. 326-total 15,246. Capital: Burlington. Public Works: Iron R. R.

LaWpignce county, Penn. Situate W., on State line, and contains $35 \mathrm{~s} \mathrm{sq} . \mathrm{m}$. Drained by Beaver $\mathrm{r}$. and its brauches, Mahoning r., and Shenango and Neshannock creeks. Surface hilly and broken; soil excellent, and water-power abundant All the grains grow well, and produce large crops. It has fine pastures, and raises beef and pork, wool and stock for export. Its greatest resources are its mines of coal and iron, which are very rich and extensive. These are much wrought, and iron is manufictured, both cast and wrought, very largely. For all tits produce good markets are easily accessible in every direction. Farms 1,606; manuf. 49 ; dwell. 3,657 , and pop.-wh. 20,947, fr. col. 182total 21,179. Cuntal: New Castle. Public Wul's: Pennsylvania and Ohio Canal.; Beaver and Erie Canal.

LAWRENCE county, Temn. Situate centrally on S. line, and contains 564 sq. $\mathrm{m}$. Drained by Buffalo r., flowing TV., and Blue Water cr., and Moody's fork, flowing south ints the Tennessee. Surface uneven, and soil furtile. Com and wheat are the staples. A great deal of pork is exportm. It has good mill streams, and extensive manufactures of iron, cotton, leather, and flour. Farms 993; manuf. 43; dwell. 1,364, and pop.-wh. 8,095, fr. col. 23, sl. 1,162-totsl 9.280. Cunitul: Lawrenceburg. Pul.2ic Wuks: Nashville and New Orleans R. R.; Memphis and Naslaville R. R.

LAwrevce, t. and p. va, Van Buren co., Mich.: $81 \mathrm{~m}$. W. S. W. Lansing. Drained by Pawpaw r., which is navigable for balteanx. Surface varied, and soil mostly groul. The village is on the S. side of the Pawpaw. Population of t. 510 .

LAWreNce, sta., Stark county, Ohio: on the Ohio and Pennsylvania R. R., 15 W. of Canton.

LAwrexce, t. and p. o., Washington county, Ohio: $92 \mathrm{~m}$. F.S. E. Columbus, Drained by Little Muskingum r., which has good mill-seats. Surface uneven, and soil fertile. Coal, iron ore, and salt springs are found. Pop. S1.

LaWrevce, t. and p. v., Essex co., DLass. : $26 \mathrm{~m}$. N. by W.

Boston. The Merrimac r., which passes through the t., furnishes an immense water-power, by means of a stone darn 369
900 feet long, with wings 324 and 405 feet, affording a head and fall of $2 S$ feet for the whole river, and a water-power equal to that enjoyed by Lowell. This dam was erected by the Essex Company, organized, with Hon. Abbot Lawrence at its head, in 1815. For manufacturing purposes a canal 5,330 feet long, 100 feet wide at its head, and 60 at its tail, and 12 feet deep, and runuing parallel with the river 400 feet distance, has been excavated, and between the canal and river the space is occupied by the factory buildings. With these facilities, the progress of manufactures and general industry has been rapid and sustained; and numerous mills for the manufacture of cotton and woolen goods, ete., have sprung into existence, chiefly belonging to companies; the Atlantic Cotton Mills employ 1,000 hands, and consume annually 14,000 to 15,000 bales in the manufacture of coarse sheeting and shirting. The Bay State Mills employ about 2,000 hands in the manufacture of woolen goods, and consume between three and four million pounds of wool annually. The Plymouth Company, manufacturing ducks, and the Pacific Mills for the manufacture of bareges, lawns, ete., are also large establishments. The Essex Company, the original owners of the property, have a large machine shop here, at which are manufactured steam-engines, machinery, locomotives, and employ 700 or 800 hands. Paper-hangings are also manufactured by the Charter Paper Company. Besides these, there are various smaller establishments, among which may be named a steam saw-mill, a piano-forte factory, a carriage factory, a steam planing mill, etc. The city is well planned, and contains a town hall, a handsome brick building, 120 feet by 62 , containing the town offices, and a hall capable of containing 1,600 persons; and a common of 18 acres in the centre of the t. has been planted and laid out in walks for the benefit of the inhabitants. There is also a bank in the village. The public buildings and factories are lighted with gas, supplied by the Lawrence Gas Light Company; and water is supplied from a reservoir 150 feet above the canal, and of $1,400,000$ gallons capacity, into which water is pumped by the force pumps of the several mills. Such is the material of the $\mathrm{v}$. or future city. Its religious and edueational welfare is equally well attended to; it has 7 chureh edifices, and 10 religious societies of various denominations; and its school department consists of a high schnol, 2 grammar schools, and 15 others, with an aggregate of $2 S$ teachers, and 1,800 scholars. Provision is also made for public lectures, and a public library. Two newspapers are published in the village, the "L. Courier" (whig), and the "L. Sentinel" (dem.), both weekly issues, and circulating upward of 1,000 copics each. There are 5 railroads centering here, viz., the Lowell and Lawrence R. R., the Boston and Maine R. R., the Essex County R. R., the Newburyport R. R., and the Manchester and Lawrence R. R. Lawrence was taken from Methuen and Andover in 1517, and contains 2,030 aeres, of which area 1,980 acres belonged to the latter, and 2,050 to the former. It took its name from the Lawrence family, the great manufacturing heroes of Massachusetts, and the liberal and enlightened patrons of literature and education. Pop. of t. in $1850,8,283$; in $1852,12,186$; increased 3,902 , or 47 per cent. in two years.

Lawrevce, p. o., Monroe co., Miss. : 18 m. N. E. by N. Jackson.

LATrence, p. o., Marion co., Ind.

LAWrenceiburg, p. city, and cap. Dearborn co., Ind.: on the Ohio, $2 \mathrm{~m}$. below the mouth of the Great Miami, $\pi 9 \mathrm{~m}$. S. E. by E. Indianapolis. It is built on a rich bottom, and the terrace back of it is the outlet for the rich valleys of the Miami, and $W$. Whitewater. The Whitewater Canal terminates here, and furnishes fine water-power. It contains a court-house, bank, several academies, 8 large flouring mills, a very large distillery, and numerous minor manufactories. Its advantages for trade and commerce are great, and the shipping business very heary. The Lawrenceburg and Upper Mississippi $\mathbf{R} . \mathbf{R}$. commences here, and is connected with the Cincinnati and St. Louis R. R. near the city The "Indiana 
Register" (dem.), and "Independent Press," are published weckly. Incorporated a city 1346 . Pop. 3,500.

Lawresceburg, p. v., and eap. Anderson co., $K_{y} y_{*}: 9 \mathrm{~m}$. S. Frankfort. It contains a court-house, jail, academy, and several stores.

Lawrexcenorg, p. v., Armstrong co., Penn.: on the W. bank of Alleghany r., $153 \mathrm{~m}$. W. N. W. Harrisburg. A furnace of 1,400 tons annual capacity is near it, and the Alleghany Valley R. R. passes through it.

Lawrencebure, p. v., and cap. Lawrence co., Tenn.; on Shoal cr. of Tennessee $\mathbf{r}_{n}, 67 \mathrm{~m}$. S. by W. Nashville. It contains a court-house, jail, an academy, high school, a bank, several stores, and 400 inhabitants. A weekly paper, the "Middle Tennessean" (whig), is published.

LAWRENCerokt, p. Y., Lawrence co., Indd. : on Driftwood r., $68 \mathrm{~m}$. S. by W. Indianapolis.

LAWrences, sta, Colleton dist., S. Car.: on the South Carolina H. R., $28 \mathrm{~m}$. from Charleston.

LAWrenceville, p. v., and cap. Monroe county, Ark.: about $4 \mathrm{~m}$. E. of White r., $62 \mathrm{~m}$. E. by S. Little Rock. It contains a court-house and several stores.

LaWrenceville, p. v., and cap. Gwinnett co., Ga.: $81 \mathrm{~m}$. N. W. by N. Milledgeville. It contains a court-house, jail, academy, several Iarge stores, and 350 inhabitants.

LAWREXCEVILLE, p. v., and cap. Lawrence co., $I U$.: on the W. side of Embarras r., 131 m. S. E. by E. Springfield. The $\mathrm{v}$. contains the county buildings, several stores and mills, and 350 inhabitants. The "L. Banner" (whig) is published weekly.

LAWRENCEVILLE, p. Y., Dearborn co., Ind.: $76 \mathrm{~m}$. S. E. Indianapolis.

La reneeville, p. v., Mercer co, N. Ter. : 6 m. N. N. E. Trentou. It contains an academy, several stores, and 200 inhabitants.

LAWRENCEVH.LE, p. v. and sta., St. Lawrence co., $N_{0}, Y_{\text {.: }}$ : $156 \mathrm{~m} . \mathrm{N}$. N. W. Albany. The station is 41 miles $\mathrm{E}$. of Ogdensburg, on the Northern (Ogdensburg) R. R.

Lawrenceville, p. v. and sta., Tioga co, Penn.: on Tioga r., which supplies it with water-power, 112 miles $\mathbb{N}$. by W. Harrisburg. It has a large trade in lumber. The sta. is on the Corning and Blossburg R. R., $15 \mathrm{~m}$. from Corning.

LAWrencevilite, p. o., Henry co., Ala.: 94 m. S. S. E. Montgomery.

LAWRENCEVILLE, p. V., and cap. Brunswick co, Virg.: on a branch of Meherrin r., $55 \mathrm{~m}$. S. S. W. Richmond. It contains a court-house, jail, academy, several stores, and 400 inlrabitants.

Latwsonvilie, p. v., Rockingham co., N. Car.: 77 m. N. W. by W. Raleigh.

Lawsville Centre, p. o, Susquehanna county, Pern.: 118 m. N. N. E. Harrisburg.

Lawton, p. o, Van Buren co., Mich.: 83 m. W. by S. Lansing.

LAw ToNville, p. 0., Beaufort dist., S. Car. : 84 m. S. by W. Columbia.

LAw xersville, p. $\nabla_{\text {. }}$, Schoharie county, $N$. $Y_{0}$ : on the Cobleskill, $36 \mathrm{~m}$. W. by N. Albany. It contains several mills and 200 inhabitants.

LaYsvilizi, p. v., New London co., Conn.

LAYTonsville, p. V., Montgomery co., Md.: W. N. W. Annapolis.

Lazaretro, sta, Delaware county, Pern.: $11 \mathrm{~m}$. from Philadelphia, on the Philadelphia, Wilmington, and Baltimore R. R.

Leachinax, p. o., Buchanan co., Mo.: near the Missouri, $165 \mathrm{~m}$. W. N. W. Jefferson City.

Leacock, t. and p. o., Lancester county, Penn.: $42 \mathrm{~m}$. E. S. E. Harrisburg. Drained by Conestoga and Pecquea creeks. Surface even, and soil rich. It has fine mill streams and large flouring mills, distilleries, and various manufacturing establishments. Pop. 3,829.

LeAdrig CreEk, p. o., Lewis county, Firg.: near the branch of Little Kanawha r, so called, 195 m. W. N. W Richmond.

Leadstille, p. o., Pandolph county, Tirg.: $158 \mathrm{~m}$ N. W. by W. Richmond.

Leadvale, p. o., Jefferson co., Tenn. : 193 m. E. Nashville, LEAKa county, Mis. Situate centrally, and contains 685 sq. $m$. Drained by Pearl $r$. and its branches, Tuscalameta, Yocanucani, and Yalobusha ereeks, which furnish some water-power. Surface pleasantly diversified, without great elevations; soil of average fertility. Cotton is the staple product. Corn yields good crops. Great numbers of eattle and hogs are raised, and beef and bacon are considerable exports. Farms 437; manuf. 4; dwell. 685, and pop.-wh 3,982, fr. col. 2, sl. 1,549-total 5,583. Capitat : Carthage.

LEAKE's STORE, p. 0., Washita co., Ark. : 78 m. 8. 8. W Little Rock.

Lisakesville, p. v., Newton co, Ga.: 48 m. N. W. Milledgeville.

Leakesville, p. v., and cap. Greene co., Miss.: on Chickasawha r., 118 m. S. E. by E. Jackson. It contains a court-house and jail, and a few houses and stores.

Leaksville, p. v., Rockingham co., $N$. Car.: near the confluence of Smith's and Dan rivers, $91 \mathrm{~m} . \mathrm{N}$. W. by W. Raleigh.

LEANDER, p. o., Graves county, $K y_{*}: 229$ m. W. S. W. Frankfort.

Leasbura, p. o., Caswell county, $N$. Car.: on Tycotee.r. $62 \mathrm{~m} . \mathrm{N} . \mathrm{W}$. Raleigh.

Leatimertood, p. o., Guernsey co., Ohio: on the cr. so called, $83 \mathrm{~m}$. E. Columbus.

Leatnekwood, p. o., Clarion co., Penn.: 143 m.W. N.W. Harrisburg, A furnace of 1,400 tons annual capacity is loeated here.

LEATHERWOOD's STORE, p. o., Ilenry co., Virg.: $143 \mathrm{~m}$. S. W. by W. Richmond.

Leavensworth, p. o., Darlington dist., S. Car. $\therefore 59 \mathrm{~m}$. E. N. E. Columbia.

Leaviti, p. o., Carroll county, Ohio: 106 m. E. N..E. Columbus.

Lebaxon county, Penn. Situate S. E. centrally, and contains $876 \mathrm{sq} . \mathrm{m}$. Drained by Swatara cr., an affluent of the Susquehanna, and its branches. Surface moderately uneven, with some broken tracts; soil exceedingly rich, constituting an excellent farming and dairy co., where wheat, rye, corn, oats, and potatoes thrive almost equally, and all produce largely, where eattle and sheep find the best of grass, and the products of the dairy are hardly surpassed. But it has also abundant water-power, good timber, and great quantities of iron ore and coal. Its manufactures are rarious and extensive, but cast and wrought ironware is the most important product. Woolen goods and earthen. ware are largely made. Farms 1,449; manuf. 146 ; dwell. 4,452; and pop.-wh. 25,985, fr. col. 86-total 26;071. Capital: Lebanon. Public Works: Union Canal.

Lebanos, p. v., and cap. De Kalb co., $A l_{\text {. }} \tau_{*}$ : on. W. side of Big Wills er. of Coosa r., $134 \mathrm{~m}$. N. by E: Montgomery. It contains a court-house, jail, U. S. land office, several stores, and 300 inhabitants.

Lebaron, p. v., and cap. Searcy co., Ark. : on the S. side of Buffalo fork of White r., 85 m. N. N. W. Little Rock. The v. consists of a court-house and a few dwellings.

LEBANON, p. o., Laclede county, $\mathbf{M O}_{\mathrm{o}}: 66 \mathrm{~m}$. S. S. W. Jefferson City.

Lebanon, t., p. V., and sta, New London co., Conn. $26 \mathrm{~m}$. E. S. E. Hartford. Drained by branches of Yantic r., which afford numerous mill-seats. Surface hilly, but not rugged; soil a deep mold, and exceedingly fertile. Farming and the dairy engross attention, and their products are not exceeded in amount or quality by any t. in the State. It has also several mills and factories. The New London, Willimantic, and Palmer R. R. crosses the E. part, and the sta. is. $8 \mathrm{~m}$. S. of Willimantic. The $\mathrm{v}$, lies near the centre, and consists of a wide street, about $1 \mathrm{~m}$. long, and mostly, 
though not compactly built, with a flourishing academy. Pop. of t. 1,901.

Lebaros, p. o., Cobb co., Ga.: about $3 \mathrm{~m} . \mathrm{N}$. Chattahoochee r., $95 \mathrm{~m}$. N. W. Milledgeville.

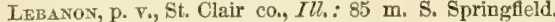
It has considerable manufactures, though destitute of waterpower, and contains an academy, several stores, and 600 inhabitants. $M^{\prime}$ Kendree College, founded in 1835 , is located here, and in 1850 had 9 instructors, 72 alumni, of whom 23 were ministers, 83 students, and 7,000 volumes in its library. The " Illinois Advocate" (Meth.) is published weekly.

Lebanon, p. v., and cap. Boone co., Ind.: $24 \mathrm{~m} . \mathrm{N}$. W. Indianapolis, It contains a court-house, jail, academy, several stores, and 600 inhabitants. The Lafayette and Indianapolis R. R. passes through it, $37 \mathrm{~m}$. from Lafayette.

Lebanon, p. v., and eap. Marion $\mathrm{co}_{.}, K_{y}$ : on a small branch of Salt $x_{\text {., }} 44 \mathrm{~m}$. S. by W. Frankfurts It contains a court-house, jail, several stores and workshops, and 700 inluabitants.

LEBANoN, t. and p. o., York co., Me.: $87 \mathrm{~m} . \mathrm{S}$. W. by S. Augusta. Drained by branches of Salmon Falls r., which separates it from $\mathrm{N}$. Hamp., and furnishes water-power. Surface uneven, and soil well adapted to farming and grazing, which are the leading interests. Pop. 1,473.

LFBANON, t. and p. v., Grafton co., N. Hamp. : on the Connecticutr., 45 m. N.W. Concord. Drained by Mascomy r., which, rising in a pond on its $\mathrm{E}$. line, flows through it into the Connecticut, and affords fine water-power. It contains extensive meadows on both the rivers, and is an excellent farming region. Veins of lead and iron ore are found. The $\mathrm{v}$. is in a plain, near the centre, at the falls of Mascomy r., and has extensive trade, and valuable manufactures. It contains a bank, an academy, and several stores and mills. The "Granite State Whig" is published here weekly. It is on the Northern R. R., 4 m. from its connection with the Vermont Central R. R., at White River Junction. Pop. of $t .2,136$.

Lebaxon, t. and p. v., Hunterdon county, $N_{\text {. }} J_{\text {. }}: 29 \mathrm{~m}$. N. by W. Trenton. Drained by Spruce Run and S. branch of Paritan r. Surface hilly; soil rich loam, well cultivated. The streams furnish many mill-sites, which are much improved in various manufactures. The New Jersey Central R. R. crosses the t., and the sta. is $54 \mathrm{~m}$, from New York. The $\mathrm{v}$, contains an academy, several distilleries and stores, and 500 inhabitants. Pop. of t. 2,127.

Lebaros, t. and p. o., Madison county, $N . Y .: 98 \mathrm{~m}$. W. by N. Albany. Drained by Chenango r. and its branches, which furnish power for many small mills. Surface uneven; soil clayey loam, and very productive of grain. It is a farming $t$. Pop. 1,709.

Lebanos, p. V., and cap. Warren county, Ohio: $72 \mathrm{~m}$. S. W. by W. Columbus. Turtle cr. furnishes some waterpower, and flour, iron, and woolen goods are manufactured. It contains a court-house, jail, and aeademy, and is the terminus of a branch of the Miami Canal. The "Western Star" (whig) is published weekly. Pop. 2,0ss.

Lebanon, p. b., and eap. Lebanon county, Penn.: $24 \mathrm{~m}$. E. by N. Harrisburg. The b. contains a court-house, jail, and other county buildings, an academy, 2 furances, produeing 7,000 tons of iron per annum, a bank, a dozen stores, and several large warehouses on the Union Canal, which passes it $38 \mathrm{~m}$, from Middletown, its terminus, on the Susquehanna. Four weeklies are published, the " $\mathrm{L}$. Courier" (whig), and the "L. Advertiser," "L. Democrat," and "True Democrat" (dem.) Pop. about 3,000. The t. is drained by Swatara cr. and branches, and has an uneven face and generally fertile soil. Leather, earthen ware, and iron are the leading mechanical products. Pop. of t. 7,360 .

Lebanon, p. o., Abbeville dist., S. Car.: $73 \mathrm{~m}$. W. by N. Columbia.

Lebayon, p. v., and cap. Wilson co., Tenn.: on a branch of Cumberland r., $27 \mathrm{~m}$. E. Nashville. It has a pleasant location amid a greut tobacco district, and contains a court$8 \pi$ house, jail, 8 academies, 20 stores, and 1,700 inhobitants In the vicinity are extensive cotton factories. Cumberland. University was founded here in 1844, and in 1850 had 6 instructors, 30 alumni, of whom 21 were ministers, 63 stidents, and a library of 5,000 volumes. Connected with the University is a Law School, which had in 18008 instuctors and 56 students. Two weekiy papers are published, tho "L. Packet" (whig) and "Banner of Peace."

Lebanon, p. Ya, and cap. Russell co., Virg.: near Big Cedar cr. of Cliach r., 163 m. W. by S. Richmond. It contains the county buildings, and several stores and dwellings.

LebanoN Wifte Stlpinue Springs, p. o., Augusta co., Virg.: $86 \mathrm{~m}$. W. N. W. Richmond.

Le ClaTEe, p. F., Scott co., Iq.: on the Mississippi, $62 \mathrm{~m}$. E. by S. Iowa City.

Le Coupte Valley, p. o., (Unknown) co., Utah Ter. LEDliEs, p. o., Meigs co., Ohia: 68 m. S. E. Columbus,

LEDYARD, t. and p. v., New London co., Conn.: on the E. side of Thames r., $42 \mathrm{~m}$. S. E. Hartford. Surface pleasantly diversified; soil mostly productive. Farming is the chief employment. Good granite is found in abundance. The Norwich and Worcester R. R. terminates at Allyn's Point on the Thames, 7. m. S. of Norwich, where is a ferry and a growing village, with a brisk trade, and some commerce. Pop of t. $1,5 \mathrm{ss}$.

LEDYARD, to and p. o., Cayuga co., $N$. Y.: on the E. side of Cayuga Lake, $154 \mathrm{~m}$. W. by N. Albany. Drained by small streams flowing into the lake. Surface rolling. Soil, clay and loam. Marl is abundant, and great crops of grain are raised. In the town are 2 academies. Pop. 2,043.

LEE county, $G a$. Situate S. W., and contains 506 sq. m. Bounded E. by Flint r., and drained by its affluents, Muckalee, Eickafoonee, and other creeks. Surface agreeably varied; soil mostly fertile. Cotton is extensively cultivatecl, and forms the great staple, a very large amount being raised. Other branches of agriculture are little attended to, corn-growing an exception. It has considerable waterpower, which is not much used. Farms 387; manuf. 7; dwell. 550, and pop.-wh. 3,025, fr. col. 8, sl. 3,626-total 6,659. Capital: Starkville.

LEs county, $I l$. Situate N. W. centrally, and contains 718 sq. m. Drained by Rock r., which erosses the $\mathrm{N}$. W. corner, and its branch, Green r. Surface undulating or level; soil very fertile. It has much prairie, interspersed with occasional groves of timber, and some large swamps. Large crops of corn and wheat are grown, and the grazing is excellent. Rock $r$. affords fine water-power, and a bottom of great fertility. Farms 478; manuf. 12; dwell. 905, and pop.-wh. 5,28S, fr. col. 4 -total 5,292. Capital: Dixon.

LEE county, $I a$. Situate S. E. corner, and contains 476 sq. m. Bounded N. E. by Skunk r., E. by Mississippi r., and S. W. by Des Moines r., and drained by their affluents, IIalf Breed and Sugar creeks, etc. Surface pleasantly diversified; soil very productive. A superior farming co., which raises large crops of wheat and corn, affords excellent pasture, and exports live stock, beef, and pork. It has also fine timber, and abundance of water-power, which is much used in manufacturing. Its means, natural and artificial, for transportation of produce and passengers, are extensive, and make it a great thoroughfare for emigration and freight destined E. or S. Farms 1,350; manuf. 78; dwell. 3,252 , and pop. wh. $-18,809$, fr. col. 51-total 18,860. Capital: Fort Madison.

LEE county, Virg. Situate S. W. corner, and contrins 623 sq. m. Drained by Powell's r., a branch of Clinch r., and its affluents, Stone Fork, and Indian, Martin's, and Pigeon creeks. Surface broken, the Cumberland Mountains bounding it $\mathrm{N}$. W., with beautiful valleys. Soil very fertile in the lower parts, and excellent pasturage in the higher. Corn and wheat are grown largely, and are the staple grains. Most arains thrive, and some tobaceo is raised. Grent numbers of cattle and sheep are kept, and large quantities of 
pork exported. It has fine facilities for manufacturing, and plenty of iron ore. Farms 595; manuf. 5 ; dwell 1,536, and pop.-wh. 9,440, fr. col. 40, sl. 787-total 10,267. Capital: Jonesville.

LFe, t. and p. o., Penobseot co., Me.: 106 m. N. E. Augusta. It has several large ponds, which are the sources of Passadumkrag and Mattakeunk rivers, and afford good mill-streams. It produces fine crops of grain, and is well timbered. Pop. 917.

Lee, t. and p. v., Berkshire co., Mass.: 113 m. W. Boston. Drained by Housatonic $r$. and its branches, which supply it with superior water-power. Surface hilly; soil adapted to grazing, with fine farms and meadows on the larger streams. It has fine facilities for manufacturing in its abundant water-power and fuel, and convenient markets, and makes a great variety of articles, among which paper is the most important, and employs a large capital. Other leading articles are cotton and woolen goods, leather, boots and shoes, bar iron, iron castings, mechanical and agricultural implements, cabinet and wooden ware, etc. Excellent iron ore and marble are abundant. The $\mathrm{v}$. contains an academy, a bank, and several stores and workshops, and is $11 \mathrm{~m}$. S. of Pittsfield on the Housatonic R. R. Pop of t. 3,220 .

Lee, t. and p. v., Strafford co., N. Hamp.: 27 m. E. S. E. Concord. Drained by Lamprey $r$, and its branches, which move several saw-mills. Surface uneven, and soil mostly good. Farming is the chief busincss. Pop. S61.

LEE, t. and p. v., Oneida co., N. Y.: $104 \mathrm{~m} . \mathrm{W} . \mathrm{N}$. W. Alhany. Drained by branches of Fish, Wood, and Lansing's creeks, which furnish numerous mill-sites. Surface undulating; soil clayey or sandy loam, and very fertile. It has fine timber, and makes iron, leather, woolens, and flour. Pop. 3,033 .

LEE, t. and p. 0., Athens co., Ohio: 64 m. S. E. Columbus. Pop. 961.

LEE, p. o., Warwick county, Ind.: 124 miles S. S. W. In lianapolis.

LEE, p. v., Ogle co., $I l l$. : $159 \mathrm{~m}$. N. Springfield.

Lefe Cextre, p. v., Lee co., $I l$. : $13 \mathrm{~s}$ m. N. Springfield.

LeE Cristre, p. o., Oneida co., N. Y.: $106 \mathrm{~m}$. W. N. W. Albany

Teechotra, p. $\nabla_{0}$, Armstrong co., Penn.: on the N. bank of Conemaugh r., $143 \mathrm{~m}$. W. by N. Harrisburg. It is on the W. division of the Pennsylvania Canal, $37 \mathrm{~m}$. from Pittsburg.

Learcir rute, p. o., Beaufort co., N. Car.: 112 m. E. by S. Raleigh.

LEEDS, t. and p. v., Kennebec co., Me. : on the E. side of Androseoggin r., $21 \mathrm{~m}$. W. S. W. Augusta. Androscog-

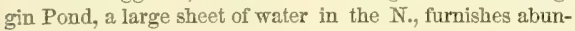
dance of water for manufacturing, which is an important interest, though excelled by farming, for which the soil is excellent. The $\mathrm{r}$, is on the $\mathrm{r}$., and contains an academy and several stores. The Androscoggin R. R. passes through the town, and joins the Androseoggin and Kennebec R. R. in the S. part. Pop. of t. 1,952.

LeEnS, p. o., Hampstire co., MFass. : $95 \mathrm{~m}$. W. by N. Boston.

LEEDs, p. v., Greene co., $N$. Y.: on Catskill cr., $4 \mathrm{~m}$. from Catskill, $28 \mathrm{~m}$. \$. by W. Albany. It contains a hotel, furnace, and several flouring mills, with 300 inhabitants.

LEens Centre, sta., Kennebec co, M $\boldsymbol{M}_{*}:$ on the Androscoggin R. R., $7 \mathrm{~m}$. from its junction with the Androscoggin and Kennebec P. P.

Lexis Maxom, p. o., Fauquier county, Firg.: 86 m. N. Richmond.

Leeds Potrt, p.. ., Atlantic co., N. . Ter.: about $2 \mathrm{~m}$. S. of Little Egg Harbor r., 53 m. \$. \$. E. Trenton.

Leeds Station, p. Oo, Kennebec county, Me.: 17 miles W. \$. W. Augusta. The Androscoggin R. R. here diverges from the Androseoggin and Kennebec R. R., 44 m. from Purtland.

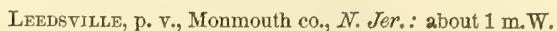
of Navesink r., $33 \mathrm{~m}$. E. by N. Trenton.

Leedstille, p. v., Duchess co., N. Y.: on Ten Mile er $58 \mathrm{~m}$. S. by E. Albany. It contains a bank, several mills, and 450 inhabitants.

LeEpertown, p. v., Bureau county, $I l l .: 116 \mathrm{~m} . \mathrm{N}$ Springfield.

Lefesborougir,

LeEsBurg, p. o. Cherokee co., Ala.,: 126 m. N. N. E. Montgomery.

Leesburg, p. v., Kosciusko co., Ind.: 107 m. N. by E. Indianapolis.

Lembiveg, p. o., Harrison county, Ky.: 31 m. E. by N. Frankfort.

Leesburg, p. v., Highland co., O7io: 62 m. S. W. by \$. Columbus. The Cincinnati, Hillsboro', and Parkersburg R. R. passes the v. $50 \mathrm{~m}$. from Cincinnati.

Leesburk, p. v., Mercer co., Penn.: on the E. side of Neshanock cr., 188 m. W. N. W. Harrisburg. On the creel is a furnace of 900 tons annual capacity.

Leesburg, p. v., Washington county, Tenn.: 235 m. E. Nashville. It contains several stores, a high school, and 200 inhabitants.

Leesburg, p. F., and cap. Loudon co., Virg.: about $2 \mathrm{~m}$. W. of the Potomac, $107 \mathrm{~m}$. N. Richmond: It occupies a commanding position at the base of Kittoctan Mountains. is tastefully laid out, and has a fine aquednct leading from the hills. It contains a court-house and jail, a bank, 3 academies, 30 stores, several manufactories, and about 3,000 inhabitants. The "Washingtonian" and Loudon Chronicle" are published weekly.

LeE"s Cove, p. o., Shelby county, Ala.: 59 m. N. N. W. Montgomery.

LeE's CreeK, p. 0., Clinton county, Ohio: $56 \mathrm{~m}$. S. W. Columbas.

LeE's Cross Roads, p. o., Cumberland co, Penn.: $29 \mathrm{~m}$. W. S. W. Harrisburg.

LEE's Mrlis, p. o., Owen co., Ky.: N. Frankfort.

Leesport, p. o., Berks county, Penn. : 48 m. E. by N. Harrisburg.

LeE"s Ridge, p. 0., Randolph co., Ala. : 73 m. N. N. E. Montgomery.

Leestille, p. v., Middlesex co., Conn.

Lisesville, p. v., Lawrence county, Ind.: 63 miles $\mathrm{S}$. Indianapolis.

LeEsfille, p. v., Hart county, Ky.: on Bacon cr., $74 \mathrm{~m}$. S. S. W. Frankfort.

LEESYILLE, p. v., Schoharie co, $N_{0} Y_{.:} 49 \mathrm{~m} . \mathrm{W}$. by N. Albany.

Leesville, p. v., Robeson co., N. Car.: on a branch of Lumber r., $89 \mathrm{~m}$. S. by W. Raleigh.

Leesville, p. T., Carroll eounty, Ohio: 95 m. E. N. E. Columbus.

LeEsvilue, p. o., Lexington dist., S. Car.: $27 \mathrm{~m}$. W. by S. Columbia.

Leesville, p. V., Campbell co., Virg.: at the junction of Goose er. and Stanton r., 104 m. W. S. W. Richmond. It contains several mills and 150 inhabitants.

Lefisville Cross Roads, p. o., Crawford co., Ohio: $57 \mathrm{~m}$. N. by E. Columbus.

Leetown, p. v., Jefferson co., Firg.: on Ocoquan r., $124 \mathrm{~m}$. N. by W. Richmond. It contains several mills and 200 inhabitants.

Lee Valley, p. o., Hawkins county, Tenn.: $3 \mathrm{~m}$. S. of Clinch r., 236 m. E. by N. Nashville.

LeFerer, p. o., Bartholomew co., Ind: $39 \mathrm{~m}$. S. by E. Indianapolis.

Lefloke, p. o., Carroll eounty, Miss.: $\$ 3$ m. N. by E. Jackson.

Legal Law, p. v., York dist., S. Car. : $6 \pi \mathrm{m}$. N. Columbia Lenr Crtx, v., Utah co.; Utah Ter.: on the E. side of Jordan r., and at the outlet of Utah Lake, $104 \mathrm{~m}$. N. by E. Fillmore City. It is one of the Mormon settlements. 
Leni, p. o., Jefferson co., Ark. : S. S. E. Little Rock.

Leurgir county, Penn. Situate E. middle, and contains $321 \mathrm{sq}$. m. Drained by Lehigh r., which runs on its N. E. border, and its branches. The Blue Ridge occupies the N. border, and parts of the county are broken-most is delightfully varied; soil generally excellent, raising fine crops of wheat, corn, rye, and oats, and feeding large dairies. It has much water-power, and its manufactures are very large. The chief of these is iron, which is found in abundance, with inexhaustible beds of coal in the vicinity. Cotton and woolen goods, powder, leather, stoneware, and distilled liquors are also made. Farms 2,074; manuf. 270; dwell 5,589, and pop.-wh. 32,431, fr. col. 48-total 32,479. Capital: Allentown. Public Works: Philadelphia and Delaware Water Gap R. R.; Easton and Mauch Chunk R. R.

LEHGH river, Penn.: a tributary of Delaware river. It rises in Luzerne county, near Wilkesbarre, and flows about $100 \mathrm{~m}$, to Easton. Along this river, by means of locks, dams, and canals, a navigation is opened from Easton to Whitehaven, $84 \frac{1}{2} \mathrm{~m}$, of which $30_{2}^{t}$ consist of pools, $39 \frac{1}{3}$ of canal, 2 of locks, and the remainder of sluices. This forms a most important opening to the coal mines, to which railroads are continued. The river in its upper part is a rapid mountain stream, with many falls and cascades.

LeHigh Gap, p. v., Carbon co., Penn.: 74 m. E. N. E. Marrisburg. The Lehigh r. here passes through the Blue Mountain, which rises about 1,200 feet above the chanuel on either hand, and forms a spectacle of great grandeur. Water cement is made in the $\mathrm{r}$. from limestone found here. A few miles distant are 2 bloomeries and a charcoal forge, which together make 220 tons of burs per annum, mostly from the magnectic ores of New Jersey.

Lefighton, p. v., Carbon co., Penn. : on Lehigh r., 76 m. N. E. Harrisburg. A bridge crosses the river. In and near the $\mathrm{v}$. are 2 bloomery forges, producing 75 tons of bars per annum, and a charcoal furnace of 2.060 tons capacity.

Lehman, t. and p. 0, Luzerne county, Penn.: $82 \mathrm{~m}$. N. E. by N. Harrisburg. Drained by Lehman's, Harvey's, and other creeks, which furnish fine mill-sites. Surface much broken, and soil good. Farming and grazing are the principal pursuits.

Leicrster, t. and p.. ., Worcester co, Mrss. : $46 \mathrm{~m}$. W Boston. It lies on the highest land between Boston IIarbor and the Connecticut, and has many hills, from which descend branches of Chicopee, Quinnebaug, and Blackstone rivers, affording numerous mill-seats, Surface very uneren, and soil deep and fertile. It contains many excellent farm and large dairies and orchards. Woolen and cotton goods are largely manufactured, and machinery of various kinds, cards, combs, chairs, cabinet-ware, farming implements boots and shoes, etc. The Western $R$. R. has a sta in the E. part $9 \mathrm{~m}$. W. Worcester. The v. is on a hill commanding an extensive and charming riew, is beautifully laid out, and contains a celebrated and well-endowed academy, incorporated in 1784, a bank, several hotels, stores, and workshops, and many elegant mansions. Pop. of t. 2,269 .

Lricester, t. and p. o., Addison co., Verm. : $35 \mathrm{~m}$. S. W. Montpelier. Drained by Otter er, and its branches. Great Trout Pond, a large sheet of water, lies partly in it on the $\mathbf{N}$. Surface broken, and in the E. mountainous; soil, except in the highest parts, a fertile sandy loam, with some clay flats. The Rutland and Burlington $R, R$. crosses the W. part along Otter er. Pop. 596.

LeightoN, p. v., Lawrence co., Ala. : $171 \mathrm{~m}$. N. N. W. Montgomery. The Memphis and Charleston R. R. passes here.

LEIGHTON's, p. 0., Yalabusha co., MFiss.: 118 m. N. by E. Jackison.

Leiantox's Corizes, p. o., Carroll co., N. Hamp. : $85 \mathrm{~m}$. N. E. Concord.

LEIPER's Fork, p. o., Williamson co, Tenn, : on a branch of Harpett r. so called, 22 m. S. S. W. Nashville. Leipergviliz, p. v., Delaware co., Penn.: about 1 m. Fashville. from Delaware r., $84 \mathrm{~m}$. E. by S. Harrisburg. A canal, 2 m. long, leads through it from stone quarries on Ridley's cr to the Delaware.

Lerpsic, p. v., Kent co, Del. : on Little Duck cr., $7 \mathrm{~m}$. N. Dover.

Leipsic, p. o., Putnam co., Ohio: $95 \mathrm{~m}, \mathrm{~N}$. W. by N. Columbus.

Leistrille, p. v., Pickaway county, Ohio: 23 m. S Columbus.

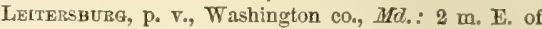
Antietam cr., 77 m. N. W. Annapolis. Pop. 298.

LelaNaU county, Mich. Situate N. W. on Lower Peninsula, and contains $687 \mathrm{sq} . \mathrm{m}$. Bounded W. and $\mathrm{N}$. by Lake Michigan, and N. E. by Grand Traverse Bay, and drained by Betsie r., and other small rivers flowing into the lake. Surface in parts low and marshy, with bold blufis on the lake shore and hills farther back. It has numerous ponds filled with fine fish, and is well timbered, the last being the the chief attraction, as the co. is little settled. It includes Great and Little Manitou islands, which have a beautiful appearance on the water, and are resorted to for hunting and fishing. Unorganized in 1850 .

Leland"s Mru, p. o., Sauk co., Wisc.

LemingtoN, t. and p. o., Essex county, Verm.: on the Connecticut, $67 \mathrm{~m}$. N. E. Montpelier. Drained by several small streams, on one of which is a beautiful cascade of $\mathbf{5 0}$ feet. Surface mountainous, and mostly incapable of cultivation. Pop. 1 s7.

Lemon Place, sta., Lancaster co., Penn.: 12 m. E. of Lancaster, on the Columbia and Philadelphia $\mathrm{R} . \mathbf{R}$.

Lewont, p. v., Cook county, Ill.: 167 m. N. E. by N. Springfield.

Lempster, t. and p. o., Sullivan co., N. Hamp. : 83 m. W. Concord. Drained by heads of Cold and Sugar rivers, which supply water-power. Surface uneven, and in the E. mountainous; soil best adapted to grass. It contains several small manufactories. Pop. 906.

LENAWEE county, DFich. Situate S. E., and contains 739 sq. m. Drained by Raisin r. and its branches, Macon and Little Raisin rivers, and Bear, Wolf, and Evan's ereeks, and N. and S. branches of Raisin r.; and W. by Tiffin's or Bear er. of the Maumee. Surface mostly undulating-in the N. somewhat hilly; soil a bluck, sandy loam, free from stone, and very prolific of wheat, corn, oats, and grass-a superior furming or grazing $\mathrm{co}$. The $\mathrm{S}$. is well timbered. In tho N. W. are several large ponds or lakes, the largest being Michemanetue, or Devil's Lake, Wampler's and Evans's, and the co. is abundantly supplied with excellent waterpower, and has extensive manufactures. Marl is abundant, and good iron ore is found. Wheat, corn, live-stock, beef, and pork are leading exports. Farms 2,470; manuf. 156 ; Awell. 4,892, and pop,-wh. 26,252, fr. col. 90-total 26,372 Capital: Tecumseh. Public Works: Michigan Southern R. R.; Erie and Kalamazoo R. R.; Tecumseh Branch Railroad.

LeNN's CreEk, p. o., Kanawha county, Firg.: 137 m. W. N. W. Richmond.

LFYOIR county, $N$. Car. Situate S. E., and contains 358 sq. m. Intersected by Neuse r., and drained by Mockasin and Trent rivers, and smaller branches of it. Surface mostly level or slightly uneven; soil on the streams rich, but back of them sandy and much less fertile. Corn is the chief crop; wheat, cotton, sweet potatoes, and, in the marshes, rice, are successfully cultivated. It has considerable excellent pine timber and some water-power. Farms 362 ; manuf. 17 ; dwell. 702, and pop.-wh. 3,567 , fr. col. 145 , sl. $4,116-$ total 7,S2S, Capital: Kingston, Public Works: Goldsboro' and Newbern R. R. (projected).

Levorz, p. Y., and cap. Caldwell co., $N$. Car.: $166 \mathrm{~m}$. W. by N. Raleigh. It contains a court-house and jail, and several dwellings.

Lexorn's, p. 0., Roane county, Tenn.: 141 m. E. by S. 
LEvox, t., p. v., and cap. Berkshire co., Mass. : $115 \mathrm{~m}$. W. Boston. Drained by Housatonic r, which flows on its E. border, and affords some water-power. Surface checkered with rugged hills and lovely valleys, and soil very productire. It has rich deposits of iron ore and quarries of beautiful marble, both of which are wrought, but is chiefly a farming town, the attractive scenery of which has made it the favorite retreat of genius, native and foreign, and a summer resort of the beauty and fashion of the land. The $\mathrm{v}$. is neatly built on elevated ground, and contains a court-house, jail, an academy, founded in 1803, and many elegant mansions. The Housatonic R. R. passes along the river, and Lenox sta. is $9 \mathrm{~m}$. S. of Pittsfield. Pop. of ₹. 1,598.

Levox, to and p. Oo, Madison co., N. Y.:108 m. W.N.W. Albany. Drained by Oneida, Canaseraga, Cowaseon, and Chittenango creeks, flowing into Oneida Lake, its $\mathrm{N}$. boundary. It is a large t, and has an extensive swamp in the N. The surface is mostly level, and soil adapted to wheat, and very fertile. It contains an academy, and several manufactories. The Syracuse and Utica $R, R$, and Erie Canal cross the town. On the latter is the v. of Lenox Basin, where are several stores and warehouses, $2 \pi \mathrm{m} . \mathrm{E}$. of Syracuse. Pop. of $t .7,597$.

Lenox, t. and p. o., Ashtabula co., Ohio: $161 \mathrm{~m}$. N. E. Columbus. Drained by branches of Grand $\mathbf{r}$. Surface uneven, and soil generally good. Pop. 781 .

Lexox, t. and p. o., Susquehanna co., Penn.: $112 \mathrm{~m}$ N. E. by N. Harrisburg. Drained by Tunkhannock and Martin's creeks. Surface rough, and soil adapted to pasturage. Timber is largely exported. The Lackawanna and Western R. R. crosses the W. part.

Levox, t. and p. o., $\mathrm{M}^{*} \mathrm{Comb} \mathrm{co}_{\text {. }}, \mathrm{Mi} \mathrm{ch}$ : $87 \mathrm{~m}$. E. Tansing. Drained by branches of Clinton and Saline rivers. It is well timbered, and has a salt spring in the S. part. Pop. 654 .

Levox Castue, p. o., Rockingham co., N. Car.: $78 \mathrm{~m}$ N. W. by W. Raleigh.

LeNox FurNace, p, o., Berkshire co., Dfass. : $116 \mathrm{~m}$. W. Boston.

Lenoxville, p. v., Susquehanna co, Penn.: $116 \mathrm{~m}$. N. E. by N. Harrisburg.

Leo, p. o., Allen co., Ind.: 128 m. N. E. by E. Indianapolis.

LEn. p. o., Tashington co., N. Car.: $119 \mathrm{~m}$. E. Paleigh.

Leo, p. o., Habersham county, $G a_{0}: 107$ m. N. by W. Milledgeville.

Leominster, t. and p. v., Worcester co., Mass.: $37 \mathrm{~m}$. W. N. W. Boston. Drained by branches of Nashua r., on which are many fine mill privileges. Surface moderately uneven, with no large hills; soil clayey and mostly of excellent quality - on the large streams are extensive meadows. Rich rock alum is found. Farming and grazing are the chief occupations; but numerous and various manufactories are operated. Paper, cabinet-ware, boots and shoes, combs, chairs, harnesses, carriages, and mechanics' tools are made. The $\nabla$. contains an academy and several stores. The Fitchburg P. R. and Fitchlurg and Worcester R. R. pass through the t. The station of the latter is $9 \mathrm{~m}$. S. of Fitchbarg. Pop. of t. 3,121.

LEON county, Flor. Situate $\mathbb{N}$. middle, and contains 995 sq. m. Drained by Little and Ocklockony rivers, which bound it W., and St. Marh's r., all flowing into Appalachee Bay. Surface moderately uneven, with low marshes in parts, and largely eovered with a growth of pine; soil various-much is very fertile. It has large ponds or lakes in the $\mathrm{N}_{\text {., }}$ but its streams are small, though furnishing many mill-seats. Cotton is the great staple, and is raised in very large quantities. Corn and sweet potatoes yield well, and some sugar is made. Farms 356 ; manuf. 15; dwell. 737, and pop. - wh. 3,153 , fr. col. 46, sl. 8,203-total 11,432. Crupital: Tallahassee, Public Works: St. Marks and Tallahassee $\mathrm{R} . \mathrm{P}$.

LEON county, Texo. Situate E. centrally, and contains $1,154 \mathrm{~s}$. m. Bounded W. by Navasoto r., a branch of the
Brazos, and E. by Trinity $x$. Drained W. by Birch and Deer creeks; E. by Alligator, Buffalo, Upper and Lower Keechi, Leona, and Boggy creeks. Surface undulating-in the E. are hills of gentle ascent, but no great elevation; soil on the Navasoto and Trinity a deep loam, variously mixed with sand and clay, and of great fertility - in the S., between the rivers, are sandy ridges. Corn and cotton produce great crops, and most of the grains thrive. It is also a fine grazing co., and many cattle and horses are sent to market. On the Trinity are dense forests of excellent timber, but a large portion is prairie, dotted over with post oak groves. The Trinity is a large stream navigable for light draft steamboats, and the Navasoto is boatable in most seasons. Farms 151; manuf. 5; dwell. 231, and pop.-wh. 1,325, fr. col. 0, sl. 621--total 1,946. Capital: Leona.

LEoN, t. and p. o., Cattaraugus co., N. $Y_{0}: 278 \mathrm{~m}$. W. by S. Albany. Drained by Conewango cr., on which are numerous saw-mills. Surface generally level; soil sandy loam. A good farming t. Pop. 1,340.

Leos, p. o., Madison county, Virg.: 78 m. N. W. Richmond.

Lenow, p. On, Ashtabula co., Ohio: 152 m. E. Columbus,

Lrona, p. v., and eap. Leon co., Tex.: about midway between Navasoto and Trinidad rivers, $121 \mathrm{~m}$. N. E. by E. Austin City. It is in a rolling and somewhat sandy region, but sparsely settled, and contains a court-house, jail, and 150 inhabitants.

Leonardtown, p. v., and eap. St. Mary's co., Md. : on the E. side of Britton's Bay, a small branch of the Potomac, $46 \mathrm{~m}$. S. by W. Annapolis. It contains a court-house, jail, academy, several stores, and 350 inhabitants. The "St. Mary's Beacon" is published weekly.

Leonardsville, p. v., Madison co., $N$. $Y_{\text {.: }}$ on Unadilla river, $81 \mathrm{~m}$. W. by N. Albany. It contains several mills and 400 inhabitants.

LæoNI, t. and p. o., Jackson co., Mich.: 36 m. S. S. E. Lansing. Drained by heads of Grand river, flowing from numerous ponds within it, and furnishing mill-seats. Surface undulating, and soil rich loam, producing large crops of grain. The Michigan Central R. R. crosses the $\mathrm{N}$. part. Pop. 290.

LEONidas, t. and p. o., St. Joseph's county, Mich.: on St. Joseph's river, $59 \mathrm{~m}$. S. W. by S. Lansing. Drained by Bear and Pine creeks; soil a fertile prairie. Pop. 858.

Lifopold, p. Y., Perry co., Ind.: about $7 \mathrm{~m}$. from the Ohio, $114 \mathrm{~m}$. S. by W. Indianapolis.

Le Raysville, p. v., Jefferson co., $N . Y .: 142 \mathrm{~m} . \mathrm{N}$. W. Albany.

Le Paysville, p. v., Bradford co., Penn.: 109 m. N. N. E. Harrisburg. It contains an academy, several stores, and 300 inhabitants.

LF Ror, p. v., M.Lean county, $I l l .: 53 \mathrm{~m} . \mathrm{N}$. E. by E. Springfield.

LE Ror, t. and p. v., Genesee co, $N, Y_{*}: 226 \mathrm{~m} . \mathrm{W}$. by N. Albany. Drained by Allen's cr., which affords great waterpower. Surface mostly level; soil sandy loam, and exceedingly productive of wheat and other grain. The Buffalo, Corning, and New York R. R. crosses it. The v. is on the creck, which falls 125 feet within 2 miles, and is largely engaged in manufacturing flour, oil, and leather. It is mostly built of stone, and contains a bank, an academy, 25 stores, sereral large flouring mills, and about 2,000 inlabitants. The "L. Gazette," and "Genesee Courier" (both whig), are published here weekly. Pop. of t, 8,472 .

Le Roy, p. o., Medina county, Ohio: 89 m. N. E. by N. Columbus.

LE Rox, t. and p. 0., Dodge county, Wisc. : $56 \mathrm{~m} . \mathrm{N} . \mathrm{E}$. Madison. The t. has fine land in the E., but the W. is a portion of the great Winnebago Marsh. Pop. 397.

Le Rox, t. and p. o., Bradford county, Penn.: $91 \mathrm{~m} . \mathrm{N}$ Harrisburg. Drained by Towanda creek and its branches which move numerous saw-mills. Surface uneven, and soil good; woolens are manufactured, and lumber exported. 
LE Rox, t. and p. o., Ingham co., Bfich.: 19 m. E. S. E. Lansing. Drained by Cedar $\mathrm{r}$, and its branches. It has a fertile soil, and is well supplied with timber and mill-sites. Pop. 254.

Leslie, t. and p. v., Ingham co., Mich.; 21 m. S. by E. Lansing. Drained by a branch of Grand r. Surface level, and soil finely adapted to grain. Pop. 673 .

LE Sourds ville, p. v., Butler co., Ohio: $\$ 9$ m. W. S. W. Columbus.

Legser Cross RoAds, p. 0., Somerset co., N. Jer.: 34 m. N. Trenton.

Lesslex, p. 0., Benton co., Mo.: on Beaver creek of the Osage, $63 \mathrm{~m}$. W. S. W. Jefferson City.

Lester"s District, p. o., Burke co., Ga.: 84 m. E. by S. Milledgeville.

LestervidLe, p. o., Reynolds co., Mro.: on the E. side of Big Black Water r., 98 m. S. E. Jefferson City.

Letart Falls, p. v., Meigs co., Ohio: on the Ohio r., 92 m. S. E. Columbus.

LETCHER eounty, $K y$. Situate S. E., and contains 305 sq. m. It has the Cumberland Mountains on the S. E., and gives rise to the Kentucky r., by small head streams of which it is drained-Boone's, Carr's, King's, and Line Fork creeks, Surface broken, with fine mill-streams in parts, and many rich bottoms. Soil generally very fertile; corn and oats grow finely, and the pastures are excellent, feeding many cattle, horses, and sheep. Pork is the principal export. Farms 348 ; manuf. 0 ; dwell. 416 , and pop.-wh. 2,440, fr. col. 10, sl. 62-total 2,512. Capital: Whitesburg.

Letcher, p. o., Harlan co., Ky. : 107 m. S. E. Frankfort. LeIcimerville, p. V., Greene co, $I l l_{0}: 48$ m. W. S. W. Springfield.

Letimberville, p. v., Marion county, Otrio: $49 \mathrm{~m} . \mathrm{N}$. Columbus.

LetTer A No. 2, t. and p. o., Oxford county, Me.: $61 \mathrm{~m}$. W. by N. Augusta. Surface elevated, and moslly covered with heavy timber. It is little cultivated. Pop. 108.

Letter B, t. and p. o., Oxford co, Me. : $66 \mathrm{~m}$. W. N. W. Augusta. Lake Umbagog occupies the N, and its affluents afford abundant mill privileges. Soil fertile; lumbering is the chief business. Pop. 174.

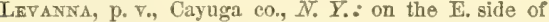
Cayuga Lake, $156 \mathrm{~m}$.W. by N. Albany. It has a steamboat landing, and contains a flouring mill, several warehouses, and 400 inhabitants.

IEVANNA, Y., Brown co., Ohis: on the N. bank of the Ohio r., opposite Dover, 92 m. S. S.W. Columbus. Pop. 174.

Levart, t. and p. v., Penobscot co., MYe.: 59 m. N. E. Augusta. Drained by Kenduskeag $\mathrm{r}_{\text {., }}$ which crosses the E. part, and its branches. Surface uneven, and soil fertile. The $\mathrm{v}$. is on the $r$, which turns several mills. Population of $t .1,842$

Levart, p. y., Chautauque co, $N_{*} Y_{*}:$ on Conewango cr, $287 \mathrm{~m}$. W. by S. Albany.

LEVEE, p. o., Montgomery county, $K y .: 62 \mathrm{~m}$. E. by S. Frankfort

Lever, p. o., Richland dist., S. Car.: on Rice cr., 12 m. $\mathrm{N}$. by E. Culumbia

LEVEL, p. o., Warren county, Ohio: 74 miles W. S. W. Columbus

LeVEi Greex, p. O., Giles county, Firg.: $164 \mathrm{~m}$. W. Richmond.

LEVEXWOETH, p. V., and cap. Crawford co., Ind.: on the Ohio, $107 \mathrm{~m}$. S. Indianapolis. It has a fine landing, and an extensive trade with the interior. In the vicinity is the coa region, and ship timber is abundant. It contains a courthouse, several stores, and 600 inhabitants

LETERETT, t. and p. v., Franklin co., Mrass. $74 \mathrm{~m} . \mathrm{W}$. by N. Boston. Drained by affluenty of the Connecticut, which furnish power for small mills. Surface uneven, with large fertile meadows, and superior pasture land. Farming and grazing form its great interests, but timber is plenty, and much maple sugar is made. Wooden-ware, leather, and $3 \pi 4$ woolens are manufactured. The Amherst and Belchertown R. R. passes through it. Pop. $94 \mathrm{~S}$.

LeVering, p. o., Knox co., Oh.: $43 \mathrm{~m}$. N. by E. Columbus. Levernigton, p. o., Philadelphia county, Penn.: $92 \mathrm{~m}$. E. by $\mathrm{S}$. Harrisburg.

Levi, p. 0., Jackson co., OTio: 78 m. S. S. E. Columbus.

Levy county, Flor. Situate on the neck of the peninsula, W. side, and contains 778 sq. m. Bounded N. W. by Suwanee r., and S. by Withlacoochee r., between which Wakasse, Wakasassa, and Ten Mile creeks enapty into Wakasassa Bay. Surface low and level, and covered extensively with swamps abounding in heavy timber, with occasional dry elevations. Soil, when tillable, very rich, producing abundantly corn, cotton, and semi-tropical fruits and melons. Farmis 0; manuf. 0; dwell. 64; and pop.wh. 320 , fr. col. 0 , sl. 145-total 465, Capital: Wakasassa.

LEwEs, p. v., Sussex co., Del.: 33 m. S. S. E. Dover. It contains an academy, several stores, and 350 inhabitants.

Lewes and Rehobotr, hund., Sussex co., Del.: at the mouth of Delaware Bay, with the Atlantic on the E. and Rehoboth Bay on the S. Has a level surface, sandy soil, and an area of 35,030 acres. The Delaware Breakwater is on its N. coast. Pop. 2,015.

LEwIS county, $K y$. Situate N. E., and contains 316 sq. m. Bounded $N$. by the Ohio, and drained by its affluents, Salt Lick and Kinniconink creeks, and North Lick, a branch of Licking r. Surface uneven, and soil fertile. Corn and wheat are staple cereals. It has good pastures, and raises considerable pork for export. In the N. copperas, limestone, and fine clay for fire-brick and stoneware are found. Farther $\mathrm{S}$, are the Esculapian Springs, a celebrated watering-place, and salt-springs are found. Farms 651; manuf. 21; dwell. 1,223, and pop.-wh. 6,869, fr. col. 11, sl. 322total 7,202. Capital: Clarksburg. Public Works: Covington and Ohio $R$. $R$.

LEwIS county, MO. Situate N. E., and contains 519 sq. m. Bounded E. by the Mississippi, and drained by Wyaconds r., and N., Middle and S. Fabius rivers, and Taylor's fork. Surface rolling or slightly uneven. Soil highly productive, affording excellent grass and grain lands; raising large crops of corn and wheat, and good tobacco, and feeding numerous cattle and sheep. It has fine mill streams, abundance of timber, and growing manufactures. The forests furnish mast for great numbers of swine, and pork is a large article of export. Bituminous coal, salt springs, and lead, exist abundantly in parts. Farms 448; manuf, 15; dwell. 905, and pop.-wh. 5,364, fr. col. 8, sl. 1,206-total 6,578. Capital: Monticello.

LEWIS county, $N . Y$. Situate N., a little E. of Lake Ontario, and contains $1,122 \mathrm{sq}$. $m$. Drained by Black $r$, and its tributaries, Beaver r., Independence r., Otter cr., and Moose river, all E., and several minor ones W.; S. W. by Salmon river of Lake Ontario, and Fish cr. of Lake Oneida, and $\mathrm{N}$. by Indian $r$ and $W$. fork of Oswegatchie r., flowing into the St. Lawrence. Surface in the E. hilly, rising from Black river toward the mountains $\mathrm{E}$. of it: W. rolling, with frequent hills, and an inclination to the W. and S. ; on Black r. are broad allurial flats. Soil various; the bottoms are very fertile; the rest a gravelly, sandy, or elayey loam, produces well under good cultivation, and is especially fitted for pasture. The E. has large forests of pine, spruce, hemlock, beech, maple, and ash. From the maple much sugar is made. Farming and grazing are the chief pursuits. Potatoes, oats, whent, and barley, the chief crops, and the produce of the dairy very large. The streams afford waterpower almost without limit, but it is little used. Flour, lumber, leather, and woolen goods are the chief manufactures. Wool, butter, and cheese, the chief exports. W. of Black r. fine limestone abounds. Superior iron ore is found in abnndance, and lead ore in smaller quantities. Farms 2,374; manuf. 67 ; dwell, 4,624, and pop.-wh. 24,524, fr. col. 40total 24,561. Capital: Martinsburg. Public Works: Black River Canal; Saratoga and Sackett's Harbor R. Puo, eto. 
Lewrs county, Oregon. Situate N. W., and covers an area of about 80,000 sq. m. It has the British Possessions and Strait of Juan de Fuea on the N., the Paciflc on the W., and extends $\mathrm{S}$. to the Columbia, with Pacific co, occupying the corner $N$. of the lower part of that river. There are sereral inlets from the ocean around it; Shoalwater Bay, Gray's Harbor, Hood's Channel, Puget Sound, and Admiralty Inlet, into which flow streams of considerable length, but of difficult or impossible navigation. These are Chikeelis $\mathbf{r}$. of Gray's Harbor, and its branches, $\mathrm{M}^{6}$ Kenzie's Fork, Newankum, and Skukumchuck rivers; and Tenalquit or Shute's and Nisqually rivers, with others of Puget's Sound. It is deficient in harbors, except in the Straits of Fuca, the inlets and mouths of the rivers being obstructed by shifting sandbars, which render their entrance uncertain and hazardous. The rivers abound in fine fish, particularly salmon, and fishing is extensively pursued, furnishing the natives and recent emigrants with a large share of their food. The coast abounds in all varieties of shell-fish, which are taken in great quantities, and furnish an important article of diet. Whales are often caught off the shore, and even in the straits of Fuca Surface broken by spurs of the Cascade Mountains, and much varied. There are dense forests in all parts of excellent timber, pine, fir, spruce, white and red oaks, ask, cedar, and maple. Soil various, from a brown loam to a thin regetable mold, and generally productive of all kinds of grain, corn excepted. The climate is mild, snow seldom remaining longer than a week together, except in the most $\mathrm{N}$. and elevated parts, and free from extremes of heat or cold. This county is little settled, but is scoured by hunters in search of the abundant game and fine furs it produces. Coal is found on the Chilieelis and Cowlitz rivers in abundance. In 1850 it had-Farms 55; manuf. 3 ; dwell. 146, and pop.-wh. 45 \% , fr. col. 101-total 558. Capital: Monticello.

Lewvis county, Ténn. Situate W. middle, and contains 387 sq. m. Drained by Buffalo and Duck rivers, brauches of Tennessee r., and their affluents. Surface pleasantly diversified; soil fertile. Corn is the staple. Wheat and tobaceo grow well, and there is much good grazing land. Pork is largely exported. Farms 394; manuf. 18; dwell. 599 , and pop.-wh. 3,697 , fr. col. 5, sl. 736-total 4,438. Capital: Newburg.

LEWTS county, Firg. Situate N. W., and contains 608 sq. $\mathrm{m}$. Drained by heads of $\mathrm{E}$. and W. forks of Monongahela r., and branches of Little Kanawha r., Leading, Sand, Stone, Coal, and French creeks. Surface elevated and much broken; soil generally very productive, raising good crops of wheat, corn, and potatoes, and furnishing excellent pasture. Large numbers of cattle and sheep are reared, and wool and pork are exported. It has fine mill streams, and many small manufacturing establishments. Coal and iron are found. Farms 878; manuf. 27; dwell. 1,533, and pop.-wh. 9,621, fr. col. 42, sl. 368-total 10,031. Capital : Weston.

LEwIs, p. o., Vigo county, Ind.: 67 miles W. S. W. Indianapolis,

LEwIS, t. and p. o., Essex co., N. Y.: $113 \mathrm{~m}$. N. by F. Albany, Drained by Boquet $r$. and its branches. Surface mountainous in the W., in the E. more even. Soil generally good, and everywhere heavily timbered. It is rich in iran ore, and contains several forges, and numerous mills for sawing lumber. Pop. 2,058.

Lewrs, t. and p. o., Brown co., Otico: on the Ohio, $88 \mathrm{~m}$. S. W. by S. Columbus. Drained by White Oak and Eagle creeks. Surface somewhat uneven, and soil very fertile. Pop. 1,997.

Lewisberrer, p. v., York co., Penn.: 8 m. S. Harrisburg. LEWTSBoRougH, t. and p. o., Westchester co, $N, Y .: 95$ m. S. by E. Albany. Drained by branches of Croton r., its W. boundary. Surface uneven, and soil sandy loam of good fertility. A farming town. Pop. 1,609.

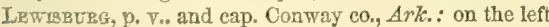

bank of Arkansas r., $37 \mathrm{~m} . \mathrm{N}$. W. Little Rock, It has a good landing, a court-house and jail, and 200 inhabitants.

Lewisburg, p. v., Cass co., Ind.: on the N. bank of Wabash r., $66 \mathrm{~m}$. N. Indianapolis. The Wabash and Erie Canal passes through the $\mathrm{v} ., 8 \mathrm{~m}$. from Logansport.

Lewisidra, p. v., Preble county, Oh.: $81 \mathrm{~m}$. W. by S. Columbus.

LewISBURG, $\mathbf{7}$, Champaign county, Oh.: $51 \mathrm{~m}$. W. by N. Columbus. Pop. 302.

Lewisburg, p. b., Union co., Penn.: on the right bank of Susquehanna r., just below the mouth of Buffalo cr., 48 $\mathrm{m}$. N. by W. Harrisburg. A short branch crossing the river connects it with the W. branch division of the Pennsylvania Canal. It has a brisk trade in farming products, and con. tains an academy and about 20 stores. A college wvas founded here by the Baptists in 1849, and in 1851 had 5 instructors and 46 students. Three newspapers are published, "Der Christliche Botschafter," a religious semi-monthly, in German, and the "L. Democrat" (dem.), and "L. Chronicle" (independent), weekly. Pop. 2,012.

Lewisburg, p. V., and eap. Marshall co., Tenn. : near a branch of Duck r., $43 \mathrm{~m}$. $\mathrm{S}$. Nashville. It is the centre of a rich corn region, and contains a court-house, jail, several stores, and 300 inhabitants.

Lewisberg, p. v., and cap. Greenbrier co., Firg.: 162 m. W. by N. Richmond. It contains a court-house and jail, two academies, several large stores, and about 1,000 inhabitants. Within a few miles are the celebrated White and Blue Sulphur Springs, which are reached through the v., and add much to its other attractions. The " $\mathrm{L}$. Chronicle" is issued weekly.

LEWIS' Fork, p. o., Wilkes co., N. Car.: on a branch of Yadkin r. so called, $162 \mathrm{~m}$. W. N. W. Raleigh.

LEWISPORT, p. v., Hancock co., Ky.: on the S. bank of the Ohio, $112 \mathrm{~m}$. W. by S. Frankfort. It contains 3 stores, 30 houses, and 250 inhabitants.

LEWIs' STORE, p. o., Spottsylvania co., Virg.: $47 \mathrm{~m}$. N. by W. Richmond.

Lewiston, Virg. See Lunenburg C. H.

LEwiston, t. and p. v., Niagara co., $N . Y_{.}:$on the E. side of Niugara r., $278 \mathrm{~m}$. W. by N. Albany. Surface generally level; soil calcareous or sandy loam, and mostly fertile. The Rochester, Lockport, and Niacara Falls $R$. R. passes through it, and a branch extends to the v. The v., at the head of steamboat navigation, $7 \mathrm{~m}$. from Lake Ontario, has a good landing and constant communication, and an extensive trade with most of the lake ports. A ferry connects it with Queenstown, and railroads leading west. It contains an academy, about 20 stores and warehouses, and 1,000 inhabitants. Pop. of t. 2,938.

Lewistox, t, and p. v., Lincoln co., Mre.: on the E. side of Androscogrin r., $28 \mathrm{~m} . \mathrm{S}$. W. Augusta. The t. stretches along the $\mathrm{r}$. about $13 \mathrm{~m}$., and has a fine soil, which is well cultivated. The leading interest is manufactures, and cen. tres in the r., on the r., which descends about 50 feet in 15 rods, A dam has been thrown across it, and almost unlim. ited water-power obtained. Large cotton-mills are built, and it bids fair to become one of the large manufacturing places of the Union. A bridge, 1,000 feet long, connects it with Auburn, on the opposite side. The Androscoggin and Kennebec R. R. passes it, $33 \mathrm{~m}$. from. Portland. The " $\mathrm{L}$. Falls Journal" (neut,) is published weekly. Pop. of t. 3,581 . LEwistows, p. v., and cap. Fulton co., $7 l_{.}:$about $4 \mathrm{~m}$. from Spoon r., $48 \mathrm{~m}$. N. W. Springfield. It contains a courthouse, jail, high school, and about 400 inhabitants.

Lewistown, p. V., Logan co., Oh.: on the E. side of Miami r., $56 \mathrm{~m}$. N. W. by W. Columbus.

Lewistown, p. b., and cap. Mifflin co., Penn.: on the N. side Juniata r, at the mouth of Kisheoquil cr., $43 \mathrm{~m} . \mathrm{N}$. W. by W. Harrisburg. It is regularly laid out, with a square in the centre, containing the court-house and other co. buildings. It also contains an academy, 25 stores, a furnace of 1,800 tons capacity, and a force producing 500 tons of blooms 
per annum. In the vicinity are mineral springs, and a furnace of 1,600 tons capacity. The "L. Gazette" (whig) and "True Democrat" (dem.) are published weekly. The Pennsylvania Canal passes through it, $88 \mathrm{~m}$. from Hollidaysburg, and the Eastern division of the Pennsylvania P. R., $61 \mathrm{~m}$. from Harrisburg. Pop. 2,735.

Lewisvicle, p. v., and cap. Lafayette co., Ark. : about 6 m. E. of Red r., and $126 \mathrm{~m}$. S. W. Little Rock. It is surrounded by rich cotton and corn plantations, and contains a courthouse, a few stores, and 200 inhabitants.

Lewisvilie, p. v., Monroe co., Ohio: $92 \mathrm{~m}$. E. by S. Columbus.

Lewisville, p. v., Henry co., Ind.: on the E. side of Flat Rock cr., 39 m. E. Indianapolis. The Indiana Central R. R. passes near it.

Lewisvilte, p. o., Chester dist., $S$. Car. : near Fishing cr., $48 \mathrm{~m}$. N. by E. Columbia.

Lewisvillie, sta., Orangeburg dist., S. Car.; on the Columbia Branch R. R., $87 \mathrm{~m}$. from Columbia.

Lewtsville, p. 0., Brunswick co., Virg.: 62 m. S. by W. Pichmond.

Lewisville, p. จ., Chester co., Penn.: 62 m. E. S. E. Harrisburg.

LexingtoN district, $S$. Car. Situate W. centrally, and contains 884 sq. m. Drained by N. Edisto r, its S. W. boundary; Saluda $\mathrm{r}$. and its branches in the N., and Broad r., which, uniting with the Saluda, takes the name of Congaree r., and forms the N. E. boundary, and has small affluents, which drain the central and E. portions. Surface diversified, with moderate swells, and a few considerable elevations. Soil generally of good quality, producing cotton, corn, wheat, and potatoes largely, and furnishing pasture for large numbers of cattle. Some of the low lands grow good rice in small quantities. It has much water-power along its rivers, a part of which is profitably employed in manufactures. Farms 837 ; manuf. 40 ; dwell. 1,312, and pop.-wh. 7,352, fr. col. 21, sl. 5,557-total 12,930. Capital: Lexington.

Lexington, p. o., Lauderdale co., Ala.: about $3 \mathrm{~m}$. E. Blue Water creek of the Tennessee, 184 miles N. by W. Montgomery.

LexingtoN, p. v., and cap. Oglethorpe co., Ga. : 59 m. N. Milledgeville. It contaius a court-house, jail, a well-endowed academy, a public library, 20 stores, and 300 inhabitants. The Athens branch of Georgia R. R. passes a little W. of the v., $17 \mathrm{~m}$. from Athens.

Lexington, p. Y., M'Lean co., $I l l$.: about $2 \mathrm{~m}$. N. of Mackinau er., 74 m. N. E. Springfield.

LexingtoN, p. F., and eap. Scott co., Ind, : 81 m. \$. S. E. Indianapolis. It is connected with Madison by a plankroad, and contains a court-house and 600 inhabitants.

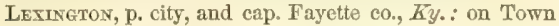
branch of Elkhorn r., 24 m. E. S. E. Frankfort. Lat. $36^{\circ} 6^{\prime}$ N., and long. $84^{\circ} 18^{\prime} \mathrm{W}$, and by railroad distant from Louisville $65 \mathrm{~m}$, from Covington $96 \mathrm{~m}$, from Maysville $75 \mathrm{~m}$, from Danville $85 \mathrm{~m}$., from Nashville $187 \mathrm{~m}$., from Savannah $716 \mathrm{~m}$., from Charleston $732 \mathrm{~m}$, and from Mobile $975 \mathrm{~m}$. It is one of the oldest cities of Kentucky, and was formerly capital of the State. The city occupies a square of $2 \mathrm{~m}$, and is laid out in wide, rectangular streets, the main street being 80 feet wide, and containing many elegant buildings. There is a square in the centre of the city, upon which is the market-house. The public edifices are generally of brick, and substantially built, as are also many of the stores and dwellings. The public buildings are the court-house, jail, and several literary and benevolent institutions, etc. Transylvania University is the oldest college in the State, having been established in 1798 ; it has departments of law and medicine, and every department is in a flourishing condition. The University Hall and Medical College are fine buildings. The State Lunatic Asylum is also located here, and is a noble institution. Lexington has several manufuctories and large tobacco warehouses, and its trade with the 376 interior is extensive. It is the head-quarters of the Northern Bank of Kentucky, and there is also a branch of the Bank of Kentucky. The newspapers published here are the "Kentucky Statesman" (dem.) and the "Obscrver and Reporter" (whig), both semi-weekly issues, and the "Locomotive" (neutral), a daily paper. The railroads diverging from Lexington are the Louisville and Lexington R. R., the Frankfort and Lexington $\mathbf{R}$. $\mathbf{R}$, the Covington and Lexington R. R., the Maysville and Lexington R. R., the Lexington and Danville R. R., ete. There are also several turnpikes diverging from the city. About $1 \frac{1}{\mathrm{r}} \mathrm{m} . \mathrm{S}$. E. of the City is Ashland, the seat of the late lamented statesman, Hon. Henry Clay, and there are many others in the vicinity which give tone and character to the country. Lexington was settled about 1779 ; incorporated by the Virginia Legislature in 1782 , and was chartered as a city in 1831.

Lestrgton, t. and p. o., Somerset co., $\boldsymbol{M e}$.: $51 \mathrm{~m} . \mathbf{N} . \mathbf{N} . \mathrm{W}$. Augusta. It has several ponds flowing into Seven Mile branch of Kennebec $r_{\text {., }}$ and affording fine mill-seats. Surface uneven; soil fertile. Timber forms the chief source of wealth. Pop. 538.

Lexington, t. and p.. ., Middlesex co., Mass. : $10 \mathrm{~m}$. N. W. Boston. Drained by branches of Shawsheen $r$. Surface pleasantly varied, with many hills and extensive meadows; soil of medium quality, rendered highly productive by skillful cultivation. It is principally a farming t., with excellent gardens and orchards, but manufactures boots and shoes, cabinet-ware, farming and mechanical implements, carriages, etc. The $\mathrm{v}$. contains an academy and about 75 houses and stores, neatly arranged around a pleasant green. Here was fought, on the 19 th of April, 1775, the first action of the American Revolution. A tasteful monument, ereeted by the State, marks the spot and commemorates the valor of the first victims. The $\mathrm{v}$. is $11 \mathrm{~m}$. from Buston, on the Lexington and West Cambridge Branch of the Fitchburg R. R. Pop, of t, 1,894.

Lexington, t. and p. V., St. Clair county, Mich. : $105 \mathrm{~m}$. E. N. E. Lansing. Black r. crosses the W. part and Lake Huron lies on the E. It is well timbered, and lumbering is the chief business. Pop, 1,176.

Lexington, p. v., and cap. Holmes co., Miss. : on Black cr. of the Yazoo, $54 \mathrm{~m}$. N. by E. Jackson. It comprises a court-house, jail, several hotels, stores, and smail manufacfactories, and a pop. of 600. Two weeklies are published, the "L. Advertiser" (whig), and "Equal Rights" (dem.)

Lexingtor, p. v., and cap. Lafayette co., Mo.: about $1 \mathrm{~m}$. S. of the Missouri, $95 \mathrm{~m}$. W. N. W. Jefferson City. It contains a court-house and jail, an academy, a bank, several large stores, and 600 inhabitants. Two newspapers are published, the "L. Weckly Journal" and the "Western Missouri Express."

Limingtov, t. and p. v., Greene co., $N$. $Y .: 45 \mathrm{~m} . \mathrm{S} . \mathrm{W}$. Albany. Drained by Schoharie cr., on which are many saw-mills. Surface much broken by the Catskill Mountains; soil generally good. Timber is abundant, and tanning extensively carried on. Pop, 2,263. Hallcott is a new town, set $\mathrm{cff}$ from Lexington in 1851.

Lexivgton, p. v., and cap. Davidson co., N. Car. : about $1 \mathrm{~m}$. W. of Ablot's cr. of the Yadkin, $97 \mathrm{~m}$. W. by $\mathrm{N}$. Raleigh. It contains the county buildings and several stores, and is on the line of the North Carolina Central R. R.

Lexington, p. v., Richland co., Ohio: on Clear fork of Mohiccan er, which has a good fall here, $51 \mathrm{~m}$. N. by E. Columbus. It contains several stores and mills, and 500 inhabitants. The Sandusky, Mansfield, and Newark R. R. passes through it $9 \mathrm{~m}$. from Mansfield.

Lexingtox C. H., p. . ., and cap. Lexington dist., S. Car.: on a branch of Saluda r., $12 \mathrm{~m}$. W. Columbia. It contains a court-house, jail, an academy, several fine stores, and 300 inhabitants. A Lutheran Theological Seminary was founded here in 1835, and in 1350 had 2 instructors, 10 students, 20 alumni, and a library of 2,000 volumes.

Lexurgtor, p. v., and cap. Henderson co., Tenn.: at the 
head of Beech r., $92 \mathrm{~m}$. W. S. W. Nashville. Great numbers of hogs are fatted in the vicinity of the v., which contains a court-house, jail, an academy, sereral mills and stores, and 800 inhabitants.

Lexington, p. v., and cap. Rockbridge co., Virg. : on the W. side of North $r_{n}, 107 \mathrm{~m}$. W. by N. Richmond. It lies on a high bank of the river, and contains a court-house, jail, an academy, a female seminary, 15 stores, and 1,500 inhabitants. Washington College was founded here in 1795 , and liberally endowed by George Washington. In 1850 it had 6 instructors, 600 alumni, 42 of whom were ministers, 50 students, and a library of 5,000 volumes. The Virginia Military Institute, modeled after that at West Point, was located here in 1839, and in 1850 had 6 instructors, 107 alumni, 120 students, and 2,000 volumes in its tibrary. The "L. Gazette" (whig), and "Valley Star" (dem.), are published weekly.

Lexington, p. v., Clatsop co., Oreg. Ter. : on the W. or left bank of Willamette r., $49 \mathrm{~m}$. N. by E. Salem.

LEYDEN, t. and p. v., Franklin co., Mrass. : 84 m. W. N.W. Boston. Drained by Green r., a branch of Deerfield r., on which are fine mill-sites. Surface mountainous, and soil adapted to grazing. Large numbers of sheep and good dairies are kept. On Green $\mathbf{r}$. is a narrow ravine, inclosed by high rocks, called the "Glen," or "Ghor," which attracts many visitors by its wildness and beauty. Pop. of t. 716 .

LEYDen, p. v., Cook county, Ill.: 179 m. N. N. E. Springfield,

Leyden, t. and p. o., Lewis co., N. Y.: 104 m. N.W. by W. Albany. Drained by branches of Black r., which forms its E. line, and falls 63 feet before leaving the town. Surface hilly, and soil a fertile sandy loam. A large farming town. The Black River Canal passes down the river to the falls. Pop. 2,253.

Lerden, p. o., Rock co., Wisc. . S. E. Madison.

ITBERTY county, $G a$. Situate S. E. on the Atlantic, and contains 759 sq. m. Drained N. E. by Little Cannowehee r. and Taylor's cr., E. by Newport and Midway rivers, and TV. by Beard's and Doctor's creeks and Altamaha r. Surface level, and in parts low and marshy; soil mostly of great fertility near the water-courses, with poorer land at a distance from the shore. Cotton is the staple. St. Catharine's Island forms a part of the eounty, and raises seaisland cotton of a superior quality. Corn and potatoes produce largely, and the marshes on the coast and some of the creeks raise much excellent rice. Cattle are reared in large numbers, though the grains do not succeed. It has valuable forests of pine, hickory, and live oak. Farms 244; manuf. 4; dwell. 360, and pop.-wh. 2,002, fr. col. 16, sl. 5,905-total 7,926. Capital: Hinesville.

LIBERTY county, Tex. Situate S. in E. part, and contains $2,746 \mathrm{sq}$. m. 'Trinity $\mathrm{r}$, flows S. through the middle; on the N. E. is Big Sandy cr, and farther S. Pin Island bayou, both affluents of the Neches; S. E. are Oyster and East Bay bayoux, flowing into East Bay; and W. it is drained by E. fork of San Jacinto r. and Cedar bayou, flowing into Galveston Bay, which, with the Gulf of Mexico, forms its S. boundary. Surface level, with scarcely a noticeable hill; soil of various fertility -in the S. a thin, black mold, resting on sand and shells; in the $\mathrm{N}$. the mold is deeper, and frequently has a substratum of yellow loam; on the Trinity is rich bottom land, often overflowed, and exceedingly productive. The $\mathbf{S}$. is a grassy plain destitute of trees, and adapted to grazing. The $\mathrm{N}$. is prairie, with lines of wood on the streams, and is excellent cotton land. The Trinity is a large stream, about 80 yards wide and 10 feet deep, and navigated by steamers through the county and a considerable distance $\mathrm{N}$. of it. Farms 149; manuf. 1; dwell. 312, and pop.-wh. 1,623, fr, col. 7, sl, 892-total 2,522. Capital : Liberty.

LIBERTY, p. V., Adams co., $I l .: 76 \mathrm{~m}$. W. Springfleld.

LiBertr, p. o., Jackson county, $A l a .: 165 \mathrm{~m}$. N. by E. Mintgomery.
Libertix, p. v., and cap. Union co., Ind. : $62 \mathrm{~m}$. E. by $\mathrm{S}$. Indianapolis. It contains a court-house, jail, academy, and 700 inhabitants.

Liberty, p. v., and cap. Casey co., Ky.: on Greene r., here a small stream, $59 \mathrm{~m}$. S. Frankfort. It contains a court-house and jail, several stores, und 200 inhabitants.

Libertx, t. and p. o., Waldo co, Mre.: $22 \mathrm{~m}$. E. Augusta. St. George's $r$. rises from a large pond in the N., and Muscongus r. flows from the S. part. Surface uneven, and soil adapted to grass. Pop. 1,116.

LIBERTX, t, and p. o., Jackson eo., Mrich : $42 \mathrm{~m}$. S. by E. Lansing. Surface undulating, and soil productive of all the grains and grasses. Pop. 891.

Libertx, p. v., and cap. Amité co., Miss. : on a branch of Amité r., 82 m. S. S. W. Jackson. It contains a courthouse and jail, and 200 inbabitants.

Liberty, p. V., and cap. Clay co, MIo.: about $3 \mathrm{~m}$. N. of the Missouri, $134 \mathrm{~m}$. W. N. W. Jefferson City. It has a convenient landing on the Missouri, and carries on an extensive trade with the back region. It contains a court-house and jail, 3 academies, several large stores, and 800 inbabitants.

Limerty, t. and p. o., Sullivan co., $N_{*} Y_{0}: 78 \mathrm{~m} . \mathrm{S} . \mathrm{W}$. Albany. Surface elevated and hilly, giving rise to Collikoon and Mongaup creeks of the Delaware, on which are numerous saw-mills; soil gravelly loam. Lumber is a large export. Pop. 2,612.

Lizerty, p. v., Montgomery co., Ohio: $71 \mathrm{~m}$. W. by S. Columbus.

Liberty, t. and p. o., Tioga co., Penn.: $92 \mathrm{~m}$. N. by W. Harrisburg. Drained by branches of Pine and Lycoming creeks, which turn many saw-mills. Surface rough, and grazing is the chief business. Iron and coal are found.

Liberty, p. v., De Kalb county, Tenn.: on a branch of Caney fork of Cumberland $r_{0}, 44 \mathrm{~m}$. E. by S. Nashville.

Linertr, p. v., and cap. Bedford co. Firg.: on a branch of Otter r., $112 \mathrm{~m}$. W. by S. Richmond. It contains a courthouse and jail, several stores and small manufactories, and 500 inhabitants. It is on the Virginia and Tennessee $R_{v}, R_{\text {. }}$, $25 \mathrm{~m}$. from Lynchburg.

Liberty, sta., Alleghany co., Penn.: on W. division of Pennsylvania $R, R ., 5 \mathrm{~m}$. from Pittsburg.

Liberty, p. v., and cap. Liberty co., Tex.: on the left bank of Trinity r., about $30 \mathrm{~m}$. from its mouth, $174 \mathrm{~m}$ E. by S. Austin City. It has a good landing, and steamboats touch here on their way from the interior to Galveston, which is $70 \mathrm{~m}$. S. of it. The vicinity produces fine cotton. The v. contrins a court-house and 200 inhabitants.

Luberty, p. o., Racine co., Wise.: 74 m. E. S. E. Madison. Liberty, p. o., Washita co., Ark.: 91 m. S. by W. Little Rock.

Liberty Corner, p. o., Somerset co., N. J.: about $1 \mathrm{~m}$. from Dead River, a branch of the Passaic, $30 \mathrm{~m}$. N.'by E. Trenton.

Liberty Corners, p. o., Crawford co., Ohio: $63 \mathrm{~m} . \mathrm{N}$. Columbus.

Lmerty Falls, p. v., Sullivan co., $N_{0} Y_{.}: 81 \mathrm{~m} . \mathrm{S} . \mathrm{W}$. Albany.

LiberTy Hali, p. o., Warren co., Ohio: $72 \mathrm{~m}$. W. S. W. Columbus.

Limerty Hall, p. o., Netwberry dist., S. Car.: 46 m. N. W. Columbia.

Ltberty Hali, p. 0., Washington eo., Firg.: $216 \mathrm{~m}$ W. S. W. Richmond.

Linerty HuL, p. 0., Dallas county, Alat: $61 \mathrm{~m}$. Ty. Montgomery.

Liberty Hili, p. v., New London co., Conn.: in the N. part of Lebanon, $32 \mathrm{~m}$. E. by S. Hartford.

Liberte Hill, p. o., Piko co., Ga.: $56 \mathrm{~m}$. W. by N. Milledgeville.

LiвеRту Hilu, p. o., Iredell co., N.Car. : near South Tadkin $\mathrm{r.}, 165 \mathrm{~m}$. W. Raleigh.

Liberty FInd, p, 0., Kershaw dist., S. Car. : $83 \mathrm{~m}$. N. by E. Columbia. 
Liberty Hili, p. o., La Fayette co.g Miss. : 135 m. N. N. E. Jackson.

Liberty Milus, p. v., Wabash co., Ind.: on Eel r., 88 m. N. by E. In itianapolis.

Liberty Mills, p. o., Orange co., Virg.: 51 m. N. W. Riclımond.

Lrberty Sequare, p. o., Lancaster co., Penn.: E. S. E. Harrisburg.

Libertr Town, p. $\nabla .$, Frederick co., MI.: $2 \mathrm{~m}$. N. of Linganore er., $25 \mathrm{~m}$. N. W. Annapolis.

Limerty ILLE, p. v., Lake co., $M l_{*}:$ on the W. side of Des

Plaines r., $194 \mathrm{~m}$. N. N. E. Springfield.

Libentrville, p. v., Jefferson co., Ia.: 53 m. S. S. W. Iowa City.

Libertyville, p. v., Sussex co, N. Jer. : about $3 \mathrm{~m} \mathrm{E}$. of Blue Mountain, $54 \mathrm{~m}$. N. Trenton.

LibertyvilLe, p. v., Ulster co., N. Y.: on the Wall Kill r.,

$65 \mathrm{~m}$. S. by W. Albany. It contains a hotel and several mills. Limrary, p. o., Alleghany co., Penn.: 168 m. W. by N. Harrisburg.

Lick Brance, p. o., Parke county, Ind.: $54 \mathrm{~m}$. W. Indianapolis.

Lrok CREEK, p. v., Sangamon co, $M l$.: on a branch of Sugar cr. so called, 11 m. S. s. W. Springîeld.

Lick CreEK, p. o., Ralls co., Mo.: on a branch of Salt $r$. so called, $61 \mathrm{~m}$. N. by E. Jefferson City.

Lick Creer, p. V., Van Buren co., Ia, : near the branch or Des Moines r. so called, 59 m. S. S. W. Iowa City.

Lrck CreEk, p. o., Hickman co., Tenn, : on a branch of

Duck r. so called, $32 \mathrm{~m}$. S. W. Nashville.

Lioks, p. o., Fannin co., Texo. : 269 m. N. N. E. Austin City.
Lick ForK, p. o., Daviess county, MIO. : on a branch of Grand r., $136 \mathrm{~m}$. N. W. Jefferson City.

Lickivg county, Ohio. Situate centrally, and contains 638 sq. m. Drained by Licking r. and its branches, Rocky fork, North fork, Raccoon cr., and South fork, which furnish abundance of excellent water-power. Surface elevated and rolling, or nearly level; soil highly productive, and under thorough cultivation. It is an excellent farming, and superior grazing en. Wheat and corn are raised in great quantities. Buckwheat grows easily, and tobacco is a profitable crop, and receiving increased attention. The dairies are very fine, and cattle and sheep are kept in large numbers. Live stock, beef, and especially wool and pork, are leading exports. Most of its water-power is occupied by extensive and various manufactories, in which a large capital is invested. Iron-ware is made, and iron ore is abundant. Farms 3,313; manuf. 332 ; dwell. 6,639, and pop.-wh. 38,731 , fr. col. 115total 38,846. Capital: Newark. Public Works: Ohio Canal; Ohio Central R. R.; Columbus and Lake Erie R. R. Licking, p. o, Texas eo, Mo. : $122 \mathrm{~m}$. S. by E. Jefferson City.

LICKING river, $K y_{0}:$ a tributary of the Ohio. It rises in Floyd co., and has a course of about $100 \mathrm{~m}$, reaching its confluence at Newport, opposite Cincinnati. It is navigable for 70 miles.

LICKING river, Ohio: a large W. branch of the Muskingum, formed by the union of three principal branches at Newark. It furnishes extensive water-power, particularly by a dam at its mouth.

Lickville, p. o., Greenville district, S. Car.: 78 miles N. W. by W. Columbia.

\section{LIGHT-HOUSES OF THE UNITED STATES.}

(Names in Italics are "Floating Lights.")

\begin{tabular}{|c|c|c|c|c|c|c|}
\hline \multirow{2}{*}{\multicolumn{2}{|c|}{ Names. }} & \multirow[b]{2}{*}{ Geographical Position. } & \multicolumn{2}{|c|}{ Astronom. Position. } & \multirow{2}{*}{$\begin{array}{c}\text { Character } \\
\text { of } \\
\text { Liglat. }\end{array}$} & \multirow{2}{*}{ | 10 eet. } \\
\hline & & & $\begin{array}{c}\text { Latitude. } \\
\text { d. m. s. }\end{array}$ & $\begin{array}{l}\text { Long'ude } \\
\text { d. m. s. }\end{array}$ & & \\
\hline 政 & & Por & 4339007 & 70170 & Fixed & \\
\hline eguin ............... & " & On S. Island, off mouth of Kennebec River........ & 4341366 & 69440 & Fixed & \\
\hline Whitehead ................ & “ & On W. Island, S. W. of W. entrance to Penob. Bay & 4357006 & 690400 & Fixed & \\
\hline Franklin Island ............ & " & On N. end of F. Isl., and W. of ent. to St. George's B. & 4352006 & 691900 & Fixed & \\
\hline Vood Island ............... & 66 & On W. Island, near entrance to Saco Harbor ....... & 4327007 & 701830 & Revol'g & \\
\hline West Quoddy' Head.......... & $" 6$ & OnW. Q. H., near Eastpc & 4149186 & 665900 & Fixed & \\
\hline Petit Manan............... & 66 & end of P. M. Isla & 4422006 & 674900 & Fixed & \\
\hline Island.... & 6 & and, W. side of entr & 4345006 & 694600 & Fixed & \\
\hline nt Island................ & " & send Harb., Lincoln co. & - & - & Fixed & \\
\hline y Island ..... & 6 & achias Bay............. & 4434006 & 67220 & Fixed & \\
\hline Monlicgan ........ & \& & it & 4344300 & 691800 & Revol'g & 1 \\
\hline Dwl's II cad........ & 6 & ent. of Penob. Bay & 4403506 & 690000 & Fixed & 117 \\
\hline Coose Peak........ & 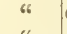 & ent. to Bay of Fundy & 412500 & $\begin{array}{lll}67 & 31 & 09\end{array}$ & Revol'g & \\
\hline Fatinicus Rock .... & 6 & & 4346246 & 684900 & Fixed & \\
\hline emaquid Point... & 6 & etc. & 434800 & 692930 & Fixed & \\
\hline r's Island..... & 66 & enchn's Bay & 411320 & 680800 & Fixed & \\
\hline Elizabeth............ & " & ats) ... & $43 \quad 33867$ & 701136 & F.\&R. & 14 \\
\hline fees flead...... & 6 & & 4123126 & $6 S 4930$ & Fixed & 11 \\
\hline Iendrick's Head............. & 66 & & 434730 & 693900 & Fixed & \\
\hline Desert Rock......... & 4 & Mt. Desert Isl. & 4355006 & $68 \quad 0030$ & Fixed & \\
\hline 's Head....... & 6 & Penobscot Bay & 4405006 & 654600 & Fixed & \\
\hline I's Point ... & 6 & & 4353206 & 691300 & Fixed & 3 \\
\hline Goat Island. . . . . . . . . . . . . & “ & & 4321007 & 70.2500 & Fixed & 3 \\
\hline Negro Island............... & 6 & entr. to Camden Harbor, Penobscot Bay & 441100,6 & 685900 & Fixed & 5 \\
\hline Fort Point...... & 6 & above Castine-ent. Prospect Harbor & - & - & Fixed & \\
\hline & 66 & & $430800 \%$ & 702900 & Fixed & ic \\
\hline Island Point .. & 66 & Bay & 442400,6 & 684600 & Fixed & 100 \\
\hline is Island ...... & " & & 4427006 & 674300 & F'ixed & $4 \tau$ \\
\hline land .... & "6 & Baker's I. & 4416006 & 651200 & Fixed & the \\
\hline Saddleback Ledge. & 66 & Haut, E. side of ent, to Bay & 4359006 & 683630 & Fixed & 62 \\
\hline le River....... & "6 & th of L. R. Harbor, in Cutler. & -1 & - & Fixed & - \\
\hline Prospect Harbor... & 66 & & - & 一 & Fixed & 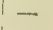 \\
\hline Grindel's Point............. & & At Gilkey's Harbor, in Penobscot Bay .... & - & - & Fixed & \\
\hline
\end{tabular}




\begin{tabular}{|c|c|c|c|c|c|}
\hline \multirow[b]{2}{*}{ Names. } & \multirow[b]{2}{*}{ Geographical Position. } & \multicolumn{2}{|c|}{ Astrinom. Position } & \multirow{2}{*}{$\begin{array}{c}\text { Cliaracter } \\
\text { of } \\
\text { Light. }\end{array}$} & \multirow{2}{*}{ foet. } \\
\hline & & $\begin{array}{l}\text { Latitude. } \\
\text { d. } \mathrm{m} . \mathrm{s} .\end{array}$ & $\begin{array}{c}\text { Lnng'ude } \\
\text { d. m. в. }\end{array}$ & & \\
\hline & On Indian Isl.- entrance to Camden Harbor. & - & 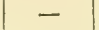 & & \\
\hline & & 430330 & 70430 & & 80 \\
\hline White Island (red and rotite) & On W. Isl., the \$. W. island of the Isles of Shoals & 425800 & 703730 & Re & $S \tilde{i}$ \\
\hline Whale's Back (2 lights) ..... & N. and E. side of outer ent to Portmouth Harbor. . & 430300 & 704100 & Fixed & 58 \\
\hline ... MIass. & N. side main outer entrance to Boston Harbor & 421941 ; & $7053 \quad 43$ & (l'g & 90 \\
\hline Thatcher's Island (2 lights).. & On T. island, about $2 \mathrm{~m}$. off Cape Ann ..... & 423821 & 703445 & Fixed & 97 \\
\hline Baker's Island (2 lights)..... & Harbor & $42 \quad 3212$ & 704725 & $\mathrm{Fi}$ & $\delta 1 \frac{1}{2}$ \\
\hline Plumb Island (2 lights) ..... & On P. island, S. side of entrance to Newb & 424529 . & 704905 & Fixed & 54 \\
\hline Cape Cod (Highlands) ...... & of Coma Cod Tr & 420223 & 700355 & & 150 \\
\hline mouth (2 lights).... & Harb. & $42 \quad 00 \quad 12$ & $7036 \quad 21$ & $\mathrm{~F}$ & 90 \\
\hline Wigwam Point...... & oint, E. side entrance to $\mathrm{Sq} \mathrm{r}$ & 423943 & $\begin{array}{lll}70 & 41 & 12\end{array}$ & & 50 \\
\hline Scituate (2 lights) .... & ituate Harbor & $\begin{array}{lll}42 & 12 & 17\end{array}$ & $\left|\begin{array}{lll}70 & 43 & 15\end{array}\right|$ & Fixed & 40 \\
\hline Race Point.......... & od $\ldots \ldots$ & $\begin{array}{lll}42 & 03 & 41\end{array}$ & $70 \begin{array}{lll}70 & 153\end{array}$ & $\mathrm{rol}^{\prime} \mathrm{g}$ & 32 \\
\hline Long Island Fead. .......... & Long & $42 \quad 19 \quad 45$ & $\begin{array}{llll}70 & 57 & 41\end{array}$ & Fixed & So \\
\hline Ten Pound Island.......... & & $42 \quad 35 \quad 10$ & 704000 & ed & 45 \\
\hline Billingsgate Island. .... & 0 & 415135 & $7004 \quad 32$ & & 40 \\
\hline Sandy Neck............ & & $\begin{array}{lll}41 & 43 & 21\end{array}$ & $\begin{array}{llll}70 & 17 & 09\end{array}$ & Fixed & 40 \\
\hline ong Point . .......... & Har. & 420150 & $\begin{array}{lll}70 & 10 & 50\end{array}$ & & 35 \\
\hline er Point..... & & $\begin{array}{lll}42 & 34 & 49\end{array}$ & $\begin{array}{lll}70 & 40 & 10\end{array}$ & Fixed & 57 \\
\hline Haren ... & & $\begin{array}{lll}42 & 39 & 41\end{array}$ & $\begin{array}{llll}70 & 35 & 36\end{array}$ & & 40 \\
\hline d. ......... & & $\begin{array}{lll}42 & 32 & 08\end{array}$ & $70 \quad 5005$ & Fixed & 40 \\
\hline lights)...... & & $\begin{array}{lll}42 & 41 & 08\end{array}$ & $\begin{array}{lll}70 & 46 & 17\end{array}$ & $R$ & 40 \\
\hline lead ................. & & $41 \quad 20 \quad 54$ & $70 \quad 50 \quad 26$ & ol'g & 172 \\
\hline s Point ............ & & $\mid \begin{array}{lll}41 & 35 & 34\end{array}$ & $\begin{array}{llll}70 & 54 & 21\end{array}$ & & 52 \\
\hline Cutterhunk Island. . & ay & 412 & $\begin{array}{llll}70 & 57 & 17\end{array}$ & $\mathrm{Fi}$ & $4 \mathrm{~S}_{\frac{1}{2}}$ \\
\hline Nantucket ........... & and & $\begin{array}{lll}41 & 23 & 24\end{array}$ & $\begin{array}{llll}70 & 03 & 01\end{array}$ & & 70 \\
\hline Nantucket Beacon.......... & & $\begin{array}{lll}41 & 17 & 24\end{array}$ & 700551 & $F$ & 40 \\
\hline tucket Harbor L & & $41 \quad 1600$ & $\begin{array}{lll}70 & 06 & 00\end{array}$ & & - \\
\hline Cape Poge ............... & & $41 \quad 2515$ & $\begin{array}{llll}70 & 27 & 19\end{array}$ & & $5 \breve{5}$ \\
\hline$m(2$ lights)... & & 414 & $69 \begin{array}{lll}69 & 57 & 12\end{array}$ & & 70 \\
\hline ammon............ & Aar. & $413 t$ & $\begin{array}{lll}70 & 16 & 16\end{array}$ & $\mathrm{Fi}$ & 70 \\
\hline Hole..... & & 412557 & $\begin{array}{llll}70 & 36 & 27\end{array}$ & & 60 \\
\hline lin Core... & $\cdots$ & 412 & $70 \quad 45 \quad 45$ & Fixed & 80 \\
\hline$\pi$ & & $\begin{array}{lll}41 & 45 & 09\end{array}$ & $\begin{array}{llll}70 & 43 & 21\end{array}$ & Revol'g & 31 \\
\hline int ..... & 0 & $41 \quad 3835$ & 695956 & & 33 \\
\hline nt ... & & $\begin{array}{lll}41 & 30 & 57\end{array}$ & $\begin{array}{llll}70 & 39 & 37\end{array}$ & $\mathrm{Fi}$ & 80 \\
\hline g Rock ........... & ght & $\begin{array}{lll}41 & 32 & 17\end{array}$ & 705536 & & 43 \\
\hline (2) & $\cdot$ & $\begin{array}{lll}41 & 23 & 27\end{array}$ & $70 \begin{array}{lll}70 & 29\end{array}$ & $\mathrm{Fi}$ & 50 \\
\hline$\cdots$ & : LVew Dearura .. & $\begin{array}{lll}41 & 41 & 01\end{array}$ & $\begin{array}{lll}76 & 02 & 00\end{array}$ & $\mathrm{Fi}$ & - \\
\hline 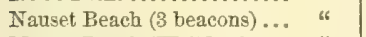 & & $4151 \quad 40$ & $6957 \quad 21$ & Fixed & 90 \\
\hline (Wellfleet).... & Bay & 425500 & 700200 & ed & 30 \\
\hline Tantucket Cliff ( 2 beacons).. & & - & - & Fixed & 150 \\
\hline ankaty Head ............ & m.) & $41165 s$ & 695816 & Revol'g & - \\
\hline Hyannis ................. & & 413800 & $7018 \quad 00$ & Fixed & - \\
\hline Wing's Neck.............. & & - & - & Fixed & - \\
\hline ner's Island .... & On $\mathrm{N}$. & - & - & Fixed & 27 \\
\hline t's Rock.............. & Rocks, 9 & $\begin{array}{lll}42 & 16 & 08\end{array}$ & $7045 \quad 55$ & Revol'g & 66 \\
\hline Harbor (2 lights) .... & ro. & - & - & $\& \mathrm{R}$ & - \\
\hline ndyroine Shoal (129 tons) & & - & - & - & 45 \\
\hline cernuck Shoal ......... & $\mathrm{mp} \& 8$ wicks) & - & $\longrightarrow$ & - & 35 \\
\hline Fineyard Sound........... & 8,9 wicks ea.). & - & 一 & - & 50 \\
\hline Pollock's Rip .............. & & - & 一 & 一 & 40 \\
\hline$\ldots \ldots \ldots \ldots \ldots$ R. I & & 112630 & $\begin{array}{lll}71 & 24 & 24\end{array}$ & Fixed & 95 \\
\hline$\ldots \ldots \ldots \ldots \ldots$ & 2 m. & $41 \quad 1809$ & 715208 & Revol'g & 73 \\
\hline at Judith... & & $\begin{array}{lll}41 & 21 & 35\end{array}$ & $71 \quad 2925$ & Revol'g & 74 \\
\hline t Island .... & port Harbor. & 418000 & $71 \quad 1950$ & Fixed & 43 \\
\hline teh Island ............. & 0 & 412980 & $\begin{array}{lll}71 & 26 & 00\end{array}$ & Fixed & 56 \\
\hline rnwick Neck. ............ & & 413100 & 712900 & Fixed & - \\
\hline oint. .......... & (bay ligh & 414400 & 712200 & Fixed & 33 \\
\hline Block Island (2 lights). & & $41 \quad 1324$ & $71 \quad 3504$ & Fixed & 53 \\
\hline Poplar Point ... & V & 413500 & 712640 & Fixed & - \\
\hline .. Term. & lo ent. to Burlington & 442700 & 731300 & Fixed & 95 \\
\hline ... Conn. & W. side of entrance to River Thames....... & $41 \quad 18 \quad 55$ & 720556 & Fixed & 111 \\
\hline Faulkner's Island. & & 411235 & 728946 & Fixed & 93 \\
\hline Lynde Point ...... & r, W. side.... & $41 \quad 1613$ & $72 \quad 2059$ & Fixed & 74 \\
\hline "6 & & $41 \quad 1934$ & 715452 & Fixed & 62 \\
\hline Point. & ound, near Mystic.. & 411854 & 715954 & Fixed & - \\
\hline " & Harbor, E. side .... & 411452 & $72544 t$ & Fixed & 85 \\
\hline a & $\pi$ & $\begin{array}{ll}41 & 09\end{array}$ & 0 & & \\
\hline
\end{tabular}




\begin{tabular}{|c|c|c|c|c|c|c|}
\hline \multirow{2}{*}{\multicolumn{2}{|c|}{ Names, }} & \multirow[b]{2}{*}{ Geographical Position, } & \multicolumn{2}{|c|}{ Astronom. Position. } & \multirow{2}{*}{$\mid \begin{array}{c}\text { Character } \\
\text { of } \\
\text { Ligit. }\end{array}$} & \multirow{2}{*}{ 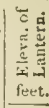 } \\
\hline & & & $\begin{array}{l}\text { Latitude. } \\
\text { d. m. s. }\end{array}$ & $\begin{array}{c}\text { Long'ude. } \\
\text { d. m. в. }\end{array}$ & & \\
\hline & Conn. & Entrance to Black Rock Harbor, Fairfield . & $41 \quad 05 \quad 27$ & 7813 & Fixed & \\
\hline$\cdots$ & “ & At entrance of Norwalk River ............ & 410250 & 7325 & Revol'g & \\
\hline Great Captain's Island & “ & On G. C. Island, near Greenwich Pt., Fairfield co. & 405352 & $73 \quad 3759$ & Fixed & \\
\hline North Dumplin............. & " & On North Dumplin Island, in Fisher's Island Sound & - & - & Fixed & \\
\hline Bartlett's Reef (145 tons) .... & " & Off New London (1 lamp, 9 wicks) ... & - & - & - & \\
\hline Eel Grass Shoal (41 tons)... & " & On Eel Grass Shoal (1 lamp, 12 wicks)............ & - & - & - & \\
\hline Eaton's Neck......... & N. $Y$. & On E. side of Huntington Bay, Long Island....... & $4057 \quad 09$ & 732418 & Fixed & $13 \pm$ \\
\hline Execution Rocks... & “ & Off Sand's Point, Long Island Sound ........ & -1 & - & Revol'g & \\
\hline Sand's Point ......... & $"$ & On Sand's Point, E. entrance to Cow Bay........... & $40 \begin{array}{lll}40 & 52\end{array}$ & $73 \quad 4421$ & Fixed & \\
\hline Old Field Point .... & " & Point, N. side L. Isl., opposite Strat. Light & t 405333 & $\begin{array}{lll}73 & 07 & 41\end{array}$ & Fixed & $67 \frac{1}{3}$ \\
\hline Fire Island Inlet........... & " & de of F. Island Inlet, S. sile of Long Island & 403746 & 731838 & Revol'g & \\
\hline Throgg's Neck ............. & 6 & On S. E. point of Throgg's Neck, E. of Hell Gate & $4049 \quad 15$ & $73 \quad 48 \quad 01$ & Fixed & \\
\hline Stony Point ......... & “ & On W. side of Hudson River, below West Point... & -1 & - & Fixed & \\
\hline Fort Tompkins ............. & “ & On Staten Island, W. sido of Narrows ............. & 403757 & 740350 & Fixed & \\
\hline Coxsackie........... & “ & On the W. side of Hudson River, near Coxsackie.. & - & - & Fixed & \\
\hline Point ..... & "6 & Hudson, W. side of river & - & - & Fixed & \\
\hline -...... & " & ties Creek......... & - & - & Fixed & \\
\hline esant ........... & “ & Q. side of Hudson & - & - & Fixed & \\
\hline Rondout Creek............. & " & h of R. Cr. and ent. Del. \& Hud. Canal & - & - & Fixed & \\
\hline Montauk................ & “ & ng Island ...................... & 410410 & 715158 & Fixed & 160 \\
\hline ull Island..... . & 6 & 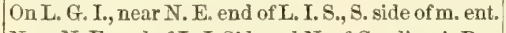 & - $41 \quad 1218$ & $\begin{array}{lll}72 & 06 & 57\end{array}$ & Fixed & \\
\hline and ................ & " & er's Bay & $4 \begin{array}{lll}41 & 10 & 21\end{array}$ & $\begin{array}{lll}72 & 13 & 14\end{array}$ & Revol'g & \\
\hline Buffalo (on pier) ..... & 6 & At & 425000 & $\begin{array}{lll}78 & 59 & 00\end{array}$ & Fixed & 47 古 \\
\hline and Harbor ...... & “ & At Portland, S. E. shore of Lake Erie... & $42 \quad 32 \quad 41$ & 一 & Fixed & 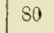 \\
\hline Dunkirk .................. & " & E. shore of Lake Erie... & - & - & Fixed & \\
\hline Galloo Island.............. & " & of Toke 0 & $\mid \begin{array}{lll}43 & 51 & 00\end{array}$ & - & Fixed & \\
\hline Oswego Beacon ............ & “ & ....... & 432500 & - & Fixed & 2 \\
\hline Cattaraugus Beacon......... & " & , Lake Erie.. & - & - & Fixed & \\
\hline Dunkirk Beacon............ & $"$ & D & - & - & Fixed & \\
\hline$($ temp. beacon $) .. .$. & " & Entr & $\begin{array}{lll}43 & 12 & 30\end{array}$ & 一 & Fixed & \\
\hline Sodus Bay and Beacon...... & " & W. s & $\begin{array}{lll}43 & 19 & 00\end{array}$ & - & R.\& F. & 66 \\
\hline ibbett's Point.............. & “ & S. E. & 440900 & - & Fixed & 52 \\
\hline Horse Island.............. & " & of Sackett's Harbor. & - & - & Fixed & tor \\
\hline Niagara Fort...... & " & Erie, E. side. & $4318 \quad 20$ & - & Fixed & 8 \\
\hline Stony Point ............... & $"$ & Point, E. end of Lake Ontario........... & - & - & Revol'g & - \\
\hline Ogdensburg.......... & " & On St. Lawrence River, month of Oswegatchie R.. & 444500 & $\begin{array}{llll}75 & 30 & 00\end{array} \mid$ & Fixed & 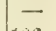 \\
\hline Irince's Bay ................ & “ & On Stat & 4030227 & $74 \quad 13 \quad 24$ & Fixed & 106 \\
\hline Esopus Meadows...... & “ & & -1 & - & Fixed & 一 \\
\hline Robbin's Reef............. & " & Y. Bay & $40 \begin{array}{lll}40 & 39 & 21\end{array}$ & $7404 \quad 30$ & Fixed & 36 \\
\hline Codar Island......... & “ & bor .... & $\begin{array}{lll}41 & 02 & 18\end{array}$ & $72 \quad 1606$ & Fixed & 2 \\
\hline Silver Creek ................ & $"$ & Entrance to Silver Creek Iarbor, on Lake Erie... & - & - & Fixed & 7 \\
\hline Salmon River .............. & " & ance to Port Ontario.............. & - & - & Fixed & 52 \\
\hline ock Island Beacon........ & “ & St. Lawr'nce R. & - & 一 & Fixed & 一 \\
\hline Rock Beacon....... & " & R... & 一 & 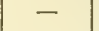 & Fixed & - \\
\hline Conover Island Beaeon ..... & " & 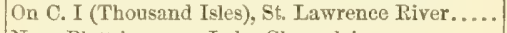 & - & - & Fixed & - \\
\hline Cumberland Head.......... & “ & plain & 414200 & $\left|\begin{array}{lll}73 & 20 & 00\end{array}\right|$ & Fixed & 45 \\
\hline Split Rock ................ & “ & Lake $\mathrm{Ch}$ & 4412007 & $73 \quad 18 \quad 00$ & Fixed & 110 \\
\hline Stratford Point (100 tons) .. & " & Off St. Pt., on middle ground, L. I. Sound (2 & - & - & - & 一 \\
\hline Sirndy IItok (230 tons)....... & " & $7 \mathrm{~m}$. outside $\mathrm{S}$. Hook, in 15 fathom water (2 lights). & $\overline{0}$ & $-\overline{1}$ & - & 60 \\
\hline (light and $26 \mathrm{~ns}) \mathrm{A}$ & det & cons) & 4027397 & $74 \quad 00 \quad 42$ & Fixed & 90 \\
\hline Highl'ds of Nev'sink (2 lights) & " & & $40 \quad 23407$ & $73 \quad 59 \quad 42$ & R. \& F. & 249 \\
\hline egat Shoals............ & “ & & 3945547 & 740656 & Fixed & - \\
\hline Cape May................ & " & S. W. point of C.M. and N. of entrance to Del. Bay & 3855457 & $7453 \quad 38$ & Revol'g & 8 \\
\hline Egg Island (gas) ............ & " & DeL Bay, N. side, nearly N. N. W. of Cape May.. & 391028 & 750356 & Fixed & 42 \\
\hline Cohanzey Creek (gas) ...... & " & e Cohangy Creek and N. side Delaware Bay & $\begin{array}{llll}39 & 20 & 15 & 7\end{array}$ & $75 \quad 22 \quad 12$ & Fixed & 42 \\
\hline Tucker's Bench (red shades) & " & New Inlets...... & $\left.\begin{array}{llll}39 & 30 & 17\end{array}\right]$ & $\begin{array}{llll}4 & 17 & 31\end{array} \mid$ & Fixed & - \\
\hline n Foint ............. & " & $\mathrm{ks}$ of B. point & 一 & - & Fixęl & - \\
\hline ice River... & " & On the bank of M. R. Cove and S.W. side Hays'k I. & - & - & Fixed & - \\
\hline Pnssaic Piver .............. & $"$ & Near head of Newark Bay .................... & - & - & Eixed & - \\
\hline Presque Island............ & & At entrance of Presque Island Bay, Lake Er & $\begin{array}{lll}42 & 08 & 14\end{array}$ & - & 'Fixed & 73 \\
\hline Beacon..... & “ & "6 & - & - & Fixed & 26 \\
\hline $\min . . . . . .$. & 68 & On pier in Delaware River, opposite Fort Mifflin.. & - & - & Fixed & - \\
\hline ne Shoal. . & , & On Brandywint Shoal in Delaware Bay .......... & - & - & - & - \\
\hline Cape Ifenlopen............. & Del. & On Cape Henlopen, S. side of entrance to Del. B.. & 3546357 & 75053 & Fixed & 150 \\
\hline Cape Henlopen Beacon..... & “ & About three-fourtbs of a mile from main light..... & $384721 ?$ & $\begin{array}{lll}75 & 05 & 44\end{array}$ & Fixed & - \\
\hline Bonbay IIouk .... & “ & N. W. end of Bombay IIook Isle, in Delaware Bay & 3921437 & $75 \quad 31 \quad 13$ & Fixed & 46 \\
\hline s Ditch & 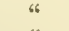 & On Mahon's Ditch, S. side Delaware Bay .......... & 3910137 & 752438 & Fixed & - \\
\hline ion Creek... & “ & M. Creek, in Delaware Bay, S. side.. & 3856347 & $75 \quad 1924$ & Fixed & - \\
\hline $\begin{array}{c}\text { Christiana River (gas) ....... } \\
380\end{array}$ & " & & 48 & & Fixed & \\
\hline
\end{tabular}




Names.

Reedy Island (gas) ........ Del. Breakwater (red)........... Five Fathom Rock (195 tons) " Upper Middle Shoal (131 tons) “ Bodkin Island............. MId. North Point, No. 1 ......... " " " 2 ".......

Thomas' Point .............

Pool's Island..............

Smith's Island.

Coneord Point.

Cove Point................

Point Lookout .............

Lazaretto Point.............

Clay Island ...............

Turkey Point .............

Piney Point...............

Sharp's Island............

Greenbury Point ...........

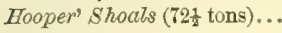

Cape Henry................ Virg.

old Point Comfort..........

Smith's Point ..............

New Point Comfort.........

Smith's Island..............

Back Piver Point .........

Assateaque Island..........

Little Watt's Island..........

Smith's Point (120 tons) .... Craney Island (70 tons) .... Tilloughby's Spit (400 tons) Wolftrap Shoals (180 tons).

Windmill Point (125 tons)... Boncler's Rock (5t tons).....

Upper Cedar Point (72 tons)

Loncer Cedar Point (72 tons)

Bald Head................. Car

Federal Point..............

Cape Hatteras.............

Pamptico Point..............

Body's Island..............

Ocracoke ................

Cape Lookout.............

Oak Island ( 2 beacons)...... Orton's Point...............

Price's Creek (2 beacons).... Campbell's Island.......... Long Shoul (115 tons)....... S.W. pt. of R.Shoal (140 tons) Nine Feet Shoal (70 tons)... Mouth of Neuse R. (125 tons) Brant Island Shoal (125 tons) Harbor Island (72 tons).... Wade's Point shoal (76 tons) Roanoke Island (72 tons)... Mouth Roanoke R. (130 tons) Horse Shoe (72 tons)........ Charleston (aud beacon)....S. Car Paccoon Key............... Nortly Island.

Morris' I. (2 beacon lights).. Sullivan's I. Beacon, No. 1. .

Beacon, No. 2..

St. Helena Bar (72 tons)....

Tybee

Tybee Beacon................

Fig Island Bencon ..........

St. Simon's Isiand . . ..........

Sapelo Island
On Reedy Island, entrance of Delaware River....

Geograplical Position.

On Delaware Breakwater.................. 3847507507 (8) Fixed.

On Sandbank off Cape May (2 lights) ........... -

N. W. of Brandy wine Shoal, near middle of Del. B. - $\quad$ - $\quad-\quad-\quad 45$

On B. Island, S. side of entrance to Patapseo River 390800762550 Fixed On N. side of ent, to Pat. R. and Port of Baltimore $\left\{\begin{array}{llllll}39 & 00 & 45 & 76 & 27 & 17 \\ 39 & 00 & 35 & 76 & 26 & 54\end{array}\right\}$ Fixed _ S. of entrance to Annapolis......................... $38 \quad 542576 \quad 27 \quad 34$ Fixed In Chesapeake Bay, N. E. of North Point.........39 1722761621 Fixol In Chesapeake Bay, opposite entrance to Potomac 37 \begin{tabular}{llllll|l}
53 & 13 & 74 & 39 & Fixed
\end{tabular} At entrance of Susquehanna River.................. 393230760542 Fixed -

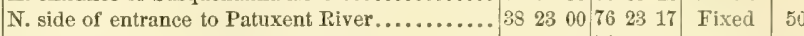
N. side of entrance to Potomac River................ 38 02 14761943 Fixed — N. side of entrance to Baltimore Harbor.......... $39153976 \quad 34$ 35 Fixed _. N. extremity of Tangier S'nd, mo'th of Nanticoke R. $38 \quad 1352755850 \quad$ Fixed 36 At entrance of Elk River, W. side .............. 392655760054 Fixed -

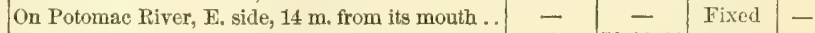
Off the entrance of Choptank River............. $38 \quad 37427622 \quad 36$ Fixed _. N. side of entrance to Annapolis Harbor ........ - $\quad$ - $\quad$ Fixed 81

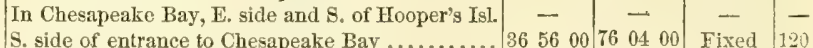
N. side of entrance to Hampton Roads............ 370000.762212 Fixed Near the mouth of Potomac River, S. side........ 375100.762200 Fixed S 85 $18 \mathrm{~m}$. N. of O. P. C. and W. side Chesapeake Bay 371800762100 Fixed N. E. of C. Charles and of N. ent. to Chesapeake B. 371300755200 Revol'g About 5 m. N. E. O. P. C. and S. side of ent. to B. R. 370500762100 Revol'g 40 On an isl. between C. Hen. and C. Char. on the ocean 375436752145 Fixed On L. W's I., E. side of C. B., N. E. of S. ent. T.S. 374500760400 Fixed 8. E. of S. P. in Ches'ke B. and of m'th of Potomac Near C. I., W. side of ent. to Eliz. R. and Norfolk S. side of entrance to Hampton Roads ........... Between mouths of York and Rappaliannock Rivers Off W. P., N. side of entrance to Rappahannock R. Near said rock in Rappahannock River.

Off said Pt b the Narrows, and $44 \mathrm{~m}$. b. Mt. Verno Between said P. and Y ate's P. above Kettle Bottom Near mouth of C. Fear River, E. side............. On Federal Point, N. side of inlet to C. Fear River. On C. Hatteras, about $1 \mathrm{~m}$. N. of high-water mark. S. side of entrance to Pamptico River............. S. W. of C. Hatteras, and E. side of Ocracoke Inlet. 350630755800 Rerol'g 75 Near the end of the Cape........................34 3700743300 Fixed 95 Lights range with chan. on entering Cape Fear $R$. On W. bank of Cape Fear River. .

On W. bank of C. Fear R., mouth of Price's Creek On C. I., in C. Fear R., S. W. cor. of its lower end On E. point of Shoal, in Pamlico Sound. .

On pt, of Shoal, Pamlico S'd.W., $9 \mathrm{~m}$. from Ocracoke $4 \mathrm{~m}$. N. by W. of Ocracoke, \& N. E. side of Royal S Near ent. of P. into Pamlico Sound, off Marsh Pt. On point of Shoal in S. part of Pamlico Sound... On H. Isl. Bar, between Pamlico and Cove Sounds S. side of Pasquotank River, on Albemarle Sound Near R. I., between Pamlico and Albemarle Sounds Near its entrance into Albemarle Sound

On H. S., bet'n N. in. and Price's Cr. in C. Fear R.

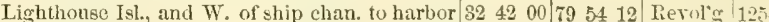
On C. Romain, $10 \mathrm{~m} . \mathrm{S}$. W. of ent. to Santee River 3301007924 no Fixel $\mid$ si On S. end of N. Isl., E, side of ent. to Peedee River 330730790130 Fixed 89

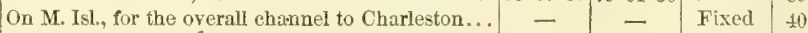
$\left.\begin{array}{l}\text { Back of } \mathrm{S} \text {. Isl., } \\ \text { S. of F. Moultrie, }\end{array}\right\}$ to guide over Charleston Bar $\left\{\begin{array}{llllll}32 & 46 & 51 & 79 & 53 & 60 \\ 30 & 45 & 29 & 70 & 5 \% & 5\end{array}\right\}$ Fixed Off the entrance to St. Helena Sound, etc........ N. E. end of T. I., and S. side of ent. to Savannah R. $3200 \quad 00$ S0 5200 Fixed 100 ${ }_{3}^{3} \mathrm{~m}$. E. light-house..................... Fixed 50 On E. end of F. I., in Savanaah River (red shades) - _ - Fixed On S. end of St. S. Isl., and N. side ent, to the Sound 310800818600 Fixed so On S. end of S. Isl., and N. ent. to Doboy Sound.. $31 \quad 21 \quad 30, \$ 12400$ Revol'g 74 


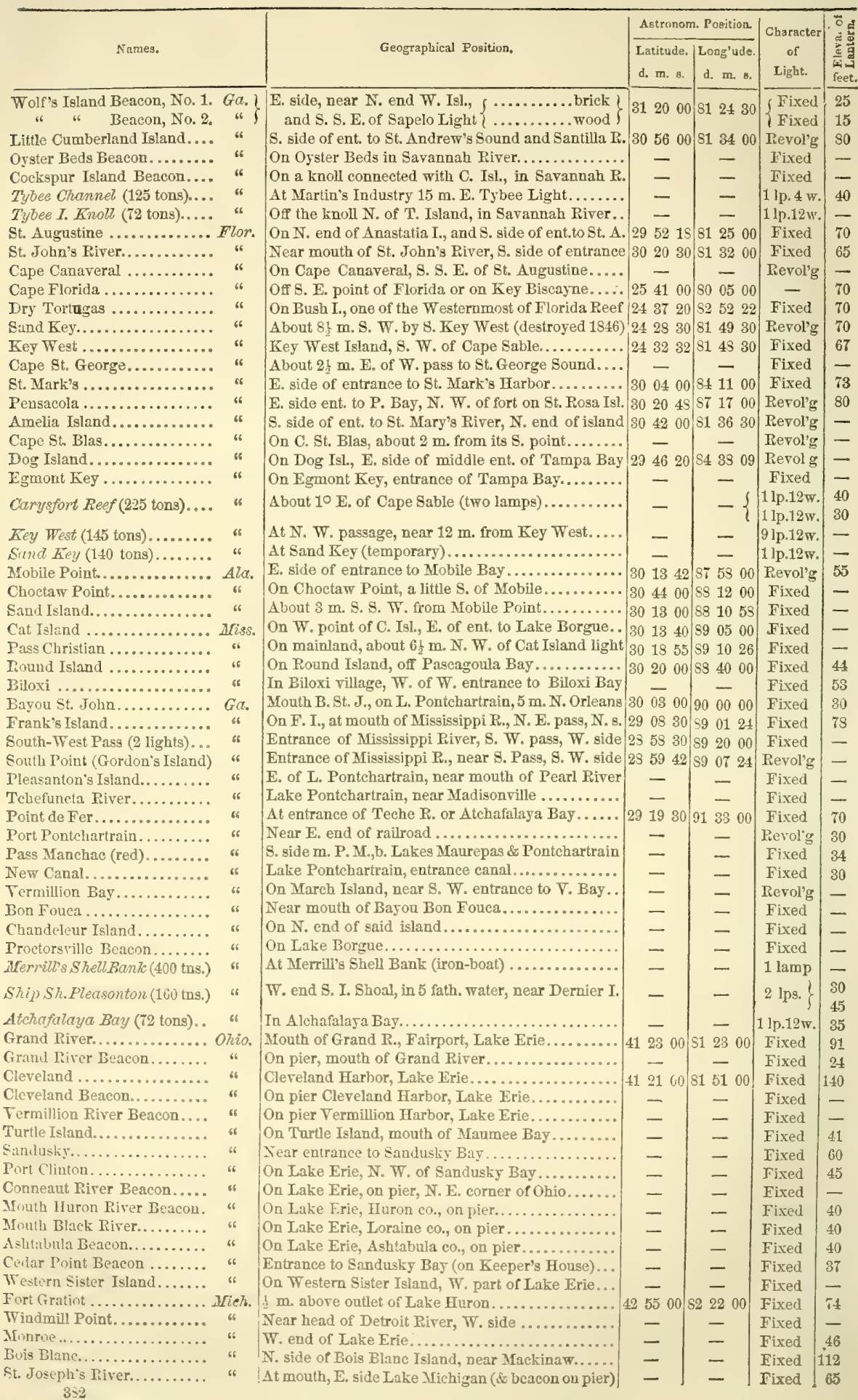




\begin{tabular}{|c|c|c|c|c|c|}
\hline \multirow[b]{2}{*}{ Names. } & \multirow[b]{2}{*}{ Geographical Position. } & \multicolumn{2}{|c|}{ Astronom. Position. ! } & \multirow{2}{*}{$\begin{array}{c}\text { Character } \\
\text { of } \\
\text { Light. }\end{array}$} & \multirow{2}{*}{ 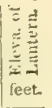 } \\
\hline & & $\begin{array}{c}\text { Latitude. } \\
\text { d. m. } 9 .\end{array}$ & $\begin{array}{c}\text { Long'ude } \\
\text { d. m. s, }\end{array}$ & & \\
\hline .... Mich. & ke Huron, N. E. o & - & - & & \\
\hline Gibraltar............... " & Louth of Detroit River........... & 一 & 一 & & \\
\hline Grand River......... & side of Lake Michigan...... & - & 一 & Fixed & 4 \\
\hline Manitou Island .......... & part of Lake Michigan .......... & - & 一 & Fixed & \\
\hline New Buffalo (and beacon)... & ear S. end, E. side of Lake Michigan... & 一 & 一 & Fixed & \\
\hline Presque Isle............. & . W. shore of Lake Huron................... & - & - & Revol'g & \\
\hline Kalamazoo Piver...... & E. shore of Lake Michigan........ & 一 & - & Fixed & 42 \\
\hline Pottawottamie....... & n Pottawottamie Island, entrance Gr & - & - & Fixed & 120 \\
\hline Saginaw Bay....... & gginaw River..... & - & - & Fixed & \\
\hline Clinton Piver.............. & nton River, in Lake St. Clair.... & - & - & Fixed & \\
\hline Point aux Barques.. & 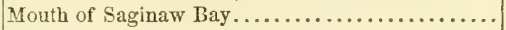 & - & 一 & Fixed & \\
\hline Detour.................. & L. Huron & - & - & ed & \\
\hline White Fish Point...... & On White Fish Point i & - & 一 & Fixed & \\
\hline Copper Harbor........ & At Copper IIarbor, in Lake Superior........ & 一 & 一 & ced & \\
\hline Eagle Harbor....... & uperior & 一 & 一 & Fixed & \\
\hline Manitou Island . . . . . . . . . . & ke Superior... & 一 & 一 & & \\
\hline Grass Island Beacon . . . . . . . . & $\ldots \ldots$ & - & 一 & Fixed & \\
\hline Lamajuda Beacon. ......... & $\ldots \ldots$ & - & $\longrightarrow$ & ed & \\
\hline killagalee Rock........... & Ro & 一 & 一 & ed & \\
\hline Straits (121 tons) & and Michiga & - & 一 & $1 \mathrm{Ip} .12 \mathrm{w}$. & \\
\hline igan City.. & & 一 & $\longrightarrow$ & red & 60 \\
\hline Chicago (and beacon)....... Ill. & S. bank C. River, Lake Michigan (beacon on pier) & - & - & Fixed & 一 \\
\hline Fort... & L. F. V., S. side of r., S. W. shore L. Michigan & - & - & Fixed & \\
\hline Iilwaukie (and beacon)..... Wisc. & Mouth of Milwaukie River, W. side of L. Michigan & - & $\longrightarrow$ & Fixed & - \\
\hline bot River (Racine)........ " & Mouth of Root River, W. side of Lake Michigan. . & 424938 & 874022 & Revol'g & \\
\hline heboygan .............. & Mouth of Sheboygan River, W. side Lake Michigan & - & - & Fixed & \\
\hline Ianitouwoc $\ldots \ldots \ldots$. & igat & - & 一 & Fixed & \\
\hline South Port (Kenosha)... & Island, & - & 一 & Fixed & - \\
\hline Tail Point.............. & River, Green $\mathrm{Ba}$ & - & - & Fixed & \\
\hline Port Washington... & ngton, N. E. part of Green Bay & 一 & - & & \\
\hline ort de Mort... & 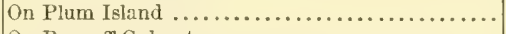 & - & 一 & & \\
\hline alventon Bar (145 tons).... Tex. & On Bar, off Galveston... & $\overrightarrow{40}$ & $\overline{0}$ & & \\
\hline
\end{tabular}

Point Lobos............. Calif. |S. side of entrance to San Francisco Harbor....... 3749221222833 Fixed 392

BRITISI LIGMT-IIOCSES IN THE BAY OF FUNDY, ETO.

Cape Enragè-Fixed light: 161 feet above high tide. Lat. $45 \circ 36^{\prime}$, and long. $64^{\circ} 46^{\prime} 40^{\prime \prime}$.

Quaco.-Revolving lights (white and red): 70 feet above high tide. Lat. $45^{\circ} 19^{\prime} 33^{\prime \prime}$, and long. $65^{\circ} 31^{\prime} 54^{\prime \prime}$.

St. John Harbor.- On Partridge Island. Fixed light: 119 feet above high tide. Lat, $45^{\circ} 14^{\prime} 03^{\prime \prime}$, and long. $66^{\circ} 35^{\prime}$.

St. John Harbor.-Beacon tower. Fixed light : 41 feet above high tide. Lat $45^{\circ} 15^{\prime}$, and long. $66^{\circ} 03^{\prime} 36^{\prime \prime}$.

Point Lepreau.-Two fixed lights, 28 feet apart: 81 and 53 feet above high tide. Lat. $45^{\circ} 03^{\prime} 50^{\prime \prime}$, and long. $66^{\circ} 27^{\prime} 30^{\prime \prime}$. Campo Bello Island.-Fixed light: 64 feet above high tide. Lat. $44^{\circ} 57^{\prime} 40^{\prime \prime}$, and long. $66^{\circ} 53^{\prime} 55^{\prime \prime}$.

St. Andrewo's Point.-Fixed light: 42 feet above high tide. Lat. $45^{\circ} 04^{\prime} 13^{\prime \prime}$, and long. $67^{\circ} 03^{\prime} 43^{\prime \prime}$.

IFachias Seal Islands.-East Isl. Two fixed lights, 200 feet apart: $48 \mathrm{ft}$. above tide. Lat. $44^{\circ} 30^{\prime} 03^{\prime \prime}$, long. $67^{\circ} 06^{\prime} 10^{\prime \prime}$. Gannet Rock.-Revolving (20 seconds) : 56 feet above high tide. Lat. $44^{\circ} 30^{\prime} 40^{\prime \prime}$, and long. $66^{\circ} 52^{\prime}$.

Bryer Istand.-West part. Fixed light: 92 feet above high tide. Lat. $41^{\circ} 15^{\prime} 51^{\prime \prime}$, and long. $66^{\circ} 23^{\prime} 02^{\prime \prime}$.

Annapolis Gut.-Fixed light: 76 feet above high tide. Lat. $44^{\circ} 40^{\prime} 50^{\prime \prime}$, and long. $65^{\circ} 47^{\prime} 20^{\prime \prime}$.
Bryer Island Light Beacon.-At S. entrance to Westport Two white lights: 40 feet above high tide.

Barrington Light.—On Cape Latour. Revolv'g light: 50 feet above sea level. Lat, $43^{\circ} 26^{\prime} 09^{\prime \prime}$, and long. $65^{\circ} 28^{\prime} 07^{\prime \prime}$.

And the following lights are on the outer coast of Nova Scotia:

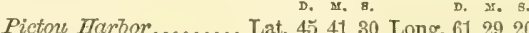

Cansco Gut............ " 454149 " 612920

Guysboro' Harbor...... " 452200 " 613100

Cunsean............. " 452000 " 605146

Sidney ................ " 461616 " 601000

Scatarie Istand........ " " $4602 \quad 17$ " 595400

Louisung Harbor...... " " 455300 " 595000

Beaver 1szands......... * 444900 " 625100

Halifaw Harbor........ " " 413605 " 633540

Sambro Istand......... " "44 2617 " 633516

Lumenburg Bay........ " 442200 " 640600

Liverpool Bay......... " 410150 " 614049

Shelbourne IIarbor.... " 433731 " 651630 Seul Islend ........... " 422350 " 660020

Iormouth............. "
LiguTs CORNERs, p. O., Waldo co, Me. : about $1 \mathrm{~m}$. E. of Museongus r., 25 m. E. by S. Augusta.

Light Street, p. v., Columbia co., Penn.: on the E. side of Fishing er., $56 \mathrm{~m}$. N. by E. Harrisburg. It contains 2 anthracite blast furnaces, of 2,000 tons capacity each, and 459 inhabitants.

Ligonere, to and p. v., Westmoreland county, Penn. : weekly.
$119 \mathrm{~m}$. W. Harrisburg, Drained by Loyalhanna cr. and branches, which turn several large flour and saw mills. It is mostly a rich valley, on the W. side of Laurel Hills, and farming and grazing are the leading interests. The village contains an academy, several stores, and a printingoffice, whence the "Ligonier Free Press" (neut.) is issued 
Ligonier, p. v., Noble co., Ind.: on Elkhart r., $118 \mathrm{~m}$. N. by E. Indianapolis.

LIKENS, to and p. o., Crawford county, Ohio: $65 \mathrm{~m} . \mathrm{N}$. Columbus. Drained by branches of Sandusky r. Surface varied, and soil adapted to grain. Pop. 1,155.

Lilesville, p. o., Anson co., N. Car.: 94 m. S.W. by W. Raleigh.

Lillecase, p. v., Will county, $M$.: 158 miles $N$. N. E. Springfield.

Lrma, p. o, Adams county, $I l l$.: about $6 \mathrm{~m}$. E. of the Mississippi, $93 \mathrm{~m}$. W. by N. Springfleld.

Lrws, p. v., La Grange county, Ind.: on the N. side of Pigeon r., $137 \mathrm{~m}$. N. by E. Indianapolis. It enjoys a large trade with the fertile country around it by means of several plank-roads centering here, and contains an academy, several mills and stores, and 800 inhabitants. The "La Grange Whig" is published weekly.

Lrm., t. and p. v., Washtenau co., Mich.: 43 m. S. E. Lansing. Drained by Mill cr. and its N. branch, affluents

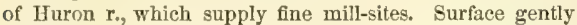
rolling, and soil excellent for wheat and corn. The Michigan Central R. R. crosses the N. part. The $\mathrm{v}$. is on the N. branch, and eontains several stores and mills. Pop. of t. 912.

LiMA, t. and p. v., Livingston co., N. Y.: $202 \mathrm{~m}$.W. by N. Albany. Drained by Honeoye cr. and its branches, which furnish good mill-sites. Surface rolling; soil clay and calcareous loam, and under high cultivation. A superior farming t., with several flouring mills and small manufactories. The $v$. is not compact, but very pleasantly built, and contains a number of stores, and 500 inbabitants. The Genesee Wesleyan Seminary, incorporated here in 1834, is a large, well endowed, and flourishing institution. The Canandaigua and Niagara R. R. crosses the t. Pop. of t. $2,433$.

Lima, p. v., and cap. Allen co., Ohio: on Ottawa cr., a branch of Maumee r., $79 \mathrm{~m} . \mathrm{N}$. W. Columbus. It contains a court-house and jail, an academy, a dozen stores, and 757 inhabitants. The "L. Argus" (dem.) is published weckly.

Lrus, p. v., Delaware county, Penn.: 78 m. E. by $\mathrm{S}$. Harrisburg.

Lrus, p. o., St. Tammany par., La.: 69 m. E. Baton Rouge.

Lima, t. and p. 0., Rock co., Wisc.: $33 \mathrm{~m}$. S. E. by E. Madison. Surface undulating, and soil very productive. The Milwaukie and Mississippi R. R. passes through it. Pop. 839.

Lima, sta., Stark county, Ohio: on the Cleveland and Pittsburg R. R., $53 \mathrm{~m}$. from Cleveland.

Lmaville, p. v., Stark co., Ohio: 116 m. N. E. by E. Columbus.

Liniber Lost, p. o., Adams co., Ind.: on a branch of Wabash r., 82 m. N. E. Indianapolis.

LrMerick, t. and p. v, Tork county, Me.: $72 \mathrm{~m} . \mathrm{S} . \mathrm{W}$. Augusta. Drained by Little Ossipee $r$. and a cr, flowing into it, which furnish good mill-sites. Soil very productive of most farming staples. The v. contains a large and flourishing academy, incorporated in 1512, several stores and industrial establishments, and a printing office, where the "Free Will Baptist Repository" is published weekiy. Pop. of t. 1,473.

Limertos, p. v. and sta., Jefferson co., $N$. $Y$ : on Perch cr., $152 \mathrm{~m}$. N. W. Albany. It contains several stores and 300 inhabitants. The sta. is $8 \mathrm{~m}$. W. of Watertown, on the Watertown and Rome R. R.

Linerick, t., p. o., and sta., Montgomery co., Penn.: on the left bank of Schuylkill r., $71 \mathrm{~m}$. E. Harrisburg. Surface varied, and soil highly productive. The Philadelphia and Reading $R_{\text {. }} \mathrm{R}$. passes along the $r_{0}$, and the sta. is $14 \mathrm{~m}$. from Peading. Pop. of t. 2,165.

Limertck Bridge, p. o., Montgomery co., Penn. : $69 \mathrm{~m}$. E. Harrisburg.
Lime Ridge, p. O., Columbia co, Penn, 58 m. N. N. E. Harrisburg.

Lny Rock, p. o., Litchfield co., Conn.: near Salmon cr. of the Housatonic, $41 \mathrm{~m}$. W. by N. Hartford. The iron mines of Salisbury are in its vicinity.

LIME Rock, p. v., Providence co., R. T.: 8 m. N. by W Providence. The chief business carried on is the manufacture of lime, which employs a large capital and many bands. It contains a bank, an academy, and several stores.

Lnestone county, Ala. Situate N., and contains 549 sq. m. Drained by Elk r., Moody's Fork, Swan, Pinery, and Limestone creeks, affluents of the Tennessee, which forms its S. boundary. Surface gently broken, with some quite low land; soil very productive. Cotton is the leading staple, and is raised in very large quantities, the land being inferior to little in the State for its cultivation. Corn yields fine crops, and wheat and oats generally do well. Pork is an important article of export. Its streams afford many water privileges, and its manufactures are considerable and rapidly increasing. Farms 649; manuf. 28; dwell. 1,429, and pop. -wh. 8,405, fr. col. 15, sl. 8,063-total 16,483. Capital: Athens.

Linestone county, Tex. Situate E. centrally, and contrins $856 \mathrm{sq} . \mathrm{m}$. Drained by Navasoto $\mathbf{r}$. and its branches, Lake, Plumer, Cbristmas, and Steel's creeks, and Big cr. of the Brazos. Surface considerably broken and hilly; in the $\mathrm{s}$. undulating. Much of the $c 0$. is prairie, with groves of post oak, and the soil a deep loam of great fertility. Corn and cotton grow finely, and the grazing is superior. Limestone and sandstone are abundant, and salt springs are found. Iron ore in immense quantities is found in or near the billy regions; and coal is supposed to be in the ricinity. Farms 279 ; manuf. 0 ; dwell. 380 , and pop.-wh. 1,990, fr. col. 0 ; sl. 618-total 2,608. Capital: Springfiel 1.

Limestone, p. o., Buneombe co., N. Car. : 228 m. W. by S. Raleigh.

Limestone, p. o., Clarion co., Penn.: 139 m. W. N. W. Harrisburg.

Limestone, p. o., Hamilton co., Tenn.: 107 m. S. E. Nashville.

LrMestoNe, p. o., Cattaraugus co., $N . Y .: 257 \mathrm{~m}$. W. by S. Albany.

Limestone, p. v., Iroquois co., $\pi$ ill. : on the left bank of the Kankakee r., 181 m. N. E. Springfield.

Lluestone River, p. 0., Aroostook co., Me.: $13 \mathrm{~S} \mathrm{~m}$. N. N. E. Augusta.

Lungstone Springs, p. 0., Spartanburg dist., S. Car. : $78 \mathrm{~m}$. N. N. W. Columbia.

Lniestone Spriygs, p. o., Greene co., Tenn. : 221 m. E. Nashville.

Lisestome Weli, p. o., Forsyth co., N. Car.: $109 \mathrm{~m}$. W. N. W. Raleigh.

Lnetows, p. o., Washington co., Penn.: $173 \mathrm{~m}$. W. Harrisburg.

Limingrov, t. and p. o., York co., Me.: 65 m. S. W. Augusta. Bounded N. and E. by Saco r., and 8. by Little Ossipee r., its branch, on which are numerous water priyileges. Surface broken; soil very fertile, and excellent grain land. Incorporated in 1762. Pop. 2,116.

Lrrcoly county, $G a$. Situate N. E., and contains 195 sq. m. Bounded E. by Savannah River, S. by its branch, Little r., and drained by their branches, Broad r., Fishing, Soap, and Loyd's creeks. Surface diversified, in parts hilly ; soil fertile. Cotton is the great and almost exclusive staple, being universally cultivated, and producing great crops, Corn and wheat are raised with considerable success, and large numbers of swine are fatted. It has good mill streams, on which are several flourishing manufactories. Farms, 273; manuf. 13; dwell. 378, and pop.-wh. 2,187, fr. col. 31, sl. 3,780-total 5,993. Capital: Lincolnton.

LINCOLN county, $K y$. Situate E. centrally, and contains 369 sq. m. Drained N. E. by Dick's r. and its branch, Hanging Fork, affuents of the Kentucky, and S. and W 
by small affluents of Cumberland r., and heads of Green $r$. Surface elevated table land; soil very productive, and well adapted to rearing cattle. Corn is the staple cereal ; wheat, rye, and oats yield well. Particular attention is given to raising cattle, horses, and sheep. Live stock, wool, and pork are important exports. The streams are small, but furnish many raill-seats. Farms 614; manuf. 67; dwell. 1,145, and pop.-Wh. 6,635, fr. col. 103, sl. 3,35อ̄-total 10,093. Capitul: Stanford.

LLYCoLx county, Mfe. Situate S. W., and contains $824 \mathrm{sq} . \mathrm{m}$. Androscogrin $r$, bounds it $S . W$.; in the W. Kennebec $r$. and farther $\mathrm{E}$. Sheepscott, Damariscotta, Muscongus, and St. George rivers flow through the co. into the Atlantic, which forms the S. boundary. In the $\mathrm{S}$. are Sheepscott and Muscongus bays, and E. the mouth of Penobscot Bay, with numerous smaller ones, which, sheltered by innumerable islands that cover nlmost the whole coast, furnish many excellent harbors. Surface much varied, and cut up by ponds and large water-courses; soil mostly very fertile, and superior grazing land. Corn, barley, oats, wheat, and rye are grown with profit; but the staple is the potato crop, which is very large, and furnishes a valuable export. sheep are special objects of care, and the shearings are very large and of superior quality. Water-power is abundant, and the manufactures of lumber, leather, woolen goods, ironware, and earthenware are extensive. Large cotton factories have lately been built in the W., and bid fair to become its leading interest. Its rivers are navigable for vessels of all sizes; the lumber trade and ship-building are much prosecuted ; and its facilities for commerce are hardly equalled. It has a large trade with the West Indies, and is extensively concerned in the coast trade and fisheries. Farms 4,975; manuf. 526; dwell. 12,176, and pop.-Wh. 74,616, fr. col. 259-total 74,875 . Capitals: Warren, W iscasset, and Topsham. Public Works: Portland and Kennebec R. R., Penobscot and Kennebec R. R., etc

Incour county, Mo. Sitnate E. on the N. of Missouri r., and contains 577 sq. m. Drained by Au Cuivre r., its branches Indian cr. and Eagle Fork, and smaller affluents of the Mississippi, which forms its E. boundary. Surface generally uncven: soil very fertile, and well adapted to grain and grass. Corn is the staple cereal. Wheat and tobacco are successfully cultirated. Cattle and pork are exported. The streams are of good size, with considerable water-power, and timber is plenty. Farms 849 ; manuf. 10; dwell. 1,239, and pop.-wh. 7,339, fr. col. 5, sl. 2,027-total 9,411. Capital: Troy.

Liscoln county, $N$. Car. Situate W., and contains 269 sq. m. Drained by Catawba and Little Catawba rivers and their branches. Surface somewhat broken; soil of good fertility. Cotton, corn, and wheat are the staples, and largely raised. It has fine pasture, and exports live stock and pork. The streams are uumerous, and afford much water-power, a large part of which is used in manufacturing flour, leather, oil, and cotton goods. Farms 711; manuf. 61; dwell. 1,022, and pop.-wh. 5,661, fr. col. 30, sl. 2,055-total 7,746. Cupital: Lincolnton.

Lircoln county, Tenn. Situate eentrally on S. line, and contrins $832 \mathrm{sq}$. m. Drained by Elk $\mathbf{r}$. and its branches, affuents of the Tennessee. Surface moderately elevated, and somewhat hilly; soil highly productive. Corn is the chief staple. Cotton and wheat are good crops, and pork is a very large export. A fine co. for farming or grazing, with good mill streams and large manufactures of flour, leather, liquor, cottons, etc. Farms 1,926; manuf. 100; dwell. 3,010, and pop.-wh. 17,S09, fr. col. 62, sl. 5,621-total 23,492. Capital. Fayetteville.

Lircolw, t. and p. o., Penobseot co, MYe. 95 m. N. E. by N. Augusta. It lies on the left bank of the Penobscot, below Matakeunk r.. and has a large territory of fertile soil, with numerous ponds, and abundance of timber. The lumber trade is very heavy. Pop. 1,35 .

Lricolix, t. and p. v., Middlesex co., Mass.: $13 \mathrm{~m}$. W. N. W. Boston. Drained by branches of Sudbury its W. boundary, and a branch of Charles $r$. Surface rough and hilly; soil various. It has many excellent farms, and a pond, much visited for its fine pickerel. Various manufactures are carrict on in a small way. The Fitchburs P. R. passes through it, and has a sta. about $2 \mathrm{~m}$. from the $\mathrm{v}_{\text {, }}$ and $17 \mathrm{~m}$. W. of Boston. Pop. of t. 682 .

Lincolv, p. o., Yazoo co., Miss. : on a branch of Yazoo r., $81 \mathrm{~m}$. N. N. W. Jackson.

LINCOLN, p. v., Winnebago co., $I U$. : $182 \mathrm{~m}$. N. Springfleld. Lncols, t. and p. o., Grafton co., N. Hamp.: $59 \mathrm{~m}$. $\mathrm{N}$. by W. Concord. It is very mountainous, subject to frequent land slides, and has a sterile soil, but abounds in game of all kinds, and is a fayorite summer resort. Pop. 57.

Lincolis, t. and p. o., Morrow co., Ohio: $34 \mathrm{~m}$. N. by E. Columbus, The Cleveland, Columbus, and Cincinnati P. P. crosses the N. W. corner. Pop. 891.

Lincolv, t. and p. o., Addison county, Verm.: $23 \mathrm{~m}$ W. S. W. Montpelier. Drained by New Haven r., a branch of Otter cr., which supplies it with fine mill-sites. Surface uneven, and soil better adapted to grazing than grain growing. The elip of wool is large, and several forges are successfully operated. Pop. 1,057.

Lincoln Centre, p. v., Penobscot co., Me.: on the left bank of Penobseot r., $101 \mathrm{~m}$. N. E. by N. Augusta.

Lincolnton, p. v., and eap. Lincoln co., Ga. : 73 m. N. E Milledgeville. It contains a court-house, jail, academy, and 200 inhabitants.

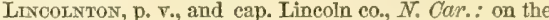
E. side of Little (or South) Catawba r., $178 \mathrm{~m}$. W. by S. Raleigh. It contains a court-house, 3 academies, 15 large stores, and about 1,000 inhabitants. Its trade is extensive, and near it are several mills and furnaces, producing large amounts of cotton goods, ironware, etc. The "Courier" and "Republican" are published weekly.

Lincolnville, t. and p. o., Waldo co., Me. : $37 \mathrm{~m}$. E. Augusta. The t. lies on the W. side of Penobseot Bay, and has a large pond in the W., which, and a stream on the N.line, afford good water-power. It has a fine soil for grain and potatoes, and manufactures woolens, leather, and lumber. Duck Trap in the N. E. is a grod harbor, and the t. has a valuable coasting trade. Pop. 2,174.

LIND, p. 0., Winnebago co., Wisc.: 84 m. N. N. E. Madison. LINDEN, p. v., and cap. Marengo co., Ala.: on Chickasaw Bogue, $9 \mathrm{~m}$. E. of the Tombigbee, $85 \mathrm{~m}$. W. Montgomery. It contains a court-house, jail, 2 academies, several large stores, and 400 inhabitants. Two weekly papers are published, the "L. Free Press," and the "Alabama Argus." Linden, p. o., Copiah co., Miss.: 37 m. S. S. W. Jackson,

LINDEN, p.. ., and cap. Atchison county, MFo.: 249 miles N. W. by W. Jefferson City. It contains a court-house, hotel, and a few stores.

Linden, p. v. and sta., Genesee county, N. Y.: $281 \mathrm{~m}$ $\mathrm{W}$. by $\mathrm{N}$. Albany. The sta. is $7 . \mathrm{m}, \mathrm{E}$. of Attica on the Buffalo and New York City R. P.

Linden, p. v., Lycoming co., Penn.: on the N. bank of Susquehanna r., 68 m. N. by W. Harrisburg. The Pennsylvania Canal passes through it $8 \mathrm{~m}$. W. of Williamsport.

LINDEN, p. $\mathrm{v}_{n}$, Iowa co., Wisc.: on a branch of Pecketonica $1 ., 44 \mathrm{~m}$. W. by S. Madison. Nining is the chief business.

Linden, p. v., and eap. Perry co., Tenn.: 66 m. W. S. W. Nashville. It contains a court-house, and a few stores and dwellings.

LINDEN Grove, Kenton co., Ky.: the site of a fine cemetery, about a mile from Covington.

LINDENville, p. v., Ashtabula co., Ohio: 153 m. N. E. Columbus.

LINDENTOOD, p. V., Ogle county, $\pi l$.: $16 t$ miles N. by $\mathrm{E}$. Springfield.

LiNDLex's, p. 0., Ohio co., Ky.: near Green r., 132 m. TV. S. W. Frankfort.

LINDLEX's Store, p. o., Orange county, $N$. Car.: $87 \mathrm{~m}$. N. W. Raleigh. 
Lindleytown, p. v., Steuben co., $N$. $Y .: 181 \mathrm{~m}$. W. by S. Albany. It is near Tioga r., along which the Corning and Blossburg R. R. passes.

LiNduy's Mruls, p. o., Washington co., Penn.: $182 \mathrm{~m}$. T. Inarisburg.

Lindsar's Mul, p. o., Trigg co., Ky.: 191 m. S. W. by W. Frankfort.

Lindsax's TURxout, sta., Albemarle co., Virg.: on the Virginia Central R. R., 5 m. S. W. of Gordonsville.

LINE, p. o., De Kalb co., $M l_{\circ}: 167 \mathrm{~m}$. N. by E. Springfield. LiNe, p. o., Fulton co., $K y_{\bullet} ; 255 \mathrm{~m}$. W. S. W. Frankfort. LiNe Creek, p. o., Laurens district, S. Car.: 74 miles N. W. by W. Columbia.

LiNe CreeK, p. o., Montgomery co., Ala. : 26 m. E. S. E. Montgomery.

LiNe Creyk, p. 0., Oktibbeha county, Afïss.: $104 \mathrm{~m}$. N. E. by N. Jackson.

Lne Lexirgtor, p. v., Bucks county, Penn. : 83 m. E. Harrisburg. It contains about 100 inhabitants, and lies on the county line, where three towns meet in it.

Line Mrus, p. o., Crawford county, Penn.: 207 miles N. W. by W. Harrisburg.

Line Mountain, p. o., Northumberland co., Penn. : $34 \mathrm{~m}$. N. by E. Harrisburg.

Line Port, p. 0., Stewart co., Tenn. : 55 m. W. N. W. Nashville.

LiNe STORe, p. o., Hinds county, $1 / 2 s s .: 17$ m. S. by W. Jackson. The New Orleans, Jackson, and Northern R. R. passes here.

Linglestown, p. v., Dauphin co., Penn. : 8 m. N. N. E. Harrisburg.

Livklaten, t. and p. o., Chenango co., N. T.: $109 \mathrm{~m}$. W. Albany. Drained by branches of Otselic r. Surface even, and soil adapted to grain growing, which is the leading interest. Pop. 1,196.

LINN county, Ia. Situate centrally, and contains 720 sq. m. Drained by Prairie and Cedar creeks and branches, and $\mathrm{N}$. E. by Buffalo er. and Wapsipinicon r. Surface undulating, and soil very fertile, equally adapted to grain and grass, raising heavy crops of corn and wheat, and feeding many cattle and sheep. The streams are large, with considerable falls, and skirted with good timber. Farms 526; manuf. 23; dwell. 991, and pop.-wh. 5,411, fr. col. 8-total 5,414. Capital: Marion.

LiNn county, M5o. Situate N. middle, and contains 645 sq. m. Drained by Locust, Elk, Turkey, Tellow, and Little Yellow ereeks, branches of Grand $\mathbf{r}$. Surface rolling, and soil generally fertile. It has plenty of timber, fine grazing, and abundauce of mast, and exports corn and pork in large quantities. Farms 429 ; manuf. 0 ; dwell. 625 , and pop.wh. 3,651, fr. col. 0, sl. 877-total 4,058. Oapital: Linneus.

Livy county, Oreg. Ter. Situate S., and contains about 18,000 sq. m. It has the Willamette for its W. boundary, and is drained by its branches, North and South forks of Santiam r., with their affluents, Thomas, Crab Tree, and Beaver creeks, and Calapooga and M'Kenzie's forks. The settled parts are between Cascade mountains and the Willamette, where the surface is but slightly broken, and the valleys alluvial bottoms of great beauty and fertility. Grains, fruits, and regetables of most kinds yield abundantly. The water-power is very superior, and timber of the tallest kint. Farms 136; manuf. 6; dwell. 172, and pop.wh. 994, fr. col. 0-total 99!. Capital: New Albany.

Lixv, p. v., and cap. Osage co., MFo.: at the head of Loose cr. of the Missouri, $18 \mathrm{~m}$. E. by S. Jefferson City. It consists of a court-house, an academy, and several stores.

Lavx Crrx, p. v., Washington co., Oreg. Ter..: on the lef bank of the Willamette, $33 \mathrm{~m}$. N. E. by $\mathrm{N}$. Salem. It is situate at the extreme bend of the r., opposite to Oregon City, and has a great water-power, which is improved by several saw and flouring mills. Pop. about 185.

Luxieses, to and p. 0., Aroostook county, $M e_{\text {.: }} 154 \mathrm{~m}$. N. E. by N. Augusta, It has several ponds, which give 386 rise to streams flowing into the St. John and Penobscot. An elevated surface, and a dense growth of timber. The soil is fertile. Pop. 561.

LINNEUS, p. V., and eap. Linn co, MFo.: on a branch of Locust er., $102 \mathrm{~m} . \mathrm{N}$. W. by N. Jefferson City. It contains a court-house and several dwellings.

Linn F LAT, p. o., Nacogdoches co., Tex. : 216 m. E. N. E. Austiu City.

Linn Grove, p. F., Adams county, Ind.: on W. side of Wabash r., $82 \mathrm{~m}$. N. E. Indianapolis.

LiN v vilue, p. v., Licking co., Ohio : 34 m. E. Columbus, Pop. 188

LiNviLle Creek, p. o., Rockingham co., Virg. : 106 m, N. W. by W. Richmond.

Linnvilie River, p. o., Burke co., N. Car.: on a branch of Catawba r. so called, $184 \mathrm{~m}$. W. Raleigh.

Liston, p. v., Des Moines co., Ia. : $45 \mathrm{~m}$. S. by E. Iowa City.

Lпvтon, p. v., Greene co., Ind.: 72 m. S.W. Indianapolis, LLNwood, p. 0., Cherokee county, Tex.: 184 m. E. N. E. Austin City.

Lion's Beard, p. o., Sevier co., Ark. : 128 m. W. S. W. Little Rock.

Lionvilue, p. v., Chester co., Penn,: 64 m. E. by S. Harrisburg.

Lisbon, t. and p. v., Nerv London county, Conn.: $36 \mathrm{~m}$, E. S. E. Hartford. It lies chiefly between Shetucket and Quinnebang rivers, which unite in the $\mathbf{S}$., and with their branches supply fine water-power. Surface uneven; soil sandy or gravelly inam, and excellent farming land, with extensire meadows on the streams. Farming is the leading pursuit. Cotton and woolen goods are made, and several Finds of "Yankee notions." The Norwich and Worcester R. R. passes through the E. part along the Quinnebang. Pop. 937.

Lisbox, p. v., Kendall county, $\Pi l_{0} ; 134 \mathrm{~m}$. N. E. by N. Springfield.

Lisbon, t. and p. o., Lincoln county, Me.: 27 m. S. S. W. Augusta. Drained by Little $r$. and the Androscoggin, which bounds it $S$., and has fiue falls here, $6 \mathrm{~m}$. below Lewiston falls. Soil very fertile, and well cultivated. Cotton and woolen goods are made, and large saw-mills run. A bridge crosses the $r$. here. Pop. of t. 1,495.

Lisbor, p. v., Howard co., Md.: on the Baltimore and Frederick turnpike, $13 \mathrm{~m}$. from Ellicott's Milis, $37 \mathrm{~m}$. N. W Annapolis.

Lision, t. and p. v., Grafton county, N. Hamp. : $68 \mathrm{~m}$. N. by W. Coneord. Drained by Ammonoosuc r. Surface varied. In the S. is Blueberry Mountain. Soil fertile, and divided into alluvial meadows and strong uplands. It is well timbered, makes maple sugar largely, and abounds in iron ore and limestone. Pop. 1,882.

Lisbon, t., p. o., and sta., St. Lawrence co., N.. .: on St. Lawrence ras $166 \mathrm{~m}, \mathrm{~N}$. W. by N. Albany. Surface undulating and heavily timbered with pine, oak, and hemlock. Soil a fertile loam. Lumber and dairy products are valuable exports. The sta, is $9 \mathrm{~m}$. E. of Ogdensburg, on the Northerm (Ogdensburg) R. R. Pop. 5,295.

Lisbox, p. o. and sta., Bedford co., Virg. : on the Virginia and Tennessee R. R., $32 \mathrm{~m}$. W. of Lynchburg, $121 \mathrm{~m}$. W. by S. Richmond.

LisBon, to and p. o., Waukesha co., Wisc. : $59 \mathrm{~m} . \mathbf{E}$ Madison. Drained by heads of Rock $\mathbf{r}$, affording numerous mill-sites. Soils adapted to grass or grain. A plank-road to Milwaukie passes through the S. part. Pop. 1,056.

Lisbon, p. o., Union co., Ark.: 106 m. S. by W. Little Rock.

Lision, p. v., Noble co., Ind.: 119 m, N. N. E. Indianapolis. A plank-road from Fort Wayne passes through it.

Iiszon Cestre, p. 0., St. Lawrence co, $N$. $Y .: 162 \mathrm{~m}$. N. W. by N. Albany.

Lisbura, p. o., Sampson co., $N$. Car.: on Black $\boldsymbol{r}_{\text {., a }}$ branch of Cape Fear r., $69 \mathrm{~m}$. 8. by E. Raleigh. 
Irsitrs, p. F., Cumberland co., Penn.: on Fellow Breeches er. $7 \mathrm{~m}$. S. S. W. Harrisburg. It contains a charcoal force, which makes 520 tons of blooms, and 30 tons of bars per annum.

LIsHA's Kul, p. o, Albany co., $N$. $Y$.

LISIE, p. V., Osage co., Mo.: on the E. bank of Osage r., ahout $3 \mathrm{~m}$. from its mouth, $10 \mathrm{~m}$. E. by S. Jefferson City. It has a fine landing, and considerable trade.

Lisce, t, and p. o., Broome co., N. Y.: $122 \mathrm{~m}$. W. by S. Albany. Drained by Tioughnioga r., on which are numerous saw-mills. Surface undulating, and soil well adapted to grazing. Timber is abundant. Pop. 1,681.

LITCHFLLD county, Conn. Situate N. W., and contains 885 sq. m. Drained W. by Housatonic r, and its branches, and E. by Naugatuck and Farmington rivers and their branches. Surface hilly, and in parts rugged and mountainous; soil a gravelly loam, well cultivated, very productive of all the grains, and generally capital grazing. Largo dairies are kept, and a large amount of wool sheared. The exports are butter, cheese, beef, pork, and wool. It laas an abundance of excellent water-power, and very extensive manufactures. Iron ore of great fineness, and a kind much sought after, is found in parts, and largely wrought, and a valuable copper mine lies in the S. E. Farms 3,621 ; manuf. 487 ; dwell. 8,721, and pop.-wh. 44,266, fr. col. 987-total 45,253. Capital: Litchfield. Pubtic Wortcs: Housatonic R. R.; Naugatuck R. R.; Hartford, Providence, and Fishkill R. P.

Litcherteld, t., p. b., and cap. Litchfield co., Conns: $28 \mathrm{~m}$. W. by S. Hartford. The $t$. lies between the Naugatuck and Shepaug rivers, and is well drained by their affluents and other streams, many of which have large water-power. Great Pond occupies 900 acres, and is the largest watersurface in the State. Surface elevated, and diversified by hills and valleys; soil generally loam, and admirably adapt. ed for grazing. Tile $\mathrm{v}$. on Litchfield Hill is environed by a rich and glowing scenery, and is built mainly on two streets crossing each other at right angles, at the intersection of which is an elegant square. It contains a court-house, jail, etc, an academr, and several schools, 3 churches, 2 printingoffices, and about 700 inhabitants. Two newspapers are published here, the "L. Enquirer" (whig), and the "L. Republican" (dem.), both issued weekly, and circulating about 1,200 copies each. There are several other villages in the t., South Farms, Milton, ete. The t. has numerous manufactures of woolens, paper, leather, iron, etc., and mills of al descriptions. It has also a good wholesale and retail trade, and is connected with the sea-board and interior by the Naugatuck R. R., which follows the valley of the river in the east border of the town. Pop. of t. 3,957. Litchfield has been the birthplace of many men distinguished in national history, science, and in literature.

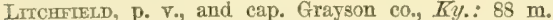
W. S. W. Frankfort, It contains a court-house, jail, academy, and several stores. The Nashville and Louisville R. R. will pass through it.

LTCHनrex, t, and p. v., Kennebec co, Me.: $12 \mathrm{~m}, \mathrm{~S} . \mathrm{W}$. by $\mathrm{S}$. Augusta. In the $\mathrm{N}$. and $\mathrm{E}$. are two large ponds, tributary to the Kennebec, which afford mill-sites. Surface rough in parts, and soil very productive of grain and potatoes. The $\mathrm{v}_{\mathrm{v}}$ is in the $\mathrm{N}_{\text {., }}$ and contains several stores. Pop. of t. 2,106 .

LitchFueid, t. and p. v., Hillsdale co., Dfich. : $47 \mathrm{~m}$. S. by W. Lansing. Drained by St. Joseph's and Sandy rivers, which furnish excellent water privileges. Surface diversified; soil very productive of wheat. Sandstone and iron ore are found. The $\nabla$. is on St. Joseph's $r$, and has extengive mills and a considerable trade. Pop. of $t$. 1,362.

LirchrtetD, to and p. 0., Herkimer co., $N . Y_{*}: 116 \mathrm{~m}$. W. by $N$. Albany. Surface broken, and soil calcareous loam. A farming town, well supplied with timber. Pop. 1,676.

Lxtchrieid, th and p. o., Medina co., Ohio: 95 m. N. E. by N. Columbus. Drained by branches of Black $r$. Surface elevated, and soil fertile. Pop. 1,382.
Litchererd, t. and p. o., Bradford co, Penn.: on the $\mathrm{N}$. line of the State, $114 \mathrm{~m}$. N. by E. Harrisburg. Drained by Weposseping cr. Surface rough, and soil adapted to grazing. It is mostly covered with fine timber, which constitutes its realth.

Litcimield Corners, p. o., Kenncbec co.g Me.: $17 \mathrm{~m}$. S. S. W. Angusta.

Lrтzgow, p. o., Duchess co, $N . Y_{.: 59} \mathrm{~m}$. S. Albany.

Limenoni, sta., De Kalb co., Go. : 24 m. E. of Atlanta, on the Georgia R. P.

Lrruopolis, p. v., Fairfield county, Ohio: $15 \mathrm{~m} . \mathrm{S} . \mathrm{E}$. Columbus. P'op. 396.

Litiz, p. v., Lancaster co., Penn. : 30 mo. E. by S. Harrisburg. It contains an academy, and about 500 inhabitants.

LtTtle Beaver BrIDGE, p. V., Columbiana co., Ohio: on Little Beaver cr., and Sandy and Beaver Canal, about $8 \mathrm{~m}$. from the Ohio r., $136 \mathrm{~m}$. E. by N. Columbus.

IrTtue Buug Rrver, p. 0., Shelby co., Ind. : near a branch of White r. so called, $28 \mathrm{~m}$. E. S. E. Indianapolis.

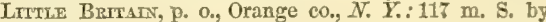
W. Albany.

IrTTL CACAPON, sta., Hampshire co, Virg: on the Baltimore and Ohio R. R., 21 m. E. Cumberland.

Litrue Chucky, p. o., Greene county, Tenn. : 213 m. E. Nashville.

Litule Chutw, p. v., Brown co. Wisc. : on the left bank of Neenah or Fox r., 103 m. N. N. E. Madison. The r. has a fall here of 32 feet in less than $2 \mathrm{~m}$., and affords superior facilities for manufacturing.

Lttrle Compton, to and p. o., Newpori co., R. $I_{0}: 25 \mathrm{~m}$ S. S. E. Providence. It lies on the Atlantic, at the E. side of Narragansett Bay, and has a somewhat uneren surface, and a very fertile and highly cultivated soil. Farming is the chief pursuit, and wool, live stock, and dairy produce, the staples. At Seaconnet Point, in the S. W. corner, is a breakwater, erected by government. The $t$, is a favorite summer resort for those in search of sea-air. Pop. 1,462.

Little Compton, p. o., Carroll ca, Mo.: on Grand r. $88 \mathrm{~m}$. N. W. Jefferson City.

LrTtus Creak, hund., Kent co., Del.: extends across the State, bounded S. by Dover hund., and $\mathrm{N}$. by Little cr., containing 45,300 acres. Surface even, with small elevations in the W., and soil productive. Lumber is exported. Population 2,237

Lrtrle Creek, hund., Sussex county, Del. : occupies the S. W. corner of the State, has a fertile soil, well timbered, and numerous mill-sites. Bog-iron ore is found. Area 61,030 acres. Pop. 3,226.

Litride Creets Landine, p. v., Kent co., Del, : on the cr. so called, about $8 \mathrm{~m}$. N. E. Dover.

LitTle DelawARE river, $N_{*}, Y_{*}$ a an affluent of the Mohawk or W. branch of Delaware r. It rises in the $t$. of Bovina, in Delaware co., and flows W. to its confluence.

Litrue Detrotr, p. v., Tazewell co., IUl. : on the left bank of Illinois r., $66 \mathrm{~m}$. N. Springfield.

ItTrue EAgLe, p. o., Scott co, Ky, : E. N. E. Frankfort: LiTtLe EimtaRT, p. o., Elkhart co., Ind. : 132 m. N. by E. Indianapolis.

Litrif Falis, p. $\nabla$. ., Passaic co., N. Jer.: on the Passaic r. $49 \mathrm{~m}$. N. E. by N. Trenton. The r. here falls 38 feet, and furnishes immense water-nower, used in extensive cotton factories and large iron works. An excellent freestone is quarried here. The Morris Canal crosses the river on an aqueduct, $80 \mathrm{~m}$. from Jersey City. Pop. 700.

Limrue Falus, Herkimer co., $N$. $\bar{Y}$. (see Rocktov).

Lixtle Flat, p. 0., Bath county, $\bar{K} y .: 58$ miles E. by $\mathbf{S}$. Frankfort.

Litrie Gap, p. o., Carbon co., Penn.: 69 m. N. E. by E. Harrisburg.

LitTle Genesee, p. 0., Alleghany co., IT. Y.: $298 \mathrm{~m}$ W. by S. Albany.

LitTle Grove, p. o., Montgomery county, Tenn. : $51 \mathrm{~m}$ W. N. W. Nashrille. 
LitTle Gunpowder, p. o., Baltimore co., Mrd.: on W. side of cr. so called, $2 \mathrm{~m}$. from Gunpowder r., $34 \mathrm{~m}$. N. by E. Aunapolis.

LiTTLE HockiocktNG, p. v., Washington co., Ohio: on the Olio, at the mouib of the $\mathrm{r}$, so called, $81 \mathrm{~m}$. S. E. by E. Columbus.

LitTle Level, p. o., Pocahontas county, Virg.: near Greenbrier r., $155 \mathrm{~m}$. W. by N. Richmond.

Little MLarsi, p. o., Tioga co., Penn.: $107 \mathrm{~m}$. N. by W. Harrisburg.

Litrle Meadows, p. o., Susquehanna co., Penn. : $119 \mathrm{~m}$.

N. N. E. Harrisburg.

Ltitle Mrul Creik, p. o., Delaware co., Ohio: $32 \mathrm{~m} . \mathrm{N}$.

Columbus.

Limple Mrus, p. 0., Richmond co., N. Car.: 85 m. S. W. Raleigh.

Litrite Mudot, p. o., Franklin co., Ill. : abnat $1 \mathrm{~m}$. E. of Little Maddy er., a branch of Big Muddy r., $132 \mathrm{~m}$. S. by E. Springfield.

LITTLE OSAGE, p, o., Bates co, Mo.: on a branch of the Osage so called, 126 m. W. S. W. Jefferson City.

Little Prie Craek, p. 0, Lycoming con, Penn.: $82 \mathrm{~m}$. N. N. W. Harrisburg.

Litrle PrNey, p. o., Pulaski co., Mo. : near the junction of Little Piney creek with Gasconade river, $43 \mathrm{~m}$. S. by $\mathrm{E}$. Jefferson City.

Little Plymodti, p. Y., King and Queen county, Fïrg.: 33 m. E. by X. Richmons. It contains an academy and about 100 inhabitants.

Little Pralrie, p. o., Crawford co., M0. : 47 m. S. E. by S. Jefferson City.

Limtle Pramre, p. o., Cass county, Ga.: 132 m. N. W. Milledgeville.

Litmle Pramre, p. o., Chatahoula parish, La.: $94 \mathrm{~m}$. N. N. W. Baton Rouge.

Litrle Pealrix, p. v., Walworth co., Wisc. : 53 m. S. E. Maclison.

LitTle Prairie Ronde, p. v., Cass county, Mfich.: $\$ 1 \mathrm{~m}$. S. W. Lansing.

Litrue Rest, p. o., Duchess co., N. $Y$.

Litrute Rrvee, p. v., Blount co., Tenn.: on a brapch of

Tennessee r. so called, $257 \mathrm{~m}$. E. by S. Nashville.

Litrue River, p. 0, Columbia co., Flor.: 91 m. E. by \$. Tallahassee.

Litrle Rrene, p. o. Caldwell co., $N$. Car.: on a branch of Catawba r., $149 \mathrm{~m}$. W. by N. Ralejgh.

LtTtle Rrver, p. o., Horry dist., S. Car. : on a stream of that name, flowing into the Atlantic, $128 \mathrm{~m}$. E. by S. Columbia.

LitTle Riser, p. 0., Floyd co, Firg.: on a branch of New r., 171 m. W. S. W. Richmond.

Limle Rirer Virlage, p. v., Lincoln co, Me.: near the junction of Little $r$. and the Anilroseoggin, $27 \mathrm{~m}$. S. S. Tr. Ausustit, It contains several mills and tou inhal,itarts.

LitTLE river: a tributary of Peedee river, and forms the boundary between North and South Carolina.

LTrte river, $\bar{\kappa} y$. : a tributary of Cumberland rirer.

LrTwe river, Ind.: a tributary of Wabash r., which it enters above Tincennes.

LiTtue river, Ga. : a tributary of the Savannah, which it

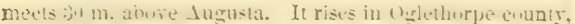
an! in its coutse to the E. passis Lurutugh Taliaferm, and between Wilkes and Lincoln on the N.s and Warren and Columbia on the $S$., forming their boundaries.

IrTrLe Rock, p. Y., and cap. Pulaski county, $\Delta r k_{*}:$ and capital of the State of Arkansas; on the S. side of Arkansas river, 300 miles above its mouth-lat. $34^{\circ} 40^{\prime} \mathrm{Y}$. and long. $92012^{\prime} \mathrm{W} .-1,086 \mathrm{~m}$. W. by $\mathrm{S}$. Wasbington. It was first settled in 1529. The v., as its name implies, is situate on a high rocky bluff, 150 to 200 feet abore the r., and is the first place where rochs appear above its month. It is regularly laid cut, the strects fuicrsecting at ri-ht angles. whi contains the state House and the State Penitentiary, the 335
County Court-house, jail, etc., and a United States arsenai, the offices of the Surveyor General of Public Lands for the district of Arkansas, and a Register and Receiver's Office: It has also numerous stores and warehouses, and several flour and saw mills, both steam and water. It has a large trade with the interior, and may be considered as the depot of all the region extending far into the Indian Territory. Many of the churches are well built, and even elegant, and number some dozen, including the Catholic Cathedral of St. Andrew. The Catholic Bishop of the diocese of Little Rock, and the Protestant Episcopal Bishop of the diocese of Arkansas reside in the village. There are several academies and schools, and in this connection it may be stated that the Catholies have charge of the most efficient and flourishing. At Little Rock is the head of ordinary steam navigation; during high flood, however, steamboats ascend the river to Fort Gibson, $1,000 \mathrm{~m}$. further up. Pop. 2,167.

LtTtze Rock, p. 0., Kendall co., $I u_{\text {. : }} 146 \mathrm{~m}$. N. by E. Springfield.

Litrue Rock Fist, p. o., Cumberland co., $N$. Car.: on a branch of Cape Fear r., $59 \mathrm{~m}$. $\mathrm{S}$. Raleigh.

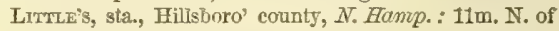
Lowell, on Nashua and Lowell $R$. R.

Little SANDesky, p. v., Wyandott co., Ohio: on a branch of Sandusky river, $53 \mathrm{~m}$. N. by W. Columbas, It contains several stores and 300 inhabitants.

LitTle St. Joseph river, Ind.: a constituent of Maumee river. It rises in Ohio, and after passing through De Kalb and Allen counties of Indiana, joins St. Mary's r. at Fort Wayne-the two forming the Naumee. It is otherwise called St. Joseph of Lake Erie.

LiTtle SANDy, p. 0., Morgan co., Ky.: 89 m. E. by S. Frankfort.

IrtTle Scioto, p. o., Marion co., O7io: $45 \mathrm{~m}$. N. by W. Columbus.

LiTtLe SkTN Creek, p. o., Lewis county, Firg. : $187 \mathrm{~m}$. W. N. W. Richmona.

Litrle Sodes, p. v., Cayuga $C D_{n}, N$. $Y$.: on Little Sodus Bay, $161 \mathrm{~m}$. W. by N. Albany.

Lrrthe Sodus bay, Cayuga co., $N$. $Y$.: a small inlet of Lake Ontario, about $3 \mathrm{~m}$. deep and $1 \mathrm{~m}$. wide. It is situate about $18 \mathrm{~m}$. E. of Sodas Bay, in the town of Sterling, and receives near its outlet Sodus cr. The water is deep, but a bar obstructs the entrance from the lake.

Litrlestows, p. $\vee .$, Adams co., Penn.: 84 m. S. S. W. IIarrisburg.

LitrletoN, p. V., Schayler co, $M l_{\text {. }}: 43 \mathrm{~m}$. W. N. W. Springfield.

Limtuetor, t. and p. V., Middlesex co., Mass.: $24 \mathrm{~m}$. N. W. by W. Boston. Drained by Stony Brook, a branch of the Merrimac, and Beaver r, a branch of Concord r., which supply it with water-power. Surface uneven, and snil gencrally of good quality. Superior rye and hops aro raised, and fine dairies kept. Various small factories occupy the streams, which are fed by two large ponds. A rariety of limestone is quarried. The Fitchburg $\mathrm{R}$. $\mathrm{R}$. crosses the $\mathrm{t}$, and has a sta. $31 \mathrm{~m}$. from Boston. Pop. of t. 991.

Limtuetox, t. and p. v., Grafton co., $N$. IIump.: $76 \mathrm{~m}$. $\mathrm{N}$. by W. Concord. The t. extends $14 \mathrm{~m}$. on the Connecticut $r_{\text {., }}$ which, for the whole distance, has an impetuous current that no boat can stem, known as the Fifteen Mile Falls. Surfite lorohen by numerous ligh hills, and soll alapted to grazing chiefly. Drained S. by Ammonoosue r., on which are fertile meadows; and the v., which is at the falls, contains several mills and factories. Pop. of t. 2,008.

Lritletos, p. o, Morris co., N. Jer.:44 m. N. T. E. Trenton.

Lrmberox, p. o. and sta., Halifax co., $N$. Car.: $63 \mathrm{~m}$. N. E. by N. Raleigh. It is on the Gaston and Raleigh R. R. 9 m. fum Gaston.

Litrletow, p. o, and sta., Richland dist., $\$$. Car.: at the junction of Little and Iroal rivers by the Greenville and Celumbia R. R., 15 m. from Columbia. 
Liтmetox, p. o., Sussex county, Virg.: 46 m. S. by E. Richmond.

Little Traterse bay, afich.: in the N W. part of the Lower Peninsula. It has the best harbor N. of Grand $r$. and Saginaw Bay. The anchorage is good, and vessels may eome writhin 10 feet of the shore.

Little Utica, p. o., Onendaga co, $N . Y_{0}: 126 \mathrm{~m}$. W. by N. Albany.

Litrue VAllex, t., p. v., and sta., Cattaraugus co., $N$. $Y$.: $282 \mathrm{~m}$. W. by S. Albany. Intersected by Alleghany r., and drained by its branches, which furnish many mill-sites. Surface broken, and soil of average fertility. Timber is plenty. The Erie R. R. crosses the N. part of the t., and the sta. is $38 \mathrm{~m}$. E. of Dunkirk. Pop. 1,383.

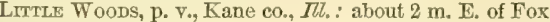
r., and near the Galena and Chicago Union R. R., $172 \mathrm{~m}$. N. N. E. Springfield.

LfTtle Y YDETN, p. o., Stokes co., N. Car.: on a branch of Yadkin r., $11 \mathrm{~s} \mathrm{m.} \mathrm{W.} \mathrm{N.} \mathrm{W.} \mathrm{Raleigh.}$

LETTLE YORE, p. v., Warren co., $M l$. : on S. side of Henderson's r., $101 \mathrm{~m}$. N. W. by N. springfield.

LITTLE YorE, p. o., Washingtors co., Ind. : 74 m. S. by E. Indianapolis.

ITTTLE YORK, $\beta, 0 .$, Hrinterdon co., $N_{0}$ Jer.

LiTTuE York, p. o., Cortlandt co, $N . Y_{.}: 126 \mathrm{~m}, \mathrm{~W}$. Albany.

LiTtLe Toke, p. v., Montgomery co., Ohio: on the Miami r., $67 \mathrm{~m}$. W. by S. Columbus.

Lirwalton, p. o., Lancaster co., Virg.: 51 m. E. by N. Richmond.

Lrvely, p. v., St. Clair eo., Ill.: on the left bank of Kaskaskia $\mathrm{r} ., 105 \mathrm{~m}$. S. Springfield.

LIVELY OAF, p. o., Lancaster county, Virg. : $54 \mathrm{~m}$. E. Richmond.

ITVE OAK, p. o., Ascension par., La. : 26 m. S. S. E. Baton Rouge.

LrVE OAK, p. O., Dewitt co., Tex. : 86 mo. S. S. E. Austin City.

LIVERMORE, p. O., Ohis county, Ky.: 118 m. W. S. W. Frankfort.

ITVERMore, t. and p. o., Oxford eo., Me.: on the right bank of Androseoggin r., $22 \mathrm{~m}$. W. Augusta. Soil excellent, and large crops of wheat and potatoes are raised. The $\mathbf{r}$. has a large descent, and moves several factories and mills. Pop. 1,764.

Ltvermore, p. v., Westmoreland co., Penn.: on the S. side of Conemaugh r., $127 \mathrm{~m}$. W. by N. Harrisburg. The Pennsylvania Canal passes through it.

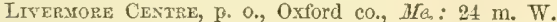
Augusta.

LIVERMORE FALLS, p. v., Kennebec co, Me.: on the left bank of Androsenggin r., $23 \mathrm{~m}, \mathrm{~W}$. N. W. Augusta. The r. furnishes excellent water-power, which is improved to move several factories, mills, and mechanic shops. The Androscoggin R. P. terminates here, $20 \mathrm{~m}$. from its junction with the Androscoggin and Kennebec R. R. Pop. 450.

Liverpool, p. v., Onondaga co, $N . Y .:$ on the E. side of Onondaga Lake, $132 \mathrm{~m}$. W. by N. Albany. The manufacture of salt from the springs here is the principal business of the $V_{\text {, }}$ and the produce in 1850 was 645,832 bushels of fine or table-salt. It is on the Oswego Canal, $5 \mathrm{~m}$. N. of its junction with the Eric Canal at Srracuse, and contains a dozen gtores, and about 1,000 inhabitants.

Liverroot, t. and p. o., Medina eounty, Ohio: $99 \mathrm{~m}$. N. E. hy N. Columbas. Drained by Rocky r., which furnishes water-power. Surface somewhat broken, and soil fertile. Iron ore, salt, sulphw, and rock oil are found. Pop. 2.164.

Liverpoot, t. and v., Columbia m., Ohio : $132 \mathrm{~m}$. E. N. E. Columbus. The Ohio r. flows on its S. boundary. The v. is situate on the r., about $50 \mathrm{~m}$. below Pittsbure, and has 835 inhabitants. The manufacture of earthen-ware is carried on extensively. Pop. of t. 1,564.
Liverpool, t, and p. b., Perry co., Penn.: on the W. side of Susquehanna r., $24 \mathrm{~m}$. N. by W. Harrisburg. Surface rough in parts, with rich loamy valleys. It is well supplied with water-power and timber, and has many flour and saw mills. The $\mathbf{v}$. is on the $r$, at the mouth of a cr., and contains several stores and establishments for making iron.

Liverpoou, p. o., Brazoria co., Tess.: on Chooolate Bayou, 157 m. E. S. E. Austin City.

Liverpoou, p. v., Fulton co., Ill.: on the right bank of Illinois $x ., 44 \mathrm{~m}$. N. N. W. Springfirle.

Livingston county, Ill. Situat; N. E., and contains $1,029 \mathrm{sq} . \mathrm{m}$. Drained by Vermillion $\mathrm{r}$, of the Illinois and its branches. Surface level; soil fertile. It consists mostly of extensive prairies, some of which are low and wet, with few streams, and little timber. It has some water-power, and in parts, deposits of cool and limestone. Farms 185; manuf. 0 ; dwell, 261, and pop.-wh. 1,552, fr. col. 0total 1,552. Capital: Pontiac.

LIVINGSTON county, $\bar{k} y$. Situate $\mathbf{W}$, and contains 236 sq. m. Bounded N. and W. by the Ohio, and S. by the Tennessee, and intersected by the Cumberland. Surface plensantly varied, and soil very productive. Tobaceo is the farming staple, but eorn and wheat are fine crops. It exports a great deal of pork, and manufactures leather, and agricultural machinery. Farms 4S5; manuf. 13 ; dwell. 915, and pop.-wh. 5,404, fr. col. 56, sl. 1,118-total 6,578. Capital: Salem.

Livingston parish, La. Situate B. E., and eontains 786 sq. m. Bounded W. and S. by Amitie r. and Lake Marrepas, into which it flows, and E. by Tangipahoa r., entering Lake Pontcharirain, between which are Tickfaw r. and many small streams. Surface level, with extensive marshes; soil fertile. Cotton, corn, and rice, are staples. There are on some of its streams water-privileges, which are profitably employed. Farms 219: manuf. 13; dwell, 490, and pop.-wh. 2,523, fr. col. 20, sl. 842-total 3,385. Capital: Springfield. Pullic Works: New Orleans, Jackson, and Northern P. P.

Lryingston county, Mich Situate S. E., and containg 576 sq. m. Drained N. by heads of Shiawassee r., W. by heads of Cedar $r_{\text {, a }}$ branch of Grand $r_{m}$ and $\mathrm{S}$. by heads of Huron $r$. Surface undulating. The $\mathrm{N}$. is heavily timbered; the $\mathrm{S}$. is open land, a black, sandy, or clayey loam, and superior for grain-growing. The grain and pork are the exports. It has nurnerous ponds and streapas, furnishing abundant water-power for its growing manufactures. Good iron ore is extensively found, and salt springs in parts. Farms 1,644; manuf. 40; dwell. 2,368, and pop.-wh. 13,411, fr. col. 4-total 13,485. Capital; Howell.

Livingston county, MLo. Situate N. W., and contains 537 sq. m. Drained by Grand $r_{s}$ and its affluents, Medicine, Indian, and Shosl creeks, and Crooked Fork. Surface undulating or level ; soil fertile, well timbered, and much of it excollent pasture. Corn is the staple product, and pork a large and the chief export. Farms 457; manuf. 2 ; dwell. 65\%8, and pop.-wh. 3,933, fi. col. 6, sl. 308-total 4,247. Capital: Chillicothe.

Livingston county, $N, Y$. Situate $W$. middle, and contains 563 sq. m. Drained by Genesee r. and its branches, Cashaqua and Canaseraga rivers, and Conesus outlet. The last carries to it the water of Conesus Lake, which, with IIemlock Lake, lies in the co., and both feed its tributaries. Surface elevated in the S., and slopes toward Lake Ontario in two terraces divided N. and S. by the Genesee which flows in a deep valley of 3 or 4 miles width. Soil very fertile; a sandy loam mixed with decomposed limestone, on which the co. rests, and especially adapted to grain. Wheat, pork, and cattle, are the great staples. Butter, wool, corn, and oats, are large exports, and in the Genesee valley great quantities of hemp and fiax are grown. It has abundant water-power, and extensire manufactures of flour, paper, iron, leather, lumber, etc., and unsurpassed facilities for reaching markets in all parts of the Union. 
Gypsum is abundant; bog-iron ore and sait springs are found, and sulphur springs, long known and visited by the Indians, and now widely celebrated. Farms 2,503; manuf. 363 ; dwell. 7,172 , and pop. wh. 40,690, fr. col. 185-total 40,875. Cupital: Geneseo. Public Works: Genesee Valley Canal; BuffaIo, Corning, and New York R. R ; Canandaigua anả Niagara Falls R. R., etc.

Livingstox, p. v., and cap. Sumter co., Ala. : near Suquinochee r., a branch of the Tombigbee, $107 \mathrm{~m}$. W. by N. MIontgoniery. It contains a court-house, jail, academy, and 350 inhabitants. The "Sumter County Whig" is published weekly.

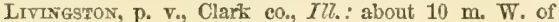
Wabash r., $112 \mathrm{~m}$. E. by S. Springfield.

LiviNGSTON, t. and p. v., Livingston eo., Mfich. : $45 \mathrm{~m}$. E. S. E. Lansing. It occupies high lanå on Woordruff's cr., which has a large fall, and moves several mills. Pop. 450 .

Livingston, p. o., Madison co., Miss.: $16 \mathrm{~m}$. N. Jacksin.

Imringstox́, p. v., and cap. Polk co., Tex. : on the E. side of Long King cr. of Trinity r., $16 \mathrm{~S} \mathrm{~m}$. E. by N. Austin City. It is surrounded by rich cotton plantations, and contains a court-house and several stores.

Livingston, t. and p. o., Essex co., N. Jer.: on the E. side of Passaic r., $42 \mathrm{~m}$. N. N. E. Trenton. Short Hills or Second Mountains occupy the E., but the W. is more even; soil of average fertility. Pop. 1,151.

Livingston, t. and p. o., Columbia co., $N$. $Y .:$ on the E. side of Hudson r., $35 \mathrm{~m}$, \$. Albany. Drained by Copake and Rocliff Jansen's creeks. Surface varied; soil clayey or gravelly loam. It belongs to the Livingston manor, and has in it several furnaces, flouring mills, and other manufactories. The Hudson Piver R. R. passes through it. Pop. 2,022.

Livivgstox, p. v., and cap. Overton co., Tenn.: $79 \mathrm{~m}$. E. by N. Nashrille. It contains a court-house, severa stores, and 150 inhabitants.

Livingstonville, p. v., Schoharie county, $N . \quad \bar{X}: 27 \mathrm{~m}$, W. S. W. Albany.

LIVONLA, p. v., Washington co., Ind. : $82 \mathrm{~m}$. W. S. W. Indianapolis.

LivoniA, p. 0., Point Coupee par., La.: 37 m. N. W. Baton Rouge.

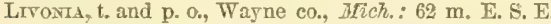
Lansing. Drained by Power"s and Bell's creeks, and W. branch of Rouge $r_{\text {, }}$, affording good mill-seats, Surtace rolling: soil clayey loan, and fine grazing land, gemerally timbered. Pop. 1,376.

Lrvosis, to and p. o, Livingston county, $N . Y_{0}: 204 \mathrm{~m}$ $\pi$. hy N. Albany. Drained by the outlets of Ifemleck and Conesus Lakes, which lie partly in it. Surface rolling; soil loam, on a substratum of limestone, and very fertile of grain. It has an academy, and several flouring mills and woolen factories. The Buffake, Corning, and New Fork R. R. passes through it. Pop. 2,627.

Irvosra Ceartre, p. o., Wayne co., Mfich.: 66 m. I. S. E. Lansing.

Llewels.y, p. v., Schujlkill co., Penn. : 42 m. N. E. Harrisburce.

Llord, t. and p. O., Ulster co., $N . Y .:$ on the W. side of In loam, overlying limestone. It has some water-power on Black er. and tike Wallkill, and is a superior farming region. Ineoriprated in 15t5. Pop. 2,1:35.

Lloyds, p. o., Essex county, Firg.: 39 miles N. N. E. I'ichmuाt.

Lloyd's Neck, Queen's co., $N . Y_{*}:$ a peninsula on the N. side of Long Island, in the t. of Otster Bay. It has Thuntington Bay on the E., and Oyster Bay on the W., with a deep indentation from Fruntiagton Bay on the S., called Lloyd's Harbor.

Loscmapora, p. o., Macon co., Atca.: on the line of the Montgomery and West Point R. R., 53 miles E. by N. Miontgomery.
LoAg, p. o., Chester oo., Penn. : 51 m. E. by S. Farrisburg LOBACHSTIliE, p. o., Berks county, Ponn.: 54 miles E. Harrisburg.

LoBdell's STore, p. o., W. Baton Rouge par, $L a$.

Local, p. o., Talladega co., Ala.: $71 \mathrm{~m}$. N. by E. Montgomery.

Loodtion, p. o., Coweta county, Ga.: $92 \mathrm{~m}$. W. by N. Milledgeville.

Lock, p. 0., Knox co., Ohio: 47 m. N. E. Columbus.

Lock Beriss, p. y., Wayne co., N. Y.: $169 \mathrm{~m}$. W. by $\mathbb{N}$. Albany. It is $4 \mathrm{~m}$. E. of Lyons, on the Erie Canal.

Lockbourise, p. v., Franklin co., Ohio: on Big Walnut cr., $11 \mathrm{~m}$. S. by E. Columbus. The Ohin Canal passes through it, $45 \mathrm{~m}$. from Newark, and a branch diverges hence to Columbus.

Locks, t. and p. 0., Cayuga co., N. Y.: 138 m. W. Albany. Drained by Owasco inlet, which affords power for several flour-mills and woolen factories. Surface hilly; soil gravelly loam, raising fine crops of grass. Pop. 1,478.

LockE, p. o., Elkbart county, Ind.: 124 m. N. by E. Indianapolis.

LockE"s Mrlus, p. o., Miffin con, Penn.: 47 m. W. N. W. Harrisburg.

Locke's Mints, p. v. and sta Oxford co, Me, : near the head of Alder r., $45 \mathrm{~m}$. W. Augusta. The sta. is $65 \mathrm{~m}$. from Portland, on the Atlantic and St. Lawrence R. P

Lockinar, p. v., and cap. Caldwell co., Tex.: on Plum cr. of the San Marcos, $24 \mathrm{~m}$. S. by E. Austin City. It lies in a fine grazing and mineral district, and contains a courthouse, academy, several stores, and 300 inhabitants.

Lockhart's Stork, p. o., Holmes co, Miss. : 2 m. W. Big Black r., 57 m. N. N. E. Jackson,

Lock Haven, p. b., and cap. Clinton co., Penn. : between and near the confluence of Bald Eagle cr., and the Susquehanna, $67 \mathrm{~m}$. N. N. W. Harrisburg. The Pennsylvania Canal here crosses the Susquehamna, and proceeds up the valley of Bald Eagle cr. to Bellefonte. It contains a courthouse, academy, and several stores and warehouses, and has an extensive trade. The "C. Tribune" (whig), and " $\mathrm{C}$. Democrat" are publisbed weekly. Pop. $\$ 30$.

LockevgToN, p. v., Shelby county, Ohio: $68 \mathrm{~m}$. W. by N. Columbus.

Locklaxd, p. o., Macon courty, Ald : 53 m. E. by $\mathrm{S}$. Montgomery.

Locklard, sta., Hamilton co., Ohio: on the Cincinnati, Hamilton, and Daston R. R. $11 \mathrm{~m}$. from Cincimati.

Lock Levex, p. 0., Lunenburg co., Firg. : $58 \mathrm{~m}$. S. W. Richmond.

Lock Loxond, p. o., Goochland co., Tirg.: W. N. W. Richuond.

LOCKPORT, p. v., Will co., $T$ J.: on the E. side of Des Plaines r. $151 \mathrm{~m}, \mathrm{~N} . \mathrm{E}$. by N. Springfield. It is on the Illinois and Michigan Canal, $6 \mathrm{~m}$. from Joliet, with 50 feet descent by locks between. This, and 15 feet fall in the Des Plaines, near the v., furnish abturdant water-power, and large quarries of limestone ample building material. It has valuable manufactures, an extensive trade, and 1,500 inhabitants. The "L. Telegraph" is published weekly.

LOCKPOET, p. v., Carroll co., Ind.: on the N. bank of TVabash $\mathrm{r}, 67 \mathrm{~m} . \mathrm{N} . \mathrm{N}$. W. Indianapolis. It is on the Wabash and Erie Canal, $17 \mathrm{~m}$. from Logansport.

LOckport, p. o., Menry co., Ky.: N. W. Frankfort.

LоскPовт, t., p.. ., and cap. Niagara co., N. Y.: $219 \mathrm{~m}$. W. by N. Albany. Lat. $43^{\circ} 11^{\prime}$ N., and long. $78^{\circ} 46^{\prime}$ W. Drained by streams flowing $\mathrm{N}$. into Lake Ontario, and $\mathrm{S}$. into Tonaranda cr. Surface elevated and varied, sloping from a ridge or terrace which forms the water-shed dividing the streams above noticed. Soil calcareous and sandy loam, rery furtile, anil admirably adapted to grazing. There are extensive quarries of fine building-stone in the town. The v., one of the most prosperous of the W. section of the State, is situate on the line of the Eric Canal, $31 \mathrm{~m}$. from Buffalo, and on the Canandaigua and Niagara Falls Ru. R., 23 in 
from Niagara Falls. The business activity depending on these avenues of commerce is immense; and the waterpower created by the surplus of the canal, which here rises 60 feet by locks, is of the greatest importance to the manufacturing interests of the place. Among the large number of manufactures carried on, especial mention may be made of its cotton and woolen mills, its furnaces, its machine-shops, agricultural machinery and implement factories, and of its flouring, grist, saw, plaster, and other mills, and in the neighborhood manufactures are rapidly springing into existence. Four banks are located here. The village contains a courthouse, jail, and other county buildings, 17 or 18 churches of various denominations, several good schools and academies, and numerous common schools, and has a public press numbering four separate publications, viz.: the "L. Courier" (whig), daily and weekly, the "Niagara Democrat" (dem.), the "Niagare Cataract" (F. S.), and the "Iris of Niagara" (lit.), all weekly issues. The $\mathrm{v}$. was incorporated in 1827 , and will probably, at no distant period, be entered on the list of cities. The population of the $t$. in 1830 was 3,822 ; in 1 sto it was 9,125 , and in 155012,323 , having increased from 1830 in the decennial ratio of $138^{\circ} 68$ and $35^{\circ} 04$ per cent. The railroad from Canandaigua has been opened since the latter period, and its access eastward thus fully established, which will greatly accelerate its growth in wealth and population.

Lockporr, sta., Westmoreland co., Penn.: on the W, division of the Peansylvania $\mathrm{R} . \mathrm{R}$., $65 \mathrm{~m}$. E. of Pittsburg. Here is a thriving v., with a brisk trade, on the Conemaugh r. and W. division Canal, and a charcoal furnace of 1,000 tons annual capacity.

LockPoRt, p. V., Williams co., Ohio: on W. side of Tiffin cr., $123 \mathrm{~m}$. N. W. by N. Columbus.

LockPort, v., Licking co., Ohio: on the Ohio Canal, $31 \mathrm{~m}$.

E. by N. Columbus. Population 42.

LOCEPORT, v., Tuscarawas co., Ohio: on the Ohio Canal, about a mile S. of New Philadelphia, and $83 \mathrm{~m}$. E. N. E. Columbus. Pop. 178 .

Lockrfige, p. v., Jefferson county, $I a_{0}: 47 \mathrm{~m}$. S. by W. Iowa City.

Lock's VILLAGE, p. v., Franklin co., Mass. : $71 \mathrm{~m}$. W. by N. Boston.

LockVIlle, p. v., Fairfield co., Ohio: 17 m. \$. E. by E. Columbus. It is on the Ohio Canal, $30 \mathrm{~m}$. from Newark

Lockw0od, p. o., Sussex co., N. Jer.: 49 m. N. Trenton.

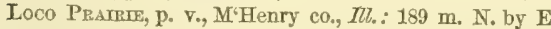
Springfield.

Locust Barou, p. 0., Washita eo., Ark.: on an affuent of Washita r. so called, $98 \mathrm{~m}$. S. S. W. Little Pock.

Locust Conner, p. 0., Clermont co., Ohio: $76 \mathrm{~m} . \mathbb{S} . \mathrm{W}$. Columbus.

Loctst Creek, p. o., Louisa county, Virg. : 29 m. N. W. Richmond.

Locust Dale, p. o., Madison co., Virg.: on a branch of Rapid Ann r., $62 \mathrm{~m}$. N. W. Richmond.

Locust Grove, p. o., Searcy co., Ark. : 93 m. N. by W. Little Rock.

Locust Grove, p. o., Henry co., Ga.: 56 m. W. N. W. Milledgeville.

Locost Grove, p. o., Callaway county, $\bar{K}_{\text {. }}: 112 \mathrm{~m}$

S. W. hy W. Frankfort.

Locusr Grove, p. v., Williamson co., $I l l .: 146$ m. S. S. E. Springfield.

Locust Grove, p. v., Adams co., Ohio: on the E. side of Brush er., $67 \mathrm{~m}$. S. by W. Columbus.

Locust Grove, p. o., Weakly co., T6nn.: 98 m. W. by N. Nashville.

Locust Grove, p. o., Orange co., Firg.: 58 m. N. W. Richmond.

Locust Grove, p. o., Montgomery county, Ind. : $44 \mathrm{~m}$. W. N. W. Indianapolis.

Locust Grove, p. O., Henry co., Mo.: about $8 \mathrm{~m}$. S. of Grand $r_{\text {. }}, 76 \mathrm{~m}$. W. by S. Jefferson City.
Locust Hru, p. o, Caswell co., N. Car, : 66 m. N. W. Raleigh.

Locust Hru, p. 0., Washington county, Penn.: 141 W. Harrisburg.

LOCUsT Firm, p. o., Anderson district, S. Car.: $105 \mathrm{~m}$. W. N. W. Columbia,

Locust Lane, p. o., Fayette co., Tirg. : 194 m. W. by N. Richmond.

Locusr Mrils, p. 0., Bracken co., Ky. : 58 m. N. E. by E. Frankfort.

Locust Mount, p. 0., Accomac co., Firg.: 96 m. E. N. E. Richmond.

Locust MounT, p. o., Washington co., Tenn.: $233 \mathrm{~m}$.

E. Nashville.

Locust Sirade, p. O., Overton county, Tenn.: $82 \mathrm{~m}$. E. Nashville.

LocUST SPRING, p. v., Macoupin co., Illo: 27 m. S. S. W. Springfield.

Locust Sprine, p. o., Cumberland county, Ky. : $106 \mathrm{~m}$. S. by W. Frankfort.

Locust Tree, p. 0., Niagara co., N. $Y_{0}: 263 \mathrm{~m}$. W. by N. Albany.

Loevstrille, p. 0., Accomac c0., Virg.: 89 m. E. by N. Richmond.

LoDpr, p. o., Hamilton co., Tenn.: near Saluda cr, of tho Tennessee, 79 m. E. S. E. Nashville.

Lodi, t. and p. Oe, Bergen eounty, N. Jer.: 53 m. N. E Trenton. It is mostly level, and lies between Hackensack $r$. on the E. and the Passaic and its branch, Saddle r., on the W., which furnish good mill-sites. The Union R. R. crosses the Passaic on its W. border, $12 \mathrm{~m}$. from New York. Pop. 1,113.

LodI, p. o., Coweta county, Ga.: 106 m. W. by N Milledgeville.

Lodi, p. O., Choctaw co, Miss. : 88 m. N. N. E. Jackson,

Lodr, p. v., Clark co., Ml. : 106 m. E. by S. Springfield.

Lonr, t. and p. o., Washtenaw co., Mich.:52 m. S. E. Lansing. Surface level, and soil admirably adapted to grazing. Pop. 1,234.

Lopr, t. and p. v., Seneca co., $N . Y_{.}$: on the E. side of Seneca Lake, $164 \mathrm{~m}$. W. Albany. Surface rolling; soil clayey loam, and very fertile. Farming is the chief pursuit Gypsum is found. Pop. 2,269.

Lodr, to and p. os, Columbia co., Wisc. : on the E. side of Wisconsin r., $18 \mathrm{~m}$. N. Madison. Drained by Ockee cr. It has a good soil and excellent timber. Pop. 308

LoDr, p. v., Medina co, Ohio : on E. branch of Black r., $87 \mathrm{~m}$. N. E. by N. Columbus. It contains several mills and 200 inhabitants.

LodI, sta., Seneca co., Ohio: $23 \mathrm{~m}$. from Sandusky on the Mad River and Lake Erie R. R.

LodI, p. o., Abbeville dist., $S$. Car.: about 2 m. T. of Saluda r., $56 \mathrm{~m}$. W. by N. Columbia.

LoDr, p. o., Jackson co., Tenn.: $67 \mathrm{~m}$. E. N. E. Nashville

LODI BAR, p. o., Sumter dist., S. Car.: E. Columbia.

Lodi Centre, p. o., Seneca co., $N . Y_{0}: 161 \mathrm{~m}$.W. Albany

Lodiville, p. v., Parke co., Ind. : on the E. bank of Wabash $\mathrm{r} ., 44 \mathrm{~m}$. W. by N. Indianapolis. It is at the mouth of Coal cr. and on the Wabash and Erie Canal.

Lodore, p. o., Amelia co., Firg. : 32 m. S. W. Richmond. LOGAN county, $\pi l$. Situate centrally, and contains 538 sq. m. Drained by Salt er., a branch of Sangamon r., and its affluents, Lake Fork, Sugar, and Kiekapoo ereeks. Surface undulating and nearly level; soil exceedingly fertile, being mostly rich prairie with occasional groves of timber; and producing large crops of corn and whent with little effort. It is especially adapted to grazing, and live-stock; beef, and pork, are the exports. Farms 476 ; manuf 14 ; dwell. 885, and pop.-wh. 5.12s, fr. col. 0-total 5.128. Capital: Postville. Public Works: Central R. R.; Chicage and Mississippi R. R.

LOGAN county, $K y$. Situate S. W., and contains 591 sq. m. Drained S. by Red and Big Whippoorwill rivers, 
branches of the Cumberland, and N. by Elk Lick, Wolf Lick, and Big Muddy creeks of Green r. Surface elevated table-land; soil generally fertile. Tobacco, corm, oats, and wheat are staple products. It has fine facilities for manufactures, and they are extensively improved in producing woolen and cotton goods, flour, leather, earthen-ware, etc. Farms 1,130; manuf. 40 ; dwell. 1,917, and pop.-wh. 10,751, fr col. 363, sl. 5,467-total 16,581. Capital: Russellville.

LoGAN county, Ohio. Situate W. centrally, and contains 438 sq. m. Drained E. by Rush, Mill, and Big Darby creeks of the Scioto; W. by Little Miami and branches, Stony and Cherokee creeks, ete. Surface undulating or slightly broken; soil productive and well adapted to grain. Corn is the staple. Wheat is a successful crop and pork an export. It has many mill-streams and flourishing fictories, with convenient markets. Farms 1,626; manuf. 88 ; dwell. 3,243, and pop.-wh. 18,631, fr. col. 531-total 19,162. Capital: Bellefontaine. Public Works: Bellefontaine and Indiana R. R.; Mad River and Lake Erie R. R., etc.

LOGAN county, Virg. Situate S. W., and contains 702 sq. m. Tug fork of Big Sandy r. bounds it W., the Guyandotte and branches drain it $\mathrm{E}$., and Laurel and Caney creeks flow between into the Ohio. Surface hilly and broken; soil fertile, and excellent pasturage. Corn, oats, and potatoes are staples. It has fine mill-streams, which are used principally to work up the timber of the higher portions. Farms 469 ; manuf. 0 ; dwell. 572, and pop.-wh. 3,533, fr. col. 0 , sl. S7-total 3,620. Cupital: Logan C. H.

LogAN, p. v., Dearborn county, Ind. : 74 m. E. S. E. Indianapolis,

Logar, p. o., Tompkins co., N.Y.: $161 \mathrm{~m}$. W. Albany.

Logar, p. v., and eap. Hocking co., Olizo: on the $\mathrm{N}$. bank of Hocking r., $42 \mathrm{~m}$. S. E. Columbus. It contains a court-house, jail, academy, and several mills. Excellent water-power is furnished by the falls, which are $1 \mathrm{~m}$. above the v. The "H. Sentinel" (dem.), and "H. Valley Republican" (whig), are published weekly. The Hocking Canal passes through the v. $28 \mathrm{~m}$. from Athens, Pop. 798.

LogAx, p. o., Laclede county, Mo.: $69 \mathrm{~m}$. S. by W. Jefferson City.

LoGaN C. H., p. V., and cap. Logan co., Virg.: on the right bank of Guyandotte $\mathrm{r}, 244 \mathrm{~m}$. W. Richmond. It contains a court-house and several stores.

Louan Milis, p. o., Clinton co., Penn.: 59 m. N. N. W. Harrisburg. A charcoal furnace of 800 tons annual capacity is located here.

Logav's Creek, p. o, Reynolds co., MYo.: 127 m. S. S. E. Jefferson City.

Logan's Ferro, p. o., Alleghany co., Penn.: $125 \mathrm{~m}$. W. Harrisburg.

Logansport, p. v., De Soto par., La.: on the left bank of Sabine $x_{0}, 191$ m. N. W. by W. Baton Rouge.

Logansport, p. v., and cap. Cass co., Ind.: at the junction of Eel r. with the Wabash, $65 \mathrm{~m}$. N. by W. Indianapolis. It is at the head of steamboat navigation, and just beluw the falls, which furnish immense water-power. and has a large trade, by river, canal, and plank-roads, with the fertile region on every side; the products of which are shipped here for the E. and S. markets. It contains a e urthouse and jail, 2 banks, an academy, several large mills, and 2,251 inhabitants. The "L. Tournal" (whig), and the "Democratic Pharos," are published weekly.

Logav's Store, p. o., Rutherford co., N. Car.: $211 \mathrm{~m}$. W. by S. Raleigh.

Log ANPTLLe, p. v., Logan co., Ohio: on Miami r., 54 m. W. N. W. Columbus.

Loganville, p. v., York co, Penn. : 26 m. S. Harrisburg.

LoG CABIN, p. o. Morgan co., Ohio: 64 m. E. S. E. Columbus.

LoG Lick, p. o. Switzerland county, Ind.: 87 m. S. E. Indianapolis.

Logtown, p. 0., Wachita par., La.: 151 m. N. N. W. Baton Pouge.

892
Lombardy, p. o., Columbia co., Ga.: 69 m. E. N. E. Milledgeville.

Lombardy Grove, p. o., Mecklenburg co., Ting.: $68 \mathrm{~m}$. S. 8. W. Richmond.

Lomra, t. and p. o., Dodge co., Wisc.: $62 \mathrm{~m}$. N. E. Madison. Drained by heads of Rock r., furnishing good mill-seats. Surfuce varied, and soil excellent. Pop. 653.

Lonaconing, p. v., Alleghany co, $\boldsymbol{M I}_{\text {. }}$ : on W. side of George's cr., about $6 \mathrm{~m}$. from the Potomac, $141 \mathrm{~m}$. W. N. W Annapolis. It is in the mining region, and. connected by a private railway with the Baltimore and Olio $R$. R. A furnace here produeing 3,000 tons of iron per annum.

London, p. v., and cap. Laurel co., Ky.: 83 m. S. S. E. Frankfort. It consists of a court-house and a few dwellings. The Knoxville and Lexington $\mathrm{R}$. R. will pass through it.

Londow, t, and p. o., Monroe co., Afich.: $67 \mathrm{~m}, \mathrm{~s}$. E Lansing. Drained by Stony cr. and a branch of Piver Raisin. Surface level, and well-timbered; soil very pro ductive of wheat. Pop. 626 .

Lombox, p. v., Mercer co., Penn.: 138 m. W. N. W. Harrisburg.

London, p. v., and eap. Madison co., Ohio: 25 m. W. by S. Columbus. It contains a court-house, jail, and an academy, and has a large trade in domestic products. The Columbus and Xenia R. R. passes through it, $85 \mathrm{~m}$. from Xemia. The "L. Sentinel" is published weekly. Pop. 513.

London Bridge, p. o., Princess Anne co., Virg.: $86 \mathrm{~m}$. E. S. E. Richmond.

London CrTY, p. พ., Fayette co., $M l_{*}: 64$ m. S. E. by S. Springfield.

LoNDONDERRy, t. and p. v., Rockingham co., N. Hamp.: 29 m. S. by W. Coneord, Drained by Beaver r., a branch of the Merimac, which touclzes the N. W. corner. Surface uneven; soil fertile, making it a very superior farming and dairy district. The Manchester and Lawrence R. R. erosses the N. part, and the sta, is $6 \mathrm{~m}$. S. of its connection with the Concord $R . P$. at Manchester. The $\mathrm{v}$, is in the $\mathrm{S}_{\text {., }}$ and contains an excellent and well-endowed academy. Population of $t .1,731$.

LoNDONDERry, t. and p. o., Guernsey co., Ohio: $88 \mathrm{~m}$. E. by N. Columbus. Drained by a branch of Tuscarawas r. Surface rolling, and soil excellent for grass and grain. Pop. 1,551.

LONDONDERRY, t. and p. o., Windham co., Verm. : $74 \mathrm{~m}$. W. by S. Montpelier. Drained by branches of West $\mathbf{r}$. which furnish good water-power. Surface uneven; soil nn the streams very fertile-in the higher parts fit only for grazing. Wool is a large export. It has several manufactories of woolens and farming implements. Pop. 1,274.

Londonderry, t. and p. o., Chester co., Penn.: $62 \mathrm{~m}$. E. S. E. Farrisburg. Drained by Doe Run, a branch of the Brandywine. Surface even, and soil sandy and well cultivated. Farming is the ehief business.

London Grove, to and p. o., Chester co., Penn.: $59 \mathrm{~m}$. E. S. E. Marrisburg. Drained by White Clay er, and its branches, which furnish raluable mill privileges, Surface somewhat uneven, and soil a rich loam. It has extensive manufactories of cotton and woolen goods, flour, leather, etc. LONE JACK, p. O., Jackson co., Mo.: 106 m. W. by N. Jefferson City.

Lone Star, p. o., Titus co., Tex. : 271 m. N. E. Austin City.

Loxe Tree, p. o., Bureau co., $I l^{\circ}$ : $99 \mathrm{~m}$. N. Springfield. Loxg-a-contrg, p. v., Camden co., N. Jer. : 30 m. S. by W. Trenton.

Long Botroa, p. o., Meigs co., Ohio: $83 \mathrm{~m}$. \$. E. by E. Columbus.

Lovg Bottox, p. o., Marshall co., Firg.: 234 m. N. W. Richmond.

Long Braxce, p. O., Monroe co., Mo.: on a branch of Salt r., $52 \mathrm{~m}$. N. by E. Jefferson City.

LoNg Bravich, p. o., Franklin co., Virg.: 145 m.W. S. W. Richmond. 
Long Bratren, p. v., Monmouth county, $N$. Jer.: $35 \mathrm{~m}$. E. by $N$. Trenton. The beach known by that name is a long sandy peninsula, having the Atlantic on the E. and Shrewsbury r. on the W., and is much resorted to in summer for its fine bathing, fishing, and gunning. Ample accommolistions are afirmded for visitors, and many cottages are occupied by permanent residents. In the vicinity there are miny piensant and romantic villages, and much fine natural scenery. Steamboats ply regularly in the summer season from New Tork City.

Loxg Cane, p. o., Troup county, Ga.: about $2 \mathrm{~m}$. E. Chattahoochee r., $117 \mathrm{~m}$. W. Milledgeville.

LoNg CaNe, p. o., Abbeville district, $S$. Car.: $78 \mathrm{~m}$. W. Columbia.

LoNg Creer, p. o., New Hanover county, N. Car.: $97 \mathrm{~m}$.

S. S. E. Raleigh.

Long Crees, p. o., Louisa county, Virg.: 34 m. N. W. Richmond.

LoNg CreEK, p. o., Panola co., Miss. : 146 m. N. Jackson.

LoNg FALLS CREEK, p. 0., Daviess co., $K y_{2}$ : : on a branch of Green r. of that name, $136 \mathrm{~m}$. W. S. W. Frankfort.

Long GLade, p. o., Augusta co., Firg. : 102 m. W. N. W. Richmond.

LoNG GREEN ACADEMY, p. o., Baltimore co., Md.: $34 \mathrm{~m}$. N. Annapolis.

LoNG Grove, p. r., Lake co, IZl.: on Buffalo cr, of the Des Plaines, $189 \mathrm{~m}$. N. E. by N. Springfield,

Lovg Hall, p. o, Caldwell co., Ky.: 191 m. W. S. W. Frankfort.

Long Hrue, p. o., Morris county, N. Jer. : 44 m. N. N. E. Trenton.

Loxa IsLavo, $N$. Y.: a long narrow island, forming the S. E. portion of the State of New York, and lying between the Atlantic on the South and Long Island Sound on the North. Its length from the "Narrows" to Montauk Point is $113 \mathrm{~m}$., and its general width varies from 12 to 20 miles. It is dirided into the counties of Kings, Queens, and Suffolk, and coutains about $1,448 \mathrm{sq} . \mathrm{m}$. Its coasts are much broken by indentations, forming inqumerable small bays and harbors, many of which embosom marshy islands, and almost the whole south eoast is lined with a long sandy beach, between which and the main island is a fine inland navigation for small craft. A ridge or chain of hills, more or less elevated, but not exceeding 300 feet in height, extends east and west; the surface $\mathrm{N}$. of the ridge is in general rough and broken, while on its $\mathrm{S}$. side the surface is a plain, gently falling toward the Atlantic. On both sides of the island are numerous streams emptying into bays and inlets, affording, however, but small hydranlic power-the bays abounding in fine fish, oysters, etc. The streams at the W. end of the island are destined to furnish water for the cities of Broolilyn. Williamsburg, etc., by means of dans and culverts. Lighthouses have been erected at sereral poinis on both sides of the island and on Montauk Point, its E, extremity. The Long Island $R$. $R$. traverses the island almost through its middle from Brooklyn to Greenport.

Lovg Island sound, $N . Y_{.}:$a large and important body of water, between the State of Connecticut and Long. Island. It is about $100 \mathrm{~m}$. Iong, and from 10 to $20 \mathrm{~m}$. wide, and receives from Connecticut all its great rivers. The sound connects with the ocean on the E., and on the W. with New York Bay, through Hell Gate and the East river. The coasting vessels and the steamers plying between New Tork and the New England States almost invariably take the sound or inside route.

LoNG JoחN, p. o., Will county, $I l$. : $157 \mathrm{~m}$. N. E. by N. Springfield.

Loyg Lakf, p. o., Genesee co., Mich.: near a pond so called, tributary to Shiawassee $\mathrm{r} ., 43 \mathrm{~m}$. E. Lansing.

Long IAaNe, p. 0., Dallas county, Mo.: 68 miles S. S. W. Jefferson City.

Long Marser, p. o., Queon Anne co., MIa. . 37 m. E. N. E. Ansapolis.
Losg MEAdow, to and p. v., Hampden co., Mass.: on the E. side of Connecticut river, and $\mathrm{S}$. line of the State, $81 \mathrm{~m}$ W. S. W. Boston. Drained by small affluents of the Connecticut. Surface mostly level, a large part of the town being alluvial meadows. Soil very fertile and highly cultivaled. It has several tanmeries, anu makes excellent bricks, but is eminently a farming to, with markets for its produce at its doors. A superior kind of red building stone is abundant, and extensively quarried. The New Haven, Hartford, and Springfield R. R. passes through it, and has a sta. $4 \mathrm{~m}$. S. of Springfield. The $\mathrm{v}_{\text {, }}$ a long broad street, about $1 \mathrm{~m}$. from and parallel with the river, is beautifully shaded by rows of tall elms, and contains many elegant farm houses and country residences. Population of town 1,252 .

Long Meadow, p. o., Page county, Firg.: on E. side of Shenandoah r., $91 \mathrm{~m}$. N. W. Richmond.

LoNGMIRE, p. o., Washington county, Tenno: near the Nolichucky r., $245 \mathrm{~m}$. E. Nashville.

LONGMIRE's Stork, p. o., Eulgefield dist., $S$. Car : $63 \mathrm{~m}$. W. Columbia.

Long OLd Frelds, p. o., Prince George's co., MId. : $26 \mathrm{~m}$. W. S. W. Annapolis.

Long Perclumon, p. O, Yallabusha co, Afiss.: $119 \mathrm{~m}$. N. by E. Jackson,

Long Plain, p. o., Bristol county, Mass. : 46 m. S. by E. Bostin.

LONG POINT, p. Y., Livingston $c_{0}, I l l .:$ on a W. branch of Vermillion r., $95 \mathrm{~m}$. N. N. E. Springfield.

Lovg Pornt, p. 0., Washington county, Tex. : $92 \mathrm{~m}$. E. Austin City

LoNG POND, p. o., Caldwell co., $\overline{K y}$ : 186 m. W. S. W. Frank fort.

Long Pratrie, p. o., Wahnahta co., Minn. Ter.: near the river of that name, a branch of Crow Wing r., $103 \mathrm{~m}$. N. W. St. Paul.

LoNg Ridge, p. 0., Fairfield co, Conn.: $55 \mathrm{~m} . \mathrm{S} . \mathrm{W}$. Hartford.

Long Run, p. o., Jefferson co., Ky.: $26 \mathrm{~m}$. W. by $\mathrm{N}$. Frankfort.

Long SAvanNaH, p. 0., Hamilton county, Tenn.: $140 \mathrm{~m}$ S. E. by E. Nashville.

LoNG's Brmge, p. o., Hancock co., Ga.: near Buffalo cr. of the Oconee, $17 \mathrm{~m}$. E. by N. Milledgeville.

LoNG's Mills, p. o., Randoiph county, $N$. Car.: $61 \mathrm{~m}$. W. by N. Raleigh.

Long Streiet, p. o., Moore co., N. Car.: 35 m. S. W. Raleigh.

Long Street, p. 0., Pulaski co., Ga.: $42 \mathrm{~m}$. S. by W. Milledgeville.

Long Street, p. o., Lancaster dist., S. Car. : about $3 \mathrm{~m}$. E. of Catawba r., $42 \mathrm{~m}$. N. by E. Columbia.

Long Swamp, p. O., Marion co., F'lor: $169 \mathrm{~m}$. S. E. Tallahassee.

Long Swamp, t. and p. o., Berks county, Penn.: $66 \mathrm{~m}$. E. by N. Frarrisburg. Drained by Little Lehigh $r$., on which are several mills and small factories. Surface hilly, and soil gravelly loam. Leather, powder, and iron are made. At the $\mathrm{v}$, is a furnace of 1,000 tons capacity.

Longtown, p. O., Fairfield dist, S.Car.: 23 m. N. N. E. Columbia.

Longtown, p. o., Panola co., Afiss. : 133 m. N. by E. Jackson.

Long VAllew, p. o., Monroe co., Penn.: 93 m. N. E. by E. Harrisbarg.

LONG VIEW, p. o., Bradley co., Ark. : on the W. bank of Sabine $x$, of the Washita, $94 \mathrm{~m}$. S. by E. Little Rock.

LoNG VIsW, p. o., Morgan county, Tenn.: 127 m. E。 Nashville.

Long Vnew, p. o., Christian co., $E_{y} .: 176$ m. W. S. W. Fraukfort.

LoNGWood, p. o., Fayette county, Ind.: 49 m. S. by E. Indianapolis. 
Longmoov, p. O., Sabine co., Tex.: near Patroon bayou, 249 m. E. X. E. Austin City.

Loxawood, p. o., Union county, $K y .: 171 \mathrm{~m} . \mathrm{W}$. by $\mathrm{S}$. Frankfort.

Loxsdale, p. v, and sta., Providence co, $R . I_{*}$ : on Blackstone $\mathrm{r} ., 7 \mathrm{~m}$. N. Providence. It has a good share of trade, and is largely interested in manufactures of various kinds, for which its situation is well fitted. The sta. is $7 \mathrm{~m}$. from Providence on the Providence and Worcester R. R.

Loxsville, p. o., Pike county, $K y_{*}: 143$ m. E. S. E. Frankfort.

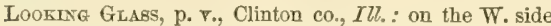
of Sugar cr. of Kaskaskia r., $89 \mathrm{~m}$. S. Springfield.

Looknt Guass (or Wabenassebee) river, Mich. : a beautiful clear stream rising in a small lake on the $\mathrm{S}$. border of Shiawassee co, flowing first $\mathrm{N}$. and then W. throngh Shiawassee, Clinton, etc., into Grand $r$. It is $70 \mathrm{~m}$. long and about 40 yards wide, and navigable for canoes to near its sources. The country near its sources is somewhat swampy, but in its lower course is well timbered and fine lands.

Look Otx, p. 0., Cole co., Mo. : N. side of N. Moreau cr. $15 \mathrm{~m}$. W. Jefferson City.

Lookour mountain, $G a$. a remarkable elevation in the N. W. part of the State, At its highest culmination it is crowned with a watch-tower of rock palisades, from which the eye obtains a most extensive and beautiful prospect of the wild seenery of the country.

Loomisvilue, p. V., Kent co., Mich.: $52 \mathrm{~m}$. W. N. W. Lansing.

Loonex's Creek, p. o., Marion co., Tenn.: on an affluent of the Tennessee so called, $97 \mathrm{~m}$. S. E. Nashville.

Looniesville, p. v., M'Donald co., MFo.: on Elk r., an E, branch of the Neosho, $172 \mathrm{~m}$. S. W. by S. Jefferson City.

Loosamstchee, p. o., Shelby co., Tenn.: near an affluent of Mississippi r. so called, $174 \mathrm{~m}$. W. S. W. Nashville.

Loose Cresk, p. O., Osage county, MO.: 14 m. E. S. E. Jefferson City.

Looxamora, p. o., De Soto co., Miss. : $156 \mathrm{~m}$. N. Jackson.

Lorado, p. O., Greene co., Ark: : 147 m. N. E. by N. Little Rock.

Lorars county, Ohio. Situate N. on Lake Eric, and contains $727 \mathrm{sq} . \mathrm{m}$. Drained by Black r. and its branches, and W. by Fermillion $r$. Surface undulating and sloping to the $\mathbb{N}$.; soil fertile, adapted equally to grass and grain. Wheat and corn are the cereal staples, and they yield luxuriantly. It has large dairies, and many, sheep are reared. Livestock, beef, wool, and pork are important exports. The streams afford excellent water-power, and manufactures are extensirely prosecuted. It also has a large trade on the lake. Farms 2,430; manuf. 64 ; dwell. 4,674, and pop.wh. 25,S24, fr. col. 262-total 26,086. Capital: Elyria. Puzlic Works: Cincinnati, Cleveland, and Columbus R. P.; Toledo, Norwalk, and Cleveland R. R. ; Junction R. R., etc.

Loraure, t. and p. o., Shelby co, Orio: $74 \mathrm{~m}$. W. by N. Columbus. Drained by branches of Miami r, ; soil mostly fertile. Miami Canal passes the N. E. corner, and the Bellefontaine and Indiana R. R. crosses it. Pop. 1,049.

Lonentz's Store, p. o., Lewis co., Firg. : 152 m. W. N.W. Richmond.

Lorestzothle Fotrder, p. o, Shenandoah co., Firg.: $107 \mathrm{~m}$. N. W. Eichmond.

Loretio, p. 0., Essex county, Firg.: 41 m. N. E. by N. Richmond.

LoRemTo, p. o, Marion co., $K y_{.}: 49$ m. S. S. W. Frankfort. Lonetro, p. 0., Cambria co., Penn. : $94 \mathrm{~m}$. W. by N. Harristurer.

LorratNe, t. and p. o., Jefferson county, $N . Y .: 138 \mathrm{~m}$. N. W. by W. Albany. Drained by branches of Sandy cr., which move several flour and numerous saw mills. Surface broken, and soil clay and sandy loam, well fitted for grazing. A fine farming t. and heavily timbered. Pop. 1,511.

Los Avgeilos county, Calif. Situate S., and comprises about $15,000 \mathrm{sq} . \mathrm{m}$. The streams emptying into the Paciflc, 324 along the coast of which the county extends about $150 \mathrm{~m}$. are Santa Clara, the N., and Santa Anna, the S. boundary, San Pedro, San Gabriel, and Los Angelos; the principal stream E. is Mohave r., a branch of the Colorudo. San Pedro Bay, on the $\mathbf{8}$., is a good harbor, anl opposite it is Santa Catalina, and separated from the $\mathrm{N}$. by the channel of Santa Barbara, is Santa Cruz, two large and beautiful islands. Surface broken in the W. by the Sierra Nevada Mountains and their spurs, extending to the coast; in the E. are many high hills, with extensive sandy plains. The soil has been suffered to lie waste a long time, but is capable of producing in abundance all the grains and fruits of the Atlantic coast, with bananas, plantains, pomegranates, indigo, and olives. Grapes and olives are abundant of the best quality. Corn is the staple. The climate is equable, mild, and very healthy. The white population is about 10,000. Capital: Los Angelos.

Los Angeros, p. v., and cap. Los Angelos co., Catif. : on the W. side of the Rio de los Angelos, which falls into San Pedro Bay, and $300 \mathrm{~m}$. S. S. E. Vallejo. It is the seat of an ancient mission, and was capital of California Alta previous to the Mexican War. The $v$. has several substantial military and ecclesiastical buildings, and in many respects is now a flourishing inland place. It was here that General Kearney and Colonel Fremont had their famous dispute for command, which led ultimately to court-marshalling of the latter. Lat. $1900015^{\prime \prime} \mathrm{N}$., and long. $100^{\circ} 22^{\prime} 45^{\prime \prime} \mathrm{W}$.

Loss Creek, p. o., Crawford county, Ohio: $55 \mathrm{~m}$. N. Columbus.

Lost Crezk, p. O, Saline co., Ar/s. : 36 m. W. Little Roek. Lost Creex, p. o., Lincoln co., Mo.: about $3 \mathrm{~m}$. W. of the Mississippi, 79 m. E. N. E. Jefferson City.

Lost Creek, p. 0., Campbell co., Tenn.: between Powell's and Clinch rivers, $163 \mathrm{~m}$. E. by N. Nashville.

Lost CREek, p. o, Harrison co., Firg.: on a branch of Monongahela $\mathrm{r}$. so called, $189 \mathrm{~m}$. N. W. by W. Richmond.

Lost Creek, p. 0., Breathitt co., Ky.: on a branch of Kentucky r., 102 m. E. S. E. Frankfort.

Lost Grove, p. 0., De Kalb co., $12 l .: 157$ m. N. by E. Springfield.

Lost Mountaln, p. o., Cobb co., Ga.: 109 m. N. W. Milledgeville.

Los' RIVER, p. o., Orange co., Ind. : near the branch of White r. so called, $78 \mathrm{~m}$. S. by W. Indianapolis. Lost $r$. rises in Washington $\mathrm{co}_{\text {, }}$ and takes a W. course throngh the N. part of Orange, and forms a junction with Lick er., and falls into the E. fork of White $r$. near the $\mathrm{S}$. line of Martiu county. This stream, as well as many of its tributaries, sinks and runs underground for considerable distances, and then rises again.

Lost Rrver, p. o, Hardy co., Firg.: on a branch of Great Cacapon r., $118 \mathrm{~m}$. N. W. Richmond.

Lost Village, p. o., New Madrid co., Mo.: 94 m. S. E. Jefferson City.

Lotremge, p. o., Athens co., Ohio: $69 \mathrm{~m}$. S. E. Columbus,

Lorns, p. 0., Edgefield dist., S. Car. : 35 m. W. Columbia. Lomsburg, p. o., Northumberland co, Firg.: $55 \mathrm{~m}$. E. N. E. Richmond.

Lomrsville, p. v., Warren co., Penn.: on Little Broken Straw cr., which affords power for several mills here, $177 \mathrm{~m}$. N. W. Harrisburg.

Loudon county, Virg. Situate N. E., and contains 478 sq. m. Bounded N. E. by the Potomac, and drained by its affluents, Goose, Kittoctan, and other small creeks. Surfaco broken by several ridges of mountains, and very uneven, with beautiful and fertile valleys; soil various, but mostly very productive. Wheat, corn, oats, and rye bring large crops, and are the staples. Great numbers of cattle and sheep are raised; beef and wool are exported, and pork largely. It has good water-power, and numerous flourishing manufuctnries, especially of flour and lumber. Farms 1,256; manuf. 139 ; dwell. 2,834, and pop.-wh. 14,0s1, fr. col. 1,357, sl, 5,641-total 21,079. Capital: Leesburg. 
Lotdox, t. and p. v., Merrimac co., N. Hump.: $6 \mathrm{~m}$. the Mississippi. Limestone, copper, and lead are found. N. E. Concord. Drained by Suneook r., which supplies it Farms 395; manuf, 18; dwell. 842 , and pop.-wh. 4,913, with fine water-power. Suncook r. rises from a poucl in the E. Surface hilly; soil on the Suncook fertile, and gencrally nulapted to grass. The $r$, is in the S., and contitins sertral ul lls. Pop. of t. 1.553 .

Loudox, p. b., Franklin co., Penn.: 57 m. W. S. W. Harrisburg. Here are 2 chareoal forges, making 90 tons of bars per annum, and $2 \mathrm{~m}$. distant is a charconl furnace of 800 tons annual empacity

Logdor Cextre, p. o., Merrimac co., N. Hamp.: $10 \mathrm{~m}$. N. E. Concord.

Loodon Rmge, p. o., Merrimac co., N. Hamp.: $11 \mathrm{~m}$. N. Х.. Y. Concord.

LOCDONrILLE, p. v., Ashland co., Ohio: on Black fork of Walhonding $\mathrm{r} ., 58 \mathrm{~m}$. N. E. by N. Columbus.

Loddstille, p. v., Eabersham co., Ga. : $126 \mathrm{~m}$. N. by W. Milledgeville. It lies in the beart of the gold region, and near the head of Chestatee river.

Louts A county, $I a$. Situate S. E., and contains 413 sq. m. Drained by Iowa r., its branches, Cedar r., and Long cr., and Muscatine Slough. Surface moderately uneven; soil very fertile, equally adapted to grass and grain. Corn, wheat, beef, and pork, are leading products. It has large streams, which afford abundance of water-power. The Iowa crosses the co. from N. W. to S. E. diagonally, and is navigable the whole length, and the $\mathrm{E}$. line is formed by

fr. col. 26-total 4,939. Capital: Wapello.

Lours a county, Virg. Situate E. centrally, and contains 427 sq. m. Drained by N. and $\mathrm{S}$. Anna rivers, which form the Pamunky, and flow into York $r$. Surface diversifled, with pleasant river vallevs; soil of great productiveness. Tobacco is a very large crop, and the staple. Corn and whent yield finely, and there is much good pasture. Waterpower is plentiful for working up all the products, and gold in small quantities bas been found. Farms 838; manuf22 ; dwell. 1,254, and pop.-wh. 6,423, fr. col, 404, sl. 9,864total 16,691. Capital: Louisa C. II. Putlic Works: Virginia Central R. R.

Lovis A, p. o., Randolph county, Ala.: 79 miles N. N. E. Montgomery.

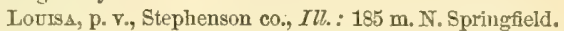
LouIss, p. v., and cap. Lawrence co., $K y_{.}$: near the junction of Big Sandy r. and its W. fork, $129 \mathrm{~m}$. E. Frankfort. Louisa C. H., p. v., and cap. Louisa co., Firg. : $42 \mathrm{~m}$ N. W. Richmond. It contains a court-house, jail, academy, and several stores and dwellings. The Virginia Central R. P. passes the v. $62 \mathrm{~m}$. from Richmond.

Loods bURG, p. v., and eap. Franklin co., N. Car. : on the left bank of Tar r., $31 \mathrm{~m}$. N. N. E. Raleigh. It has an extensive trade, and contains a court-house, jail, an academy, a dozen stores, and 500 inhabitants.

\section{THE STATE OF LOUISIANA.}

Lotisiana occupies all the territory of the purchase of 1803 below the $33 d$ parallel, and that portion of Spanish Florida west of Pearl River, and below the 31st parallel, its front stretehing along the Gulf of Mexico for nearly 300 miles. It lies generally between the latitudes $29{ }^{\circ}$ and $33^{\circ} \mathrm{N}$., and between longitudes $88^{\circ} 40^{\prime}$ and $91^{\circ} 23^{\prime} \mathrm{W}$.; and is bounded north by Arkansas and Mississippi ; east by Mississippi, from which it is divided by the river of the same name, and Pearl River; south by the Gulf of Mexico; and west by Texas, the Sabine River being its boundary in this direction more than twothirds the distance. The area of the land surface of the State is computed at 46,431 square miles.

The surface of Louisiana is low and generally level, with some hilly ranges of little elevation in the western part, and numerous basins or depressions of the soil. The great delta of the Mississippi, included within the Atchafalaya and the Iberville, and amounting to one-fourth part the area of the State, is seldom elevated more than ten feet above the sea, and is annually inundated by the spring floods. A great part of the delta is composed of sea marsh, which also forms the whole southern coast to the Sabine, and which, through its whole extent, is subject to inundations by the high tides. To the north of this marsh, spreads out the vast level of the prairies, which is but slightly elerated above the former district. The western margin of the Mississippi is also a low country, intersected by numerous small rivers, and liable to inuncation. To the west and north of these is an extensive region comprising one-half of the State, considerably broken, but nowhere exceeding 200 feet in elevation. The section north of the Iberville and Lake Pontehartrain and east of the Mississippi is of a similar description with the north-western region, and, like that, is principally covered with pine.

The State presents but a limited geological field. It is divided into the leading grades or divisions of tertiary, diluvial, and alluvial. The tertiary, occupying about two-fiflhs of the State, lies north of a waving line, commencing on the Sabine near the mouth of the Neches, crossing Ped River 20 miles north of Alexandria, and the Washita 10 miles north of Harrisburg. Its beds contain coal (aluminous brown coal), salt, iron, ochre, gypsum, and marls. The coal is inferior to that of Pittsburg, and could not compete with it in the market, but is worth developing for use in those portions of the State where the better coal would not bear the expense of transportation. It abounds in Sabine, Natchitoches, Caddo, and De Soto, and all the parishes thence east to the Washita. Salt springs are common in Natchitoches and Rapides, and hare been wronght in earlier times. A saline bed, it is thought, underlies the tertiary series generally. Iron is found in great quantities in all the tertiary parishes, and is well worth the attention of those who would develop the State's resources. Ochre, grpsum, and marls, too, are found-the first in the native form, and the others co-extensive with the tertiary beds. The gypsum is very fine, equal to any known to commerce, and the marls very rich in the regions where they will be most needed.

About one-fifh of the whole surface is periodically overflowed by the waters of the Mississippi, and a great portion of these inundated lands is rendered unfit for cuitivation in its present state. This immense alluvial tract embraces soil of various descriptions, whick may be arranged into four classes--the first, which is thought to be equal to two-thirds of the Thole, is covered with heavy timber, and an almost impenetrable undergrowth of cane and other shrubbery. This portion is quickly drained as the river retires into its natural channels, and has a soil of the greatest fertility. The second class consists of cypress swamps: these are basins or depressions of the surface, from which there is no natural outlet, and which, being filled with water by the floods, remain covered with it until carried off by evaporation or alosorption; these, by draining, might become excellent rice lands. The third class embraces the sea marsh, a belt of land partially covered by common tides, and subject to inundation from the high waters of the Gulf during the equinoctial gales; it is generally ritheut timher, and its soil is partially clayer, and, in part, as black as ink, cracking by the heat of the sun into fissures wide enough to admit a man's arm. And the fourth class consists of small bodies of prairie land dispersed in different parts of the alluvial territory. These spots are elevated and without timber, but of great fertility. The pine lands have usually a poor soil, but the interval lands on the rivers, or bottoms, as they are universally called in the West, are always rich. On the Red River the soil contains a portion of salt, and is of a dark-led color, from its containing the oxide of iron. $\Delta$ areat prortion of the prairies is seconl-rate land, and some of them are sterile. The richest tract in the State is a nar. 
LOUISIANA.

row belt, ealled the coast, lying along the Mississippi on both sides, and extending from 150 miles above to 140 miles below New Orleans; it is from 1 to 2 miles wide, and lies below the level of the water in the river in ordinary times of flood, and is only difinded from drowning by a dyke or levée 6 or 8 fect in height, and sufficiently broad for a highway. The wholo of this tract is under cultivation, and produces valuable crops of sugar.

The prairies, or unwooded plains, occupy the interior section between the Teche and Sabine; the water-courses are here lined with trees, and occasionally little groves or clumps, called, from their isolated appearance in these grassy expanses, " islands," are met with. Northward of the prairies is an extensive tract, before alluded to as the tertiary region, reaching to the northern boundary, and approaching the Washita on the east, the surface of which is much broken into hills, though of moderate height. It consists mostly of pine barrens covered with a vast forest of pitch pine, interspersed with oaks, elms, cypress, honey-locust, etc., in low spots and on the margins of the streams. The tract east of the Mississippi and north of the Iberville and the connected lakes, closely resembles that last described in its surface and finest growths. It is, in fact, a part of the same upland plain whose margin on the western side is separated from the river-bed by the low, inundated lands, but on the east comes up to the channel of the river, in many places forming those prominent bluffs on which stand Baton Rouge, St. Francisville, Fort Adams, Natehez, and Vicksburg.

The Mississippi, after having formed the boundary of the State for about 450 miles, enters its limits 350 miles from the sea, by the course of the river channel. Throughout this distance of 800 miles, its western bank is low, and flooded in high stages of the water. At the point where it enters the State, it throws off its first outlet, the Atchafalaya, and here may be said to commence the delta of the river. The Atchafalaya, here called the Chafalio, receives the waters of the Mississippi only in flood, and the navigation is obstructed by collections of timber, often covered with mud and weeds, which choke up its channel. The Teche and Courtableau are its principal tributaries. The Bayou Plaquemine, the next considerable outlet of the Mississippi, discharges the waters of that river into the Atchafalaya during the floods, and is the channel of trade between the country on the Atchafalaya and New Orleans. Lower down is the La Fourche outlet, which has high banks along its upper course, and admits vessels of 4 or 5 feet draft nearly to its head. On the left bank the Bayou Manchac, a little below Baton Rouge, or the last highland passed in descending the Mississippi, is the first and principal outlet; after receiving the River Amite from Mississippi, it takes the name of Iberville River. It may here be remarked that the term "bayou," applied to arms of rivers in Louisiana, is generally confined to those that have no proper current, but are sometimes stagnant, and flow sometimes in one direction, and sometimes in another, according to the high or low stage of the waters-it appears to be a corruption of boycur, used in the sense of the corresponding English sea-term "gut."

The Red River is the most important and, indeed, with the exception of two or three magnificent streams on the eastern side above Baton Rouge, the only tributary of the Mississippi within this State; for the surrounding country being lower thon the river banks, its waters can not gain access to the bed. The Red River rises in the Rocky Mountains, and flowing eastwardly along the north border of Texas, and into Arkansas, turns to the south, and passes into Louisiana. Soon after entering this State, its bed is choked up by an immense accumulation of fallen timber, called the "Raft," and the water is dispersed into numerous channels, and spread over wide expanses. The Raft extended formerly over a distance of 160 miles, but its length has been materially diminished, and, in fact, its complete removal is considered certain. Below Nachitoches the river divides into several arms, which again unite above Alexandria, and its waters reach the Mississippi just above the first outlet, after a course of 2,000 miles, of which 1,500 miles is open to steam navigation. The Black River, its principal tributary, is formed by the junction of the Tensas, Washita, Catahoula or Little River, all considerable streams, and navigable by steamboats; but most of the country along their courses is overflowed. The Bayou du Bon Dieu is also a large and navigable river, which enters it above the Black. There are numerous lakes in this section of the State, formed chiefly by the overflowings of the rivers, which fill the low basins back of their banks. Iu the south are the Vermillion, Mermentean, and Calcasieu, which, rising in a tract of pine hills to the south of the Red River, and flowing through the great pastoral plains of the west, reach the low marshy strip to the Mexican Gulf, and spread into shallow lagoons. The Sabine, which partakes of the character of the last described rivers, is, however, a considerable stream, rising farther to the north in Texas, and is a navigable river beyond the Louisiana boundary, but its mouth is obstructed by a bar. From the north-enstern pine region, the Pearl, Tangipaod, Chefuncta, and Iberville, Iarge navigable rivers, flow into the lakes and passcs which separate that region from the fluviatile district. The Iberville, formed by the junction of the Amite from the north, and the Manchae from the west, enters the head of Lake Maurepas, which is from 10 to 12 feet deep, and connected with Lake Pontehartrain by the Pass Manchac. Lake Pontchartrain is about 40 miles long, and 24 miles wide, with an average depth of 10 fathoms, but is shallow near the shores. Vessels drawing 8 feet of water can, however, go up to Madisonville and to the mouth of Bayou St. John, in the rear of New Orleans; and not more than that draft can be carried through the passes or ehannels ealled the Rigolets and Chef Menteur, through which it communicates with Lake Borgne. This last is, properly speaking, no lake, but the termination of Pascagoula Sound; it approaches to within 15 miles of New Orleans, and boats can go up the bayoux that empty into it to within a short distance of the city. It is of about the same average depth with Lake Pontchartrain, but somewhat deeper along the shores.

Louisiana is remarkably destitute of good harbors. Vessels drawing 8 feet of water can go up to Madisonville on Lake Pontehartrain, but the other inlets on the coast are shallow. There is, however, a good roadstead on the west sile of Chandeleur Islands, called the Road of Naso, in which the heavy vessels of the English fleet lay during the expedition against New Orleans. Numerous sheets of water, improperly ealled lakes, lie along the coast. Of Lake Borgne mention has alreauły been made. Barataria, Vermillion, Côte Blanche, Atchafalaya, and Simballier Bays, are shallow tide basins. In the interior, lakes LiAllemands and Chetimaches are large bodies of waters.

Although Louisiana extends more than a degree farther south than any other portion of the Union, except the Peninsula of Florida, its winters are longer and more severe there than in the corresponding latitudes on the Atlantic borders. Thus, according to Darby, New Orleans has the winters of Charleston, which is nearly two degrees farther north, and the live oak, which on the Atlantic is found as far north as $34^{\circ}$, does not in Louisiana oceur above $30^{\circ} 30^{\prime}$; but that writer has overlooked the fact that the live oak is a maritime tree, and does not grow more than 20 or 25 miles from the sea. The tall palmetto, or cabbage palm, and the long leafed pine, so eharacteristic of the southern Atlantic States, do not appear here; nor does the China orange thrive higher than 30030 . The climate is favorable to the peach and fig tree; but the apple can not be eultivated to advantage, and the cherry is wholly unproductive. The agricultural staples are cotton and sugar ; rice, maize, or Indian corn, and tobacco, are also cultivated, but have been neglected for the first named articles; and indigo, which was formerly a staple, has been abandoned. The prairie lands of the west afford valuable pastures; and here are found large herds of cattle and horses. In the north-western part of the State, between the Mississippi and 


\section{LOUISIANA.}

Grain Crops.-Wheat, 417 bushels; rye, 475 bushels; Indian corn, $10,226,373$ bushels; oats, 59,637 bushels; barley, 0 bushels; and buckwheat, 3 bushels. The crops of 1539-40 were-wheat, 60 lushels; barley, 0 bushels; oats, 107,353 bushels; rye, 1, 812 bushels; buckwheat, 0 bushels; Indian corn, 5,952,912 bushels.

Other Situle Crops.-Rice, 4,425,349 (in 1Sเ0, 3,604,534) pounds; tobacco, 26,s7s (in 1840, 119,524) pounds; ginned cotton, 178,737 bales of 400 pounds each, or $71,494,800$ (in 1840, 152,555,368) pounds ; sugar-maple, 255 pounds, and cane, 226,001 (in 1840, 119,947 ) hogsheads of 1,000 pounds ; and molasses, $10,931,177$ gallons.

Iriscollaneons Crops.-Peas and beans, 161,732 bushels; potatoes-Irish, 95,632, and sweet, 1,428,453 bushels; hay, 25,752 tons ; clover-seed, 2 bushels, and other grass-seeds, 97 busluels; hops, 125 pounds; hemp-dew-rotted, 0 tons, and water-rotted, 0 tons; flax, 0 pounds; flax-seed, 0 bushels; wine, 15 gallons, ete. The value of orchard products for the year was, $\$ 22 ; 359$, and of market-garden products, $\$ 145,329$.

Products of Animals. - Wool, 109,897 (in 1840, 49,283) pcunds; butter, 683,069 pounds; cheese, 1,957 pounds; and value of animals slaughtered during the year had been $\$ 1,45 \$, 990$. Silk cocoons were produced to the amount of 29 (in $1840,317)$ pounds; and beeswax and honey, to that of 96,701 pounds.

Home-made manufactures for the year ending 1st June, 1850, were produced to the value of $\$ 139,232$

The comparison of the principal crups in 1840 and 1850 results as follows:

\begin{tabular}{|c|c|c|c|c|c|c|c|c|c|c|}
\hline Staples. & \multicolumn{2}{|l|}{1840.} & \multicolumn{3}{|c|}{1850.} & \multicolumn{3}{|c|}{ Movement. } & & \\
\hline dian Corn & $5,952,912$ & bushels & & $10,226,373$ & oushels & inc & $4,278,461$ & ushels, & , or 71.79 & er cent. \\
\hline Rice.............. & $3,604,534$ & pounds & $\ldots$ & $4,425,349$ & oounds & . iner. & 820,815 & ounds, & or 22.78 & " \\
\hline obaceo. & 119,524 & " & $\ldots$ & 26,878 & " & .... decr. & 92,916 & " & or 77.57 & " \\
\hline ed Cotto & 2,5 & "6 & $\ldots$ & $71,494,800$ & “6 & ... decr. & $81,060,568$ & " & or 5314 & " \\
\hline lane Sugar......... & $1,947,720$ & "s & $\ldots$ & $226,001,000$ & 6 & .... incr. & $106,053,280$ & " & or 88.42 & “ \\
\hline
\end{tabular}

It is thus apparent that all the great crops, except that of cotton, have materially increased; but the falling off in the cotton crop is more apparent than real, the greater part of it having been destroyed by the extraordinary and destructive floods, which swept over whole plantations in the fall of 1849 , to which ycar the census returns of 1850 refer. It is a twollknown fact, however, that the culture of sugar in Louisiana is employing the labor formerly devoted to cotton, and this change of crops is annually progressing.

Manufactures.-Aggregate capital invested, $\$ 0,000,000$; valuo of raw material, fuel, etc., consumed, $\$ 0,000,000$; average number of hands employed, 00,000 -males, 00,000 , and females, 0,000 ; average monthly cost of labor $\$ 000,000-$ male $\$ 000,000$, and female $\$ 00,000$; total value of products for the year ending 1st June, $1850, \$ 0,000,000$. The whole number of manufacturing establishments in the State producing to the value of $\$ 500$ and upward annually, at the above date was 1,021-in western district 121, and in eastern district 900 ; and of these, 8 were manufacturing castings of iron, and there were 15 tanneries, the remainder consisting of mills, and other establishments usual in a Southern agricultural State.

The iron manufacture employed a capital of $\$ 255,000$; pig iron consumed, 1,660 tons; mineral coal consumed, 3,205 tons; value of all raw material used, $\$ 75,300$; hands employed, 347 ; average monthly wages, $\$ 3560$; castings made, 1,570 tons; value of entire products, $\$ 312,500$.

The tanneries employed a capital of $\$ 3 \$, 500$; value of raw material used, $\$ 26,440$; average number of hands employed, 51 -males 51, and females, 3 ; monthly cost of labor-male, $\$ 930$, and female, $\$ 22$; number of skins tanned, 2,850, and of sides, 21,000 ; value of skins and hides when tanned, $\$ 55,025$.

The distribution of the manufactures is very unequal, and many of the parishes are entirely without them: of the 900 cstablishments in the eastern district, 521 are in Orleans parish, 147 in West Feliciana, 54 in Jefferson, 49 in East Felieiana, 36 in Livingston, 33 in St. Tammany, 14 in St. John Baptist, 10 each in Wegt Baton Rouge and Iberville, 9 in St. Felena, 6 in St. James, 4 each in La Fourche and Terre Bonne, and 3 in St. Charles-Ascension, Assumption, East Baton Ronge, Plaquemines, Point Coupee, St. Bernard, and Washington, returning no manufactures; and of the 121 in the western district 24 are in Madison, 18 in St. Laundry, 11 in Rapides, 10 in Carroll, 9 each in De Soto and Nachitoches, 6 each in Tensis and Jackson, 5 each in Avoyelles and Sabine, 4 each in Morehause and Wuchita, 3 each in Catahoula and Claiborne, 2 in Bienville, and one each in Caldwell and Union-Bossier, Caddo, Calcasieu, Concordia, Franklin, Lafayette, St. Martin, St. Mary, and Vermillion returning none.

Commerce.--In the aggregate of exports and imports, Louisiana is second only to New York, but in the amount of its imports both Nassachusetts and Pennsylvania exceed it. The total value of its exports to foreign countries in the year ending 30th June, 1850 , was $\$ 38,105,350$, of which $\$ 37,695,2 \pi 7$ was the value of domestic produce exported, and $\$ 407,073$ the value of re-exported foreign produce. The value of domestic produce carried in American bottoms was $\$ 20,927,751$, and in foreign bottoms $\$ 16,770,526$; and the value of foreign re-exports carried in American bottoms, was $\$ 328,930$, and in foreigu bottoms $\$ 7 \$, 143$. The total value of imports was $\$ 10,760,499$, of which the value brought in American bottoms was $\$ \$, 107,929$, and in foreign bottoms $\$ 2,652,570$. The shipping employed in this trade was as follows:

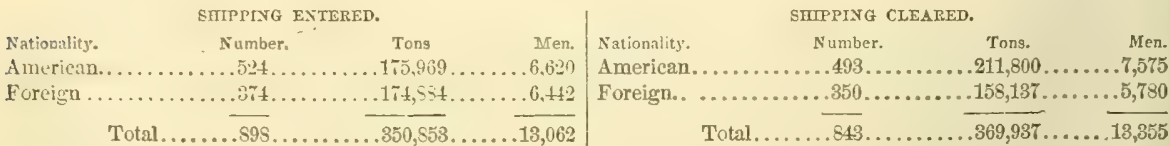

The whole of this commerce and navigation belongs to the district of which New Orleans is the port of entry, except two American ships of 904 tons and 14 men, which are entered in the district of Teche.

The aggregate of the shipping owned in Louisiana amounted at the date specified to 250,090 tons, of which the whole, cxcept 1,3S1 tons enrolled and licensed shipping owned in the district of Teche, belonged to the district of New Orleans. Of the agregrate, $\$ 3,665$ tons were revistered, 160,632 tons werc enrulled and licensed, and 5,759 tons were licensed (under 20 tons.) Of the registered shipping, $6,5 \$ 9$ tons, and of the two latter classes 144,724 tons were navigated by steam; and during the year 24 vessels, viz, 1 ship, 16 schooners, 3 sloops, and 4 steamers, of an aggregate burden of 1,592 tons, were built in the State. 


\section{IOUISIANA.}

The statisties of the foreign trade of the State for a series of years, exhibit the following movement:

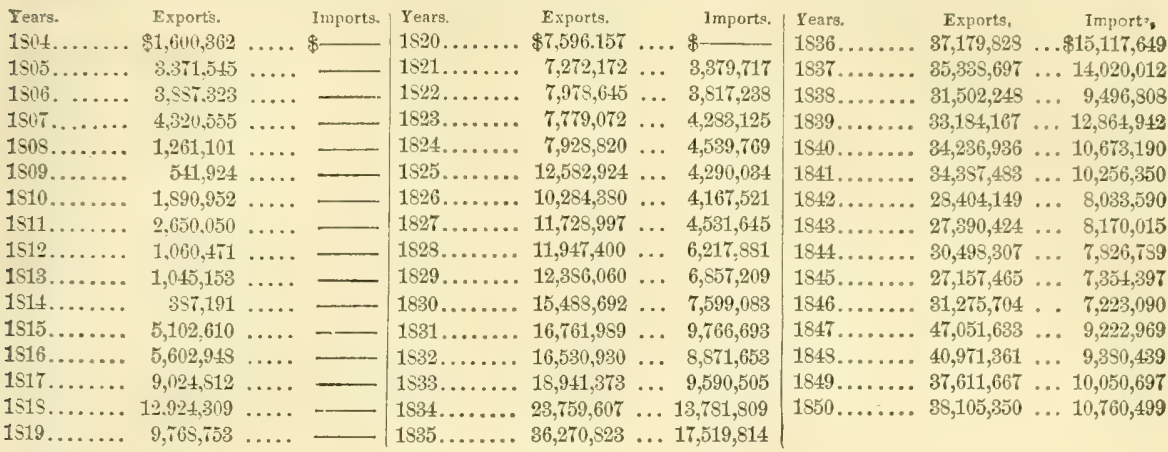

Coasting and River Trade.-The coasting trade of Louisiana is equally valuable with its foreign trade, and its trade with the interior is perhaps fully equal to both the foreign and coastwise trade together. These, however, will be fully examined under the head of "New Orleans," and hence, in this connection, the aggregates alone need be exhibited. The arrivals and clearances in the coasting trade for the year ending 30th June, 1.851, were as follows:

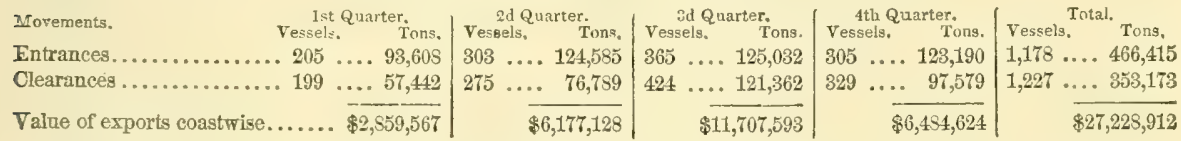

The following will show the quantity and destination of some of the principal staples of export in the year above quoted:

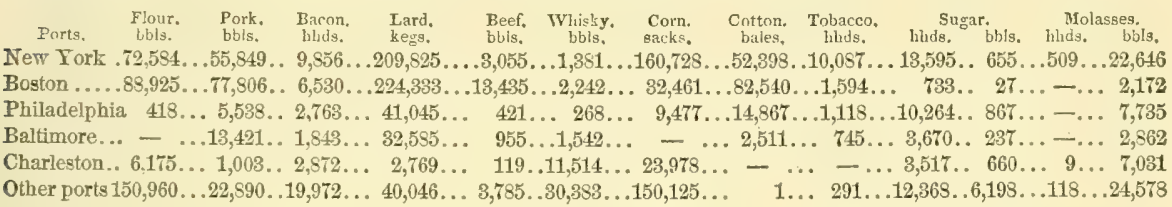

The total quautities of the above specified articles exported to foreign and domestic ports, were as follows:

$583,418 . .192,737 \ldots 46,241 \ldots .738,956 \ldots 42,415 \ldots 67,392 \ldots .535,382 \ldots 997,458 \ldots 54,501 \ldots .44,147 \ldots 8,644 \ldots 636 \ldots 67,024$

The receipts from the interior by the Mississippi Piver in the same year $(1850-51)$ were valued at $\$ 106,924,083$, and comprised all the various staples for which the several regions of production are noted, alike mineral, vegetable, and animal; and there is, besides the river trade, an immense traffic on the new eanal. The total number of flat-boats arriving at New Orleans during the year was 941, of which 215 were from Ohio, 58 from Kentucky, 298 from Indiana, 12 from Virginia, 222 from Pennsylvania, 19 from Illinois, 104 from Tennessee, and 10 from Mississippi; and the whole number of steamboat arrivals was 2,918 .

Internal Improvements.--Hitherto Louisiana has depended with confidence on the great natural facilities for inland communication the State exjoys by means of the magnificent river and its dependencies which traverse its surface; but when it was discovered that the North had, by means of the Illinois Canal, constructed an artificial outlet for this great river into the lakes, this dream of security vanished, and the people interested in the commerce of the Gulf ports at once beset themselves to remedy the impending destruction of a commerce unequaled in extent by but one other section of the Union. The magnificent lines of railroads from the "father of waters" to the Atlantic Ocean, were also diverting a vast amount of the legitimate trade which naturally concentrated at New Orleans. And all these changes in the avenues of trade had been allowed to proceed, and with the exception of a few local railroads, Louisiana had not even extended her arms to arrest their influences. Awakened to a sense of duty, however, by the results of these new works-decreased receipts of produce, and decreased returning merchandise-no time was lost in premises, but the whole south-west met in convention at New Orleans, and unanimously resolved to cope with the leviathans which were sapping the foundations of their commercial prosperity. The principal remedies proposed were the extension of the railroad from New Orleans and the Gulf ports to the north and north-east, and seek a new market in the west by building lines into Texas, $\Delta$ rkansas, etc. The first would countervail the northern improvements, which had superseded the old river-course of trade, and by offering a more direct and rapid channel to the sea, recover the preference the deposit at New Orleans had formerly enjoyed. The improvement of the channel of the Mississippi below New Orleans, was also recommended, and will doubtlessly be undertaken by the general government at no distant period. The results of the convention have been an active enforeement of its recnmmendations, and numerous lines of railroad are being laid out and constructed in the directions indicated, the most important of which are the New Orleans, Jackson, and Northern R. R., and the railroads from the Mississippi toward Texas, from Lake Providence, via Shreveport, Marshall, etc., from Natchez, via Shreveport, etc., and from New Orleans, via Opelousas, Huntsville, etc. Railroads are also being built in almost every direction, to connect with the lines of other States, or afford facilities to the gulf ports generally ; and at no distant day, it may be foreseen, Louisiana will be on a par with, or have outstripped many of her now successful competitors.

Banks, etc,-In Decenber, 1850, the bank returns of Louisiana showed that there were at that period 5 banks, and 20 branch banks in the State, the aggregate condition of which was as follows: Liabilities-capital $\$ 12, \$ 70, \$ 90$, circulation 
$\$ 5,059,229$, deposits $\$ \$, 464,3 \$ 9$, and due other banks $\$ 1,334,232$; and assets-loans and discounts $\$ 19,309,108$, real estate $\$ 2,255,169$, other investments $\$ 2,042,149$, due by other banks $\$ 2,225,896$, specie funds $\$ 1,200,000$, and specie $\$ 5,716,001$. The whole number of banks are located at New Orleans, the country banks being their branches.

Gocernment.-The present constitution, which superseded the first constitution of the State, formed in 1512, was ratifled by the people on the 5 th Novemaber, 1845.

Every free white male person 21 years of age, two years a citizen of the United States, or resident in the State for two consecutive years next preceding the election, and the last thereof in the parish in which he proposes to rote, is allowed the right of suffrage. Absence from the State for more than 90 consecutive days, unless his house or place of business be occupied by his family or servants, interrupts the residence of the absentee.

The Legislature consists of a House of Representatives and a Senate; representatives not less than 70, nor more than 100 in number (now 97), and 16 senators, being half the whole number of senators, are chosen every second year, on the first Monday in November, and convene at the capital every second year, on the third Monday in January. Representatives must be free white males, 21 years of age, citizens of the United States, and residents of the State for the three years and residents of the parish for one year next preceding their election. A census will be taken in 1855 , and every ten years thereafter, which will form the basis of apportionment; but every parish is entitled to at least one representative. Senators are chosen for four years. A senator must be 27 years of age, ten years a citizen of the United States, four years a resident of the State, and one year of the distriet he represents. Dedueting the population of New Orleans from that of the State, the remainder, divided by 28 , is the senatorial ratio for the districts. No session of the legislature shall last more than 60 days, and no act passed after being 60 days in session is valid. Members may address either house in the French or English languages, and the proceedings are published in both languages. Any one who fights a duel, acts as second, or sends or accepts a challenge, shall neither hold an office, nor enjoy the right of suffrage in the State.

The Governor is chosen by a plurality of votes, and holds office for four years. He must be 35 years of age, and a eitizen of the United States, and resident in the State for 15 years next preceding his election. The Lieutenant-governor is elected for the same term, in the same manner, and must be similarly qualified. The governor is ineligible for the four years succeeding his term. He may veto a bill, but two-thirds of both houses may pass it again, and it thus becomes law. The lieutenant-governor is ex-officio president of the Senate.

The principal administrative officers are the Secretary of State, State Treasurer, Surveyor-general, Adjutant and InEpector-general, Auditor of Accounts, etc. The Treasurer is chosen biennially by joint ballot of the legislature.

The Judiciary consists of the Supreme Court and District Courts. The Supreme Court consists of a Chief Justice and three associate Justices, appointed by the Governor, with the advice and consent of the Senate, for the term of eight years. The Court sits in New Orleans from the first Monday in November to the end of June inclusive. The Supreme Court has appellate jurisdiction only when more than $\$ 300$ is in dispute, when the legality of any tax is in question, on all fines and penalties imposed by municipal corporations, and in criminal cases on points of law where death, hard labor, or a fine of more than $\$ 300$ is imposed. The Court may issue writs of habeas corpus in all eases where they bave appellate jurisdiction. If the Judges are equally divided, the judgment appealed from stands affirmed. The Court has a reporter and clerks in New Orleans, Opelousas, Alexandria, and Monroe. The State is divided into seventeen districts. One district judge is appointed for each district, except for the district of New Orleans and Lafayette, where as many are appointed as are necessary. District judges must be citizens of the United States, above thirty years old, resident of the State for five years, and have practiced law therein five years. District Courts have jurisdiction when more than $\$ 50$ is at stake, and in ali criminal eases.

The State has an Attorney-general, and in each district there is a District Attorney, appointed for two years. All civil officers, except the governor and the judges, are removable on an address of a majority of both houses of the legislature.

Amendments of the constitution must first be approved by three-fifths of both houses, then published in the newspapers throughout the State three months before the next general election, then approved by a majority of both houses in the next succeeding legislature, then published again as before, then submitted to the people, and if ratified by a majority of voters, the amendments shall form a part of the constitution.*

The militia of Louisiana consists of 43,823 men of all arms, of which number 1,392 are commissioned officers, and 42,431 non-commissioned officers, musicians, artiflcers, and privates. Of the commissioned officers 10 are general officers, 55 general staff oficers, 159 field officers, and 1,16s company officers. Every free white male person between the ages of 18 and 45 is liable to militia duty, unless exempt by law.

The most noted of the benevolent institutions of the State is the Charity Hospital at New Orjeans, the benefits of which have been experienced by thousands who have been taken sick in that malarious city, and as many thousands have blessed the nursing hand of the kind sisters whose vocation it may have been to attend to their wants. In 1849 the number of admissions to this famous hospital was 15,555 , of which 1,782 were natives of the United States, and 13,634 were foreigners, and 71 were blacks and 12,216 white makes, and 3,342 white females. The number of deaths was 2,745 , of which 2,369 were males and 376 females, and 1,122 died of Asiatic cholera, 515 of yellow fever, 224 of typhus fever, and 56 of other fevers. The number of patients remaining in the hospital on the 1st January, 1850, was 719. The income of the hospital for the year was $\$ \$ 9,95130$, and the expenditures $\$ 92,99343$, averaging $\$ 426$ for each patient. Such an institution as this is an oasis in the wilderness of humanity.

Finances, Debts, etc.-The financial statement is made up biennially. The total receipts into the treasury for the year $1 S 50$ were $\$ 1.00 \$, 17591$, and for the year $1851 \$ \$ 36,24744$-total $\$ 1, \$ 44,42335$; and the expenditures for 1850 were $\$ 951,545$, and for $1851 \$ 552,7 \mathrm{S7} 54$-total $\$ 1,804,83254$, leaving a balance of $\$ 40,090$ 81 for future appropriation.

In 1845 the liabilities of the State on account of the property banks amounted to $\$ 14,321,596$; this has since been reduced $\$ 3, \pi 41,596$, leaving the liabilities of the State in $1850 \$ 10,577,000$. The State debt proper amounted at the latter period to $\$ 915,566$. The State holds property not now productive valued at $\$ 2,416,938$.

The constitutional provisions respecting legislative finance were made very stringent in the new fundamental law. The constitution provides that the credit of the State shall not be lent to any person or corporation whatever, but new

* A conrention was held at Baton Rouge in July, 1852, to rerise the constitutinn, and the revised constitution would be submitted to the people for ratification on the 21 Norember of the same year. If ratified, the general elections were to take place on the fourth Monday of December, and the frst Lezislature would meet on the third Fionday of January; 1853. The rerised constitution provides for annual sessions of the Legislature, an electire judiciary, and removes some of the restrictions against the State's contracting debts, and permits the establishment of corporations. 


\section{LOUISIANA.}

bonds may be issued to replace outstanding bonds. No State debt shall be contracted for more than $\$ 100,000$, cxcept in case of war, invasion, or insurrection, unless authorized by law for some distinctly specifled object or work, which law shall impose taxes to pay the current interest during the whole term of the debt, and also to pay the debt itself at maturity, and this law shall be irrepealable till the debt and interest are fully discharged, and shall not go into force till again enacted by the next legislature after its first passage. The State shall not subscribe to the stock of any company or corporation. No corporate. company shall be hereafter created, renewed, or extended with banking or discounting privileges. After 1590 the charters of all corporations may be revoked, and no charter shall now be granted, except for municipal or political purposes for more than 25 years.

The assessed value of all real and personal property in Louisiana, on the 1 st June, 1850 , was $\$ 220,165,172$; but the true or estimate valuation of the same amounted, according to the returns of the federal census, to $\$ 233,908,764$.

Federat Representation.-Louisiana, according to the law of $23 \mathrm{~d}$ May, 1850 , apportioning federal representation, is entitled to send four representatives to Congress.

Religions Denominations.-The statistics of the several religious denominations in 1550, as ascertained by the census of that jear, were as follows:

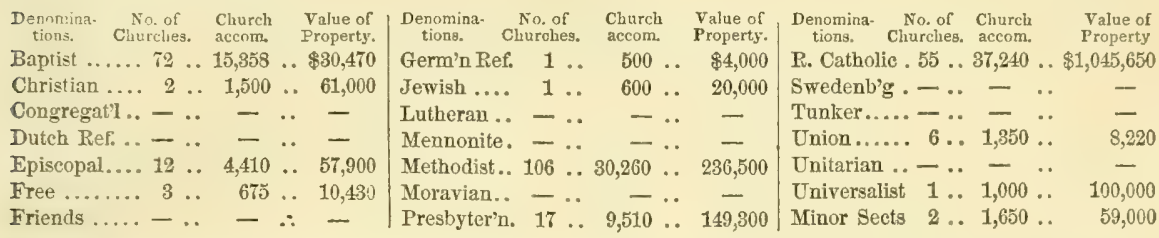

Making the agrgregate number of churches 265 , valued as property at $\$ 1,792,470$, and capable of accommodating 104,053 persons, Louisiana forms a diocese of the Protestant Episcopal Church; and the arch-diocese, or province of New Orleans in the Roman Catholic Church, which has for its suffragan sees, Mobile, Natchez, Galveston, and Little Rock.

Education.-The constitution provides that "there shall be a superintendent of education, to hold office for two years. Free public schools shall be established throughout the State; the proceeds of lands granted for the purpose, and of lands escheated to the State, shall be held as a permanent fund, on which six per cent. interest shall be paid by the State for the support of these schools." The school fund, 1st January, 1850 , amounted to $\$ 40,27268$, on which $\$ 19,10584$ of interest had accrued up to that date; and besides the proceeds of the school fund, the yearly sum of $\$ 250,000$ is appropriated for the support of the free schools of the State, and is derived from a mill tax on property, and a poll tax of one dollar on each white male inhabitant. The whole number of school districts in the State on the 30th September, 1849, was 521; number of schools in operation, 704; number of children between 6 and 16 years of age, 53,716 ; average attendance for the year, 22,927 ; and 20,262 children did not attend school. The average period of tuition was 6 months and 13 days. Amount expended for teachers' salaries, $\$ 195,3 \$ 9$; expended for building, renting, and purchasing \$chool-houses, $\$ 134,689$. There are also in almost every parish numerous private, classical, and other high schools. The principal collegiate institutions in the State are-the University of Louisiana at New Orleans, founded in 1849, and established with 7 professors; it has also a medical department, which in 1850 had 7 professors and 188 students; the Centenary College (Methodist), at Jackson, founded 1839 -in 1850 it had 7 professors, 40 alumni, 94 students, and a library of 5,000 volumes; the St. Charles College (Roman Catholie), at Grand Coteau, founded 1835-in 1850 it had 21 professors and 103 students, with a valuable library of about 4,000 volumes; Baton Rouge College, founded 1838-in 1850 it had 4 professors and 45 students; Franklin College, at Opelousas, founded 1839-in 1850 it had 4 professors and 70 students; and several others, among which are the Catholic Colleges at Baton Rouge and New Orleans, both of which are flourishing institutions.

Libraries.-One State library, 7,000 volumes; 1 social library, 10,000 volumes; 4 college libraries, 18,000 volumesbeing a total of 6 libraries and 30,000 rolumes. The census makes no returns of students' libraries, the libraries of academies and professional schools, the libraries of seientifie and historical societies, nor of school libraries, although there are numbers of each description in the State.

Periodical Press.-The whole number of periodicals and newspapers published in the State on the 1st June, 1850, was 60 , of which 17 were whig and 17 were democratic-the remaining 26 being neutral in politics or devoted to literature, science, religion, etc. Of the whole number 11 were issued daily, circulating 31,780 copies; 2 tri-weekly, 1,900 copies; 6 Bemi-weekly, 3,300 eopies; 40 weekly, 32,017 copies; and 1 monthly, 12,200. Among the publications in New Orleans are many of the best conducted and most talented papers of the Union; and no other eity can boast of such a magazine of statistical information as De Bow's Review.

Pauperism and Crime.-The whole number of paupers that received support within the year ending June 1st, 1850, was 423 , of which 138 were native born, and 290 foreign; and the whole number of paupers at the above date was 106 , of which 76 native born, and 30 foreign annual cost of support, $\$ 39,306$. The State Penitentiary is at Baton Pouge. The number of convicts remaining in confinement, 1st October, 1818, was 152, and the number received during the year following was 105-male, 257; 52 discharged, 2 pardoned, 7 died, and 2 escaped-in all 63, leaving, 1st October, $1849,194$. The receipts for the year were $\$ 49,28374$; and the expenditures, $\$ 42,62869$-making a net gain from conviet labor equal to $\$ 6,65505$

Distorical, s7ietch.-The legends of De Soto, Marquette, and La Salle, shall not arrest our attention. These wild and daring passages belong rather to the romancer than to the historian. Louis XIV. seized upon the proposal of Iberville, and addressed himself in earnest to a new and vast country, which dazzled his ambition. Iberville, and Bienville, his brother, founded a colony of Frenchmen on the shores of Louisiana in 1699. This is the earliest era in the history of Lonisiana.

In 1712 the King of France granted a charter to M. Crozat, which covered the whole province. The aims of both parties were commercial, and included the whole of the Mississippi and its tributary bays, lakes, rivers, and bordering territories. ML Crozat was endowed for twenty years with exclusive privileges of trade in these countries-to work mines for gold and precious stones, with a large share of the results. The laws, edicts, and ordinances of the realm, and the customs of Paris were extended over Louisiana. The privileges allowed to Crozat were ample; but so vain are the caiculations of men when employed upon novel enterprises, they satisfied not one of his greedy desires after wealth in the 


\section{LOUISIANA.}

Western World. The grant was surrendered, after five years, into the hands of the king, with the bitter complaint that from the imbecility of the colony, the strength of the Indians, the presence of the British, and the sterility of the soil, it had proved of no kind of value whatever to him, but rather a ruinous expense.

There settled in Paris about this time a man from Seotland by the name of John Law ; he was a restless projector, a daring financier, and full of enterprise. This extraordinary man soon succeeded in gaining an influence over the Duke of Orleans, then regent, obtained a charter for a bauk of $\$ 1,200,000$, substituted paper for specie, and set the whole Jrench nation mad with magnificent schemes of creating wealth, as it were, by the wand of a magician. The Chancellor D'Aguesseau opposed this daring scheme with infinite peril to himself. To the Royal Bank of Law was attached a great commercial company, in which were to be concentred all the rights, privileges, and possessions of all the trading companies then chartered in France. To this company was granted the great territory of Louisiana as it was surrendered up by Crozat. All France was in commotion-every man, woman, and child became a financier: the boot-black and collier of to-day were the grandees of to-morrow, and their splendid equipages dazzled the bewildered populace. The Royal Bank stock went up to six hundred times its par value, and dividends were rendered at 200 per cent. The exhaustless mines near the Mississippi would reimburse any investment, it was said; but in three years John Law was a bankrupt, the government itself was prostrated, the deluded rotaries of stock-jobbing were undone, the magnificent Western Company -the Mississippi Scheme-became a by-word; the banking bubble, when inflated to the skies, had burst! The charter of the company was granted for twenty-five years; it was to have exclusive privileges of trade, and of the purchase of beaver skins for exportation. To it belonged by preseription the right to make all Indian wars and treaties, work all mines, grant lands, construct fortifications, nominate governors, and appoint inferior judges. Its vessels and crews to be of the French nation, and the descendants of the colonists to be counted natural born subjects of France, etc. There are different accounts of the condition of Louisiana during the time it remained under the Western Company, who enjoyed the privileges granted to Law. By some it is represented to have been in a deplorable condition; while others assert that these were the best years which Lonisiana knew under the dominion of France, the white population having increased from 700 to 5,000 , and the black from 20 to 2,000 ; "a vast number of handsome cottages lined both sides of the river at the German coast; the culture of rice, indigo, and tobacco, and a regular administration of justice were provided for." The Western Company, in despair of finding the gold they had anticipated in Louisiana, from mineral researches turned their attention to agriculture. To promote their aims, large grants were made to powerful and weaithy individuals : to Law they granted a plot of twelve miles square. These grantees were to introduce settlers, but they succeeded to an extent far less than was anticipatod, while sanguinary Indian wars desolated the colony. The company, in utter hopelessness, threw up their charter in April, 1732, which the king accepted, and declared the commerce of Louisiana thenceforward free.

The French colonial government was now initiated. The commissioner, Salmon, took possession for the king. The new government established consisted of a Superior Council, of the Governor-general of New France, the Governor and Commissary of Louisiana, the King's Lieutenant, and the Town Mayor of New Orleans, six councilors, an attorney, and a clerk. A war broke out between Great Britain and France in 1760, the influence of which was felt throughout all America. In this war our own Washington began his career of glory. Canada fell into the hands of the English, and rather than submit to the consequences, large numbers of its inhabitants sought a home in southern elimes, fixing themselves on the Acadian coast of Louisiana, or taking their course westward of the river, formed the settlements of Attakapas, Opelousas, and Aroyelles.

France looked to Spain in her emergencies, and the Duc de Choiseul, the minister, entered into a family compact with the Bpanish king on the 15th August, 1760, and on the $3 \mathrm{~d}$ Nov., 1762, a secret treaty between the two governments ceded the territory of Louisiana west of the Mississippi, with New Orleans, to Spain. The bad system of government under which Louisiana had long suffered, was attended with the consequences which were to be expected from it, and the sovereignty of the finest country of the world, says Marbois, a country which might have become another France, was of no use to the parent State, but was even a charge to her. After the experience of several jears, the government, wearied with a possession which its faults and ignorance had made burdensome, felt disposed to abandon it. In 1768 Great Britain, France, and Spain entered upon the Treaty of Paris, and terminated their difficulties. France abandoned to Great Britain all her northern possessions, the whole of Louisiana east of the Mississippi, except New Orleans, and the navigation of that river was made free to the subjects of either nation. Thus did France, by her cessions to Britain and Spain, divest herself of every foot of territory she held in North America. The private treaty of cession to Spain was long heId secret, and it was not till 1764 that D'Abadie was ordered by Louis XV. to announce the fact to the colony. D'Abadie was broken-hearted at the intelligence, and died before he could communicate it. The duty devolved upon his successor, Aubry. A day of lamentation and sorrow had dawned upon the Louisianians, and they heard their fate with settled glonm. A general meeting of the leading inhabitants was hastily assembled in New Orleans, and entreaties were sent up to the throne that this painful treaty might not be made to go into effect. The king declared the treaty to be irrevocable.

Don Ant, de Ulloa arrived in Louisiana in 1766, appointed, as he professed, by Charles of Spain to take possession of the province. His powers being demanded by the colonists, were not shown, and hence he was notified to depart, which he did in a few days, amid the universal rejoicing of the people. Scarcely, however, had the colony breathing time, before it was announced that a Spanish frigate was upon the coast, and notwithstanding the threats of the populace, Don Alex. O'Reilly, commander of the Spanish forces, landed and sent up a message to Governor Aubry, informing him that he was prepared to take possession of the country, and that any show of resistance would be signally punished. The in habitants returned a declaration to the Spaniard, declaring their intention to abandon the colony, and requested two years delay to effect the arrangement. O'Reilly consented with apparent cheerfulness and with the warmest professions of regard. He soon after landed at the eity and took formal possession in the name of the king. But this display of clemency was but the precursor of the worst excesses of tyranny. Some of the first eitizens were arrested and thrown into prison, declared guilty of treason, and tried under the statute of Alphonzo, making it death to incite insurrection against the king. Sentence and execution followed. "Posterity," says the historian Martin, "will doom this act to public execration," and posterity, we may add, has already branded it as one of the blackest which it is the shame of history to record. What was the precise eharacter of the powers conferred upon $0^{\prime}$ Reilly has never yet been satisfactorily determined. The King of France, in writing to D'Abadie at the period of the cession, conceded that the laws, forms, and usages of the colony would be preserved, but this does not appear to have been inserted in the treaty of cession. O'Reilly, as soon as he was at ease in his government, made a proclamation to the people, declaring himself empowered to establish that form of gorernment, dependence, and subordination which should accord with the good of his master's 


\section{LOUISIANA.}

service and the happincss of his subjects in the colony. The laws of Spain were now gradually extended over Louisiana, and in the end but little trace of French legislation remained. The transition, however, was not sudden, and little inconvenience resulted from it. When the American Revolution had progressed, and Spain, in an endeavor to mediate between the contestants had failed, the Catholic king prepared himself for war. Galvez, governor of Louisiana, threw himself upon the British garrison at Baton Rouge, and captured it. An American minister was sent to Madrid to negotiate a favorable treaty for his countrymen, and to obtain for them, if possible, the free navigation of the Mississippi to the sea. The treaties between Great Britain, France, and Spain, and the United States concluded in 1753, opened the navigation of the river, ceded the Floridas to Spain, and bounded the possessions of the two countries by a line eastward of the 31st parallel on the Mississippi to the Appalachicola River, through the middle of that river to its junction with the Flint, from the Flint to the head of St. Mary's River, and down the St. Mary's to the Atlantic. These treaties were soon followed by embarrassing disputes, in which the Spaniards laid claim to a large tract of country and an exclusive right to the navigation of that portion of the Mississippi which passed through their territories, against both which claims the United States protested.

It may be remarked that very little, if any, intercourse was tolerated by the Spaniards through the Mississippi, with the people of the United States. Any attempt to navigate the river, or to introduce merchandise into New Orleans by boats was resisted and the property seized. About the year 1787, General Wilkinson, a revolutionary officer, conceived the design of making a settlement of American families in Louisiana, for which he expected to receive some commercial favors from the Spaniards. He descended the river to New Orleans with a small adventure of tobacco, flour, etc., and by an artifice, so worked upon the fears of Miro, the governor, that he was disposed to listen to the proposals of opening a traffic with the people of the Western States. Miro flattered himself that the result would be a division of the States of the Union, and that those westward of the Alleghanies would attach themselves to the interests of Spain. In 1788 the navigation of the Mississippi was conceded to the young West, on condition of its forming an empire distinct from that of the Atlantic States. That the people of the West entertained the project can not be denied, but on second thoughts returned loyally to their country, and on the admission of Kentucky into the Union, the whole scheme of separation fell through.

In 1790 it was again attempted to procure from Spain the navigation of the Mississippi for the United States, also the island on which New Orleans is situate, and the Floridas. The propositions were not assented to, but five years after the American plenipotentiaries signed, at San Lorenzo, a treaty stipulation for the freedom of the river to their countrymen, and a freedom to use for ten years the City of New Orleans as a depot for their merchandise.

Spain had no sooner signed the treaty than she began to regret her liberality. Her alliance with France and the position of the United States, determined her by all means to hold on to the territory of Upper Louisiana, which she had agreed to cede. In vain the United States sent its officers to take possession of the ports and settlements-in vain the settlers protested against the delay. A magnificent scheme had been planned and was in progress, the design of which was to prevent Louisiana forever from falling into the hands of the American government. The Baron de Carondolet endeavored to sound General Wilkinson on the subject, and to bring him over to the plan by flatteries and by the most liberal offers. Wilkinson, however, dismissed the messenger with an expression of views little favorable to the project that had been opened to him. The blame or innocence of the general on these premises is a canvassed subject, and need not be further mentioned in this connection. Nor need we here mention his connection with Burr on a future occasion, further than to state that whatever plans of aggrandizement either might have entertained were never brought to fruition, and are subjects now only interesting to the historical antiquary.

The face of European affairs in May, 179s, influenced the American people to put on their armor. Washington was again appointed to the head of the army, and difficulties with regard to Louisiana, and consequent losses to the government, forced upon all minds the absolute necessity for the acquisition of New Orleans, whatever might be the hazard. Iouisiana, indeed, occupied an unenviable position at this time. She had been abandoned by France, and the French people had regarded the cession with regret and indignation, so much so, indeed, that on the breaking out of hostilities with the Spaniards, Mons. Genet, the young and rash minister from France, employed himself, immediately after his arrival, in devising and carrying out a comprehensive scherne for the invasion of Lonisiana with troops and arms procured in the United States. How his course was denounced at Washington-how he appealed from the President to the peopleand though his conduct was disowned by his own government, how that same government demanded the restoration of Louisiana to the French Republie, are matters of general history. In other respects was the position of Louisiana remarkable. The United States had long been regarding with jealousy the existence of a territory in the hands of a foreign powrer, capable of influencing the destiny of the great central valley. A plot had been laid, too, by an American citizen. Blount, then governor of Tennessee, the object of which was to throw down upon Louisiana, during the wars between England and Spain, in 1797, through the medium of the western waters, large numbers of British troops from Canada. The plot was discovered, Blount degraded by the Senate, and the English Government exonerated from the charge of any knowledge of the proceedings. The eyes of Spain were not closed to the difficulties of her position. Bonaparte bad by this time assumed the reins of government, and he cherished the idea of bringing back to the parent country a province he conceived had been unnaturally severed from her. His sophisms soon prevailed over Spain; he represented "that Louisiana, restored to France, would be a bulwark for Mexico, and a security for the tranquillity of the Gulf." On the 1st October, 1800, was concluded the celebrated treaty of San Ildefonso, and Louisiana again became a French colony. Bonaparte took immediate steps to enter upon his new possession. Gen. Victor was appointed Commissioner for accepting the transfer, and proclamations announeing the changed circumstances of the colony were issued. The Louisiatians prepared an address in reply, in which they declared that the proclamations had filled the people with joy, and that they already felt the happiness of their reunion with their ancient nationality. Every thing, indeed, seemed favorable for the re-establishment of the French government in the province-and all was rejoicing and congratulation, when a vessel arrived at the levée from Bordeaux, and the news soon spread that the Corsican had sold their country and themselves to the neighboring republic. The treaty of Paris, signed 13th April, 1808, had ceded Louisiana and all its appurtenances forever to the United States; and the United States had agreed to pay $60,000,000$ franés to discharge certain claims of their citizens on France. The difficulties which immediately followed the acquisition were perplexing; and even in the United States many there were who viewed the treaty as unconstitutional; but, like all difficulties, these came to an end, and the American flag waved over the city of New Orleans on the 20th December-the same day having witnessed the descent of the Snanish ensign and the elevation of the tri-color, the latter only having been raised to be re-placed by the stars and stripes. 


\section{LOUISIANA.}

The first act of Governor Claiborne, on taking the chair of authority, was to organize a judiciary, which he did by es. tablishing a Court of Pleas, consisting of seven justices. The Act of Congress, 20th March, 1804, established a territorial government, Louisiana was divided into two sections, of which that now constituting the State of the same name was to be known as the Territory of Orleans. The Act provided for a governor, appointed for three years, a secrutary fur fuur years, a legislative council of thirteen freeholders, a judiciary, according to the regulations of the legislative council, but to be appointed by the President. The period that elapsed between the Act of 1804 and the one of $2 d$ March, 1805, which set up another territorial government, was one of dissatisfaction to the people. They complained that the governor was unacquainted with the language, their laws, and their interests, and that he favored only his own countrymen, cit. On these subjects the citizens memorialized Congress. The council as established in the meanwhile passed several acts bearing apon the proper organization ot the territory, dividing it into 12 parishes or counties, with inferior courts in eack, instituting modes of procedure, defining crimes, ete., chartering the city, and establishing (on paper) a university. The effect of the dissatisfaction before alluded to produced the territorial act of 1805 , by which Congress set ap a government in Louisiana similar to that of the Mississippi Territory, and provided for its admission into the Union when it should have 60,000 inhabitants. This act gave to the people the election of a legislature, and to the legislature the election of a legislative council or Upper House. The first acts of the new government were the adoption of the "code Noir," or black code, for the goverument of the slaves, and the appointment of a commission to prepare a civil code based upon the former laws of the country. The latter was completed in 1808 , and embraced, besides the compilation of the old codes, many of the provisions of the "code Napoleon."

Having settled these points, Louisiana was prepared to meet the position of things which was forced upon her in relation to Spain, and in the anxieties which arose in relation to boundaries, and the opposing claims of the two nations, it is likely that hostilities would have oceurred, had not the intimation of a vast scheme on foot for the separation of the western country from the Union, at the head of which was Aaron Burr, influenced Gen. Wilkinson and the Americans to compromise matters with the Spaniards, and concentrate every thing to meet the threatened danger. The reports which reached Louisiana each day in relation to this plot were alarming; military preparations were being urged on all sides, and Burr himself, after a reward offered for his arrest, was taken at Fort Stoddard, and conveyed to Richmond.

The conflicting claims of the United States and Spain, to the strip of territory east of the Miseissippi River, and south of the 31st parallel to the Perdido River, were brought to something like a crisis in 1810, by the seizure of the Spanish post at Baton Rouge, the holding a convention at St. Francisville, declaring their independence, and setting up a constitution, and, by a proclamation of the President, taking possession of the territory. The event was peaceable, and the parishes of Feliciana, East Baton Rouge, St. Helena, St. Tammany, Biloxi, and Pascagoula were soon after established.

On the 11th February, 1811, an act of Congress was passed to enable the inhabitants of Louisiana to form a constitution aurl State government, if the same should be the desire of the people, signiffed by the calling of a convention. This body being called, assembled at New Orleans, and unanimously signed a constitution based upon that of Kentucky, on the 22d January, 1812. This constitution was superseded by that of 1815 , and another constitution, or a revision of the latter, is now about to be roted on by the people.

The share that Louisiana took in the war of 1812, though signalized in history, is so familiar as to require only a short sotice. Wilkinson took possession of the country west of the Perdido, then in the occupation of Spain. The English eolonel, Nichols, arrived at Pensacola, and made proclamation to all Englishmen, Spaniards, and Frenchmen to join his standard, and resist the encroachments of the United States. To the people of Kentucky this officer proposed similar terms; and to the privateer La Fitte and his followers at Barrataria, he was most prodigal in his offers. The overtures, says Marbois, were repelled with indignation, and the men who saw no degradation in enriching themselves by plunder, had a horror of treason. The course of General Jackson, in relation to the Spaniards and Engtish at Pensacola, is familiar to all.

An attack on New Orleans being now inevitable, the most extraozdinary preparations were made to raise forces, and provide fortifications and armaments to meet the impending danger. The city was all excitement. "The people were preparing for battle, as if for a party of pleastre," says a historian, "the streets resounded with martial airs, several corps of militia were constantly exercising, every bosom glowed with the feelings of national honor." The west was pouring down upon the city-martial law was prociaimed. The battle of New Orleans, of Sth January, 1815̆, was fought and won to the high honor of the American people, and the lasting laurels of the great man who commanded, and who, whatever his faults, is becoming every day more and more honored in the memory of bis grateful and admiring countrymen.

The history of Louisiana, since she has become a State, has yet to be written. The uninterrupted prevalence of peace in our country takes away from this chapter those lively features which characterize anterior periods. The records of revolution, of changing dynasties, of deeds of arms and high renown, are not presented here, and perhaps to the general reader the whole is a hopeless blank. But to those seeking higher views of indiviảnal good and national destiny, the onward march of the arts of peace, the extraordinary development of industrial resources, the unmatched angmentation of population and wealth, the erection of an opulent State, with laws, government, and order, in a former French and Spanish proviuce, are events worthy of the liginest efforts of the historian, replete with iuterest, and deserving of careful stuily.

B.tox RotGE, on the east bank of the Mississippi. has been the seat of government since the constitution of 1S45 went into effect, until which time New Orleans was the State capital.

Louisiaxa, p. v., Pike co., Mo. : on the left bank of the 200 inhabitants. Here the Legislature of the State met from Mississippi, about $2 \mathrm{~m}$. below the mouth of Salt r., $82 \mathrm{~m}$. N. E. 1835 to 1837, and here, on the 13th February, 1796, the cele Jefferson City. It has a good landing, and considerable brated Yacoo Acts were burned.

river trade. It contains several stores, warehouses, and Loutsville, p. v., Clay co., $m$.: on the W. bank of jumber vards, and 1,340 inhabitants, of whom 130 are slaves. Little Wabash r., and E. side of Twelve Mile Prairie, $94 \mathrm{~m}$. Two weekly papers are published, the "L. Weekly Riecord" S. E. Springfield. (whig), and the "Democratic Banner."

Loulsviles, p. O., Barbour con, $A l \alpha_{.}: 8$ m. E. of Pea r., 57 m. S. E. Montgomery.

Loursture, p. v, and cap. Jefferson co., Ga. : a little E. of Ogeechee r., $54 \mathrm{~m}$. E. by S. Milledgeville. It contains a court-honse, formerly the State house, an academy, jail, and

Lousvrilu, p. city, port of entry, and eap. Jefierson co.s

Ky. : on the S. or left bank of the Ohio r., at the head of the rapids, $51 \mathrm{~m}$. W. Frankfort. Lat. $38^{\circ} 03^{\prime} \mathrm{N}$., and iong. $85080^{\prime} \mathrm{W} .-590 \mathrm{~m}$. W. by S. Washington; and by the course of the river $625 \mathrm{~m}$. below Pittsburg, and $394 \mathrm{~m}$. above the mouth of the Ohio. Jeffersonville, the terminus of the 404 
Jeftersnnrille R. R. from Indianapolis, lies on the opposite side of the riser. The navigation of the Ohio is here interrapted by rapids, and except in the time of flood Louisrille is the natural head of steam navigation, but the navigation is continued around this obstruction by means of the Louisville and Portland Canal, which is capacious enough to admit the passage of the largest river craft. It is 50 feet wide, 10 feet deep, and $2 \frac{1}{2} \mathrm{mo}$. in length. Its influence in directing trade to the upper ports, however, is supposed to be prejudicial to Louisville.

This city is the commercial and manufacturing metropolis of the State, and is the natural entrepot of a large country, reached by several railroads and turnpikes. The lines of railroad diverging from this point (including those in progress) are the Louisville and Lexington $R$. $R$., which at Lexington connects with railroads to the Gulf and Southern Atlantic ports, the Louistille and Covington R. R., which at the latter plaee meets the railroads of Ohio and those pointing to Boston, New York, Philadelphia, Baltimore, Richmond, etc., and the Louisville and Nashville $R_{0} R_{\text {., }}$, pointing to the South, and the Jeffersonville R. R. gives it access to the $\mathrm{N}$. and $\mathrm{N}$. W., via Indianapolis. A company has also been organized for the purpose of bridging the Ohio at Louisville. Hitherto the railroads have had comparatively little influence on its trade; their benefits are in the future.

Louisville was laid out as early as 1773 , but no settlement was made for the subsequent five years, nor until after the expulsion of the British from their posts on the Wabash. The first block house was built in 1778 , but this was subsequently remored to make way for Fort Nelson, erected in 1752 . In 1750 the town was established by an act of the Legislature of Virginia. At this period the inhabitants numbered only thirty. In 1800 the population amounted to 600 ; in 1510 to 1,300 ; in 1520 to 4,000 ; in 1830 to 10,311 ; in 1840 to 21,210 ; and in $1 \$ 50$ to 43.186 .

The city is built on a spacious sloping plane 70 feet above low water mark, and is laid out with regularity, the streets intersecting at right angles, in a direction with and from the river, on which are extensive wharves. Ten streets run parallel with the river, and thirty streets intersect them. It contains the County Court-house and a City Hall, both extensive and handsome edifices, the county jail, the city prison, a marine hospital, and numerous benevolent institutions, the University of Louisville, a School of Medicine, and a Law School, departments of the Tniversity, and two banks and one branch bank, two savings banks, several insurance companies, ete. It is liberally supplied with churches and schools, some of the church buildings being ine specimens of architecture. Louisville may proudly claim a pre-eminence both as to the early foundation, the progress and the present condition of its public schools, and within the limits of the city there are besides many private and church schools, which would compare well with the best eastward of the mountains. It has orphan asylums and a Magdalen retreat, a school for the blind, a public hospital, and many other liberally supported establishments, designed to relieve the unfortunate of the city. The streets are Jighted with gas, and it is supplied with excellent water: both accomnodations by eompanies. Its hotels are spacious and fitted with every convenience, and its markets abound in aly esculent produets, for which the vicinity is famed. Among the literary and seientific institutions of the eity the mrst prominent are the Mereantile Library Association, the Kentucky Historical Society, the Agrieulfaral and Forticultural Society, etc. The whole number of chureh builings is 40 , capable of accommodating 19,610 prorens, and valuerl as promerty at $\$ 590,900$. Of these 5 are Baptist, 3 Episcopal, 17 Methodist, 5 Presbyterian, 4 German Evangelical, 1 German Lutheran, 1 German. Reformed, 2 Disciplua, 1 Unitarian, \pm Rotnan Catholic, and 2 Jewish. The pullic press of Louisville is eonducted with great talent, and several of the papers are rich in statistical information. The daily papers are the "Democrat" (dem.),
"Journal" (dem.), the "Advertiser" (neut.), the "Courier" (whig), the "Journal of Commerce" (whig), and the "Beobachter am Obio" (Germ.), and of these the Democrat and the Journal have tri-weekly and weekly editions, the Advertiser and Beobachter semi-weekly and weekly editions, and the Courior and Journal of Commeree weekly editions, The weekly papers, others than those above named, are the "Presbyterian Herald" and the "Baptist Banner" (relig.), and the "Indian Adrocate," and the monthly periodicals are the "Baptist Review" (relig.), the "Ciceronian Magazine" (liter.), the "Medical cournal" (med.), and the "Examiner," devoted to the cause of negro emancipation. The papers having the largest circulation are the Democrat, Journal, and Courier.

The manufactures of Lorisville are very extensive, and embrace a great variety of objects. It has several founderies and machine-shops, at which a vast amount of machinery, ete., is annually turned out; several large steam bagging factories and ropervalks, eotton and woolen factories, tobacco factories, flouring mills, distilleries, breweries, agricultural implement factories, and numerous other establishments, small and large, which in the aggregate constitute a vast industry. Louisville is also extensively engaged in ship-building, and in the year ending 80th June, 1850 , no less than 34 steamers, of 6,460 tons, were built in the district. The shipping owned at the period specified amounted to 14,820 tons, all navigated by steam and employed in the river trade.

As a commercial and shipping point, Louisville is the third in importance on the Ohio. Its immediate trade extends into all the surrounding country, and embraees, within the State of Kentucky, a circuit of the most productive region in the world. Its wharves are at all times thronged by steamboats and other river craft, carrying to and fro a merchandise in amount inferior only to that coming to and going from Cincinnati and Pittsburg. The value of its commerce has been estimated at $\$ 70,000,000$ per annum. Its exports consist chiefly of tobacco, bagging, rope and cordage, spirits, pork, flax and hemp, live-stock, machinery for steamboats and railroads, factories, mills, and farms, and a great amount of groceries and assorted goods, which are carried to every river-town, or to the sea-board for exportation; and its exports comprise every article and product needed in its interior commercial range. In the year 1850 its chief imports were as follows: Sugar, 13,320 hhds., 9,200 bls., and 755 boxes ; molasses, 13,010 bls.; coffee, 34,572 bags; rice, 752 tierces ; bagging, 65,250 pieces ; rope, 56,300 coils; twine, 2,056 bales; hemp, 15,354 bales; cotton, 7,857 bales; cheese, 20,378 boxes ; flour, 75,350 bls; ; whisky, 39,897 bls. ; liquors and wines, 5,988 easks ; nalils, 45,261 kegs ; tobacco, $7,425 \mathrm{hhds}$, and 6,530 boxes; salt-Kanawha, 112,250 bls.; Turks Island, 40,525 bags; and Liverpool, 10,350 bags; merchandise, 105,750 boxes, bales, and pkgs. drugs, dyes, ete., 14,378 pkgs.; hides, 18,891 dozen ; merchandise, 5,132 crates and casks; hogs for slaughter, 197,750 ; pork, $75,500 \mathrm{bls}$., ete. In addition to this quantity of pork, there are annually received thousands of tons of bacon by wagon, etc., which is packed in this city in casks, and largely exported. The detail of the exports can not well be ascertained, as no record whatever has been kept of them; but some estimate may be formed as to their amount from the foregoing. Steam-packets, carrying the mail and passeugers, come and go several times daily. It is estimated that at least 10 steamboats leave the port daily, and also from 6 to 7 packets.

The following statistical information is from Mr. Casseday's History of Louisville: "Louisville contains 25 exclusively wholesale dry goods houses, whose sales are made only to dealers, and whose market reaches from Northern Louisiana to Northern Kentucky, and embraces a large part of the States of Kentucky, Indiana, Tennessee, Alabama, Illinois, Mississippi, and Arkansas. The aggregate amount of annual sales by these houses is $\$ 5, \$ 53,000$, or an average 
of $\$ 234,000$ to each house. The sales of three of the largest of these houses amount in the aggregate to $\$ 1,789,000$. Neither this statement nor those which follow include any auction sales. In boots and shoes, the sales of eight houses of the above description reach $\$ 1,184,000$, or $\$ 184,000$ to each house. The sales of the three largest houses in this business reach $\$ 630,000$. The aggregate amount of eight houses in drugs, ete., is $\$ 1,123,000$, or $\$ 140,375$ to each house ; and the sales of the three largest houses amount to $\$ 753,000$. The sales of hardware by nine houses amount annually to $\$ 590,000$, being an average of $\$ 65,555$ to each house. The sales of saddlery reach $\$ 980,000$, of which nearly one-half is of domestic manufacture. The sales of hats and caps, necessarily including sales at retail, anount to $\$ 683,000$. The sales of queens-ware, less reliably taken, reach $\$ 265,000$. There are thirty-nine wholesale grocery houses, whose aggregate sales reach $\$ 10,623,400$, which gives an arerage of $\$ 272,400$ each." The amount of imports, before given, will perbaps afford a better idea of this business than these figures, and hence are referred to. The following recapitalatory table will enable the reader to see at a glance all that has just been stated:

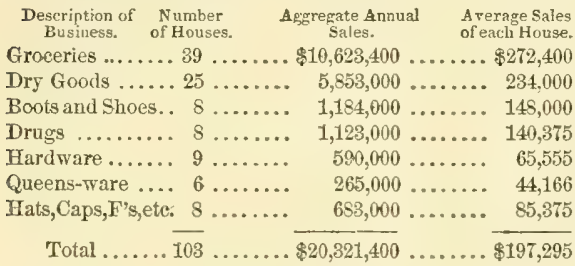

Louisville was named by the Virginia Legislature after Louis XVI. of France, in commemoration of his alliance with the great Republic of the West, then just rising from its probationary condition of colonial dependence.

Lovisvilue, p. v., and cap. Winston co., Miss.: $82 \mathrm{~m}$. N. E. Jackson. It contains a court-house, jail, 3 academies, several large stores, and 400 inhabitants. The "L. Telegraph" is published weekly.

LoursvIleE, p. 0., Iincoln co., Mo. : 64 m. N. E. Jefferson City.

Lounswlite, t. and p. v., St. Lawrence eo., $N_{\text {. }} Y_{\text {. }}$ : on the St. Lawrence, 169 m. N. N. W. Albany. Drained by Grasse river. Surface undulating; soil fertile loam, lying upon limestone. Agriculture is the leading interest. The $\mathrm{v}$. lies on Grasse r., and contains a bank and several stores. Pop. of t. 2,054 .

Looisviliz, p. v., Stark co, Ohio: 104 m. N. E. by E. Columbus. It is on the Ohio and Pennsylvania $R$. $R$. $12 \mathrm{~m}$. from Alliance.

LounBvilur, sta., Licking co., Ohio: on the Sandusky, Mansfield, and Newark R. R., 7 m. from Newark.

Lotisville, p. $v_{4}$, Blount co., Tenn.: on the S. or left bank of Temnessce r., $154 \mathrm{~m}$. E. by $\mathbf{S}$. Nashville.

Loutsville LanDing, p. v., St. Lawrence co, $N$. Y: on the bank of St. Lawrence r., $172 \mathrm{~m} . \mathrm{N}$. N. W. Albany.

LOUTRE IsLaND, p. o., Montgomery co., Mfo.: near the entrance of Loutre r, into the Missouri, $41 \mathrm{~m}$. E. by N. Jefferson City.

Lovelace, p. o., Wilkes co., N. Car.: $162 \mathrm{~m}$. W. by N. Raleigh.

Lovelacevthre, p. o., Ballard co., Ky.: 242 m. W. S. W. Frankfort.

Loteladr, p. o., Caldwell co., N. Car. : $158 \mathrm{~m}$. W. by N. Raleigh.

Loveland, p. 0., Clinton co., Penn.: $\mathrm{S} 2 \mathrm{~m} . \mathrm{N}$. W. by N. Harrisburg.

Loveraxp, p. v, and sta., Clermont county, Ohio: $82 \mathrm{~m}$. s. W. by W. Columbus. The sta. is $27 \mathrm{~m}$. from Cincinnati, by the Littlo Miami $R$. R., and from this point the Cincinnati, Fillsboro', and Parkersburs R. R. diverges. 406
Lovelra, p. v., Monroe co., Ia.: 77 m. W. S. W. Iowe City.

Loveci, t. and p. o., Oxford co., MFe.: $67 \mathrm{~m}$. W. S. W. Augusta. It contains a large, and many small ponds, sending out branches of Saco $\mathrm{r}$, on one of which is a curious fall, of 40 feet perpendicular descent. Soil very fertile, and water-power and timber abundant. Pop. 1,196

Lovely Mount p. o., Montgomery co., Virg.: near New river, $167 \mathrm{~m}$. W. by S. Richmond.

Love's Milis, p. o., Washington county, Firg.: 235 miles W. by S. Richmond.

Love's, sta., Baltimore co., MA.: on the Baltimore and Susquehanna R. R., $20 \mathrm{~m}$. N. of Baltimore

LotetTsVule p. V., Loudon county, Firg. : 114 miles $\mathbb{N}$. Richmond.

Lovetrs, p. o., Adams county, Ohio: 78 miles S. by W Columbus.

Loveriule, p. v., New Castle co,, Del. : 39 m. N. Dover.

Lovingston, p. V., and cap. Nelson county, Virg.: $76 \mathrm{~m}$. W. by N. Richmond. It contains a court-hrouse, jail, and several stores.

LoviNgToN, p. v., Moultrie $c_{*}, M_{.}: 46 \mathrm{~m}$. E. Springfield

Lowelu, p. o., Randoiph co., $G a_{0}$ : on Patoula cr. near its entrance into Chattahoochee river, 149 miles S. W. Milledgeville.

Lowell, p. v., Henry co., Ia.: on the left bank of Skunk ziver, $57 \mathrm{~m}$. S. Iowa City.

Lowely, p. O., Johnson co., N. Car. : 26 m. S. E. Raleigh. Lowell, t. and p. o., Penobseot co., Me.: 91 m. N. E. Augusta. A large pond lies on the N., and Passadumkeag river flows through the $\mathrm{S}$. into the Penobscot, turning sereral lumber-mills. Lumbering is the principal occupation. Pop. 378.

Loweli, t., p. city, and one of the caps. Middlesex co.s IIass.: $24 \mathrm{~m} . \mathrm{N} . \mathrm{W}$. Boston. Drained by Concord r., which falls into the Merrimac in the N. E. part of the town. Lowell was taken from Chelmsford in 1826, and embraces also some territory and the $\mathrm{v}$. of Belvidere, $\mathrm{E}$. of Concord $r_{*}$, formerly belonging to Tewksbury. The city lies at the confluence of the Concord, in lat. $42^{\circ} 38^{\prime} 46^{\prime \prime} \mathrm{N}$., and long. $71019^{\prime} 02^{\prime \prime} \mathrm{W}$. It is this eity which, from the amount, variety, and character of its manufactures, has been appropriately designated the "Manchester of America." Few other places in the Union have sustained so rapid a growth. In 1820 searely 200 inhabitants were found within its limits, nor was it until 1821 that the site was chosen whereon to establish a manufacturing community. In the next succeeding year the Merrimac Manufacturing Company, with a capital of $\$ 1,500,000$, was established, and their first mill went into cperation in 1823. From these small beginnings the city has risen to its present eminence and world-wide celebrity. In thirty years what a change!

In 1850 it had ten manufacturing companies making cotton or woolen goods, and two other companies-one bleaching and the other owning the machine shop, and the aggregate condition of the establishments of each at that period was as follows:

Companies. When Company No, No, of No, of Hands Finp Mer. Manf. Co. 1S23 $\$ 2,500,000 \quad 6 \quad 69,440 \quad 2,108 \quad 645 \quad 1,614$ Ham. Maf. Co. $1825 \quad 1,200,000 \quad 4 \quad 38,416 \quad 1,124 \quad 325 \quad 810$ Appleton Co. $1828 \quad 600,000 \quad 2 \quad 17,920 \quad 600 \quad 120 \quad 400$ Low. Manf. Co. $1328 \quad 1,500,000 \quad 3 \quad 11,362 \quad 154 \quad 225 \quad 550$ $\begin{array}{lllllll}\text { Middlesex Co. } 1832 & 1,000,000 & 4 & 16,340 & 403 & 575 & 730\end{array}$ $\begin{array}{lllllll}\text { Suf. Manf, Co. } 1832 & 600,000 & 3 & 17,528 & 590 & 100 & 400\end{array}$ $\begin{array}{lllllll}\text { Tremont Mills } 1832 & 600,000 & 2 & 14,560 & 557 & 100 & 400\end{array}$ Law. Manf. Co. $1833 \quad 1,500,000 \quad 5 \quad 44,800 \quad 1,382 \quad 200 \quad 1,200$ Low. Bleacls'y $1 \$ 32 \quad 26 ?, 400$ - $\quad$ - 20020 Boott Cot.Mills $1586 \quad 1,200,000 \quad 5 \quad 49,434 \quad 1,432 \quad 262 \quad 870$ Mass. Cot.Mills $1840 \quad 1,800,000 \quad 6 \quad 45,720 \quad 1,550 \quad 250 \quad 1,250$ Low. Mach.Sh. 1S45. 600,000 - $\quad$ - 700 - 
In the ten cotton and woolen establishments, consisting of forty mills, the weekly consumption of cotton was 705,400 pounds, and of wool 69,000 pounds; and the number of yards of fabric produced was $2,135,477$, of which $1,190,000$ yards were cotton, 20,477 woolen, 15,000 carpeting, and 40 rugs. In the dyeing and bleach works the goods finished per week amounated to $9,889,000$ yards. In these manufactures the consumption of coal was annually 28,520 tons, of chareoal 34,998 bushels, of wood 2,270 cords, of oil 107,577 gallons, of starch $1,390,000$ pourds, and of flour 1,640 barrels. The whole of these establishments are warmed by steam and lighted with gas. The average wages of females, clear of board, is $\$ 2$ per week, and the average wages of men, clear of board, 80 cents a day. Medium produce of a loom, No. 14 yarn, is 45 yards a day, and of No. 80 yarn, 33 yards-average per spindle, $1 \frac{1}{3}$ yard a day. The Middlesex Company also own the Wameset Carpet Mill on Concord River, where are consumed annually 93,600 pounds coarse wool and 36,400 pounds of worsted yarn, producing annually 91,000 yards of ingrain carpeting. Other manufactures are produced in the city than those specified above, of a value of $\$ 1,500,000$, employing a capital of $\$ 400,000$, and about 1,500 hands, and embracing several different handicrafts-powder-mills, paper-mills, batting-mills, a foundery, a planing-mill, etc., owned by individuals. The Lowell Machine Shop, included among the establishments noted in the table, can furnish machinery complete for a mill of 6,000 spindles in three months, and a mill can be built in the same time.

The association called "The Proprietors of the Locks and Canals on the Merrimac River," are the principal owners of the water-power at Lowell. This company was organized 1792, for the construction of a canal from the head of Pawtueket Falls, in Merrimac River, to Concord River, and open a passage for boats and rafts. This canal is $1 \frac{1}{2} \mathrm{~m}$. long, 60 feet wide, and 6 or 8 deep, and is still used to some extent for its original purpose; but the company's revenue chiefly consists of rents for supplying water-power to the several mills. In 1847 this canal was found to be insuffcient for the increasing wants of the community, and the company constracted a new canal of greater capacity; this is a mile long, and 100 feet wide, and 15 feet deep, and for solidity of workmanship and completeness in its arrangements, is unsurpassed by any Jike work in the Union. The facilities thus created have been the means of building up the important manufactures which distinguish the place, and place it so far ahead of all other manufacturing centres.

Lowell, as a city, is regularly planned, and has many important public buildings and institutions. The Court-house, City Hall, Market-house, Hospital, Mechanics' Hall, ete, are edifices worthy the greatness of the place. The Mechanics' Hall was erected by an association of mechanics in 1845, and is a splendid building, with philosophical apparatus and a mineralogical museum, and lectures on scientific and literary subjects are delivered in it at stated periods. The library, containing about 7,000 volumes, is open to all at a charge of 50 cents a year. The Hospital was erected in 1839 by the several companies, for the convenience and comfort of persons employed by them respectively when sick, and is under the superintendence of an able surgeon and physician.

Among the institutions of Lowell, perhaps none speak more loudly of a moral community than its two savings institutions - the Lowell and the City. The Lowell had on deposit the first Saturday of November, 1850, from 4.609 depositors $\$ 736,62312$; and the City, from 615 depositors \$75,970 51. The operatives in the mills are the principal depositors in these institutions. For business purposes Inwell has four banks.

The churehes of the city are many of them neat and substantial ediffces, and ate twenty-three in number, including sectaries of every denomination. These are well attended by the young people employed in the mills. Sehools are also amply provided for. The appropriation for the purposes of education in 1850 was $\$ 43,000$, which goes toward the support of the City High School, 10 grammar schools, and 46 primary schools. The total expenditure of the city in the same year was $\$ 178,614$. The public press of Lowell consists of one daily, two tri-weekly, three weeklies, and two monthly publications. The daily is the "L. Journal" (whig), which has also a weekly edition; the tri-weeklies are the "L. Advertiser" (whig), and "L. American" (dem.), the latter of which issues also a weekly edition; the weeklies are the "Patriot and Republican" (dem.), the "Vox Populi," and the "Business Directory;" and the monthlies, the "New England Offering," and the "Insurance Intelligencer." The "Offering" was originally written and edited by the ladies attached to the factories, and was one of the best edited periodicals of the State, reflecting credit alike on the fair editors themselves and the institutions which could furnish education suffieiently extended to fit them for such oceupations.

A reservoir of great capacity has been built on the high ground in Belvidere, east of the eity, for the purpose of furnishing a ready supply of water to any part of the city in cases of fire. The water is conveyed into the reservoir by force-pumps from the Lowell Machine Shop. Pipes are laid from the reservoir to various parts of the city, at which points hose can be attached to the hydrants without delay, when necessary.

The railroads diverging from Lowell are the Salem and Lowell R. R., the Boston and Lowell R. R., the Nashua and Lowell $R . R$, and the Lowell and Lawrence $R . R$. and these connect it with the sea-board and interior, and make it a great centre of transportation and local trade.

The population of Lowell in 1830 , was 6,474 ; in 1840 , 20,796 , and in $1850,33,383$, being an increase from 1830 to 1840 of 221.22 per cent., and from 1840 to $1850,60.52$ per cent. The present (1853) population can not be less than 40,000 .

LowetL, t. and p. o., Dodge co., Wisc.: 33 m. N. E. by E Madison. Drained by Beaver dam (or Crawfish) r., the W. branch of Rock r. and its branches. Soil superior for grass growing. Pop. 834.

LowELL, p. o., Oneida co., $N$. $Y$.

Lowel, p. v., Washington co., Ohio: on the left bank of Muskingum r., $\$ 3 \mathrm{~m}$. E. by S. Columbus.

Lowelz, to and p. $\mathrm{O}_{n}$, Orleans con, Verm.; $38 \mathrm{~m}$. N. by E. Montpelier. Mississippi $r$, rises in the S., and furnishes water-power. Surface somewhat rugged, but soil mostly fertile and productive. Pop. 637.

LoweLL, p. ve, La Salle county, Ill. : on the W. side of Vermillion r., $109 \mathrm{~m}$. N. by E. Springfield. Here are considerable falls in the river, and extensive mills.

Lowellville, p. v., Mahoning co., Ohio : on the left bank of Mahoning r., $143 \mathrm{~m}$. N. E. by E. Columbus.

Lower Bartuett, p. V., Coos co., $N$. Hamp. : on Saco r. $61 \mathrm{~m}$. N. N. E. Concord.

Lower Bern, p. o., Berks co., Penn.: 48 m. E. by N. Harrisburg.

Lower Chanegrord, t. and p. o., Fork co., Penn. . $35 \mathrm{~m}$. S. E Harrisburg. Susquehanna r. bounds it E., and NFuddy cr., which furnishes good water-power, on the $\mathrm{S}$, and $\mathrm{W}$ Surface varied, and soil very productive. The Tidewater Canal passes through it along the Susquehanna.

Lower Columbia, p. o, Coos co., N. Hamp. $106 \mathrm{~m}$, N. by W. Coneord.

Lower Gilmaxton, p. o., Belknap co., N. Itemp.: $13 \mathrm{~m}$ N. E. Coneord.

Low E. S. E. Columbus.

Lower Mahantango, t. and p. o., Schuylkill county; Penn.: $29 \mathrm{~m}$. N. E. Harrishurg. Drained by Deep and Swatara creeks, on which are large saw-mills. Surface mountainous; soil in the valleys very fertilo. Anthracito 
coal is largely found and conveyed east and west by railroads.

Lower Mardborough, p, v., Calvert co., Md.: on the E. side of Patuxent r., 24 m. S. S. W. Annapolis.

Lower Merion, t. and p. o., Montgomery co., Penn. : on the W. side of the Schuylkill, $86 \mathrm{~m}$. E. by S. Harrisburg. Drained by Mill and Cobb's ereeks, and well supplied with water-power. Surface moderately uneven, and soil a highly cultivated loam. It is extensively engaged in manufacturing cotton and woolen goods, paper, etc. The Columbia and Philadelphia R. R. and Philadelphia and Reading R. R. pass through it.

LOWER NEWPORT, p. F., Washington co., Ohio: on the Ohio r., 96 m. E. S. E. Columbus.

Lower Peach Tree, p. v., Wilcox $c_{0}, A$, $\alpha$. : on right bank of Alabama r., $76 \mathrm{~m}$. W. S. W. Montgomery. Here is a good landing, several stores, and 200 inhabitants.

Lower SALEM, p. v., Washington county, Ohio : 86 m. E. by $\mathbf{S}$. Columbus.

Lower Saucon, t. and p. o., Northampton co., Penn.: on the S. side of Lehigh $\mathbf{r}, 83 \mathrm{~m} . \mathrm{E}$, by $\mathrm{N}$. Harrisburg. Drained by Saucon cr., and well furnished with mill privileges. Surface hilly, and soil adapted to grass or grain. Two bridges cross the Lehigh, along which the Lehigh Navigation Canal passes.

Lower Squankum, p. v., Monmouth co, $N$. Jer.: $34 \mathrm{~m}$. E. S. E. Trenton.

Lower Three Runs, p. o., Barnwell dist., S. Car. : on a branch of Savannah r., 66 m. S. S. W. Columbia.

Lower W ATERFord, p. v., Caledonia co., Term. : near the Connecticut r., $82 \mathrm{~m}$. E. by N. Montpelier.

Lowers, p. 0., Barnwell dist., S. Car.: \$. W. Columbia. Loweville, p. 0., Meriwether county, $G a x_{0}: 97 \mathrm{~m}$. W. Milledgeville.

Low HamptoN, p. ₹., Washington co., $N_{0} Y_{*}: 51 \mathrm{~m}$. N. N. E. Alvany. It is near the Rutland and Washington Railroad.

Lowhilt, t. and p. o., Lehigh co, Penn.: 69 m. E. N. E. Harrisburg. Surface hilly; soil gravelly loam and mostly productive. It has considerable trade in lumber, and several small manufactories.

Lowndes county, Ala. Situate S. centrally, and contains 869 sq. m. Drained by Pintala, Big Swamp, and Mask creeks, affuents of the Alabama, which is its N. boundary. Surface rolling or gently uneven; soil of average fertility. Cotton and corn are the leading crops. Swine are fed in great numbers, and the export of pork is very large. It las several mill streams, and a good growth of pine forest. Farms 874; manuf. 2 ; dwell. 1,354, and pop.-wh. 7,258, fr. col. 8, sl. 14,649-total 21,915. Capital: Haynesville. Pubtic Works: Montgomery and Mobile Railroad (projected).

Lowndes county, Ga, Situate S., and contains about $1,650 \mathrm{sq}$. m. Drained by Allapahaw r., its E. boundary, Withlacoochee, Little, and New rivers, all branches of the Suwanec, which flows into the Gulf. Surface level or undulating; soil various -in parts very fertile, in parts sandy barrens. It is generally well wooded, and has some excellent timber near the rivers. Cotton, corn, buckwheat, and potatoes produce largely, but the great business is raising cattle and swine. Live-stock, beef, butter, and pork are the exports. It is on the $\mathrm{S}$. line, and the State boundary is in dispute with Florida. Farms 649; manuf. 2; dwell. 932, and pop.-wh. 5,845, fr. col. 22, sl. 2,4S4 -total 8,351. Capital: Troupsville. Public Works: Brunswick and Florida R. R. and Albany Branch R. R.

Lowndes county, Mriss. Situate N. E., and contains 559 6q. $m$. Drained by Little Tombigbee $r$. and its numerous branches. Surface undulating, and somewhat uneven; soil very fertile. Cotton is the great staple, and it is one of the largest cotton-crowing countics in the state. Corn rields a gool crol, and some narts grow whont. It has fine waterpower and extensive apd rapirlly increasing manufactures.
Lying at the head of navigation on the Tombigbee, it has easy access to market, and is the outlet for a large district. Farms 725; manuf. 63 ; dwell. 1,168, and pop.-wh. 6,523, fr. col. 29, sl. 12,993-total 19,544. Capital : Columbus.

Lowndes, p. o., Wayne county, Mo.: 187 m. S. E. Jefferson City.

LoWNDESBOROUGH, p. o., Lowndes county., $A 7 a_{0}: 18 \mathrm{~m}$. W. by S. Montgomery

LowNDESVILLe, p. 0., Abbeville dist., $\$$. Car.: about $5 \mathrm{~m}$. E. of Savannah r., $94 \mathrm{~m}$. W. by N. Columbia.

Low Ponv, p. v., Woodford co., $7 l .: 71 \mathrm{~m}$. N. by E. Springfield. Pop. 140.

Low Pornt, sta., Duchess con, $N, Y .:$ on the left bank of the Hudson, $11 \mathrm{~m}$. S. of Poughkeepsie by the Hudson River R. R. Here is a ferry to Newburg on the W. side, and a convenient landing for vessels and steamboats, with several large warehouses.

Lowbance's Mtux. p. 0., Lincoln co., $N$. Car.: $113 \mathrm{~m}$. W. by $\mathrm{S}$. Raleigh.

LowRy, p. o., Athens co., Ohio: 81 m. 8. E. by E. Columbus.

Lowry's Crossnga, sta., Bedford co., Virg.: $19 \mathrm{~m}$. W. of Lynchburg, on the Virginia and Tennessee R. R.

Lowryville, p. v., Madison eo., $I l l .: 68 \mathrm{~m}$. S. by W. Springfield.

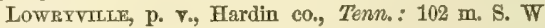
Nashville.

Low's Coreter, p. o., Sullivan county, $\mathcal{N} . Y_{*}: 84 \mathrm{~m}$ S. W. by S. Albany.

Lowvilet, t. and p. v., Lewis co., $N$. $Y$.: $122 \mathrm{~m}$. N. W. Albany. Drained by branches of Black r., which turn many saw and grist mills. Surface rolling; soil very fertile, especially in the E. on Black r. A superior farming $t$, wel timbered. The $\mathbf{v}$, is near Black r., and contains a bank, an incorporated academy, a dozen stores, several mills, and 800 inhabitants. Two weekly papers are published, the "L. County Republican" (dem.), and "Northern Journal" (whig). Pop. of t. 2,377.

Low vilLE, t. and p. o, Columbia co., Wisc.: $24 \mathrm{~m}$ N. by E. Madison. Surface slightly broken, and soil fine grain land. Pop. 297.

Loydsville, p. Y., Belmont co., Ohio: 103 m. E. by N Columbus.

Lox's Cross Roads, p. 0., Anderson co., Tenn.: 154 m. E. Nashville.

LUBEC, to and p. v., Washington $c_{0}, M e_{0}:$ at the W. entrance of Passamaquoddy Bay, 146 m. E. N. E. Augusta; soil fertile. The chief interests are commerce and the fisheries, and centre in the $\mathrm{y}$, which occupies a point of land extending into the harbor, $3 \mathrm{~m}$. from Eastport. The harbor is of ensy access, admits ressels of any size, and is well protected by Grand Menan and Campobello islands. On the most E point of the $t$. is W. Quoddy Fead light-house. An extensive coasting trade is carried on, and cod and mackerel fish ing largely followed. Pop, of t, 2,514.

Lubec Milis, p. 0., Washington co., Me. : 141 m. E. N. E. Augusta.

Lrcis county, $I \alpha$. Situate S. middle, and contains 439 sq. m. Drained by Fox cr. and Chariton $x$. of the Missouri, and White Brenst River, and other branches of the Des Moines. Surface rolling, and soil fertile, adapted to grass or grain, and generally timbered, with a sufficiency of mill-seats, Little settled. Farms 82 ; manuf. 0 ; dwell. 92, and pop.-wb. 471 , and fr. col. 0 -total, 471. Capital: Polk.

LuCAs county, Olio. Situate N. W., and contains 332 eq. m. Drained by Ottawa and Maumee rivers, and Swan cr. emptying into Maumee Bay, the W. end of Lake Erie, which is the $\mathrm{E}$. boundary of the county. Surface generally even, and soil mostly fertile. Wheat, corn, oats, and barley grow easily and produce well. It is a good grazing $\mathrm{co}_{\text {. }}$ and rears many eattle, and exports much pork. Waterpower is abunclant, and its manufactures, already large, are 
growing rapidls. It has considerable lake-trade, and is the great thoroughtare for $\mathrm{W}$. travel and freight, by water and lind ruutes. Farms $6 \$ 3$; manuf. 101 ; dwell. 2,225 , and pop.-wh. 12,223, fr. col. 140-total 12,363. Capital: Maumee City. Pullic Works: Wabash and Erie Canal; Erie and Kalamazoo R. R., ete.

Lccss, p. o., Richland county, Ohio: 66 m. N. by E. Columbus.

Lucastille, p. v., Scioto co., Ohio: on the left bank of Scioto r., 73 m. S. Columbus.

LuCERse, p. o., Washtenau eo., Mich.: 51 m. s. E. Lansing.

LUCEgrNe, p. o., Knox co., Ohio: 47 m. N. E. Columbus. Itcisda Furvace, p. o., Clarion co., Penn.: $148 \mathrm{~m}$. W. N. W. Harrisburg. Here is a charcoal furnace of 1,500 tons annual capacity.

Luchy Hux, p. 0., Limestone co., Ala.: $176 \mathrm{~m} . \mathrm{N}$. by W. Montgomery.

LUDA, p. O., Washita co., Ark.: 81 m. S. S. W. Little Rock.

LoDrow, t. and p. $\nabla$. . Hampden county, Mass.: $73 \mathrm{~m}$. W. by S. Boston. Drained by Chicopee r. and its branches, which afford good water-power. Surface agreeably uneven; soil productive and well tilled. It is mostly a farming to and well wooded. In the S. on the Chicopee, and near the Western R. R., is a thriving manufacturing village where are cotton factories with abundance of water. Pop. of t. 1,186.

LUDLOw, p. o,s, Scott co., Miss.: E. Jackson.

LCDLow, sta., Hamilton co., Ohio: $\mathrm{S}$ m. N. of Cincinnati, on the Cincinnati, Hamilton, and Dayton R. R.

LoDLow, t. and p. v., Windsor co., Term.: $61 \mathrm{~m} . \mathrm{S}$. Montpelier. Drained by Black and Williams' rivers, which afford excellent water-power. Surface hilly, and soil finely adapted to grazing. Live-stock and wool are valuable exports. The $\mathrm{v}$. is on Black r., and has a large trade and growing manufactures. It contains a flourishing academy, and several stores and mills, and is $28 \mathrm{~m}$. by the Rutland and Burlington R. R. from Bellows Falls. Pop. of t. 2,063.

LUDLowrille, p. v., Tompkins co., $N$. Y.: on Salmon er., near the E. side of Cayuga Lake, $146 \mathrm{~m}$. W. Albany. The cr. has a very large fall here, and in the $\mathrm{v}$. are 6 or 8 mills, and 660 inhabitants.

Ltamier Bridge, p. O., Robeson co., N. Car.: $85 \mathrm{~m}$. s. by W. Raleigh.

LuMber Crtx, p. o., Telfair co., Ga.: near the confluence of Oconee and Ocmulgee rivers, $89 \mathrm{~m}$. S. by E. Milledgeville.

LUMBERLAND, t, and po o., Sullivan co., $N$. $Y_{\text {.: }}$ On Delaware r., 96 m. S. W. by S. Albany. Drained by Mongaup $r$, and other branches of the Delaware, on which are great numbers of large saw-mills. Surface hilly, and soil gravelly loam, and densely covered with pine and oak timber. The soil is little tilled, but lumber, which is exported by the $r$. and canal in immense quantities, and leather, are products of great value. The Delaware and Hudson Canal passes along the $r$ in the $S_{\text {., }}$ crossing it at the month of Lackawaxen cr., and the Erie R. R. enters the t. some miles above from the Pennsylvania side. Pop. 2,685 .

Lonierport, p. os, Harrison county, Firg.: 203 m. N. T. by TV. Pichmond.

LturBer Rrvere, sta, Horry district, S. Car.: on the Wilmington and Manchester R. R., $72 \mathrm{~m}$. from Wilmington.

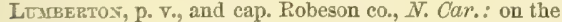
Zi. bank of Lumber r., $83 \mathrm{~m}$. S. by W. Raleigh. It contains a court-house and several stores, and is engaged in the turpentine and lumber trade.

Lumberton, p. o., Clinton county, Ohio: $65 \mathrm{~m} . \mathrm{S}$. W. Colurabus.

Itarierton, p. v., Burlington co., N. Jer.: 19 m. S. by W. Trentron.

Lembertiluz, p. v., Bucks co., Penn.: on the right bank of Delaware r., $96 \mathrm{~m}$. E. by N. Harrisburg. The Delaware division of the Pennsylvania Canal passes through it, $27 \mathrm{~m}$. S. of Easton.

LUMPKLN county, $G a$. Situate N., and contains $546 \mathrm{sq} . \mathrm{m}$. Drained by Chestatie r., a branch of the Chattahonchee, and Etowah r. of the Coosa, heads of the Alabama and Appalachicola respectively. Surface rugged and mountainous, with beautiful fertile valleys on the streams. Corn and pork are the staples. It has some excellent grazing and good dairies, and raises fine wheat in small quantities. It is in the heart of the gold region, and has the richest mines E. of the Mississippi, and a branch mint at its capital. Farms 598; manuf. 0; dwell. 1,881, and pop.-wh. 7,993, fr. col. 22, sl. 939-total 8,954. Coppital: Dablonega.

LUMPEIN, p. v., and cap. Stewart county, Ga.: $123 \mathrm{~m}$. S. W. by W. Milledgeville. It contains a court-house, jail, a dozen stores, and 300 inhabitants.

Lumpkin"s, sta., Burke c0., Ga.: on the Augusta and Waynesboro' R. R., $41 \mathrm{~m}$. from Augusta.

LUNENBCRG county, Virg. Situate S. E., and contains $40 \mathrm{sq} . \mathrm{m}$. It has Nottoway r. on the N., and Meherrin r. on the $\mathrm{S}$., which form the Chowan, and is drained by their branches. Surface diversified agreeably, with some considerable hills: soil of good fertility, yielding great crops of tobacco, which is the staple product, and fair crops of corn and wheat, It has many mill-streams and small manufactories. Farms 548; manuf. 13 ; dwell. 820, and pop.wh. 4,310, fr. col. 195, sl. 7,187-total 11,692. Capital: Lunenburg $\mathrm{C}$. H.

Lunenbure C. H., p. V., and cap. Lunenburg co., Virg.: $61 \mathrm{~m}$. S. W. Richmond. It contains a brick court-house, juil, and clerk's office, and 150 inhabitants.

Lunenture, to and p. vo, Worcester co., Mass. : $39 \mathrm{~m}$. W. N. W. Boston. Drained by branches of Nashua $r$. which are fed by three large ponds. Surface elevated and uneven; soil clayey and adhesive, and generally productive. Farming and grazing are the leading pursuits, but it manufactures boots and shoes, leather, cabinet-ware, and agricultural implements, ete., in small amounts. The Fitchburg R. R. passes through the S. part, and has a sta. there $8 \mathrm{~m}$. E. of Fitchburg. Pop of t. 1,249.

Lunenburg, t. and p. o., Essex co., Verm.: on Conneclicut r., $45 \mathrm{~m}$. E. by N. Montpelier. It lies immediately above the Fifteen Mile Falls on that $r_{\text {r., }}$ and is well furnished with water-power by Neal's and Catbow branches. Surface uneven and soil very stony, but mostly fine pasture. Cattle and dairy products are the chief exports. Pop. 1,124.

LunEX's CREEK, p. o., Hardy county, Virg.: 161 m. N. W. Richmond.

LURar, p. v., Henry county, Ind.: 44 miles E. N. E. Indianapolis.

LURAY, v., Licking co., Ohio: on the S. branch of Licking river, $23 \mathrm{~m}$. E. Columbas. Pop. 88.

Lurat, p. v., and eap. Page co., Virg.: on a branch of Shenandoah r., $88 \mathrm{~m}$. N. W. by N. Richmond. It contains a court-house, several stores, and 500 inhabitants.

Luthersidurg, p. v., Clearfield county, Penn.: $113 \mathrm{~m}$. W. N. W. Ularrisburg. Limestone is quarried near it,

Luthersvilue, p. o., Meriwether co., Ga.: $97 \mathrm{~m}$.W. by N. Milledgeville.

Luzerne county, Penn. Situate X. E., and contains 1,265 sq. m. Bounded S. E. by Lehigh r., and W. by the Susquehanna, and drained by its numerous branches, the largest, Lackawanna r., and its affuents, draining the $\mathrm{N}$. half. Surface much diversiffed, in parts rugged and broken, with lovely valleys; soil generally very fertile; parts are untillable. Oats, corn, wheat, buckwheat, rye, and potatoes are all fine erops, and produce largely. It is a fine grazing region, and feeds great numbers of sheep, and markets much live-stock, beef, and pork. Anthracite coal abounds, and forms a valuable export. It has great facilities for manufactures, which are very largely prosecuted, especially of flour, iron, iron-ware, and lumber. Farms 1,936; manuf. 175; dwell. 9,537, and pop.-wh. 55,699, fr. col. 373- 
total 56,072. Capital: Wilkesbarre. Public Works: Lackawanna and Western R. R.; Cobb's Gap R. R.; Pennsylvania Coal Co. R. R.; North Branch Division of Pennsylvania Canal, ete.

LUZERNe, t. and p. v., Warren co., N. Y.: $36 \mathrm{~m}$. N. Albany. Bounded W. and $\$$. by Hudson river, on which are Hadley and other large falls. Surface very hilly in the $\mathrm{E}_{*}$; on the Hudson level bottom of great fertility. Lumber is the chief product. The $\mathrm{v}$. is on the $\mathrm{x}$., and contains several mills and 300 inhabitants. Pop. of t. 1,300.

Lxcoming county, Penn. Situate N. centrally, and contains $927 \mathrm{sq}, \mathrm{m}$. Drained by W. branch of the Susquehanna, and Pine, Lycoming, Lycosock, and Muncy creeks, its affluents. Surface broken and mountainous in the middle; more even, though hilly, in the N. and S. parts. Soil of great fertility, especially on the streams, in its numerous valleys. Wheat, corn, buckwheat, rye, oats, and potatoes are the staples, all growing excellent crops of superior quality. It is eminently a grazing co., pasturing large numbers of cattle and sheep, with fine dairies and valuable exports of butter, cheese, wool, and pork. Water-power it has in abundance, and superior timber. Its manufactures are varied, extensive, and employ a large capital. Iron, flour, lumber, leather, liquors, and woolen goods are made. Farms 1,561; manuf 232 ; dwell, 4,586, and pop.-wh. 25,890, fr. col. 367-total 26,257. Capital: Williamsport. Public Works: Penasylvania Canal; Williamsport and Elmira R. R.

Lxcoming Creek, p. 0., Lycoming county, Penn: $78 \mathrm{~m}$. N. by W. Harrisburg.

LYELL's STCRE, p. 0., Richmond county, Virg.: $44 \mathrm{~m}$. E. N. E. Richmond.

LYMAN, t. and p. o., York co., Me.: 74 m. S. W. by S. Augusta. Drained by a branch of Saco r. and Kennebunk r., which rises in a pond near its centre. Surface somewhat uneren, and soil fertile and well cullivated. The Tork and Cumberland R. R. passes near the N. corner. Pop. 1,376.

LrMAN, t. and p. v., Grafton co., N. Hamp.; on the Connecticut river, $78 \mathrm{~m} . \mathrm{N} . \mathrm{N}$. W. Concord. Drained E. by branches of Ammonoosuc river. Surface uneven, but not mountainous. Soil generally productive, and good pasture land. The v. is on the Connecticut, which has several falls, and is crossed by a ferry. Pop. of t. 1,412.

Lrmax Centre, p. v., Fork co, $\mathrm{H}$ Fe.: $76 \mathrm{~m}$. S. W. by S. Augusta.

Lymaxsville, p. v., Potter co., Penn.: 119 m. N.W. by N. Harrisburg.

Lxare, t. and p. v., New London co., Connz. : at the mouth of the Connectieut, on the E. side, $39 \mathrm{~m}$. S. S. E. Hartford. Drained by Blackhall and Four Mile rivers, and other small streams flowing into the river and Sound. Surface in the S. mostly level, with extensive salt meadows; in the $\mathrm{N}$. broken and stony, with much excellent pasture. Farming and grazing are leading interests, and wocl a considerable export. Small factories of cotton and woolen goods are operated on the streams, and the indentations of the coast afford several harbors and give it facilities for commerce. The village is a wide street, lined with fine farm-houses, half a mile $E$. of the river, and has a landing for steamboats and a ferry to Saybrook. The New Haven and New London R. R. crosses the town, and connects with the W. side of the river by a ferry. The station at the ferry is $16 \mathrm{~m}$. W. of New London. Pop. of t. 2,663.

Lrave, t. and p. v., Grafton co., N. Hamp.: on the Connecticut, $52 \mathrm{~m} . \mathrm{N}$. W. by N. Concord. Drained by small affluents of the Connecticut, on which are numerous sawmills. Surface moderately uneven, and soil generally fertile and well timbered. The village is on the Connecticut, and contains a flourishing academy and several stores. Pop. of t. 1,618.

Lrase, t. and p. o., Huron county, Ohio: S3 m. N. by E. Columbus. Drained by Pipe cr., which flows into Lake Erie. Surface level, and soil superior for grain-growing. The Toledo, Norwalk, and Cleveland R. R., and Mad River 410 and Lake Erie R. R. pass through it and intersect near its W. line. Pop. 1, 559

Lyacunurg, p. v., Campbell co., Virg.: on the S. side of James r., $22 \mathrm{~m}$. below Balcony Falls, and $91 \mathrm{~m}$. W. by $\mathrm{s}$. Richmond. Lat. $37{ }^{\circ} 36^{\prime} \mathrm{N}$., and long. $799^{\circ} 22^{\prime} \mathrm{W}$. The James River and Kanawha Canal, now finished W. to the mouth of North $r_{\text {, }}$ is at present the great channel of its commerce with the sea-board ; but it is soon to be connected E. and W. by a magnificent line of railroads - the South Side R. R. to Petersburg, $120 \mathrm{~m}$., and Richmond, $122 \mathrm{~m}$. and the Virginia and Tennessee $R$. $R$, and connections to and beyond the Ohio $\mathrm{r}$. and the Mississippi, passing through the principal commercial centres of the great interior basin ; these lines are rapidly being completed, and before the expiration of the year 1855 the whole will be in operation. The $\mathrm{r}$. is well located for business and health, on ground rising gently from the river, and on every side environed by magnificent scenery, overlooked on the W. by the lofty peaks of the Blue Ridge mountains, rising in one placethe Peaks of Otter-to an elevation of 4,260 feet above the sea level. In 1793 Lynchbarg contained but five dwellings, and it is now one of the largest, most wealthy, and busy places of the State, and has an amount of trade surpassed by no other place between the Olio River and the Atlantic sea-board. Its buildings, public and private, are substantial, and in many instances handsome structures; and its warehouses are lurge and filled with the produce of a wide tributary country. It has 6 or 7 extensive tobacco warehouses, in which from 10,000 to 12,000 hogsheads of tobacco are annually inspected, and there are some 25 or 30 tobacco factories, each of which on an average turn out 1,500 boxes annually. Cotton and iron are also manufactured here to a considerable extent, and there are sereral extensive flouring and other mills. Lynchburg has three banks; and there are published in the $\mathrm{v}$. three newspapers, the "L. Virginian" (whig), the "Virginia Patriot" (whig), and the " $\mathrm{L}$. Re publican" (dem.); the water-power applicable to manufactures is large and valuable, and has been greatly increased by a dam above the $v_{\text {., }}$ which latter also creates the reserroir or source of the water supplied to the inhabitants, which is raised to an elevation by means of pumps and distributed through pipes. Below this, and connecting the eity with the opposite bank, a bridge crosses the river, orer which is the road to Charlottesville. Pop. about 8,071 .

Lrincmburg, p. v. and sta., Highland $\mathrm{co}_{\text {, }}$ Olio: on the E, branch of Little Miami river, which affords several fine mill-sites, $68 \mathrm{~m} . \mathrm{S} . \mathrm{W}$. by S. Columbus. The station is $10 \mathrm{~m}$. from Hillsboro', on the Cincinnati, Hillsboro', and Parkersburg $\mathrm{P} . \mathrm{R}$

LymcinURg, p. o., Lincoln co., Tenn. : 56 m. \$. bj E. Nashville.

Lrvcriburg, sta., Sumter dist., S. Car, : on the Wilmington and Manchester R. R., $28 \mathrm{~m}$. from Manchester.

Irncris Creek, p. O., Marion district, $S$. Car.: on the stream so called, $87 \mathrm{~m}$. E. by S. Columbia.

LrNor's creek, $S$. Car, : rising in North Carolina, after a S. S. E. course of $125 \mathrm{~m}$. flows into Great Pedee r., and is navigable through half its length.

Lyмсн"s Lake, p. O., Williamsburg dist., S. Car. : $81 \mathrm{~m}$. S. S. E. Columbia.

Lxicnwoon, p. 0., Kershaw dist., S. Car.: on the W. side of Lynch's er., $47 \mathrm{~m}$. N. E. by E. Columbia.

LYNDEBorover, t. and p. O. Hillsborough co., N. Hamp.: $26 \mathrm{~m}$. S. W. by S. Concord. Drained by branches of Souhegan r. Surface rough and stony, but it has very superior pastures, and some good farms. Pop 968.

Lxmos, p. v., Whitesides co., $I l l_{0}$ : about $1 \mathrm{~m}$. W. of Rock r., $134 \mathrm{~m}$. N. by W. Springfleld. It was the former cap. of the co., and contains an academy, several stores, and 450 inhabitants.

Lrspos, t. and p. v., Caledonia co., Term.: $35 \mathrm{~m}$. N. E. Montpelier. Drained by Passumpsic r. and its branches, which supply it with an abundance of excellent water-power. 
The Great Falls of the Passumpsic descend 65 feet in 30 rods, within the $t$, and the Little Falls 18. Surface undulating, and soil rich loam, free from stone, and of easy tillage. Live-stock, wool, and dairy products, form heavy exports. The $\mathrm{v}_{\mathrm{*}}$ is on the Passumpsic, and contains an academy, and severa! manufuetories. The Connerticut and Passumpsic Rivers R. R. passes through the t. Pop. of t. 1,752.

Lradon Centre, p. o., Caledonia co., Verm.: 37 m. N. E. Montpelier.

LMDONVILLE, p. v., Orleans c0., N. Y. : on Johnson's er. $246 \mathrm{~m}$. W. by N. Albany. It contains several mills and stores, and 500 inhabitants.

Limestmle, p. $\nabla$. , Granville county, $N_{0}$ Car.: $55 \mathrm{~m} . \mathrm{N}$. Raleigh.

LrNs, to, p. city, and port, Essex co., Mass.: $9 \mathrm{~m}$, N. E. Boston. The town extends some $6 \mathrm{~m}$. along the sea, and is almost surrounded with water. On the W. is Saugus river, on the S. the harbor, on the S. E. the ocean, and on the N. are the Lakes of Lynn, a chain of ponds. The S. part of the $t_{\text {t }}$ is an inclined plane, bounded on the $\mathrm{N}$. by bold porphyritic hills, beyond which the surface is thickly covered with timber. From its S. E, corner, extending into the ocean $4 \mathrm{~m}$., is Nahant peninsula, at the S. extremity of Which is located the celebrated watering-place of the same name. Phillip's Point, another peninsula, is also a fine summer resort, and in the $\mathrm{N}$. part of the $t$. is a noted mineral spring, much frequented by invalids. The city of Lynn is pleasantly situated, and well laid out in broad and airy streets, and has an excellent harbor. Lat. $45027^{\prime} 51^{\prime \prime} \mathrm{N}$. and long. $70^{\circ} 5 \tau^{\prime} 25^{\prime \prime}$ W. It contains 15 churches, 10 school-houses, an academy, 2 banks, a savings institution, 2 insurance offices, and several literary, scientific, and benevolent institutions. Two newspapers, the "L. News (whig) and the "Bay State" (dem), are issued weekly. It is celebrated for its manufacture of ladies' shoes, and its extensive coul and mackerel fisheries. The shoe business is the life of Lynn. Only womens', misses', and childrens' shoes are made here. Engaged in this business, there are of manufuclurers, or men who "carry on the business," 89 ; of cutters, or men who "cut out" the shoes, 175; of men and boys employed in "making" shoes, 2,458; of men and boys so employerl, but living out of the town, about 900 ; of women and girls employed in "binding" shoes, 4,925; of the same so employed, and living out of the town, about 1,600 ; making of emplovees an aggregate of 10,058 . The number of men and boys employed in making shoes is more than 70 per cent. now than it was in 1542 . The iLcrease in the number of women and girls employed in binding shoes has been correspondingly great. The number of pairs of shoes made last year (1849), was $3,540,000$ pairs. The cost of material of these was $\$ 1,585,545$; that of making them $\$ 957,080$-making the cost of the $3,540,000$ pairs of shoes to hare been $\$ 2,392,5 \pi 5$. Shoe-making was a principal business of the inhabitants before the Revolution, and hence the people of the "City of Shoes" ought to be endowed with good understandings. The population of the town in 1790 was 2,291 ; in $1800,2,837$; in $1810,4,087$; in $1820,4,515$; in $1830,6,138$; in $1840,9,367$, and in 1850 , 14,259 -the increase for the last two decennial periods having been upward of 52 per cent. The Lastem R. l. passes through Lynn, $9 \mathrm{~m}$, from Boston,

Lrsxy, p. o., Susquehanna co., Penn.: 114 m. N. N. E, Harrisburg.

Lrsw, p. o., Randolph county, Ind.: 53 m. E. by W. Indianapolis.

LXNN CAMrP, Knox county, Ky.: 93 m. S. E. by S. Frankfort.

LrTSFIELd, to and p. v., Essex co., Mass.; $12 \mathrm{~m}$. N. Bosfon. Drained by Inswich and Saugus rivers, which afford good water-power. Surface rugged; soil unproductive, with arme arabla land of superior quality, mostly well woodr.d. and in parts eovered with large forests. Worlens, boots and shoes, iron-ware, and several kinds of tools, etc., are manufactured. Its romantic scenery makes it a favorito resort in summer of parties from the neighboring cities. The South Reading Branch of the Boston and Maine R. R. passes through it, and has a sta. $6 \mathrm{~m}$. W. of Salem. Pop of t. 1723 .

Lrnnfield Centre, p. v., Essex co., Mass. : 15 m. N. Boston.

LYNNFORD, p. o., Jefferson county, $\overline{K y}$ : 41 m. W. Frankfort.

Lynnvilue, p. v., Morgan county, $I l l \cdot: 37$ m. W. by $S$. Springfield.

LYNNVILLE, p. 0. Jasper $c_{0}, 1 a_{0}: 79 \mathrm{~m}$. W. of Iowa City.

LYNNVILLE, p. v., Warrick co., Ind.: 121 m. S. W. by S. Indianapolis. A plank-road leads hence to Newburg on the Ohio.

Lrwnvilue, p. v., Lehigh county, Penn. : 64 m. E. N. E. Harrisburg. Here is a furnace of 800 tons capacity.

LrnNville, p. o., Giles co., Tenn.: on a branch of Flk r., $54 \mathrm{~m}$. S. by W. Nashville.

Lross, p. v., Clinton co., Ia. : on the Mississippi, $71 \mathrm{~m}$. E. by $\mathrm{N}$. Iowa City.

LYoNs, t. and p. v., Ionia county, Mich.: $32 \mathrm{~m}$. N. W. Lansing. Drained by Maple and Grand rivers and their branches, Surface level or rolling. Soil a rich alluvium, producing fine grass and grain. The $\mathrm{v}$. is $1 \mathrm{~m}$. above the union of Maple and Grand rivers, on the latter, and at the head of steamboat navigation. The $r$, has a considerable fall, and the facilities for manufacturing are very good. Pop. of t. 850 .

I.xoNs, t., p. v., and cap. Wayne county, N. $Y .: 172 \mathrm{~m}$ W. by N. Albany. Surface hilly. Soil sandy and calcareous loam, and very productive of grain. Flour, leather, and earthen-ware, are important manufactures. The Erie Canal passes through it, on which is the v. $44 \mathrm{~m}$. E. of Rochester, and near the junction of Mud cr. and Canandaigua r., which form the Clyde, and from which it is amply sup. plied with water-power by a canal half a mile in length. It is largely engaged in manufacturing flour, iron cast. ings, leather, carriages, etc. It contains a court-house, jail, and the county offices, several large hotels, 25 stores, an excellent high school, and 2,000 inhabitants. Two weeklies are published, the "W. County Whig," and "L. Gazette" (dem). A railroad from Rochester to Syracuse direct will pass through it. Pop. of t. 4,926.

Lxons, p. o., Fulton co., Ohio: 122 m. N. N. W. Columbus. Lyons, p. v., Cook co., 1 l. : 168 m. N. E. Springfield.

Lyons, p. v., Walworth co., Wise. : on a branch of Fox r., $63 \mathrm{~m}$. E. S. E. Madison.

Lrons, p. o., Fayette co., Tex.: 49 m. E. S. E. Austin City.

LYoNsDALE, p. v., Lewis co., $N_{.} Y$. : about $2 \mathrm{~m}$. S. of Moose r., $99 \mathrm{~m}$. N. W. Albany.

Lron's Horlow, p. 0., Steuben co., N. I.: 204 m. W. by S. Albany.

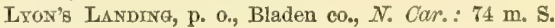
Raleigh.

Lxons' Store, p. o., Hawkins co, Tenn. : 222 m. E. by N, Nashville.

Lxonstrue, p. v., Cook co, $7 l_{\text {, : }}$ about two miles W. of Des Plaines r., $165 \mathrm{~m}$. N. E. Springfield.

Lrra, p. o., Scioto co., Ohĩo: $86 \mathrm{~m}$. S. Columbus.

LYsander, t. and p. o., Onandaga county, N. I.: $142 \mathrm{~m}$. W. by N. Albany. Bounded E. by Oswego r., and S. by Seneca r. Surface mostly level, and soil of excellent qualify. It is a large t., principally devoted to agricultural pursuits, for which it is admirably adapted. The Oswego and Syracuse R. R, crosses the E. part, and has a sta. near Seneca r. Pop. 5,838 .

Lxthonta, p. o. and sta., De Kalb county, Ga.: on the Georgia R. R., $24 \mathrm{~m}$. from Atlanta, $71 \mathrm{~m}$. N. W. Milledgeville.

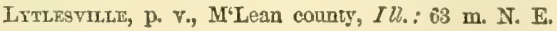
Springfield. 


\section{M.}

M.Afee, p. o., Mfereer eo., $k y .: 23 \mathrm{~m}$. S. Frankfort.

M'Alevy's Fort, p. o., Huntingdon co., Penn.: $59 \mathrm{~m}$.

W. by N. Harrisburg.

M'Allister's Cross Roads, p. o., Montgomery co., Tenn.:

$89 \mathrm{~m}$. N. W. Nashrille.

M:Allisterville, p. v., Juniata co., Penn.: 85 m. N. W. Harrisburg:

M'Artaur, p. o., Vinton co., Ohio: 53 m. S. E. Columbus. M'Arthurstown, p. v., and cap. Vinton co., Ohio: on a branch of Raceoon er, $55 \mathrm{~m}$. S. E. Columbus. There is an extensive buri-millstone factory here. The "Vinton co. Republican" (whig) is published here. Pop. 424.

M'BeEN, p. o., Richmond county, Ga.: 85 m. E. by N. Milledgeville.

M·Brme's Mrus, p. o., Heard co., Ga.: $97 \mathrm{~m}$. W. by N. Milledgeville.

M'Brmestille, p. v., Union dist., S. Car.: near M'Bride r., $69 \mathrm{~m}$. N. W. Columbia.

M'CalL's Creek, p. O., Franklin co., Afiss: $71 \mathrm{~m} . \mathrm{S} . \mathrm{W}$. Jackson.

M'CAILUM's Store, p. o., Montgomery co., N. Car.: 71 m. S. W. Raleigh.

M'Clellandtown, p. v., Fayette co., Penn.: $155 \mathrm{~m} . \mathrm{W}$. by S. Harrisburg.

M'Clennar county, Texs: situate centrally, and contains about 940 sq. m. It lies on the upper part of, and mostly to the $\mathrm{W}$. of Brazos $r$, that river intersecting the E. part and its branches, the largest of which is N. Bosque r., draining it. It is a new co. erected since 1850 , and but little settled.

M'Cosm, p. v., Hancock county, Ohio: 73 m. N. N. W. Columbus.

M'Connellsburg, p. Va, Fulton con, Penn.: in a valley on Big Cove cr., 59 m. W. S. W. Harrisburg. The Hanover Blast Furnaces of 2,000 tons capacity are at this village. The Fulton County "Democrat" is issued weekly.

M'Conneli's Geove, p. o., Stephenson co., Ml.: $179 \mathrm{~m}$. N. Springfield.

M'Connelistown, p. o., Huntingdon co., Penn.: $63 \mathrm{~m}$. W. by N. Harrisburg.

M.Consellstulle, p. 0 , Oneida county, $N . Y .: 135 \mathrm{~m}$, W. by N. Albany.

M.Compellsville, p. Vu, and cap. Morgan co, Ohio: on the E. side of Muskingum r., $68 \mathrm{~m}$. E. S. E. Columbns. The T. is situate on an elevation of from 15 to 20 feet above high water mark. There is a C. H., jail, 2 churches, and several tanneries here. The "Morgan Chronicle" (dem.), and "Morgan IIerald" (whig), are published weekly. Pop. 1,660

M'Corstrles, p. o., Juniata eounty, Penn.: 35 m. N: W. Harrishurg.

$M^{*}$ Cracken county, $K y$. Situate $\mathrm{W}_{\text {, }}$ and contains $223 \mathrm{sq}$. m. Bounded N. by the Ohio, E. by the Tennessee, and drained by Chark's and Mayfield's rivers. Surface mostly even, and soil fertilc. Corn is the staple; wheat and tobaceo are considerably raised. It has good pastures, and exports a large quantity of pork. Its manufactures are important, and fast increasing. Farms 313 ; manuf. 38; dwell. S35, and pop.-wh. 5,241, fr. col. 18, sl. 808-total 6,067 . Cupital: Paducah.

M'Collocir's Mrlis, p. o., Juniata county, Penn.: $37 \mathrm{~m}$. W. N. W. Harrisburg.

M'Cutchenvirte, p. o., Vanderburg co., Ind.: $181 \mathrm{~m}$. S. Tr. Indianapolis.

M'Cutcienville, p. o., Wyandott enunty, Olio: on a branch of the Sandusky r., $71 \mathrm{~m}$. N. by W. Columbus, and $2 \mathrm{~m}$. E. from Mad River and Lake Eric R. R.

$\mathrm{M}^{\prime}$ Cotcrov's, p. o., St. Charles par., $L a$. : 59 m. S. E. Baton Rouge.

M'D ANIEX's, p. o., Orange county, N. Car.: $41 \mathrm{~m} . \mathrm{N} . \mathrm{W}$. Raleigh.
M'Donard county, Mo. Situate S. W. corner, and con tains $519 \mathrm{sq} . \mathrm{m}$. Drained by Elk $\mathrm{r}$. and its branches, affluents of Neosho. Surface pleasantly diversified, and soil of superior fertility. Corn is the staple. It grows grass or grain in profusion, and is an excellent grazing co. It is well timbered, and has very good water-power. Farm 126 ; manuf. 42 ; dwell. 371 , and pop.-wh. 2,132, f. col. 21 , sl. 83-total 2,236. Capital: Rutledge.

M'Donald, p. o., Wilkinson co., Ga.: $17 \mathrm{~m}$. S. Milledgeville. The Central (Georgia) R. R. passes it $160 \mathrm{~m}$, from Savannah, and $31 \mathrm{~m}$. from Macon.

M'Donald, p. v., Barry co., MO.: on Flat cr., $157 \mathrm{~m}$. S. W. Jefferson City.

M'Donalo's Mrul, p. o., Montgomery co., Firg.: $159 \mathrm{~m}$. W. by S. Richmond

M'Doxovgr county, $I l l$. Situate N. W., and contains 576 sq. m. Drained by Drowning Fork, Troublesome, Turkey, and Grindstone creeks, branches of Crooked cr., a branch of the Illinois. Surface level, or gently undulating. Soil very fertile, in the W. particularly. In the $\mathrm{E}$. is a strip of prairie; the rest is sufficiently wooded. It has a few mill. streams. Corn and wheat are staples, and pork a large export. Farms 843; manuf. 19; dwell. 1,262, and pop.-wh 7,611, and fr. col.5-total 7,616. Capital: Macomb. Public Works: Central Military Tract R. R.

M'Donougr, p. o., New Castle co., Del. : 23 m. N. Dover. M'DoNovgr, p. v., and cap. Henry co., $G a_{\text {. : near a branch }}$ of the Ocmulgee r., $63 \mathrm{~m}$. W. N. W. Milledgeville. It contains a fine court-house, jail, and two churches, an academy, 60 dwellings, and about 350 inhabitants.

M.Donough, t. and p. v., Chenango co, $N$. Y.: $109 \mathrm{~m}$ W. by S. Albany. Drained by Geneganslette cr. Surface uneven; soil fertile, and well adapted to grazing. The $\nabla_{\text {. is }}$ situnte on Geneganslette cr., and has several mills, tanneries, and a printing-office. Pop. of t. 1,522.

M.DOWELI county, $N$. Car. Situate W., and contains 545 sq. m. Drained by Catawba $r$. and its heads, Turkey, Goose, and Crooked creeks. Surfaee elevated, and in parts mountainous, the water-shod between $\mathrm{E}$. and W. rivers lying on its W., ancl the Catawba rising here. Soil mostly fertile, adapted especially to grazing and producing fine crops of wheat and corn, with some cotton and tobacco. It has much water-power and flourishing manufactures, This is in the gold region, and the production has been considerable. Farmas 508; manuf. 29 ; dwell. 860 , and pop.-wh. 4,777 , fir. col. 207, sl. 1,262-total 6,246. Capital: Marioz.

M'Dowel., p. o., Highland co., Virg.: 123 m. N. W. Richmond.

M.Etaver Fort, p. o, Huntington co., Penn. The Rebecea Blast Furnace, of 800 tons annual capacity, also a charcoal forge (of same name), which produces 200 tons of blooms annually, are located here.

M'Ewzin's Cross-Roads, p. o., Morrow co., Olio: $49 \mathrm{~m}$. N. by E. Columbus,

M•Eweysvilue, p. o., Northumberland co., Penn.: $55 \mathrm{~m}$. $\mathrm{X}$. IIarrisburg.

M'FARLAND's, p. O., Lunenburg co., Virg. : 57 m. S. W. Richmond.

M:Gamersville, p. o, Rockingham co., Virg.: $93 \mathrm{~m}$. T. W. Richmond.

$M^{*}$ GARY, p. o., Hancoek eo., $M l_{0}: 89 \mathrm{~m}$. N. W. Springfield. M'GeF's p. o., Polk co., Tex. : 169 m. E. by N. Austin City. M'GeE's BrtDGe, p. o., Yallabusha co., Miss. : $119 \mathrm{~m}, \mathrm{~N}$ by E. Jackson.

II-GineE's STOre, p. o., Jackson co., Otio: 63 m. S. by E. Columbus.

M.Grawrille, p. v., Cortlandt ro., $N$. $Y$.: on a branch of Tioughnioga r., $131 \mathrm{~m}$. W. Albany. Contains several churches, and a number of workshops and stores. The "Cortlandt County Express" (neutral), "Morning Star" (R. Meth.), and "Christian Contributor" (Baptist), are issued here. It is the seat of a college for the promiscuous edncacation of colored and white persons. 
M. Gregor's LıDrig, p. V., Clayton co., $I(t$. : in N. E. part of $\mathrm{co}_{\bullet}$, on W. bank Mississippi r., $91 \mathrm{~m}$. N. Iowa City.

M.Hargue's Mrtus, p. o, Knox co., $K y_{0}: 107$ m. S. E. Frankfort.

M.Haxr county, $\pi l$. Situate N. E., and contains 486 6q. m. Drained E. by Fox r, and its branches, and W. by Piskashau and Rush creeks, and $N$. branch of Kishwaukee r. affluents of Rock r. Surface undulating; soil mostly a aandy loam, and very productive. On Fox $r$. is much good timber; the W. mingled grove and prairie. Wheat, corn, osts, and potatoes yield well, and great numbers of cattle and hogs are raised. It has many ponds in the $\mathrm{E}$., and a sufficiepcy of water-power. Farms 1,950; manuf. 17; dwell 2,650, and pop.-wh. 14,977, fr. col. 2-total 14,979. Capital: Dorr (formerly Woodstock). Public Work: Galena and Chicago Union R. R., etc.

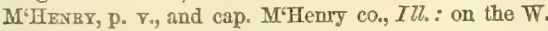
side of Fox r., 195 m. N. N. E. Springfleld. The country round about the $\mathrm{v}$. is excellent farming land.

M'Indor's Falrs, p. 0, Caledonia co., Verm.: on W. bank Connecticnt r., $27 \mathrm{~m}$. E. Montpelier, and at the head of navigation. The Connecticut and Passumpsic Rivers R. R. passes through the $\mathrm{F}$., $48 \mathrm{~m}$. from White river junction.

M'Istose county, Ga. Situate S. E. on the Atlautic, and contains $5 \pm 5 \mathrm{sq}$. m. Altamaha r. bounds it S., and S. Newport r. N., and drain it by their affluents. Sapelo r. flows into Sapelo Sound between them. Surface level, and much of it low and swampy; soil fertile generally, in parts exceed ingly rich. The $\mathrm{W}$. is a pine barren; on the coast are rery productive rice marshes. Sapelo I, which lies off shore little, is very fertile, as is the land between the barrens and coast, and produces Sea Island cotton largely. Rice is a very large and the chief crop. Cotton and corn are much less raised, but the former is very superior. Farms 117; manuf. 10 ; dwell. 283, and pop.-wh. $1,32 \pi$, fr. col. 72 , sl. 4,629-total 6,028. Capital: Darien.

M'Katg's Mrts, p. va, Columbiana con, Ohio: $121 \mathrm{~m}$. E. N. E. Columbus.

M.KAx, p. o., Ashland county, Ohio: 65 m. N. N. E. Columbus.

M'Kar, p. o., Dallas co., Ia.: 125 m. W. Iowa City.

M.Kear county, Penn. Situate N. W., and containg $1,122 \mathrm{sq}$. $m$. Drained by Alleghany $r$. and its branches, Potato and Kenjua creeks, and affluents of W. branch of the Susquehanna. Surface rough and hilly; soil generally good, and adapted to grazing. Wheat, corn, oats, and potatoes are raised in small quantities. Cattle and sheep are Iargely reared, and live-stock, butter, and wool exported. It has abundant water-power, and timber, and valuable manufactories of salt, iron, lumber, etc. It abounds in coal, Iron ore, and salt-springs. Farms 246; manuf. 40; dwell. 953, and pop.-Wh. 5,21s, fr. col, 36--total 5,254. Capital: Smithport.

M'KEAN, t. and p. v., Erie co., Penn.: 205 m. N. W. Harrisburg, and $9 \mathrm{~m}$. S. Erie. Drained by Elk cr. Surface varied, in parts hilly; soil sandy loam. It has several mills. Pop. of t. 2,809 .

M'Keansburg, p. v., Sehuylkill co., Penn. Situate about $1 \frac{1}{2} \mathrm{~m}$. W. Little Schuylkill river and railroad, $58 \mathrm{~m}$. N. E. Harrisburg.

M-Kran's Otd Stard, p. o, Westmoreland co., Penn.: $135 \mathrm{~m}$. W. Harrisburg.

M.KeE's HaJF Falls, p. o., Union co., Penn.: 41 m. N. Harrisburg.

M.KeE's Port, p. v., Alleghany co., Penn.: on the E. side of Monongahela r., near the mouth of the Youghiogeny r. $155 \mathrm{~m}$. W. by N. Harrisburg. It contains a church, several stores, and 6 schools with 310 scholars. Pop, 1,392.

M'Krituer county, Tex. Situate S. W., and contains 3,959

sq. $m$. It lies between the Neuces and Grand rivers, the latter its W. boundary for 150 miles, the former its E. for 120. San Felipe, Pedro, Mavericks, Zoquette, Las Morus, Elm, and San Arnurosio creeks flow into the Grand and
Turkey, Elm, Live Oak, Mustang, and St. Mary's creekg, into the Neuces. Surface much varied; in the N. mount ain ridges and broken intervals, in the $\mathrm{S}$. plains of great extent, with ravines and high hills in parts; soil various; on the large streams fertile, producing corn abundantly, with most of the grains, fruits, and vegetables. A large part of the co. is but moderately productive, and used mostly to pasture horses and cattle, which thrive with little or no attention in this mild climate. The Grande is here a stream of good size, but too swift for navigation; the Nezces is smaller; the banks of both are generally well wooded, as are their branches. The parts back of the rivers are somewhat deficient in timber. This large tract is recovering the population it has lost in long border strifes, but is as yet sparsely settled. Capital: Fort Dunean. Unorganized in 1850 .

M'Krnler, p. v., Marengo county, Ala. : 71 m. W. by $\mathrm{s}$. Montgomery.

M'Kirnex, p. v., and cap. Collins co., Tex. Situate contrally between Ten Mile and Honey creeks, $215 \mathrm{~m}$. N. by E。 Austin City.

M'Kinstry's Milus, p. o., Carroll county, $7 r d .: 37$ m. E Annapolis.

M'KissaCk's Grove, p. o., Fremont county, $I a_{0}: 219$ m. W. 8. W. Iowa City.

M'Lains Milis, p. v., Waldo co, Me : on the St. George r., 81 m. E. by. S. Augusta.

M.LEAN county, Ill. Situate N. E. centre, and contains 1,061 sq. m. Drained by Mackinau, Kickapoo, and Sugar creeks, affluents of the Illinois. Surface elevated and undulating; soil very fertile. A large share is prairie, dotted with groves of excellent timber. Its streams afford good mill-seats, and limestone and coal are found in parts. Corn is the staple, on which pork is largely fatted for export. Wheat is a good crop, and the grazing very fine. Farms 916 ; marruf. 8 ; dwell. 1,851 , and pop.-wh. 10,121, fr. col 42-total 10,163. Capital: Bloomington. Public Works: Mlinois Central R. R.; Chicago and Mississippi R. R. Peoria and Oquawka R. R., ete.

M'LeaN, p. v., Tompkins co., $\mathcal{N}_{\text {. }} \bar{Y}$.: $133 \mathrm{~m}$. W. Albany on Fall cr, which affords gxeat water-power. It has severa manufactories, mills, and workshops, 60 dwellings, and about 400 inhabitants.

M'Lfiansgorouge, p. $\mathrm{v}$, and cap. IIamilton co., $M l$. $133 \mathrm{~m}$. S. S. E. Springfleld. It contains a court-house and jail, ete.

M'Leav's Store, p. o., Tippah co., Miss.: 167 m. N. E. Jackson.

M'Leansville, p. o., Jackson co., Tenn. : 59 m. E. by N. Nashville.

M'Lemaresville, p. v., Carroll co., Tenn. : $97 \mathrm{~m}$. W.by S. Nashville.

M'LeOD's, p. v., Greene county, MFiss.: on W. side of Pascagoula $\mathbf{r}, 101 \mathrm{~m}$. \$. E. Jackson.

M'Manus, p. o., Greene co., Miss. : 99 m. S. E. Jackson. M'MAтн', 8 , p. Y., Tuscaloosa co, $A Z \alpha_{0}$ : on the Tuscaloosa and Ellington post-road, $75 \mathrm{~m}$. N. W. Montgomery.

MMenis's, p. v., Fairfield dist., S. Car.: 23 m. N. N. W. Columbia.

M'Muluaiv's, p. o., Panola county, Tero.: 247 m. N. E. Austin City.

M'Millen's Grove, p. 0., Du Page co., $T l l:$ : $161 \mathrm{~m}$. N. N. E. Springfield, ana $31 \mathrm{~m}$. W. $\frac{1}{2}$ N. Chieago.

M'Murn county, Tenn. Situate 8. E., and contains 508 sq. m. Bounded N. W. by the Tennessee, S. W. by its branch, the Hiwassee, and drained by its affluents. Surface varied, with broken land and hills $E$, and $S_{\text {., which send }}$ down many streams, affording excellent water-power; soil generally fertile, and good pasture. Corn is the leading crop, and wheat yields largely. Pork and beef are exported, and it has very fine horses. Its facilities for manufacturing are well improved by many extensive and flourishing es tablishments that produce cotton and woolen goods, flour, 
leather, lumber, liquors, oil, etc. Farms 1,683; manuf. 115; dwell. 2,040 ; and pop.-wh. 12,286, fr. col. 52, sl. 1,56s-total 13,906. Capital: Athens. Public Works: East Tennessee and Georgia R. R.; Chattanooga and Charleston Railroad, ete.

M.MLvarnle, p. v., and cap. Warren co., Tenn. : on N. side Barren Fork, which flows into the Caney, a fork of the Cumberland r., $61 \mathrm{~m}$. S. E. Frankfort. The M'Minnville and Manchester R. Ro, a branch of the Nashville and Chattanooga $\mathrm{R}_{\text {. }} \mathrm{R}$., comes up to the village from Tullahoma, and it is the $S$. terminus of the Danville and M.Minnville $R$. $R$. Pop. about 600 .

M'NAIRT county, Tern. Situate S. W., and contains 871 sq. m, Drained W. by heads of Big Hatchie r., and E. by White Oak, Mud, Snake, and Owl creeks of the Tennessee. Surface moderately uneven; soil of good fertility. Corn, wheat, and tobacco are leading crops. Pork is a heavy export. It has good mill-streams, and some manufactures of much importance. Farms 1,379; manuf. 33; dwell. 1,395, and pop.-wh. 11,447, fr. col. 24, sl. 1,893-total 12,864. Capital: Purdy. Public Works: Memphis and Charleston Railiroad.

M:Nutr, p. O., Sunflower co., Miss.: $93 \mathrm{~m} . \mathrm{N}$. by W. Jackson.

M'RaE's Mrils, p. 0., Montgomery co., N. Car.: $71 \mathrm{~m}$. S. W. Raleigh.

M'RAE's Store, p. o., Telfair co., Ga. : near a tributary of the Altamaha r., $85 \mathrm{~m}$. S. by E. Milledgeville.

M'Sherristown, p. v., Adams co., Penn.: in the S. E. part of the co., $30 \mathrm{~m}$. S. by W. Harrisburg.

M'Vertown, p. v., Mifflin co., Penn.: on the W. side of the Juniata r., and on the line of the E. division of the Pennsylvania R. R, 14 miles S. W. Lewiston, and 49 miles T. N. W. Harrisburg.

M.Wuluamstown, p. o., Chester co., Penn.: $61 \mathrm{~m}$. S. E. Harrisburg.

Mabiettsville, p. o., Dutchess county, $N . Y_{0}: 63 \mathrm{~m} . \mathrm{S}$. Albany.

MABEE"s, p. O., Jackson co., Otio: 70 m. S. E. Columbus, Macedon, t. and p. F., Wayne co., N. Y.:190 m. W. by N. Albany. Drained by Mud cr. Surface uneven; soil very fertile, The Erie Canal passes through the centre of the $t$. It has a number of mills, ete. Pop. of t. 2,384.

MACEDON, p. O., Mercer county, Ohio: $97 \mathrm{~m}$. W. N. W. Columbus.

Macedon Cartre, p. o., Wayne co., $N . Y .:$ in centre of Macedon t., $193 \mathrm{~m}$. W. by N. Albany.

Macedonia, p. 0., Montgomery co., N. Car.: $71 \mathrm{~m}$. S. W. Raleigh.

Macedonta, sta., Summit co., Orio: on the Cleveland and Pittsburg R. R., 20 m. S. E. Cleveland.

Macedoria, p. v., Carroll co., Tenns: on a tributary of Obion r., in N. part of $\mathrm{co}_{\text {., }} 95 \mathrm{~m}$. W. Frankfort.

MLACedonia, p. o., Pottowotamie co., Ia. ; $203 \mathrm{~m}$. W. by S. Iowa City.

MACE's, stan, Middlesex co., Mrass. : on the Lowell and Lamrence R. R, $113 \mathrm{~m}$. W. Lawrence.

Mscilis, to, p. V., port of entry, and cap. Washington co., Me.: $123 \mathrm{~m}$. E. N. E. Augusta. Drained by the Machias $\mathrm{r}$. which passes through the t., and a number of small lakes in the X. E. part, which ennnect with the r. by a small creek. Surface varied; soil good, with much timber land. The $\mathrm{v}$, is situate un the Machias r., near its month, and contains the usual number of public buildings. It has a fine harbor, admitting vessels of 250 tons to within a very short distance of the place. It is the seat of numerous mills, and carries on the lumber trade and fisheries. The $r$. was first settled in 1762 , incorporated in 1784 , and was the first corporate town between Penobseot and St. Croix rivers. It is now an interesting and flourishing place. Whitneyville is the name of a $\mathrm{Y}$, and $\mathrm{p} . \mathrm{O}$. in the $\mathrm{N} . \mathrm{W}$. of the town, from which to Machias Port, a distance of $9 \mathrm{~m}$., the Franklin R. R. extends. Pop. of t. 1,590
Macuids, to and p. v., Cattaraugus county, N. Y.: $225 \mathrm{~m}$ W. by S. Albany. Drained by outlet of Lime Lake, which empties into Cattaraugus cr., and other small streams flowing into Nine Mile cr. Surface elevated, but even or table land; soil fertile and adapted to grazing. There are in the $t$ several stores and mills. The v. is situate in N. E. part of t. near Lime Lake, and contains several stores, mills, ete., and about 45 dwellings. Pop. of t. 1,342 .

Machlas river, Me. : rises in two main streams, which originate in small lakes in Washington co., and unite at Machias Port, in their courses affording extensive mill. power. The bay of the same name lies between Machias Port and Chester, and is $10 \mathrm{~m}$. long, and from 4 to 5 wide at its mouth, and contains several coves, harbors, and islands

Macrias Porí, to and p. vo, Washington co, Me $:$ at the mouth of Machias $\mathrm{r}_{n}, 3 . \mathrm{m}$. S. of Machias, $123 \mathrm{~m}$. E. N. E. Augusta. It is a port of entry, having an excellent harbor for vessels of all classes. The fishing and lumber trade is carried on to a great extent, and considerable navigation in coasting. It has several mills and considerable trade in lumber. Pop. 1,266.

Mackesviele, p. o., Clark county, Miss.: $85 \mathrm{~m}$. E. by S. Jacksonville.

Mackivac, p. v., and eap. Michilimackinac co., Mich.: $219 \mathrm{~m}$. N. Lansing. Situated or S. side of an island of same name, $4 \mathrm{~m}$. N. the W. extremity of Bois Blanc Island, in Lake Huron. Fort Mackinac, on an eminence commanding the $\mathrm{v}$. and surrounding coast, is a U. S. military post. The harbor is very fine and secure, capable of accom. modating some 200 vessels. Furs and fish are the materials of the chief traffic, the former quite extensive. There is a court-house and several dwellings here.

MaCKINAW, p. $\nabla_{\bullet}$, Tazewell county, $I l l .: 53 \mathrm{~m} . \mathbf{N}$. by E. Springfield. The $\mathrm{v}$. is situated on and surrounded by fine prairie land, near Mackinaw river.

M $\Delta$ CIINAW creek, $I l_{0}$ : an excellent mill-stream, falling into the Illinois $3 \mathrm{~m}$. below Pekin. It has rich bottoms, but the bluffs have a thin and poor soil.

M $\triangle$ Chsiburg, p. o., Giles county, Firg.: $171 \mathrm{~m} . \mathrm{W} . \frac{7}{2} \mathrm{~S}$. Richmond.

Mack's Place, p. 0., St. Clair co., Mich. : 95 m. E. by N. Lansing.

MaCKSVILLE, p. v., Randolph co., Ind: : on the W. Fork of White r., $59 \mathrm{~m}$. N. E. Indianapolis,

Mackville, p. v., Washington co., Ky.: in E. part of eo., $31 \mathrm{~m}$. S. by T. Frankfort.

Macomb county, Mich. Situate S. E., and contains $459 \mathrm{sq}$. $\mathrm{m}$. Drained principally by Clinton river and its branches, S., Red r., and N. E. fork, N. branch and midide branch flowing into Lake St. Clair, its S. E. boundary. Surface E. mostly level, W, rolling and somewhat broken; soil generally very fertile, adapted particularly to grass and wheat. The $\mathrm{E}$. is heavily timbered, and ship building is carried on extensively near the lake. The W. is mostly openings and prairie. Most of the grains produce well, and fine dairies are kept. It has excellent water-power and rapidly increasing mauufactures. Valuable salt springs are found, and a fine clay for pottery. Farms 1,277 ; manuf. 65 ; dwell. 2,666, and pop.-wh. 15,516, fr. col. 14-total 15,580. lpitell: Mount Clemens.

MAcovs, p. v., and cap. M'Donough county, Ill.: near Downing Fork, a branch of Crooked creek, $69 \mathrm{~m} . \mathrm{N}$. W* Springfield. It contains a court-house, a few stores, and about 200 inhabitants. The $\mathrm{v}$, is situate on a fertile prairie MAcomB, t. and p. 0., Macomb county, Mich.: $81 \mathrm{~m}$. E. Lansing. Drained by Clinton $r$ and Middle and Partridge, two of its branches. Surface gently undulating; soil rich loam, well adapted to grain. The rivers afford excellent water-power. There are several grist and saw mills in the town. Pop. 757.

Macoms, p. o., St. Lawrence co., N. $Y_{0}: 143$ m. N. W. Albany.

Macon county, Ala. Situate S. E., and contains 983 sq. m. 
Drained by Tallapoosa river and its branches, Ufawpee, Callebee, Crepia, and Oakfuskee creeks. Surface moderately uneven: soil of arerage fertility. Corn and cotton are the leading products. It has good mill-seats and plenty of fine timber. Farms 1,208; manuf. 19; dwell. 1,849, and pop. wh. 11,280, fr. col. 22, sl. 15,596-total 26,398. Capital: Tuskegee. Prbblic Works: Montgomery and West Point R. R.; Girard and Mobile R. R., etc.

Macor county, $G a$. Situate S.W. centrally, and contains s73 sq. m. Intersected by Flint river," and drained by its branches, N. and S. Whitewater and Beaver creeks. Surface uneven; soil very productive. Cotton is the staple, and the crop very large. Corn is an excellent crop, and very large numbers of eattle and swine are fatted. Farms 419 ; manuf. 0 ; dwell, 679 , and pop.-wh. 4,090, fr. col. 1 , sl. 2,961-total 7,052 . Capital: Lanier. Public Works: Muscogee R. R.; South Western R. R.

Nacos county, $M l$. Situate near centre, and contains 469 sq. $\mathrm{m}$. Sangamon $\mathrm{r}$. passes $\mathrm{W}$. through the middle, and with its branches drains the co. Surface undulating or level; soil generally fertile. Much of the co. is prairie, but there is some good timber. Corn is the chief, and wheat a good crop. Pork is a large export, and the pastures are excellent. It has not much water-power. Farms 487; manuf. 17; dwell. 693, and pop.-wh. 3,98s, fr. col. 0,-total 8,988. Capitat: Decatur. Public Works: Illinois Central R. R. ; Sangamon and Morgan R. R. ; and extensions to Terre Haute and Covington, etc.

MAcon county, Mo. Situate N. E., and contains 828 sq. m. Drained by Wolf er., Chariton and E. Chariton rivers of the Missouri, and N. and S. forks of Salt river of the Mississippi. Surface moderately elevated and mostly even; soil very fertile and fine, adapted to grazing. Corn is the leading crop. Tobacco is considerably raised. Mast is abundant; cattle and sheep are largely reared, and pork is a heavy export. It is well furnished with timber and water-power. Farms 711 ; manuf. 8 ; dwell. 1,079, and pop.-wh. 6,262, fr. col. 0, sl. 303-total 6,565. Capital: Bloomington.

Mucon county, N. Car. Situate W., and contains 776 sq. m. Drained by Tennessee r, and its branch, Tuckaseege r. Surface elevated and in parts mountainous, with many broad and fertile valleys. Corn is the staple; the other grains are not extensively grown, and the $c_{0}$. is better adapted to grazing. It has fine mill-streams and numerous small manufactories. Iron ore is found. Farms 631; manuf. 18; dwell, 986, and pop.-wh. 5,613, fr. col. 106, s1. 549, Indians 121-total 6,389. Capital: Franklin.

Maros county, Tenn. Situate N. middle, and contains 244 sq. m. Drained by branches of Big Barren r, on the N.; on the S. by branches of Cumberiand r. Surface somewhat hilly; soil very fertile. Corn, wheat, and tobacco are the staples. Pork is fatted and exported largely. It has good mill-sites. Farmos 782; manuf. 3; dwell. 1,044, and pop.-wh. 6,137, fr. col.45, sl. 766-total 6,918. Capital: Lafayette.

MAcor, p. v., Marengo county, Ala. : near E. side Black Warrior r., $83 \mathrm{~m}$. W. $\frac{1}{2} \mathrm{~N}$. Montgomery.

MAcoN, city, and cap. Bibb con, Ga.: on the W. side of the Oemulgee r., at the head of steamboat navigation, $29 \mathrm{~m}$. 8. W. Milledgeville, at the junction of the Central (Georgia) R. R. with the Macon and Western and Bouth Western R. R. which connect it with Savannah, Augusta, and Charleston. A bridge 300 feet in length affords communication with the opposite shore. A number of steamboats and other craft are employed on the river chiefly in carrying cotton, of which a large amount is shipped from here. From a mere village (in 1822) Macon has risen to be quite an important commer cial reprit. Ther: is now a fine court-house and jail, markethouse, and several churches, besides foreign commission houses, printing offices, stores, lumber yards, and grist mills. The "Journal and Messenger" (whig), "Georgia Telegraph" (dem.), "Georgia Citizen" (dem.), and "Southern Tribune," weekly, and "Reformer" (med.), monthly issues, are published here. It is the site of the Wesleyan Female College, founded in 1839, having (in 1850) a president, 8 professors, 156 alumni, and 198 students. This institution is said to have been the first female college founded in the United States. Pop. 4,95\%.

Macon, p. v., and cap. Noxubee co., Jfiss.: on Noxubee r., $107 \mathrm{~m}$. N. E. Jackson. The "Planter"s Adrocate" (neut.), a weekly issue, is published here.

Macon, t. and p. 0., Lenawee co., Mich. : 57 m. 8. by E. Lansing. Drained by the Middle and South branches of Macon r. Surface somewhat hilly; soil black sandy loam, adapted to grass, corn, oats, and wheat. Ridgeway is the name of a $\mathrm{v}$. in the $\mathrm{S}$. W. part of the town. In the t. there are some saw-mills. Pop. of t. 1,030 .

MAOON, p. o., Fayette co., Tenn. : on a branch of Wolf cr., $163 \mathrm{~m} . \mathrm{S}$. W. Nashville.

Macon, p. o., Powhattan co., Virg.: $27 \mathrm{~m}$. W. Richmond. Macon Depôt, p. v., Warren co., N. Car. : $51 \mathrm{~m}$. N. E. Raleigh. The Gaston and Raleigh R. R. passes it, $20 \mathrm{~m}$. from $G$ aston and $67 \mathrm{~m}$. (by railroad) from Raleigh.

Macoupin county, Ill. Situate S. W., and contains 864 sq. m. Drained by Apple, Otter, Macoupin, and Cahokia creeks, affluents of the Illinois and Mississippi. Surface undulating; soil highly productive-a large part is prairie and equally adapted to grass and grain. Corn and wheat are the staples, and heavy crops. Live-stock, beef, pork, and wool are the exports. It has fine water-power and rapidly increasing manufactures. Farms 1,183 ; manuf. 24 ; dwell, 2,037, and pop.-wh. 12,272, fr. col. 83-total 12,355. Capital: Carlinville. Public Works: Chicago and Mississippi R. R., etc.

MacoupIN river, $I l l$. : a considerable stream rising in the N. part of Montgomery county, and running $\mathbf{S}$. W. into Greene county to the Illinois, which it enters $26 \mathrm{~m}$. above its mouth. Its branches are Phill's, Dry Fork, Bear, and Hodge's creeks and Lake Fork. The country along its banks is generally fertile, suitably apportioned into timber and prairie.

M $\triangle$ CUngie, $t$, and p. o, Lehigh co., Penn。: 69 m. E. N.E. Harrisburg. Drained by tributaries of Lehigh r. Surface in most part level; soil fertile, and well cultivated. It is rich in minerals as in agricultural resources.

MADBURY, sta., Stratford co., N. Hamp.: on the line of Boston and Maine R. R. 7 m. S. Dover.

Maddenville, p. o., Hunlingdon co., Penn.: $59 \mathrm{~m}$. W. Harrisburg.

Maddox, p. o., Hanover co., Virg.: 23 m. N. Richmond. Madisox county, Ala. Situate on N. line, and contains 763 sq. m. Bounded S. by Tennessee r. and drained by its branches. Surface somewhat hilly; soil highly productive. Cotton is the staple, and in quantity produced this is about the first county in the State. Corn and wheat are also very large crops. It has much fine pasture, and exports a large amount of pork. The facilities for manufacturing are very fine and extensively improved. Farms 1,080 ; manuf. 92 ; dwell. 2,046, and pop.-wh. 11,937, fr. col. 164, sl, 14,326total 26,427. Capital: Huntsville. Public Works: Memphis and Charleston R. R.; Huntsville Canal, ete.

MADISON county, Ark. Situate N. W., and contains 963 sq. m. Drained by White $\mathbf{r}$, and its branches, Kings $\mathbf{r}$, and War Eagle and Richland creeks. Surface elevated, in the S. mountainous; soil productive, and well adapted to grass. Corn is the leading cereal. Other grains and tobaceo do well. Hogs are fatted largely. It has abundant timber and water-power, and is rich in galena or lead ore. Farms 660 ; manuf. 12 ; dwell. 843 , and pop. -wh. 4,659, fr. col. 0 , sl. 164-total 5,823. Capital: Huntsville.

MADIsON county, Flor. Situate N. middle, and contains 2,946 sq. m. Bounded E. by the Suwanee and W. by Aucilla (or Ocilla) r., and has a few creeks flowing into the Gulf. Surface even or rolling; soil very fertile S. E., middle poor, and N. and W. excellent. Cotton and corn are leading crops, It has some fine sugar lands, and swamps 
well fitted for rice growing. Timber is abundant, pine, cypress, and cedar. The Gulf is its S. W. boundary, and markets are eonvenient. Farms 262 ; manuf. 4 ; dwell. 498, and op.-wh. 2,802, fr. col. 0, sl. 2,68s-total 5,490. Capital: Madison.

Mudrson connty, $\mathrm{Ga}$. Situate N. E., and contains 272 sq. m. Drained by Huđson's and South forks, and Beaver Dam cr, of Broad r., a branch of the Savannah. Surface elevated and somewhat hilly; soil of average fertility. Cotton is grown largely for the region, and corn is the staple grain. Other crops are not large, Grazing is the chief use of much of the county. Mill-streams are plenty, and valuable mineral springs are found. Farms 404 ; manuf. 3 ; dwell. 692, and pop.-wh. 3,767 , fr. col. 3 , sl. 1,933-total 5,703. Crpital:Danielsville.

Madison county, $I l l$. Situate S. W. on the Mississippi, and contains 728 sq. m. Drained by Wood $\mathrm{r}$, and Cahokia cr. of the Mississippi, and silver er. and its E. fork of the Kaskaskia. Surface on the Mississippi low, and in places marshy, but of exceeding fertility; this is separated by bluffs from the back country, which is an elevated tableland, gently undulating; soil very rich. The W. parts have excellent timber in abundance; the $\mathrm{E}$. is mostly prairie, with wood on the streams. The principal crop is corn. Wheat, oats, and potatoes produce good crops, and the pastures are very fine. Cattle, sheep, and particularly swine, are reared largely. Corn, beef, pork, horses, and lumber are heavy exports. Coal, limestone, and freestone are abundant, the last a fine building and monumental material, and excellent water cement is made. It lies opposite the mouth of the Missouri, and has very superior advantages for commeroe and manufactures, the last are very large and important. Farms 1,367; manuf. 182; dwell. 3,490, and pop.-wh. 19,990, fr. col. 446-total 20,436. Capital: Edwardsville. Public Works: Ohio and Mississippi R. R.; Mississippi and Atlantic R. R.; Terre Haute and Aiton R. R. ; Chicago and Mississippi R. R., etc.

Madisox county, Ind. Situate centrally, and contains 370 sq. m. Drained by W. fork of White r., and Pipe, Killbuck, Fall, and Lick creeks. Surface level or undulating, with some wet prairies and a few hills; soils various, generally clayey loam, mixed with sand, and very productive. Wheat and corn are raised largely, and much stock fatted. It has excellent mill-sites and extensive manufactures, and was originally well timbered. Limestone and marble abound. Farms 1,494; manuf. 67 ; dwell. 2,159 , and pop.wh. 12,358, fr. col, 17-total 12,375. Capital: Anderson. Public Works: Indianapolis and Bellefontaine R. R. ; Richmond and Neweastle R. R.; Logansport R. R., etc.

Madison county, $\mathrm{Ia}$, Situate $\mathrm{S}$. Wo, and contains 576 sq. m. Drained by North and Middle rivers, and Prairic branch, affluents of the Des Moines. Surface rolling, and soil fertile, adapted to grazing. It has abundant timber and rvater-power, with a sparse population as ret. Farms 58 ; manuf. 0 ; dwell. 180 , and pop.-wh. 1,179 , fr. col. 0 -total 1,179. Capitur: Tinterset.

Madsox county, $F y$. Situate E centrally, and montams $45 S$ घq. m. Bounded N. and N. E. by the Kentucky drained by its branches, Paint Lick, Silver, Muddr, and Drowing creeks, and S. by affluents of the Cumberland. Surface considerably broken; soil very productive. Corn is the staple; rye, wheat, and tobacco yield well. Shcep are reared in large numbers, and pork is a very heavy export. Fine horses for the Eastern markets are raised here. Its mill-seats are numerous and extensively occupied. Farms 1,1S5; manuf. 39 ; dwell. 1,817, and pop.-wh. 10,270, fr. col. 64, sl. 5,393-total 15,727. Capital: Richmond. Public Works: Knoxville and Covington R. R., etc.

MADrsor parish, $L a$. Situate N. E., and contains 656 8q. m. Bounded E. by the Mississippi and W. by Bayou Macon, and drained by Tensas r., and Walnut, Roundaway, and Vidal bayoux. Surface level, in parts low and marshy; Boil, where tillable, exceedingly rich. Cotton is the almost exclusive product. The plantations on the Mississippi are very large and profitable, and the cotton crop is enormous It is well timbered and has some water-power. Farms 218; manuf. 24; dwell. 448, and pop-wh. 1,416, fit. col. 4, sl. 7,353-total 8,773. Capital: Richmond.

Madisor county, Miss. Situate W. centrally, and contains 656 sq. m. Bounded W. by Big Black r., S. E. by Pearl r. and drained by their affluents. Surface moderately uneven soil exceedingly rich. Cotton is the great staple, and this county is one of the best in the State for cotton growing. It has also good pasturage, and rears large numbers of cattle and swine. Water-power is plenty, and markets very convenient. Farms 552; manuf. 10 ; dwell. 767, and pop.wh. 4,328, fr. col. 2, sl. 13,843-total 18,173. Capital: Canton, Public Works: New Orleans, Jackson, and Northern R. R. ; Mississippi Central R. R.

Madison county, Mo. Situate S. E., and contains 653 sq. m. Drained by St. François r. and Big, Castor, and Twelve Mile creeks. Surface considerably broken and hilly; soil of average fertility. Corn is the leading crop. Wheat, oats, and potatoes are grown in small quantities, Pork is the chief farming export. It has much good waterpower, and is exceedingly rich in lead, copper, and iron ores. In the $\mathrm{N}$. is Pilot Knob, an iron mountain 300 feet high, where ore containing 80 per cent. of pure metal is found in huge masses of several tons weight. Farms 515; manuf. 19; dwell. 878, and pop.-wh. 5,278, fr. col. 29, sl. 696-total 6,003. Capital: Fredericktown.

Madison county, $N . Y$. Situate centrally, and contains $582 \mathrm{sq} . \mathrm{m}$. Drained $\mathrm{S}$. by Chenango $\mathbf{r}$. and $\mathrm{N}$. by Chittenango, Corrasalon, and Canaseraga rivers flowing into Oneida Lake, its N. W. boundary. Surface generally hilly, with a great swamp on the border of Oneida Lake, and the water shed of the Ontario and Susquehanna streams in the middle; soil fertile, very rich in the valleys $-\mathbb{N}$. better for grain, and $\mathrm{S}$. for grazing. It is well wooded with hemlock, maple, and beech. The dairies are large and superior, and sheep raising the leading business of a large part. Wool, hops, butter, cheese, maple sugar, and potash are large exports. Iron ore much used for castings, water lime, and gypsum are abundant. Sulphur and salt springs, and marl are extensively found. Water-power is abundant, and manufactures very largely carried on. Flour, leather, lumber, woolens, iron, and potash are the leading articles made. Farms 3,545 ; manuf. 404; dwell. 8,198, and pop.-wh. 42,783, fr. col. 289-total 43,072. Capital: Morrisville. Public Works: Erie Canal; Chenango Canal; Syracuse and Utica R. R.

Madrson county, Ohio. Situate W. centrally, and contains $420 \mathrm{sq} . \mathrm{m}$. Drained by Little and Big Darby and Deer creeks of Sciotor. Surface undulating or slightly broken; soil fertile, adapted to grass or grain. Corn and wheat are the staple crops. Grazing is the great business. Live-stock, beef, wool, butter, cheese, and pork are exported largely. It has very good mill-seats and flourishing manufactures. Farms $4 \pi 4$; manuf. 48 ; dwell. 1,742, and pop.-wh. 9,946, fr. col. 69-total 10,015. Capital: London. Public Works: Columbus and Xenia R. R.; Springfleld and London R. R. ; Columbus, Pequa, and Indiana R. P.., etc

MADISOX county, Tenn. Situate W., and contains 906 sq. m. Drained by branches of Big Hatchie and Forked Deer rivers, afluents of the Mississippi. Surface somewhat broken; soil very productive. Cotton and corn are the staples. Wheat and tobacco are successful crops. It has some water-power, which is well improved in making woolen and cotton goods, flour, leather, and iron. Farms 1,408; manuf. 49 ; dwell. 2,282 , and pop.-wh. 12,861, fr. col. 57, sl. 8,552-total 21,470. Capital: Jackson. Publio Workes: Mississippi Central R. R.

Madison county, Texo. A new county set off in Feb., 1753 , from portions of Walker, Grimes, and Leon counties. It extends from the Trinity to the Navasoto, and is drained by Bedais cr. and other affiuents of theso rivers.

Madron county, Virg. Situate N. E. centrally, and con- 
tains 261 sๆ. m. Dritined by Robertson, Wolf, and Conway rixurs, branches of the Rappahannock. Surface elevated, uneren. an! in parts mountainous, the Blue Ridge forming its $\pi$. boundary; soil geuerally good, with rich and beautiful ralleys. Corn and wheat are the staple cereals. Rye and tobaceo are successfully cultivated. It has fine pasture and grass land. Manufactures of flour, lumber, and woolen gonds are large and flourishing. Farms 513: manuf. 35; 1well. $52 \pi$, and pop.--wh. 4,45s, fr. col. 149, sl. 4,724-total 9,331. Capital: Madison.

Madisos, to and p. v., New Haven co., Conn.: $31 \mathrm{~m}$. S. Hartford. Bounded on the S. by Long Island Sound, and embraces Hammonasset Point. Drained by East and Neck rivers, Hammonasset r. forming its $\mathrm{E}$. boundary. Soil stony and hard to cultivate, but is made quite productive by plowing in velite fish, which are taken in the Sound in large quantities. This place has a small but secure harbor, and some navigation. There is a large quantity of lumber here, and ship-building is carried on to some extent. The $\mathrm{v}$ is situate near the coast, on the line of the New Haven and New Londun R. R., $20 \mathrm{~m}$. distant from New Haren and $30 \mathrm{~m}$. from New London. It contains some fine buildings. There are in the t. sevecal mills and some manufactories. Pop. of t. 2,063.

Madisox, p. v., and cap. Madison co., Flor.: 59 m. E. Tallahassee. Situate in the N. part of co., and contains a court-house, etc.

Madison, p. F., and eap. Morgan co., Ga. : 38 m. N.N.W. Milledgeville. Situate on a branch of the Oconee $\mathbf{r}$. and on the line of Georgia R. R., $104 \mathrm{~m}$. W. Angusta. It has a court-house, jail, 2 academies, a number of stores, and about 80 dwellings.

Madrson, p. o., city, and cap. Jefferson co., Ind.: on the N. side of the Ohio r., at the S. terminus of the Madison and Indianapolis R. R., $86 \mathrm{~m}$. S. by E. Indianapolis. It is the seat of the county court-house. The $v$. is finely laid out and neatly built, and there is much traffic, both wholesale and retail. There are a number of manufactories of various descriptions in active operation. The elevated ground in the rear of the v. affords a delightful prospect. The "Madison Courier" (whig), and "Republican Banner" (dem.), are issued here, Pop. of v. 7,800 .

Madisar, p. 0., Livingston co., Mrich.: $37 \mathrm{~m}$, W. by S. Lansing.

Mladisox, p. T., Monroe co., Mo.: on N. side of Elk fork of Salt r., $63 \mathrm{~m}$. N. Jefferson City.

Madison, p. v., Morris co., N. Jer.: 37 m. N. N. E. Trenton. The Morris and Essex R. R. passes through the village $28 \mathrm{~m}$. W. New York and $16 \mathrm{~m}$. S. E. Dover.

Madisor, t. and p. v., Madison co., N. $._{0}: 93 \mathrm{~m}$. W. by N. Albany. Surface bigh and rolling; soil rich and fertile. Drained by Chenango $\mathrm{r}$. S., and Oriskany cr. N., which empties into the Mohawk r. The Chenango Canal passes through the town. The village, incorporated in 1816, is situate on the Cherry Valley Turnpike, and contains several considerable factories and numerous stores, and about 600 inhabitants. Pop. of t. 2,405.

Madisor, p. 0., Rockingham co, N. Car.: $81 \mathrm{~m} . \mathrm{N}$. W. Paleigh.

MADISON, to and p. v., Lake co., Ohio $157 \mathrm{~m}$. N. E. Columbus. Drained by Grand r., which passes through it centrally. Surface rolling; soil fertile. The Cleveland and Erie R. R. passes through the $N$. part of town $40 \mathrm{~m}$. from Cleveland. Enionville and Centreville are villages on the post rrarl; on the R. R. is Madison Station. Population of t. 2,987 .

Madison, p. จ., Westmoreland co., Penn.: $143 \mathrm{~m}$. W. Harrisburg.

Madisos Court-House, p. v., and eap. Madison county, Virg. : in centre of county, $73 \mathrm{~m} . \mathrm{N} . \mathrm{W}$. Richmond. There are several stores and mills here, and a population of about 3\%o.

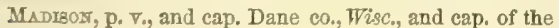

State of Wisconsin : on what are called the Four Lakes, atmost directly S. of the portage between Wisconsin and Fox rivers, $71 \mathrm{~m}$. W. Milwaukie. Madison occupies the isthmus between the Third and Fourth lakes. It is in the centre of the county, near the centre of the basin of the Catish. The land on which it is located rises abruptly from the shore of the Third Lake about 50 feet, and from thence ascends gradually until the centre of the Capitol Park is reached, about 70 feet above the lakes. From thence it descends gradually until near the Fourth Lake, when it rises with considerable abruptness about 75 feet, and then falls off boldly to the shore of the Fourth Lake-distance across being about three-fourths of a mile. Following the cardinal points, the ground descends every way from the Capitol, all the streets from the corners of the square terminating in the lakes, save the western, which slopes gradually about half a mile, and then rises until, at a distance of exactly one mile from the capitol, it attains an elevation of at least 125 feet. This is College Hill, the magnificent site of the Wisconsin University, founded in 1819. It is rapidly increasing in its population, buildings, and other improvements. A telegraph line connects with the lakes and the Mississippi There is excellent water-power, which is used in running some of the most extensive mills in the State. It contains several stores and workshops. There are three papers issued here, the "Wisconsin Express" (whig), "Wisconsin Argus" (dem.), "Wisconsin Democrat" (dem.) Pop. (in 1550) 1,871. The Milwaukie and Mississippi R. R. will probably intersect Madison.

Madrsonborodge, p. v., Alachua county, Flor.: $121 \mathrm{~m}$ E. S. E. Tallahassee.

Madison Centre, p. v., Somerset co., Me.; $29 \mathrm{~m} . \mathrm{N}$. Augusta, and near a beautiful pond, the outlet of which is at Skouhyau.

Madison Cross Roads, p. v., Madison co., Ala. : $169 \mathrm{~m}$. N. by W. Montgomery.

Madison Mruls, p. o., Madison co, Virg.: $75 \mathrm{~m}$. N. W. Richmond.

Madibon Springs, p. v., Madison eounty, Ga.: $83 \mathrm{~m} . \mathrm{N}$. Milledgeville, in N. part of the co., near Broad $r$. There is a chalybeate spring here which is beneficial in many complaints, and there is a fine hotel for the accommodation of visitors to the springs.

MadisonviLLE, p. v., and cap. Hopkins co, $K y_{v}$; situate on the E. side of Green r. (on an elevation), 169 m.W. S. W. Frankifurt. It contains a court-house and about 60 inhabitants.

MADrsonviLLE, p. v. and seaport, St. Tammany par., $L a$. on the N. bank of Lake Pontchartrain, and W. of Bogue Fallia, which empties itself at this point, $59 \mathrm{~m}$. E. Baton Rouge, and $29 \mathrm{~m}$. $\mathrm{N}$. New Orleans. It is an important place, and will be made the W. terminus of the line of railroad from Alabama toward New Orleans, to which city the connection will be by steamboat.

Madisonvilue, p. o., Madison co., Miss.: 21 m. N. by E. Jackson.

Madisonvilie, p. v., Ralls co., Mo.: on Spencer's cr., 71 m. N. E. Jefferson City,

Madisonville, p. v., Hamilton co., Ohio: 91 m. S. W. Columbus, $4 \mathrm{~m}$. N. of the Ohio river. It contains about 650 inhabitants.

Madisonrmle, p. v., and cap. Monroe co., Tenn.: $137 \mathrm{~m}$. S. E. Nashville.

MAD river, Ohio: a large branch of the Great Miami from the E., rising in Logan co, and after a course of $50 \mathrm{~m}$. terminates at Dayton. It has a rapid and broken current, and supplies an immense water-power.

M $\triangle D E I D$, t. and p. Os, Franklin co., MFe.: 49 m. N. W. Augusta. Drained by branches of Sandy river. Surface varied; in some parts mountainous, containing a part of Saddleback Mountain. Soil is excellent, well adapted to wheat, of which it yields a large quantity. Pop. of t. 404 . Madrid, to and p. V., St. Lawrence co., N. Y.: $161 \mathrm{~m}$ 
N. W. Albany. Drained by Grass river and several small creeks flowing into the St. Lawrence r., which bounds it on the N. W. The "Isle au Rapid Platt" belongs to the t. Surface undulating; soil of good quality, rich and productive. The t. contains several manufactories, mills, ete. in active operation. The $\mathbf{v}$, is situate on the line of the Northern Ogdensburg R. R., in S. part of town. The "True Democrat" (dem.) is issued here. Pop. of t. 4,856.

Magnouta, p. o., La Rue county, $K_{y}: 59$ m. S. W. Frankfort.

Magnolia, p. v., Putnam county, $m l_{\text {.: }} 91 \mathrm{~m}$. N. by E. Springfield. Situate on the S. boundary of the county, surrounded by prairie land.

Magnolis, t. and p. v., Rock county, Wisc.: $29 \mathrm{~m} . \mathrm{s}$. Madison. Drained in the $\mathrm{N}$. by a branch of Sugar r., and in the S. by Bass cr. Surface level; soil fertile. The v. is on the Janesville post-road. There are some mills and workshops in the t. Pop. 673.

Magnolia, p. o. and sta., Harford county, Md.: on the Philadelphia, Wilmington, and Baltimore R. R., 18 m. N. E. Baltimore, and $43 \mathrm{~m}$. N. N. E. Annapolis.

Magnolis, p. Y., Chautauque co., $N_{.}, Y_{*}:$ on W. side of Chautauque Lake, $303 \mathrm{~m}$. W. by \$. Albany.

Magnolta, p. v., Crawford county, Ind.: 103 m. S. 1 W. Indianapolis, $4 \mathrm{~m}$. N. Ohio river.

Magnolia, p. v., Stark co., Ohio: on the Tuscarawas r., $99 \mathrm{~m}$. N. E. Columbus. The Beaver Canal passes through the village.

Magnolit Sprivgs, p. o., Jasper county, Tex.: $227 \mathrm{~m}$.

E. by N. Austin City.

Mahala, p. o., Adams county, Ohio: 79 m. S. by W. Columbus.

Manavoy, p. v., Northumberland co., Penn.: on a tributary of the Susquehanna r., $33 \mathrm{~m}$. N. Harrisburg.

MAHASKa county, $I a$. Situate S.E. centrally, and contain 576 sq. m. Drained by Des Moines r, and N. and S. forks of Skunk r. Surface undulating; soils very fertile, equally adapted to grass and grain. Corn and wheat, cattle and pork, are the leading products. It has abundant waterpower and timber, with some rich prairie. Farms 480; manuf. 18; dwell. 981, and pop.-wh. 5,988, fr. col. 1-total 5,989. Capital: Oskaloosa.
Maromex, p. v., Champaign co., $I l l$ : on the $W$. side of the North Fork of Sangamon r., $67 \mathrm{~m}$.W. N.W. Springfleli. Magontag county, Ohio. Situate N. E., and contains 506 sq. m. Drained by Mahoning r. and its branches. Surface rolling and somewhat broken; soils highly productive and admirably adapted to grazing. Corn, wheat, and oats are the staple grains. Cattle and swine are fatted largely; the dairies are superior, and live-stock, beef, pork, and wool are heavy exports. Excellent water-power is abundant, and manufactures of woolens, leather, lumber, flour, etc, extensive; marl, common and water limestone, and iron ore are found. Farms 2,052; manuf. 105; dwell. 4,298, and pop.-Wh. 23,646, fr. col. 89-total 23,735. Capital: Canfield. Public Works: Pennsylvania and Ohio Canal; Cleveland and Mahoning R. R.; Ohio and Pennsylvania R. R., ete.

Manosivg, p. O., Stark county, Ohio: $95 \mathrm{~m}$. N. E. Columbus.

Manonivg, t. and p. o., Indiana county, Penn.: $125 \mathrm{~m}$. W. N. W. Harrisburg. Drained by Mahoning er. Surface uneven; soil loam, mixed with clay. Iron ore is found in the t. It has several distilleries and grist and saw mills.

Maнonivg river, Ohio and Penn: a large tributary of Beaver $r$., which it joins in Pennsylrania. The Pennsylvania and Ohio Canal follows the valley of the stream, and will also the Cleveland and Mahoning R. R.

Manopad, p. o., Oakland co., Mich.: 55 m. E. Lansing.

Maнорac, p. o., Putnam co., $N_{.} Y_{0}:$ near a lake of same name, $87 \mathrm{~m}$. S. Albany.

Mamen Creek, t. and p. 0, Berks co., Penn.: $101 \mathrm{~m}, \mathrm{E}$. Harrisburg. Drained by Schuylkill river and Maiden cr. Surface finely diversified; soil fertile. It contains several grist and saw mills.

MAIDFN Spring, p. $\nabla .$, Tazewell co., Firg.: on N. side of a fork of Clineh r., $235 \mathrm{~m}$. W. s. W. Richmond.

Mamstone, t. and p. Y., Essex co, Verm. : 53 m. N. E. Montpelier. Drained by branches of Connecticut river and Maidstone Lake, which has its outlet into Paul's stream. Surface undulating; soil fertile, and productive of grain. There are in the town several grist-mills, stores, and workshops. The village is one mile W. Connecticut r. Population of $\mathrm{t} .237$.

\section{THE STATE OF MAINE.}

MAINE, occupying a little less than one half the surface of New England, is of a long, irregular shape, extending between latitudes $43^{\circ}$ and $47^{\circ} 30^{\prime} \mathrm{N}$., and between longitudes $66^{\circ} 52^{\prime}$, and $71^{\circ} 06^{\prime} \mathrm{W}$. from Greenwich, or $5 \circ 56^{\prime}$ and $10^{\circ} 10^{\prime} \mathrm{E}$. from Washington. The boundaries of Maine* as established by the treaty of Washington, 1842, are the result of a controversy with Great Britain of a quarter of a century's standing, and one which came near involving the two countries in a war. By the treaty, the St. Croix, and a line running due north from a monument at its source to St. John's River form the boundary on the east. On the north the line follows the St. John's and St. Francis rivers to Lake Pohenagamook. On the north-west it follows the highlands from that lake in a south-west direction to the north-east corner of New Hampshire which State forms the greatest length of its west boundary. The Atlantic lies on the south. Within these limits the estimated area contains 80,000 square miles.

There are said to be as many islands on the coasts, and in the bays of Maine, as there are days in the year. Most of these are small, but many are of considerable size, fertile, and inhabited. The bays and inlets are proportionally numerons, and afford a series of excellent harbors. The length of the const in a straight line from- Kittery Point to Quoddy Head is about 225 miles, but following its windings, nearly 1,000 miles. The Isles of Shoals are seven in number, $†$ and lie about eight miles sonth-easterly from the mouth of the Piseataqua River. Four of them belong to Maine, and the three others to New Hampshire. These islands are little more than masses of rock, but at one time had 500 or 600 inhabitants,

\footnotetext{
* The following are the astronomical positicns of sereral important points on the line of the new boundary survey,

\begin{tabular}{|c|c|c|c|c|}
\hline & $\begin{array}{l}\text { I.at. N } \\
\text { D. s. } 8 \text {. }\end{array}$ & $\begin{array}{c}\text { Long. W. } \\
\text { D Is. s. }\end{array}$ & & $\begin{array}{l}\text { Lat. N. } \\
\text { D, s. B. }\end{array}$ \\
\hline Sh River, mouth of.. & & ... $6835 \pm 0$ & Pine Island of Seven Islands (St. Joln River). & $464653 \quad \ldots .69735$ \\
\hline irliels, \{urper block house \}...... & $40 \div 0$ o7 & $\ldots$ & L Lake (monument at outlet)...... & 472733 \\
\hline Fort Fairfield, (Inwer block house)............... & - & $\ldots .674942$ & Polienagmonk Lake (head of )............... & 473139. \\
\hline 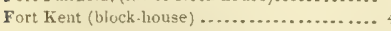 & 491509 & $\ldots .6 \times 3 ; 25$ & Saduleback Youn:ain ........................ & 452056 . \\
\hline (n............ & 450739 & $\ldots .674900$ & ument at source) ......... & 435637 \\
\hline Jolın River) ....... & 470520 & .... $6903 \quad 34$ & ond's Barn near m'th of) & 471057 \\
\hline Head o & 45 & $\ldots 713257$ & Taschereau's House ........................... & 454837 \\
\hline oulton (Lutel) & & $67+925$ & & \\
\hline
\end{tabular}

† The "Isles of Shouls" are seven in number, riz., Hog, Smutty. Nose, Star, Duck, White, Malaga, and Londonner Islands. The three frst constitute the town of Gossport, Y. Hamp., and the four latter the to nn of Isles of Shoals, Me. They were oriminally called Smith's Islands, having been discovered by the celebrated John $\Sigma_{m i}$ it in 1614 . 'The present population is 132-in Y. Hamp. 103, and in Maine 29.
} 


\section{MAINE.}

attracted thither by the superior advantages they afforded for the pursuit of the fisheries, and they became celebrated for their dried fish, known by the name of Isles of Shoal dun-fish, which were prepared by drying them slowly and carefully on the rocks. Their population in 1850 was 132. Casco Bay, a spacious basin between Cape Elizabeth and Cape Small Point, contains a great number of fine islands, among which Great Gebrag and Sebascodegan Islands are the largest. The shores of the bay afford several excellent harbors. Seguin Island, further east, is a noted landmark at the mouth of the river Kennebec. Parker's Island, on which is Georgetown, the island of Cape Newagen, and Jeremisquam, are large bodies of land betweeen the Kennebec and Damariscotta rivers, south of which are the Damariscove islands, a group of small but inhabited islets. Farther from the shore are Monhegan, St. George's, Matinic, and Matinieus islands. Monhegan was formerly famous for its fisheries. The Fox Island, Long Island, and Deer Island, are the principal islands in Penobseot Bay, which extends from White Head, on the west, to lle au Haut on the east, and runs up about 35 miles inland. But the largest island on the const is Mount Desert, containing about 60,000 acres. Several of its heights are conspicuous objects far off at sea, and some of them attain an elevation of from 1,500 to 1,500 feet. Farther east is Petit Menan, often corrupted to Titmenan, and at the entrance of Passamaquoddy Bay is Grand Menan, belonging to New Brunswick, to which province, also, Campobello and Deer Island, in that bay, are politically attached. Moose Islands belong to Maine.

The surface of the interior country beyond the coast region, which is somewhat flat and sandy, is, in general, pleasantly varied with hills and valleys. There is no connected ridge of mountains in the State, but the north-western part contains numerous detached elevations, which may be considered as "outliers" of the White Mountains, and from this section all the principal rivers descend in different directions. The Bald Mountain, to the west of Moosehead Lake, Katahdin Mountain, between the east and west branches of Penobseot River, Saddleback, Mt. Abraham, and Mit. Bigelow, between the Androseoggin and the Kennebec, and the Sugar Loaf Mountains at the head of the west branch of the Walloostook are thought to be the loftiest points. The highest point of land in the State is Mt. Katahdin, which rises 5,355 feet above the sea level.

It is estimated that one tenth part of the State is covered with water; and every portion is abundantly supplied with streams and rivulets which, for the most part, flow from or through lakes, and are copiously supplied from these reservoirs throughout the year. The rivers of Maine are characterized by numerous falls, which, while they impede the navigation of large craft, do not interrupt the descent of logs and rafts, and furnish excellent mill-seats. Along the coasts the tide-waters often penetrate far inland, filling natural channels, which take the name of rivers, but which are, in truth, arms of the sea. The whole of the northern part is drained by the constituents of St. John River-the St. Francis, and Madawaska from the north, and the Walloostook, Allagash, and Aroostook from the south. The great river of the southern section is the Penobscot, which collects its tribute of waters from the whole breadth of the State. Its western branch rises near the heads of the Chaudiere, and flows east, receiving in its course several streams from the vicinity of the sources of the Allagash and Walloostook, and passing through Chesuncook and Pemadumcook lakes below which it has a fall of 50 feet. Il receives the eastern or Seboois branch formed by confluents coming from the same tract which sends off the Aroostook to the north. The Mattawamkeag and the Piscataquis, its principal tributaries, then come in from opposite sides, and at Orono the river falls about 50 or 60 feet to the tide level. The tides at Bangor, 60 miles from the sea, and 30 from Belfast Bay, rise 15 feet, and the river is navigable for the largest vessels to that place, but navigation is closed four or five months in the year by ice. The total length of its course is about 350 miles. The Kennebec preserves a remarkable parallelism with the Penobscot, but drains a less extent of country. Its head stream, the Moose, rising in the highlands, from which issue the south-eastern branches of the Chaudière, flows east into Moosehead Lake, the outlet of which takes the name of Kennebec, and runs snuth to the sea. It is broken at Embden by the Carrituck Falls; at the mouth of Sandy River by the Norridgewock Falls; below Norridgewock by Skowhegan Falls, and at Waterville by Teconnet Falls. The tide flows up to Augusta, 50 miles from the sea, and small vessels and steamboats go up to that place, and its whole length is about 200 miles. Below Merry Meeting Bay, where it unites with the Androscoggin, it often has the name of Sagadahock. The Androscoggin runs in a winding course, much broken by falls from the north-west corner of the State, south through Moosetogmagunke and Umbago lakes, into New Hampshire, then turning east repasses into Maine, and pursues a south-easterly direction to Merry Meeting Bay. At Brunswick, a few miles from its month, are Pejepseot Falls, with a total descent of 50 feet, and higher up are Lewiston Falls, and Pennacook Falls in Rumford. The Magalloway, which flows into Lake Umbagog, is its principal tributary. The Dead River and Sebasticook are useful mill streams flowing into the Kennebec. The Srco, Union, and Machias, are small streams. The St. Croix, or Schoodic, which forms a part of the boundary toward New Brunswick, is formed by the confluence of two large branches, each issuing from a cluster of lakelets; the northern branch, called also the Cheputnatecook, is a rapid and broken stream, and there are several falls below the junction of the west branch. At Calais, 12 miles from its mouth, the tide rises 15 feet.

The lakes of Maine are so numerous, and some of them so extensive, as to form one of the characteristic fentures of the country. Some of them are remarkable for the picturesque beauties of their scenery, and many of them will be usefill channels of enmmunication whon their neighborhoods beeome more thickly peopled. In the north the Temiseouata discharges its waters into the Madawaska, and the Baamchenungamook and Pongokwahem are the reservoirs from which the Allagash is fed. In the centre are Moosehead Lake, the largest in the State, being about fifty miles in length, but very irregular-from five to fifteen miles in width, Chesuncook, twenty miles long, and Pemadumcook. The Moosetogmaguntic and Umbagog are on the western border, and the Schoodic, and the Upper Shoodic lakes on the eastern border. These are the largest and most conspicuous on the map, but there are hundreds of others, in every direction, giring rise to, and receiving streams of various magnitudes.

Maine is a country chiefly of primary rocks, with a large division of those that refer to the transition period, and toward New Brunswick it has an important region of the lower secondary formation. Everywhere it has alluvial and diluvial deposits, and vast igneous formations, not only in the interior, but forming a barrier against the ocean surge along a considerable part of an iminense sea-coast. Its mineral deposits are various, and extensively distributed throughout its limits. Iron ore of excellent quality is found in great abundance, and in the south-eastern district, between the Kennebec and the St. Croix, there are indications of the existence of bituminous coal. Marble, granite, and limestone, however, constitute the principal mineral products, and all are extensively quarried. Lime is abundant, particularly at Thomaston and Camden, where it is burnt in great quantities for exportation. Maine, indeed, supplies most of the States with this article Granite is chiefly found near Hallowrell, and is peculiarly well adapted for material in public buildings. It is abundant also in many nther parts. Hica, taleose, and other slates occur in extensive beds between the Kennebec and the St. John. 


\section{MAINE.}

Soapstone, sandstone, and brecciated rocks of many varieties are found; also jasper, including the beautiful greenstone trap and its varieties and porphyry. The trap.dykes are numerous and exceedingly distinct; they eut through most of the other rocks, and produce upon them most distinctly those peculiar effects which to a demonstration prove their igneous origin; while the diluvial deposits, the boulders and ruins, the diluvial furrows in the rocks, the sea-shells now adhering to and inherent in rocks, which once formed the sea-coast, although now elevated 26 feet above the water, a salt spring at Lubec, and many other interesting phenomena illustrate other parts of scientific geology. Maine is also sald to have its gold region, and of late some excitement has been produced among the inhabitants, by reports of successful mining, but it does not seem that any great amount of the mineral has been collected, nor is the estimate important enough to beguile the more wary from their usual occupations. There is no doubt, however, of its existence in the State. It is found on the streams that rise on the east side of the height of land, and flow east into the west branch of the Penobscot, and also in the tributaries of Moose River. The whole neighboring country is mountainous, and similar, in many respects, to the mining regions of other countries. The Chaudiere River, on the British side, is also said to yield the metal in considerable quantities.

The soils of this State are of various compost and fertility : near the sea the lands are sandy, and generally unsuited to the purposes of agriculture. In the more mountainous regions, though the soil is thin and not of the best quality, extensive tracts are found which might be used as grazing lands. The district between the Penobscot and Kennebec rivers, however, is eminently rich, fertile, and productive. That part of the State lying between the Penobscot and the Passamaquoddy, is what is called "White Pine Lanil"-the soil is moist and of considerable strength, and the principal natural growth is the white pine mixed with oak, white ash, and beech. At Wells and Searboro are several tracts of salt marsh.

Naine has a climate of extremes, but it is seldom so severe as to interrupt farm operations. Vegetation commences late, but it is rapid and vigorous. The season of growth extends from the middle of April to the middle of October, but it does not continue in its full force for more than three and a half months. The temperature ranges between $100^{\circ}$ above and 200 belowo gero, but the changes are seasonal, and seldom interfere with personal health. Near the coast the summers are tempered and rendered pleasant by the recurrence of sea breezes, and in the eastern districts the atmospherie temperature is modified by the fogs and vapors rising from the Gulf Stream which in these latitudes sweeps the shores. The frosts of winter are uninterrupted, and the lakes and rivers may be passed upon the ice from December to the beginning of April. The less hardy cereals frequently suffer from the early frosts.

The greater part of the surface of Maine is corered with dense forests of pine, oak, beech, birch, ete. White pine and spruce, when dressed into masts, boards, and shingles, are largely exported. There is also abundance of timber suitable for ship-building, and from the facilities with which it is procured, Maine has become the greatest ship-building State of the Union, and in this department of industry on an avcrage of years produces more tonnage than the three great States of Massachusetts, New York, and Pennsylvania together, or more than one-third that of the whole Union.

Of the aboriginal tribes that formerly luunted in the deep forests of Maine, but few now inhabit the country. There are about 500 still in the State; they live principally on the islands of the Penobscot River, which they own, and eajoy a cousiderable annuity secured to them by the government. There is also an Indian settlement on the western side of Passamaquoddy Bay. The present inhabitants are chiefly of British descent, and the greater portion of them the immediate descendants of the original colonists of New England. There are, however, large numbers of emigrants from other European countrics, but the propurtion of these elasses is by no means so great as in most of the other States. TLe colored races form but a small moiety of the people.

Maine is divided into 13 counties, the general statistics of which and the capitals of each, in 1850, were as follows :

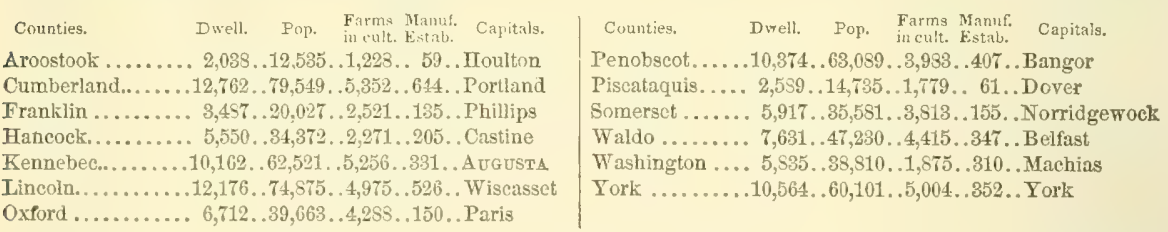

The whole number of dwellings in the State was, at the above date, 95,797 ; of families, 103,757 ; and of -inhabitants, 583,083; viz., whites 581,763-males 296,635, and females 285,125 ; free colored 1,325 -males 705 , and females 620 . Of the whole population there were, deaf and dumb-wh. 229, fr. col, 1-tital 230; blind-wh. 201, fr. col. 0-total 201; insane-wh. 583, fr. col. 8 -total 586, and idiotic-wh. 555, fr. col. 3-total 558. The number of free persons born in the United States was 551,129 , the number of forcign birth 31,4506 , and of birth unknown 584 ; native population originated as follows: Maine 517,117, N. Hamp. 13,509, Verm. 1,177, Mass. 16,535, R. I. 410, Conn. 460, N. Y. 973, N. J. 134, Penn. 201, Del. 36, Md. 113, Dist. of Col. 23, Virg. 94, N. Car. 27, S. Car. 31, Ga. 24, Flor. 24, Ala. 6, Miss. 16, La. 21, Tex. 9, Ark. 6, Tenn. 6, Ky. 14, Oh. 6S, Mieb. 19, Ind. 5, Ill. 38, Mo. 11, Ia. 1, Wisc. 10, Calif. 2, Territories 4. And the foreign population was composed of persons, from-England 1,949, Ireland 13,871, Scotland 532, Wales 60, Germany 290, France 143, Spain 18, Poriugal 5S, Belgium 2, Holland 12, Turkey 4, Italy 20, Austria 3, Switzerland 11, Russia 2, Denmark 47, Norway 12, Sweden 55, Prussia 27, China 3, Asia 5, Africa 5, British America 14,181, Mexico 2, Central America 0, South America 31, West Indies 61, Sandwich Islands 1, and other couniries, 51.

The following table will show the decennial progress of the population since the first census of the State taken by the United States authorities:

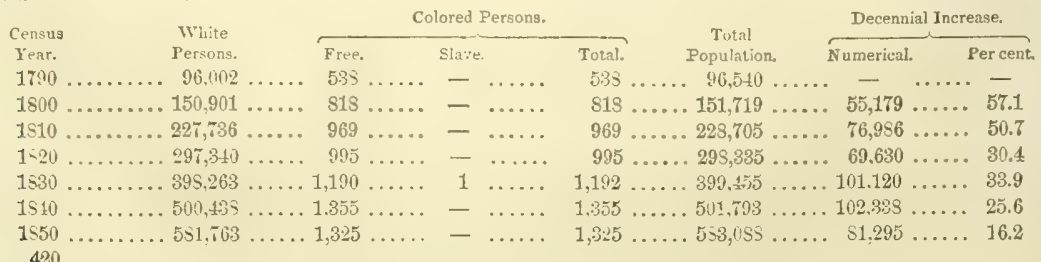




\section{MAINE,}

The statistical returns of the wealth and industry of Maine, as furnished by the census of 1st June, 1850, and other official documents referring to that period, are as follows:

Ocupried Lanils, ete.-Improved lands 2,039,596 acres, and unimproved lands 2,515,797 acres-valued in cash at $\$ 54,861,743$. Number of farms under cultivation, 46,760 ; value of farming implements and machinery, $\$ 2,281,554$.

Live-Stock:-Horses, 41,721; asses and mules, 55; milch cows, 133,556; working oxen, 83,898; other cattle, 125,890; sheep, 451,577 ; and swine, 54,598-total value of live-stock, $\$ 9,705,726$. In 1840, there were in the State-horses, mules, etc., 59,208 ; neat cattle of all descriptions, 327,255 ; sheep, 649,264 ; swine, 117,386, ete.

Grain Crops,-Wheat, 296,259 bushels; rye, 102,916 bushels; Indian corn, 1,750,056 bushels; oats, $2,181,087$ bushels: barley, 151,781 bushels; and buckwheat, 104,523 bushels. The same crops in 1840 amounted to-ivheat, 848,166 bushels; rye, 137,941 bushels; Indian corn, 950,52S bushels; oats, 1,076,409 bushels; barley, 355,161 bushels; and buckwheat, 51,513 bushels. Thus, while the wheat and barley crops have diminished about five-eighths, all the other crops have increased, and most of them have doubled in quantity.

Other Food Crops.--Pens and beans, 205,541 bushels; Irish potatoes, 3,436,040 bushels. In 1840, the production of the potato erop aroounted to $10,392,280$ bushels, or nearly three times that of 1850 .

Iriscellaneons Crops.-Hay, 755,8s9 (in 1840, 691,358) tons; clover-seed, 9,097 bushels; other grass-seed, 9,214 bushels; hops, 40,120 (in 1840, 36,910) pounds; flax, 17,0s1 pounds; flax-seed, 580 bushels ; maple sugar, 93,542 pounds; molasses, 3,167 gallons; bees wax and honey, 189,618 pounds; silk cocoons, 252 (in 1840, 211) pounds; wine, 724 gullons. The value of orchard products was $\$ 342,865$, and of market-garden products, $\$ 122,357$.

Products of Animals.-Wool, 1,364,034 (in 1840,1,465,551) pounds; butter, 9,248,811 pounds ; cheese, $2,434,454$ pounds ; and the value of animals slaughtered during the year was $\$ 1,646,773$.

Home-made Manufuctures for the year ending 1st June, 1850, were produced to the value of $\$ 513,599$.

Ifanufactures.-Aggregate capital invested, $\$ 00,000,000$; value of raw material, fuel, etc., consumed, $\$ 00,000,000$; arerage number of hands employed, 00,000 -males, 00,000 , and females, 0,000 ; monthly cost of labor, $\$ 000,000$-males $\$ 000,000$, and females $\$ 00,000$-total value of products for the year, $\$ 00,000,000$. The whole number of manufacturing establishments in the State, in 1850, producing to the value of $\$ 500$ and upward, was 3,682 ; and of these, 12 were cotton factories, 36 woolen factories, 213 tanneries, and 26 establisbments for the manufacture of iron-26 for castings, and 1 for pigiron.

The cotton manufactures employ a capital of $\$ 3,329,700$; value of all raw material consumed, $\$ 1,573,110$; monthly cost of labor-male $\$ 22,895$, and female $\$ 35,9 \tau 3$; value of entire products, $\$ 2.596,356$. In this department of manufactures 31,531 bales of cotton were used, and 2,921 tons of coal consumed; and the number of hands employed-males 780, and females 2,959 . The products for the year were $32,552,556$ yards of sheeting, etc.

The rcoolen manufactures employ a eapital of $\$ 467,600$; and use $1,438,434$ pounds of wool, valued at $\$ 495,940$; number of hands-males 31.0 , and females 314 ; monthly cost of labor-male $\$ 6,998$, and female $\$ 3,697$; value of entire products, $\$ 753,300$, and quantity of products, $1,023,020$ yards of cloth, and 1,200 pounds yarn.

In tanneries, the invested capital is $\$ 732,747$; value of hides and skins, $\$ 592,343$; hands employed-males, 787 , and females 3 ; monthly cost of labor-male $\$ 17,229$, and female $\$ 28$; skins tanned 31,350 , and sides of leather tanned 632,668 ; value of products, $\$ 1,620,636$.

In the manufacture of pig iron, the capital invested is $\$ 214,000$; value of all raw material, fuel, etc., $\$ 14,939$; hands cmployed-males, 71 ; monthly cost of labor, $\$ 1,562$; pig iron made, 1,484 tons; value of products, $\$ 36,616$. The material consumed consisted of 2,907 tons ore, and 213,970 bushels coke and charcoal.

In the manufacture of iron castings, the invested capital is $\$ 150,100$; value of raw material, fuel, etc., $\$ 112,570$; number of hands employed-males 243 , and females 1 ; average wages per month-to males $\$ 29$, and to females $\$ 5$ entire value of products $-3,691$ tons castings $-\$ 265,000$. The material and fuel consumed consisted of pig iron, 3,591 tons : old metal, 215 tons; mineral coal, 1,319 tons; and coke and charcoal, 14,000 bushels.

Besides the above, Maine has other considerable interests-numerous mills, and various mechanical establishments, ete., which, in the aggregate, make up a long list of industrial pursuits, for the profitable prosecution of which the fine streams of the country afford special facilities.

Commerce, Navigation, otc,-The total value of merchandise exported to foreign countries, from Maine, during the year ending 30 th January, 1850 , was $\$ 1,556,912$, of which $\$ 1,536, \$ 18$ was the value of domestic produce and manufactures, and $\$ 20,094$ that of foreign goods re-exported. The value of domestic merchandise, exported in American vessels, was $\$ 1,135,998$, and in foreign vessels $\$ 400,820$; and the value of foreign merchandise, re-exported in American vessels, was $\$ 14,264$, and in foreign vessels $\$ 5,530$. The total value of imports for the same year was $\$ 856,411$, of which $\$ 609,155$ was the value of goods carried in American vessels, and $\$ 247,256$ in foreign vessels. The following table exhibits the statistics of shipping employed in the foreign trade:

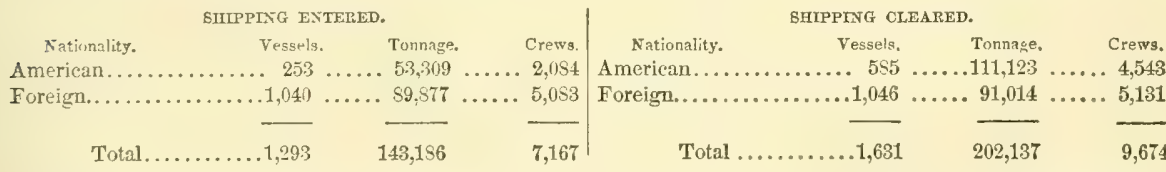

The tonnage cleared from Passamaquoddy district was 63,367 tons; from Machias, 5,145 tons; from Penobscot, 3,441 tons; from Waldoboro', 2.546 tons; frum Wiscasset, 4.509 tons; from Belfast, 11,950 tons; from Bath, 19,382 tons; from Bangor, 12,310 tons; from Portland, 77,615 tons; from Kennebuck, 1,843 tons ; and from Saco, 496 tons ; and the tonnage entered at Passamaquoddy was 58,458 tons; at Machias, 399 tons; at Penobseot, 4,140 tons; at Waldoboro', 492 tons; at Wiscasset, 1,025 tons; at Belfast, 820 tons; at Bath, 10,094 tons; at Bangor, 3,365 tons; at Portland, 64,195 tons, and at Saco, 213 tons. The shipping owned in the State, on the 30th of June, 1850, amounted to 501,421 tons; registeredpermanent, 193,955 tons, and temporary, 41,524 tons; enrolled and licensed-permanent, 259,845 tons, and temporary 499 tons: licensed (under 20 tons)-employed in coasting 904 tons, and in the cod fisheries 4,694 tons. Of the registered shipping 321 tons, and of the enrolled and licensed shipping 5,259 tons, were navigated by steam. The proportion of the eripl! m and licensed shipping employed-in coasting was 209,079 tons, in the cod fisheries 37,218 tons, and in the mackerel fisheries 12,016 tons. 
MAINE.

The statistics of the commerce of Maine for a series of years exhibit the following movements :

\begin{tabular}{|c|c|c|c|c|c|c|c|c|}
\hline Exports. & & Imports. & Exports. & & Imports. & Exports. & & Imports. \\
\hline$. \$ 1,105,081$ & $\ldots$ & & $\$ 805,5 \pi 3$ & $\ldots$ & 941,407 & $\$ 1,050,523$ & & + \\
\hline $1821 \ldots \ldots \ldots 1,040,848$ & $\ldots$. & 980,294 & . 981,443 & ... & $1,123,326$ & $1513 \ldots \ldots \ldots 6652,591$ & . & 2 \\
\hline $1822 \ldots \ldots \ldots 1,036,6 \pm 2$ & $\ldots$ & 943.765 & $.1,019, \$ 31$ & & $1,350,305$ & $1844 \ldots \ldots \ldots 1,176,135$ & & \\
\hline $1523 \ldots \ldots \ldots .895,501$ & $\ldots$ & 891,614 & .. 815,277 & $\cdots$ & $1,060,121$ & $\ldots .1,255,105$ & . & \\
\hline $1824 \ldots \ldots \ldots 900,105$ & $\cdots$ & 768.443 & $1835 . \ldots \ldots \ldots 1,059,367$ & $\cdots$ & 853,359 & $\pm S 46 \ldots \ldots \ldots 1,325,36 \mathrm{~s}$ & .. & r \\
\hline $1825, \ldots \ldots \ldots 1,031,127$ & $\ldots$ & $1,169,940$ & ... $\$ 50,986$ & $\ldots$ & 930,086 & 1547. & - & \\
\hline $1826 \ldots \ldots \ldots 1,052,575$ & $\ldots$ & $1,245,235$ & $1837 \ldots \ldots \ldots .955 .852$ & $\cdots$ & 801,404 & $.1,957,395$ & ... & \\
\hline $1827 \ldots \ldots \ldots 1,070,131$ & $\ldots$ & $1,338,390$ & $1535 \ldots \ldots \ldots 935,532$ & .. & 899,142 & $1849 \ldots \ldots \ldots 1,286,681$ & .... & 721,4 \\
\hline ..1,019,517 & $\ldots$ & $1,246,509$ & . $893,4 \$ 5$ & . & $982, \pi 24$ & $1850 \ldots \ldots \ldots . .1,556,912$ & -.. & \\
\hline $1829 \ldots \ldots \ldots \pi 3 \pi, 532$ & $\ldots$ & 747.751 & $1840 \ldots \ldots \ldots 1,018,269$ & $\ldots$ & 628,762 & ..1,551,435 & $\cdots$ & $1,176,5$ \\
\hline $1830 \ldots \ldots \ldots 670,522$ & $\ldots$ & $5 \tau 2,606$ & $1511 \ldots \ldots \ldots 1,091,565$ & .... & 700,961 & $1852 \ldots \ldots \ldots$ & ... & - \\
\hline
\end{tabular}

Internal Communication,-The bays and estuaries of Maine, many of which, however, penetrate to a considerable distance inland, are the only natural ways for internal intercourse enjoyed by the State. The great interior back from the sea-board district is beyond their reach, and the chief rivers, except as far as they can be made to float down the timber and rafts of the rast forests which abound at their upper courses, are almost useless to navigation. The State, then, has had to depend on artificial channels for travel and trausportation; and from necessity, these are extensive and systematic. But the position of Maine to the British provinces has demanded of it something more than roads to the interior, and hence we find its system, completed and projected, extending into Canada on the one hand, and into New Brunswick and Nova Scotia on the other; while lines of railroad are in operation from the south-east part of the State to Boston, connecting with the general system of the Union, and furnishing a link in the great chain extending from Halifux, the northern terminus of European steam navigation, to the ports of the Gulf of Mexico. The Atlantic and St. Lawrenco Railroad, one of the greatest enterprises of the age, gives to Montreal and Quebec an outlet on the Atlantic, and avoids the tedious navigation down the St. Lawrence River. The European and North American Railroad will greatly facilitate and shorten the period of travel between Europe and the Union. The first of these is now about complete, and the latter has so far progressed as to insure its completion within the next four or five years. With the exception of one or $t$ wo short lines, the railroads as yet complete are found in the south-east part of the State, between the Kennebec River and the line of New Hampshire. The total length of completed railroad in the State, on the 1st January, 1853, was 417 miles. The State has also constructed the Cumberland and Oxford Canal, connecting Portland with Sebago Pond, twenty and a half miles long. It has 25 locks, and by another lock, in Saco River, it is extended through Brandy and Long Ponds, making its whole length 50 miles.

Banks.-The bank returns for October, 1950 , reported 32 banks. The following statement exhibits their condition at that period: Iiabilities - capital $\$ 8,245,000$, circulation $\$ 2,651,208$, deposits $\$ 1,22 \$, 671$, due other banks $\$ 48,036$, and other liabilities $\$ 38,285$; and assetts-loans and discounts $\$ 5,830,330$, real estate $\$ 111,805$, due by other banks $\$ 778,955$, notes of other banks $\$ 187,435$, aud specie $\$ 475,599$. The banks are subject to the control of Bank Commissioners appointed by the Governor.

Government, etc.-The constitution of Maine went into operation in 1520, on the separation of the State from Massachusetts. It confers the vight of suffrage on every white male citizen (except paupers, persons under guardianship, and Indians not taxed) 21 years of age, and for three months next preceding any election a resident, and such citizen may rote in the town where a residence is so established. The general election is held annually on the second Monday in September.

The Legislature is composed of a House of Pepresentatives and a Senate; representatives not less than 100 , nor more than 200 in number (now 151), and elected annually, must be 21 years of age, five years citizens of the United States, one year residents of the State, and three months next preceding the election inhabitants of the town they may represent. A town having 1,500 inhabitants, is entitled to one representative; having 3,750 , twoo; having 6,775 , three; having 10,500 , four; having 15,000, five; having 20,250, sios; and having 26,250, seven; and no town can ever be entilled to more than seven representatives. Senators not less than 20 nor more than 31 in number (now 31 ), must be 25 years of age, and otherwise their term of office and qualifications same as for representatives. Vacancies in the Senate shall be filled by joint vote of the senators and the representatives, from those who had the highest number of votes in each district at the popular election. The Senate tries all impeachments, and a two-thirds vote is necessary to conviction; but judgment in such cases only extends to removal from and disqualiffention for office, the party being still liable to indictment. No senator or representative shall, during his term, be appointed to any civil office of profit that may have been created, or its emoluments increased during such term; and no member of Congress, or person holding office under the United States, postoffioers excepted, can hold a seat in either house. The legislature convenes on the second Wednesday in January annually.

The Governor is chosen by a plurality of rotes, and holds office for ono year. Te must be 30 years of age, a natural born citizen of the United States, and for five years. and at the time of his election, and during his term, a resident of the State. If no person has a majority of rotes, the House of Represcntatives, from those having the four highest numbers, if there be so many, shall elect two, and return their names to the Senate, one of whom the Senate shall elect and declare governor. No person holding office under the United States, this State, or any other power, shall be governor. If the office become vacant, the president of the Senate, and after him the speaker of the Representatives, shall act as governor, A two-third vote of both houses in favor of a bill vetoed by the governor, nullifles his objection, and it becomes law nevertheless. The gubernatorial term commences on the second Wednesday of May.

The Executive Council consisting of seven councilors, not more than one from any senatorial district, is chosen annually by joint ballot of the senators and representatives. They must be citizens of the United States, and residents of the State; and their proper office is to advise the governor in the executive part of the government.

The principal administrative officers are the Secretary of State and the State Treasurcr. They are chosen annually in the same manner as the executive council. The Treasurer is not eligible more than five years successively.

The constitutional organization of the judiciary was essentially altered by an act of the Legislature of 1852. The disrrict courts, which took the place of the old courts of Common Pleas were, abolished, and all their jurisdiction transferred 422 
MAINE.

to the supreme judicial court, to which three additional justices were authorized by the above act. The State is now divided into three judicial districts-western, middle, and eastern, and for the purpose of hearing and determining questions of law and equity, instead of being as heretofore held in the several counties, the terms are annually held for these districts; at Portland for the western distriet, at Augusta for the middle district, and at Bangor for the eastern district. The other classes of cases are tried as formerly in the several counties where they are commenced. There is a probate court in each county, with a judge and register; and each county has a clerk of the judicial court. Municipal and police courts are established at Portland, Bath, Bangor, Augusta, Gardiner, Belfast, Calais, Roekland, and Brunswick. All State judges are appointed by the governor, with the advice and consent of the council, and hold office for seven years, unless sooner removed for cause.

Among the general provisions of the constitution, are the following: Quakers, Shakers, justices of the Supreme Court and ministers of the gospel, shall be exempt from military duty. Suitable provision shall be made by towns to support and maintain public schools. No grant shall be made by the legislature to any literary institution, unless it has control over its charter. No religious test shall be required as a qualification for any offlce or trust. In all libel cases, the truth may be given in evidence, and the jury shall determine both the law and the facts.

Amendments to the constitution must receive a two-thirds vote of both houses, and be submitted to the people at the next general election; and if a majority is in favor of the amendment, it shall become a part of the constitution.

The militia of Maine, aceording to the returns of 1851, consists of 62,533 men of all arms and grades, of which 183 are commissioned officers, and 62,350 non-commissioned officers, musicians, artificers, and privates. Of the commissioned officers, 12 are general offlcers, 18 general staff offìcers, 24 field officers, and 129 company officers. All persons between 18 and 45 years of age, not exempt by law, are liable to do military duty.

Maine has several benevolent institutions, among which the Insane Hospital at Augusta stands pre-eminent. On the 4th of December, 1850, the two wings and most of the main building were destroyed by fire; the books, library, and papers of the institution were saved, but 27 of the inmates and one of the assistants perished in the flames. The north wing was made habitable by the 1 st of January, 1851, and has since been occupied. The returns for the year ending 31st March, 1850, exhibited the condition of the hospital at that time as follows: number of patients in hospital at the commencement of the past year, 127; and received during the year, 126-total 253, of which number 142 were males, and 111 females. Discharged during the year: recovered-males 38 , and females 28 ; improved-males 10 , and females 10 ; unimproved-males 8 , and females 8 ; and died-males 8 , and females 7 ; making a total of 117 . Of the 126 admitted, 61 were married-males 35 , and females 29 ; 50 were single-28 males, and 22 females; and 12 were widows; and of the number, 97 had been diseased less than one year, and 29 more than a year. In ordinary cases, the expenses, including board, washing, medical attendance, etc, do not exceed, for males, $\$ 250$, and for females, $\$ 225$ per week. In 1850 a commission was appointed to establish a Reform School, and construct appropriate buildings therefor.

Finances, Debt, etc.-According to the annual report of the State Treasurer, the amount of receipts for the year ending 30th April, 1S50, was $\$ 525,68926$, which, with a balance remaining from the last past year of $\$ 79,03326$, made the total resources of the Treasury $\$ 604,72652$. The expenditures for the same period amounted to $\$ 478,80245$, leaving a surplus of $\$ 125,92107$ for future appropriation. The principal objects of expenditure were-pay of Legislature, $\$ 41,690$; exeeutive expenses, $\$ 5,00793$; salaries, $\$ 25,16302$; clerks, $\$ 2,800$; roll of accounts, $\$ 13,04420$; printing, ete., $\$ 2,500$; cost of criminal prosecutions, $\$ 23,57866$; officers of the State prison, $\$ 4,75625$; Insane Hospital, $\$ 1,51950 ;$ deaf, dumb, and blind, $\$ 9,75009$; school fund, No. 16, $\$ 24,43556$; Teachers' Institute, $\$ 2,600$; Board of Edueation, $\$ 785$; Penobscot Indians' fand, $\$ 4,15733$; agricultural products of Indians, $\$ 21980$; Indian annuities, $\$ 1,500$; State roads and bridges, $\$ 1, \$ 00$; militia pensions, $\$ 2,123$; Maine Reports, $\$ 1,560$; Eastman's Digest of the same, $\$ 1,875$; agricultural societies, $\$ 2,20290$; connty taxes, $\$ 24,47992$; furniture and repairs, $\$ 1,100$; contingent fund of Treasurer, $\$ 1,000$; State prison, $\$ 3,300$; public debt paid, $\$ 124,250$; interest on debt, $\$ 61,57429$; temporary loan, $\$ \$ 2,350$, etc. ; and the chief sources of income were-direct taxes, $\$ 190,97660$; land office, $\$ 132,34095$; permanent school fund, $\$ 2,00930$; school fund, No. 17, $\$ 27,23021$; county taxes, $\$ 14,50814$; interest on United States loan, $\$ 8,100$; premium on United States stock sold, $\$ 7,725$; interest, $\$ 3,67808$; bank dividends, $\$ 700$; dulies on commissions, $\$ 2,170$, etc. The resources of the State are estimated at $\$ 519,26739$, among which are enumerated, besides cash on hand and the proceeds of the annual taxes, 100 shares in the Augusta Bank, $\$ 10,000$, and United States six per cent, stock due 1856, $\$ 20,000$. The whole amount of the public debt at the date above referred to was $\$ \$ 54,750$, which pays an annual interest of about $\$ 55,000$.

Federat, Representation.-Maine, according to the provisions of the Act of $28 \mathrm{~d}$ May, 1850, apportioning representation, is entitled to send 6 representatives to the United States Congress.

Religious Denominations.-According to the census returns of the United States, taken in 1850, the statistics of the several religious denominations in this State wero as follows:

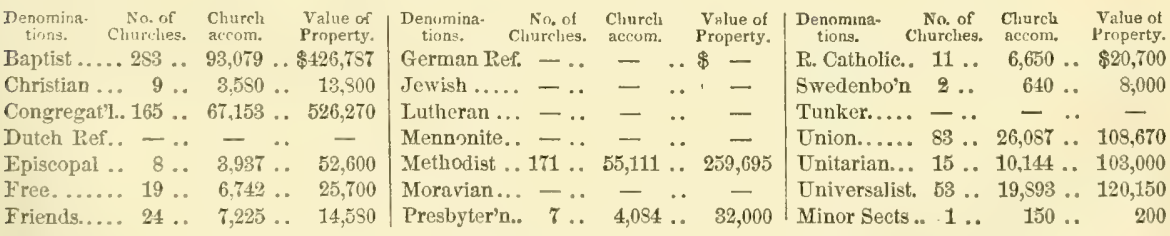

-making a total of 851 churches, with accommodation for 304,475 persons, and valued as property at $\$ 1,712,152$. Maine constitutes a diocese of the Protestant Episoopal Church, and a part of the Roman Catholic diocese of Boston.

Educution.-The Board of Education has been abolished, and an Act has been passed, authorizing, instead thereof, the appointment by the governor of a school commissioner for each county, to hold office for one year from 1st May, and it is made the duty of each commissioner to spend 50 days at least in his county during the winter term of the schools, in visiting and examining the scholars, etc.

In 1:2y twenty townships of public land were reserved as a basis for a school fund-the proceeds of the land already sold are $\$ 101,36363$, which constitute the permanent sehool fund of the State; and in 1850. twenty-four half townships were added to this fund. The banks pay oue-half of one per cent. of their eapital stock semi-annually for school use. Tlis tax in 155 amounted to $\$ 27,23027$. Of the school fund thus constituted, $\$ 33.49210$ was apportioned among the 
MAINE.

towns, and the towns receiving their share are obliged to raise an amount of school money equal to 40 cents for each irhabitant. In 3,948 districts and 279 part districts, which made returns for 1850 , there were 2,706 male and 3,921 female teachers; average monthly wages-male $\$ 16 \quad 66$, and female $\$ 592$; average length of schools in weeks, 18.7 ; schools suspended by incompetency of teachers, 152; number of good school-houses, 1,596; number of poor school-houses, 2,012 ; number of school-houses built the past year, 120 ; whole number of scholars, 230,274 ; whole attendance in winter, 151.360 ; average attendance, 91,519 . The whole amount of school money raised by tax was $\$ 264,35117$, which was $\$ 11,01031$ more than required by law. The sum of $\$ 29,92146$ was expended for private schools. There were school libraries in 9 towns. The whole number of chartered academies in the State in 1850 was 92 , of which $6 \pm$ sustain schouls during a greater or less part of the year. Teachers' institutes have been in suecessful operation for several years; 1,732 teachers attended them in 1850-801 males, and 981 females; and the session of each institute lasted ten days.

The two great colleges of Maine are Bowdoin and Waterville colleges, Bowdoin College, at Brunswick, was founded in 1802, and in 1850 had 14 professors, 1,062 alumni, of whom 157 had entered the ministry, 129 students, and a library of 27,500 volumes; and Waterville College, of Waterville, under Baptist jurisdiction, was founded in 1820 , and in 1850 bad 5 professors, 267 alumni, of whom 82 had entered the ministry, 88 students, and a library of 15,500 volumes. There is a Theologieal Seminary at Bangor, under Congregational auspices. It was founded in 1816, and in 1850 had 3 professors, 87 students, 202 graduates, and 7,000 volumes in its library. The Maine Medical School, at Brunswick, was founded in 1820, and in 1850 had 5 professors, 51 students, and 634 graduates. These institutions are liberally endowed, and have all the appliances, apparatus, ete., necessary to illustrate the various subjects taught.

Public Libraries.-One State library-9,000 volumes; two social libraries-6,370 volumes; two college libraries-16,800 volumes; six students' libraries-13,134 volumes; two academical and professional libraries-10,800 volumes; one scientific and historical library-300 volumes; seventeen public school libraries-152 volumes-total 31 libraries and 56,856 volumes. There is a great discrepancy between the account of the college libraries given by the census as above and that published in the annual catalogues of the respective institutions.

Periodical Press. - The whole number of periodicals in Maine, according to the ascertainments of the census of 1850 Was 55, of which 15 were whig in polities, 15 democratic, and 25 neutral or devoted to literature, science, religion, etc.; and of the whole number 4 were published daily, 3 tri-weekly, 4 semi-weekly, 43 weekly, and one semi-monthly. The aggregate circulation of each issue of the dailies was 6,100 ; of the tri-weeklies, 370 ; of the semi-weeklies, 1,350 ; of the weeklies, 53,567; and of the semi-monthly, 2,500. Of the dailies 2 were published in Portland, and 2 at Bangor; of the tri-weeklies, 2 at Portland, and 1 at Bath; of the semi-weeklies, 1 at Gardiner, 1 at Bath, 1 at Thomaston, and 1 at Biddeford; of the weeklies, 9 at Portland, 1 at Farmington, 4 at Augusta, 1 at Hallowell, 2 at Waterville, 4 at Bath, 1 at Newcastle, 1 at Lewiston, 1 at Rockland, 2 at Paris, 2 at Norway, 1 at Dover, 4 at Bangor, 9 at Skowhegan, 3 at Calais, 2 at Belfast, 2 at Saco, and 1 at Limerick; and the semi-monthly, the "Scholar's Leaf," at Portland. The "Maine Farmer," an agricultural paper, published at Augusta, circulates 5,300 copies at each issue, and has the highest circulation of any periodical in the State. The "Transeript," a literary issue, published at Portland, circ.alates 4,608 copies, and has the second highest circulation.

Pauperism and Crime.-The whole number of paupers who received support within the year ending 1st June, 1850 , was 5,503, of which 4,553 were natives, and 950 foreign born; and the whole number of paupers on the list at the above date was 3,535 , of which 3,209 were natives, and 326 foreign born; annual cost of support, $\$ 154,664$. The State prison is located at Thomaston. The whole number of convicts in this institution 80 th $\Lambda$ pril, 1849 , was 97 , and the number received in the year next following was 31-total 98. Discharged by expiration of sentence 17 , by pardon 5 , and by death 1 ; and on the 30th April, 1850, 75 remained incarcerated, Of those convicted in 1849-50,4 were for arson, 5 for burglary, 2 for forgery, 49 for larceny, 5 for murder, and 1 for passing counterfeit coin. The whole number of convicts received into the prison since $2 d$ July, 1824, up to the end of the official year 1850 , was 981.

Historical Sketch.-The first settlements of Maine were for a long period interrupted by savage incursion. Though visited at an early period, no permanent colonies were established until the commencement of the seventeenth century. In 1604 the French settled on the Kennebec, and in $1607 \mathrm{Sir}$ John Gilbert arrived at the mouth of the same river with 100 colonists, but having passed the winter in great suffering, the party returned to England, representing the country as a "cold, barren, and mountainous desert." The unfortunate result of this enterprise discouraged any further attempts on the part of the English for some years. The French, however, had established themselves on different parts of the coast, and the Dutch also had a settlement at a place called Newcastle. After the formation of the Plymouth Company a more regular system of colonization was attempted, but no effectual settlement by the English was made before 1685 . In that year the country was parceled into shares, but none of the holders, except Sir Ferdinand Gorges, who received a grant of the lands between the Piscataqua and Kennebec, obtained their patents. His charter, granted in 1639, gave him despotic power over the district, and the laws he promulgated on taking possession were aristocratic and feudal in their character, and little suited to the English emigrant of the time. The population of the province seems acoordingly to have increased but slowly. The first general couneil was held at Saco in 1640. The government was administered in the name of Gorges until 1617, when, on his death being announced, the people took the administration of affairs into their own hands, and elected a governor from among themselves until 1652, in which year the province was incorporated with Massachusetis, and so remained until Charles II. restored it to the heirs of Gorges. The government of Massachusetts, however, shortly afterward purchased the whole country for $£ 1,200$ sterling, and thenceafter it was governed as part of her territory, and was included in the new charter of Massachusetts in 1691. At that time the present State of Maine was divided into two parts-the country between the Piscataqua and Kennebec, which contained the principal settlements, and was exclusively called Maine, and that between the Kennebec and the St. Croix, which was known by the ancient French name of Acadie. The province was not supposed to extend back from the sea farther than 120 miles, and the territory beyond that distance was considered as crown lands. The whole country, from the Piscataqua to the St. Croix, was now granted to Massachusetts.

From its first settlement to the middle of the eighteenth century the inhabitants suffered grievously from Indian warfare. The savages opposed step by step the progress of the colony. In 1675 almost all the settlements were destroyed, and from 1692 to 1703 the province was a uniform scene of rapine. In 1720 the harassing conflict was renewed, and the settlers suffered severely until 1726, when a treaty was concluded which secured peace for several years. So late as 1744 and 1748 many of the inhabitants were killed or carried off from the towns. Since 1749, however, when another treaty was made, tranquillity has prevailed, and at the present time few Indians remain within the State.

From the period of the union with Massachusetts to the final separation in 1820, the history of Maine has been merged 
in that of Massachusetts. We hear little of the former during the Revolutionary War. In the war of 1S12-15 a portion of the district was compelled to submit to the British arms, and remained under their control until the return of peace. No attempt was made to dislodge the enemy.

The separation of the district from the jurisdiction of Massachusetts, and its erection into an independent State, were frequently attempted, but without success. In October, 1755, a convention met at Portland for the purpose of considering the subject. In the sncceeding year the question was submitted to the people of Maine, to be decided in town meetings, when it was found that a majority of the freemen were against the measure. The subject was renewed in 1802 , when ngain a majority appeared adverse to a separation. In 1819, numerous petitions having been presented to the Legislature, an act was passed for ascertaining the will of the people, in conformity to which a vote was taken in all the towns. A large majority now voted in favor of the separation, and in consequence of the desires of the inhabitants thus expressed, a convention was called under the authorization of the Legislature of Massachusetts. A constitution was adopted which received the approbation of the people, and on the 15th March, 1820, the District of Maine became an independent Statc and a member of the United States.

AUGtsra, on the Kennebec River, is the political capital and seat of the State Government.

MATre, t. and p. v., Broome co., N. Y.; 125 m. W. S. W. Albany. Drained by two creeks flowing into the Susquehanna $\mathbf{r}$. Surface much broken; soil best adapted to grazing. The $\mathrm{v}$. is situate in S. W. part of t., on Nanticoke cr. The t. contains several saw-mills, grist-milis, and tanneries. Pop. 1,543 .

MAINE, p. 0., Cook co., Itl.: 175 m. N. E. Springfield.

Mannesburig, p. o., Tioga county, Penn.: $108 \mathrm{~m}$. N. Harrisburg.

MLanterince, p. v., Columbia co., Penn.: 61 m, N. N. E. Harrisburg. There is a cold biast furnace (the Cattarvissa), constructed in 1815 , of 1,300 tons annual capacity, alsc a forge of same name, constructed in 1524, which produces annually 100 tons of bars.

MataGa, p. v., Gloncester co., N. Jer.: near Scotland Branch fork of Maurice $\mathbf{r}, 47 \mathrm{~m}$. S. S. W. Trenton. It contains a glass manufactory, several stores, and workshops,

Malaga, i. and p. v., Monroe co., Ohio: 95 m. E. by S. Columbus. Drained by tributaries of Seneca cr. Surface hilly and rough ; soil varied. The $\mathrm{v}$. is situated in N. part. Pop. 1,561.

Malcolv, p. v., Jefferson co., Miss. : 61 m. S. W. Jackson. There is a railroad running from Natchez to this $v$, a distance of 29 miles.

Maldex, t. and p. v., Middlesex co., Mass.: 5 m. N. Boston. Bounded on the S. by Mystic r., which separates it from Charlestown, to which it is connected by a bridge. Drained by Charles $r$. Surface uneven, abounding in sal meadows and timber lands. Malden, like Medford, Sommerville, and Cambridge, is considered as a suburb of Boston. First settled in 1648, incorporated in 1649. It is a busy town, with several manufactures, workshops, and numerous stores. The Boston and Maine R. R. passes through it, from which point the Medford Branch R. R. diverges Pop. of t. 3,520

MALDEN, p. V., Ulster co., N. Y.: on the W. side of the Hudson r. $41 \mathrm{~m}$. S. by W. Albany. There is a regular steamboat landing, and large quantities of leather and flagging stones are shipped.

Malden Beidge, p. v., Columbia county, $N_{*} Y_{*}:$ on Kinderhook er., $17 \mathrm{~m}$. S, by E. Albany.

MALTEURECX islands, La.: a small cluster of islands lying off the mouth of Lake Borgne.

Mallet Ceeek, p. v., Medina co., Ohio: on a fork of Rocky r., $97 \mathrm{~m}$. N. N. E. Columbus.

Mallorysvirie, p. v., Wilkes co., Ga.: 66 m. N. N. E. Milledgeville

Mazone, t., p. $\mathrm{v}_{.}$and eap. Franklin co., N. Y.: $145 \mathrm{~m}$. N. by W. Albany. Drained by Salmon and Trout rivers, which flow into Canada. The Northern (Ogdensburg) $R$. $R$. crosses the N. part of the t., running through the v., which is pleasantly situate on both sides of Salmon $r_{\text {, }}$, over which there is a bridge built of stone. Surface level; soil in general fertile. There are very fine specimens of the Potsdam sandstone quarried here. Magnetic iron ore, bog fron ore, and other minerals, are to be found along the river. There is fine water-power, which is employed extensively in manufactories, of which there are a great number. The v. is the seat of justice for the county, and has several manufactories of colton goods, leather, scythes, pails, etc. The "Franklin Gazette" (dem.), and "Frantier Palladium" (whig), are issued weekly. Pop. of t. 4,547.

Malta, t. and p. o., Saratoga co., N. Y.: 23 m. N. Albany. Drained by a small stream which bounds it on the $\mathrm{N}$. and Saratoga Lake on the E., and Anthony's Kill (outlet of Round Lake), in the S. Surface undulating; soil fertile. In the t. there are several stores, mills, and manufactories. Pop. 1,349.

Malta, to and p. v., Morgan co., Ohio: 61 m. E. S. E. Columbus, Drained by Muskingum r., which forms its E. boundary. Surface uneven; soil fertile. The v. is situate in the N. E. part of the $t$, on the Muskingum river. Pop. of $t_{0} 1,302$.

Maltaville, p. v., Saratoga co., N. Y.: $21 \mathrm{~m}$. N. by W. Albany, near Round Lake. It contains a factory and mill, and about 25 dwellings.

Malugin Grove, p. o., Lee co., Ill.: 133 m. N. by E. Springfield.

Malvern, p. o., Carroll county, Ohio: $101 \mathrm{~m}$. N. E. Columbus.

Mamakativg, to and p. o., Sullivan co, N. Y.: $81 \mathrm{~m}$ S. S. W. Albany. Surface hilly and mountainous, having on the E. the Shawangunk Mountain, and in the W. a high ridge; through the centre flows Bashe's Kill, and the Delaware and Hudson Canal. The New York and Erie R. R. crosses the S. part of town. It contains numerous stores, 6 tanneries, 3 distilleries, a number of grist-mills and saw-mills. Pop. of $t .4,107$.

Manfaroneck, t. and p. v., Westchester co, $N_{.}, Y_{\text {.: }} 119$ m. S. Albany. Drained by Mamaroneck cr., flowing into Long Island sound, which bounds it on the S. The Ner York and New Haven R. R. passes through the t. Surfice uneven-in parts hilly; soil good and well cultivated. The v. is situate on the Sound. Several sloops owned here ply between the v. and New York. There are 2 churches, several stores, and a salamander safe manufactory in the v., and about 300 inhabitants. Pop. of t. $92 S$.

MAMмотн CAVE, p. o., Edmonson county, $\bar{K}_{y}: 25 \mathrm{~m}$ S. W. Frankfort, and near Green river. It is situated midway between Louisrille and Nashville, and is a fashionable place of resort. The cave is approached through a romantic shade. At the entrance is a rush of cold air; a descent of 30 feet by stone steps, and an advance of 150 feet inward brings the visitor to the door, in a solid stone wall, which blocks up the entrance of the cave. A narrow passage leads to the great vestibute or ante-chamber, an oval hall, 200 by 150 feet, and 50 feet high. Two passages, of 100 feet width, open into it, and the whole is supported without a single column. This chamber was nsed by the races of yore as a cemetery, judging from the bones of gigantic size which are discovered. A hundred feet abnve your head you catch a fitful glimpse of a dark-gray ceiling, rolling dimly away like a cloud, and heary buttresses. apparently bending under the superincumbent weight, project their enormous masses from the shadowy wall. The scene is vast, solemu, and awful. In the silence that per- 
vades, you can distinctly hear the throbbings of your heart. In Audution Avenue, leading from the hall, is a deep well of pure spring water, surrounded by stalagmite columns from the floor to the roof. The Little Bat Room contains a pit 280 feet deep, and is the resort of myriads of bats. The Grand Gallem is a vast tunnel, mant miles long and fifty feet high, and as wide. At the end of the first quarter of a mile is the Kentucky Cliffs and the Church, 100 feet in diameter and 63 feet high. A natural pulpit and organ-loft are not wanting. "In this temple religious services have frequently been performed." The Gothic Avenue, reached by a flight of stairs, is 40 feet wide, 15 feet high, and $2 \mathrm{~m}$. long. Mummies have been discovered here which have been the subject of curious study to science; there are also stalagmitcs and stalactites, Louisc's Bower, and Vulcan's Furnace. On the walls of the Register Rooms are inscribed thousands of names. "The Gothic Chapel, when illuminated with lamps, inspires the beholder with feelings of solemnity and awe." At the foot of the Devil's Arm Chair is a small basin of sulphur water. Then there is the Breast 20ork, the Elephant's Head, Lover's Leap, Gateroood's Dining Table, and the Cooling Tub, a basin 6 feet wide and 3 feet deep, of the purest water-Napoleon's Dome, etc., ete. The Ball Room contains an orchestra 15 feet high ; near by is a row of cabins for consumptive patients-the atmosphere being always temperate and pure. The Star Chamber presents an optical illusion. "In looking up, the spectator seems to see the firmament itself, studded with stars, and afar off a comet with a bright tail." The Temple is an immense vault, covering an area of two acres, and covered by a single dome of solid rock, 120 feet high. It rivals the celebrated vault in the Grotto of Antiparos, which is said to be the largest in the world. In the middle of the dome there is a large mound of rocks rising on one side nearly to the top, very steep, and forming what is called the Mrontain. The River Hall descends like the slope of a mountain; the ceiling stretches away before you, vast and grand, as the firmament at midnight. A sloort distance on the left is a steep precipice, over which you can look down by the aid of torches upon a broad, biack sheet of water, 80 reet below, ealled the Dead Sea. This an awfully impressive place, the sights and sounds of which do not easily pass from memory. The Mammoth Cave is said to be explored to the distance of ten miles without reaching its termination, while the aggregate width of all the branches is over forty miles! Next to Niagara, it is the wonder of nature in the western world, or perhaps throughout all her domains,

Manack, p. o., Lowndes county, Ala.: 27 m. S. W. Montgomery.

Manamawirn, p. v., Oeean co., $N$. Jer.: on Manahawkin cr., 4 m. W. Little Egg Harbor Bay, 45 m. S. E. Taunton. It contains 3 churches, several small stores, and about 260 inhabitants.

Maxaldpax.p. on. Monmouth co, M. J.: $21 \mathrm{~m}$. E. Trenton. Manasquar, p. v., Monmouth co., N. Jer.: on Manasquam cr., 35 m. E. S. E. Trenton.

Masaseram river, Monmouth county, N. Jer.: rises in Freehold $t_{\text {, }}$ and after a $\mathrm{S}$. E. course of $18 \mathrm{~m}$., enters the Atlantic by Manasquam inlet. The tide-water, $3 \mathrm{~m}$. above its mouth, is crossed by Squam Eridge.

M $\triangle$ NAsses GAr, p. o., Warren co., Tirg.: the gap is a pass on the Blue Ridge, which here divides the counties of Fauquier and Warren. The Manasses Gap R. R., from Alexandria to Front Royal, passes through it.

Manataifnx, th and p. o., Berks county, Penn.: $61 \mathrm{~m}$, E. N. E. Harrisburg, Drained by Sacony cr., a tributary of Maiden er. Surface level; soil loam and gravel, and very productive. The v. of Kutztown is situated in the W. part of t., and has a church, 3 stores, and about 90 dwellings.

MAYATEE, p. Y., Hillsboro' co., Flor. : on an arm of Spiritu Santo Bay, $37 \mathrm{~m}$. S. Tampa, $241 \mathrm{~m}$. S. S. E. Tallahassee.

Masayusk, t. and p.v., Philadelphia co., Penn.: one of the suburban districts of Philadelphia, $7 \mathrm{~m}$. N. N. W. Phila426 delphia, and $\$ 9 \mathrm{~m}$. W. by S. Harrisburg. It is situate on E. bank Schuylkill river, at the junction of Philadelphin and Reading R. R. with the Philadelphia, Germantown, and Norristown $R$. R. It has fine water-power, created by the waste water of the canal. Two bridges cross the Schuylkill river at this place. There is a forge situate here, as also a rolling mill ; the latter produced (in 1849) 600 tons hoiler and flue iron, and otherwise considerable manufacturing and other business are carried on. Pop. 6,139.

Manchac, p. v., E. Baton Rouge par., La. : on E. bank Mississippi r., 9 m. s. Baton Rouge,

Manchao House, p. o., Travis county, Tex.: $11 \mathrm{~m}$. S. Austin City.

Manchadg, p. v., Worcester co., Muss. : on a fork of Blackstone r., $39 \mathrm{~m}, \mathrm{~S} . \mathrm{W}$. Boston.

Manchester, t. and p. v., Hartford co., Conn.: $9 \mathrm{~m}$. E. Hartford. Drained by Hockanum $r$, which affords excellent water-power. Surface uneven; soil fertile and productive. In 1794 the first cotton-mill in the State was built here. It is a very important manufacturing town. There are several paper-mills, 2 powder-mills, and a number of woolen and other manufactories. The $\mathrm{v}$. is pleasantly situated in the $\mathrm{N}$. of $\mathrm{t}$., on line of the Hartford, Providence, and Fishkill R. R., $23 \mathrm{~m}$. W. by N. Willimantic. Pop. of town, 2,546

MANCHEster, p. v., Scott county, $I l l_{0}: 40$ m. W. S. W. Springfleld.

Manchester, p. v., Dearborn county, Ind. : $72 \mathrm{~m}$. S. E. Indianapolis.

Manchester, p. v., and cap. Clay $\mathrm{co}_{\text {, }} \bar{K}_{y}$.: situate on $\mathrm{S}$. side of Little Goose cr., a tributary of Kentucky r., 93 m. S. E. Frankfort. There are salt works in the vicinity, It contains a court-house, etc.

Mancuester, p. Y., Carroll county, $M d_{*}: 49 \mathrm{~m}$. N. by W. Annapolis.

MANCHester, to and p. r., Essex county, Mass.: on Massachusetts Bay, $7 \mathrm{~m}$. N. E. Marbleherd, $21 \mathrm{~m} \mathrm{~N}$. E. Boston. Manchester has a fine harbor, suitable and safe for vessels of moderate draft. Fishing is the chief cmployment of the inhabitants. The surface of the $t$. is rough, and the soil varied. Ship-building is carried on to some extent, besides which there are manufactories of leather, boots, shoes, cabinet-ware, palm-leaf hats, and ships' wheels are manufactured here. The village is pleasantly situated, and commands a delightful prospect. The Gloucester Branch R. R. passes through it, connecting at Beverly $(9 \mathrm{~m}$. W. with the Eastern R. R. Pop. of the t. 1,63s.

Maxchester, p. 0., Washtenaw co., Mich.: $45 \mathrm{~m}$. S. E. Lansing.

Mavenester, p. v., St. Louis co., Mo, : on the St. Louis and Jefferson City post-road, $18 \mathrm{~m}$. W. St. Louis, $98 \mathrm{~m}$. E. Jefferson City.

Maschester, t., p. city, and one of the capitals Hillsborough con, N. Hamp.: 18 m. S. $\frac{1}{2}$ E. Concord. Drained by a number of small streams which discharge themselves into the Merrimac r., which forms the W. boundary, and affords excellent water-power. Massabesick Pond is on the E. border of the t., from which Cohas brook issues and flows into the Merrimac river. Surface undulating; soil varied, that along the river being easy of cultivation and very productive. The canal by Amoskeag Falls, $1 \mathrm{~m}$, in length, is in this town. These are the largest falls on the Verrimac, having a descent, in the course of a mile, of from 50 to 60 feet. There are now in operation at this place seceral large cotton-mills, owned and operated by the Amoskeag Manufacturing Company, and three by the Stark Mills Corporation, consuming annually 36,000 bales of cotton, 635,000 pounds of potato starch, 31,000 gallons sperm oil, 6,700 cords wood, 1,200 tons anthracite coal, and producing $39,500,000$ yards of sheeting, shirting, ticking, denims, merino stripes, and cotton flannel. There is a blue-dyeing establishment, cotton warehouses, repair shops, countinghouses, and numerous blocks of dwelling-houses used for 
boarding-houses for the operatives, all built of brick, and neat in appearance. There is an extensive machine-shop and foundry owned by the Amoskeag Company, with houses adjoining for the accommodation of the hands employed. The Murselin De Laine Works, owned by the Manchester Print Works Corporation, produce $10,000,000$ yards of mousselin de laine and fine prints annually, which are celebrated for their superior quality. There is quite a large village near the mills, having a good town-house, two stories high, with a spacious hall, cupola, clock, ete., and the usual number of other public buildings, a large number of neat dwellings and stores, and several hotels and schools. The eity of Manchester is situate on a plain about 95 feet above the river ; it is neatly laid out with wide streets, the principal one being 100 feet wide, extending more than a mile $\mathrm{N}$. and $\mathrm{S}$; ; the chief part of the other streets intersect it at nearly right angles, while four run parallel with it. There are extensive public squares, ornamented with trees. A public cemetery, called the Valley, containing some 20 acres, laid out with winding paths and arenues, is situate near the $\mathrm{v}$. by the side of a beautiful stream. The $t$, is connected by bridges with Gofistown and Bedford. The villages of Piscataquog and Amoskeag, on the W. side of the r., are connected by these bridges with Manchester, and constitute with it but one place of business. The growth of the eity is rapid and unrivaled by any other in the country except Lowell. The Manchester and Lawrence R. R., Coneord R. R., and the New Hampshire Central R. R., all diverge from this point, $18 \mathrm{~m}$, distant from Coneord. The eity is lighted with gas. There are 10 churches in the town-2 Congregational, 1 Episcopalian, 3 Baptist, 2 Methodist, 1 Universalist, and 1 Unitarian; 2 banks, the Manchester Bank, capital $\$ 125,000$, and the Amoskeag Bank, eapital $\$ 150,000$. The "Granite Farmer" (weekly, agric.), "Manchester Messenger" (week1v), "Manchester American" (weekly, whig), "Manchester Mirror" (daily), and "The Democrat" (weekly, dem.), are published here. Pop. of t. 13,923.

MANchester, p. o., Ocean county, N. Jer.: 35 m. S. E. Trenton.

Maichester, to and p. v., Ontario county, $N . Y .: 183 \mathrm{~m}$. W. by N. Albany. Drained by ontlet of Canandaigua Lake. Surface undulating; soil sandy loam and clay, underlaid by lime, and very fertile, being well adapted to wheat. There is a sulphur spring in the E. part of town, called Clifton Springs, of some celebrity. The v. is situate on Canandaigua outlet, and contains several churches, stores, a woolen factury, a furnace, 35 dwellings, and about $251)$ inhabitants. There are in the t. a number of manufactories. Pop. of t. 2,940 .

Marcirster, p. v., Adams co., Ohio: 91 m. S. by W. Columbus. Pleasantly situate on the N. side of the Ohio $\mathbf{r}$.

Manchester, t. and p. o., York co., Penn.: situate on the S. side Susquehanna r., between Conewago cr. and Codorus creek, 15 m. S. E. Harrisburg. Surface uneven; soil fertile. There are several distilleries, a flour and grist mill, and saw-mills. There is a hot blast furnace situate here, the annual capacity of which is 1,400 tons. Pop. of t. 6.139.

M $\triangle$ scuestrer, p. v., Sumter dist., \$. Car. : 31 m. E. S. E. Columbia, The Wilmington and Manchester R. R. passes it $156 \mathrm{~m}$. from. Wilmington, and $6 \mathrm{~m}$. from the junction.

Maxchester, p. V., and cap. Coffee co, Tenn.: on a fork of Duck r., W. part of county, 49 m. S. E. Nashville.

Maxcirester, t., p. v., and cap. Bennington co., Verm.: 81 m. S.W. Montpelier. Situate between the Green and Equinox mountains. The scenery is very beautiful. Drained by Battenkill r. and its branches, which afford good waterpower. The soil along the water-course is good, but the principal part of the $t$. is better adapted to grazing than tillage. There are extensive quarries of beautiful marble, and also several manufactories, saw-mills and grist-mills. The $v$. is pleasantly situate in the centre of $t$, on an elevation. The Western Vermont $\mathrm{P}$. R. passes through it $30 \mathrm{~m}$. from Rutland, Pop.1,78?.
Manonester, p. v., Chesterfield co., Virg.: on the W. bank of James r., $2 \mathrm{~m}$. below Richmond. Mayo's Bridge connects the v. with Richmond. It contains several factories and mills, 400 dwellings, and about 2,000 inhabitants. Immense water-power is furnished by the falls at this place. Manchester Bridge, p. 0, Duchess co., N. Y.: $63 \mathrm{~m}$. S. Albany.

Manchester Centre, p. o., Ontario co., N. $Y_{.}: 181 \mathrm{~m}$. W. by N. Albany.

Manchester Station, p. o., Hartford co., Conn. : 9 m. E. Hartford.

Mandana, p. v., Onondaga co., $N$. $\Gamma_{0}$ : near Skaneatles Lake, $141 \mathrm{~m}$. W. by N. Aibany.

Mandarin, p. v., Duval co., Flor.: on E. bank of St. John's r., $165 \mathrm{~m}$. E. Tallahassee.

Maxdetille, p. v., St. Tammany par., La.: on N. bank of Lake Pontehartrain, $63 \mathrm{~m}$. ‥ ㅊ. S. Baton Rouge, and $13 \mathrm{~m}$. E. Pass Manchac.

Maxgomok, p. o., King William co., Virg.: $27 \mathrm{~m}$. N. E. Richmond.

Manmasset, p. v., Queens co., $N . Y_{.:}$at the head of Cow Neck, 127 m. S. Albany.

Maniattan, p. v., Putnam co., Ind.: 39 m. W. S. W. Indianapolis, $2 \mathrm{~m}$. W. Eel river.

Manhattan, t. and p. v., Lucas co, Ohio: $117 \mathrm{~m} . \mathrm{N}$. by W. Columbus. Situate at the mouth of the Maumee r., which divides it in two parts, and bounded on the N. E. by Manmee Bay. Drained by the Maumee and Ottawa rivers, and the Wabash and Erie Canal terminates here. Surface level ; soil fertile. Pop. 541

Manhattan island. (See New York Crti).

Maniattanfilie, p. v., New York co,,$N$. I.: on the line of the Hudson River R. R., 8 m. from City Hall, New York, 130 S. Albany, Situate on the E. side of the Fudson river, contains several stores and a white-lead factory, etc. and there is a fine wharf here. About half a mile distant, on an elevation, is the New York Lunatic Asylum.

Mavietu, t. and p. $\nabla .$, Herkimer co., N. Y.: $63 \mathrm{~m} . \mathrm{N}$. W. Albany. Bounded on the $\mathrm{S}$. by the Mohawk r. Drained by East Canada cr, which flows into the Mohawk r. Surface level; soil rich and very productive on the allurial flats along the river. It contains several stores and mills, The village is situate in S. part of town, near the line of the Utica and Schenectady R. R. Pop, of t. 1,902.

MaNhetm, t. and p. v., Lancaster co., Penn.: 25 m. E. S. E. Harrisburg. Drained by Great Conestoga and Little Conestoga creeks, which bound it on its E. and S. W. sides. Surface uneven; soil calcareous loam and clay. It has flouring, grist, and saw mills, and an oil mill. The "Sentinel," a weekly issue, is published here. Pop. of t. 2,089.

Manhem Centre, p. o., Herkimer co., $N_{0} . Y_{.}: 65 \mathrm{~m}$. N. W. Albany.

Manilla, p. v., Rush co., Ind.: on the W. boundary of county, $29 \mathrm{~m}$. S. E. Indianapolis, and on the Rushville and Shelbyville R. R., $11 \mathrm{~m}$. from Rushville.

Manistee county, Mch. Situate N. W. on Lower Peninsula, and contains $551 \mathrm{sq} . \mathrm{m}$. Drained by Manistee and M.'Moosic rivers, flowing into Lake Michigan, its N. boundary. Capital: Manistee. Not organized in 1850.

MANistee, p. o., Manistee county, Mich.: $125 \mathrm{~m} . \mathrm{N}$. W. Lansing.

Masitowoo county, Wise. Situate E. on Lake Michigan, and contains 584 sq. m. Drained by Manitowoc, Centre, and $\mathrm{E}$. and W. Twin rivers, and smaller streams. Surface considerably broken; soils deep and rich, generally clay, with strips of sandy loam. Most grains do well, and the pasturage is fine. It is heavily timbered with pine, oak, and maple, and the lumber trade is the chief business. The rivers furnish fine mill-seats, and on the lake it has a good harbor, with a growing lake trade. Farms 35 ; manuf. 22 ; dwell. 715, and pop.-wh. 3,702, fr. eol. 0-total 8,702. Capital: Manitowoe.

Masirowoc, t., p. v., and cap. Manitowoe county, Tisc. 
$113 \mathrm{~m}$. N. T. Madison. Surface undulating; soil fertile, with good timber lands. Drained by Manitowoe r., which fulls Into Lake Michigan. The $\mathbf{v}$. at the mouth of the $\mathbf{r}$, has considerable trade, and is indicated as a future place of importance. Exports in 1851, $\$ 13,719$, and imports, $\$ 49,129$. Pop. of t. 766.

Manitow oo Rapios, t. and p. o, Manitowoe co., Wisc.: $107 \mathrm{~m}$. N. E. Madison. Drained by Manitowoe r. and Silver cr. Surface undulating; soil fertile, with much timber land. It has exeellent water-power, capable of supplying a large number of mills. Pop. of t. 966.

Maxmadixar county, Finn. Situate N., and contains about $18,000 \mathrm{sq} . \mathrm{m}$. The territory thus named stretehes from the Mississippi to the Missouri, and is drained by Tehan Sansan or a'Jaques $r$, a branch of the Missouri, and Red r., of the N., flowing into Lake Winnipeg, with their branchs, and innumerable smaller streams. The $\mathrm{E}$. is almost covered with small lakes, which abound in fish, and furnish abundance of wild rice. This region is chiefly inhabited by Indians, and visited only by hunters and fur traders, who collect great numbers of skins and furs for the eastern and European markets. Farms 9; manuf. 0; dwell. 16, and pop.-wh. 15S, fr. col. 0-total 15s. Not yet organized.

MAvics, t. and p. o., Allegan county, Mich. : $73 \mathrm{~m}$. W. Lansing. Drained by Kalamazoo and Rabbit rivers. Surface undulating; soil varied-on the banks of the river, rich alluvion. There is lumber here in abundance. The v. of Richmond is situate in the N. W. part of the $t_{\text {n, }}$ on the N. side of the Kalamazoo r. Pop. of t. 82 .

Mantues, t. and p. o., Onondaga co., N. Y.: $127 \mathrm{~m}$. N. W. Albany. Drained by Limestone and Chittenango cr. Surface level; soil ealcareous loam and vegetable mold, very productive. The $\mathrm{r}$. is situate in centre, on the Syracuse and Utica R. R. There are sulphur springs in the vicinity. Pop. of t. 6,29S.

Maxtius Centre, $p_{*} v_{*}$, Onondaga co., $N . Y_{*}:$ on the Erie Canal, 129 m. N. W. Albany.

Maxuy, p. o., Ashe co., $N$. Car.: 155 m. W. by N. Raleigh. Manlyville, p. o., Henry co., Tenn.: 83 m. W. by N. Nashville.

Maxweorotgi, p. v., Amelia county, Firg.: $2 \mathrm{~m}$. S. Appomattox r., and $23 \mathrm{~m}$. S. by W. Richmond.

Mannixginam, p. v., Butler co, Ala.: near a branch of Cedar r., 41 in. S. W. MFontgomery.

Mannngton, p. v., Leon county, Flor.: 5 m. N. E. Tallahassee.

Many's Choice, p. o., Bedford co., Penn.: 87 m. S. S. W. Harrisburg.

MANxsfilte, p. v., Jefferson co., N. $Y .: 1 \pm 1 \mathrm{~m} . \mathbb{N}$. W. Albany. The Watertown and Rome R. R. passes through the village.

Manvy, p. v., and cap. Sabine par, La.: on Bayou Jaspoon, $5 \mathrm{~m}$. S. Fort Jessup, $158 \mathrm{~m}$. N. W. Baton Rouge.

Masora county, $I a$. Situate $N$. W., and contains 780 sq. m. Drained by Little Lion and Soldier rivers, affluents of the Missouri, its $\mathrm{T}$. boundary. Tmorganized in 1550 .

Maxor, to and p. v., Lancaster co., Penn, : on the N. side of Susquehanna r., 31 m. S. E. IIarrisburg. The Conestoga $r$. forms its S. E. boundary, by which and its branches it is watered. Surface hilly; soil fertile. It has several flouring, grist, and saw mills. Pop. of t. 8,826 .

MAxor, sta., Suffolk co., N. $Y .:$ on the Long Island R. R., $66 \mathrm{~m}$. E. New Yurk.

Manor Hili, p. o., Huntingdon co., Pernn.: 65 m. W. Harrisburg.

Manorville, p. o., Suffolk co., $N$. I.: $131 \mathrm{~m}$. S. by E. Albany.

Maxsfreld, t. and p. r., Tolland co, Conn.: 23 m. E. IIntford. Draincd by Natehaug r. and its hranches, tributaries of Willimantic r., which latter bounds it on the W. Surfice uneven-in parts hilly; soil fertile. It has excellent water-power. This t, is important for its silk manufactories, which are the most extensive in the United States. Besides the silk, there are cotton and other factories in the town. 425
The $\mathrm{v}$. is situate on N. side of the $t_{\text {, }}$, near the New London, Willimantic, and Palmer $\boldsymbol{R}_{\text {. }}$ R., $38 \mathrm{~m}$. N. New London. Eagleville is the name of a $\mathrm{v}$. in $W$. part of $t_{\text {. }}$ situate on the railroad. Pop. of t. 2,530 .

MANSFIELD, p. V., De Soto par., $L \alpha_{0}$ : on a small cr. flowing into Big Pierre Lake, $115 \mathrm{~m}$. N. W. Baton Rouge, It contains the court-house of the parish. The "Mansfield Advertiser" (lit.) is issued weekly.

Mansfield, t. and p. v., Bristol co., Mass.: 24 m. S. by W. Boston. Drained by branches of Taunton $r$. Surface level soil good. This place bids fair to be of some importance as a coal region. A mine of anthracite coal is situate here (discovered 20 years ago), the vein 5 feet in thickness, dipping to $\mathbf{N}$. W.; besides which there are numerous other veins. The coal is of fine quality. There are several cotton and wool manufactories, as also a nail factory. Mansfield sta. is in N. part of t., on the Boston and Providence R. R. at which place the New Bedford and Taunton, and Taunton Branch R. R. diverges. Pop. of t. 1,789.

Mansfield, p. v., Warren co., N. Jer. : $37 \mathrm{~m}$. N. N. W. Trenton. The Morris Canal passes through the village.

Maxsferd, sta., Cattaraugus co., $N$. $Y$. : on the Corning and Blossburg R. R., $25 \mathrm{~m}$. from Corning.

Mansfield, p. o., Henry county, Tenn. : 83 m. W. by N. Nashville.

Mansfield, p. Y., and cap. Richland co., Ohio: on the Sandusky, Mansfield. and Newark R. R., $67 \mathrm{~m}$. N. by E. Columbus. It is pleasantly situated, and has a court-house, jail, 2 churches, several stores and workshops, and a large number of dwellings. There are 5 papers published here, the "Richland Democrat" (dem.), "Richland Jeffersonian" (whig), "Shield and Banner" (dem.), "Mansfield Herald" (whig), the "Rainbow" (lit.). Pop. of t. 3,557.

Massfield, p. v., Kendall county, $I l l_{*}: 135$ m. N. F Springfield.

Mansfield, p. o., Tioga co., Penn.: 113 m. N. by W. Harrisburg.

Manseield, p. o., Louisa county, Virg. : 37 m. N. W. Richmond,

Mansfield Centre, p. v., Tolland co., Conn.: on the cross roads, in S. E. part of Mansfield t., near Natchaug r., $25 \mathrm{~m}$. E. Hartford.

Mansfield Depôt, p. v., Tolland county, Conn. : on the New London, Willimantic, and Palmer R. R., $38 \mathrm{~m}$. N. by W. New London and $21 \mathrm{~m}$. E. Hartford.

MANSFIELD mountains, Ferm.: a branch of the Green Mountains, which presents some of the lofticst culminations in the State.

Maxsier's Creek, p. o., Davidson co., Tenn. : 13 m. N. Nashville.

Mansura, p. v., Avoyelles par., La. : on W. side of Red river, and about $2 \mathrm{~m}$. N. Mississippi r., $53 \mathrm{~m} . \mathrm{N}$. W. Baton Rouge.

Maxri Crmy, ,., Sanpete co., Vtah Ter.: in a hilly region, nearly 5,000 feet above the sea, and $45 \mathrm{~m}$. N. E. Fillmore City.

Mantox, p. o., Providence county, $R . I_{n}: 11 \mathrm{~m} . \mathrm{W}$. Proviaence.

Mantox, p. o., Narion county, Ky. : 47 m. S. by W. Frankfort.

Mantua, p. o., Pickens county, Ala.: 119 m. N. W. Montgomery.

Martua, p. o., M'Minn county, Tenn.: 125 m. S. E. Nashville.

Mantua Centre, p. o., Portage co, Ohio: $125 \mathrm{~m}$. N. E. Columbus.

MavpIlle, p. v., Providence co, $R . I .:$ on the Blackstone river, and line of Providence and Worcester R. R., $12 \mathrm{~m}$. N. Providence.

MANTARLNG's, p. 0., Shelby county, Ind.: $23 \mathrm{~m}$. S. E. Indianapolis.

Maon, p. o., Panola co., MFss. : $133 \mathrm{~m}$. N. Jackson.

Maple, p. O., Ionia co., Mich.: at the junction of Maple 
river with First cr., branches of Grand river, $25 \mathrm{~m}$. N. W. Lansing.

Mafle, p. 0., Brown co., Ohio: 81 m. S. S. W. Columbus.

MAPLe river, Mich.: a considerable stream, rising near the centre of Shiawassee co, and pursuing a N. W. course through Shiawassee, etc., into Gratiot, and then a S. W. course through Gratiot, etc., into Ionia co., where it enters the Grand river, about $8 \mathrm{~m}$. below the mouth of Lookingglass river. It is 60 yards wide at its month, and is not less than 100 miles long. The bottoms on this stream are exceedingly rich and fertile.

Maple Botrom, p. o., Iredell county, N. Car.: $119 \mathrm{~m}$.W. Raleigh.

Maple Cresk, p. o., Washington co., Penn.: $169 \mathrm{~m}$. W. Harrisburg.

Maple Furnace, v., Butlex co., Penn.: 169 m. W. N. W. Harrisburg. There is a coal blast furnace here (constructed in 1843) which has an annual capacity of 1,400 tons.

MAPLE Grove, t. and p. o., Barry county, Mich.: $31 \mathrm{~m}$. S. S. W. Lansing. Drained by a small er., tributary of Bigg Fork of Thorn-apple r. Surface undulating; soil fertile; abounds in fine timber lands. Pop. 153.

Mapue Grove; p. o., Aroostook co., Me.: 133 m. N. E. Augusta.

MAPLe Grove, sta., Berkshire co., Mass.: on Pittsfield and North Adams R. R., $13 \mathrm{~m}$. Pittsfield, $107 \mathrm{~m}$. W. by N. Boston.

Maple: Grove, p. o., Knox county, Ohio: 3っ m. N. E. Columbus.

Maple Grove, p. o., Otsego county, N. $Y_{:}: 85 \mathrm{~m}$. W. Albany.

MAPLE Hris, p. o., Davidson co., N. Car.: 85 m. W. Raleigh.

Maple Sprutgs, p. o., Red River co., Teso.: 285 m. N. E Austin City.

Maplesville, p. v., Bibb county, Ala.: on N. side of Mulberry er., $41 \mathrm{~m} . \mathrm{N}$. W. Montgomery.

MLapletos, p. o., Abbeville dist., S. Car.: $79 \mathrm{~m} . \mathrm{W}$ Columbia.

Maptikton, p. o., Niagara co., N. Y.: $271 \mathrm{~m}$. W. by N Albany.

Mapleton, p. o., Waukesha county, Wisc.: $59 \mathrm{~m}$. E. Madison.

Mapleton, p. O., Stark co., Ohio: $25 \mathrm{~m}$. N. E. Columbus.

Mapletown, p. v., Greene co., Penn.: on Whitelay cr. $159 \mathrm{~m} . \mathrm{S}$. by W. Harrisburg.

Maplevilie, p. o., Providence county, R. I.: $9 \mathrm{~m}$. W. Providence.

MAQUOKETA, p. v., Jackson county, $I a_{\text {. }}$ : in $\mathrm{S}$. part of co., on a branch of the Maquoketa r., $53 \mathrm{~m}$. N. E. Iowa City.

Maquox, p. v., Knox co., Ill.: situate in a fertile prairie $1 \mathrm{~m}$. W. Spoon r., $73 \mathrm{~m}$. N. N. W. Springfield.

Maramec, $p_{0}$ v., Crawford co., Mo.: situate in an extensive iron region on the W. bank of the Maramee $r_{*,} 52 \mathrm{~m}$. S. E. Jefferson City. There is a blast furnace and severa forges (called "Massey's Iron Works") in operation, yielding from 1,000 to 1,500 tons bar iron annually of excellent quality. "Big Spring" (so called, at the junction of the river), affords excellent water-power to the $\mathrm{v}$., on the site of which are several saw and grist mills.

Maraxec river, MOo: rises in Dent county, whence its course is generally N. E. through Craw ford and into Franklin, and thence it passes in an E. and E. N. E. direction into Jefferson and St. Louis counties, and falls into the Mississippi about $20 \mathrm{~m}$. below St. Louis City. Its principal affluents are Osage Fork and Big r. from the S, and Bourbeuse cr. from the W., besides many smaller streams from both directions. The river is about $180 \mathrm{~m}$. long, and navigable for steamboars 60 miles.

Maratron county, Wisc. Situate N. middle, and contains about 5,100 sq. m. Drained by Wisconsin $\mathrm{r}$ and its branches, heads of Black and Chippewa rivers, and of Montrcal r. of Lake Superior. Many of the rivers have lakes, or chains of lakes, at their sources, and most furnish water-power. The surface is much varied, and parts are very hilly. The soil is various, with much excellent grain land, and is generally well timbered. Only the $\mathrm{S}$. is yet settled, and that but sparsely. Farms 7 ; manuf. 15; dwell. 76, and pop.-wh. 508, fr. col. 0-total 508, Capitul: Wassau.

Marathon, t. and p. V., Cortlandt co., N. Y.: $123 \mathrm{~m}$. W. $\frac{1}{2}$ S. Albany. Drained by Tioughnioga $r$ and its branches, which pass through the town. 'Surface undulating; soil gravelly loam, intermingled with lime and slate, and very fertile. The $\mathrm{v}$. is situate on the $\mathrm{E}$. side of the Tinughnioga. Pop. of t. 1,149.

Marathon, p. o., Clermont county, Ohio: 85 m. S. W. Columbus.

Marble Crekek, p. o., Jessamine co., Ky.: 26 m. S. E. Frankfort.

Marble Dale, p. o., Litehfield co., Conn.: $37 \mathrm{~m} . \mathrm{W}$. Hartford.

Marble Furnace, p. o., Adams co., Ohio: 91 m. S. by W. Columbus.

Marble Halu, p. o., Hawkins co., Tenn。 : 203 m. E. by N. Nashville.

Marblenead, p. o., Ottowa county, Ohio: $107 \mathrm{~m}$. N. Columbus.

MARBLFHeAD, to, p. V., and port of entry, Essex co., MFass. : $14 \mathrm{~m}$. N. E. Boston. Situate on a peninsula formed by the harbor of Salem on the N. and Nahant Bay on the S. Surface elevated and rocky. The $\mathrm{v}$. is pleasantly located on a deep inlet of the coast called the harbor, and is aceessible to the largest vessels; and a branch of the Eastern R. R. comes up here. The people are noted for their devotion to the fisheries and coast navigation. The clearances in the foreign trade in 1850 numbered 176 vessels (11,414 tons), and the entrances 177 vessels $(12,086$ tons) - nearly all foreign shipping from the British provinces. Shipping owned in the district 6,842 tons, of which 2,281 tons were employed in coasting, 2,699 tons in the cod fisheries, and 248 tons in the mackerel fisheries, etc. Coasting steamers touch at this point several times daily. Pop. of the t. 6,167.

Marblemead, p. o., Gilmer county, Ga.: $135 \mathrm{~m} . \mathrm{N}$. W. Milledgeville.

Marbie Hrux, p. v., Prince Edward co., Firg.: on a fork of Appomattox r., 99 m. S. W. Riclımond.

Mardue Hul, p. o., Franklin county, Tenn.: $61 \mathrm{~m}$. S. Nashville.

MaRBletown, t. and p. v., Uister county, N. I.: $57 \mathrm{~m}$. S. by W. Albany. Drained by Esopus cr. on the N. E. and Rondout Kill on the S. E., both which afford excellent water-power. The Shawangunk Mountains are in the S. E. part of town. Surface hilly; soil on the mountains barren, and in the lower parts fertile, being a rich regetable mold. The $\mathrm{v}$. is situate near Esopus cr. The t. has numerous mills, tanneries, etc., and 3,839 inhabitants. The Delaware and Hudson Canal passes tbrough it.

Marburvivile, p. v., St. Tammany par, $\alpha_{0}$ : on E. bank of Tangipahoa r., $43 \mathrm{~m}$. E. by N. Baton Rouge.

Marcelline, p. o., Adams county, $I l l .: 79 \mathrm{~m}$. N. by W. Springfield,

Marceilon, $t$, and p. v., Columbia co., Wisc.: $37 \mathrm{~m} . \mathrm{N}$. Madison. Drained by branches of Wisconsin $r$. Surface varied; soil fertile, with good timber land. The $v$. is in the S. E. part of t., on a branch of Wisconsin $x$. The t. has excelleni water-power and some mills. Pop. 505.

Marcellus, p. o., Washington county, Ia.: $27 \mathrm{~m} . \mathrm{s}$. Iowa City.

MaReelles, to and p. Y., Onondaga co., N. Y.: $131 \mathrm{~m}$. W. by N. Albany. Drained by Nine Mile cr. Surface uneven, in parts hilly; soil calcareous loam, and highly fertile. The $\mathrm{v}$. is situate on Nine Mile cr. in N. part of t., and on the line of the Rochester and Syracuse $R$. R. There are sereral mills and factories in operation. Pop. of t. 2,759.

Marcellus Falis, p. v., Onondaga co., $N$. Y.: situate 
about $1 \mathrm{~m}$. S. Marcellus on Nine Mile cr., 129 m. W. by N. Albany.

Marcandi, p. o., Indiana co., Penn.: $117 \mathrm{~m}$. W. by N. Harrisburg.

Marous, p. v., Jackson co., Ga.: on a fork of the Oconee r., 83 m. N. N. W. Milledgeville.

Maricus Hoors, p. v., Delaware co., Penn. : on the Delaware $\mathrm{r}, 81 \mathrm{~m}, \mathrm{E} . \mathrm{S} . \mathrm{E}$. Harrisburg. It is on the line of the Philadelphia, Wilmington, and Baltimore $R . R ., 18 \mathrm{~m}$. Philadelphia.

Maroy, p. o., La Grange county, Ind.: $127 \mathrm{~m}$. N. by E. Indianapolis.

Marcr, p. v., Wankesha co., Wisc.: on the Milwaukie post-road, $63 \mathrm{~m}$. E. Madison.

Marcy, t. and p. o., Oneida co., $N . \Gamma .: 83 \mathrm{~m}$. W. N. W. Albany. Drained by Nine Mile cr. ; and Mohawk r. bounds it on the S. Surface hilly, the Hassencleaver Mountain covering it in part; soil clay and sandy loam. Pop. of t. 1,857.

Mardisville, p. v., Talladega co., Ala.: near Talladega river, $113 \mathrm{~m}$. N. Montgomery. A United States land office is situate here. There are a number of stores and dwellings in the village.

MARENGo county, Ala. Situate S. W., and contains $1,08 S$ sq. m. Bounded W. by Tombigbee r, and drained by its affluents, and E. by affluents of the Alabama. Surface moderately uneven; soil in parts pine-barrens, but most of it is very fertile. Cotton is the great and almost exclusive product. Corn is largely grown in parts; some rice and tobaceo is raised; coal and iron ore are found. Farms 818; manuf. 4; dwell. 1,353, and pop.-wh. 7,101, fr. col. 37 , sl. 20,693-total 27,831. Capital: Linden. Public Works: Alabama Southern R. R.

Maringo, p. T., and eap. Iowa co., I $x_{0}$; on S. side of Towa river, $29 \mathrm{~m} . \mathrm{W}$. by N. Iowa City. A post-road passes through the $\mathrm{v}$, connecting with the contemplated line of the Dubuque and Keokuk R. R. and Iowa City.

Marejgo, p. o., Laurens district, S. Car.: $67 \mathrm{~m} . \mathrm{N}$. W. Columbia.

Marevgo, p. v., M'Henry county, $\pi l_{0}: 175$ m. N. N. E. Springfield, on the Kishwaukee $r$, and on the Galena and Chiengo Union R. R., $66 \mathrm{~m}$. from Chicago.

Marexgo, t, and p. v., Calhoun co., Mich. : 31 m. S. by W. Lansing. Drained by Kalamazoo $\mathrm{r}$. and Rice cr., one of its brancles. Surface undulating; soil of a rich sandy loam. There are extensive sand-stone quarries along the banks of the river, which here affords excellent water-power. The $y$. lies on the S. side of the Kalamazoo. The Michigan Central R. R. passes through the $t$, on N. side of the r., and a short distance from the village, $101 \mathrm{~m}$. W. Detroit, and $177 \mathrm{~N}$. E. Chicago, Pop, of t. 1,013.

Marengo, p. v., Wayne co., $N_{0} Y_{*}: 167 \mathrm{~m}$. W. by N. Albany.

Marengo, p. o., Morrow co., Ohio: $39 \mathrm{~m}$. N. Columbus.

Margallawas river, N. Mump.: rises in the highlands which separate Canada from Maine, and after a shnrt course enters the latter; and from thence, after flowing a distance of $40 \mathrm{~m}$., turns into New Hampshire, and enters the Androscomein r. a fuw miles below Umbagog Lahe.

Mapgaretta, p. v., Clark co., Ill.: 3 m. E. North Fork Embarras r., 93 m. E. S. E. Springfield.

Margaretta, sta, Frie co, Ohio: on the Mad River and Lake Erie R. R., $211 \mathrm{~m}$. Cincinnati, $97 \mathrm{~m}$. N. Columbus.

Margaretta Furvace, p. 0., Fork co, Penn. $25 \mathrm{~m}$

S. E. Harrisburg. There is a furnace here with annual capacity of 1.200 tons, construeted in 1523

Margarettspille, sta., Northampton co., N. Car.: on the Sea-board and Roanoke R. R., $17 \mathrm{~m}$. N. E. Weldon.

Maria Creek, p. v., Knox co., Ind. : on a cr, of West

Fork Thite river so called, $85 \mathrm{~m}, \mathrm{~S}$. W. Tadianapolis.

Maria Forge, p. o., Talladega co., $A l \alpha_{0}$ : $51 \mathrm{~m}$. N. by E. Montgomery.

Mariana, p. v., and cap. Jackson eo., Flor.: on the Chipota r., $63 \mathrm{~m} . \mathrm{N}$. W. Tallahassee; contains the county 430 court-house and other public buildings, a number of stores and workshops.

Marta Stern, p. o., Mercer county, Ohio: 139 m. W. N.W. Columbus.

Mariatille, t. and p. o., Hancock co., Mee. : $75 \mathrm{~m}$. N. E. Augusta. Drained by Union $r$, and its branches, Surface uneven; soil good. The river affords extensive waterpower, which keeps several mills in active operation. There is a great quantity of lumber sent from here. Potatoes and wool are the chief agricultural products. Pop. 375.

Mariaville, p. o., Schenectady co., N. Y. : $25 \mathrm{~m}$. W. by N. Albany.

Marietta, p. v., and cap. Cobb eo., Ga.: $7 \mathrm{~m}$. W. by N. Chattahoochie r., $100 \mathrm{~m}$. N.W. Milledgeville. The Western and Atlantic R. R. passes through it $20 \mathrm{~m}$. from Atalanta. It contains the county buildings, 2 academies, and about 150 dwellings." The "M. Advocate" (dem.), and "Coustitutional Union" (union), are issued weekly, and "Masonic Journal," monthly. The business of a fine agricultural region centres at this point.

Marietra, p. v., Fulton co., $M l$. : on S. side Sheen's cr., 61 m. N. W. Springfield. Situate on a fertile prairie.

Marietta, p. o., Onondaga county, $N_{0} Y_{*}: 137$ W. by N. Albany.

Marietta, p. v., Shelby county, Ind. : on the E. branch White $\mathrm{r} ., 27 \mathrm{~m}$. S. E. Indianapolis, and on the Shelbyville Lateral Branch R. R., 7 m. from Edinburg.

MARIETTA, t., p. v., and cap.Washington co., Ohio: $87 \mathrm{~m}$. S. E. Columbus. Its W. part is crossed by the Muskingum river at its entrance into the Ohio river. The Ohio bounds it in the S. W., and it is drained by Duck cr. and Little Muskingum $r$. The streets are well laid out and thickly built. There is a court-house, jail, U. S. land office, a banking establiskment, all handsomely built, and forming ornaments to the place. Several mounds are iound in the vicinity. The Marietta College is situate here, founded in 1835, baring (in 1850) a president, 6 professors, 113 alumni, of whom 44 are in the ministry, and 55 students, with a library containing 6,400 volumes. The t. was founded in 17S8, and is the oldest in the State. There are a number of steam saw-mills, flouring-mills, tanneries, foundries, and other factories here. The $\mathrm{v}$. is pleasantly situate on the $\mathrm{N}$. bank of the Ohio $r$., at the mouth of the Muskingum river. There are two newspapers published in the village, the "M. Intelligencer" (whig), and the "M. Republican" (dem.), both weekly issues. Marietta is destined to be a place of considerable business, and its future railroad connections will give it direct access to the principal centres. Several steamboats are owned here, and ply regularly to Pittsburg, Cincinnati, etc. Pop. of the t. 4,292, of which 3,133 are in the village.

Mariefta, p. o., Itawamba county, Miss. : 159 m. N. E. Jackson.

Marietta, p. b., Lancaster county, Penn.: 25 m. S. E. Marrisburg, on the $\mathrm{E}$. bank of Susquehanna r., and near the mouth of Little Chiques cr. It contains about 1,000 inhabitants.

MARIV county, Calif. Situate W. middle, and contains 516 sq. m. Bounded W. by the Pacific, and E. by Pablo Bay, and lies on the N. side of the entrance to San Francisco Bay. The streams are small, American river flowing W.. and Petaluma cr. S. E., are the principal. The surface is broken with extensive valieys. Soils very productive of whent and most other grains, and generally well wooded. Pop. about 1,036. Capital: San Raphael.

Marine Milis, p. v., St. Croix co., Wisc.: on E. side of St. Croix r., 225 m. N. W. Madison.

Martae Setrlenent, p. o., Madison co., $\pi l .: 71 \mathrm{~m} . \delta_{.}$ Springfield, near Silver cr., on a rich and fertile prairie.

Variox county, Ala. Situate N. W., and contains 1,082 sq. m. Drained by Buttahatchie $\mathrm{r}$. of the Tombigbee, Big Bear cr. of the Tennessee, and E. by Nine Island cr. Surface rolling or slightly broken; soil of moderate fertility, 
best fltted for grazing. Corn, wheat, and cotton are raised, but cattle and pork are leading products. It is well wooded with oak, pine, hickory, and chestnut. Farms 573; manuf. 5; dwcll. 1,108, and pop.-wh. 6,922, fr. col. 3, sl. 908-total 7,S33. Capital: Pikeville.

Marroy county, Ark. Situate N. middle, and containg 537 sq. $\mathrm{m}$. Drained by Crooked cr. and other branches of White r., which flow S. E. through it. Surface varied; soil very fertile and excellent grazing. Corn is the chief crop, and live-stock and pork the exports. White river is navigable to this co., and is skirted with noble forests of pine timber, and its branches furnish good mill-seats. Farms 255; manuf. 2; dwell. 361, and pop.-wh. 2,047, fr, col, 129, sl. 126-total 2,302. Cupital: Yellville.

Marion county, Flor. Situate on N. part of the peninsula, and contains $3,127 \mathrm{so} . \mathrm{m}$. Drained E. by Ocklawaha r., a branch of St. John's r., and S. W. by Withlacoochee r. Surface low and level, with numerous lakes and swamps; soil exceedingly fertile, producing large crops of cotton, sugar, and corn, and raising many semi-tropical fruits and regetables in profusion. It has extensive forests of valuable live oak, cedar, and cypress timber, and in parts fine waterpower. Sulphur and magnesia springs of great medicinal virtues attract many invalids who seek a mild elimate, and salt springs are found. Farms 329 ; manuf. 0 ; dwell. 394, and pop.-wh. 2,068, fr. col. 1, sl.1,269-total 3,338. Capitat Ocola.

Mariox county, Ga. Situate S. W., and contains 519 sq. m. It lies midway between Chattahooehee and Flint rivers, and is drained by small branches of both, N. and $\mathrm{s}$. Whitewater creeks being the largest. Surface moderately hilly ; soil fertile. Cotton is the chief product, and the crop a very large one. Corn is an average crop, and wheat not much grown. Grazing is generally good, and cattle and swine receive much attention. Farms 563; manuf. 4 ; dwell. 1,101, and pop.-wh. 6,568, fr. col. 8, sl. 3,604-total 10,150. Cupital: Tazewell. Pullic Works: Nuscogee R. R.

MARiox county, $I l l$. Situate $\$$. centrally, and contains $576 \mathrm{sq} . \mathrm{m}$. Drained by Crooked cr. and E. fork of the Kaskaskia, and E. by Adam's and Skillett forks of the Little Wabash. Surface gently undulating; and soil of good fertility. It lies on the E. side of the Grand Prairie, and is largely made up of prairie, with wood on the streams, which afford some good mill-seats. Corn is the staple. Cattle are raised in large numbers, and pork is an important export. Bituminous coal and water-lime are found. Farms 827; manuf. 9 ; dwell. 1,132, and pop.-wh. 6,716 , fr. col. 4 total 6,720. Cupitul: Salem. Public Worlis: Ohio and Mississippi R. R.; Chicago Branch of Illindis Central Railroad, etc.

Mariox county, Ind. Situate centrally, and contains 316 sq. m. Drained by W. fork of White $r_{\text {, }}$ Fall, Eagle, and other creeks. Surface beautifully rolling and diversiffed by slight elevations toward the streams. Prairie bottoms and woodlaud are pleasantly mingled. Soil generally a black loam, mixed with sand or clay, and resting on limestone, and is very fertile. Corn, wheat, and oats are all large crops, and the chief farming products. The grazing is very fine; cattie and sheep are raised in great numbers, and pork is a large export. It has much water-power, and very extensive manufactures of woolen and cotton goods, flour, lumber, leather, liquors, oil, earthen-ware, ete. Farms 1,581; manuf. 179; dwell. 3.984 , and pop.-wh. 23,453 , fr. col. $650-$ total 24,108. Capital: Indianapolis. Pubtic Works: Madison and Indianapolis R. R.; Indiana Central R. R.; Terre Haute and Richmond R. R.; Lafayette R. R.; Indianapolis and Peru R. R.; and Indianapolis Bellefontaine $R_{\text {. }} \mathrm{R}_{\mathrm{v}}$; Jeffersonville $\mathrm{R}_{\text {. }} \mathrm{R}_{\text {s, }}$ etc., all of which centre here at the union depot.

Marios county, $I a$. Situate $\mathrm{S}$. centrally, and contains 576 sq. m. Drained by the Des Moines and its branches, Coal, English, and Cedar creeks, and Whitebreast r.; Skunk r. tonches the N. E. corner. Surface somewhat broken; soil fertile, adapted equally to grass and grain. Corn, wheat, live-stock, and pork are the leading products of the farm. It has excellent water privileges, growing manufactures, and much fine timber. Coal and iron ore are found near the Des Moines. Farms $342 ;$ manuf. 24 ; dwell. 930, and pop.-wh. 5,453, fr. col. 29-total 5,482. Capitat: Knoxville.

Marion county, $\bar{K} y$. Situate centrally, and contains 332 sq. m. Drained by Rolling Fork of Salt r., a branch of the Ohio, Surfuce uneven, but not rough; soils generally fertile. Corn and wheat are the staple cereals. Rye, oats, and tobacco are successfully cultivated. Large numbers of sheep are kept, and a good deal of pork exported. Tlis region is stocked with fine horses, which are much attended to and furnish Eastern markets largely. Water-power is plentiful, and manufactures an important interest. Farms 963 ; manuf. 47 ; dwell. 1,428, and pop.-wh. 8,599, fr. col. 80, sl. 3,056-total 11,765. Capital: Lebanon. Public Works: Danville and Nashville R. R., ete.

MARION county, Miss. Situate $\mathrm{S}$., and contains $1,514 \mathrm{sq} . \mathrm{m}$, Drained by Pearl $r$. and its branches, Surface level or undulating; soil sandy and of no great fertility, except on the streams, where is much excellent land. Cotion and corn are the staples. Rice is grown in the marshes. Great numbers of cattle and swine are reared, and form the leading interest of the co. It is well timbered with pine. Farms 322 ; manuf. 7 ; dwell. 377 , and pop.-wh. 2,215 , fr, col. 0, sl. 2,195-total 4,410, Capital: Columbia.

MARION county, Mo, Situate N. E., and contains 423 sq. m. Drained by N. and S. Fabiug and N. and S. two rivers and their branches, affluents of the Mississippi, its E. boundary. Surface moderately uneven; soil very rich. Corn, wheat, oats, and potatoes yield great crops, and the pasture is very fine. Live-stock, beef, wool, and pork are exported. It has excellent mill streams and very important manufactures, and abounds in timber, bituminous coal, and lead. Salt springs are found. Farms 810 ; manuf. 75 ; dwell. 1,595, and pop.-wh. 9,322, fr. col. 76, sI. 2,832-total 12,230. Capital: Palmyra

Marion county, Ohio. Situate N. centrally, and contains 303 sq. m. Drained by Scioto $\mathbf{r}$. and its branches, Push cr. and Whetstone r. Surface mostly a level table land; soil very productive, adapted to grass or grain. Corn, wheat, rye, oats, and potatoes produce largely. It is a superior grazing co., supports fine dairies and large numbers of cattle and sheep, and exports live-stock and pork to a large amount. It has also good water-power, and considerable manufactures of flour, lcather, and woolens. Farms 919; manuf. 14; dwell. 2,15s, and pop.-wh. 12,597, fr. col. 21total 12,618. Capital: Marion. Public Works: Bellefontaine and Indiana R. R.

Marion county, Oreg. Ter. Situate centrally, and contains $21,000 \mathrm{sq} . \mathrm{m}$. It has Cluckamas co. on the N., Poik on the W., and Linn on the S., and is drained by branches of the Willamette, its W. boundary, Butte, Aberque, Silver, and Mill creeks, and $\mathrm{N}$. fork of Santiam r. Surface diversified; extensive and very rich valleys in the W., and in the E. elevated and mountainous; soil in the bottoms a black vegetable loam ; in higher lands a stiff clay or loose gravel, mostly very productive. All kinds of grain except corn grow finely, and fruits and vegetables are abundant. It has the best of timber, pine, fir, spruce, and oak, and very superior water-power. Farms 293; manuf. 11; dwell. 502, and pop.-wh. 2,740, fr. col. 9-total 2,749. Capital: Salem.

MARIOX district, S. Car. Situate E., and contains 1,032 sq. m. Drained by Great and Little Pedee rivers, and Lynch's cr. and their branches, Lumber r. and Jeffries and Catfish creeks. Surface level, much of it low and marshy; soil generally of good fertility, and many parts best adapted to grazing. Corn and cotton are the principal crops. The marshes produce considerable rice. Many cattle are raised and great quantities of pork fatted. It has a large growth of pitch-pine timber. Farms 1,374; manuf, 0 ; dwell. 1,\$56, 
and pop, - wh. 9,784, fr. col. 108, sl. 7,520-total 17,407. Cajutal: Marion. Public Works: Wilmington and Manchester R. R.

Marion county, Tenn. Situate S. E., and contains 588 sq. $m$. Drained by the Tennessee and its branches, Sequatchy r., Little Sequatehy, and Battle creeks. Surface elevated and broken; soil fertile and fine pasture land. Corn, wheat, and onts are the staple grains. Great numbers of cattle and swine are reared, and live-stock and pork are henvy exports. Farms 724; manuf. 9; dwell. 957, and pop.-wh. 5,720, fr. col. 43, sl. 551-total 6,314. Capital: Jasper. Public Works: Nashville and Clattanooga R. R.

MarroN county, Virg. Situate N. W., and contains 163 sq. m. Drained by Monongahela r., E. and W. forks, and Buffalo cr. Surface elevated and uneven; soil very fertile, and excellent grazing land. Corn, wheat, oats, and potatoes are raised largely, and great numbers of cattle, sheep, and swine are reared. It has fine water-power and extensive manufactories of iron, flour, woolen goods, leather, Iiquors, etc. Iron ore and coal are found in abundance in parts of the co. Erected in 1812 from Harrison and Monongalia. Farms 904; manuf. 44; dwell. 1,786, and pop.-Wh. 10,438, fr. col. 20, sl. 94-total 10,552. Cupitul: Fairmount. Pullic Works: Baltimore and Ohio R. R.

Marion, p. v, and cap. Perry county, $A l a$. : on E. side Washington cr., $61 \mathrm{~m}$. W. N. W. Montgomery. It contains a college, a theological seminary, several schools, a courthouse, and about 1,500 inhabitants. The "South-Western Baptist" (Baptist) and "Alabama Commonwealth," weekly issues, are published here. Howard College, situate here, was founded in 1841; in 1850 it had a president, 6 professors, 29 alumni, 88 students, and a library of 2,200 volumes ; and Howard Theological Institution was founded in 1843; in 1850 it had a professor and 13 students, and a library of about 1,000 volumes. Both are Baptist schools.

Marion, p. v., and cap. Crittenden co., Ky.: $187 \mathrm{~m}$. W. \&. W. Frankfort. It contains a court-house, severa stores, and workshops.

Marion, sta., Shelby county, Ind.: on the Knightstown and Shelbyville R. R., 4 m. N. Shelbyville, 25 m. S. E. Indianapolis.

Marion, p. v., and cap. Twiggs co., $G a$. : near a branch of the Oemulgee r., $32 \mathrm{~m}$. S. W. Milledgeville.

Martox, p. v., Williamson co., Ill.: on a branch of Big Muddy r., $145 \mathrm{~m}$. S. S. E. Springfield.

Marior, p. v., and cap. Grant co., Ind.: on the Mississinewa r., $59 \mathrm{~m}$. N. E. Incianapolis. The "Whig Thermometer" (whig) is issued weekly.

M $\triangle$ Rion, p. v., and cap. Linn co., I $a_{*}$ : on a fork of Cedar $r$ in centre of co, $23 \mathrm{~m}$. N. Iowa City. The $\mathrm{v}$. is situated on the edge of a beautiful grove, and contains several stores, saw-mills, etc., and the county offices.

Mrakios, p. o., Union par., La.: 169 m. N. W. Baton Rouge.

MARIox, to and p. v., Washington $c_{0}$, Me.: $126 \mathrm{~m}$. E. N. E. Augusta. It has on its W. a large pond which separates it from Mechisses $r$, and by which it is drained. Surface hilly; soil variable, chiefly good. It has several saw-mills. The $\mathrm{v}$. is situate on N. E. part of $t$, on the post-road leading to Dennyville. Pop. of t. 207.

Marron, p. v., and eap. Angelina co., Tex. : on S. bank of Augelina r., 209 m. E. N. E. Austin City.

MARIoN, t. and p. o, Livingston co., dfich, : $81 \mathrm{~m} . \mathrm{S} . \mathrm{E}$ Lansing. Drained by a number of small streams, tributaries of Shiaw assee and Cedar rivers. Surface generally undulating; soil fertile. There are several small ponds in S. part. Pop. 873 .

Marion, p. v., and cap. Lauderdale co., IFiss.: at the head of Oetibbeha cr., $\$ 9 \mathrm{~m}$. E. by N. Jackson.

Marion, p. v., and cap. Cole co., Mro.: on the S. bank of the Missouri r., 5 m. N. by W. Jefferson City.

Marrox, t. and p. v., Wayne co., $N_{.} Y_{0}: 183$ u. W. N. W. Albany. Dritined by a branch of MIud er. Surface much 432 broken by hills and ridges; soil fertile, and well adapted to grain. The $\mathrm{v}$. is situate ceatrally. There is a steam-furnace, grist-mill, and tannery here. Pop. of t. 1,839.

Marion, p. v., and cap. M'Dowell co., $N$. Car, : near a fork of the Catawba r., $190 \mathrm{~m}$. W. Raleigh.

Marion, p. Y., and cap. Marion co., Ohio: $41 \mathrm{~m}$. N. by W. Columbus. Drained by a fork of the Seioto r., which passes through its W. part. Surface level; soil fertile. The $\mathrm{v}$, is situate in S. part of $t$. and contains many flne buildings, the most conspicuous of which are the court-house, jail, and churches. There are also tanneries, grist-mills, saw-mills, and flouring-mills. There are 2 newspapers printed here, the "Buckeye Eagle" (whig), and "Democratic Mirror" (dem.) Pop. of v. 1,307, and of t. 2,287 .

Marion, p. v., Franklin co., Penn.: $47 \mathrm{~m}$, W. S. W. Harrisburg.

Mapron, p. o, Hartford co., Conn. : $7 \mathrm{~m}$. N. Hartford.

Marios, p. V., and cap. Smyth co., Jirg.: on \$. side middle fork Holston r., $237 \mathrm{~m}$. W. S. W. Richmond. The Virginia and Tennessee R. R. passes through the village.

Marion, p. o., Kenosha county, Wisc.: $77 \mathrm{~m} . \mathrm{S}, \mathrm{E}$ Madison.

Marion CtTx, p. v., Marion co., Mo : $93 \mathrm{~m}$, N. E Jefferson City, on the W. bank of the Mississippi r., $7 \mathrm{~m}$ below Quincy, and $7 \mathrm{~m}$. E. Palmyra, the capital of the county, for which latter place it is the shipping port. The country round about is very rich, and abounds in excellent timber and coal. It contains sereral steam, saw, and other mills, and has about 600 inhabitants.

Marion C. H., p. v., and cap. Marion dist., S. Car. : on the E. side of Catfiish cr., an affluent of Great Pedee River, 91 m. W. N. W. Columbia. The Wilmington and Manchester R. R. runs through the $v$. It contains a court-house, jail, several stores, and dwellings. The "Marion Star" (ind.) is issued weekly.

Marion Mrucs, p. o., Washington con, Me.: $125 \mathrm{~m}$. E. Augusta.

Mariposa county, Calif. Situate $\mathbf{S}$. middle, and contains about 16,000 sq. m. It lies $\mathrm{E}$. of the Coast Range, and extends to the E. line of the State. The N.W.part is drained by the San Joaquin and its branches, and forms the head of the San Joaquin valley. This part is rich in gold mines, which are much wrought, and very productive. The soil here is very fertile. The Sierra Nevada, or Snowy Mountains and their spurs, occupy a large part of the N.E., and $\mathrm{E}$. of the county, passing through it in a S. S. E. direction. Between them and the Coast Range in the $S_{\text {; i }}$ a large basin, drained by numerous small rivers, emptying into Tulare Lake, a sheet of water 50 miles long, and 10 or 12 broad. In this basin is excellent grain and grass land, but little of which is under cultivation.

MariposA, p. Y., and cap. Mariposa co., Calif.: on the $\mathrm{S}$. bank of a r. so called, an affluent of the San Joaquin. It is a growing place, and in common with an extensive tract around it, is owned by Colonel Fremont. The quartz in this region is highly auriferous, and is attracting the attention of capitalists and miners.

Marissa, p. V., St. Clair, co., $M l_{\text {. : }}$ situate on the border of a fertile prairie, S. E. part of county, 109 miles $\mathbf{S}$. Springfield.

MartT's, p. o., Momow co., Ohio: 39 m. N. Columbus.

Markesax, p. o., Marquette county, Wisc.: $45 \mathrm{~m}, \mathrm{~N}$. Madison.

Markfsborougr, p. o., Warren co., N. Jer.: $53 \mathrm{~m} . \mathrm{N}$. Trenton.

Marksvilte, p. V., and cap. Aroyelles par., La.: near Lake Pearl, $67 \mathrm{~m}$. N. W. Baton Rouge. It is the seat of the parish court-house.

Markstilze, p. V., Page co., Firg.: in a valley of the Blue Ridge Mountains, which form the E. boundary of the co., 85 m. N. W. Richmond.

Marliozo, p. o., Carroll con, Tomn. : $88 \mathrm{~m}$. W. by $\$$. Nashrille. 
Mariborotgr district, S. Car. Situate N. E., and conmins $41 \mathrm{~s} \mathrm{sq} . \mathrm{m}$. Bounded W. by the Great Pedee, and drained by its branches, and E. by heads of Little Pedee. Surface elevated and somervhat uneven. Soil generally fertile. Cotton is the chief product. Corn is a good crop, and large numbers of hogs are reared. It has fine water privileges, and valuable manufactures of cotton goods and flour. Farms. 621; manuf. 23 ; dwell, 929, and pop.-wh. 5,083, fr. col. 156, sl. 5,600-total 10,7s9. Capital: Bennetsville.

Marlborotgh, p. o, Hartford co., Conn.: 5 m. Hartford. Marlborough, t. and p. v., Middlesex co., Mass.: $25 \mathrm{~m}$. W. Boston. Drained by branches of Concord $r_{\text {, }}$, and a number of small ponds. Surface undulating, and soil very fertile. Agricultural pursuits are the chief employment of the inhabitants. Products of the t. are large, consisting of cattle, pork, the dairy, ete., which are sent to Boston market chiefly by the Lancaster and Stering Branch R. R., which passes through the N.W. part of t., at Feltonville, and connects with road to the eity. Manufactures of t. consist of boots, shoes, and cabinet-ware. The $\mathrm{v}$. is pleasantly situated, surrounded by beautiful scenery. Pop. of t. 2,941 .

Marbirorotge, t. and p. v, Cheshire county, N. Hamp.: $41 \mathrm{~m}$. S. W. Coneord. Drained by branches of Ashuelot $\mathrm{r}$. Surfuce uneven: soil rocky, but good for grazing. There are a number of small ponds in the t. There are several mills, manufactories, and workshops. The v. is in W. part, and through it the Cheshire $\mathrm{R}_{\mathrm{v}} \mathrm{R}$. passes, distant $36 \mathrm{~m}$. from Fitchburg, Pop. of 't. 886 .

Marlborouge, p. o., Monmouth co., $N$. Jer, : $81 \mathrm{~m}$. E。 Trenton.

Marlborough, to and p. F., Ulster con, $N . Y_{0}: 69 \mathrm{~m} . \mathrm{S}$. Arbany. Drained by Old Man's Kill, flowing into the Hudson r., which latter bounds it on the E. Surface very uneven ; soil clay loam, and very fertile. The $\mathrm{v}$. is situate near the Hudson r. and OId Man's Kill. It contains several lumber Jards, manufactories, etc. Pop. of t. 2,405.

MARLBorotgh, t. and p. v.,Stark co., Ohio: $107 \mathrm{~m}$. N. E. Columbus. Drained by several small streams. Surface uneven; soil very good, abounding with beech and sugar maple. The $\mathrm{v}$. in N. E. part of $\mathrm{t}$. is a thriving settlement Pop. of t. 2,133.

Marliorodgh, t. and p. o., Chester co., Penn. : $63 \mathrm{~m}$. S. E: Harrisburg. Drained by several small streams flowing into the Delaware. Surface rolling; soil, red shale. Iron ore is found in the vicinity.

Marlborougr, $t_{n}$ and p. v., Windham co., Term. $99 \mathrm{~m}$. S. Montpelier. Drained by a branch of West $r$. and Whetstone brook. Surface rolling: soil fertile, and very productive of all kinds of grain, fruit, and potatoes. There are some mineral and medicinal springs in the $t_{0}$; and it has several stores, mills, and workshops. The v. is in N. part of t., through which the Brattleboro' and Bennington postroad passes. Pop. of t. 896 .

MaribruoK, p. 0., Hempstead co., Ark. : 115 m. S. W. Little Rock.

Marley"s Mruls, p. 0., Randolph co., N. Car. : $71 \mathrm{~m} . \mathrm{W}$. Raleigh.

Marlir Bottoy, p. o., Pocahontas co., Firg.: $147 \mathrm{~m}$. W. N. W. Pichmond.

Marlow, t. and p. v., Cheshire co., N. Hamp.: W. by $\mathbf{S .}$ Concord. Drained by Ashuelot r. Surface level; soil good. The $v$. is situate $N$. of the r. The t. has several mills and workshops. Pop. 708 .

Marlton, p. 0., Burlington co., N. J.: $25 \mathrm{~m}$. S. Trenton.

Marple, to and p. on, Delaware con, Penn.: 83 m. E. S. E. Harrisburg. Pop. 902.

Marquetre county, Mich. Situate N. W. on Upper Peninsula, and contains $3,880 \mathrm{sq}$. m. It touches Lake Superior on the N. E, and is drained by Esconaba, Ford, and hearls of Menomonee r., flowing into Green Bay and Sturgeon and Ontrmagon rivers of Lake Superior. Surface diversified, but not rugged or very hilly. Soil of moderate fertility, covered largely witl immense forests of pine, which constitute the chief wealth of this region. The streams are small, but are supposed to furnish abundant water-power to work up the timber which must, ere long, be very valuable. It is little visited except by hunters and fur traders. Unorganized in 1550 .

Marquette county, Wisc. Situate \$. centrally, and contains $860 \mathrm{sq} . \mathrm{m}$. Drained by the Neenak or Fox r. and its branches. In the S. are 3 large ponds, Buffalo, Puckaway, and Green lakes; and the streams furnish much waterp)wer. Surface beautifully diversified; soil of great fertility, producing grass or grain in profusion, and furnishing excellent pasturage. Corn, wheat, live-stock, and pork, are the leading products. The facilities for manufacturing are very superior, and good timber is abundant. Farms 327 manuf. 7; dwell. 1778, and pop.-wh. 8,622, fr. col. 20-total 8,642. Capital: Marquette.

Marquerte, t., p. v., and cap. Marquette co., Wisc.: 45 m. N. Madison. Drained by Neenah r., a tributary of Wisconsin $r$. Surface even; soil excellent. Puckaway Lake, an expansion of Neenah r., bounds the t. on the $N$. The $\nabla$. is pleasantly situated on the $\$$. bank of the lake. Population of $t .246$.

Marquette, t. and p. O., Marquette co., Mich.: $289 \mathrm{~m}$, N. W. Lansing. Pop. 186.

Mariotistille, p. o, Anne Arundel co., $M d_{0}: 25 \mathrm{~m}$. $\mathrm{N}$. W. Annapolis.

MarRoWbone, p. v., Cumberland co., Ky.: $97 \mathrm{~m}$. S. by W Frankfort.

Mars, p. vo, Bibb co., $A l a_{0}$ : in N. W. part of co., $73 \mathrm{~m}$, N. W. Montgomery.

Mars Blufr, p. t., Marion dist., S. Car, : on the E. side of Great Pedee r., $81 \mathrm{~m} . \mathrm{N} . \mathrm{N}$. E. Columbia. The Wtmington and Manchester R. R. passes through the v. $101 \mathrm{~m}$. Wilmington, and 61 miles from the junction.

Marseilles, p. v., La Salle, $\mathrm{co}_{0}, \mathrm{Ill}$ 。: on the N. side Mllinois $r$., at the Grand Rapids, $113 \mathrm{~m}$. N. E. Springfield. An immense water-power for manufacturing purposes is afforded by the rapids, on which there are a number of lumber and flour mills, etc. The Illinois and Michigan Canal runs through the village.

Marsetlles, p. v., Noble co., Ind : on the Fort Wayne and Ontario post-road, $123 \mathrm{~m} . \mathrm{N}$. N. E. Indianapolis.

Marseilles, t. and p. o., Wyandott co., Ohio: $58 \mathrm{~m} . \mathrm{N}$. by W. Columbus. Drained by branches of Tyenochee $r$. Surtace Ievel, or table land; soil fertile. Pop. 539.

Marsi, p. o., Chester county, Penn.: 59 m. E. by S. Harrisburg.

Marshall county, Ala. Situate N. E., and contains 645 sq. m. Drained N. by the Tennessee and its branches; $\mathrm{S}$. by Mulberry and Locust forks of the Black Warrior. Surface uneven, in parts broken; soil very productive. Cotton is the great staple, and the erop very large. Corn yields well generally, and pork is a considerable export. It has fine water privileges, and valuable and increasing manufactures. Farms 586; manuf. 12; dwell. 1,301, and pop. -wh. 7,953, fr. col. 25, sl, 868-total 8,846. Capital: Warrenton. Public Works: Alabama and Tennessee Rirer Railroad.

MARSHAL county, $\pi l$. Situate N. centrally, and contains $472 \mathrm{sq} . \mathrm{m}$. Intersected by the llinois, and drained by its branches, Crow, Sand, and Senachwine crecks. Surface level or gently undulating. Soil very rich, consisting of large prairies, and heavily wooded alluvial bottoms. Corn and wheat are the leading crops. The pasturage is superior, and raising cattle and sheep much attended to. Farms 164 ; manuf. 11; dwell. 910, and pop. - wh. 5,178, fr. col, 2total 5,180. Capital: Lacon. Public Works: Illinois Central R. R.

MARSHALl county, Ind. Situate N. middle, and containe $442 \mathrm{sq} . \mathrm{m}$. Drained by Yellow r. centrally, and Pine er. N. W., branches of Kankakee r., and S. E. by Tippecanoe r. Surface mostly level, sometimes rolling, and about one 
half good timber land. Soil fertile, and adapted for farming in all its branches. Corn and wheat, live-stock and wool, are produced. Water-power is plentiful, and iron ore abundant. Farms 570; manuf. 10 ; dwell. 928, and pop.-wh. 5,346, fr. col. 2-total 5,348. Capital: Plymouth.

Marshall county, $I a$. Situate centrally, and contains 576 sq. m. Drained by the Iowa and its branches. Surface slightly uneven; soil fertile, and finely adapted to grazing. It has excellent mill streams and abundance of timber. Farms 34; manuf, 0; dwell. 62, and pop.-wh. 338, fr, col. 0-total 338. Capital: Timber Creek.

Marsiall county, $K y$. Situate W., and contains 278 sq. m. Bounded N. and E. by the Tennessee, and drained by its affluents, Clark's r. and Jonathan's cr. Surface diversified, and in parts hilly; soil very productive. Corn, wheat, oats, and tobaceo, are the agrieultural products. Pork is exported in large quantities. Water-power is plentiful, and manufactures increasing. Farms 415; manuf. 7; dwell. 865, and pop.-wh. 5,020, fr. col. 0, sl. 249-total 5,269. Capital: Benton.

Marsirall county, Miss. Situate N., and contains 806 sq. m. Drained N. by Wolf er, and branches of Cold Water r., affiuents of the Mississippi, and S. by Tallahatchie r., a branch of the Yazno. Surface rolling, or moderately uneven; soil fertile. The staple produets are cotton and corn, which are excellent crops. Wheat, oats, and potatoes are successfully cultivated, and large numbers of neat cattle and swine are raised, the lattor furnishing a considerable export. It has extensive manufactories of cotton and woolen goods, flour, lumber, and leather. Farms 1,611; manuf. 54; dwell. 2,306, and pop.-wh. 14,271 , fr. col. 1, sl. 15,417-total 29,659. Capital: Holly Springs.

Mrarsinal county, Tonn. Situate S. centrally, and contains $267 \mathrm{sq} . \mathrm{m}$. Drained by Duck r., a branch of the Tennessee, and its affiluents. Surface diversified, in parts somewhat broken; soil highly productive. Corn is the staple cereal, and a very heavy crop. Wheat, cotton, oats, and tobaceo are all profitable crops. It is also a superior grazing county, and feeds large numbers of cattle and sheep, besides exporting a great deal of pork. Good mill streams are numerous, and occupied by many small manufactories. Farms 1,032; manuf. 38; dwell. 2,061, and pop. -wh. 11,916, fr. col. 66, sl. 3,634-total 15,616. Capital. Lewisburg.

Marsirall county, Firg. Situate N. W., and contains 871 sq. m. Drained by Wheeling, Big and Little Grave, and Fish creeks of the Ohio, which forms its W. boundary. Surface various, in parts quite hilly; soil fertile. Corn, wheat, oats, and potatoes are thrifty crops, and it is well fitted for grazing. It has good water-power, and rapidly increasing manufactures of flour, iron, lumber, etc. Coal and iron ore are extensively found. Farms 8t7; manuf. 19; dwell. 1,668, and pop.-wh. 10,050, fr. col. 39, sl. 49total 10,135. Capital: Elizabethtown. Pullic Works: Baltimore and Ohio R. R.

Marsmali, p. $\nabla_{*}$ and cap. Clark co, $M l_{0}:$ on the National Road, $105 \mathrm{~m}$. E. S. E. Springfield. It contains a court-house and other county offices. The railroad between Terre Iautc and Alton will pass through it.

M.AR:-1LL, t., p. v., and eap. Calloun co., Jich.: $31 \mathrm{~m}$. S. S. W. Lansing. Drained principally by Kalamazoo rive and Rice er. There are a number of other small streams running through it. Surface undulating ; soil, sand and rick clay loam, producing large quantities of grain. It has extensive water-power, and a number of mills, manufactories, and a furnace. The $\mathrm{v}$. is pleasantly situate at the confluence of Fice er. with the Kalamazoo, It contains the court house and several fine buildings. The Michigan Central R. R. passes through it, $105 \mathrm{~m}$. from Detroit. There are 2 weekly papers here, the "Statesman," and "Democratic Expounder." Pop. of t. 2,\$23.

Mrarshall, p. y, and eap. Saline co, Mo. : nenr Salt Fork, a branch of Black r., $68 \mathrm{~m}$. N. W. Jefferson City.
Marsmall, to and p. o., Oneida county, $N . Y .: 89 \mathrm{~m}$, W. N. W. Albany. Surface rolling; soil fertile. Drained by Oriskany er. The Chenango Canal passes through its N. W. part. Deans v. is situate on the canal. The to has several flouring and grist mills, and some other industrial establishments. Pop. 2,115

Marsitall, p. o., Bath co., $K y .: 59$ m. E. Frankfort.

Marsmale, p. v., Highland co., Ohio: at the head of a fork of Brush er., $59 \mathrm{~m}$. S. S. W. Columbus, and on the Cincinnati, Hillsboro', and Parkersburg R. R., 7 m. E. Irillsboro"

Marshale, p. o., Marshall county, Ind.: 107 m. N Indianapolis.

Marsmatl, p. v., and eap. Frarrison co., Tex.: on the water-shed between the Sabine $r$, and Caddo Lake, $266 \mathrm{~m}$. N. E. Austin City, and distant about $24 \mathrm{~m}$. from Shreveport, La. It is a flourishing v., containing the co. offices, etc., and has two newspapers, the "Texas Republican" and the "Star State Patriot," both issued weekly. The Texas and Louisiana R. R. will probably pass through Marshall, as does now the post-road from Shreveport. Pop. about 2,000.

Marshall's Creek, p. o., Monroe co., Penn.

Marshall's FerRy, p. o., Grainger co., Tenn. : on Holston r., 193 m. E. Nashville.

Marshatlstille, p. v., Wayne co., Ohio: 91 m. N. E. Columbus.

Marshallswille, p. v., Macon county, Ga.: 65 m. S. W. Milledgeville. The South-western R. R. passes through it, $85 \mathrm{~m}$, from Macon.

Marsiralitox, p. v., Chester co., Penn.: 65 m. E. S. E. Harrisburg.

MarshField, t. and p. v., Plymouth co, MFass.: $27 \mathrm{~m}$. S. E. Boston. Drained by North and South rivers. Surface level; soil fertile. It is finely situate on Massachusetts Bay. Ship-building is carried on to some extent, and there are several manufacturing establishments in the town. North, East, and South Marshfield, are names of villages. The homestead and farm of the late Hon. Daniel Webster is situate in the S. part of the t., about $12 \mathrm{~m}$. N. Plymouth. Pop. of t. 1.837 .

Marshifeld, p. o., Erie county, N. Y.: 263 m. W. by N. Albany.

Marsheteld, t. and p. F., Washington co, Ferm.: $13 \mathrm{~m}$. E. by N. Montpelier. Drained by Onion r. and its branches, which pass through it. Soil varied; a part is good and well timbered, the rest wet and stony. The $v$. is situate on the left side of the r. Pop. of t. 1,102.

Mars Hill, Me.: a celebrated mountain near the line of Maine, toward New Brunswick, in lat. $46^{\circ} 33^{\prime}$ N. The approach to this mountitin is difficult; its sides are rugged and its summit bold. It has two culminations, one 1,363 feets and the other 1,506 feet above the waters of Goose Quill r., New Brunswick.

MAFSIPEE district, Barnstable co., Mass. : 59 m. S. S. E. Boston. This is an ancient Indian settlement, and is still chiefly inlabited by the descendants of the Marshpee tribe, but of mixed blood. It contains 15,000 acres, or about 16 sq. $\mathrm{m}$., and is secured to the Indians in perpetuity. The Marshpee and Quashmet are considerable streams, which, with numcrus ponds and the ocean, afforil an abundant supply of fish. The inhabitants are occupicd chiefly in agriculture and in the manufacture of various kinds of Indian ware. Many occupy themselves in the fisheries. They are docile and hospitable, and have long supported a Christian minister. The population numbers only 102 , and yet it is the largest remnant of any of the tribes that once were lords of the whole country.

MArsu's, station, Edgefield diste, S. Car.: on the South Carolina R. Ro, $12 S \mathrm{~m}$. from Charleston, and $55 \mathrm{~m} . \mathrm{s} . \mathrm{W}$. Columbia.

Marstox's Mills, p. o., Barnstable co., Mass. : 61 m. S. I. Boston.

Martua Furnace, p. o., Hardin co., Ill. : 175 m. S. E. Springficld. 
Martita Furnace, p. o., Centre co., Penn. : 45 m. N. W. Harrisburg. There is a furnace here having an annual capacity for 1,100 tons; it was construeted in 1832 .

Martha Milss, p. 0., Fleming county, $K y_{.}: 73$ m. E. Frankfort.

Marthasvilie, p. v., Warren co., Mo.: on the N. side of the Missouri r., $63 \mathrm{~m}$. E. Jefferson City.

Marthasptuxe, sta., Macon co., Ga. : on the South Western R. R., 42 m. S. by W. Macon.

Martul's Vliexakd, p. o., Chatham co., $N$. Car. : $36 \mathrm{~m}$. W. Raleigh.

Martha"s Vinetard, Mass.: an island lying off the S. shore of Massachusetts, S. of Falmouth, and W. N. W. of Nantucket Island. It is $21 \mathrm{~m}$. long, and is a component of Dukes co. The soil is poor, and some sheep and cattle are reared, but the inhabitants are chiefly engaged in the fisheries. An Indian church was founded here in 1666. Originally the colony was governed independently; in 1661 it was united to New York, but in 1692 it was granted to Massachusetts.

Marmckinle, p. v., Lancaster co., Penn.: 37 m. \$. E. Harrisburg.

Martix county, Ind. Situate S. W., and contains 334 sq. m. Drained by E. fork of White r. and its branches, Lick, Beaver, and Indian creeks. Surface somewhat hilly. A large part of the co. is heavily timbered, and the soils are various; but mostly of clay, and generally fertile. Corn is the staple cereal; the pastures are fine, and beef, pork, and flax-seed are exported. It has good mill streams, and exports much lumber in various forms. Farms 633; manuf. 18; dwell. 1,025, and pop.-wh. 5,844, fi: col. 97-total 5,941. Capital: Mount Pleasant. Putlic Works: Cincinnati and St. Louis $R$. R.

Martiv county, N. Car. Situate N. E., and contains 341 sq. m. Bounded N. by the Roanoke, and drained by its small affluents. Surface level, with marshes in parts; soil of moderate fertility. Corn is the chief cereal. Cotton and rice are good crops in some portions. The wealth of the co. lies in extensive forests of pine timber, which furnish large quantities of lumber, tar, pitch, and turpentine for exportation. Farms 510; manuf. 17 ; dwell. 923 , and pop.Th. 4,615, fr. col. 325, sl. 3,367-total 8,307. Capitul: Tilliamston.

Martex, t. and p. o., Allegan county, Mič.: 51 miles W. S. W. Lansing. Drained by a branch of the Kalamazoo and Rabbit rivers. Surface undulating; soil varied, i11 most parts fertile. It has extensive wooded plains. Pop. 329.

Martiddate, p. 0., Mecklenburg co., N. Car.: $109 \mathrm{~m}$.

B. W. Raleigh.

Martixdale, sta., Rensselaer co., $N$. $Y$.: on Harlem R. R., $35 \mathrm{~m}$. E. Albany.

Martivez, p. v., Contra Costa co., Calif.: on the S. shore of the Strait of Carquines, between San Pablo and Suisun bays. It is farorably situate for commerce, and has been commenced under such auspices as to insure its future prosperity. The strait is here about a mile wide, and on the opposite shore are the cities of Vallejo, the State capital, and Benicia.

Martnsbukg, p. V., Washington co., Ind.: 89 m. S. by E. Indianapolis. It is a small v., in S. E. part of co., containing about 200 inhabitants.

Martinsibrg, t., p. v., and cap. Lewis co., $N$. Y.: $119 \mathrm{~m}$. N. W. Albany, Drained by Martin's er., which flows into Black r., which latter bounds it on the E. Surface undulating; soil fertile loam, well adapted to grain. The v. is situate on the post-road between Utica and Ogdensburg, and contains a court-house, jail, female academy, banking-house, and several fine stores. There is a valuable lead mine in the vicinity. Pop, of t. 2,677 .

Martrisburg, p. v., Knox co., Ohio: on a tributary of the Muskingum r., $39 \mathrm{~m}$. N. E. Columbus, It contains 90 dwellings, and about 500 inhabitants.
Martinsburg, p. v., Pike co., $I l l .: 63 \mathrm{~m}$. S. S. W. Springfield.

Martinsburg, p. v., Ripley co, MLo.: on a branch of Current r., 158 m. S. E. Jefferson City.

Martinsiogk, p. V., Blair co., Penn.: near a fork of Clover cr., $75 \mathrm{~m}$. W. Harrisburg, There is a blast furnace here with an annual capacity of 1,500 tons.

Martinsiurg, p. F., and cap. Berkeley co., Virg.: on the Baltimore and Ohio R. R., $19 \mathrm{~m}$. from Harper's Ferry, and $131 \mathrm{~m}$. N. by W. Richmond. The "Virginia Republican" (whig), and "Virginia Patriot" (dem.), are issued weekly. Marlinsburg enjoys a large country business, and has several considerable manufacturing establishments. It contains the court-house and county offices, and is well provided with schools and churches. Pop. about 2,000.

Martiv's Creik, p. o., Northampton co., Penn.: $89 \mathrm{~m}$. N. E. Harrisburg.

Martix's Creek, p. o, Carroll co., Tenn. : 95 m. E. by S. Nashville.

Martix's Creek, p. o., Pickens district, S. Car.: on an affuent of Savanjah River so called, $119 \mathrm{~m}$. N. W. Columbia.

MARTiY's Derồ, p. o, and sta., Laurens dist,, S. Car.: $52 \mathrm{~m}$. N. W. Columbia. The p. o. was formerly called Huntsville, and the sta. is $16 \mathrm{~m}$. from Newberry court-house on the Laurens R. R.

Martix's Ferrx, p. o., Belmont county, Ohio: $117 \mathrm{~m}$. E. by N. Columbus.

Martin's FerRy, sta., Merrimac co., N. Hamp. : on the Merrimae r., and on line of the Concord R. R., $13 \mathrm{~m}$. from Concord.

Martiv"s IILL, p. an, Chemung co., $\Delta . Y_{.}: 165 \mathrm{~m}$. W. by S. Albany.

Martin's Landing, p. o., Perry co., Ind.: on N. side of Ohio r., $111 \mathrm{~m}$. $\mathrm{s}$. by W. Indianapolis.

Martin's Lime Kulns, p. o., Stokes co., N. Car.: $101 \mathrm{~m}$ N. W. Raleigh.

Martin's Mills, p. o., Buchanan eo., MOo. : 157 m. N. W. Jefferson City.

Martixstille, p. v., Clark co., $M l .:$ on the E. side of N. fork of Embarras r., 95 m. E. by S. Springfield.

Marminvilie, p. o., Lancaster co., Penn.: 39 m. S. E. Harrisburg.

Martinstille, p. v., and cap. Morgan co., Ind.: about half a. mile E. of the E. fork of White r., and W. terminus of the Martinsville R. R., 25 m. S. W. Indianapolis. The county court-house and other public buildings are situate here. The "Morgan County Gazette" (neut.) is a reekly issue. Pop. about 600 .

Martinsville, p. v., Somerset co., $N$. Jer.: on N. bank of Raritan r., $29 \mathrm{~m}$. N. Trenton.

Maptinsville, p. v, Clinton co., Ohio: at the head of E. fork Little Miami r., $59 \mathrm{~m}$. $\$$. W. Columbus. It contains several stores, a steam-mill, 50 dwellings, and about 300 inhabitants.

Martinstille, p. o., Niagara co., N. $Y:: 273 \mathrm{~m}$. W. by $\mathrm{N}$. Albany.

Martinsville, p. v., Henry co., Firg.: near Smith's r., a branch of Dan r., 143 m. S. W. Richmond. The county court-house and other public buildings are situate here, and it contains about 180 inhabitants.

Martville, p. v., Cayuga co., N. . $_{2} 154 \mathrm{~m}$. N. W. Albany. It is situate on Little Sodus cr., and contains sereral mills, etc., and about 260 inhabitants.

Marvec, p. v., Vernon co, Mo.: on the N. side of Marais des Cygnes r., 129 m. W. S. W. Jefferson City.

Marvir, p. 0., Chautauque co., $N_{0} Y_{.: 2} 2 \pi 7 \mathrm{~m}$. W. by $\mathrm{S}$. Albany.

Marx, p. o., Pulaski co., Ark.

Mary (or Humbold r) river, Ttah Ter.: rises by two branches in the Humboldt River Mountiins, in Weber and Tooele counties, running W. $95 \mathrm{~m}$., and S. $63 \mathrm{~m}$., empties into IIumboldt Lake. 
MARTLAND.

\section{THE STATE OF MARYLAND.}

MARYLAND, the most southern part of that division of the United States of America usually called the "Middle States," is situate between the latitudes $33^{\circ}$ and $39^{\circ} 43^{\prime}$ north, and between the longitudes $75^{\circ} 03^{\prime}$ and $79 \circ 32^{\prime}$ west from Greenwich, or $20^{\circ} 3 \mathrm{I}^{\prime}$ and $10^{\circ} 5 \mathrm{~S}^{\prime}$ east from Washington. It outline is extremely irregular, except on the north and east, where Mason and Dixon's line constitutes the frontier, and separates Maryland from the adjoining states of Pennsylvania and Delaware. On the south the Potomac River, with a winding channel and círeuitous general course, is its limitary stream, and divides it from Virginia. The main body of the eastern section is bounded by Delaware State line; but a narrow strip, projecting eastward to the sea, intrudes itself between that State and the Virginia portion of Chesapeake peninsula. The periphery of the State is estimated to be about 766 miles, namely : from the mouth of Potomac River to the source of its north branch, 320 miles; thence north to the Pennsylvania line, 35 miles; thence along that line eastward, 199 miles; thence along the west and south line of Delaware, 122 miles; thence along the Atlantic Ocean, 32 miles; thence across the peninsula to the mouth of Pocomoke River, 20 miles; and directly west to the confluence of Potomac River with Chesapeake Bay, the place of beginning, about 38 miles. Within this outline is contained a superficies of 13.959 square miles; but of this extent only 9,674 square miles are land, the residue being covered by the waters of Chesapeake Bay and its numerous inlets and bays.

Maryland is naturally divided into three distinct geographieal sections. The first section comprises that portion lying to the east of Susquehanna River and Chesapeake Bay, known locally as the "Eastern Shore," and which contains the counties of Worcester, Somerset, Dorchester, Talbot, Caroline, Queen Anne, Kent, and Cecil. It forms a part of that long peninsula which, projecting southward toward and into the Atlantic Ocean, divides the waters of Chesapeake and Delaware bays, and which, though of very limited extent, comprises the whole of one state, and portions of two others. The surface of the whole tract is level, and but slightly elevated above the sea; and in every part its soils are more or less sandy, but, in their general character, may be considered as above the average in respect of their adaptation to the purposes of agriculture. Few rocks are found in any part, and the mineral deposits are chiefly bog-iron ore, chromes, ete., with aluminous and magnesia salts. Marl, shcll-lime, marsh mud, peat or turf, and other agents used as fertilizers, abound. In the northern districts of this region, however, the country is hilly, and in some parts has a rocky substratum-the rocks chiefly sandstone and slate. The forest growths consist principally of oaks of various species, hickory, chestnut, pine, locust, walnut, cedar, gum, beech, and a great variety of shrub and herbaceous annuals. Wheat, Indian corn, and tobacco are the staple productions; and in the more southern counties, the cotton plant is said to succeed well. The climate is temperate, and highly favorable to the enjoyment and extended duration of life. The land area of this section is computed at 3.896 sqare miles, or 2,167,040 acres. The peninsula, of which this portion of Maryland forms a part, is about 180 miles in length from the north line of the State to Cape Charles, and has an area of about 5,950 square miles; the neck between the inclosing bays is only about 17 miles wide; but as it stretches southward, it expands gradually to the width of 70 miles, and then as gradually contracts until it terminates in a long, narrow tongue, called Acomac Peninsula, about 50 miles in length and 10 miles wide. The coast on the Chesapeake is deeply indented by numerous spacious gulfs and estuaries; such as those at the confluence with the bay of the Pocomoke, Nanticoke, Choptank, Chester, and Elk rivers, each receiving considerable streams from the interior and affording great facilitics to navigation. The eastern coast presents a striking contrast when compared with the western coast. "Between the ocean and the cultivated portion of the country, there is a prolonged sandy beach, varying from a few hundred yards to a quarter of a mile or upward in breadth, and extending the whole length of the coast, without a single outlet to the ocean, from Indian River, in Delaware, to the southern extremity of Chincoteague Island, in Virginia. Between this beach and the mainland lies Sincpuxent Bay, from one to four or five miles wide, and nearly 30 miles in Iength. It is a shallow sheet of water, narigable only to a short distance above South Point, at the lower end of Sinepuxent Neck." Some inlets that formerly existed in this beach, and admitted the sea, are now closed, and the waters of the bay have become comparatively fresh. The second section, comprising what is usually called the Western Shore, consists of unother peninsula lying inland between the Potomac Iiver and Chesapeake Bay, and up to the line of the river falls, which extend from above Port Deposit to above Georgetown. In its general fentures, soil, and productions, it closely resembles the section of country already described. It is alluvial in its formation, and lying principally on the western shores of the bay, or upnn the eastern lamk of the lower Potomac. has the same climate as the "liastern Shore." The counties comprised in this section are St. Mary's, Calvert. Charles, Prince George, Anne Arundel, Howard, parts of Montgomery, Baltimore, and Flarford. The territurial extent of these counties is about 3,69S square miles, or 2,366,520 acres. The leading geographical feature of the nurth-western part of this section, is the ledge of primitive rocks which runs from the left bank of the Potomac, in Arontgomery County, north-eastwarily to the Susquehanna River, where it erosses the north line of the State. The primitive ledge forms a naturnl boundary between the alluvial region and the mountainous distriet of Maryland, which latter constitutes the third, or western section, passing through which we meet with, in succession, South-East Mountrin, or Parr's Rirdge, terminating with Sugar-Los Mountain, on the Potomae; Catoctin Mountain, reaching the same river at the Point of Rocks: South Mountain, or Blue Ridge, crnssing it at Harper's Ferry; the Kittatinny, crossing it at Hancock ; Rugged Mountain. Wills Mountain, and other detached ridges; and the great Alleghany ridge, traversing the far western part of the State. Nany fine valleys interlie the monntains, which in climate and soil are not surpassed by the most favored regions of the arih. This seetion extends along the left bank of the Potomac to the western boundary of the State, and fullowing the simusitics of th. river, is nearly 175 miles in length. but so irregular in shape, that though it is more than 100 miles wide at the enstern end, it is mmpressed in the middle by the near approach of the border lines of Virginia and Pennsylvania to a width of less than 3 miles. From the base of the primitive ledge, which is, in fact, a lower branch of the Appalachian chain, the surface gradually rises to the head waters of the Potomac River 2,000 or more feet. This represonts the rise from tide-water at Baltimore to the dividing grounds in Alleghany County, between the waters of the Potomae and those falling into Ohio River. Fmbraced in this section are Carroll, Frederick, Washington, and Alleghany counties, which tngether cover an area of 2,590 square miles, or 1,657.600 acres.

Chesapeake Bay, which divides the State into two unequal parts, in its greatest extent, lies within Mary]and. It is a noble sheet of water, equaled in its commercial capacities by few of the great cstuaries that in various parts of the world have attracted the notice and admiration of the mariner. Its entrance between Cape Charles and Cape Henry, in

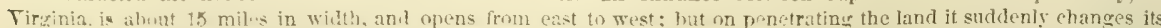

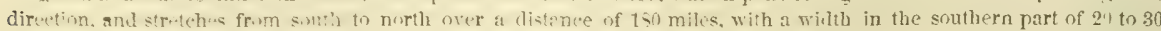

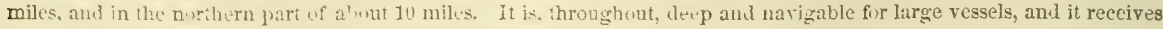


MARYLAND.

a great many deep and navigable rivers, of which the largest and principal are frum Virginia. Its area is about 8,500 square miles. The Susquehanna River has its lower course in Maryland; the tide reaches Port Deponit 5 miles from its mouth, above which there are falls; the Patapsco River is a fine mill stream falling into the bay of the same name below Baltimore; the Patuxent, the principal river of the Western Shore, is a wide stream, flowing nearly parallel with the Potomac, and navigable to Nottingham, about 50 miles, for large vessels; the Elk, Chester, Choptank, Nanticoke, and Pocomoke, on the Eastern Shore, are navigable for 80 or 40 miles; and the Monocacy River, Antietam and Conecocheague creeks are the principal tributaries of the Potomac in Maryland. All these contributo to the rolume of the waters of Chesapeake Bay, and, in their several courses, furnish fine avenues of internal trade, or provide water-power sufficicnt for all the purposes of extensive manufacturing operations. The Potomac, common to Virginia and Maryland, forming the boundary between the two, is the most important of all the streams of the latter, and the largest of the tributaries of the Chesapeake. It rises in the recesses of the Alleghany Mountains, and reaches the bay between Point Lonkout and Smith's Point. This river is $\tau \frac{1}{2}$ miles wide at its mouth, and navigable for ships of the greatest burden for 300 miles from the sea, 3 miles below the head of tide-water. Above this point, the navigation is obstructed by a succession of falls, around which, however, canals have been dug, and the navigable channel so far improved as to render the river passable for boals to Cumberland, 191 miles above Washington. The descent of the Potomac, from the mouth of Savage River to Cumberland, a distance of 31 miles, is $445 \mathrm{feet}$; from Cumberland to the Shenandoah Falls, 130 miles, it is 490 reet; hence to Great Falls, 40 miles, 39 feet; and between these and tide-water, 12 miles, 143 feet; making the whole descent from the mouth of Savage River to tide-water, a distance of 213 miles, 1,117 feet, or on the average $5 \frac{1}{6}$ feet in each mile. Rising westward of the Alleghany Mountains is the Youghiogeny, the only river of Maryland that does not empty its waters into Chesapeake Bay; it flows northward through Alleghany County, and passing into Pennsylvania, falls into Monongahela River, 18 miles south-east of Pittsburg; and thence its waters are carried through the Ohio and Mississippi rivers to the Gulf of Mexico.

To comprehend the geology of Maryland, we must understand the general facts as to the structure of the broad plain which skirts the oceau in the Middle and Southeru States; of the less elevated region lying west of this plain, called sometimes the Atlantic slope; and of the great Apalachian chain, which inclades the greatest variety of rocks and the most important formations.

Commencing at the ocean and proceeding westward, wo find a low and almost level region. This plain extehds from New Jersey through the Southern States. As the soil composing this plain consists of incoherent materials, which are easily washed away, the tide flows across it and forms large estuaries, where it neets the rivers which flow from the interior. This plain does not now present an unbroken surface, but is marked by minor irregularities and undulations, which have been due to the action of brooks, creeks, and rain torrents; still, the general character of a broad level is preserved, as it is in the ocean, notwithstanding its surface is broken by waves. The portion of the plain lying in Maryland, which is sometimes called the tide-water district, embraces nearly one-half of the territory of the State. This great region, which once formed the bed of an ancient ocean, and has risen by means of those elevatory forces which have acted upon all the continents, contains beneath its surface unquestioned records of the epochs when its materials were deposited. In the strata which compose this plain toward the north, in New Jersey, fossils are found indicating that the strata belong to the cretaceous or chalk formation, which occupios in the geological scale the upper part of the secondary formation. The cretaceous strata, if they cxist in Maryland, are concealed by the overiying deposits; but they probably form the floor of these deposits from New Jersey to North Carolina, where they again appear at the surface. The fossils found in the cliffs and banks of the Atlantic plain, prove that the strata which compose it belong principally to the tertiary formation, which lies next the chalk. $t$ All the terliary deposits, with the exception of the pliocene, occur in the State. The inclination of the tertiary beds in Maryland is very slight, and toward the south-east, so that the Potomac below Washington presents sections of each of the divisions, the lower beds rising to the surface as we proceed west.

The later tertiary, or post pliocene, which represents the epochs next antecdent to the introduction of the human race, occurs in Maryland only in limited patches. The principal one is in St. Mary's County. To this period are referred the numerisus beds of oysters which skirt the low margins of the islets and rivers of Maryland, and which are usually attributed to the ageney of the aborigines. The deposit in St. Mary's County is interesting, as containing several southern species, and particularly the gnathadon caneatus, which is now found only in the warmer waters of the Gulf of Mexico; a fact indicating the prevalence in this region of a climate like that of Florida, at the period of the formation of this deposit. The miocene formation, which underlies the last named deposits, is the most widely extended of the tertiary beds. The principal marl beds are in this formation. It occurs near Chestertown, Wye Mills, on Choptank River, near Easton, and at other places near the Eastern Shore; also through the counties of St. Mary's, Calvert, etc. Within the miocene, at Piscataway, has been traced a remarkable bed of silicious clay, entirely composed of silicious cases (of infusoria) so minute as only to be detected by a powerful microscope, yet containing distinct specific characters, enabling us to refer them to the miocene. Of the shells in the mincene deposits in this State, about seventeen per cent. have been identifled with living species. Thus, at this remote period, the peculiar distribution of living mollusea, which now exists, had begun to prevail in the region of Maryland, while at this geological era the fauna were so distinct from the present, that four-fifths of the species now living had not come into existence.

An abrupt line of demarkation exists between the fossil groups of the miocene and eocene, which lies next below the former. Before the deposition of the miocene beds, some event has occurred, like a sudden fall in the temperature of the ocean, which has destroyed every kind of animal life; for in the miocene deposits not a single form of the lower tertiary bed exists, even where the two beds are in juxtaposition. The eocene, which toward the ocean has been bunk beneath the miocene, rises shortly after passing a line from Fort Washington to Annapolis. Of two hundred species of shells found in this formation, not one now exists on the coast, or is found in the more recent deposits of the United States, although many are identical with the eocene fossils of the Paris basin. A circumstance of much economical interest in relation to this formation is the oceurrence, in many localities of the eocene, of that most valuable fertilizer, the green sand, which occurs in the secondary beds of New Jersey, and has added so much to the agricultural weabth of

* The wbole of this article on geology is taken from the censug of Maryland, the less important points being omitted or abbreviated.

+ By collerting all the fosils contained in any tertiary deposit, and comparing them with existing species, the geologist is enabled to classify the depasits intn one of three great groups. In the lowest deposit, or group, but few recent specieg are found. It is thence called the encene, or dawn of recert species. The next above contains a minority of recent species, and is thence called miocene. Orer this occurs a deposit contain ing a majority of recent species, which is called pliocene, and above the last a deposit called the post pliocene 
that State. The decomposed shells, or mart, of the tertiary have contributed, in scarcely a less degree, to the fertility of the lower counties of Maryland.

The head of tide-water forms the limit of the tertiary. On the western borders of this formation, all along the Atlantic coast, all the great rivers descend by falls and rapids. At these points the narigation is stopped, and large cities have sprung up. Thus the western boundary of the tertiary is a line of great geographical and political interest. Proceeding westward from the limit of the tertiary, we find a belt of stratified metamorphie, or hypogene rocks, which ranges nearly parallel with the Atlantic coast. These rocks include gneiss, micaceous, chloritic, and talcose slates, and beds of serpentine, granite, and limestone. The width of this belt, in Maryland, from its eastern border to the points where its rocks begin to be covered unconformably with new red sandstone, is from 20 to 30 miles. This region is characterized by hills generally of moderate height, but sometimes rising as high as 900 feet above mid tide. Their summits are rounded, and present a striking contrast to the long, steep, paralled ridges of the Alleghanies. The beds of the rivers which pass through this region are in deeply-cleft valleys, with rounded or abrupt sides, that afford small tracts of alluvial soil. The general inclination of these hypogene rocks is to the south-east, at an angle of about $45^{\circ}$; the direction of the range is north-east and south-west. The principal minerals and rocks of economical value in this belt are the gneiss, which forms an excellent and indestructible material for ordinary bifilding purposes; primary limestone, or saccharoidal marble, extensively used for building purposes in Baltimore and Washington; hydrosilicates of magnesia, which furnish a material for the production of a large amount of magnesia. The serpentine of Harford County, and the northern border of Cecil County, has yielded a large amount of ferroxide of chrome, for making pigments and dyes; titaniated iron, which oecurs in gneiss, has been worked with success in Harford County. Ores of brown hematite, extensively used in Maryland for the manufacture of iron of excellent quality, occur in beds of clay and loam, particularly on the borders of the primary limestone within this belt.

Near Frederick, in passing westward, we perceive that the hypogene rocks begin to be covered with unconformable beds of red sandstone. This group of rocks is one of the mast remarkably uniform in the country, possessing the same characteristics from the Hudson to North Carolina. It consists of dark reddish brown argillaceous sandstones, of crumbly-brown shales and coarse conglomerates. The strata dip gently toward the north-west, or toward the mountains. The beds, which show themselves along the south-eastern edge of the tract, consist mostly of coarse sandstones, alternating with red shales. The central parts consist more exelusively of brown shales and brown argillaceous sandstone. The uppermost k.e:ls, or those occurring along the north-western margin of the formation, have frequently the character of coarse conglomurates, made up of pebbles derived from a great variety of rocks, chiefly those which occur at the base or on the side of the adjoining South Mountain. The beds of rock on the Potomac, which have furnished the material from which the columns in the House of Representatives in the Capitol at Washington have been constructed, belong to this formation, the pebbles and the cementing materials in these beds being of limestone. The few fossil fishes and shells found in this formation establish its age to be that of the upper new red sandstones of Europe, or the period of the middle ages of geological history. To this formation belong the most important localities of copper ores in Maryland. Indeed, this formation is the depository of the principal copper mines in the United States, the beds containing the copper of Lake superior being referred to this formation.

After passing the formation of new red sandstone, which occapies, as we have seen, a narrow trough in the hjpogene or metamorphic rocks, proceeding westwardly, we approach the first ridge of the Alleghanies, or the great Apalachian chain. A rapid glance at the general features in the structure of the whole chain will enable us to comprehend more fully the portion of the chain which exists in this State. This ehain, geologieally considered, extends from Vermont to Alabama, being more than 1,000 miles $10 n g$, from 50 to 100 miles broad, and varying in height from 800 to 4,000 feet. Unlike the great chains of many countries which contain a prineipal central mountain, to which all the minor ranges tend, this system consists of a broad zone of almost innumerable parallel ridges of nearly equal parallel height. The characteristic features of the ridges are great length, narrowness, and steepness, the evenness of their summits, and their remarkable parallelism; many of them are almost straight for more than 50 miles. This feature, combined with their steep slopes and sharp and lcvel summits, gives them the appearance, seen in perspective, of so many colossal intrenchments. The first belt of the chain, having in a less degree the characteristics above mentioned, is the narrow undulating mountain range, called in New York and New Jersey, the Highlands; in Pennsylvania, the South Mountain ; in Maryland, the South Mountain or Blue Ridge - the latter name being applied to the range in Virginia-the Catoctin Mountain, which is the first chain of importance which presents itself in Margland as we proceed west, being a spur of the Blue Ridge. The rocks of this belt are, for the most part, of the older metamorphic strata, including gneiss, micaceous, chloritie, argillaceous, and talcose slates, and the Pottsdam sandstone. Such is the character of the rocks exposed by the canal and railroad excavations at Harper's Ferry. Immediately north-west of this mountain range is the great Apalachian Valley, which ranges from Vermont to Alabama under various local names. The portion lying in Maryland is called the Hagerstown Valley. The latter, like the continuation of the same valley north and south, is principally based upon the Trenton limestone, remarkable as containing all the great eaverns in the country. Beyond this valle- to the north-west is a wide belt of long, narrow, parallel ridges and included valleys, spreading north-westward to the foot of the great plateau of the Alleghany or Cumberland Mountain. This belt has a breadth rarying from 30 to 60 miles. These narrow and parallel ridges consist of stra's folded into a succession of convex and eoncave strata, which have been subsequently laid open by denudation. They consist of silurian, deronian, and carboniferous formations, adopting the terms applied to similar formations in England-the older groups, or silurian, lying chiefly along the south-eastern flank of the Apalachians, and the carboniferous making their appearances as we proceed west. It is evident that these beds, now so much folded and fractured, were originally horizontal, and formed continuous deposits with the rocks of the great western coal field. It appears that the bending and fracture of the beds is greatest on the Atlantic side of the chain, and the strita becomes less and less disturbed as me proceed towarl the west. The most important feature in the geology of the Apalachian chain, 23 it exists in Maryland, is the occurrence among its strata of the carboniferous formation, and its included beds of coal and ores of iron. There are three important coal areas within the State; two north-west of the so-called Backbone of the Alleghany IFountain; the north-wrest, or Yioughiogeny field, estimated to contain 250 square miles; the middle area, between Negro and Meadow mountains, estimated to contain 120 square miles. These flelds, lying in the midst of a forest region, have not been thoroughly explored. The estimates of their value can not be much relied on. This is of comparatively little importance, as from their location they must remain for a long time undisturbed. The Frostburg, or Cumberland coal basin, lies between Daris Mountain to the east, and Savage Mountain to the west, extending within the State 20 miles in length, with an arerage breadth of $4 \frac{1}{2}$ miles. The carboniferous strata, composing 


\section{MARYLAND.}

the coal series, consisting, as elsewhere, of shale, grit, sandstone, limestone, argillaceous iron ore, and coal, dip on every side toward the centre of the trough. The suceessive beds have been compared, in shape, to a great number of Indian canoes, placed one within the other. The entire thickness of the coal measures about 1,500 feet. The present surface of the basin is irregular, as it has been intersected by numerous deep ravines, formed by streams and rivers. By these means large portions of the beds have been swept away. Wherever the beds have been cut off by the intervention of a valley, they are seen on the oppcsite sides at the same level, showing that the beds were once continuous. The whole amount of denudation has been estimated at 26,250 acres, 86,847 acres or 135 square miles, being the supposed present area of the coal. This denudation has given great facility for exploration of the strata and working the coal, and saves the large expenditures necessary in other regions for draining the mines. The whole quantity of coal may be extracted without the use of a shaft. The principal seam has been 10 feet in thickness of workable coal, and there are several other workable beds of less thickness; the whole thickness of available coal having been estimated at 45 feet. The data above given, supposing the whole coal to be accessible, would make the gross amount in this basin $6,305,137,827$ tons, and the available quantity, making the ordinary deductions, over four thousand million tons. The analysis of the Cumberiand coal shows it to be of the kind denominated dry or close burning, or intermediate between the fat coal of Pittsburg and the anthracite of Pennsylvania. Experiments prove that this coal, in evaporative power, occupies the very highest place among American coals. This is further demonstrated by its extensive use in the ocean steamers.

It will be seen from this rapid sketeh, in which, from want of space, many interesting details are omitted, that the State of Maryland, in the extended range of its geological formations, is favored with one of the most important physical clements of prosperity. The same canse has been, in a high degree, conducive to the wealth of England. The tertiary of Maryland has contributed a soil of easy tillage and inexhaustible supplies of the best and cheapest material for enriching it. Its incoherent beds have suffered the tide to penetrate far inland, thus giving the advantages of the sea-board to the inhabitant of the interior. The metamorphic rocks furnish the best materials for construction near the points where they are most needed, and producing waterfalls on the rivers at the borders of the Atlantic plain, have placed the sites of manufactures near the great water highways. The shales and sandstones of the secondary have formed new varieties of soil, and contributed new material for architecture and metallurgy. To the siturian formation is due the broad and fertile valley resting $n$ n the Trenton limestone, and to the peculiar structure of the Apalachian chain, the rich glades of the upper mountain valleys. Finally, the carboniferous beds supply without limit the minerals most essential to commerce and the arts-coal, the indispensable aliment of industry, and iron, the instrument with which all wealth is created.

Maryland, in 1850, was divided into twenty counties, the general statistics of which, and the capitals of each, was as follows:

Count:es.

\section{Dwell, Pop. Farms Manuf. Capitals.}

Alleghany.... 3,850.. 22,769.. 892.. 24..Cumberland Anne Arundel . 8,710.. 32,393..1,295. . 159. ANNAPOLIS Baltimore .....30,065. .210,616. 1,655..2,377 . Balt'e City Calvert....... 1,006.. 9,6t6.. 434.. 0..Pr. Fredto'n Caroline...... 1,526.. 9,692. 730.. 0..Denton Carroll ....... 3,476. 20,616..1,387.. 121..Westminster Cocil ......... 3,056.. 18,939. 1,208.. 170..Elkton Charles........ 1,335.. 16,162..709.. 0..Pt. Tobacco Dorchester..... 2,705.. 18,877..1,049.. 12. Cambridge Frederick .... 6, 697.. 40,987..1,993.. 253.. Frederick.
Counties, Dwell. Pop. Farms Manuf.
Capitals. Harford.......2,977..19,356..1,278. . 70.. Bel-Air Kent .........1,584..11,3\$6..667..34..Chestertown Montgomery ...1,923..15,\$60. .1,051. . 80. . Rockville Prince George's 1,875 . 21,549 . . 885.. 28.. Up'r Marlboro' Queen Anne's . .1,864. .14,484.. 986. . 29..Ceutreville St. Mary's. . . . . 1.512. .13,698. . 813. . 11..Lconardstown Somerset...... .3,158. .22,456. .1,485.. 90...Princess Anne Talbot ..........1,751..13.511.. 793.. 36...Easton Washington....5,052. 30,818 . 1,292..169 .. Hagorstown Worcester ......2,8S4..18,859..1,318. . 45. . Snow Hill

The whole number of dwellings in the State, at the period referred to, was 81,708 , of families 87,384 , and of inhabitants $5 \$ 3,034$, viz. : whites 417,913 - males 211,187 , and females 206,756 ; free colored 74,723-males 35,192, and females 39,531; and slaves 90,368-males 45,944, and females 44,424, Of the whole population, there were deaf and dumb-wh. 195, fr. col. 36, and sl. 23-total 254; blind-wh. 198, fr. col. 71, and sl. 43-total 307; insane-wh. 477, fr. col. 52, and sl. 24total 55.; and idiotic-wh. 268, fr. col. 53, and sl. 72-total 393. The number of free persons born in the United States was 438,916 ; the number of foreign birth 53,288; and the number of birth unknown 462 . The native population originated as follows: Maine 456, N. Hamp. 260, Verm. 262, Mass. 1,421, R. I. 209, Conn. 484, N. York 2,646, N. Jer. 1,321, Penn. 16,076, Del. 4,373, Maryland 400,594, Dist. of Col. 1,940, Virg. 7,030, N. Car. 225, S. Car. 15s, Ga. 74, Flor. 3i, Ala. 51, Miss. 143, La. 181, Tex. 24, Ark. 14, Tenn. 39, Ky. 131, Ohio 535, Mich. 16, Ind. 65, Ill. 54, Mo. 86, Ia. 5, Wisc. 4, Calif. 1, and territories 1; and the foreign population was eomposed of persons from-England 3,467, Ireland 19,557, Scotland 1,093, Wales 260, Germany 26,936, France 507, Spain 18, Portugal 29, Belgium 5, Holland 106, Turkey 11, Italy 82 , Austria 16, Switzerland 63, Pussia 23, Denmark 35, Norway 10, Sweden 57, Prussia 188, Greece 0, China 1, Asia 2, Africa 10, British America 215, Mexico 8, Central America 0, South America 52, West Indies 279, Sandwich Islands 2, and other countries 251 .

The following table will exhibit the decennial progress of the population since the first census of the State taken by the Enited States authorities:

\begin{tabular}{|c|c|c|c|c|c|c|}
\hline Census & white & & tionsed & sons. & Total & Decennial Increase. \\
\hline Years. & Jersons. & ree. & Slave. & Tutal. & Population. & Numerical. \\
\hline 1790 & $2) 9.619$ & ... 8,048 & .. 103,036 & 075 & $.319,72 \mathrm{~S}$. & - \\
\hline 1 sni! & 216.326 & .19 .537 & 105,685 & 222 & . 341,548 & $21,820 \ldots \ldots 6.52$ \\
\hline 1510 & 29,5 & $.83,927$ & ..... 111,502 & $\ldots 1$ & . $390,546 \ldots \ldots$. & $35,998 \ldots \ldots 11.41$ \\
\hline 1520 & .260 .222 & $.39,730$ & . 107.898 & 1 & . $407,350 \ldots \ldots \ldots$ & $26,801 \ldots \ldots \quad 7.04$ \\
\hline $1=39$ & .291 .103 & $.52 .9: 38$ & ... 1112,994 & ..... 155,932 & $.447,040 \ldots$ & $39,690 \ldots \ldots .9 .74$ \\
\hline 154 & 31 & . 62.1 & .. 89 & 1 & .. 470,019 ... & $22.979 \ldots \ldots \quad 5.14$ \\
\hline 1850 & $\ldots \ldots 417,943$ & ...... 74 & 90 & 1 & $034 \ldots$ & 24.04 \\
\hline
\end{tabular}

The statistics of the wealth and industry of the State, as ascertained by the census of 1550 , and in accordance with other official documents referring to the same period, are as follows:

Occupied Lands.-Improved lands 2,797,905 acres, and unimproved lands 1,336,445 acres-valued in cash at $\$ 57,178,545$. The whole number of farms under cultivation on the 1st June, 1850, 21,860. Value of farming implements and machinery, $\$ 2,163,4 ! 3$. 
Live-Stock.-Horses, 75,684; asses and mules, 5,614; milch cows, 86,859; working oxen, 81,135; other cattle, 9S,595; sheep, 177,902; and swine, 352,911-the value of these in the aggregate, $\$ 7,997,634$. In 1840 the number of horses, mules, etc., was 92,220 ; of neat cattle, including milch cows, working oxen, and other cattle, 225,714; of shcep, 257,922; and of swine, 416,913. These statistics exhibit in the decade intervening, a decrease of 10,892 horses, mules, ete., of 6,125 cattle, of 80,020 sheep, and 64,032 swine.

Grain Crops.-Wheat, 4,494,6 $\$ 0$ bushels; rye, 226,014 bushels; Indian corn, 10,749,859 bnshels; oats, 2,242,151 bushels; barley, 745 bushels; buckwheat, 103,671 bushels The production of the same crops, according to the census of 1840, was: wheat, $3,345,785$ bushels; rye, $723,5 \pi 7$ bushels; Indian corn, 8,233,086 bushels; oats, 3,534,211 bushels; barley, 3,591 bushels; and buckwheat 73,606 bushels.

Other Food Crops.-Peas and beans, 12,816 bushels; and potatoes-Irish, 764,939 bushels, and sweet, 208,993 bushols. The potato crops together in $1839-40$, were $1,036,433$ bushels.

Miscellaneous Crops.-Tobacco, 21,407,497 (in 1840, 24,S16,012) pounds; hay, 157,956 (in 1810, 106,687) tons; cloverseed, 15,217 bushels; other grass-seed, 2,561 bushels; hops, 1,870 pounds; hemp-dew-rotted, 63 tons, and water-rotted, 0 tons; flax, 35,636 pounds; flax-seed, 2,446 bushels; maple sugar, $4 \pi, 740$ pounds, and maple molasses, 1,430 gallons (all from Alleghany County); wine, 1,431 gallons, ete. Value of orchard products, $\$ 161,051$; and of market-garden products, $\$ 200, \$ 69$.

Products of Animals.-Wool, 480.226 (in 1540, 488,201) pounds; butter, 3,806,160 pounds; and cheese. 8,975 pounds. Value of animals slaughtered during the year, $\$ 1,954,800$. Silk cocoons were produced to the amount of 39 pounds; and beeswax and honey to that of 74,802 pounds.

Aggregate value of home-made manufactures for the year, $\$ 111, \$ 21$.

Manufactures-Capital invested, $\$ 14,753,143$; value of raw material, fuel, etc., $\$ 17,326,734$; average hands employed, 30,124 -males 22,641 , and fomales $7,4 \$ 3$; average monthly cast of labor $\$ 614,556$-male $\$ 544,931$, and female $\$ 69,625$; annual value of products $\$ 32,477,702$. The amount of eapital invested in 1810 was $\$ 6,450,284$, and hence the manufacturing interests of Maryland have duplicated in the decade.

The whole number of industrial establishments, manufacturing to the value of $\$ 500$ and upward, on the 1st June, 1850 , was 3,708 , comprising 148 several pursuits, and of these 76 were agricultural implement factories, 232 blacksmith shops, 461 boot and shoe shops, 61 brick flelds, 141 cabinet-ware factories, 234 carpenters' and builders' shops, 125 cigar factories, 265 clothing shops, 52 coach, etc., factories, 99 conpers' shops, 21 curriers' shops, 16 distilleries, 33 cotton factories, 43 woolen factories, 5 forges, 10 brass founderies, and 18 iron founderies, 19 furnaces, 15 machine shops, 245 flour-mills, 147 gristmills, 25 paper-mills, 118 saw-mills; mines -3 coal, 3 copper, 1 gold, and 21 iron; 10 piano-forte factories, 12 plumbing shops, 71 saddleries, 24 ship-building yards, 116 tanneries, 33 wheelwright shops, etc., the remaining handicrafts being those common to every civilized country. The following table will show the details of some of the largest manufactures:

\begin{tabular}{|c|c|c|c|c|c|}
\hline Manufactures. & $\begin{array}{l}\text { Capital In. } \\
\text { vested. }\end{array}$ & $\begin{array}{l}\text { Value of Raw } \\
\text { Daterial, etc. }\end{array}$ & $\begin{array}{l}\text { Arerage Hands } \\
\text { Employed. }\end{array}$ & $\begin{array}{l}\text { Monthly Cost } \\
\text { of Labor. }\end{array}$ & $\begin{array}{l}\text { Valne of Anaual } \\
\text { Froducts. }\end{array}$ \\
\hline Boot and shoe. & $\$ 297,965$ & $\ldots \$ 504,210$. & $\ldots 2,756 \ldots$ & . $\$ 50,264 \ldots$ & . $\$ 1,372,353$ \\
\hline rick-kilns ........ & 2811,536 & ... 124,279 . & $\ldots 1,351 \ldots$ & . $33,334 \ldots$ & 471,450 \\
\hline Cabinet-ware....... & 301,215 & $\ldots \ldots \ldots \ldots 208,595$. & $903 \ldots$ & $23,081 \ldots$ & 705,175 \\
\hline lothing .......... & 628,940 & $\ldots 1,327,451$. & $\ldots .5,293 \ldots$ & • $\tau 0,616 \ldots \ldots \ldots \ldots$ & - $2,662,127$ \\
\hline Distilleries........ & 154,300 & $\ldots \ldots \ldots \ldots \quad 45$ & $\ldots \ldots \ldots \ldots \ldots$ & $35 \ldots \ldots \ldots$ & . 50 \\
\hline actories-Cotton ... & $2,248,600$ & $\ldots 1,35$ & $\ldots 3,217 \ldots$ & . $88,112 \ldots \ldots \ldots \ldots$ & - $2,021,396$ \\
\hline Woolen . & 00 & ......... $1 i$ & ... $370 \ldots \ldots \ldots \ldots$ & $6,144 \ldots \ldots \ldots \ldots$ & $2: 10$ \\
\hline Forges-Iron....... & 94,500 & $\ldots \ldots \ldots \ldots$ & $90 \ldots \ldots \ldots \ldots$ & $2,353 \ldots \ldots \ldots \ldots$ & 00 \\
\hline Foundries " ...... & 258,100 & .......... 23 & $\ldots \ldots \ldots \ldots \ldots, \quad 555 \ldots \ldots \ldots \ldots$ & 4 ........... & $\$ 62$ \\
\hline Furnaces " ...... & $\mathbf{1}, 033,500$ & $\ldots \ldots \ldots \ldots \ldots 576,225$. & $\ldots \ldots \ldots \ldots \ldots 1,351, \ldots \ldots \ldots$ & $1 \ldots \ldots \ldots \ldots$ & - 1,0 \\
\hline Machinery ........ & 257,500 & …..... 121 & $\ldots \ldots \ldots \ldots .458, \ldots \ldots \ldots \ldots$ & . $12,591 \ldots \ldots \ldots \ldots$ & . 49 \\
\hline Mills-Flour ....... & $1,83:$ & $\ldots \ldots \ldots \ldots 4,12$ & .. $502 \ldots \ldots \ldots \ldots$ & $9,055 \ldots \ldots \ldots \ldots$ & - 4,9 \\
\hline Grist........ & 264,150 & $\ldots \ldots \ldots \ldots .432 .553$. & .. $155 \ldots \ldots \ldots \ldots$ & $2,506 \ldots \ldots \ldots \ldots$ & 689 \\
\hline Paper....... & 134 & $\ldots \ldots \ldots \ldots 11$ & .. $156 \ldots \ldots \ldots$. & $2,401 \ldots \ldots \ldots$ & 231,365 \\
\hline Rolling...... & 196,000 & $\ldots 210$ & .. $175 \ldots \ldots \ldots \ldots$ & $5,015 \ldots \ldots \ldots \ldots$ & 531 \\
\hline Saw.......... & 195,350 & ... 185,630 . & - $304 \ldots$ & $5,191 \ldots \ldots$. & 399,778 \\
\hline Mining-Coal ...... & 605,000 & n.......... & $\ldots \ldots \ldots \ldots .210 \ldots \ldots$ & $5,450 \ldots$ & 000 \\
\hline Iron ...... & 34,750 & $\ldots \ldots \ldots \ldots$ & .. $274 \ldots \ldots$ & $4 \ldots \ldots \ldots$ & 171,675 \\
\hline lding ...... & 161,000 & $\ldots \ldots \ldots \ldots \ldots \quad 2 \pi 3,9$ & $\ldots \ldots \ldots \ldots .673 \ldots \ldots$ & . $26,722 \ldots \ldots \ldots$ & $\$ 32,100$ \\
\hline Tanneries.......... & $62 \$, 900$ & ….... $725,612$. & ......... $479 \ldots \ldots \ldots$ & $8,03 t \ldots \ldots \ldots \ldots$ & . $1,103,139$ \\
\hline
\end{tabular}

In the cotton manufacture there were consumed 23,325 bales of cotton; in the woolen manufacture, 430,300 pounds of wool ; and in the tanneries, 169,585 hides and 68,810 skins.

Intemal Communication.-Maryland has projected and completed a magnificent system of railroads and canals. At an early period of its State history the necessity of opening communication with the west and the interior was agitated, and in some measure the projects of that day were matured by opening the navigation of the Upper Potomac, and more recently by building the great national road west from Cumberland. These works, however, have been superseded by the Chesapeake and Ohio Canal, extending from Alexandria in Virginia to Cumberland, 191 miles, and the Baltimore and Ohio Railroad, from Baltimore to Wheeling, on the Ohio River, 319 miles. These two great thoroughfares secure to the principal sea-port of the State a vast amount of Western commerce, and open to the markets of the East the rich mineral deposits of Alleghany County, etc. The other great avenues within the State are the Philadelphia, Wilmington, and Baltimore Railroad, the Baltimore and Susquehanna Railroad, and the Washington Branch Railroad, etc., which, with their external connections, communicate with every portion of the Union. Besides these there is a short canal and railroad across the neck of the Delaware Peninsula, the canal being navigable for sloops and barges, and also the Susquehanna and Tide-water Canal. The total length of completed railroad within Maryland in January, 1853, was 511 miles, or in the proportion of 1 mile to every 18 square miles of its territory, or to every 1,072 inhabitants.

Foreign Commerce.-In regard of foreign commerce, Maryland ranks fifth or sixth among the United States. According to the report of the Register of the Treasury for the year ending 30th June, 1550, the total exports were valued at 
$\$ 6,907,353$; the value of domestic produce was $\$ 6,599,481$, of which the value fof that portion carried in $A$ merican ships Was $\$ 4,657.185$, and of that carried in foreign, $\$ 1,932,296$; and the value of forcign produce was $\$ 377,572$, of which the value exported in American ships was $\$ 250,861$, and in foreign ships, $\$ 127,011$. The value of imports amounted to $\$ 6,124,201$, of which $\$ 5,529,682$ was the value of merchandise carried in American ships, and $\$ 594,515$ of that carried in foreign ships. The character, tonnage, and crews of the shipping employed in the fureign tride were ats fsilowsEntrances:" Vessels 43., burden 99,588 tons, and crews 4,111 men and boys, viz., American, 295 vessels, 70,427 tons, and

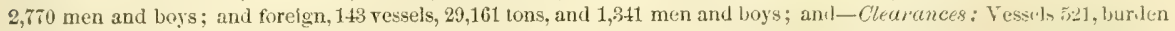
126, $\$ 19$, and crews 5,275 men and boys, viz., American, 359 vessels, 89,296 tons, and 8,605 men and boys; and forcign, 102 ressels, 37,523 tons, and 1,670 men and boys. The shipping owned within the State, at the date above appearing, was as follows:

\begin{tabular}{|c|c|c|c|c|c|c|c|c|c|}
\hline \multirow[b]{2}{*}{ Districts. } & \multicolumn{3}{|c|}{ Registered. } & \multicolumn{2}{|c|}{ Enrolled and Licensed. } & \multirow{2}{*}{$\begin{array}{c}\text { Tirenced } \\
\text { (under20 tons.) }\end{array}$} & \multirow{2}{*}{$\begin{array}{l}\text { Agrrengte } \\
\text { Tumnige. }\end{array}$} & & \multirow{2}{*}{ 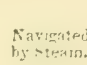 } \\
\hline & Perm't. & & p'ry. & Perm't. & $\overrightarrow{p ' r y .}$ & & & & \\
\hline Baltimore ........ & 67,061 & $\ldots \ldots$ & & .57 & ... & 737. & $.149,019$ & & 13,115 \\
\hline Oxford............. & - & $\ldots \ldots$ & - & $\ldots \ldots 12$ & $\ldots$ & 277. & & & - \\
\hline$\ldots \ldots \ldots$ & - & $\ldots \ldots$ & 一 & 14 & $\ldots \ldots-$ & 537. & & & 一 \\
\hline $1 \ldots \ldots \ldots$ & - & ..... & 一 & - 9, & $\ldots$ & 285. & & & 一 \\
\hline 's .......... & - & $\ldots \ldots$ & 一 & - 2,1 & $\ldots \ldots-$ & 42 . & & & - \\
\hline ek....... & - & $\ldots \ldots$ & - & - 2, & $\cdots$ & $-\ldots$ & & & - \\
\hline$\ldots \ldots \ldots$ & - & $\ldots \ldots$ & - & ..... 2,299 & $\ldots \ldots-$ & $25 \ldots$ & 2,324 & $\ldots \ldots$ & 336 \\
\hline
\end{tabular}

The total amount of shipping built in the State, in the year ending as above, was 15 vessels, of an agrregate burden of 15,965 tons, of which 16 were ships, 5 brigs, 125 schooners, and 4 steamers; and of the whole amount, 66 vessels (11,683 tons) were built in Baltimore district, 31 schooners (1,758 tons) in Oxford, 27 schooners (1,533 tons) in Vienna, and 26 schooners (990 tons) in Snow Hill.

The following table exhibits the movements in the ralues of imports and exports for a series of years embraced between 1791 and 1850 inclusive :

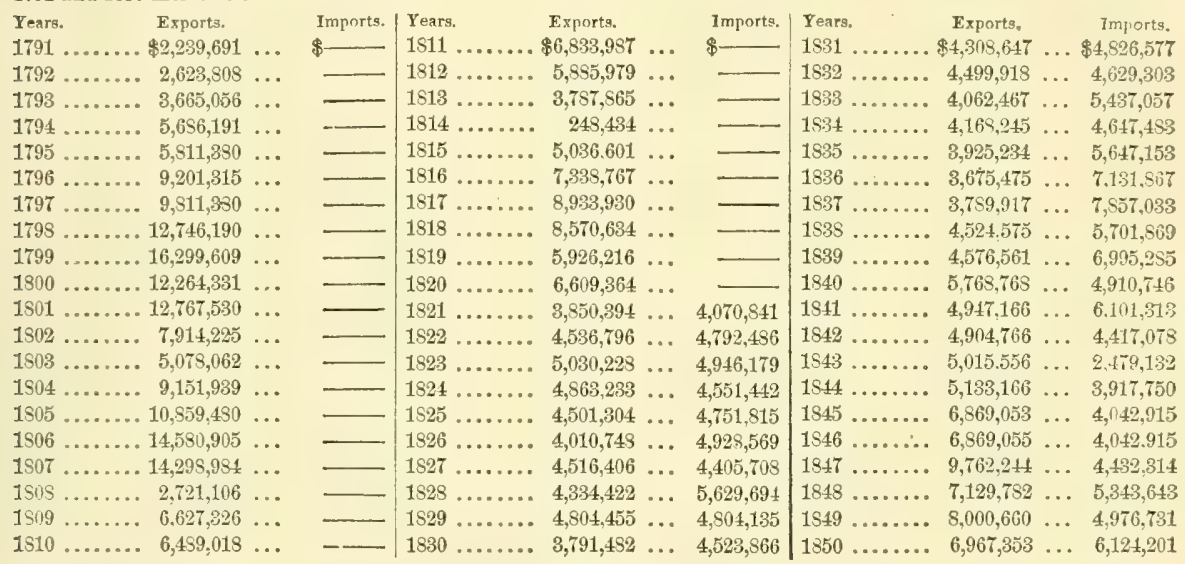

Banks.-The aggregate condition of 23 banks and 2 branch banks in Maryland, according to the returns of January, 1851, were as follows: Liabilities-capital $\$ 18,128,8 \$ 1$, circulation $\$ 3,532,869$, deposits $\$ 5,833,706$, due other banks $\$ 1,923,206$, and other liabilities $\$ 9,895 ;$ and assets-loans and discounts $\$ 14,900,816$, stocks $\$ 760,417$, real estate $\$ 405,245$, other investments $\$ 768$, due by other banks $\$ 1,178,200$, notes of other banks $\$ 965,796$, specie fund $\$ 7 \$, 552$, and specie $\$ 2,709,055$.

Government.-The present constitution of Maryland was done in convention 13th May, 1851, ratified by the people 4 th June, 1851, and went into operation 4th July, 1851. It supplanted the old constitution of 1776 , which had, however, been amended more than twenty times. This constitution provides that every free white male citizen of the United States, 21 years of age, resident in the State ono year, and in the county, town, or city where his vote is offered, for the six months next preceding the election, may vote. Citizens removing from one part of the State to another do not lose one residence before acquiring another. Persons convicted of giving or receiving bribes, and persons knowingly casting illegal votes, are forever disqualified to hold any office of trust or profit, or to vote at any election thereafter, and are in addition punishable by fine and imprisonment. No citizen convicted of larceny or other infamous crime, unless pardoned, and no lunatic or non compos can vote. The general election is held on the first Wednesday in November.

The Legislature is composed of a Senate of 22 members, one from each county and the city of Baltimore, and chosen for four years, and a House of Delegates, composed of not less than 65 nor more than 80 members (now 74 ) chosen for two years from single districts. Members of both houses must have resided in the State for three years, and in the district for which elected for the last year thereof, and Senators must be at least 25, and delegates 21 years of age. After the returns of each federal census are published, commencing with that of 1850 , the Assembly shall reapportion the delegates according to population, bat Baltimore city shall always have four delegates more than the most populous county, and no county shall have less than two members. After 1854 the sessions will be biennial. No bill shall become a law unless passed by a majority of all the members elected, and on its final passage the ayes and noes shall be recorded; and no law shall take effect until the 1st June next after the session when it is passed. The Legislature meets at Annapolis on the frst Wednesday in January annually. 
MARYLAND.

The Governor is chosen by a plurality of votes, and his term, commencing on the $2 \mathrm{~d}$ Wednesday of January, shall continue four years. He must be 30 years of age, a citizen of the United States, and a resident of the Stale for five years preceding his election, and three years a resident of the district from which he is elected. For the purpose of electing the Governor the State is divided into three districts, and he is elected from each successively. The first district comprises St. Mary, Charles, Calvert, Prince George, Anne Arundel, Montgomery, and Howard counties, and Baltimore City; the second district, the eight counties of the Eastern shore, and the third district, Baltimore, Frederick, Washington, Alleghany, and Carroll counties. He is obligated to reside at the seat of government during his official term. He may grant pardons, but not until after a publication in the newspapers of the applications made therefor and the day when a hearing will bo had, and he shall report every case to the Legislature. In ease of vacancy the President of the Senate, and after him the Speaker of the House of Delegates shall act as Governor until an election by the pcople.

The administrative officers of the State are-a Secretary of State, appointed by the Governor to bold office during his term; a State Treasurer and Comptroller, whose accounts the Governor is bound to examine semi-annually, or oftener if necessary; Commissioners of the Land Office, of Stamps, and of Public Works, and an Adjutant-general, the latter of which is appointed by the Governor, with the consent of the Senate, to hold office for six years.

The Judiciary consists of a Court of Appeals, Circuit Court, Orphans' Court, ete. The Court of Appeals has appellate jurisdiction only; the judges, four in number, are elected from districts by the voters therein for 10 years, unless they before reach the age of 70 years. They must be above 30 years of age, citizens of the State at least five years, resident of the judicial district from which elected, and have been admitted to practice in the State. The court appoints its own clerk, to hold office six years, and he may be re-appointed at the end thereof. The Governor, with the consent of the Senate, may designate any one of the four judges elected to be Chief Justice. The judicial districts are, 1st-Alleghany, Washington, Frederick, Carroll, Baltimore, and Harford counties; 2d-Montgomery, Howard, Anne Arundel, Calvert, St. Mary, Charles, and Prince George's counties; 3d-Baltimore City; and 4th-the eight counties of the Eastern shore. For the holding of circuit courts the State is divided into eight circuits, eacn of which elects a judge of the circuit court to hold office for 10 years. The circuits are, 1st-St. Mary, Charles, and Prince George counties; 2d-Anne Arundel, Howard, Montgomery, and Calvert counties; 3d-Frederick and Carroll counties; 4th-Washington and Alleghany counties; 5th-Baltimore city; 6th-Baltimore, Harford, and Cecil counties; 7th-Kent, Queen Anne, Talbot, and Caroline counties; and 8th-Dorchester, Somerset, and Worcester counties. The qualifications of judges of the circuit courts are the same as those required for judges of appeals, except that they must be citizens of the United States, and residents for two years in their judicial districts. There is in the 5th district a court of common pleas, with jurisdiction in civil cases between $\$ 100$ and $\$ 500$, and exclusive jurisdiction in appeals from justices of the peace in the city of which it is composed; and a superior court, with jurisdiction in cases over $\$ 500$. Each of these courts consist of one judge, elected by the people for ten years. There is also a criminal court, consisting of one judge, elected for six years. Clerks of the circuit courts in each county, and of the Baltimore courts, are chosen for six years, and are re-eligible. Each county, and Baltimore city, elects three persons as judges of the orphans' court, to hold office for four years; a register of wills for six years; justices of the peace, two sheriffs, and constables for two years. Attorneys for the commonwealth are chosen in each county by the people for four years. The office of Attorney-general was abolished by the new constitution. The conrt of chancery will cease to exist on the 4th July, 1853, having been granted that time to finish up its business.

Among the provisions of the constitution are the following: "Teachers of religion, and those holding offices of profit under the State or United States, except justices of peace, are ineligible to the House of Delegates; two commissioners to revise and eodify the laws of the State, and one or more to revise and simplify the practice, form of pleading, and conveyaneing, were to be appointed by the legislature at its first session; persons any way engaged in any duel shall be forever incapable of holding any office of honor or trust in the State, and holders of public money are ineligible until they pay the same into the treasury ; the Assembly shall pass laws to protect and secure the property of married women; imprisonment for debt is abolished; a reasonable amount of debtor's property, not exceeding in amount $\$ 500$, is exempt from seizure; the relation of master and slave, as now existing, shall not be altered by the legislature; no bank shall be established, except with the individual liability of the stockholders to the amount of their shares; corporations shall not be created by special laws, except for municipal and other specified purposes; private property shall not be taken for public use unless compensation be first paid or tendered; the rate of interest shall not exceed six per cent, ; in all criminal cases the jury shall be judges of the law as well as the facts; all officers, except the Governor, whose pay exceeds $\$ 3,000$ per annum, shall account for the excess under oath; after 1st April, 1859, no lottery scheme shall be drawn nor ticket sold, and until that time the system shall be under a commissioner of lotteries; no debt shall be contracted exceding $\$ 100,000$, nor unless the act creating it shall provide for a tax sufficient to pay the interest as it falls due, and the principal in 15 years, nor shall such taxes be repealed or applied to other purposes; the credit of the State shall never be given nor lent, nor shall the State be any way concerned in internal improvements; the monies levied to pay the public debt shall never be diverted until the debt is paid, or until the sinking fund equals the outstanding debt.

At its first session after every federal census, the legislature shall pass a law to ascertain the sense of the people in regard to calling a convention to revise the constitution; and if a majority vote therefor, a convention shall be called at the earliest convenient day-the delegates to be elected by the several counties, and Baltimore city, in proportion to their representatives at the time when the convention may be called.

The militia of Maryland, according to the Adjutant-general's return of 1850, consisted of 46,864 men of all arms, of which 2,397 were commissioned officers, and 44,467 non-commissioned officers, musicians, privates, and artiflcers; and of the commissioned officers, 22 were general officers, 65 general stafi officers, 5.14 fichl officers, etc., and 1,763 company offcers. All free white male persons between 18 and 45 years of age, and not exempt by law, are liable to do military duty.

Finances, Public Debt, etc.-The nominal debt of the State on the 1st December, 1850, amounted to $\$ 15,424,38146$; but, deducting Baltimore and Obio Railroad Ioan, $\$ 3.266,000$, total county loan, $\$ 163,65967$, and Susquehanna and Tidewater Canals loan, $\$ 1,000,000$, otherwise provided for, the real debt amounted only to $\$ 10,960,69179$. The sinking fund at the above date amounted to $\$ 2,000,726$, and must be deducted from the debt to get the present liabilities of the State. To mect these liabilities, in addition to the proceeds of a special annual tax, the State has $\$ 5,311,50184$ in productive property, consisting of stocks, bonds, etc., and $\$ 15,910,01317$ in property not now productive.

The balance in the treasury 1 st December, 1849 , was $\$ 4 \$ 4,89296$, and the receipts during the year were $\$ 1,227,98624$, being a total of resources for the year ending 1 st December, 1850, amounting to $\$ 1,712,87920$; and the expenditures in the same year were $\$ 1,467,47086$, leaving a balance of $\$ 245,40884$ for future appropriation. The prineipal objects of expentiture were-for Annapolis and Elridge Railroad $\$ 3,950 \$ 3$, civil officers $\$ 14,61497$, colleges, academies, and schools 


\section{MARYLAND.}

$\$ 21 . \$ 99$, indigent deaf and dumb $\$ 2,34050$, judiciary $\$ 3 \$, \$ 1350$, legislature $\$ 56,68601$, militia $\$ 1,100$, penitentiary $\$ 30,090$, pensious $\$ 5,67968$, surplus revenue $\$ 34,06936$, State colonization $\$ 10,000$, interest on public debt $\$ 690,54636$, redernption of funded arrears of interest $\$ 500,50909$, State tobacco inspection and warehouses $\$ 21,961 \quad 77$, contingent expenses $\$ 9,33349$, and miscellaneous expenses $\$ 21,17294$; and the chief sources of income were-auction duties and licenses $\$ 25,63544$, railroads $\$ 129,84030$, bank dividends and bonus $\$ 37,35606$, fines and forfeitures $\$ 5,03236$, licenses by county clerks $\$ 127,83502$, road stock dividends $\$ 46,490$, stamps $\$ 52,57975$, lotteries and stamps on lottery tickets $\$ 38,633 \$ 2$, canal companies $\$ 67,090$, direct tax $\$ 438,03638$, taxes on State and city of Baltimore stocks $\$ 46,38624$, on collateral inheritances $\$ 23,06073$, on commissions of executors and administrators $\$ 29,16626$, on commissions of trustees $\$ 5,28926$, on foreign assurances $\$ 7,48487$, on policies of insurance $\$ 6,056$, on protests $\$ 4,923$, on certain offleers $\$ 10,55156$, on civil eommissions $\$ 7,221 \$ 0$, and on ineorporated institutions $\$ 25,87058$, tax on colonization $\$ \$, 668$ 04, and State tobacco inspection in Baltimore $\$ 51,51993$.

The assessed ralue of all real and personal estate subject to taxation in 1850 , according to the returns of the census of that year, was $\$ 196,603,625$, but truly assessed, it would amount to $\$ 207,257,523$. The aggregate of all taxes assessed amounted to $\$ 1,334,429$; of this amount $\$ 444,866$ was for State purposes, $\$ 3 \$ 0,727$ for county purposes, $\$ \$ 9, \$ 10$ for sehool purposes, $\$ 22,651$ for support of paupers, $\$ 14,866$ for road repairs, etc., and $\$ 381,509$ for other purposes.

Federal Representation.-Maryland, in accordance with the provisions of the act of Congress, 23d May, 1850, sends six representatives to the national legislature.

Education.-The provisions for education in Maryland, though by no means sufficient for the amount of population in the State, are still very respectable. The law with regard to schools has been recently amended, and in consonance with its provisions, the counties have been divided into school districts, in which it is imperative on the inhabitants to establish and maintain schools for a certain period in each year. Many of the counties, however, have not yet complied with the law, but nevertheless there have been great improvements effected, and the prospect of future efficiency in all that pertains to public schools is very promising. The means of obtaining education in this State, as they existed 1st June, 1850, are returned in the census as follows:

1. Primary schnols-number 923 , teachers 1,104 , scholars 34,467 , total annual income $\$ 225,260$-namely, income from endowment $\$ 2,959$, from taxation $\$ 75,296$, from public funds $\$ 67,412$, and from other sources $\$ 79,563$.

2. Academies, etc--number 174 , teachers 427 , scholars 7,759 , total annual income $\$ 206,430-$ namely, ineome from endowments $\$ 12,365$, from public funds $\$ 15,227$, and from other sources $\$ 178,808$.

3. Colleges and universities-number 12 , professors 95 , students 1,112 , total annual income $\$ 124,714$-namely, income from public funds $\$ 3,200$, and from other sources $\$ 121,514$. The principal collegiate institutions of the State are- $\$$ t. John"8 College at Annapolis (formerly a branch of the University), founded in 1784; St. Mary's College (Catholic), at Baltimore, founided 1805; St. James' College (Episeopal), in Washington County, founded 1842; Mount St. Mary's College (Catholic), at Emmettsburg, founded 1880; Washington College, at Chestertown, founded 1783; Medical School of the University, at Baltimore, founded 1807; Washington Medical College, also at Baltimore, founded 1827, etc., etc.

The whole number of white children who attended school within or during any part of the year, was 60,417 , of which 82,214 were males, and 28,283 females; and the total number of free colored children was 1,616, of which 886 were males, and 930 females. Of all classes, amounting to 62,063 ; those of native birth numbered 60,386 , and those of foreign birth 1,679 . of those classed, "adults who enn not read or write," the whites numbered 20,815-8,557 males, and 12,258 females; and the free colored numbered 21,062-9,422 males, and 11640 females; and of the total number of white persons of this class, 17,364 were native born, and 3,451 foreigners.

Libraries.-Public libraries 17 , containing 54,750 volumes; private libraries $325-222,455$ volumes; schnol libraries $\$$ 6,335 volumes; Sunday-school libraries $\$ 4-23,315$ volumes; college libraries $10-33,792$ volumes; and church libraries 5 1,850 volumes; total 449 libraries, and 347,497 volumes.

Periodical Press.-The whole number of periodicals published in Maryland in 1850 was 68 , circulating at each issue an aggregate of 124,287 copies, and annually $19,612,724$ copies. Of this number, 39 were political-22 whig in principlc, circulating at each issue 19,172 copies; and 17 democratic, circulating 12,465 copies; 20 were misccllaneous $-71,000$ copies; 6 religions $-13,950$ copies; 1 agricultural $-6,000$ copies ; 1 musical $-1,000$; and 1 colonization-700 copies; and of the whole number 6 were published daily, and issued annually 15,806,500 copies; 4 tri-weekly -499,700 copies; 54 weekly-3,166,124 copies ; 1 semi-monthly- 48,000 copies; and 3 Inonthly-92,400 copies. The dailies are all published in Baltimore city-the "Sun," the "Clipper," the "American," the "Patriot," the "Republican and Argus," and the "German Correspondent;" the tri-weeklies are also published solely in Baltimore, and, with the exception of the "B. Herald," are editions of the dailies, viz. : the "American," the "Patriot," and the "Republican and Argus;" the weeklies are published-3 at Cumberland; 2 at Annapolis; 1 at Ellicott's Mills; 10 at Baltimore, four of which are editions of dailies, namely, of the "Sun," of the "Clipper," of the "Patriot," and of the "Republican and Argus;" 2 at Washington; 2 at Elkton; 1 at Port Tobacco; 1 at Denton; 2 at Cambridge; 5 at Frederick; 1 at Catoctin; 1 at Emmettsburg; 1 at Havre de Grace; 1 at Bel-Air; 1 at Charlestown; 1 at Rockville; 1 at Upper Marlboro'; 2 at Centreville; 1 at Princess Anne; 1 at Leonardstown; 2 at Easton; 1 at Boonsboro'; 1 at Clear Spring ; 7 at Hagerstown; and 1 at Snow Hill; the semi-monthly-ihe Lutheran Christian Messenger, was published at Baltimore; and the three monthlies also at Baltimore.

Religious Denaminations. - The statistics of the several religious denominations in the State, in 1S50, which are taken from the census returns of that year, were as follows:

\begin{tabular}{|c|c|c|c|c|c|c|c|c|}
\hline 2. $\mathrm{N}$ & & & a- No. of $\quad$ Churches. & & & $\begin{array}{l}\text { No. of } \\
\text { Churches. }\end{array}$ & & \\
\hline & & & ( & & & lic. . 65 & & \\
\hline & - & - & $\ldots \ldots 3$ & & & o'n. - . . & & \\
\hline & - & - & n.... 42 & & & $\ldots 6$. & & \\
\hline & - & - & & & & 10 & & \\
\hline .133 & 60,105 & .. 6 & $\ldots 479$ & & & & & \\
\hline & - & - & & & & ist.. 1 & & \\
\hline 26 & 7,760 & 114,05 & terian 57 & 23,235 & 378 & Minor Sects. - & - & - \\
\hline
\end{tabular}

- making a total of 909 churches, having accommodation for 390,065 persons, and owning property to the aggregate value of $\$ 3,947,884$. Maryland forms a diocese of the Protestant Episcopal Church; and with the District of Columbia, and the county of Alexandria, in Firginia, the Roman Catholic archdiocese of Baltimore, which has for its suffragan sees, Philisdelphia, Pittsburg, Charleston, Savannah, Richmond, and Whecling. 


\section{MARYLAND.}

Pauperism and. Crime.-The whole number of paupers who received support within the year ending 1 st $J u n e, 1550$, was 4,494-2,591 native-born, and 1,903 foreigners; and the whole number of paupers in the State, at that period, was $2,001-$ 1,681 native-born, and 320 foreigners. Annual cost of support $\$ 71,668$. The whole number of eriminals convieted within the same year was 207-163 native-born, and 24 foreigners; and the number in prison on the 1st June, 1850, was $397-$ 325 native-born, and 72 foreigners.

Historical Sketch.-Kent Island was the site of the first white settlements within the limits of Maryland. In 1631, William Claiborne commenced a colony on this island. But the charter under which Maryland was permanently established was granted to Cecilius, Lord Calvert, second Lord Baltimore, by Charles I., and bears date 20th June, 1632. Terra Mariæ, or Maryland, was given it in honor of Henrietta Maria, queen of the reigning monarch. The first settlers, chiefly Roman Catholics, sailed from the Isle of Wight, $22 d$ November, 1633, and landed on the island of St. Chement, 25th March, 1634, and immediately took possession of the country with religious ceremonies. On the 27 th, they commenced a settlement on the main land, at St. Mary's; and this is counted the date of the foundation of the colony. These settlers of Maryland were refugees from ecclesiastical tyranny; and have been denominated by historians the "Pilgrims of St. Mary's." The first governor was Leonard Calvert. The first legislature convened in 1639, and adopted many wise and useful laws. Tobacco had already become so important a staple, that it was deemed expedient to tax its exportation, as a source of revenue. The great revolution in England now began; the proprietary was a Catholic and adherent of the king, and a congregation of Puritans, from Virginia, who had been expelled as non-conformists, in 1642, having settled in Maryland, now attempted to gain ascendancy in the government, and to some extent succeded; but they were overthrown again in 1646. In 1649, the Assembly passed that noble act of religious toleration, which threw the mantle of charity over all, and in the benefits of which Catholic, Quaker, and Puritan, partlcipated, for all had experienced the rigors of persecution. Monarchy having been overthrown in England, the Puritan power rapidly increased, and again the proprietary was for a time suspended. In 1654, Lord Baltimore made efforts to regain the colony, and succeded; but scarcely had he resumed the reins of govermment when the Puritans again deposed him, and for the space of three years thereafter the peace of the colony was compromised by excesses on both sides. During this period the Puritans were concentrated at Providence, now Annapolis, which they considered the actual seat of government, although St. Mary's continued to be the nominal capital. The power of the proprietary was now restored, and Philip Calvert, his brother, was appointed governor. In 1660 , twenty-six years from the foundation of the colony, the population of Maryland was about 12,000 ; in 1665 , it was 16,000 ; and in 1671 , it had increased to 20,000. The extension of political organization had kept pace with population. Up to this period, seven counties had been founded, but there were no considerable towns. Importations supplied the place of domestic manufactures, except such as were made in the families of the settlers. Mention of negro slaves is flrst made in the laws of Maryland in 1663 , but it is probable that slavery existed in the colony anteriorly to that time. In 1671, an act was passed to encourage their importation. Philip Calvert was superseded in 1662, as governor, by Charles, son of the Lord Proprietary, who acted in that capacity until 1675, when, on the death of his father, he succeeded to his rights, and appointed Thomas Nately as his representative. On the occurrence of the Revolution, in 16s8, the king assumed the government, and in 1791, appointed Sir Lione Copley governor. Among the first acts of the new government was the removal of the capital from St. Mary's to Providence, thenceafter known as Annapolis. The government was again restored to the family of the proprietary, in 1715. At this period, the population was estimated at 30,000 , and the almost exclusive staple of production was tobaceo. Before 1697 , the colonists had been without manufactures of their own ; but in that year an effort had been initiated to make woolen and linen cloths. Every attempt of this kind, however, was closely watched by the English government, and hence these efforts to supply a domestic manufacture either failed at onoe, or languished out a sickly existence. In 1714, Charles, Lord Baltimore, died, and his son, Benedict Leonard Calvert, succeded to the province, but lived only long enough to have his rights acknowledged. The principal obstacle to the recognition of the claim of this family was now removed, for the young heir had been educated a Protestant. In 1715, therefore, the authority of the proprietary was restrod, and a commission in his name was issued to Hart, the last of the governors appointed by the king. From this period intil the breaking out of the French war, in 1753, the history of Maryland is not marked by any great event. Its local annals are filled with relations of contentions between the proprietary and the people-the one struggling to maintain his hereditary privileges, and the other to establish their hiberties. In all these struggles are discernible the germs of the Revolution of 1776 . In 1740, Maryland contributed 500 men and $£ 7,500$ to the disastrous expedition against the Spanish Main. A noble fleet of nearly 100 vessels, including 30 ships of the line, commanded by Admiral Vernon, and an army of $12,000 \mathrm{men}$, under General Wentworth, assembled at Jamaica, in 1741 . With this imposing force, a descent was made on Cartagena, which was renlered abortive rather by the malignity of the climate than the prowess of the enemy. It was calculated that nine out of ten of these levies perished in this most fatal enterprise. The province, in 1748 , contained about 130,000 inhabitants, of whom 94,000 were white, and 36,000 colored persons. In 1745 , the first, and for a long time the only newspaper in the colony, the "Maryland Gazette," was published at Annapolis, but a printing press had been set up some forty years before this, for printing the laws and public documents. In 1756 , the number of inhabitants was computed at 154,188 , exhibiting the very satisfactory increase of 24,158 , or about 18.6 per centum in eight years.

The development of the resources of the province had perhaps hardly kept pace with this advancement of population. The policy of England continued to be rigorous in the disconragement of domestic manuf ctures, and its repressive measures were not without effect. Meanwhile the legislature of the province offered bounties in land for the erection of flourmills, iron furnaces, and forges, and other works of industry, and its efforts succeeded to a considerable extent. In 1749, there were in the colony eight furnaces and nine forges. In 1742, copper works were in operation. The great staple export, however, was tobacco-in $1747,5,000$ hogsheads were exported. For many purposes tobacco was the currency of the provinee, and in certain years the great depression in the price of this article drew out the specie of the colony to meet the balance accruing in its foreign trade. The government sought to remedy this evil by an issue of bills of credit, which experiment, of course, proved unavailing. In 1732 , tobacco was made a legal tender at one penny per pound, and Indian corn at 20 pence a bushel; but the issue of paper money continued, even after this expedient, to supply the place of a safe and eonrenient currency.

The houndary disputes of Maryland with the adjoining provinees have become somewhat famous among controversies of that kind; the most celebrated was that which concerned her northern and part of her eastern frontier, and which resulted in the establishment of "Mason and Dixon's Line." This dispute had an even date almost with the original grant to Lord Baltimore. Fis grant, it was contended, covered all the territory bordering the Atlantic and Delaware Bay, between $35^{\circ}$ and $40^{\circ} \mathrm{N}$. lat, including the whole of the present State of Delaware and a considerable strip of Penn- 
MARYLAND.

sylvania; but this portion of his grant was at the time occupied by settlements of the Swedes, who were subseguently conquered by the Duteh. After the latter were dispossessed, the territory wrested from them was conferred by a special grant from the Duke of Fork, in 1652, upon Wiltiam Penn. A decree was obtuined in 1655 by Penn, coufirming to him the boundaries named in his grant; but the Proprietary of Maryland refused to submit, and from this time to 1732 the dispute was the cause of almost ceaseless litigation between the Proprietaries of the two colonies, and of violence and outrage on the border. At length, in consequence of a decree in chancery in favor of the heirs of William Penn, granted in 1750 , comrnissioners were appointed to determine and mark the line mentioned in the decree of 1685 . The "scientific gentlemen' employed in this important service, probably the chief surveyors, were Messrs. Mason and Dixon, from whom this celebrated boundary received its name. They began at the angle formed by the intersection of the boundary line between Delaware and Maryland with that between Pennsylvania and Maryland, and proceeded westward 130 miles, whon their operations were suspended by fear of hostilities from the Indians. At the end of every mile they set up a stone, with the letter-" P" and the arms of the Penns engraved on the north side, and "M," with the escatcheon of Lord Baltimore, on the south. In 1752-3 a continuation was made of "Mason and Dixon's line" to its western terminus; tuis, however, was looked upon as a mere temporary arrangement, and the controversies aud recriminations continued; and complaints were made to the Governor of Virginia, who appealed to the Supreme Executive Council of Pennsylvania to come into some arrangement to effect a permanent and acknowledged boundary. "For this desirable purpnse each State selected the best and most suitable men within its reach, so that their work, when completed, would merit and receive entire confidence in its accuracy." The commissioners on the part of Pennsylvania were David Rittenhouse, John Ewing, and Captain Flutchins; those on the part of Virginia were Andrew Eliicott, Pev. James Madison, Rev. Robert Andrews, and T. Page. They performed the duty assigned them in the fall of 1784 . The line having been thus carried to its western terminus, it only remained to ran a meridian line from that point to the Ohio River to close this long-protracted controversy. This task was committed to Messrs. Rittenhouse and Porter, on the part of Pennsylvania, and Andrew Ellicott and Joseph Neville on that of Virginia. They entered on their work in May, 1785, and on the 23d August they had made a final report, locating the western boundary of Pennsylvania, as now acknowledged, from the south-western corner of the State to the Ohio River; for Virginia had no special interest in extending the line further north, having finally relinquished in favor of the general government her claims to territory north and west of the Ohio the year befire.

In the contest which annihilated French duminion in America Maryland bore a gallant part. Braddock's unfortunate expedition against Fort Duquesne was organized in this province, and marched from Frederick in the spring of 1754 . After the defeat and death of this general a fearful panic pervaded the frontier region of all the Middle States, and extended in Maryland even to the Bay Shore. Numbers of the inbabitants fled to Baltimore, and even prepared to leave the country altogether. From this time until the capture of Fort Duquesne in 1758, the western part of Maryland was kept in constant terror, and of course the incidents of the war fully occupied the attention of the people and the public authorities. The progress of population during these years of Indian warfare was necessarily slow. The inhabitants in 1761 numbered 164,007, of whom 114,382 were whites, and 49,675 slaves, showing an increase for five years following 1756 of somewhat less than 10,000 . The relative increase was but little over half as great as that of the preceding five years. The extension of settlements toward the west was also suspended during the war.

From the enclusion of the French war until the commencement of the Revolution, the history of Maryland, like that of most of the other colonies, is a narrative of usurpations upon public liberty attempted by the royal government and resisted by the people. In $\mathbf{1 7 6 5}$, the stamp act, and afterward the tea tax, excited general indignation and hostility. The most violent opponents of these measures took the name of "Sons of Liberty" As the contest drew toward the issue which had been inevitable from the beginning, the Proprietary government fell, as a matter of course, giving place to local and general committees of safety, and to conventions assembled in the name of the people, to supply the want of a more regular authority. The war, which had long been expected, and for which great preparations were made, commenced with the desultory fight at Lexington, 19th April, 1775.

The Revolution having now fairly commenced, elections were held throughout the province in August, 1776, for delegates to a convention to frame a Constitution and State Government. This body assembled August 14th, and by the 10th September a bill of rights and a constitution were reported. On the $3 d$ November the constitution was adopted in convention, and elections ordered to carry it into effect. The system of government established by this first conslitution of Maryland was republican, and as nearly democratic as the state of public opinion of that day, and the circumstances under which it was adopted, gave reason to expect.

The elections took place in November, as provided for in the constifution, and the legislature convened at Annipolis on the 5th February, 1777. On the 13th February Thomas Johnson was chosen first constitutional governor of Maryland.

Thronghout the Revolutionary War the servioes of the Maryland troops were marked by gallantry and efficiency. In the first considerable action after that of Bunker's Hill, the "Maryland line" signalized its valor and took a high position among the several corps of the continental army. They were under the command of Col. Wm. Smallwood, who afterward became a major-general, and one of the most distinguished officers whose achievements in the struggle illustrate the bravery of his native state. In the battle of Long Island, and in those of Harlem Heights, White Plains, and Fort Waslnington, the Maryland regiments were conspicuous for their courage and discipline; nor were they less so in the memorable actions at Trenton and Princeton. With the exception of actions in the campaign against Burgoyne, indeed, there was no prominent battle of the war, from Brooklyn Heights to Yorktown, in which the Marylanders did not take an active part; and under every commander-Washington, La Fayette, De Kalb, and Greene-they earned special notice and applause for gallantry and good ennduct. The number of troops furnished by Maryland during the war was 15.229 regulars, and 5,407 militia; and the expenditures of the State amounted to. $\$ 7,568,145$ in specie, a large portion of which Was raised by the sale of confiscated British property within the State.

On the 23d December, 1783, the brilliant drama of the Revolution was elosed by Washington's resignation of his commission. This event took place at Annapolis, in the presence of Congress, the State legislature, many officers who had served through the war, and a crowd of deeply interested spectators. The ceremony constitutes a scene in our history second in solemnity and importance only to the reading of the Declaration of Independence.

The Federal Constitution was readily and heartily adopted by Maryland. The convention that accepted it on the part of the State met on the 21st April, 1788, and adjourned on the 28th, having agreed to the instrument, without reservation or amendment, by a vote of 63 to 11 .

From this period to the war of 1812, the history of Maryland presents nothing calling for special notice. During that war Admiral Cockburn, commanding the British naval forces, committed on the shores of Chesapeake Bay a scries of 


\section{MARYLAND}

wanton outrages against the property and persons of the citizens. In the spring of 1313 the villages of Frenchtown, Harre de Grace, Fredericktown, and Georgetown, were plundered and burned by his orders, and in August, 1S14, occurred the expedition of General Ross against the city of Washington. Cockburn, since the opening of the preceding year, had been cruising about the bay and the mouth of the Potomae with four ships of the line and six frigates; in the course of the summer he was largely re-enforced; and in August a landing was effected at Benedict, on the Patuxent, some thirty-five miles south-east of Washington. The land force was under the command of General Ross, and was 5,000 strong. It proceeded toward Washington; the militia of Maryland and of the District assembled under General Winder to oppose their march; but the Americans were in no condition to resist their numerous and well disciplined enemies. The army retired to Bladensburg, and was re-enforced by General Stansbury with 2,100 Maryland troops, including the sailors and marines of Commodore Barney. At this point it was resolved to risk an action in defense of the national capital. The result of the conflict that ensued was not fortunate to the American arms.

The British gained a complete victory, though at a cost of life much greater than the loss sustained by the Americans. The victors marched on to Washington, occupied the city as long as they thought advisable, and then returned to their shipping at Benedict. They, however, sullied the laurels which their daring and successful expedition might have gained for them by an act of Vandalic barbarism to which the annals of modern warfare among civilized nations hardly furnishes a parallel. While in secure possession of the seat of government, they burned and destroyed the Capitol, the president's house, the offices of the treasury, war, and navy, all the national records accessible to them, the public library, and othe property belonging to the public and individuals. Their loss in this expedition is said to have been four hundred in killed and wounded, and five hundred prisoners. At nearly the same time Alexandria was oceupied and plundered, or laid under tribute. The remaining principal incidents of the war particularly belonging to the history of Maryland, are the battle of North Point and the defense of Baltimore. The British forces engaged at North Point numbered 5,000 , and were under General Ross. He was killed in a skirmish between parties of the advance immediately before the battle. The Americans were commanded by General Striker, who had under his command 3,200 men. The result of the engagement was unfavorable to the invaders, though the American general judged it prudent to retire toward Baltimore. The British Iost about 400 men, and the Americans about half that number. The battle of North Point was fought 13th Sept., 1814. On the evening of next day the enemy commenced a bombardment of Fort M'Henry, the work chiefly relied upon for the defense of the city. The attack was gallantly repelled, and the failure of the operations during the night, which were conducted by land and water, was so complete that a day or two after the land forces were taken on board the shipping, and all attempts against Baltimore were abandoned. On the 16 th of the month the hostile fleet was seen standing down the bay.

From the earliest period the condition of the African race in Maryland had attracted much attention. By gradations, which there are now no means of tracing, this class of the population had attained in 1790 the number of 111,079 , of which $\$, 043$ were free, and 103,036 were slaves. The tendency of public opinion in this State, for many years subsequent to the commencement of the Revolution, seemed farorable to emancipation, and its effect was perceived in the gradual increase of frce blacks. It was shown by the census of 1800 that the free colored had gained 11,514 during the preceding ten years, equal to 143 per centum, while the slaves bad increased only 2,599 , or about $2 \frac{1}{3}$ per centum. The decennial census from this period exhibited an equally remarkable increase of free negroes and decrease of slaves, so that from 1790 to 1850 the free negroes had increased 821 per centum, and the slaves had decreased more than 12 per centum. The decennial movement is shown elsewhere. But during the first twenty years of this period there had been a small increase of slaves, so that for the next thirty years to 1840 the falling off had been 21,765 , or about 19 per centum; which decrease, if sustained, would bave extirpated slavery in Maryland in a very short time; but owing to various circumstances in the history of the times, the policy of emancipation, without a provision for the removal of the persons whose condition was affected by it, began to be looked upon with disfavor, and a provision was inserted in the constitution of 1836, declaring "That the relation of master and slave in this State shall not be abolished, unless a bill for that purpose shall be passed by a unanimous vote of both branches of the General Assembly, be published three months before a new election, and be unanimously confirmed by a succeeding Legislature." Thus was checked effectually the disposition to public emancipation; but individuals continued to exereise it, and the prevalence of this desire to confer freedom upon slaves gave occasion to the institution of the American Colonization Society about the year $1819 ; \mathrm{a}$ branch of the association rvas established in Maryland, but in order to obviate certain features in the organization and proceedings of the General Society not acceptable to the friends of colonization in this State, it was determined to establish an independent colony in Africa for the blacks of Maryland. The Legislature extended its fostering care to the enterprise, and an annual appropriation of $\$ 20,000$ was allowed to the Society, which is yet continued. The Maryland colony has flourished, having now a considerable trade, and being visited at stated periods by regular packets from Baltimore.

LxNAPOLIs is the political capital of the State.

MarYland, to and p. $v_{\circ,}$ Otsego county, $N . \bar{Y}$. $63 \mathrm{~m}$. W. $\frac{1}{2}$ S. Albany. Drained by Schenevas cr. and its branches. Surface varied, in some parts mountainous; soil rich and fertile, with excellent pasturage. The $\mathrm{v}$. is situate centrally on the Albany and Ithaca post-road, and contains several mechanic shops. saw-mills, etc. Pop. of t. 2,152.

Maryland Lixe, p. o, Baltimore co. $M d .:$ on the $N$. line of the State, and the Baltimore and Susquehanna R. R., $52 \mathrm{~m}$. N. Annapolis.

MARrsville, p. city, and cap. Yuba co, Calf.: on the $\mathrm{N}$. bank of Iuba r., 98 m. N. N. E. Vallejo. It contains the court-house and clerk's office, 6 hotels, a number of mills, and some stores and shops. A steamer plies daily between this city and Benecia, touching at Sacramento. There are two newspapers printed here, the "California Express," and "Marysville Herald," both tri-weekly and weekly issues, The population of Marysville is between 7,000 and $S, 000$.

Marrstille, p. v., and cap. Union co., Ohio: $25 \mathrm{~m}$. N. W. Columbus, on the $\mathrm{S}$. side Mill er., a branch of the 446
Scioto r. It contains a court-house, jail, and several dwellings. The "Tribune" (whig) is published here. Population 605 .

Marystille, p. o, Paulding co., Ga.: 127 m. N. W. Milledgeville.

MARysthle, p: v., and cap. Blount co., Tenn. : on a branch of Pistol er., $15 \mathrm{~m}$. S. Knoxville, and $157 \mathrm{~m}$. E. S. E. Nashville. The $\nabla$. contains the county court-house and other public buildings, also the South-western Theological Seminary (founded in 1S21), and which had (in 1550) 8 professors, 24 students, and 90 graduates, with a library containing 6,000 rolumes. Pop. of the v. about 600 .

Marysville, p. r., and cap. Benton co. Oreg. : on the W. side of Willamette r., at the mouth of Mary's r., $32 \mathrm{~m}$. S. S. W. Salem. The village site is prairie, which extends 6 or $7 \mathrm{~m}$. northward; but timber is plentiful on the rivers. The mouth of Mary's r. may be considered as the head of navigation above the falls at Oregon City, owing to rapids which steamers stem with great difficulty. 
Marsstule, p. v., Campbell co., Firg.: on N. side of Staunton r., $103 \mathrm{~m}$. W. S. W. Richmond.

Marystrule, p. v., Benton co., Ia. : in the N. E. part of co., 5 m. S. Cedar r., 35 m. N. W. Iowa City.

Marmvilte, p. v., Nodaway co., Mo.: on W. aide of One Hundred and Two r., $194 \mathrm{~m}$. N. W. Jefferson City.

Masardis; to and p. 0 ., Aroostook county, MMe. : $171 \mathrm{~m}$. N. N. E. Augusta, Drained by St. Croix, or Masardis r. and its branches. Surface varied; soil good, with fine timber lands. Pop. of t. 122.

Mascoutae, p. V., St. Clair co., Ill.: $91 \mathrm{~m}$. S. by W. Springfield, on the edge of a fertile prairie, 2 m. E. Silver $\mathrm{er}$.

Mashapadg, p. o., Tolland county, Conn。: 19 m. E. Hartford.

Masos county, $M l$. Situate W. centrally, and contains 468 sq. m. It has Illinois r. on the W., and the Sangamon and Salt cr. on the S., occupying the tongue of land between them. Surface undulating; soil very fertile; the largest part is prairie, and the lowest parts subject to inundation. Corn, whent, and most grains yield largely, and parts are excellent pasture. Farms 727; manuf. 3 ; dwell. 1,041, and pop.-wh. 5,898, fr, col. 23-total 5,921. Capital: Bath.

MAsoN county, Ky. Situate N. E., and contains 194 sq. m. Drained S. by Johnson's cr. and North Lick, branches of Licking r., and N. by small affluents of the Ohio, which forms its $\mathrm{N}$. boundary. Surface various; soil of great fertility. Tobaceo, flax, hemp, corn, and wheat are all large products. Rye, oats, and potatoes are good erops. Great numbers of sheep and swine are reared, and pork is a large export. It has superior facilities for commerce and manufactures, and the latter are very extensive, consisting of cotton and woolen goods, flour, leather, liquors, earthen-ware, cordage, bagging, iron castings, etc. Most of the imports and exports of the N. E. part of the State reach the Obio through this co. Farms 888 ; manuf. 221; dwell. 2,423, and pop.-wh. 13,675, fr. col. 385, sl. 4,2s4-total 18,344. Capital: Washington. Pullic Works: Maysville and Lexington R. R., Naysville and Big Sandy R. R.

MASOY county, Bfich. Situate W. on Lake Michigan, and contains 504 sq. m. Drained by Memoosic, Sable, and Notipecago rivers. This co, is little settled and unorganized, visited only or mostly by lumbermen in quest of the fine timber with which it is densely covered. Farms 0 ; manuf. 5 ; dwell. 12, and pop.-wh. 93, fr. col. 0-total 93.

Mason county, Firg. Situate W., and contains 372 sq. m. Bounded N. and W. by the Ohio, and intersected by the Great Kandwha, which receive a few small streams in the co. Surface hilly; soil very productive, and excellent pasture land. Corn is the staple crop. Superior wheat is raised in modelate quantities. It has good water-power, convenient markets, several valuable salt-springs, and some coal. Farms 563; manuf, 9 ; dwell. 1,151, and pop.-wh. 6,8 43, fr. col. 49, sl, 647,-total 7,539. Capital: Point Pleasant. Putlic Works: Covington and Ohio R. P.

MASON, p. v., Ingham $\mathrm{CO}_{n}$, Mich: on a branch of Willow cr., $13 \mathrm{~m}$. S. by E. Lansing. It has several buildings, and about 300 inhabitants.

Mason, t. and p. v., Hillsboro co., N. Hamp.: $33 \mathrm{~m} . \mathrm{s}$. Concord. Drained by Souhegan $x$. and several small streans. Surface rugged and hilly; soil strong and deep, but stony, well adapted to grass or grain. The streams afford motive power to several mills. Mason Village, at the terminus of the Petersboro' and Shirley R. R., in N. part of $t$, is the seat of a number of cotton and woolen manufactories, and other handicrafts. Pop, of t. 1,226.

Mason, p. o., Warren co., Ohic : $71 \mathrm{~m}$. S. W. Columbus.

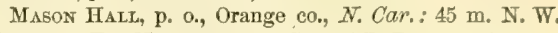
Raleigh. The North Carolina Central R. R. passes it.

Masonto College, Marion co., Mo.: $12 \mathrm{~m}$. W. Palmyra. The college was founded in 1831-in 1850 it had a president, 5 professors, and 45 students. It has also a good library. This was originally a manual labor establishment, and owns a large tract of highly improved farming land.

Mason's Grove, p. o., Madison co., Tenn. ; on the S. fork of Deer r., $127 \mathrm{~m}$. W. S. W. Nashville.

Masonsville, sta., Windham co., Conn. : on the Norwich and Worcester R. R., $44 \mathrm{~m}$. N. Allyn's Point.

Masontown, p. v., Fayette county, Penn.: $3 \mathrm{~m}, \mathrm{E}$. Monongahela r., $159 \mathrm{~m}$. W. by s. Harrisburg.

Masonville, p. v., Lauderdale co., Ala.: $2 \mathrm{~m}$. N. Muscle Shoals of Tennessee r., $187 \mathrm{~m}$. N. N. W. Montgomery.

Masonville, t. and p. v., Delaware co., N. Y.: $87 \mathrm{~m}$. S. W. Albany. Drained by tributaries of the Susquehanna r. Surface for the most part mountainous-a ridge of mountains extending through it; soil varied-in the valleys rich and fertile. There are excellent timber lands, producing pine and other timber. Principal manufactures are flour, leather, and fulled cloths. The $\mathrm{r}$. is situated in the N. W. part of the t. on a small er., and contains several fine dwellings, and about 600 inhabitants. Population of the t. 1,550 .

\section{THE STATE OF MASSACHUSETTS.*}

MASSACHtSETTS, the parent State of New England, and the chief manufacturing district of the United States, is bounded north by New Hamshire and Vermont, east by the Atlantic Ocean, south by the Atlantic, Rhode Island, and Connecticut, and west by New York. It is sitnated between $41015^{\prime}$ and $422^{\circ} 52^{\prime}$ Iatitudes north, and between $699^{\circ} 54^{\prime}$ and $73^{\circ} 54^{\prime}$ longitudes west from Greenwich, or $3028^{\prime}$ and $7008^{\prime}$ east from Washington. This State has a genernl breadth of not more than 50 miles, with a length of about 160 miles; but in the eastern part it extends abruptly to the breadth of 90 miles, and shoots a Iong narrow tongue of sand into the ocean, which extends nearly 50 miles beyond the mainland. The area of the State is estimated at 7,800 square miles. Although the surface is generally hilly, and in some places ruggeed, no part of it rises to an elevation of 4,000 feet, the isolated peak called Saddle Mountain, in the north-western corner of the State, the loftiest summit within its limits, being not more than 3,600 feet above the level of the sea. The Green Mountains enter the western part of Massachusetts from the north, forming the Hoosie and Taghkannuc or Taconic ridges, which run nearly parallel to each other southward into Connecticut. The Taghkannue ridge is near the western bnundary of the State-its most elevated peaks are Saddle Mountain, above referred to, on the north, and Taghkannuc Mountain, in the south, the latter being 3,000 feet in height. The Hoosic ridge has no summits above half these elevations; it divides the waters of the Connecticut from those of the Mousatonic. The White Mountain range enters this State from New Hampshire, a little to the east of the Connecticut, and running southerly, divides below Northampton into the Mount Tom and Lyme ranges. Mount Tom and Mount Holyoke are peaks in this range-the flrst 1,214 feet and the latter 880 feet above the level of the Connecticut River, which flows between them; Wachusett, a solitary mountain in the north-eastern part of Worcester County, is 2,018 feet above the level of the sea. Eastward of these ranges, the surface is for the most part broken by gentle swells, and in the south-east, spreads out into a level sandy plain, which extends from the margins of the ocean, and is continued in the peninsula of Cape Cod.

* The name of this State probably arose from the name of a tribe of Indians formerly at Barnstable, or from two Indian words, mas and wetusot, the former signifying an. Indian arruw.head, and the litter a fill. It is stated that the Sachem who governed in this region, on the landing of the

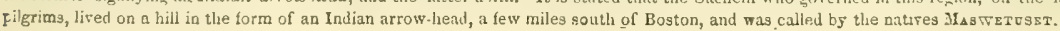




\section{MASSACHUSETTS.}

The county of Barnstable is a peninsula commonly called the Peninsula of Cape Cod. Its shape is that of a man's arm bent inward both at the elbow and at the wrist. A great part of this peninsula is barren, and in many places wholly destitute of vegetation. The inhabitants derive their support principally from the ocean. Nantucket Island lies south of Cape Cod. It is of a triangular form, 15 miles long, and in its widest part about 11 miles; and is little more than a heap of sand without a tree of native growth upon it-yet it maintains a numerous population distinguished for uctivity and enterprise. The island affords some pasturage, and cattle and sheep in considerable numbers are raised on it. The climate is much milder than that of the neighboring continent. South-east of this island, out of sight of land, lie the Nantucket Shoals, a dangerous sand-reef about 50 miles long and about 45 miles broad, and which has been the scene of many dreadful shipwreeks. Martha's Vineyard, to the west of Nạntucket, is about 21 miles long, and from 2 to 10 miles broad. The soil is for the most part poor, but many sheep and cattle are raised, and the people are much employed as pilots or in the fisheries. There is a spacious harbor on the north side of the island called Holmes's Hole, and vessels bound to the eastward are frequently seen here in great numbers, waiting for a wind to enable them to double Cape Cod. It is calculated that more than 1,000 vessels anchor here in the course of a year. The Elizabeth Islands are sixteen in number, extending in a line from the elbow of Cape Cod Peninsula westward, and forming the south-eastern side of Buzzard's Bay. No Man's Land is a small island south-west of Martha's Vineyard. Plum Island, off the east coast, extends from Newburyport southward to Ipswich. It is 9 miles long and 1 broad, and is separated from the mainland by a narrow sound, over which a bridge has been built. In the season when plums are ripe, this island is the resort of the neighboring inhabitants, and a scene of lively amusement.

The valley of the Connecticut, which, varying in width, extends through the State in a direction north and south, consists, for the most part, of a sandy alluvion. The lower flats are fertile, and produce rich crops of grain. In the vicinity of Hadley in this valley are extensive fields of broom-corn, and the manufacture of this article into brooms absorbs a considerable portion of the labor of the towns in the neighborhood. A portion of this valley is oceupied by sandy tracts, which yield light crops of rye and maize. Some of these plains are covered with low pine forests. The valley of the Housatonic extends nearly in the same direction with that of the Connecticut, and consists of alluvial tracts of the same deseription. The valley of the Hoosic in the north-west consists of an almost uninterrupted succession of intervale, about a mile in width, extremely rich, and omamented with the liveliest verdure. The waters of this stream are remarkably limpid, and wind their way along this valley through luxuriant meadows and pastures, green to the water's edge, and fringed with willows and other moisture-loving growths.

Every part of the State is well watered; but in general the streams are more useful for agricultural and manufacturing purposes than as channels of communication. The Connecticnt erosses the western part of the State from north to south, intersecting the counties of Franklin, Hampshire, and Hampden, and passes into Connecticut. By means of short canals round several falls of the river, it has been made navigable for small vessels through its whole course in this State. Its principal tributaries are the Deerfield and Westfield Rivers from the west, and Miller's and Chicopee Rivers from the east-all of which afford the best of water-power, and at their several falls are seenes of busy industry. The upper waters of the Housatonic lie on the west of the mountains, and flow southward into Connecticut. The Quinnebaug and Blackstone Rivers have also their sources in this State. Charles' River, reaching the sea at Boston, and Taunton River, which falls into Narragansett Bay, are useful mill-streams. The Nashua and Concord Rivers are tributaries of the Merrimac, which last finds the sea at Newburyport, near the northern boundary line. The Merrimac, after entering this State from New Hampshire, has a course east and north-east, and is navigable for sloops to Haverhill, 20 miles from its mouth.

The northern shore of Massachusetts is bold and rocky, and the coast everywhere is deeply indented, and presents several far projecting peninsulas and headlands, forming bays of immense extent. Massachusetts Bay, which gires its name to the State, extends between Cape Ann, which projects sea-ward about 15 miles on the north, and Cape Cod on the south. It is about 70 miles in length, and comprises Boston Bay and Cape Cod Bay. On the southern coast is Buzzard's Bay, about 30 miles in length, and comprising a large number of fine and secure harbors. Boston Harbor is one of the finest in the world-capacious, safe, easy of access, and ensily defended; but in the winter season it is often ice-bound. New Bedford on Buzzard's Bay has a fine harbor, and is the greatest whale-ship depôt of the Union. The Peninsula of Nahant, a few miles north of Boston Harbor, is connected with the mainland by Lynn Beach, two miles in length, and from its fine open situation, has been a favorite place of resort during the hot season of summer.

Massachusetts is not, as far as yet ascertained, rich in minerals. Iron is found in various parts of the State, and is extensively worked. It appears chiefly in the form of bog ore. Sulphuret of iron, or pyrites, occurs in the central districts, where it is used for the manufacture of copperas: and the plumbago found at Worcester and Stockbridge is used in the manufacture of lead pencils and crucibles. Lead mines exist in the Connecticut valley. The white clay of Martha's Vineyard furnishes alum; and anthracite coal is now obtained in the graywacke district to the west of Taunton River.

It is on its building material, however, that Massachusetts relies for distinction. Granite of excellent quality abounds in Quincy and ricinity, and is extensively quarried and shipped to nearly every Atlantic port, in greater or lesser degree. The Astor House at New York, the front of the Tremont House at Boston, and the Bunker Hill Monument, are built of this stone. Blocks and shafts of almost any dimensions may be obtained. Granite suitable for building is also found at Gloucester, Fall River, Fitchburg, and many other places. Gneiss, nearly answering the same purposes, is found in many parts, and serpentine, suitable for ornamental architecture, exists in Mildlefield, West Field, Newbury, etc. Limestone is extensively distributed. Berkshire is renowned for the fine marble it produces, denominated primitive marble. Its prevailing color is white, and some of the varieties admit of a fine polish; more or less is quarried in almost every town of Berkstire. The City Hall in New York, and the Girard College in Philadelphia, are built of marble from this district. Soap-stone, and argillaceous or roofing slate, are found in rarious parts, and potter's clay, nsed in the manufacture of common delf, and kaolin, or porcelain clay, are abundant. Peat is found and used as a common fuel in many towns in the eastern part of the State; and what adds to the importance of this article is, that it is frequently situated where woon is scarce.

The climate of Massachusetls, thongh identical in many respects to that of the three States lying north of it, is not so extreme as that of either. It is very favorable to health, and a large ratio of the inhabitants attain to a good old age. The extremes of temperature are from $20^{\circ}$ below zero to $100^{\circ}$ above, but such are rare and of short continuance. The season of growth commences earlier than in the more northern States, and the summer is more prolonged. On the eastern and southern shores the summer season is delightfully tempered by the breezes from the ocean.

The Indian population, a small remnant of the once powerful tribes that inhabited Massachusetts prior to the arrival of Europeans in the country, now numbers less than 1,000 souls. With the exception of the Nalicks, who are scattered 
over the Commonwealth, they all live in separate communities; but few of these are of pure blood, the majority coming under those classes which in South America would be termed Meztizos or Zambos, mixtures of white and Indian, and of black and Indian. The following tribes are enumerated in a report of a commission appointed in 1948 to inquirs into the condition of these people:

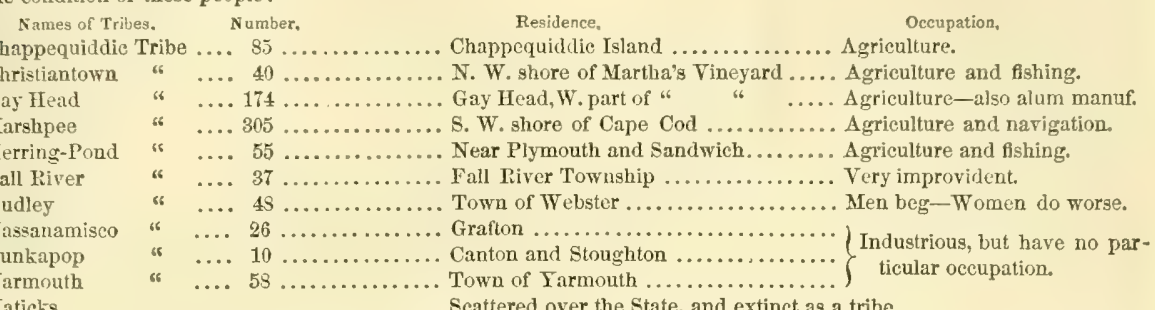

The more industrious of these tribes not only enjoy the necessaries of life, but also many of the comforts and even luxuries of civilization. Nearly all live in good houses, most of them decently furnished; and their schools and churches are represented to be in a flourishing condition. Only two of the tribes are represented as degraded. The Indians are not members of the body politic; they pay no taxes, nor do they have a voice in legislation. The State, indeed, allows to each tribe a small annuity for the promotion of their civilization.

Massachusetts is divided into 14 counties, the general statistics of which, and the capitals of each in 1850, were as follows:

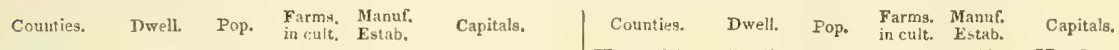

Barnstable.. 6,532. . 35,276. 789.. 423.... Barnstable Hampshire . 5,905.. 35,732 ..2,965.. 319.... Northampton

Berkshire... 8,633.. 49,591..2,897.. 357....Lenox

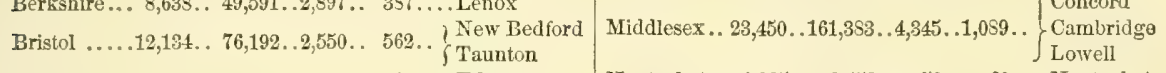

Dukes..... 771.. 4,540.. 265.. 18....Edgartown Nantucket.. 1,255.. 8,452.. 58.. 60.... Nantucket

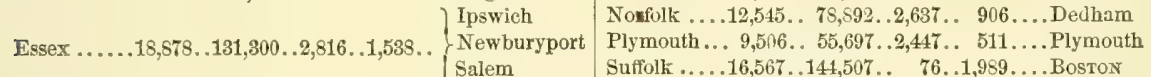

Franklin ...5,832. . 30,867..2,535.. 255....Greenfield $\quad$ Worcester ..21,709..130,789..7,239..1,161.... Worcester

Hampden... 9,083.. 51,281,.2,616, . 389 .... Springfield

The whole number of dwellings in the State was, at the above date, 152,835; of families 192,679, and of inhabitants 994,499 , viz. : whites 985,704 - males 484,294, and females 501,420, free col. 8,795 -males 4,314, and females 4,4\$1.

Of the whole population, there were deaf and dumb-wh. 360, fr, col. 4-total 364; Zlind-wh. 490, fr. col. 7-total 497; insane-wh. 1,629, fr. col. 18-total 1,647; and idiotic-wh. 785, fr. col. 6-total 791. The number of free persons born in the United States was 830,066 ; the number of foreign birth 160,909, and of birth unknown 3,539 . The native population originated as follows: Maine 29,507, N. Hamp. 39,592, Verm. 17,646, Massachusetts 695,236, R. I. 11,414, Conn. 15,602, N. York 14,483, N. Jer. 778, Penn. 1,831, Del. 90, Md. 744, Dist. of Col. 196, Virg. 796, N. Car. 196, S. Car. 224, Ga. 237, Flor. 32, Ala. 71, Miss. 34, La. 179, Tex. 10, Ark. 10, Teun. 25, Ky. 75, Ohio 593, Mich. 122, Ind. 60, III. $165, \mathrm{Mo} .59$, Ia. 12 , Wisc. 32 , Calif. 7 , Territories 9 ; and the foreign population was composed of persons fromEngland 16,685, Ireland 115,917, Sentland 4,469, Wales 214, Germany 4,319, France 805, Spain 178, Portugal 290, Belgium 36, Holland 138, Turkey 14, Italy 196, Austria 10, Switzerland 72 , Russia 38 , Denmark 181, Norway 69, Sweden 253, Prussia 98, Sardinia 1, Greece 23, China 2, Asia 31, Africa 27, British America 15,862, Mexico 32, Central America 7, South America 84, West Indies 303, Sandwich Islands 81, and other countries 466.

The following table will show the decennial progress of the population since the first census of the State taken by the Cnited States authorities:

\begin{tabular}{|c|c|c|c|c|c|c|c|}
\hline \multirow{3}{*}{$\begin{array}{c}\text { Census } \\
\text { Year. } \\
1790 .\end{array}$} & \multirow{2}{*}{$\begin{array}{l}\text { W'hite } \\
\text { Persons. }\end{array}$} & \multicolumn{3}{|c|}{ Colored Persons. } & \multirow{2}{*}{$\begin{array}{c}\text { Total } \\
\text { Population. }\end{array}$} & \multicolumn{2}{|c|}{ Decennial Increase. } \\
\hline & & Free. & Slave. & Total. & & Numerical. & Per ceut. \\
\hline & .373 & $.5,4$ & - & 5. & $375,717$. & 一 & \\
\hline 1800 & 416,793 & 6 & - & 6 & 423,245 . & . 44,528 . & 1.7 \\
\hline 1810 & 46 & & - & 6 & .4 & 95. & $\ldots 11.5$ \\
\hline 1829 & .516 & 6 & - & 6 & 52 & 17. & $\ldots 1$ \\
\hline 1830 & .6118 & 15. & 1 & 7 & 98 . & 21. & $\ldots 16.6$ \\
\hline $1 S 40$ & .72 & $\ldots \ldots 8,6$ & 一 & . 8 & 737 & .. 12 & . 20.8 \\
\hline 1850 & .....995,704 & $\ldots \ldots \ldots 8,795 \ldots \ldots$ & - & $\ldots .8,795$ & .. 994,499 . & . 256,500 . & 34.8 \\
\hline
\end{tabular}

The statistical returns of the wealth, industry, products, and institutions of the State, according to the census of 1850 and other official documents referring to the same period of time, are as follows:

Occupied Lands, etc.-Improved farm lands, 2,183,436 acres, and unimproved lands, 1,222,576 acres-valued in cash at $\$ 109,076,347$. The whole number of farms under cultivation, $\$ 4,235$. Value of farming implements and machinery, $\$ 3,209,584$.

Live-Stock-Horses, 42,216; asses and mules, 34 ; milch cows, 130,099; working oxen, 46,611; other cattle, 83,2S4; sheep, 183,651; and swine, 81,119-valued in the aggregate at $\$ 9,647,710$. The number of auimals of these deseriptions in 1840 was-horses, mules, etc., 61,484 ; neat cattle of all kinds, 282,574; sheep, 378,226; and swine, 143,221 . These comparative figures show an enormous filling off in every deseription of live-stock.

Products of Animals-Wool, 555,136 (in 1840,941,906) pounds; butter, 8,071,370 pounds; cheese, $7,083,142$ pounds; and the value of animals slaughtered during the year, $\$ 2,500,924$. Silk cocoons were produced to the amount of 7 (in $1849,1,741$ ) pounds; and beeswax and honey, to that of 59,508 pounds.

Grain Crops.-Wheat, 31,211 bushels; rye, 481,021 bushels: Indian corn, 2,345,490 bushels; oats, 1,165,106 bushels; 
barley, 112,355 bushels; and buckwheat, 106,095 bushels. In 1839-40 these crops yielded as follows: wheat, 157,328 bushels; barley, 165,319 bushels; oats, 1,319,680 bushels; rye, 536,014 bushels; buckwheat, 87,000 bushels; and Indian corn, $1,809,192$ bushels.

Other Food Crops.-Peas and beans, 43,709 bushels; potatoes, Irish, 3,555,334 bushels. In 1S39-40 the potato crop amounted to $5,385,652$ bushels.

Miscellaneous Orops.-Tobacco, 138,246 (in 1840, 64,955) pounds; hay, 651,807 tons; clover-seed, 1,002 bushels; other grass-seed, 5,085 bushels; hops, 121,595 pounds (in 1840, 251,795) pounds; flax, 1,162 pounds ; flax-seed, 72 bushels ; maple sugar, 795,525 pounds ; molasses, 4,693 gallons ; wine, 4,658 (in 1840,193 ) gallons, etc. Value of orchard products, $\$ 163,995$, and of market-garden products, $\$ 600,020$.

Home-made manufactures for the year ending 1st June, 1850, were produced to the value of $\$ 205,383$. The same class of productions, according to the census of 1840 , were valued at $\$ 231,942$.

Manufactures.-Aggregate capital invested, $\$ 00,000,000$; value of raw material, fuel, ete., $\$ 00,000,000$; average number of hands employed, 000,000 - males 00,000 , and females 00,000 ; average monthly cost of labor, $\$ 000,000$ - male $\$ 000,000$, and female $\$ 000,000$; total value of products for the year ending 1 st June, $1550, \$ 000,000,000$. The whole number of industrial establishments producing to the value of $\$ 500$ and upward, annually, was, at the date referred to, 9,637; and of these 213 were cotton factories; 119 woolen factories, 248 tanneries, and 80 iron manufactories-6s for castings, 6 for pig iron, and 6 for wrought iron.

The cotton manufactures employ a capital of $\$ 28,455,630$; value of raw material, fuel, etc., $\$ 11,289,309$; and value of entire products $\$ 19,712,461$; cotton consumed 223,607 bales; coal 46,545 tons; and products-sheeting, etc., $298,751,392$ yards, and yarn 353,660 pounds. The number of hands employed is-males 9,293 , and females 19,437 ; and the monthly cost of labor-male $\$ 212, \$ 92$, and female $\$ 264,514$; average monthly wages-to males $\$ 2301$, and to females $\$ 1355$.

The capital invested in the woolen manufactures was $\$ 9,089,342$; value of all raw material, ete. $\$ 8,671,671$, and value of entire products for the year $\$ 12,770,565$. Woul consumed $22,929,952$ pounds ; coal 15,440 tons; and products $25,865,659$ yards of cloth, ete., and 749,555 pounds of yarn. Average hands employed-males 6,167 , and females 4,963 ; monthly cost of labor-male $\$ 141,533$, and female $\$ 70,581$; average wages-to males $\$ 2295$, and to females $\$ 1422$ per month.

The tanneries employ a capital of $\$ 1,377,725$; value of hides, skins, ete. $\$ 2,311,178$; value of products $\$ 3,519,123$. Skins tanned 293,000 , and sides tanned $1,500,410$; hands employed-males 1,510 , and females 32 ; monthly cost of labor-male $\$ 41,245$, and female $\$ 360$.

The iron manufactures, in extent and value, according to the returns of 1850 , were as follows:

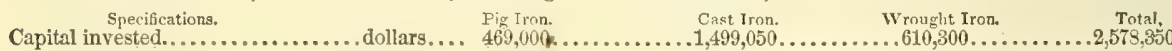

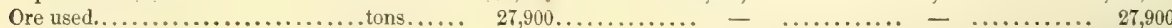

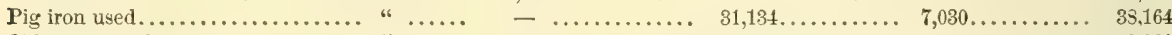

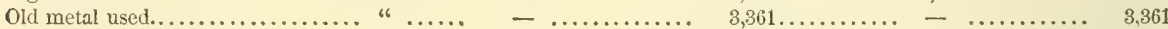

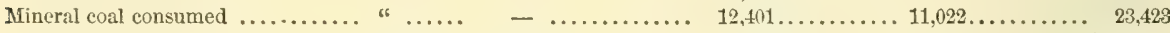

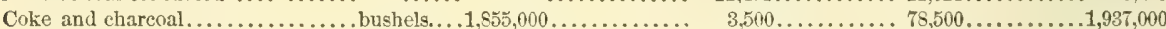

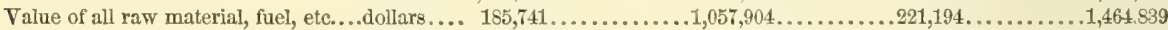

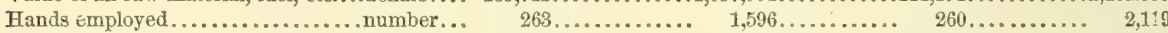

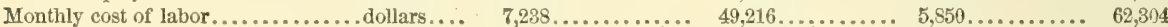

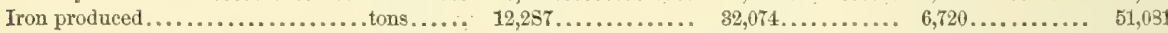

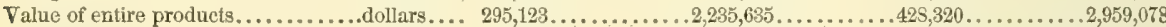

The above exhibited manufactures, comprising what may with propriety be termed national manufactures, compose but a moiety of the aggregate industrial establishments within the State. Besides these there are in the State immense interests in the manufacture of shoes and boots, carpeting, sperm candles and oil, soap, carriages and cars, cabinet-ware, copper-ware, cordage, cutlery, engines and bollers, fre-arms, glass, glue, hats and caps, hollow-ware, etc., hosiery, lead paints, linen thread, lumber and shingles, machinery, musical instruments, paper, powder, ploughs, etc., saddlery, etc. snuff, tobacco, etc., building stone, straw hats, etc., sugar, tin-ware, tools, upholstery, wooden-ware, etc., and a large number of minor, but still profitable manufactures. Massachusetts, indeed, is the great manufacturing State of the Union, and in reference to its extent and population, has no superior. It manufactures at least one sixth of the aggregate articles produced in the workshops of the United States. The products of its cotton-mills constitute one-third of the whole of that staple, and its woolen manufactures are equally preponderant.

Conmerce, Navigation, etc.-Massachusetts, in the year ending 80th June, 1850, exported to foreign countries to the value of $\$ 10,681,763$, and imported to that of $\$ 30,374,684$. Of the exports, $\$ \$, 253,473$ was the value of domestic produce-in American vessels $\$ \tau, 000,103$, and in foreign vessels $\$ 1,253,370$, and $\$ 2,425,290$ the value of foreign produce-in American vessels $\$ 1,898,497$, and in foreign ressels $\$ 529,793$; and of the imports $\$ 22,106,011$ in American vessels, and $\$ 8,265,673$ in foreign vessels. The entrances and clearances in the same year were as follows:

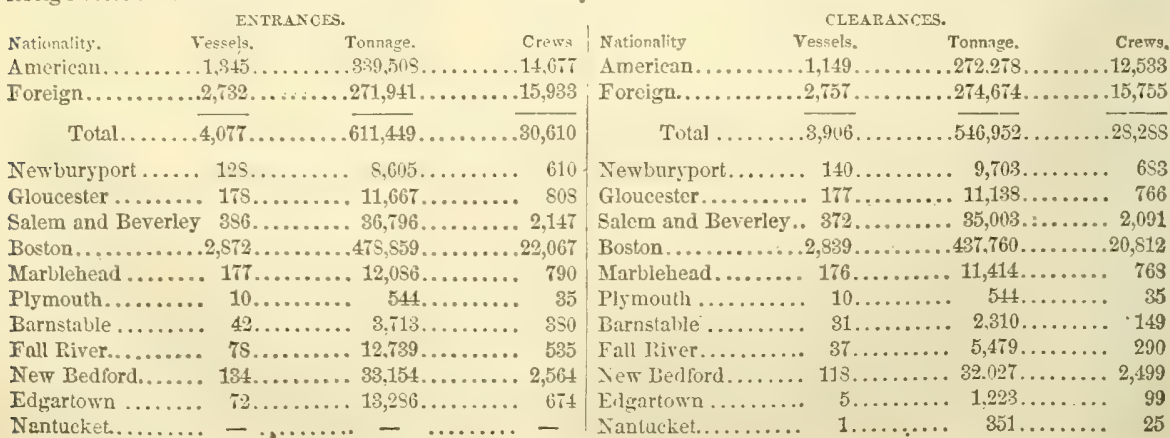




\section{MASSACHUSETTS.}

The total shipping owned in the State at the date referred to amounted to 684,442 tons; registered-permanent 411,973 tons, and temporary 61,350 tons; enrolled and licensed-permanent 208,767 tons; and licensed (under 20 tons)-in the coasting trade 1, S21 tons, and in the cod fisheries 1,74S tons. Of the registered shipping 122,676 tons were engaged in the whale fishery, and the enrolled and licensed tonnage was employed-in the coasting trade 115,546 tons, in the cod flshery 40,003 tons, and the mackerel fishery 42,895 tons; and 7,903 tons were navigated by steam-power. The tonnage of the several districts was-Newburyport 23,262 tons, Ipswich 578 tons, Gloucester 22,474 tons, Salem 28,916 tons, Bevericy 8,173 tons, Marblehead 6,S12 tons, Buston 320,6S7 tons, Plymouth 10,722 tons, Fall River 13,102 tons, New Bedford 127,960 tons, Barnstable 91,102 tons, Edgartown 7,609 tons, and Nantucket 29,018 tons.

The shipping built in the State during the year amonnted to 121 ressels of all kinds -51 ships, 19 brigs, 46 schooners, 3 sloops, and 2 steamers - of an aggregate burden of 35,836 tons; and of the whole number $10(4,657$ tons) were built at Newburyport, 26 (1,996 tons) at Gloucester, 1 (29s tons) at Salem, 3 (S17 tons) at Marblehead, 43 (23,430 tons) at Boston, 5 (579 tons) at Plymouth, 5 (1,254 tons) at Fall River, 4 (781 tons) at New Bedford, 23 (1,861 tons) at Barnstable, and 1 (109 tons) at Edgartown. The statistics of the foreign commerce of the State for a series of years-1791 to $1850-$ exhibit the following movements in the value of exports and imports:

\begin{tabular}{|c|c|c|c|c|c|c|c|c|}
\hline ar. & $\begin{array}{c}\text { Exports. } \\
\$ 2,519,651 \ldots\end{array}$ & Imports. & $\begin{array}{l}\text { Year, } \\
1811 .\end{array}$ & $\begin{array}{c}\text { Exports, } \\
11,235,465 \ldots\end{array}$ & & & 8. & \\
\hline $92 \ldots \ldots$ & $2,888,104 \ldots$ & & $1812 \ldots \ldots$ & $\begin{array}{r}11,235,465 \ldots \\
6,553,338 \ldots\end{array}$ & & 1831. & 63 . & \\
\hline $93 \ldots \ldots$ & $3,755,347 \ldots$ & & $1813 \ldots$ & $1,507,923 \ldots$ & & 1833. & $\begin{array}{r}11,993,605 \\
9,683,122 .\end{array}$ & $\begin{array}{l}18,1 \\
19,9\end{array}$ \\
\hline $94 \ldots \ldots$ & $5,292,441 \ldots$ & & $1814 \ldots \ldots$ & $1,133,799 \ldots$ & & 1834. & $4,672,746$. & \\
\hline $95 \ldots . .$. & $7,117,907 \ldots$ & & $1815 \ldots \ldots$ & $5,280,053 \ldots$ & & $1835 \ldots \ldots$ & 10,0 & \\
\hline $96 \ldots .$. & $9,949,345 \ldots$ & & $1816 \ldots . .$. & $10,186,489 \ldots$ & & $1836 \ldots$ & $10,350,346$ & \\
\hline $97 \ldots \ldots$ & $7,502,047 \ldots$ & & $1817 \ldots$ & $11,927,997 \ldots$ & & 1837. & 190 . & 15 \\
\hline $98 \ldots . .$. & $52 \ldots$ & & $1818 \ldots$ & $56 \ldots$ & & 1838 . & 62 & 13,8 \\
\hline .... & $91 \ldots$ & & $1819 \ldots$ & $11,399,913 \ldots$ & & 1839 & 085 & 19,385, \\
\hline .... & $76 \ldots$ & & 1820. & $11,008,922$. & & 1840 & 10,1 & 16,513, \\
\hline ... & $56 \ldots$ & & 1821. & 12,48 & 32 & 1841. & 11 & 20,31 \\
\hline $02 \ldots \ldots$ & $13,492,632 \ldots$ & & $1822 \ldots$ & 12,5 & & 1842 & 9,8 & It \\
\hline $03 \ldots . .$. & $6 \ldots$ & & $1823 \ldots$ & $13,683,289 \ldots$ & 17, & $1843 \ldots$ & 07 . & 16 \\
\hline .... & $88 \ldots$ & & $1824 \ldots$ & $10,434,328 \ldots$ & 15 & $1844 \ldots$ & 9,0 & \\
\hline$\cdots$ & 19,435 & & 1825. & 11,432 & 41 & 1845 . & 10,3 & 22 \\
\hline$\cdots$ & $21,199,243$. & & $1826 \ldots$ & $10,098,862$ & 17,0 & 1846 & 10,3 & 24 \\
\hline$\ldots$ & $21,112,125 \ldots$ & & 1827 . & $10,424,383$ & 13,8 & 1847 & 11,2 & 34 \\
\hline & $5,128,322$ & & 1828 . & $9,025,785$. & 15 & 1848 & 699 & 23, \\
\hline & 12,14 & & $1829 \ldots \ldots$ & $8,254,937$. & 12,5 & 1849 & 10,2 & 24, \\
\hline 810 & 18,01 & & $1530 \ldots$ & $7,213,194 \ldots$ & $10,453,544$ & 1850 & $10,651,763$ & 30,37 \\
\hline
\end{tabular}

Internal Improvements, - In proportion to surface no other State of the Union is so thoroughly supplied with railroads and other means of communication as Massachusetts. It was the first State to adopt the railroad, and it has ever since maintained a pre-eminence in respect of railroads, and at the present time the several lines extend in every direction, forming a net-work of iron bands. The principal lines are those extending from Boston and Worcester toward Maine and New Hampshire, passing through the great manufacturing towns of the north-east section, and those extending southward from those centres to the Atlantic and Long Island Sound. Two great lines also extend through the length of the State from Boston via Worcester to Albany, and from Boston via Greenfield to Troy on the Hudson River, both forming links in the chains toward the great lakes and the far West. The total length of railroad in the State in 1853 was 1,261 miles, or about 1 mile of road to every 6 t miles of surface. Massachusetts has also several canals, as the Blackstone Canal, from Worcester to Providence, 45 miles long; the Middlesex Canal, from Boston to the Merrimac River, 27 miles long; the Hampshire and Hampden Canal, 22 miles long, and several short eanals and river improvements for the purpose of overcoming falls and rapids in the rivers. The canals in this State, however, are at the present time little used as means of commercial intereourse, but in some instances their waters are valuable for manufacturing purposes.

Banks and Savings Institutions.-In 1851 there was a total of 130 banking institutions in Massachusetts, of which 30 were in Boston and 100 in other parts of the State. The following exhibits their condition in the aggregate in that year:

Liabilities, Boston Banks, Other Banks. Total, Capital.............. \$21,760,000 $\$ 16,505,000 \$ 38,265,000$ Circula_-\$5 and upward $\quad 6,679,316 \quad 9,656.379 \quad 16,365,195$

" - less than $\$ 5 \ldots \quad 1,001,363 \quad 2,828,140 \quad 8,329,503$ Net profits on hand.... $\quad 2,465,373 \quad 1,359,235 \quad 3,824,608$ Due other banks....... 6,787,148 214,773 7,001,921 Deposits without interest $\quad 8,796,575 \quad 4,178,200 \quad \mathbf{1 2 , 9 6 9 , 7 7 5}$ at interest..... $601,317 \quad 268,811 \quad 870,128$

Total......... \$4\$,090,092 \$34,537,559 \$82,627,651

\begin{tabular}{|c|c|c|c|}
\hline Resourcès. & Boston Bank & ther Bank & Total. \\
\hline Specie ................... & $\$ 1, \$ 17,388$ & $\$ 661,471$ & $\$ 2,478,859$ \\
\hline Real estate............. & 590,394 & 407.519 & 993.213 \\
\hline Bills of other banks in Sta & te 5,302 & 535,245 & 5,53 \\
\hline " elsewh" & 311 & 53,111 & 397 \\
\hline Due from other banks.. & $3,228,354$ & $3,326,879$ & $6,550,2$ \\
\hline $\begin{array}{l}\text { Notes, bills of exchange, } \\
\text { and all other stock .. }\end{array}$ & $36,811,525$ & $29,529,583$ & $66,3 \pm 1,1$ \\
\hline
\end{tabular}

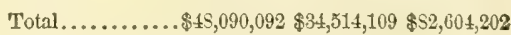

Average diridends of 30 Boston banks in October, 1550, was a fraction over 3.4 per cent.-in April, 1851, it was a fraction over 3.9 per cent; average dividends of 100 other banks in October, 1850, a fraction over 3.39 per cent., and in $A$ pril, 1851, a fraction over 3.7 per cent.

In 45 saving' institutions that made returns there were $\$ 6,537$ depositors, and $\$ 15,554,053$ deposits securely invested. The average dividends for the year was 4.78 per cent. The whole expense of managing these institutions lres been $\$ 13,707$ during the year.

Goremment. - The constitution of this State was framed in 1750 , amended in 1821, and since that period has undergone several modifleations. According to its provisions every male citizen, of the age and upward of 21 years, paupers and persons under guardianship excepted, resident the last past year in the State, and the last past six months at the place of roting, and who, unless exempt from taxation, shall have paid any state or county tax within the list two years, enjoys the right of voting at all popular elections. The general election is held on the second Monday in November annually. 
MASSACHUSETTS.

The Regislative authority is vested in a General Court, consisting of a Senate and Iouse of Representatives. The representative, at present 299 in number, are chosen by towns in ratio of their population. "Every town containing 1,200 inhabitants may elect one, and an additional representative for every 2,400 above that number; and every town of less than 1,200 inhabitants may elect a representative as many times within 10 years as 160 is contained in $1,2 v 0$; and every two or more towns may unite and form a representative district; and all these numbers shall be raised one-tenth when the population of the State shall be 770,000 , and at the same rate for every increase of 70,000 thereafter." Iicpresentatives must be residents for the last past year of the towns which return them. The Senate consiats of 40 members, elected from districts of equal population, but no county is divided in the apportionment, and Nantucket and Duke's counties have only one senator conjointly. The Legislature meets annually on the first Wednesday in January. For the purpose of settling the ratio of representation and the senatorial districts a census is taken every ten years.

The chief executive power is vested in a Governor, and a Lieutenant-governor is elected with the same qualifications and in the same manner as the governor, viz., annually by a majority of rotes. He must have resided in the State for the last past seven years, and be seized of a freehold of $\$ 1,000$ value. If there be no choice by the people, the representatives choose two of the four candidates, if so many there be, having the highest number of votes, and of which two the Senate chooses one for governor. The governor can veto any bill of the general court, but two-thirds of the members thereof afterward voting in favor of such negatived bill it becomes law nevertheless. The governor is advised and assisted in his duties by an Executive Council, of which the lieutenant-governor is ex-officio a member, and which is chosen annually by joint ballot of the legislature. The lieutenant-governor, in ease of a vacaney occurring in the office of governor, exercises the chief executive powers, and both failing, the same is exercised by the council. The Secretary of State and Treasurer are chosen in like manner.

The Judiciary consists of a Supreme Court, Courts of Common Pleas, Probate Courts, etc. The supreme court has a chief justice and four other justices, who are appointed by the governor and council, and hold office during good behavior. It has exelusive cognizance of all capital crimes, and exelusive chancery jurisdiction, and coneurrent original jurisdiction in all civil cases where the amount in dispute exceeds $\$ 600$ in Suffolk and $\$ 300$ in the other counties. It holds law terms in eight of the fourteen counties, and nisi prius terms in all the counties. The court of common pleas is held for the trial of civil cases above $\$ 20$, and, except in Suffolk County, has criminal jurisdiction in all cases not capital. There are six judges, one of whom is chief judge, and frequent terms are held in each county. In Suffolk eriminal jurisdiction is exercised by the municipal court. Trial justices and justices of the peace exercise local civil and eriminal jurisdiction in cases of minor importance. A court of insolvency is held in each county on the first Tucsday of each month before special commissioners, and a probate court, consisting of a judge and register, is established at each county scat. Permanent and honorable salaries are provided for all judicial officers.

The State militia of Massachusetts in 1S50, according to the returns of the Adjutant-general, consisted of 119,690 men of all arms, of which number 549 were commissioned offleers, and 119,141 non-commissioned officers, musicians, artificers, and privates. Of the commissioned officers 10 are general officers, 35 general staff officers, 112 field officers, ete., and 392 company officers. The enrolled militia consists of all able-bodied white male citizens of the age of 18 years, and under that of 45 years, and the active militia consists of volunteers who have a per diem allowance when on duty. The latter are comprised in three divisions and six brigades, embracing two division corps of eadets, one troop of cavalry, four regiments, one battalion, and one company "annexed" of artillery, and nine regiments of light infantry.

Among a large number of benevolent institutions for the relief of the unfortunate which exist in Massachusetts, the following are conspicuous for their extent and efficiency: The State Lunatic Asylum at Worcester, founded in 1833; the Massachisetts General Hospital, at Boston, incorporated in 1811; Perkins Institution, or Massachusetts Asylum for the Blind, at Boston, instituted in 1831; the Boston Lying-in Hospital, instituted in 1832; the U. S. Marine Hospital, at Chelsea ; the Lowell Hospital ; and the M.Lean Asylum for the Insane, at Somerville, a department of the General Hospital. The Asylum at Worester is nne of the best institutions of the hind anywhere established. On the 1st December, 1819, the number of inmates was 429-220 males and 209 females; admitted during the year 241-129 males and 112 females; remaining in the IIospital, 30th November, 1s50, 441-22s males and 213 females, and of this number 169 were foreigners. Of those admitted during the year 194 were committed by the courts, 16 by the overseers, and 31 were private boarders ; aud of the number discharged, 125 were recovered, 15 improved, 28 incurable and harmless, 4 incurable and dangerous, aud 57 dicd. Tutal means of the institution for the year, $\$ 62,470$; expenditures, $\$ 46,776$. The average annual expense of each patient, for the 18 years the hospital has been in operation, is $\$ 11875$. Besides the institutions above named, there is a School for Idiots, at Newton, and an Eye and Ear Infirmary, at Boston. The deaf and dumb of the State are provided for in the Amerienn Asylum, at Ifartford. In 1850, the sums appropriated by the legislature for the support of unfortunates were as follows: Asylum for the Blind, $\$ 14,000$; Asylum for the Deaf and Dumb, $\$ 8,206$; Eye and Ear Infirmary, $\$ 7,000$; State Lunatic Asylum, $\$ 3,200$; School for Idiots, $\$ 2,500$, etc.

Finances, Delt, etc.-The ordinary revenue received into the public treasury, during the year ending 1st January, 1851, amounted to $\$ 492,81064$, and all other receipts (including $\$ 495,600$ temporary loans), to $\$ 98 \$, 95038$ - total receipts, $\$ 1,481.761 \mathrm{02}$; to which add cash on hand, 1st Janaury, $1850, \$ 58,55 \mathrm{~S} 38$, and the total means of the treasury is exhibited st $\$ 1.540,31940$. Ordinary expenditure, $\$ 566,05554$; expenditure on other accounts (including $\$ 495,600$ loans repaid), $\$ 550,22525$ - total expenditures, $\$ 1,416,23079$. Excess of expenditures on account of ordinary revenue, $\$ 73,24490$; excess of receipts on other accounts, $\$ 133,72513$; and excess of aggregate receipts, $\$ 65,43023$, or, including the cash on hand at the commencement of the year, $\$ 121,03861$, of which sum $\$ 5,80922$ is on account of ordinary revenue, and $\$ 118.22939$ on all other interests.

The public debt of Massachusetts on its own account, on the 1st January, 1851, was $\$ 1,210,375$; liability for scrip loaned to the various railroads, $\$ 5,(149,55556$-total absolute and contingent debt, $\$ 6,259,93056$. The value of all property belonging to the commonwealth, at that date, was $\$ 10,386,35745$. Excess of resources over liabilities, $\$ 4,126,426 \$ 9$. The total value of personal and real estate assessed for taxation, in 1850 , was $\$ 546,003,05 \pi$; but the estimate, or true valuation, according to the census of that year, was $\$ 573,342,256$.

Federal Representation.-Massachusetts, in pursuance of the provisions of the Act of Congress, 23d May, 1850, is entitled to send eleven representatives to the National Legislature.

Education,-According to the school report of 1850 , the towns raised by taxation for school purposes $\$ 561,667$, and besides this, 48,714 , income of the "surplus revenue," was so appropriated-total, $\$ 878,332, \omega$ which must also be added

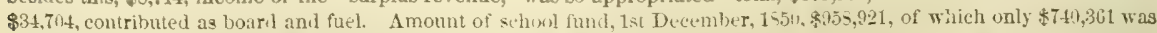
productive, and yielded $\$ 10,0$ en fur dietribution among the towns. The whole uumber of children in the State, from 5 to 452 


\section{MASSACHUSETTS.}

15 years old, was 193,282 -the number under 5 years attending school was 17,752 , and over 15 years, 18,209 . Number of publie schools, 3, ST, taught by S,427 teachers-males 2,442, and females 5,955. Average scholars in winter schols, 194,403; and in summer schools, 176,344 . Arerage monthly wages, inclusive of board to males, $\$ 98459$, and to females $\$ 1442$.

There were, at the date above referred to, 67 incorporated academies in this State, with 3,717 pupils, and an aggregate expenditure of $\$ 5 \pi, 444$ for tuition; also, 845 unincorporated academies, private sehools, etc., with 19,534 scholars, and an aggregate income for teaching of $\$ 261,241$. There are also local funds (endowments) for the support of academies, ètc., to the amount of $\$ 354,620$, yielding an income of $\$ 21,584$. Value of school libraries $\$ 42,707$, and of apparatus $\$ 23,826$. The value of public school-houses, in 1848 , was $\$ 2,750,000$, of which $\$ 2,200,000$ had been expended since 1839 ; probably in 1850 the value would not fall short of three millions. There are three normal schools supported by the State at an annual cost of $\$ 6,500-$ one at Westield, one at West Newton, and one at Bridgewater-averaging annually, in all, 225 pupils.

Massachusetts has four celebrated colleges: Harvard University, at Cambridge, founded 1638; William's College, at Williamstown, founded 1793; Amherst College, founded 1821; and College of the Holy Cross (catholic), founded 1843. There is also a Theological Seminary, at Andover, founded 1507, and the Newton Theological Institution, at Newton, founded 1525. Phillip's Academy, incorporated 1780, and located at Andover, stands first among the academic institutions of the State. Harvard University is generally considered as the best collegiate institution in the United States, and certainly is the best endowed. It has Divinity, Law, and Medical departments, and the Lawrence Scientific School, lately endowed by Hon. Abbot Lawrence, is also a department. Its libraries contain 84,200 volumes. In the college department proper, in 1850, there were 20 professors, 293 students, and 6,342 alumni ; in the Law School, 3 professors and 98 students; in the Divinity School, 2 professors and 23 students; and in the Medieal School, 6 professors, 117 students, and 575 graduates. There is also the Berkshire Medical School, at Pittsfield, founded in 1823, which, in 1850, had 5 professors, 103 students, and 473 graduates. William's College had 8 professors, 1,317 alumni, 179 students, and a library of 13,751 volumes. Amherst College had 12 professors, 963 alumni, 182 students, and a library of 14,000 volumes; and this college has recently added a scientific department to its foundation. Holy Cross College had 14 professors, 120 students, and a library of 4,220 volumes--this last institution, however, has been destroyed by fire, and at present its collegiate exercises are suspended.

Public Libraries.-One State library, 7,400 volumes; 23 social libraries, 126,269 volumes; 4 college libraries, 71,693 volumes; 15 students' libraries, 28,735 volumes; 9 libraries of academies and professional schools, 45,450 volumes; 10 libraries of scientific and historical societies, 44,572 volumes ; 700 public school libraries, 91,539 volumes-total, 762 libraries, and 415,65 solumes.

Periodical Press.-The whole number of perindicals and newspapers published in Massachusetts, in 1850, was 209, of which 70 were devoted to politics -46 whig, and 24 democratic in opinion; and 139 were devoted to literature, religion, science, etc., including all the character of which is not specially denoted in the returns; and of the whole number, 22 were published daily, 4 tri-weekly, 11 semi-weekly, 125 weekly, 3 semi-monthly, 29 monthly, and 7 quarterly. The total circulation of the dailies at each issue was 138,088 copies, of the tri-weeklies 3,000 copies, of the semi-weeklies 19,901 copies, of the weeklies 389,102 copies, of the semi-monthlies 2,570 copies, of the monthlies 113,100 copies, and of the quarterlies 6,000 copies. Boston is one of the principal literary eities of the Union, and many of its publications are farorably known throughout the world; and in many other towns the periodical issues are conducted with great talent.

Religions Denominations.-In the table underneath will be found the statistics of the several religious denominations, as returned in the census of $1 \& 50$ :

\begin{tabular}{|c|c|c|c|c|c|c|c|c|}
\hline $\begin{array}{l}\text { enomina- No. of } \\
\text { tims. Churciles }\end{array}$ & $\begin{array}{l}\text { Church } \\
\text { s. accum. }\end{array}$ & $\begin{array}{l}\text { Value of } \\
\text { Property. }\end{array}$ & $\begin{array}{c}\text { Denomiaa. } \\
\text { tions. }\end{array}$ & $\begin{array}{l}\text { No. of } \\
\text { Churches. }\end{array}$ & $\begin{array}{l}\text { Clurch } \\
\text { accom. }\end{array}$ & $\begin{array}{l}\text { Value of } \\
\text { Property. }\end{array}$ & $\begin{array}{l}\text { Denomina- No. of Church } \\
\text { tious. } \\
\text { Clutrclies. accom. }\end{array}$ & $\begin{array}{r}\text { Val } \\
\text { Prop }\end{array}$ \\
\hline Baptist.....262 & $. .114,140$ & $\$ 1,460,350$ & Germ'n Ref & f...- & - & $\$-$ & R. Catholic . 36 .. 30,315 . & $\$ 477,500$ \\
\hline 2n... 29 & .. 11,0 & $84, \%$ & a.... & $1 \ldots$ & 200 . & 1,200 & b'g . 3. & 66,000 \\
\hline at' 1.4339 & $. .237,237$ & $3,279,089$ & & 1 . & 450 & 11,193 & ...... & \\
\hline F.. - & - & .. & te. & $-\ldots$ & - & 一 & .... $6 \ldots 1.810$ & 9,5 \\
\hline 1.. 53 & 95 & .. & & .. 255 & 011 & 931,350 & $.162 \ldots 92,938$ & $2,320,1$ \\
\hline ... 8 & 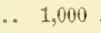 & 0 & & - & - & - & list.117 . 49 & 6 \\
\hline ds ... 37 & 13,823 & 108,600 & ytern & n. 15 & 7,785 & 82,500 & Minor Sects $11 \ldots 3,850$ & 17 \\
\hline
\end{tabular}

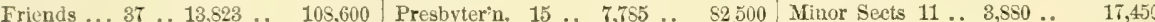

-making a total of 1,430 churches, having accommodation for 682,908 persons, and valued as property at $\$ 10,205,284$ Massachusetts constitutes a diocese of the Protestant Episcopal Church, and is a portion of the Poman Catholic diocese of Boston, province of New York.

Pauperism and Crime.-The number of persons relieved or supported as paupers, in 1850, was 25,981, of whnm 7,900 were town paupers, and 16,05S State paupers; and of these State paupers 12,334 were foreigners. There were in the State 204 alms-houses, with 20,654 acres attached, the whole valued at $\$ 1,255,125$. Number relieved in the alms-houses 12,547, (the average being 4,825), of whom 6,429 were unable to labor. Number relieved out of alms-house, 13,757. Average weekly cost of each pauper-in the alms-house $\$ 108 \%$, and out-doors $\$ 0$ 98. Net expenses of alms-houses, including interest, $\$ 467,959$. Estimated value of pauper labor in alms-houses, $\$ 17,966$. And the report shows that 1,591 foreign paupers had come into the State during the year; that 676 insane persons and 390 idiots had been relieved or supported, and that 969 are paupers by reason of insanity or idiotey, and it is probable that 14,674 were made paupers by intemperance in themselves or others.

There were in the State prison at Charlestown, on the 1st Oetober, 1849,849 convicts, and 221 were received during the year immediately following, and 130 were discharged. The number in prison, on the 30th September, 1s50, was 440 , of which 373 were committed for offenses against property, and 67 for offenses against the person. Scntences-for life 21, for 35 years 1 , for 30 years 1 , for 20 years 1 , for 18 years 3 , for terms below 18 and abore 2 years 270 , and for two years or less 143; and 161 were natives of Massachusetts, 143 of other States, and 136 foreigners. Average number of convicts for the year, 111 . The expenses of maintenance, etc., was $\$ \$ \$ 5,261$, and the prrseeds of convict labor $\$ 45, \$ 17$.

At Westboro" there is a State reform school for juvenile delinquents. On the 1st December, 18:19, there were 810 inmates; received during the year 106 , and discharged 94 ; leaving 824 inmates on the 30 th November, 1850 . All the boys are employed, during a portion of the day, at some mechanical, agricultural, or domestic labor; they do their own washing, ironing, and cooking, and make and mend their own clothes. Each day, 4 hours are devoted to school, 6 to labor, $S \frac{1}{3}$ to sieep, and $5 \frac{1}{3}$ to rucreation and miscellaneous duties. The buildings can accommolate 850 bors. The boys are healthy, and bat four deaths had occurred during the year. 


\section{MASSACHUSETTS.}

The jails and houses of correction, in 1849-50, received 10,661 prisoners, and 1,112 remained in confinement on the 11 th November, 1850. Of the whole number, 9,130 were males, and 1,481 females-1,619 minors, 535 colored, 3,533 able to read and write, 23 insane, 1,546 natives of Massachusetts, 832 natives of other States, 5,854 foreigners, 2,429 nativity not known. Average cost of board for each prisoner, per week, $\$ 166$. Total expense for the year, $\$ 102,271$. Estimated value of labor in houses of correction, $\$ 22,312$.

Historical Sketch, - The firsi accurate account of the country now called New England, was furnished by Bartholomew Gosnold, who, sailing from England in 1602 in a course nearly west, discovered a promontory which he called Cape Cod. Navigating the coast southwest, he touched at various points and examined the eountry. On his return, he gave so favorable an account of its climate and soil, as at once to revive the slumbering spirit of adventure and colonization. By the exertions of Hackluyt, a man of science and learning, two companies were formed in 1606-the first consisting of adventurers chiefly of London, and the other of merchants of Plymouth and Bristol. The former settled Virginia, and the latter the provinces of New England. The Plymouth company was unfortunate in its first attempts. In 1607, a party of about one hundred persons were landed, but those, discouraged, returned the ensuing year, and no further attempts were made for some time afterward. Religious fervor, however, effected what commercial enterprises had failed to accomplish. In 1620, a congregation of English puritans, whom oppression had driven to Holland, obtained from the London company grants of land within their patent, and (in number 102) sailed from Plymouth for the river Hudson, on the banks of which they had intended to have formed settlements. They were carried further north, however, and landed near Cape Cod. Their first care was now to form a eivil government. They chose a governor, and to aid him an assistant, but the number of assistants was afterward inereased to seven. The supreme power resided with the whole people, and it was not until 1689 that they established a representative body. In imitation of the primitive Christians they threw all their property into common stock, but experience soon taught them the impracticability of such a system. In 1630, they obtained from the Plymonth company a grant of the land on which they had settled. These original colonists are now known by the title of the "Pilgrim Fathers," and the anniversary of their arrival is still religiously observed by their descendants.

Although many detached parties were constantly arriving, the settlement progressed slowly. The first permanent town erected was Salem, and afterward Charlestown was built A fresh spring, however, was given to the exertions of the Plymouth company in 1628 , in which year it received a new patent, and its powers, which had previously been exereised in England, were now removed to America. Emigration hence became considerable; in July, 1630, seventeen ships arrived at Salem with 1,500 persons, by some of whom Boston was founded. The early years of the colonies were passed under a complication of troubles-the French and Indians hovered around them, and the policy of the people was distasteful to the Stuart dynasty, 1n 1635 Charles I. appointed commissioners, with absolute powers "to make laws and constitutions eoncerning either the State, public, or the utility of individuals." Two years afterward he forbade the emigration of all non-conformists, and in 1638 a quo warranto was issued, upon which judgment was given against the colonists without affording them a hearing. The state of affairs at home, however, prevented any further prosecution of these designs on the part of the king.

The political axiom of the times was, that the peace of the State depended upon the unity of religious opinion, and it was mainly the enforcement of this axiom that led to the persecution of dissenting sects by the established government. The experience of their own sufferings in England, from religious persecution, unfortunately taught the colonists no lesson of toleration. Scarcely had they organized themselves, than they began to put in practice a similar mode of compelling uniformity to that pursued by their own persecutors, and all not professing the peculiar views of the puritan government, then in vogue, were excluded from its protection. In 1635 the famous dispute arose respecting the covenant of grace and the covenant of works, and those who espoused the side of the latter being the most numerous, resorted to the accepted and ancient mode of glorifying God by persecuting their opponents. The leaders of the Antinomian party were banished, and thus contributed to the settlement of Rhode Island, which had been begun the year previous by Roger Williams and a party exiled for a similar cause.

The downfall of monarchy in England checked the progress of emigration, by securing protection to the puritans at home, but was, in many other respects, advantageous to the colonies. Their civil liberties were safer, and some exiraordinary privileges were granted to their commerce. The prospects of hostilities with the Indians, however, compelled Massachusetts, Plymouth, Connecticut, and New Haven to form a defensive confederation. On the Restoration Massachusetts was found to have increased in importance to such a degree, that the anxiety of the king was naturally awakened, lest an impression should be made in favor of the superior advantages of democratic institutions, and accordingly coercive measures were adopted by the crown, and commissioners were appointed to superintend affairs. The navigation laws were enforced, and the destruction of the colonial charters resolved upon, but death marred the execution of the project by Charles II. His successor James was equally hostile to freedom. He determined to unite all the provinces of Nerv England into one government under a president and' council, and found a fit agent for his purpose in Sir Edmond Andross. After dissolving the charter governments of Connecticut and Rhode Island, the president proceeded to Massachusetts, where he compelled a temporary submission. Remonstrances were in vain. The infatuated monarch was determined to crush the spirit of freedom in both hemispheres, and in furtherance of his designs, annexed New York and New Jersey to the Union already formed. The government of Andross expired with that of his royal master, and the former order of things was immediately restored.

The people of Massachusetts, however, derived no great advantages from the Revolution. They petitioned for the legal restoration of their charter, which the judges of Charles II. had declared to be forfeited, but they found to their dissatisfacm tion that they were not to expect the same liberal provisions as before. The king was to appoint the governor, and by him the assembly was to be called, proroguer, and dissolved, and by him all officers were to be appointed. By the new charter Plymonth was now finally united to Nassachusetts. Notwithstanding its objectionable provisions, the new government went into operation without any interference on the part of the people, and this may not seem extraordinary when it is considered that the right of voting, which hitherto had been confined to church members, was now extended to all freeholders.

Almost the first act of the governor and counsel, on their coming into offece, was the institution of a court to try the unfortunate vietims of popular delusion accused of witcheraft at Salem. This delusion took possession of the minds of all, and so firmly convinced were the magistrates that the Prince of Darkness was in their midst, using human instruments to accomplish his purposes, that the slightest testimony was deemed sufficient to justify a committal for trial. Many were tried, and received sentence of death. The jails were full of the accused, and, alas! beforo the spell of infatuation was 
broken, which was not before the rich and influential became involved by accusations, no less than twenty unfortunates had undergone the penalty of the law!

The war with the French and Indians, which began in 1690, was not yet terminated, For seven years the frontiers were ravaged. Peace between England and France, which was concluded in 1697, was soon followed by peace with the sarages. When war again broke out in Europe, in 1707, Massachusetts again joined in arms with the mother country, and contributed largely in money and men. While thus supporting the wars undertaken by England, however, the assembly did not forget its own rights, and was warmly engaged in contests with the royal governor. Every session presented a scene of altercation, and public business was with difficulty transacted, through the determination of the representatives not to give a fixed salary to their governor, which the latter was resolved to obtain.

War again broke out between France and England in 1745, and an expedition against Louisburg was projected in Massachusetts. A powerful armament was prepared principally by this province, and the command given to Colonel Pepperell, a rich merchant of Boston. The fort was taken, but at the subsequent peake Louisburg was restored to the French, a proceeding which caused great discontent in Massachusetts. In the war which ended in the subjugation of Canada, Massachusetts surpassed her former exertions in supporting the arms of England. In the year 175t she had 9,000 men in the field, and maintained this number until the return of peace in 1763 .

The extraordinary expenses of this war led to the imposition of internal taxes on the very colonies which had expended so much blood and treasure in their support. Massachuseits was the first to remonstrate against, and the most strenuous to oppose, this injustice. At the recommendation of her court it was that the first continental songress was convened. When, after the repeal of the stamp act, the duty on tea was attempted to be imposed, the earliest popular movements appeared at Boston. The attempts of the British ministry to enforce obedience only strengthened the cause of the colonists, and the flame of war which broke out in Massachusetts gradually extended itself over the whole Anglo-American possessions. Massachusetts was, in the early part of the contest, the theatre of hostilities, by which she suffered much, while she contributed greatly by her exertions to the successful issue of the conflict.

The extreme pressure of the taxes consequent on these exertions led to serious discontent among the people after the peace of 1788. The government was feebly administered, and at length, in 1786, an open insurrection took place in the western counties. The insurgents, under a popular leader, named Shays, committed great excesses, and all order for a time was suspended. They were at length overcome by General Sheppard, and their leaders driven out of the State.

Massachusetts ratified the federal constitution on the 6th February, 1788.

The policy of the State, during the war of 1812, was in opposition to that of the general government. Her political weight had always been east in the scale of the federal party. The whole people were vehemently opposed to the war, and her governors refused to place the State militia under the control of their political opponents. From this period to the Convention at Hartford, in which Massachusetts took an active part, the acts of her party leaders uniformly tended to embarrass the goveriment. Massachusetts suffered somewhat in her commerce during the latter part of the war, but except in the occupation of a part of the then district of Maine by British forces, experienced little injury from the contest. It was during the wars which succeeded the French Revolution, and this war, that the manufacturing interests of Massachusetts took root, and obtained a permanent stability.

Maine hitherto had been attached to Massachusetts, but in 1820 this connection was dissolred by mutual consent, and the former was admitted as an independent State of the United States.

Boston, on Massachusetts Bay, is the political capital of the State.

MAssac county, $17 l$. Situate in the extreme S., and contains $234 \mathrm{sq} . \mathrm{m}$. Ohio $\mathrm{r}$. is its $\mathrm{S}$. boundary, and in the $\mathrm{N}$. is the Pond Slough, a line of ponds and marshes, with islands of rich land between, but it has no considerable streams. On the Ohio is a tract of dry barrens, and further N. much excellent land. Corm is the staple product. Tobacco is raised, and beef and pork are exported. Farms 385; manuf. 11; dwell. 704, and pop.-wh. 4,070, fr. col. 22total 4,092. Capital : Metropolis.

Massandton, p. o., Page co., Virg.: $97 \mathrm{~m}$. N. N. W. Richmond. Near it is a beautiful sheet of water on Massanutton Mountain, which has an unbroken fall of near 50 feet, below which the water flows in a deep chasm of limestone rock with banks nearly perpendicular. The fall presents a beautiful spectacle.

MassevA, t. and p. v., St. Lawrence co., $N$. $Y$.: $165 \mathrm{~m}$. N. by W. Albany. Drained by Rackett and Grass r., flowIng into the St. Lawrence, the latter bounding it on the $\mathrm{N}$. Surface pleasantly diversifled: soil rich and fertile, producing grass and grains. There is an extensive sulphur spring near Racket $x$., which evolves large quantities of sulphureted hydrogen gas, and contains carbonates of soda, lime, magnesia, and sulphur. There is extensive water-power here which is improved, and moves several large mills. The v, contains several mills, workshops, and stores, and about 400 inhabitants. Pop. of t. 2,915 .

Massix's Cross Roads, p. o., Kent co., Md. : 45 m. N. E. Annapolis.

Massilon, p. $\vee$., Stark co., Ohio: on the left bank of 'Tuscarawas r., $93 \mathrm{~m}$. N. E. Columbus. At this point also the Ohio Canal and the Ohio and Pennsylvania $\mathrm{R}$. R. intersect, furnshing avenues of travel and transportation in every direction. Massilon was founded in 1926-in 1840 it contain- ed 1,422 inhabitants, and in 1850 upward of 3,500 inhabitants. It is one of the most flourishing interior towns of the State, and is the depôt of a rich and extensive agricultural vicinity, It has been called, and not inaptly, the "wheat city," its trade in that staple being enormous. The $\mathrm{v}$. is neatly and substantially built, and many of the dwellings and warehouses are of stone, which is abundant in the neighborhood, and the bridge over the Tuscarawas is also an elegant stone structure. The manufactures of Massilon are in a flourishing condition, and comprise a considerable variety of handicrafts-iron-ware and flour being the principal products. Bituminous coal of an excellent quality is abundant, and has been mined for several years. The aggregate exports and imports of this place are estimated at nearly $\$ 5,000,000$ annually. A bank is located here. The newspapers published here are, the "M. News" (indep.), the "Wheat City Mercury" (dem), and the "Missionary Messenger" (Luth.), all published weekly. The v. has several good schools, among which the Union School stands pre-eminent, and also churches of the principal Christian denominations. The location of Massilon is well chosen, and is one abounding in rich and warm scenery; its vicinity is thickly settled, and villages have sprung up on all sides. On the west side of the river is a suburb of the v., called West Massilon, which will probably become a large place, having equal facilities with the original village.

Massiuon, p. v., Allen co., Ind.: in S. E. part of county, $99 \mathrm{~m}$. N. E. Indianapolis.

Massruon, p. v., Clinton co, I $a_{*}$ : near W. boundary of county, $2 \mathrm{~m}$. N. Wapsipinicon $\mathrm{r}$., $37 \mathrm{~m}$. N. E. Iowa City.

Masten's Corner, p. o., Kent co., Del.: 5 m. W. Dover.

Mastersonvule, p. v., Laneaster co., Penn。: 39 m. S. E. Harrisburg 
Mastertox, p. v., Monroe co., Ohio: 99 m. E. by S. Columbus,

Mast Hope, sta., Sullivan co., $N_{0} Y_{.:}$on the New York and Erie R. R., $126 \mathrm{~m}$. New York.

MAst Y Y of Contoocook r., a branch of the Merrimac r., $7 \mathrm{~m}$. W. Concord. The Concord and Claremont R. R. passes through the $\mathrm{v}$., distant $19 \mathrm{~m}$. from Bradford, at which place stages connect with cars for Newberry, Sunapee, Newport, Claremont, etc.

Matagorda county, Tex. Situate S. E. on the Gulf, and contains $992 \mathrm{sq}$. m. Colorado $\mathrm{r}$. flows $\mathrm{S}$. through the middle, and many small streams empty into Matagorda Bay, the largest being the Trespalacios and Caney bayoux. Surface almost uniformly level. Most of the county is open prairie, but the Colorado and Caney have broad forests on either side, and the smaller streams have all narrow belts of timber. Soil exceedingly rich, being generally a deep black mold, free from stones, with a substratum of red loam; near the Caney it is of a mulatto color, light and friable, but clammy and adhesive near the prairies. Corn and cotton produce large crops. Tobacco of the very best kind is raised in the $\mathrm{S}$., and the coast region is eminently fitted for rice-growing. The sugar raised is superior, and the county is admirably adapted to its cultivation. When the rafts are removed the rivers will open abundant communication with the interior. Farms 39 ; manuf. 0 ; dwell. 176, and pop.-wh. 913, fr. col. 3, sl. 1,208-total 2,124. Capital: Matagorda.

M $\triangle$ TAGORDA, p. v., and cap. Matagorda co., Tex. : on an elevated plain at the $\mathrm{S}$. W. corner of Bay Prairie, $2 \mathrm{~m}, \mathrm{~F}$. of the outlet of Colorado r., on the N. bank of Matagorda Bay, 133 m. S. E. Austin City. It is the only important v. in the county, it has an excellent harbor, and is at all seasons approachable by vessels drawing 8 and 9 feet of water. When the raft of the Colorado shall have been removed, this town will become the depst of one of the most fertile, productive, and extensive sections of Texas. "The Colorado Tribune" is the name of a weekly issue.

Mataxora, p. o., Hardeman co., Tenns: 155 m. S. W. Nashville.

Matamoras, p. o., Montgomery co., N. Car. : $\$ 1$ m. S.W. Raleigh.

MathertoN, p. 0., Ionia county, Mfich. : $25 \mathrm{~m} . \mathrm{N} . \mathrm{W}$. Lansing.

Matildaville, p. V., St. Latrence co, N. Y.: on Racket r., 117 m. N. N. W. Albany.

Matildaville, p. v., Clarion co., Penn. : on the S. side of Clarion r., $67 \mathrm{~m}$. N. by E. Pittsburg, and 155 W. N. W. Harrisburg.

MaTtaponx river, Tirg.: rises in Spottsylvania county, and is formed by the junction of $\mathrm{Mat}, \mathrm{Ta}, \mathrm{Po}$, and $\mathrm{Ny}$ rivers. At the S. E. point of King William County it unites with Pamunky r, to form York river.

Mattapoisetr, p. 0., Plymouth co., Mass. : on Buzzard's Bay, $53 \mathrm{~m}$. S. by E. Boston. The fishery is the chief employment of the inhabitants, and is carried to a great extent. There is a fine harbor by the same name which makes up to the $v$, and affirds good anchorage.

Mattawankeag, p. v., Penobseot co., Mfe.: on the E. side of the Penobseot r., 113 m. N. E. Augusta.

Matrawax, p. v., Van Buren co., Mrich.: $69 \mathrm{~m}$. S. W. Lansing. The Michigan Central R. R. passes the v. $126 \mathrm{~m}$. distant Detroit and 127 Chicago.

Matteaman, p. v., Duchess co., $N_{\text {. }} Y_{\text {. : }}$ on Fishkill er. $1 \frac{1}{7} \mathrm{~m}$. from the landing on the Hudson, $77 \mathrm{~m}$. S. Albany. The creek has here a fall of 40 feet, and affords extensive water-power, which is improved for manafacturing purposes. The $\mathrm{v}$. contains about 2,000 inhabitants, and is the seat of extensive iron-works and machine shops, and has besides these sereral cotton and other factories, chiefly engaged in the manufacture of heavy goods.

Matrmews county, Firg. Situate S. E. on the Chesa456 peake, and contains 89 sq. m. Piankatank r. is its $\mathrm{N}$ boundary, and Mobjack Bay lies on the S., into which East r. flows, the largest stream of the county. Surface low and level; soil of average fertility. Corn is the staple, and there is some good wheat land. The bays and creeks abound in fine oysters, and the shad and herring fisheries are very valuable. It has no mill-streams, but wind-mills and tide-mills are used. On the Piankatank is excellent ship timber. Farms 293; manuf. 3; dwell. 711, and pop.wh. 3,644, fr. col. 147, sl. 2,923.-total 6,714. Capital: Matthews C. $\mathrm{H}$.

Matxhew's C. H., p.v., and cap. Matthews co., Firg. : in the centre of county, $9 \mathrm{~m} . \mathrm{N}$. W. New Point Comfort, and 59 m. E. Richmond.

Mattintw's Milis, p. o., Richland co., $I l l .:$ on W. side Fox r., 109 m. S. E. Springfield.

Matthew's Store, p. 0., Anne Arundel co., Dfd.: $15 \mathrm{~m}$. N. by W. Annapolis.

Matthewstille, p. v., Pocahontas co., Virg.: $123 \mathrm{~m}$. W. N. W. Richmond. The v, is situate at the foot of the Alleghany Mountains, which bound the county on the $\mathbf{E}$.

Mattison, t. and p. o., Branch co., Mfich.: $61 \mathrm{~m} . \mathrm{s}$. W. Lansing. Drained by St. Joseph's r. and Swan cr., one of its branches. There is a pond in the S. E. part of the $t_{\text {. }}$ Surface rolling; soil dark, rich, sandy loam, with oak openings. The timber land affords excellent grazing, the remainder is well adapted to grain. Pop. of t. 475 .

MatтrTucK, p. v., Suffolk co., $N$. Y.: on the Long Island R. R., $83 \mathrm{~m}$. New York, $133 \mathrm{~m}$. S. E. Albany. It is a small v. situate midway between Great Peconic Bay and Long Island Sound. It contains a church and about $35 \mathrm{dwellings.}$ Mattoax, sta., Amelia co., Virg. : on the Richmond and Danville R. R., 27 m. S. W. Richmond.

Mader Crung, t., p. v., and cap. Carbon co., Penn.: $71 \mathrm{~m}$. N. E. Harrisburg. Surface mountainous ; soil gravelly. Drained by Beaver, Mauch Chunk, and other creeks which empty into the Lehigh $\mathrm{r}$. The $\mathrm{v}$. is situate at the head of the Lehigh Canal, on which the great bulk of the coal is carried to market, and on the W. bank of Lehigh r., in a beautiful ravine, walled in on either side by rocky mountains of a great height, forming a very picturesque appearance. This being an important coal region, the iuhabitants are chiefly employed in mining and shipping coal. There is but little of the t. under culture, provisions being brought from a distance. There are two anthracite blast furuaces here, each having an annual eapacity of 2,000 tons. The great coal mine is reached by an inclined plane some 700 feet in length with a 200 feet rise. A railway extends to the mine. The Mauch Chunk and Summit Hill R. R. verges from here and connects with the Philadelphia and Reading $R$. $R$. by stage from Summit Hill to Tamaqua, distance by stage $6 \mathrm{~m}$. Besides the court-house and usual public buildings, there are some fine stores, dwellings, and a number of mills and workshops in the $t$. There are two weekly newspapors published here, the "Carbon Democrat" (dem.), and "Carbon County Gazette" (whig). Pop. of t. 2,5058.

MAUCKPORT, p. v., Harrison co., Ind.: on the N. bank of the Ohio $r_{0}$, near the mouth of Buck cr., $115 \mathrm{~m}$. $\mathrm{s}$. Indianapolis.

Maulding's Mruts, p. o., Wayne co, Ill.: 115 m. S. E. Springfield, on the W. side Skillet Fork of Little Wabash.

MaUMEe Citr, p. v., and cap. Lucas co., Ohio: on the W. side of Maumee r., at the foot of the rapids and at the head of navigation, $118 \mathrm{~m} . \mathrm{N}$. N. W. Columbus. The Wabash and Erie Canal passes the $v_{\text {.o }}$ and is connected with the river by a side cut, affording it excellent commercial facilities. It contains a court-house and other county buildings, churches of several denominations, numerous stores, and several factories and flouring mills driven by the excellent water-power afforded by the rapids above the place. Pop. 1,757, The "Maumee River Times" (whig) is published here weekls.

MacMee river, Ohio. This river rises in the N. E. part 
of Indiana, and flowing N. E., enters Lake Erie through Maumee Bay. It is furmed by the junction of Little st. Jostph's, St. Mrory's, and Great and Little Auglaise rivers. Its length is about $100 \mathrm{~m}$., and $50 \mathrm{~m}$. from its mouth it is 70 rods wide. The navigation is open to schooners and steamboats is $\mathrm{m}$. to Perrysburg, and in spring and fall is boatable to Fort Wayne, and at all times furnishes extensive waterpower. The Wabash and Erie Canal is constructed along its banks. The country on its borders is very productive.

Macamlle, p. o., Pulaski co., Ark.: 15 m. N. W. Little Rock.

MAURICE river, $N_{0}$ Jer.: a tributary of Delaware $x_{\text {. from }}$ Groucester co. It is navigable $20 \mathrm{~m}$. for vessels of 80 or 100 tons. It has fine embanked meadows, and on its upper course affords valuable water-power. Excellent oysters are taken at its mouth.

Mauricetown, p. .., Cumberland county, N. Jer.: on W. bank of Maurice r., $10 \mathrm{~m}$. from its mouth and $61 \mathrm{~m} . \mathrm{S}$. $\frac{1}{2} \mathrm{~W}$. Trenton.

Madrids, p. v., Vigo co., Ind.: near a fork of Furman's cr., $71 \mathrm{~m}$. W. S. W. Indianapolis.

MaUry county, Tenn. Situate W. centrally, and contains 498 sq. m. Drained by Duck $r$. and its branches. Surface diversiffed; soil very fertile, adapted equally to grass or grain. Corn is the great staple, and the crop very large. Cotton is a heavy product; and wheat and the other grains and tobaceo all succeed well. The pastures are fine, and feed great numbers of cattle and sheep. Pork is a very heary export. It has extensive and flourishing manufactures of cotton and woolen goods, liquors, leather, flour, iron-ware, etc. Farms 1,501; manuf. 112; dwell. 2,961, and pop.wh. 16,760, fr. col. 90, sl. 12,670-total 29,520. Capital. Columbia. Public Works: Nashville and Alabama R. R.

Mavars, p. v., Osage co, Mo.: on W. bank of Mavais cr., a tributary of Osage r., $23 \mathrm{~m}$. S. by E. Jefferson City.

MATEx, p. v., Oglethorpe co., Gas: $47 \mathrm{~m}$. N. Milledgeville, on the Athens Branch of Georgia R. R., $13 \mathrm{~m}$. from Union Point station.

Maxfield, to and p. v., Penobscot co., Me.: $87 \mathrm{~m} . \mathrm{N} . \mathrm{E}$. Augusta. Drained by Piscataquis river and Sebois stream. Surface rolling; soil fertile; well adapted to grain. The v. is pleasantly situate on N. side of Piscataquis r. Waterpower is good and is used by several saw-mills. Population of the t. 186.

Maxwell, p. o., Delaware co., Ohio: $21 \mathrm{~m}$. N. Columbus,

Mar, p. O., Lancaster county, Penn.: 39 m. E. by $\mathbf{S}$. Harrisburg.

Mayberry, p. o., Lewis county, Mo.: $105 \mathrm{~m}$. N. by E. Jefferson City.

Marbinton, p. v., Newberry dist., S. Car.: on a small cr. which flows into the Congaree r., $39 \mathrm{~m}$. N. W. Columbia

MAYFIELD, p. o., Warren county, Ga.: on the E. side of Ogeechee r., 39 m. N. E. Milledgeville.

Matfield, p. v., and cap. Graves co., $K y_{.}:$on a branch of Mayfield r., $229 \mathrm{~m}$. S. W. Frankfort. It contains a courthouse, jail, scveral stores and dwellings, and about 200 inhabitants.

Ma YFIELD, p. 0., Jackson county, Tenn.: 61 m. N. N. E. Nashrille.

Matrield, to and p. v., Fulton co., $N . Y_{.}: 33 \mathrm{~m} . \mathrm{N}$. W. Albany. Drained by tributaries of Sacondaga r. Surface mountainous: soil sandy and clay loam, well adapted to grain. The Mayfield ridge crosses the N. part. The v, of Marfield is situate centrally, and contains about 30 dwellings. The town has several considerable and importan manufactures, Pop. 2,429.

Marfieid, t. and p. o., Cuyahoga co., Ohio: $129 \mathrm{~m}$. N. E. Columbus. Drained by Chagrine $r$, and some small creet which empty into Lake Erie. Surface level; soil fertile. Pop. of t. 1,117.

MAYFIELD, p. o., Isle of Wight co., Virg.: $57 \mathrm{~m} . \mathrm{S}$. E. Pichmond.

MaY Flower, p. o., Otsego eo., $N . Y_{*}: 63 \mathrm{~m}$. W. Albany.
Mar HILl, p. o., Lee co., Ill.: 133 m. N. Springfield.

Maxo, p. Y., Halifax county, Virg.: on the Halifax and Boydton post-road, 93 m. S. W. Richmond.

MaYoning, p. o., Patriek county, Firg.: $157 \mathrm{~m} . \mathrm{S} . \mathrm{W}$. by W Richmond.

Mayport Mulis, p. v., Duval co., F'lor.: on the N. bank of St. John's r., $157 \mathrm{~m}$. E. Tallahassee.

Max's LaxDing, p. Y., and eap. Atlantic co, N. Jer, : on Great Egg Harbor r., at the head of sloop navigation, $16 \mathrm{~m}$. from the ocean, and $51 \mathrm{~m} .8$. Trenton. It has a considerable trade in wood and lumber, and ship-bullding is carried on to some extent. It is built on both sides of the $r$, and contains a court-house, several stores, and workshops. Pop. about 250 .

MaY's Lick, p. o., Mason co., Ky.: near Johnson's cr. $61 \mathrm{~m}$. N. E. Frankfort

MAYsville, p. v., and cap. Clay co, Ill.: on the outskirts of Twelve Mile Prairie, $99 \mathrm{~m}$. S. E. Springfield, $2 \mathrm{~m}$. W. Little Wabash $\mathbf{r}$. The court-house is situated here.

Maysville, p. v., Mason co., Ky.: on the S. side of Ohio river, $73 \mathrm{~m}$. N. E. Frankfort. It is situate on a high bank, and is backed by hills which rise to a considerable height For many years it was known as "Limestone," from the creek of that name, which here enters the Ohio. It is regularly laid out, the streets crossing each other at right angles, and most of its stores and dwellings are substantially built. The principal buildings are the city hall, 7 or 8 churches, 12 schools and seminaries, a hospital, a bank, 2 steam cotton factories, a bagging factory, 2 foundries, 5 or 6 rope-walks, several saw and flour mills, and other factories, about 50 groceries, wholesale and retail, 27 dry goods stores, several pork-packing establishments, 4 lumber yards, and numerous other manufacturing and trading establishments. The newspapers published here are the "Post Boy" (indep.), and the "M. Eagle" (whig), both issued tri-weekly and weekly, and the "M. Flag" (dem.) and the "M. Frerald" (whig), both weekly issucs. Maysville is one of the most important places in Kentucky ; it has a good harbor, and is the port of a large and productive section of the State, and when the ruilroads now in progress-the Maysville and Lexington R. R., and the Maysville and Big Sandy R. R.are completed, its commercial ficld will be immeasurably enlarged, and the prospects of its becoming a first-rate mart greatly favored. The great road leading irom Chillicothe, in Ohio, to Lexington, passes through this place. The v. was first settled in 1784, under the auspices of Simon Kenton; in 1786 it was the residence of Daniel Boone, the famous pioneer; until 1815 it made little progress; in 1833 it was incorporated ; in 1840 it contained 2,711 inbabitsnts, and in $1850,4,255$ inhabitants. Its population within the past two years since 1850 is supposed to have gained 50 per cent. in numbers, an increase dependant on the great facilities its railroad connections will give to its trarte.

MaIsville, p. o., Jackson county, Ga. : $78 \mathrm{~m} . \mathrm{N}$. N. W. Milledgeville.

Maysville, p. 0. , Madison county, Ala.: $167 \mathrm{~m}$. N. $\frac{1}{4}$ W. Montgomery.

MAYsville C. H., p. v., and cap. De Kalb co,, M $n_{0}:$ on a branch of Blue ereek, centre of co., $149 \mathrm{~m} . \mathrm{N}$. E. Jefferson City.

Marsville, p. v., and cap. Buckingham co., Firg.: on Slate r., $57 \mathrm{~m}$. W. Richmond. It contains the county buildings, several stores, and about 300 inhabitants.

MaYsville, p. v., Benton $\mathrm{co}_{0,}$ Ark, : on a branch of Fling cr., near Bates Prairie, $175 \mathrm{~m}$. N. W. Little Rock.

Marsville, p. v., Huntingdon county, Ind.: 79 m. N. E. Indianapolis.

Maysville, po o., Greenbrier co., $\operatorname{Tirg} .: 173 \mathrm{~m}$. W. by N. Richmond.

Maytows, p. V., Lancaster co., Penn.: 21 m. S. E. Harrisberg. It is located about $3 \mathrm{~m}$. N. E. from Susquehanna $r_{\text {., }}$ and contains several stores, and ahout 200 inhabitants. 
Maypille, p. v., and cap. Chautauque co., $N . Y_{.:}$at the N. W. end of Chautauque lake, $299 \mathrm{~m}$. W. by S. Albany. It contains the county buildings. The $\mathrm{v}$. is pleasantly situated, and is accessible by steamboat. The "M. Sentinel" (dem.), "M. Beacon" (whig), and "M. Express" (dem), are published here. It has sereral shops and stores, and about 600 inhabitants.

MaYvllue, p. v., Dodge co., Wisc. : on N. side of Rock $\mathbf{r}$, 47 m. N. E. Madison.

Mazon, p. v., Grundy co., Ill.: on the W. side of Mazon r., and on the border of Grand Prairie, which covers the S. E. part of the county.

Meade county, $\bar{K} y$. Situate N. W., and contains 279 sq. m. Drained by Otter, Wolf, and Spring creeks, small affluents of the Ohio, which forms its N. boundary. Surface uneven, and in parts hilly; soil mostly fertile. Corn, wheat, and tobacco are the principal crops. It has considerable water-power and manufactories of woolen and cotton goods, flour, and liquors. Farms 489; manuf. 7 ; dwell. 947 , and pop.-wh. 5,799, fr. col. 21, sl. 1,573-total 7,393. Capital: Brandenburg.

Meaderville, p. o., Macon co., Tenn.: $47 \mathrm{~m}$. N. E. Nashville.

Meadow Bluff, p. o., Greenbrier co., Virg.: on W. bank of Meadow r., $179 \mathrm{~m}$. W. by N. Richmond.

Meadow Branoh, p. o., Jackson county, Ohio: $61 \mathrm{~m}$. B. by E. Columbus.

Meadow CreEk, p. o., Orange co., $N$. Car. : $35 \mathrm{~m}$. N. W. Raleigh.

Mradow Crezix, p. o., Whitley co., $\bar{y} y .: 97$ m. S. by E Frankfort.

Meadow Dale, p. o., Highland co., Virg.: 119 m. N. W. Richmond

Meadow Farm, p. o., Muskingum co., Ohio: 53 m. E. Columbus.

Mead's Bason, p. $\nabla_{*}$ Passaic co., $N_{0}$ Jer.: on the Morris and Essex Canal, 57 m. S. by W. Trenton.

MeAd's Corner8, p. o., Crawford co, Penn. : 191 m. N.W. Harrisburg.

Mead's Mru, p. o, Wayne co, Mfich. : 65 m. S. E. Lansing. Meadsqule, p. o., Jackson county, Ala.: 155 miles $N$. Montgomery.

MeAdville, p. v., and cap. Franklin co, Miss.: on Morgan's Fork, a branch of Homochitto $r_{\text {, }} 69 \mathrm{~m}$. S. W. Jackson The court-house is situate in this village.

Meadtrle, p. v., and cap. Orawford co., Penn.: on the E. side of French er., $93 \mathrm{~m}$. N. W. by W. Harrisburg. It is very pleasantly located on an elevation rising gradually from the $r$. In the centre is a fine square, on one side of which is the court-house, built of brick and cut stone, and ornamented with a fine cupola. It contains a number of churches, an academy, and a State arsenal, and is the seat of the Alleghany College, founded in $\mathbf{1 8 1 7}$, having (in 1850) a president, 7 professors, 114 alumni, and 106 students, with a library containing 8,200 volumes. The Western Theological School, also situated here (commenced in 1844), has 4 professor and 40 students. The library contains 8,000 volumes. Meadrille is also a manufacturing place. It has several furnaces, tanneries, distilleries, mills, ete., and here are published four newspapers, the "Crawford Democrat" (dem.) the "M. Gazette" (whig), the "Pennsylvania Sentinel" (dem.), and the "Whig Journal" (whig), all issued weekly. Pop. 1,725.

Meappille, p. o., Halifax county, Virg.: 105 m. S. W. Pichmond.

MeAdWAY, p. o., Burke county, Ga.: $75 \mathrm{~m}$. W. by S. Milledgeville.

Meansviule, p. o., Union dist., S. Car. : 67 m, W. N. W. Columbia.

MeccA, to and p. 0., Trumbull county, Ohio: $149 \mathrm{~m}$. N. E. Columbus. Drained by the Musquito r. and its branches, a tributary of the Ohio r. Surface undulating; soil fertile, and adapted to grazing. Pop. of t. 872 .
Mechanicsburg, p. v., Lehigh co., Penn. : 69 m. E. N. E. Harrisburg.

Mrehaniosburg, p. $\nabla .$, Sangamon co., $M l_{0}: 18 \mathrm{~m} . \mathrm{E}$, by N. Springfield, on a fertile prairie, $4 \mathrm{~m}$. W. Sangamon $x$.

Meohanicsbura, p. v., Champaign co., Ohio: on Little Darby cr., 33 m. W. Columbus. It contains several milis, mechanic shops, etc., and 682 inhabitants.

Mecranicsiurg, p. o., Henry county, Ind. $89 \mathrm{~m}$. N. E, Indianapolis.

Mechanicsbuta, p. b., Cumberland co., Penn : $12 \mathrm{~m}$. W. by S. Harrisburg. The Cumberland Valley R. R. passes through it, $10 \mathrm{~m}$. from Carlisle. It contains a number of distilleries, flouring-mills, saw-mills, etc., and about 800 inhabitants.

Mконanicsburg, p. o., Macon co., Mo.: $91 \mathrm{~m}$. N. N. W. Jefferson City.

Mechanicsbura, p. $\nabla .$, Van Buren co., Ia. : in a beautiful and well-cultivated district, 108 m. S. S. E. Iowa City.

Mechanicsburg, p. v., Giles co., Virg. : on a branch of

New r., near Walker's min., 199 m. W. by \$. Richmond.

Mechasio's Falis, p. V., Cumberland co., Me. : on the Androscoggin r., 34 m. S. W. Augusta. The Buckffeld Branch R. R. here diverges from the Atlantic and St. Lawrence $\mathrm{R}$. R., $36 \mathrm{~m}$. from Portland. The water-power is here immense.

Mechanic's Grove, p. o., Lancaster co., Penn. : $35 \mathrm{~m}$. S. E. Harrisburg.

Mechanicstows, p. V., Frederick co., Md.: $65 \mathrm{~m} . \mathrm{N}$. W. Annapolis.

Mechantcstown, p. v., Carroll co., Ohio: 113 m. E. N. E. Columbus.

Meciranicsvilie, p. v., Jasper co., Ga. : about $1 \frac{1}{2}$ m. F. Oemulgee r., and $43 \mathrm{~m}$. N. W. by W. Milledgeville.

Mechantcsville, $v_{\text {, and }}$ sta., Westehester con, $N . Y_{.:}$on the line of the Harlem R. R., $45 \mathrm{~m}$. from City Hall of New Fork City.

Mechanicsville, p. v., Saratoga co., $N$. $Y_{.}$: on the W. bank of the Hudson $x_{.}, 17 \mathrm{~m}$. N. Albany, and at the mouth of Anthony's Kill, the outlet to Round Lake. There are several mills of different kinds, a number of factories and workshops, and a match factory here. The Champlain Canal and Rensselaer and Saratoga R. R. pass through the ₹., $11 \mathrm{~m}$. N. Troy.

Mechanicsvilue, p. o., Cannon co., Tenn. : 45 m. E. S. E. Nashville.

Mechanicsville, p. v., Sumter dist, S. Car, : on the Sumterville post-road, $41 \mathrm{~m}$. E. by N. Columbia.

Mғсналicspiuze, p. 0., Rutland co., Term. : 49 m. S. W. Montpelier.

Mechanicsville, p. v., Bucks co., Penn.: 95 m. E. Harrisburg. This place was formerly ealled Newark.

Mechavicsville, p. V., Louisa co, Virg. : $46 \mathrm{~m}$. N. W. Richunond.

Mechun's Rives, p. 0., Albemarle co., Firg. : $107 \mathrm{~m}$ W. N. W. Richmond. The river is here crossed by the Virginia Central R. R., 10 m. W. Charlotteville.

Mecklenburg county, $\boldsymbol{N}$. Car. Situate S. W., and contains $578 \mathrm{sq} . \mathrm{m}$. Bounded W. by the Catawba, and drained by its branches, $\mathbf{M}^{*}$ Alpin's, Great and Little Sugar, Davidson's, and other creeks. Surface moderately uneven, and soil very fertile. Cotton is the staple. Corn and wheat are very fine crops, and the grazing is excellent; live-stock, wool, and pork are exported. Fine mill-seats are abundant, and it has large flouring-mills and distilleries. Several rich gold-mines are in this county. Davidson College, founded 1838 , is in the N. E. part of Mecklenburg, and has a president and 4 professors, and in 1850 had 140 alumni, 60 students, and a library of 5,000 volumes. Farms 1,080; manuf. 16 ; dwell. 1,632, and pop.-wh. \$,2S4, fr. col. 153, sl. 5,473-total 13,914, Capital: Charlotte. Putlic Works. North Carolina Central R. R.; Charlotte and South Carolina R. R., etc.

Meckienburg county, Tirg. Situate E. on S. line, and 
contains 685 sq. m. Bounded N. by Meherrin river, and drained by branches of the Roanoke, which flows E. through the S. part. Surface uneven-in parts hilly; soil generally fertile, with many tracts of pasture land. Tobacco is the staple, and the production very large; cotton and wheat are also excellent crops, and the number of sheep reared is large. It has good water-power, fine timber, and manufactures flour, leather, iron castings, etc. Randolph Macon College is in Mecklenburg. Farms 666; manuf. 25; dwell. 1,500, and pop.-wh. 7,256 , fr. col, 912, sl. 12,462-total 20,630. Capital: Boydton. Public Works: Roanoke Valley R. R.

Mecklexburg, p. v., Knox co., Tenn.: on the E. side of Holston r., above the junction of French Broad r., 166 m. E. Nashville, and $12 \mathrm{~m}$. E. by S. from Knoxville.

Mecklenburg, p. v., Tompkins co., N. $Y$. : on the Ithaca post-road, $159 \mathrm{~m} . \mathrm{W}$. Albany. There are a number of mills, factories, and workshops here, and about 400 inhabitants.

Mecosta county, ARich. Situate centrally on Lower Peninsula, and contains 720 sq. m. Maskegon river flows S. W. through the W. part, and has numerous branches which drain the co. In the N. are many ponds, among them Chippewa Lake, the souree of Chippewa river, whose waters flow into Lake Huron. The surface is elevated and rolling, with a fine growth of timber. It is unorganized.

Medart, p. o., Putnam county, Ohio: $106 \mathrm{~m}$. N. W. Columbus.

Medfield, t. and p. v., Norfolk co., Mass.: $15 \mathrm{~m}$. S. W. Boston. Drained by Charles and Stop rivers. Surface diversified; soil fertile and well cultivated. There are in the town several mills and manufactories, among the latter of which there are some of straw goods, which are in a flourishing condition. The $\mathrm{v}$, contains several stores and workshops, and about 50 dwellings. Pop. of t. 966.

Mrdford, t. and p. v., Middlesex co., Mass.: at the head of narigation, on the Mystic river, $5 \mathrm{~m}$. N. by W. Boston. Drained by Mystic r. and its branches. Surface undulating; soil good and well cultivated. Medford is a flourishing t., having a large number of manufactories of various kinds, producing linseed oil, spirits, bricks, leather, plows, etc., together with a number of mills and workshops. Shipbuilding is carried on successfully to a large extent. The

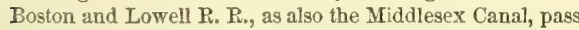
through it, the latter $7 \mathrm{~m}$. from Boston. The village, situate centrally, contains a number of stores and workshops. West Medford is the name of a station on the line of the R. R., 21 miles from Lowell. Pop. of $t, 3,749$.

MedFord, p.. ., Burlington co., N. Jer.: $23 \mathrm{~m}$. S. Trenton. It contains a Friends' meeting-house, half a dozen stores, and about 300 inhabitants.

Medora county, OTiro. Situate N. E., and contains 416 sq. m. Drained by Rocky $\mathbf{r}_{\text {., }} \mathrm{E}$. branch of Black $\mathbf{r}_{\text {., and }}$ branches of Chippewa and Cuyahoga rivers. Surface rolling; soil of great fertility, equally adapted to grass and grain. Wheat and corn are the leading cereals. The grazing lands are very fine-the dairies large, and wool and pork considerable exports. It has some water-power and numerous small manufactories. Farms 2,461; manuf. 77; dwell, 4,430, and pop.-wh. 24,411, fr. col. 30-total 24,441 . Capital: Medina.

Mediva county, Texo. Situate S. W., and contains 1,214 8q. m. Bounded N. E. by Medina and San Antonio rivers, and drained by Hondo, Seco, and Deer creeks of the Rio Frio and Chacan and Perez creeks of the San Miguel. Surface undulating, with elevations of considerable height in the N., and mostly a rolling prairie, with narrow strips of wood on the streams. Soil very fertile, producing large crops of corn, and furnishing the best of pasture for droves of horses and cattle that roam at large over the plains. The streams are small, but afford sufficient mill-seats, and the climate is very salubrious, Limestone, marl, and iron are found. Farms 40; manuf. 0; dwell. 177, and pop.-wh. 8s1, Ir. col, 0, sl. 28-total 909. Capital: Castrovilie.
MediNA, p. V.g Winnebago county, $I l l .: 214 \mathrm{~m} . \mathrm{N}$. Springfield.

MeDINA, t. and p. v., Lenawee co., Mich. : $67 \mathrm{~m}$. S. Lansing. Drained by Tiffin's cr. Surface undulating; soil, sand and argillaceous loam; very fertile. There are a number of mills in the $t$; the $\nabla$, is in N. E. on Tiffin's cr., and contains several stores and workshops. Pop. of t. 1,6\$5.

Medins, p. v., Orleans con, N. Y.: on the Erie Canal, at the junction of Oak Orehard er., which is used as a feeder, and the Rochester, Lockport, and Niagara Falls R. R., $80 \mathrm{~m}$ E. by N. Niagara Falls, and $247 \mathrm{~m} . \mathrm{W}$. by N. Albany. There are several mills and factories, together with a number of warehouses, stores, and workshops, and a furnave in the village. The "Medina Citizen" (dem.) is issued here. Pop. about 800 .

Medina, t., p. v., and cap. Medina co., Ohio: $97 \mathrm{~m}$. N.E. Columbus. Drained by Rocky river and its branches. Surface undulating; soil fertile. The river affords good waterpower. The $v$, is very pleasantly situate on an eminence in S. W. part of t, on the Cleveland post-road, and contains the court-house and usual number of public buildings, as also a number of stores, mills, and workshops, and $1,008 \mathrm{in}$ habitants. The "Democratic Whig" (whig), and "Medina Democrat" (F. S. D.) are issued here. Pop. of t. $2,010$.

Medon, p. v., Madison county, Tenn.: $120 \mathrm{~m}$. W. S. W. Nashville.

Medusa, p. o., Albany co., $N . I_{0}: 15 \mathrm{~m}$. W. Albany.

MEDW AX, t. and p. v., Torfolk co., Mass.: $25 \mathrm{~m}$. S. W. Boston. Drained by Charles river and its branches, which afford it excellent water-power. Surface undulating; soil fertile, producing fine grain. Incorporated in 1713 , and has several stores, a number of mills and manufactories-among the latter, several cotton manufactories. The $\mathrm{v}$. is at the terminus of a branch of the Norfolk County R. P., and contains a number of stores and workshops, and about 60 dwellings. Pop. of t. 2,778.

Medwar, p. O., Clark county, Ohio: $49 \mathrm{~m}$. W. by $\mathrm{S}$. Columbus.

Medwat, p. o., Greene co., $N . Y_{.}: 31 \mathrm{~m}$. S. W. Albany.

MEDYBemrs, t. and p. v., Washington co., Me.: $132 \mathrm{~m}$. E. N. E. Augusta. There is a pond on the N. of the $t_{\text {, }}$ by the outlet of which it is drained. Surface rugged; soil varied, with good wood lands. Pop. of t. 187.

MEeK's Hill, p. o., York district, S. Car, : $76 \mathrm{ma}, \mathrm{N}$. Columbia.

MeENe, t. and p. v., Manitouwoc co., Wisc.: $101 \mathrm{~m}$. N. E. Madison. Drained by a number of small streams flowing into Lake Michigan. Surface various; soil rertile and heavily timbered. The v. is situate centrally. Pop. of t. 210 .

Meeting Street, p. v., Edgefield dist., $S$. Car.: $52 \mathrm{~m}$. W. by S. Columbia.

MeHerrix river, Virg. : rises in Charlotte co., and running E. through several counties, enters North Carolina, and unites with Nottoway $r$. to form the Chowan.

Menoopanr, p. v., Wyoming co., Penn.: on Mehoopany cr., near its confluence with the Susquehanna river, $96 \mathrm{~m}$. N. N. E. Harrisburg.

Mergs county, Ohio. Situate S. E., and contains 403 sq. m. Bounded E. by the Ohio, and drained by Leading cr., Shade r., and smaller affluents. Surface diversified-in parts hilly. Soil fertile; corn and wheat are large crops, and the staple cereals. Large numbers of sheep are raised, and much wool exported. Large deposits of coal are found near the Ohio, which are wrought with much profit, and are demanding increased attention. It manufactures iron eastings, machinery of various kinds, cordage, flour, and leather. Farms 1,149; manuf. 57 ; dwell. 3,136, and pop.-wh. 17,924, fr. col. 47-total 17,971. Capital: Pomeroy. Public Works: Cincinnati, Hillsboro, and Parkersburg R. R.; Pomeroy Branch R. R.

Meigs county, Tenn. Situate S. E., and contains 182 sq. m. Bounded W. by the Tennessee, and S. by the Hiwassee. Surface broken, and soil mostly fertile, Corn is 
the slaple. Wheat and oats thrive, and small patches of cotton and tobaceo may be seen. Pork is an export. Farms 59s; manuf. 1; dwell. 819, and pop.-wh. 4,483, fr. col. 1 , s. 395-total 4,879. Capitul: Decatur.

Meigs Creek, p. 0., Morgan co., Ohio: 66 m. E. by S. Columbus.

Meigsville, t. and p. v., Morgan county, Ohio: $63 \mathrm{~m}$. E. by S. Columbus. Drained by Meigs cr. and its branches, which flow into the Muskingum $x$. Surface uneven; soil fertile. It has good hydraulic power. There are a number of mills and manufactories in the $t$. The village contains several dwellings, stores, and workshops. Population of t. 1,512 .

Meigstille, p. v., Jackson co., Tenn.: on the W: side of Cumberland r., 66 m. E. N. E. Nashville.

Melendez, p. v., and cap. Benton co., Flor. : 150 m. S. E. Tallahassee.

Mellenville, p. v., Columbia co., $N . Y .:$ on the line of the Hudson and Berkshire R. R., $9 \mathrm{~m}$. E. Hudson, $29 \mathrm{~m}$. S. Albany. It contains several factories and mills.

Melloxville, p. v., and eap. Orange co., Flor.: on the

S. shore of Lake Momroe, 196 m. S. E. Tallahassce.

MeldvileE, p. o., Chatlooga co., Ga.: 169 m. N. W. Milledgeville.

Meluope, p. . ., Seneca co., Ohio: on the N. side of Honey cr., a branch of Saudusky r., $72 \mathrm{~m}$. N. by W. Columbus.

Melow, p. o., Harrison county, Virg.: 203 m. N. W. Richmond.

Mrlpise, p. o., Muscatine county, $I a_{0}: 30 \mathrm{~m}$. S. E. Iowa City.

Merrose, p. o, Roekingham co, Firg.: $114 \mathrm{~m}$. W. Richmond.

Melrose, p. v., Clark co., Ill.: 108 m. E. S. E. Springfield. Melrose, t. and p. v., Middlesex co., Mass.: $3 \mathrm{~m} . \mathrm{N}$ Boston; formerly the N. part of Malden. Drained by the head of Mystic r. Surface nneven; soil good. The v. is on the line of the Boston and Maine R. R., $5 \mathrm{~m}$. from Boston, from which point the Medford Branch R. R. diverges. It is a very desirable place of residence for merchants doing business in Boston. Pop, of t. 1,260

Melrose, p. o., Rush county, Ind.: 39 m. E. S. E. Indianapolis.

Melrose, p. v., and cap. Nacogdoches co., Tex.: on the old military road, 219 m. N. E. Austin City.

Meltox"s, p. 0, Navarro county, Tex, : $143 \mathrm{~m}$. N. by E. Austin City.

Meltonstixu, p. v., Marshall county, Ala.: $132 \mathrm{~m} . \mathrm{N}$. Montgomery.

Meltoxsville, p. v., Anson co., N. Car.: on Big Brown cr., $102 \mathrm{~m} . \mathrm{S} . \mathrm{W}$. Raleigh.

Melis, p. o., Ballard county, $K y .: 243 \mathrm{~m}$. W. S. W. Frankifort.

Melticy's MrLs, sta., Merrimac co., N. Hamp.: on the line of the Concord and Claremont R. R., $23 \mathrm{~m}$. W. from Concord.

Melmiv Village, p. O, Carroll co,, N. Hamp.: 39 m. N. E. Coneord.

Memrris, p. V., Pickens co., Ala.: on the W. side of Tombigbee r., $126 \mathrm{~m}$. W. N. W. Montgomery.

MevpIIS, sta., Clark co., Ind.: on the line of the Jeffersonville R. R., $15 \mathrm{~m}$. N. Jeffersonville, and $87 \mathrm{~m}$. S. by E. Indianapolis.

Mrempris, $p_{0} \mathrm{Y}_{4}$, and cap. Scotland $\mathrm{CO}_{0,}, \mathrm{MO}_{4}:$ on North Fabius r., $186 \mathrm{~m}$. N. Jefferson City.

Meypus, p. $v_{*}$, and cap. Shelby co., Tenn: on the $\mathrm{F}$ bank of the Mississippi r., beautifully situated on the fourth Chickasaw bluff, just below the mouth of Wolf r., $191 \mathrm{~m}$. W. S. W. Nashville. This spot was formerly the site of For Assumption, used for the purpose of protecting the country against the Chickasaws. The bluff on which it stands is thirty fet above the highest floods, and its base is washed by the river for a distance of $3 \mathrm{~m}$., while a beit of sandstone. the only known stratum of rocks below the Ohio, juts into 460 the stream, and forms a convenient landing. From the mouth of the Ohio to Vicksburg, $650 \mathrm{~m}$., it is the only site for a commereial mart on either side of the Mississippi. Some distance from the brow of the bluff, a handsome range of fine buildings extends for several squares. Every day gives additional evidence of the increasing prosperity of this already prosperous city; and although the commerce is great, yet the citizens do not intend to rely on that alone. Manufuctories will soon claim a part in adding to her wealth. Preparations are making for building a boat yard on as extensive a scale as any in the west. The gentleman who opens the yard is said to be one of the most experienced boat builders in the Union. In addition to this, there is an extensive flour-mill just completed, capable of making 62,000 barrels of flour annually; also a large cotton manufactory, employing a large number of operatives. There is a fine, well laid out navy yard situate here, with facilities to build the largest size vessels, at which a commander and usua complement of officers are stationed. It bids fair to be one of the finest navy yards in the United States. The public spirit is such in Memphis, that it will soon be one of the finest cities in the West. The Memphis and Charleston $\mathrm{R}$. $\mathrm{P}$. is now partially in operation, and other public works are in contemplation. There are a large number of fine dwellings, stores, workshops, etc. The "Inquirer," daily and weekly (dem.), "Eagle," daily and weekly (whig), "Appeal," weekly and semi-weekly (dem.), "Express," daily and weekly (dem.), "Christian Adrocate," weekly (Meth.), "The Southerner," weekly (Indepen.), and "Daily Dime," daily (neut.), are the names of the newspapers published here. Pop. 8,889.

Mevpris, p. o, St. Clair co., Mich. : 95 m. E. Lansing.

Mrmpiremagog lake, Verm. This lake lies on the $N$. boundary, and the greater part within Canada. It is between 30 and 40 miles long, and from 2 to 3 wide-but 7 or 8 miles only is within the United States. It covers about 15 sq. $m$. in Vermont, and receives Clyde, Bartron, and Black rivers; and its own waters are discharged through St. Francis r. into Lake St. Peter's, an expansion of St. Lawrence $\mathbf{r}$. On an island 2 miles within the Canada line is found a quarry of novaculate, known by the. name of "Magog oil-stone," which is in high repute.

Mexallex, t. and p. 0., Adams co., Penn. : $30 \mathrm{~m}$. S. W. Harrisburg. Drained by Conewago cr. and its branches. Surface hilly, in some parts mountainous; soil fertile. The water-power is excellent. There are a large number of mills, some manufuctories, and several stores in the t. Bendersville and Middletown are names of viliages. Pop. of t. 2,623.

Mevan islands, Me. Petit or Little Menan lies off the harbor of Steuben in the Atlantic, $3 \mathrm{~m}$. S. S. E. Gouldsborough IIarbor; and Grand Menan, a large island, lies off Passamnquoddy bay, and is within the British lines. There is a light-house on Petit Menan. (See Liguthocsis of the UxtTed States)

Mevard county, $I Z l$. Situate W. centrally, and contains $307 \mathrm{sq}$. m. Drained by Sangamon r. and Salt cr. Surface undulating; soil laroely prairie, a deep rich loam mixed with sand, and exceedingly fertile. Timber is found plentifully in groves, and near the rivers. A superior farming co. raising heavy crops of corn, wheat, oats, and potatoes, and exporting live-stock, wool, and pork. It has good mill streams, and considerable manufactures. Farms 706 ; manuf. 39 ; dwell. 1,035, and pop.-wh. 6,323, fr. col. 21total 6,349. Capital: Petersburg.

Mexasma, p. $\nabla .$, Winnebago co., Wisc. : on the N. shore of Winnebago Lake, $96 \mathrm{~m}$. N. N. E. Madison. The U.S, land office for the Menasha district is at this village.

Mexinur, t. and p. v., Morris county, N. Jer.: $37 \mathrm{~m} . \mathrm{N}$ Trenton. Drained by Indian $r$, and the head waters of Whippany r. Surface hilly, in the N. mountainous; soil fertile. There are in the $t$. several mills and manufactories, and a number of stores and workshops. The $r$. is situate on the Morristown post-road, and contains a nnmber of 
dwellings and stores and several workshops. Population of the t. 1,720 .

Mendocrvo county, Calif. Situate N. W., and contains about $3,500 \mathrm{sq} . \mathrm{m}$. The Pacific forms its W., and Russian r. most of its E. boundary. It has few streams of any considerable size, but all flow into the Pacific from the range of mountains which lies near its $\mathrm{E}$. border. The surface is much broken by spurs of the coast range, which extend nearly to the ocean. The county is unorganized and little settled, the population being only 416.

Mendor, p. O., Madison county, Ind.: $35 \mathrm{~m}$. N. E. Indianapolis.

MeNdor, p. V., Adams county, Ill.: $85 \mathrm{~m} . \mathrm{W}$. by $\mathrm{N}$. Springfield.

MENDON, t. and p. v., Worcester co., Mass. : $35 \mathrm{~m}$. S. W. Boston. Drained by branches of Blackstone and Mill rivers. Surface variegated; soil of good quality and well cultivated. The products of the dairy are large and valuable. It has excellent water-power. There are several mills and manufactories of different kinds in the t., and a large quantity of cotton and woolen is manufactured. First settled about 1647; incorporated, 1667. The $\mathrm{v}$. is situate on an elevation on E. side of Mill r., in S. E. part of t., and contains some fine houses, a number of stores, and several workshops. Pop. of t. 1,301.

Mendon, p. 0., Lenawee county, Mich.: 65 m. S. by E. Lansing.

MExdon, t. and p. v., Monroe co., N. Y.: $197 \mathrm{~m}$. W. by N. Albany. Drained by tributaries of Genesee r. Surface gently undulating; soil fertile. There are several mills and manufactories, besides stores, and a number of workshops in the $t$. The $v$. is situate on Irondequoit cr. Was incorporated in 1833, and contains several dwellings, some stores, and workshops. North Mendon and West Mendon are also names of villages. Pop. of $t .3,353$.

MExDoN, p. o., Mercer co., Ohio: 103 m. W. N. W. Columbus.

Mendor, t. and p. o., Ratland co., Term.: 44 m. S. by W. Montpelier. Drained by branches of Otter cr,; surface varied; in the W. hilly, in the E. mountainous. Soil in the rnountains good, but too far up for cultivation. Pop. of the t. 504 .

Mrndota (or St. Peter's), v., Daeotah co., Minn. Ter.: on the W. bank of the Mississippi, S. of the confluence of Minnesota r., $5 \mathrm{~m}$. W. by N. St. Paul. It has been ocenpied by the American Fur Company for several years as a depot for their trading establishments among the Indians of the north-west. Two stores and a few houses constitute the village. It is, however, a fine town site, and being situate at the junction of two great rivers, and near the head of steanu navigation, its importance in a commercial point of view has not been overlooked. It is within the military reservation, and whites are not allowed to resicle here without permission of the U. S. government. Pop. 122.

Mexeios, p. o., Madison co., Ky.: S. E. Frankfort.

MEXOMONEE river, Mich : rises in the country $\$$, of Lake Superior, and runs E. by S. about $100 \mathrm{~m}$., and falls into Green Bay. It forms the $\mathrm{S}$. boundary of the upper peninsula, separating it from Minnesota.

Menomonee Falis, p. o, Waukesha co., Wisc. : $63 \mathrm{~m} . \mathrm{E}$. Madison.

Mexter, p. v., Sheboygan co., Wisc.: on a branch of Onion r., $87 \mathrm{~m}$. N. E. by E. Madison.

Mentor, t. and p. v., Lake co., Ohio: $141 \mathrm{~m}$. N. N. E. Columbus. Lake Erie makes its $N$. boundary. Drained by a stream flowing into the lake. Surface undulating soil good, adapted to grain. There are some mills and manufactories in the $t$. The $\mathrm{v}$. is on the line of the Cleveland and Erie P, R., $23 \mathrm{~m}$. N. E. Cleveland, and contains a number of stores and workshops. Pop. of t. 1,571.

Mequox River, p. o., Washington co., Wisc. : on the W side of Milwaukie r., S. of the confluence of Mequon r., $74 \mathrm{~m}$. E. by N. Madison.
Merata, p. o., Jefferson co., Penn.: $128 \mathrm{~m}$. N. W. by W. IIarrisburg.

MERCER county, $7 l$. Situate N.W., and contains $549 \mathrm{sq} . \mathrm{m}$ Drained by Edward's, Pope's, and Itenderson's rivers, flowing into the Mississippi, its W. boundary. Surface undulating; soil fertile. A large part of the co, is prairie, with excellent timber on the streams, and near the Mississippi. Corn and wheat are the staples, and pork a large export. Farms 517; manuf. 0; dwell. 892, and pop.-wh. 5,244, free col, 2-total 5,246. Capital: Millersburg.

Mercer county, $K y$. Situate E. centrally, and contains 248 sq. m. Bounded N. E. by the Kentucky, E. by Dick's r., and drained W. by heads of Salt $r$. Surface uneven; soil very productive. Corn is the great staple. Wheat, rye, and oats yield largely, and the pastures are very superior. Live-stock, beef, wool, and pork, are large exports. It manufactures cotton and woolen goods, flour, iron castings, and leather. Farms 881; manuf. 87; dwell. 1,762, and pop.wh. 10,472, free eol, 335, sl, 3,260-total 14,067. Capital: Harrodsburg.

Mercer county, Mro. Situate on N. line, and contrins 521 sq. $\mathrm{m}$. Drained by $\mathrm{E}$. and W. forks of Medicine er. Muddy cr., Weldon r., and Crooked Fork of Grand r. Surface somewhat uneven, with few hills; soil generally fertile, and adapted to grazing. Corn, live-stock, and pork, are the principal products. The county is well timbered, and has abundant water-power. Farms 272; manuf. 3; dwell. 112, and pop.-wh. 2,671, free col. 6, slaves 14-total 2,691. Capital.: Princeton.

Mercer county, $N$. Jer. Situate W. middle, and contains 272 sq. m. Bounded E. by a branch of Raritan r., and W. by the Delaware, and drained by small affluents of both. Surface mostly even; soil very productive, and under high cultivation. Corn, wheat, rye, buckwheat, oats, and potatoes, are all fine crops. It has very superior gardens and orchards, and furnishes for the adjacent markets excellent vegetables and fruits, particularly apples and peaches. It has a large capital employed in manufactures of cotton and woolen goods, liquors, leather, earthen-ware, iron castings, and machinery, flour, cordage, paper, oil, and lumber. Farms 1,051; manuf. 191; dwell. 4,624, and pop.-wh. 25,987, free enl. 1,999, sl. 6-total 27,992. Capital: Trenton. Pullic Works: Delaware and Raritan Canal ; New Jersey R. R.; Belvidere Delaware R. R.; Trenton Branch R. R. Camden and Amboy R. R.

Mercer county, Ohio. Situate on W. line, and contains 451 sq. m. Drained by St. Mary's and Wabash rivers and their branches. Surface gently undulating, and soil mostiy fertile. Corn is the staple product. Wheat, oats, and potatoes are successfully cultivated, and snme live-stock and pork exported. Farms 675; manuf. 9 ; dwell. 1,312, and pop.wh. 7,401, free col. 811-total 7,712. Capital: Celina.

Mercer county, Penn. Situat N. W., and contains $61 \mathrm{~s}$ sq. m. Drained by Shenango, Neshanock, Pymatuning, Deer, and Sandy creeks. Surfice hilly and broken: soil generally fertile, and better adapted to grass than grain. Wheat, corn, buckwheat, rye, oats, and potatoes, are for the most part successful erops. Grazing demands the chief attention, and the dairics are large and very fine. The amount of wool sheared is very large, and live-stock, beef, and pork, are very heavy exports. It has abundance of water-p ower, bituminous conl, and iron ore, and is largely engaged in the manufacture of iron. Woolen goods, leather, and earthenware, are also extensively made. Farms 2,959: manuf. 150 ; dwell. 5,402, and pop.-wh. 32,8s1, free eol. 291-total 33,192. Capital: Mercer. Public Works: Beaver and Erie Canal.

Mercer county, Tirg. Situate S. W., and contains 583 sq. m. New r. forms the E. boundary, and unites in the N. with the Greenbricr, to form the Great Kanarwha. Blue Stone, and East rivers. Brush and Lick creeks drain the co. Surface elevated, with a mountain range on the W., and extensive valleys in the $\mathrm{E}$.; soil fertile in the lower 
grounds, and generally best adapted to grazing. Corn, oats, and wheat, yield moderate crops. Farms 472 ; manuf. 2 ; dwell. 655 , and pop.-wh. 4,018, free col. 27, sl. 177-total 4,222. Capital: Prince.on. Public Works: Covington and Ohio R. R.

Mercer, t. and p. v., Somerset co, Me.: 24 m. N. by W. Augusta. Drained by Sandy $r$. in the N. W. corner, and a mill-pond makes part of the S. boundary. Soil fertile, and adapted to grain. It contains some mills and manufactories. The v. is situate centrally on a small pond, and contains a number of dwellings, stores, and workshops. Pop. of t. 1,1S6

Mercer, p. o., Mercer co., Oh.: 103 m. W.N.W. Columbus

Mercer, p. b., and eap. Mercer co., Penn. .' on the $\mathrm{N}$. side of Neshanock cr., 186 m. W. N. W. Harrisburg, and near the proposed line of the Alleghany $\nabla$ alley R. R. It contains the court-house and usual number of county buildings. It has a manufactory of copperas. There are 4 furnaces here a chareoal hot-blast furnace of 1,000 tons annual capacity, a raw bituminous coal hot-blast furnace of 1,500 tons capacity, and 2 steam-power charcoal cold-blast furnaces of a capacity each of 1,350 tons. There are a number of stores and several manufactories in the b.; and here are published the "Western Press" (dem.), "Mercer County Whig" (whig) "Mercer County Luminary" (free soil), and "Free Presbyterian," all issued weekly. Pop. 1,014.

Mercersiburg, p. b. Franklin co., Penn.: on a branch of Conecocheague cr., $81 \mathrm{~m}$. S. W. by W. Harrisburg. Incorporated in 1881. It is the seat of "Marshall College," founded in 1836, and had (in 1850) a president, 11 professors, 94 alumni, and 81 students, with a library containing 1,300 volumes. The German Reformed Theo. School commenced in 1825, and had (in 1850) 2 professors, 18 students, and 121 alumni, with a library containing 6,000 volumes, is also situate here. Pop. 1,222.

Merchavis's Buofr, p. o., Darlington dist., S. Car.: $53 \mathrm{~m}$. E. N. E. Columbia.

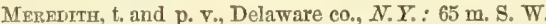
Albany. Drained by branches of Susquehanna and Delawar rivers. Surface uneven, and somewhat broken; soil fertile. It has good water-power and several mills and manufactories, also a number of workshops. The $\mathrm{v}$. is situate on an elevation in S. W., and contains several dwellings and stores. Pop. of t. 1,684.

Mereurth Brmge, sta., Belknap co., $N$. Hamp. : on the line of the Boston, Concord, and Montreal R. R., $44 \mathrm{~m}$. from Concord.

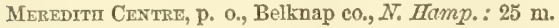
Warren, and $27 \mathrm{~m}$. N. Concord.

Merediti Mrls, p. 0, Fulton county, Ind.: $85 \mathrm{~m} . \mathrm{N}$. Indianapolis.

Merediti's TAvern, p. 0., Monongalia co., Firg.: $203 \mathrm{~m}$. N. W. Richmond.

Merediti VIllage, p. V., Belknap co., $N$. Hamp. : at the outlet of Winnipiseogee Lake, and on the line of the Boston, Concord, and Montreal R. P., $37 \mathrm{~m}$. N. Concord.

Mifredosia, p. V., Morgan co., Ill.: on the E. bank Illinois $\mathrm{r}, 6 \mathrm{~m}$, above Naples, and $49 \mathrm{~m}$. W. Springfield. The name is a corruption from Marais d'Ogee. The $\mathrm{v}$. is situate on an elevalt d sand riklge, and has a good landing at ordinary stages of the water. Here are several mills, stores, and a considerable population. Meredosia may be considered as the port of Jacksonville, and is the outlet of a fine country.

Merines, t. and p. v., New Haven county, Conn.: $17 \mathrm{~m}$. S. W. Hartford. Drained by Quinnipiak r, and its branches. Surface uneven, in parts hilly; soil fertile. There are sevcral manufactories here, principally in hard-ware. The v. is on a branch of Quinnipiak r., and on the line of the New Haven, Hartford, and Springfield R. R., $18 \mathrm{~m}$. from New Haven, and $44 \mathrm{~m}$. from Springfield. It contains sereral dwellings and stores, and a number of workshops. Pop. of t. 3,526 .

Mermex, p. o., Sullivan co, $N$. Hamp. : $35 \mathrm{~m}$. W. N. W. Concord.
Mertwian, p. o., Mercer county, $I l_{0}: 113$ m. N. N. W. Springfield.

Meridar, p. o., Cayuga co., N. $Y_{0}: 151 \mathrm{~m}$. W. by N. Albany.

Mermian Springs, p. v., Hinds co., Miss.: at the source of Bayou Chitto cr., $12 \mathrm{~m}$. N. Jackson.

Mermiavrillie, p. v., Madison county, Ala.: 166 m. N. Montgomery. The Meridian line of the U. S. surveys of Northern Alabama passes through this place.

Mertvilie, p. 0, Montgomery co., Tenn.: 87 m. N. W. Nashville.

Meraram, p. o., New Castle co., Det.: $25 \mathrm{~m}$. N. Dover.

Mermentad river, $L a$. This river drains the extensive prairies of S. W. Louisiana, and after a course of some 200 m. falls into the Gulf of Mexico, $200 \mathrm{~m}$. W. of the Missis. sippi $r$. The country through which it flows is covered with grass, excepting narrow lines of timber along the watercourses. Live oak is found on its borders. The r. passes through a lake of the same name; at its mouth it is very shoal, not having more than three feet of water on the bar.

Mrrom, p. v., Sullivan co., Ind. : on the E. bank of the Wabash r., $91 \mathrm{~m}$. S. W. by W. Indianapolis.

Merona, p. v., M'Henry co., IUl. : on the borders of a prairie, $180 \mathrm{~m}$. N. E. Springfield.

Mrreel, p. o., Greene county, Ga.: $23 \mathrm{~m}$. N. by E Milledgeville.

Meprick, p. o., Queens co, N. Y.: $135 \mathrm{~m} . \mathrm{S}$. Albany.

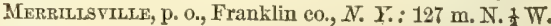
Albany.

Mereilltown, p. v., Travis co, Tex.

Merriluville, p. o., Lake county, Ind.: 139 m. N. W. Indianapolis.

Merrmac county, $N$. Hamp. Situate $\mathrm{S}$. centrally, and contains $847 \mathrm{sq.} \mathrm{m}$. Drained by the Merrimac $r$ and its branches-W. Blackwater and Contoocook, and E. Soucook and Suncook rivers. Surface very uneven, in the N. rugged and mountainous; soil mostly fertile, and excellent pasture land. Corn, wheat, potatoes, and rye are the staples. It has very fine dairies, and shears an immense amount of wool. Sunapee Lake lies in the W., and on the Merrimac it has almost unlimited water-power, most of which is oecu pied by large cotton and woolen factories, and numerous lumber, flour, and grist mills. It also manufactures leather, earthen-ware, glass, paper, books, etc. In the E. is a quarry of granite, highly valued for building purposes. Farms 3,220 ; manuf. 215 ; dwell. 7,400 , and pop.-wh. 38,364 , fr. col. 81-total 35,440. Capital: Concord. Putulic Works. Portsmouth and Concord R. R.; Contoocook Valley R. R. Concord R. R.; Concord and Claremont R. R.; Conoord and Montreal R. R.; Northern R. R.; New Hampshire Central R. P.

Merrmac river, $N$. Hamp. and Mass.: one of the largest rivers of New England. It is formed by the union of Pemegewasset $r$, which rises near the Notch of the White Mountains, with Winnipiseogee $r$., which proceeds from the lake so called. The junction takes place at Saubornton, 70 miles below the source of the former, which is the main stream. Its general course is $\mathrm{S}$. by $\mathrm{E}$. until it enters the State of Massachusetts, when it eurves to a general course of nearly N. E. and E., until it falls into the Atlantic, a little below Newburyport. It is navigable for vessels of 200 tons to Harerhill, and by means of the Middlesex Canal from Chelmsford to Boston harbor, and canals and locks around the Falls, a boat narigation is opened to Concord, New Hampshire. Bow Canal, a few miles below Concord, completed in 1812 , cost $\$ 20,000$ : six miles farther down, Hookset Canal cost $\$ 15,000$, overcoming a fall of 17 feet; Amoskeng Canal cost $\$ 50,000$, overeoming a fall of 45 feet; below Amoskeag Canal the $\mathrm{r}_{\text {. }}$ for $9 \mathrm{~m}$., is converted into the Union Canal, overcoming six distinct falls; and $5 \mathrm{~m}$, below are Cromwell's Falls, made passable by a canal. Union Canal focluding that of Cromwell's, cost $\$ 50,000 ; 15 \mathrm{~m}$. below, in Massachusetts, is Wecassee Canal, cost $\$ 14,000$; and $3 \mathrm{~m}$ 
below is the entrance of the Middlesex Canal. The r, by means of these canals, furnishes an incredible amount of water-power, which has resulted in the establishment of the principal manufacturing towns of the Union along its course. It is bridged in almost every town along its banks.

Merrluan's Shop, p, o., Prince Edward co, Firg. : $59 \mathrm{~m}$. S. W. Richmond.

Merritt's Brtoge, p. O., Lexington dist., S. Car.

Mernitrstown, p. Y., Fayette co., Penn. : on W. side of Dunlap's cr., $156 \mathrm{~m}$. W. by S. Harrisburg. It contains a number of dwellings, stores, and a few workshops.

Merritssille, p. v., Greenville dist., $S_{\text {. }}$ Car.: on the N. fork of Saluda r., $106 \mathrm{~m}$. N. W. Columbia.

Merriwether county, $G a$. Situate W. middle, and contains 476 sq. m. Bounded E. by Flint r., and drained by its branches, and W. by branches of the Chat tahoochee. Surface pleasantly diversified; soil very fertile. Cotton is the great staple, and comminds almost exclusive attention. Corn and wheat yield more than average crops, and neat eattle and swine are reared in large numbers. In the $\mathrm{S}$. are white sulphur and warm springs. Farms 824; manuf. 0; dwell. 1,428, and pop.-wh. 8,451, fr. col. 2, sl. 7,993-total 16,476. Capital: Greenville.

Merryald, p. o., Bradford county, Penn.: 113 m. N. Harrisburg.

Merry Hul, p. v., Bertie co., N. Car.: 103 m. E. by N. Raleigh.

Merrx Meentig bay, N. Hamp.: a $\mathbf{S}$. E. branch of Winnipiseogee Lake, 1,600 rods long.

Merrx Meetrng bay, Me.: an expansion of Kennebec r., at the confluence of Androscoggin r., above Batb.

Merry Mount, p. o., Warren co., N. Car,: 53 m. N. N. E.

Raleigh.

Merri OAks, p. V., Barren county, $\bar{k} y_{.}$: 102 m. S. W.

Fiankfort.

MerRy Oaћs, p. o., Hamilton co., Tenn.: 114 m. S. W. Nashville.

Mershox's Cross Roads, p. 0., Laurel county, Ky. : 78 m. S. S. E. Frankfort

Merton, t. and p. v., Waukesha co., Wisc. : 52 m. E. by N.

Madison. Drained by several streams, and contains several small lakes. Surface undulating; soil fertile. The $v_{\text {. is }}$ connected with Milwaukie by a plank-road. Pop. of t. 1,768.

Merwissburg, p. o., Monroe co., Penn. : 97 m. N. E. Harrisburg.

Miesopotami, t. and p. v., Trumbull co., Ohio: $143 \mathrm{~m}$. N. E. Columbus, Drained by Grand $r$, and several affluents. Surface undulating; soil fertile. There are in the t. a number of mills and workshops. Pop. 959.

Messiva Sprivas, p. o., Onondaga con, N. Y.: $129 \mathrm{~m}$. W. by N. Albany.

Messonao, p. o., Accomac co., Virg. : 104 m. E. by N. Richmond.

Metamora, p. ซ., Woodford co, Ill.: $69 \mathrm{~m}$. N. by E. Springfield. The $\mathrm{v}$. is on the border of fine prairie land.

Metamora, p. o., Franklin co., Ind. : on the N. side of White Water r., $58 \mathrm{~m}$. E. S. E. Indianapolis.

Metamora, $t$, and p. o, Lapeer co., Mich. : 67 m. E. by N. Lansing. Drained by forks of Flint $r$., which have their sources in this t. Surface undulating; soil fertile. It contains a few stores and mills. Pop. of t. 821 .

Metamora, p. Y., Fulton co., Ohio : on S. side Ottowa r., 129 m. N. N. W. Columbus.

Metanora, p. o., Pike county, Penn.: 118 m. N. E. Harrisburg,

Meted, p. v., Cass co., Ind. : 79 m. N. Indianapolis.

Metederouck, p. v., Ocean co., $N$. Jer. : on the S. side, and near the mouth of Metedecouck r., $33 \mathrm{~m}$. S. by E. Trenton.

METHUEN, t. and p. $\nabla .$, Essex co., Mass. : on the N. bank of the Merrimac $\mathbf{r}$., which forms its $\mathrm{S}$. boundary, $25 \mathrm{~m}$. N. $\frac{1}{2}$ W. Boston. Drained by Spigot r., which has a waterfall of from 30 to 85 feet, affording excellent hydraulic power. Surface uneven; soil fertile, yielding abundantly. There are a number of mills and manufactories in the $t$ Wood is to be found here in abundance. There is also an extensive bed of excellent peat. The $\nabla$. is romantically situated on an eminence on both sides of Spigot $r$, at the falls, and on the line of the Manchester and Lawrence R. P., 24 $\mathrm{m}$. Manchester, and contains a number of stores, several mills and manufactories, and some workshops. Pop. of t. 2,513.

Metomex, t. and p. 0., Fond du Lac co., Wisc. : $52 \mathrm{~m}$. N. by E. Madison, Drained by tributaries of Wisconsin $r$ Pop. 756.

Metompen, p. o, and isle, Accomac con, Virg.: on the Atlantic coast, $107 \mathrm{~m}$. E. by N. Richmond.

Metropolis Citr, p. v., and eap. Massae co., $\mathbb{M l}_{\circ}$ : on a high bank on the N. side of the Ohio r., 194 m. S. S. E. Springfield. It contains the court-house and usual number of public buildings, and 400 inhabitants. The "Metropolitan" (dem.), and "Metropolis Register" (whig), are weekly issues.

Mrss, p. o., Steuben county, Ind.: 143 m. N. N. E. Indianapolis.

Metuchen, p. v., Middlesex co., $N$. Jer.: on the line of the New York and Philadelphia R. R., $26 \mathrm{~m}$. Jersey City, and $30 \mathrm{~m}$. N. E. Trenton.

Mexico, p. V., Miami co., Ind. : on the E. side of Eel $\mathbf{r}_{*}$ $73 \mathrm{~m}$. N. Indianapolis.

Mexico, p. o., Jefferson county, Ala.: 96 m. N. by W. Montgomery.

Mexico, t. and p. v., Oxford co., Me. : $35 \mathrm{~m}$. W. N. W. Augusta. Drained by Webb's branch on the E., Androscoggin r. on the S. boundary, and by Swift brook on the W., near the mouth of which is the village. Soil fertile, and adapted to wheat. Pop. 491.

MExico, p. V., and cap. Audrain co, Mo.; on the E, side of the S. fork of Salt r., $44 \mathrm{~m}$. N. N. E. Jefferson City. It contains the court-house.

Mexioo, t. and p. v., Oswego co, $N_{.} \boldsymbol{Y}_{.:} 137 \mathrm{~m} . \mathrm{N} . \mathrm{W}$. Albany. Drained by Salmon er., which flows into Lake Ontario, and forms the N. boundary. Surface varied; soil clay loam, and very fertile. Water-power is very good. There are in the $t$, several mills and factories and a number of workshops The $v$. is situate on Salmon cr., and is the site of a number of mills, etc. Colosse, Texas, and Union Square are names of other post-offices in the town. Pop. of t. 4,221 .

Mexico, p. V., Wyandott co., Ohio: on the E. side of Sandusky r., $71 \mathrm{~m}$. N. N. W. Columbus.

Mexrco, p. v., Juniata co., Penn. : on the S. side of Juniata r., $33 \mathrm{~m}$. N. W. Harrisburg, and $44 \mathrm{~m}$. from Harrisburg by the Pennsylvania R. R., which passes through the village.

Mexico, Gulf of: a great inland sea between the coasts of Mexico and the United States-that part within the United States washing the shores of Texas, Louisiana, Mississippi, Alabama, and Florida. It receives the Mississippi, the Rio Grande, and a number of other but smaller rivers from the central valley and the southern slope.

Mexer's Mrlls, p. o., Somerset co., Penn.: $127 \mathrm{~m} . \mathrm{W}$. Harrisburg.

Mererstows, p. v., Lebanon co., Penn.: on the head waters of Tulpehocken cr., $31 \mathrm{~m}$. E. N. E. Harrisburg. The Union Canal passes the village.

Mram county, Ind. Situate N. centrally, and contains $376 \mathrm{sq} . \mathrm{m}$. Drained by the Wabash and its branches, Eel and the Mississinewa rivers and Deer cr. Surface generally level, somewhat hilly on the Wabash. About one-half is prairie or bottoms, the rest well timbered, and the soil universally fertile. Corn is the leading staple, and pork a large export. Most of the grains succed well, and the raising of horses and stock receives much attention. The county has good water-power, and large and rapidly increasing manufactures of flour, lumber, iron castings, machinery, leather, etc. Farms 1,184; manuf. 45; dwell. 1.944 , and pop.-wh. 11,293, fr. col. 11-total 11,30t. Capital: 
Peru. Pullic Works: Wabasb and Erie Canal; Peru and

Indianapolis R. R., with the Groshen Extension.

Mramr county, Ohio. Situate W. middle, and contains 414 sq. m. Drained by Miami r. and its branches, Panther, Greenville, and Stillwater ereeks. Surface slightly uneven; soil very productive, and well adapted to grazing. Corn, wheat, rye, and oats are large staples. The dairies are very fine, wool is sheared largely, and beef and pork are heavy exports. Water-power is plenty, and flour, leather, woolens, earthen-ware, and liquors are manufactured. Farms 1,Ss2; manuf. 177 ; dwell. 4,391, and pop.-wh. 24.39s, fr. col. 598-total 24,996. Capital; Troy, Public Works. Miami Canal; Columbus, Urbana, and Piqua R. R.

MiAm, p. V., and eap. Dade co., Flor.: on Key Biscayne Bay, 429 m. S. E. Tallahassee. Here is a flourishing v. with ample accommodation for invalids, and a climate unsurpassed for equable temperature and elasticity of the atmosphere.

Miam, p. V., Saline co., Mo. : on the S. bank of the Missouri r., 63 m. N. W. Jefferson City.

Miam, t. and p. o., Hamilton eo., Ohio: on the N. bank of the Ohio r., $103 \mathrm{~m} . \mathrm{S}$. W. Columbus. The t. is bounded on the $\mathrm{N}$. and $\mathrm{W}$. by the Miami r., several small branches of which serve to drain it. Surface, a series of beautiful hills; soil very productive, and ander high cultivation, with some excellent wood lands. There are some fine mill-sites on the banks of the rivers, and several manufactories have been established. North Bend and Cleves are names of places: the former is the place originally laid out by Judge Symmes for the great eity of the West. All traces of a village have disappeared, and it is now only noted as the former residence and grave of the lamented President Harrison, a short distance from which is also the grave of the
Hon. John Cleves Symmes. The latter is a beautiful and thriving village, with about 300 inhabitants. The proposed line of the St. Louis and Cincinnati $\mathrm{P}$. R. crosses the S, part of the t. Pop. 1,55̃

Mrami, p. v., Miami county, Ind. : on Deer er., $58 \mathrm{~m}$. N. Indianapolis. The contemplated line of the Peru and In. dianopolis R. R. passes through the village.

Miami river, Ohio: a large tributary of the Ohio $r$. which rises in Hardin county, and after a S. W. course of $100 \mathrm{~m}$., enters the Ohio in the S. W. corner of the State. It is 200 yards wide at its mouth; the current is very rapid, but it is navigable only to a limited extent for $75 \mathrm{~m}$., and its waters are connected with those of the Auglaize, a S. branch of Maumee r., by a portage of only 5 miles. It receives many important branches, and affords extensive and valuable waterpower, which has been improved at several points.

Miamisburg, p. v., Montgomery co., Ohio: on the Miami Canal, $53 \mathrm{~m}$. N. Cincinnati, and on E. side of the Miami river, $71 \mathrm{~m}$. W. by $\mathrm{S}$. Columbus. The $\mathrm{v}$. communicates with the Cincinnati. Hamilton, and Dayton R. R. by a bridge across the river, $24 \mathrm{~m}$. $\mathrm{N}$. by $\mathrm{E}$. from Hamilton, It contains a number of fine stores and warehouses, some mills and factories, and about 160 dwellings.

Mianisville, p. o. and sta., Clermont co.; Ohio: on the line of the Little Miami R. R., $17 \mathrm{~m}$. from Cincinnati, and S1 m. S. W. Cohmbus.

Mianus, p. 0., Fairfield co., Conn.: 45 m. S.W. Hartford. Mroanopy, p. 0., Alachua co., Flor. : 119 m. E. S. E. Tallahassee.

Miccosukee, p. v., Leon co., Flor. : on the W. border of Miceosukee Lake, $19 \mathrm{~m}$. N. E. Tallahasse.

Mremaglswhi. p. o., Ilarford co., MId. : $46 \mathrm{~m}$. N. by E. Annapolis,

\section{THE STATE OF MICHIGAN.}

Mrching Ax, consisting of two peninsulas, lies between latitudes $41045^{\prime}$ and $480 \mathrm{~N}$., and between longitades $82 \circ 25^{\prime}$ and $90034^{\prime} \mathrm{W}$. from Greenwich, or $5 \circ 23^{\prime}$ and $13 \circ 32^{\prime}$ from Washington. It is bounded* north, north-east, and east by Canada, from which it is separated by Lake Superior, the Sault St. Marie, Lake Huron, the Strait and Lake St. Clair, Detroit Strait, and Lake Erie; on the south by the States of Ohio and Indiana; and on the west by Lake Michigan. which divides it from Illinois and Wisconsin, and the Monomonie and Montreal rivers, separating it from Minnesota Territory. The total land surface comprises an area of 56,243 square miles, and the area of the waters within the constitutional limits of the State is computed at 36,824 square miles. The lake coast of Michigan is more than 1,400 miles long.

The location of the separate peninsulas determines their nomenclature. The Southern, or Michigan Proper, is bounded on the south by Indiana and Obio; on the east by Lake Erie, Detroit Strait, the Lake and Strait St. Clair, and Lake IIuron; on the north by the Strait of Michilimackinac, and on the west by Lake Nichigan. In these limits are comprised nearly two-thirds the land surface of the State. The Northern Peninsula extends from the Montreal and Monomonie rivers to the St. Marie River, and has Lake Superior on the north and Lake IIuron on the south of it.

The surface of the Northern Peninsula is much diversified by mountains, hills, valleys, and plains, The eastern portion, from the head of the peninsula to the "Pictured Rocks," is represented as undulating, rising gradually from lake Michigan and Superior to the interior, where it terminates in a more elevated table-land, with a shore on the north sandy, and on the south calcareous rock. Westward the country becomes broken into hills, with intervening plains, until it is interrupted by the Porcupine Mountains, which form the dividing ridge separating the waters of Lake Superior from those of Lake Michigan. The highest peaks toward the western boundary have been estimated at from 1,300 to 2,000 feet high. The ridge is often broken through by the larger streams, bordered by extensive valleys, The spurs of these mountains project in different directions, often exhibiting their denuded cliffs upon the northern shores. This ridge has a greater proximity to the northern coast, which it lines with rock, from the Pictured Rocks to the western extremity of this peninsula, except where interrupted by occasional plains of sand. The structure of a part of the northern and eastern portion is of the primitive, and the southern of the secondary formation. Many parts exhibit little else than "developments of sublime scenery, and some portions appear like a dreary, deserted solitude, surrounded by all the frightful terrors incirlent

* The boundaries of Yichima, as definel by an Act of Congress, passed 15th June, 1926, are as follows: "Beginning at the point where a line diche the egstern boundary line of the Etate of lind:ana, and running thence with the said line to the said most northerly cape of the Maumee Bay, -and thence from the Frie - thence, with the swid boundary line hetween the Cnited States and Canada, through the Detroit River, Lake Huron, and Lake Superior, to a Erie,-tlience, with the said boundary line hetween the "nited States and Canada, through the Detroit River, Lake Huron, and Lake Superior, to a mouth of the Yentren| River-thence, throngh the middle of the main channel of the said River Montreal, to the middle of the Lake of the Desert, thenee by the sitid line, to the main channel of the said Mfonomonie River,-thence, down the centre of the main channel of the same, to the rentre of the most usual ship thannel of the Green Bay of Lake Michiran,-thenre, through the centre of the most usual ship cbannel of the said bay, to the middle of Lihe Michigan,-thence, through the middle of Lake Michigan, to the northern boundary of the State of Indiana, as that line was

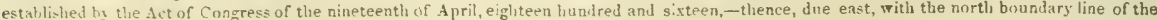
said state, if lowiana, to the purth-east corner thereof,-and thence south, with the east boundary line of Indiana, to the place of beginning ") 


\section{MICHIGAN.}

to such northern latitudes. The greater portion of the peninsula, the sand plains excepted, is covered with immense furests, principally of white and yellow pine, a portion of spruce, hemlock, birch, oak, and aspen, with a mixture of maple, ash, and elm, especially upon the rivers. Of the pine lands, there are millions of acres stretching between the Sault St. Marie, the Ontonagon, and Montreal rivers. To convert this material into lumber, there are discharging into the lakes forty large and sixty smaller streams, which will furnish a hydraulic power sufficient for all purposes. These streams, the largest of which does not exceed 150 miles, irrigate the country abundantly, and by their facilities for navigation, furnish easy access to the interior. The head branches of the opposite lake-streams often interlock, and when they do not communicate, furnish an easy portage from one to the other, by which navigation between the lakes is easily effected with the lighter craft. The lake coast of this section of the State has been estimated at between scven hundred and eight hundred miles in length, and that five-sevenths of the entire peninsula may be reached by the common lake vessels. This peninsula (the northern part of which has sometimes been called the Siberia of Michigan), it is probable will never be noted for its agricultural productions, or immediately for the density of its population. With the exception of the fertile intervals on the rivers, the soil of the northern portion has all the evidences of sterility, as is exhibited in its mountains and barren sand plains. The southern part is more congenial in elimate and soil. This is the limestone region, which extends to an undetermined line, separating the primary and secondary formations, Throughout this region the sugar maple tree is abundant, interspersed with the white and red oak, the beech, and occasionally tracts of spruce and other forest trees. It is here that the more even and fertile tracts of land are found, and where, at some future day, will cluster the agricultural population of the peninsula. The soll is admirably fitled for grasses and all esculent roots; the potato also finds here a congenial locality, and the ordinary garden vegetables grow luxuriantly. Wheat and other small grains may be cultivated, but for corn the country and climate appears to be uncongenial. The lake fisheries, on both sides of the peninsula, are destined to be of no mean importance to the welfare of the settlers. In variety numerous, and in the greatest abundance, the fisheries in these waters have long attracted the attention of those counting the resources of the section. The Indians formerly derived a considerable portion of their subsistence from this source, and from the first settlements of the Freach to the present day their value has always been asserted. But this peninsula is also the great mineral region-not only of the State, but of the Union, and on that interest will its future prosperity mainly depend. Iron* and copper are found in all the western and northern parts, from the Pictured Rocks and the Kewenaw Point to the Montreal River, the iron being chiefly a magnetic ore, equal in purity and quality to that of Missouri, and the copper, often in native boulders, more plentiful than elsewhere occurring. The production of these minerals, however, has hitherto been small, on account of the distance and inaccessible nature of the country; but the time has now arrived for the mines to be opened on an extensive scale, and such, indeed, has in a partial degree been accomplished; yet, until the difficulties opposing navigation to Lake Superior be overcome, the expense of transportation will be too grcat to admit of a full development of the wealth of this region. It has been proposed to form this peninsula into the State of North Michigan, and thus separate it from Michigan Proper politically, as it now is physically separate. There are many reasons that would indicate the necessity of such a change.

The Southern Peninsula has generally a level or rolling surface, and in some parts is broken and hilly. The eastern portion, for a distance varying from 5 to 25 miles from the shore, is almost a dead level ; but westward the land rises into an irregular ridge, in some parts of which it attains a height of from 600 to 700 feet above the sea level. This ridge has a much greater proximity to the eastern than to the western margin, and serves to separate the tributaries discharging into Lake Michigan from those flowing into Huron, the Strait, and Erie. The portion of the southern part of the State denominated hilly, branches off from the principal ridge in different directions through the adjoining counties. The hills consist of an irregular assemblage of somewhat conical elevations, necasionally attaining a height of from 150 to 200 feet, but ordinarily of not more than from 30 to 40 feet. From the main portion of the table land passing westward to Lake Michigan, the country, with the exceptions noted, assumes a very gradual descent, exhibiting a gently undulating but very rarely broken surface. The ridge of land before spoken of, again takes its rise near the mouth of Au Sable river, and is seen from the lake to stretch on for many miles along and beyond the coast. This constitutes the Highlands of Au Sable. Its height has not been ascertained, but it has hitherto been estimated to be much the highest part of the peninsula. A considerable portion of it has generally been unfavorably represented, as being interspersed with sand ridges and marshes, having an abrupt descent from the highlands eastward, and a gradual slope toward the west. Taking the great extent of the lower peninsula into consideration, it may, in a comparative point of view, be said to possess a great evenness of surface, with a sufficient declivity, however, to allow its waters to drain off in lively and healthy streams. Such are the general features of the interior. The coasts form an exception. The coast of both Michigan and Huron is sometimes exhibited in high, steep banks. The coast of the former is frequently seen in bluffs and banks of sand, varying in height from 100 to 300 feet. To the traveler, the country presents an appearance eminently picturesque and delightful. Through a considerable portion the surface is so even and free from brush, as to admit of carriages being driven through it, with the same facility as over the prairie or common road. The lowering forest and grove, the luxuriant prairie, the erystal lake and limpid rivulet, are so frequently and happily blended together, especially in the southern section of the peninsula, as

* The Tnited States Geolngists thus speak of the iron of the Lake Superinr Land District in the Northern Peninsula of Michican, in their report for 19.51 . In designating the lands contaning iron $* * * *$ the beds are found on a scale of such magnitude, and the ore is of such purity, that it requires little search :o discover them, and little caution in pronouncing on their value. This iron region is, perlians, tlie most valuable and extensive in the world, for the manufacturing of the finer varieties of wrought iron and steel. When we consider the immense extent of the district, the monntain masses of ore, its purity and adajtation to the manufacture of the most valuable kinds of iron, and the immense forests which cover the surfare, suitable for charroal, this district may be pronounced unrivaled. * * * * The iron occurs in a metamorpluc formation, bounded by two granite belts, one on the north, and the other on the south, and it is prolonged westerly bejond the Machiganig Rirer. This formation consists of liornblende, talmese, and chinrite slates, with assuciated beds of homblende and feldspar rocks, evidentiy trappern in their origin. The ore consists mainly of the sperular or peroxide of iron, with an admixture of the fine grained magnetic. In some instances, the whole ritge or knob eppears to consist of one mass of pure ore-so pure that no selection is required, but an unlimited quantity might be quarried, or picked up in loose blucks aronnd the slopes. In others the ore is mixed with seams of quartz or jasper which renders it less valuable, and requires more care in tle selection, The iron, in such cases, presents a banded structure, or alternating seams of steel grey and brilliaut red. The appearance of a mountain cliff thus made op is extraordinary. This region possesses an inexhaustible supply of iron ore, of the best quality, removed from twelve to thirty miles from the lake shore, with a soil by no means sterile, and covered with a heavy growth of maple, yellow birch, pine, and oak-and that it is to this source that the great West vill ultimately louk for the finer varieties of bar iron and steel. The "Iron Mountain" of Missouri becones insignificant cumpared with these immense deposits. This region also containg extensıve beds of marble. Flesh red is the prevailing tint, wilh veins of a deeper hue. The Novaculite slates are valuable, affording hones equal to the Turkey or Scotch stones 


\section{MICHIGAN.}

to confer additional charms to the high finishing of a landscape, the beauty of which is probably second to that of no other part of the Union.

The geological structure of Michigan is extremely various. The Southern Peninsula is exclusively secondary in its formation. The Northern Peninsula, bordering on Lake Superior, is primitive, but the portions bordering on Lake Michigan and Green Bay secondary. Primitive boulders, or "lost rocks," are discoverable in every part of the State, especially upon the coasts, and upon the margin or in the beds of the rivers. These are found of enormous dimensions on the coast of Huron, especially north of Snginaw Bay. Here granite masses exist, weighing from 1 to 100 tons, or eren more. Michigan bears evident marks of once having been partially or entirely inundated. It is akirted by a belt of heavily timbered land, about 25 miles deep, surrounding the entire lake coast, which lies several feet below the adjoining plains and openings, and seems to have been the bed of the lakes long after the waters receded from the plains and burst their barriers through the Gulf of St. Lawrence. The Southern Peninsula is of the same geological formation as Western New York, its rocks consisting of mostly horizontal strata of limestones, sandstones, and shales; the limestones being generally found in the beds of the rivers, near the lakes, and the sandstones in the interior. The soil covering these shales is either alluvial or diluvial, and has a depth varying from 1 to 150 feet. The upper sandstone occupies the central and more elerated portions of the peninsula, and discovers itself often immediately under the surface of the soil. Its thickness and general inclination are uncertain. Quarries of this stone have been opened in numerous localities on and. south of Grand River. It generally admits of being easily quarried, furnishing a good building material, and is frequently used for grindstones. The stratum underlying the sandstone is a gray-colored limestone. It has been traced from the rapids of the Maumee, in Ohio, to Charity Islands of Saginaw Bay, and has been noticed at the river Raisin, the bed of which it forms at several places, at Stony Point, and other points along the coast of Lake Erie, and in numerous other places. Associated with this rock is found calcareous spar, strontian, barytes, gypsum, etc., varying with locality. The limestone of Michigan is for the most part of a subgranular structure, quite compact, and well adapted to agricultural purposes, and though at many points it is capable of producing a valuable lime upon burning, it is not unfrequently too silicious to answer that purpose. Below the gray limestone formation the graywacke, or lower sandstone, stratum is supposed to exist. This is noticed on the Lake Huron shore, on the St. Mary's Strait, at the Pictured Rocks, and at various other points in the upper peninsula. Gypsum is found in several places; and in all those localities where the superior stratum, or carboniferous limestone formation exists, there are indications of the existence of bituminous coal. Marl is abundant; it is composed of deposits of recent shells, and when submitted to the process of calcination, it has been found to produce lime of a superior quality. It is likewise an excellent manure for lands when judiciously applied. Deposits of marly clay are quite common. A fine bed oceurs in the county of Macomb, near the middle branch of Clinton River, and it exists also near Ann Arbor, where pottery is manufactured from it with success. The sand comprising the downs that border Lake Michigan shore is said to be of a quality in some instances fitted for the manufacture of glass. The best bed of sand for this purpose, however, occurs near Monroe; it is composed of small, snowy white, angular grains of pure quartz, which has proceeded from the disintegration of a silicious lime rock.

In the upper peninsula the great mineral region lies in the primitive formation; here are the most stupendous copper and iron deposits in the world, containing a sufficiency of mineral to supply the markets for many centuries. Of the iron mention has been made heretofore. The great copper region is principally confined to the Kewenaw peninsula. The extreme length of the deposit is about 135 miles, and it has a width varying from 1 to 6 miles. The mineral, however, does not exist in every portion of this region, for miles may intervene and no trace be ascertained. In some of the river beds immense boulders of native copper are met with. These mines are now being actively wrought, and are in general proving remunerating to the companies working them, but until the navigation of Lake Superior is opened to shipping, the expenses of transportation to market will prove a formidable obstrcle to the full development of the capacities of the mines. Salt springs are also known to exist in different parts of the State. The saline district lies mostly north of a line drawn from Monroe to Grandville. Medieinal waters, mostly chalybeate, and sulphur springs, also occur in numerous localities, and are useful in cutaneous and chronic disorders generally. One near Havre is 85 feet deep and 150 feet in circumference, and produces a volume of water sufficient to propel a run of stones.

The rivers of Michigan are in general comparatively smaller but more numerous, baving in the lower peninsula a greater length from their mouths to where they head, than is commonly observed in most other sections of the Union. This latter circumstance may, perhaps, be attributed not only to the uniformity of descent, but to the more favorable structure of the interior to furnish them constant supplies. The Detroit, St. Clair, and St. Mary's are more properly called straits and not rivers. They are tranquil, deep, copious, and expansive streams, uniting the great lakes, the waters of which they conduct toward the occan. The largest rivers of the lower peninsula are the Grand, Maskegon, St. Joseph, and Kalamazoo, which flow into Lake Nichigan; the Cheboygan and Thunder Bay rivers, that discharge into Lake Huron, and the Saginaw into Saginaw Bay. The streams flowing eastward are small, owing to the position of the dividing ritge, which is considerably east of the middle of the peninsula; the largest are the Raisin, Furon, Clinton, and Rouge. The Iargest rivers of the upper peninsula are the Montreal, the Great Iron, the Ontonagon, the Huron, the St. John's, and the Chocolate, which put into Lake Superior; and the Menomonie and Manistee, which flow, the former into Green Bay, and the latter into Lake Michigan. There are several other considerable streams, though of a smaller grade, and these, with few exceptions, are lively, pure, and healthy, supplying mill-power, and draining the fine agricultural lands through which they course.

Michigan is encompassed by five lakes, four of which are the largest collections of fresh water on the globe. These are Lake Superior, Lake Michigan, Lake Huron, Lake St. Clair, and Lake Erie, which are connected by the Straits of Detroit, St. Clair, Michilimackinac, and St. Mary. Of these immense Mediterranean waters, Lake Superior is by far the largest. It lies directly north of the upper peninsula, and the greater part of its southern coast is bordered by it. Lake Michigan is the second in size. It is a long narrow lake, stretching a little north-eastwardly between the lower peninsula and the States of Wisconsin and Illinois. The northern part, together with the straits, separate the two peninsulas from each other. Lake Huron is next in dimensions, and is situate on the north-esstern border of Lower Michigan, separating it from Canada West. The shape of this lake is extremely irregular; its principal indentations are Saginaw Bay, which extends down into the interior, and two others, one immediately north of Manito islands, and the other south-east of them. The latter, sometimes called the Manito Bay or Georgian Lake, is very large, estimated at one-fourth of Lake Huron. It empties through the Strait St. Clair, into St. Clair Lake, the smallest of the five bordering on Michigan, and this again discharges itself through Detroit Strait into Lake Erie. More than 30 miles of this latter borders Michigan, and opens to the State a free navigation to the principal ports along its cuasts, Buffalo, Dunkirk, Erie, Sandusky, etc. Nor is this 


\section{MICHIGAN.}

State merely surrounded by lakes, but the interior is interspersed with them from one border to the other. The eountry indeed is literally maculated with small lakes of every form and size, from an area of 1 to 1,000 acres, though, as a general rule, they do not perhaps average 500 acres in extent. They are sometimes so frequent that several of them may be seen from the same position. They are usually very deep, with gravelly bottoms, waters transparent, and of a cool temperature at all seasons. This latter fact is supposed to be in consequence of springs which furnish them constant supplies. Water fowl of various sorts inhabit their shores, and their depths are the domain of abundance of fish, trout, bass, pike, pickerel, dace, perch, cat-fish, sucker, bull-head, etc., which often grow to an extraordinary size. It is usual to find some creek or rivulet originating in these, but what is a singular fact, and not easily accounted for, many of these bodies of living water have no perceptible outlet, and yet are stored with fish. A lake of this description, with its rich stores of fish and game, forms no unenviable appendage to a farm, and is properly appreciated. But with all its length of lake coast, Michigan can boast of but few good harbors, yet there are several that afford excellent shelter from the storms that frequently sweep over these great inland seas, and lash them into turmoil.

Michigan is divided into 43 counties, the general statistics of which and the capitals of each, in 1850, were as follows:

Counties. Dwell. Pop. Farms Manuf. Capitals.

Allegan ....... 997..5,125.. 270.. 36..Allegan

Barry........1,037.. 5,072. 733.. 26.. Hastings

Berrien.........2,126..11,417. . 690.. 64. . Berrien Spring

Branch ........2,300..12,472..1,442 . 53. . Cold Water

Calhoun. .......3,433..19,162 . 1,724. . 61...Marshall

Cass ..........1,914..10,907.. 950.. 21..Cassopolis

Chippewa...... 187.. 898.. 17.. 10..Ste. Mario

Clinton ....... 916.. 5,102.. 614.. 13..De Witt

Eaton.........1,328. . 7,059.. 746.. 48..Charlotte

Genesce ......2,257..12,031 . 1,255. . 33. . Flint

Hillsdale . . . . . . 2,965 . 16,159 . 1,411. . 45. . Hillsdale

Houghton...... 116.. 708.. 13.. 5.. Eagle River

Hurun........ 52, 210.. 18.. 0.. -

Ingham.......1,553. 8,631.. 991.. 32.. Mason

Ionia .........1,367.. 7,597. 601.. 17..Ionia

Jackson.........3,510,.19,431, 2,250, . 95..Jackson

Kalamazoo.....2,387..13,179..1,098. . 51..Kalamazoo

Kent..........2,251..12,016. . 819 . 67..Grand Rapids

Lapeer.... . . . . 1,286 . 7,029 . . 623. . 45. . Lapeer

Lenawee......4,892 . 26,372 . 2,470..156..Adrian

Livingston ....2,865..18,485. .1,614. . 40. . Howell

Macomb .......2,666..15,530..1,277. . 65...Mount Clemens

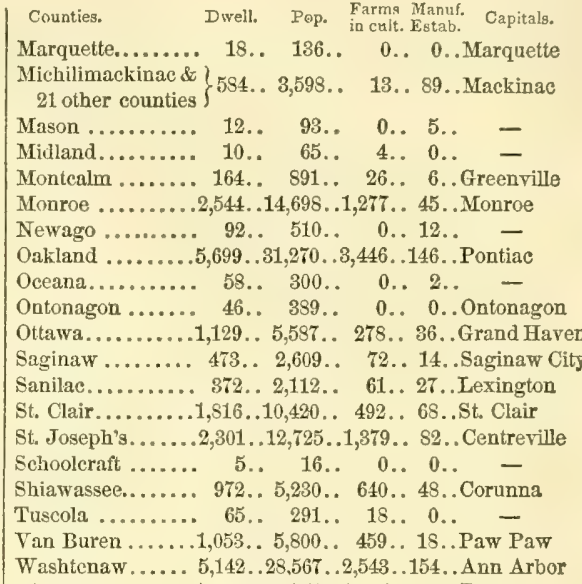

Wayne .........7,063..42,756..1,685..244..Detroit

The whole number of dwellings in the State was, at the above date, 71,616 ; of families, 72,611; and of inhabitants, 397,654 ; viz., whites 395,097 -males 208,471 , and females 186,626 ; free colored, 2,557-males 1,412 , and females 1,145 . Of the whole population there were, deaf and dumb-wh. 121, fr. col. 1-total 122; blind-wh. 122, fr. col. 0-total 122; insane-wh. 135, fr. col. 1-total 136, and idiotic-wh. 187, fr. col. 3-total 190. The number of free persons born in the "United States was 341,591 , the number of foreign birth 54,352 , and of birth unknown 1,211; native population originated as follows: Me. 1,117, N. Hamp. 2,744, Verm. 11,113, Mass. 8,167, R. I. 1,031, Conn. 6,751, N. Y. 133,756, N. J. 5,572, Penn. 9,451, Del. 368, Md. 537, Dist. of Col. 45, Virg. 1,504, N. Car. 312, S. Car. 81, Ga. 68, Flor. 12, Ala. 19, Miss. 34, La. 30, Tex. 4, Ark. 25, Tenn. 101, Ky. 402, Oh. 14,677, Michigan 140,648, Ind. 2,003, I1I. 496, Mo. 92, Ia. 59, Wisc. 332, Calif. 3 , Territories 36 ; and the foreign population was composed of persons, from-England 10,620, Ireland 13,430, Scotland 2,361, Wales 127, Germany 10,070, France 945, Spain 10, Portugal 2, Belgium 112, Holland 2,542, Turkey 2, Italy 12, Austria 21, Switzerland 118, Pussia 75, Denmark 13, Norway 110, Sweden 16, Prussia 190, Sardinia 2, Greece 1, China 1, Asia 0, Africa 3, British America 14,008, Mexico 4, Central America 0, South America 5, West Indies 31, Sandwich Islands 2, and other countries 66.

The following table will show the decennial progress of the population since the first census of the State taken by the United States authorities :

\begin{tabular}{|c|c|c|c|c|c|c|c|c|}
\hline \multirow{3}{*}{$\begin{array}{c}\text { Censns } \\
\text { Tears. } \\
1810\end{array}$} & \multirow{2}{*}{$\begin{array}{l}\text { White } \\
\text { Persons. }\end{array}$} & & \multicolumn{3}{|c|}{ Colored Persons. } & \multirow{2}{*}{$\begin{array}{c}\text { Total } \\
\text { Popuiation. }\end{array}$} & \multicolumn{2}{|c|}{ Decennial Increase. } \\
\hline & & & Free. & Slave. & Total. & & nerical. & t. \\
\hline & 4,618 & $\ldots$ & 120 . & .24 & 144 . & . $\quad 4,762$. & $-\ldots$ & $\ldots \ldots-$ \\
\hline $1 S 20$ & 8,591 & . & 305. & .. - . & 305 . & $6 .$. & 4. & $\cdots$ \\
\hline $1 \leqq 30$ & - 31.346 & & 261 & 32. & 293. & 31,639 . & ... $22,713$. & .. 255. \\
\hline 1840 & $.211,560$ & & 707 & - & 707 & $212,267 \ldots$ & .. 180,623 . & .. 570.9 \\
\hline 1850 & 395,097 & & 2,557 & 一. & 2,557 & $397,654 \ldots$ & .... 185,387 . & 87.3 \\
\hline
\end{tabular}

The statistics of the wealth, productinn, manufactures, and institutions of Michigan, as exhibited by the census of 1850 , and other official returns referring to the same period, are as follows:

Occupied Lands, etc.-Improved lands 1,929,110 acres, and unimproved lands 2,454,780 acres-valued in cash at $\$ 51,872,416$. The whole number of farms 34,089. Value of farming implements and machinery, $\$ 2,590,371$.

Live-Stock:-Horses, 58,506; asses and mules, 70 ; milch cows, 99,676; working oxen, 55,350; other cattle, 119,471 ; sheep, 746,435 ; and swine, 205,847 -valued in the aggregate at $\$ 8,008,734$. The returns of 1840 exhibited the live-stock in the State as follows: horses, mules, etc., 30,144 ; neat cattle of all descriptions, 185,190 ; sheep, 99,618 ; and swine, 295,590 .

Prorlucts of Animals.-Wool, 2,013.2S3 (in 1S40, 153.375) pounds ; butter, 7,065,S7s pounds ; cheese, 1,011,492 pounds; and value of animals slaughtered during the year, $\$ 1,328,327$. Silk cocoons were produced to the amount of 8 (in $1810,266)$ pounds; and beeswax and honey to that of 359,232 pounds.

Grain Crops.-Wheat, 4,925, 889 bushels ; rye, 105,S71 bushels; Indian corn, 5,611,420 bushels; oats, $2,566,056$ bushels; Darley, 75,249 bushels; and buckwheat, 472,917 bushels. The crops of the same cereals, in 1810, were: wheat, 2,157,108 
bushels: Indian corn, 2,277,039 bushels; oats, 2,114,051 bushels; rye, 34,236 bushels; barley, 127,502 bushels; and buckwheat 113,592 bushels.

Other Food Crops.-Peas and beans, 74,254 bushels; and potatoes-Irish, 2,359,897 bushels, and swect, 1,177 bushels. The potato crop of 1810 amounted to $2,109,205$ bushels.

If iscellaneous Crops.-Tobacco, 1.245 pounds; hay, 404,934 tons; clover-seed, 16,989 bushels; other grass-seed, 9,785 bushels; hops, 10,663 (in 1840,11,381) pounds; hemp-dew-rotted 166 tons, and water-rotted 37 tons; flax, 6.994 pounds (crop of hemp and flax in 1840, 755 tons); flax-seed, 1,421 bushels; maple sugar, 2,43s,9si pounds ; molasses, 19.523 gallons; wing, 1,654 gallons, etc. The value of orchard products was $\$ 132,650$, and of market-garden products $\$ 14,738$.

Home-made manufactures for the year 1849-50 were produced to the value of $\$ 1,32 S, 327$. In 1839-40 the same description of products were valued at $\$ 113,955$.

Manufactures.-Aggregate capital invested, $\$ 0,000,000$; value of raw material, fuel, etc., consumed, $\$ 0,000,000$; average number of hands employed $00,000-$ males 00,000 , and females 000 ; average monthly cost of labor $\$ 000,000-$ male $\$ 000,000$, and female $\$ 0,000$; total value of produets for the year ending 1 st June, $1 \$ 50, \$ 0,000,000$. The whole number of manufacturing establishments in the State producing to the value of $\$ 500$ and upward annually, at the abore date, was 1,979 , distributed among the several counties, as shown in the general table, and of these 15 were woolen factories, 64 iron factories-63 for castings, and 1 for pig iron, and 60 tanneries.

The acooten manufactures employed a capital of $\$ 94,000$, consumed annually 162,250 pounds of wool, valued at $\$ 43,402$, employed 78 males and 51 females, at a monthly cost-for male labor, $\$ 1,659$, and for female labor, $\$ 5 \$ 5$, and produced 141,570 yards of cloth, valued at $\$ 90,212$.

The foundries manufacturing eastings employed a capital of $\$ 195,450$; used 2,494 tons pig metal, 901 tons mineral coal, and 16,200 bushels coke and charcoal, valued at $\$ 91,865$; employed 337 hands, at average wages amounting to $\$ 2863$ to each hand, and produced 2,070 tons of castings and other products, valued in the aggregate at $\$ 279,697$. The capital employer in making pig iron was $\$ 15,000$, and the quantity manufactured was 660 tons, valued at $\$ 21,000$.

In the tanneries, the invested capital amounted to $\$ 236,000$; value of raw material userl, $\$ 213,450$; hands employed, 265 ; monthly cost of labor, $\$ 6,782$; skins 23,600 , and sides 144,730 tanned; value of both, $\$ 363,980$.

The manufactures of Michigan, other than those enumerated, are various and large, consisting of flour-mills, saw-mills, asheries, potteries, machine-shops, axe and edge-tool factories, distilleries, paper-mills, ete., ete. There are about 260 fleur-mills in the State, chiefly driven by water-power, and eapable of making between 700,000 and 800,000 barrels of flour annually; and the number of saw-mills is not far short of 650 , of which 79 are driven by steam.

Foreign Commerce.-The total value of the exports from Michigan to foreign countries during the year ending 30 th June, 1550 , was $\$ 132,045$, of which $\$ 57,232$ was the value of products earried in American bottoms, and $\$ 74,813$ in foreign bottoms; and the total value of imports was $\$ 144,102$, all of which were brought in American bottoms.

The shipping employed in the carrying trade was 56,963 tons inward, and 54,701 tons outward-in detail as follows :

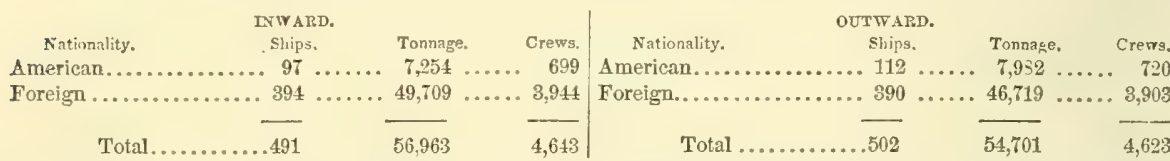

Of the aggregate shipping inward, 54,130 tons entered in Detroit district, and 2,833 tons in that of Michilimackinac; and of the aggregate outward, 52,554 tons cleared from Detroit, and 2,147 from Michilimackinac districts. The shipping owned in the two districts amounts to 38,144 tons, all of the class enrolled and licensed, and of which 18,015 tons are navigated by steam-power. In the Detroit district 14 vessels - 5 schooners, 6 sloops, and 3 steamers - of an aggregate burden of 2,062 tons, were built during the yeur above referred to. The greater portion of the external commeree of Michigan is with the adjoining British prorinces. The following table exhibits the movements of the foreign commerce of the State for a series of years:

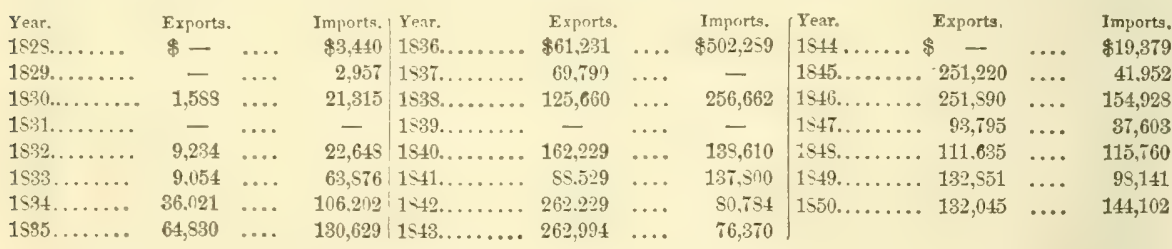

Lake Commerce.-This department of commerce in Michigan is large, and yearly increasing. Twenty years ago it had no existence, and even ten years ago it was of very trifling importance compared with its present extent. of the commercial movements on Lake Superior, no statistics have been published, but it is well understood that all the products of the country boriering on it, from their very nature being mineral, must seek a distant market, and that the great bulk of necessaries of life must be carried to the miners-thus creating a large commerce, and that an increasing one. A navigable canal, 5,267 feet long, around the Sault Ste. Marie, is about to be constructed, and hence the commerce on Lake Superior will be at once established on a sure and lasting basis. On Lake Haron the exports from the two districts of Sault Ste. Marie and Michilimackinac in $1550-51$ amounted to $\$ 553,615$, and the imports 1 (1) $\$ 291.534$; on the lake and river St. Clair, from the districts of Algonac, St. Clair, Trenton, and Mount Clemens, the exports in the same year amounted to $\$ 4 \$ 3,660$, and the imports to $\$ 155, \$ 63$; and on Lake Michigan, from district of St. Joseph's, the exports were valued at $\$ 513,594$, and the imports at $\$ 6 \tau 2, \$ 92$-making a total of exports by lake valued at $\$ 1,581,172$, and of imports valued at $\$ 1.323,259$. The above figures embrace the total imports and exports on Lake Huron, and also on the river and Lake St. Clair, so far as domestic commerce is concerned; the total commerce on Lake Michigan, inclusive of that of St. Joseph's above, was in the same year-exports $\$ \$, \$ 36,10 \$$, and imports $\$ 15,4 \$ 4,728$, or a total value of exports and imports amounting to $\$ 24,320, \$ 36$, of which $\$ 393,083$ belonged to Indiana, $\$ 11,903,777$ to Illinois, and the remainder to Wisconsin.

Internal communication.-Wichigan has two transverse railroads-one extending from Detroit, via New Buffalo, to 


\section{MICHIGAN.}

Chicago, and the other from Toledo and Monroe, via White Pigeon and the Indiana Northern Railroad, to the same destination. These two roads form links in the great chains running east and west connecting the northern Atlantic States and sea-board with the Mississippi, and ultimately with the shores of the Pacific Ocean. On these lines the transit of goods and passengers is immense, being the shortest routes hitherto constructed on the longitudinal extent of the country. Their connections with the railroads and steam navigation lines of other States and of Canada give to Michigan aeceso by railroad aud water to vast regions hitherto accessible only by ordinary ronds, and tend to swell the already large commercial connection of the State. There are also several short railroads in the State, as the one from Detroit to Pontiac, and from White Pigeon to Constantine; and others are projected, as the line from Toledo to Detroit, and from Detroit to the mineral regions in the upper peninsula. A line is also projected from Jackson, on the Central Road, to Lansing, the capital. The total length of completed railroad in the State, on the 1st of January, 1853, was 481 miles, which had cost about $\$ 12,000,000$, or about one mile of railroad to every 117 square miles of territory. A canal is also about being constructed around Sault Ste. Marie, which will connect the waters of Lake Superior and the lower lakes, and thus open up the commerce of the richest mincral region of the world to the markets of the east.

Banks, -On the 1st January, 1851, there were in the State five banks and one branch bank, the financial condition of which, at the date affixed, was as follows: Liatilities-capital $\$ 764,022$, circulation $\$ \$ 97,364$, deposits $\$ 416,147$, due other banks $\$ 42,559$, and other liabilities $\$ 312,816$; and assets-loans and discounts $\$ 1,319,303$, stocks $\$ 420,521$, real estate $\$ 221,626$, other investments $\$ 65,033$, due by other banks $\$ 404,691$, notes of other banks $\$ 109,086$, specie fund $\$ 195$, and specie $\$ 125,722$.

Government.-The government is based on the constitution approved by the people, in November, 1850. It provides that the right of suffrage be enjoyed by every white male citizen; every white male inhabitant who, six months previously, has declared his intention to become a citizen of the United States, or who has resided in the State two and a half years, and declared his intention as aforesaid, and every civilized male Indian, not a member of any tribe. Every elector shall bo above 21 years of age, and have resided in the State three months, and in the township or ward in which he offers his rote ten days preceding an election. Duelists are disqualified from voting, or being elected to any office. The general elections are held on Tuesday succeeding the first Monday in November, biennially (even years).

Legislative ponver is vested in a Senate and House of Representatives. Senators, 32 in number, are elected from single districts for two years, and Representatives, not less than 64 nor more than 100 in number (now 66 ), from districts, and for the same term. When any town or district is entitled to more than one representative, the number to which it is entitled is elected by general ticket, but counties entitled to more than one are divided into districts. Senators and representatives shall be citizens of the United States and qualified electors, and shall hold no other office under the State. A subsequent vote of two-thirds of all the members elected abnegates the governor's veto to any bill, and it becomes law. The legislature meets biennially (odd years), on the first Wednesday in February.

Exceutive power is vested in the Governor. The Governor and Lieutenant-governor are elected biennially by a plurality of votes. Each must have attained the age of 30 years, have been a citizen of the United States for five years, and of the State two years next preceding. The powers of the governor are those usually enjoyed by that officer. No person holding any other office under the authority of the United States or of Michigan shall execute the office of governor, nor shall the governor or lieutenant-governor be eligible for any other office during the time for which they may have been chosen.

The administrative officers are, a Secretary of State, State Treasurer, a Commissioner of the State Land Office, Superintendent of Public Instruction, an Auditor-general, and an Attorney-general, elected at the biennial election, their terms to commence on the 1st January, 1853, and of every second year thereafter. The three first-named constitute a Board of State Auditors, to examine and adjust all claims against the State not otherwise provided for by general law, and also a Board of State Canvassers, to determine the results of all elections for State officers.

The judiciary is vested in one Superior Court, in Circuit Courts, in Probate Courts, and in justices of the peace. There are also municipal courts of civil and criminal jurisdiction. All judges and justices are elented by the people. The Supreme Court has general superintending control over all inferior courts, and holds four terms annually. It has power by general rules to modify, amend, and simplify the praetice of the courts, and the legislature is enjoined to abolish, as far as practical, the distinctions between law and equity proceedings. The Circuit Court consists of eight judges, one for each judicial circuit, who hold office for six years. These enurts have original jurisdiction in all matters not excepted in the constitution or prohibited by law, and appellate jurisdietion from all inferior courts. Judges are ineligible for any other office during their respective terms, and for one year thereafter. A circuit court is held twice a year in every county organized for judicial purposes, and four times in each year in counties of more than 10,000 inhabitants. The probate courts of the several counties have jurisdiction as provided by special law-the judges hold office for four years. The whole of the above are courts of record, and have a common seal. Justices of the peace are chosen for four years, and each town may have four-cities may have more than that number. In eivil eases, justices of the peace have exclusive jurisdiction to the amount of $\$ 100$, and coneurrent to $\$ 300$, which may be increased by law to $\$ 500$. They have also criminal jurisdiction in minor offenses. Courts of conciliation may be established. Any suitor in any court of Michigan hils the right to prosecute and defend his suit either in his own person or by an attorney or agent of his own choice. In all prosecutions for libel, the truth may be given in evidence. Treason against the State shall consist only in levying war against it or adhering to its enemies, giving them aid and comfort, ete.

Any amendments to the constitution may be proposed in either house, and if agreed to by two-thirds of each house, such shall be submitted to the electors at the next general election, and if a majority of the clectors voting thereon ratify and approve them, the same shall become a part of the constitution. All amendments to take effect at the commencement of the political year after their adoption. In 1866 , and every sixteenth year thereafter, the question of a general revision of the constitution shall be submitted to the electors, and in ease a majority shall decide in favor of a convention, the legislature, at its next session, shall provide by law for the election of delegates to such convention.

The militia of the State of Michigan in 1850, according to the report of the adjutant-general for 1851, consisted of 61,178 men of all arms, of which number 2,798 were commissioned officers, and 61,145 non-commissioned officers, musicians, artificers, and privates. Or the commissioned officers 30 were general officers, 154 general staff officers, 401 field officers, etc., and 2,208 company officers.

The principal beneoolent institutions of the State are, the Asylum for the Insane at Flint, and the Asylum for the Deaf and Dumb and the Blind at Kalamazoo. These institutions are endowed with lands, and are under the control of a board of five trustees elected by the legislature. 


\section{MICHIGAN.}

Finance, Debts, etc.-The total arailable means in the treasury for the year ending 30th November, 1850, was $\$ 454,71567$, of which sum $\$ 55,41739$ was a balance from the fiscal year $1 \$ 49$, and $\$ 429,26 \$ 2 S$ receipts during the year ending as above. The total expenditures amounted to $\$ 449,35540$, leaving a balance of $\$ 35,36027$ for future appropriation. The chief sources of income were-general taxes and sales of land about $\$ 300,000$, and speeifle State taxes $\$ 24,404$; and the principal objects of expenditure were-legislation $\$ 54,60758$, constitutional convention $\$ 31,46305$, execulive $\$ 11,95316$, judiciary $\$ 9,15483$, state prison $\$ 6,000$, counties for taxes $\$ 6,63727$, expenses of sales of tax lands $\$ 14,04537$, State library $\$ 14286$, school moneys apportioned $\$ 42,79444$, university $\$ 9,64470$, ete. The aggregate debt of Michigan as stated by the auditor-general in his report of 1st December, 1850 , was $\$ 2,809,90583$, bearing interest mostly at six per cent. The resources and property of the State, other than State buildings and furniture, are stated at $\$ 628,22455$, leaving the actual State debt, over and above the resources of the State, $\$ 2,181,6 \$ 148$. The total value of real and personal estate assessed for taxes in 1850 , was $\$ 30,877,223$; but the true or estimated value of the same was $\$ 59,787,255$.

Federal Pepresentation.-Michigan, in accordance with the provisions of the act of $23 d$ May, 1850 , apportioning the federal representation, is entitled to four representatives in Congress.

Education.-Michigan, in 1850, contained 3,097 schools, of which 2,525 only made returns in that year. According to the report of the Superintendent of Public Education, 132,234 children, between the ages of 4 and 18, attended school during the year; the number drawing public money, 125,866. Number of scholars under 4 years of age, 2,056, and over 18 years of age, 8,346 . Amount of school money appropriated, $\$ 42,79444$, and raised by tax, $\$ 81,392 \$ 4$ for support of teachers. Raised for purchasing, building, etc., school-houses, $\$ 46,79701$. Received from local funds, $\$ 5,38959$. Volumes in township libraries, 84,823 . Mill tax for township libraries and support of schools, $\$ 7,95730$. Total amoun expended for school purposes, $\$ 194,330$ 78. The number of seholars atlending unincorporated, select, or private sehools, was 4,065. A State normal school has been established at Ypsilanti, with an endowment of school lands, and is under the control of the Board of Education. The principal collegiate institution of Michigan is the Unirersity at Ann Arbor. It is under a Board of Regents, who have control of the University fund. In 1850 it had 7 professors, 91 alumni, 64 students, and a library of 6,000 volumes. The medical department of the University in the same year had 5 professors and 95 students. An agricultural department is provided for by the new constitution. St. Philip's College, near Detroit, is a Roman Catholic institution, founded in 1839, and in 1850 had 4 professors, 30 students, and a library of 3,000 volumes. There are numerous academies and other literary institutions in the State, the former connecled with the University, and receiving an apportionment of the University Fund.

Libraries.-One State library, 4,400 volumes; 2 social libraries, 3,315 volumes ; 4 college libraries, 10,300 volumes; 374 school libraries, 47,220 volumes - total 381 libraries, and 65,235 volumes. The number of volumes in the school libraries, as given in the report of the Superintendent of Public Instruction, differs essentially from the above census aecount, being stated at 84,823 volumes.

Periodical Press.-The whole number of periodicals published in the State in 1850 was 67 , of which 37 were devoted to politics-16 whig and 21 democratic - and 30 were devoted to literature, science, religion, ete. Of the whole number 3 were issued daily and semi-weekly, 53 weekly, 2 semi-monthly, and 4 monthly; and the eirculation of the dailies at each issue was 5,000 , of the semi-weekly, 200 , of the weeklies, 31,568 , of the semi-monthlies, 2,600 , and of the monthlies, 13,300 . The dailies are published at Detroit; of the weekly issues, 1 is published at Allegan, 3 at Niles, 1 at Coldwater, 2 at Marshall, 1 at Sault Ste. Marie, 1 at Cassopolis, 1 at De Witt, 1 at Eaton Rapids, 2 at Flint, 2 at Hillsdale, 1 at Jonesville, 1 at Lansing, 1 at Ionia, 2 at Jackson, 2 at Kalamazoo, 2 at Grand Rapids, 1 at Lapeer, 1 at Arrian, 1 at Howell, 1 at Romeo, 2 at Mount Clemens, 2 at Monroe, 2 at Pontiac, 1 at Holland, 1 at Saginaw, 1 at Corunna, 1 at St. Olair, 1 at Port Huron, 2 at Centreville, 1 at Paw Paw, 2 at Ann Arbor, 2 at Xpsilanti, and 6 at Detroit; the semi-monthlies are published at Lansing and Jonesville, and the monthlies at Adrian, Monroe, and Detroit.

Religions Denominations.-The statistics of the several religious denominalions in this State were, in accordance with the census of 1850 , as follows:

\begin{tabular}{|c|c|c|c|c|c|c|c|c|c|c|}
\hline C & $\begin{array}{l}\text { No. of } \\
\text { Churclies. }\end{array}$ & & $P_{r}^{Y}$ & $\begin{array}{l}\text { No. of } \\
\text { Churches. }\end{array}$ & & P & a- & $\begin{array}{l}\text { No. of } \\
\text { Cliurches. }\end{array}$ & & $y$. \\
\hline$\ldots$. & .. $5 \mathrm{~S}$ & & & Ref. - & - & & & & & \\
\hline & .. & & & $\ldots-$ - & & - & & - & $-\ldots$ & - \\
\hline & 1.. 29 & & & n... 12 & 3,205 & 12,6 & & 一 & 一 & 一 \\
\hline & .. & & & e.. - & - & 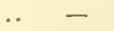 & & & 800 & 1,40 \\
\hline & .. 25 & & & $\ldots 103$ & & & & . $\rightarrow$. & - & - \\
\hline & & & & & & & & & & \\
\hline 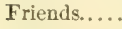 & .. & 400 & 50 & ter'n.. $67 .$. & 2,530 & $1.42,650$ & Minor Sects & $\$$ s.. & 800 & 15,00 \\
\hline
\end{tabular}

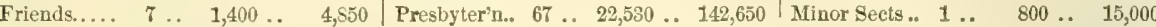

- making a total of 362 churches, with accommodation for 11\$,\$92 persons, and valued as property at $\$ 123,200$. Michigan constitutes a diocese of the Protestant Episcopal Church; and also the Roman Catholic diocese of Detroit.

Pauperism and Orime.- Whole number of paupers who were relieved or received support within the year ending 1st June, 1850, 1,190-649 native-born, and 541 foreigners; whole number of paupers receiving support at the date specifled, 429-248 native-born, and 151 foreigners; total annual cost of support $\$ 27,556$. The State prison is located at Jackson. The number of convicts on the 30 th November, 1849 , was 109 ; received during the year 50 , and discharged during the year 28 , leaving in prison 30 th November, 1850,131 , of whom 115 were white, and 16 colored. Of the 50 received, 25 were committed for larceny, 8 for burglary, and 5 for burglary and larceny; and of the $2 S$ discharged, 21 by expiration of sentence, 2 by pardon, 2 by death, 2 by escape, and 1 by order of Supreme Court. The income of the prison was $\$ 10,70058$, and the expenditures $\$ 16,73614$, the defleiency being supplied by the State. Of the 131 prisoners remaining under sentence, 5 were educated at college, 1 at a medical school, 8 in academies, and 91 in common schools; 94 can read and write, 34 can read only, and 8 can not read; 19 learned to read in prison; 86 were native-born, and 45 foreign-born.

Historical Sketch.-The discovery and early settlement of Michigan is due to the French, whose motives seem to have been the prosecution of the fur trade, and incidentally the conversion of the Indians. In prosecution of the latter object, Father Sagard reached Lake Huron in 1632 , seven years subsequent to the founding of Quebec, but the present site of the city of Detroit had been visited as early as 1610. Soon after the middle of the 17 th century, tracling-posts were established at Sault Ste. Maric, Michilimackinac, and Green Bay-the two first, in a military point of view, important positions, and the latter post is noted as the starting-point of the expedition of Joliet and Marquette in search of the Mississippi, in 
1673. In 1702, an expedition sent out by the Governor of New France laid the foundation of Detroit. From this period until the erection of the country into a territory of the United States, the history of Michigan is simply a history of that post, and though full of romantic interest, and perhaps of useful information relating to the progress of settlement, is not of suficient importance to require notice in this place. The Indian wars may also be passed over in silence. The definitive treaty of peace which acknowledged the independence of the United States, gave to the young republic a vast western domain, of which Michigan formed a part. It had been ceded to the English in 1763 , when France renounced her vast American possessions. The disturbed state of affairs at the period referred to, however, delayed the United States in taking possession of the territory; nor was it until 1796 that the Americans entered Detroit. Michigan from this time Fas included under the government of the territory north-west of the Obio, and hence has ever been amenable to the ordinance of 1757. In 1505, the territory of Michigan was constituted, and on the 1st July of that year the government was organized at Detroit by Gen. William Huil, its first governor. In 1812, war against Great Britain was declared by Congress, and the first shock fell upon Michigan. Detroit was given up to the British, and the country becane the scene of rapine and bloodshed. The history of this war is one of the most disgusting episodes of which cruelty and treachery can boast, and in which the Briton and the Indian were compctitors for distinetion. On the re-occupation of the territory, the governorship was vested in Gen. Lewis Cass. In 1835, it having been found that Michigan had a population greater than required by law to enable her to become a State, a convention was ordered, and having convened at Detroit, a constitution was framed; and by an act of Congress, approved 26th January, 1837, Michigan was declared " to be one of the United States, and admitted into the Union on an equal footing with the original States in all respects whatever"

IArsivg is the political capital of the State; until December, 1847, Detroit was the seat of government, and is still the largest and most important place.

Mrchigax lake. One of the five great lakes of North Ameriea, and the largest body of water lying wholly within the limits of the United States. It is situate between latitudes $41035^{\prime} 58^{\prime \prime}$ and $46^{\circ} \mathrm{N}$., and the longitudes $84^{\circ} 40^{\prime}$ and $87^{\circ} 8^{\prime}$ W. It is a long and narrow lake, stretching a little northcastwardly between the lower peninsula of Michigan on the east, and the States of Illinois and Wisconsin on the west, and on the south it also washes the shore of Indiana. The northern part, together with the strait of Michilimackinac, which connects it with Iake Huron, separates the two peninsulas of Michigan. The area of its waters is stated at $16,981 \mathrm{sq} . \mathrm{m}_{\text {, }}$ or $11,067, \$ 40$ acres, being inferior in surface ouly to lakes Superior and Huron. It is 330 miles in extreme length, and on an average 60 miles broad, and its eleration above tide-water 574 feet, its depth at the same time being about 900 feet. Green Bay, its largest arm, lies on the $\mathrm{N}$. W., and itself is a large sheet of water, 120 miles long, and from 25 to 28 miles wide. It is the recipient of the waters of Winnebago lake through Fox river, and has nther minor affluents both from Wisconsin and the northern peninsala. The lake receives also a number of large and small rivers; from the lower peninsula it receives Grand, Maskegon, St. Joseph, and Kalamazoo rivers ; from Indiana, Calumet river, ete. ; from Illinois, Chicago river, etc. ; from Wisconsin, the Milwaukie, Sheboygan, and other streams, and from the upper peninsula, Manistee river and a number of other small rivers. Many of these have fine harbors at their confluence, and commercial towns rapidly progressing to importance have been built in every direction." The commerce of the lake, indeed, has already become considerable, and its increase from year to year has been such as to astonish the most sanguine. In 1850-51 the imports and oxports from the several ports on the lake were as follows:

Porta. Tmports. Exports. Green Bay......... \$151,537.......... \$\$ \$ $\$ 330$

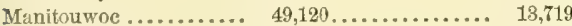
Sheboygan . . ......... $571,800 \ldots \ldots \ldots \ldots \ldots \ldots .12,191$ Port Washington ...... 27s,311 ........... 48.267 Milwaukie . .......... $3,828,650 \ldots \ldots \ldots \ldots \ldots . . \ldots 2,098,469$ Southport .......... $629,791 \ldots \ldots \ldots \ldots \ldots \ldots .583,608$

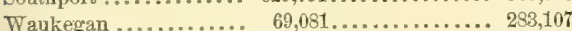
St. Joseph . . . . . . . . . . $672,592 \ldots \ldots \ldots \ldots \ldots \ldots .543,894$ Michigan City . . . . . . . 28,915............. 369,168 Chicago.............7,751,872,..........4,151,905

- making for all the ports an aggregate of imports valued at $\$ 15,434,728$, and of exports an agoregate valued at $\$ 3,836,108$. This amount would undoubtedly be much larger if the caral from Chicago to the navigable waters of the Illinois, and the numerous railroads diverging from the same point, did not carry off the great bulk of the commercial material needed and produced in the country on the west side of the lake, but these also act as its feeders. The geographical position of the lake, indeed, is most advantageous for its becoming the channel of an immense commerce. Its length lies in the direction between the Mississippi and the great lakes, and it is navigable for vessels of the greatest tonnage Steamboats ply regularly between all the ports, and to and from these and the ports of Lake Erie, having Buffilo, Erie, Cleveland, Sandusky, etc., as their eastern destination, and at these connecting with the great lines to the interior and Atlantic sea-board.

Michigan Citr, p. v., La Porte co., Ind, : at the mouth of Trail cr., on Lake Michigan, $12 \mathrm{~m}$. N. W. of Laporte, and $137 \mathrm{~m}$. N. by W. from Indianapolis. This is the only lake harbor in the State. It was first settled in 1636. The Michigan Central R. R. passes through the $v ., 54 \mathrm{~m}$. from Chicago, and $228 \mathrm{~m}$. from Detroit. It is the proposed terminus of a number of other railroads. There are a number of large warehouses situated on Trail creek, for the storage and shipment of wheat, and had the improvement of the harbor been continued as was contemplated, the great emporium of the northern trade of the State would have been here; as it is, vessels can only be loaded by means of lighters, and in pleasant weather. Dry goods, grocery, and provision stores are numerous, and there are also in the place several factories and workshops. A branch of the State bank is situate here. The "Michigan City News" (whig) is published weekly. There is a light-house (fixed light) on the beach, the lantern being 60 feet above the level of the sea. Pop. about 1,000 .

Michigantown, p. v., Clinton co., Ind.: 39 m. N. by W. Indianapolis, and $42 \mathrm{~m}$. by the Michigan plank-road.

Mrohilmackivac county, Mich. Situate E. on S. side of Upper Peninsula, and contains about 1,260 sq. m. Drained by Pine and Carp rivers, and other small streams flowing into the straits of Mackinaw, its S. boundary. It embraces many islands, of which Mackinaw, Bois Blanc, and Great Bearer (setlled by the Mormons) are chief. The main land is visited mostly by fur traders; the waters adjacent abound in fish, principally white fish and bass, and tho fisheries are very valuable. Pop. about 3,000 . Capital: Mackinaw.

Midaridge, p. o., Giles county, Tenn.: 72 m. S. by TV. Nashville.

Middeborodgr, t. and p. v., Plymouth co., Mrass. : $87 \mathrm{~m}$. S. S. E. Boston. Drained by Assawamset and Long Pond, together with several smaller ones, which discharge their waters into Taunton r., affording excellent hydraulic power. Surface in parts rocky; soil varied. Iron ore is found in abundance. There are 2 forges, an air and cupola furnice, several mills, and a number of manufactories in the $t$. The village is on the line of the Fall River $R$. R., at the junction 
with Cape Cod Branch R. R., $19 \mathrm{~m}$. from Fall River, and has numerous manufactories. Pop. of t. 5,336.

Mindlebocrine, p. v., Guemasey co., Ohio: on Will's cr., $84 \mathrm{~m}$. E. Columbus.

Midplebodrate, p. vo, and cap. Tyler co., Virg.: on the E. side of Middle Island cr., $236 \mathrm{~m}$. N. W. Richmond. It contains the court-house and a few dwellings.

Middie Branch, p. o., Stark county, Ohio: $104 \mathrm{~m}$. N. E. Columbus.

Middle Brook, p. v., Augusta co., Virg.: on a fork of Shenandoah r., $102 \mathrm{~m}$. W. N. W. Pichmond.

Middletbrook Milis, p. v., Montgomery co., Ma.: on Seneca cr., 38 m. W. N. W. Annapolis.

Mindrebdeg, p. v., Casey co., $K y .:$ on Pine cr., $58 \mathrm{~m} . \mathrm{S}$. Frankfort.

Mmdleburg, p. v., Carroll co., Ma.: between Sam's and Big Pipe creeks, $2 \mathrm{~m}$. from their junction, $13 \mathrm{~m}$. W. of Westminster, $54 \mathrm{~m}$. N. W. Annapolis.

Mmdieberg, t. and p. v., Schoharie co., N. Y.: $31 \mathrm{~m}$. W. by S. Albany. Drained by Catskill er. and Schoharie Kill, which afford excellent water-power. Surface uneven; in parts hilly. Soil varied, in many places rich and productive. There are a number of mills and manufactories, besides several workshops, here. The $\mathrm{v}$, is on the E. sirle of Schoharie cr., and has a number of mills and a furnace. Pop. of t. 2,967.

Middleburg, p. v., Union county, Penn.: on Middle cr., $41 \mathrm{~m}$. N. by W. Harrisburg. Beaver Furnace at this place has an annual capacity of 1,600 tons.

Mindleburg, p. v., Hardeman county, Tenn.: on the Memphis post-road, 144 m. W. S. W. Nashville.

Mmplebure, to and p. O., Shiawassee co., Mich. : $28 \mathrm{~m}$. N. $\frac{1}{3}$ E. Lansing. Drained by branches of Maple r. Surface rolling; soil fertile, adapted to grain. Pop. of t. 132.

MiddlebtrG, p. v., Loudon co., Firg. : on a tributary of the Potomac r., $99 \mathrm{~m}$. N. Richmond.

Middleburg, t, and p. o., Cuyahoga co., Ohio: $113 \mathrm{~m}$. N. N. E. Columbus. Drained by E. branch of Rocky x. and Cuyahoga r. Surface level; soil very fertile, producing excellent grain and grass. There are furnaces and sereral mills here. Berea is the name of a pleasant $\mathrm{v}$. and station in the $\mathrm{N}$. W. part of the t., on the line of the Cleveland, Columbus, and Cincinnati P. R., which passes through it $12 \mathrm{~m}$. S. W. Cleveland, Pop. of t. 1,490.

Midplebure, p. o., Boone co., Mo.: 29 m. N. by W. Jefferson City.

Middleburg, p. v., Duval co., F'lor. : on Black cr., $152 \mathrm{~m}$. E. by S. Tallahassee.

Middlebury, t. and p. v., New Haven co., Comn. : $27 \mathrm{~m}$. 8. W. Hartford. Drained by Hope Branch of Naugatuck r. and Quassepaug pond, outlet of which empties into the Housatonic $r_{\text {s, }}$ furnishing excellent water-power. Surface very uneven; in parts rocky; soil excellent for grazing and the growth of rye. Copper has been found near Quassepaug pond. Incorporated in 1807 , and contains sereral mills and manufactories. The $\mathrm{r}$. is situate centrally, and has several stores and workshops. Pop. of t. 763 .

Mindelebury, p. V., Elkhart co., Ind.: on the S. W. side of Little Elkhart r., $132 \mathrm{~m}$. N. by E. Indianapolis.

Mimdiesurx, t. and p. v., Wyoming co., $N_{0} Y_{\text {. }}$ : on the line of the Buffalo and New York City R. R., $43 \mathrm{~m}$. from Buffalo, and $229 \mathrm{~m}$. W. Albany. Drained by branches of Genesee r. and Tonawanda cr. Surface uneven; soil of fine quality, productive of grain or grass. It has excellent water-power, which propels several factories and mills. The v. contains a number of stores, mills, and workshops. Pop. of $t .1 .799$.

Mrodlebury, p. v., Mercer co., Mo.: on the E. side of Muddy cr, $145 \mathrm{~m}$. N. N. W. Jefferson City.

MmDLebusy, p. v., Summit co., Ohio: on the Cleveland and Taunton post-road, $108 \mathrm{~m}$. N. E. Columbus.

Miodleburr, t., p. v., and cap. Addison county, Term. :

$27 \mathrm{~m}$. S. W. Montpelier. Drained by Otter cr. (which passes 472 through the W. part of $t_{\text {. }}$ ) and Middlebury r, affording excellent hydraulic power. Surface generally level, Chipman's Hill, 440 feet above Otter cr., being the greatest elevation; soil fertile and very productive. There are a large number of manufactories and mills here in successfal operation; also a furnace and forge. The $\mathrm{v}$, is pleasantly situate on the bank of Otter cr., at the falls, the Rutland and Burlington R. R. passing through it $38 \mathrm{~m}$. from Burlington. There are some extensive manufactories and a large num. ber of fine dwellings, stores, and workshops in the village. A large quarry of superior white and variegated marble is situated near the $\mathrm{v}$, which is extensively wrought. It is the seat of the Middlebury College, founded in 1800, having (in 1S50) a president, 6 professors, 877 alumni, of whom 397 were in the ministry, and 63 students, with a library of 6,000 volumes. The college is built of stone, and is a fine structure. The "Middlebury Register" (whig) is issued weekly. East Middlebury is the name of a post-office in the E. part of the town. Pop. of the t. 3,517.

Middefedry river, Term.: rises in Haneock $t$, in a hilly region, and flowing W. and N., through Goshen and Middlebury, empties into Otter cr. It is $14 \mathrm{~m}$, in length, and affords several mill-seats.

Midplebusi, po o. Somerset county, N. Jer.: $23 \mathrm{~m}$. N. Trenton.

Midole Creek, p. o., Monroe county, Ohio: $101 \mathrm{~m}$. E. Columbus.

Mrodle Creek, t. and p. O., Union co., Penn.: $28 \mathrm{~m}$. N. IIarrisburg. Drained by Middle cr., which flows into the Susquehanna r. Surface hilly; soil fertile. It has some manufuctories, and several stores and workshops. Pop. of the $t$. about 575 .

MIDDLE Cresk, p. vo, Wake co, N. Car : on N. side of a cr. so called, $11 \mathrm{~m}$. S. Raleigh.

Middle Crefek Milis, p. 0., Boone co., $K y$.: $56 \mathrm{~m} . \mathrm{N}$, Frankfort.

Middde Fabtus, p. v., Scotland co., Mo.: on Middle Fabius cr., and on W. boundary of co., $127 \mathrm{~m}$. N. Jefferson City.

Middlefiexd, t. and p. v., Hampshire co., Mass. : $98 \mathrm{~m}$. W. Boston. Drained by several affluents of the W. branch of Westfield r. Surface elevated and uneven; soil well adapted to grazing. The Western $R$. R. passes through the v., $182 \mathrm{~m}$. from Boston. The t. contains several manufactories. Pop. 1,737.

Mindefieid, $t$. and p. v., Otsego co., $N . T_{0}: 68 \mathrm{~m} . \mathrm{W}$. Albany. Drained by Cherry Valley cr., and bounded on the W. by Otsego Lake and a branch of Susquehanna r., its outlet. Surface uneven, in parts hilly ; soil fertile. Waterpower is extensive. There are in the $t$. a large number of mills, and several manufactories and workshops. The $\mathrm{v}$. is in N. part, and contains several stores, mills, and workshops. Pop. of t. 8,131.

Mrddrefield, p. v., Geauga county, Ohio: 141 m. N. E。 Columbus.

Middlefizld Cextre, p. v., Otsego co., N.Y.: on E. side of Otsego Lake, $63 \mathrm{~m} . \mathrm{W}$. Albany ; contains several mills.

Middleford, p. o., Sussex co., De. : 36 m. S. by E. Dover. Mrddele ForK, p. o., Clinton co., Ind.: $46 \mathrm{~m}$. N. by W. Indianapolis.

MIDDLE ForE, p. 0., Randolph co., Virg.: 159 m. N. W. Richmond.

MidDle Fork, p. 0., Henderson co.,Tenna: 102 m.W. S.W. Nashville.

Mmple Fork, p. v., Macon co., Mfo.: between Middle Fork and East Chariton r., tributaries of the Missouri, $95 \mathrm{~m}$. N. by W. Jefferson City.

Mrdule Gravtille, p. vo, Washington co., $N$. $Y$. : on line of the Rutland and Washington $\mathrm{R}, \mathrm{R}, 61 \mathrm{~m} . \mathrm{N} . \mathrm{N}$. E. Troy, and $67 \mathrm{~m} . \mathrm{N}$. N. E. Albany; contains a cotton factory and some mills.

Mrdole Grove, p. o., Fulton $e_{0}, I l l . ;$ on the Monmouth post-road, $71 \mathrm{~m}$. N. W. Springfield. 
MidDLe Grote, p. o., Suratoga county, N. Y.: $25 \mathrm{~m}$. N. Albany.

Middle Grove, p. O., Monroe county, Mo. : 57 miles N. Jefferson City.

Mrodle HadDAM, p. v., Middlesex con, Conn.: on the Portland and East lfaddam post-ruad, near the E. bank of Connecticut r., $19 \mathrm{~m}$. S. by W. Hartford.

Midde Hope, p. o., Orange co., N. Y.: 87 m. S. by W. Albany.

Middle Island, p. v., Sufiolk eo., $N_{.} Y_{.}: 3 \mathrm{~m}$. N. Long Island R. R., 129 m. S. E. Albany.

Mudple island, Mich.: a small island in Lake Huron, about $1 \mathrm{~m}$. E. of the N. E. part of Alpena county.

MiddLe Island creek, Tirg.: rises by two branches in the E. part of Dodridge co., flows N.W. to Middlebourne v., and from thence S. W. to its confluence with the Ohio r., a short distance below Grape Islaud.

Middle Laxcaster, p. o., Butler county, Penn. : $174 \mathrm{~m}$. W. N. W. Harrisburg.

Mrdole Mulss, p. o., Chippewa eo., Wisc.: 175 m. N. W. Madison.

Mimdle Mountain, p. o., Botetourt co., Firg.: on the W. border of the county, $145 \mathrm{~m}$. W. Richmond.

MtDDle PoRT, p. v., and cap. Iroquois co, $I l l_{0}:$ on $\mathrm{S}$. side of the Iroquois r., $124 \mathrm{~m} . \mathrm{N}$. E. Springfield; contains the court-house, jail, and a few dwellings. The country round about is composed of fine meadow land.

Mmpleport, p. F., Niagara $c_{*}, N_{0} Y_{0}:$ on line of the Rochester, Loekport, and Niagara Falls P. R., $45 \mathrm{~m}$. W. Rochester, $253 \mathrm{~m}$. W. N. W. Albany. The Erie Canal also passes through it. The $\mathrm{v}$. contains several stores, warehouses, and mills.

Midddeport, p. v., Schuylkill co, Penn.: 51 m. N. E Harrisburg, and is chiefly inhabited by miners from the neighboring coal regions.

MIDDLe Ridge, p. o., Newton county, Ga.: 54 m. N. W. Nilledgeville.

Middule River, p. v., Franklin county, Ga. : 103 m. N. Milledgeville.

Mrddre River, p. o.g Allen county, Ohio: $83 \mathrm{~m} . \mathrm{N}$. W. Columbus.

Mroduesex county, Conn. Situate S. middle, and conLains $342 \mathrm{sq} . \mathrm{m}$. Druined by small affluents of the Connecticut, which flows S. through it, and small streams emptying into Long Islund Sound, its S. boundary. Surface generally uneven, but not rough; soil mostly good-on the Connecticut very fertile. It raises good crops of corn and potatoes, has some fine dairies, and shears considerable wool, but is better adapted for commeree and manufactures. The Connecticut is here broad and deep, and the county has an extensive coasting trade, while the streams afford fine water-power, which is all employed. Cotton and woolen goods, flour, paper, cordage, powder, earthen-ware, and liquors are leading manufactures. Ship-building is also extensively carried on. The celebrated quarries of Portland stone are on the banks of the Connecticut, and a variety of feldspar, used to glaze porcelain, is abundant in their vicinity. Farms 2,018; manuf. 303; dwell. 5,3S2, and pop.-wh. 80,397, fr. col. 253-total 30,680. Cupituls: Middletown and Haddam. Public Works: New Haven and New London R. R.: Middletown Branch R. R.

Midduesex county, Mrass. Situate N. E., and contains 923 sq. m. Drained by Merrimac, Charles, Mystic, Concord, and Nashua rivers, which supply an abundance of water-power unsurpassed by any in the Union. Surface uneven-in parts hilly. Soils various, with some excellent land. Corn and potatoes are the farming staples. The dairies are fine, but attention is directed mainly to furnishing the eities with fruits and vegetables. The absorbing interests are commerce and manufactures, the former confined to a few towns near Boston, the latter extending to every town in it, and embracing almost every imaginable article of utility or luxury. Cotton and woolen goods of all kinds, carpets, de laines, iron-ware, iron castings, and machinery of every description, are prominent tiianufactures. Farms 4.345; manuf. 1,0S9; dwell. 28,450), and porp. - wh. 160,694, fr. col. 689-total 161,388. Capitals: Cambridge, Concord, and Lowell. Pullic Works: Middlesex Canal Boston and Lowell R. R. ; Boston and Maine R. R.; Boston. and Woreester R. R. ; Eastern R. R.; Fitchlourg R. R.; Lowell and Lawrence R. R.; Nashua and Lowell R. R.; Salem and Lowell R. R.; Stony Brook R. Ru, ete.

Middlesex county, N. Jer. Situate N. E., and contains 284 sq. m. Drained by Raritan, Millstone, and Rahway rivers. Surface generally even; soils variou;-in purts sandy, and mostly under high cultivation. Corn, wheat, rye, buckwheat, oats and potatoes, for the most part, produce average crops, and much attention is pait to gardens and orchards, the products of which are superior and very valuable, Raritan Bay on the $\mathrm{E}$, is a good harbor; Raritan river is navigable through the co., and it is extensively engaged in ship-building and commeree. Its manufactures are very large and important, consisting of flour, leather, cotton goods, iron castings, cordage, glass, carriages, earthenware, canvas, paper, etc., etc. Farms 1,523; manuf. 196 dwell. 4,657, and pop.-wh. 27,255 , fr. col. 1,369, sl. 11total 28,635. Capital: New Brunswick. Public Works. Delaware and Raritan Canal; Camden and Amboy R. R.; New Jersey R. R., etc.

MiddLesex county, Firg. Situate E., and contains 106 sq. m. It lies between the Rappahannock on the $\mathrm{N}$. E., the Piankitank on the S. W., and Chesapeake Bay on the E., and has few streams of any size. Surface level, or slightly broken; soil of moderate fertility, but largely covered with valuable timber. Corn is the chief crop. Wheat is raised in parts. Wood and ship timber are exported. Farms 280 ; manuf. 14; dwell. 401, and pop.-wh. 1,903, fr. col. 149, sl. 2,342-total 4,394. Capital: Urbana.

Middlesex, to and p. v., Yates co., N. $Y$.: $155 \mathrm{~m}$. W. Albany. Bounded on the W. by Canandaigua Lake, and drained by West creek, which forms its outlet. Surface uneven-in parts hilly; soil fertile, well adapted to grains. There are some mills and manufactories in the $t$. The $v$. is situate on West creek. Pop. of t. 1,385.

Midplesex, v. and fur., Mercer co., Penn.: on the Beaver and Erie Canal, $195 \mathrm{~m}$. W. N. W. Harrisburg. There is a raw bituminous coal hot blast furnace here, with an annual capacity of 2,000 tons.

Mindlesex, t. and p. v., Washington co, Term. : immediately W. of Montpelier. Drained by a branch of Onion river, which latter bounds it on the S. Surface uneven; in parts mountainous; soil in general fertile. Along the banks of the river it is rocky. A mountain, called "Hogback," is situate near the N. W. boundary. There is some good timber here. The $\mathrm{v}$. is situate on Onion $\mathrm{r}$., and on the line of the Vermont Central R. R., 83 m. N. by W. Windsor, and $74 \mathrm{~m}$. S. E. Rouse's Point, It contains a number of mills, and several stores and workshops. Pop. of t. 1,365,

Midnlesex VIllage, p. V., Middlesex co., Mass, i at the junction of the Middlesex Canal, on the Merrimac $x_{0}, 27 \mathrm{~m}$. N. W. from Boston.

Mindle Three river, $I a$.: rises in Madison and Guthrie counties, and flows N. E. across Warren into Polk con, and empties into the Des Mojnes, near Dudley village.

Mrdoleton, to and p. v., Essex county, Mrass: $16 \mathrm{~m} . \mathrm{N}$. Boston. Drained by Ipswich $r$., which divides it, and sererai small affluents. Surface varied, with a well cultivated soil. The t. contains several stores and an extensive paper manufactory. The $\mathrm{v}$. is on the line of the Essex County R. R., $9 \mathrm{~m}$. from Salem, and contains several workshops. Pop. of t. 832.

Middeleton, to and p. v., Strafford co., N. Hamp.: $27 \mathrm{~m}$. N. E. Concord. Incorporated in 17T3. Surface, with the exception where Moose Mountain separates it from Brookfield, very level. There are no ponds or streams in the town. Pop. 476. 
Middleton, p. v., Carroll co., Miss. : 83 m. N. Jackson. Mrdpleton, t. and p. o., Dane co., Wisc.: immediately W. of Madison. Drained by Black Earth r., which flows into Wisconsin $r$. Surface rolling; soil fertile, and well adapted to fruit, Pop. of t. 304.

MLDDLETOWN, to, p. eity, port of entry, and one of the caps. Middlesex eo, Conn.: 14 m. S. E. Hartford. Drained by several streams flowing into Connecticut $r$, which here bounds it on the $\mathbb{E}$. Surface generally undulating; soil of average fertility. There are fine meadows in this $t$., and waterpower is furnished by several streams, on which are seated extensive manufactures. A range of hills crosses the Connecticut about $2 \mathrm{~m}$. below the city, compressing the channel into a strait only 35 rods wide, and rising trom 400 to 600 feet above the river. Here occurs an inexhaustible deposit of feldspar, used in the manufacture of porcelain. That portion of the t. formerly known as Upper Middletown, has been recently erected into a separate t. under the name of Cromwell. There are silver and lead mines in the t. the silver ore yielding about 58 per cent. of metal, and the lead $\$ 4$ per cent. The works are extensive and very valuable.

The city is situate on ground gently rising from the river, here from 80 to 100 rods wide. Lat. $41^{\circ} 33^{\prime} 08^{\prime \prime} \mathrm{N}$., and long. $72^{\circ} 39^{\prime} \mathrm{W}$. The streets are laid out at right angles with each other, the main street running parallel with the water, and on this are the principal stores, hotels, the Court House, Custom House, and other buildings. The more elevated portions of the city, west of the main street, are adorned with many elegant mansions. Several of the public edifices are of beautiful construction. The buildings of Wesleyan University, situate here, are also handsome structures.

Middletown is a busy commercial town and a port of entry. The wharves are commodious, and the river sufficiently deep to admit of any vessels that ean pass the bar at its mouth. Foreign shipping seldom arrives here, but it has a comparatively extensive coasting trade; and the shipping owned in the district in 1850 , amounted to 12,129 tons, chiefly employed in coasting, and of which 1,940 tons were navigated by steam. The shipping built in the district in the year above named amounted to 1,831 tons. The New York and Ifartford steamboats call here daily, and there is a branch railroad connecting it with Hartford. Middletown will also be intersected by the New York and Boston direct line of railroad now being constructed. The Wesleyan University was founded in 1831 , and has a president and 7 professors, and in 1850 its alumni numbered 402 and its students 116. The library contains about 12,000 volumes. The institution has also a valuable philosophical apparatus. There are also several academies in the city and numerous public schools. The newspapers published here are, the "Sentinel" (dem.), the "Constitution" (whig), and the "Weekly News." There are 8 commercial banks in the city and a savings institution. Pop. of t. in $1820,6,479$; in 1530 , 6,592 ; in $1840,7,010$; and in $1850,8,791$, about one-half residing in the city.

Middetuwn, p. vo, Livingston co., Mfich.: 31 m. S. E. Lansing.

Mindletown, p. v., New Castle co, Del.: near Appoquinimink cr., $23 \mathrm{~m}$. N. $\frac{1}{2} \mathrm{~W}$. Dover.

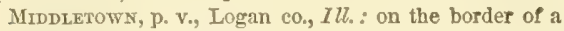
prairie, $20 \mathrm{~m}$. N. E. Springfleld.

Mrndetown, p. v., Henry co., Ind.: 39 m. N. E. by E. Indianapolis.

Midnlexowy, p. v., Jefferson county, $K_{y_{*}}: 36 \mathrm{~m}$. W. Frankfort, and 12 m. E. Louisville.

Mrddetewn, p. v., Frederick co., $\boldsymbol{M} d .:$ on tho E. side of Catoctin cr., on the Hagerstown turnpike, $9 \mathrm{~m}$. W. of Frederick City, and $88 \mathrm{~m} . \mathrm{N}$. W. of Annapolis. Middle cr, joins Catoctin $\mathbf{r}$. N. of the rillage.

Middletowa, p. o, Montgomery co, Mo.: 56 m. N. E. Jefferson City.

Middietown, t. and $\mathrm{p}_{0} \mathrm{v}_{*}$, Monmouth co., N. Jer.: $81 \mathrm{~m}$.
N. E. Trenton. Bounded on the N. by Raritan and Sandy Hook bays, on the $\mathbf{E}$. by the Atlantic Ocean, on the $\mathrm{S}$. by Navesink and Swimming rivers, and on the W. by branches of the latter. Drained by branches of Navesink and \$wimming rivers, and a number of small streams flowing into the bays, affording in all excellent water-power. Surface varied -in the centre and E. part hilly or mountainous, the remainder even; soil very fertile and productive. In the $\mathrm{N}$. part of the to, adjoining the ocean, are the Highlands of $\mathrm{Na}$ vesink, in height some 350 to 400 feet, on which are 2 lights, 1 revolving and 1 flxed. Lat, $40^{\circ} 23^{\prime} 40^{\prime \prime}$ and long. $73 \circ 59^{\prime} 42^{\prime \prime}$ Sandy Hook, a sandy beach, extends N. from Shrewsbury inlet, and $\mathrm{S}$. point of the Highlands, and is from one-half to a mile in width ; and on the $\mathrm{N}$. part there is a flxed light and 2 beacons, the light 90 feet above the sea. Lat. $400^{\circ} 27^{\prime} 37^{\prime \prime}$, long. $74^{\circ} 00^{\prime} 42^{\prime \prime}$. There are a number of villages in the $t$. The $\mathrm{v}$. of Middletown is in the centre, in the hilly part, and contains several stores and dwellings, and a number of workshops. There t. has several mills and manufactories, and a number of distilleries. The "Democratic Banner" (dem.) is the name of a weekly issue. Pop. of t. 3,245.

Middetown, p. v., Des Moines co., Ia.: 63 m. S. by E. Iowa City.

Middletown, p. $\nabla_{*}$, Orange co., $N . Y_{*}:$ on line of the Erie R. R., 77 m. N. W. New York, 89 m. S. S. W. Albany. This is a beautiful and flourishing $\mathrm{v}$. , and contains several workshops, etc.

Middiléwe, p. v., Hyde county, N. Car.: on Pamlico Sound, $151 \mathrm{~m}$. E. by S. Raleigh.

Mrdpletows, p. v., Butler co., Ohio: on the E. side of Miami r., on the Miami Canal, $41 \mathrm{~m}$. N. Cincinnati, and 71 m. W. S. W. Columbus. A bridge across the river connects the v. with the Cincinnati, Hamilton, and Dayton R. R., 28 m. s. by W. Dayton. It contains several stores and manufactories, and 1,092 inhabitants.

Midolftowr, p. b., Dauphin co, Penn : on the E. bank of the Susquehanna r., above the confluence of Swatara cr., $10 \mathrm{~m}$. S. E. by E. Harrisburg. The Middletown furnaces at this place have an annual capacity of 2,150 tons. The Harrisburg and Lancaster $R$. R. passes through the v., and the Union Canal here enters the Susquehanna river.

Mrodletown, to and p. v., Rutland co., Term.: between two mountains, $10 \mathrm{~m}$. S. by W. Rutland. Drained by Poultney $r$, a branch of Carleton $r$. Surface uneven, in parts mountainous; soil best adapted to grazing. It has several saw-mills, etc. The $\mathrm{v}$. is pleasantly situate in the valley of the mountains, and has a marble manufactory. Population of t. 875 .

Middletows, p. ₹., Frederick co., Virg.: on Meadow Pun, a fork of the Shenandoah r., $131 \mathrm{~m} . \mathrm{N}$. N. W. Richmond. The $\mathbf{v}$. has excellent water-power, and contains several mills and workshops, together with a wagon manufactory. Pop. about 450 .

Middletown Centre, p. o., Delaware co., N. $Y_{*}: 57 \mathrm{~m}$. 8. W. Albany.

Mmoxetows Ponst, p. v, and port of delivery, Monmouth co., N. Jer. : on E. bank of Middletown cr., $29 \mathrm{~m}$. N. E. Trenton. The v, is pleasantly situate on an elevation of some 60 feet from the water. It is a flourishing $\mathbf{v}$., with some fine stores and dwellings, and considerable trade. The Farmers' and Mechanics' Bank is situate here. Capital $\$ 50,000$

Middle Vulage, p. o. Queens co., N. Y.: $129 \mathrm{~m}$. S. Albany.

Mmdlevilie, p. Y., Barry co., Mich.: on W. fork of Grand Haven r., $49 \mathrm{~m}$. W. Lansing.

Midpleville, p. o., Sussex county, N. Jer.: $61 \mathrm{~m}$. N. Trenton.

Midplevilie, p. v., Herkimer co., N. $Y .:$ on West Can. ada cr., $71 \mathrm{~m} . \mathrm{N}$. W. Albany. It contains several stores, mills, and manufictories, among the latter is an extensive chair and cabinet factory.

Midoleway, p. V., Jefferson co., Firg.: 127 m. N. by W* 
Richmond. The Winchester and Potomac R. R. passes near the village.

Mroland county, HFich. Situate E. at head of Saginaw Bay, and contains $722 \mathrm{sq} . \mathrm{m}$. Drained by Tittibawassee $\mathrm{r}$. and its branches, Salt, Pine, and Chippewa rivers. Surface undulating; soil well adapted to grass and grain. In the N. and S. E. are dense forests of Norway and white pine timber, which are very valuable, and the county contains abundance of gypsum and excellent salt springs. It is thinly settled yet. Farms 4 ; manuf. 0 ; dwell. 10, and pop. -wh. 64, fr. col. 1-total 65. Capital: Midland.

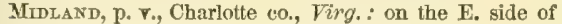
Staunton r., $78 \mathrm{~m}$. 8. W. by W. Richmond.

Minvilue, p. r., Burke co., Ga.: on the N. side Ogeechee r., $75 \mathrm{~m}$. E. S. E. Milledgeville, on the line of the Central R. R., $94 \mathrm{~m}$. from Savannah, and $91 \mathrm{~m}$. from Macon.

MmWay, p. o., Giles eounty, Virg.: $174 \mathrm{~m}$. W. by S. Richmond.

Mroway, p. v., Barbour co., Ala. : on a fork of Pea $\Gamma_{.}$ 46 m. E. S. E. Montgomery.

Mroway, p. o., Fulton county, Ill.: $5 s$ miles N. W. Springfield.

Mroway, p. V., Spencer co., Ind.: on the E. side of Little Pigeon cr., $133 \mathrm{~m}$. S. S. W. Indianapolis.

Mmwar, p. v., Woodford con, Ky, on the line of the

Lexington and Frankfort R. R., 15 m. E. Frankfort.

MrDway, p. o., Madison co., Mizs. : $23 \mathrm{~m}$. N. Jackson.

Mroway, p. V., Cooper co., Mo.: on the Bofnville and

Jefferson City post-road, $26 \mathrm{~m}$. N. W. Jefferson City.

Midwar, p. v., Davidson co., N. Car.: $85 \mathrm{~m}$. W. by N. Raleigh.

MIDWAy, p. v., Barnwell dist., S. Car.: on the line of the South Carolina R. R., $72 \mathrm{~m}$. from Charleston., $54 \mathrm{~m}$. S. Columbia.

Mrdway, p. o., Newton county, Tex. : 139 m. E. by N. Austin City.

Midway, p. o., Hot Springs county, Ark. : 47 m. S. W.

Little Rock.

Midwax, p. V., Monroe co., Tenn.: 131 m. E. S. E. Nashville.

Midwax Junction, p. v., Prince Edward co., Firg.: on the Prince Edward and Marysville post-road, $65 \mathrm{~m}, \mathrm{~S} . \mathrm{W}$. Richmond.

Mrer, p. o., Grant co, Ind.: $58 \mathrm{~m}$. N. by E. Indianapolis. Mrer, p. v., Wabash co., Ill.: 132 m. S. E. Springfield.

Mres, p. o., Madison county, Missouri: $125 \mathrm{~m}$. S. E Jefferson City.

Mrrfiry county, Penn. Situate centrally, and contains $223 \mathrm{sq} . \mathrm{m}$. Drained by the Juniata and its branches. Surface uneven, and much broken. Soil, except in the most rugged parts, very rich. Wheat, rye, corn, and oats produce fine crops, and the shearings of wool are heavy, and dairies large. It has excellent mill streams, and manufactures woolen goods extensively. Iron ore is abundant, and the manufacture of iron is the leading interest of the county. Farms 787; manuf. 102; dwell. 2,591, and pop.-wh 14,570, fr. col. 410-total 14,980. Capital: Lewistown Public Works: Pennsylvania Canal; Pennsylvania R. R.

MTrFut, t. and p. o., Ashland con, Ohio: 62 m. N. N. E. Columbus. Drained in the W. by Black Fork of Wat honding r. ; soil fertile and well cultivated. Pop. 891.

MTFELI, $t$, and p. v., Iowa co., Wisc.: $52 \mathrm{~m}$. W. by $\mathrm{S}$. Madison. Drained by branches of Picannica $\mathbf{r}$. Surface various; soil fertile, with good woodlands. The $\mathrm{v}$. is situate in the S. part of the town, and will be intersected by the Milwaukie and Mississippi Railroad as projected. Population of $t .640$.

Mrrfitis, p. v., Crawford co., Ind.: $102 \mathrm{~m}$. S. by W. Indianapolis.

MrFrtrs, p. v., Henderson co., Tenn.: 107 m. W. S. W. Nashrille.

Mrfplingurg, p. bo, Union co, Penn.: on the S. side of Buffulo cr. $49 \mathrm{~m}$. N. by W. Harrisburg. Incorporated in
1827; has several manufactories, a number of stores and workshops, 145 dwellings, and 783 inhabitants.

Mifflintown, p. b., and cap. Juniata co., Penn.: on the $\mathrm{N}$. bank of the Juniata $\mathrm{r}, 31 \mathrm{~m} . \mathrm{N}$. W. Harrisburg. The Pennsylvania Canal passes through the borough. It has a number of dwellings, several stores, and workshops. The "Juniata Register," and "Juniata Sentinel" (whig), are weekly issues. Pop. 485.

Mmflimville, p. v., Columbia co., Penn.: on the $\mathbf{S}$ side of the Susquebanna r., $57 \mathrm{~m}$. N. N. E. Flarrisburg.

Mridx county, Texo. Situate E. centrally, and contains 1,243 sq. m. Drained by Little r., a branch of the Brazos, its E. boundary, and its branches Indian, Elm, and Brushy creeks, and San Gabriel r. Surface undulating or level, a large part open prairie, but with a plenty of timber in every part. Soil mostly very fertile, producing great crops of cotton, corn, Irish and sweet potatoes, and admirably adapted to grain-growing and grazing. Indigo grows spontaneously in great abundance. It is rich in minerals, and has $\mathrm{val}$ uable stone quarries, millstone grit, and numerous salt springs. Farms 152 ; manuf. 1; dwell. 414, and pop. $\rightarrow$ wh 2,469, fr. col. 2, sl. 436-total 2,908. Capital: Cameron.

Mrlav, p. Y., and cap. Sabine co., Tex.: on the Old Military Road, 247 m. N. E. Austin City.

MrLan, p. Y., Ripley county, Ind.: 65 miles S. F Indianapolis.

Mrlan, t. and p. O., Monroe co, Mich.: $47 \mathrm{~m}$. S. E. Lansing. Drained by $\mathbf{N}$. branch of Macon $\mathbf{r}$. Surface undulating; soil fertile, adapted to grain. It contains a number of mills and manufactories, and several workshops. Pop. of $t .642$.

Mrlan, p. V., and cap. Sullivan co., Mro.: on the E. fork of Locust cr., $124 \mathrm{~m}$. N. N. W. Jefferson City. The U. S. Land Office for the Milan district is here.

Mruan, to and p. v., Cons co., N. Hamp.: 91 m. N. $\frac{1}{2} \mathrm{E}_{\text {. }}$ Coneord. Drained by the Androseoggin r. and S. branch of Upper Ammonoosuc r. Surface uneven; in N. E. and S. W. mountainous; soil adapted to grazing. Here are some mills and manufactories. Chartered in 17\%1. The $\mathrm{v}$. is situate centrally on the line of the Atlantic and St. Lawrence R. R., $104 \mathrm{~m}$. N. W. Portland (Me.), $19 \mathrm{~m}$. E. Northumberland. It contains several stores and workshops. Population of $t .498$

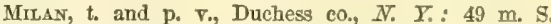
Albany. Drained by several creeks flowing into the Hudson r. Surface uneven, and parts hilly; soil clay loam. It contains the $v_{\text {. }}$ situate centrally, and has some stores, several mills and manufactories, and a number of workshops. Pop, of t. 1,764.

Mran, t. and p. v., Erie county, Ohio: 93 m. N. by E. Columbus. Drained by Huron $r$. and its branches, Surface hilly; soil fertile and productive. The $\mathrm{v}$. on the S. bank of the river is pleasantly located on a bluff some 70 feet above the water, on the site of an old Indian town. It is connected with Huron harbor $8 \mathrm{~m}$. by a ship canal, by which vessels pass up to the village. It is a flourishing village, and contains churches, an academy, a number of stores, several mills, and various mechanic shops. The t: has in it a number of schools. The "Milan Tribune" (whig) is issued weekly. Pop, of t. 2,697 .

Mruar, p. o., Bradford county, Penn.: 118 m. N. Harrisburg.

Milberg, p. o., Greenville dist., S. Car.: 98 m. N. W. Columbia.

Milesburg, p. v., Centre co., Penn.: in an extensire coal region, on S. side of Bald Eagle cr., 67 m. N.W. Harrisburg. The country round about is mountainous. There are in the village a cold blast furnace of 1,100 tons annual capacity, 2 charcoal forges, producing 450 tons blooms each, and 2 rolling mills, producing 600 tons each annually.

Mruestown, p.v., St. Mary's co., Mrd.: E. of Wicomico r., and $41 \mathrm{~m}$. S. by W. Annapolis.

Mnestowr, p. v., Philadelphia county, Penn.: on an 
eìcration, $\$ 9$ miles $\mathrm{E}$. by $\mathrm{S}$. Harrisburg, and 9 miles $\mathrm{N}$. Philadelphia.

Milford, t. and p. v., New Haven co., Conn.: $43 \mathrm{~m}$, S. S. W. Ifartford. Bounded on the S. by Long Island Sound, and in the W. by the Housatonic r. Drained by Wepawaug river and several small creeks flowing into the Sound. Surface undulating; soil fertile; and there is a quarry of beautiful serpentine marble in the town. It has a fine harbor for vessels of from 150 to 200 tons burden. Many of the inhabitants are engaged in the oyster and clam trade and in coasting. The Washington bridge crosses the Housatonic r. near Milford Point to Stratford, at which place there is a draw to admit vessels The $\mathrm{v}$. is very pleasantly situate at the mouth of Weparvaug $r$, at the head of the harbor, on line of the New York and New Haren R. R. $10 \mathrm{~m}$. from New Haven. There are in the t. severa stores and mills, together with a number of manufactories. Pop. of t. 2,465 .

MILFORD, to and p. v., Jefferson co., Wisc.: $27 \mathrm{~m} . \mathrm{E}$ Madison. Drained by Beaver dam branch of Pock river. Surface varied; soil fertile, with good timber lands. The v. is situate on Rock $\mathbf{r}_{\text {., }}$ and contains several stores and dwellings. Pop. of t. 728

Mirford, p. v. and hund., Kent co., Del. : on N. bank of Mispillion cr., $16 \mathrm{~m}$. $\mathrm{s}$. Dover. There are in the hund. numerous stores, several mills, manufactories, and workshops. Area, 47,500 sq. m. The "Milford Beacon" is issued weekly. Pop. 2,529.

MrLford, p. v., Hunterdon co, N. Jer.: on the E. bank of the Delaware r., $29 \mathrm{~m}$. N.W. Trenton.

MrLford, p. v., Iroquois co, $I U l,:$ on the N. side of Sugar creek, $113 \mathrm{~m}$. N. E. Springfield. The $\mathrm{v}^{\text {is }}$ is surrounded by excellent prairie land.

MrLeord, p. v., Kosciusko county, Ind. : $115 \mathrm{~m}$. N Indianapolis. There is a railroad in course of coustruction from Peru to Goshen, which will pass through the village.

MrLforD, t. and p. v., Penobseot co, MFe: $76 \mathrm{~m}$. N. E. Augusia, on the E. side of the Penobscot r., by which and the Sunkhaze $r$. the $t$. is drained. Orono lies on the opposite side of the river. Pop. 687 .

Milford, to and p. v., Worcester co., MIass. : $29 \mathrm{~m}, \mathrm{~S}$. W. Boston. Drained by branches of Pawtucket and Charles rivers, which afford excellent hydraulic power. Surface pleasantly diversified; soil fertile and well eultivated. There are a number of mills and several manufactories of varivus kinds in successful operation here. The $v$. is very pleasantly siluate on the borders of a pond in centre of t. The Milford Branch R. P. connects the $v$, with Farmington, 13 $\mathrm{m}$. distant, where it forms a junction with the Boston and Worcester $\mathrm{P}_{\mathrm{w}} \mathrm{P}$. There are a number of fine dwellings, some stores, and several workshops in the rillage. The "Practical Christian" is the name of a semi-monthly issue Pop. of the t. 4,819.

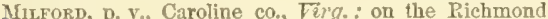
Fredericksburg, and Potomac R. R., $35 \mathrm{~m}$. from Richmond.

Mrsford, t. and p. v., Oakland co., Mich.: $49 \mathrm{~m}$. E. by $\mathrm{s}$. Lansing. Drained by branches of Huron $r$. Surfacé undulating; soil very fertile, and produces grain. The village is on a branch of Huron r., and has several neat dwellings. Pop. of t. 1,470.

Mruford, p. V., Bracken county, $\bar{k} y$. : on a branch of Licking r. 55 m. N. E. by E. Frankfort.

MrLFord, t. and p. v., Hillsborough co., N. Hamp.: $29 \mathrm{~m}$. S. $\frac{1}{2}$ E. Concord. Souhegan river divides the $t_{2}$, running through the $\mathrm{N}$. part, by which and its branches it is drained, and produces excellent water-power. Surface undulating: soil rich. The $\mathrm{v}$. is on the Wilton $\mathrm{R} . \mathrm{R}_{\text {. }}, 4 \mathrm{~m}$. from Wilton. The t. has considerable manufactures. Pop. of t. 2.159.

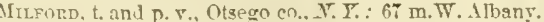
Drained by Susquehanna r. and its branches. Surace very 456 uneren-in parts much broken; soil strong rich loam, and very fertile. The $\mathrm{v}$. is pleasantly situate on a level plain near the Susquehanna r., and contains several stures, mills, and tamneries. Pop. of t. 2,227.

MrLFord, p. v., Clermont co., Ohio: on the E. sicle of the Little Miami r., $81 \mathrm{~m}$. S. W. Columbus, and connected by a bridge with the station on the Little Miami R. R., on the W. side of the river, $14 \mathrm{~m}$. from Cincinnati. Population about 600

Milford, t., p. v., and cap. Pike county, Penn.: $129 \mathrm{~m}$ N. E. Harrisburg. Drained by several small lakes, empty. ing into the Delaware r., which bounds the town on the S. E. Surface mountainous and much broken; soil inferior, exeept along the banks of the river, where it is good. The village, on the $W$. bank of the Delaware, is very pleasantly situated on an elevation, at which point a substantial bridge affords communication with the opposite shore. Pop. 858

MiLford, p. v., Greenville district, S. Car. $\therefore$ on a fork of Congaree r., $94 \mathrm{~m}, \mathrm{~N} . \mathrm{W}$. Columbia.

Milford Centre, p. v., Union eo., Ohio: on S. side of Big Darby cr., $31 \mathrm{~m} . \mathrm{N}$. W. by W. Columbus. Pop. 211. Mrlfordton, p. o., Knox co., Ohio: $28 \mathrm{~m}$. N. E. by N. Columbus.

Militafex Bounty Tract, $M l$ : the region generally denominated the Military Bounty Tract, was surveyed during the years 1815 and 1816 , and the greater part subsequently appropriated in bounties to the soldiers of the regular army, who served in the late war between the United States and Great Britain. It is situated between the rivers Mississippi and Illinois, and extends from their junction due north by a meridian line, denominated the fourth principal meridian, 169 miles, presenting an irregular, curvilinear triangle, the acute angle of which is at the junction of these two rivers. From this point the two rivers diverge, so as to make a distance of 90 miles between the extreme points of the northern boundary. Half way between the extremes the width is 64 miles. The base line rumning due east and west, and commencing just above Quincy, on the Mississippi, and terminating at the Illinois, a little below Beardstown, intersects the fourth prineipal meridian at right angles above the junction of the Mississippi and Hlinois rivers. The whole tract, aecording to the public surveys, contains 207 entire townships, of six miles square, and 61 fractional townships-altogether $5,860,000$ acres, of which $3,500,000$ have been appropriated in military bounties. This tract of country lies between $35^{\circ} 51^{\prime}$ and $41^{\circ} 40^{\prime}$ of north latitude, and $13^{\circ}$ west longitude from Washington City, and bounded on the south-west for 255 miles by the Mississippi river, and for about the same distance on the south-east by the Illinois. Thus do these two great rivers in their diverging course, with Rock river approximating from the north, form a spacious peninsula, furnishing a border to the bounty lands by a sheet of navigable waters for steamboats more than 500 miles in extent, leaving no part of the tract more than 45 miles, and the greater part not exceeding 20 miles from steamboat navigation. The water communication now completed between the Mississippi and the lakes, by means of the Illinois and Chicago Canal, greatly increases the value of the bounty lands, by affording a choice of markets for their products, either at Chicago, Detroit, Buffalo, New Tork, Montreal, or Quebee, by way of the Illinois Canal and the lakes, or by the natural channels of the rivers south, at St. Louis and Nery Orieans. In the interior of the tract, traversing it in various directions, are several rivers and creeks of less consequence, in a commercial point of view, but nevertheless of great utility to the settlements in their ricinity, of these, Spoon, Henderson, Edwards, and Pope's rivers, and Crooked, Kickapoo or Red Bud, Copperas, Otter, $\mathbf{M} \cdot K e e ' s, \mathbf{M}^{*}{ }^{*}$ raney's, IIadley's Mill, and Bear creeks, are the most considerable. About two-thirds of this tract is timbered, and the other third is mostly prairie of good quality. It has become considerably settled, and yearly 
furnishes considerable amounts of products for export. Corn, wheat, barley, hemp, and potatoes, are the principal productions.-C'urtiss' Western Portraiture, 1 s52.

Mrditary Grote, p. o., M.Dowell co., N. Car.: 188 m.W. Raleigh.

Mildtary Ixstrtute, p. O., Franklin co., Ky. : at Drennon Springs, $1 \frac{1}{2} \mathrm{~m}$. W. Kentucky r., $20 \mathrm{~m}$. N. Frankfort. The annual session of this college commences the second Monday in September, and the second term of the session on the first Monday in February of each year. Its course of studies embraces the scientific course of the United States Military Academy at West Point, and thorough instruction in history, internalional and constitutional Law, the Greek and Latin languages, and civil engineering. Great facilities are also offered for the study of the modern European languages. A flourishing law school is connected with the institute, and affords great advantages to the students. The military feature introduced is not merely for the purpose of diffusing military knowledge, but as the means of exercising complete control, and of securing to the student the personal advantages of a uniform and economical distribution of time, habits of punctuality, health, physical development, and a consequent increase of mental vigor. The location of the Institute is very healthy, and is removed from the allurements, the vices, and the dissipations usually incident to college life. Situated on the Kentucky river, it may be reached by steamboat from Louisville or Cincinnati, or by railroad from Louisville to Eminence, on the Louisville and Frankfort road, and thence by stage to Drennon, a distance of 12 miles. Institute charges for tuition, boarding, lodging, fuel, lights, washing, servants' attendance, and use of furniture and arms, $\$ 30$ per term. Surgeon's fee, $\$ 5$ per session. Charges in the law school for the above and use of textbonks, $\$ 160$ per term; each term commencing and ending with the semi-annual session of the Institute.

Militarix Road, p. 0., Jefferson co., N. Y.: 151 m. N. W. Albany.

Military Sprirgs, p. o., Fayette county, Ala.: $138 \mathrm{~m}$. N. W. Montgomery.

Millan, p. o., Pike co., Miss. : $73 \mathrm{~m}$. S. Jackson.

MILLAIR county, Utah Ter. Situate S. W., and contains about $20,000 \mathrm{sg} . \mathrm{m}$. The $\mathrm{S}$. line is the parallel of $38030^{\prime}$; the E. the meridian of $34^{\circ} 40^{\prime}$ W. from Washington, and the $\mathrm{W}$. the California State line. It is about $60 \mathrm{~m}$. wide, and embraces a great variety of surface, soil, and climate, of which little is known definitely. In the $\mathrm{W}$. are several large lakes and rivers, of which Walker $r$. and lake, and Carson $\mathrm{r}$. and lake are the largest, and in the E. is Nicollet r., flowing $N$. into Nicollet lake. Several mountain chains intersect it, and the surface is mostly elevated. On the E. border is a high ridge, on which, at an elevation of 4,790 feet above sea level, and in lat. $33^{\circ} 5 \mathrm{~s}^{\prime} 40^{\prime \prime}$, is Fillmore City, the cap. of the co. and territory. The co. was a part of San Pete in 1850 .

Millard, p. o., Walworth county, Wisc.: 53 m. S. E. Madison.

Mrlqardstille, p. v., Susquehanna co., Penn.: $127 \mathrm{~m}$. N. N. E. Harrisburg.

Milr Apr, p. 0., Fulton county, Ind.: 53 miles $\mathrm{N}$. Indianapolis.

Mrribacr, p. o., Lenanon county, Penn. : 23 m. E. N. E. Harrisburg.

Mill Baxov, p. V., Mississippi co., Artc, : 133 m. N. E. Little Rock.

Mur Bend, p. o.g Hawkins co., Tenn.: $216 \mathrm{~m}$. W. by N. Nashrille.

Millborodgir Sprixgs, p. v., Bath county, Firg.: $123 \mathrm{~m}$. TV. N. W. Richmond, on the line of the Virginia Central Pailroad.

Mrllbridge, t. and p. o., Washington co., Me.: $95 \mathrm{~m}$. E. hy N. Augusta. Drained by Naragnagus river, which divides it. It enntains Naragnagtis bay, which sets up from the sea, and the p. o. so called is on the E. side of the r. in N. part. Coasting trade and fishery is the chief occupa.tion of the inhabitants. Pop. of t. 1,170.

Mrll Brook, p. o., Litchfleld co., Conn. : 26 m. W. N. W. Hartiord.

Mill Brook, p. o., Warren co., N. Jer. : 47 m. N. by W. Trenton.

Mill Brook, p. v., Wayne county, Ohio: $71 \mathrm{~m}$. N. E. Columbus. It contains several stores and dwellings, and some mechanic shops.

Mrul Brook, p. o., Warren co, N. Y. Y.: $68 \mathrm{~m} . \mathrm{N}$. Albany.

Millburn, p. v., Ballard county, $\pi y_{.}: 246$ m. W. S. W. Frankfort. The contemplated line of the Mobile and Ohio R. R. passes through this village.

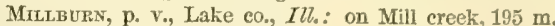
N. N. W. Springfield.

Millibury, t. and p. v., Woreester county, Mass.: $37 \mathrm{~m}$, W. S. W. Boston. The to is divided by the Blackstone r., by which and its branches it is drained, affording valuable water-power. Surface uneven, in parts hilly; soil of gnod quality and very productive. There are extensive manufactories and a large number of mills and workshops in the town. Incorporated in 1813. The Blackstone Camal passes through the town. The village is on the line of the Providence and Worcester R. R., $6 \mathrm{~m}$. S. Worcester, and contains several churches, an academy, some fine dwellings and stores, a number of mills, and several workshops. The Millbury Bank is situate in the village. Population of the town 3,031 .

Mru, Creek, p. o., Pulaski county, IUJ. 173 m. S. by E. Springfield.

Mrll Creek, p. v., Ripley co., Mo.: on the W. side of Current river, at the confluence of Mill cr., $153 \mathrm{~m}$. S. S. E. Jefferson City.

Mrlu Creer, p. o., Person con, N. Car.: $59 \mathrm{~m} . \mathrm{N} . \mathrm{N}$. W. Raleigh.

Mill CreeK, p. o., Carroll county, $K y_{.}: 35 \mathrm{~m}$. N. by W. Frankfort.

Mul Cresk, p. o., Kent county, Mich. : 53 m. W. by N. Lansing.

Mrlu Creek, p. v., Huntingdon co., Penn.: N. side of the Juniata r., and on the line of the Eastern Division of the Pennsylvania R. R., $92 \mathrm{~m}$. W. Harrisburg. The country round about is mountainous and abounds in iron. Thero is in the $\mathrm{v}$. a hot-blast furnace of 1,000 tons, and a cold-blast furnace of 1,400 tons annual capacity.

Mili Creek, fur., Venango co, Penn. The furnace located here has an annual capacity of 1,000 tons.

Mill Creek, p. o., Fulton co., Ohio: 132 m. N. W. by N. Columbus.

Mill Crfes, hund., New Castle co., Del.: between Red and White Clay creeks, $37 \mathrm{~m}$. N. by W. Dover. Area 27,760 square miles. Pop. 3,522.

Mrll Creek, p. o., Berkeley co., Firg.: 136 m. N. by W. Richmond.

Mill CreeE, p. o., Sabine par., La.: 147 m. N. W. Baton Rouge.

Mill Creek, Ind. : rises in S. W. part of Henry co., flows S. through N. W. part of Morgan and S. E. part of Putnam into Owen, where it takes a sudden bond, and returning into Putnam in a N. W. direction, flows into Eel $r$., a fork of White river.

Milldale, p. v., Warren co., Miss. : 4 m. E. of Tazoo r., and $36 \mathrm{~m}$. W. by N. Jackson.

Mrludale, p. O., Deflance county, Ohio: $12 \mathrm{~S}$ m. N. W. Columbus.

Milldale, p. 0., Warren county, Firg.: 107 m. N. N. W. Richmond.

Mill Dax, p. o., Madison county, .250: 129 m. S. E Jefferson City.

Mruledgrille, p. city, and cap. Baldwin co., $G \alpha .:$ and eapital of the State: at the head of navigation of Deonee $r$., and at the confluence of Fishing er., in lat. $33^{\circ} \tau^{\prime} 20^{\prime \prime} \mathrm{N}$., and long. $88^{\circ} 19^{\prime} 45^{\prime \prime}$ W. -612 m. S. W. Washington. Tho 
city is built on an elevated and somewhat uneven site in the midst of a rich and populous cotton-growing region, and is the centre of a considerable commerce. It is laid out regularly, having ten streets running parallel with the river, and ten others intersecting them at right angles, all of which are 100 feet wide, except Washington Street, which is 120 feet. There are three public squares, named respectively, StateHouse Square, Governor's Square, and Penitentiary Square, the sides of each of which are 450 feet long. State-House Square is near the centre of the city, and on elerated ground, and on this is built the State House, a fine Gothic edifice, surmounted by a cupola, and containing in its halls portraits of Gen. Oglethorpe and other eminent men of olden times. The building cost about $\$ 120,000$. On this square are also the State arsenal and a powder magazine. Other prominent buildings are the penitentiary and the governor's house, which give names to two of the squares, a market-house, 4 or 5 churches, etc. Five perindicals are published here; the "Federal Union" (whig), the "Southern Presbyterian" (relig.), and the "Southern Recorder," all weekly issues; and the "Star of Truth" (literary), and the "Gem" (literary), monthly issues. The Milledgeville and Gordon R. R. extends hence $17 \mathrm{~m}$. to a connection with the Georgia Central R. R. at Gordon, $170 \mathrm{~m}$, from Savannah, and 11 from Macon. A railroad is also completed to Eatonton. The Oconee $r$. is bere spanned by a toll-bridge. Milledgeville was founded in 1503-in 1810 it had 1,256 inhabitants; in 1820, 1,411; in $1830,1,599$; in $1840,2,095 ;$ and in 1850 , about 3,200 . In the v. of Medway, near Milledgeville, is located Oglethorpe College, founded 1836 -in 1850 it had a president, 6 professors, 83 alumni, and $\$ 5$ students, and its library contaized 4,500 volumes.

Mrlledgetille, p. $\nabla$. , Carroll co., Ill.: on the W. side of Elkhorn cr., $152 \mathrm{~m}$. N. Springfield.

Mrlledgeville, p. o., Lincoln co., $K y .: 47 \mathrm{~m}$. S. by E. Frankfort.

Milledgeville, p. v., Montgomery co., N. Car.: $73 \mathrm{~m}$. W. S. W. Raleigh,

MILLEN, sta., Burke co., Ga.: on the line of the Central (Georgia) R. R., at which point the Augusta and Waynesboro' R. R. diverges, $15 \mathrm{~m}$. S. Augusta, and $111 \mathrm{~m}$. E. Macon. It is named after the famous engineer so called.

MrLter county, Mro. Situate S. centrally, and contains 549 sq. m. Drained by Bushy fork, Tavern cr., and other branches of the Osage, which flows through the N. part. Surface somewhat broken; soil mostly very fertile, and adapted especially to grazing. Corn is the staple, and pork the principal export. It has fine mill-seats, and abundance of timber. Farms 369 ; manuf. 0 ; dwell. 592, and pop.wh. 3,645, fr. col. 0, sl. 189-total 3,834. Capital: Tuscumbia.

Mruler's, p. o., Fayette co, Texs. : 57 m. S. E. Austin City.

MrLlikr's, sta., Cook co., IUl.: on line of the Northern Indiana R. R., $29 \mathrm{~m}$. from Chicago.

MilleR's, p. o., Lawrence county, Ohio: 79 m. S. S. W. Columbus.

MiLt.ER's river, Mass.: rises in ponds in Ashburnham and Winchenden, passing W. through Royalston, Athol, Orange, and Wcndell, flows into the Connecticut $r$. at Irving village. It has many tributaries, and affords excellent mill privileges.

MrLlek's river, Verm. : rises in Sheffield, waters a part of Wheelock, and empties into the Passumpsic, in Lyndon. It affords good mill privileges, particularly in Wheelock, where there is a considerable fall.

MrtLleR's B.AY, p. 0., Jefferson con, N. Y.: $143 \mathrm{~m} . \mathrm{N}$. W. Albany.

Mrulersborg, p. v., and cap. Mercer co., $I l l$.: on the N. side of Edward's r., $112 \mathrm{~m}$. N. N. W. Springfield. It contains the county court-house and several dwellings.

Mrluersberg, p. v., Bourbon co., Ky. : on a branch of

Licking r., $36 \mathrm{~m}$. E. by N. Franbfirt.

Mimlersburg, p. Y., Callaway c0, MFo.: on a branch of Cedar cr., 23 m. N. Jefferson City.

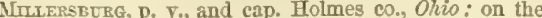
$4 i s$
E. side of Killbuck cr., $67 \mathrm{~m}$. N. E. Columbus. It contaius the court-house, jail, and usual number of public buildings, a number of stores and dwellings, and about 800 inhabitants. The Cleveland, Zanesville, and Cincinnati $R$, R., formerly

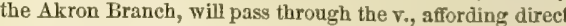
communication with Cleveland and Zanesville. The road now (1853) extends several miles below Clinton. The "Holmes County Farmer" (dem.), " Holmes County Demo crat" (dem.), and "Holmes County Whig" (whig), are issued weekly.

Mrllersedra, p. v., Dauphin co., Penn.: on the E side of the Susquehanna r., and at the mouth of Wisconisco creek, $20 \mathrm{~m}$. N. by W. Harrisburg.

Mrluersburg, p. v., Rutherford co., Tenn.: on the Nashville post-road, $41 \mathrm{~m}$. $\mathrm{S}$. E. Nashville.

Millek's Creek, p. 0., Estill county, Ky.: 53 m. S. E. Frankfort.

Murleris Crexk, p. o., Davis county, Utah Ter.: 155 m. N. Fillmore City.

Muler's Mrlu, p. o., Christian co., $\overline{k y}$. : 174 m. S. W. by W. Frankfort.

MrLleR's MrLu, p. O., Bath co., Tirg.: 137 m. W. by N. Richmond.

MrLLER's Place, p. vo, Suffolk co, N. Y.: on Long Island Sound, 127 m. S. S. E. Albany. It contains an academy and several dwellings.

Mnlersport, p. v., Fairfield county, Ohio: on the Ohio Canal, $191 \mathrm{~m}$. Cleveland, and $24 \mathrm{~m}$. Columbus. Pop. 126.

MIULER's TAFerN, p. o., Essex co., Virg.: 42 m. N E Richmond.

Mitlerstown, p. v., Grayson co., Ky.: on W. bank of Nolin cr., $78 \mathrm{~m}$. S. W. Frankfort.

Mrlerstown, p. o., Champaign co., Ohio: $48 \mathrm{~m}$. W. by N. Columbus.

Millemstown, p. v., Perry co., Penn.: on the left bank of the Juniata $r$, and on line of the $\mathrm{E}$. division of the Pennsylvania R. R., 33 m. N. W. Harrisburg.

Millersville, p. o., Adair county, $K y_{0}: 78$ m. S. by W. Frankfort.

Mrlierstille, p. v., Anne Arundel co., Mrd.: on the W. side of Severn r., $10 \mathrm{~m} . \mathrm{N}$. W. Annapolis, and on the line of the Annapolis and Elkridge R. R., equidistant between the two places.

Mrluersville, p. v., Lancaster co., Penn.: on a branch of the Conestoga cr., $83 \mathrm{~m}$. S. E. by E. Harrisburg, $4 \mathrm{~m}$. S. Lancaster.

Muluersvilue, p. v., Marion co., Ind.

Millerton, sta., Columbia co., $N . \bar{Y} .:$ on the line of the Harlem R. R., 66 m, S. Albany.

Mrrlfield, p. v., Athens co., Ohio: on Sunday cr., $53 \mathrm{~m}$. S. E. Columbus. There are salt-works in this vicinity, producing large quantities of salt annually. The $\mathrm{v}$. contains several stores, workshops, and dwellings.

Minlford Mills, p. o., Prince William co., Tirg.: $89 \mathrm{~m}$ N. Richmond.

Mrlu Greex, p. o., Hartford co., MId.: $48 \mathrm{~m}$. N. Annapolis Mrul Grove, p. F., Cobb county, Ga.: $101 \mathrm{~m}, \mathrm{~N}$. W. Milledgeville.

Milu Grove, p. 0, Erie co., N. $x_{0}: 257 \mathrm{~m}$. W. $\frac{1}{2}$ N. Albany. Milu Grovf, p. v., Owen co., Ind.: on the E. side of Mill er., $35 \mathrm{~m}$. S. W. by W. Indianapolis.

Mrul Grove, p. v., Sumter disto, S. Car : on the Darling. ton and Sumterville post-road, 41 m. E. N. E. Columbia.

Mrtl Hali, p. os, Clinton co., Penn.: on the S. side of Bald Eagle cr., 67 m. N. N. W. Harrisburg. The Mill Hall iron furnace, situate here, has an annual capacity of 1,600 tons.

Mrux HAvex, p. v., Scriven co., Ga.: $101 \mathrm{~m}$. E. by $\mathrm{S}_{a}$ Milledgeville.

Mrumeis, p. v., Centre county, Penn.: 54 m. N. W. Harrisburg,

Mrlu. IIrl, p. o., Cabarras co., N. Car. : 93 m. W. S. W. Raleigh. 
Mil. HotsEN, p. v., Decatur county, Ind. : 53 m. S. E. Indianapolis.

MillicaN, p. o., Brazos co., Tero, 85 m. E. N. E. Austin City,

Mrluigex's Bevd, p. o., Madison par., La.: on W. side of the Mississippi $x_{0}, 137 \mathrm{~m}$. N. Baton Rouge.

MrLI.Ex, p. O., Burke co., $G a_{.}$: on the E. side of Ogeechee r., 98 m. E. S. E. Milledgeville. The Central R. R. passes through this $\mathrm{r}$., $79 \mathrm{~m}$. from Savannah, and the Augusta and Waynesboro' $\mathrm{P}$. R. diverges from it, $51 \mathrm{~m}$. S. from Augusta. Is is named from M. B. Millen, Esq., the eminent engineer of the Central P. P.

Mrltington, p. Y., Middlesex co., Conn : on the East Haddam and Bozrah post-road, 27 m. S. E. Hartford.

Mrulivgros, p. v., Kent co., Md.: on the N. side of Chester r., 18 m. E. of Chestertown, and 53 m. N. E, Annapolis. It is a flourishing village.

Millington, p. o, Somerset co, $N$. Jer.: on the Passaie r., $36 \mathrm{~m}$. N. N. E. Trenton.

Mrllington, p. v., Albemarle co., Firg.: near the fork of Pevanna r., $73 \mathrm{~m} . \mathrm{N}$. W. Richmond.

Milunoket lake, Penobscot $c_{0}, M_{e_{*}}$ : borders on the E. boundary of Piscataquis co., and receives several rivers. Its outlet is the river so called, which with it forms an important source of the W. branch of the Penobscot river, and connects it with Pemadumcook lake, near the great falls so called.

Mrlu Platn, p. v., Fairfield co., Conn.: on the Danbury post-road, $51 \mathrm{~m}$. S. W. Hartford.

Mrul Poirt, p. o., Sullivan co., Tenn. : 248 m. E. by N. Nashville.

Mill Ponnt, p. o., Pocahontas co, Firg.: 151 m. W. N. W. Richmond.

Mrlu Porst, p. o., Ottawa co, Mfeh.: 85 m. N. N. W. Lansing.

Mri, Port, p. v., Fayette co., Ala. : on the Fayette postroad, $131 \mathrm{~m}$. N. W. Montgomery.

Mullport, p. v., Chemung co., $N$. $Y$.: on Catherine's cr., and on the line of the Canandaigua R.R., $12 \mathrm{~m}$. N. Elmira, $167 \mathrm{~m}$. W. S. W. Albany. The Chemung Canal passes through the village. It has extensive water-power, which supplies a large number of mills of different kinds. There are several manufactories, and a boat-yard for building and repairing canal boats. Large quantities of lumber are annually exported.

Mrlu Port, p. o., Potter county, Penn. : 128 m. N. N. W. Harrisburg.

Mrr., Port, p. ₹., Washington co., Ind.: on the Muscatatuck r., $69 \mathrm{~m}$. S. Indianapolis.

Mmu Rar, p. o., Bullock co., Ga.:108 m. S.E. Milledgeville.

Mrlu RIDGe, p. o., St. Francis co., Ark.: 71 m. E. N. E. Little Rock.

Mrtu. River, p. v., Berkshire co,, Mass.; on a branch of the Housatonic r., 117 m. W. S. W. Boston.

Milu River, p. o., Henderson county, N. Car.: $282 \mathrm{~m}$. W. by S. Raleigh.

Milis county, $I a$. Situate S. W., and contains $326 \mathrm{sq} . \mathrm{m}$. Bounded W. by the Missouri, and drained by Nishnabatona $\mathrm{r}$. and Mosquito and Key creeks. It lies just $\mathbf{S}$. of Council Bluffs, and is yet but little settled. Unorganized in 1850 .

Mildsborotgh, p. v., Sussex county, Del. : on S. side of Indian r., 41 m. S. $\frac{1}{2}$ E. Dover.

Mrlusborovgr, p. v., Washington co., Penn.: on the W. side of the Monongahela r. and $\mathrm{N}$. of the confluence of Ten Mile cr., $164 \mathrm{~m}$. W. Harrisburg.

Mrlis" Bridge, p. o., Pike county, Ga.: 74 miles W. Milledgeville.

Mrlus' Corners, p. on, Fulton co, $N_{.} Y_{*}: 37 \mathrm{~m}$. N. W. Albany.

Milis' Gap, p. 0., Rutherford co, N. Car, : 206 m. W. by S. Raleigh.

Mruts' Mriss, p. o., Alleghany co., N. Y.: 225 m. W. by S. ¿lbany.
Mills' Prairie, p. v.g Edwards co., $R l .: 122$ m. S. E. Springfield.

Mults river, $I l l_{\text {, }}$ riscs in N. part of Jackson co, makes a semicircular bend into Perry, and empties into the Mis. sissippi $r$. in Randolph County.

Mul SPRixg, p. O, Jefferson county, Tenn.: 194 m. E. Nashville.

Mill Sprivg, p. v., Wayne co., Ky.: on the S. side of Cumberland r., 86 m. S. Frankfort.

Millstadt, p. v., St. Clair co., I U.: on the Waterloo and Belleville post-road, 96 m. S. by W. Springfield

Milistone, p. V., Oglethorpe co., Ga.: on the S. side of Broad r., $67 \mathrm{~m}$. N. by E. Milledgeville.

Millstone, p. v., Somerset co, N. Jer, : on W. side Millstone r., $22 \mathrm{~m}$. N. by E. Trenton; contains a number of very neat dwellings, some stores, and several workshnps.

Milistone river, $N$, Jer. : rises in Millstone, Monmouth County, flows in a N. and W. by N. course to Kingston, forming the division between Middlesex and Mercer, and thence N. through Somerset, joins the Raritan r. about $2 \frac{1}{2} \mathrm{~m}$. E. Somerville. This is a rapid stream and has many tributaries affording excellent mill-sites, The Delaware and Raritan Canal follows this river a considerable distance.

Milltown, p. o., Chester county, Penn.: 68 m. E. by 8. Harrisburg.

Milutows, p. V., Crawford co, Ind.: on the W. bank of the Great Blue r., $157 \mathrm{~m}$. S. Indianapolis.

Milltown, p. o., Washington co., $M e_{\text {. : }} 128 \mathrm{~m}$. E. by N. Augusta.

Milltown, p. o, Chambers co, $A l a .: 73$ m. N. E. by E. Montgomery.

Minltown, p. ₹., Putnam co., N. Y.: $81 \mathrm{~m}$. S. Albany; contains several stores, a foundry, and a few mills.

Millview, p. o., Fauquier co., Firg.: 94 m. N. by W. Richmond.

Mrluview, p. o., Sullivan county, Penn. : 84 miles N. Harrisburg.

Milivrcle, p. V., Butler county, $A l \alpha_{0}: 43$ miles 8. Montgomery

Mileville, p. v., $\mathrm{T}_{0}$ Daviess co., $\eta_{*}$; on a fork of Apple r., 193 m. N. Springfield.

Millville, p. v., Clayton co., Ia. : on $\mathrm{S}$. bank of Turkey r., $74 \mathrm{~m}$. N. by E. Iowa City. There are in this v. a number of fine farms and some mills. The country round about is well cultivated, and lead is to be found along the banks of the river.

Millpille, p. v., Worcester co., Mass.: on the Providence and Worcester R. R., 20 m. from Providence, $35 \mathrm{~m}$. S. W. Boston.

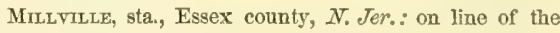
Morris and Essex R. R., 10 m. W. Newark, and 24 m. S. E. Dover.

Mullville, t. and p. v., Cumberland co., $N$. Jer.: $49 \mathrm{~m}$. S. Trenton. Drained by Maurice $r$ and its branches. Surface even; soil inferior and unproductive. There are a number of mills and workshops in the t. Glass is manufactured here to a considerable extent. The $\mathbf{r}$, is situate on the E. bank of Maurice r., and contains a number of stores and some fine dwellings. Pop. of the t. 2,332.

Millville, p. v., Orleans co., $N . Y .: 245 \mathrm{~m}$. W. by $\mathrm{N}$. Albany. It contains several dwellings, an'incorporated academy, a number of mills, and a earriage manufactory.

Millville, p. v., Butler co, Ohio: on a branch of Miami r., $96 \mathrm{~m}$. W. S. W. Columbus. It contrins several dwellings, a number of stores and workshops, and about 300 inhabitants.

Milurilue, p. V., Columbia county, Penn.: on the line of the Catawissa and Towanda R. R., 57 miles N. by E. Harrisburg.

Millville, p. v., Spartanburg dist., $S . C a \gamma^{\prime}$ : on a fork of Congaree r., $74 \mathrm{~m}$. N. W. Columbia.

Millville, p. o., Lincoln county, Tenn. : 69 m. S. by E. Nashville. 
Millville, p. v., Ray co., M50, : on a branch of Wyaconda cr., $112 \mathrm{~m} . \mathrm{N}$. W. by W. Jefierson City.

Millville, p. o., King George co., Virg.: 53 m. N. by E. Richmond.

Mill wees, p. 0., Anderson dist., S. Car.: 108 m. W. N. W. Columbia.

MrLlwood, p. v., Dooly county, Ga.: 77 m. S. S. W. Milledgeville.

Millwood, p. v., Lincoln county, Mo.: 68 m. N. E. Jefferson City.

MrLwwood, p. v., Jackson co., Fllor.: 54 m. N. W. by W. Tallahassee.

MrLLW00D, p. F., Knox co, Ohio: on the N. side of Vernon r., $47 \mathrm{~m}$. N. E. Columbus.

Mrluwood, p. v., Clark co., Firg.: on the W. side of Shenandoah r., 113 m. N. by W. Richmond,

Mrulwood, p. o., Collin county, Tex. : 209 m. N. by E. Austin City.

Minner, p. V., Pike co., Ga.: $61 \mathrm{~m}$. W. Milledgeville. The Macon and Western R. R. passes the $v .47 \mathrm{~m}$. from Macon.

Milnerstille, p. o., Guernsey co., Ohio: $47 \mathrm{~m}$. E. by N. Columbus.

Mrro, t. and p. v., Piscataquis co., Me.: $75 \mathrm{~m}$. N. N. E. Augusta. Drained by the Piscataquis $r$, and its branches, Sebec and Pleasant rivers. Surface pleasantly diversified; soil fertile, especially on the banks of the rivers; well adapted to grain. There are a few mills and some manufactories here. The $\mathrm{v}$. is situate on the N. side of sebec r., and contains a number of dwellings, stores, and workshops. Pop. of the t. 932 .

Mru, t. and p. V., Yates co., N. Y.: $169 \mathrm{~m}$. W. Albany. Drained by a small stream, which bounds it on the $N$., and connects Crooked lake with Seneca lake, the former bound. ing it on the W. and the latter on the E. Surface undulating; soil fertile. It is quite a flourishing $t$, and contains scveral stores, a number of mills and manufactories, and a furnace, all in active operation. The $\mathrm{v}$. is in $\mathrm{S}$. E. part, near Seneca lake, and contains a number of mills, stores, and workshops. Penn Yan, a considerable village, and capital of the county, is situate in the N., on the outlet of Crooked lake. Pop. of $t, 4,791$.

Mrio, p. v., Bureau co., $M_{n}: 93 \mathrm{~m}$. N. Springfleld. Surrounded by good prairie lands.

Mulo Centre, p. v., Yates co., $N$. $Y$.: at the head of Crooked lake, on the line of the Canandaigua and Elmira R. R., $39 \mathrm{~m}, \mathrm{~N}$. by W. Elmira, and $171 \mathrm{~m}$. W. Albany. The country round about is very rich, producing large crops of wheat annually.

Milror, p. v., Rush co., Ind.: on Little Flat Rock cr., 39 m. S. E. by E. Indianapolis.

Murrox, p. o., Mifflin county, Penn.: 48 m. N. W. Harrisburg.

Miltox, p. v., Autauga co., Ala. : on a branch of Coosa r. $83 \mathrm{~m}$. W. N. W. Montgomery.

Muton, p. v., Litchfield co., Conn.: on the Litchfield post-road, on E. side of Shepaug r., $31 \mathrm{~m}$. W. Hartford.

Mrron, p. v., Sussex co., Del.: on N. side of a small er. flowing into Delaware Bay, $27 \mathrm{~m}$. S. Dover.

Mrtox, p. v., and cap. Santa Rosa co., Flor.: on the W. side of Blackwater r., $15 \mathrm{~m}$. N. Pensacola, $165 \mathrm{~m}$. W. Tallahassee. The country round about the $\nabla$. is celebrated for excellent live oak.

Mutox, p. v., Pike co., $7 l$.: 54 m. W. by $\mathrm{S}$. Springfield.

Mrtox, p. v., Wayne co., Ind.: on the W. branch of the White Water r., $68 \mathrm{~m}$. E. Indianapolis, The White Water Canal passes through the village.

Mrutos, p. V., Trimble co., $\bar{y}$. $_{\text {: }}$ on the S. bank of the Ohio r., $44 \mathrm{~m}$. N. W. Frankfort. A small v., containing a number of stores and workshops, a few dwellings, and about 250 inhabitants.

Mrltoy, t. and p. v., Norfolk county, Mass.: 7 m. S. Boston. Bounded on the N. and W. by Neponset r., by 450 which and its branches it is drained. Surface undulating, except in the $S_{\text {. }}$, where it is mountainous; suil very fertile. The river affords extensive hydraulic power, and has some fine mill-sites, of which there are quite a number, as also manufactories. Extensive and valuable granite quarries are found here. The $\mathbf{v}$. (called the Mills) is situate on the Neponset $x$., at the head of navigation, and is in a very thriving condition, being the seat of considerable trade and manufacture. A fine granite bridge here crosses the Neponset river, and the Dorchester and Milton Branch R. R. diverges hence, and connects with the Old Colony $R . R$. at Neponset, $5 \mathrm{~m}$. from Boston. Milton contains some fine country seats and beautiful scenery. Blue Hill, a celebrated land-mark for sailors, 710 feet abore the sea, is in S. part of the t., $12 \mathrm{~m}$. from Boston. Pop. 2,241.

Miltox, p. o., Lafayette co., Miss.: $135 \mathrm{~m}$. N. N. E. Jackson.

Mrtuo, p. v., Randolph co., Mo.: on Elk Fork, a branch of Salt River, $63 \mathrm{~m}$. N. $\mathrm{x}$ W. Jefferson City.

Milton, p. v., Morris co., $N$. Jer. : E. side Rockaway r., near Hamburg Mountain, 55 m. N. $\frac{1}{2}$ E. Trenton.

MrltoN, t. and p. v., Strafiord co., N. Hamp.: 27 m. N. E. Concord. Bounded on the E. by Salmon r., by the branches of which it is drained. Surface various; in the E. is Tencriffe, a rocky mountain, near which is Milton Pond, connecting with Salmon r. Soil good. It has extensive hydraulic power. The $\mathrm{F}_{\text {. }}$, in N. part of $\mathrm{t}$., is a pleasant settlement, and has a number of stores and workshops. Pop. of t. 1,619 .

Multox, p. v., Ulster co., $N$. $Y_{\text {.: }}$ on W. side of the Hudson r., at the head of a Ianding, $73 \mathrm{~m}$. S. by W. Albany. The country round about is very productive, yielding a large amount of produce, which is sent away annually by means of barges which ply between the village and New York. There are 75 dwellings, with several stores and workshops, and about 475 inhabitants in the village.

Milfon, t. and p. v., Mahoning co., Ohio: 127 m. N. E. Columbus. Drained by affluents of Mahoning $r$. Surface undulating; soil fertile and well cultivated. It has excellent water-power. The $\mathrm{r}$. is situate on a branch of Mahoning $\mathbf{r}$, in $\mathrm{N} . \mathrm{W}$. part of to, and contains several stores and workshops. Pop. 1,120.

Muros, p. v., Caswell co., $N$. Car.: on the S. side of Dan $\mathrm{r} ., 66 \mathrm{~m}$. N. N. W. Raleigh. A newspaper, the " Milton Chronicle" (whig), is here issued weekly.

Milton, p. b., Northumberland co., Penn.: on the E. side of the $W$. branch of the Susquehanna $r_{\text {, }}$, at the confluence of Limestone $\mathbf{r}, 58 \mathrm{~m} . \mathbf{N}$. by W. Harrisburg. A bridge crosses the Susquehanna r. at that point. The b. contrins about 300 dwellings, numerous stores, and several manufactories, The "Miltonian" (whig), a weekly paper, is issued here. Pop. 1,646.

Miltos, p. F., Rutherford co., Tenn.: 81 m. E. S. E, Nasbville.

Mrtox, p. o, Wilkinson county, $G a$ : 19 miles $\$$ Milledgeville.

Mrlton, p. v., Laurens dist, $S$. Car. : on Little $x_{.,} 53 \mathrm{~m}$. N. W. by W. Columbia.

Mruros, t. and p. v., Chittenden co., Term.: 34 m. N. W. Montpelier. Drained by Lamoille river and its branches. Surface pleasantly diversified; soil good, with fine pasturage. It has immense hydraulic power, owing to an extensive waterfall in the river. There are a number of mills and manufactories. The $t_{0}$ is bounded on the $W$. by Lake Champlain. Sand Bar bridge connects it with South Hero, on Grand Isle. The $\nabla$. is pleasantly situate on Lamoille $r_{\text {. }}$ near the falls, and on the line of the Vermont Central R. R, $121 \mathrm{~m}$. from Windsor. It contains several mills and some manufactories, together with a number of workshops and about 60 dwellings. Pop. of t. 2.451.

Miltox, t. and p. o., Rock county, Wisc.: 29 m. S. E. Madison. Bounded on the N. by Koshkonong lake, by the outlets of which it is drained; and diversified by a num- 
ber of small ponuls. Surfice undulating: soil fertile. There are sureril mills and manufactories in the town. The $\mathrm{v}$. is on the line of the Milwaukie and Mississippi R. R., $62 \mathrm{~m}$. W. S. W. Nilwaukie, and contains several dwellings, a number of stores, and workshops. Pop. of t. 1,032.

Mriton Mrlis, p. o., Strafford county, N. Hamp.: $25 \mathrm{~m}$. N. E. Coneord.

Mintonsiurg, p. v., Monroe co., Ohio: on the Woodficld post-road, $96 \mathrm{~m}$. E. Columbus.

Miltorville, p. Y., Wood con, Olio: on the E. bank of the Maumee r., $109 \mathrm{~m}$. N. N. W. Columbus.

Mirrilte, p. 0., Rusk co., Tex. : 219 m. N. E. Austin City. MrLwa kire county, Wisc. Situate S. E. on Lake Michigan, and contains $25 \mathrm{sqq}$. m. Drained by Cak cr. and Root and Milwaukie rivers. Surface gently rolling, with a slope toward the lake; soil highly productive. Corn and wheat, with the other grains, live-stock, beef, pork, and wool, are the farming staples and large exports. The $c 0$. was originally heavily timbered, and is extensively engaged in the lumber trade. It has fine harbors, and a very large trade on the lake. The basis of the co. is limestone, which furnishes an excellent building material and good lime. It has various and extensive manufactures, and exports great numbers of bricks of a superior lind. Farms 935 ; manuf. 236; dwell. 5,630, and pop.-wh. 30,967, fr. col. 110-total 21,07.. Copital: Milwaukie, Pullic Horks: Milwankie and Mississippi R. R.; Lake Shore R. P. ; Milwaukie and Fond du Lac R. R.; plank-roads, ete.

MirwaUkie, p. $\mathrm{v}_{*}$, Clackamas $\mathrm{co}_{2}$, Oreg.: on the E. bank of the Willamette r, some $6 \mathrm{~m}$. below the falls, and $37 \mathrm{~m}$. N. E. Salem. It may be said to be at the head of ship nayigation on the Willamette. Above the v. the $r$. is unsuited to ship navigation. In a commercial point of view, this is an important site, and is a very prosperous village.

Mirwattse, t, p. eity, and eap. Milwaukie co., Wisc. on the W. shore of Lake Michigan, $75 \mathrm{~m}$. E. Madison. Lat, $4300 x^{\prime \prime}$, long. $87^{\circ} 57^{\prime}$. Drained by Milwaukie r. and branch, which former, running parallel with the lake, divides the $t$. Surface uneven, along the banks of the river and lake hilly; soil rich and very productive. The shore on Lake Michigan consists of a bank of clay from 20 to 100 feet high, and as nearly perpendicular as the nature of the material will admit of. The country rises gradually to the W. The city is the most important town on Lake Michigan (exceryt Chicingo, which is some 90 miles farther $\mathrm{S}$.), and is of some twenty years' growth. The inhabitants, of whom a larce number are Dutch, Swiss, Norwegians, and Irish, are of a quiet, industrious turn. It is noted for its splendid blocks of buildings, and its superior brick, which probably surpass those of any part of our nation. They have become a valuable article of export, being hard, smooth, and of a beautiful straw color. The Milwaukie and Mississippi $\mathrm{R}$. R, extends from here as far as Janesville, a distance of 70 miles, and, when completed, will extend to Dubuque, thus connecting the lake with the Mississippi river. The city is situate on the river of same name, near its mouth, on an elevation, $90 \mathrm{~m}$. from Chicago, and $78 \mathrm{~m}$, due $\mathrm{E}$. from Mrarlison. It was laid out as a village in 1535 , and such was the rapidity of its increase, that in June of the suceeding year it numbered 1,206 inhabitants. The bay is a semicireular indentation of Lake Michigan, about $6 \mathrm{~m}$. across, and $3 \mathrm{~m}$. deep. The $\mathrm{N}$. and $\mathrm{S}$. points, or capes, protect the slipping from the effects of all storms and gales of wind,

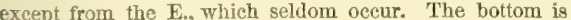
compnged of clay, affording excellent anchorage ground. There are 39 sail vessels owned in and sailing out of this port, of which the total tonnage is 5,542 ; also stock in steamboats and propellers of 3,000 tons, making the total tonnage owned in the port 8,512. Sixteen sail of vessels are engaged exelusively in the lumber trade, and the remainder in freighting produce and merchandise. The arrivals durinc the scason of 1918 were, steamboats, 498 ; propellers, 245; barks and brigs, 119 ; schooners, 511 ; making a total of 1,176 . The exports of wheat from 1815 to 1819 inclusive, was $4,372,400$ bushels, as follows: $1845,133,310$; 1846 , 292,$228 ; 1847,662,211 ; 1848,1,076,134 ; 1849,2,208,517$ bushels, being an increase at the rate of more than 100 per cent. per annum. There are invested in manufactories over two million of dollars, the products of which consist of woolen goods, machinery, castings, earriages, wagons, leather, lumber, cabinet-ware, tin, sheet iron, and copper manufactories, saddles and harness, soap and candles, burr mill-stones, steam-boilers, sails, rigging, plows, fanning mills, paper, elothings, smithings, tobaceo, and segars, bookbinding, coopers' wares, brick, ete. In addition to this, there are 5 flouring mills, propelled by water-power, and 1 by steam containing 17 runs of stones, each run capable of turning out 80 to 100 barrels of flour per day, and consuming in all 7,000 bushels of wheat daily. The imports amount to near four million dollars annually, consisting chiefly of merchandise, salt, furniture, cral, lime, plaister, fruits, lumber, etc. The exports, amounting to two and a hal million dollars annually, consist of wheat, barrels of flour, pork, beef, lead, shot, hides, and sundry manufactured articles. There is a United States land office situate here. The "Wisconsin Banner," daily, tri-weekly, and weekly (dem.), "Taglicher Volksfreund," daily and weekly (dem.), "Commercial Advertiser," daily, tri-weekly, and weekly (dem.), "Milwaukie Sentinel," daily, tri-weekly, and weekly (whig), "Free Democrat," daily, tri-weekly, and weekly (free soil), tri-weekly, and weekly "Wisconsin," daily (dem.), are the names of newspapers published here. The progress of the city has been most remarkable. In 1834 it was surrounded by a wilderness, and contained only two Iog-houses, since which time it has increased rapidly. In 1810 , there were 1,700 inhabitants; $1842,2,700 ; 1346$, June $1,9,655 ; 1849$, December $15,15,071 ; 1850$, the city, 20,061 , but including the town, 21,461 .

Milwaukie bay, Wisc.: an inlet of Lake Michigan, in the county so called. At the head of the bay is the city above described.

Micwatcie river, Wisc.: a large stream rising by a number of branches in Fond du Lac and Sheboygan counties, flows S. to Salisbury, E. to Fredonia, thence S. through Washington and a part of Milwaukie co., empties into Milwaukie Bay of Lake Michigan at Milwankie City, from which point the Milwankie and Mississippi R. R. direrges.

MiNa, t. and p. v., Chautauque co., N. Y.: W. part of $c 0$. $313 \mathrm{~m}$. W. by s. Albany. Drained by French cr. Finley's Lake is in W. part of $t$. Surface uneven; soil of good quality. It contains a few mills and munufactories, and several dwellings. The village is situate in N. E. part, on French cr., and has some neat dwellings, and a number of stores and workshops. Pop. of t. 996.

Muraville, p. o., Montgomery co, $N . \quad \bar{X}: 33 \mathrm{~m} . \mathrm{N} . \mathrm{W}$ Albany.

Mrnden, p. o., Pusk co., Texo : 223 m. N. E. Austin City. Minden, p. v, Claiborne par, $L \alpha_{0} ;$ on an outlet of Lake Bisteneau, $193 \mathrm{~m}$. N. W. Baton Rouge. It contains a courthouse, jail, a number of dwellings, and some workshops, The "Minden Herald," a weekly isste, is published here.

Menden, t. and p. o., Montgomery county, $N . Y: 53 \mathrm{~m}$. W. N. W. Albany. Bounded on the N. and E. by the Mohawk r. and Erie Canal, by which and Otsquake cr. it is drained. Surface variable, in parts hilly; soil rarions, rich in the valleys, and very productive. There are a number of manufactories, mills, and some workshops liere. Pop. of t. 4,623

Mridentilis, p. 0., Montgomery county, $N . Y_{.: 5} \mathrm{~m}$. W. N. W. Albany.

Minf Creek, p. O., Hempstead co., Ark. : 109 m. S. W. Litlle Rock.

Mune Kilx Falis, p. O., Schoharie co, N. Y.: $39 \mathrm{~m}$. W. Albany.

Mrne La Motre, p. v., Madison co., Mfo.: on a branch of St. Francis r., $123 \mathrm{~m}$. S. E. by E. Jefferson City: There 
is an extensive lead mine here yielding 72 per cent. pure metal. The ores are ensily reduced, and 6 ounces of silver is procured per ton. The carbonate is reduced by means of a blast furnace. Copper and zinc ores are found in the vicinity; manganese ores are also very abundant, and in time will be sought after with much avidity. Cobalt has become an object of exploration. It is found associated with nickel, in the form of the sulphuret, or the black oxide. An apparatus for the preparation of cobalt oxide has been fitted up at the mine, and it is estimated that the tract will produce from 3,000 to 5,000 pounds of the article per annum. Cobalt is an invaluable article in the manufacture of porcelain and pottery, all the blue colors of which are derived from it.

Mremat Porvt, t., p. v., and cap. Iowa co, Wisc. : $43 \mathrm{~m}$. S. W. Madison. Drained by head branches of Pecatonica $r$. Surface rugged; soil fertile, and very productive, with a basis of limestone. There are a number of farms and several dwellings in the $t$. The $\mathbf{v}$. is on a branch of Pecatonica $r$, and contains, besides the usual public buildings, a U.S. land office, a number of stores and dwellings, and a few workshops. Lead and copper of an excellent quality are to be found here in abundance; there are several furnaces used for smelting. Pop. of t. 2,554.

Minerax Sprixe, p. o., Anderson dist., S. Car.: $114 \mathrm{~m}$. W. N. W. Columbia.

Mrnerat Sprivgs, p. O. Bexar co., Tex. : 77 m. S. Austin City. There is a spring here, whose waters have for ages been held in high estimation by the aborigines for their medicinal qualities.

Mryeral Springs, p. V., Columbia co., Flor : on the S. side of Suwanee r., $71 \mathrm{~m}$. E. Tallahassee.

Mrneral Sprivgs, p. 0., Lotwndes con, Ga.: 156 m. S. Milledgeville.

Mexerstile, p. b., Schuylkill co., Penn.: 41 m. N. E.
Harrisburg. It contains about 125 dwellings, several stores and one newspaper, the "Minersville Bulletin," is issued weekly, There are a number of anthraclte coal mines in the vicinity. Pop, about 1,600 .

Minersille, p. v., M'Dowell co., $N$. Car,: at head of Cane cr., $175 \mathrm{~m}$. W. Raleigh.

Minerva, p. r., Houston co, Ga. : at the source of Benver er., $62 \mathrm{~m}$. S. W. Milledgeville.

Mrnerva, p. v., Mason county, Ǩy.: 72 m. E. N. E. Frankfort.

Mnerva, t. and p. v., Essex co., $N_{0} \boldsymbol{Y}_{.:}: 79 \mathrm{~m}$. N. $\frac{1}{2}$. Albany. Drained by Hudson r., and Boreas, Cedar, and Indian rivers, its forks. Surface hilly, in parts mountainous, the Adirondack Mountains being situate here. In the valley is to be found some fertile land. Water-power is good; there are several mills and some manufactures here. The v. in which the post-office is situate is in the S. E. part of the t. Pop, of the t. 5S6.

Minerva, p. V., Stark co., Ohio: on the line of the Sandy and Beaver Canal, 107 m. E. N. E. Columbus. It contains several stores, and about 450 inhabitants.

Mnemto, p. o., Oswego co., N. Y.: 137 m. N. W. Albany. Mixgo Fuat, p. o., Randolph co., Firg.: 137 m. N. W. Pichmond.

Minisink, t. and p. v., Orange co, $N . Y_{.:} 97 \mathrm{~m} . \mathrm{S} . \mathrm{S} . \mathrm{W}$. Albany. Bounded on the E. and S. E. by Wallkill, by which and its branches it is drained. Surface in the W. hilly and in the E. varied, being partly covered by what is termed the drowned lands; soil in parts fertile and productive. There are in the t. a large number of mills, several manufactories, and a variety of stores. The New York and Erie R. R. crosses the N. W. part of the t. The $\mathrm{v}$. is near the Wallkill, and has several stores and workshops. Westtown is the name of a post-office in the S. part. Population of t. 4,972 .

\section{THE TERRITORY OF MINNESOTA.}

MrNnesota occupies "all that part of the territory of the United States which lies within the following limits, to wit: beginning in the Mississippi River, at the point where the line of $43^{\circ} 30^{\prime}$ of north latitude crosses the same; thence running due west on said line, which is the northern boundary of the State of Iowa, to the north-west corner of the said State of Iowa; thence southerly along the western boundary of the said State to the point where the said boundary strikes the Missouri River; thence up the middle of the main channel of the Missouri River to the mouth of the White-earth River; thence up the middle of the main channel of the White-earth River to the boundary line between the possessions of the United States and Great Britain; thence east and south of east along the boundary line between the possessions of the United States and Great Britain to Lake Superior; thence in a straight line to the northernmost point of the State of Wisconsin in Lake Superior; thence along the western boundary line of said State of Wisconsin to the Mississippi River; thence down the main channel of said river to the place of beginning." - Act of Congress, $3 d$ March, 1S49. Within this territory the area may be computed at 140,000 or 150,000 square miles; according to the census report it is only 83,000 square miles, which is eridently an error.

This immense region is bountifully watered by the Mississippi, of which it contains the true sources, the Minnesota, the Missouri River, and the Red River of the north, and their numerous tributary streams, which traverse it in every part. There are also innumerable bodies of fresh water, which abound in fish of various kinds, the white fish especially being found in great numbers in the more northern or large lakes. The general character of Minnesota is that of a high rolling prairie, but the streams and lakes are bordered with heavy bodics of timber, which contain every species of wood known along the Mississippi below, except beech and sycamore. At a point about 8 miles above the Falls of St. Anthony, West of the Mississippi, commences a large and remarkable forest, which extends to the south nearly at a right angle across the Minnesota, or St. Peter's River, to the branches of the Makato, or Blue-earth River. This vast body of woodland is more than 120 miles in length and from 15 to 40 in breadth. Many beautiful lakes of limpid water are found within its limits. In this fine country are to be found all the requisites to sustain a dense population. The soil is of great fertility and unusual depth, covered as it is with the mold of a thousand years. The soil of Minnesota, indeed, is admirably adapted to the cultivation of all the cereal grains. Wheat, oats, and barley are safe crops, even as far north as the Red River settlement on the British line. The country is destined to become a great agricultural region, and its prairies are well calculated for the raising of stock. There is also such an extent of water-power throughout its broad surface that no reason can be perceived why manufactures would not flourish also. The reports of those scientific men who have explored the country justify the belief that the territory is rich in copper ores, and also in gralena or lead ores. Whether coal exists is a problem yet to be solved. If it should be found in any considerable quantities, the discovery will be of more real advantage than the richest mines of silver and gold.

On the upper portion of the Mississippi and St. Croix valleys lies the great region of pine which has been and will continue to be a great source of wealth to the Territory and State for centuries to come. The manufacture of pine lumber already necupies a large part of the industrial labor of the people. Nuch of this is needed for home consumption, caused. by the rapid inerease of population, but the larger portion is sent to St. Louis, where it meets with a ready sale. The climate of Minnesota is not subject to sudden variations, especially in winter. Although in some years the snow falls to a 


\section{MINNESOTA.}

great depth, yet, as a general rule, it is far less than is experienced in New England or the northern part of the State of New York. The comparative absence of moisture in the country is attributable, doubtless, to the fact that no very. large bodies of water are to be found, although, as before stated, small lakes abound. During the coldest weather in winter the air is perfectly still; consequently the weather is much more tolerable, and even pleasant, than could be supposed by those who reside in the same latitude on the Atlantic coast. The navigation of the Mississippi, however, is not to be relied on after the first week in December, and steamboats arrive in the spring about the middle of April, so that the river may be considered as closed about five months in the year.

Minnesota, in 1850 , according to the census of that year, was divided into nine counties, the general statistics of which and the capitals of each were as follows:

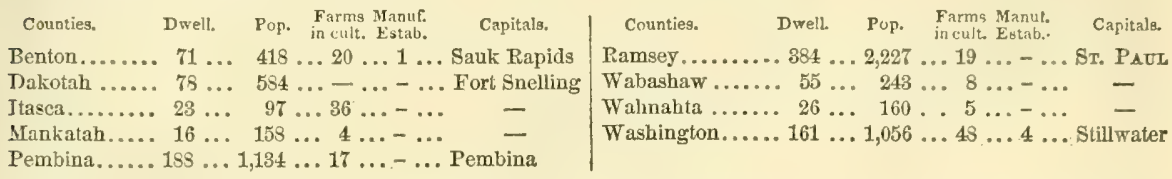

The whole number of dwellings in the Territory was, at the above date, 1,002, of families 1,016, and of inhabitants 6,077 , viz. : whites 6,035-males 3,695, and females 2,343 ; and of free colored persons 39 -males 21 , and females 18 . Of the whole population, there were deaf and $d u m b-w h .0$, fr. col. 0-total 0; blind-wh. 0, fr. col. 0-total 0; insane-wh. 0, fr. col. 0 -total 0 ; and idiotic-wh. 1, fr. col. 0-total 1. The number of free persons born in the United States was 4,007 ; the number of foreign birth, 2,048; and the number of birth unknown, 22 . The native population originated as follows: Maine 365, N. Hamp. 47, Verm. 100, Mass. 92, R. I. 3, Conn. 48, N. York 488, N. Jer. 115, Penn. 227 , Del. 3, Md. 31, Dist. of' Col. 3, Virg. 59, N. Car. 6, S. Car. 4, Ga. 4, Flor. 0, Ala. 6, Miss. 0, La. 4, Tex. 0, Ark. 11, Tenn. 21, Ky. 71 Ohio 291, Mich. 41, Ind. 35, Ill. 168, Mo. 90, Ia. 81, Wisc. 301, Calif. 1, and territories 7 ; and the foreign population was composed of persons from-England 84, Ireland 271, Scotland 39, Wales 2, Germany 141, France 29, Holland 16, Spain 1, Portugal 0, Belgium 1, Turkey 0, Italy 1, Austria 1, Switzerland 32, Russia 2, Norway 7, Denmark 1, Sweden 4, Prussia 5 , Sardinia 0, Greece 0, China 0, Asia 0, Africa 0, British America 1,417, Mexico 0, South America 0, Central America 0, West Indies 0 , Sandwich Islands 0 , other countries 4.

The statistics of the wealth, industry, institutions, etc., of the Territory, according to the seventh census of the United States taken in 1850 , and other official returns referring to the same period of time, are as follows:

Occupied Lands, etc.-Improved farm lands 5,035 acres, and unimproved lands 23,846 acres, valued in cash at $\$ 161,948$; number of farms under cultivation, 157 ; value of farming implements and machinery, \$15,951.

Live-Stock.-Horses 860 , asses and mules 14 , milch cows 607 , working oxen 655 ; other cattle 740 , sheep 80 , and swine 734-valued in the aggregate at $\$ 92, \$ 59$.

Animal Products.-Wool S5 pounds, butter 1,100 pounds, cheese 0 pounds; and the value of animals slaughtered during the year had been $\$ 2,840$.

Grain and Food Crops.-Wheat 1,401 bushels, rye 125 bushels, Indian corn 16,725 bushels, oats 38,582 bushels, barley 1,216 bushels, and buckwheat 515 bushels. Peas and beans were produced to the amount of 10,002 bushels, and potatoes -Irish 21,145 bushels, and sweet 200 bushels.

Miscellaneous Crops.-Hay 2,019 tons, maple sugar 2,950 pounds; value of the produce of market gardens $\$ 150$.

Manufactures, of course, can not be looked for in so young a community as that of Minnesota. Aceording to the census there were in the Territory only five industrial establishments producing to the value of $\$ 500$ and upward annually. The commerce of the country is wholly carried on by means of steamboats navigating its rivers, and there is some overland intercourse maintained between the Pembina settlement on the Red River and the south-eastern towns, but to no great amount. Regular steamers ply between St. Louis and St. Paul via Fevre River, etc.

Government.-The government is based on the act of Congress constituting the Territory, passed 30 th March, 1849. This act gires the right of suffrage to every free white male inhabitant 21 years old, and who has taken an oath to support the Constitution of the United States and the act forming the Constitution of the Territory. All electors are eligible to be elected.

The Legistature consists of a Council and House of Representatives. The Council has 9 members elected in districts by a plurality of votes, for two years, and the House 18 members elected for one year. The legislature may increase the number of councilors to 15 , and the number of representatives to 39 . Members of either body must reside in their district, and every district shall be represented according to its population after deducting Indians. No session of the Legislative Assembly shall exceed sixty days. No law shall be passed interfering with the primary disposal of the soil; no tax shall be imposed on the property of the United States; nor shall the property of non-residents be taxed higher than that of residents. All laws shall be submitted to Congress, and if disapproved shall be null.

The Govemor is appointed by the President and Senate for four years, and until his successor be appointed and qualified, unless sooner removed by the President. He is ex-officio superintendent of Indian affairs, and commander-inchief of the militia. He may grant pardons for offenses against teritorial laws, and reprieve, until the decision of the President be known, for offenses against the laws of the United States. His veto may be defeated by a subsequent twothird vote of the Legislative Assembly. The Secretary of the Territory, whose mode of appointment and tenure of office, is the same as the Governor's, would assume his functions in case of his absence, or the vacation of his office.

The judiciary consists of a Supreme Court, District Courts, etc. The Supreme Court consists of a Chief Justice and two associates, appointed by the President and the Senate for four years, any two of whom constitute a quorum, and hold an annual term at the seat of government. The Territory is divided into three districts, in each of which one of the three justices reside, and hold a District Court, having the jurisdiction of the United States District and Circuit Courts in all cases arising under the laws or constitution of the United States, for jury trials, subject to appeal to the Supreme Court, in which issues at law only are heard. From the Supreme Court writs of error and appeals lie to the Supreme Court of the United States (as from a Circuit Court), where the matter in dispute exceeds in value $\$ 1,000$. Both the District and Supreme Courts possess chancery powers. Justices of the peace bave no jurisdiction where the title or boundaries of land are in dispute, or where the sum claimed exceeds $\$ 100$. An attorney and marshal of the Texritory are appointed by the President and Senate for four years. Inhabitants of the Territory are secured all the rights heretofore granted to the 
inhabitants of Wisconsin, and the laws of Wisconsin, at the date of its admission as a State, so far as compatible with the present organization, until repealed or modified. A delegate to the House of Representatives in Congress is chosen by a plurality of rotes for two years.

The financial condition of the Territory is exhibited in the official reports to the 1st January, 1852: Territorial taxes for 1550 , collected $\$ 56141$, and delinquent $\$ 27108$, or a total of $\$ 83249$; territorial taxes for 1851 , due, etc., $\$ 1.28231-$ making a total revenue for 1850 and ' 51 amounting to $\$ 2,11480$. Warrants drawn on the Treasury, in 1850 , $\$ 1,18150$, and in $1851 \$ 350$ - total for the two years $\$ 2,03150$. Excess of revenue, including unpaid tax, $\$ 8330$.

The militia force of Minnesota, in 1850, consisted of 2,003 men of all arms, of which 7 were commissioned ofticers, and 1,996 non-commissioned officers, musicians, artificers, and privates. Of the commissioned officers 2 were general officers, and 5 general staff officers.

Education.-Schools are established in the more thickly populated seetions, and are supported chiefly by lncal tax. The United States Government appropriates also $\$ 12,000$ to the purposes of education. Two sections of the land from every township are reserved for the support of schools-in the older settled States only one section in each town was thus set apart. Congress also appropriated $\$ 20,000$ for a public library.

Religious Denominations-The census of 1850 does not record any thing respecting the denominations in this Territory. The following are from the annual reports of the several churches: The Roman Catholics, in 1853 , had 7 churches, and 10 clergymen, chiefly employed on missions. The Territory was ereeted into the Roman Catholic diocese of St. Paul, on the 28th June, 1850. The Episcopalians have a church at St. Paul, and several others in different parts, and are under a missionary bishop. The Methodists and Baptists have also congregations, and perhaps number larger than any of the other sects, but it seems that the newness of the settlements, or distance from the central establishments, has prevented the usual reports being sent in. So little, indeed, is known of the religious condition of the people of Minnesota, that it were perhaps better to advance no opinion on the subject until reliable information ean be obtained.

Nor is there any definite information respecting the public press. The census is silent on this point, but there are at St. Paul at least two newspapers, and others may or may not be published elsewhere. Nor have any records of crime and pauperism as yet been published.

Historical Sketch.-Previous to Minnesota being erected into a Territory by the Act of Congress of $3 \mathrm{~d}$ March, 1849 , that portion of it east of the Mississippi River formed a part of Wisconsin Territory, and that west of that river a part of Iowa Territory. The Territory derives its name from minni-sotah, the Indian name for St. Peter's River-minni in their language meaning "water," and sotah "muddy or slightly turbid." The country originally belonged to the French by priority of discovery. At an early period their traders, missionaries, and solcliers had penetrated into the western wilderness. The United States had little authority in this region until 1812. In 1816 a law of Congress excluded foreigners from the Indian trade, and for the encouragement of our own citizens the military post at Fort Snelling was established in 1519. Among the explorers of this country the names of Carver, Pike, Cass, Long, Beltrami, Schoolcraft, Nicollet, Owen, ete, will ever be intimately connected with its history. The honor of verifying the sources of the Mississippi belongs to Schoolcraft. The Territorial Government was organized by Governor Ramsey. The first legislature, which adjourned after a session of 60 days on the 1 st November, 1S49, was chiefly employed in consolidating the government aud dividing the Territory into suitable civil districts, and appointing civil officers to enforce the laws. Among its most important acts were those establishing the judiciary, a school system, and relative to the improvements of the roads. All these will have a paramount influence over the future destiny of the country. Perhaps one of the most humane and politic acts of the legislature was the admission to citizenship of "all persons of a mixture of white and Indian blood who shall have adopted the habits and customs of civilized men;" and not less politic is that law which requires the establishment of schools throughout the Territory. The act of the General Government, erecting the Territory; appropriates two sections in every township for the support of common schools. No other State had previously received more than one section in each township for such purpose. In June, 1849 , the citizen population numbered 4,780; in June, 1850, it had increased to $6, \pi$, - a fact which speaks well for the future progress of this rising Territury.

"Congress may hercafter divide said Territory, or annex any portion of it to another State or Territory.-Act of Congress, 3d Jarch, 1849.

St. PAUI, on the left bank of the Mississippi River, is the political capital of the Territory.

Minot, t. and p. o, Cumberland county, $\boldsymbol{M e}_{\mathrm{e}}$ : $31 \mathrm{~m}$. 8. W. by W. Augusta. Drained by Little Androseoggin r. and its branches, which afford exeellent hydraulic power. Surface diversified; soil fertile, and well eultivated. The inhabitants are chiefly employed in agricultural pursuits. There are a number of mills here, and it is imporiant for its manufuctories. The $\mathbf{v}$, of West Minot is in the N. W. part of the $t$, on a branch of the Little Androscogrin $r$, and on the line of the Buckfield Branch R. R. (which crosses the W. part of the t.) $9 \mathrm{~m}$. from Buckifield. Pop. of the $t .1,734$ Mrsster, p. v., Auglaize co., Ohio: on the Miami Canal, $122 \mathrm{~m}$. N. Cincinnati, and $65 \mathrm{~m}$. W. N. W. Columbus.

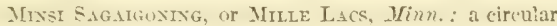
lake lying in Ramsay and bordering on Washington County $79 \mathrm{~m}$. N. St. Paul. Its principal outlet is Rum r. on the $\mathrm{S}$., which empties into the Mississippi.

Mixtoxstule, p. v., Gates co., N. Car.: 128 m. E. N. E. Paleith.

Mrnt Sprixa, p. 0., Augusta co., Firg.: 98 m. W. N. W. Richmond.

Mrrabile, p. Oo, Caldwell county, MO.: $12 \mathrm{~S}$ m. N. W. Jefferson City.

Mmanda, p. v., Rowan co., $N$. Car.: $108 \mathrm{~m}$. T. by S. Raleigh.
Mrnick ville, p. O, Bristol co., MIas8.: 35 m. S. Boston. MISERY river, Dich.: rises in a pond in the W. part of Houghton County, flows N. W., and empties into Lake Superior.

Misrawaka, p. v., St. Joseph cn., Ind.: on the line of the Northern Indiana R. R., and on the S. side of the St. Joseph's r., $131 \mathrm{~m}$. N. Indianapolis.

Mismcotr, p. vu, Manitouwoc co, Wisc.: W. side of East Twin r, 121 m. N. E. Madison.

Mispilion, hundred, Kent co., Det. : between Mispilion and Mother Kill creeks, which flow into Delaware Bay, $13 \mathrm{~m}$. S. Dover. Area, 72,530. It contains several stores, mills, and manufactories, and a number of mechanic shops. Mispilion creek, Det. : rises in the $\mathbf{N}$. part of Sussex co., flowing N. E. divides it from Kent, and empties into Delaware Bay.

Missionary Station, p. v., Floyd co., Ga.: on the $\mathbb{N}$. side of Coosa r., $157 \mathrm{~m}$. N. W. by W. Milledgerille.

Missatree county, Mich. Situate N. centrally on Lower Peninsula, and contains 576 sq. m. Drained by branches of Manistee and Maskegon rivers, which flow into Lake Michigan. Unorganized.

Miśrox Poixt, p. o., La Salle co., Ill.: $130 \mathrm{~m}$. N. N. E. Springficld. 
Mrssios Sax Joss, p. o., Contra Costa co., Calif. : $25 \mathrm{~m}$. S. Tallejo.

Mis:IsQCE bay, Fem. : a large sheet of water, an arm of Lake Champlain, extending into Canada, between Swanton and Highgate E, and Albany W. On the Canada line its width is about $5 \mathrm{~m}$., and extends $\mathrm{N}$. the same distance. It corers an area of 35 square miles. Several streams flow into it, the principal of which is the one so called.

Mrssisque river, Vemm : this crooked river rises in the hilly part of Lowell, flows N. through Westfield and Troy into Canada, where it receives a large stream from the N. E.; running W. several miles, it returns into Vermont through Richford, and after a westeriy course through Berkshire, Enosburg, Sheldon, Highgate, and Swanton, returns N. into Highgate, and empties into Missisque Bay, Lake Champlain, at Highgate, near the Canada line. At Enosburg it receives Trout r., besides which Black cr, and Tay- lor's Branch are its most important tributaries, affording a number of valuable mill-sites. Its length, including windings, is about 75 miles. It has a number of falls in its course. Navigable for vessels of 50 tons burden to Swanton Falls, distant $6 \mathrm{~m}$., where there is extensive hydraulic power.

Mrssigsinawa, t. and p. o., Darke co., Ohio: $94 \mathrm{~m}$. W. by N. Columbus. Drained by Mississinawa r. Surface level; soil fertile, adapted to grain. Danemora $v_{0}$ is in the E. part of the t. on Mississinawa r. Pop. of t. 378.

Mississinawa river, Ind, : rises in W. part of Darke co, Ohio, flowing in a N. W. course into Indiana, passes through the counties of Randolph, Delaware, Grant, and Wabash, and empties into the Wabash river, in Miami co., a short distance below Peru. It forms one of the principal tributaries of the Wabash river. Its upper parts furnish good mill-seats, and its lower is navigable at high water for boats of 10 tons burden.

\section{THE STATE OF MISSISSIPPI.}

MIrssisstrpr is bounded on the north by Tennessee, on the east by Alabama, on the south by the Gulf of Mexico and Louisiana, and on the west by Pearl and Mississippi rivers, which separate it from Louisiana and Arkansas. Like Alabama, it has a narrow strip of land about 90 miles long and 50 miles wide, south of the main body of the State to the Gulf of Mexico. Independently of this tract, it lies between $311^{\circ}$ and $35^{\circ}$ latitudes north, and extends from $88^{\circ} 12^{\prime}$ to $91^{\circ} 36^{\prime}$ longitudes west from Greenwieh, or $11^{\circ} 10^{\prime}$ and $14^{\circ} 34^{\prime}$ from Washington. In the north, the width is about 116 miles, but it expands pretty regularly to 189 miles in the south, and its length, exclusive of the strip above mentioned, is about 276 miles, comprising an area of 47,156 square miles.

The surface of Mississippi has a general slope to the south-west and to the south, as appears from the course of the rivers; but a small section sends off its waters to the south-east. There are no mountains within the limits of the State, yet numerous ranges of hills of moderate elevation give to the greater part of the surface an undulating and diversified character : some of these eminences terminate abruptly upon a level plain, or upon the banks of a river, and bear the names of bluffs or river hills. The western border on the Mississippi is an extensive region of swamps; and between the Mississippi and Yazoo there is a tract of 170 miles in length by 50 in width, with an area of nearly 7,000 square miles annually overflowed. "The broad and extensive low grounds or flats, between Memphis and Vicksburg, are subject to frequent inundations to the depth of many feet, and a width of from 10 to 20, and even occasionally 30 miles. Much of the surface is occupied by swamps, morasses, lagoons, slashes, ete., through which the Yazoo River has its course; the whole of which, from the junction of the Cold Water and Tallahatchee rivers, lies between this valley region. From the circumstances already detailed, this extensive tract has been denominated by some the Mississippi, and by others the Tazoo Swamp. During the prevalence of high floods, it assumes the character of a marine forest rather than that of a woodland bottom." The south-eastern counties are generally low, but have an undulating surface; and the southern part of the State, generally for about 100 miles from the Gulf of Mexicn, is mostly a sandy level country, covered with a pine forest, interspersed with cypress swamps, prairies, water-marshes, and a few hills of slight elevation.

Every portion of the State is well watered; clear and running streams penetrate it in every direction, and its rivers are numerous and wide-spreading. The Tennessee Piver laves the north-eastern corner, and the Tombigbee, which rises in this section, has been navigated by steamboats to A berdeen, in Monroe County. The Mississippi washes the whole western border for a distance, by the circuitous course of its channel, of 530 miles, but in a straight line of not half that distance. From Memphis, just above the northern frontier of Mississippi, to Vicksburg, a distance of 450 miles, the uplands or river hills are separated from the river by inundated bottoms of greater or less width, and afford no site suitable for a port ; below Vicksburg, the only eligible port is Natchez, 100 miles south, and below this point there is no bank of much magnitude above the reach of high water till we come to Baton Rouge, in Louisiana. The Mississippi, however, receives several considerable streams from the most valuable part of the State. The Yazoo is formed by the junction of the Yallabusha and Tallahatchee, which rise in the northern part of the State, near the head waters of the Tombigbee, and flows into the Mississippi 12 miles above Vicksburg, after a course of 200 miles, 50 miles of which are navigable for large boats. Big Black River is next in point of size, and enters the Mississippi immediately above Grand Gulf by a mouth 40 yards wide. Its length is 200 miles, and it is navigated by steamboats for 50 miles. The Bayou Pierre and the Homnchitto are the other principal tributaries of the Mississippi from this State; the latter enters the Mississippi 43 miles below Natchez. The other rivers have a southerly course to the Gulf of Mexico and the lagoons connected with it. The Amitie has but a small part of its course in Mississippi. The Pearl River rises near the centre of the State, and flows through a fertile and populous region into the Rigolets, or outlet of Lake Pontchartrain. Below $31^{\circ}$ north latitude it divides the State from Louisiana, and has been navigated by steamboats to Jackson. The Pascagoula waters the south-eastern section. It is formed by the confluence of the Chickasawha and Leaf rivers, and empties into the sound of the same name. It is navigable for 50 miles for vessels of 6 feet draft of water, and for boats 100 miles farther, but the bay at its mouth has only 4 feet of water.

The coast, which extends along the Gulf of Mexico for about 60 miles, has no harbors except those of Mississippi City and Shieldsboro', which, however, do not admit large vessels. A chain of low sand islands, six or seven miles from the shore, inclose several bays or sounds, the largest of which are Pascagoula Sound and Lake Borgne. Ship and Cat islands are eligible stations for ocean steamers. The ports on the Mississippi are Vicksburg, Grand Gulf, and Natehez.

The upper portion of the State is generally known as North Mississippi, though the region thus designated includes a portion only of the north. This section of the State (the Chickasaw cession) came into market and cultivation some fifteen years ago. The surface of the ground is rather rolling, but generally is very clean; has an open champaign appearanee, and is beautifully wooded with nak, hickory, etc., devoid of undergrowth. The uplands produce very abundantly, but the substratum of the country being sandy, they are soon ruined by the heavy rains. The valley lands, as they are termed, are much more durable, the soil being heavier and darker, and are highly productive; but they are 


\section{MISSISSIPPI.}

liable to be and frequently are submerged, acres at a time, under billows of sand washed from the uplands during heary freshets. Cotton has hitherto been the staple product. The ehicf oullet of this region is by wagons to Nemphis. Another section of North Mississippi is ealled the "Prairie," or "Tombigbee" country, covering the north-east part of the State, and sweeping far down on the Alabama line. This country is uniformly level, with scarcely a tree, covered by rank grass, dotted sometimes with pools and marshes, and intersected by dull, sluggish branches. The soil is a dark, heavy loam, coal-black, and of surprising strength and fertility. The mold is different from that of Lower Louisiana in this, that it is more of an original and less of a depository character; and also in being thick and highly adhesive, instead of light and ashy, as the former. It is also corrosive and deeply impregnated with lime-strong and apparently inexhaustible. The crop is and ever will be cotton, of which the yield is abundant. Corn also yields profusely. This region, though lying by the Chickasaw counties, finds its market at Mobile by means of the Tombigbee River principally. The border counties, down the Alabama line, change from the prairie and partake more of the character of the Chickasaw lands. It is a beautiful and healthy range of counties, finely watered, and produces cotton and the lighter grains. A large portion of the State is known as East Mississippi, which really includes the south-east and part of the southern sections. Though one of the oldest, it is one of the thinnest settled parts of the State. The character of the land is mixed - some poor and some very rich; broken hills and fertile valleys. Cotton is produced, but to no great extent; corn and small grain abundantly, and sometimes rice; it is also famous for its cattle. Indeed, the region possesses many of the pleasant characteristics of a pastoral country. The natural market of this section is Mobile, although a small portion of its trade is done at Jackson, and some of it seeks New Orleans by way of Pearl River. The portion of the State bordering on the sea-shore, with its bathing, fish, oysters, and pleasant summer retreats, is well known to the dust-covered denizens of New Orleans, and is becoming to the South what Newport and Cape May are to the North. Back from the sea-coast is generally a sandy, broken tract, covered by quantities of fine pine, which is now being worked off the land for timber and naval stores. The south-west and country above it is the oldest settled portion of the State; the soil is rich, and the population wealthy. Commencing some 50 miles below the mouth of the Yazoo River, inclining to the interior for about 100 miles in a line gently circling northward up through the centre, then diverging to the north-west to a point below Memphis, is to be found as noble a sweep of country as any in the world. It is washed by the Mississippi from Memphis to Vicksburg, and is intersected by the Yazoo, its head waters and tributaries, throughout its greatest extent. The facilities for market are unequaled. The Yazoo River running through nearly its whole extent, is an excellent stream, affording steam navigation as high as the south-west corner of Marshall County. The soil is of a most productive chardcter, being, as it is called, sucamp land. It possesses all the strength of the prairie lands without their adhesive and corrosive nature. This region has but recently come into cultivation, it having hitherto been considered damp and unhealthy; but this idea experience has much modified. One drawback on these Iands, however, is their liability to overflow from freshets in the Mississippi River. The section last spoken of embraces the counties of Yazoo, Sunflower, Washington, Bolivar, Coahoma, Tunica, Tallahatchie, and a portion of De Soto, Panola, Yallabusha, Carroll, and Holmes, and is generally known as the region of the "River Counties." [Several valuable articles on the topography ete., of Mississippi will be found in "De Bow's Industrial Tesources," etc., volume II.]

Mississippi is divided into 59 counties, the general statisties of which in 1850 were as follows:

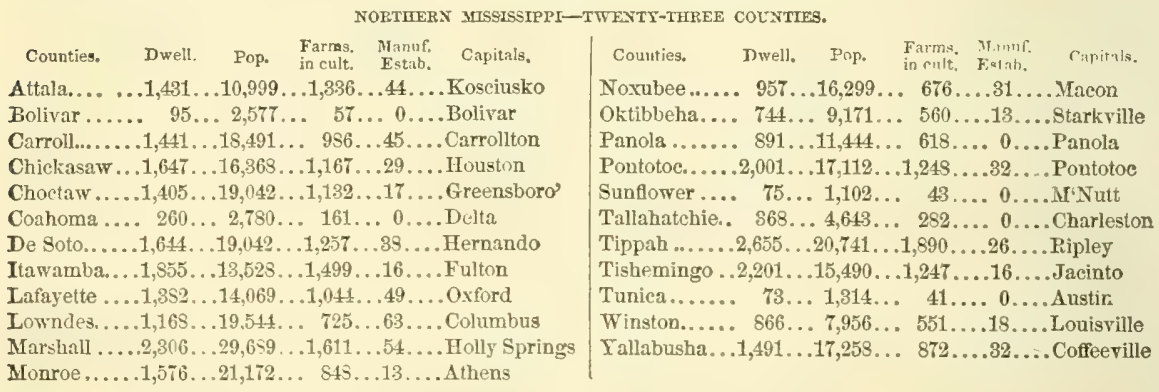

SOUTIERN MISSISSIPPI-THIRTY-SII COUNTIES.

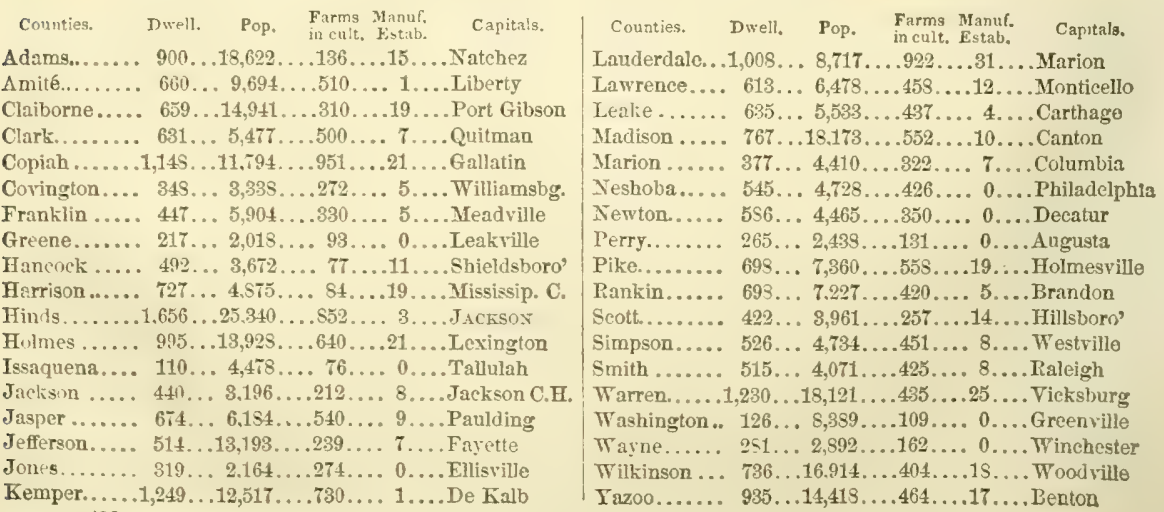




\section{MISSISSIPPI.}

The whole number of dwellings in the State was, at the above date, 51,681, of families 52,107, and of inhabitants 606,565 , viz.: whites 295,758 -males 158,260 , and females 139,498 , free colored 889 -males 473 , and females 426 ; slaves 309,893 . Of the whole population, there were deaf and dumb-wh. 81, fr. col, 1, sl. 26-total 10s; blind-wh. 180, fr. col. 1, sl. 86total 217 ; insane-wh. 127, fr. col. 0, sl. 22-total 149; and idiotic-wh. 141, fr. col. 5, sl. 61-total 210 . The number of free persons born in the United States was 291,114 ; the number of foreign birth 4,958, and of birth unknown 576 ; the native population originated as follows: Maine 189, N. Hamp. 100, Verm. 141, Mass. 389, R. I. 62, Conn. 242, N. York 952, N. Jer, 221, Penn, 981, Del. 67, Md. 791, Dist. of Col. 93, Virg. 40,777, N. Car. 17,009, S. Car. 2,919, Ga. 1,254, Flor. 67, Ala. 2,067, Mississippi 140,885, La. 2,557, Tex. 139, Ark. 456, Tenn. 27,439, Ky. 3,948, Ohio 564, Mich. 101, Ind. 413, Ill. 311, Mo. 303, Ia. 7. Wisc. 4, Calif. 1, Territories 5; and the foreign population was composed of persons fromEngland 593, Ireland 1,928, Scotland 817, Wales 10, Germany 1,064, France 440, Spain 49, Portugal 2, Belgium 3, Holland 8, Italy 121, Austria 16, Switzerland 41, Russia 9, Denmark 24, Norway 8, Sweden 14, Prussia 71, Asia 2, Africa 6, British America 79, Mexico 13, Central America 1, South America 4, West Indies 25, and other countries 110.

The following table will show the decennial progress of the population since the first census of the State, taken by the United States authorities in 1800 :

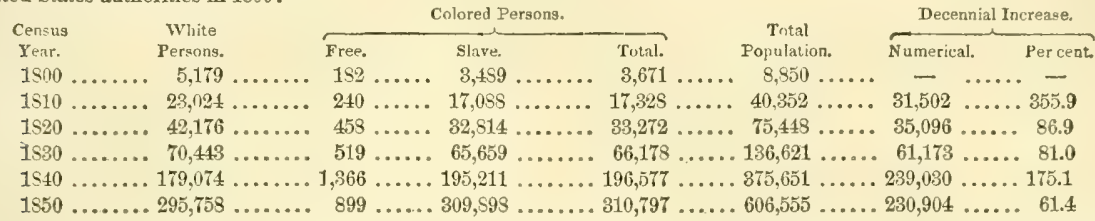

The statistics of the wealth, industry, and institutions of the State, as exhibited by the seventh census of the United States, taken in 1850 , are as follows:

Occupied Lands, etc.-Improved farm lands, 3,444,359 acres, and unimproved lands, 7,046,061 acres-valued together at $\$ 54,738,634$. Total number of farms under cultivation 1st June, $1850,33,960$; in the Northern District, 19,851 ; and in the Southern District, 14,109. Value of farming implements and machinery, $\$ 5,762,927$.

Live-Stock.-Horses, 115,460; asses and mules, 54,547; milch cows, 214,231; working oxen, 83,485; other cattle, $436,25 \pm$; sheep, 304,929; and swine, 1,552,784-valued in the aggregate at $\$ 19,403,662$. According to the census of 1510 , there were in the State at that date, 109,227 horses, mules, etc.; 623,197 neat cattle of all kinds; 128,367 sheep; and 1,001,209 sheep.

Products of Animals,-Wool, 559,619 (in 1840, 175,196) pounds; butter, 4,346,234 pounds; cheese, 21,191 pounds; and the value of animals slaughtered in the year was $\$ 3,636,5 \$ 2$. The quantity of beeswax and honey produced was 397,460 pounds.

Grain Crops.-Wheat, 137.990 bushels; rye, 9,606 bushels; Indian corn, 22,446,552 bushels; oats, 1,503,288 bushels; barley, 229 bushels, and buckwheat, 1,121 bushels. The crops of the several grains, according to the census of 1840 , were -wheat, 196,626 bushels; rye, 11,444 bushels; Indian corn, 13,161,237 bushels ; oats, 668,624 bushels; barley, 1,654 bushels ; and buckwheat, 61 bushels.

Other Food Crops.-Rice, 2,719,S56 bushels; peas and beans, 1,072,757; potatoes-Irish, 261,492, and sweet, 4,741,795 bushels. The rice crop, according to the returns of 1840, amounted to 777,195 pounds; and the crop of potatoes to $\mathbf{1}, 630,100$ bushels.

Miscellaneous Crops.-Tobaceo, 49,960 (in 1840, 83,470) pounds; ginned cotton, 484,293 bales of 400 pounds (in 1840 , $193,401,577$ pounds); hay, 12,505 (in 1840, 171) tons; clover-seed, 84 bushels; other grass-seed, 533 bushels; hops, 473 pounds; hemp-dew-rotted, 7 tons, and water-rotted, 0 tons; flax, 665 tons; flax-seed, 26 bushels; silk cocoons, 2 pounds ; sugar-maple, 0 pounds, and cane, 383 hogsheads of 1,000 pounds; molasses, 18,318 gallons; wine, 407 gallons, etc. ; value of orchard products, $\$ 50,405$, and of market-garden products, $\$ 46,250$.

The table annexed exhibits the absolute and relative difference in the chief crops, as ascertained under the censuses of 1840 and 1850 :

\begin{tabular}{|c|c|c|c|c|c|c|c|c|c|c|c|}
\hline \multirow{3}{*}{$\begin{array}{c}\text { Stiples. } \\
\text { Wool.............. } \\
\text { Indian Corn ...... }\end{array}$} & \multicolumn{2}{|l|}{1840.} & & \multicolumn{2}{|l|}{1850.} & \multicolumn{4}{|c|}{ Movement. } & \multirow{2}{*}{\multicolumn{2}{|c|}{219.4 per cent }} \\
\hline & 175,196 & pounds & , ...... & \multicolumn{2}{|l|}{559,619} & \multicolumn{4}{|c|}{384,423 pounds, or } & & \\
\hline & $13,161,237$ & pushels & ...... & $22,446,552$ & ushels & - iner. & $9,285,315$ & ush & or & 70.5 & "6 \\
\hline ice ............. & 777,195 & pounds & ...... & $2,719,356$ & ounds & ...... iner. & $1,942,661$ & oun & or & 249.9 & 6 \\
\hline obacco.......... & 83,471 & 46 & . . & 49,960 & 66 & ...... decr. & 33,511 & 6 & or & 40.1 & 6 \\
\hline$t \operatorname{ton} \ldots . . . \ldots \ldots$ & $3,401,577$ & 66 & ....... & $93,717,200$ & " & ...... incr. & 315,623 & "6 & or & 0.16 & "6 \\
\hline dgar ........... & 77 & "6 & ...... & 358,000 & " & ...... incr. & 387,923 & 66 & or 5 & 3.796 .1 & 6 \\
\hline
\end{tabular}

Thus it would appear that of all the staples, except tobacco and cotton, the ratio of increase has been immeasurably ahead of the ratio of the increase of the population. Cotton has almost exactly kept its absolute status, which, in fact, is a relative decline in the production of the staple; and if it had increased in like proportion with the population, the crop should bave been about $322,350,000$ pounds. This result in the crop of 1550 is accounted for by the terrible inumdations of the Mississippi in 1849, and may in part be set down to drafting of labor to other fields; the lecline, however, is not permanent.

Home-made Manufactures for the year ending 1st June, 1850, were valued at $\$ 1,161,020$. The same denomination of manufactures in 1839-40, according to the census of the latter year, were valued at $\$ 682,945$.

Manufuctures.-Total capital invested $\$ 0,000,000$; value of all raw material, fuel, ete., consumed, $\$ 0,000,000$; average number of hands employed, 00,000 -males 00,000 , and females 0,000 ; average monthly cost of labor, $\$ 000,000$ - male $\$ 000,000$, and female $\$ 00,000$; value of manufactures produced in the official year, $\$ 0,000,000$. Amount of eapital inrested in manufactures in $1840, \$ 1,797,722$. The whole number of industrial establisluments in the State, producing to the value of $\$ 500$ and upward on the 1 st June, 1850 , was 866 -in the northern district 536 , and in the southern district 380 , and dis. tributed to the counties, as shown in the general table. Of the whole number, 2 were cotton factories, 92 tanneries, and 8 forges, besides which there are several machine-shops, carriage factories, etc.; but the greater part of the capital invested is in grist and saw mills, and other establishments usual in an agricultural country.

Capital employed in the cotton manuficture, $\$ 38,000$; annual consumption of cotton, 430 bales, valued at $\$ 21.500$; hands employed, 36 ; monthly cost of labor, $\$ 371$; annual products, 171,000 pounds yaru; value of entire produets, $\$ 30,500$. 


\section{MISSISSIPPI.}

Capital invested in the iron mumfucture, $\$ 100,000$; material consumed in the ycar-pig fron 1.197 tons, mincral coal 248 tons, and coke and charcoal 92,000 bushels-valued together at $\$ 50,370$; hands employed, 112 ; average wages per month, $\$ 3791$; castings made, 924 tons; total value of products, $\$ 117,490$.

Capital nvested in tanneries, $\$ 145,615$; value of all raw material, $\$ 111,474$; hands employed, 269 ; monthly cost of labor, $\$ 4,949$; skins tanned 9,730 , and sides tanned 104,630 ; value of products, $\$ 229,407$.

Internal Communication.-Mississippi has hitherto been most miserably provided with the means of intercommunication; and had it not been that nature had given it highways in the form of navigable rivers, its great and fertile interior must have remained a wilderness in the midst of thriving populations. Its present condition, even, is little removed from such abnormal uselessness. Excepting its ordinary roads, which, however, are none of the best, the genius of moilern times had done little or nothing to facilitate its access to the markets. True, it has not been backward in projects, yet none but in the single instance of the Vicksburg, Brandon, and Jackson Railroad has been brought to fruition. If rer, then, is the present condition of the commercial avenues of the State. Its prospects for the future are more encouraging. There are now in progress the Mobile and Ohio Railroad, and the New Orleans, Jackson, and Northern Railroad traversing the State north and south, and forming in Mississippi links in the great chain that is to unite the Upper Mississippi and the great lakes with two of the great ports of the Gulf of Mexico; and traversing the State east and west are the Memphis and Charleston Railroad on the north line; a line of railroad from Selma, Ala., westward to Brandon, there uniting with the already complete railroad to Vicksburg, and a line from Madisonville, on Lake Pontehartrain, eastward to a junction with the Mobile and Ohio Railroad near Mobile. These are the trunk lines now in progress, from which it is proposed to build lateral lines to the prineipal centres of production, and so build up a system convenient both for through travel and transportation and for local communication. The exterior connections of these lines will connect the State with every part of the Union; with the Atlantic through the East Tennessee, Alabama, and Georgia lines and their continuations; with the north-eastern portion of the central valley through the lines going to and diverging from Nashville, and with the upper country through the lines terminating at and diverging from the mouth of the Ohio River. Westward it will connect with Texas through the lines from New Orleans and Vicksburg in that direction. The beneficial effect of these great lines on the development of the resources of the State, its commerce and general welfare, can not be doubted. Its rich agricultural regions will be rapidly settled, and the lands which are now lying waste will become the scenes of a busy industry in the cultivation of the great staples for which the State is famous, while its consumption of manufactures to be exchanged for its productions, will create a commerce as extensive as it will be profitable to all sections of the Union concerned in the interehange.

Commerce.-The commercial material of Mississippi is carried to New Orleans and Mobile by river for exportation to foreign countries and the home ports, and its imports are received through the same channels. The direct commerce of the State is therefore inconsiderable, and in fact it is very seldom that an arrival or departure in the foreign trade is recorded; years may pass by and the Treasury reports make no mention of either. In 1849-50 no direct foreign enmmerce or navigation is noted. Its navigation is consequently almost entirely confined to its rivers and the Gulf. The shipping employed in the coasting and river trade is chiefly owned in the adjoining States of Louisiana and Altbama. The tonnage owned in this State amounts only to 1,827 tons, of which 675 tons is navigated by steam; and of the whole, 1,367 tons is owned in the district of Pearl River, and 460 in that of Vieksburg. Of all the States having a front on the sea, Mississippi is nost destitute of harbors, and has the least direct seaward navigation; but its access to its natural ports by river fully compensates for the specified disability.

Bunking. - No returns of the banks of this State are made public, and as a general thing their issues are of a doubtful character. The Northern Bank of Mississippi, at Holly Springs (capital $\$ 100,000$ ), is said to be the only sound banking institution in the State.

Government.-The government is based on the constitution that went into effect in 1817. The right of suffrage is granted to every adult free white male person, a citizen of the United States, resident in the State one year and in the town or county four months next before the election. The general elections are held on the first Monday and Tuesday in November.

The Legislature is composed of a House of Representatives and a Senate. Representatives, not fewer than thirty-six, nor more than one hundred in number (and not less than one to each county), are chosen every second year for two years; they must be qualified voters, and have resided two years in the State, and one year in the place they represent. A census is taken at intervals of not more than eight nor less than six ycars, and the appointment of members made accordingly. Senators, in number not less than one-fourth nor more than one-tlird the number of representatives, must be thirty years of age, for four years citizens of the United States, and for one year residents of their district, and be chosen for four years, one half biennially. The legislature meets at Jackson on the first Monday in January biennially.

The Governor must have attained the age of 30 years, have been a citizen of the Uniled States for 20 years, and for five years a resident of the State. He is chosen by a plurality of votes for two years, and ean not hold the office for more than four out of any six years. He may veto a bill, but it may be passed and become law, notwithstanding his veto, by a subsequent vote of both houses of the legislature.

All officers are elected either in districts or counties, or by the people at large. No person denying the being of God or a future state of rewards and punisuments, can hold office. No money can be expended for internal improvements, except by a vote of two-thirds of both houses; and no State loan can be raised unless the bill be passed by a majority of each house, be published three months before the next election, and be confirmed by a majority of each house, at the next legislature. The legislature can not emancipate slaves without the owner's consent, except on account of great public services, and then must pay for them; nor can it prevent immigrants from importing slaves of the same deseription with those in the State, if they be bona fide property, and not criminals. It may pass laws enabling owners to emancipate slaves, saving the rights of ereditors and the public from being at their charge; and laws directing a sale, on the owner's account, if he treat his slaves cruelly. The introduction of slaves as merchandise after 1st May, 1833, is prohibited, but settlers may import them for their own use until 1845. (These two periods being passed, it is probable that the importation of slaves is now probibited). No grand jury is necessary in the prosecution of slaves for crimes not eapital.

The Judiciary consists of a High Court of Errors and Appeals, a Superior Court of Chancery, District Chancery Courts, and District or Circuit Courts. The jurisdiction of the "High Court" is exclusively appellate. There are two terms each year at Jackson, commencing on the first Monday of January and November. The court may continue in session as long as business requires, and may order a special term, or adjourn to meet at any time. 'The judges are also suthorized to meet annually on the third Monday in June, in the town of Oxford, to receive the written, and hear the oral, arguments 


\section{MISSISSIPPI.}

of causes from the third district, provided the State is not a party. The Legislature appoints the reporter. and has abolished the common law form of pleading, and adopted a system somewhat similar to that of chancery or civil law. The "Superior Court of Chancery," held by the chancellor at the capital, is in law considered always open. "The chancellor is authorized to hold the same at such times and for such periods as business may require, upon giving three weeks' notice in the public newspapers. There are in the State three chancery districts; the "District Chancery Courts," each with a vice-chancellor, have concurrent power and jurisdiction with the Superior Court within their respective districts where the amount in controversy does not exceed $\$ 500,000$. Special terms of these courts may be held by giving thirty days" public notice. For the purpose of holding district or circuit courts, the State is divided into seven districts. The "Circuit Court" has original jurisdietion in eivil eases in which the sum in controversy exceeds $\$ 50$, and it has also exclusive criminal jurisdiction. For each of the districts a judge and attorney are elected every four years.

Amendments to the constitution, if they be passed by two-thirds of each house, shall be submitted to the people six months before the next general election, and if approved by them shall be adopted.

The Militia force of Mississippi consists of 36,084 men of all arms, of which 825 are commissioned officers, and 35,259 non-commissioned officers, musicians, and"privates. Of the commissioned officers 15 are general officers, 70 general staff officers, 392 field officers, ete., and 318 company officers.

The benevolent institutions of the State are the Institution for the Blind, and the Mississippi Lunatic Asylum at Jackson.

Finances, etc.-The receipts into the treasury for the year ending 30 th April, 1850, amounted to $\$ 397,40263$, and the expenditures by warrant during the same year to $\$ 284,99958$. Excess of means, $\$ 94,40305$. The chief sources of ineomo and the amounts collected from each, were-State tax $\$ 334,689$, internal improvement fund $\$ 13,196$, the sinking fund $\$ 19,857$, penitentiary $\$ 3,189$, the seminary fund $\$ 1,251$, redemption of lands $\$ 4,001$, land sales $\$ 2,720$, ete; ; and the principal objects and amounts of expenditure, were-Legislature $\$ 48.731$, judiciary $\$ \$ 2,307$, executive $\$ \$, 369$, contingent fund (executive) $\$ 4,195$, appropriations $\$ 26,179$, penitentiary $\$ 25,266$, printing $\$ 5,323$, executed slaves $\$ 3,762$, University $\$ 10,957$, Common Schools $\$ 17$, Lunatic Asylum $\$ 5,000$, Institution for the Blind $\$ 2,455$, seminary fund $\$ 3,920$, commissions for assessing $\$ 9,540$, clections $\$ 2,024$, ten per cent. fund $\$ 35,312$, etc. The State tax is based on personal and real estate, and the objects of taxation are occupied lands and town lots, money at interest, merchandise scld, bank stock, auction sales, pleasure carriages, watches, clocks, ten-pin alleys, race-tracks, bowie-knives, pistols, eattle over 20 head, horses, stallions, jacks, pianos, male free negroes, slaves under 60 years old, free white polls, etc. The absolute debt of the State amounts $\$ 2.271,707$, and the contingent debt to $\$ 5,000,000-$ total, $\$ 7,271,707$. The annual interest on the absolute dent is about $\$ 136,000$. The State has property to the value of $\$ 2,000,000$, but this is at present unproductive. The total assessed value of taxable property in the State in 1850 was $\$ 20 \$, 422,167$; the true value of property, as ascertained by the census of 1850 , amounts to $\$ 228,304,332$.

Federal Representation.-Mississippi, in accordance with the act of $23 \mathrm{~d}$ May, 1850 , apportioning representation, sends five representatives to the Congress of the United States.

Education.-Mississippi has never had an efficient common school system, the sparseness of the population having proved a formidable obstacle to the success of any general system. A law was passed in 1846 giving the appointment of school commissioners to the Board of Policy in each county, with power to levy taxes, etc. All the large towns organized schools under this system; but by a later act essential alterations have been made in the law, and speeial laws for particular counties now govern these institutions. The means of the State for school purposes are ample, consisting of funds arising from leases of the sixteenth sections of land, from fines and forfeitures, and from licenses of hawkers and pedlars, keepers of billiard-tables, retailers of liquors, and brokers. Besides the common schools, there are in the State numerous seminaries, to the support of which the State contributes annually. The collegiate institutions of Mississippi are-the University at Oxford, founded 1844; Oakland College, founded 1830, and Mississippi College at Clinton. The University is partly supported by the State, and in 1850 had 6 professors and 134 students.

Public Libraries.-One State library, 5,000 volumes; 3 college libraries, 5,189 volumes; 2 students' libraries, 2,411 volumes; 102 public school libraries, 3,050 volumes-total libraries, 108 , and 15,650 volumes.

Periodical Press.-Whole number of periodicals and newspapers, 56-16 whig, 21 democratic, and 19 neutral in politics, the latter number, including also those devoted to litorature, science, religion, and all the character of which is not ascertained. Of the whole number, 2 are issued tri-weekly, and circulate 3,500 copies at each issue, or 546,060 copies annually; 2 semi-weekly, 858 copies, or annually 92,352 copies; and 52 weekly, 26,452 copies, or annually 1,377,064 copics. The tri-neeklies are the "Vichsburg Sentinel" and the "Vicksburg Whig ", the semi-weeklies are the "Natchez Courier" and the "Natchez Free-Trader" and the weeklies are publisbed-2 at Vicksburg, editions of the tri-weeklies; 2 at Natchez, editions of the semi-weeklies; 3 at Kosciusko, 1 at Liberty, 2 at Carrollton, 1 at Port Gibson, 3 at Houston, 1 at Gallatin, 1 at Hernando, 1 at Gainesville, 1 at Biloxi, 4 at Jackson, 2 at Lexington, 1 at Paulding; 2 at Fayette, 1 at Monticello, 1 at Marion, 2 at Oxford, 1 at Columbus, 2 at Canton, 2 at Holly Springs, 2 at $A$ berdeen, 1 at Macon, 1 at IIolmesville, 1 at Panola, 2 at Pontotoc, 1 at Brandon, 1 at Jacinto, 1 at Ripley, 2 at Woodville, 1 at Louisville, 1 at Grenada, and 1 at Coffeeville.

Religions Denominations.-The statistics of the several religious denominations in the State, according to the census of 1850 , were for that year as follows:

\begin{tabular}{|c|c|c|c|c|c|c|c|c|c|}
\hline $\begin{array}{c}\text { Nor of } \\
\text { Churches. }\end{array}$ & & $\begin{array}{l}\mathbf{V} \\
\mathrm{Pr}\end{array}$ & na- $\begin{array}{l}\text { No, of } \\
\text { Churclies. }\end{array}$ & & 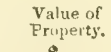 & $\begin{array}{l}\text { No. of } \\
\text { Cliveches. }\end{array}$ & & & rty: \\
\hline 090 & & & n Ref. - & 一 & & olic.. 8 & & & \\
\hline .. 8 & & . & $\ldots \ldots-\ldots$ & 一 & - & o'n. - & 一 & & 一 \\
\hline t'l.. - . & 一 & .. & an ... $-\ldots$ & - & - & $\ldots . .-$ & - & & \\
\hline ef... - .. & - & . & $\ldots-\ldots$ & - & 一 & $\ldots 5$ & $1 \mathrm{SO}$ & & 4 \\
\hline ... 13 & & & $\ldots 406 \ldots$ & 112,9 & 109 & .. - & - & & - \\
\hline ... 3 & 7 & & $\cdots$ & - & - & st.. - & - & & \\
\hline iends..... - & - & 一 & Presbyterian 135 .. & 47,166 & $1 S 3,0 S^{\circ}$ & 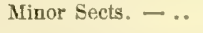 & 一 & -. & \\
\hline
\end{tabular}

-making a totnl of 914 churches, with accommodation for 275,979 persons, and valued as property at \$i54,542. Mississippi constitutes a diocese of the same name of the Protestant Episcopal Church, and uiso the Roman Catbolic diocese of Natchez, a suffragan of the ecclesiastical province of New Orleans.

Pruperism and Crime.-The whole number of paupers relieved or supported in the year ending 1st June, 1\$50, was 260 , of which 245 were native-born and 12 foreigners; and the whole number of paupers at the date specified, $25 \pi$, of 
which 245 were native-born, and 12 foreigners; annual cost of support, $\$ 18,132$. The State prison is located at Jacksoa. The whole number of convicts on the 30th November, 1849, was \$8, and the whole number received since the establishment of the prison in 1540 was 217 , averaging 31 per annum. Of the number in prison in 1848, 7 were foreigners, and 81 natives, and 5 were confined for attempts to kill, 13 for manslaughter, 14 for negro stealing, 5 for forgery, 29 for petty larceny, and 11 for grand larceny. The discharges for the year ending as above were-by expiration of sentence 10, by pardon of governor 13, and by writ of error 1.

IIistarical Sketch -Mississippi was discovered by De Soto in 1542 , but no permanent settlement was attempted by him. The Indians inhabiting the country were the Choctaws, Chickasaws, Natchez, etc., with which, from the time of the first white trespasser on their lands to the cession of 1763 , there was a constant warring. La Salle, descending the rivers from the Illinois country, visited the section bordering on the Mississippi in 1681; and in 1698 the first attempts to found permanent settlements were made by Iberville, the Governor of Louisiana. His colony arrived at Ship Island in 1700 , and after exploring the country along and beyond the Mississippi, the parties returned and built a fort at Biloxi, at the month of the river of the same name, about 20 miles north of the island. Other settlements were made on the Mississippi River, as New Orleans, Natchez, ete. Fort Rosalie, on the present site of Natchez, was surprised and captured by the Natchez Indians in 1729, and great distress was also, at this time and for many years after, caused by tho hostility of this tribe and the Chickasaws. The Choctaws were generally allies of the white settlers, and fought bravely by their side. These hostile tribes were subsequently brought to sue for peace under Bienville, and are now only known by the history their warlike opposition has made for them-not one remains to tell the story of their wrongs. The war between England and France, which forms so conspleuous a page in the history of the middle of the 18th century, ended in 1763, France relinquishing to Britain all her possessions east of the Mississippi, and to Spain all west of that river. Spain at the same time gave up Florida to the British. In 1788 the country north of the parallel of 310 north was included in the limits of the United States by the treaty acknowledging the independence of the Union; and the Floridas reverted to the Spanish crown. By its charter granted in 1732, Georgia extended westward to the Mississippi, and hence, though at that perind Mississippi was de facto a French colony, yet, on its coming into the possession of the English, it of course fell into the limits of the Georgia charter. These extensive territories were subsequently ceded to the United States, both in sovereignty and ownership. In 1798, they were formed into a Territorial Government, which included also the present State of Alabama. In 1s11, that portion of the country south of $31^{\circ}$ was attached to the territory, having been wrested from Spain-because that nation could not take care of it. In 1817, the territory was divided, the eastern portion forming a territory under the name of Alabama, and the western portion was erected into the State of Mississippi. The date of its admission into the Union as a State was the 1st March, 1817.

$J_{A C K 60 \mathbb{N}}$, on the west bank of Pearl River, is the political capital of the State.

Mississippr county, Ar\%. Situate N. E., and contains 1,129 sq. m. Bounded E. by the Mississippi, W. by the St. Francis, and drained by Whitewater river and its affluents. Surfice low and swampy in many parts, with several large lakes. Soil very fertile, where capable of cultivation, and covered mostly with fine timber. Corn is the principal product. The most hazardous navigation of the Mississippi, and the first cotton plantations descending the river, are on the S. border. Farms 170 ; manuf. 2; dwell. 2S4, and pop.-wh. 1,496, fr. col. 7, sl. 865-total 2,368. Capital: Oceola.

Mississrppr county, MFo. Situate S. E., and contains 368 sq. m. Bounded E. by the Mississippi, and drained by Cypress and James bayous. Surface low and marshy, and in parts subject to inundation; soil very fertile. Corn is the staple, and the crops are very large. Timber is abundant. Farms 27 ; manuf. 0 ; dwell. 443 , and pop.-wh. 2,373 , fr. col. 3, sl. 746-total 8,122. Capital: Ohio City.

Mrssissippr CrTY, p. vo, and cap. Harrison co, Afiss. : on Pascagoula Sound of the Gulf of Mexico, 67 m. E.N. E. New Orleans, and $145 \mathrm{~m}$. S. E. Jackson. It contains the usual county buildings, and bas some coasting trade.

Mississmpri river: an immense river of the United States, which, whether we consider its great length, its vast tributaries, the extent of country which it drains, and the distance to which it is navigable, well deserves the title which the Indians give it of the "father of waters." The import in the Algonquin language of Missi Sepe, the name by which it is designated, is great river. It drains a country of over $1,000,000$ square miles in extent, eminently fertile, and sending through it to its destined market a vast amount of produce, and receiving in return the productions of other parts of the world. Its extreme source was discovered by Schnolcraft in July 13 th, 1832 , to be Itasca lake, in $47010^{\prime} \mathrm{N}$. lat., and $91^{\circ} 5 t^{\prime} \mathrm{W}$. long., at an elevation of 1,500 feet above the ocenn, and 3.160 miles from its entrance ints the Gulf of Mexico. Itasen lake, or Iac la Biche of the French, is a beautiful sheet of water, of an irregular shape, about $8 \mathrm{~m}$. long, situated among hills covered with pine foresis, and fed chiefly by springs. It has its outlet to the $\mathrm{N}_{\text {., }}$ which is about 10 or 12 feet wide, and from 12 to 18 inches deep, and flow490 ing northwardly, it passes through Iakes Irving and Traverse, and then turns eastwardly, and proceeding through several small lakes, it enters Lake Cass. This lake is about $16 \mathrm{~m}$. long, contains several islands, is about $3,000 \mathrm{~m}$. from the Gulf of Mexico, at an elevation of 1,330 feet above the ocean, and $182 \mathrm{~m}$. below Lake Itasca, the source of the Yississippi. It then flows E. to Lake Winnipec, and S. E. to Little Lake Winnepec, below which it receives Leech lake fork, the outlet of a considerable body of water of a very irregular form, called Leech lake. This was formeriy regarded as the source of the Mississippi. The most northerly point obtained by the Mississippi is a little short of $45^{\circ} \mathrm{N}$. lat. From the junction of Leech lake fork the river expands to 100 feet in width, and increase of depth, and flows with a mean current of $1 \frac{1}{2}$ miles per hour, and a descent of $3 \mathrm{in}$. in a mile, through a low prairie country covered with wild rice, rushes, sword-grass, and other aquatie plants, and is the favorite resort of water-fowls and various amphibious quadrupeds. At the falls of Peckagama the first rocky stratum and the first wonded island is seen, at the distance of $685 \mathrm{~m}$. above the falls of St. Anthony. At the fall of Peckagama the river descends 20 feet in 300 yards, by a rapid which entirely obstructs navigation. At the head of these falls the prairies entirely cease, and below a forest of elm, maple, birch, oak, and ash overshadow the stream. The river now takes a southerly course, curving to the west, and again to the east, to the falls of St. Anthony. The fall of the river above may be computed at 6 inches in a mile, with a current of $3 \mathrm{~m}$, an hour, exclusive of some rapids, and has some dry prairies on its shores, the resort of the buffalo, elk, and deer, and are the only part of the Mississippi in which the buffalo is now found. At the falls of St. Anthony, $813 \mathrm{~m}$. above the mouth of the Missouri, the river has a perpendicular descent of about 25 feet, with a formidable rapid above and below. The rapid above the falls has a descent of 10 feet in the distance of 300 yards, and below the falls a descent of 15 feet in the distance of half a mile. An island at the brink of the falls divides the current into two parts, the largest of which is on the west of the island, and immediately below the falls are large fragments of rock, in the interstices of which some alluvial soil has accumu- 
lated, supporting a stinted growth of cedars. The whole fall has a descent of about 41 feet in less than three-fourths of a mile. This fall has nothing of the grandeur of Niagara, but the cataract and the surrounding scenery are widely picturesque and beautiful. In times of high floods it may approach to the sublime. The width of the river above the falls is 500 or 600 yards, and at the falls is 227 yards, but zarrows to 200 yards a short distance below. The portage around the falls is about 260 rods. In 1505 the United States purchased of the Sioux tribe of Indians a tract of $9 \mathrm{~m}$. square, including the falls of St. Anthony, for a military post, for the sum of $\$ 2,000$. On this territory Fort Snelling is situated. A considerable tract of fertile land has been put under cultivation by the garrison. As an indication of the climate, the first green peas were eaten here on the 15th of June, and the first green corn on the 20th of July; and on the last of July Schoolcraft found much of the corn too hard to be boiled for the table, and some ears might have been selected sufficiently ripe for seed corn. A little below the falls of St. Anthony the Minnesota river enters from the W., and is much the largest tributary of the upper Mississippi. For $200 \mathrm{~m}$. above its entrance Carver found it about 100 yards wide, with a great depth, and it receives several important tributaries. It is 150 yards wide at its mouth, and 10 or 15 feet deep. About $44^{\circ} 45^{\prime} \mathrm{N}$. lat. the St. Croix enters on the N. E. side, which is 100 yards wide at its mouth. About 500 yards above its mouth it expands into a lake called St. Croix lake, which is $36 \mathrm{~m}$. long, and from $1 \frac{1}{2}$ to $3 \mathrm{~m}$. broad, and the river is said to be navigable for boats for 200 miles. About $15 \mathrm{~m}$. below the mouth of the St. Croix the Mississippi expands into a beautiful sheet of water called Lake Pepin, which is $24 \mathrm{~m}$. long, and from 2 to $4 \mathrm{~m}$. broad, and is $100 \mathrm{~m}$. below the falls of St. Anthony. On the $\mathrm{E}$. shore is a range of limestone bluffs, and on the W. an elevated level prairie, covered with a luxuriant growth of grass, and nearly destitute of forest trees, with occasional conical hills, which sppear like artifieial mounds. At the lower termination of Lake Pepin Chippeway river enters from the N. W., after a course of about $300 \mathrm{~m}$. In $43^{\circ} \mathrm{N}$. lat. Wisconsin river enters on the $\mathrm{E}$. side; it is navigable 200 miles, and a canal is in construction near Fort Winnebago, Columbia co, which, $1 \frac{1}{2}$ m. long, will connect with Jeenah river, and thereby with the great lakes. A little below this eomes in Turkey river from the W. A little below $42 \circ \mathrm{N}$. lat, enters the Wapsipinicon, a considerable river from the $\mathrm{W}$., and a little down, Rock river, a clear and beantiful stream, enters on the $\mathrm{E}$. side. A little above Rock river are long rapids, which at low water render it difficult for boats to ascend. At $41010^{\prime}$ enters the Iowa, a large river from the W.., and below that enter on the same side Skunk and Des Moines rivers. The latter is perhaps the largest western tributary above the Missouri. It is 150 yards wide at its mouth, and said to be boatable for nearly 300 miles. A few miles above its mouth are rapids, $9 \mathrm{~m}$. long, forming a serious impediment to navigation at low water; but these obstacles will be overcome by a canal now in construction. In about $39^{\circ} \mathrm{N}$. lat. comes the Illinois river, a noble, broad, and deep stream, and the most considerable tributary of the Mississippi above the Missouri. It is nearly 400 yards wide at its mouth, is about $400 \mathrm{~m}$. long, and navigable to Peru, $269 \mathrm{~m}$. from its mouth, at which point commences the Illinois and Michigan Canal, exteriding to Chicago, $100 \mathrm{~m}$. long. A little below $39^{\circ} \mathrm{N}$. lat. comes in from the W. the mighty Missouri, which is longer and probably discharges more water than the Mississippi; and had it been earlier explored it would probably been considered as the parent stream, but it will henceforth be considered only as a tributary. The Mississippi above the junction is a remarkably clear stream, but this is entirely destroyed by the entrance of the turidid Missouri, which commurieates its own muddy appearance to the Mississippi through the remainder of its course, thus asserting its superiority. (see Mrssourt river). Near $38^{\circ} \mathrm{N}$. lat. the Kaskaskia river comes in on the E. side. It is $S 0$ yards wide at its mouth, flows through a beautiful country, is over $300 \mathrm{~m}$. long, and is boatable in high water over $100 \mathrm{~m}$. Near $37^{\circ} \mathrm{N}$. lat, comes in from the E. the beautiful Ohio, "La Belle Riviere" of the French, and is much the largest eastern tributary, and from the densely populated and highly fertile country on its borders, it is at present much the most important branch of the Mississippi. The large tributaries, the Cumberland, Tennessee, and Wabash, contribute to its magnificence and importance. At $34^{\circ} 40^{\prime}$ the St. Fraucis enters from the W., 200 yards wide at its mouth, and supposed to be navigable by one of its forks for 300 miles. At $34^{\circ} \mathrm{N}$. lat. White river enters on the $W$. side, by a mouth from 300 to 400 yards wide, and is probably about $1,200 \mathrm{~m}$. long. Thirty $\mathrm{m}$. below, at $33^{\circ} 48^{\prime}$, the Arkansas enters from the W., by a mouth 500 yards wide, and is supposed to be $2,500 \mathrm{~m}$. long. It is, next to the Missouri, the largest western tributary, and its waters are of a dark flame color when the river is full. At $32^{\circ} 24^{\prime}$, a little above the Walnut hills, in the State of Mississippi, near Vicksburg, the Yazoo river enters on the E. side, by a mouth from 200 to 300 yards wide. At $31004^{\prime}$ Red river enters on the W. side. It is nearly as large as the Arkansas, and discharges about as much water. Here the Mississippi carries its greatest volume of water, as immediately below this, and at intervals after, it sends off several large outlets. Three $\mathrm{m}$, below the mouth of Red river passes off on the $W$. side, the Atchafalaya or Chaffalio Bayou, as it is called, which is supposed to carry off as much as the Red river brings in. . Here the Mississippi has a famous "cut-off," by crossing the isthmus of a large bend, so that the main channel does not pass the mouth of Red river. The Atchafalaya has been supposed to be the ancient bed of Red river, by which its waters were discharged without mingling with the Mississippi, and much of its water is now discharged by this outlet. A little below Baton Rouge the Iberville passes off on the $\mathrm{E}_{\text {. side, going through lakes }}$ Maurepas, Pontchartrain, and Borgne into the Galf of Mexico. In times of flood it carries off considerable water. Between this outlet on the $\mathbf{E}$. and Atchafalaya on the W. is what is called the Delta of the Mississippi. Between Atchafalaya and New Orleans pass off, on the W. side, Plaquemine, which joins the Atchafalaya, and La Fourche, which pursues an independent course to the Gulf of Mexico. At the distance of $105 \mathrm{~m}$. below New Orleans by the course of the river, and $90 \mathrm{~m}$. in a direct line, this majestic river enters the Gulf of Mexico by several mouths, the principal of which are called the Balize or north-east pass, in $2907^{\prime} 25^{\prime \prime}$ N. lat., and $89^{\circ} 10^{\prime} \mathrm{W}$. long., and the south-west pass in $29^{\circ} 8^{\prime} \mathrm{N}$. lat., and $89^{\circ} 25^{\prime} \mathrm{W}$. long. The depth of water on the bar at each of these passes is 12 feet, but much greater a little without and within the bar. Most of the vessels enter and leave the river by the north-east pass. It might naturally be expected from the extent of enuntry drained by the Mississippi that the spring floods would be great. From the mouth of the Missouri the flood commences in March, and does not subside before the last of Mar, at an average height of 15 feet. From the Missouri to the Ohio it rises 25 feet, and for a great distance below the ohio it rises 50 feet. At every flood it overspreads the country, ehiefly on its $W$. side, for $500 \mathrm{~m}$. from its mouth, to the distance of from 10 to 30 miles. From the falls of St. Anthony to the mouth of the Missouri it has a medial current of $2 \mathrm{~m}$. an hour; and at every place, except at the rapids of the Des Moines, it has a depth of water of not less than 4 feet at the lowest stages. Below the Missouri its depth is greatly increased, but its width, except in the forests and swamps, when overflowed, is very little increased. To the mouth of the Ohio it has in the channel 6 feet of water at its lowest stages, and at the highest of 25 feet. From the mouth of the Ohio to the St. Francis there are various shoal places, where at low water pilots are often perplexed to find a sufficient depth of water. Below that point there is no difficulty for vessels of any draught, except to find the right channel. Above Natchez the flood begins to decline; at 
Bator Rouge it seldom exceeds 30 , and at New Orleans 12 feet. This river is exceelingly winding in its course, and sometimes a bend will occur of 30 miles, where the distance across the neck will not exceed a mile. The mighty volume of water often carries away a large mass of earth, with its trees, from a projecting point, and frequently endangers vessels. Trees are also often bedded in mud, with their tops projecting, producing snags and sawyers, as they are called, dangerous to navigators. The whirls or eddies which are produced by the tortuous course of the river and its projecting points, render the navigation to a degree difficilt and dangerons. Below the Missouri the medial current is about $4 \mathrm{~m}$, an hour. It is difficult, on viewing it for the first time, to have an adequate idea of its grandeur, and the amount of water which it earries. In the spring, when below the mouth of the Ohio its banks are overflowed, although the sheet of water that is making its way to the gulf may be $30 \mathrm{~m}$. wirle, yet finding its way through forests and swamps which conceal it from the eye, no expanse of water is seen but that which is included between its wooded banks, which seldom exceeds but often falls short of a mile in width ; but when it is seen, from time to time, to swallow up many large rivers, it will be easily conceived that it must have a great depth. At the lowest water, at the efflux of the Atchafalaya, at the head of the Delta, it is from 75 to 80 feet deep; at the outlet of La Fourche, at Donaldsonville, 130 feet: upward of 100 feet at New Orleans, and from 75 to $\mathrm{S} 0$ feet $3 \mathrm{~m}$. above the main bars. Vesssis are often from 5 to 30 dass in ascending from the mouth of the river to New Orleans, though they will, with a farorable wind, often deseend in 12 hours. Before the introluction of steamboats it required 8 or 10 weeks to go to the lllinois. Boats of 40 tons ascend the river to the falls of St. Anthony, more than $2,000 \mathrm{~m}$. from its mouth. The use of steamboats has nearly superseded all other vessels for ascending the river. Large flat-bottomed boats, denominated arks, which are not designed to return, are extensively used for transportation down the river. The first steamboat on the western waters was built at Pittsburg, in 1811; there are now over 300 on the Mississippi and its tributaries, many of them of great burthen. The passage from Cincinnati to New Orleans and back has been made in 19 days. Large ships, moved by sails, rarely ascend above Natchez. There are no tides in the Mississippi.

Distances navigable by steam on Mississippi river and its principal branches:

\begin{tabular}{|c|c|}
\hline Miles. & $\mathrm{Mi}$ \\
\hline Mississippi . & Missouri \\
\hline you La Fourche..... & Des Moines. \\
\hline Black............ & Cedar... \\
\hline $200 \ldots \ldots \ldots \ldots \ldots \ldots, 300$ & Iowa. \\
\hline insas........ & Rock \\
\hline te............... 500 & Wisconsin \\
\hline rancis........... 300 & Black... \\
\hline $.1,000$ & Chippewa..... \\
\hline raskia ............ 150 & Minnesota..... \\
\hline ec...$\ldots \ldots \ldots$ & \\
\hline
\end{tabular}

MississipPi Sprivgs, p. v., Hines co, Miss.: $10 \mathrm{~m}$. W. Jackson.

\section{THE STATE OF MISSOURI.}

Irssoter is situated generally between the latitudes of $36^{\circ} 30^{\prime}$ and $40^{\circ} 30^{\prime}$ north, and the longitudes of $85^{\circ} 55^{\prime}$ and $95^{\circ} 39^{\prime}$ West from Greenwich, or $11^{\circ} 53^{\prime}$ and $15^{\circ} 36^{\prime}$ from Washington. It is bounded on the north by Iowa, on the east by Illinois and Kentucky, on the south by Arkansns, and on the west by the Indian and Nebraska territories. More specifically its eastern boundary is the Mississippi River, beginning at latitude $36^{\circ}$ and running north to the mouth of the Des Moines River, whence the line follows the latter up to its rapids $\left(40^{\circ} 30^{\prime}\right)$; thence along that line westward to where it cuts the Missouri River; thence down that river to the mouth of the Kansas, whence it runs due south to $36^{\circ} 30^{\prime}$, and along that line eastward to the St. Francis; thence follows that river to $36^{\circ}$, and traverses that line to the place of beginning. Its general extent from north to south is 278 miles, but including the narrow strip between the St. Francis and Mississippi rivers 312 miles; and greatest extent from east to west is 318 miles, and its least extent less than 200 miles; and the area of its superficies is estimated at 67,390 square miles.

The river Missouri separates this State into two parts, distinguished from each other by dissimilar geographical and geologieal features. South of that river, as far west as the Osage, the surface of the country is rolling, and gradually rises into a hilly and mountainous district, forming the outskirts of the Ozark Mountains. Beyond the Osage, at some distance, commences a vast expanse of prairie land, which stretches away to the Rocky Mountains. The chief geological deposits of the region are solid strata of carboniferous and siturian limestone and sandstone, reposing on or around the unstratified primary rocks. In the hilly and broken mineral region, which includes the greater part of the State south of the Missouri, the soil is formed of decomposed sandstone, sienite and magnesian limestone. Soils constituted of the two last elements are fertile, but in many of the districts of the mineral region their productiveness is impaired by the admixture of oxyde of iron. Other districts, as the Bellevue Falley, and the valleys of the Maramec, Gaseonade, and Osage are well fitted for cultivation or for pasture. Around the head waters of the White, Eleven Points, Current, and Big Black, where the land is most mountainous, the soil is formed of decomposed semivitreous sandstone, and is in general unproductive, though it supports a magnificent growth of yellow pine, valuable for its lumber. The intervening vallers, however, are decidedly fertile, but of small extent. The lands situated more immediately south of the Missouri are partly sandy and partly calcareous, and in general where alumina or clay sufficiently abounds the soil is excellent and well adapted to the production of the staples of the State.

That part of the State lying north of the Missouri River is in no place mountainous, but either rolling or quite flat. It contains a much richer soil than the southern division, and is in a more advanced state of cultivation. Its geological substratum is chiefly carboniferous limestone. The coal measure of Illinois extends west of the Mississippi at St. Louis, and is probably commensurate with the northern division of the State, being limited on the south by the narrow strip of land above spoken of, lying south of the Missouri. The soils of this region are chiefly calcareous and arenaceous, the aluminous being limited in extent. The calcareous, or those abounding in lime, which are predominant, are fertile, particularly near the margins of rivers. Or this character are the lands in the western parts along the Missouri. The counties of Clay, Platte, and Buchanan can not readily be surpaesed in productiveness, and the other western and interior counties are nearly equal in fertility. In the eastern part of this region arenaccous or sandy soil predominates. These lands, which are comparatively barren, are found nn the southern flank of the prairies which have their origin in north Missouri, and extend to the head waters of the Mississippi River.

The south-eastern part of the State, the surface of which was once capable of cultivation, became after the earthquakes of 1811-12 marshy. This district eontains on estimate 1,517,2s7 acres, and extends south from the neighborhood of Cape Girardeau into the northern part of Arkansas, a distance, in Nissouri alone, of 108 miles, and westwardly as far as the river St. Francis. The land is well located, as regards facilities of transport, and is said to be as fertile as any in the 


\section{MISSOURI.}

talley: and as the greater portion can be reclaimed, it may be bronght under cultivation at some future time. This inundated tract is for the most part heavily timbered.

Missouri is bountifully supplied with navigable water courses, affording an easy access to every portion of the State. Omitting the Mississippi, which washes the eastern houndary for 470 miles, the great river, and the one from which it derives its name, is the Missouri. This river rises in the Rocky Mountains, not fur from the head waters of the Columbia, 3,095 miles from its mouth. The last 400 or 500 miles of its course above lie within the limits of this State. The trough through which the river flows is from 4 to 5 miles wide, and is bounded by rocky limestone hills, whieh rise to the height of from 100 to 300 feet. Nearly all the bottoms of the Missouri are on its north side, and ordinarily they are not subject to inundation. In this respect they differ widely from those of the Mississippi, which latter are of greater width and formed of a less sandy soil, and are less easily percolated by water. The Missouri flows down an inclined plane, the upper strata of which are easily disintegrated, and the particles mingling with the rapid current, give a turbid appearance to its waters. The alluvial lands lying along its course are subject to be covered, during inundations, with drifting sand; they are, however, occupied by a luxuriant vegetation both of trees and herbs. Those bottoms are favorites with settlers, and are capable of supporting a dense population. The river is navigable to its falls, 2,000 miles, but is rapid and can only be readily ascended by steam-power. Of the tributaries of the Missouri, the largest is the Osage River, which disembogues 120 miles from its mouth. At this point it is 400 yards wide, and is navigable for boats of light draft for about 200 miles at high water. About the head waters of this stream are found the best cotton lands in the State. The Gasconade comes into the Missouri east of the Osage, near the village of Hermann, and is important for the supplies of fine plank and timber it furnishes to the country below. The Maramee, a beautiful river, runs through the mineral region, and flows into the Mississippi 18 miles below St. Lonis. Further south are the rivers St. Francis and White, which pass into Arkansas after spreading numerous branches over the southern part of this State. Several tributaries of the Arkansas water the south-west section, but are not navigable.

North of the Missouri are Salt and Copper rivers, which empty into the Mississippi; and the northern tributaries of the Missouri are the Grand and Chariton rivers, both navigable, and composed of numerous branches, which drain a large country. Further west, and falling also into the Missouri, are the Platte and Nodaway. Many of the rivers of Missouri are obstructed by rafts and fallen trecs, and more especially is this the ease with the Grand, Osage, Salt, Maramee, and St. Francis; the navigation of these, however, will be improved at no distant period, or as soon as the wants and interests of the people demand such improvements. Other rivers than those mentioned are of minor importance.

The mineral region of Missouri occupies an area of about 18,000,000 acres, As early as 1718 it was described in a French chart as "au pays plein de mines." It extends from the head waters of the St. Francis to the Maramec River, a distance of about 70 miles in length, and from the Mississippi in a south-westerly direction, about 60 miles. The elevation of the district above the sea level varies from 600 to 1,200 feet. The climate is equable and salubrious, and the superincumbent soil moderately fertile. No one of the mining districts of Europe enjoys such facilities of supporting a large population; and yet the Harz Mountains, with an area of 300,000 acres, sustains 60,000 inhabitants; the Erzgebirge, of Saxony, with about 1,500,000 acres, sustains 500,000 inhabitants; and Cornwall, with 760,000 acres, 300,000 inhabitants. Populated as the Erzgebirge, in the ratio of one inhabitant to every three acres, the mineral region of Missouri wonld sustain $6,000,000$ of souls, and probably the working members of such a population might find here employment for ages. Excepting gold and platina, most of the important and useful metals and ores are known to exist in Missouri. The following mincrals, metalic and non-metallie, arranged here according to their intrinsic value, have been found within its limits-lead, iron, copper, cobalt, silver, nickel, zine and ealamine, manganese and wadd, coal, rock salt, barytes, sand and quartz, carbonate and sulphate of lime, alumine and potter's elay, fuller's earth, variegated marble and oolite, saltpetre, antimony, tin, tungsiate of iron and lead, diamonds, chalcedony and feldspar, and some others of perhaps a minor importance.

The lead mines have been wrought since the first settlement of the country. The ore is in the form of sulphuret and carbonate, and in the upper mines at Potosi it is found mixed with calamine and blende. The lead region extends over the counties of Madison, St. François, St. Louis, Washington, ete. Formerly the carbonate was considered as worthless, hut it is now reduced in blast furnaces, and yields 72 per cent. The sulphuret yields from 66 to 80 per cent., and contains about 6 per cent. of silver. Iron in the form of hematite, and the ochrey, the micaceous and red oxydes, are fouzd in the greatest abundance. The ores exist throughout the mineral region, and extend even into the coal formation, which oscupies so large s. surface. Abundant, easily manufactured, and the transportation easy, this is essentially the staple of Missouri. Her celebrated mountains of micaceous oxydes-the Iron Mountain and Pilot Knob-are almost inexhaustible. They form the eastern extreme of the Ozarks, and are situated in St. François County, a few miles east of Potnsi, and only 40 miles from St. Genevieve, on the Mississippi. The two peaks are about 6 miles apart, the more northerly of the elerations, the Iron Mountain, is $1 \frac{1}{2}$ miles long and 444 feet high. Its whole top is a solid mass of iron, and one sees nothing but iron lumps as far as the eye can reach. The ore yields 60 per cent. of pig, and is deemed a most superior metal. Pilot Knob is 1,500 feet high. Dr. Feuchtwanger estimates the quantity of pig iron embedded in these mountains alone at $600,000,000$ of tons, enough to supply the world for more than a century. The mines of Elba, of Sweden, or of Norway, together, do not contain an amount equal to this. The mincs of copper are chiefly found in the south and wcst portions of the mineral region, but exist in other parts. The ore is of every variety and usually very rich. It is found in combination with lead and iron, frequently with manganese, cobalt, and nickel, and oceasionally with silver. It is generally pyritous, but oxydes and carbonates are frequently found. The ores appear as a cement uniting angular fragments of lime rock forming a breccia, and much of it is easily removed by a pickaxe alone. As a general thing the yield is about 34 per cent. of metal. Hitherto mining for copper has been little attended to, but it is now probable that operalions will be commenced on a large scale, and as the indications of extensive lodes have been traced for miles, this priduct is destined to be one of the most valuable of the State; indeed, the copper mines of Missouri are said to be more valuable than even those of Lake Superior. The several metals found in combination with the above, namely, silver, zinc, manganese, cobalt. nickel, etc., give an additional value to the mines, and as tin has been found near Caledonia, it may be said of Missouri, that no other State or country is richer in metallic weallh, or has better prospects of future prosperity. The substantial wealth of England and Belgium is drawn from their mines, but neither of these countries can compare in any one respect with this State.

Mincrals of the non-metallic kinds are everywhere as abundant as could be desired. The carboniferous limestono formation, on which St. Louis is built, and which extends throughout the northern division of the State, forms a beantifu? and compact building material. Sandstones are abundant, but coarse and loose in texture. The white sandstone of St. 


\section{MISSOURI.}

Generiere makes superior glass. Porphyries, susceptible of a high polish, are numerous in Southern Missouri, and are well fitted for architectural and ornamental uses. Sienite is also found, and marbles of various textures exist in several counties. Gypsum has been discovered in Jackson County; and in eaverns near the Maramec, Current, and Gasconade, saltpetre exists in vast quantities. Sulphate of baryta, or heavy spar, is found in the lead diggings.

The northern coal measures of Missouri are continuous with those of Illinois; it is in geutral called bituminous conal. At Côte sans Dessein, however, it assumes the form of cannel. It has been discovered at several distinct points in Cole and Callaway counties, and as high as forty miles upon the Osage. Some of its layers are of great thickness, and on distillation it yields excellent coke and a gas that burns with a bright and copious flame; and being destitute of sulphur, it is well adapted to furnaces and manufacturing purposes.

A great variety of clays, useful for economical purposes, are found in different parts. The subsoil of the region around St. Louis, abounding as it does in oxyde of iron and alumina, makes brick of a handsome red tint and smooth texture; it is fitted, too, for the manufacture of pottery. Variegated clays are found in the same vicinity. Kaolin, or porcelain clay, and pipe elays have been discovered near Caledonia and Cape Girardeau, and delft-ware is manufactured in St. Louis from clays obtained near Commerce, in Scott County.

Except on the prairies, Missouri is well timbered. The river bottoms, in particular, are covered with a luxuriant growth of oak, elm, ash, hiekory, cotton-wood, and black and white walnut. In the more barren districts are found white and pin oak, and sometimes forests of yellow pine. Many of the trees and shrubs met with differ from those found in the same latitude in Obio. The crab-apple, pawpaw, and persimmon are abundant, as also the hazel and pecan. Three wild species of grape-vine are common throughout the country. The prairies are clothed in the proper season with numerous varieties of flowers, and with a coarse, tall grass, which, either green or cured, is excellent fodder for cattle. The general capacity of the country for agriculture is unsurpassed, and every kind of grain and esculent vegetable, with flax and hemp, find in one part or another a congenial soil and climate. Tobaceo is also a staple production; and table fruits, as the apple, pear, peach, nectarine, ete., grow in profusion. As a grazing country, Missouri is one of the best; the prairies are excellent natural pastures, and the business of rearing cattle is almost reduced to the simple operation of turning them upon these prairies and lelting them fatten until the owner thinks proper to claim the tribute of their hides and other products. Hogs are also raised with great ease in the forests.

Missouri is divided into 100 counties, the general statistics of which and the capitals of each, in 1s50, were as folows:

Counties. Dwell. Pop. Farms Manuf, Capitals. Adair ........ 383.. 2,342.. 326.. 5... Kirksville Andrew .......1,377.. 9,433.. 873.. 33..Savannah Atchison....... 291.. 1,648.. 188.. 5..Linden Audrian.......4 493.. 3,506.. 417.. 10.. Mexico Barry ........544.. 3,467.. 399.. 2..M'Donald Bates ........6.626. 3,669.. 472. 0.. Batesville Bcnton........ 789.. 5,015.. 510.. 10.. Warsaw Boone .........1,924..14,979 ..1,376.. 21. . Columbia Buchanan.....2,080..12,975..1,258.. 89..Sparta Butder......... 265. 1,616. . 143. . 0..Cane Creek Caldwell ...... 358.. 2,316.. 232.. 7..Kingston Calloway.......1,612..13,\$27..1,169.. 33..Fulton Camden ....... 360,. 2,383.. 214.. 0.. Erie Cape Girardeau 2,108..13,912. .1,019.. 31..Jackson Carroll........ $770 \ldots$ 5,441.. 353.. 15. Carrollton Cass ......... 938. . 6,090,. 729 . 19..Harrisonville Cedar......... 561.. 3,361.. 347.. 7..Fremont Chariton .......1,096.. 7,514.. 659.. 24. Keytesville Clarke........ 805.. 5,527.. 425.. 12.. Waterloo Clay ...........1,352..10,382.. 944.. 42..Liberty Clinton........556.. 3,786.. 334.. 0..Plattsburg

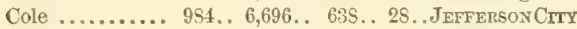
Cooper........1,717..12,950..1,064.. 79. Booneville Crawford.......994..6,397.. 715.. 9..Steelsville Dade ......... 659 . 4,246. 567.. 13. Greenfield Dallas ....... 597.. 8,648.. 861.. 8.. Buffalo Dariess ....... 754.. 5,298. . 342. . 8. Gallatin De lialb ...... $835 \ldots .2,075 \ldots$ 229.. 1. Maysville Dodge......... 57.. $353 . .49 . . \quad 0$. Butler Dunklin ....... 215.. 1,229 .. 76. . 2..Chillitecaux Franklin .......1,925..11,021..1,096. . 32...Newport Gasconade ..... 950.. 4,996.. 533.. 16..Hermann Gentry ........ 708.. 4.245.. 414.. 0..Athens Greene ......2,046..12,785..1,283.. 50.. Springfield Grundy ....... 477.. 3,006. 255.. 5..Trenton Harrison ....... 357.. 2,447.. 141.. 0..Bethany Henry........ 561.. 4,052. . 355.. 11.. Clinton Hickory ........ 364.. 2,329.. 190.. 6..Hermitage Holt .......... 614. 3,957. 30. 3. 5. . Oregon Howard . . . . . . 1,685. . 13,969 . .1,105 . . 35. . Fayette Jackson........1,719. .14,000. . 986. . 78. . Independeuce Jasper......... 664.. 4.223.. 405.. 8. Carthage Jefferson .......1,119. 6.925 . 704.. 12.. Hillsboro' Johnson.......1,030. 7,464. . 750.. 2S. . Warrensburg $49 \pm$

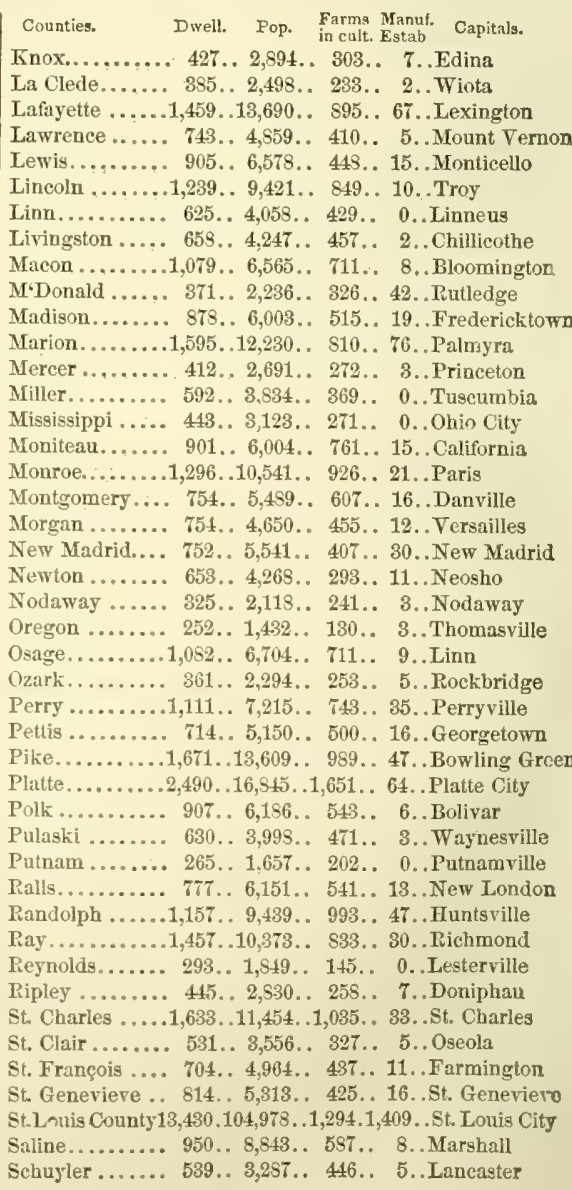




\section{MISSOURI.}

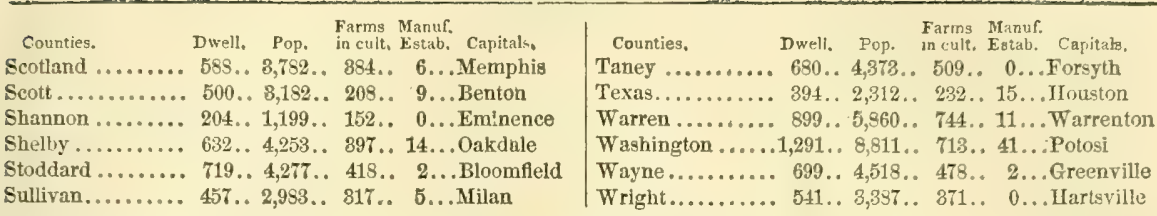

The whole number of dwellings in the State was, at the above date, 96,849 ; of families, 100,890 ; and of inhabitants, 6S2,043*; viz., whites 592,077-males 312,986, and females 279,091 ; fr. col. 2,511-males 1,339, and females 1,2066, and sl. $57,122$. Of the whole population there were, deaf and dumbewh. 244, fr. col. 0, sl. 15-total 259; blind-wh. 180, fr. col. 3, sl. 25-total 211; insane-wh. 271, fr. col. 2, sl. 9-total 2S2; and idiotic-wh. 304, fr. col, 0, sl, 29-total 333. The number of free persons born in the United States was 520,826 , the number of foreign birth 72,474 , and of birth unknown 1,322 . The native population originated as follows: Me. 811, N. Hamp. 304, Verm. 630, Mass. 1,108, R. I. 124, Conn. 742, N. Y. 5,010, N.J. 855, Penn. 5,291, Del. 518, Md. 4,253, Dist. of Col.238, Virg. 8,357, N. Car. 21,487, 8. Car. 27,908, Ga. 17,506, Flor. 629, Ala. 34,047, Miss. 65s, La. 746, Tex. 24s, Ark. 2,120, Tenn. 44,970, Ky. 69,694, Oh. 12,737, Mich. 295, Ind. 12, i52, III. 10,917, Dfissouri 277,604 , Ia. 1,366 , Wisc. 123, Territorles 80 ; and the foreign population was composed of persons from-England 5,379, Ireland 14,734, Scotland 1,049, Wales 176, Germany 44.852, France 2,138, Spain 46, Portugal 11, Belgium 58, Holland 189, Turkey 7, Italy 124, Austria 71, Switzerland 984, Russia 29, Denmark 55, Norway 155, Sweden 37, Prussia 697, Sardinia 1, Asia 3, Africa 7, British America 1,053, Mexico 94, Central America 0, South America 20 , West Indies 50, Sandwich Islands 1 , and other countries 954.

The following table will show the decennial progress of the population since the first census of the State taken by the United States authorities:

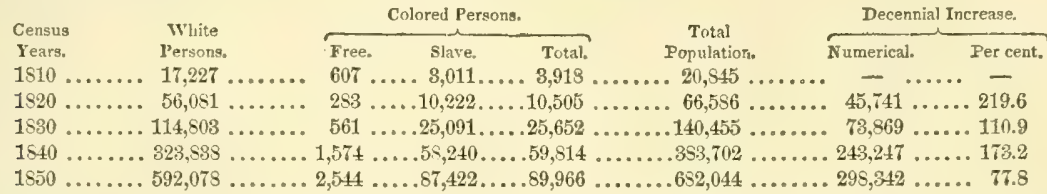

The statistics of the wealth, industry, and institutions of the State, as exhibited by the census of 1850 , and other offlcial documents referriug to the same period of time, are as follows:

Occupied Lands, ete.-Improved farm lands, 2,924,991 acres, and attached lands unimproved, 6,767,937 acres-valued together in cash at $\$ 63,057,482$. Whole number of farms under cultivation, 54,458 . Value of farming implements and machinery, $\$ 3,965,945$.

Live-Stock:-Horses, 228,593; asses and mules, 41,508; mileh cows, 228,553; working oxen, 111,268; other eattle, 445,615 ; sheep, 756,309 ; and swine, $1,692,043$-valued in the aggregate at $\$ 19,766,851$. In 1840 , according to the census of that year, there were in the State: 196,032 horses, mules, etc. ; 433,575 neat cattle of all kinds; 348,018 sheep; and $1,271,161$ swine.

Products of Animals.-Wool, 1,615,860 pounds; butter, 7,792,499 pounds; cheese, 202,122 pounds; and the cash value of animals slaughtered during the year amounted to $\$ 3,349,517$. The production of silk cocoons was 186 pounds; and the quantity of beeswax and honey obtained was $1,327,812$ pounds.

Grain Crops.-Wheat, $2,966,928$ bushels; rye, 44,112 bushels; Indian corn, $36,069,543$ bushels; oats, $5,243,476$ bushels ; barley, 9,681 bushels; and buckwheat, 23,590 bushels. The crops of these cereals, according to the census of 1840 , were: wheat, 1,037,396 bushels; rye, 68,068 bushels; Indian corn, 17,382,524 bushels; oats, 2,234,947 bushels; barley, 9,801 bushels; and buckwheat, 15,318 bushels.

Other Food Crops.-Rice, 700 pounds; peas and beans, 45,974 bushels; and potatoes-Irish, 934,627 bushels, and sweet, 332,120 bushels. The potato crop reported in the census of 1840 was $7 \$ 3,768$ bushels.

Miscellaneous Crops.-Tobacco, 17,100,894 pounds; hav, 116,743 tons; clover-seed, 615 bushels; other grass-seed, 4,337 bushels; hops, 3,130 pounds; hemp-dew-rotted 17,207 tons, and water-rotted 5.351 tons; flax, 520,008 pounds; flax-seed, 13,641 bushels; maple sugar, 178,750 pounds; molasses, 5,636 gallons; wine, 10,563 gallons, ete. The value of orehard products was $\$ 512,527$, and of market-garden products $\$ 99,454$. In the census of 1840 the production of cotton is noted at 121,122 pounds-this crop is not noticed in the census of 1850 .

The following table will exhibit the increase of live-stock, and of the principal crops in the deeade euding 1 st June, 1550 :

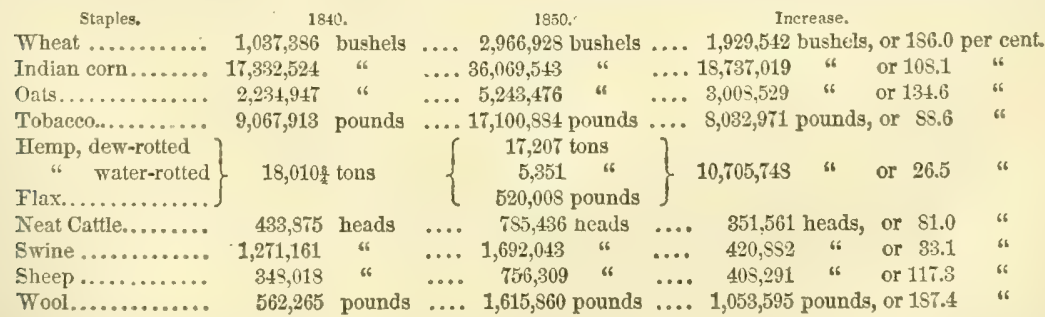

-furnishing results indicative of the more rapid development of the agricultural interests of the State, than the ratio of increase in the population would warrant; and these results are the more astonishing, when the increase of mining and manufacturing interests, which have been relatively extensive, are taken into consideration. 


\section{MISSOURI.}

Home-made manufactures for the year ending 1 st June, 1850 , were valued at $\$ 1,663,016$. The same class of goods made in $1539-40$, were vulued at $\$ 1,149,544$.

Manufuctures.-Aggregate capital invested, $\$ 0,000,000$; value of raw material, fuel, etc., consumed in the year, $\$ 0,000,000$; average number of hands employed $00,000-$ males 00,000 , and females 0,000 ; average monthly cust uf labor $\$ 000,000$-male $\$ 000,000$, and female $\$ 00,000$; total value of products for the year ending 1 st June, 1850 , $\$ 0,000,000$. The whole number of manufacturing establishments in the State producing to the value of $\$ 500$ and upward annually, at the above date, was 3,030, and of these two were cotton factories, one a woolen factory, 13 iron manufactories- 6 of eastings, 5 of pig iron, and 1 of wrought Iron, and 145 were tanneries. Nearly one-half the total number of establishments are in and about st. Louis, where almost every trade and handieraft has gained a footing, while in the interior eounties the manufactories consist of the kinds usually found in agricultural and mining countries. The total capital inyested in manufactories in 1540 was $\$ 2,704,405$.

The cotton manufactures employ a capital of $\$ 102,000$, and consume annually 2,160 bales of cotton, and 1,658 tons of coal, valued at $\$ \$ 6,446$; employ 155 hands-males 75 , and females 80 ; monthly cost of labor, $\$ 1,620$; products, 13,260 bales of batting, and value of entire products, $\$ 142,900$.

In the voooten manufacture $\$ 20,000$ are invested; 50,000 pounds of wool is used annually; total value of raw material, fuel, etc., $\$ 16,000$; hands employed $25-15$ males and 10 females, at a monthly cost amounting to $\$ 515 ;$ products of the Jear, 12,000 yards of cloth, and 6,000 pairs of blankets, valued in the whole at $\$ 56,000$.

The irom manufactures are stated, in the census of $1 \$ 50$, as follows:

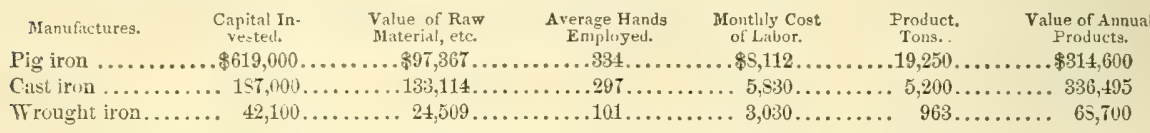

In 1840 there were 80 men employed in the manufacture of iron, and the capital invested in all iron manufactories amounted only to $\$ 79,000$, and hence the increase has been nearly 1,000 per cent. in the 10 subsequent years.

The lead mines have been comparatively deserted for the past few years, on account of the miners having gone to California, and other circumstances. The receipts of lead at St. Louis alone, in 1550, was 568,300 pigs of 70 pounds, being a decrease of 210,169 pigs from the receipts of $151 \%$. Of the receipts at other ports on the Hissouri there are no aceessible reports.

In tanneries the capital invested amounts to $\$ 22 S, 095$; value of hides and skins used, $\$ 247,956$; hands employed, 417 ; monthly cost of labor, $\$ 5,347$; sides of leather produced, 241,334 , and shins tanned, 44,493 ; value of products, $\$ 466,214$.

Foreign Commerce.-Missouri, from its inland position, can never enjoy any large share of direct commerce with foreign nations. The U.S. Treasury reports, except for the year 1844 , have not mentioned exports being made directly, and for that year they were valued at $\$ 293,901$; but for many years imports, increasing in value year by year, are entered at the ports. In 1850 the imports were valued at $\$ 359,643$. The ralue of imports in a series of years, commencing with 1833 , were as follows: in $1833, \$ 5, \$ 81$; in $1836, \$ 3,227$; in $1839, \$ 15,921$; in $1840, \$ 10,600$; in $1341, \$ 33,575 ;$ in $1842, \$ 31.137$; in $1814, \$ 120,673$; in $1845, \$ 514,291$; in 1816 , $\$ 73,569 ;$ in $1817, \$ 167,195 ;$ in $1848, \$ 148,560 ;$ in $1849, \$ 130,382 ;$ in 1850 , $\$ 359,613$. The shipping owned in the district, of which St. Louis is the port of entry, amounted in 1850 to 28,907 tons, all employed in the river trade, and of which 21,955 tons were navigated by steam. During the year ending 30 th June, 1850 , five steamers, with an aggregate tonnage of 1,353 tons, were built in the district.

Rixer and Internal Trade.-Missouri, if shut out from forcign commerce, has a river and internal trade, which fully compensates its disadvantages. The Mississippi River forms its great external highway, and the Missouri River, with its wide-spreading affluents, gives it access to the interior. On these rivers an immense trade is constantly being carried on, St. Louis being the great receiving and distributing depôt of the State. It would be almost impossible to estimate the extent or value of this commerce. In 1551 of steamboats alone 2,641 arrived at St. Louis, and of these 300 were from New Orleans, 401 from ports on the Ohio River, 634 from the Ilinois River, 639 from the Upper Mississippi, 301 from the Missouri River, 43 from the Cumberland River, 119 from Cairo, and 175 from other ports. These bring and take away the material of a vast trade, and give to St. Louis all the advantages that port could have if near the sea-board. But beside these, barges and keel boats navigate all the waters, and perhaps transport an equal amount of merehandise with the stearoboats. The whole tonnage entered in the year above named was 683,140 tons.

Internal Improvements.-Common ruads and bridges excepted, Missouri is almost blameless of works of internal improvement. Every other interest of the State is far ahead of this, the most needful to its permanent prosperity. At the commeneement of 1850 there were only five macadamized roads in the whole country, and these, all eentering at St. Louis, only passed a few miles into the interior. The spirit of modern improvement, however, has not slept, nor have the perple been unmindful of the benefit that the railroad will realize to the country. A splendid system of railroads has bcen provided for, which will carry two lines directly across the State-one from IIannibal, on the Mississippi, to St. Josephe, on the Missouri, and the other from St. Louis to the mouth of Kansas Iiver-both intended to be carried ultimately to the Pacific Ocean, and from the latter a south-westeru branch will be built to the borders of $\Lambda$ rkansas. From St. Louis will also be built a railroad northward and through Iowa to the settlements of Minnesota. Besides these a railroad will be built from St. Louis to the Iron Mountain; and other roads contemplated are the Platte County Railroad, the Lexington and Daviess County Railroad, and the Canton and Bloomfield Railroad. The whole length of these railroads projected is about 1,200 miles, but less than 40 miles was in use on the 1st January, 1s5\%. The following sums have becu apyropriated by the General Issembly to ald in their construetion: for the Ifannibal and St. Josephs Railroad, $\$ 1,500,000$; the Pitcifie Tailroad and its south-western branch, $\$ 4,000,000$; the Yorth Missouri Railroad, $\$ 2,000,000$; the Iron Mountain

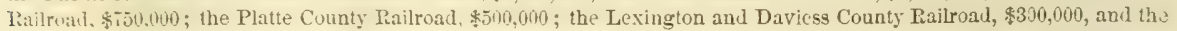
Cimton ami Bloomfield Railroad, $\$ 300,000$. The right of way through the fublie lands is also granted by the General Government. With these means and facilities the works ought to progress rapidly to completlon.

Bunks.-The Bank of the State of Missouri, at St. Louis, and its brauches at Lafayette, Jackson, Lexington, Palmyra, and Springfield, were the only banking institutions in operation on the 1st January, 1851, and their aggregate coadition at that late was as follwws: Linbilities-capital, $\$ 1,209.151$ (of which $\$ 951,205$ were owned by the State, and $\$ 25-1,926$ by individuals); circulation, $\$ 2,522,500$; deposits, $\$ 1,098,9 \$ 1$, and due other banks, $\$ 76,250$; and-assets: loans and discounts,

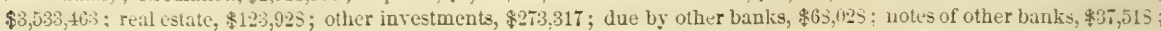




\section{MISSOURI.}

and specie, $\$ 1,193,268$. There is a constitutional prohibition against establishing more than one bank, with not more than five branches, and the capital is limited to $\$ 5,000,000$, of which at least one half must be held by the State.

Gover 'nment. - The government is based on the constitution "done in convention" on the 12th June, 1S20. The right of suffrage is enjoyed by every free white male citizen of the United States, twenty-one years old, resident in the State one year before the election, and three months in the place where he offers his vote. The general election is held on the tirst Monday in August biennially.

Legislative powor is vested in a General Assembly, composed of a House of Representatives and a Senate. Represent. atives, in number not above 100 , and chosen in counties every second year, shall be free white male citizens of the United States, 24 years of age, inhabitants of the State for two years, and of the county for one year next before the election, and shall have paid a tax. Senators, in number not more than 33 , nor less than 14 , shall have attained the age of 30 , and be citizens of the United States, residents of the State four years, and shall be chosen for four years, one half of the senators retiring every second year. The General Assembly convenes at Jefferson City on the last Monday in December, biennially. No laws shall be passed to emancipate slaves without the consent and payment of their owners, or to prevent immigrants from bringing with them slaves of the same description with those in the State; but laws may be passed prohibiting the importation of the slaves who have committed a high crime, or as merchandise, slaves, or the offepring of slaves, im. ported into the United States, and permitting emancipation, saving the rights of creditors. Owners are obliged to treat their slaves with humanity, and slaves, in criminal cases, shall have a trial by jury, and have the same pruteetion in their lives and persons as white persons. Free negroes and mulattoes are prohibited from coming into the State. The laws of the General Assembly shall be revised and digested every ten years.

The Governor must be 35 years of age, a native citizen of the United States, or a citizen thereof at the adoption of the constitution, or an inhabitant of the territory now called Missouri at the time of its cession, must have resided in the State four years next before election, and is chosen for a term of four years, but can not serve two successive terms. The lieutenant-governor, who is ex-officio president of the Senate, must have the same qualifications, etc., as the governor, and is elected at the same time and for the same term. The governor may veto a bill of the General Assembly, but a subsequent majority of both houses makes it law notwithstanding. A vacancy occurring in the office of governor, is filled first by the lieutenant-governor, and after him by the president of the Senate pro tempore, and he failing, by the Speaker of the House; but a new election shall be had after three months' notice, unless the vacancy occur within 18 months of the end of the term.

The principal administrative officers of the State are the Secretary of State, who is also Superintendent of Public Schools, the Autlitor of Accounts, the State Treasurer, the Attorney-general, the Register of Lands, the Adjutant-general, Quartermaster-general, and Surveyor-general, and the President and Cashier of the Bank of the State.

The judiciary consists of a Supreme Court and Circuit Courts, County Courts, Justices' Courts, ete. 'The supreme court has appellate jurisdiction only. The three judges of this court are elected for six years by the qualified roters of the State, and are re-eligible at the expiration of the term. Two sessions are held annually, one at Jefferson City, and one at St. Louis. The attorney-general is ex-officio reporter of the decisions of the Court. A circuit court is held twice a year in eaeh county; its jurisdiction extends to all matters of cost and contract over $\$ 90$, where the demand is liquidated, and over $\$ 50$, where the agreement is parole; and it has exclusive criminal jurisdiction, and a supervision over the county courts and justices of the peace, subject to the correction of the supreme court. The judges of the circuit court are elected by the qualified voters of their respective circuits, and for the term of six years. The jurisdiction of the conty courts is limited to matters of probate and local county affairs, as roads, etc. A county court sits in each county, and is composed of three justices, who are elected by the people, and hold their offices for four years. Appeal lies to the circuit court. The county court of St. Louis County is composed of seven justices. In addition to the cireuit and county courts, St. Louis has a Court of Common Pleas, with jurisdiction very similar to the circuit court; a Criminal Court; a distinct Court of Probate, which relieves the county court from probate duties; and a Recorder's Court. The judges of the circuit and criminal court are elected in the same manner and for the same term as the circuit judges. There is also a distinct Court of Common Pleas for the city of Hannibal. These are local tribunals, exercising jurisdiotion only in their counties, except the Recorder's Court of St. Louis, the jurisdiction of which is confined to small offenses, and within the eity limits. From the Court of Common Pleas and the Criminal Court appeal lies to the Supreme Court, and the judges of the Common Pleas are appointed like the circuit judges, with like tenures. The probate judge is elected by the people of the county for four years, and the recorder by the people of the eity of St. Louis for two years.

Amendments to the constitution may be proposed by a vote of two-thirds of the members of the General Assembly, and shall be published twelve months before the general election; and if at the first session thereafter they are confirmed by a vote of two-thirds of the members, they become a part of the constitution.

The militia force of the State, according to the Army Register for 1850, consists of 61,000 men of all arms, of which 3,919 are commissioned officers, and 57,0s1 non-commissioned officers, musicians, artificers, and privates. Of the commissioned officers 45 are general officers, 94 general staff officers, 790 field officers, etc., and 2,990 company officers.

The State institutions for the relief of the unfortunate, are the Lunatic Asylum at Fulton, completed in 1852, and which in that year received twenty-three patients; and the Deaf and Dumb Asylum at the same place, and yet completed but partially, which had seventeen inmates. At St. Louis there are several benevolent institutions, hospitals, ete., which in part are supported by the State.

State Finances, Debt, etc-The receipts into the Treasury for the two years ending 30 th September, 1850 , amounted to $\$ 757,08871$, to which must be added balance from the biennial period $1847-48$ of $\$ 405,40490-$ making a total means of $\$ 1,192,49361$. Expenditures in 1849-50, $\$ 532,58582$, leaving a balance of $\$ 659,90779$, of which sum $\$ 569,03619$ belongs to the revenue fund. The State debt, exelusive of the surplus revenue deposited with the State, was $\$ 922,261$, which was the exact amount of State bonds sold and outstanding, Of these bonds, $\$ 34,000$ have been redeemed and cancelled during the year. The sinking fund, at the date of report, amounted to $\$ 9,394.7 \mathrm{~S}$, and had claims to $\$ 3,49754$, dividends not re-invested; and the State owns bank stock in the Bank of Missouri, amounting to $\$ 954,20522$, as follows: Of the seminary fund, $\$ 100,000$; of the State school fund, $\$ 575,66796$; of the sinking fund, $\$ 6,27366$; and in its own right, $\$ 2 \pi 2,26360$; but the bank claims a due from the State for money advanced and interest, $\$ 124,02647$. The vrlue of all property, real and personal, assessed for taxation in 1550 , amounted, aceording to the State reports, to $\$ 95,595,463-\mathrm{but}$ as truly estimated by the census of the same year, to $\$ 137,247,707$.

Federal Representution.-In aceorlance with the act apportioning representation, passed on the 23d May, 1S50, Missouri sends seven representatives to the Congress of the United States. 


\section{MISSOURI.}

Education.-The prblic education is under the charge of the Secretary of State, who is ex-officio superintendent of common schools. The principal of the common school fund amounts to $\$ 575,66796$, and has been loaned on bond to the State Bank, which pays interest on the amount semi-annually. The proceeds of this are distributed among the counties according to the number of children reported, and this proportion is distributed among teachers therein. There is also a seminary fund, amounting to $\$ 100,000$. Private schools and academies are established throughout the State; and besides these there are six collegiate establishments: the Missouri University, the University of St. Louis, St. Vincent's College, the Masonic College, St. Charles College, and Fayette College. The statistics of these several establishments in 1850, were as follows:

Names. Location.

Founded. Professors, Students.

Alumni, Libraries.

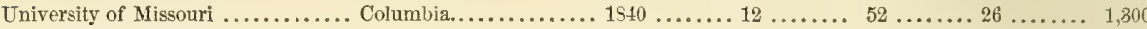

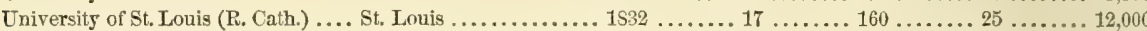

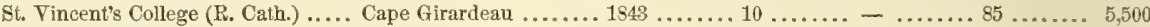

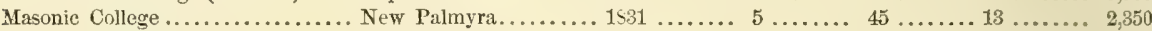

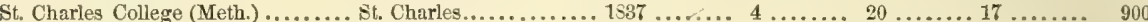
Fayette College ............... Fayette........... $\ldots \ldots \ldots .2 \ldots \ldots \ldots 75 \ldots \ldots \ldots \ldots \ldots$

There are medical departments attached to both universities; and besides the above, there are several theological seminaries in the State.

Libraries.-One State library, 4,637 volumes; two social, 5,799 volumes; five college, 18,465 volumes; fiv students', 1,605 volumes; one academic or professional, 500 volumes; one scientific and historical, 300 volumes; four public school, 6,200 volumes-total, 19 libraries, 37,506 volumes.

Periodical Press.-The whole number of periodicals published in Missouri in 1850 was 71 , circulating at each issue \$0,000 copies, or annually 4,675,650 copies. Of this number 16 were whig in politics, 17 demoeratic, and 41 neutral, or papers devoted to religious, literary, scientific subjects, etc., including all the characters of which is not named in the returns; and of the whole number 7 were published daily, issuing 10,500 copies, or $1,220,400$ annually; 3 tri-weekly, 1.200 copies, or annually 157,200 copies; 3 semi-weekly, 2,200 copies, or annually 228,800 copies; 51 weekly, 56,140 copies, or annually 2,919,250 copies; and 7 monthly, 10,000 copies, or annually 120,000 copies. The daities are all published at St. Louis-the "Times," the "Intelligencer," the "Organ and Reveille," the "Republican," the "Union," and two German papers; the tri-weekties at St. Louis, and are editions of the dailies, the "Times," the "Republican," and the "Union"; the semiweekties at St Louis, Independence, and Bonnville; the weeklies-12 at St. Louis, 5 of which are editions of the dailies, 1 at Warsaw, 1 at Columbia, 2 at Sparta, 1 at Fulton, 1 at Jackson, 2 at Cape Girardeau, 1 at Brunswick, 1 at Liberty, 2 at Jefferson City, 2 at Boonville, 1 at Union, 1 at Hermann, 2 at Springfield, 2 at Fayette, 2 at Glasgow, 1 at Indepcndeace, 2 at Lexington, 1 at Bloomington, 1 at Palmyra, 2 at Hannibal, 1 at New Madrid, 2 at Louisiana, 2 at Weston, 2 at St. Genevieve, 1 at St. Charles, 1 at Oseola, 1 at Paris, 1 at Monticello, and 1 at Chillicothe ; and the monthlies, 1 at Hermann, the "Licht Freund," a German rationalist advocate, and 6 at St. Louis, the "Valley Farmer," the "St. Louis Probe," the "Insurance Reporter," the "Western Journal," the "Bank Note Detector," and the "Signet"

Religious Denominations.-The statistics of the several religious denominations in the State for the year 1850 , according to the census, were as follows:

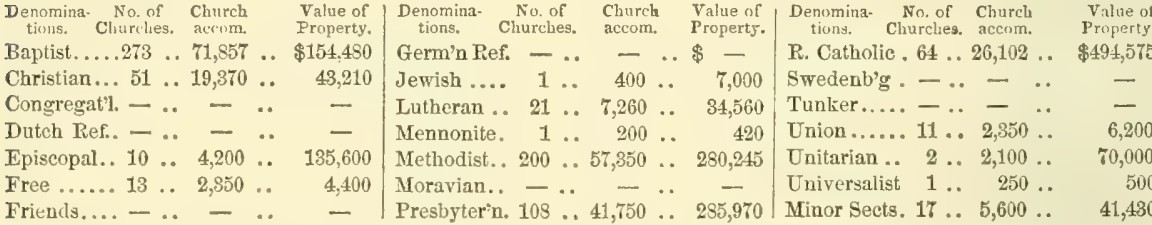

-making a total of 773 churches, having accommodation for 241,139 persons, and valued at $\$ 1,553,590$. Missouri constitutes a diocese of the Protestant Episcopal Church; and also the Roman Catholic diocese of St. Louis, in the ecclesiastical prorince of the same name.

Historical Sketch.-Hernando de Soto may be said to have been the first European that beheld the river Mississippi, called by him (April, 1541) on its discovery the Rio Grande. Crossing this stream, probably some 30 miles below Helena in the State of Arkansas, he traversed at the head of his adventurous band a goodly portion of the territory beyond. He is thought by some, but without sufficient reason, to have come during his march into the present limits of Missouri. The Mississippi was first explored in 1673 by Joliet and Marquette, and more fully in 1652 by La Salle, and by the latter all the region between the so-called Illinois country and the Gulf of Mexico was called Louisiana, and declared to be an appendage of France. From this time settlements began to be made in the valley, advaneing from its northern and southern extremities into the interior. Canada had long (from 160s) been inhabited by colonists from France; but not till the beginning of the eighteenth century was the region bordering on the Gulf alike distinguished. Natchez was settled in 1700 , New Orleans in 1718 , and within a few years the whole territory was protected from Spanish invasion by a chain of forts extending from the lakes to the Gulf. Among these was built in 1719 Fort Orleans, near the mouth of the Osage, not far from the present capital of the State. In legal proceedings the region, now known as Missouri, was included by the French and Spanish in the Illinois country, but popularly and historically it was denominated Upper Louisiana. The State of Arkansas was included in the same division. Situated in the central part of the valley, the progress of Missouri was not rapid. Its lead mines were worked as eariy as 1720 . In 1755 its oldest town, St. Genevieve, was founded; St. Louis in 1764; and afterward a number of towns in quick succession. Meanwhile (1763) the jurisdiction of the valley passed from France to Spain and England, the Mississippi being the dividing line between their respective apportionments; and by the same treaty Canada also reverted to England. France, after a violent contest, had been despoiled of all her territorial possessions in North America. During the contest, numbers of Canadian French emigrated by way of the lakes, and going southward located in bothUpper and Lower Louisiana. Hence the first important impulse to the colon ization of Missouri. The population of Spanish Louisiana, at the time of the public transfer (1769), was estimated at 13,840 persons, of whom 5,556 were whites, and the remainder negroes. New Orleans alone contained 3,190 souls domi- 


\section{MISSOURI.}

ciliated in 468 dwellings. A river trade had sprung up between the northern and southern portions of the province, and the exports at this period amounted to $\$ 250,000$ annually.

The character of the new government was conciliating. The laws of Spain were promulgated as the law of the land. The highest tribunal in Louisiana was that of the governor, and in Upper Louisiana that of the Lieutenant-governor. The commandants of the various posts in the provinces were the inferior tribunals. Lands were granted liberally to colonists, and every facility was given to settlers. Numerous emigrants from Spain flocked into the country. In 1775, St. Louis, originally a depot for the fur-trade, had increased in population to 800 , and St. Genevieve contained 460 inhabitants. At this time the American Revolution was commencing, and Spain, siding with the English colonists, entered into hostilities against England. In Lower Louisiana and Florida the arms of Spain were successful. Meanwhile, St. Louis was attacked (1780) by a body of English and Indians, 1,540 strong, from Michilimackinac and the southern extremity of Lake Michigan. During the siege, which lasted a week, about 60 persons were killed in the town and vicinity, and it is impnssible to tell to what extent the enemy might have gone, had not the timely arrival of General Clarke from Kaskaskia turned the tide of fortune in favor of the settlers. The general peace of 1783 put an end to hostilities. Spain retained her previous possessions, and received, in addition, the whole of Florida, of which she had been deprived 20 years before. Great Britain resigned East Louisiana, called also the Illinois country, to the United States, retaining only her northern possessions.

Emigration into Spanish Louisiana began once more on the restoration of peace, and trade and agriculture to flourish. The hardy settlers of the western part of the United States now built their cabins in numerous places on the west side of the Mississippi. As might have been expected, difficulties soon arose between Spain and the Union. The foreign power became jealous of the increasing greatness of the latter. A dispute relative to the navigation of the Mississippi was settled by treaty (20th Oct., 1795), by which Spain granted to the United States free navigation of that river. But Spain never acted faithfully in this matter, and threw obstacles in the way of Americans navigating that stream. War, indeed, seemed inevitable, and was only prevented by the cession of Louisiana to Franee, or the 21st March, 1801, aud its disposal by that power to the United States on the 30th April, 1803. At the time of this last cession, the province contained 49,500 inhabitants, of whom 6,028 were living in Upper Louisiana. The products of its agriculture in 1802 had been chiefly cotton and sugar - f the former 20,000 bales, and of the latter 5,000 hogsheads. The commerce of New Orleans had become extensive; its exports coming from the province and the western States and territory, and consisting chiefly of flour, pork, salt beef, tobaco, cotton, sugar, molasses, peltries, naval stores, etc., amounted to 40,000 tons. The commerce of Upper Louisiana was flourishing, and a prosperous trade was already carried on between St. Louis and New Orleans, and with the settlements on the Ohio, Cumberland, and Tennessee rivers. The annual crop was about 88,000 minots (264,000 bushels) of wheat, 84,000 minots of Indian corn, and 2S,627 pounds of tobaceo. The mines produced 1,700 quintals of lead, and the salines about 1,000 barrels of salt. The fur trade brought in about $\$ 70,000$. Louisiana henceforth formed part of the United States, itself "an empire," bought, to use the words of Napoleon, "for a mere trifle."

The new purchase was immediately divided into the "Territory of Orleans" (since 1812, the State of Louisiana) and the "District of Louisiana," erected in 1305 into a territorial government, administered by a governor and judges, under the title of "Territory of Louisiana." The seat of the government was St. Louis ; its districts, St. Charles, St. Louis, Cape Girardeau, New Madrid, and Arkansas. In 1812, on the admission of the present State of Louisiana into the Union, the name of this territory was changed to "Missouri Territory." The territory extended from latitude $33^{\circ}$ to $41^{\circ}$ north, and the government became representative. The first governor under the new government was William Clarke. The legislature consisted of a council of 9 members appointed by the President, and a House of Representatives, one member for every 500 free white males, elected by the people. The limits of the Territory on the west were gradually extended by treaties with the Indians. People from the western States began to move in from the time of the purchase, so that in 1810 the population numbered 20,845 , of whom all but about 1,500 belonging to Arkansas were settled within the present limits of the State of Missouri. The French settlements were now overrun by Americans from Kentucky, Tennessee, Ohio, etc., and American habits, usages, laws, and institutions soon became prevalent. The original settlers were quickly merged and almost lost among the later and more active population, until at length the whole became a homogeneous people. Immigration was so rapid, that in 1817 the territory contained 60,000 souls. St. Louis counted at this time 5,000 inhabitants against 1,000 in 1804. It had already become the emporium of the Upper Mississippi. In 1817, application was made by the Assembly to Congress for authority to frame a State constitution preliminary to admission into the Union. A fierce and stormy debate arose at once on the subject in Congress. A powerful party demanded that the new States should exclude slavery by their constitutions. The discussion raged for two years, threatening to tear the Union asunder; at length, however, the debate was stopped by the passage of the compromise resolutions of Mr. Clay, by which it was agreed that the institution of slavery should be recognized in Missouri, but in no other new State north of latitude $360^{\circ} 30^{\prime}$. The State constitution, somewhat modified since its adoption, was framed by a convention of forty delegates, which met at St. Louis on the 12th June, 1820, and adopted on the 19th July following The new State was found, by a census taken the same year, to contain a population of 66,586 , of whom 10,222 were slaves. From this time until the present there has flowed a constant tide of immigration from the snuthern, western, and northern States, and from Europe; agriculture and commerce have more than kept pace with the increase, and mining and manufactures, though not made prominent industrial pursuits, have been gradually developed. Few other States, indeed, can boast of so rapid a development of the material resources it may possess, which, though in a great measure due to the facilities afforded by the country itself, yet much must be accorded to the enterprise of its hardy, intelligent, and industrious inhabitants.

Jarferson Citr, on the south bank of the Missouri River, 143 miles from its mouth, is the political capital of the State.

Mrssouri, p. v., Pike co., Ala.: 44 m. S. E. Montgomery. Missouri river: a large river of the United States, rises in the Rocky mountains, and takes this name after the union of three branches, denominated Jefferson, Gallatin, and Madison, in $45^{\circ} 10^{\prime} \mathrm{N}$. lat., and $110^{\circ} \mathrm{W}$. long. The springs which give rise to the Missouri are not more than a mile distant from some of the head waters of the Columbia, which flows W. into the Pacific ocean. At the distance of $411 \mathrm{~m}$. from the extreme point of the navigation of its head branches, are what are denominated the "Gates of the
Rocky Mountains," which present a view exceedingly grand. For the distance of $5 \frac{s}{m} \mathrm{~m}$. the rocks rise perpendicularly from the margin of the river to the height of 1,200 feet. The river is compressed to the width of 150 yards, and for the first $3 \mathrm{~m}$. there is only one spot, and that only of a few yards, on which a man could stand, between the water and the perpendicular ascent of the mountain. At the distance of $110 \mathrm{~m}$. below this, and $521 \mathrm{~m}$. from its source, are the Great Falls, 2,575 m. above its entrance into the Mississippi. The river descends, by a succession of rapids and falls, 357 
feet in about $16 \frac{1}{3} \mathrm{~m}$. The lower and greatest fall has a perpendicular piteh of 87 feet; the second of 19 feet; the third of 47 feet; the fourth of 26 feet. Between and below these falls are continual rapids of from 3 to 18 feet deseent. These falls, next to those of Niagara, are the grandest on the continent. The course of the river above these falls is northerly. The Yellowstone river, 800 yards wide at its mouth, probably the largest tributary of the Missouri, enters it on the $\mathrm{S}$. W. side, $1,216 \mathrm{~m}$. from its navigable source, and about $1,880 \mathrm{~m}$. from its mouth. This river, at the place of junction, is as large as the Missouri. Steamboats ascend to this place, and could go farther by each branch. Chienne river, 400 yards wide at its mouth, enters the Missouri on the S. W. side, $1,310 \mathrm{~m}$. from its mouth, in $44^{\circ} 20^{\prime} \mathrm{N}$. lat. White river, 300 yards wide, enters it on the S. W. side, $1,130 \mathrm{~m}$. from its mouth. Big Sioux river, 110 yards wide, enters it $853 \mathrm{~m}$. from its mouth, in $42^{\circ} 4 \mathrm{~S}^{\prime} \mathrm{N}$. lat., on the N. E. side. Platte river, 600 yards wide at its mouth, enters it on the S. W. side, $600 \mathrm{~m}$. from its mouth, in $40^{\circ} 50^{\prime} \mathrm{N}$. lat. Kanzas river, 283 yards wide at its mouth, enters it on the S. W. side, in $3905^{\prime} \mathrm{N}$. lat., at the distance of $340 \mathrm{~m}$. from its mouth. Grand river enters it on the $\mathrm{N}$. E. side, 240 miles from its mouth, and is 190 yards wide. La Mine river, 70 yards wide, enters it 200 miles from its mouth. Osage river, 397 yards wide at its mouth, enters it on the S. W. side, in $35^{\circ}$ $81^{\prime} \mathrm{N}$. lat., $138 \mathrm{~m}$. from its mouth. Gasconade river euters it on the S. W. side, in $38^{\circ} 45^{\prime} \mathrm{N}$. lat., $100 \mathrm{~m}$. from its mouth. The Missouri enters Mississippi river $3,096 \mathrm{~m}$. from its source, which, added to 1,253 m., the distance to the Gulf of Mexico, makes its whole length $4.349 \mathrm{~m}$., and it is probably the longest river in the world. Through its whole course there is no substantial obstruetion of the navigation before arriving at the Great Falls.

Distances navigable by steam on Missouri river and its principal branches:

\begin{tabular}{|c|c|}
\hline iles & \\
\hline$\ldots \ldots 1,50$ & Grand .. \\
\hline de............. 6 & Kanzas \\
\hline $\ldots \ldots \ldots \ldots \ldots \ldots{ }^{27}$ & Pla \\
\hline
\end{tabular}

The alluvial fertile soil on this stream and its tributaries is not rery broad, and back of this are prairies of rast extent. Through the greater part of its course the Missouri is a rapid and turbid stream, and in the upper part of its course flows through an arid and sterile country. It is over half a mile wide at its mouth, and through a greater part of its course it is wider. Notwithstanding it drains such an extensive country, and receives so many large tributaries, at certain seasons it is shallow, hardly affording sufficient water for steamboat navigation, owing to its passing through a dry and open country, and being subject to extensire evaporation.

Mrssourtion, p. v., St. Charles co, Mo.: on the N. W. bank of Missouri r., $77 \mathrm{~m}$. E. Jefferson City.

Mitcirel county, $I a$. Situate $E_{\text {. }}$ on $N$. line, and coutains $\mathbf{4} 32 \mathrm{sq} . \mathrm{m}$. Drained by heads of Cedar river, a branch of the Iowa. Unorganized.

Mrtcrel, p. o., Sheboygan co., Wise. : $77 \mathrm{~m}$. N.E.Madison, MıтондLIs, p. 0., Walker county, Tex. : 133 m. E. N. E Austin City.

Nittchell's Mitrls, p. o., Indiana co., Penn.: $128 \mathrm{~m}$. W. by N. Yiarrisburg.

Mrtchell's Peak, Alleghany co, $N$. Car. This peak enjoys the reputation of being the highest summit on the E. side of the Rocky mountains. It derives its name from Professor Mitchell, of Cincinnati, who determined its altitude to be more than 250 feet higher than Mount Washing ton, in New Hampshire. Its height is 6,720 feet.

Mircireli's SAlt Works, p. 0., Jefferson co., Ohio. : $124 \mathrm{~m}$ E. N. E. Columbus.

Mitchellstili, p. จ., Robertson co., Tenn.: 83 m. N. by

E. Nashville; on the line of the proposed R. R. between Louisville and Nashville.
Mitonelisville, p. n., Boone co, $K y_{.}: 58$ m. N. by Frankfort.

Mixervilue, p. o., Franklin county, Ind.: 60 m. E. S. E. Indianapolis.

Mrstown, p. o., Tioga county, Penn.: $101 \mathrm{~m} . \mathrm{N}$. by W. Harrisburg.

MoBIL county, Ala. Situate S. W. corner, and contains $1,316 \mathrm{sq} . \mathrm{m}$. It has the Gulf of Mexico on the S., Mobile bay and river on the E., and a few small streams flowing into them. Surface mostly level, with some hills in the N., and covered largely with pine forests; soil of very moderate fertility, producing small crops of corn and potatoes, and furnishing pasture for cattle in considerable numbers. The important interest of the county is commerce, which is of immense extent, as it has the transportation of most of the products of a back country, comprising the largest and best part of the State. Farms 249 ; manuf. 61 ; dwell. 3,027, and pop.-wh. 17,306 , fr. col. 938, sl. 9,356-total 27,600 . Capital: Mobile. Public Works: Mobile and Ohio R.R., ete.

MовпL, p. city, port of entry, and cap. Mobile en., Ala. : on the W. bank Mobile river, just above its entrance into Mobile bay, $163 \mathrm{~m}$. S. W. Montgomery. Lat. $30^{\circ} 41^{\prime} 48^{\prime \prime} \mathrm{N}$., and long. $87^{\circ} 59^{\prime} 04^{\prime \prime} \mathrm{W}$. The site is but very little elevated above the water, but sufficiently so for all purposes of convenient drainage. The soil is dry and sandy. Immediately opposite the city, on the $\mathrm{E}_{0,}$ is a large low island, covered with high grass and rushes, and known as "the marsh ;" above on the $\mathbf{N}$. is a large swamp, extending along the banks of the r.; and back of the city on the N. W., W. and $\mathrm{S}$., the dry sandy pine hills commence, affording delightful and healthy retreats from the heat, sickness, and annoyances of the city during the summer; and here have sprung up the pleasant villages of Toulminville, Spring Hill, Cottage Hill, Summerville, and Fulton. South from the city, the shores of the bay are dotted for many miles with elegaut residences, and these spots have been usually exempt from epidemic diseases.

The eity is not compactly built, except in the portions occupied by the commercial and business houses. The streets generally are wide, and run mostly north and south, and east and west. Much attention has been paid of late years to planting shade trees along the pavements, and the comfort and probably the health of the place has been much improved thereby. The prevailing winds during the winter months are the N. and N. E.; from the middle of April (at which time the warm spring weather begins), the $\mathrm{s}$. winds, cool, refreshing, and laden with moisture, make the heat quite bearable, and these, being also the prevailing summer winds, even in that hot season, negative in a great measure the climatic extreme. The elimate, however, is warm and relaxing to the energies, and even in the winter months is trying to the constitution, from the many and sudden changes that occur. During the coldest weather the ground is but seldom frozen. Most rain falls in December, January, June, and July.

No system of underground drainage has ever been attempted at Mobile; the light, porous character of the soil answering the same purpose, and making the streets dry immediately after the heaviest fall of rain. The city is supplied with good wholesome water through the water-works from a strean some few miles distant.

The sanitary condition of Mobile has greatly improved of late years; for a long period it enjoyed the unenviable reputation of being a very unhealthy place, and the devastating epidemics of 1819-25-29-37-39, and ' 43 , in truth gave a coloring to the aceusation. Since the last-named year there has been no severe visitation of sickness, which may be accounted for in some measure by the fact, that the wet, muddy morasses that until then had occupied the northern part of the city have been flled in, and their places are now the sites of large cotton presses and warehouses. The deaths in 1849-50 numbered only 611 , or one to every $35 \frac{1}{2}$ living. A better system of drainage has also been adopted, and 
more exertion has been used in cleansing and purifying the streets than heretofore.

Mobile contains the county court-house, several United States courts, the municipal courts, the city hall, a jail, and other pirblic buildings; a splendid Roman Catholic eathedral, numerous churches of various denominations, hospitals, schools, markets, a theatre and circus, several first-class hotels, etc. The hospitals-the United States Marine Hospital and the City Hospital-are large and commodious buildings, each capable of accommodating from 250 to 300 patients; and there are other charitable institutions worthy of notice, among which stand pre-eminent the Catholic and Protestant Orphan Asylums, the Benevolent Snciety, which, among other functions, has charge of destitute widows, and the Samaritan Society, A blind asylum has also been founded, and an asylum for the deaf and dumb provided for. There are three cemeteries belonging to the eity.

Mobile was originally a Spanish settlement, and at a later period a portion of Louisiana. It was surrendered to the Americans in 1813. In 1814 it was chartered as a town, and in 1819 became a city. In 1814 the total valuation of property in the town was only $\$ 350,950$; in $1819, \$ 764,510$; in $1824, \$ 1,107,500$; in $1829, \$ 2,719,148$; in $1884, \$ 6,756,025$; is $1 \mathrm{~S} 39, \$ 24,480,315$; in $1844, \$ 18,098,877$; in $1849, \$ 12,629,700$ and in $1550, \$ 11,955,790$. The population of the eity in 1830 was 3,194 ; in $1840,12,672$; and in $1850,20,513$.

The commercial statistics of the eity will be found under the head of ALABAxa. Mobile is the only sea-port of the State open to foreign commerce, and from this point is shipped the great bulk of the cotton of Eastern Mississippi and Western Alabama. The total quantity shipped for the year ending 31st August, 1852, was 575,104 bales, or onesixth of all the cotton produced in the Union. Of this amount 307,513 biles were sent to England, 95,917 to France, and 27,048 to other foreign States; and 144,626 coastwise to domestic ports, Staves, lumber, and naval stores, are also shipped in large quantities. There are two commercial banks in the city-the Bank of Mobile and the Southern Bank of Alabama. The Planters' and Merchants' Bank has lately closed its business. Mobile has four newspapers-the "Alabama Tribune" (indep.), daily; the "M. Advertiser" (whig), daily and semi-weekly ; the "Register and Journal" (dem.), daily and weekly; and the "Alabama Planter" (agric.), weekly. The local trade of Mobile is very extensive and valuable. The Mobile and Ohio R. R. will connect the city with the whole north-west; the Girard and Mobile R. R. will connect it with the Atlantic ports, and a railroad to Madisonville will connect it with New Orleans. None of these are built except a portion of the first named.

As a commercial mart of the Gulf, Mobile is second only to New Orleans in its facilities and available position. Immense rivers connect it with an extensive and highly productive interior, and a fine bay gives it access to the sea. Mobile Bay sets up from the Gulf, and is $30 \mathrm{~m}$. long, and on an average $12 \mathrm{~m}$. broad; it communicates with the Galf by two straits, one on each side of Dauphin Island. The strait on the W. side will not admit of vessels of more than 5 feet draft ; but that on the E. side, between the island and Mobile Point, has 18 feet water, the channel passing within a few yards of the point. There is a bar across the bay near its upper end, which has only eleven feet water. Mobile river, which falls into the bay immediately below the city, is formed by the junction of the Alabama and Tombigbee rivers $50 \mathrm{~m}$. above the city. A few miles below the junction it divides into several channels. The main W. channel is called Mobile, and the main E. channel, which is the deepest and widest, is called the Tensaw. It is navigable for vessels drawing less than six feet water by the Tombigbee branch to St. Stephen's, and by the Alabama branch to Claiborne. In times of food it sometimes rises 50 or 60 feet. The entrance to the harbor is defended by Fort Morgan, situated on a long, low, sandy point, at the mouth of the bay, $80 \mathrm{~m}$. below the city, opposite to Dauphin Island.
MoвILe bay, Ala.: sets up from the Gulf of Mexico, with which it communicates by two struits, one on each side of Dauphin Island. The strait on the $\mathbf{E}$. side, between the island and Mobile Point, has 18 feet water, while the one on the $\mathrm{W}$. has only 5 feet. The channel passes within a short distance of the point. The bar at the upper end has only 11 feet water on it. Mobile City is situate at the head of the bay.

MobrLe river, Ala.: the great river of the State, is formed by the junction of the Alabarna and Tombigbee, 50 miles above Mobile bay; a few miles below the junetion, it gives out a large branch, called the Tensaw, which also receives an arm from the Alabama, and reaches Mobile Bay below Blakely, and at the city of Mobile. It is navigable as far up as St. Stephen's, 93 miles, on the Tombigbee, for vessels drawing 6 feet of water, and steamboats of moderate burden ; to Tusealoosa, on the eastern branch, 300 miles, and to Columbus, in Mississippi, on the Western branch; its length is about 450 miles. Its tributaries are inconsiderable compared with its great length: the Buttahatchee, Sipsey, and Okanoxubee, are the principal. The Alabama, or eastern branch of the Mobile, is navigable to Claiborne, 100 miles from the bay, by the same class of vessels that go up to St. Stephen's, and for smaller steamboats about 300 miles by the windings of the stream. The two branches unite in lat. $81006^{\prime} \mathrm{N}$., and long. $11005^{\prime} \mathrm{W}$. In times of flood it sometimes rises from 50 to 60 feet.

Мов $J_{\text {AOK }}$ bay, Virg. : an arm of Chesapeake Bay, makes up between Mathews and Gloucester. The Gloucester courthouse is at the head of the bay.

Mobley Pond, p. v., Scriven co., Ga.: on a small er., flowing into the Savannah river, $104 \mathrm{~m}$. E. Milledgeville.

Mockville, p. v., and cap. Davie co., N. Car.: $103 \mathrm{~m}$. W. Raleigh, and contains the county court-house and other public buildings.

Modena, p. 0., Ulster co., $N . Y_{.}: 73 \mathrm{~m}$. S. S. W. Aibany.

Modest Town, p. v., Accomack county, Tirg.: $102 \mathrm{~m}$. E. by $\mathrm{N}$. Richmond, and $2 \mathrm{~m}$. from the Atlantic coast. It contains about 60 inhabitants.

Muireeli's Point, p. O., Coles co., $7 l .: 85$ m. E. by S. Springfield.

MofferT's Stone, p. o., Columbia co., N. Y.: 28 m. \$. E. Albany.

Mofretesville, p. v., Anderson dist., S. Car.: ne3r the Savannah r., $101 \mathrm{~m}$. W. by N. Colambia.

Mofftr's Mrles, p. o., Randolph co., N. Car.: $73 \mathrm{~m} . \mathrm{W}$. Raleigh.

Mogadore, p. o., Summit county, Ohio: $118 \mathrm{~m}$. X. E. Columbus.

MонАWк, p. v., Herkimer co., $N . Y_{\text {.: }}$ on the S. side of the Mohawk r., and on the line of the Erie Canal, $95 \mathrm{~m}$. from Albany. The Mohawk Valley Bank is situate here. The v. contains several stores and workshops, and about 600 inhabitants.. The "Mohawk Times" (free soil), is issued weekly.

Monawk river, $N, Y_{0}$ : the principal tributary of the Hudson r., rises in the S. part of Lewis co., flows S. to Rome, where, turning to the S. E., it continues that course, and enters the Hudson r. by several mouths at Waterford, 8 or 10 m. above Albany. It receives West Canada er. from the N. and Schoharie cr. from the $\mathrm{S}$. There are several rapids and two large falls in its course. At Little Falls it desoends over a stony bed, and through a remarkable gorge in the mountain, 42 feet in the course of a mile, At Cohoes Falls, $2 \mathrm{~m}$. from its mouth, it has a perpendicular descent of 70 feet, a short distance below which there is a bridge across the river. The Erie Canal passes along its S. bank, nearly through its whole course, in consequence of which the channel is little used for navigation. The banks of the river are very fertile -its whole length is $135 \mathrm{~m}$. Along the banks of the river there are a number of populous and thriving villages and wealthy cities. The great wheat district of the State commences in the valley of the Mohawk above Little Falls. 
Moнawк Valiet, p. o., Coshocton co., Ohio: 67 m. N. E. Columbus.

Monegan, sta. New London co., Conn.: on the line of the New London, Willimantic, and Palmer R. R., 9 m. N. New London, and on the W. bank of Thames r., $38 \mathrm{~m}$. S. E. Hartford.

MoHican, t. and p. o., Ashland co., Ohio: 64 m. N. N. E. Columbus. Drained by a branch of Walhonding r. Surface rolling; soil fertile and productive. Jeromesville and Mechanicsville are names of villages in the $t$. Population of $t .1,775$.

Mohrsfille, p. o, and sta., Berks co., Penn.: on the line of the Philadelphia and Reading R. R., $65 \mathrm{~m}$. N. W. Philadelphia. The Windsor iron furnace located here has an annual capacity of 1,200 tons.

MorrA, t. and p. v., Franklin co., N. Y.: $157 \mathrm{~m}$. N. N.W. Albany. Drained by branches of Salmon and St. Regis rivers. Surface even; soil fertile. The Northern (Ogdensburg) $R$. R. crosses the $t_{\text {, }}$ on which is the sta., $47 \mathrm{~m}$. E. of Ogdensburg. Pop. of t. 1,340.

Molalla, p. o., Clackamas co., Oreg. Ter.: about $29 \mathrm{~m}$. N. E. Salem.

Mourne, p. v., Rock Island co., $I Z l$ : on the E. side of the Mississippi, 5 m. above Rock Island City, $127 \mathrm{~m}$. N. N. W. Springfield. It lies opposite the bead of Rock Island, where there is excellent water-power, is extensively engaged in manufacturing and milling, and has about 1,000 inhabitants.

Mouino, p. 0., Lineoln county, Tenn.: 68 m. S. by E. Nashville.

Molrro, p. o., Tippah co., Miss. : 188 m. N. E. Jackson. Morno, p. o., Randolph co., $A l a$ : $82 \mathrm{~m}$. N. E. Jackson. Moltro Dex Rey, p. 0., Arkansas eo., Ark. : $10 \mathrm{~m}$. W of White r., 66 m. S. E. by E. Little Rock.

Moluthorn, p. o., Newberry dist., S. Car.

Molltows, p. o., Berks county, Penn.: 56 m. E. N. E. Harrisburg.

Moutnkus river, $M e_{0}$ : rises near the $\mathrm{E}$. line of Penobgcot co. and empties into the Matawamkeag, about $1.0 \mathrm{~m} . \mathbf{E}$. of its S. entrance into the Penobscot. Its course is S. S. E. and passes through a densely timbered region about $50 \mathrm{~m}$, affording great water-power.

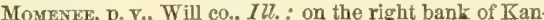
kakee $\mathbf{r}, 144 \mathbf{m}$. N. E. Springfield.

MoNadrock mountain, Cheshire co., $N$. Hamp.: lies between the towns of Jaffrey and Dublin, $10 \mathrm{~m}$. $\mathrm{N}$. of the $\mathrm{S}$. line of the State, and extends $\mathrm{N}$. and $\mathrm{S}$. about $5 \mathrm{~m}$. and E. and W. about $3 \mathrm{~m}$. The highest peak, called Grand Monadnock, is 3,718 feet above the ocean level, and commands a view of the country around it for $50 \mathrm{~m}$. on every side. The summit is bare rock, but the prospect is one of remarkable beauty. At its base is a mineral spring, and large quantities of plumbago are found on the E. side.

Monagan, p. o., St. Clair co., Mo. : on a branch of Osage r. so called, $102 \mathrm{~m}$. W. S. W. Jefferson City.

Monches, p. 0., Waukesha co., Wisc.: $55 \mathrm{~m}$. E, by N. Madison.

Monclova, p. o., Lucas county, Ohio: $114 \mathrm{~m}$. N. by T. Columbus.

MoNeEn, p. o., Winneshiek co., Ia.: 108 m. N. by W. Iowa City.

Money Creek, p. o., M'Lean co., Ill.: on a branch of Mackinaw cr., 69 m. N. N. E. Springfield.

Morgaup, p. o., Sullivan co., $N_{0}$..$: 92 \mathrm{~m}$. S. W. by S. Albany.

Mongaup Falzex, p. o., Sullivan county, $N_{0} Y_{0}: 86 \mathrm{~m}$. S. W. by S. Albany.

Mongoquinong, p. Y., La Grange co., $I_{n} d_{.}$: on the $\mathbf{N}$. side of Pigeon r., 137 m. N. by E. Indianapolis. A plankroad connects it with the Michigan Southern $R, R$.

Monistioue river, Schooleraft co, Mich.: rises near the S. shore of Lake Superior, and empties into the $\mathbf{N}$. end of Lake Michigan, after draining with its numerous branches the $\mathrm{E}$. half of Schoolcraft co., and receiving from the W. the 502 waters of Monistique lake, a large sheet of water on its S. border.

Moniteat county, Mro. Situate centrally, and contains 389 sq. m. Drained by Moniteau cr. and Straight and South forks of Moreau cr., affluents of the Missouri, which forms its N. E. boundary. Surface uneren; soil mostly fertile, and adapted for grazing. Corn is the staple cereal. Wheat and tobacco are successful crops, cattle are reared in large numbers, and pork is a considerable export. It has good mill streams, plenty of timber, and some iron ore. Farms 761 ; manuf. 15 ; dwell. 901 , and pop.-wh. 5,434, fr. col. 4, sl. 566-total 6,004. Capital : California

Monk's Conners, p. o., Charleston district, $S_{0}$ Car.: on Cooper cr., near its head, $\$ 1 \mathrm{~m}$. S. E. Columbia.

Monk's Store, p. o., Sampson co., N. Car.: 44 m. S. S. E. Raleigh.

Monktow, t. and p. o., Addison co., Verm.: 26 m. W. Montpelier. Drained by Lewis er. and its branehes, on which are several mills. Surface uneven, and soil fertile. It is a fine grazing t., exporting live-stock, wool, and dairy produce. In the S. superior iron ore and porcelain clay are extensively dug. Pop, 1,246.

Monkton Mruls, p. v., Baltimore co., Md.: on Great Gunpowder Falls, $34 \mathrm{~m}$. N. by W. Annapolis. It is on the Baltimore and Susquehanna $R_{.} R_{n}, 22 \mathrm{~m} . \mathrm{N}$. Baltimore, and contains large flouring mills.

Monмo tr county, $N$. Jer, Situate E, middle, and contains 618 sq. m. Raritan and New York bays bound it N., the Atlantic E., and it is drained by small streams flowing into them and the Delaware. Surface generally level, with the Highlands of Navesink in the N.; soil of marine formation, with parts too sandy for tillage; but abundance of marl, by the application of which and good cultivation, it is mostly very productive. Corn, rye, potatoes, wheat, buckwheat, and oats are all good crops. It has some excellent dairies, and exports beef, wool, and pork. Iron ore and marl are extensively found, and pine timber abounds in parts. Its water-power is considerable and manufictures various, principally lumber, liquors, iron, iron-ware, leather, woolens, and cordage. Farms 2,014; manuf. 214 ; dwell. 5,155 , and pop.-wh. 27,927 , fr. col. 2,311 , sl. 75 -total 30,313 . Capital: Freehold.

Monmoutr, p. v., and cap. Warren co., $I l l .:$ about $3 \mathrm{~m}$. S. of Cedar fork of Henderson's r., $91 \mathrm{~m}$. N. W. by $\mathrm{N}$. Springfield. It has a fine situation for trade in farming products, with limestone and coal abundant in the vicinity, and contains a court-house and jail, a high school, and 15 or 20 stores. The "M. Atlas" (indep.) is published here weekly. MonmouтH, p. v., Adams co., Ind.: on St. Mary's r., 116 m. N. E. Indianapolis. A plank-road passes along the river from Decatur to Fort Wayne. Near the $\mathrm{v}$. are good mill-sites and several mills.

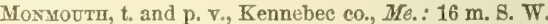
Augusta. It contains several large ponds which feed excellent mill streams. Surface uneven; soil fertile, producing good grain crops and supporting fine dairies. The v. contains an academy and several stores. The Androscoggin and Kennebec $\mathrm{R}$. R. crosses the t. and has a sta. in it., $47 \mathrm{~m}$. from Porland. Pop. of t. 1,925.

Moxocacr, sta., Frederick county, $M d .: 59 \mathrm{~m}$. W. of Baltimore, on the Baltimore and Ohio R. R.

Movocacy river, Penn, and Ma. : rises in Adams co. Penn., and flows $\$$. \$. W. about $70 \mathrm{~m}$., emptying into the Potomac $23 \mathrm{~m}$. below Harper's Ferry.

Moxoyor island, Mass.: a long, narrow island in the Atlantic Ocean, on the $\mathrm{S}$. side of Barnstable co., belonging to Chatham.

Monon, p. o, White county, Ind.: 82 m. N. N. W. Indianapolis.

Moxona, p. O., Clayton co., Ia. : 94 m. N. by E. Iowa City. Monovganera river, Firg, and Penn.: rises in Randolph co., Virg, on the W. base of the Laurel Mountains, and after a generally $\mathbb{N}$. course of about $300 \mathrm{~m}$., unites with 
the Alleghany at Pittsburg, the Ohio being formed by their junction. Its principal affiuents are Cheat and Yioughiogeny rivers, which flow into it from the $\mathrm{E}$. It is ascended by boats in favorable seasons $200 \mathrm{~m}$, and large boats can always come up to Brownsville, $60 \mathrm{~m}$. from its mouth.

Monongahera City, p. V., Washington co., Penn.: on the left bank of Monongahela $\mathrm{r} ., 156 \mathrm{~m}$. W. Harrisburg. It is on the National Road, and contains several mills and stores.

Mosongalia county, Virg. Situate N. W., and contains 308 sq. m. Drained by Monongahela and Cheat rivers. Surface elevated and broken; soil very fertile, with excellent pastures. Corn, wheat, and oats are the staples, and usually large crops. Fine dairies, large numbers of cattle, and very large flocks of sheep are supported on the grazing land, and wool is a valuable export. The county abounds in iron ore and bituminous coal, and manufactures iron, flour, leather, woolens, and distilled liquors. Farms 727; manuf. 57 ; dwell. 2,124, and pop.-wh. 12,092, fr. col. 119, sl. 176 - total 12,387. Capital: Morgantown. Public Workes: Baltimore and Ohio R. R.

MoNoedet, p. v., Kosciusko co., Ind.: about $2 \mathrm{~m}$. W. of Tippecanoe r., $123 \mathrm{~m}$. N. by E. Indianapolis.

Monros county, Ala. Situate S. W., and contains 1,063 sq. m. Bounded W. by the Alabama, and drained by its affluents, Little $r$, and Flat and Limestone creeks. Surface mostly level or slightly uneven; soil of average fertility, with some very productive land on the streams, near which are also marshes adapted to rice-growing. Cotton is the staple and corn the leading cereal. Farms 692; manuf. 23; dwell. 1,005 , and pop.-wh. 5,648 , fr. col. 40 , sl. 6,325 -total 12,013. Capital: Claiborne.

Mosioe county, Ark. Situate E. middle, and contains $1,059 \mathrm{sq}$. $\mathrm{m}$. Drained by White $\mathrm{r}_{\text {, }}$ Cache $\mathrm{r}$., and Lick cr. Surface level, and in parts low and swampy; soil fertile. Corn and cotton are the ehief crops, and the produce not large. Pork is exported and cattle are reared in small numbers. It has excellent ash and cypress timber. Farms 133; manuf. 0 ; dwell. 310 , and pop.-wh. 1,652, fr. col. 2 , sl. $395-$ total 2,049. Capital: Lawrenceville,

MoNroz county, Flor. Situate S., and contains about $2,050 \mathrm{sq}$. m. Caloosahatchee $\mathrm{r}$. bounds it N., and it has but few streams, all which flow into the Gulf. Surface low and mostly swamps, densely covered with pine, cypress, cedar, and magnolia trees of great size. The main land is scarcely settled by whites. The islands known as the Florida Keys are comprised in its limits. The principal business of the inhabitants is assisting wrecked vessels, which are often lost on the dangerous reefs around them. Farms 6 ; manuf. 11; dwell. 420, and pop.-wh. 2,086, fr. col. 126, sl, 431-total 2,643. Capital: Key West.

Monroz county, Ga. Situate W. centraily, and contains $422 \mathrm{sq} . \mathrm{m}$. Bounded E. by the Ocmulgee and drained by its branches. Surface pleasantly diversified; soil very fertile. Cotton is the staple, and a very large amount is raised. Corn is the chief grain, and wheat a very successful crop, but cotton commands the most attention. Farms 746 ; manuf, 2 ; dwell. 1,194, and pop.-wh. 6,810, fr. col. 5, sl. 10,170-total 16,985. Capital: Forsyth. Public Works: Macon and Western R. R.

Modroe county, $I l l$. Situate S. W., and contains 414 sq. m. Drained by Fcuntain er. of the Mississippi, which is its W. boundary, and Richland and Horse creeks of the Kaskaskia. Surface level, broken only by the bluffs along the Mississippi, and much of it prairie; soil of great fertility; the celebrated "American Bottom" lies between the bluffs and the Mississippi, which is wooded near the river, and back is prairie of inexhaustible fertility. Corn is the chief crop. Wheat grows well, and the rearing of cattle and the fattening of pork is much attended to. It lies opposite the great lead region of Missouri, and lead, copper, and iron are found in the W. part. Farms 874; manuf, 33; dwell. 1,421, and population-wh. 7,633, fr. col, 46-total 7,679. Capital. Harrisonville,
MoNROT county, Ind. Situate S. W. centrally, and con tains 420 sq. m. Drained by Salt, Clear, and Bean Blossom creeks. Surface mostly uneven, rolling near the centre, and originally heavily timbered; soils excellent; in the bottoms very rich. Corn and wheat are the staples, and pork a considerable export. It has good water-power, and extensive manufactories of iron, flour, woolens, and leather. Iron ore is abundant, and salt springs are found. Farms 1,280; manuf. 46 ; dwell. 1,892, and pop.-Wh. 11,259, fr. col. 27 total 11,286. Capital: Bloomington. Pultic Works: New Albany and Salem R. R.

Monroe county, $I a$. Situate S. E. centrally, and contains 432 sq. m. Drained by Cedar, Gray's, Miller's, Upper and Lower Avery's, and Soap creeks, branches of the Dos Moines, which touches the N. E. corner. Surface rolling and slightly broken; soil fertile, well timbered, abundantly supplied with mill streams, and adapted to grain or grass. Corn, live-stock, beef, and pork are the chief products. Farms 337 ; manuf. 0 ; dwell. 515, and pop.-wh. 4,882, fr. col. 0-total 4,882. Capital: Albia.

MoNroz county, $K y$. Situate on $\mathbf{S}$. line centrally, and contains $312 \mathrm{sq} . \mathrm{m}$. Drained W. by Big Barren $\mathrm{r}$, and its branches, and E. by the Cumberland. Surface various, generally uneven; soil fertile. Corn is the staple grain. Wheat and tobacco are profitable crops, and some cotton is raised. Pork is the great export. Farms 740 ; manuf. 9 dwell. 1,190, and pop.-wh. 6,902 , fr. col. 23 , sl. 880-total 7,755. Capital: Tompkinsville.

Monroe county, Mich. Situate S. E. corner, and contains 547 sq. m. Drained by Huron r., Swan, Sandy, Stony, and Half-way creeks, and River Raisin, all flowing into Lake Erie, its E. boundary. Surface N. and E. level and heavily timbered; S. and W. rolling, and alternate prairie and grove: soil mostly fertile; in parts sandy, and S. a sandy loam; admirably fitted for grazing. Corn, wheat, oats, and potatoes are good erops; cattle and pork are exported. It has good water-power, and manufactures flour, woolens, leather, glass, and machinery of various kinds. It is favorably situated for trade on the lake, and is the great thoroughfare for western emigration. Limestone for building is plenty, marl abundant, sulphur springs are found, and a superior fine sand for manufacturing glass. Farms 1,277; manuf. 45 ; dwell. 2,544 , and pop.-wh. 14,642, fr. col. 56 total 14,698. Capital: Monroe. Public Works: Erie and Kalamazoo R. R.; Michigan Southern R. R.; Toledo and Detroit R. R., etc.

Monroe county, Miss. Situate N. E., and contains 723 sq. $m$. Drained by the Tombigbee and its branches, Buttahatchee r., W. fork, etc. Surface agreeably diversified and somewhat uneven, with good water-privileges, and generally a sufficiency of good timber; soil fertile; on the streams very productive of corn and cotton, the staples of the co. Wheat, oats, and potatoes are thriving crops, and the pasturage fine. Neat cattle are raised in large numbers, and pork is exported. It manufactures flour, cotton goods, earthen-ware, iron castings, lumber, and leather. Farms 848 ; manuf. 13 ; dwell. 1,576 , and pop.-wh. 9,417 , fr. col. 3 , s1. 11,717-total 21,172. Capitat: Hamilton, Putlic Works: Mobile and Ohio R. P.

MONROE county, MO. Situate N. E., and contains 657 sq. m. Drained by Salt $\mathrm{r}$. and its branches, N., S., Otter, and Elk forks, Crooked cr., and Long branch. Surface moderately uneven ; soil fertile, a part prairie, and most well fitted for grazing. Corn is the staple; wheat, tobaceo, and potatoes are fine crops, and pork a very large export. It has fine mill streams, plenty of timber, and some manufactures. Farms 926 ; manuf. 21 ; dwell. 1,296, and pop.-wh. S, 464 , fr. col. 29, sl. 2,048-total 10,541. Capital: Paris.

Monroe county, $N . Y$. Situate W. on Lake Ontario, and contains $607 \mathrm{sq} . \mathrm{m}$. Drained by G'enesee $\mathrm{r}_{\text {., }}$ its branches, Black, Allen, and Honeoye creeks, and Sandy, Salmon, and Little Salmon creeks, emptying into the lake. Surface sloping toward the lake, and broken into two terraces 
parallel to it; soil a very deep, gravelly loam, of great fertility, and produces more grain than any other co. in the State. It yields the best of Genesee wheat, which is the great staple, and large crops of corn, oats, and potatoes, besides pasturing great numbers of sheep. The falls of the Genesee afford unsurpassed water-power, and move the largest flouring mills in the Union. Lumber, iron, cloths, paper, and leather are largely manufactured. The Genesee is navigable through the co. On the lake are good harbors, and the county has a large trade with the interior. Marl is abundant, gypsum is largely found, iron and lead ores in smaller quantities, and in parts a valuable fire stone for lining furnaces and stoves. Farms 4,113; manuf. 526; dwell. 15,027, and pop.-wh. 86,973, fr. col. 677-total 87,650 . Capital: Rochester. Public Worles : Erie Canal; Genesee Valley Canal; Buffalo and Rochester R. R.; Rochester, Lockport, and Niagara Falls R. R. ; Syracuse and Rochester Railroad, ete.

Monroz county, Ohio. Situate S. E., and contains 522 sq. m. Bounded E. by the Ohio, and drained by Muskingum r., Clear, Sunfish, and Seneca creeks. Surface uneven and broken; soil generally fertile. Wheat, corn, oats, and potatoes are produced largely. Tóbaceo is extensively cultivated, and pork and wool are exported. It manufactures flour, iron, woolens, leather, ete. The W. abounds in iron and coal. Farms 2,637; manuf. 43; dwell. 4,892, and population-wh. 28,2S1, fr. col. 70-total 2S,351. Capital: Woodsfield.

Monroe county, Penn. Situate N. E., and contains 494 sq. m. Bounded W. by the Lehigh, E. by the Delaware, and drained by their affluents. Surface rough and broken; soil very fertile in the lower parts. Corn, rye, buckwheat, oats, and potatoes are all fine crops. Sheep are reared largely, and fine dairies are kept. It has much water-power, and manufactures flour, iron, leather, lumber, and woolens. Farms 904; manuf. 76 ; dwell. 2,155, and pop.-wh. 13,170, fr. col. 100-total 13,270. Capital: Stroudsburg. Public Works: Cobb's Gap R. R.

Monroe county, Tenn. Situate S. E., and contains 768 sq. m. Drained by Tellico r., Cilico and Lyon's creeks, and Tennessee r., which touches the N. part. Surface various; on the S. E. line a mountain ridge, and W. and middle large valleys; soil generally rich, and much of it superior pasture. Corn is the principal crop. Wheat and oats are successfully cultivated, and pork exported. Water-power is plenty, and manufactures of flour, lumber, earthen-ware, iron castings, etc., are rapidly increasing. Farms $91 \mathrm{~s}$; manuf, 59 ; dwell. 1,816, and pop.-wh. 10,623, fr. col. 63, sl. 1,1Ss-total 11,8r4. Capital: Madisonville. Public Worke: East Tennessee and Georgia R. $\mathrm{R}$.

MoNroe county, Virg. Situate S. W., and contains 573 sq. m. Drained by Greenbrier and Great Kanawha rivers, the last forming its W. boundary. Surface elevated, with the Alleghany mountains on the $\mathbf{E}$., and delightful valleys in every part; soil a rich loam, especially adapted to grazing. Corn, wheat, rye, and oats are very fine crops. It has superior dairies, and exports largely of live-stock, beef, and wool. Water-power is abundant, and small manufactories of flour, leather, liquors, woolens, and oil numerous. It has celebrated red and salt sulphur springs, and much visited sweet springs. Farms 910; manuf. 30 ; dwell. 1,576, and pop.-wh. 9,062, fr. col. S1, sl. 1,061-tota! 10,204. Capital. Union. Public Works: Covington and Ohio R. R.

Monroe, p. v., Morgan county, Alla.: $148 \mathrm{~m}$. N. by W. Montgomery.

Monroe, t. and p. Y., Fairfield co., Conn.: 43 m. S. W. Hartford. Drained by Mill and Pequannock rivers and branches of the Housatonic. Surface uneven; soil stony, but fine pasture land. Farming and grazing are the chief pursuits. The Housatonic R. R. passes through ito The $\mathrm{r}$. is on high ground, and contains an academy and several stores, Pop, of $t, 1,440$.

Monroe, p. v., and cap. Walton co., Ga.: 55 m. N. N.W. 504
Milledgeville. It contains a court-house, jail, academy, a dozen stores, and 500 inhabitants.

Monroe, p. 0., Perry co., Miss. : on Leaf r., $78 \mathrm{~m}$. S. E. Jackson.

Monroe, p. v., Tippecanoe co., Ind.: $45 \mathrm{~m} . \mathrm{N}$. W. by N. Indianapolis.

Monroe, p. o., Jasper co., Ia.: $82 \mathrm{~m}$. W. by S. Iowa City. Monroe, t. and p. 0., Bedford co, Penn.: $78 \mathrm{~m}$. W. S.W. Harrisburg. Drained by Sliding Hill cr., and affluents of Raystown branch. Surface broken; soil very fertile in parts, and generally good pasture land. Tarming and grazing the chief pursuits.

Monroe, p. o., Hart county, Ky. : $78 \mathrm{~m} . \mathrm{s}$. W. by s. Frankfort.

MoNroe, p. v., and cap. Wachita par., $L \alpha_{*}$ : on the E. side of Wachita r., $146 \mathrm{~m} . \mathrm{N}$. N. W. Baton Rouge. It is at the head of steamboat navigation, and is the shipping-place for the cotton of a large and fertile district. It has also a valuable trade, and contains a court-house, jail, academy, several stores and warehouses, and 500 inhabitants.

Monroe, t. and p. o., Waldo co., dre.: 43 m. E. N. E. Augusta. Drained by Marsh r., a branch of the Penobscot. Surface varied; soil fertile of grain and grass, and well timbered. Wool and lumber are exported. Pop. 1,606.

Monroz, t. and p. o., Franklin co., Mass.: on the N. line of the State, $101 \mathrm{~m} . \mathrm{W}$. N. W. Boston. Drained by branches of Deerfield river. Surface elevated and mountainous; soil adapted to grazing, which is the chief business. Pop. 254 .

Monroe, t., p. eity, and eap. Monroe co., Mrich.: on Lake Erie, $87 \mathrm{~m}$. S. E. Lansing. Drained by Raisin r. and small creeks flowing into the lake. Surface mostly level; soil sandy, and fertile of grass and grain. Building stone and sulphur springs are found. The city is on the river, $2 \frac{1}{2} \mathrm{~m}$. above its mouth, and has superior facilities for manufactures and commerce, the river affording great water-power and communication with the lake ports and eastern markets, It contains a court-house, jail, several elegant churches, an academy, numerous flouring-mills, and manufactories of various kinds, and 2,809 inhabitants. Three papers are published-two weeklies, the "M. Commercial," and "Free Citizen," and a literary monthly, the "Seminary Waifs." This city is an imporiant point in the great thoronghfare of travel and transportation between the $\mathrm{E}$. and W., being the E. terminus of the Michigan Southern $R$. R., which here connects with steamers for all the lake ports. The Toledo, Norwalk, and Cleveland $R$. $R$. will soon be extended to Detroit through this place, giving it a continuous railroad communieation with the Atlantic eities. Pop. of t. 3,647 .

Mosiroe, p. v., Sussex county, N. Jer.: 60 m. N. by E. Trenton.

Monroe, t. and p. v., Orange co., N.Y.: $92 \mathrm{~m}$. S. by W. Albany. Drained by Ramapo r., a branch of the Passaic, which furnishas good water-power. Surface hilly and broken; soil adapted to grazing, with some fine farms. It is well timbered, and abounds in iron ore. The Erie $\mathrm{R}, \mathrm{R}$. passes through the $\mathrm{t}$. Monroe station is $59 \mathrm{~m}$. from New

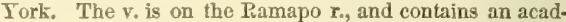
emy, several large stores and mills, and about 1,000 inhabitants. It is surrounded by a great dairy region, and about 3,000 gallons of milk are sent daily by railroad to New Xork from this place. Pop. of t. 4,250.

Monroe, p. v., and cap. Union co., N. Car.: on Richardson's cr., a W. affiuent of Yadkin river, $111 \mathrm{~m}$. W. S. W. Raleigh. It contains a court-house, jail, and several stores. MoNroe, p. v., Butler co., Ohio: about $5 \mathrm{~m}$. E. of Miami river, $81 \mathrm{~m}$. S. W. by W. Columbus. It contains an academy, several stores, and 213 inhabitants.

MoNsor, p. v., Overton co., Tenn.: about $5 \mathrm{~m}$. S. of E. fork of Obeys $\mathbf{r}_{\text {. }} 85 \mathrm{~m}$. E. by N. Nashville. It contains a jail and several stores, and was the former capital of the co. Monroz, p. v., and cap. Greene co., Wisc. : $37 \mathrm{~m}$. S. by W. Madison. Drained by branches of Peckatonica r. Surface moderately uneven; soil generally fertile. It lies in the 
mineral region, and lead abounds. The $\mathrm{v}$, contains the co. buildings and several stores, and has a valuable trade in the staples of the district. A literary weekly, the "Greene County Union," is published here. Pop. of t. 1,146.

Monros lake, Orange co., Flor.: an expansion of St. John's r., near the centre of the county.

Monroe Centre, p. o, Waldo co., Me.: 41 m. E. N. E. Augusta.

Monroe Centre, p. v., Ashtabula co., Ohio : 174 m. N. E. Columbus.

Monroe Mruls, p. v., Knox county, Ohio: oa Vernon r., 43 m. N. N. E. Columbus.

Monroeton, p. v., Bradford co., Penn.: on Towanda er., $95 \mathrm{~m} . \mathrm{N}$. by E. Harrisburg.

Monroeton, p. o., Rockingham county, $N$. Car.: $76 \mathrm{~m}$. W. N. W. Raleigh.

Monroeville, p. v., Monroe county, Ala.: $82 \mathrm{~m}$. S. W. Montgomery. It was the former capital of the county, and contains several stores and 250 inhabitants.

Moxroeville, p. v., and new cap. Colusi county, Calif.: $142 \mathrm{~m}$. N. by E. Vallejo. It is a new v. on the Upper Sacramento, near Stone creek, and lies at the head of low water navigation. Boats of 3 feet draft come up to this point at the lowest water, and at high water first-class steamers land bere. The land around it is of the best in the Sacramento Valley,

MoNroevilie, p. v., Huron co., Ohio: on Huron r., $86 \mathrm{~m}$. $\mathrm{N}$. by E. Columbus. It has fine water privileges, and contains several mills and 12 stores. It is $16 \mathrm{~m}$. 8 . of Sandusky City, on the Sundusky, Mansfield, and Newark R. R, which here intersects the Toledo, Norwalk, and Cleveland R. R.

Monroeville, p. vo, Alleghany co., Penn. : $72 \mathrm{~m}$.W. by N. Harrisburg.

Monroe Works, p. $\nabla$, and sta., Orange co., $N . Y_{.}$: on Ramapo river, $98 \mathrm{~m}$. S. by W. Albany. Iron of a superior quality for the manufacture of cannon is abundant in the ricinity, and wrought in the works here, which are on the Erie R. R., $52 \mathrm{~m}$. from New York.

MoNeovia, p. v., Morgan county, Ind.: 21 m. S. W. Indianapolis.

MoNrovid, p. v., Frederick co., Md. : on Bush cr., $46 \mathrm{~m}$. N.W. Annapolis, The Baltimore and Ohio R. R. passes through it $50 \mathrm{~m}$. W. of Baltimore.

Monsey, p. o. and sta., Rockland county, $N . Y$.: $106 \mathrm{~m}$. S. by W. Albany. The sta. is $5 \mathrm{~m}$. E. of Suffern's, and $37 \mathrm{~m}$. from New York.

Monson, t. and p. o., Piscataquis co., Me : $69 \mathrm{~m}$. N. by E. Augusta. It bas several ponds, the sources of affluents of the Piscataquis, which furnish mill-sites. Surface varied, and soil mostly fertile. It has many good farms, and abundance of timber. Pop. 654 .

Moxson, t. and p. v., Hampden co., Mass. : on the S. line of the State, $68 \mathrm{~m}$. W. $\mathrm{s}$. W. Boston. Drained by branches of Chicopee r., which supply excellent water-power. Surface agreeably varied; soil very fertile. It has superior farms and orchards, and is extensively engaged in manufacturing cotton and woolen goods, and various kinds of machinery. The New London, Willimantic, and Palmer R. P. crosses the t., and has a sta. at the factories, $4 \mathrm{~m}$. S. of Palmer depôt, where it intersects the Western R. R. The v. at the centre contains a hotel, several stores, and an old, well endowed, and highly popular academy. Pop. of t. 2,831

Montacute, p. o., Polk co., I $a_{n}$ : $99 \mathrm{~m}$.W. Iowa City.

Montague, t. and p. o., Franklin co., Mass.: on the E. side of the Connecticut, $77 \mathrm{~m} . \mathrm{W}$. by N. Boston. Drained by Saw-mill r. Surface uneven, and soil various. It has many fine farms, and is well-wooded. A bridge crosses the river, above which, in the $\mathrm{N}$. part of the t., are Turner's Falls, much visited for the wildness of their scenery. Copper and iron ores are found here. A dam thrown across the river, and a canal $3 \mathrm{~m}$. long, with 70 feet lockage, facilitate navigation, and furnish excellent water-power. The Vermont and Massachusetts R. P. crosses the t, and Montague station is $4 \mathrm{~m}$. E. of Greenfield. Pop. 1,518,
Montague, t. and p. v., Sussex co., N. Jer : on Delaware fiver, in the extreme $\mathrm{N}$. of the State, $72 \mathrm{~m}$. N. Trenton. Drained by Mill brook, and Big and Little Flat kills, which afford power for several mills. Surface mountainous on the E., the Blue Mountains occupying the E. border; in the W. alluvial meadow. Soil exeellent and well cultivated. The $v$. is on the Delaware, which is here crossed by a bridge, and contains several mills on Chambers cr. Pop. of t. 1,009.

Montague, p. o., Essex co., Virg. : about $3 \mathrm{~m}$. W. of Rappahannock r., 44 m. E. N. E. Riichmond.

Montague Canal, p. v., Franklin co., Mass.: on the E. side of Connecticut r., $79 \mathrm{~m}$. W. by N. Boston.

Mont Axto, p. Y., Franklín co., Penn.: 46 m. S. W. Harrisburg. Here are located a furnace of 1,800 tons capacity, a forge producing 300 tons of blooms, and 200 tons of bars per annum, and a rolling-mill making 350 tons of bars and rods per annum, moved by the waters of Anlietam cr., and together employing about 500 hands.

Montauk, p. 0., Crawford co., Mo.: 63 m. S. E. Jefferson City.

MonTaUk PoInT, $N_{0} Y_{0}:$ is a bold promontory, constituting the extreme E. end of Long Island, on which is a stone light-house, erected in 1795 . Lat. $41^{\circ} 4^{\prime} 10^{\prime \prime}$, long. $71^{\circ} 51^{\prime}$ $58^{\prime \prime}$. It is $19 \mathrm{~m} . \mathrm{S}$. of Stonington, and $116 \mathrm{~m}$. E. by N. of New York. The ocean presents peculiar phases of grandeur here, whether in calm or storm, and attracts many visitors to this place in the summer season.

Montcalm county, Mich. Situate S. centrally, on Lower Peninsula, and contains $376 \mathrm{sq} . \mathrm{m}$. Drained by Flat r. and Fish and Prairie creeks of Grand r., and Pine r., a branch of the Tittibawassie. Surface undulating, and generally well wooded with oak, ash, maple, and black walnut; soil black sandy loam, and mostly very fertile, with but little waste land, equally adapted to grass and grain, and free from stone. Farms 26 ; manuf. 5 ; dwell. 164, and pop.-wh. 891, fr. col. 0-total 891. Capital: Greenville.

Montcalm, t. and p. o., Montcalm co., Mich. : $42 \mathrm{~m} . \mathrm{N}$.W. Lansing. Drained by tributaries of Grand r. Pop. 135.

Moytebello, p. v., Haneock co, $I l l .:$ on the left bank of Mississippi r., $96 \mathrm{~m}$. W. N. W. Springfield.

Montello, p. o., Marquette co., Wisc.: 49 m. N. by E. Madison.

Monteli's, sta., Baltimore co., Md.: 11 m. N. Baltimore, on the Westminster Branch P. R.

Monterer county, Calif. Situate W. middle, and contains 2,779 sq. m. Drained by Pajaro and Monterey or Salinas rivers. The Coast Range forms the E. boundary, separating the co. from the San Joaquin valley, and the Santa Cruz mts. in the middle parallel to them, dividing the co. into two extended valleys. San Juan valley, oceupying the E. part, is a beautiful and very fertile plain, with few large streams, but rich mines of quicksilver and gold in the N.; the W. valley is drained by the Monterey, a large and welltimbered strcam, is fertile, and easy accessible, lying on the Pacifie, and having a fine harbor. Pop. in 1852, 2,758. Capital: Monterey.

Monterex, p. o., Red River co., Tex.: 291 m. N. E. by N. Austin City.

Monterey, p. o., Pulaski county, Ind. :'98 m. N. N. W, Indianapolis.

Monterex, p. 0, Davis co., Ia.: $76 \mathrm{~m}$. S. W. Iotva City. Monterey, t. and p. o., Berkshire co., Mass.: $112 \mathrm{~m}$. W. by S. Boston. Drained by Mill r., a branch of the Housatonic. Surface elevated and rough; soil good pasture Iand, and covered with fine timber. Grazing is the leading interest. Incorporated in 1849. Pop. 761.

Monterex, $t$, and p. o, Allegan county, Mich, : $66 \mathrm{~m} . \mathrm{W}$. Lansing. Drained by Rabbit $r$. and branches. Surface uneven; soil fertile and well timbered with pine. Pop. 238. Monterex, p. o., Berks county, Penn.: $4 S$ m. E. N. E. Harrisburg.

Monterex, p. o., Dutehess co., $N . Y .: 39 \mathrm{~m}$. S. Albany. MoNTEREY, p. 0., Clermont co. Olio:86 m. S. W. Columbus, 
Moxterex, p. v., and eap. Highland co., Virg. : $124 \mathrm{~m}$. W. N. W. Richmond. It contains a court-house, academy, and several stores.

MoNterey, p. o., Abbeville district, S. Car: : 78 m. W. Columbia.

Monterex, p. o., M:Nairy county, Tenn.: 118 m. S. W. Nashville.

Monterex, p. o., Butler co., Ala.: about 3 m. S. of Cedar cr., $46 \mathrm{~m}$. S. W. Montgomery.

Monterey, p. o., Owen co., Ky.: $21 \mathrm{~m}$. N. Frankfort.

Monterey, p. v., Calhoun co., I $l_{\text {.: }}$ on the right bank of Illinois r., opposite the mouth of Otter cr., $68 \mathrm{~m} . \mathrm{s}$. W. Springfield.

Monterex, p. o., Waukesha co., Wisc.: 54 m. E. by S. Madison.

Monterey, p. v., and cap. Monterey co, Calif:: on the S. side of Monterey Bay, in lat. $36^{\circ} 36^{\prime} 24^{\prime \prime} \mathrm{N}_{\text {., }}$, and long. $121^{\circ}$ $52^{\prime} 25^{\prime \prime} \mathrm{W}$., $101 \mathrm{~m}$. S. by E. Vallejo. This was one of the largest and most frequented towns of California Alta before the cession of 1848 , and was originally the site of a Catholic Mission founded more than a century ago. The harbor is unequaled for safety and access, and is capacious enough to contain the navies of the whole world together. Behind it the coast range of mountains rises to a majestic height. The $\mathrm{v}$. is built on a wide, gently-sloping terrace, not far distant from the shore, and only about $3 \frac{1}{3} \mathrm{~m}$. inland from the W. point of Punto Pinos. The vicinity is full of splendid scenery, and has a climate beautiful as the oft-sung clime of Italy. Not being directly interested in the mining regions, this place has been neglected, but there is no doubt of its eventually becoming an important point in the navigation of the Pacific Ocean. It was constituted a port of entry by the aet of Congress, 28th September, 1550, and the collection district of the same name includes the counties Monterey, San Luis Obispo, and Santa Cruz. Pop. of y. about 1,600.

Montevallo, p. o., Shelby co., Ala.; $58 \mathrm{~m}$. N. W. by N. Montgomery.

Montevideo, p. O., Elbert co., Ga.: about $4 \mathrm{~m}$. W. of Savannah r., 92 m. N. N. E. Milledgeville.

Montezdra, sta., Macon co., Ga.: $2 \mathrm{~m}$. N. of Oglethorpe, on the South-western R. R.

MonteZuMa, p. $\nabla$. ., Pike co., Ilt.: on the right bank of minois r., 53 m. W. S. W. Springfield.

MontezuMA, p. 0., Greene county, Wisc.: 28 m. S. by W. Madison.

Montezurs, p. Y., Parke co., Ind.: on the left bank of Wabash r., $61 \mathrm{~m}$. W. Indianapolis. It contains several stores and warehouses, and has a large trade in the staples of a rich district, brought to it on plank-roads from the $E$, and W., and shipped by the Wabash and Erie Canal.

Montezura, p. vo, Cayuga co., $N_{0} Y_{0}:$ at the junction of the Cayuga and Seneca Canal with the Lrie Canal, $158 \mathrm{~m}$. $\mathrm{W}$. by $\mathrm{N}$. Albany. Here are several salt springs, from which is manufuctured sait of the best and purest quality. It is $34 \mathrm{~m}$. by canal $\mathrm{E}$. of Syracuse, and containg several stores and large warehouses, and a population of 800 .

MontezUMA, p. o., Union co., Ky.: 172 m. W. by $\mathrm{S}$. Frankfort,

Montezuma, p. v., Mercer co., Ohio: $89 \mathrm{~m}$. W. by N. Columbus.

Mostezuma, p. va, and cap. Poweshiek co., I $\alpha_{\text {. : }} 64 \mathrm{~m}$. W. Iowa City. It is near Fisher's cr. of English $r$, and contain. the co. buildings and sereral stores.

Monmonrerx county, Ala. Situate S. E. centrally, and contains $941 \mathrm{sq}$. m. Bounded N. W. by the Coosa, and drained by the Tallapoosa and Oakfuskee, Coloms, an Pintala creeks. Surface moderately uneven: soil exceedingly fertile. Cotton and corn are the almost exclusive agricultural products. The amount of cotton raised is surpassed by few counties in the State or Union, and the quality excelled by none. Corn is also a very large crop, and in parts some wheat is grown, and on the rivers a little rice. It lies favorably for transportation of its products by water, 506 and commands the trade of several adjacent counties Farms 962 ; manuf. 6 ; dwell. 1,881, and pop.-wb. 10,172 fr. col. 112, sl. 19,511-total 29,795. Capital: Montgomert Public Works: Montgomery and West Point R. R.; Montgomery and Mobile R. R.

MonTGOMERx county, Ark. Situate W. centrally, and contains 1,073 sq. $\mathbf{m}$. Drained by Washita $\mathbf{r}$, and Fourche Caddo and their branches. Surface varied, with hilly portions in the $\mathrm{N}$. and level tracks in the S.; soil mostly productive, and well adapted to grazing. Corn and live-stock are the staples. It has some coal and fine sulphur springs. Farms 215; manuf, 6; dwell. 319, and pop.-wh. 1,891, fr. col. 1, sl. 66-total 1,958. Capital: Mount Ida.

MontGoMerx county, $G a$. Situate S. E. centrally, and contains $1,106 \mathrm{sq} . \mathrm{m}$. Drained by Ocmulgee, Little Ocmulgee, Oconee, Pendleton's, and Great Ohoopee rivers. Surface generally even, and covered with a growth of pine; soil sandy and of moderate fertility, except on some of the streams, where rich swamps abound. Corn and cotton are raised in small quantities, and a little sugar and rice. Lumber and tar, piteh and turpentine are small exports. Farms 168; manuf. 0; dwell. 286, and pop.-wh. 1,541, fr. col. 0, sl. 613-total 2,154. Capital: Mount Vernon, Priblic Works: Savannah and Albany R. R.

MoNTGomery county, $7 l$. Situate $\mathbf{S}$. W. centrally, and contains 720 sq. m. Drained by Macoupin, Shoal, and Beaver creeks. Surface high and undulating; soil very fertile. Corn and wheat are the staple cereals. Live-stock, beef, and pork are the principal exports. It has some fine mill-seats and growing manufactures. Farms 811 ; manuf. 17; dwell. 1,051, and pop.-wh. 6,258, fr. col. 18-total 6,276. Capital: Hillsboro?. Public Works: Terre Haute and Alton R. R.

MoNTGOMERY county, Ind. Situate W. middle, and contains $504 \mathrm{sq} . \mathrm{m}$. Drained by Sugar, Big, and Little Raccoon creeks, and other tributaries of Wabash r. Surface various, in the centre rolling, $\mathrm{S}$. level, and near the creeks somewhat hilly; soil every where rich. Most of the county was originally heavily timbered. Corn is the great staple, and wheat a very fine crop. Live-stock, beef, wool, and pork are exported, the last very largely. It has excellent water-power, and extensive manufactures of four, woolens, leather, oil, lumber, and earthen and iron ware. Farm 1,880; manuf. 87; dwell. 2,971, and pop.-wh. 17,955, fr. col. 129-total 18,084. Capital: Crawfordsville. Public Works: New Albany and Salem R. R.; Lafayette and Crawfordsville R. P. MONTGOMERY county, Io. Situate S. W., and contains 432 sq. m. Drained W. by Nishnabatona $r$., and E. by Nodaway r., branches of the Missouri. Erected simce 1850 Montgonerey county, $\bar{K} y$. Situate N. E. centrally, and contains 544 sq. m. Drained by Red r., of the Kentucky and Slate cr. of the Licking. Surface diversified, and soil excellent for grain and grass. Corn is the slaple, and the produce very large; wheat and rye are also fine crops. Horses, cattle, wool, and pork are important exports, the last especially. It has abundant water-power and growing manufactures. Iron ore is found. Farms 856 ; manuf, 32; dwell, 1,103, and pop.-wh. 6,671, fr. col. 159, sl, 3,073-total 9,903. Capital: Mount Sterling.

Montgomery county, Ma. Situate W. middle, and contains 440 sq. m. Bounded N. E. by Patuxent r., 8. W. by the Polomac, and drained mostly by affluents of the Potomac, which afford excellent mill-sites. Surface diversified, with many hills in the N. parts; soils various, some thin and sterile, and some very rich, and productive of wheat, corn, and tobaceo, the leading products. It has manufactories of woolen and cotton goods, flour, leather, lumber, and machinery, flour being the heaviest article. A variety of iron ore, used in making pigments, and gold, found in small quantities, are the chief minerals, Farms 1,051; manuf. 71; dwell. 1,923, and pop.-wh. 9,435, fr. col. 1,811, sl. 5,114total 15,860. Capital: Rockville. Public Works: Chesapeake and Ohio Canal. 
Montgomery county, Mo. Situate E. middle, and contains 594 sq. m. Drained by Oak cr. and Au Cuivre r., of the Mississippi and Loutre r., a branch of the Missouri, which forms its S. boundary. Surface moderately uneven; soil generally fertile, on the large streams very rich. Corm and tobacco are the chief crops. Much of the county is adapted to grazing, and the rearing of cattle. Mill streams are numerous, timber abundant, and markets convenient. Farms 607 ; manuf, 16 ; dwell, 754 , and pop.-wh. 4,449, fr. col. 8 , sl. 1,037-total 5,499. Capital: Danville.

MOXTGOMER county, $N$. $Y$. Situate E. centrally, and contains $356 \mathrm{sq}$. $\mathrm{m}$. Drained by Mohawk r. and its branches, the principal of which is the Scoharie. Surface hilly and somewhat mountainous, with alluvial plains on the Mohawk and some of its branches; soil a gravelly or clayey loam, and generally very productive of grass and all the grains. The dairy is a great object of attention, and potatoes and all the grains yield fine crops. Butter, cheese, and wool are exported, the last largely. Mill-sites are abundant, and occupied by numerous manufactories of flour, woolen goods, distilled liquors, and leather. There are in the county several valuable limestone quarries. Farms 1,883; manuf. 267 ; dwell. 5,358, and pop.-wh. 31,579, fr. col. 413-total 31,992. Capital: Fonda. Pullic Forks: Erie Canal; Utica and Schenectady R. R.

Montgomery county, $N$. Car. Situate S. in W. part, and contains 483 sq. m. Bounded W. by the Yadkin, and drained by its branches, Little r., Ultarie r., etc. Surface rough and mountainous, with beautiful valleys; soil mostly fertile. Cotton is the staple; corn and wheat are heavy crops, and in parts tobacco flourishes. It has much good pasture land, and superior horses and duiries. Water-power is plenty, and cotton goods, flour, leather, and distilled liquors are extensively made. Farms 541 ; manuf. 14; dwell. 902 , and pop.-wh. 5,050, fr. col. 44, sl, 1,773-total 6,872. Capital: Troy.

MoNTGOMERY county, Ohio. Situate S. W., and contains $46 \mathrm{sq}$. m. Drained by Miami and Mad rivers and their branches. Surface gently undulating. Soil of great fertility, equally adapted to grass and grain. Corn and wheat are the leading crops; rye, oats, and potatoes but little inferior. Very large amounts of pork are exported, the clippings of wool are heavy, and the produce of the dairies very valuable. It has great facilities for manufacturing in an abundance of superior water-power, and easy communication with markets in every direction. The principal articles made are flour, cotton and woolen goods, iron castings, and machinery, paper, and earthen-ware. Farms 2,068; manuf. 221; dwell, 6,527, and pop.-wh. 37,973, fr. col. 246-total 35,219. Capital: Dayton, Public Works: Miami Canal; Mad River and Lake Erie R. R. ; Cincinnati, Hamilton, and Dayton R. R.; Little Miami R. R.; Dayton and Western P. R.; Greenville and Miami R. R.; Dayton and Michigaul R. Ro; Dayton and Xenia R. Ro, etc.

Montgoxers county, Penn. Gituate S. E., and contains 505 sq. m. Drained by the Schuylkill, which runs on its 8. W. border, and its branches, which furnish excellent water-power in abundance. Surface moderately uneven soil very fertile, especially on the Schuylkill. Corn, wheat, rye, oats, and potatoes are all very large crops. The dairies are large, and the land under very high eultivation, but the leading interest is manufactures. The $\mathrm{S}$. E. consist largely of iron works, the native ore being abundant, flouringmills, tanneries, lumber, paper, and powder mills, and woolen factories, besides machine shops, and almost every branch of mechanism. Farms 4,456; manuf. 697 ; dwell. 10,022, and pop.-wh. 57,442, fr. col. 849-total 58,291. Capitcl: Norristown. Public Works: Philadelphia and Reading R. R.; Norristown Branch R. R.

Moxtgomers county, Tenn. Situate W. on N. line, and contains 488 sq. m. Intersected by Cumberland r., and drained by its branches, Red r., Barren and Montgomery borks, and Yellow cr. Surface varied; soil very fertile.
Corn and tobacco are the chief crops, the produee of the latter being very large; wheat and oats yield well. Large numbers of cattle are raised, and pork is a heavy export Though a superior farming county, manufactures are flotrishing and rapidly advancing, particularly of iron, for which it furnishes excellent ore. Farms 1,227; manuf. 59 ; dwell. 2,086, and pop. wh.-11,900, fr. col. 74, sl. 9,071-total 21,045. Capital: Clarksville. Public Works: Nashville and Henderson R. R.

Montgomery county, Tex. Situate'S. E., and contains 1,182 sq. m. Drained by San Jacinto $r$, and its numerous branches, the largest being Peach, Caney, Spring, and Mill creeks. Surface undulating and nearly level, The streams are skirted with timber, the rest is mostly prairie; soil in the bottoms a deep black mold of very great fertility, and the prairies are excellent pastures. Corn, cotton, and potatoes produce great crops; most of the grains do well. Sugar can easily be grown when the land is cleared, and cattle and sheep raised in immense numbers. Pine predominates in the San Jacinto bottom, and in the W. excellent building timber is abundant. Ledges of "rotten-stone" and clay beds are found plentifully in the $\mathrm{S}_{\circ}$, and sulphur and salt springs and iron ore are also found. Farms 180; manuf. 8; dwell. 260, and pop.-wh. 1,439, fr. col. 0, sl. 945-total 2,384. Capitat: Montgomery.

MonTgomerx county, Tirg. Situate S. W., and contains 485 sq. m. Bounded S. W. by New r. and Brush cr., and drained by heads of Roanoke r., which rises in this enunty. Surface rough and mountainous, with beantiful and fertile valleys; soil mostly good, and in parts very productive. Wheat and corn are large crops, and tobacco grows finely in the bottoms. It has excellent pastures, and, lying between the Blue Ridge and spurs of the Alleghany Mountains, many small mill streams. Farms 546; manuf. 0 ; dwell. 1,121, and pop.-wh. 6,822, fr. col. 66, sl. 1,471-total 8,359. Capital: Christiansburg. Public Work's: Virginia and Tennessee R. R. ; and branch toward the Ohio r., ete.

Montgomeri, p. city, and eap. Montgomery co., Ala., and capital of the State: on the left bank of the Alabama $r$, and at the head of steamboat navigation thereof, in lat. $32022^{\prime} \mathrm{N}$., and long. $86^{\circ} 26^{\prime}$ W., $118 \mathrm{~m}$. S. E. by E. Tuscaloosa, the old capital, which it succeeded in 1817. The city is built on a high bluff, and contains the capitol and other State buildings, and the usual county offices, also churches of the principal denominations, and is the location of the U. S. land office of the Montgomery land district. The sarrounding country is one of the most productive cotton regions of the State, and from this point that staple is shipped down the river to Mobile, or carried east to the Chattahoochee by the Montgomery and West Point R. R, $88 \mathrm{~m}$. to West Point, and shipped to Appalachicola, in Florida. When the La Grange R. R. is finished there will be a continuous railroad route from Montgomery to Savannah, 467 miles, and to Charleston, 483 miles. A railroad is also projected from Montgomery via Greenville to Mobile. The newspapers published here are, the "State Gazette" (dem.), daily and weekly; the "Atlas" (dem), and the "Alabama Jour11al" (whig), both daily, tri-weekly, and weekly; and the "Alabama State Register" (whig), tri-weekly and weekly. It is one of the most progressive cities of the South-west; it was laid out in 1817-in 1810 had 2,170 inhabitants, and in $1850,4,957$.

Montgomery, to and p. o, Hampden co, Mrass.: $94 \mathrm{~m}$. W. by S. Boston. Drained by branches of Westfield r., its S. W. boundary, along which the Western R. R. passes. Surface hilly and broken; soil adapted to grazing. It has much timber, and produces live-stock, butter, cheese, and wool. Pop. 383.

Montgomery, t. and p. $v_{\text {., Onange }}$ co., N. $Y_{.}: 81 \mathrm{~m}$. S. by W. Albany. Drained by the Wallkill and its branches, which supply it with numerous mill-sites. Surface hilly; soil clayey and gravelly loam, very productive of grass and grain, and under high eultivation. The meadows abound 
in bones of the mastodon, and the most complete specimen ever discorered was found in the E. part in 1845. Manufactures of various kinds are largely prosecuted, particularly in the $\mathrm{v}$., which is on the E. bank of the Wallkill, and contains an academy, a dozen stores, and a foundry, several mills, and 1,000 inhabitants. Pop. of t. 3,933.

Montgovery, p. v., Hamilton co., Ohio: 86 m. S.W. by W. Columbus.

Montgoyery, p. o., Sumner con, Tenn.: 18 m. N. N. E. Nashville.

Montgovery, p. v., and cap. Montgomery county, Tex.: about equidistant from Lake cr, and San Jacinto r., $121 \mathrm{~m}$. E. Austin City. It lies in a district heavily timbered with the best of building material, and contains the county buildings and several stores.

Montgomery, t. and p. o, Franklin co., Term.: $45 \mathrm{~m} . \mathrm{N}$. Montpelier. Drained by Trout r., a branch of Missisqui r., which furnishes superior water-power. Surface rough, except on the river, where is a fertile interval. It is well wooded and has good pastures. Pop. 1,006.

Monteouerr, p. o., Jennings co., Ind.: 65 m. S. S. E. Indianapolis.

Montgomery Centre, p. Ү., Franklin eounty, Term. : on Trout r., 46 m. N. Montpelier.

Montgomery Cross Roads, p. v., Woods co., Ohio : on an

E. branch of Cortage r., 94 m. N. N. W. Columbus.

Montgonery's Ferey, p. 0., Perry co., Penn.: on the right bank of Susquehanna r., 14 m. N. W. Harrisburg.

Montgomerprille, p. v., Montgomery co., Penn.: $73 \mathrm{~m}$. E. Harrisburg"

Monthatia, p. o., Panola county, Miss.: $147 \mathrm{~m} . \mathrm{N}$. Jackson.

Monticello, p. $\nabla$., and cap. Jefferson co., Flor. : $25 \mathrm{~m}$. E. by $\mathrm{N}$. Tallahassee. It lies on elevated ground, about 4 m. E. of Mickosukie Iake, surrounded by rich eotton plantations, and contains a court-house and jail, an academy, and 300 inhabilants.

Montrcello, p. v., and eap. Jasper county, $G a$.: $31 \mathrm{~m}$. W. N. W. Milledgeville. It contains a court-house, jail, academy, about 20 stores, and a population of 600 .

Monticello, p. v., and eap. Drew co., Ark.: 75 m. S.S.E. Little Rock. It contains a court-house and a few stores.

Monticello, p. V., and cap. Piatt co., $I l_{*}$ : about $2 \mathrm{~m}$. E. of the N. fork of Sangamon r., $59 \mathrm{~m}$. E. by N. Springfield. It contains a court-house, jail, and several stores.

Monticello, p. v., and cap. White co., Ind. : on the right bank of Tippecanne r., $72 \mathrm{~m}$. N. N. W. Indianapolis. It lies on a high bank on the edge of the Grand Prairie, and has a valuable trade and superior facilities for manufacturing. The river may be made to yield a great power, and already moves large flouring-mills. The v. contains a courthouse and jail, an academy, and several stores. The "Prairie Chieftain" is published weekly.

Monticello, p. V., and cap. Wayne co, $K y$ : about $8 \mathrm{~m}$. S. of Cumberland r., $92 \mathrm{~m}$. S. Frankfort. It contains a courthouse, jail, and a population of 300 .

Mexticello, t and p. o., Aroostook county, Me. : $169 \mathrm{~m}$. N.E. by N. Augusta. Drained by Meduxnekeag r, a branch of St. John's r. It is densely covered with timber, the preparing of which for market forms the chief business. Population 227 .

Moxticello, p. o., Pike county, Ala. : 47 miles S. E. Montgomery.

Moxticello, p. o., Jones county, Ia. : 49 m. N. N. E. Iowa City.

Mosticelio, p. v., and cap. Lawrence co., Miss, : on the right bank of Pearl river, $51 \mathrm{~m}$. S. by E. Jackson. It has a favorable location for trade, und is the shipping point for a large cotton region, and contains a court-house, jail, academy, several warehouses and stores, and 500 inhabitants. The "Southern Journal" (dem.) is published weekly.

MoNticel, Lo, p. $\nabla_{*}$, and cap. Lewis $\mathrm{CO}_{*}, \mathrm{MO}_{0}:$ on North

Fabius river, $107 \mathrm{~m}$. N. by E. Jefferson City. It contains 505 a court-house, academy, several stores, and a population of 450 .

Monticelro, p. v., and cap. Sullivan $\mathrm{co}_{\circ}$, N. I.: $86 \mathrm{~m}$. S. W. by S. Albany. It has an elevated position near a branch of Mongaup creek, and contains a court-house and jail, the clerk's office, 2 banks, a dozen stores, and 800 inhabitants. Two weekly papers are published, the "Republican Watchman" (dem.), and the "Sullivan County Whig." Monticello, p. o., Guilford co., N. Car.: 65 m. W. N. W. Paleigh.

Moxticello, p. v., Fairfield dist., S. Car.: about 3 m. E. of Broad river, $25 \mathrm{~m}$. N. W. Columbia. It contains an academy, several stores, and 350 inhabitants, and was for a time the capital of the county.

Montroello, p. o., Greene co., Wisc.: 29 m. S. S. W. Madison.

Monticello, p. v., and cap. Lewis co., Oreg.Ter.: $142 \mathrm{~m}$. N. Salem. On the 25 th Nov., 1852, a convention of the citizens of Northern Or'gon was held at this place, and a memorial to Congress agreed upon, asking for the division of the present territory, and the erection of a new territory from all that portion $\mathrm{N}$. of the Columbia and $\mathrm{E}$. to the Rocky Mountains. This section was erected into the "Territory of Washington" in March, 1853

Monticello, p. o., Carroll parish, $L a$ : 149 miles $N$. Baton Rouge.

Montmorencr county, Mich. Situate N. E. on Lower Penineula, and contains $576 \mathrm{sq} . \mathrm{m}$. Drained by Thunder Bay $r$, and its branches flowing into Lake Huron. Ereeted since 1850

Montonga, p. o., Drew county, Ark: 72 m. S. S. E. Little Rick.

Montour county, Penn. Situate E, centrally, and coutains $206 \mathrm{sq} . \mathrm{m}$. Drained by Roaring and Potts creeks, af fuents of $\mathbf{E}$. branch of the Susquehanna, which intersects the county and furnishes abundance of water-power. Surface broken; soil of superior fertility, adapted to grass or grain. Wheat, rye, corn, oats, and potatoes afford large crops, and the pastures feed fine dairies and great numbers of sheep. Live-stock, butter, cheese, and wool are the exports. Iron ore abounds, and the manufacture of iron employs a large capital. Flour, leather, woolens, and distilled liquors are largely made. Farins 738; manuf. 89 ; dwell. 2.289, and pop.-wh. 13,155, fr. col. 84-total 13,239. Capital: Danville. Puttic Works: North Branch Canal : Extension of Pennsylvania Coal Company's R. R. to Northumberland, etc. Moxrour's, p. o., Alleghany co., Penn.: $154 \mathrm{~m}$. W. by N. Harrisburg.

Montpelier, p. o., Marengo county, Ala. : $76 \mathrm{~m} . \mathrm{W}$. Montgomery.

Mostrelier, p. o., Nonroe county, Ga.: $47 \mathrm{~m}$. W. by $\mathrm{N}$. Milledgeville.

Moxtpelier, p. v., Blackford co., Tnd. : on the S. side of Salamonie r., 68 m. N. E. by N. Indianapolis.

Montpelier, p. o., Williams co., Ohio: $137 \mathrm{~m}$. N. W. by N. Columbus.

Moxtpelirs, p. o., Adair county, $K y_{*}: 83$ m. S. by W. Frankfort.

Mostpelier, p. o., Richmond co., $N$. Car.: about $4 \mathrm{~m}$. W. of Lumber r., 65 m. S. S. W. Raleigh.

Mostpelier, $t$, p. V., and cap. Washington co., Verm., and capital of the State: on Winooski r., in lat. $44^{\circ} 17^{\prime} \mathrm{N}$., and long. $72 \circ 36^{\prime}$ W., $524 \mathrm{~m}$. N. N. E.Washington. Drained by tributaries of the Winooski, which afford fine waterpotver and numerous mill-seats. Surface uneven and hilly; soil various-on the hills furnishing fine pastures. The $\mathrm{v}$. is the centre of a large commerce and of roads diverging in every direction. The Vermont Central R. R. touches Montpelier, $77 \mathrm{~m}$. from Windsor, and $40 \mathrm{~m}$. from Burlington. The public buildings are the State House, court-house, jail, etc. The State House is an elegant granite structure, 150 feet long-the centre, including portico, 100 feet deep, and the wings 72 feet deep; the centre front has a fine Dorio 
portico of 6 columns, each 6 feet diameter and 36 feet high, and the whole ediffce is surmounted by a dome 100 feet from the ground. In the interior are convenient State offices and spacious and elegant rooms for the Senate and Representatives. Montpelier became capital in 1805. It has several workshops and factories, a bank, and numerous wholesale and retail stores; and five newspapers, the "Vermont Patriot" (dem.), the "Verm. Watchman" (whig), the "Green Mountain Freeman" (free snil), the "Christian Repository," and the "Christian Messenger"-all weekly publications. Pop. in 1880, 1,792; in 1840,3,725; and in 1850, 2,310. The t. of East Montpelier was taken from the original $t$, in 1848, and in 1550 contained 1,447 inhabitants.

Mojtpeliek, p. o., Hunover co., Virg.: 21 m. N. N. W. Richmond.

Moxtra, p. o., Shelby county, Ohio: 68 m. W. N. W. Columbus.

Moxtreal river, $M F i c h$. and Wisc.: rises in several lakes in Wisc., and flows N. W. into Lake Superior, forming the boundary between the two States.

Montrose, p. v., Lee e., Ia : on the Mississippi, $12 \mathrm{~m}$. above the mouth of the Des Moines, $92 \mathrm{~m}$. S. Iowa City. It is opposite Nauroo, and was first settled by Spaniards in 1799 .

Montrose, p. o., Jasper county, Miss.: 63 m. E. S. E. Jackson.

Montrose, p. b., and cap. Susquehanna co., Penn. : $115 \mathrm{~m}$. N. by E. Harrisburg. It occupies an elevated position, and is compactly built, containing a court-house and jail, an academy, 20 stores, several manufactories, and 916 inhabitants. Two weekly papers, the "S. Register" (whig), and the "M. Democrat," are published. The Lackawanna and Western R. R. passes a few miles E., and Montrose sta. is $13 \mathrm{~m}$. S. of Great Bend, on the Erie R. R.

Montrose, p. o., Smith county, Tenn.: 44 m. E. N. E. Nashville.

Montrose, p. o., Summit co., Ohio: 113 m. N. E. by N. Columbus.

Montrose, p. O., Westmoreland co., Virg. : 49 m. N. E. Richmond.

Montrose Defôt, p. o. and sta., Susquehanna co., Penn.: on the Lackawanna and Western R. R., $18 \mathrm{~m}$. S. of Great Bend, 118 m. N. N. E. Harrisburg.

Monturesville, p. v., Lycoming co., Penn.: on the left bank of the W. branch of Susquehanna r., $66 \mathrm{~m}$. N. by W. Harrishurg. It is on the W. branch of Pennsylvania Canal, $6 \mathrm{~m}$. E. Williamsport.

Movtrale Springs, p. o., Blount co., Tenn. : 163 m. E. by S. Nashville.

Mostrille, t. and p. o., Waldo co., Me.: $24 \mathrm{~m}$. E. by N. Augusta. Drained by heads of Sheepscot and St. George's rivers. Surface varied, and soil fertile, and adapted to grain. A superior furming t. Pop. 1,878.

Montrille, sta., New London co., Conn.: on the right bank of the Thames, $6 \mathrm{~m}$. N. of New London, on the New London, Willimantie, and Palmer P. P.

Mostrille, t. and p. o, Geauga co, Ohio: $148 \mathrm{~m}, \mathrm{~N}, \mathrm{E}$. Columbus. Drained by a branch of Grand r., and the head of Cuyahoga r., which rises in it. Surface somewhat uneven, and soil very fertile. Pop. 702.

Mostrille, p. v., Morris co., $N$. Jer.: on a N. brauch of Rockaway $\mathrm{r}_{\text {., }} 51 \mathrm{~m}$. N. N. E. Trenton. It lies in a deep valley on the Morris Canal, $40 \mathrm{~m}$. from Jersey City, and contains several stores and mills.

Monumkxт, p. O., Pike county, Ill.: $89 \mathrm{~m}$. W. by S, Springfield.

Movument, p. o. and sta., Barnstable co., Mfcss.: on the Cape Cod Branch R. R., 21 m. S. E. Middleboro, 49 m. S. S. E. Boston.

Monument Islaxt, p. o., Delaware co., $N_{0} Y_{*}:$ on Delaware r., 94 m. W. S. W. Albany.

Moones, p. o., Middlesex co., Conn.: on an E. branch of the Connecticut, $23 \mathrm{~m}$. S. E. by S. Hartford.
Moody's Mriss, p. o., Morgan co., Ohio: 68 m. E. S. E. Columbus.

Mookn's, t. and p. v., Clinton co., $N . Y_{.:}$on the Canada line, $118 \mathrm{~m}$. N. Albany. Drained by Chazy r. of Lake Champlain, and English r, an affluent of the St. Lawrence. Surface hilly, and heavily timbered; soil various, principally adapted to grazing, which is the leading interest. The v., $2 \mathrm{~m}$. S. of the Canada line, on the N. side of Chazy r., is extensively engaged in manufactures. It is $20 \mathrm{~m}$. N. of Plattsburg, on the Plattsburg and Montreal R. R., which 1. m. N. of the $\mathrm{v}$. intersects the Northern (Ogdensburg) R. R., $12 \mathrm{~m}$. W. of Rouse's Point. Pop. of t. 8,365.

Moos, t. and p. o., Alleghany co., Penn. : on the left bank of the Ohio, $173 \mathrm{~m}$. W. by N. Harrisburg. Drained by affluents of the Ohio, which furnish water-power. Surface hilly; soil loam, and for the most part very fertile. It contains several flouring-mills and small manufactories, but farming is the chief pursuit.

Mookex, p. 8., Philips co., $\Delta r k .: 87$ m. E. by S. Little Rock.

Mooner, p. o., Jackson co., Ind.: about $2 \mathrm{~m}$. S. of Salt cr., $58 \mathrm{~m}$. S. Indianapolis.

Moos's, p. o., Fayette co., Orio: on Rattlesnake er., $44 \mathrm{~m}$. \$. W. by $\mathrm{S}$. Columbus.

Moor's, sta., Cobb co., Ga.: on the Western and Atlan tic R. R., $30 \mathrm{~m}$. N. of Atlanta.

Moore county, $N$. Car. Situate centrally, and contains 864 sq. m. Drained S. by Lumber r., N. by Deep r., and many other branches of Cape Fear r. Surface diversified, and generally somewhat uneven; soil of average fertility, with superior land on the larger rivers, Cotton and corn are the leading crops; wheat, oats, and potatoes, and some tobacco are cultivated; but none of its products are very large. Farms 713 ; manuf. 4 ; dwell. 1,286, and pop.-wh. 7,197, fr. col. 169, sl, 1,976-total 9,342. Capital: Carthage. Moorefield, p. v., Switzerland co., Ind. : 81 m. S. E. by S. Indianapolis.

Moorefield, p. o., Nicholas county, Ky.: $45 \mathrm{~m}$. E. by $\mathrm{N}$. Frankfort.

MoorfField, t. and p. v., Harrison co., Ohio: 94 m. E. by $\mathrm{N}$. Columbus. Drained by branches of Tuscarawas $r$. Surface slightly uneven, and soil mostly very fertile. The' $\mathrm{v}$. contains 44 inhabitants. Pop. of t. 1,066.

Moorefield, p. v., and cap. Hardy co., Firg.: on the E. side of the S. forl of Potomac r., $131 \mathrm{~m}$. N. W. by N. Riclsmond. It has growing manufactures, favored by the extensive water-power of two branches of the r. uniting here, and contains a court-house, jail, academy, several mills, and 500 inhabitants.

MonkE"s, p. o., Bowie co., Tex. : 306 m. N. E. Austin City. Mooresborotgir, p. o., Cleveland co., N. Car. : on Sandy Run of Broad r., $169 \mathrm{~m}$. W. by S. Raleigh.

Mooresburg, p. V., Pulaski co., Ind.: on an E. branch of Tippecanoe r., $85 \mathrm{~m}$. W. by N. Indianapolis.

Mooresburg, p. v., Montour co., Penn. : about 3 m. N. of Susquehanna $r$. and the Pennsylvania Canal, $49 \mathrm{~m}$. N. by E. Harrisburg. A charcoal furnace of 1,400 tons capacity is located here.

Mooresburg, p. o., Hawkins co., Tenn. : $205 \mathrm{~m}$. E. by N. Nashville.

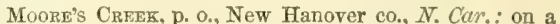
branch of Cape Fear r., $91 \mathrm{~m}$. S. by E. Raleigh.

Moore's Cross Roads, p. o., Hardeman county, Tenn. : $169 \mathrm{~m}$. S. W. by W. Nashville. It is near the S. line of the State, and on the line of the Memphis and Charleston R. R. Moore's Fork, p. o., Clinton county, $N . Y_{*}: 114 \mathrm{~m} . \mathrm{N}$. Albany.

Moore's Hild, p. v., Dearborn county, Fnd.: $71 \mathrm{~m}$. S. E. by E. Indianapolis.

Moore's Mrlus, p. o., Jackson county, Virg. : $287 \mathrm{~m}$. W. N. W. Richmond.

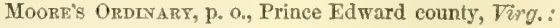
61 m. W. S. W. Richmond. 
Moore's Pratrie, p. o., Jefferson co., Ml. : 126 m. S. S. E. Springfield.

Moore's Rest, p. O., Anderson co., Texo.: 148 m. N. E. Austin City.

MOORE's SALT-WORKs, p. v., Jefferson county, Ohio: on Yellow er., $116 \mathrm{~m}$. E. N. E. Columbus.

MOORE's Store, p. o., Shenandoah co., Firg.: $107 \mathrm{~m}$.

N. W. by N. Richmond.

Moore's Store, p. 0., Caswell co., N. Car.: 68 m. N. W. Raleigh.

Moorestown, p. v., Burlington co., N. Jer.: 5 m. E. of Delaware r., 20 m. S. S. W. Trenton.

Mooresvili.e, p. v., Limestone $0_{\text {., }}$ Ala.; between Shoal and Limestnne creeks, about $5 \mathrm{~m}$. N. of the Tennessee, 153 m. N. by W. Montgomery. It has an academy, and in the vicinity are fine water privileges and several cotton-mills.

Moorestille, p. r., Morgan co., Ind, : on the E. side of White Lick cr., $16 \mathrm{~m}$. \$. W. Indianapolis.

Moorestlule, p. o., Orange co., N. Caro: 54 m. N. W. Raleigh.

Moorestille, p. o., Union par., La.: 167 m. N. N. W. Baton Rouge.

Mooresville, p. V., Marshall co., Tenn.: $47 \mathrm{~m}$. S. by W. Nashville.

MOORE's VINEYARD, p. 0., Bartholomew co., Ind. : 46 m. ธ. S. E. Indianapolis.

Mookheadville, p. v., Erie county, Penn.: 206 miles N. W. by W. Harrisburg.

Moorlavd, p. v., Wayne county, Ohio: 85 m. N. E. Columbus.

Moorville, p. O., Itawamba co., Miss. : 165 m. N. E. Jackson.

Mooseheloo, Grafton co., N. Hamp.: lies in the E. part of Benton, and consists of two peaks, the N. 4,556, and the S. 4,636 feet above the ocean level. The summits are bare masses of granite, on which the snow lies the year round.

Moose river, $N_{0} Y_{0}$ : has its source in Hamilton co. in several large lakes, and flows W. across Herkimer into Lewis co., where it empties into Black r., above the High Falls.

Moose river, $M F_{\text {e }}$ : rises in the highlands, on the W. line of the State, and flows E. through several lakes into Monsehead lake, being its largest affuent.

Moosemead lake, Me.: lies between Somerset and Penobscot counties, and is the principal source of Kennebec $r$. It contains several large islands, and is about $35 \mathrm{~m}$. long, varying in width from 4 to 12 miles.

Moose Meadow, p. o., Tolland co., Conn.

Moose River, p. o., Somerset co., Me.: 95 m. N. by W. Augusti.

Moosor, p. o., Windham co, Conn。: on an E. branch of the Quinnebaug, $41 \mathrm{~m}$. E. by $\mathrm{S}$. Hartford.

Mopuelumre,. ., Calaveras co., Calif: : about $2 \mathrm{~m}$. W. of the $\mathrm{N}$. fork of the r, so called, $104 \mathrm{~m}$. E. by N. Vallejo.

MOQUfLUNNE river, Calif. : a tributary of Joaquin r. from the Sierra Nevada. It flows through a rich gold region.

Moquelunne Hind, v., Calaveras co., Calif... on the S. side of the S. fork of Moquelumne r., $106 \mathrm{~m}$. E. by N. Vallejo.

Morales De Lavaca, p. o., Jackson co., Tex.: 106 m. S. S. E. Austin City.

MLoravia, t. and p. v., Cayuga co., $N . Y .: 189 \mathrm{~m}$. W. Albany. Drained by Owasco inlet, which affords fine millsites, and flows into Owaseo lake in the N. W. corner. A broad and fertile valley borders the inlet, back of which the surface is billy and the soil indifferent. The $\mathrm{v}$. is on the inlct, and contains several factories and the Moravian Institute. Pop. of t. 1,s70.

Moreav, t. and p. o., Saratoga county, $N, Y_{0}: 38 \mathrm{~m} . \mathrm{N}$. Albany. Bounded $\mathbf{N}$. and $\mathrm{E}$. by the Hudson, on which, in the N. E. coraer, are Glen's and Baker's falls, which supply immense water-power. Surfice mostly even, with hills in the E.; soil sandy and clayey loam, generally fertile. Black marble of superior beauty is plentiful on the Fidson, which 510 is spanned by a bridge above the falls. The Saratoga and Washington R. R. passes through it. Pop. 1,884.

Moreav Stration, p. o. and sta, Saratoga con, N. $Y_{*}: 40$ $\mathrm{m} . \mathrm{N}$. Albany, on the Saratoga and Washington R. R., $16 \mathrm{~m}$. N. of Saratiga.

Morefield, p. 0., Greene county, Wisc. : 27 m, S. S. W. Madison.

MOREHAUSE parish, La. Situate N. E., and contains 845 sq. m. Drained by Washita and Au Bouf rivers and bayou Bartholomew-the first forming its W. and the last its E. boundary. Surface undulating, and in parts swampy, with a fine growth of timber; soil fertile, on the margins of the streams especially so, and productive of large crops of cotton and corn, the staples of the county. It has good pasture land, and raises many cattle and fattens pork largely. Farms 260 ; manuf. 4 ; dwell. 372 , and pop.-wh. 1,877, fr. col. 30, sl. 2,006-total 3,913. Capital: Bastrop. Public Works: Louisiana and Texas R. R.

Morenadseville, p. v., and cap. Hamilton co., $N$. $Y_{.:}$ $78 \mathrm{~m}$. N. W. Albany. A small v., surrounded by fine pasture lands and forests of excellent timber, containing a court-house and 150 inhabitants.

Moreland, p. O., Bourbon county, Ky. : 30 m. E. by S. Frankfort.

Moreland, p. o., Fauquier co., Firg.: $71 \mathrm{~m}$. N. by W. Richmond.

Moreland, p. 0., Chemung co., N. Y.: 103 m. W. by S. Albany.

Moreland, to and p. o., Lycoming co., Penn.: $63 \mathrm{~m} . \mathrm{N}$. Harrisburg. Drained by Little Muncy er. It has a hilly surface, a gravelly soil, and abundance of white pine timber. which affords material for numerous saw-mills.

Moreman's River, p. o., Albemarle co., Virg.: $62 \mathrm{~m}$. W. N. W. Richmond.

MorearcI, p. o., Lenawee county, Mich.: 42 m. S. S. E. Lansing.

Morestilue, p. T., Delaware co., N. $Y_{0}: 45 \mathrm{~m} . \mathrm{W} . \mathrm{S} . \mathrm{W}$. Albany.

Moretown, t. and p. va, Washington co., Verm.: $8 \mathrm{~m}$. W. Montpelier. Drained by Mad r., a branch of Onion $r$. which furnishes good water-power. The Vermont Central R. R. passes along Onion r., the N. boundary of the t. Surface mountainous and in many parts untillable. The v. is on Mad r., and contains several mills and stores. Population of t. 1,335.

Moretz Mrri, p. O., Ashe co., N. Carv: $161 \mathrm{~m}$. W. by N. Ralcigh.

Morgar county, $A l a$. Situate N. middle, and contains 714 sq. m. Bounded N. by the Tennessee, and drained by its affluents. Surface varisd, in the S. broken and uneven; soil in the N. very fertile, producing very heavy cotton crops, which constitute the staple, and large corn crops; in the S. belter adapted to grain and grass, yielding good returns of wheat and oats, and rearing large numbers of neat cattle and swine, and exporting beef and pork iu large quantities. It has some mill streams and growing manufactures of cotton goods. Farms 584; manuf. 13; dwell. 1,103, and pop. -wh. 6,68s, fr. col. 50, sl. 3,437-total 10,125. Capital: Somerville. Public Works : Memphis and Charleston R. R. Morgan county, $G a$. Situate N. centrally, and contains $274 \mathrm{sq}$. $\mathrm{m}$. Drained by Little $\mathrm{r}$. and other branches of the Oconee, which forms its E. boundary. Surface gently uneven, with many mill streams; soil very fertile. Cotton is raised in great quantities, forming the staple product and almost excluding other crops. Its manufactures are rapidly increasing, particularly of cotton goods. Farms 336 ; manuf. 31: dwell. 621, and pop.-wh. 3,634, fr. col. 16, sl. 7,094-total 10,744. Capital: Madison, Prblic Works: Georgia R. $R_{m}$ Morgar county, Ill. Situate W. middle, and contains 539 sq. m. Drained by Indian and Mauvaiseterre creeks, branches of the Illinois, which forms the W. boundary. Surface undulating or nearly level; soil of great fertility, largely made up of prairies, which afford the very best of 
grazing lands. Corn and wheat are very heavy crops, Iive-stock, beef, wool, and pork are large exports. Timber is found near all the streams, which afford considerable fine water-power. Flour, leather, woolen goods, iron castings, and machinery are leading manufactures. Farms 1,574; manuf. 89 ; dwell. 2,661, and pop.-wh. 15,939, fi. col. 125total 16,064. Capital: Jacksonville. Public Works: Sangamon and Morgan R. R.

MoRGAN county, Ind. Situate S. centrally, and contains 453 sq. $\mathrm{m}$. Drained by W. fork of White $\mathrm{r}$. and its branches, White Lick, Big Indian, Mill, and Stott's creeks. Surface undulating or level, with hills near the streams and wide bottoms on their marging; soils everywhere excellent and well timbered. Corn and wheat are heavy staples, and pork a large export. Wool is extensively grown, and fine dairies kept. Farms 1,392; manuf. 14; dwell. 2,401, and pop.-wh. 14,502, fr. col. 74-total 14,576. Capital: Martinsville. Public Works: Martinsville R. R.

Morgar county, $K y$. Situate N. E., and contains 802 sq. m. Drained by Licking and Reel rivers and their tributaries. Surface much diversified, and in parts rugged or mountainous; soil of average fertility, better adapted to grazing than grain-growing. Corn is the chief cereal produced; other grains are raised in small quantities, and pork is the principal export. It has abundant timber and waterpower. Farms 615; manuf, 0; dwell. 1,201, and pop.-wh. 7,395, fr. col. 38, 8l. 187-total 7,620. Capital: West Liberty.

Morgax county, Mo. Situate centrally, and contains 649 sq. m. Drained by the Osage $r$., which runs on and near its S. border, and its branches, and N. by Flat er., a branch of La Mine r. Surface moderately uneven, in parts prairie, but generally well wooded. Corn is the staple, but other grains thrive, and tobacco flourishes in parts. Fine pasturage is abundant, and the rearing of cattle and sheep demands much attention. Pork is the principal export. Water-power is abundant. Farms 455; manuf. 12; dwell. 754, and pop.-wh. 4,292, fr. col. 5, sl. 453-total 4,750. Capital: Verseilles.

Morgar county, Ohio. Situate S. E., and contains 354 sq. m. Intersected by Muskingum r., and drained by its branches, and branches of Hocking r., which furnish fine water-power. Surface somewhat broken; soil very fertile. Wheat and corn are the staple cereals, and the produce very large. Tobaceo is cultivated with marked suecess and profit. It has very fine dairies, shears a large amount of wool, and exports pork extensively. Bituminous coal is found, and numerous salt-springs, which formerly furnished a great quantity of salt. It manufactures salt, leather, woolens, iron castings, machinery, liquors, and stone-ware Farms 2,126; manuf. 95; dwell. 4,886, and pop.-wh. 28,515, fr. col, 70-total 28,585. Capital: M'Connellsville.

Morgan county, Tenn. Situate N. E., and contains 883 sq. $\mathrm{m}$, Drained $\mathrm{N}$. by branches of Cumberland $\mathrm{r}$, and $\mathrm{s}$. by Emery's r. and its branches, affluents of Clinch r. Surface rough and uneven, being crossed by Cumberland mts.; soil better adapted to grazing than grain. Corn, oats, and potatoes are the chief crops, and pork the principal export. Its mill streams are numerous and fine. Farms 430; manuf. 3 ; dwell. 5S1, and pop.-wh. 3,301, fr. col. 28, sl. 101-total 3,430. Capital: Morgan.

Morgan county, Firg. Situate N. E., and contains 295 sq. m. Drained by Cacapon $r$. and Sleepy cr., affluents of the Potomac, which forms the N. and N. W. boundary. Surface much broken, in parts mountainous; soil in the valleys very fertile; parts are too rugged for cultivation. Corn, wheat, rye, oats, and potatoes are raised, generally in good crops, though the amounts are not large. Sheep find good pasturage. It has superior mill-seats, and manufactures flour, woolens, leather, and earthen-ware. Farms 300 ; manuf. 9 ; dwell. 606, and pop.-wh. 3.431, fr. col. 3, sI. 123 total 3,55̃7. Capital: Bath. Public Works: Baltimore and Ohio R. R.
MORGAN, to and p. 0., Ashtabula co., Ohio: 159 m. N. E. Columbus. Drained by Grand $r$, and its branches, which afford good mill-sites. Surface even, and soil productive. Various small manufactories are operated. Pop. 891.

MorgaN, p. vo, and eap. Morgan co, Tenn: on Emery's r., a branch of Clinch r., $113 \mathrm{~m}$. E. Nashville. It contains a court-house and jail, and several stores and workshops, with about 200 inhabitants.

Morgan, to and p. 0., Orleans con, Verm.: 45 m. N. E. Montpelier. Seymour's lako, a tributary of Clyde $\mathbf{r}_{\text {ry }}$ occupies the central part. Surface uneven, but not rough; soil mostly good. Grazing is the chief pursuit. The St. Lawrence and Atlantic $R$. $R$. crosses the E. part. Pop. 486.

Morgan CrTy, sta., Morgan co, Ill.: 9 m. E. of Naples, on the Sangamon and Morgan $\mathrm{P}$. R.

Morganfiel, , p. vo, Union co., Ky.: ahout $8 \mathrm{~m}$. S. of the Ohio, $167 \mathrm{~m}$. W. by s. Frankfort. It contains a court-house, academy, several stores, and 300 inhabitants.

Morgansburg, p. o., Fauquier co., Firg. : $84 \mathrm{~m}$. N. by W Riehmond.

Morgax's Corners, sta., Delaware co., Penn.: $14 \mathrm{~m}$. from Philadelphia, on the Columbia and Philadelphia $\mathrm{R}$. R. and Philadelphia and Westchester R. R

Moranx's Creek, p. o., Benton co., Tenn.: near the left bank of the Tennessee, $68 \mathrm{~m}$. W. by $\mathrm{S}$. Nashville.

Morgan's Creek, p. 0., Orange county, N. Car.: $41 \mathrm{~m}$. W. N. W. Raleigh.

Morgax's ForK, p. o., Pike county, Ohio: $66 \mathrm{~m} . \mathrm{s}$. Columbus.

Morgan's Milis, p. o., Union county, N. Car.: 103 m, W. S. W. Raleigh.

MoRgan's RiDGe, p. O., Marion county, Virg.: 205 m. N. W. by W. Richmond.

Morganstille, p. v., Morgan co., Ohio: on a W. branch of the Muskingum, $58 \mathrm{~m}$. E. S. E. Columbus.

Morgansville, p. v., Genesee co., N. Y.: on Black er., $232 \mathrm{~m}$. W. Albany. It contains several stores and mills, and 300 inhabitants.

Morgantown, p. v., Morgan co., Ind. : on the N. side of Big Indian er., $28 \mathrm{~m}$. S. by W. Indianapolis. The Martinsville R. R. passes through it $13 \mathrm{~m}$. W. of Franklin.

Morgantown, p. V., and cap. Butler $c_{*}, K y_{*}$; on the $S_{\text {. }}$ side of Green r., 118 m. S. W. by W. Frankfort. Large quantities of grain and tobacco are sent from this place down the r., which is navigable for boats of light draught at all times. It contains a court-house, jail, academy, several stores and small manufactories, and 400 inhabitants.

Morgantown, p. v., Berks co., Penn。: 52 m. E. by S. Harrisburg. It contains several stores, and 500 inhabitants.

Morgantowr, p. ., and cap. Burke co., N. Car. : on the S. side of Catawba r., $166 \mathrm{~m}$. W. Raleigh. It lies on ele vated gxound, surrounded by a rich grain country, with flourishing manufactories in the vicinity, and has an extensive trade. It contains a court-house, jail, academy, bank, a dozen stores, and a population of 500 .

Morgantown, p. v., Blount co., Tenn. : on the E. side of Tennessee r., $145 \mathrm{~m}, \mathrm{E}$. by $\mathrm{S}$. Nashville.

MorgaNTown, p. v., and cap. Monongalia co., Firg.: on the E. side of Monongahela r., $197 \mathrm{~m}$. N. W. Richmond. It lies at the head of steamboat navigation, and has a large trade and rapidly increasing manufactures, for which there is ample water-power and abundance of coal in the ricinity. It contains a court-house, jail, two academies, a dozen stores, several mills, and a population of 1,000 . The "Monongalis Mirror" and the "Watehman" (literary), and the "Mountain Messenger" (Baptist), are published weekly.

Morganville, p. o, Nottaway county, Fing.: $38 \mathrm{~m}$, S. W. by W. Richmond.

Morganviue, p. v., Hillsdale county, Mich. $62 \mathrm{~m}$. S. Lansing.

Moriak, t. and p. v., Essex co., N. Y.: on Lake Champlain, $98 \mathrm{~m}$. N. Albany. Surface very uneven; soil fertile 
in the valleys. Marble of good quality is found. Iron ore and timber are abundant, and attention is principally directed to them. The $\mathrm{v}$. is on high ground, about $3 \mathrm{~m} . \mathrm{W}$. of the lake, and contains an academy, several stores, and 1,000 inhabitants. Pop. of t. 3,065.

Moricues, p. v., Suffolk co., N. $Y_{0}$ : on the S. side of Long Island, 136 m. S. S. E. Albany.

MoriveriLle, p. o., Chatham co., N. Car.: $18 \mathrm{~m}$. W. of Paleigh.

MorINGrille, p. v. and sta, Westchester co., $N . Y_{*}:$ on Bronx r., $112 \mathrm{~m}$. S. Albany. It is $25 \mathrm{~m}$. N. of New York, on the Harlem R. R.

Mortax's Grove, p. o., Wayne co., Ill. : 119 m. S. E. by 8. Springfield.

Mozicey, p. o., St. Lawrence co., N. Y.: 153 m. N.W. by N. Albany.

Mormox Huz, p. O, Marshall co, Ia. : 81 m. W. N. W. Iowa City.

MoRMON IsLaxd, p. o., Sacramento co., Calif.: on the $\mathrm{S}$. fork of American r., $74 \mathrm{~m}, \mathrm{E}$. N. E. Vallejo. It was here that the first discoveries of gold were made in 1848 .

Mornivg Sux, p. o., Louisa co., Ia.: $81 \mathrm{~m}$. S. S. E. Iowa City.

Morntre Sun, p. v., Preble con, Ohio: on Four Mile cr., $95 \mathrm{~m} . \mathrm{W} . \mathrm{s} . \mathrm{W}$. Columbas. The Four Mile Valley R. R. passes through it.

Momitag Scx, p. o., Shelby co., Tenn.: 170 m. W. S. W. Nashvilie.

Moro, p. o., Calhoun co., Ark.: 68 m. s. by W. Little Rock.

Morritr's, sta, Cumberland co., Me.: $3 \mathrm{~m}$. from Portland, on the Yark and Cumberland $R$. R.

Morkis county, N. Jer. Situate N. middle, and contains 406 sq. m. Drained by Pequannock r., its N. boundary, Passaic r., its E. boundary, and W. by branches of the Raritan and Delaware. Surface broken $N$. and $W$. by ranges of high hills; in the $\mathrm{S}$. is the beautiful valley of the Passaic. Soil generally very productive, and in parts fine grazing land. Wheat, corn, rye, buckwheat, oats, and potatoes, are all good crops, and the rye and buckwheat of a superior quality. Large products of the dairy, beef and wool, are the farming exports. It has valuable mines of magnetic iron ore, which are wrought extensively and with mach profit, the metal obiained being much sought after, and highly prized. Manufactures of almost every kina are prosecuted, the more important being iron cast and wrought, cotton and woolen fabrics, leather, distilled liquors, paptr, carriages, and eahinet furniture. Farms 1. 4 43 ; manuf. 242; dwcll. 5,076, and nop.-wh. 29,146, fr. col., 993, sl. 19-total 30,158. Capital: Morristown. Public Works: Morris Canal ; Morris and Essex R. R.

Manne, $\Gamma$. v.. and cap. Grundy co.. $M l .:$ on the right bank of Illinois r., $121 \mathrm{~m} . \mathrm{N}$. N. E. Springfleld. $\mathrm{It}_{\mathrm{t}}$ is on the Illinois and Michigan Canal, $23 \mathrm{~m}$. S. W. of Juliet, and has an extensive trade in the staples of the surrounding country, which are shipped here in. great amounts, and growing manufuctures. It lies on a gentle slope toward the r., and contains a court-house and jail, numerous stores and warehouses, and about 1,000 inhabitants. A weekly newspaper is published here.

Morris, p. o., Otsego co., N. Y.: 63 m. W. Albany.

Munris, t. and p. O. Tioga co., Penn.: $96 \mathrm{~m}$. X. . Y. W. Harrisburg. Drained by Pine cr. and its branches, which afford much water-power. Surface hilly; soll clayey and corered with heavy timber. Coal and iron ore are found.

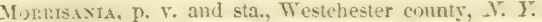
1i) m. $\mathrm{X}$. of the City Hall, in New York, by the Harlem P. I. $126 \mathrm{~m} . \mathrm{S}$. Albany. It is in the S. part of West Farms $\mathrm{t}$, on the E. side of the Harlem r., is laid out with the regularity of a city, and being rapidly built up into a suburb of the great metropolis, Pop, about 3,000 .

Morris' Cictrce, p. o., Campbell county, Virg.: $92 \mathrm{~m}$. T. br S. Richmond.
Morris' Cross Roads, p. o., Fayette co., Penn. : 148 mo W. by S. Harrisburg.

Morrisdale, p. o., Clearfleld co., Penn。: about $3 \mathrm{~m} . \mathrm{W}$. of Mushanon cr., $84 \mathrm{~m}$. N. W. by W. Harrisburg.

Morkis' HiL., p. 0., Alleghany co., Virg. : 146 m. W. by N, Richmond.

MoRrisox's Butfr, p. o., Johnson co., Ark: on the right bank of the Arkansas, $83 \mathrm{~m} . \mathrm{W} . \mathrm{N}$. W. Little Rock.

Morrison's Stone House, p. o., Monroe co., Ill. : about $1 \mathrm{~m}$. W. of Kaskaskia r., $107 \mathrm{~m}$. S. by W. Spriugfield.

Mokrison's TAN-Yard, p. o., Mecklenburg co., N. Car. : $118 \mathrm{~m}$. W. s. W. Raleigh.

Morris' Plains, sta., Morris co., N. Jer.: $34 \mathrm{~m} . \mathrm{W}$ : of Trenton, on the Morris and Essex R. R.

Morristown, p. v., Henry co., Ill.: about $3 \mathrm{~m} .8$. of Green r., on a small creek, $116 \mathrm{~m}$. N. N. W. Springfleld.

Morristown, p. v., Shelby co., Ind.: about $1 \mathrm{~m}$. E. of Bine r., $24 \mathrm{~m}$. E. by $\mathrm{S}$. Indianapolis. The Knightstown and Shelbyville R. R. passes through it, $13 \mathrm{~m}$. N. of Shelbyville. Morrigtown, p. F., and cap. Morris co., N. Jer.: $41 \mathrm{~m}$. $\mathrm{N}$. by $\mathrm{E}$. Trenton, It lies on an elevated plain, on the $\mathrm{S}$ side of Whippany $\mathbf{r}$, and is regularly laid out, with a large square in the centre. It contains a court-house and jail, 2 academies, a bank, about 40 stores, and 3,000 inhabitants, Manufactures of various kinds are extensively carried on, particularly of paper, iron eastings, earriages, machinery, etc. The Morris and Essex R. R. passes through it $32 \mathrm{~m}$ W. of New York. Three papers are published-the "Jerseyman" (whig), and "Free Democratic Bamner" (dem.), weekly, and the "New Jersey Freeman" (abolitionist) monthly. The $t$ is called Morris, is well supplied with waterpower by Passaic and Whippany rivers, and has an uneven surface and fertile soil. Pop. of t. 4,992.

Morristown, to and p. V., St. Lawrence co., $N$. $Y$.: on the St. Lawrence, $164 \mathrm{~m}$. N. W. by N. Albany. Surface slightiy rolling, and soil fertile. Black lake lies on the S. E. The $\mathrm{v}$, is on the St. Lawrence, and a regular landing-place for steamboats. Pop. of t. 2,274.

Morristown, t. and p. vo, Lamoille co., Term。: $23 \mathrm{~m} . \mathrm{N}$. Montpelier. Drained by Lamoille r. and its branches, which supply good mill privileges. Surface somewhat hilly; soil fertile, especially on the $\mathbf{r}$. I $t$ is a fine farming t., exporting cattle, wool, and dairy products, to a large amount. The v is on the r., and contains several stores and mills. Pop of t. 1.142.

Mobristown, p. v., Belmont co., Ohio: on M'Mahon's er of the Ohio, $99 \mathrm{~m}$. E. by N. Columbus. It contains several stores and mills, and 455 inhabilants.

Morristown, p. v., Grainger co., Tenn. : on a branch of IIolston r., 159 m. E. Nashville.

Morristown, p. o., Cuss co., MO. : 181 m. W. Jefferson City. Morrisvilue, p. v., Hendrick's co., Ind.: on the Terre Maute and Richmond R. R., $25 \mathrm{~m}$. W. by S. Indianapolis.

Morrisville, p. $\nabla$., and cap. Madison co., $N_{0} Y_{\text {.: }}$ on a branch of the Chenango r., $102 \mathrm{~m}$. W. by N. Albany. It contains a conrt-house, jail, elerk's office, academy, several stores and mills. and about S00 inhabitants. Two weekly papers are published here-the "M. County Journal" (whig), and the "Madison Observer" (dem.)

Morristille, p. o., Wake co., N. Car.

Morrisville, p. b., Bucks co., Penn.: on the right bank of Delaware r., $109 \mathrm{~m}$. E. Harrisburg. It is opposite Trenton, with which it is connected by a bridge 1,100 feet long; and has fine water privileges, which are improved by various extensive manufactories. It is $29 \mathrm{~m} . \mathbf{N}$. E. Philadelphia on the Philadelphia and Trenton R. R.

Moreisville, p. v., Lamoille co., Verm. : on Lamoille r., 21 miles N. Montpelier. Here is good water-power and several mills.

MorrisvmLe, p. v., Fauquier co., Tirg.: 66 m. N. by W. Richmond.

Morrow county, Ohio. Situate N. centrally, and contains $397 \mathrm{sq}$. m. Drained by branches of Whetstone $\mathbf{r}_{\text {., }}$ 
Vernon r., and Clear fork of Walhonding r., the first a branch of the Scioto, the last two of the Muskingum river. Surface rolling; soil fertile, and adapted equally to grass and grain. Corn and wheat are the staples. Tobacco is cultivated. Sheep are raised in great numbers, and wool and pork are large exports; live-stock and beef are also exported. Manufactures are of considerable though minor interest, consisting principally of woolen goods, leather, liquors, and farming implements. Farms 1,552; manuf. 51; dwell. 3,65̃, and pop.-wh. 20,270 , fr. col. 10-total 20,280. Capital: Mount Gilead. Public Works: Cleveland, Columbus, and Cincinnati Railroad; Springfield and Mount Vernon and Pitsburg R. R.

Morrow, p. v., Warren co., Ohio: on Little Miami river, $74 \mathrm{~m}$. S. W. by W. Columbas. The Little Miami R. R. passes it $41 \mathrm{~m}$. N. of Cincinnati.

Morse CreEK, p. o,, M*Nairy co., Tenn. : on a branch of Big Hatchie 1., 116 m. W. S. W. Nashville.

Morrisville, p. v., Schoharie co., N. Y.: 42 m. W. Albany. Monston, p. o., Sullivan co., N.Y.: 86 m. S. S. W. Albany. Montos, p. o., Tazewell county, $\Pi l$ : $46 \mathrm{~m}$. N. by E. Springfield.

Mortor's Store, p. o., Alamance co., $N_{\text {. }}$ Car.: 53 m. W. N. W. Raleigh.

Moproxsville, p. o., Woodford co., $K y_{*}$ : about 2 m. E. of Kentucky, 15 m. S. by E. Frankfort.

Mortonvilie, p. v., Orange co., N. Y.: 85 m. S. S. W. Albany.

Mortonvilue, p. v., Chester co., Penn.: 59 m. E. S. E. Harrisburg.

Morves, p. o., Anson co., $N$. Car.: about $6 \mathrm{~m}$. W. of

Yadkin r., 86 m. S. W. Raleigh.

Morvex, p. o., Clark county, Ala.: 103 m. W. S. W. Montgomery.

Mosalem, p. o., Dubuque co., $I c .:$ about $2 \mathrm{~m}$. W. of the Mississippi, 68 m. N. E. Iowa City.

Moscow, p. on, Marion county, Alla. : 141 m. N. W Montgomery.

Moscow, p. V., Rush co., Ind.: on the W. side of Flat

Rock er.. 38 m. S. E. by E. Indianapolis.

Moscow, p. v., Muscatine co., Ia.: on Cedar r., near the entrance of Sugar er., $24 \mathrm{~m}$. E. by S. Iowa City. It has a superior location for trade and manufactures, and contains sereral stores and mills.

Moscow, p. o., Hickman county, $K y_{\circ}: 249$ m. W. S. W. Frantifort.

Moscow, t. and p. o., Hillsdale county, $\not F i c h .: 38$ m. S. Lansing. Drained by S. branch of the Kalamazoo. Surface rolling; soil sandy loam, producing large crops of all the grains. A good building stone is quarried. Pop. 942.

Moscow, p. v., Livingston co., $N$. $Y$.: on a small affluent of Genesee r., $214 \mathrm{~m}$. W. by N. Albany. It lies on high ground, $1 \mathrm{~m}$. W. of Genesee Flats, and contains several stores and 500 inhabitants.

Mosoow, p. v., Clermont co. Ohio: on the Ohio, $95 \mathrm{~m}$. S. W. by S. Columbus. It has a steamboat landing, a valuable trade with the interior, and about 500 inhabitants.

Moscow, p. o., Luzerne county, Penn.: 85 m. N. E.

Harrisburg.

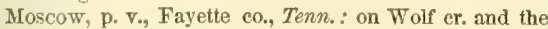
line of the Memphis and Charleston R. R., $161 \mathrm{~m}$. W. S. W. Nashville.

Moscow MrLus, p. o., Morgan co., Ohio: 66 m. E. by \$: Columbus.

Moselem, p. o., Berks county, Penn. : 58 m. E. by N. Harrisburg. A charcoal furnace of 1,350 tons capacity is located here.

MIoseley Hall, p. o., Lenoir co., N. Car.: about $8 \mathrm{~m}$. N. of Neuse r., $58 \mathrm{~m}$. E. S. E. Raleigh.

Moseler IIazl, p. 0., Madison co., Flor.: 45 m. E. by $\mathrm{S}$. Tallahassee.

Moselex's Grove, p. o., Dallas county, Ala.: $56 \mathrm{~m}$. W. Montgomery.
Moselly, p. o., Jo Daviess co., $I l l$ : about $1 \mathrm{~m}$. E. of the Mississippi, $\mathbf{1 7 6}$ m. N. by W. Springfield.

Moselie Furnace, p. 0., Franklin co., Mo, : $71 \mathrm{~m}$. E. by $\$$. Jefferson City.

Mosely Halt, p. o., Madison co., Flor. : 43 m. E. by $\mathrm{S}$. Tallahassee.

Mosely's SToRe, p. o., Franklin co., Ga.: $102 \mathrm{~m} . \mathbb{N}$. Milledgeville,

Moss, p. o., La Fayette co., Mo.: on Dan's Fork of Black river, $92 \mathrm{~m}$. W. by N. Jefferson City.

Moss Side, p, o., Alleghany co., Penn. : 169 m. W. by N. Harrisburg.

Mossy Creek, p. 0., Augusta co., Firg.: on a W. affluent of the Shenandoah so called, 104 m. N.W. by. W. Richmond: Mossx CReEK, p. o, Jefferson couniy, Tenn. : 179 m. E. Nashville.

Mother KILL, hund., Kent co., Del. : extends across the State, with an area of 89,320 acres. Drained W. by heads of Choptank r., and E. by Jones and Mother Kill creeks. Surface even, with small elevations in the W. It has good timber and water-power. Pop. 4,973

Motier, p. o., Pendleton county, $K y_{.}: 52$ miles N. E. lirankfort.

Motley, p. o., Allen co., $K y$. : $124 \mathrm{~m}$. S. W. Frankfort.

Motт HAveN, p. v, and sta., Westehester co., N. I.: 126 m. S. Albany, It is $8 \mathrm{~m} . \mathrm{N}$. of the City Hall in New York, on the Harlem R. R., and New York and New Haven R. R. Motr's Corners, p. v. Tompkins co, . $_{\text {. }} Y_{\text {. }}$ : on $\mathrm{Six}$ Mile ereek, $137 \mathrm{~m}$. W. by S. Albany. It contains several stores, mills, and manufactories, and 400 inhabitants.

Mottville, t. and p. v., St. Joseph's co., Mich.: on the S. line of the State, $86 \mathrm{~m}$. S. W. Lansing. Drained by Pigeon and St. Joseph's rivers, which furnish water-power. Surface undulating; soil very fertile. The Michigan Southern R. R. passes through the t. into Indiana. The $\mathrm{v}$, is on the St. Joseph's, and contains several stores. Population of $t .610$.

Mottville, p. V., Onondaga co., $N . Y_{0}:$ on the outlet of Skaneatles lake, $\mathbf{1 4 1} \mathrm{m}$. W. by N. Albany. It contains several stores, a foundry, machine shop, and 500 inhabitants, and lies $3 \mathrm{~m}$. S. of the Rochester and Syracuse R. R., with which a branch road connects it.

Moultow, p.. ., and cap. Lawrence co., Ala.: near the head of Big Nance cr, of the Tennessee, $151 \mathrm{~m}$. N. N. W. Montgomery. It contains a court-house, jail, academy, and about 400 inhabitants. The "M. Advertiser" (neutral) is published weekly.

Monltonвoro', t, p. v., and cap. Carroll co, $N$. Hrmp. : $38 \mathrm{~m}$. N. by E. Concord. Drained by Red Hill and Melvin rivers. Surface hilly. Red Hill and Ossipee mountains, large elevations, are within it, and much of it is occupied by ponds. Squam lake lies on the W., and Winnipiseosec lake on the S., into which a long neck extends. Snil fertile. Iron ore, and mineral springs containing sulphur, are found. Numerous Indian relies have been dug up on the shores and on the islands of the lake. The village contains a court-house, jail, and an academy. Pop, of t. 1.74s.

Moultonvilce, p. v., Madison co., $I l_{\mathrm{e}}: 72 \mathrm{~m}$. S. by W. Springfield.

Moultrie county, $I l l$. Situate E, centrally, and contains $335 \mathrm{sq} . \mathrm{m}$. Drained by Kaskaskia $\mathbf{r}_{\text {, }}$, which flow's through the $\mathrm{S}_{\text {., }}$ and its branches. Surface undulating or level, largely open prairie, with good timber in the $\mathrm{S}$., and scattered groves everywhere. Soil fertile, and excellent grazing land. Corn is the staple, and live-stock the principal export. On tie Kaskaskia are good mill-sites. Farms 304; manuf. 11; dwell. 554, and pop.-wh. 3,225, fr, col.9-total 3.234. Capitul: Sullivan. Public Works: Chicago Branch of Central Illinois R. R.; Terre Haute and Alton R. R., ete.

Moultrie, p. 0., Spartanburg dist., S.Car.: 85 m. N.W. Columbia

Moultrie, p. o. and sta., Columbiana co., Ohio $8 \mathrm{~m}, \mathbf{S}$. of Alliance, on the Cleveland and Pittsburg R. R: 
Mound Bayou, p. o., Tensas parish, La. : 98 m. N. Baton Rouge.

Mound CrTx, p. v., Crittenden co., Ank. : on Mississippi r., $\delta \mathrm{m}$. above Memphis, $123 \mathrm{~m}$. E. N. E. Little Rock.

Moundstille, p. v., Marshall co., Firg.: on the Ohio r., at the mouth of Big Grave cr., $235 \mathrm{~m} . \mathrm{N}$. W. Richmond; on the creek, just above the $\mathbf{v}$, are many mounds, one 75 feet high and 40 rods in circuit, on which is an observatory. The v. contains an academy, a steam flouring-mill, and several stores. Elizabethtown, the co. seat, lies opposite, on the upper side of the cr., and the two contain about 1,500 inhabitants. The "Marshall Beacon" (whig) is published weekly. The Baltimore and Ohio R. R. passes through it, $11 \mathrm{~m}$. S. of Wheeling.

Moundrilue, p. Y., Marquette co., Wisc. : 47 m. N. by E. Madison.

Motnt AdaMs, Coos co., N. Hamp.: a peak of the White Mountains, 5,960 feet high.

Mount Adaus, Oreg. Ter.: an eastern spur of the Coast Range, lat. $46^{\circ} 12^{\prime}$, and long. $121020^{\prime}$.

Modntair Cove, p. v., Fayette co, Vir : $:$ on the E. side of Great Kanawha river, $196 \mathrm{~m}$. W. by N. Richmond, A colony of spiritualists and spirit mediums have commenced a settlement here, and publish a periodical, called the

"Mountain Cove Journal," to propagate their views.

Mountain Creek, p. o., Catawba con, N. Car.: about

$3 \mathrm{~m}$. W. of Catawba r., $124 \mathrm{~m}$. W. Raleigh.

Mountary CREek, p. o., Anderson,dist, S. Car.: $103 \mathrm{~m}$. N. W. by W. Columbia.

Mountats Falts, p. 0., Frederick co., Firg.: $117 \mathrm{~m}$. N. N. W. Richmond,

Mountate Grove, p. o., Bath co., Virg.: 87 m. W. by N.

Richmond.

Mountats Homs, p. o., Lawrence county, Ala. : $153 \mathrm{~m}$.

N. N. W. Montgomery.

Mountard Hone, p. 0., M'Dowell con, N. Car.: $194 \mathrm{~m}$. W.

Raleigh.

Mountatn Shoais, p. o., Spartanburg dist., S. Car.: on

the N. side of Ennoree r., $66 \mathrm{~m}$. N. W. Columbia.

Modntatn Sprnig, p. o., Martin co., Ind.: 76 m. S. S. W. Indianapolis.

Mountaty Stard, p. o., Marshall co., Ala. : 119 m. N. Montgomery.

Mountadx Top, p. 0., Augusta co., Virg. : 85 m. W. N. W. Richmond.

Mountant View, p. o., Abberille dist., S. Car.: $83 \mathrm{~m}$. W. Columbia.

Mount ArRx, p. . and sta., Carroll county, Mrd.: on the Baltimore and Ohio R. R., $44 \mathrm{~m}$. W. of Baltimore, $43 \mathrm{~m}$.

N. W. Annapolis.

MoUNT Arry, p. O., Randolph co., MIO.: 64 m. N. N. W. Jefferson City.

Mount AlRy, p. 0., Hamilton county, Ohio: $8 S \mathrm{~m}$. S. W. Columbus.

Modxt Arry, p. 0., Berls co, Penn.: 5 S m. E, by N. Harrisburg.

Mooxt Atry, p. o., Surry co., N. Car.: 116 m. W. N. W. Raleigh. The "Siamese Twins," of exhibitionary notoriety, are settled here, and cultivate a large plantation.

Mooxt Aury, p. o., Bledsoe co., Tenn. : about $2 \mathrm{~m}$. W. of Sequatchy r., SS m. E. S. E. Nashville.

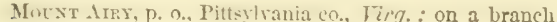
of Dan r., $98 \mathrm{~m}$. W. S. W. Pichmond.

Moryt Alb.N, sta.. Warren county, Trss : $6 \mathrm{~m}$. E of Ticksthurg, on the Yicksbury, Jackson, and Brandon Railroad.

MOUNT ANDRET, p. 0., Barbour co., Ala. : 57 m. E. S. E. Montgomery.

MoUnt AUburx, p. 0., Christian co., IU. : 19 m. E. by S. Snringfield.

Mount Atburi, p. F., Shelby co., Ind.: about $2 \mathrm{~m}$. E. of the Knightstown and Suelbyville R. R., 29 m. S. S. E. Indianapolis.
MoUnT BAKER, Oreg. Ter.: a peak of the Cascade Range, 10,340 feet high, in lat. $48^{\circ} 45^{\prime}$, and long. $121080^{\prime}$.

Mount Bernandivo, San Diego con, Calif, : an elevated peak of the Coast Range, in lat. $34^{\circ}$, and long. $117^{\circ}$

Mount Bethet, p. o. Northampton con, Penn。: $118 \mathrm{~m}$. E. N. E. Harrisburg.

Mount Bethei, p. o., Newberry dist, S. Car. : about $8 \mathrm{~m}$. S. of Ennoree r., 36 m. N. W. Columbia.

Motnt Blanchard, p. ve, Hancock county, Ohio: on Blanchard's Fork of Maumee r., $81 \mathrm{~m}$. N. W. Columbus,

Mount Caltarx, p. o., Davis co., Ia. : $78 \mathrm{~m} . \mathrm{s}$. W. by $\mathrm{s}$. Iowa City.

Mount Castbeis, p. o., Niagara co., N. Y.: 257 m. W. Albany.

Mount Carbon, p. o., Hampshire county, Virg. : $147 \mathrm{~m}$. N. W. by N. Richmond.

Mount Carbon, sta., Schuylkill co., Penn.: $34 \mathrm{~m}$. N. of Reading, on the Philadelphia and Reading R. R. The vicinity is noted for its anthracite mines.

Mount Carues, p. o., Henry co., Ga.: 64. m. W. N. W. Milledgeville.

Mount CaRmEL, p. v., and cap. Wabash co., $\pi l l$.: on the right bank of Wabash $r$., below the rapids, and opposite the mouth of White r., $142 \mathrm{~m}$. S. E. Springfield. It has a favorable site for trade and manufactures, and contains a court house and jail, about 30 stores and warehouses, several flouring-mills and machine shops, and 1,500 inhabitants.

Mount Carime, p. o., Franklin co., Ind.: about 2 m. E. of Ped Cedar Grove cr., 68 m. E. S.E. Indianapolis.

Mount Carmer, p. o., Fleming co., Ky.: 77 m. E. N. E. Frankfort.

Mount Carmer, p. o., Covington co., Miss. : 48 m. S. S. E. Jackson,

Modnt Carmer, p. o., Cooper co., Mo.: $42 \mathrm{~m}$. W. by N Jefferson City.

Mount Carmet, p. o., Clermont co., Otio: 86 m. S. W. Columbus.

Mount CARjIEL, p. o., Halifax co., Virg: 88 m. S.W. by W. Richmond.

Motnt Carver, p. o., Northumberland co., Penn.: $85 \mathrm{~m}$. N. by E. Harrisburg.

Mount Carmel, p. o. and sta., New Haven co., Conn.: $8 \mathrm{~m}$. N. of New Haven, on the N. H. and Northampton Railroad.

Mount Carroli, p. $v_{*}$, and cap. Carroll co, $M l_{0}$ : on a branch of Plum r., $10 \mathrm{~m}$. E. of the Mississippi, and $162 \mathrm{~m}$. N. by W. Springfield. It contains a court-house, jail, several stores, and 500 inhabitants.

Mounx Chestrut, p. o., Butler county, Penno: $173 \mathrm{~m}$. W.N.W. Harrisburg.

Mount Clare, sta., Baltimore co., Md $d_{0}$ : on the Baltimore and Ohio R. R., 2 m. from Baltimore.

Mount Clemens, p. v., and cap. Macomb co., Mich.: on the $\mathrm{N}$. bank of Clinton $x, 4 \mathrm{~m}$. from its entrance into Lake St. Clair, $85 \mathrm{~m}$. E. by S. Lansing. It is favorably located for ship-building, having abundance of timber in its vieinityis at the head of navigation, and communicates by steamboat with ports $\mathrm{N}$. and $\mathrm{S}$. of it. Glass is manufactured from a superior sand abundant here. It contains a court-house and jail, a bank, an academy, several mills, and a dozen stores. Two papers, the "Macomb Gazette" (dem.), and the "Macomb County Herald" (whig), are published weekly. Mount Crifton, p. o., Shenandoah co., Virg.: $112 \mathrm{~m}$. N. W. Richmond.

Mount Curvtox, p. o., Rockingham co., Virg.: 85 m. N. W. Richmond.

Motat Cuto, p. o., Sumter dist., S. Car.: about 3 m. E. of Black r., $44 \mathrm{~m}$. E. Columbia.

MounT Cомтовт, p. o., Hancock county, Ind.: $24 \mathrm{~m}$. E. by N. Indianapolis.

Mount Coxront, p. 0., Fayette county, Tenn.: $153 \mathrm{~m}$. W. S. W. Nashville.

Mount Ceawford, p. o., Rockingham co., Virg.: on a 
W. branch of Shenandoah river, $98 \mathrm{~m} . \mathrm{N}$. W. by W. Richmond.

Mount Croghan, p. o., Chesterfield dist., S. Car.: $69 \mathrm{~m}$. N. E. Columbia.

Modnt Defrance, Essex co., N. Y.: on the W. shore of Lake Champlain, has an elevation of 750 feet above tidewater.

Modne Desert, t. and p. o., Hancock co., Me.: in the N. W. part of the island of that name, $72 \mathrm{~m}$. E. Augusta. The soil is productive, but the chief business is the coasting trade-for this, its singular position and excellent harbors are peculiarly adapted. The fisheries are also very lucrative, and ship-building is carried on. Pop. 777.

Mount Desert island, Me.: lies off the $\mathrm{S}$. shore of the State, on the W. side of Frenchman's Bay, and forms a part of Hancock County. Its greatest length and breadth are 12 and $15 \mathrm{~m}$., but the coast has many indentations, forming excellent harbors, which give it great facilities for the coasting trade and fisheries. It contains three towns, Eden, Mount Desert, and Tremont, and 3,329 inhabitants.

Mount Eaton, p. v., Wayne county, Ohio: 81 m. N. E. Columbus.

Mount Enen, p. o., Spencer co, $K y_{*}: 23$ m. W. by S. Frankfort.

Nount Elba, p. o., Bradley co., Ark. : on Saline r., 60 m. S. by E. Little Rock.

Mourt Exon, p. o, Darlington dist., S. Car, : about $6 \mathrm{~m}$. E. of Lynch's cr., 53 m. E. N. E. Columbia.

Mount Eminence, p. 0., Orange co.g Virg. : 56 m. N. N.W. Richmond.

Modnt Emonos, Hamilton co, N.Y.: is an isolated peak, elevated about 3,500 feet above tide-water.

Mount Enterreise, p. o., Rusk co, Tex.: about $3 \mathrm{~m}$. E. of Big Shawnee er. of the Angelina, $216 \mathrm{~m}$. N. E. by E. Austin City.

Mount Eoura, p. o., Union co., Ga.: 143 m. N. N. W. Milledgeville.

Mount EpHratm, p. ₹., Guernsey co., Ohio: $68 \mathrm{~m}$. E. Columbus. It contains several stores and 121 inhabitants.

Modvi Exra, p. v., Huntington co., Ind.: on the S. side of Wabash r., 78 m. N. N. E. Indianapolis.

Mount Everetr, Berkshire co., Mass.: one of the highest peaks of the Taghkannic range, lies in Mount Washington t. in the S.W. corner of the State, and rises to the height of 2,634 feet. The summit is scantily covered with scrub-pine and bushes, but commands the grandest scenery in the State, overlooking mountains on all sides, and affording glimpses of rare beauties between and beyond them. Near it is the Bashapish Fall, which descends 150 feet in two perpendicular leaps, and has worn out a dome-like cavity, called the "Gorge," 194 feet deep. The wildness of the surrounding region and the grandeur of their localities, attract many tourists hither in the summer.

Mount Frfedom, p. o, Jessamine co., Ky,: 29 m. S. E. Frankfort.

Mount Freedor, p. o., Pendleton county, Virg.: 123 m. N. W. by W. Richmond.

Mounis Gallagmer, p. o., Laurens dist, S. Car.: about $8 \mathrm{~m}$. E. of Saluda r., $71 \mathrm{~m}$. W. N. W. Columbia.

Mount GILead, p. o., Franklin co., Ark.: on the S. side of Arkansas r., 98 m. W. N. W. Little Rock.

Moont GILEAD, p. o., Mason co., Ky.: 68 m. E. N. E, Frankfort.

Mount Gilead, p. v., and cap. Morrow co., Ohio: on the $\mathrm{E}$. branch of Whetstone r., $40 \mathrm{~m}$. N. by E. Columbus, It is about $3 \mathrm{~m}$. E. of the Cincinnati, Cleveland, and Columbus $R_{a} R_{\text {, }}$ and in the vicinity are numerous mills and factories. It contains a court-house, jail, academy, a dozen stores, and 500 inhabitants. Pop. of Gilead t. 1.680.

Modne Gruead, p. o., Montgomery co., N. Car.: about $3 \mathrm{~m}$. N. of Yadkin r., $77 \mathrm{~m}$. W. S. W. Raleigh.

Mount GrLead, p. v., Loudon co., Tirg.: on Kittoctan

Mountain, $106 \mathrm{~m}$. N. Pichmond. It is regularly laid out on a commanding elevation, and contains several stores and 150 inhabitants.

Mount Hawkovs, p. o., Perry co, $\pi_{0}$ : $122 \mathrm{~m}$. S. by E. Springfield.

Mount Hawlex, p. o., Peoria co., Ill. : about $8 \mathrm{~m}$. W. of Peoria lake, $72 \mathrm{~m}$. N. Springfield.

Modnt Healthy, p. v., Hamilton county, Ohio: $93 \mathrm{~m}$ S. W. by W. Columbus.

Mount Heasthy, p. v., Bartholomew county, Ind.: on White cr., $48 \mathrm{~m}$. S. by E. Indianapolis.

Mount? Hebron, p. o., Greene co., Ala.: $107 \mathrm{~m} . \mathrm{W} . \mathrm{N} . \mathrm{W}$. Montgomery.

Mount Heron, p. 0., Darke county, Ohio: $86 \mathrm{~m}$. W. Columbus.

Mounт Hickory, p. o., Chattooga co, Ga. : $162 \mathrm{~m} . \mathrm{N} . \mathrm{W}$. Milledgeville.

Mount Hickory, p. o., Chambers county, Ala.: on an E branch of Tallapoosa r., $66 \mathrm{~m}$. N. E. by E. Montgomery.

Mount Hilu, p. o., Morgan co., Alla.: 134 m. N. by W. Montgomery.

Mount Hril, p. o., Abbeville distriet, S. Car.: $78 \mathrm{~m}$ W. N. W. Columbia,

Mount Hiluind, p. o., Pike county, Ala. : 42 m. B. E Montgomery.

Modxt Holly, p. 0., Union co., Ark. : 108 m. S. S. W. Little Rock.

Mount Houly, p. v., Randolph co., Ind. : about $3 \mathrm{~m}$. $\mathrm{S}$. of Mississinewa river, and $2 \mathrm{~m}, \mathrm{~W}$. of the Ohio line, $72 \mathrm{~m}$. E. N. E. Indianapolis,

Mount Holix, p. v., and eap. Burlington co., N. Jer. on the $\mathrm{N}$. branch of Rancocus cr, $16 \mathrm{~m}$. S. Trenton. It lies at the head of navigation, and contains a court-house and jail, an academy, a bank, several mills for making paper, woolens, etc., and about 1,500 inhabitants. Two weekly papers, the "New Jersey Mirror" (whig) and "Mount Holly Herald" (dem.), are published. A branch railroad, $6 \mathrm{~m}$. long, connects it with the Camden and Amboy $\mathbf{R}_{\text {o }} \mathbf{R}$. at Burlington.

Mount Holix, p. o., Warren county, Ohio: 71 m. S. W. Columbus,

Mount Holly, t. and p. o., Putland co., Verm.: $51 \mathrm{~m}$. S. by W. Montpelier. Drained by Black r. of the Connectiout, and Mill r., a branch of Otter cr. Surface elevated, in parts mountainous; soil adapted to grazing, which is the leading interest, and furnishes for export large amounts of wool, beef, butter, and cheese. The Rutland and Burlington R. R. crosses the N. E. part. Mount Holly sta., in the N. E., is $15 \mathrm{~m}$. S. E. of Rutland. Pop. 1,534

Motnt HolYoke, p. o., Henry co., Tenn.: 98 m, W. by N. Nashville.

Mount Hoon, Oreg. Ter.: a peak of the Coast Range, on the S. side of Columbia r., elevated about 12,000 feet abote the ocean.

Modnt Hope, p. o., Tyler county, Tex.: 209 m. E. by N. Austin City.

Mount Hope, p. o., Lawrence co., Ald : near the head of Town cr, of the Tennessee, $152 \mathrm{~m} . \mathrm{N}$. N. W. Montgomery.

Mount Hope, p. o., De Kalb co., Ind.: 127 m. N. N. E. Indianapolis.

Movnt Hope, p. 0., Delaware co., I $c_{0}: 51 \mathrm{~m}$. N. Iowa City.

Modnt Hope, p. o., La Fayette co., Mo.: about $4 \mathrm{~m} . \mathbf{S}$. of the Missouri, $87 \mathrm{~m}$. W. N. W. Jefferson City.

MOUNT HOPE, to and p. $v_{0}$ Orange county, N. Y.: $92 \mathrm{~m}$. S. S. W. Albany. Drained by Shawangunk er. Surface hilly and broken; soil gravelly loam, and adapted to grazing; it is well timbered and supplied with water-power. Tanning and various manufactures are extensively prosecuted. The village contains an academy and about 400 inhabitants. The Erie R. R. passes through the t. Pop, of the $t .1,512$.

Mount Hope, p. o., M'Lean co., $I l_{0}$ : 44 m. N. E. by N. Springfield. 
Mount Hope, p. o., Holmes co., Ohio: 74 m. N. E. by E. Columbus.

Mount Hope, p. o., Laneaster co., Penn. : 37 m. E. by S. Harrisburg. Here is a charcoal furnace of 1,450 tons eapacity.

Mount Hope bay, $R$. I. : sets up from the N. E. corner of Narragansett bay, between Bristol and Tiverton, and receives the waters of Taunton river.

Mount Horeb, p. o., Nelson co., Virg.: at the E. base of the Blue Ridge, $84 \mathrm{~m}$. W. by N. Richmond.

Mount IdA, p. v., and cap. Montgomery co., Ark.: on Brushy fork of Washita $r_{\text {. }}, 74 \mathrm{~m}$. W. by S. Little Rock. It contains a court-house and a few stores and dwellings.

Mount Ida, p. o., Montgomery co., $K y .: 57$ m. E. S. E. Frankfort.

Muunt Isaber, p. o., De Soto county, Bfiss, : $171 \mathrm{~m} . \mathrm{N}$. Jackson.

Mount Israel, p. o., Albemarle co., Virg. : near the line of the Virginia Central R. R., at the base of the Blue Ridge $78 \mathrm{~m} . \mathrm{W} . \mathrm{N}$. W. Richmond.

Mount J Jckson, p. v., Lawrence co., Penn.: on Hickory cr., $194 \mathrm{~m}, \mathrm{~W}$. by N. Harrisburg. It is about $3 \mathrm{~m}$. W. of Mahoning river, and the Beaver and Erie Canal, and has good water-power on the cr. above and below it, where are several mills and factories. It has a valuable trade, and contains a number of large stores.

Mount Jackson, p. o, Shenandoah co, Firg. : on the N. fork of Shenandoah r., $104 \mathrm{~m}$. N. W. Richmond.

Mount Jefrerson, p. oø, Chambers county, $A l a_{0}: 59 \mathrm{~m}$ E.N. E. Montgomery.

Mount Jefrerson, Oreg. Ter.: a peak of the Cascade Range, in lat. $44^{\circ} 40^{\prime}$, and long. $121^{\circ} 32^{\prime}$.

Mount Jefrerson, Coos co., N. Hamp.: a N. peak of the White Mountains, in the S. part of Randolph, 5,860 feet above the acean level.

Mount JeFferson, p. o., Carroll co., Ind. ; $57 \mathrm{~m}$. N. by W. Indianapolis.

Mount Jor, t. and p, o., Lancaster co, Penn.: $17 \mathrm{~m}$ E. S. E. Harrisburg. Drained by Little Chiques and Conewago creeks, which supply good mill-seats. Surface rolling: soil gravelly loam of excellent quality, and well tilled. It has several flouring-mills and other manufactures, and is fine grazing land. The Harrisburg and Laneaster R. R. crosses it, and Mount Joy station is $12 \mathrm{~m}$. W. of Lancaster. Population of t, 2,626.

Mount Kingston, p. o., Montgomery co., $m l_{\star}$ : about $4 \mathrm{~m}$. W. of Shoal er., $49 \mathrm{~m}$. S. Springfield.

Mounт Kisko, p. o, Westchester co., $N . Y .: 91 \mathrm{~m} . \mathrm{s}$. Albany.

Mouxt Lafarette, Grafton co, N. Hamp.: lies on E. line of Bethlehem and Franconia, and rises 4,723 feet above the ocean level.

Mount Lavgum, p. on Iroquois co., $I l l$, : about $3 \mathrm{~m} . \mathrm{S} . \mathrm{E}$. of the junction of Kankakee and Iroquois rivers, 188 m. N. E Springfield.

MoUnt LaUrel, p. o., Halifax co., Ting.: about $2 \mathrm{~m}$, W. of Roanoke r., 82 m. W. S. W. Richmond.

Mount Lacrel, p. v., Burlinglon county, N. Jer.: $20 \mathrm{~m}$. S. S. W. Trenton.

Mount Lebaxon, p. o., Claiborne par, La.: about $5 \mathrm{~m}$. E. of Bayou Dorcheat, $187 \mathrm{~m}$. N. W. by N. Baton Rouge.

Mount Lebaxion, p. 0., Spartanburg dist., S. Car.: $87 \mathrm{~m}$. N. W. by N. Columbia.

Mount Level, p. o., Dinwiddie county, Firg.: near the South Side R. R., $2 S$ m. S. S. W. Richmond.

Mount Liberty, p. O., Marion co., Ill.: 95 m. S. S. E. Springfield.

Mutxt Libertr, p. v., Knox co., Ozio: 81 m. N. E. by N. Columbus.

Mouxt Lrscols, Hampshire co., Muss. : lies in the N. part of Pelham, and is 1,24S feet above the ocean level.

Mouxt Madison, Coos co., N. Hamp.: a peak of the White Mountains, 5,620 feet high above the ocean lovel. 516
Modnx Marcy, Essex co., $N . Y_{0}:$ lies in the $S_{\text {. part of }}$ Keene, and is the highest of the Adirondack group, being 5.467 feet above the ocean level. In the same to are other peaks almost as high.

Mount M.Intire, Essex county, $N . Y$. : a peak of the Adirondack group in Keene, has an elevation of 5,188 feet above the ocean.

Mount M'Laughuin, Oreg. Ter.: a peak of the Cascade Range, in lat. $43^{\circ} 36^{\prime}$, long. $121^{\circ} 50^{\prime}$.

Mount M.Martin, Essex county N. Y.: a peak of the Adirondack group in Keene, is about 5,000 feet above tidewater.

Mount Meigs, p. o., Montgomery co., Ala. ; about 4 m. S. of Tallapoosa r., $18 \mathrm{~m}$. E. Montgomery.

Mount Meridian, p. v., Putnam co., Ind. : on Deep cr., $34 \mathrm{~m} . \mathrm{W}$. by S. Indianapolis. A plank-road connects it with the New Albany and Salem R. R.

Mount Meridian, p. o., Augusta co, Firg. : on the base of the Blue Ridge, $84 \mathrm{~m}$. W. N. W. Richmond.

Mount Metawampe, Hampshire co., Mass. : lies on the E. side of Connecticut $x$, opposite Sugar-loaf Mountain, and between Sunderland and Leverett. It is about 1,100 feet high, and wooded to the summit, which commards a more extensive but less beautiful view than Holyoke. At its base are "Sunderland Cave," and the "Roaring Brook."

Mount Moxroe, Coos co., N. Hamp.: a peak of the White Mountains, 5,510 feet above tide-water.

Modnt Mortar, p. o., Hempstead co., Ark. : on a S. affluent of Little Missouri r. $95 \mathrm{~m}$. S. W. Little Rock.

Mount Moriah, p. o., Mechlenburg co., N. Car.: $117 \mathrm{~m}$. W. by S. Raleigh.

Mount Moriah, p. o., Brown county, Ind.: $42 \mathrm{~m}$. S. Indianapolis.

Mount Morse, p. o., Pike county, Ga.: $\tau 4$ miles W. Milledgeville.

Mount Morris, Essex county, N. Y.: a peak of the Adirondack group, 4,576 feet above the ocean level.

Mount Morris, p. v., Ogle con, $M l_{0}$; on Pine er, of Rock river, $159 \mathrm{~m}$. N. Springfield. It contains a flourishing seminary, several manufactories of farming and mechanical implements, and 600 inhabitants. The "M. M. Gazelte" (whig) is published weekly.

Mount Morris, t. and p. v., Livingston co., N.Y.; $218 \mathrm{~m}$. W. Albany. Drained by Genesee $r$. and its branch, Cashaoua cr., which supply abundant water-power. Surlace varied; portions are high table land; soil clayey loam, and very productive of wheat. It is a supexior farming $t$., with extensive and valuable manufactories of flour, woolen goods, leather, iron castings, etc. The village, half a mile $\mathrm{E}$. of the Genesee, has excellent water-power obtained from the $r$, by a dam and raceway, and a favorable location for trade, lyins on the Genesee Valley Canal, $37 \mathrm{~m}$. S. of Rochester. It contains an academy, several flouring and other mills, a furnace, 30 stores, and 1,500 inhabitants. Population of t. 4,531 .

Mudxt Morris, p. v., Greene co., Penn.: on Dunkard"s cr. of the Monongahela, $165 \mathrm{~m}$. W. by S. Harrisburg. I lies on the Virginia line, and contains several mills.

Mount Mourne, p. o., Iredell county, N. Car.: $115 \mathrm{~m}$. W. by S. Raleigh.

Mount Nebo, p. o., Lancaster co., Penn.: 46 m. E. by $S$ Harrisburg.

Molnt Nfвo, p. o., Yadkin co., N. Car.: 129 m.W. N.W. Raleigh.

Mount Niles, p. o., St. Clair co., Ala.: on Canoe cr. of Coosa r., $95 \mathrm{~m}$. N. Montgomery.

Mount Norworruck, Hampshire co., Mfass.: on E. peak of the Holyoke range, $4 \mathrm{~m}$. from the Connecticut, separating Amherst and Granby ; is, next to Mount Holyoke, the highest of the-chain, having an elevation of 800 feet, and commands a fine view N. and S.

Mount Olive, p. o., Coosa county, Ala, : 39 m. N. by E. Montgomery. 
Mount OLtre, p. o., Macoupin co., $M$.: 46 m. S. S. W. Springfield.

Mount Olive, p. o., Elkhart co., Ind. : 122 m. N. by E. Indianapolis.

Mount Ortve, p. o., Clermont co., Ohio: 79 m. S. W. Columbus.

Mount Ourve, p. 0., St. Mary's county, Ma. : 46 m. \$. Annapolis.

Mount OLrve, p. 0., Izard co., Ark. : on the left bank of

White r., $89 \mathrm{~m}$. N. by E. Little Rock.

Mount OLivet, p. 0, Bracken coø $\bar{K} y_{*}: 62$ m. N. E. Frankfort.

Mount Palatine, p. o, Putnam co., $I l l_{*}: 93 \mathrm{~m}$. N. by E. Springficld.

Mount Parthenon, p. 0., Newton county, Ark.: $97 \mathrm{~m}$. N. W. by N. Little Rock.

Mount Pelia, p. o., Weakley county, Tenn.: $117 \mathrm{~m}$.

W. by N. Nashville.

Mount Perry, p. o., Perry county, Ohio: 46 m. E. S. E.

Columbus.

Mount Petrea, p. o., De Witt co., Tex. : 82 m. S. by E. Austin City.

Mount Pusson, p. o, Jefferson co., Ala : 88 m. N. by W.

Montgomery.

Mount Pinsox, p. 0., Jackson co, $A x \%$. : 85 m. N. E. by N.

Little Rock.

Mouxt Prison, p. o., Madison co, Tenn.: 124 m. W. by S.

Nashville.

Mounr Prggan, p. o., Alexander county, N. Car.: $129 \mathrm{~m}$.

W. by N. Raleigh.

Mount Pisgan, p. 0., La Grange co., Ind. : 132 m. N. N. E. Indianapolis.

Mount Pisqai, p. o., Clermont co., Ohio: 86 m. S. W. Columbus.

Modnt Pixt, Oregon Ter.: a peak of the Cascade or Coast Range, on the W. side of Klamath lake, in lat. $422^{\circ} 23^{\prime}$, long. $122 \circ 17^{\prime}$.

Mount Pleasant, to and p. o., Greene co., Wisc.: $24 \mathrm{~m}$. S. by W. Madison. Drained by a W. branch of Sugar r., on which are good mill-seats. Surface mostly even, and soil productive of corn and grass. Lead is found. Pop. 579.

Moent Pleasant, p. o., Monroe con, Alla.: about $4 \mathrm{~m}$.

E. of Alabama r., 104 m. S. W. Montgomery.

Mount Pleas axt, p. O., Carroll co., Ark.: 108 m. N. N. W. Little Rock.

Mount Pleasant, p. o., Union co., $\pi l_{*}: 167 \mathrm{~m}$. S. by E. Springfield.

Mount Pleasant, p. V., Marlin co., Ind.: on the W. side of the E. fork of White r., $84 \mathrm{~m}$. S. S. W. Indianapolis. It was the former cap. of the $\mathrm{co}_{\text {, }}$, and contuins several stores, and 350 inhabitants.

Mount Pleasant, p. $\nabla$., and cap. Henry co., Ia.: about $2 \mathrm{~m}$. E. of Big cr., $61 \mathrm{~m}$. S. Iowa City. It lies on elevated ground, and contains a courthouse and jail, an academy, and numerous stores. A heavy business is done here in the products of a large and fertile district, Two papers, the "Iowa Observer" (whig), and the "True Democrat," are published weekly.

Mount Preasaxt, p. v., and cap. Titus co., Tex. : about midway between White Oak and Big Cypress bayous, $272 \mathrm{~m}$.

N. E. Austin City. It is a thriving settlement, containing county buildings and several stores.

Mount Pleasant, p. 0., Frederick co., $M d_{*}$ : $53 \mathrm{~m} . \mathbf{N}$. W. Annapolis.

Molnt Pleasant, p. Y., Oakland county, Mich.: $44 \mathrm{~m}$.

E. by N. Lansing.

Mount Pleasant, p. o., Talbot co., Ga. : $86 \mathrm{~m}$. W. by S. Milledgeville.

Mount Pleasant, p. o, Lawrence co., Mo.: on the W. base of the Ozark Mountains, 149 m. S. W. Jefferson City.

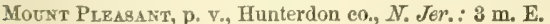
of Delaware r., $28 \mathrm{~m}$. N. W. by N. Trenton.

Mouxt Plzasaxt, p. o., Saratoga co., N. $Y$.
Mount Pleasant, t. and p. V., Jefferson co., Ohio: $115 \mathrm{~m}$ E. by N. Columbus. Drained by Short er., which supplies fine water-power. Surface uneven; soil fertile. A good grazing t., which manufactures flour, leather, woolens, agricultural implements, etc., to a large amount. The v.contains a bank, an academy, a dozen stores, and 800 inbabitants. Pop. of t. 1,848.

Modnt Pleasant, p. o., Cabarras co., N. Car.: on Duteh Buffalo er. of Rocky r., $93 \mathrm{~m}$. W. by S. Raleigh.

Mount Pleasant, t. and p. y., Westmoreland co., Penn. $189 \mathrm{~m}$. W. by S. Harrisburg. Drained by Jacob's cr. Surface moderately uneven; soil a fertile gravelly loam. A superior farming and grazing $t$. The $\mathrm{v}$. contains a flouring mill, tannery, several stores, and 700 inhabitants.

Mount Pleasant, p. o., Maury co., oTenn.: about $2 \mathrm{~m}$ E. Duck r., 45 m. S. S. W. Nashville.

Mount Pleasant, p. o., Spottsylvania co., Virg.: $41 \mathrm{~m}$ N. N. W. Richmond.

Mount Pleasant, t. and p. o., Racine co., Wisc.: about $6 \mathrm{~m}$. W. of Lake Michigan, 83 m. E. S. E. Madison. Surface rolling ; soil prairie, of great fertility. Grain and dairy products are the staples. Pop. 1,078 .

Mount Pleasant p. o, Caldwell par, La.: $134 \mathrm{~m}$. N. N. W. Baton Rouge

Modnt Pleasant Mruls, p. O., Union co, Penn. : on a branch of W. Mahantango cr., $38 \mathrm{~m}$. N. by W. Harrisburg.

Mount Pozk, p. o., Benton co., Ala. : on an E. branch of Coosa r., 99 m. N. by E. Montgomery.

Mount Prospect, p. v., Crawford county, Ind.: $96 \mathrm{~m}$. S. by W. Indianapolis.

Mount Prospect, p. O., Whitesides co., Ill.: $142 \mathrm{~m}$ N. by W. Springfield.

Mount Prospecr, p. o, Obion county, Tenn,: $127 \mathrm{~m}$ W. by N. Nashville.

Mount Pulaski, p. o., Sangamon co, $I l l_{0}: 23 \mathrm{~m}$. E. by N. Springfield.

Mount Rainter, Oreg. Ter.: a peak of the Cascade Range, 10,231 feet high, in lat. $46^{\circ} 47^{\prime}$, long. $121033^{\prime}$.

Mount Rock, p. o., Cumberland county, Penn. : 17 m. W. S. W. Harrisburg.

Mount Rose. p. v., Mercer co, $N$. Jer.: $1.0 \mathrm{~m} . \mathrm{N}$. by E, Trenton.

Mount St. Helfirs, Oreg. Ter.: a peak of the Cascade Range, 12,000 feet high, on the $N$. side of Columbia $r$., in lat. $46^{\circ} 13^{\prime}$

Mount St. Joseph's, Shasté co,, Calif. : a peak of the

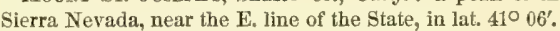

Mount SATEM, p. o., Kanawha county, Virg.: $218 \mathrm{~m}$. W. N. W. Richmond.

Motns Salem, p. o., Sussex county, $N$. Jer. : 57 m. N. Trenton.

Mounr Sarage, p. V., Alleghany co,, Md.: on Jennings Run, 133 m. W. N. W. Annapolis. The Mount Savage Iron Works are located here, and a branch of the Baltimore and Ohio R. P., $10 \mathrm{~m}$. long, diverges from Cumberland to this place. It is one of the best mining regions of the Union.

Mounx Satagk, p. o., Carter county, $\overline{k y}$ : 107 m. E Frankfort.

Mount Serene, p. o., Barbour co., Ala.: 66 m. E. S. E Montgomery.

Mount Seward, Franklin co., $N . Y_{.:}$a branch of the Adirondack group, with an elevation of 4,000 feet above the ocean.

Mount SHAsté, Shasté co., Califf: : a peak of the Coast Range, 14,390 feet high, in lat. $41034^{\prime}$, long. $121^{\circ} 43^{\prime}$.

Mount Smnkx, p. v., Augusta co, Firg.: 98 m. W. N. W Richmond. It is about $4 \mathrm{~m}$. N. of Middle r., and contains an academy, several stores, and 300 inhabitants.

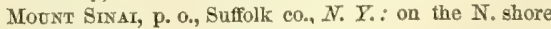
of Long Island, 124 m. S. S. E. Albany.

Modnt Solon, p. 0., Augusta co., Firg.: 112 m. W. N. W. Richmond. 
Mount Sterding, p. o., Choctaw co., Ala. : on a W. branch of Tombigbee r., $127 \mathrm{~m}$. W. S. W. Montgomery.

Mount Sterling, p. o., Crawford co., Wisc. : on Copper creek, about $8 \mathrm{~m}$. E. of the Mississippi, $83 . \mathrm{m} . \mathrm{W}$. by N. Madison.

Mount Steritng, p. v., and cap. Brown co., $I l l .: 59 \mathrm{~m}$.

$\mathrm{W}$. by $\mathrm{N}$. Springfield. It contains a court-house and jail, an academy, several stores, and 500 inhabitants.

Motnt Sterlixg, p. v., Switzerland co., Ind.: about $1 \mathrm{~m}$. E. of Indian cr., and $4 \mathrm{~m}$. N. of the Ohio, $87 \mathrm{~m}$. S. E. Indianapolis.

Modnt Sterling, p. v., and cap. Montgomery co., Ky.: $52 \mathrm{~m}$. E. by S. Frankfort. It has a large trade in live-stock and hemp, and the products of a rich grain region, and contains a court-house, and jail, an academy, a dozen stores, and 700 inhabitants. The "Kentucky Whig" is published weekly.

Mount Sterling, p. o., Gasconade co., Mo.: on the E. side of Gasconade r., $32 \mathrm{~m}$. E. by S. Jefferson City.

Mount Sterling, p. v., Madison co, Ohio: on Deer cr., 21 m. S. S. W. Columbus. Pop. 117.

Mount SunNer, p. 0., Jo Daviess co., Ill.: $189 \mathrm{~m}$. N. Springfield.

Mount Surrerise, p. o., Luzerne co., Penn. : 67 m. N. E Harrisburg.

Mount Syluan, p. 0., Lafayette county, Miss.: $138 \mathrm{~m}$. N. by E. Jackson.

Mount Syltania, p. o, Washington co., Oreg. Ter. about $53 \mathrm{~m}$. N. by E. Salem.

Modxt TABor, p. v., Monroe co., Ind.: on Bean Blossom cr., about $2 \mathrm{~m}$. E. of the New Albany and Salem R. R. $39 \mathrm{~m} . \mathrm{S} . \mathrm{W}$. by S. Indianapolis.

Mount TABor, p. o., Union dist, $S$. Car.: about $3 \mathrm{~m}$. W. of Broad r., $57 \mathrm{~m}$. N. N. W. Columbia.

Mount Trrzah, p. o., Person co., N. Car.: about $3 \mathrm{~m}$. E. of Flat r., a head stream of the Neuse, $41 \mathrm{~m} . \mathrm{N} . \mathrm{N}$. W. Raleigh.

Mount Tor, Hampshire co., Mass.: lies on the W. bank of Connecticut $r_{v}$, opposite Mount Holyoke, and is 1,214 feet high. It belongs to a range, which $\mathrm{E}$. of the river takes the name of Holyoke, and extends S. to near New Haven.

Mount Uluah, p. O., Rowan county, N. Car.: 104 m. W. Raleigh.

Mount Union, p. v., Stark co., Ohio: 113 m. N. E. by E. Columbus. It is about $3 \mathrm{~m}$. W. of the Cleveland and Pittsburg $\mathrm{R}$. R., and $1 \mathrm{~m}$. S. of the Ohio and Pennsylvania Railroad.

Mount Untos, p. o. and sta., Huntingdon co., Penn.: on the Juniata, $57 \mathrm{~m}$. W. by N. Harrisburg. The station is $11 \mathrm{~m}$. E. of Huntingdon, on the E. division of the Penosylvania $R . R$

Motnt UptoN, p. v., Chenango con, $N . Y_{\text {.: }}$ on the W. side of Unadilla r., $89 \mathrm{~m}$. W. by S. Albany. It contain several stores and mills, and 400 inhabitants.

Mount Vkroxon, p. V., Mobile co., Ala.: about $4 \mathrm{~m} . \mathrm{W}$. of Mobile r., $134 \mathrm{~m}$. S. W. Montgomery. It contains a U.S. arsenal, several stores, and about 400 inhabitants.

Mount Vervon, p. V., and cap. St. Francis con, Ark. about $5 \mathrm{~m}$. W. of St. Francis r., $88 \mathrm{~m}$. E. by N. Little Rock. It contains a court-house and jail, several stores, and a population of 300 .

MfooNT VERYON, p. $v_{\text {., and }}$ cap. Jefferson co, $M_{0}$ : on a branch of Big Muddy r. and the E. side of Casey's Prairie, $109 \mathrm{~m}$. S. S. E. Springfield. It contains a court-house and jail, several stores, and 300 inhabitants.

Modex Versoy, p. v., and cap. Posey co., Ind.: on the Ohio $\mathrm{r}, 16 \mathrm{~m}$. above the mouth of the Wabash, $153 \mathrm{~m}$. S. W. by S. Indianapolis. It is built on a high bank, and contains a court-house, jail, academy, numerous stores and warehouses, several flouring-mills, and 1,200 inhabitants. It commands a large trade with the interior and on the river. The "South-western Adrocate," neutral in politics, is published weekly.
Mount Vervon, t. and p. o., Kennebec co, Me.: $15 \mathrm{~m}$. N.W. Augusta, It contains several large ponds, from which it is well supplied with water-power, and has a very fertile soil. A superior farming t., and well timbered. Pop. 1,479. Mount Vernon, p. v., and eap. Rock Castle co., $\bar{K} y$. 64 m. S. S. E. Frankfort. It contains a court-house, jail, several stores, and a population of 250 . The Knoxville and Lexington R. R. will pass through it.

Mount Vernox, p. v., and cap. Montgomery co., Ga: on the E. side of Oconee r., $76 \mathrm{~m}$. S. S. E. Milledgeville.

Mount Vernox, p. 0., Macomb county, Mich.: $82 \mathrm{~m}$. E. Lansing.

Modnt Vernon, p. 0., Wabashaw co., Minn. Ter.

Mount Vernon, p. o., Lawrence co., Mo.: 132 m. S. W. Jefferson City.

Modnt Vernon, t. and p. o., Hillsboro' co., N. Hamp.: $24 \mathrm{~m}$. S. S. W. Concord. Drained by branches of Souhegan r.y which afford good mill-sites. Surface elevated and uneven; soil adapted to grazing, which is the principal business. The v. lies on high ground, and contains an academy and several stores. Pop. of t. 722 .

Mount Vernon, p. o., Westchester co., N. Y.: $109 \mathrm{~m} . \mathrm{S}$. Albany.

Mount Vernon, p. o., Rowan co., N. Car.: $97 \mathrm{~m}$. W. Raleigh.

Mount Vernon, p. v., and eap. Knox co, Ohio: on Vernon r., $37 \mathrm{~m}$. N. E. Columbus. The river supplies waterpower, and the trade of a rich agricultural district centres here, giving it importance as a manufacturing and commercial place, which is much increased by its railroad communication. The Sandusky, Mansfield, and Newark R. R. passes through it, $24 \mathrm{~m} . \mathrm{N}$. of Newark and $36 \mathrm{~m} . \mathrm{s}$. of Mansfield, and will be intersected here by the Springfield, Mount Vernon, and Pittsburg P. R., which will bring it near markets for its produce and manufactures in all directions. It contains an elegant court-house, a jail, an academy, a bank, several flouring-mills, foundries, manufactories of railroad equipments, etc. Three newspapers are published weekly, the "Democratic Banner," "M. V. Free Whig," and "Ohio Times" (free soil). Pop. 3,710.

Mount VernoN, p. o., Linn co., Ia.: N. Iowa City.

Mount Vernon, p. o., Chester co., Penn. : 58 m. E. S. E. Harrisburg.

Modnt Vernon, p. v., Providence co., $R$. $I_{\text {. }}$ : on a small branch of Moosup r., $17 \mathrm{~m}$. W. by $\mathrm{S}$. Providence.

Mount Vernon, p. o, Monroe co., Tenn.; 143 m. E. S. E. Nashville.

Mount Vernon, Fairfax co., Virg.: on the W. side of the Potomac, $6 \mathrm{~m}$. below Alexandria, was the residence of George Washington. Here he died, and here, on an eminence commanding a wide view of the noble river, his remains repose.

Mount View, p. o., Davidson co., Tenn.

Modnt VIEW, p. o., Benton co., Mo.: 68 m. W. S. W. Jefferson City.

Mountrulle, p. v, and sta., Lancaster co., Penn.: $8 \mathrm{~m}$ W. of Lancaster, on the Columbia and Philadelphia R. R. 28 m. S. E. by E. Harrisburg.

Motntville, p. v., Troup county, Ga.: 109 miles W. Milledgeville.

Modntville, p. o., Laurens district, S. Car.: $58 \mathrm{~m}$. N. W. by W. Columbia.

Mountvilie, p. o., Loudon county, Firg.: $89 \mathrm{~m}, \mathrm{~N}$. Richmond.

Mount Vrico, p. o., Buckingham co., Virg.: $64 \mathrm{~m}, \mathrm{~W}$. Richmond.

Mount Visron, p. v., Otsego co., $N_{.}, Y_{0}:$ on Otsego cr. of Susquehanna $\mathrm{r}_{.}, 70 \mathrm{~m}$. W. Albany. It contains a woolen factory and several mills.

MoUnt WApren, p. o., Weakley county, Tenn.: $112 \mathrm{~m}$. W. by N. Nashville.

Mount Wasmlvgron, p. o., Morgan county, Ind : $27 \mathrm{~m}$. S. W. Indianapolis. 
Mount Wasmegton, p. o., Bullitt co., Ky.: about $4 \mathrm{~m}$. N. of Salt r., $88 \mathrm{~m}$. W. S. W. Frankfort.

Motnt W Asmivgtor, Coos co., N. Hamp.: is the highest peak of the White Mountains, being 6,428 feet above the ocean level. Its top, always covered with snow, is visible to mariners when more than $50 \mathrm{~m}$, from shore, or about $125 \mathrm{~m}$. distant

Mount Washrigton, p. o., Steuben co., $N, Y .: 182 \mathrm{~m}$. W. by $\mathbf{s}$. Albany.

MounT Washington, t. and p. o., Berkshire co., Mas8.: in the S. W. corner of the State, $126 \mathrm{~m}$. W. by S. Boston. Drained by affluents of Salmon cr., which furnish many mill-seats. Surface mountainous. The Taghkonnic range crosses the $t$., and one of its peaks is 3,150 feet high. Woolgrowing is the leading interest. Timber is abundant, and iron ore is found. Pop. 351 .

Mount Washongton, p. O., Hamilton co., Olio: $98 \mathrm{~m}$. S. W. by W. Columbus.

Mount Welcone, p. o., Clay county, Ky.: 95 m. S. E. Frankfort.

Mount Wridivg, p. o., Lowndes co., Ala.: 32 m. S. W. Montgomery.

Mount Wrinvg, p. o., East Feliciana par., La. : $19 \mathrm{~m}$. N. Baton Rouge. It is about 10 miles $\mathbf{N}$. E. of Port Hudson, and on the line of the Clinton and Port Hudson Railroad.

Moumt Wrulivg, p. o., Orange co., $N$. Car.: about $6 \mathrm{~m}$. E. of Haw r., 43 m. W. N. W. Raleigh.

Mount Willns, p. o., Edgefield dist., S. Car. : $36 \mathrm{~m}$. W. Columbia.

Mount Wouf, p. o., York county, Penn.: 18 m. S. Harrisburg.

Monnt Yovah, p. O., Habersham co., Ga.: on Chestatee river, $118 \mathrm{~m}$. N. by W. Milledgeville.

Mount Zion, p. o., Tallapoosa county, Ala. : 37 m. N. E. Montgomery,

Moent Zion, p. v., Hancock county, Ga. : 25 m. N. E. Milledgeville. Here are an academy and several stores.

Mount Zron, p. o., Lebanon co., Penn. : 28 m. E. by N. Harrisburg.

Mount Ziox, p. o., Spartanburg district, S. Car.: $84 \mathrm{~m}$. N. W. by N. Columbia

Mount Zion, p. o., Campbell co., Firg.: $96 \mathrm{~m}$. W. by S. Richmond.

Mount Zion, p. 0., Simpson co., Miss. : 33 m. S. S. E. Jackson.

Mousp Creek, sta., M'Minn county, Tenn.: 21 m. S. of

Loudon, on the East Tennessee and Georgia R. R.

MouTH of Hiwassee, p. o., Meigs co., Tenn.: near the confluence of Hiwassee and Tennessee rivers, 109 m. E. S. E. Nashrille.

Moetri of Indian, p. O., Monroe co., Virg.: on the E. side of New r., $183 \mathrm{~m}$. W. Richmond.

Modth of Little River, p. o., Blount co., Tenn.: on Tennessee r., $156 \mathrm{~m}$. E. by S. Nashville.

Moutu of Poca, p. o., Putnam co., Virg.: on the Great Kanawha, $246 \mathrm{~m}$. W. by N. Richmond.

Modxh of Sardy, p. o, Fenry co., Tenn. : at the entrance of Big Sandy river into the Tennessee, $73 \mathrm{~m}$. W. by $\mathrm{N}$. Nashville.

Movth of Seneca, p. o., Pendleton co., Virg.: $106 \mathrm{~m}$. N. W. by W. Richmond.

Mouth of WIIsow, p. o., Grayson co., Virg.: on the W. side of New r., $221 \mathrm{~m}$. W. S. W. Richmond.

Moeth of Yelrow Creek, p. v., Jefferson co., Ohio : on the Ohio $\mathrm{x}$, and the Cleveland and Pittsburg R. Ru, $3 \mathrm{~m} . \mathrm{S}$. of Wellsville, $124 \mathrm{~m}$. E. N. E. Columbus.

Madrystown, p. v., Highland co., Ohio: on White Oak cr., 69 m. S. S. W. Columbus.

MvсHтזrPe, p. o., Logan county, Ohio: $46 \mathrm{~m}$. N. W. Columbus.

Mocralusit, p. 0., Neshoba county, Miss. : $71 \mathrm{~m}$. N. E. Jackson.
Mod Berdge, p. o., Cabell co., Virg.: on an E. branch of Guyandotte r., $249 \mathrm{~m}$. W. by N. Richmond.

Mud CreeE, p. o., St. Clair co., $M l_{0}$ : on a branch of the Kaskaskia so called, $106 \mathrm{~m}$. S. Springfield.

MUd Creek, p. o., Eaton county, Mfich.: 26 miles W Lansing.

Mod CREeK, p. 0., M'Nairy co., Tenn.: on an affluent of the Tennessee so called, $106 \mathrm{~m}$. S. W. by W. Nashville.

Mud Creek, p. o., Henderson co, N. Car?: on an E. branch of French Broad r., so named, $219 \mathrm{~m}$. W. by s. Raleigh.

Muddy Creers, p. o., Preston co., Tirg.: 192 m. N. W. Richmond.

Muddy Creek, p. o., Forsyth co., N. Car.: on an E. branch of the Yadkin, $98 \mathrm{~m}$. W. by N. Raleigh.

Moddy Creer Forks, p. o., York co., Penna: 877 m. \$. E. Harrisburg.

MUdDy Fork, p. o., Cleveland co., N. Car : on a fork of Buffalo cr., $148 \mathrm{~m}$. W. by $\mathrm{S}$. Raleigh.

Muddy LaNe, p. o., M'Donough co., $T l . .52 \mathrm{~m} . \mathrm{N}$. W. Springfield.

Mud Lick, p. o., Chatham co., N. Car.: 46 m. W. by N. Raleigh.

Mud Spring, p. o., El Dorado co., Calif. : 103 m. E. N. E. Vallejo.

Mud Spring, p. o., Denton co., Tex. : 206 m. N. by E. Austin City.

MUHLenburg county, $\bar{k} y$. Situate W. centrally, and contains 568 sq. m. Green $x$, forms its N. E. and Pond $r$. its W. boundary, and it is drained by Cypress, Clifty, Big Muddy, and other creeks of Green r. Surface varied, and soil of good quality in most parts. Corn and wheat are the staples, and tobaceo thriving in the best land. Raising cattle and sheep, and fattening pork are objects of much attention, and furnish valuable exports, especially of the last. The county possesses good water-power, and manufactures iron castings, flour, and leather. Farms 921 ; manuf. 16; dwell. 1,451, and pop.-wh. 8,250, fr. col. 37, sl. 1,522-total 9,809. Capital: Greenville.

Munlenderg, p. o., Luzerne co., Penn.: 84 m. N. N. E. Harrisburg.

Moker, p. o., Washington co., Wisc.: $69 \mathrm{~m}$. E. by N. Madison.

MukwA, p. v., and eap. Waupaca co., Wisc.: on Wolf $x$, near the confluence of Waupaca r., $92 \mathrm{~m}$. N. by $\mathrm{E}$ Madison. It is a well located and growing v. in a newlyorganized county.

MokWarago, t. and p. o., Waukesha co, Wisc: $56 \mathrm{~m}$. E. by S. Madison. Drained by affluents of Fox $r$. Surface level, and soil adapted to grain. The Milwaukie and Mississippi R. R. passes through the N. W. corner. PopuIation 1,094 .

Mulberry, p. o., Autauga co., Ala.: $2 S \mathrm{~m}$. W. by N. Montgomery,

Molberrx, p. o., Jackson co., Ga.: 79 m. ‥ N. W. Milledgeville.

Melberky, p. o., Wilkes co., N. Car.: 139 m. W. N. W. Paleigh.

Mulberry, p. v., Clermont co., Ohio: $84 \mathrm{~m}$. S. W. by W. Columbus.

Mulberry, p. o., Lincoln co., Tenn.: on a branch of Elk r., $63 \mathrm{~m}$. S. by E. Nashville.

Mulbernx, river, Ala.: a large W. branch of the Black Warrior, rises in the N. part of Blount county, flows nearly parallel to the main stream in a $\mathbf{S} . \mathrm{W}$. course for $\$ 5$ miles, and empties into it on the W. line of Jefferson county. It crosses a region rich in deposits of coal.

MulberRy Corners, p. V., Geauga co., Ohio: 188 m. N. E. Columbus.

MUlberry Gap, p. o., Hancock co., Tenn. : about $3 \mathrm{~m}$. S. of Powell's r., 199 m. E. by N. Nashville.

Mulberry Grove, p. o., Harris co., $G a_{0}$ : about $6 \mathrm{~m}$. E. of Chattahoochee r., $111 \mathrm{~m}, \mathrm{~W}$. by S. Milledgeville. 
Mulberry Grove, p. o., Bond con, Ill. : about $8 \mathrm{~m}$. W. ce Hurricane cr., 62 m. S. S. E. Springfield.

MUlberRx Grove, p. o., Hopkins county, $K y_{*}: 163 \mathrm{~m}$. \%. S. W. Frankfort.

Moll Grove, p. o., Lincoln county, N. Car.: $152 \mathrm{~m}$. W by $\mathrm{S}$. Raleigh.

Mullicas (or Littue Egg Harbor) river, $N$. Jer. : rises among the heads of Rancocus cr., and flows S. E. between Burlington and Atlantic counties, into Great Bay and the Atlantic Ocean. Vessels of 60 tons can ascend it 20 miles.

Mullico HrL, p. v., Gloucester county, $N$. Jer.: on Racenon cr., $41 \mathrm{~m}$. S. W. Trenton. It contains several stores, and about 500 inhabitants.

Mullingar, p, o., Warren co., Penn. : 158 m. N. W. by W. Harrisburg.

Mullox's, p. o., Robertson co., Tenn.: 26 m. N. by W. Nashville.

Multonoman island, Oreg. Ter.: lies in Columbia r., and extends $15 \mathrm{~m}$. down the $r$., from the mouth of the Willamette, varying in width from 1 to 2 miles.

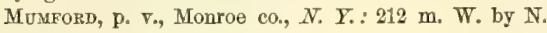
Albany. It contains several stores and mills, and 300 inhabitants.

Muxchetows, p. $\nabla .$, and cap. Delaware co., Ind.: on the S. side of White r., $48 \mathrm{~m}$. N. E. by E. Indianapolis. It is regularly built on elevated ground, and has a heavy trade in the products of a rich grain region. It contains a courthouse and jail, an academy, 20 stores, and 1,000 inhabitants. Two newspapers, the "Whig Banner" and "Muncietonian," are published weekly. It is on the Indianapolis and Bellefontaine $R_{v}, R_{v}, 18 \mathrm{~m} . \mathrm{E}$, of Andersontown, and will be intersected by the Fort Wayne and Southern R. R.

Muncr, p. b., Lycoming co, Penn, : about $1 \mathrm{~m}$. E. of the Susquehanna, and S. of Muncy cr., $64 \mathrm{~m}$. N. Harrisburg. It is largely engaged in the lumber trade, and contains a dozen stores, and 910 inhabitants. The W. branch division of the Pennsylvania Canal passes it $24 \mathrm{~m}$. N. of Northumberland. The "M. Luminary" (whig) is issued here weekly. The $\mathrm{t}$. is Muncy Creek, and has a hilly surface and clayey soil; drained by Big and Little Muncy creeks. It is well timbered, and contains several woolen factories,

Mundy, t. and p. o., Genesee co, Mich. : $45 \mathrm{~m}$. E. by N. Lansing. Drained by Swartz's cr. and other S. affluents of Flint r., which supply good water-power. Surface rolling; soil sandy loam, in parts covered with pine. Pop. 786.

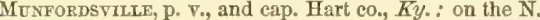
side of Green r., $79 \mathrm{~m}$. S. W. Frankfort. It has a valuable trade in corn and tobacco, and contains a court-house and jail, several stores, and 350 inhabitants.

Munger's Mrlis, p. o., Shannon Co $_{*}$ MIo.: 98 m. S. E. by S. Jefferson City.

Mungo Park, p. o., Washington co., Penn. : $184 \mathrm{~m}$. W. Harrisburg.

Munnsville, p. $\nabla_{\text {, }}$ Madison co., $N$. $Y_{\text {: : }}$ on Oneida cr., $9 S \mathrm{~m}$. W. by N. Albany. It contains a flouring mill, several stores, and 400 inhabitants.

Munntown, p. v., Washington co., Penn.: 168 m. W. Harrisburg.

Munnville, p. v., Coshocton co, Ohio: 63 m. E, N. E. Columbus.

Monsonvule, Putnam county, Flor,: 168 m. E. S. E. Tallahassee.

Mussonfille, p. v., Cheshire county, $N_{\text {. }}$ Hamp.: $33 \mathrm{~m}$. W. S. W. Concord.

Murat, p. o., Paulding co., Ohio: 118 m. N. W. by W. Columbus.

Murdocksviule, p. v., Washington co., Penn.: $176 \mathrm{~m}$. W. Harrisburg.

Murfee's Depôt, p. 0., Southampton co., Firg.: $52 \mathrm{~m}$. S. S. E. Richmond.

Murfaesboro', p. V., Pike co., Ar\%: : on the E. side of Hickory cr. of Little Missouri r., 97 m. S. W. by W. Little Rock.
Murfreesboro', p. v., Hertford con, $N$. Car.: on the $\mathbf{S}$. side of Meherrin r., 93 m. E. N. E. Raleigh. It contains an acadeny and several stores, and has a large trade in lumber.

Murfreesboro', p. b., and cap. Rutherford co., Tenn.: on a branch of Stone $\mathbf{r}, 28 \mathrm{~m} . \mathbf{S}$. E. Nashville, It is well laid out on an eminence overlooking a very fertile region of corn and tobacco land, and is neatly built, mostly with brick. It was formerly the capital of the State; and has a heavy trade in the products of a large and highly cultivated district. It contains a court-house, jail, bank, an academy, college, many large stores and warehouses, and about 2,000 inbabitants. Union College was founded here, in 1843, and in 1850 had 5 instruetors, 6 alumni, 100 students, and 2,000 volumes in its library. The "R. Telegraph" (whig), and "Circle of Honor" (temp.), are published weekly. It is on the Nashville and Chattanooga R.R., $32 \mathrm{~m}$. from Nashville.

MURPHex, p. v., and cap. Cherokee co., N. Car. : at the confluence of Valley and Hiwassee rivers, $313 \mathrm{~m}$. W. by $\mathrm{S}$ Raleigh. It lies in a valley, with a superior farming district around it, and several thriving manufactories in the vicinity. It contains a court-house and jail, an academy, and 400 inhabitants. The "Cherokee Sentinel" is published weekly.

Murphree's Vallet, p. 0., Blount co., Ala. : $107 \mathrm{~m} . \mathrm{N}$. Montgomery,

Murphy's, p. o., Calaveras co., Calif.: on Stanislaus $\mathbf{r}_{\text {. }}$ 94 m. E. by S. Vallejo.

Murphrsborodgr, p. v., and cap. Jackson co., $I Z l_{\text {. : on }}$ the right bank of Big Muddy r., $143 \mathrm{~m}$. S. by E. Springfleld. It has a valuable trade, and ships large quantities of grain down the $r$. It contains a court-house and jail, several stores and warehouses, and 500 inhabitents.

Murpiystile, p. v., Mason co., $K y$. : on an E. branch of Licking r, $67 \mathrm{~m}$. E. N. E, Frankfort.

Murrax county, $G a$. Situate N. W., and contains 586 sq. m. Drained by Coosawatte and Connasauga rivers, head waters of the Coosa. Surface much broken by ranges of hills and mountain spurs, but finely diversified with valleys of good size and great fertility. Corn is the largest product; wheat of excellent quality and some cotton are grown. Superior grazing abounds, fine dairies are kept, and wool is sheared largely. The streams furnish many mill-seats, which are fast being occupied with flourishing manufactories. Iron ore is found, and valuable mineral springs. Farms 1,034; manuf. 25 ; dwell. 2,047 , and pop.wh. 12,492, fr. col. 11, 8l. 1,930-total, 14,438. Capital: Spring Place. Public Works: East Tennessee and Georgia R. R., and Western and Atlantic R. R.

Murear, p. o., Wells co., Ind.: 78 m. N. E. Indianapolis. Murray, p. V., Callaway co., $\bar{K} y_{\bullet}:$ on the E. side of Clark's ro, $213 \mathrm{~m}$. S. W. by W. Frankfort. It was for a time the capital of the county, and contains several stores, and 200 inhabitants.

Murray, t. and p. o., Orleans co., $N . Y_{*}: 10 \mathrm{~m}$. S. of Lake Ontario, 228 m. W. by N. Albany. Drained by Sandy and Little Salmon creeks flowing into the lake, which furnish good mill-seats. Surface nearly level; soil fertile. It is a fine grazing t., with several thriving manufacturing villages in it. The Rochester, Lockport, and Niagara Falls R. R. and Erie Canal pass through it. Murray sta. is $25 \mathrm{~m} . \mathrm{W}$. of Rochester. Pop. 2,520.

Mcrray's Ferri, p. 0., Williamsburg dist., S. Car. : 66 m. E. S. E. Columbia.

Murraystule, p. v., Jackson co, Firg.: on the Ohio $\boldsymbol{r}, 258 \mathrm{~m}$. W. N. W. Richmond. It oceupies a narrow tongue, with the $r$, on the $N$. and $S_{*}$, and is engaged in boat-building.

MureIll's Shop, p. o., Nelson co., Firg. : 74 m. W. by N. Richmond.

Murrisstille, p.. ., Butler co., Penn. : 168 m. W. N. W. Harrisburg.

Moreysvilue, p. v., Westmoreland co., Penn.: on an E. branch of the Monongahela, $144 \mathrm{~m}$. W. by N. Harrisburg. It contains several stores and a woolen factory. 
Muscative county, $I a$, Situate S. E., and contains 441 sq. m. Bounded S. E. by the Mississippi, and drained by Cedar r. and its branches. Surface rolling; soil very fertile. Corn, wheat, oats, and potatoes, are excellent crops. It is a rery fine farming county, and almost as good for grazing. The streams afford abundant water-power, and the location is very favorable for commerce, making it the thoroughfare of the immigration and transportation of a large back country. Farms 460 ; manuf. 19 ; dwell. 999, and pop.wh. 5,663, fr, col, 68-total 5,731. Capital: Muscatine.

Muscatine (formerly Bloomirgton), p. v., and cap. Mus-

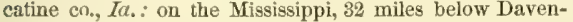
port, $31 \mathrm{~m}$. S. E. by E. Iowa City. It has an excellent steamboat landing, and is a large commercial place, being the shipping port of the rich district between Iowa City and the Mississippi, the trade of which it mostly commands. It has advantages for trade and commerce which must make it a place of great wealth and importance. It contains a court-house, jail, 2 academies, several handsome churches, numerous large stores and warehouses, and 2,534 inhabitants. Two weekly papers are published-the "Democratic Inquirer" and "M. Journal."

MuscodA, p. 0., Grant co., Wisc. : on the S. side of Wisconsin r., $54 \mathrm{~m}$. W. by N. Madison.

Moscoger county, $G a$. Situate middle on W. line, and contains $376 \mathrm{sq}$. m. Drained by Upatoi er. and smaller tributaries of the Chattahoochee, which forms the W. boundary. Surface diversified; soil exceedingly fertile on the Iarge streams, and generally of good quality. Cotton is the staple. Corn is a fine crop, and good wheat is grown. Water-power in abundance is furnished by the falls of the Chattahoochee, and large manufactories of cotton and woolen goods are in successful operation on and near that river. The same stream, being navigable at all seasons, afiords great facilities for the transportation of the products of a large and fertile region, which pass through this county. Farms 581; mannf, 30; dwell. 1,884, and pop.-wh. 10,360, fr. col. 62, sl. 8,156-total 18,576. Capital: Columbus Public Works: Muscogee R. R.

Mush Creek, p. o., Greenville dist., S. Car.: 98 m. N.W. Columbia.

Mughulatile, p. o., Noxubee co., Miss. : 108 m. N. E. Jackson.

Muskeego, p. o, Milwaukie co, Wisc.: $72 \mathrm{~m}$. E. by S. Madison.

Muskeego Centre, p. o., Waukesha co, Wisc.: $67 \mathrm{~m}$. E. by S. Madison.

Muskegor, to and p. o., Ottawa county, Mich. : $85 \mathrm{~m}$, W. N. W. Lansing. Drained by Muskegon r. and its branches. Surface even, and soil very productive and heavily timbered with oak and pine. Marl is found in large quantities. Pop. 434.

Musket, p. o., Navarro county, Tex. : 146 m. N. N. E. Austin City.

Mcskingum county, Ohio. Situate S. E. centrally, and contains 809 sq. m. Drained by Muskingum r. and its branches, Licking $\mathbf{r}$. and Wills' and Salt creeks, which afford almost unlimited water-power. Surface somewhat hilly; soil of great fertility, equally adapted to grass and grain. Wheat and corn are the great staples, and the crops very large. Mnst of the grains thrive. Large dairies are kept, and great numbers of sheep and swine raised. Livestock, beef, wool, and pork are extensively exported. The county contains valuable salt springs, which formerly yielded immense quantities of salt. The product, though much less now, is still large. It has large beds of bituminous coal and nuarrics of burr stone, much used for mill-stones, and a superior clay for pottery. Its manufactures are various and very large-flour, stone and earthen-ware, salt, colton and woolen goods, leather, distilled and malt liquors, iron eastings, and machinery being the principal. Farms 2,680; manue 358; dwell. 7.757, and pop.-wh. 44,421, fr. col, 628 -total 45,049. Capital: Zanesville. Public Works: Ohio
Canal; Cleveland, Zanesville, and Cincinnati R. R.; Central Ohio R. R.; Cincinnati, Wilmington, and Zanesville Railroad,

Muskingtim, t. and p. o., Muskingum co., Otio : $49 \mathrm{~m}$. E. by N. Columbus, Bounded E. by Muskingum r., and drained by a branch of the Licking. Surface slightly uneven; soil very fertile, It has numerous salt springs. Pop. 1,509

Musknisum river, Ohio: formed by the union at Coshocton of Walhonding and Tuscarawas rivers, which rise in the S. part of the Connecticut Reserve, flowg about $120 \mathrm{~m}$. in a $\mathrm{S}$. E. course, and empties into the ohio at Marietta. It is 225 yards wide at the mouth, and by means of locks, dams, and short canals is navigable $96 \mathrm{~m}$. to Dresden. The Ohio Canal here connects with it by a side cut, and proceeds up the valley of the Tuscarawas, and the Walhonding Canal follows the other constitutent, diverging from the former at Roscoe. The numerous falls of the river afford almost unimited water-power.

Mustang, p. o, Lavaca county, Tex, : $76 \mathrm{~m}, \mathrm{~S}, \mathrm{~S} . \mathrm{E}$. Austin City.

Mutual, p. o., Champaign co., Ohio: $46 \mathrm{~m}$. W. by $\mathrm{N}$. Columbus.

MxatTe, p. o., Fulton co., Ark. : on a creek so called, a N. affluent of Syring r., $118 \mathrm{~m}$. N. by E. Little Rock.

Mrersitra, p. v., Bradford co., Penn. : 98 m. N. by E. Harrisburg.

Myerstown, p. v., Lebanon co., Penn. : on Tulpehocken cr, and the Union Canal, $31 \mathrm{~m}$. E. by N. Harrisburg. The "M. Gazette" (dem.) is published weekly. Pop, 400.

Mxersvilue, p. y, Frederick county, $M d .: 67$ m. N. W. Annapolis.

Mrers' MrLLs, p. 0., Vermillion co., $\Pi_{\text {s }}$ : on the N. fork of Big Vermillion r., 109 m. E. by N. Springfield.

Mrrick's, sta., Bristol co., Mass. : on the Fall River R. R. and New Bedford and Taunton R. R. at their intersection, $12 \mathrm{~m}$. from Fall River and $14 \mathrm{~m}$. from New Bedford.

Mrrtle Springs, p. o, Bowio co, Tex.: 291 m. N. E. Austin City.

Mrstic, p. va, New London county, Conn.: on Mystic r. 45 m. S. E. Hartford.

Mrstic Bridge, p. v., New London county, Conn.: on Mystic r., $2 \mathrm{~m}$. above its mouth, $48 \mathrm{~m}$. S. E. Hartford. The $\mathrm{v}$. lies on both sides of the river, which is spanned by a toll bridge, and is navigable for vessels of 400 tons burden. Ship-building and the coasting and West India trade are the leading interests of the $v_{\text {., }}$ which contains 2 banks, an academy, and about 1,000 inhabitants.

Mrstic Piver, p. o.g New London co, Conn.: 47 m. S. E. Hartford.

\section{$\mathrm{N}$.}

Na AMan's Creek, p. o. and sta., New Castle co., Del. : on Naaman's cr. of Delaware $r_{4}$, and on the Philadclphia and Baltimore R. R., 20 m. S. W. Philadelphia

NaAusat, p. o., Kendall county, $I l l .: 135$ m. N. N. E. Springfield.

Nacogdoches county, Tew. Situate toward the N. E. and contains $948 \mathrm{sq} . \mathrm{m}$. Drained by branches of Attoyac r. which forms its western boundary, and by branches of Angelina $r$., which runs on the $\mathbf{S}$. W. and W. Surface level, or gently undulating ; soil very fertile, particularly on the Attoyac and Angelina rivers, where the land is rich and well adapted to the culture of cotton, corn, and fruits of different kinds. Grapes are abundant, and might, with cultivation, be rendered valuable. It is well wooded, and has some fine springs and streams of clear running water of excellent quality. It contains some minerals. Farms 287; manuf. 8; dwell. 681, and pop.-wh. 3,75s, fr. col. 81, sl. 1,404-total 5,193. Capital: Nacogdoches. Public Works: Spanish Military Road. 
Nacogdoches, p. v., and cap. Nacogdoches co., Tex.: is on an elevated angular plain, between and above the junction of the beautiful streams Bonito, on the W., and Lanana, on the F., the main branches of Bayou Lanana, $210 \mathrm{~m}$. N. E. by E. Austin City. This r. was one among the first settled by the Spanish in Texas, and grew to eonsiderable importance; but under the wars wilh Mexico it suffered greatly. In 1582, the Mexican Centralist troops were expelled by the citizens and inhabitants of the neighboring country. It is now rapidly progressing in prosperity

NAcooche, p. o., Habersham co., Ga.: 118 m. N. by W. Milledgeville.

Naglesfille, p. v., Monroe county, Penn.: 96 m. N. E. Harrisburg. Cobb's Gap R. R. passes through this village.

Naнant, peninsula and p. o, Essex co., Mass: $9 \mathrm{~m}$. N. E. Boston. This peninsula is part of the town of Lynn, from which it projects S. 4 m. into Massachusetts Bay, forming on the E. side Nahant Bay, and on the W. side Lynn Harbor. It consists of four parts : Long Beach, Little Nahant, Bass Neck or Nahant Beach, and Great Nahant. Long Beach, which connects it with Lynn, is $1 \frac{1}{2} \mathrm{~m}$, in length, smooth and very hard, affording a most delightful ride, Little Nahant contains 42 acres, of which a part is cultivated. Bass Neck connects this with the outer and main portion of the peninsula, called Great Nahant, or more gGnerally, Nahant, which is $2 \mathrm{~m}$. long, in parts $1 \frac{1}{2} \mathrm{~m}$. wide, and contains 463 acres. The surface is uneven, being from 40 to 100 feet above the level of the sea. The shore mostly consist of precipitous rocks, with a great depth of water below. At times the roar of the ocean surge is sublime. In fair weather the scenery is delightful. During the summer months it is greatly resorted to from Boston and vicinity, by steamboats hourly plying. A large hotel and other boarding-houses provide excellent accommodations.

Natrryoo bay, Door co., Wisc.: an inlet of Green Bay, W. from Sturgeon Bay.

Namusta, p. o. and sta., Wayne co., $N$. Car.: on Wilmington and Weldon R. R., $10 \mathrm{~m} . \mathrm{N}$. Goldsboro', $42 \mathrm{~m}$. E. S. E. Raleigh.

Natl Factory, p. o., Gaston county, N. Car. : $138 \mathrm{~m}$. W. S. W. Raleigh.

Natrix, p. O., Scioto co., Ohio: 75 m. S. by E. Columbus.

Namantun, p. o., Marquette co., Wisc.: 55 m. N. by E。 Madison.

NAMAsket river, Bristol co, Mass. : unites with Bridgewater $r$. in Taunton.

Namebin lake, Lat Pointe co., Wisc. : one of the sources of $\mathrm{Bad} \mathrm{r.,} 24 \mathrm{~m}$. S. S. W. from its entrance into Lake Superior.

Navekegon river, La Pointe co., Wisc. : rises in Nidjikwe lake, drains S. part of La Pointe county, and is a head branch of St. Croix river.

Nasozise, p. o., Amelia co., Virg.: on Namozinc cr., $27 \mathrm{~m}$. W. S. W. Richmond.

Narafalra, p. V., Marengo co., Ala.: on the E. side of Tombigbee r, $1 \mathrm{~m}$, from the bluff and landing, $99 \mathrm{~m}$. W. by S. Montgomery.

Natcevont, p. 0., Cass co., Ml.: $24 \mathrm{~m}$. N. W. by W. Springield.

Nanjemor, p. v., Charles co, Mrd.: W. of Nanjemoy Bay, $47 \mathrm{~m}$. S. W. Annapolis, is a port, and has considerable trade.

Naxjexrox bay, Charles eo., $\boldsymbol{M} \boldsymbol{d}$. : a small inlet on $\mathbf{E}$. side of Potomac r., S m. S. W. Port Tobacco.

NAvkIr, t, and p. o., Wayne co., Mich.: 64 m. E. S, E. Lansing. Drained by the W. and $\mathbf{S}$. branches of Rouge $\mathbf{r}$. Surfuce undulating; soil sandy loam; is first-rate grass land. There is considerable water-power on both branches of the Touge. The greater portion of this and adjoining towns is heavily timbered. Pop, 1,617.

NANErs, p. $\nabla_{4}$, Ashland co., Ohio: on a branch of Walhonding $r_{*}, 74 \mathrm{~m}$. N. N. E. Columbus.

Naxsevoxd county, Firg. Situate S. E., and contains 520
$444 \mathrm{sq}, \mathrm{m}$. Drained by branches of Nansemond $r$, which falls into James $\boldsymbol{r}_{\text {, }}$ on the $\mathrm{N}$. border. Surface even; soil in general fertile, and produces good crops of cotton, Indian corn, ete. It contains a portion of the Dismal Swamp and Lake Drummond, which supplies the Dismal Swamp Canal by a feeder five miles long. Farms 731; manuf. 82 ; dwell. 1,523, and pop.-wh. 5,425, fr. col. 2,143, sl. 4,715-total 12,283. Capital: Suffolk. Public Works: Sea-board and Roanoke R. R.; Petersburg and Norfolk R. R.; Dismal Swamp Canal, etc.

NANBEMOND river, Nansemond co., Firg.: rises in Dismal Swamp, and from Suffolk to its entrance into Hampton Roads, is navigable for vessels of 100 tons.

Nantasket, sta., Plymouth co., Mass.: on South Shore R. R., $19 \mathrm{~m}$. from Boston.

Nantasker Beacr, peninsula, Plymouth $\mathrm{co}_{,}, \mathrm{Mass}_{*}: 9 \mathrm{~m}$. E. S. E. Boston. This peninsula, in Boston harbor, which is part of the ancient town of Hull, is now a place of much resort during the summer months from Boston and vicinity. A fine steamboat makes several trips daily. Here are nu. merous houses of entertainment, opportunities for bathing, fishing, ete.

NaNtasket RoAD, Mass, : one of the main entrances into Boston harbor, S. of the light-house; affords good anchorage, with five or six fathoms water.

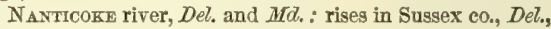
flows $\mathrm{S}$. W. in $\mathrm{Md}$., receives Marshy Hope $r_{\text {., }}$ and enters a branch of Chesapeake bay, by a wide estuary, $45 \mathrm{~m}$. from its source.

Nanticoke, hund., Sussex co., Del.: 80 m. S. Dover. Drained by creeks of Nanticoke $r$, which form its W. boundary. Area, 63,910 acres.

Nantrcoke, p. v., Luzerne co., Penn. : on S. side of E. branch of Susquehanna r., $75 \mathrm{~m} . \mathrm{N}$. E. by N. Harrisburg

Nartcoke Falis, Penn. : in Susquehanna r., $8 \mathrm{~m}$. below Wilkesbarre. A dam which is here erected for feeding the North Branch Canal, supplies a vast quantity of surplus water and great water-power.

Nanticoke Springs, p. v., Broome co, $N$. Y.: $126 \mathrm{~m}$.W. by S. Albany. Contains a sulphur-spring, hotel, etc. - The $\mathrm{r}$. is in t. of Nanticoke, which is drained by head branches of Nanticoke er.; has undulating surface. Pop. of t. 576.

Nantucket county, Mass.: situate in the Atlantic ocean, and comprising the island of Nantucket and other smalier islands adjacent; the main island is distant from Martha's Vineyard $10 \mathrm{~m}$. E., and from Cape Cod $30 \mathrm{~m}$. S., and contains an area of $50 \mathrm{sq}$. $m$. Surface in the $S$. level, in the $N_{\text {. }}$ somewhat elevated; soil in general barren, and no tree or shrub of any size is to be found on the island. Most of the land is common, on which large numbers of cattle are fed. The inhabitants are chiefly employed in navigation and the fisheries. Off the S. E. of the island are Nantucket Shoals. Farms 58 ; manuf. 60 ; dwell. 1,255, and pop,-wh. 8,110, fr col. 842-total 8,452. Capital: Nantucket.

Nantucker, port of entry, t., p. v., and cap. Nantucket co., Mass.: on N. side of Nantucket island, 90 m. S. S. F Boston. Lat. N. $41^{\circ} 16^{\prime} 56^{\prime \prime}$; long. W. $70^{\circ} 6^{\prime} 12^{\prime \prime}$. The $v$ is situated at the bottom of the bay, which is $6 \mathrm{~m}$. long, and almost entirely land-locked, being divided from the ocean by a narrow beach. The projecting points of beach, which thus lock in the harbor, are $\frac{m}{4}$. apart, and furnished with light-houses, as is also the harbor. The harbor is good. 'Two miles $\mathrm{N}$. of the harbor is a bar, with $7 \frac{1}{2} \mathrm{ft}$, of water at low tide. The shore on which the $\mathrm{v}$, is built is more inclined to the water than the rest of the island. It is built very compactly, with narrow streets. In 1846, July 13th, it suffered most severely by a conflagration, which destroyed in a few hours 360 buildings : amount of loss, $\$ 1,000,000$; amount insured, $\$ 320,000$; number of families who suffered, 450 : contributions received from Boston and other places, $\$ 65,000$. This place was the first to engage in the whale fisheries, and is still more largely engnged than any other town in the United States, except New Bedford, where this business was estab- 
lished by persons from Nantucket. On 30th June, 1850, Nantucket had an aggregate permanent tonnage of 29,012 tons; of which 25,837 were registered, and 3,175 enrolled and licensed. Registered in the whale flshery, 19,055 tons : enrolled and licensed in cod fishery, 403 tons; in mackeral fishery, 592 tons; in coasting trade, 2,180 tons; in steam navigation, 479 tons. The receipts from the whale fishery in 1819 were 17,887 barrels sperm oil, and 6,461 barrels whale oil, and 68,200 pounds whale-bone. The Athenæum has a good building, 2,500 volumes in library, and a valuable collection of curiosities. A steamboat plies daily to New Bedford. The Pacific Bank has a capital of $\$ 200,000$. The " $N$. Inquirer" is published tri-weekly and weekly; the "N. Mirror" (neut.), weekly. Pop. of t. 8,452.

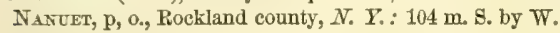
Albany.

NAPA county, Calif. Situate W. and to the N. of San Pablo Bay, which lies on its $\mathrm{S}$. border, and receives its drainage by the Napa r. Surface mountainous with extensive valleys; the Coast Range traversing it. Pop. in 1853, 2,116. Capital: Napa.

NAPA, p. Y., and cap. Napa co., Calif.: on E. bank of Napa cr., 26 m. N. N. W. Vallejo, in the eentre of one of the most beautiful, fertile, and extensive valleys which border on San Pablo bay, and promising to become the flourishing centre of this rich agricultural district.

NaPATOCK, p. v., Ulster county, $N . Y .: 70$ m. S. S. W. Albany, on Rondout cr. $\frac{1}{2} \mathrm{~m}$. from Delaware and Hudson Canal.

Naperville, p. v., and cap. Du Page co, $M$.: on E. side of W. fork of Du Page r., $161 \mathrm{~m}$. N. E. by N. Springfield. Contains the court-house and county buildings. Two newspapers are issued weekly_ "Du Page County Recorder" (dem.), and "Democratic Plaindealer" (dem.) Pop. 2,000.

NAples, t., p. v., and sta., Seott co., Ill. : on E. side of Illinois r., $2 \mathrm{~m}$. above the mouth of Mauvaiseterre cr., $30 \mathrm{~m}$. W. Springfield. This is the W.terminus of the Sangamon and Morgan R. R., $55 \mathrm{~m}$. from Springfield. The "N. Observer" (dem.) is issued weekly.

Naples, t. and p. o., Cumberland county, Me.: N. side of Sebago pond, $50 \mathrm{~m}$. S. W. Augusta. Watered by Sebago and Long ponds, and Crooked and Sango rivers, which afford mill privileges. The v. is on E. side of Long pond, or Bay of Naples. Pop. of t. 1,025.

NAPLES, t. and p. v., Ontario co., $N_{0} Y_{0}: 192 \mathrm{~m}$. W. Albany. Surface hilly; soil clay loam; drained by inlets of Canandaigua and Honeoye lakes. The $\mathrm{v}$. contains numerous mills and factories. Pop. of t. 2,376.

Napoleon, p. v., Desha co., Ark. : on W. bank of Mississippi r., at junction of Arkansas r., 99 m. S. E. Little Rock.

NAPOLEON, p. v., Ripley county, Ind.: 58 miles S. E. Indianapolis.

Nafoleon, p. v., Gallatin co., Ky. : 42 m. N. Frankfort.

NAPOLEOX, to and p. $\nabla_{\text {.. }}$ Jackson co., Mich.; 41 m. E. S. E. Lansing. The to is well timbered, has several large lakes, and fine streams. White sandstone of superior quality abounds. Surface undulating; soil rich sandy loam. The $\nabla$. is in N. E. corner of the t. Pop. of t. 1,208.

NAPOLEON, t., p. v., and cap. Henry county, Ohio: on N. bank of Maumee r, $78 \mathrm{~m} . \mathrm{N}$. W. Columbus, on the Wabash and Erie Canal. Pop. of t. 566 .

NAPOLEONville, p. v., and eap. Assumption par., La.: on W. bank of Bayou la Fonrehe, $36 \mathrm{~m}$. S. by E. Baton Rouge. A newspaper, "Le Pionnier de l'Assumption," is published weekly.

NAPoli, t. and p. o., Cattaraugus county, N. Y.: $204 \mathrm{~m}$. W. by S. Albany. Surface of town undulating; soil good. Drained by Cold Spring cr. Pop. 1,233.

NARraganseTT, p. o., Washington co., $R$. $I$.

NARRAGamsetT bay, $R$. $I$. This beautiful bay sets up N. from the Atlantic, between Seaconnett rocks on the E. and Point Judith on the $W$., which are $17 \mathrm{~m}$. apart. It contains the Large [r]auds Phode, Canonicut, Prudence, and numer- ous small ones, extends N. $29 \mathrm{~m}$, and terminates in Providence r. Its more inland portions are called Providence Bay, Mount Hope Bay, and Greenwich Bay. It is one of the finest bays in the United States, being always accessible, capacious, safe, and deep enough for the largest vessels.

Narragtagus, p. o., Washington co., Me.: on E. bank of Narraguagus ro, $96 \mathrm{~m}$. E. by $\mathrm{N}$. Augusta.

Narraguagus river and bay, Washington co., Me.: rises in ponds $\mathrm{N}$. of town of Beddington, runs S. S. E. $35 \mathrm{~m}$. draining the towns of Beddington, Deblois, Cherryfield, and Millbridge, and empties into Narraguagus bay, which contains a number of islands, has a good entrance, and on the $\mathrm{E}$ connects with Pleasant Bay.

Narrows, p. o., Pike county, Penn.: on Laxawason cr., $118 \mathrm{~m}$. N. E. Harrisburg.

Narrows, p. o., Noddaway county, MYo.: $186 \mathrm{~m} . \mathrm{N} . \mathrm{W}$ Jefferson City.

NARrows, New York Harbor-the channel from New York Bay to the lower bay, $1 \mathrm{~m}$. wide; defended on Staten Island side by Forts Richmond and Tompkins, and on Long Island side by Forts Hamilton and La Fayette.

NARBows, p. o., Jefferson county, $N . Y_{\circ}: 164 \mathrm{~m} . \mathrm{N}$. W. Albany.

NARrowsBurg, p. v., and sta., Sullivan county, $N . Y_{.}$: on Delaware r., 98 m. S. W. Albany ; sta. of Erie R. R., $132 \mathrm{~m}$ from New York. Near N. are many tanneries, owing to the abundance of hemlock. The scenery of the vicinity is very beautiful. The "Narrows" of the Delaware r. are crossed by a wooden bridge having a span of 184 feet.

NARROW VALLEY, p. o., Benton co., Ala. : 102 m. N. N. E. Montgomery.

NASH county, N. Car. Situate toward the N. E., and contains 588 sq. m. Drained by Tar r, and its branches. Surface level; in some parts it is broken; soil in general fertile, and well adapted to grain. On the streams there is much good land, and cotton is grown extensively. Farms 718 ; manuf. 24 ; dwell. 1,248, and pop.-wh. 5,972, fr. col. 629, sl. 4,056-total 10,657. Capital: Nashville. Public Works: Wilmington and Weldon R. R., on its E. border.

NasHotan lakes, Waukesha co., Wisc.: these two small lakes present a most beautiful appearance. On the E. bank of the N. lake is the Nashotah mission school, college, etc., of the Episcopal Church.

NASEPORT, p. v., Muskingum county, Ohio: on N. bank Licking r., and on the Ohio and Erie Canal, $37 \mathrm{~m}$. E. by $\mathrm{N}$. Columbus.

NAsh's Ford, p. o., Russell con, Firg.: 247 m. W. S. W. Richmond.

NASH's STrEAMr, N. Hamp.: a short branch of Upper Ammonoosuck r., draining W. part of towns of Stratford and Northumberland.

NASHU A, t. and p. v., Hillsboro' co., N. Hamp.: on W. side of Merrimac r., at confluence of Nashua r., $31 \mathrm{~m}$. S. by E. Concord. The $t$. is bounded on the $\mathrm{N}$. and W. by Nashua river, separating it from the town of Nashville, which, until 1842 , with it formed the town of Nashua. Surface of town is level on the $E_{\text {., }}$ uneven on the W.; soil on the streams fertile. This town, formerly called DunstiabLe, was the first one settled in the S. part of New Hampshire, and suffered much by attacks from Indians. The $\mathrm{v}$. is in the N. E. corner of the town, and is now a very important manufacturing village, deriving a great water-power from Nashua river, which in two miles falls 65 feet. In 1822-3 the greater portion of the lands in the village and on the river up to the falls was purchased by the "Nashua Manufacturing Company," which, with a capital of $\$ 300,000$, commenced building a dam, canal, and other works for factories. This company now has a capital of $\$ 1,000,000$, and 4 large mills manufaeturing shirting and drills, printing eloths, and jeans, and sheetings. Whole number of spindles is 37,450 ; looms, 1,089; male operatives, 150 ; females, 850 . These mills manufacture $13,000,000$ yards of cloth yearly, using 10,000 
bales of cotton, or 4,000,000 lbs., 150,000 lbs, starch, 8,000 gallons of sperm ofl, $\$ 4,000$ worth of leather, 800 cords wood. The "Jackson Company" have 2 mills manufacturing sheetings and shirtings, using yearly 4,500 bales of cotton, or 1,800,000 lbs., 50,000 lbs. starch, etc. The machine-shop, built by the Nashua Company in 1845, is occupied by manufacturers of steam-engines, machinists' tools, locks, guns, axes, etc., and here several hundred men are employed. The "Nashua Iron Company," established in 1845, have a capital of $\$ 100,000$, and employ 60 men; they use 3,500 tons coal yearly ; their sales are $\$ 175,000$. Baldwin's factory of shuttles and spool bobbins employs 120 men; yearly sales, $\$ 100,000$. There are other large factories, foundries of stoves, large iron castings, etc. Summary of N. eotton manufactures: no. of spindles, 49,994 ; looms, 1,483 ; male operatives, 240 ; females, 1,200 ; yards manufactured, $18,000,000$; capital invested, $\$ 1,480,000$. The total capital invested in factories in $\mathrm{N}$. is about $\$ 2,000,000$; male operatives, 1,000 ; females, 1,300. The Nashua and Jackson companies each have a savings institution for their employees. Four railroads connect $\mathrm{N}$. with the large towns adjacent, viz, Lowell and Nashua, Worcester and Nashua, Nashua and Wilton, and Concord R. R. There are 2 banks, capital $\$ 225,000$, and 7 churches. Three newspapers are published weekly: "N. H. Telegraph" (whig), "N. Gazette" (dem.), "The Oasis" (lit.) Pop. 5, \$20.

NASHUA river, N. Hamp, and Mass.: rises in Worcester co., Mass., being formed by 2 branches uniting in Lancaster, flows chiefly in a N. N. E. course, and empties into Merrimac r, at Nashua, N. Hamp.

Nasirvilte, p. vo, Lee co., Ia.: on the W. bank of Mississippi r., $80 \mathrm{~m}$. S. by E. Iowa City.

NASHville, p. T., and cap. Washington co., $I l l_{0}:$ at the heads of Little Crooked creek of Illinois r, $102 \mathrm{~m}$. S. by E. Springfield. It contains a court-house, several stores, and about 40 dwellings.

Nasiville, p. v., and eap. Brown co., Ind.; 39 m. S. by W. Indianapolis.

Nasntille, p. v., Lowndes co., Miss. ; on the N. bank of Tombigbee r., at junction of Kincades er., $126 \mathrm{~m}$. N. E. Jackson.

Nasitille, p. v., Boone co., Mro.: on N. side of Missouri river, $24 \mathrm{~m} . \mathrm{N} . \mathrm{N}$. W. Jefferson City.

Nasirille, t., p. v., and sta., Hillsborough co, N. Hamp. on W. side Merrimac $r$, and $N$. side of Nashua $r$. The $Y_{\text {. }}$ in S. E. part of t., is connected with Nashua village, and contains numerous factories. Pop. 3,122 .

Nashvilre, p. O., Chautauque county, N. Y.: $270 \mathrm{~m}$. W. Albany.

Nashiville, p. v., and cap. Nash co., $N$. Car.: on S. side Stony er. of Tar r., $30 \mathrm{~m}$. N. E. Raleigh.

Nasirildie, p. v., Iolmes county, Ohio: $41 \mathrm{~m}$. N. E. Columbus.

Nashyille, p. eity, port of entry, and cap. Daridson co., Tenn., and cap. of the State of Tennessee: on the left bank of the Cumberland river, $120 \mathrm{~m}$. above its entrance into the Ohio, and at the head of steamboat navigation thereof. Lat. $86^{\circ} 09^{\prime} 83^{\prime \prime}$, and long. $86^{\circ} 49^{\prime} 03^{\prime \prime}-714 \mathrm{~m}$. W. by s. Washington. The city is built on an elevated bluff of limestone, and on every side presents to the approaching traveler an imposing appearance. From Capitol Hill, within he city, a more interesting scene is seldon witnessed. Covering the base of the hill, and crowding to the extremest margin of the business-laden Cumberland, is the eity itself, its streets alive with the bustle of an active commerce, and its suburbs literally growing under the eye of the spectator. Surrounding it with a border of beautiful cultiration, lie extensive and valuable farms, intersecled by numerous turn. pikes, which, centering in the city, radiate to opposite neighborhonds; and in every direction is seen the railroad, complete and incomplete, which will open outlets to one of the richest agricultural and mining regions of the great West; and girding in all to a quiet security, rise a range of low and pleasant hills, partly covered with native cedars, and adorned with graceful dwellings. But it is not altogether the natural beauties of the lveality that attract the traveler's attention; the country for miles around is rich in soil and abounding in minerals, yielding to industry a compensatory reward, and to commerce material of no mean valuation.

Nashville was laid out at the latter part of the last century, but although always a place of some consideration, the tido of its prosperity rose slowly until within the last half tho term of its existence. In 1830 it contained only 5,566 inhabitants, and even in 1840 only 6,929 . In 1850 its population had increased to 10,478 , or in the ratio of 51.2 per cent. in the decade between 1840 and 1850. Its commerce has increased in even a larger proportion, owing to the extent of roads having been multiplied, and to the improvements in the navigation of the river. The tonnage owned in the district of which Nashville is the port amounted in 1550 to 3,797 tons, all comprised in steamers, some of them magniflcent passenger boats, navigating the Cumberland and its tributaries, or sailing between Nashville and the ports of the Ohio river. The railroads centering here are the Nashville and Chattanooga $R$. R., extending in a S. E. direction to Chattanonga, on the Tennessee river, where it connects with the railroads to Charleston and Savannah, the distance from Nashville to the first being $599 \mathrm{~m}$., and to the latter $583 \mathrm{~m}$. the New Orleans and Nashville R. R., extending S. W. in the direction of the first named place; the Memphis and Nashville R. R.; the Nashville and Paris R. R. : the Nashville and Henderson R. R.; the Louisville and Nashville Railroad, and the Lexington and Nashville $R$. R. Of these several lines only the first is completed, but most of the others are progressing, or under contract to be built forthwith, and the whole system will probably be in operation in three or four years from the 1st Jan., 1853. These, when completed, will connect this commercial centre with every part of the Union-with the Gulf, the Ohio and Mississippi, the great lakes, and the Atlantic, from Maine to Floridaand make it one of the most important receiving and distributing depôts of the internal commerce of the central valley.

The city was originally laid out on a plot of 200 acres, but it has long since overstepped the limits its projectors assigned to it, and hence suburbs almost equal in extent and popula. tion to the city proper have grown up around it. The eity has a handsome public square, on which stands the county court-house, market-house, ete. The court-house is a splendid building, 105 feet in front by 63 feet deep, with basement and two stories, surmounted by a dome, the top of which is 90 feet from the ground, and supported by eight Ionic columns; the market-house is also a spacious and substantial edifice, a portion of which is occupied as a city hall and clerk's office. The other public buildings are the State-house, the University, the Lunatie Asylum, the State Prison, 12 or 14 churches of various denominations, numerous schools and academies, 3 banks (capital $\$ 3,658,500$ ), ete, The State-house is loeated on one of the highest eminences of the city. It was built about 10 years ago, on a four acre plot, presented by the city to the State, and is a noble edifice, towering above the place, and serving as a landmark for miles around, being the first object descried by the approaching traveler. It has spacious halls for the legislature, and other convenient offices. The Lunatic Asylum is a large and commodious building, three stories high, and will accommodate 100 patients. The Penitentiary or State Prison is located in the western suburbs, and has a front of 810 feet, and is 350 feet deep. It has apartments for the keeper, an hospital, guard-room, and cells for 200 convicts The Halls of the University were founded in 1806. The main building is 200 feet long and 50 feet deep, three stories high, with wings, and an extensive building used as a chemical laboratory. All the college buildings, except the president's house, are within the college campus, an area of $S$ acres. In 1550 it had 7 professors and 75 students, and 
its librury contained 10,207 yolumes. The number of its alumni at that date was 398 . The medieal department had 7 professors. Near Nashville is also Frânklin College, founded in 1845 , and which, in 1850 , had 5 professors, 26 alumni, 80 students, and a library of 3,000 volumes. Many of the churches are large and elegant structures; the Episcopal church is a magnificent Gothic building, and the schonl-honses, of which there are many, are in general neat and commodious. Nashville is the see of a Roman Catholic diocese of the same name, and there are within the city efficient Catholic schools for both boys and girls.

The newspaper and periodical press of the cily consists of 5 daily and 7 weekly papers, and 2 monthly periodicals. The dailies are the "American" (dem.), the "Gazette" (neutral), the "Republican Banner" (whig), the "Evening Reporter" (neutral), and the "N. Union" (dem.); the weeklies, the "Western Christian Advocate" (Meth.), the "Tennessee Organ" (temp.), the "Presbyterian Record" (relig.), the "Gazette," an edition of the daily, the "Tennessee Baptist" (relig.), the "True Whig," and the "West Tennessee Whig" and the monthlies are the "Christian Magazine" (Campbellite) and the "Sunday School Companion."

No town in the great valley of the West enjoys in a greater degree the blessings of health. Situate in about $36^{\circ} \mathrm{N}$. lat, it possesses a temperate climate, and from its local position it is free from fevers which characterize many of the western cities, particularly such as are situated upon water courses, It is true that a small portion of Nashville, at the upper and lower ends, are in times of high flood inundated; but these inundations continue but a few days, and sometimes at intervals of several years, and produce no injurious effect upon the salubrity of the town. Although the summer heats are occasionally oppressive, the winters are mild and moderate, with none of the severe cold of the northern and eastern states, nor the relaxing heats of the south. It is a climate, indeed, preferable in many respects to all others, and here and in the vicinity it is seldom necessary to house cattle, even in the coldest winters. In summer thousands flock to the city to escape from the malarial influences of the lower regions of the country.

About 13 or $14 \mathrm{~m}$, to the $\mathrm{N}$. E. of the city is the Hermitage, the homestead of the late Andrew Jackson, President of the United States. In this secluded rural abode the last days of that great patriot were passed, and here, on the 8th June, 1845 , at the patriarchal age of 79 , died the illustrious statesman and warrior.

Nasiville, p. v., Milam co, Tex,: on W. side of Brazos river, $2 \mathrm{~m}$. below the confluence of Little r., $76 \mathrm{~m}$. N. E. by $\mathrm{E}$. Austin City ; formerly called Viesca. It has one of the most delightful situations in Texas, an abundance of excellent water, and is very healthy.

Nasovville, p. o., Providence co, $R . T$.

Nassat, p. V., Lee co, Ia.: on a bank of Des Moines r., near its mouth, $86 \mathrm{~m}$. S. by E. Iowa City.

Nasgat, t. and p. v., Rensselaer co., N. Y.: $12 \mathrm{~m} . \mathrm{S} . \mathrm{E}$ Albany. Surface of t. hilly ; soil gravelly loam-well drained by Kinderhook cr. and its branches, and contains several mills, factories, and tanneries. Pop. of t. 3,261.

Nassau river, Nassau con, Flor. : rises in W. part of co. flows E., widens into Nassau inlet, and empties into Atlantic Ocean.

Natcravg river, Windham county, Conn.: is the main branch of Shetucket r., rises in Woodstock and Union, and flows S. S. W. to its confluence in Mansfield with the Shetucket.

Naxcriez, p. city, port, and cap. Adams co., Mfiss: : on E. bank of Mississippi $r_{0}, 87 \mathrm{~m}$. S. W. by W. Jackson. Lat. N. $31034^{\prime}$, long. W. $91024^{\prime} 42^{\prime \prime}$. This is the principal city in Mississippi, its importance arising from its being the depôt of cotton from the flne lands around it and in the interior, and being also the main entrepôt of the internal commerce of the State. By the river it is $309 \mathrm{~m}$. from New-Orleans, but in a direct line $127 \mathrm{~m} . \mathrm{N}$. W. by N. A part of the city is built at the landing on the margin of the river, but this chiefly consists of warehouses, stores, etc., while the larger and more agreeable portion is on a bluff, 200 feet above the level of the river. This part, though uneven in surface, is regularly laid out with broad streets, crossing at right angles. Many of the houses, though built plainly of wood, present an elegant appearance, having piazzas and balconies, surrounded with trees, beautiful shrubbery, etc. Its elevated site affords a fine view of the river and vieinity. It contains the court-house and jail, a hospital, orphan asylum, academies, several churches, ete. Here are oil-mills, manufacturing oil from cotton-seed. Two newspapers, the "N. Courier" (whig), and "N. Free Trader" (dem.), are each published semi-weekly and weekly. Pop. 5,239.

Natchez, p. v., Martin co., Ind.: $85 \mathrm{~m}$. S. S. W. by $\mathrm{S}$ Indianapolis.

Natchitoches parish, $L a$. Situate N. W., and contains $2,257 \mathrm{sq}, \mathrm{m}$. Drained by Red $\mathrm{r}$, which passes through its centre, Old r., a branch of Red r., and Black lake, Cedar and Sable creeks, with other streams. Surface level, and much diversifled with lakes; soil varied-on the streams being fertile, and well adapted to grain, cotton, and Indian corn, but a large portion of the land is sterile and covered with forest timber. Farms 842; manuf. 9 ; dwell. 1,432, and pop.-wh. 5,466, fr. col. 881, sl. 7,854-total 14,201. Capital: Natchitoches. Public Works: New Orleans, Opelousas, and Great Western R. R.

Natchitoches, p. V., and cap. Natchitoches, par., $L \alpha_{0}$ : on W. side of Red r., $143 \mathrm{~m} . \mathrm{N}$. W. Baton Rouge, handsomely situated at the foot of a bluff. It is a very old town, haring been settled by the French in 1717. The present population is a mixture of American, French, and Spanish. It has considerable trade, and is a growing place. Contains a court-house and jail, an U. S. land office, several churches and academies. The "N. Chronicle" (dem.), is published weekly.

Nathan's Creek, p. o., Ashe county, $N$. Car.: $168 \mathrm{~m}$, W. N. Ut Ralcigh.

Nathansville, p. v., Conecuh co., Ala.: on the S. side of Conecuh r., at the confluence of Murder and Burnt Cora creeks, 99 m. S. S. W. by W. Montgomery.

NATick, t., p. $\mathrm{y}_{\text {, }}$ and sta., Middlesex co, Mrass: $16 \mathrm{~m}$. W. S. W. Boston. Dratined by Charles river, and having within its limits several small lakes. The Boston and Worcester R. R. passes through the v. $17 \frac{1}{3} \mathrm{~m}$. from Boston. In 1660 , the Rev. Mr. Elliott here founded an Indian missionary settlement, which flourished under a succession of native and English ministers for many years. Considerable manufacturing is now done in this t. Pop. 2,9:1.

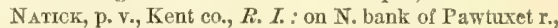
$10 \mathrm{~m} . \mathrm{S} . \mathrm{W}$. Providence : has several factories.

Natron Ford, p. o. and sta., York dist., S. Car.: S. side Catawba r., 63 m. N. Columbia, on Charlotte and South Carolina R. R.

Naturat Berdege, p. v., Jefferson co., N. $T_{.}: 136 \mathrm{~m}$ N. W. Albany, on Indian river, which is here erossed by a natural bridge 6 feet above the water, and 15 feet wide.

Natural Brmge, p. o., Rockbridge co., Virg.: near the Natural Bridge of limestone rock over Cedar creek, near its junction with James river, $120 \mathrm{~m}$. W. Richmond. This bridge is justly regarded as one of the greatest natural curiosities in the world. It is of stupendous size, as is evident from the following statement: The height of its top from the creek is 215 feet; the chasm spanned 90 feet wide at the top, and 50 feet at the bottom; the average width of the arch is 80 feet, its thickness is 55 feet. It is covered with a stratum of clayey earth, from 4 to 6 feet deep, and has on each side a natural parapet of rocks, trees, etc. The view from the top or from the creek is awfully grand. The bridge is most useful, there being no other erossing place possible for several miles above or below.

Natural Cayal, in Canton t. St. Lawrence co., $1 . Y_{\text {. }}$ is a creek which connects Oswegatchie and Grape rivers, 
$6 \mathrm{~m}$ long, very straight, 10 to 20 rods wide, and navigable at high water for boats of 10 tons burden.

Naturat DaM, p. o., Crawford $\mathrm{co}_{\text {, }}$ Ark. : on Lees ereek, 147 m. W. N. W. Little Rock.

Natural Grove, p. 0., Williamsburg dist., $S$. Car, : $78 \mathrm{~m}$. E. S. E. Columbia.

NAUGATUCK river, Conn. : the creeks forming this important mill stream rise in N. part of Litehfield co., and unite in Torrington, whence it flows $\mathrm{S} .35 \mathrm{~m}$. affording waterpower to numerous factories on its banks, and empties at Derby into Housatonic river.

NaUgatuck, t., p. v., and sta., New Haven so., Conn.: on Naugatuck r., 25 m. S. W. Hartford, $15 \mathrm{~m}$. N. N. W. New Haven. Surface of town uneven; soil good on the river. The v. is principally located on its W. bank, and contains numerous factories. The Naugatuck R. R. passes through the v. $27 \mathrm{~m}$. from Bridgeport. Pop. 1,720.

NAUNEESHA river, Wisc, : a small affluent of W. branch of Rock r., flowing from Dane co. into Dodge co.

NaUvoo, t. and p. $\nabla .$, Hancock cn., IZ.: on E. bank of Mississippi r, $103 \mathrm{~m}$. N. W. by W. Springfleld. Surface of $t_{\text {. }}$ is elevated, and commands a fine view of the $r$. and vicinity. This t. is famous as having been for several years (from 1840 to June, 1S41) the settlement of the "Latter Day Saints," or "Mormons," who here erected some fine buildings. This property is now occupied by a colony of French Cornmunists or Icarians, under the direction of Mons, Cabet The large temple was burned in Oct., 1848, set on fire by an incendiary.

NAcvoo, p. o., Tioga co., Penn.: $110 \mathrm{~m}$. N. by W. Harrisburg.

Natarivo, p. 0., Onondaga co., $N . Y_{.}: 134 \mathrm{~m} . \mathrm{W} \cdot$ by N Albany.

Natarez, p. V., Des Moines co, $I a_{4}: 53$ m. E. S. E. Iowa City, N. of Flint creek, and drained by a branch of it

NAvarre, p. v., Stark county, Ohio: 92 miles E. N. E Columbus, on the Ohio and Erie Canal, and E. side of Chippewa river.
Navarro county, Texo. Situate toward the N., and contains about 3,800 sq. m. Drained by branches of Trinity, which forms its $\mathbf{S .}$ E. boundary, and by affluents of the Rio Brazos, which flows on its W. border. Surface undulating; soil a fine, deep, vegetable mold, with sand and clay intermixed, and very fertile, especially on the streams, where it produces in abundance cotton and corn. It is also favorable to the growth of fruit, oranges, lemons, citrons, peaches, etc., yielding well. It has some excellent timber land, and much fine pasture for cattle. Fine beds of iron ore are found, and limestone and freestone are extensive formations. F arms 304 ; manuf. 13 ; dwell. 576, and pop.-wh. 3,444, fr. col. 11 , sl. 388-total 3,843. Capital: Corsícana.

Natarro, p. o., Leon co., Tex, : 129 m. N. E. by E. Austin City.

Napasota river, Tex. : its source is in Limestone county, draining also Leon, Robertson, Grimes, and Brazos counties, emptying into the Brazos r. opposite the $\mathrm{v}$. of Washington. Its current is not rapid, and is navigable for keel boats for" 30 to $40 \mathrm{~m}$. from its mouth. This is a clear and beautiful stream of wholesome water.

NAVIDAD river, Tex, : rises in Fayette co, draining its $S$ part, flows S. and S. W. through Lavaca and Jackson counties, and empties into Lavaca r. $10 \mathrm{~m}$. from Lavaca bay. It is navigable as far as Texana for steamboats. Its waters are clear, pure, and wholesome.

NAYLoR's StORE, p. o, St. Charles co., Mo. : 79 m. E. by $\mathbb{N}$. Jefferson City.

Nazareth, p. 0., Northampton co., Penn.: $87 \mathrm{~m} . \mathrm{E} . \mathrm{N} . \mathrm{E}$ Harrisburg.

Neashoz, p. T., and cap. Newton co., Mo.: S. side of Neh-hah r., 165 m. S. W. Jefferson City.

Neatsvinf, p. va, Adair county, $K y_{0}: 66$ m. S. by W. Frankfort.

Nebo, p. o., Hopkins county, $K_{y}: 156$ m. W. S. W. Frankfort.

NEro, p. o., Jefferson county, Ohio: $120 \mathrm{~m}$. E. by N. Columbus.

\section{THE TERRITORY OF NEBRASKA.}

NesRASTA is an unorganized Territory of the United States, occupying all the country below the parallel of $42^{\circ}$ north latitude to the north boundaries of the Indian Territory, the State of Texas, and the Territory of New Mexicn, and extending east and west between the Rocky Mountains, bordering Oregon and Utah Territories, and the western line of the States of Iowa and Missouri. The area of this immense region is estimated at 136,700 square miles.

Across this Territory flow several of the great rivers of the Continent-the Nebraska, or Platte, from which the Territory takes its name, the Kansas and its wide-spreading tributaries, the Arkansas, etc. The Missouri River forms a great part of its eastern boundary, and is the common recipient of the rivers above named, except the Arkansas. The Nebraske rises by two forks in the Rocky Mountains, and these uniting in latitude $41^{\circ} 05^{\prime} 05^{\prime \prime} \mathrm{N}$., and longitude $101^{\circ} 21^{\prime} 24^{\prime \prime} \mathrm{W}$., flow in a united stream to a confluence with the Missouri, in latitade $41003^{\prime} 13^{\prime \prime} \mathrm{N}$, or about 620 miles above the entranco of the latter into the Mississippi, and 52 miles below Council Bluffs. It has few tributaries, and none of any great size; the principal are Elkhorn River, Loup Fork, and Wood River on the north, and Saline River on the south. It is from one to three miles broad, and so shallow, that, excepting in high flood, it is fordable in almost any part. It is full of islands covered with cotton wood, willows, and shrubs, and the shifting sands in its bed, together with the rapidity of its current, effectually prevent navigation. Colonel Long estimates that only 40 miles of its lower course are open to steamboat navigation. The north fork of the river rises in the same region as the Colorado of the West, about $40^{\circ} 30^{\prime} \mathrm{N}$., and having received Sweet-water River and other affluents in its course northward, breaks through the main range of the Rocky Mountains, and flows thence in a direction E. S. E., and the South Fork rises near the sources of the Arkansas, and flows E. N. E. to the junction. The great emigrant* route to Oregon, Utah, and California, follows this river and its North Fork-the Fremont route of 1843 takes the South Fork. The Kansas River meets the Missouri in $39^{\circ} 06^{\prime} 03^{\prime \prime}$ north latitude, and $94^{\circ} 32^{\prime} 54^{\prime \prime}$ west longitude, nearly equidistant between Fort Leavenworth and Independence. It is navigable for steamboats for 150 mailes from its mouth, and its width at its entrance into the Missouri is 340 yards. The sources of this river are near the eastern base of the Rocky Mountains, between the Nebraska and Arkansas, and the distance between its two forks-the Republican and Smoky Hill forks-is at least 120 miles through the greater part of their course. Republican Fork rises in a considerable lake in latitude $39^{\circ} 52^{\prime}$, and longitude $103^{\circ} 30^{\prime}$, and Smoky Hill Fork rises in the mountain region eastward of the South Park; the junction is made near the meridian of $96^{\circ} 30^{\prime}$. These, as well as the main stream, receive numerous large tributaries, which drain at least one half the Territory. The Arkansas rises to the south of South Park and Pike's Peak, near the sources of the Rio Grande del Norte, and has a general east course, forming in part the north boundary of the Indian Territory, and then taking a course to the south-east, it passes through

* For a mirute descrintion of this route, the reader is referred to "Horn's Overland Guide to Cai:fornia," published by J. H. Coltun, No. 86 Cedar-street. New York, 1852. Refer, also, to Fremont's Reports 
that country to the Mississippi, which it strikes on the parallel of $33^{\circ} 40^{\prime}$, and is navigable for steamboats 603 miles from its confluence. This river was formerly the boundary between the Mexican Republic and the United States, westward of the 100 th meridian; but by the recent changes in the political divisions of the country, the whole length from that point has been thrown into the present Territory of Nebraska.

The whole of this country is yet in its primitive wilderness state. Little or nothing is known of its topography, and the delineations on maps are but the isolated reminiscences of travelers and traders. The red man still roams over its prairies and mountains in quest of game and plunder; and as the ocean to the sea-farer, so its wilderness to the emigrant, it is only traversed as the highway to countries beyond its limits. The great features of the Territory, however, are known; in the east it is chiefly prairie, and in the west are the outliers of the Rocky Mountains, which rise up in grandeur and majesty, forming the water-shed between the mighty rivers that drain the western portion of the Centrai Valley and the Pacific slope of the Continent. The central portions are unprofitable, irreclaimable wilderness, with scarcely an oasis to reliere the monotony of its dreariness; it is the great Americar. Desert, in crossing which the way-farer has more to dread than the mariner that dares the deep, not only on account of the inhospitable character of the country, but also from the hostilities of the native savages besetting his path and seeking his destruction. Thousands have perished under the rifle and tomahark, and at every step the grave of some unfortunate gives warning of dangers to be avoided, or tells of the sufferings endured by the hardy men whose tracks are the tide-marks of empire flowing to its western destination.

Nebraska, with the exception of a small strip on its southern border, south of the Arkansas, was a portion of the Louisiana purchase, and came into the possession of the United States in 1803. It has never received as yet any white settlers, except those engaged in the service of the United States as Indian agents and military occupants, or missionaries of the several Christian denominations. Fort Leavenworth and Council Bluffs are within this Territory-the first a military station, established for the surveillance of the Indians, and the latter an Indian agency. But it is now proposed to organize the Territory, and prepare it for the emigrant. For this purpose, a bill was introduced into Congress as early as 1845 , but was not acted upon; and another bill was brought forward in 1853 , with the like result. The day, however, is not far distant when the white settlements will break through their present limits, the Indian be driven back, and the portions of the country in the immediate Valley of the Missouri be opened to the enterprising pioneer. Whither wil the Indian retreat, and what his destiny before the tide of civilization? The past and present will answer for the future.

Nmaraska, p. o., Crawford county, Ind. : on the Ohio r., $115 \mathrm{~m}$. S. by W. Indianapolis.

Nebraska river: a large tributary of the Missouri. (See the "Territory of Nebraska.")

NeCHE's SALINE, p. o., Smith co., Tex. : on the W. side of Neche's r., 190 m. N. E. Austin City. Salt is here manufactured in large quantities.

Neche's river, Tex. : its source is in Vansandt co., and drains Smith, Henderson, Anderson, Cherokee, Houston, Angelina, Trinity, Tyler, Jasper, and Jefferson counties, emptying into Sabine lake $208 \mathrm{~m}$. from its source in a direct line, and $255 \mathrm{~m}$. in its meanderings. It is navigable by flat boats $100 \mathrm{~m}$., and by steamboats nearly as far from its mouth. Necot, p. v., Linn co, Ia.: 28 m. N. Iowa City.

NeEdHa3r, t. and p. v., Norfolk co., Irass.: 8 m. S. W. Boston. Drained by Charles r., on the N. E. and S. affording 2 waterfalls, which are improved for manufacturing. At each fall there is a thriving $\mathrm{v}$. The $t$, is diversified by hills and plains, well watered, with good soil, and the encircling river gives beauty to the scenery. There is a dcpôt of the Boston and Worcester R. R. at W. Needham, $15 \mathrm{~m}$. from Boston. Pop. of t. 1,944.

NeEL's Creet, p. o., Jefferson co., Ind.: 80 m. S. E. by S. Indianapolis.

Neelysvilite, p. o., Morgan co., Ohio: 63 m. E. S. E. Columbus,

NeENAH, t. and p. v., Winnebago co., Wisc.: at outlet of Winnebago lake, $96 \mathrm{~m}$. N.N. E. Madison; is a fine growing town. Pop. of t. 1,520 .

NeENAF river, Wisc. : this important navigable river is formed near Fort Winnebago, Columbia County, by the junction of its head branches, which rise in the N. E. part of the county. At this point it is distant only 11 $\mathrm{m}$. from Wisconsin $r$. The natural advantages thus presented to form a continuous route of steamboat navigation from the lakes through the Wisconsin river with the Mississippi, have been improved by the Portage Canal Company, who are here constructing a canal between the rivers. From Fort Winnebago the Neenah flows N.; in Marquette county it widens into Buffalo lake, whence, flowing with smaller streams in a S. E. direction for five miles, it again expands into Puckawa lake; thence its course is N. E. into the centre of Winnebago county, where it again expands into a lake called Great Butte des Morts (meaning Great Hill of the Dead, from the Indian mornds supposed to contain dead bodies), and thence flows 8 . E. into Lake Winnebago at
Oshkosh, of which it is the outlet, into Green Bay by a N. E. course. In its descent it falls about 160 feet, chiefly by a succession of rapids, of which the most important are at the Grand Chute, a descent of 29 feet in 8,525; at the Little Chate, 31 feet in 9,200; at the Grand Kakalin, 44 feet in 8,600 . The estimated cost of rendering these rapids navigable is $\$ 500,000$. The splendid water-powers which these rapids afford are being improved by Eastern capitalists.

NEEPEESKUNK lake, Wisc. : lies $12 \mathrm{~m}$. W. Winnebago lake, in Winnebago and Fond du Lac counties, and has a N. outlet into Neenah river.

Neersville, p. v., Loudon co., Firg. : 105 m. N. N. W. Richmond.

Neffspille, p. v., Lancaster co., Penn. : 32 m. E. S. E. Harrisburg, $4 \mathrm{~m}$. N. Lancaster.

Negro F'oot, p. o., Hanover co., Tirg.: 18 m. W. N. W. Richmond.

Neнамтсо, p. o., Russell co., Alan : 66 m. E. Montgomery. NeILI's CREEK, p. o., Cumberland co., N. Car.: on a cr. so called of Cape Fear r., $24 \mathrm{~m}$. S. Raleigh.

Nekama, p. v., Winnebago co., Wisc.: on W. side of Winnebago lake, 75 m. N. N. E. Madison. Pop. of t. 910.

NeIson county, $K y$. Situate centrally, and contains 357 sq. m. Drained by Rolling and Beech forks of Salt $\mathrm{r}$, and their affluents. Surface level; soil fertile, and adapted to the culture of grain. On the streams the land is rich, and produces in abundance wheat, Indian corn, and other grain, which form the staples. The sugar-cane is cultivated. Farms 844; manuf. 52 ; dwell. 1,613, and pop.-wh. 9,550 , fr. col. 109, sl. 5,130-total 14,789, Capital: Bardstown.

NeLson county, Virg. Situate centrally, and contains 438 sq. m. Drained by Rock, Rock-fish, and Tye rivers. Surface uneven and hilly ; in parts mountainous ; soil in general fertile, and produces abundantly wheat, Indian corn, and tobacco. In the $\mathrm{N}$. W. portion lies the Blue Ridge. Farms 638 ; manuf. 70 ; dwell. 1,217 , and pop.-wh. $6,4 \pi 8$, fr. col. 138, sl. 6,142-total 12,758. Capital: Covington. Public Works: James River and Kanawha Canal; and it is proposed to extend the Orange and Alexandria $R$. R. throngh the county to Lynchburg.

Netson, t. and p. o., Cheshire co., N. Hamp.: $83 \mathrm{~m} . \mathrm{S} . \mathrm{W}$. Concord. Surface elevated and hilly; contains four ponds, outlets from which are branches of Ashuelot and Contoocook rivers, and afford water-power to several mills. Population 751.

Nelson, to and p. o., Madison co., N.Y.: $102 \mathrm{~m}$.W. by N. 
Albañy. Surface undulating; soil, clay and calcareous loam, and well drained. Pop. 1,965.

Netson, t, and p. o., Porlage county, Ohio: $110 \mathrm{~m}$. N. E.

Columbus, in N. E. corner of county. Drained by branches of Mahoning river. Soil fertile, adapled to grain and grass. Pop. 1,383.

Nelsonport, p. o., Potter co., Penn.: 115 m. N. N. W.

Harrisburg.

Nelson's, p. o., Tioga county, Penn.: on N. side of Cotwanesque cr., $118 \mathrm{~m}$. N. by W. Harrisburg.

Nelsox's Laxding, p. o., Chippewa co., Wisc, : on E. bank of Mississippi r., at junction of Chippewa r., $167 \mathrm{~m} . \mathrm{N}$. W. Madison.

Nexsonvilue, p. v., Athens county, Ohio: on N. bank Hocking river, $53 \mathrm{~m}$. S. E. Columbus. The Hocking Canal passes through it.

Nenelau river, Mich.: rises in Alcona county, and flows N. E. through Alpena county into Thunder Bay river.

NEOsho, p. v., Dodge county, Wisc.: 47 m. E. N. E. Madison.

Neperav, p. 0., Westchester county, N. Y.: $103 \mathrm{~m} . \mathrm{s}$. Albany.

NepeUskun, p. o., Winnebago co., Wisc. : 84 m. E. N. E. Madison.

NePHI City, p. v., Juab co., Utah Ter.: 45 m. N. N. E. Fillmore City.

Neponser river, Mass.: draining Norfolk co., it empties into Dorchester bay. It is navigable for $4 \mathrm{~m}$. to Milton for vessels of 150 tons.

Neponset Village, p. y. and sta., Norfolk co, Mass. : on the S. side of Neponset r., $5 \mathrm{~m}$. S. Boston. There are sereral manufuctories at the falls of the river. The Old Colony R. R. passes through, $5 \frac{1}{2} \mathrm{~m}$. from Boston.

Neptune, p. va, Mercer co., Ohio: $90 \mathrm{~m} . \mathrm{N}$. W. by W. Columbus, on a cr. of St. Mary's river.

Nero, p. o., Henderson county, Tenn.: 96 m. E. S. E. Nashville.

Nes runs $N$., dividing the t. into Long Island Sound, is navigable 5 miles.

Nescopeck, t. and p. v., Luzerne co., Penn.: on the S.W. side of the Susquehanna r., $61 \mathrm{~m}$. N. N. E. Harrisburg. The surface is uneven, with good bottom-lands on the streams. The $t$ is drained by Big and Little Wapwollopen and Nescopeck creeks. The $\mathrm{r}$. is at the entrance of Nescopeck er. into the Susquehanna, which is here crossed by an expensive roofed bridge, 1,256 feet long.

Nescopeck mountain, Luzerne co, Penn.:" this mountain is parallel to Wyoming Mountain, $20 \mathrm{~m}$. long, 850 feet high, and on N. side of Nescopeck cr.

Nemiraying river, Penn. : rises in Hilltown, Bucks co., and after a winding course of $35 \mathrm{~m}$., chiefly $\mathrm{S}$. E., empties into Delaware r., $3 \mathrm{~m}$, below Bristol.

Neshizoro, p. o., Marquette co, Wisc.: $53 \mathrm{~m}$. N. by E. Madison.

Nesнoвa county, Miss. Situate E. centrally, and contains $578 \mathrm{sq} . \mathrm{m}$. Drained by Pearl r. and jts branches, aud other small streams. Surface level; soil, black caleareous mold, fertile, and adapted to cotton, which is the staple. Good crops of grain are raised, and tobacco is produced in some quantity. Farms 426; malut. 0; dwell, 5£5, and pop.-wh. 3,393, fir. col. 0, sl. 1,335-total 4,725. Capital: Philadelphia.

Nesqualit, p. o., Lewis co., Oreg. Ter. : on E. side of Puget Sound, $146 \mathrm{~m}$. N. by E. Salem. This settlement is mainly occupied by the "Puget's Sound Agricultural Company," which supplies provisions to the Hudson Bay Company's employees $\mathrm{W}$. of the mountains, and has bere very extensive and highly cultivated farms; as also on the Cowlitz r.

Nesqually river, Oreg. Ter.: a considerable stream, emptying into a S. estuary of Puget's Sound, flowing in due W. course from its source in the mountains.

Nesquemonrag, p. o., Carbon co., Penn.; on the S. side 523 of Broad Mountain, $66 \mathrm{~m}$. N. E. Harrisburg. Near by are extensive coal-mines,

Nestorville, p. o., Barbour co., Firg.: 174 m. N W. Richmond.

Netherland, p. o., Overton co., Tenn.: 84 m. E. by N Nashville.

Netiner Providence, to and p. v., Delaware co., Penn.: S3 m. E. by S. Harrisburg. Drained by Ridley cr, on the W., and Cram er. on its E. boundary, both emptying into the Delaware river. The surface is level; soil rich and productive clay, and well tilled. It contains several mills and stores.

NetTle Carier, p. o., Overton co., Tenn。: 80 m. E. by N. Nashrille.

Nettle Lake, p. 0., Williams co., Ohio: 140 m. N. W. Columbus.

Neuse river, $N$. Car.: rises in Person and Orange counties, flows in a course mainly E. by S., about $200 \mathrm{~m}$., and empties by a broad estuary into Pamlico Sound.

Nevada county, Calif. Situate on E. line of State, in lat. $39^{\circ} 20^{\prime}$, and chiefly occupied by the Sierra Nevada. Drained by numerous affluents of Yuba river, which runs on its $\mathrm{N}$. border, and by Bear creek and $N$. fork of American river. Surface mountainous, with extensive valleys. Gold is the chief product; but there are many localities suitable for farms. Pop. 21,365, of which 3,266 are Indians, and 4,669 foreigners, Capital: Nevada City.

Nevada, p. 0., Greene county, Wisc.: $32 \mathrm{~m}$. S. by W. Madison.

NevadA CTTY, p. ₹., and cap. Nevada co., Calif.: $117 \mathrm{~m}$. N. E. Vallejo. Situate between Deer cr, and Barlow's creek of Tuba $\mathbf{r}$.

Neversivk, to and p. 0., Sullivan co., N.Y.: $68 \mathrm{~m}$. S. S. W. Albany. Surface hilly and mountainous; soil adapted to grazing. Drained by Neversink r., Roundout and Beaver creeks. Pop. 2,281.

Neverslas river, $N_{0} Y_{.}:$rises in $\mathrm{N} . \mathrm{W}$. part of Tlster co., runs S. through E. portion of Sullivan co, and empties into Delaware r., at Port Jervis. Upon its banks are numerous tanneries and saw-mills.

Nefille, p. v., Clermont co., Ohio: on Ohio r., $98 \mathrm{~m}$. S. W. by S. Columbus.

Nevis, p. o., Highland county, Ohio: 60 m. S. S. W Columbus.

Nevisink Higmlards, Monmouth co., N. Jer.: on the Atlantic coast, in t. of Middletown, 300 to 400 feet high, covered with trees, are a well-known land-mark for sailors. Nevisrve river, Monmouth co., N. Jer.: flowing between towns of Middletown and Shrewsbury, in N. E. direction, with wide estuary into Sandy Hook bay.

NEW AGGEN cape, $M e_{0}$ : an island, extending below to of Boothboy into the sea, forming E. boundary of Sheepscot bay, $40 \mathrm{~m}$. S. by E. Augusta.

Newago county, Afich. Situate W. on the S. peninsula, and contains $\$ 64 \mathrm{sq} . \mathrm{m}$. Drained by Maskegon, White, and Notipicago rivers. Surface level; soil generally deep and fertile. Farms 0 ; manuf. 12; dwell. 92, and pop.-wh. 509, fr. col.1-total 510. Capital: Newago.

NeWAgo, t. and p. o., Newago co., Mrich.: $76 \mathrm{~m} . \mathrm{N}$. W. Lansing. Drained by Maskegon r. and its branches.

New Albany, p. va, Mahoning county, Ohio : on Little Beaver cr., 128 m. N. E. by E. Columbus.

New Albany, p. eity, and cap. Floyd co., Ind.: on Ohio r. $100 \mathrm{~m}$. S. by E. Indianapolis, $4 \mathrm{~m} . \mathrm{N}$. W. Louisville. This city, which is now the largest in the State, was laid out in 1813. It is beautifully situated, has wide streets, parallel to the $\mathbf{r}$, which are crossed at right angles by others. The largest business is that of building and repairing steamboats and other vessels, which employ several hundred men. There are large iron foundries, machine shops, and factories. The New Albany and Salem R. R. is now completed to Juliet, 65 miles, and will be continued to Chicago A brisk trade is carried on with the interior and the valleys 
of the Ohio and Mississippi. The State Bank of Indiana has here a branch. There are 9 churches and a lyceum. The academies and schools are well conducted, and much attention is generally given to education. Two newspapers are published, each daily and weekly-the "Ledger" (dem.) and "Bulletin" (whig). Pop. 9,785.

New Ar.Baxy, p. v., Pontotoc co., Miss. : on Tallahatchee r., 157 m. N. N. E. Jackson.

New Axbant, Linn co., Oreg. Ter. Seo Albant, Oreg. New Albavy, p. v., Bradford co., Penn. : 92 m. N. by E. Harrisburg.

New Albion, to and p. o., Cattaraugas co, $N_{0} Y_{0}: 240 \mathrm{~m}$. W. by S. Albany. The Erie R. R. passes through the town. Pop. 1,683.

New Aterander, po o., Columbiana ca, Ohio: $125 \mathrm{~m}$. N. E. by E. Columbus.

NeW Alexaxdria, p. v., Jefferson county, Ohio: $121 \mathrm{~m}$. E. by N. Columbus.

New Almixandria, p. v., Westmoreland co., Penns: on the $\mathrm{E}$, side of Loyalhanna r, $130 \mathrm{~m}$. W. Harrisburg.

NEW AlSACE, p. o., Dearborn county, Ind. : 80 m. S. E. Indianapolis.

NeW Arstead, p. O., Cheshire co., $N_{0}$ Hamp.: on $\mathrm{S}$. side of Cold r., $33 \mathrm{~m}$. W. S. W. Concord.

New Austerd AM, p. v., Harrison co., Ind.: on Ohio r., near mouth of Indian cr., $113 \mathrm{~m}$. S. Indianapolis.

New ANтiocr, p. F., Clinton county, Ohio: 54 m. S. W. Columbus.

Newark, p. v., New Castle co., Del. : on the N. side of Christiana 6 r., $37 \mathrm{~m}$. N. N. W. Dover. The Philadelphia and Baltimore R. R. passes through the v., $40 \mathrm{~m}$. from Philadelphia, and $58 \mathrm{~m}$. from Baltimore. Is a pleasant village, and the seat of Delaware College, founded 1833. In 1850 it had 5 professors, 78 alumni, 30 students.

NewARK, p. v., Linn county, Ia.: N. side Cedar r., $20 \mathrm{~m}$. N. by W. Iowa City.

NEWARK, p. V., Kendall co., IUl.: on the S. E. side of Fox r., 136 m. N. N. E. Springfield.

Newark, p. 0., Warrick co, Ind. : near Big Pigeon er., on ine of Wabash and Erie Canal, 130 miles S. S. W. Indianapolis.

NEWARK, p. ఛ., Worcester county, MLd.: on a creek of Sinepuxent bay, 88 m. S. E. Annapolis.

NEWARK, t. and p. v., Rock county, Wise. : $41 \mathrm{~m}$. S. by E. Madison. Pop. 798.

New ARK, p. Va, Knox county, MOo.: on N. side of South Fabius r., $100 \mathrm{~m}$. N. Jefferson City.

NEW ARK, t., p. city, port of entry, and cap. Essex co., N. T. : on W. bank of Passaic r., $3 \mathrm{~m}$. above its entrance into New$\operatorname{ark}$ Bay, 47 m. N. E. Trenton, 9 m. W. New Tork. Lat. $40^{\circ} 45^{\prime}$ N., long. $74^{\circ} 10^{\prime} \mathrm{W}$. This is the most populous and flourishing place in the State. It is pleasantly located on a fertile plain, somewhat elevated above the river. In its W. part the ground rises, affording fine sites for residences. It is regularly laid out with very broad and straight streets, many of which are bordered with very large and lofty elms, presenting a most beautiful appearance. Two spacious public parks are also well shaded by fine trees. It is lighted with gas, and supplied by a company with pure water from a spring $2 \mathrm{~m}$. distant, conveyed through iron pipes. The court-house, which occupies a commanding position in the W. part of the eity, is a large and elegant building of brown freestone, in the Egyptian style of architecture. The railroad depôt is also a splendid structure of freestone. There are 30 churches, of which several are very fine specimens of architecture; and 3 literary associations -1 has a library of 3,000 volumes. The $\mathrm{N}$. Wesleyan Institute is the principal seminary. Newark is very extensivcly engaged in manufactures. The principal articles made are the various fabrics of leather and India rubber, carriages, wagons, railroad cars, machinery, jewelry, paper hangings, cutlery, soap, candles, etc. The extensive paint factory of the N. J. Zine Company daily manufactures ten tons of paint. The commerce of $\mathrm{N}$. is considerable and steadily increasing. The river is navigable to this place for vessels of light draft. A fine passenger steamboat plies twice daily to New York. On June 30th, 1850, the total tonnage of $\mathrm{N}$. district was 6,629 tons, of which 78 tons were registered, and 6,551 tons enrolled and licensed; 1,227 tons were employed in steam navigation; 6,406 tons were in the coasting trade. During the year ending June 30 th, 1850 , there were 11 clearances for foreign countries, having 1,131 tons, $62 \mathrm{men}$; number of entrances from foreign countries (all foreign vessels), was 17 , having 1,601 tons, 95 men. There are 4 banks with $\$ 1,800,000$ capital. Three newspapers are published daily, "Advertiser" (whig), "Mercury" (whig), "Eagle" (dem.); two weekly, "Sentinel of Freedom" (whig), "Eagle" (dem.) The New Jersey R. R. affords constant communication with New York, the trains running each way every half hour. Very many persons doing business in New York have here their permanent residences. The Morris Canal passes through the city. The Morris and Essex R. R. here terminates, connecting with New Jersey R. R. Pop. in 1830, 10,953 ; in $1840,17,290$; in $1850,38,894$.

Newark, p. v., Wayne co., N. Y.: on the Erie Canal, $176 \mathrm{~m}$. W. by N. Albany. Contains several churches, stores, and factories.

NeWARK, t., p. v., and cap. ticking co., Ohio: situate at the confluence of three principal branches of Licking $r$., $38 \mathrm{~m}$. E. by N. Columbus, with which it is connected by the Central Ohio R. R. It is also connected with Sandusky by railroad, and is a station of the Ohio and Erie Canal. Besides a court-house and jail, it contains several churches and academies. Three newspapers are published weekly, "Advocate" (dem.), "Gazette" (whig), "Licking Herald" (dem.)-the Iatter publish semi-weekly editions. Pop of $\mathrm{v}$. 3,778 , of $t .5,006$

NEWARK, p. o., White county, Tenn。: 75 m. E. S. E. Nashville.

Newark, t. and p. o., Caledonia co, Verm. : 45 m. N. E. Montpelier. Drained by head waters of Passumpsic river. Pop. 434.

NEWARK, p. v., Wirt co., Firg.: 232 m. N. W. Richmond.

Newark Vallex, p. v., Tioga county, $N . Y .: 132 \mathrm{~m}$. W. S. W. Albany, on E. Owego cr., in t. of Newark. Pop. of t. 1,983.

New Askford, to and p. o., Berkshire co., Masa.: $112 \mathrm{~m}$. W. by N. Boston. Drained by head branches of Green and Housatonic rivers. Surface mountainous; soil adapted to grazing. Considerable attention is given to raising of sheep. A variegated marble is quarried in this t. Pop. of t. 186 .

New A thens, p. v., Harrison co., Ohio: $104 \mathrm{~m}$. E. by N. Columbus. Pop. 331. Seat of Franklin College, founded 1825. In 1850 it had 4 professors, 90 alumni, 80 students, 2,200 vols. in library.

New Atuens, p. v., Clarion co., Penn.: 145 m. W. N.W Harrisburg.

New Babrlon, p. o., Paulding county, Ga.: 124 miles N. W. by W. Milledgeville.

New Bartimore, t. and p. v., Greene co., N. Y.: W. side Hudson r., $15 \mathrm{~m}$. S. Albany. Surface of t. hilly; soil clay and sandy loam, well drained. The $\mathrm{v}$. has a convenient steamboat landing, and contains some brick-yards. A ship canal from this place to Albany has been chartered by the legislature of 1853 . Pop, of t. 2,381.

New Baltmore, p. v., Stark co., Ohio: 111 m. N. E. Columbus. Drained by a creek of Cuyahoga river.

New Balmarore, p. v. Fauquier county, Firg.: $8 T$ m. N. by W. Richmond.

New Bafaria, p. o., Henry county, Ohio: 108 miles N. W. by N. Columbus.

NEW BeDFord, p. city, port of entry, and semi-cap. Bristol co., Mrass.: on W. bank of Acushnet r., $4 \mathrm{~m}$. from its entrance into Buzzard's bay, $51 \mathrm{~m}$. S. by E. Boston. Lat. N. $41^{\circ} 35^{\prime} 7^{\prime \prime}$; long. W. $70^{\circ} 55^{\prime} 49^{\prime \prime}$. The harbor is spacious, safe, and deep. The site of the city rises rapidly from the 
river, and being thus built upon a bold elevation, regularly laid out, and having many fine buildings, it presents a very commanding and beautiful appearance. The principal public buildings are the town hall, custom-house, courthouse, and some handsome churches. The town hall, built of granite, 100 feet long, 61 feet wide, 3 stories high, at a cost of $\$ 60,000$, is justly regarded as one of the handsomest town halls in New England. The custom-house, also of granite, presents a very fine appearance. Much attention is given to general education in the public schools. The Friends' academy for young ladies is a handsome structure, with beautiful grounds. The Social Library contains over 4,000 volumes. Two newspapers are published daily: "Mercury" (whig) and "Evening Standard;" 3 weekly: "Mercury," "Standard," and "Whaleman's Shipping List;" 1 monthly: "Golden Age" (lit.). The New Bedford and Taunton P. P. runs hence, $31 \mathrm{~m}$. to Mansfield sta., on Boston and Providence R. R. A steamboat plies daily to Nantucket. There are 4 banks (capital $\$ 1,900,000$.) This is one of the wealthiest cities in America in proportion to its population, and has derived its wealth mainly from the whale fishery. At present two-thirds of the total tonnage of $\mathrm{U} . \mathrm{S}$. vessels in the whale fishery belong to this port. The principal business in the city is connected with the whale fisheries, in receiving the oil and bone, and preparing them for market. The quantity of sperm oil brought to the port in 1849 , was 46,333 barrels, whale oil 72,961 barrels, and whalebone $797,300 \mathrm{lbs}$. About 30 manufactories of oil and candles are in constant operation. The cooperage business employs a great number of hands. A very large steam cordage factory (capital $\$ 60,000$ ), manufactures 400 tons of cordage annually. Other large manufactories are devoted to making iron hoops, copper and iron rivets, butt hinges, etc. Here also is a manufactory of Prussian-blue, and some print-works. Ship-building and repairing is carried on cxtensively. The N. B. Railway and Wharf Co. (cap. $\$ 50,000$ ) use a marine railway at their ship-yard, which is of much service in speedily raising small ressels to be repaired. On 30th June, 1850, the total tonnage of New Bedford district was 127,960 tons, of which 119,026 were registered, and 8,934 enrolled and licensed. Of the registered tonnage, 116,852 tons were permanent, 2,144 temporary ; 96,420 tons were in the whale fishery. Of the enrolled and licensed tonnage, 8,444 tons were permanent, 7,949 tons were in the coasting trade, 151 in the cod fishery, 344 in the mackerel fishery, $5 \mathrm{~s}$ tons propelled by steam. The tonnage licensed (under 20 tons) in the coasting trade was 253 tons; in the cod fishery, 232 tons. During the year ending June 30th, 1850, the number of elearances for foreign countries was 11882,027 tons; entrances from do. $131-33,154$ tons. Vessels built, 2 ships and 2 schooners-7S1 tons. Pop. in 1S30, 7,592 ; in $1840,12,087$; in $1850,16,464$.

Netr Bedrord, p. v., Coshocton county, Ohio: $70 \mathrm{~m}$. N. E. by E. Columbus.

New BedFord, p. v., Lawrence county, Penn. : near the Ohio State line, $196 \mathrm{~m}$. W. N. W. Harrisburg.

New Berlis, t. and p. v., Chenango eo., $N$. $Y .:$ on W. side of Unadilla r., $81 \mathrm{~m}$. W. by S. Albany. Surface of $t$. undulating; soil moist clay loam. The $\mathrm{v}$. contains several churches, mills, and factories. Pop. of t. 2,562.

New BerliN, p. v., Stark co, Ohio: 100 m. N. E. by E. Columbus.

New Berlin, t., p. v., and eap. Union co., Penn.: on the N. side of Penn's cr., $43 \mathrm{~m}$. N. by W. Harrisburg. It contains the court-house, jail, several stores and manufactories. Five newspapers are published weekly: the "Evangelical Messenger" (relig.), "Union Democrat" (whig), "Union Times" (dem.), "Good Samaritan" (temp.), and the "Union Star" (whig),

Net Brestr, p. v., Milwaukie co., Wisc. : 70 m. E. by S. Madison.

New Berlat Cextre, p. 0., Chenango co., $N . Y_{.}: 85 \mathrm{~m}$. W. by S. Albany.
Newbers, p. v., port of entry, and cap. Craven county N. Car.: on S. W. bank of Neuse r., at confluence of Trent river, $47 \mathrm{~m}$. above Pamlico Sound, $100 \mathrm{~m}$. E. S. E. Raleigb. Lat. N. $35^{\circ} 20^{\prime}$; long. W. $77^{\circ} 5^{\prime}$. The Neuse is here $1 \frac{1}{2} \mathrm{~m}$. wide, and Trent r. $\frac{8}{4} \mathrm{~m}$., with sufficient depth of water for steamboats, etc. It is a well-built and healthy city, and was formerly eapital of the State; contains a court-house, jail, 2 banks (eapital $\$ 375,000$ ), and 4 churches. It has considerable trade; its chief exports are lumber, naval stores, and agricultural products. On 30 th June, 1850 , the total tonnage of Newbern district was 5,208 tons, of which 1,519 tons were registered, and 3,689 enrolled and licensed. Of registered tonnage 1,077 tons were permanent, and 442 tons temporary. of enrolled and licensed tonnage 3,508 tons were in the coasting trade, 119 tons propelled by steam. Entrances from foreign countries during year previous, $23-2,664$ tons; clearances, $30-3,643$ tons; vessels built, $8-867$ tons. Newbern has considerable inland trade, wholesale and retail. Two newspapers are published weekly: "Newbernian" (whig) and "Republican" (dem.) It is about to be connected with the interior by railroad to Goldsboro', etc. Pop. in $1830,3,776$; in $1840,3,690$; in $1850,4,722$.

New ber, p. v., Greene county, Ala.: $73 \mathrm{~m}$. W. by N. Montgomery.

Newberi, p. จ., Jersey county, $l l l .: 86$ m. S. W. by $\mathbf{8}$. Springfield.

New BERN, p. v., Bartholomew co., Ind.: on S. bank of Clifty cr., $42 \mathrm{~m}$. E. S. E. Indianapolis.

Newbers, p. v., and cap. Pulaski county, Firg.: $178 \mathrm{~m}$. W. S. W. Richmond.

NeWBerRy distriet, S. Car. Situate N. W., and contains 757 sq. m. Drained by affuents of Broad r., whieh flows on its E. border, and by branches of Saluda r., which forms its S. boundary. Surface generally level; soil varied-a large portion is very fertile, and there is excellent pasturage for catile. Staples, cotton, wheat, Indian corn, and potatoes. Farms 1,045 ; manuf. 39 ; dwell. 1,494, and pop.-wh. 7,213, fr. col. 212, sl. 12,685-total 20,143. Capital: Newberry Court-House, Pultic Works: Greenville and Columbia R. R.; Laurens R. R.

Newberry, p. V., Wayne co., Ky. : on W. side Otter cr. of Cumberland r., $96 \mathrm{~m}$. S. Frankfort.

Newberry, p. y., Greene co., Ind.: on E. bank of W. fork of White r., and on line of Wabash and Erie Canal, $72 \mathrm{~m}$. S. E. by S. Indianapolis.

Newberry, p. v., Lycoming co., Penn. : on the $\mathrm{N}$. side of the Susquehanna $r$, and the W. side of Lycoming cr., $65 \mathrm{~m} . \mathrm{N}$. by W. Harrisburg. There is a blast furnace, one forge, and one rolling-mill at this place. With the opening of railroads this $\mathrm{v}$. has good business prospects.

New Lerry, p. v., sta., and cap. Newberry dist., S. Car.: on Greenville and Columbia R. R., $47 \mathrm{~m}$. W. N. W. from Columbia. Contains the court-house, jail, 6 churehes, 2 hotels, 15 stores, 2 academies. The $\mathrm{v}$. is noted for the wealth, refinement, and edueation of its citizens. The "N. Sentinel" (dem.) is published weekly. Pop, 1,250. A mile W. of the v., the Lamrens $\mathrm{R}$. R. diverges from the main track.

Newberrtown, p. v., York co., Penn.: 9 m. S. \$. E. Harrisburg.

New Berres, p. o., Benton co, Ala. : $102 \mathrm{~m}$. N. by E。 Nontgomery.

NEw BeTher, p. v., Marion county, Ind. : 9 miles S. E. Indianapolis.

New Befulemex, p. $\mathrm{v}$, Clarion co., Penn, : on the N. side of Red Bank cr., $141 \mathrm{~m}$. W. N. W. Harrisburg.

NEw Bloommeld, p. V., Callaway county, Mo.: $12 \mathrm{~m}$. N. N. E. Jefferson City.

New Broommetid, p. b., and cap. Perry co., Penn. : $20 \mathrm{~m}$. N. W. by W. Harrisburg. It contains the court-house, jail, several stores, and is surrounded by a thriving agricultural district.

Newbors, p. $\nabla .$, Newton county, Ga.: 45 miles N. W. Milledgeville. 
New Boston, p. v., Lee county, Ia.: $75 \mathrm{~m}$. S. Iowa City; and $7 \mathrm{~m}$. W. Nauvoo, Ill.

New Bostox, p. o., Windham co., Conn. : on the Quinnebaug r., 41 m. E. N. E. Hartford, 72 m. N. E. New Haven; has several fiactories.

New Bostox, p. v., Mercer co., $M .:$ on the N. E. side of Mississippi $r_{\text {. }}, 1 \frac{1}{6} \mathrm{~m}$, above the mouth of Edwards $\mathrm{r}_{\text {. }}, 114 \mathrm{~m}$. N. W. Springfield. The $\mathbf{v}$. has a good landing on the r., and is surrounded by a fertile country.

New Boston, p. V., Berkshire co., MLass.: on the W. side of Farmington r., $106 \mathrm{~m}$. W. by S. Boston.

New Boston, sta., Worcester co., Mass. : on Worcester and Nashua R. R., $18 \mathrm{~m}$. from Worcester.

New Boston, t. and p. 0., Hillsborough co., N. Hamp.: on S. branch of Piscataquog r. $20 \mathrm{~m}$. S. S. W. Coneord. Surface hilly; soil fertile, Contains numerous mills, and 2 churches. Pop. 1,476.

New Braintret, to and p. v., Worcester co., Miass.: $54 \mathrm{~m}$. W. Boston. Drained by numerous brooks, and on the N.W. by Ware $r$. Surface uneven; soil fertile in parts, and particularly adapted to grazing. Pop, of t. 852 .

New Braungels, t., p. v., and eap. Comal co, Tex. $:$ on Gaudaloupe and Comal rivers, at their junction, $45 \mathrm{~m}$. S. S. W. Austin City. This place occupies a very beautiful site, in the most fertile portion of Texas. The inhabitants are mostly Germans. They are mainly Lutherans, but there is also a Catholic chapel.

New Brever, p. v., Auglaize co., Ohio: 80 m. W. N. W. Columbus, on Miami Canal. Pop. 344.

NetV BrEMre, p. 0., Cook county, Ilt.: 154 miles N. E. Springfield.

New Bremev, to and po 0., Lewis co, $N . Y$.: on E. side of Black $r_{n}, 87 \mathrm{~m} . \mathrm{N}$. W. Albany. Drained by Black r. and branches. Pop. 1,510.

NEW BRTDGE, p. o., Lumpkin co., Ga.: on the E. side of Chestatee r., $111 \mathrm{~m}$. N. by W. Milledgeville.

New Bridgeqrile, p. o., York county, Peni.: $32 \mathrm{~m}$. S. Harrisburg.

New Brigrton, p. b., Beaver co., Penn. : on the E. side of Beaver r., $3 \mathrm{~m}$. above its mouth, and $180 \mathrm{~m}$. W. by $\mathrm{N}$. Harrisburg. The Ohio and Pennsylvania R. R. passes through this place, $28 \mathrm{~m}$. from Pittsburg. The $\mathrm{r}$. here affords water-power, and a very considerable manufacturing and local commercial business is done. The $\mathrm{b}$. is regularly laid out, and contains many beautiful residences and substantial business houses. Two bridges span the r., one at either end of the village.

Nrw Brightor, p. v., Richmond co., $N, \quad Y .: 6 \mathrm{~m} . \mathrm{S}$. W. New York, $132 \mathrm{~m}$. S. by W. Albany. This v. is most beautifully situated on Staten Island, and is a favorite resort of the citizens of New York City in the summer months. No place in the vicinity of New York affords more delightful views of the bay and city.

Neiv Britain, t., p. b., and sta., Fartford county, Conn. $27 \mathrm{~m}$. N. by E. New Haven, 9 m. S. S. W. Hartford; station on the Hartford, Providence, and Fishkill R. R. Drained by Mill r. Contains numerous factories, chiefly of brass and hardware. The Condecticut State Normal School, established here in 1\$51, has an annual appropriation of $\$ 2,500$, and employs four instructors. The "New Britain Journal" is published weekly. Pop, of t. 3,028 .

New Britale, p. o., Columbia co., N. Y.: 22 m. S. E. Albany.

New Brenswick, po city, port, and cap. Middlesex co., N. Jer.: on Raritan r., 26 m. N. E. Trenton, $31 \mathrm{~m}$. by New Jersey R. P. from New York, $55 \mathrm{~m}$. from Philadelphia This flourishing city is at the head of navigation on the Paritan, $14 \mathrm{~m}$. from its mouth, and is accessible for vessel drawing eight feet of water. Here terminates the Delaware and Raritan Canal, which connects with these rivers here and at Bordentown. It is $43 \mathrm{~m}$. long, 75 feet wide, and $\tau$ feet deep; admitting the passage of vessels of 100 tons. It has a rise and fall of 116 feet by 14 locks. New Brunswick was incorporated as a city in 1784. It is the dep $t$ of a fertile district, and has considerable trade and manufactures. The oldest portion of the city is built upon the river, on low ground, having narrow and crooked streets, but the rest is built upon a declivity, with regular and broad streets, presenting a handsome appearance, and commanding fine prospects. Many houses are elegantly surrounded by gardens. Upon the highest part of the city is Rutger's College, founded in 1770 . In 1350 it had 7 instructors, 66 students, 513 alnmni, and 10,000 vols in library. In the vieinity is the Theol. Seminary of the Dutch Reformed Church, established in 1784, having 3 professors, 34 students, 179 alumni, and 7,000 vols, in library. The oity contains the court-house and jail, 9 churches, etc. ; 2 banks, cap. $\$ 200,000$, and several large factories. Three newspapers are issued weekly - " $\mathrm{N}$ Jersey Union" (dem.), "N. B. Times" (dem.), "Fredonian" (whig.) The constant communication of New Bruuswick with New York for the last few years has greatly increased its business and population. Pop. in 1880, 7,831; in 1840, 8,663 ; in $1850,13,357$.

NEw BUDA, p. v., Decatur co., I $\alpha_{0}$ : on Crooked fork of Grand r., 133 m. S. W. by W. Iowa City. This is a new Hungarian settlement, planted by the exiles who came over to the United States with Gov. Ujhazy.

New Buffalo, t. and p. v., Berrien co., Mfich.: on Lake Michigan, $125 \mathrm{~m}$. W. S. W. Lansing, at mouth of Galain r. which is here an estuary $3 \mathrm{~m}$. wide, affording a good harbor. The $\mathrm{v}$. was formerly the termination of the Michigan Central R. R., now extended to Chicago.

New Bufralo, p. v., Peiry co., Penn.: on W. side of Susquehanna r., $5 \mathrm{~m}$, above the mouth of Juniata r., $16 \mathrm{~m}$. N. by W. Harrisburg.

Newburg, p. v., Macon county, Mo.: 100 m. N. by W. Jefferson City.

Newburg, p. v., Franklin co., Ala.: 159 m. N. N. W. Montgomery.

NewbURG, p. v., Warrick co., Ind.: on Ohio r., $138 \mathrm{~m}$. S. S. W. Indianapolis. It has a convenient steamboat landing, and contains several stores and warehouses, and a population of about 600 . The "Warrick Democrat" is published weekly.

NewBurg, t. and p. o., Cass county, MFich.: $88 \mathrm{~m} . \mathrm{S} . \mathrm{W}$. Lansing. Pop. 38s.

Newburg, p. o., Washington co., Wisc.: 68 m. E. N. E. Madison.

Newburg, p. v., and cap. Lewis co, Tenn.: 54 m. S. S.W. Nashville.

Newburg, t. and p. o., Penobseot co, Me.: $49 \mathrm{~m}$. N. E. Augusta. Drained by a branch of Sowadabscook r. Soil fertile. Pop. 1,399.

Newburg, t., p. v., and semi-cap. Orange co., $N_{0} Y_{0}:$ on W. bank Hudson r., $84 \mathrm{~m}$. S. by W. Albany, $54 \mathrm{~m}$. N. New

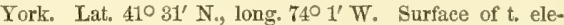
vated, somewhat broken, and hilly. Drained by the Hudson and small creeks. Soil clay and gravelly loam, fertile, but best adapted to grazing. This vicinity, with the rest of Orange co., is celebrated for its superior dairy products and excellent live-stock. The $\mathrm{v}$. is handsomely situated on an acclivity rising from the shore to an elevation of 300 feet, where is afforded a most delightful and extensive prospect of the river, which here widens into Newburg Bay, fertile and beautiful valleys, the Highlands, and the villages of West Point and Fishkill. This v. was settled in 1701 by Germans, and incorporated in 1800. General Washington had here his head-quarters during the winter of $1752-3$, at which period the celebrated Newburg letters were written. The old stone-house in which he resided is still standing in good preservation. On $28 \mathrm{~d}$ June, 17\&8, the troops here stationed were disbanded. The v, contains a court-house and jail, numerous churches, seminaries, etc. The Theological Seminary of Assoc. Ref. Church, established in 1836, has 1 professor, 11 students, 143 alumni, 3,200 vols. in library. There are large factories of carriages, machinery, chairs, 
cordage, plaster, flour, candles, etc., iron foundries, breweries, tanneries, stone and lumber yards, etc.; 4 banks have a capital of $\$ 700,000$. A steam ferry connects the $\nabla$. with Fishkill and Hudson River R. R. The Newburg branch R. R. connects with Erie R. R. at Chester junction, $19 \mathrm{~m}$. The immense quantities of agricultural products, etc., of the vicinity and interior, which are here received for the New York markets, with the other commerce of the v., constantly employ many freight barges, sloops, and steamboats. Four newspapers are issued weekly, "N. Gazette" (whig), "Telegraph" (dem.), "Excelsior" (dem.), "Highland Courier" (dem.) Pop. in 1830, 6,424; in 1840, 8,933; in 1850, 11,415.

New Burg, t., p. v., and sta., Cuyahoga co., Ohio: $123 \mathrm{~m}$. N. E. by N. Columbus, $8 \mathrm{~m}$. S. E. Clereland, on Cleveland and Pittsburg R. R. Soil of to fertile. Drained by Mill cr., upon which the $\mathrm{v}$. is situated, at a fall in the stream, affording extensive water-power. Pop. of t. 1,542.

Newberg, p. o., Cumberland co., Penn.: on N. side of Conedogwinit cr, $37 \mathrm{~m}$. W. by S. Harrisburg.

New Burlington, p. o., Delaware co., Ind.: on Prairie cr., 47 m. E. N. E. Indianapolis.

New Burlitgtor, p. 0., Clinton co., Ohio: $54 \mathrm{~m}$. S. W. Columbus.

Newbtry, t. and p. o., Merrimac co., N. Hamp.: $24 \mathrm{~m}$. W. N. W. Concord, It is bordered on the N. W. by Sunapee lake. Drained by a branch of Warner r.; has two churches. Pop. 735 .

Newbury, t. and p. o., Geauga co., Ohio: 121 m. N. E. Columbus. Surface of t. diversified; soil fertile; timber abundant. Drained by the heads of Chagrin and Cuyahoga rivers. Pop. 1,253.

Newterry, t., p. ₹., and sta., Orange eo., Verm.: on Connecticut r., 27 m. E. S. E. Montpelier. Wells' r., in the N. part of t., affords good water-power. The Connecticut and Passumsic R. R. passes through the t. The Newbury Seminury is a flourishing Methodist academy, and has six teachers. The "Aurora of the Valley" (lit.) is published weekly. Pop. 2,954.

NewBtryport, p. city, port of entry, and one of the caps. Essex co., Dfass.: on the $\mathrm{S}$. bank of Merrimac r., $4 \mathrm{~m}$. from the ocean, $34 \mathrm{~m}$. N. N. E. Boston. Lat. $42 \circ 4 \mathrm{~S}^{\prime} 32^{\prime \prime}$ N., long. $70^{\circ} 52^{\prime} 47^{\prime \prime} \mathrm{W}$. The harbor is safe and spacious, and protected by a break-water, but its entrance is obstructed by a sand-bar. The city is beantifully situated on a gentle acclivity, and very regularly laid out, with wide streets, those parallel with the river rising like terraces. This place has suffered severely by fires, commercial losses, and otherwise, but for the last few years it has been steadily increasing in wealth and importance. A. U. S. naval officer is stationed here. It is still largely engaged in the mackerel and cod fisherics, coasting trade, and foreign commerce. Five large cotton manufacturing companies have a capital of $\$ 1,150,000$. Ship-building is extensively carried on. There are 3 banks; capital $\$ 570,000$. The principal buildings are, customhouse, of rough granite, with fine wrought Doric portico court-house, of brick; stone jail, 10 churches, a fine academy, Iyceum, ete, Much attention is given to education. The Putnam High School is endowed with $\$ 70,000$. Another institution, chiefly for classical studies, has a large fund, giren by Mr. Moses Brown. Rev. George Whitefield, the celebrated divine, died in this town, Sept. 21, 1770; his tomb and monument are in the First Presbyterian Church. The Eastern R R. passes through the city, $34 \mathrm{~m}$, from Boston. The Newburyport R. R. branches off to Bradford, connecting with the Boston and Maine R. R. Two daily papers are issued, "Herald" (whig), "Union" (dem.); 1 semi-weekly, "N. Herald" (whig). On 30th June, 1850, the total tonnage of N. district was 23,262 tons, of which 16,214 tons were registered, and 7,048 tons enrolled and licensed. Of registered tomnage, 14,018 were permanent, and 2,196 temporary. Of the enrolled and licensed tonnage, 7,045 were permanent, 494 tons were employed in the coasting trade, 3,739 tons were in the cod fishery, and 2,515 tons in the mackerel 532 fishery. During the year previous the number of clearances for foreign ports was $140-9,703$ tons; number of entrances 12S-8,605 tons. Vessels built, 10 ( 8 ships, 2 schooners), 4,657 tons. Pop. in $1830,6,375$; in $1840,7,161$; in 1850 , 9,572 .

Newbr's Bridge, p. o., Perquimans co., N. Car. : $130 \mathrm{~m}$. N. E. Raleigh.

New Carfforma, p. T., Grant co., Wise. : 60 m. W. S.W Madison.

New Calffornia, p. o., Union co, Ohio: 30 m. N. W. Columbus.

New CanaAN, t. and p. v., Fairfield co, Conn. : $82 \mathrm{~m}$. W. S. W. New Haven, $61 \mathrm{~m}$. S. W. Hartford. Surface of t. uneven; soil gravelly loam, well watered by several streams from Long Island Sound. Contains a number of mills and has some manufactures. The $\mathrm{v}$. is on high ground, and contains 3 churches and an academy. Pop. of t, 2,601.

New Canaxdaigua, p. o., Oakland co., Mfich.: $65 \mathrm{~m}$. E. by S. Lansing.

New Cantos, p. Y., Hawkins co., Tenn. : $225 \mathrm{~m} . \mathrm{E}$. by N. Nashville.

New Cantor, p. Y., Buckingham county, Forg.: on S. side State er., a quarter of a mile from James $\mathbf{r}$., $45 \mathrm{~m}$ W. N. W. Richmond. Four miles W. are the extensive Virginia flour-maills.

New Carlisle, p. v., St. Joseph county, Ind.: 183 m. N. by W. Indianapolis.

New Carilste, p. v., Clark co., Ohio: $54 \mathrm{~m}$. W. by $\mathrm{S}$. Columbus. Pop. 634.

New CARthage, p. v., Madison par., La. : N. side of a bend of Mississippi r., $120 \mathrm{~m}$. N. Baton Rouge.

New CAstue county, Del. Situate N., and contains 923 sq. m. Drained by Christiana, St. George's, Brandywine, Red Clay, Naman's, Blackbird, and Duck creeks. Surface varied-in the N. and W. being hilly, in the $\mathbf{E}$. low and marshy and unfit for tillage; soil, where capable of cultivation, is fertile. Staples, wheat, Indian corn, and potatoes; and in this county are the principal manufacturing establishments of the State. Farms 1,662 ; manuf. $2 S 1$; dwell. 7,098, and pop.-wh. 34,822, fr. col. 7,568, sl. 394 total 42,784. Capital: New Castle. Public Works: Philadelphia, Wilmington, and Baltimore R. R.; New Castle and Frenchtown R. R.; New Castle and Wilmington R. R. Chesapeake and Delaware Canal, etc.

New Castle, hund., p. v., port of entry, and eap. New Castle co., Del. : on W. bank of Delaware r., $31 \mathrm{~m}$. N. Dover, $5 \mathrm{~m}$. S. Wilmington. Lat, $39040^{\prime} \mathrm{N}$., long. $75 \circ 33^{\prime} \mathrm{W}$. The hund. is bounded on the N. and W. by Christiana cr. Surface moderately hilly; soil fertile. The $\mathrm{v}$. is an old town, and once the capital of the State. Its harbor is well protected by long piers. Railroads to Wilmington and Frenchtown afford direct connection with Philadelphia and Baltimore. It contains the court-house, jail, town-house, arsenal, market-house, 1 bank-capital $\$ 133,000$; 5 churches, and public library of 4,000 vols. Here is a large manufactory of steam-engines, locomotives, etc. The total tonnage of $\mathrm{New}$ Castle district on the 30th June, 1850, was 7,259 tons enrolled and licensed, of which 7,124 tons were permanently employed in the coasting trade, 135 tons were licensed under 20 tons ; 1,345 tons were propelled by steam. Pop. 3,500 .

New Castue, p. o., Gentry county, Mo.: 162 m. N. W. Jefferson City.

NEW CAstue, p. v., sta, and cap. Henry county, Ind.: on E. side Blue r., $40 \mathrm{~m}$. E. by N. Indianapolis. The New Castle and Richmond R. R. passes through the village. It contains a court-house and jail, sereral good schools, and numerous stores.

New CASTLE, to and p. Y., Lincoln co., Me.: 24 m. S. S. E. Augusta, between Damariscotta and Sheepscot rivers. The Damariscotta $\mathbf{r}$. is navigable for large ressels to the $\mathbf{v}, 15 \mathrm{~m}$. from the ocean. There are numerous mills of different kinds in the $v$. and $t$. The "Lincoln Democrat" is published weekly. Pup. 2.012. 
New Castle, p. o., Logan co., $I l l .:$ on the N. side of Kiekapoo cr., 37 m. N. E. by N. Springfield.

NEW Castie, t., p. v., and sta., Westchester co., $N$. $X_{\text {.: }}$. $102 \mathrm{~m}$. S. Albany. Surface of t. hilly; soil gravelly and sandy loam. The Harlem R. R. passes through the $t_{. g} 40 \mathrm{~m}$. from New York. Pop. 1,800.

NEW CAsTLE, t. and p. vo, Coshocton co., Ohio: $48 \mathrm{~m}$. E. N. E. Columbus. Drained by Walhonding river and branches. Pop, 1,227.

NeW CaStle, p. V., Wilkes co., N. Car.: 188 m. W. N. W. Raleigh.

New Castue, p. b., and exp. Lawrence co., Penn.: at the junction of the shenango and Neshannock creeks, $187 \mathrm{~m}$. W. by N. Harrisburg. The Beaver and Erie Canal passes through the $\mathbf{v}$. Iron ore deposits are found in the vicinity; 2 rolling-mills, 1 blast-furnace, several manufactories, and a number of stores, make this a place of considerable business importance. There are two newspapers issued weekly - the "N. C. Gazette" (whig), and "Lawrence Journal" (dem.)

New Castle, p. v., Hardeman county, Tenn. : $147 \mathrm{~m}$. W. S. W. Nashville.

New Castle, t. and p. o., Rockingham co., N. Hamp. $43 \mathrm{~m}$. E. S. E. Concord. Consists of an island in Portsmonth harbor, connected with Portsmouth by a bridge. Here are Fort Constitution and the light-house; also 1 church. The island is much resorted to from Portsmouth, for the purpose of fishing. Pop. 891.

New Castle, p. v., Botetourt co., Virg. : on Craig's cr., $145 \mathrm{~m}$. W. Richmond.

New Caftle C. H., p. v., and cap. Henry co., Ky.: $21 \mathrm{~m}$. N. W. Frankfort.

Nen Cextretilie, p. v., Jennings co., Ind.: on S. side Vernon Fork r., 68 m. S. S. E. Indianapolis.

New Chasmersborg, p. v., Columbiana co., Ohio: $114 \mathrm{~m}$. N. E. by E. Columbus.

New Chester, p. o., Adams co., Penn.: on Conewago cr., $26 \mathrm{~m}$. S. S. W. Harrisburg.

New Church, p. 0., Accomac county, Virg.: $101 \mathrm{~m}$ E. by N. Richmond.

New Coldurbia, p. ., Union co., Penn.: on W. side of W. branch of Susquehanna r, $53 \mathrm{~m}$. N. Harrisburg.

New Columbia, p. v., Newton co., Tex.: on W. side of Saline r, $258 \mathrm{~m}$. E. by N. Austin City; has a good landing for steamboats.

New Coldurbus, p. o., Luzerne co., Penn.: 68 m. N.N.E. Harrisburg.

New Comerstown, p. v., Tuscarawas co., Ohio: on W. bank Tuscarawas r., and on the Ohio and Erie Canal, $75 \mathrm{~m}$.

E. N. E. Columbus, Pop, 476 .

New Concord, p. Y., Callaway co., $K y_{*}: 213$ m. S. W. Frankfort.

New CoNCord, p. v., Muskingum county, Ohio: $65 \mathrm{~m}$. E. by N. Columbus. Has an academy, several churches, and mills. Pop. 334 .

New CorwL, p. o., Highland co., Ohio: $60 \mathrm{~m}$. S. W. by S. Columbus.

New Corydon, p. v., Jay co., Ind.: on S. side of Wabash r., $85 \mathrm{~m}$. N. E. Indianapolis.

New Cumbertand, p. b., Cumberland co., Penn.: on W. side of Susquehanna $r$, at the confluence of the Yellow Breeches cr., $3 \mathrm{~m}$. 8. Harrisburg. The York and Curaberland $\mathrm{R}$. R. passes through the $\mathrm{b}$., to connect with the Cumberland Valley and other lines. Here are several stores, and some manufacturing is done.

New Cumberland, p. 0., Brooke county, Virg.: $254 \mathrm{~m}$.

W. N. W. Richmond.

NEW Derry, p. v., Westmoreland co., Penn. : $124 \mathrm{~m}$. W.

Harrisburg. The Pennsylvania $R, R$. passes through town of Derr, $49 \mathrm{~m}$. from Pittsburg.

Now Drgens, t. and p. v., Lafayette co., Wisc. : on Ferer r., $63 \mathrm{~m}$. S. W. Madison. Pop. 1,742.

New Dermak, p. v., La Porte county, Ind.: $125 \mathrm{~m}$. N. X. E. by N. Indianapoiis.
NEW Durhax, t., p. o, and sta., Strafford co, N. Hamp. 22 m. N. E. Concord, on Cocheco R. R., 22 m. from Dover. Surface very uneven; soil moist, and adapted to grazing Pop. 1,048.

New Durham, p. v., Hudson co., N. Jer.: $55 \mathrm{~m} . \mathrm{N}$. E Trenton.

New Egrpt, p. v., Ocean co., N. Jer. : 15 m. S. E. by E. 'Trenton, on Crosswick's cr., upon which are numerous and valuable mills.

Newelr, p. o., Anderson dist., S. Car.: $95 \mathrm{~m} . \mathrm{N} . \mathrm{W}$. Columbia.

New England Fillage, p. v., Worcester co., MLas8.: $38 \mathrm{~m}$. W. Boston, $7 \mathrm{~m}$. S. E. Worcester, $1 \mathrm{~m}$. from Boston and Worcester R. R., on Quinsigamond cr., the outlet of Long Pond. This stream in its descent falls 50 feet, affordding great water-power. This is a very flourishing and growing village.

New Fatrfield, t. and p. o, Fairfield co., Conn。: $48 \mathrm{~m}$ W. S. W. Hartford, 32 m. W. N. W. New Haven, Surface of t. rough and hilly; soil gravelly. Drained by Rock r. Pop. 927.

Newfane, t. and p. o., Niagara county, N. Y.: $262 \mathrm{~m}$. W. by N. Albany. Drained by Eighteen-Mile er. Surface inclined toward the lake; soil sandy loam. Pop. 3,255.

NEWFIELD, t. and p. o., York county, Me. $76 \mathrm{~m}$. \$. W Augusta. Drained by Little Ossipee $r$., on which there are some mills. Pop. 1,418

NewFIELd, t. and p. v., Tompkin's co., N. Y.: $148 \mathrm{~m}$. W. by S. Albany. Surface of t. broken and hilly; soil gravelly loam and very fertile; is well drained.

New Florexce, sta., Westmoreland co., Pa. : on S. side Conemaugh r., $114 \mathrm{~W}$. by $\mathrm{N}$. Harrisburg, on Pennsylvania R. R, $70 \mathrm{~m}$. from Pittsburg.

Newfound, lake and river, Grafton co., $N$. $H$. The lake is six $\mathrm{m}$. long, 2 to $3 \mathrm{~m}$. wide; its outlet, or the river, is a considerable stream, flowing into Pemigewassett $r$.

Newfoundland, p. O., Morris co., N. Jer, : on S. bank of Pequannock $\mathrm{r}_{*}, 53 \mathrm{~m} . \mathrm{N}$. N. E. Trenton.

New Frangfort, p. o., Scott co., Ind. : on N. side of Sucker's Fork, 75 m. S. S. E. Indianapolis.

New FrankliN, p. v., Stark co., Ohio: 111 m. N. E. by E Columbus.

New FrankuIN, p. 0., Wayne co., $n l_{\text {. }}$ 113 m. S. E. by S Springfield.

New Freedous, p. o., York county, Penn.: $25 \mathrm{~m}$. S. Harrisburg.

NeW GARDEN, p. o., Wayne co, Ind.: 65 m. E. Indianapolis.

New GARDen, p. o., Russell co., Firg. :261 m. W by $\mathrm{S}$ Richmond.

NEW GARDEN, p. v., Guilford co., N. Car. : $78 \mathrm{~m}$. W. N.W. Raleigh.

New GARDEN, p. v., Columbiana county, Ohio: $118 \mathrm{~m}$. E. N. E. Columbus.

New Garden, to and p. o., Chester co, Penn.: $68 \mathrm{~m}$. E. S. E. Harrisburg. Surface level; soil calcareous loam. Drained by Red Clay and White Clay ereeks.

NeW GAscosy, p. v., Jefferson co., Ark.: on N. bank of Arkansas r., 42 m. E. S. E. Little Rock.

New Genev s, p. v., Fayette co., Penn.: on E. side of Monongahela r. above the confluence of George cr., $160 \mathrm{~m}$ W. by S. Harrisburg.

New Germantown, p. v., Hunterdon county, N. Jer.: W. of Lamington r., $32 \mathrm{~m}$. N. Trenton. Contains several churches and stores and an academy.

New Germantown, p. vo, Perry eo, Penno: $36 \mathrm{~m}$. W. Harrisburg.

Ney Gilead, p. y., Moore co., N. Car.: 60 m. S. W. Raleigh.

New Grarts, p. o., Green co., Wisc. : on fork of Sugar r. $25 \mathrm{~m}$. S. S. W. Madison.

NeW Glabgow, p. v., Amherst eo., Virg.: $87 \mathrm{~m}$. W. Richmond, 
New GLotcester, t, p. o, and sta., Cumberland co., Me.: $86 \mathrm{~m}$. S. W. Augusta. Drained by Royal's r., which affords water-power to mills of various kinds. The Atlantic and St. Lawrence R. R. passes through this $t ., 22 \mathrm{~m}$. from Portland. Pop, 1,845.

NEW Gosmen, p. o., Vigo county, Ind.: 70 m. W. S. W. Indianapolis.

New Gotinngen, p. v., Guernsey co, Otio: $65 \mathrm{~m}$. E. Columbus. Pop. 54.

New Grambinberg, p. o., Herkimer co., $N . Y .: 70 \mathrm{~m}$. W. N. W. Albany.

New Gren $\triangle$ da, p. o., Fulton co., Penn.: 70 m. W. S. W. Harrisburg.

\section{THE STATE OF NEW HAMPSHIRE.}

NEw HAMrPSHRE is situated between $422^{\circ} 41^{\prime}$ and $45^{\circ} 11^{\prime}$ latitudes north, and between $70^{\circ} 40^{\prime}$ and $72 \circ 2 S^{\prime}$ longitudes, west from Greenwich, or between $4^{\circ} 34^{\prime}$ and $6 \circ 22^{\prime}$ east from Washington. It is bounded on the north by Lower Canada, on the east by the State of Maine and the Atlantic Ocean, on the south by the State of Massachusetts, and on the east by that of Vermont, from which it is separated by the Connecticut River. From north to south its length is 168 miles, and its width, from east to west, from 90 to 20 miles, its form tapering toward the north. It contains an area of 9,280 square miles.

New Hampshire has a sea-coast of but 15 miles in length. The shore is little otherwise than a sandy beach, bordered in front by salt marshes, and indented by creeks and coves, which form, however, eligible harbors for small craft. Behind there is a narrow, level, or gently undulating tract of 25 or 30 miles in width, and beyond this zone the general surface becomes mountainous, principally in the north, the hills increasing in height as they recede from the sea, until they swell to the lofty grandeur of the White Mountains. This range, which may be considered as a continuation of the Alleghanies, enters New Hampshire between the Connecticut and Merrimac rivers, and of which the Grand Monadnock, 3,251 feet in height, Sunapee, $4,636 \mathrm{feet}$, and Monsheloc, 4,636 feet, appear to be links, reaches its greatest elevation in Mount Washington, the summit of which is 6,428 feet above the level of the sea, and the highest cnlmination east of the Rocky Mountains. The other principal peaks in this range, for as such it may be described, although it is not always continuous, are: Mount Adams, 5,960 feet; Mount Jefferson, 5,860 feet; Mount Madison, 5,620 feet, Mount Monroe, 5,510 feet; Mount Franklin, 5,050 feet, and others little inferior in elevation, and the Kearsarge Mountains rise to the height of 2,480 feet. These mountains are composed of huge rocks of granite and gneiss, and round their bases are forests of heavy timber, which is succeeded by a belt of stunted fir trees, from 10 to 1 f feet high, above this a growth of thick bushes, and farther up the surface is covered with a dark pall of mosses and lichens. The snow lies on their summits for nine or ten months of the year, giving them the appearance from which they take their name. The "Notch" is a remarkable chasm two miles in length, and where narrowest it is only 22 feet wide. It is the only pass through the great mountain barrier. Throtigh the high, steep precipices, which form its walls, flows one of the head branches of the Saco River, and in its course receiving the waters of several cascades which leap down the declivities. This stream, after a heavy fall of rain, becomes fearfully swollen, and frequently at such times sweeps away all opposing obstacles, and fills the valley with ruin. In 1836 , a violent rain storm caused a slide of earth, rocks, and trees, which choked up the streams, and flooding the country, spread desolation far and wide, and in the general confusion a family of eleven persons, residing at the Notch House, were overwhelmed.

The general slope of the State is from north to south, and in that direction the principal rivers flow, following the courses of the local valleys. The slope toward the Connecticut valley is short and precipitous, and in this direction the only gtreams of consequence are the Ammonoosuc and Ashuelot. The Androscoggin passes through the north-eastern part of the State, but this is properly a river of Maine. The Piscataqua, the only considerable river that has its whole course within the State, is formed by the junction of Salmon Falls and Cocheco rivers from the north, and several smaller streams from the west, and it is oaly from this junction to the sea, a distance of ten miles, that it bears the name of Piseataqua. At its mouth is the harbor of Portsmouth, one of the finest in the United States. The Merrimac rises in the White Mountains, not far distant from the sourees of the Saco, and running south through the centre of the State, passes into Massachusetts, where it turns and runs in a north-easterly direction, and falls into the Atlantic. The principal tributaries of the Merrimac are from the west, the Nashua, which, anter bending beyond the State line, again enters New Hampshire, and empties itself in the town of Nashua; the Contoocook, which empties itself at Concord, and Baker's River, which rises in Moosheloc Mountain, and empties itself at Plymouth; and from the east the principal tributaries are Winnipiseogee River, the ontlet of the lake of the same name, and Squam River, which is the outlet of Squam Lake. Noue of the rivers of New Hampshire, however, are much used for navigation, but afford the best of mill-sites.

It is estimated that 110,000 acres of the surface of this State are covered with water. Lake Winnipiseogee (Win-ne-pesok-ee, Indian) is the most extensive sheet of water within its limits. It is 23 miles in length, and from 2 to 10 in breadth. Upward of 360 islands are sprinkled over its bosom, and its shores are indented by numerous bays formed by gentle owells of land projecting into the lake and rising gracefully from its waters. It abounds in fish, and its waters are remarkably pure. Being on the route to the White Mountains, it is much visited by travelers, and a steamboat is employed on the lake during the summer season. Lake Umbagog, on the eastern State line, and others in the south and west, are smaller, but all have attractive scenery, and are the recipients and outlets of several streams.

Off the cnast are the Isles of Shoals, seven in number, which belong partly to Maine and partly to New Hampshire (see MaIve). They lie about eight miles out to sea, between Portsmouth and Newburyport, and are hardly more than a cluster of rocks rising above the water. For more than a century before the Revolution they were quite populous, containing at one time 600 inhabitants, who found there an advantageous situation for carrying on the fisheries. To this day the best cod are those known under the name of Isles of Shoals sun-fish. From 3,000 to 4,000 quintals were once annually taken and cured here, but the business has of late years declined.

New Hampshire has been called the "Switzer]and of America." Its scenery is full of grandeur and wild magnificence. 534 


\section{NEW HAMPSHIRE.}

From the lofty summits of its rugged mountains the eye surveys one of the wildest, and at the same time enchanting, countries of the world, and is never drowsed by monotony. Rocks piled on rocks, clothed in gigantic forest growths and shrubs, placid lakes embosoming countless verdant islets; pleasant valleys and farm lands in the highest state of cultivation, successively greet the eye, while the foaming cataract and leaping cascade, now rushing down the slopes and dashing to the vales, and now reposing into the gently gliding streams, and anon swelling into rivers, coursing like molten silver through the plains, and winding their way to the sea, enchant the senses and cheat the mind of its cares, From Mount Washington the prospeot is noble and extensive, only bounded on the one hand by the dim distance of the ocean, and on the other by the blue horizon resting on the green base of the land. From Monadnock and Moosheloc, and many of the other higher elevations, the scenery is not less alluring. Nor is that of the lakes inferior. Surrounded by forest-clad hills, these beautiful basins interspersed with islets, and reflecting from their glassy bosoms the bright blue sky, and the neighboring slopes, are truly a feature of loveliness, and well might the Indian, eharmed by the beauties of the scenery around Winnipiseogee, call it "The smile of the Great Spirit." Umbagog, Sunapee, and others, have their charms; they are smaller, indeed, but all are highly picturesque, and abound with the most lovely scenery.

The mineral resources of New Hampshire are by no means insignificant. The recent geological survey by Dr. Charles F. Jackson, one of the most scientific geologists of New England, has resulted in many highly valuable discoveries. His cxaminations have brought to light the existence of several beds of iron, and a valuable one of limestone, not hitherto known, which will prove sources of great wealth to the State. Iron exists in almost every county. The ore beds tbat have been chiefly worked are at Franconia and Lisbon, in the northerly part of the State, and these are considered as among the richest in the United States, the ores yielding from 60 to 70 per cent. of metal, Ores of copper are found also at Franconia, Warren, Eaton, and other places, which want only a judicious investment of capital and labor to develop their treasures. The zine ore mines of Warren are described as abounding and rich, and a very rich mine of tin ore has been discovered in the town of Jackson, near the foot of the White Mountains, which promises to yield from 40 to 60 per cent. in pure worked metal. This is the first valuable tin mine that has been discovered in the United States. In the town of Eaton there are also extensive deposits of ores of zine and lead, mixed in some of the shale with veins of silver, the amount of which is sufficiently great to allow of its being profitably separated.

There is no State which possesses greater quantities of granite, suited to the purposes of architecture, than New Hampshire. At various points on the very margins, or near the banks of the Merrimac and Connecticut, are found immense and apparently exhaustless ranges of this stone. It is of the best texture and color, and capable of yielding blocks of any required size. Marble is also abundant, as also most of the rocks attributed to the primary era.

The soils of New Hampshire are generally of a stubborn nature, and not of the most fertile description. They require considerable labor to make them moderately productive; those of the intervals are the most profitable, and are moderately rich. All, however, yield well to the industry applied to them, and under proper management, the natural ruggedness of the country has been converted into a garden-like scene. The climate is somewhat colder than that of Maine, and more steady; the difference of elevation, however, decides the prevailing temperature, and in some cases the difference between that of the base and summit of the mountains is from 180 to $25 \%$. The temperature of the summer is great, and sometimes rises to $100^{\circ} \mathrm{Fahr}$. In the winter season it has been known to sink so low as to freeze the mercury in the tube. These extremes, however, seldom oecur, and are of short duration. In the neighborhood of the White Mountains, the peaks of which are almost always capped in snow, the winters are excossively cold. No part of the State, however, is wnhealthy, but on the contrary, many instances of longevity are recorded, and it is no unusual thing to find persons enjoying good health at the patriarchal age of 100 years and upward. William Perkins, of New Market, died in 1732 , at 116 ; William Scory, of Londonderry, in 1754, at 110; Robert Metlin, in 1785, at 115; Samuel Welch, of Bow, in 1823, at 113; and more recent instances are not wanting. In 1840 there were living in the State 10 persons of 100 years of age and upward, and in 1550,13 persons. The cold weather sets in about the middle of September, and continues till May; the severity of winter, however, does not commence before November, from which time to the opening of the spring season, the country is clothed in a thick mantle of snow, and the rivers are frozen to their sources.

The natural growths of the country are various kinds of useful timber, as oak, pine, hemlock, ash, beech, and birch; and these in former times constituted the chief merchantable products of the region, and when formed into masts, staves, plauls, boards, ete., were largely exported. The sugar-maple is also abundant, and the piteh-yielding pine. Wolves, bears, and other fur-bearing animals are still found in the State, and although a bounty has long been paid by the government for their destruetion, the farmers continue to complain of their visits. The rivers and lakes are well stored with fish, and wild fowl and game are plentiful in all parts.

New Hampshire is divided into 10 counties and 243 townships, the general statistics of the counties and the capitals of each, in 1850, were as follows:

\begin{tabular}{|c|c|c|c|}
\hline Counties. & Dwell. & $\begin{array}{l}\text { Farms Manuf, } \\
\text { in cult. Estab. }\end{array}$ & Capitals, \\
\hline Belknap & $\ldots 3,436 \ldots 17,721$ & $.2,438 \ldots 163$. & . Gilford \\
\hline arroll . & $. .3,724 \ldots 20,156$ & $.2,805 \ldots 135 \ldots$ & Ossipee \\
\hline heshire. & $. .5,302 \ldots . .30,1$ & $\ldots 2,805 \ldots 377 \ldots$ & Keene \\
\hline ons & $4 \ldots 1$ & $. .1,439 \ldots 69$. & caster \\
\hline
\end{tabular}

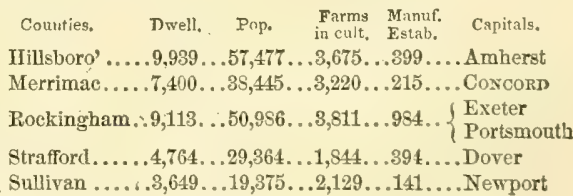

The whole number of dwellings in the State was, at the above date, 57,389 , of families 62,297 , and of inhabitants 317,861 , viz., whites 317,389-males 155,902, and females 161,4s7; free colored 475-males 143, and females $232 . \quad$ Of the whole population, there were deaf and dumb-wh. 163, fr, col. 0-total 163; blind-wh. 134, fr. col. 2-total 136; insane-wh. 35. fr. ecr. 0-total 8S5; and idiotic-wh. 34s, fr. col.1-total 352. The number of free persons born in the Tnited States, was 304,227 ; the number of foreign birth, 12,571; and of birth unknown, 178 . The native population originated as follows: Maine 9,635, New Hampshire 261,591, Verm. 11,256, Mass. 18,495, R. I. 364, Conn. 1,105, N. York 1,17, N. Jer. 49. Penn. 145, Del. 10, Md. 34, Dist. of Col. 14, Virg. 45, N. Car. 10, S. Car. 21, Ga. 16, Flor. 1, Ala. 13, Miss. 9, La. 9, Tex. 2, Ark. 8, Tenn. 3, Ky. 11, Ohio 66, Mich. 48, Ind. 20, Ill. 31, Mo. 12, Ia. 4, Wis. 10, Calif. 1, Territories 2 ; and the foreign population was composed of persons from-England 1,469, Ireland 8,811, Scotland 467, Wales 11, Germany 147, France 69, Spain 8, Belgium 0, Holland 1, Italy 0, Austria 1, Switzerland 9, Denmark 8, Norway 2, Sweden 12, Prussia 2, Asia 4, Africa 3, British America 2,501, Mexico 5, Central America 0, South America 31, West Indies 17, Sandwich Islands 3 , and other countries 7 . 


\section{NEW HAMPSHIRE.}

The following table will show the decennial progress of the population since the first census of the State, taken by the United States authorities:

\begin{tabular}{|c|c|c|c|c|c|c|c|}
\hline \multirow{3}{*}{$\begin{array}{c}\text { Census } \\
\text { Years. } \\
1790 .\end{array}$} & \multirow{2}{*}{$\begin{array}{l}\text { White } \\
\text { Persons, }\end{array}$} & \multicolumn{3}{|c|}{ Colored Persons. } & & \multicolumn{2}{|c|}{ Decennial Increase. } \\
\hline & & Free. & Slave. & Total. & Population. & Numerical. & Percent. \\
\hline & 141,111 & 630 & 158 & $7 S S$ & . 141,899 . & . $\quad-$. & . - \\
\hline 1500 . & 182,878 & .856 & $\ldots \ldots$ & ... $86 t$ & .. 183,762 & . 41,863. & . . 29.5 \\
\hline 1510. & .. 213,390 & . . 970 & $\ldots-$ & .. 970 & 214,360 & 30,598 & $\ldots 16.6$ \\
\hline 1820. & .. 243,236 & .. 925 & $\ldots-$ & 925 & . 244,161 & 29,801 . & $\ldots 13.9$ \\
\hline 1530 & $\ldots 265,721$ & 604 & 3 & .. 607 & . 269,328 & 25,167 & $\ldots 10.3$ \\
\hline 1840 & ...... 284,036 & $\ldots \ldots 587$ & $\ldots \ldots$ & $\ldots 538$ & 284,574 & 15,246 & .. 5.6 \\
\hline 1850. & ....... 317,389 & .475 & .... - & ... 475 & . 317,864 & 33,290 & $\ldots 11.16$ \\
\hline
\end{tabular}

The statistics of the wealth, productions, manufactures, and institutions of New Hampshire, as ascertained by the census of the State, taken in 1850, and other official reports referring to the same year, are as follows:

Occupied Lands, etc.--Improved lands, 2,251,488 acres; and unimproved lands, 1,140,926 acres-valued in eash at $\$ 55,245,997$. Whole humber of farms under cultivation, 29,229 . Value of farming implements and machinery, $\$ 2,314,125$.

Live-Stock.-Horses, 34,238; asses and mules, 19; milch cows, 94,277; working oxen, 59,027; other cattle, 114,606; sheep, 381,756 ; swine, 63,487 -valued in the aggregate at $\$ 8,871,901$. The returns of 1840 exhibited the live-stoek as follows: Horses, mules, etc., 43,892 ; neat cattle of all descriptions, 275,562 ; sheep, 617,390 ; and swine, $121,671$.

Products of Animals.-Wool, 1,361,034 (in 1840, 1,260,517) pounds; butter, 6,977,056 pounds; cheese, 3,196,563 pounds; and the value of animals slaughtered in the year, $\$ 1,522,878$. Silk cocoons were produced to the amount of 4,191 (in $1840,4198)$ pounds, being two-sevenths the whole product of the United States; and beeswax and honey to the amount of 117,140 pounds.

Grain Crops.-Wheat, 185,653 bushels; rye, 183,117 bushels; Indian corn, 1,573,670 bushels; oats, 978,381 bushels; barley, 70,256 bushels; and buckwheat, 65,265 bushels. The crops of 1539 , according to the census of 1840 , were as follows: Wheat, 422,1\%4 bushels; rye, 308,14S bushels; Indian corn, 1,162,572 bushels; oats, 1,296,114 bushels; barley, 121,899 bushels ; and buckwheat, 105,103 bushels.

Other Food Crops.-Peas and beans, 70,556 bushels; and potatoes, Irish, 4,304,919 bushels. The potato crop of 1839-40 amounted to $6,206,606$ bushels.

Miscellaneous Orops.-Tobacco, 50 pounds; hay, 598,554 (in 1840, 496,107) tons; elover-seed, 829 bushels; other grass-seed, 8,071 bushels; hops, 257,174 (in 1840, 213,425) pounds; flax, 7,652 pounds; flax-seed, 189 bushels; maple sugar, 1,294,863 pounds; molasses, 9,811 gallons; wine, $3 \mathbf{1 4}$ gallons, etc. Value of orchard products, $\$ 248,563$; and of market-garden products, $\$ 56,810$.

Home-made Mfanufactures were produced in the year ending 1st June, 1850 , to the value of $\$ 393,455$.

Manufactures.-Aggregate capital invested, $\$ 00,000,000$; value of all raw material, fuel, ete., $\$ 0,000,000$; hands employed-males 00,000 , and females 00,000 ; monthly cost of labor, $\$ 000,000$; entire value of products, $\$ 00,000,000$. The capital employed in manufactures in 1840 , was $\$ 9,252,448$. The whole number of manufacturing establishments producing to the value of $\$ 500$ and upward annually, on the 1st June, 1850, was 3,301 ; and of this number 44 were cottou factories, 61 woolen factories, 163 tanneries, and 29 iron manufactories-26 making castings, 1 pig iron, and 2 wrought iron. The following are the general statistics of these several manufactures :

In the cotton manufacture a capital of $\$ 10,950,500$ is invested, and hence in this interest New Hampshire is second only to Massachusetts, and equal to one-seventh the aggregate of the United States. It consumes annually 83,026 bales of cotton, and 7,679 tons coal, valued together at $\$ 4,839,429$, and employs $12,12 \xi$ hands $-2,911$ males and 9,211 females, at a monthly cost of $\$ 199,844$ - to males $\$ 75,713$, and to females $\$ 121,181$. The annual products are $113,106,247$ yards of sheeting, etc., and 149,700 pounds of yarn-valued at $\$ 8,330,619$. In $1 S 40$-capital invested, $\$ 5,523,200$; hands, 6,991 ; value of proảucts, $\$ 4,142,304$.

The woolen manufacture employs a capital of $\$ 2,437,700$; wool consumed, $8,604,103$ pounds ; and coal, 3,600 tonsvalued at $\$ 1,267,329$; hands, 2,127 -males 926 , and females 1,201 ; monthly eost of labor, $\$ 38,628$-male $\$ 21,177$, and female $\$ 17,451$; annual products, $9,712,840$ yards of cloth, and 165,200 pounds yarn-together valued at $\$ 2,127,745$. In 1840 -capital, $\$ 740,345 ;$ hands, 893 ; value of products, $\$ 795,784$.

Tanneries use a capital of $\$ 441,976$; value of all raw material, $\$ 543,779$; hands, 502 ; monthly cost of labor, $\$ 11,737$; skins tanned, 109,595 , and sides of leather tanned, $333,15 \mathrm{~s}$; value of products, $\$ 900,421$. In 1840, capital $\$ 386,402$; hands, 776 .

The statisties of the iron manufacture are as follows:

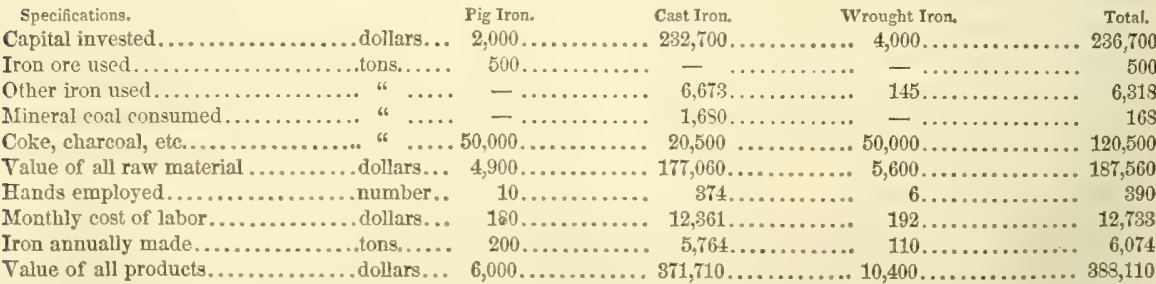

Besides the above principal manufactures, there are in New Hampshire a great variety of others, less conspicuous, indeed, but which in the aggregate are little less valuable. Among these may be mentioned her numerous grist and saw mills, her carriage factories, paper-mills, powder-mills, machine-shops, hardware, cutlery, etc., factories, etc.

Commerce, Navigation, etc.-New Hampshire, in the year ending 30 th June, 1850, exported to foreign countries, produce and merchandise to the value of $\$ 8,927$, and imported to that of $\$ 49,079$. Of the exports, $\$ 8,722$ was the value of domestic produce-in American ressels $\$ 2,535$, and in foreigu ressels $\$ 5,957$, and $\$ 205$ was the value of foreign produco re-exported; and of the imports, $\$ 19,962$ was the value of goods carried in American ressels, and $\$ 29,117$ that of goods carried in foreign vessels. The entrances and clearances for the same year were as follows: 
NEW HAMPSHIRE.

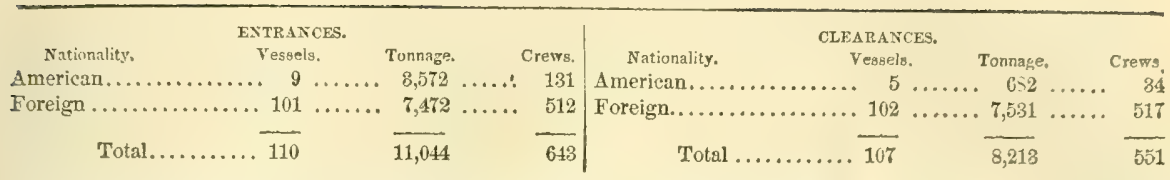

This commerce belongs to the port of Portsmouth, the only port of entry in the State. The great bulk of the commercial material of New Hampshire is carried to Boston for exportation, and its foreign supplies are chiefly brought through the same channel. The following table will exhibit the variations of the imports and exports for a series of years:

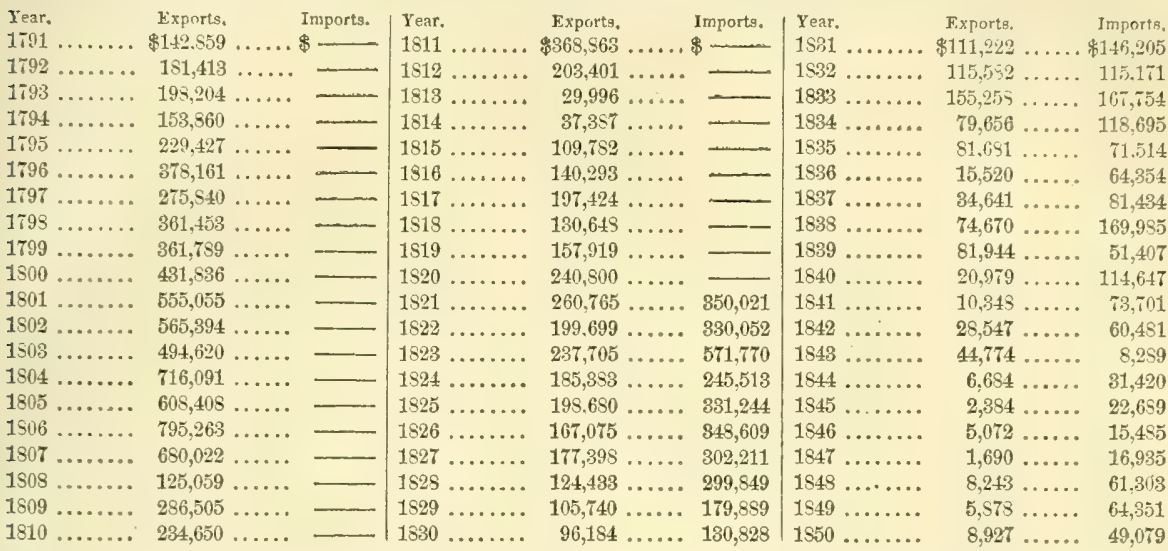

The total shipping owned in the State at the date referred to amounted to $23,096:$ registered shipping, 14,979 tons; enrolled and licensed, 7,593 tons; and licensed (under 20 ton boats), 224 tons. The proportion of the enrolled and licensed tonnage employed in the coasting trade was 4,025 tons, in the cod fishery 2,664 tons, and in the mackerel fishery 1,204 tons. The shipping built in the State during the year consisted of 8 ships and 2 schooners, with an aggregate burden of 6,914 tons.

Internal Improvement.-New Hampshire has completed a fine system of railroads, the principal lines being in a N. W. and a S. E. direction, or between the Atlantic sea-board at Boston and Portsmouth, and the Connecticut River, where connection is made with the Vermont lines to Lake Champlain and Canada. The great Atlantic and St. Lawrence Railroad also traverses the State in the North section. Most of the lines in the southern part of the State centre at Concord, the capital, and thence diverge in every direction. The total length of completed railroad in the State, on the 1st of January, 1853, was 480 miles, or 1 mile to every 17 square miles of territory, or to every 662 inhabitants.

Banks, etc.-There were 22 banks in the State, in December, 1850, the condition of which was as follows: Liabititiescapital, $\$ 2,375,900$; circulation, $\$ 1,897,111$; and deposits, $\$ 566,634$; and assets-loans and discounts, $\$ 3,821,120$; real estate, $\$ 13,670$; due by other banks, $\$ 477,453$; notes of other banks, $\$ 91,444$; and specie, $\$ 129,399$. Thirteen savings' institutions at the above date had deposits to the amount of $\$ 1,641,512$.

Government. - The constitution of 1784 , as amended in 1792 , is the fundamental law of the State. A new constitution Was framed by a convention in 1550 , but was subsequently rejected by the people.

The right of suffrage is secured to every male inhabitant 21 years old, excepting paupers and persons excused from paying taxes at their own request. The general election is held on the $2 \mathrm{~d}$ Tuesday in March annually.

The General Court consists of a House of Representatives and a Senate. Representatives shall have resided for the last two years in the State, shall have an estate valued at $\$ 100$ (at the rate of six shillings and eight pence the ounce of silver), one-half thereof to be freehold within their district, and shall be inhabitants of their district. Every town of 150 rateable polls, 21 years old, may choose 1 representative, and every 300 such polls additional shall entitle the town to another representative. There are also classed towns, and towns allowed by special act to send representatives. The Senate consists of 12 members, who must be 30 years old, inhabitants of the State for seven years, and seized of a freehold of $\$ 200$ value within the State. Senatorial districts, 12 in number, shall be set off "according to the proportion of public taxes pail by the said districts." In case of a vacancy in a senatorial district, one of the two candidates having most rotes in the district shall be chosen by the legislature on joint ballot. The legislature thus constituted meets on the 1st Monday of June annually.

The Executive Council consists of 5 councilors, and is elected annually by the people. Councilors must be 30 years of age, 7 years resident in the State, and possessed of an estate of $\$ 500$, of which $\$ 300$ shall be freehold. Vacancies are filled as in the Senate. The governor convenes the council, and their resolutions and advice are recorded in a public record, and signed by those agreeing thereto.

The Governor shall have the qualifications of a councilor, except as to his estate, which shall be $\$ 300$, one-half freehold. If there be no choice of governor by the people, one of the two highest candidates shall be chosen by the General Court on joint ballot. The governor may veto a bill, but two-thirds of both houses voting subsequently in favor of its passage, it becomes law nevertheless. With the assistance of the council he shall nominate and appoint all judicial officers, the Attorney-general, solicitors, sheriffs, and registers of probate. The goveruor and council shall have a negative on each other, both in nominations and appointments.

The Judiciary consists of the Superior Court, Courts of Common Pleas, Courts of Probate, etc. The superior court consists of a chief-justice and four associate justices. At the session of the legislature in June, 1851, provision was made 


\section{NEW HAMPSHIRE.}

for appointing four cireuit justices of common pleas; two only are now appointed. If a vacancy other than in the office of the chief-justice occurs in the superior court, it is not to be flled, but an additional eircuit justice of the common pleas is to be appointed until the whole number of four is flled up, and after that the superior court will consist of the chiefjustice and two associate justices, any two of whom will be a quorum. Two terms of the superior court are held annually at Coneord, on the $2 \mathrm{~d}$ Tuesdays of July and December, for the hearing and determining of questions of law and petitions for divorce from all the counties in the State. This court is also vested with chancery powers. At the trial of capital cases two justices of the superior court, or one justice of the superior court and one circuit judge are required to be present. The judges of the superior court of judicature are exwofficio judges of the court of common pleas. This court, before which all actions for recovery of debts, enforcement of contracts, etc., and all jury trials are brought, consists of one of the justices of the superior court, or one of the circuit judges of the court of common pleas, and of any two county justices, who are generally appointed from among the yeomanry, whose principal duty it is to attend to the ordinary business of the county, its roads, expenses, etc. Terms of the common pleas are held semi-annually in each county. Grafton County is divided into two judicial districts, and terms are held semi-annually in each district. County treasurers and registers shall be elected by the counties. Justices of the peace are appointed for five years, with jurisdiction in cases below \&4. Clerks of courts shall be appointed by the courts. All judicial officers shall hold office during good behavior, or until 70 years of age, but are removable on address of both houses of the legislature.

No person can hold any office of profit or honor under this government unless he be of the Protestant religion.

Every seven years the people shall vote for or against amending the constitution, and if a majority of the votes be in favor thereof, the general court shall call a convention; and if their amendments be approved by two-thirds of the votes when submitted to the people, they shall be adopted.

The militia force of New Hampshire comprises 32,151 men of all arms, of which 1,348 are commissioned officers, and 30,803 non-commissioned officers, musicians, privates, etc. Of the commissioned officers 12 are general officers, 51 general staff-officers, 386 field officers, etc., and 949 company officers. There is a school of instruction for officers. Every white male between 18 and 45 years of age, except such as the law excepts, is enrolled annually. Parades were abolished by the legislature in 1850 ; but volunteer companies may remain organized, and new companies be formed, and each volunteer who has performed his duty acceptably shall receive $\$ 3$ annually from the select-men of the town to which he belongs. The militia is organized in 4 divisions, 8 brigades, and 42 regiments. The governor is commander-in-chief.

The New Hampshire Asylum for the Insane, located at Concord, is a State institution. It is one of the most efficient establishments of the kind in the Union. Adjoining the asylum are more than 120 acres of valuable lands, well adapted to the wants of the institution, which is cultivated by the labor of the patients. The number of patients in the asylum 81st May, 1849, was 144; admitted during the year following, 103; discharged during the year, 90; recovered, 45; partially recovered, 18 ; not relieved, 20 , and died, 7 . Remaining under treatment 1 st January, 1850, 127, of which 58 were females. The sum of $\$ 1,600$ was granted by the legislature June, 1850 , for the relief of the indigent insane. The price of board, ete, for patients from this State is $\$ 225$ for the first 13 weeks, and $\$ 2$ for all subsequent time. The blind are provided for in the Perkins Institution of Massachusetts, and the deaf and dumb in the American Asylum of Connecticut.

Finances, Debts, etc.-The total receipts into the State treasury for the year ending 5th June, 1850, was $\$ 172,05655$, and the expenditures for the same period, $\$ 167,01163$-excess of receipts, $\$ 5,04492$. The chief sources of income were: balance in treasury 6 th June, $1849, \$ 6,12680$; railroad tax, $\$ 49,41429$; money borrowed, $\$ 51,400$; civil commissions (fees), $\$ 175$; State tax for 1849 and previous years, $\$ 59,54721$; allowance by United States of Indian Stream claim, $\$ 5,36256$ : and the principal objects of expenditure were: salaries, executive and judicial, $\$ 19,018$ 35; pay of council, $\$ \$ 8540$; pay of senate, $\$ 1,07850$; pay of representatives, $\$ 20,12740$; money borrowed and repaid, $\$ 58,145-83$; State printing, $\$ 2,95150$; publishing laws, $\$ 3 \$ 050$; New Hampshire Asylum for Insane (new building), $\$ 15,000$; Perkins Institution, education of the blind, $\$ 750$; American Asylum, education of deaf and dumb, $\$ 2,075$; officers' school of instruction, $\$ 7,73120$. The state of the treasury on the 5 th June, 1850, was: total amount of available funds, $\$ 5,60384$; and total amount of indebtedness, $\$ 26,60167$; balance against the treasury, $\$ 2,99781$. The assessed value of real and personal property in the State in 1550 , was $\$ 92,177,953$, and the true or estimated value was $\$ 103,6 \$ 2,835$.

Federal Representation.-New Hampshire, in accordance with the federal act of $23 \mathrm{~d}$ May, 1850, sends three representatives to the Congress of the United States.

Edrucation.-The common schools of the State are under county commissioners, who form a board of education, and meet at Concord on the third. Wednesday in August annually. Their duty is to recommend such books as may appear to them most suitable to be used in the schools, and such methods of instruction, modes of government and discipline, as may best promote the advancement of the schools. In each town is a superintending committee, which reports to the Secretary of the State by the first day of April, the condition and progress of each school, and the secretary is requested to hand over the several returns so received to the Secretary of the Board of Education. Each county commissioner spends at least one day in each town of his county to promote the cause of education by addresses, ete., and he bas also charge of any teachers' institute that may be held in his county. The office of State Sehool Commissioner was abolished by the general court of 1850 . The whole number of school districts reported June, 1850, was 2,167; average attendance in the winter schools, 60,271 , and in the summer schools, 46,225 ; average length of winter schools, $94-5$ weeks, and of summer schools, $92-5$ weeks。 Arerage monthly wages of male teachers, $\$ 1473$, and of female teachers, $\$ 621$; number of male teachers in winter schools, 1,246, and of female teachers, 961 ; money raised by taxes for schools, $\$ 145,892$; amount contributed in board and fucl, $\$ 9,738$; income of local funds, $\$ 8,097$; interest of literary fund, $\$ 10,790$; amount for teachers and institutes, $\$ 1,020$, being an aggregate of $\$ 174,517$ raised for the district schools. The number of incorporated academies in the State at the date referred to was 38 , and the whole number of pupils attending them, 2,261 . Number of unincorporated academies, private schools, and schools kept to prolong common schools, 74, altended by an average of 3,698 scholars.

Dartmouth College is the only collegiate institution of the State; it was founcled in 1769, and is located at Fanover. The academical faculty ensists of a president and 10 professors, and in 1850 it had 3,710 alumni, of which about 800 were in the ministry, and 237 students. Its library contained nearly 25,000 volumes. The New Hampshire Medical College at the same place, founded 1795 , is a department of Dartmouth. It has a president, six professors, and a demonstrator of anatomy, and in 1850 had 45 students. Its graduates of that date numbered 850 . The Chandler School of Science and the Arts opened August, $1 \$ 52$, and, founded on a donation of $\$ 50,000$, bequeathed by the will of the late Mr. Chaniller, of Boston, is attached to the Dartmouth College. There are in the State four theological schools: the New Hampton Academical and Theologieal Institution, founded 1825; the Methodist General Biblical Institute, founded 1847, and located at 


\section{NEW HAMPSHIRE.}

Concord; the New Hampshire Conference Seminary at Northfield, and the Gilmanton Theological Seminary, foundec in 1835 .

Public Libraries.-One State library -4,700 volumes; 9 social $-13,875$ volumes ; 1 College $-6,400$ volumes ; 5 students 16,200 volumes; 7 professional and academic-10,700 volumes; 2 scientific and historical-2, 500 volumes; 25 public school-2,500 volumes; total, 50 libraries, and 57,178 volumes.

Periodical Press.-The whole number of periodicals and newspapers published in New Hampshire in 1šno, was 41of which 10 were whig, and 10 democratic in politics, and 21 neutral, or devoted to religion, science, literature, etc., including all the character of which had not been ascertained; and of the whole number 2 were published daily, 36 weekly, 1 semi-monthly, and 2 monthly. The total circulation of the dailies was about 1,500 copies at each issue; of the weeklies, 58,426; of the semi-monthly, 600; and of the monthly, 1,150 copies. The dailies were published at Manchester and Portsmouth; the weeklies, 1 each at Winchester, Lancaster, Manchester (Cons co.), Lebanon, Haverhill, Peterboro', Nashua Village, Amherst, Exeter, Claremont, and Newport; 2 each at Meredith Bridge, Nashua, and Great Falls; 8 each at Keene and Portsmouth; 4 each at Manchester and Concord, and 5 at Dover; the semi-monthly at Concord; and the monthlies at Hanover and Dover.

Religious Denominations.-The general statistics of the several religious denominations in the State, for the year 1550, were as follows:

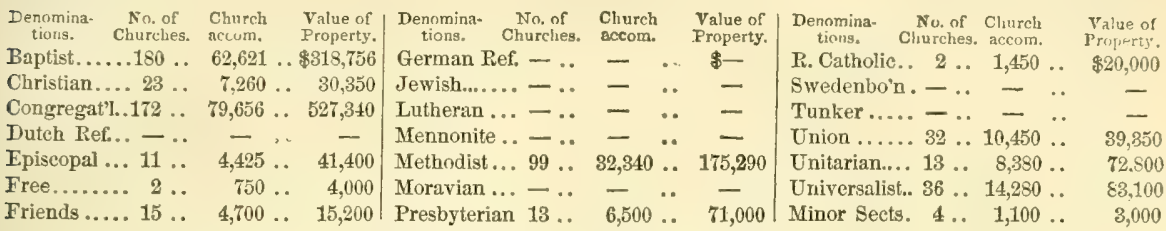

-making a total of 602 churches, having accommodations for 233,892 persons, and valued as property at $\$ 1,401,586$. New Hampshire constitutes a diocese of the Protestant Episcopal Chureh, and a portion of the Roman Catholic diocese of Boston.

Pauperism and Crime.-The whole number of paupers who were relieved or supported in the State during the year euding 1st June, 1850 , was 3,600 , of whom 2,853 were native-born, and 747 foreign-bom; and the whole number of paupers on the list at the date specified, was 2,183, of whom 1,998 were native-born, and 186 foreigners. Annual cost of sup. port, \$157,351. The State Prison is located at Concord, and was first opened for the reception of convicts in 1812 , from which period to June, 1850, there had been 796 commitments. Whole number of inmates on 31st May, 1849, eighty-troo; reccived in 1849-50, thirty-sio; and discharged, 27 ; leaving in prison $91-88$ males, and 3 females; and of these 72 were committed for offenses against property, 1 for arson, 8 for rape, 2 for manslaughter, and 4 for murder. Expenditure for the year, $\$ 7,509$.

The first settlements in New Hampshire were made by Gorges and Mason, two of the most active members of the Plymouth Company. In 1621, Mason obtained a grant of all the lands between the Naumkeag and Merrimac, and in the next year another grant was made to Mason and Gorges of the country between the Merrimac and Sagadahock rivers The first tract was named Mariana, and the latter Laconia. Designing to establish fisheries, they sent over in 1623 a colony-one division of which landed at Little Harbor, on the southern shore of the Piscataqua, and the other settled at Dover. Other settlements were effected on the eoast both by the granters under Mason, and by emigrants from Plymouth and Massachusetts. Fishing and trading being the sole objects of these parties, the settlements were slow in their progress for many years.

In 1629, Mason procured a further grant of the land between the Piscataqua and Merrimac, and extending 60 miles into the country, and this he called New Hampshire. In 1631, a house, ealled the Great House, was built at Strawberry Hill, now Portsmouth. In 1638, John Wheelwright, the brother of the celebrated Mrs. Hutchinson, banished from Massachusetts for his Antinomian principles, came with a number of his adherents to Squamscot Falls, where they founded Exeter. Here they combined, as a body politic, chose rulers and swore to obey them. Similar governments were established by the colonists at Dover and Strawberry Hill. All these petty establishments, however, placed themselves under the protection of Massachusetts in 1641, and were governed as a part of that colony until 1680, the year previous to which a decree was passed constituting New Hampshire a separate province. A president and council were now appointed by the crown, and a house of representatives elected by the people. The first assembly, consisting of eleven persons, met at Portsmouth the same year. At this session a code of laws were enacted, of which the first declared, "That no act, imposition, law, or ordnance should be imposed upon the inhabitants of the province, but such as should be made by the assembly, and approved by the president and council." From 1675, to the accession of James II., the colony was much disturbed by contentions between the heirs of Mason and the holders of land; nor was it, indeed, until 1747, that peace was secured-in that year all claims having been purchased by the government. These contentions retarded greatly the progress of the colony, and were a main source of the grievances which alienated the public affections from the mother country.

On the accession of James to the English throne, new schemes of oppression were meditated for the colonies, and erery vestige of liberty was to be erased. In 1686, Sir Edmond Andros arrived at Boston, commissioned as Governor in Chief over all New England, and authorized with his council to make such laws and impose such taxes as he thought proper. New Hampshire had already declared her will, which was offensive to the governing powers, and, like her sister colonies, became a prey to his tyranny-the press was shackled, liberty of conscience invaded, and oppressive taxes imposed, and, to prevent complaints being heard, no person was allowed to leave the country without express license. This state of things continued until the Revolution in England, when Andros was seized by the people and sent home a prisoner.

New Hampshire being now without a govermment, the people determined to return to their ancient connection with Massachusetts. This union only lasted three years, a separation having been determined on and effected by the English authorities.

New Hampshire was, perhaps, of all the colonies, the one that suffered most from Indian hostilities. From her earliest Bettlement her progress was retarded by savage inroad, nor did the Indian cease from his forays until the reduction of 
Quebec. In the twelve years of peace that followed, New Hampshire increased wonderfully in population and wealth. Her settlements extended farther west than the original limits prescribed by the patents, and until 1764 it was supposed that the territory which now forms the State of Vermont was part of the province, and grants were accordingly made by the authorities in that direction. The district, however, was allotted to New York, and a vexatious controversy ensued, which continued until the independence of Vermont was acknowledged in 1790. During the contest many towns lying near the Connecticut attached themselves to the Vermontese, but in the end returned to their former allegiance.

The State bore an active and honorable part in the war of the Revolution. On the arrival of news of the battle of Lexington, 1,200 men marched to the assistance of their brethren at Boston. The royal governors were obliged to seek safety in flight, and a temporary government was established. In 1792, a permanent constitution was formed.

The present prosperous condition of the State may be attributed to the unswerving patriotism and virtues which have ever distinguished its people. Still there are many points in the institutions of New Hampshire which savor of intolerance and bigotry, and of these none stand so prominently pre-eminent as the Protestant clauses of the Constitution, and the virtual exclusion of the moneyless man from the higher offices of State. A closer contact with the neighboring States, which the railroad system of the country will now insure, must, however, at no distant day, liberalize the views of the people, and effect all desirable reforms. The provisions of the rejected constitution of 1850 would have done much toward this end had it been approved, and all cause of reproach would have hence been removed. The document referred to, indeed, is a sufficient indication that no little progress has been effected, and that New Hampshire has sons who know how and are willing to redeem her from the antiquated errors that envelop her government policy.

Coxcord, on the Merrimac river, is the political capital of the State.

New Harrpton, t. and p. v., Belknap co., N. Hamp.: on E. side of Pemigewassett r., $30 \mathrm{~m}$. N. by W. Concord. Surface uneven; soil remarkably fertile. The Boston, Concord, and Montreal R. R. passes through the N. E. part of the t. "The New Hampton Academy and Theological Institution" is one of the best seminaries in the State. The theological department was established in 1825 , and in 1850 had 2 professors, 36 students, and 2,000 volumes in library. Pop. of $t .1,612$.

New Hampton, p. v. and sta., Hunterdon co, $N$. Jer. on E. side of Musconetong er., $35 \mathrm{~m}$. N. N. W. Trenton, and by the New Jersey Central R. R., $65 \mathrm{~m}$. from New Fork.

NeW HAMPTON, p. v., Orange co, , N. Y.: on W. bank of the Wallkill, 90 m. S. S. W. Albany; is a station on the Erie R. R., $74 \mathrm{~m}$. from New Tork.

New HaTrover county, N. Car. Situate S. E., and contains 993 sq. m. Drained by N. E. branch of Cape Fear r. and its tributaries, Surface level and Iow, a large part being awamps in the $\mathbf{E}$. section of the co.; soil, where not too wet for cultivation, is fertile. Staples, rice, cotton, and Indian corn. Excellent grazing land is gained by the draining of the swamps. On the Atlantic shore, which bounds it on the S. E., are long narrow islands, the land lying low, and hav. ing inlets to the inner basin. Farms 559; manuf. 186; dwell. 1,\$84, and pop.-wh. 8,190, fr. col. 897, sl. 8,587-total 17.66s. Cupital: Wilmington. Public Wrorks: Wilmington and Weldon R. R.; Wilmington and Manchester R. R.

New Ifayoter, t. and p. v., Montgomery co., Penn.: $70 \mathrm{~m}$. E. Harrisburg. Drained by Swamp er. Surface uneven; soil red shale and loam, tolerably productive. The $\checkmark$. is on Swamp cr., where are several mills.

NEW HARMony, t. and p. F., Posey co, Ind.: on E. bank of Wabash r., $143 \mathrm{~m}$. S. W. by S. Indianapolis. This to is remarkable for its history as the theatre of two "social communities." In 1814 a society of Germans, under the direction of George Rapp, removed here from Butler co., Penn. where they had first settled upon their arrival from Europe. Here they purchased about 17,000 acres of land of excellen quality, which they cleared, planted, and fineiy cultivated, erecting good houses, churches, etc. They lived and labored in common until 1824, when they sold their settlemeut to Robert Owen, and moved to their present settlement at Economy, Beaver co., Penn. The community of Robert Owen was for a time very large, but nltimately became discordant, and broke up as a complete failure.

New Harrasiurg, p. v., Carroll eo., Ohio; 102 m. E. N. E. Columbus.

NEw HARTFord, t. and p. o., Litehfleld $\mathrm{co}_{\text {, }}$ Conn. : $18 \mathrm{~m}$, W. by N. Hartford, $39 \mathrm{~m} . \mathrm{N}$. by W. New Haven. Surface hilly; soil gravelly loam. Drained by head branches of Farmington r. ; contains several factories. Pop. 2,663.

New Hartford, p. V., Pike $c 0_{n}, I l l .: 67 \mathrm{~m}$. W. by $\mathrm{S}$. Springfield.
New HARTFORD, t. and p. v., Oneida co.,.,$Y . Y . ; 86 \mathrm{~m}$. W. N. W. Albany, Surface of t, diversified; soil rich, calcareous loam, very fertile, and well cultivated. Drained by Sadaquada cr., which affords extensive water-power to numerous factories. Two cotton factories of the v. are very extensive, Pop, of t. 4,847.

New Hartford Centre, p. v., Litchfield county, Conn.: $19 \mathrm{~m} . \mathrm{W}$. by N. Hartford, $39 \mathrm{~m} . \mathrm{N}$. by W. New Haven. Drained by Farmington r.; contains several factories.

NEw HAVEN county, Conn. Situate $\mathrm{S}_{\text {., }}$ and contains 545 sq. m. Drained by Naugatuck, Pomperaug, Quinnepac, Mill, West, and Menunkatuck rivers. Surface uneven; soil varied, in some parts being strong and very productive, and in others consisting of a light sandy loam, and less fertile. Farms 2,794; manuf. 521; dwell. 10,204, and pop.-wh. 60,730, fr. col. 1,396-total 62,126. Capital: New Haven. Pullic Works: New Haven, Hartford, and Springfield R. R.; New Haven and Northampton R. R.; Naugatuck R. R.; New York and Boston (air line) R. R. ; New Haven and New York R. R.; New Haven and New London R. R., etc.

NEW HAVEN, t., p. city, port of entry, and cap. New Haven co., Conns: one of the capitals of Connecticut, is situated at the head of New Haven Bay, which sets up N. $4 \mathrm{~m}$. from Long Island Sound. Lat. N. $41^{\circ} 18^{\prime} 23^{\prime \prime}$, long. W. from Greenwich $72^{\circ} 56^{\prime} 45^{\prime \prime}$, and E. from Washington $4^{\circ} 5^{\prime} 15^{\prime \prime}$. It is $36 \mathrm{~m} . \mathrm{S} . \mathrm{S} . \mathrm{W}$. Hartford, the other capital of the State; from Boston by $\mathrm{P}, \mathrm{R}, 160 \mathrm{~m}$; f from New York $76 \mathrm{~m}$; f from Washington $223 \mathrm{~m}$. New Haven colony was settled in April. 1638; the city incorporated in 1784. The eity is on a lirge and beautiful plain, slightly inclined to the water, surrounded on three sides by hills, the termination of the western trap range, of which the extreme points, called East and West Rocks, are very bold, rocky eminences-the former 370 , the latter 400 feet high; these are rude, bare trap rocks, of light-red color, with nearly perpendicular fronts, the most notable natural objects in the vicinity, and much visited in summer by citizens and strangers to enjoy the delightful prospect which they afford of the city, bay, and Sound. New Haven (city) occuples about 6 sq. m., and is very regularly laid out. The streets are so generally lined with noble elms that the city is called "the City of Elms." The central square, a public park, is bordered and crossed with numerous rows of elms, and is considered the finest public ground in the United States. The "Temple-street row of elms" is not surpassed for beauty in the world. In this square are 3 fine churches, the State House, an elegant edifice of Grecian architecture, built of brick, painted white, and the monument to Colonel Dixwell, one of the regicides, erected in 1849. The profusion of foliage, the fine and cleanly streets, with the rural appearance of many houses, surrounded by trees, shrubbery, and gardens, which characterize this city, combine in it the attractions of both city 
and country. The churches, 22 in number, are handsome structures. Of these, 8 are Congregational, 4 Episcopal, 4 Methodist, 2 Baptist, 2 Catholic, 1 Universalist, 1 Jewish Synagogue. The cemetery, in the N.E. part of co., is beautifully laid out, has an imposing entrance of freestone, in Egyptian arehitecture, and surrounded by high and massive iron fence and stone wall. Here are interred the remains of Eli Whitney, Noah Webster, Rev. J. Ashmun, Colonel Humphrey, and many other eminent men. The new cemetery, and Wooster Square, are flne grounds, well laid out. The State Hospital, founded in 1832 , is a substantial stone edifice, on elevated ground. The new R. R. Station-house is one of the finest structures of the kind in the United States. A few of the manufactories are very extensive, particularly those of carriages and clocks. There are 4 banks, with a capital of $\$ 1,957,625$. The taxable property in 1851 was assessed at $\$ 12,720,911$. Three newspapers are published daily, publishing, also, tri-weekly and weekly editions: "Journal and Courier" (whig), "Palladium" (whig), "Columbian Register" (dem.), two quarterlies, "New Englander" (Cong.), and "Church Review" (Episc.) The "American Journal of Science," commenced in 1819 by Professor Silliman, now published bi-monthly, ranks with the ablest scientific journals in Europe." The Yale Literary Magazine" is published by the students monthly.

Yale College.-This noble institution (the third college established in United States), founded in 1700, and removed here in 1717 , is, next to Harvard College, the principal university in America. At present, and for a number of years past, it has had a larger number of students in the collegiate course than any other. Total number of alumni in 1850 , 5,932 , of whom 1,587 had entered the ministry; instruetors, 22 ; students, 432 ; volumes in library, 51,000; commencement, last Thursday in July. The edifices present a fine appearance, fronting the public green. In the front range are five large brick edifices, four stories high, occupied by students; three buildings, having cupolas, between the college halls, are used as chapel, recitation rooms, eto. In the rear are the library buildings, mineralogical cabinet, Trumbull Gallery, etc. ; the former are fine edifices of brown freestone, of Gothic architecture, divided into five separate fire-proof compartments. The central edifice, 151 feet long, contains the college library; the others contain libraries of societies of students. The cabinet of minerals and geological specimens is the most valuable in the United States, and surpassed by only two in Europe. The Trumbull Gallery, erected 1831, contains the splendid collection of paintings of Col. John Trumbull, consisting of eight historical paintings from subjects founded on the American Revolution, and about 250 portraits of distinguished persons. With the college proper are associated four professional schools, viz., of medicine, law, theology, and scientific department. The Medical College, founded in 1813, has a fine edifice, valuable anatomical museum, 6 professors, 38 students, 595 graduates. The Theologieal Department, established 1522, has 3 professors, 35 students, 621 graduates, 900 volumes in library. Law School, 2 professors, 26 students. Scientiffe School, 2 professors, 30 students. Besides $\bar{Y}$ ale College, New Haven has many seminaries, male and female, of high reputation, various learned societies, and two popular lyceums, having libraries, reading-rooms, ete.

Commerce.-The harbor is spacious but shallow, and gradually filling up. It receives three rivers, Quinnipiac and Mill r. on the E., and West r. on the W. To aceommodate large vessels, a wharf, called "Long Wharf," was constructed many years since. The flling up of the harbor has several times required its extension; it is now nearly a mile in length, the longest in the United States. New Haven has a larger commerce with foreign countries than any other port in the State, and an extensive coasting trade. Its fisheries in oysters, elams, etc., are extensive and valuable. The total tonnage of New Haven district, on 30th June, 1850 , was 15,731 tons, of which 4,995 tons were regis- tered "permanent," and 10,736 tons were enrolled and licensed. Of the latter 10,440 tons were employed in the coasting trade, and 2,568 tons were propelled by steam. During the year ending 30 th June, 1850, the total of clearances was 72-13,400 tons, men in crews, 591; number of entrances, 89-16,177 tons, men in crews, 695 . Vessels built during the year, 12-1,110 tons, A passenger steamboat plies daily to New York. Four important railroads now terminate at New Haven, and connect at the main station: to New York, $76 \mathrm{~m}$; ; to Springfield, $62 \mathrm{~m}$; to New London, $50 \mathrm{~m}$. ; to Tariffville, $45 \mathrm{~m}$., which will be continued to North ampton. To these will be added the direct line to Boston, via Middletown. Pop. of city in $1830,10,180$; in 1\$40, 12,96ij; in $1850,20,345$. Pop. of city and t. in $1840,14,890$; in $1850,22,539$.

New HaveN, p. v., Gallatin co., $I u_{0}$ ? on the $\mathrm{S}$. W. side of Little Wabash r., $2 \mathrm{~m}$. above its entrance into the Wabash river, and $153 \mathrm{~m} . \mathrm{S} . \mathrm{S}$. E. Springfield. It has several stores, and is surrounded by a very fertile country.

NEW HAVEX, p. o., Allen county, Ind.: 100 m. N. N. E. Indianapolis.

New Ifaven, p. v., Nelson co., Ky. : on the Rolling Fork of Salt r., $54 \mathrm{~m}$. S. W. Frankfort. Near the v. is the large "Abbey of La Trappe," established in 1848 from Nantes, France. The community now number 62 religious. The farm embraces 1,400 acres.

New Haven, p. o., Macomb county, Hich. : 80 m. E. Lansing.

NeW HAVkeN, t. and p. T., Oswego co., N. Y.: $145 \mathrm{~m}$. W. N. W. Albany. Surface of t. undulating; soil sandy loam. Drained by Catfish cr., flowing into Lake Ontario. Pop. 2,015.

NEW HAvEN, t., p. o., and sta., Furon co., Ohio: $74 \mathrm{~m}$. N. by E. Columbus. Drained by head branches of Huron river. Station on the Sandusky and Mansfleld R. R., $34 \mathrm{~m}$. S. Sandusky. Pop. 1,398.

NeW HAVEx, t., p. o., and sta., Addison co., Verm.: $30 \mathrm{~m}$ W. S. W. Montpelier, on Rutland and Burlington R. R. $26 \mathrm{~m}$. from Burlington. Drained by Otter cr. and branches, which furnish water-power. Here are quarries of excellent marble. Pop. 1,663.

New Hafex Mrils, p. o, Addison county, Verm。: on N. bank of branch of Otter er., $28 \mathrm{~m}$. S. W. by W. Montpelier.

New Herron, p. o., Crawford co., $\Pi l$. : $115 \mathrm{~m}$. E. S. E. Springfield.

New Holuasd, p. v., Pickaway co., Ohio: 32 m.S.S. W Columbus.

New Hollaxd, p. vo, Laneaster co., Penn.: 42 m. E. by $\mathrm{S}$ Harrisburg.

NEW HoLdaND, p: v., Wabash co., Ind.: on S. bank of Salamonie $\mathrm{r}, 73 \mathrm{~m}$. N. N. E. Indianapolis.

New Holstein, t. and p. 0., Calumet co., Wise.: $90 \mathrm{~m}$. N. E. Madison. Drained by branches of South and Sheboygan rivers.

New Hope, p. v., Madison co., Ala.: on the W. side of Paint Rock r., $144 \mathrm{~m}$. N. Montgomery.

NeW Hope, p. o., Nelson co., Ky, 43 m. S. W. Frankfort. New Hope, p. o., Spencer county, Ind.: $120 \mathrm{~m}$. S. by W, Indianapolis.

New Hope, Lincoln co., MFo. : 129 m. E. N. E. Jefferson City.

New Hope, p. v., Iredell co., $N$. Car.: on the S. side of Rock er. of Yadkin r., $125 \mathrm{~m}$. W. Raleigh.

NEw Hope, p. O., Tishemingo co, Mriss ; 192 m. N. N.E Jackson.

NEw HoPE, p. v., Brown co., Ohio: on E. bank of White Oak er., 80 m. S. W. by S. Columbus. Pop. 106.

NEw Hope, p. v., Bucks co., Penn. : on W. side of Delaware $\mathrm{r} ., 101 \mathrm{~m}$. E. Harrisburg. At this place Delaware $\mathrm{r}$. is crossed by a fine covered bridge, supported by nine piers. This is a flourishing village, with numerous stores and manufactories.

New Hope, p. o., Spartanburg district, S. Car.: $85 \mathrm{~m}$. N. W. by N. Columbia. 
NEW Hope, p. v., Caroline co., MYd. : 30 m. E. Annapolis. New Hope, p. v., Augusta county, Virg. : on creek of Shenandoah r., $87 \mathrm{~m}$. W. N. W. Richmond.

New House, p. o., York dist., S. Car.: $73 \mathrm{~m}$. N. by W. Columbia.

New Hudson, t. and p. o., Alleghany co., N. Y.: $239 \mathrm{~m}$. W. by S. Albany. Surface undulating; soil good for grass. Drained by Black cr., ete. Pop. 1,435 .

New Hurlex, p. o., Ulster co., $N . Y_{.:}$on E. side of the Wallkill, on a branch, $76 \mathrm{~m}$. S. by W. Albany.

New Iberta, p. v., St. Martin's par., La.: on W. side of Bayou Teche, 45 m. S. W. Baton Rouge.

New In lzit, $N$. Car.: the passage between Federal Point and Smith's Island, $25 \mathrm{~m}$. S. Wilmington.

Newington, p. o. and sta., Hartford co., Conn.: $5 \mathrm{~m}$.
S. W. by S. Hartford, on IIartford and New Haven R. R. and Hartford and Fishkill R. R. The inhabitants are chiefly engaged in agriculture.

Newligton, t. and p. o., Rockingham co., N. Himp.: on Piscataqua r, bounded W. by Great Bay, $85 \mathrm{~m}$. E. S. E. Concord. The soil is sandy and unproductive, except on the streams. Pop. 472.

New Irswicr, t. and p. v., Hillsboro' county, N. Hamp. : $37 \mathrm{~m}$. S. W. by S. Concord. Drained by Souhegan r, and branches; soil fertile. There are several cotton factories in this $t$; the first was erected in 1803 . The academy in the $\mathrm{v}$. was incorporated in 1789 , and has educated many distinguished men; 1 bank, eap. $\$ 100,000$. Pop. of t. 1,877.

NEW J JGPER, p. o., Greene county, Ohio: 50 m. W. s. W. Columbus.

\section{THE STATE OF NEW JERSEY.}

NEW JERSEY lies between $35^{\circ} 5 S^{\prime}$ and $41^{\circ} 21^{\prime}$ latitudes north, and between $73^{\circ} 5 S^{\prime}$ and $75^{\circ} 29^{\prime}$ longitudes west from Greenwich, or $10^{\circ} 33^{\prime}$ and $3^{\circ} 04^{\prime}$ east from Washington. It is bounded on the north by New York; on the east by New Fork, from which it is here separated by the Hudson River and the Atlantic Ocean; on the south by the Atlantic Ocean and Delaware Bay, the latter dividing it from the State of Delaware, and on the west by the Delaware River, which separates it from Pennsylvania. The State is almost encircled by water, the Hudson River, the Atlantic Ocean, and Delaware Bay and River, surrounding it, except on the north, where its boundary is a conventional line running northwest from a point on the Hudson River, in lat. $410 \mathrm{~N}$. to the Delaware River, which it strikes in lat. $41021^{\prime}$. It greatest length from Cape May to Carpenter's Point is 167 miles, and its breadth varies from 40 to 96 miles, being narrowest in the centre. The superficies of the State is 8,320 square miles.

The north-western part of the State is hilly, rather than mountainous, being traversed by the prolongation of several mountain ridges from Pennsylvania. These hills nowhere rise to a great height, but they abound in bold and raried scenery, and are interspersed with fertile and pleasant valleys, comprising some of the finest lands in the Union. Schnoley's Mountain, the most prominent of these elevations, is much resorted to in summer, on account of the salubrious effect of its atmosphere, and for the purpose of using its mineral waters, which possess medicinal properties.

The eastern line of the State is formed by a bold ridge of trap rock, called the Palisades, or Cloister Hill, which, presenting a precipitous wall to the river at several places, as at Wcehawken, 200 feet in height, gives an air of picturesque wildness to the scenery. This wall of rock extends about 20 miles along the shore, and forms one of the principal objects which distinguish the noble panorama of the Hudson River, and many historical recollections and national traditions are connected with its localities.

The southern part of the State, from Raritan Bay and Trenton to Cape May, consists of a great sandy plain, nowhere rising more than 60 feet above the sea, except at the Navesink Hills, which, although only 300 feet high, form a prominent object on the general level.

From the low projecting sand-bank, called Sandy Hook, opposite the Narrows, to the similarly formed point of Capo May, the whole eastern coast consists of a long line of sandy beaches, here and there interrupted by inlets, and inclosing narrow, shallow lagoons, behind which extends for several miles inland a low marshy tract. This coast is constantly changing-several old inlets having been closed, and new ones opened since the settlement of the country; and being exposed to the heavy surf of the Atlantic, and affording no efficient harbors, it has been the scene of many dreadful shipwrecks. Barnegat, Great Egg Harbor, and Little Egg Harbor inlets, are the principal points of access to the inland waters. The south-western coast on Delaware Bay consists chiefly of a strip of salt marsh, which gradually terminates in the predominating sandy plain. On the shores of the Delaware River the land is more elevated, the line being intersected by the mountain ridges tending eastward from the State of Pennsylvania, and over a ledge of which, crossing the Delaware River, the Falls of Trenton leap.

The rivers of New Jersey are better adapted for economical purposes than for narigation. None of them admit of the passage of ships of a large size. The Hackensack and the Passaio fall into Newark Bay. The former, which rises in New York, near the line of this State, is navigable for sloops to Hackensack village, 15 miles from its mouth, and the latter, which rises in Morris County, after receiving several considerable streams from the north-west and south, has a fall of 72 feet at Paterson. The great falls of the Passaic are surrounded by a scene of wild beauty, but much of their natural magnificence has been destroyed by turning their waters for mill purposes, and it is now only in time of flood that their normal grandeur is recognized. From these falls the course of the river is south, and it is navigable for small vessels from Aquackannock to its confluence with the Bay, a distance of 12 miles. About 5 or six miles above Paterson, the river has another descent of 51 feet, by two leaps, and a rocky rapid in the distance of half a mile-these descents are called the Little Falls of the Passaic. The Raritan, which is navigable for small craft to New Brunswick, 17 miles up, rises to the south of the hills; and having collected the waters of its several tributaries, it takes a course eastward, almost across the State, and falls into Raritan Bay, opposite the southern point of Staten Island. The principal streams in the southern part of the State are Great and Litlle Egg Harbor rivers, which admit of sloop navigation for about 20 miles inland, and Maurice River, which falls into Delaware Bay. The streams emptying into the Delaware River are numerous, but not navigable.

Although the State is bounded on three sides by navigable waters, it possesses few harbors. The sea-coast and shores of Delaware Bay present many inlets and coves, but none frequented by large shipping. Raritan Bay, between Sandy IIook and Staten Island, affords a ready communication from Amboy, the principal sea-port of the State, to the ocean. Newark Bay, to the mouth of Staten Island, has navigable communications through the "Kills," narrow straits, with New Tork Bay and Raritan Bay. Delaware Bay washes the south-western shore. The southern extremity of the State is Cape May, the northern point of the entrance from the ocean into Delaware Bay. Sandy Hook, the southern cape of Raritan Bay, is a low, sandy island, about three miles in length, and is constantly extending by the accumulation of sand and other debris, and thus is alwass influencing and changing the currents to and from the Bay of New Fork. 
The geological structure of New Jersey has been explored by seientifle men, and many of the most useful minerals have been found embedded in its hills. All the rocks referable to the primitive, secondary, and transition eras exist; gneiss sienite, graywacke, and graywacke slate, calcareous rocks, etc., are the principal formations in the northern region, and contain vast masses of metals and metallic oxides. Iron in all its forms occurs abundantly, and copper, which appears in the secondary formations, is also found in eonsiderable quantities. Nearly a century ago, several lumps of virgin copper were ploughed up near New Brunswick, and a mine, near Belleville, on the Passaic, was discovered as early as 1719. There are many veins in the latter which might be worked with proft, and it is said that these mines contain a good quantity of silver ore. There is still another mine north of Somerville, which contains, according to Dr. Torrey, a native copper, carbonate and phosphate of copper, green and red oxide of copper, native silver, green quartz, chrysophase, phrenite, ete. In the mountain section, which extends in breadth varying from 15 to 35 miles in right angles, with the general course of the mountains, the geologica! formations are strongly blended. Rocks of a pretty uniform character, however, are found in the primitive ridges, but they are of a coarse and uneven texture, and surface aggregated with crystals of quartz and felspar. Sometimes they contain shorl, garnets, hornblende, epodite, and mica. Granite, gneiss and sienite are formed in this section by the blending and combination of these materials; and at some points the primitive greenstone is seen. The richest and most productive iron mines are also found here; some of the beds are from 8 to 12 feet in thickness. There is also found here large quantities of graphite. Black mica is found on the Ramapo River, near the Monroe works, and highly magnetic iron ore in Schooley's and Musconetong mountains. Wallkill Valley, west of the Hamburg Mountains, is noted for the number and variety of its minerals. The bottom of the valley rests on white chrystaline limestone and marble. The first bed of minerals, which is at Franklin Furnace, appears like a black mountain mass, but it contains iron ore, very little magnetic, and, as a new metallic combination, it has received the name of "Franklinite" It is composed of 60 per cent. of iron, 16 of zinc, and 17 of red oxide of manganese. This ore is not only irreducible to iron, but it obstructs the fusion of other ores. Large masses of this mineral are also found at Sterling. In Schol's Mountain, capacious mines of magnetic iron ore are worked, and the same exists plentifully through the whole primitive region. At Mendham a beautiful marble is found, which is capable of being bighly polished, and is suitable for ornamental architecture, resembling much in its appearance the marble of Florence.

The recently discovered zinc mines of Sussex County are among the most valuable of the world, and are now being successfully worked by the New Jersey Exploring and Mining Company. The principal mines are at Sterling Hill, on the westerly side of Wallkill. Foliated, or lamellar zine, which has hitherto been considered a rare produetion and highly prized for cabinet collections, is abundant in these mines, and in one instance a mass weighing over 1,200 pounds, seven-tenths of which was foliated, was excavated. The ore, however, is chiefly in the form of red oxide associated with iron and manganese, neither of which being volatile leave a very fine metal on reduction. The zinc ores of Europe are either carbonates or sulphurets, and in many instances are mechanically combined with galena, arsenic, and antimony, volatile metals which deteriorate the chemical purity of the fused metal. The company working these mines is at the present time confining its operations to the manufacture of zinc paint, and for this purpose have erected extensive works at Newark. This paint is said to be more durable and less liable to injure the health than the paints having the oxides of lead for their bases.

The soils of New Jersey vary materially with the topography of the country. The mountain section is principally in its natural state, only now and then a cultivated farm being seen on the hill-sides. The soil best adapted for agricultural purposes is found in the alluvial valleys, in which every description of farm vegetable is successfully cultivated. The sandy plain in the south is not unfruitful, but the soil requires some considerable preparation to render it profitable to industry. Clay and marl abound in some districts, and are eminently useful to the farmers as manures for the more sterile soils. The vegetation of New Jersey is similar to that of the central region of the United States generally: on the mountains are found the oak, pine, and other forest trees, which in many instances occupy large tracts, in which the deer, bear, wolf, and most of the wild animals indigenous to that region still roam. Abundanee of stunted oaks and other trees cover the southern plain, and these, though useless for building purposes, have been found a valuable resource for steamboats and for consumption at the glass-houses which have been established in this region. The middle section is the most highly improved and wealthy part of the State. The apples and eider of this section are as noted for their superior quality as the peaches of the southern section, and these find a ready market in New York and Philadelphia. The climate of New Jersey is in many respects similar to that of Southern New York, but is much influenced by locality and elevation: in the north, where the hills are highest, it is much cooler than in the south, where the influence of the ocean is most felt, and where a low situation and reflecting sands accumulate heat in the superincumbent atmosphere. In those parts where the mephitic vapors of the swamps taint the air with their poison, agues and fevers of a malignant type prevail, but generally the State, especially in the higher lands, is very salubrious, and at Shrewsbury, on the eastern coast, and at Cape May in the summer season invalids and pleasure-seekers find a balmy retreat, in which they may enjoy all the luxuries and benefits of country retirement and refined society.

The earliest estimate of the inhabitants of New Jersey was that of 1701 , when the number was stated at 15,000 ; in 1760 , it had increased to 60,000 , and on the taking of the first United States census in 1790, it amounted to 184,139, From the latter period to 1840 , its decennial rate of increase was very equal, having generally not varied much from 15 per cent.; but from 1840 to 1850 , this rate has been doubled, most probably a result attributable to the influx of people from New Xork and Philadelphia, who, while doing business in those cities have their fomilies residing on their opposite shores, and perhaps in some meastre to the immigration of persons engaged in the manufactories and mines, which of late years have attracted the attention of capital in a greater degree than formerly. The general movement of the popuiation will exhibit the results more definitely, and are as exhibited in the subjoined table:

\begin{tabular}{|c|c|c|c|c|c|c|c|c|}
\hline \multirow{2}{*}{$\begin{array}{l}\text { Census } \\
\text { Years. }\end{array}$} & \multirow{2}{*}{$\begin{array}{l}\text { White } \\
\text { l'ersons. }\end{array}$} & \multicolumn{3}{|c|}{ Colored Persons. } & \multirow{2}{*}{$\begin{array}{c}\text { Total } \\
\text { Population. }\end{array}$} & \multicolumn{3}{|c|}{ Decennial Increase. } \\
\hline & & Free & Slave. & Total. & & & Numerical. & Per cent. \\
\hline 1790 & 169,954 . & 2,762 & $.11,423$. & $.14,185$ & $.184,139$. & & - & .. - \\
\hline 1800 & . 195,125 & 4,402 & $\ldots 12,42$ & $.16,824$ & . 211,949. & & 27,810 . & .. 15.1 \\
\hline 810 & 226,861 & & ..10,85 & $\ldots 18,694$ & 245,555 . & & 83,606 & .. 15.9 \\
\hline 1820 & 257,409 . & $.12,609$. & . 7,55 & $. .20,166$ & $.277,575$ & & 82,020 & $\ldots 13.0$ \\
\hline 1580 & 300,466 . & $.18,1$ & . 2,25 & $\ldots 20,357$ & ..320,523. & & 43,245 & .. 15.5 \\
\hline 8.10 & .. $851,5 \varsigma 8$. & .21, & 67 & ..21,718 & .373 .306$. & & 52,453 & $\ldots 16.3$ \\
\hline కรธั0 & $\ldots 466,240$. & $.23,093$. & 222 & $.23,315$ & . 459,5555 . & . & 116,249 & .81 .1 \\
\hline
\end{tabular}




\section{NEW JERSEY.}

New Jersey is divided into 20 counties, the general statistics of which and the capitals of each, in 15j0, were as follows:

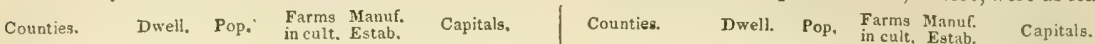
Atlantic ..... 1,584. 8,961. . 327.. 62..May's Landing Mercer ...... 4,624..27,992..1,051..191..TREMT0N Bergen ...... 2,606..14,725..1,128.. 71..Hackensack Middlesex .... 4,657..28,635..1,523. .196... New Brunswick Burlington.... 7,356. .43,208..1,635. .452 . . Mount Holly Cape Мay..... 1,218.. 6,433.. 285. 4. 4ape May C. H. Camden ......44,090 . 25,422.. 731..145. Camden Cumberiand... 3,281..17,189 .. 884. . 19..Bridgeton Essex .......10,964. .73,950..1,745. .836.. Newark Gloucester .... 2,600..14,655. . 954..141. . Woodbury Hudson...... 2,861..21,821.. 254.. 52...Bergen Hunterdon... . 5,167. .28,989 . 2,486..309.. Flemington Passaic....... 3,369. .22,575. . 610. .247. .Paterson Salem........ 3,545. .19,467. .1,313,.142. . Salem Somerset..... 3,445. .19,638 . 1,550 . .137..Somerville Sussex........ 3,851..22,989..1,653..184. . Newton

Warren....... 3,854. .22,355. .1,537 . .341. . Belvidere

The whole number of dwellings in the State was, at the above date, 81,064 ; of families, 89,080 ; and of inhabitants, 489,555 ; viz., whites 466,240 -males 233,746 , and females 232,494 ; fr. col. 28,093 -males 11,542 , and females 11,551 , and sl. 222. Of the whole population there were, deaf and dumb-wh. 192, fr. col. 11, sl. 0-total 203; blind-wh. 186, fr. col. 27, sl. 0-total 213; insane-wh. 375, fr. col. 11, sl. 0-total 386; and idiotic-wh. 310, fr. col. 16, sl. 0-total 326. The number of free persons born in the United States was 434,431, the number of foreign birth 489 , 326, and of birth unknown 521. The native population originated as follows: Me. 2S7, N. Hamp. 301, Verm. 280, Mass. 1,494, R. I. 264, Conn. 2,105, N. Y. 20,561, Newo Jersey 385,429, Penn. 15,014, Del. 1,384, Md. 1,400, Dist. of Col. 82, Virg. 628, N. Car. 98, S. Car. 141, Ga. 87, Flor. 17, Ala. 36, Miss. 43, La. 83, Tex. 6, Ark. 2, Tenn. 21, Ky. 64, Oh. 372, Mich. 66, Ind. 61, Il. 61, Mo. 28, Ia. 7, Wise. 15, Calif. 3, Territories 1; and the foreign population was composed of persons from-England 11,377, Ireland 31,092, Scotland 2,263, Wales 116, Germany 10,656, France 942, Spain 23, Portugal 16, Belgium 43, Holland 357 , Italy 30 , Austria 20, Switzerland 204, Russia 22, Denmark 28, Norway 4, Sweden 34, Prussia 57, Sardinia 1, Greece 4, China 4, Asia 10, Africa 18, British America 581, Central America 2, Mexico 23, South America 27, West Indies 265, and other countries 66 .

The statistics of the wealth, industry, and institutions of the State, as exhibited in the census returas of 1850, and other official documents referring to the same period, are as follows:

Occupied Lands, etc.-Improved farm land, 1,767,991 acres, and unimproved land, 984,985 acres-together valued in cash at $\$ 120,237,511$. The total number of farms under cultivation 1st June, 1850, was 23,905. Value of farming implements and machinery, $\$ 4,425,503$.

Live-Stock--Horses, 68,955; asses and mules, 4,089; milch cows, 118,736; working oxen, 12,070; other cattle, 80,455; sheep, 160,488 ; and swine, 250,370 - valued in the aggregate at $\$ 10,679,291$. The live-stock in 1840 numbered as follows: horses, mules, etc. 70,502 ; neat cattle of all kinds, 220,202 ; sheep, 219,285 ; and swine, $261,443$.

Products of Animals.-Wool, 375,396 (in 1840, 397,207) pounds; butter, 9,457,210 pounds; cheese, 365,756 pounds ; and the value of animals slaughtered during the year, $\$ 2,638,552$. Silk cocoons were produced to the amount of 23 pounds, and beesivax and honey to that of 156,694 pounds.

Grain Crops.-Wheat, 1,601,190 bushels; rye, 1,255,578 bushels; Indian corn, 8,759,704 bushels; oats, 3,378,063 bushels; barley, 6,492 bushels; and buckwheat, 878,934 bushels. The crops, according to the census of 1840 , were as follows: wheat, 774,203 bushels; rye, 1,665,620 bushels; Indian corn, 4,361,975 bushels; oats, 3,083,524 bushels; barley, 12,501 bushels; and buck wheat, 856,117 bushels.

Other Food Crops.-Peas and beans, 14,174 bushels; and potatoes-Irish, 3,207,236 bushels, and sweet, 508,015 bushels. The potato crop of 1839 amounted to $2,072,069$ bushels,

Ifiscellaneous Crops.-Tobacco, 310 pounds; hay, 435,950 tons ; clover-seed, 28,280 bushels; other grass-seed, 63,051 bushels; hops, 2,133 pounds; flax, 162,965 pounds; flax-seed, 16,525 bushels; maple sugar, 2,197 pounds ; molasses, 954 gallons; wilue, 1,811 gallons, ete. Value of orchard products, $\$ 607,268$, and of market-garden products $\$ 175,242$.

The following table exhibits the crops of certain staples in 1840 and 1850 comparatively:

\begin{tabular}{|c|c|c|c|c|c|c|c|c|c|}
\hline $\begin{array}{c}\text { Staples. } \\
\text { Wool.............. }\end{array}$ & $\begin{array}{l}1840 \text {. } \\
897,207 \text { pounds }\end{array}$ & & $\begin{array}{l}1850 \text {. } \\
875,396 \text { pounds }\end{array}$ & decr. & $\begin{array}{l}\text { Moveme } \\
21,811\end{array}$ & unds, & or & \multicolumn{2}{|c|}{5.5 per cent. } \\
\hline Wheat............. & 774,203 bushels & ...... & $1,601,190$ bushels & ..... incr. & 826,987 & ishels, & or & 106.8 & “ \\
\hline Indian Corn ....... & $4,361,975$ & $\ldots \ldots$ & $5,750,704$ & ......incr. 4 & $4,397, \pi 29$ & 6 & or & 100.8 & 6 \\
\hline Potatoes .......... & $2,1072.009$ & $\ldots \ldots$ & $3, \pi 15.251$ & ..... incr. & $1,613,1 S 2$ & 66 & or & 79.3 & " \\
\hline IIay ............. & 331,561 tons & $\ldots \ldots$ & 435,950 tons & ..... incr. & 101,05 & & or & 30.2 & "6 \\
\hline
\end{tabular}

Home-made manufactures for the year ending 1st June, 1850, were valued at $\$ 112,781$. The same description of goods, according to the census of 1540 , were valued at $\$ 201,625$.

Wunufuctures. - Aggregate eapital inrested, $\$ 00,000,000$; value of all raw material, fuel, ete. used, $\$ 0,000,000 ;$ average number of hands cmployed, 00,000 -males 00,000 , and females 0,000 ; monthly cost of labor, $\$ 000,000$-male $\$ 000,000$, and female $\$ 100,000$ : Falue of products for the rear, $\$ 00,000,000$. Capital emplosed in manufactures in $1540, \$ 11,517,532$. The whole number of industrial establishments producing to the value of $\$ 500$ and upward annually, on the 1st June, 18550 , was 4,874 ; and of these 21 were cotton factories, 41 woolen factories, 133 tanneries, and 108 iron manufactories, riz., 10 for pig iron, 45 for castings, and 53 for wrought iron.

The cotton factories have capital, $\$ 1,453,500$; use annually, 1,437 bales of cotton, 4,467 tons of coal and other material, valued in gross at $\$ 666,615$; hands employed, 1,712 - 616 males, and 1,096 females; monthly cost of labor, $\$ 21,565$; value of prolucts for the year, $\$ 1,109,521$; products, $\$, 122,550$ yards sheeting, etc., and $2,000,000$ pounds yarn. Capital in 1510 , $\$ 1.722, \$ 10$.

The vooten factories hare capital $\$ 494,274$; wool consumed annually, $1,510,289$ pounds; value of all raw material, fuel, ete., $\$ 5 \pm \$, 367$; hands employed, $\$ 98-411$ males, and 457 females; monthly cost of labor, $\$ 14,559-$ male $\$ 10,367$, and female 4.192 : annual products, 771,100 yards cloth, and 350,000 pounds yarn; value of entire products, $\$ 1,161,116$. Capital in $1540,5: 31.600$.

The tanneries have capital $\$ 572,557$; value of hides and skins used annually, \$423,537; hands employed, 405 ; monthly cost of labur, $\$ \$ .916$; skins tanned 120,731. and sides leather tanned, 202,970; value of entire products, $\$ 721,466$. Capital in $1510, \$ 115,725$. 


\section{NEW JERSEY.}

The iron manufacture for the year 1849-50, is exhibited in the following statistics:

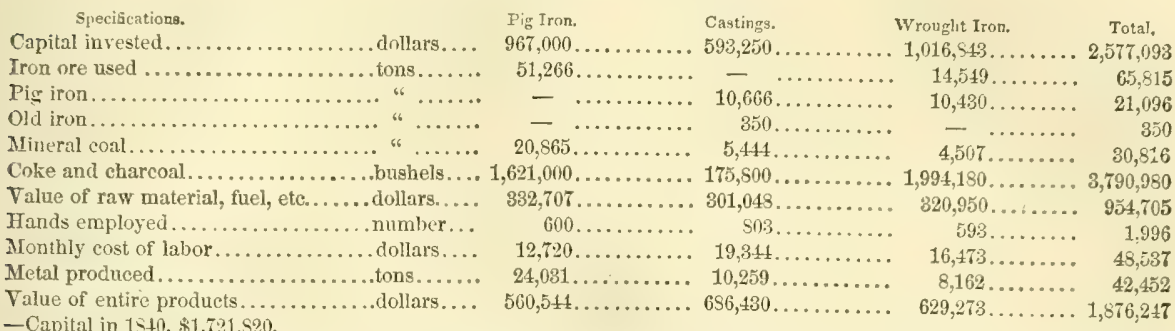
-Capital in $1810, \$ 1,721,820$.

Besides the above, New Jersey is distinguished for its machine shops, saddleries, carriage and locomotive factories, jew. elry works, glass-houses, potteries, fire-brick yards, paper manufactories, small arms factories, distilleries, paint-works, etc. and has also a large number of grist, saw, and other mills. The principal seats of manufacturing industry in the State are Newvark and Patterson. Trenton and Jersey City have also considerable manufacturing interests, and. many of the interior towns are employed in the manufacture of shoes and boots, hats, etc.

Commerce. - The foreign business of New Jersey is mostly transacted at the ports of New York and Philadelphia, and hence the direct commerce as reported in the United States treasury returns, is comparatively insignificant. The value of direct exports to foreign countries in the year ending 30 th June, 1850 , was $\$ 1,655$, and the value of imports $\$ 1,494$. Entrances 17 (1,601 tons), and clearances 11 (1,181 tons). Total amount of shipping owned in the State at the period above referred to, 80,300 tons, viz: : registered shipping 201 tons, enrolled and licensed shipping 77,735 tons, and licensed shipping (vessels under 20 tons), 2,364 tons. Of the enrolled and licensed shipping, 5,489 tons are navigated by steam. The importance of the several districts in relation to their tonnage is as follows: Perth Amboy 22,084, Bridgetown 14,472, Great Egg Harbor 14,0S4, Burlington 7,578, Camden 6,569, Newark 6,628, Little Egg Harbor 6,183. Fifty-seven vessels of all kinds, with an aggregate capacity of 6,242 tons, were built during $1849-50$, viz., 1 ship, 1 brig, 35 sehooners, 17 sloops, and 3 steamers; and of the whole number and capacity, Perth Amboy built 21 (2,637 tons), Bridgetown 9 (926 tons), Camden 9 (425 tons), Newark 2 (271 tons), Little Egg Harbor 5 (599 tons), and Great Egg Harbor 11 (1,342 tons). The value of the commerce of New Jersey for a series of years from 1791, exhibits the following variations:

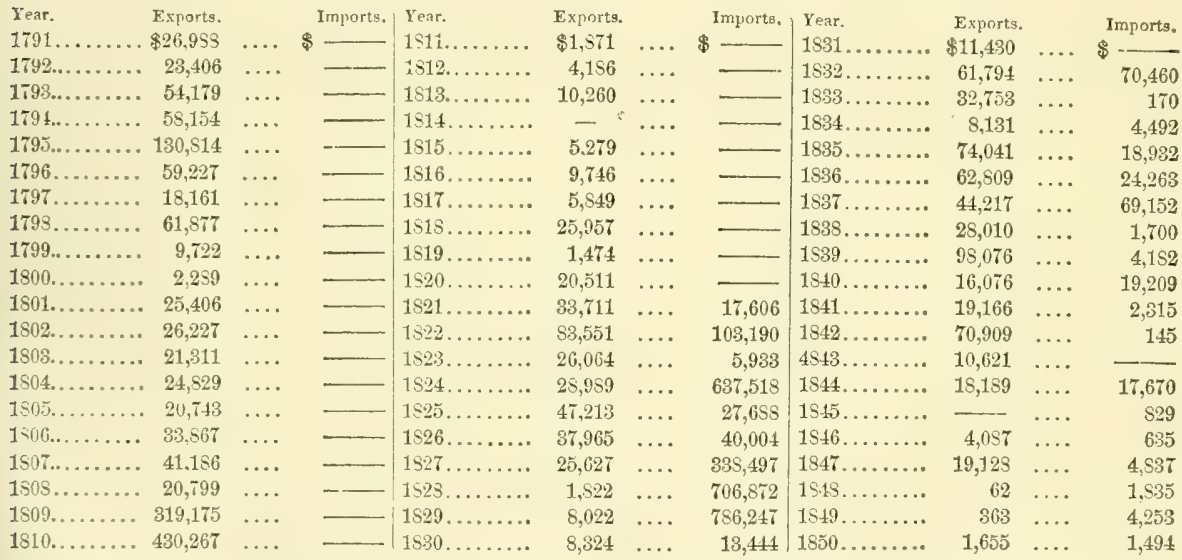

Internal Improvement.-The railroads of New Jersey, as well as the canals, are mostly constructed with a view to intercourse between New York and Pennsylvania. The Union Railroad is the only line running in any other direction, and this connects the travel west and east on the New York and Erie Pailroad with New York, passing through Paterson, one of the chief manufacturing eities of the State. The canals are, the Morris Canal and the Delaware and Raritan Canal-the first extending from Easton to Jersey City, and forming an outlet of the anthracite region of Peansylvania; and the latter extending from Bordentmwin and Trenton, on the Delaware, to New Brunswick, on the Raritan, and is the channel through which the coal of Maryland is brought to the New York market. All these lines are of infinite advantage to internal commerce and through travel. The total length of completed railroad in the State on the 1st January, 1853 , was 345 miles, being in the proportion of 1 mile to every 27 square miles of territory and to every 1,406 inhabitants.

Bunks.-On the 1st January, 1851, there were 26 banks in operation, and their condition in the aggregate at that period Was as follows: Liabilities-capital, $\$ 3,754.900$; circulation, $\$ 3,046,658$; deposits, $\$ 2,411, \$ 61$; due other banks, $\$ 378,453$; and assets-loans and discounts, $\$ 7,05 \$, 977$; real estate, $\$ 270,516$; other investments, $\$ 183,468$; due by other banks, $\$ 1,578,068$; specie, $\$ 622, \$ 84$. Since the above return was made a Free Banking Law has been adopted, and numerous banks have organized under its provisions.

The constitution under which the State is organized was adopted on the 13th August, 1844, and went into operation on the $2 d$ September of the same year.

The right of voting is conceded to every white male citizen of the United States of 21 years of age and upward who has resided in the State for one year and in the county where he claims to vote for fire months next before the election. All rotes are taken by ballot. The general election is held on the second Tuesday in October annually. 


\section{NEW JERSEY.}

The legisluture consists of a Senate and General Assembly (house of representatives). Each county is entitied to return one senator, and the members of the assembly, not to exceed 60 in number, are apportioned among the counties in ratio of their population; but each county is entitled to at least one member. The ratio is determined according to the decennial censuses of the United States. Senators must bave attained the age of 30 years, and members of the assembly that of 21 years. One-third of the senators and all the members of the assembly are elected annually; and the legislature meets at Trenton on the second Tuesday in every January.

The chief executive officer is styled Governor. He must be at least 30 years of age, have been a citizen of the United States for 20 years, and a resident of the State for seven years next before his election. He is elected by a plurality of the popular votes, or in case of an even vote, by a majority of the members of both houses of the legislature in joint meeting. The term of office is three years, and the same person is not eligible for the three years next following. The powers of the governor are limited; he may veto a bill, but a majority of both houses may pass it notwithstanding his objection; he may also grant reprieves for 90 days after conviction, and he, the chancellor, and the judges of the court of error and appeals may jointly grant pardons. During the last week of his official term he is forbid to nominate or appoint to any office. There is no lieutenant-governor, but in case of vacancy in the office of governor, the President of the Senate, and after him the Speaker of the General Assembly becomes ea officio governor; but if the vacancy occur more than 30 days before the general election, a successor is to be chosen at such election; if within 30 days, then at the succeeding election. The greater portion of administrative officers are appointed by the governor.

The judiciary consists of a Court of Errors and Appeals, a Court of Chancery, a Supreme Court, Circuit Courts, Courts of Common Pleas, etc. The "court of errors and appeals" consists of the chancellor, the justices of the supreme court, and six judges appointed by the governor, with the consent of the senate, for six years, one every year. The chancellor and supreme court judges, on appeals from their respective decisions, may state the reasons of their judgment, but can not vote. The Secretary of State is clerk of the court. The court holds terms at Trenton on the third Tuesday in January, April, July, and October. The chancellor is appointed by the governor, with the consent of the senate, for seven years, and with a clerk constitutes the "court of chancery." He is also ordinary and judge of the Prerogative Court. The court of chancery holds four terms annually at Trenton on the third Tuesday in March, June, September, and December. The "supreme court" consists of a chief judge and at least two (now four) associate judges, who are appointed by the governor for seven years. This court holds four terms each year, at the same time and place as the terms of the court of errors; and the judges of this court hold "cireuit courts" and "courts of oyer and terminer" four times a year in each county, except in the counties of Atlantic and Cape May, in which only two terms are held. The circuit court has within the county a common law jurisdiction, except in eriminal cases, coneurrent with the supreme court; and its final judgments may be declared in that court. The "court of common pleas" consists of not more than five judges in each county ; the judges of this court are chosen by joint ballot of the legislature for the term of five years, and are paid by fees. Justices of the peace are chosen for five years by the people in towns. The attorney-general, clerks of the supreme court and the court of chancery are appointed by the governor for five years. Clerks and surrogates of counties are elected by the people thereof for five years, and sheriffs and coroners annually; but sheriffs and coroners can not serve for more than three consecutive years. No person can be imprisoned for debt, except in cases of fraud; and in libel cases the truth may be given in evidence, and if published with good motives and for justifiable ends, is a sufficient defense-the jury to determine the law and the facts.

The powers-of the legislatare are limited by the Constitution. In no case can it lend the credit of the State, nor create any debt which shall raise the whole State debt above $\$ 100,000$, except in ease of war, invasion, or insurrection, and unless such be authorized by a law for some single object or work, to be distinctly specified therein, which law shall provide the ways and means, exclusive of loans, to pay the interest of each debt or liability as it falls due, and also to pay and discharge the principal within thirty-five years from the time of the contracting thereof; and no such law shall take effect until, at the general election, a majority of the people voting shall have sanctioned it. No dirorce shall be granted, or lottery authorized, and no lottery tickets shall be sold in the State. Every law shall have but one object, and that object shall be expressed in its tille. No special law can be passed for the sale of property belonging to minors or persons under legal disability. Bank charters shall be granted, continued, or amended, only by a vote of three-fifths of the members elected to each house, and for a term not exceeding 20 years.

Finances, Debts, etc.-The financial condition of the State is exhibited in the treasury report up to the close of 1850 . The available means of the treasury had been for the year commencing 1st January, $1850, \$ 138,544$, of which $\$ 9,961$ was a balance from the preceding year, and the disbursements, ordinary and extraordinary, for the same period had been $\$ 125,013$, le2ving a balance of means over expenditures of $\$ 13,001$. The chief sources of income are transit duties, and dividends on the stock of railroads and canals, taxes on railroad stock, etc. The principal expenditures were for the support of the executire, judiciary, and legislature, of State prison, and of the indigent deaf and dumb, blind, and insane, ete. The resources of the treasury are ample, amounting to $\$ 1,455,658$, of which $\$ 290,987$ is productive, consisting of railrosd and canal shares, of company bonds, of dividends, etc., and $\$ 764,671$ unproductive, being surplus revenues loaned to several counties, and pajing no interest. The absolute debt of the State amounts to $\$ 71,810$.

The principal benerolent inslitution under State patronage is the State Lunatic Asylum at Trenton. It was first opened for the admission of patients 15 th May, 1S4S. On the 1st Jan., 1S50, there were in the Asylum 110 patients -62 males and 48 females; received during the year 110-52 males and 58 females; and discharged 53-28 males and 30 females. Since the opening of the building 292 patients have been received, and 105 discharged, cured, or improred. The building is a substantial edifice, warmed by steam, lighted by gas, and ventilated thoroughly. A House of Refuge has been cstablished at Kingston, Midulesex Cuunty, and the buildings are partially complete, but wurh in them has been suspended for the present.

Federal Representation.-New Jersey, in accordance with the act of $23 d$ May, 1850, sends five representatives to the Congress of the United States.

Education.-In 1550 there were in the State 1,575 school districts, and of these 1,476 made returns. Children between 5 and 16 years of age, 114, 722 ; whole number of children taught during the year, 75,245 , of which number 13,676 attended school less than 4 months, 14,816 less than 8 months, and 10,599 less than 12 months. Colored children included in the above 1,607. Average length of schools 81 months; average cost of tuition per quarter to each scholar, $\$ 210$. The school fund amounls to $\$ 3 \$, 09970$, less $\$ 11,169$ \$5 nuavailable. Appropriated or received for school purposes $\$ 152,57362$, and expended $\$ 99,56013$. In every part of the State there are grammar schools, academies, etc. The principal colleges are-the College of New Jersey at Priuceton, founded 1746; Rutger's College at New Brunswick, 546 


\section{NEW JERSEY.}

founded 1770; and Burlington College (Episcopal), founded 1846. The college at Princeton has a law school, and at the same place is the Theological Seminary of the Presbyterian Church. The Theological Seminary of the Reformed Dutch Church, at New Brunswick, is a department of Rutger's College.

Libraries.-One State library-5,000 volumes; 3 social $-4,360$ volumes : 3 college-19,000 voiumes; 2 students $-7,000$ volumes; 1 academic or professional-9,000 volumes; 1 scientific and historical-826 volumes; 6 public school-218 volumes. Total, 17 libraries, and 46,305 volumes.

Periodical Press. - Whole number of periodicals and newspapers published in the State 1 st June, 1550, 61-of which 22 were whig, 20 democratic, and 19 neatral in politics, the last including all devoted to literature, religion, science, ete.; and of the whole number 8 wero issued daily, ciroulating 6,950 copies at each issue; 50 weekly, circulating 35,944 copies; and 3 monthly, circulating 960 copies. Of the datilies 3 were published at Newark, 1 at Elizahethtown, 3 at Trenton, and 1 at Deckertown; of the weeklies, 1 each at Buriington, Elizabethtown, Woodbury, Lambertville, Hightstown, Princeton, Middletown, Dover, and Deckertown, 2 each at Mount Holly, Bridgeton, Newark, Plainfield, Jersey City, Flemington, Rahway, Morristown, Paterson, Salem, Somerville, Newton, and Belvidere ; 3 each at Camden and New Brunswlek; 4 at Trenton, and 5 at Freehold; and of the monthlies, 2 at Princeton, and 1 at Morristown.

Religious Denominations.-The statistics of the several religious denominations in the State for the year 1850, as ascertained by the census of that year, were as follows:

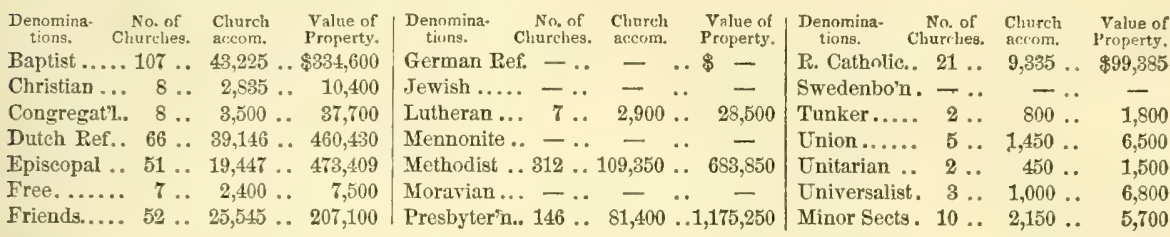

-making a total of 807 churches, with accommodation for 344,933 persons, and valued as property at $\$ 3,540,436$. The State constitutes the diocese of New Jersey, a see of the Protestant Episcopal Church; and in the Roman Catholic Church is divided between the arch-diocese of New York and the diocese of Philadelphia.

Pauperism and Crime.-The whole number of paupers relieved or supported within the year ending 1st June, 1850, was 2.392, of whom 1,816 were native-born, and 576 foreigners; and the whole number of paupers on the list at the date noted was 1,578, of whom 1,389 were native-born, and 239 foreigners. Annual cost of support, $\$ 93,110$. The State Prison is located at Trenton. The number of convicts in that institution on the 31 st December, 1849 , was 185 ; received during the year 122 , and discharged 97 , leaving 210 in prison at the end of the year 1550 . Of the last number 140 were white males, and 9 white females; and 59 colored males, and 4 colored females. Committed for manslaughter 6 , for murder in the second degree 10 , for rape 6 , for forgery 8, for burglary 21 , for larceny 41 , for violent assaults 41 , and for burning 4 . Native-born 167, and foreigners 43.

Historical Sketch -No precise date is assigned to the first white settlement in this State. The Dutch from New York planted themselves in the eastern part; while in the west, bordering on the Delaware, small bodies of Swedes were setthed. The Dutch claimed the whole country from the Connecticut to the Delaware, and protested against the Swedish occupation. Without regard, however, to the validity of the title of either party, Charles II., in 1664, granted to his brother, the Duke of York, a patent for the whole Dutch claim. In the same year the duke sold the distriet between the Hudson and Delaware rivers to Lord Berkely and Sir George Carteret. To encourage immigration, liberal grants were made to settlers, and the important privilege of self-government secured to them, the proprietors reserving to themselves the appointment of the executive. Philip Carteret was the first governor. The colony continued to thrive under the prudent management of the proprietors until 1673, when the Dutch, having re-taken New York, extended their power again over this province. Their government, however, was of brief duration; for on the conclusion of peace, the country was restored to England. The duke's patent was re-eonfirmed; but he, considering his grant to Berkely and Carteret annulled, claimed immediate jurisdietion not only over New York, but also over the Territory of New Jersey, and appointed Sir Edmund Andros governor of his Territories from the Connecticut to the Delaware. This tyrant arrived in America in 1674, and proceeded to the excreise of his functions. In the same year Lord Berkely assigned his undivided half of New Jersey to William Penn and three others, and Carteret subsequently agreed to receive East Jersey as his share of the province. The rights of the original proprietors were not acknowledged by the duke until 1680, and then not until forced by the highest legal opinion in favor of their claims. About this time the province receired a considerable accession of inhabitants by the arrival of a number of Quakers, who principally settled in the neighborhood of the present towns of Burlington and Salem, which they built. In 1682 Carteret transferred his interest in the province to William Penn and eleven other persons of the sect of Quakers ; these immediately conveyed one-half of the province to a company of Scotchmen, at the head of whom was the Earl of Perth. After this event many immigrants arrived from Scotland. The first governor of East Jersey under the proprietors was Robert Barkley, the celebrated author of the "Apology for the Quakers." After the accession of the Duke of York to the throne, a writ of quo roarranto was directed to issue against the proprietors, who, finding there was no other resource, endeavored to save what they could by voluntary submission, and made a formal surrender of their patent, praying only for a grant of the soil. It was intended by the new king that the whole province, together with that of New York, should be united with New England in an arbitrary government; and arrangements were making to carry the design into execution, when the Revolution of $16 s$ fortunately $^{2}$ put an end to his power. In 1702 the proprietary of both parts was surrendered to Queen Anne, and the provinces which had experienced no repose in separation, were again united under a single government. Lord Cornbury was the first royal governor; he was also Governor of New York, and abused his functions in both provinces. From this period to the epoch of the American Revolution, New Jersey was not the scene of any memorable event. Its population and prosperity augmented under an orderly and prudent administration of affairs. From its connection with England, hotrever, the province became involved in the wars of that country; and though remote from the scene of action, we find it contributing on several occasions to the expeditions undertaken for the conquest of the French possessions. The last royal governor of the province was William Temple Franklin, a son of the celebrated Benjamin Franklin. During the Revolution New Jersey suffered much, and Trenton, Princeton, Milstone, Red Bank, and Monmourh, are famous as 
the scenes of American triumphs. When the blessings of peace were again restored to the United States, New Jersey soon recovered its former prosperity; and the usual accompaniment of prosperity, a barrenness of striking events, attends her history from that period.

Trenton, on the Delaware, is the political capital of the State.

New Jerusalem, p. o., Berks co., Penn. : 58 m. E. by N. Harrisburg. There are in this vicinity beds of iron ore, a furnace, and a foroe.

New Kent county, Firg. Situate toward the E., and contains 241 sq. m. Drained by Pamunky and Chichhominy rivers, branches of James and York rivers. Surface level; soil of a verage fertility. Staples, wheat, oats, and Indian corn. Farms 313; manuf. 12; dwell. 535, and pop.-wh. 2,221, fi. col. 433, sl. 3,410-total 6,064. Capital: New Kent C. H New Kent, p. v., and cap. New Kent co., Virg. : 25 m. E. Richmond. Besides the court-house and jail, it contain only a few dwellings.

New Kingston, p. o., Cumberland county, Penn.: $15 \mathrm{~m}$ W. by S. Harrisburg.

New Krek's Mrlss, p. 0., Fulton county, N. Y.: $49 \mathrm{~m}$ N. W. Albany.

New Laxcaster, p. o., Tipton co., Ind.: on branch of Duck cr. of White r., $35 \mathrm{~m}$. N. by E. Indianapolis.

New Laycaster, p. v., Warren county, $I l l . ; 86$ m. N. W. Springfield.

New Lebanox, p. o., De Kalb co., Ill.; 165 m. N. N. E. Springfield.

New Lebanon, p. o, Mercer co., Penn.: 177 m. W. N. W. Harrisburg.

New Lebarox, p. o., Sullivan county, Ind.: $85 \mathrm{~m}$. S. W. Indianapolis.

New Lebanox, t, and p. v., Columbia co, $N . Y_{*}: 23 \mathrm{~m}$ S.E. Albany, Drained by Lebanon and Kinderhook creeks, which here unite. Surface on E. and W. sides hilly and mountainous; the rest being chiefly a rich valley. Contains 3 principal settlements, New Lebanon, New Lebano Springs, and New Lebanon Shaker Village. Pop. of t. 2,300

New Lebaron, p. 0, Montgomery county, Ohio: $66 \mathrm{~m}$ W. by S. Columbus.

New Lebanox Centre, p. o, Columbia co., $N . Y_{.}: 24 \mathrm{~m}$ S. E. Albany

New Lebanon Sprixgs, p. v., Columbia county, $N$. $Y$. $25 \mathrm{~m}$. S. E. Albany, near the Mass. State line. This fashionable watering-place of great resort is justly celebrated for the medicinal qualities of its springs, salubrity of climate, and beautiful scenery. Here are several fine hotels. A railroad is in construction from Bennington to Chatham Four Corners, to pass through the $\mathrm{v}$. The usual number of visitors to these springs per annum is from 7,000 to 8,000 . In this $\mathrm{v}$. is the Thermometer Manufactory of the Kendal brothers, who make 25,000 yearly.

New Lexington, p. .., Somerset co., Penn. : on E. side of Laurel Hill cr., $124 \mathrm{~m}$. W. by S. Harrisburg.

New Lexington, p. V., Tuscaloosa co., Ala. : on the W. side of North r., 111 m. N. W. Montgomery.

NEW LExirgtoN, p. r., Van Buren co., Ia. : on N. ban of Des Moines r., $80 \mathrm{~m}$. W. by S. Iowa City.

New Lexuigton, p. v., Perty co, Ohio: 45 m. E. S. E. Columbus.

New Liberty, p. V., Owen co, $K y_{*}: 27 \mathrm{~m}$. N. Frankfort.

New Lrberty, p. F., Pope con, $I u_{*}$ : on E. side of Ohio r. $196 \mathrm{~m}$. S. by E. Springfield.

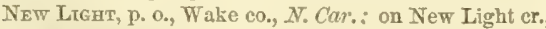
$24 \mathrm{~m}$. N. Raleigh.

New LismoN, p. v., Henry co., Ind.: 85 m. E. by $\mathbb{N}$. Indianapolis.

New Lisior, t. and p. o., Otsego county, $N . Y_{.}: 76 \mathrm{~m}$. W. Albany. Surface of t. hilly; soil, sandy loam. Drained by Butternut and Otego creeks. Pop, 1,773.

New Lrsbor, p. v., Burlington co., $N$. Jer.: on Rancocus cr., $16 \mathrm{~m}$. S. by E. Trenton.

New Lisbon, p. v., and cap. Columbiana county, Orio 126 m. E. N. E. by N. Columbus, on N. side of Middle Fork 543 of Little Beaver r., and on the Sandy and Beaver Canal. The $r$. furnishes a large water-power, which is used by several saw-mills, flour-mills, and factories. Besides the court-house and jail, it contains 7 churches. Four newspapers are published weekly, "American Palladium" (whig), "American Patriot," "Ohio Patriot" (dem.), "Aurora" (F. S)

New London county, Conn. Situate S. E., and contains 550 sq. m. Drained by Thames $\mathbf{r}$. formed by the junction of Yantic and Shetucket rivers, which supply good waterpower. Connecticut $r$, bounds it on the $\mathrm{S}$. W. and Pawcatuct on the S. E. Surface billy; soil fertile and adapted to the production of different kinds of grain. On Long Island Sound, which bounds it on the $S$., are a number of fine harbors. Chief productions, wheat, Indian corn, oats, and potatoes. Farms 2,619 ; manuf. 765; dwell. 8,336, and pop. -wh. 50,328, fr. col. 1,493-total 51,821. Capital: New London, Putlic Works: New Haven and New London R. P. ; New London and Stonington R. R.; New London, Willimantic, and Palmer $P_{b}$. R.; Norwich and Woreesler R. R., ete.

New Londor, t., p. city, port of entry, and semi-cap. New London co., Conn.: on W. bank of Thames r., $3 \mathrm{~m}$. from its entrance into Long Island Sound, $43 \mathrm{~m}$. S. E. Hartford, 43 m. E. New Haven. Lat. N. 410 22', long. W. $72 \circ 9^{\prime}$. The harbor is the best in the State, and one of the best in the United States. It has a depth of 30 feet, is spacious and safe. Its entrance is narrow and defended by forts Trumbull and Griswold; the former is garrisoned by a company of U. S. Artillery. It is one of the whaling ports of New England. In 1549 it received 1,949 barrels of sperm oil, 35,030 barrels of whale oil, and 301,100 pounds of whalebone. The city is built upon an acclivity, rising from the $r$, toward the W. and N. Back of the city is a summit of high ground, where the observer has a fine view of the harbor and surrounding country. The surface is uneven, lying on granite rocks, on which account the city was laid out irregularly; but lately various improvements have been made. This t. was settled in 1646 , and a large portion of it burnt by the British under Amold, Sept. 6, 1781. It contains the county buildings, 7 churches, academies, etc. There are 3 banks with capital of $\$ 414,625$. New London is connected by railroad with New Haven, $50 \mathrm{~m}$; ; with Willimantic, $80 \mathrm{~m}$; ; and with Worcester from Allyn's Point, $66 \mathrm{~m}$. There is also a daily line of steamboats from New York. Two newspapers are published daily, "Chronicle" (whig), and "Morning Star" (dem.); two weekly, "Chronicle," and "Democrat." This is the principal port in the State; and the inhabitants are extensively engaged in the coasting trade and the fisheries. On the 30 th June, 1850, the total tonnage of this district was 40,485 tons. The registered tonnage was 23,364 tons, of which 22,504 were permanent and 860 temporary; 2,622 tons were in the whale fishery. The enrolled and licensed tonnage was 17,121 tons, of which $16,17 \mathrm{~S}$ tons were permanent, 3,879 propelled by steam, 11,577 were in the coasting trade, 3,594 in cod fishery, 1,007 in mackerel fishery; of tonnage licensed under 20 tons, 181 tons were in the coasting trade, and 762 in cod fishery. During the year preceding, the clearanees for foreign countries were $18-4,943$ tons; number of entrances, do., 26-7,876 tons; number of vessels built, 8 (schooners) -606 tons. Pop. in $1830,4,356$; in $1840,5,519$; in $1850,9,006$.

NEw Loxpox, p. v., Henry county, Ia. : $51 \mathrm{~m}$. S. by E. Iowa City.

New Londox, p. F., Frederick co., MU.: $50 \mathrm{~m}$. N. W. Annapolis.

New Lownox, p. v., and cap. Ralls co., MO. : on S. side Salt r.. son n. N. X. E. Tefferson City.

New Londos, t. and p. o., Merrimac co, N. Hamp.: 
27 m. N. W. by W. Concord. Surface uneven; soil good. Sunipee lake lies on its S. W. border; and there are 3 other pouds in the t. At the outlet of Pleasant pond, on Blackwater $r$, is a scythe factory, making 86,000 scythes yearly. Pnp. 945.

New Loxpor, p. v., Oneida co., N. Y.: $102 \mathrm{~m}$. W. N. W. Albany, on Erie Canal.

New LoNDow, p. v., Howard co., Ind.: on S, side of Wild Cat cr. of Wabash r., $45 \mathrm{~m}$. N. by W. Indianapolis.

New Loydor, t., p. v., and sta., Huron co., Ohio: $82 \mathrm{~m}$. N. N. E. Columbus. Drained by Vermillion r. and branches. The $\mathbf{v}$, is situated on E. side of the $r$. The Cincinnati, Cleveland, and Columbus $\mathrm{P}$. R. passes through it, $47 \mathrm{~m}$. from Cleveland, $88 \mathrm{~m}$. from Columbus. Pop, of t. 1,329 .

New London, p. Y., Campbell co., Virg.: on branch of Staunton r., $95 \mathrm{~m}$. W. by S. Richmond; is one of the oldest towns in the State, though of small population. The U. S. Armory, now at Harper's Ferry, was originally located here.

New Lowdon, t. and p. v., Chester county, Penn.: $61 \mathrm{~m}$. S. E. by E. Harrisburg. Drained by Clay cr., and by Elk cr., which is its W. boundary. Surface nearly even, with slight declivities; soil sandy loam. The $v_{\text {. contains several }}$ stores, and considerable manufacturing is done in the town. At New London Cross-roads there is a forge and a rollingmill.

New Lrme, t. and p. o., Ashtabula co., Ohio: $156 \mathrm{~m}$. N. E. Columbus. Drained by branches of Grand r. Pop. 628.

New Madrson, p. o., Darke county, Ohio: on a creek of Whitewater river, $92 \mathrm{~m}$. W. Columbus,

NEw Madrm county, Mo. Situate S. E.g and contains 573 sq. m. Drained by Whitewater river, which traverses its western portion, and by the lakes, which occupy a large portion of the county. Surface low and level, and liable to submersion, in consequence of which the soil is in many parts unfit for cultivation, but in other sections is fertile and productive. Farms 407; manuf. 30 ; dwell. 752, and pop.wh. 4,057, fr. col. 3, sl. 1,481-total 5,541. Capital: New Madrid.

New Madrid, p. v., and cap. New Madrid co., Mo.: on the Mississippi r., on the N. W. bank of a large bend, and at mouth of St. John river. It contains the court-house and county offices. The "Commercial Herald" (Miscel.) and "Journal of the Times" (Miscel.) are published weekly. This place suffered severely by earthquakes in 1811 and '12. The bluff bank, upon which the v. was built, was thereby lowered 15 or 20 feet. Since then the river has washed away a portion of the bank.

New Mahonng, p. o., Carbon county, Penn.: $70 \mathrm{~m}$. N. E. Harrisburg.

Newman's Mruss, p. v., Indiana county, Penn.: 106 m. W. N. W. Harrisburg. A plank-road $43 \mathrm{~m}$. long, passing through Indiana v., connects this v. with the Pennsylvania Paiuroad.
Newmansville, p. 0., Greene county, Tenn. 220 m. E. Nash ville.

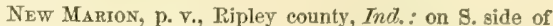
Graham's Fork, 65 m. S. E. by S. Indianapolis. A plankroad runs hence to Madison.

New Market, p. v., Madison county, Ala.: $171 \mathrm{~m} . \mathrm{N}$. Montgomery, $3 \mathrm{~m}$. S. Tennessee State line.

New Market, p. o., Vigo co., Ind. : 1 m. E. Illinois State line, $70 \mathrm{~m}$. W. S. W. Indianapolis.

New Marker, p. v, Marion co., $\bar{k} y_{0}:$ on $N_{\text {. }}$ side of Polling Fork of Salt r., 48 m. S. S. W. Frankfort

New Market, p. v., Frederiek $c_{\text {., }} M d_{\text {: }}$ : on $\mathbb{N}$. bank of Bush cr., $47 \mathrm{~m}$. N. W. by W. Annapolis, $1 \mathrm{~m}$. from Monrovia, on Balt, and Ohio R. R. ; has some trade.

New Market, p. v., Platte co., Mo.: 153 m. W. N. W. Jefferson City,

New Market, t., p. o., and sta., Rockingham county, N. Hamp. : 30 m. E. S. E. Concord. Bounded on the E. by Great Bay. Drained by a branch of Lamprey r. The Boston and Maine R. R. passes through the $t_{0}, 57 \mathrm{~m}$. from Boston. Pop. 1,689

New Market, p. v. and sta., Middlesex co., N. Jer. : $30 \mathrm{~m}$. N. E. Trenton, and $17 \mathrm{~m}$. from Elizabethport, on the New Jersey Central $\mathrm{R}$. R.

New Markex, p. v., Randolph co., N. Car : 69 m. W. Raleigh.

NEw Marker, p. v. Van Buren co., Ia. : on $\mathrm{S}$, side of Des Moines r., 63 m. S. S. E. Iowa City.

New Market, t, and p. o., Highland co, Ohio: $63 \mathrm{~m}$. S. W. by S. Columbus. Pop. 1,528.

Nww Market, p. o., Abbeville district, S. Car.: $63 \mathrm{~m}$. W. by. N. Columbja

New Market, p. v., Jefferson county, Tenn. : 180 m. E Nashville.

New Market, p. v., Shenandoah co., Virg.: on the N. for's of the Shenandoah r., $98 \mathrm{~m}$. N. W. Richmond.

NEW Market, p. o., Monroe county, Ga.: 48 m. W Milledgeville.

New MARket, p. o., Lewis co., Oreg. Ter..: on a southerm inlet of Puget Sound, 143 m. N. by E. Salem.

New Marlborough, t. and p. v., Berkshire co., Mass. : $112 \mathrm{~m}$. W. by S. Boston. Drained by Konkapot $\mathrm{r}$., and a small lake with its outlet in the S. part of the town, which empties into Blackberry $\mathbf{r}$, in Conn. Surface generally uneven, with a ridge of high hills traversing from $\mathrm{N}$. to $\mathrm{S}$. soil adapted to grazing. The t. contains several stores and manufactories. Pop. 1,847.

New Martinsville, p. o., Wetzel county, $\operatorname{Vir}^{\circ} \ell_{\circ}: 225 \mathrm{~m}$. N. W. Richmond.

New Maxsville, p. v., Putnam county, Ind.: $30 \mathrm{~m}$. W. Indianapolis.

New Maysville, p. o., Pike county, $I l l_{*}$ : W. by S. Springfield.

\section{THE TERRITORY OF NEW MEXICO.}

NEw MExrco, as now organized, lies between the latitudes $32^{\circ}$ and $38 \circ$, and stretehes east and west between Texas on the one hand and Vtah and California on the other. Its definite boundary begins "at a point in the Colorado River, where the boundary line of the Republic of Mexico crosses the same; thence eastwardly with said boundary line to the Rio Grande; thence following the main channel of said river to the parallel of the $32 d$ degree of north latitude; thence eastward with same degree to its intersection with the 103d degree of longitude west from Greenwich; thence north with said degree of longitude to the parallel of the 38 th degree of north latitude; thence west with said parallel to the summit of the Sierra Madre; thence south with the crest of said mountains to the 37th parallel of north latitude; thence west with the said parallel to its intersection with the boundary line of the State of California; thence with the said boundary line to the place of beginning." Within these boundaries the area is estimated at 210,744 square miles.

That portion of New Mexico westward of the Sierra Madre can only be considered as a temporary appendage to the Territory. It is bounded south by the Rio Gila, and extends north to the 37th parallel, being watered by the Colorado and numerons affuents of the river bounding it on the south. In the north-east part it is occupied by considerable mount. ains and mountain valleys, and the whole eastern line is also mountainous and rugged. The interior forms a raried country, with much fine agricultural lands, and the country bordering on the Gila, which is hilly and broken, abounds in mines of copper, gold, silver, ete., accounts of which are recorded by the Commissioners of the Boundary Survey. It is divided into the counties of Rio Arriba and Socorro, and comprises about two-fifths of the area of the Territory. It is 


\section{NEW MEXICO.}

solely inhabited by Indians - the Navajoes in the north-east, the Apaches in the east and south-east, the Pimos in the west and south-west, and the Pah-Utahs in the north-west.

New Mexico proper, in its general aspect, is mountainous, with a large valley in the middle, running from north to south, and formed by the Rio Grande. The valley is generally about twenty miles wide, and bordered on the east and west by mountain chains, continuations of the Rocky Mountains, which have here received various names, as Sierra Blanca, Sierra de los Organos, Sierra Oscura, etc., on the east side, and Sierra Madre, Sierra de los Grullas, de Acha, de Ios Mimbres, etc., on the west side. The height of these mountains south of Santa Fé may, upon an average, be from 6,000 to 8,000 feet, while near Santa Fé, and in the more northern regions, some snow-capped peaks are seen that may rise from 10,000 to 12,000 feet above the sea. The mountains are principally composed of igneous rocks, as sienite, granite, diorit, basalt, ete. On the higher mountains excellent pine timber grows; on the lower, cedars, and sometimes oaks, and in the central valleys, mezquite, etc.

The main artery of New Mexico is the Rio Grande, a large and long river. Its head waters were explored in 1807 by Captain Pike, between $37^{\circ}$ and $35^{\circ}$ north latitude, but its highest sources are some two degrees farther north, in the recesses of the Rocky Mountains, near the head waters of the Arkansas and the Colorado of the West. Following a generally southern direction, it passes through the territory, where its principal affluent is the Rio Chamas from the west, and winds its way in a south-eastern direction, dividing in its course, below $32^{\circ}$ north latitude, the United States from the Mexican Republic, to the Gulf, into which it falls in $25^{\circ} 50^{\prime}$ north latitude, Its tributaries velow New Mexico are, from the north, the Rio Pecos, and from the south the Conchos, Salado, Alamo, and San Juan. The length of the river in a straight line is about 1,200 miles, but from the meanderings of its lower course, it runs at least 2,000 miles from the region of eternal snows to the almost tropical climate of the Gulf. The elevation of the river above the sea at Albuquerque is about 4,800 feet; at El Paso about 3,800 feet; and at Reynosa, about 300 or 400 miles above its mouth, not more than 170 feet. The fall of the water between Albuquerque and El Paso is from two to three feet in a mile, and below El Paso about one foot in two miles. The fall of the river is seldom used as a motive power, except for some flour mills, which are oftener worked by mules than by water. The principal advantage at present derived from the stream is for agriculture, by a well-managed system of irrigation. As to its navigation in New Mexico, it is doubtful if even canoes could be used, except, perhaps, during May or June, when the river is in its highest stage, from the melting of the snows in the mountains. It is entirely too shallow, and interrupted by too many sand bars to promise any thing for navigation. On the southern portions of the river steamboats may ascend from the Gulf as far as Laredo, a distance of about 700 miles. "Whenever a closer connection between this head point of navigation and New Mexico shall be considered," says Dr. Wislizenus, "nothing would answer but a railroad crossing from the valley of the Rio Grande to the high table-land in the State of Chihuahua."

The soil in the valley of New Mexico is generally sandy, and looks poor, but by irrigation it produces abundant crops, and though agriculture is carried on in a very primitive way, with the hoe alone, or with a rough plow, made entirely of wood, without any particle of iron, the inhabitants raise large quantities of Indian corn and wheat, beans, onions, red peppers, and some fruits. The most fertile part of the valley begins below Santa $\mathrm{F}$, along the river, and is called "Rio Abajo," or the country down the river. It is not uncommon there to raise two crops within the year. The general dryness of the climate, and the aridity of the soil, however, will always confine agriculture to the valleys of the water-courscs. "But this important defect," says Dr. Wislizenus, "may be remedied by artesian wells.o On several oecasions I remarked on the high table-lands of Santa F'e south, that in a certain depth layers of elay are found that may form reservoirs of sunken water-courses from the eastern to the western chain, which, by the improved method of boring, might be easily made to yield their waters to the surface. If experiments to that effect should prove successful, the progress of agriculture in New Mexico would be more rapid, and even manj dreaded 'jornada' might be changed from waterless deserts into cultivated plains." But at present irrigation from a water-course is the only available means of carrying on agriculture. The irrigation is effected by leading the waters over the cultivated lands through canals. The consequence of this is that the inhabitants locate themselves together, and allot water to each at certain periods. The corn fields are generally without fenoes, which are less needed here, as the grazing stock are tended by herdsmen. The best cultivated lands are found in the "estancias," or large estates belonging to the rich. These haciendas are apparentiy a remnant of the old feudal system, and were granted with the Indians and all other appurtenanees by the Spanish erown to favorite vassals. The great number of human beings attached to these estates are nothing more than mere serfs, receiving from their task-masters food, lodging, and clothing. How far the American element in the constitution of society in the Territory may modify this industrial monstrosity has yet to be seen.

The inhabitants pay considerable attention to raising stock, and the great owners are possessed of large numbers of horses, mules, cattle, and sheep. These, however, are of small size, because little attention has been given to improving the breeds; but they increase very rapidly, and little trouble is experienced in rearing them, as no housing is required in winter. The pasturage in the uncultivated parts is extensive, and thousands of stock graze thereon the year through. The Indians prove the greatest enemies to the farmers, and frequently carry off whole herds of cattle, etc.

The mines of New Mexico are very rich, but mining operations have been much neglected, and a great many of the most valuable which were formerly worked have been entirely deserted, owing chiefly to the unsettled state of the country, the invasions of the Indians, and other impediments. Gold, silver, iron, copper, etc., are abundant in all the mountain country. Gold has been found in the Santa F6 district and south of it for a hundred miles, as far as Gran Quivira, and north one hundred and twenty miles up to the Rio Sangre de Cristo. The poorer classes occupy much of their time in washing out gold dust, which is largely deposited in the mountain streams about Santa Fé; these washings are very rich, and some gold mines are also worked there. These mines, according to Dr. Wislizenus, are the only mines of any consequence worked at the present time in all New Mexico. Several rich silver mines were worked by the Spaniards at Avo, at Cerrillos, and in the-Nambe Mountains, but operations have long since ceased. Copper is abundant throughout the country, but especially at Las Tijeras, Jemez, Abiqui, Guadalupeta de Mora, ete. Only one mine south of the placeros is at the present time worked. Iron, though equally abundant, is entirely overlooked, being considered of little value, in comparison with the precious metals. Coal has been discovered in a number of places, as in the Raton Mountains, near the village of Jemez, south-west of Santa Fé, and other places to the south. Gypsum, common and selenite, is also found in large quantities; the common is used as lime for white-washing, and the selenite or crystalline instead of window-glass. About 100 miles south-east of Santa. Fé, on the high table-lands between the Del Norte and Pecos, are some extensive salt lakes or salinas, from which all the domestic salt used in New Mexico is procured. Lirrge 


\section{NEW MEXICO.}

caravans go there from the capital in the dry season, and return with as much as they can conveniently transport, and the merchants exchange their salt for wheat, bushel for bushel, or sell it for one or even two dollars a bushel.

"Not far from these salinas," says Dr. Wislizenus, "the ruins of an old eity are found-of the fabulous 'la Gran Quiviri." The common report in relation to this place is, that a very large and wealthy eity was once here situated, with very rich mines, the produce of which was once or twice a year sent to Spain. $\Delta t$ one season, when they were making extraordinary preparations for transporting the precious metals, the Indians attacked them; whereupon the miners buried their treasures, worth forty millions, and left the eity together; but they were all killed except two, who went to Mexico, giving the particulars of the affair, and soliciting aid to return. But the distance being so great and the Indians so numerous, nobody wotild advance, and the thing was dropped. One of the two went to New Orleans, then under the dominion of Spain, raised five hundred men, and started by way of the Sabine but was never heard of afterward. So far the report. Within the last few years several Americans and Frenchmen have visited the place; and although they have not found the treasure, they certify at least to the existence of an aqueduct, about 10 miles in length, to the still standing walls of several churches, the sculptures of the Spanish coat-of-arms, and to many spacious pits, supposed to be silver mines. It was, no donbt, a spanish mining town, and it is not unlikely it was destroyed in 1680 , in the general successful insurrection of the Indians in New Mexico against the Spaniards. Dr. Samuel G. Morton, in a late pamphlet, suggests the probability that it was originally an old Indian city, into which the Spaniards, as in several other instances, had introduced themselves, and subsequently abandoned it. Further investigation, it is to be hoped, will clear up this point."

The climate of New Mexico is generally temperate, constant, and healthy. Considerable atmospheric differences, however, are experienced in the mountain distriets and in the low valley of the Rio Grande. In the latter, the summer heat sometimes rises to $100^{\circ}$ Fahrenheit, but the nights are always cool and pleasant. The winters are comparatively long, and the higher mountains are always covered with snow, and ice and snow are common at Santa Fé, but the main river is never frozen over strong enough to admit the passage of horses and earriages. The sky is generally elear and dry, owing to the condensation of moisture on the surrounding hills. The months of July and October inclusive, constitute the rainy season, but the rains are neither so heavy nor so regular in their returns as on the more southern part of the continent. Discase is little kuown, except some inflammations and typhoid fevers in the winter season.

The constitution of society in New Mexico, irrespective of the changes effected by the intermixture among the people of the American residents, is much similar to that of other nations of Spanish origin. While the higher classes conform to the dictates of modern fashion, the mass of the people adhere to the manners and customs of former times. The men are faithful to their serapes, or colored blankets, and to their wide trowsers, with glittering buttons, and split from hip to ancle, to give the white cotton drawers a chance to be seen; and the women of all classes retain the rebozo, or small shawl, drawn over their heads, which gives them so coquettish an appearance, and adds so greatly to their irresistible charms. Both sexes enjoy their cigaritos, their siesta, and their evening amusement at monté or fandango. Their dances are very graceful, and combine the waltz and quadrille. The prominent ingredient in the Mexican race is their Indian blood-it is visible in their features, complexion, in their acts and disposals. The men are ill-featured, but the women are graceful in their deportment and manners. The difference in the sexes are nowhere more observable. The men are lazy, mendacious, treacherous, and cruel, while the women are open-hearted, and when their affections are requited, faithful wives; but they are too often considered as mere household drudges. As a general remark, the females are devoid of education, but possess a strong common sense and natural aptness and sympathy, which are often of more practical use than the most refined book education. The sufferings of the Texans captured while prosecutiag the Santa Fé expedition were much mitigated by the benevolent attentions and disinterested kindnesses of the women - acts which, when contrasted with the barbarities and insults heaped upon them by the male portion of the inhabitants, will ever reflect honor on their many virtues.

New Mexico is divided in seven counties, the general statistics of which, and the capitals of each, in 1850, were as follows:

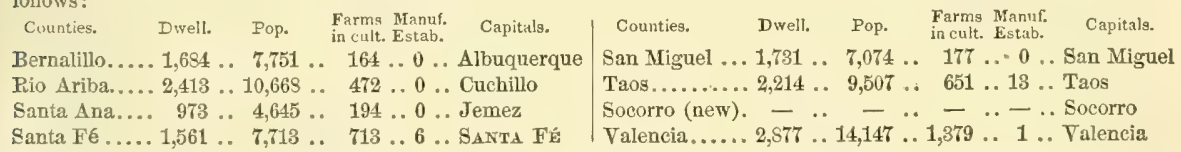

The whole number of dwellings in the State was, at the above date, 13,453 , of families 13,502 , and of inhabitants 61,505 , viz. : whites 61,458 -males 31,706 , and females 29,782, fr. col. 17-males 14, and females 3. Of the whole population there were deaf and dumb-wh. 14, fr. col. 0-total 14; blind-wh. 98, fr. col. 0-total 98; insane-wh. 11, fr. col. 0total 11; and idiotic - wh. 38, fr. col. 0-total 38. The number of free persons born in the United States was 59,261, the number of foreign birth 2,063, and of birth unknown 223. The native population originated as follows: Me. 12, N. Hamp. 6, Verm. 8, Mass. 24, R. I. 1, Conn. 10, N. Y. 101, N. Jer. 9, Penn. 97, Del. 6, Md. 37, Dist. of Col. 12, Virg. 77, N. Car. 18, S. Car. 18, Ga. 9, Flor. 5, Ala. 5, Miss. 0, La. 4, Tex. 46, Ark. 17, Tenn. 25, Ky. 62, Ohio 34, Mich. 8, Ind. 11, In. 24, Mo. 63, Ia. 3, Wisc. 1, Calif. 6, Nero MLexico 58,451, Territories 56; and the foreign population was composed of persons from-England 43, Ireland 292, Scotland, 29, Wales 1, Germany 215, France 26, Spain 8, Portugal 1, Belgium 0, Holland 2, Italy 1, Austria 0, Switzerland 11, Russia 4, Denmark 2, Norway 2, Sweden 1, Prussia 14, Sardinia 0, Greece 0, China 0, British Ameriea 5S, Mexico 1,365, West Indies 2, and other countries 5 .

The slatistical returns of the wealth, industry, products, ete., of the Territory, according to the census of 1850 , and other official documents referring to the same period of time, are as follows:

Occupied Lands, etc.-Improved farm lands 166,201 acres, and unimproved lands 124,370 acres-valued in cash at $\$ 1,653,952$; number of farms under cultivation 3,750 ; value of farming implements and machinery $\$ 77,960$.

Live-Stock,-Horses, 5,079; asses and mules, 8,654; mileh cows, 10,635; working oxen, 12,257; other cattle, 10,085; sheep, 377,271 ; swine, 7,314 -in the aggregate valued in cash at $\$ 1,494,629$.

Products of Animals,-Wool, 32,901 pounds; butter, 111 pounds; cheese, 5,54S pounds; and the ralue of animals slaughtered during the year $\$ 82,125$. Neither silk, nor beeswax and honey are returned by the census takers, although it is well known that both are produced to a considerable amount.

Grain and other Food Crops.-Wheat, 196,516 bushels; rye, 0 bushels; Indian corn, 365,411 bushels; oats, 5 bushels; barley, 5 bushels; and buckwheat, 100 bushels. The other food erops consisted of 15,688 bushels of peas, and three bushels of Irish potatoes. 


\section{NEW MEXICO.}

Miscelluneous Crops.-Tobaceo, $8,46 \pi$ pounds; molasses, 4,230 gallons; and wine, 2,363 gallons. Falue of orchlard products, $\$ 3,231$, and of market-garden products, $\$ 6,679$.

Home-made Mranufuctures for the year ending 1st June, 1550 , were valued at $\$ 6,039$. There is but one tannery in the Territory with a capital of $\$ 500$.

"The New Mexicans are celebrated for the manufacture of coarse blankets, which is an article of considerable traffic between them and the southern provinces, as also with the neighboring Indians, and on some occasions with the States eastward of the country. The finer articles are curiously woven in handsome figures of various colors. These are of different qualities, the most ordinary being valued at about two dollars, while those of the finest texture, especially their imitations of the serape Navajo, will sell for twenty dollars or more. There have been also made in New Mexico a few imitations of the seraps Saltillero, the blanket of Saltillo, a cily of the South, celebrated for the manufacture of the most splendid fancy blankets, singularly figured with all the colors of the rainbow. These are often sold for more than fifty dollars each. What renders the weaving of the fancy blankets extremely tedious is, that the variegation of colors is all effected with the shuttle; the texture in other respects being perfectly plain, without eren a twill. An additional value is set upon the fine serape on account of its being a fashionable substitute for a cloak. Indeed, the inferior serape is the only over-dress used by the peasantry in the winter.

"Besides blankets, the New Mexicans manufacture a kind of coarse twilled woolen stuff called gerga, which is checkered with black and white, and is used for carpets, and also by the peasantry for clothing; which, in fact, with some other similar domestie stuffs, together with buckskin, constituted almost the only article of wear they were possessed of, till the trade from Missouri furnished them with foreign fabrics at more reasonable prices than they had been in the habit of paying to the traders of the southern provinces. Their domestic textures are nearly all of wool, there being no flax or hemp, and but little cotton spun. The manufacture even of these articles is greatly embarrassed for want of good spinning and weaving machinery. Much of the spinning is done with the huso, or malacate (the whirligig spindle), which is kept whirling in a bowl with the fugers, while the thread is drawn. The dexterity with which the females spin with this simple apparatus is truly astonisbing." -Gregg.

New Mexico receives most of its foreign goods by the overland route. This trade is carried on by caravans that traverse the desert at stated periods annually. Before 1822 it had scarcely an existence, but since that time it has gradually increased and become profitable; and it is probable that the total value of goods thus annually brought into the territory is not less than a million of dollars; but a great portion of the goods representing this amount is smuggled into Chihuahua and other Mexican States. The established post or entrepot for depositing the goods bruught on the voyage upward by the Missouri for the Santa Fé trade, is the town of Independence, situate about twelve miles from the Indian border and two or three sonth of the Missouri River.

Government.-The government is based on the act of Congress approved 9th September, 1550, establishing the Territory. It provides-That every free white male inhabitant 21 years of age, who shall have been a resident of the territory at the time of the passage of the act above named, shall be entitled to vote. The right of suffrage and of holding office shall be exercised only by citizens of the United States, including those recognized as citizens by the treaty with the Republic of Mexico, conclnded 2d February, 1848.

The Legislative Assembly consists of a Council and House of Representatives. The coumoil consists of 13 members, to serve for two years, and the house of 26 members, to serve for one year. Members are to be residents in and inhabitants of the district from which elected. A plurality of votes elects, and in case of a tie, the governor orders a new election. All acts passed by the legislature and approved by the governor, shall be submitted to Congress, and if disapproved, shall be of no effect.

The Governor is appointed by the President of the United States for four years, and until his successor be qualified. He must reside within the territory, and is excofficio Superintendent of Indian Affairs. He may pardon for offenses against the laws of the Territory, and reprieve convicted offenders against those of the United States, until the will of the President be known. A Secretary of State is appointed in like manner, for four years, unless sooner removed, who shall act as governor when said office is vacant, or the governor is necessarily absent.

The Judiciary is vested in a Supreme Court, District Courts, Probate Courts, and in justices of the peace. The supreme court consists of a chief justice and two associate justices, any two of whom form a quorum. A term is held at the seat of government annually. The Territory is divided into three judicial districts, and a district court is held in each by one of the justices of the Superior Court, at such time and place as may be prescribed by law, and the said justices are obliged to reside in the districts assigned them. The supreme and district courts possess chancery as well as common law jurisdietion. Writs of error, exceptions, and appeals from the district courts, lie to the supreme court, but in no case removed to the supreme court shall there be a trial by jury. Where the value of property in question exceeds $\$ 1,000$, final appeal lies to the supreme court of the United States. Probate courts are established in the several counties. Justices of the peace are not competent to try any cause in which the boundaries of land may be in controversy, nor where the amount elaimed exceeds $\$ 100$. There is also an attorney and marshal appointed for four years. The other township, district, or county officers shall be appointed or elected as the law may provide.

Congressional Delegation. - A delegate to Congress shall be elected by a plurality of the qualified voters.

When the lands of the Territory shall be surveyed, under the directions of the general government, preparatory to bringing the same into market, sections numbered 16 and 36 in each township shall be reserved for schools in the Territory, and in the states and territories hereafter to be erected out of the same. The Constitution, and all the laws of the United States which are not locally inapplicable, shall have the same force and effect within the Territory as elsewhere within the United States; and no citizen of the United States shall be deprived of his life, liberty, or property, except by the judgment of his peers and the laws of the land.

The assessed value of all real and personal estate in the Territory, in 1850 , was $\$ 5,174,471$.

Religious Denominations,-New Mexico is an Apostolic Vicariate of the Roman Catholic Church, and at present is governed by the Right Rev. John Lamy, D.D., who was consecrated November 24th, 1850. According to the census of 1850 , the number of churches of this denomination, which, before the session of 1848 , was the established religion, and that professed by the whole population. was 146 . having aceommodation for 76.100 persons, and the buildings being valued as property at $\$ 158,200$. The fact of the country being now a part of the United States has done away with the exclusive nature of this church ; and although no other churches are noticed in the official returns as existing within the Territory, yet it is assumable that others do exist for the accommodation of those eitizen immigrants from the old States whose religious views do not coincide with the general and popular creed. Assuredly there is no impediment to their foundation. 
Hixtorical Shetch. - Now Mexico became known to the spauards about the year 1591, and formal prossessiom was taken of the country in 1598. Christianity and slavery were early and simultaneously introduced among the Indians, and conrersion and personal service enforeed by the sword. The converted Indians were made to live in villages, and were distinguished from the roving bands by the title of Pueblos. Many towns, of which only the ruins now remain, were established at this time. The mines were successfitly worked, and the occupation of the country seemed to be secured, when, quite unexpectedly, in 1680, a general insurrection of all the Indian tribes broke out against the Spanish yoke. The Spaniards were either massacred or driven southward, where they founded El Paso del Norte. The country was not recovered for ten or twelve years. Several insurrections have since occurred, but none so universal or disastrous as this one. The deep rancor of the Indians, however, bequeathed from sire to son for successive generations, still animates the race, and is often displayed in the most bloody and cruel outbreaks, which, however, have not been very frequent since the United States became master of the ciuntry. This country followed the fate of Mexico after the revolution that overthrew the Spanish power, and since that period, to within the last few years, has been silently degenerating. The history of New Mexico, previous to the invasion by the Americans, has little to arrest attention. It is a continuous record of barbarism and tyranny. On the Sth September, 1846, Santa Fé was captured by the Americans under General Kearney, and soon after several of the river towns were visited on his route to California. A civil government was now established. On the 19th of January, 1847, an insurrection broke out against the Americans, and in several pueblos many Americans were murdered, among whom was Mr. Bent, the governor. Taos, Arroyo-Hondo, and Rio Colorado were the chief scenes of strife. The battles of La Canada and El Embudo also occurred in this month, and in February the battle of Tans, in all of which the Mexicans were completely vanquished. Some few skirmishes oceurred after these, but none of importance, and from this period the United States authorities exercised exclusive power. On the 2d February, 1843, a treaty of peace and cession was signed at Guadalupe Hidalgo, by which New Mexico was assigned to the Union, und on the 9 th September, 1850 , the country within its present limits was erected into a territorial government. In the interim, however, the people had formed for themselves a State constitution, but this was revoked by Congress, and the country remanded back to a territorial condition, under which it is now flourishing and happy.

SANTa FÉ, on the east side of the Rio Grande, is the political capital of the Territory.

New Mrahigan, p. o., Livingston co.; Ml..: 96 m. N. E. Springfield.

New Mrdpletows, p. v., Mahoning co., Ohio: $144 \mathrm{~m}$. N. E. by E. Columbus. Drained by a er. of Mahoning $r$.

New Mrlford, t. and p. r., Litchfield co, Conn.: $41 \mathrm{~m}$. W. S. W. Hartford, 32 m. N. W. by W. New Haven, on Housatonic r. and R. R., $37 \mathrm{~m}$. from Bridgeport. Surface uneven and hilly: soil gravelly and clay loam, well watered by Housatonic river and its branches. The t. contains 10 churches, several tanneries, and mills. The v. is very handsome, the streets being wide and well shaded. Population of t. 4,508.

New MIfFord, p. o., Winnibago co., $\eta l_{\text {: : }} 183$ m. N. by E. Springfield.

NRW MTLFord, p. o., Orange co., N. $Y$;: $102 \mathrm{~m}$. S. by W. Albany.

New Milford, t. and p. v., Susquehanna co., Penn. $124 \mathrm{~m}$. N. N. E. Harrisburg. Drained by Mitchell's and Salt Lick creeks; the surface is hilly, with a soil of clay and gravel, There is some manufacturing done in the t. The Lackawanna and Western R. R. passes through the t., and connects with the New York and Erie R. P., 6 m. distant.

New Mnutown, p. o., Lancaster co., Penn.: 83 m. S. E. IIarrisburg.

New Mruton, p. o., Doddridge co., Firg.: 214 m. N. W. Richmond.

New Mount Pleasant, p. 0., Monroe co., Penn.: 93 m. N. E. Harrisburg.

New Mount Pleasant, p. v., Jay co, Ind. : 67 m. N. E. Indianapolis, A plank-road from Bluffton to Richmond passes through the $\mathrm{v}$.

Newnar, p. v., and cap. Coweta co., Gas : $97 \mathrm{~m}$.W. by N. Milledgeville. It contains the court-house, jail, and several stores. The La Grange R. P. passes through the v., $40 \mathrm{~m}$. from Atlanta, The "Georgia Banner" (dem.) is published weekly.

Newnansilize, p. v., and eap. Alachua county, Flor. $122 \mathrm{~m}$. E. S. E. Tallahassee. It contains a U. S. land office. New Orto, p. o., Broome co., N. Y.: 112 m. W. S. W. Albany.

New ORLEass, p. city, port of entry, and cap. Orleans par., La.: on the E. or left bank of the Mississippi river, $105 \mathrm{~m}$. above its mouth, and in a direct line $78 \mathrm{~m} . \mathrm{S}$. E. Baton Rouge. Lat. $299^{\circ} 57^{\prime} 30^{\prime \prime} \mathrm{N}$., and long. $90^{\circ} \mathrm{W}$.

A traveler is struck on entering the city "with the old and narrow streets, the high houses ornamented with tasteful cornices, iron balconies, and many other eircumstances peculiar to towns in France and Spain, and pointing out the past history of this eity, fated to change its masters so often." The newer parts of the city are, however, built more in the American style, the streets being wide and regularly laid out. Many of the dwellings are built in a style of magnificence and beauty that will rival those of any other city, while the beautiful grounds altached to them, filled with the luxuriant foliage of the south, give to thern an air of comfort and ease which are seldom enjoved by the city resident. There are in the city six public squares, laid out with taste, inclosed with handsome fencing, and adorned with a variety of trees and shrubbery. These afford a pleasant retreat from the heat and glare of the strects, and tend also to improve the health of the eity. The old eity is built in the form of a parallelogram. The present city consists of this part, the suburbs of St. Mary's, Anunciation, and $\mathrm{La}$ Course, called Faubourgs, and the City of Lafayette above, and the suburbs of Mangney, Dournois, and Declouet below, and Treme and St. John in the rear. Including these, it extends about 5 miles along the river, and is rapidly being extended back toward Lake Pontehartrain, with which it communicates by means of the Basin, Canal, and Bayou St. John, with Mobile, Pensacola, and the whole Gulf shore. It also communicates by means of the bayoux Plaquemine and Lafourche with the Attakapas country, and has many other communications by means of the numerous bayoux and lakes with the lower part of Louisiana.

The charter of this now opulent city was granted in 1505 . In 1836 it was thought advisable to divide the city into three separate municipalities, each with distinct municipal powers. These municipalities extended backward six miles to Lake Pontchartrain. The first municipality was divided into five wards, and the second and third into four wards each. Each had a recorder and twelve aldermen, except the third, which had only seven aldermen. A mayor and twelve aldermen, four aldermen from each municipality, elected by general ticket, and called the general council, presided over the whole city. This system was altered in 1852 , when the city was organized into one comnunity, embracing also the city of Lafayette, under a single administration.

The Mississippi opposite the city is half a mile wide, and from 100 to 160 feet deep, and continues of this depth to near the Gulf, where there are bars, having only from 13 to 16 feet of water. The city is built on an inclined plane, the declivity falling gently from the river to the swamps in the 
reur. Al mgh watur it is rrom three to nine feet below the water surface, and, to protect it from inundation, an embankment called the Levee is raised on its border. "Isevee" is a French word of primary importance within the State of Louisiana; it pervades its statute books, and is heard daily within its halls of justice. There is little or no land on the banks of the river in this State, if we except an inconsiderable quantity in the neighborhood of Baton Rouge, which would not be covered with the waters of the Mississippi in the spring months, were it not for the artificial embankment which the industry of man has raised to exclude them. The Levee of New Orleans is one continuous landing-place or quay, four miles in extent, and of an average width of 100 feet. It is 15 feet above low water mark, and 6 feet above the level of the city, to which it is graduated by an easy descent. Like the river it margins, it holds a serpentine course, advancing or receding as the Mississippi encroaches upon the city, or falls off toward the opposite bank. It is constructed of deposit, a rich alluvion swept from the $\mathrm{N}$., and held in suspension by the waters until their rapidity is checked by a sudden change of direction, or swollen to overflowing, they spread over the adjacent swamps again to retire and again to bless the land they have visited by an increase of soil. The deposit is so great, and the consequent formation of new land so rapid immediately in front of that portion of the quay, which is most used for the purposes of commerce, that it has within a few years become necessary to build piled wharves, jutting out from 50 to 100 feet into the river. The new formation which is governed as to its locality by what may well be termed the freaks of the Mississippi, is called "batture," and when it has progressed to such an extent as to be left bare by the returning water at its lowest stage, is held capable of ownership. Here may be seen what New Orleans was before the application of steam to navigation. IIundreds of long, narrow, black, dirty-looking, crocodile-like rafts lie sluggishly without moorings upon the soft batture, and pour out their contents upon the quay-a beterogenous compound of the products of the Upper Mississippi and its tributaries. These are rafts, or flat-boats, as they are technically called, each fiequently carrying cargoes valued at from $\$ 3,000$ to $\$ 15,000$. Twenty years ago, and these were the only craf on the river! nor has their number been decreased since the introduction of the steamboat. Not less characteristic of New Orleans is the landing of the latter class of craft. The quay is here all action, and the very water is covered with life. Huge ressels float upon its bosom which acknowledge none of the powers of air and wait no tide. One is weighed down to the guards with cotton, a freight of 3,000 bales_ $\$ 150,000$ ! Twenty more lie side by side laden with the same commodity. Huge piles, bale upon bale, story above story, cover the levee. Pork without end, as if the Ohio had emptied its lap at the door of New Orleans; and flour by the thousand barrels rolled out upon the quay and heaped up-a large area is covered with these two products of the up-country, and still appears seemingly undiminished, although the seller, the buyer, and drayman are busy in the midst of it. Here is a boat freighted with lead from Galena; and another brings furs and peltry from the head waters of the Missouri, 3,000 miles to the north-west! The Illinois, the Ohio, the Missouri, the Arkansas, and Red River, all are tributaries to this commercia] depot, and send down to its wharres merchantable material of the annual ralue of one liundred million of dollars more or less. Nearly 20,000 miles of inland navigation is tributary to this city. The quay appropriated to the foreign and coastwise shipping presents another and a different scene. Here the cotton bale, tobacco hogshead, pork and flour barrel, and the whisky cask yield to bales of foreign and domestic manufactures, pipes of wine, and crates of wares. The shipping stretches away as far as the eye can reach, two miles or more in extent three tiers deep, with their heads to the current curving with the rirer $-\mathrm{a}$ beautiful crescent. The knglish, the Freuch, the Spanish, the Dane, the Russian, the Swede, the Hollander, etc., are here commingled, and compete for the commerce of the teeming West.

The following statisties will exhibit the extent and value of the trade of New Orleans, in 1850-51:

1.-Receipts down the Mississippi, from the interior:

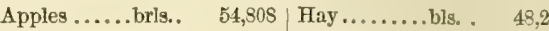
Bacon........cks. . 49,602 Iron, pig ....tons. Bacon.......brls. . 9,274 Lard ........tes... 115.570 Bacon, hams. " .. 44,478 Lard........... . 159 . 157,931 Bacon in blk. lbs. . 235,000 Lime........brls.. 37,738 Bagging..... pcs. . 72.304 Lead ........pigs. 325,5i/5 Bale rope....coils. 107,224 Lead ......... bars. 629 Beans ....... brls. $\quad 4,236$ Lead, white...kegs. $\quad 1,930$ Butter...... kegs. 54,967 Molasses.....brls.. 184,483 Butter......brls. . 2,720 Oats......." .. 479,74t Beeswax ....brls. 230 Onions....." .. 14,297 Beef ........ bl. \& tc. 48,066 Oil, linseed ... ".. 478 Beef, dried...lbs. . 15,300 Oil, castor.... ".. 4,145 Buff, robes...ples. $\quad 155$ Oil, lard ..... 66 .. 17,157 Cot.,La.\& Mi. bales 618,156 Pickles...... . . . 893

"Lake... "6 .. 14,399 Potatoes... . " .. 192,922 N. Ala. \& Ten. ...."6 "Ark. ...." ". " Montg..." .. "Mobile..." . "Florida ." .. Texas ..." .. Corn meal ... brls. . Corn in ears . ". Corn shelled.sks. . Cheese ...... bxs. . Candles....." Cider .......bris. Coal, western.bsh. . Drd. peaches." Dried apples."

Flax-seed ...tes... Flour .......brls. . Furs........ pligs. Feathers. ....bgs. . Hemp ........bls. . IIides.........No. . Pork ........ 66 .. 786,084

236,821 Pork........bxs. . 1,980

62,793 Pork ........hhds. 1,231

15,051 Pork in bulk.lbs. .10,513,895

24,473 Porter \& ale..brls. . 351

11,091 Packing yarn.rls... $\quad 4,190$

9,252 Skins, deer ..pks.. $\quad 1,119$

3,662 Shot.........kgs . 2,044

42,526 Sugar........hhds. 125,750 1,298,982 Sugar........brls. . 18,675

78,894 Soap ........bxs. . 9,451 80,748 shingles........ 50. 51,000

245 Staves.......... 9,000,000 700,000 Tallow ......bris. . 6,164

2,6S5 Tobacco, leaf.hhds. $\quad 64,030$

4,163 Tobaceo, ? kgs.. 4,115

204 chewing. $f$ so.

941,106 Tobacco.....bls...

1,289 Twine...... bils.

3,645 Whisky ......brls. . 157,741

25,116 Window glassbxs. . 16,428 140,335 Wheat, brls. \& sks.. $\quad 85,797$

Value in 1\&50-51,\$106,924,0S3 | Value in 1548-49, \$\$1,989,692 $1819-50,96,517,573$ " $1517-49,79,779,151$

2.-Receipts by Lake Pontchartrain and the New Canal :

\begin{tabular}{|c|c|c|c|}
\hline Cotton....... bls. . & 40.329 & Tobacco, le & \\
\hline Timber ..... feet & $3,107,000$ & Merchandise.bxs. . & \\
\hline Wood.........crds. & 27,520 & Moss ... & \\
\hline Bricks....... No. . & $1,000,000$ & Cotton seed...bgs.. & \\
\hline and ........brls. . & 197,600 & Wool........ & \\
\hline ells ......" .. & 52,200 & Sugar .......hhds, & \\
\hline arcoal ...." .. & 110,600 & Molasses......brls. . & \\
\hline Tar ........" .. & 2,239 & Fish ......." .. & \\
\hline gles ..... No. . & $2,392,0$ & Knees........No. . & \\
\hline Laths........" . & $3,160,000$ & Pickets......" .. & \\
\hline $8 \ldots . . .66$. & 632,000 & Clapboards..." .. & \\
\hline door prs.. & 7,800 & gs..bls. . & \\
\hline ....brls.. & 3,0 & es ... No. . & 40 \\
\hline$\ldots 6 \ldots$ & & d cattle. " .. & \\
\hline .....sks. . & 15,799 & ......brls. & \\
\hline n gins....No. . & & ...bdls. & \\
\hline ....... & 8,955 & oil.... cans. & \\
\hline$\ldots 6$... & 70 & . brls. & \\
\hline stics.... bls. . & 959 & .......eks. & \\
\hline skins ..." & 0 & ..bls... & \\
\hline$y \ldots . . .6$ & 35 & nt ..... brls. . & \\
\hline uckets ..... do & 632 & Plaster....... hhds. & \\
\hline
\end{tabular}


3.-Principal exporte, conetwise, including expos ls via Pontulartrain Fillroud and New Canal, to Mobile, etc. :

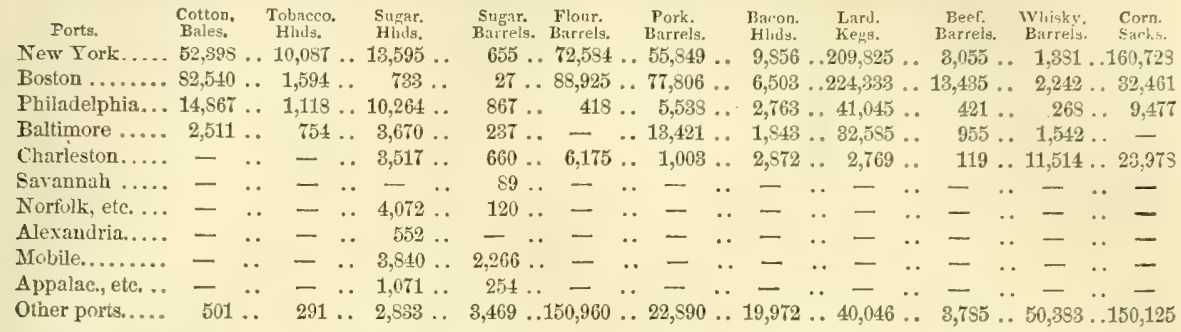

4.-Principal exports to foreign countries, in 1849-50:

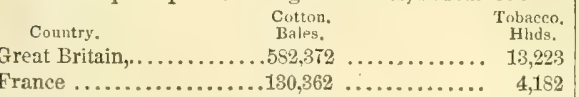

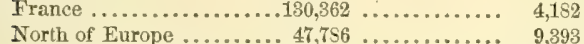

South of Europe, ete. ...... $81,120 \ldots \ldots \ldots . . .13,859$

Flour, 264,356 barrels; pork, 16,230 brls. ; lard, 188,353

kegs; beef, 20,615 barrels ; corn, 158,613 sacks.

The arrivals at New Orleans from the interior, ete., in 1849 50 were: flat boats 941 -from Ohio 218, from Kentucky 53, from Indiana 298, from Virginia 12, from Pennsylvania 222, from Illinois 19, from Tennessee 104, and from Mississippi 10 ; and the river steamboats 2,918.

The total value of domestic merchandise exported from New Orleans to foreign countries from the 1st July, 1850 , to 30th June, 1851, amounted to $\$ 53,98 \$, 013$, of which to the value of $\$ 35,022,609$ was carried in American, and $\$ 15,965,404$ in foreign bottoms; and the total value of foreign merchandise re-exported was $\$ 445,950$, of which to the value of $\$ 398,265$ was carried in American, and $\$ 57,685$ in foreign bottoms. The following are the entrances and clearanees in the foreign trade in the year above named:

Clearatces:

Quarter ending $\overbrace{\text { Vessels. }}^{\text {American: }} \overbrace{\text { Tonnage. }}^{\text {Foreign. }}$

80th September, $1850 \ldots 109 \ldots .44,549 \ldots . .52 \ldots 19,867$ 31st December, G ...114... 53,946...66 ... 20,987 31st March, $\quad 1851 \ldots 188 \ldots 85,747 \ldots 119 \ldots 53,762$

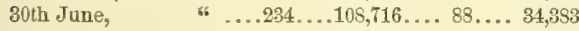
Entrances: Total. .... $645 \ldots . \overline{292,958} \ldots . \overline{325} \ldots . \overline{128,949}$ Quarter ending $\overbrace{\text { Vessels, }}^{\text {American. }} \overbrace{\text { Tonnage. }}^{\text {Foreign. }} \overbrace{\text { Vessels. Tonnag }}^{\text {Tels. }}$ 30th September, $1850 \ldots 61 \ldots 16,177 \ldots 42 \ldots 14,347$ 31st December, "6 ...158...661,487...106... 40,827 31st March, $\quad 1851 \ldots . .178 \ldots 64,104 \ldots 97 \ldots .45,208$ 30th June, $\quad$ "6 $\ldots .146 \ldots 53,368 \ldots 88 \ldots 86,618$ Total.....543...195,136,...333....137,000, 1850 , was as follows:

\begin{tabular}{|c|c|c|c|c|c|c|c|c|}
\hline \multirow[b]{2}{*}{ Banks-Specie paying. } & \multicolumn{2}{|c|}{ Cash Liabilities. } & \multicolumn{4}{|c|}{ Cash Assets. } & \multirow[b]{2}{*}{$\begin{array}{l}\text { Total Liabilities, } \\
\text { exclusive of Capital. }\end{array}$} & \multirow[b]{2}{*}{$\begin{array}{l}\text { Total } \\
\text { Assets. }\end{array}$} \\
\hline & Circulation. & Total. & & Specie. & & Total. & & \\
\hline Louisiana Bank........... & $\$ 831,239$ & $\ldots \$ 3,939,406$ & ... & $\$ 1,354,088$ & $\cdots$ & $\$ 5,701,551$ & $\ldots . \$ 3,939,406 \ldots$ & $\$ 5, \$ 62,741$ \\
\hline Canal and Banking Co...... & $1,301,595$ & $\ldots 2,761,022$ & $\ldots$. & $1,126,140$ & $\ldots$ & $3,595,059$ & ... 2,761,028 ... & $\tau, 010,966$ \\
\hline Iouisiana State Bank...... & $1,712,975$ & $\ldots 4,445,714$ & $\ldots$ & $1,649,045$ & $\ldots$ & $4,971,969$ & $\ldots 4,419,714 \ldots$ & $6,7+15,7 \pm 1$ \\
\hline Mechanies' and'Traders'Bank & 932.855 & ... $3,153,043$ & $\cdots$ & $1,526,957$ & $\cdots$ & $4,177,313$ & $\ldots .3,153,843 \ldots$ & $\tilde{0}, 223.457$ \\
\hline $\begin{array}{c}\text { Union Bank................ } \\
\text { Non Specie paying. }\end{array}$ & 25,810 & 69,692 & ... & 81,717 & $\ldots$ & $408,66 \mathrm{~S}$ & $69,892 \ldots$ & $4,159,931$ \\
\hline Citizens' Bank............ & 11,061 & 13,608 & $\ldots$ & 14,448 & $\cdots$ & 245,008 & $6,943,496 \ldots$ & $6,457.779$ \\
\hline Consolidated Association.... & 20,295 & 21,047 & $\ldots$ & 7,694 & ... & 14,767 & .... 1,63s,491 . & $1,281,189$ \\
\hline
\end{tabular}

A branch of the United States mint is located here; also the U.S. land office for the land district of New Orleans; the U. S. custom-house, and other federal establishments. The mint has extensive buildings on the Esplanade; the main edifice is 252 feet long and 108 feet deep, and its two
The total number of entrances in the coastwise trade in $1850-51$ was 1,227 vessels, of the aggregate burden of 353,175 tons, and the total number of clearances was 1,178 , of the aggregate burden of 435,892 tons.

The manufactures of New Orleans are not extensive. There are several furnaces, machine shops, distilieries, sugar refineries, lumber yards, steam saw-mills, tobacco factories, etc.-in all using a capital of some three millions of dollars; and besides these there are the handicrafts common to all large cities, which in the aggregate make up a respectable list of occupations. The most extensive foundry and machine shop of the south-west is that of John Leeds \& Co. in this city; it employs 175 men, and from 4 to 5 tons of metal are daily melted down and run off into the thousand-and-one things for which iron and brass may be used -a steam-engine and sugar-mill down to a nut and screw. This establishment has grown up from a little shop owued. by the father of one of the principals 20 years ago, and is a fair illustration of what, from small beginnings, American energy, perseverance, and enterprise, can accomplish. Its cotton presses are among the largest in the Union, and cover an immense area. The New Orleans Cotton Press occupies an area of 194,656 square feet, most of which is covered by the buildings. On an average, 160,000 bales of cotton are annually pressed at this establishment. The market houses of New Orleans are in general substantial and expensive buildings; the meat market on the Levee is a conspicuous building, and is one of the principal objects seen from the river; St. Mary's Market is 486 feet long, and 42 feet in width ; and Washington Market is also an extensive building. These are well supplied with all kinds of south-western produce, and abound in tropical fruits and esculents. The retail trade of New Orleans is extravagantly provided for ; its stores and sales-rooms are magnificent, and their patronage beyond precedent large. The dress, habits, and customs of the inhabitants require this lavish exhibition of merchandise, and they willingly support it at an immense cost to individual revenue. The New Orleans banks are seven in number, and their condition on the 30 th Nor., Crsh Assets.

wings are 81 feet by 29 feet, the whole of three stories. The coinage at this branch is only gold and silver. For the year ending 1st July, 1851, the value of gold deposits was $\$ \$, 285,637$, and of gold money coined, $\$ 5,994,000$; of the deposits, $\$ 5,152,579$ was California gold, and of the coinage, 
$\$ 6.6 \pi 0.000$ were double eagles, $\$ 1,495,000$ eagles, $\$ 160.000$ half eagles, $\$ 510,000$ quarter eagles, and $\$ 154,000$ dollar pieces; and the value of silver deposits was $\$ 822,085$, of Which $\$ 57.572$ was silver extracted from California gold, and of the coinage $\$ 3,000$ were dollar pieces, $\$ \$ 56,000$ half dollars, $\$ 69,000$. quarter dollars, $\$ 53,000$ dimes; $\$ 51,500$ half dimes, and $\$ 18,000$ three cent pieces. Total deposits, $\$ 9,107,722$-coinage, $\$ 10,044,500$. The custom-house at this place, when eompleted, will be one of the most expensive buildings in the Union, and a great ornament to the eity. It is situate on the Levee at the corner of Canal Street. The building will also contain apartments for the U.S. Courts, and other accommodations for the general government. It will be almost as large as the Capitol at Washington with the additions now being made. The material is to come from the celebrated Quincy quarries. On the right and left of the eathedral on the Place d'Armes are the district and city offices-one in the Tuscan and the other in the Doric style, and both two stories high. These accommodate the city council, the courts of the distriet and parish, the police, city guard, etc. New Orleans was eapital of the State until 1849, in which year the State records were removed to Baton Rouge. The old State-house, formerly the Charity Hospital, is a good building, occupies a square between Common and Canal streets, and consists of a main building and two detached wings.

New Orteans is magnificent in its church buildings, fhough there are complaints that there is not sufficient ae commodation for the large population it contains. Including chapels, there are 19 Catholic places of worship. The Cathedral of St. Louis, on the Place d'Armes, is a venerable and imposing structure. It was founded in $1792 \mathrm{by}$ Don Audré on the condition that masses be offered every Saturday evening for the repnse of his soul, and the tolling of the bell at sunset on that day still proclaims the observance of the custom. The Eplscopalians, Presbyterians, Methodists, etc., have also churches. The Methodist church on the corner of Poydras and Carondolet streets is a splendid copy of the temple of Theseus, with a steeple 170 feet in height. The Second Presbyterian church in Lafayette Square, is also a hanilsome structure, and has a fine purtico of Green-Doric architecture. The Episcopal churches, of which there are 3 , are substantial, without any distinguishing features.

The newspaper press of New Orleans is world-renowned, and its issues are among the most talented in the Tnion. There are 9 daily newspapers, the "Crescent" (neat.), the "Delta" (dem.), the "Pieayune" (whig), the "True Delta" (neut.), all of which also issue weekly editions, the "Bulletin" (whig), which has also a semi-weekly edition, the "Orleanean" (nent.), the "State Gazette" (dem.), the "Bee" (whig), and the "Courier" (dem.) The "Franco-American" is issued tri-weekly, and the "Prices Current" semi-weekly. The weeklies are "La Propagateur Catholique" (relig.), and "La Patria" (whig). De Bow's "Review of the Southern and Western States" (statistical), is published monthly. The last-named is one of the most useful and complete works of the kind in the Union, and ought to be in the library of every person wishing to keep up with the progress of the country. The "Resourecs of the Southern and Western States" lately published by Professor De Bow, is also a work of great and lasting value, more exact and detailed in its subjects than any work hitherto issued from the American press, and has been of essential service in the compilation of this Gazetteer.

The means provided for education are ample. Besides the public schools and academies, the city contains several collegiate establishments and literary institutions. The University was founded in 1519. The buildings consist of a central edifice 1 no feet front and 104 feet deep, with two detached wings. The main building is occupied by the medical department, and contains three large lecture-rooms, each of which will contain more than 600 persons, a large museum of anatomy, dissecting-rooms, etc., and the other 556 buildings are approprated to the academic, law, and other departments. There are 7 professors in the academic department, 3 in the law department, and 7 in the medical department. There is also a chair of political economy, at present ably filled by Professor J. D. B. De Bow, head of the Census Bureau at Washington. The students in the medical department enjoy clinies in the Charity Hospital, an institution which surpasses all others in the United States as a school of practical instruction. This hospital is situate on Common Street, between St. Mary and Girond streets, and is 290 feet long, and three stories high. There are generally 1,000 patients in the wards. In 1851 the whole number of patients admitted was 15,476, discharged 15,989, and died 1,884 , leaving 1,603. The surgical cases numbered about 2,600 ; and about one-half the medical cases were intermittent and remittent fevers-of the first 6,871 eases, and of the latter 2.366 cases are reported. From the cupola of the building the view is magnificent. This institution is the refuge alike of the citizen and stranger in times of sickness, and is attended chiefly by those exemplary women whose deeds of charity reflect so great an honor on the Catholic Church.

New Orleans has nine cemeteries: the Protestant, the Catholie, Cypress Grove, the Odd Fellows', st. Vincent de Paul, St. Patrick's, Potter's Field, the Charity Hospital, and Lafayette. These are all conspicuous appendages of the city. The Catholic and Protestant cemeteries are unique in place and method of interment. Each is inclosed in a brick wall of arched cavities, or ovens, as they are here called, made just large enough to admit a single coffiu, and raised tier upon tier to the height of about 12 feet, with a thickness of 10. The whole inclosure is divided into plats, with gravel paths intersecting each other at right angles, and is densely covered with torabs built wholly above ground, and from one to three stories in height, This method of sepulebre is adopted from necessity, and burial underground is never attempted excepting in the Potter's Field, where the stranger without friends, and the poor without money find an uncertain rest, the water with which the soil is always saturated often forcing the coffin and its contents put of its narrow and shallow cell, to rot with no other covering than the arch of heaven. The cemeteries here indeed look as if modeled after a growing city. The tombs have an air of freshness about them; the peculiarity of their structure, their close juxtaposition, filling plats like blocks of buildings, the wellgraveled walks between, the walls about the whole, with their numerous receptacles of the dead, rising story above story, almost persuade the risitor that he stands in the midst of a panorama of the great mart of commerce, the former inhabitants of which now inhabit these eities of the dead. The total number of burials in the several cemeteries in 1319 was 9,862 , of which 3,569 were of foreigners, 1,308 of the United States, of which number only 774 were natives of New Orleans, and 4,955 of birth unknown. These facts speak volumes-one half the deaths of persons without name or country ! and yet thousands press on to fill the void thus createrl, and in their turn to be numbered with the unknown dead.

The hotels and theatres of New Orleans are also distinguishing features of the city, and among its most splendid buildings the St. Charles Theatre, on the east side of St. Charles Street, cost about $\$ 350,000$, and is 132 fcet long, by 170 feet deep. The Orleans, or French Theatre, is also a large and expensive building, running from Orleans Street to St. Anne Street, and the performances are done in the French language. The American theatre, corner of Camp and Pordras streets, is 160 feet by 60 , and cost about $\$ 130,000$. These three theatres will in the aggregate accommodate 4.500 persons, and are nightly filled, often to suffocation. Among the hotels, the principal are St. Charles', Exchange, City Exchange, Verandah, Orleans, and others, almost equal in extent and good accommodations. Some of these are not surpassed in beauty of structure, substantiality, and popular- 
ity by any in the Union. The St. Charles' was destroyed by fire in 1850 , and is now being rebuilt on a more magnificent scale than before, at a cost estimated at $\$ 600,000$. As the majority of persons having business in the city reside there ouly temporarily, these are constantly crowded with boarders.

The eity is supplied with water from the Mississippi. The water-works, which belong to the Commercial Bank, cost about $\$ \pi 25,000$. The reservoir, into which the water is raised by a steam-engine, is construeted on an artificial mound, and is 21 feet high at its base, with sides 250 feet in length, and capable of containing nearly $10,000,000$ gallons. The reservoir has four compartments, and when the water is cleared, it is distributed through iron pipes to the city. There is also an aqueduct built at the expense of the city, costing $\$ 120,000$, which, by conducting water to cleanse the gutters, tends greatly to neutralize or wash away the filth of the streets, and to the promotion of general health in the hot season.

New Orleans, from its low situation, more than from its warm and moist climate, suffers periodically from the yellow fever. No summer, indeed, passes over without the visitation of this terrible malady, and it not unfrequently rages as an epidemic. In $1841,94,97$, this distemper was very fatal, while in 1842, '44, ' 46,445 , and ' 49 , the number of eases were comparatively small, and in 1815 only one case is reported. In 1847 the admissions into the Charity Hospital, on account of yellow fever, numbered no less than 2,811 , and the admissions for intermittent and remittent fevers were commensurately great, having been nearly 4,000 . These visitations have no doubt been the means of retarding the growth of the city, but that the salubrity of the climate is gradually being improved is certain, and when in a few years the swamps in the neighborhood are filled in, the location will be as healthy as that of any other southern port. During the winter and spring the climate is reputed healthy, and thousands flock to the eity from all quarters of the world-some for health, others for pleasure, and still more in connection with the immense business of all kinds which is here transacted.

Perhaps no city of the Union is so diversified in its population. The sunny isles of the Antilles, Mexico, Central America, and South America, France and Spain, and the other States of Europe, and the sister States northward, have each representatives among the inhabitants. The colored races, however, preponderate, and slave or free make up onehalf at least. Of the white races, the American, French, and Spanish constitute the larger portion, and in these classes are found what may be denominated the aristocracy. The Irish here, as in other quarter's, though forming a large class, are but the "hewers of wood and drawers of water"-the laborers and levee-men, respectable only on election day and among themselves. The English and Scotch are few in proportion, and are chiefly connected with the foreign commerce as merchants or fuctors, seldom remaining longer in the city than is necessary for the transaction of their particular business ; nor do the Germans form a large class. This admixture of races is in some degree embarrassing; so many languages, various customs and manners, and in habits so different, no thorough amalgamation can take place ; and it is even necessary to support newspapers and periodicals of different languages, each of which in its opinions and ideas is at variance with the other. But this circumstance has also its edvantages-it elicits much that is useful and cosmopolitan, fending to soften the asperity of nationalities, and to the fraternization of races. The vices and virtues of such a community stand in bold relief, and Sunday bull-baiting, gaming, and balls, contrust harshly with the divine exercises appropriate to that day of rest.

The railroads diverging from New Orleans are as yet few in number, designed chiefly to facilitate the transit of goods by short routes to and from the adjacent shipping places. These are the roads to Lake Pontehartrain, to Lake Borgne, and to Carrollton on the Mississippi. The commercial men of the city, however, have determined upon the prosecution of several important lines, which will secure to it a commerce which was fast lapsing to the Atlantic ports. The principal of these are the New Orleans, Jackson, and Northern R. R.; the New Orleans, Opelousas, and Great Western R. R.; the New Orleans and Nashville R. R.; and a railroad from Mobile, connecting with the navigation of Lake Pontchartrain, which will supersede the tedions navigation of the passes along the southern shore of Mississippi. The canals of New Orleans have been opened with the same design as that fulfilled by the existing railroads

Opposite to New Orleans, and connecting with it by a ferry, is the town of Algiers, the principal workshop of the city. Here are several extensive ship-yards, and numerous artisans engaged in building and repairing vegsels. At Macdonough, above and adjoining it, is the United States Marine Hospital, a splendid building, used for the purpose its name designates. Belleville lies below and also adjoins Algiers, and has many fine residences. Many of the seats in the suburbs of the city are surrounded with spacious gardens, splendidly ornamented with orange, lemon, magnolia, and other trees.

The history of New Orleans in its early epochs is that of the whole French settlements in Lower Louisiana. This will be found under its appropriate caption. The city was founded in 1717, and named after the Duc d'Orleans, then regent of France, but the site was abandoned soon after, and not settled again until 1722. Soor after this it began to prosper, and constant accessions were made to the population by the arrival of immigrants, By the treaty of 1763, New Orleans, with all Louisiana west of the Mississippi, was transferred to Spain by treaty. The population now numbered 3,190. The transfer greatly provoked the French inhabitants, and some opposition was made, but in the end the Spanish laws were gradually introluced, and, by a beneficent administration, the eity so flourished under the new government, that the population in 1785 had increased to 4,980 - a great movement in those days. In 1792 , the city was divided into four wards, and its police greatly improved, and two years later the first newspaper was published. The country was prosperous at the commencement of the French Revolution; but in 1801, Spain having fallen into the power of France, it was retroceded to that nation, and in 1808 was sold to the United States by the French. The population was now over 8,000 . In 1804 , New Orleans was made a port of entry, and in 1505 was incorporated. Early in 1812 the first steamboat arrived from the Ohio! The war of 1812-15 now broke out, and the British made a descent on the city, and on the Sth of Jan., 1515, the greatest batlle or the war was fought-the result is known to every schoolboy. The modern progress of the city now commenced; the settlement of the valley of the Mississippi, and the consequent trade with the only port of its outlet, increased rapidly and proportionally. The increase is sill going on, and will raise New Orleans to the first rank among commercial eities. It is now the great depot of the export trade of the valley; and when its railroads to the north are completed, much of the import trade now having its course from the northern Atlantic coast will certainly make New Orleans its entrepôt. The difficult up-navigation of the river, even by sleamboats, has hitherto been the great drawback, but with this line of road, New Orleans will compete successfilly with New Iork, Boston, and Philadelphia for the golden fleece of the great west.

Population in $1703,3,190$; in $1755,4.980$; in $1804,5 . M m 0$ : in 1810, 17,242; in 1520, 27,175 ; in 1530, 49,$20 ;$ in 15411, 102,193; and in 1550. 119,461. The population ol Lithyctte in 1840 was 3,207 , and in $1550,14,190$.

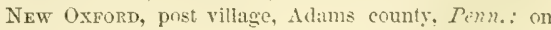
the east side of Conewago ereek, 27 miles south by west Harrisburg.

New Palestrye, p. v., Clermont co., Ohio: on the Ohio r., $92 \mathrm{~m} . \mathrm{S} . \mathrm{W}$. Columbus; is a small village of considerable 
business, particularly in the manufacture of brick, which is mainly taken to Cincinnati.

NEW PaLTZ, to and p. v., Ulster co., N. Y.: $70 \mathrm{~m}$. S. by W. Albany, on the Wallkill. Surface hilly; soil mostly loam and fertile. The v. contains a flourishing academy and 3 churches. Pop. of t. 2,729.

New Paltz Landing, p. o., Ulster co., N. Y.: on W. bank of Irudson r., opposite Poughkeepsie, 9 m. E. New Paltz village.

NeW Paris, p. v., Preble county, Ohio: $80 \mathrm{~m}$. W. by S. Columbus, on W. bank of Whitewater r., which affords good water-power.

New Petersberg, p. v., Highland co., Ohio: on S. side Paint cr. 51 m. S. S. W. Columbus.

New Pmiladelphia, p. o., Pike co., $l l l$. : on Bay er., $62 \mathrm{~m}$. W. by S. Springfield.

New Philadelphi, p. o., Washington co., Ind.: on N. side of Great Blue r., $80 \mathrm{~m}$. S. by E. Indianapolis.

New Phuladelphia, p. v., and cap Tuscarawas co., Ohio: 86 m. E. N. E. Columbus, on E. bank Tuscarawas r., opposite the mouth of Sugar cr. The $\mathrm{v}$. is on a handsome plain, and has considerable business. It contains the court-house and jail. Two newspapers are published weekly, "Tuscarawas Adrocate" (whig), and "Ohio Democrat" (dem.) Pop. 1,415.

New PrtTsserg, p. v., Wayne co., Ohio: on E. side of Muddy fork of Walhonding r., $74 \mathrm{~m}$. N. E. by N. Columbus New Plymouth, p. o., Vinton co., Ohio: 57 m. S. E. by S. Columbus.

New PoINT CoMrort, Firg.: the S. E. extremity of Matthews co., between Chesapeake and Mob Jack bays.

NewPort county, $R . I$. Consisting of several islands in Narragansett Bay, with a portion of the mainland, containing in the whole an area of 136 sq. m. Rhode Island, containing 37 sq. m., forms the most important portion of the county. Surface uneven; soil fertile, and produces good crops of grain, ete., and affords fine pasturage for cattle. The other chief insular portions of the county are Providence, Canonicut, and Block islands. Chief productions wheat, Indian corn, and potatoes. The advantages connected with navigation are considerable, and fishing is much followed by the inhabitants. Fossil coal is found in this county. Farms 1,027; manuf. 68 ; dwell. 2,936, and pop. -wh. 19,311, fr. col. 666-total 20,007. Capital: Newport.

Newrort, p. v., New Castle county, Del.: on N. side of Christiana cr., $88 \mathrm{~m}$. N. Dover. The Philadelphia, Wilmington, and Baltimore R. R. passes through the $\mathrm{v} ., 32 \mathrm{~m}$. from Philadelphia, $66 \mathrm{~m}$. from Baltimore.

NewPort, p. v., and cap. Wakulla county, Flor. : on St. Mark's I., 16 m. E. S. E. Tallahassee. The "Wakulla Times" is published weekly.

Newport, p. v., and cap. Fermillion co., Ind.: on $\mathrm{S}$ bank of Little Vermillion r., $2 \mathrm{~m}$. above its junction witl the Tabash $r_{.,} 65 \mathrm{~m}$. W. by $\mathrm{N}$. Indianapolis, It contains a court-house, jail, several stores, and is surrounded by a very fertile country.

Newport, p. v., and cap. Campbell co., $K_{2} . \therefore$ on Ohio $r_{\text {., }}$ above the junction of Lieking r., $63 \mathrm{~m}$. N. N. E. Frankfort. It is situated on an elevated plain eommanding a flne view of Cincinnati directly opposite, with which eity there is steam ferry connection. Here is a garrison of U. S. army, several factories and churches. The "Newport and Covington News" is published daily.

Newrort, t. and p. v., Penobseot county, $\boldsymbol{M} e_{0}: 48 \mathrm{~m}$. N E. lw Y ducusta. Pop. 1,212.

Newport, p. v., Charles co., $M F d_{*}$ : on stream of Allen"s Fresh, 14 m. S. E. Port Tobacco, 43 m. S. by W. Annapolis. Newpoet, p. v., Franklin co., Jfo.: S. side Missouri r., $54 \mathrm{~m}$. E. Jeffurson City.

NewPORT, p. v., Nionroe co., Mich.: on an estuary of Lake Erie, the mouth of Swan cr., S1 m. S. E. Lansing.

Newrort, p. v., St. Clair co., Jrich.: on St. Clair r., at mouth of Belle r., $103 \mathrm{~m}$. E. by S. Lansing; is well situated, 558 and has a very large business in sawing and exporting pine timber, which abounds in this section.

NEwPort, t., p. v., and cap. Sullivan co., N. Tamp.: $34 \mathrm{~m}$.W. N.W. Concord. Drained by Sugar r. and branches, Surface uneven; soil fertile on the streams. The E. and S. branches of Sugar $r$. unite near the $v$. and afford waterpower to several mills. The "N. H. Argus and Spectator" (dem.) is published weekly. Pop. 2,020.

NewPort, t. and p. v., Herkimer county, $N . Y .: 76 \mathrm{~m}$. N. W. by W. Albany, on West Canada cr. Surface of $t$. hilly; soil sandy and ealcareous loam. The $\mathrm{v}$. has some manufactures, and is a thriving place. Pop. of t. 2,126.

Newport, p. v., Cumberland co., N. Jer.: 65 m. S. S. W. Trenton, on Nautuxet cr., $5 \mathrm{~m}$. above its mouth.

NEW PORT, t. and p. v., Washington co., Ohio: on Ohio r., $12 \mathrm{~m}$. E. Marietta, $100 \mathrm{~m}$. E. S. E. Columbus. Surface of t. level; soil alluvial. Pop. 1,427. The vo is finely situated, and is a thriving place. Pop. of t. 1,427.

Newrort, p. v, and sta, Perry co, Penn.: on W. side of Juniata r., above the confluence of Little Buffalo cr., $24 \mathrm{~m}$, N. W. Harrisburg. The Pennsylvania R. R. and Pennsylvania Canal pass through this village. There is a blast furnace at Newport, $3 \mathrm{~m}$. distant.

NeWPORT, p. v., and cap. Cocke co., Tenn.: on S. side French Broad r., 204 m. E. by S. Nashville.

NEWPORT, t., p. v., port of entry, and cap. Newport co., R. $I_{\text {s. }}$ and one of the capitals of the State: on $\mathrm{S}$. W. side of Phode Island, $5 \mathrm{~m}$. from the ocean, $24 \mathrm{~m}$. S. by E. Providence, $70 \mathrm{~m}$. S. by W. Boston. Lat. $41029 \mathrm{~N}$., long. $71019^{\prime} 12^{\prime \prime}$ W. from Greenwich, and $5042^{\prime} 48^{\prime \prime} \mathrm{E}$. from Washington. The $t$. is in form an irregular semi-circle, as also is the harbor upon which the $\mathrm{v}$. is situated. Surface undulating, presenting variety of scenery; soil very fertile. The harbor is one of the best in the U. S., and celebrated for its beauty. It is very accessible, spacious, safe, and deep enough for the largest vessels-defended by forts $A$ dams and Wolcott, which are garrisoned by companies of U. S. artillerr. The former is very large, of great strength, and was built at great expense. A U. S. naval officer is stationed herc. The v. occupies a beantiful acclivity, which rises gradually from the harbor, presenting a beautiful appearance. It was settled in 1638, grew rapidly, and was very flouxishing unt'i the Revolutionary War, at which time its popnlation was about 10,000 . During the war it was chiefly held by the British, and at its close the population was about 5,500. It then somewhat revived for a time, until the embargo preceding 1812 ; but subsequently its trade was much diverted to Providence and other places. Many of the inbabitants are engaged in the coasting trade and fisheries. Some large cotton and woolen factories have been established. The principal public buildings consist of the State-house, markethouse, custom-house, and Redwood Library and Atheneum, containing 4,000 vols. Besides 12 churches there is a Jews' synagogue, now unused but kept in fine repair by avails of a legacy. There is also 1 savings' bank, 7 banks, with a capital of $\$ 680,000$. The total valuation of property in Newport in 1850 , was $\$ 4,720,450$, tax assessed, $\$ 15,577$. By the Fall River line of steamboats it has daily communication with New York; a steamboat also plies daily to Providence. Projects of connecting Newport by railroad with Fall River, Bristol, and Providence, are in agitation. Two newspapers are published daily, "News" (whig), and "Advertiser" (whig); 3 weekly, "Newport Mercury" (whig), established in 1758, "Flerald and Rhode Islander" (whig), and "Advertiser" (whig), Commerce.-on the 30th June, 1850, the total tonnage of Newport district was 10,579 tons; registered 5.645 , enrolled and licensed 4.934. Of registered tonnage 4,279 tons were permanent, 1,365 were temporary, and 1,517 tons were in the whale fishery. Of the enrolled and licensed tonnage, 4,560 tons were permanent, 4,112 in the coasting trade, 256 were propelled by steam, 320 in mackerel fishery, and 327 tons in cod fishery. During the year previous, the number of clearances for foreign countries was 
$17-2.752$ tons ; number of entrances do., $17-2,602$ tons; 1 schooner built, 96 tons. During the calendar year 1849 , 1,055 barrels of sperm oil were brought into this port. Newport has long been a very favorite fashionable summer resort. It is attractive because of its beautiful scenery, cool and salubrious sea breezes, fashionable company, large and well-kept hotels, opportunities for fishing, bathing, etc. In the vicinity of Newport is a curious monument of antiquity - the Old Tower, or Old Stone Mill, of which the age and origin are unknown, and have been the subject of much learned discussion. Pop. of t. in 1830, 8,010; in 1840, 8,383; in $1850,9,563$,

Newport, t. and p. o., Orleans co., Verm. : 50 m. N. by E. Montpelier. Bouncied on N. E. by Lake Memphremagog. Pop. 748.

New PORT, p. v., Giles co., Virg.: on S. bank of creek of New r., $170 \mathrm{~m}$. W. by S. Richmond.

Newport, p. 0., Lake eounty, $I l_{\text {. }}$ : about $2 \mathrm{~m}$. E. of Des Plaines r., 208 m. N. N. E. Springfield.

New Portage, p. v., Summit co., Ohio: 100 m. N. E Columbus, on the line of Akron Branch R. R., and on E bank of Wolf creek.

Newport Centae, p. o., Luzerne county, Penn.: $78 \mathrm{~m}$. N. E. by N. Harrisburg,

New Portland, t. and p. o., Somerset co., Me. : $45 \mathrm{~m}$. N. N. W. Augusta. Drained by Seven Mile brook and its branches. Soil fertile and adapted to grain. Population 1,460 .

New Portland, p. v., Ralls eo, Mo, : on N. side of Salt river, $70 \mathrm{~m}$. N. by E. Jefferson City.

New Portlaxd, Stewart co, Tenn. : 63 m. W. N. W. Nashville.

Newportsviute, p. v., Bucks co, Penn. : on N. E. side of Neshaming creek, at the head of navigation, about $3 \mathrm{~m}$. frum its mouth, 103 m. E. Harrisburg,

New Preston, p. v., Litehfield co., Conn. : 37 m. W. by S. Hartford, $36 \mathrm{~m}$. N. W. New Haven, on W. side of E. Aspetuck r., 1 m. S. Raumaug lake.

New Princeton, p. v., Coshocton county, Ohio: $60 \mathrm{~m}$. E. N. E. Columbus.

New Prospect, p. o., Orange county, Ind.: on S. side of Lick cr., 85 m. S. by W. Indianapolis.

New Prospecr, p. v., Greene co., Ala. : 89 m. W. N. W. Montgomery.

New Prospect, p. o., Winston co., Miss.: 87 m. N. E, Jackson.

New Prospect, p. v., Bergen co., $N$. Jer.: on Hohokus creek, $63 \mathrm{~m}$. N. E. by N. Trenton. The v. is finely situated on elevated ground. Considerable water-power is afforded by the creek, and is improved by several paper and grist mills, etc.

New Prospect, p. o., Wayne co., Ohio : on Chippewa r., $87 \mathrm{~m}$. N. E. by N. Columbus.

New Prosenct, p. v., Spartanburg dist., S. Car.: $98 \mathrm{~m}$. N. W. by N. Columbia.

New Providence, t. and p. v., Essex co., $N$. Jer.: on E. side of Passaic r., $37 \mathrm{~m}$. N. E. by N. Trenton. Surface of $t_{\text {. }}$ hilly; soil sandy loam. Drained by Passaic r. Pop. of $t$. 1.216. The Morris and Essex R. R. passes through the $\mathrm{N}$. part, at Summit sta.

New Providence, p. o., Lancaster co., Penn.: $41 \mathrm{~m}$. E. S. E. Harrisburg.

New Protidexce, p. v. and sta., Clark co., Ind.: $87 \mathrm{~m}$. S. by E. Indianapolis, $19 \mathrm{~m}$, by railroad from New Albany, on the New Albany and Salem R. R. Drained by the Muddy Fork of Silver creek.

New Providence, p. v., Montgomery co., Tenn.: $47 \mathrm{~m}$. N. W. Nashville.

New Retreat, p. o., Washington county, Ind.: $80 \mathrm{~m}$. S. Indianapolis.

New Richlaxd, p. v, and sta., Logan co., O7io: $52 \mathrm{~m}$. N. W. by W. Columbus; station on Mad River and Lake Erie $\mathrm{P}$. P
New Riohmond, p. v., Clermont co, Ohio: 95 m. S. W. Columbus, on Ohio r., near Muddy cr, ; is very flourishing. New Richmond, p. o, Crawford county, Penn. : $187 \mathrm{~m}$. N. W. by W. Harrisburg.

New Piommond, p. v., Montgomery county, Ind. : $50 \mathrm{~m}$. N. W. Indianapolis.

New River, p. v., Columbia co., Flor.: on New river, a branch of Santa Fé r., $127 \mathrm{~m}$. E. by $\mathrm{S}$. Tallahassee.

NeW RIver, p. O., Ascension par., La. : F, side Mississippi r., 18 m. S. S. E. Baton Pouge.

New river, Ascension par., $L a$, : rises near the Mississippi river, flows E., paralleI to Amitié r., into Lake Maurepas.

NEw river, Onslow co., $N$. Car.: rises in $N$. W. part of the co., flows through it centrally toward the coast, and empties into New river inlet.

New river, Beaufort dist., S. Car. : rises near the centre of the dist., and flows S. S. W., parallel to Savannah river, emptying into Calibogue Sound.

NEw river, Virg. : rises in N. part of $N$. Car.: its general course is N. N. W., through the S. W. portion of Virg. until it receives Gauley river, after which it is called Great Kanawha river, and flows $\mathrm{N}$. W. to its confluence with the Ohio river.

New River InLet, Onslow co., $N$. Car.: $57 \mathrm{~m} . \mathrm{W}$. by $\mathrm{S}$ Cape Lookout.

NEW RoAD, p. o., Delaware co., $N_{*} Y_{.}: 81 \mathrm{~m}$. W. S. W. Albany.

New Rocrelle, t., p. v., and sta., Westchester co., $N . Y$. $134 \mathrm{~m}$. S. Albany. Surface of t. undulating; soil, clay loam, and well cultivated; watered on the S. side by Long Island Sound. The $\mathrm{v}$. is a station of the New York and New Haven R. R., $20 \mathrm{~m}$. from New York, with which it has also constant steamboat connection. It is handsomely situated, overlooking $\mathrm{L}$. I. Sound, and is a fashionable resort in the summer months. It contains several churches, three good academies, and a few factories. Pop. of t. 2,458.

New Rochester, p. v., Wood co., O7rio: $98 \mathrm{~m}$. N. by W. Columbus, on Portage river.

New Row, p. v., Allen county, $\not y y .: 120$ m. S. S. W Frankfort.

New Ross, p. o., Montgomery co., Ind.: on S. bank of Sugar cr. of Rock r., 35 m. W. N. W. Indianapolis.

New Rumlex, p. v., Harrison co., Ohio : 105 m. E. N. E. Columbus.

New Russia, p. o., Essex county, $N . \quad Y .: 110 \mathrm{~m}$. N. Albany.

Newry, p. o., Jackson co., Ind.: on E. side of Vernon Fork, $63 \mathrm{~m}$. S. by E. Indianapolis.

Newry, to and p. o., Oxford co., Me.: on N. side of Androscoggin r., $51 \mathrm{~m}$. W. by N. Augusta Drained also by Bear brook, and another cr, which afford water-power. Population 459.

Newry, p. v., Blair co., Penn. : $83 \mathrm{~m}$. W. by N. Harrisburg. Poplar r., a tributary of the Frankfort branch of Juniata $r$. passes near the village.

News, p. o., Calhoun co, $I l l .: 73$ m. S. W. Springfield.

New Salen, p. o., Rush co., Ind.: 40 m. E. S. E. Indianapolis.

New Salex, p. o., Rusk co., Tex.: 225 m. N. E. Austin City. NeW SALEM, t. and p. v., Franklin county, Mass.: $67 \mathrm{~m}$. W. by N. Boston. Drained by Miller's r. and an affluent of it, and a branch of Middle r.; surface elevated, and a part mountainous; soils fertile, and adapted to grazing. The t. contains 2 handsome villages, several stores, and a few fac tories. Pop, 1,253.

New SAlem, p. o., Albany county, $N . Y_{.: 11} \mathrm{~m}$. W. by $\mathrm{S}$ Albany.

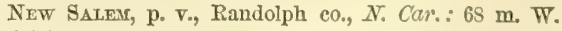
Raleigh.

NEw SAlEx, t. and p. v., Fairfield county, Ohio: $28 \mathrm{~m}$, E. by S. Columbus. Pop. 210.

Nrw S $\triangle$ Lex, p. 0., Pike county, $I l l$ : $73 \mathrm{~m}$. W. by $\mathrm{s}$ Springfield. 
NEW SALEM, p. v., Fayette co.g Penn. : 154 m. W. by S. Harrisburg.

New SuLEM, p. o., Harrison co., Firg. : on the line of the

North Western (Va.) R. R., $207 \mathrm{~m}$. N. W. Riehmond.

New Saltsburx, p. v., Harrison co., Ind. : on N. side of Indian cr., $100 \mathrm{~m}$. S. Indianapolis.

New Scothaxd, t, and p. o., Albany county, $N . Y .: 6 \mathrm{~m}$. W. by S. Albany. Surface hilly; drained by Normanskill. Pop. 3,459

New SHaror, t. and p. o., Franklin $\mathrm{co}_{4}$, Me. : on E. side of Sandy r., $23 \mathrm{~m}$. N. N. T. Augusta. Pop. 1,732.

New Sharow, p. o., Monmouth co., $\mathcal{N}$, Jer. : $24 \mathrm{~m}$. E. Trenton.

New Saeffield, p. v., Beaver co., Penn.: 178 m. W. by N. Harrisburg, on a tributary of the Ohio river.

New SHorehaM, t. and p. o., Newport co., $R .1 .: 13 \mathrm{~m}$. S. S. W. Point Judith; 15 m. N. N. E. Montauk Point, L. I. The t. comprises Block Island, $8 \mathrm{~m}$. long, and 2 to $4 \mathrm{~m}$. broad. Surface uneven; soil sandy and gravelly loam. The inhabitants are mostly fishermen. Peat is ased as fuel. Pop. 1,262.

New SArrexa, p. $\nabla$. , Orange co., Flor.: on Mosquito inlet, $229 \mathrm{~m}$. E. S. E. by S. Tallahassee, is a U. S. military post. It has an improting commerce.

New Somerset, p. V., Jefferson co, Ohio: 129 m. E. N. E. Columbus.

Newsor, p. o., Bibb co., Ga.: 35 m. S.W. Milledgeville. NEWSOy's DEP6́t, p. o. and sta., Southampton co., Virg.

$70 \mathrm{~m}$. S. by E. Richmond, on the Sea-board and Roanoke R. R., $50 \mathrm{~m}$. from Portsmouth, $30 \mathrm{~m}$. from Weldon.

New Sprtigereld, p. v., Mahoning co., Ohio: $139 \mathrm{~m}$. N. E. by E. Columbus.

New Startor, p. v., Westmoreland co., Penn, : $141 \mathrm{~m} . \mathrm{T}$. Harrisburg.

Newstean, t. and p. o., Erie co., $N$. $Y_{.:}$on $\mathrm{S}$. side of Tonawanda cr., $255 \mathrm{~m}$. W. by N. Albany, Pop. 2,599 .

Newstead, p. o., Christian county, Ky.: 168 m. S. W. Iirankfort.

New Store, p. o., Buckingham co., Firg.: $65 \mathrm{~m}$.W. by S. Pichnaond.

New SufFouk, port, Suffolk co., $N$. $Y$ : this small port, in Southold t., fronts on the N. E. portion of Great Peconic Bay. Its tonnage is chiefly employed in the fisheries. On January 1st, 1550 , it had 227 tons in the whale fishery, and during 1849 it received 242 barrels of sperm oil, 314 barrels of whale oil, and 1,200 pounds of whalebone.

New SwEDEx, p. v., Clinton co., $N . Y_{\text {: }}$ on $N$. side of Sable r., $125 \mathrm{~m}$. N. Albany.

New Toy county, Ark. Situate N. toward the W., and contrins 733 sq. m. Drained by Buffalo fork of Thite r. and other streams. Surface varied; in the $\mathrm{S}$. being hilly and broken, the residue generally level. Soil fertile, and well adapted to corn. Galena and other ores abound in this region. Farms 230; manuf. 0 ; dwell. 2ss, and pop. $-w h$. 1,704, fr. col. 7, sl. 47-total 1,759. Capital: Jasper.

Newton county, $G a$. Situate N. centrally, and contains $414 \mathrm{sq} . \mathrm{m}$. Drained by Alcopahatchee and Yellow rivers, tributaries of Ocmulgee $r$. Surface undulating, and soil fertile and very productive. Cotton is the staple, but wheat and corn are raised in considerable quantities. Agriculture is much attended to by a large portion of the population. Timber is abundant. Farms 812 ; manuf. 23; dwell. 1,374, and pop.-wh. 8,079 , fr. col. 30 , sl. 5,15i-total 13,296. Capital: Corington, Public Works: Georgia R. P.

N'шттох county, Miss. Situate E. middle, and contains 576 sq. m. Drained by head branches of Chickasawha $r_{\text {., }}$ and branches of Tuscalameta cr. Surface even; soil fertile, and generally productive; it is well adapted to cotton, which is the staple. Farms 5.50 : manuf. 0 : awell. 5<6, and pop.-wh. 3,432, fr. col. 1, sl. 1,032-total 4,465. Capital: Decatur. Public Works: Mobile and Ohio R. R. ; Alabama and Mississifuni R. R.

Dewtus county, Yo. Situate $S$. W., and contains 639 $560^{\circ}$ sq. m. Drained by Neh-hah r. and other streams, all tributaries of Neoshor. Surface level; soil fertile, and adapted to grain. There is much good timber on the land. Farms 293 ; manuf. 11 ; dwell. 653, and pop.-wh. 4,013, fr. col. 14 sl. 211-total 4,268. Capital: Neosho.

Newtox county, Tex. Situate E., and contains 1,196 sq. m. Drained by branches of Sabine $\mathbf{r}_{n,}$ which forms its E. boundary. Surface varied, in the $\mathrm{N}$. being hilly, but in the S. undulating; the land, in general, is thickly wooted. Soil a black mold, with sand intermixed, and generally fertile, producing good crops of cotton, sugar, corn, wheat, te It has some fine timber land, and contains many streams of pure water. Petrified trunks of trees are found in the northern part, which are so hard that they are used in many cases as flints. Farms 141; manuf. 5; dwell. 219, and pop. -wh. 1,255, fr. col. 8, sl. 426-total 1,659. Capital: Burkeville.

Newtow, p. v., and eap. Dale co., Ala.: on S. side of Choctawhatchee $r_{0,} 84 \mathrm{~m}$. E. S. E. Montgomery; contains the court-house and several stores.

Newtor, p. v., and cap. Baker co., Ga.: on W. side of Flint r., $143 \mathrm{~m}$. S. S. W. Milledgeville; contains the courthouse and several stores.

Newtow, p. v., and cap. Jasper co., IUl.: on S. W. side of Embarras r., $94 \mathrm{~m}$. S. E. Springfield. It contains the court-house and several stores, and is the central business $\mathrm{v}$. of the county.

Newrox, t., p. T., and sta, Middlesex co., Mass. : $9 \mathrm{~m}$. W. Boston. Drained by Charles $r$, and affuents; surface varied; soil fertile and highly eultivated. Charles r. bounds the t. on the N.T. and S., having two falls, at each of which is a v. containing manufactories, At the Upper Falls the $\mathbf{r}$ descends 35 feet in half a mile. At the Lower Falls the $v$. lies partly in the t, of Needham. The Boston and Worcester R. R. passes through it. The Newton Theological Seminary (Bapt.) was founded in 1525; the building-at Newton Centre-is a brick edifice, 85 feet long, 49 wide, and 3 stories high. Pop. 5,258.

Newtor, t. and p. o., Calhoun co., Mich.: $45 \mathrm{~m}$. $\mathrm{S}$. W. Lansing. Drained by branch of St. Joseph's river. Population 569

New tov, p. v., and cap. Jasper co., $T a_{.}: 79 \mathrm{~m}$. W. Iowa City, is a beautiful and flourishing town, on a prairie between the branches of Skunk river.

Newtox, t., p. o., and sta., Rockingham co., N. Hamp.: 34 m. S. E. Concord. The Boston and Maine R. R. passes through the $\mathrm{t} .41 \mathrm{~m}$. from Boston. Pop. 535.

Newtox, t., p. v., and cap. Sussex co., $N$. Jer. : $55 \mathrm{~m} . \mathrm{N}$. Trenton. Surfuce of $t$ diversified; drained by the Paulin's kill. The $\mathrm{v}$. is well situated and laid out, and contains, besides the court-house and jail, several churches and schools. Two newspapers are published weekly: "Sussex Register" (whig), and "New Jersey Herald" (dem.) There is $1 \mathrm{bank}$ capital \$134,450. Pop, of t. 3,279 .

Newtos, p. v., and cap. Catawba co., $N$. Car.: near South Catawba r., 138 m. W. Raleigh.

Newtox, t. and p. o., Muskingum county, Ohio: $48 \mathrm{~m}$. E. by S. Columbus. Surface of t. undulating; soil good well watered by numerous creeks of Mluskingum river. Pop. 2,356.

Newton Cextre, p. v., Middiesex co,, Mass.: $7 \mathrm{~m}$. W. Boston, on the Boston and Worcester R. P. This $r$. contains the Newton Theological Seminary, the mansion-house for the students, and dwellings of the professors, besides many pleasant residences.

Nentox Cornens, p. 0., Jefferson co., Wisc.: 32 m. E. Madison.

NewtoN FActory, p. o., Newton co, Ga. : $59 \mathrm{~m}$. N. W. Milledgeville.

Newton Falls, p. o., Trumbull co., Ohio: 132 m. N. E. Columbus, on Pennsylrania and Ohio Canal, at junetion of the two branches of Mahoning river, which afford extensive Water-power to several mills and factories. 
Newtox Geove, p. o., Sampson con, N. Car.: $54 \mathrm{~m}$. S. S. E. Raleigh.

New Ton Lower FALLs, p. v. and sta., Middlesex county, Mass.: on Charles r., 11 m. W. Boston. A branch of the Boston and Worcester R. R. extends to the village.

Newton Stew ART, p. o, Orange co., Ind. : on S. bank of Patoka cr., $95 \mathrm{~m} . \mathrm{S}$. by W. Indianapolis.

Newtoxs ville, p. 0., Clermont county, Ohio: 85 m. S.W. Columbus.

Newtonsvilue, p. 0., Attala county, Miss. : 63 m. N. N. E. Jackson.

Newton Upper Falds, p. $\nabla$. and sta., Middlesex county, Mfass.: on Charles r., 9 m. W. S. W. Boston. The fall of the river is 35 feet, used by extensive manufactories. The Charles River Branch R. R. extends to this v. from West Newton.

New Topsarl INLET, N.Car, : 18 m. N. E. Wilmington.

Newrown, t., p. b., and sta., Fairfield co., Conn.: $41 \mathrm{~m}$. S. W. Hartford, $23 \mathrm{~m}$. W. N. W. New Haven, on the Housatonic R. R., $19 \mathrm{~m}$. from Bridgeport. Surface of $t$. hilly; soil gravelly loam, fertile, adapted to grain and fruit. Drained by the Potatuck and other creeks of Housatonic r., and contains several factories, mills, and churches. The borough is beautifully situated on high ground. Pop. of t. 3,353 .

Newtown, p. v., Fountain co., Ind.: on Coal cr., $60 \mathrm{~m}$. W. N. W. Indianapolis.

Nватошм, p. v., Scott co., Ky. : 24 m. E. by N. Frankfort Netrtown, p. v., Worcester co., Md.: on W. side of br. of Pocomoke r., $5 \mathrm{~m}$. N. W. Snow Hill, 76 m. S. E. Annapolis. Newtown, p. ., Hinds co., Miss. : on W. side of Pearl r., $9 \mathrm{~m}$. S. S. W. Jackson, on line of Jew Orleans, Jackson and Northern R, R.

Newrows, t. and p. v., Queen's county, $\lambda$. $Y$. The t. is bounded on $N$. side by East $r_{n}$, and is also drained by Newtown cr. Surface of t. various; soil sand and clay loam, fertile, and adapted to fruit. Horticulture and agriculture are the chief occupations of the inhabitants. Pop. of t. 7,208

NawTowN, p. F., Hamilton co, Ohio: on Es side Little Miami r., $90 \mathrm{~m}$. $\mathrm{S}$ W. Columbus.

Newrown, t. and p. b., Bucks county, Penn.: $99 \mathrm{~m}$. E. Harrisburg. Drained by Newtown er., which affords hydraulic power. Surface even, soil fertile clay loam, well cultivated. The $\mathrm{b}$. is on the cr., and contains several stores and factories, and is a considerable place.

Newrows, p. F., King and Queen county, Virg.: $29 \mathrm{~m}$. N. N. E. Richmond.

Newtown creek, $\mathcal{N} . Y_{\text {. }}$ : rises in Newtown, Queen's co. flows W. and enters East river, opposite New York.

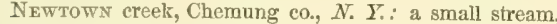
affording mill-sites, rising in $t$. of Erin, and entering Chemung r. near Elmira.

Newtown Hamiton, p. o., Mifflin county, Penn. : $47 \mathrm{~m}$. N. W. Ilarrisburg.

Newtown Square, p. v., Delaware co., Penn.: $78 \mathrm{~m}$. E. S. E. Harrisburg.

Newtown Stephensibeg, p. v., Frederick co., Firg.: $112 \mathrm{~m}$. N. N. W. Richmond. Pop. 400.

New Trentox, p. v., Franklin co., Ind.: on Whitewater r. and canal, $20 \mathrm{~m}$. N. Lawrenceburg, $70 \mathrm{~m}$. E. S. E. Indianapolis.
New Trier, p. o, Cook co, $I l l_{0}: 164$ m. N. E. by N. Springfleld.

New Tripolx, p. v., Lehigh co., Penn. : on a branch of Maiden er., $64 \mathrm{~m}$. N. E. by E. Harrisburg.

New UTRECHT, t. and p. o., King's county, $N . Y .: 6 \mathrm{~m}$. 8. Brooklyn, $140 \mathrm{~m}$. S. Albany; is a fashionalule resort during the summer months. Pop. 2,129.

NEW VERNoN, p. v., Morris co, N. Jer.: 40 m. N. N. E. Trenton.

New Verios, p. o., Orange co., N. I.: 92 m. S. B. W. Albany.

New Vernon, p. o., Mercer co., Pemn.: 196 m. W. N.W. Harrisburg.

New VienNa, p. o., Clinton county, Ohio: 50 m. S. W. Columbus,

New VIenna, p. v., Dubuque co,, Ia. : 62 m. N. N. I. Iowa City.

New Village, p. v., Warren county, $N$. Jer.: $41 \mathrm{~m}$. N. W. by N. Trenton.

New Village, p. o., Suffolk co., N. Y.: 100 m. S. S. E. Albany.

New rille, p. v., De Kalb county, Ind.: 103 m. N. N. E. Indianapolis.

Newville, p. o., Herkimer co., $N . Y_{*}: 76 \mathrm{~m}$. N. W. by W. Albany.

Newrule, p. v., Richland co., Ohio: 54. m. N. E. by N. Columbus, on N. bank of Clear Fork r., which affords water-power to several mills and factories.

Newville, p. b. and sta, Cumberland co., Penn. : on $\mathbf{S .}$ side of Conedogwinit er., $27 \mathrm{~m}$. W. by S. Harrisburg. The Cumberland Valley R. R. passes through the b., $34 \mathrm{~m}$. from Harrisburg.

Newville, p. Y., Sussex county, Firg.: 40 m. S. S. E. Richmond.

New VזNE, p. V., Dubuque co., Ia.: on E. side of Fall r., $63 \mathrm{~m}$. N. N. E. Iowa City.

New Vinexard, t. and p. o., Franklin co., Me. : $38 \mathrm{~m}$. N. N. W. Augusta. Drained by a branch of Seven Mile brook. Pop. 635.

NeW WAKefleLD, p. Y., Washington co., Ala.: 124 m. S. W. Montgomery.

Net WASHington, p. v., Clark co., Ind.: on E. side of Fourteen Mile er., $90 \mathrm{~m}$. S. S. E. Indianapolis.

New Washington, p. o., Clearfield co., Penn. : on W. side of W. branch of Susquehanna river, at the junction of Cusb r., 107 m. W. N. W. Harrisburg.

New Wasmiggton, p. o., Crawford co., Ohio: $56 \mathrm{~m} . \mathbb{N}$, Columbus.

New Wrstrille, p. o., Preble co., Ohio: 90 m. W. by S. Columbus.

New Whitehald, Lehigh co, Pemi.: the location of a blast furnace, $70 \mathrm{~m}$. E. N. L. Harrisburg.

New Wilmington, t. and p. o., Lawrence co., Penn. : on a branch of Neshanock er., $187 \mathrm{~m}$. W. N. W. Harrisburg. NrW Winciester, p. v., Hendricks co., Ind.: $27 \mathrm{~m}$. W. Indianapolis.

New Wrnchester, p. v., Crawford co., Ohio: on E. side of W. branch of Whetstone r., $51 \mathrm{~m}$. N. Columbus,

NeW Windsor, p. v., Carroll co., $M d_{\text {.: }} 6 \mathrm{~m}$. S. W. Westminster, $50 \mathrm{~m}$. N. W. Annapolis.

New Woodstook, p. v., Madison county, $\mathcal{N}$. $Y .: 112 \mathrm{~m}$ W. by N. Albany; has a few mills.

\section{THE STATE OF NEW YORK.}

NEw ToRk, the most flourishing, wealthy, and populous State of the Union, is situated between $39045^{\prime}$ and $45^{\circ}$ latitudes N., and between $71^{\circ} 56^{\prime}$ and $79055^{\prime}$ longitudes W. from Greenwich, or $5006^{\prime}$ E., and $2 \circ 53^{\prime}$ W. from Washington. It is bounded on the north by Lake Ontario, the River St. Lawrence, and Lower Canada; on the east by Lake Champlain, Vermont, Massachusetts, and Connecticut; on the south by the Atlantic Ocean, New Jersey, and Pennsylvania; on the west by Pennsylvania, Lake Erie, and the Niagara River. Exclusive of Long Island, it is about 408 miles long, but including that island, about 480 miles, and its breadth from north to south is about 310 miles-the whole including a Euperficial area of $46,15.5$ square miles.

The Hudson and Mohawk rivers naturally divide the State into three geographical sections of unequal size. The first, 


\section{NEW YORK.}

or eastern section, comprises Iong Island, Staten Island, and that portion of the State lying east of the Iudson River and Lake George; the second, or northern section, embraces all the country lying north of the Mohark and Oswego rivers; and the thirch, or southern section, the vast fertile tract lying south and west of those rivers.

The State forms a portion of the elevated table-land of the United States, broken in some places by mountain ranges, and containing sorne remarkable depressions which form the basins of lakes and channels of rivers. The loftiest part of this table-land occurs in the western part of the State, where Lake Chautauque is from 1,800 to 2,000 feet above the level of ths sea; and although it is but nine miles from Lake Erie, it discharges its waters by the Alleghany and Ohio into the Mississippi, and thus affords boat narigation to the Gulf of Mexico. Franklinville and Angelica, to the east, although situated in valless, are respectively 1,550 and 1,430 feet above the sen.

In the eastern section the Taghlinnuc or Taconic Mountains lie upon the border of the State from Lake Champlain southward to Putnam County, at which point their course, diverging to the south-west, crosses the Fiudson at West Point, and is continued thence into New Jersey and Pennsylvania, under the name of the Kittating Mountains. This range forms the dividing line between the waters flowing into the Hudson and those which flow into the Housatonic

The northern section has six several ranges of mountains. The Palmerstown Pange (in some parts called the Black and Tongue Mountains) rises in the northern part of Saratoga County, runs north-east through the tongue of land which separates Lake George from Lake Champlain, and terminates in bold and precipitous eliffs at the shore of the Iatter, south of Ticonderoga. The Kayaderosserus, or Lucerne Mountains, are about six miles wide and seventy long, running from Montgomery County, through Saratoga and Warren counties, along the western side of Lake George to Ticonderoga. The Hudson River breaks through this range on the line of Saratoga and Warren counties. The Clinton Range extends from Montgomery County north-east through Fulton, Hamilton, Saratoga, Warren, and Essex counties, to Point Trembleau, on Lake Champlain. It is the largest range north of the Mohawk River, and at its most elevated portion there are numerous distinct peaks, forming a remarkable group, known as the Adirondack Group. The Mohawk forces a passage through its south-western extremity, and the range itself is the dividing shed between the tributaries of the St. Lawrence and those of the Mohawk. Au Sable, or Peru Range, commences in Montgomery County, and running parallel with the Clinton Range, terminates in the southern part of Clinton County ; it is 160 miles long, and has a greater general elevation than the preceding ranges. The Chateaugay Range is the longest and highest chain of mountains in the State; it commences on the line of the Kaätsbergs, in Herkimer County, has a general height of 2,000 feet through the counties of Hamilton. Franklin, and Clinton, and erossing the Canada line, it terminates upon the Canada plains. The St. Lawrence Range, commencing ten or twelve miles north of the Chateaugay Range, and trending along the slope of the St. Lawrence Valley, has been little explored, and is of less extent than the last named. The St. Regis, Grasse, and other rivers descending into the St. Lawrence, divide it into several distinct portions. This section of the State has also two minor ranges, worthy of notice: the Highlands of Black Piver, extending from the sources of Black Creek, west aud north-west, about sixty miles, cover much of the country between Black River on the one side, and the plains north of Oneida Lake on the other. Their altitude is from 1,200 to 1,600 feet, and in some parts their summits have a rolling surface several miles in width. The Hassenclearer Mountains, the second of these minor ranges, extend from Herkimer into Oneida County, and occupy the space between the Highlands and the Mohawk River; they are twenty miles loug, and about nine miles broad at their base, with an altitude varying from 800 to 900 feet, with a rolling surface.

The Seuthern section may be divided into two portions-the Eastern and the Western. In the Eastern division there are three distinct ranges-1, the Highlands of Orange and Putnam counties; 2, the Shawangunk Mountains, skirting the valley of the Rondout; and-3, the Kaätsbergs, or Catskill Mountains, the direction of which is through the counties of Ulster, Albany, and Schoharie, to the valley of the Mohawk, the portions in Albany and Schoharie being also called the Helderbergs. The western division of this section rises gradually to successive terraces from the shores of Lake Ontario, till it attains its greatest elevation in the Southern fier of counties. The first of the terraces composing this ascent, extends from the Genesee, near Rochester, to the Falls of Niagara and Lewistomn, a distance of 80 miles, and is from six to ten miles in width. It is called the "Ridge Road," and is supposed to have formed at one period the shore of Lake Ontario. The second terrace extends from this ridge to the falls of the Genesee at Nunda and Portageville, where there is another abrupt acelivity of nearly 300 feet. This surmounted, the ascent is gradual to the summit level, at the height of from 1,500 to 2,000 feet in the Southern portion of Chautauque, Cattaraugus, Alleghany, and Steuben counties. These terraces, though all quite fertile, are euch characterized by a difference of soil and of forest trees.

The principal culminations of the several ranges, and the heights of each in feet, above the sea-lerel, are named in the following table:

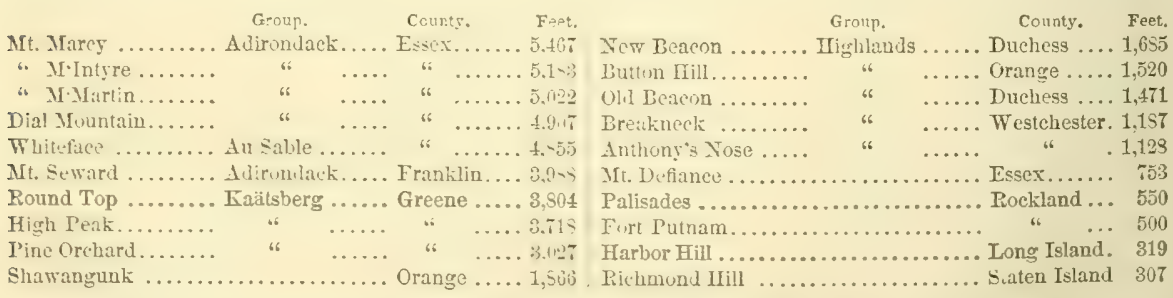

The most distinguishing feature of Jew Iork is, perlans, its vast system of water-wass, which bound and intersect it in almost every direction.

Its lakes are the common highways of an extended commerce. Numbers of these lie wholly within the State, but the great lakes, properly so called, lie on its borders-Ontario and Erie on the North and West, and Champlain on the East.

of these great exterior lakes, Erie is the most extensive; it is 268 miles in length and from 30 to 54 miles in breadth, with an area of 8,030 square miles. The elevation of its surface abore tide water is 565 feet, and above Lake Ontario, with which it communicates by the Niagara. River, 334 feet, having a maximum depth of 270 feet; but in general the depth is not more than 121) feet. Only bi) miles of its const lies within this State, but the amount of business carrier on from thence is immense, and constantly increasing with the progressive development of the States lying west. Ontario is the scend in size, and the whole southern coast east of Jiagara Rirer is wiolly within New York. Its form is 502 
eliptical; it is 190 miles in length and 56 in extreme breadth, with a circumferenee of 498 miles and an area of 5,400 square miles. In some places its depth is 600 feet, but the average depth is only 490 feet, and everywhere deep enough for the largest ships. The surface is 281 feet higher than tide water. The ports of this lake are usually open earlier in the spring than those of Lake Erie, and it is not so subject to those desolating storms that frequently sweep over that lake. Lake Champlain is a long narrow sheet of water, of exceeding beauty, and containing a large number of islands. Of these, Valcour and Schuyler, with several others, belong to this State. In extreme length it is 134 miles, with a breadth varying from $\frac{1}{3}$ a mile to 10 miles, and its depth is from 50 to 230 feet. Its outlet is the Sorelle or Pichelieu River, which is navigable, and forms the connecting link between the lake and the St. Lawrence River. The aboriginal name was Caniad-eri-quarinte, or "lake that is the gate of the country." All these lakes abound with salmon, trout, sturgeon, pickerel, and other fish. Lake George, or Horicon, is wholly within the State; its surface is 243 feet above tide water, and it discharges itself into Lake Champlain by a descent of 150 feet. The lake is inclosed around by hills from 1,200 to 1,500 feet high, and the rich and varied scenery that surrounds it, the numerous outlets that stud its peliucid surface, and the fine atmosphere, all combine to render it one of the most delightful of summer resorts. The French call it Lae Sacrament on account of the purity of its waters; the Indian name was Caniad-eri-oit, $i . e$. " the tale of the lake."

The northern portion of the State abounds with small lakes, and of these there are probably not less than 200 in number. Some of them among the Adirondack group of mountains are greatly elevated. Avalanche Lake, in Essex County, is 2,900 feet; Colden Lake, in the same county, 2,750 feet; and Racket Lake, in Hamilton County, 1,781 feet above tide. Many of these form the sources of rivers emptying into the St. Lawrence, Lake Champlain, the Hudson River, and Lake Ontario.

The western portion of the State contains several series of lakes of considerable size, many of which are of the highest importance to commercial navigation. They extend through the counties of Oneida, Oswego, Onondaga, Cayuga, Seneca, Yates, Ontario, and Livingston, and are scarcely surpassed any where in point of scenery. The principal of these are the Seneca, Cayuga, Oneida, Crooked, and Canandaigua lakes. The other lakes in this connection are Onondaga, Cross, Otiseo, Cazenovia, Skaneateles, Owasco, Hemlock, Canadice, and Conesus. Otsego and Canaderoga, in Otsego County, and Chautauque Lake, in the county of the same name, are also important waters. Extensive salt springs abound on the shores of Onondaga, the waters of which, notwithstanding, are as fresh and pure as those of any others of these lakes.

The rivers of New York, in connection with a splendid system of internal improvements, afford an immense stretch of inland navigation.

The Hudson is the largest, and one among the most magnificent water-courses of North America. It is 320 miles long, having its sources in the Adirondack group of mountains, and flowing in a generally southward direction to the Atlantic, which it meets at the Narrows below New York. It is navigable for the largest class of river steamers for the greater part of the year to Troy, 160 miles from its mouth, and the largest merchantmen may safely pass up as far as Hudson City. The principal branches of the Hudson are the Mohawk, on the west, and the Hoosic, on the east. The Mohawk rises in Oneida and Lewis counties, and at first pursues a southerly course, then changing east and south-east it forms the valley of the Mohawk, and after passing over the Little Falls and the falls at Cohoes, enters the Hudson by several mouths between Troy and Waterford. The scenery around the falls is beautiful, but these are destitute of that grandeur which inspires the mind on beholding the great falls of Niagara. The length of the river is about 135 miles, and in its course it passes through Rome, Utica, and Schenectady. The Hoosic River rises in Massachusetts, and, though a comparatively small stream, is very useful for local purposes. The Croton River, another tributary, is famous as sne source of the great supply of water it furnishes to the City of New York. The other tributaries are-from the east, Schroon branch, the outlet of Schroon Lake, Battenkill, and Kinderhook, and-from the west, Wallkill, Rondout, Esopus, Kaäterskill, and Sacandaga, besides several smaller streams.

The river St. Lawrence forms, in part, the northern boundary of the State, and is the outlet of the great northern lakes. It conveys to the ocean a larger volume of water than any other river of the world, except the Amazon. It is navigable for sloops to Ogdensburg, 60 miles fiom Lake Ontario, but below this point its navigation is difficult and dangerous, on account of the frequent rapids by which it is interrupted. The Lake of the Thousand Islands, the name of which implies sufficiently its character, is an expansion of the St. Lawrence. The group of islands that studs its surface, however, is said to number about 1,500, some of which belong to this State. The next important river of New York is the Oswego, which is about 120 miles in length. Under the name of Mud Creek it has its rise in Ontario County, and flowing eastwardly, it receives through the Canandaigua outlet the waters of the lake of the same name; proceeding eastwardly under the name of Clyde, it receives the waters of Seneea and Cayuga lakes, through their common outlet, and thence assumes the name of Seneca; after a still further enlargement by the waters of Onondaga Lake, it takes the title of Oswego River, and suddenly curving toward the north-west, collects from the Oneida River its tribute of the waters of Lake Oneida. It has a fall of about 100 feet after assuming its proper name, and furnishes, by its constant supply of water, valuable mill privileges. Seven thousand square miles of territory are drained by its course, and by means of the Oswego Canal and locks, it is navigable through its whole length. The Alleghany, a constituent of the Ohio, rises in Alleghany County, and is navigated by small steamers to Olean. The Susquehanna and Delaware both have their sources in this State, and in their first courses afford an immense water-power. The other principal rivers are the Niagara, the Genesee, the Black, the Chenango, the Chemung, the Oswegatchie, ete. The Niagara, which is the connecting link between lakes Erie and Ontario, forms the celebrated falls of the same name. The Genesee, distinguished for its valuable mill-sites, is used as a feeder to the Genesee Valley Canal. It is navigable almost to Rochester, and is 140 miles long, emptying into Lake Ontario. The Black River, one of the largest of the State, also falls into that lake; it is 120 miles in length, and is navigable 40 miles from its mouth. The Chenango and Chemung are important tributaries of the Susquehanna, and the Oswegatchie is the principal tributary of the St. Lawrence. Other streams flowing into the St. Lawrence are Indian, Grasse, Racket, St. Regis, Salmon, etc. Tho Chazy and Saranac are the principal streams flowing into Lake Champlain.

The falls and cascades of the rivers of this State being among its most distinguishing features, may with propriety be enlarged upon in this connection. The great falls of Niagara are described in a former page. Those of the rivers wholly within New York are as follows: the Falls of the Genesee, at Rochester, which have a descent of 96 feet; those of Fall Creek, in the township of Ithaca, which descend 498 feet in the space of one mile, forming several cataracts, at one of which the whole sheet of water is poured over a rock 116 feet high, and the banks above have an elevation of 100 feet; the Falls of the Mohawk, at Cohoes, where the water is precipitated over a broken rock 62 feet high, the banks of the river forming precipitous walls 140 feet above the stream, and Little Fulls, some miles above, where the river passes 
through a fissure in the rocks, which rise on each side 500 feet above its surface. Trenton Falls, on West Canada Creels, a tributary of the Mohawk, are much admired for their picturesque scenery; for the distance of several miles there is \& sucession of rapids and eataracts, and the bed of the river is frequently narrowed by rocky precipices, and overhung with trees, while its banks in some places rise perpendicularly to the height of 140 feet. At Glenn's Falls, 18 miles from Saratoga, the Hudson flows over a ledge of rocks into a deep basin below, with a descent of 70 feet. Numerous minor falls exist in various rivers, especially in the northern part of the State, and furnish in many instances motive power of immense importance to the manufacturing interests of the State.

The sea-coast of New York is nearly all comprised in the shores of Long IsIand. which contain a few harbors and inlets, but none that are much frequented by shipping. The bay and harbor of New York is the great depôt of the commerce of the State, and the most magnificent harbor-water on the Atlantic sea-board. Easily accessible, perfectly safe, capacious enough for the navies of the whole world, and never obstructed by ice, it has advantages possessed by no other port. Its boundaries toward the sea are Long Island and Staten Island, between which it connects with the Atlantic by the Narrows, an outlet formed by projections from each shore. It extends 9 miles below the eity, and is from 2 to 5 miles broad, containing several islands, which are fortified in the strongest possible manner, as are also both sides of its entrance at the Narrows. The Hudson enters the Bay from the north; the East River, or channel between New York and Long Island, communicating with Long Island Sound on the east, and the Kills, a strait between Staten Island and the Jersey shore, on the west. At low water the entrance by the Narrows is somewhat difficult for large ships, and the entrance from the Sound is obstructed by a rocky strait, called Hell Gate, a name corrupted from "Horil Gatt," the Dutch for whirlpool. In 1852, however, a great portion of the dangerous rocks of this channel were blasted away, and vessels of large size may now pass without much danger.

There are several harbors on Lake Ontario, the most noted of which is Sackett's Harbor, toward the east end of the lake; it is deep and safe, and was an important naval station during the war of 1S12. The harbors of Buffalo and Dunkirk on Lake Erie are also important commercial stations, being the terminus of the two great lines of railroad between the Hudson and the lakes. The harbors of Lake Champlain are much used by Canadian traders, and those of Burlington and Plattsburg are fast rising into importance.

Long Island is the largest appendage to this State. It projects into the Atlantic opposite the southern shore of Connectieut, a distance of 140 miles. Its average breadth is 10 miles, and its greatest breadth about twenty miles. The shape is that of a great whale, and a rocky ridge, called the. Spine, extends lengthwise nearly through it, and at the western end forms the heights of Brooklyn. South of the ridge the land is level and sandy-on the north it is more uneven. The island abounds with wild fowl and game, and its waters with fish in great variety, which furnish the markets of the City of New York and other places plentifully. In the western section are some fine orchards and market gardens. Staten Island, at the mouth of New York harbor, is separated from Long Island by the Bay and Narrows. It is $15 \mathrm{miles} l o n g$, and 8 miles broad. Manhattan, or New York Istand, which is oceupied by the city of the latter name, is 13 miles long, with an average breadth of one mile and a half. The small islands in the bay are Governor's Island, on which stand Fort Columbus, the principal strong-hold ; Castle William overlooking the confluences of the Hudson and East rivers, and South Battery overlooking the entrance by the Narrows; Bedloe's Island, on which stands Fort Wood, and is now used as the chief recruiting depôt of the United States army; and Ellis' Island, on which is a naval magazine and some fortifieations. The defenses at the entrance of New York Bay are Fort Hamilton and Fort Diamond, on the north shore of the Narrows, the latter an insulated castle, and Fort Richmond on the south shore.

The climate of New York can not be described in general terms. Each locality has its own peculiarities. The mean average temperature of the whole State is $46^{\circ} 49^{\circ}$ Fabr. The mean maximum $922^{\circ}$, the mean minimum $12^{\circ}$ below zero, and the mean annual range 104\%. These data furnish a standard of comparison. The southern section of the valley of the Hudson, and the whole of Long Island, are the most equable portions of the State-the greatest heat is about $2^{\circ}$ less, and the greatest cold from $10^{\circ}$ to $18^{\circ}$ less than the average-the spring is somewhat backward, but the harvest commences earlier than in the interior, and the first frosts happen at a much later period in the fall season. In the river counties, above the Highlands, the seasons are more extreme, both summer and winter being beyond the average, aud the spring is from 10 to 15 days later at Albany than at New York. The Mohawk Valley has a climate which does not vary greatly from the mean arerage; north and east of the Mohawk the region is characterized by a low, average temperature, backward seasons, and early frosts. The mean temperature is at least $2 \circ$ below the assumed standard. The region south of the Mohawk, extending to the smaller lalies, has a mean temperature 10 or $2 \circ$ below the given average, yet the cold is not so intense, nor do the frosts occur so early as in the regions on the north side of the valley. The lake region assimilates the climate of Long Island, and the mean temperature does not vary much from the average, but the range is about $S^{\circ}$ less, indicating greater uniformity. The average time throughout the State, from the blooming of the apple-tree to the first killing frost, is 174 days-on the west end of Long Island it is 12 or 13 days more, and in the St. Lawrence district 22 or 28 days less. The prevailing winds are from the south-west. On the sea-board, easterly winds almost invariably bring rain, while westerly winds are sure precursors of fine, dry weather, and in winter of continued frosts. The quantity of rain that falls during the year may average for the State 49 inches. From these data it will be perceived that the climate is everywhere one of great extremes, and although in the same latitudes which in Europe produce the fig and the olive, its severer character admits only of the culture of the hardier plants and grains. Though subject to sudden and severe changes, the State as a whole is extremely healthy, and if the mortality of the larger cities be omitted, the ratio of deaths is not greater than in the best climates of Europe. In the eastern counties consumption and other diseases of the respiratory organs are the prevailing maladies, while in the western counties bilious aficetions predominate. In the large eities, during summer and fall, cholera infantum is the most common and fatal disease; about one half of the deaths during the year occur in children under five years of age, a mortality which must be attributed to other causes than climate, and in chief to badly constructed dwellings and to badly regulated diet.

The geological structure of New York has been scientifically examined under the authority of the Legislature, as also its botany and animal kingdom. The secondary formations of geologists, as well as the upper formations of the transition system, have no existence in this State, and in most parts the tertiary system is wanting. The existence of small beds of oolite in Saratoga County, and a somewhat doubtful era of red sandstone in Rockland County can searcely be considered as exceptions to this statement in regard to the transition system.

Coal is not noted in the subjoined table. All the formations of New York, except the alluvial and diluvial deposits, and the beds of tertiary on the St. Lawrence, are below the coal measures, the Kaätsbergs, which are the highest members of the transition system being the layer immediately beneath. It is true that there are layers of anthracite a few inches in 


\section{NEW YORK.}

thickness, and extending over a small surface between the strata of rocks of an earlier date in various parts, but coal does not exist in quantities sufficient to be of any practical value. The prevalence of limestone in nearly all the formations is worthy of notice, affording, as it does, the basis rock best adapted to yield the materials for fertilizing the soil.

The following table exbibits the geological formations of the State, as arranged by the State geologists. Captions III. IV., and $V$. are comprised under the general head of the transition system of geologists:

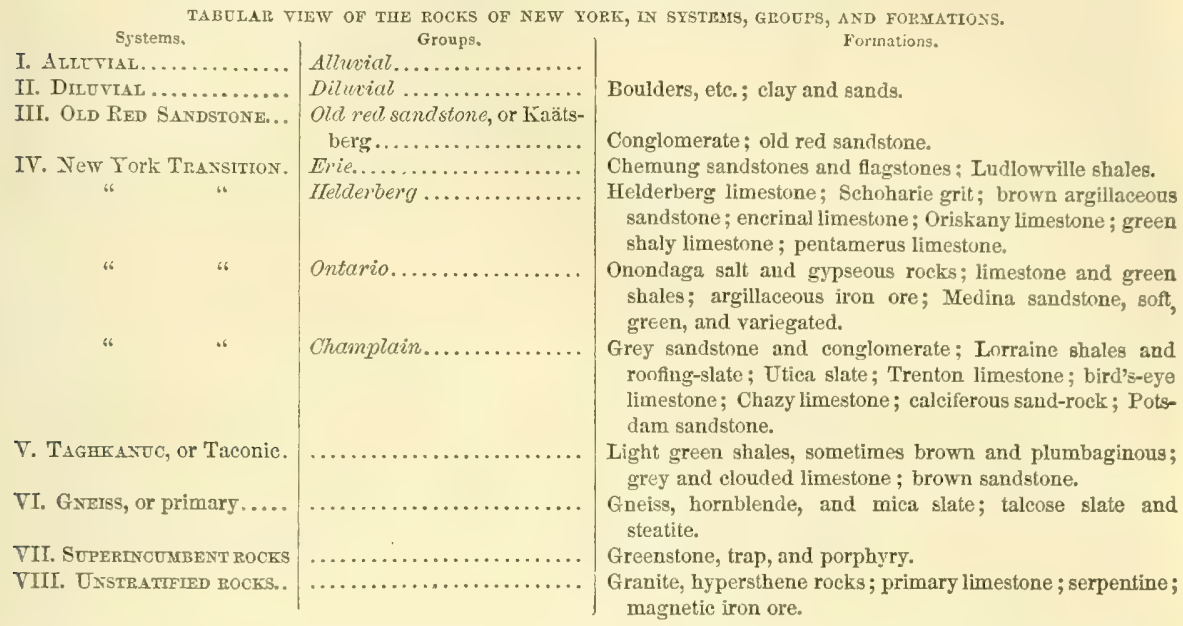

There are two tracts of primary and unstratified rocks; the first is nearly circular in form, and occupies the counties of Essex, Warren, and Hamilton, and parts of the adjoining counties; and the second is in the south-east, of a somewhat triangular form, and comprises Putnam and Westchester, with the larger part of New York, and part of Rockland, Orange, and Duchess counties. These two sections, together, oceupy nearly one-third part of the State. They contain extensive iron mines, and mines of lead and plumbago. Their surface is generally broken and elevated-in the Adirondack group towering up to the height of a mile above tide-water, and attaining in the beetling cliffs which overlook the waters of the Hudson a considerable though less lofty altitude. The soil is less arable and fertile than in the lands of limestone formation, but is naturally covered with a gigantic growth of oak, pine, and hemlock. The gneiss of this system furnishes a fine building material, and under the name of granite is abundantly quarried. The serpentine, primitive limestone and steatite are also largely produced for the purposes of the arts. These rocks abound in minerals, as garnet, beryl, chrysoberyl, pyroxene, sphene, tourmaline, apatite, colophonite, scapolite, labradorite, epodite, etc.

The Taconic system is composed of brown sandstone, gray limestone, green shales, etc., and contains some minerals. It furnishes fine limestone for building, but has few or no fossils. The overlaying soil is often highly fertile. Its range comprises the whole of Washington, Rensselaer, and Columbia, part of Duchess, Ulster, Greene, Albany, and Saratoga, and trending westward occupies a narrow tract in Schenectady, Montgomery, Herkimer, and Oneida, and expands more widely in Oswego and Jefferson counties.

The New York system comprises four distinct groups. The constituents of the Champlain group are various kinds of sandstone and lithestone, slate, conglomerate, and a peculiar stone, composited of lime and sand, and hence called calciferous (lime-bearing) sand-rock. Of these, the Potsdam sandstone furnishes a beautiful and durable building material; the Trenton and birds-eye limestone are used in the arts; Lorraine shales and Utica slate are employed for roofing: while the gray sandstones and conglomerates furnish stone suitable for grind-stones. The rocks of this group abound in fossils of the earlier periods-encrinites, trilobites, and numerous others, unlike any of the crustacea now in existence. The soil throughout the territory occupied by this group is generally good, and much of it highly fertile, being constantly enriched by the decomposing limestone, ete. The group occupies a very considerable but irregular territory; it appears occasionally in small beds, then dips, and again appears as a surface rock. In the form of Potsdam sandstone, etc., it bounds the great primary region of the north-east in every direction, varying in width from two to fifty miles, and also appears in narrow beds on both sides of the Hudson Piver.

The Ontario group consists of three distinct portions. The lowest, a marly sandstone, decomposing rapidly when exposed, is called Medina sandstone; next a series of soft, green, slaty rocks, also easily decomposed, and overlaid by clayey and flinty limestone, alternating with each other, and finally terminating on the limestone over which the Niagara pours its cataract; and, lastly, a group of limestones containing gypsum, hydraulic cement, water-lime, and salt, known as the Onondaga salt group. This group is the most valuable of the transition system. It includes the salt springs of Salina, etc., and furnishes in its gypsum one of the most potent of fertilizers, and in its water-lime an indispensable material in the construction of aqueducts, ete. The fossils of this group are numerous and interesting. Shells of bi-valve mollusca, corallines, and madrepores, together with traces of vegetable existence, mark this era. Minerals are not numerous here. The clayey limestone containing iron ore, fluor spar, and selenite, appear occasionally, and sulphur springs gush up in various sections. Its soil is of unsurpassed and permanent fertility, and its territorial limits compose the granary of the State. The nak, beech, maple, elm, butter-nut, hickory, and black walnut, are the principal forest trees. The Ontario group commences at the north-west extremity of Lake Ontario, and extends eastward, with a mean breadth of 20 miles, to its termination in Montgomery County.

The Helderberg series comprises four kinds of limestone, and three of sandstone (see table). Many of its constituents abound in fossils. The Helderberg limestone is cavernous, and many of the caves have been explored for a considerable distance, and have been found to eontain stalaclites and stalagmites of great variety and beauty. The principal minerals 
of this group are bog-iron ore, fitor spar, jasper, strontian, satin spar, alum, bitumen, and small veins of anthracite. The soil overlying the rocks is either a fine clay, or sand lying upon elay. Marl is also of frequent occurrence. 'The growths are chiefly oak, chestnut, hickory, pine, ete. By suitable cultivation good crops of grain may be grown. This group occupies the narrow tract commencing in Orange, and passing through Ulster, to the Hudson, thence along the banks of that river to Albany, where it turns westwardly, and passes through the centre of the State, south of the Ontario group, forming the beds of most of the small lakes in Western New York, and terminates on the shores of Lake Erie.

The Erie group is composed of two portions. The lower, or Ludlowville shales, is composed of soft, slaty rocks, alternating with their beds of limestone, easily decomposed; and the upper, or Chemung series, consists of thin, even beds of gray sandstone, with intervening shales or beds of slate. Some of the fossils found in this group possess great beauty. Ferns, etc., frequently occur, indicating the approach to that period of vegetable luxuriance which marks the coal formation. The avienla delthyris and other conchilera are found embedded in the rocks. Petroleum, called Seneca oil, occurs in several localities, and in a number of places carburetted hydrogen is evolved from the surface, and in such quantities as to be used for illumination. The soil where the Ludlowville shales form the surface rock is fertile, though rough and broken; in the higher regions occupied by the Chemung limestone, the character of the soil is different, and the white pine and hemlock take the place of the oak, maple, and beech of the lower lands, and attain a gigantic growth. These lands produce grasses abundantly, and as they become cleared will afford pasturage of the best character. The Erie series covers nearly the whole of Chautauque, Cattaraugus, Wyoming, Alleghany, Steuben, Yates, Tompkins, Chemung, and Tioga counties, together with portions of Broome, Chenango, Cortland, Ontario, Livingston, Genesee, and Erie, as well as a narrow tract in Sullivan, Ulster, Greenc, Schoharie, and Otsego counties.

This completes what for convenience has been termed the New York transition system. The remaining group properly belongs to the transition system of the English geologists, and is by them denominated old red sandstone, that rock being its principal constituent. It is predominant in the Kaättsberg, and hence the State geologists have given it the name of that locality. It consists of old red sandstone, overlying the Chemung sandstone, and of conglomerate, which is immediately beneath the coal-bearing limestone of Pennsylvania. The sandstone imparts its red hue to the soil that covers it. It contains comparatively few fossils-the scales and bones of some lizard-like fish have been discovered in it. Bogiron ore and calcareous spar are the only minerals of consequence found in this formation. The conglomerate affords fine grind-stones, and has been used to some extent for mill-stones. The overlying soil is good. Hemlock, beech, maple, elm, basswood, butternut, etc., are the principal trees-oak seldom occurs. This series is chiefly local, and occupies only the south-western counties in the neighborhood of the Kaätsbergs.

The diluvial regions are chiefly in the neighborhood of the St. Lawrence, Lake Champlain, and the Hudson, and compose the surface of the northern half of Long Island. They consist of a stifi, blue clay beneath, a yellowish-brown clay above this, and sand on the surface. The marine shells found in these clays, belong in some instances to extinct species, To this system belong also the boulders scattered so widely over the State.

The alluvial deposits, consisting of gravel, sand, loam, ete., thrown up by the waters, and deposited on the lake shores and river banks, and still in process of aggregation, constitute the last of the geological formations. To these belong portions of the valleys of the rivers and lakes, and the southern half of Long Island. The soil of both the diluvial and alluvial deposits is mainly fertile.

Trap and porphyry do not in this State constitute a separate formation. They occur either in columnar masses, like the Palisades, or in narrow dykes traversing rocks of an entirely different constitution, and their position is evidently the result of the action of subterranean fire. Porphyry is only found occupying a tract of a few miles in length on Lake Champlain.

In connection with the geology of the State, the "ridge road" is worthy of more extended notice. This road consists of a bank of sand, gravel, etc., varying in height from 100 to 150 feet, and extending along the whole southern coast of Lake Ontario at a distance of six or eight miles from it, forming a natural highway. It is said that a somewhat similar ridge exists along the northern shore of the lake. That this ridge once, and at no distant period, formed its shore, is proved by the existence of small sand hillocks, evidently heaped up by the action of the waves, by the absence of Indian mounds and fortifications on the north side of the ridge, and their frequent occurrence immediately south of it, and, above all, by the structure and composition of the ridge itself.

The deep channels cut in the rocks by many of the rivers are also subjects of geological interest. The Hudson, the St. Lawrence, Oswego, ete., either have banks sloping to the water's edge, or if they occasionally pass throngh narrow and precipitous defiles, have not worn themselves a passage by the action of their waters upon the rocky barrier which opposed them, but have availed themselves of a route opened by some convulsion of nature. Such is not the case with the Mohawk, the Chenango, the Genesee, and the Niagara. Descending from elevated table-lands, they have, by their ceaseless flow, hewn out a channel through the shales, slates, and marly sand and limestones, in some instances 400 or 500 feet below the level of the surrounding country. The constant action of the waters upon these decomposing rocks has also caused the Falls of Niagara to recede, as some geologists suppose, a distance of five or six miles, and this recession is still in progress.

Among the useful metals, iron is that most abundant in New York. It is found in five forms. The magnetic oxide is most abundant in Essex, Clinton, Franklin, Warren, Orange, and Putnam counties; the abuadance is immense; a single vein (the Stafford vein, in Essex County) being estimated by Professor Emmons to contain ore sufficient to yield $3,000,000$ tons of malleable iron. This ore is confined to primary rocks. The specular oxide is found chiefly in St. Lawrence, Jefferson, and Franklin counties imbedded in sandstone, and though less abundant than the former, is still found in large quantities. The argillaceous ore, ealled also bog ore, is found in various parts, evidentiy deposited by dilurial and alluvial action in the olay and gravel. The hematitic ore frequently oceurs in crystals of fantastic and beautiful forms; it is found extensively in Richmond, Orange, Ulster, Putnam, Duchess, Clinton, Warren, and Wayne counties; also in Westchester and Rockland, and usually makes its appearance in the lower limestones of the transition system. The earburet of iron, or graphite, occurs abundantly in Duchess County, and in considerable quantities in Essex and Clinton counties.

Lead is found in immense quantities in St. Lawrence County, and less abundantly in the Shawangunk Mountains, in Sullivan and Ulster counties, etc. It does not seem to be confined to any geological era, but occurs in nearly all the formations. Zine and copper occur in various parts, and arsenic bas been discovered in Putnam County. Barytes and strontian are abundant in Schoharie and Jefferson, and alum is found in many districts. The existence of gypsum and hydraulic cement has already been noticed. Serpentine and its kindred minerals, soapstone, talc, carbonate, hydrate and sulphate of maguesia, together with asbestos, and amiantbus, occur abundantly in Putnam, Orange, Wostehester, 


\section{NEW YORK.}

Jefferson, and St. Liwrence counties, and in considerable quantities in other parts. Numerous other minerals, of interest only to the professed geologist, are found everywhere.

Mineral springs, the waters of which are of great value, exist in varions districts. The chalybeate springs of Saratoga, the sulphur springs of Avon, Rochester, and Chittenango, the brine springs in Genesee, Erie, and Orleans counties, the petrifying springs of Madison and Saratoga counties, etc., are well known and appreciated. The oil springs found in Cattaraugus and Alleghany counties, the nitrogen springs of New Lebanon and Hoosic, and the carburetted hydrogen springs in the neighborhood of Lake Erie and the Niagara River, are also well worthy of notice. The village of Fredonia, and the light-house at Barcelona, are illuminated by the latter. Springs of the same character are alsu found in Duchess, Oneida, and Monroe counties.

The botany of this great State is exceedingly diverse in its characteristics. Holding a geographical position midway between the north and the south, the trees, shrubs, grasses, ete., of both extremes are found within its borders. Immense forests still occupy the uncultivated regions north and west, consisting mostly of oak, pine, beeeh, etc., while chestnut, hickory, and maple, with a number of others less numerous, but not less valuable trees are seattered over its territory. The mountain sides and woods are clothed in a shrubby undergrowth, and in the open plains flourish hundreds of more humble herbaceous plants, among which may be found many that are rare and curious. Flowery shrubs and plants cover the surface; the anemone, ranunculus, and violet put forth their flowers in every sheltered place; and the dock tribe flourish luxuriantly in the marshes. Among the lobelia tribe there is the cardinal flower, Indian tobacco (inflata), etc.; and in the deep recesses of the forests, the arum and orchis tribes, of strange forms and brilliant colors, are met with. In the fall season the asters and golden-rods are the pride of the plain. Medicinal plants are in abundance-the cicuta, conium, stramonium, are found on every side, and the mints are abundantly distributed. Among the shrubs also are many highly useful in medicine.

But the most important vegetation of the State is undoubtedly its forest trees. Of the coniferce there are nine distinct families, viz. : the pitch pine, white pine, hemlock, spruce, balsam fir, black spruce, white spruce, tamarack, ete, also the red cedar, white cedar, arbor vitæ, and the yew. Oaks are more numerous in spesies, and among these are many of the most valuable kinds of timber; white, black, scarlet, black chestnut, willow, swamp, mossy, black-jack, etc., are the best known. Elm, ash, maple, walnut, beech, ete., in numerous species, are found in different parts. Of the maple species, the sugar maple is most valuable, on account of its furnishing domestic sugar, which is now used by the farmers of the interior almost to the exclusion of cane sugar.

No class of plants is so widely distributed as that of grasses. The Flora of this State contains many native species, but only a small number of these is of any ralue, and the meadow grasses, with few exceptions, are of foreign origin. The principal of these are, the timothy, sweet vernal, meadow, blue and rough grasses. Wheat, rye, and oats are eultivated extensively, and the zigania aquatica, a wild rice, which forms a principal article of the food of the Indian, grows abundantly in the northern counties. Wild oats and chess are common. Some grasses are confined to particular soils. Many in sandy soils have matted roots, and by forming a thick sod, prevent the loose soil from being carried away by the flood or winds, and others by their annual decay fertilize soils which otherwise would be arid and unproductive Ferns and fern-like plants occupy a wide extent of territory, while mosses and rushes are equally abundant, and form in many instances most valuable adjuncts to the comforts of domestic life.

The whole number of flowering plants in this State is about 1,450 , and of these 1,200 are herbaceous, and 150 may be regarded as ornamental. Of woody plants there are 250 species, including about 80 that attain to the stature of trees. Of plants that are reputed medicinal, there are, native and naturalized, about 160 species.

The animal kingdom is replete with objects of interest, and opens a wide field for the study of natural history. The carnivorous animals existing in this State are the black bear, the raceoon, wolverine, skunk, fisher, weasel, pine martin, ermine weasel, mink, otter, native dogs, the gray and black wolf, the panther, wild cat, bats, the mole, and the shrew. Of the marsupial, or pouched, animals the opossum is the only species. The order rodentia, or gnawers, are numerous, and comprises the beaver, muskrat, rabbit, prairie hare, squirrels, woodehucks or marmots, and rats and mice of numerous kinds. The American deer, the moose, stag, and reindeer, belonging to the ungulata, were formerly numerous; to this family belong also the horse, ass, ox, hog, goats, and sheep, but these are not indigenous. In the waters are many cetaceous animals-whales of several species, with the porpoise, grampus, etc. The mastodon has been found in a fossil state in all parts, and the teeth and other remains of elephants, etc., have been occasionally dug up.

Among the birds of prey natives of New York there are, of the vulture tribe, the turkey buzzard; of the falcon tribe, the golden and bald eagle, the goshawk, the fish hawk, the marsh harrier, with four other species of hawk, and six of buzzard, and of the owl tribe, ten species; of birds of passage, 20 different tribes and 149 species are enumerated; belonging to the gallinacea are the wild turkey, American quail, partridge, grouse, prairie hen, etc. The grallo, or waders, are very numerous, counting 62 species in seven families. Lobipedes, or lobe-footed birds, are represented in the coot, the horned, crested, and red-necked grebe, and the dipper; and among the natatores are puffing loons, petrels, pelicans, gulls, and the goose and duck, in all 6 families and 71 species. Among the latter are the canvas-back duck, so famous with epicures, the American widgeon, and the American swan. Of the buzzard tribe the blue-tailed shink, or striped buzzard, and the brown swift-legged are the only species, the first in the southern counties, and the latter frequenting the woods in every district.

There are but three orders of reptiles in New York. Among the turtle tribe we find the green turtle, which, though a native of more southern latitudes, frequently appears in the waters of this State; the leather turtle, a gigantic species; the soft shell turtle, which inhabits the Mohawk and the lakes; the snapping turtle, terrapins, tortoises (the geographic and pseudo-geographic), etc. Serpents are numerous, but of these only two species, the copper-head and northern rattle-snake, are considered to be venomous. In all there are about 40 species known to naturalists.

The amphibious animals are comprised in four families; of the ranidæ, or frog tribe, there are 13 species: of salamanders, 12 species; of the triton tribe, 4 species; and of the proteus tribe, 2 species. The banded proteus is a very singular animal, having the body of a lizard and the gills of a fish.

The fishes indigenous to the waters of the State are very numerous. Bony fishes are comprised in six orders: among the pectinibranchi the best known are the perch, bass, bull head, sheep head, porgee, pilot fish, mullet, black fish, mackerel, etc.; of the abdominals, the shad, herring, salmon trout, eat fish, carp, pike, pickerel, minnow, etc.; of the jugulares the cod, haddock, hake, halibut, flounder, turbot, sole, ete.; of the apodales, the eel and the conger; of the Iophobranchi, the pipe fish and the Hudson Piver sea-horse; and of the electrognathi, the balloon fish, the puffer, the globe fish, ete. The cartilagurous family comprises three orders, viz., the cleutheropomi, of which ihe sturgeon is the only example; the 
plagiostomi, which embraces the shark and the ray ; and the cyclostomi, of which the lamprey, or lamper ecl, is the representative. Twenty-five or thirty species of fishes have been found in a fossil state, and of these several species belong to families now extinct.

The crustaceæ are embraced in 10 orders. There are but 27 species of the order decapoda, of which lobsters, crabs, shrimps, etc., are the best known species; of the stomapoda there are but three species, among which are the opossumshrimp and squill; of the amphipoda four species exist, as the sand flea, etc.; of the loemipoda, the whale-louse and seameasuring worm are the only specimens; of the isopoda there are 14 species, 7 of which are parasitical-barnacles are an example of this order; of the pocilipoda 5 species, as the horse-shoe, etc.; of the phyllopoda, lophryopoda, branchtopoda, and ostrapoda, but few specimens are found, and those few are known only to the curious zoologist.

Molluseous animals are very numerous. Among the cephalopoda are the cuttle fish, spirula, etc. The clio is a representative of the pteropoda. The gasteropoda include a vast variety of snails and animals inhabiting turbinated shells. Oysters, clams, ete., which are arrayed under eight sub-divisions, consist each of several species. Members of the orders cirrhopoda and tunicata are not very numerous. Geologists have discovered many specimens of fossil molluscr imbedded in the limestone and sandstone formations - the most remarkable of these are various species of the trilobite, the encrinite, the pentamerus, ete.

No full account of the insects of New York has yet been published, but these are very numerous, and many of them of rare and beautiful appearance. The coleoptera, or beetle tribe, alone numbers some 1,200 varieties, and many of these have brilliant colors, and are of great magnitude. The orthoptera, or roach tribe, includes the the coekroach, cricket, grasshopper, etc., everywhere as plentiful as need be for comfort. The katydid, so well known by the peculiar shrill sound it produces, belongs to this order. The homoptera include a large variety of locusts, anong which there is one remarkable for remaining 17 years in the grub state. The hcemoptera comprise many bugs injurious to vegetation, particularly the May bug, the lady-bug, the apple-tree blight, etc. The order of lepidoptera probably numbers not less than 1,000 species, and includes butterflies and moths, the size and brilliant colors of many being astonishing. Spiders, which range under the order arachnido, number 200 species, some of which are very large, and possessed of great beauty. The long-legs, the clawed-spider, the tick, the mite, the louse, etc., also belong to this order. The vermes, or worm family, and the animalculæ of the State, have not been scientifleally examined, but their species are as abundant and prolific as most persons could desire. One drop of "pure Croton," which is so extolled by the citizens of New York, is said to contain myriads of organized beings ranging under these heads.

Let us now take a view of man. The aboriginal inbabitants, formerly a great and numerous people, are now sleeping with their fathers, or pursuing their pleasures in the spirit-land of their creed. A small remnant, however, is still left in the Western counties of the State, but this seems to be a mere wreek of former days. The present inhabitants are of European origin, and vastly diversified in their races and tongues. The English in their descendants predominate, and perhaps the Irish, Dutch, and German, are next in numerical proportion. The early enumerations are not sufficiently exact to make them of any account. In 1701 , the population is stated to have been about 30,000 ; in $1731,50,000$; and in $1750,100,000$. The census of 1771 exhibited the total population at 163,338 . The enumerations since taken under the authority of the United States at decennial periods, commencing 1790 , exhibit more accurate returns, and furnish the following results:

\begin{tabular}{|c|c|c|c|c|c|c|}
\hline \multirow{3}{*}{$\begin{array}{c}\text { Census } \\
\text { Years. } \\
1790 .\end{array}$} & \multirow{2}{*}{$\begin{array}{l}\text { White } \\
\text { l'ersons. }\end{array}$} & \multicolumn{2}{|c|}{ Colored Persons. } & \multirow{2}{*}{$\begin{array}{c}\text { Total } \\
\text { Populntion. }\end{array}$} & \multicolumn{2}{|c|}{ Decennial Increase, } \\
\hline & & Slave. & Total. & & Numerical. & Per cent. \\
\hline & 314,142 & $4,651 \ldots .21$ & $.25,978$ & $340,120 \ldots$ & 一 & - \\
\hline 1800 . & ...... 556,039 & t....20, & $\ldots 8$ & . $556,756 .$. & $246,636 \ldots$ & . . 72.5 \\
\hline 1810 . & ...... 918,699 & $.25,333 \ldots \ldots .15,017$ & ...40,350 & 959,049 . & 372 & .. 68.4 \\
\hline 1820 & $.1,330,744$ & $0 \ldots \ldots 10,088$. & $\ldots .42,068$ & $.1,372,812$. & 413,763 & .. 43.1 \\
\hline 1830 & $\ldots 1,868,061$ & $\ldots 44,870 \ldots$. & $. .44,945$ & $.1,913,006$ & 540,194 & .. 32.0 \\
\hline 1840 . & $\ldots \ldots 2,378,890$ & $\ldots 50,027 \ldots \ldots$ & ...50,081 & $.2,42$ & 15. & .. 26.9 \\
\hline 1850 & $\ldots . .3,019,151$ & $.47,914 \ldots$ & . .47,914 & $.3,097$ & 668,473 & $\ldots 2$ \\
\hline
\end{tabular}

New York is divided into 59 counties, the general statistics of which, and the capitals of each, in 1850, were as follows:

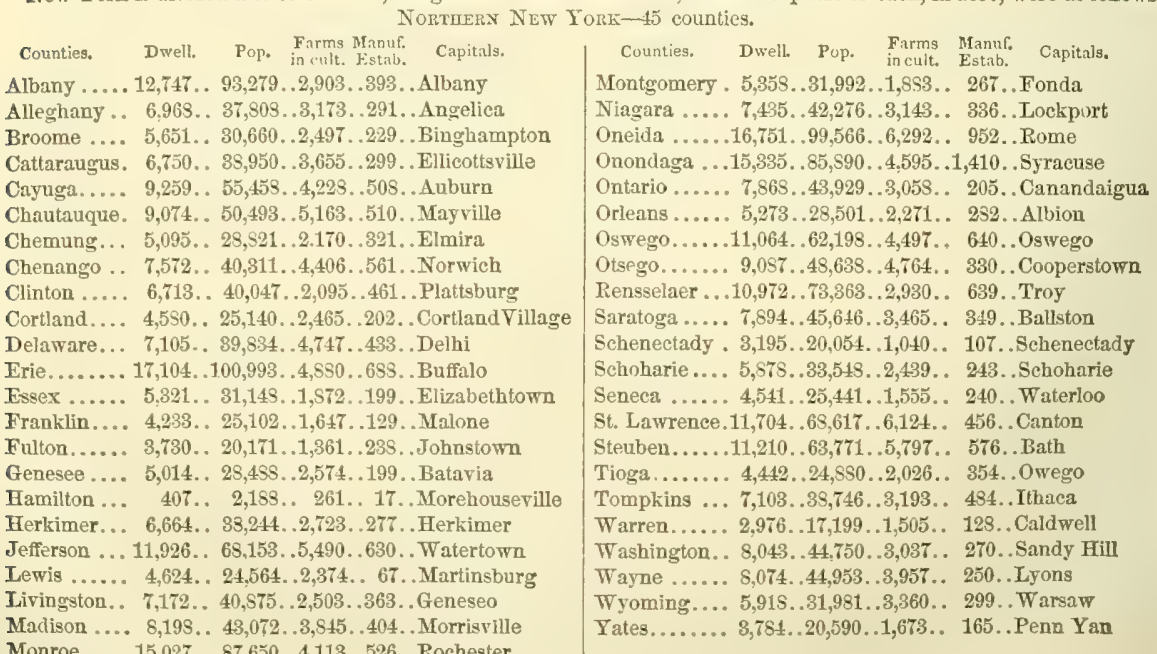

Monroe..... 15,027..87,650..4,113..526. . Rochester 
NEW YORK.

Soutmern New York-14 countics.

\begin{tabular}{l|l|l|l|l} 
Counties, Dwell, Pop. Farms Manuf. Capitals. & Counties, Dwell, Pop. Farms Martuf. & Capitals, \\
in cult. Estab.
\end{tabular} Columbia... 7,029..43,073.2,511.. 208..Hudson $\quad$ Quecns .... 6,230.. 36,533..2,303.. 89... . Henpstead Duchess .... 9,562.. 55,992.,3,208.. 415..Poughkeepsie $\quad$ Richmond .. 2,334.. 15,061.. 212.. 37.. Richmond

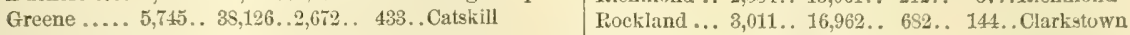

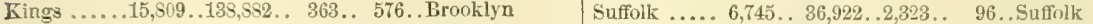

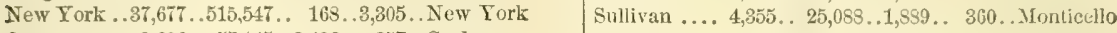

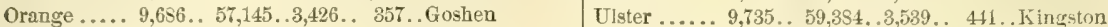
Putnam ... 2,425.. 14,138.. 989.. 89..Carmel

The whole number of dwellings in the State, at the above date, was 473,936 , of families 566,869 , and of jnhabitants 3,097,394, viz., whites 3,049,457-males 1,545,052, and females 1,504,405; fr. col, 47,937-males 22,978, and females 24,959. Of the whole population there were deaf and dumb-wh. 1,297, fr. col. 10-total 1,307; Zlind-wh. 1,221, fr. col. 51-total 1,272; insane-wh. 2.544, fr. col. 36-total 2,580; and idiotic-wh. 1,721, fr. col. 18-total 1,739. The number of free persons born in the United States was $2,439,296$; the number of foreign birth, 651,801 ; and of birth unknown, 6,261. The native population originated as follows: Maine 4,509, N. Hamp. 15,519, Verm, 52,599, Mass. 55,773, I. I. 13,129, Conn. 66,101, Newo York 2,151,196, N. Jer. 35,319, Penn. 26,252, Del. 899, Md. 39,533, Dist. of Col. 538, Virg. 3,347, N. Car. 673, S. Car. 935, Ga. 510, Flor. 135, Ala. 184, Miss. 164, La. 563, Tex. 46. Ark. 20, Tenn. 116, Ky. 369, Ohio 3,743, Mich. 1,921, Ind. 415, Ill. 605 , Mo. 178 , Ia. 70, Wisc. 360 , Calif. 7 , Territories 53. The foreign population was composed of persons from-England 84,520, Ireland 343,111, Scotland 28,418, Wales 7,582, Germany 115,398, France 12,515, Spain 461, Portugal 194, Belgium 401, Holland 2.917, Turkey 12, Italy 833, Austria 168, Switzerland 1,850, Russia 617, Denmark 429, Norway 392, Sweden 753, Prussia 2.211, Sardinia 0, Greece 0, China 34, Asia 66, Africa 80, British America 47,200, Mexico 88, Central America 29, S. America 179, West Indies 1,067, Sandwich Islands 40, and other countries 1,941.

The statistics of the industry and institutions of the State, according to the returns of 1850 , are as follows:

Occupied Lands, etc.-Improved farm lands, 12,408,968 acres, and unimproved lands attached, 6,710,120 acres-ralued in cash at $\$ 554,546,642$. Total number of farms under cultivation 1st June, 1850, 170,621-in the northern district, 143,749 , and in the southern district, 26,872. Value of farming implements and machinery, $\$ 22,084,926$.

Live-Stock.-The number of live-stock or domestic animals at the two periods 1840 and 1850 , was as follows:

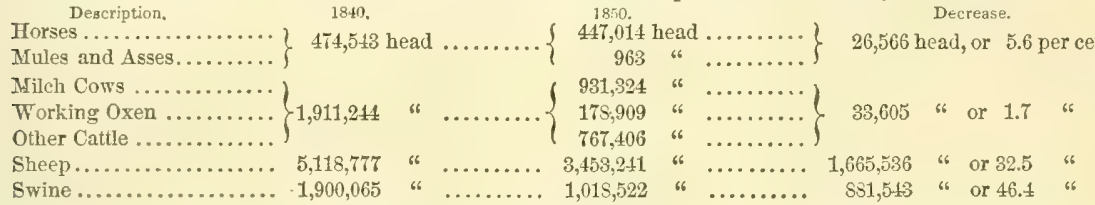

- the live-stock of 1850 was valued in the aggregate at $\$ 73,570,499$.

Products of Animals.-Wool, 10,071,301 pounds; butter, 79,766,094 pounds ; cheese, 49,741,413 pounds ; and the valne of animals slaughtered in the year had been $\$ 13,573,983$. The wool crop, according to the returns of 1840 , amounted to 9,815.295 pounds; and hence the increase exhibited in 1850 was 226,006 pounds, or 2.3 per cent. The product, per fleece, in 1840, was 1 lb. $148 \mathrm{gz}$; and in $1850,2 \mathrm{lb} .14 \frac{1}{2} \mathrm{oz}$, or 52.1 per cent. increase. The butter produced is one-fourth of the production of the United States; and the cheese produced one-half the whole.

Grain Crops.-Wheat, 13,121,49s bushels; rye, 4,149,182 bushels; Indian corn, 17,858,400 bushels; oats, 26,552,814 bushels: barley, 3,555,059 bushels; buckwheat, 3,183,955 bushels. In proportion to the crop of the United States, that of wheat is approximately one-eighth, that of rye one-fourth, that of Indian corn one thinty-second, that of oats more than one-sixth, that of barley troo-thirds, and that of buckwheat one-third of the aggregate. The comparison of the several crops in 1840 and 1850, as returned by the censuses of those years, was as follows:

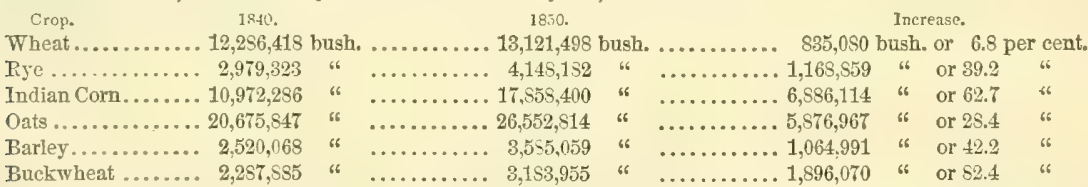

Other Food Crops.-Peas and beans, 741,636 bushels; and potatoes-Irish, 15,398,362 bushels, and sweet, 5,623 bushels. The potato crop of 1839 , as exhibited in the census of 1540 , was $30,123,614$ bushels, showing a decrease of $14,719,292$ bushels, or 48.8 per cent. in the subsequent decade.

Miscellaneons Crops.-Tobacco, 83,189 pounds; hay, 3,728,797 tons; clover-seed, 88,222 bushels; other grass-seed, 96,493 bushels; hops, 2,536,299 pounds, being three-fourths of the aggregate crop of the Union; hemp-dew-rotted, 1 ton, and water-rotted, 3 tons; flax, 940,577 pounds; flax-seed, 57,968 bushels; silk cocoons, 1,774 pounds; maple sugar, $10,35 \pi, 484$ pounds; molasses, 56,529 gallons; beeswax and honey, 1,756,190 pounds; wine, 9,172 gallons, etc. $\nabla$ alue of orchard products, $\$ 1,761,950$, or nearly one-fourth the value of these products in the United States; and of marketgarden products, $\$ 912,047$, or more than an eighth the aggregate. On comparing the above with the returns of 1840 , the following results are obtained: Crops, etc.

Tobacco ................

Hay ...................

Hops ..................

Flax........................

Maple Sugar .............

Wine.
1810.

714 lits.

$3,127,041$ tons

$\left\{\begin{array}{l}\cdots \cdots \\ 1 \text { ton } \ldots \ldots \ldots\end{array}\right.$

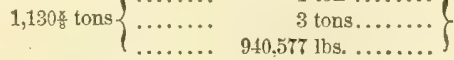

$10,04 \mathrm{~S}, 109 \mathrm{lbs}$

6,799 gals.
1350 . incr. $\quad \$ 2,445 \mathrm{Ibs}$, or $11,0 \$ 1.3$ per cent.

incr, 601,756 tons, or 19.2 "

incer. $2,089,049 \mathrm{lbs}$, or $412.5 \quad$ แ6

decr? 1,5S3,063 Ibs., or 62.5

incr. 309,375 lbs., or $\quad 3.1$

$\begin{array}{rrr}\text { incr. } & 309,375 \text { lbs., or } & 3.1 \\ \text { incr. } & 2,373 \text { gls., or } & 32.9\end{array}$ 
Homesmade manufuctures were produced in the year ending 1 st June, 1850 , to the value of $\$ 1,280,388$. The same class of goods for the year antecedent to the census of 1810 , were valued at $\$ 1,636,547$. Decrease, $\$ 3,356,214$, or 72.4 per cent.

Munafuctures.-Capital invested, $\$ 00,000,000$; value of all raw material, fuel, etc., consumed, $\$ 00,000,000$; hands employed, 000,000 - males 000,000 , and females 00,000 ; monthly cost of labor, $\$ 0,000,000$-male $\$ 0,000,000$, and female $\$ 000,000$; value of products, $\$ 00,000,000$. Number of manufacturing establishments in operation 1st June, 1550 , and producing to the value of $\$ 500$ and upward annually, 23,823 -in northern district 16,877 , and in southern district 6,946 , and distributed to the counties as shown in the general table. Of this number 86 were cotton factories, 249 woolen factories, 942 tanneries, and 401 manufactories of iron-323 making cast iron, 18 pig iron, and 60 wrought iron. The total capital invested in 1540 amounted to $\$ 55,252,779$.

Capital invested iu cotton manufactures, $\$ 4,176,920$; cotton used, 37,778 bales; coal consumed, 1,539 tons; value of all raw material, fuel, etc., $\$ 1,935,973$; hands employed, 6,320-males 2,632, and females 8,688 ; monthly cost of labor, $\$ 63,943$-male $\$ 45,244$, and female $\$ 35,699$; average monthly wages-to males $\$ 1833$, and to females $\$ 968$; annual products, $44,901,475$ yards sheeting, ete., and $2,180,600$ pounds of yarn-in all valued at $\$ 3,591,989$. Capital in 1810 , $\$ 4,900, \pi 72$; hands employed, 7,407 ; value of goods produced, $\$ 3,640,237$.

Capital invested in voolen manufactures, $\$ 4,459,370$; wool consumed, $12,538,786$ pounds; value of all raw material, etc., used, $\$ 3,838,292$; hands employed, 6,674-males 4,262, and females 2,412 ; monthly cost of labor, $\$ 113,524$-male $\$ \$ 5,147$, and female $\$ 28,377$; average monthly wages - to males $\$ 2146$, and to females $\$ 1141$; cloth manufactured, $7,924,252$ yards, and yarn, 261,700 pounds-in all valued at $\$ 7,030,604$. Capital in 1840, $\$ 3,469,349$; hands, 4,636; value of goods produced, $\$ 3,537,337$.

Capital invested in tanneries, $\$ 5,025,143$; value of all raw material used, $\$ 6,065,221$; hands, 4,945-males 4,914 , and females 31 ; monthly cost of labor, $\$ 103,161$-male $\$ 11,245$, and female $\$ 368$; tanned-skins, 871,894 , and sides, $3,415,721$ in all valued at $\$ 9,804,000$. Capital in $1840, \$ 3,907,348$; hands employed, 5,579 .

In the manufacture of malt and spirituous liquors the capital invested is $\$ 2,585,900$; quantities and kinds of grain, etc., consumed-barley 2,062,250 bushels, rye 909,067 bushels, oats 6,707 bushels, apples 60,940 bushels, molasses 24,500 hogsheads, and hops 551 tons; hands employed, 1,350; quantity of Liquors produced-ale, etc., 641,700 barrels, whisky and high wines $9,281,700$ gallons, and rum 2,488,800 gallons.

The statistics of the iron manufactures in operation within the State, at the date of the taking of the seventh census, were as exhibited in the annexed table:

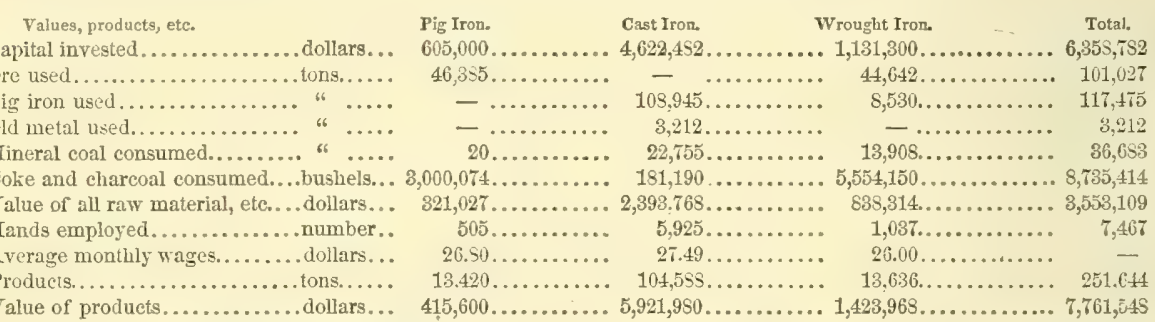
Value of products............ dollars... $415,600 \ldots \ldots \ldots \ldots .5,921,980 \ldots \ldots \ldots \ldots .1,423,968 \ldots \ldots \ldots \ldots . .7,761,015$ -total capital in $1810, \$ 2,103,418$; hands, 3,456:

Foreign Commerce.-The imports from foreign countries in the year ending $30^{\mathrm{t} h \mathrm{~h}}$ June, 1850 , were valued at $\$ 111,125,524$, and the exports at $\$ 52,712,789$. Of the exports, $\$ 11,502,800$ was the value of domestic produce, of which $\$ 38,934,409$ represented the value of merchandise carried in American bottoms, and $\$ 7,565,391$ that carried in foreign bottoms; and $\$ 11,209,989$ was the value of foreign goods reëxported, of which $\$ 7,086,6 \$ 7$ in American bottoms, and $\$ 4,123,302$ in foreign bottoms. Of the imports, $\$ 85,147,721$ was the value of merchandise brought in American bottoms, and $\$ 22,975,808$, that brought in foreign bottoms. The statistics of the shipping employed in this branch of industry for the same year, exhibits the annexed aggregates: SITPPLYG EMPLOYED IN THE FOREIGN TRADE, 1S19-50.

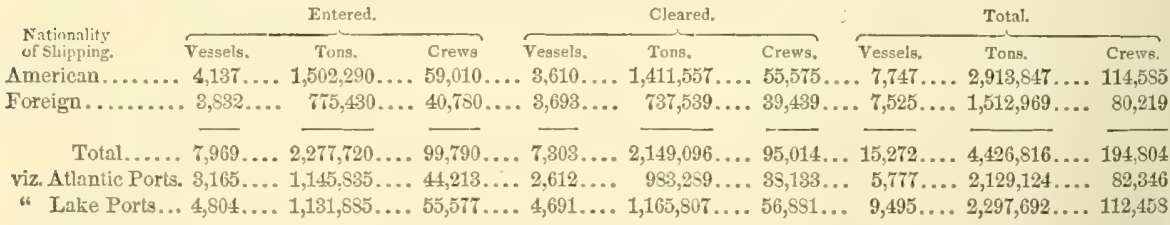

The Atlantic ports are included in the collection districts of New York, Cold Spring, Greenport, and Sag Harbor; and the lake and St. Lawrence ports, in the districts Oswego, Oswegatchie, Niagara, Cape Vincent, Sackett's Harbor, Buffalo Creek, Champlain, and Genesee. New York entered 3,163 vessels, 1,145,331 tons, and 44,166 men in crews, and cleared 2,609 vessels, 932,478 tons, and 35,060 men, thus monopolizing the great bulk of the Atlantic trade. The relative importance of the Lake Ports is exhibited in the order observed in the priority of their arrangement in the list above noted. The total amount of shipping owned within the State at the period referred to, was 911,319 tons; registered (all belonging to the Atlantic ports) $45 \mathrm{~S}, 903$ tons - 375.955 tons of the class permanent register, and 82,945 tons temporary ; enrolled and licensed 473.556 tons-354,790 tons in the Atlantic districts, and 85, 766 tons in the lake districts; and licensed (under 20 tons) $11, \$ 90$ tons of the registered shipping, 36,148 tons were navigated by stenm-power, and 6,029 tons were employed in the wliale flisheries. The proportion of the enrolled and licensed shipping employed in the coasting and river trade was 485,109388,289 tons in the Atlantic districts, and 97,870 tons in the lake districts, and in the cod fisheries 337 tons. Of the coasting shipping there is employed in steam navigation, 94,809 tons-in the Atlantic districts, 61,191 tons, and in the lake districts, 30,61S tons. As a ship-building State, New York is only second to Maine. During the year 1S19-50, there were built an 570 
the Atlantic ports, chiefly at New Fork city, 205 ressels, of an aggregate burden of 55,944 tons, and of these 26 were ships, 8 brigs, 44 schooners, 104 sloops and canal boats, and 28 steamers. In the ports of the lakes and the St. Lawrence, the number of ships built was 22 (2,898 tons) - 1 brig, 6 schooners, 8 sloops, ete., and 4 steamers. Of the lake ports, Oswego built nine, Buffalo seven, Niagara two, and Genesee one. The movement of exports and imports for a series of years commeneing 1791 and ending 1550 , was as follows:

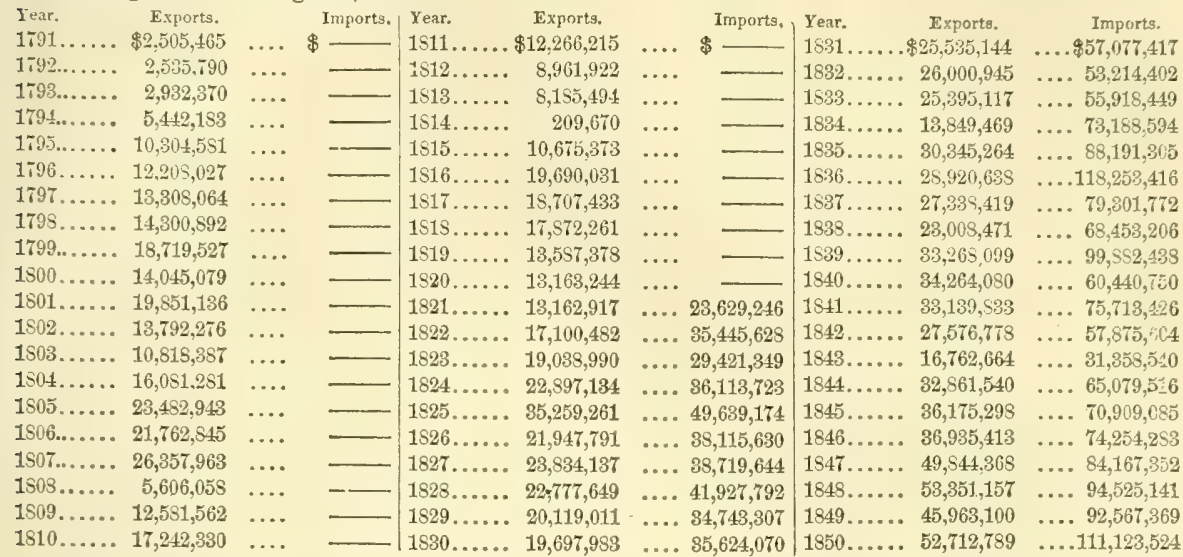

Coasting, Lake, and Internat Trade-No other State in the Union has such facilities for external and internal commerce as that enjoyed by the State of New York. Favorably located with regard to its seaward outlet, and its immense lakes and noble rivers, the first bounding it outwardly, and the latter penetrating to its very centre, it seems as if it had been designed by nature for the proud preëminence to which it has attained. Thousands of ressels are constantly traversing its waters, carrying freight valued at millions of dollars, and furnishing to every part, facilities for the interchange of commodities. It is also preëminent in its grand works of internal improvement-its canals, railroads, plankroads, and turnpikes, while the magnetic telegraph extends in every direction, an instantaneous communicator af information between the several commercial centres. The canals of New York are features in its economy which distinguish it from other States-they extend from the waters of the Hudson to Lake Erie, a distance of 364 miles, and have branches in every direction: to Lake Champlain, to Lake Ontario, and several to the south, and others, more local in their utility, are formed in various parts. The traffic on the Erie Canal is immense, and this forms the great highway between the Western States and the sea-board. The Delaware and Hudson Canal is chiefly used for the transportation of coal from Pennsylvania. The railroads have a present length of nearly 2,500 miles, and others are constantly being opened; and with regard to plank-roads, which for many purposes are equal to the railroad, almost every trade centre is connected by them with the producing regions. The turnpikes and the county and town roads are everywhere well kept, and in excellent condition. (For the details of the canals and railrouds, see APPENDrX.)

Banks.-On the 30 th June, 1850, there were in the State, 192 banks and branch banks, and their financial condition at that date was as follows:

RESOURCES.

Loans and discounts................. \$91,193,645

Loans and discounts to Directors........... 4,799,227

All sums due from brokers. ............. 2,487,909

Real estate.......................... $3,344,514$

Bonds and mortgage................... $3,069,168$

Stocks............................. 12,627,494

Specie ............................... 11,653,339

Cash items........................... 9, 9,181,481

Eills of solvent Banks on hand............. $3,071,749$

Due from solvent Banks on demand........ 10,551,966

Due from solvent Banks on credit............
497,501
ITABLITIES.

Capital............................. \$47,779,727

Profits.......................... 8,113,064

Notes in circulation not registered........... 615,768

Registered notes in eireulation............. 23,59s,573

Due Treasurer of the State of New York...... 1,473,901

Due depositors on demand............... 46,691,465

Due individuals and Corporations other than

Banks and depositors................ $\$ 21,305$

Due Banks on demand.................... 22,180.537

Due Banks on credit ................... 751,252

Due to others......................... $1,853,318$

Total resources (including the above)......\$153,095,287| Total liabilities (including the above)..... \$158,095,287

Government, etc.-The constitution of New York was adopted in convention October 9th, 1846, and ratified by the people on the $2 d$ November following.

Every adult white male citizen who shall have been such for ten days, a resident of the State for one year, of the county for four months, and of the district for 30 days next preceding an election, may vote at all elections in his place of rcsidence; but no man of color is eligible as an elector unless he shall have resided in the State for 3 years, be a freeholder to the value of $\$ 250$ above all encumbrances for one year, and have paid taxes thereon. Persons convicted of infamous erimes, and persons betting on the result of an election, are by law deprived of the franchise. The general election is held on the Tuesday succeeding the first Monday in November annually.

The Legislature is composed of a Senate and House of Assembly; the Senate consists of 32 members elected from single districts, and the Assembly of 128 members apportioned among the several counties-senators are elected for two years, and assemblymen for one year. Every white male voter is eligible for election. Members of both houses are paid $\$ 3$ a day during their session, and 10 cents for each mile of travel. No person holding office of profit under the State or Vnited States can sit as a member. The Legislature meets at Albany on the first Tuesday in January annually. 
Executive powers are vested in the governor, who holds office for two years. No person can be governor who has not attained to the age of 30 years, nor unless a citizen of the United States and resident for the last five years of the State. The governor has the right to veto any act of the legislature, but a two-thirds vote subsequently legalizes the act. The lieutenant-grovernor is elected in the same way as the governor, and is ex-officio president of the senate, in which, however, he has only a casting vote. On the demise or disability of the governor, he, and after him the president of the senate pro tempore, sueceeds to the chair. The Secretary of State, comptroller, treasurer, attorney-general, etc., are elected for two years; the three canal commissioners and three inspectors of State prisons for three years, one of each set of officers annually; and county, town, eity, and village officers, for one year.

The Judiciary of the State is composed of several courts provided for in the constitution: the court for the "trial of impeachments" is composed of the President of the Senate (who is president of the court), the members of the senate, and the judges of the courts of appeals. It is a court of record, and when summoned, meets at Albany, and has for its clerk and officers the clerk and officers of the senate; if the governor be impeached, the chief judge of appeals, and not the lieutenant-governor, presides. Two-thirds of the members present must concur before a conviction can be had, and the judgment of the court extends only to removal and disqualification, the party adjudged being still liable to indictment. The court of appeals is composed of eight justices, of whom four are elected (one every second year) by the people at large, and four selected each year from the justices of the Supreme Court having the shortest time to serve. The judge (of those elected) whose term first expires, presides as chief judge, and any six of these judges constitute a quo rum. Four terms are held annually, and every two years there nust be one term in each judicial district. This court has power to correct and reverse the decisions of the supreme court or of the old supreme court and court of chancery The supreme court has general jurisdiction in law and equity and power to review judgments of county courts and old courts of common pleas. For the election of justices, the State is divided into eight districts, each of which elects four justices, to serve respectively eight years, one judge retiring every second year. The justice in each district whose term first expires, and who is not justice of the supreme court, is the presiding judge, and the clerks of the several counties serve as clerks. One general term must be held annually in every county having 40,000 inhabitants, and in all others one term biennially; and every county has at least two special terms and two cireuit courts, except the county of New York, in which the circuit court has four sessions. Any three or more (including the presiding judge) hold the general terms, and any one or more the special terms, at which are heard all equity causes, and the circuit courts, which are held exclusively for the trial of issues of fact. The county or surrogate's courts have local jurisdiction only. Each county, except that of New York, elects one judge for four years, who acts also as surrogate; but counties having 40,000 inhabitants elect a separate surrogate. The powers of the court extend to all eases when the debt or damages are not above $\$ 2,000$; to actions for personal injury or trespass, where the claim is not over $\$ 500$, and to replevins, where the property claimed is not above $\$ 1,000$, etc. Surrogates' courts have the ordinary jurisdiction of courts of probate.

The criminal jurisdiction of the State is vested in courts of oyer and terminer and courts of sessions. The court of oyer and terminer in each county, except that of New York, is composed of a justice of the supreme court, who presides, the county judge, and two justices of the peace chosen members. In New York county this court is composed of a justice of the supreme court and any two of the following officers: judges of common pleas of the county, and the mayor, recorder and aldermen of the city. Courts of sessions are composed of the county judge and two justices of the peace, designated as members. All these courts are held at the same time and at the same place as circnit courts.

The civil courts of the city and county of New York are the superior court and the court of common pleas, the former of which has six justices, and the latter three justices. There is also the marine court, which has two judges,

Federal Representation,-In accordance with the law of $23 d$ May, 1850, New York sends thirty-two representatives to the United States Congress.

The militia force of the State, in accordance with the United States Army Register for 1851, consisted of 265,293 men of all arms, of which 7,662 were commissioned officers, and 257,631 non-commissioned officers, musicians, artificers, and privates. Of the commissioned officers, 99 are general officers, 315 general staff officers, 1,543 field officers, ete., and 5,705 company officers. Every white male citizen, between $18 \mathrm{nnd} 45$ years of age, is liable to military duty, unless exempt by law or having paid the commutation fine. The volunteer and uniformed militia of the State, and especially of the city, is the best instructed body of soldiers in the Cnion.

New York has numerous benevolent institutions, many of which are partly supported from the public funds and partly from local sources. The principal of these are the Institution for the Deaf and Dumb, and the Institution for the Blind, both at New York City, the State Lunatic Asylums at Utica, the New York City Hospital, etc; and besides these, almost every eity has numerous similar institutions, which will compare well with those of the oldest European States. The number of pupils in the Institution for the Deaf and Dumb, on the 31st December, 1550, was 227-128 males and 99 females; receipts $\$ 39,21639$, and expenditures $\$ 39,48298$. The Institution for the Blind had 135 pupils; receipts $\$ 30,11785$, and expenditure $\$ 28,451$ 19. The State Lunatic Asylum had 449 inmates -226 males and 223 females.

Finances-The general fund and railroad debt, at the close of the fiscal year ending $30 t h$ September, 1850 , was $\$ 6,359,69332$; and the canal debt at the same period was $\$ 16,171,109$ 16-in the aggregate $\$ 22,530,80248$, on which accrues annually nearly $\$ 1,235,360$ interest. There is also a contingent debt, consisting of State stock and controller"s bonds of $\$ 933,036$, upon which the State does not pay interest. This will make the total State debt, absolute and contingent, $\$ 23,463,83861$.

The property of the State, in addition to the educational funds mentioned hereafter, consists of the works of internal improvement, which at their cost valuation ( $i . e_{\text {. }}$, the amount expended upon them to date), are worth $\$ 35,115,23775$. But the whole amount of tolls derived from them during the year was $\$ 3,254,05171$-which gave, after deducting expenses, the net income of $\$ 2,650,20649$, which is 6 per cent. interest upon $\$ 14,170,108$, a sum which in reality represents the value of the works. The average net annual income for the last five years is $\$ 2,518,04487$, which is equal to a capital of $\$ 11,967,41450$, at 6 per cent. interest. The amount of debt ineurred for their construction, and yet unpaid, is 203 stated above $\$ 16,171,109$. The taxable property in New York in 1819 , was $\$ 727,494,583$, being $\$ 571,690,807$ the assessed value of $27,912,076$ acres of real estate, and $\$ 153,183,456$ of personal estate. The state and connty taxes amounted to $\$ 1, \$ 92,051$, and the town taxes to $\$ 1,420,736$ - total $\$ 6,812,737$; making the rate of State, county, and town taxes, 8.6 mills on a $\$ 1$ valuation. The highest rate was 25.7 mills on $\$ 1$ in Hamilton County, and the lowest 3.1 mills in Ontario and Putnam counties.

The revenue of the General Fund, on which are charged the ordinary expenses of governmeat, for the year ending 30th September, 1S50. was $\$ \$ \$ 1,24157$, and the expenditures for the same period, $\$ 526,72029$-excess of revenue, $\$ 51,52128$. 572 


\section{NEW YORK.}

The chief sources of income were-auction duties, $\$ 55,90969$; salt duties, $\$ 14,36103$; fees of secretary's office, $\$ 2,11071$; peddlers' licenses, $\$ 1,700$; foreign insurance companies, $\$ 80279$; interest on arrears of county taxes, $\$ 4,27819 ;$ surplas revenue of canals (annual appropriation), $\$ 209,000$; State tax, $\$ 272,42225$; sales of lands, $\$ 3,70083$; redemption of Jind sold for taxes, $\$ 3 \pm, 23047$; arrears of county taxes, $\$ 25,04846$; Columbia County, for enforcing law, $\$ 5,000 ;$ Duchess County, for ditto, $\$ 93497$; miscellaneous and tempolary receipts, $\$ 31,85667$; and the principal objects of expencliture were: Executive expenses, $\$ 37,55465$; judieiary, $\$ 100,91158$; legislature, $\$ 96,00799$; commissary's department, $\$ 14,48768$; commissioners of code, $\$ 2,450$; commissioners on practice and pleading, $\$ 2,86028$; State printing, $\$ 92,52 S 53$; deaf and dumb, $\$ 25,7 \$ 410$; blind, $\$ 11,91885$; agricultural societies, $\$ 6,107$ : Onondaga Salt Springs, $\$ 29,027$; State prisons, $\$ \$ 2,37697$; State Library, $\$ 6,93752$; postage, $\$ 3,50442$; Hospital at New York, $\$ 22,500$; House of Refuge for Western New York, $\$ 18,000$ : foreign poor, $\$ 20,000$; orphan asylums, $\$ 5,500$; New York Arsenal, $\$ 920$ 08; geological survey, $\$ 16,918$ \$2 : Attorney-general's Library, $\$ 1,49949$; miscellaneous and temporary expenditures, $\$ \$ 4,23848$.

The special funds held by the government in trust are the Bank Fund, the Free Bank Fund, and the School Fund:

The Bank Fund is made up by annual contributions from the incorporated Safety Fund banks, of one half of one per cent. on their respective capitals, and is by law appropriated to the payment of the debts of such banks, liable to contribute the same as may become insolvent. The fund has been exhausted, and there are $\$ 721,33011$ of 6 per cent stock now outstanding to meet the wants of the fund-which stock, except $\$ 59,45054$ now in the treasury or invested, is to be provided for out of the future contributions by the banks to the fund. The whole circulation redeemed for insolvent banks is $\$ 1,508,74064$, and debts paid, $\$ 1,028,6 \$ 4$ 43-total $\$ 2,596,42507$. The aggregate amount of contributions up to January, 1866, when all the safety fund bank charters expire, will be $\$ 994,22560$. The notes of every insolvent bank have been redeemed. There are now (1850) 73 of these banks in operation, and one branch, the agregate capital of which amounts to $\$ 27,664, \$ 60$; circulation to which they are entitled, $\$ 22,161,370$; and actual circulation, $\$ 20,669,17850$.

The Free Bank Fund consists of bonds, and mortgages, and stocks deposited with the Bank Commissioner, and moneys rcceived on the same and held by him for the redemption of the circulating notes issued by banks and individual bankers under the general banking law. The whole number of associations is seventy-one, and of individual banks sioty-five-in all 136, the aggregate capital of which (1st December, 1850) was $\$ 14,203,115$; and the whole amount of deposits $\$ 14,823,08746$.

Of the funds devoted to education, the eapital and revenue of each description for the year ending 30 th September, 1850, was as follows: "Common School Fund," capital $\$ 2,290,67323$, and revenue $\$ 123,09078$; the "United States Deposit Fund," capital $\$ 4,014,52071$, and revenue $\$ 255,328$ 85; and the "Literature Fund," capital $\$ 272,88012$, and revenue $\$ 37,948$ 12. Total-eapital $\$ 6,578,074$ 06, and revenue $\$ 416,367$ 75. There has also been paid from the general fund for the instruction of the deaf and dumb, $\$ 25,7 \$ 410$, and to the Institution for the Blind, $\$ 11,918$ 85, making the whole Bum paid during the year for education, $\$ 45 \pm, 07070$. The Common School Fund also owns about 301,759 acres of land, and the Literature Fund, about 10,880 acres. Of the funds devoted to education, as above what is exclusively the Common School Fund, may be stated as follows: Productive capital of the School Fund, $\$ 2,290,67323$; such an amount from the United States Deposit Fund as will produce $\$ 165,000$ - the sum annually appropriated therefrom for the support of common schools, at six per cent. interest, $\$ 2,750,000$ - and sum reserved by the constitution to be added annually to the capital of the School Fund, $\$ 25,000$, making a total of $\$ 5,065,67333$. The annual interest on this sum, at six per cent., is $\$ 303,340$ 39. The balance of the income of the United States Deposit Fund (\$90,328 85) is appropriated to the support of colleges, academies, the Normal Schnol, Indian schools, teachers' institutes, etc. The income of the Literature Fund must, by the constitution, be applied to the support of academies. The whole amount of public money received from all sources by the commissioners of cities and town superintendents, during the year ending 1 st July, 1850, was $\$ 1,085,854$, 85, of which was apportioned to teachers" wages $\$ 730,79812$, and for libraries $\$ 91,36390$, leaving a balance apportioned for contingent expenses amounting to $\$ 213,69283$. The amount paid on rate bills for teachers' wages besides public money, was $\$ 508,72456$. Total cost of supporting common schools, $\$ 1,544,57941$.

Education.-In the 878 towns and 81 wards of eities of the State, there were on 1st July, 1S50, S,394 common school districts, and 5,625 parts of districts; and returns were received from 8,336 whole, and 5,475 parts of districts. The average length of schools in all districts, 8 months. Volumes in district libraries, 1,449,950. Children taught during the year, 794,500 , and the number of children between 5 and 16 years of age returned, 735,188 ; of these 200,128 pupils attended schools less than 2 months, 198,022 less than 4 months, 167,732 less than 6 months, 106,100 less than 8 months, 59,310 less than 10 months, 13,455 less than 12 months, and 9,07912 months. In 52 schools for colored ehildren there were 4,971 Bcholars, and for the support of these $\$ 11,4 \$ 044$ was appropriated. There were besides, schools for the instruction of Indian children in the sevcral reservations; in 1849, 641 Indian children between 5 and 16 years of age, were reported, and about 500 attended school; about 250 attend the Normal School at Albany annually, and on the 1st January, 1851 , there were 226 pupils in the institution-77 males, and 149 females. The whole number of graduates Tras $494-276$ males, and 218 females; and during the year then ending 9 Indian youth-6 males, and 3 females-were taught, to prepare them for teachers among their own penple. Teachers' institutes are held annually in the counties, but the reports say that of late a diminished interest in regard of them has been observed.

Most of the large centres of population have incorporated academies which are supervised by the Regents of the University; and there are a large number of unineorporated academies, seminaries, and private schools, self-supporting. About 75,000 children are annually taught at the private institutions.

The collegiate establishments within the State are also numerous and highly efficient as institutions of learning. The principal of these, including academic, law, medical, theologieal, etc., with their statistics in 1S50 0 , are as follows:

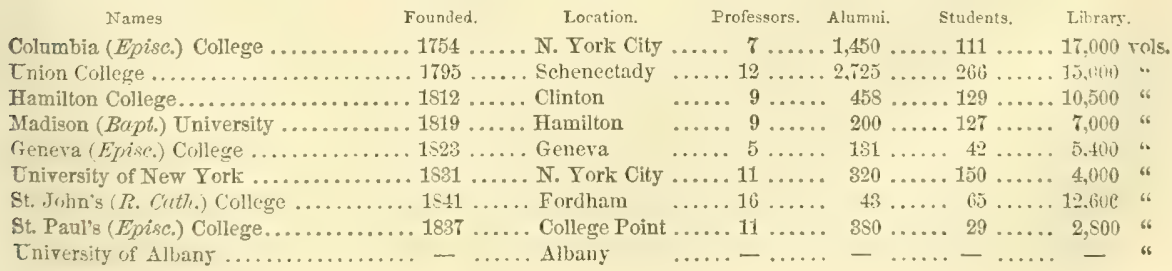


NEW YORK.

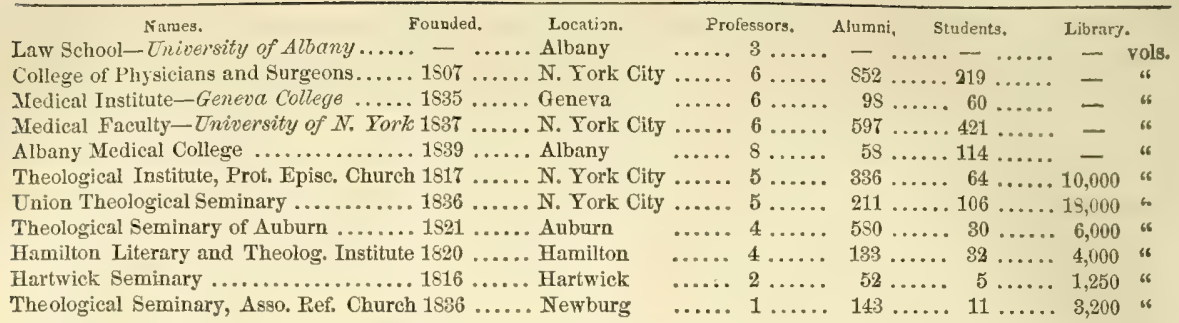

There are numerous other local schools besides the above, as the ward schools of cities, various mechanics' schools, endowed schools, the Free Academy at New York and others, which are not included in the above returns, but which are nevertheless of essential utility in the field of education; aud with regard to literary, scientific, and artistic institutions, no other State in the Union is so amply provided with them.

Public Libraries.-Three State libraries-34,099.volumes; 21 social-151,894 volumes; 8 college-43,376 volumes; 21 students'-19,319 volumes; 171 academic and professional-143,465 volumes; 4 seientific and historical-25,253 volumes 8,070 public school-1,388,845 volumes. Total \$,298 libraries, and 1,756,254 volumes.

Periodical Press,-The whole number of periodicals published in the State, on the 1st June, 1S50, was 458 , and of these 141 were whig, 110 democratic, and 207 neutral in politics, in the latter class being also included all literary, religious, scientific, etc., periodicals, and all the character of which had not been ascertained. Of the aggregate number, 54 were published daily, 1 four times a week, 13 tri-weekly, 13 semi-weekly, 813 weekly, 13 semi-monthly, 25 monthly, and 3 quar terly; and the circulation at each issue of the dailies was 230,995 , or $72,301,435$ annually ; of the one published 4 times a week 1,100 , or 228,800 annually; of the tri-weeklies 36,975 , or $5,768,100$ annually ; of the semi-weeklies 30,365 , or $3,157,960$ annually; of the weeklies 694,414 , or $36,109,528$ annually; of the semi-monthlies 78,500 , or $1,884,000$ annually; of the monthlies 433,750 , or $5,205,000$ annually; and of the quarterlies 6,150 , or 24,600 annually; total copies at each issue $1,512,249$, or $124,679,423$ annually. In the city of New York the periodicals numbered, 14 dailies, 8 semi-weeklies, 58 weeklies, 8 Sunday papers, 5 semi-monthlies, 39 monthlies, and 2 quarterlies. In Albany County there are 5 d. and 9 w.; in Alleghany, 3 w.; in Broome, 1 d. and 3 w.; in Cattaraugus, 5 w.; in Cayuga, 1 d., 5 w., and 1 m.; in Chautauque, 9 w.; in Chemung, 9 w.; in Chenango, 4 w.; in Clinton, 3 w. and $1 \mathrm{~m}$. ; in Columbia, 1 d., 6 w., and 1 s.-m. ; in Cortland, 5 w.; in Delaware, 8 w.; in Duchess, 6 w.; in Erie, 6 d., 1 four times a week, 4 t.-W., 1 s.-W., 10 w., and 2 m.; in Essex, 3 w and $1 \mathrm{~m}$; in Franklin, 2 w.; in Fulton, 2 w.; in Genesee, 4 w.; in Greene, 3 w. ; in Herkimer, 4 w.; in Jefferson, 5 w. ; in Kings, $8 \mathrm{~d}$. and $8 \mathrm{w}$.; in Lewis, $8 \mathrm{w}$; in Livingston, $6 \mathrm{w}$. and $1 \mathrm{s.-m}$. ; in Madison, 5 w. and $1 \mathrm{s.-m}$.; in Monroe, 3 d., 9 t.-W., 10 w., 2 s.-m., and 2 m.; in Montgomery, 6 w.; in Niagara, 1 d. and 4 w.; in Oneida, 4 d., 13 w., 2 s.-m., aud $1 \mathrm{~m}$.; in Onondaga, 4 d., 1 s.-w., 12 w., 1 s.-m., and $3 \mathrm{~m}$. ; in Ontario, 5 w.; in Orange, 2 s.-w., 6 w., and 1 q.; in Orleans, 4 w. ; in Oswego, 2 d. and 6 w.; in Otsego, 4 w.; in Putnam, 1 w.; in Queens, 5 w.; in Rensselaer, 3 d., 4 w., and 1 m.; in Richmond, 1 w.; in Rockland, 2 w.; in St. Lawrence, 7 w.; in Saratoga, 8 w.; in Schenectady, 2 w.; in Schoharie, 2 w.; in Seneca, 4 w.; in Steuben, 5 w.; in Suffolk, 1 s.-w. and 6 w.; in Sullivan, 3 w.; in Tioga, 2 w.; in Tomplins, 1 d. and 2 w.; in Ulster, 5 w.; in Washington, 7 w.; in Wayne, 7 w.; in Westchester, 5 w.; in Wyoming; 2 w.; and in Yates, 3 wreeklies.

Religious Denominations.-The statistics of the several religious denominations, in 1850, were as follows:

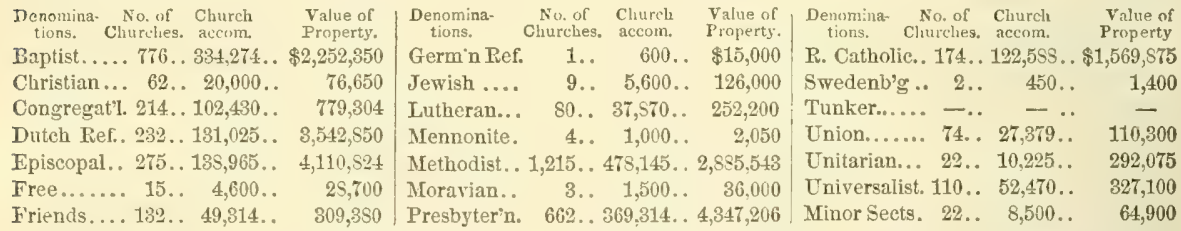
-making a total of 4,0\$1 churches, accommodating 1,\$96,229 persons, and valued as property at $\$ 21,132,707$. The State constitutes two dioceses of the Protestant Episcopal Church, viz, the diocese of New York, and the diocese of Western New Fork; and in the Roman Catholic Church, it constitutes the dioceses of Buffalo and Albany, and the arch-diocese of New York, in the latter of which, East New Jersey is included.

Panperism and Crime.-The whole number of paupers that received assistance and support within the year ending Ist June, 1850 , was 59,855 , of whom 19,275 were native-born and 40,580 foreign-born; and the whole number receiving public charity at that date was 12,833 , of whom 5,755 were native-born and 7,075 foreigners. Annual cost of support $\$ \$ 17,336$. In the above, the foreign paupers under charge of the Commissioners of Emigration are not accounted for, as they are chargeable on a special fund raised by capitation tax on themselves. The number of convictions in courts of record in the year 1849, was 1,531-1,437 males, and 94 females: offenses against the person, $397-385$ males and 12 females; offenses against property, with violence, 150-146 males and 4 females; offenses against property, without violence, 545 - 500 males and 45 females; offenses against the currency, 37 (all males); and other offenseg, $404-371$ males 33 females. The ratio of convictions of females to those of males is as 1 to 15.18 . Upon convictions, 4 were sentenced to be hung. 545 to the State prison, 51 to House of Refuge, 299 to the local prison, 32 to be fined and imprisoned, 565 to fine, and the sentences of 33 were suspended. The State prisons are at Sing Sing, Auburn, and Clinton. The whole number of convicts in these on the 81 st December, 1849 , was 1,454 ; received during the year, 600 , and discharged-by expiration of sentence, 352 ; by death by disease, 30 ; by accidental death, 3 ; by escape 9 ; by pardon, 45 ; by habeas corpus, 4; to House of Refuge, 2; to Lunatic Asylum, 10; to other prisons, 17-in all, 472 . Remaining in prison 1st December, $1850,1,611$. Of the 600 admitted, 585 were first convietions, 56 second, 7 third, and 2 fourth convictions, The daily average of all these prisons was 1,556. The whole number of punishments in all the male prisons was $613-$

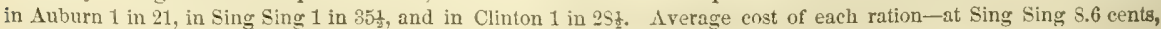
at Auburn 6.7 ceats, and at Clinton 8.3 cents. Of the 1,611 remaining in prison, 11 were committed for murder, 41 for 
NEW ẎORK

manslaughter, 69 for assault with intent to kill, 44 for rape, 24 for assault to commit rape, 353 for burglary, 587 for grand lareeny, 82 for robbery, 104 for petit larceny, and 81 for counterfeiting and uttering. A common English education has been given to 472 of these conviets. The receipts from labor at the prisons amounted to $\$ 216,680$ 86: from Sing Sing $\$ 99,53970$, from Auburn $\$ 79,57311$, and from Clinten $\$ 37,56755$; and the expenditures to $\$ 204,6 \$ 649$ : at Sing Sing $\$ 95$, S28 64, at Auburn $\$ 71,16407$, and at Clinton $\$ 37,69397$.

IIistorical Sketch.-Verrazano, a Florentine, in the service of France, is said to have discovered New York Bay in 1524; but the history of the State commences with the arrival of Hudson, an Englishman in the Duteh service, in 1609 , who ascended the river, bearing his name, as far as the present site of Albany. The country thus discovered was inhabited by the Mohawks, a formidable and warlike tribe, and the Manhattans, who inhabited the island on which New York city is built, were also a flerce and warlike nation. In 1610, a ship was sent from Amsterdam to trade with these Indians, and other voyages were made during the succeeding years. In 1613 , small trading forts were erected on the river, and several houses were built on Manhattan Island. On the 29th March, 1614, the States' General of the United Netherlands passed an ordinance granting to all original discoverers of lands in North America the exclusive privilege of making four voyages to each, for the purposes of trade. Under this ordinance five ships were dispatched the same year by a company of merchants. They explored extensively the coast near New York. Blok, one of the commanders, discovered and named Block Island, south of Rhode Island, and also the East River, and Captain Mey, proceeding southward, discovered eapes May and Henlopen; and on the return of these ships, a Captain Henrickson was left on the coast to prosecute discoveries. The country extending between the Connecticut and Delaware rivers received the name of New Netherlands, and the exclusive right to trade there for three years from that date (11th October, 1614), was granted to the discoverers, who, upon the passage of this grant, formed themselves into a company called the United New Netherlands Company. This company erected the same year a fort and trading house on an island just below the present eity of Albany, and garrisoned it with ten or twelve men. Another fort was erected on the southern point of Manhattan Island. The grant expiring in 1818, the company petitioned for its renewal in vain. Private traders, however, continued to visit the country for the purposes of traffic.

In June, 1621, was passed the charter of the Duteh West India Company, an armed mercantile association. This company sent out a ship called the New Netherlands, on the 20th June, 1623, to their newly aequired possessions, under the direction of Mey, already noticed, and Tienpont. The former of these proceeded to the Delaware, and established a fort near the present town of Gloucester, which he named Fort Nassau, and the same year a fortified post, called Fort Orange, was erected on the site of AJbany. In 1624, Peter Minuit having been appointed director, arrived out with several families of Walloons, inhabitants of the frontiers of Belgium and France. These settled on a bay of Long Island, and called from them Wahlebocht, or bay of foreigners, a name since corrupted into Wallabout. The government was vested in the Director and a Council of Five. The other important officer of the colony was the Schout Fiscal, who filled both the offices of sheriff and attorney-general. Under the superintendence of these authorities the trade of the colony prospered. In 1626, Staten Island was purchased of the Indians, and in the same year Manhattan Island was purehased for twenty-five dollars. The fort upon this latter island received the title of Fort Amsterdam, and the colony that of New Amsterdam. The exports this year amounted $\$ 19,000$. In 1627 , the settlers of Plymouth Colony set up a claim to the region watered by the Connecticut, which the Dutch denied. Up to 1829 , the settlements were simply trading posts. On the 7 th June, 1629, a mensure was adopted which is still felt in the State, and under this extensive seignories, with feudal rights, were granted to certain individuals. Active exertions were now made to colonize these vast estates. In 1632, Minut was recalled, and the government of Wouter Van Twiller installed, and after a lapse of five years of mal-administration, Twiller was suceeded by William Kieft. During the administration of Twiller, difficulties arose between the English settlers, on the Connecticut, and the Dutch authorities. In 163s, the restrictions which had hitherto been placed by the company upon trade were taken off and free traffic encouraged. This measure gave a new impulse to immigration. Persecution, too, drove many from New England and Virginia to settle among the more tolerant Dutch. In the meantime the aggressive disposition of the English continued. They founded a colony at New Haven, oceupied the Tunxis (Farmington) Valley, and even went so far as to plow and sow the company's land around Fort Good Hope, at Hartford. Remonstrances were vain. Not satisfied with these encroachments, the Plymouth Company granted the whole of Long Island to the Earl of Sterling, and a settlement was soon after effected by Lyon Gardiner, at Gardiner's Island The Dutch, meanwhile, were active in establishing settlements at the western extremity of the island-in Breuckelen, at Gowannus, and Gravenzande. In May, 1640, emigrants from Lynn, Mrassactusetts, settled on Cow Neck, but were driven off by the authorities. In the autumn of the same year, however, they returned, and founded the towns of Southampton and Southold. The Indians saw, with daily increasing envy and dislike, the heritage of their fathers thus falling from them. War was the consequence, which desolated the colony for five years. In 1645 , Peter Stuyvesant became governor, and only terminated his administration by the capture of his colony by the English, on the 6th September, 1661.

The name of the colony and city was now changed to that of New York, and Colonel Nichols was appointed by the Duke of York, to whom the territory had been granted by the King, as governor. On the 12th June, 1666, the governor granted a charter to the city of New York. The colony was recaptured by the Dutch on the 7 th August, 167s. The name of the city was now changed to New Orange, that of Albany to Williamstadt, and the fort previously called Fort James to William Hendrick. Captain Anthony Colve was appointed governor. The country, however, was not destined to be Dutch, for by the treaty of 9th February, 1674, it was restored to the English, and given up the following autumn.

Some doubts existing relative to the validity of the Duke of York's patent, both on account of the Dutch occupancy and the fact that it was wrested from that nation in time of peace, he deemed it advisable to obtain a new patent from his brother, the king, in 1764. In the autumn of that year Major Edmond Andros, afterward so well known as the tyrant of New England, arrived in New Fork and assumed the office of Governor. In February, 1685, the duke ascended the throne, under the title of James II., and among the first acts of this bigot were his instructions to allow no printing press to be established in the colony. But his reign was short, having been put an end to by the Revolution of 1658 , and the proclamation of William and Mary as heritors of the throne. No important event occurred from this time for many years. In 1741 occurred the negro plot, so famous in the annals of New York. In 1744 war was declared between England and France, and the colonists prepared to carry it on with vigor. In $1745 \mathrm{New}$ England and New York united in an attack upon the French fortress at Louisburg, and New York furnished ten pieces of cannon and $£ 8,000$ toward the expedition. It was surrendered in July of that year. The colonies were so severely molested during the year 1746 by the Indians in pay of the French, that it was determined to attack Crown Point and Niagara, and to capture Quebec. For this purpose New Tork raised $f 40,000$. The enterprise proved unsuccessful, and the peace of $\Delta$ ix la Chapelle was concluded in 1748 . 
For a few years after this the colony prospered, and began to recover from its losses by the wars. In $17 \bar{t}+$ a convention. from all the colonies north of Mason and Dixon's Line met at Albany, to devise some plan of common defense against the French, who had again commenced hostilities. At this convention, Dr. Franklin, afterward so eminent in the histury of the Revolution, proposed a plan of political union. In the spring of the following year an expedition was sent against Fort $\mathrm{Du}$ Quesne, but entirely failed, Braddock, the leader of the expedition, having been killed. Nor was the campaign of 1756 more successful. In 1755 Wiliam Pitt was placed at the head of the English government, and a new impulse was given to the energies of the nation. Success soon followed. Forts Frontenac and Du Quesne were captured. Stimuluted by these successes, New York, in 1759 , raised $\$ 625,000$ and a force of 2,680 men. Ticonderoga was captured early in the season, and Crown Point surrendered a few days later. Fort Niagara was reduced, and on the 13th September the brave General Wolfe laid down his life, in the moment of victory, when the English banners floated over the towers of Quebec. The ensuing year the French made an unsuecessful effort to recapture Quebec, and on the 8th September all the French possessions east of the Mississippi were surrendered to the British, and the French power extinguished. Two small islands off the southern coast of Newfoundland alone were preserved to them of their former vast possessions. About this time the difficulties between New Hampshire and New York commenced, respecting their respective limits, which only ceased with the admission of Vermont into the Union after the Revolution. The imposition of the Stamp Act, in 1764, and the other atroeities of the British Government which followed it, and which led to the overthrow of the British power in the colonies, need not be enlarged upon in this connection, being a part of the general history of the Union. On the first Tuesday in October, 1765 , a congress, composed of delegates from the New England and Middle States, assembled at New York, to take into consideration their grievances. South Carolina had also delegates. This congress made declaration of the privileges and rights of the colonies. Liberty-poles had, at this period, been frequently erected in New York city, and as often been destroyed by the British soldiery. On the 5th September, 1774, a congress from several colonies met at Philadelphia, in which, however, New York was not represented. In April, 1775, a provincial convention met at New. York, and elected delegates to the second congress. The news of the battle of Lexington caused great excitement in the city, and the arms of the city were ordered to Boston, but seized by the authorities before their shipment. The war had now commenced. Tieonderoga, Crown Point, and Whitehall, in this State, were captured by the provincials, and the entire command of Lake Champlain was obtained. On the 9 th July, 1771 , the provincial congress met at White Plains, and took the tille of Representatives of the State of New York. On the flrst day of their meeting they received the Declaration of Independence, and immediately passed a resolution approving it. The fortunes of the continental army from this time to the acknowledgment by England of the will of the sovereign people were various, and in New York were fought many of the famous battles of the period-those of Brooklyn Heights, Harlem Heights, Bemis' Heights, Stony Point, Ticonderoga, Fort Schuyler, Stillwater, and Saratoga, at the last of which Burgoyne surrendered to the Americans.

On the 12th March, 1777, a constitution for the State of New York was reported by a committee of the provineial congress, and on the 20th April ensuing was adopted as the basis of the government. Under the new constitution George Clinton was elected Governor. At this time there were fourteen counties in the State, viz., New York, Richmond, King's, Queen's, Suffolk, Westchester, Duchess, Orange, Ulster, Albany, Tryon, Charlotte, Cumberland, and Gloucester. The last two, together with part of Albany and Charlotte counties, were within the limits of the present State of Vermont. In 1790 the difficulties which for so long a time had existed between New York and Vermont were amicably adjusted, and New Tork. in its present limits, entered upon her career of greatness, untrammeled by fraternal animosities. In 1791 the industry of the State received a new impulse from the organization of a snciety for the promotion of agriculture, arts, and manufactures. The next year companies were organized to improve the navigation of the Hudson and Mohawk Rivers, and open canals to Lake Champlain and Ontario. In 1807 Robert Fulton made his first trip with the Clermont, the first steamboat which ever plied successfully on the waters. In this enterprise he was aided by Robert $R$. Livingston, one of the most distinguished statesmen of the nation. The war of 1812-15 soon followed. On the 24th of December, 1814, the treaty of Ghent was signed, and peace again restored the land to its wonted prosperity. Of the events which have happened since the war there are many living witnesses, and a brief notice only is required. The canal project was revived, and in 1816 the subject was brought before the legislature, and in 1817 the Erie and Champlain canals were commenced. The first was completed in 1825, and the latter in 1823. In 1835 a law was passed, ordering the enlargement of the Erie Canal. Railroads had already been commenced in the State. Both have been since prosecuted with untiring energy, and these works have no doubt had a mighty influence on the prosperity of the country. In 1821, and also in 1816, the fundamental laws were revised, and many important additions made to them. As a State, New York stasds at the head of the American Union.

ALEANx, on the right bank of the Hudson, 145 miles above New York city, is the political capital of the State.

New YorE, city and port of entry, New York co., $N, Y_{0}$ : Situated at the head of New York Bay, and at the confluence of the Hudson $r$. and the strait called East r., which connects the bay with Long Island Sound. The city and county have the same limits, comprising the whole of Mauhattan, or New York Island, which has an extreme length of $13 \frac{1}{2} \mathrm{~m}$, and an average width of $13-5 \mathrm{~m}$. Its greatest breadth is on the line of Eighty-eighth Street, about $2 \frac{1}{8} \mathrm{~m}$.; its area is about 14,000 acres. It is separated from the main land, in Westchester County, by Harlem r., 2 navigable watercourse $8 \mathrm{~m}$. long, connecting the Hudson and East rivers.

The latitude of the City Hall ( $\frac{8}{3} \mathrm{~m}$. from the Battery) is $40^{\circ} 42^{\prime} 40^{\prime \prime} \mathrm{N}$.; its longitude is $74^{\circ} 01^{\prime} 08^{\prime \prime} \mathrm{W}$. from Greenwich, and $8000^{\prime} 22^{\prime \prime} \mathbf{E}$. from Washington. Its distance by the most direct railroad from Albany is $145 \mathrm{~m}$. ; from Boston, $236 \mathrm{~m}$; from Philadelphia, $87 \mathrm{~m}$; from Baltimore, $185 \mathrm{~m}$.; from Washington, $223 \mathrm{~m}$; from Cleveland $503 \mathrm{~m}$; f from Cincinnati, $75 \mathrm{~s} \mathrm{~m}$; from Chicago, $856 \mathrm{~m}$; ; and from Alton, via Chicago (St. Louis from Alton $20 \mathrm{~m}$. by steamboat), 1,113 miles.
New York has a greater population, commerce, and wealth than any other eity in the United States, and is surpassed in importance by only two other cities in Europe, namely, London and Paris. For facility of examination and reference, its description and statistics will be given in the following order.

Surfuce.-The island was originally much diversified, and in its upper portion, where least populated, it still retains somewhat of its original character. With the increase of population, improvements have been made according to an uniform system, in laying out avenues and streets, grading them, providing seworage, etc. The ground rises from each river with gentle ascent, thus forming a central ridge throughout nearly the entire length of the island. A considerable portion of the lower part of the eity, particularly that near the rivers, is made ground. The Battery, a public park of 10 acres, at the S. extremity of the city, was built upon a low ledge of rocks, much beyond the original water line.

Formation.-The soil is a sandy alluvium, and less fertile 
than in many other parts of the State. Its basis is principally gneiss, but the nurth part of the island is composed of granular and primitive limestone, which is much quarried. In miny parts the limestone is at the snrface, and occupies large patches. On the W. side of the city, not far from the Iludson r., between 50th and 60th streets, and in some other parts, a number of streets are cut through this limestone.

Eatent of Irontses, etc.--In April, 1858, the eity was compactly built from the Battery to $42 \mathrm{~d}$ street, 4 miles. The density of population is least in the upper portions of the city, but is increasing with astonishing rapidity. A very great impulse has lately been given to this increase by the sale of large tracts of ground, lately held by the city, and by the erection of the Crystal Palace, arljoining the Croton Reservoir, in Sixth Avenue, between 40th and 42d streets.

Plan.-The general plan of the city is regular. In the lower and business portion, the streets were laid out to suit the shape of the island, and though the plan is not uniform, its general divisions are regular, with wide streets, crossing at right angles. At Houston Street (1 mile from City Hall, and $1 \frac{8}{2} \mathrm{~m}$. from the Battery) enmmences the uniform plan. of avenues and streets. Above this point, the entire island is divided longitudinally by 14 parallel avenues, 100 feet wide, which are crossed at right angles by 156 streets, numerically designated, ruuning direct from river to river, which are $S 0$ feet wide, except 16 , which are 100 feet wide, of which 14th street is the first that extends entirely across the island. The principal street is Broadway, particularly that portion of it which occupies. the central ridge of the island, extending from the Batiery northwardly in a direct line nearly $2 \frac{1}{2} \mathrm{~m}$. to Tenth Street, Grace Church. This splendicl street, one of the finest in the world, has an uniform width of so feet, is well paved, and contains many of the most splendid edifices of the eity.

Public Parks.-The public grounds of New York are nt commensurate with its extent and wealth. However, because of its peninsular situation, these are less necessary than in most Iarge cities, of late there has been some agitation of a project to provide a great public park in the upper part of the city, but as yet the city authorities have taken no definite action on the subject. The number of eity parks is 13 , which have. an aggregate area of 170 acres. Of these the following are the principal grounds: the Battery, at the S. extremity of the city, of irregular form, containing 10 acres, is in summer a delightful and much frequented resort, fanned by the breezcs from the bay, and well shaded with large trees. The Park, fronting on Broadway, in form nearly triangular, has 10 量 acres, adorned by shade-trees and a beautiful fountain. It contains the City Hall, the Hall of Records, the new City Hall, and other public buildings(of which see suhsequent description.) Washington Square, $2 \frac{1}{4} \mathrm{~m}$. from the Battery, lies W. of Broadway, containing $9 \frac{1}{2}$ acres, neatly laid out, and abounding with shade-trees, is : favorite promenade and resort for military parade, as is also Tompkin's Square, $10 \frac{1}{3}$ acres, E. from Broadway. The other parks in the upper portions of the city, are Union Place, containing $3 \frac{1}{4}$ acres; Stuyvesant Square, $3 \frac{8}{4}$ acres,

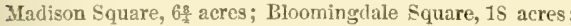
Hamilton Square, 24 acres; Observatory Place, 25: acres; Nanhattan Square, 19 acres; and Mount Morris, 20 acres.

Business Locations. - The upper portion of the city is principally composed of residences, while the lower, or southern part, accommodates the great bulk of commerce and general tracle. The principal business portion lies south of Fulton Street. Wall Street is the focus of the great monetary operations, and in this locality the principal speculations in stocks, bonds, houses, lands, and other merchandise, are carried on. It is occupied by bankers, brokers, insurance companies, etc., and contains also the Merchants' Exchange and Custom House. At its head stands Trinity Church, the noblest ecclesiastical edifice in the land. South Street is occupied by the principal shipping-houses, and the offices of several of the principal packet lines. West Street also has the same characteristics, but not to so great an extent. The dry goods, jobbing, and importing business, formerly confined to Pearl Street, has extended to William, Broad, Pine, Cedar, Liberty, etc. On Water and Front streets, and vicinity, are the wholesale grocers, commission merchants, and mechanics, connected with the shipping business. Broadway is not less an avenue of business than the promenade of beauty and fashion. Its lower part is now almost all taken up by splendid stores and warehouses. It contains the chief book-stores, jewelry, upholstery, hat and cap, tailoring, millinery, retall dry goods, and other like establishments. In Cedar Street, just off Broadway, is the fumous Map and Geographical Emporium of

\begin{tabular}{|l|l|l|}
\hline No. & J. H. COL T ON, & No. \\
\hline 86. & H. \\
\hline
\end{tabular}

the largest and most varied in the Union. Grand Street and Catherine are devoted to heavy dry goods and variety stores. Ferry, Jacob, Gold, and neighboring streets, constitute the great leather district. The hardware trade is chiefy in Platt, John, and Pearl streets. In Nassau are extensive newspaper establishments, book-binderies, and publishing concerns, and in William Street are a great variety of hosiery and fancy goods stores. Maiden Lane and Cortland Street, and Broadway, near the junction of these, is the location of the principal wholesale jewelers.

Wharves.-The water edges of the eity are fringed with seven miles of wharves and docks. On each side there are about 60 piers, averaging 200 to 300 feet in length, and from 50 to 60 feet wide. The shipping lies along these as safely as in a tide-water dock. Foreign shipping lies mostly at the wharves of the Enst River, as being a more secure position than on the other side. Usually these docks are crowded with vessels of all nations, and on an average 2,000 coasting vessels are in harbor at a time. Some loading, some unloading, and others waiting their turn for berths. With all these vast accommodations for shipping, however, there is scanty ronm for so large a commerce as centres at this port; and to furnish the additional facilities which the increasing commerce of the city demanded, the Legislature, in 1840, chartered the Atlantic Dock Company with a capital of $\$ 1,000,000$. Their docks at Brooklyn are spacious, and deep enough to float the largest vessel ever built. The British steamers dock at Jersey City.

Rivers and Ifurbor.-The width of the North River is one mile to Jersey City, at the ferry, and one mile and a half to Hoboken. The width of the East River is from one third to half a mile. At the South Ferry it is 1,300 yards, at Fulton Ferry 731 yarils, and at Catherine Ferry 736 yards. The Bay of New York is from $1 \frac{1}{2}$ to $5 \frac{1}{2}$ miles hroadaverage 3 miles, 8 miles long and about 25 miles in periphery, forming a basin of capacity sufficient to receive the navies of the world. The Bay of New York communicates with Newark Bay, through the Kills, in the west, between Staten Island and Bergen Neck, and with another bay, at the south, called the outer or lower harbor, through the Narrows a compressed strait between Staten and Long islands. This latter bay opens directly into the ocean. The inner harbor, as well as being one of the best, is also one of the most benutiful in the world. Besides all the natural beauty of the scene, there can hardly be a finer spectacle than is presented in the great eity spread before it, with its piers crowded with a dense forest of masts, bearing the flags of all nations the shipping at anchor, and the countless steamboats and vessels coming and giving p:rpetually.

The depth of Water and Tides, - The currents in the rivers and bay are very strong, keeping these waters open often when the rivers and bays much farther south are frozen up. The whole harbor was covered with a solid mass of ice in 1750 , and again in 1520 . Very rarely since has cillucr river been frozen. In the month of January, 1552, the East River was obstrueted for a short period, but the North River remained open. Thousands crossed over the ice from Brooklyn 
to New York. The rise of the tide is nearly 7 feet. Going northward the rise increases, and in the Bay of Fundy is 90 feet, the maximum of the coast. Southwardly it decreases, and in the Gulf of Mexico is but 18 inches. The time of the tide at other places on the coast, or on waters connecting with the ocean, varies from that of New York as followsearlier: Halifax, N. S., 2 h. 15 m.; New Bedford, 1 k. 40 m.; Providence, 0 h. 41 m.; Sandy Hook, 2 h. 45 m.; Norfolk, 0 h. 41 m.; and Richmond, 2 h. 25 m. ; and later : Eastport, 2 h. 9 m. ; Portland, 1 h. 39 m. ; Boston, 2 h. 19 m. ; Holmes' Hole, 1 h. 4 m.; Philadelphia, 5 h. $19 \mathrm{~m}$; Baltimore, 5 h. 07 m. ; Charleston, 10 h. 19 m.; Mobile Point, 1 h. 54 m.; Albany, 6 h. 34 m.; Quebec, 8 h. 49 m. The depth of water at the wharves is 6 or 7 feet, and increases rapidly outward. It is sufficient in either river to float the largest ships. At the old channel, on the bar at Sandy Hook, the depth is 21 feet at low tide, and 27 at high tide. That of the New, or Gedney's Channel, is at low water 32 feet. The channel inside varies from 35 to 60 feet.

Defenses.-The harbor is well defended. The principal works are at the Narrows, which, at the point selected, is but one-third of a mile wide. Here are built, on the Long Island side, forts Hamilton and Lafayette, the latter on a reef of rocks 200 yards from the shore, with three tiers of guns. On the Staten Island side are Forts Tompkins and Rich- mond, the former on the heights, and provided with a num ber of sabterranean passages. These forts are in excellent condition. The entrance from the Sound to the East River is defended by Fort Sehuyler, on Throg's Neck. Within the harbor are batteries on Bedloe's and Ellis' islands, on the west side of the bay, and on Governor's Island, 8,200 feet from the eity, are Fort Columbus, in the form of a star. commanding the south side of the channel; on the southwest point, Castle William, a round tower 600 feet in circuit and 60 feet high, with three tiers of guns, and South Battery, on the south-west side, commanding the entrance through Buttermilk Channel. In case of war, too, the whole surrounding heights could be readily fortified, and Castle Garden, and the Battery esplanade would furnish ready-made site for an extensive armament. No port in the world, indeed, is better defended by permanent fortifleations, or could be more easily placed in a condition of defense.

Manufactures,-Although New York employs the greater portion of its capital in foreign commerce and domestic trade, it is also distinguished as the greatest manufacturing city in the United States, having a greater capital therein invested, more hands employed, and deriving a greater profit therefrom, than any other eity. The general returns of the census are exhibited in the following table:

\begin{tabular}{|c|c|c|c|c|c|c|}
\hline \multirow{3}{*}{ Wards. } & \multirow{3}{*}{$\begin{array}{c}\text { No, of productive } \\
\text { or manufacturing } \\
\text { establislinients, } \\
\ldots \ldots 137 \ldots \ldots\end{array}$} & \multirow[b]{2}{*}{ Capital invested. } & \multicolumn{2}{|c|}{ Hands ensployed. } & \multirow{3}{*}{\multicolumn{2}{|c|}{$\begin{array}{c}\text { Annual product, or } \\
\text { value of articles } \\
\text { mannfactured, } \\
\ldots \ldots . \$ 3.906,337\end{array}$}} \\
\hline & & & & & & \\
\hline & & & & & & \\
\hline 2 & $\ldots . .851 \ldots . .$. & . $12,672,995 \ldots \ldots \ldots \ldots \ldots$ & 19,618 & $\cdots$ & & 3 \\
\hline 3 & $9 \ldots \ldots \ldots \ldots$ & $0 \ldots \ldots \ldots \ldots \ldots$ & 653 & & o. & \\
\hline 4. & $\ldots \ldots 189, \ldots \ldots \ldots \ldots$ & $\ldots \ldots \ldots \ldots \ldots$ & 1, & $\cdots \cdots$ & ... & \\
\hline 5. & $\ldots . .83 \ldots \ldots \ldots \ldots$ & $\ldots \ldots \ldots \ldots \ldots$ & 1 , & & $6 \ldots \ldots$ & \\
\hline $6 .$. & $\ldots \ldots 156 \ldots \ldots \ldots \ldots \ldots$ & $\ldots \ldots \ldots \ldots \ldots$ & 2 , & $2 \ldots$ & $0 . \ldots \ldots$ & \\
\hline 7 & $\ldots \ldots 422 \ldots \ldots \ldots \ldots \ldots$ & $\ldots \ldots \ldots \ldots \ldots$ & 4, & $\cdots$ & ; $\ldots \ldots \ldots$ & \\
\hline & $\ldots \ldots 233 \ldots \ldots \ldots \ldots$ & $\ldots \ldots \ldots \ldots \ldots$ & 2 , & .... & ......... & \\
\hline 9 & $\ldots \ldots 159 \ldots \ldots \ldots$ & $\ldots \ldots \ldots \ldots \ldots \ldots$ & 2, & .. & $4 \ldots \ldots \ldots \ldots$ & \\
\hline & $\ldots \ldots 96 \ldots \ldots \ldots$ & $\ldots \ldots \ldots \ldots \ldots$ & & & $5 \ldots \ldots \ldots \ldots$ & \\
\hline & $\ldots 149 \ldots \ldots \ldots$ & $\ldots \ldots \ldots \ldots \ldots$ & 4,1 & $\ldots$ & $4 \ldots \ldots$ & \\
\hline & $\ldots \quad 19 \ldots \ldots \ldots$ & $\ldots \ldots \ldots \ldots$ & & & -... & 506 \\
\hline & $\ldots 172 \ldots \ldots \ldots$ & ............ & 99 & $\cdots$ & $1 \ldots \ldots$. & \\
\hline & $\ldots 72 \ldots \ldots \ldots$ & .............. &. & & ....... & \\
\hline & $\ldots 93 \ldots \ldots \ldots \ldots$ & ........ & & & ........ & \\
\hline & $\ldots \ldots, 129 \ldots \ldots \ldots \ldots$ & $\ldots \ldots \ldots \ldots$ & .... & & $3 \ldots \ldots \ldots . . .$. & \\
\hline & $\ldots \ldots 145, \ldots \ldots \ldots \ldots$ & …... & $5 . .$. & & $35 \ldots \ldots$ & \\
\hline & $\ldots . \ldots 199 \ldots \ldots \ldots \ldots$ & $\ldots \ldots \ldots \ldots$ & $6 \ldots$ & $2 . \ldots$ & 9....... & 2. \\
\hline & $\ldots \quad 44 \ldots \ldots \ldots \ldots \ldots$ & $0 \ldots \ldots \ldots \ldots . . . .$. & $56 \mathrm{~S} \ldots$ & $102 \ldots$ & $670 \ldots \ldots \ldots$ & 1,2 \\
\hline
\end{tabular}

By these statistics it appears that the operatives in the manufactories, etc., form nearly one-sixth of the whole population of the city; that the proportion of the annual products to the capital invested, is 307 per cent.; and that the average value of the product of each operative is $\$ 1,25 \$$. The manufacturing interests have had as rapid increase as those of commerce. In 1810 , the total capital in manufactures was $\$ 11,228, \$ 94$; and in 1850 , as stated above, it amounted to $\$ 34,282, \$ 22$.

The branches of manufacturing industry which are here most extensively prosecuted are these directly developed by the great commerce of the city. Pre-eminent among these the the great iron foundries and machine-shops, of which the largest are the Novelty Works, Morgan Works, Allaire Works, and the Fulton and West Street foundries. The two former employ each about 900 men. These and other establishments are engaged in casting and molding the largest class of steamship engines, their bed plates, and other iron works, locomotives, mills, presses, gearing, boilers, etc. There are 10 sugar refineries, all of which are very large establishments, superior to any others in the Cnited States, and having a greater annual product. The value of cabinet furniture annually made is above $\$ 1,000,000$. There are numerous breweries and distilleries, which employ a large capital. The following summary statement of the number of establisbments which in 1850 prosecuted the principal branches of manufacturing industry, is compiled from the "Business Directory" for that year: Boat-building. 27 ; boiler manuf., 16 ; brass and bell founders, 39; breweries, 42; bakeries, 475; black and whitesmithing, 1S5: britannia-ware manuf, 13; block and pumpmaking, 33 ; bookbinders, 55 ; boot and shoemaking, 1,377 ; brushes, etc., 40 ; building of houses, etc., 136 ; cabinetmaking, 255 ; carpentering, 260; chairmaking, 34 ; clockmaking, 29 ; clothing, 285; coaches and carriages, 58 ; confectionery. 265 ; cordage, etc., 6 ; dressmaking, 440 ; edge tools, 11; goldbeating, 21; gold pen manuf., 20; guns, etc., 20; ink manuf., 11; iron foundries, 38 ; lock manul, 24 ; machinery, 79 ; millinery, 256 ; morocco manuf., 28 ; musical instruments, 41 ; nails, 15 ; organs, 5 ; pateut medicines, 54 ; perfumery, 26 ; piano-fortes, 55 ; saddles and harness, 90 ; sails, 51 ; sash and blind manuf., 61 ; segars, 119 ; ships, 19 ; silver manuf., 39 ; silver plating, 27 ; soap and candle, 43 ; steam-engine manuf., 77 ; steel manuf., 10 ; tailoring, 561 ; trunk factories, 59 ; type foundries, 9 ; varnish manuf., 14; white lead manuf., 9.

Commerce.-Comnercial interests originated the settlement of New York, developed its rapid grow th, have always 
directly influenced its changes of fortune, and are now the main support of its greatness. With the fluctuation of the course of events, with regard to general commerce, there has always been a corresponding change in the ratio of the increase of its population, and of its general prosperity. Its first period of great prosperity, subsequent to the Revolution, was from 1790 to 1800 ; during which decale its population increased at a ratio of $\$ 2.16$ per cent-viz., from 33,131 (1990), to $60,459(1800)$. During this period the old world, involved in wars, was making constant demand upon the industry of the new ; and the produce of the interior and of the neighboring States was pressing to the Atlantic, whence the shipping of New York carried it abroad, returning again with goods for distribution, both in its own and the neighboring markets. The business of the city consequently wonderfully increased, and its attendant advantages drew thither capital and also men to participate in the profits arising from the large investment then made. During the next decade (1800 to 1810) there was a falling off of the ratio of increase of population and wealth, and business enterprise was greatly depressed. Though the population increased in this period at a ratio of $59 \frac{1}{8}$ per cent. [from $60,489(1800)$, to $96,373(1810)$,] the increase in wealth was but $S$ per cent,-viz., from $\$ 24,486,370$ to $\$ 26,436,370$. In the succeeding ten years, the war of 1812 with Great Britain entirely destroyed the foreign commerce of the city for 3 Jears; after which, from 1815 to 1820 , it again revived and greatly advanced in wealth. The increase of its wealth during the entire decade (1810-20) was 163 per cent. (from $\$ 26,436,370$ to $\$ 69,530,753$ ). While the increase in population was only 281 per cent. $(96,373$ to 123,706$)$, which ratio is less than that of any other decade, and exhibits with extraordinary clearness the dependence of New York city upon comnerce, since during this same period the increase of the population of the State was more rapid than ever.

In'1520 commerce again revived, and steadily increased until 1525 , in which year it reached a climax that was not again attained until 1831. In 1826 the completion of the Erie Canal opened a new source of prosperity to commerce, and which assisted in the formation of the great speculations which soon characterized the financial career of the city. The revulsion which followed this unnatural expansion, and for a time prostrated all branches of business, most seriously affected the commercial interests of the city. Since its recovery from that reversion of fortune, its commercial prosperity has for the most part been steadily on the increase, though, of course, somewhat affected by the changes in the tariffs of the national government, and the changing relations of the nations with which it has intercourse.

The following table shows the amount of imports and experts of the port of New York, and the amount of duties collected on the importation in each year, from 1821 to 1851 , inclusive:

\begin{tabular}{|c|c|c|c|}
\hline . & $\begin{array}{l}\text { Imports from } \\
\text { Foreign counirieg. }\end{array}$ & $\begin{array}{l}\text { Amrunt of Juties } \\
\text { on imports. }\end{array}$ & $\begin{array}{c}\text { Exports to } \\
\text { For'gn count's. }\end{array}$ \\
\hline & $\$ 36,020,012 \ldots$ & - $\$ 7,243,542$. & \\
\hline & & & \\
\hline &, $455 \ldots$ & 35. & 2 \\
\hline & $35,147 \ldots$ & & \\
\hline & $3: \ldots$ & & \\
\hline & $4 \ldots$ & . 11 & \\
\hline & & & ... 2 \\
\hline & & & .... 22 \\
\hline & & & $\ldots \quad 17$ \\
\hline & & & \\
\hline & & & \\
\hline & 4 ... & & 2 \\
\hline & & & 21 \\
\hline & 72 & & \\
\hline & & . 14 & ... 29 \\
\hline & 11 & 305 & $\ldots \quad 27,4$ \\
\hline & & $9,487,598$ & 9 \\
\hline
\end{tabular}

\begin{tabular}{|c|c|c|c|}
\hline & $\begin{array}{l}\text { Imports from } \\
\text { Foreign countries. }\end{array}$ & $\begin{array}{c}\text { Amount of duties } \\
\text { on imports, }\end{array}$ & $\begin{array}{r}\text { Expo } \\
\text { For'gn }\end{array}$ \\
\hline 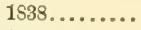 & & & \\
\hline & $97,078,687$ & & \\
\hline$\ldots$ & 56 , & & \\
\hline & 75 & 10,9 & \\
\hline & 52 & $22 \ldots$ & \\
\hline & 50 , & & \\
\hline & 75 & & \\
\hline & 68 & $8 \ldots$ & \\
\hline & 71 & $75 \ldots$. & \\
\hline & 95 & $32 \ldots$ & \\
\hline & 89 & $31 \ldots$ & \\
\hline & 86 & $34 \ldots$. & \\
\hline & & 10. & \\
\hline & 130 & - 31,7 & 53 \\
\hline & 7 & 910 & . \\
\hline
\end{tabular}

Of the whole value of the imports into New York, very nearly one-half consists of dry goods. The following table exhibits the value of the importations of dry goods, of dif ferent kinds, compared with the whole importation of foreign merchandise in the last four flscal years:

Manufactures, 1848-9. 1849-50, 1850 51. 1851-52. Woolen .... \$9,199,578.\$14,637,060.\$17,067,031.\$14,388,565 Cotton..... 10,783,507. 10,660,857. 11,671,500。9,982,547 Silk . ......14,301,316, 16,679,227, 24,858,850, 22,319,951 Flax...... 4,245,513. 7,084,663. 8,058,731. 6,346,299 Miscellan'us。 $4,144,525 ， 2,320,828$ ３,957,635. 4,183,740

Tot. im. d.g. $\$ 41,674,739$. $\$ 51,3 \$ 2,635 . \$ 64,613,747$. $\$ 57,221,062$ "6 mer. $68,932,207.108,250,503.130,683,030.117,739,457$ Pro. d.g. w. 1. . 60.5 p. ct. . 49.7 p. ct. .. 49.5 p. ct...48.6 p. ct.

The following table gives a statement of the duties collected at the port of New York, compared with the total collections of the United States, in various years between 1789 and the present:

Years, New York, U, S. Y Years, New York, U, S, 1789. $\$ 145,320 . \$-\quad 1825 . . \$ 15,752,100 . \$ 20,098,714$ 1792.. 1,233,903. $3,443,071 \quad 1830$. 15,012,553. 21,922,391 \begin{tabular}{lll|l}
$1795 . .2,717,361$. & $5,558,461$ & $1835 . .14,468,116.19,391,811$
\end{tabular} 1800. $3,611,558$. 9,080,983 1840. $\quad 7,537,441$. $13,499,502$ $\begin{array}{llll}1805 . & 6.958,008\end{array}$ 1810.. $5,223,696.8,583,309 \quad 1850$. . 24,487,610. 39,668,6S6 $\begin{array}{llll}1816.10,785,354.36,306, S 75 & 1851.31,757,199.49,017,597\end{array}$

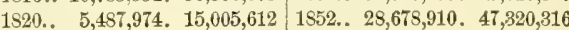

The revenue collected at New Tork compared with that of the other principal ports of the United States in the year ending June 30,1851 , was as follows:

New York......\$31,757,199| New Orleans.....\$2,296,636 Boston ....... 6.577,540 Baltimore....... 1,047,27S Philadelphia.... $3,667,838$ Charleston, S. C. . $\quad 600,712$

According to the Business Directory of the city for 1950 , the number of importers of different articles was as follows of dry goods, 139 ; fancy goods, 100 ; hardware, 107 ; watches, 61 ; wines and liquors, 108 ; silks, 21 ; laces, 36 ; woolens, 11; drugs, 34 ; essential oils, 15 ; china-ware, 40 ; plate glass, 11; hides, 12 ; hosiery, 7 ; buttons, 7 ; baskets, 5 ; burr blocks 3: general importers, 23 , etc.

The imports and exports of specie and bullion are not included in the above table, but the following will exhibit their amounts for the last six years :

Years, Imports. Exports, Years. Importa Exports, $184 \pi \ldots \$ 8,307,390 ， \$ 905, \$ 41 \quad 1850 ., \$ 10,502,115 . \$ 5,585,103$ 1S4S.. 1,173,106. 12,02S.798 1851.. 10,390,501. 26,622.781 1849.. 2,813,380. $4,739,903 \quad 1852$. 2,52S,391. 37,273,703

For the calendar year 1851, the import of gold and bullion from California, was $\$ 43,671,432$, and the export of gold and silver to all countries, was $\$ 43,723,209$. 
Tonnage of New York City.-The following statement from the annual reports of the secretary of the treasury, exhibits the registered, the cnrolled and licensed, and the total tonnage belonging to the district of New York from the year 1826 to the present time. The year ends with December 31, up to 1835 , thence with September 30, to 1843, and from that time it ends with June 30 :

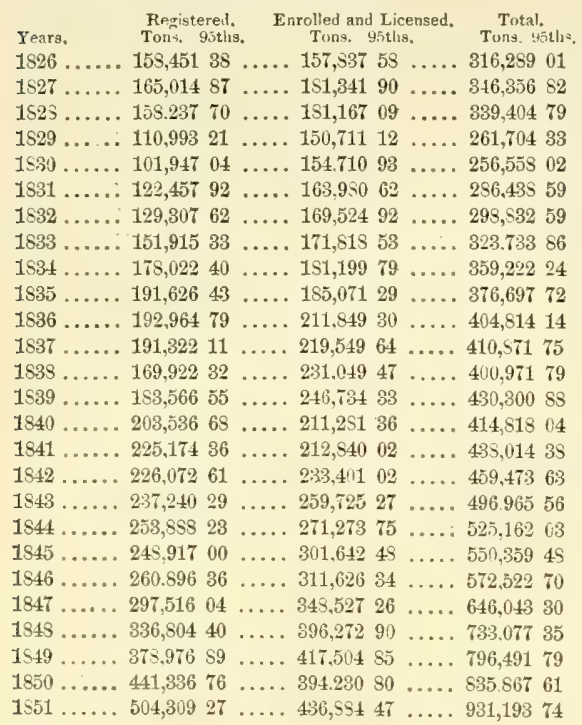

Within this period of 25 years, it will be seen that the tonnage of this district has nearly trebled in amount.

Comparison of the tonnage of New York with that of Boston, and of the United States at different periods:

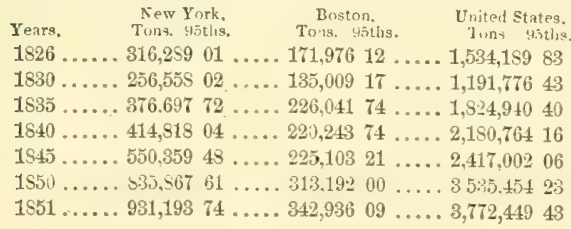

The tonnage of several other of the leading ports was, in 1851, as follows:
Tone. 9iths.

New Orleans... . 251,9u0 11

Philadelphia.....222,428 90

Baltimore .......160,511 64

New Bedford.... 181,409 46

Bath, $M e_{.} \ldots \ldots$.... 103,795 91
Tons. 95ันไร

Walloboro', Je. 103,593 51 Portland " 97.57170

Barnstable, Mass. 72,99744 San Francisco ... 58,063 54 Charleston, $S$. C.. $31,910 \quad 2 \%$
Emplomment of Tonnage.-The following tablu presents the proportions of the tonnage employed in coasting trade, in steam navigation, and in the whaling business since 1829.

The table of the coasting trade embraces only the "enrolled and licensed tomnage." and does not inclutie the tonnage "licensed under 20 tons," of which a subsequent statement is given, for the years ending June 30th, 1849, and June 3 " th, 1 ร็๊ 0.

The table of steam navigation includes both "registered" and "enrolled and licensed" tonnage. A separate comparative statement of these classes for the years ending June 80 th, 1849 , and June $3: t h, 1350$, is also given subsequently under "stecrin marine."

\begin{tabular}{|c|c|c|c|c|}
\hline Years. & $\begin{array}{l}\text { Conast Trade. } \\
\text { Tuns. G5ths. }\end{array}$ & $\begin{array}{l}\text { Steam Navig } \\
\text { Ions. } \$ \text { thtlis. }\end{array}$ & & $\begin{array}{l}\text { Whaling. } \\
\text { Tons. ysting }\end{array}$ \\
\hline 1829 & $\ldots 173,130 \$ 1 . . .$. & 1,04564 & ..... & - \\
\hline 1830 & $142,52933 \ldots$ & 12,10330 . & $\cdots$ & - \\
\hline 1831 & $146,7 \mathrm{SS} 33 \ldots \ldots$ & 12.75656 & & - \\
\hline 1532 & $4945 \ldots \ldots$ & 3352 & $\ldots$ & 一 \\
\hline 1833 & $1519 \ldots \ldots$ & 1291 & & - \\
\hline 1534 & $780 \ldots$ & 894 & $\ldots$ & - \\
\hline 1535 & $384 \ldots \ldots$ & 0328 & ....... & 2,13657 \\
\hline 1836 & $7765 \ldots \ldots$ & 5157 & $\ldots$. & 93463 \\
\hline 1837 & $635 \ldots \ldots$ & 853 & $\ldots \ldots$ & 71431 \\
\hline 1 Sริ & $189 \ldots$ & 936 & & 86391 \\
\hline 1839 & $2472 \ldots \ldots$ & 441 & ...... & 2,4604 \\
\hline 1840 & $967 \ldots \ldots$ & $=36$ & & - \\
\hline 1841 & $5219 \ldots \ldots$ & 721 & ... & 1,76183 \\
\hline 1842 & $687 \ldots \ldots$ & 081 & & $1.4517 \tau$ \\
\hline $15+3$ & $7727 \ldots \ldots$ & 753 & & 37023 \\
\hline 184 & ....2.261 & 530 & & 47327 \\
\hline $1 S 45$ & ...... 291,209 66 ... & 001 & & 37023 \\
\hline 1816 & $\ldots \ldots .399, \$ 9423 \quad \ldots \ldots$ & 5793 & & 37957 \\
\hline $1 S 17$. & ....... $33 \pi, 66354 \ldots .$. & $52,420 s 8$ & & - \\
\hline $18+5$ & ...... $355,02049 \ldots$ & 64,22919 & . & - \\
\hline $1 S 49$ & $\ldots \ldots \ldots 406.15645 \ldots \ldots$ & 71.31973 & & - \\
\hline 50 & .... 8\$2,\$86 $71 \ldots$ & 95,11556 & & 4650 \\
\hline 65 & $\ldots \ldots 426.74719$ & 54152 & & - \\
\hline
\end{tabular}

The following table exhibits the tonnage "licensed under 20 tons," for the two fiscal years specified:

\begin{tabular}{|c|c|c|}
\hline $\begin{array}{l}\text { Tonnage licensed } \\
\text { wuder } 20 \text { toms. }\end{array}$ & $\begin{array}{l}\text { Year ending } \\
\text { June :0. } 1849 . \\
\text { Trms. 9.5ths. }\end{array}$ & $\begin{array}{l}\text { Year ending } \\
\text { June } 30,1850, \\
\text { Tons, 95ths. }\end{array}$ \\
\hline Coasting trade & 11,19990 . & . 11,22790 \\
\hline
\end{tabular}

\section{Cod fishery ........... $14842 \quad \ldots \ldots \ldots . \quad 11614$}

of enrolled and licensed tonnage, none was employed during these two years in the mackerel fishery.

Sterm. Tonnage.-The following table exhibits the amount and elassification of the steam tonnage for the two fiscal years specified:

\begin{tabular}{|c|c|c|}
\hline Steam tonnage. & $\begin{array}{l}\text { Year ending } \\
\text { June an, I:41.। } \\
\text { Tons, t5ths. }\end{array}$ & $\begin{array}{l}\text { Year ending } \\
\text { 'June } 20,1350 . \\
\text { Tons. 95tlis. }\end{array}$ \\
\hline Registered & $10,642 \quad 76$ & $\ldots 39,145 \quad 47$ \\
\hline Enrolled and licensed. & $61,175 \quad 92$ & 55.96709 \\
\hline Total & $71,518 \quad 73$ & $95,115 \quad 56$ \\
\hline
\end{tabular}

This table exhibits a part of the great increase of registered steam tonnage, which, beginning in 1847, has since been steadily increasing, and now pre-eminently characterizes New Tork. Further statisties of the steam tonnage will be found under the heads of "vessels buit" and "ocean steamslips." The total steam marine of New York is nearly equal to that of the empire of Great Britain with all its d"pendencies, which in 1851 was stated at 1,184 boats of 142,180 tons. According to the U. S. Treasury Report on the U. S. steam marine in 1851 - the number of passengers earried on the Hudson river in the year ending July 1, 1851, was 995.100 , between New York and Philadelphia by steamboats $\$ 40,000$, and on Long Island Sound 302,39T.

The steam tonnage of New York compares as follows with that of several other cities-of the several coasts, in land divisions, etc.-and of the United States in 1551:

New Orleans ....... 156.65-4 $\quad$ Baltimore ......... 14.2S5 New Tork ........ 121,541 | Northern frontier.... 69,165 Pitshurg......... 47.911 Ohio basin.. ...... 67.601 St. Louis .......... 29568 । Mississippi valley ... 67,957 Detroit.......... 21,944 Atlantic coast...... 154,270 Philadelphia ...... 20,717 Gulf of Mexico.... 23,244 Buffalo........... 19,9s8 Pacific coast....... 37,986

Total U. S. steam marine...... . 583, $\overline{607}$

Amirals and Departures.-Annexed is a tabular statement of the atnount of tonnage entered and eleared the port of New York; from and for foreign ports, in each year from 1521 to $15 \% 1$; a period of 91 years. distinguishing the American from the total tonnage. The years end with September to 154 ? thenes with June. 
Amount of tomage entered the port of New Tork from, and the amount cleared the port of New Tork for foreign ports:

\begin{tabular}{|c|c|c|c|c|}
\hline \multirow[b]{2}{*}{ Years. } & \multicolumn{2}{|c|}{ ENTERED, } & \multicolumn{2}{|c|}{ CLEARED. } \\
\hline & $\begin{array}{c}\text { American } \\
\text { Tons. }\end{array}$ & $\begin{array}{l}\text { Total } \\
\text { Tons. }\end{array}$ & $\begin{array}{l}\text { Ainerican } \\
\text { Tons. }\end{array}$ & $\begin{array}{l}\text { Total } \\
\text { Tons. }\end{array}$ \\
\hline $18: 1$ & $.155,723$. & $171,963$. & $. .143,741$. & 154,472 \\
\hline 1522 & ..203,0S2 . & 226.790 & $. .158,970$. & 150,223 \\
\hline 1823 & $.204,308$. & 226,789 . & ...196,189. & 217,202 \\
\hline $1 \leqslant 24$ & $.206 .080 \ldots$ & $353, \pi 69$ & $\ldots 215,480$ & 233,931 \\
\hline 1825. & $. .259,524$. . & 230,179 & $.245,512$. & 263,431 \\
\hline 26 & $.246,174 .$. & $274,997$. & ..213.234. & 232,466 \\
\hline 26 & $.255,276 \ldots$ & 292.572. & ..223,224. & 256,563 \\
\hline 228. & $.236,308 .$. & $275,677$. & $. .207,124$. & 248,267 \\
\hline 1829. & ..2555,691. & $281,512$. & ..200,768. & 226,201 \\
\hline $1830 \ldots$ & $.280,91 \mathrm{~s}$. & 814.715. & ..209.599. & 243,285 \\
\hline $18: 31 \ldots$ &. $.274 .237 \ldots$ & $33 \pi, 009$ & ..234,469. & 294,235 \\
\hline 1532. & $.295,293$ & 401.718. & $.221,657$. & 316,120 \\
\hline 1533. & $.320,083$. & 430,91S.. & $.239,415$. & 341,527 \\
\hline 1584. & $.352,225$ & $411,904 \ldots$ & $\ldots 235,768$ & 325,566 \\
\hline $1835 \ldots$ & $.373,465$ & $464,464 \ldots$ & ..259,55ั2. & 369,590 \\
\hline $1836 \ldots$ & $.407,095$. & $556,730$. & $\ldots 2 \pi 1,746 \ldots$ & 404,957 \\
\hline $183 \pi$. & . 36s,011. & $539,372$. & ..218,786. & 405,959 \\
\hline 1838. & $.877 .263 \ldots \ldots$ & $468,890$. & $.268,587 \ldots$ & 356,654 \\
\hline 1539. & $.422,349 \ldots \ldots$ & $565,335$. & $.331 .590 \ldots$ & 464,347 \\
\hline 1540 . & $.409,458 \ldots$ & $527,594 \ldots$ & $.275,393 \ldots$ & 392,597 \\
\hline $1 \$ 41 .$. & $.428,952 \ldots$ & 549,045 . & $.296,543 \ldots$ & 407,325 \\
\hline $1512 \ldots$ & $.406,623 \ldots$ & $555,315$. & $.300,738 \ldots \ldots$ & 451,559 \\
\hline $1543 \ldots$ & $.247,950 \ldots$ & 312,214 . & $.221,733 \ldots$ & 255,481 \\
\hline $1814 \ldots$ & $.434,690 \ldots \ldots$ & $576,480$. & $.371,968 \ldots \ldots$ & 498,254 \\
\hline 1845. & $439,676 \ldots$ & $579,218 \ldots$ & $341,094 \ldots \ldots$ & 483,525 \\
\hline $1 S \pm 6$. & $.493,995 \ldots . .$. & 655,877 & $.396,498$. & 558,716 \\
\hline 1847 . & $.543,065 \ldots$ & $853,663$. & $.495,509 \ldots$ & 785,745 \\
\hline $1548 \ldots$ & $.639,305 \ldots .$. & $932.493 \ldots$ & $.491,219 \ldots \ldots$ & $7 \mathrm{~S}, 335$ \\
\hline 1849. & $.711,720 \ldots \ldots 1$ & $, 117,500 \ldots$ & $.569,711 \ldots$ & 931,509 \\
\hline 1550 & $.734 .431 \ldots$ & 45,331 . & $596,812 \ldots$ & 982,475 \\
\hline 51 & $56,579 \ldots$ & 768 & $793,229 \ldots$ & $1,230,082$ \\
\hline
\end{tabular}

The entrances and clearances at New York, at different periods, compare as follows with those of the United States for the same years:

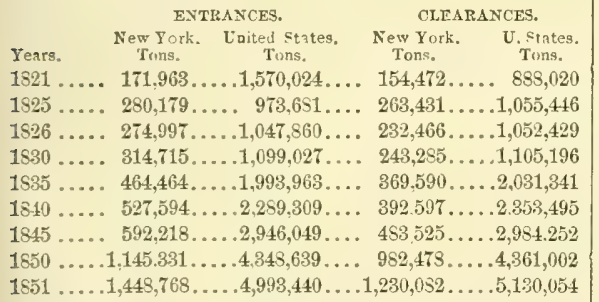

During the year ending 31 st December, 1851, the nationality and character of vessels arriving at New York was as follows:

\begin{tabular}{|c|c|c|c|}
\hline Nationality. & & Nationality. & No \\
\hline $\begin{array}{l}\text { merican. } \\
\text { ritish.... }\end{array}$ & & $\begin{array}{l}\text { Italian...... } \\
\text { Spanish.... }\end{array}$ & 12 \\
\hline French ... & 30 & Brazilian...... & 20 \\
\hline Bremen............. 1 & 139 & Oldenburg ............ & 9 \\
\hline Swedish............... & 45 & Sardinian ............. & 8 \\
\hline Austrian ................ & 9 & Venezuclan ........... & 5 \\
\hline Norwegian ........... & 54 & Eruguay.............. & 2 \\
\hline Sicilian $\ldots \ldots \ldots \ldots \ldots$ & 7 & Lubec .......... & 3 \\
\hline Hamburg. . . . . . . . . . . & 44 & Mechlenburg ........... & 4 \\
\hline Danish................ & 24 & IIanoveran ............. & 4 \\
\hline Russian ............... & 12 & Rinstock........ & 1 \\
\hline Duteh ................ & 28 & Genoese ............... & 1 \\
\hline Belgian ................ & 19 & Peruvian............... & 1 \\
\hline Prussian . .............. & 29 & Central America, & \\
\hline Columbian ............. & 2 & (Guatamalan).. & \\
\hline Neapnlitan ........ & 4. & & \\
\hline
\end{tabular}

Portuguese........... $4{ }_{14}^{4} \quad$ Total.........3,sss
Of these 941 were ships, 883 barks, 1,303 brigs, 588 schooners, 166 steamships, 2 ketches, 1 sloop, and 4 galliots. Vessels Built in the District of New York.-Table showing the number of vessels of all kinds built in the district of New York, with their measurement, from 1834 to 1851, compiled from the Treasury reports, the years ending with December 31 , to 1834 , thence with September 30 , to 1843 , thence with June 30 :

Years. Slips. Brigg. Sch'rs. Slonpa and Steamb'ts. Total. Tons.

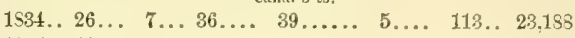
$1835 \ldots 16 \ldots 2 \ldots 33 \ldots .51 \ldots \ldots .7 \ldots 109 \ldots 17,368$

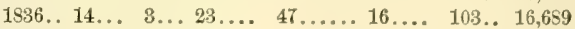
$1837 \ldots 10 \ldots 5 \ldots 25 \ldots .62 \ldots \ldots 16 \ldots .6118 \ldots 20,303$ 1838.. $7 \ldots .8 \ldots 28 \ldots . .55 \ldots \ldots .7 \ldots . .6105 . .14,229$ $\begin{array}{llllllll}1839 & 10 \ldots & 7 \ldots & 17 \ldots & 44 \ldots \ldots & 16 \ldots & 94 \ldots & 16,688\end{array}$ $1840 \ldots 6 \ldots 13 \ldots 17 \ldots .24 \ldots \ldots .6 . .68 . .13 .357$

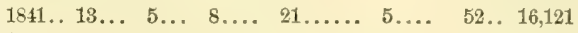
$1842 ., 6 \ldots 3 \ldots 12 \ldots .132 \ldots \ldots .18 \ldots .171 \ldots 18,835$ 1843.. 5... 2... 8... 102.... 5... 122.. 13,179 1844.. 11... $6 \ldots 16 \ldots .89 \ldots \ldots 14 \ldots .136 \ldots 15,026$ $1845 \ldots 18 \ldots 2 \ldots 25 \ldots 130 \ldots \ldots$ 17 ... 192.. 26,621 $1846 \ldots 11 \ldots 3 \ldots 37 \ldots . .160 \ldots \ldots 23 \ldots .231 . .29,465$ $1847 \ldots 16 \ldots 2 \ldots 43 \ldots .117 \ldots \ldots 15 \ldots .193 \ldots 37,591$ $1848 \ldots 26 \ldots 3 \ldots 59 \ldots .200 \ldots \ldots .19 \ldots .307 . .57,977$ $1849 \ldots 15 \ldots 7 \ldots 44 \ldots . .145 \ldots \ldots 17 \ldots$ 228.. 37,933 $1850 \ldots 26 \ldots 2 \ldots 42 \ldots .104 \ldots \ldots 28 \ldots 202 \ldots 55,525$ 1851.. 23... 1... 56... 81..... 47... 208.. 71,214 Which compare in different years with the ship-building of the whole United States, as follows:

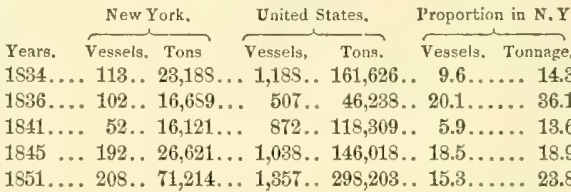

The following exhibits a comparison of ship-building in New York, in 1851, with that of the other leading shipbuilding States and districts:

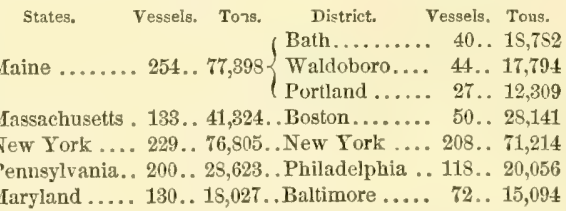

Commercial Resume.-Summary view of the proportion of New York, in the whole imports, exports, custom-reve= nue, and tonnage of the United States at different periods:

\begin{tabular}{|c|c|c|c|c|}
\hline \multirow{2}{*}{$\begin{array}{c}\text { Years. } \\
1769 . .\end{array}$} & $\begin{array}{l}\text { Imports } \\
\text { percent. }\end{array}$ & $\begin{array}{l}\text { Exports } \\
\text { percent. }\end{array}$ & $\begin{array}{l}\text { Dutieg } \\
\text { per cent. }\end{array}$ & $\begin{array}{l}\text { Tonnage } \\
\text { per cent. }\end{array}$ \\
\hline & ..14.14.. &..- . & $\therefore-\ldots$ & $\ldots-$ \\
\hline 92. & . - & .. 9.71 . & ..35.83. & .. - \\
\hline 1795 . & . & ..15.34.. & ..48.88.. & - \\
\hline $1800 .$. & . - & $\ldots 14.85 \ldots$ & ..39.77. . & $\ldots-$ \\
\hline $1805 .$. & $\ldots-\ldots$ & ..23.12. . &. $.53 .78 \ldots$ & - \\
\hline $1810 .$. & .. - & ..25.12. . & $.60 .56 \ldots$ & - \\
\hline $1516 .$. & .. - & .15.90.. & $.29 .70 \ldots$ & ... - \\
\hline $1820 .$. & .. - & $.16 .90 \ldots$ &. $.36 .57 \ldots$ & - \\
\hline $1821 .$. &. $.57 .55 \ldots$ & ..16.89 . & .36 .57$. & $\ldots-$ \\
\hline $1825 .$. & ...51.92. . & ..44.80.. & $. .78 .37 .$. & $\ldots 20.62$ \\
\hline $30 .$. & $.54 .54 \ldots$ & ..23.93.. & $.68 .43 .$. & ...21.53 \\
\hline 1535. & ..59.58 & ..23.86. &. .74 .61$. & $\ldots 20.64$ \\
\hline $1840 .$. & ..53.05 . & $\therefore 22.85$. & ..55.84.. & $\ldots 19.02$ \\
\hline $45 .$. & $\ldots 58.78 \ldots$ & ..29.s8. . & .64 .18$. & $\ldots 22.77$ \\
\hline $50 .$. & ..57.96.. & ..25.44. & $.61 .73 .$. & $\ldots 23.64$ \\
\hline $51 .$. & - & $-\ldots$ & 64.78 . & $\ldots 24.6 \mathrm{~S}$ \\
\hline
\end{tabular}


Ocean Steamships.-New York is distinguished for its great lines of ocean steamships, which have all becn brought into existence since 1846. These vessels have all been built at New York shipyards, and received their machinery from New York foundries. The total number of steamships built at this port, and launched previous to 1853 is 59 ; of which the number launched in 1849 , was 3 ; in 1850,14 ; in 1851,11 ; in 1852,11 . The present number (1S53) of steamship companies is 16 , having 76 steamers, with total tonnage of 129,010 tons. Of these, the following table will exhibit the different lines, the number of their ressels, with their aggregate tonnage, etc. :

\begin{tabular}{cc|cc} 
Lines. No. of Total & No. of Total \\
Vessels, Tomage. & Lines. & Vessels. Tonnage,
\end{tabular} Liverpool....... 5... 15,000 Richmond...... 2... 962 Havre........ 2.. 4,400 Mobile, etc..... 1.. 1,900 Bremen ....... 2... 3,400 Savannah....... 3... 3,950 Charleston..... 4... 6,200 Norfolk ....... 2.. 2,100 New Orleans.... 2... 2,000 New Orleans, ete. 3... 4,500

California Lines.-Aspinwall, C. A., 10 vessels, 19,600 tons, which connects with Pacific Mail Co., consisting of 14 steamers, 15,5:36 tons. The New York and San Francisco Steamship Co. consists of 4 steamers (2 on each side), aggregate tonnage 7,400. The Empire City Line for San Francisco consists of 3 steamships, with aggregate tonnage of 6,000. Vanderbilt's line, via Nicaragua, consists of 10 yessels, with aggregate tonnage of 18,000 tons.

The British Royal Mail Line (Cunard) have 11 steamers, 16,000 tons. The Glasgow Line has 1 steamer, 2,000 tons; and a second in construction.

Domestic Trade.-The amount of trade carried on by New York with the coast cities and the interior of the United States, vastly surpasses in magnitude that of its foreign commeree. Of this internal trade full accounts are not made.

An approximate statement of particular divisions of this trade is exhibited by the following statistics.

The statistics of total tonnage arriving at Albany by way of the Erie Canal, which follows, exhibit approximately the receipts of New York, since by far the greater part of them are directly sent to New York, and whatever proportion is not sent is fully compensated by the trade furnished from the towns and counties on the IIudson River:

Total tonnage arriving at tide-water 1836-1852 by the Erie Canal:

\begin{tabular}{|c|c|c|c|}
\hline ear. & $\begin{array}{c}\text { From Western States. } \\
\text { Tuns. }\end{array}$ & $\begin{array}{l}\text { From N. Y. State. } \\
\text { Tons. }\end{array}$ & Total \\
\hline 836 & $5-219 \ldots$ & .364 .906 & \\
\hline 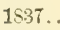 & $\ldots$ & 1. & \\
\hline . & $\ldots$ & $.3=$ & \\
\hline 39 & .... 121, & .26 & \\
\hline & .... 1: & ..3 & \\
\hline 1 & $\ldots \ldots 224$ & ....81 & \\
\hline 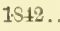 & $\ldots .221$ & $\ldots 2$ & \\
\hline 4 & $\ldots .256$ & $\ldots 37$ & \\
\hline 4 & $\ldots .3113$ & $\ldots 4$ & \\
\hline 4 & $\ldots .304$ & ..6 & \\
\hline 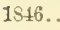 & $\ldots .506$ & . 6 & \\
\hline 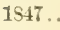 & $\ldots . \$ 12$ & .6 & \\
\hline 40 & .... 660 & $\ldots 58$ & \\
\hline 849 . & ... 765 & $\ldots 49$ & 1. \\
\hline a & $\ldots .773$ & $\ldots 59$ & \\
\hline & &. .54 & \\
\hline & 1 & 40 & \\
\hline
\end{tabular}

of the abore total amount, the whole quantity of wheat and flour which came to the Hudson River, from 1544 to 1852 inclusive, with the aggregate market value of the same:

\begin{tabular}{|c|c|c|}
\hline $\begin{array}{l}\text { Year. } \\
1 S 44 .\end{array}$ & $\begin{array}{cc}\text { Tons. } & \text { Value. } \\
277,865 & \ldots 11.211,077\end{array}$ & \begin{tabular}{|ccc} 
Year. & Tons. & Value. \\
$1819 \ldots$ & $434,414 \ldots$ & $\$ 19,308,595$
\end{tabular} \\
\hline $1 S 45$. & $.320 .463 \ldots 15.962 .250$ & $1550 \ldots 461,7 S 1 \ldots 20,218,18 \mathrm{~S}$ \\
\hline $1 S 46$ & $.419,366 \ldots 15.336 .412$ & $1851 \ldots 45 \pi, 624 \ldots 16.457,653$ \\
\hline 1847. & $.501,205 \ldots 82,590,935$ & $1852 \ldots 576,772 \ldots 22,564,256$ \\
\hline 1818. & $431,611 \ldots 21,145,421$ & \\
\hline
\end{tabular}

1818...431,611,. 21,145,421 582
The following is a statement of several of the leading articles arriving coastwise, in 185̌1:

Articles, Amount | Articles. . . .... Cotton, bales. . . . . .456,637 Rice, tres........ 49,433 Coffee, bags ....... 62,331 Salt, bushels....... 10,180 Figs, drums........ 77,350 Sugar, hhds........ 21,448 Hemp, bales........ 19.476 " tres........ 58 Hides, No........203,62S " " bbls........ 36,268 Lead, pigs..........176,589 "6 boxes........ 3,599 Molasses, hhds...... 12,650 " bags....... 13,733 " $\quad$ tres...... 1,217 Tobacco, hhds..... 14,\$27 "b bbls...... 39,797 " bales, etc... 428 Raisins, boxes...... 32,041 Wool, bales ....... 10,692 easks ...... 1,035

The aggregate of the trade carried on by means of the various railroads which centre at New York is most immense. Of these railroads the principal one is the Erie Railroad, which bears a relation to the entire southern portion of New Iork, and northern of Pennsylvania, ete., very similar to that sustained by the Erie Canal to the northern part of New York State. On all the railroads diverging from this city toward Philadelphia, Boston, and Albany, the traffic is also immense, and ever increasing. The following are the several principal lines from this city:

Miles.

Miles,

Camden and Amboy.... 90 Hudson River........ 150

Central (N. J.)....... 78 Harlem............ 153 Morris and Essex..... 44 New York and New Itnion............. 83 Haven.......... 76 New Jersey, etc....... 87 Housatonic........... 110 New York and Erie.... 469 Long Island.......... 96

By means of these railroads, New York is directly connected with every section of the country; and the various lines with which these are interwoven form a great network of several thousand miles of iron highway.

of the total internal trade furnished from the eity, dry goods form probably the greatest portion; but that of manufactures is well-nigh as extensive. Book-publishing is a principal business, and from the mercantile arrangements of the trade, by semi-annual trade sales, commission publishers, etc., has become a great feature of the internal trade of the city, and a branch it has acquired at the expense of other cities.

of the general eharacter of the internal trade of New York, it may summarily be said, that it surpasses that of all other cities in the Union, and differs from that of the entire nation only in degree.

Bunks.-.There are 40 banks, with an aggregate capital of $\$ 35,831,950$. In 1830, the bank capital of New York was $\$ 15,280,000$; in $1836, \$ 20,361,200$. The following statement exhibits the capital and rate of dividends of the banks of the city in each year, from 1815 :

Years, Capital, per cent. $\mid$ Years, Capital. $\begin{gathered}\text { Dir. } \\ \text { percent. }\end{gathered}$ 1845...\$23,0\$4,100 ...6.21 $1819 \ldots \$ 24,457,890 \ldots 8.28$ $\begin{array}{lllll}1846 \ldots & 23,054,100 & \ldots .7 .09 & 1550 \ldots 27,440,270 & \ldots .8 .69\end{array}$ $1847 \ldots 23,084,100 \ldots .7 .25 \quad 1851 \ldots 28,057,450 \ldots 8.93$

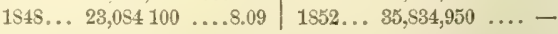

Insurance Componies.-There are 37 fire and marine insurance companies, with an ngregate capital of $\$ 6,654,010$; and 6 life insurance and trust companies, with an aggregate capital of $\$ 5,060,000$.

I'uzlic Buildings.-The C'ity Hall, standing near the centre of the Park, is a handsome ediflce, built chiefly of white marble, and is 216 feet long, 105 feet wide, and 51 feet high. It is two stories high above the basement, with a third story in the centre, from which rises a cupola of very beautiful proportions, surmounted by a colossal figure of Justice; ereeted $1803-12$, at a cost of $\$ 538,731$. It contains 28 rooms and public offices fir the accommodation of the mayor, common council, etc., of which the Governor's Room 
is the principal one, and contains many large portraits of great national characters. Other rooms contain valuable paintings, etc. The New City Hall is a large brick building in the rear of this edifice, which is oceupied by the courts, public offices, etc. East of the City Hall is the Hall of Records, where are preserved all the records and public documents of the city. The Custom House is one of the most perfect buildings of its size in the world. Its site is at the corner of Wall and Nassau streets. and was formerly occupied by the Old City Hall, in which Washington was inaugurated first president of the United States, and the American Congress held their sessions in New York. It is built in imitation of the Parthenon, at Athens, in the Doric order, of white marble, and is 200 feet long, 90 feet wide, and 80 feet high. Each of the north and south fronts has a portico of 8 Doric columns, 5 feet 8 inches in diameter and 32 feet high. The entire exterior, including the roof, is constructed of white marble, excepting the steps, which are of granite. In the construction of the interior, marble, granite, and brick alone were used, thus rendering it perfectly fire-proof. Some of the largest blocks of marble used weigh 33 tons. It was commenced in May, 1534, and finished in May, 1841. Its cost, ground included, was $\$ 1,195,000$-building alone, $\$ 950,000$. The interior is divided into a grand rotunda and numerous spacious offices. The rotunda is a magnificent room, 60 feet in diameter and 80 feet in the recesses; its dome is supported by 16 columns 30 feet high, which are beautifully wrought, and have capitals of the most exquisite workmanship. The number of officers employed in the Custom House is about 350 . The Merchants' Exchange, in Wall Street, is the most magnificent edifice in New York. It covers the entire block bounded by Wall Street, William Street, Hanover Street, and Exchange Place. Its front upon Wall Street is 198 feet, its height 77 feet-to the top of the dome 124. feet. It is construeted in the most substantial form, and perfectly fire-proof, of Quiney granite, and cost, including the ground, $\$ 1, \$ 00,000$. The front on Wall Street has a recessed portico, with 18 massive columns, 38 feet high and 4 feet 4 inches in diameter, each formed from a solid block of stone, and weighing 43 tons, which cost $\$ 3,000$ each, and are among the largest in the world. The building belongs to the "Merchants' Exchange Company," incorporated in 1823 , with a capital of $\$ 1,000,000$. It contains a grand central rotunda and numerous spacious offices used by bankers, insurance companies, etc. The rotunda is a most magnificent room, 80 feet in diameter, with 4 recesses, and 51 feet high, and is surmounted by a dome which ascends 30 feet higher, terminating in a sky-light 37 feet in diameter. The dome is supported in part by 8 columns of Italian marble, 41 feet high, in the Corinthian order, and splendidly polished. In this spacious hall, at exchange hours, the chief merchants of the city daily assemble. The Board of Brokers also meet here daily, and the Chamber of Commerce here holds its monthly sessions.

The IIalls of Justice occupy an entire block between Centre, Elm, Leonard, and Franklin streets, having their principal front upon Centre Street. The building is constructed of granite, in the most massive manner, in Egyptian architecture, and is 253 feet long and 200 feet wide. Its front has a recessed portico, supported by 14 massive granite columns. The edifice is occupied by the Court of Sessions, police courts, nfficers' rooms, prison cells, ete. The gloomy aspect of the building has won for it the general name of "The Tombs."

The City Penitentiary, with the buildings of the Lunatic Asylum, Almshouse, Workhouse, etc., are situated on Blackwell's Island, about 5 miles from the City Hall. These are very large stone buildings, and, though of simple architecture, present a very imposing appearance. They are seen to fine advantage from steamboats in passing through the East Iiver. The penitentiary has an entire length of nearly 500 fuet, and consists of a central building 4 stories high, surmounted by a square tower and two wings, each 4 stories high and 200 feet long. The almshouse is 3 stories in height, 325 feet in length, and 55 feet wide, with two large wings at each end. The lunatic asylum consists of a central edifice, with four wings.

The new State Arsenal, situated on Fith Avenue, between Sixty-second and Sixty-fourth streets ( $4 \mathrm{t}$ miles from the City Hall), a large and commodious edifice, containing arms and munitions belonging to the State, was erected in 1848, costing $\$ 30,000$. It is built in the Golhic castellated style, presenting a massive and appropriate appearance; its dimensions are 200 feet in front, by 50 feet deep, exclusive of the towers, of which there are $8-4$ in front, and 1 at each angle -69 feet high. The frst story is of brown stone, the remainder of brick, and the roof is of iron. It contains great numbers of cannon, small arms, etc., and some interesting trophies taken from the English during the Revolution and the last war.

The Post Office, formerly the Middle Duteh Church, in Nassau Street, between Liberty and Cedar streets, is noteworthy for its history. It was erected before the Revolution, and much of its interior woodwork and steeple was brought from Holland. During the Revolutionary War, this church, in common with others used by the British, was much injured from its oceupation as a prison, hospital, etc. In 1790 , it was repaired, and again used for public worship, in which service it continued until rented by the U.S. Government for the general post office of the city.

The descriptions of the large and commodious edifices used by the benevolent institutions of the city, also those of education, etc., will be found under their appropriate heads.

The Crystal Palace, for the exhibition of the industry of all nations, built in 1853 , for the purposes of a World's Fair, is situated on Sixth Avenue, between Fortieth and Forty-second streets, on Reservoir Square, adjoining the Distributing Reservoir of the Croton Aqueduct, 31 miles from the City Hall. The Association which has erected this magnificent structure, was incorporated for the purpose by the Legislature, March 11, 1852, having previously received the lease of the square from the Common Council of the city, on Jan. $3 d, 1852$. It was incorporated with a capital of $\$ 200,000$, with leave to increase it to $\$ 300,000$. The plan of the building was adopted 26 th $\mathrm{Aug}$., 1852, and its foundation formally laid Dec., 1852. The building is entirely constructed of iron and glass, with the exception of the floor. The general plau is that of a Greek cross, with a dome over the intersection. Its site is a nearly square piece of ground, having an extreme length from Fortieth to Forty-second Street, of 455 feet; and an extreme width, from the Sixth Avenue to the Reservoir, of 445 feet. The Crystal Palace occupies the greater part of this square, and consists of 2 principal stories, the second being of less extent than the first, a third chiefly ornamental, and a magnificent central dome. The area of the first floor is 111,000 square feet, of the galleries 62,000 square feet-total area, 173,000 square feet. By direction of the U.S. Treasury Department, the building will be made a bonded warehouse, during the exhibition, so as to receive all foreign goods free of duty, and encourage the coöperation of foreign nations in this fair of world-wide interest.

IIotels.-Among the public buildings of New York, its large hotels form a great feature. Of these the Astor House is the most distinguished. It is situated on Broadway, opposite the Park, and forms the block between Vesey and Barclay streets. It is built of Quincy granite, in the most substantial and splendid manner, is 5 stories high, and contains upward of 360 rooms. In its appointments and general style of accommodations, it is not surpassed by any hotel in the world. It was erected by J. J. Astor, at a cost of $\$ \$ 00,000$, and was opened in May, 1S36. The Irving House, on Broadway, occupying the block between Chambers and Reade streets, is built of granite, 5 stories bigh, contains about 300 rooms, and is a hotel of much resort. 
The St. Nicholas IIotel, on Broadway, between Broome and Spring streets, is a new and very large hotel, built of white marble, 6 striries high, containing 270 rooms, and surpassing, in the splendor of its apartments and general magnificence, all other hotels in the city. The Metropolitan Hotel, on Broadway, corner of Prince Street, 6 stories high, built of brown freestone, is a very imposing edifice. It contains about 400 rooms, many of which are elegantly painted and furnished. The eutire cost of the building, without furniture, was about $\$ 500,000$. The New York Hotel, on Broadway, occupying the block between $W$ ashington and Waverley places, is a very large and fashionable family hotel. It is built of brick, in piain style, but very spacious, and sontaining about 280 rooms. The Union Place Hotel, in Union Place, is a large and fashionable establishment. Many other public houses in the eity are very large, well kept, etc.; but their great number precludes their particular description. The United States Hotel, on Fulton Street, occupying the block between Pearl and Water strects, is built of marble, 7 stories high, and was the first of the mammoth hotels. It contains 225 rooms, and cost $\$ 350,000$. Hotel-keeping, as practiced in New York by the best houses, is brought nearer perfection thin in any other city in the world.

Chupches.-Many of the churches of New Tork are very costly edifices, and are among the most splendid ornament of the city. Of these, Trinity Church, on Broadway, opposite Wall Street, is the most distinguished. This edifice, which is the third built upon the same site, was erected $1841-45$, at a cost of about $\$ 400,000$. It is of Gothic architecture, and constructed entirely of brown sandstone. Its dimensions are-length $159 \mathrm{feet}$, width $\$ 4$ feet, height-to the eaves of the clerestory 64 feet, to the apex of the spire 264 feet. The interior presents a very impressive appearance. There are no galleries, and it accommodates only about 900 persons with seats. The church is generally regarded as the finest specimen of pure Gothic architecture in the United States. The ediflces of the Protestant Episcopal Church are generally more elaborale and expensive structures than those of other denominations, which mainly results from the great wealth of the corporation of Trinity Chureh. Of these the most noted are-Grace Church, on Broadway, corner of Tenth Street, a most elaborate structure of white marble, of Gotbic architecture, erected in 1815 , at a cost of $\$ 200,000$; St. George's Church, near Stuyvesant Square, a very large edifice in the Roman style, of brown freestone; St. Paul's Chapel, on Broadway, between Fulton and Vesey streets, a large but plain edifice, of dark brown stone, having a spire of very graceful proportions, 203 feet high; St. John's Chapel, frouting on St. John's Park, an imposing edifice of brown sandstone, in the Corinthian order, erected in 1807 , having a splendid portico of 4 very large Corinthian columns, and lofty spire 215 feet high; St. Thomas' Chureh, on Broadway, corner of Houston Street, of stone, rebuilt 1552, a handsome Gothic edifice; Church of the Holy Communion, on Sixth Avenue and Twentieth Street, erected in 1845 , of well-dressed red granite, one of the most correctly built Gothic church edifices in the Union; Church of the Annunciation, in W. Fourteentl Street, an imposing stone edifice, of gray stone; Calvary Church, Fourth Avenue; Trinity Chapel, in Fifh Avenue besides many others which are costly edifices and very fine specimens of architecture. Of Roman Catholic churches, the best ediflces are-St. Patrick's, the cathedral, in Prince Street, a very spacious church, of stone, in Gothic architecture, erected in 1S15, having an interior of imposing appearance, with arched nave, side aisles, etc.; St. Peter's, in Barclay Street, a very massive edifice of granite, with grand Ionic portico; Church of the Redeemer, in Third Street, a very large structure of brick, erected 1552, and used by a German congregation; St. Bridget's, near Tomp. kins Square, etc.

The First Presbyterian Church, in Fifth Avenue, present a majestic appearance-it is of reddish hewn stone, in full
Gothic architecture, with large buttresses, pinnacles, and tower, and spire 160 feet high. The Church of the Puritans (Cong.), in Union Place, is a splendid edifice of white marble. The Dutch Reformed churehes in Lafilyette Place and University Place are noted for their elegance, Two Unitarian churches, both in Broadway, are fine structures. The First Baptist Church, in Broome Street, is a handsomo Gothic edifice of blue limestone, ereeted in 1841.

The total number of ehurches in New Xork is 250, of which there are 45 Episcopal, 46 Presbyterian, 40 Methorlist, 31 Baptist, 21 Roman Catholic, 20 Dutch Reformed, 10 Congregational, 5 Lutheran, 4. Universalist, 4 Friends', 4 Trimitive Christians, 2 Unitarian, 2 New Jerusalem, 2 Second Adrent, 1 Moravian, and 12 Jews' Synagogues. This table gives nearly the proportion of 1 church for every 2,100 of the popalation. The average number which can be accommodated is probably not more than 800 , giving the aggregate of church accommodation 200,000 seats, or about $\frac{1}{8}$ of the present (1553) population.

Theatres, etc.-The places of amusement in New York aro numerous and well patronized. Of the theatres, the Broadway is the largest and principal one, and chiefly devoted to the regular drama. Niblo's Theatre has a diversity of representations, and is one of the most popular resorts in the city. The Astor Place Opera House is but little used. Metropolitan Hall is a very spacious and magnificent hall, much used for concerts, public meetings, etc, and will aecommodate 4,000 people. Burton's Theatre is a small but very popular resort, chiefly devoted to comedy, etc. Other theatres are, the Bowery and National; besides which the American Museum presents dramatic and comic representations, and contains a collection of figures, curiosities, etc. Among other permanent amusements are the different companies of "Ethiopian Minstrels," etc. ; while the more changing attractions consist of an endless number of panoramas, dioramas, concerts, balls, etc.

Education.-The provisions of the eity for general education are upon a liberal scale. It is believed that there is less attention given to education by the illiterate and poorer classes of the population than in most cities of the United States, but these are chiefly of foreign birth, and are compelled to use their ehildren to gain a livelihood. According to the census of 1550 , the total number of adult people unable to read and write in the city, was 18,807 , being a percentare of 3.65 of the entire population, or 1 in $27 \frac{1}{2}$ persons. of this total, 16,449 were of foreign birth, 1,667 were native negrocs, and 691 were born in America. According to the annual report of the Board of Education for the year 1S5051 , the whole number of schocils within its jurisdiction during the year ending 30th April, 1851, was 207, of which the number belonging to the "Public School Society" was 114, ward schools 72, corporate schools 21, and among which were 17 schools for colored children. The whole number of ehildren taught during the year ending February 1, 1851, was 107,363 ; number during the year $1849-50$ was 102,974 ; while the average attendance during $1850-51$ was 40,055 ; and in $1849-50,35,998$. The following tabular statement exhibits the most important statisties for the schools during four years each ending on February 1st:

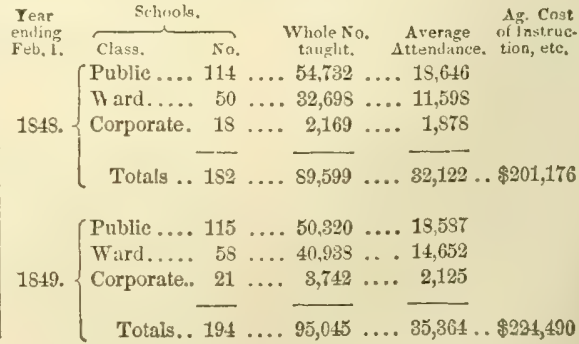




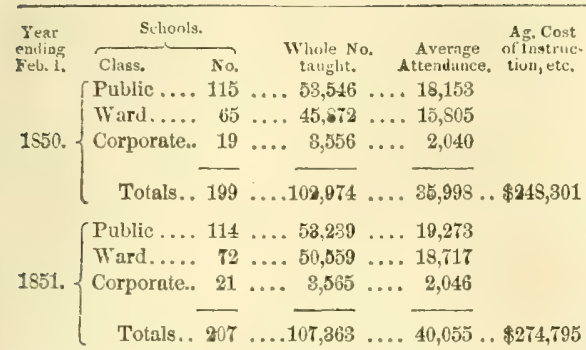

The cost per scholar for 240 day' instruction, etc., in the year ending Feb. 1, 1S4s, was $\$ 626$; ditto in $1 \$ 49, \$ 684$; ditto in $1550, \$ 6 \$ 7$; ditto in $1851, \$ 6 \$ 6$-the average cost fir the four years per scholar, $\$ 658$. By an act of the Legislature in 155:3, the Public School Society is discontinued, and the general district system of the State introduced.

The Free Academy is a public high school of the city, established "for the purpose of extending the benefits of education gratuitously to those who have been pupils in the common schools of the city and county of New York." The project was submitted to the popular vote of the citizens in 1S46, and approved by a very large majority. The building erected for the purpose, and opened January $27,18 \pm 9$, is situated at the corner of Lexington Avenue and Twentythird Street. It is a spacious and elegant structure, built in the Gothic style, after the manner of the Town Halls of the Netherlands. Its dimensions are 125 feet long, 80 feet wide, and 5 stories high. The cost of the building was about $\$ 50,000$, of the lot $\$ 20,000$, and of its furniture and apparatus $\$ 10,000$. It will accommodate about 1,000 scholars. In its construction utility and ornament are admirably combined. The number of instructors in the academy are 11; the number of students admitted at the opening of the institution was $5 \mathrm{~S}$; has since steadily iucreased with successive terms, and now amounts to several hundred. There are in the city a great number of private academies. Of female seminaries, two are very large, and of great reputation-the Putger's Female Institute in Madison Street, and Spingler Institute in Union Place-each of which bave fine stone edifices, are well furnished with apparatus, etc., and have over 500 pupils.

Colleges.-There are in the city 2 collegiate institutions, 8 medical colleges, and 2 theologieal seminaries. Columbia College was founded in 1754 , by royal charter as King's College. In 1784 its name was changed by the legislature to Columbia College. In 1850 it had 7 instruct ors, 1,450 alumni, 111 students, and 17,000 volumes in its library. It is under the direction of the Protestant Episcopal Church. Its buildings are in a beautiful square, a little west from the City Hall, and consist of a large and handsome edifice, 200 feet long by 50 feet wide, with wings at each end etc. The University of the City of New York was founded in 1831. In 1850 it had 11 instructors, 320 alumni, 151 students, and 4,000 volumes in library. Its edifice, on the east side of Washington Square, occupying one block, is the most splendid collegiate building in the United States, and is one of the finest ornaments of the city. It is constructed of white marble, in the Gothic style of Euglish collegiate architecture. Its dimensions are 180 feet long, 100 feet wide, and 4 stories high, flanked with square towers on its 4 corners, which rise one story above the side walls, and having a central bailding which, rising much higher than the sides, is 55 feet broad, and 85 feet deep, crowned with turrets, and in common with the side walls of the whole building, bas an ornamented embattled parapet. This central building is an imitation of King's College Chapel, Cambridge, England, and is used as the principal chapel of the University. It is probably one of the flnest rooms of the kind in America. Connected with the University is a very flourishing grammar school, and the University Medical College.
The College of Physicians and Surgeons is a very flour. ishing medical institution, founded in 1S07. In 185\% it had. 6 professors, 219 students, and 852 graduates. It is loeated at 67 Crosby Street, las a commodious edifice, which contains an extensive medical museum, and library of over 1,000 volumes. The University Medical College was founded in 1837 , and is connected with the University of the City of New York. In 1S50, it had 6 professors, 421 students, and 597 graduates. Its ediflee is a very large, commodinus, and elegant building, recently erected in East Fourteenth Street, near Union Square. The New York Medical College is an institution opened in 1851, and occupying a handsome structure, in East Thirteenth Street, near Fourth Avenue. These schools enjoy the advantages of clinical instruction at the various hospitals.

The General Theological Seminary of the Protestant Episcopal Church was founded in 1817. It occupies an entire square, between Ninth and Tenth arenues, anc? 'Twentieth and Twenty-first streets. Its edifices are two large, handsome buildings of stone, in Gothic architecture. Iu 1950 , it had 5 professors, 64 students, 336 graduates, and 10,000 volumes in its library. It is well endowed, and in a flourishing condition.

The Union Theological Seminary, a Presbyterian institution, was founded in 1836. Its edifice, in University Place, near Washington Square, is a handsome structure of brick. In 1850, it had 5 professors, 106 students, 211 alumui, and 18,000 volumes in its library.

Libraries, etc.-The New York Society Library, established 1754, is the oldest literary association in the city. During the Revolutionary War, its volumes were scattered and lost. On the restoration of peace it was reëstablished. In 1838 and '39, it erected its present edifice, on Broadway, corner of Leonard Street, at an expense, including the ground, of $\$ 120,000$, which is one of the finest library buildings in the Union. It contains about 45,000 volumes, which have been selected with much care. In 1553, it has disposed of its builuing, and will be removed to the upper part of the city. The Mercantile Library Assoeiation, formed in 1820, for merchants' clerks, occupies a large portion of Clinton Hall, on Beekman and Nassau streets which was erected in 1830 for its accommodation, at a cost of $\$ 53,000$. Its library is particulariy rich in periodical literature, and contains about 36,000 volumes.

The New York Historical Society, founded in 1804, have a very valuable library of American history, of 17,000 volumes. and some collections of historical interest. The Society have monthly meetings, and have published numerous volumes of their researches, ete. Their rooms are at the University, but a building for their accommodation is in contemplation. The Geographical and Statistical Society hold monthly meetings, and have commenced the formation of a library. The transactions of this society are published in a "Bulletin," the first number of which was issued in August, 1852. The Apprentices' Library, established in 1820, occupies a large building at 82 Crosby Street, and contains 14,000 volumes. The American Institute have 6,000 volumes; the Typographical Society, 8,000 volumes, free to printers, etc.; the New York Law Institute, in the City Hall, 5.000 volumes; the Mechanics' Institute, 3,000 volumes; besides which, the New York Lyceum and the Lyceum of Natural History have each valuable libraries and other collections.

The Astor Library was founded by John Jacob Astor, who, in his will, appropriated $\$ 400,000$ for "the establishment of a public library upon the most ample scale and liberal character, for general use, free of expense to persons resorting thereto." Of this amount, Mr. Astor directed that a sum, not exceeding $\$ 75,000$, should be expended in the erection of a building, on the $\mathbf{E}$. side of Lafayette Place; that $\$ 120,000$ should be expended in the first outlay for books and other objects; and that the resicue, over $\$ 200,000$, should be permanently invested as a fund for its maintenance and gralual increase. The library edifice, built of 
brown freestone and brick, is a very handsome structure, both in exterior and interior. Its dimensions are-65 feet front, 120 feet in length, and 2 stories in height, 67 feet from the side-walk to the top of the parapet. The interior is most commodiously arranged, and will conveniently contain 100,000 volumes. Orer 60,000 volumes have already been purchased, chiefly in Europe. The library will be opened for publie use in 1558.

Periodical Press,-The whole number of periodicals published in the city in June, 1850, was 125 , of which 14 were issued daily, 8 semi-weekly, 58 weekly, 8 on Sunday, 5 semi-monthly, 30 monthly, and 2 quarterly. Names of dailies: "Herald" (indep.), "Tribune" (whig), "Sun" (neutral), "Courier and Enquirer" (whig), "Journal of Commerce" (neutral), "Express" (whig), "Morning Star" (neutral), "Commercial Advertiser" (whig), "Evening Post" (free soil), "Evening Mirror" (whig), "Merchants' DayBook" (whig), "Globe" (dem.), Deutsche Schnell Post" (German), and "New Yorker Demokrat" (German). Each of these issue other editions weekly or semi-weekly. The dailies, with many of the weeklies, surpass those of any other eity in the Union in their intrinsic merits, size, capital involved, and cireulation. The total circulation of the 8 dailies in 1850 , at each issue, was 154,261 copies, being over one-sixth of all the dailies printed in the United States. The largest circulations attained by different issues, were: Of dailies, the "Sun," 55,000 copies; of weeklies, the "Tribune," 48,000 ; of monttulies, the "American Messenger" (relig.), 211,000.

City Government, Departments, Institutions, Public Works, etc.-The government is vested in the mayor, recorder, and Common Council, which body consists of the two boards of aldermen and assistant aldermen, each composed of 19 members, 1 from each ward. The mayor and aldermen are elected once in 2 years, the assistant aldermen annually. There are 9 executive departments, viz., police; finance, streets, repairs and supplies, streets and lamps, Croton Aqueduct, city inspectors, alms-house, and law. The number of civil courts is 4 , besides 5 ward courts; of criminal courts, 3 , besides 3 police courts.

Expenses of Government -The total expenses of the cits government in each year since 1800 , is exhibited in the following statement of the amount raised each year for city purposes:

Years. Amount. Years. Amount. Years. - Amount.

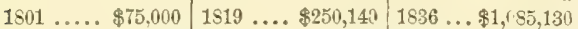

$\begin{array}{lllllllll}1802 & \ldots . & 75,000 & 1520 & \ldots & 270,361 & 1837 & \ldots & 1,260,000\end{array}$

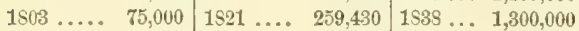

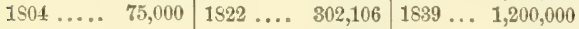

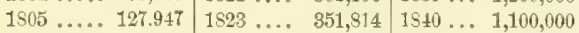

$\begin{array}{llllllll}1506 & \ldots . & 127,815 & 1824 & \ldots . & 353,328 & 1841 \ldots & 1,265,000\end{array}$

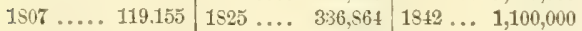

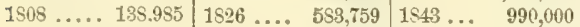

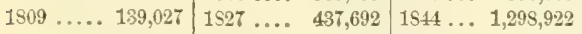

$\begin{array}{lllllllll}1810 & \ldots . & 129,727 & 1528 & \ldots & 485,752 & 1845 & \ldots & 1,389,487\end{array}$

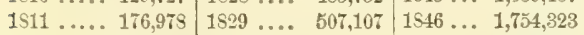

$\begin{array}{lllllllll}1512 & \ldots & 174.920 & 1830 & \ldots & 509,178 & 1817 & \ldots & 1,746,361\end{array}$

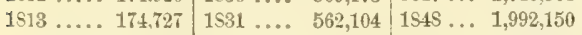

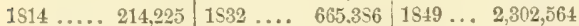

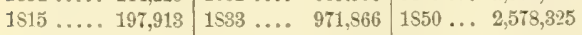

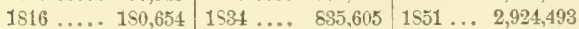

$\begin{array}{lllllllll}1817 & \ldots . & 216,720 & 1835 & \ldots & 965,613 & 1852 \ldots & 3,378,385\end{array}$

$1518 \ldots . .255,741$

The debt of the city, on 1st January, 1815, was:

$$
\begin{aligned}
& \text { Permanent Debt............... \$12,\$s1,750 } 42
\end{aligned}
$$

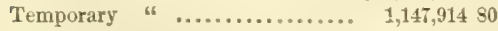

$$
\begin{aligned}
& \text { Total " .............. } \$ 14,029,66522
\end{aligned}
$$

In 1852, according to the message of the mayor, it was: Permanent debt redeemable from sink. find $\$ 14,578,90800$ Temporary debt redeemable from taxation .
The following table exhibits the amount of taxation in decades of years since 1800 , and the comparative increase of taxation and population during the same periods:

\begin{tabular}{|c|c|c|}
\hline \multirow[b]{2}{*}{ Periods. } & \multirow{2}{*}{ Amount. } & Increase of \\
\hline & & Tax. perct. Pup. perct. \\
\hline \multirow{2}{*}{\multicolumn{3}{|c|}{$1801-10 \ldots \ldots \ldots \$ 1,082,656 \ldots \ldots \ldots-\ldots \ldots 59$}} \\
\hline & & $1811-20 \ldots \ldots \ldots .2,112,379 \ldots \ldots \ldots 9 . \ldots \ldots .98$ \\
\hline \multicolumn{3}{|c|}{$1821-30 \ldots \ldots \ldots \quad 4,127,030 \ldots \ldots$} \\
\hline \multicolumn{3}{|c|}{$1831-40 \ldots \ldots \ldots 9.945,694 \ldots \ldots \ldots 141 \ldots \ldots .54$} \\
\hline $341-5$ & $16,367,132$ & .65 \\
\hline
\end{tabular}

Total tax in 50 years, $\$ 38,634,891$; in 1851 and $' 52, \$ 6,302,528$. Total tax in 52 years, $39,937,719$.

The rate of tax, per head, in different years was as fol lows:

Years. Rate. | Yeare. Rate. Years. Rate. Years. :Rate. \begin{tabular}{l|l|l|l|l}
$1500 \ldots$ & $\ldots \$ 1.24$ & $1815 \ldots \$ 2.32$ & $1530 \ldots \$ 2.51$ & $1815 \ldots \$ 3.61$
\end{tabular} \begin{tabular}{l|l|l|l|l|l}
$1805 \ldots .61 .69$ & $1520 \ldots 2.18$ & $1535 \ldots$ & 3.57 & $1550 \ldots 5.00$
\end{tabular} \begin{tabular}{l|l|l|l|}
$1810 \ldots$ & 1.35 & $1825 \ldots 2.03$ & $1840 \ldots 3.52$
\end{tabular}

The amount of corporation property owned by the city in 1851, consisting chiefly of real estate, piers, wharves, etc., as estimated under direction of the controller, was $\$ 19,505,31088$. Of this property, a large portion lying in the upper part of the eity was sold at auetion in 1852. The same estimate gave as the total cost of the Croton Aqueduct, $\$ 14,041,58395$; of the Receiving Reservoir, $\$ 134,00000$; of the Distributing Reservoir, $\$ 152,00000$.

The statisties of the various departments of the city are as follows:

Police Department.-The city is divided into 19 patrol distriets, each ward constituting one, which are patrolled by a total force of 941 policemen, a veraging 50 to each ward.

Criminal Statistics.-The statisties of the criminal courts of the city for the years 1851-52 are as follows :

Whole number of trials $\quad 1852 . \quad 1851$.

In the Court of Oyer and Terminer........ $14 \ldots .14$

In the Court of General Sessions............ $447 \ldots 417$

In the Court of Special Sessions............2,405 . . 2,079

To.al...................2,866 .. 2,510

The total number of convictions in these courts during the year 1851 was 2,494 ; of which 1,530 were for petit larceny ; for assault and battery, 703 ; burglary, 47 ; grand larceny, 105 ; forgery 17 , ete. During 1851 , the number committed to the city prison was 16,522 , making, with 221 remaining on January $1,16,513$. Of these, 12,955 were discharged, 3,390 sent $\omega$ the penitentiary, 192 to the State prison, and 3 were executed. The statistics of the penltentiary on Blackwell's Island for the year 1.852 were as follows:

Remaining in penitentiary Dec. $31,1851 \ldots . . .$.

Received during the year 1852, males........2,017 fermales.......2,843 4,365

Total......................

Discharged, males......................1,918

females.....................2,290 4,203

Remaining in penitentiary Dec. $31,1852 \ldots . . . . \quad 1,041$

Alms-Honse Department.-This department has charge of all the city institutions for the relief of the poor, etc.; the penitentiary, prisons, work-house, asylums, hospitals, ete. The prineipal buildings on Blackwell's Island are very large, and contain several thousand inmates. The charge of these institutions is committed to a board of 10 governors. The real estate occupied by this department was valued in 1851 at $\$ 1,200,000$

The combined statistics of the total expenses of the city hospitals, asylums, nurseries, and prisons for the year 1850 , were as follows: 
Institutions,

Alms-IIouse

Total Expenses.

$\ldots \ldots \ldots, 10838$

Bellevie Hospital. . . . . . . . . . . . ........... 45,27913

City Prison....................... 13,802 81

Colored Home................... 7,66458

Colored Orphan Asylum.............. 2,607 13

Lunatic Asylum ..................... 31,04411

Nursery ..................... 35,206 53

Nursery Hospital................... 14,040 93

Office........................... 23,127 69

Out-Door Poor ..................... 60.507 04

Penitentiary...................... 69,895 52

Penitentiary Hospital................ 8,91762

Police, Office of the Chief of ........... 5501

Prison, 2d District..................... 1,695 98

Prison, 3d District .................... 1,369 44

Randall's Island.................... 10,507 83

Small Pox Hospital. .................... 64355

Storehouse, Blackwell's Island......... 29,45 68

Storehouse, Pandall's Island.............. 10,S89 75

Work-House.................... 11,430 35

New Work-House Building........... 2,455 40

Total monthly cost of supplies, $\$ 406,65260$.

Of 4 of these institutions, the following are some of their statistics for the year 1852 .

$$
\begin{aligned}
& \text { NUMBER OF INMATES. } \\
& \text { Remaining Admitted Discharged Remaining } \\
& \text { Dec. } 31,1851 \text {. } \\
& \text { in } 1852 . \quad \text { and died. Dec, } 31,18,2 .
\end{aligned}
$$

Bellevue Hospital. $609 \ldots . .5,089 \ldots .5,182 \ldots . .516$

Alms-House .....- .... - ... - ..... 1,267

Lunatic Asylum.. $517 \ldots \ldots \quad 495 \ldots \ldots .485 \ldots \ldots .527$

Nursery . . . . . . 1,419 .... 1,773 . . . 1,881 . . . . 1,811

of the Alms-House inmates-1,022 were born in foreign countries, and 245 in the United States; 653 were males, $61+$ females. There are three large dispensaries, whose free charitable ministrations have for many years been of very great assistance in relieving the medical wants of the poorer classes. According to recent police returns, 18,450 persons were found living in 3.742 underground basements. Nearly one-third of these persons were classified as dirty in person, and their basements of the same description.

Croton Aqueduct Department.-The Croton Aqueduct was commenced in 1837, and its completion celebrated Oct. 14th, 1842. It is $40 \frac{2}{2} \mathrm{~m}$. long, commeneing at the Croton $\mathrm{r}_{\mathrm{og}}$ in Westchester co., $5 \mathrm{~m}$. from Hudson r. The dam, built of stone and cement, is 250 feet long, 40 feet high, 70 feet thick at its base, and 7 at its top. The pond thus ereated is $5 \mathrm{~m}$. long, covering 400 acres, and estimated to contain $500,000,000$ gallons of water. The aqueduct, built of stone, brick, and cement, and arched over and under, is 6 feet 9 inches wide at its bottom, 7 feet 5 inches wide at the top, and 8 feet 5 inches high, has a descent of $13 \frac{1}{3}$ inches per $m_{*}$, and will discharge $60,000,000$ gallons in 24 hours. It crosses Harlem r. on a magnificent bridge of stone, 1,450 feet long, supported by 14 stone piers, and which cost nearly $\$ 1,000,000$. The receiving reservoir is between Sixth and Seventh avenues, and Seventy-ninth and Eighty-sixth streets, covering 35 acres, containing $150,000,000$ gallons of water, and cost $\$ 134,000$. The distributing reservoir, on Fifth Avenue and Forty-second Street, is a most massive structure, is 2,120 feet square, covering over 4 acres, containing $25,000,000$ gallons, and cost $\$ 152,000$. Thence the water is distributed over the city in iron pipes, of which, in $1552,215 \mathrm{~m}$. length had been laid. The daily consumption is about $30,000,000$ gallons. The supply is considerud adequate for three or four times the present population of the city. In 1851 the total cost of the Croton Aqueduct and its connections was $\$ 14,041,5 \$ 1$. Its revenue now amounts to nearly $\$ 500,000$, and is steadily increasing.

Fire Department.-Engine companies in 1851, 49, with 34 engines, 49 hose companies, with earriages, and 58,500 feet of hose, 8 hook and ladder companies, 3 hydrant companies; whole number of firemen 2,172 . The real estate used by the Fire Department was valued, in 1951 , at $\$ 151,800$. Statistics of fires in 1552 -total number, 325 ; of false alarms, 193; loss of buildings by flre, $\$ 223,428$; loss on stock, $\$ 1,359,603$; number of persons who lost their lives by fires, 13

MLarkets, ete.--There are 14 principal markets, the buildings of which occupy large areas of ground, bnt are utterly unworthy of the city, occupying real estate, valued in 1851 at $\$ 1,109,000$. Of these, the largest and most important is Washington Market, in Washington Street, fronting on the Hudson River. Its business is chiefly whole sale, and more extersive than any other in the United States. The following are approximate estimates of its aggregate yearly sales:

Meat trade ..... \$5,000,000| Poultry tracle.... $\$ 1.000,000$ Fruit " ..... 2,500,000 Vegretable" ... 17,500,000 Butter " .... 450,000 Eggg " Honey " ..... 9,000 Nut " $\quad$ *. 15,000 Fish "6 ......

Total yearly sales of all kinds of produce....\$2\$,452,000.

The other markets are more occupied with the retail trade.

The following statistics of the cattle trade, for the years 1851 and '52, give only an approximate statement of the consumption of meat in the city.

Sales of beeves, etc., in the New Fork cattle market, in 1851 and 'כ2:

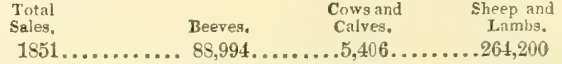

$1852 \ldots \ldots \ldots \ldots 105,225 \ldots \ldots \ldots 5,658 \ldots \ldots \ldots 323,000$

Licenses.-Total number of licensed omnibuses, Feb. 1, 1550,425 , paying $\$ 7,630$; number of same in 1852,30 lines, having a full number of 800 stages, of which 445 licenses pay $\$ 12,380$; total number of licensed hacks in 1850,431 , paying \$2,183. Of other principal licenses, the following is a summary for 1852 : Cartmen, 4,233 ; dirt carts, 1,460 ; public porters, 245 , ete

Summary of tavern licenses daring 1850-52, the years ending Dec. 31 ; and of liquor licenses during $1850-52$, the years ending May 1 ; also the number of licenses granted in 1552, after May 1; and the total number of places where rum is sold, as reported by the police:

1850. 1851. 1852. After May 1, Sold Tavern licenses $.4,528 \ldots .5,047 \ldots 5,980 \ldots-\ldots$ - ... Liquor $\quad 66 \quad \ldots 3,956 \ldots .4,553 \ldots 5,190 \ldots .5,796 \ldots 6,309$

City Railroads.-The Fourth Avenue R. R., belonging to the Harlem $\mathrm{R}$. R., has been in operation for several years. During 11 hours of the day, ears run every 7 minutes from the Astor House to Twenty-seventh Street-fare 6 cents. The Sixth Avenue R. R. went into operation on Aug. 11, 1S52. Cars are run every 4 minutes for 12 hours of the day, from Vesey Street to Forty-fourth Street-fare 5 cents. An immense number of persons, averaging, in 1852 , over 10,000 daily, use these cars, as also those of Eighth Avenue $R . R$. The receipts from its opening to Dec. 1,1852 , were $\$ 40,451$. The Eighth A venue R. R.went into operation 31st Ang:, 1852. The cars run every 4 minutes during the greater part of the day and evenings, from Vesey to Fify-first streets-fare 5 cents. The daily number of passengers, in 1852, averaged over 11,000 . The receipts of the road, from its opening, during the year 1552 ( 4 months 1 day) were $\$ 59,500$. In 1853, branches of the above roads are extended through Canal Street to Broadway. Other avenue railroads are in rapid construction, of which the principal are on the Second and Ninth avenues, extending to the lower part of the city.

Benerolent Institutions.-The charitable institutions, not under the charge of the city corporation, but established and sustained by the sympathetie liberality of associations and the citizens, are highly creditable to the character of New York. Of these, the New York Hospital, in Broadway, opposite Pearl Street, is among the principal. It was 
founded in 17\%1. It consists of 3 large stone edifices, finely located in a beautiful, spacions yard, very commodious, and well fitted up, and will accommodate 400 patients. It has a large annual revenue, but which is annually expended. The total number of patients admitted from December 81 , 1829 , to December 31,1852 , was 54,076 . The number remaining December 31, 1851, was 301; number of admissions during $1552,3,418$; number discharged in $1852,3,407$; number remaining December $31,1852,342$. It is the only general hospital of any note in the eity.

The Blonmingdale Asylum for the Insane, Iocated at Bloomingdale, near the Hudson river, between Tenth and Eleven!h avenues, One Hundred and Seventeenth and One Hundred and Twentieth streets, 7 miles from the City Hall, is a branch of the New York Hospital, which went into operation in June, 1821. There are three very large and commodious buildings of hewn stone, with 40 aeres of ground beautifully laid out into pleasure-grounds, gardens, etc. The statistics of this institution for the year $\mathbf{1 8 5 2}$ are as follows:

Number of patients in Asylum Jan. 1, 1852....

Admitted during the year....................

Discharged "

Died

Number of patients in Asylum Dec. 31, 185̌2.....

Receipts during the year................... $\$ 31,1374$ Expenditures ..............\$30,251 61

Balance in treasury...................... \$\$s2 $\$ 6$

Value of products of the farm in $1852 \ldots \ldots \ldots \ldots . \$ 5,26100$

The total number of patients treated since the opening of the Asylum approximates 5,000.

The New York Institution for the Instruction of the Deaf and Dumb is located between Fourth and Fifth avenues, and Forty-ninth and Fiftieth streets, $3 \frac{1}{2}$ miles from the City Mall. The principal edifice, occupied since 1829 , is a yery hondsome structure, 5 stories high, 110 feet long, and 60 feet wide. The whole number of patients at the institution in 1852 was 308 ; number discharged during the year, 44; number remaining Dec. $31,1852,259$; of whom 143 were males and 116 females. These were supported as follows: by the State of New York, 182; by the eity of New York, 16; by the State of New Jersey, 13; by their friends, 31; by the Institution, 16; by the Commissioners of Emigration, 1. Expenses in $1852, \$ 43,000$; receipts, $\$ 41,000$.

The Institution for the Blind, on Ninth Avenue, Thirtythird and Thirty-fourth streets, is a large and splendid edifice of granite, in Gothic style, and one of the finest ornamenis of the cily. The total number of inmates during $1 S 52$ was 150 ; number remaining Dec. 31, 1552, 103.

Orphan Asylums.-The New York Orphan Asylum, situated at Bloomingdale, near Hudson river, on Seventy-first Street, $4 \mathrm{~g} \mathrm{~m}$. from City Hall, is a handsome building of stone, in Gothic sty!e, 120 by 60 feet, connected with 9 acres of ground, and contains several hundred children. The Protestant Half-Orphan Asylum is in Sixth Avenue, between Tenth and Eleventh streets. The Colored Orphan Asylum, on Fifth Avenue, between Forty-second and Fortythird streets, is a large institution in flourishing condition. Number of ehildren $J_{a n .} 1,1852,201$; admitted in 1852 , 57 ; remaining Dec. $31,1852,207$-boys, 130 ; girls, 77 ; total number admitted since opening of the asylum, 631 ; receipts and expense's during 1552 , ench about $\$ 16,000$. The Roman Catholic Orphan Asylum, in Prince Street, near the Cathedral, is a very large institution, under charge of the Sisters of Charity. On Dee. 31,1852 , it contained about 700 children -300 girls and 400 boys. Expenses of the year, $\$ 25,000$.

Other asylums are, the Home for Aged Indigent Females, having. in 1552, 87 inmates; expenses and receipts in same year, about $\$ 4,000$. Asylum for Lying-in Women, which, in 1852 , accommodated 141 women in conflnement, etc; the Colored Home, Magdalen, Friendless Boys, and others.

There are five dispensaries, which mnually afford medieal aid to vast numbers of the population. Of these the 558
New York Dispensary was established in 1790 , the Northern in 1527 , the Eastern in 1830 , the Demilt in 1851, the Northwestern in 1552. The aggregate applications to the first three, in 1852 , for medical aid, was 79,379 ; number of raccinations, 6,816 .

Institutions for Seamen.-On Staten Island are three large and most excellent institutions for seamen; viz., the Marine Hospital at Tompkinsville, near the Quarantine ground, consisting of 3 buildings; the Seaman's Retreat; and the Sailor's Snug Harbor, on the N. side of the island, which provides a home for aged and decayed seamen, and possesses an estate, bequeathed by Capt. Randall, now valued at $\$ 1,000,000$.

Religious Societies.-New York contains many of the central offices and publication establishments of those great religious denominations and societies which embrace in their labors the whole nation. Some of their printing offices are among the largest in the city-viz., American Bible Society, which in $15 \overline{2} 2$ erected a splendid edifice in Fourth Avenue, cor. Ninth Street, consisting of an entire block, six stories high: Metholist Book Concern in Mulberry Street; American Tract Society in Nassau Street, and many others. The anniversaries of these societies are celebrated during the second week in May, and are oceasions of much interest.

Population.-The following statistics exhibit the amount of the population of New York at various intervals since its foundation, as furnished by the enumerations and estimates of the earlier period, and later by the official returns of the census, periodically taken under the authority of the State, and of the United States, together with the numerical increase between the consecutive periods with the actual ratio for such times, and the corresponding ratio for decennial periods, where the interval is more or less than ten years:

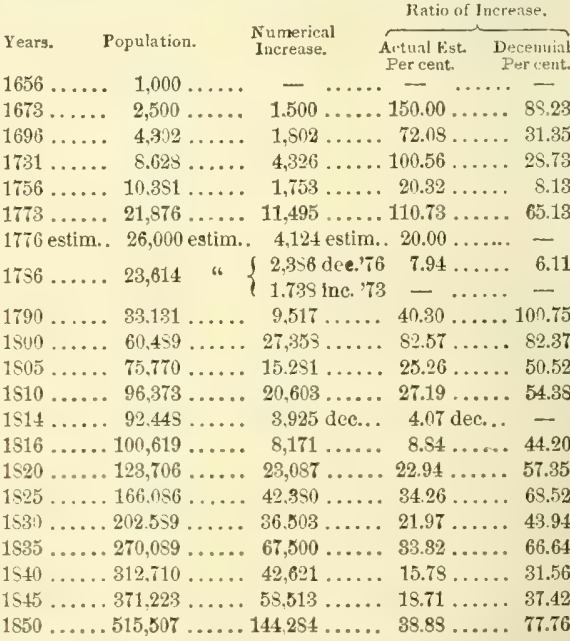

The average decennial increase from 1656 to 1550 , is about 40 per cent., which has been steadily ahead, except during the two periods of war with Great Britain. The ratio of increase in other periods has been materially checked by the following causes: French and Indian war of 1659-97; yellow fever in 1741-2; the "negro plot" of the same years; great fire of 1741 ; and the French wars of $1744-48$, and 1754. There has been no period of ten years' length, since 1756 , in which the population has not increased.

POPULATION BY PERIODS OF GOVERNMENT.

Perinds, Pop, at close, Increase. Ratio, Dec, equit, Dutch ...1613-1664 ... 1,700... 1.700... - .... -

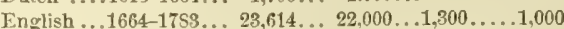
American .1783-1850 . .515,507 ..491, $993 \ldots 2,283 \ldots . .3,411$ 
BEFORE AND AFTER TIE UNITED STATES CONSTITUTION. Periods. Pap. at close. Increase, Ratio. Cent. equiv. Before ....1613-1790, . 33,181 . 33,131 . _ _ ... -

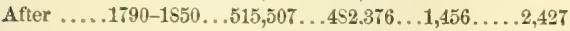

The population of the city has doubled, since 1656 , nine times, or in each average period of $21 \frac{1}{2}$ years ; since $179 \%$, four times, or in each 15 years; since 1800, thres times, or in each arerage period of $16 \frac{9}{8}$ years.

Comparison of the growth of the cities of New York, Philadelphia, Boston, and Baltimore, since 1790:

Years. N. York. Philad. Boston, Balt, Three N. Y's per 1790 . 33,131 . 42,520 . 18,038 . 13.503 . 74,061 ...44.7 $1800 \ldots 60,489 \ldots 81,005 \ldots 24,297 \ldots 26.514 \ldots 181,816 \ldots .45 .9$ $1310 \ldots 96,373 \ldots 111,210 \ldots 35,250 \ldots 46,455 \ldots 192,915 \ldots \ldots . .50 .0$ 1820 . 123,706 . . 137,097 . 43.298 _ .62.733 . 243,133 . . . .51.0 $1830 \ldots 202,5 \$ 9$.188,961 . 61,392 . $\$ 80,620 \ldots 330,973 \ldots . .61 .2$

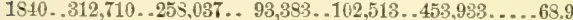

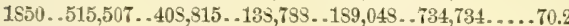

By the census of 1850 , New York exceeds in population fourteen of the States of the Union.

Bfortality.-The annual ratio of deaths to the population has for several years been 3 per cent., which large proportion is to be attributed in a very great degree to the foreign immigration, the alms-houses, etc., and not to the natural unhealthiness of the city.

Wealth,-The following statements exhibit the valuation of property in the city from 1800 to 1852 inclusive. The first statement exhibits the total valuation until 1825; the second table, from 1825-52 inclusive, distinguishes each class of estate :

\begin{tabular}{|c|c|c|c|}
\hline & Total & & \\
\hline $\begin{array}{l}\text { Years. } \\
1800\end{array}$ & $\begin{array}{r}\text { Valuation, } \\
\$ 24.4 \$ 6.370\end{array}$ & $\begin{array}{l}\text { Years, } \\
1515\end{array}$ & $\begin{array}{r}\text { Valuation, } \\
\$ \$ 1,636042\end{array}$ \\
\hline 150.5 & ..... 25,645.567 & 1816 & $82,074,201$ \\
\hline 1806 & .. $26.529,630$ & 1817 & $\ldots \ldots \ldots \ldots .78,595,725$ \\
\hline a & .. 24,9 & $1 \mathrm{~S} 1 \mathrm{~s}$ & $\ldots \ldots \ldots \ldots s 0,2$ \\
\hline 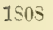 & $\ldots 25$ & 1819 & $\ldots \ldots \ldots \ldots \ldots \tau 0,1$ \\
\hline 1809 & - 21,78 & 1520 & . . 69.5 \\
\hline 5 & 26,43 & 1521. & . . $6 \varsigma, 2 \$ 2,070$ \\
\hline 1 & $\ldots \ldots \ldots \ldots 26,0$ & 1822 & $\ldots \ldots \ldots \ldots, 71,28$ \\
\hline$\$ 1$ & .. 26,2 & 1828 & $\ldots \ldots \ldots \ldots 70,940,820$ \\
\hline $\mathrm{Si3}$ & .. $27.640,230$ & 1824. & $\ldots \ldots \ldots \ldots 883,075,67$ \\
\hline & 80001 & & \\
\hline
\end{tabular}
$1825 . . . \ldots \ldots . \$ 58,435, \$ 95 \ldots . \$ 12,734,131 \ldots . . \$ 101,160.046$ 1926....... 64.912,851 ... $42,534.931 \ldots . .107 .477,781$ $.1827 \ldots \ldots .72,617.770 \ldots .39,594,156 \ldots 112211.926$ 1828....... $77,139,850 \ldots 76.879,653 \ldots . \quad 114,019,583$

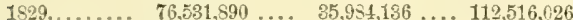
$1830 \ldots \ldots \ldots . \quad 87,603,550 \ldots . \quad 37,684,939$.... $126,235,518$

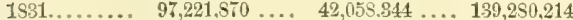
$1882 \ldots \ldots \ldots .104,042,405 \ldots . \quad 42,260,213 \ldots \ldots 146,302,618$

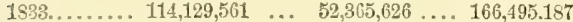
$1834 \ldots \ldots . .123 .249 .280 \ldots 6.63,299,231 \ldots .186 .548,511$ $1835 \ldots \ldots \ldots \quad 143.732,452 \ldots .74 .981 .278 \ldots .218 .723 .703$ $1836 \ldots \ldots \ldots 233.743 .303 \ldots .75,758,617 \ldots . \quad 309,501,920$ $1837 \ldots \ldots \ldots \quad 194,450,109 \ldots 6 \quad 67,297,241 \ldots 263,747,350$ 1835....... 194549,359 ... $69,609,552 \ldots .264,152,941$ $1839 \ldots \ldots \ldots \quad 196,778,131 \ldots .70,014,796 \ldots 266,759,230$ $1849 \ldots \ldots .187,121.464 \ldots 6 \quad 65,721,699 \ldots 6252,843.163$

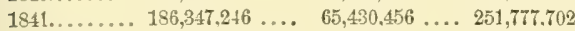
$1842 \ldots \ldots \ldots 176.512,342 \ldots .61,294.559 \ldots 237.806,901$ $1543 \ldots \ldots \ldots .6164,950,515 \ldots .63,046,576 \quad \ldots . \quad 227.997,091$ 1844 ....... $171,936,591 \ldots .64,023,456 \ldots .235,960,047$ $1845 \ldots \ldots \ldots 177.160,790 \ldots 6 \quad 62,777.525 \quad \ldots .239,935,318$ $1846 \ldots . \ldots .183 .490 .934 \ldots 61.471 .571 \ldots 244.952,505$ $1817 \ldots \ldots \ldots 187.311 .856 \ldots .59 .537,917 \ldots .247,152.806$ 1848. . . . . 193.027 576 ... $61.161 .451 \ldots .254,192,027$ $1819 \ldots \ldots \ldots .197 .761 .919 \ldots .58 .455 .174 \ldots .256 .217,098$ $1850 \ldots \ldots \ldots 207,146,173 \ldots .79 .939,240 \ldots 286,055.416$ 1551....... 227.013 $556 \ldots .93,094.502 \ldots .320 .108 .35 \mathrm{~S}$ $1852 \ldots \ldots .252,186,753 \ldots 95,520,043 \ldots 851,706,796$
Tho amount of wealth per head at the different periods named, has been as follows:

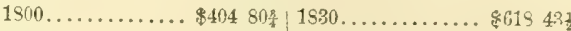
$1810 \ldots \ldots \ldots \ldots \ldots .27431 \frac{7}{8} \quad 1840 \ldots \ldots \ldots \ldots$ sin 11

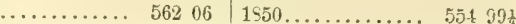

In 1850,2 estates were assessed for over $\$ 1,000,000$. Exclusive of incorporated companies, T estates on $\$ 500,000$ and upward. The several properties above $\$ 17,500$ were:

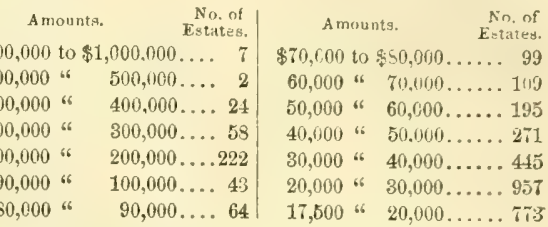

The proportionate increase of population and wealth in New Tork, in each consecutive period of 10 years, since 1800 , is as follows:

Increase.

Increase.

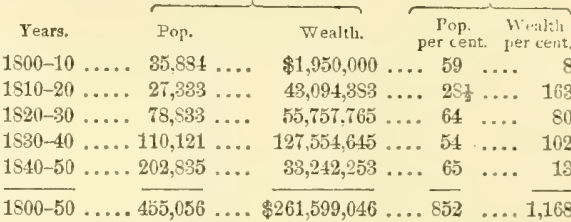

Iristorical Sketch.--The history of New Fork city is direclly divided into three periods, during which it has belonged to the three governments, Holland, England, and the State of New York, viz., 1609-1664, 1664-17S3, 1783-1S53.

Dutch period: Sept. 3, 1609, Hendrik Hudson discorered the island; 1613 , the settlement of "New Amsterdam" was commenced; 1621, the Dutch West India Company commenced operations; 1626 , the island was purchased for $\$ 24$; 1652, New Amsterdam was incorporated, and the government passed from the West India Company into the hands of 2 burgomasters and 5 assistants called schepens, and 1 schout or sheriff; Sept., 1664, the English took the province.

English period: 1664, name changed to New Iork; July, 1673 , retaken by the Duth and called "New Orange," and held by them 1 year; 1686, James II. abolished the representative system, etc.; 16s9, Leisler insurrection; 1690, a colonial congress assembled here; Nov., 1696, city lighted by ordinance; 1711, slave market established in Wall Street; 1720,2 per cent. laid on European imports; 1725 , "New York Gazette" appeared: 1730, enlarged charter granted by Gov. Montgomerie; 1732, stage routes established to Boston and Philadelphia, traversed once a month; Sept. 21 , 1776,493 houses consumed by fire, $\frac{1}{3}$ of whole eity : 1711-2, "Negro plot" and yellow fever; 1765 , a colonial congress assembled here; 1776-1783, Revolution; Nov. 25, 1783, eracuation of British army and end of English rule

American period: April 39, 1759. Washington inaugus ated first president at Federal Hall, on site of present custom-house; 1798 , yellow fever, 2,086 deaths, which returned in $15 \cup 3$ and in $15 \times 5$, and again in 152:2; 1 s0. 5 . Fulton's steamboat on Hudson river; 1811, large fire: 1812-15, war with Great Britain, which suspended all commerce; $1 \leqslant 26$, Erie Canal completed and great celebration; 15:32, Asiatic Cholera-4,360 deaths: Dec, 16, 1835, conflagration of 645 buildings, total loss $\$ 25,000,000: 183 \overline{7}$, commercial revulsion; Oct. 14, 1542, celebration of completion of Croton Aqueduet; 1545, conflagration of 546 buildings-loss $\$ 6,00 !, 000 ; 1849$, cholera; 1850, Collins' Steamers to Liverpool; MaJ, 1551, Frie R. R. completed to Dunkirk; 1852, avenue railroads; 1853 , success of the Eriesson Caloric Steanship ; city charter reformed. 
The environs of the eity, though physieally separated, and of themselves large cities (separately described in their alphabetical order), are, to all intents and purposes, part of the metropolis, originating from, and dependent upon, its prosperity. See Brooxlyn, WilltamsBupg, etc.

Of the entire metropolitan district, now the first in the New World, it may summarily be said, that the past is indicative of its future, promising to increase with each succeeding year its permanent prosperity, until it surpasses all cities, ancient and modern.

NeW YoRK, p. v., Sumter county, Ala.: 116 miles W Montgomery.

NEW York (of the Pacific), p. v., Contra Costa county, Calif.: $26 \mathrm{~m}$. E. by \$. Vallejo, at junction of Sacramento and San Joaquin rivers, which here form the bay of Suisun. Vessels of large size can go up from the sea to this point.

NEW YokK, p. 0., Montgomery co., Tenn. : 40 m. N. W. Nashville.

New York Mrus, p. v., Oneida county, $N . T .: 90 \mathrm{~m}$. W. N. W. Albany, on Sadaquada er., $2 \mathrm{~m}$. S. Whitesboro', noted for its extensive cotton factories, etc.

NEY, p. o., Deflance co., Ohio: $120 \mathrm{~m}$. N. W. Columbus.

NFx, p. o., De Kalb co., Ill.: $163 \mathrm{~m}$. N. by E. Springfield.

Niagara county, $N . Y$. Situate W., and contains 484 sq. m. Drained by Tonawanda, Tusearora, Johnson's, Howell's, and Cayuga creeks. Surface various, rising in gradual swells from the $\mathrm{N}$. to the ridge in the interior of the county, and thence declining gently toward Tonawanda $\mathrm{cr}$. -in general it may be said to be level; soil fertile and easy of tillage, but best suited for pasturage-in some portions it is productive in grain, fruits, etc. Chief productions wheat, Indian corn, and potatoes; it is also a fine dairy county. It contains many minerals and abounds in fossils; it also has some sulphur springs. This county, in connection with Niagara district of Canada, contains the celebrated cataract of Niagara. Farms 3,143; manuf. 336; dwell. 7,435, and pop.-wh. 41.973, fr. col. 301-total 42,274. Capital: Lockport. Public Works: Rochester, Lnckport, and Niagara Falls R. R.; Buffalo and Niagara Falls R. R.; Buffalo and Lockport R. R.; Canandaigua and Niagara Falls R. R.; Erie Canal, ete.

Niagara, t., Niagara co., $N$. $Y$.: on E. side of Niagara $r$., $270 \mathrm{~m}$. W. by $\mathrm{N}$. Albany. This t. is situated on the Mountain Ridge, and declines toward the S. Surface undulating; soil calcareous gravelly loam, underlaid by lime and gypsum. Drained by a few small streams, and on its W. side by Niagara river. Attached to this $\mathrm{t}$, are Goat Island, and other islands, and the American division of Niagara Falls. Fop. of t. 1,951.

Niagara river and falls, $N . Y_{.}:$this river, connecting Lake Erie with Lake Ontario, is $36 \mathrm{~m}$. long, and its general course N. N. W. Commencing at Buffalo, it is there $\mathrm{m}$. wide, from 40 to 60 feet deep, and flows with a current of $4 \mathrm{~m}$. per hour. Three miles below Buffalo, at Black Rock, it furnishes water to the Erie Canal, by the State pier built in the channel, upward of a mile in length, 50 feet wide at its base, 30 feet wide at its top, and cost $\$ 300,000$. From Black Rock is a steam ferry to Waterloo, Canada. The river now gradually widens in its deseent toward Grand Island, which it meets $6 \mathrm{~m}$. below Buffalo, and passes with its main channel on the W. side. Grand Island is $12 \mathrm{~m}$. long, in its widest part $6 \mathrm{~m}$. wide, contains 17,381 acres, belongs to New York, etc. (See Grand island.) Below Grand Island, in the main channel, near the Canadian side, is Navy Island, containing 304 acres, which belongs to Canada, and was occupied by the insurgents in 1537-8, under Mackenzie. Having passed these islands, $3 \mathrm{~m}$. above the falls, the divided branches of the river re-unite, flowing with rapid current, $2 \mathrm{~m}$. broad, but narrowing as it approsches the falls. About $\frac{1}{3} \mathrm{~m}$. above the falls commence the Great Rapids, which, before reaching the falls, have a descent of 52 feet, presenting a grand appearance. At the falls the river is $\frac{m}{4} \mathrm{~m}$. wide, but is divided by Goat Island, which is 590 f $\mathrm{m}$. long, $\frac{1}{4} \mathrm{~m}$. wide, contains 71 acres, and extends to the brow of the precipice, where it presents a mass of rocks, nearly perpendicular, extending from the brink to the bote tom of the fall. Owing to the declivity of the bed of the river before reaching the fall, being greater upon the Canadian side than on the American, to a bend in the river, and to Goat Island being nearer to the American than the Canadian side, by far the greater body of water falls on the Canadian side of Goat Island, or, as it is generally called, Horseshne Fall. The following table exhibits in comprehensive form the measurements of the

FALIS OF NIAGARA.

Extent of the Horseshoe Falls on the Canadian side................................ 2,200 feet.

Breadth of Goat Island, between it and the American side........................ 980 " Breadth of falls on the American side........ 1,140 " The whole extent, or more than $\frac{8}{\alpha}$ mile ......... 4,321 " Height of the Horseshoe Falls ............... 150 " Height of the American Falls ............. 160 "

Extent of the Cave beneath the Horseshoe Falls from the outside of the Termination Rock... 153 " Height of the Cave is estimated by Capt. Hall at 100 " The estimated quantity of water discharged over the falls is calculated at $48,524,000$ cubic feet, or $113,510,000$ gallons per minute.

Depth of the river above the falls as near as can

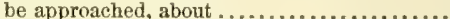
Breadth of the river at the ferry ............. 1,170

In the rapids above the American Falls, about midway between the shore and Goat Island, is Bath Island, 24 rods in length, and containing about 2 acres. From the shore to this island is a bridge 28 rods long, crossing the rapids 64 rods above the falls. From Bath Island, another bridge, 16 rods long, extends to Goat Island. On Goat Island fine views are obtained of both falls. At the $\mathrm{S}$. W. angle of this island, on some rocks near the verge of the precipice, and which are reached by a footway called Terrapin Bridge, extending from rock to rock, there has been erected a stone tower, 45 feet high; upon its top is an open wooden gallery, whence is afforded a direct view of the abyss below. From the front of Goat Islund there is a descent (155 feet) to the bottom of the falls by a covered staircase (erected by the Iate Nicholas Biddle, Esq., of Philadelphia): From the foot of this staircase there are paths for some distance behind each of the falls. Behind the Central Fall is the celebrated Cave of the Winds, formed by a recess in the wall of the precipice, 153 feet long, 50 feet wide, and 100 feet high. The best and most comprehensive view of the entire falls is obtained on the Canada side at Table Rock. On the American side a descent is afforded by cars on an inclined plane to the shore below, whence a steam ferry boat named Maid of the Mist, plies over these foaming depths near the falls, to the Canada side, where a winding carriage road is constructed to the heights above. The width of the river is here $\frac{1}{4}$ mile, and its depth 250 feet. The banks of the river below the falls have a gradual ascent for $6 \mathrm{~m}$., from which, and other facts, many suppose that the falls have, in the course of ages, receded from below to their present position. A mile and a half from the falls is the wire suspension bridge, 800 feet long, 40 feet wide, and 230 feet above the water. It is supported by 16 wire cables, 1,100 feet long, and upward of 12 inches in circumference, having a strength equal to 6,500 tons tension strain. The Whirlpool, $3 \mathrm{~m}$. beIow the falls, is produced by the projection of a rocky promontory, and in it logs and trees are frequently whirled around for weeks in succession. One mile below this whirlpool is an excavation from the side of the bank, containing about 2 aeres, and 150 feet deep, ealled the Devil's Hole. The river, in its descent to Lewiston, $7 \mathrm{~m}$., falls 104 feet, and flows with great velocity. Near Lewiston the bank is 310 feet high, but below it diminishes to 25 or 30 feet, and 
holds this height to Lake Ontario. The river falls 2 feet in its descent from Lewiston to Lake Ontario, a distance of $7 \mathrm{~m}$., making a total descent of 334 feet in its course of $36 \mathrm{~m}$. from Lake Erie to Lake Ontario. At its mouth it is defended on the American side by Fort Niagara, famous in history, and garrisoned by U. S. artillery, and on the Canadian side by Fort George. Here also is Fort Niagara Lighthouse. See Lignt-Houses.

Nlagara Falis, p. v., Niagara co., N. Y.: on E. bank of Niagara r., at the falls, $270 \mathrm{~m}$. W. by $\mathrm{N}$. Albany. This beautiful and thriving $\mathrm{v}$. derives its business and importance mainly from its proximity to the falls and its accessibility by railroads-from Buffalo, $22 \mathrm{~m}$., and from Lockport, $21 \mathrm{~m}$. A railroad to Lewiston is also in construction. Here are several very large hotels, accommodating in the best style thousands of visitors annually. In the $v$. are 3 churches, 2 academies, and a number of mills using water-power from Niagara river. Pop. about 1,000 .

Niaxtio, sta., New London co., Conn.: on New Haven and New London R. R., $5 \mathrm{~m}$. W. by S. from New London.

Nicсотт00, p. V., Arkansas county, Ark. : on S. bank of Arkansas r., 60 m. S. S. E. Little Rock.

Nrcholas county, $\bar{K} y$. Situate toward the N. E., and contains 281 sq. m. Drained by Licking $r$. and its branches. Surface rolling; soil fertile, and there is much fine pasture for cattle, etc. On the streams is some excellent land, well cultivated, and very productive. Staples, sugar, wheat, Indian corn, and tobacco. Farms 711; manuf. 33; dwell. 1,497, and pop.-wh. 8,683, fr. col. 165, sl. 1,513-total 10,361. Capital: Carlisle, Public Works: Lexington and Maysville $R$. P.

Nicholas county, Virg. Situate W. centrally, and contains $676 \mathrm{sq} . \mathrm{m}$. Drained by Guuley and Elk rivers and their branches. Surface moderately uneven; soil fertile It is bounded on the S. W. by the Great Kanawha river. Chief productions, wheat and Indian corn, and it is a fine grazing county. Farms 418; manuf. 1; dwell. 602, and pop.-wh. 3,899, fr. col. 1, slaves 3,390-total 7,789. Capitul: Nicholas C. H. Public Works: Covington and Ohio Railroad.

Nicuolas, p. o., Sutter co., Oreg. Ter.: on E. bank of Feather r., 81 m. N. E. by N. Vallejo.

Nicmolas C. H., p. o, and cap. Nicholas county, Firg.: $192 \mathrm{~m}$. W. N. W. Piehmond.

Nicholastrule, p. v., and cap. Jessamine co., $\bar{K} y_{\text {. }}:$ on a branch of Kentucky r, 27 m. S. S. E. Frankfurt.

Nicuols, t. and p. vo, Tioga co, $N . Y_{0}:$ on S, side Susquehanna r., 145 m. W. S. W. Albany. Surface of t. hilly ; soil gravelly loam. The $\mathrm{v}$, is situated on the river upon a plain, very fertile and highly cultivated. Pop. of t. 1,905.

Nicholsos, t. and p. v., Wyoming co., Penn.: drained by Tunkhannock cr. and tributaries, $103 \mathrm{~m}$. N. N. E. Harrisburg. The Tunkhannock Mountain extends across its N. part,

Nicholson's Store, p. 0., Choctaw county, Ala.: $134 \mathrm{~m}$. W. by S. Montgomery, near Mississippi State line.

Nicholsorville, p. o., Putnam co., Ind.: 40 m.W.S.W. Indianapolis.

Nicholsville, p. o., Clermont co., Ohio: 84 m. S. W. Columbus.

Nicholvilue, p. o., St. Lawrence co., N.Y. : on E. branch of St. Regis r., $143 \mathrm{~m}$. N. N. W. Albany.

Nickell's Milis, p. o., Monroe co., Virg. : 290 m.W. S.W. Richmond.

Nickojack CAVE, Dade co., $G a$. This remarkable cave is in the extreme $\mathbf{N}$. W. corner of the State. It contains numerous passages, spacious rooms, with tall columns, arches, ete. From its mouth issues a large stream, called Nickojack er, which, for more than a mile within the cave, is 20 feet wide and boatable. The mouth of the cave is 177 feet wide; the height from the water to the roof, 49 feet; thickness of the roof above, 82 feet.

Nicolads, p. v., and cap. Sutter co., Calif. : on left bank of Feather r., $80 \mathrm{~m}$. N. E. by N. Yallejo. It has a delight ful location, and is supported by a fine back country. The main stage road between Sacramento and Marysvillo passes through it. Pop. about 1,000,

Nicollet lake, Juab co., Utah Ter.: 80 m. S. \$. E. from Great Salt Lake, $60 \mathrm{~m}$. W. N. W. Filimore City.

Nicoldet river, Utah Ter: rises in the mountains in Iron county, $100 \mathrm{~m}$. S. by W. Fillmore City. It first runs N. N. E., draining the eastern portions of Iron and Millard counties; in the latitude of Fillmore City it bends to the $\mathrm{N}$. W., and on reaching the boundary of Juab co. it runs nearly due W. for $45 \mathrm{~m}$, and empties into Nicollet lake.

Niconza, p. o., Miami co., Ind. : $70 \mathrm{~m}$. N. Indianapolis.

NidjIKwe lake, La Pointe co., Wisc.: between Meminis and Namebin lakes, the head of Namekagon $r$.

Nigit's Pratrie, p. o., Hamilton co., Ill.: 138 m. E. S. E. Springfield.

Nrle, p. o., Alleghany county, N. Y.: 230 m. W. by s. Albany.

Niles, t., p. $\nabla$., and sta., Berrien co, Mich. : on E. bank of St. Joseph's river, near entrance of Dowagiake r., $111 \mathrm{~m}$. S. W. by W. Lansing. The Michigan Central R. R. passes through the v, $191 \mathrm{~m}$. from Detroit, $91 \mathrm{~m}$. from Chicago. The v. is pleasantly situated, contains numerous mills, and does a large business, connected with the fine farming country around it. Here is located a branch of the State University, Three newspapers are published weekly: the "Intelligencer" (whig), "Republican" (dem.), "Express" (dem.)

Niles, t. and p. O., Cayuga co, $N . Y_{0}:$ situate between Skaneateles and Owaseo lakes, $141 \mathrm{~m}$. W. by N. Albany. Surface rolling; soil exceedingly productive, especially of wheat. Pop. 2,053.

NrLes, p. V., Conk co., Ill. : on W. side of the N. branch of Chicago r., $174 \mathrm{~m} . \mathrm{N}$. N. E. Springfield.

Niles, p. o., Trumbull co., Ohio: $144 \mathrm{~m}$. N. E. Columbus. Nrussma, p. v., Summit co., Ohio: $96 \mathrm{~m}$. N. E. Columbus. Nrmmon's Cross Roads, p. O., Morrow co., Ohio: $85 \mathrm{~m}$. N. Columbus

Nine Eagles, p. V., Decatur co, Ia.: 130 m. W. S. W. Iowa City. Drained by branch of Crooked Fork of Grand $\mathbf{r}$. Nine MrLe, p. o., Bledsoe county, Tenn.: 93 m. E. S. E. Nashville.

Nine MiLe creek, $N . Y_{.}:$rises in S. part of Onondaga co. and flows $\mathrm{N}$. into Onondaga lake.

Nine Mrle Prairie, p. o., Perry co., Ill.: 126 m. S. by E. Springfield.

Nine Points, p. O., Lancaster co., Penn. : 35 m. E. S. E. Harrisburg.

Ninety-Six, p. o. and sta., Abbeville dist., S. Car.: $75 \mathrm{~m}$. from Columbia, on Greenville and Columbia R. R.

Ninever, p. v., Broome co., N. Y.: on W. side of Suse quehanna r., 102 m. W. S. W. Albany.

Nineper, p. o., Johnson co., Ind.: on Nineveh cr. of E fork of White $\mathrm{r}, 27 \mathrm{~m}$. S. by E. Indianapolis.

NiNever, p. o., Warren county, Virg.: $10 \mathrm{~S}$ m. N. N. W. Richmond, on branch of Manassas Gap R. $R$.

Nirpenose, t. and p. o., Lycoming county, Penn.: $67 \mathrm{~m}$ N. by W. Harrisburg. Drained by Nippenose cr. on its W. side, and the $W$. branch of the Susquehanna on the $N$. border. Surface hilly; soil calcareous loam.

Nishrabatona river, $T a$, and $M{ }_{0},:$ rises in Audubon co. $I a_{\text {, }}$ flows S. W., and passing through $\mathrm{N}$. W. corner of $M C_{0}$, empties into the Missouri river.

Nrskaruna, t. and p. o., Sehenectady co., N. Y.: $12 \mathrm{~m}$. N. N. W. Albany, on S. side Nohawk r. Pop. 7S3.

Nittany, p. o., Centre county, Penn.: $70 \mathrm{~m} . \mathrm{N}$. W. Harrisburg.

Nivervilie, p. v., Columbia co., $N . Y_{*}: 18 \mathrm{~m}$. S. by E Albany; has several mills and factories.

Nixberg, p. o., Coosa county, Ala.: 82 m. E. N. E. Montgomery.

NoAI, p. o., Shelby co. Ind : 30 m. S. E. Indianapolis. 
Nossк, p. o., New London county, Conn.: 45 m. S. E. IIartlord.

NoBue county, Ind. Situate N. E., and containg 423 sq. m. Drilned principally by Elkhart $r$. and its branches, which traverse its $N$. and central portions. Surface level and diversified, with lakes; soil fertile, and adapted to the growth of grain. Chief productions wheat, Indian corn, potatoes, pork, butter, and vegutables of all kinds. Timber is found on the land. Farms 722 ; manuf. 16 ; dwell, 1,395, and pop.-wh. 7,940 , fro col。 6-total 7,946. Cupital: Albion.

Noble county, Ohio. Situate toward the S. E., and contains $896 \mathrm{sq} . \mathrm{m}$. Drained by head branches of Wills er., a tributary of Muskingum r., and by branches of Duck creek, a tributary of the Ohio. Surface uneven, and in parts hilly; soil fertile, and adapted to corn, wheat, and fruit. Pine and other timber is found on the land, and bituminous coal is extensively distributed. Noble was erected in 1851. Capital: Sarahsville.

Noble, p. v., Noble county, Ind.: $110 \mathrm{~m} . \mathrm{N}$. by E. Indianapolis.

Noblrborotgr, t. and p. v., Lincoln co., Me. : on E. side of Damariscotta r., $23 \mathrm{~m}$. S. E. Augusta. The lumber business and ship-building are carried on extensively. Population 1,408.

Noble Centre, p. o., Branch co., Mfich.: on N. side of Fawn r., $71 \mathrm{~m}$. S. S. W. Lansing.

Noble Iron Works, p. o., Noble county, Ind.: $112 \mathrm{~m}$. N. by E. Indianapolis.

Noblestown, p: v., Alleghany co., Penn.: on a branch of Chartier's creek, $170 \mathrm{~m}$. W. Harrisburg, $10 \mathrm{~m}$. S. W. Pittsburg.

Noblesville, p. v., sta., and cap. Hamilton co., Ind.: on E. bank of W. fork of White r., 20 m. E. N. E. Indianapolis, on the Peru and Indianapolis R. R. It contizins the courthouse, a fine county seminary, sereral hotels, and numerous stores, four churches. "The Plaindealer" (neut.) is published weekly. Pop. 2.000.

Nonscue Pontt Light, Mass. See Light-hotses.

Nocnw ax, p. o., Randolph county, Ga.: 136 miles S. W. Mrilledgeville.

NovAWAY county, Ifo. Situate N. W., and contains 720 sq. m. Drained by Little Platte $r$, and its branches, tributaries of the Missouri river. Surface generally even; soi a deep, dark loam, and fertile. It has some good timber. Farms 241 ; manuf. 3 ; dwell. 325 , and pop.-wh. 2,048, fr col. 0, sl. 70-total 2,118. Capital: Nolaway C. H.

Nonawax, p. o., Page co., Iu.: $250 \mathrm{~m}$. W. S. W. Iowa City.

NodAway, p. ve, Andrew county, MTo.: $180 \mathrm{~m} . \mathrm{N}$. W. Jefferson City.

NodAway river, $I a_{0}$ and Mo.: rises in Adair co., $D I_{0}$, flows S. through Adams and Page counties; then passing into $\mathrm{N}$. W. corner of $\mathrm{MF}_{\text {, }}$ falls into the Missouri $\mathrm{r}$. betwcen Holt and Andrew counties.

Nooec's, sta., Hanover co., Fïrg. : on Virginia Central R. R. $83 \mathrm{~m}$. from Richmond.

Nokar river, Benton co., Minn.: rises in a chain of lakes, flows S. W., and empties into Mississippi r. at Fort Gaines.

Noland's river, Navarro co., Texo.: rises in the Cross Timbers, flows mainly in $\mathrm{S}$. direction, and enters Brazos $\mathrm{r}$. above Fort Graham.

NoLAND's FerRT, p. o, Loudon county, Tirg.: $112 \mathrm{~m}$. N. Pichmond.

Nolanstrlle, p. o., Bell co.. Tee.: on Noland's cr. of Leon r., 62 m. N. by E. Austin City.

Nolesstille, p. v., Tilliamson co., Tenn.: $18 \mathrm{~m}, \mathrm{~s} . \mathrm{E}$. Nashrille.

Numencess river. $\mathbf{X}$. Cor, and Tenn.: rises in Taneey co., $N$. Car., flows W, through the Blue Ridge, and enter: French Broad r.. S m. Y. W. Tewport.

NoLIN, p. v., Hardin co., $\overline{K_{2}}$ : 93 m. S. W. Frankfort. 592
Norrs creek, $K y_{0}:$ rises in Hardin and La Rue counties, flows S. W., forming the boundary between Grayson and Hart counties, and empties into Qreen r. near Brownsville, Edmondson county.

No Mav's Lavd island. Dukes on., MFass, : lies off S. W. end of Martha's Vineyard, 4 m. s. Gay Head. It consists chiefly of a mass of rocks.

Nomsy Grove, p. o., Westmoreland co., Firg.: $51 \mathrm{~m}$. N. E. Richmond.

Non Coxmer, p. o., Fayette co., Tenn.: 156 m. W. S. W. Nashville.

Nonparen, p. o., Knox county, Ohio: 36 miles N. E. Columbus.

Norfolk county, Mrass. Situate E., and contains 350 sq. m. Drained by the Charles and Neponsett rivers and their affluents. Surface uneven, and in parts rocky; soil generally fertile and well cultivated. In Quincy a fine granite quarry is found, the products of which are carried down to the Neponsett $r$. by a railroad $3 \mathrm{~m}$. long, the first built in the United States. This co. has many important manufactures. Farms 2,637; manuf. 906; dwell. 12,545, and pop.-wh. 78,661, fi. col. 231-total 78,592. Cupital. Dedham. Public Works. Norfolk County R. R.; Old Colony R. R.; Boston and Providence R. R.; Fall River R. R.; Boston and Worcester R. R.; South Shore R. R.; and numerous branches, also the New York, New Haven, and Boston (air line) R. R., now in progress,

Nonfolk enunty, Virg. Situate S. E., and contains 432 sq. m. Drained by Elizabeth and Pasquotank rivers. Surface level; soil moderately fertile. Indian corn is the chief agricultural product. It contains the greater portion of the Dismal Swamp. Commerce is by far the greatest interest of the county. Farms 618; manuf. 175; dwell. 3,906, and pop-wh. 20,370, fr. col, 2,266, sl. 10,400-total 33,036. Cupital: Norfolk City. Public Works: Sea-board and Roanoke R. R.; Petersburg and Norfolk R. R.; Disma] Swamp Canal, ete.

Noprolk, to and p. v., Litehfield county, Conn.: $36 \mathrm{~m}$. W. N. W. Irartford. Surface of t. mountainous; soil grevelly loam, and stony, Drained by Blackberry river and branches. Contains several mills, tanneries, and factories. Pop. 1,641.

Norfolk, t. and p. $v_{.}$, St. Lawrence co., $N . Y_{0}$ : on Racket r. $163 \mathrm{~m}, \mathrm{~N}, \mathrm{~N}$. W. Albany. Surface of t. undulating; soil rich loam. The $\mathrm{r}$. is sittated at a fall in the river which affords great water-power, used by several mills, etc. Pop. of $t .1,753$.

Norfols, p. b., port of entry, and eap. Norfolk county, Firg. : on the N. E. bank of Elizabeth $\mathbf{r}$, at the confluence of its two branches, $8 \mathrm{~m}$. above Hampton Rnads, $32 \mathrm{~m}$. from the ocean; $80 \mathrm{~m}$. S. E. by E. Richmond. Lat. $\mathrm{N}$, $36^{\circ} 50^{\prime} 50^{\prime \prime}$; long. W. $76^{\circ} 18^{\prime} 47^{\prime \prime}$. This is the chief commercial port in Yircinia, and is remarkable for its harbor, which is very accessible, spacious, and deep enough for the largest ressels. Its site is on low and marshy ground, and formerly uninealthy, but is now provided with sewers, and kept elean. The streets are generally irregular, though some are wide, straight, and neat. The houses are not remarkable for elegance, but many of them are substantial buildings. It contains a court-house, jail, fine market-house, custom-house, an athenæum, with a library, academy, orphan asylum, 3 banks-capital $\$ 991,000$, some good hotels, and 8 churches. The cemetery, ornamented with cypress trees, is very beautifully laid out and adorned. Norfolk is chiefly distinguished as being the principal naval station in the United States, haring the finest navy yard, dry dock, and naval hospital in the nation. The nary yard is on the $W$. side of the $r$. at fasport. The dry dock is constructed of hewn granite, and cost $\$ 974,536$. At this station is the ship Pennsrlvania, built at Philadelphia, and launched in 1837 , fiurdecker, tire largest in the nary, mounting 120 guns, which is hare used as a receiving ship. The hositital is on a print directly opposite Norfolk, very large, commodious, and 
healthily situated. A naval officer is stationed at this port. The total tonnage of Norfolk district on 30th June, 1850, was 24,135 tons, of which 10,542 were registered, 13,593 were enrolled and licensed. Of registered tonnage 3,144 tons were permanent, and 7,398 tons temporary. Of the enrolled and licensed tonnage 12,351 were permanently employed in the coasting trade ; 1,354 tons were propelled by steam; 1,242 tons were licensed under 20 tons. During the year ending June 30,1850 , the total number of clearances for foreign countries was 140 , tons 26,765 , men in crews 1,163 ; total number of entrances from foreign countries 74 , tons 14,281 , men in erews 684 . Vessels built during the year 6 , total tonnage, 608 . Norfolk is connected by the Sea-board and Roanoke R. R. (from Portsmouth to Weldon, $\mathrm{N}$. C., $80 \mathrm{~m}$.), with the great line of $\mathrm{R} . \mathrm{R}$. on the Atlantic coast. A railroad from Petersburg to Norfolk is in construction. A line of steamships plies semi-weekly to New York. Four daily newspapers are published at Norfolk: "Beacon," (neut.), "Argus" (dem.), "Courier" (neut.), " $N$. and P. Herald" (whig). Each of these issue tri-weekly editions. Pop. in $1840,10,920$; in $1850,14,320$.

NormanskmL, $N . Y_{0}$ : rises in schenectady co, flows S. E. through Albany co., and empties into Hudsou r. at Bethlehem.

NORRIDGEWOCK, t., p. $\nabla_{\text {., }}$ and cap. Somerset co., Me.: on Kennebec r., 23 m. N. Augusta. The v, on the N. bank of the $r_{0}$ in the bend is very pleasant, having broad street lined with fine trees; contains the co, buildings, church, and academy. $A$ bridge across the $r$. connects it with $\mathrm{S}$. Norridgewock. This $t$, is noted in history as the seat of the Norridgewock Indians, and for a French Jesuit mission. Pop. 1,848.

Norris CrekK, p. o., Lincoln co., Tenn.: 66 m. S. by E Nashville.

Norristown, p. v., Pope co., Ark.: on N. bank of Arkansas r., 66 m. N. W. Little Rock.

Norristuwa, p. v., Carroll co., Ohio: 102 m. E, N. E. Columbus.

Norristown, tu, p. b., and cap. Montgomery co., Penn.: on N. bank of Schuylkill r., $80 \mathrm{~m}$. E. Harrisburg. Surface of t. level; soil red shale, and fertile. The Schuylkill has here been dammed so as to create an immense waterpower, and is used by extensive manufacturing establishments. A fine bridge here spans the Schuylkill, which cost $\$ 32,000$. The Norristown and Philadelphia R. R. connect these places $17 \mathrm{~m}$. distant. On the opposite side of the river passes the Philadelphia and Reading R. P. Here also are the locks of the Schuylkill Navigation Co., around which and the railroad depôt is a small village.

Norrtontille, p. v., Montgomery co., Penn.: 84 m. E. Harrisburg.

NortII river, St. John's co., Flor.: a small stream running parallel with the Atlantic coast, emptying into St. Augustine harbor.

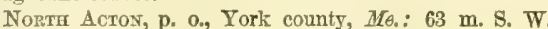
Augusta.

Nortir AdArs, p. $\nabla$. and sta., Berkshire co., Mass.: on Hoosae r., 108 m. W. N. W. Boston. Here terminates the N. Adams and Pittsfield R. R., $20 \mathrm{~m}$. from Pittsfield. I contains 8 cburches; 1 bank, capital $\$ 1 \$ 5,000$; and numerous factories moved by water-power from Hoosac $r$. The principal manufactures are cotton goods and woolens. The Troy and Boston R. R. will pass through this place

Norti ADays, p. 0., Jefferson county, N. $Y_{0}: 146 \mathrm{~m}$. N. W. by W. Albany.

NortI AdAys, p. Oa, Hillsdale county, Mich.: $56 \mathrm{~m} . \mathrm{S}$. Lansing.

North AoriaN, p. v., Lenawee co., Mich.: 60 m. S. S. E. Lansing.

North Albanx, p. o., Oxford co., Mre.: on Crooked r., $51 \mathrm{~m}$. W. Augusta.

North AlmoNd, p. o., Alleghany co., N. Y.: $278 \mathrm{~m}$. W. by S. Albany.
North A wherst, p. vo, Hampshire co., Ma88.: 76 m. W. Boston; contains several stores and manufactories.

Northampton county, $N$. Car. Situate N. E., and contains $480 \mathrm{sq} . \mathrm{m}$. Drained by branches of Meherrin $\mathrm{r}$. in the N. E., and of Roanoke in 8 . W., which rivers form its boundaries in the directions indicated. Surface even and diversified; soil very fertile, and there is some good pasture land Cotton, Indian corn, and tobacco are the chief productions, Farms 644 ; manuf. 7 ; dwell. 1,341, and pop.-wh. 5,994, fr. col. 830 , sl. 6,511-total 13,335. Capital: Jaekson. Public Works: Petersburg R. R.; Sea-bnard and Roanoke R. R.; Greenville and Roanoke R. R., etc.

Northampton county, Penn. Situate E., and contains 418 sq. $m$. Drained by Lehigh river and other small streams, tributaries of the Delaware. Surface uneven and hilly, and is pleasantly diversified with fertile valleys; soil exceedingly fertile, and produces large crops of wheat, Indian corn, potatoes, etc. Pine and other timber is found on the land. Its manufactures are extensive, and great attention is paid to agrieulture. Farms 2,102; manuf. 424; dwell. 6,836, and pop.-wh. 40,099 , fr. col. 136-total 40,235. Capital:

Easton. Public Works: several railroads from Easton westward are projected.

Northampton county, Virg. Situate S. on the eastern shore, and contains $410 \mathrm{sq} . \mathrm{m}$. Drained by numerous small creeks falling into Chesapeake Bay and the Atlantic Ocean. Surface low and level; soil generally fertile. Chief produe tions, Indian corn and potatoes. Farms 376 ; manuf. 11; dwell. 693 , and pop.-wh. 3,105 , fir. col. 745 , sl, 3,618-total 7,498. Capital: Eastville

Northampton, Peoria co., $I l l_{\text {: }}: 77 \mathrm{~m}$. N. Springfield.

Northampton, t., p. v., and cap. Hampshire co., Mass. on W. bank of Connecticut r., $81 \mathrm{~m}$. W. Boston. Lat. N. $42^{\circ} 19^{\prime} 9^{\prime \prime}$, long. W. $72^{\circ} 38^{\prime} 15^{\prime \prime}$. Surface of t. pleasantly diversified; soil very fertile and well cuitivated. The scenery of this to is celebrated as among the most beautiful in New England. The v. is irregularly but handsomely laid out, and contains many handsome dwellings and grounds. The public county buildings are handsome, substantial structures. There are 2 banks, with cap. of $\$ 100,000$. A fine stream, passing through the centre of the t., affords good water-power to several manufactories of cotton goods, sewing silk and ribbons, woolen goods, ete. On an elevation W. of the V., called Round Hill, is an extensive watercure establishment. A fine bridge, 1,080 feet long, crosses the Connecticut r. to Hadley, Mount Tom, in this t., 1,214 feet high, and Mount Holyoke, on $\mathbf{E}$. side of the $\mathbf{r}$., 830 feet high, are much visited for the delightful prospects afforded of Connecticut valley. The "Hampshire Gazette" (whig) and "N. Courier" (fr. soil) are published weekly. Churehes in t., 8. The Connecticut River R. R. passes through the $\mathrm{v}$., $17 \mathrm{~m}$. from Springfield. Pop. in 1830, 3,613 ; in 1840, 3,750; in $1850,5,278$.

Nortilampton, t. and p. o., Saginaw co., Mich. : on the Shiawassee r., 36 m. N. E. by N. Lansing. Pop. 122

Northanpton, t. and p. o., Fulton co., N. Y.: on Sacandaga r., $38 \mathrm{~m}$. N. W. by N. Albany. Surface of t. mostly level; soil sandy loam, of good quality, and well watered. Pop. 1,701 .

Norti ANDover, p. v. and sta., Essex county, Mass. : on Great Pond, a small lake, emptying into Merrimac river, $26 \mathrm{~m}$. N. by W. Boston. The Boston and Maine R. R. and the Essex R. R. pass through this v. Great Pond covers nearly 500 acres; its outlet affords water-power.

Nortin Anson, t. and p. o., Somerset co., Me. $\therefore$ on W. side of Kennebee r., and intersected by Seven Mile brook, $83 \mathrm{~m}$. N. by W. Augusta. Pop. of t. 1,168.

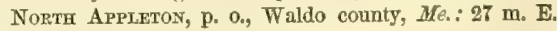
Augusta.

North ARgYle, p. o., Washington co., $N_{0} Y_{*}:$ on Moses kill, 44 m. N. N. E. Albany.

North Asmburnhakr, sta., Worcester county, MFass. : on Cheshire R. R., 13 m. from Fitchburg. 
Norte Asmford, p. v., Windham county, Conn.: $28 \mathrm{~m}$.

E. by N. Hartford.

North Attleboro', p. v., Bristol county, DLass. : $30 \mathrm{~m}$.

8. 8. W. Boston. Here are several manufactories.

North Auburn, p. o., Cumberland co,, Me. : on W. side of Androscoggin r., $27 \mathrm{~m}$. S. W. Augusta.

North Augusta, p. v., Des Moines co., Ia. : on N. bank of Skunk r., $63 \mathrm{~m}$. S. by E. Iowa City.

North Bangos, p. o., Penobscot co., Me.: on W. side of

Penobscot r., 66 m. N. E. by E. Augusta.

North Bangor, p. o., Franklin county, $N . Y .: 154 \mathrm{~m}$. N. by W. Albany.

North Barnstead, p. 0, Belknap co., $N$. Hamp. : $18 \mathrm{~m}$.

N. E. Concord.

North BarrivgtoN, p. O., Strafford county, N. Hamp. :

$23 \mathrm{~m}$. E. Concord.

North BAx, p. o., Oneida co., N. Y.: 112 m. W. N. W. Albany.

North Béretr, p. v, and sta., Berkshire county, Mass.:

105 miles W. Boston, on Western Pailroad, 37 miles from Springfield.

North Belgrade, p. $\%$, and sta., Kennebec co., Me.: on W. side of Snow's pond, $12 \mathrm{~m}$. N. Augusta. The Androscoggin and Kennebec R. R.passes through the V., $10 \mathrm{~m}$. from Waterville.

North Bellevite, p. $\mathbf{v}$. and sta., Hendricks co., Ind.: $19 \mathrm{~m}$. W. S. W. Indianapolis, on Terre Haute and Richmond P. R.

North Benaont, p. 0., Waldo co.. $M e_{\text {. }}$ : $32 \mathrm{~m}$. E. by $\mathrm{N}$. Augusta.

North BeltinghaM, p. Y., Norfolk county, Mass.: $27 \mathrm{~m}$. B. W. by S. Boston.

NorTH BEND, p. Y., De Kalb co., Ala : on E, side of Wills cr., 144 m. N. by E. Montgomery.

North BeNd, p. o., Stark co., Ind, : on Tippecanoe r., at its greatest bend, $98 \mathrm{~m}$. N. by W. Indianapolis.

Nortr Beid, p. V., Piatt county, $I l l .: 67$ m. E. N. E. Springfield.

NoBTH BENNTNGTON, p. v. and sta, Bennington co., Term a

$104 \mathrm{~m}$. S. S. W. Montpelier. Here the Western Vermont

R. R. connects with the Troy and Bennington R. R. The

₹. contains woolen, cotton, and hardware factories.

North Bentox, p. o., Mahoning co., Olio: 130 m. N. E。

by E. Columbus.

North Bentonsport, Des Moines co., Ta. : on N. bank of

Des Moines $r_{s}, 65$ m. S. S. W. Iowa City.

North Bergen, p. o, Genesee co, $N . Y_{*}: 223 \mathrm{~m}$. W. by N. Albany.

North Bernardstown, p. v., Franklin co., Mass.: $81 \mathrm{~m}$. W. by N. Boston. The Connecticut River R. R. passes through the $t_{\text {. }}, 42 \mathrm{~m}$. from Springfield.

North Benwick, t., p. v., and sta., York co, $M \epsilon_{0}: 8 S \mathrm{~m}$.

B. W. by S. Augusta. Drained by a branch of Salmon r.

The Portland, Saco, and Portsmouth R. R. passes through the Y., $34 \mathrm{~m}$. from Portland. Pop. of t. 1,593.

North Bether, p. o., Oxford co, Me.: on S. bank of Androscoggin r., $41 \mathrm{~m}$, W. by N. Augusta.

North Blackstone, p. O., Worcester co., Mass.: $85 \mathrm{~m}$. B. W. Boston.

North Blasford, p. v., Hampden co., Mass. : 99 m. W.

Boston,

North Blenhen, p. O., Schoharie co, $N_{.} Y_{.}:$on Schoharie r., $37 \mathrm{~m}$. W. by S. Albany.

Norti Blooxriet, p. V., Ontario county, N. Y.: $201 \mathrm{~m}$. W. by N. Albany.

NorTh BloomfletD, p. o., Trumbull $\mathrm{CO}_{*}$, Ohio: on E. side of Grand r., $147 \mathrm{~m}$. N. E. Columbus.

\section{THE STATE OF NORTH CAROLINA.}

Nortm Carolixa is situated between the latitudes $33^{\circ} 50^{\prime}$ and $36030^{\prime}$ north, and the longitudes $75^{\circ} 25^{\prime}$ and $84^{\circ} 30^{\prime}$ west from Greenwich, or $1037^{\prime}$ east, and $7028^{\prime}$ west from Washington. It is bounded on the north by Virginia; on the east by the Atlantic Ocean; on the south by South Carolina and Georgia; and on the west by Tennessee. Presenting a broad 594
Augusta.

NorTH BootH BaY, p. V., Lincoln co, MFe. : 83 m. 9. S.W. Augusta.

NonmmorodGt, $t$, and p. $\nabla .$, Worcester co., Mass. : $81 \mathrm{~m}$ . Boston. Drained by Assabet river and small affluents. Surface moderately even; soil fertile and well cultivated. The t. has considerable manufactures. Pop. 1,535.

Noeth Boston, p. 0., Erie county, $N . Y_{.}: 262 \mathrm{~m}$. W. Albany.

North Branch, p. o, Hillsboro' county, N. Hamp, : on North Branch r., $23 \mathrm{~m}$. W. S. W. Coneord.

North Branch, p. o., Baltimore co., Mrd.: on N. branch of Patapseo r., $16 \mathrm{~m}$. W. Baltimore, $36 \mathrm{~m}$. N. W. Annapolis. Nonth Beavch, p. o., Somerset co., N. Jer. : on N. branch of Raritan r., $30 \mathrm{~m}$. N. Trenton.

Norta Brarch, p. o., Sullivan co., N. Y.: 89 m. S. S. W. Albany.

Nozth Brastrord, t. and p. v., New Haven co., Conn. $9 \mathrm{~m}, \mathrm{~N}$. E. New Haven. Surface of $t$. hilly and mountainams. Pop. 1,013.

NorThBRtDGe, t., p. v., and sta., Worcester co., Mass.: $35 \mathrm{~m}$. S. W. Boston. Drained by Blackstone and Mumford rivers and other tributaries, which afford extensive waterpower. Surface uneven, and somewhat rocky ; soil fertile and well cultivated, particularly in the intervals of the streams. The Providence and Worcester R. R. passes through the village, $12 \frac{1}{\mathrm{~m}} \mathrm{~m}$. from Worcester. There are several extensive manufactories in the $t$. Pop. 2,229.

Notthbrioge Centre, p. v., Worcester co,, Mass.: $36 \mathrm{~m}$

North Bridgetor, p. o., Cumberland co., $M e_{0}$ : at $\mathrm{N}$. W. corner of Long Pond, 51 m. W. S. W. Augusta.

North Bridgewater, p. O., Oneida county, $N$. $\bar{Y}$ : $80 \mathrm{~m}$. W. by N. Albany.

NoetH BeIDGEWATEB, to, p. V., and sta., Plymouth county, Mass. : 19 m. S. Boston. Drained by Salisbury r. Surfaco level; soil generally fertile, and well cultivated. The Fal Piver R. R. passes through the $\mathbf{v}$. The commercial and manufacturing interests are large. Pop. 3,940.

North Broadatiri, p. o., Fulton county, $N_{\text {. }} Y_{.}: 85 \mathrm{~m}$. W. by N. Albany.

Norti Brookfield, t. and p. V., Worcester co., Mass. $\mathrm{m}$. W. Boston. Drained by small streams, with an artificial pond covering nearly 800 acres, for hydraulic power. Surface undulating; soil fertile, and well cultivated. The manufactures are considerable. The Western $R$. R. passes through this t. at East Brookfield, $64 \mathrm{~m}$. from Boston. Population 1,939.

Norte BrookrielD, p. o., Madison co.g $N_{0} Y_{0}: 84 \mathrm{~m}$ r. by N. Albany,

Nortil Brownstule, p. o., Piscataquis co., Me.: $84 \mathrm{~m}$. E. by N. Auguste.

North Bucksport, p. v., Hancock co., Me.: on E. bank Penobscot r., 55 m. E. N. E. Augusta.

Norte Cambridge, p. o., Lamoille co., Verm. : on N. side Lamoille r., 81 m. N. N. W. Montpelier.

Notri CaMrbrtoge, p. o., Washington co., $N$. $Y .: 32 \mathrm{~m}$. E. by N. Albany.

North CaMmen, p. Y., Lorain co., Ohio: 95 m. N. N. E. Columbus.

North Canrrov, p. 0., Steuben county, $N_{0} Y_{0}: 192 \mathrm{~m}$.

North CaNton, p. v., Hartford co., Conn. : near Cherry reek, $15 \mathrm{~m} . \mathrm{N}$. W. Hartford. 
front to the ocean, it gradually contracts in its breadth, and terminates westward in a narrow strip. Its length from east to west is about 450 miles, and its breadth in the eastern section from 120 to 180 miles, but in the west diminishing from 90 to 20 miles; and it has an area of 45,000 square miles.

The face of the country presents three distinctive physical conditions. The seaward section is a low plain, covered with swamps, and traversed by sluggish streams; to this succeeds a belt of undulating country, watered by fresh and rapid streams, and in many portions variegated by hills and knolls; and the western section is an elevated table-land.

The maritime section forms, as it were, a chaos of land and water. The entire coast is lined by low, narrow, sand islands, broken at intervals, and forming communications between the ocean and the lagoons which lie between the islands and the main land. South of Cape Lookout these inlets are numerous, and the lagoons narrower; north of that headland the converse obtains. Extensive shoals extend from the shore seaward, and render navigation dangerous and uncertain, and within the lagoons the bars and banks are constantly changing their position. Furious gales, too, are prevalent, so that it is difficult for a skillful pilot to avoid the dangers. Ocracoke inlet is the only navigable pass north of Cape Lookout, and this at low tide, even in the main channel, contains only six feet water. Roanoke inlet, opposite the island of that name, is now obstructed, but the pass may again be opened. To the northward, between the mainland and Narrow Beach Island, stretching down from Cape Henry, lies Currituck Sound, 50 miles long, and from 2 to 10 miles broad. West of this, running inland, is Albemarle Sound, 60 miles long, and from 5 to 15 broad. Its waters are fresh, and not subject to rise and fall from tidal influences, but they are affected by particular winds. These two sounds communicate with Pamlico Sound, which lies south of Currituck, and is 86 miles long, and from 10 to 20 miles wide. Its depth is in general about 20 feet, but shoals abound within it. It opens to the ocean through Ocracoke inlet, and is somewhat influenced by the tides. The capes, formed by the sand islands, are the dread of mariners. Cape Lookout and Cape Fear indicate by their names the dangers that surround them. But the most formidable headland is Cape Hatteras, the elbow of a triangular island forming the seaward limit of Pamlico Sound. Its shoals extend a great distance from the land, and render it one of the most ugly projections of the American coast. The whole series of islands which beset this coast are barren and desolate, entirely useless to agriculture, and are inhabited only by a few hardy fishermen and pilots.

From the sea-coast, for a distance of 60 or 80 miles, the country is perfectly level, traversed by sluggish and muddy streams, and abounding in swamps and marshes. The soil, except along the banks of the streams, where it is sometimes fertile, is sandy and barren. The swamps, so numerous in this section, cover an area equal to one-tenth part of the whole State. The Great Dismal Swamp, parily in this State, and partly in Virginia, is 30 miles long, and from 10 to 12 miles broad, extending over a surface of 100,000 acres. In some places it is densely covered with cedars, pines, and cypress, and in others is impervious, on account of tall and rank grasses and undergrowths. In the centre is Drummond Lake, 20 miles in circuit. The soil is covered knee deep with water, and though firm in some parts, consists chiefly of a soft, yielding bog. Similar in its character, and nearly as large, is Alligator or Little Dismal Swamp, on the peninsula between Albemarle and Pamlico sounds. There are other swamps further south (Catfish, Green, etc.), usually overgrown like those spoken of, and equally impenetrable. Many of these have been drained by canaling, and the recovered lands have proved excellent for the cultivation of rice and cotton.

Advancing into the country, its physical aspect becomes more and more changed. Immediately beyond the level country, the land begins to rise into small hills, stones appear on the surface, and the streams ripple in their courses. A little further westward, the scene opens in all the variety of hill and dale that belongs to a fertile country. For 40 miles behind the flat region there extends, as far as the lower falls of the rivers, a belt of land, of a surface moderately uneven, with a sandy soil, of which pitch-pine is the natural growth. Above the falls the surface is undulated, and still further, beyond the Yadkin and Catawba, is an elevated region, forming a part of the great central plateau or table-land of the United States, and lying 1,000 to 2,000 feet above the sea-level. The peaks of the Blue Ridge of the Alleghanies, which have distinct local appellations, tower high above this. Black Mountain, the highest culmination east of the Rocky Mountains, and about 250 feet higher than the loftiest summit of the White Mountains of New Hampshire, has an elevation of 6,426 feet; Roan Mountain, the summit of which is a broad meadow, is 6,038 feet high; Grandfather Mountain is 5,556 feet high, and Table Mountain has an elevation of 3,420 feet above the sea. Mount Ararat or Pilot Mountain, in Surrey County, situated in a comparatively level region, exhibits a striking symmetry of structure; its form is very nearly that of a cylinder, and it is ascended by a path in some places nearly perpendicular. The view from its summit is grand and cxtensive, although its elevation is much inferior to the peaks above named. King's Mountain, another isolated hill, is a ridge extending from Lincoln and Cleaveland counties into York district, in South Carolina, and is celebrated as the site of a battle, fought in 1780. Between the several mountains in the western part of the State, the soil is productive, and highly favorable to agricultural operations, and, being well grassed, forms extensive pastures, on which large herds and flocks find a plentiful subsistence.

The rivers of North Carolina, though of goodly dimensions, are not navigable for large vessels. They are, however, well adapted to boat navigation, and in their upper courses supply immense mechanical power, which at a future day will be extensively used. As a general thing they all have shallow bars, and are frequently interrupted. Many loose themselves in lagoons difficult of access. The principal river, the course of which lies wholly within the State, is Cape Fear River. It is, moreover, the only large stream that flows directly to the ocean. The primary constituents of this river are the Haw and the Deep, which rise near the northern boundary line, and form a junction at Haywood in Chatham County: it falls over the first ledge in the low country at Averasboro'; at Fayetteville it can be navigated by large boats, and above Wilmington it forms two branches, which reunite below that town, and hence flows on in a broad, sluggish stream obstructed by sand-bars, and difficult of navigation. These defects, however, have been somewhat remedied by diminishing the breadth of the river, and by stopping up the smaller outlets, so that the depth of the main channel, as far as Wilmington, has now from 12 to 18 feet of water. The direction of its flow is south-east, and the length of its course about 280 miles. The main entrance to the river, south of Smith's Island, has a depth of water varying from 10 to $14 \frac{1}{3}$ feet on the bar. The Chowan and Roanoke rivers flow into Albemarle Sound; the former, which is formed by the union of the Meherrin and Nottaway, admits of small vessels to Murfreesboro', and the latter is navigable for the Sound craft a distance of 30 miles. Both are navigable for boats to a greater distance-the Roanoke to Weldon, at the foot of the falls, 75 miles; and above the falls it affords, with the aid of side cuts, a boat navigation to Salem, 245 miles. The whole length of the Roanoke, from the valley of Virginia, is more than 400 miles. The Tar and the Neuse empty into Pamlico Sound. The Tar, which in the Iower part of its course expands into a wide estuary called Pamlico River, is navigable for vessels drawing only 8 feet of water, to Washington, 30 miles; and for boats to Tarboro', 90 miles; and the Neuse, which has a longer course, is navigable for large boats to Kingston. The ocean entrances to both these rirers are channels in which 
there is only 10 feet water at high tide. The Waccamaw passes into South Carolina, flowing for a considerable distance near and parallel with the coast. The Lumber and Yadkin also pass into that State, in which they are known as the Little and Great Pedee. The Yadkin is a long river traversing the State from near its northern boundary, and is narigable for boats almost to its source. The Catawba, which rises in the Blue Mountains, also flows into South Carolina, and there takes the name of the Wateree. From the western slope of the same mountains flow New Rivers, the Watauga, the French Broad, the Little Tennessee, and the Hiwassee, the waters of which, cutting through the Iron or Smoky Mountains, are ultimately carried off, and mingle with those of the Ohio and Mississippi, and join the ocean at a distance of 1,500 miles from the outlets of the waters rising from the opposite slope of the Blue Ridge, and emptying into the Atlantic.

The geological formation of the State has been scientifically examined by Professor Olmstead. Its mineral resources are extensive, and as valuable. The low country consists of deposits of sand and elay, similar, and belonging to the same age (tertiary) as those of Eastern Virginia and Maryland. These beds contain few minerals, but abound in shell deposits, marl, fossiliferous limestone, copperas, and bog-iron ore. A ledge of micaceous rocks, seen in the ravines and. river cuttings, forms the line which divides the low from the upper country. West of this there is a belt of mica slate, chlorite slate, gneiss, and granite, and among the minerals of this section are hœmatitic iron ores (Nash and Johnson counties), plumbago (Wake County), and occasionally soapstone and serpentine. This strip is succeeded by a belt of sandstone running south-westerly from Granville across the State. Freestones and grindstones are abundant in some parts of the formation, which also contains argillaceous iron ore and some coal measures (Orange, Chatham, etc., counties). Next to this is situate the great slate formation, about 20 miles in breadth, and running in a direction northeast and south-west across the country. Within this district are also found numerous beds of porphyry, soapstone, serpentine, greenstone, and hone or whetstone slate. After the slate formation there succeeds next another belt of primary rocks reaching nearly to the Blue Ridge; and in this is comprised the gold region. Iron ore is also found abundantly (Rockingham, Stokes, Surry, and Lincoln counties) chiefly in the form of the magnetie oxide, and has been extensively wrought.

The gold region of the Atlantic States is broader and more productive in this State than in any other. The gold is found in superficial deposits or in rock veins. The system of metamorphic rocks, in which the gold-bearing veins occur, have undergone different degrees of change in different localities. While in some parts the original slaty structure is preserved, in others the lamination has been partly obliterated, and the texture altered by the evident effects of heat. In some points there is an intermingling of rocks of the gneissoid character, with such as still retain the slaty structure. In certain parts the granitic rocks prevail, and there the auriferous veins have various directions apparently wholly irrespective of the general trend of the gold formation. Thus, between the town of Charlotte and the Catawba River, and within a circuit of three or four miles in diameter, are found veins which have been more or less extensively worked, with directions running N. 64 E., N. 47 E., N. $8 \frac{1}{3}$ W., N. 261 E., and N. 34 W., so that if these directions were prolonged, they wonld, in some cases, be found intersecting each other at right angles. In regard to the vein stone, in which the auriferous particles are found, they differ very widely -in some cases the material is an argillaceous slate of a silky lustre, much interspersed with minute cubes of pyrites of iron or of copper, or of both, as at the Russell mine on the Newberry in Montgomery County ; in other cases it is partly in quartz, and partly in the slaty walls of the reins, and in others still, it is wholly in the quartz, being scarcely at all impregnated with the precious metal. The materials which exist in the reins are either such as have been acted on by meteorie influences, and partly decomposed, or, lying beyond the reach of such influences, have eseaped decomposition, and may be regarded as the true exponents of the deeper vein-stone. These latter are in general less rich in gold than the former, chiefly on account of having lost a part of their solid material by decomposition. But the deep ores owe their inferior value, in no small degree, also to the difficulty of extracting the gold from its combination, with the sulphurets which near the surface have been reduced by the combined action of air, water, and other materials from the atmosphere. The axis of the gold formation passes in a north-east and south-ivest direction through the counties of Rockingham, Guilford, Davidson, Rowan, Cabarras, and Mechlenburg, embracing the section of both sides of the Blue Ridge, and extending eastward beyond the Yadkin.

That gold is an important product of this State, admits of no question; the region in which it is found is very extensive. The principal mines are Anson's, Read's, and Parker's. The first named is in Anson County, and bas yielded richly, but on account of the ownership of the land on which jt is situated being in dispute, operations have been retarded. Read's mine is in Cabarras Connty, and was the one first wrought; large masses of the virgin metal have at several periods been dug up, and pieces weighing 400,500 , and 600 pennyweights are met with. On one occasion, a mass weighing 29 pounds avoirdupois in its crude state was exhumed. Parker's mine is situated on a small stream four miles south of the Tadikin. The metal is here found chiefy in flakes and grains; but lumps of considerable size-one weighing 4 pounds 11 ounces avoirdupois-hare been dug up. In the mining districts, gold contained in a goose-quill fornas a currency, its value being fixed by weight. The larger portion of the products of the mines is bought up by dealers at from 90 to 91 cents per pennyweight, and much is carried to the mint at Charlotte for coinage; but the returns published by that institution by no means indicate the value of the mines, as a considerable quantity finds its way to the manufacturer, and the banks receive no small moiety of the whole in deposit.

The coal region of North Carolina, chiefly in Chatham and Moore counties, and along the Valley of Deep River, so far as examined, occupies a space fifteen miles in length, and from five to six in width, throughout which area the deposits of this mineral are immense and of every variety-bituminous, semi-bituminous, and anthracite, and Professor Johnson has pronounced them to be of the best qualities. The indications are, he adds, that the deposits are at least thirty miles in length, and comprise an area of one hundred and fifty square miles. The mean thickness of the beds is said to be seven and a half feet, a greater depth than any similar deposit in England. Coal is also found in other distriets. Iron ore is found in juxtaposition with the coal measures of Deep River, overlying the coal. These discoveries have led to much speculation, and it is said that in a few years the result will be an inflow of capital and prosperity to the State equal to that now enjoyed by Pennsylvania.

The climate of North Carolina is much influenced by the diversified character of the surface; no single description would apply to the whole State. The western section, where the land is elevated and traversed by high ranges, is much cooler than the sea-board section, and the interior has a climate partaking of both extremes. The winters throughout the State, however, are much less rigorous than farther north. The atmosphere in the hilly and in the lower middle region is pure and salubrious, anil the heats of summer are in thes. tempered by the coslness of the nights: but in the low country, near the coaste, the summers are hot and sultry, and the air unhealihy and loaded with miasms. The annual 
average range of the thermometer at the University at Chapel Hill is $86^{\circ} \mathrm{Fahr}$, the greatest heat being 960 , and the lowest $10^{\circ}$, with a mean temperature of 59.07. Peaches blossom in February, and the first frost occurs generally in October. The average number of rainy days in the year is ninety-eight, of eloudy days three hundred and thirty-three, and of clear days only thirty-two.

The pine-forests of North Carolina cover neariy the whole eastern section. In the plain of the low country this tree is almost the exclusive natural growth, and attains here a much fuller development than in the States farther north; in the swamps it grows to an enormous bulk, and the moisture of the atmosphere loads the trees with a long spongy moss, which hangs in clusters from the limbs, and gives the forests a singular appearance. Cedars and cypresses are also abundant in the swamps. These forests contribute greatly to the general wealth, and furnish not only lumber for exportation, but also nearly all the resinous matter used in the United States. In the elevated parts of the State the timber growths are the oak, elm, walnut, cherry, lime, etc., and the maple, poplar, and some others, are indigenous in every section. The white-oak trees found here are well suited for making staves, being taller and more free from knots than the northern variety. Several valuable medicinal plants also grow spontaneously, as the ginseng, snake-root, etc., and the bottoms are overgrown with canes, the leaves of which continue green throughout the winter, and afford a grateful food for cattle. Grapes, plums, and blackberries are among the indigenous fruits.

North Carolina is divided into seventy-nine counties, the general statistics of which, and the capitals of each, in 1850 , were as follows:

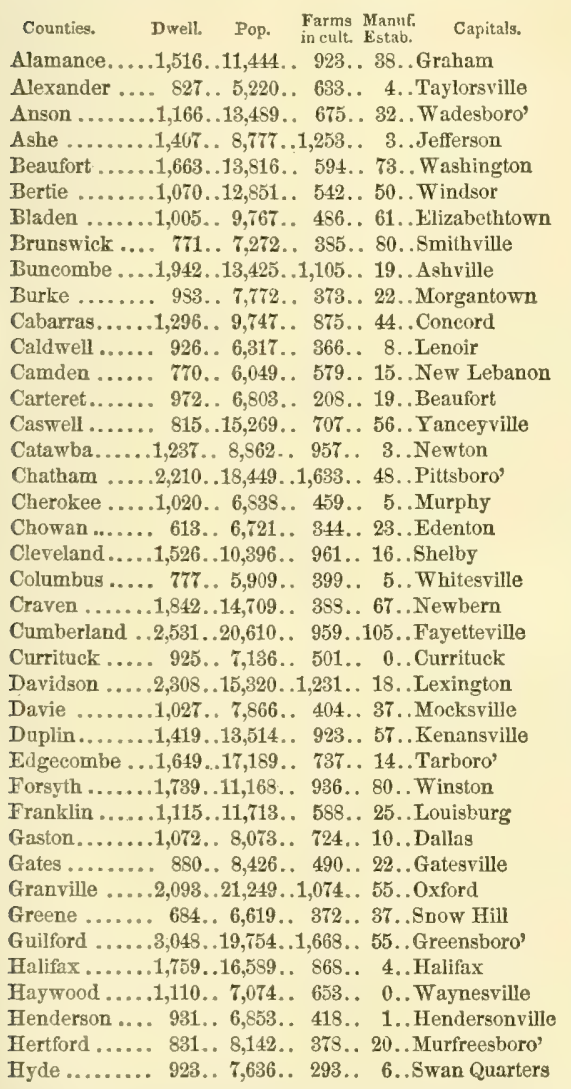

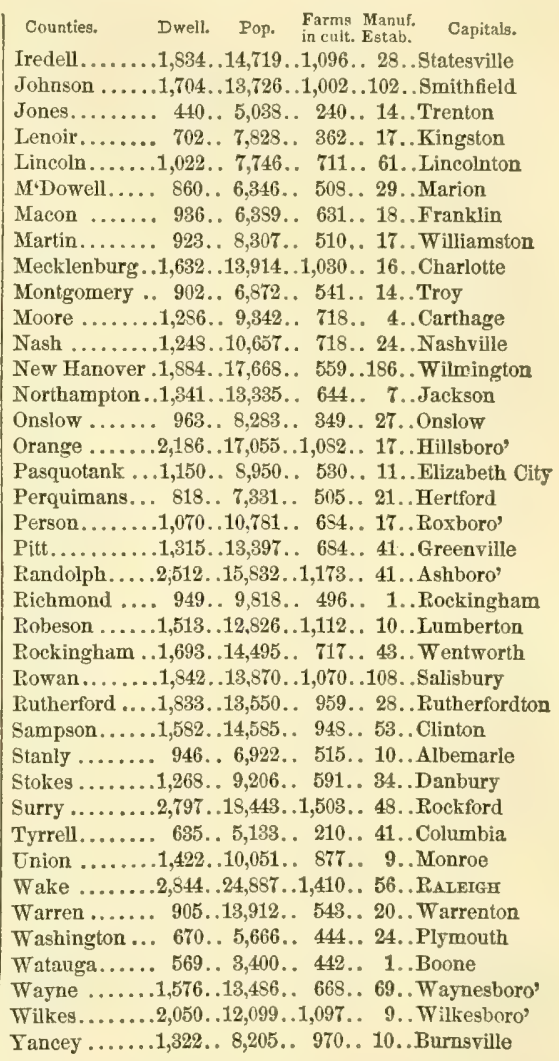

The whole number of dwellings in the State, at the above date, was 105,542; of families, 106,023; and of inhabitants, 868,903 ; viz., whites 552,461-males 272,369, and females 280,095 ; Indians, 831 -males 420 , and females, 411 ; free colored, 27,196-males 13,226, and females 13,970; slaves, 298,412. Of the whole population there were, deaf and dumb -wh. 351, fr. col. 4, sl. 52-total 407; blind-wh. 387, fr. col. 28, sl. 117-total 582; insane-wh. 462, fr. col. 5, sl. 24total 491; and idiotic - wh. 604, fr. col. 32, sl. 138-total 774. The number of free persons born in the United States was 577,750 , the number of foreign birth 2,524, and of birth unknown 217. The native population originated as follows: Me. 65, N. Hamp. 26, Verm. 27, Mass. 251, R. I. 59, Conn. 272, N. York 468, N. Jer. 134, Penn. 665, Del. 96, Md. 635, Dist. of Col. 28, Virg. 10,838, North Carolina 556,248, S. Car. 4,430, Ga. 844, Flor. 54, Ala. 131, Miss. 57, La. 14, Tex. 6, Ark. 1, Tenn. 2,047, Ky. 141, Oh. 48, Mich. 2, Ind. 67, Ill. 23, Mo. 33, Ia. 3, Wise. 4, Calif. 0, Territories 0; and the foreign population was composed of persons from-England 894, Ireland 567, Scotland 1,012, Wales 7, Germany 344 , France 43, Epain 4, Portugal 12, Belgium 1, Holland 4, Turkey 0, Italy 4, Austria 2, Switzerland 3, Russia 8, Denmark 6, Norway 0 , Swerlen 9, Prussia 19, Sardinia 0, Greece 0, China 2, Asia 0, Africa 2, British America 30, Mexico 2, Central America 4, South America 8, West Indies 37, and other countries 5. 


\section{NORTH CAROLINA.}

The following table will show the decennial progress of the population since the first census of the State taken by the United States authorities:

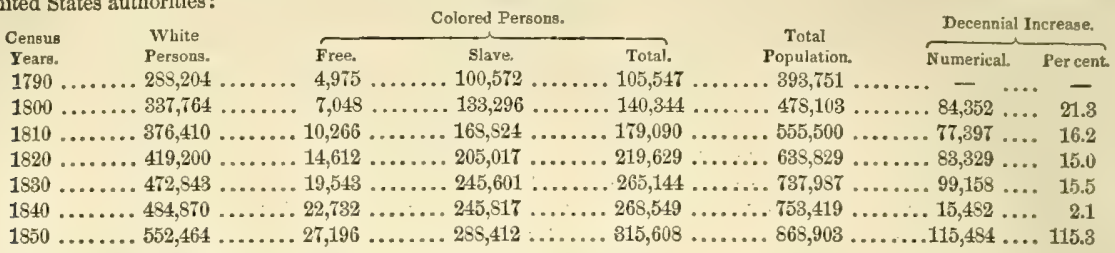

-the total of 1850 , including 831 Indians, not otherwise accounted for.

The statisties of the products, industries, wealth, and institutions of the State, according to the census of 1850 and othe official returns referring to the same period of time, are as follows:

Occupied Land's, etc.-Improved farm lands, 5,453,977 acres, and lands attached to farms unimproved, 15,543,010 acres-together valued in cash at $\$ 67,891,766$. Whole number of farms under cultivation on the 1st June, $1850,56,916$. Value of farming implements and machinery, $\$ 3,931,532$.

Live-Stock.-Horses 148,693 , asses and mules 25,259 , milch cows 221,799 , working oxen 37,309 , other cattle 434,402 , sheep 595,249 , swine $1,812, \$ 13$ - in the aggregate valued in cash at $\$ 17, \pi 17,617$. The census of 1540 returned the following numbers: horses, mules, etc. 166,608 , neat cattle of all kinds 617,371 , sheep 538,279, and swine $1,649,716$.

Products of Animals.Wool, 970,738 (in 1840, 625,044) pounds; butter, 4,146,290 pounds; cheese, 95,921 pounds; and the value of animals slaughtered during the year, $\$ 5,767,866$.

Grain Crops.-Wheat, 2,130,102 bushels; rye, 229,563 bushels ; Indian corn, 27,941,051 bushels; oats, 4,052,078 bushels ; barley, 2,735 bushels; and buckwheat, 16,704 bushels. The crops, according to the census of 1840, were: wheat, 1,960,855 bushels; rye, 213,972 sushels · Indian corn, $23,593,763$ bushels; oats, 3,193,941 bushels; barley, 3,574 bushels ; and buckwheat, 5,391 bushels. Thus, ixcepting the barley and buckwhea crops, the increase in the decade has been liberal.

Other Food Crops.-Rice, 5,465, 668 (in 1840, 2,820,383) pounds; peas and beans; 1,584,252 bushels; potatoes--sweet, $5,095,709$ bushels, and 1 rish, 2,735 bushels. The potato crop of 1839 amounted to 2,609,239 bushels.

Miscellaneous Orops:-Tobacco, 11,984,786 pounds; ginned cotton, 73, 849 bales of 400 pounds ; hay, 145,662 tons; cloverseed, 576 bushels; other grass-seed, 1,275 bushels; hops, 9,246 (in 1840, 1,063) pounds; hemp-dew-rotted, 0 tons, and water-rotted, 3 tons; flax 393,796 pounds; flax-seed, 39,196 bushels; silk cocoons, 229 (in 18t0, 3,014) pounds; maple sugar, 27,932 pounds; molasses, 104 gallons; beeswax and honey, 512,2s9 pounds; wine, 11,05s gallons, etc. Value of orchard. products, $\$ 34,34$, and of market-garden products, $\$ 39,462$.

The following table exhibits the actual and comparative quantities of the principal staples produced in the year preceding the censuses of 1810 and 1850 :

\begin{tabular}{|c|c|c|c|c|c|c|c|c|}
\hline $\begin{array}{l}\text { Crops. } \\
\text { Rice } \ldots \ldots \ldots \ldots \text {. }\end{array}$ & $\begin{array}{l}1840, \\
2,820,383 \text { pounds }\end{array}$ & ...... & $\begin{array}{l}1850 . \\
5,465,568 \text { pounds }\end{array}$ & ,..... & $\begin{array}{l}\text { Decennial Movement. } \\
\text { incr. } 2,645,480 \text { pounds, }\end{array}$ & or & \multicolumn{2}{|c|}{93.8 per cent. } \\
\hline Potatoes........... & $2,609,289$ bushels & $8 \ldots \ldots$ & $5,098,414$ bushels & ...... & incr. $2,439,239$ bushels, & or & 95.4 & 66 \\
\hline Tobacco.......... & $16,772,359$ pounds & $\ldots \ldots$ & $11,984,786$ pounds & $\ldots \ldots$ & decr. $4,787,573$ pounds, & or & 28.5 & 6 \\
\hline Cotton............ & $51,926,190$ & $\ldots \ldots$ & $29,539,600$ & ...... & decr. $22,356,590$ & or & 43.1 & “ \\
\hline Hay............... & 101,369 tons & ..... & 145,662 tons & $\ldots \ldots$ & 44,293 tons, & or & 43.7 & 6 \\
\hline $\operatorname{Temp} \ldots \ldots \ldots \ldots \ldots$ & $9,579 \frac{1}{8}$ " & $\begin{array}{l}\ldots \ldots \\
\ldots \ldots\end{array}$ & $\begin{array}{c}3 \\
593,796 \text { pounds }\end{array}$ & $\begin{array}{l}\cdots \cdots \\
\ldots \ldots\end{array}$ & 21,529,191 pounds, & or & 97.3 & " \\
\hline Vine............ & $2 S, 752$ gallons & $\ldots \ldots$ & 11,055 gallons & $\ldots \ldots$ & 17,694 gallons, & or & 61.2 & 66 \\
\hline
\end{tabular}

Home-made manufactures were produced to the value of $\$ 2,0 \$ 6,522$. The same quality of products, according to the census of 1840 , were valued at $\$ 1,413,242$.

IFanufactures.-Aggregate eapital invested, $\$ 0,000,000$; value of all raw material, fuel, etc., used, $\$ 0,000,000 ;$ average number of hands employed, 00,000 -males 0,000 , and females 0,000 ; average monthly cost of labor, $\$ 000,000-$ male, $\$ 000,000$, and female, $\$ 00,000$; total value of products for the year ending 1 st June, $1850, \$ 0,000,000$. The whole number of manufactories producing to the value of $\$ 500$ and upward annually, 2,528 ; and of these 28 are cotton factories, 1 woolen factory, 151 tanneries, and 26 iron works, viz., 5 making castings, 2 pig iron, and 19 wrought iron. The total capital employed in manufactures in 1840 was $\$ 3, \$ 35,900$.

Cotton manufactures employ a capital of $\$ 1,058,800$; annual consumption of cotton, 13,617 bales; value of all raw material, $\$ 531,903$; average hands employed, 1,619-males, 412 , and females, 1,17 ; entire wages per month, $\$ 12,369-$ to males, $\$ 5,153$, and to fenales, $\$ 7,216$; annual products, $2,470,110$ yards of sheeting, etc., and $2,267,000$ pounds of $y a r n-$ in all valued at $\$ 531,3 \pm 2$. Capital invested in $1540, \$ 995,300$, and hands employed, 1,219 . Annual value of products, $\$ 435,900$.

Woolen manufactures employ a capital of $\$ 18,000$; annual consumption of wool, 30,000 pounds; value of all raw material, $\$ 13,950$; number of hands employed, 75 -males 40 , and females 35 ; entire wages per month, $\$ 1,635-t o$ males, $\$ 1,099$, and to females, $\$ 536$; annual products, 340,660 yards of cloth, valued at $\$ 53,750$. Capital in $1 \$ 10, \$ 9,800 ;$ hands, 4 .

Tanneries employ a eapital of $\$ 251,055$; value of raw material, etc., consumed, $\$ 191,237$; hands employed, 8733 ; monthly wages, $\$ 5,295$; tanned-21,035 skins, and 155,610 sides of leather, ralued at $\$ 352,535$. Capital in $1810, \$ 271,797$; hands, 645 ; tanneries, 353.

In the manufacture of malt and spirituous liquors the capital invested is $\$ 21,930$; quantities and kinds of grain, etc. consumed-corn, 64,650 bushels, and rye, 4,700 bushels; hands employed, 75 ; quantity of liquors produced-whisky and high wines, 158,030 gallons.

The iron manufactures are represented in the following tabular statistics:

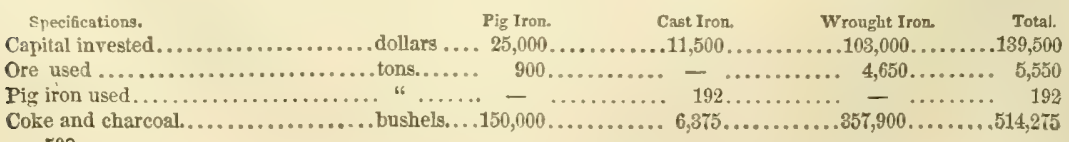




\section{NORTH CAROLINA.}

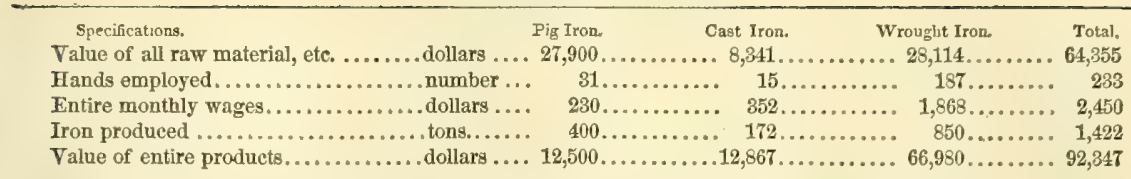

-Capital in iron manufactures in 1840, \$94,961; hands, 465 . There are also in the State several machine shops, hardware factories, soap and candle manufactories, potteries, carriage manufactories, etc., and numerous grist, saw, flour, and other mills, which, in the aggregate, make up a respectable manufacturing industry in a State so much devoted to agriculture as is North Carolina.

Commerce, Navigation, etc.-North Carolina, in the year ending 30th June, 1850, exported to foreign countries merchandise, etc., to the value of $\$ 416,501$, and imported goods to the value of $\$ 323,692$. Of the exports (all of which were of domestic origin), to the value of $\$ 259,616$ was carried in American, and to $\$ 156,885$ in foreign bottoms; and of the imports, to the value of $\$ 179,249$ was earried in Amexican, and to $\$ 144,443$ in foreign bottoms. The entrances and clearances in the same year were as follows:

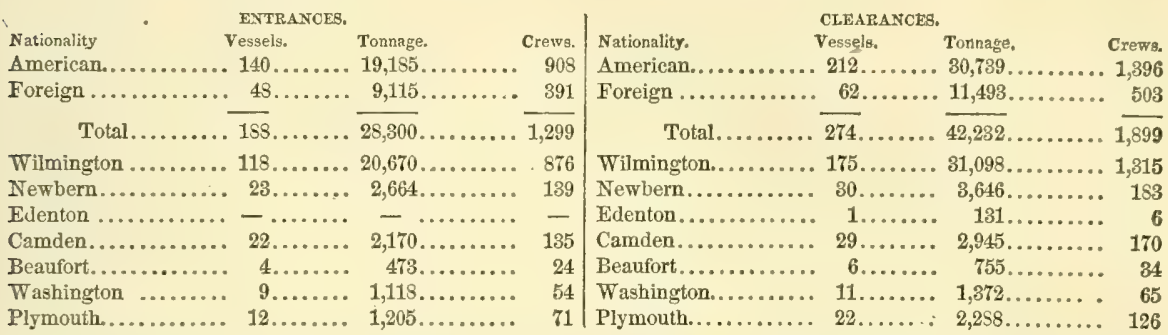

The total shipping owned in the State at the date specified was 45,218 tons, of which 14,932 tons were registered, 27,535 tons enrolled and licensed, and 2,751 tons licensed (under 20 tons.) All enrolled and licensed shipping was employed in coasting, and of this 3,226 tons were navigated by steam-power. The whole of the licensed tonnage was also employed in coasting. The tonnage of the several districts was-Wilmington 15,198 tons, Newbern 5,208 tons, Washington 5,703 tons, Edenton, 1,145 tons, Camden 11,948 tons, Beaufort 2,260 tons, Plymouth 2,328 tons, and Ocracoke 1,428 tons. The number of vessels built in the several districts was 33, viz, 1 ship, 2 brigs, 23 schooners, 2 sloops, and 5 steamers, and their tonnage 2,652. Of the whole number 4 (483 tons) were built at Wilmington, 8 ( 867 tons) at Newbern, 1 ( 34 tons) at Washington, 5 (256 tons) at Edenton, 9 (693 tons) at Camden, 3 (206 tons) at Beaufort, and 3 (114 tons) at Plymouth. The statistics of the foreign commerce of the State for a series of years-1791 to 1850 -exhibit the following movements in the values of exports and imports.

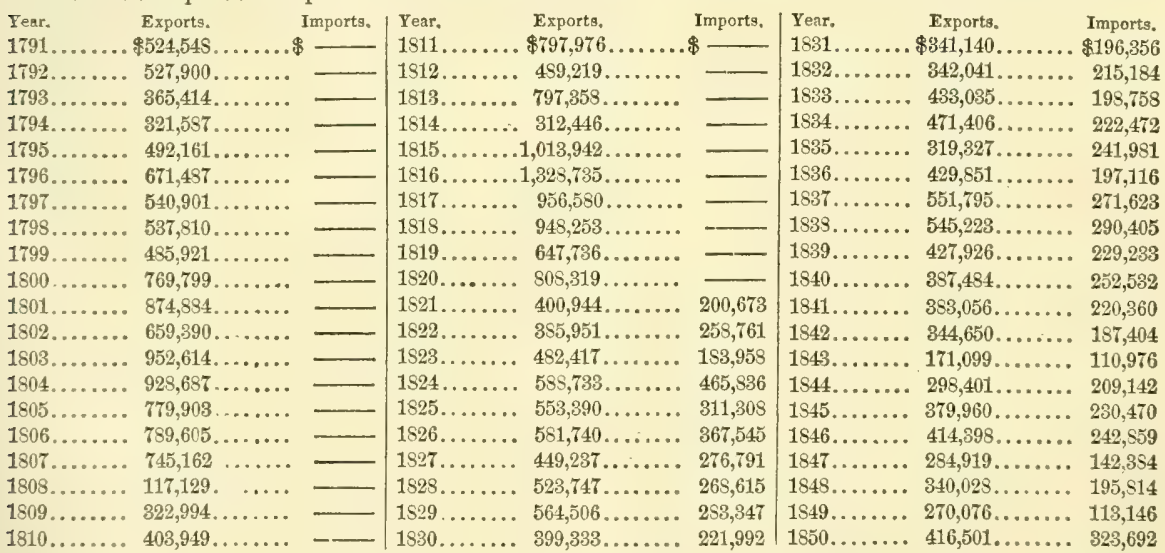

Internal Improvements:-Great efforts are being made in this State to build up a system of railroads between the interior and the sea-board, and also to connect the railroads of North Carolina with those of the adjoining States. As yet, however, the only through line is the Weldon and Wilmington $\mathbf{R}$. $R$. at Weldon, uniting with the Petersburg $\mathbf{R}$. $R$., running north, and the Sea-board and Roanoke R. R. to Norfolk, and at Wilmington with the Wilmington and Manchester R. P., which forms a connection with the South Carolina railroads. The North Carolina Central $R$. $R$., running from a point above Goldsboro', on the Weldon and Wilmington R. R., through Raleigh, Hillsboro', Greensboro', Lexington, and Salisbury, forms a junction with the South Carolina system at Charlotte, and this road will probably be extended from its eastern terminus to Beaufort. A railroad has long been in operation from Gaston, on the Roanoke, to Raleigh, at which latter point it connects with the central and at Gaston with the Greenville and Roanoke $R$. R., which leaves the great Southern line at Hicksford. The total length of eompleted railroad in this State on the 1st Jan., 1853 , was 249 miles, or in the proportion of one mile to every 18 square miles of territory. The only canals in use within the State are the Dismal Swamp Canal and its north-west branch, which are used chiefly for lumbering purposes, and Harlow Canal, extend- 


\section{NORTH CAROLINA.}

ing from the Neuse to Beaufort. Important improvements are also contemplated in Deep and Cape Fear rivers, so as to make them an outlet for the mineral wealth of their vicinities,

Banks.-According to the bank returns of November, 1550 , there were in the State 5 banks and 15 branch banks, the aggregate condition of which, at that period, was as follows: Liabilities-capital, $\$ 7,759,250$; circulation, $\$ 4,249,953$; deposits, $\$ 942,098$; due other banks, $\$ 60,682$; all other liabilities, $\$ 1,825$; and assets-loans and discounts, $\$ 6,1) 56,783$; stocks, $\$ 150,000$; real estate, $\$ 127,806$, other investmenis, $\$ 1 s, 785$; due by other banks, $\$ 1,074,794$; notes of other banks, $\$ 4 \$ 3,947$; and specie, $\$ 1,645,028$. The Bank of Cape Fear, located at Wilmington, has branches at Asheville, Fayetteville, Greensboro, Raleigh, Salem, Salisbury, and Washington, and the Bank of the State of North Carolina, at lialeigh, has branches at Charlotte, Elizabeth City, Fayetteville, Milton, Morgantown, Newbern, Tarboro', and Wilmington. Banks besides these are also established at Fayetteville, Wadesboro', Washington, Wilmington, and Newbern.

Government, etc.-The government of the State is based on the constitution of 1786 , as amended in 1835 .

The right of suffrage is allowed to every free white man, 21 years old, an inhabitant of his district 12 months preceding an election, and owner of a freehold within the same for six months. Such may vote for senators, but in voting for representatives, the freehold qualification is not needed, if the voter has paid taxes. But no descendant of a negro, to the fourth generation, though one ancestor in each generation be white, is to be accounted a white man. The general elections are held biennially on the 1st Thursday in August.

The Legislature is composed of a House of Commons and a Senate. Members of the House of Commons (120 in number) must have resided in their respective counties one year, and have owned for six months next before their election 100 acres as freehold, and are chosen biennially, not less than one in each county. Senators (50 in number) are chosen biennially in districts set off on the basis of taxation, and must be possessed for the same time of 300 acres therein in fee, An apportionment of both houses was made in 1851, and apportionment will be made every twenty years thereafter. The General Assembly, thus constituted, convenes on the third Tuesday in November biennially. No special law shall be passed to alter the name of any person, to legitimize bastards, or to restore to citizenship persons convieted of infamous crimes; but general laws for these purposes may be passed.

The Governor is chosen by the persons qualified to elect members of the house for two years (but no such elected person shall serve more than four years out of any six years) by a plurality of votes, or in case of an even vote by the two houses of the General Assembly on joint ballot. An Executive Council of State, consisting of seven councilors, shall be chosen at every regular session, who shall keep a journal of their proceedings, open to the General Assembly. The governor may lay an embargo for thirty days, with the consent of the council. If the office of governor be vacant, it is to be filled by the Speaker of the Senate, and he failing, then by the Speaker of the House of Commons. No clergyman, while in the exercise of his duties as such, shall be a member of the council.

Among the miscellaneous provisions of the constitution, are the following: Every foreigner who comes to settle may take take the oath of allegiance and hold real estate. Judges of the Supreme and Superior courts are appointed by joint ballot of both houses, and may be removed for mental or physical inability upon a resolution of two-thirds of the members thereof. Their salaries shall not be diminished during their term. No person who shall deny the being of a God or the truth of the Ohristian religion, or the divine authority of the Old or New Testament, or who shall hold religious principles incompatible with the freedom or safety of the State, shall hold any civil office.

To amend the constitution, a convention of the people may be called by a vote of two-thirds of the members of both houses. Amendments, if agreed to by three-fifths of the members of each house, shall be published six months before the next election; and if approved by two-thirds of both houses, shall be submitted to the people; and if approved by a majority of votes of the voters qualified to elect members of the House of Commons, shall be adopted.

The judiciary consists of a Supreme Court, Superior or Circuit courts, etc. The Supreme Court consists of a chiefjustice and two associate justices, the attorney-general, a reporter and two clerks, one at Raleigh, and one at Morgantown. This court holds three sessions in each year-two in the city of Raleigh, on the $2 \mathrm{~d}$ Monday in June and the last Monday in December; and one at Morgantown, on the 1st Monday of August, for the western part of the State, and continues to sit at each term until all the business on the docket is determined or continued upon gaod cause shown. It has power to hear and determine all cases in law or equity brought before it by appeal or by the parties; and has original and exclusive jurisdiction in repealing letters patent, and has also power to issue all writs necessary and proper for the exercise of its jurisdiction. The Superior or Circuit courts are composed of one judge and solicitor in each eircuit; these are courts of law and of equity, and are held twice a year in each county of the State. There are seven circuits, of about ten counties each, which the judges ride alternately, never visiting, however, the same circuit twice in succession. The judges of these courts have complete equity jurisdiction.

The militia of North Carolina is composed of 79,415 men of all grades, of which number 4,267 are commissioned officers, and 75,181 non-commissioned officers, musicians, artificers, and privates. Of the commissioned officers, 28 aro general officers, 183 general staff officers, 657 field officers, ete, and 3,449 company officers. Every white male citizen, between the ages of 18 and 45 y ears, unless exempt by law, is liable to military duty.

The charitable and benevolent institutions supported by the State are the North Carolina Institution for the Instruction of the Deaf and Dumb, and the Asylum for the Insane. The foundation stone of the Institution for the Deaf and Dumb was laid on the 14th April, 1548. It is located at Raleigh on a plot of four acres, and near the State-House. The Lunatic Asylum is not yet commenced. The legislature of 1850 imposed a tax of one cent and three-quarters on every one hundred dollars-worth of land, and five and a quarter cents on every taxable poll per annum for four years to raise a fund for building an institution of this description-taxes which are expected to yield $\$ 80,000$ in the time speciffed. The legislature, also at the same session, passed a bill authorizing an agricultural, mineralogical, and botanical survey of the State. The surveyor, whose appointment rests with the governor, is required personally or by his assistants, "to visit every county of the State and examine every thing of interest or value in either of the above departments, to ascertain the nature and character of its products, and the nature and character of its soil, as well as to give an account of its minerals."

Public Debt, Finances, etc.-The receipts from all sources for the year ending 31st October, 1850, amounted to $\$ 219,00647$, and the expenditures in the same year to $\$ 228,17321$-being an excess of expenditures orer receipts of $\$ 9,16677$. The chief sources of income are the public taxes, bank taxes, interest on railroad bonds, income from interest in railroads, etc. ; and the principal objects of expenditure are executive, legislative, and judicial expenses, public printing, interests on investments, repayments of loans, etc., election expenses, public library, etc. North Carolina, properly epeaking, has no public debt; it has, however, a contingent liability, which arises from its endorsement by the State 


\section{NORTH CAROLINA.}

of bonds of railroad companies to the amount of $\$ 1,100,000$, but from this must be deducted $\$ 13,000$ for bonds not used and $\$ 110,000$ for bonds paid, which reduces the amount for which the State may be liable, to $\$ 977,000$. Since the above date other liabilities have been assumed for the progressing railroads. The value of real and personal estate of tho inhabitants of North Carolina, including the value of slave property in 1550 , was assessed at $\$ 212,071,213$. True valuation, $\$ 226,800,4 \pi 2$.

Federal Representation.-North Carolina, in accordance with the law of $23 \mathrm{~d}$ May, 1850 , is entitled to eight representatives in the Congress of the United States.

Education.-Before the Revolution, literature was hardly known in this State, much less a subject of cultivation. Thero were in the province at the end of the royal government, only two schools in operation, one at Newbern and one at Edenton. The constitution of 1776 , directed that "a school or schools shall be established by the legislature for the convenient instruction of youth, with such salaries to the masters, paid by the public, as may enable them to instruct at low prices; and all useful learning shall be duly encouraged and promoted in one or more universities." Till within late years, however, no system of free schools was introduced throughout the State. Liberal provision was made for the purpose in 1825 , by the creation of a school fund. This fund now amounts to nearly half a million dollars, besides the income of stock held by the State in several railroads, the proceeds of the sale of swamp lands, and the tract acquired from the Chcrokees in the south-west. In order to apply these funds, a Board of Literature was established in 1837, to devise a plan of common schools; but as yet nothing efficient for the increasing population has been. brought to fruition. At the present time there are some 200 academies, and between 800 and 900 common schools in the State, at which from 18,000 to 20,000 youth are annually taught. The principal collegiate establishments in the State are the University, Davidson College, and Wake Forest College. The University of North Carolina is located at Chapel Hill, in Orange County, and in 1850 had a president, 10 professors, and 230 students. It was founded in 1789 , and its alumni numbered 964 , of which about 70 had entered the ministry. It has an excellent library of 13,500 volumes. In 1853 a sehool of science and art was attached to it: In the law department there were, in 1850, ten students. Davidson College, founded in 1838 , is situate in Mechlenburg County, and in 1850 had 4 professors, 60 students, and a library of about 5,000 volumes, and its alumni aum bered 140, of which 24 were in the ministry. Wake Forest College (a Baptist institution) was founded in 1838, and in 1550 had 3 professors, and 24 students; its alumni numbered 11, of which 6 were in the ministry, and its library contained 4,700 volumes.

Pullic Libraries.-One State library-3,000 volumes; 3 college-9,401 volumes; 2 students'-8,S16 rolumes; 2 academic and professional-3,000 volumes; total, 8 libraries, and 24,247 volumes. This account, which is from the census of 1550 , differs essentially from the returns of the colleges, and is probably under-rated.

Periadical Press. - The whole number of newspapers, etc., published in the State in 1850, was 52 , of which 24 advocated whig principle, and 9 that of the democracy, and 19 were neutral in politics, or devoted to literature, religion, ete. Of the whole number, 1 was published tri-weekly, circulating 340 copies at each issue, or 53,040 copies annually; 3 semi-weekly, circulating 8,437 copies, or 399,088 annually; 41 weekly, circulating 28,427 copies, or $1,478,204$ annually ; 4 semi-monthly, circulating 3,775 , or 90,000 annually; and one monthly, circulating 450, or 5,400 annually. The counties in which published are-Anson, 1 s.-w. and 1 w.; Buncombe, 2 w.; Beaufort, 1.w.; Caswell, 1 w.; Chowan, 1 w.; Cherokee, 1 w.; Craven, 2 w.; Cumberland, 8 w.; Chatham, 1 s.-m.; Edgecombe, 1 w.; Guilford, 1 w. and 1 m.; Granville, 1 w.; Halifax, 2 w. Lincoln, 2 w.; Mechlenburg, 2 w.; New Hanover, 1 t.-w., 2 s.-w., and 3 w.; Orange, 2 w.; Pasquotank, 2 w. and 1 s.-m. Rutherford, Randolph, and Rowan, each 1. W.; Wake, 1 s.-W., 6 W., and 3 s.-m.; Wayne, 2 w.; and Washington aud Warren, each 1 weekly.

Religious Denominations, - The statisties of the several religious denominations in the State, were as follows:

Denomina- No. of Church Value of Denomina- No. of Church Value of Denomina- No. of Cluurch Value of Baptist. ....573 .. 195,727 .. $\$ 201,445$ German Ref. 15 .. 5,725 .. $\$ 17,200$ R. Catholic... 4 .. 1,400 .. $\$ 5,900$ Christian.... 29 . 11,600 . 10,575 Jewish..... - . - .. - Swedenbo'n .. . - .. -

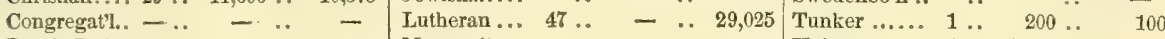
Dutch Pef.. - .. - .. - $\quad$ Mennonite.. - .. - .. - Union ..... 4 .. 1,200.. Episcopal ... 47 .. 14,970 .. 112,100 Methodist... 727 .. 19,550 .. 284,930 Unitarian.... - .. - .. Free....... 51 .. 14,545 ... 15,860 Moravian ... $7 . . .214,937$.. 31,000 Universalist... - .. - .. -

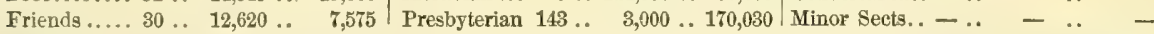
-making a total of 1,675 churches, having accommodation for 555,204 persons, and valued as property at $\$ 5 \$ 9,393$. The State forms the Protestant Episcopal diocese of North Carolina, and is a constituent portion of the Roman Catholic diocese of Charleston.

Pauperism.- The whole number of persons relieved or supported during the year ending 1st June, 1850, was 1,931, of which number 1,913 were native-born and 18 foreign-born; and the whole number receiving support at the date specifled was 1,550; viz, 1,567 native-born and 13 foreigners. The cost to the public amounted to $\$ 60,085$.

Fistomical Sketch.-The first English settlement in North America was made in $\mathbf{1 5 S 5}$ on Roanoke Island, in this State. The patron of the infant colony was Sir Walter Paleigh, to whom Queen Elizabeth granted, in 15St, a patent for such lands as he might discover in America, "not possessed by any Christian people." The same year he dispatched two small vessels to make discoveries, and these dropped their anchors early in July in Ocracoke inlet. The adventurers landed on an island near Roanoke, called by the natives Wococon, where they were received with every mark of hospitality. After visiting the neighborhood they returned to England and gave a bighly favorable account of the climate and soil. The name of Virginia was bestowed upon the country, and Raleigh's patent was confirmed by act of Parliament. Sir Walter sent out at once, under Ralph Lane as governor, the colony above mentioned. Soon, however, Indian hostilities, provoked by the tyrannieal behavior of the leaders of the colony, were commenced, and much suffering from this cause, as well as scarcity of provisions, was endured by the adventurers. They became discouraged, and finally returned home. A few days after their departure, a ship, under Grenville, arrived, and learning the destination of the colonists, left 15 men, with provisions for two years, to keep up the settlement.

Cndeterred by his first failure, Raleigh sent out another colony in 15s7, with orders to settle on Chesapeake Bay, where they were to build the projected "City of Raleigh." The new colonists, however, were put ashore, at Roanoke, They found no trace of Grenville's men, who had probably fallen under the wrath of the Indians; and searcely had they themselves landed than they were engaged in combat with the natives. Their governor, White, returned to England for expplies, but owing to the troubles consequent on the Spanish invasion of England, he was detained from revisiting the 


\section{NORTH CAROLINĀ.}

colony until the autumn of 1590 . On arriving, he found the site of the settlement inclosed by a strong palisade, but not a colnnist remained, and to the present day their fate has been a subject of conjecture. Thus ended Raleigh's attempt to colonize Virginia.

Early in the reign of Charles I. (1630) a tract of land south of the Chesapeake, designated as Carolina, was granted to Sir Robert Heath, but as he planted no colony on it the grant was revoked. Out of the same territory Charles II. formed, in 1663, the province of Carolina, and conveyed it by charter to eight royalist noblemen of England. This charter, as amended in 1665 , defines the limits of the province to be the 29 th parallel of north latitude on the south, the Paciflc on the west, the Atlantic on the east, and or the north the parallel of $36^{\circ} 30^{\prime}$-afterward and now better known as the Missouri Compromise Line. The grantees were made proprietors of the soil, and were intrusted with powers of jurisdiction over the colonists.

Already previous to this conveyance, settlers had located in the northern part of the province, and for some years refugees from Virginia had been coming, a few at a time, into the neighborhood of the Sound afterward called Albemarle, in honor of General Monk, whose ducal title was such. A little colony had also been planted by adventurers from New England near the mouth of Cape Fear River. The soil, however, proved sterile, and the colony dwindled slowly away, and would have totally disappeared, had not some planters from Barbadoes, under Sir John Yeamans, removed thither in 1605, and formed the settlement of Clarendon, by which the few remaining New Englanders were rapidly absorbed. These new settlers supported themselves with difficulty by shipments of boards, shingles, and staves. Gradually, by numerous migrations southward, the colony again became reduced, until at length, before 1690 , it was entirely exhausted. The proprietaries in 1670 sent out emigrants under the command of William Sayle to form a new settlement, to be called the County of Carteret. The colonists located themselves first at Port Royal, South Carolina, but they soon removed, and formed a settlement between Cooper and Ashley rivers, which they called Charleston. Sayle dying next year, Sir John Yeamans was appointed governor of Carteret, the southern province. Thus there were in 1671 two permanent settlements in Carolina, Albemarle and Carteret, and these two constituted the nuclei of North and South Carolina as now existing.

At the request of one of the proprietors, the celebrated Joln Locke framed a scheme of government for the whole province of Carolina. "The Grand Model," as it was called, though complete of its kind, was too complicated, if not too monarchical for an infant colony, yet the proprietaries adopted it as the fundamental law of the province, and such for 20 years it nominally remained. As a matter of fact, however, it was never brought into operation, though the governor of each district of the province strove hard to comply with its requisitions, in spite of the continued and ultimately successful opposition of the colonists.

The settlement at Albemarle was augmented by accessions from Virginia, New England, and the Bermuda islands; William Drummond was appointed first governor. He was succeeded by Samuel Stevens, under whom were enacted the first laws of the colony, by an assembly composed of the governor, the council, and twelve delegates. Every encouragement was given by these laws to whomsoever proposed settling in the colony; bounty-lands were granted at a moderate quit-rent (ifd. per acre); taxes could be imposed only by consent of the assembly; and religious liberty was promised to members of every Christian denomination. Intestine commotion, proceeding partly from discontent with the "Madel System," and partly owing to a general feeling of restlessness prevalent sometimes in new colonies, soon disturbed the peace and welfare of Albemarle. The Culpepper and other rebellions distinguish this period. This discontent and turbulence were not removed until the arrival (1695) of John Archdale, one of the proprietors, as governor, invested with nnusually extensive powers. Sagacious, and possessed of rare prudence, the Quaker Archdale succeeded in reducing both provinces to comparative order. During the preceding period, North Carolina had received a decided check to her prosperity. Many fled the country. At the beginning of the troubles, the province contained 1,400 taxable inhabitantsin 1694, 787 were all that could be found within its limits. Under Archdale, the colony began again to flourish. Settlements were made (169s) on the Pamlico River, upon the Tar and the Neuse, and Bath County was set off to the southward. Rice and tar, two of the staples of North Carolina, began now to be exported; churches were for the first time erected, and religion began to receive the support of the authorities, given, however, in an illiberal and sectarian spirit, inconsistent with the promise to the first colonists. The Episcopalians had a majority in the legislature, and failed not to use their power to the repression of all dissenters. The Carey rebellion now disturbed the prosperity of the colony, which was not quelled till sereral engagements had been fought and much blood spilt. Meanwhile the province was involved in a general war with the Indians. Since the settlement of Albemarle, until this time, uninterrupted peace had existed between the whites and Indians. As the settlement increased, however, the Indian began, not without reason, to fear for his future safety.

In 1707 a colony of Huguenots had removed from Virginia and settled on the Trent, and in 1709 a colony of Germans from Heidelberg and vicinity founded the settlement of New Berne (Newbern) at the confluence of the Trent and the Neuse; they received a liberal grant from the proprietaries, and it was the surveying of these lands that led to the Indian outbreak. Regarding these surveys as encroachments on their independence, the Tuscaroras seized the surveyor-general and put him to death, and an immediate attack was also made on the white settlements south of Albemarle Sound. Other tribes joining the Tusearoras, the war became general. All Carolina did not at that time contain 2,000 men capable of bearing arms; yet when assistance was sought from the southern province, it was at once obtained. The Indians were worsted in several actions, and finally compelled to take refuge in a fort near the Neuse. Here they would have been forced to surrender at discretion, but the commander of the colonists concluded with them a hasty and disadvantageous peace, and shortly afterward hostilities were renewed. The situation of the colony now became truly critical; aid was again sought of the neighboring provinces, which was granted. The war was prosecuted with vigor, and in 1713 the power of the Tuscaroras was completely broken; and haring emigrated to the North, the tribe confederated with the Senecas and other tribes, which afterward became the "Six Nations." The other hostile tribes sonn after submitted to the mule of the victors, and in 1717 peace was finally concluded. The sufferings of the colony during the Carey rebellion and the Indian war were extreme. Not a few settlers abandoned their homes altogether; and notwithstanding the new accessions and the natural increase of the population, the number of taxable inhabitants in 1717 did not exeeed 2,000 .

For some time after this period the country was demoralized by the imposition of a worthless succession of governors. In July, 1729, the king purchased for $£ 17,500$ seven-eighths of the whole province: the remaining eighth was retained by Lord Carteret, and was laid off for him (not, however, till 1743) adjoining the Virginia line. Previous to this the bound. ary between the two had been settled upon its existing basis. The spirit of anarchy and resistance to legal authorith 


\section{NORTH CAROLINA.}

hitherto prevalent, was now brought more under control; still justice and obedienco to the laws were by no means universal.

During the Indian troubles paper money had been issued by the Assembly, but although gradually sunk by taxes, it depreciated. In $1729, £ \pm 0,000$ were issued, and in $1734 £ 10,000$ additional. Depreciation went on, until in 1733 the rate was seven and a half for one of sterling. This depreciated currency the Assembly attempted in 1738 to circulate, by making it a legal tender for quit rents. In the disputes that ensued, the governor, who was opposed to paper money, dissolred two successive assemblies. Other acts, equally unjust and impolitic, were passed at various times, nor was the governor wholly free from the imputation of irregular and partial administration. These, and other adverse circumstances, as M.Culloch's speculation in erown lands, the breaking out of hostilities between England and Spain, by which the Carolinas were involved in war with the Spanish settlements of Florida, retarded in no small measure the progress of the colony. In spite of all, however, the increase in inhabitants was decidedly rapid. During Johnstone's administration, three distinct and extensive settlements were made: one chiefly by Presbyterians from the north of Ireland, who settled in Carteret's lands in the north-west; another by Moravians, who obtained from Carteret a grant of 100,000 acres between the Yadkin and Dan; and the third by a large body of Highlanders, chiefly from Argyleshire, for whom land had been purchased by their leader, Neal M'Neal, near the present Fayetteville. All these colonies were successfully established, and their numerous descendants inhabit the State at this day.

Notwithstanding every effort at conciliation, unfriendly Indian tribes, especially after Braddock's defeat (1755), harrassed the western frontiers. Among these tribes the Cherokees were foremost in committing depredations; they, as well as the upper Creeks, by whom they had been joined, were finally forced to sue for peace. Differences between the governor and legislature also at this time existed, and the dissatisfaction was constantly increasing. To allay it, William Tryon, a military officer, was sent ont, who subsequently himself became governor. Tryon (1765) found the colony restless and unquiet. Many were ripe for open rebellion. But the new incumbent ruled with a steady hand, and maintained the laws. Early in his administration the dispute between England and the colonies began. He managed for a time to avoid a collision with the Assembly, but at length, when that body declared (4th November, 1769) against the right of Englaud to tax North Carolina, he dissolved it. Previous to this, however, the country was distracted by a formidable insurrection of the so-called "Regulators;" neither property nor life was safe from their violence. Tryon at length (1771) raised a body of troops and marched against these disturbers, who were chiefly poor and aneducated men, but led on by wily, political anarchists. Encountering them near Great Allamance, 3,000 strong, he attacked them with his 1,000 militia, and gained a decisive victory. After their defeat the insurgents in general took the oath of allegiance. In the following August Tryon, who, on the whole, had been a popular ruler, was succeeded by Josiah Martin. One of his first acts was the settlement of the boundary line between North and. South Carolina. Disputes soon arose between him and the Generas Assembly, and the trouble was increased by the persistence of England in her policy of taxing the colonies. The governor sided with the crown, as also did the Regulators, whom he had the meanness to conciliate by the detraction of Tryon, but the remaining inhabitants generally adopted the cause of the colonists.

North Carolina, in spite of the Governor's opposition, was represented in the first Continental Congress (Sept. 1774), and its delegates joined in adopting the Declaration of Colonial Rights. The Provincial Congress approved of their proceedings, and appointed delegates to the next. An association for the defense of colonial rights was also formed, and the citizens of Mechlenburg County even went so far (May 21, 1775) as formally to declare their independence of the British connection. Alarmed at the progress of the disaffection, the Governor retired (July) on board a ship of war in Cape Fear River. The revolution in North Carolina was now complete. A State Convention was formed (20th August), and the raising of three (afterward five) regiments of troops authorized, and all were taken by Congress into Continental pay. The Tory influence, however, was strong, especially among the Regulators, and attempls, which failed, however, were made to form a junction with General Clinton, who was on the coast, waiting for reinforcements from England preparatory to making a descent upon the country -850 of them were captured and made prisoners. Four more regiments were now ordered to be raised. Clinton, though reinforced, despairing of local assistance, sailed away to the attack of Charleston. In April succeeding (1776), the Convention taking the lead, authorized their delegates in Congress to join with other colonies in declaring independence. On the 4th July that independence was solemnly declared. Meanwhile the Cherokees, in league with the British, ravaged the western frontiers. Promptly met by a strong force from the Carolinas and Virginia, they were subdued, and forced to surrender to their conquerors a large tract of country, including the yet infant settlements on the Tennessee. The territory apportioned to North Carolina was erected into the District of Washington, the original province being now (since December 18th, 1776) a State, having a regular government. Settlers were encouraged to locate in the District, lands being granted at the rate of $£ 210 s$. per 100 acres.

In 1779 the Southern States were the chief scene of the Revolutionary War. In May, 1780, Charleston surrendered to the British, and within a month all South Carolina was in possession of the victors. The loyalists at once flew to arms; of two parties assembled to aid the British one succeeded in reaching the outposts, but the other was dispersed by the militia, After the defeat of Gates at Camden (6th August) there was left no organized force in either of the Carolinas. Cornwallis prepared to make an eruption into the North State - the battles of King's Mountain, of the Broad River, of the Tyger River, and of the Cowpens followed in quick succession. The mutual animosities of the Whigs and Tories now exhibited itself in savage ferocity. Fort Watson, Hobkirk's Hill, and Ninety-Six were also the scenes of warfare. The fortunes of war had hitherto vacillated; at one time the State was, to all appearances, subdued, and at another, elated by success. On the 8th September, 1781, the British were totally defeated by Generul Greene. Soon after the capture of Comwallis (17th October) Wilmington was evacuated (January, 1782), and toward the end of the year peace was declared, and the British dominion within the State ended.

The history of North Carolina, since the Revolution, exhibits few changes and few events of more than ordinary importance. During that period she acted with fortitude, and by her great sacrifices in men and money contributed much to the successful result of the struggle. The Legislature acceded to the federal constitution on the 27th November, 1759 , by a vote of 193 yeas to 75 nays, and since then the people of no other State have adhered more firmly to the Union. RALEIGH is the political capital of the State.

Norrg CARVER, p. O., Plymouth co., Mass. : 35 m. S. S. E. Boston.

Norti CASTIEE, p. 0., Hanccek co., Me. : 54 m. E. by N. NorTH CAstLe, t. and p. o., Westchester county, $N . Y_{\text {.: }}$ $106 \mathrm{~m}$. S. Albany. Drained by Byram r. Surface of $t$ Augusta. hilly; soil, sandy loam and clay. Pop. 2,189.

North Castue, t., Schuylkill co, Penn.: $49 \mathrm{~m}, \mathrm{X}, \mathrm{E}$ 
Harrisburg. Drained by branches of the Schuylkill. Surface hilly and rugged; soil difficult of cultivation. The whole region is underlaid with anthracite and iron. The capital invested in coal mining, in 1850 , was $\$ 503,560$, and the value of the annual products was $\$ 3 \$ 1,314$.

North Crfarlestown, p. v, and sta., Sullivan county, N. Hamp.: on Connecticut r.; $44 \mathrm{~m}$. W. by N. Concord; $13 \mathrm{~m}$. from Bellows Falls by Sullivan R. R

North Chathaм, p. v., Barnstable co., Mass. : 73 m. S. E. Boston.

Nortr Chathasr, p. o., Clinton co., Penn. : 93 m. N. N.W. Harrisburg.

North Chatham, p. v., Columbia co., $N$. $Y$.: on E. side of Kinderhook er., 15 m. S. S. E. Albany.

North Chelmsford, p. Y., Middlesex co, Mfass.: on the S. side of Merrimac r., $24 \mathrm{~m}$. N. W. Boston, on the line of the Nashua and Lowell R. R., $4 \mathrm{~m}$. from Lowell. Here is a very large iron foundry.

Norti Chelsea, p. v. and sta, Suffolk co., Mass. : $4 \mathrm{~m}$.

N. N. E. Boston, on Eastern R. R.

North Chereng, p. o., Chemung county, $N$. I.: $153 \mathrm{~m}$. W. S. W. Albany.

North Chester, p. o., Windsor county, Verm. : $68 \mathrm{~m} . \mathrm{S}$. Montpelier.

North Chestre, p. 0., Hampden co., Mass: $96 \mathrm{~m}$, W. Boston.

North Chesterville, p. o., Franklin co., Me.: $23 \mathrm{~m}$. N. W. Augusta.

North CHTChester, p. o, Merrimac co., N. Hamp.: $8 \mathrm{~m}$. I. N. E. Concord.

North ChIII, p. o., Monroe co., N. $Y . ; 216 \mathrm{~m}$. W. by N. Albany.

North Clapence, p. o., Erie county, N. Y.: $238 \mathrm{~m}$. W. Albany.

Nortir Clarendox, p. v. and sta., Rutland co., Term. on Otter er., 53 m. S. S. W. Montpelier, and 3 m. S. E. from Rutland, by Rutland and Burlington R. R.

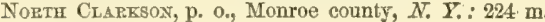
W. by N. Albany.

NoRti CoHassex, p. v., Norfolk county, Mass.: 14-m. S. E. Boston, by the South Shore Railroad, $22 \mathrm{~m}$. from Boston.

Nortн Соностол, p. o., Steuben co., N. Y.: $200 \mathrm{~m}$. W. Albany.

Nortr Colfaroos, pi o, Litchfield co., Conn.: 28 m. N. W. by W. Hartford.

NorTi Coluns, p. 0., Erie county, $X_{1}, Y_{1}: 257 \mathrm{~m} . \mathrm{W}$. Albany.

North Conwar, p. 0, Carroll county, N. Hamp.: $58 \mathrm{~m}$.

N. N. F. Concord.

NortI Concord, sta., Merrimac co, $N$. Zlamp. : $5 \mathrm{~m} . \mathrm{N}$. Concord, on Boston and Montreal R. R.

Norti Cove, p. 0, M·Dowell county, N. Car.: $186 \mathrm{~m}$. W. by N. Raleigh.

Nortir CreEE, p. o., Laurens district, S. Car. : 68 m. N.W. Columbia.

North Creek, p. o., Phillips co., Ark.: 98 m. E. by $\mathrm{S}$. Little Rock.

NortI Darvers, p. v., Essex co., Mass.: 11 m. N. by E. Boston, on the line of the Essex R. R., $5 \mathrm{~m}$. from Salem.

Nortin Danfilie, p. 0., Caledonia county, Term. : 26 m. N. E. by E. Montpelier, 4 m. W. St. Johnsbury.

North Dartwouti, p. v., Bristol co., Mass. : on the E side of Pomanset r., 51 m. S. Boston.

North DrghtoN; p. o., Bristol county, Mass. : $36 \mathrm{~m} . \mathrm{S}$. Boston.

Nortir Disurount, pi o., Penobscot co., Mre, 41 m. N. E, Augusta.

North Dorser, p. v., and sta. Bennington co., Term.

$72 \mathrm{~m}$. W. S. W. Montpelier, $22 \mathrm{~m}$. 8. Rutland, by Western Vermont R. R.

Norte Dorer, p. v., Cuyahnga county, Ohio: $115 \mathrm{~m}$. N. E. by N. Columbus, near Lake Erie. 00.-
North Duanesburg, p. o., Sehenectady co., N. $Y .: 23 \mathrm{~m}$. W. by N. Albany.

Nortu Dunbarton, p. o., Merrimac county, N. Iramp.: $7 \mathrm{~m}$. S. W. by s: Concord.

North E Est, p. O. and sta., Cecil co, $M d_{0}$ : on E. side of North-east r., 54 m. N. N. E. Annapolis, on the Philadelphia and Baltimore R. R., $52 \mathrm{~m}$. from Philadelphia, 46 from Baltimore.

NoRrr EAST, t. and p. v., Duchess county, $N_{.} Y_{.}: 50 \mathrm{~m}$. 8. by E. Albany. Drained by Ten Mile cr. and branches. Surface partly mountainous; soil adapted to grazing. The Harlem $\mathrm{R}, \mathrm{R}$. passes through the $\mathrm{t}, 96 \mathrm{~m}$. from New York. Pop. 1,555.

Nortri East, t., p. b., and sta., Erie co., Penn.: bounded N. by Lake Erie, and E. by New York State. Drained by Sixteen and Twenty Mile creeks. The t. contains numerous saw and grist mills. The Erie and North-east R. R. passes through the t. $15 \mathrm{~m}$. from Erie.

North East Centre, p. O., Duchess co., $N, Y_{0}: 52 \mathrm{~m}$. S. by E. Albany.

NoRTII EAsthaMr, p. o., Barnstable co., Mass. ; 63 m. S. E. Boston.

Norti EastoN, p. o., Bristol co, Mass.; 20 m. S. Boston. North EastoN, p. o., Washington co.,,.,$Y$. : on Batten Kill, 28 m. N. N. E. Albany.

NoRTh EatoN, p. o., Lorain co,, Ohio: 105 m. N. E. by N. Columbus.

NoRTI EDGECOME, p. O., Lineoln co, Me.: on E. bank of Sheepscot r., 27 m. S. S. E. Augusta.

North Egremont, p. v., Berkshire county, Mass, : on a branch of Housatonic r., near New York State line, 116 m. W. by S. Boston.

Norti Eliba, p. o., Essex co., N. Y.: 103 m. N. Albany. Norti Ellsworth, p. 0., Hancock county, Mre : $67 \mathrm{~m}$ E. N. E. Augusta.

Norti End, p. o., Mathews co, Virg.: $51 \mathrm{~m}$. E. by S. Richmond.

Nortr Enfield, p. v. and sta., Grafton co., N. Hamp. on Mascomy river and pond, $43 \mathrm{~m}, \mathrm{~N}$. W. Coneord. The Northern R. R. passes through the V. $59 \mathrm{~m}$. from Concord. North Erans, p. 0., Erie county, N. Y : $276 \mathrm{~m}$. W. Albany.

NoRTI FArIUS river, MLo : in N. W. portion of the State, flows S. W. through Scotland and Marion counties, and euters Mississippi r. opposite Quincy, 11 .

Norti Fairfax, p. 0., Franklin county, Terms: 38 m. $\mathrm{N}$. W. by N. Montpelier.

Norti Fatrifeld, p. o., Somerset county, Me.: $25 \mathrm{~m}$. N. Augusta.

NoRTH FATRETELD, p. o., Huron co., Ohio: 79 m. N. by E. Columbus.

North FATRHAVEN, p. v., Bristol co., Mass.: on E. bank of Acushnet r., $49 \mathrm{~m}$. S. Boston.

Norti Falmodth, p. $\nabla_{4}$, Barnstable co., Mass, : $55 \mathrm{~m}$. S. S. E. Boston, on inlet of Buzzard's bay.

North Farmington, p, o., Oakland co., Mich.: $62 \mathrm{~m}$. E. S. E. Lansing.

Nortr FAYETte, p. o., Kennebec county, Me.: $18 \mathrm{~m}$. W. N. W. Augusta.

Norti Ferristiore, p. o, and sta., Addison co, Verm. $32 \mathrm{~m}$. W. Montpelier, $15 \mathrm{~m}$. S. Burlington by Rutland and Burlington R. R

NorthFien, p. ₹., Litchfeld co., Conn. : 24 m. W. by \$. Hartford, in S. E. part of Litehfield town. Surface rough; soil adapted to grazing.

NorthFteld, p. o., Cook county, $I l l .: 177 \mathrm{~m}$. N. N. E Springfield, $19 \mathrm{~m}$. N. W. Chicago.

NorThField, p. v., Boone county, Ind. : 19 m. N. N. W. Indianapolis, Drained by Eagle creek.

NorthFieLd, t. and p. o., Washington county, Me.: on Machias r., 118 m. E. N. E. Augusta. Pop. 246.

Northries.D, t., p.v., and sta., Franklin co., Mass. 78 m. W. N. W. Boston. Drained by Connecticut river, which 
divides the town, and by several small affluents. Surface undulating, with large tracts of alluvial plains in the intervales; soil fertile and well cultivated. The t. was first settled in 1673. The vo is beautifully situated on an elevated plain about $1 \mathrm{~m}$, from the $\mathbf{r}$, on the $\mathbf{E}$. side. The $\mathbf{t}$, contains a few stores and manufactories. The Brattleboro' Branch of Vermont and Massachusetts R. R. passes through the t. Pop. 1,772.

Nortarietd, to and p. o., Washtenaw co., Mich.: $44 \mathrm{~m}$. E. S. E. by S. Lansing. The V. is in the N. W. corner of t. on Whitmore's lake, which is connected with Huron r. by a small stream. Pop. 1,116.

Nortirfiesd, t. and sta., Merrimac co, N. Hamp.: on W. side of Merrimac r. and S. side Winnipiseogee r., $13 \mathrm{~m}$. N. by W. Concord. The Boston, Concord, and Montreal R. R. passes through this town. Near Sanbornton Bridge is the New Hampshire Conference Seminary, a Methodist institution, having flve teachers. Pop. of t. 1,332.

NorthiteLD, t. and p. o., Summit county, Ohio: $116 \mathrm{~m}$. N. E. by N. Columbus. Surface of t. undulating; soil fertile; well watered by Cuyahoga $r$. and its branches. The Cleveland and Pittsburg R.R. and Ohio Canal pass through this t. Pop. 1,474.

NorTHFIELD, t., p. o., and sta., Washington $\mathrm{co}_{0 .}$, Verm. 10 m. S. S. W. Montpelier. Drained by Dog river, which affords water-power. Surface uneven; soil fertile. The Vermont Central R. R. passes through the v. $10 \mathrm{~m}$. from Montpelier.

North Flat, p. o., Wyoming co., Penn.: 95 m. N. N. E. Harrisburg.

Northford, p. v., New Haven co., Conn.: 11 m. N. E. New Haven. Has several factories.

North Fork, p. o., Izard co., Ark.: on Big North Fork river, $111 \mathrm{~m}$. N. Little Rock.

North Fork, p. o., Vermillion co, $1 l l .:$ on the W. side of the North fork of Big Vermillion river, $104 \mathrm{~m}$. E. by N. Springfield.

North Fork, p. v., Mason co., Ky.: 72 m. E. N. E. Frankfort.

Nortir Fork, p. o., Ashe co., N. Car.: on North fork of New r., $171 \mathrm{~m}$, W. N. W. Raleigh.

NORTH FoRK, p. o., Washington co., Tirg. : on N. fork of Holston r., $275 \mathrm{~m}$. W. S. W. Richmond.

North Fori of White river, $B$ fo. and Arf.: drains Ozark co., Mo., flows S. into Ark., and enters White r, at Liberty, in $\mathrm{N}$. W. corner of Izard county.

North FrankForT, p. O, Waldo co., Me.: on W. side of

Penobseot r., 56 m. N. E. by E. Augusta.

Norti Frankun, po 0., New Loudon co., Conn. : $32 \mathrm{~m}$

E. S. E. Hartford.

Norti Franklin, p. 0., Delaware co., N. Y.: $72 \mathrm{~m}$.

W. S. W. Albany.

North Fryeburg, p. o., Oxford co., Me. : on Saco r., $61 \mathrm{~m}$.

W. S. W. Augusta.

Norti GAge, p. o., Oneida co., N. Y.: 82 m. N.W. by W. Albany.

Norti Galway, p. o., Saratoga county, N. Y.: $30 \mathrm{~m}$. N. N. W. Albany.

North G GRDEir, p. o., Albemarle co., Virg. : 65 m.W.N.W. Richmond.

North Georgerown, p. F., Columbiana county, Ohio: $117 \mathrm{~m} . \mathrm{N}$. E. by E. Columbus. Drained by branch of Mahoning river.

NorTII GosHex, p. v., Litchfield co., Conn. : 30 m. W. N.W. Hartford.

Norti Granbr, p. v., Hartford co., Conn. : 18 m. N. N.W. Hartford,

North Gravrilue, p. V., Washington co., $N . Y_{0}: 58 \mathrm{~m}$. N. N. E. Albany, on Pawlet r.

Norti Greece, p. 0., Monroe co., N. Y.: 272 m. W. by N. Albany.

Noetr GrentricI, po o., Fairfield co., Conn. : $41 \mathrm{~m}$. W. S. IV. NeT्T IJaven.
North Greenwiou, p. o., Washington co., N. Y.: $84 \mathrm{~m}$. N. by E. Albany.

Nortur Groton, p. o., Grafton co., N. Hamp.: $38 \mathrm{~m}$. N. N. W, Coneord.

Nortix Grilford, p. v., New IIaven co., Conn.:12 m.

E. N. E. New Haven. Drained by Menunkatuck $r$.

Nortu GUILFord, p. O., Chenango $c_{0}, N_{*} \quad Y_{*}: 92 \mathrm{~m}$. W. by S. Albany.

Norti Haduex, p. v., Hampsbire co., Mass.; on E. side of Connecticut r., $87 \mathrm{~m}$. W. Boston.

North Handen, p. o., Delaware county, $N .7 .: 72 \mathrm{~m}$. s. W. by W. Albany.

North Hamden, p. 0., Penobscot co., Me.: 56 m. N. E. Augusta.

Nortir Havpton, p. v., Peoria county, $I U L_{\text {: }}: 78 \mathrm{~m} . \mathrm{N}$. Springfield. A small settlement in a rich agricultural district. NorTh HaMPTOs, t., p. o., and sta., Rockingham county, N. Itamp.: 38 m. E. S. E. Concord ; bounded on the E. by Atlantic Ocean. The Eastern R. R. passes through the t, 8 m. from Portsmouth. Pop. 822.

North Hampton, p. o., Clark eounty, Ohio: $48 \mathrm{~m} . \mathrm{W}$. Columbus.

North Haxcock, p. o., Hancock co., Me. : 74 m. E. by N. Augusta.

Nortir Hakson, sta, Plymouth co, Mass. : on Old Colony R. R., 23 m. E. S. E. Boston.

North Harpersfield, p. o., Delaware co., $\lambda_{\text {. }} Y_{.}: 54 \mathrm{~m}$. W. by S. Albany.

NorTz HARTLAND, p. v, and sta., Windsor co., Term.: on Connecticut r., $49 \mathrm{~m}$. S. by E. Montpelier. Sta. of Vt. Central R. R., $8 \mathrm{~m}$. from Windsor.

Nortu Haven, t., p. vo, and sta., New Haven co., Conne. $S \mathrm{~m} . \mathrm{N}$. N. E. New Haven, on Wallingford $r$. Surface of $t$, mostly level; soil sandy and very fertile. A large tract is a salt marsh, producing large quantities of grass. Vast quantities of brick are made here. The Hartford and New Haven $\mathrm{R}$. R. passes through the t. Pop. 1,325.

North HAvEN, p. o., Hancock co., MYe.: on N. Fox Island, in Penobscot bay, 51 m. E. S. E. Augusta.

Norti Havermil, p. v., Grafton county, N. Hamp.: on Connecticut r., $70 \mathrm{~m}$. N. N. W. Concord, on the line of the Boston, Concord, and Montreal R. P

North Haverstraw, p, o, Rockland co, $N$. $Y_{\text {. }}:$ on W side Hudson r., 96 m. S. by W. Albany.

North fferrov, p. o., Washington co, $N_{.} Y_{*}$ i on Black cr., 48 m. N. N. E. Albany.

Norti Heoror, p. o., Tompkins co, N. Y.: on E. side of Seneca lake, $164 \mathrm{~m}$. W. Albany.

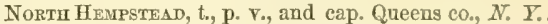
$130 \mathrm{~m}$. S. Albany. The surface is uneven and hilly, being traversed by the ridge of the island. The soil is sandy, but is made productive by cultivation. It is penetrated by several bays of Long Island Sound. Success Pond, a fine sheet of water, lies on its W. border, and is well stored with fish. The v., on the N. edge of H. Plains, and $\frac{1}{2} \mathrm{~m}$. N. of the R. R., contains a court-huuse, jail, and several dwellings. The t. has a dozen mills and some manufactures, stores, etc Pop. of t. 4,291.

North Henderson, p. o., Mercer co., $I l l_{\text {: }}: 101$ m. N. W. Springfield.

Nortu Hermox, p. o., Penolseot countr, Mre. : $5 i$ m. N. E. by E. Augusta, 9 m. W. by N. Bangor.

North Hero, to, p. v, and eap. Grand Isle co., Verm. $51 \mathrm{~m} . \mathrm{N} . \mathrm{W}$. Montpelier. The surface of this island contains 6,272 acres; the soil is very fertile. The $\mathrm{r}$. contains the county buildings. Pop. of t. 730

North Hogav, p. v., Ripley county, 7 rd $^{2}: 65 \mathrm{~m}$. S. E. Indianapolis. Drained by branch of Laughery's cr.

NorTH Holuis, p. v., York co., MFe : on W. side of Sreo r., 45 m. S. W. Angusta.

Nortr Hoosici, p. o. and sta., Rensseleer co., N. $\bar{Y}$ $28 \mathrm{~m}$. N. E. Albany, and station of the Troy and Boston R. R., $27 \mathrm{~m}$. from Troy 
North Hopr, p. o., Butler co., Penn. : 165 m. W. by N. Harrisburg.

North Hudson, t. and p. 0., Essex co., $N_{*} Y_{*}: 96 \mathrm{~m} . \mathbf{N}$. Albany. Drained by Schroon r., and contains several small lakes. Surface mountainous; soil broken but fertile. Timber of large size is very abundant; and there are extensive veins of iron. Pop. 561.

Noвth Hydepark, p. o., Lamoille co., Verm. : $27 \mathrm{~m} . \mathrm{N}$. Montpelier.

NorTh INDUStry, p. v., Stark co,, Ohio : 98 m. N. E. by E. Columbus, on Tuscarawas r., which affords power to several mills.

North Indestry, p. o., Franklin co, $M e_{*}: 30$ m. N. N.W. Augusta.

Northengtow, p. v., Cumberland co., $N$. Car. : on S. side of Cape Fear r., 24 m. S. S. W. Raleigh.

Noetr island, Georgetown dist., S. Car,: at N. entrance of Winyaw bay.

Nortr J J CEsox, p. o., Mahoning county, Ohio: $132 \mathrm{~m}$.

N. E. by E. Columbus.

North Janespille, p. 0., Rock co., Wisc. : 34 m. \$. S. E. Madison.

North JAvA, p. o., Wyoming county, N. Y.: $248 \mathrm{~m}$. W. Albany.

Norti JAY, p. o., Franklin county, Me.: $27 \mathrm{~m} . \mathrm{N} . \mathrm{W}$. Augusta.

North Kennebunk Port, p. v., York county, Me. : $74 \mathrm{~m}$. S. W. by S. Augusta.

North Krlivgly, p. v., Windham co., Conn. : on E. side Quinnebaug r., 43 m. E. by N. Hartford.

Nonth Kontright, p. o., Delaware county, $N . Y_{.} .57 \mathrm{~m}$. W. S. W. Albany.

North Lansung, p. 0, Tomplins co, $N . Y_{\text {. }}: 144 \mathrm{~m}$. W. Albany.

Normi Law rence, p. o., St. Lawrence co, $N_{0} Y_{*:} 156 \mathrm{~m}$. N. N. W. Albany.

North Leeds, p. 0 , and sta., Kennebec co, Me.: on E. side of Androscoggin r., $20 \mathrm{~m}$. W. Augusta; sta of Androscoggin R. R., $10 \mathrm{~m}$, from junction of Androscoggin and Kennebec $\mathbf{R}$, $\mathbf{R}$.

North Leominstren, p o., Worcester county, Mass. : $39 \mathrm{~m}$. W. N. W. Boston.

North LEverext, p. v., Franklin county, Mass.: $74 \mathrm{~m}$ W. by N. Boston.

North Lewisborg, p. o., Champaign co., Ohio: $42 \mathrm{~m}$. W. by N. Columbus.

North Liberty, p. v., Mercer co., Penn. : on Wolf cr. $176 \mathrm{~m}$. W. N. W. Harrisburg.

North Libeitis, p, o, Knox co., Ohio: 33 m. N. E, by N. Columbus.

North Liberty, p. o., St. Joseph co., Ind. : on a branch of Kankakee r., 120 m. N. by W. Indianapolis.

Norti Lims, p. v., Mahoning co, Ohio : 136 m. N. E. by E. Columbus.

Norti LnNcolN, p. V., Penobscot co., Me.: on E. bank of Penobscot r., 104 m. N. E. Augusta.

Norta Inkluan, p. o., Chenango co., $N_{*} Y_{.}: 112 \mathrm{~m} . \mathrm{W}$. Albany.

North Littleton, p. o., Grafton co., $N$. IIamp. : \$3 m. N. by W. Concord.

North Lrfermore, p. v., Oxford co., Me. : 24 m. W. by N. Augusta, $2 \mathrm{~m}$. W. from Kennebee $r$.

North Londonderry, p. 0. and sta., Rockingham county, N. Hamp.: 23 m. S. by E. Concord, on Manchester and Lawrence R. R., $20 \mathrm{~m}$. from Lawrence, $6 \mathrm{~m}$. from Manchester. NorTH LovexL, p. o., Yell co., Ark.: 66 m. W. N. W. Little Rock.

Nortr Lrarax, p. 0., Grafton copnty, N. Hamp.: $76 \mathrm{~m}$ N. by W. Coneord.

Noвтн Lrme, p. v., New London sounty, Conn. $32 \mathrm{~m}$ E. by N. New Haven. Drained by a branch of Conn. $r$.

Nortr Madisox, p. v., New Haven co., Conn.: on W. side Hammonassett $r, 17 \mathrm{~m}, \mathrm{E}, \mathrm{N} . \mathrm{E}$. New Haven 606
North Madison, p. o, Jefferson county, Ind, : $2 \mathrm{~m} . \mathrm{N}$ Madison, $80 \mathrm{~m}$. S. S. E. Indianapolis. It contains the principal workshops of the Madison and Indianapolis $\mathbf{R}$. $\mathbf{R}$.

North MaNchester, p. V., Wabash co, Ind,: on Eel $r_{\text {. }}$ $85 \mathrm{~m}$. N. by E. Indianapolis.

North Marlow, p. o., Cheshire co., N. Hamp.: $34 \mathrm{~m}$ W. by S. Concord.

North Marshall, p. O., Calhoun county, MFich.: $37 \mathrm{~m}$. S. W. by S. Lansing.

North Marshfield, p. O., Plymouth co., Mass, : on S. side of North r., 23 m. S. E. Boston.

North Mrodleborodgh, p. v., Plymouth co., Mass, : $31 \mathrm{~m}$ S. by E. Boston.

North Mmdlesex, p. 0., Yates co., $N$. $Y .:$ on W. side of Canandaigua lake, $186 \mathrm{~m}$. W. Albany.

North Mrodleton, p. v.. Bourbon co., Ky. : 43 m. E. by $\$$. Frankfort.

North Moxmouth, p. o., Kennebec county, Me.: $15 \mathrm{~m}$, S. W. Augusta, near Androscoggin and Kennebec R. R. $49 \mathrm{~m}$. from Portland.

North Montpelier, p. o., Washington co., Verm.: $6 \mathrm{~m}$ N. Montpelier.

Nozth Mountan, p. 0., Berkeley co., Firg. : $145 \mathrm{~m}$. W. of N. Richmond.

Noeth Mount Pleasant, p. v., Marshall co, Mfiss. $184 \mathrm{~m}$. N. by E. Jackson, near Tennessee State line.

Nozte Newburg, p. 0., Penobscot co., Me. : 49 m. N. E. Augusta.

North New burx, p. o, Geauga co, Ohio: 133 m. N. E. Columbus.

NoRth Newpokt, p. o., Penobscot county, Me.: $49 \mathrm{~m}$. N. E. by N. Augusia.

NontH NEWPOex river, Liberty co., $G a$. : is navigable to Riceboro', $20 \mathrm{~m}$, from the ocean.

North New Portuand, p. 0., Somerset co., Me.: on $\mathbb{N}_{\text {. }}$ branch of Seven Mile brook, $45 \mathrm{~m}$. N. N. W. Augusta.

North New SAleM, p. v., Franklin co., Mass: 66 m. W. by N. Boston.

North Norway, p. o., Oxford co, Me.: 43 m. W. by S. Augusta.

North Norwion, t. and p. o, Chenango co, $N_{*} Y_{*}: 95 \mathrm{~m}$. W. Albany. Drained by Chenango $r$. The $\nabla$. is on the $W$. bank of the $r$. in the N. W. part of the town, and on the Chenango Cansl. Pop. of t. 1,172.

North Norwich, p. 0., Huron county, Ohio: $78 \mathrm{~m} . \mathrm{N}$. Columbus.

North Oravge, p. v., Franklin co., Mass.: $65 \mathrm{~m}$.W. by N. Boston.

Norter Orwelu, p. o., Bradford co., Penn. : 114 m. N. by E, Harrisburg.

Norte OxFoRD, p. v., Worcester co., Mass. : 44 m. W. by S. Boston.

North Paleriro, p. o., Waldo co., Me.: 20 m. E. N. E, Augusta.

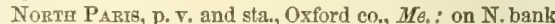
of Little Androseoggin r., $40 \mathrm{~m}$. W. Augusta. The Atlantic and St, Lawrence $R$. R. passes through the v. $55 \mathrm{~m}$. from Portland.

Nortin Pabra, p. o., Monroe co., N. Y.: $281 \mathrm{~m} . \mathrm{W}$. by N. Albany.

Noetr PAtsongfield, p. v., Tork co., Me. : 73 m. S. W. Augusta. Drained by cr. of Ossipee river.

North Penóscot, p. 0., Hancock co., Me. : 59 m. E. by N. Augusta.

North Perry, p. o., Lake co, Ohio: 150 m. N. E. by N. Columbus. The t. is on the line of the Cleveland and Erie R. R. $36 \mathrm{~m}$. from Cleveland.

Nortir Perrysburg, p. o., Cattarangus co., $N_{\text {. }} Y_{*}:$ on S. side Cattaraugus cr., $276 \mathrm{~m}$. W. Albany.

North Prtrsor, p. V., Kennebec co., Me.: on E, side of Kennebec r, 7 m. S. Augusta.

Nontir Plans, t. and p. o., Ionia county, MFich.: N. side Maple r., 26 m. N. W. by N. Lansing. Soil of $t$, is rich 
sandy loam, very fertile on the numerous creeks which How through it. Pop. 292.

Nortu Puyaptor, p. v., Plymouth county, Mass. : $29 \mathrm{~m}$. S. S. E. Boston

Norte Porvт, sta., Baltimore co., Ma. : near Baltimore, on Philadelphia and Baltimore P. R.

North Point Light-house, Baltimore county, Ma.: on North Point Cape. Lat. $39^{\circ} 11^{\prime} 45^{\prime \prime}$; long. $76^{\circ} 27^{\prime} 17^{\prime \prime}$; $15 \mathrm{~m}$. E. of $\mathrm{N}$. Annapolis, is one of the most important lighthouse stations on the Atlantic sea-board. Here the British debarked in the war of 1812 .

NorthPoRT, p. o., Tuscaloosa co, Ala.: on N. W. side of Black Warrior r. opposite Tuscaloosa, $92 \mathrm{~m}$. N. W. by W. Montgomery.

Northport, p. v. Noble co., Ind. : on N. side of North

Fork of Elkhart r., 125 m. E. N. E. Indianapolis.

NozthPoRT, t. and p. o., Waldo county, Mre.: $43 \mathrm{~m}$. E. Augusta, on W. side of Penobseot bay. Some shipbuilding is carried on here. Pop. 1,260

Northrort, p. o., Suffolk county, N. $Y_{\text {: : } 124}$ m. S. by E. Albany.

North Potsdam, p. o., St. Lawrence co., $N_{0} Y_{\text {.: }} 158 \mathrm{~m}$.

N. N. E. Albany.

North Pownal, p. o., Cumberland county, $M e_{\star}: 36 \mathrm{~m}$.

S. S. W. Augusta.

Nonth PoWnaI, p. o, Bennington couny, Verm.: 108 m.

S. S. W. Montpelier.

North Prante, p. 0., Knox co., $17 l . ; 97$ m. N. W. by N. Springfield.

North Prescott, p. v., Hampshire co., Mass.: $66 \mathrm{~m}$. W. by N. Boston.

North Prospeot, p. v., Waldo co, Me.: 47 m. E. N. E.

Augusta. Drained by a creek of Penobscot $r$.

North Ratsinville, p. o., Monroe county, Mich.: $74 \mathrm{~m}$.

S. S. E. by E. Lansing.

North RAYMoND, p. o., Cumberland county, Me. : $45 \mathrm{~m}$. §. W. Augusta.

North Readrvg, p. v., Middlesex co, Mass.: on N. side

of Ipswich r., $16 \mathrm{~m}$. N. Boston, on the line of Salem and Lowell R. R., $10 \mathrm{~m}$, from Salem.

Norti Reading, p. o., Steuben co., $N$. $Y$.: on W. side of

Seneca lake, $169 \mathrm{~m}$. W. by S. Albany.

North Rвновотн, p. v., Bristol co., Mass. : 35 m. S. by W.

Boston.

North Ridgeville, p. v., Lorain co., Ohio: 108 m. N. E.

by $\mathrm{N}$. Columbus, Drained by $\mathrm{N}$. br. of Black $r$.

North Ridgeway, p. o., Orleans county, $N$. Y.: 244. m. W. by N. Albany.

North Rrver, p. v., Tuscaloosa co., Ala.: on W. side of North r., 98 m. N. W. Montgomery.

North River Meituvg-House, p. o., Hampshire county,

Virg.: on branch of Great Cacapon r., 127 m. N. W. Richmond.

Norit Rrver Mrus, p. o, Hampshire county, Firg.: on branch of Great Cacapon river, 138 miles N. N. W. Richmond.

North Rochestere, p. v., Plymouth county, Mass. : $42 \mathrm{~m}$. S. by E. Boston.

Nortil Rome, p. o., Bradford co, Penn. : 110 m. N. by E. Harrisburg.

North Royaltox, p. o., Cuyahoga co., Ohio: $111 \mathrm{~m}$. N. E. by N. Columbus.

North Russeld, p. o., St. Lawrence co., N. Y. : $143 \mathrm{~m}$. N. W. by N. Albany.

NortH SALEM, p. ₹., Hendricks co, Ind.: on branch of Walnut fork of Eel r., W. N. W. Indianapolis.

North SALEM. p. 0., Rockingham co, N. Hamp.: $34 \mathrm{~m}$. S. W. by $\mathrm{S}$. Concord.

Nozth S_ateM, t. and p. ₹., Westchester co., $N$. Y.: $93 \mathrm{~m}$. S. by E. Albany. Surface of $t$, hilly; soil well adapted to grass and summer crops. The v. contains a few mills and stores. The Harlem $\mathrm{P}_{\mathrm{v}} \mathrm{R}$. passes through the W. part of the town. Pop. 1,335.
Nortir Saluda, Greenville disi., S.Car. : on North Saludg river, $115 \mathrm{~m}$. N.W. Columbia.

Norti SajbonNtoN, p. 0., Belknap co., N. Hamp. : $23 \mathrm{~m}$. N. by W. Cohcord.

Nortr SANDwich, p. v. and sta., Barnstable co., Mass.: 49 m. S. E. by S. Boston, on Cape Cod Branch R. R.

North Sandwich, p. o., Carroll co., N. Hamp. : $45 \mathrm{~m}$. N. Concord.

Norti Scituate, p. V., Plymouth county, Mass. : 17 m. S. E. by E. Boston.

Nortil Soltuate, p. V., Providence co., $\boldsymbol{R} . I_{*}: 9 \mathrm{~m}$. W. Providence.

North Searswount, p. o, Waldo con, Me.: $27 \mathrm{~m}, \mathrm{E}$. Augusta.

North Searsport, p. o., Waldo co, $M e_{0}: 45$ m. E. N. E. Augusta.

Norti Stedgewick, p. o., Hancock co., Me.: 60 m. E. Augusta.

North Sewickly, t. and p. o., Beaver co., Penn.: on W. side of Beaver r. and S. side of Conequenessing cr., $180 \mathrm{~m}$. W. by N. Harrisburg. Surface rolling; soil calcareous loam.

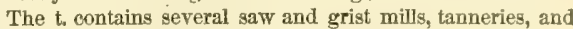
stores. The Beaver and Erie Canal passes through the to on bank of Beaver river.

North SHapleige, po o, York co, Me.: 79 m. S. W. Augusta.

Norti SIIEFFIELD, p. 0., Ashtabula county, Ohio: $174 \mathrm{~m}$. N. E. Columbus.

North SheldoN, p. o., Wyoming con, $N$. $Y .: 244 \mathrm{~m} . \mathrm{W}$. Albany.

Nortu SheritrN, p. o, Rutland county, Verm.: $44 \mathrm{~m}$ S. by W. Montpelier.

Norter Shore, p. o., Richmond county, $N_{0}, Y_{0}: 140 \mathrm{~m}$, S. by W. Albany.

North SkUNK river: runs parallel to Skunk r. on its $\mathrm{N}$. side for $70 \mathrm{~m}$. when it joins it in Keokuk county.

North Smithield, p. 0., Bradford co., Penn : $109 \mathrm{~m} . \mathrm{N}$ Harrisburg.

Nortн Somers, p. 0., Tolland co, Conn. : 22 m. N. N. E. Hartford, near State line.

Norta Sparta, p. o., Livingston co., $N_{0} \bar{Y}_{\bullet}: 210 \mathrm{~m} . \mathrm{W}$ Albany.

Nonth Spencer, p. $\nabla .$, Worcester county, Mass.: $48 \mathrm{~m}$ W. by S. Boston.

North SprLve, p. o., Jackson co., Tenn. : 62 m. E. N. E. Nashville.

North Sprtigfteld, p. V., Windsor co., Term. : on E. bank of Black r., 68 m. S. by E. Montpelier.

North Sprixgfield, p. o., Summit co, Ohio: $107 \mathrm{~m}$. N. E, Columbus.

North Stamford, p. v., Fairfleld co., Conn. : on W. side of Mill r., 37 m. W. S. W. New Haven.

North Star, p. o., Washington co., Penn.: 178 m. W. Harrisburg.

North Star, p. o., Darke co., Ohio: $84 \mathrm{~m}$. W. Columbus. North Stephentown, p. o., Rensselaer co., $N . Y_{0}:$ on Kinderhook cr, 16 m. E, S. E. Albany.

North Sterling, p. o., Cayuga co., $N . Y .:$ on W. side of Little Sodus Bay, $158 \mathrm{~m}$. W. by N. Albany.

Nortн Sтоскномм, p. 0., St. Lawrence co., $N . Y_{\bullet}: 159 \mathrm{~m}$. N. N. W Albany.

North Stonington, t. and p. o, New London county, Conn.: 47 m. E. S. E. Hartford, 56 m. E. by N. New Haren. Surface uneven and hilly; soil gravelly loam, good for grazing, Watered by Paweatuck r. and its branches, which afford water-power to a number of tanneries, saw, and grist mills. Pop. 1,937.

Nortu StrafFord, p. o., Strafford co., N. Hamp.: $20 \mathrm{~m}$. E. N. E. Concord.

North Sudburr, p. v., Middlesex co., Mass. : on S. side of Concord r., $21 \mathrm{~m}$. W. by N. Boston.

North Swansea, p. v., Bristol co, Mass. ; $42 \mathrm{~m}$. S. by TV Boston. 
Nortu Tewrввuвy, p. V., Middlesex co., Mass. : $23 \mathrm{~m}$. N. N. W. Boston.

Nortu TheTford, p. v, and sta., Orange co., Term.: on W. bank of Connecticut r., 36 m. S. E. by E. Montpelier. The Connecticut and Passumpsic Rirers R.R. passes through the $v, 17 \mathrm{~m}$. from White River Junction, and $43 \mathrm{~m}$. from St. Johnsburg.

Nortin Trox, p. o., Orleans county, Term. : on E. side of Missisque r., $52 \mathrm{~m}$. N. by E. Montpelier.

North Truro, p. v., Barnstable co., Mass. : 58 m. E. S. E. Boston.

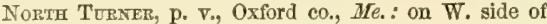
Androscoggin r., 25 m. W. by S. Augusta.

North Turner Bridge, p. O., Oxford co., Me.: on Androscoggin r., $22 \mathrm{~m}$. W. by S. Augusta.

Northomberland county, Penn. Situate E. centrally, and contains 431 sq. m. The Susquehanna r. passes through it centrally from E. to W., and forms its $\mathbf{S}$. W. boundary. It is drained by this $r$. and its affluents. Surface varied; in most parts it is mountainous and much broken, but along the $r$. there are some level bottoms; soil in general poor; the land on the river, however, is fertile, and produces good crops of wheat, Indian corn, and potatoes; tobaceo is also grown. It is extensively engaged in manufactures and mining. It contains iron ore and coal, and has some good timber land. Farms 1,748; manuf. 153 ; dwell. 4,062, and pop.-wh. 23,150, fr. col. 92-total 23,272. Capitul: Sunbury. Putlic Thorks: Sunbury and Frie R. R., and several railroads to the raines from Sunbury, ete.

Northumberlaxd county, Firg. Situate E. on Chesapeake bay, and contains $143 \mathrm{sq}$. m. Drained by small streams which flow into the Potomac and the Chesapeake. Surface generally level; soil of average fertility. Chief productions, cotton and Indian corn. Farms 492; manuf. 3; dwell. 639, and pop.-wh. 3,072, fr. col. 509, sl. 3,755-total 7,316. Capital: Heathsville.

Northumberlaxd, t., p. v., and sta., Coos co., N. Hamp. on Connecticul $r$. and both sides of Upper Ammonoosuc r., $98 \mathrm{~m}$. N. Concord. The soil along the Connecticut is very fertile. Here are falls in the r., and a dam across its whole width affords great water-power on each side to mills of various kinds. The Atlantic and St. Lawrence R. R. passes through the F., 122 m, from Portland. Pop. of t. 429.

Northombreland, t. and p. o., Saratoga co., $N_{0} \bar{Y}_{\text {.: }}$ on W. side Hudson r., 36 m. N. by E. Albany. Surface level ; soil sandy loam, well drained. The Saratoga and Washington $\mathrm{R} . \mathrm{R}$. passes through the N. W. part. Pop. 1,775 .

Nortircmberlavd, p. b., Northumberland co., Penn.: at the confluence of the $\mathbf{E}$. and W. branches of the Susquehanna r., $54 \mathrm{~m}$. N. Harrisburg. A bridge spans each branch of the $r$. The Shamoken dam, 2,783 feet long, crosses the river, having a chute 650 feet long and 64 feet wide. The Susquehanna $N$. and W. branch canals meet here, but do not afford as much business to the place as formerly. A railroad is contemplated to pass through to connect with the
Catawissa branches E., N., N. E., N. W., and S. routes. The streets are regularly and well laid out, and the village affords a quiet and pleasant place ot residence.

North Uniof, p. o., Washington co., Ohio: 82 m. E. S. E. Columbus.

Norte Union, p. o., Lincoln county, Me. : on E. side of Muscongus r., 27 m. E. S. E. Augusta,

North Uniontown, p. o, Highland co., Ohio: $63 \mathrm{~m}$. S. W. by S. Columbus.

North Urbana, p. o., Steuben co, $\boldsymbol{N} . \boldsymbol{Y}_{\mathrm{z}}$ : on W. side of Crooked Iake, 186 m. W. by S. Albany.

North Vassalborodgh, p. O., Kennebec co., Me.: on E. side of Kennebec r, 14 m. N. N. E. Augusta.

Nortil Veryor, p. o., Shiawassee county, Mfich.: $32 \mathrm{~m}$. E. N. E. by E. Lansing.

Northville, p. v., Litchfield co., Conn.: on E. Aspetuck river, $38 \mathrm{~m}$. W. by S. Hartford.

Northrnze, p. v., La Salle county, $\pi l$.: 97 m. N. N. E. Springfield.

Northviliz, sta., Plymouth co, Mass.: on Bridgewater Branch R. R., 22 m. from Boston.

Northrille, p. v., Wayne county, Mich. : 57 m. E. S. E. Lansing, on the W. branch of the Rouge r., at the confluence of the outlet of the Walled lake. Here are great natural advantages for manufacturing, there being 37 feet of water-power. Considerable capital is already employed. Nortuvilte, p. o., Fulton co., $N$. $Y_{1}$; on E. bank of Sacondaga r., $44 \mathrm{~m}$. N. W. by N. Albany.

Nonthvil.te, p. v., Erie co., Penn.: 208 m. N. W. by W. Harrisburg.

North WaldoborougIr, pr o., Lincoln co, $M e_{\text {. }}: 23 \mathrm{~m}$. S. E. by E. Augusta.

Norti Wardsborotgr, pa o, Windham co, Tem.: 81 m. S. Montpelier.

North Washirgton, p. v., Westmoreland co., Penn.: $141 \mathrm{~m}$. W. by N. Harrisburg.

Nortt W ATERFoRd, p. 0, Oxford con, $M e_{n}: 49 \mathrm{~m}$. W. by $\mathrm{S}$. Augusta.

North WaYNe, p. o., Kennebec co., Mb.: $17 \mathrm{~m} . \mathrm{W}$. Augusta.

Noxtr WeST, t. and p. o., Williams co, Ohio: $144 \mathrm{~m}$. N. W. Columbus. Soil fertile. Drained by branches of St. Joseph's r. Pop. 313.

Nortu West bay, $N_{\text {. }} \boldsymbol{Y}_{\text {.: }}$ on W. side of Lake Champlain.

North West Bridgewatei, p. o, Plymouth co., Miass.: 22 m. S. Boston.

Nokti Western, p. o, Oneida county, $N$. Y.: $101 \mathrm{~m}$. W. N. W. Albany.

North West Fork, hund., Sussex co., Del. : on W. side of Nanticoke r., 30 m. S. by W. Dover. Area, 76,490 acres. Nortu West Mive, p. o., Houghton co., Mich. : $300 \mathrm{~m}$. N. N. W. Lansing, One of the most productive mines of the State.

North West River Bridge, p. o., Norfolk co, Tirg.: on North West r., 95 m. S. E. Richmond.

\section{THE NORTH WEST TERRITORY.}

ThE Norti TFst Territnrs is situate between the parallels of 430 and 490 latitudes north, and extends east and west between 9901120 longitudes west from Greenwich, or $21055^{\prime}$ and $34055^{\prime}$ from Washington. It is bounded on the north by the British possessions, on the east bF White Earth and Missouri rivers, which separate it from Minnesota Territory, on the south by Nelraska Territory, and on the west by the crest of the Rocky Mountains, which divides it from Oregon and Tashington territories. On the east and west its outline is irrecular, conforming to the course of the Missouri on one side, and to that of the Rocky Mountains on the other side. The average length of the country, east and west, is about 530 miles, and the arerage breadth, north and south, about 420 miles, with an area of 223,000 square miles. (The extent of the region, according to the census of 1550 , is stated at 5\$7.564 square miles, a statement evidently incorrect).

The general surface of this region is highly diversified by mountains, valleys, and plains. The greater portion of the country is inclosed between the Focky and Trind River mountains and the Black Hills, a continuation of the latter northward. The immense basin formed by these monntains is drained by the Missouri and its great tributary, the Yellow Stone, which, with their numerous affluents, reach to its farthest boundaries west, south, and east. On the north of the basin is also a watersbed dividing the streams flowing northward through the British possessions from those tributary to the great rivers just noticed. It is thus hemmed in on every side, and forms a distinet geographical section. The Yissouri rises in numerous head streams from the Rocks Mountains in the vicinity of the sources of the southern branch of 
the Columbia of Oregon. Its course is first north, then east to the Black Hills, near the edge of which it receives the Telfow stone, a river having its principal sources in the Wind River Mountains, and after turning the Black Hiils in about latitude $45^{\circ}$ north, it has a course south-east and south, forming in its meanderings the eastern border of the Territory. From the east side of the Black Hills it also receives numerous tributaries, but none of large size. The slopes of the country are indicated by the direction of its streams: within the basin the inclination is to the north and north-cast up to the Missouri, and from thence the country rises to the north, and outside, east of the Black Hills, it slopes to the east. Both the Missouri and Yellow Stone are navigable for light draft steamers, and hence, whenerer this cruntry becomes the residence of civilized man, the capacity of these streams will open to him a highway to the markets of the South and East, while their tributary streams, rapid and broken as they are, will afford every facility for milling and the manufactures. On the whole, it is an eligible country for settlement, having timber of various kinds of magnificent growth, a fine soil, and a elimate, if not congenial to the tender plant, on account of its northern inland situation, yet one in which most of the usual farming operations may be profitably carried on. For salubrity it is unsurpassed. It is a second Utah, as regards its topography, without its deserts and sandy plains.

This Territory formed a part of the Louisiana purchase. It is not yet organized, but retains the name of the North West Territory, from its being the only unorganized remnant of that once large district so named, and to which it was attached soon after its acquisition by the United States. The hunter and trapper, or the red man of the forests, are its sole occupants at the present time, but the day is not far distant on which the pioneer of civilization will cross the great river to make his home in its rich valleys, and drive his flocks aud herds to the hills for range and pasture.

North WETHERSFELD, p. O., Wyoming co., $N_{0} Y_{0}: 234 \mathrm{~m}$, W. Albany.

NoRTH WEYMOUTH, p. v. and sta., Norfolk co., Mass.: 11 m. S. S. E. Boston, $13 \frac{2}{3}$ m, from Boston by South Shore railroad.

Norti Wrarton, p. o., Potter county, Penno: 108 m. N. W. by N. Harrisburg.

North Whtte CreEK, p. v., Washington co, $N_{0} Y_{.}: 32 \mathrm{~m}$. N. E. Albany. The "Washington Co. Post" (whig) is published weekly.

NoBTI W WITEFIELD, p. ., Lincoln co, Me.: on E. side of Sheepseot r., 14 m. S. E. Angusta.

Nozth Whitehalu, to and p. v., Lehigh co., Penn.: $70 \mathrm{~m}$. E. N. E. Harrisburg. Drained by Copley and Jordan creeks, and other tributaries of Lehigh $\mathbf{r}$, by which it is bounded on the N. E. Surface even; soil calcareous loam, fertile and well cultivated. There are numerous saw and grist mills, tanneries, and distilleries.

North Wuta, p. o., Jefferson co., N. Y.: 137 m. N. W. Albany.

North Wtrton, p. o., Franklin con, Me. : 31 m. N. W. Augusta.

Norti Wruton, p. o., Fairfield co., Conn.: 27 m. W. by S. New Haven, near Danbury and Norwalk P. P.

North WINDHAM, p. Y., Windham co., Conn.: $27 \mathrm{~m}$. E. by S. Hartford.

North Windram, p. ₹., Cumberland county, Me.: $41 \mathrm{~m}$.

S. W. Augusta, near S. end of Little Sebago Pond.

North Wolfborodgh, p. 0., Carroll co., N. Hump: $38 \mathrm{~m}$. N. N. E. Concord.

NorTi WOODstock, p. v., Windham co., Conn:: on a branch of Quinnebaug r., $36 \mathrm{~m}$. E. N. E. Hartford.

North Woodstock, p. o., Oxford county, Me.: $40 \mathrm{~m}$. W. Augusta. The Atlantic and St. Lawrence P. R. passes through $\mathrm{t}$. of W., having sta. at Bryant's Pond, $62 \mathrm{~m}$. from Portland.

Nontri Wrenthax, p. . and sta., Norfolk co., Mass.: $22 \mathrm{~m}$. S. W. Goston, on the Norfolk County R. R., $22 ! \mathrm{m}$. from Boston.

NorrII YAM Hrul, p. o., Yam Hill co., Oreg. : 30 m. N. W. Salem.

NorTH YARMOUTH, t., p. o., and sta., Cumberland co., $M e_{0}: 40 \mathrm{~m} . \mathrm{S} . \mathrm{W}$. by $\mathbf{S}$. Augusta. The Atlantic and St. Lawrence R. R. passes through the t. $15 \mathrm{~m}$. from Portland. Pop. 1,221.

Norton, t., p. v., and sta, Bristol co., Mass.: $27 \mathrm{~m}$. 8. by W. Boston. Drained by Rumford, Cocasset, and Canoe rivers and other small streams. Surface diversified; soil moderately fertile. The v, is on Taunton Branch R. R., $4 \mathrm{~m}$. from Mansfield. Pop. of t. 1,967.

Norton, p. $\nabla .$, Delaware co., Ohio: on W. side of W. branch of Whetstone $\mathrm{r}, 41 \mathrm{~m} . \mathrm{N}$. by W. Columbus.

Norton Cenvtre, p. o., Summit co., Ohio: 99 m. N. E. Columbus.
Norton's Mults, p. o., Ontario co, N. Y. :193 m. W. by N. Albany.

Nortonstille, p. 0., Albemarle co., Tirg.: 69 m.W.N.W. Richmond.

Nortonsviule, p. o., Ottawa co., Mich. : 80 m. W. N. W. Lansing.

Norvell, p. o., Jackson co., Mich.: 32 m. S. Lansing.

NorwalK, t., p. b., and sta., Fairfield co., Conn.: on both sides of Norwalk r., bounded $\mathrm{S}$. by Long Island Sound, 30 m. W. S. W. New Haven, 63 m. s. W. Hartford. Surface of $t$. uneven; soil very fertile. The $b$. is on both sides of the $r$, which is navigable to this point for ressels drawing 6 feet of water. Here are 3 churches, and 1 bank-capital $\$ 175,330$. The to contains 2 extensive factories of felt beaver cloth, besides other manufactories. Two newspapers are published weekly, "N. Gazette" and "Fairfield Co. Republican." The New York and New Haven R. R. passes through the b., $44 \mathrm{~m}$. from New York, $32 \mathrm{~m}$. from New Haven, connecting here with' Danbury and Norwalk R, R Two m. S. is the p. v. of South Norwalk, the terminus of D. and N. R. Ru, and the landing of the New York steamboats. Pop. of t. in 1840, 3,863 ; in 1850, 4,651.

NoRWALK, t., p. v., and cap. Huron co., Ohio : on E. side of Huron $r_{0}, 87 \mathrm{~m} . \mathrm{N}$. by E. Columbus. Soil of to is very fertile, and finely adapted for grain and grass. Drained by Huron $r$, and br. The $\mathrm{r}$. is well situated, and is the main station on the Toledo, Norwalk, and Cleveland, R. R. Contains 5 churches, several mills, and other factories, Two newspapers are published weekly, "Huron Reflector" (whig), and "Norwalk Experiment" (dem.) Pop. of v. 1,$441 ;$ of t. 3,159 .

Norwalk river, Fairfield co, Conn.:" flows through a beautiful and fertile valley in $\mathrm{S}$. direction, about $20 \mathrm{~m}$, into Long Island Sonnd. Along its banks runs the Danbury and Norwalk R. R. It is navigable to Norwalk borough.

Norwax, t. and p. v., Oxford con, Mes: $42 \mathrm{~m}$. W. by $\mathrm{S}$. Augusta. Soil fertile, and well watered by Norway Pond, Little Androscoggin and Crooked rivers. The $\mathrm{v}$. is at the outlet of Norway Pond. Two newspapers, the "Pine State News" and "Norway Advertiser," are published weekly. Pop. 1,962

Norway, p. 0., La Salle county, Ill.: 121 m. N. N. E. Springfield.

NorwAY, t. and p. o., Racine co., Wisc.: $6 \mathrm{~S}$ m. E. S. E. Madison. Drained by branches of Fox $x$. Surface undulating. Contains several large ponds, and has a good soil. Pop. 570.

NorTy A, t. and p. v., Herkimer con, N. Y. $: 76 \mathrm{~m} . \mathrm{N} . \mathrm{W}$. Albany. Surface of t. hilly; soil sandy loam, and adapted to grass. Drained by branches of West Canada cr. The $v$. contains ehurches and stores. Pop. of t. 1,052 .

Norwegran, t., Schuylkill countr, Penn. : 46 miles N. E. Harrisburg. Drained by Schuylkill r. and its branches. Surface billy and mountainous. It is an important centre of 
the Schuylkill coal mining region, and the present terminus of the Philadelphia and Reading $\mathrm{R}$. R., $93 \mathrm{~m}$, from the former, and several railroads diverge from Pottsville to the neighboring mines in East Norwegian, Frailo, Pine Grove, Tremont, North Castle, Schuylkill, ete., townships, and to Sunbury and Danville on the Susquehanna. The capital invested in the coal mines in 1850 was $\$ 611,147$, and the value of the annual products of the mines was estimated at $\$ 150,2 \$ 5$ : The Delaware Coal Company's capital is $\$ 500,000$. In East Norwegian township the capital invested in mines was $\$ 156,000$, and the value of the annual products $\$ \$ 0,350$. There are several furnaces and numerous saw-mills in the town, and stores of every description. Population of Norwegian 10,002.

Norwict, t., p. city, and semi-cap. New London co., Conn.: on Thames r., at head of navigation; 36 m. E. S. E. Hartford, 47 m. E. N. E. New Haven. Lat. N. 410 33', long. W. $72 \circ 7^{\prime}$. The surface of $t_{\text {t }}$ is uneven and hilly; soil fertile, well watered. The t. contains, besides the city, three $\mathrm{v}$., Norwich Town, Norwich Falls, and Greenville. The city is situated at the junction of Quinnebaug and Yantic rivers, on a steep declivity, and presents a very beautiful and romantic appearance. It contains a court-house, jail, town hall, 8 churches, ete. There are 4 banks, with cap. of $\$ 1,987,725$, and 3 large insurance companies. Two newspapers are published, "N. Courier" (whig), tri-weekly and weekly; and "N. Aurora" (dem.), weekly. Three railroads pass through the city; from New London, $13 \mathrm{~m}$; from Worcester, $59 \mathrm{~m}$. ; from Willimantic, $57 \mathrm{~m}$. A line of steamboats plies daily from Allyn's point to New York. Both Quinnebaug and Yantic rivers afford very great water-power, which is improved by numerous manufactories of paper, cotton, and woolen goods, hardware, pottery, etc. The Y antic Falls are a picturesque cataract, and invested with historical interest. Pop. in 1830 , of city, 3,144 ; t. inc. eity, 5,179 ; in 1840 , eity, 4,200 ; of $t$. inc. city, 7,239 ; in 1850 , $t$. inc. city 10,265 .

Norwich, t. and p. o.g Hampshire co., Mass.: $91 \mathrm{~m}$. W. by S. Boston. Surface mountainous, Drained by Westfield $r$., which affords water-power. The Western $\mathbf{R}$. $\mathbf{R}$. touches the S. W. cor, at Chester Village, 119 miles from Boston, $81 \mathrm{~m}$. from Albany. Pop. 756.

Norwich, t., p. V., and cap. Chenango co., N. Y.: on Chenango r., $95 \mathrm{~m}$. W. by S. Albany. Surface of t. diversifled; soil is generally good for grazing. The flats on the sides of the r. are very fertile, and highly cultivated. The $\mathrm{F}$, is handsomely situated on the W. bank of the $r_{\text {. }}$, contains the court-house and jail, several churches, mills, and factories, and 1 bank, cap. $\$ 120,000$. The Chenango Canal passes through the $\nabla$. Two newspapers are issued weekly, "Chenango Telegraph" (whig), "Chenango Union" (dem.) Pop. of t. 3,615 .

NoRwICH, p. v., Muskingum county, Ohio: 63 m. E. Columbus, on the National Road. Pop. 324 .

Norwich, t. and p. v., M'Kean county, Penn.: $124 \mathrm{~m}$. N. W. Harrisburg. Drained by Potato cr., on the E, side of which is the v., containing several stores.

Norwich, t., p. v., and sta., Windsor co., Term. : on W. side Connecticut r., 43 m. S. S. E. Montpelier. The Connecticut and Passumpsic Rivers R. R. passes through the $\mathrm{v}$. $9 \frac{1}{4} \mathrm{~m}$. above White River Junction. The Norwich University, established here in 1834, has 6 instructors, 60 students, 100 alumni, and a library of 1,700 vols. Pop. of t. 1,975.

Norwich Falus, sta., New London co., Conn. : on New London, Will. and Paimer R. R., $1 \mathrm{~m}$. from Norwich.

Norwicn Town, p. v. and sta, New London co, Conn. $1 \frac{1}{2} \mathrm{~m} . \mathrm{N}$. city of Norwich. Has several large factories and 2 churches. The New London, Willimantic, and Palmer R. R. passes through the place.

Norwood, p. Y, Stánley co, N. Car..: 96 m. W. S. W. Raleigh.

Norwoon, p. o, Bedford co., Firg.: $116 \mathrm{~m}$. W. by S. Richmond.

NotasuleA, p. $\mathrm{v}$, and sta, Macon county, $A l a: 41 \mathrm{~m}$. 610
E. N. E. Montgomery. The Montgomery and West Poin I. $R$. passes through this village.

Notipecago river, Mich. : the sources of this large stream unite in Lake co., and flowing in W. direction through Mason co., it empties into Marquette lake.

Notre Daxe, p. v., St. Joseph co, Ind.: $2 \mathrm{~m}$. N. South Bend $130 \mathrm{~m} . \mathrm{N}$. by W. Indianapolis. Here is located the University of Notre Dame du Lac, established in 1843. With it, associated on an extensive farm, a novitiate for the priests, and a manual labor school for boys.

Notraway, t. and p. v., St. Joseph's co., Mich. : $63 \mathrm{~m}$. S. W. Lansing. Surface of t. undulating; soil very fertile Drained by St. Joseph and Prairie rivers. Pop. 1,165.

Nottinghay, p. v., Prince George's co, $M d_{*}:$ on W. side of Patuxent r., $20 \mathrm{~m}$. S. S. W. Annapolis.

NotTINGRA r., 80 m. N. E. Indianapolis.

Notтineham, t. and p. o., Harrison county, Ohio: $95 \mathrm{~m}$. E. by N. Columbus. Drained by branch of Tuscarawas $r$. Pop. 1,236.

Notrixghar, t. and p. O., Rockingham co, N. Hamp.: 21 m. E. S. E. Concord. Pop. 1,268.

Notingham, p. o., Davis co., Ia. : $77 \mathrm{~m} . \mathrm{S}$. W. by S. Iowa City.

Notringham TURNPIEE, p. O, Rockingham co., N. Hamp.: $21 \mathrm{~m}$. E. by S. Concord.

Notrla, p. o., Cherokee co, N. Car.: 320 m. W. S. W. Raleigh.

NotTOWAT county, $\bar{V} \gamma^{r} g$. Situate $\mathrm{S}$. E. centrally, and contains 264 sq. m. Drained by Nottoway river and its branches, and tributaries of the Appomatox river. Surface an extended plain ; soil fertile, and very productive. Chief articles of production, Indian corn, tobacco, and cotton. Farms 342 ; manuf. 17 ; dwell. 492 , and pop. wh. $-2,251$, fr. col. 136, sl. 6,050-total 8,437. Capital: Nottoway C. H. Public Works: Richmond and Danville R. R.; South Side R. R. Notroway, p. v., and cap. Nottoway county, Firy. : on Nottoway r, 44 m, S. W. Richmond.

Notrowax river, Virg. and $N$. Car.: rises in Prince Edward co, flows mainly in S. E, direction, through S. W portion of Virg., and passing into N. Car., unites with Meherrin r., in Gates co., forming Chowan river.

Novi, t. and p. v., Oakland co., Hich. : 57 m. E. S. E. Lansing. Surface of $t$, is rolling, and is well timbered; soil good. Drained by the W. branch of the Rouge $r$. and its creeks. The $\mathrm{v}$. is on the $\mathbf{E}$. side of $\mathrm{r}, 2 \mathrm{~m}$. $\mathrm{S}$. of Walled lake. Pop. of t. 1,42S.

Noxapater, p. o., Winston county, MFiss.: 84 m. N. E. Jackson.

Noxubee county, Miss. Situate E., and contains $67 \mathrm{sq}$. $\mathrm{m}$. Drained by tributaries of W. fork of Tombigbee river. Surface moderately even; soil fertile. Chief productions, cotton and Indian corn. Farms 676; manuf. 81 ; dwell. 957, and pop.-wh. 4,976, fr. col. 0, sl. 11,323-total 16,299. Capital: Macon. Public Works: Mobile and Ohio R. R.

Noresvilie, p. v., Cook co., Ill.: on the Des Plaines r., $167 \mathrm{~m}$. N. E. by N. Springfield. Galena and Chicago Union R. R. passes through the village, $10 \mathrm{~m}$. W. Chicago.

Nubin Ridge, p. 0., Hardeman county, Tenn.: $140 \mathrm{~m}$. S. TV. Nashville.

Nueces county, Tex. Situate $S_{\text {. }}$, and contains about 6,200 sq. m. Drained by branches of the Rio Nueces, which forms its $\mathrm{N}$. and $\mathrm{N}$. W. boundaries, and by the rivers $\mathrm{Agua}$ Dulce, San Fernandes, and Trinidad, which fall into the bays in the S. E. portion of the county. Surface undulating, some parts slightly elevated; soil on the streams very fertile, consisting of a deep mold, intermixed with sand, and favorable to cotton and corn, but in general is best adapted for pasturage. A portion of the county is prairie, and a small part is thickly wooded. Salt Lagoon is situate $\mathrm{S}_{+} \mathrm{E}_{\text {, }}$, and Laguna del Madre forms the eastern boundary. The Neuces is the principal river, and is navigable for small boats fur about 100 miles from its mouth. Farms 8 ; manuf. 
1; dwell. 151, and pop.-wh. 650, fr. col. 1, sl. 47-total 698. Cupital: Corpus Christi.

Nueces river, Tex. Its remotest source is in the mountains of Bexar co, and with its tributaries drains an extensive surface of country. Its general course is $\mathbf{S}$. E., being about $300 \mathrm{~m}$. long in its windings, and $226 \mathrm{~m}$. from its source to its mouth, where it empties into Nueces bay. Its principal tributary is the Rio Frio. The Nueces $\mathrm{r}$. is navigable for $100 \mathrm{~m}$., but is much encumbered by sand-bars in its upper portions.

NulHegan river, Essex co, Verm.: formed from two "branches, uniting in Bloomfield, forming a rapid stream, and enters Connecticut r. above Brunswick.

Nuxuss Mrtus, p. o., Fayette co., Ind.: 73 m. E. by S. Indianapolis.

Norra, p. o., Parke co., Ind.: on E. side of Wabash r., on the canal, $62 \mathrm{~m}$. W. by $\mathrm{S}$. Indianapolis.

Number 1, p. o., Wayne co., Ohio: 55 m. N.E. Columbus.

NUMBER 2, p. o.g Marion county, Flor.: $176 \mathrm{~m}$, S. E. Tallahassee.

Novres 8, p. O., Aroostook county, Me. : 131 m. N. N. E. Augusta.

NUNDA, t., p. $\nabla$. , and sta., Livingston co., N. Y.: $221 \mathrm{~m}$. W. Albany, Drained by branches of Genesee r. Surface undulating; soil good for wheat. The v, is on Cashagua cr., and is a station of the Buffalo and New York City R. R $62 \mathrm{~m}$. from Buffalo. Besides several churches, and a flourishing academy, it has some factories. The "Nunda Telegraph" (whig) is published weekly. Pop. of t. 3,128.

Nuтвбвн, p. O., Warren co., $N$. Car.: on Nutbush cr., $60 \mathrm{~m}$. N. Raleigh.

NYACK, p. v., Rockland co., N. Y.: on W. bank of Hudson r., $113 \mathrm{~m}$. S. Albany. A flourishing v., containing several churches, etc., and having regular communication with New York. Two newspapers are issued weekly - "Rockland County Journal," and "Rockland Messenger." Pop. about 1,000 .

Nyack Turnpike, p. o., Rockland co., $N . X_{*}: 102 \mathrm{~m}$. S. by W. Albany.

\section{0.}

OAK, p. O., Williams co., Otio: $182 \mathrm{~m}$. N. W. Columbus. OAK creek, Otsego co., N. Y.: the outlet of Schuyler's lake, which flows S. through the town of Otsego, and empties into the Susquehanna $r$.

OAkachoraira, p. o., Tallabusha county, Miss. : $108 \mathrm{~m}$. N. N. E. Jackson.

OAK Blufrs, p. 0., Greene co., Ark. : near a branch of

St. Francis $\mathrm{r}, 144 \mathrm{~m}, \mathrm{~N}$. E. Little Rock.

OAK Bowery, p. o., Chambers co., Ala. : 51 m. N. E. by E. Montgomery.

OAK Crefk, p. $\nabla$., Milwaukie co., Wisc.: on a cr. of Lake Michigan, 78 m. E. by S. Madison.

OAKDale, p. v., and cap. Shelby co, Mo.: 83 m. N. by E. Jefferson City. The court-house is situate here.

OAKDale, p. v., Worcester co., Mass.: on the Nashua r. and Worcester and Nashua R. R., $25 \mathrm{~m}$. Worcester, and $39 \mathrm{~m}$. W. Boston.

OAKFIELD, p. o., Genesee co., N. Y.: 232 m. W. Albany. OAkField, p. v., Fond du Lae co., Wisc.: $62 \mathrm{~m}$. N. E. Madison.

OAKFIELD, p. Oog Perry county, Ohio: 42 m. E. S. E. Columbus.

OAKFIELD, t. and p. O., Kent county, Mfich, : $61 \mathrm{~m} . \mathrm{N}$. W. Lansing, and $39 \mathrm{~m}$. E. Grand Haven. Drained by Flat r. and its tributaries. Surface rolling; soil deep vegetable loam. It abounds in forests of heavy pine timber. Pop. 404.

ity.

Oax Fuat, p. v., Pendleton co., Virg.: on a branch of the Potomac $r_{c}$, and at the foot of the Shenandoah Mountain, $123 \mathrm{~m} . \mathrm{N}$. W. Pichmond.
OAK Forest, p. 0., Wayne co., Ky.: 85 m. S. Frankfort. OAK Foress, p. o., Iredell county, $N_{0}$. Car.: $121 \mathrm{~m}$. W. Raleigh.

OAI Fonest, p. v., Franklin co., Ind.: near Oak creek, $59 \mathrm{~m}$. E. S. E. Indianapolis.

OAK Fonzst, p. o, Cumberland county, Virg.: $35 \mathrm{~m}$. W. Richmond.

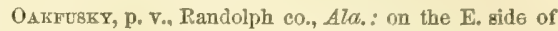
the Tallapoosa $\mathrm{r}_{-9} 75 \mathrm{~m}$. N. by E. Montgomery.

OAK Grove, p. o., Montgomery county, $A l a .: 15 \mathrm{~m}, 8$ Montgomery.

OAK GROVE, p. O., Hempstead co., Ark. : 101 m. S. S. W. Little Rock.

OAK GRove, p. o., Christian county, Ky. : $172 \mathrm{~m} . \mathrm{S}$. W. Frankfort. The Nashville and Henderson R. R. passes near the location.

OAK GROVE, p. $_{\text {., W }}$ Washington par., $L a_{0}$ : situate between M'Gee and Big Silver creeks, in N. part of par., 63 m. N. E. Baton Rouge.

OAK Grove, p. o., Livingston county, Mich.: $33 \mathrm{~m} . \mathrm{S} . \mathrm{E}$ Lansing.

OAK GRott, p. 0., Chickasaw co., Miss.: 123 m. N. E Jackson.

OAK GRove, p. o., Titus co., Tex. : 257 m. N. E. Austin City.

OAK GRove, p. V., Jackson co,, Mo.: $112 \mathrm{~m}$. W. by N. Jefferson City.

OAK Grove, p. o., Jefferson county, Tenn.: 193 m. E. Nashville.

OAK GRovE, p. o., Westmoreland co., Virg.: 49 m. N. E. Richmond.

OAK Grove, p. o, Linn co., Ia.: 23 m. N. Iowa City.

OAK GRove, p. o., Dodge co., Wisc. : $52 \mathrm{~m}$. N. Madison.

OAK Grote Furkace, p. o.,Perry co., Penn.: in the village of Landisburg, $23 \mathrm{~m}$. W. by N. Harrisburg. A coal blast furnace, with an annual capacity of 1,100 tons, is situate here.

OAKHAM, t. and p. v., Worcester co., Mass. : $53 \mathrm{~m} . \mathrm{W}$. Boston. Drained ehiefly by Ware r., which bounds it on the $N$., and also by several small rivulets passing through it. Surface rolling; soil good, affording excellent pasturage for cattle. Pop. 1,187.

OAKHILL, p. v., Newton co., Ga. : near one of the forks of Ocmulgee r., $59 \mathrm{~m} . \mathrm{N}$. W. Milledgeville.

OAK HrL, p. o., Franklin county, Ala.: 185 m. S. S. E Montgomery.

OAK HILL, p. o., Hardin county, Ky.: about 67 m. S. W. Fronkfort.

OAK HiLl, p. o. and sta., Cumberland co., Me.: on the line of the Kennebec and Portland $\mathrm{R}, \mathrm{R}, 23 \mathrm{~m}$. from Portland and $30 \mathrm{~m} . \mathrm{S} . \frac{1}{2} \mathrm{~W}$. Augusta.

OAK Hill, p. $v_{\text {, }}$ Lake co., Ill. : near Lake Michigan, $195 \mathrm{~m} . \mathbf{N}$. E. Springfield.

OAK HrLl, p. V., Jefferson co., Wisc.: $40 \mathrm{~m}$. W. by S. Madison.

OAK HILL, p. o., Greene co., $N . Y_{.:}$on the line of the Hudson River R. R., 110 m. from New York City, $32 \mathrm{~m}$. S. W. Albany.

OAk HrL, p. o., Granville co., N. Car.: about $48 \mathrm{~m} . \mathbf{N}$. Raleigh.

OAK HiLu, p. v., Jackson co, Ohto: on the line of the Scioto and Hocking Valley R. R., $77 \mathrm{~m}$. S. S. E. Columbus. There are several furnaces within a short distance of the village.

OAK Hirr, p. v., Laneaster co, Penn, : $53 \mathrm{~m}$. $\mathrm{W}$. by $\mathrm{S}$. Philadelphia and $53 \mathrm{~m}$. S. E. Harrisburg; There are situate here 2 charcoal forges, yielding annually 400 tons bloom iron and 230 tons bars, and a rolling-mill producing 400 tons annually.

OAK HIIL, p. o., Overton county, Tenn. : 85 m. E. by N. Nashrille.

OAK Hrul, p. V., Fauquier co., Firg.: on the Manassas Gap R. R., 98 m. N. by W. Richmond. 
OAk HrL, p. o., Panola county, Miss.: $133 \mathrm{~m}$. N. Jackson.

OAKLAND county, MFich. Situate S. E. of the S. peninsula, and contains $896 \mathrm{sq}$. m. Drained by Clinton $r$. and its affluents, and branches of Flint, Rouge, Shiawassee and Huron rivers. Surface undulating and diversified with numerous small lakes; soil fertile, and rields good crops of wheat, Indian corn, and potatoes. Farms 3,416 ; manuf. 146; dwell. 5,699, and pop.-wh. 31,207, fr. col. 63-total 31,270. Capitul: Pontiac. Pullic Works: Detroit and Pontiac R. R.

OAKLAND, p. o., St. Francis co., Ark.: $70 \mathrm{~m} . \mathrm{W} . \mathrm{N} . \mathrm{W}$. Little Rock.

OAKLAND, p. $\nabla .$, Coles county, $\pi l$.: on a branch of the Embarras r., 85 m. E. Springfield.

OAKraAND, p. v., Christian co, Ky.: $175 \mathrm{~m} . \mathrm{S}$. W. Frankfort. Situate directly on the boundary line between Christian and Caldwell counties.

OAKLAND, to and p. o., Oakland co., Mich.: $51 \mathrm{~m}$. E. Lansing and $25 \mathrm{~m}$. N. Detroit. Drained by Paint $\mathrm{cr}$. and a branch of Stony cr. Surface hilly; soil of great varietyin some parts marshy. Pop. of t. 978 .

OAKLAND, p. o., Yallabusha co., Afiss. : 131 m. N. by E. Jackson.

OAKLAND, p. v., Laclede co., Mo.: on the Osage Fork of the Gasconade r., $64 \mathrm{~m}$. S. by W. Jefferson City.

OAKLAND, p. O., Chatham county, N. Car.: $36 \mathrm{~m}$. W. Raleigh.

OAKLAND, sta, Alleghany co., Mrd.: on the Baltimore and Ohio R. R., $283 \mathrm{~m}$. W. Baltimore.

OAKLAND, p. O., Spencer county, Ind.: 119 m. S. S. W. Indianapolis.

OAKTAND, sta., Marion county, Ind.: on the Indianapolis and Bellefontaine R. R., 14 m. N. E. Indianapolis,

OAKLAND, p. 0., Lavacea county, Texe : 77 m. S. E. Austin City.

OAKLAND, p. O., Livingston co., $N . \quad Y_{0} ; 208 \mathrm{~m}$. W. by S. Albany.

OAKLAND, p. O., Clinton county, Ohio: $57 \mathrm{~m}$. S. W. Columbus.

OAKLAND, v., Fairfield co., Ohio: $31 \mathrm{~m}$. S. E. Columbus. Pop. 133.

OAKtand, p. o., Armstrong co., Penn.: 145 m. W. N. W. Harrisburg.

OAKLAND, sta., Chester co., Penn. : on the Columbia and Philadelphia R. R., $30 \mathrm{~m}$. from Philadelphia.

OAKLAND, p. o., Edgefield dist., S. Car : 49 m. W. S. W. Columbia.

OAKLAND, p. O., Fayette county, Tenn.: 155 m. S. W. Nashrille.

OAKLAND, p. V., Morgan co., Tirg.: $143 \mathrm{~m}$. N. by W. Richmond.

OAkxard, p. v., Jefferson county, Wisc.: $23 \mathrm{~m}$. S. W. Madison.

OAKLAND, p. o., Lauderdale county, Ala. : $175 \mathrm{~m}$. N. W. Montgomery.

OAKL AND, p. v., Tuolumne co., Calif.: on the N. side of the river De los Mereed, branch of San Joaquin r., $115 \mathrm{~m}$. S. E. Vallejo.

OAKLAND COLLEGE, p. v., Claiborne county, Afiss. : $60 \mathrm{~m}$. W. S. W. Jackson. The college was founded in 1830, and in 1850 had 6 professors, 114 alumni, 84 students, and a library of 9,000 volumes.

OAkLaNd Grove, p. v., Prairie co., Ark.: on a fork of Crpress Bayou of White r., $24 \mathrm{~m}$. N. E. Little Rock.

OA kLaxd Mrts, p. o., Juniata co., Penn. : 35 m. W. N. W. Harrisburg.

OAK LATw, p. o., Baker county, Ga.: 185 m. S. S. W. Millergeville.

OAK L LWW, p. O., Cabarras co., N. Car. : 97 m. S. S. W. Raleigh.

OAK LEVEr, p. 0., Benton connty, Ala : $103 \mathrm{~m}$. N. by E. Montgomery,

612
OAk Lever, p. o., Henry county, Firg. : 181 m. S. W Richmond.

OAKLeY, p. o., Overton county, Tenn.: 85 m. E. by N. Nash ville.

OAKLEY, p. o., Macon co., IIl. : 35 m. E. Springfield.

OAKLEX, p. v., Mechlenburg co., Virg.: on a branch of Dan r., $59 \mathrm{~m}$. S. W. Richmond.

OAKLEY, p. o., Lewis co., MFo. : $106 \mathrm{~m}$. N. by E. Jefferson City.

OAKLEY, p. 0., Franklin parish, $L a_{n}: 119 \mathrm{~m} . \mathrm{N}$. by W. Baton Rouge.

OAkMUtgee, p. o., Bedford county, Virg.: on line of the " Virginia and Tennessee R. R., $29 \mathrm{~m}$. W. of Lynchburg, $97 \mathrm{~m}$. W. by S. Richmond.

OАконАт, p. O., Covington co., Miss. : 52 m. S. E. Jackson. OAK ORchard, p. vo, Orleans co., N.Y.: $243 \mathrm{~m}$. W. by N. Albany.

OAK Platis, p. o., Livingston co., Muich.: 32 m. S. E. Lansing.

OAK PoInt, p. o., St. Lawrence county, N. Y.: $157 \mathrm{~m}$. N. by W. Albany.

OAK PoInt, p. 0., Clatsop co., Oreg. Ter.: on the S. side of Columbia r., $80 \mathrm{~m}$. N. Salem. It occupies a site immediately opposite the E. end of Gull Island.

OAs PoLst, p. 0., Van Buren co., Ia.: 63 m. S. by W. Iowa City.

OAK RIDGE, p. o., Hancock co., Ohio: $72 \mathrm{~m} . \mathrm{N} . \mathrm{N} . \mathrm{W}$. Columbus.

OAE RTDGE, p, 0., Greene co., Ark.; on a branch of EeI river, $114 \mathrm{~m}$. N. E. Little Rock.

OAK RIDGE, p. 0., Graves county, Ky.: 227 m. S. W. Frankfort.

OAK RIDGe, p. o., Meriwether county, Ga.: $85 \mathrm{~m}$. W. Milledgeville.

OAE RDGE, p. O., Guilford co., $N_{0} C^{\prime} t r .: 75 \mathrm{~m} . \mathrm{W} . \mathrm{N} . \mathrm{W}$. Paleigh.

OAK's CoRNers, p. v., Ontario co., N.Y.: $173 \mathrm{~m}$. W. by N. Albany.

OAK SHADE, p. o., Culpepper co., Tirg. : $63 \mathrm{~m}$. N. by W Richmond.

OAK SpRIYG, p. O., Ballard county, Ky.: $241 \mathrm{~m}$. S. W. Frankfort.

OAK SPRITG, p. v., Davis co., Ia. : on S. side of Soap cr., $75 \mathrm{~m} . \mathrm{S} . \mathrm{W}$. Iowa City.

OAs's Shop, p. o., Pittsylvania co., Virg.: $115 \mathrm{~m}$. S. W. Richmond.

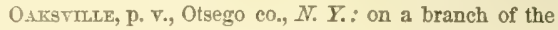
Susquehanna r., 67 m. W. Albany.

ОАБтіввенА, p. O., Kemper co., Miss. : 95 m. E. N. E. Jackson.

OAkvilue, p. o., Union co., Ark. : 107 m. S. by W. Little Rock.

OAIVILLE, p. v., Lawrence county, Ala.: 145 m. N. W. Montgomery.

OAKvILle, p. O., Madison county, Tenn॰: 121 m. S. W. Tashville.

OAknul.t, p. o., St. Mary's co., dfd. : 41 m. S. Annapolis. OAKVILLE, p. ., Monroe co., Mich. : 70 m. S. E. Lansing. OAKville, p. v., St. Louis co., Mo.: near the W. side of the Mississippi, $1.57 \mathrm{~m}$. E. Jefferson City, and $1 \mathrm{~S} \mathrm{m.} \mathrm{S.} \mathrm{by} \mathrm{W.}$ St. Louis City.

OAKVILLe, p. o., Union county, N. Car.: $313 \mathrm{~m} . \mathrm{S} . \mathrm{W}$. Raleigh.

OAkville, p. o., Cumberland county, Penn.: W. from Harrison.

OAKruLE, p. T., Lexington dist., S. Car.: $13 \mathrm{~m}$. N. W. Columbia.

OAKVILLF, p. o., Appomattox c0., Tirg. : about $65 \mathrm{~m}$. W. Pichmond.

$\mathrm{O}_{\text {A }}$ woods, p. o., Fleming county, $K_{y} .: 71 \mathrm{~m}$. E. by $\mathrm{N}$. Frankfort.

OAK Woods, p. 0., Grant county, Ind.: 57 m. N. E. Indianapolis. 
OAsrs, p. o., Marquette co., Wisc. : 52 m. N. Madison. OAtrands, p. o., Loudon co., Virg. : 103 m. N. Richmond.

O'Baxnoxs, sta., Jefferson county, $K y$. : on the Louisville and Frankfort R. R., $15 \mathrm{~m}$. E. Louisville, and $14 \mathrm{~m}$. W. Frankfort.

OBERLiN, p. V., Lorain co, Ohio: on the E, side of W. branch of Black $r_{\text {, }}$ where it is crossed by the Toledn, Norwalk, and Cleveland R. R., $99 \mathrm{~m}$. N. N. E. Columbus. It is the seat of Oberlin College, to the benefits of which both male and female students are admitted-manual labur forming part of the instruction. It is under Congregational influence; was founded in 1834, and in 1550, had a president, 12 instructors, 199 alumni (of whom 130 are in the ministry), and 66 students. There is a library attached to the college containing 4,200 volumes. Its theological department has 3 professors, 20 students, and 124 alumni, with a library containing 250 volumes, The "Oberlin Evangelist" (relig.), a semi-monthly paper, is published here.

Obron county, Tenn. Situate N. W., and contains 1,012 sq. m. Drained by Redfoot and Obion rivers, tributaries of the Mississippi r., which forms its western boundary. Surface level, and on the Mississippi low and subject to submersion; soil fertile and adapted to cotton and tobacco. It has some timber land and good pasturage for cattle. Farms 658 ; manuf. 6 ; dwell. 1,131, and pop.-wh. 6,572, fr. col. 4, sl. 1,057-total 7,633. Capital: Troy. Public Works Mobile and Ohio R. R.; Nashville and Mississippi R. R.

OBIoN, p. o., Hickman co., $\bar{k} y .: 253$ m. S. W. Frankfort.

OBIoN river, Tenn.: the principal head branches rise in Henry and Carroll counties, and pursuing a W. and S. W. course flow into the Mississippi at Hales Point. Obion, Weakly, Henry, Carroll, Gibson, and Dyer counties are well drained by this river and its tributaries.

O'BrIEN county, Ia, Situate N. W, and contains 576 sq. m. Drained by branches of Little Sioux $\mathbf{r}$. Surface rolling, a large portion being prairie; soil fertile, and is well adapted to wheat, corn, fruit, etc. ; valuable timbers line the streams, Capital: Ainsley.

Occoquas, p. v., Prince William co., Virg.: on W. side of the Occoquam r., $75 \mathrm{~m}$. N. Richmond.

OCCOQUAM river, Firg.: the most important tributary of the Potomac, rises in Fauquier and Prince William counties, flows S. E., separating Fairfax and Prince William counties, and empties into the Potomac. The tide flows up $7 \mathrm{~m}$, to the town of the same name, above which the river descends 72 feet in the distance of a mile and a half, and to which small sea vessels ascend.

Occupacis, p. o., Essex county, Firg.: 37 miles N. E. Richmond.

OCEAY county, $N$. Jer. Situate E. toward the S., and contains 435 sq. m. Drained by Tom's r. and Cedar, Manahocking, and Westecunck creeks. Surface level; soil in parts fertile, and consisting chiefly of sand with clay intermixed. There is good pasturage for cattle. Farms 379 manuf. 52 ; dwell. 1,758, and pop.-wh. 9,583, fr, col. 149total 10,032. Capital : Tom's River Village.

OCEAN, t, and p. o, Monmouth co., N. Jer.: running parallel with the Atlantic Ocean, $36 \mathrm{~m}$. E. Trenton. Drained by Whale Pond cr., Corlies or Great Pond cr., and other small streams emptying into the ocean. Surface in the W. hilly, otherwise level; soil loam, sand, and clay. In the N. E., on a promontory extending several miles, is Sandy Hook, on which is a revolving light and two beacons. The $\mathrm{t}$. is well supplied with water privileges, and contains several mills and manufactories. Set off from Shrewsbury in 1849. Pop. 3,767 .

Oceara county, Mich. Situate N. W. of the S. peninsula, and contains $763 \mathrm{sq}$. m. Drained by White and Maskegon rivers, the former of which traverses its central part. Surface slightly undulating; soil fertile and productive. Farms - manuf. 2 ; dwell. 58, and pop.-wh. 282 , fr. col. $19-$ total 301. Capital:
Ocean Port, p. o., Monmouth co., N. Jer. : 39 m. E. Trenton.

Oceola county, Ia. Situate N. W., and contains 432 8q. m. Drained by head branches of Little Sioux $r$. Surface undulating, and diversified with lakes. Much of the land is prairie, and a portion of it is well wooded. Laid off since 1850 .

Oceota, p. o., Cherokee county, Ala.: 133 m. N. by E. Montgomery.

Oceor.A, p. V., and cap. Mississippi co., Ark.: on the Mississippi $r_{*}, 87 \mathrm{~m}$. above Memphis, Tenn., $157 \mathrm{~m}$. E. N. E. Little lioek, at the head of I'lumb Point Burs, the most difficult and dangerous part of the Mississippi r. Many steamboats have been sunk hare, and portions of them may be seen at low water. It contains the court-house, etc.

Oceola, p. v., Crawford co., Ohio: on Broken Sword ce of Sandusky r., 61 m. N. by W. Columbus.

Oceola Crantre, p. o., Livingston county, Mrich. : $85 \mathrm{~m}$. F. by S. Lansing.

Ochesee, p. r., Calhoun eo., F'lor. : on W. bank of Appalachicola r., and on the Appalachicola post-road, $38 \mathrm{~m}$. W. by N. Tallahassee.

OCKLockony, p. O., Thomas co., Ga.: $181 \mathrm{~m}$. S. by W. Milledgeville.

OCNulgee, p. o., Perry county, Ala.: 43 m. W. by N. Montgomery.

OCMULGEE river, $G a$.: rises in the hilly region $\mathrm{S}$. of the Chattahoochee in De Kalb and Gwinnett counties, flowing $250 \mathrm{~m}$, in a $\mathrm{S}$. and E. direction, is joined by the Oconee $\mathrm{r}$ on the S. border of Montgomery co., where they form the Alatamaha, which empties into the sound so called of the Atlantic Ocean. The river is navigable for small steamboats as far up as Macon, Bibb co. It has several branches, which afford excellent water-power to several counties in its course.

Ònulgenvilue, p. o., Telfair co., Ga.: 79 m. S. by E. Milledgeville.

Ocos, p. 0., Polk co., Tenn.: 187 m. S. E. Nashville.

Ocol. , p. v., and eap. Marion county, Flor.: on the St. Augustin and Tallahassee post-road, $157 \mathrm{~m}$. \$. E. Tallahassee. Situate about $5 \mathrm{~m}$. N. from Fort King. It is the seat of the county court-housc. The "Ocola Argus" (whig) is published weekly.

Ocona Lufry, p. o., Haywond co., $N$. Car.: situate in the W. part of the county, $263 \mathrm{~m}$. W. S. W. Raleigh.

Oconee, p. v., Washington co., Ga.: on the E. side of Oconee r., and on the line of the Central (Georgia) R. P., $147 \mathrm{~m}$. N. W. Savannah, and $23 \mathrm{~m}$. S. E. Milledgeville.

OCONEE river, $G a$ : : rises in the hilly region near the Chattahoochee $r$. in Hall co., running a S. by E. course 200 m. ; connects with the Ocmulgee, and forms the Alatamaha $r$, which flows into the Atlantic Ocean. Appalachie river and Indian creek are its principal branches.

Oconee Station, p. v., Pickens distriet, $S$. Car. : $181 \mathrm{~m}$. N. W. Columbia

Ocovourowock, t, and p., , Waukesha co., Wisc.: $45 \mathrm{~m}$ E. Madison. Drained by branches of Rock r., which pass throush the $\mathrm{N}$, and $\mathrm{S}$, of it, affording excellent water-power. Three lakes form the S. boundary. There is some good timber land in the town. The $\mathrm{V}_{\text {., }}$ which is small, is in the S. part, on a branch of Rock river. Pop. of t. 1,21s.

Ocracoke, p. Y., Hyde co., N. Car. : on the island near Ocracoke inlet, and about $25 \mathrm{~m}$. $\mathrm{S}$. by W. Cape Hatteras, $153 \mathrm{~m}$. E. by S. Raleigh.

OCtarara, p. o., Laneaster co., Penn.: near a ereek by same name, 53 m. E. S. E. Harrisburg:

Ofrca, p. o, Jefferson co., Wisc. : $29 \mathrm{~m}$. W. Mirlison.

OGALLA, p. 0., Ghippewa co., Wisc, : $162 \mathrm{~m}$. N.W. Madison.

OgDen, p. v., Henry co., Ind.: on the Indiana Central R. R. $31 \mathrm{~m}$. E. by N. Indianapolis

OGDEN, t. and p. 0., Monroe co., $N_{\text {. }} \bar{Y}_{\text {; }}$, $221 \mathrm{~m}$, W. by $\bar{N}$. Albany, and $13 \mathrm{~m}$. Rochester. Surface level; soil gravelly loam. Drained by Salmon or. The Rochester, Lockport 
and Niagara Falls R. R., and Erie Canal pass through, on the latter of which Adam's Basin is situated. There are in the t. several stores and mills, a furnace, and a number of other industrial establishments. Pop. 2,59S.

OGDEN, p. v., New Madrid co., Mo.: between Lake St. John's and St. Mary, $188 \mathrm{~m}$. S. E. Jefferson City.

OGDEN Citr, p. v., Weber co., Utah Ter.: on N. side of Weber r., $157 \mathrm{~m}$. N. Fillmore City.

OGDensmtrg, p. v. and port of entry, St. Lawrence co., $N_{0}, \bar{Y}_{*}:$ on the right bank of St. Lawrence $r_{.}$, at the mouth of Oswegatchie r., $161 \mathrm{~m}$. N. W. Albany. The Northern R. R. has its western terminus at this place, and steamers ply hence daily for the river and lake ports, making it a depot of great importance. Prescott, a large town, lies on the opposite side of the river, here $1 \frac{1}{3} \mathrm{~m}$. broad, and is connected by a steam ferry. The v, contains immense depôts, and other warehouses, stores of every description, 3 banks, foundries, machine shops, and other industrial establishments, schools, and churches, and, on the whole, is one of the most progressive villages of the State. The manufactures of this place find an immense water-power on the Oswegatchie, on which there are falls. It is at the lower termination of sloop navigation, but steamboats go to the rapids, $40 \mathrm{~m}$. below, and thence pass by Ogdensburg to the various places on Lake Ontario. Pop. about 6,000. The r. is connected with Boston and New York by railroad-distance to Boston $403 \mathrm{~m}$., and to New York City 452 miles. Ogdensburg has 4 newspapers, the St. Lawrence Republican" (dem.), the "O. Sentinel" (whig), the "O. Forum" (whig), and the "Northern New Yorker" (neut.), all published weekly. The shipping owned here in 1850 amounted to 1,985 tons, all navigated by steam. The foreign arrivals, in the district of which Ogdensburg is the port of entry, in 1850 , were 380 vessels, and 196,915 tons, and the departures 375 vessels, and 189,705 tons. This is exclusive of the yast amount of shipping engaged in the domestic coasting trade, and is indicative of the extent of its connection with the British provinces. The constwise trade is valued at $\$ 7,000,000$ annually.

OGEECHEE river, $G a .:$ rises in the E. part of Greene co., and flowing in a S. F, direction $200 \mathrm{~m}$, empties into Ossa- baw sound of the Atlantic Ocean. Its principal branches are Lambert creek, in Jefferson co., Litle Ogeechee $\mathbf{r}_{*}$, in Scriven co, on the E., Williamson's S. W. cr. and Connouchee $r$. on the W., forming in all extensive water-power. It is navigable for vessels of 30 tons as far up as Louisville, in Jefferson co., and for sloops $40 \mathrm{~m}$. from its mouth.

OGEecheE, p. v., Seriven ca., $G a_{0}$ : on N. side of Ogeechee r., $60 \mathrm{~m}$. from Savannah, near the Central (Georgia) R. R. $97 \mathrm{~m}$. S. E. Milledgeville.

OgEuAw county, Mich. Situate N. E., and contains 576 sq. m. Drained by Rifle r. and a branch of the Aux Grais. Surface generally level; soil a deep, black, vegetable mold. Set off since 1850 .

OGLE county, $I l l$. Situate N., and contains $576 \mathrm{sq}$. m. Drained by Rock $r$. and its tributaries. Surface undulating; in parts it is low and marshy, and unfit for eultivation; soil in general fertile, and produces wheat and Indian corn. The marshes, when drained, make good grazing land. Some portions of the co, are thickly envered with valuable timber. Farms 1,055; manuf. 30 ; dwell. 1,678, and pop.wh. 9,990, fr. col. 30-total 10,020. Capital: Oregon City. Public Works: Central Illinois R. R.; Rockford and Rock Island R. R., etc.

OgLe, p. Oa, Butler county, Penn.: 165 m. W. N. W. Harrisburg.

OGLE, p. v., Ogle co., I I . : at the head of Washington cr. $153 \mathrm{~m} . \mathrm{N}$. by E. Springfield.

OGLETHORPE county, $G a$. Situate toward the N. E., and contains $515 \mathrm{sq} . \mathrm{m}$. Drained by branches of Broad river, which runs on the N. E., and of Oconee $x$., which bounds it on the S. W. Surface level; soil varied; in general very fertile. Cotton is the chief production, but fine crops of wheat, Indian eorn, and potatoes are raised. There is some good timber on the land. Farms 555; manuf. 13; dwell. 519, and pop.-wh. 4,352, fr. col. 3, sl. 7.S74-total 12,2\%9. Capital: Lexington. Prollic Work's: Athens Branch R. Pr. OGLETHORPE, p. v., Macon co., Ga.: on Fluit river, $71 \mathrm{~m}$ 8. W. Milledgeville. The South-western R. R. passes through the $\nabla_{0,} 50 \mathrm{~m}$. from Macon.

OGUNQOIT, p. v., York co., Me.: on N. side of Ogunquit r. $1 \mathrm{~m}$. from the Atlantic coast, $86 \mathrm{~m}$. S. W. Augusta.

\section{THE STATE OF OHIO.}

OEro, the most wealthy and prosperons of the new States, north-west of the Ohio River, is situated between $3 S^{\circ} 24^{\prime}$ and $42^{\circ}$ latitudes north, and between $80^{\circ} 34^{\prime}$ and $84^{\circ} 42^{\prime}$ longitudes west. It is a compact mass of land, lying between Pennsylvania and Tirginia on the east; Kentucky on the south, from which it is separated by the Ohio River; Indiana on the west, and Michigan and Lake Erie on the north, along which its coast-line extends 257 miles: Its general length is 200 miles, and its breadth, north and south, about 140 miles, with an area of 39,964 square miles.

Though the surface is much and delightfully varied, it nowhere presents any considerable elevations above the general level; but the country is a lofty table-land, which, in its middle zone, is about 1,000, and on the northern and southern borders from 600 to 800 feet above the sea level. A slightly elevated ridge of highlands divides the waters flowing north into Lake Erie from those flowing south into the Ohio. From this there is a rather rapid descent to the level. The lake, and the courses of the rivers on the Erie slope, are rapid, and considerably broken by falls. The general slope toward the Ohio on the south is interrupted by a subordinate ridge, which crosses the State in the latitude of Zanesville and Columbus, between which and the river the surface is very much diversiffed with hills and valleys. The central belt consists of extensive flat tracts, with numerous broad swells rising gently from the plains; and swamps and morasses occasionally occur. The northern or Erie slope also contains extensive morasses. The extent of swamp lands in the State, however, is only 303.329 acres, or one-eighteenth part of the whole. Nine-tenths of the surface of the State is susceptible of cultivation, and nearly three-fourths of the soil is eminently productive; even the hills are generally cultivable to their summits, and covered with a fertile soil. The river bottoms are extensive and exuberantly fertile. In the centre and north-west, prairies or natural meadows are numerons and extensive, but the greater part of the country was originally covered with magnificent forests of gigantic trees, and even at the present day timber is abundant.

The rivers of Ohio debouch either into the Ohio or into Lake Erie. The Ohio runs along the southern border for nearly 500 miles, and the principal rivers falling into it are the Muskingum, the Hockhocking, the Scioto, the Little Miami, the Miami, etc. The Mfuskingum, which enters the Ohio at Marietta, rises in the northern watershed, near the head waters of the Cuyahoga, and drains a beautiful and fertile district. It is about 120 miles in length, and is navigable during a greater part of the year by small steamboats to Zsnesville, 75 miles, and by batteaux to Coshocton, 110 miles, and above this small boats ascend to within a mile of the Cuyahoga, Sandy River and Wills Creek, on the east, and Walkonding or White-woman's River, and the Licking, from the west, are its principal tributaries, and are useful mill streams. The Hockhocking rises on the southern ridge, and reaches the Ohio at Inoking Port, after a course of 50 miles throngh a hilly and picturesque country, abounding in yellow pine. It is narrow and deep, and navigable for small boats to Athens. The 
OHIO.

Hocking Cunal follows the course of this river. The Scioto is a fine navigable stream, entering the Ohin at Portsmouth. It flows through a wide and fertile valley, and in the upper part of its course is surrounded by rich and beautiful prairies. Boats have ascended almost to its source, near Bucyrus, and passed by a portage of 4 miles into the Sandusky and Lake Erie. Delaware, Columbus, Circleville, Chillicothe, and Piketon are the principal places on its banks. The Little Mrutmi has its rise in the southern ridge, and although too much broken by falls to be useful as a navigable channel, it is a fine mill stream, furnishing an abundant supply of water for manufacturing purposes. It enters the Ohio about 12 miles above Cincinnati. The head waters of the Miami, or Big Miami, approach very near to those of the Seioto, the Auglaise, and the St. Mary's; its current is rapid, but it is navigable for some 70 or 80 miles. At several points-at Sidney, Troy, Dayton, and Hamilton-it furnishes excellent water-power, especially at Dayton, where it has been greatly improved for manufacturing purposes. It is 200 yards wide at its mouth, and enters the Ohio in the south-western corner of the State, after a course of 100 miles. Among the northern rivers are the Maumee, Sandusky, Cuyahoga, ete. The Ifaumee, or Miami of the Lake, which has its source in Indiana, is the principal; it is formed by the junction of Little St. Joseph"s, St. Mary's, and Great and Little Auglaize rivers. Its length is about 100 miles, and 50 miles from its mouth it is 70 rods wide. The navigation is open to schooners and steamboats 18 miles to Perrysburg, and in spring and fall it is boatable to Fort $W$ ayne, and at all times furnishes extensive water-power. The river bottoms are extensive and fertile, and the banks are high and heavily timbered. It enters Lake Erie through Maumee Bay. The Sandusky is a rapid stream, but navigable during high stages of the water. To Fremont City the navigation is always open. It enters the lake through Sandusky Bay, an immense basin, destined to be the scene of a mighty commerce. Sandusky City, on its south-east shore, is one of the principal ports of the lake, and the terminus of several lines of railroad, connecting with the interior and the shore district. The Cuyahoga rises near Lake Erie, but taking a south-westerly course, it approaches the head of the Muskingum, and thence flows northward into the lake at Cleveland. It is one of the most important rivers of Northern Ohio. It is more than 60 miles long, and has numerous falls and is an excellent mill stream. Along its banks several flourishing manufacturing villages have sprung up. The mouth of the river, which has been improved and extended by piers, forms the harbor of Cleveland. Besides these there are other important streams flowing into the lake, as Portage Piver, navigable for 12 miles from Port Clinton; Huron River, navigable to Milan, 14 miles, and entering the lake at Port Huron; Vermillion River, Black River, Rocky River, ete., all of which are navigable to a greater or less extent, and which, at their mouths, furnish harbors.

Ohio is one of the richest mineral States of the Union. Iron, coal, and lime-the most useful of minerals-abound in all the eastern portion of the State, and are deposited in beds of vast thickness. Salt springs are numerous in the same region. The coal of Ohio is bituminous, and lies very accessible, requiring comparatively little capital to handle it, but as yet there is, except in some of the principal cities-Cincinnati, Dayton, Cleveland, etc-but little manufacturirig, and in a large portion of the State the people are not sufficiently near the mines or public works to use coal in competition with wood. Time and the axe, however, are rapidly destroying the forest, and wood is fast rising in price; and the period is not distant when the whole people of the Central West will use coal. The progress of the railroad will hasten this revo. lution fo the industrial and domestic economy of the State. The marketable production of coal in Ohio may be determined approximately by the report of the Board of Public Works. The principal points of coal mining are at Talmadge, Summit County ; Pomeroy, Meigs County ; Nelsonville, Athens County ; and some points in Stark and Cushocton counties, The amount brought to market from these several points in 1850-51 was as follows: from Akron, 3,052,850 bushels; from Mrassilon, 186, $\$ 93$ bushels; from Dover, 59,150 bushels ; from Roscoe, 260,256 bushels; from Nelsonville, 930,150 bushels; and from Pomeroy, about 2,000,000 bushels-in all, 6,499,299 bushels. This is but a sixteenth part of the coal brought to market from Easton, Pennsylvania, yet it is a large amount, and a large increase on the production a few years since. It is about the production of Pennsylvania 15 years ago. May not the increase of the coal trade in Ohio be as rapid as that of Pennsylvania? If so, what an important effect it will have on the industry and internal commerce of the State. The consumption of coal in the interior towns is gradually increasing. In 1850, Columbus took 285.521, and in 1851, 499.951 bushels; Circleville, in 1550, 66,109, and in 1851, 93,529; Chillicothe, in 1850, 183,139, and in 1851, 205,567; M'Connellsville, in 1850, 46,2S5, and in 1551, 68,414; Middletown, in 1S50,19,025, and in 1851, 16,805; Dayton, in 1S50, 89,958, and in $1851,63,810$; and Piqua, in 1850, 8,868, and in 1851, 9,677 bushels; total in these places-in 1850, 639,900 bushels, and in $1551,957,893$ bushels. These are nominally small quantities, but the increase (50 per cent.) in one year is quite remarka. ble, and proves that as wood rises in price, as manufactures increase and railroads extend, that the consumption of coal will increase more than proportionately. The coal carried to market annually by Pennsylvania brings back to her $\$ 20,000,000$. An income like this, dug out of the earth, in a single article, is alone enough to stimulate other States, possessing it to foster its production, and become prosperous and independent through the same means.

That the iron business of the same region is destined at no distant day to become of equal magnitude and importance, must be apparent to the most casual observer. Extending through the counties of Lawrence, Gallia, Jackson, Meigs, Vinton, Athens, and Hocking, is a belt of iron ore, averaging some twelve miles in width, and extending a distance of one hundred or more in length, each square mile of which can be made susceptible of keeping up a furnace employing one hundred hands, and yielding eight tons of iron per day, for any desirable period of time. Coal of the very best quality, from three to twenty, and even thirty feet in thickness, also underlies, as before remarked, the counties named, together with others, sufficient to last for ages as a means of fuel for manufacturing in their midst as well as supplring the market demand north, west, and south of the mineral region. England, with an available coal region oceupying an area less than the counties of Meigs and Athens united, produces annually $\$ 50,000,000$ worth of iron, and yet at this day the mineral region of Ohio alone is susceptible of being rendered four-fold more valuable than the entire mineral region of England. If a patch containing but a few square miles has done so much for central England, what may not the flelds containing many hundred square miles do for Ohio?

That the salines of Ohio are immensely valuable, although not in the same proportion as its collieries and iron deposits; can not admit of a doubt. There are salt wells on Yellow Creek, above Steubenville; on Will's Creek; on the Muskingum River, from the Coshocton to near its mouth; on the Hockhocking; on Leading Creek, and in numerous other places. At the lower wells on the Muskingum, the salt rock is reached at 900 feet from the surface, and in some of the localities farther up theiriver at 650 to 700 feet. Of brine from the former, 100 gallons yield as many pounds of salt of an excellent quality; the upper springs are not so strong. On the Hockhocking the salt is reached near Athens at a depth of 800 feet, and higher up the river it is much nearer the surface.

Marble and freestone, well adapted for building purposes, and gypsum, also occur. The Yellow Springs, in Greene County, aixty-four miles north of Cincinnati, are situated in a delightful region, and have been resorted to with adrant- 
age in some cases of chronic diseases. The White Sulphur Springs, in Delaware County, have also been found effleaciols in some complaints.

The agricultural productions of Ohio are such as are common to the Eastern and Middle States. Indian corn is the staple grain, and of this crop Ohio produces a larger quantity than any other State, and exactly one-tenth of the whole crop of the United Sates; its wheat crop is one-seventh of the aggregate of the Union, and only surpassed by that of Penusylvania; Pennsylvania and New York alone produce larger crops of oats and buckwheat, and New York alone a larger crop of barley. It ranks seventh as a tobacco-producing State, second in relation to wines, and fifth for silk culture. New York alone exceeds it in the value of its live-stock. It owns one-tenth the number of horses in the Union, and more than any other State; only one State (New York) has a larger number of mileh cows and other cattle. It has more sheep than any other State, and in only four States are there a larger number of hogs. Cincinnati, its largest city, is renowned as the greatest hog-packing eentre of the West. One-ninth of the butter produced in the United States is made in Oho, and one-fifth of the cheese-in the production of the first Pennsylvania and New York exceed it, and of the latter New York alone. In the production of wool it has no competitor, and of this article one-fifth of the whole product of the country is clipped in Ohio. No markets in the United States are more profusely or cheaply supplied with meats and vegetables than those of the large cities of Ohio. Fruits of all hinds are raised in great plenty, especially apples, which grow to a large size, and are finely flavored. Its potato crop is only exceeded by the crops of two other States.

The rapid growth of Ohio has never been paralleled; in the sixty years from 1790 to 1850 , its population rose from 3,000 to $1,980,408$. Its fertile lands attracted immigrants from all parts to settle in its smiling valleys and rich plains. The Germans, among the foreign population, are in the largest number; next the Irish, English, French, British American, Welch, Scotch and Swiss, most numerical in the priority of position here assigned them.

Ohio is divided into 87 counties, the general statistics of which, and the capitals of each, in 1850, were as follows:

Counties. Dwell. Pop. Farms Mamuf. Capitals,

Adams ..... 3,205.. 18,883..1,509.. 26.. West Union

Allen ....... 2,070.. 12,109. .1,146.. 51. . Lima

Ashland .... 4,123.. 23,792, 2,285.. 71..Ashland

Ashtabula... 5,306. . 28,766..2,243.. 251..Jefferson

Athens ..... 3,121 . 18,215.1,872. . 60..Athens

Auglaize... 2, 2,020.. 11,338..1,373.. 30.. Wapakonetts

Belmont.... 5,823 . 34,600..2,552.. 185...St. Clairsville

Brown...... 4,838.. 27,332. .1,843.. 92. Georgetown

Butler..... 5,315 . . 30,789 . 2,262.. 269.. Hamilton

Carroll..... 3,068.. 17,655..1,926.. 41..Carrollton

Champaign . 3,437.. 19,762..1,677.. 93..Urbana

Clark ..... 3,753. .22,178..1,398.. 156..Springfield

Clermont ... 5,437.. 30,455 ..2,095.. 178.. Batavia

Clinton..... 3,245.. 18,838..1,366.. 83.. Wilmington

Columbiana $5,334 \ldots 33,621 . .2,335 . .180 \ldots$. New Lisbou

Coshocton... 4,325. . 25,674..2,736.. 155.. Coshocton

Crawford... 3,070.. 18,177. 1,210.. 8. Bucyrus

Cuyahoga... 8,299 . 45,099..2,228.. 162..Cleveland

Darke..... 3,476.. 20,274..2,151.. 10..Greenville

Defiance... 1,237.. 6,966. 296.. 31. Defiance

Delaware... 3,754.. 21,817..1,855.. 95..Delaware

Erie....... 3,362.. 18,568..1,021.. T3. .Sandusky

Fairfield.... 5,207.. 30,264..2,8S8.. 162..Lancaster

Fayette.... 2,155. 12,726..1,007. . 29.. Washington

Franklin... 6,701.. 42,910,.2,666. . 241. Columbus

Fulton..... 1,355.. 7,7S1.. \$26,. 32..Ai

Gallia ..... 2,975 . 17,068..1,190.. 9..Gallipolis

Geauga .... 3,210.. 17,827..1,906.. 36..Chardon

Greene.... 3,760.. 21,946..1,626.. 132..Xenia

Guernsey... 5,079 . 30,438 . 2,209 . . 78.. Cambridge

Hamilton. . .21,021 . 156, 543 . 2,602 . 1,463. . Cincinnati

Hancock.... 2,S24.. 16,751..1,636.. 35. . Finlay

Hardin..... 1,402. 8 8,251.. 783.. 26..Kenton

Harrison.... 3,526. . 20,157. 1,668.. 74. .Cadiz

Henry..... 610.. 3,435. 347.. 15.. Napoleon

Higlaland... 4,477.. 25,781. 2,323.. 151. Hillsboro'

Hocking... . 2,367. . 11,119..1,180, . 15..Logan

Huimes.... 3, $436 \ldots 20,452, .2,171 \ldots$ 122.. Millersburg

Furon ..... 4,619，26,203, 2,414，250. Norwalk

Jackson .... 2,120.. 12,721..1,161.. 14..Jackson

Jefferson.... 5,191.. 29,132..1,838. . 381..Steubenville

Knox ......44,853.. 25,573..2,265.. 117... Iount Ternon

Lake ...... 2,700.. 14,654..1,419 .. 250..Painesville

Lawrence .. 2,553.. 15,246. . 254.. 29...Burlington

The whole number of dwellings in the State, was at the above date 336,098 , of families 848,528 , and of inhabitants 1,950,408, viz., whites 1,956,10s-males 1,001,111, and females 951,997; fr. col. 24,300-males 12,289, and females 12,061 . Of the whole population there were denf and dumb-wh. 939, fr. col. \& - total 947; blind-wh. 653, fr. col. 12-total 665; insane-wh. 1,355, fr. col, 17-total 1.352; and idiotic-wh, 1,350, fr, col. 19-total 1,399. The number of free persons born in the United States was 1,757,556; the number of foreign birth, 21S,512; and of birth unknown, 4,398. The native 616

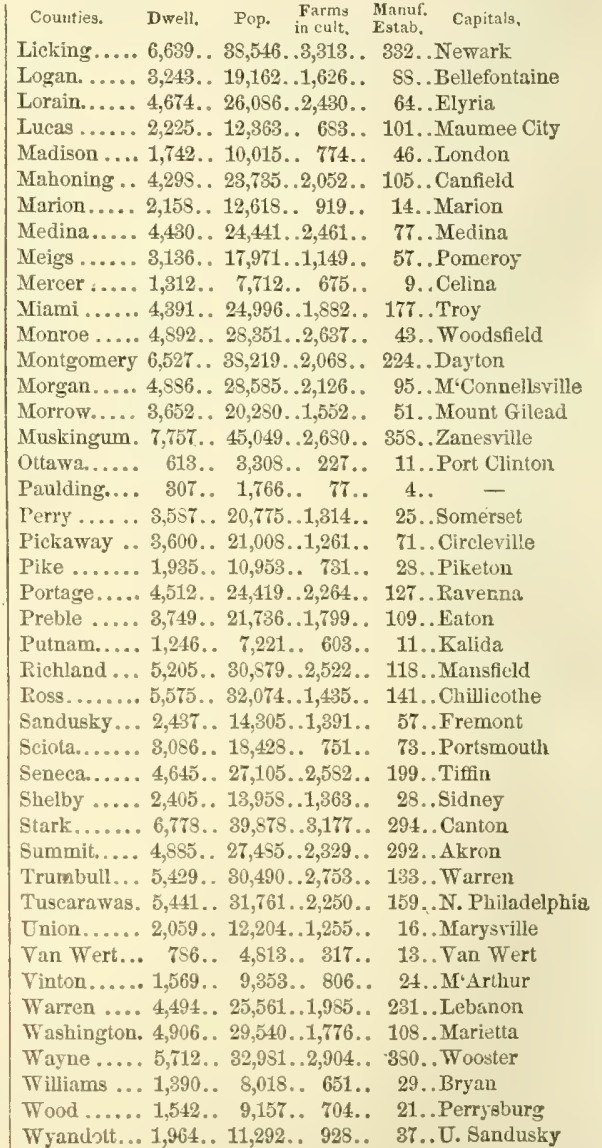




\section{OHIO.}

population originated as follows: Maine 3,314, N. Hamp. 4,821, Verm. 14,320, Mass. 18,763, R. I. 1,959, Conn. 22, 555 , Ner Iork \$3,979, N. Jer. 23,532, Penn. 200,634, Del. 4,715, Md. 36,698, Dist. of Col. 598, Virg. 85,762, N. Car. 4,807, S. Car. 1,468, Ga. 447, Flor. 17, Ala. 219, Miss. 422, La. 64S, Tex. 29, Ark. 141, Tenn. 1,873, Ky. 13,829, Ohio 1,219,432, Mich. 2,238, 1nd. 7,377 , III. 1,415, Mo. 656, Ia. 378, Wisc. 196, Calif. 0 , Territories 24. And the foreign population was composed of persons from-England 25,660, Ireland 51,562, Scotland 5,232, Wales 5,849, Germany 111,257, France 7,375, Spain 18, Portugal 7, Belgium 103, Holland 348, Turkey 1, Italy 174, Austria 29, Switzerland 3,291, Russia 81, Denmark 53, Norway 18, Sweden 55, Prussia 765, Sardinia 15, Greece 0, China 8, Asia 6, Africa 7, British America 5,880, Mexico 26, Central America 12, S. America 41, West Indies 86, Sandwich Islands 1, and other countries 544.

The following table will show the decennial increase of the population, since the first census of the State taken by the Tnited States authorities:

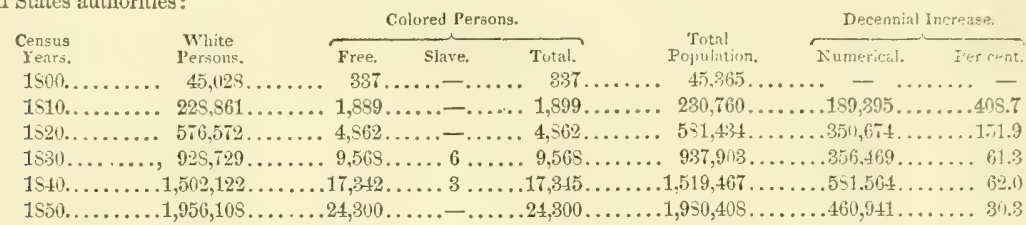

The defnite statisties of its wealth, productions, industry, and institutions, according to the census of 1850 and other official returns, are as follows:

Live-Stock.-The number of animals of the several descriptions in 1840 and 1850 are shown in the following table, also the ratio of increase and decrease from the first to the latter period:

Description. 1840 。 1850.

Horses ............... 430,527 head....... 403,397 head

Asses and Mules..........

Milch Cows...............

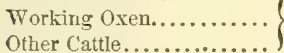

Sheep................ 2,028,401 "

Swine................... $2,099,746$ " $\ldots \ldots \ldots . .1,964,770$ "

-in 1850 , the whole was valued at $\$ 44,121,741$

Grain Crops.-Wheat, 14,487,851 bushels; rye, 425,718 bushels; Indian corn, 59,078,695 bushels; oats, $13,472,742$ bushels; barley, 354,358 bushels; and buckwheat, 638,064 bushels. On comparing these with the roturns of 1840, the following results are attained:

Crops. 1840

Wheat. ........... 16,571,661 bushels

Rye. . 814,205 "6

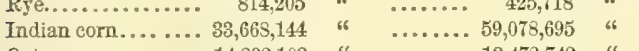

Oats ............ 14,393,108 "6 ....... 18,472,742

Barley.......... $212,410 \quad$ " $\quad \ldots \ldots \ldots . \quad 354,358$

Buckwheat....... 638,189 "f ...... 688,064
Morement. deer. 2,084,310 bushels, or 12.5 per cent $\ldots \ldots$ decr. 388,487 .........decr. 920.361 "6 or 7.1 .......... incer. 141,918 "s or 60.7 ......... incr. 4,925 " 0.9 $\ldots \ldots$ incr. $25,410,551$ "6 or 75.5

("In some of the largest wheat-growing States, the crops of 1849 fell far below the average. In the State of Ohio, especially, was there great defieiency, and was made apparent by the returns of the wheat crop for the ensuing year-made in pursuance of an act of the legislature of that State. From the almost universal returns of "short crop" by the marshal in that State in 1849, which fell below that of 1839 two millions of bushels and the ascertained crop of 1850 , we are fully satisfied that the average wheat crop of Ohio would appear thirty per cent. greater than shown by the census returns. The same causes which operated to diminish the wheat crop of Ohio were not without their effects upon that of other States bordering on the upper portion of the valley of the Mississippi.")-Rop. of Supt. of Census .Bureau, 1st December, 1852 .

Other Food Crops.-Peas and beans, 60,168 bushels; potatoes-Irish, 5,057,769 bushels, and sweet, 187,994. bushels. The potato crop of 1839 , as shown by the census of 1840 , amounted to $5,505,021$ bushels; and hence there has been a decrease in the orop of 559,258 bushels, or 9.7 per centum.

Ifiscellaneous Crops.-Tobacco, 10,454,449 pounds; hay, 443,142 tons; clover-seed, 102,197 bushels; other grass seed, 37,310 bushels; hops, 63,731 pounds; hemp-ndew-rotted, 140 tons, and water-rotted, 50 tons; flax, 446,937 pounds ; flaxseed, 188,880 bushels; silk cocoons, 1,552 pounds; sugar-maple, 4,585,209 pounds, and cane, 197,000 pounds; molasses, 308,308 gallons; bees-Wax and honey, 804,275 pounds; wine, 48,207 gallons, etc. Value of orchard products, $\$ 695,921$; and of market-garden products, $\$ 214,204$. The principal of these, compared with the crops of the similar staples produced in 1839 , exhibit the following movement:

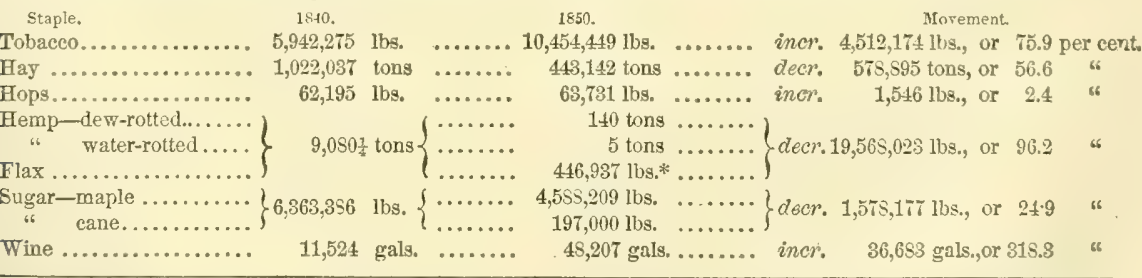

* The correctness of the returns as to liemp in the seventl census has not yet been perfectly verified, in a Few in tances there being some doubt whetler the marshals have not written tons where they meant pounds,..Report of Supt. of Census Burcan, 1st Dec.. 1Sñ?. (If they had irritten

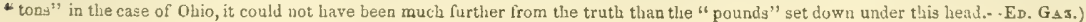


Products of Animals.-Wool, 10,196,371 pounds; butter, 84,449,379 pounds; cheese, 20,\$19,512 pounds; and the ralue of animals slaughtered during the year $1549-50$, was $\$ 7,439,243$. The wool crop, according to the census of 1840 , amounted to $3,685,515$ pounds, and hence the increase of that of 1850 was in the ratio of 176.6 per centum. In 1840 , the average clip per fleece was 1.82 pounds, and in $1850,2.59$ pounds, making an increase equal to $12.3 \mathrm{oz}$. nearly, or 42.3 per centum, and exhibiting an improvement in the breeds in a like ratio.

Ocoupied Lands, etc.-Improved farm lands, 9,\$51,493 acres, and unimproved lands belonging to farms, 8,146,000 acres, together valued at $\$ 358,765,608$. The whole number of farms under cultivation on the 1st June, 1850, was 143,887 . Value of farming implements and machinery, $\$ 12,750,535$.

Home-made Manufactures were produced in the year ending 1st June, 1850, to the value of $\$ 1,712,196$. The same class of goods for the year represented in the census of 1810 was valued at $\$ 1,853,987$.

Manufactures.-Aggregate capital invested, $\$ 00,000,000$; value of all raw material, fuel, etc., consumed, $\$ 00,000,000$; average number of hands employed, 000,000 -males, 000,000 , and females, 0,000 ; wages paid per month, $\$ 000,000$; to males, $\$ 000,000$, and to females, $\$ 00,000$; value of manufactures produced in the year, $\$ 00,000,000$. The whole number of industrial establishments in the State, producing to the value of $\$ 500$ and upward annually, on the 1st June, 1850 , was 10,550 , and distributed as shown in the general table of counties - of the whole number 8 were cotton factories, 130 woolen factories, and iron-works 219-35 for the manufacture of pig iron, 183 for castings, and 11 for wrought iron-and 706 tanneries. Ohio has also a large number of machine shops, hardware and cutlery manufactories, distilleries, breweries, barness manufactures, railroad car and carriage factories, tobacco factories, soap, candle, and oil factories, potteries, paperIr ills, flouring, grist, saw, and other mills, and other manufacturing establishments, large and small, which in the aggregate make up the summary above presented. The total capital invested in 1840 was $\$ 16,905,257$.

In cotton manufactures capital invested amounted, at the date specifled, to $\$ 297,000$; the value of all raw material, fuel, etc., consumed to $\$ 237,060$; number of hands employed, 401-132 males and 269 females; entire wages per month, $\$ 4,725$ - to males, $\$ 2,191$, and to females, $\$ 2,534$; products of the year, 280,000 yards sheeting and 433,000 pounds of yarn, valued together at $\$ 394,700$. Cotton consumed, 4,270 bales, and coal, 2,152 tons. In 1840, the cotton manufactures had a capital of $\$ 113,500$, and employed 246 hands; and the value of products was $\$ 139,378$.

The woolen manufactures have a capital of $\$ \$ 70,220$; wool consumed in the year, 1,657,726 pounds; coal consumed, 2,110 tons ; value of all raw material, fuel, etc., $\$ 578,423$; average hands employed, 1,201-males, 903, and females, 298 ; entire wages per month, $\$ 21,441$-to males, $\$ 18,191$, and to females, $\$ 3,250$; cloth manufactured in the year, $1,374,08 \pi$ yards, and yarn, 65,000 pounds, valued together at $\$ 1,111,027$. The capital in woolen factories in 1840 , was $\$ 537,985$; hands employed, 935 , and value of products, $\$ 6 \$ 5,757$.

The statisties of the iron manufacture were as follows:

$$
\text { Specilications. }
$$

Pig Iron.

Capital invested....................dollars.... 1,503,000

Iron ore used.

Pig iron used.

old metal used....

Blooms used....

Mineral coal consumed .............. " .......

Coke and chareal consumed ..... bushels ...5,429,800 ...

Value of raw material, etc ......... dollars.... $680,037 \ldots \ldots \ldots .1,199,790 \ldots \ldots \ldots$

Hands employed-males .........number... $\quad 2,415 \ldots \ldots \ldots . \quad 2,758 \ldots \ldots \ldots$

Monthly wages-males........... dollars... $59,129 \ldots \ldots \ldots . \quad 75,343 \ldots \ldots \ldots$

Iron manufactured ..............tons..... $52,658 \ldots \ldots \ldots . \quad 37,399 \ldots \ldots \ldots$

Cast Iron, Wrought Iron,

Total.

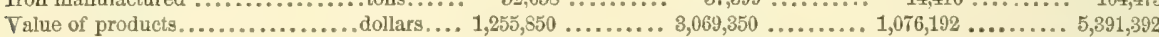

In 1540 , there were in the State 72 furnaces, producing 35,236 tons, and 19 bloomeries, forges, and rolling-mills, producing 7,466 tons; capital invested in iron manufactures, $\$ 1,161,900$, and hands employed, 2,268 .

The tanneries employed a capital of $\$ 1,340,359$; value of hides and skins used, $\$ 1,118,080$; hands employed, 1, \$26 ; monthly wages, $\$ 35,830$; sides of leather tanned, $6 \$ S, 560$, and skins tanned, 228,493 ; value of products for the year, $\$ 1,964,591$. In 1840 , there were $\$ 12$ tanneries in the State, with an aggregate capital of $\$ 957,388$, and employing 1,790 hands; products of the year, 161,630 sides of sole leather and 234,037 sides of upper leather.

The capital invested in the manufacture of malt and spirituous liquors was $\$ 1,262,974$; quantities and kinds of grain, etc., consumed-barley, 380,950 bushels; corn, 3,5Ss,140 bushels; rye, 281,750 bushels; oats, 19,500 bushels; hops, 178 tons; hands employed, 1,033; quantities of liquor produced-ale, 96,943 barrels; whisky and high wines, 11,865,150 gallons. In the manufacture of spirits, Ohio has a much larger interest than any other State, and in reference to the aggregate produced in the United States, the quantity produced in this State amounts to upward of one-fourth; and one-Lwelfth of the ale, etc., brewed is the product of Ohio. In 1840, the capital invested in these interests amounted to $\$ \$ 93,119$; hands employed, 798 ; 390 distilleries produced 6,329,467 gallons, and 59 breweries, 1,422,5\$4 gallons.

Foreign Commerce.-The direct intercourse between Ohio and foreign states is of very limited amount, and is chiefly confined to a trade between the lake ports and Canada, the great bulk of its merchantable material being carried either to the sea-board at Philadelphia, New York, Boston, or to New Orleans. The latter port is the natural depôt of Southern Ohio. The direct imports from foreign countries in the year ending 30th June, 1850, were valued at $\$ 582,504$, and the exports at $\$ 217,632$. Of the imports, the value carried in American bottoms was $\$ 395,999$, and in foreign bottoms, $\$ 1 \$ 8,505$; and of the exports the value of domestic produets was $\$ 217,582$-in American bottoms, $\$ 117,989$, and in foreign bottoms, $\$ 99,543$, and of foreign produets, $\$ 100$ carried in foreign bottoms. The statistics of the shipping employed in this branch of industry for the year quoted are embraced in the annexed aggregates:

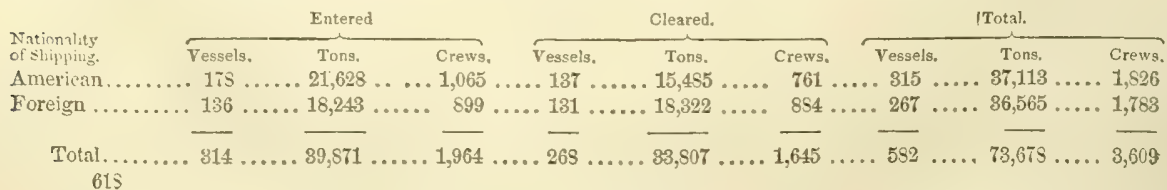


OHIO.

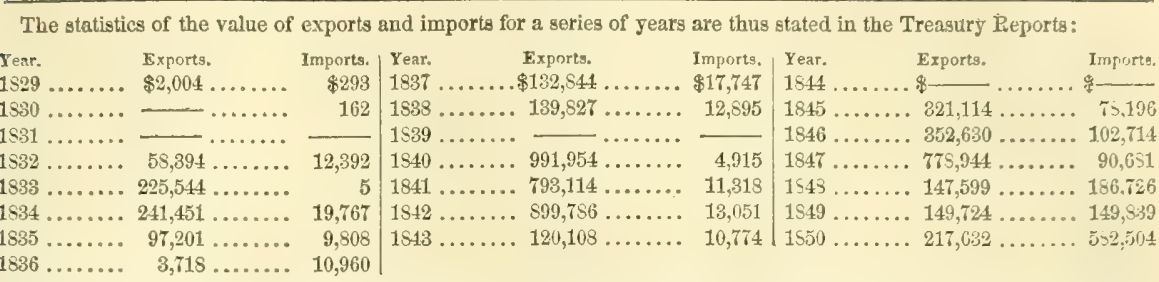

The total shipping owned in the: State amounted to 62,462 tons, of which 36,594 was owned in the district of Cuyaboga, of which Cleveland is the port of entry, 7,32S in that of Sandusky, 17,1S9 in that of Cincinnati, and 2,629 in that of Miami. The two first are lake districts, and the two latter districts on the Ohio River. All this shipping, except 72 tons of the class "licensed under 20 tons," was " enrolled and licensed," and employed in the coasting and river trade; and of the whole, 28,653 tons were navigated by steam-power, viz., in Cuyahoga district, 9,994 tons; in that of Sandusky, 1,214 tons; in that of Cincinnati, 16,906 tons; and in that of Miami, 539 tons. During the year there had been built in the several districts 31 vessels -4 schooners, 11 sloops, and 16 steamers, of the aggregate burden of 5,215 tons-in Cuyahoga district, 9 schooners and sloops (6S7 tons); in Sandusky, 5 schooners and sloops (421 tons); and in Cincinnati, 16 steamers and 1 sloop $(4,107$ tons $)$.

Domestic Commerce.-As before remarked, Ohio sends the great bulk of its productions to the sea-board by the lake, river, canal, and railroad routes, and by the same routes its imports are carried. The value of this commerce is immense, but can not well be stated in figures, except in isolated cases, which serve more as indices of its vastness by all the routes, than as a definite reply to the question. The exports and imports of the lake ports, and of those of the principal points on the Ohio River, are ascertained, and partially so the tonnage and value of goods carried on the railroads; but these, also, in some measure, are not sufficient data from which to ascertain the exact commerce of the State, as they include a large amount of the products of, and goods destined to, the States farther west. If the annual commerce be set down at $\$ 160,000,000$, it will not be far from its actual value. The exports from the lake ports alone amounted, in 1850 , to $\$ 17,627, \$ 85$, and the imports to $\$ 25,035,955$. The exports of Sandusky increased from $\$ 3,099,939$ in 1850, to $\$ 20,027,0$ S1 in 1852 , and the imports from $\$ 7,010,304$ to $\$ 45,072,406$; and those of the other lake ports in like proportion. The exports of Cincinnati average $\$ 24,000,000$ a year, and the imports $\$ 40,000,000$. These are at the principal outlets of the State, and serve to illustrate its general commerce, but there are numerous other points at which the commercial movement is also on an extensive scale. This vast commerce is yearly increasing, but to what amount it may ultimately attain can only be determined by the progress of settiement and production. Its immense mineral wealth, its fertile soils, and the facilities it enjoys for manufactures generally, are such as to invite the attention of both capitalist and producer, and within the State there is as much habitable space as is required for a population equal to that of the British islands, and hence its progress in wealth, population, and industry, can only be impeded by the attainment of a like status with that nation.

Internal Improvements.-Ohio has completed and is prosecuting numerous enterprises in the way of internal improrement. Its canals and railroads are on a most magnificent scale, crossing and recrossing in every direction, bringing the interior to the borders, and uniting there with the like improvements in the adjoining States. The map of Ohio presents in its several lines a complete net-work of avenues, the principal running from the lake to the river-from Cleveland and Sandusky to Cincinnati, and from the States eastward to those on the west-from Pittsburg, Wheeling, and Parkersburg, toward the Mississippi. The chief railroad centres are Cleveland and Sandusky on the lake coast; Mansfield, Mount Ternon, Newark, Zanesville, Columbus, Xenia, Bellefontaine, Sidney, Springfield, Greenville, Dayton, and Hamilton, in the interior; and Cincinnati on the river. From all these points lines radiate in every direction. Its great valleys are traversed by canals. With respect to Macadamized roads, turnpikes, and common roads, few other States are so amply provided; and in every direction connecting the commercial centres with each other, and with the adjoining States, lines of magnetic telegraph have been in existence for several years. The total length of canal in the State is 930 miles, and the total length of railroad on the 1st January, 1853, was 1,468 miles, and 1,400 miles of the latter was then in progress of construction. The latest statistics respecting canals and railroads will be found in the APPENDIX.

Government.-The present constitution of Ohio was done in convention 10th March, 1851, ratifled by the people 17th June, and went into operation 1st September of the same year. It provides:

The right of suffrage is enjoyed by every white male citizen of the United States, twenty-one years old, resident in the State one year next preceding the election, and in the county, town, or ward in which he lives such time as may be provided by law; but no idiot or insane person is allowed to vote, and the General Assembly may disfranchise and make ineligible to hold office any person convicted of bribery, perjury, or other infamous crime. All votes are given by ballot, and the general elections are held on the second Tuesday of October biennially.

The General Assembly consists of a House of Representatives and Senate, the House consisting of one hundred members and the Senate of thirty-five members, elected in districts for two years, their terms commencing on the 1st January after the election. The apportionment of representatives and senators is based on the results of the federal decennial census. Members must be residents of their respective districts one year next preceding their election, unless absent on the public business of the State or of the United States. No person convicted of embezzling public funds, or who shall be in any way connected with a duel, can hold office, nor any person holding public monies have a seat in the Assembly. No member during his term, and for one year after its expiration, shall be eligible to any office that may have been created, or the pay of which may have been increased, during his term. No money shall be paid by special act or any claim unless by a two-thirds vote of the members elected. In all elections by the Assembly the vote shall be vird voce.

The exceutive functions are vested in a Governor, who is elected biennially by a plurality of votes. The Lieutenantgovernor, Secretary of State, Treasurer, and Attorney-general are elected in the same way and for the same term, to commence on the second Monday of January. The Auditor is elected for four years. These officers continue in affice until their successors are elected and qualified. The Governor has power to pardon, except in cases of treason and impeachment, but must report each case, with his reasons, to the Assembly. In case of the death of the Governor, the Lieutenant-governor succeeds; after him the President of the Senate; and he failing, then the Speaker of the House. The Lieutenant-governor is ex-officio President of the Senate. The Auditor Treasurer, Secretary, or Attorney-general 
dying, being disabled, or removed, the Governor may fill the vacant office pro tempore, but the vacancy shall be fillel at the frst general election that occurs more than thirty days after it happens; and the person then elected shall hold office for the full term.

The Judiciary consists of a Supreme Court, Courts of Common Pleas, Probate Courts, ete. The Supreme Court consists of five judges chosen by the people at large, a majority of whom form a quorum and pronounce a decision. One judge is elected annually for five years. The court has original jurisdiction in quo warranto, mandamus, habeas corn pus, and procedendo, and such appellate jurisdiction as may be provided by law, and holds at least one term in each year at the seat of government. For the purpose of electing judges to and holding Courts of Common Pleas, the State is divided into nine districts (of which Hamilton County forms one), and each district is subdivided into three parts, from each of which one judge-to reside while in office in his district-is chosen by the electors of each subdivision for five years. Courts of Common Pleas are held by one or more of the judges in every county as often as the law may provide, and more than one court may be held at the same time in each district. District courts, composed of the judges of the Court of Common Pleas of the respective districts, and one of the judges of the Supreme Court, any three of whom forms a quorum, are held in each county of the several districts at least once in each year. The district courts have original jurisdietion in the same classes of cases as the Supreme Court, and such appellate jurisdiction as may be provided by law. In each county there is a Probate Court, open at all times, holden by one judge chosen by the voters of each county for three years. Justices of the peace are elected in the several townships also for three years. All other judges are chosen by the voters of their respective judicial districts for not more than five years. Tacated judgeships are filled pro tempore by the Governor, but a successor to the vacating judge is elected at the next general election, if occurring more than thirty days after the vacancy happens. A Clerk of the Common Pleas is chosen in each county for three years, and such clerk is clerk of all the courts of record in his county, unless otherwise provided by law. Courts of Conciliation may be established. The Legislature, at its first session, provided for the appointment of three commissioners to revise and simplify the practice, ete., of the courts, and, as far as practical and expedient, to abolish distiuct forms of action, and the difference between law and equity. In Cleveland and Cincinnati there is also a Superior Court, and in Cincinnati a Commercial Court, the jurisdiction of all which is local.

A Board of Public Works, consisting of three members, one elected annually for three years, has charge of the cauals, railroads, and other works belonging to the State.

Among the other principal provisions of the constitution are the following: no new county shall be made, or county line or county seat changed but by a vote of the county; lotteries, and the sale of lottery tickets, shall be prohibited; a bureau of statistics may be established; imprisonment for debt, except in cases of fraud, shall be abolished; compensation, assessed by a jury, shall be paid for all property taken for the public use without deduetion for benefits to any adjacent property of the owner; all white male citizens, resident in the State, between the ages of eighteen and forty-nive years, shall be enrolled in the militia; the principal of all funds arising from the sale of lands or other property granted or entrusted to the State for educational and religious purposes, shall be forever inviolable, and the income thcrefrom faithfully applied to the specific objects of the original grants; a thorough and efficient system of common schools shall be secured throughout the State; institutions for the benefit of the insane, blind, deaf and dumb, shall always be fostered and supported by the State; the State shall never contract any debt for the purposes of internal improrement, but it maly contract debts to meet casual defects in the revenue, or expenses not otherwise provided for-the aggregate never to exceed $\$ 750 ; 000$; it may further contract debts to repel invasions, etc., or to redeem the present outstanding debt; the credit of the State shall never be lent to any individual or corporation, nor shall the State become a stockholder in any association, or assume any debt except in the cases above provided for; the Secretary of State, Auditor, and Attorneygeneral shall be the commissioners of the Sinking Fund, which consists of the net annual income of the public works and stocks, and of such funds raised by taxation or otherwise as may be provided by law, which shall be made sufficient to pay the accruing interest on the public debt, and annually not less than $\$ 100,000$.

To amend the constitution, it is necessary that three-fifths of the members elected to each house shall yote in favor of the proposed amendments, which shall be entered upon the journals, with the yeas and nays, and shall be published in at least one newspaper in each county for six months preceding the next general election, and at such election the amendments shall be separately submitted to the people; and if a majority rote therefor, they shall become a part of the constitution. At the general election, in 13i1, and every trventieth year thereafter, the question, "Shall there be a convention to revise, alter, or amend the constitution?" shall be submitted to the people; and at any time, if considered necessary by two-thirds of the Assembly, and a subsequent majority of the people, a convention may be called for the same purpose.

The militia force of the State consists of 176,455 men of all arms, of which 2,051 are commissioned officers, and 174,404 non-commissioned officers, musicians, artificers, and privates. Of the commissioned officers 91 are general officers, 217 general staff officers, 462 field officers, etc., and 2,205 company officers.

The principal benevolent institutions of the State are the Ohio Lunatic Asylum, the Deaf and Dumb Asylum, and the Institution for the Blind. All these are located at Columbus. The number of patients in the Lunatic Asylum, on the 15th November, 1849, was 323-169 males, and 154 females; the number received during the subsequent year, 193-112 males and 81 females, and the number discharged during the year, 198-108 males and 90 females. Of those discharged, 9949 males, and 50 females, were recovered; $9-5$ males and 4 females, much improved; 15 improved ; 53 unimproved ; (43 chronic cases) and 22 died. The Asrlum for the Deaf and Dumb has been in actual operation 21 jears, and during that period there have been 462 pupils. The number in the Institution for the Blind, including graduates and pupils, on the $25 \mathrm{th}$ December, 1550 , was $73-40$ males and 33 females; 13 pupils were received during the year, and 10 discharged. Applicants for almission must be between the ages of 6 and 21 years. If able to pay, the two last institutions charge $\$ 100$ for the 10 months' session, from 1st Oetober to 1st August.

Finances, etc.-The total amount of receipts, for the year ending 'Norember 15 th, 1850 , was $\$ 2,536,55840$; total resources of the treasury (including balance for former year), $\$ 3,091,993 \$ 0$. Disbursements for the same period, $\$ 2,960,92718$. Excess of resources, $\$ 131,06612$. The "chief sources of income" were-taxes on real and personal property, includin a arrears, $\$ 1,243,56483$; taxes on professions, peddlers and foreign insurance companies, and auction duties, etc., $\$ 30,29752$; taxes on banks and State insurance companies, $\$ 56,42895$; eanal tolls, water rents, ete., $\$ 728,0 \$ 573$; dividends, turnpike, and canal, $\$ 29, \$ 8 \$ 20$; principal of surplus revenue, $\$ 177,21385$; interest on surplus revenue, $\$ 5 \$, 741$ SS; canal lands sold, $\$ 42,69143$; road tolls, $\$ 19,103$ 04; taxes paid through $A$ uditor of State, $\$ 37,38047$; school and ministerial lands sold, $\$ 65,371$ 03; claims collected, 4.27152 ; and miscellaneous, $\$ 7,46754$; and the principa] 
"objects of expenditure" were-bills drawn for appropriations, $\$ 391,15648$; common school fund, $\$ 200,000$; interest c foreign debt, $\$ 1,022,35595$; interest on special sehool and trust fund, $\$ 97,27281$; intercst on domestic bonds, $\$ 23,691$ c 6 ; repairs on canals and public works, $\$ 329,595$; repairs on national road, $\$ 47,24266$; State debt paid, $\$ 657,88634$.

The State debt, on the 15 th November, 1550 , amounted to $\$ 18,744,59432$, the annual interest on which was $\$ 1,121,53613$. The constituents of this debt were-domestic bouds outstanding, $\$ 493, \$ 24$, drawing annually $\$ 20,940) 10$ interest; irreducible stock, school and trust funds, $\$ 1,688,996$ 63-annual interest, $\$ 101,03980$; and foreign debt, $\$ 16,566,77369$-annual interest, $\$ 996,55623$. During the year ending as above, $\$ 35,76838$ of the domestic bonds had been redeemed. The irreducible stock, on which the State pays 6 per cent. interest to the townships and districts from which the funds were received, forms part of the State debt which is not to be repaid. The United States surplus revenue, amounting to $\$ 2,007,26034$, and loaned to the fund commissioners of the counties, was due to the State January 1st, 1850, except certain balances not due until 1852: \$1,016,226 53 has already been repaid. After due, if not paid, the counties must pay 6 per cent. on what remains in their hands. The State owes $\$ 3,011,85 \$ 71$ of turnpike, railway, and canal stock. The gross income of publie works, for the year 1850 , was $\$ 728,08572$. Total value of taxable property, real and personal, was $\$ 439,876,340$, यpon which the State tax was $\$ 1,413, \$ 8042$. The total valuation of property, in 1844 , was $\$ 136,142,666$, and the taxes levied $\$ 9 \pm 5,99613$, showing an immense septennial increase, as compared with the valuation and taxation of 1850 . The number and value of domestic animals in the State by the assessors for 1850 , were as follows : horses 513,652 , valued at $\$ 19,142,759$; mules 2,180 , valued at $\$ 86,828$; cattle $1,103,811$, valued at $\$ 11,815,560$; sheep $3,812,707$, valued at $\$ 1,984,983$; hogs, 1,6 i2,173, valued at $\$ 1,902,029$. Total valuation of domestic animals, $\$ 34,432,189$. The whole value of personal property, exclusive of the above, upon the duplicates, was $\$ 95,487,502$. These numbers and values, it will be perceived, differ essentially from those given in the census of the same year by the United States authorities.

Banks.-According to returns made to the office of the Auditor of the State, on the 1st August, 1851, the condition of the banks was as follows: RESOURCES. 12 Independent Banks. $\quad 41$ Branches of State Banks. 5 old Barks. Notes and bills discounted

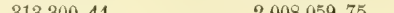

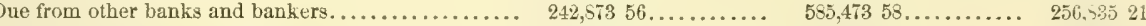

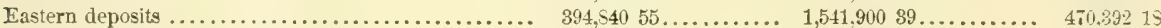
Checks and other cash items.................. $\quad 99,09282 \ldots \ldots \ldots \ldots . \quad 45, \$ 9158 \ldots \ldots \ldots$ Bonds deposited with State Treasurer ............ 1,465,4\$0 $88 \ldots \ldots \ldots \ldots$ Real estate and personal property............... 113,695 $92 \ldots \ldots \ldots \ldots$ Other resources............................. $65,14954 \ldots \ldots \ldots .$. $922,32840 \ldots \ldots \ldots$ $199,27476 \ldots \ldots \ldots . . \quad 149,00204$ $270,94150 \ldots \ldots \ldots \ldots . \quad 132,57325$

Total resources. $\$ 5,536,45910$ $\$ 17,502,27456$ $.85,413,73170$ LIABILITIES.

Capital stock paid in .

$\$ 864,63000$.

$\$ 4, \$ 36,24000 \ldots \ldots \ldots \ldots \$ 1,928,92600$

Circulation $1,375,29500$ $8,623,70250 \ldots \ldots \ldots \ldots . . \ldots 36,78400$

Safety Fund...

$1,262,31089 \ldots$

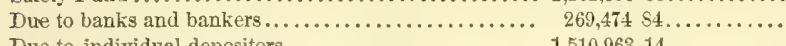

Due to individual depositors.

Surplus and undivided profits.

Bills payable and time drafts.

Discounts, interest, etc.

Dividends unpaid.

$25,14410 \ldots \ldots \ldots \ldots$

$112,07133 . \ldots \ldots \ldots$.

71,726 31..........

$12,98593 \ldots \ldots \ldots$.

Other liabilities........................ $31, \$ 5697 \ldots \ldots \ldots \ldots \quad 1,611 \quad 50 \ldots \ldots \ldots$

59,94694

$-$

$344,97399 \ldots \ldots \ldots \ldots, 502,67639$

$3,005,00658 \ldots \ldots \ldots \ldots . .1,000,19389$

$225,65139 \ldots \ldots \ldots \ldots .387,13004$

$185,84081 \ldots \ldots \ldots \ldots . \quad 15,97500$

$238,14906 \ldots \ldots \ldots \ldots . \quad 12,39619$

$22,82180 \ldots \ldots \ldots \ldots .6,76450$

Total liabilities.

$. \$ 5,536,45910$

$\$ \overline{17,502,27456}$

$\$ 5,443,731 \pi 0$

-thus it appears that the aggregate capital of the Ohio banks is $\$ 7,614,756$; specie, $\$ 2,759,743$; circulation, $\$ 13,635,751$; and discounts, $\$ 17,542,112$.

Federal Representation.--In accordance with the act passed on the 23 d May, 1850, apportioning representatives to Congress, Ohio is entitled to twenty-one members.

Education.-The whole number of "common school" districts in the State, in 1S50, was 9,590, and of fractional districts 1,342. The number of common schools was 12,279, taught by 7,924 male and 5,168 female teachers. Enrolled scholars, 421,783-males, 236,827 and females, 184,906; average daily attendance of scholars, 837,S75-males 190,\$91, and femiles, 146,984. Wages paid to teachers from public funds, $\$ 506,469$ 16-males, $\$ 393,64209$ and females, $\$ 112, \$ 2707$; and paid from other sources, $\$ 125,65257$-males, $\$ 100,04944$ and females, $\$ 25,60313$ : total $\$ 632,12173-$ males, $\$ 493,69158$ and females, $\$ 138,430$ 20. School-houses built during the year, 248 -expense, $\$ 64, \$ 2322$. Amount of building funds raised, $\$ 76,34547$; amount of tax on duplicates, $\$ 309,40865$; and received by reporting counties from State fund, $\$ 145,01363$ : total from all sources, $\$ 560,76499$.

The principal " collegiate establishments" in Ohio are-Ohio University, at Athens, founded 1S04; Miami (Assoc. Pej.) University, at Oxford, founded 1809; Franklin College, at New Athens, founded 1825; Western Reserve (Presty yierian) College, at Hudson, founded 1826; Kenyon (Episcopal) College, at Gambier, founded 1827; Granville (Baptist) College, at Granville, founded 1831; Marietta College, at Marietta, founded 1535; Oberlin (Congregational) College, at Oberlin, founded 1834; Cincinnati College, at Cincinnati, founded 1819, which in 1550 had 8 professors and 84 students, and in the law department 3 professors and 25 students; St. Xavier (Rom. Cath.) College, at Cincinnati, founded 1S 10 ; Woodward College, at Cincinnati, founded 1831; Ohio Wesleyan University, at Delaware, founded 1842; and Wittenberg (Christian) College, at Springfield, founded 1845. The statisties of these several institutions, in 1850, were as follows:

Colleges. Prof stur

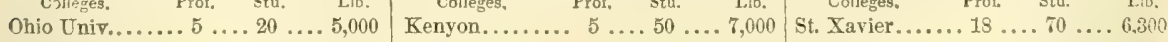

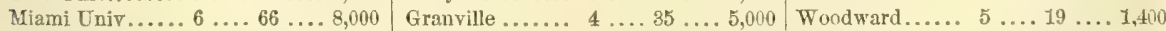

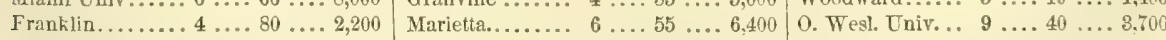

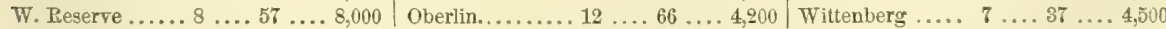

Theological departments are attached to Kenyon, Western Reserve, Granville, Oberlin, and Wittenberg, and there sre 
Lane Seminary, at Cincinnati, and the Theological Seminary of the Associate Reformed Church, at Oxford. The statistics of these are as follows:

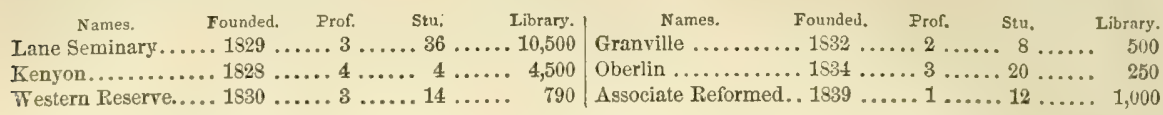

The medical schools within the State, and their statistics for 1851, are-the Western Reserve Medical College, at Cleveland, founded in 1844 ( 6 professors, 202 students, and 411 graduates); the Medical School of Ohio, at Cincinnati, founded 1819 ( 8 professors, 130 students, and 331 graduates); Western College of Homceopathic Medicine, at Cleveland, founded 1850 ( 8 professors, 62 students, and 17 graduates); Starling Medical College, at Columbus, founded 1847 ( 8 professors, 124 students, and 53 graduates).

Besides the above, there are in all the large towns numerous academic and denominational schools, etc., supported partly by endowment and partly by charges for education. Among these the Roman Catholic convents, nuuneries, schools, etc., are conspicuous, and as a general fact these are better conducted, more extended in their curricula, and, aside from their religious bearing, everywhere unexceptionable and worthy of imitation by all sectaries.

Public Libraries.-One State library-12,500 volumes; 8 social-21,295 volumes; 13 college-35,510 volumes; 19 student-20,205 volumes; 3 academic and professional-12,529 volumes; 1 scientifie and historical-10,000 volumes; 3 public school-1,595 rolumes. Total libraries 48, and volumes 104,631.-Report of Librarian of Smithsonian Institute.

Periodical Press. - The whole number of periodicals published in the State, on the 1st June, 1850, was 302, of which 103 advocated whig and 93 democratic principles, and 106 were neutral in politics, or devoted to science, religion, kiterature, etc. Of the whole number 28 were published daily, circulating at each issue 90,656 copies, or 29,214,323 copies annually ; 6 tri-weekly, 1,961 copies, or 305,915 annually ; 4 semi-weekly, 2,800 eopies, or 291,200 annually ; 222 weekly, 211,862 copies, or 11,016,824 annually; 7 semi-monthly, 32,920 copies, or 790,080 annually; and 20 monthly, 65,500 , or 786,000 annually. Total copies issued annually 42,404,34S. The counties and number of periodicals issued in each wasAdams, 1 w.; Allen, 1 w.; Ashland, 2 w.; Ashtabula, 3 w.; Athens, 1 w. ; Auglaize, 2 w. ; Belmont, 2 w. and 1 m. ; Brown and Butler, each 3 w.; Carroll and Champaign, each 2 w.; Clark, 1 t.-w. and 4 w.; Clermont and Clinton, each 2 w.; Columbiana, 6 w.; Coshocton, 2 w. and 1 s.-m.; Crawford, 1 w.; Cuyahoga, 3 d. and 5 w.; Darke, Defiance, and Delaware, each 2 w.; Erie, 2 d., 3 w., and 1 m.; Fairfield, 2 d. and 3 w. ; Fayette, 1 w.; Franklin, 2 d., 2 t.-w., 6 w., 2 m., and 1 occasionally; Gallia and Geauga, each 2 w. ; Greene, 1 w.; Guernsey, 2 w. ; Hamilton (Cincinnati), 8 d., 1 t.-w., 32 w., 1 s.-m., and 14 m.; Hanock, 3 w.; Harríson, Hardin, Highland, and Hocking, each 2 w.; Holmes, 3 w.; Huron and Jackson, each 2 w.; Jefferson, 6 w.; Knox, 6 w. ; Lake and Lawrence, each 1 w.; Licking, 2 s.-w. and 4 w.; Logan, 2 w. ; Lorain, 2 w. and 1 s.-m. ; Lucas, 2 d., 2 t.-w., and 3 w. ; Madison, 1 w. ; Mahoning, Marion, and Medina, each 2 w. ; Meigs and Mercer, each 1 w.; Miami, 1 s.-W., 5 w., and 1 m.; Monroe, 1 w. ; Montgomery, 4 d. and 6 w. ; Morgan and Morrow, each 2 w. ; Muskingum, 1 d., 1 t.-w., 6 w., and 1 annually; Perry, 2 w.; Pickaway, 1 s.-w. and 3 w. ; Pike, 1 w. : Portage, 3 w.; Preble, 2 w.; Putnam, 1 w.; Richland, 5 w.; Ross, 2 d. and 4 w.; Sandusky, 3 w.; Seioto, 2 d. and 2 w.; Seneca 4 w.; Shelby, 2 w.; Stark, 6 w.; Summit, 3 w. and 1 s.-m.; Trumbull and Tuscarawas, each 3 w.; Union, 1 w.; Van Wert, 2 w.; Vinton, 1 w. ; Warren, 2 w. and 1 m.; Washington, Wayne, and Williams, each 2 w., and Wood, 1 weekly.

Religious Denominations.-The statistics of the several religious denominations, according to the census returns of 1850 , are exhibited in the annexed form:

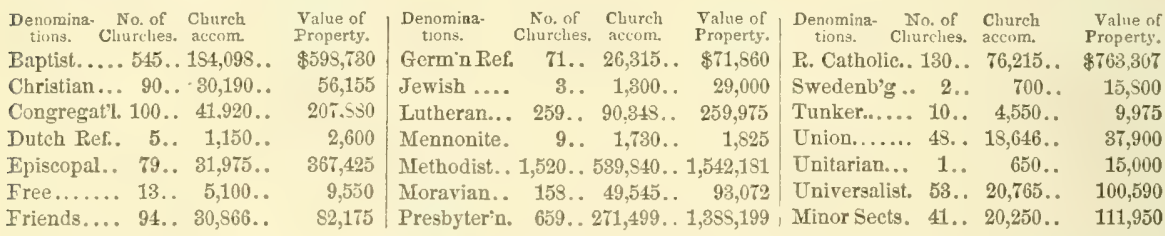

-making a total of $3, \$ 90$ churches, having accommodation for 1,447,652 persons, and owning property to the value of $\$ 5,765,149$. The State forms a diocese of the Protestant Episcopal Church, and comprises the Roman Catholic archdiocese of Cincinnati, and the suffragan diocese of Cleveland. The towns of Covington and Newport, in Kentucky, and the adjacent territory for three miles, belong also to the province of Cincinnati.

Pauperism and C'rime.-The whole number of paupers that received assistance and support within the year ending 18t June, 1S50, was 2,518, of which 1,904 were native-born, and 609 foreigners; and the whole number on the rolls on the 1st June as aforesaid, was 1,673 , of which 1,254 were native-born, and 419 foreigners. Annual cost of support, $\$ 95,250$. From the report of the attorney-general it appears that during the year 1550 there were 2,008 prosecutions, 1,273 convictions, and 295 acquittals. The punishments were-penitentiary for life, 3 ; for ten years and over, 6 ; and for under ten years 118 ; and 221 were sent to the county jails. The amount of fines was $\$ 14,2215 \$$, of costs $\$ 19,29060$, and of collectable costs $\$ 9,0 \pi 608$. The Ohio penitentiary, on the 30 th November, 1849 , contained 336 convicts; admitted during the year 193, and discharged 105, leaving 421 in confinement at the end of the official year 1850. Of those discharged, 42 was by expiration of sentence, 32 by pardon, 21 by death, 5 by writ of error, 2 by pardon of President of the United States, and 3 escaped; and of the 193 committed 145 were convicted of offenses against property, 7 of arson, 13 of forgery, and 32 of offenses against the person. Receipts from convict labor $\$ 35,74074$, and expenses of maintaining prison $\$ 26, \$ 7756$-balance in favor of prison $\$ \$, \$ 6318$. There is a library of nearly $\$, 000$ volumes connected with the prison, for the use of the convicts.

Historical Sketch.-As a district territory, Ohio dates from the first year of the present century. Previous to this time it constituted a portion of the "Territory North-west of the Ohio," over which Congress had exercised jurisdiction since $17 \mathrm{ST}$.

The French were the first to explore the waters of the Ohio. In 1680, La Salle traversed the tract between the lakes and the Mississippi, and for upward of half a century Freuchmen seem to have been the only visitors of this region. Their object was the fur trade; nor did they, like their English neighbors, manifest any disposition to appropriate the country by settlements. Within the actual limits of Ohio, indeed, no settlements appear to have been ever made by the French. About the midalle 
of the eighteenth century, a controversy, between the Canadian traders and the English, respecting this country, sprung ap and finally involved both nations in war, and ended only with the overthrow of French power in America. The charters of many of the British provinces extended their claims to the Pacific, and their settlements had proceeded gradually westward. The French claims, on the other hand, proceeded from north to south, and consequently intersected those of the English, or, as respects actual occupation, their possessions formed a cordon round those of the English. In 1750 , an association, chiefly residing in Virginia and England, obtained from the crown a grant of 600,000 acres lying in the country claimed by both nations. Trading houses were immediately established, and surveys commenced, of which measures the governor of Canada soon became acquainted. France and England being then at peace, remonstrances were made on the subject, but expostulation and threats having had no effect, the French seized two British subjects, who were found trading with the Indians, and sent them to Presque Isle, on Lake Erie, where a strong fort had been erected. This and other acts of violence determined the governor of Virginia to send an officer to the French posts. The illustrious Washington, then a major of militia, was commissioned for the purpose, who, after great difficulties, delivered a letter to the commandant, at a fort on the river La Bœuf, requiring him to withdraw from the British territory on the Ohio. The answer was of such a nature that, on the return of Washington, the Virginia legislature caused a regiment to be raised, in which he received the second command. In April, 1754, his chief having died, the command devolved upon himself, and he, with two companies, advanced into the disputed country; but, on his route to the head of the Alleghany and Monongahela, was attacked by a superior force, and compelled to surrender. Soon after this event, open war was declared, and the British government sent out a powerful force under General Braddock. The object of the campaign of 1755 was the capture of Fort Du Quesue, and the secure possession of the country on the Ohio. The expedition was unsuccessful, and the Frenoh maintained possession of the country until the surrender of Canada in 1763, which included also the whole country westward to the Mississippi.

From whatever cause, though now thrown open to the American trade, the beautiful valley of the Ohio was left in undisturbed occupancy of its original inhabitants. The government, indeed, seems to have had no disposition to encourage settlement. The Indians were still numerous and powerful, and, on the breaking out of the Revolution, were incited by the British against the frontier settlers, and committed many barbarous excesses. During all this period occupancy was impossible. The treaty of peace, although it transferred the sovereignty of the country, yet left it subject to Indian depredation, and it was not until 1787 that any settlement was begun within the limits of the present State. Previous to that year, the right of soil, subject to the Indian title, was claimed by several of the States, as having passed to them by their charters, and soon after the peace of 1783 jealousies had arisen in eonsequence of the vast extent of these possessions, which were only allayed by the cession of the whole to the United States. Virginia, however, reserved a portion of land (3,709,848 acres) near the rapids of the Ohio for her State troops, and Connecticut a tract near Lake Erie (3,666,921 acres). These were subsequently confirmed to the several elaimants. In 1800, jurisdiction over these reservations was also relinquished by the States owning them, reserving to themselves elaim to the soil. Other tracts, known as Symmes' purchase (284,69s acres), and the Ohio Company's purchase (1,144,509 acres), were subsequently recognized, as were also several individual claims. It now remained for the United States to purchase from the Indians the soil and right of possession, which, owing to the hostility of these people, was not completely effected for many years, nor until much blood had been shed on both sides. In 1757, Congress began to exercise jurisdiction over the territory. A territorial government was instituted consisting of a governor, secretary, and three judges, who, in addition to their ordinary functions, had also a partial legislative power. The officers appointed under these provisions administered the government of the whole territory until 1799. During a greater part of the period of the temporary government, a harassing warfare was kept up with the Indians, instigated, if not assisted, by the British. In 1791, General St. Clair, who had been sent against the Miamis, was surprised and totally routed. This disaster operated as a serious check upon the progress of settlement. In 1794, however, a decided victory was obtained by General Wayne, and in the succeeding year bostilities were suspended, and the treaty of Greenville terminated the war. Ohio was now free from savage incursion, and began to prosper; settlements which had been suspended recommenced with increased vigor. Up to the year 1787 , only 118,582 acres of land had been sold by the general government-none was disposed of betweeu that period and 1799 , in which year 640 acres were sold. In $1800,70,948$ acres were disposed of; in $1801,486,787$ acres, and up to $1810,2,833,662$ acres had been sold. To 1820 , the total dispositions amounted to $6,705,361$ acres; to 1830 , to $8,224,495$ acres ; to 1840 , to $18,180,57 \pi$ acres, and to 1849 , there only remained in the hands of the government 509,230 acres. The aggregate disposed of to the latter period was $25,067,730$ acres, viz., sold, $12,490,215$ acres; donated-to schools, 675,094 ; to colleges, 24,320 ; to internal improvements, 1,260,051, and to individuals, 32,141; military bounties-old war, 1,301,326; war of 1812, 63,\$42, and Mexican war, 49,429; reservations--salaries, 24,216; Indians, 16,331, and companies, 8,805,976 (including Virginia and Connectieut reserves, etc.); private claims, 26,460; swamp lands (granted to State), 303,329 acres. Thus it will be seen that, in fifty years from the institution of a regular representative government, the whole land has been virtually taken up, and generally settled upon.

In 1799 the North-western Territory, having a sufficient population, was admitted to a second grade of territorial government, which entitled it to a representative body, composed of delegates chosen by the people, and a council appointed by Congress from nominations made by the House of Representatives. Shortly after, the country composing the State of Ohio was detached from the general territory, and formed into a distinct government. On the 30th April, 1502, on the petition of the people, Congress passed a law enabling them to form a constitution and State government, and the conditions prescribed by that act having been complied with, Ohio became a sovereign State and member of the Union in 1803.

Thus admitted to the privileges of self-government, the growth of Ohio has been uninterrupted. No other State of the Union has surpassed it in rapidity of progress. The disposition of its lands, and the population at decennial periods (before given), show an augmentation unparalleled in history. Its position with respect to the old States may in some measure account for this, but it has had many disadvantages to contend with. The first pioneers had no steam horses to drag them to their desert home, no steamboats to skim their rivers, nor telegraphs whereby to communicate with their friends in the east. Their journeyings were toilsome and their fare hard, nor was there rest for them when their travels ended; the Indian met them with menace, and the thick forests had to be hewn through before a crop could be planted. How different the things of to-day, when the immigrant has little more to do than throw himself in a well padded car, and be set down at his future residence without trouble of any sort, the wide prairie ready to receive the seed of his first harvesty and a thriving country around him. These matters ought to be considered when the settlement and progress of $O$ hio are compared with those of other States. It was not until the year 1825 that any road was built from the sea-board States into Ohio. On the 4th July of that year the ceremony of breaking ground on the National Road west of the Ohio was 
celebrated. On the same day ground was broken at Licking Summit for the construction of the Ohio Canal. To-day canals, railruads, turnpikes, and every means and mode of transportation and travel are open to all parts, and enjoyed by the people in a greater degree than in most other States of the Union, and certainly than in any European country, with the cxception of Great Britain.

Coldmbur, on the east side of the Scioto River, is the political capital of the State.

Orro county, Ind. Situate S. E., and contains 98 sq. m. Drained by Laughery cr. and other small streams of the Ohio $r_{\text {., }}$ which runs on its eastern border. Surface in general hilly; soil of average fertility. The county is well timbered. Chief productions, wheat and Indian corn. Farms 386; manuf. 34; dwell. 946, and pop.-wh. 5,299, fr. col. 11-total 5,310. Capital: Rising Sun.

OHIO county, $K y$. Situate toward the N. W., and contains $728 \mathrm{sq}$. m. Drained by Rough cr., a branch of Green r., and its branches. Surface level; soil generally fertile, and highly productive. Staples, tobaceo, Indian corn, pork, etc. Farms 1,122; manuf. 24 ; dwell. 1,425, and pop.-wh. 8,568, fr. col. 49, sl. 1.132-total 9,749. Capital: Hartford.

OHo county, Virg. Situate N. W., and contains 112 вq. m. Drained by Wheeling cr. and other small streams, which enter the Ohio r. on its W. border. Surface in general broken and hilly; soil fertile, and on the banks of the Ohio are some fine tracts of land. Chief productions, wheat and Indian corn. It contains a large quantity of bituminous conl, and some iron. Farms 376; manuf, 143; dwell. 3,097, and pop.-wh. 17,607, fr. col, 235, sl. 114-total 18,006. Capital: Wheeling. Public Works: Baltimore and Ohio R. R., etc.; Hempield R. R.

OHIo, t. and p. v., Herkimer co.,.,$Y . Y .60 \mathrm{~m} . \mathrm{N} . \mathrm{W} . \mathrm{Al}-$ bany. Drained by West Canada cr. and its branches. Surface very hilly; soil good. There are several mills in the town. The $\mathrm{v}_{0}$ is small, and centrally situated. Population of t. 1,051 .

Omro, p. v., Andrew co., Mo.: $276 \mathrm{~m}$. N. W. Jefferson City.

OHIO river: a large river of the United States which separates the states of Virginia and Kentucky from Ohio, Indiana, and Illinois, second in importance only to the Mississippi, is formed by the confluence of Alleghany river from the $\mathrm{N}_{\text {., }}$ and Monongabela from the $\mathrm{S}_{\text {., at Pitsburg, in }}$ the western part of Pennsylvania. The Alleghany $r$. rises in Potter co., Pa., on the W. side of the Alleghany mountains, flows into the State of New York, and returns into Pennsylvania, and is the most important tributary of the Ohio. It is navigable for boats of a hundred tons, and of a light draft to Olean, Cattaraugus co., N. Y., $270 \mathrm{~m}$. from its mouth in the Ohio, 600 feet above the level of the river at Pittsburg, 1,280 feet above the level of the ocean, and 2,500 miles from the Gulf of Mexico. The Monongahela rises in Virginia, and where it unites with the Alleghany is more than 400 yards wide. It is navigable at a good stage of the water for large boats, $100 \mathrm{~m}$. from its mouth. The Alleghany, though not larger than the Monongahela at the juna tion, is the more important stream. Immediately below the junction, the Ohio is over 600 yards wide, and is a placid and beautiful stream. At Pittsburg it is $6 \mathrm{~S} 0$ feet above tidewater; at the mouth of the Muskingum, 541 feet; at the mouth of the Scioto, 464 feet; at Cincinnati, 414 feet; at its mouth in the Mississippi, 800 feet. Its length from Pittsburg to its mouth, is generally stated at $959 \mathrm{~m}$.; but the distance in a direct course is about $614 \mathrm{~m}$. Its average descent is not quite five inches in a mile. The French called it la belle riviere, or the beautiful river; but its name, according to Heckewelder, is derived from the Indian word Ohiopekhanne, meaning a very white stream, alluding to the while caps with which its gentle surface is covered in a high wind, omitting all but its first part for ease of pronunciation. The Ohio, for some distance below Pittsburg, is rapid, and the narigation interrupted at low water by chain of rocks extending across the bed of the river. The scenery is exceedingly beautiful, though deficient in grandeur, exhibiting great sameness. The hills, two or three hundred 624 feet high, approach the river, and confine it on either side. Their tops have usually a rounded and graceful form, and are covered with the verdure of an almost unbroken forest Approaching Cincinnati, the scenery becomes still more monotonous. The hills recede from the river, and are less elevated. Heavy forests cover the banks, and limit the prospect, but exhibiting a beautiful verdure, and often exuberant with blossoms. The river exhibits the same scenery, as we continue to descend it, except that the hills become less bold and rocky. Cities, villages and farm-houses are passed through the whole course of the river; but as the bottom-lands on its immediate margin are liable to be overflowed, the inhabitants prefer to settle a little back from the river, so that the dwellings in view do not correetly exhibit the population in the vieinity. Between Pittsburg and the mouth of the Ohio, there are as many as 100 considerable islands, besides a great number of sand-bars and tow-heads. These last are low sandy islands, incapable of cultivation, and covered with willows. Some of the islands are of exquisite beauty, and furnish desirable situations for a retired residence. The principal tributaries of the Ohio are the Muskingum, Great Kanawha, Big Sandy, Scioto, Great Miami, Kentucky, Green, Wabash, Cumberland, and Tennessee. The last three are the most important, of which the last is the largest. One remarkable cireumstance respecting the Ohio, as well as other western rivers, is its great elevations and depressions. In the summer and autumnal months, it often dwindles to a small stream, affording limited facilities for narigation. Among the hills of Pennsylvania and Virginia, it is seen rippling over chains of rocks, through which a passage is barely afforded to boats of the lightest burden. Farther down, sand-bars either extend across the siream, or project into the bed of the river. Steamboats are sometimes grounded on the bars, where they are obliged to wait in peril for the periodical rise of the river. The lowest water is generally in tho months of July, August, and September. The melting of the snows in the spring and heavy rains in autumn or winter, fill the river to overflowing, and many of its islands and the bottoms on its margin are covered with water. These rises are generally gradual, and attended with no danger. As the waters rise, trade and navigation are quickened into activity; the largest steamboats, often of large tonnage, now float in security. The average rise of the water from low water mark is 50 feet, but in the year 1832 an extraordinary flood was experienced. The river began to rise early in February, and on the 18th of that month it was 63 feet above low water mark, and the lower parts of Cincinnati and Covington were flooded. The river here is 1,006 feet wide, and the velocity of the stream at its height $61-5$ miles per hour. The water discharged by the rise of the river above low water mark alone, would fill a lake of one square mile in surface, 107 feet deep, in one hour. The surface drained by the Ohio and its numerous tributaries is about 77,000 sq. m.; and water four inches in depth on this surface would be sufficient to maintain the river at the above height and velocity for fourteen days. Such a flood as this has scarcely been known since the first settlement of the country. There are no considerable falls in the river, excepting at Louisville, Ky., where it descends $22 \frac{1}{3}$ feet in the course of two miles. Even over these boats pass in high water. But they have been obviated by a canal around them, which admits of the passage of the largest steamboats. The current of the Ohio is very gentle; at the mean height of the river the current is about 3 miles an hour, at high water it is more, but at low water not more than two miles. During five or six weeks in winter, the navigation is ob- 
siructed by floating ice. The Ohio and its tributaries have not less than 5,000 miles of narigable waters. The following distances have been derived from good authority, and are doubtless correct. From Pitsburg to Steubenville, $\mathrm{O}$, is 70 miles; to Wheeling, $\mathrm{Va}, 92$ miles; to Marietta, O., 174 miles; to Gallipolis, O., 264? miles; to Portsmouth, O., 819 miles; to Maysville, Ky., 397 miles; to Cincinnati, O. $455 \frac{1}{3}$ miles ; to Lawrenceburs, Ia., $479 \frac{1}{2}$ miles ; to Louisville, Ky., 587 miles; to New Albany, Ia., 591 miles; to the mouth of Cumberland river, Ky., 900 miles; mouth of Tennessee river, Ky., $911 \frac{1}{2}$ miles; month of Ohio 959 miles. Distances navigable by steam on the principal branches of the Ohio river: 'Tennesse, 720 miles; Cumberland, 400 miles; Wabsh , 400 miles; Green, 150 miles; Salt, 35 miles; Kentreky, 62 miles; Scioto, 50 miles; Big Sandy, 50 miles; Kanawlua, 65 miles; Muskingum, 70 miles; Monongahela, 60 miles; Alleghany, 200 miles

Ӧто Cтту, p. v. and cap. Mississippi co., $M$. : $195 \mathrm{~m}$. 8. E. Jefferson City, on an elevated bank on W. side of the Mississippi $r_{n}, 28 \mathrm{~m}$. below and opposite Cairo, in Illinois, and contains the court-house and usual number of public buildings. It is in a flourishing condition, and bids fair to become a considerable place.

OHro Citr, p. v., Cuyahoga co., Orio: at the mouth of Curahoga r., opposite Cleveland, and on Lake Erie, $126 \mathrm{~m}$. N. E. Columbus. It may be considered as a suburb of Cleveland, with which it is connected by bridges, over one of which the Cleveland, Columbus, and Cincinnati R. R. passes. The ground on which it stands is uneven, and presents many fine building sites. It contains several foundries, furnaces, mechanic shops, ete., and is a weIl built and reguIarly planned place. Its commerce on the lakes is large, but is so blended with that of Cleveland as to admit of no separate statistical exhibit. Population, which includes also that of Brooklyn town, 6,375 .

OnIo FARM, p. v., Kendall co., Ill.; in the S. part of co. 193 m. N. N. E. Springfield.

Omo Grove, p. o., De Kalb co., $\Pi l_{\text {. }}: 161 \mathrm{~m}$. N. N. E. of Springfield.

Oertorille, p. V., Beaver co., Penn.: $2 \mathrm{~m}$. N. of the Ohio r., $187 \mathrm{~m}$. Harrisburg. It contains about 200 inhabitants.

OnL's Town, p. o., Trumbull county, Ohio: 149 m, N. E.

Columbus.

OHOOPEE river, $G a_{*}$ : rises in Washington co., flows S. E. forming the division between Emanuel and Montgomery counties, and passing through Tatnall, empties into the Alatamaha. This is the onlv considerable tributary of the Alatamaha, and is navigable 40 miles.

OIL Cresk, t, and p. o., Crawford county, Penn.: $171 \mathrm{~m}$. N. W. Harrisburg. Drained by Oil er. and its branehes. Surface undulating, with good wood; soil average fertility. Oil cr. affords bituminous oil, which is valuable in pharmacy. Iron ore is found in the vicinity. The $v$. of Titusville is in S. of t., near the creek. Pop. of t. about 775 .

Orl creek, Penn.: enters the Alleghany river, $8 \mathrm{~m}$. E. Franklin. It derives its name from a spring on its bank, on the surface of which floats an oil valuable for its medicinal qualities.

Oxt MrLus, p. 0, Clark co., Ky.: 37 m. S. E. Frankfort

Or. Mull VIllage, p. y. and sta, Hillsboro' county,

N. Hamp.: on a braneh of the Merrimac r., on the line of the New Hampshire Central R. R., 11 m. from Manchester, and $17 \mathrm{~m}$. S. Concord.

On SPTixg Teservatiox, $N, T$. An Indian reservation abnut $1 \mathrm{~m}$. square. It contains a pool of water, the surface covered wlth an oily substance much used for its cure of different diseases in man and beast. Situate in the towns of Cuba and Hinsdale.

Oil Trovgh, p. o., Independence co., Ark.: on the $\mathbf{S}$. bank of Arkansas r., 75 m. N. N. E. Little Rock.

OKanUMKa, p. o., Marion county, Flor.: $165 \mathrm{~m}$. S. E. Tallahassee.

OKaToxuben river, $A z a_{0}:$ is formed in $M$ iss. by the junc- tion of the Noxubee, Dancing Rabbit, Horse Hunter, and other creeks, flows S. E. into Sumter co., $A l a$, and enters the Tombigbee at Gainesville.

OKapilco, p. v., Lowndes co., Ga.: on Okapileo r., $157 \mathrm{~m}$. S. by W. Milledgeville.

OkAw, p. o., Washington co., $17 l$. : near Elkhorn cr., 97 m. S. Springfield.

OKaucmee, p. o., Waukesha county, Wisc.: 59 m. E. Madison.

Oroloxa, p. O., Chickasaw county, Mriss. : 119 m. N. E. Jackson.

Okonagon river, Oreg. Ter.: rises in the British possese sions, flows S., and enters Clark's fork of Columbia, at Fort Okonagan.

OктиввнA county, Miss. Situate toward the N. E., and contains $618 \mathrm{sq} . \mathrm{m}$. Drained by Oktibbeha $\mathrm{r}$, and its tribntaries. Surfuce even; soil deep calcareous, and adapted to cotton and grain. Farms 560; manuf. 13; dwell. 744, and pop. -wh. 4,309 , fr. col. 18, sl. 4,S 11 total 9,171. Capital: Starksville.

Ol

Penobseot r., $2 \mathrm{~m}$. N. of the mouth of Olamon $\mathrm{r}_{\text {., }}$ and $\$ 4 \mathrm{~m}$.

N. E. Augusta.

Ozcotт p. V., Niagara co., $N . Y_{\text {. : }}$ close on the $\mathrm{S}$. shore of Lake Ontario, $259 \mathrm{~m}$. W. by. N. Albany.

Old Bridge, p. v., Middlesex en., N. . . . : on South r., and near the Camden and Amboy R. R., 24 m. N. E. Trenton.

Old Cedar Springs, p. o., Spartanburg dist., S. Car.: $79 \mathrm{~m}$. N. W. Columbia.

Old Church, p. v., Hanover county, Virg.: 13 m. N. E. Richmond.

Oxd Court House, p. 0., Bryan co., Ga.: 127 m. S. E. Milledgeville.

Oldeindrg, p. V., Franklin co, Ind.: on a branch of Salt cr., $55 \mathrm{~m}$. S. E. Indianapolis.

Oldenburg, p. 0., Smith county, Texe: $209 \mathrm{~m}$. N. F. Austin.

Oldfield Fork of ElK, p. o, Pocahontas co, Firg. $155 \mathrm{~m}$. W. N. W. Richmond.

Old Forge, p. o., Luzerne county, Penn.: 179 m. N. E. Harrisburg.

Oud Font, p. o., M'Dowell county, N. Car.: 192 m. W. Tarrisburg.

Old Forr, p. V., Centre co., Penn. : on the Belle Fonte post-road, $57 \mathrm{~m}$. N. W. Harrisburg.

Otd Furnace, p. o., Gaston co, N. Car.: 133 m. W. S. W. Raleigh.

OLdHar county, $K y$. Situate $N_{\text {.y }}$ and contains 178 sq. m. Drained by head branches of Floyd's fork of Salt r., Harrod's, and other small creeks. Surface level, excepting on the Ohio, where it is rising and presents high bluffs to the river. Soil in general fertile, and the land well adapted to grain, etc. Tobacco is also a valuable staple, and pork is exported to some extent. Farms 414; manuf, 8; dwell. S53, and pop.-wh. 5,156, fr. col. 49, sl. 2,424 -total 7,629, Capital: Westport. Public Works: Lomisville and Frankfort R. R.; Louisville and Covington R. R., etc.

OLdfAir, p. v., Crittenden con, Ark: : W. side of the Mississippi r., 122 m. E. N. E. Little Rock.

Ordhay's Cross Roads, p. o., Testmoreland con, Firg.: 49 m. N. F. Richmond.

Oxp Hickory, p. on, Wayne county, Ohio: $84 \mathrm{~m}$. N. E. Columbus.

Oto Frckors, p. o., Simpson co., Mfiss.: $29 \mathrm{~m}$. S. by E. Jackson.

OLD Hтckory, p. o., Botetourt co., Firrg.: about $131 \mathrm{~m}$.

W. Richmond.

OLd Hickory, p. o., Weakly county, Tenn.: $107 \mathrm{~m}$. T. Nashville.

Old Hickory, p. 0, Bradford county, Penn.: $101 \mathrm{~m} . \mathrm{N}$. Hlarrisburg.

OLD Mrnes, p. v., Washington co., Mo.: 82 m. S. E. Jefferson City, 
OLo Mrssion, p. o., Winnisheik co., Ia.: $113 \mathrm{~m} . \mathrm{N} . \frac{1}{2} \mathrm{~W}$. Iowa City.

OLd Porvi Confort, p. 0., Elizabeth City, Firg.: the N. point at entrance of James r., $69 \mathrm{~m} . \mathrm{S}$. E. Richmond, and $21 \mathrm{~m}$. W. by N. Cape Henry. Fortress Monroe, on the extreme point, is used both as an arsenal and military post, and in connection with Fort Calhoun, on the Rip Raps, commands the entrance to the river. The Point is much resorted to in summer, and has commodious hotels.

Oud Ripley, p. o., Bond county, $I l l . ; 63$ m. S. by E. Springfield.

Or. Tows, p. v., Philip's co., Ark. : on the W. side of the Mississippi r., $95 \mathrm{~m}$. E. by S. Litlle Rock. In the vicinity are to be found many aboriginal relics.

OLD Tuws, p. v., Greenup co., Fy.: on old Old Town cr., at its entrance into Little Sandy r., 115 m. E. N. E. Frankfort.

OLD Town, t. and p. v., Penobscot co., Me.: on the W. side of Penobseot river, $69 \mathrm{~m}$. N. E. Augusta. Drained by Birch stream and Pushaw $r$. There is a large pond on the W. border of the town; soil fertile, adapted to grain. Indian Old Town, on an island in the river, is within this town, and contains an Indian settlement, having a church and several small dwellings. The Orono and Old Town R. R. extends from here to Bangor. The river at this point is much higher than at Bangor. The town contains a large number of mills, and a vast amount of lumber is manufactured for the Bangor market. Pop. of t. 3,087.

OLD Town, p. Y., Alleghany co., Md.: on N. side of the Potomae r., 115 m. W. N. W. Annapolis. The Baltimore and Ohio R. R. passes the village $2 \mathrm{~m}$. distant.

Ord Tows, p. O., Forsyth co., N. Car.: $97 \mathrm{~m}$. W. N. W. Raleigh.

Old Town, p. o., Claiborne co., Tenn.: 167 m. E. by N. Nashville.

OLn Town, p. o., Coffee county, $A l a_{a}: 71 \mathrm{~m}$. S. by E. Miontgomery.

Otd Washington Court-Hotse, p. o., Washington co., $A l a .: 130 \mathrm{~m}$. S. by E. Montgomery.

OleaN, p. o., Ripley co., Ind.: 65 m. S. E. Indianapolis,

OLEAN, t. and p. ₹., Cattaraugus county, $N . T .: 255 \mathrm{~m}$. W. by S. Albany. Drained by the Alleghany r. and its tributaries. Surface very uneven, and in parts much broken; soil sandy, abounding in pine forests. A great quantity of lumber is exported annually down the Alleghany $r$. to the Ohio, much of which, as also scantling, in many cases reach the levee of New Orleans. The t. contains several stores and mills. The $\mathrm{v}$, is situate at the mouth of Oil cr., on the Alleghany $r_{\text {, }}$ at the point where the Genesee Valley Canal and the Erie R. R. intersect each other and meet the river. It contains several churehes, stores, dwellings, and a number of mills. A steamboat of light draft has ascended the Alleghany to Olean, but there is much olstruction in the narigation. Below it is an Indian village, inhabited by several hundred Senecas and Onondagas. Pop. of t. 899.

Olfander, p. o., Marshall county, Alan. $131 \mathrm{~m}$. N. Montgomery.

Olexa, p. v., Henderson county, $I U .: 81 \mathrm{~m} . \mathrm{N} . \mathrm{W}$. Springfield.

Otexa, p. o., Huron co., Ohio: $72 \mathrm{~m}$. N. by E. Columbus, Olestaigr, p. o., Crawford county, Ohio: $59 \mathrm{~m}, \mathrm{~N}$. Columbus.

Olentaxgy, or Whetsone river, Ohio: one of the principal tributaries of the Scioto, rises in W. part of Richland co., flows W. into Crawford, and then S. through Marion and Delaware into Franklin, where it joins the Scioto at Columbus.

Olex, t. and p. o., Berks co., Penn.: 59 m. E. Harrisburg. Drained by Manatawny and Manookisy creeks. Surface even; soil very fertile and highly productive. The "Oley Forge," constructed in 1780 , having an annual production of 200 tons blooms, is situate here. There are in the t. a number of dwellings, stores, and mills, and some workshops. Pop. 2,309.
Olinda, p. o., Pike co., Ill.: $71 \mathrm{~m}$. W. by S. Springfleld. Olio, p. o., Sheboygan co., Wisc.: 81 m. N. E. Madison. Outo, p. v., Stoddaru co., Mo. : 180 m. S. E. Jefferson City. OLIVE, t. and p. o., Ulster co., $N . \quad Y .: 56 \mathrm{~m} . \mathrm{S} . \mathrm{S} . \mathbb{W}$. Albany. Drained by Esopus cr. Surface, central and E.s. rolling, and in the W. mountainous; soil, sandy and clay loam. It has two stores, a factory, and a number of mills. Olive and Caseville are the names of the post-offices. Pop. of $t$. 2,710 .

OLIve, t. and p. o., Clinton co., Mfich.: $7 \mathrm{~m}$. N. Lansing. Drained by Muskrat lake and Stony er. Surface generally level; soil good, and heavily timbered. Pop. of t. 223.

OLIVE, t. and p. v., Morgan co., Ohio: 75 m. E. S. E. Columbus. Drained by a branch of Duck er. Surface varied, and soil generally fertile, well adapted to grain and grass. The village is situate on $\mathrm{E}$. side of a branch of Duck creek. There are in the t. several mills and workshops. Pop. of t. 2,015

OLIVE, p. O., Marion co., Ind. : a few miles distant from Indianapolis.

Olive Bratce, p. o., De Soto county, Miss. : $157 \mathrm{~m}$. N. Jackson.

Olive Branch, p. o., Clermont co., Ohio: 78 m. S. W. Columbus.

Olive Braxch, p. v., Holt county, Mo.: $196 \mathrm{~m} . \mathrm{N}$. W. Jefferson City.

Olive Bridge, p. o., Ulster co., N. Y.: $59 \mathrm{~m}$. S. by W. Albany.

Olive Grove, p. v., Decatur co., $G a .:$ on the E. side of Chattahoochee r., $175 \mathrm{~m}$. S. W. Milledgeville.

OLIVE Hilu, p. 0., Carter co., Ky. : near Tygert's cr., and 97 m. E. by N. Frankfort.

Oltve Hill, p. o., Person co., N. Car. : $49 \mathrm{~m}$. N. by W. Raleigh.

Olivers, p. o., Anderson county, Tenn. : near Poplar cr., $137 \mathrm{~m}, \mathrm{E}$. Nashville.

Oliver's Prairie, p. v., Newton co., Mo. : 157 m. S. W. Jefferson City.

OtIvesberg, p. v., Richland co., Ohio: on Black Fork of Walhonding r., $66 \mathrm{~m}$. N. by E. Columbizs.

OLIVET, p. o., Eaton co., Mich.: 15 m. S. W. Lansing.

OLiver, p. O., Armstrong co, Penn.: $132 \mathrm{~m}$. W. by $\mathrm{N}$. Harrisburg.

Olivet, p. 0., Russell co., Ala.; 59 m. E. Montgomery. OLmstead, t. and p. v., Cuyahoga county, Ohio: $112 \mathrm{~m}$. N. N. E. Columbus, Drained chiefly by rocky r. and its branches-in the W. by the head branches of Black $r_{\text {o }}$ of Lake Erie. Surface diversified; soil rich and fertile. The principal v. is situate centrally, and there is also a station of the same name on the Cleveland, Columbus, and Cincinnati R. P., $15 \mathrm{~m}$. from Cleveland. The t. contains several manufactories and mills. Pop. of t. 1,216.

Oxwey, p. o., Pickens county, Ala.: 107 m. W. N. W. Montgomery.

OLxex, p. 0., Philadelphia county, Penn. : 96 m. S. S. E. Harrisburg.

Ozxer, p. v., and cap. Pichland co., $M l$.: on W. side Fox r., $113 \mathrm{~m}$. S. E. Springfield. It contains the county court-house. The "OIney Republican" (a weekly issue) is published here.

OLNerville, p. o., Providence co., R. I.

OLUSTEe, p. v., Columbia co., Flor.: near the source of Swift er., $117 \mathrm{~m}$. E. by S. Tallahassee.

Oltstee Creek, p. o., Pike county, Ala.: 35 m. S. E. Montgomery.

OLYupia, p. v. and port of entry, Lewis co., Oreg. Ter.: on the E. side of the estuary of Tenalquit or Shutes r., on Puget's sound, $147 \mathrm{~m}$. N. Salem. The first log cabin of this settlement was built in 1847, by Wm. E. Sylvester, who now (1 552$)$ keeps an elegantly furnished hotel in the place. The $v$. contains 400 or 500 inhabitants, and has well-filled stores and various mechanic shops, with two sary-mills and a grist-mill in the vicinity. $\Delta$ newspaper, the "Columbian," is pub- 
lished here weekly. The first American settlers north of the Columbia river located themselves on the prairies, near Olympia, in October, 1545 . They were 15 days in making a journey of 60 miles, from Cowlitz Landing to the Sound, having been compelled to cut a road through the heavily timbered part of the country. In 1846, other settlements were made, and the first grist-mill of the neighborhood erected, previous to which event the inhabitants had been obliged to subsist on boiled wheat, or grind it by hand. The U. States Revenue collection distriet of Puget's sound, of which Olympia is the port of entry, was organized in 1651 . OLTMPian SPRings, p. v., Bath county, Ǩy.: $65 \mathrm{~m}$. E. Frankfurt.

OLxMPUs, p. v., Overton co, Tenn.: on the E, fork of Obeys r., 87 m. E. by N. Nashville.

Orar, p. o, Jefferson co., $N . Y .: 149$ m. N. W. Albany, OMEENA county, Mfich. Situate N. W., and contains 504 sq. $m$. Drained by Grand Traverse river and its tributaries. Surface even; soil generally rich and fertile. Organized since 1850 .

OMEga, p. o., Pike co., Ohio: 61 m. S. Columbus.

OMro, p. Y., Winnebago co., Wisc.: on S. side of Nenah or Fox r., 75 m. N. E. Madison.

Oxaxcock, p. v., Accomac co., Firg.: on Onancock inlet of Chesapeak bay, $77 \mathrm{~m}$. E. by N. Richmond.

O'Neal's Muls, p. o., Troup county, Ga.: $65 \mathrm{~m}$. W. Milledgeville.

ONECHO, p. O., Montgomery co., Tenn.: 43 m. N. W. Nashville.

$\mathrm{ONECO}_{\text {, p. }}$., Stephenson co., $M l_{\text {. : }}$ situate on Richmond cr., $189 \mathrm{~m}$. N. Springfield.

ONEDA county, $N . Y$. Situate N. centrally, and contains 1,101 sq. m. Drained by Black and Mohawk rivers and their affluents, and Fish, Wood, Oneida, and Oriskany creeks, all of which furnish valuable water-power. Surface yarious, being pleasantly diversified by low hills and wellcultivated valleys. In the $\mathrm{N}$, and $\mathrm{N}$. $\mathrm{E}$, it is more hilly. It contrins beds of iron ore, gypsum, marl, peat, water limestone, and other minerals. This county may be said to embrace a greater variety of geological formations than any other in the State. Farms 6,292; manuf, 952; dwell. 16,751, and pop.-wh. 98,918, fr. col. 653-total 99,566. Capitals: Rome, Thitesboro, and Utica. Pullic Works s Utica and Syracuse R. R. ; Watertown and Rome R. R.; Black River and French Creek R. R.; Black River Canal; Erie Canal; Chenango Canal, etc.

ONeIDA, t. and p. o., Eaton co., Mich. : $13 \mathrm{~m}$. W. Lansing. Grand r. forms its N. E. boundary, by the tributaries of which the $t$, is drained. Surface gently undulating; soil calcareous and sandy loam, with thick vegetable mold. It has good timber lands. There is a valuable sand-stone quarry on Grand r., in the N. E. part of t., which is wrought to a considerable extent. Pop. of t. 492 .

ONema, p. O., Brown co., Wisc. : 119 m. N. E. Madison.

Oneida creek, $N . Y$.: rises in Eaton, Madison county, flowing $N$. by W., in part divides the counties of Madison and Oneida, and empties into the lake so called. Its tributaries afford good mill-seats. The cr. is used as a feeder to the Erie Canal, and is navigable as far as Oneida Castle.

ONETDA lake, $N_{0} . Y_{*}:$ bordering on the counties of Oswego, Oneida, Madison, and Onondaga. Is $22 \mathrm{~m}$. long, and from 4 to 6 in width. It receives Wood, Oneida, and Chittenango creeks and other small streams. Its shores are low and swampy. Its waters abound wilk excellent fish. Limestone is found on the borders of Madison co. Its outlet flows into Oswego river.

ONEIDA, river, $N_{0}, Y_{.}$: outlet of the lake so called. Runs W. in a circuitous course, and uniting with Seneca, forms Oswego river.

ONeida Castle, p. . $_{\text {, Oneida }} 0 ., N_{\text {. }} Y$.: on Oneida cr., which divides it, $97 \mathrm{~m}$. W. by N. Albany. Ineorporated in 1841. Contains 2 churches, a few stores, several dwellings, and between 309 and 100 inhabitants.
Oneida Depot, p. v., Madison co., $N . Y_{*}$ : on Verona er. and on line of the Syracuse and Utica R. R., $27 \mathrm{~m}$. Utica, 99 m. W. N. W. Albany.

Onetda Mrlis, p. 0., Carroll co., Ohio: 108 m. E. N. E. Columbus.

ONeida Valley, p. o., Madison co., N. Y.: 90 m. W. by N. Albany.

ONEONTA, $t$, and p. v., Otsego co., N. Y.: $69 \mathrm{~m}$. W. by $\$$. Albany. Drained by Charlotte $r$. and Otsego cr., branches of the Susquehanna. Surface rugged, except along the streams, where it becomes flat and fertile. The $\mathrm{v}$. is on the $N$. side of the Susquehanna $r$, and contains 3 churches, a distillery, and several dwellings. There are in the t. 2 furnaces and several mills. Pop. of t. 1,903.

Oneonta, p. o., Sauk co., Wisc.: 28 m. N. W. Madison.

ONIoN Rrver, p. v., Sheboygan co., Wisc.: on W. bank of the river of same name, $91 \mathrm{~m}$. N. E. Madison.

ONION river, $\nabla t$.: one of the most important rivers in the State. About $70 \mathrm{~m}$. in length, in its course improving a large tract of land, and furnishing great hydraulic power. It rises in Cabot and Peacham, runs $\mathrm{S}$. and W. to Montpelier, and thence N. W., passing through the centre of the counties of Washington and Crittenden, empties into Lake Champlain, $5 \mathrm{~m}$. N. Burlington village. In its passage through the mountains, there are places where there is barely sufficient room for the road, which is the only easy access across the narrow valleys, subject it at times, to great and sudden rises. In many places, natural bridges, caverns, and waterfalls are to be found. It has many tributaries, the principal of which are North branch in the N., and Mad Dog, and Stevens rivers on the $\mathrm{S}$.

ONoNDAGA county, $N . Y$. Situate N. centrally, and contains 711 sq. m, Drained by Seneca and Oneida rivers, which, uniting, form Oswego river, and Butternut, Onondaga, and Nine-Mile creeks. Surface in the N. even, in the S. hilly, and fitted for grazing. Soil a rich loam, of a calcareous nature, intermixed with regetable mold, fertile and productive. It contains many minerals, and fine salt springs, which yield a large revenue to the State, also good marble quarries. Otisco, Onondaga, and Skaneateles lakes, are within the limits of this county. Chief agricultural productions, wheat and Indian corn. Farms 4.595; manuf. 1,410 ; dwell. 15,385, and pop.-wh. 85,285, fr. col. 605total 85,890. Capital: Syracuse. Public Works: Utica and Syracuse R. R.; Rochester and Syracuse R. R.; Oswego and Syracuse R. R.; Rochester and Syracuse (direct) R. R.; Syracuse and Binghampton R. R.; Erie Canal; Oswego Canal, etc.

ONondaga, p. o., Marshall county, Ind.: $105 \mathrm{~m}$. N. Indianapolis.

ONoNdagA, to and p. o., Ingham county, MFich.: $19 \mathrm{~m} . \mathrm{S}$. Lansing. Watered by Red Cedar $\mathrm{r}_{\text {, }}$ crossing its S. W. part. Surface uneven; soil rich, sandy loam, with excellent timber lands. Pop. of $t .819$.

ONoNDAGA, t. and p. v., Onondaga co., $N . Y .: 181 \mathrm{~m}$. W. by $\mathrm{N}$. Albany, and $6 \mathrm{~m}$. $\mathrm{S}$. Syracuse. Drained by Onondaga $\mathrm{cr}$. Surface uneven, in parts hilly; soil, clay loam, fertile, and well cultivated. The v., formerly the co. capital, has an elevated site on Onondaga Hill, $1 \frac{1}{2} \mathrm{~m}$. from the $\mathrm{r}$., and commands a fine prospect; it contains several stores, and about 300 inhabitants. There is an Indian reservation in the S. part of the $t$. on both sides of the cr., and through which the Syracuse and Binghampton R. R. will pass. Population of t. 5,694 .

ONONDAga CASTLE, p. o., Onondaga co., N. Y.: $129 \mathrm{~m}$. W. by $N$. Albany.

OvoNDAGA lake, $N . \bar{Y}:$ toward the centre or N. of county so called, $8 \mathrm{~m}$. Iong, and from 2 to 4 in width. It abounds in fish, and is noted for the salt springs which are found on its borders, though its own waters are fresh.

ONovruxe, p. o., Cattaraugus $c_{0}, N . Y_{.}: 63 \mathrm{~m}$. W. by $\mathrm{S}$. Albany.

OxsLow county, $N$. Car?. Situate S. E., and contains 523 
sq. m. Drained by New river and its branches. Surface level, and in general the land lying low. Soil moderately fertile. Chief productions, cotton and Indian corn. On the Atlantic shore, bounding it on the $\mathbf{E}$., are a number of small islands, with oceasional inlets. Farms 349 ; manuf. 27; dwell. 963 , and pop.-wh. 5,005, fr. col. 170, sl. 3,108-total 8,293. Capital: Onsluw.

Oxscow, p. v., and eap. Onslow co., $N_{\text {. }}$ Car. : on E. side New r., $97 \mathrm{~m}$. S. E. Raleigh ; it contains the court-house and other public buildings, and several dwellings.

Oxslow bay, $N$. Car.: a portion of the Atlantic Oceun between Cape Fear and Cape Look-out, where the shore has a considerable curve inward, along which, at a distance of 1 or 2 miles, stretches a chain of narrow, long, and low islands, with shallow inlets between them.

Ontario county, $N . Y$. Situate W. centrally, and contains 612 sq. m. Drained by Honeoye, Flint, and Mud creeks, and Canandaigua outlet. Surface various, the eastern portion being spread into beautiful, swelling plains, the W. interspersed with fertile vales and hills, and in the S. W. the land rising considerably, in some places having an altitude of 1,200 or 1,400 feet; soil generally produetive, being a rich, fertile loam. This county contains beds of iron ore, gypsum, and marl, with other minerals, and some sulphmr springs. It contains Canandaigua, Canadice, and other lakes. It has fine water-power and valuable manufactures. Farms 3,058 ; manuf. 205; dwell. 7,568 , and pop.-wh.43,430, fr. col. 499-total 43,929. Capital: Canandaigua. Publie Works: Rochester and Syracuse R. R.; Canandaigua and Niagara Falls R. R.; Canandaigua and Elmira R. R., etc. Ostario, p. $\nabla .$, La Grange co., Ind.: on the N. bank of Pigeon r, $137 \mathrm{~m}$. N. by E. Indianapolis.

Oxtario, t. and p. v., Wayne co., N.. . : 250 m.W. N.W. Albany, and 18 m. N. E. Rochester. Drained by several small streams flowing into Lake Ontario, which bounds it on the N. Surface very level; soil gravelly. The r. is about $4 \mathrm{~m}$. from the lake. It contains a furnace, forge, and several mills. Pop. of t. 2.246.

Ontario, p. 0., Richland eounty, Ohio: 59 m. N. by E. Columbus.

ONTARIO, p. v., Knox co., Ill. : 103 m. N.W. Springfield. Ortario lake, $N . Y_{0}:$ the easternmost and smallest of the great northern lakes. It lies between $43^{\circ} 10^{\prime}$ and $44^{\circ}$ latitudes N., and between $76^{\circ}$ and $80^{\circ}$ Jongitudes W. It receives the Niagara river, the great outlet of the upper lakes, in its S. W. part, and has its outlet, by the St. Lawrence river, in its $\mathrm{N}$. E. part, in which, immediately below the lake, is the cluster denominated "The Thousand Islands." Its shape approaches to a long and narrow ellipse, being 190 miles long, and 55 miles in its widest part, and about 480 miles in cireumference. It is very deep, being in some places 600 feet, so that its bottom is considerably below the level of the Allantic. It is 334 feet below the level of Lake Erie, and 281 feet above ticle-water, and in every part has a sufficint denth fir the largest ships. Its harbors are numerous and good, and except in shallow places near the shore, its waters are seldom frozen. The principal streams that enter it on the south side are the Genesee, Oswego, and Black rivers, and a large number of crecks. The Bay of Quinte is a long and irregular body of water in its eastern part, which receives a considerable river, the outlet of several small lakes; and Burlington Bay is in its western part. Both of these bays are in Canada. It has several important places on its shores, the principal of which are Kingston, Toronto, and Coburg, in Canada; and Oswe. go, Sackett's Harbor, and Port Gencsee, or Charlotte Harbor, in New York. It is subject to violent storms and heavy swells; but the numerous steamboats which navigate it pass quietiy through it, having a great depth of water. It is connected with the Erie Canal and Hudson r. by the Genesee $r$. navigation and the Oswego Canal, which connect with the Erie Canal at Rochester and Syracuse, and also by several railroads with the great central road of New Tork. 628
Several lines of railroad are also being built along its shores in Canada, and others into the interior of that country. Much of the trade of the Western States passes through these avenues to the sea-board. The Welland Canal connects it with Lake Erie; it is 26 miles long, with 34 locks, and admits the pasage of the largest vessels which navigate the lakes. This canal commences at Sherbrooke, near the mouth of Grand r., and terminates at Port Dalhousie, 9 miles west of Niagara village. Its entrance being a considerable distance west of the outlet of Lake Erie, it is open earlier than the Erie Canal at Buffalo, where the ice often accumulates in the spring. The commerce on this lake is very valuable. In 1816 it amouuted to $\$ 14,025,507$, and in 1818 to $\$ 28,141,000$. This is exclusive of the passenger trade. The following table exhibits the number of vessels wbich entered the several districts of the lake during the year ending 30 th June, 1850 :

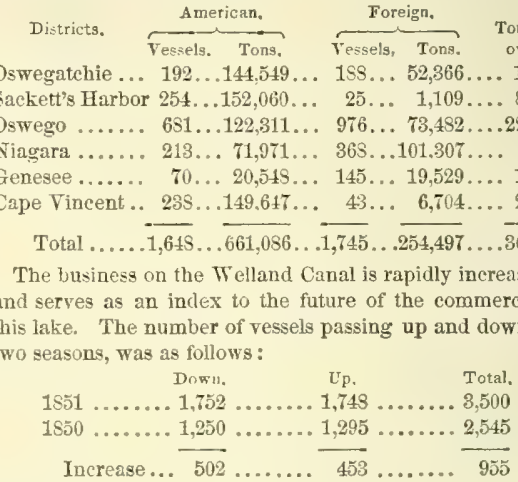

Of the vessels passing down in 1851, there were 924 American bound to American ports, and 163 bound to Lritish ports; and 359 British bound to British ports, and 306 to American ports. Of the vessels down, 1,230 were bound to American, and 522 to British ports. Of the vessels passing up, 1,176 were bound to American, and $5 \pi 2$ to British ports. This shows that a large portion of the business in the Welland Canal is American.

The increasing commerce on this lake is now demanding greater facilities of outlet on the American coast, and to afford this, several projects have been proposed, two of which, the Sodus Canal, and Sodus Point and Southern R. R., are now in process of construction.

The trade between the United States and Canada is principally through Lake Ontario, and this trade is increasing with wonderful rapidity. The exports to Canada, in 1819-50, werc valued at $\$ 5,930, \$ 21$, and the imports, exclusive of specie, at $\$ 3,559,101$. The exports of manufactured goods to Canada, were $\$ 3,961,222$. The total of this class of goods exported from the United States, in 1849-50, exceeded those of $1 \$ 4 \mathrm{~S}-9$ by $\$ 3,09 \mathrm{~S}, 1 \mathrm{~S} 7$, and of this excess $\$ 2,457,915$ went to Canada; so the increase to Canada exceeded five-fold all the increase to other countries trading with the United States.

Oxtoragon county, Mich. Situate W. of the N. peninsula, and contains 2,32s sq. m. Drained by Ontonagon, Montreul, and Presque Isle rivers. Surface for the most part even. In the N. W. are the Porcupine Hills, a low range of mountains, having acquired their name from the jagged appearance of the surface. Immense deposits of iron and copper ore are found in this region. Farms $\theta$; manuf. 0 ; dwell. 46 , and pop.-wh. 383 , fr. col. 6-total 389. Capital: Ontunagon.

ONTONAGON, p. v., Ontonagon co., Mich.: at the mouth of the Ontonagon $x ., 359 \mathrm{~m}$. N. W. Lansing. Copper of a superior quality is to be found here and in the vicinity in abundance. The Ontonagon Copper Company are workirg 
a vein in which they eneounter boulders of pure copper, Weinling from 25 to 50 pounds, containing considerable silver. There are a number of mines along the river course, worked by different eompanies, yiching abundantly. For certain purposes in the arts the copper in this region stands unrivaled, and surpasses all the ores of copper in density and tenacity.

OxTusagon river, Mich.: rises by three branches-the $\mathrm{E}$. one in Marquette $\mathrm{m}_{\text {, }}$ the middle in small lakes near the borier of Wisc, and its W. branch in Agngebic lake. The main stream flows $\mathrm{N}, \mathrm{W}_{\mathrm{s}}$, between bold and picturesque banks, much broken by falls, and empties into Lake Superior. On its border is found a eelebrated mass of native copper, about 20 cubic feet in bulk, and weighing from four to five tons.

ONWard, p. D., Stewart co., Tenn. : near the Cumberland river, $61 \mathrm{~m}$. W. by $\mathrm{X}$. Nashrille

Oosoou, p. 0., Somerset co., DГe.: N. Augusta.

Ootmcaloga, p. o., Cass county, Ga.: 103 miles N. W. Milledgeville.

Opalika, p. o., Walker county, Ga.: 169 m. N. W. Milledgeville.

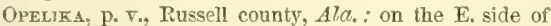
Cfawpee cr., and on the line of the Montgomery and West Point R. P., 21 m. from West Point, and $54 \mathrm{~m}$. E. by N. Montgomery

Opelousas, p. $\nabla$, and cap. St. Landry par., La.: at the hoad of Vermillion r., $55 \mathrm{~m}$. W. Baton Rouge. The country round about is pleasant and very fertile. The Franklin College, situate liere, founded in 1839 , has a president, 4 professors, and 70 students. There is also a United States land office here. The $\mathrm{y}$, contains the court-house, 2 banks, 4 churches, and several stores. The "St. Landry Whig" (whig), daily, and "Opelousas Gazette" (neut.), semi-weelIy, are published here. The New Orleans, Opelousas, and Great Western R. R. will pass through it.

Opfar Posd, p. o., Henry county, Ala.: $\$ 3$ m. S. E. Montgomery.

OPEQUAN riter, Fing.: rises in the S. E. part of Frederick co., flows N. E., separating Clark and a part of Jefferson from Frederick and Berliley counties, and empties into the Potomac river.

OpHri, p. 0., La Salle county, $7 l$. : 103 m. N. by E. Springfield.

OpHip, p. v., and cap. Butte co., Calif.: on the E. side of Feather r., 128 m. N. N. E. Vallejı. Pop. 3,000,

Oporto, p. o., St. Joseph caunty, Hich. 69 m. S. W. Lansing.

OpPENHEIr, t, and p, v., Fulton co, N. $Y_{0}: 61 \mathrm{~m}, \mathrm{~N}$. W Albany. Drained by small streams which flow into the Mohawk r. Bounded on the W. by East Canada er. The $\mathrm{v}$. is in the centre of $\mathrm{t}$. The $\mathrm{t}$. contains several stores and a number of mills. Pop. of t. 2,315.

OQUAWKA, p. V., and cap. Henderson $\mathrm{co}_{*}, I l l_{*}:$ on the $\mathbf{E}$ bank of the Mississippi r., a few miles above the mouth of Henderson r., $105 \mathrm{~m}$. N. W. Springfield. Situate on a sand ridge that extends from Henderson $\boldsymbol{r}$, to the Mississippi. It is the landing for this and the adjoining counties, and principal depôt for freights between the Des Moines and Rock River Rapids. A railroad is in progress to connect this r. with Peoria. It contains the county court-house and usual number of public buildings. The "O. Spectator" (lit. is published weekly. Pop. 1,200.

Oras, p. v., Onondaga eo., N. Y.: on a branch of Canaseraga cr., $121 \mathrm{~m}$. W. Albany.

Oran, p. v., Kosciusko co., Ih d. : on La Porte post-road, $1005 \mathrm{~m} . \mathrm{N}$. Indianapolis.

Oraxge county, Flor. Situate E. of the peninsula, and contains $5,253 \mathrm{sq}$. m. Drained by St. John's r., which in its course from $\mathrm{S}$. to $\mathrm{N}$. (where it enters the Atlantic in Dural co.), passes through the different lakes by which the face of the country is diversifixt. The land is in general low and part of it marshy; soil fertile. Chief productions cotton, rice, Indian corn, wheat, fruits of all kinds, vegetables, et.c. On the Atlantic side are large lagoons, the land on the eastern shore stretching out and forming Cape Canaveral. Farms 19; manuf. 0; dwell. 55, and pop.-wh. 238, fr. col. 2, sl.226-total 466. Cupital: Mellonville.

ORANGE county, Ind. Situate S. toward the W., and contains $395 \mathrm{sq} . \mathrm{m}$. Draincd by Lick cr. and branches, tributaries of the E. fork of White $r$. Surface varied-in the $N$. being rolling or undulating, and in the S. hilly; soil fertile and very productive. Staples, wheat and Indian corn, Timber is abumlant. It has fine watr.r privileges. Farms 1,118 : manuf. 8 ; dwell. 1,811 , and pop.-wh. 10,559 , fr. col. 250-total 10,809. Capital: Paoli. Puzlic Works: New Albany and Salem R. R.

ORANGE county, $N, Y$. Situate $\mathrm{S}$, and contains $760 \mathrm{so}, \mathrm{m}$. Drained by Wallkill, Nevisink, and Shawangunk rivers in the entral portion, and branches of Delaware r. in the W. surface various-in parts being rather mountainous, in the W. are the Shawangunk range, and in the S. E. the Highlands, the remaining portion is pleasantly diversified with hills and valleys; the soil is fertile and well adapted to grazing. This county is celebrated for its fine milk and butter, which, with wheat, Indian corn, and potatoes, form its chief productions. It abounds in minerals, and has large beds of magnetic iron ore. Farms 3,426 ; manuf. 357 ; dwell. 9.6S6, and pop-wh. 54.783, fr. col. 2,362-total 57.145. Capital: Goshen, Public Works: New York and Erie Railroad.

Orange county, N. Car. Situate N. centrally, and contains $676 \mathrm{sq} . \mathrm{m}$. Drained by branches of Haw and Neuse rivers. Surface level; soil fertile, and adapted to the growth of tobacco, etc.; some cotton is also raised. Farms 1,082 ; manuf. 17 ; dwell. 2,186, and pop.-wh. 19,330, fr. col. 4S1, sl. 5,244-total 17,0503. Crepital: Hillsboro', Public Works. North Carolina Central R. P.

Orange county, Verm. Situate E, and contains $740 \mathrm{sq} . \mathrm{m}$. Drained by Waits and Ompompanoosuc rivers and branches of White $r$. Surface in the N. and N. W. rocky and mountainous, but in the eastern portion, along the banks of the Connecticut $\mathbf{r}$, are some fine traets of land; soil various, gencrally suited for grazing, but producing good crops of grain and vegetables. Chief productions wheat, Indian corn, and potatces. This county contains iron and lead ores, slate and granite quaries, and has immense deposits of ochres. Farms 2,677; manuf. 86 ; dwell. 5,192, and pop. -wh. 27,277, fr. col. 19-total 27,296. Capital: Chelsea. Public Works: Connecticut and Passumpsic Rivers R. R.

Orange county, Tirg. Situate centrolly toward the E. and contains $376 \mathrm{sq}$. m. Drained by branches of North Anna and Rivanna rivers. Surface hilly; soil fertile. Chief productions Indian corn and tobaceo. Rapid Anna river runs along its N. W. border. Furms 335 ; manuf. 45 ; dwell. 756 , and pop.-wh. 3,962 , fr. col. 184. sl. 5,921-total 10,067 Capital: Orange, Public Works: Orange and Alexandria R. R. ; Virginia Central R. R., ete.

Orange, p. v, Cherokee co., Gan: situate on a branch of the Etowah r., $111 \mathrm{~m}$. N. W. Milledgeville.

Orange, p. o., Fayette county, Ind.: $81 \mathrm{~m}$. E. by S. Indianapolis.

ORAxGE, t. and p. v., Franklin co., Mass.: $67 \mathrm{~m}$. W. by N. Boston. Drained by Miller's $x$, Surface uneven; soil better adapted to pasturage than culture. There are several manufactories of different kinds. The $\mathrm{v}$. is situated on the line of the Vermont and Massachusetts R. P., $87 \mathrm{~m}$. from Fitchburg. The t. contains several stores and mills. Pop. of t. 1,700 .

Oraxge, p. o., Branch county, Mlich.: 57 m. W. by S Lansing.

Opavge, t, and p. v., Essex co, N. Jer, : $45 \mathrm{~m}, \mathrm{~N}, \mathrm{E}$, Trenton. Drained by head waters of Raloway and Second rivers, and Peckman's branch of Passaic r., affording excellent water-power. Surface mountainous; soil red shale, fertile, and in a good state of cultivation. There are several 
mills and manufactories in the t. The $\mathrm{v}$. is on the line of the Morris and Essex R. R., 18 m. New York City, and contains 4 churches, a number of stores, and about 200 dwellings. A chalybeate spring is situate near the village. Shoemaking forms a great business in this neighborhood. Pop. of t. 4,385 .

OraNer, t. and p. o., Steuben co., N. $I_{*}: 175 \mathrm{~m}$. W. by S. Albany. Drained by sereral small creeks, which flow into the Coshocton $\mathbf{r}_{\text {, }}$ and bounded on the $\mathrm{N}$. by an outlet of Seneca lake. Surface rolliug; soil very fertile. Population of t. 2,055 .

Oraxge, p. v., Mahoning county, Ohio: 138 m. N. E. Columbus.

Orange, p. o., Luzerne county, Penn.: 85 m. N. N. E. Harrisburg.

Oraxge, t. and p. v., Orange co., Verm. : $11 \mathrm{~m}$. E. by $\mathrm{S}$ Montpelier. Drained by Wait's branch of White r., and Stevens' branch of Onion r., producing very valuable waterpower. Surface mountainous; soil along the banks of the rivers rich and productive, the remainder inferior. Granite is found in large quantities, principally on Knox Mountain in $\mathrm{N}$. E. part of the t. White mica of excellent quality is also found here several inches square. The timber is mostly hard wood. Products of the t. consist chiefly in cattle and wool. The v, is on the Bradford post-road, in centre of town. Pop. of t. 1,007.

OrANGe, p. v., and eap. Orange co., Virg.: at the junction of the Orange and Alexander R. P. with the Virginia Central R. R., $57 \mathrm{~m}$. N. W. Richmond. It contains a courthouse, jail, 2 churches, a number of stores, about $80 \mathrm{dwell}-$ ings, and 450 inhabitants.

Orangebdrg district, $S$. Car. Situate S. centrally, and contains 1,453 sq. m. Drained by North Edisto $r$, and its branches, and branches of South Edisto, which bounds it on the S. Surface level; soil moderately fertile. Chief productions cotton, rice, and Indian corn. Farms 1,0S2; manuf. 17; dwell. 2,166, and pop.-wh. 19,330, fr. col. 4S1, sl. 5,244 - total 17,055. Capital: Hillsboro'. Pubtic Works: South Carolina R. R.; Columbia Branch R. R, etc.

Orangeburg, p. v., and eap. Orangeburg dist., $S$. Car.: on North Edisto r., and on the line of the Columbia Branch of the South Carolina R. R., $50 \mathrm{~m}$. from Columbia. It contains the court-house, jail, and other public buildings. Several thousand pounds of Indigo are made here annually and carried to Angusta, Columbia, and Charleston; there are two kinds-the tame and the wild-the latter of which is the most valuable. Pop. S00.

Oravgeburg, p. o., Mason county, $\overline{y_{1}}: 71 \mathrm{~m}$. N. E. Frankfort.

Orange Hric, p. o., Washington co., Flor.: 87 m. W. Tallahassee.

Orange Lake, p. 0., Marion co., Flor. : 125 m. S. W. Tallahassee.

Oraxge Port, p. o., Niagara co., $N$. Y.: on the Rochester,

Lockport, and Niagara Falls R. R., $51 \mathrm{~m}$. Rochester, $257 \mathrm{~m}$. W. by N. Albany.

Orange Springs, p. V., Marion co., Flor.: on W. side

of Octawaha r., and on the $\mathrm{N}$. boundary of county, $157 \mathrm{~m}$.

S. E. Tallahassee.

Orange SPRINGs, p. v., Orange co., Virg.: on a branch of North Anna r., $49 \mathrm{~m}$. N. W. Richmond.

Orangevil.t, t. and p. v., Wyoming co., $N_{\text {. }} Y$.: $239 \mathrm{~m}$. W. Albany. Drained by Tonawanda cr. Surface hilly soil alluvial. The $\mathrm{v}$. is in the centre There are in the $t_{\text {. }}$ several stores and mills, ete. Pop. 1,438.

Orangevilue, p. o., Trumbull co., Ohio: $152 \mathrm{~m}$. N. E. Columbus.

Orangerille, p. v., Columbia co., Penn. : 55 m. N. by E. Harrisburg.

Orbisonia, p. v., Huntingdon county, Penn.: 65 m. W. Harrisburg. There are situate here 3 hot-blast furnaces, with an aggregate annual capacity of 1,500 tons each, 1 cold-blast furnace, 800 tons annual capacity, and 1 forge, producing 250 tons blooms and 75 tons bars annually.

Orcutr, sta., Tolland co., Comn.: on line of the New London, Willimantic, and Palmer R. R., $53 \mathrm{~m}$. New London. Orcott Creek, p. o., Bradford county, Penm. : 99 m. N. IIarrisburg.

Orfateid, p. o., Lehigh county, Penn.: 73 m. N. N. E. Harrisburg.

\section{THE TERRITORY OF OREGON.}

OREGoN, as relinquished by Great Britain to the United States in 1846, extends from $42^{\circ}$ to $49^{\circ}$ latitude north, and from the crest of the Rocky Mountains to the Pacific Ocean. As at present constituted, it is limited north by the Columbia river, to latitude $46^{\circ}$, and by that line to the mountains aforesaid, the upper portion of the original territory having lately been erected into a territorial government, under the title of the "Territory of Washington." For the convenience of exhibiting the statisties of the country, however, it will be necessary to describe it as it existed before the separation. It contains altogether an area of $3 \pm 1,463$ square miles.

Oregon is naturally divided into three principal parallel sections, determined by the course of the mountains traversing it. The western section is bounded by the Cascade Mountains, and extends from them to the Pacific Ocean; the midule section lies between the Cascade Mountains and the Blue Mountains, and the eastern section between the latter and the crest of the Rocky Mountains. These several divisions have each distinct elimatic characteristics, and differ in soil and productions. The mountain rangus extend in general in lines parallel with the coast, and often attain a height far above the summer snow line.

The Cascade, or coast range, sometimes called the President's Range, runs through the Territory north and south, at a distance from the sea-coast varying from 100 to 150 miles, and in many places rises in regular cones to the elevation of 12,000 to 14,000 feet above the lerel of the sen. Except when the Columbia breaks through it, the communication between the east and west is almost interrupted, and where there exists any mountain pass, the difficulties besetting it are such as to render it of litle ase to the traveler. The climate of the section west of this range is mild and genial the year round, and the winters remarkably short. Snow seldom lies on the ground a week together. The soil on the northern parts varies from a light brown loan to a thin vegetable earth. with gravel and sand as a subsoil. In the middle parts a rich, heavy loam prevails, but in many localities clay and a black loam, based on trap-rock, are found. The soils of the Willamette valley and southern part generally are good, varying from a black vegetable loam to decomposed basalt, with clay, and portions of loose gravel soil. The hills are generally basalt, stone, and slate. Between the Umpqua and the southern boundary, the rocks are primitive, consisting of slate, hornblende, and granite, which produces a poor and gritty soil. There are in the latter region, however, some rich lands, covered with oak. Gold has been found extensively in the rivers of the south. For the most part, the whole country west of the Cascades is well timbered. It is intersected by spurs from the main range, which render the surface much broken, and these are covered with dense forests of pines, firs, spruce, oaks, ash, arbnr vitæ, etc., with a dense undergrowth for hazels, rubus, roses, ete. The prairies and river bottoms are excellent farming lands, and the uplands abound in rich pasturage.

The Blue Mountains have an irregular course, and are frequently interrupted, but generally run north and south, comnencing in the flamath range, near the Califurnia line. They are broken through by the Saptin, or Snake River, at the 
OREGON.

junction of the Kooskooskee, and branch off in hills of moderate elevation, until they again appear on the north side of the Columbia River, above the Okonagan, and finally connect with the Rocky Mountains, in the British territory. The climate of the middle section is much more extreme than in the west of the Cascade range, and its range more frequent and greater. It is, however, extremely salubrious, and the air bracing. No dew falls in this section. The soil in the hills is barren, but in the valleys a rich alluvian, varied indeed, but generally fertile. The general elevation of this section is about 1,000 feet above the sea level. In the north, the surface is broken by mountains and rivers, and quite unfit for agricultural purposes. The parts south of this, including the vicinities of the Columbia and Saptin rivers, the surface is rolling, and in every way a fine grazing country. Further south there is little goorl land, the whole being broken and desert, with scarcely a tree or useful vegetable, the artemesia alone seeming to flourish in the solitudes.

The Rocky Mountains, forming the eastern border of the Territory, commence on the Aretic coast, and continue with little interruption until their subsidence at the central isthmus of the eontinent. Along all the line bounding Oregon, only one eligible pass has yet been discovered, and that-the Great South Pass--lies on its extreme south-east corner, forming the gate of the country. Through this pass the emigration from the east comes in, and it is also the great thoroughfare of travel to Utah and California. The section immediately west of this can never be made available for settlement. Its climate is variable, and in a single day the temperature may pass from winter to summer heat. Rain seldom falls, and but little snow. The surface is rocky, and presents an almost unbroken waste, while stupendous mountain spurs traverso it in all directions. This country is partially timbered.

The Columbia is the great river of the country, and the recipient of all the other rivers of the Territory, having their origin eastward of the coast range of mountains. Its $\mathrm{N}$. branch rises in the Rocky Mountains in about $50^{\circ} \mathrm{N}$. lat. and $116^{\circ}$ W. long., and thence pursues a N. route to near M'Gillivray's Pass. Here the river is 3,600 feet above the sea-level, and, receiving Canoe River, it then turns $S_{\text {. }}$ and in its course to Fort Colville it successively takes up the waters of numerous tributaries, the chief of which are the Kootanie, or Flat Bow, and Flat Head or Clark's rivers. The Columbia is thus far surrounded by high mountains, and often expands into a chain of lakes. At Colville its elevation is 2,049 feet above the sea, having fallen 556 feet in 220 miles. To the S. of this point it tends to the W., receiving Spokan River from the E. ; thence it pursues a W. course for 60 miles, and bending to the $\$$., receives Okonagon River, which has its source in a line of lakes extensively susceptible of canoe navigation. The Columbia thence passes S. until it reaches Walla. Walla, in $45^{\circ} \mathrm{N}$. lat., and receives the Saptin or Lewis River; here the elevation of the Columbia is 1,286 feet, and its width about 3,500 feet. It now takes its last turn to the W., receiving the Umatilla, Quisnel's, John Day's, and Chute rivers from the $\mathbf{S}$., and Cathlatates from the $\mathrm{N}$., and pursuing a rapid course for 80 miles, it passes the gorge of the Cascade Mountains in a series of falls and rapids, that form an insurmountable barrier to the passage of boats, even in time of flood, and are overcome by portages. From this point there is still-water navigation for 40 miles, when rapids again interrupt free sailing, but hence to the ocean, 120 miles, the river, though frequently obstrueted by bars, is open to vessels of less than 12 feet draft. In this part of its course it receives the Willamette River from the $\mathbf{S}$., and the Cowlitz from the $\mathrm{N}$. The Willamette is navigable for small vessels to within 3 miles of its falls. Within a distance of 20 miles from the ocean, the Columbia is greatly increased in width, and at its mouth, between Cape Disappointment and Cape Adams, its width is 7 miles, but from each of these capes a sand-bar extends which renders the actual navigable channel contracted and narrow. The mouth of the Columbia was discovered by Capt. Gray, of Boston, commander of ship Columbia, of 220 tons, on the 11th May, 1792; and on the strength of this discovery the United States based their right to the territory watered by its tributaries.

The Chekalis, to the north of the Columbia, is a considerable river, and perhaps next to it in importance. It rises from several sources in the Caseade Mountains, and after a very tortuous course, receiving some small streams issuing from the lakes in the high ground, near the head waters of Hood's Canal and Puget's Sound, discharges in Gray's Harbor. Its current is rapid and much obstructed, nor is it navigable except by cances. Emptying into Puget's Sound are the rivers Nesqually and Tenalquit, or Shute's River, both affording excellent water-power and some navigation. On both these rivers there are flourishing settlements, and Olympia, a port of entry, lies at the mouth of the latter.

The rivers south of the Columbia are Clatsop, Killamook, Yaquinna, Alseya, Umpqua, Sequatehie, and Rogue rivers, all falling into the Pacific Ocean. But two of these are worthy of notice, the majority of them being small and insigniftcant streams. The Umpqua meets the sea in about $43^{\circ} 54^{\prime} \mathrm{N}$. lat.; it is a large river, rising in the Cascade Mountains by two main branches, which meet in about lat. $43^{\circ} 20^{\prime}$, and thence, after a due north course of about 20 miles, the river turns suddenly to the west, expanding to a considerable width in its lower course. Its principal tributaries are the Elk and Smith"s rivers. Settlements have been made along the course of this stream by gold hunters, brought here by the reported richness of its washings. Rogue's River rises in the same range, but farther south, and flows directly W. from its source. It has also become famous for its golden sands, and has attracted to its banks many adventurers. None of these rivers form harbors capable of receiving vessels of more than 8 feet draft, and their bars are dangerous on account of the surf that sets up to the coast.

The character of the great rivers of Oregon is peculiar; exceedingly rapid and sunk much below the general level, with perpendicular banks, they are, as it were, in trenches, it being diffleult to get at the water in many places, owing to the steep basaltic walls; and during their rise, which takes place in February and November, they are in many places confined by narrows, which back the water some distance, submerging lands and tracts of low prairie, giving the appearance of extensive lakes to the overflown country. The bars of these rivers are constantly changing, and it may be said that there is not a river on the Oregon coast, entrance to which is safe. Gray's Harbor will not admit vessels of more than 10 feet draft. This, however, is not the case within the harbors formed within the straits of Juan de Fuca, of which there are mariy, and no part of the world forms finer inland sounds, or a greater number of harbors, than can be found here, capable of receiving the largest class of vessels, and without a danger in them that is not visible. From the rise and fall of the tides (18 feet) all facilities are afforded for the erection of works for a great maratime nation.

The fisheries on the coast and in the rivers of Oregon are most extensive. The rivers abound in salmon of the finest flavor, and these form a great part of the subsistence of the Indians. The Columbia produces the largest, and probably affords the greatest numbers. The great fishery at the Columbia is at the Dalles, but all the rivers are well supplied. In the rivers and sounds are found several kinds of salmon, salmon trout, sturgeon, cod, carp, sole, flounders, ray, perch, herring, lampreys, and a kind of smelt, called "shrow," in great abundance; also large quantities of shell fish, viz., crabs clams, oysters, muscles, ete., which are all used by the natives. Whales are found along the coast, and frequently in and at the mouth of the Straits of Juan de Fuca.

To the hunter Oregon is a paradise, Game, such as the elk, deer, antelope, bears, wolves, foxes, muskrats, marting, beavers, etc, exist in great abundance. In the middle section no game is found. In the eastern section the buffalo is 
met with. The fur-bearing animals are decreasing in numbers yearly, and even alrealy are so scarce as scantily to repag the expense of hunting them. The Hudson's Bay Company bave almost the exclusive monopoly in this busincas. In the spring and fall the rivers are literally covered with ducks, gecse, and other water fowl.

Oregon, in 1550, was divided into 10 cuunties, * the generil statistics of which, and the capitals of each, ir 1550 , were as follows:

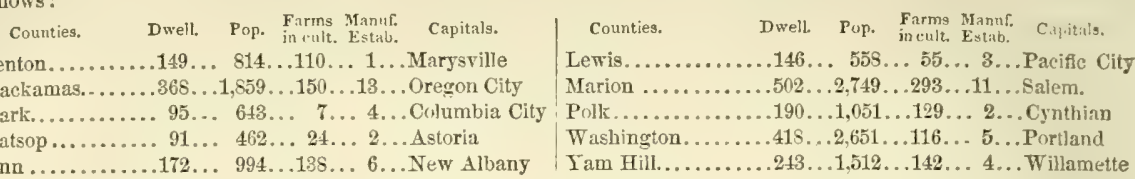

The whole number of dwellings in the State was, at the above date, 2,874, of families 2,374, and of inhabitants 13,293 , viz. : whites 13,057 -males 8,142 , and females 4,945 , fr. col. 206 -males 119 , and females 87 . Of the whole population, there were denf and dumb, $0 ;$ zlind, $0 ;$ insane-wh. $t$, fr. col, 0 -total 4 ; and idiutic-wh. 4, fr. col. 0-total 4. The number of free persons born in the United States was 11,992, the number of foreign birth 1,159, and of birth unknown 143 ; the native population originated as follows: Maine 129, N. Hamp. 44, Verm. 111, Mass. 187, R. I. 20, Conn. 72, N. Y. 618, N. Jer. 69, Penn. 337, Del.1S, Md. 73, Dist. of Col. 15, Virg. 469, N. Car. 201, S. Car. 31, Ga. 22, Flor. 4, Ala. 20, Miss. 8, La. 6, Tex. 15, Ark. 61, Tenn. 402 Ky. 730, Ohio 653, Mich. 37, Ind. 736, Il. 1,023, Mo. 2,206, Ia. 452, Wisc. 10, Calif. 25, Oregon 3,178, Territories 7 . And the foreign population was composed of persons from-England 207, Ireland 196, Scotland 106, Wales 9, Germany 125, France 45, Spain 0, Portugal 0, Belgium 11, Holland 1, Italy 5, Austria 0, Switzerland 8, Russia 1, Denmark 2, Norway 1, Sweden 2, Prussia 1, China 2, Asia 0, British America 293, Mexico 1, South America 6, West Indies 0, Sandwich Islands 50, and other countries 57.

The general statisties of the products, industries, institutions, ete., of the territory, according to the census of 1850 and other official documents referring to the same period, are as follows:

Occupied Lands, ete.-Improved farm lands 132,857 acres, and farm lands unimproved 299,951 acres-valued together at $\$ 2,849,170$. Whole number of farms under cultivation on the 1 st June, $1850,1,164$. Value of farming implements and machinery, $\$ 133,423$.

Live-Stock.-Horses, 8,046 ; asses and mules, 420 ; milch cows, 9,427; working oxen, 8,114; other eattle, 24,188; sheep, $15,3 \mathrm{S2}$; and hogs, 30,285. Value of live-stock, $\$ 1,376,189$.

Products of Animats.-Wool, 29,686 pounds ; butter, 211,461 pounds; and cheese, 36,980. Value of animals slaughtered during the year, $\$ 164,530$. The average clip of wool per sheep was thus $11 \mathrm{~b}$. $14 \frac{7}{\mathrm{~b}} \mathrm{oz}$.

Grain Crops.-Wheat, 211.943 bushels; rye, 106 bushels; Indian corn, 2,918 bushels; oats, 65,146 bushels; barley 0 bushels, and buckwheat, 0 bushels.

Other Food Crops.-Peas and beans, 6,566 bushels; potatoes-Irish, 91,326 bushels, and sweet, 0 bushels.

Miscellaneous Crops.-Tobaceo, 325 pounds; hay, 373 tons; clover-seed, 4 bushels; other grass-seed, 22 bushels; hops,

8 pounds; flax, 610 pounds; molasses, 24 gallons, etc. Value of orchard products $\$ 1,271$; market-garden products $\$ 90,241$. Home-made Manufuctures were produced in the year to the value of \$

Manufactures.Capital invested, $\$ 00,000$; value of all raw material, fuel, ete., consumed, $\$ 00,000$; hands employed, 000 -males 000 , and females 00 ; monthly cost of labor $\$ 00,000$-male $\$ 0,000$, and female $\$ 000$; total value of annual products $\$ 000,000$. Number of manufacturing establishments producing to the value of $\$ 500$ and upward annually, 51 .

Commerce,-Oregon has a considerable coasting trade with California in lumber, boards, and agricultural produce, and it has also some trade with the Atlantic ports, especially New York and Boston. With foreign countries its trade is limited. The amount of this can only be guessed at, as no general returns appear in the Treasury books. A report of the commerce of Astoria was made by the collector at that port for the year ending 1st April, 1850, but of the other ports no accounts have been received. According to the document referred to, there had entered that port 6 ships, 30 barks, 28 brigs, and 5 schooners - total 69 vessels, and 16,437 tons; from foreign ports 1,639 tons foreign, and 669 tons American shipping, and coastwise 14,129 tons American shipping. The daties collected for the year amounted to $\$ 26,40$.

The exports for the year were-sawed lumber, 4,597,317 feet; square timber, 312,097 feet; round logs, 355; house frames, 40 ; shingles, 599,038 ; leather, 124 sides; flour, 8,766 barrels; beef, 18 barrels; pork, 6 barrels; salmon, S3S barrels; bread 37 barrels; oats, 497 bags; apples, 15 barrels; cranberries, 6 barrels; bacon, 600 pounds; fire-wood, 8 eords ; Eauer kraut, 10 barrels; onions, 20 sacks, 12 hampers, and 42 bushels; butter, 23 barrels, 62 kegs, 2 firkins, and 8,000 lbz.; cheese, 5,200 pounds, and 4 boxes; eggs, 6 boxes, and 42 dozen; potatoes, 64 bushels, 40 barrels, and 750 sacks. An account of the imports, says the collector, would furnish no satisfactory results, as the cargoes of vessels entering the Columbia are mostly of small assorted lots, and although in the aggregate of considerable value, still they can not be ascertained in detail. The navigation of the Columbia River is free to the Hudson's Bay Company, but goods introduced into the country through the mouth of the river, and landed for any other purpose than for portage, in aid of their being carried up the river and out of the territory, are subject to the duty.

Gocernment.-The constitution of Oregon was promulgated in the law of Congress of the 14th Angust, 1845 :

Every white male inhabitant of the Territory at the time of the passage of that law, 21 years old, who was a citizen of the Enited States, or who had on oath declared his intention to become such, or who should take the requisite oaths, was allowed to vote or be chosen to office at the first election; but the legislature may prescribe further limitations.

The Legislature is styled the General Assembly, and consists of a council of 9 members, and of a Ilouse of Pepresentatives, of not less than 18 , nor more than 30 members. Members of both houses must have the qualifications of voters. Councilors are chosen for three years, and representatives for one year. All laws passed by this legislature must be submitted to Congress for approval or rejection. No session must continue more than 60 days. No bank, or any thing like a bank, shall be chartered or permitted to exist in the Territory, as a branch of an institution chartered elsewhere or otherwise, and the Territory shall issue no scrip, neither pledge its faith, nor in any way borrow money. Salmon must not be prevented from passing up and down the streams.

The governor, appointed by the President, holds office for four years, and until his suecessor is appointed and qualifled.

* Pacific, Lian, Ĺmpqua, and Lane, are new counties. Lewis, Clark, and Pacific counties are now compriseư in the Territory of Washington, and together, in 1850 , contaiued 1,801 inhabitants 


\section{OREGON.}

He is remorable by the appointing power. The governor is ex-officio Superintendent of Indian $\Lambda$ ffais ; may grant pardons and respites for offenses against territorial laws, and reprieve until the President's will be known, for those against the laws of the United States. The secretary, justices, attorney, and marshal, are also appointed by the President, The secretary holds office for five years, is removable by the President, and in default of the governor fills his place.

The Judiciary consists of a Supreme and District eourts. There are three judicial districts, in each of which a judge appointed for four years and until a successor be appointed and qualified, holds a district conrt, with law and equity jurisliction as may be regulated by statute, and the same three judges hold the supreme court, to which, eases not to be tried by a jury may be removed by appeal from the district courts. Writs of error and appeal from the decisions of the supreme court, lie to the Supreme Court of the United States where the matter in dispute exceeds $\$ 2,000$, or where the constitution, or a treaty of the United States, or acts of Congress, are in question. In cases arising out of the Constitution of the United States, or of territorial laws, the district courts have the same jurisdiction as the United States district and circuit courts.

Other prominent provisions of the fundamental law, are: The Secretary of the Treasury of the United States shall regulate all disbursements of money intrusted to the governor or secretary; the inhabitants shall enjoy the bencfils of the Ordinance of 1757 ; existing laws, compatible with the constitution of the United States, and with this act, unless repealed by the legislature shall remain in force, except those affecting the title to land, which are void; a delegate to Congress, who shall be a citizen of the United States, shall be chosen by a plurality of votes ; $\$ 5,000$ is appropriated to the purehase of a territorial library; sections 16 and 36 in every township are set apart for the benefit of schools; all the ports of the mainland form the collection district of Oregon, and Astoria is made a port of entry; a port of delivery may be established on Puget's Sound, and one other elsewhere; $\$ 15,000$ is appropriated for light-houses and buoys, etc.

On the $27 \mathrm{th}$ September, 1850 , an act was passed, providing for a Surveyor-General of the Territory, and to provide for the survey, and to make donations to settlers of the public lands. Its principal provisions are as follows:

There is granted to every settler or oceupant of the pubfic lands, American half-breed Indians included, above the age of 18 , a citizen of the United States, or having made a declaration of his intention to become a citizen, or who shall make such declaration on or before Dec. 1,1851 , now residing in said Territory, or who shall become a resident on or before Dec. 1, 1S50, and who shall have resided upon and cultivated the same for four consecutive years, and shall give satisfactory proof of settlement and cultivation. within 12 months after the surveys bave been made, one half-section or 320 acres of land, if a single man, and if married, or if he shall be married within one year from Dec. 1 , 1S50, one section or 640 acres, one half to himself and the other half to his wife, to be held by her in her own right; and the surveyor-general shall dosignate the part enuring to the husband and that to the wife, and enter the same on the records of his office, and when married persons become entitled to a grant, and either shall die before the patent issues, the survivor and children shall be entitled to equal portions of the estate, unless it is disposed of by will, under the laws of Oregon. When an alien has declared his intention to become a citizen, and shall die before naturalization, his possessory right shall go to his heirs or devisees. Donations shall embrace the land actually occupied by the settler, shall be in a compact form, and shall be taken as nearly as practicable by legal subdivisions, and shall be elaimed within three months from the completion of the survey. Contracts for the sale of the land before the patent is issued are void. If any settler shall die befure the expiration of said four years, his right shall descend to his heirs in equal parts.

To all white male citizens of the United States, or persons who shall have made a declaration of jntention to become such, above the age of 21 , emigrating to and settling in said Territory between Dec. 1 , 1850, and Dec. 1 , 1853 , and to all white male American citizens, not hereinbefore provided for, becoming 21 years of age in said Territory and settling there between the times last aforesaid, who shall comply with the foregoing provisions, there is granted one-quarter section or 160 acres of land, if a single man; or if married, or if he shall be married within one year from his arrival in said Territory, or within one year after becoming 21 years of age, then one half-section or 320 acres, one half to the husband and the other half to the wife in her own right, to be designated by the Surrejor-General. No person shall ever receive a patent for more than one donation of land in said Territory, in his or her own right.

No claims upon sections 16 and 36 for residence and cultivation of the same, after the survey, shall be valid. Certa in lands are given for the endowment of a university. No mineral lands, nor lands reserved for salines, can be elaim ed under this act.

All persons claiming land under this act, by virtue of settlement and cultivation commenced subsequent to Dec. 1,1850 , must first make oath that the land claimed by them is for their own use and cultivation; that they are not acting as agents for others in making such claims; and that they have made no sale or transfer, or any agreement for any sale or transfer, or by which the said land shall enure to the benefit of any other person, and persons making false or fraudulent oaths or affirmations shall be subject to all the pains and penalties of perjury.

Religious Denominations. - The statistics of the several religious denominations in the State in 1850, according to the census of that year, were as follows:

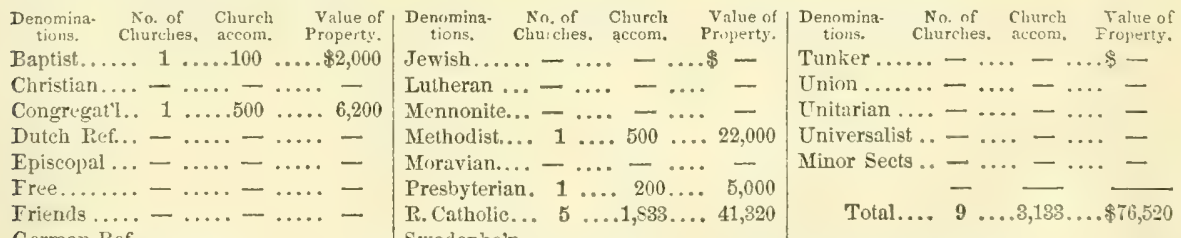

German Ref. - ..... -

Oregon Territory forms a part of the Roman Catholic Ecelesiastical province, of which Oregon City is the metropolitan sce, and comprises the diocese of Oregon City, Wallawalla, Fort Hall, and Colville. The Episcopal Church has not Jet been established in the Territory.

Educational Statistics.-It is not expected that education in so sparsely populated a Territory as Oregon can hare marle much progress. No statisties are yet published on which dependence can be placed, but it is well known that in all the cities there are not only common schools, but respectable academies, and provision has already been male for a college or university. The grant of the 16 th and 36 th section in each township of land for edueational purposes is double the amount allowed to the western and other new States, and in course of time will become an ample fund. 
Oregon, as a field of labor for the furmer, mechanic, and scholar, or the Christian, has become conspicuous, and will continue to attract more and more the attention of the virtuous and industrious who shall emigrate from the Atlantic States. While California, poor in soil and most of the conditions for steady industry, holds out her peculiar attractions to those who, by a temporary sojourn, would make haste to be rich, Oregon offers a home to all who would become permanent members of a community relying upon the pursuits of agriculture and the arts for prosperity. What the first bas been in the eves of men of commerce, the last has come to be in the view of those who cultivate the soil or follow the mechanic arts. These two countries, though adjoining, differ no less widely in their physical capabilities than in the examples they are furnishing of the law of colonization. In the one case wealth precedes educational and religious establishments and the reign of law and order; native gold dug from the earth or gathered from its surface, or separated from the pulverized rock, furnishes the means of support for churches, school-houses, and colleges, long before a community appears that recognizes them as indispensable elements in the machinery of the State. In the other, while wealth is an ticipated as the reward of long-continued effort, and as incidental to the sure and steady growth of a different class of interests, the members of the new community can not dispense with institutions which should accompany the colonizer as their household gods. This mode of settlement is one that commends itself to those who hope well for the ultimate character of those portions of our country yet to be oceupied. It is the only way in which a great State can ever be built up. The deep foundations of prosperity rest upon the labors of a colony actuated by such views of life and effort.

The sovereignty over this Territory was long elaimed both by the United States and Great Britain, and after 1818 was held in joint occupancy, being, however, subject to neither. The coasts of this country were discovered by the Spaniards in the 16th century, but in 1792 the discovery of the Columbia River, by Captain Gray, gave to the United States a claim to sovereignty. The British derived their claim from discovery and occupation. In 1804-5-6 Captains Lewis and Clarke explored the country from the mouth of the Missouri to the mouth of the Columbia, and spent the winter of $1805-6$ on the Pacific. In 180 s the first trading house established on the waters of the Columbia was erected by the Missouri Fur Company on Lewis River. In 1810 the Paciflc Fur Company, at the head of which was the late John Jacob Astor, of New York, was founded, and in the following year Fort Astoria was built at the mouth of the Columbia. This fort was taken during the last war by the English, but peace returning, it was again delivered by the British Government to its original owners. The disputes respecting the sovereignty were renewed in 1845 , and in 1846 a treaty between England and the United States defined the line of 490 as the division between the territories of the two nations. The people of Oregon hitherto had existed under a government of their own, and made their own laws. A bill to establish a territorial government passed the House of Representatives 16th January, 1847, but was not acted on by the Senate. In 1848 a bill passed both houses of Congress, and was approved by the President, 14th August. The government was soon after organized according to the provisions of the new law, and the independent government ceased. The emigration to Oregon is continually increasing in numbers.

SALEM, on the east side of the Willamette River, is the political capital of the State.

OREGON county, 3fo. Situate S., and contains 1,756 sq. m. Drained by Eleven Point and branches of Spring rivers. Surface generally even; soil moderately fertile, and yields average crops of corn, wheat, etc. This is a fine mineral county, containing excellent beds of iron, copper, and lead ores, with others of importance. King's Mount is situate in the $\mathrm{N}$. Much of the land is covered with pine and other timber. Farms 130 ; manuf. 3 ; dwell. 252, and pop.-wh. 1,392, fr. col. 22, sl. 18-total 1,432. Capital: Thomasville. OrEgON, p. o., Jefferson county, Ala. : 84 miles N. W. Montgomery.

Oregon, p. o., Lancaster county, Penn.: 31 m. E. by S. Har risburg.

Ortgon, p. o., Clarke county, Ind.: 87 miles S. by E. Indianapolis.

OrEgon, p. v., and eap. IIolt co., DFo.: $195 \mathrm{~m} . \mathrm{N}$. W. Jefferson City, and near the left bank of the Missouri r. It contains the court-house and several dwellings.

OreGON, p. o., Chautauque co., $N . Y_{.:} 295 \mathrm{~m} . \mathrm{W} . \mathrm{S} . \mathrm{W}$. Albany.

OREgon, p. o., Warren co., Ohio: $71 \mathrm{~m}$. S. W. Columbus. Oregon, sta., Seneca co., Ohio: on the line of the Mad River and Lake Erie R. R., $46 \mathrm{~m}$. Sandusky City.

OrEgor, $t_{\text {. }}$ and p. $v_{0}$, Dane co., Wisc., in the $S_{\text {. part of }}$ the county. Drained by a branch of Sugar r. Surface rolling. The lands are very good, and the soil well adapted to agricultural purposes. Pop. of t. $63 \mathrm{~s}$.

OrEGoN, p. O., Lincoln county, Tenn.: 67 m. S. $\frac{1}{3}$ E. Nashville.

Oregon Citr, p. v., and cap. Ogle co., $M l_{0}$ : on the right bank of Rock r., 159 m. N. $\frac{1}{2}$ E. Springfield. Pop. 540.

Oregor Crty, p. v., and eap. Clackamas co., Oreg. Ter.: on the right bank of the Willamette $r_{0}, 34 \mathrm{~m}$. N. E. Salem and $12 \mathrm{~m}$. above Portland. The falls at this place afford it an immense water-power, which has been improved to some extent. It was formerly the territorial capital, and contains the co. buildings. The "Statesman" and "Spectator" are newspapers published here. The v. has thriving trade, and may be considered as the commercial depot of 634 the upper Willamette country. The office of the U. S. sarveyor-general is stationed here. Pop. 697.

OREGONIA, p. 0., Tuscaloosa en., Ala.: $87 \mathrm{~m}$. W. N. W. Montgomery.

Ore Hris, p. o., Litchfleld co., Conn. : $37 \mathrm{~m}$. W. Hartford. OrFord, to and p. o., Grafton co., N. Hamp. : on the Connecticut $\mathrm{r} ., 51 \mathrm{~m} . \mathrm{N}$. W. Concord. Drained by several small streams flowing into the Connecticut $r$. Soil in general fertile. Near the centre of the t. are situate mounts Cuba and Sunday. At the foot of a high mountain, near the river, limestone is found in abundance-grey granite and a fine quality of soap-stone are found in many places, Galena or lead ore, of fine texture, has been discorered in considerable quantities. There are some flourishing farms along the banks of the river. The $\mathrm{v}$. is connected with Fairlee by a bridge, at which point there is a station on the Connecticut and Passumpsic R. R., $22 \mathrm{~m}$. N. White River Junction, Verm. The t. contains several mills. Pop. of t. 1,406.

OrfordtILle, p. v., Grafton county, N. Bamp.: on the Wentworth post-road, $54 \mathrm{~m}$. N. W. Coneord.

ORIENT, t, and p. O., Aroostook co, Me.: $143 \mathrm{~m} . \mathrm{N}$. E. Augusta. Chapatnetecook, or Grand, and North lake, form its E. boundary. Drained by a stream flowing into North lake. It is a fine agricultural town. Pop, 207.

OrIENT, p. V., Suffolk county, $\boldsymbol{N}_{\text {. }} \boldsymbol{Y}_{*}:$ until recently ealled "Oyster Pond," 193 m. S. E. Albany. Is very pleasantly situated, commanding a view of Long Island Sound on the $N$., and Gardiner's bay on the $\mathrm{S}$. and $\mathrm{E}$.

OrIoN, p. o., Pike co., Ala.: 38 m. S. E. Montgomery.

Orrov, p. v., Henry co., Ill. : 113 m. N. N. W. Springfield. OrIoN, p. o., Richland county, Wisc.: 58 miles W. by N. Madison.

OrIskANY, p. $\nabla_{*}$ Oneida co, $N_{0} Y_{*}:$ on Oriskany cr, and on the Syracuse and Utica R. R. and Erie Canal, $7 \mathrm{~m}$. from Utica, and $89 \mathrm{~m} . \mathrm{N}$. W. Albany. The "Oriskany Manufacturing Company" have large manufactories here, and aro extensively engaged in the manufacture of woolen goods.

OrısKaNy creek, $N$. $Y$.: rises in Madison co., and flowing $\mathrm{N}$. E. enters the Mohawk r. at Oriskany village, Oneida $\mathrm{eO}_{3}$ 
It is a valuable mill stream. On it are situate extensive cotton and woolen factories.

Ortskany Falls, p. ve, Oneida co., $N_{.} Y_{.}: 95 \mathrm{~m}$. W. by N. Albany, on the Oriskany cr. and Chenango Canal, where the fall is from 30 to 35 feet, affording excellent water-power. There are a number of mills at this point.

Orizaba, p. o., Tippah county, Miss.: 167 m. N. by E. Jackson.

Orland, p. v., Steuben county, Ind.: on Fawn r., 141 m. N. E. Indianapolis.

Ortaxd, p. o., Cook co., $n l .: 175$ m. N. E. Springfleld.

OrLAND, t. and p. v., Hancock co., Mle.: on the E. side of Penobscot r., $53 \mathrm{~m}$. E. by N. Augusta. There are a number of ponds in the town, by the outlets of which it is drained. Soil is good. It has fine facilities for trade by water, but none of importance is carried on. Orphan island is directly opposite, and but a short distance from the t. Population of t. 1.580.

OrLean, p. o., Fauquier county, Firg.: $79 \mathrm{~m} . \mathrm{N}$. by W. Richmond.

OrLeans parish, La. Situate S. E., and contains 153 sq. $\mathbf{m}$. It is almost insulated by the adjacent lakes and rivers. On the $\mathrm{N}$. is Lake Pontchartrain and the Rigolets, on the S. E. Lake Borgne, and on the S. the Mississippi $r$ and Bayou Bienvenu, which latier connects the r. with Lake Borgne. Between the Pigolets and Lake Borgne are several swamp islands, on one of which is Fort Pike, commanding the entrance to Lake Pontehartrain. The main-land is also a continuous swamp, but in parts is capable of being used for sugar, rice, cotton, etc., and here also are produced large supplies of garden vegetables and fine delicious fruits, which are so abundant in the New Orleans markets. The production is very small, however, in relation to the extent of the parish; but perhaps no other part of the world receives a greater share of commercial material from tributary districts, New Orleans, its capital, being the depôt of the great Mississippi valley. Farms 51; manuf. 521; dwell 15,621, and pop.-wh. 91,355, fr. col. 10,038, sl. 18,06s-total 109,461. Capital: New Orleans, Public Works: New Orleans, Jackson, and Northern R. R.; Mexican Gulf R. R. ; New Orleans and Carrollton R. R.; New Orleans, Milneburg, and Lake Pontchartrain R. R., etc.

Orleass county, $N$. $Y$. Situate N. W., and contains 372 sq. m. Drained by Johnson's, Oak Orchard, and Sandy creeks, which fall into Lake Ontario. Surface is divided into three distinct terraces, rising successively one above the other, the highest elevation being about 400 feet above the level of the lake; soil fertile, a deep loam, with sand and clay intermixed. It contains some beds of bog-iron ore, and some brine and sulphur springs. Agriculture is the leading pursuit. Farms 2,271; manuf. 232; dwell. 5,273, and pop.-wh. 28,399, fr. col. 102-total 28,501. Capital: Albion. Public Works: Rochester, Lockport, and Niagara Falls R. P. ; Erie Canal.

Orlears county, Verm. Situate N., and contains 641 sq. m. Drained by Black, Barton, and Clyde rivers, which flow into Memphremagog lake in the $N$., and by chief branches of Onion and Nussisque rivers. Surface undulating and diversified with small lakes; soil fertile and easy of cultivation, suited for grain. It has considerable commerce with Canada by way of Lake Memphremagog. Farms 2,055; manuf. 68 ; dwell. 2,780, and pop.-wh. 15,693, fr. col. 14-total 15,707. Capital: Irasburg. Public Works: Atlantic and St. Lawrence $\mathrm{R} . \mathrm{R}_{\text {., and a projected railroad }}$ from this toward Rouse's Point.

OrLeans, p. v., Orange co., Ind.: on the New Albany and Salem R. R., $57 \mathrm{~m}$. from New Albany, and $75 \mathrm{~m}$. S. by W. Indianapolis.

OrLeans, p. 0., Alleghany co, MYd.: 137 m. W. N. W. of Annapolis.

Orlearg, t, and p. v., Barnstable co., Mass.: 68 m. S. E. Boston. It extends across Cape Cod, with Nauset harbor on the X. E, and washed by Pleasant bay on the S. A very pleasant $v$. is situated in the centre of the t., about 20 miles from the court-house. Surface rolling; soil barren. Chief oecupation of inlsabitants, flshing and manufacture of salt. There are several islands in the bay belonging to this town. Pop. of t. 1,848.

Orleans, p. v., Polk county, Mo.: on the E. fork Sac r. $100 \mathrm{~m}$. S. W. Jefferson City.

Orleans, p. o., Ontario county, N. Y.: $173 \mathrm{~m}$. W. by N. Albany.

Orleans Four Coriners, p. o., Jefferson county, $N$. $Y$. : $153 \mathrm{~m} . \mathbf{N} . \mathrm{N}$. W. Albany.

ORME's Store, p. o., Bledsoe county, Tenn.: 91 m. S. E. Nashville.

Orvevilue, t. and p. v., Piscataquis co., Me.: $67 \mathrm{~m} . \mathrm{N}, \mathrm{E}$ Augusta. Drained by the head waters of Pushaw (a branch of Penobscot $r$.), which has its source in a pond in the centre of the t. Surface rolling; soil fertile; adapted to grain. The Bangor post-road passes through the $\mathrm{v}$. Pop. of t. 424 Oro, p. v., and cap. Placer co., Calif.: on E. side of Feather r., 29 m. N. E. Vallejo. Pop, about 3,000 .

Orovo, t. and p. v., Penobseot co., Me : on the right bank of the Penobscot r., $67 \mathrm{~m}$. N. E. Augusta. Drained by two small streams flowing into Pushaw lake on its $\mathrm{N}$. W. border. The soil is well adapted to the production of wheat, which is raised in large quantities. March's island, in the Penobscot $r$., in fact belongs to the town. Extensive trade in lismber is carried on between here and Bangor. The Bangor and Piscataquis R. R. passes through the t., on which is a station called Upper Stillwater, $9 \mathrm{~m}$. from Bangor. The t contains several lumber-yards and workshops, numerous mills, and a number of stores and dwellings. Pop. 2,755.

Oronoco, p. O., Amherst co., Firg.: $79 \mathrm{~m}$. W. Richmond. Orpiray's island, Penobscot county, Mre.: its N. part lies directly opposite the $t_{\text {. }}$ of Bucksport, to which it is attached; it divides the Penobscot r. into two branches; on the W. or main branch, called the "Narrows," is a fort constructed by the United States government. Its $\mathrm{E}$, branch is called East River. The island derived its name from an orphan who inhabited it at one time, it being her part of the Waldo estate. It is $4 \mathrm{~m}$. in length, and contains 5,000 acres of land.

Orrington, t. and p. v., Penobseot co., Mre.: on E. side of Penobscot r., $59 \mathrm{~m}$. N. E. Augusta. A pond and a small stream flowing into the Penobscot $r$., affords good waterpower and fine mill-seats. Soil of good quality, well adapted to wheat, which is raised in large quantities. The facilities for navigation are exeellent. The village is pleasantly situated on the banks of the Penobscot, and is a place of considerable manufacturing industry. Population of town 1,852 .

Orrstown, p. v., Franklin co., Penn.: on a fork of Conedogwinit cr., $40 \mathrm{~m}$. W. S. W. Harrisburg.

Orrsville, p. v., Gwinnett co., Ga.: on E. side of Chattahoochie r., $93 \mathrm{~m}$. N. N. W. Milledgeville.

Orrsvilite, p. v., Armstrong co, Penn.: on E. bank of the Alleghany r., at mouth of Mahoning cr., $141 \mathrm{~m}$.W. N.W. Harrisburg.

Orrville, sta., Wayne co., Ohio: on the line of the Ohio and Pennsylvania R. R., 11 m. E. from Wooster, and $84 \mathrm{~m}$.

N. E. Columbus.

OrrviLle, p. o, Mecklenburg co., N. Car. : 115 m. W. S. W. Raleigh.

OrRyilue, p. o., Dallas co., $A 7 a_{0}: 47 \mathrm{~m}$. W. Montgomery. OrweLL, t. and p. v., Oswego co., $N . Y_{0}: 133 \mathrm{~m}$. W. N.W. Albany. Drained by Salmon r. and its branches. Surface rolling; soil fertile in parts; generally sandy, with good woodlands. The $\mathbf{v}$. is situated in the centre of the town. Pop. of t. 1,106 .

ORWELr, t. and p. v., Ashtabula co, Ohio: 152 m. N. E. Columbus. Drained by Grand $r$, and its branches. Surface elevated and well wooded; soil good. Pop. of t, S25.

Orwell, t. and p. o., Bradford co., Penn. : 109 m. N. $\frac{1}{1}$ E. Harrison. Drained by two creeks flowing into the Susquehanna $r$. Surface uneven, in parts billy; soil fertile. The 
manufactures cunsist principally of woolen goods. Population of t. $1,32 \pi$.

Orwest, t. and p. พ., Rutland co., Term.: on E. side of Lake Champlain, opposite Ticonderoga, $N . Y, 45 \mathrm{~m} . \mathrm{S} . \mathrm{W}$. Montpelier. Drained by a branch of Onion $r$. and a stream flowing into the lake. Surface varied, in parts rugged, the remaining even and very fertile, producing grain in great abundance. The streams afford ex ellent mill privileges. Epsom salts are procured from a spring in the to, near the lake shore. Mount Independence is in the W. part of the t., near the lake-celebrated in the Revolutionary War. First settled in 1783. The vo is situate centrally. Population of $t .1,4 i 0$.

Orwigsizurg, p. b., and eap. Schuylkill county, Penn.: $49 \mathrm{~m}$. N. E. Harrisburg and $3 \mathrm{~m}$. N. of the line of the Philadelphia and Reading $R$. $\mathrm{R}$., on which is a station of same name, $7 \mathrm{~m}$. from Pottsville. The $\mathrm{b}$. contains the courthotse, jail, and other public buildings. The "Skenna des Folks" (dem.), is a weekly issue. Pop. 903.

OsAGE county, No. Situate E. centrally, and contains 855 sq. m. Drained by Gasconade $r$. and other streams of the Missouri, which bounds it on the $N$. Surface hilly; snil fertile. Timber is found on the land. Farms 711; manuf. 9: dwell. 1.082, and pop.-wh. 6,434, fr. col. 0, sl. 270-total 6,704. Capitul: Linu.

OSAGE, p. v., Craw ford co., MLo.: on Osage fork of Maramec r., 67 m. S. E. Jefferson City.

Osage, p. o., Carroll co., Art. : on Osage fork of King $r$. 116 m. N. W. Little Rock.

OsAGE, p. o., Fremont co., Ia. : $223 \mathrm{~m}$. S. W. Iowa City. OSAGE river, MLo. : rises in the Indian Territory, flows into the State of Missouri, and after a wincling enurse through the counties of Bates, St. Clair, Benton, Camden, and Miller, forms the division between Cole and Osage, and enters the Missouri r. at Formosa village, $9 \mathrm{~m}$. E. Jefferson City. It is 375 yards wide at its moutb, and navigable for steamboats $275 \mathrm{~m}$. Length about $400 \mathrm{~m}$. The land along its borders is in general very fertile. It has numerous tributaries which afford extensive hydraulic-power to several counties in its course.

OSAGE Pornt, p. o., Benton co., Ark.: on Prairie creek, $152 \mathrm{~m}$. N. W. Little Rock.

Osixipra, p. o., Chambers countr, Ala.: $67 \mathrm{~m}$. N. by E. Montgomery.

OsBur, p. v. Thek co, Wisc. : $25 \mathrm{~m}$. S. by E. Marlison. Osburx, stan, Greene co.. (1hio: on Marl Liver and Lahe

Erie R. R., $148 \mathrm{~m}$. Sandnsky and $70 \mathrm{~m}$. Cincinnati.

Osburse IJollow, p. o., Broome county, $N . Y: 115 \mathrm{~m}$.

W. by S. Albany.

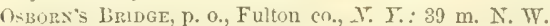
Alhany.

OsBorx's Ford, p. v., Scott county, Firg.: on Clinch r., $175 \mathrm{~m}$. S. W. by S. Richmond.

Osceo, stan, Hillsdale co., Mich. : on the Michigan Southern R. R., $64 \mathrm{~m}$. W. Monroe and $58 \mathrm{~m}$. S. Lansing.

Osceola county, Mich. Situate W. centrally of the South Peninsula, and contains $576 \mathrm{sq} . \mathrm{m}$. Drained by the Maskegon r. and its affluents, and branch of the Manistee r. Surface elevated, but level; soil generally deep and rich mold. Organized since 1850 .

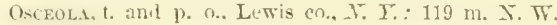
Albany. Drained by Salmon $r$ and its tributaries. Population of t. 4 ?2.

Oscona county, Mich. Situate N. E. of the South Peninsula, and contains $576 \mathrm{sq}$. m. Drained by Au Sable r. which traverse's its central part. Surface level; soil in most parts fertile. Set off since 1850 .

Oselichi, p. o., Chambers county, Ala.: $61 \mathrm{~m} . \mathrm{N}$. E. Montgomery.

Oseut.1, p. Y.. and eap. St, Clair co., Jfo.: on the S. sille of Osage r., $98 \mathrm{~m}$. W. S. W. Jefferson City. The county court-house is situate here. The "Oseola Independent" (whig) is issued weekly. Pop. 600.
Oshaukuta, p. o., Columbia co., Wisc. : $31 \mathrm{~m}$. N. Madison. Osurose, p. v., and eap. Winnebago co, Wisc. : on W. side of Lake Winnebago, and $73 \mathrm{~m}$. N. E. Madison. There are two papers, the Oshkosh Democrat" and "Telegraph," issued here. Pop. about 600.

Osiraloosa, p. v., and cap. Mahaska county, $I a_{0}$ : on the Iowa City posi-road, near a branch of the Des Moines $r$., $61 \mathrm{~m}$. S. W. Iowa City. It contains the county court-house. The "O. Herald" (whig) is issued weekly. Pop. 625.

OSNABURG, t. and p. v., Stark county, Ohio: 104 miles N. E. by E. Columbus. Drained by the tributaries of Sandy river. Surface hilly; soil good, with forest of good oak timber. The $\mathrm{v}$, is a thriving place, and has several stores and mechanic shops. Pop. of t. 2,227.

Ossabaw island and sound, Bryan co, $G a_{\text {s }}$ : at the mouth of Ogeechee $r$. The island is flat and sandy, the sound is an inlet between this island and Warren island. The island is $10 \mathrm{~m}$. long.

Ossawa, p. O., Clinton county, Mich.: $37 \mathrm{~m}$. W. by N. Lansing.

Ossiax, t. and p. v., Alleghany county, N. Y.: $178 \mathrm{~m} . \mathrm{W}$. Albany. Drained by Canaseraga cr. and a few small streams which flow into the Genesee $r$. The Buffalo and New York City R. R. passes through the S. W. part of t. Surface rolling: soil very fertile. There are in the to several mills and dwellings, and places of instruction. The $\mathrm{v}$. is situated on a. tributary of Canaseraga cr. Pop. of t. 1,283.

Osstav, p. v., Wills co., Ind.: on a branch of Bee er., $91 \mathrm{~m} . \mathrm{N}$. E. Indianapolis.

Ossipee, t., p. v., and eap. Carroll co., N. Hamp.: 31 m. N. N. E. Conerril. Drained by Ossipee r., outlet of a lake so called, lying on its N. E. border. There are several small streams and ponds in the t. ; soil fertile. Ossipee Mountain lies in the N. W. part and extends into the adjoining towns, it is 6-or 8 miles in length, and is so elevated that in easterly storms the wind breaking over the summit frequently canses much injury to the farms and buildings at its base. There is a mound near the W. shore of Ossipee lake 45 or 50 feet in diameter and 10 feet high, from which have been taken several entire skeletons, and also tomahawks, etc., giving cause to the supposition, that the tribe of Indians once so powerful in this ricinity had their principal residence here. Incorporated in 1785. The $v$, is on the W. side of Ossipee lake, and contains the court-house and other public buildings, a number of stores, and some mills. Pop. of $\mathrm{t}, 2,123$.

Ossipez mountains, Carroll co., N. Iramp.: a little N. of the N. part of Wimnipisengee lake, extending E. $8 \mathrm{~m}$., to within about $4 \mathrm{~m}$. of Ossipce lake. Ossipee forms in part what is termed the Eastern Range.

OsteNd, p. o., M:Fenry county, Ill.: 169 m. N. N. E. Springfield.

Ostexd, p. O., Washington county, Ohio: 83 m. S. E. Columbus.

Osterville, p. v., Barnstable co., Mass.: opposite Grand island, $54 \mathrm{~m}$. S. E. Boston.

Oswayo, p. o., Potter co., Penn. : 115 m. N.W. Harrisburg. Oswegatchite river, $N . Y$.: rises by two branches in $\mathrm{N}$. part of Herkimer co., pursues a circuitous course of $125 \mathrm{~m}$. through St. Lawrence $c_{0}$, in a N. W. direction, and flows into the St. Lawrence river at Ogidensburg.

OsweGo county, $N, Y$. Situate in the N., to the $\mathrm{E}$. of Lake Ontario, and contains $923 \mathrm{sq}$. m. Drained by Oswego and Salmon rivers, and Salmon, Catfish, Scott, Seriba, and Black creeks, by which good water-power is supplied. Surface in general rolling, but in the N. rising to hills; soil f rtile, producing fine crops of grain. This county contains some minerals, the principal being bog-iron ore. It has some fine ponds or lakes by which the face of the country is diversifled. Farms 4,497; manuf. 640; dwell. 11,06t, and pop.-wh. 61.950, fr. col. 218 - total 62,195. Capitals: Oswego and Pulaski. Pullic Works: Oswego and Syracuse R. R.; Watertown and Rome R. R.; Oswego Canal, etc. OSWEGo, t. and p. v., Kendall co., $\pi l$ : on the left bank of 
Fox r., a constituent of the Illinus r., $143 \mathrm{~m}$. N. E. SpringGith. The Aurora Extension Railroad runs on the opposite side of the r., about $2 \mathrm{~m}$. distint. Pop. 1,599.

OswEGo, p. city, port of entry, and alternately with $\mathrm{Pu}$ laski, cap. Oswego co., $N$. $Y$.: on both sides of Oswego r., at its cntrance into Lake Ontario, 149 m.W. N.W. Albany. The month of the river forms the harbor, which has been math improred by artificial worlis, and it labs falls just atbove which, thush presenting its being navigated, furmi-h immense bydraulic power. Next to Sackett's IIarbor, that of Oswego is the best on the south side of the lake. The harbor improvements consists of piers jutting into the lake, forming a "gut," in which the water has a depth of from 12 to 20 feet. It is connected with the Erie by the Oswego Canal at Syracuse, and with the Central Railroad by the Syracuse and Oswego line. These afford it facile communication with tide-water, and are the channels of an immense commerce coastwise, and from Canada. At present it is the chief American depôt for the trade passing through the Welland Canal, and from Toronto and other British ports on the lake.

The collection district of which Oswego is the port of entry, commences at Stony Point, and extends to the W. shore of Sodus Bay, 80 miles. The shipping places are Texas, Port Ontario, Sandy ereek, Oswego, Litile Sodus, and Sodus Point. The tonnage of vessels enrolled and licensed within the district in 1550 was $22,4 / 4$ tons, of which 4,079 tons were navigated by steam. Nine vessels (500 tons) were built during the year. The clearances in the foreign trade in 1850 were 1,598 ( 251,799 tons), of which 660 were American (182,759 tons), and 938 foreign ( 69,010 tons); and the entrances were 1,657 (195,793 tons), of which 681 were American ( 122,311 tons), and $\mathbf{9} \mathbf{7 6}$ foreign ( $\mathbf{7 3 , 4 8 2}$ tons).

The commerce of the port of Oswege for the year 1843, according to the report of T. D. Andrews to Congress, in December, 1850 , is exhibited in the annexed tables:

\begin{tabular}{|c|c|c|}
\hline $\begin{array}{l}\text { vessels. } \\
\text { Antrican...... } \\
\text { Forrign ....... } \\
\text { Coastwise ..... }\end{array}$ & 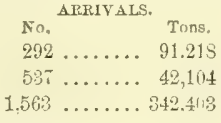 & $\begin{array}{cr} & \\
& \text { Men. } \\
\ldots \ldots \ldots & 4,101 \\
\ldots \ldots \ldots & 2,560 \\
\ldots \ldots \ldots & 16,489\end{array}$ \\
\hline Total ..... & $2,392 \ldots \ldots \ldots 475,925$ & $\ldots 23,150$ \\
\hline $\begin{array}{l}\text { Vesels. } \\
\text { American...... } \\
\text { Foreign ....... } \\
\text { Coustwise ..... }\end{array}$ & 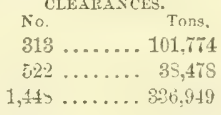 & \begin{tabular}{rr} 
& \multicolumn{1}{c}{ MIen. } \\
$\ldots \ldots \ldots$ & 4,219 \\
$\ldots \ldots \ldots$. & 2,417 \\
$\ldots \ldots \ldots$ & 15.5 .32
\end{tabular} \\
\hline & $\because$ & ... 2: \\
\hline
\end{tabular}

The total value of imports from foreign countries was $\$ 52 \pm, 045$, of which $\$ 105,360$ was the value of merchandise brought in foreign vessels, and $\$ 415,685$ of that brought in American vessels; and the total value of goods exported to foreign countries was $\$ 1.391 .471$, of which 9939.514 was the vaine of foreign, and $\$ 452,927$ of dontestic goods of the foreign goods exported, the value carried in American vessels was $\$ 242,609$, and in foreign ressels, $\$ 95,935$. Among the imports are enumerated the following articles:

Arirles, Paying Duty, Free uf Duty, Wurehorsed. Lumber......26,640,000 feet .. - ... - feet Wheat ...... 95, (1) bush. . - ... 58.708 bush. Flour ....... 19 l.bls. .. - .... 49,252 bbls. Fuol ........ 21.29 Ibs. .. — ... 2,000 lus.

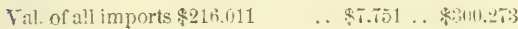

Among the exports of foreign goods, the following are enumerated:

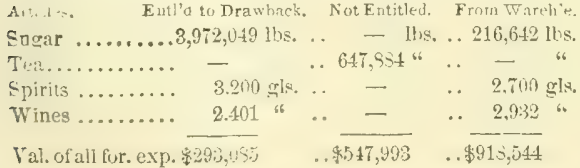

Among the exports of domestic goods are the following: In American Vessels, In Foreign 7 equels. Articles. Salt, bbls...........15,529 . \$17,020..62,141. \& \$66,450 Flour " .........1,172,. $5,860 \ldots 471 \ldots \quad 2,886$ Rice, tierces ........ $55 . . \quad 1,650 \ldots 1,827 \ldots \quad 5,460$ Leather, rolls......... 155... $3,600 \ldots \quad 230 \ldots \quad 4,470$ Merchanclise, pligs.... - . 99.281$). \quad$ - . 1:6.000 Tobaceo, boxes ....... 1,539.. $88.500 \ldots$ 8,499.. 6.797 Tiullow, bbls......... $846 \ldots \quad 6,230 \ldots \quad-\ldots \quad 6,515$

Groceries ......... - . $19.210 \ldots \quad-\ldots \quad 45 .(100)$ Cotton \& wool manufactures, and boots and shoes

$50,396$.

Total (including sundries) . ... \$252,650 . . .\$\$52,927

The following is an abstract from the canal offlce-books of property landed at Oswego, in the year 1848, with the estimated value and its original destination:

Articles. Western States. Canada. New Yr,rk.

Forest Products.... $\$-\ldots . \$-\ldots . \$ 16.753$ Animal " $\quad \ldots \ldots \ldots \quad 737 \ldots 20,510 \ldots . \quad 27,343$ Vegetable Food .... $\quad 99 \ldots . \quad 48 \ldots . \quad 854,059$ Manufactures...... $476,374 \ldots . \quad 100,114 \ldots . \quad 182,029$ Merchandise ..... 3,796,892 ... 2,126,037 ... 3,754,469 Other articles ..... $15,473 \ldots . \quad 8,969 \ldots \quad 59,272$

Total $\ldots \$ 4,289,575 \ldots \$ 2,255,678 \ldots \$ 4,313,914$

The ahove are the latest uniform series of statistics on the conmerce of the port accessible. Had we the returns for 1852 complete, they would show at least 100 per cent, increase in its amount and value-a fuct indicatcd by isolated returns on different articles. The canal tolls, for instance, which in 1845 were only $\$ 71,564$, had risen in 1852 to $\$ 104,366$, in spite of great reduction in the rates; and the following table exhibits a few leading articles carried on the canal in 1851:

From Oswego. To Oswego.

Flour ...... 898,181 bbls. $\quad$ R. R. iron... 98.351,007 lbs. Wheat ..... 1,676,212 bush. Iron ...... 6, 6, 32.567 * Corn ....... 1,192,217 "6 Nails \& Spks. 3,698,267 "6 Barley...... 179,971 "6 Steel....... 490,352 " Pork...... 23,5t5 buls. Merchandise, 25,517,535 "6 Beef........ 15,854 " Sugar...... 14,214,821 " Sawed lmbr. $82,925,6 \pi 6$ feet. $\mid$ silt. . . . . . 131,904,616 68

The tonnage of all properly reaching Oswego in 1550, was 129,252 tons, and in 1851, 180,715 tons-incrense in one year, 51,463 tons.

A few of the leading articles from Canada in 1949 and 1550 , comparatively show the rapid increase of business in that direction:

Articles

Flour, barrels.

Wheat, bushels .......... $632,930 \ldots . .1,091,414$

Oats, bushels............ $55,700 \ldots . \quad 90,156$

Potatoes, bushels.......... $6,648 \ldots .610,372$

Lumber, feet. . . . . . . . . . . 44,187,287 . . . 50,685,682

Butter, lbs............ 115,759 ... 285,057

Peas and beans, bushels.... $16,32 . \ldots . \quad 2.350$

The annexed table copied from the books of the customhouse, exhibits the total value of foreign and domestic imports and exports for six years:

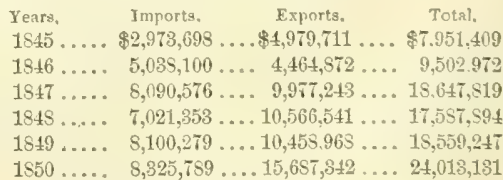

A large proportion of the commerce of Lake Ontario and Oswego comes from Lake Erie throngh the Welland Canal, the incrense of business on which, from 1550 to 1551, was 
nearly 40 per cent. The same increase is also apparent in the subsequent year, 1852. The revenue from the canal (36 miles long), for 1851 , amounted to $\$ 200,000$. Many articles, the product of the Mississippi valley, are also preferring the lake to the southern route, and of course seeking the port nearest to the point of destination. Oswego as such port has many advantages, but will perhaps have a competitor when the Sodus Canal and railroad are completed. That the rapid progress of Oswego, however, is not temporary, is too apparent to allow of a doubt. The past is but a prelude to the future, which will pour upon Oswego an amount of commerce unprecedented and astonishing. When the proposed system of railroads in Canada is completed, the commerce of Lake Ontario will become even greater than that of Lake Erie as being nearer to tide-water, and more accessible at a less cost from the sea-board cilies.

As before remarked, Oswego is built on both sides of the river. The two parts are united by a bridge 700 feet long, and the ground rising on both sides from the river, affords excellent drainage, and many beautiful sites for building. The place is laid out with streets running at right angles, and public squares on which are the principal buildings. The streets are 100 feet wide. Many of the residences are costly and handsome structures; the court-house is located on the east side of the river, and on an elevation to the west of the river are the Presbyterian and Episcopal churches, two of the best edifices of the place. There are also Baptist, Methodist, Roman Catholic, and other churches. Other buildings of much architectural beauty are found in various directious, and much taste is everywhere developed in both the public and private edifices.

Oswego has great advantages as a manufacturing city. The water-power afforded by the river and canal is immense, and is used in a variety of manufactures, but chiefly by several extensive flouring-mills. On both sides of the river large manufacturing establishments are located, among which is a large starch manufactory, which supplies an extensive market with that article. The water-power of the place has been greatly improved by the construction of a leader dam $7 \frac{1}{2}$ feet high, about a mile above.

In the place there are a number of commission houses in the foreign trade; numerous warehouses and retail stores, several fine hotels, an extensive railroad depôt, the canal warehouses, a custom-house, three banks, several insurance offices, printing-offices, lumber yards, etc.

The periodicals printed here are-the "Commercial Times" (whig), daily and weekly; the "Daily News;" the "O. Paladiam" (dem.), weekly; and the "People's Journal," weekly. Besides the common schools, which are numerous, there are also located here an incorporated academy, and a first-rate female seminary, both in a very flourishing condition. There are also numerous private schools.

The city is defended by Fort Oswego, a strong fortification built on the site of the old fort of the same name, celebrated in the French and colonial wars. It is built on the E. side of the river, near the lake, on a tract of land ceded to the Tnited States for such purpose. It commands the harbor, and is a sufficient defense against an enemy.

Daily lines of steamboats, for the conveyance of passengers, run between this port and the lake ports of the United States, and Canada generally.

0.wego wats incorporated in 15.9. In 1830, it had 2,703 inholvitauts $;$ in $1540,4.605$, and in $15,50,12.215$ - the increase between 1530 and 1840 was 72.53 per cent., and in the last decade the increase was 161.62 per cent.

OswEGo, t., Oswego co., N. Y.: $148 \mathrm{~m}$. W. N. W. Albany. It occupies a triangle of land formed on two sides by the Oswego r. and Lake Ontario. Near its N. point is located the port of Oswego. The town is drained by several small streams flowing into the lake. Surface generally level, but varied; soil sandy loam of good quality, and very fertile. The interests of this town are much the same as those of the city. Manufactures are numerous and extensive, and along the river are several flour and saw mills. Pop, 2,445.

OsweGo, p. v., Kosciusko co., Ind. $\therefore$ on the S. W. bank of Lake Tippecanoe, $69 \mathrm{~m}$. N. by E. Indianapolis.

Oswego river, $N$. $Y$.: formed by the junction of Seneea and Oncida rivers. The Seneca is the common outlet of Seneca, Cayuga, Crooked, Canandagua, Owasco, Skaneateles, and Cross lakes. The Oneida is the outlet of Oneida lake. After the junction, Oswego river pursues a N. W. course 24 miles until it enters Lake Ontario. For some distance it forms the Oswego Canal, the falls being overcome by a suceession of locks, and along its banks is a tow-path. The water-power afforded by this river is immense, and has been greatly improved. Manufacturing establishınents line its banks below the falls, and the manufacturing establishments, mills, ete., of Oswego derive their motive power from this source. The harbor at its mouth is commodious, but will require considerable enlargement to accommodate its future commerce. It is made by extending piers into the lake on each side, thus forming an open canal, in which vessels of all the capacities sailing on the lake may enter and moor in safety. The falls prevent navigation above the port.

Oswego Falis, p. O., Oswego co., N. Y.: at the falls of Oswego r., 147 m. W. N. W. Albany.

Oswego Vinhage, p. o., Duchess co, N. $Y_{0}: 47 \mathrm{~m} . \mathrm{S}$. Albany.

Oswrснe, p. o., Russell county, Ala.: $71 \mathrm{~m}$. E. by S. Montgomery.

OTEGo, t. and p. $\mathrm{v}_{\text {., Otsego }} \mathrm{co}_{4}, N_{0} Y_{.:}: 63 \mathrm{~m} . \mathrm{W}$. by $\mathrm{S}$. Albany, and $24 \mathrm{~m}$. S. W. Cooperstown. Drained by the Susquehanna r. and tributary. Surface uneven, except upon the banks of the Susquehanna, where it becomes quite level; soil fertile. The $\mathrm{v}$. is pleasantly situated on the Otsdawa cr. in the S. part of t. There are in the $t$. several stores and mills, and a few manufactriries. Pop. of t. 1,792.

Oris, t. and p. v., Berkshire co,, Mrass.: $107 \mathrm{~m}$. W. by $\mathrm{S}$. Boston. This t. was once comprised of the t. of Loudon and district of Bethlehem, but was incorporated under its present name in 1810 (after the Hon. Harrison Gray Otis, of Boston, then Speaker in the House of Representatives). Drained by a number of ponds, which, with a small strean, forms the source of Farmington r. Surface very uneven; soil fertile and productive. There are fine forests of hard wood, and also granite in the t. The manufactures consist chiefly of leather, boots, shoes, cabinet-ware, and lumber. The $\mathrm{v}$. is in the S. of t. Pop. of $\mathrm{t} .1,224$.

Otrsco, t. and p. o., Ionia co., MFich.: $39 \mathrm{~m}$. N.W. Lansing. Drained by Flat ro, which divides it, affording good waterpower. Pop. of t. 1,018.

OTisco, t. and p. v., Onondaga co., $N_{0} Y_{0}: 97$ m.W. by $N_{\text {. }}$ Albany. Otisco lake forms its W. boundary, by the outlet of which the t. is drained. Surface rolling; soil good, and in fine state of cultivation. The $\mathrm{r}$, is on the $\mathbf{E}$. side of the Iake, and contains 2 churches and a number of dwellings. There are in the $t$. several stores, workshops, and a number of mills. Pop. 1,804.

Otrsco lake, Onondaga county, $N . Y_{0}:$ in the towns of Spafford and Otis, is $5 \mathrm{~m}$. long and $2 \mathrm{~m}$. wide; its outlet flows $\mathrm{N}$. into Onondaga lake.

OTISFIELD, t. and p. v., Cumberland county, Me. : $42 \mathrm{~m}$. W. S. W. Augusta. Drained by Crooked r. flowing into Sebago pond. There is a large pond on the $\mathrm{E}$. border of $\mathrm{t}$. Soll is of good quality, producing wheat plentifully. The $\mathrm{v}$. is situate centrally, and on the post-road. Pop. of t. 1,171. Otusville, p. O., Orange co., $N$. $Y .:$ on the line of the Erie R. R., 72 m. S. by W. Albany.

OTSDAWA, p. V., Otsego county, $N$. $Y$.: on a small cr., a tributary of the Susquehanna r., $76 \mathrm{~m}$. W. by S. Albany.

OTsego county, Afich. Situate $\mathbf{N}$. of the $\mathbf{S}$. Peninsula, and contains 576 sq. m. Drained by Sheboygan river and branch of the Au Sable river. Surface level, and diversiffed with small lakes. Set off since 1850 .

OTSEGO county, $N . Y_{\text {. }}$ Situate E. centrally, and contains 
892 sq. m. Drained by Susquehanna r., Butternut, Otego, Otsdawa, and Cherry Valley creeks, all wbich are tributaries of Susquehanna r. Surface elevated; in some parts it is mountainous, and in others diversified with low hills and valleys; soil though various, in most parts is fertile. A large quantity of lumber is exported. It contains some minerals and good marble quarries, also sulphur springs, which are remarkable for their medieinal qualities. In Burlington, considerable quantities of stone, consisting principally of marine petrifactions, are found. Farms 4,761; manuf. 330 ; dwell, 9,087 , and pop.-wh. 48,481, fr. col. 157 -total 48,638. Capital: Cooperstown.

OTsEgo, p. V., Lake co., Ill. : 5 m. W. from Lake Michigan, $204 \mathrm{~m}$. N. N. E. Springfield.

OTSEgo, to and p. v., Columbia co, Wisc. : $24 \mathrm{~m}$. N. by E. Madison. Drained by Rock cr. Surface level; soil fertile. The $\mathrm{v}$. is on Rock cr., in the centre of t. Pop. of t. 420.

OTSEgo, to and p. v., Allegan co., Mich. : 91 m. W. S. W. Lansing. Drained by the Kalamazoo r. and a number of small creeks. Surface undulating-in some parts hilly; soil varied, but along the banks of the Kalamazoo, black alluvion; it has fine wood-lands. The $\mathrm{r}$. is pleasantly situated on the Kalamazoo river, at an elevation of 30 feet. Popnlation of t. 818

Otsego, p. o., Muskingum county, Ohio: 55 miles E. Columbus.

Otsego, t., Otsego co., $. . Y . Y .: 62 \mathrm{~m}$. W. Albany. It lies between Otsego and Canaderaga lakes, the outlet of the latter, Oak cr., affording good water-power. Surface somewhat hilly; soil clay and gravelly sand and loam. It has considerable manufactures and numerous mills. Pop. in $1840,1,421$, and $1850,1,792$.

OTSEGO, p. O., Ray county, MO. : 113 m. W. N. W. Jefferson City.

Otsago lake, Otsego county, $N . Y_{0}:$ in the towns of Springfield, Middlefield, and Otsego, is $9 \mathrm{~m}$. in length and 2 in width, and has for its outlet the source of the Susquehanna $r$. This lake is remarkable for the beauty of its scenery. At its outlet is the flourishing village of Cooperstown.

OtSelxc, t. and p. v., Chenango co., N. Y.: $104 \mathrm{~m}$. W. Albany. Drained by the Otselic $r$., which passes through it. Surface uneven and much broken; soil clay loam. There is some very fine wood-land here. The $\mathrm{v}$. is situate in the $\mathrm{N}$. of the t., at which there is a p. o. The t. contains several mills. Pop. of t. 1,800 .

Otsentc river, $N . Y$. : rises in Eaton, Madison co., flows in a S. S.W. direction through N.W. part of Chenango and S. E. part of Cortland co., and enters the Tioughnioga r. in Broome county.

OTTA QUEecher river, Verm, : rises in Sherburne, Rutland co., flows S. E. through Bridgewater, N. E. through Woodstock into the S. part of Hartford, thence S. E. through the N. E. part of Hartland, and empties into the Connecticut, $2 \mathrm{~m}$. above Queechee Falls, and $3 \mathrm{~m}$. below the v. so called. In its course it receives a number of considerable mill streams and several other tributaries. It is $35 \mathrm{~m}$, in length, and waters over 200 sq. m. Also called Water Queechee and Queechee river.

Ortawa county, Mich. Situate W. of the S. Peninsula, and contains 828 sq. m. Drained by Grand $r$ and its tributaries, Black and Maskegon rivers. Surface rolling, and presenting to the lake shore high sand-bluffs. Soil generally fertile, producing wheat, Indian corn, and potatoes. Farms 278; manuf. 36 ; dwell. 1,129, and pop.-wh. 5,582, fi. col. 55-total 5,587. Capital: Grand Haven.

OTTAWA county, Ohio. Situate N., and bounded on the N. E. by Lake Erie, the eastern portion stretching considerably into the lake, and forming Sandusky bay. It contains about $320 \mathrm{sq} . \mathrm{m}$. Drained by Portage and Toussaint rivers. Surface level, and in many parts very low ; soil in general fertile. Pine timber is found on the land. Sandusky bay forms its S. E. boundary. Farms 227; manuf. 11; dwell 613, and pop.-wh. 3,307, fr. col.1-total 3,308. Cap- ital: Port Clinton, Putlic Works: Cleveland, Norwalk, and Toledo $\mathrm{R} . \mathrm{R}$.; Junction $\mathrm{R} . \mathrm{R}$, etc.

OtraWA, p. v., and cap. La Salle co., $M$.: at the junction of Fox r.,with the Illinois (which divides it into three parts), $119 \mathrm{~m}$. N. N. E. Springfield. It is laid off on both sides of the Illinois $\mathrm{r}$, and is accessible by steamboats at high water, for which there is a very good landing. Below for the distance of 8 or $9 \mathrm{~m}$, are rapids and shoals formed by barriers of sand and limestone rock. The Illinnis and Michigan Canal passes through the village $85 \mathrm{~m}$, from Chicago, and $15 \mathrm{~m}$. Pera, thereby opening communication by water to the lake and the Mississippi $r$. The Chicago and Pock Island R. R. passes through the village $63 \mathrm{~m}$. from Chicago. Founded in 1830, and contains the court-house and other buildings. It is one of the most important sites for commercial business in the State. The water-power derived from the canal and river is immense. The Ottawa $\mathrm{Hy}$ draulic Company have a valuable water-power on the Illinois r., one-fourth of a mile above Ottawa. The surface of the country around is undulating, and well adapted to farming, with some groves of timber; soil rich. Lime and coarse freestone in great abundance. The "Constitutionalist" (whig), and "0. Free Trader" (dem.), are published weekly. OTTAWA, p. o., Ottawa county, Ohio: $121 \mathrm{~m} . \mathrm{N}$. by W. Columbus.

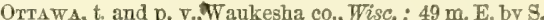
Madison. Drained by forks of Rock $r$, on the N. and $\mathrm{S}$. Surface rolling; soil good. There are a number of small ponds in the t. Like the rest of the co., this t. has excellent timber.

Ottawa Lake, p. o., Monroe co., Mich. : near Ottawa r. 98 m. S. E. Lansing.

OTTER creek, Verm.: rises in Peru t., Bennington co., and flows in a N. by W. direction, through Putland and Addison, and enters Lake Champlain at Ferrisburg. It is navigable for lake vessels as far up as Vergennes, dist. 6 m., and for boats from Middlebury to Pittsford, $25 \mathrm{~m}$. The falls at Middlebury, Weybridge, and Vergennes, afford extensive water-power. Large-sized vessels have been built at Vergennes, and the flotilla of Commodore M.Donough fitted out there in 1814

OTTER BRIDGe, p. o., Bedford co., Firg. : on a branch of Staunton r., $103 \mathrm{~m}$. W. by S. Richmond. The Virginia and Tennessee R. R. passes near this location.

OTTER Creek, p. o., Jersey co., Ill.; on a fork of creek by same nabae, $63 \mathrm{~m}$. S. W. Springfield.

Otrer Creiek, p. o., Addison co., Verm.: on a cr. of same name, $37 \mathrm{~m}$. W. by $\mathrm{S}$. Montpelier.

OtTER CRzeK, p. o., Jackson co., Mich.: $29 \mathrm{~m}$. S. by E. Lansing.

Otter Dale, p. o., Chesterfield county, Firg.: 18 m. S. Richmond.

Otter, Peaks of, Firg.: a portion of the Blue Ridge (Alleghany Mountwins), situated between Bedford and Botetourt counties, $116 \mathrm{~m}$. W. Richmond. These peaks shoot up in projecting summits to the height of 4,260 feet, and are the highest land in the State.

Otter Village, p. v., Ripley county, Ind.: $61 \mathrm{~m} . \mathrm{S} . \mathrm{E}$ Indianapolis

OtTerville, p. v., Cooper co., Mo.: on the W. side of the river á la Mine, and $50 \mathrm{~m}$. W. by N. Jefferson City;

Oтто, t. and p. v., Cattaraugus co., $N . Y_{\text {. }}: 265 \mathrm{~m}$. W. by S. Albany. Drained by Cattaraugus cr, and branches. The cr. bounds it on the N., and the N. Y. and Erie R. R. crosses its S. W. part. Surface hilly; soil adapted to grain. Lumber and grain are the chief products. The $\mathrm{v}$, is in the S. W. part of the t. Pop. of t. 2,267 .

Orro, p. $\mathrm{v}$., Fulton $c 0_{\text {, }}, I l l_{0}$ : on S. side of Otter cr., $45 \mathrm{~m}$. N. W. Springfield.

Оттовгхе, p. 0., Rockingham co., Virg.: 101 m. N. W. Richmond.

Ottsville, p. v., Bucks county, Penn.: 90 m. E. by N Harrisburg. 
Omrrwy s, p. v., and cap. Wapello co., $I l l_{.}:$on the Des Moines r.. centrally in co., $68 \mathrm{~m}$. S. W. Iowa City. It contains the county court-house, and several dwellings.

Orachita Cirt, p. v., Union par., La.: 159 m. N. W. Baton Rouge. A United States land office is situate here. The "Ouachita Gazette" (dem.) is issued weekly.

Otreant, p. o., Delaware co, $N, Y_{8}: 64$ m. S. W. Albany. Ourys, p. o., Iramilton co., Ohio: $97 \mathrm{~m}$. S. W. Columbus. Oetagame county, Wise. Situate toward the E., and contains $615 \mathrm{sq} . \mathrm{m}$. Wolf river enters it in the W., and passes through it in a northerly direction, by which an its branches it is drained. Surface varied, in most parts being hilly and broken, but there is much level land; soi fertile. Pine and other timber abounds, and there is fine pasturage for cattle. Erected since 1850.

Outlet, p. O., Lake co., Ind. : on Cedar cr., 119 m. N. W. Indianapolis.

Overalls, p. o. Warren co., Fi’g.: $103 \mathrm{~m}$. N. by W.

Pichmond.

Ovelifeld, p. o., Barbour county, Firg.: $175 \mathrm{~m} . \mathrm{N}$. W.

Richmond.

Overman's FerRy, p. o., Muscatine co., Ia. : 29 m. S. E.

Iowa City.

Ovfrslaugr, $\mathcal{N}$. $\boldsymbol{Y}_{\text {.: }}$ a shoal in the Hudson r., a few miles below Albany, consisting of a succession of bars or flats, through which there were narrow channels, with a small depth of water at low tide. The obstruction has beeu partially removed by the government.

Overton county, Tenn. Situate N., and contains 526 sq. m. Drained by Roaring river in the S. W., and by Obey's river and its branches in the $\mathrm{N}$., and central portions. Surface undulating; soil a fine deep mold, and very fertile, the land on the streams being rich and productive. Staples, cotton, tobacco, and Indian eorn. It has good pasturage for cattle, and some excellent timber land. Farms 929; manuf. 9 ; dwell. 1,673, and pop.-wh. 10,086, fr. col. 60, sl, 1,065total 11,211. Capital: Livingston.

Ovid, p. v., Lee co., $I l l_{*}:$ on a branch of the Illinois $\mathbf{r}_{\text {, }}$ $133 \mathrm{~m}, \mathrm{~N}$. $\frac{3}{8} \mathrm{E}$. Springfield.

OvID, p. 0., Madison co., Ind.: 29 m. N. E. Indianapolis. OvID, t. and p. o., Branch county, Mich.: 63 m. S. S. W. Lansing. Drained by two small creeks. Surface rolling; soil of a dark, rich loam; abounds in fine timber lands and excellent grazing. Pop. of t. 710 .

Ovid, t. and p. v., Seneca co., $N . Y_{\text {. }}: 60 \mathrm{~m}$. W. Albany. Bounded on the E. by Cayuga, and on the W. by Seneca lake. Drained by a number of small streams flowing into the lakes. Surface hilly; soil fertile. The v. is on an eleration, and has a good landing on the lake. The "O. Bee" is a weekly issue. Pop. 2,258.

OvID, p. v., Franklin co., Otio: on the W. side of Big Lick creek, 12 m. N. E. Columbus.

OWASco,t. and p. v., Cayuga co., N. Y.: $144 \mathrm{~m}$. W. by N. Albany. Bounded on the W. by Owasco lake, by which and the cr, it is drained. Surface rolling; soil rich sand and loarn, and well cultivated. The v. is in the S. E. part of t., and contains two churches and several stores and dwellings. There are in the th a number of mills. Pop. 1,254.

Owasco Lake, p, o., Cayuga co., $\mathcal{N}$. $I_{0} .183$ m. W. 18 . Albany.

Ow ssco lake, Cayuga co., $N . Y .: 12 \mathrm{~m}$. in length, and 1 mile wide, running $\mathrm{N}$. and $\mathbf{S .}, 145 \mathrm{~m}$. W. from Albany, in the t. of Owasco, Fleming, Niles, and Scipio. The banks of the lake are very hilly and picturesque. It abounds in fine fish. Its outlet, so called, flows into Seneca river, and affords excellent water-power.

Owasco river, $N . Y .:$ outlet of Owasco lake, flows $N$. into Scneca river, in the $t$, of Metz. It affords extensive waterpower, and has some fine mill-sites already occupied.

Owsscus, p. 0., Fond du Lac co., Wisc.: 63 m. N. E. Midison.

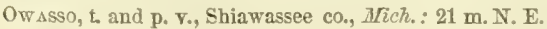

Lansing. Drained by Shiawassee and Maple $r$. Surface 610 generally level; in parts swampy, and well adapted to the raising of cattle. There are fine mill-sites on the Shiawassee and Maple rivers. The $\mathrm{v}$, is situate on the Shiuwassee river. Pop. of t. 392 .

OWEgo, t, p. v., and cap. Tioga co., N. Y.: 182 m. W.S.W. Albany, and $160 \mathrm{~m}$. Dunkirk. The Susquehanna $\mathrm{r}$. divides the $t$, by which and its tributaries it is draincul. Surface various; in parts hilly, while along the river there are extensive flats; soil fertile, and well cultivated. The $\mathrm{v}$. is on the $\mathrm{N}$. bank of the Susquehanna r., at the mouth of Owegro creek; was incorpurated in 1527 , and now contains the court-house, jail, and other public buildings, a bank, several hotels, and an academy. Water-power is derived by means of an hydraulic canal, supplied from Owego ereek, which is an important and never-failing mill stream. The Erie R. R. passes through the $v_{\text {., }}$ and the Cayuga and Susquehanna R. P. extends from here to Cayuga, distant 70 miles. The manufactures consist of wool and wooden-ware. Lumber, plaster, and salt, are the chief commodities of trade. The "O. Advertiser" (whig) and "O. Gazette" (dem.) are issued weekly. Pop. of the t. 7,159 .

OWEGo creek, $N . Y$.: rises in the S. part of Cortlandt and Tompkins counties, and flowing S., affording good water privileges to several villages, empties into the Susquehanna river, at Owego village, Tioga county.

Ow kiv county, Ind. Situate S. W. centrally, and contains 449 sq. m. Drained by branches of Eel river, and W, fork of White river. The falls of the former furnish excellent water privileges. Surface undulating in the larger portion of the county; the land in the E. is hilly, and on the rivers level; soll fertile, being a deep vegetable mold, and is very productive. Timber is abundant on the streams. Coal is found, and there are some fine beds of iron ore. Farms 1,412, manuf. 26 ; dwell. 2,000 , and pop.-wh. 11,950, fr. col, 156-total 12,106. Capital: Spencer.

OWIN county, $\bar{K} y$. Situate N., and contains 289 sq. m. Drained by Eagle and Cedar creeks, and other small streams. Surface level; soil generally fertile, and making fine pasture land. Chief productions, tobacco and Indian cortu, wheat, sugar, etc. Farms 917 ; manuf. 6 ; dwell. 1,628, and pop.-wh.8,900, fr. col. 30, sl. 1,514-total 10,444. Cupital: Owenton. Pullic Works: Vincennes and Indianapolis R. R.; Wabash and Erie Canal.

Owes, p. o., Wabash county, Ind.: $69 \mathrm{~m}$. N. by E。 Indianapolis.

OWEN river, Calif. $:$ rises in the Snowy Mountains, $174 \mathrm{~m}$ E. by S. $\frac{1}{2} \mathrm{~S}$. Vallejo, flows through a mountainous district, E. by S. about $27 \mathrm{~m}$., and $\mathrm{S}$. about $53 \mathrm{~m}$., emptying into a lake so called.

Owensborougr, p. v., and cap. Daviess co., $K y .:$ on the banks of the Ohio r., $9 \mathrm{~m}$. below Rockport, and $123 \mathrm{~m}$. W. S. W. Frankfort. Situate in a very fertile regiom, abounding in mineral resources. It contains the courthouse, several churches, an academy, and a number of stores and dwellings. The "American," a weekly (Indep.) is published here. Pop. 1,214.

Owessburg, p. 0., Green county, Ind.: 59 miles S. W. Indianapolis.

Owexsville, p. v., Saline county, $A r k .:$ on middle fork Saline r., 28 m. W. S. W. Little Rock.

OWensville, p. V., Gibson co., Ind.: near Polk's mill stream, $125 \mathrm{~m}$. S. W. Indianapolis.

OWexsulle, p. V., Clermont county, Ohio: $75 \mathrm{~m}$. S. W. Columbus.

OWexton, p. v., and cap. Owen co., $K y .:$ situate in $\mathrm{S}$. W. part of $\mathrm{co}_{.}, 19 \mathrm{~m}$. N. Frankfort, and contains the court-house and several dwellings.

OWEYrule, p. O., Sampson co., N. Car, : 49 m. E. S. E. Raleigh.

OWIrG'S LAsE. station, Baltimore co., Ifd.: on the TFestminster Branch of Baltimore and Susquehanna I. R., 13 m. from Baltimore.

OWuxg's Mirus, p. v. and sta., Raltimore co., MLd.; on line 
of the Westminster Branch of Baltimre and Susquehanna R. R., $17 \mathrm{~m}$. N. Baltimore, $41 \mathrm{~m}$. N. Annapolis.

Otrugasville, p. v., and eap. Bath co., Ky.: 3 m. N. Slate er., in centre of co., and $61 \mathrm{~m}$. E. Frankfort. It contains the court-house, etc., and 265 inhabitants.

Owl Pratrie, p. v., Daviess co., Ind.: on the W. side of Wavash and Erie Canal, and near the W. fork of White $r$, $75 \mathrm{~m}$. S. W. Indianapolis.

OWSLEX county, $K y$. Situate E. centrally, and contains $3 s 9$ sq. m. Drained by Kentucky river and its branches, South fork, and Sturgeon creek. Surfuce even; soil a fine deep loam, very fertile, and well adapted to grain. Chief productions, wheat, Indian corn, and tobacco. Farms 481; manuf. 25 ; dwell. 588, and pop. wh. $-3,616$, fr. col. 22, sl, 136-total 8,774. Capital: Booneville.

Otw yee river, Oreg. Ter.: tributary of Lewis, a fork of Columbia r., rises in Weber co., Utah Ter., makes a circuitous course W. and N. W. into Oregon, flowing $\mathrm{N}$. and N, E. enters Lewis r. 15 m. S. Fort Boisse.

OxBow, p. o., Wyoming co., Penn. : 95 m. N. N. E. Harrisburg.

Oxвоw, p. $\nabla_{n}$, Jefferson co., $N_{.} Y_{.}:$on the Oswegatchie river, $117 \mathrm{~m}$. N. by W. Albany, and $31 \mathrm{~m}$. N. E. Sackett's Пlarbor.

Oxвow, p. o., Putnam county, Ill.: 101 m. N. by E. Springfield.

OxFord county, Mre. Situate W. toward the S., and contains 1,\$76 sq. m. Drained by Androscogoin river and its branches, and by Saco river. Surface in general broken and hilly, and is pleasantly diversified with numerous lakes; soil in many parts is very fertile. Chief productions, wheat, Indian corn, and potatoes. It has some good timber land. Farms 4,258; manuf. 150 ; dwell. 6,712, and pop.-wh. 39,65ัs, fr. col. 5-total 39,663. Capital: Paris.

OxFori, p. y., Talbot co., MIL.: on an inlet of Chesapeake bay, $27 \mathrm{~m}$. S. E. Annapolis.

OxFord. t. and p. v., New Haven en., Conn. : $32 \mathrm{~m}$. S. W. Hartfurd. Drained by Ilousatonic and Naugatuck rivers and branches, affording extensive water-power and fine mill-seats. Surface generally uneven, in parts hilly, with a fertile and productive soil. Among the manufacturing establishments, those of satinet and hat are the most important. In the $\mathrm{S}$. part there is a mineral spring called "The Pool," much used in the cure of salt rheum and other complaints. The $\mathrm{v}$, is on the line of the Norwich and Worester R. R., $11 \mathrm{~m}$. Worcester. It contains 2 churches and several dwellings. Pop. of t, 1,562.

OXFord, p. v., Newton eo,, Ga.: $55 \mathrm{~m}$. N. W. Milledgeville. The Emory College (founded in 1S37) is situate here, having (in 1850) a president, 5 professors, and 138 alumni, of whom 16 are in the ministry, and 115 students. The library contains 1,700 volumes. Pop. about 600 .

OxFord, p. v., Henry co., $\boldsymbol{I l l}$.: on the Monmouth and Prophetstown post-rnad, $105 \mathrm{~m}$. N. by W. Springfleld.

OXFord, p. O., Benton eo., Ind.: situate $3 \frac{1}{2} \mathrm{~m}$. dist. Big

Pine creek, $75 \mathrm{~m} . \mathrm{N}$. W. Indianapolis.

OXFORD, p. O, Scott co., $K_{y}:$ : 15 m. N. E. Frankfort.

OxFORD, t., p. V., and sta., Oxford county, MYe.: 33 miles W. S. W. Augusta. Drained by Little Androseoggin r. and a number of ponds. The soil is fertile, producing excellent grain. There are several mills on the banks of the river. The $\mathrm{v}$. is in S. part of $\mathrm{t}$. The Atlantic and St. Lawrence R. Ti. passes through it, on which is the sta., $40 \mathrm{~m}$. from Portland. Pop. of t. 1,233.

OXFord, p. o., Grafton co., N. Hamp.: $45 \mathrm{~m}$. N. by W. Concrerd.

OXFoRd, t. and p. T., Worcester co., Mass, : $47 \mathrm{~m} . \mathrm{S} . \mathrm{W}$. Boston, and $10 \mathrm{~m}$. S. Worcester. Important for its manufactures, consisting chiefly of woolen and cotton goods, boofs and shoes. It is a very pleasant $t$, well watered by French river, a branch of the Quinebaug. Surfice rugged; soil gravelly. There are in the town several stores, mantfactories, grist and saw mills, and a machine and other me- chanic shops. The village is on a street running $\mathrm{N}$. and $\mathrm{S}$. Pop. of t. 2,380.

OXForD, t. and p. O., Oakland county, Mich: : $68 \mathrm{~m}$. E. Lansing. Watered by Stony and several other smaller lakes and streams. Surfuce hilly, interspersed with marshes ; soil varied, in parts sandy. The $\mathrm{p}_{0} \mathrm{o}$. is in the $\mathrm{N}$. of the town. Pop. of t, 1,019 .

OXFORD, p. v., and eap. Lafayette co., Mfiss.: at the source of a branch of the Yocanapatapha river, $143 \mathrm{~m}$. N. N. E. Jackson. It has a college (the University of Miss.), founded in 18t4, havirg (in 1550) a president, 6 professors, and 134 students, with a library containing 2,450 volumes. Contains the court-house, and usual number of public buildings. There are two newspapers pullished here, the "Organizer" (S. R.), and the "Star of the Union" (union), both weekly issues. The High Court of Errors sits here once every year. Pop. about 1,600 .

OXFoRd, t. and p. v., Chenango co, $N . Y .: 97 \mathrm{~m}$. W. by S. Albany. Surface rolling; soil very fertile, and well cultivated. The Chenango $r$ and canal pass through it. There is a factory and several mills in the town. The $\mathrm{v}$. is on the Chenango r., which divides it. It has a foundry, tannery, and several carriage manufactories. The canal passes through the $\mathrm{v}_{\text {., }}$ which affords easy communication with the eity of Utica. Oxford abounds in rich grazing land, fine hores and cattle. The "C. County Whig," and "Free Democrat," are published here, Pop. of village 1,350-of town 3,227 .

Oxford, sta., Orange co., $N . Y_{\text {. }}$; on the Erie $\mathrm{R}_{\text {. }} \mathrm{R}_{\text {., }}, 62 \mathrm{~m}$. New York, $87 \mathrm{~m}$. S by W. Albany.

OxForD, p. v., and cap, Granville county, N. Car : $39 \mathrm{~m}$. N. Raleigh, and near Fishing ereek. It contains the courthouse, jail, market-house, hospital, and 2 academies, 360 dwellings, and 1,97s inhabitants.

OXFord, t. and p. v., Butler co., Ohio: 96 m. W. S. W Columbus. Drained by affluents of Great Mirmi r. Surface moderately uneven; soil of extraordinary fertility. The village lies on the W. side of Four Mile cr., and near the union of the Four Mile Valley and Junction R. R. from Indiana. The Miami University is situated in the town founded in 1809, and had in 1550 a president, 6 professors, and 343 alumni (of which 102 are in the ministry), 66 students, and a tibrary containing 8,000 volumes. The Theologiéal Seminary commenced in 1834, had (in 1850) instructors, 20 students, and a library of 1,500 volumes. Pop. of v. 1,034, and of t. 2,007.

OxFord, p. o., Benton county, Ala $a_{n}: 97$ miles $\mathrm{N}$. by E. Montgomery.

Osford, p. v., Chester county, Penn.: 57 miles S. E. Harrisburg.

OxFord, p. o., M'Minn county, Tenn.: 113 miles S. E. Nashville.

OxFord Depôt, p. v., Orange co., $N . Y_{.}$: on the line of the New York and Erie R. R., 62 m. N. N. W. New York city, $\$ 7 \mathrm{~m}$. S. by W. Albany.

OXford FurNace, p. v., Warren county, $N$. Jei: . on a branch of Pequest river, $41 \mathrm{~m}, \mathrm{~N}$. W. Trenton. There is a furnace situate in the village, and iron ore of a rich quality is found in abundance in the vieinity, and easily smelted.

Oxford Vallex, p. o., Bucks county, Penn.: 103 m. E. Harrisburg.

OXAUKEe, p. v., and eap. Washington co., Wisc. : on the bank of Lake Miehigan, $83 \mathrm{~m}$. W. by N. Madison. The county court-house is at Washington.

Orster Bay, t. and p. v., Queens co., N. Y.: $125 \mathrm{~m}$. S. Albany, and $23 \mathrm{~m}$. New York city. Extends across Long Island, being washed on the N. by the bay so callet, and on the S. by Great South bay. Surface varied-on the N. quite hilly; soil loam and rocky, on the S. it is very sandy and even. The $\mathbf{v}$. is situate at the head of the bay so called, and is a filvorite resort in the summer season. It contilins several churehes and dwellings. Numerons slons and steambosts ply between here tînd New York eity. There are in the 
town several stores, lumber yards, factories, and mills, and a number of schools and academies. Population of town 6,900 .

Orster bas, $N . Y_{.}$: sets up from Long Island Sound, and is connected with the harbor so called, and Coldspring harbor. It abounds with wild fowl and excellent scale fish. Orster creek, Tex.: rises in Fort Bend co., $8 \mathrm{~m}, \mathrm{~N}$. Richmond, flows S. E. and S., parallel with Brazos r., and empties into the Gulf of Mexico,, $2 \mathrm{~m}$. N. of its mouth.

OTster river, $N$. Hamp.: one of the principal branches of the Piscataqua r., rises in Lee, and flows through Durham t. Upon both sides of the $r$. a deep agilaceous loam prevails, which is favorable to the production of grasses. Abundance of oysters are found in its waters, from which it derives its name. Large quantities of superior granite are found on the borders.

Ozark county, Mo. . Situate $S_{\text {.g }}$ and contains 1,593 sq. m Drained by branches of White r. Surface hilly and broken ; soil generally fertile and adapted to grazing. Farms 253 manuf. 5 ; dwell. 361 , and pop.-wh. 2,279 , fr. col. 0, sl. $15-$ total 2,294. Capital: Rockbridge.

Ozark, p. v., and cap. Franklin co., Ark.: on the N. side of the Arkansas r., $100 \mathrm{~m}$. N. W. Little Rock. It contains the county court-house and 84 inhabitants.

Ozark, p. v., Greene co., Mo. : on S. side of Finley cr., 123 m. S. S. W. Jefferson City.

\section{P.}

Pazlo bay, Calif. See San Pablo bay.

PAce's, p. o., Barren county, Ky.: 108 m. S. W. by S. Frankfort.

PAchitta, p. V., Early county, $G a_{\text {.: }} 143$ m. S. W. Milledgeville.

Pacrac, p. o., Franklin county, N. Car.: $32 \mathrm{~m}$. N. E. Raleigh.

Pactic Crty, p. v., port, and cap. Pacific co., Oreg. Ter, on the $\mathrm{N}$. bank of Columbia r., at its entrance into Pacific ocean, 100 m. N. W. by N. Salem.

PACKARD's, sta., Berkshire county, Mass.: $3 \mathrm{~m}$. N. of Pittsfield, on the Pittsfield and North Adams R. R.

Pack's Freri, p. o., Monroe county, Virg.: $182 \mathrm{~m}$. W. Richmond.

Packsvmue, p. v., Sumter dist., S. Car.: 37 m. E. S. E. Columbia.

Pacoler Mris, p. 0., Union dist, S. Car. : 72 m. N. N. W. Columbia.

Pactolus, p. $\nabla .$, Pitt county, N. Car.: on the N. side of

Tar r., about $12 \mathrm{~m}$. above its mouth, $81 \mathrm{~m}$. E. Raleigh.

PADDLEFoRD's, sta, Ontario co., $N_{.}, Y_{.}: 9 \mathrm{~m}$. W. of Cauandaigua on the Rochester and Syracuse $R$. $R$.

Paddock's Grove, p. V., Madison co., Ill.: about $3 \mathrm{~m}$. W. of Cahobia cr., 64 m. S. S. W. Springfield.

PADDr Mruss, p. o., Shenandoah county, Firg.: 104 m. N. W. Richmond.

Paddr's Run, p. o., Butler co., Ohio: 102 m. W. S. W. Columbus.

PADUCAI, p. ., and cap. M'Cracken co., Ky.: on the Ohio r., just below the mouth of the Tennessee, $214 \mathrm{~m}$. W. S. W. Frankfort. It is the depot for the products of the valley of the Tennessee, and in a great measure commands the trade of that river, which gives it great importance as a shipping port, and has rapidly increased its population. It contains a court-house, jail, 2 banks, about 50 large stores and warehouses, and 2,428 inhabitants. The "P. Journal" (whig), is published weekly.

PAGE county, $I a$. Situate S. W., and contains 576 sq. m. Drained by Elkhorn r., and branches. Surface generally level. Set off since 1550 .

PAge county, Virg. Situate toward the N. E., and contains $185 \mathrm{sq}$. m. Drained by the S. fork of Shenandoah $\mathbf{r}$. Surface hilly and broken; soil generally fertile. Chief produets wheat and Indian corn. On the $\mathrm{E}$. is the Blue 612
Pidge. Farms 526; manuf. 28; dwell. 1,059, and pop.wh. 6,332 , fr. col. 311 , sl. 957-total 7,600. Capital: Luray. Page's Conners, p. v., Herkimer county, $N . Y .: 61 \mathrm{~m}$. W. by $\mathrm{Y}$. Albany.

Pagesville, p. v., Newberry dist., S. Car.: 51 m. N. W. by W. Columbia, The Laurens R. R. passes through it.

Pagevifle, p. v., Barren co., Ky. : 109 m. S. W. by \$.

Frankfort.

Patrcotrtille, p. v., Assumption parish, $L a$ : $84 \mathrm{~m}$. S. by E. Batan Rouge.

Paine's Hollow, p. V., Herkime county, N. Y.: $68 \mathrm{~m}$. W. N. W. Albany.

Patne's Potnt, p. o., Ogle co., $12 l .: 6 \mathrm{~m}$. E. of Rock r. 159 m. N. by E. Springfield.

Pannesville, t., p. v., and cap. Lake co., Ohio: on Lake Erie, $147 \mathrm{~m}$. N. E. by N. Columbus. Drained by Grand r. which affords water-power. Surface level, and soil of average fertility. The $\mathrm{v}$. is on the r., about $3 \mathrm{~m}$. S. of the lake, and contains a court-house, jail, bank, academy, a large furnace and stove manufactory, several flouring and other mills, and about 1,000 inhabitants. It is on the Cleveland and Eric R. R., $29 \mathrm{~m}$. E. of Cleveland, and a branch railroad diverges to Fairport $\nabla$., at the mouth of Grand $r$. 'The "P. Telegraph" (fr. soil) is published weekly. Population of town 3,128 .

Patresville, p. v., Amelia co., Tirg.: on Flat er. of Appomattox r., $29 \mathrm{~m}$. W. S. W. Richmond. - In the vicinity are a cotton faciory and several mills.

Patnestille, p. v., Chittenden co., Term.

Paint Braxch, sta. Prince George co., $M d .: 8 \mathrm{~m}$. E. of Washington, on the Washington Branch R. P.

Panti Creer, p. o., Washtenaw co., Mich.; on a branch of Stoney cr, so ealled, $68 \mathrm{~m}$. S. E. Lansing.

Patri Creer, p. o., Kanawha co., Firg.: on a S. branch of Great Kanawha r., 221 m. W. by N. Richmond.

Panted Post, t., Steuben co., $N . Y_{.}$: on both sides of Chemung r., 165 m. W. by S. Albany. Surface hilly; soil gravelly loam, and highly productive on the streams aud flats. Drained by Chemung $r$. and its creeks. The business is rery extensive, particularly in lumber and coal, and is mainly transacted at the large and flourishing v. of Corning (see ConNING), where three railroads connect, and the narigable feeder of Chemung Canal commences. Population 4,372 .

Panvied Post, p. $\nabla$. and sta., Erwin t., Steuben co., $N . Y_{\text {.: }}$ at junction of Conhocton and Tioga rivers, which here form the Chemung r, $166 \mathrm{~m}$. W. by $\mathrm{S}$. Albany. The Erie R. R. passes through it, $302 \mathrm{~m}$. from New York, and $167 \mathrm{~m}$. from Dunkirk, also the Buffalo, Corning, and New York R. R. Two falls in the $r$. afford great water-power. This $\mathrm{v}$. is a very old settlement, and derives its name from its location near an Indian burying ground, in which a painted post was erected over the grave of a chief. At this spot in the $v$. the inhabitants have placed a high painted post, surmounted by a metal figure of an Indian chief. The village contains several mills and stores, a church, etc. Pop. about 700 .

Patnterstlle, p. v., Greene co., Ohio: 53 m. W. S. W. Columbus.

PanvT Lick, p. 0, Garrard co., $\bar{K} y .:$ on a \$. branch of Kentucky r., so called, 46 m. S. E. Frankfort.

PAnTspille, p. v., and cap. Johnson co., $K y_{.}:$on Big Paint cr, an affluent of the W. fork of Big Sandy r., $118 \mathrm{~m}$. E. by S. Frankfort. It contains a court-house, jail, sereral stores, and 250 inhabitants.

PAKWAUKEE, p. v., Marquette co., Wisc.: on the W. side of Buffalo lake, a large expansion of Neenah river, $49 \mathrm{~m}$ N. by W. Madison.

Patatine, t. and p. ₹., Montgomery co., N.Y.: on the $N$ side of Mohawk r., $49 \mathrm{~m}$. W. N. W. Albany. Drained by Garoga cr. Surface broken; on the river is the hill called Anthony's Nose; soil of great fertility. The Utica and

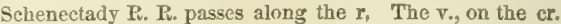
contains several mills and factories. Pop. of t. 2,854. 
Pauarive, p. v., Marion co., Virg.: about $8 \mathrm{~m}$. E. of Monongahela r., $191 \mathrm{~m}$. N. W. Richmond.

Palative, p. v., Cook county, $M l_{\text {. }} 196$ m. N. E. by N. Springfield.

Paratine Bridge, p. V., Montgomery co., $N$. $Y .:$ on the Mohawk, $47 \mathrm{~m}$. W. N. W. Albany. A bridge connects it with Canajoharie, on the S. side of the $\mathrm{r}$. It is on the Utica and Schenectady R. R., $40 \mathrm{~m}$. E. of Utica, and has a quarry of fine building stone.

Palkntulue, p. V., Greene county, N. Y.: 28 m. \$. S. W. Albany.

Palermo, t. and p. V., Waldo co., Me.: 17 m. E. N. E. Augusta. It contains several ponds, the sources of Sheepscot r. Surface undulating; soil very productive. A superior farming and grazing t. Pop. of t. 1,659.

Palerro, t. and p. o., Oswego co., N.Y.: 106 m.W.N.W. Albany. Drained by Catflsh er. Surface undulating; soi! sandy loam. A farming t., with good water-power. Population 2,053 .

PaLestine, p. $\nabla_{\text {., Crawford }}$ co., $\pi u_{0}$ : about $3 \mathrm{~m}$. W. of the Wabash, $122 \mathrm{~m}$. E. S. E. Springfield. It lies on the E. border of the Lamotte prairie, and was formerly the co. seat. It contains a U. S. land office, a dozen stores, and 800 inhabitants. The surrounding country produces heavy crops of corn, and the $\mathrm{v}$. has a large trade in grain and livestoek.

Patestine, p. v., Washington par., La.: 57 m. E. N. E. Baton Rouge.

Palestine, p. v., Koseiusko co., Ind. : on a S. affluent of Tippecanoe r., $96 \mathrm{~m}$. N. by E. Indianapolis.

Palestine, p. 0., Adams county, Miss.: 87 miles $\mathrm{S}$. W. Jackson.

PALESTINE, p. V., Pickaway county, Ohio: 18 m. S. s. W. Cullimbus.

Palrstine, p. V., and cap. Anderson co., Tex.: $162 \mathrm{~m}$. N. E. by E. Austin City. It lies about midway between the Trinity and the Neches, and contains the county buildings, several stores, and 500 inhabitants, "The Wonder" is published weekly.

Palfistive, p. o., Hickman co., Tenn.: 46 m. W. S. W. Nash ville.

Palkstines, p. ₹., Greenbrier co., Firg.: $163 \mathrm{~m}$. W. by N. Richmond.

Patistine, sta, Columbiana co., Ohio: on the Obio and Pennsylvania R. R., $33 \mathrm{~m}$. E. of Aliance.

Patisades, N. J.; this mountainous range extends $20 \mathrm{~m}$. along the W. bank of the Hudson r., commencing near Fort Lee, opposite the extreme upper part of New York, and terminating at Piermont. They are for the most part 300 to 500 feet high, with perpendicular rocky front on the bank of the r., presenting most impressive scenery.

PALL M.ALL, p. O., Fentress co., Tenn.: 97 m. E. by N. Nashville.

PALMer, t. and p. o., Hampden co., Mass.: 66 miles W. by S. Boston. Drained by Chicopee, Ware, and Swift rivers, which furnish abundant water-power. Surface hilly; soil fertile. A good farming town, containing several manufacturing villages. Cotton and woolen goods, canvas, etc., are largely made. The Amherst and Belchertown $\mathrm{R}$. R. and the Western R. R. pass through it. Pop. 3,974.

Palmer Depôt, p. vo and sta., Hampden co., Mass.: on Chicopee river, and the Western R. R., 83 miles (by route) W. by S. Boston. The Amherst and Belchertown R. R., and New London, Willimantic, and Palmer R. R. here connect with the Western R. R., making it an important centre of business and travel. It contains 3 large hotels, and a dozen stores, mostly of brick. Opposite the v. on the S. side of the river, is one of the 3 State Alms-houses, with a farm of 175 acres attached to it. The "Yalmer Journal" (neut.) is published weekly.

PaLsier's, p. o., Polk county, Texo.: 158 miles E. by $\mathrm{N}$. Austin City.

Palmes's Springs, p. 0., Mecklenburg, co., Firg, : on the
S. side of Roanoke river, near the $\$$. line of the State $76 \mathrm{~m}$, S. W. by W. Richmond.

Palmer's Store, p. o., Weakley county, Tenn.: $114 \mathrm{~m}$. W. by N. Nashville.

Palmer's Tavern, p. o., Prince George's co., Md.: on Potomac r., 28 m. W. S. W. Annapolis.

Palmetro, p. O., Pontotoc co., Mis8.: 139 m. N. N. E. Jackson.

Pavetro, p. o. and sta., Coweta co, Ga: on the Ia Grange R. R., 25 miles S. Atlanta, $118 \mathrm{~m}$. W. N. W. Milledgeville.

Patimra, p. v., Lee county, $G a_{0}:$ on a W. branch of Flint river, about $5 \mathrm{~m}$. from its mouth, $119 \mathrm{~m} . \mathrm{S} . \mathrm{W}$. by W. Milledgeville.

Palmyra, p. v., Harrison county, Ind,: 91 miles S. Indianapolis, A plank-road passes through it to New Albany.

Palmyra, t. and p. v., Somerset co, Me.: 43 m. N. N. E Augusta. Drained by Sebasticook $r$, which affords waterpower. Surface rolling; soil very productive of grass and grain, to which attention is mostly directed. Population of $\mathrm{t} .1,625$.

PALmyra, t., p. r., and sta., Lenawee co., Mich.: $72 \mathrm{~m}$. S. S. E. Lansing. Drained by Raisin river and Bear ereek, which supply fine water-power. Surface level or undulat ing; soil sandy loam and deep bottoms, producing all the grains in abundance. The village is on the $\mathrm{r}_{\text {, }}$ and contains several stores and mills. The Michigan Southern R. R., and the Erie and Kalamazoo R. $R_{\text {. cross the }}$., and the station is $4 \mathrm{~m}$. E. of Adrian on the latter. Pop. of t. 1,098.

Palmyra, p. va, and cap. Marion co., Mo:: $8 \mathrm{~m}$. W. of Marion City, its port on the Mississippi, $89 \mathrm{~m}$. N. N. E. Jefferson City. It contains a court-house, jail, academy, bank, U. 8. land office, several handsome churches, 25 stores, 963 inhabitants. The "Missouri Whig" is published weekly. In the vicinity is Masonie College, which was founded in 1831 , and in 1850 had 5 instructors and 75 students. A railroad to connect the $\mathrm{v}$, with the $\mathrm{r}$. has been chartered.

Palmyra, t. and p. v., Wayne co., $N . \bar{Y}: 182 \mathrm{~m}$. W. by $N$. Albany. Drained by Mud er. Surface somewhat uneven; soil ealcareous loam, and very productive of grain. Mormonism had its origin here in 1829. The Buffalo and Syracuse (direct) R. R. passes through it, and the Erie Canal, on which is the v., $29 \mathrm{~m}$. E. of Rochester. It has a large trade in lumber and grain. The chief street, $1 \mathrm{~m}$. long, rests at each end on the canal, and is beautifully shaded. It contains an incorporated academy, a bank, several manufactories of flour, iron castings, mechanics' tools, etc., 40 stores, and 2,200 inhabitants. The' "P. Courier" (whig), and "W. Sentinel" (dem.) are published weekly. Pop. of t. 3,593 .

Palmrra, p. v., Halifax con, N. Car.: on the right bank of Roanoke river, $76 \mathrm{~m} . \mathrm{E} . \mathrm{N}$. E. Raleigh. Here is a good landing, from which large quantities of corn, cotton, and lumber are shipped.

Palmyra, sta., Camden co., N. Jer. : $6 \mathrm{~m}$. N. of Camden, on the Camden and Amboy R. R.

Palurra, t. and p. o., Portage co., Ohio: 124 m. N. E. Columbus. Drained by branches of Mahoning $\mathrm{r}$. Surface rolling; soil fertile. Large dairies are kept. Pop. 1,093.

PAlimyra, p. V., Lebanon co., Penn。: $14 \mathrm{~m}$, E. by $\mathrm{N}$. Harrisburg.

PanmXra, p. v., Montgomery co., Tenn. : on Cumberland river, $44 \mathrm{~m} . \mathrm{W} . \mathrm{N} . \mathrm{W}$. Nashville. It contains several stores and mills, and 300 inhabitants.

Palmyra, p. v., and cap. Fluvanna county, Firg.: on Rivanna r., about $12 \mathrm{~m}$. N. of its entrance into James river, $46 \mathrm{~m} . \mathrm{W} . \mathrm{N}$. W. Richmond. A bridge here spans the river, on which in the vicinity are several flouring-mills and factories. The v. contains the co, buildings, an academy, and about 300 inhabitants.

Pacurra, p. v., Warren co., Miss.: on the Mississippi, 
$49 \mathrm{~m}$. W. by $\mathrm{S}$. Jackson. It is $25 \mathrm{~m}$. by the $\mathrm{r}$. S. of Vicks-

burg, and has a steamboat landing and some trade.

Palmyra, t. and p. o., Jefferson co., Wisc. : $43 \mathrm{~m}$. E. S. E.

Madison. Drained by E. affluents of Rock r., affurding good mill-seats. Surface varied; soil generally very fertile.

The Milwaukie and Mississippi R. R. crosses the t., and the sta. is $42 \mathrm{~m}$. W. from Milwaukie. Pop. 997.

Palmrra, p. o., Simpson county, $\bar{K} y_{\text {.: }} 131$ m. S. W. Frankfort.

PALO, p. o., Linn co., Ia. : on the W. side of Cedar river, $81 \mathrm{~m}$. N. N. W. Iowa City.

PALO, p. o., Fayette co., Ala. : 127 m. N. W. Montgomery

Palo Alto county, $I a_{\text {. }}$ Situate $\mathrm{N}$. toward the $\mathrm{W}$., and contains $576 \mathrm{sq}$. m. Drained by the Moingonan r., a tributary of the Des Moines. Surface undulating and diversified. Set off since 1850 .

Palo Alto, p. v., Jasper co., Ga. : 38 m. N. W. by W. Milledgeville.

Pato Alto, p. o., Highland co., Firg. : 1.27 m. W. N. W. Richmond.

Palo Alto, p. o., Lawrence co., Tenn.: 62 m. S. S. W. Nashville.

Palo Alto, p. v., Louisa co., $1 a$.: about $4 \mathrm{~m} \mathrm{W.} \mathrm{of} \mathrm{the}$ Mississippi, 45 m. S. E. by S. Iowa City.

PALO Alto, p. o, Hamilton county, $I l l .: 131$ m. S. S. E. Springfield.

Palo Axto, p. o., Onslow county, N. Car.: 92 m. S. E. Raleigh.

Palo Alto, p. 0., Chickasaw co., Miss. : 118 m. N. E. by N. Jacksnn.

Palova, p. 0., Greenville district, S. Car.: $105 \mathrm{~m} . \mathrm{N}$. W. Columbia.

Palos, p. o., Miami co., Ind. : 74 m. N. Indianapolis. Palos, p. o., Cook co., IU.: 162 m. N. E. Springfield.

Pamelia Four Corners, p. v., Jefferson co., $N . \quad Y: 4 \mathrm{~m}$. N. of Watertown, $148 \mathrm{~m}, \mathrm{~N}$. W. Albany.

Paxlico river, $N$. Car. : is a broad estuary leading from Tar river into Pamlico sound, $40 \mathrm{~m}$. long, 1 to $8 \mathrm{~m}$. broad, and deep enough for all vessels which navigate Pamlico Sound.

Panlico sound, $N$. Car.: is separater from the Atlantic Ocean by long sandy islands about $1 \mathrm{~m}$. wide, is $80 \mathrm{~m}$. long, 8 to $30 \mathrm{~m}$. wille, receives Tar and Nense rivers, is entered by Oeracolie inlet, and connects on the $\mathrm{Y}$. with Albemarle sound. The land around it is low, and in some places marshy

Panunkr river, Firg.: formed by the junction of $\mathrm{N}$, and S. Anna rivers, between IIanover and Caroline counties, thence flows in a S. E. course, until it unites with Mallapond $r$. , which then form York $r$.

Panama, p. o., Chautauque co., $N . Y_{0}: 305 \mathrm{~m}$. W. by $\mathrm{S}$. Albany.

Pavaxa, p. o., Defance county, O7zio: $127 \mathrm{~m}$. N. W. Columbus.

Pancoastiorg, p. V., Fayette co, Ohio: 34 m. S. S. W. Columbus.

Pandora, p. O., Johnson county, Tenn.: 268 m. E. by N. Nashville.

PAxola county, Miss, Situate N. W., and contains 758 sq. m. Druined by Tallahatchie r. and branchcs of Cold Water r. Surface generally level; soil fertile, and making fine pasture. Chief productions, cotton and Indian corn. Farms 61S; manuf, 0 ; dwell. 891, and pop.-wh. 5,021, fr. col. 3, sl. 6,420-total 11,444. Capital: Panola.

PANols county, Tex, Situate E. toward the N., and contains S:ls sq. m. Drajned by sabine $r$, and its brinches. Surface diversified by low hills and fertile valleys; soil fertile. Pine and other timber abounds. Farms 209: manuf. 0 ; dwell. 456, and pop.-wh. 2,676, fr. col. 2, sl. 1,193-total 3,S71. Cunital: Carthage.

Parou, a, p. F., and cap. Panola county, Miss.: on Tallahatehie r., $13 \pm$ n. N. by E. Jackson. It contains a crurthouse, jail, an academy, several stures, and 500 inliblitants. 611
The "Panolean" (dem.), and "P. I'icayune" are publishred weekly.

Paxteqo, p. o, Beaufort co., $N$. Car.: on a small aftucnt of Pungo r., $106 \mathrm{~m}$. E. Raleigh.

Panther, p. v., and cap. Polk co., Ark.: $110 \mathrm{~m}$. W. by $\mathrm{S}$ Little Rock. It is a small settlement, in which the enunty business is transacted, containing a hotel and 3 or 4 stores.

Panther Creek, p. o., Cass co., Ill. : about 2 m. \$. of Sangamon r., 33 m. W. N. W. Springfleld.

Panther Creek, p. o., Surry co., N. Car.: 127 m. W. N. W Raleigh.

PAnther Fork, p. on, Greenville district, S. Car. : $112 \mathrm{~m}$. N. W. Columbia

Panther's Gap, p. 0., Rockbridge co., Virg.: on the E. base of Mill mt., $102 \mathrm{~m}$. W. by N. Richmond.

Panther Springs, p. 0., Jefferson co., Tenn.: 185 m. E. Nashville.

Panthersville, p. v., De Kalb co., Ga.: on a head of Ocmulgee r., 89 m. N. W. by W. Millergeville.

Pantox, t. and p. O., Addison county, Verm.: on Lake Champlain, 37 m. W. S. W. Montpelier. Bounded E. by Otter er, and drained by a S. branch. Surface very level; soil of average fertility. Pop. 559.

Pax Y Y , p. 0., Racine county, Wisc: 69 miles E. S. E. Marlison.

Paoli, p. v., and cap. Orange co., Ind.: on the $\mathrm{N}$. side of Lick cr, $83 \mathrm{~m}$. S. by W. Indianapolis, It contains a courthouse, jail, academy, a dozen stores, several flouring and other mills, and 461 inbabitants. A plank-road leads hence $40 \mathrm{~m}$. to New Albany.

PAOLI, p. v., Chester co, Penn.: 73 m. E. by S. Harris. burg. Two miles S. W. of the v. is a monument on the spot where, on the $20 t h$ of September, 1777 , Gen. Wayne was defeated by the British under Gen. Grey. The $\mathbf{v}$. is $21 \mathrm{~m}$. from Philatelphia, on the Columbia and Philadelphia R. R., beyond which a branch road to Westchester diverges here.

PAPACTON river, $N . Y$. the $\mathrm{E}$. branch of Delaware $r$. rises in E. part of Delawarc co, and flows $\mathrm{S}$. W. $65 \mathrm{~m}$. to ils junction with W. branch of the Delaware $\mathrm{r}$.

Papaktink, 0. 0, Delaware co, $N . Y_{.:}$on Papacton $r$. $52 \mathrm{~m} . \mathrm{S}$. W. Albany; now called Halcottsville.

Paper-Mill Village, p. Y., Cheshire co.. $N_{\text {. Hamp. : on }}$ Cold $r_{.}, 5 \mathrm{~m}$. E. of the Connecticut, $89 \mathrm{~m}$. W. by S. Concord.

Papertown, p. o., Cumberland co, Penn.: W. Harrislyurg. A furnace of 1,400 tons annual capacity, using waterpower, is located here.

Paperville, p. v., Sullivan con, Tenn.: on a N. branch of Holston r., near the Virg. line, $258 \mathrm{~m}$. E. by N. Nashville. Papinstille, p. V., Bates co, Mo.: on Osiage r., $103 \mathrm{~m}$. W. S. W. Jefferson City.

Parachifta, p. V., and cap. Sevier co., Ark.: on Cossato cr. of Little r., 121 m. S. W. by W. Little Rock. It contains a court-house, hotel, and several stores.

Paradise, p. O., Coles co., $1 l l .: 69$ m. E. S. E. Springfield. Paralise, sta., Wayne co., Olio: $8 \mathrm{~m}$. E. of Wooster, on the Ohio and Pennsylvania R. R.

Paradise, p. v., Lancaster county, Penn。: 47 m. E. S. E. Harrisburg.

PARAdis:, p. 0., Rockingham co., Firg.: 108 m. N. W. Richnond.

Paradige Fubrack, p. 0., Huntingdon co., Penn.: $62 \mathrm{~m}$. W. Harrisburg. The furnace uses water-power, and has annual capacity of 1,000 tons. A forge, capable of producing 5ilo tons blo mis per annum, is also located here.

Paradise Valley, p. Y., Monroe county, Penn.: $97 \mathrm{~m}$. N. E. by E. Harrisburg.

Parcmer's Corsers, p. o., Fulton county, Ohio: $129 \mathrm{~m}$ N. N. W. Columburs.

PArdievilli, p. v., Columbia co., Wise.: on the Neenah, near the E. end if Swan like, $34 \mathrm{~m}$. N. Matison. It contains several mills and stores, and a population of 200 .

Parinam's LAxivg, p. o., Catahoula par, La.: $101 \mathrm{~m}$. N. N. IV. Baton Rouge. 
Parfay's Store, p. o., Sussex co., Firg.: 37 m. S. S. E. Richmond.

PARIs, p. v., and cap. Edgar co., Ill.: $106 \mathrm{~m}$. E. by S. Springfield. It lies on the $\mathrm{E}$. border of a large prairie, and contains a court-house, jail, academy, a dozen stores, and 600 inbabitants. The proposed railroad from Terre Haute to Springfield passes through it. The "Prairie Beacon" (whig) is published weekly.

PARIs, p. v., Jennings co, Ind.: on the E. side of Graham's fork of Muscatatuk r., $68 \mathrm{~m}$. S. S. E. Indianapolis. It contains several stores and about 500 inhabitants.

PARIS, p. v., and cap. Bourbon co., Ky.: on the S, branch of Licking r., $81 \mathrm{~m}$. E. Frankfort. It contains a court-house and jail, a bank, two academies, several large commercial houses, and $1.3>1$ inhabitants. The Maysville and Lexington R. R. passes through it, and the propnsed road from Louisville to Knoxville, Tenn, The "Western Citizen" (whig) is published weekly.

PAsis, t., p. v., and cap. Oxford co., Me. : $37 \mathrm{~m}$. W. by $\mathrm{S}$. Augusta. Drained by Little Androseoggin r. and branches, supplying much water-power. Surface uneven; in parts rough; soil very productive of grass and grain. A superior farming town, with several large factories and mills. The Atlantic and St. Lawrence R. P. crosses the W. part along the $r$. The $\mathrm{v}$, , on an $\mathrm{E}$. branch of the r., has a brisk trade, and contains a court-house, jail, and academy. The "Oxford Democrat" and "Second Advent Review" are issued weekly. Pop. of t. 2,853.

PARIs, t. and p. 0., Kent county, Bfich.: 58 m. W. by N. Lansing. Drained by Gypsum (or Plaster) cr., a S. aftuent of Grand r. Surface rolling and well timbered; soil vegetable loam and very fertile. Gypsum is abundant on the er. and salt springs are found. Pop. 521

PARIS, p. v., and cap. Monroe co, MO.: on the S. fork of Salt r., 62 m. N. by E. Jefferson City. It contains a courthouse, jail, academy, and about 500 inhabitants.

PARrs, t. and p. o., Oneida county, N. $Y_{\text {. }}: \$ 1 \mathrm{~m}$. W. by N. Albany. Drained by Sahada or Sauquoit cr., which supplios fine water-power. Surface high and rolling; soil sandy and calcareons loam of exeellent quality, and highly cultivated. It is well timbered, and has several manuficturies of cotton and woolen goods, paper, etc. Pop. of t. 4,253.

PAris, p. O., Coweta county, Ga.: 92 miles W. by N. Milledgeville.

PARIS. p. Y. Lafarette co, Miss. : 151 m. N. by E. Jackson.

PARIS, t. and p. v., stark county, Ohio: $107 \mathrm{~m}$. N. E. by E. Columbus. Drained by Sandy er. and branches, afiording water-power. Surface rolling or hilly; soil fertile. The v. entains sereral factories and 500 inhabitants. Population of t. 2,740 .

Paris, p. ०, Tashington county, Pern.: 173 m. W. Iarrisburg.

Parif, p. v., and eap. Herry co., Tenn. : on a branch of Big Sandy river, a W. tributary of the Tennessee, 86 miles W. by N. Naskville. It contains a court-house, jail, academy, and several stores, and 400 inhabitants. "The RepubIic" (whig) is published here weekly.

Paris, n. va, and cap. Lamar co., Texo. : 267 m. N. N. E. Austin City. It contains a court-house, jail, academy, and Eeveral stores. The "Western Star," a weekiy issue, is published.

Paris, p. V., Fauquier eounty, Firg.: 103 m. N. N. W. Richmond. It lies at the E. base of the Blue Ridge, and contains Bereral stores and 250 inbabitants.

Parts, t. and p. 0., Kenosha co., Wisc. : 79 m. E. S. E. Iradisn. Drained by Des Plaines r., on which are numerous mill-sites. Surface mostly even, and soil very productive of the grains. A fine limestone is quarried. Pop.947.

Parisburg, Giles co., Virg. See Gilms C. H.

Parisur, \& and p. 0., Oswego co., N. Y.: 133 m. W. N. W. Albany. Drained by Salmon cr. Surface undulating: soil strtile loam. A farming $t$, with superior dairies. Population 1.749

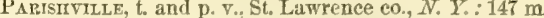
N. N. E. Albany. Drained by Racket and St. Regis rivers. Surface rolling; soil adapted to grass, corn, and rye. It is heavily timbered and well supplied with mill-seats. The $\mathrm{v}$. is on St. Regis r., and contains several mills and about 500 inhabitants. Pop. of t. 2.132.

Parisville, p. v., Portage co., Ohio: on the W. branch of Mahoning r., $128 \mathrm{~m}$. N. E. Columbus.

PARK, t. and p. 0., St. Joseph's co., Mich. : $76 \mathrm{~m}$. S. W. Lansing. Drained by Portage $\mathbf{r}$, of the St. Joseph's, which furnishes gnod mill-sites. Surface undulating; soil very productive. Pop. 823.

Parke county, Ind. Situate W., and contains 423 sq. m. Drained by Sugar and Big and Little Racoun creeks, tributaries of the Wabash, which runs on its western border, and by these good water-power is geuned. Surface slightly undulating, and partly diversified with low hills; soil a deep black loam, with sand intermixed, and very fertile. Chief productions wheat, Indian corn, and tobaceo. There is some rich prairie-land and much fine timber. It contuins coal, and has some excellent beds of iron ore. Farms 1,390; manuf. 63 ; dwell. 2,468 , and pop.-wh. 14,711 , fr. col. 227 total 11.968. Cupital: liockville. Public Works: Wabash and Erie Canal.

Parker's, sta., Millsboro' co, N. Tamp.: 10 m. N. W. of Manchester, on the New Hampshire Central R. R.

Parkersibrg (furmerly Schoolex's Mount), p. v., Morris co., $N_{\text {. Jer.: }} 38 \mathrm{~m}$. N. by W. Trenton. A mineral spring here, with the beauty of its location on the E. side of Schnoley's Mountain, has made it a popular place of summer resort, with ample accommodation for visitors.

Partiersidrg, p. v*, Richland county, $I l l_{*}: 119 \mathrm{~m}$. S. E. Springfield.

Parkersitrg, p. v., Jasper co., Ia. : $82 \mathrm{~m}$. W. Iowa City

Parkersburg, p. v., Montgomery county, Ind.: $19 \mathrm{~m}$. W. by $\mathbf{N}$. Indianapolis.

Parkersburg, p. o., Yell co., Ark. : on Petite Jean r., $70 \mathrm{~m}$. W. by N. Little Rock.

Parkersburg, p. v., and cap. Wood co., Frrg.: on the Ohio, immediately above the entrance of Little Kanawha $r$. $252 \mathrm{~m}$. W. N. W. Richmond. It has an extensive river and inland trade, and valuable manufactures, which must be greatly increased by the completion of the Cincinnati, Hillsboro', and Parkersburg R. R. and the North Western R. R., the latter to connect the Baltimore and Ohio $R$. R. with the Ohio r. at this place. It contains a court-house and jail, a bank, 2 academies, a dozen stores, 2 steam saw-mills, 2 steam flouring-mills, numerous smaller manufacturing establishments, and a population of $1,21 \mathrm{~s}$ souls. The " $\mathrm{P}$. Gazette" (whig) and "P. News" are published weekly.

Parker's Head, p. o, Lincoln co., Mfe : on the Atlantic, 37 m. S. S. E. Augusta.

PARKeR's Store, p. o., Franklin co., Ga.: about $3 \mathrm{~m} . \mathrm{W}$. of Savannah r., $106 \mathrm{~m}$. N. by E. Milledgeville.

Parkersville, p. v., Chester co., Penn.: 62 m. E. S. E. Harrisburg.

Parkfirstile, p. o., St. Tammany par., La.: 63 m. E. Baton Rouge.

Parkesiora, p. v. and sta., Chester co., Penn.: on the Columbia and Philadelphia R. R., $45 \mathrm{~m}$. W. of Philadelphia, $61 \mathrm{~m}$. E. S. E. Harrisburg. It contains the State machine shops, several depôts and warehouses, 3 stores, a hotel, and between 50 and 60 dwellings

Parkerille, p. Y., Noxubee county, Miss.: 112 miles N. E. by E. Jackson.

Park Hall, p. o., St. Mary's county, $M I d .: 46$ miles $\mathbf{S}$. Annapolis.

ParK HEad, p. o., Washington county, Mra.: $s 9$ miles N. W. by W. Annapolis.

Parkison, p. o., Beaver co., Penn.: $184 \mathrm{~m}$. W. by $\mathbf{N}$. Harrisburg.

Pariman, t. and p. o., Piscataquis county, $M e_{.}: 59 \mathrm{~m}$. N. N. E. Augusta. Drained by branches of Piseataquis r. 
Surface moderately uneven; soil fertile and well wooded. $\Lambda$ superior dairy town. Pop, 1,243.

ParkMan, t. and p. o., Geauga co., Ohio: $136 \mathrm{~m}$. N. E. Columbus. Drained by branches of Cuyahoga and Grand rivers, which furnish good mill-seats. Pop. 1,383

PARK's, p. o., Seott co., Ark.: on La Fave r., 94 m. W. Little Rock.

PARK's, p. o., Edgefield dist., S. Car.: about 4 m. E. of Savannah r., $78 \mathrm{~m}$. W. by S. Columbia.

Park's Corners, p. v., Boone co., $I l l$ : 186 m. N. by E. Springfield.

PARK's StoRe, p. o., Cabarras co., N. Car.: $101 \mathrm{~m}$.W. by S. Raleigh.

PAT.'s Store, p. o., Jackson co., $A l \alpha_{.}: 164$ m. N. by E. Montgomery.

PARksville, p. v., Sullivan county, N. Y.: 83 m. S. W. Albany.

ParkToN, p. v. and sta., Baltimore co., MId.: on the N. side of Great Gunpowder Falls, where it is crossed by the Baltimore and Susquehanna R. R., $28 \mathrm{~m}$. N. of Baltimore.

Parkville, p. o., Platte co., Mo.: on the left bank of the Missouri, 139 m. W. N. W. Jefferson City. Pop. 309.

PArMa, t, and p. o., Monroe co, N. $Y_{*}$ : on the S. shore of Lake Ontario, $217 \mathrm{~m}$. W. by N. Albany. Drained by Salmon cr., flowing into Braddock's bay. Surface generally even; soil sandy or gravelly loam, and very productive. It is chiefly a farming town, but has several manufactories. Pop. 2,946.

Parka, t. and p. o., Cuyahoga county, Ohio: $115 \mathrm{~m}$. N. E. by N. Columbus. Drained by branches of Cuyahoga r. Surface level, and soil adapted to wheat. Pop. 1,329.

PARMa, sta., Jackson co., Mich. : on the Michigan Central R. R., $10 \mathrm{~m}$. W. of Jackson.

Parma Centre, p. o., Monroe co., N. Y.: 215 m. W. by N. Albany.

Parkassus, p. oo, Wilcox co., Ala. : about $4 \mathrm{~m}$. W. of Alabama r., $76 \mathrm{~m}$. W. by S. Montgomery.

Parnassus, p. o., Augusta co., Virg.: 106 m. W. N. W. Richmond.

Parowan City, p. v., Iron county, Utah Ter.: near S. extremity of Little Salt Lake, $105 \mathrm{~m}$. S. S. W. Fillmore City.

PARRISH, p. v., Des Moines con, Ia : about $3 \mathrm{~m}$. N. of Skunk r., 59 m. S. by E. Iowa City.

Parrotstille, p. v., Coeke co,, Tenn. : on a branch of

French broad r., $209 \mathrm{~m}$. E. by N. Nashville.

Parrystrlle, p. v., Carbon co, Penn.: on the E. side of Lebigh r., at the mouth of Big creek, $72 \mathrm{~m}$. N. E. by E. Harrisburg.

Parsippany, p. v., Morris co., N. Jer.: on Parsippany r., $47 \mathrm{~m} . \mathrm{N} . \mathrm{N}$. E. Trenton. It contains an academy and several stores and mills.

Parsonage, p. o., Williamsburg dist., S. Car.: $79 \mathrm{~m}$. E. S. E. Columbus,

PARSONSFIELD, to and p. v.; Tork co., Me.: 74 m. S. W. Augusta. Bounded N. by Ossipee r., and W. by N. Hamp. Surface broken and rough ; soil productive. Several ponds feed fine mill streams. Iron ore and zine are found. Farming and various manufactures are extensively carried on. The v. contains an incorporated seminary for both sexes. Pop. of t. 2,322 .

PARtLow's, p. 0., Spottsylvania co., Virg.: $46 \mathrm{~m}$. N. by W. Richmond.

Partiersimp, p. o., Charles county, $y d$. : 41 m. S. W. Anmapolis.

Partridge Island, p. o., Delaware co., N. Y.: $92 \mathrm{~m}$, \$. W.by. W. Albany.

Pascagoula, p. V., Jackson co., Jiss.: at the mouth of Pascagoula r., $155 \mathrm{~m}$. S. E. by S. Jackson.

Pascagoula river, Mfiss.: formed by the junction of Chickasawha and Leaf rivers, and finws S. by E, aboul $60 \mathrm{~m}$. into Pascagoula Sound of Gulf of Mexico. It is navigable for vessels drawing 6 feet water.

Pascagotia sound, Mfiss.: off the mouth of Pascagoula 616 r., separated from the Gulf of Mexico by several long, narrow islands, $55 \mathrm{~m}$. long, and $8 \mathrm{~m}$. in average breadth.

PASco, p. o., Dallas co., MYo.: $79 \mathrm{~m}$. S. W. Jefferson City.

PascosG, p. v., Providence co., R. I.: on Paseoag r., a $^{2}$ S. affluent of Branch r., $19 \mathrm{Ir}$. N. W. by W. Providence. It contains a bank, and several factories and mills.

Pashawa, p. o., La Grange co., Ind.: on the E. side of Little Elkhart r., $131 \mathrm{~m}$. N. by E. Indianapolis.

Paskack, p. on, Burgen co., N. Jer.: on the W. side of Paskack r., a W. branch of the Hackensack, 65 miles N. E. by N. Trenton.

PASQUOTANE county, N. Car. Situate N. E., and contain 241 sq. m. Drained by small streams of Pasquotank $x$. Surface level, a portion of it being low and marshy, and unfit for cultivation; soil various, owing to the diversity of the surface; where fit for cultivation, it is fertile and adapted to grain. Chief products, wheat and Indian corn. Farms 530 : manuf. 11; dwell. 1,150, and pop.-wh. 4,611, fr. col. 1,234, sl. 3,105-total 8,950. Capital: Elizabeth City.

PASQUotank river, $N$. Car.: rises in the Dismal Swamp, flows S. E., and with broad estuary enters Albemarle Sound. It is connected with Elizabeth r., Virg., by the DismaI SW AMrP CaNar, which see.

Passadumkeag, t. and p. $0_{0}$, Penobseot co, $M e_{0}:$ on the E. side of Penobscot r., $85 \mathrm{~m}$. N. E. Augusta. Drained by Passadumkeag $r$. Surface varied; soil fertile. Lumber getting engrosses attention. Pop 294.

Passadumkeag river, Me : an E. branch of Penobscot $r_{0}$, which it enters at Passadumkeag $\mathrm{v}_{\text {., }}$ affording in its course fine mill sites.

Passaio county, $N$. Jer. Situate toward the N. E., and contains $198 \mathrm{sq}$. m. Drained by Passaic river and its branches. Surface broken, and in parts hilly; soll various, but for the most part is fertile, and produces good crops of wheat, Indian corn, and potatoes. It has some good timber land. Farms 610 ; manuf, 247; dwell. 3,369 , and pop,--wh. 21,922, fr. col. 630, sl. 23-total 22,575. Capital : Paterson Public Works: Union R. R. ; Morris and Essex Canal

PASSAIO river, $N$. Jer.: rises in Mendham, Morris co., and flows with very irregular course $70 \mathrm{~m}$. to its entrance into Newark bay. At Paterson it has a perpendicular fall of 50 feet, and a total descent of 70 feet, affording an immense water-power. It is navigable for sloops to Acquackanock, 12 miles.

Passaio Brtoge, sta, Passaic co., N. Jer.: on the Union R. Pu, $12 \mathrm{~m}$. from New York

I'ASSAMAQUODDY bay, $M \varepsilon_{0}$ : lies partly in Maine, and partly in the British province of New Brunswick, $12 \mathrm{~m}$. long, and averaging $7 \mathrm{~m}$. wide. It is separated from the ocean by Deer and Campobello islands, and many smaller islands. It has everywhere a sufficient depth of water for the largest vessels, and is never closed by ice. Its waters abound with mackerel, herring, cod, and other fish. The tide varies from 25 to 38 feet. The statistics of Passamaquoddy collection district are given under EASTPORT, which is its port of entry.

Pass Christian, p. v., Harrison co., Miss. : on the E. side of the pass into St. Louis bay, opposite Shieldsboro', $141 \mathrm{~m}$. S. S. E. Jackson.

Passurpsic, p. v. and sta, Caledonia co., Verm.: on Passumpsic r., and the Connecticut and Passumpsic Rivere Pailroad, $4 \mathrm{~m}$. south of St. Johnsbury, 29 m. E. N. E. Montpelier.

PAsSUMPSTC river, Verm. : rises from a pond in Westmore t., flows by $\mathrm{s}$. course $34 \mathrm{~m}$. , and enters Connecticut $\mathrm{r}$. It has several falls, particularly in Lyndon, where it descends 65 feet in 30 rods, producing great water-power. The Connecticut and Passumpsic $R$. $R$. runs along the river, and is now completed to St. Johnsbury.

Passrecre, to and v, Philadelphia county, Penn.: $98 \mathrm{~m}$. S. by W. Harrisburg. Bounded S. by Schuylkill and Dela. ware, and drained by Hollander's cr. Surface level; soil alluvium and loam. League island, on the Delaware, be- 
longs to it, and is covered with gardens and readows. The bank of the Schuylkill is high and steep. Pop. 1,607.

Patapsco river, MId. $_{0}$ : rises in Baltimore co., and enters Chesapeake bay, by a broad estuary. It is navigable to Fell's Point, in Baltimore, $14 \mathrm{~m}$., for vessels drawing 18 feet water. In its course it affords extensive water-power, which has been improved by the establishment of numerous mills on its banks, some of which are large and profit able concerns.

Pataskala, sta., Licking co., Ohio: on the Central Ohio R. R., $26 \mathrm{~m}$. W. of Newark.

Patchin, p. O., Erie co., N. Y.: 257 m. W. Albany.

Patchogte, p. v., Suffolk co., $N . Y_{.:}$on the S. side of Long Island, near Great South bay, $133 \mathrm{~m}$. S. S. E. Albany. A stream passes through it, supplying ample water-power. It contains several factories and mills, and about 500 inhabitants. In summer it is much frequented by sportsmen for the excellent fishing and fowling the neighborhood affords. There are many fine prospects from this locality.

Paterson, sta., Putnam co., N. Y. : $63 \mathrm{~m}$. N. of New York, on the Harlem R. R.

Paterson, p. city, and cap. Passaic co., N. Jer.: on the Passaic, immediately below the falls of that river, $4 \mathrm{~m}$. from tide water and $26 \mathrm{~m}$. above its confluence with Newark bay, in lat. $40^{\circ} 55^{\prime} \mathrm{N}$., and long. $74^{\circ} 19^{\prime}$ W., $57 \mathrm{~m}$. N. E. by N. Trenton, and $17 \mathrm{~m} . \mathrm{N} . \mathrm{N}$. W. New York city. $\mathrm{It}$ is situate midway on the lines of the Union (formerly the Paterson and Hudson) R. R., which, extending to Jersey City, gives it easy access to New York, and to Suffern's, where the road connects with the great New York and Erie R. R., from the Mudson, at Piermont, to Dunkirk, on Lake Erie, by which it has also connection with the whole interior of Western New York and Lake Ontario. The Morris Canal, extending from Jersey City to Easton, Penn., $102 \mathrm{~m}$., also accommodates its large and valuable commerce, and is the channel through which, as a manufacturing city, it receires its fuel.

The fall has a perpendicular descent of 50 feet. The advantages derivable from the great fall in the river have been improved with much judgment. A dam $4 \frac{1}{2}$ feet high, strongly framed and bolted to the rock in the bed of the river above the falls, turns the stream through a canal excavated in the trap rock of the bank, into a basin, whence through strong guard gates it supplies in succession three canals on separate planes, each below the other, giving to the mills on each a head and fall of about 22 feet. The falls and the improvements afford a constant and abundant supply of water for the vast number of manufacturing establishments in operation in the eity, which is now one of the most important manufacturing places in the United States, and in New Jersey second only to Newark. The falls of the Passaic is a beautiful sheet of water, and in its passage, through the lapse of ages, the waters have worn a deep ehasm into the solid rock, which is obviously retreating, as the abraded banks below testify. No spectacle can be more imposing than is presented by the falling water, as it glides gently over the brow of the precipice, and in flood the scene is magnificent.

Paterson contains the county court-house, the jail, and other public offices, 16 or 17 churches of varions denominations, some of which are elegant and substantial structures, many large hotels, numerous school-houses, and its buildings devoted to manufacturing purposes aro generally construeted of stone. On the whole, it is more than usially substantial in its buildings. The streets are generally laid out with regularity, although in some parts they conform more to the peculiar topography of the ground than to mathematical design. The eity is lighted with gas, and its streets are well paved and the sidewalks flagged. The manufactures of the city are on an extensive scale, consisting of cotton goods, of which there about 20 factories; woolen goods, dyeing and printing establishments, fulling-mills, gun and pistol factories, machine shops, car and carriage factories, which turn out large numbers of railroad and other carriages, founderies of brass and iron, paper-mills and a variety of mills and factories of less note. Two banks are established here, also a savings' bank, and several insurance agencies. For mental culture there is ample provision; a philosophical society for young men, which has a respectable library, and a mechanics' society, for the advancement of science and the mechanic arts, with a library, philosophical apparatus, etc., have been established for many years. There are also night-schools, at which the mechanics whose daily occupations debar them the ordinary advantages of education, are instructed in the usual branches. The public press of the city consists of the " $\mathrm{P}$, Guardian" (dem.) and the " $P$. Intelligencer" (whig), each of which circulates from 800 to 1,000 copies weekly.

Paterson was founded by an association, incorporated in 1791, for the purpose of fostering manufactures, and is said to have been projected by Alexander Hamilton, at that time U. S. Secretary of State. The year preceding this date saw machine eotton spinning first established in New England - the factory of Samuel Slater having been established at Pawtucket, $R . I$, in 1790 . The plans of this company, which had a capital of $\$ 1,000,000$, failed of success, and the enterprise, for which the times were not sufficiently advanced, was abandoned. In after years, however, the project was revived, and the design of the original assnciation carried out by others. The city of Paterson is the great monument of the success that crowned and rewarded their persistent labors.

The population in 1810 was 292 ; in $1820,1,575$, and in $1830,7,731$. In 1840 it was only 7,596 , but in 1850 it had increased to 11,388 - the increase in the decade having been at the rate of 49.26 per centum.

In the vicinity of Paterson, and on the opposite side of the Passaic, is New Manchester, which, though under a separate organization, is to all intents and purposes a part of the eity, having the same interests and being connected with it by two bridges. It contains numerous factories and mills, and is a highly fourishing place. The population of the town of Manchester in 1850 was 2,781. Goffle, Oldham, and Totowa, are villages in the same town.

РАтокA, p. v. and sta., Gibson co., Ind.: on the N. side of Patoka cr., $117 \mathrm{~m}$. S. W. by S. Indianapolis. It is on the Evansville and Illinois R. R., $30 \mathrm{~m}$. N. of Evansville, and contains several stores and mills.

$\mathrm{P}_{\text {ATOKA }}$ river, Ind.: rises in $\mathrm{S}$. part of Orange $\mathrm{co}_{\circ}$, flows W., and empties into the Wabash just below the mouth of White $\mathrm{r}$. It is about $100 \mathrm{~m}$. long, 150 feet wide, and navigable in high water over 60 miles.

PatoN, p. o., Cape Girardeau co., Mro.: on Whitewater cr., $142 \mathrm{~m}$. S. E. by E. Jefferson City.

PATrick county, Virg. Situate S., and contains 506 sq. m. Drained by branches of Smith's, S. Mayo, and Little Dan rivers. Surface hilly and broken; soil moderately fertile. Chief products, Indian corn and tobacco. On the N. W. runs the Blue Ridge. Farms 748 ; manuf. 27 ; dwell. 1,248, and pop.-wh. 7,197, fr, col. 88, sl. 2,324-total 9,609. Capital: Patrick C. H.

Patrick C. H., p. v., and cap. Patrick countr, Firg.: on South Mayo r., a branch of the Dan, $163 \mathrm{~m}$. W. S. W. Richmond. It contains a court-house and jail, a flouring-mill, several tooaceo factories, and about 500 inhiabitants. The $\mathbf{r}$. is also called Taylorsville.

Patricktown, t. and p. o., Lincoln county, Me.:15 m. E Augusta. The W. is oceupied by a large pond, the source of Sheepscot r. Surface varied; soil very productive, and well wooded. Pop. 552.

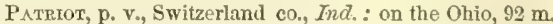
S. E. Indianapolis, It is $49 \mathrm{~m}$. below Cincinnati, has a convenient landing, and contains about 600 inhabitants.

Patriot, p. v., Gallia county, Ohio: on the E. side of Symmes cr., 86 m. S. S. E. Columbus It contains several stores and about 400 inhabitants. 
Patten, to and p. o., Penobscot co., M/e.: 135 m. N. N. E. Augusta. Pop. 470.

Patten's Home, p. o., Rutherford co., $N$. Car.: $191^{\circ} \mathrm{m}$. W. by S. lialeigh.

Patren's Mrlls, p. o., Washington county, $N$. $Y .: 47 \mathrm{~m}$.

N. by E. Albany.

Patterson, t. and p. v., Putnam co., $N . Y_{.: 8} 88 \mathrm{~m} . \mathrm{S}$. by E.

Albany. Drained by Croton $r$. Surface broken; soil fertile in the valleys, and under high cultivation. The Harlem R. R. crosses it, and P. sta. is $80 \mathrm{~m}$. N. of New York. The $\nabla$. is on Croton r., and contains an academy and several stores. Pop. of t. 1,371.

Patterson, p. o., Wayne county, Mo.: 137 m. S. E. Jefferson City.

Patterson, p. r., Delaware co., Ohio: on the W. side of Scioto r., $28 \mathrm{~m}$. N. by W. Columbus.

Patterson, sta, Wyandot $\mathrm{co}$, Ohio: $84 \mathrm{~m}$. N. of Bellafontaine, on the Mad River and Lake Erie R. R.

Pattensox's Butff, p. o., Johnson co., Ark. : on the right

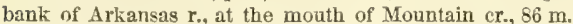
N. W. by W. Little Roek.

Patterson's Derôt, p. v. and sta., Hampshire co., Virrg. on the S. side of Potomac r., $8 \mathrm{~m}$. E. of Cumberland by the Baltimore and Ohio R. R., $152 \mathrm{~m}$. N. W. by N. Richmond.

Patterson's Mills, p. 0., Washington co., Penn. : 168 m. W. Harrisburg.

Patterson's Store, p. o., Allamance co, $N$. Car.; $49 \mathrm{~m}$. W. N. W. Raleigh.

Pattersonville, p. v., St. Mary's par., La. : on Bayou Teché, $49 \mathrm{~m}$. S. by W. Baton Rouge. Great quantities of cotton and sugar are produced in the vicinity, and sent down the $r$. from this point.

Pattillos, p. o., Jefferson co, Tex.: near Cow bayou of the Sabine, $229 \mathrm{~m}$. E. by S. Austin City.

Pattonsburg, p. v., Davies co., Mo.: on Big cr., about 5 m. N. of Grand r., 143 m. N. W. Jefferson City.

Patronsburg, p. v., Botetourt co., Virg.: on the N. side of James r., $122 \mathrm{~m}$. W. Richmond. A bridge connects it with the v. of Buchanan on the S. side, and the two contain a dozen stores, several mills and tobacco factories, and about 500 inhabitants.

Pattonsfille, p. v., Scott co., Virg.: 257 m. W. by S Richmond.

Pattoxstrle, p. v., Hocking co., Ohio: on the Hocking Canal, E. side of Hocking r., $49 \mathrm{~m}$. S. E. Columbus. It is $22 \mathrm{~m}$. by canal N. W. Athens.

Pattonville, p. v。, Bedford co, Penn.: $82 \mathrm{~m}$. W. by S Harrisburg.

Paturent, p. V., Anne Arundel co., MLa.: on the E. side of Patuxent r., $19 \mathrm{~m}$. N. W. Annapolis.

Patusfent river, Md. $\therefore$ the longest $r$ in the State, rises in the N. part of Montgomery and Howard counties; flows S. E. $40 \mathrm{~m}$., then, bending to the $\mathrm{S}$, flows $50 \mathrm{~m}$, in that direction, nearly parallel with Chesapeake bay, which it enters by a large estuary. It is navigable to Nottingham, $50 \mathrm{~m}$., for vessels of 250 tons, and further for smaller vessels.

Padidne county, Ga. Situate W. toward tho N., and contains $663 \mathrm{sq} . \mathrm{m}$. Drained by head branches of Tallapoosa $r$. and branches of Etowah $r$. Surface varied-in the $\mathrm{N}$. being hilly, the remainder level land; soil fertile. Chief productions, cotton, Indian corn, and fruit. It has some fine timber land. Farms 422 ; manuf. 10 ; dwell.1,059, and pop.wh. 5,560, fr. col. 2, sl.1,477-total 7,039. Capital: Van Wert.

Patuding county, Ohio, Situate W, toward the N., and contains $436 \mathrm{sq}$. m. Drained by Maumee r. and Auglaize r. and its branches Crooked and Blue creeks. Surface level soil very productive, and is well adapted to grain. Farms 77 ; manuf. 4 ; drell. 307, and pop.-wh, 1,765, fr. col. 1total 1,766. Capital: Paulding C. H. Pullic Works: Sandusky and Fort Wayne and St. Louis R. R.; Wabash and Erie Canal; Miami Canal, ete.

PAuldixg, p. v., and cap. Jasper county, Miss. : $67 \mathrm{~m}$.

E. by S. Jackson. It contains a court-house, jail, academv, 618 several stores, and 400 inhabitants. The " Eastern Clarion" (dem.) is published weekly.

PAUldivg, p. v., and eap. Paulding co., Ohio: on Crooked cr., a W. branch of the Auglaize, 114 m. N. W. Columbus. It contains the co, buildings and several stores and mills.

Paulina, p. v., Warren co., $N$. Jer.: on the S. side of Paulin's Kill, 52 m. N. by W. Trenton.

Paulinsinl, r., N. Jer.: rises in Sussex co, and flows in S. W. course about $40 \mathrm{~m}$., entering Delaware $r$. in $\mathrm{N}$. W corner of Warren co, near Columbia.

PAvilion, p. v., Kendall co., Ill. : about $1 \mathrm{~m}$. S. of Fox r., $142 \mathrm{~m}$. N. N. E. Springfield.

Pavilion, t. and p. o., Kalamazoo county, Mich.: $68 \mathrm{~m}$. S. W. Lansing. Drained by Portage r. of the St. Joseph's, into which flow several large ponds. Surface level; soil adapte 1 to grasi and grain. Pop. 495.

Pavilion, t. and p. o., Genesee county, N. Y.: $223 \mathrm{~m}$. W. by N. Albany. Drained by Allen's cr. Surface rolling; soil clayey loam. A superior t. for wheat growing. Pop. 1,610 .

Pavilion Centrei, p. v., Genesee county, N. Y.: $221 \mathrm{~m}$. W. by N. Albany.

PAWCATUCK, river, $R, I$, and Conn.: formed in Washington co., by the junction of Wood and Charles rivers, which afford extensive water-power; flows in S. W. course to the State line, thence $\mathrm{S}$., forming the dividing line between the States, to its entrance into Nautigansick bay.

Pawlet, t., p. V., and sta., Rutland co., Ferm. : on the W. line of the State, $71 \mathrm{~m} . \mathrm{S} . \mathrm{S} . \mathrm{W}$. Montpelier. Drained by Pawlet $\mathbf{r}$. Surface broken; soil very productive of corn and grass. Grazing is much attended to, and various manufactures carried on. The Rutland and Washiogton $R . R$. crosses the W. part, on which is the sta., $18 \mathrm{~m}$. s. of Castleton. The $\mathrm{v}$. contains an academy. Pop, of $1.1,813$.

PAwlet river, Verm. and $N$. $Y$.: rises in Dorset, $V$ t., flotys N. W. into Lake Champlain, and affords good waterpower.

PaWLINGs, to and p. F., Duchess county, $N . Y .: 77 \mathrm{~m}$. S. by E. Albany. Drained by branches of Fishkill and Croton rivers. Surface a larga valley with hills on the E. and W. sides; soil moderately fertile. It contains several ponds and has good iron ore. The $\mathrm{v}$, is $67 \mathrm{~m}$. from New Tork by the IIarlem R. R., and contrins a bank and several stores. Pop. of t. 1,720.

PAW PAW, D. V., Miami county, Ind.: on the E. side of Eel r., at the mouth of Paw Paw cr., $76 \mathrm{~m}$. N. by E. Indianapolis. It is on the proposed railroad from Peru to Goshen.

PAw PAW, p. V., and cap. Van Buren co., Dfich.: on the $\mathrm{S}$, branch of Paw Paw r., $81 \mathrm{~m}$. S. W. by W. Lansing. It contains the co. buildings, several mills, 8 or 10 stores, and 500 inhabitants. The "P. Free Press" (dem.), is published weekly. Paw Paw sta, is $4 \mathrm{~m}$. S. E. of the v. on the Michigan Central R. R.

PAW PAW, p. v. and sta., Morgan co., Firg.: $146 \mathrm{~m}$. N. N. W. Richmond. It is $15 \mathrm{~m}$. E. of Cumberland on the Baltimore and Ohio R. P.

PAW PAW Grove, p. o., Lee co., Ill.: $138 \mathrm{~m}$. N. by E. Springfield.

PAwTuCKet, t. and sta., Bristol co., Mass.: on Pawtucket r. $37 \mathrm{~m} . \mathrm{S}, \mathrm{S}, \mathrm{W}$. Bostou, and $4 \mathrm{~m}$. N. by E. Providence, on Boston and Providence R. R. This small t. embraces part of the $\mathrm{v}$, of Pawtucket, and is noted for its factories of cotton and woollen goods. Pop. of to in 1830, 1,459; in 1810, 2,1S4; in 1850, 3,758.

Pawtucket, p. v. and sta, Providence county, $R . T .:$ on Pawtucket $r, 4 \mathrm{~m}$. N. Providence, on Worcester and Providence $R$. $R$. This large and flourishing $v$, is located on both sides of the r., which here furnishes great water-power. The first manufacture of cotton goods in this country by water-power machinery was commenced here in 1790 , by Mr. Samuel Slater, an Englishman. The present factorics are for the most part engaged in making cotton goods. There are 7 churches, 3 banks, 12 cotton factories, ete. The 
"Gazette and Chronicle" (miscel.) is issued weekly. Pop. 7,000 .

Pawtecket, river, $R$. I.: This important river above Pawtucket v., in Mass., is called Blackstone r. (which see), and below the falls takes the name of Seehonk $r$. At the $r$. it has a descent of 50 feet, affording great water-water. Betow the falls it is narigable $4 \mathrm{~m}$. to its entrance into Providence r. below Providence.

Pawtuset, p. v., Kent co., R. $I_{\text {. }}$ : on Pawtuxet r., near its mouth, $8 \mathrm{~m}$. S. Providence. The harbor is spacious, safe, and convenient. The $r$. is upon both sides of the $r$. and crossed by a bridge. The great water-power here afforded is improred by extensive factories of eotton and woollen goods, grist-mills, etc. Pop. about 1,500.

Pamtoxet, p. o., Wakulla con, Flor.: 23 m. S. by W. Tallahassee.

Pawtuxet, river, R. I. : rises in W. part of Providence co., flows E. S. E. until it receives its principal branch in Warwich t.; thence E. N. E., and enters Providence bay $3 \mathrm{~m}$. below Providence. It affords great water-power, used by numerous factories, particularly those of cotton goods.

PAstros, t. and p. o., Northumberland co., Penn. Here are a furnace of 1,100 tons capacity, and a forge prodncing 250 tons of blonms per annum, both using water-power. Soil fertile. It contains good farms and pastures, and is well wonded. Pop. 890 .

PAxton, t. and p. v., Worcester county, Mass.: $47 \mathrm{~m}$. W. Boston. Surface very high, dividing the streams of the Connecticut and the Merrimac, and much broken.

PAY Down, p. o., Osage co., Mo.

Patnesville, p. v., Pike co., Mo.: about $6 \mathrm{~m}$. W. of the Mississippi, 79 m. N. E. by E. Jefferson City.

Patnetille, p. v., Sumter co., Ala.: $118 \mathrm{~m} . \mathrm{W}$. by N. Montgomery.

Parson, p. v., Adams county, Ill.: about $6 \mathrm{~m}$. E. of the Mississippi, $84 \mathrm{~m}$. W. Springfield.

Peace Dale, p. v., Washington co., R. I. : 26 m. S. by W. Providence.

Peachar, t. and p. v., Caledonia county, Term.: $21 \mathrm{~m}$. E. by N. Montpelier. Onion r. rises in a pond in the W., and small streams afford water-power. Surface slightly uneven; soil fertile. Limestone is found, and in the $\mathrm{E}$. great quantities of marl. A superior farming $t$. The $\mathrm{v}$. contains a large academy. Pop. 1,377.

Peach Воттом, t. and p. v., York co., Penn.: on the S. line of the State, and W. side of Susquehanna r., $44 \mathrm{~m}$. S. E. Harrisburg. Bounded N. by Muddy er., by branehes of which it is drained. Surface level; soil gravelly and generally fertile. The Susquehanna or Tide-Water Canal passes along the $r$., on which is the $\mathbf{v}$. containing a factory and several stores and mills.

Peach Botrov, p. 0., Grayson co., Tirg.: on a W. branch of New r., $211 \mathrm{~m}$. W. S. W. Richmond.

Peaci Creek, p. 0., Panola co., Miss. : 129 m. N. by E. Jackson.

Peacir Grove, p. o., Fairfax county, Virg.: $93 \mathrm{~m}$. N. Richmond.

PeAch ORChard, p. o, Lawrence co., Ky.: $117 \mathrm{~m}$. E. Frankfurt.

Pracn Tree, p. o, Cherokee co., N. Car. : on the N. side of Hiwassee r., $304 \mathrm{~m}$. W. by S. Raleigh.

Peach Tree Grove, p. o., Nash eounty, N. Car.: $37 \mathrm{~m}$. E. by N. Raleigh.

PEAKE's, sta., Hanover co., Firg. : $15 \mathrm{~m}$. N. of Richmond, on the Virginia Central R. R.

Peaksville, p. v., Bedford co., Virg.: $98 \mathrm{~m}$. W. by S.

Richmond.

Pealer's, p. o., Columbia county, Penn.: 65 m. N. N. E. Harrisburg.

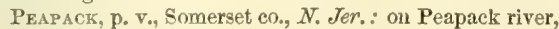
$35 \mathrm{~m}$. N. by E. Trenton.

Pea Ringe, p. o, Union district, S. Car.: $65 \mathrm{~m} . \mathrm{N}$. W. Columbia. l'ea linge, p. o., Houtgomery county, Tenn. : $34 \mathrm{~m}$. W. N. W. Nashville.

PEA PIDGe, p. 0., Benton co., Ark.: $15 \mathrm{~S}$ m. N. W. Little Rock.

Pea River, p. o., Pike to., Ala.: on the E. side of the $\mathrm{r}$. 80 called, $59 \mathrm{~m}$. S. E. Montgomery.

Peakl river, Wir... $:$ is formed from several liranuhes near the eentre of Mliss., runs $\mathrm{S}$. W., until below Jackson it benis, and thence flows S. by E. th the (julf of Mr xien. From lat. $310 \mathrm{~N}$. it forms the dividing line between $A l r$. and $L a$. The navigution is olstrueted by sand-hary, stallows, etc., but admits small vessels to Jackson. For statistics of Pearl river collection district, see SuIELdSEoros, its port of entry.

Pearlingtor, p. o., Iancock co., Miss. : on Pearl river, about $10 \mathrm{~m}$. above its mouth, $141 \mathrm{~m}$. S. by E. Jackson.

Peart, Valley, p. O., Neshoba co., Jriss.: aboul $5 \mathrm{~m}$. N. of Pearl r., $69 \mathrm{~m}$. N. E. by E. Jackson.

Pea Vine, p. o., Walker county, Ga.: 181 m. N. W. Milledgeville.

Pecan Grove, p. o., Carroll par., La.: 145 m. N. Baton Rouge.

Pecan Point, p. o., Mississippi co., Ark. : on the Mississippi, 141 m. E. N. E. Little Rock.

Peck's Ruv, p. o., Barbour co., Firg.: 109 m. N. W. by W. Richmond.

Pecksville, p. v., Duchess co., $N . Y_{\text {. }}: 79 \mathrm{~m}$. S. Albany. Peconic bays, $N . Y_{0}:$ lie at the E. end of Long Island, dividing it into two peninsulas. Great Peconic bay is separated from Gardiner's bay on its E. by Shelter island, and is a large body of water, $14 \mathrm{~m}$. long by 4 to $5 \mathrm{~m}$. wide. It is separated from Southold harbor by Little Hog Neck, and contains Robbins' island, E. of its centre. Little Peconic bay is its more western portion, extending inland 4 or $5 \mathrm{~m}$., and receives from that Peconic r., which is narigable for sloops to Riverhead.

Pecos river, N. Mex.: the main N. tributary of the Iio Grande; rises in the table-lands E. of Santa Fé, and flows in a S. S. E. enurse through the valley between the Guataloupe Mountains and Sierra Blanea $500 \mathrm{~m}$., to its confluence with the Rio Grande.

PedeE, p. v., Cedar co., Ia.: 17 m. E. Iowa City.

PEDEe rivers, Great and Little, \&. Car.: Great Pellee r. rises in the N. W. part of $N$. Car, and is called Tadkin $r$. until it enters $S . C a r^{2}$, througl which it fiows, in a S. S. E. course, into Winyaw bay, an inlet from the Atlantic. It is navigable $200 \mathrm{~m}$. for bonts of 60 or 70 tons. Little Pedee $r$. rises in $\mathrm{S}$. E. part of $N$. Car., and flows in a southerly course to its confluence with the Great Pedee $\mathrm{r}_{\mathrm{s}}, 32 \mathrm{~m}$. above its mouth.

Pedlak's Hili, p. o., Chatham co., N. Car.: $36 \mathrm{~m}$. T. Raleigh.

Pedlar"s Mili, p. o., Amberst co., Virg.: on a N. branch of James r., $94 \mathrm{~m}$. W. Richmond.

Pedricktown, p. v., Salem co., N. Jer.: on Oldman's cr. $2 \mathrm{~m}$. E. of the Delaware, $46 \mathrm{~m} . \mathrm{S}$. W. Trenton.

Peedee, p. o., Anson co., N. Car.: 83 m. S. W. Raleigh. Peersicilu, p. v. and sta., Westehester en., $N . Y_{.:}$on the E. side of Hudson r., $43 \mathrm{~m}$. N. of New York, and $101 \mathrm{~m}$. S. of Albany by the Hudson River R. R. It is pleisantly situated, contains 8 churehes, an incorporated academy, 6 large iron foundries, casting chiefy stoves and agricultural implements, several tanneries, etc., and one bank, capital $\$ 200,000$. A large business is done by barges, sloops, etc., in conveying to the New York markets live-stock and regetable produce here collected from the fertile agricultural distriet surrounding it. A steam ferry-boat plies across the Hudson to Caldwell's Landing. The "P. Republican" (whig) is issued weekly. This place is invested with interest from its connection with the Revolution. Pop, about 8,000 . Peeled OAk, p. O., Bath co. Ki/s: $61 \mathrm{~m}$. li, Trankfort

Peer Tree, p. o., Harrison co., Virg.: $201 \mathrm{~m}$. N. W. by W. Richmond. 
PIeERY's Store, p. 0., Tazewell co., Firg.: $241 \mathrm{~m}$. W. by S. Richmond.

Peirceville, p. T., Dane county, Wisc.: 13 m. E. N. E. Madison.

Pekatonica river, Wisc, and $I l l .:$ rises in Iowa co., Wisc., and flows $\mathrm{S}$. and $\mathrm{E}$. into Rock r., in Ill., $6 \mathrm{~m}$. below its $\mathrm{N}$. boundary. Near its mouth it receives from the N. Sugar cr, a considerable branch. It is navigable for flat boats to Mineral Point, Wise.

PEKTN, p. v., Tazewell co.. IIl.; on the left bank of the Illinois, $54 \mathrm{~m}$. N. Springfield. It is $182 \mathrm{~m}$. from the mouth of the $\mathrm{r}$., and largely engaged in shipping the agricultural products of an extensive and fertile district for the $\mathbf{E}$. and $\mathbf{S}$. markets. Though commerce is the leading interest, its manufactures are rapidly increasing, and must soon be of great importance. It contains an academy, several steam flouring and saw mills, about 40 stores and warehouses, and 2,500 inhabitants. Two weekly newspapers, the "Tazewell Mirror" (whig), and "Illinois Reveille" (dem.), are published here.

PEkIN, p. v, and sta, Niagara co., N. $Y_{0}:$ on the Rochester, Lockport, and Niagara Falls R. R., 10 m. W. of Lockport, $259 \mathrm{~m}$. W. by N. Albany.

PekIN, p. o., Jessamine co., $\bar{k} y . ; 26$ m. S. E. Frankfort.

Pekrs, p. v., Carroll co., Ohio: on Sandy cr. and the Sandusky and Beaver Canal, 107 m. E. N. E. Columbus.

Persar, p. o., Jackson co., Tenn.: 57 m. E. Nashville.

PEETr, p. v. and sta., Washington co., Indr. : on Lick cr. of Great Blue r., $81 \mathrm{~m} . \mathrm{S}$. Indianapolis. It is $24 \mathrm{~m}$. N. of New Albany, on the New Albany and Salem R. R.

Pelearr, to and p. o., Westehester co., N. $Y_{0}$ : on Long Is'and Sound, 121 m. S. Albany. Drained by Eastehester cr., flowing into Eastchester bay. Surface mostly Jevel; soil sandy, but well tilled. The New York and New Haven R. R. crosses the N. part. Pop. 577.

Pelhas, to and p. v., Hampshire co., MFass: $78 \mathrm{~m}$. W. of Boston. Drained by Swift and Fort rivers, which furnish mill-sites. Surface high and uneven; soil of average quality. Asbestos is found, and springs containing iron and sulphur. Building stone is abundant. Pop. of t. 958.

PeLHAN, to and p. o., Hillsboro' county, N. IIamp.: $38 \mathrm{~m}$. S. S. E. Concord. Drained by Beaver r., an affluent of the Merrimac. Surface broken; soil fertile on the streams. Farming and grazing are the chief occupations. Population of t. 1,071 .

Pelmam, p. 0., Grundy co., Tenn. : 76 m. S. E. Nashville.

Pella, p. v., Marion co., Ia. : on a fine upland, equi-distant from the Des Moines and Skunk rivers, $72 \mathrm{~m}$. W. by S. Iowa City, A colony of Hollanders, under President Sehaulter, has settled here.

Peltonville, p. v., Steuben co, $N_{0}, Y_{0}$ : about $2 \mathrm{~m}$. W. of Crooked lake, $181 \mathrm{~m}$. W. Albany.

Peviduncoor lake, Mfe. : lying in the E. part of Piscataquis co., is a large body of water, of irregular shape, surrounded by some of the best timber-land in the State, and affords excellent transportation for the iumber, etc.

PeNaqum, p. o., Lincoln co., Me, : near the Atlantic coast, 86 m. S. S. E. Augusta.

Pemberton, to and p. v., Burlington co, $N$. Jer.: $17 \mathrm{~m}$. S. S. E. Trenton. Drained by branches of Rancocus cr., which furnish water-power. Surface mostly level; soil saudy loam of grood quality. The $\mathrm{v}$, is on the $\mathrm{N}$. branch of the cr., and contains a furnace, cotton factory, several mills and stores, and about $\mathrm{S} 00$ inhabitants. Pop. of $\mathrm{t} 2,866$.

Penrbertox, piv., Goochland co., Firg.: $27 \mathrm{~m}$. W. N.W. Richmond.

Pembra county, Minn. Ter. Situate N., and contains 45,000 sq. $\mathrm{m}$. This large county lies between lat, $47^{\circ}$ and 490 , and extends from the Missouri and White Earth rivers on the W. to the Mississippi, which in part forms its E. boundary. The sources of the Mississippi nceupy the $\mathrm{E}$. section of the county, and consist of a series of lakes, large and small, which are soread over thousands of square miles. Westward of this is the height of land diriding the waters 650 of the Mississippi flowing S. from those of the Red r. of the $\mathrm{N}$., the latter of which passes throngh the county from the S., and fells into Lake Winnipeg above the national boundary. The extreme $\mathrm{W}$. is drained by numerous affluents of the Missouri. Little is known of this far northern region, except of the immediate banks of the Red River, where, at Pembina, are located the followers of Lord Selkirk. The county is well wooded, and the soils, where settlement has been made, are found to be very fertile, but the short summers and long winters must ever prevent the dense population of the country, so long as there is room to spare in the milder elimates and fine lands of the more genial South. Farms 17; manuf. 0; dwell. 188, and pop.-wh. 1,134, fr. col. 0-total 1,134. Capital: Pembina.

Pembina, p. v., and cap. Pembina co., Bfinn. Ter.: on E. bank of Red r. of the $N_{\text {., at the }} \mathrm{N}$. boundary line of the State, 334 m. N. N. W. St. Paul. This settlement contains upward of 1,000 population, principally persous of mixed Indian and white blood, who subsist ehiefly by agrieulture and hunting. There is a Catholic ehurch in which to accommodate the varied population; sermons are preached in English, French, and Chippeway.

PeMrroke, t. and p. o., Christian co., Ky.: $166 \mathrm{~m}$. S. W. by W. Frankfort.

Pramboke, t. and p. v., Washington co., Me.: on the $\mathrm{N}$. side Cobscook bay, 136 miles E. by N. Augusta. Surface varied; soil fertile and well tilled. The eoasting-trade and fisheries are leading interests. Pop. of t. 1,712.

Pensbroks, t. and p. v., Plymouth county, Mass.: $24 \mathrm{~m}$. S. S. E. Boston. Drained by branches of North r., which afford good power. The $r$. is deep, and navigable into the t., and ship-building is carried on extensively along its course. In the $\mathrm{S}$. are several ponds. Cotton goods, iron castings, cabinet-ware, etc., are manufactured. The v. contains an academy. Pop, of $t, 1,3 s 8$.

Peмrioke, to and p. v., Merrimac co., $N$. Hamp.: $7 \mathrm{~m}$. S. E. Concord. Bounded W. by the Merrimac, and S. by the Suncook, which supply water-power. Surface pleasantly diversified; soils various, mostly fertile, and on the rivers very rich. The Portsmouth and Concord R. R. passes along the Merrimac. The $\mathrm{v}$. extends about $3 \mathrm{~m}$. paralle! to that r., and contains a large and flourishing aeademy. Pop. of t, 1,732.

Penrbroke, t. and p. v., Genesee county, $N . Y_{.}: 22 \mathrm{~s}$. W. by N. Albany. Drained by Tonawanda $\mathrm{cr}_{\text {., }}$ which has several falls. Surface even or undulating; soil clayey loam, and very productive of wheat. The Canandaigua and Niagara Falls R. R. and Buffalo and Fochester R. R. cross the th; on the latter is P. sta, $11 \mathrm{~m}$. W. of Batavia, The v. on the creek contains a furnace and several mills. Population of $t .2,279$.

PвмввокE, p. O., Giles county, Virg. : 163 m. W. by \$. Richmond.

Penigewassett river, $N$. It ent stream of Merrimac r., rises in the White Mountains, E. of Franconia, and flows in general S. course to its junction in Franklin t. with Winnipiseogee r., there forming the Merrimac river.

PEriscot county, MFo. Situate S. E., and contains about $300 \mathrm{sq}$. m. Drained by White Water r. and its branches in the N. W. portion. Surface low and level; a large portion is swampy, and unflt for caltivation; soil is fertile where cultivated, and adapted to grain. It produces abundantly wheat, corn, fruits, ete., and has some good timber land. It contains some minerals and good coal-beds. In the S. W. is Lake Pemiscot, occupying a large portion of the $\mathrm{co}$. The Mississippi bounds it on the E. A new county since 1550 . Capital: Little Prairie.

Penataquit, p. 0., Suffolk co., N. $Y$.

Pencader, bund., New Castle co., Del. : on the. W. line of the State, and contains 29,250 acres. Surface elevated and uneven; soil clayey, in parts marshy, and moderately productive. The Philadelphia, Wilmington, and Baltimore 
R. R., the New Castle and Frenchtown R. R., and the Chesapeake and Delaware Canal pass through it.

Pexdaktis' Store, p. 0., Wayne co., Ga.: 145 m. S. E. by S. Milledgeville.

Pendleton county, $K y$. Situate $N$., and contains 286 sq. m. Drained by Licking $r$, and its branches, Grassy, Kincaid's, and Fort Lick creeks. Surface generally level, but in the N. E. rather hilly, and presenting high bluffs to the r. shore; soil fertile and productive, and there is some good grazing land. Staples, Indian corn and tobaceo. Farms 606 ; manuf. 7 ; dwell. 1,057, and pop.-wh. 6,230, fr. col. 35, sl. 509-total 6,774. Capital: Falmouth. Public Torks: Covington and Lexíngton R. R.; Covington and Maysville R. R.

Pendleton county, Virg. Situate N. centrally, and contains 612 sq. m. Drained by S. branch of Potomae r., which traverses its central portion. Surface mountainous and rough, the co. being an elevated table-land lying between two ridges of the Alleghany Mountains; soil barren in general. Chief production, Indian corn. Farms 693; manuf, 56 ; dwell. 891 , and pop.-wh. 5,443, fr. col. 30, sl. 322-total 5,775. Capital: Franklin.

Pendleton, p. v. and sta., Madison co., Ind.: on Fall cr., $25 \mathrm{~m}$. N. E. by E. Indianapolis. It is $28 \mathrm{~m}$. from Indianapolis by the Indianapolis and Bellefontaine R. R., and has good water-power on the cr. It contains several stores aud mills, and 600 or 800 inhabitants. There are quarries of limestone and marble near it.

Pendletor, t. and p. v., Niagara county, $N$. $Y .: 252 \mathrm{~m}$. W. by N. Albany. Drained by affluents of Tonawand $x$ cr., its S. boundary. Surface undulating; soil fertile caleareous loam. It contains a noted sulphur spring. The Canandaigua and Niagara Falls R. R. erosses the S. part. The Erie Canal also passes through it, on which is the $\mathrm{F}, 7 \mathrm{~m}$ S. W. of Lockport, $24 \mathrm{~m}$. N. E. of Buffalo. Pop. of t. 2,166 . Pendletox, p. 0., Putnam county, Ohio: 95 m. N.W. Columbus.

Pendleton, p. v., Anderson dist., S. Car.: on Eighteen Mile cr., an affluent of Savannah $\mathrm{r}_{.,}, 121 \mathrm{~m}$. W. N. W. Columbia. It contains 2 academies, a dozen stores, and about 700 inhabitants. The "P. Messenger," a weekly issue, is published. The proposed route of the Rabun Gap R. R. passes through it.

Pendleton river, $G a_{0}$ : rises in Lawrence county and flows S. E. into Tatnall county, there joining the Great Ohoopee r.

Pendleton Centre, p. v., Niagara co, $N, Y_{0}: 254 \mathrm{~m}$. W. by N. Albany.

Pendleton Hili, p. o, New London co., Conn.: $26 \mathrm{~m}$. S. E. Hartford.

Penfikld, p. v., Greene co., Ga.: 41 m. N. Milledgeville. It has a pleasant location, is well laid out and neatly built, and the seat of a college and theological seminary under the direction of the Baptists. Mercer University was founded in 1838, and in 1850 had 7 instructors, 32 alumui (of whom 10 were ministers), 71 students, and a library of 3,400 volumes. Mercer Theological Seminary, founded in 1844, had in 1850, 2 professors, 6 students, 3 graduates, and 2,200 volumes in its library. Pop. about 800 .

Penfield, p. v., Kane eo., Ill.: on the right bank of Fox r., at the entrance of Big Rock cr., 142 m, N. N. E. Springrield.

Penfirld, to and p. V., Monroe county, $N . Y_{.}: 157 \mathrm{~m}$ W. by N. Albany. Drained by Irondequoit cro, emptying into Irondequoit bay, its W. boundary. Surface undulating; soil loam, mixed with sand, gravel, or clay. Limestone is plenty, and wheat the chief product. The $\mathrm{r}$. is on the creek, and contains an academy, several factories, and flouring and other mills, and a population of $\$ 00$. Population of $\mathrm{t} .3,185$.

Pexfield, t. and p. o., Lorain co, Ohio: $94 \mathrm{~m}$. N. N. E. Columbus. Drained by E. branch of Black $\mathrm{r}$. Pop. fiz.

Peninsela, p. v., Summit co, Ohio: on Cuyahoga r. and the Ohio Canal, $24 \mathrm{~m}$. S. Cleveland, $113 \mathrm{~m}$. N. E. Columbus.

Penv Distriot, t., Philadelphia co., Penn. See PritaDELPHIA.

Penney's, p. o., Randolph co., Mo.: $65 \mathrm{~m} . \mathrm{N}$. by W. Jefferson City.

Pennfield, p. 0., Davidson co., N. Car.: $93 \mathrm{~m}$. W. Raleigh. Pennfielio, t. and p. o., Calhoun co., Mich. : $41 \mathrm{~m}$. S. W. Lansing. Drained by Battle cr., a N. branch of the Kalamazoo, on which are numerous water privileges. Surface rolling; soil very productive of grain. Pop. 598.

Penningtos, p. v., Mereer co., N. Jer. : $8 \mathrm{~m}$. N. by W Trenton. It contains an academy and 8 or 10 stores.

Penningtonville, p. vo and sta., Chester e0., Penn. : on the Columbia and Philadelphia R. R., $43 \mathrm{~m}$. W. of Philadelphia, $52 \mathrm{~m}$. E. $\mathbf{S}$. E. Harrisburg. Near the v. is a furnace of 1,200 tons annual capacity, and a forge producing 350 tons of blooms per annum. It contains several stores about 40 dwellings

Penn Lrne, p. 0., Crawford co., Penn.: near the W. line of the State, $208 \mathrm{~m}$. N. W. by W. Harrisburg.

Penn Run, p. o., Indiana co., Penn.: 118 m. W. N. W. Harrisburg.

Pennsborovgh, p. v., Ritchie county, Virg.: 232 miles N. W. by N. Richmond.

Pennsborough, p. o., Irwin co., Ga.: $112 \mathrm{~m}$. S. by W. Milledgeville.

Pennsiurg, p. o., Montgomery county, Penn.: $75 \mathrm{~m}$. E Harrisburg.

Penn's Creek, p. 0., Union co, Penn.: on a W. affluent of the Susquehanna so ealled, $43 \mathrm{~m}$. N. by W. Harrisburg.

PenN's Grote, p. o., Salem co., N. Jer.: on Delaware r., $49 \mathrm{~m}$. S. W. Trenton.

PenN's Grove, p. O., Delaware co, Penn。: 74 m. E. S. E. Harrisburg.

Penn's Seuare, p. o., Montgomery co., Penn.

Penn's Store, p. o., Patrick co., Virg.: on North Mayo r., $152 \mathrm{~m} . \mathrm{W} . \mathrm{S} . \mathrm{W}$. Richmond.

Pennsville, p. v., Morgan co., Ohio: about 3 m. W. of Muskingum r., 64 m. E. S. E. Columbus.

Penngvilue, p. v., Fayette co., Penn.: 187 m. W. by S. Harrisburg.

\section{THE STATE OF PENNSYLVANIA.}

PeNistrianta, from her central position, her natural resources, and her grand system of transit lines, one of the most important States of the Union, lies in the form of a parallelogram, between $39^{\circ} 43^{\prime}$ (Mason and Dixon's line) and 420 latitudes N., and extends from $74^{\circ} 40^{\prime}$ to $80^{\circ} 36^{\prime}$ longitudes W. from Greenwich, or $2 \circ 22^{\prime}$ E. and $3035^{\prime}$ W. from Washington. It is bounded on the north by Lake Erie and the State of New York; on the east by New Jersey, from whieh the Delaware River separates it; on the south by Delaware, Maryland, and Virginia; and on the west by Virginia and Ohio. With a length from east to west of 315 miles, and a breadth, exclusive of the strip of land jutting toward Lake Erie, of 160 miles, its area covers a surface of 46,000 square miles.

Pennsylvania, with the exception of Virginia, is the only State which stretches quite across the great Appalachian srstem of mountains, and is thus naturally divided into three strikingly distinct regions-the eastern or Atlantic slope, the rentral or mountain region, and the western, or Ohio and Erie table-land.

The principal mountain chains definitely traceable in this State are as follows:

1. The South Mountain enters it from New Jersey, between Northampton an. Bucks counties, and after being inter- 
PENNSYLVANIA.

rupted by the Schuylkill above Pottstown, and by the Susquehanna near the southern border of the State, it passes into Maryland.

2. The Blue Ridge enters Pennsylvania below Easton, where it is piereed by the Delaware; pursuing a south-westerly direction, it is intermpted by the Schuylkill at Reading, by the Susquehanna below Harrisburg, and passes out of the State between Adams and Franklin counties. The elevation of the former ridge nowhere exceeds 1,000 feet, and that of the latter is somewhat more elevated.

3. The Blue Mountain, or Kittatinny, also enters this State from New Jersey, and is broken by the Delaware at Water Gap, further west by a pass called the Wind Gap, by the Lehigh, by the Schuylkill above Harrisburg, and by the Susquehanna five miles above Harrisburg. It then passes between Franklin and Bedford eounties into Liaryland. Its clevation in Pennsylvania varies from 800 to 1,500 feet above the sea level. Between the Kittatinny Mountain and the north branch of the Susquehanna River, a distance of about 35 miles, is the great anthracite coal region.

4. The Broad Mountain, which lies in the intervening space between the Kittatinny Mountain and Susquehanna, forms a less continuous but more elevated chain than the last mentioned. It is continued south-west of the Susquehanna by the Tuscarora Mountains, which are pierced by the Juniata between Miffin and Perry counties, and passes into Maryland a little west of the Kittatinny chain.

5. Sideling Hill forms a well-defined ridge from the Maryland line to the Juniata, on the south-west corner of Mifflin County.

6. The next well-defined chain is the Allcghany Mountain, which forms the dividing ridge between the Atlantic basin and the Valiey of the Ohio. It is therefore the height of land between those two basins, although its summits do not rise to so great an elevation above its base as do those of Broad Mountain above the base of that chain. The Alleghany rises in Bradford County, is pierced by the north branch of the Susquehanna below Towanda, traverses Lyeoming County, where it crosses the west branch of the Susquehanna, and pursuing a southerly course, separates Huntingdon and Bedford from Cambria and Somerset counties.

Westward of the Alleghany chain, and on the Ohio table-land, two well-defined chains cross the State from north to south, in a direction nearly parallel to that of the first-mentioned, under the names of ( $\bar{\tau}$ ) the Laurel Ridge, about twentyfive miles west of the Alleghanies; and (3) Chesnut Ridge, ten miles farther west. Neither of these chains is very elevated.

Though in some places rude and rocky, many of these mountain ranges consist of gradually rising swells, cultivated to the summits, and the whole mountain region is interspersed with highly bentiful and productive valleys, some of which are of considerable extent and under an excellent system of cultivation. The enstern and western parts of the State are generally level, or agreeably diversified with hills and vales.

Every part of Pennsylvania is well watered, and abounds in rivers, streams, rivulets, and brooks; but some of the rivers are so much obstructed that they serve rather as canal feeders than as navigable channels.

The Delaware, that rises in the Kaätskill Mountains in New York, and bathes the eastern border, may yet be considered as belonging to Pennsylvania, from which it receives its prineipal tributaries. Pursuing a southerly course, and piercing the Kittatinny and Blue Ridge, the Delaware meets the tide 130 miles from the sea at Trenton, to which place it is accessible for sloops; at and above that point the navigation is impeded by a fall and shoals. Large ships aseend to Philadelphia, about 40 miles below which it expands into a broad bay. Its whole course is about 320 miles in length. The numerous canals connected with various points of the coal region, and uniting its waters with those of the Hulson, the Raritan, and Chesapeake, have greatly increased its importance as a channel of trade. Its principal tributaries in Pennsylvania are the Lackawaxen, the Lehigh, and the Schuytkill, which rise in the anthracite region. The Schnylkill hins a course of about 130 miles, and is navigable fur vessels of above 300 tons to Philadelphia, six miles below which it falls into the Delaware.

The Susquehanna is the principal river of Pennsylvania in point of size, but it is so much broken in its course by rapids and bars as to afford little advantage to navigation without artificial aid. It rises in Otsego Lake, in the State of New York, and flowing in a circuitous but general southexly direction, nearly parallel with the Delaware, it reaches the Chesapeake 470 miles from its source. Its principal tributaries are all from the right-they are the Unadilla and Chenang, in New York: and the Tingi or Chrmung, the West Branch, and the Juniati, in Pennsylvania. The nust considerable from the west are the Lackawannock, Swatara, and Conestoga. The channels of the Susquehanna are so winding and broken that even the descending navigation is extremely difficult and dangerous, and practicable only at certain seasons in particular stages of the waters, and its tributaries partake of the same character. The Juniata rises in the Alleghany ridge, but the West Branch rises in numerous streams from the Laurel Hill, and pierces the Alleghany above Dunstown.

The great rivers of Western Pennsylvania are tributaries, or, rather, constituents of the Ohio. The Alleghany, rising in the north-western slope of the same range, with some of the remote sources of the West Branch, flows first north into Now York, and then south to its junction with the Monongahela. It is navigable to Olean, in New Fork, 240 miles frnm its mouth, and to Waterford, on French Creek, its principal tributary, 14 miles from Lake Erie. The Kiskimenitas, or Conemaugh, the principal tributary to the east, rises in the western declivity of the Alleghany Mountains, near the head waters of the Juniata, and pierces the Laurel and Chestnut ridges. The other constituent branch of the Ohio is the Monongahela, which descends from the Alleghany range in Virginia, and before its junction with the Alleghany receives the Youghiogeny, a large stream from Maryland. Both of these rivers afford boat navigation for a considerable distanco. The Big Beaver is the only large tributary of the Ohio within this State, and is navigable for some distance abnve the falls near its mouth. After the junction of the Alleghany and Monongahela, the Ohio has a short part of its course on the borders of Pennsylvania.

Pennsylvania, skirting on Lake Erie, has a coast of ahout 30 miles in length. Seamard, the State has no coast, but its noble river, the Delaware, is easily accessible, and furnishes harbors of the greatest importance. Westward of the mountains, its rivers open a highway toward the Great West, and ultimately to the Gulf of Mexico. And both systems of rivers and outlets are so connected by vast internal improvements as to create continuous lines of communication, which not only permit of a free passage through the State, but bring to a focus all its most distant parts.

The numerous geological formations which are observable throughout Pennsylvania are generally compnsed of successive strata or layers of rock, based one upon another, from the lowest prinary in the series up to the highest rocks containing the anthracite and bituminous coal. The rocks which contain these stratifications are the highest in the regular ascending order found in the State. If rocks of a more recent furmation than the coal are found anywhere in the State, 
PENNSYLVANIA.

their area is of a very limited character, and they must, in all probability, have been deposited since the formation of that rast system of lower secondary strata which occupies so large a purtion of the territory. In traveling through this state, the attention of the most casual observer can not fail to be attracted by the course or range of the various groups and beds of rocks, which run in nearly a north-east and south-west direction, in many places forming a curvature of consirleralele magnitude, and at the same time corresponding with the mountain ridges which traverse the State. The position of thuse strata is not in all places the same, their inclination or dip verging in evers degree of slope, from horizuntil to perpendicular.

The rocks of the secondary series, being sedimentary, present a beautiful stratified appearance, and, as a matter of course, are composed of a succession of water deposits, indienting to us that they must have originally lain in a horizontal position. The different rock belonging to the primary stratified elass chiefly consist of gneiss, mica, slate, tale-slate, and their suborinate varieties. These oceupy the south-eastern portion of Pennsylvania, including a part of Chester, Lancaster, York, Montgomery, Bucks, and Delaware, and the whole of Philadelphia County. There are, however, unsiratified rocks of a crystalline strueture, comprising granite, sienite, ete., discovered in small local and irregular veins, generally in the southernmost portion of the primary range. This range of rocks extends from Trenton, on the Delaware, downward to the very southern boundary of the State. It also runs westwardly to the south-eastern part of Adams county. The crystalline limestone of Chester and Montgomery counties, which sometimes forms good marble, is found above this triangular belt as we proceed north; and in some places north of this limestone, gneiss, with talc and micaslate, have been discovered.

Continuing northward, we come to the red sandstone formation, which stretches across the State from the Delasware above Trenton to the Maryland line. This formation extends through Bucks, Dauphin, Chester, Montgomery, Berks, Lancaster, York, and Adams counties. Some geologists have classed this group with the middle secondary period. Be this, however, as it may, one thing is certain-it presents a remarkable uniformity with respect to its material and appearance throughout its whole range. It is composed of dark, reddish brown, argillaceous sandstone, soft, crumbling, red and brown shales, with now and then bands of conglomerate. The dip of the strata is almost invariably to the northward, descending at an angle of from 12 to 25 degrees. The conglomerates which this group contains are prineipally discovered in the under strata, near the southern formation of the margin, or along its northern border in the highest. In both cases, where the red sandstone overlies the older limestone in the vicinity, it is frequently that a large portion, if not the whole, of the imbedded pebbles, consists of rounded fragments of variously colored limestone. The paste which cements them together is so highly calcareous that the whole mass can be easily burned and converted into tolerably good lime. Portions of this conglomerate, were they to undergo a polishing process, would make a beatiful variegated marble of the breceia species. The marble from which the representative chamber of the Capitol, at Washington, is made, and which was quaried on the Potomac, is of this character, and belongs to this formation. It is observable at severul points in the north rn bordes of the red sandstone, in the upper part of Bucks and the southern parts of Berks, but more especially near the Schurlki!l, two or three miles below Reading. It is also found in several other places, but in less quantity. Numerous hills and dykes of trap rock, or greenstone, which sometimes form hills of considerable height, traverse the red sandstone formation in the same direction as the other ranges of the State. Generally this rock assumes a dark-gray color, with some shade of green erystalline in its structure, being chiefly composed of hornblende and feldspar, quite closely mixed. Although this rock is exceedingly tough and very difficult to break, yet it is frequently used as a material for buildings; but in consequence of its being seattered over the surface in irregular masses of all sizes, it is seldom quarried for that purpose. It is very erident that this rock is of an igneous origin; and having been brought to the surface in a state of fusion, by an uphearal through the dislocated beds of red sandstone, in a highly heated state, it has transformed the texture and color of the shale and sandstone in the neighborhood, turning them into a baked, hard, blue rock, entirely different from their original character. In a number of the ridges which cross the upper parts of Bucks and Montgomery ounties, this rock only is visible, the trap baving never reached the surface; but the heat, however, from beneath has been so intense as to chanco the color and texture of the shales and sandstone above. The soil where this rock is generally found is of a cold, clayey character, and but little esteemed for agricultural purposes, while the unaltered soil of the shale and sandstone is exceedingly productive,

Another belt of primary rocks, which forms a chain of hills stretehing south-west across Northampton, Lehigh, Bucks, Lancaster, York, Cumberland, Adams, and Franklin counties to the Maryland line, is found on the Deliware, below Easton, north of the middle secondary sandstone. This irregular range is generally called the South Mountain, and though frequently interrupted, is nearly continuous across the State. Continuing south-west along this ridge, the primary rocks disappear as we approach the Schuylkill, and although they are seen oceasionally west of that even, they are invariably covered throughout the remainder of the range by overlying roeks of the secondary series.

The mineral wealth of Pennsylvania consists chiefly in its vast deposits of coal and iron. The coal is of two distinet varieties, viz, anthracite, anasphaltic or non-bituminous, and bituminous.

The anthracite of Pennsylvania is found in the Wyoming and Lackawanna villeys, situated between the Blne Piclge and the Susquehanna. The coal district is chiefly occupied by mountains which run parallel to the Blue Pidge, and are 1.500 feet high. But little of this surface, with the exception of a few narrow valleys, invites cultivation. These mountains are chiefly in a wild state, and offer a secure retreat to congars, wolves, bears, and other animals.

The rocks of the above described region are of a transition class, and present little diversity. Graywacke slate occurs in abundance, loose on the surface and in ledges. It is sometimes based on old red sandstone, and surmounted by unstratified rocks, an aggregate of quartz, pebbles of various dimensions, with a cement usually silicious. In the Bluo Ridge, in addition, a silicious graywacke, resembling fine-grained granular quartz, is common. It appears in some places massive, but is often slaty. Its cement is chitfly silicious; some alumine, however, is indicated in its composilion. The beds and veins of anthracite range from north-east to south-west, and may often be traced for a considerable distance by the compass. The veins have the inclination of the adjacent strata of graywacke, with whith they are often alternate, usually between 200 to 450 . In a few places they are horizontal and vertical. The beds and veins of anthracite have narrow strati of dark colored, fine grained, argillaceous schist for the roof and floor. This slate generally contains sulphuret of iron, and disintegrates on exposure to the atmosphere. The sulphates of iron and alumine are often observed in the schist, and it frequently presents impressions of plants, and smmetimes of maritime shells. Impure pulverulent eoal is usually connected with this slate, and is said to be a good material for printers ink.

Anthracite has been found in the greatest quantity in sections of coal regions most accessible by water. Exteusiro beds and veins range from the Lehigh to the Susquebanna, crossing the hend waters of the. Schurlkill and swatara about 10 
PENNSYLVANIA.

miles north-west of the Blue Ridge, and it abounds contiguous to the Susquehanna and Lackaranna. But in no part of the district does anthracite occur in such apparently inexhaustible beds, or is so abundantly raised, as in the vicinity of Mauch Chunk, a village situated on the Lehigh, 35 miles from Easton, and 108 miles by water from Philadelphia. The coal is there excavated on the flat summit of a mountain that rises nearly 1,500 feet abore the ocean. It is of good quality, and presents beds of unparalleled extent, is disclnsed for several miles on the summit, and is indicated in many places by a coal slate in a pulverulent state on the surface. The mountain rises with a steep acelivity, particularly on the north-west side, and when penetrated at various altitudes, discloses coal at about the same distance from the surface. Strata of graywacke slate, containing mica, sometimes rest on the coal, parallel with the mountain side. In the deep excarations made on the summit no termination of the coal bed has been found, and it is not improbable that the authracite forms the nucleus of the mountain for a considerable distance.

This coal mountain range is described as extending in a south-west direction to the Susquehanna. To the north-east, beyond the Lehigh, it is connected with the Broad Mountain, the first considerable elevation west of the Blue Ridge. The Lehigh, from Mauch Chunk to the Water Gap, 11 miles, winds between rocky mountains, with a brisk current, but presents no falls. In its passage through the Kittatinny the river has a tranquil but slightly inclined course. On the adjacent elevation yellow pine, hemloek, and spruce are interspersed with deciduous trees. From the Water Gap to the Delaware the river pursues its course in a deep ravine, seldom with alluvial borders of much extent. In this district of country the soil generally rests on limestone sinks, indicating caves, and fissures in the rocks are often observed that must in some places render canaling difficult. From the confluence of the Lehigh with the Delaware to tidewater the descent is 150 feet.

Next to Mauch Chunk, Mount Carbon, or Pottsville, as it is now ealled, situated at the head of the Schuylkill Canal, has worked the principal anthracite coal fields. Many large veins are worked within three miles of the landing, and some have been opened seven miles to the north-east, in the direction of the Lehigh beds. On almost every eminence adjacent to Pottsville indications of coal are disclosed. The veins generally run in a north-east direction, with an inclination of about $45^{\circ}$, and are from 3 to 9 feet in thickness; commencing at or near the surface they penetrate to an unknown depth, and can often be traced on hills to a considerable distance by sounding in a north-east or south-west direction. Some veins have been wrought to the depth of 200 feet without the necessity of draining, the inclined slate roof shielding them from water. The coal and slate are raised by horse-power, in wagons, by a railway that has the inclination of the vein.

Table showing the quantity of antbracite coal sent to market annually, from its commencement in 1820 :

\begin{tabular}{|c|c|c|c|c|c|c|c|c|c|c|}
\hline Years. & $\begin{array}{c}\text { Total } \\
\text { Lehigh. }\end{array}$ & Schuylkill. & $\begin{array}{c}\text { Little } \\
\text { Scbuylkill. }\end{array}$ & $\begin{array}{c}\text { Total } \\
\text { Scluylkill. } \\
\end{array}$ & Lackawanna. & Pine Grove. & $\begin{array}{l}\text { Lykens } \\
\text { Valley. }\end{array}$ & Shamokin. & wyoming. & Total Supply \\
\hline 1820 & 365 & - & - & - & - & - & - & - & - & 365 \\
\hline 1821 & 1,073 & - & - & - & - & - & - & - & - & 1,073 \\
\hline 1822 & 2,441 & - & - & 一 & - & - & - & - & - & 2,441 \\
\hline 1823 & 5,023 & 一 & - & - & - & - & - & - & 一 & 5,023 \\
\hline 1524 & 9,511 & - & - & - & - & - & - & - & - & $9.5 \pm 1$ \\
\hline 1825 & 28,396 & 6,500 & - & 6,500 & 一 & - & - & - & - & 34,896 \\
\hline $1 \$ 26$ & $31,2 s 0$ & 16,767 & - & 16,767 & - & - & - & - & - & $45,04 \pi$ \\
\hline 1827 & 32,074 & $.31,360$ & 一 & 31,360 & - & - & 一 & - & 一 & 63,434 \\
\hline 1528 & 30,232 & 47,294 & - & 47,284 & - & - & 一 & - & - & 77,516 \\
\hline 1529 & 25,110 & 79,972 & - & 79,972 & 7,000 & 一 & - & - & - & $112,0 \mathrm{S3}$ \\
\hline 1830 & 41,750 & 89,954 & - & 89,984 & 42,700 & - & - & - & - & 176,734 \\
\hline 1831 & 40,966 & $81,8 \tilde{1} 1$ & - & 81,854 & 54,000 & - & - & - & - & 170,820 \\
\hline 1832 & 75,000 & 195,271 & 14,000 & 209,271 & $84,5 \rightarrow 0$ & - & - & - & - & $368,7 \pi 1$ \\
\hline 1833 & 123,000 & 216.210 & 36,761 & 252,971 & 111,777 & - & - & - & - & 487,743 \\
\hline 1534 & 106,244 & 191,540 & 35,152 & 226,692 & 43,700 & - & - & - & - & 376,636 \\
\hline 1535 & 131,250 & 302,024 & 37,494 & $339,51 \mathrm{~S}$ & $9 \mathrm{~S}, \mathrm{~S} 45$ & 5,500 & - & - & - & 575,103 \\
\hline 1536 & 146,522 & 398,975 & 39,070 & 432,045 & 104,500 & 9,978 & 5,439 & - & - & 698,484 \\
\hline 1837 & 225,937 & 491,230 & 31,922 & 523,152 & 115,397 & 16,726 & 6,430 & - & - & 857,632 \\
\hline 1533 & 214,211 & 421,569 & 12,306 & 433,575 & $\tau 6,321$ & 16,665 & 6,005 & 4,104 & - & 746,151 \\
\hline 1539 & $2: 22,042$ & $383,92 \pi$ & 8,249 & 442,176 & 122,300 & 19,227 & 5,372 & 11,930 & - & 823,479 \\
\hline 1810 & 225,591 & 438,263 & 19,028 & 452,291 & 148,470 & 19,463 & 5,302 & 15,928 & - & 867,045 \\
\hline $18 \pm 1$ & 142,507 & 543,280 & 41,412 & 581,692 & 192,270 & 15,306 & 6,176 & $22,1 \overline{2}$ & - & 964,255 \\
\hline $1 S 42$ & 271,913 & 491,602 & 26,831 & 511.504 & 205,258 & 31,437 & 181 & 10,098 & 47,316 & $1,107,732$ \\
\hline 1513 & 267,125 & 647,308 & 30,005 & 677,813 & 227,605 & 22,579 & - & 9,570 & 57,740 & $1,262,532$ \\
\hline 1541 & 376,363 & 782,070 & 58,309 & 840,379 & 251,005 & 27,719 & - & 13,037 & 114,906 & $1,623,459$ \\
\hline $15+5$ & 430,993 & $1,008,901$ & 76,122 & $1,0 \mathrm{~S} 5,023$ & 266,072 & $31,20 \mathrm{~s}$ & 一 & 10,135 & 175,401 & $2,002,877$ \\
\hline $1 s+6$ & 522,518 & $1,150, \$ 28$ & 86,155 & $1,236,983$ & 311,400 & 55,346 & - & 12,646 & 158,008 & $2,333,49 \pm$ \\
\hline $1 S 47$ & 643,563 & $1,467,499$ & 105,345 & $1,572.941$ & $359.2 n$ & 61.239 & - & 14,904 & 259,598 & $2,970,597$ \\
\hline $18 \pm s$ & 680,193 & $1,490,209$ & 162,625 & $1,652, \$ 34$ & 431,267 & 56,938 & 2,000 & 19,357 & 237,271 & $8,082, \$ 60$ \\
\hline $1 \leq 19$ & 800,987 & $1,425,156$ & 174,757 & $1,605,626$ & 451,240 & 75.299 & 25,000 & 19,658 & 258,080 & $3,241,890$ \\
\hline 1850 & 722.655 & $1,500,0 \pm 7$ & 211,960 & $1, \pi 12,007$ & $543, \$ 56$ & 62,809 & 35,000 & 19,921 & 275.109 & $3,371,420$ \\
\hline 1551 & 959,251 & $1, \$ 68,277$ & 310,307 & $2,178,594$ & 793,455 & 00,000 & 53,150 & 23,959 & 336,018 & $4,399,476$ * \\
\hline 1852 & - & - & - & - & - & - & - & - & - & - \\
\hline 1553 & - & 一 & - & - & 一 & - & - & - & - & 一 \\
\hline 1554 & - & - & - & - & - & - & - & - & - & - \\
\hline 1555 & - & - & - & - & - & - & - & - & - & - \\
\hline 1556 & - & - & - & - & - & - & - & - & - & - \\
\hline $1 \$ 57$ & - & - & - & - & - & - & - & - & - & - \\
\hline 1553 & - & - & - & - & - & - & - & - & - & 一 \\
\hline 1859 & - & - & - & - & - & - & - & - & - & - \\
\hline 1860 & - & - & - & - & - & - & - & - & - & - \\
\hline
\end{tabular}




\section{PENNSYLVANIA.}

The western part of Pennsylvania is abundantly supplied with bituminous coal, as the eastern is with anthracite. It is found in the rivers Conemaugh, Alleghany, and Monongahela, and in numerous placeson the west of the Alleghany ridge, which is generally its eastern boundary. It occurs on this mountain at a considerable elevation, and elsewhere in nearly a horizontal position, alternating with gray sandstone that is often micaceous, and bordered by argillaceous schist. The veins are generally narrow, rarely over six feet in width. This mineral is abundant, and of good quality, near Pittsburg, where it is valuable for the extensive manufactures carried on in that place. Beds of bituminous coal are reported as occurring in Bedford County, in the Nortl-west part of Luzerne, and in Bradford County. In the last-named county, nine miles from the Susquehanna, there is an extensive bed of coal regarded as bituminous. It has been penetrated 30 feet without fathoming the depth of the strata. Bituminous coal occurs on the Tioga, and on the Chemung, a branch of that river. It exists also on the numerous streams that descend the Western side of the extensive peninsula situated between the north and west branches of the Susquehanna. The coal of Tioga is nothing inferior to the best Liverpool or Newcastle coal.

According to the statistical tables of C. G. Childs, Pennsylvania contains an area of 46,000 square miles, of which upward of 15,000 square miles, or about one-third part of the State, is coal lands, principally lying above or near the water level. England, Scotland, Wales, and Ireland combined, according to the best authority, contain only 11,000 square miles of coal in an area of 120,000 square miles of territory. This coal, in many cases, lies from 900 to 1,800 feet below the surface of the ground, and is raised by machinery. In relation to the quantity of iron ore, nearly the same relative proportions exist between Great Britain and Pennsylvania. It will thus be seen that in these articles of the first necessity, and indispensable to a state of civilization, Pennsylvania possesses three times as much as all Great Britain. If to the anthracite coal trade of the State the bituminous coal mines in its western part be added (believed to exceed 1,300,000 tons in 1551), the total quantity would be about $6,300,000$ tons, worth at tide water $\$ 340$ per ton, and we have a total of TWENTY MILLIONS OF DOLLARS as the value of the coal trade of the State for the year 1851.

The annexed analysis of the different kinds of eoal, analyzed under direction of the Navy Department, will be of value as determining their relative quality :

\begin{tabular}{|c|c|c|c|}
\hline $\begin{array}{l}\text { Descriptions. } \\
\text { Bituminous: }\end{array}$ & $\begin{array}{l}\text { Bituminous or } \\
\text { rolatile matter. }\end{array}$ & $\begin{array}{l}\text { Cubic feet } \\
\text { evaporated per hour, }\end{array}$ & $\begin{array}{l}\text { lbs steam pe } \\
\text { cubic ft, of coz }\end{array}$ \\
\hline Pittsburg .... & $.36 .16 \ldots$ & $\ldots 10.56 \ldots$ & ......3St \\
\hline Liverpool........ & $\ldots .54 .90 \ldots \ldots \ldots \ldots \ldots 39.96 \ldots$ & $\ldots 13.43 \ldots \ldots$ & ......375 \\
\hline Pictou........... & $\ldots \ldots 60.74 \ldots \ldots \ldots \ldots \ldots 25.97 \ldots \ldots$ & $\ldots \ldots .16 .45 \ldots \ldots$ & $\ldots \ldots .417$ \\
\hline Cannelton, Ind... & ....58.44_..............33.99... & $\ldots \ldots . .15 .05 \ldots \ldots$ & ......318 \\
\hline \multicolumn{4}{|l|}{ Semi-bituminous: } \\
\hline Blossburg . . . . . . & $\ldots 73.11, \ldots \ldots \ldots \ldots \ldots .14 .78 \ldots$ & $\ldots 13.69 \ldots$. & $\ldots .515$ \\
\hline Dauphin......... & $\ldots \ldots 74.24 \ldots \ldots \ldots \ldots \ldots \ldots 13.84 \ldots \ldots$ & $\ldots \ldots . .13 .35 \ldots . .$. & $\ldots . .472$ \\
\hline \multicolumn{4}{|c|}{ Anthracite or non-bituminous: } \\
\hline Peach Orchard... & $\ldots \ldots 2.96 \ldots$ & $\ldots . .14 .04 \ldots$. & $\ldots 545$ \\
\hline Lackawanna..... & $\ldots \ldots .8 .91 \ldots$ & $\ldots \ldots .11 .91 \ldots \ldots$ & $\ldots \ldots 477$ \\
\hline Lehigh & ..... 5.2s... & $\ldots 11.63 \ldots \ldots$ & $\ldots .432$ \\
\hline
\end{tabular}

Almost every county in the State contains deposits of iron in one or other of its multifarious forms. It exists in the greatest measure, and in its most valuable ore, in the bituminous coal region, especially in the neighborhood of Pittsburg, where it has been wrought to an immense extent for a number of years past. Pennsylvania, indeed, is said to produce nearly one half of the whole iron manufactured in the United States. The State is also rich in many of the other useful metals. Extensive copper and lead formations have lately been discovered near the Schuylkill, some of the veins of which have already been profitably worked. The copper ore is said to bear a striking resemblance to that of Cornwall and Cuba. The average yield of 20,000 tons has been 20 per cent, of fine copper. The argentifercus lead ore, which is also abounding, has been analyzed, and carries about 75 per cent. of lead, and will yield of silver about $\$ 35$ per ton. The Perkiomer mine, which is near the newly discovered veins, has been worked to the depth of 300 feet, and more than a quarter of a mile in length. Already (1851) $\$ 61,000$ have been received for ore, and about 400 tons more have been mined. This, with the new veins, gives evidence of a field of mineral wealth whieh promises to add to the fame of Pennsylvania as the greatest mineral region in the world. Zine is also a product of the State. Limestone, marbles, granites, etc., with a vast variety of other valuable building materials, alum, and other useful earths, etc., are distributed over the State in an unexampled profusion. Salt is chiefly derived from the springs of the Kiskiminetas, Alleghany, and Beaver rivers. There are also in this State many mineral and saline springs, which have become the centres of summer recreation.

Pennsylvania has a elimate intermediate between the extremes of the northern and southern sections of the country. The south-eastern part, in which Philadelphia is situated, has a changeable atmosphère, and the annual extremes are great. Among the mountains and in the northern counties, it is more settled, but much colder, particularly in the winter season. To the west of the Alleghanies the weather is generally milder than to the eastward, owing principally to the prevalence of south-east winds. The annual mean temperatures of Philadelphia and Pittsburg are almost similar, although varied in distribution through the year, from local causes. The temperature of Philadelphia during the year varies from $98^{\circ}$ to $6^{\circ}$ Fahr., and at Pittsburg the extremes are $94^{\circ}$ and $10^{\circ}$. The winters and summers are decidedly marked, but the spring is short, variable, and uncertain. The fall, however, is the pleasantest part of the year, and the weather in that season, though sometimes interrupted by excessive heat, is serene and delightfful. The State, on the whole, is considered one of the most salubrious on the continent, and life is of more than average duration. It is also highly favorable for agricultural pursuits.

The great extent of limestone formation in Pennsylvania assures to the soil fertility and productive strength, and though extending over so large a surface, it is, in the main, of excellent quality. The anthracite region, however, which is composed chiefly of a rugged surface, is forbidding and sterile. Many of the mountains admit of cultivation to their summits, and the valleys between them are often of a rich soil, suited to the various kinds of grass and grain. West of the mountains the soil is a deep mold, equal in fertility to the best lands of America. To the east the soil is also excellent, and everywhere is the State abundantly watered by fine streams and rills of living water. The natural growths vary with locality and elevation, but do not differ in their character from those of other portions of the middle Atlantic region. The trees most common in the forests are beech, hemlock, and sugar maple, the oak, hickory, and elm, ehestnut, mulberry and locust. The wild plum and crab apple grow in abundance, and grape-vines are common, Every description of 


\title{
PENNSYLVANIA.
}

fruit and garlen vegetable is cultivated. Wild animals, as the cougar, wolf, etc., still haunt the uncultivated parts, but most of these have been extirpated by the on ward march of eivilization.

Pennsylvania is divided into 63 counties, the general statistics of which, and the eapitals of each, in 1S50, were as follows:

\section{Eastern Pennsylvania-21 countíes.}

Counties, Dwell. Pop. $\begin{gathered}\text { Farms } \\ \text { in cult. }\end{gathered} \begin{gathered}\text { Manuf, Ket, Capitals, } \\ \text { Ke }\end{gathered}$

Adams..... 4, 4,356 . 25,981 ..1,902 . . 124. Gettysburg

Derks .....12.931 . 17.129 . 4,750 . 1,286 . Reading

Jucks .... 9,757.. 56,091..4,707.. 686. . Doylestown

Carbon..... 2.544.. 15,656.. 246.. 158... Mauch Chunk

Chester..... 11,580. . 66,438. 4,835 .1,056. Westchester

Cumberland. 6,021 . 34,327..1,812 . . 258. . Carlisle

Dauphin.... 6,033.. 35,754..1.956. . 253. . HARrisBuRg

Delaware ... 4,118. . 24,679. 1,376. . 299. . Chester

Franklin ... 6,690.. 39,904. .2,247. 455. . Chambersburg

Lancaster... . 17,138. . 95,914..5,629. .1,146. . Lan easter

Lebanon . ... 4,452 . 26,071..1,449 . . 146..Lebanon

\begin{abstract}
Counties. Dwell. Pop. Farms Manuf. Capitals. Lehigh. . . . . 5,589 . 32,479 ..2,074.. 270.. Allentown Monroe .... 2,155.. 13,270.. 904.. 76..Stroudsburg Montgomery.10,022. . 58,291. 4,456. . 697. . Norristown Northampton $6,836 \ldots 40,285$. 2,102 . 4 424..Easton Perry .... . . . 3,412. . 20,188. .1,456. . 232 ... N. Bloomfleld Philadelphia 61,27S . .408,762 . 1,530 . 4,589.. Philadelphia Pike....... 964.. 5, ss1.. 370.. 40.. Milfired Sehuylkill....10,671.. 60.713..1,247.. 954..Orwigsburg Wayne..... 3,719 . 21,\$90..1,336.. 200.. Bethany York...... 9,927.. 57,450 . 3,734.. 533.. York
\end{abstract}

\section{Western Pennsylvania-42 counties.}

Counties. Dwell. Pop. Farms Manul. Capitals. Alleghany ...22,551..138,290 . .8,729 . 1,290...Pittsburg Armstrong ... 5 5,052 . 29,560..1,612.. 93..Kittaning Beaver .......4 4,564.. 26,689..1,841.. 186. Beaver Bedford ..... 3,896.. 23,052,.1,875. . 117..Bedford Blair ........ 3,718.. 21,777.. 826.. 130...Hollidaysb'g Bractford..... 7,391 . 42,831 ..5,096. . 562. . Towanda Butler ....... 5,254. . 30,346.2,945. . 148.. Butler Cambria...... 2,898.. 17,773..1,0\$9. . 126..Ebensburg Centre....... 3,936.. 23,355..1,043.. 171..Bellefonte Clarion...... 4,008,. 29,565..1,726. . 246..Clarion Clearfield .... 2,157.. 12,586..2,317.. 122 .. Clearfield Clinton ...... . 1,980.. 11,207.. 685. . 149. Lockhaven Columbia.... 2,924.. 17,710,.1,179.. 291..Bloomsburg Crawford .... 6,592.. 37,549..4,070.. 218.. Meadville Elk........ 643.. 3,531. 254.. 50.. Riilgeway Erie........ 6,825.. 38,742..3,334.. 250ั..Erie Fayette..... 6,597.. 39.112..2,139.. 232..Uniontown Fulton....... 1.383.. 7,567.. 581.. 49.. Harrisonville Green ....... 3,777.. 22,136..1,759.. 95.. Waynesboro' Huntingdon .. 4,298 . 24,786, 1,445 . . 193.. Huntingdon Indiana......4,644. $27,170 \ldots 2,496 \ldots 75 .$. Indiana

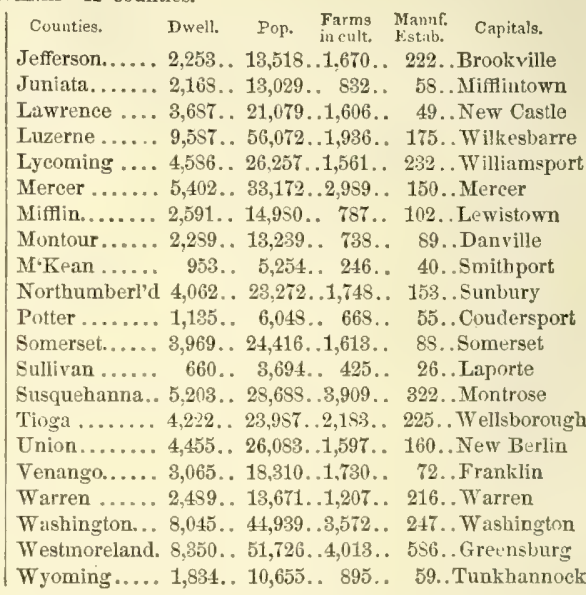

The whole number of dwellings in the State was, at the above date, 886,216 , of families 408,497 , and of inhabitants $2,311.756$, viz., whites $1,180,056$-males 589,294 , and females 590,762 ; fr. col. 40,007-males 18,352, and females 21,665 . Of the whole population there were deaf and dumb-wh. 9S6, fr. col. 18-total 1,004; blind-wh. 798, fr. col. 31-total 829; insane-wh. 1,842, fr. col. 49-total 1,891; and idiotic-wh. 1,356, fr. col, 62-total 1,448. The number of free persons born in the United States was $2,014,619$; the number of foreign birth, 294,871; and of birth unknown, 2,296. The native population originated as follows: Maine 1,157, N. Hamp. 1,175, Verm. 4,532, Mass. 9,330, R. I. 1,946, Conn. 9,266, N. York 58,835, N. Jer. 29,117, Pennsylvania 1,\$41,672, Del. 12,552, Ind. 21,013, Dist. of Col. 767, Virg. 10,410, N. Car. 409, S. Car. 559, Ga. 176, Flor, 21. Ala. 87, Miss. 101. La. 157, Tex. 17, Ark. 10, Tenu. 155, Ky. 497, Ohio 7,729, Mich. 224, Ind. 399, Ill. 323, Mo. 220, Ia. 70, Wisc. 45. Calif. 3, Territories 2 ; and the foreign population was composed of persons fromEngland 35,048 , Ireland 151,723, Scotland 7,292, Wales 8,920, Germany 78,592, France 4,053, Spain 101, Portugal 34, Belgium 126, Holland 257, Turkey 2, Ttaly 172, Austria 49, Switzerłand 914, Russia 139, Denmark 97, Norway 27, Sweden 183, Prussia 413, Greece 7, China 1, Asia 42, Africa 40, British America 2,500, Mexico 42, Centrul America 4, S. America 83, West Indies 666, Sandwich Islands 3 , and other countries 361.

The following table will show the decennial progress of the population since the first census of the State taken by the United states authorities:

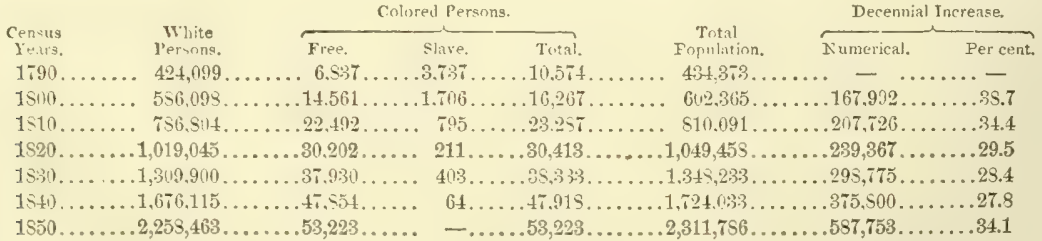

The statisties of the productions, manufactures, general industry, and institutions of the State, according to the census of 1850 and other official returns referring to the same perind, are as follows:

Occupied Lands, etc.--Improved farm lands, 8,628,619 acres, and attached lands unimproved, 6,291,728 acres-together valued at $\$ 407,876,099$. Total number of farms in cultivation on the 1 st June $1850,127,577$-in Eastern Pennsylvania 50,178 , and in Western Pennsylvania, 77,399. Value of farming implements and machinery, \$14,722,541.

Live-Stock, etc-Horses, 350,398 ; asses and mules, 2,259 ; milch cows, 532,224 ; working oxen, 61,527 ; other cattle, 656 


\section{PENNSYLVANIA.}

562.195 : sheep, $1 . \$ 22,357$, and swine, $1,040,366$. Aggregate value of live-stock, $\$ 11.500,053$. Compared wilh the stock owned in the State according to the census of 1840 , the following results are obtained:

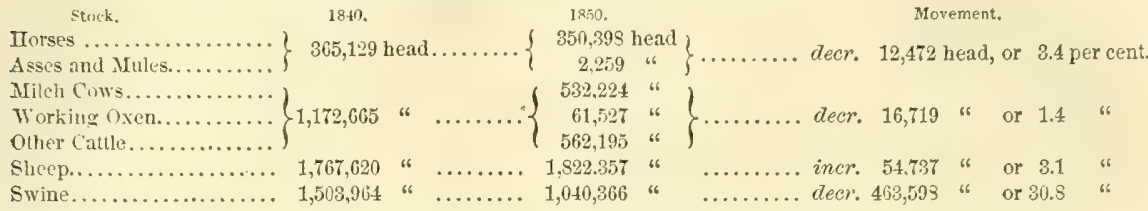

Products of Animals.-Wool, 4,4\$1,570 pounds; butter, 39,878,418 pounds; and cheese, 2,505,034 pounds. Value of animals slaughtered during the year, $\$ 8,219,848$. The quantity of wool reported in the census of 1840 was $3,048,561$ pounds, and hence the increase of production has been 31.9 per cent.; and the clip per sheep has advanced from 1.72 in 1840 to 2.46 pounds in 1850 , or at the rate of 43 per centum in the decade.

Grain Crops,-The crops, according to the returns of 1840 and 1850 comparatively, are as follows:

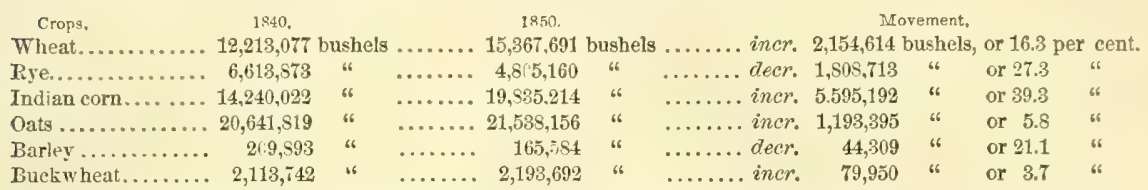

Other Food Crops.-Peas and beans, 55,231 bushels; potatoes-Irish, 5,950,732 bushels, and sweet, 52,172 bushels. The potato erop returned in the census of 1810 amounted to $9,535,663$ bushels; and heuce the decrease of production in the decade has been $3,502,759$ bushels, or in the ratio of 36.7 per centum.

Miscellaneous Crops.-Tobaceo, 912,651 pounds; hay, 1,842,970 tons; clover-seed, 125,030 bushels; other grass-seed, 53.913 bushels; hops, 22,058 pounds; hemp-dew-rotted, 282 tons, and water-rotted, 2,006 tons ; flax, 528,079 pounds ; flaxseed, 41,650 bushels; silk cocoons, 255 (in 1640, 7.2621 ) pounds ; maple sugar, 2,326.525 pounds; molasses, 50,652 gallons ; bees-wax and honey, 835,509 pounds; wine, 25,590 gallons, ete. Value of orchard products, $\$ 723,389 ;$ and of marketgarden products, $\$ 685,714$. The more important of these several crops, compared with the like crops returned by the census of 1840 , exhibit the following results:

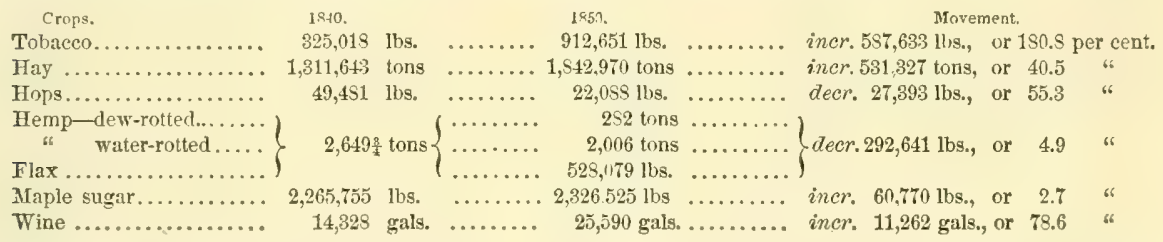

Home-made Mcanufactures were produced in the year to the value of $\$ 749,132$. The same manufactures, according to the census of 1940 , were valued at $\$ 1,303,093$. Decrease in value, $\$ 553.961$, or 42.5 per centum.

Manufactures.-A ggregate capital invested, $\$ 00,000,000$; cost of all raw material, fuel, etc., consumed, $\$ 00,000,000$; average number of hands employed, 000,000 -males 00,000 , and females 00,$000 ;$ monthly wages paid, $\$ 000.000$ - to males $\$ 000,000$, and to females $\$ 00,000$; value of products for the year, $\$ 00.000,000$. Total number of manufacturing establishments producing to the annual value of $\$ 500$ and upward, on the 1 st June, 1850, 22,036-in the eastern district 13,852 , and in the western district 8,154 . Of the total number of establishments 208 were cotton factories, 380 woolen factories, and 631 iron-works, viz*, 320 manufacturing castings, 180 pig iron, and 131 cast iron. The number of tanneries was 1,039 .

In the manufacture of cotton the capital invested amounts to $\$ 4,529,925$; material and fuel consumed $\$ 3,152.530$; products of the year, $45,746,790$ yards of sheeting, ete., and $5,308,561$ pounds of yarn; total value of products, $\$ 5,322,262$. Cotton used, 44,162 bales; coal consumed, 24,189 tons; hands employed, 7.663-males 3,564, and females 4,099: entire wages per month, $\$ 104,29 S$ - to males $\$ 63,642$, and to females $\$ 40,656$. The capital employed in 106 cotton factories in 1840 was $\$ 3,325,400$; hands employed, 5,522 ; value of articles manufactured, $\$ 5,013,007$.

In the rooolen manufactures the capital invested amounts to $\$ 5,005,064$; wonl used, $7,560,379$ pounds; coal consumed, 10,777 tons; value of all raw material, fuel, etc. $\$ 3,292,718$; hands employed, 5, i26-males 3,490, and females 2,236; entire wages per month, $\$ 90,417$ - to males $\$ 67,138$, and to females $\$ 23,279$; products of the year, 10,$099 ; 234$ yards of cloth, and $1,941,621$ pounds of yarn; value of entire products, $\$ 5,321,366$. Capital in 1540 , $\$ 1,510,546$; hands employed, 2.930 ; value of products, $\$ 2,319,061$.

The capital invested in tanneries amounts to $\$ 3,540,318$; value of all raw material, etc., used, $\$ 3,169.309$; hands employed, 2,980; monthly cost of labor, $\$ 54,501$; skins tanned, $293, \pi 98$, and sides tanned, $1,852,900$; value of products for the year, $\$ 5,275,492$. In 1840 there were in the State 1,170 tanneries; hands, 3,445 ; and capital, $\$ 2 ; 783,636 ;$;ides of sole leather tanned, $\Delta 15,655$, and of upper leather, 405.933 .

In the marufacture of malt and spirituous liquors, the investment amounts to $\$ 1,719,960$; quantities and kinds of grain, ete., consumed-barley 550,105 bushels, corn 1,483,555 bushels, rye 517.180 bushels, oats 24,990 bushels, apples 51.20 bushels, molasses 10 hogsheads, and hops 263 tons; hands employer, 911 ; quantities of liquor produced--ale. ete., 189,551 harrels, whisky and high wines 6,545.810 gallons, and rum 1,500 gallons. The census of 1840 returned 1,010 distilleries, producing $6,210,193$ gallons of spirits; and 87 breweries, produeing $12,765,974$ gallons of ale, ete.; hands employed, 1,607; capital invested, $\$ 1,559,471$. New York and Ohio produce more spirits, and New York alone more ale, etc., than Pennsylvania. 
PENNSYLVANIA.

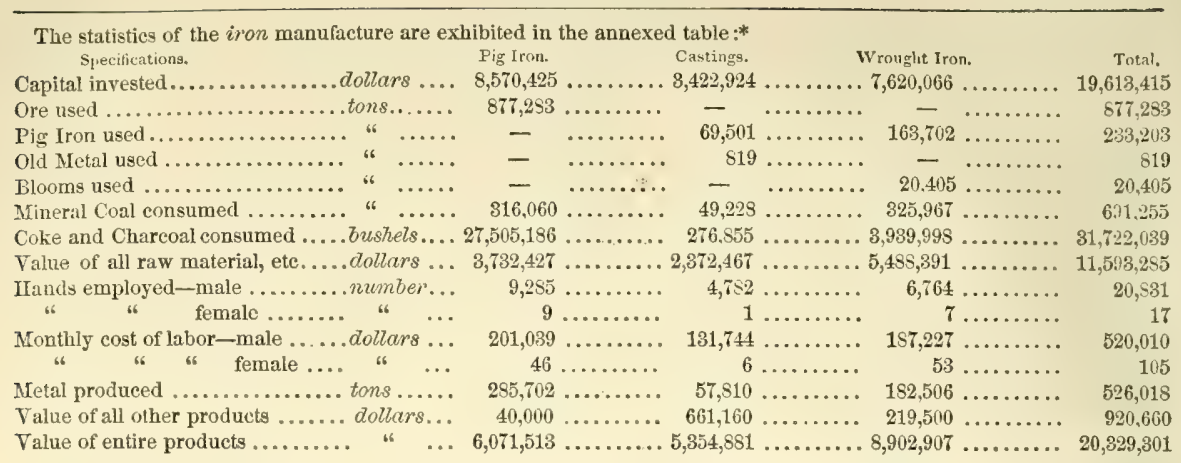

-about two-thirds of the aggregate capital is employed in Eastern Pennsylvania, and one-third in Western Pennsylvania. In 1840 there were in the State 213 establishments, manufacturing annually 93,395 tons of cast-iron, and 169 bloomeries, forges, and rolling mills, manufacturing 87,244 tons of bar iron; total fuel eonsumed, 355,903 tons; hands employed, 11,522 , and capital invested in the manufacture, $\$ 7,781,471$. The counties having the largest interest in the iron trade in 1850 were Alleghany, Armstrong, Lancaster, Chester, Berks, Clarion, Columbia, Blair, Huntingdon, and Luzernein these ten counties more than one-half the invested capital is employed. Of the sixty-two counties of the State, forty-five contain iron-works, and of the remaining seventeen, nine abound in iron and coal, so that only, eight ean be regarded as not suited to the manufacture of iron. The following will exhibit the relation the iron manufacture of Penusylvania holds to that of the whole Union:

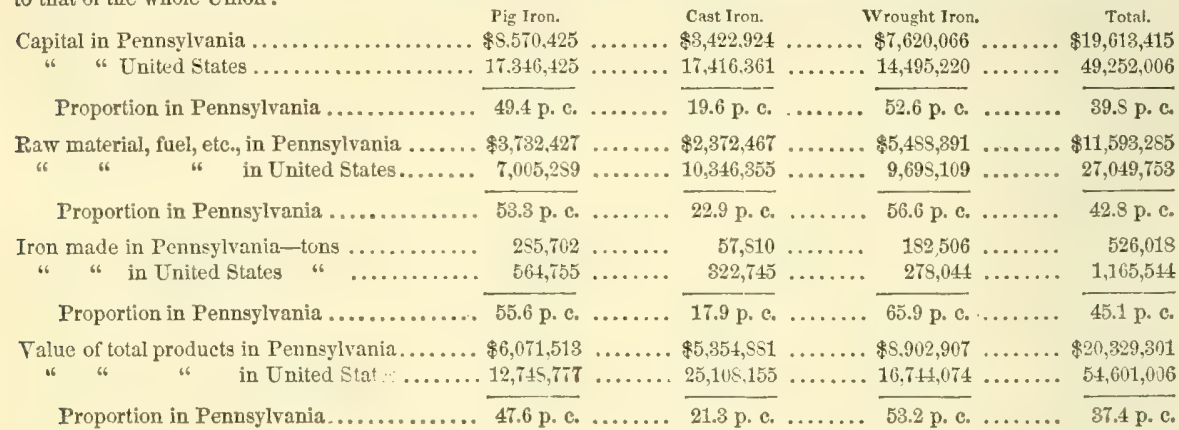

Besides the above manufactures, Pennsylvania has many others, which, though neither so extensive nor valuable, are very important in their bearing on the interests of the commonwealth. It is conspicuous for its manufacture of railroad machinery and carriages, its extensive cabinet-ware manufactures, and numerous other erafts, which in the aggregate employ the vast capital indicated by the late census returns. As a manufacturing State, indeed, it is only less important than New York and Massachusetts. Its great manufacturing centres are Philadelphia in the east and Pittsburg in the west, and there are also extensive manufactures carried on in the towns on the Delaware and Susquehanna rivers, and others in the interior. If Pennsylvanta is mentioned as the great producer of coal and iron, it is only because those interests are paramount, and eclipse minor interests which in the aggregate are really as valuable and important.

* The table given above is from the census of 1850. A fuller and more elaborate series of tabular statistics on the iron manufacture of Pennsylvauia is published in "Hunt's. Herchants' Muguzine" for November, 15i1, to which those interested in the subject are directed. The following is a compend of the article referred to, which, though differing somewhat in its results from the census ascertainments, is nevertheless of great value:

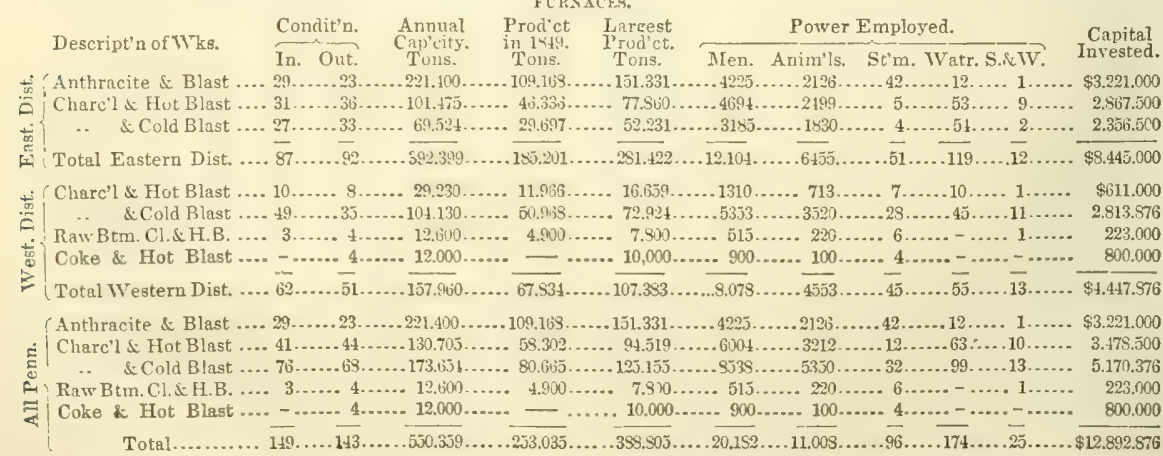
655 
PENNSYLVANIA.

Foreign Commerce-Pennsylvania, in regard to its foreign commerce, holds a fourth rank among the States of the Union. The official returns exhibit the value of this branch of industry to have been for the year ending 30 th June, 1850 , as follows: exports, $\$ 4,501,606$ and imports, $\$ 12,066,154$. Of the exports, $\$ 4,049,464$ was the value of domestic produets, and of this $\$ 3,428,150$ was that of merchandise earried in American and $\$ 621,314$ of merchandise carried in foreign vessels, and $\$ 452,142$ the value of foreign produce and manufactures, of which to the value of $\$ 363,225$ was carried in American and $\$ \$ \$, 917$ was carried in foreign vessels. Of the imports, $\$ 10,795,462$ was the value of those brought in American and $\$ 1,270,692$ those brought in foreign vessels. The shipping employed in the carrying trade consisted of

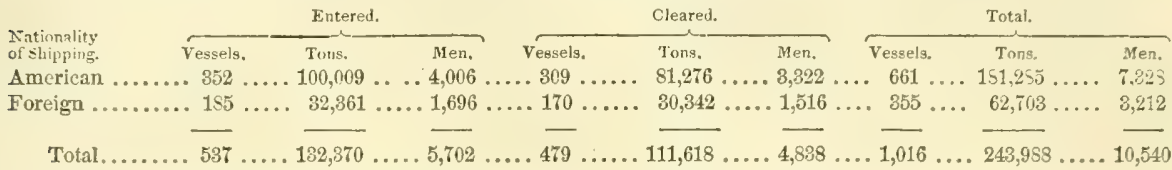

Philadelphia is the only district in which foreign commerce is carried on. In 1850 there were owned in that district 46,385 tons of permanent registered shipping and 17,820 tons of temporary registered shipping, of which latter class 66 tons were navigated by steam. The distribution of the enrolled and licensed tonnage was as follows:

\begin{tabular}{|c|c|c|c|c|}
\hline & \multicolumn{2}{|c|}{ Eurolled and Lirensed. } & \multirow[b]{2}{*}{$\begin{array}{c}\text { Licensed under } \\
20 \text { tons. }\end{array}$} & \multirow[b]{2}{*}{$\begin{array}{l}\text { Enr'd. and lic. ton. } \\
\text { Navigated by steam }\end{array}$} \\
\hline Collection Dictricts. & Permanent. & Temporary. & & \\
\hline & 136,577 & $\ldots 2,581 \ldots$ & .... 8,134 ... & 15,476 \\
\hline sque Isle on Lake Erie. & 7,570 & 一 & $\ldots$. & ... 5,351 \\
\hline tsburg on Ohio River. . & 43,476 & $\ldots-$ & . 1,095 & $.89,9 \$ 1$ \\
\hline
\end{tabular}

-total tonnage in PhiladeIphia district 206,498 tons; in that of Presque Isle 7,870 tons, and in that of Pittsburg 44,571 tons-making for the State 257,939 tons. During the year ending as above there were built in the State 185 vessels (21,410 tons): 166 ( 7 ships, 1 brig, 34 schooners, 107 sloops and canal boats, and 17 steamers), of the burden of 18,150 tons at Philadelphia ; 1 schooner (22 tons), at Presque Isle, and 18 vessels ( 4 schooners and 14 steamers-3,233 tons), at Pittsburg.

The statistics of the foreign commerce of the State from 1791 to the year 1850 , exhibit the following movements:

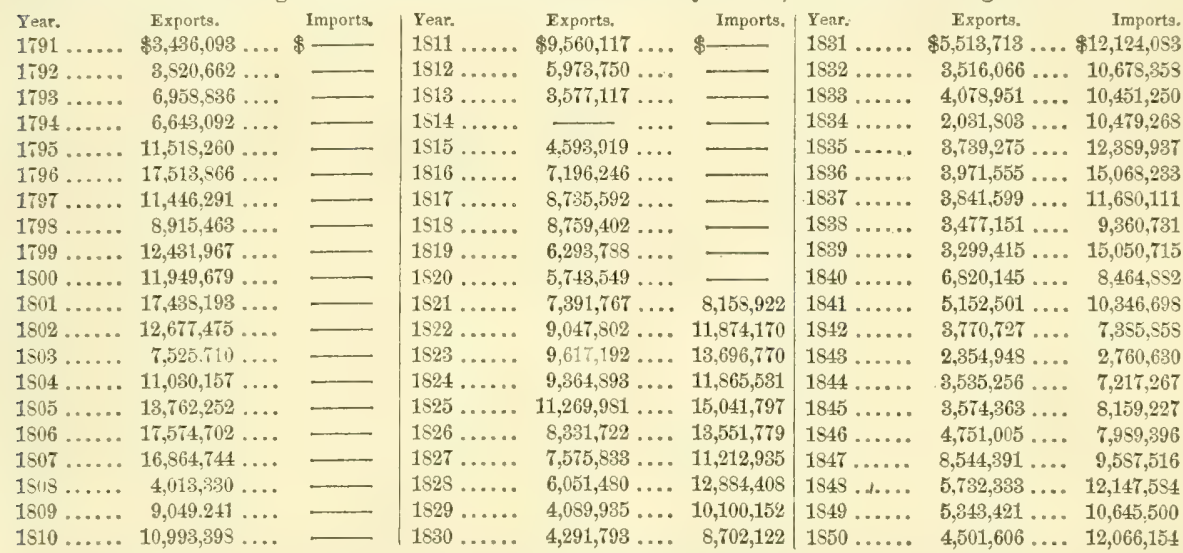

Interior Communication.-Pennsylvania has numerous magnifleent works of internal improrement, on which an immense commerce is conducted. The great line of railroad from Philadelphia to Pittsburg is one of the longest and most expensive lines in the Union, forming a road 357 miles long; and another through line from Philadelphia via Sunbury to Erie, on the lake of the same name, is in progress of construction, and, when finished, will no doubt form one

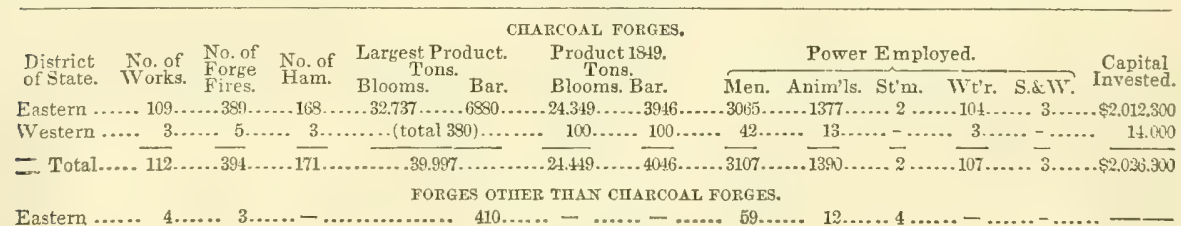

ROLLIYG MILLS.

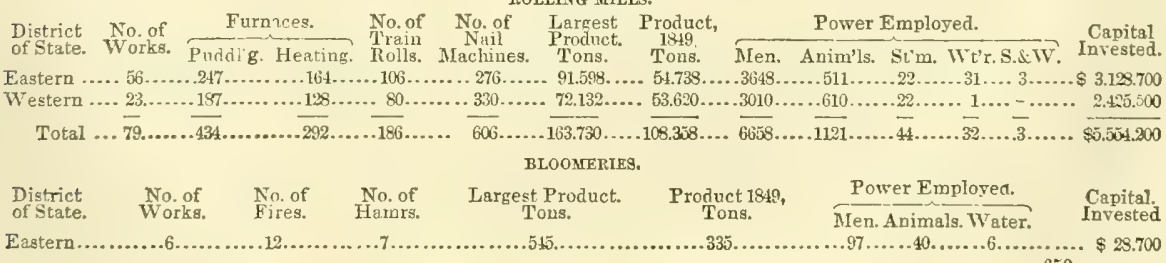


PENNSYLVANIA.

of the most profitable lines connecting the lakes with the sea-board. Other railroads connect Philadelphia with Baltimore, and in the north-eastern portion of the State there are numerous short railroads connecting the coal mines with navigation, or passing into the State of New York, furnishing an outlet for its mineral wealih in that direction. Many other railroads are in progress or contemplated, all of which will connect with or intersect the trunk lines already bnilt or provided for. The canals of this State are also magnificent works, and in their censtruction a great portion of the heavy debt nf the State has been contracted. They follow generally the great valleys of the interior, and in their courses accommodate an immense area of fertile and productive country. These are still incomplete, but every year is adding to their length and consequent value, nor can it be any long period before they will yield a revenue commensurate to the outlay that their construction has demanded. [See statistics of railroads and canals in Appendix.]

Banks, etc.-The number of banks in the State, in November, 1850, was 46, and 5 branch banks. The financial con. dition of these, at that period, was as follows: Liabilities - capital, $\$ 17,701,206$; circulation, $\$ 11,798,906$; depnsits, $\$ 17,6 \$ 9,212$; due other banks, $\$ 5, \$ 11,15 \%$, and other liabitities, $\$ 93,015$; and assets-loans and discounts, $\$ 38,423.2 i 4$; real estate, $\$ 1,114,735$; stocks, $\$ 1,417,073$; due by other banks, $\$ 4,214,174$; notes of other banks, $\$ 2,570,139$; speeie funds, $\$ 2,787,665$, and specie, $\$ 4,337,594$.

Government, etc.-The first constitution of Pennsylvania was adopted in 1776 , the second in 1790 , and the present, which was amended in 1850 , in 1838.

The right of suffrage is given to every white free man, 21 years old, resident in the State for one year, and in his election district for ten days before the election, and who has paid within two years a State or county tax, assessed at least ten days before the election, but white free men, between 21 and 22 years old, being eitizens of the United States, need not have paid a tax; and qualified voters, who are citizens of the United States, and who bave removed from the State and returned, may vote after six months' residence. The general election is held on the second Tuesday of October annually.

The legislature is composed of a House of Representatives and a Senate. Representatives, not less than 60, nor more than 100 in number (now 100), must have attained the age of 21 years, must have been eitizens and inhabitants of the State for the last three years, and for the last year of the districts they represent, and are elected annually. Senators in number not less than one-fourth, nor more than one-third (now one-third) the number of representatives, are chosen for three years, one-third of their number annually. They must be at lenst 25 years of age, must have been citizens and inhabitants of the State for the four years preceding the election, and for the last year of their distriets. The General Assembly meets on the first Tuesday of January annually. The constitution provides that there shall be an enumeration of taxable inhabitants every seven years, to fix the number of Senators and Representatives, and every county shall have at least one representative, but counties erected after 1838 shall have none until entitled thereto by their population. No representative shall be appointed to any eivil office created or incrensed in pay during his term.

The governor must have attained his 30 th year of age, have been a citizen and inhabitant of the State for the last seren years, and holds office for three years, his term commeneing on the third Tuesday in January ensuing his election. He receives a fixed compensation, and is not eligible for more than six years out of every nine years. He may remit fines, and grant pardons, except in cases of impeachment. and may veto a bill of the legislature, but it may be passed into law by a two-thirds vote of both houses, notwithstanding his objections.

The administrative officers of the State are-the Secretary of State, who is ex-officio Commissioner of Common Schools; the Deputy Secretary of state, the State Treasurer, the Auditor-general, the Surveyor-general, the Deputy Surveyorgeneral, the Adjutant-general, and the three Canal Commissioners.

The judiciary is vested in a Supreme Court, Courts of Common Pleas, District Courts of the city and county of Philadelphia, and of the county of Alleghany, County or Probate Courts, and other loeal courts. By the amended constitution all judges are now elected by the perple. The judges of the supreme court are chosen at large, and for a term of fifteen years. The judge having the shortest term to serve is chief justice. The resident judges of the several courts of eommon pleas and other courts of record, and all other judges required to be learned in the law, are elected by the electors of the districts over which they are to preside, and for a term of ten years. The associate judges of the common pleas hold their offices for five years. All judges hold office for their respective terms during good behavior, but for rensonalle cause, though not sufficient grounds for impeachment, the governor may remove them upon the address of two-thirds of each branch of the Legislature. Any vacaney is filled by appnintment of the governor, the incumbent holding office until the first Monday in December succeeding the next subsequent general election. During the continuance in office, the judges of the supreme court must reside within the commonwealth, and the wher judges in the district or county for which they were elected. The supreme court is composed of a chief and four associate justices, and the attorney-general, and has a reporter of supreme court decisions, and a prothonotary for each of the four districts into which the State is divided. The district court of the city and county of Philadelphia consists of a president and two associate judges, and that of Alleghany County of a president and one associate. For the sessions of the courts of common pleas, the State was formerly divided into 21 districts, but in 1850 the number was increased to 24 districts, each of which (except the first, enmprising the county of Philadelphia, which has also two associate judges) has a president judge. The district courts are invested with the civil jurisdiction of the common pleas in their respective districts in all cases exceeding a certain sum.

Federal Reprexentation. - In accoriance with the law of $23 d$ May, 1ऽjo, Pennsylvania is entitled to twenty-fve representatives in the Congress of the United States.

The militia force of the State consists of 276,070 men of all arms, of which 7,513 are commissioned officers, and 268,552 non-commissioned officers, musicians, artificers, and privates. Of the commissioned officers, 55 are general officers, 164 general stafs officers, 1,245 field, etc., officers, and 6,054 company officers. The govemor is ex-officio commander-in-chief of the military force of the State; and every white male citizen between the ages of 18 and 45 is liable to military duty.

Public Finances.-The debt of the State, funded and unfunded, on the 1st December, 1850, amounted to $\$ 40,775,48542$, composed as fullows: funded del,t-6 per cent. stucks. $\$ 2.312 .02251 ; 5$ per cent. stocks, $\$ 37.350,592$; and $4 \frac{1}{2}$ per cent. stocks, $\$ 200,000$; making a total funded debt of $\$ 39,062,914$ is; and unfunded dett-relief notes in circulation, \$652,164; interest certificates oulstanding, $\$ 162,18590$, and unclaimed, $\$ 4.44835$; interest on unclaimed and outstanding certificates, to be added to them when funded, $\$ 10.50457$; domestic creditors, $\$ \$ 3,31779$-make the total unfunded debt, $\$ 912,57061$. The commissinners of the sinking fund, at the date specified, held $\$ 450.1229 \mathrm{~s}$, which, th ascertain the exact liabilities of the State, must be deducted from the aggregate, which would leave it $\$ 40,316.36244$. The regular annual interest on loans amounts to $\$ 2,001.71451$, and the interest guaranteed on internal improvement companies' assumed debts to $\$ 32,500$, making the total annual interest paid by the State amount to $\$ 2.035 .21+51$. 


\section{PENNSYLVANIA}

The assets of the State consist of its canals and railroarls, which had cost $\$ 29,204,7 \$ 735$; stocks of incorporated companies amounting to $\$ 1,907.94852$-total $\$ 31.112,73585$, and deposits (unavailable) in the Bank of the United States, $\$ 25,3,400$. The financial condition of the railroads and canals owned by the State for the year ending on the $80 t h$ Novero ber, 1550 , is exhibitel in the following details:

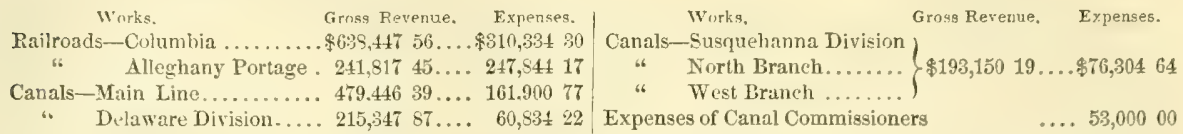

-making a gross revenue of $\$ 1,765,20946$, and an expenditure amounting to $\$ 862,52800$. Net revenue, $\$ 905,68146$.

The value of real and personal property liable to taxation under the triennial assessment of 1818 , was $\$ 103,031,45 \$$; and the tax assessed in $1550, \$ 1,545,95644$. The true value of real and personal property in 1850 , according to the census of that year, wis $\$ 72,486,120$.

The revenue and disbursements of the Treasury for the fiseal year were as follows: rovenue-receipts during the year, $\$ 1,43 \$, 13151$; balance from 1849, $\$ 926,20721$-making a total means of $\$ 5,364,33875$; and disbursements-payments during the year, $\$ 4,567,05394$; depreciated funds in treasury (unavailable), $\$ 41,03200$; surplus available funds, $\$ 754,25281$. The principal sources of revenue, and the chief objects of expenditure, were as follows: sources of revenue-lands, $\$ 16,375$ 55; auction commissions, $\$ 18,673,75$; auction duties, $\$ 44, \$ 9322$; tax on bank dividends, $\$ 153.87714 ;$ tax on corporation stocks, $\$ 136,51014$; tax on real and personal estate, $\$ 1,317,82155$; tavern licenses, $\$ 107.42749 ;$ retailers' licenses, $\$ 171,06226$; peddlers' licenses, $\$ 2,52505$; brokers' licenses, $\$ 10,22873$; theatre, circus, and menagerie licenses, $\$ 2,35450$; distillery and brewery licenses, $\$ 4.20391$; billiard room, bowling saloon, and ten-pin alley licenses, $\$ 3,04581$; eatinghouse, beer-house, and restaurant licenses, $\$ 6,53097$; patent medicine licenses, $\$ 2,63804$; pamphlet laws, $\$ 34559$; militia fines, $\$ 12,95373$; foreign insurance agencies, $\$ 2,76083$; tax on writs, wills, deeds, etc., $\$ 45,40947$; tax on certain offices, $\$ 14,04721$; collateral inheritance tax, $\$ 102,29507$; canal and railroad tolls, $\$ 1,713,84 \$ 16$; canal fines, sales of old materials, ete., $\$ 6,95364$; tax on enrollment of laws, $\$ 10,27000$; premiums on charters, $\$ 89,26221$; tax on loans, $\$ 119.35630$; loans, $\$ 270,00000$; interest on loans, $\$ 13,72127$; dividends on turnpilie and bridge stocks, $\$ 2,46000 ;$ sales of turnpike stocks, $\$ 13,65544$; accrued interest, $\$ 3,67832$; refunded cash, $\$ 13,27861$; fees of the public offices, $\$ 3,68720$; Pennsplrania State Lunatie Hospital, $\$ 17700$; miscellanenus, $\$ 1,74033$; and-objects of expenditure: public improvements, $\$ 1.488,79974$; expenses of government, $\$ 262.59971$; militia expenses, $\$ 16,28225$; pensions and gratuities, $\$ 17.27791$; charitable institutions, $\$ 62,26785$; common schools, $\$ 213,72849$; commissioners of the sinking fund, $\$ 818, \$ 64$ 03; Inans, $\$ 8,15019$; interest on loans, $\$ 2,004,71451$; guaranteed interest, $\$ 32,500$ 00; domestic creditors, $\$ 6.3 \$ 741$; damages on the public works, $\$ 28,06834$; special coramissioners, $\$ 2,55403 ;$ State Library, $\$ 1,000$ 00; public buildings and grounds, $\$ 2,00278$; eastern reservoir of the Pennsylvania Canal, $\$ 1,94700$; weigh-loek at Beach Haven, $\$ 16300$; use of patent rights, $\$ 3.00000$; penitentiaries, $\$ 19,28379$; House of Refuge, $\$ 6,00000$; conveying fugitives, $\$ 10000$; Nicholson lands, $\$ 19275$; amendments to the Constitution, $\$ 2,50000$; escheats, $\$ 1.74053$; abatement of State tax. \$3.52; 04; re-issuing relief notes, $\$ 10,94000$; counsel fees and commissions, $\$ 5,98415 ;$ miscellaneous, $\$ 5,180$ 41.

The fullowing exhibits the condition of the treasury at the end of each of the named fiscal years:

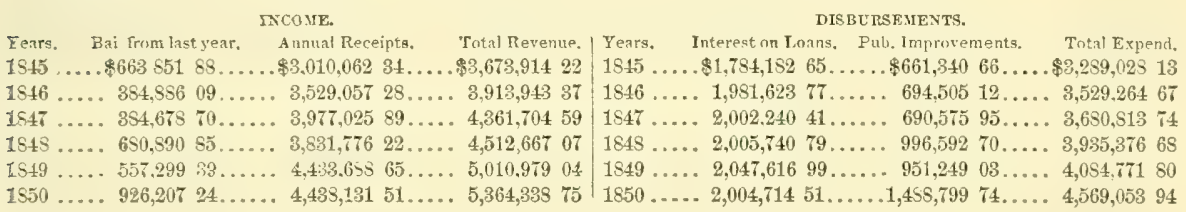

Education. "Wisdom and virtue are qualities which, because they descend not with worldly inheritances, must be earefully propagated by a virtuous education of youth." Such was the sentiment of the illustrious founder of this State; but although the prineiple of universal education was thus authoritatively reeognized at the earliest period of her history, no system of popular instruction in the commonwealth was attempted, nor common school fund established, until the 2d April, 1S31. By a legislative act of that date, certain moneys, arising from the sale of lands and other sources, were set apart as a common school fund, at an interest of 5 per cent., and this interest was directed to be added to the principal, until the proceeds should amount to $\$ 100,000$ annually. By a subsequent act (1st April, 1S34), the State was divided into aistricts, and $\$ 75,000 \mathrm{was}$ ordered to be paid ont of the school fund, for the year 1835, and annually thereafter, to be distributed among the several counties that should comply with the provisions of the said act, until the year when the fund should yield an interest of $\$ 100,000$. Provision was also made by this law for levying a tax on the districts not less than doutzle the amount of the appropriation. On the 13 th June, 1836 , an act was passed, appropriating $\$ 200,000$ for the year 1\$37, and annually therenfer, to be anportioned among the several school districts and the city and connty of Philadelphit, and authorizing the lerying of a tax not less than equal to nor more than trethe the amount of each district's porfion of the State appropriation. By resolution of $3 \mathrm{~d}$ April, $1837, \$ 500,000$ was appropriated to the common school fund for the year 1s.3., "to be applicd by the several distriets either fur building, repairing, or purchasing school houses, or for education, as they might flem bust." On the 12 th April, 1539 , the appropriation was increased to a sum equal to one dollar for every taxable inhabitant in the State, to be increased triennially, with the increase of such inhabitants, but withcat any increase of taxation above that authorized by the act of 1536 . Various acts, resolutions, and supplements were subsequently passed, not, however, materially changing any important features of the law regulating the system, until, by the act of 11 th April, 1848 , it was made to embrace every county in the commonwealth. Provision was also made by this act for the payment to those districts from which the undrawn appropriations were taken by the act of 29 th $\mathbf{A p r i l ,} 1544$, of the one-fourth of the State tax levied in such districts, to be applied exclusively to the erection of school houses therein. On the 7th April, 1S49, an act was passed, revising and consolidating all former acts relating to common sehools, and efrecting many valuable improvements in the stystem, and greatly simplifying the law. Since, and including the year ZS14, the annual aprimopriation by the State, for the support of schools, has been $\$ 200,000$. Such is the history of the 


\section{PENNSYLTANIA.}

enactments of the legislature, creating and providing a fund as the basis of the whole system of common schools. The following exhibit affords a condensed view of the operations of the system for the year ending 1st June, 1850:

Thole number of districts.........

Number paid during the year

Thole number of schools .....................

Number yet required

A verage number of months taught...............

Number of male teachers ....................

Number of female teachers ...................

Average monthly salaries-males ...............

Average monthly salaries_females .............

Number of male scholars....................

Number of female scholars ...................
1,273 Average number of scholars in each sehool.......

8,510 Cost of teaching each scholar, per month......... \$1 44

671 Amount of tax levied ..................... \$ \$65,422

5.1 State appropriations distributed................ \$ $\$ 159,367$

6,972 Total funds raised . ......................... $\$ 927,759$

3,935 Cost of instruction ..................... $\$ 609,377$

$\$ 1720$ Fuel and contingencies ..................... $\$ 63,329$

$\$ 1015$ Cost of school-houses, purchasing, renting, build-

$233,392 \quad$ ing, and repairing....................... $\$ 253,741$

190,952 Total funds expended .................... \$926,417

The following table exhibits the progress of the system in its main features, since its establishment in 1834:

\begin{tabular}{|c|c|c|c|c|c|c|c|c|c|c|c|}
\hline Year. & $\begin{array}{l}\text { Whole } \\
\text { No, of } \\
\text { Dist's. }\end{array}$ & $\begin{array}{l}\text { Districts } \\
\text { accept- } \\
\text { ing. }\end{array}$ & $\begin{array}{l}\text { Dist's. } \\
\text { paid. }\end{array}$ & $\begin{array}{l}\text { Districts } \\
\text { repoit'd. }\end{array}$ & $\begin{array}{l}\text { Whole } \\
\text { No. of } \\
\text { Schools. }\end{array}$ & $\begin{array}{c}\text { Whole } \\
\text { No. of } \\
\text { Teachers. }\end{array}$ & $\begin{array}{l}\text { Whole No. } \\
\text { of } \\
\text { Scholars. }\end{array}$ & $\begin{array}{l}\text { Apportion't } \\
\text { to accepting } \\
\text { Districts. }\end{array}$ & $\begin{array}{l}\text { Tax levied } \\
\text { on accepting } \\
\text { Districts. }\end{array}$ & $\begin{array}{c}\text { Exp'd for } \\
\text { Shebool- } \\
\text { houses. }\end{array}$ & $\begin{array}{l}\text { Exp'd for } \\
\text { instruction, } \\
\text { fuel, etc. }\end{array}$ \\
\hline 1835 & 9.7 & 536 & - & 156 & 762 & sos & $32,5 \pm 4$ & $\$-$ & $\$-$ & $\$-$ & $\$-$ \\
\hline 1836 & 987 & 745 & 603 & 573 & 3,354 & 3,394 & 139,604 & 95,670 & 207,105 & 111.503 & 193,972 \\
\hline 1837 & 1,001 & $\tau 96$ & 765 & 664 & $4,0 \$ 9$ & 4,811 & 1S2,355 & 463,749 & 231,552 & 202,230 & 493,071 \\
\hline 1538 & 1,003 & $\$ 61$ & 820 & $62 \mathrm{~s}$ & 3,939 & 5,034 & 174,733 & 323,794 & 335,788 & 149,132 & 560,450 \\
\hline 1839 & 1,050 & 879 & S5T & 633 & 3,152 & 4,666 & $1 \$ 1,913$ & 276,826 & 332,527 & 161,354 & 579,162 \\
\hline 1810 & 1,050 & $\$ 79$ & 867 & 633 & 3,152 & 4,666 & 181,913 & 264,536 & 395,918 & 161,381 & 580,262 \\
\hline $1 S 41$ & 1,072 & 902 & 855 & 634 & 5,179 & 6,056 & 227,699 & 249,400 & 397,952 & 128,004 & 524,348 \\
\hline 1842 & 1,118 & 905 & 905 & S61 & 6,116 & 7,491 & 281,085 & 250,065 & 398,766 & 119,006 & 459,872 \\
\hline 1513 & 1,139 & 945 & 945 & 865 & 6,156 & 7,594 & 255,762 & 272,720 & 419,307 & 92,749 & 484,454 \\
\hline 1844 & 1,172 & 939 & 939 & 846 & 5,993 & 7,585 & 285.402 & 264,520 & 391,340 & 75,918 & 470,228 \\
\hline $15+\tilde{y}$ & 1,189 & 1.012 & $1,01 S$ & 961 & 6,690 & 8,031 & $32 \pi .418$ & 192,513 & 370,744 & 77,173 & 375,982 \\
\hline 1846 & 1,246 & 1.067 & 1,056 & 994 & 7,096 & 8,468 & 329,505 & 186,417 & 406,740 & 60,960 & 486,475 \\
\hline 1547 & 1.249 & 1.105 & 1,054 & 1,045 & 7,320 & $8,6 \pi t$ & 381,967 & 187,269 & 436,727 & 60,410 & 487.201 \\
\hline 1818 & 1,330 & 1,330 & 1,129 & 1,079 & 7.845 & 9,096 & 360,605 & 193,035 & 501,681 & 96,539 & 505,505 \\
\hline $1 S 49$ & 1,344 & - & 1,215 & 1,194 & 8,287 & 10,050 & 385,175 & 182,583 & $5 \$ 3,157$ & 146,144 & 562,930 \\
\hline 1850 & 1.357 & - & 1.273 & - & 8.510 & 10.907 & 424,344 & 186,763 & 763,422 & 253,741 & 609,317 \\
\hline
\end{tabular}

The number of the schools in the several counties, in 1850, was as follows: Adams 127, Alleghany 250, Armstrong 128, Beaver 111, Bedford 195, Berks 214, Blair 101, Bradford 312, Bucks 189, Butler 162, Cambria 102, Carbon 45, Centre 126, Chester 265, Clarion 119, Clearfield 83, Clinton 50, Columbia 171, Craw ford 298, Cumberland 152, Dauphin 151, Delaware 69, Elk 25, Erie 271, Fayette 164, Franklin 172, Greene 118, Funtingdon 108, Indiana 164, Jefferson 82, Juniata 63, Laneaster 345, Lawrence - , Lebanon 12s, Lehigh 12S, Luzerne 252, Lycoming 146, M·Kean 51, Mereer 197, Mifflin 64, Monroe 76, Montgomery 147, Northampton 143, Northumberland 91, Perry 115, Pike 37, Potter 65, Schuylkin 133, Somerset 141, Susquehanna 216, Sullivan 31, Tioga 175, Union 141, Venango 144, Warren 120, Washington 220, Wayne 130, Westmoreland 202, Wyoming 56 , York 193.

The city and county of Philadelphia constitutes the first school district, but is not subject to the general school law. The direction of the schools is committed by law to 228 directors and 24 controllers, one each of the eleven sections into which the district is divided being governed by a separate board of directors, all being under the supervision of the Board of Controllers. Public schools were first established in the eity in 1818. The whole number of schools in 1851 was 270 , namely, the Central High School, the Normal School, 53 grammar schools, 34 secondary schools, 142 primary schools, and 39 unclassified; number of teachers, 781-\$2 males, and 699 females; number of seholars, 48,056-males 24,508, and females 23,54s. Besides these, there were 141 teachers in the evening schools. The sum expended during the year had been $\$ 366,362$, of which only $\$ 38,306$ was distributed from the State appropriation, the balance having been raised by taxation.

The prineipal universities and colleges, medical schools, theological seminaries, law schools, etc., in the State, and the statistics of each in 1850 , were as follows :

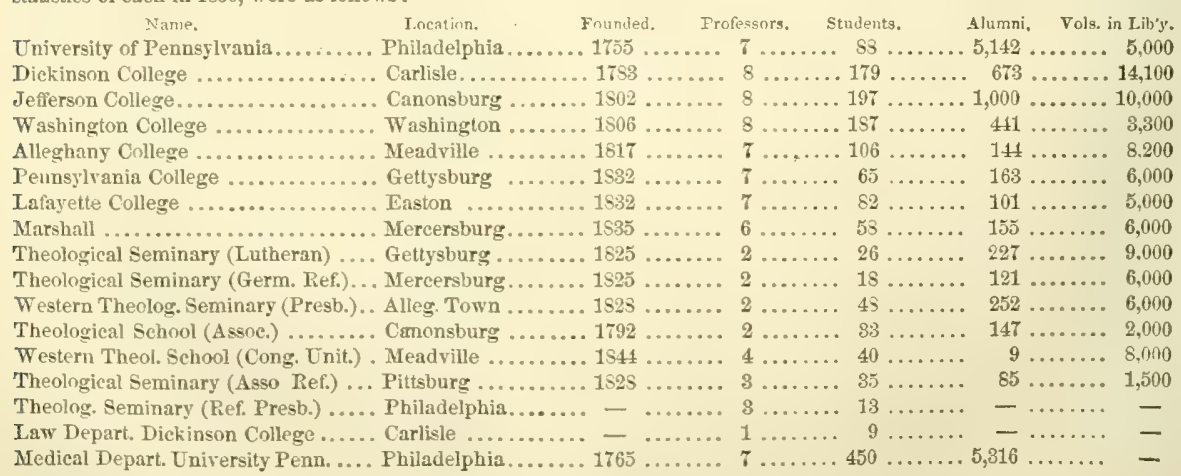
662 


\section{PENNSYLTANIA.}

Name. Location. hiludelphia .

Jefferson Medical College. Founded. Students. Alumni. Yols, in Libr's,

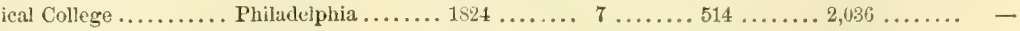

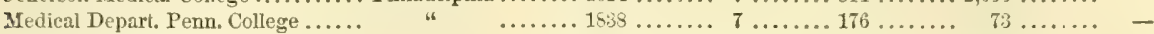
College of Medicine ............... Homoenpathic Medical College ...... Female Medical College............. College of Pharmacy ..............$$
16
$$

$73 \ldots \ldots+$

$\ldots \ldots 1816 \ldots \ldots 10 \ldots \ldots-\ldots \ldots \ldots-$

$" \quad \ldots \ldots 1849 \ldots \ldots+7 \ldots \ldots-\ldots \ldots \ldots-$

" $\ldots \ldots .1822 \ldots \ldots \ldots 4 \ldots \ldots \ldots-\ldots \ldots \ldots-\ldots \ldots$.

Besides the schools and colleges above enumerated, there are numerous academies, public and private, in every part of the State, scientific institutions, and societies founded for the encouragement of literature and the arts. Girard College, in Philadelphia, is a school for the education of orphans, and in its several departments highly efficient. Church schools are also numerous, and many of them in a highly prosperous condition. Pennsylvania, within the past ten or twelve years, indeed, has made great and wonderful progress in its educational facilities, and now stands deservedly in the foremost rank among States which make education a primary necessity in their economy.

Public Libraries.-According to the Report of the Librarian of the Smithsonian Institute, there were in the State, in 1851, the following libraries: one State library, 10,000 volumes; 16 social, 125,385 volumes; 10 college, 37,875 volumes; 12 students', 29,350 volumes; 7 academic and professional, 39,300 volumes; 5 scientific and historical, 33,478 volumes; 29 public school, 8,181 volumes; total-80 libraries, and 287,519 volumes.

Periodicul Press. - The whole number of periodicals published in the State of Pennsylvania on the 1st.June, 1550, was 328 , and of these 96 were whig, 110 democratic, and 207 neutral in polities; the latter class embraces those devoted to literature, religion, science, ete., and those the character of which was not ascertained. Of the aggregate number, 25 were published daily, circulating at each issue 152,076 copies, or $49,120,548$ annually; 3 tri-weekly, 500, or 75,000 annually; 1 semi-weekly, 600 , or 62,400 annually; 275 weekly, 526,642, or $27,335,384$ annually; 8 semi-monthly, 130,800 or $8,139,200$ annually; 12 monthly, 159,700, or 1,916,400 annually; and 2 quarterly, 1,900, or 7,600 annually; total copies at each issue, 972,218 , or 79,792,532 copies annually. The counties in which published are as follows: in Adams, 3 w. and 1 q. ; Alleghany (Pittsburg, etc.), 13 d., 2 t.-w., 20 w., 1 s.-m., and 2 m. ; Armstrong and Beaver, each 2 w.; Bedford, 3 w.; Berks, 9 w.; Blair, 4 w.; Bradford, 3 w.; Bucks, 7 w.; Butler, Cambria, and Centre, each 3 w.; Carbon, 2 w. : Chester, 5 w. ; Clarion and Clinton, each 2 w.; Clearfield, 1 w.; Columbia, 3 w. ; Craw ford and Cumberland, each 5 w.; Dauphin, 1 d., 7 w.; Delaware, 3 w.; Elk, 1 w.; Erie, 1 t.-w., 4 w.; Fayette, 10 w.; Franklin, 7 w.; Fulton, 1 w.; Greene, 2 w.; Huntingdon, 2 w.; Indiana, 3 w.; Jefferson and Juniata, each 2 w.; Lancaster, 10 w., 1 m.; Lawrence, 2 w.; Lebanon, 5 w.; Lehigh, 5 w., 1 s.-m.; Lucerne, 2 w.; Lycoming, 4 w.; M'Kean, 1 w, ; Mercer, 4 w.; Mifflin and Monroe, each 2 w.; Montgomery, 6 w.; Montour, 2 w. ; Northampton, 8 w.; Northumberland, 4 w.; Perry, 2 w. ; Philadelphia, 11 d., 1 s.-w., 38 w., 5 s.-m., 8 m., 1 q., 1 an.; Pike, 1 w.; Potter, 2 w.; Schuylkill, 9 w., 1 m.; Somerset, 2 w. ; Susquehanna, 2 w.; Tioga, 4 w.; Union, 7 w., 1 m.; Venango, 2 w.; Warren, 3 w.; Washington, 4 w.; Wayne, 2 w.; Wyoming, 2 w.; Westmoreland, 4 w.; York, 7 weekly.

Religious Denominations.-The statistics of the sereral religious denominations in the State in 1850 , were as stated in the table annexed:

\begin{tabular}{|c|c|c|c|c|c|c|c|c|}
\hline $\begin{array}{l}\text { Denomina. No. of } \\
\text { tims. Churries. }\end{array}$ & $\begin{array}{l}\text { Church } \\
\text { aceom. }\end{array}$ & $\begin{array}{l}\text { Value of } \\
\text { Property. }\end{array}$ & $\begin{array}{l}\text { Denomina- } \\
\text { tions. }\end{array}$ & $\begin{array}{c}\text { No. of Church } \\
\text { Churches. actom. }\end{array}$ & $\begin{array}{l}\text { Value of } \\
\text { Property. }\end{array}$ & $\begin{array}{c}\text { Denomina- No. of } \\
\text { tions. }\end{array}$ & $\begin{array}{l}\text { Church } \\
\text { accom. }\end{array}$ & $\begin{array}{l}\text { Value } \\
\text { Propert }\end{array}$ \\
\hline Baptist.....317.. & $127,30 \mathrm{~S} .$. & $\$ 506,395$ & Germin Ref. & E. $203 \ldots 104,262$. & $\$ 639.210$ & R. Catholic.. $139 .$. & $89,251$. & $\$ 1,084,2$ \\
\hline Christian... 19.. & $6,100 \ldots$ & 24,400 & Jewish .... & $3,175$. & 45,700 & Swedenb'g .. & 1,475 & 11 \\
\hline Congregat'l. & $3.100 \ldots$ & 17,250 & Lutheran... & $495 \ldots .259,502 \ldots$ & $1,633,356$ & Tunker..... 14.. & $6,100 \ldots$ & \\
\hline Dutch Ref:. & $6,640 \ldots$ & 79,500 & Mennonite. & 86.. $23,870 \ldots$ & 82,400 & Union...... 80.. & 00. & \\
\hline Episcopal.. 135.. & $67,324 \ldots$ & $1,453,700$ & Methodist.. & . 878. . 339,026 . & $1,715,658$ & Unitarian... & $1,630 \ldots$ & \\
\hline Free...... 22.. & $6,400 \ldots$ & 15,050 & Moravian. . & $84 \ldots \quad 32,715 \ldots$ & 221,350 & Universalist. $19 .$. & $8,920 \ldots$ & \\
\hline Friends.... 141.. & $60,974 \ldots$ & $661,787^{\circ}$ & Presbyter"n. & $755 \ldots 357,481$ & $2,574,700$ & Minor Sects. 92. & 32,560 . & 25 \\
\hline
\end{tabular}

- making a total of 3,579 churehes, having accommodation for 1,566,413 persons, and valued at $\$ 11,551, \$ 85$. This State comprises the Protestant Episcopal diocese of Pennsylvania, and the Roman Catholic dioceses of Pittsburg and Philadelphia, in the latter of which are also included West New Jersey and the State of Delaware.

Pauperism.-The whole number of paupers that received assistance or support during the year ending 1st June, 1S500, Was 11,551, of which number 5,398 were native-born, 5.653 foreigners; and the whole number of paupers on the lists at the date specified was 3,811 , of which 2,654 were native-born, and 1,157 foreigners. Annual cost of support, $\$ 232,138$.

Mistorieal Sketch.-Pennsylvania is the only State of the Union which bears and transmits to future ages the name of a private individual. William Penn, the illustrious founder of Pennsylvania, a name given to the infant colony by Charles II., was the son of Admiral Penn, who in the year 1655 acquired distinetion as a commander in the conquest of Jamaica, and in the war with the Dutch. At an early period of life, Penn had joined the Quakers, who began about that period to attract public attention, and it seems to have been the intolerance manifested toward the sect that first turned his mind toward America. He and some others purchased a large quantity of land in New Jersey, but becoming dissatisfied, he formed the design of acquiring a separate estate. The crown was indebted to his father's executors in the sum of about $£ 16,000$, and as an acquittance for this, a large tract was granted to him in severalty. His charter conveyed to him all that tract of country bounded on the east by the river Delaware, extending westward five degrees, and north and south between the 40 th and 42 d parallels, except an area around New Castle, circumscribed by a radius of 12 miles. From want of sufficient attention to former charters, this grant interfered both with that of Maryland on the south, and with the claims of Connecticut on the east, and hence arose contentions which disturbed the repose of the colonies for a century a fterward.

In May, 1681, the proprietary sent over Markham, with a few others, to take possession of the territory, and in July he sold 20.000 acres to a company of merchants, at the rate of $\$ 20$ the thousand acres, entering into articles of agreement with them, entitled "Conditions and Concessions." In the following year, Penn published his "Frame of Government," by which the supreme power was to be vested in a governor and general assembly, consisting at first in the whole body of the people, and afterward in a House of Representatives. A provincial council was established, consisting of 72 persons, to be chosen by the fremen. The governor, possessed of three votes, presided in this council, which prepared and digested all laws, leaving to the penple the entire right of rejecting or affirming. This constitution was after a while laid aside, and another, resembling those established in the other provinces, was aciopted. In October, 16\$2, Penn, accompa- 
nied by about 2,000 settlers, arrived at New Castle, on the Delaware. IIe had previrusly acruired from the Dake of Tork a conveyance of the land at present includel in the State of Delaware. II is first step on landing was to convoke an assembly, which was held at Upland (now called Chester), in December, 1652. In a short session of three days, a constitution modifying that drawn up by Penn in England was adopted, and several important laws pissed. Among other provisions, that greut principle, to an adherance to which the province owed much of its prosperity, was adopted, that "none acknowledging one God, and living peaceably in society, should be molested for his opinions or practice, or compelled to frequent or maintain any ministry whatsoever." Another principle of Penn's system, equally novel and praiseworthy, regarded the treatment of the Indians. Soon after his arrival, he summoned them to a council, and treating with them on an amicable and equal footing, as men and brethren; obtained from them, in return for valuable presents, a cession of as much land as his exigencies required. The same course was pursued in his subseqnent intercourse with them, and it was seen with surprise by mankind that kindness and good faith were as useful assistants as the sword in the affairs of a colony. No one of the colonies made such rapid advanees in prosperity as Pennsylvania. The sulubrity of the climate, and the general fruitfulness of the soil, had some influence, but the moral attractions predominated. The persecutions at home drove thousands to a place where religious worship was free, and the prospect of enjoying equal rights in civil matters, attracted from the continent of Europe a vast number of industrious and moral emigrants.

The city of Philadelphia was founded at an early period after the arrival of the first settlers, and the second assembly of the colony was held at this place, in April, 1683. Among other important laws adopted by this assembly was one abrogating the common law of England respecting deseents, and distributing the estates of persons dying intestate among the children, giving to the eldest son, however, a double share. The Revolution in England produced some change in the government of Pennsylvania. Penn, being suspected of being disaffected toward the House of Orange, was suspended from the privilege of appointing a deputy for his province; and in 1692 Pennsylvania was annexed to New York and subjected to the administration of the governor of that province. Two years after, however, the proprietary was reinstated, and appointed a new governor. Notwithstanding the paeific disposition of the governor and people, and the general concordance of their opinions, Pennsylvania proved to be no Utopia for the worthy proprietary. Bickerings about the constitution or the laws, or the manner of disposing of the lands, almost constantly existed. The charter had twice been altered, but the colonists were still discontented. A third charter was given them in 1701 , which provided that the assembly should eonsist of deputies from each county, and that it should have the right to originate, amend, or reject all bills; that the governor should nominate his own council, exercise the whole exeeutive power, and have a negative on the proceedings of the assembly. The delegates from Pennsylvanis assented to this constitution, but those from " the Three Lower Counties on the Delaware," as they were called, refused to adopt it, and seceded from the assembly. From this period the Three Counties had a distinct assembly, though they were subject to the same governor as Pennsylvania. The constitution thus adopted continued in force until the Revolution. Penn died in 1718, at the age of 74 years. Since his founding the State that immortalizes his name, his life had been a unifurm scene of vexation and disquiet. His private fortune had materially suffered by his advances to promote the infant colony, and at one time he was compelled to submit to a temporary deprivation of liberty. He left, however, to his descendants an inheritance of great value, which they enjoyed until the overthrow of the British power, when the Commonwealth became the possessor, and, as an indemnification, granted them an ample sum of money. From the death of Penn the history of the colnny is little more than a narrative of petty quarrels between the proprietary governors and the assembly. The chief subject of dispute arose from the lands of the proprietary, which it was wished to exempt from taxation, to which other lands were liable. The assembly resisted the exemption, and this disagreement frequently prevented the passage of necessary laws. In 1749, an important treaty was made with the Indians of the Six Nations at Philadelphia, in which, for goods of considerable value, they granted to the proprietary all the lands on the Susquehanna, south as far as the boundary of Pennsylvania, and north to the Kittatinny Hills, or Blue Mountain. The whole Indian title to lands within the State was subsequently merged, A large portion of the inhabitants of Pennsylvania were Quakers, but notwitbstanding their peaceful inclinations, the colony opposed. with as much zeal as her sister colonies, the arbitrary measures of the British government which led to the Revolution. The first congress of deputies from the States, and most of the subsequent sessions of the same assembly, were held in Philadelphia, and it was at the same place that the Declaration of Independence was adopted and proclaimed. During a considerable part of the war the State was the theatre of hostilities. On the Declaration of Independence the proprietary government was abrogated, and the people, by their representatives, formed a new constitution. The form of government adopted at this period was found, after the peace, to be liable to serious objections. Two parties then arnse, the republicans and the constitutionalists-the former, desiring a constitution in which the legislative power should be exercised by two branches and the executive invested in a single person, finally triumphed, and in 179n, a constitution, similar to that of the United States, was adopted. In 1791, an insurrection broke out in four of the western counties, in opposition to the law of the United States imposing a tax on spirits. From this, called the "Whisky Insurrection," serious consequences were at first threatened, but by a happy union of firmness and lenity on the part of President Washington, the revolt was quelled. In Northampton County, in 1797 , some deluded persons attempted to resist the process of the marshal, but the power of the laws again triumphed. In 1799 , the public offices and the sittings of the legislature, which, from the settlement of the colony, had been held at Philadelphia, were removed to Lancaster, and in 1812, they were transferred from Lancaster to Harrisburg, the present capital. From this period no conspicuous event of histnry has transpired. The State, indeed, has gone through many financial diffeulties, and for a time even her condition was considered as a blot on the honor of the nation. The fair name of the State, however, has been redeemed, and the debt, which circumstances forced her to suspend, is now liquidated, interest having been regularly paid for many years, and the principal is being reduced by the operation of a sinking fund. The day of her degradation indeed is passed, and she now looms up among that glorious galaxy of states which circumscribes her boundaries, as one of the most glorious and honored.

Harrisburg, on the left bank of the Susquehanna, is the political capital of the State.

Pennvilie, p. v., Jay co., Ind.: $68 \mathrm{~m}$. N. E. Indianapolis. implements, furniture, ete., and 2,500 inhabilants. The PENN $Y_{A N}$, p. v, and cap. Yates co., N. $Y_{0}$ : on the out- "Penn Yan Democrat" and "Yates County Whig" are let, $1 \mathrm{~m}$. from the foot of Crooked lake, $161 \mathrm{~m}$. W. Albany. published weekly. The outlet descends 270 feet before It contains a court-house, jail, elerk's office, an academy, 2 reaching Seneca lake, and furnishes immense water-power. banks, several large warehouses and flouring-mills, numer- Crooked Lake Canal, $8 \mathrm{~m}$. Iong, follows the outlet, and conous manufactories of castings, mechanical and agricultural nects the v., through Seneca lake, with the Erie Canal. 
Steamers ply s. to the head of Crooked lake, and the Canandaigua and Elmira R. R. passes through the v., $24 \mathrm{~m}$. S. E. of Can:ndaigua, $48 \mathrm{~m} . \mathrm{N}$. W. of Limira.

Penny's Ferry, p. 0., Henry eo, $I l$. : on Rock r., $123 \mathrm{~m}$. N. N. W. Springfield.

Penobscot county, Me. Situate $\mathbf{E}$. centrally, and contains $2,760 \mathrm{sq} . \mathrm{m}$. In the northern part it is drained by head branches of Aroostook $r$, and E. branch of Penobscot r., and in the S. by Penobseot and its affluents, Mattawamkeag, Sebec, and Fenduskeag rivers. Surface undulating, and in the N.motntainous; soil in general fertile, and produces good crops of wheat, corn, and potatoes. It is well wooded, and has gond pasturage for eattle. Agriculture is the leading pursuit. Farms $3,98: 3$; manuf. 407; dwell. 10,374, and pop.-wh. 63,026, fr. col. 63-total 63,059. Capital: Bangor. Public Works: Bangor and Oldtown R. R.; Kennebec and Penobscot R. R.; European and North American R. R.

Pexorscot, t. and p. v., Hancock co., Me, : at the head of Penobscot bay, on the E. side, $56 \mathrm{~m}$. E. by N. Augusta. A large pond lies in the N. E. part. It has a fertile soil, good water-power, fucilities for navigation, and abundance of $i$ imber. Pop. of t. 1,556.

PExósscot bay, Me.: near the middle of the coast boundary, setting up N. from the Atlantic Orean about $27 \mathrm{~m}$., receiving Penobscot $r$, at its N. extremity, called Bellast bay, The breadth of its mouth, from Owl's Head on the W. to Burnt Coat Island on the E., is about $30 \mathrm{~m}$. It contains a number of large islands, the principal of which are Deer, Haut, Long, and Fox islands, besides many smaller. It has many good harbors, and its waters contain many varieties of excellent fish. Its scenery is exceedingly beautiful, and on its borders are large and flourishing towns.

Penósсот river, Ble : this important river is the largest in the State. It is formed from two main branches, of which the largest rises in the W. part of the State near the Canada line, and flows by irregular course E. and S., and through the large lakes, Chesuncook and Pemadumeook, to its junetion with the E. branch. After the junction it flows in a S. E. course until it receives Mattawamkeag $r$. from the N. E., which is its principal tributary on the $\mathrm{E}$. side; then S. S. W. until it receives the Piscataquis, its chief W. tributary; then S. by W. to its entrunce into Penobscot bay. From its source to the ocean is about $275 \mathrm{~m}$. It is navigable for vessels of large size to Bangor, $50 \mathrm{~m}$. from the ocean, and for boats to a considerable distance above that Its upper portions have many falls and rapids furnishing excellent mill-sites. The tide rises high at Bangor, caused by the return of the Gulf stream and the wedge-like form of the bay. Above Bangor are numerous islands owned by the Penobscot Indians, who oceupy the principal oneOldtown.

Рековвсот, U. S. collection district, Me. Castine is the port oi entry. Total tonnage on 30 th .June, $1850,36,950$ tons of which 5,713 tons were registered, and 31,237 enrolled and licensed. Of registered tonnage, 5,122 tons were permanent, and 591 tons temporary. The enrolled and licensed tonnage consisted of 30,531 tons permanently enrolled; of which 15,059 tons were in the coasting trade, 11,462 tons in corl fishery, and 4,010 in the mackerel fishery, besides 700 tons "licensed under 20 tons" employed in the cod fishery. During the year ending June 30,1850 , the number of clearances for fureign countries was 19-3,441 tons; total of entrances. 14-1.140 tons. Vessels built during the year, 2 ships, 3 brirs, 14 schooners; total $19-2,835$ tons.

Pexora, p. O., Sumter county, Ala. : $122 \mathrm{~m}$. W. by N. Montgomery.

Pessacola, p. eity, port of entry, and cap. Escambia co. Flor.: on Pensacola bay, $10 \mathrm{~m}$. from the Gulf of Mexico, $176 \mathrm{~m}$. W. Tallahassee. Lat. $30^{\circ} 24^{\prime} \mathrm{N}$., long. $87010^{\prime} 12^{\prime \prime} \mathrm{W}$. The harbor is deep and affords good anchorage, but near the city is shallow, and hence a long wharf has been extenderl into the bay. The city is built on a sandy plain, 40 or 50 feet above the level of the water, and is regularly lair out with wide streets crossing at right angles, huving also two large public squares. It contains. a cour-house, customhouse, market, and 2 churches. Two newspipers are issued, "P. Gazette" (whig), weekly, and "Florida Democrat," seml-weekly. This is the principal port and eity in Florida, and has considerable trade. On 30th June, 1850 , the total tonnage of its district was 1,794 tons, of which 1.221 tons were registered and permitnent, and joiz tons enrolled and lieensed; 496 tons permanently, and 77 tons licensed under 20 tons. The latter was entirely employed in the coasting trade. During the year previous the total

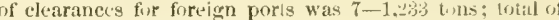
entrances, do., 2,837 tons-all of which (9) were Ameriean vessels. Vessels built during the year, 2 schooners -80 tons. The project of a railruad to Montgumery, Alie., has loug been agitated. Pop. about 2,104 .

About $6 \mathrm{~m}$. below the city, and $5 \mathrm{~m}$. from the entrance of the harbor, is the U. S. Navy Yard, cosering nearly 80 acres of ground, inclosed by a high brick wall. It contains houses for the officers, store-houses, boat-houses, etc., all of which are puilt of brick and tastefully arranged. Here is also a dry dock capable of receiving the lurgest vessels. Outside of the yard are about 25 cottages and a Catholic church. A mile and a half below the navy yard are Barrancas Barracks and the Naval Hospital. At the entrance of the har bor are forts Pickens and M'Pee, on Foster's and St. Rirsa's islands, and on the latter island is a light-house. See LigrirHOUEES.

Pexsacola, p. v., Leake en, Miss. : 41 m. N. E. Jackson. Pensacola bay, Flor.: sets up from the Gulf of Mexien in the N. W. part of Florida. It is of irregular furm, consisting of three parts. The W. arm, called Escambia bay, is about $11 \mathrm{~m}$. long and $4 \mathrm{~m}$. broad, and receives Escambia r. from the N. The N. E. arm is called Yellow Water bay, is about the size of Escambia bay, and receives Yellow Water $\mathbf{r}_{0}$; its more N. part is called Black Water bay, and receives Black Water $r$. and other ereeks. The S. part of the bay, extending E. $7 \mathrm{~m}$., is called East bay; it is entirely sheltered from the winds and admits the largest frigates Its entrance is about three quarters of a mile wide, and is well defended. There is a depth of 22 feet of water on the bar at low tide.

Pentress, p. o., Monongalia co., Virg.: 209 m. N. W. Richmond.

Pxola Mruts, p. o., Madison county, Tirg.: $76 \mathrm{~m}$. N. W. Richmond.

Peoli, p. o., Tusearawas county, Ohio: $81 \mathrm{~m}$. E. N. E. Columbus.

Peoria county, Ill. Situate N. W. centrally, and contains $648 \mathrm{sq.} \mathrm{m.} \mathrm{Drained} \mathrm{by} \mathrm{Spoon} \mathrm{r.} \mathrm{and} \mathrm{Copperas} \mathrm{and}$ Kickapoo creeks, tributaries of Illinois $r$, which forms its eastern boundary. Surface rolling; soil fertile, consisting principally of a deep mold, with clay intermixed. Chief productions wheat and Indian eorn. A large quantity of pork is exported, and it has some good timber-land. Farms 1,191; manuf. 131; dwell. 3,036, and pop.-wh. 17,461, fr. col. S6-total 17,517. Cepital: Peoria, Pullic Horks: Peoria and Oquawka R. R.

Peoria, p. v, and cap. Peoria co., Tl. : on the right bank of Illinois r., at the foot of Peoria lake, $61 \mathrm{~m}$. N. Springfield. It is $193 \mathrm{~m}$. above the mouth of the Illinois, and occupies two terraces-the first a quarter of a mile broad and from 6 to 12 feet above high water; the second 6 or $\$$ feet higher, and extending back to the bluffs, which are about 80 feet high. It is the shipping port for a large amount of grain and other products of the fertile region on every side of it, with which it has an extensive trade. It has also valuable manufactures, which are receiving increased attention. It contains a court-house, jail, an incorporated academy, a bank, about 50 stores and warehouses, several steam-mills and factories, and 5,562 inhabitants. Two weekly papers are published, the "I'. Democratic Pruss" and the "P. Lie- 
publican" (whig). The "P. Motto," a religious and statistical journal, is issued semi-quarterly. A railroad will pass through it from Bloomington, on the Illinois Central R. R., to some point on the Mississippi.

Peorla, p. o., Wyoming co., $N_{0} Y_{.}: 229 \mathrm{~m}$. W. Albany.

Peoris, p. v., Franklin county, Ind: 58 m. E. S. E. Indianapolis.

Peoris lake, Ill.: is an expansion of Illinois $\mathbf{r}$. between Peoria and Woodford counties, commencing at Chillicothe, and extending $20 \mathrm{~m}$. to Peoria. In some parts it is $4 \mathrm{~m}$. wide, but at the "Narrows," $5 \mathrm{~m}$. above Peoria, it is contracted to the usual width of the river, and then again widens. The water is clear, with gravelly bottom, has a slow current, and abounds with various kinds of fish. Most of the E. shore is low and swampy, but on the W. side are high bluffs.

Peoriaville, p. v., Peoria co., $1 l l_{\text {: }}$ 65 m. N. Springfield. Pepaoton, p. v., Delaware co., N. Y.: on Pepacton r., $69 \mathrm{~m} . \mathrm{S}$. W. by W. Albany.

Prexi lake: is an expansion of the Mississippi r., between Wisconsin and Minnesota, about $24 \mathrm{~m}$. long, terminating at mouth of Chippewa r., from 2 to $4 \mathrm{~m}$. wide. Its shores are for the most part high precipitous rocks, of which the "Maiden's Rock" is 500 feet high.

Pepptrell, t., p. v., and sta., Middlesex co., Mrass. : on the $N$. line of the State and W. side of Nashua $r, 35 \mathrm{~m}$. N. W. by W. Boston. Drained by a branch of the Nashua, which supplies mill-sites. Surface uneven, except on the streams; soil fertile. Manufacturing of various kinds are curried on. The Peterboro' and Shirley R. R. passes on the S. and the Worcester and Nashua R. R. on the E. border. The sta, is $9 \mathrm{~m} . \mathrm{s}$. W. of Nashua on the latter. The v. contains an academy. Pop. of $t .1, \pi 54$.

Perper's Ferry, p. o., Pulaski co., Firg.: on New r., $172 \mathrm{~m}$. W. by S. Richmond.

Pequannock ereek, N. Jer.: rises in Wayawanda and Wallkill mountains, Sussex county, flows S. E. and S., and enters Passaic r. Below Pompton v, it is called Pompton r. Its current is rapid, affording good water-power.

PEQUOT, p. v., Calumet co., Wisc. : on the E. side of Winnebago lake, $84 \mathrm{~m}$. N. E. Madison.

Perch Rrver, p. o., Jefferson county, N. Y.: $142 \mathrm{~m}$. N. W. by W. Albany.

PERCY's Creek, p. 0., Wilkinson co., Miss.: $95 \mathrm{~m}$. S. W. Jackson.

PERDIno river and bar, $A l \alpha$. and Flor.: the boundary line between these States, about $40 \mathrm{~m}$. long. The bay is shallow and its entrance obstructed by sandbars.

Peris's Mrils, p. v., Clermont co., Olizo: on the E. branch of Little Miami r., $\$ 8 \mathrm{~m}$. S. W. Columbus.

Perkins' Grove, p. 0., Bureau co., Ill.: $124 \mathrm{~m}$. N. by E. Springfiejd.

Perkinstille, p. v., Madison co., Ind.: on the W. fork of White r., $28 \mathrm{~m}$. N. N. E. Indianapolis.

Perkingtrle, p. v., Burke co., N. Car. : on Wilson's cr., a N. tributary of Catawbar r, $166 \mathrm{~m}$. W. by N. Raleigh.

PrRkingrille, p. v., Goochland county, Virg.: $33 \mathrm{~m}$. W. N. W. Richmond.

Perkinstille, p. v., Windsor co., Verm.: on Black r., $64 \mathrm{~m}$. S. by $\mathrm{E}$. Montpelier. It contains an academy and soveril mantifetories.

Perkiomen river, Penn.: rises in S. E. comer of Lehigh county, flows S. through Montgomery county, and enters Schuyikill r., $6 \mathrm{~m}$. W. Norristown. It affurds good waterpower, as also its tributaries.

Perkionen Bridge, p. o., Montgomery co, Penn. : $74 \mathrm{~m}$. E. II:arrishurc.

Perote, p. o., Ashland county, Ohio: 68 m. N. N. E. Columbus.

Perquimaxs county, N. Car. Situate N. E., and contains $172 \mathrm{Eq} . \mathrm{m}$, Drained by Perquimans and Little rivers, both of which discharge their waters into Albernarle Sound the S. Surfuce low and level; soil fertile where capable $666^{\circ}$ of cultivation, and very productive. Staples, cotton, wheat, and Indian corn. Farms 505; manuf. 21; dwell. 818, and pop.-wh. 3,629, fr. col. 450, sl. 3,252-total 7,381. Capital: Hertford.

Perrine, p. o., Mercer county, Penn. : 185 m. W. N. W. Harrisburg:

Perrineville, p. v., Monmouth co., N. Jer.: 17 m. E Trenton.

Perrinton, t. and p. o, Monroe county, N. Y.: $182 \mathrm{~m}$. W. by N. Albany. Drained by Irondequoit cr. Surface slightly uneven; soil fertile, and very productive of wheat, the growing of which is the leading business. The Rochester and Syracuse (direct) R. R. and the Erie Canal cross the town; on the latter is the village of Fairport, $17 \mathrm{~m} . \mathrm{E}$, Rochester. Pop. 2,891.

Prerey county, Ala. Situate W. centrally, and contains 984 sq. m. Catawba r., a tributary of Alabama r., passes through it centrally, by which and its branches it is drained, and also by branches of Black Warrior r. Surface varied; soil fertile asd well adapted to cotton, which it produces in large quantities, and which forms the chief article of commerce; it also produces good crops of wheat and Indian corn. It has some good timber-land, and fine pasturage for cattle. Farms 1,066; manuf. 21; dwell. 1,332, and pop. -wh. 8,342 , fr. col. 26, sl. 13,917-total 22,285. Capital : Marion. Public Works: Selma and Tennessee River Railroad.

PERRY county, Ark. Situate centrally, and contains 534 sq. m. Drained by La Fave r., tributary of Arkansas r. which forms its N. E. and N. boundary. Surface undulating; soil fertile, and well adapted to grain. Timber is found on the land, and it contains fine coal beds. Farms 75 ; manuf. 2 ; dwell. 154, and pop.-wh. 957, fr. col. 6, sl. 15total 978. Capital: Perryville.

Perry county, $I l l$. Situate toward the $\mathrm{S}$., and contains 432 sq. m. Drained by St. Mary's r. and by Big Beaucoup and Little Muddy creeks. Surface even; soil furtile, and adapted to corn. About one-third of the land is prairie. Farms 635 ; manuf. 7 ; dwell. 967, and pop.-wh. 5,267, fr. col. 11 -total 5,278. Capital: Pickneyville. Public Works: Illinois Central R. $\mathrm{R}$.

PERRY county, Ind. Situate $\mathbb{S}_{.}$, and contains $387 \mathrm{sq} . \mathrm{m}$. Drained by Deer, Oil, and Anderson's creeks, which flow into the Ohio $r$., the boundary of the county on the South. Surface in general hilly and broken, but along the Ohio and Anderson are some level tracts; soil moderately fertile. Chief productions wheat, Indian corn, and tobacco. 'Timber is found on the land of excellent quality. Farms 510 . manuf, 14 ; dwell. 1,231 , and pop. -wh. 7,259 , fr. col. 9total 7,268. Capital: Troy.

PERry county, Ky. Situate S. E., and contains 815 sq. m. Drained by North and Middle forks of Kentucky r. Surface uneven, and diversifled with fertile hills and vallers; soil productive, and there is much fine grazing land in the county. Wheat and Indian corn are produced. It is bounded on the $\mathrm{N}$. by Laurel Mountain. Farms 396 ; manuf, 0 ; dwell. 471, and pop.-wh. 2,972, fr. col. 3, sl. 117-total 3,092 . Capital: Perry.

Perry county. Miss. Situate S. toward the E., and contains $1,080 \mathrm{sq} . \mathrm{m}$. Drained by Black and Leaf creeks and their branches, all tributaries of Pascagoula $\mathbf{r}$. Surface slightly broken; soil indifferent, and is thickly covered with pine timber. There is fine pasture for cattle, etc. Chief productions rice and cotton. Farms 131; manuf. 0 ; dwell. 265 , and pop.-wh. 1,679 , fi. col. 10 , sl. 749 -total 2,438 . Capital: Augusta.

Perry county, Penn. Situate S. centrally, and contains $574 \mathrm{sq}, \mathrm{m}$. Susquehanna $\mathbf{r}$. forms its $\mathrm{E}$, boundary, and by its principal tributary, Juniata $r$ and other streams, it is arained. Surface much broken and mountainous; soil a fine deep regetable mold, and very fertile. Chief productions wheat, Indian corn, and potatoes. It has some good coal beds, and contains a medieinal spring which discharges 
warm water and is useful in many disorders. Farms 1,456 ; manuf. 232 ; dwell. 3,412 , and pop.-wh. 19,953 , fr. col. 135 -total 20,058. Capital: New Bloomfleld. Public Works.

Pennsylvania R. R. and Pennsylvania Canal.

Perry county, Mo. Situate toward the S. E., and contains $452 \mathrm{sq} . \mathrm{m}$. Drained by several small streams, affluent of the Mississippi, and which in their course supply good water-power. Surface varied, rising toward the E., and terminating in high land on the Mississippi; soil fertile and very productive. Minerals abound, and there are some good coal beds. It contains some fine timber-land. Farms 743; mauuf. 35; dwell. 1.111, and pop.-wh. 6,395, fr. col 20, sl. 791-total 7.215. Cupital : Perryville.

Perry county, Ohio. Situate toward the S. E., and contains $414 \mathrm{sq}$. m. Drained by affluents of Muskingum and ITocking rivers. Surface hilly and broken; soil fertile. Chief productions wheat, Indian corn, and tobaceo. Pine and other timber is found on the land. Farms 1,314; manuf 25; dwell, 3,587, and pop.-wh. 20,746, fr. col. 29-total 20,7i5. Capital: Somerset. Public Works: Scioto and IIocking Valley R. R.; Cincinnati, Wilmington and Zanesville $R, R$.

Perry county, Tenn. Situate S. W. centrally, and contains 570 sq. m. Drained by Tennessee $r$, and its branches, the principal being Buffalo r. Surface level; soil fertile Chief productions wheat, Indian corn, and tobacco. Farms 455; manuf. 4; dwell. 927, and pop.-wh. 5,504, fr. col. 4, sl. 314 -total 5,S22. Capital: Linden.

Perry, p. v., and cap. IIouston co., $G a$.: on Mossy cr., W. branch of the Ocmulgee, $53 \mathrm{~m}$. S. W. by S. Milledgeville. It contains a court-house, jail, 2 academies, a dozen stores, and about 700 inhabitants.

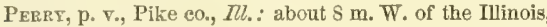
$59 \mathrm{~m}$. W. Springfield.

Perke, p. V., Allen co., Ind.: on a W. branch of Cedar cr., $112 \mathrm{~m}$. N. N. E. Indianapolis, A plank-road leads S. to Fort Wayne.

Perry, p. . $_{\text {, }}$ and cap. Perry co., Ky.: on Kentucky r., $115 \mathrm{~m}$. S. E. by E. Frankfort. It contains a court-house, several stores, and 200 inhabitants.

Pskry, t. and p. v., Washington con, Me.: on Passamaquoddy bay, $142 \mathrm{~m}$. E. by N. Augusta. On the S. is Cobscook bay. A bridge connects it with Eastport, $5 \mathrm{~m}$. S. E. It has great facilities for the coasting trade and fisheries, which, with boat-building and the Iumber business, are extensively carried on. Pop. of t. 1,324.

Perre, t. and p. v., Wyoming co., N. $Y_{.:} 211 \mathrm{~m} . \mathrm{W}$. by N. Albany. Drained by the outlet of Silver lake, which affords excellent water-power. Surface undulating; soil loam, mixed with sand and clay, and highly productive of grass and grain. The $\mathrm{v}$. is on the outlet, and extensively engaged in manufactures. It contains an academy, several furnaces, flouring and other mills and factories, and about 1,200 inhabitants. Pop. of t. 2,532 .

PERry, t., p. o., and sta., Lake co,, Ohio: on Lake Erie, 153 m. N. E. by N. Columbus. The Cleveland and Erie R. P. crosses it, and has a station $6 \mathrm{~m}$. E. of Painesville Pop. 1,131

Perry, p. o., Venango co., Penn.: 173 m. N. W. by W. IIarrisburg.

Perer, t, and p. O., Shiawassee co., Mich.: 19 m. F. by N. Lansing. Drained by Looking-glass $r$. and its branches, Surface mostly level; soil fertile prairie. Pop. 313.

Perry Centre, p. v., Wyoming county, N. Y.: $214 \mathrm{~m}$. W. by N. Albany. A literary institution, called the Perry Centre Institute, is established here.

Perrymansilile, p. v. and sta., Farford co, Ma..: on the W. side of Bush r., 84 m. N. N. E. Annapolis, The sta is $2 \pi \mathrm{m}$. E. of Baltimore, on the Philadelphia, Wilmington and Baltimore R. R.

Perryopolis, p. v., Fayette co., Penn.: on the W. side of Toughiogeny r., $117 \mathrm{~m}$. W. by S. Harrisburg. The river affurds power for several factories and mills. The v. con- tains suveral stores and about 600 inhabitants. The " $\mathrm{P}$ Clarion" (dem.) is published weekly.

Perry's Bridge, p. o., Vermillion par., La. : on Vermillion river, about $20 \mathrm{~m}$. N. of Vermillion bay, $65 \mathrm{~m}$. S. W. by W. Baton Rouge.

Perrysburg, p. v., Miami co., In. : $76 \mathrm{~m}$. N. Indianapolis A plank-road leads $12 \mathrm{~m}$. $\mathrm{S}$, to Peru.

Perrysbure, t. and p. o., Cattaraugus co., $N . Y_{.: 262 \mathrm{~m}}$ W. by S. Albany. Drained by affluents of Cattaraugus er. its N. boundary. Surface broken and well timbered; soil gravelly or elayey, and best adapted to grazing. Population 1,862 .

Perrysburg, t., p. v., and cap. Wood con, Ohio: on the right bank of Maumee r., $111 \mathrm{~m}$. N. N.W. Columbus. Surface mostly level; soil sandy, and of average fertility. The village, occupying a commanding eminence at the head of steamboat navigation, $18 \mathrm{~m}$. above the mouth of the river, has a commodious wharf and harbor, and a gnod share of lake trade. It contains a court-house, jail, several steam mills and large warehouses, 30 stores, and 1,199 inhabitants. The "Fort Meig's Reveille" (whig) is published weekly. The proposed railroad from Fort Wayne to San dusky City will pass through it. Pop, of v. 1,199, and of town, 1,780 .

Perry's Corver, p. o., Duchess county, $\lambda . Y_{.}: 53 \mathrm{~m} . \mathrm{S}$ Albany.

Pepry"s Cross Roads, p. o., Edgefield district, S. Car.: about $2 \mathrm{~m}$. $\mathrm{S}$. of Saluda r., $41 \mathrm{~m}$. W. by N. Columbia.

Perry's Mills, p. v., Tatnall co, Ga.: on the N. side of Alatamaha r., near the mouth of Cobb's cr., 98 m. S. E. by S. Milledgeville. It contains a grist and saw mill, a store, and several dwellings, and was for a time the county seat.

Perry's Mrlis, p. v., Clinton co., $\boldsymbol{N}, \boldsymbol{Y}_{\text {. }}$ : on Chazy river, $1 \mathrm{~m}$. S. of the Canada line, $7 \mathrm{~m}$. W. of Lake Champlain, $153 \mathrm{~m}$. N. Albany. It contains several mills and about 400 inhabitants.

Perrystille, p. v., Vermillion county, Ind.: on the W. bank of the Wabash, $67 \mathrm{~m}$. W. N. W. Indianapolis. It has several mill-sites, and a good trade in the stap'es of the co. which are shipped here by the Wabash and Erie Canal, side-cut of which crosses the river. It contains a dozen stores and 742 inhabitants. The "P. Eagle" is published weekly.

Perrystille, p. v., Alleghany co., Penn.: $4 \mathrm{~m}$. N. of Ohio r., $168 \mathrm{~m}$. W. by N. Harrisburg.

Perrystrle, sta, Juniata co., Penn. : on the E. division of the Pennsylvania R. R., $15 \mathrm{~m}$. E. Lewistown,

Perrystille, p. v. Washington co, $R$. $I$. : $31 \mathrm{~m}$. S. S.W Providence,

Perrytor, p. v., Licking county, Ohio: 42 m. E. N. E. Columbus.

Perrytox, p. v., Mercer county, $I l l_{*}$ : about $2 \mathrm{~m}$. N. of Edward's r., 115 m. N. W. by N. Springfield.

Prrryville, p. v., Perry county, Ala.: about $7 \mathrm{~m}$. E. of Cahawba r., 52 m. W. N. W. Montgomery.

Perryville, p. v., and cap. Perry co., A $r$. : on La Fave river, a W. branch of Arkansas $\mathrm{r}, 34 \mathrm{~m}$. W. N. W. Little Rock. It contains a few stores and the co. buildings.

Perryviluf, p. v., Boyle county, $\bar{K} y .: 35 \mathrm{~m} . \mathrm{S}$. by T. Frankfort. It contains an academy, several stores, and about 500 inhabitants.

Perryficxe, p. v. and sta., Cecil co., Mr. : on the E. side of Susquehanna r., and on the Philadelphia, Wilmington and Baltimore R. R., 38 m. E. of Baltimore, 45 m. N. E. by N. Annupolis.

Perriville, p. v., and cap. Perry co., Mro.: $9 \mathrm{~m}$. W. of the Mississippi, $135 \mathrm{~m}$. E. S. E. Jefferson City. It contains the $\mathrm{en}$, buildinos, several stores, and 800 inhabitants

Perrxville, p. v., Hunterdon co., N. Jer. : at the E. base of Musconeheong Mountain, $29 \mathrm{~m}$. N. N. W. Trenton.

Perryville, p. v., Madison co, $N . Y$ : on a $\mathrm{S}$, affluent of Oneida lake, $105 \mathrm{~m}$. W. by N. Albany. It contains sereral mills and about 400 inhabitants. 
Peretrilie, p. v., Ashland $\mathrm{co}_{\text {, }}$ Ohio: on Black fork of Mohicean er., 58 m. N. N. E. Columbus.

Perrytilie, p. v., Mifflin county, Penn。: $47 \mathrm{~m} . \mathrm{N}$. W. Harrisburg. A furnace of 1,800 tons capacity is located here.

Perriville, p. v., Decatur co., Tenn. : on the left bank of Tennessee r., 76 m. S. W. by W. Nashville. Previous to the erection of Decatur co. from Perry, it was the capital of the latter. It has an extensive trade in the exports of the surrounding district, which here find a convenient shipping place, and contains several stores and a population of about 400.

Persifer, p. o., Knox co., $\Pi l_{.}$: $3 \mathrm{~m}$.W. of Spoon r., $\$ 2 \mathrm{~m}$. N. N. W. Springfield.

Persimmon Creek, p. o, Cherokee co., N. Car.: $323 \mathrm{~m}$, W. by S. Raleigh.

Person county, N. Car. Situate N., and contains $400 \mathrm{sq}$. m. Drained by branches of Dan and Neuse rivers. Surface level; soil moderately fertile, and adapted to grain and grazing. Chief productions, wheat, cotton, and tobaceo. Farms 684; monuf. 17; dwell. 1,070, and pop.-wh. 5,590, fr. col. 295, st. 4,893-total 10.778. Capital: Roxborough

Pertir, t. and p. o, Fulton county, N. Y.: $33 \mathrm{~m}$. N. W Albany. Surface rolling; soil clayey loam. Farming and grazing are the leading pursuits. Pop. 1,140.

Perth Ambox, p. city, and port of entry, Middlesex co., N. Jer.: at the head of Raritan bay, and confluence of Raritan r. with Arthur kill, or Staten Island Sound, $32 \mathrm{~m}$. N. E. by E. Trenton. It has a spacious harbor, with 24 feet of water in the main channel, and easily accessible. It was laid out in 1698, and chartered as a city in 1784. The compact portion is chiefly on the bank of the kill, over which a ferry plies to Staten Island. It contains an academy, a manufactory of locks, mechanical implements, etc., 12 or 15 stores, and 1, 665 inhabitants. Tonnage of the district in 1550 (which includes the E. coast of the State from Elizabethtown to Little Egg Harbor), 22,085 tons; all except 13 tons engared in the coasting trade.

Perv, p. v, and eap. Miami co., Ind. : on the N. bank of the Wabash, $67 \mathrm{~m}$. N. Indianapolis. It contains a courthouse, jail, academy, hank, 20 or 25 stores and warehouses, several mills, and 1,266 inhabitants. The "Miami County Sentinel" is issued weekly. It lies on the Wabash and Erie Canal, $60 \mathrm{~m}$. W. of Fort Wayne, and the same distance E. of Lafarette, and is the shipping place of a rich district, with which it has a brisk and increasing trade. It is the northern terminus of the Peru and Indianapolis $\mathrm{R}$. $\mathrm{R}$, which will be extended to eonnect with the Northern Indiana R. R., and is intersected here by the proposed W'abash Valley $\mathrm{R} . \mathrm{R}$, which, passing through Fort Wayne and Lafayette, forms a link in the connection of Toledo with St. Louis.

PERE, t. and p. V., Oxford county, MLe: on the S. side of Androseoggin r., $34 \mathrm{~m}$. W. by N. Augusta. Drained by afluents of the r., fed by several ponds. Surface uneven; soil fertile. Pup. of t. 1,109.

Perv, p. v., La Salle county, $M l_{\text {. : }}$ on the $\mathrm{N}$. bank of the Illinots, at the head of narigation, $269 \mathrm{~m}$. above its mouth, $105 \mathrm{~m}$. N. by E. Springfield. It is $1 \mathrm{~m}$. below La Salle, the terminus of the Illinois and Michigan Canal, and forms with it one continuous v, along the r., on which are the commercial houses, the resilences occupying the high bluffs immediately back of it. The chief business is shipping the great staples by river and canal, but a large trade is kept up with the back country, with all parts of which it has, or soon will have, easy communication. A rich and highly cultivated alluvial island lies in front of it, with a channel between that floats the largest steamers, and from which a lateral branch leads to the canal. Its favorable position for commerce has given it its chief importance, and must eventually make it one of the first eities in the stale. It has a daily communication with St. Louis and the immediate ports by packets and steamers, and with Chieago by canal and the Chicigo and liock Island $R$. F. which also connects it with the Upper Mississippi; and the Central Illinois R. R., which 605 here crosses the r., will bring to it the traic and products of rich distriets $\mathrm{N}$. and $\mathrm{S}$. of it. The " $\mathrm{La} \mathrm{S}$. Co. Democrat" and the "P. Telegraph" are published weekly. Distance to Chicago $100 \mathrm{~m}$., the same by railroad and canal. Population about 3,000 .

Pero, t. and p. v., Berkshire county, Mass.: 103 m. W. Boston. Surface elevated and mountainous. It oceupics the highest land between the Connecticut and Huison. Soil adapted chiefly for grazing, which is the leading interest. Pop. 519 .

PERo, t. and p. v., Clinton co., $N$. Y.: on Lake Champlain, $124 \mathrm{~m}$. N. Albany. Drained by Little Au Sable and Salmon rivers, which supply numerous mill-sites. Surface in the E. gently inclining to the lake; in the $\mathrm{W}$. is the Au Sable range of hills; soil chiefly sandy or clayey loam, and very fertile. It is heavily timbered, and has good landings on the lake at the mouth of Little Au Sable r. and at Port Jackson, 2 m. further $\mathrm{N}$. The $\mathrm{v}$, is on the Little Au Sable, $4 \mathrm{~m}$. W. of the lake, and contains several factories and mills and about 1,000 inhabitants. Pop. of $t .3,640$.

Peru, t. and p. v., Huron county, Ohio: $83 \mathrm{~m}$. N. by E. Columbus. Drained by Ifuron r. and branches, which supply good mill-sites. Surface varied; soil very fertile and highly eultivated. The $\mathrm{v}$., on the $\mathrm{E}$. branch of the r., contains several flouring and saw mills and about 500 inhabitants. The Sandusky, Mansfield, and Newark R. R. passes on the W. border of the t. Pop of t. 1,632.

Perd, t. and p. o., Bennington co., Term.: $74 \mathrm{~m}$. S. by W. Montpelier. The Green Mountains pass through it, and give rise to streams flowing in all directions. It is wels wonded, and grazing is the leading pursuit. Pop. 567.

Peru Mrlis, p. 0., Juniata co., Penn.: 37 m. W. N. W. Harrisburg.

Percvilee, p. v., Tompkins county, N. Y.: $131 \mathrm{~m}$. W. Albany. It contains several mills and 300 inhabitants.

Pesirtego river, Wisc.: in N. E. part of Oconto county, flows mainly in S. E. corner, receiving numerous tribntaries, and enters Green bay below the mouth of Menomonee river.

Petaula, p. o., Randolph co., G $x_{*}$ : on Petanla cr., a branch of Chattahoochee $\mathbf{r}$, $142 \mathrm{~m} . \mathrm{S}$. W. by W. Milledgeville.

Peterioro', p. v., Madison co., $N$. Y.: 98 m. W. Albany. It contains a lialf-dozen stores and 400 inhabitants.

Peterisono', t. and p. v., Hillsboro' county, N. Hamp.: $32 \mathrm{~m} . \mathrm{S}$. W. Concord. Drained by Contoocook r. and branches, which afford superior water-power. Surface broken; soil very ferrile. On the streams are excellent meadows, and several cotton and woolen factnries and mills of varions kinds. Iron ore is found and wrought with saccess. 'The $\mathrm{v}$. is on the $\mathbf{r}$, and contains an academy and several stores and mills. The "Contoncook Transcript" (neut.) is published weekly. Pop. of t. 2,222

Petersidra, p. v., Elbert co., Ga. : at the confinence of Savannah and Broad rivers, $79 \mathrm{~m}$. N. E. by N. Milledgeville. A thriving $\mathrm{v}$. with a valuable trade, growing manufactures, and a population of 400 .

Petersiurg, p. . $_{\text {, and }}$ ap. Menard county, $1 l l$. : on the Sangamon, $18 \mathrm{~m} . \mathrm{N}$. W. Springheld. It contains a courthouse, jail, several stores and mills, and a population of about 600 .

Petersibug, p. V., and cap. Pike eo., Ind.: $1 \mathrm{~m}$. S. of White $r, 5 \mathrm{~m}$. below the junction of its $\mathbf{E}$. and W. forks, $103 \mathrm{~m}$. W. by S. Indianapolis. It occupies an elevated plain on the E. side of Pride's cr., and the heart of a fertile district, through which the Wabash and Erie Canal passes; $2 \mathrm{~m}$. W. of it. It contains a court-house, jail, a dozen stores, and about 700 inbabitants.

Petersbleg, p. r., Bonre co, $K y .$. on the Ohin, $56 \mathrm{~m}$. N. Frankfort, It occupies the site of an Indian burying ground. Many remains of the aborigines have been found here, and nenr the $\mathrm{v}$, are extensive fortifications in good preservation.

Perersicrg, sta., Huntingdon co., Penn.: un the N. side 
of Juniata r., $5 \mathrm{~m}$. by Pennsylvania R. R., and $\tau \mathrm{m}$. by canal X. W. of IItuntinglon.

Petersburg, sta., Monroe co., Mich.: on the S. side of Raisin r., $20 \mathrm{~m}$. W. of Monroe by the Michigan Southern R. R.

Phtersilig: p. v., and cap. Lavacea county, Tex.: on Lavacea r., $77 \mathrm{~m}$. S. E. Austin City. It contains the county buildings and several stores and dwellings.

Petersburg, to and p. v., Rensselaer co., $N$. $Y .: 21 \mathrm{~m}$.

E. N. E. Albany. Drained by Little Hoosic er., on which is a fertile valley running $\mathrm{N}$. and $\mathrm{s}$.; clstwhere the surface is much broken, and soil fitted for grazing. The $\mathrm{v}$. is on the cr., and contains several mills. Pop. of t. 1.908.

Pexersibur, p. o., Cape May county, N. Jer.: $66 \mathrm{~m} . \mathrm{S}$.

Trenton.

Petersiorg, p. v., Mahoning co, Ohio: near the E. line of the state, $141 \mathrm{~m}$. E. N. E. Columbus.

Petersiurg, p. v., Lincoln co., Tenn.: 56 m. \$. by E. Nashville.

Petersiorg, p. b. and port of entry, Dinwiddie county,

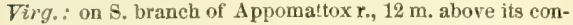
fluence with James r., $22 \mathrm{~m}$. S. by E. Richmond. Lat. N. $37^{\circ} 13^{\prime} 54^{\prime \prime}$, long. W. $77^{\circ} 20^{\prime}$. The $\mathbf{r}$. is navigable to this place for vessels of 100 tons, and the falls immediately above it afford extensive water-power A canal is cut round these falls, thus affording boat navigation upon the river above for $80 \mathrm{~m}$. This is a very handsome and important commercial town, and exports largely flour and tobacen. It suffered most severely in July, 1815, by a conflagration, which destroyed 400 buildings, and property estimated at $\$ 2,000,000$. The buildings and houses are now built principally of brick. It contains a court-house, jail, 5 churches, 8 banks with aggregate capital of $\$ 1,170,000$, insurance office, etc. There are several cotton and woolen factories, flouring and saw mills, ropewalks, and some other manufactories. Two newspapers are published daily, " $\mathbf{P}$. Intelligencer" (whig), "Daily News" (neut.); 1 tri-weekiy, "South side Democrat," Four railroads now centre at P. giving it great business advanlages, viz, Richmond and Petersburg R. P., Petersburg R. R. (to Weldon), South Side R. R., Appomatiox R. R. (to City Point:) The Petersburs and Norfolk P. R. is in construction. The steamships plying semi-weekly between New York and Richmond, and others, connect with Petersburg by Appomattox R. R. from City Point. On 30th June, 1550, the total tonnage of P. district was 2,70S tons, of which 949 tons were registered (and vermanent), and 1,759 tons enrolled and licensed. of the latter, 1.651 tons were permanently employed in the coasting trade, 80 tons in steam navigalion; licensed under 20 tons in coasting trade, 79 tons. During the year preced ing, the total of clearances for foreign countries was $5-1,946$ tons; total of entrances, do., 9-3,517 tons. Pop. in 1830 8,322 ; in 1510, 11.136; in 1550, 14.010.

Petersiurg Fotr Corners, p. v., Rensselaer co., $N$. $Y$. $23 \mathrm{~m}$. E. N. E. Albany.

Peteris' Creek, p. o., Barren co., $K y$.: on an E. branch of Big Barren r, $106 \mathrm{~m}$. S. W. by S. Frankfort.

Petres' Cremk, p. o., Stokes county, N. Car. : $102 \mathrm{~m}$. N. W. by W. lialeigh,

Petersiray, t. and p. $\nabla_{*}$. Worcester co., Mass, : $59 \mathrm{~m}$. W. by $\mathrm{N}$. Worcester. Drained by branches of Swift $r$. affording numerous mill-seats. Surface high and somewhat broken; soil good, especially for grass. A farming and grazing t. containing numerous small manufactories. Population 1,527

Peterstown, p. v., Monroe co., Virg.: on Rich cr., $2 \mathrm{~m}$. N. of New $r_{0,1} 182 \mathrm{~m}$. W. by S. Richmond. On the er., in the vicinity, are several mills and suall factories,

Petersvilli, p. v., Frederick co., MLa.: $3 \mathrm{~m}$. N. of the Potomac, 62 m. W. N. W. Annapolis. Petersville and district contains 2,351 inhabitants.

Petersyille, p. v., Northtmiston co., Penn.: on Hockendocque ereek, an E. affluent of Lehigh river, $79 \mathrm{~m}$. E. N. E. Iarrisburs.
Petite Jean, p. o., Yell co., Ark. : $3 \mathrm{~m}$. \$. of Petite Jean r., 52 m. W. N. W. Little Rock.

Petra, p. 0., Saline co., Mo.: $66 \mathrm{~m}$. N. W. Jefferson City. Perris county, Mo. Situate W. centrally, and contains $655 \mathrm{sq} . \mathrm{m}$. Drained by $\mathrm{S}$. fork of $\mathrm{La}$ Mine $\mathrm{r}_{\text {., }}$ and other branches. Surface varied; in general it is level, and there is some fine prairie land; soil a fine deep loam, and very proluctive. It has some good grazing lant, and along the streams timber is abumdant. Farms 50(); manuf. 16; dwell. 714, and pop,-wh. 4,261, fr. col. 5, sl. \$\$1-total 5,150. Capitul: Georgetown. Public Works: Pacifie R. I.

Petry's, p. 0., Lawrence co., Ill.: 127 m. S. E. Springfleld. Pewauker, $t$, and p. o., Waukesha co., Wisc. : $59 \mathrm{~m}, \mathrm{E}$. Madison. Drained by Pishtaka $r$. (called Fox $x$. in Illinois), into which flow the waters of a large lake lying in the W. part. Surface even, and soil excellent grass and grain land. The Milwankie and Mississippi R. R. crosses it, and plank roads lead E. and W. Pop, 1,093.

Pextona, p. o., Boone county, Firg.: 234 m. W. by N. Richmond.

Peytonsburg, p. 0., Pittsylvania county, Virg.: $105 \mathrm{~m}$. S. W. by W. Richmond.

Perton's Creer, p. o., Smith co., Tenn. : 48 m. E. by N Nashville.

Pextonsvilue, p. v., Williamson county, Tenn. : $22 \mathrm{~m} . \mathrm{S}$. Nashville.

Pharisburg, p. v., Union county, Ohio: 35 miles N. W. Columbus.

Pirarr's Miris, p. o., Moore co., $N$. Car.: 46 m. W. S.W. Raleigh.

Pharsalia, t. and p. o., Chenango co., $N$. $Y$.: $101 \mathrm{~m}$. W. Albany. Drained by Otselic cr. and branches of $\mathrm{Ch}$ nango r. Surface broken; soil fertile loam. Furming and grazing are the chief pursuits. Pop. 1,185 .

Pineasant Brancir, p. o., Dane co., Wisc.

Phelps, t. and p. 0., Ontario co., N. Y.: $166 \mathrm{~m}$. W. by $\mathrm{N}$. Albany. Drained by Canandaigua outlet and Flint creek, which supply fine water-power. Surface undulating; soil loam, overlying limestone, and very fertile. It contains an abundance of gypsum and water lime, and large manufactories of flour, pluster, mechanics' implements, etc. The livehester and Syracuse R. R. passes through it, and has a sta. $7 \mathrm{~m} . \mathrm{N}$. W. Geneva. The p. o. is in the $\mathrm{v}$. of Yienna, Pop. of $t .5,542$

Prelps, t. and p. o., Ashtabula co, Otio: $154 \mathrm{~m}$. N. E Columbus. Drained by Musquito and Rock ereeks, branches respectively of Mahoning and Grand rivers, which furnish water-power. Surface elerated; soil fertile and well tilled. A superior farming town.

Phelpstown, t. and p. 0. , Ingham co, MFich, $12 \mathrm{~m} . \mathrm{E}$ Lansing. Drained by Red Cedar $r$. Sulfuce rolling atzl well timbered. Soil easily tilled, and generally fertile. Populition 393.

Pirenix, p. V., Kent county, $R . I_{0}: 18$ miles $\mathrm{S}$, by W Providence.

Pinlladelpina county, Penn. Situate S. E., and contains 120 sq. m. Drained by Schuylkill r., Wissahieken, Pennepack, and Tacony creeks. On the N. E. is Pequasing, aud on the S. W. Darby creek. The Delaware, the coramon recipient of the above, forms its S. E. boundary. Surtace generally level, but much varied; soil fertile. Farms 1,530 manuf. 4,559; dwell. 61,278 , and pop.-wh. 399,324 , fr. col. 19,43S-total 40S.762. Capital: Philadelphis. Pullio Works: Philadelphia and Columbia R. R.; lieading and Potsville R. R.; Philately hia, Norristown, and Gurmantown R. R.; Philadelpluia, Wilmington, and Baltimore R. R.; Philadelphia and Westehester R. R.; New Tork and Philadelphia R. R., etc.

Philladelpiis, p. city, port of entry, and enp. Philadelphia co., Penn.: is situated between the Delaware and Schuylkill rivers, $5 \mathrm{~m}$. above their juuction, $93 \mathrm{~m}$. li. by $\mathrm{s}$. If arrisburg. From New Fork by most direct railroad, $87 \mathrm{~m}$; from Boston, $323 \mathrm{~m}$; ; from Baltimore, $93 \mathrm{~m}$.; from 
Wishington, $136 \mathrm{~m}$; f from Harrisburg, $106 \mathrm{~m}$; from Pittsburg, 357 miles.

Latitude (Independence Hall), $39 \circ 56^{\prime} 59^{\prime \prime}$; long. from Greenwich, $75^{\circ} 9^{\prime} 54^{\prime \prime}$ W., from Washington, $1^{\circ} 51^{\prime} 36^{\prime \prime} \mathrm{E}$.

Philadelphia city proper is surrounded by several incorporated districts, having their own municipal authorities; riz., Spring Garden, Penn, Northern Liberties, Kensington, and Richmond in the N., and Southwark and Moyamensing in the S., West Philadelphia, etc., which together form a densely populated area, and are always embraced in the descriptions of the city.

The city proper is situated on a plain, the highest point of which is elevated 64 feet above the ordinary high water mark in the river. This gentle elevation affords excellent drainage. The soil consists principally of clay, beneath which, at different depths, from 5 to 20 feet, is found coarse gravel. In form it is a parallelogram, $2 \mathrm{~m}$. long by $1 \mathrm{~m}$. wide. The streets are all straight, cross each other at right angles, are well pared, and kept remarkably clean. The priucipal streets are, Market Street, 100 feet wide, running $E$. and W. from river to river, nearly through the centre of the city; Broad Street, 113 feet wide, running N. and S., a little W. of the middle of the city; Arch Street, N. of Market Street, 66 feet wide; Front Street, 60 feet, and the rest 50 feet wide. The adjoining districts are for the most part laid out with regularity.

The buildings are chiefly of brick, built in plain and uniform style. Some of the public ediffees, of white marble and freestone, are distinguished for beauty and grandeur. The houses are generally on a uniform plan, 3 stories bigh, of brick, with marble steps and basements. Some of the more costly private residences are noted for their elegance. The public squares are laid out with much taste, ornamented with fine shade-trees, shrubbery, etc., provided with seats, and are favorite promenades. The business portion of the city was originally on the Delaware side, but since the opening of the coal trade, and with the increase of population, the Schuylkill side has acquired a large share of business, particularly that of the coal trade, country produce, etc. The Schuylkill affords a convenient harbor for small ressels, and numerous wharves are built for their accommodation. The foreign commerce centres upon the Delaware, which is nearly $1 \mathrm{~m}$. wide, admitting the largest vessels to the wharves. Its navigation from the ocean is somewhat intricate from banks, shoals, etcn, and in mid-winter is sometimes closed by ice.

Public Buildings.-Independence Hall, within which the Colonial Congress on July 4th, 1776, declared the independence of the Cnited States, read from its steps on that day to the assembled people, now presents the same appearance as at that time: This building, formerly the State House, fronts upon Chestnut Street, having Independence Square in the rear. It was commenced in 1729 , completed in 1784 , cost $£ 5,600$, and received the addition of its two wings in 1740. The present steeple, erected in 1825 , is a fac-simile of the former, which was removed on account of its decay. The room in which the Declaration was signed is carefully preserved, nearly in the same style of decoration with which it was originally finished. The "old bell," imported in 1752 , is also carefully preserved as a most interesting relic It bears the following inscription: "Proelaim Liberty throughout this land to all the inhabitants thereof."-Leviticus Xxy, 10. Within this renerable edifice was held the Conrention which formed the Constitution of the United States, some of the first sessions of Congress, and here Washington delivered his "Farewell Address," on his retirement from public life. The building is used by the U. S. courts and city and county offices.

The Custom House, formerly the U. S. Bank, on Chestnut Street, above Fourth, is a splendid marble edifice, in imitation of the Parthenon at Athens, and one of the finest specimens of Doric architecture erected in modern times. It wa commenced in 1519 , completed in 1524 , and cost $\$ 5190,000$, 670
It is built upon a raised platform, 87 feet front, 161 feet deep, and has fronts, each of 8 fluted Doric columns, 27 feet high, $4 \frac{1}{2}$ feet in diameter, supporting a heavy entablature. It has a very splendid interior, of which the principal apartment, 81 feet long by 48 wide, is ornamented by fluted Ionic columns and sculptured embellishments

The Merchants' Exchange, fronting on Walnut, Dock, and Third streets, is a magnificent marble building, with semi-circular portico of Corinthian columns. It is 95 feet wide, 114 feet long, and 3 stories high. The basement is occupied by the post-office and two insurance companies, and most of the building by commercial offices, etc. The Merchants' Reading Room is handsomely ornamented.

The United States Mint, in Chestnut, near Broad Street, is a handsome edifice of brick, faced with marble, in imitation of a Grecian temple of the Ionic order, having a portico 62 feet long, supported by 6 beautiful pillars, 25 feet high, 3 feet in diameter.

Many of the banking houses are distinguished as beautiful specimens of architecture. The Bank of Pennsylvania is a fine marble structure, 125 by 51 feet, erected 1799- 1801 , designed from the Temple of the Muses at Athens, having 2 porticos of 6 Ionic columns each, with dome and roof entirely of marble. The Philadelphia Bank is an imposing marble building, with an elegant elevated portico of the Corinthian order. The Girard Bank has a stately front of white marble, with portico of 6 Corinthian columns. The Bank of North America is an elegant structure of brown stone in Florentine style.

Hotels.-The Girard House, erected 1851, is the largest and finest hotel in the city, and one of the most extensive in the Union. It has a very handsome front on Chestnut Street, 5 stories in height, besides basement and attic. There are other large and well-kept houses, but not noted for architectural beauty, etc.

Places of Amusement.-The Chestnut Street Theatre, erected 1822 , is 90 by 150 feet, has a richly decorated interior, and will accommodate over 2,000 persons. Walnut Street Theatre, formerly the Olympic, is now a very fashionable resort. The Arch Street Theatre is a very handsome edifice. The Musical Fund Hall, erected 1824, is an elegmit building. Its interior, 123 feet long by 6 . Peet wide, $171 \% \rho$ ported by columns, is one of the best halls for musical effect in the United States, seats 2,000 persons, and is in constant use for concerts, lectures, balls, etc. The Philadelphia Museum building is an immense structure, 238 feet long and 70 feet wide.

Thitel Stutes Military and Naval Estblishments.-Fort Mifflin, on a small island in the Delaware, $1 \frac{1}{3} \mathrm{~m}$, below the entrance of the Schuylkill, defends the city. The U. S. arsenal, near Frankford, is an immense establishment, used for the storage and manufacture of munitions of war, and has one of the largest powder magazines in the United States, The U. S. arsenal in Moyamensing near Schuylkill r, is used as the depôt for the elothing of the army, camp equipage, ctc. The buildings consist of 4 large brick storehouses, 3 stories high, forming a hollow square.

The U. S. navy yard is situated on the bank of Delaware $r$, in the distriet of Southwark. The grounds, inclosed on 3 sides by a high brick wall, embrace about 12 acres, purchrsed in 1901 , for $\$ 3 i, 500$; now assessed at $\$ 250,000$. Tho rarious buildings are residences for officers, quarters for marines, workshops and storehouses, 2 ship-houses, molding lofts, etc. The ship-houses are anong the largest in the Union: the first is $2 \pi 0$ feet long, 103 feet high, 84 feet wide; the second is 210 feet long, 80 feet high, 74 feet wide.

Here are the $\mathrm{U} . \mathrm{S}$. dry docks, capable of raising the largest steam-vessels and ships of the line. These works, constructed in 1849-51, at a total cost of $\$ 813,742$, consist of a sectional floating dry-dock in 9 sections; a basin, 350 feet long by 226 feet wide inclosed by granite walls, having a granite floor, upon a foundation of piles, timbers, ete.; and 2 ruliways, with bydraulic cylinder, etc. 
The U. S. Naval Asylum, established in 1535, nccupies an elevated and most beautiful site, near the Schuylkill r., in Moyamensing district, and consists of 3 structures. The printipal ediflce, built of marble, is 3 stories high, has a front of 350 feet, including a central building 142 by 175 feet, which has u handsome portico with 8 Ionic columns. The grounds embrace 25 acres, beautifully adorned with trees, shrubbery, ete. The pensioners are about 140 in number, who are provided with every comfort. A naval officer is stationed at this port.

Educution.-The public schools are well organized upon a most efficient system, established in 1818, which constituted the city and county of Philadelphia, one entire school district, in 11 sections, with arrangements for uniform and harmonious grades of free instruction. The schools are under the direction of 23 controllers and 210 directors, distributed throughout the 11 sections. In 1552, there were 254 schools, classified as follows: 1 high, 1 normal, 58 grammar, 29 secondary, 130 primary, and 40 unclassified; which employed 727 teachers, and hal abnut 50,000 scholars. The school-houses generally are substantial brick edifices, 3 stories high, accommodating 500 to 1,000 pupils.

The Normal School, for the instruction of female teachers, was established in 1848; its course of instruction embracing two years, is of the very best order. The central high school, established October, 1838, is one of the best institutions in the Union. The building, ir Juniper Street, below Market, has a handsome marble front with Ionic portico. It has 11 instructors, and about 500 students. The number of private schools and academies, with parish and charity schools, female seminaries, etc., is very large, indicating the popular interest in good education.

Colleges. - The University of Pennsylvania was established as a college in 1755 , and as an university in 1779. It comprises 4 departments, academical, collegiate, medical, and law, of which the medical department is by far the most flourishing. In 1550, the collegiate department had 7 instructors, 5,142 alumni, 88 students, and 5,000 volumes in its library, The university buildings, in Ninth Street below Market, are large and handsome structures, each 85 feet front by 112 deep.

Ph:adeiphia is preëm; utly distinguished as the medical metropolis of the Union. Of medieal colleges, it contains the first established in the United States, which, with the other numerous institutions, are by far the most flourishing and important in the nation. The number of medical works and jowrnals here published is probably equal to the combined number in all other eities in the Union. The libraries of the medical colleges, etc., are large and very valuable; as also their anatomical museums, cabinets, etc. Very great advantages for clinical instruction are afforded by the various hospitals, dispensaries, etc.

The statistics of the principal institutions, in 1850 , were as follows:

Names. Founded. Prof. Stu, Graduates.

Med, Dep. Univ. Penn ... 1765 .... 7 ... 450 ... 5,316

Jefferson Med. Col...... 1824 ... T ....514 ... 2,086

Med. Dep. Penn. Col..... 1838 ... $7 \ldots 176 \ldots .73$

Phil. Col. of Med......... 1847 ... $7 \ldots .75 \ldots .250$

Other medical institutions are-Medical Institute of Philadelphia, established in 1817, which gives medical instruction in the summer, but does not confer degrees; Philadelphia Association for Medical Instruction, on the same plan; Homoeopathic Medical College of Pennsylvania, instituted 1546; Female Medical College of Pennsylvania, founded $1 S 49$, the first of the kind in the world, which in 1852 had 40 students; Eclectic Medical College of Pennsylvania, chartered in 1550; and Philadelphia College of Pharmacy, established 1822, for the instruction of druggists, ete, which has a good cabinet, library, etc., and annual course of lectures. Nearly all of these institutions have large and commodious ediflces.

The Theological Seminary of St, Charles Borromeo,
(Roman Catholic), incorporated 1845, c)ntained in 1552, 36 students, preparing for the priesthcod, and 7,000 vols. in its library.

Girard College.-This magniflcent institution, founded by Stephen Girard, with a bequest of $\$ 2,000,000$ for the gratuitous instruction and support of destitute orphans, is situated on the Ridge Road, in the district of Penn, $1 \mathrm{~m} . \mathrm{N}$. of the $\mathrm{N}$. boundary of the city proper. The corner-stone of the college was laid July $4,1 \subseteq 33$, the buildings were completed in 1847, and the institution went into operation, Jan. 1st, 1545. The grounds contain about 41 acres, inclosed by a wall 10 feet high. The college ediflces present a very imposing appearance. The central ediflce, most substantially built of marble, is one of the most magnificent structures of its size in the world. It is in the form of a Greek temple, in the Corinthian style, resting on a basement of 11 steps, which extend around the entire edifice, imparting to it a pyramidal appearance of great solidity. It is surrounded by colonnades of the most magnificent marble pillars, 6 feet in diameter, and 55 feet in height-8 columns on each end, and 11 on each side, including the corner columns both ways. Its dimensions, including the colonnades, are 160 feet wide, 218 feet long, 90 feet high; the body of the building alone is 111 feet wide, 169 feet long, and 56 feet 8 inches high. It is three stories high, each divided into 4 rooms, with restibules. The roof composed of most massive murble tiles, has an entire weight of $969 \frac{1}{2}$ tons, exclusive of its supports. In the lower vestibule rest the remains of $\mathrm{Mrr}$. Girard, beneath a marble statue of himself. Four other buildings, faced with marble, are each 52 feet wide, 125 feet long, and three stories high. The entire cost of the college buildings, with improvements of grounds, ete, was $\$ 1,933,821$ 78. The officers and teachers consist of president, secretary, 2 professors, 2 physicians, matron and assistant matron, 5 male teachers, 12 female teachers, and steward. The current expenses in 1851, were $\$ 62,900$, of which $\$ 30,500$ were for the clothing and subsistence of the pupils. Pupils in 1552, 305 .

Literary and Scientific Institutions, Libraries, and Fine Arts. - The American Philosophical Society, originated by Franklin, in 1743, is the oldest scientific association in the United States. In 1769, another similar society was united with it.' It was incorporated March 15, 1780. Its building; erected in 1759 , contains a very valuable library of 20,000 volumes, an extensive cabinet of medals, and a large collection of maps, engravinos, ete. Its published transactions, in numerous volumes, have greatly contributed to the advancement of science. The Academy of Natural Sciences, founded 1512, incorporated 1817 , has a very handsome edifice, containing a library of 13,000 volumes, and the mos raluable museum in the United States, containing, besides other collections, 25,000 specimens in ornithology, unriraled in the world, 30,000 in the herbarium, 7,000 in geological department, and the late Dr. Morton's celebrated cabinet of erania. The academy has contributed much to natural science. The Historical Society of Pennsylvania, founded 1525 , has issued various historical publications, and has a library of 2,000 volumes, with collections, ete. The Franklin Institute, incorporated March 30, 1521, mainly deroted to the promotion of mechanical seience, etc., has about 3,000 members, and library of 6,000 volumes, principally mechanical and scientific works; publishes monthly its journal, the oldest and one of the best mechanical periodicals in the Union; and holds annually an extensive exhibition of American manufactures. The College of Physicians, chartered March 26, 1789, publishes its transactions quarterly, and is one of the most valuable periodicals of medical science.

The Philadelphia Library Company, instituted 1731, principally by Dr. Franklin, has one of the most extensive libraries in this country. Its edifice, erected $1759-90$, a plain structure, presents a venerable appearance. Its entrance is surmounted by an excellent marble statue of Franklin. In 1792 , it received the valuable library of Hon. James Logan, now amounting to 10,000 volumes. These united libraries 
now embrace about 60,000 volumes, and are constantly increasing. The A thenaum, organized February 9, 1514, now occupies a very elegant edifice, built in the Italian style, corner of Sixth and Adelphi streets, erected 1545-47, contrining a library of 12,000 volumes, reading-room, etc. The Mereantile Library, established 1821, bas a handsome library building, corner of Fifth and Library streets, ereeted 1814-45, at a cost of $\$ 23,200$, which contains 10,500 volumes; its real estate is valued at $\$ 60,000$. The Library of the Law Association is a good collection of professional works. The Apprentices' Library, founded 1819, is an excellent institution, having 12,000 volumes, resorted to by 1,200 boys and 600 girls. The German Society have 8,000 volumes; the Pennsylvania Hospital 10,000 volumes of medical works : besides which, are the Friends' Free Library, Spring Garden Institute, the colleges previously mentioned, and some library companies of the incorporated districts.

The Pennsylvania Academy of the Fine Arts, organized 1807 , contains rare seulptures, with splendid paintings by the old masters, West, Allston, and Sully, and holds annual exhibitions, commencing in May. The Art Union of Philadelphia has a tree gallery of pictures constantly open, which are changed monthly, and holds a distribution of prizes in December annually. There are two associations of artists-Graphic Association and Artists' Fund Society.

Nexspapers und Periodicals-According to the census of 1850 , the periodical press then consisted of 64 publications, viz., 11 dailies, 1 semi-weekly, 37 wecklies, 5 semi-monthlies, 8 monthlies, 1 quarterly, 1 annual.

Names of dailies-" North Ameriean" (whig), "Pennsylvania Inquirer" (whig), "Pennsylvanian" (dem.), "Daily News" (whig), "The Sun" (nat. Am.), "Spirit of the Times" (dem.), "Public Ledger" (indep.), "Evening Bulletin" (indep.), "Daily Register" (neut.) The largest circulations were - of the dailies, "Public Ledger," 43.980; of the weeklies, "Dollar Newspaper" (indep.), 40,000; "Scott's Wcekly Paper" (lit.), 40,000; "Saturday Evening Post" (lit.), 42,000; "American Courier" (lit.), 35,000; of semi-monthlies, " Iouth's Penny Gazette" (relig.), 106,000; of mouthlies, "Godey's Lady's Book," 60,000.

The press is generally characterized by propriety, originality, enterprise, and large circulations. The medical journals are of high repute. The first papers were-" American Weekly Mereury," established 1719, by Andrew Bradford; "Pennsylvania Gazette," in 1723, subsequently conducted by Dr. Franklin; "Pennsylvania Packet," 1771, which, in 17\$4, was issued daily, the first daily in the United States.

Churches, Retigions Institutions, etc-Religious societies of all denominations are very numerous. The total number of churches in 1552, in the city and closely adjoining districts, was about 175, viz. : Episcopal 31, Presbyterian (of all kinds) 45, Friends' 9, Roman Catholic 17, Baptist 20, Methodist 27, Lutheran 8, German and Dutch Reformed 4, Moravian 1 , Lniversalist 4, Lnitarian 1, besides 3 Jews'synagngues and some independent churches. Compared with other cities, the church edifices of this city are not distinguisbed for arehitectural beauty, though characterized by neatnesy and comfortable convenjence. The principal edifices are-of Episcopal, Christ Church, completed 1750; St. Andrew's, in the Ionic order, a very classic structure; St. Stephon's and St. Mark's, in Gothic style. The First and Seventh Presbyterian churches; Sansom Street Baplist Church. The Roman Cathulic, St. Peter's Church, in classic Roman style, and the Cathedral, a magnificent structure, not yet completed, which will surpass in architectural splendor all others in the eity.

The American Sunday School Union, formed 1824, has a larce edifice in Chestnut Street, 5 stories high, used as depository and publicution of their books, tracts, etc. The General Assembly of the Presbyterian Church have located here three of their four principal boards, viz.: Publication, Domeshic Missinns, and Elueation, which oceupy in Chestnut Street a haucsume edifice of brown stone, $\$$ sturiets higb, $6-2$ chiefly used as publication rooms. During the year 1850-51, the board of publication printed 430,300 books and tracts. The American Baptist Publication Sucicty, furmed 1539 , occupy in Arch Street an ornamental edifice of brown sandstone, 4 stories high. Other ruligious a-siciations arePhiladelphia Tract, Edueation, Home Missionary, and several Bible societies, all of which, with the foregoing, celebrate their anniversaries in May.

Benevolent Institutions.-These are numerous, and of superior excellence. The Pennsylvania Hospital, incorpnrated 1751 , is a very extensive establishment, occupying an entire square between Spruce, Pine, Eighth, and Ninth streets, fronting on Pine Street. The main edifice has an entire length of $2 S 1$ feet, consisting of central building with wings. From 1341 to 1852 it received $13, \$ 29$ patients, of whom 9,800 were poor; in 1552 it contained 158 inmates, of whom 120 were poor. Its funds arise from legaeies and private subscriptions. In front of the building is a fine statue of William Penn, in bronzed lead. A branch of this institution is the Pennsylvania Hospital for the Insane, which, previous to 1641 , was a conjoined portion of the hospital, but has since been located on a fine farm of 111 acres, in West Philadelphia, about $2 \mathrm{~m}$. W. Schuylkill $r$. The principal building and main wings present an E. front of 436 feet, 3 stories high, and are surrounded with 41 acres of beautiful pleasure grounds. The Friends' Asylum for the Insane, near Frankford, founded 1515, has good buildings, ete. The Pennsylvania Institution for the Deaf and Dumb, founded 1820, has occupied, since 1825 , its present spacious edifice, corner of Broad and Pine streets, built of granite, with Doric portico, at a cost of $\$ 80,000)$. In 1852 it had contained 134 pupils, of whom the State of Pennsylvania supported 92, Maryland 18, New Jersey 13, Delaware 3 , and the institution 13. The Pennsylvania Institution for the Blind, founded 1833, located in Race, between Schuylkill, Second, and 'Third streets, has a large edifice, 4 stories high, with beautifully decorated grounds, and contained in 1852, 93 pupils, of whom the State of Pennsylvania supported 45, New Jersey 6, Maryland 5, Delaware 1, the institution 15 , with 15 by their own industry, and 6 by their friends. The Wills' Hospital for Diseases of the Eye and Limbs, in Race Street, opposite Logan Square, was founded by the late James Wills, of Philadelphia, with a legacy of $\$ 10 \$, 396$, bequeathed to the city for that purpose. The building, erected 1\$32-34, is a neat stone structure, 80 feet long, 50 feet deep, which cost, including lot, $\$ 57,203$, and is surrounded by ample and beautiful grounds. From its foundation to 1552 , upward of 2,000 persons had been relieved as inmates, and about 5,000 had been treated at their homes, Oth: $\mathbf{r}$ hospitals are-St. Joseph's, near Girard College; Christ Church, for indigent females of the Episcopal Church; and the City Hospital, Spring Garden, established in 1818 by the State as a pest hospital, is a brick structure of central building with wings. The U. S. Naval Asyium is previously described.

Orphan and other Asylums, etc.-The principal institution for orphans, that of the Orphans' Society of Philadelphia, founded 1814, is on Race Street and Schuylkill Fifh; a large brick structure, 110 by 153 feet, built fireproof and in the most substantial manner; erected 1523. The first edifice was destroyed by fire Jan., 1822, when 23 inmates perished. St. John's Male Orphan Asylum (Roman Catholic), is on W. side of the Schuylkill, $2 \frac{1}{2} \mathrm{~m}$. from Market Street bridge, on the Lancaster turnpike. The building, in Elizabethan Gothic style, is of brown stone; in extreme length 220 feet, consisting of central edifice 4 stories high, and wings 3 stories high, and can accommodate 250 orphans. St. Joseph"s Female Orphan Asylum, corner of Spruce and Seventh strcets, has an average number of 100 orphans. The Colored Orplans' Asylum, in Thirteenth Street, in 1552 had 67 chiluren. Other asylums are-the Widows' Asylum, instituted 1819, with 60 inmates; St. Ann's Widows' Asylum: Philadelphia Lying-in Asylum; House of Industry, in 
Moyamensing, organized 1846, with commodious buildings; Preston Retreat, used by the Fuster Home Association, which provided in 1852 for 74 children; and 3 Magdalen asylums. There are 4 dispensaries, of which the principal is the Pbilatelphia, founded in 1756 , which in 1551 treated 7,362 patients, Other charitable institutions are numerous,

The City Alms-house, fronting on W. side of the schuylkill, comprises 4 buildings, inclosing a rectangular area, each 500 feet long and 3 stories high, besides basement, surrouniled by a farm of 10 acres, with out-buildings, ete. The main front facing the city is ornamented by an elegant portico in the Tuscan order, having 6 columns, 5 feet diameter at base and 30 feet high. The average number of paupers in 1551 was 1,813 , maintained at an expense of $\$ 97,926$, or $\$ 104$ per week each. Attached is the Children's Asylum, which in 1851 contained about 1,850 children-362 boys and $1,4 \mathrm{SS}$ girls-sustained at an annual expense of $\$ 70,000$. The insane department contained in 1852, 390 inmates; the hospital 349 patients. The total cost of supporting the poor at the alms-house and in the eity and districts during 1851, was $\$ 228,977$. The Moyamensing Alms-house is the public charity for that district. The Friends' Alms-house is a private institution and has but few inmates.

Ifunicipul Governments, Departments. - The county of Philadelphia is divided into different local governments. The incorporated districts directly adjoining the eity proper, viz., Southwark. Moyamensing, Spring Garden, Northern Liberties, Kensington, and Richmond, have similar organizations, each governed by boards of commissioners. The consolidation of these districts with the eity proper into one municipal corporation, has for some lime been agitated. The government of the city proper, under the general superintendence of the mayor, is composed of police department, select and common councils, board of city commissioners, and board of city and county commissioners.

The police department, exclusive of officers, embraces 200 watchmen. The consolidated police force, established 1850, has 180 policemen, distributed as follows: eity 55, Spring Garden 26, Kensington 24, Northern Liberties 21, Southwark 18, Moyamensing 12, Penn 4, Richmond 4, West Philadelphia 3, under 12 lieutenants and the marshal. The number of arrests by this force, from Nov. 21,1850 , to Nov. 1,1851 , exceeded 12,000

Fire Department.-In 1852 there were 70 companiesengine 35, hose 33, hook and ladder 2-each having about 30 members. The Association for the Relief of Disabled Firemen, established 1835 , in 1552 possessed $\$ 17,500$ permanently invested; and had previously distributed $\$ 9,000$.

The Board of Health, consisting of 18 members, has charge of the sanitary condition of the city, the city hospital, and the lazaretto at quarantine ground, $14 \mathrm{~m}$. below the city. The statistics of the alms-house, county prison, etc., are previously given.

Mrarkets. -These are noted for their excellence, abundan supplies, cleanliness, etc. The prineipal ranges of stalls are in Mrarket Street, extending from the Delaware to Eighth Street, and from Schuylkill Sixth to Eighth streets, erected in 1836 ; there are 10 others. The wholesale provision trade is prineipally carrier on in Water Street, and near the wharres, chiefly by extensive firms. The following table shows the number of cattle offered at the Philadelphia eattle market during each of the six years, from 1545 to 1950 inclusive:

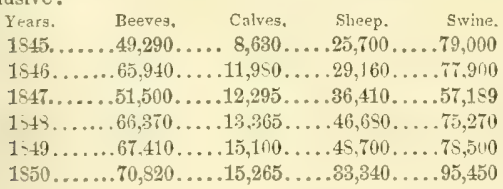

Fairmount Water-Works,-These water-works which supply the eity with water, are situated on $\mathbf{E}$. bank of Schuylkill r., a little N. of the city proper, and have been in operation since July 1, 1822. A dam extends across the river, 1,248 feet long, erected in 1819. The water backed up by the dam passes into an artificial forebay, 419 feet Iong, 90 feet wide, and 60 feet deep. The mill-building is of stone, 285 feet long, 56 feet wide, containing 8 doubleacting forcing pumps, each of which will lift about $1,250,000$ gallions into the reservoirs in 24 bours. The water is elevated 92 feet. The reservoirs, 4 in number, cover 6 acres, are 127 feet deep, constructed in very substantial manner, together contain $22,031,976$ ale gallons, and cost $\$ 133, \$ 22$. They are for the most part upon artificial ground, raised in some parts 49 feet above the original of the hill. When full, the water is 102 feet above low tide in the Schuylkill, and 56 feet above the highest ground in the city. One of them is divided into 3 sections for the purpose of filtration. The water passes from the reservoirs to the eity, through 3 main fron pipes, in diameter 20,22, and 30 inches respectively; and is then distributed through the city in pipes from 3 to 10 inches diameter, chiefly 3 and 6 inches, of which the total length in January, 1852, was: in eity proper $81 \mathrm{~m}$., in districts of Southwark and Moyamensing 26: $\mathrm{m}$. The average daily consumption of water in the city and districts in 1850 , throughout the whole year was $4,785,338$ ale gallons; in $1851,5,690,744$ gallons. Water rents in $1851, \$ 138,874$. The entire cost of these works to Dec. 31,1850 , was $\$ 1,615,170$; additional expenses in $1851, \$ 92,380$-total cost to 1852 , $\$ 1,707,550$.

Spring Garden and Northern Liberties Water-Works.Situated on E. side of the Schuylkill, about $1 \mathrm{~m}$. above Fairmount. The engine-house is of granite, in Egyptian slyle. The reservoir, 15 feet deep, 115 feet above low-water mark, contains $9,800,000$ gallons, and has 2 distributing mains, 16 inches diameter. This work was completed in 1845 , at a cost of $\$ 159,075$.

JIanufactures.-In the amount, and value, and variety of its manufactures, Philadelphia is one of the most important cities in the United States. Many of these are brought to more than an ordinary degree of perfection.

The following statement of the manufactures in the city and county of Philadelphia, is from the census returns of 1550:

Value of

\begin{tabular}{|c|c|c|c|}
\hline & $\begin{array}{l}\text { Capital } \\
\text { invested. }\end{array}$ & $\begin{array}{c}\text { Raw material } \\
\text { surl, fuel, }\end{array}$ & $\begin{array}{l}\text { A nnual } \\
\text { products. }\end{array}$ \\
\hline Phil. City proper.. & $\$ 13,207,695$. & $. \$ 12,665,211$. & $\$ 26,309,2$ \\
\hline North'n Liberties. & $3,922,251 \ldots$ & $3,764,341 \ldots$ & $7,073,0$ \\
\hline Spring Garden... & $2,918,445 \ldots$ & $3,046,216 \ldots$ & 5,37 \\
\hline Kensington ....... & $3,755,711 \ldots$ & $6,166,071$ & 10,083 \\
\hline Southwark....... & $2,171,065 \ldots \ldots$ & $2,197,347 \ldots$ & 3,7 \\
\hline Moyamensing.... & $530,364 \ldots$ & 575.237. & 1,2 \\
\hline Townships, etc... & $7,237,380 \ldots$ & $6,090,733$. & $10,237,8$ \\
\hline
\end{tabular}

The following statements of the number of hands, and their wages, are from the same souree:

\begin{tabular}{|c|c|c|c|}
\hline \multicolumn{2}{|c|}{$\begin{array}{l}\text { Average number fof } \\
\text { lands emp toyed. }\end{array}$} & \multicolumn{2}{|c|}{$\begin{array}{c}\text { Average monthly cost } \\
\text { of labor. }\end{array}$} \\
\hline Males. & Females. & i) & Fen \\
\hline 17,020 & . $9,046 \ldots$ & $\$ 445,675 \ldots$ & $\$ 97$ \\
\hline 4,4 & . $1,181 \ldots$ & 115, & 12,200 \\
\hline 4,8 & & & \\
\hline 6,723 & . $1,590 \ldots$ & $163,010 \ldots$ & 18,279 \\
\hline $2,0 S$ & . $167 .$. & 1.. & 1.344 \\
\hline 1,97 & & & 72 \\
\hline 6,7 & 2,377 . & 5็. . & 71,396 \\
\hline & & & \\
\hline
\end{tabular}

Total employees ......59,099 Month. cost of lab. $\$ 1,271,393$

Among the principal manufactures, are those of machinery, hardware, cutlery, precious metals, cordage, furniture, musical instruments, upholstery, ornamental and other iron furniture, with large sugar refineries and marble works, etc.

Bunks and Insurance Companies.-There were in 1552 
in the city and districts 13 banks, with aggregate working capital of $\$ 10,650,000$, paying fair dividends, with 4 savings banks. Number of fire insurance companies, 10 ; of fire and marine do., 4 ; of marine do. 5 ; of life, annuity, and trust do., 9-tutal 28.

Railroads, etc.-The following is the list of railroads diverging from Philadelphia, with their lengths: Philadelphia and Trenton R. R., and thence by New Jersey R. R. to New York, 87 m. ; Camden and Amboy R.R. to New York, $90 \mathrm{~m}$. ; Philadelphia, Germantown, and Norristown P. R., $17 \mathrm{~m}$; Germantown Branch R. R., 6 m.; Philadelphia, Reading, and Pottsville R. R., $93 \mathrm{~m}$; with short branch from Schuylkill falls to Port Richmond coal depôt. Columbia and Philadelphia R. R., $82 \mathrm{~m}$., which connects at Lancaster by Harrisburg and Lancaster $\mathrm{R}$. $\mathrm{R}$., with the Pennsylvania $R$. $R$, to Pittsburg, $357 \mathrm{~m}$; Philadelphia and Westchester $\mathrm{R}, \mathrm{R}, 30 \mathrm{~m}$, which branches from Columbia and Philadelphia R. R. at Paoli; Philadelphia, Wilmington, and Baltimore R. R., $98 \mathrm{~m}$.

The city derives great advantages from the Schuylkill Navigation Canal, hence to Port Carbon, $108 \mathrm{~m}$; the Chesapeake and Delaware Canal, and others which contribute to its prosperous trade.

Domestic Trade.-The following statement exhibits the number of coastwise arrivals of vessels, from 1835 to 1851 inclusive :

\begin{tabular}{|c|c|c|}
\hline Vessels. & Vessels & Tessels. \\
\hline 1835. & 1811. & $.18,069$ \\
\hline $1 S 36 \ldots \ldots 3,764$ & $1612 \ldots \ldots 7,973$ & $.2 \%, 921$ \\
\hline $1587 \ldots \ldots 7,476$ & $1843 \ldots . .7,659$ & .24 .594 \\
\hline $1838 \ldots \ldots 10,860$ & $1814 \ldots \ldots 7,717$ & . 27, , 125 \\
\hline $1839 \ldots \ldots 11,188$ & $1845 \ldots . .8,029$ & $1551 \ldots$ \\
\hline $1 \$ 40 \ldots$ & $1816 .$. & \\
\hline
\end{tabular}

The coal trade is by far the most prominent part of the domestic trade of the city. During the calendar year 1851 , the arrivals at Port Richmond, the terminus of the Reading R. R., were as follows: 3 ships, 92 barks, 467 brigs, 5,379 schooners, 202 sloops, 1,983 barges-total 8,126.

The following statements of the annual inspections of flour and meal, and of the measurement of the principal grains, from 1846 to 1850 inclusive, are derived from the Report of the Philadelphia Board of Trade of January, 1S51:

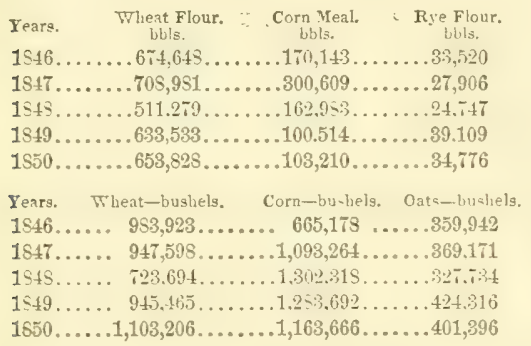

Annual inspections of tobaceo, all American, from 1839 to 1550 inclusive

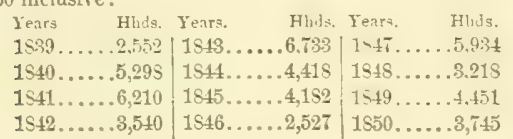

The imports of cotton, 1847-50, were-in 1847, 41,\$35 bales; in $1848,41,516$; in $1549,45,393$; in $1850,50,914$ bales. Fureign commerce.-In foreign commerce Philadclphia is now the third city in the Enion.

The following statement, prepared from official documents, exhibits the value of the imports annually into the port of Philadelphia, and the duties accruing to the United States from 1830 to 1551 inclusive:
Years. $\begin{aligned} & \text { Value of } \\ & \text { Imports. }\end{aligned} \quad$ Duties, Years, $\begin{aligned} & \text { Value of } \\ & \text { Imports. }\end{aligned}$ Duties, $1830 \ldots \$ 9,525,893 \ldots \$ 3,537,516$ | $1841 \ldots \$ 9,948,593 \ldots 1,933,652$ 1831.. 11,673,755.. 4,372,526 $1812 \ldots 6,201,177 \ldots 1,312,813$

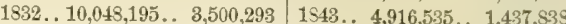
\begin{tabular}{ll|l}
$1833 . .11,153,757 . .2,955,096$ & $1844 . .8,310, \$ 65 .$. & $2,981,573$
\end{tabular} 1S34.. 10,656,078..2,110,477 . 1S15 . 7,491,497 . 2,370,516

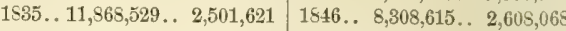
1S36. . 16,116,625 . 3,146,45\$ $1847 . .12,153,937 \ldots 2,904,749$ 1837.. 10,130,838 . 1,820,998 $1848 \ldots 10,700,865 \ldots 2,767,459$ 183S. . 10,417,815. . 2,109,955 $1849 \ldots 10,160,479 \ldots 2,694,245$ 1839.. 14,758,589.. 2,854,984 $1850 \ldots 13,381,759 \ldots 3,412,240$

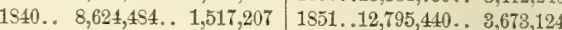

Foreign Arrivals.-The following table exhibits the total number of arrivals from foreign countries in each year from 1536 to 1851 inclusive :

Years. Arr. Years, Arr, Years, Arr, Years, Arr. $1836 \ldots . .421,1840 \ldots \ldots 456 \mid 1844 \ldots . .472,1848 \ldots . .512$ $1837 \ldots . .409 \quad 1841 \ldots .504 \quad 1845 \ldots . .357 \quad 1849 \ldots . .585$ $1838 \ldots . .464 \quad 1812 \ldots \ldots 454$ 1846.....459 $1850 \ldots . .518$

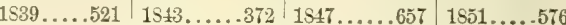

Exports.-The number of clearances for foreign countries during the two fiscal years, $1843-49$, and $1349-50$, each ending June 30 , were as follows:

$\overbrace{\text { Vess. Tons, }}^{1848-49 .}$ Men, Boys. Vess, Tons. Mex. Boys,
American. $.360 . .93,322 \ldots 3,806 \ldots 99 \quad 309 \ldots 81,276 \ldots 8,189 \ldots 133$ Foreign ...179..27,005..1,417..15 170..30,342..1,480.. 36

Total...589.120,327 ..5,228. $\overline{113} \overline{479} . \overline{111,618} . . \overline{4,669} . \overline{169}$

Exports of Breadstuffs.-These, with meat provisions, and manufactures of iron and wool, constitute the greater portion of the exports. The following is a statement of the exports of wheat flour, corn meal, wheat, and corn, from 1831 to 1851 inclusive

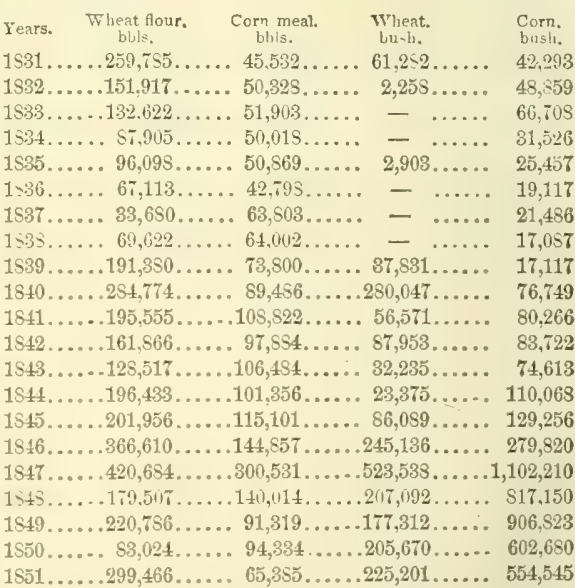

The exports of rye flour in the same years were as follows:

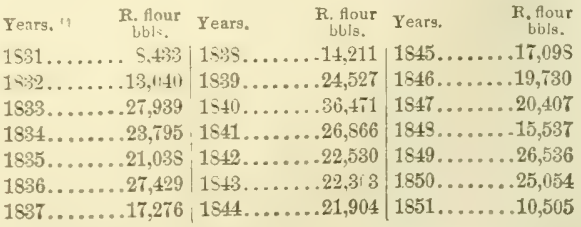

Tonnage for the two fiscal years $1848-9$ and $1849-50$, also in 1551 , which, though not from any official documents, is doubtless correct: 
TONNAGE OF PHILADELPIIA.

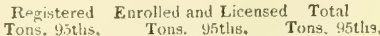

On June $30,1819 \ldots 58,82191 \ldots 184,26525 \ldots 188,08721$ $1550 \ldots 64,20510 \ldots 142,29272 \ldots 206,49782$ $1 \$ 51 \ldots$ - $\ldots \ldots$ - $\ldots 222,42890$

Classification and employment of tonnage on June 30 , 1849, and June 30,1850 :

$$
\begin{aligned}
& \text { REGISTERED TONNAGE. } \\
& \text { Permanent } \\
& \text { Tons. 95tlis. Temporary } \\
& \text { Tons. 95tus. Tons, } 45 \text { ths, }
\end{aligned}
$$

June $30,1849 \ldots 40,34326 \ldots . \ldots 13,47365 \ldots 53,82191$

« $1850 \ldots 46,38491 \ldots 17,82014 \ldots 64,20510$

Of the above, in 1850,66 tons were propelled by steam; in 1549 none.

\section{TNROLLED AND IICENSFD TONNAGR.}

Permanent Temporary Coast Trade St'm Nav"n Permanent Temporary Coast Trade St'm Nav'n
Tons, 9.5ths. Tons. 95tlis. Tons. Y5tlis, Tons. 4.5ths, June $30,1549 \ldots 121,72285 \ldots 9,53093 . .131,25383 \ldots 13,63122$ "6 $1850.136,57723.2,58187 . .139,159$ 15..15,475 56

The amount "licensed under 20 tons" in 1849 was 3,011 tons; in 1550, 3,134-all in the coasting trade.

Vessels built in the district of Philadelphia in the two fiscal years, 1845-49, and 1849-50, each ending June 30:

Years. Ships, Brigs. Sch'rs. $\begin{aligned} & \text { Sloops and Steam- Total } \\ & \text { canal b'ts, boats. Vessels. Tons. }\end{aligned}$ $1549-49 \ldots \ldots 3 \ldots . .2 \ldots 26 \ldots . \ldots 102 \ldots 9 . \ldots 142 \ldots 13,741$ $1849-50 \ldots . .7 \ldots . .1 \ldots 34 \ldots .107 \ldots 17 \ldots 166 \ldots 18,150$

Summary of Navigation.-The following table exhibits the total arrivals of vessels at Philadelphia in each year, from 1885 to 1851 inclusive. Their separate divisions into foreign and coastwise vessels are previously given under their proper heads of domestic trude and foreign commerce:

Years, Years. Years,

$1835 \ldots \ldots .4,002|1841 \ldots \ldots .9,750| 1847 \ldots \ldots .18,726$

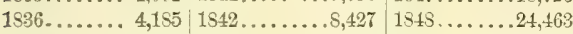

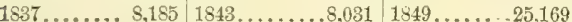

$1835 \ldots \ldots .11,344 \quad 1814 \ldots \ldots \ldots 8,189,1550 \ldots \ldots .27,553$

$1839 \ldots \ldots .11,709 \quad 1845 \ldots \ldots \ldots .8416 \quad 1851 \ldots \ldots .27,060$

$1840 \ldots \ldots .10,162 \mid 1846 \ldots \ldots \ldots 6,477$

Population.-In 1749 , the city proper had 7,391 inhabitants, and 1,861 dwellings; Southwark 595 population, 150 dwellings; Northem Liberties 244,62 dwellings. In 1750, city 7,685 . In 1777 , the British (then in possession of the city, which had decreased in population by the war) took the census of the city, Southwark, and the Northern Liberties, and found their united population 23,734, dwellings 5,985. In 1790 , by U. S. census, the eity, 28,522 ; Southwark, 5,661; unincorporated Northern Liberties, 8,337. total 42,520 .

Population of Philadelphia, city and county, from 1800 to 1550 inclusive:

1800, 1810, 18:0. 1830. 1840. 1850. City of Phila- $\} 41,220 \quad 53,722 \quad 63,802 \quad 80,458 \quad 93,665 \quad 121,417$ SOUTH OF CITY AND EAST OF SCIYUTLILL RIVER.

Southwark ... $9,621 \quad 13,707 \quad 14,713 \quad 20,740 \quad 27,516 \quad 35,799$ $\begin{array}{llllll}\text { Moyamensing. 1,592 } & 2,597 & 3,963 & 6,922 & 14,573 & 26.979\end{array}$

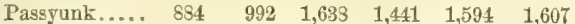

NORTH OF CITY AND EAST OF SCHUTLEILL RIVER.

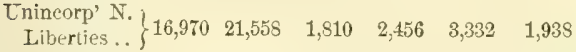
N. Liberties.... - - - $19,679 \quad 25,923 \quad 84,474 \quad 47,223$ Spring Garien* - $\quad$ - 3,498 11,141 $27,849 \quad 58,895$ Kensington* .. - - $\quad$ - 7,118 13,326 22,314 46,776

Penn District*. - $\quad$ - $\quad$ - $\quad$ -

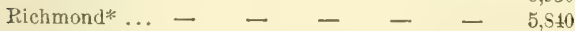

PennTownship* $\begin{array}{llllll}-\quad 3,793 & 3,105 & 2,507 & 3,342 & 2,687\end{array}$ Oxford........ 1,518 $973 \quad 1,315 \quad 1,502 \quad 1,532 \quad 1,757$

* Formerly a part of the Northern Liberties.
1800, 1810. 1820. 1830. 1840, 1850.

Frankford.... - $\quad \begin{array}{llllll}1,233 & 1,405 & 1,637 & 2,376 & 5,316\end{array}$

$\begin{array}{llllll}\text { Lower Dublin. 1,495 } & 2,194 & \mathbf{2 , 6 4 0} & \mathbf{2 , 7 0 5} & \mathbf{3}, 298 & 4,297\end{array}$

$\begin{array}{lllllll}\text { Byberry....... } 579 & \mathbf{7 6 5} & 876 & \mathbf{1 , 0 1 8} & 1,055 & 1,130\end{array}$

Moreland .... $\quad 862 \quad 400 \quad 413 \quad 418 \quad 469 \quad 493$

Bristol...... $771 \quad 965 \quad 1,257 \quad 1,425 \quad 1,734 \quad 2,230$

Germantown... $8,220 \quad 4,243 \quad 4,311 \quad 4,612 \quad 5,482 \quad 8,326$

$\begin{array}{llllll}\text { Roxborough... 1,04S } & \mathbf{1 , 2 5 2} & \mathbf{1 , 6 8 2} & \mathbf{3 , 3 3 4} & \mathbf{5 , 7 9 7} & \mathbf{2 , 6 6 0}\end{array}$

Manuyunk... - $\quad$ - $\quad$ - $\quad$ - 6.210

Bridesburg... - $\quad$ - $\quad$ - $\quad$ - $\quad$ - 915

Aramingo..... - $\quad-\quad$ - $\quad-\quad$ -

Whitehall.... - $\quad$ - $\quad$ - 459

WEST OF TIE SCHCTLETL.

Blockley..... 1,091 $\quad 1,615 \quad 2,655 \quad 3,401 \quad 8,319 \quad 5.910$

W.Philadelphia - - - - $\quad$ - 2,596 5,670

$\begin{array}{lllllll}\text { Kingessing.... } & 634 & 903 & 1,189 & 1,069 & 1,339 & 1,713\end{array}$

Total. . . . 81,005 111,210 137,097 188,961 258,087 409,045

Historical Sketch. - 1627. The colony of Swedes which had previously been settled on the Delaware Bay, arrived here and took possession. 1677. First Swede's Church built 1681. The State was granted to William Penn by James II. king of England, and in same year the first settlers arrived from London. 16\$2. William Penn arrived. 1683. City laid out, and first post established to Newcastle. 1684 Pop. 2,500. 1685. First two Friends' Meeting-houses erected. 1656. Additional colonists arrived (Baptists). 1695. Christ Church Society (Episcopal) organized, also first Presbyterian. 1698. Fürst Baptist Church erected. 1700. Second Swede Church (now standing) built, and post-office established. 1701. Philadelphia incorporated into a city. 1710. First Market (High St.) built. 1719. "American Weekly Mercury," published by Andrew Bradford. 1723. "Pennsylvania Gazette," published by S. Keiner, subsequently by Dr. Franklin. 1727. Christ Church (now standing) commenced, finished in 1753. 1729. Independenee Hall commenced, completed in 1734. 1731. Philadelphia Library Co. organized, opened in 1732, with books brought from London 1738. First Fire Co. originated. 1743. American Philo sophical Society organized, 1751. Pennyslvania Hospital incorporated. 1753. Daily delivery of letters by carriers introduced. 1754. Trimeekly post established to New York City. 1755. University of Pennsylvania (from 1750 an academy) erected into a college, in 1779 into an university. 1765. Medical Department of University established. 1771 "Pennsylvania Packet" issued weekly, in 1784 daily, first in U. S. 1774, Sept. 4th. First Colonial Congress assembled. 1776. July 4th, 2 P. M. Declaration of Independence read from the steps of the Hall. Autumn of same year, Congress retired to Baltimore. 1777, Sept. 26th. City taken by the British. 1750, March 15th. American Philosophical Society fully established. 1781. Bank of North America chartered by Congress. 1787, 17th May. Convention met, 17th Sept, following, agreed upon a Constitution for U.S. In 1793 and 99. Yellow fever prevailed. 1789. College of Physicians chartered. 1789. Present City Hall erected. 1791. Lancaster Turnpike Co. chartered, finished in four years. 1791 Southwark incorporated. 1801. Nazy yard located. 1808. First Hose Co. 1804. Germantown Perkiomen Turnpike Co chartered, completed in two years. 1817. Medical Institute founded. 1809. Masonic Hall erected. 1S20. Musical Hall finished. 1822. Fairmount Water-works completed. 1826. House of Refuge incorporated, 1829. U. S. Mint building commenced, 1833. Girard College corner-stone laid, commenced 1st Jan., 1849. 1835. Gas works erected.

Philadelphi, p. . $_{\text {, Hancock }}$ co., Ind.: on Sugar er. and the Indiana Central R. R., 14 m. E. Indianapolis.

Philadelphi, p. Y., Marion co., Mo.: 85 m. N. by E. Jefferson City.

Philadelphia, p. v., and cap. Neshoba co., Miss: about $4 \mathrm{~m}$. S. of Pearl r., $67 \mathrm{~m}$. E. N. E. Jacksou. It contains a court-house and jail, and 200 inhabitants.

Pimladelphia, t, and p. v., Jefierson co, $N . Y_{.:} 188 \mathrm{~m}$. 
N. W. Albany. Drained by Indian r. and branches. Surface rolling and well timbered; soil clayey or sandy loam, and mostly fertile. The Watertown and Potsdam R. P. crosses it. The $v$. is on Indian $r$, where are several mills. Pop. of t. 1,915.

Philadelpira, p. v., Van Buren county, Ia.: on the Des Moines, at the mouth of Lick creek, $61 \mathrm{~m}$. S. S. W. Iowa City.

Phinadelphia, p. v. and sta., Monroe co., Tenn.: on the East Tennessee and Georgia R. R., $6 \mathrm{~m}$. S. of Loundon, 133 m. E. by S. Nashville.

Philadelphus, p. o., Robeson co., N. Car. : $68 \mathrm{~m} . \mathrm{S} . \mathrm{S} . \mathrm{W}$. Raleigh.

Philanthropy, p. o., Butler co., Ohio: 98 m. W. S. W. Columbus.

Puxurs county, Ark. Situate E., and contains 755 sq. m. Drained by St. Francis r. and its chief tributary, Lanquille r. and by branch of White $r$. Surface varied, but in general is level, in the $\mathrm{S}$. the land is low and subject to inundation; soil, where capable of cultivation, is fertile, and very productive, a dry sandy loam prevailing in the $\mathrm{N}$. It is bounded on the E, by the Mississippi. Farms 409; manuf, 13 ; dwell. 809 , and pop.-wh. 4,311, fr. col. 3, sl. 2,591-total 6,935. C'upital: Helena. Public Works: Southern Pacific R. R. (proposed.)

Philips, to and p. v., Franklin co., Mre.: $46 \mathrm{~m}$. N. W. Augusta. Drained by Sandy r., a W. branch of the Kennebee, affording water-power. Surface somewhat broken; soil very productive and well wooded. Pop. of t. 1,673.

Philipsiburg, v. Warren co., N. Jer, : on the E. side of Delaware r., opposite Easton. It is the terminus of the New Jersey Central R. R., and $78 \mathrm{~m}$. W. by that line from New York. The Belvidere. Delaware $\mathrm{R} . \mathrm{R}$ will also have its $\mathrm{N}$. terminus at this point. Considerable business centres here, and the place has a flne prospect of becoming a station of some consequence.

Philtipsbure, p. v., Jefferson county, Ohio: on the Ohio, opposite Wellsburg, Virg., 122 m. E. by N. Columbus.

Pmutrsbura, p. v., Centre co., Penn. : on Mushanon cr., $20 \mathrm{~m}$. S. of its entrance into the W. branch of Susquehanna r., $82 \mathrm{~m}$. N. W. by W. Harrisburg. The er. is navigable to the $\mathrm{Y}$, which contains several stores, mills, and manufactories of various kinds of iron-ware.

PemitPsport, p. v., Sullivan co., $N . Y_{*}:$ on the Delaware and Hudson Canal, $26 \mathrm{~m}$. N. E. Port Jervis, $77 \mathrm{~m}$. S. S. W Albany.

PHurpstown, p. v., White co., $I I l_{\text {.: }}$ about $5 \mathrm{~m}$. W. of Wabash r., 148 m. S. E. by S. Springfield.

Philipgrilute, p. v., Alleghany co., N. $Y_{0}$ : on Genesee $r_{\text {. }}$ $212 \mathrm{~m}$. W. by S. Albany. It contains several mills, and is $33 \mathrm{~m}$. S. W. of Hornellsville, on the Erie R. R.

Pmoltppa, p. V., and cap. Barbour co, Virg.: on the E. fork of Monongahela r., $174 \mathrm{~m}$. N. W. Richmond, It contains an academy, the county buildings, several stores and mills, and 850 inhabitants.

Printips' Creek, p. 0., Alleghany co., N. $Y .: 218 \mathrm{~m}$. W. by S. Albany.

PmLirpston, t. and p. v., Worcester co., Mass. : $5 \mathrm{~s}$ m, W. by N. Boston. Drained by heads of Ware and Swift rivers, which move several mills and factories. Surface hilly; soil adapted chiefly to grazing. Pop. of t. 809 .

Pmlimptille, p. v., Erie co, Penn.: 9 m. S. of Lake Erie, 195 m. N. W. Harrislurg.

PHIt's CREFE, D. o, Jersey co, $I l l$ : on a $\mathrm{S}$. branch of Macoupin er., $55 \mathrm{~m}$. S. W. by S. Springfield. Name changed to Fidelity.

Pammorns, sta., Columbia co., $N . X_{0}:$ on the Harlem R. R., $81 \mathrm{~m}$, S. of East Albany.

PHILO, p. 0., Muskingum co., Ohio: $35 \mathrm{~m}$. E. Columbus.

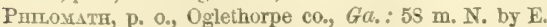
Milledgeville.

Phrovatir, p. v., Union county, Ind.: 57 m. E. by S. Indianapolis.
Pmlomont, p. o., Loudon co., Firg.: 91 m. N. by W. Richmond.

Philopolis, p. v., Baltimore co., MY. : on the W. side of Great Gunpowder Falls, $34 \mathrm{~m}$. N. by W. Annapolis, The $\mathrm{v}$. is built of stone, and contains a flourishing school. The Baltimore and Susquehanna R. R. passes $\frac{7}{2} \mathrm{~m}$. W. of it. Pop. 200. The adjacent district abounds in limestone, is highly cultivated, and inhabited by Friends mostly.

Paipp's Mruls, p. o., Venango county, Penn.: 164 m. N. W. by W. Harrisburg. Here is a furnace of 1,200 tons annual eapacity.

Phipsibrg, $t$, and p. $\mathrm{v}$., Lincoln co., Me. : on the Atlantic, at the mouth of Kennebec r., W. side, 37 m. S. Augusta. It consists of a long, narrow peninsula, with New Meadow bay on the W., and several islands; has superior faeilities for navigation, and is largely engaged in ship-building, the coasting trade, and fisheries. The $\mathrm{v}$. is on the Kennebec, and has a good harbor. Pop. of t. 1,805 .

Phanix, p. v., Oswego con, $N$ : $Y$ : on the E. side of Oswego r., and on the Oswego Canal, $17 \mathrm{~m}$. N. W. of Syracuse, $136 \mathrm{~m}$. W. N. W. Albany, It contains a half dozen stores, as many mills, and 450 inhabitants.

Phontx, p. o., Armatrong co., Penn.: $13 \mathrm{~S}$ m. W. by N. Harrisburg.

PIteNIx, p. 0., Edgefield district, S. Car.: $55 \mathrm{~m}$. W. Columbia.

Phonisville, p. V., Chester co., Penn.: on the W. side of Schuylkill $r$, and $\mathrm{S}$. side of French er., at their confluence, $72 \mathrm{~m}$. E. S. E. Harrisburg. It is supplied with good water-power, and extensively engaged in the manufacture of iron and iron-ware. It has three furnaces of 13,000 tons annual capacity, which use steam, and in 1849 made 8,025 tons of iron ; a nail factory, using water-power, which made 1,800 tons of nails; a rail-mill, using steam, which made 5,763 tons of railroad iron, and a rolling-mill, using steam and water, and capable of making 5,300 tons of bar and sheet iron per annum. In these were employed 878 men and boys. It has also several factories and mills, and a population of 2,667 . It is $27 \mathrm{~m}$. N. W. of Philadelphia, on the Philadelphia and Reading Railroad, and Schuylkil Navigation Canal.

Phosixville, p. v., Windham county, Connt.: $31 \mathrm{~m}$. E. Hartford.

Prasa, p. O., Macoupin co., Ill. : at the head of Big Piasa cr., 5 . m. S. S. W. Springfield.

Piatr county, $17 \%$. Situate E. centrally, and contains 427 sq. m. Drained by Sangamon river. Surface undulating; soil fertile, producing wheat and Indian corn. It has some prairies, and good timber land. Farms 163; manuf. 2 ; dwell. 157, and pop. - wh. 1,606, fr. col. 0-total 1,606. Capital: Monticello, Putzic Works: Great Western Central Railrond.

Prcasure, p. o., Henderson coo, $\Pi l l_{0}: 10 \mathrm{~m}, \mathrm{E}$. of the Mississippi, 89 m. N. W. Springfield.

Pickawax county, Ohio. Situate S. centrally, and contains $542 \mathrm{sq} . \mathrm{m}$. Scioto river passes through it centrally, by which and its branches it is drained. Surface even; soil a fine, deep, vegetable mold, and very fertile. Chief productions, wheat and Indian corn. It has fine pasturage, and large numbers of cattle, sheep, and hogs are fattened and sent to the eastern markets. Farms 1,261; manuf. 71 ; dwell. 3,600, and pop.-wh. 20,595, fr. col, 413-total 21,008. Cupital: Circleville. Pultic Works: Cincinnati, Wilmington, and Zanesville R. P..; Ohio Canal, etc.

Pickatay Plates, p. 0., Monroe co., Virg. : $181 \mathrm{~m}$. W. Richmond.

Prckexs county, Ala. Situate W. toward the $N_{.}$, and contains $955 \mathrm{sq} . \mathrm{m}$. Tombigbee river passes through the s. W. purtion, by which and its branches it is cirained. Surface undulating; soil fertile, and adapted to cotton, which is the staple. Good crops of wheat and corn are produced, and a quantity of live-stock fattened. Part of the land is wooded. Farms 1.435; manuf. 34; dwell. 1,896, and pop.- 
wh. 10,972, fr. col. 6, s]. 10,534-total 21,512. Capital: Carroliton.

Pickexs district, $S$. Car. Situate N. W., and contains 997 sq. m. Drained by Seneca river and its branches, it being a tributary of Tugaloo river. Surface billy and mountainnus: soil fertile, making fine grazing land, and adapted to the culture of grain. Chief productions, cotton, tobaeco, wheat, and Indian corn. Farms 1,231; manuf. 23; dwell. 2,232, and pop.-wh. 13,105, fr. col. 120, sl. 3,679total 16.904. Cupitul: Pickens. Public Works: Rabun Gap R. R. (proposed.)

Pickens C. H., p. v., and cap. Pickens dist., S. Car.: on the W. side of Keowee r., an affluent of the Savannah, $128 \mathrm{~m}$. N. W. by W. Culumbia. It contains a court-house, jail, academy, a balf dozen stores, and 300 inhabitants, The "Keowee Courier" (dem.) is published weekly.

Pickensvrlet, p. v., Pickens county, Ala.: on the E. side of Tombigbee river, 126 miles W. N. W. Montgomery. It contains an acalemy, a dozen stores, and 276 inhabitants.

Pickexsville, p. v., Pickens dist., S. Car.: 116 m. N. W. Columbia.

Pickering, p. o., Chester co., Penno: 68 m. E. by S. Harrisburg.

Ptckurington, p. v., Fairfield co., Ohio: 14 m. E. S. E. Columbus. Pep. 180.

Prcolata, p. v., St. John's co., Flor.: on the E. bank of St. John's r., $171 \mathrm{~m}$. E. by S. Tallahassee.

PIEDMONT, p. v., Harris co., Ga. : about $6 \mathrm{~m}$. E. of Chattahoochee r., $109 \mathrm{~m}$. W. by S. Milledgeville.

PIEdmont, sta., Alleghany co., Md.: $28 \mathrm{~m}$. W. of Cumberland, on the Baltimore and Ohio R. P.

Prerce county, Wisc. Situate W., and contains $640 \mathrm{sq}$. m. Drained by Trimble, Rush, and Isabella rivers; the two latter flowing into Lake Pepin, which forms part of its S. boundary, and the former into the Mississippi on its S. E. border. Surfuce varied; soll in parts fertile, but particularly so on the river bottoms, which are very productive. It is well timbered with pine and other forest trees. This county has recently been erected from the $\mathrm{S}$. portion of St. Croix.

Pirree, po 0., Armstrong co., Penn.: 138 m. W. N. W. झarrisburg.

Prengort, p. V. and sta, Rockland en, N. Y.: on W. bank of Hudson r, $115 \mathrm{~m}$. S. by W. Albany, $24 \mathrm{~m}$. N. by E. New York. It is of recent growth. consequent upon its seIection as the E. terminus of the Erie R. R. within the State of $N . Y$. It derives its name from the R. R. pier, $1 \mathrm{~m}$. long. and the abript hill (the N. termination of the Palisades) upon which it is situated. It contains 2 churches, some stures, and hotels. Its business is for the most part directly connected with the Erie $R_{\text {. }} \mathrm{R}$., which has here large depots car-houses, machine shops, ete. Pop. about 1,000.

Pierrort, sta, Orange co., Verm.: on Connecticut river, about $2 \mathrm{~m}$. below the mouth of Wait's r., opposite the village of Piermont, $N$. Hamp., $26 \mathrm{~m}$. N. of White River Junetion, ate the Connecticut and Passumpsis Rivers R. P.

Preriroxt, to and p. 0., Grafton eo., N. Heimp.: on the Connectieut, $58 \mathrm{~m}$. N. W. by N. Coneord. Several ponds in the E. feed a fine will-stream flowing into the river. Surface elevated in the E., and soll superior pasture. On the r. are brrad rich meadows. Farming is the leading businesg. Por. 948.

Pieripont, to and p. n., St. Lawrence co., N. Y.: $139 \mathrm{~m}$. X. T. by X. Albany. Drained by Racket and Grasse :Surface broken and heavily timbered; soil clavey loam. Grazing is a leading interest. Pop. 1,459.

Przepast, to arad p. 0., Ashtabula co., Ohio : on the State Zine, 1 i2 m. N. E. Columbus. Drained by keads of Aslatibula r. Surface slightly broken; soil excellent grass land. Top. 999.

PIERRepont, sta., Jefferson co., N. $Y_{*}:$ on the Watertown und Lome R. R., $15 \mathrm{~m}$. S. of Watertown.
Pierrepont Maxor, D. O., Jefferson co., N. Y.: $133 \mathrm{~m}$ N. W. by W. Albany.

PIfFARD, p. O, Livingston co, $N_{0}, Y_{*}: 193 \mathrm{~m} . \mathrm{W}$. by $\mathrm{N}$ Albany.

PIGEON river, Big, N. Car. and Tenn.: rises in Haywond co., N. Cur., and flows in N. N. W. course, to its confluence with French Broad river, near Newport, Tennessee.

Pigeon Creek, p. O., Ralls co., MIo. : on a N. branch of Silt r., $79 \mathrm{~m}$. N. N. E. Jefferson City.

Pigeon Forge, p. v., Sevier en, Tenn.: on a S. branch of Nolichucky r., $181 \mathrm{~m}$. E. by 8 . Nashville.

Pigeon Grove, p. o, Columbia con, Wise.

Pigeon River, p. o., Haywood county, N. Car.: on a $\mathrm{s}$. branch of the Nolichucky so called, $247 \mathrm{~m}$. W. Raleigh.

Pigteon Roost, p. o., Choctaw co., Miss. : 95 m. N. N. E Jackson.

Pigron Run, p. o., Campbell co., Virg.: 93 m. W. S. W. Richmond.

PIKE county, Alat. Situate toward the S. E., and contains 996 sq. m. Conecuh $r$. passes centrally through it, by which and its branches it is drained. Surface undulating; soil fertile, and well adapted to cotton, the principal production of the co. Agriculture is the leading pursuit. Farms 1,538; manuf, 5 ; dwell. 1,973, and pop.--wh. 12,102, fr. col. 24, sla. 3,794-total 15,920. Capital: Troy. Public Worles: Girard and Mobile $\mathbf{R}$. $\mathbf{R}$.

PIKE county, Ark. Situate toward the S. W., and contains $545 \mathrm{sq} . \mathrm{m}$. Drained by branches of Little Missouri $r$ surface uneven; soil fertile, and adapted to grazing. Some cotton is produced. Farms 207; manuf. 2; dwell, 306, and pop.-wh. 1,751, fr. col. 0, sla. 110-total 1,861. Capital: Zebulon.

PIKE county, Ga. Situate W. centrally, and contains 383 są. m. Flint r. runs on its W. border, by branches of which it is drained. Surface hilly; soil fertile, and well adapted to cotton, which is the chief production. Wheat, corn, and potatoes are raised in large quantities. Apples, pears, and other fruits are also produced in the co. Pine and other timber is grown in the land. It contains some minerals. Farms 807; manue. 21; dwell. 1,474, and pop.-wh. 8,686, fr. col 61, sla. 5,555-total 14,305. Capital: Zebulon. Public Works: Macon and Western R. R.

PIke county, $\mathrm{Ill}$. Situate W., and contains $735 \mathrm{sq} . \mathrm{m}$. Drained by affluents of Illinois r., which bounds it on the $\mathbf{E}$. and of the Mississippi, which forms its W. boundary, and which supply good water-power. Surface level, and in the W. low ; soil fertile. Chief produetions wheat and Indian corn. Pork and beef are exported. Pine and other timber abound. Farms 1,382 ; manuf. 37; dwell. 3,152, and pop.wh. 18,785, fr. col. 34 -total 18,819. Capital: Pittsfield.

PIKE county, Ind. Situate S. W., and contains $328 \mathrm{sq.} \mathrm{m.}$ Drained by Patoka cr. and its $\mathrm{S}$, branch. Surface rolling; soil generally fertile, being a deep and rich loam, and very productive; in the eastern portion it is indifferent, and cov. ered with timber. Chief productions wheat, Indian corn, and tobaceo. Pork and beef are exported. It contains fine beds of coal. Farms 909 ; manuf. 2 ; dwell. 1,261, and pop. -wh. 7,710, fr. col. 10-total 7,720. Capital: Petersburg. Public Works: Wabash and Erie Canal.

PIKE county, Ky. Situate E., and contains 568 sq. m. Drained by W. fork of Big Sandy river and its branches Surface billy and in parts mountainous, the Cumberland Range bounding it on the $\mathrm{S}$. E.; soil in general fertile. Chief productions cotton, tobacco, and Indian corn. Farms 418 ; manuf. 5; dwell. 905, and pop.-wh. 5,250, fr. col. 17 , 5l. 98-total 5,365. Capital: Piketon.

Pike county, Miss. Situate S. toward the W., and contains $846 \mathrm{sq} . \mathrm{m}$. Drained by Bogue Chitto river and its branches, and Tangiapaho r., which enters Lake Pontchartrain in $L a_{\text {o, }}$ the adjoining State. Surface even; soil fertile, and adapted to the growth of rice and cotton, which are the ehief productions of the co. Farms 555; manuf, 19; dwell. 698, and pop.-wh. 4,225, fr. col. 33 , sla. 3,102-total 7,860 . 
Capital: Holmesville. Public Works: New Orleans, Jackson, and Northern R. R.

Prke county, Mo. Situate E. toward the N., and contains $5 \$ 5 \mathrm{sq} . \mathrm{m}$. Drained by branches of Cuivre river in the S., and by Salt river, which runs through its N. E. portion and falls Into the Mississippi, the E. boundary of the co. Surface undulating; soil fertile, favorable to the growth of tobaceo, which is a principal production. Sugar and Indian corn are produced largely. Farms 959 ; manuf. 47 ; dwell. 1,671, and pop.-wh. 10,229, fr. col. 35, sl. 3,275-total 13,609 . Capital: Bowling Green.

PIkE county, Ohio. Situate S., and contains 502 sq. m. Drained by Scioto $r$, and its branches. Surface varied, in some parts being hilly, but in general level; soil rich and productive. Staples wheat and Indian corn. Timber is abundant. Farms 781 ; manuf. 28 ; dwell. 1,985, and pop. -wh. 10,334, fr. col. 619-total 10,953. Capital: Piketon. Pubtic Works: Cincinnati, Hillsboro' and Parkersburg R. R. ; Bainbridge Branch R. R.; Ohio Canal, ete.

Prke county, Penn. Situate E. toward the N., and contains 569 sq. m. Drained by branches of Delaware river, which bounds it on the $\mathrm{E}$. and $\mathrm{N}$., and by Lackawaxen river. Surface varied, for the most part it is mountainous and rough, but on the Delaware are some level bottoms: soil fertile on the streams, but in general poor. It has some extensive manufactures, and much benefit is derived from the water-power supplied by the streams. Farms 370 ; manuf. 40 ; dwell. 964, and pop.-wh. 5,692, fr. col. 189total 5,881. Capital: Milford, Public Works: New York and Erie R. R.; Delaware and Hudson Canal

PIKE, t. and p. v., Wyoming co., N. $Y_{0}: 216 \mathrm{~m}$. W. Albany. Drained by W. affuents of Genesee $r$. Surface rolling; soil rich mold and alluvium. Theat is a good crop, and the pastures are excellent. The v, is on West Koy cr., and contains a furnace, several mills, 8 or 10 stores, and about 800 inhabitants. Pop. of t. 2,003 .

PIkE, p. o., Washington county, Me.: 112 miles $\mathrm{E}$. by $\mathrm{N}$. Augusta.

PIKE, t, and p. o., Perry county, O7io: $45 \mathrm{~m}$. E. S. E. Columbus. Occupying the water-shed between the Hocking and Muskingum, it is drained by small affluents of both, on which are good mill-sites. Surface varied; soil generally very fertile. Pop. 2,146.

Pike, t. and p. o., Bradford co, Penn.: 109 m. N. N. E Harrisburg. Drained by Wyalusing creek, which supplies numerous water privileges. Surface broken; soil gravelly. Lumber is a large export.

Prke Creek, p. 0, Ripley co, Mo.: 139 m. S. E. by S Jefferson City.

Pike Mrurs, p. 0., Potter co, Penn.: on Pine cr., $108 \mathrm{~m}$. N. N. W. Harrisburg.

Pike PoNd, p. o., Sullivan county, $N_{.} Y_{*}: 83$ miles S. W. Albany.

Prke Row, to and p. o., Washington co., Penn.: $157 \mathrm{~m}$. W. Harrisburg. Drained by Pike Run, an aftuent of the Monongahela, which forms its $\mathrm{E}$. boundary. Surface diversified; soil productive and well tilled. The National Road crosses it.

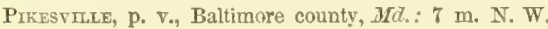
Baltimore, $31 \mathrm{~m}$. N. N. W. Annapolis. It contains an academy, and 250 inhabitants. A little S. of it is a U.S. Arsenal.

Pikmon, p. v., Mirion county, Ind.: \& miles $\mathrm{N}$. W. Indianapolis.

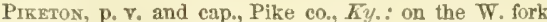
of Big Sandy r., $139 \mathrm{~m}$. E. by S. Frankfort. It contains a court-house, jail, academy, several stores and mills, and 600 inhabitants.

Pineton, p. v., and cap. Pike co., Ohio: on the left bank of Scioto r., $61 \mathrm{~m}$. S. by E. Columbus. It is $24 \mathrm{~m}$. above the mouth of the $r_{*}$, on the opposite side of which is the Ohio Canal, and contains a court-house, jail, a dozen stores, and 690 inhabitants. The Cincinnati, Hillsboru, and Parkers675 burg R. R. passes through it, $96 \mathrm{~m}$. E. of Cincinnati. The "P. Jonrnal" (whig) is published weekly.

Pike Townsmir, p. o., Berks co., Penn. : on Manatawny creek, $61 \mathrm{~m}$. E. by $\mathrm{N}$. Harrisburg. Here are 2 forges, which in 1849 made 240 tons of blooms.

Pike Vallex, p. o., Potter co., Penn.: 112 m. N. N. W. Harrisburg

Pikeville, p. v., and cap. Marion co., Ala.: about $3 \mathrm{~m}$. E. of Buttahatchie r., $143 \mathrm{~m}$. N. W. Montgomery. It contains the co. buildings, several stores, and 250 inhabitants.

Prkevilue, p. v., Chickasaw county, Dfiss.: 118 m. N. E Jackson.

Pixevilite, p. V., and cap. Bledsoe co, Tenn. : on the W. side of Sequatehy r, 92 m. E. S. E. Nashville. It contains the county buildings and 300 inhabitants.

Pilatka, p. v., and eap. Putnam co., Flor.: on the W. side of St. John's river, 178 m. E. S. E. Tallahassee. Lat. $29 \circ 38^{\prime}$. It is the place of re-shipment of the exports of the Upper St. John's and Oeklawaka rivers, and has regular steamboat connection with Savannah and Charleston. The exports are sugar, cotton, rice, etc., for the production of which the cane-brake marshes of the St. John's are so famous. It has recently been made a port of delivery.

Prloher, p. o., Belmont co., Ohio: $106 \mathrm{~m}$. E. Columbus.

Prllar Ponnt, p. o., Jefferson co., $\boldsymbol{N}$. $\boldsymbol{Y}$.: on a peninsula on the $\mathrm{N}$. side of the mouth of Black r., $146 \mathrm{~m}$. N.W. by W. Albany.

Pillow, p. o., Dauphin co., Penn.

Prilow ville, p. o., Weakly county, Tenn.: 104 m. W. Nashville.

PrLot, p. v., Vermillion co., Ill.: 4 m. N. of Vermillion river, $95 \mathrm{~m}$. E. by N. Springfield.

Pilot Grove, p. 0., Lee co, $7 a_{*}: 69 \mathrm{~m}$. S. Iowa City.

Prlot Grove, p. O., Hancock co., $I l l .: 92$ m. W. N. W. Springfield.

Pilot Grove, p. o., Cooper co., Mo.: 44 m. W. N. W. Jefferson City.

Prlot Grove, p. o., Grayson co., Texo.: on a small head stream of East Trinity r., 233 m. N. by E. Austin City.

Prlot HuL, p. v., and eap. Fulton county, $A r k$ : : $110 \mathrm{~m}$. N. by E. Little Rock. It contains the county buildings and several stores.

Pilot Hrlu, p. o., Mason co., Tl. : 42 m. N. W. Springfleld. Pılot Krob, St. Françoís co., Mo. : 21 m. S. S. E. Potosi; a mountain of iron, 1,500 feet high. See Missourr, p. 493.

Prlot Kroв, p. o., Todd con, Ky.: 158 m. S. W. by W. Frankfort.

Pilot Kков, p. o, Crawford co, $I l l,: 119$ m. E. S. E. Springfield.

Pliot PEAK, Utah Ter.: a lofty peak in the range of mountains between Great Salt Lake and the Humboldt River Mountains.

Pricknex, p. V., Livingston co, MFich. : 39 m. S. E. by E. Lansing.

Prickner, p. V., Warren con, Mo.: on the N. side of the Missouri, $51 \mathrm{~m}$. E. by N. Jefferson City.

Pinclinex, p. o., Williamson co., Tenn. : 24 m. S. by W. Nashville.

Pixcknerville, p. V., Tallapoosa co., Ala.: on the Hillabie Hatchie, a W. affluent of Tallapoosa $r_{0,52}$ m. N. N. E. Montgomery.

Pincknerville, p. ن., Gwinnett co., Ga.: on the 8. side of Chattahoochie r., $91 \mathrm{~m}$. N. W. Milledgeville.

Pinoknexpilie, p. v., and cap. Perry co., $I l l_{\text {. : }}$ on Big Beaucoup cr., a N. branch of Big Muddy r., $124 \mathrm{~m}$. S. by E. Springfield. It contains a court-house, jail, high-school, several stores, and 500 inhabitants.

Prackneyville, p. v., Union dist., $\mathcal{S}$. Car.: on the W. side of Broad $r_{\text {. }}$ near the mouth of Pacolet r., $66 \mathrm{~m}$. N. N.W. Columbia.

PrNe Bluff, p. v., and cap. Jefferson co., $A r k$ : on the right bank of Arkansas r., $36 \mathrm{~m}$. S. S. E. Litt]e Rock. It contains a court-house, jail, academy, and 460 inhabita 
ants. Corn and live-stock are sent down the $r$. from this point to a large amount, The "Arkansas Republican" (dem.) is published weekly.

Pine Bluff, p. o., Callaway co., Ky. : 206 m. W. S. W.

Frankfort.

Pine Bluff, p. O., Dane co., Wisc.

Pixe Bluff, p. o., Copiah co., Miss.: on a $\mathbf{S}$. braneh of Bayou Pierre, 32 m. S. W. Jackson,

Puxe Blefr, p. v., Pulaski co., MFo. : near the confiuence of Big Piney fork and Gasconade r., $46 \mathrm{~m}$. S. Jefferson City.

PINe Blufrs, p. 0., Red River cn., Tex.: on Red river, 296 m. N. N. E. Austin City.

PrNeburo; p. o., Marion co., Flor.: near the source of Oclawaha r., $187 \mathrm{~m}$. S. E. Tallahassee.

Pine Brook, p. v., Morris co., $N$. Jer. : on the N. side of Passate r., 48 m. N. E. by N. Trenton.

PrNe CreeK, p. o., Calhoun co, BFich, : on an affluent of the St. Joseph's, 58 m. S. W. Lansing.

Pine Creek, p. o, Tioga co, Penn.: 98 m. N. by W. Harrisburg.

Prne Crees, p. o., Ogie co., Ill.: on a W. affluent of Rock r., $158 \mathrm{~m}$. N. Springfield.

Peve Flat, p. o., Bossier parish, La.: $195 \mathrm{~m}$. N. W. Baton Rouge.

PINe Grove, p. o., St. Tammany par, La.: on the E. side of Tangipahoa r., $47 \mathrm{~m}$. E. Baton Rouge.

Pref Grove, p. o., Steuben co., N. Y.: $153 \mathrm{~m}$. W. by $\mathrm{S}$. Albany.

PrNe Grove, p. 0., Gallia co., Ohio: $82 \mathrm{~m}$. S. E. by S. Columbus.

Ptive Grove, t. and p. v., Sehuylkill co., Penn.: $31 \mathrm{~m}$. N. W. IIarrisburo. Drained by Swatara cr. and branches, which supply abundant water-power. Surface mountainous, and heavily timbered; soil best fitted for grazing. The $\mathbf{v}$. is on the cr., along which a navigable feeder of the Union Canal extends S. W. to its junction, and a branch railroad N. to the Mine Hill P. R. and the coal region. It contains a spacious basin for canal boats, 8 or 10 stores, and 612 inhabitants. A furnace of 1,200 tons capacity is $2 \mathrm{~m}$. distant, and another of 1,900 tons $6 \mathrm{~m}$. distant. In 1849, 78,299 tons, and in 1550, 62,809 tons of anthracite coal were shipped from this point. The capital invested in the coal mines in this $t$. is $\$ 27,000$; monthly wages paid, $\$ 2,024$; annual product, $\$ 3 \pi, 000$

Pine Grove, p. o., Clark county, $K y_{0}: 43$ m. E. S. E. Frankfort.

PINE GRove, p. o., Wetzel county, Virg. : 219 m. N. W. Pichmond.

Pine Grote MmLs, p. o., Centre co., Penn.: on a branch of Bald Eagle cr., 61 m. N.W. by W. Harrisburg. Near the mills, in Huntingdon county, is a furnace of 1,300 tons capacity.

Pras Hrul, p. o., Wileox county, Ala. : 53 m. W. S. W. Montgomery.

Pive Hrul, p, o., York co, Penn.

Prie HrL, p. v., Talbot eo., $G a$.: on Upatoi cr., and near the Muscogee R. R., 92 m. W. S. W. Milledgeville.

PLEE HILl, p. O., Washita par., La.: 149 m. N. N. W. Baton Pouge.

Prve Hilu, p. o., Ulster county, N. $Y .: 48$ m. S. W. Albany.

PINE HrL, p. $\nabla .$, Washington co., R. I.: $21 \mathrm{~m}$. S. W. Provideuce.

Prie Hilu, p. 0., Rusk county, Tex. : 212 m. N. E. by E. Austin City.

PINe Hook, p. V., Grant county, Wisc: 73 m. W. S. W. Madison.

Prse LAKE, o. o., Oakland county, Mich.: $62 \mathrm{~m}$. E. by S.

Lansing.

PiNe Land, p. 0., Meigs county, Tenn.: 115 m. E. S. E. Nashville.

Prive Level, p. o., Montgomery co., Ala. : near the source of Coloma cr., 26 m. \$. E. Montgomery.
Pine Lrck, p. o., Clark co., Ind.; on the N. fork of Silver cr., $83 \mathrm{~m}$. S. by E. Indianapolis.

Pine Log, p. o, Cass county, Ga: 132 m. N. W Milledgeville.

Prne Mradow, p. o., Litehfield co., Conn.

Pine Platw, p. 0, Montcalm con, Mich.: $39 \mathrm{~m}, \mathrm{~N} . \mathrm{N}$, W. Lansing.

Pine Platrs, $t$, and p. v, Duchess county, N. $Y_{:}: 44 \mathrm{~m}$. S. by E. Albany. Drained by Chicomico and Wappinger's creeks, the latter rising in a pond in this $t$. Surface an extensive plain, with high hills on the E. and W.; soil sandy or gravclly loam, and very fertile. A farming and grazing t., with various small manufactories. The v. contains bank, a half dozen stores, and 300 inhabitants. Pop. of t. 1,416.

Pine Platns, p. o., Ocean county, N. Jer.: 23 m. S. E. Trenton.

Pine Rrver, p. o., Marquette co., Wisc. : 52 m. N. N. E. Madison.

Piner's Cross Rosos, p. o., Kenton county, $K y_{0}: 53 \mathrm{~m}$

N. N. E. Frankfort

Ptne's Bridge, p. 0., Westchester county, $N$. $Y .: 91 \mathrm{~m}$ S. Albany.

Prne Streex, p. o., Elk county, Penn.: 108 m. N. W Harrisburg.

Pune Town, p. v., Cherokee co., Tex. : 192 m. E. N. E Austin City.

Pine Tree, p. o., Upshur co., Tex, : 236 m. N. E. Austin City.

Pine VALLEx, p. o, Chemung co., $N_{\text {. }} Y_{.: 157} \mathrm{~m}$. W. by S. Albany.

Pine Valley, p. o., Warren co., Penn.: 162 m. N. W. Harrisburg.

Prne Vrew, p. o., Fauquier co., Virg. : $76 \mathrm{~m} . \mathrm{N} . \mathrm{N}$. W. Richmond.

Pineville, p. v., Marengo co. Ala.: about $4 \mathrm{~m}$. F. of

Tombigee r., $103 \mathrm{~m}$. W. by S. Montgomery.

Pineville, p, 0., Gloncester co., N. Jer.: $41 \mathrm{~m}$. S. W. by

S. Trenton.

Pineville, p. o., Bossier parish, La.: 203 m. N. W. Baton Ronge.

Pineville, p. $\nabla .$, Marion co., $G a .: 105$ m. S. W. by W. Milledgeville.

Prneville, p. v., M'Donald county, Mo.: $176 \mathrm{~m}$. S. W Jefferson City.

Pineville, p. o., Smith county, Miss.: 41 m. E. S. E Jackson.

Pineville, p. V., Bucks county, Penn. : 97 miles E. Harristure.

Pinevilue, p. V., Charleston dist., $S$. Car.: about $6 \mathrm{~m} . \mathrm{S}$ f Santee r., 71 m. S. E. by E. Columbia.

Prine Woods, p. o., Madison co., $\pi l \cdot: 73 \mathrm{~m}$. S. by W Springfield.

Pinex, p. o., Johnson $\mathrm{co}_{*}, A r k$.: on a N. affluent of the Arkansas r., $76 \mathrm{~m}$. N. W. Little Rock.

Piney Creek, p. 0., Carroll co., Md.: on an affluent of Monocacy r. so called, $58 \mathrm{~m}$. N. W. Annapolis.

Piney Grove, p. 0., Sampson co., N. Car.: 54 m. S. S. E. Raleigh.

Pingree Grove, p. o., Kane co., $\Pi l .: 169$ m. N. N. E. Springfield.

Pink HiLL, p. o., Marshall co., Afiss. : 169 m. N. by E. Jackson.

Pink Hiul, p. 0., Lenoir co., $N_{\text {. }}$ Car.: 62 m. E. S. E. Raleigh.

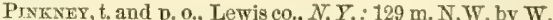
Albany. Drained by Deer and Sandy creeks. Surface mostly $\in$ veu; soil a fertile, sandy, or clayey loam. A fine grazing $t$, well timbered. Pop. 1,208.

Pinnellville, p. v., Jones co., Miss.: $77 \mathrm{~m}$. S. E. by E. Jackson.

PiN OAk, p. o, Dubuque county, I $\alpha .: 67 \mathrm{~m}, \mathrm{~N}, \mathrm{X}, \mathrm{F}$ Iowa City. 
Prituala, p. o., Montgomery co., $A l a$ • on Pintlala er., a

S. tributary of Alabama r., $12 \mathrm{~m}$. S. by W. Montgomery.

Pixtler's Conners, p. o., Ottawa county, Wich.: $73 \mathrm{~m}$.

W. by N. Lansing.

Piny, p. o., Clarion county, Penn.: 142 m. W. N. W. Harrisburg.

PINT Green, p. o., Onslow co., N. Car.: 89 m. S. E. Raleigh.

Pioneer, p. o., Greene county, 1ll. : 49 miles S. W. Springfield,

Pronerer, p. o., Williams county, ohio: $139 \mathrm{~m} . \mathrm{N} . \mathrm{W}$. Columbus.

Proneer Grove, p. v., Cedar co., Ia. : 22 m. N. E. by N. Iowa City.

Pioneer Mills, p. o., Cabarras county, $N$. Car. : $106 \mathrm{~m}$. W. by S. Raleigh.

Pipe Creek, p. 0., Madison co., Ind.: on a N. affluent of W. fork of White r., $36 \mathrm{~m}$. N. N. E. Indianapolis.

Prpersville, p. o, Bucks co., Penn.: on the S. side of Tohickon cr., $4 \mathrm{~m}$. W. of Delaware river, $92 \mathrm{~m}$. E. by $\mathrm{N}$. Harrisburg.

PIPE Stone, t. and p. O, Berrien county, Mich.: $107 \mathrm{~m}$. S. W. by W. Lansing. Drained by Pipestone cr. of the St. Joseph's. Surface rolling; soil sandy loam of great fertility. An excellent farming t., with superior grazing lands

Preta, p. v., Miami co., Ohio: on the right bank of Miami river, and on the line of the Miami Canal, $66 \mathrm{~m}$. W. by N. Columbus. The Columbus, Piqua, and Indiana R. R., and the Dayton and Michigan R. R. also intersect this point, the first running $\mathrm{E}$. and W., and the Iatter $\mathrm{N}$. and S. A considerable commerce necessarily centres here, and its prospective advance in manufuctures and trade is very encouraging. The waste water of the canal affords it good water-power, and steam-power is also used to a considerable extent. The consumption of coal in the $\mathrm{v}$. in 1850 was less than 4,000 bushels, but in 1851 at least 10,000 bushels were consumed, and the quantity must rapidly increase when the railroads connecting here are completed. This increase may be taken as an index to the increase of its manufactures. Piqua has also a large wholesale and retail trade with the adjacent country. It contains 10 or 12 churches of various denominations, about 600 dwellings, many of brick, and substantially built, and the streets are spacious and regularly laid out. The periodicals published here are the "P. Register" (whig), semi-weekly and weekly; the "Enquirer" (dem.), weekly, and the "Miami Commercial" (neutral). A branch of the State Bank is located here, capital $\$ 100,000$, and circulation in Nov., $1551, \$ 172,908$. $\mathrm{Pop}$, in $1840,1,481$, and in $1550,3,2 \pi 7$.

Prquea, p. O., Lancaster county, Penn. : 41 m. S. E. Harrisburg.

PiscataQda river, $N$. Hamp. : rises in Wakefield t., flows $\mathrm{S} . \mathrm{S}, \mathrm{E}_{*}$ and forms the boundary line between $N$. Iamp. and $M e$. Its entrance into the Alantic is by a broal colu ary forming one of the best harbors in the United States. Its upper portions, with its tributaries, are navigable for sloops.

Prscataquis county, Mre. Situate N. centrally, and contains 8,780 sq. m., comprising a large extent of country stretching to the Canada line. Drained by Piseataquis, Penobscot, Sebec, and Pleasant rivers, by which good water-power is supplied. Surface diversifled with numerous lakes and ponds, the largest of which are Moose Head, Pemadumeook, and Chesuncook. Soil fertile on the Pis cataquis, and is generally productive on the streams. It has some mountains, among which is liatihlin. Firms 1,779; manuf. 61 ; dwell. 2,559, and pop.-wh. 14,782, fr. col. 3-tolal 14,735. Capital: Dover.

Piscatacus river, Me.: a large W. branch of Penobsco river, rising in $\mathrm{S}$. W. part of Piscataquis co, and flows $\mathrm{E}$. by $\mathrm{N} .65 \mathrm{~m}$. to its junction with the Penobseot at Howland; it affords good water-power.

Prscataquog river, $N$. Iamp.: a W. branch of Merrimac 650 river, flowing through $\mathrm{N}$. part of Hillsboro' county, is a good mill stream.

Piscataway, p. v., Prince George's co, $M d .:$ on the $s$. side of Piscatway river, $7 \mathrm{~m}$. above its mouth, $33 \mathrm{~m}$. S. W Annapolis,

Piscola, p. o., Lowndes co., Ga.: near Withlacoochee river, $172 \mathrm{~m}$. $\mathrm{S}$, by W. Milledgeville.

Piseco lake, $N . Y_{\text {.: }}$ in Arietta t., Hamilton co., $6 \mathrm{~m}$. Jong. $2 \mathrm{~m}$. wide, abounding with superior trout and other fish-a noted resort for anglers. The surrounding region also abounds with game.

Pisgah, p. v., Cooper co., Mo. : 29 m. W. N. W. Jefferson Cily.

Pisgair, p. o., Butler co., Ohio: 94 m. W.S. W. Columbus,

Pismon's Ferrx, p. o., Kennebec co., Me.

Pitcairn, t. and p. o., St. Lawrence co., $N . Y_{.:} 127 \mathrm{~m}$ N. W. Albany. Drained by W. Branch of Oswegatchie $r$ Surface moderately uneven; soil clayey, and adapted to grass growing. Pop. 503.

PrTciner, to and p. v., Chenango co., N. Y.: $107 \mathrm{~m}$. W. Albany. Drained by Otselic r. and branches, on which are good mill-sites. Surface uneren, and somewhat broken; soil fertile loam. The $\mathrm{v}_{\mathrm{*}}$ is on the $\mathrm{r}_{\text {., }}$ and contains several stores and mills, and 300 inhabitants. Pop. of to 1,403 .

Pitcher Speivgs, p. v., Chenango co., N. Y. : $103 \mathrm{~m}$. W. Albany. Here are the sulphur springs, known as "Sylvan Springs," an academy, and about 40 houses.

Pitch Landing, p. o., Hertford co., $N$. Car.: on Wickason cr., a S. affluent of Chowan r., 101 m. E. N. E. Raleigh.

Pituar, p. o., Sehuylkill county, Penn。: 43 m. N. E. IIarrisburg.

Pixt county, N. Car. Situate toward the E., and contains 583 sq. m. Drained by Tar river, Tranter's creek, and Grindle's cr., its branches, and Swift's creek. Surface level ; soil fertile, and with cultivation highly productive. Staple articles of commerce, cotton and Indian corn. Farms 6S4; manuf. 41 ; dwell. 1,315, and pop.-wh. 6,664, fr. col. 100 , sl. 6,633-total 13,397. Capital: Greenville.

Pitrsboro', p. v., and cap. Chatham co., N. Car.: on Robinson's creek, a W. branch of Haw $r, 32 \mathrm{~m}$. W. by S. Raleigh. It contains a court-house, jail, academy, and 300 inhabitants.

Piтtsвoro', p. ซ., Hendrick's co., Ind. : 18 m. W. N. W. Indianapolis. Named from the preceding v., from which its founder emigrated.

Pittsiurg, p. v., Johnson co., Ark, : on the N. side of the Arkansas, $77 \mathrm{~m}$. N. W. by W. Little Rock.

Prtiseurg, p. v., Carroll co., Ind.: on the W. bank of the Tabash, $62 \mathrm{~m}$. N. N. W. Indianapolis. A dam for a feeder of the canal furnishes excellent water-power, which is used for a foundry, woolen factory, and several mills.

Pittsiong, p. Y., Van Buren co., Ia. : on the right bank of the Des Moines, at the mouth of Chequest or., $67 \mathrm{~m}$. S. S. W. Iowa City.

Pitssiugg, p. v., Hickory co., Mo.: on Pomme de Terre river, a $\mathrm{S}$. branch of the Osage, $76 \mathrm{~m} . \mathrm{S}$. W. Jefferson City.

Pitsinurg, p. city, port of entry, and cap. Alleghany co. Penn.: at the point formed by the confluence of the Alleghany and Monongahela, the great constituents of the Ohio r., and by railroad $252 \mathrm{~m}$. W. by N. Harrisburg. Lat. $40^{\circ} 32^{\prime}$ N., and long. $80^{\circ} 02^{\prime}$ W. Its suburb, Alleghany City, also occupying a point of land, is located to the north-west and on the opposite side of the Alleghany, and to all intents and purposes, having the same interests, is a part of Pittsburg. South Pittsburg and Birmingham are manufacturing villages on the opposite side of the Monongahela r.; and there are in the vicinity, in every direction within the suburban district, numerous other villages of considerable population and industrial character.

Pittsburg is built on a triangular plain, hemmed in on the rear by several hills. It is a compactly built and large eity, but has the dingy appearance which so well indicates the industrial occupations of the inhabitants. The city was 
originally laid out on the N. E. bank of the Monongahela, and planned after the model of Philadelphia, with streets running parallel with the rivers, and others erossing them at right angles. The streets on the Alleghany are laid out on a similar plan, and hence a short distance from the Alleghany the old and new streets meet in oblique directions, assimilating its appearance to that of the lower section of New Fork City. Both rivers are spanned by bridges, which with several steam ferries, connect the city with the suburbs. The Pennsylvania Canal crosses the river by an aqueduct.

The site of Pittsburg is a natural amphitheatre; the rivers flow in channels from 450 to 465 feet below the highest peaks of the neighboring hills. These hills, inclosing the city, are full of bituminous coal, which is easily mined, and affurds to the place the vast manufacturing facilities for which it is famed. The coal strata lie 300 feet above the alluvial plain, and the coal formation, as general in the Ohio valley, is horizontal. Along the base of these hills and some distance up their declivity, the eity expands itself, and on every side the eye rests upon a scene of rich and varied landscape.

Old Fort Du Quesne, so celebrated in the French and colonial wars, formerly occupied the site on which the city now stands. At the close of the Revolutionary War it was still but an insignificant village. In 1784, the ground, which belonged to the heirs of Penn, was laid out into town lois, and two years later the village contained about 100 dwellings. It was constituted the capital of Alleghany county in 1791. In 1796 , its population amounted to 1,395 .

Among the public buildings of Pittsburg, the Court-house is conspicuous. It is a handsome building of Græeco-Doric architecture, 165 feet long and 100 feet deep, and the height of the dome 148 feet from the ground. About $\$ 200,000$ were expended on its construction. The Roman Catholic Cathedral, on Grant's Hill, is also a noble edifice, and many of the other churches, between 70 and 80 in number, are in the best style of ecclesiastical building. It contains, besides, 4 large banking houses, several insurance offices, 3 markethouses, a well furmished museum, numerous large and splendid hotels, railroad depôts, ete. The Western University of Pennsylvania is located here, and numerous associations, which afford great conveniences to the inhabitants in literary and scientific pursuits.

As a manufacturing eity, Pittsburg is second in the State only to Philadelphia, and has, perhaps, no competitor in the branches of industry which are carried on in its workshops. It is the Birmingham of America. In 1850 it had 13 rolling-mills, with a capital of $\$ 5,000,000$, employing 2,500 hands, consuming 60,000 tons of pig metal, and produeing annually bar iron and nails to the value of $\$ 4,000,000 ; 30$ large foundries, with several smaller ones, with an aggregate capital of $\$ 2,000,000$ and 2,500 hands, using 20,000 tons of pig iron, and yielding articles valued at $\$ 2,000,000$ annually; 2 establishments for manufacturing locks, latches, coffee-mills, scales, and other iron casting, employing 500 hands and a capital of $\$ 250,000$, using 1,200 tons metal, and producing annually to the value of $\$ 3,000,000 ; 5$ large cotton factories, and several smaller ones-capital $\$ 1,500,000$, hands 1,500 , cotton consumed 15,000 bales, and products valued at upward of $\$ 1,500,000$ annually ; 8 flint-glass manufactories - eapital $\$ 300.000$, hands 500 , and producing various articles of glass, in the manufacture of which 150 tons lead and 200 tons pearl ash are used, to the value of $\$ 400,000$ annually; 7 phial furnaces and 11 window-glass factories-capital $\$ 250,000$, hands 600 , and annual products $\$ 600,000 ; 1$ sodaash factory, employing 75 hands, and producing annually 1.500 tons; 1 copper smelting house, producing 600 tons refined copper annually, valued at $\$ 3 \$ 0$ per ton; 1 copper rolling-mill, produeing annually 300 tons sheathing and brazier's copper ; 5 white lead factories-capital $\$ 150,000$, hands 60 , and producing 150,000 kegs annually, worth $\$ 200,000$. There are also a number of manufactories of the smaller sizes of iron, sevcral extensive manufactories of axes, hatchets, etc., and spring-steel, steel springs, axles, anvils, vices, mills, cross-eut and other saws, gun barrels, shovels, errades, firstes, hoes, cut tacks, brads, etc. The products of the manuface tures in the aggregate are valued at between $\$ 50,000,000$ and $\$ 60,000,000$ annually. There are consumed about $12,000,000$ bushels of coal annually, worth $\left.\$ 6^{\circ}\right) 0,(0 t 0)$, and an (rontal quantity is exported from the city; giving employment constantly to 4,000 hands.

As a trading mart, Pittsburg has many advantages. At the junction of two great rivers and at the hearl of the noble Ohio, it has aceess by water to the whole valley drained by the tributaries of the Mississippi. With the Atlantic sea-board it has connection by meins of the P'nnsylvania Canal and Railroad, over which an immense transit and internal commerce is carried on, and its connection with Lake Erie is provided for. Westward long lines of railroad bring it into juxtaposition with all the great cities in that direction, and open to it highways to and beyond the Mississippi. Its harbor is well suited for the river commerce. The "Orleans," the first steamer that plied on the western waters, was built here in 1811, since which perind the commerce of the city has steadily increased. In 1850 there were owned in Pittsburg 43,476 tons of shipping, of which 41,571 tons were navigated by steam. In 1951 its steam marine amounted to 47,911 tons. This is employed on the rivers in transporting passengers and goods to the various ports. Eighteen steamers and 4 schooners (3,238 tons) were built in 1850. These are floating palaces, the admiration of every one, and at any one time 30 or 40 of such may be seen at the wharves destined to various ports on the Ohio, Mississippi, and Missouri.

The retail trade of the city is also on a vast scale, the stores filled with the most splendid manufactures, articles of apparel, and all the luxuries of the table and household, are not surpassed by those of even the palaces of New York and Philadelphia. The amount of business transacted is immense and ever increasing. Pittsburg has also a large wholesale trade, and many western merchants make up their stocks at this point, instead of traveling to the great cities of the sea-board. There are four banks in the citycapital $\$ 2,418,000$.

Pittsburg is governed by a mayor, aldermen, and common council; its police is excellent, and crime and destitution less frequent than in most other large places. Perhaps this freedom from social evils may be attributed chiefly to the prosperity of the manufactures and trades. It has a well organized fire department, and numerous military companies, many of which are uniformed and well drilled. The streets, stores, and dwellings are lighted with gas, which is manufactured from bituminous coal, and water is supplied from the Alleghany river by means of machinery, and distributed through iron pipes. For civil purposes the eity is divided into nine wards. The value of taxable property in the city in 1851 amounted to $\$ 65,000,000$.

The means of education provided in the city are ample. In 1850 there were 36 public schools, and 10 others were being built: teachers, 71 -males 19 , and females 52 ; scholars, 5,141-males 2,5S3, and females 2,561; cost of instruction, $\$ 17,506$, of which $\$ 2,804$ was from the State school fund, and the remainder raised by taxation. These schools are conducted under the general law. There are also other academies, seminaries, grammar schools, ete., chiefly private establishments, at which large numbers of children are educated.

The periodical press of Pittsburg consists of 11 daily newspapers, 2 tri-weeklies, 17 weeklies, 1 semi-monthly, and 2 monthlies. The dailies are, the "P. Gazette" (whig), the "Morning Post" (dem.), the "Staats Zeitung" (whig), the "P. Courier" the "Tribune and Express" (indep.), the "Chronicle," the "Commercial Journal" (whig), the "Dispateh" (indep.), the "Transeript and Commercial Advertiser," the "P. American" (whig), and the "Daily News." 
The tri-weeklies are, the "P. Gazette" and "Commereial Journal," editions of the dailies of the same title; the weeklies are, the "P. Gazette," the "Saturday Post," the "Staats Zeitung." the "Commercial Journal," the "Dispateh," and the "P. American," editions of dailies, "Der Freiheits Freund," the "P. Mereury," the "Iron City" (1il.), the "American Protestant" (relig.), the "Ledger," the "Christian Herald" (Meth.), the "Saturday Visitor" (lit.), the "Presbyterian Adrocate," the "Preacher," the "P. Christian Advocate" (Meth.); the semi-monthly is the "Friend of Missions," and the monthlies are "Sibbet's Western Review" and the "Missionary."

The population of Pittsburg in 1810 was 4,768 ; in 1820, 7,248 ; in 1830, 12,568; in 1840, 21,115; and in $1850,46,601$. In these sums the population of the city proper is only stated. The city, including its metropolitan district, in 1850 contained 86,7\%1, and in January, 1853, 110,211 inhabitants.

Alleghany City, the principal suburb, of which a brief mention has been made in its alphabetical order, is in itself a considerable place. It enjoys the same facilities for manufactures, commerce, and internal trade as Pittsburg, but perhaps not in so advantageous a degree, and is occupied chiefly in the same pursuits. Here is assembled a population of 21,261 souls; in 1830 the eity eontained only 2,801 , and in $1840,10,089$ inhabitants, being an increase of 260.2 per cent., and the increase in the decade ending 1850 , was 110.7 per cent. Alleghany, indeed, has at the latter date the same population as Pittsburg had in 1840. The Western Penitentiary of Pennsylvania is located in Alleghany, and is a very expcnsive edifice. The Western Theological Seminary (Presb.) is also established here. It oceupies a commanding eminence, overlooking the surrounding country. The building is 150 feet long, the centre being 4 stories and the wings 3 stories high. There are about 30 churches in the eity, several of them large and elegant structures. The city has a considerable commereial and manufacturing interest. Hardware and cutlery, iron work of all kinds, machinery, cotton goods, and numerous other valuable manufactures are produced. The whole manufacturing capital of the place is nearly $\$ 4,000,000$, and goods to a great value are annually produced. It is divided into 4 wards, and is governed by a mayor and common council. In 1850 it had 27 common schools, with 42 teachers and 3,270 seholars-1,730 males, and 1,540 females.

Birmingham borough is another important suburh. It is on the $\mathrm{S}$. side of the Monongahela, about $1 \mathrm{~m}$. distant from the centre of Pittsburg. It has considerable manufactures of iron, glass, pottery, etc., and a population of 3,742 . A bridge and a ferry ernnect it with the city. South Pittsburg, adjoining it on the W., has 1,833 inhabitants, and Eus Birmimglum has 1.694 inhabitunts. Mfunchuster, on the W. of Alleghany City, has 1,7i5. Laterencerille, on the Alleghany, above Pittsburg, 1,746, and Sharpsburg, higher up on the opposite side the river, 1,229 inhubitants.

Pitssburg, t, and p. $0, \operatorname{Coos} c o, N$. Hump.: in the extreme N. of the State, $132 \mathrm{~m}$. N. by E. Concord. It comprises a large territory of rugged surface, densely wooded, and contains Conneclicut lake, and several head streams of the Connecticut. Pop. 425.

Pittsfield, p. ., and cap. Pike co., $\pi U_{n}: 64 \mathrm{~m}$. W. by S. Springfield. It lies on the high land between the Mississippi and the Illinois, about $11 \mathrm{~m}$. W. of the latter, and has a healthy location and a growing trade. It contains a court-house, jail, academy, and 15 or 20 stores. The "Pike County Free Press" (whig), and "The Cnion" (dem.), are issulul weretily.

Pittsfield, t. and p. v., Berkshire co., Ma 88. : $\mathbf{1 1 4}$ m. W Boston. Lat. N. $42026^{\prime} 55^{\prime \prime}$, long. T. $73015^{\prime} 36^{\prime \prime}$. Surface of $\mathrm{t}$ is elevated, and moderately uneven; soil fertile loam. Drained by Housatonic $r$. and the Pontoosuc, which unite near the $\mathrm{r}_{\mathrm{v}}$, and afford water-power. The $\mathrm{v}$. is pleasantly situated near the centre of the t. and is surrounded with 052 beautiful seenery. It is regularly laid out and handsomely built. At its centre is a handsome square, containing 4 acres, upon the sides of which are some of the prineipal buildings. There are four churches, 1 bank, capital $\$ 200,000$, and numerous factories. The Bérkshire Medical Institution, located here, was founded in 1823 . In 1850 it had 5 professors, 103 students, and 473 alumni. The Young Ladies' Institute is a very flourishing and popular seminary, it occupies 3 handsome buildings, and is surrounded with beautiful grounds. The Western R. R. passes through the v., $151 \mathrm{~m}$. from Boston, and $49 \mathrm{~m}$. from Albany. Here terminates the Housatonic R. R., from Bridgeport, $110 \mathrm{~m}$; and here commences the Pittsfield and North Adams R. R., $20 \mathrm{~m}$. long. Three newspapers are issued weekly - "Mass. Eagle" (whig), "P. Sun" (dem.), "Culturist and Gazette" (agric.) Pop. in $1840,3,747$; in $1850,5,872$.

PITtSField, t. and p. v., Somerset county, Mes: $37 \mathrm{~m}$. N. N. E. Augusta. Drained by Sebasticook r. and branches. Surface moderately uneven; soil fertile and well tilled. Pop. of t. 1,166.

Pittsfield, to and p. o., Washtenaw co., Mich. : $59 \mathrm{~m}$. S. E. Lansing. Drained by Mullet's cr. of Huron r. Surface undulating; soil deep loam, and very productive. A plank-road passes through to Ypsilanti, and the Michigan Central R. R. passes along the N. border. Pop. 1,232.

PitTSFLeid, t. and p. v., Merrimac con, N. Hamp.: $11 \mathrm{~m}$. E. N. E. Concord. Drained by Suncook r., which supplies water-power. Surface diversified. Catamount Mountain occupies the S.E. part; soil fertile. The v. contains a bank, an academy, and several manufactories. Population of t. 1,523.

Pitcsfietd, t. and p. 0. , Otsego co., $N . Y_{0}:$ on the E. side of Unadilla r., $82 \mathrm{~m}$. W. Albany. Drained by Wharton's creek, which with the river affords good water-power. Surface hilly; soil sandy loam, and in the valleys very fertile. An excellent farming and grazing $t$., with growing manufactures. Pop. 1,591.

Pittsfield, t, and p. o., Lorain county, Ohio: $95 \mathrm{~m}$ N. N. E. Columbus. Drained by the W. branch of Black river, which supplies water-power. The Toledo, Norwalk, and Cleveland R. R. passes on its N., and the Cleveland, Columbus, and Cincinnati R.R. on its S. border. Pup. 1,058, Pittsfield, p. v., Warren co., Penn.: on Broken Straw creek, a W. affluent of Alleghany r., $169 \mathrm{~m}$. N. W. Harrisburg. It is on the proposed route of the Sunbury and Erie Railroad.

Pittsfield, to and p. o, Rutland county, Verm.: $34 \mathrm{~m}$. S. by W. Montpelier. Drained by branches of White river. Surface mountainous; soil fit only for grazing, which is the chicf pursuit, Pop. 512.

PXTTSFORD, to, p. o., and sta, Hillsdale co., Mlich.: $66 \mathrm{~m}$. S. by E. Lansing. Drained by Tiffin's cr. and St. Joseph's, of the Maumee, which furnish water-power. Surface somewhat hilly ; soil admirably adapted to grain. The sta. is 23 miles W. of Adrian, on the Michigan Southern R. R. Population 1,223 .

PitTsford, to and p. v., Monroe co., N.Y.: 232 m.W. by N. Albany. Drained by branches of Irondequoit cr. Surface undulating; soil calcareous loam, and very productive of wheat. The Rochester and Syracuse $R . R$. and the Erie Canal cross the $t$, on both of which is the $v .10 \mathrm{~m}$. E. of Rochester. It contains 3 churches, 2 academies, several stores and warehouses, and about 800 inhabitants. Population of $\mathrm{t}, 2,061$

PrtTśord, t. and p. v., Rutland co, Verm. : $44 \mathrm{~m} . \mathrm{S}$. W Montpelier. Drained by branches of Otter $\mathrm{cr}$, which flows through and furnishes much water-power. Surface uneven, but not rugged; soil sandy or clayey loam, and very fertile. Wool-growing is a leading interest. Marble and iron ore are abundant. The v. contains several stores, and is $11 \mathrm{~m}$. N. of Rutland, on the Rutland and Burlington R. R. Pop. of t. 2,026.

Pitr's Grote, t. and p. o., Salem cn., N. Jer.: $47 \mathrm{~m}$. 
S. S. W. Trenton. Drained by Maurice r, and its branches, which move several mills. Surface level or undulating: soil sandy or gravelly loam, of ordinary fertility. It has some excellent timber land. Pop. 1,151. Upper Pitt's Grove was taken from it in 1846

PitT's Polvt, p. o., Bullitt eo., $k y_{.}: 52$ m. W. S. W. Frankfort.

Pitrston, t. and p. v., Kennebec county, Me.: on the E. side of Kennebec r., $7 \mathrm{~m}$. S. by E. Augusta. Surface pleasantly diversified; soil very productive. A superior farming and grazing t., with a sufficiency of water-power, abundance of timber, and a brisk river trade. The $\mathrm{v}$. is in the N. W., on the r. Pop. of t. 2,823.

Pittston Ferry, p. o., Luzerne county, Penn. : on the Susquehanna, at the mouth of Lackawannoc creek, $91 \mathrm{~m}$. N. E. by N. Harrisburg.

Pittstown, p.v., Hunterdon co., N. Jer. : $26 \mathrm{~m}$. N.W. by N. Trenton. It is on a W. affluent of the S: branch of Raritan river, which moves several mills in the vicinity.

Pitrstown, t. and p. v., Rensselaer co., N.Y.: 21 m. N. E. Albany. Drained by Tomhenick cr., and in the $\mathrm{N}$. by Honsic river, which furnish fine water-power. Surface uneven, and in parts broken; soil loam, mixed with sand or gravel, and productive under good cultivation. It has numerous manufactories of cotton and woolen goods, lumber, etc. The Troy and Rutland R. R., and Troy and Boston $R$. R. cross the N. part; on the latter is $\mathrm{P}$. sta., $14 \mathrm{~m}$, from Troy. Pop. of t. 3,732 .

Pitisyldania county, Firg. Situate S., and contains 866 sq. $m$. Drained by Dan and Banister rivers, and branches of Staunton r. Surface rolling; soil fertile, and generally productive. Chief products, wheat, Indian corn, and tobacco. Farms 1,524; manuf. 109 ; dwell. 2,804, and pop.wh. 15,263, fr. col. 735, sl. 12,798-total 28,796. Capital: Competition.

Pittsylfanta Court-House, p. v., and cap. Pittsylvania co., Firg.: on a N. branch of Banister $x_{.}, 112 \mathrm{~m}$. W. S. W. Pichmond. It contains a court-house and jail, an academy, several stores and workshops, and 350 inhabitants. The village is called also Competition.

Placer county, Calif. Situate E. middle, and contains 1,600 sq. m. Drained by American r. and its forks. Surface mountainous, with considerable valleys. Fremont's lake lies on its E, border. Mining is the chief business, Numerous races, flumes, and canals have been constructed, costing nearly $\$ 2,000,000$. Capital in mines, $\$ 1,427,567$, and in other industries and trade about $\$ 600,000$. Pop. in 1852 -wh. 6,945 , negroes 80 , mulattoes 9 , Indians 730 , Chinamen 3,019-total 10,783; Europeans 634. Capital: Auburn.

Placerville, p.v., and cap. El Dorado co., Calif.: $113 \mathrm{~m}$. N. E. by E. San Francisco, 91 m. E. N. E. Vallejo. Its site is uneven, and is chiefly a mining settlement. It is one of the oldest mining towns in the State, and in 1853 is pretty well worked out, and consequently there is not as much doing as formerly. Pop. varies from 2 to 4,000 . The houses are generally of clapboards. Supplies are obtained from Sacramento. The "El Dorado News" was published weekly in 1852

PlatN, t. and p. o., Wayne county, Ohio: $71 \mathrm{~m}$. N. N. E. Columbus. Drained by Muddy fork and Killbuck er. of Walhonding $r_{\text {e, }}$ which furnish numerous mill privileges, Surface varied; soil fertile and well tilled. A superior farming to, containing several manufacturing villages. The Ohio and Pennsylvania R. R. passes through it. Pop. 2,375.

Plan, p. o., Greenville district, S. Car.: $97 \mathrm{~m} . \mathrm{N} . \mathrm{W}$. Columbia.

Plamfield, p. o., Bates county, Mo.: 124 m. W. S. W. Jefferson City.

Planfeield, to. p. v., and sta., Windham co., Conn.: on E. side of Quinnebaug r., $39 \mathrm{~m}$. F. by S. Hartford. Drained by Moosup r., which affords good water-power. Surface mostly even; soil rich sandy loam. A superior farming $t$, conlaining various manufactories. The Norwich and Wor- cester R. R. crosses the W. part, on which is the sta., $16 \mathrm{~m}$. N. of Norwich. The Hartford, Providence, and Fishkill R. P. also crosses it. The $\mathrm{v}$. occupies high ground, and contains a flourishing academy, founded in 1783. Popu. lation of t. 2,730

Platnfield, p. vo, Will co, $I l l_{0}:$ on a W. affluent of Des Plaines r., $149 \mathrm{~m} . \mathrm{N}$. E. by N. Springfield. The ereck af. fords good water-power, which is used to turn several flouring and saw mills. The $v$. contains a high school, several stores, and about 600 inhabitants.

Plannfield, p. v. and sta., Hendricks co., Ind.: on White Lick cr. and the Terre Haute and Richmond R. R., $14 \mathrm{~m}$. W. by S. Indianapolis, A plank-road also leads to Indianapolis.

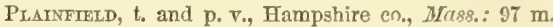
W. by N. Boston. Drained by heads of Westfield $r_{\text {. }}$, which afford water-power. Surface elevated and mountainous; soil fertile in the valleys and generally good pasturage. Many small manufactories are operated. Pop. of $t .814$.

Plainfield, p. v., Livingston co., Afich. : 34 m. E. S. E. Lansing.

Plainfield, t. and p. v., Sullivan co., $N$. Hamp.: on the Connecticut, $45 \mathrm{~m} . \mathrm{N}$. W. Concord. Surface moderately uneven; soil fertile. Large tracts of meadow border the river and its affluents. A bridge crosses the river. The Queechy Falls are opposite this town. At Meriden village, in the E., is Kimball Union Academy, a large and highly popular institution, incorporated in 1813. Pop. of t. 1,392.

Platnfield, t. and p. v., Essex county, N. Jer.: $32 \mathrm{~m}$. N. E. by N. Trenton. Drained by Green Brook, which forms its W. boundary, and E. by Robinson's branch of Rahway r. Surface mostly even; soil clayey and fertile. The New Jersey Central R. R. passes through the W. part, on which and Green Brook is the v., $28 \mathrm{~m}$. S. T. New York. It contains an academy, several mills and factories, and. about 1,000 inhabitants. The "P. Gazette" and "P. Union" (whig) are published here weekly. Pop. of t. 2,446. Set off from Westield in 1847.

Platnfield, t. and p. v., Otsego co., N. $Y$.: on the E. side of Unadilla r. $73 \mathrm{~m} . \mathrm{W}$. by N. Albany. Surface undulating, and in parts broken; soil sandy and calcareous loam, and very fertile. Farming and grazing engross attention. Population 1,449

Plainfieid, p. v., Cumberland co., Penn. : on the S. side of Conedogwinit er., $21 \mathrm{~m}$. W. by S. Harrisburg.

Plainfeleld, p. v., Coshocton co., Otvio: on Wills cr., an E. branch of the Muskingum, $65 \mathrm{~m}$. E. by N. Columbus.

Platnferd, t. and p. v., Washington co., Term.: $9 \mathrm{~m}$. E. Montpelier. Drained by Onion $r$., which affords waterpower. Surface rough; soil good. It contains a noted mineral spring, The village is on the river, where gre several mills. Pop. of t. 808.

Ptatn Grove, p. o, Laurence county, Penn.: $179 \mathrm{~m}$. W. N. W. Harrisburg.

Platnsboro', p. v., Middlesex county, N. Jer.: 12 miles N. E. by N. Trenton.

Plaiss of Dura, p. o., Sumter co., Ga. : 102 m. S. TW. Milledgeville.

Plainsville, p. v., Luzerne co., Penn. : on Susquehanna r., $91 \mathrm{~m}$. N. E. by N. Harrisburg.

Plain View, p. 0., Macoupin co., Ill.: 46 m. S. S. W. Springfield.

PlatN Vrew, p. o., King and Queen co., Firg.: $28 \mathrm{~m}$. N. E. Richmond.

Plainville, p. v., Hartford co., Conn.: 14 m. W. S. W. Hartford. It has a brisk trade, and contains several furnaces and factories. The Hartford, Providence, and Fishkill $R$. R. here intersects the New Haven and Northampton (or Canal) R. R., $27 \mathrm{~m} . \mathrm{N}$. of New Haven.

Plainville, p. v., Onondaga $\mathrm{c}_{0}, Y_{*}, Y_{0}:$ about $1 \mathrm{~m}$. W. of Seneca r. and $2 \mathrm{~m}$. E. of Cross lake, $13 \mathrm{~s} \mathrm{~m}$. W. by $\mathrm{N}$. Albany.

Plaivville, p. v. and sta., Hamilton $\mathrm{co}$, Ohio: on the 
Littie Miami R. R., $10 \mathrm{~m}$. from Cincinnati, $92 \mathrm{~m} . \mathrm{S} . \mathrm{W}$. Columbus.

Plainweli, p. o., Allegan co., Mich.: 61 m. W. S. W. Lansing.

Platstow, t., p. o., and sta., Rockingham co., N. Hamp.:

87 m. S. E. Concord. Surface uneven; soil very fertile, a

black loam mixed with clay and gravel. The Boston and

Maine R. R. crosses the $t_{\text {, }}$, on which is the sta., $12 \mathrm{~m}$. $\mathrm{s}$. W. Exeter. Pop. 748.

Plank Road, p. o., Onondaga co., N. Y.: 127 m.W. by N. Albany.

PlaNk Road, p. o., Wayne co., Mrich.: 62 m. E. S. E. Lansing. Formerly LIVoxiA.

Planter's, p. o., Attala co., Miss.: $72 \mathrm{~m}$. N. E. by N. Jackson.

Plavter's, p. o., Philips co., Ark. : $9 \mathrm{~m}$. W. of the Mississippi, 86 m. E. by S. Little Rock.

Planter's Hall, p. o., Breckenridge county, Ky.: on Rough er., $97 \mathrm{~m}$. W. S. W. Frankfort.

Planter's Stand, p. o., Madison county, Ga.: $76 \mathrm{~m}$. N. Milledgeville.

Plantersyille, p. v., Perry co., Ala.; on Mulberry cr., a N. affluent of the Albama, $43 \mathrm{~m}$. W. N. W. Montgomery.

Plantsville, sta., New Haven co., Conn.: $6 \mathrm{~m}$. E。 of

New Haven, on the New Haven and New London R. R.

Plaquearrixe parish, La. Situate S. E., and contains 967 sq. m. It is well watered by the Mississippi r., which flows through it from N. to S., forming the delta in its S. portion. Surfuce in general is low, particularly in the $\mathrm{S}$., where it is subject to inundation from the Gulf of Mexico; the land in most parts being not more than 10 or 12 feet above the Gulf level; soil indifferent, but on the banks of the river are some fertile tracts, producing large quantities of Indian corn, rice, and sugar, which form the chief articles of commeree. The coast is indented with numerous bays, the prineipal of which are West, East, Ronde, Garden Island, and Black bays. It also contains some lakes. Farms 205; manuf. 0 ; dwell. 61 , and pop.-wh. 2,221 , fr. col. 390 , sl. 4,779-total 7,390. Capital: Fort Jackson.

Plaquenise, p. v., Iberville par., $L a_{0}$ : on the right bank of the Mississippi, 28 m., by the river, below Baton Rouge. It has a fine situation, is neatly built, and earries on a large frade with the rich plantations that lie back of it, and ships great quantitics of cotton here. It was the former capital of the parish, and contains about 500 inhabitants.

Platentse harou, La.: an onthet of the Mississippir., $117 \mathrm{~m}$. above New Orleans. The waters of the Mississippi river only flow throurh it when thit river is at its extreme height.

Plaquemine Brulee, p. 0., St. Landry par., La.: $67 \mathrm{~m}$. W. Batun Rouge.

Platea, p. 0., Erie county, Penn.: 205 miles N. W. IIarristurg.

Prato, p. v., Cattaraugus co., N. $\boldsymbol{Y}_{.: 2} 246 \mathrm{~m}$. W. by S. Albany.

Plato, p. o., Lorain county, Ohio: $102 \mathrm{~m}$. N. by E. Columisus.

Plato. p. v., Iroquois co., Ill.: on the W. side of Iroquois r., 121 m. N. F. lw E. Springfield

Platte county, Mo. Situate W. toward the N., and contains 393 sq. m. Drnined by Platte r. and other tributaries of the Missouri, which forms its S. and W. boundary. Surface lewe in seneral, in the WV. it rises, and lerminates in high bluffs on the Mississippi; soil fertile, well adapted to grain and grazing. It has some gnod timber land. Farms 1,651 ; manuf. 64 ; dwell. 2,490 , and pop.-wh. 13,997 , fr. col.

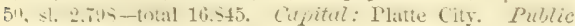

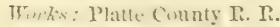

Platte river, $\left.N^{3}\right\} r$. Ter. See description of Nebraska $r$, in Nebrasea, p. 526.

Platte (ity, p. v., and enp. Platte co., Yo, : on Platte river, $1 \mathrm{~S} \mathrm{~m}$. above its entrance into the Missouri. $14 \mathrm{~s} \mathrm{~m}$. IF. X. T. Tefferson City. It contains a court-house, jail, $6 \$ 4$ academy, several stores and manufactories, and 500 inhabitants.

Platterite, t. and p. v., Ulster en, $N_{i} Y_{*} ; 69 \mathrm{~m}$. S. by W. Albany. Drained E. by Old Man's kill, and W. by branches of Wallkill. Surface uneven: soil loam, mixed with gravel and clay. A grazing t., well wooded. The $\mathrm{v}$. is $5 \mathrm{~m}$. W. of the Hudson, and contains several stores, Pop, of t. 1,998 .

Platte River, p. o., Buchanan co., Mo : on the r. of that name, at the mouth of Castile creek, $147 \mathrm{~m}$. W. N. W. Jefferson City.

Plattertlle, to and p. v., Grant co., Wisc.: $62 \mathrm{~m}$. W. S. W. Madison. Drained by Little Platte r. Surface uneven, and soil of moderate fertility. It is rich in yeins of lead and copper ores, which are extensively and profitably wrought. The $\mathrm{v}_{\text {, }}$ on a branch of Little Platte, was incorporated in 1841, and contains an academy, printing-office, a number of large stores, and 800 inhabitants.

Platisborg, p. $\mathrm{V}_{\text {, }}$, and cap. Clinton county, Mo.: on Smith's fork of Platte river, $137 \mathrm{~m}$. N. W. by W. Jefferson City. It contains a court-house, jail, U. S. land office, and 450 inhabitants.

Plattsburg, t., p. v., port, and exp. Clinton eo., $N$. Y. : on W. shore of Lake Champlain, at the head of Cumberland bay, and on both sides of Saranac river, $147 \mathrm{~m} . \mathrm{N}$. Albany. Lat. N. $44^{\circ} 42^{\prime}$; long. W. $73^{\circ} 26^{\prime}$. The surface of the town slopes toward the lake; soil clay loam, and very productive. Drained by Saranae river and Salmon creek. Black marble of excellent quality is quarried in the $t$. At the $v$. the Saranac descends by a succession of falls about 40 feet, thus affording very great water-power, which is used by numerous factories of cotton and woolen goods, tanneries, and by saw, grist, fulling, marble, and flouring mills, etc. The $v$. contains the $\mathrm{co}$. buildings, 4 churches, an incorporated lyceum and academy. Two newspapers are pullished weekly, "P. Republican" (dem.), "Clinton County Whig"-the "Northern Lancet" (med.), is issued monthly. Here commences the Plattsburg and Montreal R. R., $62 \mathrm{~m}$. in length, which is an important avenue of trade. The Plattsburg and Whitehall $\mathrm{R} . \mathrm{R}$. is in ennstruetion. Plattsburg is renowned as the scene of a most severe battle during the late war with Great Britain, on Sept. 11, 1814, in which the Americans, under Gen. Macomb, achieved a signal victory. At the same time, in the bay, befire the $\mathrm{v}_{\text {., a }}$ great naval victory was won under Com. M.Donongh. A little S. of the village is P. Barracks, an U. S. Military Post. Pop. of t. 5,61s.

Plattrille, p. $v_{\text {. }}$ Kendall co., $M$ : : 143 m. N. N. E. Springfield.

Pleasant, p. 0., Switzerland co., Ind.: 78 m. S. E. by S. Indianapolis.

Pleasant, p. 0., Kent county, Mich.: $53 \mathrm{~m}$. W. N. W. Lansing.

Plessayt, t, and po o. Putnam co, Oho: $86 \mathrm{~m} . \mathrm{N}$. W. Columbus. Pop. 714.

Plifasart Brook, p. o., Otsego county, N. Y.: $58 \mathrm{~m}$. W. Albany.

Pleasant Creek, p. o., Taylor co., Virg. : 189 m. N. W. Richmond.

Pleasant Dale, p. O., Hampshire co., Fïg.: $147 \mathrm{~m}$. X. Y. W. Richmonil.

Pleasant Exchayge, p. o., Henderson co., Tenn.: $84 \mathrm{~m}$. W. by S. Nashville.

Pleasaxt Flat, p. o., Mason co, Firg.: 258 m. W. N. W. Richmond.

Pleasait Gap, p. 0., Vernon co, Mro.: $111 \mathrm{~m}$. W. by S. Jefferson City.

Pleasaxt Gap, p. o., Centre eo., Penn. : 66 m. N. W. Harrisburg.

Plfisaxt Gap, p. o. Cherokee co., Ala.: 133 m. N. by E. Nontgomery.

Plessant Grefex, p. n., Conper co., Mfo, : about $3 \mathrm{~m} . \mathrm{F}$ of La Mine r., $45 \mathrm{~m}$. W. N. W. Jefferson City. 
Pteasayt Grove, p. o., Des Moines con, Ia. : 49 m. S. S. E. Iowa City.

Pleasant Grote, p. o., Pickens co., Ala. : about $3 \mathrm{~m}$. W. Sipsey r., 106 m. W. N. W. Montgomery.

Pleasant Grove, p. o., Jasper county, Ind.: 94 m. N. W. by N. Indianapolis.

Pleasart Grove, p. o, Effingham county, Ga.: $127 \mathrm{~m}$.

E. S. E. Milledgeville,

Pleasant Grove, p. o., Ohio co., Ky. : 116 m. W. S. W. Frankitiort.

Pleasant Grove, p. o, Clermont co., Otio: $88 \mathrm{~m}$. S. W. Columbus.

Pleasant Grove, p. v., Morris co., N. Jer.: on Schooley's mt., $37 \mathrm{~m}$. N. by W. Trenton.

Pleasant Grove, p. o., Alamance co., $N$. Car,: 46 m. N. W. Raleigh.

Pleasant Grove, p. v., Macoupin co., $M l$. : near the line of the Chicago and Mississippi R. R., $25 \mathrm{~m} . \mathrm{S}$. by W Springfield.

Pleasant Grove, p. o., Lancaster county, Penn. : 49 m. E. by S. Harrisburg.

Pleasaxt Grove, p. v., Alleghany co., MLd.: $5 \mathrm{~m}$. E. of Cumberland, 123 m. W. N. W. Annapolis. It contains a manufactory of wood types, proof presses, etc, and 100 inhabitants.

Pleasant Grove, p. on Greenville dist., S. Car.: about $3 \mathrm{~m}$. E. of Ennoree r., $101 \mathrm{~m}$. N. W. Columbia.

Pleasant Grove, p. o., Maury co., Tenn. : 37 m. S. S. W. Nashville.

Pleasant Grove, p. o, Kenozha county, Wisc.: $7 \mathrm{~S} \mathrm{~m}$. E. S. E. Madison.

Preasant Grove, p. o., De Suto par, La.: $182 \mathrm{~m}$ N. W. by W. Baton Rouge.

Pleasant Grove, p. o., Lunenburg co., Firg.: on $\mathrm{N}$.

Neherrin r., $61 \mathrm{~m}$. 8. W. by W. Richmond.

Pleasant Grove Milis, p. o., Fleming co., $\bar{k} y .: 67 \mathrm{~m}$

E. by N. Frankfort

Pleasant Hilk, p. 0., Dallas co., Ale. : 39 m. W. S. W. Montgomery.

Pleasant Hill, p. o., Franklin co., Ark. : $3 \mathrm{~m}$. N. of the Arkansas, $107 \mathrm{~m}$. N. W. by W. Little Rock.

Pleasant Hill, p. o., Neweastle county, Del. : 85 m. N. Dover.

Pleasant Hill, p. v., Talbot co., Ga. : about $4 \mathrm{~m}$. W. of Flint r., $81 \mathrm{~m}$. W. by S. Milledgeville.

Pleasañ Hrli, p. v., Pike co, $I l$. : on the bluffs about $4 \mathrm{~m}$. E. of Snyeartee slough, $6 \mathrm{~S} \mathrm{~m}$. W. S. W. Springfield.

Pleasant Hint, p. v., Montgomery county, Ind.: $54 \mathrm{~m}$.

N. W. by W. Indianapolis.

Pleasant Hilu, p. o., Lane co., Oreg. Ter.

Pleasant Hill, p. o., Cass co., Mo.: 109 m. W. by N. Jefferson City.

Pleasaxt Frut, p. o., Northampton co., $N$. Car.: near the State line, $79 \mathrm{~m}$. N. E. Raleigh.

Pleasdnt Hril, p. 0., De Soto county, Miss.: $164 \mathrm{~m} . \mathrm{N}$. Jackson.

Plensart Hril, p. o., Miami county, Ohio: $69 \mathrm{~m}$. W. Columbus.

Pleasant Hill, p. o., Lancaster distriet, S. Car. : $49 \mathrm{~m}$. N. N. E. Culumbia.

Pleasant Hilu, p. o., De Soto parish, La.: $187 \mathrm{~m} . \mathrm{N} . \mathrm{W}$. Baton Pouge.

Pleasant Hrul, p. o, Fayette con, Virg.: 159 m. W. by N. Pichmond.

Pleasant Hitu, sta., Greenville co., Virg.: $12 \mathrm{~m}$. N. of Weldon, on the Petersburg R. P.

Pleasant Hrut, p. 0, Hopkins county, Tex.: $245 \mathrm{~m}$. N. E. by N. Austin City.

Pueasant lake, N. $Y_{.}:$in Lake Pleasant t., Hamilton co., $3 \mathrm{~m}$. long, 1 to $1 \frac{1}{3} \mathrm{~m}$. wide, abounding with fine fish, and of much resort by amateurs.

Pleasant Lane, p. o., Edgefield district, $S$. Car. : $58 \mathrm{~m}$ W. s. W. Colurnbia.
Pleasant Mrlus, p. v., Adams co, Ind.: on St. Mary's r., $94 \mathrm{~m} . \mathrm{N}$. E. Indianapolis. A plank-road follows the $\mathrm{I}$.

N. W. to Fort Wayne.

Pleasant Mount, p. o, Panola county, Miss.: $142 \mathrm{~m} . \mathrm{N}$, Jackson.

Pleasart Mount, p. O, Miller county, Mo.: $28 \mathrm{~m}$. \$. W, Jefferson City:

Pleasant Mount, p. v., Wayne co.j Penn.: on a N. branch of Lackawaxen $\mathrm{r}, 122 \mathrm{~m}$. N. E. by $\mathrm{N}$. Harrisburg.

Pleasant Oaks, p. on, Brunswick county, Virg.: 58 m. S. by W. Richmond.

Pleasant OAks, p. 0., Mecklenburg co., N. Car.: $118 \mathrm{~m}$. W. S. W. Raleigh.

Pleasanton, p. v., Athens county, Ohio: $68 \mathrm{~m}$. S. E. Columbus.

Pleasanton, p.v., Itawamba co, Miss.: 173 m. N. E. by N. Jackson.

Pleabant Park, p. o., Carroll county, Mo. : $82 \mathrm{~m} . \mathrm{N}$. W. Jefferson City.

Pleasant Plant, p. o., Jefferson co., Ia. : $39 \mathrm{~m}$. S. S. W Iowa City.

Pleasant Plain, p. o., Clermont co., Ohio: Să m. S. W Columbus.

Pleasant Platis, p. o, Independence co., Ark.: 61 m. N. E. by N. Little Roek.

Pleasart Plains, p. 0., Sangamon co., $\pi l$

Pleasant Planis, p. 0., Lincoln county, Tenn.: $71 \mathrm{~m}$. S. by E. Nashville.

Pleasant Planss, p. O., Scott co., Mo. : on the N. point of the tongue of land separating lakes St. Mary and St. John, 172 m. S. E. by E. Jefferson City.

Pleasant Plans, p. 0., Duchess co., N. $Y .: 50 \mathrm{~m} . \mathrm{S}$. Albany.

Pleasant Prains, p. o., Cumberland co., N. Car.: $51 \mathrm{~m}$ S. S. W. Raleigh.

Pliasant Pratrie, p. O., Greene county, Mo.: $95 \mathrm{~m}$ S. S. W. Jefferson City.

Pleasant Retreat, p. o., Lumpkin co., Ga.: $121 \mathrm{~m}$. N. N.W. Milledgeville.

Pleasant Retreat, p. o., Scotland co, Mo.: $131 \mathrm{~m} . \mathrm{N}$ Jefferson City.

Pleabant Ridge, p. 0., Greene co., Ala.: about $3 \mathrm{~m}$. S. of Sipsey r., 112 m. W. N. W. Montgomery.

Pleasant Ridge, p. o., Tippah co., Miss. : 158 m. N. N. E。 Jackson.

Pueasant Ridge, p. o., Greene county, Ind.: 6S m. S.W. Indianapolis.

Pueasant Rtdege, p. 0, Hot Springs con, Ark. : $46 \mathrm{~m}$ S. W. by S. Little Rock.

Pleasant Ritdge, p. o. Hamilton county, O7io: $97 \mathrm{~m}$. S. W. by W. Columbus.

Pleasant Run, p. o., Hamilton county, Ohio: $95 \mathrm{~m}$ S.W. by W. Columbus.

Pueasant Run, p. o, Dallas co., Tex.: on a W. branch of Trinity r. so called, $173 \mathrm{~m}$. N. N. E. Austin City.

Pleasant Shade, p. 0., Smith co., Tenn. : $47 \mathrm{~m}$. E. by N. Nashrille.

Plafasant Shade, p. V., Perry co, IZl : on the W. side of Little Muddy cr., a N. branch of Big: Muddy r., $124 \mathrm{~m}$ S. by E. Springfield.

Pleasant Stre, p. o. Franklin county, Ala.: $162 \mathrm{~m}$ N. W. by N. Montgomery.

Pleasant Spring, p. o. Howard county, In $\bar{d}_{0}: 47 \mathrm{~m} . \mathrm{N}$. Indianapolis.

Pleasant Unitr, p. v., Westmoreland co, Penn. : on the W. side of Chestnut Ridge, $131 \mathrm{~m}$. W. Harrisburg.

Pleasant Vare, p. v., Pike co, Ill: on the bluffs, about $5 \mathrm{~m}$. E. of the Mississippi, $7 \mathrm{~S} \mathrm{~m}$. W. by S. Springfield. On Key's cr., near the v., is a salt spring, 20 foet in diameter, forming a pond from which salt is made, but not to a rery large amount.

Pleasant Vallex, p. 0., Chittenden co., Verm.: 37 m. N. W. Montpelier. 
Plgagant Vallex, p. o., Washington co., Ala. : about $3 \mathrm{~m}$. W. of Tombigbee r., $115 \mathrm{~m}$. W. S. W. Montgomery.

Pleasant Valier, p. v., Litehfield county, Conn.: $19 \mathrm{~m}$. W. N. W. Hartford.

Pleasant Vallex, p. o., Yell co., Ark.: on the S. side of Magazine Mountain, 69 m. W. N. W. Little Rock.

Pleasant Vallex, p. o., Seott co., $I a_{0}$ : about $2 \mathrm{~m}$. W. of the Mississippi, $56 \mathrm{~m}$. E. by S. Iowa City.

Pleasant Vallex, p. v., Jo Daviess co., $7 l$. : on the W. side of Plum r., $114 \mathrm{~m}$. N. by W. Springfield. The Galena and Chicago Union R. R. passes a few miles N. of it.

Pleasant Valley, p. o., Sussex co., N. Jer.: 51 m. N. Trenton.

Pleasant Valiex, p. o., Morgan county, Ohio: $62 \mathrm{~m}$. E. B. E. Columbus.

Pleasant Vallex, sta., Muskingum co., Ohio: $7 \mathrm{~m}$. W. of Zanesville, on the Central Ohio R. R.

Pleasant Vallex, t. and p. V., Duchess co., N. Y.: $62 \mathrm{~m}$. S. Albany. Drained by Wappinger's creek and branches, which furnish many water privileges. Surface various, in parts much broken; soil sandy or gravelly loam, and mostly fertile under cultivation. A grazing t, with valuable manufactures of flour, cotton goods, etc. The $\mathrm{v}$. is on the cr., and contains a cotton factory and other mills, and about 700 inhabitants. Pop. of t. 2,226.

Pleasant Vallex, p. 0., Bucks co., Penn.: on Durham creek, 86 m. E. by N. Harrisburg.

Pleasant Vallex, p. o., Lancaster dist., S. Car.: on an E. branch of Catawba r., $74 \mathrm{~m}$. N. Columbia.

Pleabanx Vallex, p. o., Wayne co., Tenn, : 87 m. S. W. Nashrille.

Pleasant Vallex, p. o., Wright co., Mo.: $83 \mathrm{~m}$. S. by W. Jefferson City.

Pleasari Valley, p. o., Fairfax county, Virg. : 92 m. N. Richmond.

Pleasant Valtex Mills, p. 0., Nicholas co., Ky.: 55 m. E. N. E. Frankfort.

Pleasant View, p. on, Juniata county, Penn。: 34 m. W. N. W. Harrisburg.

Pleasant Vinw, p. V., Shelby co, Ind.: on the W. side of Sugar cr., 14 m. S.E. Indianapolis. A plank-road passes through to Indianapolis.

Pueasant View, p. o, Jackson county, Firg.: $243 \mathrm{~m}$. W. N. W. Richmond.

Pleasant Vrew, p. 0., Schuyler co., Ill.: 58 m. W. N. W. Springfield.

Pleasant VIew, p. 0., Darlington dist., S. Car.: $59 \mathrm{~m}$. E. by N. Columbia.

Pleasaxtrilue, p. v. and sta., Testchester co., $N$. $Y$. on the E. side of Saw Mill r., $97 \mathrm{~m}$. S. Albany. The sta. is $34 \mathrm{~m}$. N. of New York, on the Harlem R. R.

Pleasantrule, p. v., Roekingham co., N. Car.: $91 \mathrm{~m}$.

N. W. by W. Raleigh.

Pleasantrulle, p. v., Fairfield co., Ohio: 27 m. E. S. E. Colmmbus.

Pleasantrille, p. v., Marion co., $T a$ : about $5 \mathrm{~m}$. S. of the Des Moines, $90 \mathrm{~m}$. W. by S. Iowa City.

Pleasaxtrille, p. V., Bucks county, Penn.: 89 m. E. Harrisburg.

Pleasantrule, p. v., Harford co., Md. : on the E. side of Little Gunpowder Falls, $37 \mathrm{~m}$. N. by E. Annapolis. It contains several mills.

Pleasantrille, p. v., Hickman co., Tenn.: on Cane er., an E. branch of Buffalo r., $57 \mathrm{~m}$. S. W. by W. Nashville.

Pleasayt Woods, p. o., Delaware county, Ind.: $47 \mathrm{~m}$.

E. X. E. Indianapulis.

Pleastrevtlle, p. v. and sta., Henry county, $\bar{k} y .: 18 \mathrm{~m}$.

N. W. by W. Frankfort. On the Louisville and Frankfort I. I.. $45 \mathrm{~m}$. E. of Liuisville.

Plenitude, p. 0., Anderson co., Tex. : 173 m. N. E. by E. Austin City.

Plesis, p. $V_{0}$, Jefferson co., $N$. $\boldsymbol{Y}_{0}$ : about $5 \mathrm{~m}$. S. of St. Lawrence r., $149 \mathrm{~m}$. N. W. Albany.
Puiny, p. o., Greenville dist., S. Car.: $9 S$ m. N. W. by W. Columbia.

Plivy, p. o., Putnam county, Firg.: 248 m. W. N. W. Richmond.

Plover, t., p. v., and eap. Portage county, Wisc. : $101 \mathrm{~m}$. N. by W. Madison. Drained by Wisconsin $\mathbf{r}_{\text {., }}$ and several branches, Big Plover r., an E. branch, being the chief. It has a productive soil, and excellent water-power. The $\mathrm{v}$. is near the confluence of the Big Plover and Wisconsin, and is the co. seat. Pop. of t. 462 .

Plowden's Mrlus, p. o., Sumter district, S. Car.: on a W. branch of Black $\boldsymbol{r}_{*}, 49 \mathrm{~m}$. E. S. E. Columbia.

Pluckemin, p. V., Somerset co., $N$. Jer. : 29 m. N. by E. Trenton.

Plum, p. o., Cook co., Ill.: 181 m. N. N. W. Springfield. PLum island, N. Y.: off Oyster Pond Point, a narrow gut separating it from Long Island. It is $3 \mathrm{~m}$. long and a mile wide, and on its W. end is a lighthouse. The surface is stony and bare of trees. It belongs to the $t$, of Southhold, Suffolk co.

Plum Bayou, p. o., Jefferson co., Ark.: 29 m. S. S. E. Little Rock.

Plum Brook, p. o., Macomb co., Mich.: 89 m. E. by $\mathbf{~}$. Lansing.

Plum Creek, p. O., Caldwell county, Tex, on a branch of the San Marcos, so called, 26 m. S. S. E. Austin City.

Puum Creer, p. o, Clinton county, Mo.: on a branch of Crooked r., 126 m. N. W. by W. Jefferson City.

Plumer, p. o., Venango co., Penn. : $165 \mathrm{~m}$. N. W. by W. Harrisburg.

Plom Grote, p. o., Blount co., Tenn.: 161 m. E. S. E. Nashville.

Prom HIrI, p. 0 , Washington county, $I l l_{\circ}: 95 \mathrm{~m} . \mathrm{S}$. Springfield.

Plumare's Mrr, p. o, Fleming co., $\overline{K y} .: 69 \mathrm{~m}$. E. of Frankfort.

Plum Prver, p. o., Jo. Daviess co., $I l$. : on W. Plum $r$, $119 \mathrm{~m} . \mathrm{N}$. by W. Springffeld.

Plumsteadrille, p. v., Bueks co., Penn. : 94 m. E. by N. Harrisburg. The t. of Plumstead is drained by Tohiokon and Neshaming creeks, and has a hilly surface with a soil of sandy loam. There are several mills on these creeks. Pop. of t. 2,187.

Plymouxh county, $I a$. Situate toward the N. W., and contains about 900 sq. m. Drained by Floyd's r., a tributary of Sioux, which forms its $\mathrm{S}$. W. boundary. Surface undulating, the larger portion is prairie; soil fertile. Set off since 1850 .

Plymodtr county, Mrass. Situate S. E., and contains 640 sq. m. Drained by North r., and branches of Taunton $r$. Surface generally level; soil productive, and in some parts very fertile, and the cultivation of the land is much attended to. Iron ore abounds in some regions, and there are some extensive factories connected therewith. Chief products, wheat, Indian corn, and potatoes. A large quantity of salt is produced in this co. Fishing is much followed by the inhabitants. Farms 2,447; manuf. 511; dwell. 9,506, and pop.-wh. 55,220, free col, 477-total 55,697. Capital: Plymouth, Pultic Works: Old Colony R. R.; Fall River R. R.; Cape Cod Branch R. P.; Bridgewater Branch R. R., ete.

Plimoctr, t., p. v., and sta., Litchfield co., Conn.: on the E. side of Naugatuck r., $21 \mathrm{~m}$. W. by S. Hartford. Drained by affluents of the r., which afford good water-power. Surface hilly; soil gravelly loam, well fitted for grazing. It manufuctures cotton and woolen goods, iron ware and clocks, the last to a great amount. A copper mine has been opened in the E. The Naugatuck R. R. follows the $r_{*}$, on which is the sta., $10 \mathrm{~m}$. N. of Waterbury. The Hartford, Providence, and Fishkill R. R. crosses it. Pop. of t. 2,568.

Prymoctu, p. v., Hancock co., $n l .: 5 \mathrm{~m}$. W. of Crooked cr., $79 \mathrm{~m}$. W. N. W. Springfield.

Plymoutr, p. v., and cap. Marshall co., Ind.: on the $N_{0}$ 
bank of yellow r., $24 \mathrm{~m}$. E. of its junction with the Kankakee, $107 \mathrm{~m}$. N. by W. Indianapolis, Plank-roads connect it with the Northern Indiana R. R., and diverge in various directions, bringing to it a large trade. It contains a courthouse, jail, bank, 15 or 20 stores, and 800 inhabitants.

Primoute, t. and p. v., Penobscot co., Me.: $42 \mathrm{~m}$. N. E. Augusta, Drained by Sebasticook r, and branches, affording water-power. Soil productive and heavily timbered. The Kennebec and Penobscot R. R. crosses it. Pop. of t. 925 .

PLxmouth, to, p. v., port of entry, and cap. Plymouth co., Mass.: on Plymouth bay, 35 m. S. E. by S. Boston. Lat. N. $41057^{\prime} 26^{\prime \prime}$, long. W. $70^{\circ} 40^{\prime} 19^{\prime \prime}$, This $t$, is memorable as the landing place of the pilgrims, Dec. $22 \mathrm{~d}, 1620$, who founded this the first settlement in New England. See Massachusetrs, Historical Sketch. The bay is spacious, but shallow; the harbor is secure, though difficult of access The $t_{0}$ is of large size, is for the most part a sandy and hilly tract covered with forests of pine, with some oak, and contains numerous ponds. The soil near the coast is generally good. The $\mathrm{y}$. in the $\mathrm{N}$. part of the $\mathrm{t}_{0}$ is pleasantly situated, is compactly built, chiefly of wood, and has many handsome buildings. It contains a court-house, jail, and 6 churches. The interesting relics of the Pilgrin Colony are carefully preserved in Pilgrim Hall, a handsome granite building, erected in 1824, for this purpose, within which the Pilgrim Society annually commemorate the landing of their forefathers. A portion of the rock on which they landed is placed in front of the hall. Plymouth is largely engaged in the fisheries, and has also some manufactories. There are two banks, cap. $\$ 200,000 ; 1$ insurance co, cap. $\$ 50,000$. Two newspapers are published weekly, viz., "Plymouth Rock" (dem.), and "Old Colony Memorial" (whig). The Old Colony P. R. extends hence to Boston, $37 \mathrm{~m}$. On 30th June, 1850, the total tonnage of $\mathrm{P}$. district was 10,722 tons, of which $3,967 \mathrm{ts}$. were registered, and $6,755 \mathrm{ts}$. enrolled and licensed. of registered t., 3,908 ts. were permanent, and 59 ts. temporary. The enrolled and licensed tonnage consisted of 6,631 ts. permanent (in cod-fishery 4,879 ts., in mackerel fishery 1,752 ts.); and 124 ts. licensed under 20 tons (in coasting trade $91 \mathrm{ts}$., in cod-fishery $33 \mathrm{ts}$.). During the year previous, the total of clearances for foreign countries was 10-544 tous; total of entrances, do. the same statistics, all of which were foreign vessels. Vessels built during the year, $5-579$ tons: Pop. in 1840, 5,281, and in 1850, 6,025.

Plimodtr, t. and p. v., Wayne co., Mich.: 62 m. E. S. E. Lansing. Drained by $W$. branch of Rouge r., which supplies excellent mill-sites. Surface undulating: soil clayey, and productive of all the grains. Salt springs are found, and flour largely manufactured. The $\mathrm{y}$. is on the W. side of the river, and contains 8 or 10 stores and 500 inhabitants. Pop. of t. 2,431.

Purmovtr, p. V., Lowndes co., Miss.: on the W. side of Tombigbee r., $126 \mathrm{~m}$. N. E. Jackson.

Plymoeтr, to, p. v., and one of the caps. Grafton county, N. Hamp.: $38 \mathrm{~m}$. N. by W. Concord. Drained E. by Pemigewrasset $r$. and N. by Baker's r. Surface rugged and broken; soil of average fertility. The Boston, Coneord, and Montreal R. R. follows both streams and passes the v., situate near their confluence, $5 \mathrm{t} \mathrm{m}$. (by route) from Concord. The $\mathrm{v}$. contains a court-house, academy, and several stores. Population of to 1,290.

Plimotre, t. and p. o., Chenango co., N. Y.: $94 \mathrm{~m}$. W. Albany. Drained by W. branches of Chenango $r$. Surface undulating; soil fertile loam, yielding excellent grain and vegetables. The Chenango $r$, and Canal are near the $\mathbf{E}$. border. Pop. 1,551.

Prysovtr, p. v., port of entry, and cap. Washington co, N. Car. : on the S. side of Roanoke r., about $8 \mathrm{~m}$. from its entrance into Albemarle Sound, 104 m. E. by N. Raleigh. $\Delta$ large trade in lumber is carried on, and a number of coasting ressels are built and owned here. The v. contains a court-house and jail, an academy, several warehouses and lumber yards, a dozen stores, and 951 inhabitants. The "P. News" (whig) is published weekly.

Plymouth, t., p. o., and sta., Richland co., Ohio: $68 \mathrm{~m}$. $\mathrm{N}$. by E, Columbus, Surface elevated, being the watershed between the Ohio and Lake Erie, and drained by heads of Huron and Walhonding rivers, which work several mills The Cleveland, Columbus, and Cincinnati R. R. and the Sandusky, Mansfield, and Newark $R$. R. cross the t. and intersect its $\mathbf{S}$. border. Plymouth sta. is in the $\mathrm{N}$. part and $36 \mathrm{~m}$. S. of Sandusky, on the latter road. Pop. 1,664.

Plymouth, t. and p. o., Luzerne co., Penn.: on the W. side of Susquehanna r, $78 \mathrm{~m} . \mathrm{N}$. E. Harrishurg, Drainer by Harvey's and Tobey's creeks, which afford good millseats. Surface mountainous in part, and in part rich valleys. It is well timbered, and contains an abundance of cosl. The N. branch of the Pennsylvania Canal passes along the $r$.

Plymoutr, to and po. 0. , Windsor co., Verm. $52 \mathrm{~m}$. S. Montpelier. Surface mountainous, giving rise to numerous streams, which furnish fine mill-sites; soil well timbered and chiefly grazing land. Limestone and soapstone are abundant. In the limestone rocks are several curious caves. Pop. 1,226

Plymotth, t. and p. o., Sheboygan co., Wise.: $88 \mathrm{~m}$. N. F Madison. Drained by Sheboygan r., which here makes a large bend and lies on its W., N., and E. borders. Surface level, in parts marshy and mostly well timbered; soil clayey or sandy loam, of good fertility.

Plimodth Hollow, p. va, Litchfield co., Conn.: $23 \mathrm{~m}$ W. S. W. Hartford, It contains several factories and stores Plymotrin Meetivg, p. v., Montgomery co, Penn.; about $2 \mathrm{~m}$. E. of Schuylkill r, $83 \mathrm{~m}$. E. by S. Harrisburg. Inhabited by Friends, who have a church here. Limestone and marble are abundant in the vicinity.

Piympton, t, p. y, and sta., Plymouth con, Mass. $31 \mathrm{~m}$ S. S. E. Boston. Drained by an E. branch of Taunton r. Surface varied; soil very productive under good cultivation. Cotton and woolen goods, cabinet-ware, mechanical and agricultural implements, etc., are made. The sta, is $7 \mathrm{~m}$. N. W. of Plymouth on the Old Colony R. R.

Podst Town, p. v., Butler co., Ohio: $7 \mathrm{~s} \mathrm{~m}$. W. S. W Columbus.

PocAmoNTAS county, $I \alpha$. Situate toward the N. W., and contains $576 \mathrm{sq} . \mathrm{m}$. Lizard $\mathrm{r}$, passes through it from $\mathrm{S}$. E to N. W., by which it is drained. Surface level; soil fertile. Set off since 1850 .

Pocahontas county, Tirg. Situate N. W. centrally, and contains $726 \mathrm{sq} . \mathrm{m}$. Drained by Greenbrier r. Surface hilly and much broken; soil barren in general. Chief productions, Indian corn and oats, Farms 858; manuf. 4; dwell. 55s, and pop.-wh. 3,30s, fr. col. 23, sl. 26i-total 3,598. Capital: Huntersville.

Pocamontas, p. v., and cap. RandoIph co., Ark. : $124 \mathrm{~m}$ N. E. by N. Little Pock. It lies on Big Black r., at the head of navigation, about $60 \mathrm{~m}$. above its mouth, and has a considerable business in the shipping of wheat, corn, and live-stnck. It contains the county buildings and $400 \mathrm{in}$ habitants.

Pocamontas, p. vo, Bond eo., Ill.: on the E. border of Looking-glass prairie, $2 \mathrm{~m}$. W. of Shoal cr., $6 \mathrm{~S} \mathrm{~m}$. S. Springfield. It is on the Mississippi and Atlantio $\mathrm{R}$. R., $124 \mathrm{~m}$ W. by S. Terre Haute.

Pocasset, p. ., Barnstable co., Mass.: on the E, side of Buzzard's bay, 68 m. S. S. E. Boston.

Pocket, p. oc, Moore co., N. Car.: on a $\mathrm{S}$. branch of Deep r., 41 m. W. S. W. Raleigh.

Pосомоке river and bay, 1 Id. $^{2}$ the river rises in Crpress Swamp, on the line between Delaware and Maryland, and runs in a $\mathbf{S} . \mathrm{W}$. direction $70 \mathrm{~m}$. to Pocomoke bay, an arm of Chesapeake bay. It is navigable for small ressels to Snowhill.

Pocotaliga, p. o., Beaufort dist., S. Car..: on a small stream of that name flowing into Broad r., $78 \mathrm{~m}$. S. Co lumbia. 
Pocotalige, p. o. Kanawha co., Virg.: on the river of that name, $236 \mathrm{~m}$. W. N. W. Richmond.

Pocotaligo river, S. Car.: a tributary of the Black $r$. from the north-west.

Pocotaligo river, Kanawha co., Firg.: rises in Gilmer county, and after a $\mathrm{S}$. W. course of $60 \mathrm{~m}$., through a district abounding in bituminous coal and iron ore, for one-third of which it is boatable, empties into the Great Kanawha, about $40 \mathrm{~m}$. from its mouth.

Poestenkilu, to and p. $v_{0,}$ Rensselaer co., $N, Y_{0}: 9 \mathrm{~m}$. E. N. E. Albany. Drained by branches of the Poestenkill, which supply good mill-sites. Surface hilly and broken; soil mostly grazing land. It has valuable deposits of marl and several manufacturing establishments. The v, contains several mills and factories. Pop. of t. 2,092.

Poestextuly river, $\mathcal{N} . Y$ : rises in Rensselaer county and flows $\mathrm{S}$. W. into the Hudson at Troy, affording many good mill-sites. It has falls on the side of Mount Ida, around which a small manufacturing village has sprung up.

Poindextrer, p. v., Marion co., Ga.: $83 \mathrm{~m}$. S. W. by W. Milledgeville.

Poindexter"s, sta., Bedford co., Firg.: $13 \mathrm{~m} . \mathrm{W}$. of Lynchburg, on the Virginia and Tennessee P. R.

Poindexter's SToke, p. o., Louisa county, Virg.: $47 \mathrm{~m}$. N. W. Richmond.

Poinsetr county, Ark. Situate toward the N. E.g and contains 1,444 sq. m. Drained by Lanquille $r$. and St. Francis baygu, tributaries of St. Francis $r$. Surface generally level; soil fertile, and adapted to corn. Farms 264; manuf. 0 ; dwell. 350 , and pop.-wh. 2,026 , fr. col. 3 , sl. 279 -total 2,308. Capital: Bolivar.

Pornsext lake, Flor.: an expansion of the St. John's r., or a lake through which that river flows, in lat. $28028^{\prime}$.

Pornsetr lake, Minn. Ten.: a small lake emptying into Sinux river.

Point Cedar, p. o., Clark co., Ark.: 64 m. W. S. W. Little Rock.

Point Cosmerce, p. V., Greene co., Ind.: on the W. side of White $r$, at the junction of Eel $r_{0}, 58 \mathrm{~m}$. S. W. Indianapolis. It is $42 \mathrm{~m}$. S. E. of Terre Haute by the Wabash and Erie Canal, and has several mills and stores.

Point Cosceptiox, Calif.: the most W. point of Santa Barbara co. Lat. $34^{\circ} 26^{\prime} 56^{\prime \prime} \mathrm{N}$., and long. $1200^{\circ} 25^{\prime} 40^{\prime \prime} \mathrm{W}$.

Point Couper parish, $L a$. Situate $\mathbf{S}$. E. centrally, and contains 429 sq. m. Drained by Bayou Fordoche and Dranches of Atchafalaya river; this latter forms its W. boundary, and along its banks are some fertile tracts of land. Surface level, and in general lying low, which makes it liable to inundation; a great portion of the county is consequently unfit for cultivation; soil where fit for tillage is fertile, and yields a rich harvest Chief productions Indian corn, cotton, and sugar. In the $\mathbf{S}$. E. is Fausse river, which probably at one time was a bed of the Mississippi. Farms 245; manuf. 0 ; dwell. 760, and pop.-wh. 2,967, fr. col. 561, sl. 7,511-total 11,389. Capital: Point Coupee.

Porst Couree, p. v., and cap. Point Coupee, par. La.: on the right bank of the Mississippi, nearly opposite St. Francisville, $\$ 6$ miles by the river above Baton Rouge. Here are a court-house, jail, and a printing-office, from which the " $P$. c. Echo" (dem.) is issued weekly. The levee extends from this point to New Orleans. The inhabitants of the village are mostly wealthy, and of French descent, and their plantations stretch for miles along the river.

Point Douglass, p. v., Wasluington co., Minn.: at the confluence of St. Croix r. with the Mississippi, $14 \mathrm{~m}$. S. E. St. Paul.

Ponvt Isabel, p. v., Clermont co., Ohio: 92 m. \$. W. Columbus.

Ponts Is Tas. : $259 \mathrm{~m}$. $\mathrm{S}$. by $\mathrm{E}$. Austin City. It lies near the S. end of the Lagruna Del Madre, a few miles W. of Brazos Santiago, and about $15 \mathrm{~N}$. of the mouth of the Rio Grande. It is a depot for military and naval stores, and a landing $6 \times 3$ place for steamers destined up the Rio Grancle, and for many of the Gulf ports. The tonnage of the district in 1550 was 401 tons engaged in steam navigation, und 274 tons in the coasting trade.

Point Jefferson, p. o., Morehause parish, La. : 169 miles N. N. W. Baton Rouge.

Point Meers, p. 0., Johnson co., Ark.: on Little Piney creek, $85 \mathrm{~m}$. N. W. Little Rock.

PoINT of Rocks, p. v. and sta., Frederick co., $M d$. : on Potomac river, and the Chesapeake and Ohio Canal, $57 \mathrm{~m}$. W. N. W. Anuapolis. The station is $12 \mathrm{~m}$. E. of Harper's Ferry, on the Baitimore and Ohio R. R. The scenery along the river is magnificent.

Point Peninsula, p. o., Jefferson county, $N$. $Y$.: on a peninsula between Chamount bay and Lake Ontario, $149 \mathrm{~m}$. N. W. by W. Albany.

Point Petee, p. o., Searcy co., Ark.: on Richland cr., $86 \mathrm{~m}$. N. Little Rock.

Pornt Peter, p. o., Oglethorpe co., Ga.: $63 \mathrm{~m}$. N. by E. Milledgeville.

Point Pleasant, p. v., New Madrid co., Mo.: on the Mississippi, $89 \mathrm{~m}$. below the mouth of the Ohio, $202 \mathrm{~m}$. S. E. Jefferson City. It contains several stores and warehouses, and has a good landing, from which great quantities of corn are sent down the river.

Point Pleasant, p. o., Ocean co., $N$. Jer.: on the N. end of Squam Beach, $33 \mathrm{~m}$. E. by S. Trenton.

Point Pleasant, p. v., Clermont co., Ohio: on the Ohio, at the mouth of Indian er., $23 \mathrm{~m}$. above Cincinnati, $90 \mathrm{~m}$. S. W. by S. Columbus. A large quantity of pork is packed here.

Point Pleasant, p. v., Bucks co, Penn. : on Delaware river and canal, at the mouth of Tohickon cr., $32 \mathrm{~m}$. S. of Easton, $95 \mathrm{~m}$. E. by N. Harrisburg. It contains several mills and about 200 inhabitants.

Potnt Pleasant, p. V., and cap. Mason co., Virg.: on the Ohio, immediately above the mouth of the Great Kanawha, $268 \mathrm{~m}$. W. N.W. Richmond. It contains an academy, court-house, steam flouring-mill, steam saw-mill, severa stores and tanneries, and about 500 inhabitants. Here, on the 10th of October, 1774 , was fought the "Battle of Poin Pleasant," the bloodiest ever fought with the red men in the state. A large body of warriors of several tribes, under the famous chief Cornstalk, attacked Colonel Lewis, commanding 1,100 Virginians; but after fighting all day, were forced back across the Ohio. The Covington and Ohio R. R. will have its W. terminus here.

Point Pratrie, p. o., Franklin co, Ark, : on the W. side of Six Mile cr., $97 \mathrm{~m}$. W. N. W. Little Rock.

Poivt Repcblic, p. v., La Salle co., $I l l .: 124$ m. N. N. E, Springfield.

Point Surtu, V., Franklin county, Ala.: on the S. side of Tennessee river, at the entrance of Big Bear creek, $193 \mathrm{~m}$. $\mathrm{N}$. W. by N. Montgomery. Here is a landing for steamboats and a number of stores and warehouses. The staples of the district adjacent are shipped here for the Southern markets. The p. o. is Chickasaw.

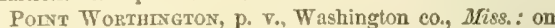
the Mississippi, $79 \mathrm{~m}$. N. W. by N. Jackson.

Pokagon, sti., Cass co., Mfich. on the Michigan Central R. R., 43 m. W. of Kalamazoo.

Pokz Barot, p. o., Independence co., Ark. : near a N. aftuent of White $r$. so called, $86 \mathrm{~m}$. N. N. E. Little Rock.

Poze Rux, p. o., Westmoreland co., Penn.: 138 m. W. Harrisburg.

Poudvd, p. v., Clay county, Ind. : 2 m. E. of Eel r., 46 m. S. W. by W. Indianapolis.

Polaxd, t. and p. v., Cumberland con, Me.: $34 \mathrm{~m}$. W. S. W. Augusta. Drained by branches of Little Androseoggin r., its N. boundary, which supply water-power. Surface uneven; soil rery fertile. A superior farming t., with abundance of timber and various manufactories. The Atlantic and St. Lawrence R. I. crusses the N. part. Pop. of t. 2,660. 
Poland, p. v., Herkimer co., $N_{.} Y_{\text {. }}$ on West Canada creek, 74 m. W. N. W. Albany. It contains several cotton fuctories, and a cutlery establishment.

Polaxd, t. and p. 0., Mahoning con, Ohio : on the E. line of the State, $1+; \mathrm{m}$. N. E. by E. Columbus. Drained by Mahoning r. and branches, which supply fine water privileges. The Pennsylvania and Ohio Canal, and the Cleveland and Mahoning R. R. pass through it. Pop. 2,126.

Polaxid Centre, p. v., Chautauque co, $N$. Y.: 268 m. W. by S. dlbany. Pop. of Puland t., 1,174.

Poux county, Ark. Situate W., and contains 1,114 sq. m. Drained by head branches of Wachita $r$. and brauches of Red r. Surface undulating; soil productive; it is generally well adapted to grain. T'imber is found of good quality. Farms 155; manuf. 1; dwell. 139, and pop.-wh. 1,196, fr. col. 00, sl. 67-total 1,263. Cupitul: Panther.

Puzk county, $I u$. Situate $\mathbf{S}$. centrally, and contains 720 sq. m. Des Moines r. passes through it from S. E. to N.W. by which and its branches it is drained. Surface undulating; soil fertile. Set off since 1 S50.

Pole county, Mo. Situate $\mathrm{S}$. W. centrally, and contains 576 sq. m. Drained by Pomme de Terre r. and Lindley's creek, branches of Osage $\mathbf{r}$, and $\mathrm{E}$. fork of Sac r., by which good water-power is supplied. Surlace diversified-in some parts hilly; soil fertile, and adapted to grazing. Fruit is produced in large quantities, and there is some good timber land in the co. Farms 543; manuf. 6 ; dwell. 907, and pop. -wh. 5,804, fr. col. 13, sl. 369-total 6,186. Capital Bolivar.

PoLs county, Oreg. Ter. Situate W. middle, between the Willamette r. and the Pacific Ocean, into both of -which there is drainage. Area 2,400 sq. m. Surface varied, and the soil very fertile. Cape Foulweather lies at its S.W. corner, the parallel of which forms its $\mathrm{S}$. boundary. The Willamette here affords extensive water-power, which is used for various mills. Farms 129; manuf, 2; dwell. 190, and pop,-wh, 1,046, fr, col. 5-total 1,051. Capital: Cincinnati.

Pouk county, Tenn. Situate S. E., and contains 282 sq. m. Drained by Hiwassee r. and its principal tributary, Tnceo $r$. Surface mountainous in general, but there is much level land; soil fertile. Chief productions, cotton and Indian corn. Farms 561; manuf. 11 ; dwell. 1,012, and pop.-wh. 5,886, fr. col. 52, sl. 400-total 6,838. Capital: Benton.

Pouk county, Tex, Situate toward the S. E., and contains $1,273 \mathrm{sq}$. m. Drained by Trinity river, which flows through it centrally. Surface undulating; soil on the r. productive, and adapted to cotton. It is thickly covered with oak, pine, cedar, and other timber, by far the greater portion of the $\mathrm{e}$. being wooded. Farms 172 ; manuf. 0 ; dw 292, and pop.-wh. 1,544, fr. col. 0, sl. 805-total 2,3:9. Cupitcl : Livingston.

PouK county, Wisc. Situate W., and contains 2,595 sq. m. Drained by Kayesikang or Shell r, and other branches of St. Croix r., which forms its W. boundary. Surface varied, part of it being hilly and broken, and part level; the soil on the latter is in general good, and with cultivation produces well: the hilly portion of the co. makes fine pasturage, and is well fitted for the raising of live-stock. It is thickly wooded. This co, has been lately set off, being formerly the northern half of St. Croix county.

Polk, p. 0., Lucas co., Ia.: 102 m.W. S.W. Iowa City.

PolK, p. 0., Ashland co., Ohio: 71 m. N. N. E. Columbus,

Polk, p. o., Venango county, Penn.: 173 m. W. N. W. IIarrisburg.

Pork Barot, p. 0., Independence county, Ark. See PoKF. BAYŨ.

PoLK Rur, p. o, Clark county, Ind.: 89 m. S. by E. Indiarapolis,

Polkтon, t. and p. o., Ottawa co., Mich.: on Grand r. $79 \mathrm{~m}$. W. N. W. Lansing. Surface rolling, and heavily timbered with Norway and white pine, and hemlock. Population 263.
Polktown, sta., Hamilton county, Ohio: $23 \mathrm{~m}$. N. E. of Cincinnati, on the Little Miami R. Is.

Polkvilux, p. o., Benton county, Ala. : 94 m. N. N. E. Montgomery.

Polkville, p. $\nabla$. , Clereland county, N. Car.: $161 \mathrm{~m}$. W. by S. Raleigh.

Polkvilue, p. v., Columbia county, Penn. : 59 m. N. by E. Harrisburg.

Poцkтille, p. V., Smith county, Mfiss.: 39 m. E. S. E. Jackson.

Polkville, p. v., Warren county, $N$. Jer, : on the E. side of Paulin's kill, 2 m. E. of Delaware river, 49 m. N. N. W. Trenton.

Polland's Mruls, p. o., Greenup county, $\bar{k} y .: 117 \mathrm{~m}$. E. by N. Frankfort.

Pollock's, p. o., Randolph co, $r l$. : on Nine Mile cr, an E. affluent of the Kaskaskia, $121 \mathrm{~m}$. S. Springfield.

Pollocksville, p. v., Jones co., $N$. Car.: on the S. side of Trent r., $92 \mathrm{~m}$. E. S. E. Raleigh.

Pomaria, p. o, and sta., Newberry district, S. Car.: on Cannon's er. and the Greenville and Columbia R. R., $82 \mathrm{~m}$. (by route) N. W. Columbia.

Pomerox, p. v., and cap. Meigs co., Ohio: on the Ohio, $57 \mathrm{~m}$. below Marietta, $81 \mathrm{~m}$. S. E. Columbus. It occupies a narrow strip of land between the river and a steep hill, and is engaged principally in the coal business, large deposits of which are in the immediate vicinity. About 300 men, mostly Welch, are employed in the mines, which were opened in 1882, and yield about $2,000,000$ bushels per annum. It was settled in 1816, made the county seat in 1841, and contuins a court-house, 15 stores, 2 foundries, 3 machine-shops, a rolling mill, rope-walk, and 2 large tanueries. The "M. County Telegraph" (whig) is published weekly. A branch R. R., $10 \mathrm{~m}$. long, connects it with the Cincinnati, Hillsboro', and Parkersburg Railroad. Pop. $1,637$.

Pompret, t., p. v., and sta., Windham co., Conn.: on the W. side of Quinnebaug r., 39 m. E. by N. Hartford. Drained by branches of the river, which supply numerous mill-sites. Surface uneven, and beautifully varied by hills and mead. ows; soil deep and strong. Many of the furms are very superior, and the grazing is excellent. Various manufactures are prosecuted. The sta. is $26 \mathrm{~m}$. S. of Worcester, on the Norwich and Worcester R. R. The Boston and New York (Air Line) R. R. crosses the t. The v, occupies a hill commanding a wide view, and contains an academy. Pop of $\mathrm{t} .1,849$.

Ponfret, t. and p. v., Windsor co., Term.: 39 m. S. by E. Montpelier. Drained by Queechy r. and a branch of Thite river, which supply good water-power. Surfuce broken; soil productive; coal is found; grazing is the chief occupation; limited manufactures are carried on. Pop. of t. 1,546. Pomfret, t., Chaulauque co., N. Y. : on Lake Erie. Surface hilly; soil, a fertile, argillaceous, gravelly, and sandy loam. Drained by Cassadaga $c r .$, an affluent of Alleghany $r_{\text {., and }}$ several small streams flowing into this lake. The villages of Dunkirk and Van Buren Harbor are in this t. and the Erie R. R, has its W. terminus here. Pop. in 1S50,4,493.

Pomfret Landivg, p. v., Windham co, Com. : $37 \mathrm{~m}$. E. by N. Hartford.

Pomonkex, p. o., Charles co., MLd.: on Pomonco cr. of the Potomae, $43 \mathrm{~m}$. S. W. Annapolis.

Pomme de TerRe river, $\overline{L O}_{0}$ : a tributary of Osage river.

Pompanoosuc, p.o. and sta, Windsor county, Term.: on Connecticut r., and the Connecticut and Passumpsic Rivers R. R. 10 miles $N$. of White river junction, $39 \mathrm{~m}$. S. E. Montpelier.

Pomper, t. and p. o., Onondaga cotnty, $N_{\text {. }} \Gamma_{\text {. : }} 109 \mathrm{~m}$. W. by N. Albany. Drained by Limestone and Butlernut creeks. Surface billy : soil losm, mixed with sand or clay, very productive, and under high cultivation. Agriculture is the principal oceupation. Pompey Hill r., in the W. part, occupies the highest land in the co, commanding an ex- 
tensive view, and contains an academy, a half dozen stores, and 500 inhabitants. Pop. of t. 4,006.

Ponper Centre, p. o., Onondaga county, N. Y.: $113 \mathrm{~m}$.

W. by N. Albany.

Pompton, t. and p. v., Passaic co., N. Jer. : 59 m. N. N. E. Trenton. Drained by Pequannock, Ringwood, and Ramapo rivers, which furnish fine water-power, and unite in the S. corner, to form Pompton r. Surface hilly and mountainous; soil clayey loam of good fertility. Iron ore is abundant, and largely dug and wrought. The v., on Ramapo r., contains an academy, a furnace, and 250 inhabitants. Pop, of t, 1,720.

Pompton river, $N$. Jer. : is formed by the confluence of the Pequannock, Ringwood, and Ramapo rivers, and dividing Passaic and Morris counties, it flows $8 \mathrm{~m}$. into the Passaic river. The Morris Canal crosses it $2 \mathrm{~m}$. above its mouth.

Ponpton Plains, p. v., Morris co., $\boldsymbol{N}$. Jer.: on the W. side of Pompton r., $57 \mathrm{~m}$. N. N. E. Trenton.

Pond Creek, p. O., Greene co., Mo.: $115 \mathrm{~m}$. S. W. by $\mathrm{S}$. Jefferson City.

Pond Eddr, p. o., Sullivan co., N. $Y$.

Pond Fork, p. o., Jackson county, Ga.: $84 \mathrm{~m}$. N. by E. Milledgeville.

Poxn Hru, p. o., Gibson co., Tenn.: 123 m. W. by S. Nashville.

Pond Settlexmext, p. ₹., Steuben county, $N$. Y.: $194 \mathrm{~m}$. W. by S. Albany.

Pond Sprivg, p. o.s Walker co., Ga.: $173 \mathrm{~m}$. N. W. Milledgeville.

Pondown, p. v., Sumter county, Ga.: 92 m. S. W. Milledgeville.

Pontchartrats lake, $L a$. : is $40 \mathrm{~m}$. long, and $25 \mathrm{~m}$. broad. It communicates with Lake Maurepas on the W., Lake Borgne through the Rigolets on the $\mathbf{E}$., and on the S. with New Orleans, through St. John's bayou and a eanal. It has 16 or 18 feut water in its deepest part, but near the shore not more than 9 feet. The Tangiapaha and Tchefuncti rivers, and other small streams, emply into it

Pontiac, p. V., and cap. Livingston co., $I U l .:$ on Vermillion r., $93 \mathrm{~m}$. N. E. by N. Springfield. It contains the county buildings and several stores.

Pontiac, p. o. and sta., Huron co, Ohio: on the Sandusky, Mansfield, and Newark R. R., $20 \mathrm{~m}$. S. of Sandusky City, $83 \mathrm{~m}$. N. by E. Columbus.

Poxtiao, to, p. v., and cap. Oakland co., Mich.: $67 \mathrm{~m}$, E. by S. Lansing. Drained by Clinton r. and branches, which, fed by numerous ponds, furnish superior water-power. Surface somewhat hilly. Soil sandy in parts, but mostly productive. The $\mathrm{v}$. is on the $\mathrm{r}$., and contains a court-house, jail, academy, iron foundry, and machine-shop, several flouring-mills and factories, and 1,500 inhabitants. The "Oakland Gazette" (whig), and "Pontiac Jacksonian" (dem.), are published weekly. The Detroit and Pontiac P. R. terminates here, $25 \mathrm{~m}$. N. N. W. Detroit. Pop of 2.819 .

Poxtrac, p. o., Erie con, $N . Y_{*}: 253 \mathrm{~m}, \mathrm{~W}$. Albany.

Poxtoosac, p. ., Hancock $\mathrm{co}, I l l_{\text {. }}$ : on the Mississippi, $85 \mathrm{~m}$. Х. W. by W. Springfield.

Poxtotoo county, Miss. Situate toward the N. E., and contains 902 sq. m. Drained by Tallahatchie river and its branches in the $\mathrm{X}$., and branches of $\mathrm{W}$. rork of Tombigbee river in the E. and centre. Surface level; soil fertile. Chief productions, cotton and Indian corn. Farms 1,245; manuf. 32 ; dwell. 2,001 , and pop.-wh. 12,136, fr. col. 8 , sl. 4,965-total 17,112. Capital: Pontotoc.

Poxtotoc, p. V., and cap. Pontotoc co., Mriss.: $113 \mathrm{~m}$. N. E. by N. Jackson. It contains a court-house, jail, academy, United States land office, a dozen stores, and about Su0 inhabitants. Two newspapers, the "American Sovereign" (dem.), and the "Political Safeguard" (whig), are issued weekly.

Poxтотоo, 7. o*, Fulton county, $\bar{K} y .: 253 \mathrm{~m}$. W. S. W. Erankfort.
Poolesville, p. v., Montgomery co., $M Z_{0}: 4 \mathrm{~m}$. E. of the Potomac, 43 m. W. N. W. Annapolis.

Pool's Mulls, p. o, Jones county, Miss.: 79 m. S. E. Jackson.

Poolsville, p. v., Warren co., Ind.: $69 \mathrm{~m}$. N. W. by W. Indianapolis.

Poolstille, p. v., Spartanburg dist., S. Cur.: $88 \mathrm{~m}$ N. W. Columbia.

Poolville, p. v., Madison co., $N$. Y.: on an E. branch of Chenango r., $88 \mathrm{~m}$. W. by N. Albany. Here are several mills.

Poor Fork, p. o., Harlan co., $\bar{k} y_{.}:$on a head of Cumberland r. so called, $126 \mathrm{~m}$. S. E. by E. Frankfort.

Poop Hru, p. o., Sullivan co., Temn, : 236 m. E. by N. Nashville.

Pope county, Ark. Situate toward the N. W., and contains $825 \mathrm{sq} . \mathrm{m}$. Drained by Great Pine $\mathbf{r}$. and Illinois $\mathrm{cr}$ and branches, tributaries of Arkansas r., which runs on the S. border, and passes through the S. W. corner of the co. Surface varied; in the N. mountainous, but level in the interior and S.; soil fertile, producing eotton, tobaceo, Indian corn, etc. Some good timber is found on the land, and it has extensive coal beds. Farms 534; manuf. 16; dwell. 695, and pop.-wh. 4,231, fr. col. 0, sl. 479-total 4,710. Capital: Morristown.

Pope county, $I l l$. Situate S., and contains 425 sq. m. Drained by Rock, Great Pierre, Big Bay, and Lusks creeks, all of the Ohio r., which forms its S. E. boundary. Surface even, excepting the bluffs on the Ohio; soil a deep loam, with sand intermixed, and productive, adapted to grain, and also raising good tobacco. It is well timbered, and in the E. is a hilly range, which makes good pasturage. Farms 504: manuf. 12; dwell. 747, and pop.-wh. 3,S71, fr. col. 104 -total 3,975. Capital: Golconda.

Pope Creek, p. o., Mercer co., Ill, : on the S. side of the cr. so called, $105 \mathrm{~m}$. N. W. by N. Springfield.

Pope's Corners, p. v., Saratoga co., $N . Y .: 1 \mathrm{~m}$. W. of Hudson r., 34 m. N. by E. Albany.

Pope's Mrucs, p. o., St. Lawrence county, $N . Y_{.}: 138 \mathrm{~m}$ N. W. Albany.

Pope's Mills, p. o., Mercer co., Ill.: on Pope's cr., about S m. E. of the Mississippi, $109 \mathrm{~m}$. N. W. by N. Springfield. Formerly called Bluff.

Pope's STore, p. o., Southarnpton co., Virg. : 63 m. S. S. E. Richmond.

Poplar, p. 0., Crawford co., Otio: $62 \mathrm{~m}$. N. Columbus.

Porlar, p. o., Orangeburg dist., S. Car.: about $4 \mathrm{~m}$. W. f Santee r., $41 \mathrm{~m}$. S. E. by S. Columbia.

Puplar island, in Chesapeake bay. Lat. $43^{\circ} 22^{\prime} \mathrm{N}$., and long. $70^{\circ} 23^{\prime} \mathrm{W}$. Its periphery measures about 10 miles.

Poplar Buuff, p. o., Butler co., Mo.: 153 m. S. E. by $\mathrm{S}$. Jefferson City.

Poplar Braxca, p. o., Currituck co, $N$. Car.: 143 m. E. N. E. Raleigh.

Poplar Corver, p. o., Madison county, Tenn.: $117 \mathrm{~m}$. W. S. W. Nashville.

Puplap (nefk, p. o, Choctaw county, Jiss.: $126 \mathrm{~m}$. N. E. by N. Jackson.

Poplar Fuat, p. o., Lewis county, $K y .: 85$ m. E. N. E. Frankfort.

Poplar Grove, p. o., Owen county, Ey.: $34 \mathrm{~m} . \mathbf{N}$. Frankfort.

Poplar Grove, p. o., Boone co., Ill.: $183 \mathrm{~m}$. N. by E. Springfield.

Poplar Grove, p. o., Iredell co., N. Car.: $122 \mathrm{~m} . \mathrm{W}$. Raleigh.

Poplar Grove, p. 0., Gibson co., Tenn. : $112 \mathrm{~m}$. W. by S. Nashville.

Poplas Hri, p. o., Vigo county, Ind.: on the S. side of Honey er. a small afliuent of the Wabash, $68 \mathrm{~m}$. W. S. W. Indianapolis.

Poplar Hul, p. o., Anson county, N. Car.: 93 m. S. W. Pitluigh. 
Poplar Hrul, p. o, Giles co., Virg.: on Walker's er., a l Clinton. The Sandusky and Fort Wayne R. R. passes

W. afliuent of New r., $181 \mathrm{~m}$. W. by S. Richmond.

Poplar Mount, p. on, Greenville county, Virg.: 47 m. S.

Richmond.

Poplar Plazns, p. o., Fleming co., $K y .: 71 \mathrm{~m}$. E. by $\mathrm{N}$.

Frankfort.

Poplar Ridge, p. o., Cayuga ca., N. Y.: $137 \mathrm{~m}$. W. by N.

Albany.

Poplar Ridge, p. o., Darke co., Ohio: $88 \mathrm{~m}$. W. by N. Columbus.

Poplar RDge, p. o, Maury co., Tenn.: 42 m. S. E. W. Nashville.

Poplar Sprina, p. o., Fairfleld dist., S. Car.: about $3 \mathrm{~m}$.

W. of Wateree r., $31 \mathrm{~m}$. N. by E. Columbia

Poplar Spring, p. a, Marshall co., Virg.: 285 m. N. W. Richmond.

Poplar Spring, p. o., Pontotoc co., Jfiss. : 146 m. N. N. E. Jackson.

Poplar Springs, p. v., Howard co., Ma.: 38 m. N. W. Annapolis.

Poplar Sprtigg, p. v., Hall county, Ga. : 98 m. N. N. W. Milledgeville.

Popliv, to and p. o., Rockingham co., N. Hamp.: $28 \mathrm{~m}$. S. E. Concord. Drained by Squamscot $r$. Surface uneven, but not rough; soil fertile. A farming t. Pop. 509 .

Poevaroc Bridge, p. o., New London co., Conn.

Poquetonuck, p. v., New London co., Conn.: 2 m. E. of the Thames, on an affluent so called, $38 \mathrm{~m}$. S. E. by E. Fartford. Sloops come up near the v, at high water. The inhabitants are chiefly sea-faring men, or interested in the coasting-trade.

Poquonock, p. v., Hartford co., Conn.: on Farmington r., $9 \mathrm{~m}$. N. Hartford. It contains several factories and mills.

Porpotse eape, Mle.: the N. E. boundary of Kennebunk harbor, in lat. $43^{\circ} 22^{\prime} \mathrm{N}$. and long. $70^{\circ} 23^{\prime} \mathrm{W}$.

Portage county, Ohio. Situate toward the N. E., and contains $648 \mathrm{sq}$. m. Drain 2 by head branches of Mahoning r. and branches of Cuyahnga r., which supply good waterpower. Surface undulating, in some parts broken; soil fertile, consisting of a fine deep mold, and adapted to wheat and Indian corn. Pine, maple, poplar, and other timber is firud on the land. Agriculture is the leading pursuit. Farms 2.264; manuf. 127; dwell. 4,512, and pop.-wh. 24,337, fr. col. 82-total 24.419. Capital: Ravenna, Putlic Works: Cleveland and Pittsburg R. R.; Cleveland and Mahoning P. R.; Pennsylvania and Obio Canal, ete.

PoRTAGe county, Wisc. Situate centrally, and contains $1,549 \mathrm{sq} . \mathrm{m}$. Wisconsin $r$. passes through it centrally, by which and its numerous branches it is drained. Surface hilly and broken, excepting on the rivers, where the land is tevel; soil fertile. A portion of the $\mathrm{co}_{\text {. }}$ is prairie. It is well timbered, and has good pasturage. Farms 5; manuf. 15; dwell. 204, and pop.-wh. 1,249, fr. col.1-total 1,250. Capital: Plover.

Portage, t. and p. 0., Kalamazoo co., Mich.: 68 m. S. W.

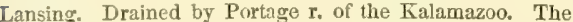
Sandy lakes are in the S. E. part. Pop. 726.

Portage, t. and p. o., Livingston co., $N . Y_{\text {.: }}$ on the E. side of Genesee r., $212 \mathrm{~m}$. W. Albany. Drained E. by Cashaqua cr. Surface rolling; soil very fertile of wheat and most grains. On the W. line are the Genesee Falls, which supply immense water-power. The Genesee Valley Canal and Buffalo and New York City R. R. pass throngh it. It Was divided in 1846, and the portion $W$. of the river made 2 new th, and called Genesee Falls. The p. o. was formerly Williams' Place. Pop. 2,478.

Purtage, to and p.o., Wond co., Ohio: $\$ 3 \mathrm{~m} . \mathrm{N} . \mathrm{N} . \mathrm{W}$. Columbus. Drained by Portage $r$. and branches, on which are scveral mills. The $\mathrm{v}$, on the $\mathrm{N}$. side of the $\mathrm{r}$. was laid out in 1836, and contains various mechanic shops, etc. Pop. of t. 405 .

Portage, t., Ottawa co., Ohio: a narrow neck of land between Sandusky bay and Lake Erie, on which is Port
Clinton. The Sandusky and Fort Wayne R. R. passe through it. Pop. 377.

Portage, p. o., Cambria co., Penn.: 104 m.W. Harrigburg Portage, t., Hancock county, Ohio: drained by the head waters of Portage r. Pop. 614.

Portagk, t., Summit co., Ohio: at the portage between the Cuyahoga and Tusearawas rivers, The Ohio Canal and the Cleveland, Zanesville, and Cincinnati R. R. pass through it. Akron, the county seat, is located in the S. E. part. Pop. of t. 4,886 .

Portage, t., Livingston co., $N . Y_{0}:$ on the Genesee $r_{\text {, }}$ at the Great Falls, at which the descent in $2 \mathrm{~m}$. is about 300 feet, affording great water-power. The scenery is magnificent. Surface elevated and rolling; soll fertile. The Genesee Valley Canal passes through the t., and also the Buffalo and New York City R. R. Pop. 2,478.

Portage, $t$. and v., Kalamazoo co., Mich.: drained by Portage r. and the Sandy lakes. Surface level prairie; soil fertile. Pop. 726.

Portage lake, Houghton co, Mich. : this lake lies on the Keweenaw peninsula, and empties into Keweenaw bay, an arm of Lake Superior. It is very irregular in its shape, and has extensions $N$. and $N$. W., which bear the local names of Houghton's lake and Torch lake-the first extending $\mathrm{N}$. W. almost to the opposite side of the peninsula. A navigation might be formed through this lake, and a canal across the portage.

Portage river, Ohio: an affuent of Lake Erie, into which it falls at Port Clinton. It affords good water-power, and drains the Black Swamp, an unhealthy, but which, if suitably drained, would make a very fertile courtry. The harbor is the outlet of a considerable region.

Portage City, p. v., Columbia county, Wisc. : $33 \mathrm{~m} . \mathrm{N}$ Madison.

Portage Lake, p. 0., Jackson co., Afich. : 34 m. S. S. E Lansing.

Portageville, p. v., Wyoming co., $N$. $\bar{Y}:$ on the W. side of Genesee r., $214 \mathrm{~m}$. W. Albany. The river here falls about 300 feet in 2 miles, principally in three perpendicular descents, which furnish immense hydraulic power, and being surrounded by high steep banks, attract many visitors by the grandeur of the scenery through which the r. passes The Genesee Valley Canal crosses the $r$. here in an aqueduct, and soon after enters a tunnel $4 \mathrm{~m}$. long. The v. con tains several factories and mills, a dozen stores, and about 1,000 inhabitants.

Port Allegmany, p. v., M'Kean co., Penn. : on the lef bank of Alleghany r., $131 \mathrm{~m} . \mathrm{N}$. N. W. Harrisburg.

Pont Allen, p. v., Louisa co., I $x_{0}$ : on the left bank of Yowa r., $26 \mathrm{~m}$. S. S. E. Iowa City.

Port Blanchard, p. v., Luzerne county, Penn.: $74 \mathrm{~m}$. N. E. by N. Harrisburg.

Port Bodega, v. and p. o., Sonoma co, Calif. : on a fine bay, opening to the Pacific, $63 \mathrm{~m} . \mathrm{N}$. W. Vallejo. It was formerly a Russian station.

Port Byron, p. v., Rock Island co., Illo: on the Mississippi, $131 \mathrm{~m}$. N. by W. Springfield.

Port Brron, p. v., Cayuga co., N. Y.: on the Erie Canal, $28 \mathrm{~m}$. W. of Syracuse, $146 \mathrm{~m}$. W. Albany. It contains a large flouring establishment, several mills, 20 stores, and 1,200 inhabitants.

Port Caddo, p. v., Harrison co., Tex.: near the W. end of Lake Caddo, $272 \mathrm{~m}$. N. E. Austin City. Steamers ply from this point to Shreveport, freighted with the staples of the co., principally cotton and corn, of which a large amount is shipped hence down Red river.

Port Carbon, p. b., Schuylkill co., Penn.: on Schuylkil river, at the junction of Mill creek and head of Schuylkill Navigation Canal, $108 \mathrm{~m}$. N. W. Philadelphia, $46 \mathrm{~m}$. N. E. Harrisburg. In 1829 there was but one house here. The $\mathrm{v}$. is the creation of the coal trade, which forms the almost exclusive employment. Pop, 2:142.

Port Chester, p. v. and sta., Westchester co., $N . Y_{.:}$on 
the W. side of Byram $r_{\text {, }}$, here the E. line of the State, $108 \mathrm{~m}$. $\mathrm{S}$. Albany. It is $1 \mathrm{~m}$. from the sound, where is a steamboat landing, from which boats ply to New York, and $29 \mathrm{~m}$. N. E. of New York, on the New York and New Haven R. R. It contains several manufactories, 20 stores, and about 1,000 inhabitunts.

Port Cunvon, p. v., port, and cap. Ottawa co., Ohio: on the $\mathrm{S}$. side of Portage river, at its entrance into Lake Erie, $115 \mathrm{~m}$. N. Columbus. It has a good harbor, with a lighthouse at its entrance, and contains a court-house, jail, several stores and mills, and 249 inhabitants. The railroad from Sunulusky City to Fort Wayne passes through it. Imports in $1850, \$ 33,978$, and exports, $\$ 24,755$.

Purt Cllaton, p. v., Lake county, $I l l .: 199$ m. N. N. E. Springfield.

Port Clenton, p. $\nabla$. , Schuylkill co., Penn. : at the confluence of the Little Schuylkill and the Schuylkill, and above the Water Gap in Biue Mountain, 51 m. E. N. E. Harrisburg. It is one of the great coal depôts of the anthracite region, and being on the line of the Schuylkill Canal and Reading $R$. R., it enjoys a large share of the trade connected wilh the mines. The Litlle schuylkill R. R. also diverges from this point, and a number of other railways connecting with the mines are indirectly connected with the port. There are large iron works in the vicinity, and in the v. a rolling mill of 1,500 tons annual capacity, also various mechanic shops, stores, etc.

Pont Conway, p. v., King George co., Firg.: on the left bank of liappthannock r., $49 \mathrm{~m}$. N. by E. Richmond. Wheat and corn are shipped here in large quantities.

Port Crave, p. v, Broome co., $N$. Y. : on Chenangor, and canal, $8 \mathrm{~m}$. N. of Binghampton, $107 \mathrm{~m}$. W. by S. Albany.

Port Deposite, p. V., Cecil co., MId.: on the E, side of Susquehanna river, $7 \mathrm{~m}$. from its mouth, $51 \mathrm{~m}$. N. E. by N Annapulis. It lies at the lower falls, and contains a bank and 300 inhabitants.

Pont Douglass, Essex county, N. $Y$.: on the W. side of Champlain lake, and the landing for Keeseville, which is 7 or $8 \mathrm{~m}$. W. of it.

Pois Elzizabete, p. $\nabla$., Cumberland county, $N$. Jer.: on Manamuskin creek, near its entrance into Maurice r., $61 \mathrm{~m}$. $\mathrm{S}$. by W. Trenton. It is $15 \mathrm{~m}$. from Delaware bay, and vessels of 100 tons come to the landing. Whod and lumber are exported in large amounts. It contains an academy, several stores and mills, and about 600 inhabitants.

PCremer county, Ind. Situate N. W., and contains 396 sq. m. Drained by Calumic r. and branches, and branch of Kankakee r, which runs on ils S. border. Surface varied, on the lake buing elevated, while in the interior and toward the S. the land is generally level; soil fertile, with the exception of some portion in the $\mathbf{N}$., and the swamp on the Kunkakec in the $\mathrm{s}$. Chite pruduetions, whe at and Indian corn. There is some prairie lund, and a large portion of the co. is covered with oak and other timber. It contains several small lakes. Farms 467; manuf. 13 ; dwell. SS5, and pop.wh. 5,229, fr. col. 5-total 5,231. Capital: Valpuraiso, Pulic Hivl: : Michigan Central Extension R. R..; Indiana Nortbern R. R.; Michigan City Branch R. R.; Fort Toyne and Chicaro R. R.; Ligansport and Chicago R. P.

Porter, sta., Porter co., Ind.: $2 \mathrm{~m}$. W. of Michigan City, on the Nichigan Central R. R.

Poprek, t. and p. 0, Van Buren co., Afich. : $82 \mathrm{~m} . \mathrm{S}$. W Lansing. It contains sevira! ponds, but has no censiderable streums. Surface mostly level, and soil of good quality. Pop, 414.

Purter, t. and p, o, Delaware co., Ohio: $25 \mathrm{~m}$. N. N. E Columbus. Drained by Walnut cr., which mores several mills, Surfuce somewhat uneven; soil very productive of grass and grutu. Tle sirringfild, Nount Ternon, and Pittsburg R. R. crosses it. Pop. $1,037$.

Porter, t. Niagara co., $\lambda$. $Y$.: facing on Lake Ontario and Niagara $r$.. aud drained by several creelis fitling into the lake. Surface level; soil argillaceous and sandy loam. 692
In the N. W. part of the town stands old Fort Niagura, ans? directly opposite, on the Canada shure, Fort Genrge. Fort Niagara was taken by the British in Dec., 1813, and delirered up again in March, 1815. Toungstown is a village on the Niagara river. $P$ op. of t. 2,455

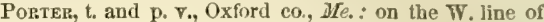
the State, and N. side of Ossipee river, $71 \mathrm{~m}$. S. W. by W. Augusta. Surface slightly uneven; soil fertile and well wooded. A farming and grazing t. Pop. of t. 1,208.

Porterfield, p. o., Venango county, Penn.: $173 \mathrm{~m}$. N. W. by W. Harrisburg,

Porter Ridge, p. o., Susquehanna co, Penn. : $117 \mathrm{~m}$. N. N. E. Harrisburg.

Porter's p. o., Carroll co, MId. : $46 \mathrm{~m}$. N. W. Annapolis.

Portel:'s, sta., Middlesex co, Mass. .: $3 \frac{3}{4} \mathbf{m}$. from Boston, on the Fitchburg R. R. The Cambridge cattle market is held weekly at this station.

Porter's Corners, p. o., Saratoga co., $N$. $Y_{\text {. : }} 34 \mathrm{~m}$. N. by W. Albany.

Porter's Cross Roads, p. o., Porter co., Ind. : $121 \mathrm{~m}$. N. N. W. Indianapolis.

Porter's Falls, p. o., Wetzel co., Firg. : 225 m. N. W. Richmond.

Poptenstille, p. v., Buller co., Penn.: 174 m. W. by N. Harrisburg.

Portersville, p. v., Tipton co., Tenn. : 171 m. W. S. W. Nashville.

Portersille, p. v., Perry co., Ohio: $45 \mathrm{~m}$. E. by S. Columbus.

Port Gibsox, p. v., and cap. Claiborne cn., Mirs.: on Bayou Pierre, $25 \mathrm{~m}$. from its entrance into the Mississippi, $52 \mathrm{~m}$. W. S. W. Jackson. The $\mathrm{v}$, has a large trade in cotton, which is sent down the bayou in keel boats most of the year, or by land to Grand Gulf, its port. It contains a court-house, jail, academy, and 500 inhabitants. The "Herald and Correspondent" (whig) is published weekly.

Port Guson, p. v., Ontario co., N. Y.: on the Erie Canal $31 \mathrm{~m}$. E. of Rochester, $107 \mathrm{~m}$. W. by N. Albany.

Port Glasgow, p. v., Wayne co., N. Y.: on the $\mathrm{S}$. side of Lake Ontario, 151 m. W. N. W. Albany.

Pont Hexry, p. v., Essex co., $N_{\text {. }} Y_{\text {. }}$ : on the W. shore of Lake Champlain, opposite Crown Point, $91 \mathrm{~m}$. N. by E. Albany. It has a convenient steamboat landing, and contains extensive iron works, for which excellent ore is obtainel in the immerliate vicinity, and about 500 inhabitants. Port Hoster, p. ₹., Jefferson co., Ohio: 122 m. E. by N. Columbus.

Port Hore, t. and p. o., Columbia co., Wisc. : $53 \mathrm{~m} . \mathrm{N}$. Madison. Drained by Neenah river, on both sides of which it lies. Surface eren, and soil rich. It has good mill privileges, and some timber. Pop. 608.

Port Hudson, p. v., East Feliciana par., La.: on the Mississippi at the mouth of Thompson's cr., $25 \mathrm{~m}$. by the r., thove Baton Rouge. It has a fine landing for steamboats, ind does a large business in the shipping of cotton, sent here by the Clinton and Port Hudson $\mathrm{P}_{\text {. }} \mathrm{R}$. of which it is the river terminus.

Port Hurox, t. and p. v., St. Clair county, Arich. : $113 \mathrm{~m}$. E. by N. Lansing. Drained by Black r., emptying into the St. Clair, its E. boundary. Surface even, and well timbered; soil highly productive. The v. lies at the confluence of Black and St. Clair rivers, $2 \mathrm{~m}$. S. of Lake Huron, has a good harbor, and superior facilities for ship-building, and is largely engianed in the lumber business. Great amounts of excellent pine timber are seut down Black river, and manufactured or shipped here. It contains several flouring and saw mills, large lumber yards and commercial houses, and $1.5-4$ inh bitants. Fort Gration is about $1 \mathrm{~m}$. N. of the $\mathrm{r}$. The "P. H. Observer" (dem.) is published weekly. Pop. of t. 2.312.

Port J Jcksox, p. v., Montgomery co., $N$. $Y_{\text {. : }}$ on the Erie Canal, and S, side of Mohawk r, $17 \mathrm{~m}$. W. N. W. Schenec tady, 25 m. I. W. Albany. 
Pont Jeffersox, p. v., Suffilk co., $N$. $Y$.: on the N. side / surfuce rises from each shore, forming throughout its entire of Long Islaud, at the head of Drowned Meadow Ilarbor, $115 \mathrm{~m}$. S. S. E. Albany. It contains several ship-yarils, and 850 inhabitants engaged in ship-building and navigation.

Port Jervis, p. v., Orange co., $\boldsymbol{N}, \boldsymbol{Y}$ : : on the left bank of Delaware $\mathbf{r}$, at the confluence of Neversink river, $94 \mathrm{~m}$. S. S. W. Albany. This place is on the Delaware and Hudson Canal, and owes its origin and growth to that work. The Erie R. R. also passes through it, and at Delaware sta. are extensive depots, engine-houses, offices, etc., belonging to the company. The business done here is chicfly in eoal and timber. The scenery around the village is magnificent. The Neversink is crossed by a bridge 55 feet high, with a span of 150 feet. The $\mathrm{v}$. contains 4 or 5 churches, a femile seminary, several schools, a large grist-mill, hotels anit stores, and about 600 inhabitants.

Port Kendall, p. v., Essex co., N. F.: on the W. shore of Lake Champlain, and N. side of Perou bay, 116 miles N. by E. Albany.

Port Kendall, p. v., Orleans county, $N . Y_{\text {.: }}$ on Lake Ontario, $32 \mathrm{~m}$. W. N. W. Rochester.

Port Kenneny, p. v., Montgomery co., Penn. : on the right bank of Schuylkill r., $4 \mathrm{~m}$. above Norristown, $77 \mathrm{~m}$. E. by S. Harrisburg. It is $21 \mathrm{~m}$. N. W. Philadelphia, on the Philadelphia and Reading $\mathrm{R}$. R.

Port Ke.st, p. v., Essex co., $N$. I.: on Lake Champlain, $12 \mathrm{~m}$. S. of Plattsburg, $122 \mathrm{~m}$. N. by E. Albany, It nceupies a commanding eminence, nearly opposite to Burlington, with which a steam ferry connects it, and contains several stores, and 300 inhabitants.

Porteand, p. $\nabla$. , Dallas co., $A l \alpha$. : on the left bank of Alabama river, 53 W. by S. Montgomery.

Portlasd, t. and p. v., Middlesex en, Conn. : on the E. side of the Connecticut, 13 is. S. by E. Hartford. Surface level meadow on the river, back of it broken and adapted to grazing. Stretching along the river for about a mile, and nearly opposite Middletown, are the eelebrated quarries of Building stone, know $n$ as the "Portland stone." About 600 men are employed, and the stone, which is used in the most elegant public and private edifices, is sent to all parts of the Union. The University in Lonilon is also built of it. The $\mathrm{v}$, is on the river, and connected by a steam furry with Middletown. It contains a flourishing academy, and several stores. At the lower end of the street, which is about $2 \mathrm{~m}$. Jong, are the quarries, and at the upper end a shipyard, where ressels are built for the river and consting rade. Pop. of t. 2.905. Taken from Chatham in $15+1$.

Portlani, p. F.. Whitesides er., Ill.: on the S. side of Rock r., $131 \mathrm{~m}$. N. by W. Springfielu.

PorTuAN, p. V., Fountain con, Ind.: on the E. side of Wabash river, and on the Wabasts and Erie Canal, 66 miles T. X. W. Indianapolis. It contains 8 or 10 stores and 500 inhabitants.

Pistlard, p. r., Van Buren co., Ir.: on the S. side of the Des Moines, 61 m. S. W. by S. Iowa City.

Portzaxd, p. v., Jefferaion co., Ky.: on the Ofio, $3 \mathrm{~m}$. ielos Louisvîle, $52 \mathrm{~m}$. W. by N. Frankfort. It is well built along the bank of the r., and contains several comznercial houses, and about 1,100 inhabitants. Omsnibuses fly hourly to Louisville, and a ferry connects it with New Aibany on the N. side of the Onio.

Pontland, p. V., port of entry, and eap. Washington co., Oreg. : on the left bank of Willamette r, above its entranee into the Columbia, $47 \mathrm{~m}$. N. by E. Salem. It is a place of considerable commeree, and has exeellent prospects of becoming a large city. Pop. 822 . The territorial penitentiary is located here.

PORTiND, t. p. city, port of entry, and cap. Cumberland $c_{0}, M e_{0}$ : is situated on an elevated peninsula, at W. extremity of Caseo bay, 54 m. S. S. W. Augusta, lat. (Mount Joy) $43^{\circ} 39^{\prime} 52^{\prime \prime}$ N.; and long. $70^{\circ} 13^{\prime} 34^{\prime \prime} \mathrm{W}$. The peninsula projects eastwardly into the bay, about $3 \mathrm{~m}$. in length, and hag an aserage width of threc-fourths of a mile. Its th an elevated ridge, which, at its extremities, again rises into considerable bills, presenting a marked outline, and very beautiful appearance. The eity is regularly laid out, and handsomely built, particularly its more modern portions, which are noted for their elegant buildings, and is lighted with gas. The main street occupies the ridge of the peninsula, extending from hill to hill. Many of the streets are lined with elms and other shade trees. The principal public buildings consist of the Exchange, which is an elegant structure, with handsome colonnade and dome, containing the post-office, custom-house, and United States court rooms ; the City Hall, built of brick : the old Customhouse, of granite, 18 churches, jail, ete. There are 6 banks, with an aggregate capital of $\$ 1,125,000$. The capital of the city is chiefly employed in commerce, coastirg trade, the fisheries, and inland tracle; hence its manufactures are, for the most part, those incident to a mereantile city. The Portland Company, with a capital of $\$ 100,000$, have a large manufactory of locomotives, railroad cars, ete. Much attention is given to education in the public sehools. These consist of a classical school for boys, a high school for girls, 4 grammar schools ( 2 for boys and 2 for girls), and the primary schools. There are also numerous private schools and an academy. The Athenæum, incorporated in 1527 , has a library of over 6,000 volumes. The Natural History Society has a valuable collection of minerals, specimens, etc. Two daily newspapers are publisher, "Advertiser" (whig), and "Eastern Argus" (dem.), which also issue tri-weekly and weekly editions, Besides these are seven weeklies,viz., "Transeript" (lit.), "Christian Mirror" (Pres.), "Zion's Advocate" (Bapt.), "Inquirer" (F. soil), "Pleasure Boat" (miscel.), "Cold Water Fountain" (Temp.), and " $\mathrm{Na}$ tional Democrat." The "Scholar's Leaf" (educa.), is issued semi-monthly. The natural advantages of this eity for trade and commerce have been well improved by its enterprising citizens. The harbor is capacious and safe, and among the best in the United States. It is protected by islands from the violence of storms, is seldom obstructed by ice, has a good entrance, and is defended by forts Preble and Scammel, the former garrisoned by U. S. artillery. At the E. extremity of the city is a tower, 70 feet high, erected for the purpose of observing vessels at sea, and furnished with signals. The harbor is connected by the Cumberland and Oxford Canal, 20 $\mathrm{m}$. long, with Sebago pond, and thence with Long pond, etc. Four important raillroads now centre at Portland, and contribute greatly to its prosperity. The Portland, Saco, and Portsmouth R. R., $51 \mathrm{~m}$. long, was opened in 1842, completing the line of railroads from Boston to this eity, $105 \mathrm{~m}$. The extension of this route, called Portland and Kennebec R. R., is completed to Augusta, $60 \mathrm{~m}$. The York and Cumberland R. P. (now open to Gorbam, $10 \mathrm{~m}$.) is in construction, to connéct at South Berwick with the Bostron and Maine R.P. The construction of the Atlantic and St. Lawrence R. P., commenced in 1844 , has been actively prosecuted from each terminus, Portland and Montreal, and will soon be completed. By contract it is to be finished in 1553. Through this important avenue will pass a large proportion of the products of the north and west for shipment to Europe and elsewhere. The foreign commerce of the city is chiefly with the West Indies and Europe. Its chief exports are lumber, ice, fish, provisions, etc. The coasting trade is principally with Boston, and during the summer a steamboat plies daily to that city. On 30 th June, 1850 , the total tonnage of district was $\$ 6.512$ tons, of which 60,304 tons were registered, and 26,195 tons enrolled and licensed. The registered tonnage consisted of 46,621 tons permanent, and 13,653 tons temporary, of which 100 tons were propelled by steam. The enrolled and licensed tonnage consisted of 25,665 tons "permanent." which were employed as follows: in eoasting trade, 19,427 tons; in cod fishery, 3.238 tons; in mackerel fishery, 3,000 tons; and 533 tons "licensed under 20 tons," which were in 
the cod fishery. During the fiscal year preceding the total of clearances for foreign countres was $523-7 \pi, 645$ tons; the intal of entrances do. Was $447-64.195$ tons. Vessels built during the year preceding, 29 (20 ships, 5 hrigs, 3 sehooners, 1 steamer)-11.477 tons. Pop. in 1830, 12,598: in 1840, 15,218; in $1851,21,815$.

Poltuand, t. and p. v., Ionia co., Mich.: $22 \mathrm{~m}$. W. N. W. Lansing. Intersected by Grand $\mathbf{r}$., which here receives Iouking-Glass $r$. from the E. Surface level; soil alluvial boltom of great fertility. The $\mathrm{r}$. is on Grand r., and contains several mills. Pop. 763.

Portuand, p. V., Callaway co., Mo. : on the N. bank of the Missouri, 27 m. E. N. E. Jefferson City.

Portland, t. and p. o., Chautauque co., N. Y.: on Lake Erie, $253 \mathrm{~m}$. W. by S. Albany. Drained by small affluents of the lake, some of which afford water-power. Surface hilly, and inclining to the lake; soil sandy loam, and generally fertile. It has a good harbor, and is crossed by the Buffalo and State Line R. R., on which is Centreville sta., $10 \mathrm{~m} . \mathrm{s} . \mathrm{W}$. of Dunkirk. Pop. 1,905. The light-house is lighted with natural gas, which issues from the ground.

Portland, p. v., and cap. Jay co., Ind. See Jay C. H. Pop. 786.

Portland Miris, p. v., Parke co., Ind : on Big Paccoon creek, $44 \mathrm{~m}$. W. Indianapolis.

Portlandville, p. v., Otsego co., N. Y.; on the Susquehanna, $62 \mathrm{~m}$. W. by S. Albany. It contains several mills and 300 inhabitants.

Port Lafacca, p. v., and cap. Calhoun co., Tex. : on the W. side of Lavacea bay, $134 \mathrm{~m}$. S. E. by S. Austin City. It has a good harbor, which has been much improved of late, is extensively engaged in the coasting trade, and is the shipping port for the products of the rich district bordering the Lavacea and its tributaries. It is also the proposed terminus of the San Antonio and Gulf R. R.

Port Lexden, p. v., Lewis co., N. Y.: 93 N. W. by W. Albany.

Port Louisa, p. v., Louisa co., Ia : on the Mississippi, $36 \mathrm{~m}$. S. E. Lowa City.

Port Mercer, p. v., Mercer co., N. Jer.: on the Delaware and Raritan Canal, $7 \mathrm{~m}$. N. E. by N. Trenton.

Port Ontario, p. v., and port, Oswego $c_{*}, N_{*} Y_{*}:$ on the E. shore of Lake Ontario, at the mouth of Salmon r., $136 \mathrm{~m}$. W. N. W. Albany. It has a good harbor, improved by a pier constructed by the general government, and contains about 300 inhabitants.

Poвт OxFord, p. v., and port, Umpqua co, Oreg. Ter.: on the coast of the Pacific, $160 \mathrm{~m}$. S. S. W. Salem. A U. S. military post is kept up here, garrisoned by dragoons.

Port Penn, p. Y., Newcastle co, Del. : on Delaware $r_{.}$ opposite Reedy Island, $24 \mathrm{~m} . \mathrm{N}$. by W. Dover.

Port Perry, p. v., Alleghany countr; Penn.: 151 m. W. Harrisburg.

Port Perry, p. v., Perry co., Mo.: on the Mississippi, $129 \mathrm{~m}$. E. by S. Jefferson City.

Port Preston, v., Refugio $\mathrm{co}_{\text {, }}$ Tess.: at the entrance of Missinn r. into Aransas bay, about $20 \mathrm{~m}$. below Refugio-the county seat.

Port Providencr, p. v., Montgomery co., Penn.: $71 \mathrm{~m}$. E. by S. Harrisburg.

Port Republic, p. v., Calvert co., Md..; 35 m. S. Annapolis, Port Republac, p. o., Atlantic co., N. Jer.: 47 m. S. by E. Trenton.

Port Republic, p. $\vee_{\text {. }}$ Roekingham county, Virg. : on Shenandoah r., at the confluence of South r., $88 \mathrm{~m}$. N. W. by W. Richmond. It contains sereral mills and 300 inhabitants.

Port Pichrond. p. v., Philadelphia co., Penn.: on the Delaware, opposite Petty's Island, about $2 \mathrm{~m}$, above Philadelphia, $94 \mathrm{~m}$. E. by S. Harrishurg. Here is the depôt and shipping place of the Philadelphia and Reading R. R. In the last 9 months of $15 j 2, S$ ships, 94 barks, $5 \pi 1$ brigs, $5,4 \leqslant 2$ schooners, 384 sloops, and 2,759 barges were loaded with coal at this place.
Port Richrond, p. Y., Richmond co., N. $Y_{.}$: on the $\mathrm{N}$ side of Stuten Island, $9 \mathrm{~m}$. S. W. New York, $131 \mathrm{~m}$. S by W. Albany. It contains a valuable granite quarry, and about 500 inhabitants. A steam ferry connects it with New York.

Port Royai, p. o., Henry co., ky.: 22 m. N. N. W. Frankfort.

Port Royal, p. V., Juniata co., Penn.; on the S, side of W. branch of Susquehanna $x_{*}, 31 \mathrm{~m}$. W. N. W. Harrisburg.

Port Royal, p. v., Montgomery co., Tenn.: on Red r. $33 \mathrm{~m} . \mathrm{N}$. W. Nashville. It contains several mills and stores and 250 inhabitauts.

Port Royal, p.v., Caroline co., Virg. : on the right bank of Rappahannock r., $44 \mathrm{~m}$. N. N. E. Richmond. Large quantities of wheat, eorn, and tobacco are shipped here, and a considerable trade with the interior is kept up. A ferry crosses the $r$. It has a good wharf and steamboat landing, and contains 2 academies, a dozen stores, and 470 inhabitants.

Portswouth, p. F., Dauphin co, Penn.: on the Susquehanna $\mathbf{r}_{a}, 8 \mathrm{~m}$. below Harrisburg.

Portsmouth, t., p. city, port of entry, and one of the caps.

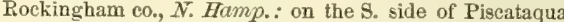
r., $3 \mathrm{~m}$. from the ocean, $41 \mathrm{~m}$. E. by S. Concord. Lat. (Unitarian church) $43^{\circ} 4^{\prime} 35^{\prime \prime} \mathrm{N}$.; long. $700^{\circ} 45^{\prime} 50^{\prime \prime} \mathrm{W}$. This is the largest town and only seaport in the State. Its site rises gradually from the harbor, is pleasant and healthy. The city is not regularly laid out, but its streets, though narrow, are neatly built, and contain many handsome buildings, This $\mathrm{t}$, was settled in 1623, and incorporated in 1633. It has several times suffered severely by fires, but has been rebuilt with improved appearance. It has long been noted for its commercial enterprise, and its capital is mainly employed in navigation. Many vessels, though owned at this port, are employed elsewhere. Ship building is largely carried on The principal manufactories are: Portsmouth steam factory, erected 1846-47, 200 feet long, 6 stories high, making fine cotton fabries, a very superior establishment; an extensive manufactory of hosiery-also one of twist; machine shop and car factory ; iron foundry, etc. There are 3 banks, aggregate cap. $\$ 491,000$. The to is supplied with good water from a fountain, $3 \mathrm{~m}$. distant, by a company formed in 1799 . Among the public buildings are 5 or 6 handsome churches, an athenæum, academy, the State lunatic hospital, 2 markethouses, alms-house, etc. The Athenæum, incorporated 1817 , has a handsome brick edifice, 3 stories high, with a library of 7,300 volumes, besides cabinets of minerals and of natural history. Portsmouth is connected with Boston by the East ern R. R., 54 m.; from Portland, $51 \mathrm{~m}$; and with Concord, by the Portsmouth and Concord R. R., $47 \mathrm{~m}$. The Piscataqua, in passing the to, is from $\frac{1}{8}$ to $\frac{\mathrm{g}}{3} \mathrm{~m}$. wide, and though it flows with such rapidity as prevents its freezing in winter, it forms one of the most secure and commodious harbors in the U.S. The harbor has 40 feet of water in the channel at low tide, and is protected from storms by headlands and its islands. It is defended by Fort Constitution, on Great Island, and other forts. The U. S. Navy Yard, located on Continental or Badger's Island, on the E. side of the river, contains a dry dock of costly construction, and 3 immense ship houses, the largest of which, 240 feet long, 131 feet wide, has its roof covered with 130 tons of slate. A naval officer is stationed at this port. The total tounage of Portsmouth district on 30 th June, 1350, was 23,096 tons. The registered tonnage was 14,979 tons, of which 12,069 were permanent, and 2,910 temporary. The enrolled and licensed tonnage consisted of 8,117 tons, of which 7,511 were permanent, 393 temporary, and 215 tons "licensed under 20 tons" in the cod fishery. The coasting trade employed 4,025 tons, end fishery 2.664 tons, mackerel fishery 1,204 tons During the year ending 30 th June, 1850, the number of clearances for foreign countries was $107-8,213$ tons; number of entrances do, 110-11,044 tons. Vessels built during the rear. 10-\$ ships, 2 schooners -6.914 tons. Newspapers"P. Dispatch," daily; "Rockingham Messenger" (indep.) 
"N. H. Gazette" (dem.), "P. Journal" (whig), weekly. Pop. in $1810,6,934$; in $1820,7,327$; in $1830,8,082$; in 1540 , 7,557; in $1550,9,739$.

Pomtsmouth, p. v., Carteret co., N. Car,: 148 m. E. by S. Raleigh. It is on the S. side of Ocracoke inlet to Pamlico Sound, and principally inhabited by fishermen and pilots.

Pontsmouth, p. v., and cap. Scioto co., Ohio: on the Ohio river, at the mouth of Scioto $x_{.}, 83 \mathrm{~m} . \mathrm{S}$. Columbus. The $t_{\text {. }}$ presents a handsome appearance from the $r_{\text {., }}$ is well built, and is surrounded by the most fertile district of the Ohio valley. The v, contains a fine court-house, several churches, an excellent academy, bank, market-house, jail, etc. Iron manufactures are extensively prosecuted, from the abundance of iron ore in the vicinity. Mineral coal and fine building-stone are also abundant; the latter is much used in Cincinnati. The building and repairing of steamboats is carried on upon the opposite side of the Scioto. Newspapers-"Tribune and Clipper" (whig), daily and weekly; "P. Dispatch" (dem.), daily ; "P. Enquirer" (whig), weekly, The Scioto and Hooking Valley R. R. runs hence through the mineral district, connecting at Newark with the several E. and W. lines, and those to. Sandusky, Cleveland, etc. Here also terminates the Ohio Canal from Cleveland, $309 \mathrm{~m}$. in aggregate length. Pop. in 1850, 4,011.

Portsmouth, p. v. and port, Norfolk co., Firg.: on the W. side of Elizabeth r., opposite Norfolk, $80 \mathrm{~m}$. S. E. Richmond. Its harbor is one of the best in the U.S., permitting vessels of the largest class to come up to the wharves. The village is regularly laid out, with streets crossing at right angles, and contains a court-house, jail, 5 churches, bank, etc. The Sea-board and Poanoke R. R. extends W. from Portsmouth to Weldon, 80 miles, connecting with the main line of coast railroad, and a line is now being constructed from Portsmouth to Petersburg. Adjoining Portsmonth is Gosport, containing the navy yard, dry dock, etc. Population, 6,371 .

Portsmouth, t. and p. v., Newport county, $R . I_{\text {. : }} 19 \mathrm{~m}$. $\mathrm{S}$. by E. Providence. It comprises the N. part of $R$. $I$. and several adjacent islands in Narragansett bay. Soil everywhere fertile, and under high cultivation. Large flocks and dairies are kept, and much grain and fruit raised. Coal and plumbago are found. Many of the inbabitants are engaged in the coasting trade and fisheries. A bridge on the E. side connects it wilh Tiverton, and on the N. a ferry plies to Bristol. Pop. 1, 333 .

Port Tовасco, p. v., $_{\text {, }}$ and cap. Charles co, MId.: at the head of Tobaceo r., $8 \mathrm{~m}$. from the Potomac, $42 \mathrm{~m}$. S. W. Annapolis. It has an extensive trade in tobaceo, the staple of the co., and contains a court-house, jail, and about 500 inhabitants. The "P. T. Times" (neut.) is issued weekly.

Port Criox, p. v., Butler eounty, Ohio: 82 m. W. S. W. Columbus.

Portville, t. and p. v., Cattaraugus co., $N, Y_{*} ;$ on the S. line of the State, $232 \mathrm{~m}$. W. by S. Albany. Drained by Alleghany $r$, and branches, on which are numerous sawmills. Surface broken; soil sandy loam, and heavily timbered with pine. Pop. 747.

Port Walthald, v. and port, Chesterfield county, Firg.: on the Appomattox r., 19 m. S. S. E. Riehmond. A short branch from the Richmond and Petersburg R. R. comes up to this place, connecting with the James river steamers plying to Norfolk, etc.

Pozt Walthall Junction, sta., Chesterfield co., Vurg. : $6 \mathrm{~m}$. N. of Petersburg, on the Richmond and Petersburg R. R. A branch R. R. diverges hence to connect with steamers at Port Walthall.

Port W asmingtoN, p. v., and port Tuscarawas co., Ohio: on the Ohio Canal and the right bank of Tusearawas $\mathbf{r}_{\text {, }}$ $78 \mathrm{~m}$. E. by N. Columbus. It contains several stores and warehouses, and 269 inhabitants. Imports in $1950, \$ 278,311$, and exports, $\$ 45.277$.

Poit Wulfay, p. vo, Franklin co, MLO.:4 m. S. of the Missouri, 67 m. E. Jefferson City.
Port Wrlliam, p. v., Clinton co., Ohio: on Anderson's fork of Little Miami r., $49 \mathrm{~m}$. \$. W. Columbus.

Posex county, Ind. Situate S. W., and contains $408 \mathrm{sq} . \mathrm{m}$. Drained by Big and Flat creeks, tributaries of the Wabash r., which forms its western boundary. Surface varied; in general it is rolling, but there are some hilly portions, and on the Ohio and Wabash the land in many places terminates in high blufis; soil moderately fertile and best adapted to corn and grazing. Chief productions, wheat and Indian corn. Pork is exported largely. It contains some good beds of coal, and has a quantity of fine timber, some of which is exported. Farms $1,2 \pi 0$; manui. 26 ; dwell. 2,260 , and pop.-wh. 12,451, fr. col. 95-total 12,549. Capital: Mount Vernon.

Poser, p. o., Madison co., Ky. : 5 S m. S. E. Frankfort.

Poserville, p. v., Posey co., Ind.: $185 \mathrm{~m}$. S. W. by S. Indianapolis.

Post Creiek, p. o., Chemung co., N. $Y .: 158 \mathrm{~m} . \mathrm{W}, \mathrm{S} . \mathrm{W}$ Albany.

Post Mill Village, p. v., Orange county, Verm.: on Ompompanoosuc r., 31 m. S. E. by S. Montpelier.

Posт OAK, p. 0., Yallabusha co., Miss.: 119 m. N. by E. Jackson.

Post OAK, p. o., Johnson co., Mo.: 85 m. W. Jefferson City.

Post OAK, p. o., Iredell co., $N$. Car.: 128 m. W. by N. Raleigh.

Post Oat Springs, p. o, Roane co, Tenn.: 119 m. E. by S. Nashville.

Post Town, sta., Butler co., Ohio: $20 \mathrm{~m}$. S. of Dayton, on the Cincinnati, Hamilton, and Dayton R. P.

Postrille, p. V., and eap. Logan co., Ill.: on Salt cr. $28 \mathrm{~m}$. N. E. by N. Springfield. It contains a court-house, jail, several stores and mills, and about 500 inhabitants.

Postrille, p. v., Allemakee co., Ia.: 95 m. N. Iowa City. Postville, p, v., Herkimer co., $N . Y_{*}: 78$ m, W. N. W. Albany.

Potato Creek, p. o., Ashe co., N. Car. : 173 m. W. by N. Raleigh.

Poтen river, Ind.Ter, : a small tributary of the Arkansas river, which it enters at Fort Smith.

Potecasi, p. o., Northampton co., N. Car.: 87 m. E. N. E. Raleigh.

PoTomac river, $M d$. and Virg.: rises in two branches the $\mathrm{N}$. and the S., which unite in Hampshire co, near the Alleghany Mountains, and thence forms, through nearly its whole course, the boundary between Virginia and Maryland. At Alexandria, $290 \mathrm{~m}$. from the ocean, it is $1 \frac{1}{4} \mathrm{~m}$. wide; it is $550 \mathrm{~m}$. long, and enters Chesapeake bay, be tween Point Lookout and Smith's Point, by a mouth $10 \mathrm{~m}$. wide. Il is navigable for ships of the line to the navy yard in Washington, $300 \mathrm{~m}$. from the ocean, and $8 \mathrm{~m}$. below the head of tide-water. Above this it is obstructed by numerous falls and rapids. Little Falls are $3 \mathrm{~m}$, above Washington, with a descent of 37 feet, around which is a canal $2 \frac{7}{2} \mathrm{~m}$. Iong with 3 locks. Great Falls are $8 \frac{1}{3} \mathrm{~m}$. above, descend perpendicularly 76 feet, around which is a canal of 5 lock3. Seneca Falls, $5 \mathrm{~m}$. above, descend 10 feet; Shenandoah Falls, $60 \mathrm{~m}$. above, are, at the passage of the river, through the Blue Ridge; Houris Falls are $5 \mathrm{~m}$. above. Around all these falls canals have been constructed. The fall of the Potomac, from the mouth of Savage $r$, which enters the Potomac at Westport, to Cumberland, $31 \mathrm{~m}$., is 445 feet from Cumberland to the Shenandoah Falls, $130 \mathrm{~m}_{\text {. }} 490$ feet; at the Shenaniloah, in $5 \frac{1}{2} \mathrm{~m}$., 13 feet: from the Shenandoah to Great Falls, $40 \mathrm{~m}$., 39 feet; and thence to tidewater, $12 \mathrm{~m} ., 143$ feet-the whole descent from the month of Savage river to tide-water, $219 \mathrm{~m}$., is 1,160 feet. Its principal tributary is the Shenandoah, $200 \mathrm{~m}$. long, and navigable $100 \mathrm{~m}$., which enters it on the S. side from Vircinia immediately before its passage through the Blue Ridge, This passage is a great curiosity, and its surrounding scenery very grand. The Potomac is 42 feet deep at its mointh, 
80 at St. George's island, 18 at Swan's Point, and thence to Alexandria.

Potust, p. v., and cap. Washington co, Mo.: $83 \mathrm{~m}$. S. E. by E. Jefferson City. It lies in the heart of a rich mining region, abounding in lead and iron ores. The lead ore, in the form of sulphuret or carbonate, yields from 70 to 80 per cent, of pure metal. Zinc blende and calamine are also found in great quantities here. The v. contains a courthouse, jail, academy, and about 1,000 inhabitants. In its vicinity are several iron furnaces.

Potosi, t. and p. v., Grant co., Wisc. : on the Mississippi, $74 \mathrm{~m}$. W. S,W. Madison. Drained by Grant and Big Platte rivers, which flow on its W. and E. borders. Surface uneven; soil moderately fertile. The $\mathrm{v}$. is largely engaged in shipping the lead, which is mined in immense quantities in the vicinity, down the river, and has a population of about 1,000. The "P. Republican" is issued weekly.

Potsda $x_{4}$ t., p. v., and sta., St. Lawrence co., $N . Y$.: on Racket river, 156 m. N. N. W. Albany. Surface undulating; soil sandy loam, and very productive, underlaid by limestone and red sandstone, very fine building materials. The $v$, receives abundant water-power from falls in Racket river, improved by various mills and factories. The St. Lawrence Academy, here located, is a flourishing chartered institution, having 2 large stone edifices, 4 stories high. The "St. Lawrence Mercury" (neut.), and the "Courier" are published weekly. The Northern R. R. passes through the town, $\mathrm{N}$. of the village, $25 \mathrm{~m}$. from Ogdensburg, $93 \mathrm{~m}$. from Rouse's Point, and the Watertown and Northern Junction R. R. is now being constructed. Pop. of t. 5,349.

Potrer county, Penn. Situate N., and contains 1,064 sq. m. Drained by affluents of W. branch of Susquehanna river, head branches of Genesee, Tioga, and Alleghany rivers, and Pine, Simremahoning, and Kettle creeks. Surface somewhat elevated; soil a rich loam, and productive. It contains fine beds of coal, and iron ore of a good quality, and is well timbered. Farms 638; manuf. 55 ; dwell. 1.185, and pop.-wh.6,042, fr. col. 6-total 6,048. Capital: Coudersport.

Potter, t. and p, o., Yates co., $N . Y_{\text {.: }} 169 \mathrm{~m}$. W. by N. Albany. Drained by Flint cr. Surface hilly: soil fertile, gravelly loam; a superior farming and grazing t. Population 2,194.

Potter Place, sta., Merrimac county, N. Hamp.: $30 \mathrm{~m}$. N. W. of Concord, on the Northern R. R.

Potten's Creiek, p. o, Ocean co, N. Jer.: 27 m. E. S. E. Trenton.

PotтkR's Hru, p. v., Washington $\mathrm{co}_{*}, R . I$. : $^{2} 29 \mathrm{~m} . \mathrm{S} . \mathrm{S} . \mathrm{W}$. Providence.

Portri's HnL, p. o., Renssclaer co., $N . \bar{Y}$.

PotTer's Hollow, p. V., Albany county, $N . \bar{Y}: 29 \mathrm{~m}$. S. W. by W. Albany; a farming settlement, near the head of the Catskill.

Potreik's Milis, p. o., Centre county, Penn.: 55 m. N. W. Harrisburg.

Potthrstilie, p. v., Hunterdon county, N. Jer.: $29 \mathrm{~m}$. N. Trenton.

Potterstille, p. V., Warren co, $N_{*} Y_{0}$ : on Schroon $r_{*}$, $71 \mathrm{~m}$. N. Albany.

Pottersville, p. Y., Mahoning co., Ohio: 129 m. E. N. E. Columbus.

Potterstille, p. v, Cheshire county, $N_{\text {. }}$ Hamp.: $38 \mathrm{~m}$. S. W. by W Concord.

Potrowatomie county, $I a$. Situate W. toward the $\mathbf{S}$. and contains about $950 \mathrm{sq}$. m. Drained by Nishnabatona $\mathrm{r}$., and $\mathrm{Keg}$, Mosquito, and Gophen creeks, all branches of Missouri r., which runs on its western border. Surface undulating; soil fertile. Set off since 1550 .

Potr's Cerek, p. o., Alleghany co., Virg. : $146 \mathrm{~m}$. W. by N. Richmond.

Pотт's Geove, p. v., Northumberland co., Penn. : $49 \mathrm{~m}$. N. Harrisburg.

Potr's Grove, t, Montgomery county, Penn.: 66 m. E. 696
IIarrisburg. Drained by Manatawny and sprogel's Iant, and the Schuylkill $r$. bounds it on the south. surfice hilly soil red shate. The p. 0 , is at Pottstown. There are several furnaces, rolling-nills, etc. in the town, and alsn, other manufactures. Pop. 2,711.

PutT's Mills, p. o., Jessamine county, $\hbar y .: 32$ m. S. E. Frankfort.

Potrstown, p. b., Montgomery con, Penn.: on the left bank of Schuylkill r., at the mouth of Manatawny cr., $65 \mathrm{~m}$. E. Ilarrisburg. It has good water-power, and conlains an academ $y$, a forge, a rolling-mill, using steam, several fictories and mills, and 1,647 inhabitants. Near it is a furnace of 1,400 tons capacity. The Schuylkill canal passes along the r., and the Philadelphia and Readiug li. R., by which it is $40 \mathrm{~m}$. from Philadelphia. Two weeklies are pablished, the "M. Ledger" (dem.), and the "Neutralist." Pop. 647.

Pottsville, p. o., Washington co., Ia

Potrsville, p. v., Schuylkill county, Penn.: near the Schuylkill, above the gorge where that river breaks through Sharp Mountain, 46 m. N. E. by E. Harrisburg. Pottsville, as incorporated in 1528, embraces also the once separate villages of Mount Carbon, Morrisville, Greenwood, Salem, Bath, and Allenville. Mount Carbon comprises the southern part of Pottsville lying in the valley between Sharp and Second mountains. The scenery of the surrounding country is wild and picturesque, and in its mountainous topography presents many romantic localities.

Pottsville is noted as a great mining depôt for the anthracite and iron regions of the Upper Schuylkill. The Scbuyikill Canal has its terminus at this point, and also the Philudelphia, Reading, and Pottsville R. R., which here connect with several railroads leading to the neighboring mines, and with the Sunbury and Erie R. R. now in course of construction between the two places. This latter road when completed will furnish one of the nearest routes from the Atlantic coast and the lakes, and insure to Pliladelphia its just share of the commerce of those inland waters. The canal and the Reading $R, R$, are the avenues over which most of the coal from the Schuylkill region is carried. The quantity of anthracite sent to market in 1851 , was $2,178,581$ tons.

The borough contains numerous iron works, machine and engine shops, extensive warehouses, stores of various kinds, mechanic shops, breweries, tanneries, and numerous mercantile houses. It has a bank-cap. $\$ 200,000$, several spacious hotels, 6 or 7 churches, generally of respectable appearance, several public buildings-the town hall, an academy, and 13 public schools with 642 scholars, and there are published here four weekly newspapers, viz, the "Mining Register" (dem.), the "P. Emporium" (dem.), the "Miner's Journal" (whig), the "Free Press" (whig), each circulating from 1,000 to 1,500 copies at each issue

The place was originated and has been sustained by the coal and iron interest. It is the largest and most important town in the county. In 1810 it contained 4,345 inhabitants, and in 1550 it had 7,916 inhabitants, being an increase in the decade of 82.9 per centum. The distance to Philadelphia by railroad is 93 miles.

Poucr Creek, p. o., Campbell co., Tenn. : 131 m. E. by N. Nashville.

Poughkeepsie, p. V., Allen co., Ind.: 108 m. N. E. by N. Indianapolis.

Poughkeepsie, t., p. vo, and cap. Duchess county, $N$. $Y$.: $66 \mathrm{~m}$. S. Albany. Drained by Wappinger's and Fall ereeks, which supply water-power. Surfuce undulating, and in some parts rough and broken; soil sand, clay, and loam, underlaid by limestone, and very fertile. The $\mathbf{v}$. lies on the E. bank of Hudson r., and is an important manufacturing and commercial point. Lat. $41041^{\prime} \mathrm{N}$.; long. $73055^{\prime} \mathrm{W}$. The ground on which built is elevated about 200 feet above the river, and extends into it by two bold promontories on the north and suth, forming a large ofent basin 
in front of the landing. The streets are regularly laid out, and are spacious, with many handsome and substantial buildings. Main Street, leading back from the landing, is the prineipal street. Many of the churches, of which there are 16 or 17 , are expensive edifices, and tasteful and elegant in their architectural embellishments. The $\mathrm{v}$, contains the county court-house, jail, 4 banks-cap. $\$ 600.000$, a savings' institution, the county poor-house, a collegiate school, an academy, and female seminaries, numerous public schools, a lyceum, two market-houses, and a variety of other public buildings and institutions. The newspapers published here are the "P. Journal and Eagle" (whig), the "P. Telegraph" (dem.), and the "P. American" (F. S.), all issued weekly, and having extensive circulation. The Collegiate School has a fine localion on a hill, about a mile from the river, and the building, modeled after the Parthenon, is 137 feet long, erected at a cost of $\$ 40,000$. The Duchess County Academy has a building in the S. E. part of the villnge, which cost $\$ 14,000$. The State and National Law School has recently been removed from Balston to Poughkeepsie. A large business with the back country is transacted at Poughkeepsie. The principal manufactures, brass and iron ware, carpets, cotton goods, pins, guns, leather, sperm oil, candles, agricultural implements, carriages, plaster, machinery, crockery, etc. Fallkill, which, winding through the village, falls through a ravine 170 feet into the Hudson, furnishes inmense water-power. The largest manufacturing establishments are company concerns. One company manufactures locomotives, railroad machinery, ete., another is incorporated for the growth and manufacture of silk, and another invests its capital in the whale fishery, and in the manufacture of oil and candles. The largest brewery in the State, located bere, makes 36,000 barrels of ale annually. The several foundries, machine shops, etc., are among the largest in the Union.

Poughkeersie has a connection with the principal river towns, Albany and New York city, by steamboats which are eonstantly plying. The Hudson river R. R. also passes through the village equi-distant between New York and Albany - the route to either being $75 \mathrm{~m}$. in length.

Poughkeepsie was incorporated in 1801. Its name is said to have originated from the Indian name of the place, Apokeepsing "safe harbor." Its population, in 1830, was 7.222 ; in $1840,10,006$; and in $1850,13,94 t$; the decennitil increase having been from 1830 to $1840,38.54$ per cent, and from 1840 to $1850,39.35$ per cent. In 1788 the State convention met here to deliberate on the adoption of the United States Constitution, and on other occasions it has been the "half-way house" between the political and commercial capitals of the State.

Povghquag, Duchess co., N. $Y .: 68 \mathrm{~m} . \mathrm{S}$. Albany.

Poultney, sta., Rutland co., Verm. : $7 \mathrm{~m}$. S. of Castleton, on the liutland and Washington R. R. The to of Poultney, drained by the river of the same name, has a diversified surface, and a warm, fertile soil. The v., near the centre, contains some 70 dwellings, and there is also a pleasant $\mathrm{v}$. in the west. In the t. are several furnaces, mills, etc., and 2,329 inhabitants.

Podltney river, Verm.: rises in Tinmouth, and flows W. into E. bay of Champlain lake. It is about $25 \mathrm{~m}$. long, in its course affording good water-power, and for a little distance is the dividing line between Vermont and New Tork.

Pound, p. o., Russell co., Virg.: at the E. base of Cumberland $m$ ts., and on a $\mathrm{s}$. fork of the W. branch of Big Sandy r., $274 \mathrm{~m}$. W. by S. Richmond.

Pounnnidge, t. and p. v., Westchester co., N. Y.: $103 \mathrm{~m}$. S. by E. Albany. Surface hilly and stony: snil gravelly loam. A farming and grazing t.. with several small manufactories. The village contains two churches, and about 40 dwelling8. Pop. 1,486.

Poterty Hruz, p. o, Edgefield dist., S. Car.: about $3 \mathrm{~m}$. E. of Savannah r., $71 \mathrm{~m}$. S. W. by W. Culumbia.
Powner Spring Gap, p. o., Grainger co., Tenn.: $156 \mathrm{~m}$. E. Nashville.

Powd LR Springs, p, o, Cobb co., Ga. : near Sweet Water cr., a W. branch of Chattahoochee $\mathrm{r}_{0}, 105 \mathrm{~m}$. N. W. by W. Milledgeville.

Powell's river, Virg.: rises from Powell's Mountain, and passing into Tennessee, unites with Clinch $\mathbf{r}$, about $4 \mathrm{~m}$. above Knoxville. It is boatable for nearly $100 \mathrm{mil}+\mathrm{s}$.

Powell's Mountain, p. o, Lee con, Virg: about $2 \mathrm{~m}$. E. of Powell's r., $298 \mathrm{~m}$. W. by S. Richmond.

Powell's Point, p. o., Currituck co., N. Car.: $153 \mathrm{~m}$. E. by N. Raleigh.

Powell's Taver, p. o., Goochland co., Tirg.: $12 \mathrm{~m}$. W. N. W. Richnond.

Poweltan, p. v.g Harrison county, Tex.: 258 m. N. E. Austin City.

Powkltox, p. o., Brunswick con, Virg.: $61 \mathrm{~m}$. S. by W. Richmond.

Powelton, p. 0., Richmond co., N. Car.: 68 m. S. W. by W. Raleigh.

Powelton, p. v., Hancoek co., Ga.: on Ogeechee r., 35 m. N. E. Milledgeville. It contains an academy, several stores and mills, and 300 inhabitants.

Powers's Mill, sta., Wauliesha co., Wisc.: $15 \mathrm{~m}$. W. of Milwaukie, on the Milwaukie and Mississippi R. R.

Powelisville, p. Y., Bracken co., Ky. : 62 m. N. E. by E Frankfort.

Pow ESIIEK county, $I c$. Situate S. E. centrally, and contains $576 \mathrm{sq} . \mathrm{m}$. Drained by N. fork of Iowa $\mathrm{r}, \mathrm{N}$. fork of Skunk r, and Beaver and Prairie creeks. Surface undulating; soil firtile. Set off since 1850 .

Powiratan county, Virg. Situate S. E. centrally, and containg $220 \mathrm{sq} . \mathrm{m}$. Drained by branclies of James' and Appomattox rivers. Surface level; soil fertile. Chief products, Indian corn and tobaceo. Farms 312; manuf. 0; dwell. 517, and pop.-wh. 2,532, fr. col. 364, sl, 5,282-total 8,178. Capital: Scottsville.

Powitatan, p. O., Lawrence co., Ark..: on Big Black $x$., $109 \mathrm{~m}$. N. E. by N. Little Rock.

Powhatan, C. H., p. v., and cap. Powhatan eo., Tirg. $28 \mathrm{~m}$. W. Richmond. It contains a court-hruse, jail, acidemy, und about 200 inhabitants. The r. is called scottsyille

Pownatan Ponvt, p. v., Belmont eo., Ohio: on the Ohio, $115 \mathrm{~m}$. E. Columbus.

Powhatan, sta., Powhatan co., Virg.: $22 \mathrm{~m}$. from Tichmond, on the Richmond and Danville R. R.

Powl's Vallex, p. 0., Dauphin co., Penn.

Pownal, t. and p. o, Cumberland co., Me. : $35 \mathrm{~m} . \mathrm{S} . \mathrm{W}$. Augusta. Soil fertile. Farming is the chief occupation. The Atlantic and St. Lawrence R. R. passes the W. border. Pop. of t. 1,074.

PowNaI, t, and p. v., Bennington county, Term.: in the S. W. corner of the State, 112 miles S. S. W. Montpelier. Drained by Hoosic r., which affords water-power. Surface broken; soil ferlile, supporting large flocks and dairies. It has several factories. The $\mathrm{v}$. is located on the right side of Hoosic r. The Troy and Boston R. R. will pass through the west part of the t. Pop. 1,742.

Pow-wow river, N. Itamp. : an affiuent of Merrimac r. It rises in Kingston, and falls into the Merrimac between Salisbury and Amesbury, Mass., where a fall of 100 feet it 50 rods affords an extensive water-power.

Pornett, p. o., Columbia county, Wisc.: 22 miles $\mathrm{N}$. Madison.

Poy SIPPI, p. o., Marquette co., Wisc. : $57 \mathrm{~m}$. N. N. E. of Madison.

Pratrie eounty, Ark. Situate E. centrally, and contains $945 \mathrm{sq} . \mathrm{m}$. Irained by branches of Arkansas $r$, the principal one being Bayou Meter, which passes through it centrally. Surface generally even; soil fertile. It las some good timber lind. Farms 155; manuf. 0: dwell. 32S, and pop.-wh. 1,812, fr. col, 12, sl, 273-totil 2,097. Capital. Brownville. 
PraIRIE, p. o., Lewis county, Mo.: about $6 \mathrm{~m}$. W. of the Mississippi, $107 \mathrm{~m}$. N. by E. Jefferson City.

Prairie, t., Franklin co., Ohio: $9 \mathrm{~m}$. W. S. W. Columbus. Drained by Darby cr. and its tributaries. Surface generally level prairie. The National Road and the Columbus and Jenia R. I. pass through it. Pop. 1,043.

Pramere river, Mich. : a tributary of St. Joseph's r., about $40 \mathrm{~m}$. long. It has its source in several small lakes, and discharges itself about $2 \mathrm{~m}$. below the v. of Three Rivers.

Prairte Bird, p. o., Shelby co., $I l l_{0}: 47$ m. E. S. E. of Springfield.

Pratrie Bluff, p. o., Wilcox co., Ala.: on the right bank of Alabama r., $67 \mathrm{~m}$. W. by S. Montgomery.

Pratrie Creek, p. o., Logan county, Ill.: $34 \mathrm{~m}$. N. E. Springfield.

Pratrie Creek, p. o., Vigo county, Ind.: $6 \mathrm{~m}$. E. of the Wabash, $76 \mathrm{~m}$. W. S. W. Indianapolis.

Pratrie du Chien, p. v., and eap. Crawford co., Wisc. on the Mississippi, $3 \mathrm{~m}$. above the mouth of the Wisconsin, $89 \mathrm{~m}$. W. by S. Madison. Lat. $43^{\circ} 03^{\prime} 06^{\prime \prime}, \mathrm{N}_{\text {., }}$ and long. $91009^{\prime} 19^{\prime \prime} \mathrm{W}$. The prairie from which it takes its name is $10 \mathrm{~m}$. long and 3 wide, and is one of the most fertile regions of the West. The $\mathrm{v}$, contains the county buildings, half a dozen churches, several school-houses, and numerous mechanie shops and places of business. Its trade is large and rapidly increasing. There are rich mines of copper and galena in the neighborhood; and numerous mounds occur in all directions, indicating it to have been a place of some consequence with the races long since defunct. Fort Crawford, a U. S. military post, is situate immediately south of the village. Pop. 2,498,

Prairie dU Long, p. o., St. Clair co., $M u_{0}$ : on a W. affuent of the Kaskaskia, $110 \mathrm{~m}$. S. by W. Springfield.

Pratrie du Rocuer, p. v., Randolph county, Ill.: on the bluffs, about $4 \mathrm{~m}$. E. of the Mississippi, $123 \mathrm{~m}$. S. by W. Springfield. The village contains a Roman Catholic ehurch and about 400 inhabitants, descendants of the French, who made an early settlement here, and whose manners and customs are still retained.

Pratrie dU SAUK, p. v., Sauk co., Wisc.: on the right bank of the Wisconsin, $22 \mathrm{~m}$. N. W. by W. Madison. It is a $\mathrm{v}$. of rapid growth, with a large trade, containing several mills and 600 inhabitants.

Prairie Mer Rovge, p. o., Morehause par, $L a .: 162 \mathrm{~m}$. N. by W. Baton Rouge.

Prairte Mount, p. o., Chickasaw county, Miss. : $129 \mathrm{~m}$. N. E. by N. Jackson.

Pratrie Plains, p. o., Grimes county, Tex.: 106 m. E. Austin City.

Pratrie Pocis, p. o., Noxubee co., Miss.: about $5 \mathrm{~m}$.W. of Tombigbee r., $119 \mathrm{~m}$. N. E. by E. Jackson.

Pratrie Rivfir, p. o., Branch co, Drich.: on a S. branch of St. Joseph's r., 74 m. S. S. W. Lansing.

Pratrie Roxne, t. and p. o., Kalamazoo co., Mich: $77 \mathrm{~m}$. S. W. Lansing. Drained by the head of Rocky $r$. Surface undulating, and mostly rich prairie, with groves of maple and hickory. An excellent t. for grain growing. PopuIation 690 .

Pratrieton, p. v., Vigo county, Ind.: on the S. side of Huncy creek, 3 m. E. of the Tabash, $72 \mathrm{~m}$. W. S. W Indianapolis.

Prairievilie, to and p. o. Barry county, Mich.: $54 \mathrm{~m}$. W. S. W. Lansing. Surface slightly broken, and dotted with numerous ponds tributary to the Kalamazoo. Population 558 .

Pratrievilise, p. v., Clinton $\mathrm{co}_{n}$ Ind. : about $2 \mathrm{~m}$. E. of the Lafayette and Indianapolis $\mathrm{R} . \mathrm{R} ., 42 \mathrm{~m} . \mathrm{X}$. W. Indianapolis.

Pramretrlue, p. va, Pike co., Mlo.: 74 m. N. E. by E. Jefferson City.

Pralcsvilife, p. v., Hunterdon co., N. Jer.: on Delaware r., at the mouth of Wickechecoke cr., $17 \mathrm{~m}$. N. W. Trenton. The Belvidere Delaware R. P. passus through it. 695
Pratt, p. o., Shelby county, Ohio: 62 m. W. N. W. Columbus.

PratT"s, sta., Worcester co., Mass. : 13 m. N. of Worcester, on the Fitchburg and Worcester R. R.

Prattsidre, p. v., Talbot co., Ga.: about $8 \mathrm{~m}$. W. of Flint r., $76 \mathrm{~m}$. W. by S. Milledgeville.

Pratiseure, p. v., Ripley co., Ind.: on an E. branch of Laughery's cr., $68 \mathrm{~m}$. S. E. Indianapolis.

Prattsburg, t. and p. v., Steuben co., N. Y.: $178 \mathrm{~m}$ : W Albany. Drained by branches of Conhocton $r_{0,}$ which furnish numerous mill-sites. Surface somewhat hilly; soil productive of wheat, but better adapted to grass. Timber is abundant. The $\mathbf{v}$. contains an incorporated academy, several mills, 6 or 8 stores, and about 600 inhabitants. Population of $t .2,786$.

Prattsburg, p. o., Orange co., N. Car: : $27 \mathrm{~m} . \mathrm{N}$. W Raleigh.

Pratt's Hollow, p. o., Madison county, N. Y.: $91 \mathrm{~m}$ W. by N. Albany.

Pratrspille, t. and p. v., Greene co., N. Y.: $43 \mathrm{~m} . \mathrm{S} . \mathrm{W}$ Albany, $32 \mathrm{~m}$. W. by N. Catskill, and $37 \mathrm{~m}$. N. W. Kingston. Drained by Schoharie cr., which runs through it from south to north, and affords considerable mill-power. Surface generally broken and mountainous; but the soil of the flats on the creek is very fertile, and the uplands are good for grazing. This t. was set off from Windham in 1532, and named after the Hon. Zadock Pratt, who here built the largest tannery in the United States. The village is handsomely situate on a flat on the N. E. side of Schoharie creek, and on the turnpike, which is lined with beautiful rows of elm and maple-trees on each side, planted 20 years ago, by the founder of the settlement. It contains 2 furnaces, 1 machine shop, 1 cotton-mill, 2 woolen factories, 2 grist-mills, 3 hat factories, 1 carriage factory, 2 glove and milten fictories, 4 hotels, 1 brewery, 1 oil-cloth factory, 1 match factory, 3 cabinet-ware manufactories, 3 blacksmith shops, 2 watch and jewelry stores, 3 tin-ware shops, 1 turning-machine shop, 4 tailors' shrps, 11 stores, 1 bank, capital $\$ 100,000$ (now winding up), 1 Duteh Reformed church, 1 Methodist church, and 1 Episeopal church, 1 incorporated academy, 9 school-houses, and a printing-office, from which is issued the " $\mathrm{P}$. Advocate" (dem.), which cirenlates from 500 to 600 copies weekly. There are about 150 dwelling-houses in the village, and 1,800 inhabitants. This is the westernmost bounds of Greene co. and here corner three counties-Greene, Delaware, and Schoharie. The Gilboa, Prattsville, and Shandaken turnpike passes through the $\mathrm{F}_{\text {., }}$ and also the Schoharie-kill bridge turnpike. A railroad is also being surveyed from Newburg to Syracuse, which will probably pass through Prattsville. The immense tannery buildings of the Hon. Zadock Pratt, at which, in 20 years, no less an amount than 1,000,000 sides of sole leather had been tanned, and around which the $\mathrm{v}$. had grown up, are now oceupied by the cotton and woolen factories above mentionerl, their original purpose having been foregone on account of the exhaustion of material (hemlock bark) for carrying on the tanning business. Of the founder of the v., it may truly be said that he is a "self-made man." Born in Rensselaer co. in 1790 , then almost a wilderness, aud trained up to labor, he has raised himself from a humble position by the powers of his own unaided energies to the enjoyment of a fortune of which a prince might be proud. In his time and generation he has made for himself a name, and for the future youth of our eountry a pattern worthy of imitation. But the most glorious trait in his character has been his honesty and integrity-he can count 30,000 employees among whom he his distributed loundreds of thousands of dollars, and throughout his long course he has never had a disagreement with one of them, nor been the defendant in any suit against him for wages or claims of any kind. $\mathrm{As}$ the ancients were used to record the lives of benefactors by sculptured stories, so at Prattsville are recorded on the native rocks the memoirs of its patron, and from the village road may be seen, in alto relievo, a fac-simile of the Pratt tan- 
neries, the bust of Mr. Pratt himself, and an emblematie conception of a great act of his life in the institution of a Bureau of Stątistics, which he effected during his term as representative in Congress from the 11th district of the State. These will long tell the story of a life well spent, and when his earthly career is run, the youth will read the lesson they convey, and strive to emulate the subject of the legends in his many virtues. Population of $t$. in $1810,1,613$, and in $1850,1.959$.

Pratistille, p. v., Vinton county, Ohio: 61 m. S. E. Columbus.

Pratrville, p. v., Autauga co., Ala.: on Autauga cr., a small N. affluent of Alabama r., $12 \mathrm{~m}, \mathrm{~W} . \mathrm{N} . \mathrm{W}$. Montgomery.

Preble county, Ohio. Situate W. toward the S., and contains $460 \mathrm{sq}$. m. Drained by Four Mile, St. Clair, and Franklin ereeks. Surface varied, in genera! it is level or rolling, and a large portion is thickly wooded; soil a fine deep mold, and very productive. Staples, wheat and Indian corn. It has some fine grazing land, and a large number of cattle and hogs are fattened and sent to Eastern markets. Farms 1,799; manuf. 109; dwell. 3,749, and pop.-wh. 21,65s, fr. col. 78-total 21,736. Capital: Eaton. Public Works: Daytou and Western R. R. ; Dayton and Greenville R. R. ; Hamilton and Eaton R. R. ; Four Mile Valley R. R.; Junction R. R.

Preble, t. and p. v., Cortlandt co., N. Y.: $119 \mathrm{~m}$. W. by N. Albany. Drained by Cold cr. Surface hilly; soil gravelly loam, very productive of grass and grain. A superior farming and dairy town. The v. contains several shops and stores, and about 300 inhabitants. Pop. of t. 1,312.

Precrnct, p. v., Boone county, $I l l_{0}:$ on the W. side of Beaver cr., $185 \mathrm{~m}$. N. by E. Springfield.

Pre-EMPTION, p. o., Mercer co., Ill.: 114 m. N. N. W. Springfield.

Prentiss Vale, p. o., M-Kean co., Penn.: 129 m. N. W. Harrisburg.

Prescotr, t. and p. v., Hampshire county, Mass.: $65 \mathrm{~m}$. W. by N. Boston. Drained by branches of Swift r. Surface rough and broken; soil chiefly adapted to grazing, which is the leading interest. Pop. 737 .

President Furnace, p. o., Venango co., Penn.: $173 \mathrm{~m}$. N. W. by W. Harrisburg. Here is a furnace of 1,100 tons eapacity.

Presque Isle county, Mrich. Situate $\mathrm{N}$. of the $\mathrm{S}$. Peninsula, and contains $725 \mathrm{sq} . \mathrm{m}$. Drained by the $\mathrm{N}$. branch of Thunder Bay r. and other streams. Organized since 1850 .

Presque Isle, p. o., Aroostook county, Mes : about $182 \mathrm{~m}$. N. E, Augusta.

Prestox enunty, Virg. Situate N. W., and contains 545 sq. m. Drained by Cheat r., main branch of Monongahela river. Surface mountainous and rough; soil various-in some parts it is very fertile. Chief product, Indian corn. It contains good grazing tand. Farms 1,019; manuf. 5 ; dwell. 1,664 , and pop.-wh. 11,574 , fr. col. 47, sl. 87-total 11,708. Capitel: Kingwood. Public Works: Baltimore and Ohio Railroad.

Preston, t. and p. v., New London co., Conn.: on the E. side of Quinnebaug and Thames rivers, $39 \mathrm{~m}$. E. S. E. Hartford. Drained by Broad and Poquetanock rivers. Surfuce rough and stony; soil better for grazing than grain-growing. The Norwich and Worcester R. R. passes on the W. border along the rivers. The $\mathrm{y}$. is near Amoss's pond, a favorite summer rescrit. Pop, of t. 1,804.

Preston, p. o., Yallabusha co., Miss.: 116 m. N. N. E. Jackson.

Prestox, t. and p. o., Chenango co., N. Y.: on the W. side of Chenango r., $94 \mathrm{~m}$. W. by S. Albany. Drained by small affluents of the river; surface uneven; soil fertile, adapted to grass or grain, and mostly well timbered. There is a small v. in the N. part of the $t$. The Chenango Canal lies on the S. E. corner. Pop. 1,082

Preston, p. o., Hamilton county, Ohio: on a branch of Whitewater $r_{0,} 102 \mathrm{~m}$. W. S. W. Columbus.
Pristox, t. and p. o, Wayne county, Penn。: $128 \mathrm{~m}$. N. E. by N. Harrisburg. Drained by affluents of Delaware river. Surface broken; soil gravelly loam, heavily timbered with pine, hemlock, and ehestnut.

Preston, p. v., Grayson county, Texc: on Red r., $238 \mathrm{~m}$. N.N. E. Austin City. Large amounts of cotton are shipped here.

Prestonberg, p. $v_{v}$, and cap. Floyd $c_{n}, K y_{0}$; on the W. fork of Big Sandy re, $129 \mathrm{~m}$. E. by S. Frankfort. It contains a court-house, jail, several mills and stures, and 200 inhabitants.

Plegeron Hollow, p. v., Albany county, $N . Y .: 27 \mathrm{~m}$. S.W. by W. Albany. It contains several mills, half a dozen stores, and 300 inhabitants.

Prestonville, v., Phea county, Tenn.: on the N. side of Tennessee r., $117 \mathrm{~m}$. E. by S. Nashville.

Prestonville, p. v., Carroll co., Ky. : on the Ohio, just below the mouth of the Kentucky, 34 m. N. N. W. Frankfort. It has a convenient landing, and contains about 300 inhabitants.

Prewrty's KNoв, p. o., Barren co, Ky. : 104 m. S. S. W Frankfort.

PrICE, p. $0_{*}$, Huntington county, Ind.: $76 \mathrm{~m} . \mathrm{N}$. N. E Indianapolis.

Priceburt, p. v., Monroe co., Penn.: 101 m. N. E. by E. Harrisburg.

Pricetown, p. v., Berks countr, Penn.: 56 m. E. by N. Harrisburg. Here is a furnace of 1,400 tons capacity, built prior to 1770 .

Pricetown, p. o., Highland co., Ohio: $62 \mathrm{~m}$. S. by W. Columbus.

Priceville, p. v., Wayne county, Penna: 119 m. N. E. Harrisburg.

PriLlamaN"s, p. o., Franklin co., Tirg, : on the N. side of Smith's r., 151 m. W. S. W. Richmond.

Prinerose, p. $v_{\text {. }}$ Lee co, $I \alpha_{0}: 68 \mathrm{~m}$. S. by W. Iowa City. Primerose, t. and p. o., Dane co., Wisco: $19 \mathrm{~m}$. S. W. Madison. Drained by Sugar r. Surface rolling; soil very fertile, a large part being vegetable mold and meadow. Farming products of all kinds are grown in profusion. Pop. 348.

Prince Edward county, Virg. Situate S. centrally, and contains $255 \mathrm{sq} . \mathrm{m}$. Drained by branches of A ppomattox r. Surface rolling; soil fertile, and generally well cultivated. Chief products, Indian corn and tobacco. It contains Hampden Sidney College, founded in 1783 , also a preparatory academy. Farms 421; manuf. 86 ; dwell. 805 , and pop. -wh. 4,177, fr. col. 488, sl. 7,192-total 11,857. Capital: Prince Edward. Pullic Works: Richmond and Danville R. R.; South Side R. R., ete.

Prince Edward, po o, Gilmer co, Ga. : near the source of Coosawattee r., $134 \mathrm{~m} . \mathrm{N}$. W. by N. Milledgeville.

Prince Edward Court-house, p. v., and cap. Prince Edward en., Firg.: 53 m. W. S. W. Richmond. A large trade in tobacco is carried on here. The $\mathrm{v}$. contains a court-house, jail, academy, and about 300 inhabitants.

Prince Fredericktown, p. ve, and cap. Calvert co, Md.: on Parker's cr., $4 \mathrm{~m}$. W. of Chesapeake bay, $31 \mathrm{~m}$. S. by W. Annapolis. It contains a court-house, jail, academy, and 450 inhabitants.

Prince George county, Firg. Situate toward the S. E., and contains 275 sq. m. Drained by Blackwater river. Surface an extended plain; soil fertile. Chief products, Indian corn and tobacco, Cotton is also grown in the co. Farms 336 ; manuf. 23 ; dwell. 661 , and pop.-wh. 2,670, fr. col. 518, sl. 4,408-total 7,596. Copitul: Prince George C. H. Public Works: Appomattox R. R.; Petersburg R. R.; Petersburg and Norfolk R. R., etc.

Prixce George"s county, $M d$. Situate W., and contains 492 sq. m. Drained by branches of Patuxent river, which forms its E. boundary, and of Potomae river, which bounds it on the S. W. Surface uneven; soil fertile, and well adapted to tobacco, which it produces in large quanti- 
ties, and which is the staple. It raises good crops of wheat and Indian corn, and has some fine timber land. Farms 855 : manuf. 25 ; dwell. 1,875 , and pop.-wh. 8,901, fr. col. 1,139. sl. 11,510-total 21,550. Cupitul of the county: Upper Marlboro'.

Prince George C. H., p. v., and cap. Prince George con, Virg.: 52 m. N. N. E. Richmond. It contains the co. buildings and several stores.

Prince's bay, N. $z_{.}$: on the S. E. side of Staten Island. It furnishes safe anchorage in a N. E. storm; and is noted for the fine flavored oysters it produces.

Princess Anne cotinty, Firg. Situate S. E., and contains 851 sq. m. Drained by North r. and E. branch of Elizabeth r. Surfuce level and somewhat elevated, presenting the ap= pearance of table-land; soil fertile. Chief production, Indian corn. Farms 712 , manuf, 8, dwell. 893 , und pop.-wh. 4,250, fr. col. 259, sla. 3,130-total 7,669. Capital: Princess Anne C. II.

Princess Arve, p. $\nabla_{*}$, and cap. Somerset $\mathrm{co}_{2}, M d_{0}:$ near the head of Manokin r., $16 \mathrm{~m}$. E. of Chesapeake bay, $65 \mathrm{~m}$. S. E. Annapolis. It is regulary laid out, and substantially built with brick, has a brisk trade, and contilins a courthouse, jail, academv, and 700 inhabitants, The "S. Herald" (whig) is published weekly.

Princess Anne C. H., p. v., and cap. Princess Anne co., Firg.: 93 m. S. E. by E. Richmond. It contains a courthouse, an acad my, and 200 inhabitants.

Princetor, p. v., and cap. Dallas co., Ark. : about midway between Wachita and Saline rivers, 56 miles $\mathrm{S}$. by $\mathrm{W}$. Little Rock. It contains the co. buildings, several stores, and 300 inhabitants.

Princison, p. v., and cap. Bureau co., $M \lambda_{*}: 8 \mathrm{~m}$. W. of the Illinois, $112 \mathrm{~m}$. N. by E. Springfield. It lies on the border of a large prairie, surrounded by a rich farming region, with which it carries on an extensive trade, and contains a court-house, jail, academy, and about 20 stores. The "Bureau Advocate" (free soil) is published weekly.

Princeiron, p. v., and cap. Gibson co., Ind.: $3 \mathrm{~m}$. S. of Patoks creek, $119 \mathrm{~m}$. S. W. by S. Indianapolis, It is surroundel by a rich furming region, with which it has a brik trade, and contains a court-luouse, jail, 2 acalemies, 2 stoces, and 806 inhabitan's. It is 27 miles N. of Evansville, and the same distance S. of Yineennes on the Evansville and Illinois R. R. Two weekly papers are published, the "G. Review" (whig) and the "Democratic Clarion""

Princeton, p. v., Sentt eo., Ia. : on the Mississippi, $24 \mathrm{~m}$ above Davenport, $60 \mathrm{~m}$. E. Iowa City.

Priverexoy, p. v. Jaclison co., Ala, on an E. branch of Paint Rock r., $161 \mathrm{~m}$. N. by E. Montgomery.

Prixcetov, p. v., Caldwell co, $K y_{0}: 179$ miles W. S. W. Frankfort. It is a thriving, busy v., the former cap. of the co, with a large trate in grain and other staples, and cuntaius about 500 inbabitants.

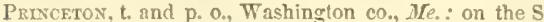
side of Schoodic Lake outlet, a W. affluent of the St. Croix, 1.5 m. E. Y. E. Augusta, Pop. 290.

Princeton, t. and p. V., Worcester county, Mass. : $44 \mathrm{~m}$. $\pi$, ly N. Boston. Drained by hramehes of Tashua an Ware rivers, which furnish mill privileges. Surface rough and hilly. Wachusett $\mathrm{Mt}$. rises in the N. 3,000 feet above the ocean, and about 2,000 above the surrounding country, commanding a wide view, and attracting many visitors in the summer months; soil fertile and well tilled. A good grazing t. with large dairies and numerous small manufactories. Pop. 1,318.

Pisixierux, p. v., an ' cap. Mashington en., Miss. : on

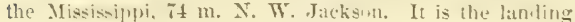
place and shipping port for the plantations on Lake Washingtum, 5 m. E.. and entatins a court-house, seviral warehousts amb stores, ant 300 inhabitunts.

Prexicetox, p. $\nabla_{-,}$and cap. Mercer co., Mo.: on Weldon $r_{.}$

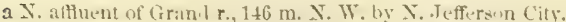
It contains the co. buildings a.d several mills and stures.
Princeron, t. and p. b., Mercer co, $N$. Jer.: 10 m. N. E. Trenton. The t. is situate in a bend of Stony Brook. which bounds it on three sides, and to the N. is the Rocky litl Drained chiefly by creeks falling into the brook. Surface beautifully diversifled with hill and valley, and soil of aver-

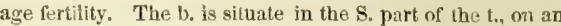
elevated ridge, commanding an extensive prospect eastw ard, and is built chiefty on one long street, the houses being remarkably neat and substantial. Lat. $40020^{\prime} 41^{\prime \prime} \mathrm{N}$., and long. $74^{\circ} 39^{\prime} 30^{\prime \prime} \mathrm{W}$. It is chiefly noted as the location of the College of New Jersey, one of the oldest collegiate establishments in the Union, having been founded in 1746, at Elizabethtown ; removed to Newark 1747 , and to this borough in 1757 . In 1850 it had 12 prof ssors and 213 studeuts; and its library contained 16,000 volumes : its alumni at that date numbered 3,031 , of whom 557 had entered the ministry. In the Law Department there are 3 professors. and in 1850 8 law students. The college edifice is called Nassau Hall it is 175 feet long, by 50 deeq, and 4 stories high; and besides a chapel, which is 40 feet square, there are other large buildings attached to the college, which contain philosophical apparatus, the musem, ete. The buillings arc of stone. The Theological Seminary of the Presbyterian Church is also located here. It was founded in 1812, and in 1550 had 5 prolessors and 153 students. Up to that date, 1,626 persons had received their education at the institution; and its library contained 11,000 volumes. The buildings of this institution are also neat, spacious, and envenient. Besides these, there are in borough four churches-2 Presbyterian, 1 Episcopal, and 1 African; and including several mechanle shops, stores, a bank, academies and public schools, about 250 houses. The periodicals published at Princeton are, the "P. Whig," issued weekly, the "P. Magnzine" (liter.), monthly, and the "Nassau Hall" a students' literary monthly. The Delaware and Raritan Canal and the Trunton and New Brunswick R. R. run along the ralley of stony Brook, about a mile S. of the borough, $47 \mathrm{~m}$. from New Yurk and $39 \mathrm{~m}$. from Philadelphia. In the t, are several mills, a tannery, and otleer inclustrial establishments, but firming is the general occupation. Cedar Grove is a small settlement in the $\mathrm{N}$. W. part of the $t_{\text {, }}$, and contains a Methodist church, etc. Pop. of $t$. in $1810,3,055$, and in $1850,3.021$. Pinceton was the secne of one of the great battles of the Revolution, fought $3 \mathrm{~d}$. January, 1777, and which resulted disastrously to the American arms.

Princeton, p. v., Butler county, Ohio: $85 \mathrm{~m}$. W. S. W. Columbus.

Princeton, p. 0., Lawrence co, Penn, : $187 \mathrm{~m} . \mathrm{W} . \mathrm{N} . \mathrm{W}$. Harrisburg.

Priscetov, p. $v$, and cap. Mercer county, Firg.: on Brush cr., a branch of blue stone r., $194 \mathrm{~m}$. W. Kiehmond. If contains the co. buildings, and has several mills in its vicinity.

Princeron, p. v., Marquette county, Wisc. : on Neenah or Fox r., 5i; m. N. by E. Matiston.

Prixcerille, p. v., Peoria county, Ill.: $78 \mathrm{~m}$. N. by W. Springfield.

PrLice Wrllad county, Virg. : situate N. E., and contains 3116 sq. m. Drained by Oceoquan r. Surfice hilly; soil diversified, in general fertile. Chief product Indian c)rn. Farms 5\%9; manul. 2S; dwell. 9ys, and pop.wh. 5,051, fr. col. 550, sl. 2,499-total 8,129. Cupital : Brentsville, Pultic Works: Alexandria and Orange R. R. Manassas Gap R. R.

Prixcf: William, p. o., Carroll county, Ind.: \& m. S. of Wild Cat cr., $49 \mathrm{~m}$. N. N. W. Indianapolis.

Prticipio Furice, p. v., Cecil county, Ma.: on Principio er., 53 m. N. E. by N. Aniapolis.

Privateer, p. 0., Sumter district, $S$. Car. : 38 m. E. by $\$$. Columbia.

Proctor, p. v., Owsley co., Ky.: on Kentucky r., near the confluence of its $\mathrm{N}$. and $\mathrm{S}$. forks, $74 \mathrm{~m}$. S. E. by $\mathrm{E}$. I raukturt. 
Proctor, p. o., Allegan county, Mich.: $74 \mathrm{~m}$. W. by s. Lansing.

Proctor, p. o., Wetzel county, Virgı: 324 m. I. W. Richmonil.

Proctor's Creik, p. o, Chesterfield con, Firg.

Pructoris Crossing, sta., Essex con, Muss.: $4 \mathrm{~m}$. from Salem, on the Salem and Lowell $R, R$.

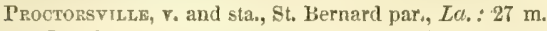
E. of New Orleans, on the Mexican Gult R. R., which terminat's here on the shore of Lake Borgne, and connects with steamers for various Gulf ports.

Proctorsville, p. v. and sta., Windsor co, Verm.: on Black r., and the Riutland and Burlington R. R., $25 \mathrm{~m}$. N. W. Bellow's Falls, 61 m. S. Montpelier. It contains a bank, extensive iron works, and several woolen fuctories.

Proupton, p. o., Wayne co., Penn.: on a N. branch of Lackawaxen r., $118 \mathrm{~m}$. N. E. Harrisburg. It contains several mills, and 300 inhabitants.

Propfieistown, p. v., Whitesides co., Ill.; on the left bank of Ruck r., $133 \mathrm{~m}$. N. by W. Springficld,

Prospecr, t, and p. o., New Haven co., Conn.: $24 \mathrm{~m}$. S. W. Hartford. Surface elevated, rough, and mountainous; soil adapted to grazing, which is the chief interest. Pop. $6 \pi 4$

Prospect, t. and p. $\mathbf{y}_{\text {. }}$ Waldo co, MYe.: on the W. side of Penobscot r., at the head of the bay, $52 \mathrm{~m}$. L. by N. Augusta. Surface generally even; soil very productive, A superior farming t., with great commercial advantages, and extensively engaged in the lumber and coasting trade. The v. on the r. has a brisk trade and a convenient landiug. Pop. of $t .2,467$.

Prospect, p. O., Oneida co., N. $Y_{*} ; 48 \mathrm{~m}$. N. W. by W. Albany.

Prospect, to and p. o., Marion co., Ohio: $35 \mathrm{~m}$. N. N. W. Columbus. Drained by Scioto r., which affords water-power. Surfuce pleasantly varied. Soil very fertile, and under high cultivation. Pop, 818.

Prospect, p. o., Butler county, Penn. : 169 m. W. N. W. Harrisburg.

Prospect. p. o., Giles co, Tenn.: on Elk r., near the Ala. line, $74 \mathrm{~m}$. S. by $\mathrm{W}$. Nashville.

Prospect, p. ค., Burleson co., Texa : 69 m. E. Austin City. Prospect, p. o., Prince Edward co., Virg.: 59 m. W. S. W. Richmontl.

Prospect Ferry, p. o., Waldo con, Me.: 53 m. E. by N. Augusta

Prospect Grove, p. O., Scotland co., Mo.: $122 \mathrm{~m}$. N. Jefferson City.

Prospect Hall, p. o., Bladen co., N. Car.: 69 m. s. Raleigh

Prospect Il $\triangle$ rior, p. v, Hancock co., Me, : 51 m. E. by N. Augrista

Prospect Hilu, p. o., Ray co, Mo.: 121 m. N. W. by W. Jefferson City.

Prospect firlu, p. 0., Caswell county, N. Car.: $55 \mathrm{~m}$, N. TW, hy IV. Raleigh.

Prospect Hrul, p. o., Fairfax co., Virg. : $9 \pi \mathrm{m} . \mathrm{N}$. by E. Richmond.

Prospect IIrr, p. o., Waukesha co., Wisc.: 54 m. E. Madisın.

Prospect Mrlus, p. 0., Lycoming county, Penn。 : $78 \mathrm{~m}$, N. by W. Harrisburg.

Prospect Planns, sta.n, Mercer con, N. Jer.: $44 \mathrm{~m} . \mathbf{S}$. of Niew York, on the Camrien and Amboy R. R.

Prosperitr, p. o. and sta, Newberry dist, $S$. Car,: on the Greenville and Columbia $\mathrm{R} . \mathrm{R}, 7 \mathrm{~m}$. $\mathrm{E}$. of the $\mathrm{C} . \mathrm{H}$., and $40 \mathrm{~m}$. (by route) N. W. Columbia.

Prosperitry, p. o., Moore co., N. Car.: on the S. side of Deepr. 5 . $\mathrm{m}$ W. by $\mathrm{S}$. Paleigh.

Prosperity, p. o., Washington co., Penn.: $173 \mathrm{~m}$. W. II. Privinter.

Propidraxce county, $R, Y$. Situate N., and contains 380 ar. m. Jur inem by Pawtucket, Providence or Narragansett,
Mashasuck, Wanasquatucket, and Pawtuxet rivers and their tributaries, by which good water privileges are secured to the county. Surface uncven and roush; scil generally dark gravelly loam. Its commercial advantages are great, and it has many extensive mantfactures, Farms 2.162, manuf. 804 ; dwell. 12,760, and pop.-wh. 85.737, fr. col 1,758-total 87,525, Capital: Providence, Public Works: Providence and Worcester P. R.; Boston and Providence I. R.; Providence and Stonington I. X'.; IJartfuril, P'suvidence, and Fishkill R. R. : New York, New Haven, and Boston R. P., ete. ; Blackstone Canal.

Providexce, p. v., Pickens co., Ala.: 128 m. N. W. by W. Montgomery.

Providexce, p. o., Sumter dist., 8. Car. : 43 m. E. by N. Columbia.

Providence, p. o., Sumter co., Ga.: 98 m, \$. W. by $\mathrm{S}$ Milledgeville.

Providence, p. o., Carroll co., Miss. : $91 \mathrm{~m}$. N. by E Jackson.

Protidence, p. v., Bureau co., $M l .:$ : $104 \mathrm{~m}$. N. Springfield Providence, p. v., Hopkins co., Ky. $:$ on Tide-water $r_{\text {., }}$ $169 \mathrm{~m}$. W. S. W. Frankfort.

Providerce, t, and p. v., Saratoga county, N. $\bar{X}: 32 \mathrm{~m}$ N. N. W. Albany. Drained by branches of Sacandaga r. which supply numerous mill privileges. Surlace mountainous and heavily timbered; soil clayey loam, adapted to grass. There is a small $v$ in the 8 , part of the town. Pop. 1.tis.

Providnace, p. O., Mecklenburg co., N. Car,: $116 \mathrm{~m}$. W. S. W. Raleigh.

Providexce, t. and p. v., Lucns co, Ohio: on the W. side of Maumee r., along which the Wabash and Erje Canal passes, 109 m. N. N. W. Columbus. Surface level; soil sandy, and in parts marshy. The $v$. is on the cancl, $26 \mathrm{~m}$. S. W. Toledo. Pop. of t. 467 .

Promiderce, t. and p. 0., Luzerne co., Penn.: $95 \mathrm{~m}$. N. E by $N$. Harrisburg, Drained by Lackawannock river and branches, which supply fine water-power. Surface even, being mostly a valley; soil fertile' and well timbered. Anthracite eoal abounds. The Lackawanna and Western $R$. $R$. crosses it. It contains several flouring and saw mils.

Providence, p. e., port of entry, and cap. Providence co. and principal capital of the State of $R .1 .:$ at the head of nnvigation of Providence r., $35 \mathrm{~m}$. from the ocean, in lat. $41^{\circ} 49^{\prime} 22^{\prime \prime} \mathrm{N}$., and long. $71^{\circ} 24^{\prime} 4 \mathrm{~S}^{\prime \prime} \mathrm{W}$. by railroad, $4 \dot{s} \mathrm{~m}$. S. S. W. Boston, and $186 \mathrm{~m}$. E. N. E. New York. The area of the city is about 9 sq. m., the compact part being divided into two nearly equal parts by the river. The surface east of the $r$. is hilly, and in its highest part 204 fuet above tidewater; on the west it is more level, the great set height hein only 78 feet. The harbor is safe and commodious, but its approach is somewhat inuricate.

The city is divided into 6 wards and governed by a mayor, 6 aldermen, and 24 common councilmen. These officers are chosen annually by the people. All other officers are appointed by the city council, consisting of the aldermen and councilors, the mayor presiding. There is a municipal court, which is also a court of probate, within the eity, and the city elerk is also register of deeds. Its police is excellent, and the city one of the cleanest in the Union. It is lighted with gas. The fire department is efficient, and eonsists of 12 engine conpanies. 2 hook and latder companies, 15 stationary forcing engines, 22 rotary engines, 8,000 feet of hose, and is maintained at a cost of $\$ 20,000$ anuually. The material used in building required this efficient force, and it was not until several extensive confligrations had occurred that the department was placed on its present footing. Including a balance of old accounts, the resources of the city treasury for the year ending $3 \mathrm{~d}$ Narch, 1351, amounted to 3150,505 , and the expenditures to $x^{1} 160$, account of interest $\$ 1,9 \$ 5$, for schnols $\$ 10.5,3$, ind fir strexts $\$ 28,999$. The debt of the city at the date specified was $\$ 155,553$. The population of the sercral nards of the eity in 1840 and 1850 comparatively were as follows: 


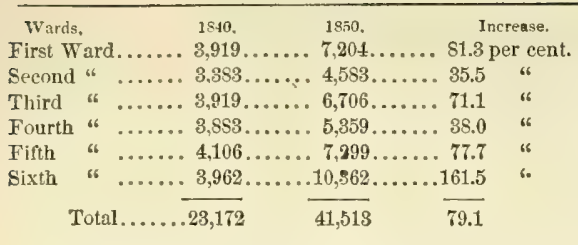

Population in $1810,10,071$, and in $1820,11.767$-increase 16.8 per cent, ; in $1830,16,833$-increase 43.1 per cent. ; in 1S40, 23,172-increase 37.6 per cent.; and in 1850, 41,513increase 79.1 per cent.

The more ancient portion of the city lies on the east side of the river, and though conforming in the outline of its streets with the topography of the site, and by no means distinguished for regularity, it contains many fine stores, warehouses, public buildings, and handsome residences. Back from the $r$. the streets become more regular, and many of the dwellings in this part are costly and elegant, delightfully situated as regards the view of the harbor and vicinity. The buildings of Brown University crown the ascent. The West part of the city is laid out with more regularity, and is more modern in appearance. The Providence Arcade, in this part, is one of the largest and most important buildings in the city; it extends from Broad to Westminster streets, and is 226 feet long, 80 feet deep, and 72 feet high. The building is of granite, and adorned with Græco-Doric porticoes and columns, the columnar shafts being single blocks 22 feet long. The lower floor is occupied chiefly by dry goods stores, and the upper stories by offices and dealers in light fancy goods. The Museum bullings and Howard Hall, on Westminster Street, are also fine buildings, and "What Cheer" building, at the junction of North and South Main streets, is a handsome freestone ediflce, occupied by offices, etc.

Among the public buildings are, the State House, various charities, the State Prison, the Athenæum, the Reform School, 25 or 30 churches and meeting-houses, and the public schnols. Most of these are substantial, and many of them costly edifices, distinguishing alike the taste displayed by the architect and the munificence of the citizens in their support.

Brown University, founded at Warren, in 1764, and removed to Providence, 1770, is situated on the highest part of the city, and consists of several halls, etc., furnishing elegant and ample accommodations. University Hall and Hope College are Iarge edifices for the lodging of students: Manning Hall contains the libraries, now counting 32.000 volumes, and Rhode Island Hall, the cabinet, chemical and philosophical apparatus, and lecture rooms. To the usual collegiate department has been added an English and scientific school for the benefit of such as do not intend entering the learned professions. The faculty of the university consists of a president and 10 professors, and in 1550 there were 195 students, and to that date the alumni numbered 1,765 , of whom 460 had entered the ministry.

The Athentum is located on the comer of College and Benefit streets, and has a library of 12,000 volumes. It is a spacious and elegant stone structure, erected in 1537, built on a lot given by the late Hon. N. Brown, and the heirs of Mr. P. Ives, who also gave large sums toward the building and library. The annual subscription is $\$ 5$, which admits members to the library and reading room.

The New England Yearly Meeting Boarding School, the object of which is to afford a "guarded" education to children, occupies a lot of 43 acres, given for the purpose by the late Moses Brown. The main buildings consist of a centre $5 t$ feet square and 3 stories high, and two wings $8 t$ by 42 feet, and 2 stories high; and there is another 2 stury building, 50 by 40 feet, which together accommodate abou So scholits. Board and tnition, $\$ 60$ a year. The late Obadiah Brown bequeathed $\$ 100,000$ toward the endowment of this institution.
The public schools supported by the city are 46 in number, of which 22 are primary, 16 intermediate, 7 grammar, and the High School. In these there were, in 1850,105 teachers and 6,000 scholars; and the cost to the cily, $\$ 40,553$. Besides these, there are upward of 30 Sunday schools, with 500 teachers, and between 5,000 and 6,000 scholars.

The newspapers published in Providence are 9 in number-3 daily, 2 semi-weekly, and 4 weekly. The " $\mathrm{P}$. Journal" (whig), issued daily, semi-weekly, and weekly editions; the "P. Post" (dem.) daily and weekly; the "Morning Mirror" (misc.), a daily; the "Republican Herald" (dem.), semi-weekly and weekly, and the "Diadem," weekly edition.

The most splendid and costly of the church edifices are, the First Congregational church, of granite; St. John's, a stone building; Grace, a Gothic structure; Westminster Congregational, the Beneficent Congregational, St. Peter's, and St. Patrick's. The First Baptist church, the oldest society in the city, is a clean wooden building. The other churches are in general neat, but not so costly. The colored inbabitants have five churches. In the whole city there are upward of 30 congregations, including all the principal denominations.

Dexter Asylum, on a ridge east of the river, is an institution erected on land given to the city by the late $\mathbf{E b}$. K. Dexter, for the accoramodation of the poor. The premises cover 40 acres, and are surrounded by a stone wall 10 feet high and 3 feet thick at the base, which cost $\$ 22,000$. The Asylum is a plain and substantial brick building, 170 feet fong, consisting of a centre building 3 stories high, and two wings, each 2 stories high.

The Butler Hospital for the Insane is located on Seekonk river. It was founded on a legacy of the late M. Brown, amounting to $\$ 30,000$, and received its present name from the late C. Butler, who gave $\$ 40,000$ toward its endowment. It was incorporated in 1844, and, until recently, was known as the Rhode Island Hospital for the Insane. On the 31st Dec., 1S50, there were 113 patients in the hospital; the ad. mittances during the next year were 68 , and the discharges 54 , of which 26 were recovered, and 8 improred, and 16 disd. Receipts $\$ 24,252$, and expenses $\$ 21,017$. The minimnm price of board is $\$ 225$ a week. The State appropriates $\$ 1,000$ annually to enable the governors to aid the poor insane, and also pays a portion of the expenses of such poor insane persons as the towns may choose to send to the hospital. The aggregate endowment of the hospital amounts to $\$ 135,000$. The grounds belonging to the institution consist of 115 acres, of which 55 are woodland and 60 under cultivation. The building stands on the W. bank of the river, which here expands to a mile in width, and admits of an extensive and delightful prospect. Patients were first admitted on the 1st December, 1547.

The State Prison is located here. On the 1st October, 1550, there were in confinement 37 convicts, and 24 had been committed, and 14 had been discharged during the ensuing year. The number of persons in Providenee jail, at the suit of the State, on the 1st Oetober, 1851, was 57; at the suit of the city, 11, and 4 debtors. During the year past, 503 had been committed, of whom 452 were males and 51 females; whites 473 , and colored 30 ; natives 293 , and foreigners 210; and besides these, 177 persons had been committed to the house of correction. The convicts in the Stite Prison are principally employed in shoe-making, and those in the Providence eounty jail at cabinct-work. The Reform School was established in 1850 . The buildings were formerly known as the Tuckwotton House, a hotel, pleasantly situate on high ground, in the S. E. part of the city, overlooking the bay, and large enough to accommodate 180 to $2: 10$ inmates. It was founded for the instruction and reformation of juvenile offenders between the ages of $S$ and 18 years. The first rear of its ocettpancy, en.ling 31st October, 15.51, it reecived 5 conviets- 49 bors and 3 girls, and thre remained in the institution at that date 45 , of whom 24 had been committed 
for theft, 6 for assault, 4 for vagrancy, and 11 for truancy; 42 were born in the United States, and of these 31 in Phode Tsland. Of each day, except Sunday, $7+$ hours are devoted to labor, 5 to school exercises, 2 to meals and recreation, 1 to religious exercises, and 8 to sleep. The labor has been employed in making such articles as are needed in the institution and in housework. An arrangement has been made by the State, by which all juvenile delinquents may be sent to this school.

The manufactures of Providence are valuable, and constantly increasing. Its water-power is fully oceupied, and steam-power, averaging 50 or 60 engines of 200 to 300 horsepower, is also employed. On the Pawtucket, and other streams, are extensive factories of cotton and woolen goods, machiue-shops, dyeing and print works, and within the eity are various establishments of similar character. The sawing and polishing marble, sawing and planing timber, and grinding grain, form extensive occupations; and a large capital is invested in the manufacture of iron of all kinds, machinery, screws, nails, furniture, small wares, shoes and boots, carringes, jewelry, and an extensive variety of other and no less raluable commodities. The total capital employed in this branch of industry is not much under $\$ 6,000,000$. In 1840 the eapital was only $\$ 3,012.588$.

Providence, however, is more a commercial than a manufacturing city, and commerce has been the main pursuit from the earliest periods. Before the last war with England, it was successfully engaged in the East India trade, but since this period this and foreign commerce has gradually declined. In the year ending 30th June, 1550, only 50 vessels ( $\$ .457$ tons) cleared for foreign ports, and the arrivals were only 69 (11,786 tons). The coasting trade is still carried on to a considerable, and perhaps an inereasing extent. The aggregate tonnage owned in the district in 1550 was 16,712 tons, of which 9,177 tons were registered, 7.298 enrolled and licensed, and 237 tons licensed (under 20 tons). Of the registered shipping, 499 tons were employed in whaling, and the proportion of the licensed and enrolled shipping was-in the coasting trade 7.202 tons, in the cod fishery 26 tons. and in the mackerel fishery 69 tons; and 53 tons were navigated by steam. Of the licensed shipping 96 tons were employed in the coasting trade, and 141 tons in the cod fishery. The shipping built during the year consisted of 1 ship, 1 schooner, 3 sloops, and 1 steamer-total 6 ships, of an aggregate burden of 1.299 tons. The products of the whale fishery brought into port in 1849, was-sperm oil 2,317 barrels, whale oil 4,512 barrels, and whalebone 30,200 pounds.

Providence, according to the Report of the Secretary of State. on the Sth September, 1S50, had 26 banks and one savings institution. The condition of the banks at that date was as follows-lictilities, capital stock, $\$ 2.518,810$; bills in circulation, $\$ 1, \$ 31,339$; deposits on interest, $\$ 159,497$; deposits not on interest, $\$ 1.138590$; debts due other banks, $\$ \$ 81,795$; dividends unpaid, $\$ 21,409$; and net profits $n$ band, $\$ 592.709$; and assets: debts due from directors, $\$ 261,914$ : from stockholders, $\$ 303.348$; and others, $\$ 12,031,937$; specie actually in bank, $\$ 177.078$ : bills of other banks, $\$ 525,464$; deposits in other banks, $\$ 428.464$; stock of bank, $\$ 1.484$; and of other banks, etc., $\$ 36,356$; real estate, $\$ 184.867$; and other property, $\$ 6.309$ - total $\$ 14,000,193$. The average semi-annual dividend amounts to $311-16$.

The retail trade of the city is extensive, and one of the main festures in its ecnnomy. Stores of every description, exhibiting goods of the richest descriptions, are numerous, and in the provision trade, both wholesale and retail, a large business is done. Many of the stores are cqual to those of New Tork, Philadelphia, and Boston, in the splendor of their assortments and the costly style in which they are furnished. The great bulk of the foreign gonds sold here are brought from Boston and New York, with which places there is ample menns of rapid communication by railroad and steamboat; and the cormunication with the interior, both for passengers and freight, is varied and comrnodious. Steamboats run regularly to Warren, Bristol, Portsmouth, Newport, Fall River, and New York. The railroads diverging from Providence are the Boston and Providence R. R., the Stonington R. R., and the Providence and Worcester R. R., and others have been ehartered to Bristol and Hartford to connect with the through lines. These railroads connect so as not to require change of cars in passing from one to the other. The station buildings are extensive, and near the centre of the business portion of the city. They are situated on three sides of a beautiful sheet of water of elliptical form, which constitutes the head of Providence r.; and between this and the railroad buildings is a beantiful promenade, 80 feet wide, which is well laid out in gravel walks and grassed plots, and ornamented with shade trees. The water is inclosed by a substantial stone wall and iron railing, with bridges to cross the small rivers flowing into it, and also its ontlet. Telegraph wires are extended from this city, and afford immediate communication with the whole Union.

Providence was founded by Roger Williams in 1637. The first landing-place, on crossing the Seekonk, he called "What Cheer," because the patriarch of the settlement was saluted by the Indians with "what cheer," on his approach. The origin of the name of the city, $\mathrm{Mr}$. Williams explains in a deed executed by him: "having a sense of God's merciful providence unto me in ray duties, I called the place Providence." The first house was built on what is now North Main Street; and near this spot it is supposed that Mr. Willians was buried, although the site of his grave is not ascertained. In 1640 a town goverument was established, and in 1649 it was incorporated. In 1832 it was chartered as a city.

Providence, p. o., Halifax co., Virg.: $92 \mathrm{~m}$. S. W. by W. Richmond.

Providence river, $R$. $I$. : an arm of Narragansett bay, extending from the city of Providence to Field's Point, about $8 \mathrm{~m}$., or to Bullock's Point, $5 \mathrm{~m}$. On the N., below Providence, it receives Seekonk or Pawtucket (Blackstone in Massachusetts) river; and above the city another stream or expanse of water into which fall Wanasquiatucket and Moshasick rivers. It is navigable for large ships to Providence, and forms a safe harbor.

Provmexce HuL , p. o., Tyler co., Tex. : 219 m. E. by N. Austin City.

Provincetown, t. and p. v., Barnstable co., Mass, : on the extreme N. W. point of Cape Cod, 48 m. E. S. E. Boston. The surface consists of beaches and sandy hills, with swamps and shallow ponds interspersed. Cape Cod harbor, within the curve of the cape, is easy of access, spacious and safe, with a sufficient depth of water for the largest ships. The v. lies along the beach for $2 \mathrm{~m}$, and is inhabited chiefly by fishermen. Salt is extensively manufactured, and the water is raised into vats for evaporation by windmills. Pop. 3,153. Proviso, p. o, Cook co, $M l_{\text {。 }}: 173 \mathrm{~m} \mathrm{~N}$. E. by N. Springfield Provo City, v., Utah co., Utah Ter.: on the E. side of Utah lake, about $96 \mathrm{~m}, \mathrm{~N}$. by E. Fillmore City. It is a new Mormon eity, laid out in 1552.

Prudexce island, $R$. $I$. : a small island in Narragansett bay, and belonging to the co. of Newport.

Prune Hill, p. o., Montgomery co., Ala.

Pronty's, p. o., Patrick county, V̌rg.: 162 m. W. S. W. Richmond.

PruntytowN, p. v., and eap. Taylor co., Firg.: on the E. branch of Monongahela r., $184 \mathrm{~m}$. N. W. Richmond. It contains the county buildings, several stores, and 300 inhabitants. The Baltimore and Ohio R. R. passes about $4 \mathrm{~m}$. N. of it, from which the North Western R. R. will diverge and pass through it.

Pryor's VAI.E, p. o., Amherst co., Firg. : at the E. base of the Blue Ridge, $98 \mathrm{~m}$. W. Richmond.

Public Squarr, p. v., Greene co., Ga. : 43 m. N. N. E. Milled geville. 
Pucketas, p. o., Westmoreland co., Penn.: $124 \mathrm{~m}$. W. Harrisburg.

Puebla, p. O., Westmoreland en., Penn.

PUtri, p. o., Brown co., Ohio: 79 m. S. S. W. Columbus.

Puerco river, $N$. Jex. : rises in the Sicrra Matre, in lat. $36^{\circ} \mathrm{N}$., and flows S. by E. nearly parallel with the Del Norte, jinto which it falls opposite the village of Ciboletta, and $12 \mathrm{~m}$. N. of Socorro, after a course of $120 \mathrm{~m}$. Its main tributary is the San José, a stream rising near the Zuni Pass of the Sierra.

PUGET"s sound, Washington Ter.: a large sound in the N. W. part of the old Oregon Territory, being the S. part of Admiralty Inlet, and communicating with the Paciflc Ocean by the straits of De Fuca. It receives several small rivers, and is full of islands. Olympia is the principal port on its waters, and there are numerous new settlements along its shores.

Pegris Hill, p. 0, Franklin co, N. Car. : 87 m. N. N. E. Raleigh.

Pughtown, p. v., Chester co., Penn.: on a branch of French cr., $63 \mathrm{~m}$. E. by $\mathrm{S}$. Harrisburg.

Pugsley's Depôt, p. o. and sta., Tompkins co., $N$. $Y$ : on the Cayuga and Susquehanna R. R., $19 \mathrm{~m}$. N. of Owego, $131 \mathrm{~m}$. W. by S. Albany.

Pulaski county, Ark. Situate centrally, and contains 1,151 sq. m. Drained by Arkansas r., which runs centrally through it, and by its several branches. Surface diversified; soil in general fertile, and is well adapted to grain and grass. There is a quantity of gond timber on the land. larms 306 ; manuf. 14 ; dwell. 808 , and pop.-wh. 4,526, fr. col. 13, sl. 1,119-total 5,655. Cupital: Little Rock, Public Works: several proposed railroads from the Mississippi.

Pulaski county, Ga. Situate S, centrally, and contains 758 sq. m. Oemulgee $r$. runs through it in a nearly central direction, by which and its tributaries it is drained. Surface hilly; soil fertile, and is best adapted to cotton-wheat and Indian corn are produced, and the hilly portions make good pasturage for cattle, sheep, hogs, etc., which are annually exported. Pine timber abounds. Farms 371 ; manuf. 2; dwell. 701, and pop.-wh. 3,784, fr. col. 39, sl. 2,804-total 6,627. Capital: Hawkinsville.

Pulaski county, $M l l$. Situate S., and contains $162 \mathrm{sq} . \mathrm{m}$. Drained by a tributary of the Ohio, which forms its S. E. boundary, Surface generally level, excepting the bluffs on the Ohio shore; soil fertile. Pine timber is found on the land. Farms 266; manuf. 1s; dwell. 418, and pop.-wh. 2,257, fr. col. 8-total 2,265, Capital: North Caledonia. Public Works: Illinois Central R. R.

Pulasisi county, Ind. Situate toward the N. W., and contains $432 \mathrm{sq}$. m. Drained by Tippecanoe $r$, and its branches. Surface varied-for the most part it is level, but through the county there are oceasional ridges of low hillsa large portion is prairie and thickly covered with timber; soil moderately fertile- the wet prairies when drained make good pasture. Chief productions, Indian corn, wheat, and potatoes. Fruit of different kinds is produced. Farms 256; manuf. 0 ; dwell. 454 , and pop.-wh. 2,595, fr. col. 0-total 2,545. Cerpitel: Winamac.

Pulaskr county, $\bar{K} y$. Situate S. E, and contains 1,120 sq. m. Drained by numerous branches of Cumberland r., which passes through its centre. Surface in some parts hilly, but generally even; soil fertile and adapted to grazing. It produces wheat, oals, and Indian corn, which form the staples of the county. Farms 1,525; manuf. 14; dwell. 2,263 , and pop.-wh. 12,861 , fr. col. 27 , sl. 1,807-total 14,195. Cupital : Somerset.

PrLASKI county, Mo. Situate $\mathbf{S}$. centrally, and contains $1,061 \mathrm{sq} . \mathrm{m}$. Drained by Gasconade $r$. and its branches, and tributaries of Osage $r$. Surface broken and hilly; soil in general fertile, and adapted to corn and tobacco. Fruits of all kinds are grown extensively. Tumbers of cattle, shcep, and swine are fed on the hills, where they find good grazing. It abounds in minerals, principally iron and lead. Tut
Farms 471 ; manuf. 3 ; dwell. 630 , and pnp.-wh. 3,555 , fr. col. 0, sl. 118-iotal 3.99S. Capital: Haynesville.

Pularki county, Virg. Situate toward the S. W., and contains 363 sq. m. Drained by New r., Which passes through the $\mathbf{S}$. portion of the county. Surface hilly and broken, in some parts mountainous; soil fertile. Chief product, Indian corn. It has some fine grazing land. Farms 301; manuf. 19 ; dwell. 585, and pop.-wh. 3,613, fr. col, 34, sl. 1,471-total 5,118. Cupital: Newbem. Pullic Works: Virginia and Tennessee $\mathcal{L}_{\text {. }}$ R., and Junction Brauch to Covington and Obio R. $\mathrm{P}$.

PULASKI, p. v., Hancock county, Ill.: 73 m. W. N. W. Springfield.

Pulaski, $t$, and p. o., Jackson co., Mich. : $46 \mathrm{~m}$. S. by W. Lansing. Drained by $\mathrm{S}$. branch of the Kalamazoo, into which flow several small ponds. Surface generally undulating, and fine wheat land. Pop. 760.

Pulaski, p. v., Panola eo., Tex.: on the Sabine, $252 \mathrm{~m}$. N. E. by E. Austin City.

Pulaskx, p. o., Scott co, JFiss, : 37 m. E. Jackson.

Pulaski, t. and p. o, Williams co., Ohio: $12 \mathrm{Sm}$. N. W. Columbus. Drained by Lick cr, and other W. branches of Tiffins r., which afford good mill-sites. Surface diversified; soil of moderate fertility. Pop. 760 .

Pulaski, p. v., Lawrence co., Penn.: on Shenango cr. and the Beaver and Erie Canal, 192 m.W. N.W. Farrisburg. Pulassi, p. v., and alternate cap. Oswego $\mathrm{co}_{2}, N$. $Y_{\text {.: }}$ on Salmon r., $4 \mathrm{~m}$. from Lake Ontario, and $108 \mathrm{~m}$. W. by N. Albany. It has considerable water-power, and contains a court-house, jail, numerous manufactures, and about 1,000 inhabitants. The Watertown and Rome R. R. passes within $4 \mathrm{~m}$. E. of the village. The river, which has a good harbor at its mouth, is navigable for small craft $14 \mathrm{~m}$. to Orwell. The "Richland Courier" and the "Northern Democrat" are published here weekly.

Pulaski, p. v., and cap. Giles co., Tenn.: on Richland er, a N. branch of Elk r., $64 \mathrm{~m}$. S. by W. Nashrille. It has a heary trade in corn, cotton, and tobacco, the staples of the rich district around it, and contains a court-house, academy, bank, 20 stores, and 1,200 inhabitants. The "Nestem Star" (whig) is published weekly.

Pulaskivilie, p. v., Morrow co, Ohio: 7 m. E. S. E. Mount Gilead, and $46 \mathrm{~m}$. N. N. E. Columbus.

Pultxey, $t$, and p. o., Stcuben co., N. $Y_{\text {. }}$ : on the W. side of Crooked lake, $173 \mathrm{~m}$. W. Albany. Surface level, with an inclination to the lake; soil clay and calcareous loam, adapted to grain and grass. A farming town. Pop. 1,815. Pultieyvilie, p. v., Wayne e., N. Y.: on the S. shore of Lake Outario, $173 \mathrm{~m}$. W. N. W. Albany. It has some lake trade, and contains a steamboat landing, several warehouses and stores, and 500 inhabitants.

Pulver's Corners, p. O., Duchess eounty, N. $I_{*}: 49 \mathrm{~m}$. S. by E. Albany.

PUMPkin, p. o., Southampton co., Virg.: 64 m. \$. \&. E. Richmond.

Pumprix Pile, p. o., Paulding co., Ga.: 128 m.W. N.W. Milledgeville.

Pempintown, p. v., Pickens district, S. Car:: $122 \mathrm{~m}$. N. W. by W. Columbis.

Pumprintown, p. v., Randolph co., Ga.: 132 m. S. W. Milledgevilie.

Pumperty Vine, p. o., Paulding co., Ga.: on a S. branch of Etowah r. so called, $119 \mathrm{~m}$. N. W. by W. Milledgeville. Puxcleon, p. 0., Allen county, Ky.: 118 m. S. S. W. Frankfort.

Pusgo Creek, p. o., Beaufort county, N. Car.: $104 \mathrm{~m}$. E. by S. Raleigh.

Pungoteague, p. v., Accomac co., Firg.: on the Eastern Shore, $92 \mathrm{~m}$. E. by N. Richmond. It contains 2 churches, a store, mill, and 200 inhabitants.

Pusta Loma, Calif: : at the mouth of Snn Diego bay, in lat. $32^{\circ} 29^{\prime} 31^{\prime \prime} \mathrm{N}_{\text {., }}$ and long. $117^{\circ} 15^{\prime} 07^{\prime \prime} \mathrm{W}$. The initial point of the line between Mexico and the United States 
commences $3 \mathrm{~m}$. $\mathrm{s}$. of this on the Pacific Ocean. A monument demarks the puint.

Pusxutw wey, p. v., Jeffersnn co., Penn.: on Mahoning creek, $115 \mathrm{~m}$. W. N. W. Harrisburg.

Purctalssille, p. o., Loudon co., Virg. : $106 \mathrm{~m} . \mathrm{N}$. by W. Richnond.

Peepr. p. F.. and eap. M'Nairy co., Tenn. : at the head of $c$ branch of Hatchee r., $114 \mathrm{~m}$. S. W. by W. Nashville. It contains the county buildings, an acndemy, and several stores.

Purdy Creek, p. o, Steulien co., N. Y. : $196 \mathrm{~m}$. W. by S. Albany.

PuRdy's Station, p. o., Westchester co., $N . Y_{0}:$ on the E. side of Croton r., and on the line of the Harlem R. R. $106 \mathrm{~m}$. from Albany.

Pervis, p. v., Sullivan co., N. Y.: 69 m. S. W. Albany.

Puserville, p. v., Lancaster co., Penn.

Pushaw lake, Penobscot co., Me. : a small lake, $8 \mathrm{~m}$. long and a mile wide, connecting in the N. with Dead stream, and having its outlet through Pushaw r., which falls into the Penorscot, opposite Old Town.

Pushmataha, p. o., Choctaw co, Alan: $118 \mathrm{~m}$. W. by $\mathrm{S}$. Montgomery.

Putram county, Flor. Situate toward the N. E., and contains 437 sq. $m$. Drained by branches of St. John's r., which bounds it on the E., and of Octawaha river, which bounds it on the S. Surface rising, or slightly undulating : soil furtile and highly productive. Staples, rice, cotton, fruits, vegetables, Indian corn, wheat, etc. Farms 20: manuf. —; dwell. 108, and pop.-wh. 473, fr. col. 10, sl. 204 -total 657. Capital: Pilatka.

Putrax county, Gu. Situate N. centrally, and contains $273 \mathrm{sq}$. m. Drained by branches of Oconee r., which forms its W. boundary. Surface even; soil a fine deep mold, and very furtile, and produces abundantly corn, wheat, and cotton, which last is the chief production. Timber is found of good quality. Farms 351 ; manuf. 32 ; dwell. 609, and pop. -wh. 3,300, fr. col. 26, sl. 7,468-total 10,794. Capital: Eatonton. Pultic Works: Eatonton R. R

Putvay county, $I l l$. Situate $N$. centrally. and contains $26 \mathrm{~S}$ sq. m. Illinois river passes through its W. portion, and forms its $\mathrm{N}$. boundary, by which and its branches it is drained. Surface uneven and diversified; a large portion is prairie; soil fertile and very productive. It is well timbered. and has much fine grazing land. Farms 317 ; manuf, 26; dwell. 686, and pop.-wh. 3,920, fr. col. 4-total 3,924 . Cupitul: Ilennepin.

Putnam county, Ind. Situate W. centrally, and contains 4 Ss sq. m. Drained by Deer and Big Raccoon creeks, and Walnut fork of Eel river. Surface varied-in general undulating or rolling, but along the streams the land is hilly and broken; soil fertile, and adapted to wheat, grain, etc., the hilly portions making fine pasture for cattle. Chief productions, wheat, Indian corn, tobacen, and sugar. It has some good timber and fine quarries of limestone. Farms 1,696; manuf. 42; dwell. 3,085, and pop.-wh. 18,581, fr. col. 34-total 15,615. Capital: Greencastle.

Potrax county, Mo. Situate $\mathrm{N}$., on the border of the State, and contains 317 sq. m. Drained by head branches of Chariton r. Surface rolling; soil fertile, and easy of cultivation, and produces corn, fruits, tobacco, etc., in large quantilies. It has some fine timber land, and may in general be sald to be productive. It contains some good beds of coal. Farms 202; manuf. 0 ; dwell. 265, and pop.- wh 1,635, fr. col. 0, sl. 19-total 1,657. Capital: Putnamville.

Putrair county, $N$. $Y$. Situate $\$$. E., and contains 216 sq. m. Drained by head branches of Croton r., Peekskill, and other small streams. Surface mountainous, making gorm grrazing land. The Highland range extends across the $\mathrm{N} . \mathrm{W}$. portion, and the Taghkanic, in the E., from $\mathrm{N}$, to S.; sril various-in the E. part, with eultivation, it is produclive, and yields good crops of wheat, grain, ete., which are its chief products. It has some extensive beds of iron ore and plumbago, with many other minerals, and granite and limestone are found. The West Point Foundry, the largest in the States, is in this county. Farms 959: manuf. 89; dwell, 2, 495, and pop.-wh. 14,008, fr. col. 130_total 14.138. Capitul: Carmel. Pullic Works: Hudson River R. R.; Harlem R. R.

Purnam county, Ohio, Situate toward the N. W., and contains $4 S 6 \mathrm{sq} . \mathrm{m}$. Drained by Auglaize $r$. and its afluents. Surface uneven, and in parts somewhat elevated; soil a deep mold, with clay intermixed, and productive. Staples, wheat and Indian corn. Pinc and other timber abounds. Farms 603 ; manuf. 11 ; dwell. 1,246. and pop.wh. 7,210, fr. col.11-total 7,221. Capital: Kalida. Pullic Worke: Miani Canal.

PUTNA county, Virg. Erected in 1848 ont of Kanawha, Cabell, and Mason. Situate W., and contains 813 sq. m. Drained by Great Kanawha river and its tributaries, Surface hilly and broken; soil various, but in general fertile. Chief products, wheat and Indian corn, with pork, etc. It contains bituminous coal. Farms 45.5; manuf. 21: dwell. 7Ss, and pop.-wh. 4,693, fr. col. 10, sl. 632-total 5,335. Capital: Putnam. Public Worles: Maysville and Big Sandy R. R. ; Covington and Ohio R. R.; James River and Kanawha Canal, ete.

Putnay, t., and p. o., Washington $\mathrm{con}_{n}, N . \bar{Y}_{0}:$ on the neck of land betwcen lakes George and Champlain, $69 \mathrm{~m}$. N. Albany. Surface tratersed by the Palmerstown range of mountains, some peaks of which are 1,500 feet high. There is little land fit for cultivation. Pop. 758. Old Fort Ticonderoga occupies the $\mathrm{N}$. extremity of the peninsula.

Putray, p. v., Muskingum co., Ohio: on the W. bank of Scioto r., at the mouth of Licking r., $50 \mathrm{~m}$. E. Columbus. Zanesville is on the opposite side of the river, with which a handsome bridge connects it. It has great facilities for manufactures, virious branches of which are extensively prosecuted, and contains a bank, an academy, a female seminary, and 1,674 inhabitants. The Cincinnati, Wilmington, aud Zanesville R. R. passes through it.

Putnam Vallex, t., Putnam co., N. $Y$.: $67 \mathrm{~m} . \mathrm{S}$. by E. Albany. Drained by Peekskill and several other streams, and studded with many small lakes. Surface traversed by the Ilighlands, and a broad and fertile valley lying between their ridges. Iron ore is abundant, and there are several furnaces, etc., with grist, saw, and other mills. Populstion 1,626 .

Putnampille, p. v., Putnam eo., Ind.: on Deep cr., and the New Albany and Salem R. R., $38 \mathrm{~m}$. W. by S. Indianapolis. It contains several mills and a population of about 500 .

Putramville, p. v., and cap. Putnam co., Mro. : 136 w. N. by W. Jefferson City.

Putnex, t. and p. v., Windham co., Term. : on Connecticut river, $92 \mathrm{~m}$. S. by E. Montpelier. Surface raried; on the streams are extensive meadows-back of them it is rugced and broken; soil fertile; on the hills good pasturage. Sackett's brook falls 75 feet in quarter of a mile, affording superior power, and moving several woolen, pupur, woodenware, and other factories. Serpentine is abundant. The Vermont Valley R. R. crosses the E. part. P. station is $9 \mathrm{~m}$. N. of Brattleboro'. Pop. of t. 1,425.

Putreyville, p. v., Armstrong co, Penn.: $143 \mathrm{~m}$. W. by N. Harrisburg.

PyLisstule, p. V., Harford county, MKC.: $7 \mathrm{~m}$. TT. of the Susquehanna, $49 \mathrm{~m}$. N. by E. Annapotis, It is bailt of stone, and contains a flouring-mill and sereral stores. In the vicinity are quarries of asbestos and slate.

Pyramo lake, Utah Ter.: on the Sicrra Nevada, 4,\$90 feet elevation above the sea level. It was discovered by Fremont in 1844, and is $35 \mathrm{~m}$. long. The pyramid, a little E. of its middle, more like the work of man than a natural elevation, measures 600 feet above the surface of the water. Lat. $40^{\circ} \mathrm{N}$., and long. $119^{\circ} 50^{\prime} \mathrm{W}$. It receives the waters of Mud lake from the $\mathrm{N}$., and of Salmon-trout r. from the S.. but has no oullet.

Prramo Crmole, Oreg. Ter.: on the overland route to 
California, at the junction of the Great Salt Lake and California roads, $1,208 \mathrm{~m}$. from Council Bluffs. It is $5 \mathrm{~m}$. long, and about $3 \mathrm{~m}$. wide, level within the walls around, and studded throughout with numerous tall white and green stones, from 60 to 150 feet high, and from 10 to 20 feet in diameter at the foot, some of them running almost to a point at the top. It is surrounded by mountains which are covered with pine and cedar trees, and is altogether a beautiful and picturesque scene. Upon these stones are written, painted, and engraved, the names of many visitors, with the dates. This circle is entirely surrounded by mountains, except an inlet at the east end of about 50 yards, and an outlet at the west end of about 20 yards wide.

Prrmont, p. o., Montgomery co., Ohio: $68 \mathrm{~m} . \mathrm{W}$. by $\mathrm{s}$. Columbus.

\section{Q.}

Quaker Botrom, p. o., Lawrence co., Ohio: $97 \mathrm{~m}$. S. by E. Columbus.

Quaker Hilu, p. o., Duchess co., N. Y.: $76 \mathrm{~m}$. S. by E. Albany.

QUAKER SprLvGS, p. v., Saratoga co, $N$. $Y .:$ about $1 \mathrm{~m}$. W. of IIudson r. and $27 \mathrm{~m}$. N. by E. Albany.

Qdaker Sprivgs, Y., Columbia co., Ga.: 71 m. E. N. E. Milledgeville. This settlement was formed in 1750 by a party of Friends, who, alarmed at the murders by the Cherokees, fled here for refuge.

QUAKer Street, p. o., Schenectady county, $N$. Y.: $25 \mathrm{~m}$. W. by N. Albany.

Quakertown, p. v., Hunterdon county, $N_{0}$ Jer. : $47 \mathrm{~m}$. N. by W. Trenton. It contains a Friends' meeting-house, 3 stores, and 20 or 25 dwellings. Sometimes called FAIRVIEW. Quakertown, p. v., Bucks co., Penn.: $79 \mathrm{~m}$. E. by N. Harrisburg. It is neatly built on a single street, and contains a Friends' meeting-house, and about 300 inhabitants.

Quallatows, p. v., Haywood county, $N$. Car.: $283 \mathrm{~m}$. W. by S. Raleigh.

Quantico, p. o., Somerset co., Md.: on a cr. so called, $58 \mathrm{~m}$. S. E. Annapolis.

Quanduck bay, Suffolk co., $N_{0} Y_{0}:$ at the E. extremity of Great South bay, and separated from Shinnecock bay by Quogue neck.

Quarryville, p. v., Lancaster co., Penn。

Quarryville, p. v., Tolland co., Conn.

Quasqueton, p. v., Buchanan co., Ta.: on E. side of Wapsipinicon r., $49 \mathrm{~m}$. N. by W. Iowa City.

Quax, p. o., Claiborne parish, La.: 189 miles N. W. Baton Rouge.

QueEche river, Term.: an affuent of the Connecticut. It rises in Sherburne, and after a course of $35 \mathrm{~m}$. falls into that $r$. in Hartland, $2 \mathrm{~m}$. above Queechee Falls. It receives a number of tributaries, and affords extensive water-power.

Queechee Village, p. v., Windsor co., Verm.: around the Falls of Queechee $r_{0}, 5 \mathrm{~m}$. from its mouth, $51 \mathrm{~m}$. S. by $\mathrm{E}$. Montpelier. There is an immense water-power here, and considerable manufactures are carried on ; and both up and down the river are mills of rarious descriptions.

QUEFe ANNe county, Md. Situate $\mathrm{E}_{\text {, }}$, toward the N., and contains $403 \mathrm{sq} . \mathrm{m}$. Drained by branches of Chester river, which flows on the N.W., and of Tuckahoe er., which forms its W. boundary. Kent island, lying to the S. W., is within the limits of the county. Surface undulating, and in parts elevated; soil fertile. Staples, wheat and Indian enrn. Farms 936 ; manuf. 29 ; dwell. 1,864, and pop.-wh. 7,040, fr. col. 8,174 , sl. 4,270-total 14,484. Capital: Centreville.

Qukex ANse, p. o., Prince George's co., Md.: on W. side of Patuxent r., 18 m. W. S. W. Annapolis.

Quenx's county, $N$. $\boldsymbol{Y}$. Situate toward the W. part of Long Island, and contains $396 \mathrm{sq} . \mathrm{m}$. Drained by several small streame which enter the sound on the $\mathrm{N}_{\text {., }}$ and the Atlantic Ocean on the S. Surface moderately even; soil in 706 the N. a deep loam, and in the S. sandy; when cultivated it is productive, and well adapted to grain and grazing. Chief products, wheat and Indian corn. This eo. contains some minerals, but none of any great importance. It has numerous bays and harbors, which abound with fish, oysters, etc. Farms 3,303; manuf. 89; dwell. 6,230, and pop.wh. 33,389 , fr. col. 3,444-total 36,\$33. Capital: North Hempstead. Public Works: Long Island R. R.; Hempstead Branch R. R.

Queensborougr, p. v., Anderson dist., S. Car.: on the W. side of Saluda r., 81 m. N. W. by W. Columbia,

QueEnsbury, t. and p. v., Warren co., N. Y.:46 m. N. Albany. Drained by Wood cr. on the N., and bounded on the S. by Hudson r. Surface undulating, and in the W. hilly; soil sand and loam, fertile. It contains the village of Glen's Falls, and has considerable manufactures and trade. Pop, of t. 5,313 .

Queknsdale, p. v., Robeson co., N. Car.: 85 m. s. S. W. Raleigh.

QUeEnstown, Queen Anne county, Md.: on S. E. side of Chester bay, $19 \mathrm{~m}$. E. by N. Annapolis.

QueExsville, p. v., Jennings co., Ind.: on the line of the Madison and Indianapolis R. R., $58 \mathrm{~m} . \mathrm{S}$. E. Indianapolis, and $2 S$ m. from Madison.

Quemahonivg, t., Somerset county, Penn.: $11 \mathrm{~m}$. N. E. Somerset. Drained by M'Conaughey r. and Quemahoning, Higgins', and Wills' creeks. Surface hilly; soil gravelly and light, but productive. Stony creek bounds it on the $\mathbf{E}$. It contaius several mills, for which it has fine water-power. Pop. 1,302 .

Quenaddentille, v., Lewis co., Oreg. Ter.: at the confluence of Chehalis r. with Gray's Harbor, $142 \mathrm{~m}$. N. by W. Salem.

Quercus Grove, p. v., Switzerland co., Ind.: 89 m. S. E. Indianapolis. It is situate about $12 \mathrm{~m}$. N. E. from Vevay, and is sometimes called "Bark Works," on account of its having been founded for the purpose of grinding and packing oak bark for the English market.

Quiet Deli, p. 0., Harrison co., Virg.: 205 m. W.N. W Richmond.

Quillinstilue, p. v., Scott co., Virg.: 291 m. W. S. W. Pichmond.

Quwcx, p. v., and cap. Gadsden co., Flor.: on the W. side of Attapulgus creek, $19 \mathrm{~m}$. W. N. W. Tallahassee. It contains a court-house, jail, etc., and about 600 inhabitants.

QuLver, p. v., and cap. Adams co., Ill.: mostly on a high Uluff, on the E. side of the Mississippi, $88 \mathrm{~m}$. W. Springfield. It is a flourishing $\mathrm{v}$. , and contains a court-house, jail, etc., a U. S. land office, numerous warehouses, stores, and workshops, and other establishments, indicative of its commercial importance. Several steamboats arrive and depart daily during the season. It is also noted for its hog-packing for exportation. The newspapers published here are the "People's Journal" (indep.), daily and weekly; the "Q. Whig" (whig), the "Q. Wochenblatt" (dem.), and the "Q. Herald and Argus" (dem.), all weekly, and the "Western Legal Observer" and the "Western Temperance Magazine," both monthly. This v. will be the W. terminus of the Northern Cross R. R., which will bring it into connection with Chicago, Springfield, and the whole North and East. The neighborhood is thickly settled and highly cultivated. Pop. in 1850, 6,911.

Quivcr, t. and p. v., Norfolk co., Mass.: on Braintree bay, an arm of Boston Harbor, 8 m. S. by E. Boston. Surface pleasantly diversified and somewhat hilly; soil of excellent quality and well cultivated. It contains large tracts of salt meadow. The $\mathrm{v}$. is centrally situate and has several neat and some costly buildings. The town-house is a noble building of granite, 85 by 55 feet. A newspaper, the " $\mathrm{Q}$. Patriot," is issued weekly. Quincy Point and Germantown are well known places on the shore, and are eligibiy situated for ship-building and the shore fisheries. Squantum is noted as having been the residence of the Indian sachem. 
Chichataubut, and is also a pleasant resort for fishing and bathing. Considerable manufactures are carried on in the town, bnt Quincy is more celebrated for its granite quarries. About $2 \mathrm{~m}$. back from the bay is a range of elevated land, in some parts more than 600 feet above the sea, containing an inexhaustible supply of that invaluable building material. This granite range extends into the neighboring towns. More than 1,000 hands are employed in these quarries, which supply a large amount of stone for building in all the great cities. The columns of the new Custom House and Exchange at Boston are of this material, and much of it is used in New York eity. Quincy has been the birthplace of several noted patriots-John Hancock, Josiah Quincy, John Adams, and John Quincy Adams were born here, and have left to posterity names of imperishable renown. Pop. of t. 5,017.

Quincr, t. and p. v., Branch co., Mich.: $61 \mathrm{~m}$. S. S. W. Lansing. Drained by Hog creek and other affluents of St. Joseph's river. Surface varied; soil fertile and adapted to grain. The $\%$. is situate on the line of the Southern Michigan R. R., $86 \mathrm{~m}$. from Monroe and $167 \mathrm{~m}$. from Chicago. The t. is eminently agricultural, and produces fine crops. Pop. 1,111.

Quncy, p. V., Monroe co., Miss. : 148 m. N. E. Jackson. QUINcy, p. v., Hickory co., MLo.: 66 m. S. W. Jefferson City.

Quincy, p. v., Logan county, Ohio: on the E. branch of Great Miami r., 57 m. W. N. W. Columbus. The Bellefontaine and Indiana $R$. R. passes through it about $12 \mathrm{~m}$. from Bellefontaine.

Quincr, p. v., Gibson co., Tenn. : on the S. side of Forked Deer cr., 133 m. W. S. W. Nashville.

Quinoy, p. v., Franklin co., Penn.: 48 m. S. W. Harrisburg. It is situate at the foot of South Mountain, in a rich iron region, and there are several manufacturing establishments in the vicinity.

Qunvor, p. o., Washita co., Ark.: 78 m. S. S. W. Little Rock.

Quinebadg, p. v., Windham co., Conn.: on Quinebaug r. 43 m. E. N. E. Hartford.

Quinemaug river, Conn.: a tributary of Shetucket r. It rises in Mashapaug pond and passes into Mass., where, in the t. of Brimfield, it receives a considerable branch, and thence returning in a $\mathbf{8}$. E. direction into Conn., it takes a S. course for $30 \mathrm{~m}$. until it unites with the Shetucket, $3 \mathrm{~m}$. above Norwich City. It has falls that afford extensive and valuable water-power.

Quivnipiac river, Conn; rises in Farmington, and after a $\mathrm{S}$. course $30 \mathrm{~m}$., enters New Haven Harbor, where it is crossed by a long bridge.

Quinn's Mults, p. 0., Clinton county, Ohio: $102 \mathrm{~m} . \mathrm{S}$. W. Columbus.

Quitray, p. v., and cap. Clark co., Miss. : on the E. side of Chickasawha r., $92 \mathrm{~m}$. E. by S. Jackson. It contains a court-house and the county offices, several stores, and about. 150 inhabitants. The Mobile and Ohio R. R. passes through it.

Quituan, p. v., Benton county, Ala.: 108 m. N. N. E. Monigomery.

Quirmas, p. 0., Van Buren county, Ark.: on N. fork of Cadron cr., 47 m. N. Little Rock.

Qurto, p. v., Talbot co., $G c_{0}$ : on the W. line of the co., $92 \mathrm{~m}$. W. S. W. Milledgeville.

Quiver, p. o., Mason county, $m l .: 27$ m. N. by W. Springfield.

QuODDy (or Wrest QUODDy) Hrad, Me : at the S. side of entrance into West Quoddy bay, in lat. $44^{\circ} 49^{\prime} 18^{\prime \prime} \mathrm{N}$., and long. $66^{\circ} 59^{\prime}$ W. West Quoddy Head Light-house is located on this headland.

Quogute, p. v., Suffolk co., $N . Y_{\text {.: }}$ on the S. side of Long Island, on a neck between Shinnecook and East bays, $145 \mathrm{~m}$. E. S. E. Albany. It is a small, scattered, but pleasant place, and is much resorted to as a summer retreat.
QUоNоснолтAUt, p. v. Waskington county, R. I. : $29 \mathrm{~m}$. S. by W. Providence.

\section{R.}

RABвтT river, Allegan co., Mrich. : rises in the N. E. part of the eo., flows S. S. W., and empties into the Kalamazoo r., $7 \mathrm{~m}$. from its mouth.

RabBitsville, p. o, Logan county, Ky.: $142 \mathrm{~m}$. s. W. Frankfort.

PaBbit Town, p. Oo, Benton co., Alo.; 103 m. N. N. E Montgomery.

RamUn county, Ga. Situate N. E., and contains 318 sq. m. Chatooga river runs on the $\mathrm{E}$. and Terrora through the S. and W., by which and their branches it is drained. Surface elevated, and forms, for the most part, table-land. In the E. and W. it is hilly, the Blue Ridge forming its eastern boundary; soil fertile. Agriculture is the leading pursuit with a large portion of the inhabitants. Pine and other timber is found of excellent quality. Farms 282 ; manuf. 0 ; dwell. 385, and pop.-wh. 2,33s, fr. col. 0, sl. 110-total 2,448. Capital: Clayton. Public Works: Rabun Gap R. R. (proposed).

Racine county, Wisc. Situate S. E., on Lake Michigan, and contains 339 sq. m. Drained by Fox, Pike, Root, and Des Plaines rivers and their affluents, which supply good water-power. Surface uneven, and diversified with lakes; soil a rich loam, and very produetive. Agriculture is the leading pursuit. Farms 971; manuf. 104; dwell, 2,578, and pop.-wh. 14,907, fr. col. 66 - total 14,973. Capital : Racine. Public Works: Chicago, Milwaukie, and Green Bay, R. R.

RaOLNE, to, p. c., and cap. Racine co., Wisc.: bordering on Lake Michigan, $73 \mathrm{~m}$. E. S. E. Madison. Drained by Root r., which, passing through in a S. E. direction, flows into the lake. Surface undulating; soil of good quality. The $\mathrm{v}$. is at the mouth ot Root r., in lat. $42^{\circ} 49^{\prime} 33^{\prime \prime} \mathrm{N}$., and long. $877^{\circ} 40^{\prime} 22^{\prime \prime} \mathrm{W}$. It contains the court-house, jail, and other public buildings; store-houses and other places of business, of various descriptions, printing-offices, etc., and an Episcopal college has been established here-Roswell Parks, D.D., President. The imports for 1851 amounted to $\$ 1,452,750$, and the exports $\$ 650,950$. The exports consist chiefly in wheat, of which a large quantity is raised in the t. and vicinity. Racine is a flourishing place, and bids fair soon to become an important commercial point for the State. The public press consists of 5 papers-the "Commercial Advertiser" (dem.), "Old Oaken Bucket" (Temp.), "Racine Adrocate" (dem.), and the "Democratten" (dem.), all weekly issues; and the "Wisconsin Farmer" (agri.), a monthly issue. The Green Bay, Milwaukie and Chicago R. R. passes through it. Pop. of the eity 5,108, and of the t. 5,880.

RACKET lake and river, $N . Y_{0}:$ the lake is in N. part of Hamilton co., an irregular body of water, $14 \mathrm{~m}$. long, 2 to 5 m. wide, abounding with large trout, etc. It connects with Long lake, from which flows Racket river, $145 \mathrm{~m}$. long, which enters the St. Lawrence, near St. Regis.

Racket RrVER, p. o., St. Lawrence co, $N . Y$.

Racoon, p. O., Marion co., $I l l$. : 95 m. S. S. E. Springfield.

RAcooN, t., Gallia co., Ohio: 88 m. S. S. E. Columbus. Drained by Racoon cr. Surface diversified; soil generally fertile. Centreville is a small setuement on a branch of the stream. Pop. of t. 1,474.

RACOON, p. O., Preston county, Virg.: $177 \mathrm{~m}$. N. W. Richmond.

R.Acoon river, Bad $\Delta x$ co., Wisc.: flows through $\mathrm{N}$. W. part of the co., into Mississippi r.

Racoon Ford, p. o., Culpepper co., Tirg.: on bank of Rapid Ann r., $15 \mathrm{~m}$. above its entrance into Rappahannock r., $63 \mathrm{~m}$. N. W. by N. Richmond.

Racoon Istaxd, p. o., Gallia co, Ohio: 90 m. S. S. E. Columbus. Racoon island is in the Ohio r., below Gallipolis, and near the moulh of Racoon creek. 
Pucoon Valles, p. o., Knox county, Tenn.: 159 m. E. Nashville.

Padfornsvilue, p. o., Perry co., Ala.: 64 m. W. N. W. Montgomery.

RADNOR, t. and p. v., Delaware co, Ohio: on E. side of Scioto r., $30 \mathrm{~m}$. N. N. W. Columbus, Surface rolling, and well timbered; soil fertile. This town is principally inhabited by Welsh, and received its rame from a place in Wales. The $\mathrm{v}$. is located about $1 \mathrm{~m}$. E. of the Scioto river. Pop. of t. 1,204.

R.ADNok, t. and p. o., Delaware co, Penn. : S1 m. E. by S. Harrisburg. Drained by Darby cr. and other streams. Surface level; soil rich and fertile. It has several manufactures. The Philadelphia and Columbia R, R, passes through it. Pop. 1,372.

RAGGed mountains, $N$. Hamp. : $25 \mathrm{~m} . \mathrm{N} . \mathrm{N}$. W. Coneord. Are a bleak precipitous range, about $10 \mathrm{~m}$. long, between Andover and Hill, in some parts nearly 2,000 feet high.

Raglesville, p. o., Daviess co., Ind.: $79 \mathrm{~m} . \mathrm{S} . \mathrm{W}$. by $\mathrm{S}$. Indianapolis.

RAHWAY, t., p. V., and sta., Essex county, N. Jer.: on Rahway r., 35̃ m. N. E. Trenton; by New Jersey R. R., $20 \mathrm{~m}$. from New York, and $67 \mathrm{~m}$. from Philadelphia. The v., chiefly in Woodbridge t. Middlesex co., is partly in Rahway L Fssex co, on both sides of Rahway $r$, at the head of tide, $5 \mathrm{~m}$. from its mouth. It contains 7 churches, an academy, female institute, 1 bank-cap. $\$ 130,000$, and has some manufactures. Two newspapers are published weekly, "Adrocate and Register" (whig), and "P. Republican" (dem.). The t. has a level surface, and the soil is red shale, and well cultivated. It is intersected by the New Jersey R. R. and two turnpikes. Pop. of t. 3,306, Rahway Port or Bucktown is situate 3 or $4 \mathrm{~m}$. further down the river.

RaIborw"s Creek, p. o., Laurens district, S. Car, : on W. side of er. of same name, $6 \mathrm{sm}$. W. N. W. Columbia.

Ratniow, p. o., Hartford county, Conn.: on N. side of Farmington $r ., 10 \mathrm{~m}$. N. Hartford.

Piatnes' Tavern, p. o., Cumberland county, Firg.: $50 \mathrm{~m}$ W. by S. Richmond.

Rainesville, p. v., Warren co., Ind.: on Big Pine cr., $i 2 \mathrm{~m}$. N. W. by W. Indianapolis.

RAINSBoro' p. v., Highland county, Ohio: $57 \mathrm{~m}$. S. S. W. Columbus.

Ratnsburg, p. v., Bedford county, Penn.: on W. side of small affuent of Raystown br. of Juniata r., $\$ 4 \mathrm{~m}$. W. by $\mathrm{S}$. Harrisburg.

Pargin, t. and p. 0., Lenawee co., MFch.: $63 \mathrm{~m} . \mathrm{S} . \mathrm{S} . \mathrm{E}$. Lansing, on buth sides of liaisin r., which affords waterpower. Suiface undulating: soil black santy loam, very productive of grain. The Tecumseh Branch R. R. passes through the t. Pop. 1,267.

RaIsIs river, Dich, Rises in Wheatland t., Hillsdale co., flows by a very circuitous course throngh Jackson, Washtenaw, Lenawee, and Monroe comnties, $140 \mathrm{~m}$.; and empties into Lake Erie, $2\llcorner\mathrm{~m}$. below Monroe. Its banks are generally high and beautiful: its current is very rapid, affording great water-power, which is extensively used. Its name is derived from the wild grape vines which formerly lined its banks.

Raisintilte, t., Monroe co., Mfich. Drained by Raisin r., on which is much fertile land. Pop. 967.

Raletgil county, Firg. Erected in 1850, out of Fayette. Situate W. centrally, and contains 5531 sq. m. Drained by tributaries of New r., or Upper Kanawhu. Surface rongh and mountainous; soil in some parts fertile. Chief products, wheat, Indian corn, pork, ete. Farms 216; manul. - ; dwell. 296, ancl pnp.-wh. 1,735, fr. col. 7, sl. 23-total 1,765. Capital: Beckley.

RALEIGI, p. v., and cap. Smith co, Mriss.: 44 m. E. S. E. Jackson. Drained by a creek of Leaf $r$., and contains the county buildings, etc.

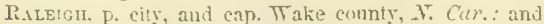
capital of the State of North Carolina, about $6 \mathrm{~m}$. W. of $70 \mathrm{~S}$
Neuse r., in lat. $85^{\circ} 47^{\prime} \mathrm{N}$., and long. $788^{\circ} 48^{\prime} \mathrm{W}$. $-286 \mathrm{~m}$. from Waskington. Smithfield, $27 \mathrm{~m}$. S. E., is the orilinary point of navigation, but in high stages of the water, vessels coms up within $8 \mathrm{~m}$. of Raleigh. It has an elevated and pleasant situation in a healthy country, and is laid out with great regularity. In the centre is Union Square, containing 10 acres, from which extend four streets, 99 fuet wide, dividing it into quarters. In the centres of these quarters are other squares, each of 4 acres, intersecter as the principal square by streets 66 feet wide. The public buildings are the State-bouse, court-house, the North Carolina Institution for the instruction of the deaf and dumb, county jail, a market-house, the Governor's house, office of the Secrstary of State, and 7 churches. The State-house, next to that of Ohio at Columbus, surpasses in architeetural beauty, those of all other States. It is built after the model of the Parthenon at Athens, and is located on Union Square. The building is 166 feet long by 90 feet wide, and is surrounded by massive columns of granite, $5 \frac{1}{2}$ feet in diameter, and 30 feet high. A beautiful dome surmounts the building. The chambers occupied by the Legislature are spacious and commodious. The cost of erecting this noble structure, was about $\$ 500,000$. The former State-house, containing a fine statue of Washington, by Canova, was destroyed by fire in 1831. The Institution for the Deaf and Dumb is lncated near the State-house on a four acre lot, and provision is also made for the erection of a State Lunatic Asylum. Raleigh is a place of considerable business, and has numerous workshops, stores, ete, 2 banks - cap. $\$ 450,000$, and supports 10 newspapers, 3 issued semi-weekly, the "Primitive Baptist" (relig.), the "Southern Advocate" (relig.), and the "R. Register" (whig); 6 weekly, the "Recorder" (relig.), tho "Spirit of the Age" (temp.), the "R. Times" (whig), the "N. Car. Standard" (dem.), the "N. Car. Star" (whig), and the "R. Register," the last an edition of the semi-weekly of the same name; and 1 semi-monthly, the "Deaf Mute" (liter.). There are four good academies in the eity, and several common schools. Raleigh is intersected by the North Carolina Central R. R., which conneets it E. with the sea-board at Newbern, and W. with the S. Carolina railroads at Charlotte; and passing throngh fertile and propulous counties, this road will bave the effect of stimulating the trade of the eity itself. The Gaston and Paleigh P. R. also terminates here, giving it access to the north. Pop. In 1810, 2.244 , and in $1850,4,518$.

hateigh. p. v., and eap. Saline co., $M_{0}:$ on a branch of Saline crcek, on a pleasant elevution, $149 \mathrm{~m}$. S S. E. Springfield.

Raletgr. p. .., and cap. Shelby co, Tenn.: on N. side of Wolf cr., $181 \mathrm{~m}$. W. S. W. Nashville. It contains a courthouse. jail, ete, and about 600 inhabitants.

R.iLitiri, p. o., Hush co., Ind.: on E, bank of Flat Rock $\mathrm{er}, 39 \mathrm{~m}$. E. Indianapnlis.

Raleigh, p. $v_{0}$, Union co., $K y_{0}:$ on E. side of Obio $r_{\text {., }}$ $6 \mathrm{~m}$. below the mouth of the Wabash r., $172 \mathrm{~m}$. W. by $\mathrm{S}$. Frankfort, It is a small but pleasantly situated village

Pall's county, Mo. Situnte toward the N. E.. and contains $475 \mathrm{sq} . \mathrm{m}$. Dritined by Salt $\mathrm{r}$., which passes throngh it from E. to W. and by its different, affluents. Surface rolling or nearly a plain; soil fertile, and very prodnctive. Timber is frund in ahundance, and gond coal heds. Farms 541; manuf. 13 ; dwell. 777 , ant pop.-wh. 4.777 , fr. col. 6 , s). 1.56s-total 6.151. Crupitul: New London. Public Works: St. Louis and Northern R. R.

Raliy Hut, p. 0., Maury co., Tenn.: 39 m. \&. by W. Nashville.

Ralpitrox, p. o., Fulton county, Ky.: 249 m. W. s. W. Frankfort.

Iillstox, p. r.. Lyeoming en., Penn.: on E. siute of Lycoining cr.. $53 \mathrm{~m}$. X. IIarrisburg. The Lyenming Talley Iron Company have a hot-blast charenal furnace here of the anulil capacity of $2.0 \mathrm{~m}$ trins. The Wriliamspor: aud Elmira R. R. passes through the village. 
Ramapo, to, Rockland co., N. Y.: $108 \mathrm{~m} . \mathrm{S}$. by W. Albany. Drained by Ramapo and Saddle rivers, affluents of the Passaic. surface billy and mountainous; in the valleys soil very productive. There are considerable iron and other manufactures in the $t$, and at Suffern's, the Union R. R. from New Jersey and Paterson uniles with the New York and Erie R. R., which latter crosses the towa. Population 3.197 .

Ravapo river, $N . Y_{.}$: rises in Orange connty, flows $\mathrm{S}$. through W. part of Roekland county into New Jersey, and empties through Pompton $r$. into the Passaic.

RaMapo Works, p. v. and sta., Rockland co., N. Y.: on Ramapo ., 104 m. W. by S. Albany, and on Erie R. R., $35 \mathrm{~m}$. from New York. The Ramapn r. here furnishes a large water-power to several iron manufactories.

RAYER, p. O., Montgomery co., Ala.

Ransaysiurg, p. v., Warren co., $N_{\text {. Jer.: }}$ on E. bank of Delaware r., $46 \mathrm{~m}$. N. N. W. Trenton. It contains an Episcopal church, a store, and a score of dwellings.

Rassioro', p. v., Guilford co., N. Car.: 103 m. W. N.W. Raleigh.

Rauser county, Mim. Situate E. midile, and contains $2,150 \mathrm{sq} . \mathrm{m}$. It is a country full of lakes and ponds and running streams. On the S. the Mississippi forms its boundary, and receives the drainage of more than half the county, through Rum, Ottonwey, and Peterah rivers. The Mississippl also furms a portion of the $\mathrm{N}$. boundary. The county is about $100 \mathrm{~m}$. long and 20 broasl, and about one-fourth part of its surface is water. The largest lake is Minsi-Sagaigoning, or Mille Lacs, which covers 300 sq. m. Farms 19 ; manuf. 0 ; dwell. $3 \$ 4$, and pop.-wh. 2,197, fr. col. $8 v-$ total 2,227. Cupital: St. Paul.

RAusex"s, sta, Bergen county, N. Jer.: on Union R. R., $28 \mathrm{~m}$. from New York, $5 \mathrm{~m}$. from Suffern's.

Ranaleburg, p. v., Mecklenburg co., N. Car. : $120 \mathrm{~m}$. W. S. W. Raleigh.

Ravcocus, p. On, Burlington co., N. Jer.: 15 m. S. S. W. Trenton.

RAxcocus creek, $N$. Jer.: an affluent of the Delaware. It rises in Monmouth county, and flowing W, through Burlington county, falls into the Delaware apposite the mouth of Pequasin cr., the N. line of Philadelphia county.

Randalistows, v., Baltimore county, $\boldsymbol{M} d_{*}: 40$ miles $\mathrm{N}$. Annapolis.

Raxidaldstille, p. v., Robeson co, N. Cur.: on a branch of Lumber $r_{a}, 63$ m. S. S. W. Raleigh.

Raxdolpi enunty, Ala. Situate E, and contains 917 sq. m. Tallaporsa $r$. flows through it centrally, by which and by its tributaries, Little Tallaponsa r. and other streams, $i_{t}$ is drained. Surface generally level; soil productive, and adapted to the growth of cotton, the staple article of commerce. Farms 969 ; manuf. 23 ; dwell. 1,904, and pop.wh. 10,616, fr. col. 29, sl. 936-total 11,581. Capital: Weedowee.

Randolpe county, Ark. Situate N. toward the E., and contains $\$ 30 \mathrm{sg}$. m. Drained by Big Black $r$. and its branches. Surface varied, but in general is even; soil fertile, and prodnees wheat, corn, etc. Timber of a good quality is found on the land. Farms 396 ; manuf. 2 ; dweil. 538, and pop.-wh. 3,028, fr. col. 3, sl. 243-total 3,275. Capital: Pocahontas.

Raspolpur county, $G a$. Sifuate S. W., and contains 713 sq. m. Drained by branches of Chattahoochee r., which forms its western boundary, and by branches of Flint r. Surface undulating, in parts hilly; soil fertile, and adapted to cotton. which is the principal production of the county. Pine timber abounds, and some minerals are to be found here. Farms 980 ; manuf. 38 ; dwell. 1,408, and pop.-wh. 7.857, fe. col. 3, sl. 5,00S-total 12.868. Capital: Cuthbert. Public Works: South Western R. P.

RANDoLPII county, $I l l$. Situate S. W., and contains 514 si. m. Kaskaskia r., a tributary of the Mississippi, passes chrough the wastern portion of the county, by which and by St. Mary's and Horse creeks, it is drained. Surface undulating, and in the S. W., on the shore of the Mississippi, terminates in high bluffs; soil fertile, produeing wheat, Indian corn, and tobacco. Agriculture is the leading pursuit. Farms 1,100; manuf. 36 ; dwell. 2.046. and pop.-wh. 10,697, fr. col. 283-total 10,980. Capital: Chester.

Randolpur county, Ind. Situate E., and containg 423 sa. $\mathrm{m}$. Drained by W, fork of White and Mississinewa rjvers and their branches, by which good water-power is supplied. Surface rolling, in some parts it is low and marshy; soil firtile, and adapted to grain and grazing. Chief productions, wheat, sugar, and Indian corn. It has some prairies, and good timber is found on the land. Farms 1.477 ; manuf. 12; dwell. 2,513, and popo-wh. 14,061, fr. col. 661-total 14,725. Capital: Winchester. Public Worlcs: Indianapolis and Bellefontaine R. R.; Union and Fort Wayne, Dayton and Greenville Extension R. R., ete.

RANDOLPH county, MOO. Situate centrally toward the N., and contains 457 sq. m. Drained by East Chariton $\mathrm{r}$, and branches, and small streams of Salt $r$. Surface even; soil fertile and very productive-it is well adapted to tobaceo, a large quantity of which is grown. Corn and fruits of different kinds are also produced abundantly, and there is some timber on the land. Bituminous coal of good quality is found in large quantity. Farms 993; manuf. 47; dwell. 1,157, and pop.-wh. 7,265, fr. col. 18, sl, 2,156-total 9,439. Capital: Huntsville.

RANDOLPU county, N. Car. Situate centrally, and contains 724 sq. m. Drained by Deep $r$. and its branches, and branches of Yadkin $r$. Surface various; soil a deep loam and very fertile, much of it being adapted to grazing. Chief productions, tobacco, cotton, wheat, and Indian corn. Farms 1,173 ; manuf. 41 ; dwell. 2,512 , and pop.-wh. 13,795 , fr. col. 397, sl. 1,640-total 15,832. Cropital: Ashboro'. Public Works: North Carolina Central R. R.

RaNDolph county, Virg. Situate toward the N. W., and contains $1,434 \mathrm{sq} . \mathrm{m}$. Drained by Cheat $r$. and its branches on the E. side of the mountains, and branches of East fork on the W. side, all constituting head branches of Monongahela $\mathrm{r}$. Surface mountainous; soil in some parts fertile, well adapted to grazing. Chief products, wheat and Indian eorn. Laurel and Cheat mountains run through the county. Farms 379; manuf. 0; dwell. 844, and pop.-wh. 5,003, fr. col. 39, sl, 201-total 5,243. Capital: Beverly.

Randolph, p. o., Bibb county, Ala.: 53 miles N. W. Montgomery.

Paydolpr. to and p. o., Crawford county, Penn.: $199 \mathrm{~m}$ N. W. Harrisburg. Drained by creeks of Venango river. Pop. about $1,500$.

RANDOLPH, $\nabla .$, Randolph county, Ind.: $68 \mathrm{~m}$. E. by N. Indianapolis.

RandolPH, p. o., Barren county, Ky.: 99 m. S. W. by S. Frankfort.

Rannolph, t., p. v., and sta, Norfolk co., Ma.ss. : on Fall River R. R., 15 m. S. Boston. Surface of t. undulating; soil productive, Drained by Mantiquot $r$. The manufacture of shoes, ete., is extensively carried on. There is 1 bank-capital $\$ 150,000$-an acalemy, and 6 churches. There are several villages in the town. Pop. of $t .4,741$.

Randozph, V., Clay county, Mo.: 128 miles W. N. W. Jefferson City.

Randouph, t. and p. o., Columbia county, Wise: $42 \mathrm{~m}$. N. N. W. Madison. Drained by tributaries of Fox and Wisconsin rivers. Surface elevated, but mostly level, and affording excellent farm lands. Pop. 618.

RANDolPH, t. and p. o., Coos county, $N_{0}$ Hamp.: $81 \mathrm{~m}$. N. by E. Concord. Drained by head branches of Israel's r. Surface mountainous, the White Mountains lying immediately S. of it. Pop. 113.

RANDoLPH, t, and p. v., Cattaraugus co., N. Y.: $272 \mathrm{~m}$. W. by S. Albany. Surface of t. hilly; soil well adapted to grazing. Drained by Conewango cr. The $r_{\text {. }}$, on Little Conewango cr., contains about 300 inhabitants. It has a 
considerable manufacturing capital and some retail trade. Pop. of t. 1,606.

Randolph, t. and p. o., Portage co., Ohio: 114 m, N. E. Columbus. Drained by branch of Cuyahoga $r$. Surface gently uneven; soil fertile-much grain is raised. Population 1,730 .

Randolph, p. v., Tipton co., Tenn.: on E. side of Mississippi r., at the mouth of Big Hatchie r., $22 \mathrm{~m}$. below Ashport, $173 \mathrm{~m}$. W. by S. Nashville. Large quantities of cotton are shipped from this place to New Orleans. It is a dilapidated town at the head of second Chickasaw bluffs. Immediately opposite is seen the first colton plantation on descending the river.

RANDOLPH, t., p. v., and sta., Orange co., Terms.: $23 \mathrm{~m}$. S. Montpelier. Drained by branches of White r. Surface of t. elevated and not much broken; soil fertile, and well cultivated. The $\mathrm{v}$, is handsomely situated, and contains a flourishing academy, a church, stores, ete. In the t. are several tanneries, saw and grist mills. The Vermont Central R. R. passes through its W, part, $46 \mathrm{~m}$. from Windsor. Pop. of t. 2,666 .

Randolph Macon College, p. o. and coll., Mecklenburg co., Virg.: $1 \mathrm{~m}$. W. Boydtown and $74 \mathrm{~m}$. S. W. Richmond. The college was founded in 1832, and is under the direction of the Methodist denomination. In 1850 it had 7 professors, 80 students, and 8,000 volumes in its libraries, and its alumni numbered 147 , of whom 31 were in the ministry.

RaNDolPh's Grove, p. O., M.Lean co, $I l l_{*}: 49 \mathrm{~m}$. N. E. Springfield.

RANEYSBURG, p. o., Washington county, Ill.: $99 \mathrm{~m} . \mathrm{S}$. Springfield.

Range, to, Madison co., Ohio: $27 \mathrm{~m}$. W. S. W. Columbus Drained by head waters of Paint and Deer creeks. Surface elevated and level; soil rich and productive. It is a fine farming country. Pop. 98s.

RANGelx, t. and p. 0., Franklin co., Me. : $63 \mathrm{~m} . \mathrm{N}$. W. Augusta. Drained by Androseoggin r. and other streams, which fall into Aquessuck lake on its S. boundary. Pop. 43.

RANisin county, Bfiss. Situate W. centrally, and contain $795 \mathrm{sq} . \mathrm{m}$. Pearl r. forms its W. and N. W. boundary, by branches of which it is drained. Surface generally level, and is thickly wooded, a large portion of the land being pine forest; soil fertile. Cotton is the stapte. Farms 420 manuf. 5 ; dwell 698 , and pop.-wh. 3.945 , fr. col. 6 , sl. 3,276-total 7.227. Capital: Brandon. Prublic Works Vicksburg, Jackson, and Brandon R. R.; New Orleans, Jaekson, and Northern R. R., ete.

Raxsom, p. v., Hillsdale co., Mfich. : 62 m. S. Lansing. Pop. 549.

Ransom, p. o., Luzerne county, Penn.: 78 miles N. E Harrisburg.

Ransom's Bridge, p. o., Nash co, N. Car.: 42 m. E. N. E Raleigh.

Ransomville, p. o., Niagara co., N. $Y_{0}: 274 \mathrm{~m}$. W. by N. Albany.

Ravtowle's, p. o., Colleton dist., S. Car.: 82 m. S. by E. Columbia.

Raphoe, t. and p. o., Lancaster co, Penn.: 23 m. E. S. E. Harrisburg. Surface of town rolling; soil caleareous loam. Drained by the Chiques creeks, which form its $\mathrm{E}$. and W boundaries. It contains numerous saw, grist, flouring, and fulling mills, tanneries, distilleries, ete. Pop. about 4,000 Mount Joy and Elizabethtown, on the Lancaster and Harrisburg $\mathrm{R} . \mathrm{R}$, and Manheim are in this town.

Rapid Axn, p. 0., Madison county, Tirg.: $71 \mathrm{~m}$. N. W. Richmond.

RAPID Avy river, Firg. : rises in the Blue Ridge, in Madison county, and joins the Rappahannock, 10 miles above Fredericksburg.

RaPIDEs parish, $L a$. Situate W. centrally, and contains 1,993 sq. m. Drained by Red $\mathbf{r}$. and its lranches, Calcasieu river, and Bocuf, Hagon, Cypress, Rapide, and Crocndile bayous. Surface level, and in some parts very low, subject710 ing it to inundation when the rivers are high; soil various, along the streams being fertile, and generally productive Staple articles of commeree cotton and Indian corn. Timber is found on the land, pine prevailing. It contains some small lakes. Farms 157; manuf. 11; dwell. 1,1182, and pop.-wh. 5,037, fr. enl. 184, sl. 11,340-total 16,581. Capital: Alexandria. Public Works: New Orleans, Opelousas, and Great Western R. R.

Rapids, p. 0., Portage co., Olivo: 120 m. N. E. Columbus,

RAPIDS, p. o., Whitesides co., Ill.: on $\mathrm{S}$. side of Rock $\mathrm{r}_{\text {. }}$ $137 \mathrm{~m}$. N. springfield.

PaptDs, p. o., Buone co., Ia.: $136 \mathrm{~m}$. W. by N. Iowa City RAPIDS, p. 0., Niagara county, N. $Y .: 260 \mathrm{~m}$. W. by N. Albany.

RAPPAHANYOCK county, Virg. Situate toward the N. E. and contains 268 sq. m. Drained by head branches of Rappabannock r. Surface level; soil fertile, adapted to grain and grazing. Chief products wheat and Indian corn. Farms 472; manuf. 34 ; dwell. 990, and pop.-wh. 5,642, fr. col. 296 sl, 3,844-total 9,732. Capital: Washington.

Rappahañock river, Virg.: rises in the Blue Ridge, and flowing in a S. E. course $130 \mathrm{~m}$, enters Chesapeake bay by a large estuary, $25 \mathrm{~m}$. S. of the mouth of the Potomac. It has four fathoms water at Hobbs' Hole, and is navigable for vessels requiring 10 feet of water to Fredericksburg, $40 \mathrm{~m}$. from its mouth.

Pappahañock Academx, p. o., Caroline co., Virg.: $36 \mathrm{~m}$, N. by $\mathrm{E}$. Riehmond.

Rapp's Barrens, p. 0., Fulton co., Ark.: 105 m. N. Little Rock.

Raritar, t., Hunterdon co., N. Jer.: 20 m. N. Trenton. Drained by Nachanie er. and several streams, affluents of S. branch of Raritan r., which forms the N. E. boundary, and also by Wickheckcoke and other streams of Delaware $r$. It is a fine farming $t$., and has numerous mills and manufactures. Flemington, to which a branch of the Belvidere Delaware R. R. will be built, is in Raritan. Pop. 3,066.

Rapitan, p. vo and sta. Somerset co., $N$. Jer.: on Raritan r., $1 \mathrm{~m}$. W. Somerville, by New Jersey Central R. R., $40 \mathrm{~m}$. from New York.

Raritan bay, $N$. Jer.: lies between Staten Island on the N., Monmouth co., N. J., on the S., and Sandy Hook on the S. E. It terminates on the W. at Amboy, to which it has $2 \frac{1}{2}$ fathoms of water.

Raritan river, $N$. Jer.: is formed by two branches which unite in Somerset co, and empty into Raritan bay at Amboy. Sloops of 80 tons ascend the r. with 8 feet of water to New Brunswick, whence also steamboats ply daily to New York.

RatclifesbuRG, p. o., Vinton county, Ohio: 57 m. S. E. Columbus.

Rathboneville, p. v, and sta., Steuben co, $N_{0} Y_{.}$; on N. E. side of Canisteo cr., $186 \mathrm{~m}$. W. by S. Albany, and on Erie R. R., 317 m. from New York, 152 m. from Dunkirk; a. handsome village, $\mathbf{P o p}$, about 500 .

Rathbun, p. o., Sheboygan co., Wisc.: 90 m. N. E. by E. Madison.

Raten CREEK, p. o., Harrison county, Ky.: 36 m. N. E. Frankfort.

Puvenna, t., p. v., and cap. Portage co., Olio: $121 \mathrm{~m}$. N. E. Columbus. Surface undulating, drained by a branch of Cuyahogi r., and by $\mathrm{W}$. branch of Mahoning $r$. The $v$. is pleasantly situated on a plain, is regularly laid out, and contains an elegant court-house of stone, a jail, semale seminary, and four churches. The Pennsylvania and Ohio

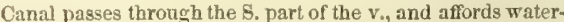
power. The Cleveland and Pillsburg R. R. passes through the v, $38 \mathrm{~m}$. from Cleveland, and $62 \mathrm{~m}$. from Wellsville, Three newspapers are published weekly, "Portage Sentinel" (dem.), "Portage County Whig," and " Ohio Star" (free soil). Pop. of t. 2,239

RAvENA, t, and p. o., Ottawa co., Mfich.: $7 \pi \mathrm{m} . \mathrm{W} . \mathrm{N} . \mathrm{W}$ Lansing. Druined by Crockery er. Pop. 77. 
RAVEY's NEST, p. o., Washington co., Virg. : 254 m. W. by S. Richmond,

Ravexswood, p. o., Jackson eo., Virg.: at junetion of Little Sandy er. with the Ohio, $253 \mathrm{~m}$. W. N. W. Richmond. Population 276.

RAVENSWOoD, V., Queen's co, $N_{0} Y_{0}$ : on the East river, opposite Blackwell's Island, and about a mile S. of Astoria Stages from Williamsburg pass through it several times a day, and steamboats from New York stop at the landing. Pop. about 300 .

Rawlingsburg, p. v., Rockingham co., N. Car.: 84 m. N. W. Raleigh.

RAWLiNgSVille, p. v., De Kalb co, Ala. : on E. bank of Wills cr. of Coosa r., 149 m. N. by E. Montgomery.

Rawlix's Station, sta., Hampshire co., Firg.: on the line of the Baltimore and Ohio R. R., $13 \mathrm{~m} . \mathrm{S}$. W. Cumberland, and $192 \mathrm{~m}$. from Baltimore.

Rawlinsville, p. V., Lancaster co, Penn。: 41 m. S. E. Harrisburg.

Ramsoxille, v., Fuiton co., N. Y.: on Fonda's Bush cr., $36 \mathrm{~m}$. N. W. Albany. It contains several factories, and about 500 inhabitants.

Rawsonvile, p. v., Wayne co., Mich.: 61 m. E. S. E. Lansing.

RAI county, Mo. Situate toward the N. W., and contains $563 \mathrm{sq}$. m. Drained by Crooked $\mathrm{r}$. and its E. and W. forks, and by other small streams, all flowing into the Missouri, which forms its S. boundary. Surface undulating; soil very fertile, and produces in abundance corn, wheat, fruits, ete. Tobaceo is grown, and there is some fine timber land. Limestone abounds. Farms 833; manuf. 30; dwell. 1,457, and pop.-wh. 8,834, fr. col. 25, sl. 1,514-total 10.873. Cerpitul: Pichmond.

Rar, t. and p. o., Macomb co., Mich.: 83 m. E. Lansing. Drained by N. branch of Clinton river, which affords waterpower. Pop. 1,232.

RaX Cextre, p. o., Macomb county, Mich.: $83 \mathrm{~m}$. E Lansing.

Raymeztown, p. o., Rensselaer co., N. Y.: 20 m. N. E. Albany.

RA YMOXd, t. and p. O., Cumberland county, Me.: 44 miles S. W. Augusta. Sebago pond forms its S. W. boundary. Chiefly devoted to agrieultural pursuits. Pop. 1,142.

Raymond, p. v., and cap. Hinds co., Miss.; on a small branch of Pearl r., $14 \mathrm{~m}$. W. by S. Jackson. It contains a court-house, several stores, and is a centre of some trade, A branch of the Vicksburg, Jackson, and Brandon R. R. comes up to the village. Pop, about 500.

RaYmond, t., p. o., and sta., Rockingham co., $N$. Hamp. $23 \mathrm{~m}$. S. E. Concord. Drained by Lamprey river and its branches, on which the soil is productive. The Portsmoutl and Concord R. R. passes through the t., $23 \mathrm{~m}$. from Portsmouth, 24 from Concord. Pop. 1,256

Raymond, to and p. o., Racine co., Wisc. : $75 \mathrm{~m}$. E. by $\mathrm{S}$. Madison. Drained by branch of Root $r$. Pop. 820 .

Rarmoxd's, p. o., Union co., Ohio: $31 \mathrm{~m}$. N.W. Columbus. RaymondilLE, p. o., St. Lawrence county, $N$. $Y$.: on W. side of Racket $r_{.}, 160 \mathrm{~m} . \mathrm{N} . \mathrm{N} . \mathrm{W}$. Albany.

Rarveay, t., Bristol county, Jfass.: 29 miles S. Boston, Drained by Taunton river, which forms its $\mathrm{S}$. border, and affords water-power. Surface level; soil light. The first forge in the United States was erected in this town in 1652, and iron to a considerable amount is still mannfactured. There are also in the town several grist and saw mills Pop, 1,541.

Paymortown, v., Queen's en., $N . \quad Y$ : on the S. post-road of Long Island, W. of Lott's cr., $23 \mathrm{~m}$. from New York. It containg a Presbyterian church, 3 mills, and about 100 in habitants. There is a fine view of the ocean from the village.

RAYrs Fork, p. o., Seott, co., Ky.: 18 m. N. E. Frankfort. Par's Hur, p. o., Bedford county, Penn.: $77 \mathrm{~m}$. W. Harrisburg,
Ratsville, p. v., Henry co., Ind.: on W. side of Blue river, $32 \mathrm{~m}$. E. Indianapolis, on line of Indiana Central R. $R$. In the vicinity is fine and well improved waterpower.

Raysville, p. v., Columbia co., Ga.. on S. side of Little r., $62 \mathrm{~m}$. N. E. Milledgeville.

RaYtown, p. v., Taliaferro co., Ga.: 46 m. N. E. by N. Milledgeville.

Raypille, p. v., Lawrence co., Mfiss.; 44 m. S. Jackson. Drained by a creek of Pearl river.

Rarwick, p. v., Marion co., Ky.: on N. side of Rolling fork of Salt r., $51 \mathrm{~m}$. S. W. hy S. Frankfort.

ReAdFIELD, t. and p. o., Kennebec co, Me. : 9 m. W. by N. Augusta. This is a fine farming $t$., with fertile soil. It has a large pond in its S. part (lying partly in Winthrop), and another in its W. part. The Maine Wesleyan Seminary, incorporated in 1522, is here located. Pop. 1,955.

Redfield Depôt, p. o. Kennebec county, Me.: $11 \mathrm{~m}$. W. by N. Augusta, and by Androseoggin and Kennebec Railroad, $59 \mathrm{~m}$. from Portland.

Reading, t., p. v., and sta., Middlesex co., Diass.: $12 \mathrm{~m}$. N. Boston. Drained by Ipswich river. Surface diversifled; snil generally good, and in some parts excellent. The manufacture of iron, shoes, chairs, and cabinet-ware is extensively prosecuted. The Boston and Maine R. R. passes through the $\mathrm{v}$., which is located in the S. part, and the Salem and Lowell R. R. crosses it in the N. Pop. 3,108,

READING, t. and p. o., Hillsdale co., Mich.: $66 \mathrm{~m}$. S. by W. Lansing. Surface diversified; soil rich sandy loam. In its W. part is a long pond, from which flows Hog r. in N. N.E. course. Pop. 956

READING, t. and p. o., Steuben co., N.Y.: $164 \mathrm{~m}$. W. by S. Albany. Drained by small streams running into Seneca lake, which on the E. forms its boundary. Surface elevated and rolling; soil clay and calearenus loam. The Canandaigua and Elmira R. R. runs along the lake shore. Population 1,434 .

Readivg, p. v., Hamilton co., Ohio : on E. side of Mill creek of the Ohio r., $1 \mathrm{~m}$. E. of the Reading Locks of the Miami Canal, $10 \mathrm{~m}$. N. by E. Cincinnati, $89 \mathrm{~m}$. S. W. by W. Columbus.

Readrvg, p. b., and cap. Berks county, Penn.: on the E. bank of Sehuylkill river, $50 \mathrm{~m}$. E. Harrisburg. Laid out in 1748 by Thomas and Richard Penn, proprietaries and governors of the province, and settled chiefiy by Germans, whose descendants constitute a large portion of its present population. The streets are spacious and straight, crossing at right angles. In a central square stands a splendid court-house, 200 feet long by 220 deep, having an imposing portico with 6 columns of red sandstone-cost $\$ 50,000$. Besides public offices, are a jail, 3 banks-capital $\$ 300,000$, an academy, female seminary, 3 public libraries, and 13 churches. The Lutheran and the German Reformed churches are large and handsome structures, with lofty spires, the former 201 feet high. The natural position of Reading, its facilities of communicatiors with the interior coal region, and the sea-coast, and its highly industrious population, have made it the centre of an retive trade and of extensire manufactures. The Schurlkill Navigation Canal, extending from Port Carbon in the anthracite coal region above Pottsville to Philadelphia passes through Reading, and the Union Canal extends hence to Middletown, on the Susquehanna. The Philadelphia and Reading $\mathrm{R}$. R. (now extended to Pottsville) passes through the place, $58 \mathrm{~m}$, from Philadelphia. A line of railrond is projected to Harrisburg. There are various large manufactories. One anthracite blast furnace has an annual capacity of 8.500 tons, and produced in 18493.250 tons, employing steam-power and 50 men. One hot-blast charcoal furnace has an annual capacity of 1,550 tons, using water-power, erns ploying $40 \mathrm{men}$, and produced in 1849450 tons. One eoldblast charcoal furnace has an annual capacity of 1.100 tons employing 100 men, using water-power, and made in 1819 
897 tons. One force, employing steam-power and 14 men, has an annual eapacity of 600 tons. There are 3 charcoal forges, employing $52 \mathrm{men}$; and 2 rolling-mills, employing steam-power and 215 men, which made in 18492,600 tons. The manufacture of hats for the southern and western markets is a large business. A cotton factory, making fine muslins, produces about 8,000 yards daily. There are also large flouring-mills, a nail factory, breweries, tanneries, a poltery, Iumber yards, etc. White wines of excellent quality are manufactured. Reading is supplied with water by an aqueduct from a spring on Penn's Mount, conducted into a reservoir, and thence distributed through the streets in iron pipes. Two fine covered bridges cross the Schuylkill, here 600 feet wide, one of which cost $\$ 60,000$. Iron ore and limestone are found in the vicinity. Water-power is furnished by the Sehuylkill and Talpehochea creek. In 1850 9 newspapers were publisbed weekly, of which 4 were in German, viz., "R. Eagle" (dem.), "Berks and Schuylkill Journal" (whig), "Berks Co. Press" (dem.), "People's Advocate" (neut.), "Gazelte and Democrat" (dem.), "Hamburger Schnell Post" (neut.), "Liberale Beobachter" (whig), "Der Geist der Leit" (dem.), and "Readinger Adler" (neut.) The citizens of Reading are noted for their general intelligence and refinement, as well as for industrial enterprise, Pop. in $1810,3,463$; in $1820,4,332$; in $1830,5,550$; in 1840 , 8,410 : in $1850,15,748$.

Readivg, t, Adams county, Penn.: $12 \mathrm{~m}$. N. Gettysburg. Drained by Conewago ereek and Muddy Run, a branch of Bermudian creek. Surface level; soil red shale and slate. The $\mathrm{v}$, of Berlin is on Conewago creek. The t. has several potteries, ete., and 1,201 inhabitants.

Readixg, t. and p. o., Fairfleld eo., Conn.: $47 \mathrm{~m} . \mathrm{S}$. W. Hartford. Drained by Saugatuck and Norwalk rivers. Surface diversiffed: soil of average fertility. The $\mathrm{v}$. is near the centre, and contains 2 churches and several dwellings. Pop. of t. 1,754

Readive, t. and p. o., Windsor co., Term.: 56 m. S. by E. Montpelier, Drained by branches of Black and Queechee rivers, and by Mill creek. Surface elevated and uneven; soil well adapted to grazing. Considerable manufactures carried on, but the chief occupation of the people is farming. Pop. 1,171.

Reading, p. v., Livingston county, $12 l_{0}: 97 \mathrm{~m}$. N. E. Springfield.

Reading Centre, p. v., Steuben county, $N$. $Y .: 167 \mathrm{~m}$. W. by S. Albany.

Reading Rmge, p. $\nabla$. , Fairfield county, Conn. : in the E. part of t. of Reading, $46 \frac{1}{3} \mathrm{~m}$. S. W. Hartford.

Readictor, t, and p. o., Hunterdon co., N. Jer, : $22 \mathrm{~m}$. N. Trenton. Drained by S. branch of Raritan r., and by Rockaway r. and branches, Surface, except in the S. W. hilly; soil red shale, clay, and loam. It is crossed by the New Jersey Central R. R. 28 m. from Easton, and 34 m. from Elizabethtown. The villages of White House, Mechanicsville, ete., are in Readington. Pop. 2,836.

Readsboro', t. and p. 0., Bennington co., Ferm.: $106 \mathrm{~m}$. S. by W. Moutpelier. Drained by Deerfield river and branches. Surface mountainous, and much of the laud unfit for cultivation. Pop. S57.

Readvilue, sta, Norfolk co., Mass.: on the Boston and Providence R. R., 8 m. S. Boston.

Reapriluz, p. r., Rutherford co., Tenn. : on Stone's r., a tributary of Cumberland r., $39 \mathrm{~m}$. S. E. by E. Nashville

Reanstows, p. v., Lancaster co., Penn.: on E. side of branch of Conestoga cr., $39 \mathrm{~m}$. E. by $\mathbf{S}$. Harrisburg.

Reaville, p. o., Hunterdon co., $N$. Jer. : 25 m. N. N. W. Trenton.

REBECCA FURNACE, .., Bottetourt co., Tirg. : on a branch of James r., navigable for boals of 5 or 7 tons, $3 \frac{1}{m}$. to the works. There is a white sulphur spring in the vicinity.

Reteresurg, p. v., Centre co., Penn.: on a branch of Penn's creek, and N. of Brush Mountain, 55 m. N. N. W. Harrisburg. It contains about 200 inhabitants.
Recrlesstows, p. v., Burlington co., $\lambda$. Jes.: : on $N_{\text {. sicte }}^{2}$ of Horner's er., $10 \mathrm{~m}$. S. by L. Trenton.

Rector's Cross RoadB, v., Fauquier county, Firg. : 95 m. N. by W. Richmond.

Rectortown, p. v., Fauquier co., Firg.: $1 \mathrm{~m}$. \$. Gonse creek, and $96 \mathrm{~m}$. N. by W. Richmond. It contuins sereral flotring-mills and stores, and a church.

RED Bank, p. 0., Lawrence county, Ark.: $1 \mathrm{~m} . \mathbb{N}$. from Spring r., $114 \mathrm{~m}$. N. N. E. Little Rock.

Red Bayk, p. v., Monmouth co,, $N$. Jer, : on S. bank of Nevisink r., $36 \mathrm{~m}$. E. by N. Trenton. This place is much resorted to in the summer, and a steamboat runs between it and New York several times a day during the season. ea air, fishing, and rural sports are the attractions. The North American Phalanx have a settlement near this village, respecting which, and other societies of a like nature, the following letter from Churles Sears, secretary to the association, will prove of great interest and value to inquirers:

The North American Phalaxx, N'ezo Jersey, April 13, 1553. f

DEAR SrR-I received your letter of 9 th inst., and, in accordance with your suggestion, inclose herewith a summary statement of our aims, organization, and statistics. It is brief as I could well make it. Ours, I believe, is the only association in this country or in the world that adopts Fourier's formula of organization. A good many similar attempts have been made, but hitherto without success. There are other forms of association in this country, and those within my knowledge are:

Hopedale Community, in Milford, Mass., Rev. Adin Ballow, leader. This is a non-resistant Christian fraternity, having many interests in common, and some separate interests.

Raritan Bay Union, near Perth Amboy, New Jersey, is about organizing this spring. This body propnses to associate capital, and when expedient or desirable, they will cooperate industrially. George B. Arnold, resident director, Perth Amboy.

BLodem Times, Long Island, 40 miles from Brooklyn, Josiah Warren, leader. This is an attempt to organize, or, rather, to iustitute justice upon a scientific basis, viz." "Individual Sovereignty," recognizing competition, and repudiating institutions, government, etc.

The German societies, such as the Ebenezer Society, near Buffalo, New York; The Society at Zoar, Ohio, under J. Bimeler; Rapp's Society, at Economy, on the Ohio, near Beaver, Penn. I believe these societies differ from each other, but I am not fawiliar with their distinctive principles. The Icarians, at Nauvoo, Illinois, under Cabet.

The Perfectionists, at Oneida, New York, J. H. Noyes, leader. There are a number of these Christian communities, claiming a scientific as well as a religious basis of organization, and of all of which I believe that Mr. J. H. Noyes of Brooklyn, New York, is the acknowledged head.

Finally, The Shakers, who also are now in the fleld as propagandist reformers.

I had forgotten to mention a society of Spirituatists, that went nut last year under the direction of Rev. T. L. Harris, late of New York City. This place is called Mountain Cove, somewhere in Western Virginia.

I am very respectfully yours, Charles Sears, Secretary.

\section{R. S. Fismer, Esq., Brooklyn.}

\section{Time North Ayerican Pratanx Assoctation,} Monmouth County, near Red. Bank, $\Lambda^{\top}$. Jer.

This Association was organized, not for the purpose of correcting any special form of evil, bat to Institure PosiTIYE RigHTs; which, being accomplished, wroxts, CONSEQUENTLY CEASF.

Those who have been active in establishing this Institution, believe with the associative school, that existing civil- 
ization, as well as the forms of society that preceded it, are phases in the growth of the IIuman Race; and that the present antagonism of interests and other disorders are, in turn, to be supurseded by Organio Forms of Societr, in which Men. Women. and Children shall, by the force of Society, be established in possession of the Right of Labor and the fruits thereof-a Home; Social Culture; and a Practical Elducation in the Affairs of Life. The genera purpose of the Association is expressed in the formula of Fourier as follows: Unity of MaN witu God, witu NATURE, AND WITI MAN.

Of practical Institutes, the following formula is adopted:

$$
\begin{gathered}
\text { Joint Stock } \\
\text { Property; Coöperative Labor; }\left\{\begin{array}{c}
\text { Association } \\
\text { of Families; }
\end{array}\right. \\
\left.\begin{array}{c}
\text { Equitable } \\
\text { Distribution } \\
\text { of Profits; }
\end{array}\right\} \begin{array}{c}
\text { Mutual } \\
\text { Guarantees } ;
\end{array} \quad\left\{\begin{array}{c}
\text { Honors } \\
\text { accorling } \\
\text { to Usefulness; }
\end{array}\right.
\end{gathered}
$$

Integral Education; Unity of Interests.

The Association organized in 1843. Its domain consists of 673 acres of rolling land, upon the Greensand Bett in Monmouth County (near-Red Bank), New Jersey, about 40 miles south of New York. The present population is about 130 persons. Agriculture in its various branches is a leading industry. Milling, and some mechanical branches, are also carried on.

In organization, the serial form is adopted, and the following are the principal departments, viz,

$\begin{array}{cc}\text { The Agricultural Serie } & \text { The Domestic Serie } \\ \text { "Stock " " } & \text { "Manufacturing Serie } \\ \text { " Mechanical " } & \text { " Festal }\end{array}$

And within the past year the Educational Serie has been organized, in which it is proposed to Educate the young IXTEGraliz, that is, to develop the bodily powers, the affections, and the intellect; and not to limit our Educational efforts mainly to the culture of the intellect, as in the current method of Education.

April, 1S53.

Prad Bayk, t., Clarion co., Penn. : $149 \mathrm{~m} . \mathrm{N}$. W. by W. Harrisburg. Drained by Red Bank, Mahoning, and Beaver creeks. Surface rolling; soil fertile loam. Alum is found in the t., and several manufactories are carried on. Population 3.276 .

Red Bank Furadce, p. o., Armstrong co., Penn.: $134 \mathrm{~m}$. W. N. W. Harrisburg. Here is a charenal cold-blast furnace, which produces annually about 2,000 tons metal, and gives employment to 100 men.

Red Banks, p. v., Marshall eo., Miss.: 174 m. N. by E. Jackson.

RED BEACI, p. o, Washington co, Mfe.: 114 m. E. N. E. Augusta.

PED BlufF, p. o., Marion district, S. Car.: 85 m. E. Columbia.

Ped BlufF, p. o., Wythe co., Tirg.: 203 m. W. by S. Richmond.

Red Bolling Sprorgs, p. o., Macon co., Tenn.: $43 \mathrm{~m}$. E. by N. Nashville.

RED BRIDGE, p. o., Ulster co., $N . Y_{.}: 56$ m. S. S. W. Albany.

Ren Bod, p. o., Randolph county, $I l l .: 115 \mathrm{~m}$. S. by W. Springfield.

Red Bud, p. o., Ozark county, Mo.: on Bryant's fork of White r., 94 m. S. Jefferson City.

PiEd CFDaR creek, Minn, Ter, : in Washington co, flows S. E. into St. Croix r., in lat. N. $45^{\circ} 45^{\prime}$.

Red Cedar lake, Minn. Ter.: in N. E, corner of Benton county, connected by an outlet with Mississippi river.

Red Cedar lake and river, Wisc.: the lake in N.W. part of the county is the most $\mathrm{S}$. of a chain of lakes, forming the source of the river, which flows S. by W. about $70 \mathrm{~m}$., and empties into Chippewa river.

RED CEDAR river, Nich, : rises in Livingston co., flows
W. by $\mathrm{N}$. through $\mathrm{N}$. part of Ingham co., and empties into Grand river, near Lansing.

RFD ClaP, p. o. and sta., Murray county, $G a$.: near Tennessee State line, on East Tennessee and Georgia P. P.. $15 \mathrm{~m}$. N. Dalton. $176 \mathrm{~m}$. N. W. by N. Milledgeville.

Red Creek, p. o, Wayne co., $N . Y$.

REDDingtox, p. V., Jaekeon con, Ind.: $1 \mathrm{~m}$. E. of E. fork of White r., $52 \mathrm{~m}$. S. S. E. Indianapolis.

RED FALxs, p. o., Greene county, $N_{0} Y_{0}: 28 \mathrm{~m}$. S. S. W. Albany.

REDFIELD, t. and p. o., Oswego county, $N$. Y.: 124 miles W. N. W. Albany. Drained by Salmon $r$. and its branches. Surface undulating; soil a moist loam, and adapted to grass. Some small manufastures are carried on. Population 752 .

RedFoot river, Tenn.: rises in N. E. part of Obion co., flows in S. S. W. course through W. part of this and Dyer counties, and empties into Obion r., near its entrance into Mississippi river.

REDFORD, t. and p. v., Wayne co., Mich.: $71 \mathrm{~m} . \mathrm{E}, \mathrm{S} . \mathrm{E}$. Lansing. Drained by N. branch of Rouge river and its branches. The $\mathrm{v}$, is on W. bank of the river, which affirds water-power used by saw-mills, etc. Pop. of t. 1.645.

RedFord, p. Y., Clinton co., $N . Y_{.}$: on N. side of Saranae r., $136 \mathrm{~m} . \mathrm{N}$. Albany. Iron ore is abundant in the vicinity, and in the $\mathrm{v}$, are glass-works, and about 500 inhabitants.

RED HILL, p. O., Marshall county, Ala.: 135 miles N. Montgomery.

Red Hru, p. o. and sta., Murray county, $G a$.: on East Tennessee and Georgia R. R., 9 miles N. Dalton, 169 miles N. W. by N. Milledgeville.

Red HuLl, p. v., Grainger county, Tenn.: 174 miles E. Nashville.

Red Hils, p. o., Hardin county, Ky.: 70 miles S. W. Frankfort.

RED HrLl, p. o., Kershaw dist., S. Car.: on E. side of Catawba r, $29 \mathrm{~m}$. N. E. by N. Columbia.

RED HrLx, N. IIUmp.: a summit a little N. of Winnipiseogee lake, and commanding an extensive and fine view of the romantic scenery of the region.

Red Hook, t. and p, v., Duchess co, N. Y.: $44 \mathrm{~m}$. S. Albany. Drained by small streams flowing into Hudson r., which bounds it on the W. Surface rolling; soil clay and loam. There are two landings from the river, called Üpper and Lower. The v. of Lpper Red Hook is abont $4 \mathrm{~m}$. baek from the landing, and enntains a church, an academy, several stores, and 300 inhabitants; and that of Lower Red llook about $3 \mathrm{~m}$. from the lower linding, and is a somewhat large settlement. There are other villages in the town, of which Tivoli and Barrytown on the river and railroad are the largest. Factories of various descriptions are established in the villnges. Pop. of $t .3,263$.

Red House, p. o., Charlotte co., Tirg.: 74 m. W. S. W Richmond.

Red House Shoals, p. o., Putnam co., Firg.: on Kanawha r., $255 \mathrm{~m}$. W. N. W. Richmond.

Red J ACKET, p. o., Erie co., $N . Y .: 256 \mathrm{~m}$. W. Albany.

ReD Land, p. v., Pontotoc co., Mriss.: on Loohaton cr. 9 m. S. Pontotoc, and $1+1 \mathrm{~m}$. N. E. by N. Jickson.

Red LAND, p. o., Bossier parish, La.: 214 miles N. W. Baton Rouge.

Red Lion, hund, and p. o., New Castle co., Del.: $32 \mathrm{~m}$. N. by W. Dover. The hund. contains an area of 13.900 acres. Drained by Red Linn creek. on the N. side of which and on the New Castle and Frenchtown R. R. is situate the $\checkmark$. of Red Lion, which derives its name from the principal tavern. The hund. is strictly a farming country, and contains about 1,600 inhabitants.

Red Li?N, p. v., Warren county, Otio: 73 m. W. S. W. Columbus. It contains several mechanic shops, and about 200 inhabitants.

Rfo Lion, v., Burlington co., $N$. Jer. : 4 m. S. of Rancocus cr., and $22 \mathrm{~m}$. S. Trenton. 
Pedian, p. 0., Jackson county, Ala.: 167 miles $N$. Montgomery.

Pied Mills, p. o., Putnam co., $N . Y$. : on a branch of Croton r., $88 \mathrm{~m}$. \$. Albany.

Red Mound, p. o., Henderson co., Tenn.: $97 \mathrm{~m}$. W. S. W. Nashville.

Red Mountain, p. o., Orange co., N. Car. : $38 \mathrm{~m}$. N. W. Raleigh.

PED OAK, p. o., Fayette county, Ga. : 85 m. W. N. W. Milledgeville.

RED OAK, p. o., Ellis co., Tex.: 165 m. N. N. E. Austin City.

Red OAK Grove, Burlington co, N. Jer.

RED OAK Grote, p, o., Charlotte co., Virg.: 73 m. S. W. Riehmond.

Red Plans, p. 0., Yadkin co., N. Car.: $115 \mathrm{~m}$. W. by N. Raleigh.

Red River county, Tex. Situate N. E., and contains $1,312 \mathrm{sq}$. $\mathrm{m}$. Red river forms its northern boundary, by branches of which and of Sulphur fork of Red river it is drained. Surface undulating and diversified; soil fertile and adapted to cotton and corn. It is well timbered. Farms 166 ; manuf. 7 ; dwell. 420 , and pop.-wh. 2,493 , fr. col. 7 , sl. 1,406-total 3,906. Capital: Clarksville.

Red Piver, p. o., Robertson county, Tenn.: $30 \mathrm{~m} . \mathrm{N}$. Nashville.

Ren river, La., Ark, etc. : is the first large r. which enters the Mississippi above its mouth. It rises at the base of the range of Rncky Mountains, near Santa Fe, in Mexico, and is formed by several main branches. It receives several large tributaries, the principal being Blue $r$, and False Washita. The S. bank forms for a great distance the boundary between the U. 8 . territories and Texas. A greater part of its course is through rich prairies of a red soil, which colors the water of the r., and has been the origin of its name. Its shores are covered with grass. and abound with grapevines, which produce an excellent fruit. About $100 \mathrm{~m}$. above Nachitoches commences what is denominated the Raft, which consists of a swampy expansion of the $r_{\text {, }}$ to the wirth of 20 or $30 \mathrm{~m}$., and length of 60 or $70 \mathrm{~m}$. The $\mathrm{r}$. divides into a great number of channels, many of which are shallow, and have been obstructed by fallen trees, brought down by floods from its upper parts. In some places the raft covered the whole $x$., and had grass and willows growing on the alluvial soil collected on it, and could even be crossed on horseback, though not without danger, but more generally the $r$. appeared between the masses of timber. At a great expense this raft has been so far removed by the United States government that steamboats pass through it. Boats Bometimes pass the raft by leaving the $r$. above it, in a channel which flows out of it into some neighboring lake, ard following the outlet of this lake until it joins the $r$, below the raft. This raft has been a serious obstruction, as the $r$. would otherwise be navigable for steamboats 400 miles, and the lands on its borders are highly fertile, and desirable for cultivation for a great distance above the raft. Below the raft, and $4 \mathrm{~m}$. above Nachitoches, the whole volume of the $r$, is again united, but very soon divides into many channels, and fills an immense number of bayous and lakes that lie parallel to it. In its lower part the main channel of the $r$. is narrower than above the raft.

Ren Riter Irox Works, p. V., Estill co, $\bar{K} y_{*}$ : on S. side of Red r., 55 m. E. S. E. Frankfort. Iron in abundance here and in vicinity, and worked successfully.

Red Rrver Landixg, p. o., Point Coupee par, La.: on S. bank of Red r., 48 m. N. W. Baton Rouge,

Red Rook, p. O., Marion co., Ia.: on N. bank of Des Moines r., $94 \mathrm{~m}$. W. by S. Iowa City.

Red Rock, p. o., Upshur co., Tex.. : 247 m. N. E. Austin City.

Ren Rock, p. o., Ramsey co, Minn. Ter.

Red Sroals. p. o., Stokes co., $N$. Cur.: 102 m. W. N. W. Raleigh.

714
Red Sperna, p. o., Polk county, Tenn.: 188 m. S. E. by E. Nashville.

Ped Stone, t. and p. 0., Fayette county, Penn.: $155 \mathrm{~m}$. W. by S. Harrisburg. Drained by creeks of Monongahela r., which bounds it on the W., and affords good water-power Mills of various descriptions are in operation. On the $r$ is Brownsville, a flourishing $\mathrm{v}, 12 \mathrm{~m} . \mathrm{N}$. W. Uniontown. Pop. of t. about 1,400 .

Red Sulphur Springs, p. 0., Hardin co., Tenm. : $97 \mathrm{~m}$. S. W. Nashville.

Red Sulphur Sprivgs, p. v., Monroe co., Virg. : on Indian cr., $181 \mathrm{~m}$. W. Richmond. The waters of these and other neighboring springs are highly recommended for certain curative effects. "The approach to the village," says a visitor, "is beautifully romantic and picturesque. Wending his way around a high mountain, the traveler is for $a_{\circ}$ moment charmed out of his fatigue by the sudden view of his resting-place, some hundreds of feet immediately beneath him. Continuing the circuitous descent, he at length reaches a ravine, which conducts him, after a few ragged steps, to the entrance of a verdant glen, surrounded on all sides by lofty mountains. The S. end of this enchanting vale, which is the widest portion of it, is about 200 feet in width. Its course is nearly N. for 150 yards, when it begins gradually to contract and change its direction to the N. W. and W., until it terminates in a narrow point. This beautifully secluded Tempe is the chosen site of the village. The $\mathrm{S}$. portion, just at the base of the east and west mountains, is that upon which stand the various edifices for the accommodation of visitors. These buildings are spacious and conveniently arranged; the servants are prompt and obedient; and the table de hote is abundantly supplied with every thing that can tempt the appetite. The promenades are beautifully embellished, and shaded from the mid-day sum by large sugar maples, the natives of the forest."

RED WING, p. o,, Wabashaw co, Minn. Ter.

Reowood, p. v., Jefferson co., $N$. $Y .:$ on W. side of Indian r., $152 \mathrm{~m} . \mathrm{N}$. W. Albany. It contains several manufacturing establishments and about 200 inhabitants.

Riedwood, p. o., Grainger co., Tenn. : 180 m. E. Nashville. ReEd island, Pulaski county, Firg.: on New r., $185 \mathrm{~m}$. W. by S. Richmond.

REed, t., Seneca co, Ohio: $8 \mathrm{~m}$. N. Columbus. Drained by creeks of Sandusky and Huron rivers. Surface elerated and rolling; soil fertile, Farming is the sole oceupation pursued. Pop. 1,494.

Reed Creer, p. o., Randolph county, N. Car.: 72 m. W. Raleigh.

Reedsburg, p. O., Sauk co., Wisc. : on E. bank of Baraboo r., $45 \mathrm{~m}$. N. W. Madison.

Rendidurg, p. v., Wayne co, Ohio: on E. side of Muddy fork of Walhonding $r_{*}, 72 \mathrm{~m}$. N. E. by N. Columbus.

ReED's Corners, p. o., Ontario county, N. Y.: $186 \mathrm{~m}$. W. Albany.

ReEd's Creek, p. o, Lawrence co., Ark. : on Reed's cr. of Strawberry r., 95 m. N. N. E. Little Rock.

ReEd's Ferre, p. o., Hillsboro' co., $N$. Hamp. : on E. side of Merrimac r., $25 \mathrm{~m}$. S. by E. Concord, The Coneord R. R. passes this place $9 \mathrm{~m}$. N. Nashua. A normal school for the education of teachers, was erected here in 1549 , at an expense of $\$ 5,500$.

ReED's Grove, p, o., Will county, $I U l_{\bullet}: 133$ m. N. E. Springficld.

ReEd's Lavoring, p. o., Wabashaw co., Minn. Ter.

Reed's Mrtis, p. O., Vinton county, Ohio: 54 m. S. S. E. Columbus.

Reed's Setrlement, p. o., Panola county, Tex.: $247 \mathrm{~m}$. N. E. by E. Austin City.

Refosville, Mifflin co, Penn.: on W, side of branch of Kishishiocoquil er. of Juniata r., $46 \mathrm{~m}$. N. W. Harrisburg. Reedtown, p. o., Seneca co., Ohio: $77 \mathrm{~m}$. N. Columbus. Premy Braxch, p. 0., Noore co., N. Car.: $48 \mathrm{~m}$. S. TV. Ralrigh. 
REEDY Creek, p. v., Jefferson co., Ga.: 55 m. E. N. E. Milledgeville.

Reedy Creek, p. o., Marion dist., S. Car. : 80 m. E. by N. Columbia.

Reedy Ripple, p. 0., Wirt co., Virg. : 231 m. W. N. W. Richmond.

REEDYVILle, p. o., Wirt county, Firg.: 232 m. W. N. W. Richmond.

REelfoor, p. o., Obion co., Tenn.: $145 \mathrm{~m}$. W. Nashville. ReEl's Miul, sta., Putnam co., Ind.: on the Terre Haute and Richmond R. R., $49 \mathrm{~m}$. W. by S. Indianapolis.

Reen's Creek, p. O., Buncombe co., $N$. Car: $216 \mathrm{~m}$. W. Raleigh.

Riefse's Mrl, p. o., Boone co., Ind.: 30 m. N. N. W. Indianapolis,

Reform, p. o., Pickens co., $A l a$. : on a small branch of Little Tombigbee r., $123 \mathrm{~m}$. N. W. by W. Montgomery.

Piform, sta., Effingham co., $G a .:$ on the left side of Ogeechee $x_{\text {. }}$ and on the line of the Central Railroad, $30 \mathrm{~m}$. from Savannah and $157 \mathrm{~m}$. from Milledgeville.

Refugio county, Tex. Situate S. E., and contains 1,645 sq. m. Drained by San Antonio and Mission rivers and other streams, all flowing into the Gulf on the $\mathrm{E}$. The Gaudalupe forms its northern boundary. Surface level, and pleasantily diversified; soil a deep black mold, fertile and well adapted to cotton and sugar. It has excellent timber land. In the winter the prairies are the resort of game of different kinds, and the inhabitants derive much profit as well as pleasure from hunting. Farms 21 ; manuf. 0 ; dwell. 56, and pop.-wh. 269, fr. col, 0, sl. 19-total 288. Capital: Refugio C. H.

Refogrio, p. v., and cap. Refugio co., Tex.; on E. bank of Mission r., 141 m. S. by E. Austin City.

Regnter's Mills, p. o., Washington county, Ohio: on a branch of Duck creek of the Ohio river, $85 \mathrm{~m}$. E. by $\mathrm{S}$. Columbus.

Rеновотн, p. v., Wilkes co., Ga.: at the cross roads between Lincolnton and Washington, $62 \mathrm{~m}$. N. E. by N. Milledgeville.

REновотн, t. and p. o., Bristol co., Mrass.: $38 \mathrm{~m}$. S. by W. Boston. Drained by Palmer's r., which affords water-power. It is a good farming region, and contains also several manufactures. Pop. 2,103.

Reновотн, p. v., Perry county, Ohio: 44 m. E. S. E. Columbus.

REновотн, p. v., Edgefield dist., S. Car.: 63 m.W. S. W. Columbia.

Rеновоті, p. v., Lunenburg co., Virg.: 63 m. S. W. Richmond.

Peitrersburg, p. v., Berks co., Penn。: 35 m. E. N. E. Harrisburg. It contains 2 churches, several stores, and 300 inhabitants.

Reidsburg, p. v., Clarion county, Penn.: on a creek of Clarion r., $146 \mathrm{~m}$. W. N. W. Harrisburg. A small v. of some 200 inhabitants. Iron abounds in the vicinity.

Reidsville, p. v., and cap. Tatnall co., Ga. : on W. side of Great Ohoopee r., $101 \mathrm{~m}$. S. E. Milledgeville. It contains the county buildings, and is on the line of the projected Savannah and Albany R. R.

Retnstille, p. v., Albany co., $N . Y_{.:} 14$ m. W. s. W. Albany.

Remsviliz, p. V., Rockingham county, N. Car.: $76 \mathrm{~m}$. N. W. by W. Raleigh.

PierLx, t. and p. O., Butler co., Ohio: $99 \mathrm{~m}$. W. S. W. Columbus, Drained by branches of Miami $r$. Surface uneven; soil fertile, producing an excellent quality of wheat. Timber abundant in the t. and vicinity. Pop. 1,716.

ReIsideer, po Oag Nodaway county, Mo.: 189 m. N. W. Jefferson City.

Reinersiburg, vo, Clarion co., Penn.: on an affluent of Red Bank cro, 146 m. W. N. W. Harrishurg. The Franklin Iron-Works are located here, and formerly employed about 80 hands and produced 1,100 tons No. 3 metal.
Retnholjostule, p. v., Lancaster county, Penn. : $36 \mathrm{~m}$. E. 8. E. Harrisburg.

Reistertown, p. v., Baltimore co., Md. : about $\frac{1}{3}$ m. E. Patapseo r., $37 \mathrm{~m}$. N. N. W. Columbia. The Westminster Turnpike passes through the village.

Relay House, sta., Baltimore eo, $M d$ : on the Baltimore and Susquehanna R. R., at the divergence of the Westminster Branch R. R., $7 \mathrm{~m}$. N. Baltimore.

RruAx House, sta, Baltimore co, Md.: on the N. side of Patapsco $r_{u}$, and on the line of the Baltimore and Ohio R. R., at the divergence of the Washington Branch $\mathrm{I}_{\text {. }} \mathrm{R}$. 9 m. S. W. Baltimore.

Relfe, p. 0., Pulaski con, Mo : 45 m. S. Jefferson City.

RelF's BlufF, p. o., Drew county, Ark. : 69 m. S. S. W Little Rock

Remixgton, p. v., Alleghany co., Penn.: 141 m. W. by N. Harrisburg.

Remsen, t. and p. o., Oneida co, $N$. Y.: $89 \mathrm{~m}$. N. W. by W. Albany. Drained by Black r. and branches. Surface hilly; soil of average fertility. The $\mathrm{v}$. contains 2 churches, several stores and mills, 70 dwellings, and 400 inhabitants. Population of t. 2,407.

Rexick Mrlus, p. o., La Fayette co., Mo.: 98 m. W. N.W. Jefferson City.

ReNROcK, p. o., Morgan county, Ohio: 68 m. E. S. E. Columbus.

Rensselater county, $N . \quad \bar{r}$. Situate E., and contains 626 sq. m. Drained by Hoosic r., and Wynantskill, and Poestenkill flowing into Hudson $r$, on the W., and affording in their course good water privileges. Surface pleasantly diversified with hills and valleys; soil fertile. Chief produets, wheat, Indian corn, and potatoes. It contains some minerals, and extensive slate quarries; the products of the latter are used principally for roofing. Farms 2,930; manuf. 639 ; dwell, 10,972, and pop,-wh. 72,387 , fr. col 1,026-total 73,363. Capital: Troy, Public Works: Hudson River R. R.; Albany and W. Stockbridge R. R. ; Troy and Greenbush R. R.; Troy and Boston R. R.; Troy and Rutland R. R., ete

Rensselaer, p. v., and eap. Jasper county, Ind.: on Iroquois r., $92 \mathrm{~m} . \mathrm{N}$. W. by N. Indianapolis.

Rensselaer, v., Rensselaer co., $N . Y .: 12 \mathrm{~m} .8$. E. Troy. It contains 8 churches, several stores and mechanic shops, and 500 inhabitants. In the vicinity there are also numerous saw and grist mills.

Rensegtanerville, t. and p. v., Albany co, $N$. $Y .: 24 \mathrm{~m}$ s. W. by W. Albany. Drained by Catskill and Foxes creeks. Surface hilly; soil sandy loam, and generally fertile. The v. on Foxes cr. contains 4 churches, an academy, a dozen stores, iron works and machine shops, and other iudustrial establishments, and about 1,000 inhabitants. In the t. are tanneries, and numerous saw-mills, ete. Pop. 3,630 .

Repton, p. o., Clark county, Ind: $89 \mathrm{~m}$. S. by E. Indianapolis.

Republic, p. o., Surry co., N. Car.: 120 m. W. N. W. Raleigh.

Republic, p. v., Seneca co., Ohio: $78 \mathrm{~m}$. N. Columbus, The Mad River and Lake Erie R. R. passes through this place, $30 \mathrm{~m}$. from Sandusky, and 128 from Dayton.

Republican, p. O., Darke co., Ohio: $98 \mathrm{~m}$. W. Columbus. Republican Grove, p. o., Halifax county, Virg.: $93 \mathrm{~m}$. W. S. W. Richmond.

Republican Mruls, p. o., Fairfax co., Firg.: $91 \mathrm{~m} . \mathrm{N}$. Richmond.

ResACA, p. v. and sta., Murray county, Ga.: $164 \mathrm{~m}$. N. W. by N. Milledgeville. The Western and Atlantic R. R. passes the place, $85 \mathrm{~m}$. from Atlunta, and 55 from Chatanooga.

Reservation, v., Erie county, $N . Y_{*}: 241 \mathrm{~m}$. W. by N. Albany.

Reserve, p. o., Miami co., Ind.: $70 \mathrm{~m}$. N. Indianapolis,

REserve, p. o., St. Joseph's county, Mich.: $6 \pm$ m. S. W Lansing. 
Kiscarvr, t., Alleghany county', Penn.: oceupies the Land at the confluence of Alleghany r., with the Ohis lying N. of Alleghany City. It has considerable manufilctures.

Retriat, p. 0., Franklin co., Tirg.: 148 m. W. S. W. Richmond.

Reveler, p. o., Scott county, Ark.: $89 \mathrm{~m}$. W. N. W. Little Rock.

Rexuure, v., Essex co., Virg. : 46. m. N. E. Richmond.

Rexford Flats, p. o., Saratoga co., N. $Y .:$ on N. side of the Molnawk r., $15 \mathrm{~m}$. N. N. W. Albany.

Revnale's Basis, p. o., Niagara county, $N$. $Y$.: on the Erie Canal, $264 \mathrm{~m}$. W. Albany.

Reynolds county, Mo. Situate toward the S. E., and contains 7 (15) sq. m. Drained by Big Black Water r. and its branches. Surface rolling; soil fertile. and produces in abunilance grain, wheat, fruits, tobacco, Indian corn, and potatoes. This is a splendid mining country, and contains many valuable minerals. It contains also fine timber land. Farms 14.5; manuf. - ; dwell. 293, and pop.-wh. 1,S24, fr. col. 0, sl. 25-utotal 1,819. Capital: Lesterville.

Pexyolnsburg, p. v., Franklin co., Ohio: on E. side of Big Lick cr., $11 \mathrm{~m}$. E. Columbus. It contains several stores, mechanic-shops, etc. The creek affords excellent millpower. Pop. 564.
Reynoldsville, p. v., Tompkins county, $N . Y_{.: 160 \mathrm{~m}}$ W. by S. Albany.

Reinuldsille, p. v. Jefferson county, Penn, : $121 \mathrm{~m}$. W. N. W. Inarrisburg.

RHeA county, Tenn. Situate toward the S. E., and contains 349 sq. $\mathrm{m}$. Tennessee $\mathrm{r}$, forms its western boundary, by branches of which it is drained. Surface undulating, in parts hilly; soil fertile. Farms 305 ; manuf. 2 ; dwell. $6 \mathrm{S1}$, and pop.-wh. 8,951 , fr. col. 28, sl. 436-total 4,415. Capital: Washington.

Rusatown, p. v., Greene con, Tenn.: about $3 \mathrm{~m}$. N. of Nolichuky r., 227 m. E. Nashville.

Phivebeck, t. and p. o., Duchess county, N. Y.: $50 \mathrm{~m}$. S. Albany. Dratned by Landtman's cr., a small stream of Fudson $r$., which runs along its W. border. Surface on the $W$. level, and on the E. rolling; soil very productive. The v., about $2 \mathrm{~m}$. from the landing on Lancltman's cr., has 3 churches, an acalemy, numerous work-shops, stores, etc., and about 1,200 inhabitants. Pop. of $t .2,816$. The Hudson River R. R. runs on the W. edge of the town.

Phiveisech Landing, v., Duchess county, $N, Y .:$ on E. bank of Hudson r., and on the line of the Hudson River R. R., $53 \mathrm{~m}$. from Albany, and $91 \mathrm{~m}$. from New York city. The Albany steamhoats stop here up and down. The v. contains about 50 dwellings.

\section{THE STATE OF RHODE ISLAND.}

PuIOde IsL.1XD (or more properly Rhode Island and Providence Plantations). although the smallest State of the Union, is ennsiderably larger than many of the sovereignties of Europe, and in point of intelligence and productive powers, far in advance of any American community of the same population. It is situated between $41022^{\prime}$ and $42003^{\prime}$ latitudes north, and between $71^{\circ} 06^{\prime}$ and $71^{\circ} 88^{\prime}$ longitudes west from Greenwich, or $5024^{\prime}$ and $5056^{\prime}$ east from Washington. Massachusetts bounds it on the north and the east, the Atlantic Ocean on the south, and Connecticut on the west. About 42 miles long, and in its greatest width 35 miles, it contains a land area of 1,360 square miles.

The surfice of the State is generally hilly and broken, but nowhere does it present any elevation deserving of the name of mountain. Mount Hope, in Bristol, the highest land in the State, is only 300 feet above the sea level. In the neighborhood of Narragansett Bay, and on the islands within it, the land is more level, and at most exhibits but slight undulations. The rivers are little more than mill streams, with courses of not more than 50 or 60 miles in length, and discharging an inconsiderable amount of water; but as they descend from 200 to 450 feet, and are steaty in their supply of water, they furnish valuable power, which is extensively appled to manufacturing purposes. The Pawtucket, ihe principal river, rises in Massachusetts, where it has the name of Blackstone River, and running south-east into this State, fills into Provilence River, one mile below the city of Providence. There are falls of about 50 feet descent four miles from its mouth-below the falls it bears the name of the Seekonk River. Providence River is formed by the Wanasquiatucket and Moshasick. two small streams which unite a short distance above the eity of the same name. It falls into the northern arm of Narragansett Bay, and is navigable to Providence for ships of 900 tons. Pawtuxet River, rising by several branches; and flowing east, enters Providence River, five miles below the city. It abounds with falls, which furnish fine Incations for mills and manufucturing establishments. Pawcatuck River, formed by Wood and Charles rivers, waters the south-western part of the State, and falls into Stonington harbor-in the latter part of its course it is the bourdary between this State and the State of Connecticut.

Narragansett Bay, a fine body of water, divides the State into two unequal proportions. It extends more than 30 miles inland, and is about 15 miles wide at its southern part, but a considerable portion of this space is oceupied by islands. It communicates with the ocean between Point Judith on the west, and Seaconet Point on the east. The north-eastern arm of the bay is called Mount Hope Bay; the north-western arm Greenwich Bay, and the northern arm Providence Bay. The prineipal rivers falling into it are the Providence and the Taunton, the latter from Massachusetts. It affords great advantages to ship navigation, having many excellent harbors, and being accessible at all seasons. New port harbor, in the channel, between Canonicut and Rhode Island, is one of the finest in the world; the entrance is protected by Fort Walcott, on Goat's Island, and Fort Adams, on Rhode Island-the latter a large stone castle of great strength.

Rhode Island, lying in Narraganselt Bay, gives name to the State. It is 15 miles long, and on an average $8 \frac{2}{2}$ miles wide, containing an area of about 50 square miles. Its climate is delightfol, and the soil very fertile. Travelers have called at the "Eden of America." and southerns have chosen it as a summer residence. Canonicut is a beautiful island to the west of Rhode Island. It is about seven miles long and one mile broad. Prudence Island lies to the nurth-east of Canonicut, and Block Island about ten miles south-west of Point Judith. The latter is about seven miles long, and about four miles broad. The islanders derive their support chiefly from frshing, but they have also large numbers of eattle and sheep. and produce cheese and butter of the finest quality.

The climate of the whole State, influenced by the vapors from the Atlantic, is mild, though changeable, and in its general charicteristics is said to assimilate that of Great Brituin. The sensons are more uniform than in the more northern parts of New England-the winters are sensibly milder, and the heats of snmmer are much modified. Spring commences in March, and summer reigns from June to September. The latter month, and also October, have delightful weather. Winter sets in with November, and continues to the mildle of Mirch. The air is at all times pure, and the longevity of the inhabitants, as indicated by the census, is a true indication of its salubrious qualities.

The mineral productions of Rhole Islanil are of little importance. Some iron ore is found in different parts, Anthracite oceurs, but althongh it has been pronounced to be of a good quality, little has been done to bring it into use. It is found chiefly in the same graywacke formation with the Massachusetl's coal. Limestone abounds in the north-eastern sectiun 
of the State, and in these calcareous shale. There are some cxcellent quarries of marble, Serpentine is also abinilani, and there are in various places extensive quarries of freestone. On the continental portion of the State the goil is generally a gravelly loam, which is tolerably furtik, but difficult of cultivation. The goil of the islanily is slaty, yet they are the most productive and valuable lands in the State. There is very little alluvial land. Pine plains are fotani in several low regions, but there are no extensive forests. Oak, walnut, and chestnut, are the prevailing growths. Fruits and culinary vegetables are produced in great perfection, and in abundance. Grain is grown in consiclerable q1aratilics, in reterence to the area of the State, but, on the whole, the lands are better adapted for grazing than fir ecribl a -1 ictilture.

Fhode Island is divided into five connties, the general stutistios of which and the capituls of each in $15 . j \mathrm{~J}$. follows:

\section{Cuunties, Dwell. Pop. $\begin{gathered}\text { Farms } \\ \text { incult. }\end{gathered} \begin{gathered}\text { Mamuf. Eatib. Capitais, } \\ \text { Eat. }\end{gathered}$ \\ Bristol...... 1,167 .. 8,514 .. 200 . 87 .. Bristol}

Kent...... 2,625 . 15,068 . 685 . 90 .. E. Greenwich

Newport . . 2, 2,936 . 20,007 . 1,027 . 6 63 . . Newport

The whole number of dwellings in the State was, at the above date, 22.379 ; of families, 28,216, and of inhabitants, 147,014 ; viz., whites $144,000 \rightarrow$ males 70,417 , and females 73,583 ; fr. col. $3,541-$ males 1,660 , and femiles 1,834 . Of the whole population there were, denf and dumb-wh. 61, fr. col. 3-total 64; blind-wh. 61, fr. col. 3-total 61; insanewh. 243, fr. col. 4-total 252 ; and idiotic-wh. 104, fr. col. 3-total 107. The number of free persons born in the United States was 124,299, the number of foreign birth 23,111, and of birth unknown 135 . The native population originated a3 follows: Me. 768, N. Hamp. 716, Verm. 459, Mass. 11,S88, Rhode Island 102,611, Conn. 3,976, N. Y. 2,055, N. Jer. 193, Penn. 447, Del. 50, Mu. 365, Dist. of Col. 64, Virg. 191, N. Car. 76, S. Car. 57, Ga, 63, Flor. 22, Ala. 13, Miss. 38, La. 21, Tex. 4, Ark. 0, Tenn. 4, Ky. 19, Oh. 99, Mich. 22, Ind. 11, Ill. 15, Mo. 13, 1a. 9, Wise. 6, Calif. 0, Territories 40; and the tioreign population was composed of persons from-England 4,490, Ireland 15.944. Sentland 985, Wales 12, Germany 230, France 80, Spain 14, Portugal 58, Belgium 2, Holland 12, Turkey 1, Italy 25, Austria 1, Switzerland 8, Russia 1, Denmark 15, Norway 25, Sweden 17, Prussia 5, Asia 1, Africa 9, British America 1,024, Mexico 7, Central America 4, South America 4 , West Indies 57, Sandwich Islands 8, and other countries 52.

The following table will show the decennial progress of the population since the first census of the State, taken by the United States authority:

\begin{tabular}{|c|c|c|c|c|c|c|}
\hline \multirow[b]{2}{*}{$\begin{array}{l}\text { Census } \\
\text { Years. }\end{array}$} & \multirow[b]{2}{*}{$\begin{array}{c}\text { White } \\
\text { P'ersons. }\end{array}$} & \multicolumn{2}{|c|}{ Colored Persons. } & \multirow[b]{2}{*}{$\begin{array}{l}\text { Totni } \\
\text { Pup. }\end{array}$} & \multicolumn{2}{|c|}{ Decennial Increase. } \\
\hline & & Free. & Tutal. & & Numericul. & Per vest. \\
\hline 1790. & . $64,6 \$ 9$. & $.3,469 \ldots$ & $.4,421 \ldots$ & $69,110 \ldots \ldots$ & - & $\ldots \ldots-$ \\
\hline 1800. & 65,437 . & $.3,304 \ldots$ & $.3,655$ & $69,122 \ldots \ldots$ & 12 & .... 0.0 \\
\hline 1510. & 73,814 & .109 & .0 & $1 \ldots \ldots$ & 7.939 & ....11.4. \\
\hline $1820 \ldots$ & . 79,413 . & $.3595 \ldots \ldots .45$ & $.3,6$ & $83.059 \ldots$ & 6,023 & . . 7.9 \\
\hline $1530 \ldots$ & 93,621 . & . 17. & .3 & $9 \ldots \ldots$ & . 14,140 & $\ldots 17.0$ \\
\hline 18 & $.1055 \$ 7$. & $.3,258 \ldots$ & 3 & $10 \mathrm{~s}$ & . 11,631 & $\ldots \ldots 11.9$ \\
\hline 35$\}.$ & 144,100 & $.3 .554 \ldots \ldots \ldots-$ & 00 & $\ldots \ldots \ldots$ & . 33,921 & ....35.6 \\
\hline
\end{tabular}

The general statistics of the wealth, productions, manufactures, etc., of the State, according to the census of 1950 and other documents referring to the same period, are as follows:

Occupied Lands, etc.-Improved lands, 356.487 acres, and unimproved lards, 197.451 acres-valued in the aggreante at $\$ 17,070,502$. The whole number of farms in operation on the 1st June, 1550 , was 5,355. Value of farming implements and machinery, $\$ 497,201$.

Lire-Stock:-Horses, 6,168; asses and mules, 1; milch eows, 29,698; working oxen, 8.159 ; other cattle, 9,375; sheel, 41,296, ant swine, 19,509 ; in all valued at $\$ 1,532,637$. In 1310 the stock consisted of 8,024 horses and mules, 36,591 neat cattle of all kinds, 90,146 sheep, and 30,659 swine.

Products of Animals.- Wool, 129,692 pounds; butter, 995,670 pounls: cheese, 316,508 pnunds; and the value of animals slaughtered during the year had been $\$ 667,486$. The wool returned in 1840 was 153,830 pounds.

Grain Crops.-Wheat, 49 bushels; rye, 26,409 bushels; Indian corn, 539,202 bushels; oats, 215,232 bushels; barley, 18,575 bushts; and buckwheat, 1,215 bushels. Compared with the erops exhibited in the census of 1840 , the following results are obtained:

\begin{tabular}{|c|c|c|c|c|c|c|c|c|}
\hline $\begin{array}{cc}\text { Cropq, } & 1940, \\
\text { Wheat ................ } & 3,093\end{array}$ & & $\begin{array}{r}1850 . \\
49\end{array}$ & sh & ......... decr. 8,049 & & & 0.4 & eres \\
\hline Fyен........... 34,521 & 4 & $\ldots \ldots \ldots \ldots 26,409$ & "6 & .. deer. 8,112 & 6 & or & 23.5 & " \\
\hline Ind an cirn............450,495 & 6 & $\ldots 539,2: 12$ & 6 & ... incr. 88,704 & "6 & or & 19.7 & 66 \\
\hline Oats . . . . . . . . .171, & "6 & $\ldots \ldots 215,232$ & "6 & . incr. 43,715 & 4 & or & 25.5 & "6 \\
\hline Barley . ........... 66,490 & “ & $\ldots \ldots \ldots \ldots 18,8,5$ & “ & ........ decr, 47,615 & “ & or & 71.6 & « \\
\hline uckwheat.......... 2,979 & 6 & $\ldots \ldots \ldots \ldots \quad 1,245$ & " & ........ decr, 1,734 & 66 & or & 41.7 & " \\
\hline
\end{tabular}

Other Fond Crops.-Peas and beans, 6,3f6 bushels; potatoes-Irish, 651,029 bushels, and sweet, 0 bushels. The potato crop of 1839 amounted to 911,973 bushels.

Mriscellaneous Crops-Hay, 74,818 (in 1810, 63,449) tons; clover-seed, 1,328 bushels; other grass seed, 3,708 bushels ; hops, 277 pounds; flax, 85 pounds; maple sugar, $2 \mathrm{~S}$ pounds; molasses, 4 gallons; beeswax and honey, 6,317 pounds : wine, 1,013 gallons, ete. Value of orchard produets, $\$ 63,994$, and of market-garden products, $\$ 95,293$.

IIome-made Mrunufactures were produced in the year to the valuo of $\$ 20,495$. The same cluss of goods returned in the census of 1.510 were ralued at $\$ 51,180$.

Menufisctures,-Total capital invested in manufactures, $\$ 00,000,000$; value of all raw material, fuel, ctc., eonsumed in the year, $\$ 00,000,000$; monthly cosit of labor, $\$ 000,000$ - male $\$ 000,000$, and female $\$ 00,000$; value of products for the year,

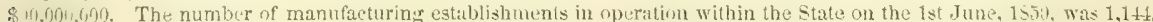
distributed among the counties as shown in the generul table. Of this number 153 were cotton factories, 45 woolen factorics, 10 tanneries. and 21 engaged in the manufacture of iron, namely, 20 in the mamufacture of castings and 1 in that of wrouglit iron. The aggregate capital invested in manufactures in 1810 amounted to $810,690,130^{\circ}$. 


\section{RHODE ISLAND.}

In the cotton manufacture the capital employed was $\$ 6,675,000$; the value of raw material, fuel, etc., consumed, $\$ 3,451.579$; and the products for the year, $96,925,612$ yards of sheeting, and 1,902,9S0 pounds of thread and yarn, valued at $\$ 6,447,120$. Cotton consumed, 50,713 bales, and coal, 13,116 tons; hands employed, 10,875-males 4,959 and females 5,916 ; entire wages paid per month, $\$ 168,938$ - to males $\$ 92,2 \$ 2$ and to females $\$ 76,656$. The census of 1840 returned 209 factories and 17 dyeing establishments ; capital, $\$ 7,326,000$; hands, 12,086 ; and value of annual products, $\$ 7,116,792$.

In the roolen manufactare the capital invested was $\$ 1,013,000$; value of raw material, fuel, etc., $\$ 1,463,900$; products of the year, $8,612,400$ yards of cloth, 46,000 pounds of yarn, etc., valued at $\$ 2,381,825$. Wool consumed, $4,108,370$ pounds, and coal, 2,032 tons; hands employed, 1,758 -males 987 , and females 771 ; monthly wages paid, $\$ 32,139$-to males $\$ 20,431$, and females $\$ 11,708$. In 1840 there were in the State 45 fulling-mills and 41 woolen factories; capital, $\$ 685,350 ;$ hands, 961 ; and value of products for the year, $\$ 842,172$.

In tanneries the capital invested amounted to $\$ 42,900$; value of hides and skins used, $\$ 40,615$; hands employed, $88-\mathrm{at}$ a monthly cost of $\$ 829$; skins tanned, 14,861 , and sides of leather tanned, 21,142 , together valued at $\$ 75,040$. In 1840 there were in the State 27 tanneries; capital $\$ 72,000$; hands employed, 89 ; products-1,534 sides of sole leather and 50,860 sides of upper leather.

The iron manufacture is comparatively a small interest on Rhode Island. No manufactures of pig iron are returned in the census of 1850. In the manufacture of castings the capital invested amounted to $\$ 428,800$; value of all raw material, fuel, etc., used, $\$ 258,267$; hands emplnyed, 800 -at average wages $\$ 2963$ per month; pig iron used, 8,918 tons, and mineral coal, 4,670 tons; castings made, 8,558 tons, and other products to the value of $\$ 119,500$; total value of products for the year, $\$ 728,705$. The capital invested in the manufacture of wrought iron was $\$ 208,000$; pig metal used, 8,000 tons, and mineral coal consumed, 6,000 tons; value of all raw material, fuel, ete., $\$ 111,750$; hands employed, 220 , at wages averaging $\$ 26$ per month; wrought iron made; 2,650 tons; value of entire annual products, $\$ 222,400$. In 1840 there were 5 furnaces in the State, producing 4,126 tons of cast iron, consuming 227 tons fuel, and employing 29 men. The capital invested in the manufacture of iron in that year was $\$ 22,250$.

In the manufacture of malt and spinituous liquors, the capital invested amounted to $\$ 17,000$; the number of hands employed was 9 ; and the consumption of barley, 12,500 bushels, and of hops, 6 tons; ale, etc., produced, 3,900 barrels. In 1840 , distilleries produced $\$ 55,000$ gallons of spirits, and 3 breweries $\$ 19,600$ gallons ale, etc.; hands, 42; and capital invested, $\$ 139,006$.

Among the manufactures of the State others than those specified above, the most important are those of hardware, machinery, cutlery, etc. There are also considerable investments in the manufacture of jewelry, hats and eaps, saddlery, paper, and in the various descriptions of mills.

Internal Improvements.-Rhode Island has several excellent railroads and other improvements. The principal railroads are those connecting it with Boston and Worcester on the one hand, and with the ports of Long Island Sound and New York on the other. The first comprise the Boston and Providence R. R. and the Providence and Worcester R. R., and the latter the Stonington $\mathrm{R}_{\text {. }}$ R., the Providence, Hartford, and Fishkill R. R., and the New York and Boston R. R., the two latter yet ineomplete. The Blackstone Canal also extends from Providence to Worcester. The condition of these several works is shown in the "Appendix."

Banks.-In September, 1850 , there were in the State 63 banking institutions, the assets and liabilities of which at that date were as follows: assets-loans and discounts, $\$ 15,492,547$; stocks, $\$ 151,277$; real estate, $\$ 283,344$; other investments, $\$ 13,461$; due by other banks, $\$ 41,164$; notes of other banks, $\$ 537,761$; and specie, $\$ 297,661$; and liabilities-capital, $\$ 11,645,492$; circulation, $\$ 2,553, \$ 65$; deposits, $\$ 1,488,596$; due other banks, $\$ 650,560$; and other liabilities, $\$ 133,733$. There are also savings' institutions, and life, fire, and marine insurance companies in all the large eities.

Foreign Commerce.-The direct foreign commerce of Rhode Island, once considerable, is now comparatively of small amount, and relatively to its population and manufacturing importance, very small indeed. Indirectly, its connection with foreign countries is commensurate with its rank as a manufacturing State. It imports and exports chiefly through the ports of Massachusetts and New York, to which it has easy access by railroads and other means. The value of the exports and imports for the year ending 30 th June, 1850, was, according to the treasury report, as follows-exports: domestic products, in American vessels, $\$ 205,969$, and in foreign vessels, $\$ 330$-total value of domestic exports, $\$ 206,299$; and foreign products, $\$ 9,966$, all in American vessels-total value of all exports, $\$ 216,265$-and imports : in American vessels, $\$ 251,708$, and in foreign vessels, $\$ 6,595$-total value of imports, $\$ 255,303$. The statistics of navigation exhibit the entrances and clearances thus:

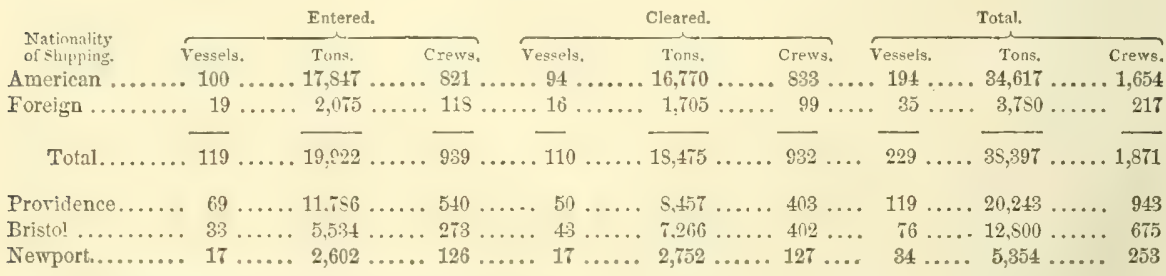

-of this aggregate, Providence entered 69 vessels (11,796 tons), Bristol 33 vessels (5,534 tons), and Newport 17 vessels (2,602 tons); and Providence eleared 50 vessels ( 8,457 tons), Bristol 43 vessels ( 7,266 tons), and Newport 17 vessels (2,752 tons). The total shipping omned in the State at the above date was 40,459 tons. The amount of registered shipping amounted to 26,065 tons, of which 21,497 tons were of permanent register, and 4,571 of temporary register, and of this 5,529 tons were employed in the whale fisheries, and the retnainder in the foreign trade. The enrolled and licensed shipping amounted to 13,722 tons, of which 13,178 tons were employed in coasting, 155 tons in the cod fisheries, and 389 tons in the mackerel fisheries, and 432 tons were navigated by steam. The licensed shipping (under 20 tons) amounted to 699 tons, of which 360 tons were employed in coasting, and 339 tons in the cod fishery. Total registered, 26,068 tons; enrolled and licensed, 13,721 tons; and licensed, 699-aggregate tonnage, 40,45s tons. 0 wned in Providence district, 16,712 tons; in Bristol, 13,19S tons; and in Newport, 10,578 tons. Fourteen vessels, viz., 5 ships, 5 schooners, 3 sloops, and 1 steamer were built in the State during the year, and of these the burden was 3,587 tons-built at Bristol, 2,191 tons; at Providence 1,299 tons; and at Newport, 95 tons. 
RHODE ISLAND.

The statistics of the imports and exports of Rhode Island from 1791-1810 exhibit the following movements:

\begin{tabular}{|c|c|c|c|c|c|c|c|}
\hline ear. & Exports. & Year, & Exports. & Imports. & Year. & Exports. & Imports. \\
\hline $91 \ldots \ldots$ & $\$ 470,131 \ldots . \$$ & $1811 \ldots \ldots$ & $\begin{array}{r}\$ 1,571,424 \ldots \\
755,137\end{array} \ldots$ & & $1881 \ldots \ldots$ & $\begin{array}{r}\$ 367,465 \ldots \\
584,459\end{array}$ & 161 \\
\hline$\cdots$ & $695,109 \ldots$ & $813 \ldots \ldots$ & $\cdots$ & & 1532. & 4 & \\
\hline$\cdots$ & $616,492 \ldots$ & $1813 \ldots$ & 236 , & & & $81, \ldots$ & 6 \\
\hline$\ldots \ldots$ & $945,599 \ldots$. & $1814 \ldots \ldots$ & $34 \ldots$ & & - & $420,955 \ldots$ & 4 \\
\hline & $, 222,917 \ldots$ & $815 \ldots . .$. & $561.183 \ldots$. & & $1935 \ldots$ & $296,1013 . .$. & 13 \\
\hline .. & $1,589,872 \ldots$ & $1816 \ldots$ & $612,794 \ldots$ & & $1836 \ldots$ & $20 \ldots$ & \\
\hline & $975,530 \ldots$ & $1817 \ldots$ & $950,467 \ldots$ & & $1837 \ldots$ & is .... & \\
\hline .. & $917,827 \ldots$ & $1818 \ldots$ & $1 \ldots$ & & $1838 \ldots$ & $7 \ldots$ & \\
\hline & $73 \ldots$ & $1819 \ldots$ & $4 \ldots$ & & $1 \$ 39 \ldots$ & $4 \ldots$ & \\
\hline 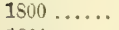 & $5 \ldots \ldots$ & $1820 \ldots$ & $52 \ldots$ & & 1 & $9 .$. & \\
\hline & $773 \ldots$. & $1821 \ldots$ & $2 S \ldots$ & & $1 S 41 \ldots$ & 27 & \\
\hline . & $2,433,363 \ldots$. & $1522 \ldots$ & $862,363 \ldots$ & 1,8 & $1842 \ldots$ & $6 \ldots$ & \\
\hline & . & $23 \ldots$ & A... & & 1 & $\cdots$ & \\
\hline$\ldots$ & $1,735,671 \ldots$ & $1821 \ldots$ & $872, \$ 99 \ldots$ & 1,3 & $1844 \ldots .$. & $7 \ldots$ & \\
\hline & $49 \ldots$ & $1825 \ldots . .$. & $467 \ldots$ & & $5 \ldots$ & 2. & \\
\hline 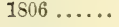 & $835 \ldots$ & $1826 \ldots$ & $540 \ldots$. & 1,1 & $1846 \ldots \ldots$ & 4 ... & \\
\hline & $64 \ldots$ & $1827 \ldots$ & $87 \ldots$ & & $1847 \ldots$ & $9 \ldots$ & \\
\hline $3 \ldots$ & 134. & $1 S 28 \ldots$ & $166 \ldots$ & & $1848 \ldots$ & $1 \ldots$ & \\
\hline & $1,2 \varsigma 4,582 \ldots$ & $1829 \ldots$ & $390,381 \ldots$ & & $1849 \ldots$ & $2 \ldots$ & \\
\hline 3 & $1,331,576$. & $1830 \ldots \ldots$ & $278,950 \ldots$ & 488,756 & $1850 \ldots$ & 216,265 . & 303 \\
\hline
\end{tabular}

Government.--Until the year 1814 the form of government was that ordained by the ancient royal charter, which was originally one of the most liberal granted to the American colonies. In that year a new constitution was formed and ratified by the people.

Every male citizen of the United States, resident in the State for the last past year, and in the town or eity in which he claims to vote, for the six months next preceding an election, and owning real estate in such town or city worth $\$ 134$ above all incumbrances, or of the clear yearly value of $\$ 7$, may vote for all civil officers, and on all questions in all legal town or ward meetings, or if the estate lie without such town or city, but within the State, he may vote for all general officers and members of the General Assembly ir the town or eity of which he is a resident, etc. No Narragansett Indian can rote, etc. The general election is held on the first Wednesday in April annually. In all elections for State officers, a majority of rotes is necessary to a choice.

All legislative poncer is vested in the General Assembly, which consists of a Senate and House of Representatives-the former consists of senators, one from each town or city, and the lieutenant-governor. The governor presides therein (and in his absence the lieutenant-governor), and has a casting vote only. The house consists of members not to exceed 72 in number, elected in ratio of population, but every town is entitled to at least one representative, and not to more than twelve. The convention of the two houses is styled the Grand Committee, and is presided over by the president of the Senate. There are two sessions of the General Assembly every year, one at Newport, on the first Tuesday of May, and the other at South Kingston, on the last Monday in October, every two years, and the intermediate years alternately at Bristol and East Greenwich, and this session adjourns every year to Providence.

The executive authority is vested in a governor. If no governor be chosen by the people, the Grand Committee elects one of the two popular candidates having the highest number of votes, and so in respect of the election of the lieutenantgovernor. The governor has not the usual veto on the acts of the legislature, nor may he grant pardons, but except in cases of impeachment he has power to grant reprieves. If the office of governor be vacant, the lieutenant-governor, and after him the president of the Senate pro tempore, acts as governor.

Every elector is qualified to hold the office for which he may be qualified to vote.

Judicial powers reside in a Supreme Court and Courts of Common Pleas. The Supreme Court consists of a chief and three associate judges, who are appointed by the Grand Committee, and hold office until they are removed by a resolution of two-thirds of both houses. On this court alone may chancery powers be conferred. The Courts of Common Pleas, formerly held by a judge of the Supreme Court and two associate justices, elected for each county, are now held by a Supreme Court judge sitting alone-the associate justices of that court dividing the duty among themselves.

The financial statement of the treasurer, for the year 1849-50, exhibits the receipts into the public treasury at $\$ 161,649$. and the expenditures at $\$ 161,414$-excess of receipts, $\$ 235$. The chief sources of income are, the bank tax $\$ 33,669$, the State tax $\$ 17,084$, public deposits $\$ 34.326$, etc. The principal expenditures are those for executive, legislative, and judicial support, and several amounts paid for the support of schools, etc. Properly speaking, Rhode Island has no public debt.

The State militia, in 1850, consisted of an aggregate of 15,037 men of all arms, of which 71 were commissioned officers, and 14,966 non-commissioned officers, musicians, artificers, and privates. Of the commissioned officers 6 were general officers, 16 general staff officers, 30 field officers, etc., and 19 company officers. The governor is exo officio commander-inchief, and all persons between 18 and 45 years of age, except those excused from military duty by law, are subject to enrollment.

The State, within its own borders, has no institutions for the support and education of the deaf and dumb, and blind; but an annual appropriation is made for these purposes, amounting to $\$ 2,500$, which is expended in furnishing facilities for such afflicted persons in the institutions of the adjoining States. The insane are provided for in the Butler Hospital for the Insane, at Providence, and the 1st.Jan., 1551, there were in the establishment 113 patients - 50 males and 63 females.

Federal representation.-In accordance with the law of the 23d May, 1850, apportioning representation, Rhode Island sends two members to the National Congress.

Edrucation-The school fund proper, which is invested in bank stock, amounts to $\$ 51,300$ : and besides the interest on this sum, the following are appropriated to the support of common schools: the interest of the State's part of the U. S. deposit fund, and the proceeds of the militia commutation tax collected in the towns. The whole number of school districts in the State, in 1850, was 882, of which 281 owned schnol-houses. There had been expended on school-houses, in the last past six years, $\$ 148,224$. Number of persons under 15 years of age, 47,557 ; number attending school, 24,442 , and verage attendance, 13,152. Number of teachers, 509-male 239, and female 270. Moneys received from public funds in 


\section{RHODE ISLAND.}

155n, $\$ 34,3 \nmid \$ 71$; and raised by towns, $\$ 50,33270$-total, $\$ 9691354$. Expended for schools, $\$ 95,291$ 16, and for sehoolhonses, $\$ 19,070$ 81. In June, 1551, the schnol liws were revisel and consolidated, and in many respects tnuel improved. Academies, grammar, and other private schools, are numerous. The chief eollegiute institntion of the State is I3rown University (Baptist), at Providence, founded 1764. It is one of the most respectable and flourishing institutions of the State. In 1850 it had 10 professors, 195 students. and 1,765 alumni, of which number 460 were in the ministry. It has valuable Jibraries of 31,000 volumes, a museum, cabinet, philosophical apparatus, etc. It was originally localed in Warren, but in 1770 was removed to Providence. The number of adults in the State who can not read and write is 3,744 .

Pudulic Libraries. -5 social libraries $-25,104$ volumes; 1 college $-24,000$ volumes; 2 students' $-7,600$ volumes ; 2 scientific and historical-3,000 volumes; 35 public school-19,637 volumes. Total-45 libraries, and 79,311 volumes, - Report of Libr. Smithsonian. Institute, 1851.

Periodical Press.-The whole number of periodicals published in the State, in 1850, was 19, of which 8 advocated "whig" principles, and 4 those of the democratic party. Seven were neutral in polities, or devoted to literature, religion, etc., including those the character of which has not been ascertained. Of the whole number, 5 were issued daily, circulating at each issue 9,750 copies, or $3,032,250$ copies annually ; 2 semi-weekly, circulating 2.000 copies, or 208,000 annually 12 weekly, circulating 14,225 copies, or 739,700 aunually. Total copies at each issue, 25,975 , or $3,979,950$ copies annually. The papers as published in the counties are-Bristol, 2 weekly; Kent, 1 weekly; Newport, 2 daily and 3 weekly; and Providence, 3 daily, 2 semi-weekly, and 6 weekly. The dailies are published in the cities of Newport and Providence.

Religious Denominations. - The statisties of the severul religious denominations in the State were, for the year 1850 , as follows:

\begin{tabular}{|c|c|c|c|c|c|c|c|c|c|c|c|}
\hline $\begin{array}{l}\text { Enomina. No of } \\
\text { tims. Clutrclies. }\end{array}$ & $\begin{array}{l}\text { Church } \\
\text { accom. }\end{array}$ & $\begin{array}{l}\text { Value of } \\
\text { Property. }\end{array}$ & $\begin{array}{l}\text { Dennmina- } \\
\text { tions. }\end{array}$ & $\begin{array}{l}\text { No. of } \\
\text { hurche: }\end{array}$ & $\begin{array}{l}\text { Churel } \\
\text { accorn }\end{array}$ & $\begin{array}{l}\text { h Value of } \\
\text { h. Property. }\end{array}$ & $\begin{array}{l}\text { Denomina- } \\
\text { tions. }\end{array}$ & $\begin{array}{l}\text { Nn: } \\
\text { Cluturit }\end{array}$ & $\begin{array}{l}\text { Church } \\
\text { acerom. }\end{array}$ & & $\begin{array}{l}\text { Value of } \\
\text { Pruperty }\end{array}$ \\
\hline apt ist.... 100.. & $40.131 \ldots$ & $\$ 366.30$ & Germ n Ref. & 一 & - & $. \$-$ & R. Catholic. & . 7 & 7,300 & & $\$ 72.5$ \\
\hline$\ldots$ & & & Jew & 1 & 300 & 1,000 & & & 325 & & \\
\hline at'l. 21. & 11.70 & $17 \mathrm{~s}$ & & 一 & - & - & & - & - & & - \\
\hline ค.. - & - & - & M1 & - & 一 & - & Unic & & 150 & ". & \\
\hline 26. & 11,6 & 24 & & 23 & 9,310 & 102,900 & Unit & 4 & 50 & .. & 26,04 \\
\hline .. & & & & 一 & 一 & 一 & & . & 30 & &, 00 \\
\hline & 6,870 & 57,800 & n. & - & - & - & 3. & 2 & 50 & & 6 \\
\hline
\end{tabular}

-ir all 221 churches, accommodating 98,736 persons, and valued at \$1,252,900. The State forms the Protestant Episcopal diocese of Rhode Island, and constitutes a portion of the Roman Catholic diocese of Hartford.

Prupe ism and Crime.-The whole number of paupers relieved or supported from the publie funds for the year ending 3nth June, 1550, was 2,560 , of which 1,115 were native and 1, 145 foreign born; and the whole number on the rolls at the date specified was 696-492 natives and 204 foreigners. Total cost of support, $\$ 45, \$ 37$. The State Prison is located at Proviclence. The whole number of convicts in confinement on the 30th September, 1849, was 25-27 males and 1 female; ermmitted during the next year, 23 ; discharged-by expiration of sentence 3 , and by the General Assembly 11-leaving in prison, at the end of the official year, 1550,37 prisoners, all males. The convicts are chiefly employed in shoemaking. Income of prison, $\$ 3,96456$, and expenditure, $\$ 9,42743$. The number of persons in Providence jail, confined at the suit of the State, was 66, and are employed principally in the manufacture of cabinet-ware.

Iístorical Sketch,-Roger Williams was the first white settler within the present limits of Phode Island. Expelled from Massachusetts for maintaining opinions for which the minds of men were not yet prepared, he sought refuge in the willtrness, and after habiting with the Indians for many weeks, he descended the Pawtucket Piver, and turning round Fox Point, slaked his thirst at a spring on the bank, and afterward erected his habitation near by. In grateful acknowIedgment of "God's merciful providence to him in his distress," he called the place Providence.

Ile foumd the land on which he had seated himself within the territory of the Narragansett Indians, and in 1636 he purchased it of their chiefs. Many soon settled around him. It was one of the charges against him in Massachusetts that he had avowed the doctrine that "to punish a man for matter of conscience is persecution." In his exile he adhered to that doctrine; he weleomed all that came, and the patriarch of the seltlement would allow no interference with religious opinions. The charter of Maryland was the first to sccure liberty of enscience to all Christian sects-the charity of Roger Williams embraced Jews, Mohammedans, and all the heathen. His benevolence was not confined to his civilized brethren; he lahored to enlighten, improve, and eonciliate the savages. He learned their language, traveled among them, and gained the entire confldence of the chiefs. He had often the happiness, by his influence over them, of saving from injury the colony that had proclaimed him an outlaw and driven him into the wilderness.

In 163S, two years after the expntsion of Williams, William Coddington and seventeen others, being persecuted for religions heresies in Massachusetts, followed him to Providence. By his advice they purchased from the Indians the island of Aquetner, now called Rhode Island. and removed thither. Coddington was chosen their ehief magistrate. Pursuing the same liberal policy which distinguished the settlers at Providence, numerous emigrants from the neighboring colonies were attracted to the settlement.

When the New England colonies, in 1643, formed their memorable confederacy, Rhode Island anplied to be admitted a member. Plymuth asserting that the settlement was within her limits, it was deeided by the commissioners that by sulmmitting th the jurisdiction of that colony she would be entitled to all the advantages of the Union. These conditions were rejected, and Rhode Island continued in separte independence. In this year Williams was sent to England as agent for the two settlements, and the next year obtained a patent from the Parliament, by which the towns of Providence, Newport, and Portsmouth were incorporated, with the power of governing themselves. In 1647 all the freemen. met at Portsmouth, enacted a code of laws, and established a civil government. An Assembly was constituted, to consist of six representatives from each town; and the execulive and chief judicial power was vested in a president and four assistants. Town courts were established for small causes, with an appeal to the president and assistants.

The Executive Committee of Parliament had given Coddington a commission to govern the islands in the bay. This interfered with the patent which had been granted to Williams, and threatened the dismemberment of the colony. In 1651 he and John Clarke were appointed agents, and sent to England to persuade the committee to revoke the commission. In this they succeeded, through the influence of Sir Harry Vane, who had been of great assistance to Williams in 1643 in procuring the eharter. Williams returned to Rhode Island, but Clarke remained in London, and long acted as the faithful agent of the colony. 
Upon the application of the inhabitants, the KKing in 1663 granted a charter, incorporating the colony of "Phode Island and Providence Plantations." It declared that no person should be molested or called to account for any difference in matters of religion. For the government of the colony it vested the supreme power in an Assembly, to consist of a governor or deputy governor, ten assistants, and representatives from the several towns, all to be chosen by the freemen.

The benevolent policy of Williams secured to the colony an almost total exemption from Indian hostilities; he continued to reside at Providence, ever active in the service of the people, sometimes their president, and at others as assistant or representative, until the period of his death, in 1683 . In his lifetime he was beloved of his people, and in his death his memory is held sacred as the founder of a prosperous State.

When Sir Edmund Andros was made governor of New England in 1685, he dissolved the charter government of the colony, and appointed a council to do his bidding; after he was depnsed and sent to England, the freemen met at Newport and re-established the ancient order of things. All the officers who three fears before had been displaced, were reinstated, and all accepted but Walter Clarke, who had been re-elected president. In his stead the A'ssembly appointed Henry Bull, a Quaker, the only one living who came with Coddington in 1638.

From this period to the commencement of the American Revolution, the history of Rhode Island is barren of events. Fortunate in living under a well-regulated government, and possessing great advantages in commeree, the inhabitants, if they played no distinguished part in the drama of life, were prosperous and happy. We find it recorded that in 1730 the population was about 18,000 , and that in 1740 it was 35,000 . In the last-mentioned year three hundred men were voted for an expedition into Canada, projected by the British government.

When the Stamp Act was attempted to be imposed, Rhode Island was as hostile to the purpose as any other colony; delegates were sent to the Continental Congress in 1765 , and a general association was entered into against the use of stamps. The subsequent proceedings of the British were resisted with equal constancy. In 1774, when the British prevented the exportation of military stores from England, Rhode Island selzed the cannon in the public batteries, and the Assembiy passed resolutions for arming the people. Every action on the part of this province was on the popular side, and from her exposed situation she was made to feel the hate of the common enemy. In December, 1776, Clinton and Parker, with strong forees, sailed from New York for the purpose of oecupying Phode Island. The American forces, unable to resist, withdrew on the approach of the fleet, and the squadron of Commodore Hopkins, and a number of privateers, found themselves blockaded in the harbor of Providence. General Sullivan, aided by the French ships of war, made several unsuccessful attempts to dislodge the British, and in 1778 laid siege to Newport, but was obliged to abandon the attempt. During the retreat an engagement took place at Quaker Hill, the result of which was indecisive. In October, 1779 , the British troops were withdrawn; and in 1780 a body of French, under Rochambeau, arrived at Newrport in a squadron under De Ternay. Clinton, on hearing of their arrival, embarked 6,000 men with the hope of surprising them, but the project was ultimately abandoned. From this period Rhode Island was unmolested, and the inhabitants again resumed their commercial pursuits.

F. Rhode Island was not represented in the convention that formed the Constitution in 1787 , and this State evinced for the time a determined hostility to the new frame of government. She was the last of the original States to ratify this instrument; and it was not until the May, 1790, that her acquiescence was secured.

Little is recorded of its history from this period until 1812. During the ensuing contest with Great Britain, the majority of the people were hostile to the policy of the General Government, and adopted the system of action of the neighboring States, lending no aid to the national arms. Delegates were sent to the memorable Convention at Hartford, and united in the report made by that body. With the exception of the occupation of Block Island by the enemy in 1813, this State remained unmolested during the war.

Up to the year 1844, the Charter granted by Charles II. was the only constitution of the State, though for more than twenty years before that date efforts had been made to obtain from the General Assembly permission to form a new and more perfect frame of government, but without effect. In the spring of 1840 an assaciation was formed, the object of which was to secure the right of suffrage to every adult white male citizen of the United States resident in the State; and in 1841 this association took the responsibility of ealling a convention to form a State constitution in accordance with their peculiar views. Such convention was held, and such constitution formed and submitted to the people, but on account of the informality under which it was prepared, only a portion of the penple, recognized or voted on the question. Those who did vote being in its favor, a majority was declared, and the instrument acknowledged by its partisans as the supreme law of the land. The legal government, however, refused to recognize it, and in the mean time had taken measures for the calling of a convention for a similar purpose; and by this convention another constitution was prepared and adopted by two-thirds of the inhabitants. Two separate forms of government were now recognized by two different portions of the people. The Suffrage Party-as the illegal party called themselves-proceeded to elect their governor and public officers, and claiming them as legitimate officers, their government was organized at Providence, under the protection of an armed force, on the $3 \mathrm{~d}$ May, 1841. Owing to the public excitement, the government under the legitimate constitution had not been able to organize, and consequently the old charter government met as usual at Newport, on the 4th May, 1842. On the 18th of the same month Thomas N. Dorr, the governor elected by the "Suffrage Party," attempted to capture the State arsenal at Providence, but failed in the attempt. Desirous of meeting the views of all parties, the General Assembly provided for another convention to form another constitution; and about the same time another attempt was made to overthrow by force of arms the charter government. The insurgents, led by their soidisant governor, took up a position at Chepachet, from which, however, they were easily dislodged by the State troops, and completely dispersed. The convention last provided for by the charter government, met in September, and on their constitution being submitted to the popular vote, it was almost unanimously adopted, the "Suffrage Party" protesting against it, yet subsequently voting under it.

The attempt on the State made by the Suffrage Party, is one of the most audacious violations of the sanctity of popular institutions on record; and well did the abettors of such treason deserve the severest penalties. Dorr was imprisoned for sererat years, but was finally released, he having become a broken-down and deserted man, and the shunned of all good citizens. His name will go down to posterity on the same page as those of Burr and Arnold - a warning to all traitors.

Providexce, Newport, Soutin Kingstam, Bristol, and East Greeximich, are the political capitals of the State. There are two sessions of the General Assembly every year: one at Newport on the first Tuesday of Mar, and the other on the last Monday of October once in two years at South Kingston, and the intermediate vears alternately at Bristol and East Greenwich; and this second session adjourns every year to Providence. 
Riblets, p. o., Richland county, Ohio: 59 m. N. N. E. Columbus.

Rice, t. and p. o., Cattarangus county, $N . \bar{X} .: 240 \mathrm{~m}$. W. by S. Albany. Drained by affluents of Alleghany r., the principal of which furnishes good water-power. Surface elevated and rolling; soil excellent for farming. Population 906.

Rrczвoro, p. v., Liberty connty, Ga.: 146 miles S. E. Milledgeville, on S. bank of North Newport r., which is navigable for sloops to this place. It contains about 160 inbabitants.

Rioe Crtx, p. v., Kent eounty, R. I.: $27 \mathrm{~m} . \mathrm{N}$. W. by W. Newport.

Rice Creek, p. o., Calhoun co., Mich. : 35 m. S. S. W. Lansing.

RicE"8, sta., M'Minn co., Tenn.: on the East Tennessee and Georgia R. R., $7 \mathrm{~m}$. N. Charleston.

Rice's Landing, p. o., Greene co., Penn. : $142 \mathrm{~m}$. W. by S. Farrisburg.

Rice's Store, p. o., Westmoreland co., Virg.: 53 m. N. E. Richmond.

Ricetille, p. v., Hanenck county, Ariss.: $2 \mathrm{~m}$. E. from Pearl r., 106 m. S. by E. Jackson.

Richville, p. o., Monmouth co., N. Jer.: on W. side of

Clay Point cr., near its junction with Nevisink river.

Riceville, p. v., Crawford co, Penn, ; on E. side of head branch of Oil cr., $181 \mathrm{~m}$. N. W. Harrisburg.

Riceville, p. 0., Pittsylvania county, Firg.: 120 mile S. W. by W. Richmond.

Ricilardsos, p. o., Vermillion co., $M u_{*}$ : on E. bank of

Iittle Vermillion $x_{\text {. }}, 110 \mathrm{~m}$. E. by N. Springfield.

Ricirardson's, p. o., Montgomery co., Tenn.: $42 \mathrm{~m} . \mathrm{N} . \mathrm{W}$. Nashville.

Richardson"s Creet, p. o., Union co., N. Car. : $101 \mathrm{~m}$. W. S. W. Raleigh.

Rromarusontilie, p. v., Edgefield dist., S. Car.: $46 \mathrm{~m}$. W. Columbia,

Richardosville, p. vo, Culpepper co., Virg.: 69 m. N. N.W. Richmond.

Ricmandstilly, p. v., Jefferson county, Penn.: $112 \mathrm{~m}$. W. N. W. Harrisburg.

Ricuborougr, p. v., Bueks county, Penn.: 91 miles E. Harrisburg.

Ricneurg, p. o., Alleghany co., N. $\bar{Y}$ : : on $\mathrm{E}$. side of branch of Oswaye cr., $228 \mathrm{~m}$. W. by S. Albany.

RICI CREEK, p. O., Logan county, Firry : 251 miles W. Richmond,

RiclfField, $t$, and p. 0. , Genesee co., AFch. : 59 m. E. N. E Lansing. Surface rolling: soil dry sandy loam. Drained by Flint $\mathbf{r}$, which furnishes mill-sites. Pop. 4S2.

Richrietd, to and p. o., Otsego co., $N, Y_{0}: 70 \mathrm{~m}$. W. by N. Albany. Drained by small branches of Cnatilla $r$, and outlets of Canaderaga lake, which lies on its $\mathbf{E}$. border. Surface elevated and uneven: soil sandy and calcareus loam. The industry of the $t$. is generally devoted to agriculture, and there are some small manufactures. Population 1.502.

Rirchrietd, t. and p. ₹., Summit co, Ohio: $110 \mathrm{~m}$. N. E. Columbus. Surface elevated, and moderately uneven; snil fertile, and well cultivated. Drained by creeks of Cuyahoga $r$. The $r$. contains various mechanic shops and about 200 inhabitants. There are other small settlements in the town. Pop, of t. 1,262.

RICHEIELD, t, Henry co, Ohio: drained by Beaver cr, of the Maumee. Pop. 136.

Ricmfield, p. o., Juniata county, Penn.: $32 \mathrm{~m}, \mathrm{~N} . \mathrm{W}$. Harrisburg.

Riohfield SpRTigs, v. and p. o., Otsego co., $N, Y_{\text {. }}$ : at head of Canaderaga lake, $68 \mathrm{~m}$. W. by N. Albany. The v contains about 300 inhabitants, and here is a celebrated sulphur spring.

RIOMFord, t. and p. ₹., Tioga co., N. Y.: $128 \mathrm{~m}$. W. by S. Albany. Drained by East and West Owego creeks. Sur722 face uneven, with fertile valleys. The v. on East Owego cr. contains about 300 inhabitants. Pop. of t. 1,208.

Richrord, t. and p. o., Franklin co., Verm. ; on the Canada line, $47 \frac{1}{2} \mathrm{~m}$. N. Montpelier. Drained by Missisque r. and its branches. Surface mountainous; soil adapted best to grazing-along the streams is some good land. Population 1.074 .

Rron Fons, p. o., Davidson co., N. Car.: $90 \mathrm{~m}$.W. by N. Raleigh.

Ricr Brus, t. and p. o., Muskingum co., Ohis: 63 m. E. Columbus. Drained by branches of the Muskingum $r$. Surface various; soil fertile. Bituminous coal and numerous salt springs are found in the vicinity. Pop. of t. 1,495. Pirer Hill, p. O., Maury co.,Tenn.: 39 m. S. S. W. Nashville Ricriaxd county, $I l l$. Situate toward the S. E., and contains $312 \mathrm{sq}$. m. Drained by affluents of the Wabash, a tributary of the Obio $r$. Surface generally level; soil fertile. It has some prairies and some fine timber land. Farms 204; manuf. 3; dwell. 704, and pop.-wh. 4,002, fi. col. 10 -total 4,012. Capital: Olney, Public Works: Ohio and Mississippi R. R.

RionuAND county, Ohio, Situate N. eentrally, and contains $468 \mathrm{sq} . \mathrm{m}$. Drained by Olentangy $\mathrm{r}$. and branches of Mohiccan cr. Surface level; soil fertile, and well adapted to wheat, corn, etc. Agriculture is the leading pursuit. Good timber is found on the land. Farms 2,522; manuf. 1'18; dwell. 5,205, and pop.-wh. 30,584, fr. col, 45-total 30,S79. Capital: Mansfield. Public Works: Cincinnat, Cleveland, and Columbus R. R. ; Sandusky, Mansfield, and Newark R. R. ; Pennsylvania and Ohio R. R., etc.

RICnLAND district, S. Car. Situate centrally, and contsins $4 S 3 \mathrm{sq} . \mathrm{m}$. Drained by branches of Congaree and Wateree rivers, the former running along the S. W. border and the latter on the eastern. Surface generally level; soil fertile, and in some parts the land rery rich. Chief productions, cotton and Indian corn. Farms 513; manuf. 87; dwell. 1,588, and pop.-wh. 6,764, fr. col. 501, sl. 12,978-total 20,243. Capital: Columbia, Public Works: Columbia Branch R. R ; Charlotte and South Carolina, Greenville and Columbia R. R.; Camden Branch R. R., ete.

RicrlaxD county, Wisc. Situate toward the S. W., and contains 756 sq. m. Drained by head branches of Baraboo and Pine rivers, Pacific and Mill creeks, all antuents of W isconsin $r$, which forms its southern border. Surface generally level; soil fertile and adapted to grain. It is well worded, and contains some minerals. Farms 58; manuf. 4; dwell. 178, and pop.-wh. 902, fr. col.1-total 903. Capital: Richland City.

Prchland, p. o., Jefferson co., Ark.: on S. bank of Arkansas r., $46 \mathrm{~m}$. S. E. by S. Little Rock.

Riomlaxd, p. v., Stewart county, Ga.: 114 miles S. W. Milledgeville.

Pirmland, p. v., Sangamon co, $T l l_{2}$; on the N. side of Prairie er, $10 \mathrm{~m}$. W. N. W. Springfield.

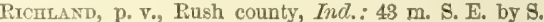
Indianapolis.

RichlaND, p. v., Keokuk co., Ia.: 40 m. S. W. bJ S. Iowa City. Pop. 239.

Pichlaxi, p. v., Holmes county, Miss.: $49 \mathrm{~m}$. N. by E. Tackson. Drained by a creek of Big Black river.

Richl $A N D$, t. and p, o, Kalamazoo county, Ifich: : $50 \mathrm{ma}$. S. W. by W. Lansing. Drained by creeks of Kalamazoo $r$. and Gull lake, on the N. E. corner. Surface level prairie. Pop. 795.

Picmlaxd, p. v., Greene co., Mo.: 104 m. S. W. by S. Jefferson City.

Richland, t., p. V., and eap. Oswego co., N. Y.: $140 \mathrm{~m}$. W. N. W. Albany, Drained by Salmon r. and other small streams, flowing into Lake Erie. Surface diversifed; soil moist clay loam. The county buildings are in the $\mathrm{v}$. of Pulaski. The manufactures of the $t$. are considerable, and its trade flourishing. Pop. 4,079. The Watertown and Rome R. R. passes through it, $42 \mathrm{~m}$. from Rome. 
Richlasd, sta., Logan co., Ohio : on Mad River and Lake Erie R. R., 51 m. N. W. Columbus, 92 m. from Sandusky, $66 \mathrm{~m}$. from Dayton.

Richland, t. Allen co., Ohio: $78 \mathrm{~m}$. N. W. Columbus. Drained by creeks of Blanchard's Fork. Surface elevated and rolling; soil rich and fertile. It occupies the N. E. corner of the co. Pop. 990.

RichlaND, t., Belmont co., Ohio: $12 \mathrm{~m}$. W. Wheeling, $108 \mathrm{~m}$. E. Columbus. Drained by. M'Mahon's and other creeks. It is a fine farming $t_{\text {. }}$, and contains St. Clairsville, the county seat of justice. It is erossed by the railroad from Wheeling westward. Pop. 4,366.

RienlaND, t., Clinton co., Ohio: $49 \mathrm{~m}$. S. W. Columbus. Drained by Rattlesnake, Todd's, and other creeks. Surface undulating, and soil rich and fertile. The Cincinnati and Zanesville R. R. crosses its S. part. Salem and Claysville are villages on the Washington and Wilmington turnpike. Pop. 1,975 .

RrCHLAND, t., Darke co., Ohio: $84 \mathrm{~m}$. W. Columbus, Drained by Stillwater ereek and its tributaries. Surface undulating; soil rich and fertile. The Bellefontaine and Indiana $R_{0} \mathrm{R}$. crosses it east and west. Pop. 798.

Ricrlayd, t., Defiance co., Ohio: 149 m. N. W. Columbus. Drained by Maumee r., which runs through it. Surface low and level; soil fertile. Pop. 702. The Wabash and Erie Canal, and the Sandusky and Fort Wayne R.R. pass through the town.

Riculard, t., Fairfield co, Ohio:33 m. E. S. E. Columbus, Drained by Rush cr. Surface elevated and undulating, and soil very productive. The Cincinnati, Zanesville, and Wheeling $\mathrm{R} . \mathrm{R}$. crosses it in a N. E, and $\mathrm{S}, \mathrm{W}$. direction. Pop. 1,77\%.

Richland, t. Holmes co, Ohio: $58 \mathrm{~m}$. N. E. Columbus. Drained by a branch of Killbuck er. and Walhonding $r$. Surface undulating; soil rich and prodnctive. Pop. 1,349.

Ricmlaxd, t., Vinton co., Ohio: 54 m. S.S. E. Colunbus. Drained by a branch of Racconn cr., and also a creek of the Scioto. The land is undulating and fertile. Pop. 1,193.

Richland, t., Wyandott con, Ohio: $66 \mathrm{~m} . \mathrm{N}$. W. Columbus. Drained by creeks of Blanchard's fork of the Maumee. Surface undulating; soil rich and fertile. The Mad River and Lake Erie R. R. passes through it in a N. E. and S. W. direction. Pop. 599.

RicituAND, p. v., Richland county, O7io: 58 m. N. N. E. Columbus.

RichlaND, p. v., Giles co., Tenn. : on branch of Elk r., a tributary of the Tennessee, $55 \mathrm{~m}$. S. Nashville.

Richland, p. o, Tazewell co., Virg.: $240 \mathrm{~m}$. W. by $\mathrm{S}$. Richmond.

RicmlAND creek, Ark: rises in the interior of Madison Co. flows W., and enters White $\mathrm{r}$. in Washington county.

Richla nd Crty, p. v., and cap. Richland co., Wisce : on

Pine r., $53 \mathrm{~m}$. W. N. W. Madison.

Pichland Crossings, p. o., Navarro co., Texo: $134 \mathrm{~m}$. N. N. E, Austin City.

Pichland Grove, p. o., Mercer co., Ill. : 113 m. N. N. W. Springfield.

Richlaids, p. 0, Onslow county, N. Car.: $\$ 4$ m. S. E. Raleigh.

Richuandtown, p. v,, Bucks co., Penn. : 75 m. E. by N. Harrisburg.

Rrchmond county, Ga. Situate E., and contains 313 sq. m. Drained by branches of Savannah river, which runs on its N. E. border, and of Brier creek, which forms its S. W. boundary. Surface hilly; soil fertile, and is in general a fine deep mold, well adapted to the growth of cotton, wheat, and corn. Of fruit-trees, apple, pear, peach, plum, etc., grow well, and produce largely. Pine and other timber is found on the land. Farms 272; manuf. 56; dwell. 1,556, and pop.-wh. 8,152, fr. col. 282, sl. 7,812-total 16,246. Capital: Augusta. Public Works : Georgia P. R.; Augusta and Waynesboro' R. R., ete.

Prспмомp county, $N, Y$. Situnte S, and includes Staten
Island. It contains $63 \mathrm{sq} . \mathrm{m}$., and is divided into 4 townships. Surface hilly and broken; soil in general sterile, but there is much good land. Chief products wheat and Indian corn. On the coast are some valuable fisheries. It contains some beds of iron ore, and other minerals. In the alluvial portions marine fossils have been found. Constant communication is kept up with New York by steamboats, which run many times daily. Fishing is much pursued by the inhabitants. Farms 212 ; manuf. 37 ; dwell. 2,334, and pop.wh., 14,474, fr. col. 587-total 15,061. Capital: Richmond. Public Works: Staten Island R. R., etc.

RICHMOND county, N. Car. Situate S., and contains 645 sq. m. Drained by branches of Little Pedee river, and other small streams. Surface even: soil generally fertile, and well adapted to the growth of cotton, which is much attended to. Staples, cotton, Indian corn, and tobacco. Farms 496; manuf. 1 ; dwell. 949, and pop-wh. 4,890, fr col. 224, sl, 4,704-total 9,818. Capital: Rockingham.

Rrommond county, Virg. Situate N. E, and contains 196 sq. m. Drained by tributaries of Rappahannock river. Surface level; soil fertile. Chief products, wheat and Indian corn. Farms 336 ; manuf. 4 ; dwell. 805, and pop.-Wh. 3,462, fr. col. 709, sl. 2,277-total 6,448. Capital: Warsaw.

Rrcrmoxd, p. o., Dallas county, Ala.: 55 miles $W$. Montgomery,

Rrchmond, p. v., Wayne co., Ind.: on E, bank of East Fork of Whitewater r., $69 \mathrm{~m}$. E. Indianapolis, $4 \mathrm{~m}$. from Ohio State line. This very flourishing $\mathrm{v}$. contains a large number of mills and factories, a branch of the State bank of Indiana, and does a large business with the fertile agricultural district surrounding it. Two newspapers are published weekIy, "Palladium" (whig), and "Jeffersonian" (dem.) The Indiana Central R.R., and the Richmond and Newcastle Iu. R. here connect with several railroads from Ohio. Pop. about 3,000 .

Rrorrond, p. o., Washington county, Ia. : $28 \mathrm{m.} \mathrm{S.} \mathrm{S.} \mathrm{W.}$ Iowa City.

Prcurosd, p. v., and cap. Madison co., $\bar{L} y_{0}:$ on a small branch of Kentucky r., $45 \mathrm{~m}$. S. E. Frankfort. Contains a court-house and jail, and about 1,000 inhabitants. The "Whig Chronicle" is published weekly.

Ricimond, p. v., and eap. Madisou parish, $L a .: 129 \mathrm{~m}$ N. Baton Rouge, on W. side of Roundaway bayou, at its junction with Brushy bayou. It contains the court-house and a few dwellings. The "Madison Journal" (neut.) is published weekly.

RICHMOND, p. 0., M·Henry county, Tll.: 201 m. N. N. E. Springfield, $1 \mathrm{~m}$. from Wisconsin State line.

Richmond, t. and p. v., Lincoln con, Me.: $16 \mathrm{~m}$. S. by W. Augusta. Drained by a mill-stream which falls into Kennebee $r$. at Merrymeeting bay. It has some navigation, and vessels are built here. The $\mathrm{v}$, is situate in the $\mathrm{S}$. W. part of the town, and on the $\mathrm{E}$. line the Portland and Kennebec R. R. passes along the river. Pop. of t. 2,056.

Ricumrond, t. and p. o., Berkshire con, MFass. : $117 \mathrm{~m} . \mathrm{W}$. Boston. Drained by branch of Housatonic $r$. It lies in a fertile valley between two hills, and is well cultivated. The Western R. R. passes through the town. Pop. 1,649.

Ricumond, t. and p. o., Macomb county, Mich.: $89 \mathrm{~m}$. E. Lansing. Surface of $t$. rolling, and heavily timbered; soil fertile. Drained by Belle r., by E. Fork of Clinton br. of Red r., and by head branches of Sonth $r_{\text {, }}$, the two latter flowing into Lake St. Clair. Pop. about 1,000 .

Rrchmond, p. v., Itawamba co., litss. : on a creek of Tombigbee river, $158 \mathrm{~m}$. N. W. by N. Jackson.

Rrchrond, p. vo, and eap. Ray co., MFo. on the S. side of Elkhorn cr., $111 \mathrm{~m}$. W. N. W. Jefferson City. It contains a court-house, jail, and about 500 inhabitants.

Ricmiond, t, and p. o., Cheshire co., N. Hamp.: $49 \mathrm{~m}$. S. W. Concord. Drained by branches of $A$ shuelot river Surface generally level; soil of average fertility. Pop. 7,128, Ricimond, p. v., and eap. Richmond county, $N_{*} \boldsymbol{Y}_{\text {: }}$ : neal the centre of Staten Island, $18 \mathrm{~m}$. S. W. New York city 
This is a pleasant village and contains the court-house, jail, 2 churches, and several stores, and about 40 dwellings.

Richarosd, p. v., Jefferson co., Otio: $2 \mathrm{~m}$. W. Ohio $x_{\text {., }}$ 117 m. E. N. E. Columbus. The "R. Clipper" (f. soil) is published weekly. Pop. about 600 .

Richmond, p. v., Northampton co., Penn. : on a small stream, $2 \mathrm{~m}$. W. of the Delaware, about $3 \mathrm{~m}$. above Belvidere, 97 m. E. N. E. Harrisburg.

Ricurond, p. v., Bedford county, Tenn. : 49 m. S. by E. Nashville.

Ricumond, p. v., and eap. Fort Bend county, Tex.: on S. bank of Brazos r., 130 m. E. S. E. Austin City.

Rrcemond, t. and p. o., Chittenden co., Verm.: $20 \mathrm{~m}$. W. N. W. Montpelier. Drained by Oninn r., which makes its $\mathrm{N}$. border, and Huntingdon r., which passes through it, both affording water-power. Surface generally uneven, with fertile fiats on the streams. At the centre is a church having 16 sides, with a neat steeple rising from the middle, and occupied by several denominations. The $\mathbf{v}$, is on the S. side of Onion r., and on the N. side the Vermont Central R. R. traverses the valley. Pop. of t. 1,453.

Richmond, p. city, port of entry, and cap. Henrico county, Virg.: and eapital of the State of Firginia ; is situated on the N. E. bank of James r., at the lower falls at the head of tide water. Lat. (Capitol) $37^{\circ} 32^{\prime} 17^{\prime \prime} \mathrm{N}$.; long. from Greenwich $77^{\circ} 27^{\prime} 28^{\prime \prime} \mathrm{W}$., and from Washington $00^{\circ} 25^{\prime} 58^{\prime \prime} \mathrm{W}$. Distance by the most direct R. R. from Washington, $130 \mathrm{~m}$. ; from Baltimore, $165 \mathrm{~m}$. ; from Philadelphia, $266 \mathrm{~m}$.; from New York, $344 \mathrm{~m}$.; from Boston, $580 \mathrm{~m}$; from Raleigh, $174 \mathrm{~m}$; f from Wilmington, $248 \mathrm{~m}$.

The situation of Richmond is highly picturesque. The eity is divided into two unequal parts by a valley, through which passes the Shockoe creek to enter James $r$. It is chiefly built upon the hills and more elevated grounds on either side of this depression, which have a beautiful variety of surface, and afford in many parts highly picturesque situations for dwellings and for public ediffices. Splendid views of the city and surrounding country are presented from different points, each varying the scene. The soil is red clay. The river flows over a bed of granite, of which there are inexhaustible quarries on its banks, extensively used for building and other purposes. The city is regularly laid out with streets crossing at right angles. Its entire area embraces abuut $3 \frac{1}{3} \mathrm{sq} . \mathrm{m}$., of which the built portisn is about $3 \mathrm{~m}$. long, and $\frac{s}{2} \mathrm{~m}$. wide. The dwelling houses are generally neat and convenient, of brick and wood. Many private residences are very elegant and costly. The capitol occupies a very commanding situation on an elevated plain called Shockoe hill, in the W. division of the city. It stands in Capitol Square, a beautiful public ground containing abont 8 acres, ornamented with trees, grass plats, walks, etc. It is a spacious and elegant building, surrounded on 3 sides by a lofty and imposing portico, in the Ionic order. It contains a statue of Washington, the only one ever taken from life, executed by Houdon, a celebrated French artist, and erected in 1788; a bust of Lafayctte, etc. The City IIall, on Iroad Street, fronting Capitol Squarc, is an elegant edifice of Grecian architecture, with a portico at each end of 4 Doric columns. The Governor's House is at the $\mathbf{E}$. end of the square. The County Court-house is about $1 \mathrm{~m}$. from the capitol. The State Penitentiary, in the W. suburbs, is 300 feet long, and 110 broad, in the form of a hollow square, surrounded by extensive grounds. The Alms-house, a spacious building, is in the N. suburbs. The Armory is a large edifice 320 feet long by 280 feet wide. The Female Orphan Asylum is supported partly by the corporation, and partly by private muniflcence. There are about 25 churches, many of which are very handsome edifices. The Monumental F.piscopal church stanis upon the site of the IRichmond Theatre, which was destroyed by fire, Dec. $26 \mathrm{th}, 1811$, and whereby 66 white and 6 colored persons lost their lives. The congregation of the African church is oire of the largest in the Union.
The Medical Department of Hampden Sidney College, founded 1S38, in 1850 had 7 professurs, 90 students, and 40 graduates. The Virginia Historical and Philosophical Society was founded in 1881. St. Vincent's and Richmond colleges, near the city, are flourishing academies. In 1850 there were 15 newspapers and periodicals, viz, dailies, "R. Enquirer," "R. Whig," "Dispatch," "Times and Conpiler," "Herald," "Future Age," and "Republican;" weeklies, "Religious Herald," "Watchman and Observer;" monthlies, "Missionary Journal," "The Commission," "Baptist Preacher," "Southern Planter," "Literary Messenger ;" quarterly, "Historical Register."

The eity government is vested in the mayor, recorder, aldermen, and city council. The city is lighted with gas, and generally well paved; the markets are well supplied. The public water-works were commenced in 1830 , and cost about $\$ 120,000$. By two forcing pumps, worked by waterpower, 800,000 gallons of water in 24 hours are lifted from James r. into 3 reservoirs, containing each 1,000,000 gallons, thence distributed over the eity in pipes.

The principal manufactures are of tobacco, flour, iron, cotton and woolens. Water-powcr of unlimited extent is furmished by James $\mathrm{r}$., which within a few miles above the eity descends 80 feet. Of tobacco there are 35 to 40 factories, and 10 or 12 stemmeries, together employing about 2,500 blacks, and manufacturing 12 to 15,000 hhds. annually. Besides smaller mills, here are two of the most extensive flouring-mills in the world, "Gallego" and "Haxall," each running 20 or more pairs of stones, and capable of producing 800 to $900 \mathrm{bbls}$ of flour daily. There are 3 iron rolling-mills, foundries of cannon, etc., and an extensive nail factory on Belle isle, producing $75,000 \mathrm{lbs}$. of nails weekly. Four cotton mills work up nearly $3,000,000 \mathrm{lbs}$. of cotton per annum, and a woolen mill $600,000 \mathrm{lbs}$. of wool annually. Besides these, are large machine-shops, a paper-mill, etc.

There are three banks, with aggregate capital of $\$ 2,114,000$, 3 insurance companies, and 3 savings banks.

Four lines of railroad here connect, viz, Richmond, Frederick, and Potomac R. R., commencing at Aquia creek on the Potomac, $75 \mathrm{~m}$. long; Richmond and Petersburg R. R., $22 \mathrm{~m}$. long; the Central R. R. to Covington, and Danville R. R. completed to Kecseville, $73 \mathrm{~m}$. The James River Canal, completed in 1835 to Lynchburg, $146 \mathrm{~m}$., and in 1552 to Balcony Falls, is the principal channel of trade with the interior.

The following statement exhibits the amount of tonnage, and its estimated value, imported into Richmond on the James River and Kanawha Canal, during each of the 5 years $1818-52$, with its freight and tolls:

\begin{tabular}{|c|c|c|c|}
\hline $\begin{array}{c}\text { Year endi::g } \\
\text { U.t. : : } 1 .\end{array}$ & $\begin{array}{l}\text { No. of } \\
\text { Tors. }\end{array}$ & $\begin{array}{l}\text { Estimated } \\
\text { value, }\end{array}$ & $\begin{array}{l}\text { Freights } \\
\text { and tolls. }\end{array}$ \\
\hline $1848 \ldots$ & $.125,054$. & $\$ 4,230,53218$. & $\$ 192,7503$ \\
\hline 1849. & $140,696 \ldots$ & $5,435,04666$. & 247,861 \\
\hline 1850. & $.137,589 \ldots$ & $6,123,86549 .$. & 213,741 \\
\hline 1851. & $.140,924 \ldots$ & 5,133, , $3362 \ldots$ & 184,839 \\
\hline $1852 .$. & $.153,377 \ldots$ & $7,145,83743 \ldots$ & 220,947 \\
\hline
\end{tabular}

\section{Total (1S48-52) 697,640 \$25,069,135 $38 \quad \$ 1,060,14065$}

The following table exhibits the amount of tonnage, with its value and freightage, imported into Richmond, on the Richmond and Petersburg $R$. R., during each of the 5 years $1848-52$

\begin{tabular}{|c|c|c|c|}
\hline $\begin{array}{l}\text { Year ending } \\
\text { Seyt ju. }\end{array}$ & Tonmage. & Estimated value. & Freight. \\
\hline $1548 \ldots$ & 20,301 . & . $\$ 632,55799$. & $\$ 18,36162$ \\
\hline $1 \leq 49 \ldots$ & 39 & $695 . \pi+240$. & 18,15971 \\
\hline $1850 .$. & $22,561 \ldots$ & $1,377,66545$. & 21,56083 \\
\hline $1 \leq 51$. & $19,533 \ldots$ & . $\quad S \$ 6,41240 \ldots$ & 18,31412 \\
\hline 1852. & 27.932. & $1,262,21885$. & 24,75289 \\
\hline & & $\$ 4, \$ 51,6$ & $\$ 101149$ \\
\hline
\end{tabular}

The following table exhibits the amount of tonnage, with its estimated value, and the freights and tolls on the same, 
imported into Riehmond during 1552 , hy the various worts of internal improvement leading into the eity:

$\begin{array}{lll}\text { Names of Compsnies. No. of Estimated } & \text { Freights } \\ \text { and tolls. }\end{array}$

James River, and ! ..153,877. .\$7,145,837 43. \$220,947 \$4 Kanawba $\mathrm{co}$.

R., Fredericksburg, \} , 4,507.. 2S5,000 00.. 19,25203 and Potomac R.R.

Richmond and Petersburg R. R.

Richmond and Danville P. R.

$27,932 \ldots 1,262,24885 \ldots 24,752$ S9

Virginia Central R. R. 17,450.. 1,000,000 00.. 55,9s9 20

Total.........256,9s7 $\$ 10,660,422$ 2S $\$ 358,56141$

The foreign export trade is chiefly in tobacco to all parts of Europe, flour and grain occasionally, and in flour to Brazil. The import trade direct from Europe, or other countries, is now inconsiderable, having gradually diminished with the increased facilities of New York, by her regular packets and steamers to Europe. The channel of the $r$. is winding, which, with the distance from the ocean, is a considerable impediment to navigation. Vessels drawing more than 10 or 11 feet water are prevented from coming up to the city by the bar, $7 \mathrm{~m}$. below it, and such load at City Point, Bermuda Hundred, or Port Walthall. On June 30,1850 , the total tonnage of $\mathrm{R}$. district was 8,455 tons. The registered tonnage was 3,161 tons, of which 1.5SS tons were permanent, and 1,573 tons temporary. The enrolled and licensed tonnage was 5,297 tons, consisting of 4:276 tons permanent, and 1,021 tons temporary, all of which were employed in the coasting trade. During the year previous, the number of elearances for foreign countries Was $69-24,321$ tons; no. of entrances do., 8-1,811 tons. Fessels buit during the year, 8 ( 1 ship, 7 schooners)1,479 tons.

The inspections of tobacen for several years are as follows: Years. Hl,ds, Years. Huds, Years. Hhds, Years. Hids, $1841 \ldots 18,267|1814 \ldots 19,147| 1817 \ldots 19.993 \mid 1850 \ldots 17,986$ \begin{tabular}{l|l|l|l|l}
$1812 \ldots .23,129$ & $1845 \ldots 21,902$ & $1818 \ldots .15,733$ & $1851 \ldots 15,678$
\end{tabular} \begin{tabular}{l|l|l|l|l}
$1813 . .22,829$ & $1846 \ldots 19,572$ & $1849 \ldots 18,803$ & $1852 \ldots 24,119$
\end{tabular}

In addition to which, from 10 to 16,000 hogsheads are here received from other inspections in the interior.

The following exhibits the inspections of flour of late zears:

Years, Bbls, | Years, Bbls, | Years, Bbls, I\$ $46 \ldots . .259,000 \quad 1545 \ldots . .190,000 \quad 1950 \ldots . .356,420$ $1847 \ldots . .159,100|1849 \ldots \ldots .276,900| 1851 \ldots \ldots$.

To which should be added 20 to 25 per cent. of inspections at Scottsville and Lynchburg, and brought to the Richmond market. The quantity of flour exported to Brazil for the year ending September 30,184S, was 74,425 barrels; 1849 , $128, \$ 80$ bbls.; $1550,65,280$ bbls.; $1851,98,245$ bbls.; 1852. 55.950 bbls. A considerable quantity of flour, destined for South America, is sent coastwise for re-shipment from New Iork, Baitimore, etc. The amount of other foreign shipments of flour in 1851, was $15,646 \mathrm{bbls}$, and increased in 15.52 to 19.122 barrels.

The coal trade is considerable, and steadily increasing. The best bituminous cosl is mined from $S$ to $20 \mathrm{~m}$. abore the city, and iron ore abounds in the country beyond. Regalar lines of steam packets run to Norfolk, Baltimore, and New Tork.

The proulation has increased within the last 10 or 15 Jears more rapidly than at any previous period. Of the prezent population, about two-fifths are blacks. Pop. in 1500 , $5,5 \% 37$; in $1310,9,785$; in $1820,12,067$; in $1830,16,060$; in $1840,20,153$; in $1850,27,483$. The exceedingly healtay location of the city rives it a very low annual rate of mortality. The cemeteries are noted for their beauty and their monuments.

Thr situ of Pichmond was first visited by white men in ¿Gis: the trimn was founcier in 1742 , and made the capital of the State in 1750 . In 1787 it contained about 300 houses. In 1794 the canal around the falls was completed, which has added so much to its commercial advantages: In 1811 , December 26 th, occurred the sad fire by which 72 persons lost their lives in the destruction of the Pichmond Theatre, among whom was the then governor of the State.

Directly opposite to Richmond are its suburbs of Manchester and spring Hill, which are connected with the eity by three bridges.

Ricruond, t. and p. o., Walworth county, Wisc.: $43 \mathrm{~m}$.

S. E. by E. Madison. Pop. 756.

Richuond Centre, p. o., Ashtabula co., Ohio: $168 \mathrm{~m}$. N. E. Columbus.

RicrmoND CoRNER, p. o., Lincoln county, $M \theta_{1}: 15 \mathrm{~m}$. S. Augusta.

Richmond Dale; p. o., Ross co, Ohio: on W. side of Salt er., near its junction with Scioto river, $54 \mathrm{~m}$. S. by E. Columbus.

Pichmond FActorx, p. v., Richmond co., $G a_{0}: 81 \mathrm{~m}$. E. by $\mathrm{N}$. Milledgeville.

Pichmond Mriss, p. o., Ontario co., $N . \bar{Y}: 200 \mathrm{~m}$. W. Albany.

Richuose SwrTcr, $\nabla$. and sta, Washington $\mathrm{co}$, R. $I_{0}:$ on the Stonington R. R., 36 m. S. S. W. Providence.

RICHMOND VAlley, p. o., Richmond county, N. Y. : $142 \mathrm{~m}$. S. Albany.

Richmondrile, p. v., Schoharie co., $N$. $Y$.: on branch of Schoharie cr., $44 \mathrm{~m}$. W. Albany. It has several mechanic shops, and 200 inhabitants.

Rich Patch, p. 0., Alleghany county, Virg.: $141 \mathrm{~m}$. W. Richmond.

Rich SouARE, p. o., Northampton county, $N$. Car.: $81 \mathrm{~m}$

E. N. E. Raleigh.

Rioh Vallex, p. o, Bedford co., Tenn. : 48.m. S. S. E. Nashville.

Rrch Vallex, p. o, Wythe co., Virg.: 204 m. W. by \$. Richmond.

Rrchview, p. o, Washington co, $I l l .: 99 \mathrm{~m}$, S. by E. Springfield.

Pichville, p. V., St. Lawrence $\mathrm{Co}_{*}, N$. $Y$. : on E. side of Oswegatehie r., $149 \mathrm{~m}$. N. W. by N. Albany. It contains several mechanic shops, stores, etc. Pop. about 200.

Richwood, p. o., Union co, Ohio: on N. side of Bogues creek, 32 m. N. W. by N. Columbus,

Rrchwoods, p. o., Izard en,, Ark. : $74 \mathrm{~m}$. N. Little Rock. Ricirwoods, p. o, Delaware county, Ind. : 48 m. N. E. Indianapolis.

Richwoods, p. o., Washington co, Me. : $105 \mathrm{~m}$. E. N. E. Augusta.

Rickot's Butre, p. o., Gadsden co., Flor.: on E. bauk of Appalachicola r., $46 \mathrm{~m}$. W. by S. Tallahassee.

PIDER's LANE, sta., Baltimore co., Mrd.: on the line of the Baltimore and Susquehanna R. R., 10 m. N. Baltimore. Ridge, p. o., St. Mary's co., $M \alpha_{.}: 60 \mathrm{~m}$. S. Annapolis Pinge, p. o., Coshocion county, Ohio: 60 m. E. N. E. Columbus.

RIDGE, p. o, Livingston co., N. Y.: 218 m. W. Albany. RtoGe, p. 0., Edgefield district, $S$. Car?: $36 \mathrm{~m}$. W. S. W. Columbia.

Ridgebury, p. Y., Fairfield co., Conn. : 52 m. S.W. by W. Hartford. It contains a church, several mechanic shops, and about 200 inhabitants.

Ridereury, p. v., Orange county, N. Y.: 96 m. S. S. W. Albany. It contains an academy, several stores, and 200 inhabitants.

Rmgeburx, t. and p. o., Bradford co., Penn.: $111 \mathrm{~m} . \mathrm{N}$. Harrisburg. Drained by Bentley and South ereeks, which flow into Tioga river. Surface hilly; soil gravelly loam. Pop. 1,400.

Ridge Farm, p. o., Vermillion county, $I l_{0}: 110$ m. E. Springfield.

Pingefresd, t., Huron co., Ohio: $86 \mathrm{~m}$. N. by E. Columbus. Irained by branches of IIuron r. Surface elevated 
and rolling; soil of average fertility. Monroeville, in this t., is intersected $\mathrm{E}$. and $\mathrm{W}$. by the Cleveland, Norwalk, and Toledo R. R., and N. and S. by the Mansifuld and Sandusky R. R. Pop. 1,914.

Ridgefeld, $t$, and p. o., Fairfield county, Conn.: $54 \mathrm{~m}$. S. W. by W. Hartford. Drained by Saugatuck and Norwalk rivers, which afford water-power, and an $\mathrm{E}$. branch of Croton r. Surface elevated; soil a fertile gravelly loam. The v, in the S., is situate on one long street, and contains several churches, an academy, several factories, workshops, stores, ete., and about 80 dwellings. The view from this $t$. is extensive and beautiful-Long Island Sound, $14 \mathrm{~m}$. distant, being seen to advantage. Pop. of t. 2,287 .

RIDGE Grove, p. o., Macon county, Ala.: 40 miles E. Montgomery.

Ridge Hall, p. o., Baltimore county, Md.: $83 \mathrm{~m}$. N Annapolis.

RidgeinaND, p. o., Henry county, Ohio: $107 \mathrm{~m}$. N. W. Columbus.

Ringeler, p. o., Madison county, $I l l_{n}: 61 \mathrm{~m}$. S. by W. Springfield.

Rtogeley, p. o., Platte co., Mo.: on E. side of Platte $\mathbf{r}_{\text {, }}$ 150 m. W. N. W. Jefferson City.

Prdeely, Macon co., Ala.: 40 m. E. Montgomery.

Ridge Post, p. o., Davidson co., Tenn.

Ridge Pratrie, p. o., Saline co, Mo.: on S. side of Black river, $64 \mathrm{~m}$. W. N. W. Jefferson City.

Rmge Spruxg, p. 0., Pitt county, N. Car.: 73 miles E. Raleigh.

Ridgevilue, p. o., Carroll county, Ma. : $45 \mathrm{~m} . \mathrm{N} . \mathrm{N} . \mathrm{W}$. Annapolis.

Ridgeville, p. v., Warren co., Ohio: on a branch of the Miami r., $66 \mathrm{~m}$. W. S. W. Columbus.

Ridentule, p. o., Cook eo., $I l l_{\bullet}: 176$ m. N. E. Springfield. Pidgevilde, p. v., Hampshire co, Füg.: $151 \mathrm{~m}$. N. W. by N. Richmond.

Ridgevilue, p. o., Colleton dist., S. Car.: $75 \mathrm{~m}$. S. S. E. Columbia.

RIDGEVILLE, p. v., Randolph county, Ind. : on N. side of Mississinewa r, 64 m. E. N. E. Indianapolis.

RIDGeville CoRners, p. o., Henry county, Ohio: $120 \mathrm{~m}$. N. W. by N. Columbus.

RIDGEwAY, t. and p. o, Lenawee co., Mich.: $66 \mathrm{~m}$. S. E by $\mathbf{S}$. Lansing. Drained by Little Raisin $\mathbf{r}$, and $\mathrm{S}$. branch of Macon r. Pop. 634.

RIDGEWAY, p. o., Muskingum county, Ohio: $51 \mathrm{~m} . \mathrm{E}$. Columbus.

RIDGeway, t, and p. o., Orleans co, $N, Y: 245 \mathrm{~m} . \mathrm{W}$ by N. Albany. Drained by Oak Orchard cr. Surface elevated, but level; soil fertile. There are numerous factories and mills in the $t$., and the Erie Canal and the Rochester, Lockport, and Niagara Falls R. R. pass through its S. part. Pop. 4,591.

Rmgeway, p. v. and sta., Warren co., $N$. Car.: $49 \mathrm{~m}$.

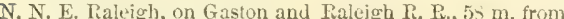
Raleigh, $29 \mathrm{~m}$. from Gaston.

Ridgewar, t., p. 0., and cap. Elk county, Penn.: 123 m. N. W. Harrisburg. Drained by Clarion r. and its branches. Surface uneven; soil of average fertility. Farming is the principal occupation. The $\mathrm{v}$. on Clarion $\mathrm{r}$. is a considerable place, and has several manufactures. The "Elk County Advocate" is published here. Pop. of $t .800$.

RIDGEWAX, p. Y. and sta, Fairfield dist., S. Car.: on the Charlotte and South Carolina R. R., 22 miles N. by E. Columbia.

Ridgew Ay, t. and p. v., Iowa co., Wisc.: $30 \mathrm{~m}$. W. by S. Madison. Pop. of t. 704

Rrdarwood, p. 0., Fairfield district, $S$. Car.: $25 \mathrm{~m} . \mathrm{N}$. Columbia.

Rrротт's, p. o., Stephenson co, $T Z_{*}:$ on E. side of small branch of Pecatonica r., $171 \mathrm{~m}$. N. Springfield.

Riegetspizue, p. o., Bucks co., Penn.; 89 m. E. N. E. Harrisburg.
Rrenzi, p. v., Tishemingo co.. Miss.: 191 m. N. E. by N. Jackson.

RIFLE river, Mich, : rises in $\mathrm{S}$. part of Oscoda co, flows $\mathrm{S}$. through Ogemaw co., and S. E. through Arenac co., into Saginaw bay.

liffle Point, p. o., Concordia par., Za.: 72 m. N. N. W. Baton Rouge.

Riga, t., Monroe co., N. Y.: $212 \mathrm{~m}$. W. by N. Albany. Orained by Black creek. Surface undulating: soil fertile. The Buffalo and Rochester R. R. passeg through it, on which is Churchville. Pop. of t. 2,159 .

RIGA, t. and p. 0., Lenawee co, Mich.: $78 \mathrm{~m}$. S. E. by S. Lansing. Bounded on the S. by Ohio State line. The Erie and Kalamazoo R. R. passes through the t., having a station at Knight's, $12 \mathrm{~m}$. from Adrian, $20 \mathrm{~m}$. from Toledo. Population of $t .208$.

Rigs, p. o., Lucas county, Ohio: on E. side of Ottawa r., $123 \mathrm{~m}$. N. N. W. Columbus.

Pigg's Cross Roads, p. o., Williamson co., Tenn. : 24 m. S. Nashville.

Riner, p. o., Vigo co., Ind.: 64 m. W. S. W. Indianapolis. Riley, p. o., M'Henry county, $l l l$ : 189 m. N. N. E. Springfield.

Rilerville, p. v., Wayne county, Penn.: 122 m. N. E. Harrisburg.

Rnmersturg, p. o, Clarion co., Penn. : 146 m. W. N. W. Harrisburg.

Pixdge. t. and p. v., Cheshire county, $N$. IIamp.: $44 \mathrm{~m}$. $\mathrm{S}$. W. by S. Concord. Drained by the outlets of a number of ponds which fiow into Miller's r. of the Connecticut, and into the Merrimac r., affording extensive water-power. The principal ponds are called Manomonack, Emerson, Pesley, Long, Grassy, and Bullet. These ponds abound in excelleat fish, and thcy were formerly much frequented by the Indians for procuring fur, etc. The soil is fertile, the land for the most part inclining to the S. Iron ore is found here, as also a species of paint resembling Spanish brown, and nearly equal to it in quality. Rindge, formerly called Rowler CANADA, or MoNadNock No. 1, was incorporated in 1768 , when it received its present name. It has some light manufactures. The v. is located in S. part of the town. Pon, of t. 1,274 .

Ringgold county, $7 a$. Situate S. toward the W., and contains 520 sq. m. Drained by head branches of One Hundred and Two r., and branch of Elkhorn r. Surface generally level; soil fertile. Set off since 1850.

Ringgold, p. o., Cook county, $I l_{0}: 170 \mathrm{~m}$. N. N. E. Springfield.

Pinggotd, p. o., Jefferson co., Penn.: 123 m. W. N. W. Harrisburg

RivgGold, p. o., Morgan county, Ohio: 63 m. E. by S. Columbus.

Rivggoud, p. v, and sta., Walker co., Ga.: on Western and Atlantic R. R. $116 \mathrm{~m}$. from Allanta, and $24 \mathrm{~m}$. from Chattanooga, and $179 \mathrm{~m}$. N. W. Milledgeville.

Rivggold, p. o., Cherokee co., Ala.: 138 m. N. N. E. Montgomery.

RINGGold, p. 0., Washington co., $M a$. : 75 m. N.W. by W. Annapolis.

Rixggold, p. o., Bienville parish, $L a .: 174 \mathrm{~m} . \mathrm{N} . \mathrm{W}$. Baton Rouge.

Ringgold, p. O., Platte county, Mo.: 157 m. W. N. W. Jefferson City.

Pinggold, p. o., Montgomery county, Tenn.: $43 \mathrm{~m}$. N.W. Nashville.

Rugggot. p. o., Pittsylvania co., Firg.: 120 m. W. S.W Pichmond.

Rixggold, p. o., La Grange county, Ind. : $126 \mathrm{~m} . \mathrm{N}$. by E. Indianapolis.

Pingons, P. v, Hunterdon con, N. Jer.: at foot of Rock Mountain, $15 \mathrm{~m}$. N. N. W. Trenton. It is a small manufacturing village, containing an academy, several stores, etc., and about 250 inhabitants. 
RLIGWOOD, p. o., M:Henry co., Ill.: 159 m. N. by E. Springfield.

lingTJood, p. o., Halifax county, $N$. Car.: $66 \mathrm{~m}$. N. E. Raleigh.

Rivosa, p。 o., Iroquois co., $M l_{\text {: : }} 136 \mathrm{~m}$. N. E. Springfield. Rio, p. v., Coweta county, Ga.: 104 m. W. by N. Milledgeville.

RIo ARrBi county, $N$. Mfex. Situate generally between lat. $35^{\circ} 30^{\prime}$ and $37^{\circ} \mathrm{N}$., and extending from the California State line to Taos and Santa Fé counties on the Pio Graude, and contains an area of $56,000 \mathrm{sq}$. m. The only part inhabited by civilizerl man is that bordering on the Rio Grande, where are several pueblas. The western part is overrun by the Narajos, Pah-Utah, and other Indian tribes, and drained by the Colorado and its tributaries. Farms 161; manuf. -; dwell. 1,6S4, and pop,-wh. 7.749 , fr, col, 2-total 7,751 . Capital: Cuchillo.

Rio Gravde, p. o., Gallia county, Ohio: 90 m. S. S. E. Columbus.

Rio Gravde river. See New Mesico.

Rro Grande CITY, p. vo, and cap. Starr county, Tex. : on E. bank of Rio Grande, opposite the confluence of Rio San Juan, 94 m.W. N.W. Matamoras, and $276 \mathrm{~m}$. S. W. by S. Austin City. Ringgold Barracks, located here, is a United States military post. The city is surrounded by a good agricultural country, and is a flourishing place. Steamboats ply here regularly from Matamoras and other places on the river.

RrPLEX county, Ind. Situate S. E., and contains 439 \&q. m. Drained by Graham's and Laughery's creeks, tributaries of the Ohio $r$. Surface in general level, but on the streums part of the land is hilly; soil fertile. Chief productions, wheat, Indian corn, and sugar. It contains some factories, which have taken advantage of the extensive water-power supplied by the streams. The under stratum in the uplands consists chiefly of blue limestone. Farms 1,495; manuf. 49 ; dwell. 2,667, and pop.-wh. 14,724, fr. col. 96-total 14,520. Capital: Versailles. Public Works: Ohio and Mississippi R. R.; Lawrenceburg and Upper Mississippi P. R.

PIPLEY county, Mo. Situate S. toward the E., and contains 1,059 sq. m. Drained by Current $\mathbf{r}$. and its branches, and by branches of Big Blackwater r. Surface hilly; soil varied. Along the streams the land is fertile and productive in corn and tobacco; in the uplands it is well adapted to grazing. Timber is found in abuadance. Farms 258; manuf. 7 ; dwell. 445, and pop.-wh. 2,731 , fr. col. 13, sl. 86 -total 2,830. Capital: Doniphan.

Riplex, to and p. v., Somerset co., Me.: $49 \mathrm{~m}$. N. N. E. Augusta. Drained by Maine stream, emptying into Monse pond, which passes through it. It is an excellent farming town, raising wheat and other grains in abundance. Pop. of $\mathrm{t} .611$.

Pipley, p. v., and cap. Tippah co., Miss. : 178 m. N. N. E. Jackson. It contains the court-house, jail, ete. The "R. Advertiser" (dem.) is published weekly.

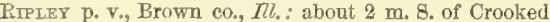
creek, a branch of Illinois r., $53 \mathrm{~m}$. W. by N. Springfield.

PIPLeY, t. and p. o., Chautauque county, N. Y.: $312 \mathrm{~m}$. W. by S. Albany. Drained by Twenty Mile creek, flowing into Lake Erie. Surface hilly ; soil clay loam, mixed with sand, and fertile. Its principal settlement is Quincy village, through which the Buffalo and State Line R. R. passes, $65 \mathrm{~m}$. from Buffalo. Pop. 1,732.

Ripley, p. v., Brown co., Ohio: on Ohio r, at junction of Red Oak creek, about $56 \mathrm{~m}$. above Cincinnati, $90 \mathrm{~m}$. $\mathrm{S}$. by W. Columbus. This is a very flourishing v., has a number of mills and factories, and 4 churches. The "RipIey Bee" (whig) is issued weekly. Pop. 1,780.

Pitplex, p. v., and cap. Landerdale co., Tenn.: S. of Cane cr., a branch of Big Hatehie r., $156 \mathrm{~m}$. W. by S. Nashville. It contains the county buildings, an academy, and about 450 inhabitants.

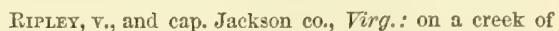
Ohio r., about $30 \mathrm{~m}$. E. Mount Pleasant, and $240 \mathrm{~m}$. W. N.W Richmond. Pop. 228.

RipleY's, p. o., Tyler co., Virg.: on Middle Island cr., $219 \mathrm{~m}$. N. W. by W. Richmond.

Riplextille, p. 0. , Huron county, Ohio: $75 \mathrm{~m}$. N. by E. Columbus.

Ripton, t. and p. v., Addison co., Verm. : 27 m. S. W. Montpelier. Drained by Middleburg river, which affords water-power, and along which is some good land. Surface mountainous, and much broken. The village is situated on the Royalton and Yergennes turnpike. 'Pop. of t. 567.

Rrsdon, p. v., St. Clair co., Ill.: 119 m. S. Springfield, $2 \mathrm{~m}$. E. Kaskaskia river, on a small creek of same, affording good water-power.

Rispon, p. o., Seneca county, Ohio: 84 miles N. N. W. Columbus.

Rising Fawn, p. v., Dade co., Ga. : near Georgia State line, $191 \mathrm{~m} . \mathrm{N}$. W. Milledgeville.

Rrsing Sun, p. v., and cap. Ohio co., Ind. : on Obio r., $9 \mathrm{~m}$. below Aurora, and $87 \mathrm{~m}$. S. E. Indianapolis. It is pleasantly located on an elevated bank, surrounded by a fertile country, and is a flourishing business place. There are cotton and woolen factories doing an extensive business. Since its establishment as the county seat it has improved rapidly. It now contains the county buildings, 6 churches, an academy, printing offices, a tannery, etc., and a few factories, Two newspapers are published weekly, "True Whig," and "Rising Sun Mirror" (lit.)

Rising Sun, p. o., Cecil co., Ma.: a few m. E. Ocatara r., 58 m. N. N. E. Annapolis.

Rising Sun, p. v., Philadelphia co., Penn. : on the Germantown road, $3 \mathrm{~m}$. from Philadelphia, and $93 \mathrm{~m}$. E. by $\mathrm{s}$. Harrisburg.

RISLEX county, $I a$. Situate $N$. centrally, and contains 576 sq. m. Drained by Boone river, a tributary of Des Moines r., and by Skmuk r. and branches. Surface undulating; soil fertile. Set off since 1850.

Ritche county, Virg. Erected in 1843 out of Lewis, Harrison, and Wood, Situate N. W., and contains 268 sq. m. Drained by the two forks of Hugh's river, a tributary of the Little Kanawha. Surface hilly and broken; soil moderately fertile. Farms 385 ; manuf. 3 ; dwell. 649 , and pop.-wh. 3,886, fr. col. 0, sl. 16-total 3,902. Capital: Ritchie C. H. Public Works: North Western R. R.

Ritchis, p. v., and cap. Ritehie county, Virg.: 225 miles N. W. by W. Richmond. It contains a court-house, jail, ete. Ritchreville, p. v., Dinwiddie county, Virg.: $37 \mathrm{~m}$. S. Richmond.

Ritcersville, p. o., Lehigh co., Penn.: on N. side of Lehigh r., 79 m. E. N. E. Harrisburg.

River, p. o., Clarion county, Penn.: $151 \mathrm{~m}$. W. N. W. Harrisburg.

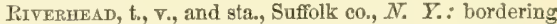
on Long Island Sound, 67 miles by railroad E. from New York, and 133 S. W. (direct) from Albany. Bounded on the S, by Great and Little Peconic bays and Peconic river, by the latter of which it is drained. Surface in general level, but about a mile from the Sound, and extending $\mathrm{E}$. and W. is a range of low hills; soil sandy loam. The $\mathrm{v}$. is loeated at the head of navigation on Peconic bay, and contains the county hall and surrogate's office. It was first settled in 1690 , and the first grist-mill erected in 1695 ; but it was for more than 100 years ere it contained over half a dozen dwellings. The courts have sat here for more than a century. It now eontains numerous substantial and neat dwellings, stores, grist and saw mills, a female academy, etc. This place is a considerable depot for wood from the adjacent country. Lighters are employed carrying it to Jamesport, $5 \mathrm{~m}$. below, from which point it is transferred to larger vessels, and carried to different ports. Sufiolk C. H. and $\mathrm{p}, \mathrm{o}$. is located in this $\mathrm{v}$. The station is on the Long Island R. R. $21 \mathrm{~m}$. W. Greenport, and $74 \mathrm{E}$. from New 
Tork. The "Suffolk Gazette" is a weekly (whig) issue. Pop. of $t .2,540$.

Rrver HuL, p. O., White co., Tenn.: $79 \mathrm{~m}$. E. by $\mathrm{S}$. Nashville.

RIVER ROAd Forks, p. o., Livingston co., N. Y.: $216 \mathrm{~m}$. W. Albany.

Piner Side, p. o., Ulster county, N. Y.: 54 m. S. by W. Albany,

Rrver Side, p. o., Cumberland co., N. Car.: $48 \mathrm{~m} . \mathrm{S}$. Raleigh.

River StyX, p. o., Medina co., Ohio: on E. side of branch of Chippewa river, $95 \mathrm{~m}$. N. E. by N. Columbus.

Pitvertown, p. V., Campbell county, Ga.; on E. side of

Chattahoochee r., $96 \mathrm{~m}$. W. N. W. Milledgeville.

Pives, p. v., Richland county, Ohio: 60 miles N. N. E. Columbus.

Rivesrille, p. v., Marion county, Virg.: 205 m. N. W. Richmond.

Rгx, p. 0., Ionia co., Mich.: 33 m. N. W. Lansing.

Rixervicle, p. v., Culpepper co., Virg. : on branch of Rappahannock river, $73 \mathrm{~m}$. N. N. W. Richmond.

RIx's Mruts, p. o., Muskingum county, Ohio: $49 \mathrm{~m}$. E. Columbus.

Road Hall, p. o., Lycoming county, Penn.: $74 \mathrm{~m} . \mathrm{N}$. Harrisburg.

RoAdstown, p. v., Cumberland count: N. Ner.: 60 miles S. S. W. Trenton.

Roadrille, p. Y., Charleston dist., S. Car.: 95 m. S. E. Columbia.

ROANE county, Tenn. Situate toward the E., and contains $468 \mathrm{sq}$. m. Tennessee r. passes centrally through it, by which and by Clinch r. and their branches it is drained. Surface level; soil a fine, deep loam, and very fertile, and produces wheat, Indian corn, cotton, etc. Farms 842; manuf. 21 ; dwell. 1,812, and pop.-wh. 10,526, fr. col. 115, sl, 1,541 -total 12,185. Capital: Kingston. Public Works: Georgia and East Tennessee R. R.

Roan Mountant, p. o., Carter county, Tenn. : 263 m. E. Nashville.

Roanore county, Firg. Situate toward $\mathrm{s}$. W., and contains 322 sq. m. Drained by head branches of Staunton river. Surface uneven and mountainous; soil fertile, and adapted to grazing. Chief products wheat, Indian corn, and tobacco. Farms 405; manuf. 5; dwell. 925, and pop.-wh. 5,813, fr. col. 154, sl. 2,510-total 8,477. Capital: Salem.

Public Works, : Virginia and Tennessee R. R.

RoANoke, p. V., Randolph county, $A l a$ : 78 m, N. E. Montgomery, $7 \mathrm{~m}$. W. Georgia State line.

RoANoke, p. v., Genesee con, $N . Y_{\text {.: }}$ on Allen's cr., $228 \mathrm{~m}$,

W. by. N. Albany. It contains a furnace and several mills.

ROAYOKE, p. O., Huntingdon co., Ind.: on W. bank of

Little r., on the Wabash and Erie Canal, $\$ 9$ miles N. N. E. Indianapolis.

Roatoke, p. O., Randolph co., MOo: 60 m. N. N. W. Jefferson City.

RoANoke river, Firg. and $N$. Car.: is formed by the junction of Staunton and Dan rivers, near the S. boundary of Virginia, and flows into the head of Albemarle Sound. It is navigable to the great falls at Halifax, $75 \mathrm{~m}$., for vessels of 45 tons. A canal round the falls opens the navigation for batteaux, to the junction of Staunton and Dan rivers, both of which are navigable some distance for boats of 5 tons.

Roanoke Brmge, p. o.s Charlotte co., Firg.: $68 \mathrm{~m}$. S. W. by W. Richmond.

Roax's Creek, p. o., Carroll co., Tenn.: $96 \mathrm{~m}$. W. by S. Nashville.

Roartag Creek, p. o., Montour co., Penn.: 46 m. N. E. Harrisburg.

Proartivg Sprikg, p. o., Trigg co., Ky. : 192 m. S. W. by W. Frankfort.

RoBbivsto:, t. and p. V., Washington co., MFe.: $137 \mathrm{~m}$. E. N. E. Augusta. It is loeated on the Schoodic or St, Croix c., opposite St. Andrew's, in New Brunswick. There are $72 S$ several ponds in the t., by the outlets of which it is drained. This place has great navigable privileges, and it is the site of considerable ship-building. The manufacture uf lumber is carried on to a great extent, and forms the chief commodity of trade. The manufacture of woolen goods and flour is also carried on. The $\mathbf{v}$, is on the bank of st. Croix r., and near its mouth. Pop. of t. 1,02s.

Roberson's Cross Roads, p. o., Bledsoe co., Tenn.: $96 \mathrm{~m}$. E. S. E. Nashville.

Roberts Conners, p. o., Jeffetson co., N. $I_{\text {. }}: 145 \mathrm{~m}$. N. W. Albany.

Robertson county, Tenn. Situate N. toward the W., and contains $454 \mathrm{sq} . \mathrm{m}$. Drained by affluents of Sycamore creek and Red river. Surface undulating; soil fertile, and very productive. Tobacco is the staple. Cotton is grown, and good crops of wheat and corn are raised. Farms 1,063; manuf. 63 ; dwell. 1,995 , and pop.-wh. 11,50. fr. col. 25 , sl. 4,616-total 16,145. Capital: Springfield.

Robertson county, Texo. Situate E. centrally, and contains 946 sq. m. Drained by Little Brazos river and branches, and tributaries of Navasota river, which forms its eastern boundary. Surface undulating; soil in general fertile, and on the streams very rich and highly productive. It yields excellent crops of cotton, corn, and potatoes. It has much prairie land covered with weeds, the soil of which, when the weeds are burnt off, is, on account of its lightness, very valuable, it being so easy of cultivation and very fertile. It has extensive beds of coal and iron ore. Farms 18; manuf. 0 ; dwell. 132, and pop.-Wh. 670 , fr. col. 0, sI. 261-total 934. Capital: Franklin.

Robertson's Store, p. o., Pittsylvania co., Firg. : $113 \mathrm{~m}$. W. S. W. Riehmond.

Robertsonvllte, p. o., Sullivan co., N. $X_{.}: 85 \mathrm{~m}$. W. by S. Albany.

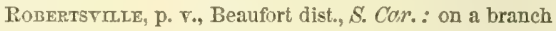
of Savannah r., $96 \mathrm{~m}$. S. by W. Columbia.

RoberTSVILIE, p. F., Anderson co., Tenn。: 156 m. E. Nashville.

RoBEson county, N. Car. Situate S. toward the W., and contains $590 \mathrm{sq} . \mathrm{m}$. Drained by Lumber river, and head branches of Little Pedee river. - Surface moderately level; soil fertile, and favors the growth of cotton. Much of the land is well adapted to grain and grazing. Chief productions cotton and Indian corn. Farms 1,112; manuf. 10; dwell. 1,513 , and pop.-wh. 7,290 , fr. col. 1,171, sl. 4,365total 12,826. Capital: Lumberton.

Robeson, p. O., Brunswick co., N. Car.: 109 m. S. by E. Raleigh.

Roseson, t. and p. o., Berks county, Penn.: $51 \mathrm{~m}$. E. Harrisburg. The Schuylkill river bounds it on the N. E. Drained by Alleghany and Hay creeks of the Schuylkill. Surface uneven, in parts hilly; soil gravelly and sterile. Iron deposits are in the vicinity, and a forge which, in 1850 , produced 600 tons blooms. The t. contains several flouring, grist, and saw mills, stores, ete.

Robiva, p. v., Panola co., Jfiss.: $132 \mathrm{~m}$. N. Jackson. Drained by a creek of Tocanapatafa river.

Robn"s Ferry, v. and sta., Merrimac co., N. Iramp.: on the right bank of the Merrimac r., and on the Concord and Nashua Railroad, $30 \mathrm{~m} . \mathrm{N}$. Nashua, and $5 \mathrm{~m}$. S. Coneord.

RoBIN's Nest, p. o., Peoria co., $\eta_{*}$; on small branch of Kickapoo cr., 69 m. N. Springfield. Jubilee College, located here, is an Episcopal seminary.

Roblison Chenk, p. 0., Pike co., Ky.: 149 m. E. S. E. Frankfort.

Robrvsox C. H., p. v. and eap. Crawford co., $I l l .: 121 \mathrm{~m}$. E. S. E. Springfield. It is located 8 miles W. of the Wabash, and contains the county buildings, ete.

Robissons, p. o., Darke co., Ohio: on N. side of Greenville cr., $79 \mathrm{~m}$. W. by N. Columbus.

Robirsox's Cross Proads, p. o., Benton co., Ark.: 144 m. N. W. Little Rock. 
Rontrsox's Muis, p. o., Menard co., Ill.: 27 m. N. W. Springfield.

Rorisson's Spring, p. o., Autauga co., Ala.

Rogixsox's Store, p. o., Lincoln co., Tenn。: 66 m. S. by E. Nashrille.

Roвio's, sta., Chesterfield co., Virg.: on the Richmond and Danville R. R., $10 \mathrm{~m}$. S. W. Richmond.

Robisonville, p. o., Bedford co., Penn. : 79 m. W. by s. Harrisburg,

Rов Ror, p. v., Fountain co., Ind.: on Big Shawnee cr., $63 \mathrm{~m}$. N. W. by W. Indianapolis. Pleasantly situated, and has valuable water-power.

Ros Ror, p. o., Jefferson co., Ark.: on N. bank of Arkansas r., at mouth of Plum bayou, $36 \mathrm{~m}$. S. E. by S. Little Rock.

RosY's CORNER, v, and sta., Merrimac co., N. Iamp.: on the Concord and Claremont R. R., 4 m. E. Bradford and $22 \mathrm{~m}$. W. Concori.

Rocheport, p. V., Boone co, MLo, in N. bank of Missouri r., $36 \mathrm{~m}$. N. W. by N. Jefferson City.

Roche Port river, Mo. : rises in S. E. part of Randolph co., and flows S. through Boone eo. into Missouri river.

Rochester, p. v., Sangamon co., Ill. : on W. bank of Sangamon r, on line of the Great Western Central R. R., near the junction of the $\mathrm{N}$. and $\mathrm{S}$. forks, $8 \mathrm{~m}, \mathrm{E} . \mathrm{N}$. E. Springfield.

Rochester, p. v., and cap. Fulton co., Ind.: on S. bank of Mill er., a tributary of Tippecanoe r., $89 \mathrm{~m}$. N. Indianapolis. Contains the co. buildings, which are neat structures. Mill er. affords valuable water-power. Pop. 1,401.

Rochester, p. o., Butler county, Ky.: 117 m. S. W. Frankfort.

RochesTER, t. and p. v., Plymouth county, Mfass.: on the N. W. side of Buzzard's bay, 44 miles S. by E. Boston. Drained by Mattapoisett, Sipican, and Weweantic rivers, the two former rising in ponds in the t., empty into the bay, and form excellent harbors. Surface varied; some parts are rocky and unfit for cultivation, while other parts are clear, with excellent soil. The streams afford extensive water-power. The manufactures cnnsist in ship-building, salt, bar iron, leather, etc. A number of vessels are owned here and employed in the coasting and fishing trade. The whale fishery is carried on to a considerable extent, and the largest sized ships are engaged in the trade, bringing large quantities of oil annually. The principal village in the $t$. is called Mattapoisett, at the head of the harbor so called. Rochester $v$. is located centrally, equidistant between Weweantic and Mattapoisett rivers. Pop. of t. 3,803.

Rochester, p. v., Oakland county, Mich.: on N. bank of Clinton r., at junction of Paint cr., $50 \mathrm{~m}$. E. by $\frac{1}{8} \mathrm{~S}$. Lansing. Water-power is afforded by both streams, and improved by a few mills, etc.

Rochester, p. v., Andrew co., Mo.: on E, bank of Platte river, $165 \mathrm{~m}$. N. W. by W. Jefferson City.

RoCHESTER, t.. p. v., and one of the caps. Strafford county, N. Hramp.: on Salmon r., which bounds it on the E, $26 \mathrm{~m}$. E. Concord. Drained by Cocheco r., running through, and Isinglass river erossing its S. part, affording excellent mill privileges. Surface uneven, with many swells, the principal of which is Squamanagaunich hill; soil deep, rich, and well cultivated. It contains a number of valuable farms, chiefly located on the hill. In the W. part of the t. oak of a hard and stony character is found in abundance. Several villages are in the town, the most noted for its trade being Norwoay Plains, the principal thoroughfare from the upper towns in the counties of Dover and Plymouth. About $2 \mathrm{~m}$. $\mathrm{S}$. W. is another v., called Squamanagaunich, on the Cocheco r., named after the falls at that place, and is also a point of considerable trade. This town was incorporated in 1772 , and the first permanent settlement made in 1725 . Tntil 1760 it was a frontier town, and is a place of historical note. The marufactures of Rochester consist in woolen goods, leather, flour, lumber, oil, etc. The $\mathrm{v}$. is connected with Dover and Alton bay by the Cocheco R. R., $10 \mathrm{~m}$. from the former and $18 \mathrm{~m}$. from the latter place, and also with Wilton and Great Falls by the Great Falls and Conway R. R., $6 \mathrm{~m}$. N. Great Falls, and $5 \mathrm{~m}$. S. from Wilton. In both an agrieultural and manufacturing point this is a flourishing place. It contains a number of manufuctsries, a bank, etc. Pop. of t. 3,006.

RocHEsTin, p. 0., Jackson par, La.: $148 \mathrm{~m}, \mathrm{~N}$. W. by $\mathrm{N}$. Baton Rouge.

Rochester, p. city, port of entry, and cap. Monroe county, N. $Y$. : is situated on both sides of Genesee $\mathrm{r}_{0,}, 7 \mathrm{~m} . \mathrm{S}$. from its entrance into Lake Ontario; by railroad $252 \mathrm{~m}$. W. of Albany, and $68 \mathrm{~m}$. E. by N. from Buffalo, Lat. (Rochester House) $43^{\circ} 08^{\prime} 17^{\prime \prime} \mathrm{N}$.; long. $77^{\circ} 51^{\prime}$ W. from Greenwich. The city is laid out with general regularity, having wide and handsome streets, many of which are lined with shade trees. Its site is somewhat uneven in surface. It rests upon a bed of limestone, but a few feet below the surface, and greatly used for building and other purposes. In summer, at low water in the r., its bed of this limestone is exposed, exhibiting for a long distance a solid base of rock. The area occupied by dwellings is very large for the population, the houses for the most part being separate dwellings. The E. and W. parts of the city are connected by 5 bridges. The principal street, called Main Street, on the E. side, and Buffalo Street, on the W. side, is a xery long, broad, and handsome avenue, passing over the central bridge, and lined with the principal stores, hotels, etc. The blocks of stores, and houses generally, are noted for their neat appearance. Brick and stone are the principal bnilding materials within the limits of the fire districts. Several large parks are reserved as public grounds, of which the principal is Washington Square. The Court-house, on Buffalo Street, is a large and elegant structure, with handsome granite portico, containing the county and eity offices. The Arcade is a handsome marble building, containing the post-office, and is a hall of great resort, with numerons business offices, etc. The Western House of Refuge for juvenile delinquents, a State institution, is a very extensive establishment, about $1 \frac{1}{2} \mathrm{~m} . \mathrm{N}$. of the centre of the eity, containing from 200 to 300 lads, confined for reformation. The building is a very large edifice of brick, presenting an imposing appearance, and is surrounded by work grounds and farm of several acres. The hotels of the city are generally very large and handsome buildings. The publie schnols have fine buildings ind are well conducted. Private schoris are numerous, and there are several female academies. The University of Rochester, established in 1850 , has 8 professors, 109 students, and 3,000 volumes in library. The Rochester Theological Seminary (Baptist), also established here in 1850, had, in 1851-52, 2 professors, 29 students, and 3,000 volumes in library. 'The Athenæum, a popular institution, has a good library of 5,000 volumes, and annual courses of lectures. The periodical press, in 1850 , consisted of 19 regular issues, viz, 3 dailies, " $P$. Democrat" (whig), "Advertiser" (dem.), "American" (whig), each of which also published tri-weekly and weekly editions; weeklies, "Rural New Yorker" (agric.), "Star of Temperance," "North Star" (anti-sla.), "Genesee Evangelist" (Presb.), "Christian Guardian" (Univers.), "Advent Harbinger" (Sec. Adv.); semi-monthlies, "Christian Sentinel" (Univers.), "Flag of Freedom " monthlies, "Genesee Farmer" (agric.) and "Eclectic Journal" (med.) There are about 30 churches, some of which are fine structures, and 2 large orphan asylums. The eity government is vested in a mayor, recorder, and common council, all of whom are elected annually. The common schools are governed by a bnard of education, composed of two members from each ward. The eity is divided into 9 wards, is generally well paved and provided with sewerage, and is lighted by gas. Water is abundant from wells. The principal city market is a commodious structure, on the W. bank of the $r$. The city almshouse is in the S. suburbs.

The rapid growth and prosperity of the city hare resulted 
from the natural advantages of great water-power here afforded by the Genesee river. Within the eity limits the $r$. las a total descent of $26 \mathrm{~s}$ feet, in which are 3 successive perpendicular falls of 96,20 , and 105 feet, and 2 rapids. The first great falls of 96 feet are a little N. of the centre of the city, and before they were disfigured by the construction of walls in the centre of the stream above for mechanical purposes, they afforded at high water a very grand appearance. From a projecting point in its centre the notorious Sam Patch made his last and fatal leap. Below the first cataract the $\mathrm{r}$. flows broad and deep for $1 \frac{1}{2} \mathrm{~m}$. to the second, where it has a perpendicular fall of 20 feet, and thence pursues a noisy and rapid course for about 25 rods to the third and last fall, by which it descends 105 feet. Through the entire distance from the upper to the lower fall it flows through a narrow ravine, over 100 feet deep. The depression of the stream commerces considerably above the first falls, and in $\frac{1}{8} \mathrm{~m}$. has a fall of 12 feet, easily used for manufacturing purposes. On each side of the r. canals have been extensively constructed for the mills. Another power of considerable amount is created by the feeder for the Erie Canal, which comes from the r. nearly $2 \mathrm{~m}$. above.

The immense water-power thus afforled is used by various mills and factories, but chiefly by flouring-mills, which are the principal business establishments of the city. In 1850 there were 22 mills, with 100 runs of stone, nearly all of which were employed on flour. An approximate estimate of the amount of flour manufactured annually is 600,000 barrels, or $3,000,000$ bushels. Of this amount, about $1,6 \pm 0,454$ bushels are left here by canal and railroad, leaving $1,359,546$ bushels to be made up by receipts from wagons, and this is about equal to the product of the county. The following table exhibits the amount left here by the Erie and Genesee Valley Canals for a series of years:

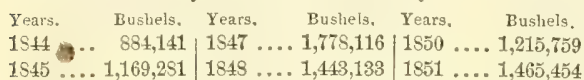

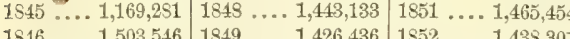

The quanties of flour shipped for the same series of years are as follows:

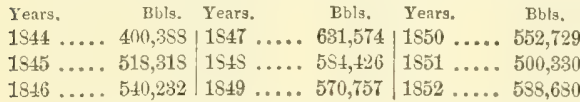

To the amount shipped should be added the amount consumed by 40,000 inhabitants, and the large population of the suburbs and vicinity.

Other manufactures are extensively prosecuted. There are several iron furnaces, casting principally stoves, agricultural implements, etc. and numerous large machinery works. The edge tool factory of Barton \& Co. employs about two hundred men; and the scale factory of Duryee \& Co. is also very large. A large stone cotton factory, 6 stories high, when in full operation, employs two hundred persons. There are several woolen factories, fulling-mills, large boatyards, breweries, tanneries, last factories, large factories of cabinet furniture, etc. There are 5 banks, with aggregate capital of $\$ 930,000,2$ savings banks, and several insurance companies.

Rochester enjoys good facilities for transportation of its imports and exports. The Erie Canal, giving it connection with the E. and W., here crosses the Genesee r. by a splendid aqueduct, 804 feet long, resting upon 11 arches, erected at a cost of $\$ \$ 0,000$. The Genesee Valley Canal, completed to Dansville, $52 \mathrm{~m}$, affords access to the interior. Though the $\mathrm{r}$, is boatable above the city to Mount Morris, $45 \mathrm{~m}$, it is little used for that purpose. The total value of property left at $R$. by both canals, during 1852 , was $\$ 5.286,994$; value of amount cleared, do., $\$ 4,304,762$. The lines of railroads here centering are, Rochester and Syracuse R. R., 104 m.; Rochester and Syracuse direct $R$. P., along the line of the canal; Buffalo and Rochester R. R., $63 \mathrm{~m}$; ; and Rochester,
Lockport, and Niagara Falls R. R., $76 \mathrm{~m}$. The Genesee Valley R. $R$, is in construction.

Rochester is the port of entry for Genesee collection district. The river is navigable for steamboats, etc., from Lake Ontario to the landing, $2 \frac{2}{2}$ miles below the center of the city. A line of steamboats from Oswego to Lewiston arrive and depart daily, and a line from Canada tri-weekly. The total tonnage of Genesee district, on June $30 \mathrm{th}, 1550$, was 1,037 tons, all of which was "enrolled and licensed," permanent, and employed in the coasting trade. During the year preceding, the number of clearances for foreign countries was $215-40,077$ tons ; number of entrances, do., the same statisties. Vessels built during the year, 1 schooner-5s tons.

Population-in 1812, 15 ; in 1815,331 ; in $1820,1,500$; in $1825,4,274$; in $1830,10,863$; in $1835,17,160$; in $1840,20,191$; in $1815,25,265$; in $1850,36,561$. The $\mathbf{E}$. side of the river has of late increased its population in greater ratio than the W. side. $\mathbf{R}$. was laid out in 1812 , incorporated as a $\mathbf{v}$. in 1517 , and as a city in 1834 . In 1512 it contained only 2 wooden frame buildings. It has frequently suffered heavy losses by fire, but has overcome these reverses. The agricultural district surrounding it is among the most fertile in the Union, and has contributed greatly to its prosperity. The health of the eity is affected by the proximity of the lake, and sudden changes of the weather, high westerly winds, etc. ; but is generally good. Mt. Hope Cemetery, in the S. suburbs, is an extensive inclosure of the most beautiful grounds, improved by art, splendid monuments, ete.

Poonester, t. and sta., Lorain county, Ohio : $84 \mathrm{~m}$. N. E. Columbus. Drained by W. branch of Black river. The Cleveland, Columbus, and Cincinnati R. R. passes through the t., $41 \mathrm{~m}$. S. W. from Cleveland, and $214 \mathrm{~m}$. N. E. from Cincinnati. Pop. $\$ 96$.

Rocuester, p. v, Warren co, Ohio: on E. side of Little Miami r., 69 m. S. W. Columbus.

Rochester, t, and p, v, Windsor county, Verm. : $30 \mathrm{~m}$ S. by W. Montpelier. Drained by White $r$. and branches, from which is derived excellent mill-power. Surface mountainous, and in parts much broken; soil good for grazing, and some excellent tracts of meadow land. The $\mathrm{v}$. has a pleasant location on the left bank of White $\mathbf{r}$, and commands considerable trade. The manufactures consist of leather, flour, lumber, ete. Pop. of t. 1,493.

Rochester, p. V., Racine co, Wisc.: on N. side of branch of Fox r., 61 m. E. S. E. Madison. Pop. 1,672.

Roohester; p. v., Beaver county, Penn. : on E. bank of Beaver r., at its junction with the Ohio $r$ and on the line of the Ohio and Pennsylvania R. R., 25 m. N. W. Pittsburg, $156 \mathrm{~m}$. W. by N. Harrisburg. Coal and iron are abundant in the vicinity.

Rochester Mrlus, p. $v_{\text {, }}$, Wabash co., $I l_{0}$; on right bank of Wabash r., about $2 \mathrm{~m}$. above Coffee Island Rapids, and $137 \mathrm{~m}$. S. E. Springfield.

Rook county, Wisc. Situate S., and contrins 720 sq. m. Pock r. passes centrally through it, by which and its branches it is drained. Surface level; soil fertile. Agriculture is the leading pursuit. Farms 1,965 ; manuf. 125; dwell. 3,618, and pop.-wh. 20,686, fr. col, 22-total 20,708. Capital: Janesville, Putlic Works: Milwaukie and Mississippi Railroad, Beloit and Madison R. $\mathrm{R}_{*}$, ete.

Rock, p. 0, and sta., Plymouth co., Mass. : on Cape Cod Branch of Fall River P. R., 5 m. S. Miduleboro' and $37 \frac{7}{2}$. S. by E. Boston.

Rock, p. o., Lancaster county, Penn. : $30 \mathrm{~m}$. E. by S. Harrisburg.

Rock river, Wisc. and $I l l$. This river has its prineipal source in a region of lakes and swamps in the vicinity of Fox r. of Green bay; flowing south for some distance, it takes a south-westerly direction till it enters the Mississippi about $3 \mathrm{~m}$. below Rock Island. After traversing some distance in Wisennsin it is joined by the Catfish, a small stream rising in Dane county, and connecting together the "Four Lakes," the head waters of which have their com- 
mencement in a swamp a few miles south of Fort Winnebago. It then continues its course $\mathrm{S}_{\text {, }}$, entering Illinois, where it receives several tributaries, the principal of which are the Green, Turtle, Pecatonica, Sycamore, and Kyte rivers. The navigation is seriously obstructed by what are denominated the Upper and Lower Rapids. The latter at Vandruff's Island, about $3 \mathrm{~m}$. above its mouth, are caused by a formation of calcareous rock three-fourths of a mile in extent, and completely crossing the stream, which is here dirided by the island into two channels. Between this point and Prophetstown, a distance of about $52 \mathrm{~m}$., is free from any obstruction, having a good channel, varying in width from 800 to 1,000 feet, in which there is never less than 4 feet water. The total fall for this distance is 28 8- 10 feet, and the velocity of the current about $3 \mathrm{~m}$, per hour. Opposite Prophetstown are shoals varying from 3 to 4 feet at low water. The Upper Rapids, at Harrisburg, extend $1 \frac{1}{4} \mathrm{~m}$., the total fall in that distance being $S \frac{1}{2}$ feet. From this point to Rockford, a distance of $63 \mathrm{~m}$, the obstructions are slight, being only 2 or 3 movable sandbars. The bed opposite Rockford is a smooth, solid rock for 260 yards, and the water at its lowest stage from 2 to $2 \frac{1}{9}$ feet. Toward the head the land is marshy, with ridges of sand and tracts of rich undulating soil interspersed. In this region is the Terre Tremblant, or trembling land, which takes its name from the shaking of the surface while passing over it. In general, till it reaches the State line, the country is beautifully undulating and the soil rich and productive; but in Illinois a large portion through which it passes is prairie. Along its banks are numerous tracts of richly timbered land. Coal of a bituminous nature is found in the bordering regions, and also some stone quarries, which supply a good building material. The water privileges it affords, and also its tributaries, are many and excellent. The Rockford and Rock Island R. R. runs along the valley of this river. Canaling and other improvements are contemplated so as to render the navigation certain at all seasons.

Rock creek, $D_{0}$. C.: separates Georgetown from Washington city, and enters the Potomac $r$. Two bridges cross it near its mouth.

Rockatway, p. v. and sta., Morris co., $N$. Jer. : on Rockaway r., on the Morris and Essex R. R., $31 \mathrm{~m}$. N. W. Newark, $47 \mathrm{~m} . \mathrm{N}$. by E. Trenton.

Rockatway, p. v., Queen's co., N. $Y_{*}$ : on Rockaway bay, near the Atlantic shore, $143 \mathrm{~m}$. S. by E. Albany.

RockawAY beach, Queen's co., $N$. Y.: a peninsula situated between Jamaica bay and the Atlantic Ocean, $16 \mathrm{~m}$ S. E. from New York and $143 \mathrm{~m}$. S. from Albany. Far Rockaway and Near Rockaway are names of villages, The latter is located on Pockaway bay, near the ocean, and contains several stores, a ship-yard, lumber-yard, etc., and a number of coasting sloops and schooners are owned here At this place is a monument erected to the memory of those who perished by shipwreck from on board the ships Bristo and Iexi(c), in 1S36-7.

Rock Botтom, p. o., Middlesex co., Mass. : 23 m. N. W. Boston.

RockвRTDGe county, Virg. Situate centrally, and contains $652 \mathrm{sq} . \mathrm{m}$. Drained by affluents of North $\mathrm{r}_{\text {, a }}$ main branch of James $\mathbf{r}$, which it joins a little above its passage through the Blue Ridge. Surface, though in general mountainous, is diversified with fertile valleys; soil various. Chief products, wheat and Indian com, with tobacco. This county contains the celebrated Natural Bridge over Cedar cr., from which it takes its name. Farms 666 ; manuf. 57 ; dwell. 1,908, and pop. - wh. 11,484, fr. col. 364, sl, 4,197total 16,145. Capital: Lexington.

Prock BrIDge, p. v., Gwinnett co., Ga.; on E. bank of Jellow r., $71 \mathrm{~m}$. N. W. Milledgeville.

Pockbeidge, p. o., Greene county, IU.: 47 m. S. W. Springfleld.

Rockbridge, p. $\nabla_{*}$, and cap. Ozark co., Mo.: $127 \mathrm{~m}$. S. Jefferson City. It contains the court-house, jail, etc.
Rock CASTLE county, $K y$. Situate S. E. centrally, and contains 312 sq. m. Drained by branches of Dicks' and Rock Castle rivers. Surface elevated, and forms a ridge separating the waters of the Cumberland $r$. from those of Kentucky r. - the land is well adapted to grazing; soil fertile, and generally productive. Staples, wheat and Indian corn. Farms 441; manuf. 3 ; dwell. 746, and pop.-wh. 4,259, fr. col. 33, 8l. 375-total 4,697. Capital: Mount Vernon. Public Works: Knoxville and Lexington R. R

Rock CAstuE, p. v., Patrick co., Virg.: 147 m. W. S. W. Richmond.

Rock CITr, p. v., Duchess co., $N_{.} Y_{*}$ : on small branch of Hudson r., $49 \mathrm{~m}$. S. Albany.

Rock Citx, Cattaraugus co, $N_{\text {. }} Y_{.}: 7 \mathrm{~m}$. from Ellicotteville and near the line between Great and Little Valley -is a remarkable natural curiosity. The rock is here conglomerate, large masses, from 15 to 35 feet high, have been left standing isolated, and are separated by alleys and passages of various widths. The whole area covered by these blocks is near 100 acres. The scene is in the highest degree imposing, and impresses upon the beholder the conviction, hat the name has not been improperly chosen.

Rook Ciry Mrlis, p. o., Saratoga county, N. Y.: $29 \mathrm{~m}$ N. by W. Albany.

Rock Creek, p. o. and sta., Bartholomew co., Ind.: on the Madison and Indianapolis R. R., $34 \mathrm{~m}$. from Madison, and $51 \mathrm{~m}$. S. S. E. Indianapolis.

Rock Creek, p. o, Carroll co., $I I l_{\text {.: }} 153 \mathrm{~m}$. N. Springfield.

Rock Crees, p. o., Cedar county, Ia. : on E. side of Cedar r., 19 m. E. Iowa City.

Rock Creek, p. o., Somerset county, MI.: 63 m. S. E. Annapolis.

Rock Creek, p. o., Lewis county, $K y$.: 98 m. E. N. E Frank fort.

Rock Creek, p. 0., Franllin co., Ala.: 185 m. N. N. W. Montgomery.

Rock Creek, p. o., Orange co., N. Car. : $56 \mathrm{~m} . \mathrm{W} . \mathrm{N} . \mathrm{W}$. Raleigh.

Rock Creek, p. 0., Yell county, Ark.: 77 m. W. N. W. Little Rock.

Rockdale, t. and p. o., Crawford county, Penn. : $192 \mathrm{~m}$. N. W. Harrisburg, Drained by French er. and tributary of Alleghany r. It has limited manufactures.

RockDale, sta., Licking co., Ohio: on the Central Ohio R. R., $18 \mathrm{~m}$. W. by N. Zanesville, and $40 \mathrm{~m}$. E. by N. Columbus.

Rockdale, p. o., Chenango co., N. Y.: 98 m. W. by S. Albany.

Rockdale, p. o, Randolph co., $A l a_{0}: 86$ m. N. E. by N. Montgomery,

RockForD, p. $\nabla$. , and cap. Winnebago co., Ill.: at the rapids on Rock r., $170 \mathrm{~m}$. N. by E. Springfield, and on the Galena and Chicago Union R. R., 92 m. N.W. by N. Chicago. It is located on a high and fertile prairie on the W. side of the river, and contains the court-house, jail, etc. Immense water-power is derived from the rapids, and there are some good mill-seats. Steamboats come up to this place. The "Rockford Forum" (whig) is a weekly issue. Pop, 2,093.

RockFORD, p. v. and sta., Jackson co., Ind.; on E. side of East fork of White r., and on the Jeffersonville R. P., 52 m. $\mathrm{N}$. Jeffersonville, and $55 \mathrm{~m}$. S. by E. Indianapolis.

RockFoRD, p. $v_{\text {., }}$ and eap. Surry co., N. Car, : on N. side of Yadkin r., $128 \mathrm{~m}$. W. N. W. Raleigh.

Rockmord Cotrt-ILouse, Coosa co, Ala.: on a branch of Hatchet cr. of Coosa r., 34 m. N. Montgomery.

Rock Grove, p. o., Stephenson co., Ill.: on a branch of Rock r., $181 \mathrm{~m}$. N. Springfield.

Rock Hall, p. v., Kent county, MId. : 18 m. N. F Annapolis.

Rock Haven, p. o., Mead county, $K y_{0}: 75 \mathrm{~m}$. W. by $\mathrm{S}$ Frankfort,

Rock Hrus, p. o., St. Louis county, Mro, : 99 m. E. Jefferson City. 
Rock HuL, p. o., Marquette co, Wisc.: 44 m. N. by $\mathbf{E}$. Madison.

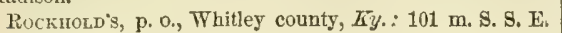
Frankfort.

RockногD's, p. o., Sullivan co., Tenn. : 244 m. E. by N. Nashville.

Rock House, p. o., Sumner co, Tenn.: 81 m. N. E. Nashville.

Rock House, p.On, Hocking co., Ohio: $42 \mathrm{~m}$. S.E.Columbus, Rookhouse Pratrie, pv 0, Buchanan co, Mo. : 1 万ั4 m. W. N. W. Jefferson City.

Roczingham county, $N$ Hamp, Situate $\$$. E., and contains 812 sq. m. Drained by Lamprey and Squamsest rivers and their affluents. Surface generally uneven; soil fertile, and generally well cultivated. The face of the country is diversified with numerous lakes or ponds, the principal of which are Great Bay, in the N. E., and Massabesic pond in the W. It has many important manufactures. Farms 3,811 ; manuf. 984 ; dwell. 9,113 , and pop.-wh. 50, 869 , fr. col. 117-total 50,986. Capital: Exeter. Publio Works: Eastern R. R.; Boston and Maine R. R.; Manchester and Lawrence R. R.; Portsmouth and Concord R. R.; Newbursport Branch $R$. R., etc.

Pockinginam county, $N$. Car. Situate $N_{\text {., }}$ and contains $412 \mathrm{sq}$. m. Drained by Dan r. and its branches, and head hranches of Haw $r$. Surface elevated, and in some parts billy, and well adapted to grazing; soil very fertile, and tobacco is grown considerably, forming one of its staples. Farms 717 ; manuf. 43 ; dwell. 1,698, and pop.-wh. 8,647 , fi. col. 419, sl. 5,329-total 14,395. Capital: Wentworth.

Rockixgray county, Virg. Situate centrally, and contains $769 \mathrm{sq} . \mathrm{m}$. Drained by Shenandoah r. and its branches. Surface broken, and in parts mountainous; soil various, adapted to grazing in the uplands-along the streams very fertile. Chief products, wheat and Indian corn. Some tobacco is also grown. Farms 1.213; manuf. 167; dwell. 3,047 , and pop.-wh. 17,498, fr. col. 465, sl. 2,331-tutal 20,294 . cupiteit: Harrisonburg.

Rocringmax, p. v., and cap. Richmond co, $N$. Car $:$ on Hitcheock's cr., 81 m. S. W. Raleigh. It contains a courthouse, jail, etc.

RockinghaM, $t$, and p. v., Windham county, Tormn.: is delightfully located on W. side of Connecticut river, $7 \mathrm{~s} \mathrm{~m}$. S. by E. Montpelier. Drained by William and Sextas rivers, tributaries of the Connecticut $\mathbf{r}$. Surface uneven; soil fertile. Its agricultural products are large, and it has extensive manufactories. The location of the t. renders it a mart of much interior trade, and has eaused the crection of a number of neat and pleasant villages. In the Connecticut r., near the S. E. corner of the t., is "Bellows Falls," around which is an interesting locality of minerals. The rocks are principally gneiss. The river here is compressed into a narrow strait, between steep rocks, and for nearly a quarter of a mile has a rapid flow. A canal, with 9 locks, passes round these falls. A bridge (erected in 1755) spans the river at this point. Immense water-power is derived from the stroms and falls, and used for manufacturing purposes. The manufuetures consist of woolen goods, paper, leather, flour, lumber, ete. The station is on William's river, and on the Rutland and Burlington R. R., $114 \mathrm{~m}$. S. E. Burlington; and the Termunt Talley R. R. passes through the t. The "Republic" (whig) is a weekly issue. Pop. of t. 2,857.

Rock IsLAxD county, $I U$. Situate $\mathrm{N}$. W., and contains 425 sq. m. Drained by Rock r. and other affuents of the Mississippi, which forms its W. boundary. Surface undulating; soil fertile, particularly along the Mississippi. Farms 585; manuf. 11 ; dwell. 1,246, and pop.-wh. 6,935 , fr. col. 2 -total 6.937. Cupitul: Rock Islund. Public Horls: Chicago and Rock Island R. R., ete.

Pock island, Rock Island co., $I l l .:$ a large island in the Mississippi $\mathrm{r}_{n}, 93 \mathrm{~m}$. below Savannah, and $131 \mathrm{~m}$. N. N. W. Epringfitl. It is $3 \mathrm{~m}$. long and about $1 \frac{1}{2} \mathrm{~m}$. wide, with limestone rock for its base. On it stands Fort A rmstrong, a strong and neat fortification of the U. States. On two sides the rock is 20 feet perpendicular in beight above the river, and forins the foundation of the fort. The S. point of the island is elevated about 40 feet above the level of the river.

Pock IslaNd, p. o, Austin county, Tex.: 95 m. E. by S. Austin City.

Rock IsLAND, p. o., Warren county, Tenn : on S. side of Caney fork of Cumberland r., $71 \mathrm{~m}$. S. S. E. Nashville.

Pock Isl,aND CiTr, p. v., and cap. Rock Island county, Ill.: at the junction of Rock river with the Mississippi river, 50 miles below Fan Buren, and 131 miles N. N. W. Springfield. It has been laid out on an extensive plan, is rapidiy increasing, and promises to become a place of considerable importance. It contains a court-house, jail, etc. The position of the city is one of the best on the Upper Mississippi, and the country surrounding it affords fine agricultural fucilities, timber, limestone, and coal in abundarce, large quantities of which are transported to other points. The "Rock Island Advertiser" (whig) is a weekly issue. The Chicago and Rock Island R. R. has its terminus at this point,

Rock IstaND RAPIDS commence at Rock Island, just above the mouth of Rock r., and extend $15 \mathrm{~m}$. up the Mississippi, with a descent of 21 feet 10 inches. The navigation at this point at low water is much obstrueted by ledges of rock, which extend across in various places. The Unitad States government has done something for their improvement.

Rockland county, $N$. $Y$. Situate S. E., and contains 172 sq. m. Drainea by Hackensack r., Ramapo and Saddle rivers, branches of the Passaic, and small streams of Hud. son r., which bounds it on the E. Surface hilly, and in some parts mountainous and much broken; soil generally fertile. It has some valuable minerals, and contains some fine beds of magnetic iron ore, and quarries of variegated marble. Large quantities of ice are exported to New York from this county. Chief products, wheat and Indian corn. Farms 682; manuf. 144; dwell. 3,011, and pop.-wh. 16.368, fr. col. 591-total 16,962. Capital: Clarkstown, Public Works: New York and Erie R. R.

Rockland, t. and p. 0., Sullivan co., $N . Y_{.}: 72 \mathrm{~m} . \mathrm{S} . \mathrm{W}$. Albany. Drained by Beaver Kill and branches, tributary of the Delaware. Surface hilly and mountainous; soil various, fertile in the valleys. It has good water-power, and there are several mill-seats. Pop. of t. 1,174.

Rockland, t. and p. o., Venango county, Penn.: 164 m. W. N. W. Harrisburg. Bounded on the W. by the Alleghany r. Drained by Reil river. Iron ore abounds in the vicinity, and there are two furnaces, one moved by steam, of 1.600 tons, and one moved by water and steam-power, of 1,350 tons annual capacity.

RockLAND, sta., Baltimore co, MI.: on the Westminster branch of Baltimore and Susquehanna R. R., 9 m. N. by W. Baltimore.

PockLAND, t. and p. O., Lincoln co., Me. : on the W. coast of Penobscot bay, and includes Ow!'s Head, $40 \mathrm{~m}$. 8. W. by W. Augusta. Formerly called East Thomaston, and taken from Thomaston in 1848. Drained by a branch of the St. George $r$. It has a fine harbor, and is famous for the manufacture of lime, obtained from the inexhaustible limestone leclyes in the ricinity, and shipped in large quantities to different parts annually, and an excellent quality of granite (quarried by the convicts in Thomaston) is shipped from this point. Ship-building is carried on here, and it is a place of considerable maritime commerce. It has steam communication with Boston and Bangor, from which latter place it is distant about 55 miles. $A$ large number of vessels pass here daily. It contains a bank; and the "Rock Gazette" (neut,) is a weekly issue. Pop. of t. 5,052.

Pockland LAKE, p. O., Rockland co., N. Y.: 103 m. S. Albany. Rockland lake is a body of very pure water, $5 \mathrm{~m}$. in circumference, 200 feet above the level of Hudson river, chiefly valuable for its ice, which is used in supplying the New Turk market. 
Rocklaxd Mrlts, p. o., Augusta county, Firg.: $101 \mathrm{~m}$. W. N. W. Richmond.

Iock Mills, p. o., Hancock county, Ga. : on W. side of Ogeechee r., 85 m. E. N. E. Milledgeville.

Rock Mrlis, p. o., Anderson dist., S. Car.: on W. side of branch of Savanuah r., $103 \mathrm{~m}$. W. N. W. Columbia.

Rock Mrits, p. o., Randolph county, Ala.: 97 m. N. E.

Montgomery.

Rock Mountain, De Kalb co, $G a_{i}$ : a bigh, solitary peak, 2,226 feet above the stream which winds around its base It is about $7 \mathrm{~m}$. in circumference.

Rock Potrt, p. o., Independence co., Ark,: on S. side of Saline cr., $69 \mathrm{~m}$. N. E. by N. Little Rock.

Rockport, p. o., Hot Springs co., Ark.: on E. side of Ouachita r., 40 m. S. W. by W. Little Rock.

Rockport, p. o., Pike co., $I l l$ : on the Snycartee Slough, $74 \mathrm{~m}$. W. by $\$$. Springfield.

RockPort, p. v., and cap. Spencer co., Ind.: on N. bank of Ohio r., $15 \mathrm{~m}$. below Maxville, $134 \mathrm{~m}$. S. S. W. Indianapolis. It is located on Rock Lady Washington, a formation of sandstone, which rises in a circular form to the height of 30 feet above the first bank of the river, presenting a bold front. The position is very commanding, and the surrounding country is exceedingly rich and fertile, producing large crops of corn, etc. It contains the county buildings, a tannery, ship-yard, ete.

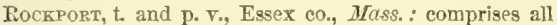
the seaward portion of the extremity of Cape Ann, $31 \mathrm{~m}$. N. E. Boston. There are two pleasant villages in the t., Sandy Bay and Pigeon Cove, about $1 \mathrm{~m}$. apart, at both of which are artificial harbors for small vessels. Although the $t$. derives its name from the character of its shores and surface, it contains many large tracts of elear laud. At Pigeon Core are extensire quarries of granite. This $t$. is of much resort in the summer months. There are some stores and a bank, capital $\$ 100,000$. Pop. of t. 3,255 .

Rockport, to, p. o., and sta. Cuyahoga co., Ohio: on W. side of Rocky r., near its entrance into Lake Erie, the N. boundary of the t., $116 \mathrm{~m}$. N. N. E. Columbus. The Cleveland, Columbus, and Cincinnati R. R. passes through its S. part, $7 \mathrm{~m}$. from Cleveland. Pop. 1,441.

Rockport, p. o., Carbon county, Penn.: 76 miles N. E. Harrisburg.

Rock Peatrie, p. 0., Rock county, Wisc.; 35 m. S. S. E. Madison.

Rock Pratrie, p. v., Dade county, DLo.: 116 m. S. W. Jeffirson City.

Rock Quarry, p. o., Pope co., Mls: on N, side of Ohio $\boldsymbol{r}_{\text {, }}$ $174 \mathrm{~m} . \mathrm{S} . \mathrm{S} . \mathrm{E}$. Springfield.

Rock Rift, p. 0., Delaware con, $N$. $Y$.

Rock River, p. a., Fond du Lac co., Wisc.: 62 m. N. E. Madison.

Rock Rux, p. o., Stephenson county, $\pi l .: 173$ miles $N$. Springfield.

Rock RuN, p. on, Harford co., MId. : $49 \mathrm{~m}$. N. Annapolis. Rocksidra, Warren county, N. Jer : $40 \mathrm{~m}$. N. W. by N. Trenton.

Rocksford, p. o., Tuscarawas co., OTio: 83 m. E. N. E. Columbus.

Rock Spring, Walker co., Ga.: on W. side of branch of

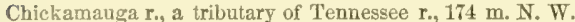
Milledgeville.

Rock Spring, Orange co., N. Car.: $47 \mathrm{~m}$. N. W. Raleigh. Rock Springs, p. o., Cecil county, Md.: $52 \mathrm{~m}, \mathrm{~N}$. E. Annapolis.

Rock Station, sta., Plymouth co., Mass.: on Cape Cod Branch R. R., 5 m. from Middleboro', 24 m, from Boston.

Rock StpEAM, p. O. and sta., Yates county, $N . Y_{0}:$ on W. bank of Seneca lake, $164 \mathrm{~m}$. W. Albany. The Canandaigua and EImira $\mathrm{P}$. $\mathrm{R}$. passes through, $40 \mathrm{~m}$. from Canandaigua, and $27 \mathrm{~m}$. from Elmira.

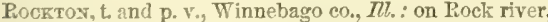
$183 \mathrm{~m}$. N. Springfield. The t. lies chiefly on the W. side of
Rock r., and is also well watered by Pekatonica r. flowing E. through its centre, and by N. Sugar er., which drains its N. portion and enters the Pekatonica $6 \mathrm{~m}$. above its mouth. Surface undulating; soil rich prairie land, with some timber. The $\mathbf{p}$, is on E. sile of Rock river.

Rocктох, p. v. and sta., Herkimer county, N. 1.: $91 \mathrm{~m}$. W. N. W. Albany. Formerly called Little Falls. Surface of t. hilly and mountainous; soil saniy and argillacenus loam, watered by Mohawk $r_{\text {., }}$ on the S. side of which runs the Erie Canal, and on the N. side the Utica unil sch:nectady R. R. The $\mathrm{v}$. is beautifully situated on both sides of the Mohawk r., and is of some resort for its romantic scenery. The gap through which the $r$. passes is comparatively narrow, and on both sides the wooded hills rise from 350 to 400 feet. Their bases are of sandstone, above which are extensire beds of blue limestone, much used for building purposes. The carial here ascends in the space of a mile, by 4 locks, about 40 feet. It is supplied with water by a feeder carried across the $\mathrm{r}$. by a handsome aqueduct of 3 arches, one of 70 feet, and two of 50 feet span. At one point the brow of a hill projects into the river, by which the canal was constructed, with expensive diggings and embankments, and by occupying a part of the river bed for the eanal. The river has here a fall of 42 feet in half a mile, affording great water-power. Its bed is of granite gneiss, very hard, but easily quarried for builling stones, and abounding with quartz crystals. The $\mathrm{v}$. is principally on the N. side of the river, and contains several flouring, plaster, and paper mills, woolen factory, machine shop, several furnaces, and other manufactories; 1 bank, capital $\$ 200,000$, academy, and 5 churches. Two newspapers are issued weekly, "Mohawk Courier" (dem.), and "Herkimer Journal" (whig). The $\mathbf{v}$, is supplied with water from a spring in the hills, 300 feet above the tops of the houses. Pop. of t. in $1840,3,851$; in $1550,4,855$.

Rock Valley, p. o., Marshall co., Firg. : 233 m. N. W. Richmond.

Rock VALLEY, p. 0., Hampden co, Mass. : 78 m. W. by S Boston.

Rockville, p. v., Washington county, $R . I_{.}: 18 \mathrm{~m}$. W. Newport.

Rockville, p. v., Tolland county, Conn. ; 14 miles N. E. IIartford. A flourishing manuficturing $\vee$., having several cotton and woolen mills.

Rockville, p. v., Putnam county, $G a$.: 15 miles $\mathbb{N}$ Milledgeville.

RockvILLE, p. ₹., Will co., Ill.: $1 \mathrm{~m}$. E. of Iroquois river, $127 \mathrm{~m}$. N. E. Springfield.

Rockvilue, p. v., and cap, Parke co., Ind.: on W. side of branch of Little Raccoon er., $54 \mathrm{~m}$. W. Indianapolis, It is on elevated ground, and surrounded by an extensive tract of rich and beautifully rolling land, comprising some of the best farms of the State. It was first settled in 1523, and now contains the usual county buildings, a flourishing county seminary, female academy, and 6 churches. The "Parke County Whig" is published weekly. Pop. about 1,200 .

Rockville, p. v., Delaware con, $T a_{0}$ : on E. bank of branch of Makoqueta r., 51 m. E. N. E. Iowa City.

RockVILLE, p. O., Waldo con, Me.

Rockville, p. v., and cap. Montgomery co, MId.: $33 \mathrm{~m}$ W. by N. Annapolis, on W. side of Rock creek of Potomac river. It contains the usual eounty buildings. The "Maryland Jourual" (whig) is issued weekly. Pop. S10.

Roczville, p. v., Norfolk county, Mass.: on W. side of Charles r., $22 \mathrm{~m}$. S. W. Boston. Has some manufactures.

Rockville, p. o., Allegany co., N. Y.: $21 \mathrm{~s} \mathrm{~m} . \mathrm{W}$. by S. Albany.

Roceville, p. v., Rowan co., N. Cur.: $111 \mathrm{~m}$. W. by N. Raleigh.

Rockville, p. vo, Adams co, Ohio: on the Ohio r., $\$ 3 \mathrm{~m}$. S. by W. Columbus.

Rockville, D. v., Chester county, Penn.: 61 miles E. S. E. Harrisburg. Here is a cold blast charcoal furnace of 1,000 tons 
annual capacity, which amount it made in 1S49, employing 75 men, using water-power.

Rockville, sta., Perry county, Penn. : on Pennsylvania R. R., $7 \mathrm{~m}$. W. by N. from Harrisburg.

Rockville, p. F., Monroe co., Tenn.: 151 m. E. S. E. Nashville.

RockVILLE, p. 0., Hanover co., Firg.

Rockvilite, p. O., Lexington district, S. Car.: $15 \mathrm{~m}$. W. Columbia.

Rockvilli Centre, p. o., Queen's co., N. Y.: 132 m. S. Albany.

RockwELL, p. v., Bond co., IIl. : on E, side of W. fork of Shoal creek, $64 \mathrm{~m}$. S. Springfield. Surrounded by first-rate prairie land. The "Western Evangelist" is issued monthly, and the "Primitive Preacher" quarterly, both Baptist publications.

Rockweli, p. o., Pickens district, S. Car.: 125 miles N. W. by W. Columbia.

Rocks river, $N$. Car.: rises by numerous branches, which drain the whole of Cabarras co., flows E., and empties into the Yadkin river.

Rockу river, S. Car.: rises in Anderson dist., flows $\mathbf{S}$. through W. part of Abbeville dist., and empties into Savannah river.

Rocky Bayov, p. O., Izard co., Art.: on E. side of Rock cr., $85 \mathrm{~m} . \mathrm{N}$. by E. Little Rock.

Rocky Braych, p. 0., Greenup co., Fy. : 118 m. E. by N. Frankfort.

Rocky CoNFort, p. o, Sevier co., Ark.: 124 m. W. S. W. Little Rock.

Rocky Creek, p. o., Iredell co., $N_{\text {. }}$ Car.: on Rocky cr, $12 S \mathrm{~m}$. W. by N. Raleigh.

Rocky Ford, p. Oa, Pontotoc co., AFiss. : 146 m. N. N. E. Jackson.

Rocky Gap, p. 0., Tazewell co., Virg.: 231 m. W. by S. Richmond.

Rocky HiLt, p. v., Hartford co., Connn.: on W. side of Connecticut $\mathrm{r} . \mathrm{r}_{\frac{1}{2}} \mathrm{~m}$. S. Hartford. It is a pleasant little $\mathrm{v}$., containing a Congregational church, etc. Some vessels are built here.

Rоску HrLx, p. o., Barren co., Ky.: 97 m. S.S.W. Frankfurt, Rocks HiLl, p. v., Somerset co., N. Jer. : on W. side of Millstone r., $121 \mathrm{~m}$. N. N. E. Trenton, containing a few mills, a woolen factory, and stores.

RockY HILL, p. o., Jackson co., Ohio: 63 m. S. by E. Columbus.

Roory Mrus, p. o, Lavacca co., Tex, : 76 m. S. E. Austin City.

Rooky Mouvt, p. v., Meriwether co., Ga.: $90 \mathrm{~m}$. W. Milledgeville.

Rocky Mount, p. 0., Kemper co., Mfiss. : 103 m. E. N. E. Jackson.

Rockт Mount, p. o., Miller co., Mro.: 29 m. W. S. W. Jefferson City.

Rockr Mount, p. v. and sta., Edgecombe co., N. Car. : on N. bank of Tar r., $49 \mathrm{~m}$. N. E. by E. Raleigh. The Wilmington and Weldon R. R. passes through the $\mathrm{v} ., 37 \mathrm{~m}$. from Weldon, and $125 \mathrm{~m}$. from Wilmington.

Rockx Mount, p. o., Fairfield dist., S. Car.: on W. side of Catawba r., $83 \mathrm{~m}$. N. by E. Columbia.

Rockr Modxr, p. v., and cap. Franklin co., Virg.: on

N. side of Pig r., a tributary of Roanoke r., $134 \mathrm{~m}$. W. S. W. Richmond. It contains a court-house, jail, stores, tannery, and an iron furnace, which emploss 100 laborers. Pop. about 450 .

Rocky Narrows, p. o., Monroe county, Ohio: 99 m. E. Columbus.

Rocky Platss, p. o., Newton co., Ga.: 53 m. N. W. Milledgeville.

Rockx Polwt, p. o., Seott co., Virg. : $281 \mathrm{~m}$. W. by S. Richmond.

Rocky PorNt, p. o, Attala eo, Miss.: 58 m, N. N. Ev Jackson.
Rocky Potyt, sta., New IIanover county, N. Carn: : on Wilmington and Weldon Railroad, $14 \mathrm{~m}$. N. by E。 Wilmington.

Rocky River, p. o., Warren co., Tenn。: 70 m. E. S. E. Nashville.

Rocky Run, p. o., Columbia co., Wisc. : 28 m. N. Madison. Rocky Sprivg, p. o., Jackson co., Ala.: 184 m. N. by E. Montgomery.

Rockx Sprivg, p. 0., Claiborne co., Miss. : 97 m. W.N.W. Jackson.

Rockr Sprisg, p. o., Grainger co, Tenn.: 179 m. E. Nashville.

RockY WeLL, p. v., Lexington dist., S. Car.: on the $\mathrm{S}$. side of Saluda r., $20 \mathrm{~m}$. W. Columbia.

RODGER's ROAD, sta., Erie co., N. Y.: on the Buffalo and State Line R. R., $10 \mathrm{~m}$. S. Buffalo, and $269 \mathrm{~m}$. W. Albany.

RoDMas, t. and p. v., Jefferson co., $N_{0} Y_{0}$ : on Sandy cr, $142 \mathrm{~m}$. N. W. Albany. Surface of t. undulating; soil sandy and elay loam of good quality. The $\mathrm{v}$. on Sandy creek contains 8 churches, saw, grist, carding, and fulling mills, several stores, ete. Pop. of t., in 1840, 1,702 ; in 1850, 1,784. RopNex, p. v., Jefferson co., Miss.: on E. side of Mississippi r., $68 \mathrm{~m}$. S. W. by W. Jackson. It contains several stores, and a fine steam saw-mill. Pop. 510.

Rouney, p. o., Gallia co., Ohio: $83 \mathrm{~m}$. S. S. E. Columbus. Roesfield, p. o., Catahoula par., La.: 103 m. N.W. by N. Baton Rouge.

Rogers' Bridge, p. o., Spartanburg dist., S. Car.: $83 \mathrm{~m}$. N. W. Columbia

Roger's FARM, p. O, M'Lean co., Ill.: on W. side of head branch of Kickapoo cr., $57 \mathrm{~m}$. N. E. Springfield.

Roger's Store, p. o.. Wake co., N. Car.: on E. side of Neuse r., $12 \mathrm{~m}$. N, by E, Raleigh.

Rogerstille, p. v., Lauderdale co., $A l a$ : about $4 \mathrm{~m} . \mathrm{N}$. of Tennessee r., $178 \mathrm{~m}$. N. by W. Montgomery.

Rogersvule, p. o., Tuscarawas co., Ohio: 77 m. E. N.E. Columbus.

Rogerstille, p. o., Halifax county, Firg.: 93 m. S. W. Richmond.

Rogersville, p. o., Madison county, $K y_{0}: 49$ m. S. F. Frankfort.

Rogerstilie, p. o., Henry co., Ind.: on N. side of head branch of Blue r., $46 \mathrm{~m}$. E. N. E. Indianapolis.

Rogerspille, p. o., Greene co., Penn.: $174 \mathrm{~m}$. W. by $\mathrm{S}$ IIarrisburg.

Rogerstille, p. v., and cap. Hawkins co, Tenn.: about $2 \mathrm{~m}$. N. of Holston $\mathrm{r}_{0}, 209 \mathrm{~m}$. Ev by N. Nashville. 'It contains a court-house, jail, several stores, etc. The " $\mathrm{R}$. Times" (whig) is published weekly.

Romrerstown, sta., Lancaster co, Penn.: on Columbia Branch R. R., 6 m. W. from Lancaster.

Romrerstille, p. v., Washington co., MMa: $76 \mathrm{~m} . \mathrm{N}$. W. Annapolis.

Rohrsburg, p. v., Columbia co, Penn.: on N. side of branch of Fishing cr., $61 \mathrm{~m}$. N. by E. Harrisburg.

Rокевг p. o., Morgan county, Olio: 63 m. E. by S. Columbus.

Rolestille, p. vo, Wake con, N. Car.: 47 m. N. E. of Neuse r., $15 \mathrm{~m}$. N. E. by N. Raleigh. Pop. about 200

Roliersville, p. v., Sandusky county, Ohio: $97 \mathrm{~m} . \mathrm{N}$ Columbus.

Rolutw, t. and p. o., Lenawee co., Mich.: 65 m. S. by E. Lansing, Michemanetuc or Devil's lake is in its N. part, whence flows Tiffin's cr. through its W. portion, affording excellent water-power. The soil is very fertile, well adapted to grain. The $\mathrm{v}$. on the creek contains flouring and saw mills. Pop, of $t$, in 1840,581 ; in $1850,1,080$.

Rollivg FokK, p. 0., Nelson county, $\overline{k y} .: 55 \mathrm{~m}$. S. W. Frankfort.

Rolling Pratrie, p. o, Marion co., Ark.: $119 \mathrm{~m}$. N. W. Little Rock

Rollissford, t. and sta., Strafford co., N. ITamp.: on W. side of Salmon r., $34 \mathrm{~m}$. E. Concord. This is a new t. reo 
cently taken from Somersworth, containing the flourishing ఛ. of Salmon Falls. Three railroads pass through the t.: Boston and Maine R. R., 71 m. from Boston; Branch R. R. to Great Falls, etc.; and the York and Cumberland R. R. now in construction. This t. contains numerous factories, fulling-mills, ete. Pop. 1,862.

Rolits's Store, p. o., Moore county, N. Car.: $32 \mathrm{~m}$. S. W. by W. Raleigh.

Rolimssthle, p. o., Darlington district, S. Car.: $63 \mathrm{~m}$. E. N. E. Columbia.

Roma, p. o., Starr county, Tex.: on the Rio Grande, $2 \mathrm{~S} 0 \mathrm{~m}$. S. by W. Austin City.

Rove, p. V., and cap. Floyd co., Gan : at junetion of Etowah and Oostanaula rivers, $164 \mathrm{~m}$. N.W. Milledgeville. The Rome $\mathrm{R}$. R. extends bence to Kingston on Western and Atlantic R. R., and will be continued S. W. to Jacksonville, Ala., there uniting with the Alabama and Tennessee River R. R. The r. contains 2 churches, an academy, and stores. Two newspapers are published weekly, "Rome Bulletin" (whig) and "Southerner" (dem.) Pop. about 800.

RoNe, p. ₹., and cap. Perry co., Ind.: on N. bank of Ohio r., $124 \mathrm{~m}$. S. by W. Indianapolis. It was first settled in 1811. It contains a fine brick court-house, stone jail, county seminary, and 2 churches. Pop. about 300 .

Rosie, p. Y., Henry co., Ia. : on W. side of Skunk r., $47 \mathrm{~m}$. S. by W. Iowa City.

Rove, t. and p. v., Kennebec co., Me.: $17 \mathrm{~m}$, N. by W. Augusta. It has a large pond on its $\mathrm{N}$. border, another on the $\mathrm{E}_{\text {o, }}$ and a third on its $\mathrm{S}$. border, all of which have their outlet into the Kennebec, at Waterville. Incorporated in 1804. The $\mathrm{r}$. is pleasant and flourishing. Pop. of t. 830 .

Rone, t. and p. o., Lenawee co., Afich.: $56 \mathrm{~m}$. S. by E. Lansing. Drained by head branches of Beaver cr. The soil is fertile, adapted to grain. Pop. in $1840,1,128$; in $1850,1,528$.

Posre, t., p. V., sta, and one of the caps, Oneida co, $N$.Y. on the Mohawk r., $91 \mathrm{~m}$. W. N. W. Albany ; by R. R. from Albany $109 \mathrm{~m}$. Surface of $\mathrm{t}$. chiefly level, or gently undulating; soil a fertile clay and sandy loam. Drained E. by Mohawk re, on which is excellent land, and Wood cr., which flows W. into Oneida lake. These streams almost interlock, being only $1 \mathrm{~m}$. separate, and were connected by a small canal before the construction of the Erie Canal, which was bought out when the latter was made. The $\mathrm{v}$. on Mohawk r. is built upon the site of old Fort Stanwyx, built in 1758 , and rebuilt in the Revolutionary War, and called Fort Schuyler. The Syracuse and Utica R. R. passes through it, $14 \mathrm{~m}$. from Utica, $38 \mathrm{~m}$. from Syracuse. Here commences the Watertown and Rome R. R., completed to Cape Vincent, $97 \mathrm{~m}$. The Erie Canal here receives the connection of the Black River Canal, affording communication by water with Lake Ontario, etc. The v., incorporated in 1819 , is, with Whitesboro', a half shire-town for Oneida co., and contains a court-house and jail, a flourishing female seminary, 2 banks, with aggregate capital of $\$ 2 \$ 7,200,6$ churches, a cotton factory, blast furnace, flouring and saw mills, ete. Here is a United States arsenal, to which are attached a magazine and a number of workshops. Two newspapers are issued weekly, " $\mathrm{R}$. Sentinel" (whig) and "Roman Citizen" (whig.) Pop. of t. in 1840, 5,650; in 1850, 7,918.

Rove, t. and p. O., Ashtabula county, Ohio: $153 \mathrm{~m}$. N. E. Columbus. Drained by Grand $\mathbf{r}$. and a branch. This town was formerly called Richfield. Pop. $7 \pm 4$.

Rove, sta., Franklin co., Ohio: on Columbus and Xenia R. R. $8 \mathrm{~m}$. W. from Columbus.

Rosre, t. and p. o., Bradford co., Penn.: on small branch of Susquehanna r., $110 \mathrm{~m}$. N. by E. Harrisburg. Contains a number of saw and grist mills, and has some manufactures. Pop. about 1,000 .

Rose, p. v., Smith co., Tenn. : on S. side of Tennessee r., $47 \mathrm{~m}$. E. Nashville.

Rosne, p. 0., Jefferson co., Wisc. : 43 m. E. by S. Madison.

RoNro, p. V., Macomb co., Mich.; on S. side of N. branch of Clinton r., $78 \mathrm{~m}$. E. Lansing. It is pleasantly situated, and is surrounded by an excellent farming country. It contains a very flourishing academy, an iron foundry, and tannery. The " $\mathrm{P}$. Investigator" (temp.) is issued weekly.

Roxeo, p. v., Greene co., Tenn.: 213 m. E. Nashville.

Romeo, p. o., N'Henry county, $I l l .: 177$ miles N. N. E. Springfield.

Romince's Milus, p. Oa, Harrison county, Firg.: $199 \mathrm{~m}$.

N. W. Richmond.

Rouner, p. o., Tippecanoe co., Ind. : on E. side of Wea cr., a tributary of Wabash $\mathrm{r}$., $51 \mathrm{~m}$. N. W. Indianapolis. It contains a court-house, and about 500 inhabitants.

Romvey, p. V., and cap. Hampshire co, Virg.: on E. side of $\mathrm{S}$. branch of Potomac r., $142 \mathrm{~m}$. N. by W. Richmond.

Rosulvs, p. o., Tuscaloosa co., Ala.: on W. side of Black Warrior r., 99 m. N. W. Montgomery.

Roxulus, t. and p. o., Wayne county, Mich. : 64 m. S. E Lansing. Pop., with Taylor and Van Buren, 2,838.

Rouvurs, t. and p. v., Seneea co., $N$. $Y_{0}:$ lies between Cayuga and Seneca lakes, $159 \mathrm{~m}$. W. Albany. The surface is high in the centre, declining $\mathrm{E}$. and W. toward the lakes ; soil of good quality, well adapted to wheat. The village is a small settlement, containing a church, tavern, a few stores, ete. Pop. 2,040.

RoNald, t, and p. o., Ionia co., Mich : $31 \mathrm{~m}$. N. W. Lansing. Drained by Prairie cr. of Grand r. and its branches. Pop. 452.

Rook's creek, Livingston county, $I l l$ : 64 miles N. E. of Springfield.

RoNDOUT, p. V., Ulster co, $N . \quad Y .:$ on N. side of Rondout $\mathrm{cr}_{\text {., }} 1 \mathrm{~m}$. above its entrance into the Hudson $\mathrm{r}_{\text {, }} 52 \mathrm{~m}$. S. by W. Albany. It derives its business importance principally from the Delaware and Hudson Canal, which terminates at Eddyville, $2 \mathrm{~m}$. above, whence the canal-boats are towed by steamboats. In the vicinity are found large quantities of hydraulic cement and quicklime, employing a number of men and vessels. A considerable amount of lumber and produce is here collected, and transported to New York. There are four boat-yards for building and repairing canalboats, two dry docks for the repairing of sloops and coasting vessels, a grist-mill, tobacco factory, etc., a female seminary, and two churehes. The " $\mathrm{R}$. Courier" (neutral) is issued weekly. Steam ferry-boats ply to Eddyville and Rhinebeck. Pop. about 1,700 .

Rondout kill or creek, $N . \bar{Y} .:$ rises in Sullivan co, and flows into the Hudson $r$, in Ulster $\mathrm{co}_{\text {. }}$ near Rondout $\mathrm{v}$., at which point is a light-house. It receives the Wallkill and other tributaries, and affords water-power. The Delaware and Hudson Canal passes along the valley of this creek.

Ponколкома lake, $N . Y_{\text {: }}$ : situated near the centre of Long Island, about $1 \mathrm{~m}$. in diameter, deep and transparent, abounding with fish, and surrounded by pine and other timber, presenting a romantic and pleasant appearance.

Root, p. v., Allen co., Ind.: on E. side of St. Mary's I., $97 \mathrm{~m}$. N. E. Indianapolis.

Rоoт, t. and p. o, Moutgomery co., $N . Y_{.}: 39 \mathrm{~m}$. W. by N. Albany. Surface in parts hilly; soil fertile loam, or slate and lime. Drained by small streams, flowing into Mohawk $r$. which bounds it on the $N$. On one of these, the Plattekill, is a water-fall, with a perpendicular descent of 50 feet. About $1 \mathrm{~m}$. ahove this fall, a vein of lead ore, found at the bottom of the creek, has been wrought to some extent by a company incorporated for the purpose. In the rocky cliffs near the river is a remarkable cave, containing numerous apartments, of which fourteen have been visited; some of these are 500 feet beneath the surface, and profusely adorned with stalactites, stalagmites, and various incrustations. Population of t. 2,736.

Root Creiex, p. 0, Milwaukie co., Wisc.: 73 m. E. by S. Madison.

Rоoт river, MFinn. Ter: a large stream in S. E. part of the State, flows E. into Mississippi river.

Rootstows, t., p. o, and sta., Portage co., Ohio: $116 \mathrm{~m}$ 
N. E. Columbus, lying directly S. of Ravenna, $43 \mathrm{~m}$. from Cleveland, on Cleveland and Pittsburg $R$. $R$. It is a fine farming t., watered by Cuyahoga $x$. Pop. in 1840, 1,112; in $1850,1,308$.

Roscor, t. and p. $\nabla_{*}$, Winnebago $c_{*}, I l l_{*}:$ on E. sido of Rock r., $181 \mathrm{~m}$. N. by E. Springfield. This is a fine farming town, on the line of the Rockford and Rock Island R. R., now in construction.

Roscow, p. v., Henry county, Mo.: 93 miles W. by S. Jefferson City.

Poscoe, p. o., Todd co., Ky. : 157 m. S. W. Frankfort.

Roscor, p. v., Coshocton co., Ohio: on W. side of Muskingum r., and on the Ohio Canal, $59 \mathrm{~m}$. E. N. E. Columbus, The Muskingum is here formed by the confluence of the Walhonding and Tuscarawas rivers, which are crossed by a fine bridge, just above their confluence. Roscoe has good water-power, an iron foundry, boat-yard, mills, and several stores. The Walhonding Canal, which extends to Rochester, $25 \mathrm{~m}$., here unites with the Ohio Canal. By these canals Roscoe has become a great depôt for wheat and other merchandise. In times of high water, steamboats occasionally run up to this point on the Muskingum. This town was first laid out in 1816, and named Caldersburg. It is a healthful and beantiful place, and surrounded by fine scenery. Pop. about 500 .

Roscomron county, Mich. Situate N. centrally, and contains 576 sq. m. Drained by the branches of the Maskegon and South rivers, and streams of Higgins' and Houghton's lakes. Surface even; soil various, but for the most part fertile. Organized since 1850 .

Rose, $t$, and p. 0., Oakland co., $37 \mathrm{c}$. : $47 \mathrm{~m}$. E. Lansing. Watered by the E. branch of Shiawassee r. Pop. in 1810 , 415 ; in $1550,836$.

Rose, t. end p. o., Wayne co., $N . Y_{.}: 7 \mathrm{~m}$. N. E. Lyons, $164 \mathrm{~m}$. W. by N. Albany. Surface undulating; soil, gravelly loam; drained by small streams flowing into Lake Ontario. It contains several saw-mills, a fulling-mill, and tannery. Pop. in $1840,2,038$; in 1850, 2,264.

Rose, t. and p. o., Carroll co., Ohio: $97 \mathrm{~m}$. E. N. E. Colum3us. The Beaver Canal passes through its N. W. corner. Pop. 1,587.

Rosebooy, p. o., Otsego co., $N$. Y.: 51 m. W. Albany.

Rosebure, p. v., Perry co., Penn.- 29 m. W. Harrisburg.

Rose Creek, p. 0., M·Nairy county, Tenn.: $120 \mathrm{~m} . \mathrm{S}$. W.

Nashville.

Rosedale, p. v., Madison county, Ohio: $25 \mathrm{~m}$. W. N. W. Columbus.

Rose Grove, p. o., Appomattox co., Virg. : 73 m. W. by S. Richmond.

Rose HrL, p. o., Seneca county, $N_{0}$ Y.: $158 \mathrm{~m}$. W. Albany.

Rose HILL, p. ve, Jasper co, $I Z_{*}$ : on E. side of Embarras r., 88 m. E. S. E. Springfield.

Rose Hill, p. o., Amité co., Misss.: on W. side of branch of Amitié r., 100 m. S. S. E. Jackson.

Rose Hill, p. o., Lee co., Firg. : about $17 \mathrm{~m}$. E. Cumberland Gap, $319 \mathrm{~m}$. W. by \$. Richmond.

Rose HILL, p. o., Mahaska co., Ia. : on N. side of Skunk r., $50 \mathrm{~m}$. S. W. by W. lowa City.

Ruselaxd, p. o., Nelson county, Tirg.: $78 \mathrm{~m}$. T. by N. Pichmond.

Rose Milus, p. o., Amherst co., Fing.: on S. side of Tye r., a branch of James $r_{*}, 87 \mathrm{~m}$. W. by N. Richmond.

RosexDale, t. and p. v., Ulster co., $N . Y$.: on N. side of Rondout Kill, $63 \mathrm{~m}$. S. by W. Albany. Here is found in great abundance the best of hydraulic cement, which is manufactured in large quantities by two cement mills. The unoccupied water-power at this place is very extensive.

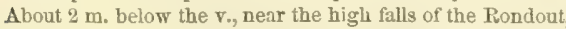
is a mineral spring, possessing valuable properties. Pop. of t. 2,418 .

Roserdare, t. and p. o., Fond du Lac co., Wisc.; $6.5 \mathrm{~m}$. N. E. by N. Madison. Pop. 714 .
Rose Tree, p. o., Delaware co., Penn.: 81 m. E. by S Harrisburg.

Roseville, p. v., Parke co., Ind.: on \$. side of Big Raccoon cr., $58 \mathrm{~m}$. W. by $\mathrm{S}$. Indianapolis.

Rosevilte, p. O., Franklin co., Ark. : on S. side of Arkansas r., $95 \mathrm{~m}$. W. N. W. Little Rock.

Roseville, p. 0., Macomb co., Jfich. : 84 m. E. Lansing.

Roseville, p. v., Muskingum co., Orio: on S. fork of Jonathan's cr., 49 m. E. by S. Columbus; contains a few mills and stores, and about 200 inhabitants.

Rosiclare, p. o., Hardin co., $1 l$ : : 1 $\mathrm{m}$. N. of Ohio $r$. $125 \mathrm{~m}$. S. S. E. Springfield.

Rosuiv, p. o., Marquette co., Wisc. : $57 \mathrm{~m}$. N. Madison.

Rosly, p. 0., Queen's co., $N$. $Y$. : at southern extremity of Hempstead Harbor, 133 m. \$. Albany.

Ross county, Ohio. Situate toward the S., and contains $644 \mathrm{sq}$. m. Scioto river flows through it from N. to S., by which and its branches it is drained. Surface varied, in the $\mathrm{N}$. being level, and in the $\mathbf{S}$. hilly and broken; soil generally fertile; in the level portions the land is rich and very productive. There is some good timber land, and it has excellent pasturage for cattle, large numbers of which are exported. It has good water privileges. Furms 1,435; manuf. 141, dwell. 5,575, and pop.-wh. 30,207, fr. col 1,867-total 32,074. Capital: Chillicothe. Public Works: Ohio Canal, etc.

Ross, t. and p. o., Butler co, Ohio: on W. side of Miami river, $94 \mathrm{~m}$. W. S.W. Columbus. Drained by Miami r.and its branches. Pop. in 1540, 1.526; in 1850, 1.643.

Ross, p. 0, Anderson co., Tenn.: 147 m. E. Nashville.

Ross Bure, p. v., Decatur co., Ind.: on S. side of branch of Salt creek, a tributary of Whitewater river, $49 \mathrm{~m} . \mathrm{S}$. E. Indianapolis.

Poss' CORNER, p. o., York county, $M e_{0}: 79 \mathrm{~m}$. S. S. W. Augusta.

Rosseat, p. v., Morgan county, Ohio: 59 m. E. S. E. Columbus.

Ross' Ferer, p. o., Livingston county, $\bar{K} y .: 199$ miles S. W. by W. Frankfort.

Ross' Grove, p. O., De Kalb co., $M$. : on W. side of Little Indian cr., $134 \mathrm{~m}$. N. by $\mathrm{E}$. Springtield.

Rossie, t. and p. v., St. Lawrence county, N. Y.: $150 \mathrm{~m}$. N. W. Albany. Surface of to undulating and smewhat broken; soil fertile loam, resting on lime, granite, and sandstone. Drained by Oswegatchie and Indian rivers. Iron and lead ore are found in great abundance. The lead ores are of the finest quality, and apparently inexhaustible. These have been extensively worked since 1837 by three companies, which have produced and sent to market larga amounts of lead. The veins have been traced $15 \mathrm{~m}$, varying in width from 6 inches to 2 feet, lying in a fissure of rock in a solid roass; and from its location, its depth is evidently very great. The mine on Cole Hill is the principal, the surface of which has been laid bare for a considerable distance, bounded on either side by granite rock. The mine is regarded by geologists as an anomaly in the mineral kingdom, and great natural curiosity, as well as a souree of inexhaustible wealth. The $\mathrm{V}_{\text {, }}$, on Indian $\mathbf{r}_{\text {, }}$ is the principal locality of these mines, and is a scattered manufacturing settiement, containing an exlensive furnace and forge, iron foundry and machine shop, 1 grist-mill, 1 saw-mill, 2 taverns, several stores, and about 900 inhabitants. Pop. of to in 1540, 1,553; in 1S50, 1,471.

Rosstows, p. o., Shelby co, Tenn.: 179 m. W. S. W. Nashville.

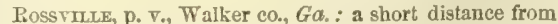
the Tennessee boundary, 153 m. N. W. Milledgeville. Formerly a missionary station in the Cherokee Nation.

Rossville, p. v., Clinton eo., Ind.: on S. side of Middle fork of Ponceanichioux r. or Wild Cat $\mathrm{cr}_{.}, 49 \mathrm{~m}$. N. N. W. Indianapolis.

Rosstille, p. v., Baltimore co., MId.: 30 m. N. Annapolia Rossvuce, p. ., Richmond co., $N_{\text {. }} Y_{*}$ : on Staten Island 
Sound, $145 \mathrm{~m} . \mathrm{S}$. by W. Albany. It contains 2 carriage manufactories, a few stores and dwellings, has a steamboat landing, and a ferry to the Jersey shore, formerly known as the Old Blazing Star Ferry.

Rossville, p. Oa, Chester district, S. Car.: $45 \mathrm{~m} . \mathrm{N}$. Columbia.

Rossrule, p. Y., Butler co, Ohio: on W. side of Miami r., $89 \mathrm{~m}$. W. S. W. Columbus. A flourishing and wealthy v. The "Miami Democrat" is issued weekly. Pop. 1,452.

Rossville, p. v., York county, Penn.: $14 \mathrm{~m}$. S. by W. Harrisburg.

Rostrater, t. and p. o., Westmoreland co., Penn. : on E, side of Monongahela r., $182 \mathrm{~m}$. W. Harrisburg.

Roswell, p. 0., Cobb co., Ga.: on N. side of Chattahoochee r., 98 m. N. W. Milledgeville.

Rotherwood, p. o., Carroll co., Ga. : $109 \mathrm{~m}$. W. by N. Milledgeville.

Rotterdav, t. and p. o., Schenectady co., $N_{0} Y_{\text {. }}: 19 \mathrm{~m}$. N. W. Albany. Surface rolling; soil sandy loam and alluvion, very productive along the Mohawk r., which bounds it on the N.; also watered by some small creeks flowing into the Mohawk. The Erie Canal passes through its $\mathrm{N}$. parb. Pop. of $t$. in 1840, 2,284; in 1850, 2,446.

Roubinoux, p. o., Texas co., Mo.: on E. side of Roubi. doux fork of Gasconade r., $79 \mathrm{~m}$. S. Jefferson City.

ROEGE river (of the Detroit), Mich.: is formed from three prineipal tributaries which rise in Oakland and Washtenaw counties, and unite in the E. part of Wayne co. The Rouge river empties into the Detroit r., $5 \mathrm{~m}$. below Detroit, and is navigable for small vessels to Dearbornville. Toward is mouth it is deep and sluggish, but the greater portion of it is very rapid, having great descent, and with its numerous branches furnishing very great water-power.

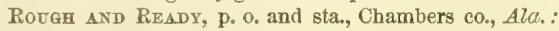
on Montgomery and West Point R. R., $68 \mathrm{~m}$. from Montgomery, $20 \mathrm{~m}$. from West Point.

Rotgr AND Ready, p. 0 , Anderson county, Ky.: $18 \mathrm{~m}$. S. S. W. Frankfort.

Rough and Readx, p. o., Hancock county, $7 l .: 83 \mathrm{~m}$. T. N. W. Sprringfield.

Rough AND ReADy, p. o. and sta., Fayette co., Ga.: on Macon and Western R. R., $11 \mathrm{~m}$. from Atlanta and $90 \mathrm{~m}$. from Macon, $79 \mathrm{~m} . \mathrm{N}$. W. by N. Milledgeville.

Rougir axd Ready, p. o., Steuben county, N. I. : $190 \mathrm{~m}$. W. by S. Albany.

Rovgir Axd Rieady, p. O., Warren co., Tenn.: 67 m. S. E. Nashville.

Rodgh aNd Ready Mruls, p. o., Henry co., Firg.: $143 \mathrm{~m}$. S. W. Richmond.

Rovgr Cremk, p. o., Charlotte co., Firg.: 71 m. W.S.W. Richmond.

Rough Ceeer, p. O.. Grayson co., Ky.: 101 m. W. S. W.

Frankfort.

Rotletre, t. and p. o., Potter co., Penn.: 122 m. N. N. W.

Harrisburg.

Round island, Mich.: a small island on the N. part of Lake Huron, between Bois Blanc and Mackinau islands.

Round lake, $N$. $Y . \therefore$ a handsome sheet of water, lying in the t. of Lake Pleasant, Hamilton co., connected by an outlet $\frac{1}{3} \mathrm{~m}$. long, with Lake Pleasant. It is surrounded by a fine region of country, abounds with trout and other fish, and much resorted to by sportsmen.

Rousd lake, $N . Y$. : in the t. of Malta, Saratoga $c_{0}$, is a small lake, abounding in perch, pickerel, and other ffsh.

Round Grove, p. o., Curroll co., Mo.: 95 m. W. N. W. Jefferson City.

Rouxd HFAD, t. and p. v., Hardin co., Ohio: 58 m. N. W. Columbus. Drained by the head branches of Scioto and Miami rivers. The v., situated on the former, contains 135 inhabitants. Pop. of $t$. in 1840, 569 ; in 1850 (including

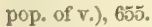

Round Hilu, p. vo, Fairfield county, Conn.: 72 m. S. W. Hartford. Contains a church and several dwellings.
Round Hrus, p. o., Cooper county, Mo.: 32 m. W. by N. Jefferson City.

Round Hill, p. 0., Orange co., N. Car. : $31 \mathrm{~m} . \mathrm{N}$. W. Raleigh.

Round Pond, p. o., Lincoln county, Me.: 26 m. S. E. Augusta.

Rodnd Pratrie, p. o., Dallas county, MYo: 75 m. 8. W. Jefferson City.

Round Tor, p. 0., Fayette co., Texe : on Cummin's cr. of Colorado $r$. on the post-road from Lagrange to Washington, $64 \mathrm{~m}$. E. by S. Austin City.

Rouse's Porve, p. v. and sta., Clinton co, $N$. Y.: on the W. side of Lake Champlain, $166 \mathrm{~m}$. N. by E. Albany. I is about $\frac{1}{2} \mathbf{m}$. S. of the Canada line. Soon after the war of 1812, the United States commenced the construction of a strong fortification, a short distance $N$. of the v., to guard the entrance of the lake. It was subsequently found that this site was within the Canada line, and the further construction of the work, upon which some $\$ 400,000$ had been expended, was abandoned. However, this spot has since been ceded to the United States, and this fine fortiflcation, now in dilapidation, may at some period be completed. At this point, the great railroad route between ogdensburg and Boston, here crosses the lake. Previous to the construction of the railroad, this place was of no importance. It is now a great depôt for merchandise and produce, and important landing-place for the boats on Lake Champlain. The railroad crosses the lake by a permanent bridge, 5,000 feet long, and a draw-bridge on pontoons, 300 feet by 30 , which is swung round when not in use, so as to give free navigation. The dock is 800 by 164 feet, and the depôt 550 by 104 feet. The improvements are all of the most permanent character. The Champlain and St. Lawrence $R$. R. extends hence to Montreal, $47 \mathrm{~m}$. Rouse's Point is distant from Ogdensburg, by the Northern R. R., $118 \mathrm{~m}$. ; from Boston, by both routes, $285 \mathrm{~m}$. The v. is generally flourishing, and increasing in population.

Rover, p. o., Bedford county, Tenn.: 47 m. S. S. E. Nashville.

Row AN county, N. Car. Situate W. centrally, and contains 332 sq. m. Drained by Yadkin $r$. and its branches. Surface undulating; soil a fine deep mold and very fertile, and well adapted to grain and grazing, fruits, etc. Chief productions, cotton, tobacco, wheat, and Indian corn. Farms 1,070; manuf. 108; dwell. 1,842, and pop.-wh. 9,901, fr. col. 115, sl. 3,854-total 13,570. Capital: Salisbury.

Row, t. and p. v., Franklin co., Mass.: 98 m. W. by N. Boston. Surface elevated and in some parts mountainous; soil best adapted to grazing. Drained by Deerfield r., which forms its W. boundary, and by Pelham brook, passing through the centre of the t., on which are the ruins of old Fort Pelham, erected in 1744. The $v$. in the centre of $t$. is a neat settlement, has some manufactures, and contains 3 churches. Pop. of t. 659 .

Rowera, p. o., Russell co., Ky.. 79 m. S. Frankfort.

Rowe's, sta., Orangeburg district, $S_{0}$. Car': on Columbia Branch R. R., $58 \mathrm{~m}$. from Columbia, $71 \mathrm{~m}$. from Charleston.

Rowe's CORNer, sta., Merrimac county, N. Hamp.; on Portsmouth and Concord R. R., 13 m. S. S. E. Concord, and $34 \mathrm{~m}$. from Portsmouth.

Rowesville, p. v., Bedford co., Tenn.: 55 m. S. \$. E. Nashville.

Row's, p. o., Ashland co., Ohïo: on W. side of Muddy fork of Walhonding r., $78 \mathrm{~m} . \mathrm{N}$. N. W. Columbus,

Rowlanusville, pi v., Cecil co., Ma. : $52 \mathrm{~m}$. N. E, by N. Anuapolis.

Rowlandeville, p. o., Stanly county, N. Car.: $108 \mathrm{~m}$. W. S. W. Raleigh.

Rowley, t., p. Y., and sta., Essex county, Mass. : $27 \mathrm{~m}$. $\mathrm{N}$. by E. Boston. Soll of $t$. diversified; a large portion is salt meadow, the arable soil is fertile. Watered by Rowley river, which, before its junction with Plum Island sound, affords harborage for small vessels. Plum island belongs to 
this $t$. The $v$, at the centre contains 2 ehurches. The Eastern R. R. passes through the t., $29 \mathrm{~m}$. from Boston. This t. was first settled in 1639, by an industrious and pious company from Yorkshire, England, who erected the first fulling-mill in New England, and manufactured the first cloth in North America. The ancient township of $\mathrm{R}$. was divided in 1838 , and its W. part incorporated by the name of Georgetown. Pop. of t, 1,075.

RoXANA, t. and p. o., Eaton county, Mich: $17 \mathrm{~m}$. W. Lansing. Pop. 353.

Roxborough, p. v., and eap. Person co., N. Car: $55 \mathrm{~m}$. N. N. W. Raleigh. It contains a court-house, jail, a fer stores, and about 150 inhabitants.

RoxbURy, t. and p. o., Oxford co., Me.: $45 \mathrm{~m} . \mathrm{N}$. W. by W. Augusta. Surface elevated and well timbered, with some good soil. Watered by Swift brook, a branch of Androscoggin r., flowing $\mathbf{S}$. through its centre. Incorporated in 1835. Pop. 246.

RoxBURy, to and p. v., Litchfield cos Conn : 36 m. W.S. W. Hartford. Surface of t. diversified; soil chiefly gravelly loam. Watered by Shepang r., a branch of the Housatonic, flowing through its W. part. The t. was aken from Woodbury, aud incorporated in 1901 . The $\mathrm{v}$, in the centre of the t. contains 2 churches, a few stores, ete. Pop. of $t_{\text {, }}$ in 1810 , 971 ; in $1550,1,114$

RoхвU lरт, t., p. city, and sta, Norfolk co., Mass.: $2 \mathrm{~m}$. S. by W. Boston, with which it is eloselj connected by a narrow neck of land-"Boston Neck"-over which there are 4 broad and pleasant avenues. The natural surface of the city was very uneven and rocky, which gave to it its name, from the abundance of rocks; and though much changed by building improvements, is still much diversified. The soll is generally fertile and highiy cultivated. The dwellings are noted for their elegance, and are generally surrounded by ornamental gardens. The eutire appearance of the city is most delightful, and it is one of the inost plcasant suburbs of Boston, with which its business and wealth are most intimately connected, and can hardly be considered as separate from the metropolis. It has, however, considerable trade of its own, and its manufactures are various and extensive. These consist of earpeting, cordage (the New England Company has a capital of $\$ 75,000$, employing $130 \mathrm{men}$ ), India-rubber goods, railroad iron, iron castings, fire-engines, steam-engines, and boilers; sheet lead, white lead, chemical preparations, turpentine, ete. ; worsted and silk fringes and lining: patent leather, hats, shoes, cabinet-ware, etc. Steam-power is employed by about 30 establishments. There is 1 bank, capital $\$ 150,000$; one institution for savings, 2 insurance companies, and 6 churches, several of which are located on elevated positions, and make a beautiful appearance. The Boston and Providence R. R. passes through the city, and is much used by the citizens in passing to and from Boston. Several lines of omnibuses afford constant communication with the city. The "Norfolk County Journal" (whig), and "Roxbury Advertiser" (neut), are issued weekly.

Roxbury was incorporated as a town Sept. $2 \mathrm{~s}, 163 \theta$ (in the same year with Boston); and as a eity, March 12, 1S46. The territory of the city is $7 \frac{8}{m}$. long, $2 \frac{1}{3} \mathrm{~m}$. broad, and comprises an area of 10,656 acres. It is governed by a Mayor, Board of Aldermen, and Counmon Council, elected annuaily. Excellent provisions are made for publie schools, etc. The following table exhibits the valuation of estates in Roxbury, from 1537 to 151 inclusive:

\begin{tabular}{|c|c|c|c|}
\hline & & & \\
\hline & & 1842. & \\
\hline & & 1543 & 18 \\
\hline & 6,72 & 1844. & 1848 \\
\hline
\end{tabular}

In the W. part of the $t$. is an extensive level, on which is situated the beautiful p. v. of Jamaica Planns, near Jamaica Pond, from which Boston was, to a considerable extent, supplied with water, until the opening of the Cuchituate Aqueduct, in 1848. The Forest Hills Cemetery is situated a short distance from the eity, on the Dedham turnpike. This bcautiful eity of the dead has an urea of about 70 acres. The grounds are picturesquely diversified, and abounding with trees, shrubbery, and flowers. Here are monuments of Grneral Joseph Warren, who fell at the battle of Bunker Hill, June 17, 1776; and of Rev. John Eliot, the "Apostle of the Indians," who was pastor of the first church in koxbury for 58 years-from 1632 until his death, in 1690 . The entrance is an ornamental strueture, in the Egyptian style On one of the highlands in the city still remains, in a very perfect state of preservation, the breastwork and intrenchments of a large military fortress constructed at that period. The population of Roxbury at different periods is as follows:

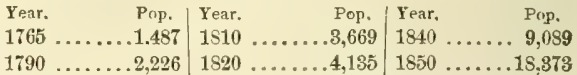

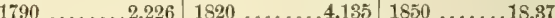
$1800 \ldots \ldots \ldots 2,765 \mid 1830 \ldots \ldots .5,217$

Roxbury, t. and p. o., Cheshire co., N. Hamp. : $39 \mathrm{~m}$ N. W. by W. Concord. Surface rough and uneven, but has excellent grazing land. Drained by $\mathrm{N}$. branch of Ashuelot r., which forms its W. boundary, and in its \$. part by Roar-

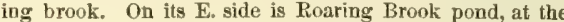
outlet of which are mills. Incorporated in 1S12. Pop. in 1840,286 ; in $1850,260$.

Roxbury, t. and p. 0., Delaware co., $N . Y_{.}: 48 \mathrm{~m} . \mathrm{S}$. W Albany. Surface hilly and mountainous, the Cattskil Mountains passing through its E. portion; soil sandy loam very productive in the valleys. Drained S. by the Papacton branch of Delaware $r$. The inhabitants are chiefly engaged in agricultural pursuits. Pop. in 1840, 3,013 ; in 1550, 2,853. Roxidry, p. v., Franklin co., Penn. : on N. side of Conedogwinnet cr., and E. side of Blue Mountain, $42 \mathrm{~m}$. W. by $\mathrm{S}$ Harrisburg. It contains a charcoal forge, constructed 1790 which, in 1849, made 90 tons of bars, employing $10 \mathrm{men}$

RoхвеRF, t., p. v., and sta., Washington co., Veryn. : $15 \mathrm{~m}$ S. by W. Montpelier. Surface elevated and uneven; snil fertile. Drained by head branches of Dog and White rivers the former affords water-power. Iron ore is found in the S. E. part. First settled in 1789. The Vermont Central R. R. passes through the $t, 60 \mathrm{~m}$, from Windsor, and $97 \mathrm{~m}$ from Rouse's Point. Pop, of t. 967.

Roxo, p. o., Marquette county, Wisc.: 52 m. N. N. E. Madison.

Rоховец, p. 0., Bertie county, N. Car.: 97 m. E. by N Raleigh.

Royal Centre, p. o., Cass county, Ind.: $65 \mathrm{~m} . \mathbb{Y}$ Indianapolis.

Royal OAK, p. 0., Talbot county, MLd. : 24 m. E. S. E. Anuapolis.

Royal Oak, t., p. v., and sta., Oakland co., MFich. : 78 m. E. S. E. Lansing. Drained in N. part by Red r., and in S. part by Bloody Pun. The Detroit and Pontiac R. R. passes through the v., 12 from Detroit, and $13 \mathrm{~m}$. from Pontiac. It contains a steam saw-mill, a few stores, and has some manufactures. Pop. of t. in 1840,860 ; in $1850,1,092$.

Royal OAKs, p. o., Cumberland co, Virg. : $73 \mathrm{~m}$. W. by \$. Richmond.

Royalston, t, p. V., and sta., Worcester co., Mass.: $61 \mathrm{~m}$. W. N. W. Boston. Surfuce diversined; soil generally productive, and upon the streams consists of exeelfent meadow land. Drained by Miller's r. and its tributaries. Several small streams, onc of which has a perpendicular fall of 20 feet, and descends 100 feet in 40 rods, unite and form Tully r., which pours into Miller's r. a great quantity of water. These various streams afford good mill-siles. There are 2 ponds within $\$ \mathrm{~m}$. of each other, which vary in height 150 fret, and abound with fish. The t. was first setled in 1754 , and incorporated in 1765. The $v$. near the centre of the $t$ is a handsome settlement. The Vermont and Ma-sichusetts R. R. passes through the S. part of the t., at South Ifoyal- 
ston, $27 \mathrm{~m}$. from Fitchburg. Pop. of t. in 1840, 1,667; in $1 \mathrm{~S} 50,1,5 \pm 6$.

Royaltox, p. V., Boone co., Ind.: on E. side of branch of Eagle cr, a tributary of W. fork of White r., 14 m. N.W. Indianapolis.

Rotaltox, t. and p. o., Niagara county, $N, Y$.: $252 \mathrm{~m}$. W. by N. Mbany. Surface undulating; soil fertile ealcareous loam. Watered by Tonawanda cr., which bounds it on the S. The to contains the villages of Middleport and Gasport, which latter derives its name from a spring of inflammable natural gas, used to some extent. The Erie Canal, and the Rochester, Lockport, and Niagara Falls R. R. pass through the towr. Pop. in 1840, 3,549; in 1850, 4,024.

Rotalton, p. v, Fairfield co., Ohio: on $\mathbf{s}$. side of branch of Little Walnut er, $21 \mathrm{~m}$. S. E, by S. Columbus. Contains a church and some stores. Pop. 252.

Roralton, t., p. v., and sta, Windsor co., Ferm. : $81 \mathrm{~m}$. S. Montpelier. Stafface broken and mountainous: soil fertile, particularly along White r., by which and its branches it is watered. The agricultural products are of considerable amount. The $\mathrm{v}$. is pleasantly situated on the bank of White $\tau_{\text {., }}$ and contains a handsome church, academy, stores, etc. It was first settled in 1771 , and suffered much from Indian hostilities. The Vermont Central R. R. passes through it, $123 \mathrm{~m}$. from Rouse's Point, $48 \mathrm{~m}$. from Montpelier, and $34 \mathrm{~m}$. from Windsor. Pop. of t. in 1S40, 1,917; in 1850, 1, 550 .

Porsi' ForD, p. o. and sta, Montgomery co, Penn. $\$ 1 \mathrm{~m}$. E. Harrisburg, on the N. bank of Schuylkill $r$., and on Philadelphia and Reading R. R., $32 \mathrm{~m}$. from Philadelphia.

Rorton, p. o., Delaware cotnty, Ind.: 49 miles N. E. Indianapolis.

PUARK, p. o., Lawrence co., $T l_{*}$ : on a small branch of Wabash r., 124 m. S. E. Springfield.

Pecherstulze, p. v., Elbert co., Ga.: on N. side of Van's cr. $80 \mathrm{~m}$. N. N. E. Milledgeville, Contains a Baptist church, academy, several stores and dwellings.

Ruokerstille, p. o., Tippah co., Miss : 176 m. N. N. E. Jackson.

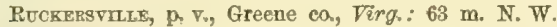
Richmond.

Ruckbrville, p. o., Clark county, $K y .: 45$ m. E. by S. Frankfort.

Reckmanvilex, p. o., Figliand county, $\overline{V i r g .: ~} 127 \mathrm{~m}$. W. N. W. Richmond.

Ruddle's Muss, p. 0., Bourbon co., Ky.: $37 \mathrm{~m}$. E. by N.

Frankfort.

Ptde's Mrzis, p. on Lewis co, Jirg.: $185 \mathrm{~m} . \mathrm{N}$. W. Richmond.

Reggles, to and p. n., Ashland co., ohio: $77 \mathrm{~m}$. N. by E, Columbus. Drained by head branches of Vermillion river. Pop. 1,085.

Purs, $\mathrm{p}$ : v., Randolph county, $I$ h : 114 miles S. by W. Springfield.

PUMFORD, t. and p. o., Oxford ca, Me.: on N. W. side of Androscoggin r., 43 m. W. N. W. Augusta. The surface is somewhat diversified. White Cap Mountain rise 600 feet and Glass-face about 400 feet above the level of the surrounding country, and present beautiful views from their summits. The soil is fertile, adapted to grain. Drained by the Androscoggin and its branches, Ellis and Swift brooks, which together furnish a great water-power. Incorporated m 1800. Popo in $1810,1,414$; in $1850,1.375$.

Remford Centree, p. o., Oxford co., Me. : $45 \mathrm{~m}$. W. N.W. Augusta.

Rumford PoInt, p. 0., Oxford con, Me: 46 m. W. N. W. Augusta.

Rummerteld Cerez, p. 0., Bradford co., Penn.: $116 \mathrm{~m}$. N. by E. Harrisburg.

Rumver, t., p. o, and sta, Grafton co., N. Hramp. : $45 \mathrm{~m}$. N. N. W. Concord. Surface is uneven, and abounds with beantiful scenery; soil moderately furtile. Drained by Baker's r. and its branches. First settled in 1765 . It con- tains scveral tanneries, saw-mills, and stores. The Boston, Concord, and Montreal R. $\mathrm{K}$, passes its $\mathrm{S}$. part, $59 \mathrm{~m}$. from Concord. Pop. in 1830, 993; in 1840, 1,116; in 1850, 1,109.

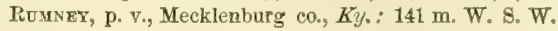
Frankfort.

Runpols's, p. o., Crawford co., Penn.: $186 \cdot \mathrm{m}$. N. W. Harrisburg.

Rupert, t., p. vi, and sta., Bennington ca, Term.: $79 \mathrm{~m}$. S. W. Montpelier. Surface mountainous; soil good for grazing. Watered by Pawlet $r$, and White cr. of Battenkill, which afford water power, improved by mills of various kinds. Some fine cattle are raised and large numbers of sheep. First settled in 1767. The Rutland and Washington R. R. passes through the $t_{0}, 36 \mathrm{~m}$. from Rutland, $49 \mathrm{~m}$. from Troy. Pop, of to in 1810, 1,086; in 1850, 1,101.

Rurai, p. o., Clermont co, Ohio: $86 \mathrm{~m}$. S. W. Columbus. Runal, p. 0., Jasper co., Mo.: 92 m. 8. W. Jefferson City. Rorax. Hilt, p. 0., Wilson ce., Tenn. : $15 \mathrm{~m}$. E. Nashville. Rukal Hru, p. on, Jefferson co., $N$. $Y_{*}: 142$ miles N. W. Albany.

RuRal Retrinat, p. 0., Wy the co., Virg. : 208 m. W. by 8. Richmond.

Rurar VALE, p. o., Lapeer ca, Mich.: 88 m. E. N. E. Lansing.

Rural Vallex, p. o., Armstrong county, Penn. : $182 \mathrm{~m}$. W. N. W. Harrisburg.

Rusr county, Ind. Situate toward the S. E., and contains 442 sq. m. Drained by Big and Little Blue rivers, and Big and Little Flat Rock ereeks, by which fine water-power is gained. Surface undulating or rolling, with occasional ridges of low hills; soil a rich vegetable mold, and very fertile. Chief productions wheat, Indian eorn, potatoes, and tobacco. There is much fine grazing land in the co., and large numbers of cattle, sheep, and hogs are fattened and exported. Fine timber is found on the land. Farms 1,809 ; manuf. 59 ; dwell. 2,824, and psp.-wh. 16,226, fr. col. 219total 16,445. Capital: Pushville, Public Works: Juno tion R. R.; Shelbyville and Rushville R. R.; Shelbyville and Knightstown R. R.; Central R. R.; Lawrenceburg and Upper Mississippi $\mathrm{R}_{\text {. }} \mathrm{R}$.

Rush, t. and p. v., Monroe co., N. Y.: nn E. side Genesee r., $201 \mathrm{~m}$. W. by N. Albany. Surface undulating; soil very fertile, producing large crops of wheat and other grain Drained by Honeoye cr., flowing W. through its centre into Genesee r. The $\mathrm{v}$, on Honeoye cr. contains 2 taverns, 2 churches, 4 stores, a flouring and saw mill, ashery, carding machine, and about 200 inhabitants. Pop. of town in 1840 ; 1,929 ; in $1850,2,015$.

Pusf, to and p. o., Susquehanna co., Penn.: on Wralusing creek, $108 \mathrm{~m}$. N. N. F. Harrisburg. Surface hilly; soil gravelly loam. It contains several tanneries, grist and saw mills, and has some manufactures. Pop. about 1,200 .

RUsir, to and p. o., Tuscarawas co., Ohio: 86 m. E. N. E. Columbus. Watered by branches of Tuscarawas river, and contains several grist, saw, and flouring mills. Pop, in $1840,1,293$; in $1850,1,332$.

RuBr, t. and p. o., Shiawassee co., Mich.: on W. side of Shiawassee r., 25 m. N. E. Lansing. Pop. about 100.

Rusir, p. o., Jo Daviess co., $M$. : $175 \mathrm{~m}$. N. by W. Springfield.

Iivsi Botron, p. on, Holt county, Mo, : 194 miles N. W. Jefferson City.

Rush Creek, p. o., Union county, Ohio: 41 miles N. W. Colvmbus.

Rughford, to and p. v., Allegany county, $\boldsymbol{N}$. $\boldsymbol{Y}$.: $280 \mathrm{~m}$. W. by S. Albany. Surface undulating; soll clay loam and gravelly mold, well adapted to grass. Drained E. by Cold cr. of Genesee r. The $\mathrm{r}$. is a thriving business place, containing 2 churehes, 3 taverns, several mills and steres, and about 800 inlubitants. Population of to in $1810,1,512$; in 1850,1, s06.

Rush LAkE, p. o., Fond du Lac co., Wisc. : 65 m. N. N. I Madison. 
RusI Tower, p. O., Jefferson co., MO.: on W. bank of Mississippi r., 107 m. E. by S. Jefferson City.

Rushrown, p. 0. Northumberland county, Penn. : $45 \mathrm{~m}$. N. by E. Harrisburg.

Rushville, t., p. v., and cap. Schuyler co., 717. : $52 \mathrm{~m}$. W. N. W. Springfield. Is a handsome and flourishing $\mathrm{v}$. pleasantly located at the $\mathrm{S}$. end of a beautiful fertile prairie, skirted by fine timber at the head of a small stream. It contains a brick court-house 2 stories high, a jail, and 4 churches, The "Prairie Telegraph" (neut.) is issued weekly. Pop. about 1,000 .

Rushville, p. v., sta., and cap. Rusle co., Ind.: on $\mathrm{N}$. bank of Big Flat Rock cr., $38 \mathrm{~m}$. E. by S. Indíanapolis. It was first settled in 1521, and contains a court-house, jail, 3 churches, several mills and stores. Two newspapers are published weekly, "Republican" (whig), and "Jacksonian" (dem.) The Rushville and Shelbyville R. R. extends hence to Shelbyville $20 \mathrm{~m}$., and is part of an extensive line of railroad now constructing across the State. Pop. in 1550, 2,108.

Rushville, p. v., Yates co., $N . Y .: 177 \mathrm{~m}$. W. Albany. Is a thriving $v_{\text {. }}$ containing 2 churches, academy, 2 taverns, 2 furmaces, mills, stores, ete., and about 600 inhabitants.

Rushrille, p. v., Fairîeld co., Ohio: on W. síde of Rush cr., $38 \mathrm{~m}$. E. S. E. Columbus. It contains 60 dwellings, and 300 inhabitants, and several mills in the vicinity.

Reshrille, p. v., Susquehanna county, Penn.: $106 \mathrm{~m}$. N. N. E. Fiarrisburg.

Rushylvanta, p. O., Logan county, Ohio: 49 miles N. W. Columbus.

Rusk county, Tex. Situate W. toward the N., and contains 1,184 sq. m. Drained by branches of Angelina and Attoyac rivers. Surface undulating; soil very fertile, and adapted to the growth of cotton, corn, fruits, etc. Pine tim. ber is abundant. Farms 567 ; manuf. 15 ; dwell. 1,045, and pop.-wh. 6,012, fr. col. 0, sl. 2,136-total 8,148. Capital: Henderson.

Rusr, p. o., Haywood county, Tenn. : 141 m. W. S. W. Nasbville.

Rusк, p. v., and cap. Cherokee county, Te0s.: 190 miles N. E. by E. Austin City. Pop. 332.

Rusk, p. 0., Surry county, N. Car. : 120 m. W. N. W. Raleigh.

Russelu county, $A Z \alpha$. Situate toward the S., and contains $858 \mathrm{sq} . \mathrm{m}$. Drained by branches of Chattahoochee $r$., which forms its E. boundary. Surface undulating; soil fertile, and is well adapted to cotton, a large quantity of which is produced in the county. The land is rich and productive, and fine crops of wheat and corn are raised. It has some good timber land. Farms 1,049; manuf. 4; dwell. 1,411, and pop.-wh. 8,405 , fr. col. 32 , sl, 11,111-total 19,54S. Capital: Crawford. Public Works: Girard and Mobile R. R. ; Montgomery and West Point R. R.

Russell county, $K y$. Situate $\mathrm{S}$. toward the E., and contains $316 \mathrm{sq} . \mathrm{m}$. Drained by Cumberland river and its branches. Surface undulating; soil fertile, and adapted in grain; a portion of the land is deroted to pasturage. Chiel" productions, rice, cotton, and tobacco. Farms 665 ; manuf. 13; dwell. 840, and pop.-wh. 4,901, rr. col. 13, sl. 435-total 5,349. Capital: Jamestown. Pullic Works: Lexington and $\mathrm{M} \cdot \mathrm{Miunville} \mathrm{R}$. $\mathrm{R}$.

Russelu county, Firg. Situate S. W., and contains 1,312 sq. $m$. Drained by Clinch $\mathrm{r}$. and head branches of $\mathrm{W}$, fork of Saudy river. Surface much broken and rocky, consisting principally of mountain ranges and valless; soil fertile. Chief products wheat and Indian corn. Farms 942 ; manuf. 14 ; dwell. 1,7S6, and pop.-wh. 10,567, fr. col. 70, sl. 932total 11,919. Capital: Lebanon.

Russecl, t., p. v., and sta., Hampden county, Mrass. : on Westfield r., $94 \mathrm{~m}$. W. by S. Boston. Surface elevated and mountainous, abounding with wild and romantic stentry. Some of the high lands afford good grazing, and in the ralleys are tracts of fertile meadow. Westfield river and its main branch, which flow rapidly through it, afford an im- monse water-power, improved by a few factories. Stone wood, and other building materials are abundant. The Western R. R. passes through the t., $18 \mathrm{~m}$. from Springfleld, 116 miles from Boston. Incorporated in 1792. Population of $t .521$.

RusseiL, t. and p. o., St. Lawrence co., N. $Y .: 151 \mathrm{~m}$. N. N. W. Albany. Surface somewhat uneren; soil sandy and clay loam, well adapted for grazing. Drained N. by Grass river flowing through its centre. The $\mathrm{r}$. is a smal settlement containing a State arsenal, severa saw-mills, a tannery, etc. Pop. of t. in 1840, 1,373; in 1850, 1,808.

Pusselz, t. and p. o., Geauga co., Ohio: $130 \mathrm{~m}$. N. E. Columbus. Watered by the $\mathrm{N}$. head branch of Chagrine river, and contains several saw and grist mills, etc. Pop. in 1840,742 ; in $1550,1,083$.

Russel L, p. 0., Atcheson county, MFo. : 213 miles N. W. Jefferson City.

Russkll Hill, p. o., Wyoraing co., Penn. : 92 m. N. N. E. Harrisburg.

Pussell Place, p. o., Kershaw digtrict, S. Oar. : $40 \mathrm{~m}$. N. E. Columbia.

Russeli's Corners, p. o., Sauk co, Wisc. : $38 \mathrm{~m}$. N. W. Madison.

Russeli's Mruxs, p. o., Tyler co., Virg.: $281 \mathrm{~m}$. N. W. Richmond.

Russell's Minls, p. o., Parke county, Ind.: 52 m. W. Indianapolis.

Russell's Place, p. o., Lawrence county, Ohio: $90 \mathrm{~m}$. S. by E. Columbus.

Russell's Store, p. o., Boone co, $\pi l_{*}: 174 \mathrm{~m} . \mathrm{N}$. by E Springfield.

Russellsville, p. v., and cap. Franklin county, $A l \alpha_{0}$ : on Cedar cr., a branch of Bear er., which flows into the Tenncssee river, $167 \mathrm{~m} . \mathrm{N} . \mathrm{N}$. W. Montgomery. It contains a court-house, jail, and some 30 dwellings.

Russellyille, p. o., Monroe co., Ga.: 49 m. W. by S. Milledgeville.

Possellyille, p. v., Lawrence co, $I l l$. : on Wabash r., 174 m. E. S. E. Springfield.

Ressertrille, p. v., Putnam eo., Ind. : betweer snall branches of Little Raccoon creek, 44 miles W. by $\mathrm{N}$. Indianapolis.

Russeltville, p. v., and cap. Logan co., Ky. : 144 m. S. W. Frankfort. It contains a court-house, jail, seminary and two churches. The "R. Herald" (whig) is published weekly. Pop. 1,272.

Russellyilde, p. v., Brown co Ohio: 79 m. S. S. W Columbus. Pop. 856.

Russellvilte, p. v., Cole county, Mo. : $15 \mathrm{~m}$. W. by S Jefferson City.

Russeltrille, p. v., Chester co., Penn. : 56 m. E. S. E. Harrisburg.

Russel.tirlibe, p. O., Jefferson county, Tenn. : $201 \mathrm{~m}$. E Nashville.

Refselsburg, p. v., Warren co., Penn.: on W. side of Conewango cr., $164 \mathrm{~m}$. N. W. Harrisburg.

Russis, t. and p. v., Herkimer co., $N . Y .: 91$ m.N.W. by W. Albany. Surface high and hilly; soil sandy loam and clay, well adapted to grass. Drained S. by West Canada creek. The $r$. contains a church, a few stores and mills, and about 250 inhabitants. Pop. of to in 1810, 2,298; in 1850, 2,349.

Russiavilie, p. v., Clinton co., Ind.: 38 m. N. by W. Indianapolis.

Rutersville, p. v., Fayette eounty, Tex.: on the main post-road from Lagrange to Washington, and Rocky oreek of Colorado r., 60 m. E. S. E. Austin City.

Retherford county, $N$. Car. Situate toward the S. W. and contains $859 \mathrm{sq}$. m. Drained by head branehes of Broad $r$. Surface varied, some portions being rather hilly, but most generally level; soil in some places very fertile, while in others it is poor and unfit for cultivation. It is generally well adapted to grazing. Chief productions, cotton, tobacco, wheat, and Indian corn. Farms 959 ; manuf 
28 ; dwell. 1, $\$ 38$, and pop.-wh. 10,425, fr. col. 220, sl. 2,905 -total 13,650. Cupitul: Rutherfordton.

RUTHERFORD county, Tenn. Situate centrally, and contains 431 sq. m. Stone r. passes through the N. E. portion, by which and its brazches and small aftuents of Cumberland $r$. it is drained. Surface hilly; soil very fertile, and produces abundantly cotton, tobaceo, whent, grain, fruits, pte. Agriculture is the leading pursuit with a large number of the population. A portion of the land is well timbered, and some minerals are to be found. Farms 1,507; manuf. 41 ; dwell. 2,595 , and pop.-wh. 16,914, fr. col. 230 , sl. 11.975-total 29,122. Cupitul: Muefreesboro'. Public Works: Nashville and Chattanonga R. R.

Retherfordton, p. v., and cap. Rutherford co., N. Car.: $193 \mathrm{~m}$. W. by S. Raleigh. Situated on a branch of Broad river, and contains a court-house, jail, academy, hotels, and flouring-mills. The "Mountain Banner" (State rights) is published weekly. Pop. 398.

R Uther Glen, p. o., Caroline county, Virg.: $33 \mathrm{~m}$. N. Richmond.

RETland county, Verm. Situate E. toward the S., and contains 948 sq. m. Drained by Otter er., and Black, White, Pawlet, and Queechee rivers. Surface elevated, and in parts mountainous; but on Otter cr. are some portions of fertile land; soll rarious-in most parts well suited for pasture. Iron ore of a good quality is found here, and some quarries of excellent marble, much of which is exported. Chief products, wheat and Indian corn. This county has good water privileges. Farms 2,668; manuf. 275; dwell. 5,661, and pop.-wh. 32,939 , fr. col. 120-total 33,059. Capital: Rutland. Problic Works: Rutland and Burlington R. R.; Western Vermont R. R.; Rutland and Washington R. R.

Puttuand, to and p. v., Woreester co, Mass.: $47 \mathrm{~m}$. W. Bostor. Siturated on the height of land between the sea and Connecticut r. Surface uneven and hilly; soil best adapted to grazing; watered by a branch of Ware river, which affords power for several mils. This t., formerly 12 miles square, was bought of the Indians for $£ 23$ in 1686 , and incorporated in 1714. The v., in the central part of the t., contains a town-house, aeademy, handsome Congregational church, seteral neat dwellings, and has some manufactures. Pop. 1,223.

Rutland, t. and p. o., Jefferson co., N.Y.: $140 \mathrm{~m} . \mathrm{N}$. W. Albany. Surface undulating; soil fertile loam, underlaid by limestone. Drained S. W. by Sandy er. and by Black r., which forms its $N$. boundary. In this $t$. and vicinity are found remains of Indian fortifications. It has some manufactures, several tanneries, saw, grist, and fulling mills. Pop. in $1840,2,090$; in $1850,2,265$.

Rutlaxd, t. and p. v., Meigs county, Ohio: on N. side of Leading creek, a tributary of the Ohio, $77 \mathrm{~m}$. S. E. by S. Columbus, containing several tanneries, grist, and saw mills, and has some manufactures. Pop. of t. in 1840, 1,410; in $1850,1,745$.

Rutland, t. and p. o., Tioga county, Penn.: $104 \mathrm{~m}$. N. Harrisburg. Surface hilly; soil gravelly loam; contains a few mills. Pop. about 750 .

RutLand, to, p. vo, sta, and cap. Rutland œ., Verm.: on Otter cr., 50 m. S. S. W. Montpelier. Surface of t. uneven; soil various, from a strong loam to a light sand, but generally fertile. Drained by Otter cr. and its branches, which afford water-power, and by a branch of Castleton $r$. Iron ore of good quality is found; also, lime, and a great abundance of white and beautifully variegated marble, of which several quarries are extensively worked. The to was chartered in 1761, and settled about 1770. During the Revolutionary War it was a frontier town, through which was the only military road from Charlestown, N. Hamp., to Ticondernga and Crown Point, on Lake Champlain. The t. is divided into two parishes, East and West; the former contains Putland village, the most important place; in the latter are two small villages, West Rutland, and Hookkin's Falls. Futland village has an elevated situation, is well built, containing many handsome dwellings, and was incorporated in 1817. Three imprortant railroads pass through it: Rutland and Burlingion R. P., 5 ? m. from Bellows Falls, and $67 \mathrm{~m}$. from Burlington: Putland and Washington R.R. from Troy $85 \mathrm{~m}$.; and Western Vermont P. R. from Troy, vic $\mathrm{N}$. Bennington, $\$ 3 \mathrm{~m}$, the opening of which has given a powerful impetus to the prosperity of the village and town. It contains a court-house, jail, 1 bank, cap. $\$ 150,000$, and 3 churches. Here are located the machine-shops and engine-houses of the Western Vermont R. R., and some large manufactories of marble, iron, slate, leather, cabinet furniture, etc. The "R. Herald" (whig), and "Vermont Union Whig," are issued weekly. The town of Rutland ranks as the second in agricultural and the first in mineral productions in the State. Population of $t_{0}$ in 1840, 2,708; in $1850,3,715$.

Rutrand, t. and p. o, Dane co, Wisc.: 24 m. S. S. E. Madison. Soil excellent, watered by branch of Catîsh cr. of Fock r. Pop. 792.

Retiand Centre, sta., Rutland county, Verm.: $2 \mathrm{~m} . \mathrm{N}$. Rutland, on Rutland and Burlington R. R.

Rutledge, p. v., and eap. Grainger co., Tenn. : 181 m. E. Nashville. It contains a court-house, jail, and about 100 inhabitants.

RetLEDGe, p. v., and cap. MrDonald co., Mra : on S. side of Elk r., $183 \mathrm{~m}$. S. W. Jefferson City.

RYE, t. and p. o., Rockingham co., N. Hamp.: on the Atluntic shore, $41 \mathrm{~m}$. E. S. E. Concord. The surface has considerable sandy beach and salt meadow, which yields large quantities of grass. It has a harbor near Goss Mill, admitting, at high water, vessels of 75 or 80 tons, and from which the fisheries are carried on. Chartered in 1719. Pop. in $1810,1,205$; in $1550,1.296$.

RYE, t., p. v., and sta., Westchester co., N. $Y .: 114 \mathrm{~m} . \mathrm{S}$. Albany. Surface, uneven and stony ; soil, clay loam; drained on the E. by Byram r., and on the W. by Blind brook, both flowing into Long Island Sound, which bounds it on the S. The v., situated $1 \mathrm{~m}$. N. of the sound, contains 3 churches, an academy, 2 taverns, a few stores, and about 250 inhabitants. The New York and New Haven R. R. passes through it, $27 \mathrm{~m}$. from New York, and $49 \mathrm{~m}$. from New Haven. Pop. of t. in $1810,1,803$; in $1850,2,584$.

RYE Cove, p. o., Scott county, Virg. : $281 \mathrm{~m}$. W. by S. Richmond.

RXEGate, t., p. v., and sta., Caledonia co., Verm. : on W. bank of Connecticut r., $25 \mathrm{~m}$. E. by $\mathrm{S}$. Montpelier. There is not much intervale land on the r., but the soil is generally productive; it is best adapted to grazing, and large numbers of sheep are kept. Watered by Wells r., which affords water-power, some smaller streams, and several ponds. At Canoe Falls, in Connecticut r., against the middle of the t., is a dam across the r., which affords extensive water-power. Chartered in 1763, and first settled in 1774, by emigrants from Scotland, from whom a large part of the present inhabitants have descended. They are chiefly devoted to agricultural pursuits, are industrious and frugal. The t. contains 2 churches-Presbyterian and Associate Reformed-2 tanneries, and several saw-minîs. The Connecticut and Passumsic Rivers $\mathrm{R}$. R. passes through the to, $44 \mathrm{~m}$. from $W$ hite River Junction, and $16 \mathrm{~m}$. from St. Johnsbury. Pop. in $1830,1,119$; in $1840,1.228$; in $1550,1,606$.

Rxersox's Statron, p. o., Greene county, Penn.: $153 \mathrm{~m}$. W. by S. Harrisburg.

Rye VAlLex, p. o., Smyth co., Firg.: 231 m. W. by S. Richmond.

Firand's Depôt, p. o. and sta., Greenville co., Virg.: on Greenville, Gaston, and Raleigh $\mathrm{R}, \mathrm{R}$, $10 \mathrm{~m}$. from Hicks ford, $76 \mathrm{~m}$. from Riekmond.

\section{S.}

Sabatus, p. 0., Lineoln co., Me.: on branch of Androseoggin r., in t. of Webster, $24 \mathrm{~m} . \mathrm{S}$. W. by S. Augusta. 
Saвbath Dax PoLNT, $N . \quad Y .:$ on W. side of Lake George, in $t$. of Hager; derives its name from the landing of some English troops on the Sabbath day, during the old French War, and their destruction by Indians.

SABILLISFILLE, p. V., Frederick co., Mfd. : on a branch of the Monocacy r., 95 m. N. W. Annapolis.

Sabina, p. v., Clinton co., Ohio: on a branch of Rattlesnake cr., 116 m. $\$$. W. Columbus. The Cincinnati, Wilmington, and Zanesville R. R. will pass through it.

SABLNE parish, $L a$. Situate W., and contains 1,257 sq. m. Drained by Haspoon, Negret, and Lannacoeo bayous. Surface generally level; soil fertile, and along the banks of Sabine $r$, which bounds it on the $W$., are large tracts of land which prove productive with cultivation. Chief products, Indian corn, cotton, etc. Farms 522, manuf. 5, dwell. 632, and pop. -wh. 3,347, fr. col. 0, sl. 1,168-total 4,515. Capital: Manny.

SabrNe county, Tex. Situate E., and contains $809 \mathrm{sq} . \mathrm{m}$. Drained by affluents of Sabine r., which forms its eastern boundary, and by Bear cr, in the S. W. Surface undulating; soil varied; in the W. and $\mathrm{S}$. W., the land being generally rich and productive, and adapted to the growth of cotton, wheat, corn, and fruit, and a large portion is covered with timber. Farms 171, manuf. 12, dwell. 238, and pop.-wh. 1,556, fr. col. 0, sl. 942-total 2,498. Capitul: Milan.

SARnNe river, Tex. and $L a_{0}$ : is formed at the $\mathrm{S}$. boundary of Hunt co., Tex., in lat. $322^{\circ} 50^{\prime} \mathrm{N}$., by the confluence of 3 principal head branches, viz., Cow Leech, Cadao, and West fork-the two former rising by several creeks in the $\mathrm{N}$. part of Hunt co. From its source it flows E. S. E. $120 \mathrm{~m}$. in very direct course toward the $\mathbf{E}$. boundary of the State, until, at the middle of the $\mathrm{N}$. boundary of Panola co., when $19 \mathrm{~m}$. from the $\mathrm{E}$. boundary line, it takes a more $\mathbf{S}$. E. course through Panola co, and reaches the boundary at the S. E. corner of the co., in lat. $32^{\circ} \mathrm{N}$, and thereafter forms, in its southerly course to the Gulf of Mexico, the boundary line between this State and Louisiana. Before it reaches the Gulf, it expands into Sabine Lake, $30 \mathrm{~m}$. long, and averaging $8 \mathrm{~m}$. wide; but on leaving the lake, $7 \mathrm{~m}$. above the Gulf, it contracts to its usual width, which it retains until 'it enters the Gulf of Mexico, in lat. $29^{\circ} 40^{\prime} 4 \mathrm{~S}^{\prime \prime} \mathrm{N}$., long. $\mathrm{S10} 35^{\prime} \mathrm{W}$. In low stages of water it has 4 feet of water on the bar at its mouth. Its entire length is about $360 \mathrm{~m}$. It is navigable $150 \mathrm{~m}$, and farther up for keel boats. Its upper portions water the most hilly parts of the State, and have a rapid current. Along Sabine co; it is generally 100 yords wide, and from 6 to 8 feet deep. In its lower course it passes through a sandy tract of land.

Samixe Crxx, p. v., Jefferson co, Tex. : at the outlet of the lake so called, abuut $10 \mathrm{~m}$. from the Gulf, $239 \mathrm{~m}$. E. by S. Austin City. The harbor is excellent, admitting vessels drawing 9 feet of water. The trade of the settlements on the Sabine, Neches, and tributaries will no doubt centre here, and in a few years it will rank with importance umong the cities of the republic.

Sabreasille, p, o., Tioga co., Penzn.: $101 \mathrm{~m}$. N. by W. Harrisburg.

SABnE Town, p. v., Sabine co, Tex.: on the right bsnk of the river so called, below the confluence of Palo Gacho bayou, $25 \% \mathrm{~m}$. E. N. E. Austin City.

SabadoUgly, p. v., Yallabusha co., Miss.: near a fork of the Yallabusha r., $109 \mathrm{~m}$. N. by E. Jackson.

SABLE cape, Flor.: the most southerly point of the mainland of the peninsula, in lat. $24^{\circ} 50^{\prime} \mathrm{N}$, and long. $S 1^{\circ} 15^{\prime} \mathrm{W}$. On it is situated Fort Poinsett.

SABLE river, $N . \boldsymbol{Y}$. See AU SABLE river.

SABULA, p. v., Jackson co., Ia. : near the Mississippi $r_{\text {, }}$ 74 m. E. N. E. Iowa City.

SAO county, Ia. Situate toward the N. W., and contains 576 sq. m. Drained by Soldier and Boyer rivers, tributaries of Missouri r. Surface generally level; soil fertile. Set off since 1850.
Saf river, Mo. : rises in tawrence and Greene counties, flows N., and enters Osage r. in St. Clair county.

SACANDAGA river, $N$. $Y$.: rises in several small lakes in Hamilton county, and after a winding E. conrse, enters Hudson r. opposite Luzerne village, Warren county.

Sacearapra, p. v. and sta., Cumberland co, $M e_{0}$ : on the Presumpseot r. and York and Cumberland R. R., $7 \mathrm{~m}$. from Portland, $54 \mathrm{~m}$. S. by E. Augusta. Great water-power is here afforded, and improved by numerous saw-mills, etc., and a large brick cotton-mill, containing 104 looms and 2,900 spindles.

SACKET's, p. o., Macomb county, Mich.: 84 m. E. by S Lansing.

SACKETT's HARBOR, p. v. and port of entry, Jefferson co. $N . Y$. : on Black River bay, at E. end of Lake Ontario $154 \mathrm{~m}$. N. W. Albany. Lat. $43^{\circ} 55^{\prime} \mathrm{N}$., long. $75^{\circ} 57^{\prime} \mathrm{W}$ This harbor is one of the best and most secure on the lake, and was an important naval station during the last war with Great Britain. On 28th May, 1813, a sharp contest here took place between the American and British forces, resulting in the defeat of the British; and subsequently another, on 30th May, 1814, with the same success. During the war the $\mathrm{v}$. increased with great rapidity, and at its close experienced a decline, from which it has now fully recovered. In 1814 the United States government here commenced the erection of the Madison Barracks, which consist of three extensive stone barracks, hospital, commissary's store-house, guard-house, and other buildings, affording accommodation for 2,000 troops, occupying a lot of about 40 acres, fronting on the bay. In the military burying grounds attached to the barracks is a monument to the brave General Pike, who fell on the $\mathrm{N}$. frontier during the last war. The government has also a ship-yard and ship-houses, in one of which the New Orleans, a 110 gun ship, commenced during the war, remains upon the stocks.

The v., incorporated in 1814 , has considerable manufactares, and trade by the lake and the river St. Lawrence. A good water-power has been obtained by the construction of a canal from the Black r., a distance of $12 \mathrm{~m}$., executed by the eitizens at a cost of $\$ 25,000$, and affording a fall of 30 feet, improved by various mills, machine shops, etc. There are 3 churches, 1 bank-cap. $\$ 200,000,4$ hotels, 2 furnaces, etc. The "S. II. Observer" (whig) is issued weekly. A railroad is in construction, to connect at Pierrepont with the Watertown and Rome R. R. On 30th June, 1850, the tonnage of Sackett's Harbor district was 8,124 tons, all of which was enrolled and licensed, permanent, and employed in the coasting trade. During the year preceding the number of clearances for foreign ports was $259-142,799$ tons ; No of entrances do, $279-153,169$ tons; of all which tonnage about ten-elevenths was American. Vessels built during the year, none. During the year 1549 the value of the amount of trade of this port with Canada alone was-im ports, $\$ 26,564$; exports, $\$ 26,446$-total, $\$ 53,010$.

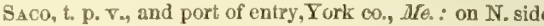
of Saco r., 67 m. S. S. W. Augusta. Lat. $43^{\circ} 31^{\prime}$ N., long. $700^{\prime}$ W. By Portland, Saco, and Portsmouth P. R., $13 \mathrm{~m}$. from Portland, 88 miles from Portsmouth ; and thenee by Eastern R. R., $92 \mathrm{~m}$. from Boston. The surface of the $t$. is somewhat uneven, and abounds with romantic and beautiful scenery. It has fine interval land on the r., by which it is well drained, and is also watered by several small streams flowing from an immense bog, called the Heath, on one of which is a fine waterfall of 60 feet, surrounded by wild scenery. From the mouth of the r, a fine beach extends along the shore about 5 miles to the E., ealled Old Orchard Beach, which is of considerable resort in summer. Another fine beach, of less extent, connects Fletcher's Nech with the main land, on which is a tavern. Saco v. is situated about $8 \mathrm{~m}$. from the mouth of the r., at the falls, where is a descent of 42 feet, presenting a beautiful appearanco and affording great water-power, and which has been extensively improved. Just bolow the falls is a fine basin, 
where ressels take in their cargoes. The factories consist of 9 large cotton-mills, 1 woolen-mill, numerous saw-mills, and rarious mechanical establishments. The York Manufacturing $\mathrm{C} \rho$. have a capital of $\$ 1.000,000$, manufacturing colored and white cotton goods, running 25,000 spindles, 850 looms, and annually consume 7,000 bales of cotton. The Saco Water-Power Co. have a capital of $\$ 2,000,000$. The lumber business is very extensive, was commenced at a very early period, and for a long time was by far the chief business on Saco $r$. The $v$. contains 2 banks, with aggregate eapital of $\$ 175,000$, savings' institution, insurance company, an academy, some handsome churches, etc. The "Maine Democrat" and "The Union" (whig) are issued weekly. The total tonnage of Saco district on 80th June, 1850 , was 2,723 tons. The registered tonnage was $1,5 \pi 0$ tons, consisting of 330 tons permanent, and 1,240 tons temporary. The enrolled and licensed tonnage was 1,153 tons, all permanent, employed as follows: coasting trade, 602 tons; cod fishery, 303 tons; mackerel fishery, 248 tons. During the fiseal year preceding, the number of clearances for foreign countries was 4-496 tons; No. of entrances do. $2-213$ tons. Vessels built during the year-1 ship, 1,018 tons. Pop. of town in 1830, 3,219; in $1840,4,408$; in 1850 , 5,794. The $\mathrm{v}$. of Biddeford, on the $\mathrm{S}$. side of the $\mathrm{r}$., in Biddeford $t_{\text {., }}$ is connected with Saco by bridges, and closely united with it in business relations, and at a little distance the two villages appear as one settlement

SACO river, $N_{\text {. }}$ Iamp, and $M_{e}$ : is formed in the White Mountains, N. Hamp., from three small head branches, the most $\mathrm{N}$, of which rises within a few rods of the source of Ammongosuc r., which flows W. to Connecticut river. The Saco, in its general course, flows S. S. E., and empties into Saco bay of the Atlantic. It enters $M$ e. in Fryeburg t, and in Cornish t. receives Ossipee r., the outlet of Ossipee lake. Its entire length is about $160 \mathrm{~m}$. It is much broken in its course by falls, preventing navigation, but affording great water-power. The principal falls are in Me., 4 in number, viz., Great Falls, at Hiram, 72 feet ; Steep Falls, at Limington, 20 feet; Salmon Falls, at Hollis and Buxton, 30 feet; and Saco Falls, at Saco, 42 feet. Pine timber abounds upon its banks, furnishing supplies for numerous saw-mills. The ordinary rise of the water, in the spring, is from 10 to 15 foet, but is much higher in freshets, when the $r$. and its falls present a very grand appearance.

SaCramento county, Calif. Situate centrally, and contains 1,000 sq. m. Drained by American r. on the $\mathrm{N}$., and Cosumes and Mokelumne rivers on the $\mathbf{S}$., all affluents of the Sacramento, which on the W. forms its boundary. Surface varied-in the $\mathrm{E}$. somewhat mountainous. In 1852 there were inrested in quartz mining $\$ 124,165$, in placer mining $\$ 89,808$, and in other mining operations $\$ 169, \$ 50$ in live-stock $\$ 1,335,698$, in farming, etc., $\$ 1,773,325$, and otherwise $\$ 5,358,394$. It is one of the richest counties in the State. Pop.-wh. 11,196, negroes 240, mulattoes 98, Indians 80, Chinese 804, etc.-total 12,589. Capital: Sacramento City.

SacrameNto, p. o. Marquette county, Wisc.: 57 m. N. Madison.

SACRAMrNTo river, Calif: $:$ rises in the mountainous range in the N. part of the State, in N. E. part of Shaste county. Its general course is $\mathrm{S}$. ; it receives numerous small streams, and the larger ones, of Feather and American rivers, Puta cr., and near its mouth is joined by the San Joaquin. Its entire length is about $300 \mathrm{~m}$., jts width varies from 200 to 300 rards; its banks are adorned with trees, and it is navigable at all seasons to Sacramento. In the rainy season it wonderfully increases in volume, overflows its banks, and floods Sacramento City and some other border settlements. The valley of the Sacramento (as also that of the San Joaquin) is but a vast basin, of which the Coast Range and the Sierra Nevada Mountains form the exterior rim, and an unusual rain, together with the melting of the snow upon the mountains, is sure to flood the lower lands with water in depth proportioned to the duration of the rain or melting of the snows. It is gonerally well adapted to agricultural purposes.

Sacramento Cuty, p. r, and cap. Sacramento co, Calif? on the Sacramento $r_{\text {. }}$, at the mouth of American r., in lat $35^{\circ} 30^{\prime} 12^{\prime \prime}$ N., and long. $121020^{\prime} 08^{\prime \prime} \mathrm{W}$., about $150 \mathrm{~m}$ N. E. San Francisco and $75 \mathrm{~m} . \mathrm{N}$. E. Vallejo. Its site is a low, level plain and is naturally overdowed in the rainy season. To prevent as far as possible this inundation, a levee has been constructed on the river banks. It was formerly called "New Helvetia" and is laid out in right angles, on the site of, and embraces the celebrated "Sutter's Fort." The streets running E. and W. are designated by the letters of the alphabet, and those running $N$. and 8 by the numerals. The original forest trees still stand in the town, and give it a picturesque appearance, and many of the streets are lined with oaks and sycamores 6 feet in diameter. It is a level and pleasantly situated place, embracing a square of about a mile and a half to the side, and derives its name from the river sn called. From a fort and its outbuildings, which a few years since constituted the whole inhabiter tenements, it has suddenly become a flourishing city, and is the grand depot for the supply of all the northern mines. In April, 1849, there were 4 houses in the place. The original price of embarcadero, or river lots, was $\$ 500$, they now command as many thousands. Every thing indicates that this place has received an impetus which other localities will find it difficult, if not impossible, to retard. According to the census of 1850 , Sacramento City contained 323 stores of various kinds, 65 blacksmith shops, 6 steam-mills, 5 soda and syrup manufactories, 2 breweries, 80 elothing stores, 8 eabinet shops, 8 livery stables, about 150 eating saloons and hotels-some of the latter of the most costly description; also 90 physicians, 70 lawyers, 6 churches-1 Episcopal, 1 Presbyterian, 3 Methodist (1 colored), and 1 Baptist. A Roman Catholic chureh is in course of erection. The number of inhabitants in the city proper, or within the city limits, was 6,000 ; but had the resident population all been in the city, the number would not have fallen much short of 12,000 , while in the country there are about 3,000 citizens. Out of the whole number there are but 1,460 females of all kinds, grades, and complexions. The banks of the river in the vicinity furnish one of the best farming regions in the State, though the crops on the low lands are exposed to great ravages from the periodical floods. The gold diggings commence about $30 \mathrm{~m}$. E. of the city, at the entrance of the hills, which rise rapidly to the eastward till they terminate in the high ridge of the Sierra Nevada. The gold was first discovered on the 8 . fork of the American r., $50 \mathrm{~m}$. from Sacramento, and all that neighborhood is still much resorted to by miners. Steamboats ply daily between this city and San Francisco, and considerable trade is carried on by sailing vessels. The river is navigable up to the town at all seasons of the year, and the trade is rapidly increasing. Like San Francisco, this city has suffered considerably by fire, which, although causing immense losses, has tended to beautify it, in the form of neater and more substantial buildings. In 1850 , the public press consisted of the "Transcript," a daily and weekly; the "Placer Times," daily and weekly (neut.); "Daily Index," daily; and the "Tribune," a daily and weekly issue. The census of 1852 gives a pop. of 10,000 .

SADAQUADA, or SAQUOTT creek, Oneida co, $N . I_{\text {: }}$ : rises in Paris t., flows $\mathrm{N}$. in general course, and empties into Mohawk r., $1 \mathrm{~m}$. from Whitesboro'. This is one of the most important mill streams of its size in the State, affording an immense water-power to numerous factories, flouring-mills, and other manufacturing establishments in the various villages and settlements on its banks.

SADDLE mountain, Mfass. : in Adams town, Berkshire co., 3,505 feet high, the highest of Massachusetts' mountains, and of comparatively easy ascent. Its summit is generally knowu as Gray Lock 
Sadplaback mountains, Franklin con, $M C_{0}:$ E. of Acquessuck lake, a few miles N. W. of Philipstown, $8,700 \mathrm{ft}$. high.

Saddle river, $\mathcal{N}$. Jer. : rises in Rockland eo, New York, a few $\mathrm{m}$. above its $\mathrm{S}$. boundary: and flows $\mathrm{S}$. $1 \mathrm{~m}$. to its entrance into Passaic r., about $1 \mathrm{~m}$. above Aquackanock. It has a rapid course, and affords extensive water-power.

Sadde Peak Mountatn, Sierra co., Calif.: 7,200 feet high.

SADDLE Rrver, t. and p. o., Bergen co., N. Jer. : $58 \mathrm{~m}$. N. E. by N. Trenton; bounded by Saddle r. on the E. and Passaic $r$. on the $\mathbf{S}$. Surface in some parts mountainous, but level on the E. between Passaic and Saddle rivers; soil red shale and loam, fertile in the valleys and well cultivated; watered by the aforesaid rivers and several brooks. It contains a few mills and stores. The inhabitants are chiefly devoted to agriculture. Pop. 816.

Sadsbury Harrisburg.

Saegerstown, p. v., Crawford co., Penn. : on the E. side of French cr.,and on the proposed line of the Pittsburg and Erie R. R., 194 m. N. W. Harrisburg.

Sageerstule, p. v., Lehigh co., Penn.: 75 m. E. N. E. Harrisburg.

Safe Harbor, p. v., Lancaster co, Penn.: on the left side of Susquehanna r., near the mouth of Conestoga cr., $34 \mathrm{~m}$. $\mathrm{8}$. E. Harrisburg. There is a furnace here, having an annual capacity of 5,000 tons, and a rolling-mill, which in 1850 made 5,567 tons rails, both moved by steam.

Sagadahock, Me.: the ancient name of a section of country at, and $\mathbf{E}$. of the mouth of Kennebec r., deriving its name from the settlement of a colony, in a locality called Sagadahock, at the mouth of the Kennebec, in 1607. This name is still much used to designate the Kennebec, or more particularly that portion of it below the confluence of the Androscoggin.

SAGE HrL, p. o, Graves county, $K y_{1}: 229$ m. S. W. Frankfort.

SAgevLle, p. o., Hamilton co., $N$. $Y .: 79$ m. N. N. W. Albany.

SAGEVILIE, p, v, Lauderdale co, Miss. : on W. side of Chickasawha r., $85 \mathrm{~m}$. E. Jackson.

SAg Harbor, p. v, and port of entry, Suffolk co., $N$. $Y$.: on an excellent harbor so called, between Gardiner's and Great Peconic bays, $92 \mathrm{~m}$. E. by N. New York city, $141 \mathrm{~m}$. S. E. Albany. First settled in 1730 , and incorporated in 1803. The site is sandy and sterile. It suffered severely by a fire in 1845 , but was soon rebuilt in a better manner than before. It contains 4 churches, an extensive clock factory, gereral mills, 1 bank, cap. $\$ 20,000$, a dry-dock for repairing vessels, and numerous stores. The "Corrector" is published semi-weekly and weekly. Considerable quantities of salt are manufactured in this vicinity by evaporation of seawater in the open air. This place is extensively engaged in the whale and other fisheries. The return cargoes are chiefiy taken to New York and other ports. In 1849, the imports here received, were 1,791 gallons sperm, and 37,379 gallons whale oil ; and 156,400 lbs. whalebone. The total tonnage of this district on 3uth June, 1550, was 15,166 tons ; consisting of 10,951 tons in registered tonnage, and 4,212 tons in cnrolled and licensed tonnage. The registered tonnage was all permanent, of which there was in the whale fishery 2,575 tons. The enrolled and licensed tonnage consisted of 8,776 tons permanently employed in the coasting trade, and 62 tons in the cod fishery; besides 374 tons "licensed under 20 tons" (319 tons in consting trade, 55 tons in cod flshery); of all which, $12 S$ tons were prom pelled by steam. During the year preceding, it had no foreign commerce. Vessels built during the year, 3 (1 brig; 2 schonners) -119 tons. Pop. 3.650.

SAGIXAW county, Jich. Situate E. centralls, in the peninsula, and contains $1, n 45$ sq. $m$. Drained by the Saginaw, Shiawassee, Flint, Tittibawassee, and Cass rivers. Surface level; soil a rich loam, of a sandy nature, on a 744 substratum of clay. In the E. and S. E., pine timber cerrirs the land to a great extent, about one-third of the co, being forest. Limestone and Gypsum are found on the bay, in the N. W. part. The chief products are wheat, Indian corn, and potatoes. Farms 72; manuf. 14; dwell. 473, and pop. -wh. 2,609, fr. col. 0-total 2.609. Capitul: Saginaw City. SAGINAW, t., p. V., and cap. Saginaw co, Mieh.: $57 \mathrm{~m}$. N. E. Lansing, Drained by the Saginaw and Tittibawassee rivers. The $\mathrm{v}$. is located on the $\mathrm{W}$. bank of the Saginaw $r$., on an elevation of 30 feet above the water. It is built on the site formerly occupied as a trading post, and during the late war as a military post. It contains a court-house, jail, a printing-office, stores and warehouses of different kinds, saw-mills (moved by steam), and workshops of various descriptions. Steamboats and sailing vessels are owned here, and employed on the river and bay. It is at the termination of the Saginaw and Detroit turnpike, and as far as natural and artificial advantages are concerned, the location is favorable to become a place of importance. The "Spirit of the Times" is a weekly issue. Pop. of $\mathrm{t}$. in 1840 , 887 ; in 1850,917 .

SAGINAW bay, Wich.: a branch of Lake Huron, on its $\mathrm{W}$. side, near the middle, setting into the mainland in $\mathrm{S} . \mathrm{W}$. direction from the lake. It is about $60 \mathrm{~m}$. $l o n g$, and $30 \mathrm{~m}$. wide, and contains a number of islands. It is navigable for vessels of any burden, and its numerous coves afford some of the best harbors on the lake. It receives Saginaw river. SAGINAW river, Mich. : is formed in Saginaw co., by the confluence of several large tributaries, of which the principal are, Cass $\mathbf{r}$. from the $\mathrm{E}_{\text {. }}$ Flint and Shiawasse $\mathrm{r}$. from the $\mathrm{S}$. and Tittibawassee $r$, from the $N$. W. The length of the Saginaw, from Flint r., where it commences, to its mouth, is about $30 \mathrm{~m}$. Its general course is N. E., emptying into the head of Saginaw bay. It varies in depth from 25 to 30 feet, and has a somewhat sluggish current. Below Saginaw city is a sand bar which has ordinarily 5 or 6 feet depth of water, but a N. E. wind frequently cumulates water to 8 feet in depth.

SAGO, p. O., Lewis co., Virg.: 189 m. N. W. Richmond.

SAr Creek, p. 0., Hamilton county, Tenn.: 108 m. S. E. Nashville.

SAILOR's Rest, p. v., Montgomery co, Tenn. : on W. side of Yellow er, $47 \mathrm{~m}$. W. by N. Nashville.

SatNT Albans, p. V., Hancock co., Ill. : on the border of a swamp, $87 \mathrm{~m}$. W. N. W. Springfield.

SAINT AlBans, t, and p. v., Somerset co, Me.: $47 \mathrm{~m}$. N. by $\mathbf{E}$. Augusta. This is a good township, having fertile soil adapted to grain. It contains a large and beautiful pond the outlet of which, Indian stream, affords water-power, and is a branch of Sebasticook river. Incorporated in 1813. I contains two pleasant villages. In the t. are several mills and stores, an academy, and some manufactories. Pop. of t. in 1830,911 ; in $1840,1.564$; in $1850,1.792$

SAINT Albaxis, t., p. v., sta, and eap. Franklin co, Verm. on Lake Chrmplain, $45 \mathrm{~m}$. N. W. by N. Montpelier; by Vermont Central R. P. 57 m. from Montpelier, 184 m. from Windsor, $23 \mathrm{~m}$. from Rouse's Point. Surface moderately uneven; soil fertile loam, and well cultivated. Drained by a small creek. First settled about 1785 . The $\mathrm{v}$. is $3 \mathrm{~m}$. E of the lake, on elevated ground, commanding a fine prospect. It is surrounded by a fertile back country, has considerable manufnctures, and a large business from its water communications with New York and Canada. It contains many handsome buildings, court-house, jail, on a handsome public square, 30 by 25 rods, an academy, 3 churches, and 1 bank, capital $\$ 50,000$. The "St. Albans Mersenger" (whig) is issued weekly, and the "Northern Advertiser" (advert.) monthly. The port of the $v$. and $t$ is at $8 t$. Alban's bay, Pop. of $t$. in 1830, 2,395; in 1810, 2,702; in 1850, 3,567 .

St. Alban's Bay, p. o., Franklin co, Verm.: on Lake Champlain, $46 \mathrm{~m}$. N. W. by N. Montpelier. Here is a good landing-place. with a wharf and several store-houses, also a bank, with capital of $\$ 100,000$. 
SALT AXderws, p. o., Orange co., $N . Y$.: 1 m. \$. by W. Albany.

SAINT ANDREW's bay and sound, Flor.: on S. coast, in W. part of the State, chiefly in Washington co. Its main body sets up N. $12 \mathrm{~m}$., with an average width of from 2 to $5 \mathrm{~m}$; ; an E. arm extends parallel with the coast $30 \mathrm{~m}$., from 1 to $10 \mathrm{~m}$. Wide; while another similarly extends W. $20 \mathrm{~m}$. separated from the gulf by a beach $1 \mathrm{~m}$. wide. The bay is easy of access, has 18 feet of water on the bar, and good anchorage within, sheltered from all winds. On its borders are some fertile settlements.

SANT ANDREW's BAY, p. o., Washington co., Flor.: at the head of St. Andrew's bay, $86 \mathrm{~m}$. W. by S. Tallahassee.

SAINT ANDrEW's sound, Ga. : receives the waters of Santills r. and some small streams, and contains Dover and other islands.

SAINT ANTHoNy's falls, MFnn. Ter.: in the Mississippi r., a little above the mouth of Minnesota $r$. Their dimensions, as surreyed by the officers at Fort Snelling, are-from W. bank to the island, 634 feet; across the island, 276 feet; the E. fall, 300 feet; total width of river, 1,210 feet. The perpendicular fall varies from 25 to 30 feet. The fall in about 260 rods in 58 feet; and from the foot of the rapids, a distance of several miles, about 100 feet. Father Hennepin named these falls.

Saint Axthony's Falls, p. v., Ramsey co, Minn. Ter. on the E. side of the Mississippi, $15 \mathrm{~m}$. by water and 8 by land abore St. Paul. It is laid out opposite and above the falls, and is a beautiful town site. A handsome elevated prairie, with a gentle inclination to the $\mathbf{r}$. bank, and of sufficient width for several parallel streets, extends indefinitely up and down the river. In the rear of this another table-land swell up some 30 feet high, forming a beautiful and elevated plateau. The houses are mostly frame built, and among them is numbered a large and well-furnished hotel for sum mer travelers. This place has good prospects. The supplies for Fort Gaines, etc., create considerable traffic and travel both by land and water, and the return traffic consist of furs and peltries, with other Indian contributions. Pop. in 1850,539 .

SALNT ARMAND, t. and p. 0, Essex county, N. Y.: $119 \mathrm{~m}$. N. by W. Albany, Drained by Saranac r., and Placid lake lies partly in the town. Surface in the N. mountainous, and in the $\mathrm{S}$. hilly; soil red shale. Iron ore and copper is found in the vicinity. Pop. 200.

SART A uBert, p. O., Callaway co., Mo.: 22 m. N. by E. Jefferson City.

SATNT AUGUSTINE, p. city, port of entry, and cap. St. John's co., Flor.: $170 \mathrm{~m}$. E. by S. Tallahassee. Lat, $29048^{\prime} 30^{\prime \prime} \mathrm{N}$., long. $81035^{\prime} 00^{\prime \prime} \mathrm{W}$. The city is situated $2 \mathrm{~m}$. back from the Atlantic on an inlet, in the rear of a small island, which protects it from the swell of the ocean, but which is low and does not obstruct the sea breezes or a view of the ocean. The inlet upon which it fronts, called Matanzas Sound, is an excellent harbor, $\frac{1}{2} \mathrm{~m}$. broad, capacious and secure. The bar at its mouth at low tide has about 9 feet of water, and within, 18 or 20 feet. The site of the city is somewhat peninsular, since the sound and a river extends in its rear up into the mainland, and is low, being not over 12 feet above the level of the ocean. Its form is a parallelogram, $1 \mathrm{~m}$. long and $\frac{3}{4} \mathrm{~m}$. wide. The houses are not compactly built, and many of them have a very antiquated appearance; they are generally two stories high, with the seeond story projecting over the first, the first story of stone, stuccoed, the second story of wood. The streets are narrow, and many of them very crooked. The elimate is celebrated for its mildness, and has made the city a favorite resort for invalids from the Northern Stales. The winter season sometimes passes without a single frost, and there are but one or two months in the year in which they ever occur. In summer, the heat of the day is tempered by the sea breezes, and the evenings are rendered cool and pleasant by the land breeze. An abundance of trees give the place a very rural appear- ance. There is a fine large public square in the E. part of the city, fronting on the sound; on its W. side is the courthouse; on the $\mathrm{N}$. side a splendid Catholic church, and on the $\mathrm{S}$. side Trinity church, Episcopal, a neat Gothic edifice. There are two other churches and a neat market-place in front of the harbor. Here is a United States land office and the station of a surveyor-general. In the S. part of the city, fronting the Matanzas, are extensive barracks. At the $\mathrm{N}$. end of the city, and commanding the harbor, stands Fort Marion, formerly the old Spanish castle of St. Mark, which was completed about a century ago. It contains a number of Spanish guns, ete, which eame into possession of the United States with the fort, one of which bears the date of 1735 . One newspaper, "The Aneient City," is issued weekly. The foreign commerce of St. Augustine, during the year ending June 30,1850 , consisted in the entrance and clearance of one foreign vessel of 68 tons, having a crew of four men. During the year no vessels were built, and it has no tonnage whatever of its own. This is the oldest settlement in the Union, having been founded in 1564 by Spaniards. The present population is about one-half eomposed of Spanish, French, and citizens descendants of other foreign countries. Since the ineorporation of the State with the Union, this portion of the population has been rapidly Americanizing. Pop. in 1850, 1,934.

Saixt Augustinw, p. v., Fulton co., $\Pi l_{*}:$ on the E. side of a branch of W. fork Spoon r, $78 \mathrm{~m}$. N. W. Springfield.

SArvt Augustive, $v_{\text {, Cecil }} o_{n}, M d$. : abont the middle of the neck of land lying between Bohemia r, and Black cr. 10 m. S. of Elkton, 49 m. N. N. E. Annapolis.

SaInt Bernard parish, $L a$. Situate S. E., and contains 562 sq. m. Drained by Bayou Cheronese and its branehes. Surface level and swampy; soil various, owing to the diversity of the surface; in those portions where it is not too wet for cultivation, and the tillage attended to, it is very fertile. Chief products, sugar, rice, cotton, and Indian corn. It is bounded on the E. by the Gulf of Mexico, and fur some distance below New Orleans includes both banks of the Mississippi. Farms 34; manuf. 0; dwell. 283, and pop.-wh. 1,406, fr. col. 73, sl. 2,323-total 3,802. Capital: Terre aux Boeufs.

SAINT BLAS cape, F'lor.: a narrow beach, bounding St. Joseph's bay on the W., $25 \mathrm{~m}$. W. Apalachicola.

SAINT CATHARINE's island, $G a$ : : lies off Newport river, between St. Catharine's sound on the N., and Sapel's sound on the $\mathrm{S}$., is $10 \mathrm{~m}$. long, $5 \mathrm{~m}$. broad, and belongs to Liberty county.

SanNT Charles county, Mo. Situate E., and contains $495 \mathrm{sq} . \mathrm{m}$. Drained by branches of Missouri r., which forms the S. E. boundary; and of Mississippi r., which flows on the N. E. Surface varied; soil fertile, and in the level portions very productive, and raising large quantities of tobacco, which is the chief production. It has fine prairie land, and some excellent timber. Iron ore of good quality is found, and there are some beds of coal. Farms 1,035; manuf, 33; dwell. 1,633, and pop.-wh. 9,492 , fr. 13 , sl. 1,949 total 11,454. Capital: St. Charles. Public Works: St. Louis and Northern R. R.

SaINT Charles parish, $L a$. Situate S. E., and contains $2 S 9$ sq. m. Drained by Mississippî $\mathbf{r}$, which passes through its N. central portion. Surface generally level ; soil fertile, particularly along the banks of the Mississippi. Chief products, sugar, rice, and Indian corn. It is bounded on the N. E. by Lake Pontchartrain, W. by Lake Allemands, and S. by Lake Washa. Farms 70; manuf, 3; dwell. 191, and pop.-wh. 867, fr. col. 121, sl. 4,132-total 5,120. Capital: St. Charles.

SatnT Charles, p. v. and sta., Kane co., $I l l_{\text {. : }}$ on the W. bank of Fox r., and on a branch of Galena and Chicago R. R. 37 m. W. Chicago, and' 160 m. N. E. Springfeld. This is a thriving village, with some good mills and other manufactories. The "Kane County Democrat" is issued weekly. 
Satvt Charles, p. o., Butler co., Ohio: 99 m. W. S. W. Columbus.

Satnt Charles, p. O., Johnson co., N. Car. : 25 m. E. S. E. Raleigh.

SaINT Charles, p. o., Arkansas county, $A r k$ : 60 m. S. E. Little Rock.

SaIv' Chardis, t., p. v., and cap. St. Charles co., Mo. on N. bank of Missouri r., $87 \mathrm{~m}$. N. by E. Jefferson City. Its site is hradsome, and upon the first elevated land on the river above its mouth. The village is about $1 \frac{1}{3} \mathrm{~m}$. long; has 5 streets parallel with the river, and contains at court-house, stone jail, brick market-house, 3 churches, a Catholic conrent, and female academy, several steam-mills, stores, ete. St. Charles College is here located, a Methodist institution, founded in 1837, which in 1850 had 4 professors, 20 students, 17 alumni, and 900 volumes in library. Here is a ferry across Missouri r., which is the great crossing-place between St. Louis and the N. and W. parts of the State. The "St. Charles Chronotype" (neut.) is issued weekly. Pop. of $\mathbf{v}$. about 2,000 ; of t. about 3,300 .

Saint Clatr county, $A l a$. Situate toward the N.E., and contains $732 \mathrm{sq} . \mathrm{m}$. Drained by branches of Coosa river, which forms its $\mathrm{E}$. boundary, the principal being Canoe and Shoal creeks. Surface undulating; soil fertile, and produces fine crops of wheat and Indian corn. Cotton is the staple. Farms 573 ; manuf. 0 ; dwell. 944, and pop.-wh. 5,501, fr. col. 7, s], 1.321-total 6,829. Capital: Ashville-

Saint Clatr county, $I U$. Situate toward the S.W., and contains $656 \mathrm{sq} . \mathrm{m}$. Drained by Kaskaskia r. and its affluents, and by Prairie du Pont end Cahokia ereeks, all tributaries of the Mississippi, which flows on its N. W. border. Surface undulating; in parts it is hilly and broken, and makes good pasture land; soil fertile, and produces fine crops of wheat and Indian corn. It is well timbered. Farms 1,961; manuf. 62; dwell. 3,727, and pop-wh. 19,606, fr. col, 575-total 20,181, Capitat: Belleville.

Sarnt Clair enunty, Mrich. Situate E. of the S. Peninsula, and contains 948 sq. m. Drained by Belle, Black, and Pine rivers, and Mill cr., and bounded on the E. by St. Clair strait. Surface undulating; soil in general fertile and productive. The chief crops raised are wheat, Indian corn, and potatoes. Farms 492 ; manuf. 63 ; dwell. 1,816, and pop.-wh. 10,396, fr. col, 24-total 10,420. Capital: St. Clair.

SaINT Clatr county, Mo. Situate toward the S. W., and contains $656 \mathrm{sq}$. $\mathrm{m}$. Drained by 0 sage river, which passes through it centrally, and by its branches, Sre r. and Clear creek. Surface rolling and diversified; soil very fertile, and adapted to the growth of tobacco, wheat, and Indian corn. Farms 827; manuf. 5; dwell. 531, and pop.-wh. 3,107, fr. col. 1, sl. 448-total 3,556. Capital: Osceola.

SAINT ClutR, t., p. vo, and cap. St. Clair co., Mfich.: on St. Clair r., $105 \mathrm{~m}$. E. Lansing. This is a thriving t., with fertile soil, watered by Pine $r_{\text {, }}$ on the S. side of which, at its mouth, is the v., on the site of old Fort St. Clair. It contains a court-house, jail, churches, a branch of the State University, some steam-mills and stores. The "St. Clair Observer" (dem.) is issued weekly. It has a good harbor, and does considerable business. During the year $15+5$ its expor's amounted to $\$ 71,525$; imports, do.. $\$ 51,044$-total value of exports and imports in $1818, \$ 122,569$. The lumber business is extensive; its annual product in year ending June 1, 1850 , amounted in value to $\$ 90,000$. Pop. of t. in 1540,418 ; in $1850,1,728$

Satnt Clatr, p. vo, Schuylkill co., Penn.: 44 m. N. E. Harrisburg. In the vicinity is a furnace moved by steam, with an annual capacity of 3.500 tons. It is an extensive mining region, and the village contains a number of dwellings, and 2,019 inhabitants, the majority of whom are engaged in mining.

SaINT ClaIr, p. o., Hawkins co., Tenn.: 210 m. E. by N. Nashville.

ST. CLATR, t. and p. o., Columbiana county, Otio: $129 \mathrm{~m}$. E. N. E. Columbus, Drained by Little Beaver r. and its 746 branches. Surface varied; in parts level, and in general productive. The Sandy and Beaver Canal passes through the E. part of the town. Pop.1.115.

SaINT Clatr lake, Mich. See Lake St. Clatr, p. 861. SAINT CLATR river or strait, Mfich.: connects Líke Huron with Lake St. Clair. It flows nearly lirect S., with a broad and deep current, for two-thirds of its course, and then divides into six ehannels, by which it enters Lake St. Clair. The N. channel, bounding the main land of the State, is the only one navigated in ascending and descending the strait. The river is $40 \mathrm{~m}$. long, with $35 \mathrm{~m}$. of ship channel, has an average width of half a mile, depth of 50 feet, currents of $3 \mathrm{~m}$. per hour, and an entire descent of 13 feet. It is an exceedingly beautiful stream of very clear water, is easily navigated, and is surrounded by varied and beautiful scenery. It has few islands besides those formed by its outlets. It receives several rivers from Michigan, the principal of which are Black, Pine, and Belle rivers, but none from Canada. On its banks are several flourishing villages.

SaInt Clatrsvmle, p. v., and eap. Belmont eo., Ohio: on the National Road, 108 m. E. by N. Columbus. It contains a court-house, jail, and other public edifices, 6 churches, a market-house, stores, ete. The "Belmont Chronicle" (whig), and the "Gazette and Citizen" (dem.), are issued weekly. Pop. about 1,500.

Saint Clatrsville, p. v., Bedford co., Penn.: $84 \mathrm{~m}$. W Harrisburg.

Sarvt Clement's Bay, p. o, St. Mary's co., Md.: at the head of an inlet so called of the Potomac $\mathrm{r}_{0}, 47 \mathrm{~m}$. S. by W. Annapolis.

Satrt Clovd, p. O., East Feliciana par., La.: 27 m. N. Baton Rouge.

SaIvT Croux county, Wisc. Situate W., and contains 792 sq. m. Drained by branches of St. Croix r., which russ on Its N. W. border, and by other streams falling into Lake St. Croix in the $W$. Surface hilly and broken, and diversified with small lakes; soil fertile. The greater portion of the county is unsettled, and as yet little has been done toward its cultivation. Farms 4; manuf. 2; dwell. 181, aud pop.-Twh. 619, fr. col. 5-total 624. Capital: Willow River.

SaINT CroIx river, Me.: constitutes the S. portion of the boundary between the United States and the British province of New Brunswick. It is also sometimes called Passamaquoddy, Cheputnetecook, and Schoodic; but the latter name is now generally given to the W. branch of the St Croix, flowing from the schoodic lakes. The St. Croix rises in Grand lake, which is connected with Cheputnetecook lake. It leaves the latter lake $54 \mathrm{~m}$. from its mouth, at an elevation of $352 \frac{1}{2}$ feet above tide-water. It has several sets of falls of considerable height, which afford great waterpower. At the confluence of Schoodic r., $20 \frac{1}{3} \mathrm{~m}$. from its mouth, it has an elevation of 166 feet above tide-water. Its total descent, in reaching sea level, is 444 feet. It is navigable for large vessels to Calais, $12 \mathrm{~m}$. , where it is crossed by a bridge.

SATNT Crotx lake and river, Wise.: rises in Upper St. Croix lake, in $\mathrm{La}$ Pointe county, and there receives several large head branches, of which the prineipal is the Namekagon r. It flows S. W. until it receives Kinebek or Snake r., and thence its general course is southerly until it empties into the Mississippi at Prescot v. About $30 \mathrm{~m}$. above its mouth it widens into an expanse called St. Croix lake, which is $1 \frac{1}{3}$ to $3 \mathrm{~m}$. wide until near its mouth. The river is narigable for steamboats about $80 \mathrm{~m}$, and for boats about 200 miles.

SATNTFIELD, p. o., Muskingum county, Ohio:52 m. E Columbus.

SAINT Francis county, Mo. Situate toward the S. E.; and contains 469 sq. m. Drained by head brunches of St. Franeis and Big rivers. Surface billy, and in the W. mountainous; soil generally fertile. This is a splendid mineral region, and the county contains the celebrated Iron Mountain, and Pilot Knob; these consist of micaccous ox- 
ide of iron, the whole top being one solid sheet. The ore rields 60 per cent. of pig inetal, and the quantity altogether is estimated at about $600,000,000$ of tons, enough to supply the world for a century. Other minerals are found. Farms 437; manuf. 11; dwell. 704, and pop.-wh. 4,233, fr. col. 51, sl. 650 -total 4,964 . Cupital: Farmington. Pullic Works: Iron Mountain R. R.

SAINT Franors county, Ark. Situate toward the E., and contains 1,011 sq. m. Drained by Caché r., and branches of St. Francis r., which runs on its E. border. Surface in general level; soil fertile, and adapted to grain. There is some fine timber on the land. Farms 348; manuf. -; dwell. 643 , and pop.-wh. 3,770 , fr. col. 2, sl. 707-total 4,479. Capital: Mount Vernon.

Sarst Francis, p. v., St, Francis co., Art.: on the W. side of the river so called, $90 \mathrm{~m}$. E. N. E. Little Rock.

Satrt Francis river, $\mathrm{MO}_{\mathrm{*}}$ and $\mathrm{Ark}$. : rises in St. Francis county, Missouri, flows S., and enters Arkansas, where it receives Whitewater river, a large branch which rises in Missouri, and for a long distance flows nearly parallel to it. It enters the Mississippi in Philip's co., and is navigable in high water nearly $200 \mathrm{~m}$. It passes through many lakes and swamps, but its waters are very clear, and abound with fine fish.

Saint Francistille, p. ve, Lawrence $\mathrm{co}_{n}, I_{\text {. }}:$ on the right bank of the Wabash r., $133 \mathrm{~m}$. S. E. of Springfield. It is surrounded by a fertile and well timbered country.

Sant Francisvilue, p. v., and cap. West Feliciana par. $L_{0}$ : on the left bank of the Mississippi river, $36 \mathrm{~m}$. above Baton Rouge. A great portion of the town is built on the plain, along the river, but the greater part is on a beautiful hill, immediately back, communicating with the Mississippi by the bayou Sara, and contains many fine buildings. It is a considerable place of trade, and has a number of extensive warehouses. The descending boats make this : stonping-place, and here also is the depôt of a railroad running to Woodville (Mississippi), by which large quantities of cotton are brought from the plantations in the interior. It contains a court-house, jail, several stores, and about 1,000 inhabitants.

Satnt Fraxcisviliz, p. $\nabla_{\text {., }}$ Clark county, Mno: on the W. side of Des Moines r., $132 \mathrm{~m}$. N. by E. Jefferson City.

SaINT Genevieve county, Mo, Situate E. toward the S. and contains $433 \mathrm{sq} . \mathrm{m}$. Drained by $\mathrm{Au}$ Vase and Establishment rivers, affluents of Mississippi river, which forms its N. E. boundary. Surface undulating; in some parts it is hilly and broken; soil generally fertile, the river bottoms being excellent land and very productive, while the uplands are more fit for pasture. It contains minerals, among which are iron and lead ores. Farms 425; ' manuf. 16; dwell. 814 and pop.-wh. 4,636, fr. col. 61, sl. 616-total 5,318, Capital: St. Genevieve.

SAIVT GeNevieve, p. v., and cap. St. Genevieve co., Mro. on the right bank of the Mississippi r., opposite the island so called, $62 \frac{1}{2} \mathrm{~m}$. below St. Louis, $117 \mathrm{~m}$. E. S. E. Jefferson City. It is pleasantly located on a healthy spot, and is a considerable place of business, particularly in the article of lead, considerable quantities of which, as well as iron and copper, exist in the neighborhood. The v. is built on Gabourie cr., a small strcam, which is sometimes boatable. It contains a court-house, jail, academy, Catholie church, convent, and female academy. The "St. Genevieve Democrat" and the "Pioneer" (dem.) are both weekly issues. The inhabitants are chiefly of French origin. Below here is a prairie of great fertility, 6,000 acres in extent, fenced and well cultivated. Pop. 718 .

Saint George, t. and p. o., Chittenden co., Ferm.: $8 \mathrm{~m}$ \$. E. Burlington, $28 \mathrm{~m}$. W. N. W. Montpelier. Pop. 147

SALxt George, t. and p. O., Lincoln co., Me.: 38 m. S. E. Augusta, on a peninsula formed by the Atlantic Ocean on the $\mathrm{E}_{\text {. }}$ and $\mathrm{S}$., and Muscongus bay on the W. Incorporated in 1803 . It has excellent facilities for navigation, and employs considerable shipping in the lumber and coasting trade, and in the fisheries. Ship-building is carried on: in 18494 vessels -657 tons, were built. Pop. in 1840, 2,094; in $1850,2,217$.

SATMT GEORGE river, Me. : rises in several ponds in Waldo county, and flows S. $40 \mathrm{~m}$. into Muscongus lay. The tide extends to Warren, $15 \mathrm{~m}$. from the sea, to which place it is navigable.

SaINT George"s, hund. and p. v., New Castle co., Del。: $23 \mathrm{~m}$. N. by W. Dover. Its ehief trade is lumber. It has also several grist and saw mills. Area, 42,680 acres. Pop. about 3,500 .

SAINT GEORGE's, p. o. and sta., Colleton district, S. Car.: on the W. side of a branch of Edisto $r_{\text {. }}$ and on the South Carolina R. R., 13 m. N. W. Charleston, and 63 m. N. by W. Columbia.

SaINT Helen, p. v., Cedar co., Mo. : on the right bank of Sac r., 105 m. S. W. Jefferson City.

Saint Helen, p. o., Washington county, Oreg. Ter.: on W. bank of Columbia r., $61 \mathrm{~m}$. N. by E. Salem.

SAINT HeLENa parish, $L a$. Situate $\mathrm{N}$. in the $\mathrm{E}$. part of the State, and contains 520 sq. m. Drained by Tickfau r. and its branches in the central portion, and tributaries of Amitie $r$. in the W. Surface uneven and broken; soil in general barren, and much of the co. is covered with pine timber; along the banks of the streams there are, however, some fertile portions, producing rice, cotton, and Indian corn. Farms 273; manuf. 9; dwell. 390 , and pop.-wh. 2,354, fr. col, 11, sl. 2,196-total 4,561. Capital: Greensburg.

Satnt Heleiva, p. vo, St. Helena par., La.: ou the W. side of Tickfau r., 35 m. E. N. E. Baton Rouge.

Satrt Helena island, Beaufort dist., S. Car. : lies between St. Helena sound on the N. E. and Broad r. on the S. W.

Saint Helena sound, S. Oar. : lies between Colleton and Beaufort distriets, receives Combahee, Coosa, Ashepoo, and other rivers, and contains several islands.

Sannt Henky's, p. o., Mercer eo., Ohio: 96 m. N. N. W. Columbus.

SAINT ILLA, p. o., Ware county, Ga. : on St. Illa, or Santilla r. $_{132} \mathrm{~m}$. S. S. E. Milledgeville.

SAINT INIGoes, p. v. and port of entry, St. Mary's co., Md.: near a creek so called, an arm of St. Mary's river, $56 \mathrm{~m}$. S. Annapolis. This is the port of entry of St. Mary's district, of which the total tonnage on 30th June, 1850, was 2,185 tons, enrolled and licensed, all of which was employed in the coasting trade. During the preceding year the district had neither foreign eommerce nor ship-building.

S Springfield.

$S_{\text {AINT }} J_{\text {AMES }}$ parish, La. Situate centrally in the E. dis. trict, and contains $329 \mathrm{sq} . \mathrm{m}$. Drained by Mississippi river, which flows through its $\mathrm{S}$. portion. Surface even; soil fertile. Chief products, cotton and sugar. It contains Jefferson College. Farms 145; manuf. 6; dwell. 591, and pop.wh. 3,285 , fr. col. 62, sl. 7,751-total 11,098. Capital: Bringiers.

S ALrT JoHN, p. v., Lake co., Ind.: on Thorn cr., $132 \mathrm{~m}$. $\mathrm{N}$. W. Indianapolis. It is situated in the centre of a German Catholie settlement, $6 \mathrm{~m} . \mathrm{N}$. W. of Crown Point, where they have ereeted a chapel.

SAINx JoHN, p. o., Dodge county, Mfo.: 138 m. N. N. W. Jefferson City.

Sarve John, p. v., Hertford co, $N$. Car : : on a branch of Pottocasy er., $96 \mathrm{~m}$. E. N. E. Raleigh.

SaINT John Baptist parish, $L a$. Situate centrally in the E. district, and entains $238 \mathrm{sq}$. m. Drained by Mississippi river, which passes through its S. W. portion. Surface diversified; soil generally unfit for cultivation, that portion lying alont the streams only being fertile; this, with cultivation, proves productive, and yields large quantities of rice, sugar, and cotton, which form the leading articles of commerce. It is bounded on the N. E. by Lake Pontchartrain. Farms 162 - manũ. 14; dwell, 530, and pop,-wh. 2,586, fr. 
col. 191, sl. 4,540-total 7,317. Capital: Bonnet Carré. Public Works: New Orleans, Opelousas, and Texas R. R.

Saint Jokv's county, Flor. Situate N. E., and contains 869 sq. m. Drained by St. John's r. and its branches, and North r. Surface generally level; snil very fertile in many parts, and in others being too low for cultivation. Chief productions, eotton, sugar, Indian corn, oranges, citrons, lemons, and vegetables of different kinds. On the St. John's river large quantities of live-oak are found. Farms 34; manuf. 7 ; dwell. 321 , and pop.-wh. 1,417, fr. col. 115, sl. 993-total 2,525. Capital: St. Augustine.

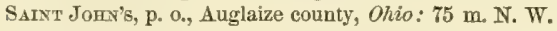
Columbus.

SAINT JoHv's, U. S. collection distriet, Flor.: embracing St. John's r. and vicinity, had, on 30th June, 1850, a tonnage of 310 tons enrolled and licensed, permanent, and employed in the coasting trade, of which 80 tons were propelled by steam, with no foreign commerce or ship-building.

SAINT JoHr's river, Flor.: this large river rises in an immense marsh in Orange co. Its general course is $\mathrm{N}$. and parallel with the coast until, in Duval co., it turns suddenly to the $\mathrm{E}$. and empties into the Atlantic. Its entire length is about $250 \mathrm{~m}$. Its width varies greatly, from $4 \mathrm{~m}$. to 3 , and even $5 \mathrm{~m}$. In the first part of its course, $150 \mathrm{~m}$. from its mouth, it flows through Lake George, $20 \mathrm{~m}$. Iong and $6 \mathrm{~m}$. wide; and on leaving that lake receives a very large stream, its main tributary, the Oeklawaha $\mathrm{r}$. At its mouth it is $1 \mathrm{~m}$. wide, and has 12 feet of water on the bar. A light-house is there erected. Fessels drawing 8 feet water can navigate it as far as Lake George and Dunn's lake, as also those lakes.

SAINT JoHN's river, Me.: rises by several branches in the N. part of Somerset co., one of which (the N. W.) extends into Canada. It flows $\mathrm{N}$. and $\mathrm{E}$, until it reaches the $\mathrm{N}$. boundary of the State, and thence constitutes the boundary line until it reaches the $\mathrm{E}$. boundary line, in about lat. $47^{\circ}$ N., when it passes into the province of New Brunswick, and flows with broad stream, in irregular course, S. and E. into the Bay of Fundy. Its entire length is about $350 \mathrm{~m}$. The tide flows up about $80 \mathrm{~m}$., through which distance it is navigable for sloops of 50 tons. It is navigable for boats, with the exception of two short portages, nearly to its source. By the late treaty with Great Britain its navigation is free to both nations.

Satnt Johnsbury, t., p. v., and sta., Caledonia co., Verm. 32 m. E. N. E. Montpelier. Surface uneven; soil fertile Watered by Passumpsic $r$. and its tributaries, which afford great water-power. Chartered in 1756; first settled in 1785 There are in the t. 3 handsome villages. On Sleeper's r. of the Passumpsic is the noted Fairbanks' scule manufactory. Here commences the Connecticut and Passumpsic Rivers Railroad, extending to White River Junction, $61 \mathrm{~m}$. One newspaper, the "Caledonian" (dem.), is issued weekly, and the v. contains a bank-capital $\$ 100,000$. Pop. of to in 1830 , 1,592 ; in $1810,1,887$; in $1850,2,758$.

Salvt Johnsburx Centre, p. O., Caledonia co., Verm. : on Passumpsic r., 38 m. E. N. E. Montpelier. Contains a Congregational church, academy, etc.

SankT Johnsb 34 m. E. N. E. Montpelier.

SAINT JoHNSvILLE, t., p. v., and sta., Montgomery county, N. Y.: 55 m. W. N. W. Albany. Drained by East Canad: and Zimmerman creeks, tributaries of the Mohawk r., which bounds it on the $S$. Surface varied, in parts hilly ; soil fertile, and much grain is raised. Organized in 1887, and bas limited manufactories, several mills, etc., a forge and furnace. The $\mathrm{v}$. is on the $\mathrm{N}$. bank of the Mohawk r., and on the Schenectady and Utica R. R., $47 \mathrm{~m}$. from schenectady. The Erie Canal passes along the opposite side of the $r$. An extensive stone quarry is located near the village, Population of t. 1,627 .

SaINT Joserm, p. v., and cap. Calhoun co., Flor.: on the bay so called, $76 \mathrm{~m} . \mathrm{S}$. W. Tallahassee. It contains a courthouse, jail, etc.
Saint Joser H, t. and p. v., Berrien co., Mich. : on Lake Michigan, 109 m. S. W. Lansing. Drained by St. Joseph and Pawpaw rivers, which unite in the t. Surface various, and heavy timber, consisting of oak, whitewood, linden, beach, elm, etc., in abundance; soil, along the banks of the streams, rich and highly cultivated. The village has a commanding site, on an elevation of some 50 or 60 feet above the harbor, at the confluence of St. Joseph river with Lake Michigan, and being eligibly located for commerce, is one of the most important places on the W. side of the peninsula. The $\mathbf{r}_{\text {., }}$ at the $\nabla_{\text {., }}$ is 900 feet in width, and the harbor admits vessels drawing $6 \frac{1}{2}$ feet water. A pier and other improvements have been constructed, and 2,000 feet of wharf is built. A bridge here spans the r., and it is contemplated to connect it with Cassopolis, New Buffalo, Niles, etc., by railroad. It contains a court-house, jail, several large forwarding and commission houses, mills, etc. The imports for the year 1848 amounted to $\$ 672,892$, and the exports $\$ 543,895$, making a total of $\$ 1,216,7 \$ 7$. It is a thriving place, and contains about 2,000 inbabitants, and the t. 3,000 SAINT JosePH, p. V., Buchanan co., Mo.: about $1 \mathrm{~m}$. E of the Missouri r., $156 \mathrm{~m}$. N. W. Jefferson City.

SAnt Josepr, p. v., Allen county, Ind.: 109 m. N. E Indianapolis. It is a pleasant $v$, with 525 inhabitants.

SFINT JOSEPH, p. v., and cap. Tensas par., La.: on the Mississippi river, $189 \mathrm{~m}$. (by water) N. Baton Rauge, and $102 \mathrm{~m}$. direct. It contains a court-house, jail, etc.

SAINT JoSEPH's county, Ind. Situate N., and contains 137 sq. m. Drained by the St. Joseph's r. in the N. and E. and by Kaukakee $r$. in the W. Surface level; soil a fine deep loam, well adapted to grazing, Chief productions, wheat, Indian corn, and potatoes. In the $\mathbf{S}$. is some fine prairie land, and a quantity of good timber. It has good water privileges. Farms 847; manuf. 45; dwell. 1.885, and pop.-wh. 10,925, fr. col. 29-total 10,954. Capital: South Bend. Pullic Works: Indiana Northern R. R.

SAINT Josmph's county, Mich. Situate S. in the S. Peninsula, and contains 580 sq. m. Drained by the St. Joseph's $r$. and its branches, also by Portage, Prairie, Rocky, and Pjgeon rivers. Surface slightly undulating; soil exceedingly fertile. The principal products are wheat, Indian corn, oats, and potatoes. The industry of the co. is chiefly applied to agricultural pursuits, but the manufactures are considerable. The branches of the St. Joseph's river supply good waterpower. Farms 1,379; manuf. 82 ; dwell. 2,301, and pop.wh. 12.699, fr. col. 26-total 12,725. Capital: Centreville. Public Works: Michigan Southern R. R.

SAINT JosepH's, p. 0., Champaign co., Ill. : 73 m. E. by N. Springfield.

SAINT Joséph's, p. o., Susquehanna county, Penn. : $120 \mathrm{~m}$. N. by E. Harrisburg. In its vicinity is St. Joseph's College, a Catholic institution, established in 1552

SAINT Josepu's bay, Flor : $22 \mathrm{~m}$. W. Appalachicola, lying within Cape St. Blas, a long and narrow sandy beach, its W. inclosure. It is $20 \mathrm{~m}$. long, about $8 \mathrm{~m}$, wide, with a broad entrance from the $N$. W., having 17 feet of water on the bar, and another deep channel near the peninsula.

SarNT Josepri's island, in the Straits of St. Mary, 36 miles N. E. Mackinaw, $20 \mathrm{~m}$. long, $8 \mathrm{~m}$. broad, dividing the passage into 2 channels nearly equal in extent, etc., through the S. one of which the U.S. boundary passes.

SAINT JosePH's river, Micho: rises in the N. E. part of Hillsdale co., flows $\mathrm{E}_{\text {, }}$, and after $\mathrm{a}$ broad $\mathrm{S}$. bend, in which it enters Indiana, it proceeds $\mathrm{N}$. W. until it enters Lake Michigan at St. Joseph. In length and volume of water it is the second river in Michigan, being about 259 miles long in its entire course, but not more than $150 \mathrm{~m}$. in direct line. It is navigable for keel boats to Lockport, $130 \mathrm{~m}$. At its mouth is a sandbar with 6 feet of water, but within is a good harbor, which, with a pier, easily accommodates all vessels in the lake navigation. It receires many tributaries, and affords considerable water-power. Its intervals are very fertile, and in some places heavily timbered. 
SALT JusEpin's river of the Maumee, Mich.: rises by several brauches in Hillsdale co, and flows in $\mathrm{S}$. W. course across the $\mathrm{N}$. W. corner of Ohio, into Indiana, and joins the St. Mary's at Fort Wayne, forming Maumee $r$. It affords considerable water-power.

Satnt Julian, p. o., Limn co., Ia. : 25 m. N. Iowa City. SanNT Landery parish, $L a$. Situate toward the $\mathrm{S}$. W., and contains 2,296 sq. m. Drained by Teche, Rouge, Cannes, and Crocodile bayous, Vermillion river, and Cartableau river, branch of Atchafalaya, which bounds it on the E. Surface diversified, but most generally a plain, and adapted to the growth of cotton; soil fertile. Chief products cotton and Indian corn. It contains one or two lakes. Farms 775; manuf. 18: dwell, 2,421, and pop, - wh. 10,139, fr. col. 1,243, sl. 10,371-total 22.253. Capital: Bayou Chicot C. IH. Public Works.: New Orleans, Opelousas, and Texas R. P.

SaInT Lawrexce comnty, $N$. $Y$. Situate $\mathrm{N}$. toward the E., and contains 2,717 sq. m. Drained by Grass, Racket, St. Regis, Oswegatchie, and Indian rivers, affiuents of the St. Lawrence river, which for a considerable distance makes its N. W. boundary. These supply navigation and good water-power. Surface much diversified, but in general level ; soil fertile, in the $\mathrm{S}$. E. it is adapted to grazing, the land being mountainous. Chief products wheat, Indian corn, and potatoes. Lead and iron ore is found extensively, and marble of excellent quality. It has many lakes, which add a beauty to the scenery of the surrounding country. Farms 6,124 ; manuf. 456 ; dwell. 11,704, and pop.-wh. 68,575, fr. col. 36-total 68,614. Capital: Canton. Public Works: Northern (Ogdensburg) R. R.; Watertown and Northern Junction R. R.; Utica and French Creek R. R.; Amsterdam and Potsdam R. R.

Sarvt Lawrence, p. v., Chatham co, N. Car.: on N. side of Rock r., $45 \mathrm{~m}$. W. Raleigh.

S.AIX LAWreitce, p. o., Jefferson county, $N$. $Y .: 145 \mathrm{~m}$. N. W. Albany.

SATNT LAWRENCE river, United States and Canada: this very large and important river is the outlet of Lake Ontario, and of the other great lakes, Erie, Huron, Michigan, and Superior, and is the main artery to the heart of the American continent. Its length from Lake Ontario to the W. end of the island of Anticosti is about 660 miles, and to the Gulf of St. Lawrence about 750 miles. The continued navigation afforded by its connection with the lakes is over 2,000 miles. It forms the boundary between the United States and Canada until it arrives $1 \mathrm{~m}$. $\mathrm{N}$. of the $45 \mathrm{th}$ degree of $\mathrm{N}$. lat. Its breadth varies, but has on the whole an increase in its descent, especially below Quebec, until at the W. end of Anticosti island it is about 100 miles wide. It is navigable to Quebec (420 m. from the GuIf of St. Lawrence) for ships of the line, and for ships of 600 tons to Montreal. From Quebec to Montreal it has an average breadth of $2 \mathrm{~m}$. The distance from Montreal to Lake Ontario is about 200 miles. This river is the natural course for direct commerce from the N. portion of North America with Europe. It runs almost upon a line of the great circle of the globe, upon which is placed the largest population of the world, that of Europe and Asia, and the great food-producing region of America; and hence upon this line is the shortest possible distance between the great centres of Asiatic, European, and the future American population. The approximative sailing distances from the principal rivals in the western trade of North America to Liverpool are:

From Quebec, by the Straits of Bellisle and North of Ireland...................., 3,000

" " by St. Paul's................. 3,300

"6 New York............................. 3,475

" New Orleans........................ 5,300

The population of the St. Lawrence valley in 1550 , including Canada, was at least $4,000,000$. The natural amount of commerce on this river is now greatly lessened by the restrictions imposed by Great Britain.
SAINT Legee, p. o., Ozark co., Mo. : 128 m. S. Jefferson City.

SAINT LeonarD's, p. $\nabla_{n}$, Calvert co., Md.: between the creek so called and Chesapeake bay, $34 \mathrm{~m}$. S. Annapolis.

SAINT Lours county, MTo. Situate E., and contains 585 sq. m. Drained by Maramec $r$. and other tributaries of the Mississippi, which forms its $\mathrm{E}$. boundary, and by branches of Missouri r., which runs on its W. border. Surface undulating; soil fertile, and consists of a fine deep mold, with sand and clay intermixed. Farms 1,294; manuf. 1,409; dwell. 13,430, and pop.-wh. 97,577 , fr. col. 1,434, sl. 5,967 -total 104,978. Capital: St. Louis. Public Works: Pacific R. R. ; St. Louis and Northern R. R.; Iron Mountain P. R. SaINT Lovis, p. city, port of entry, and cap. St. Louis co., Mo. : on the W. bank of the Mississippi r., on the first bluff, $20 \mathrm{~m}$. S. of the confluence of the Missouri $r$, and in lat. $38^{\circ}$ $37^{\prime} 2 \mathrm{~S}^{\prime \prime} \mathrm{N}$., and long. $90^{\circ} 15^{\prime} 16^{\prime \prime} \mathrm{W}$. The distances by river course from New Orleans are $1,210 \mathrm{~m}$; ; from the falls of St. Anthony, 863 m.; from St. Paul, 822 m. ; from Galena, $395 \mathrm{~m}$. from Alton, $22 \mathrm{~m}$; from Pittsburg, 1,189 m.; from Cincinnati, $705 \mathrm{~m}$; f from Louisville and Jeffersonville, $564 \mathrm{~m}$. from mouth of Ohio $x ., 170 \mathrm{~m}$; from Council Bluffs, $687 \mathrm{~m}$. from Fort Leavenworth, $413 \mathrm{~m}$; from Independence, $371 \mathrm{~m}$. and from Jefferson City, $15 \tau \mathrm{m}$. It is the great commercial depôt of the Upper Mississippi, the Ohio, and the Missouri, and their numerous tributaries, furnishing connected waterways of upward of $8,000 \mathrm{~m}$., and passing througb countries rich beyond description in mineraI, vegetable, forest, and animal products, and requiring for the support of their inhabitants a vast amount of manufactures and productions of foreign countries and the sea-board States. Next to New Orleans, it is the principal port on the Mississippi, and among western cities, is second only to Cincinnati in population and wealth.

St. Louís occupies the geographical centre of the Mississippi Valley. Its advantages, as a commercial depôt, can not be excelled, and the resources of its immediate vicinity in Missouri are immense. In a circuit of less than $90 \mathrm{~m}$. from the city, iron, coal, lead, and probably copper, are sufficiently abundant to supply the Union for indefinite ages, and of this region St. Louis is the only outret. Capital alone is wanted to develop these wonderful riches. Nor is this all ; the country around is a magnificent agricultural district, yielding abundantly of all the staples of the latitude, and at this point the hunter, the miner, and overland emigrant, take in their supplies before setting out on their various adrentures.

The locality was first settled in 1764. The site is elevated many feet above the flood-marks of the Mississippi, and is favored in this respect in salubrity. It rises from the river by two plateaux; the first, the alluvial bottom, is 20 feet above the highest flond, and the second, a limestone bank, to the level of the back country, is 40 feet higher than the first, extending away to the horizon. The ascent from the river to the first plain is rather abrupt, but to the upper terrace it is more gradual, and from its highest elevation com. mands a grand prospect of the lower city, and the country on every side.

As originally planned, the city occupied only the first terrace, and consisted of three narrow streets, parallel with the river, but after its growth commenced, which was subsequent to its coming into the possession of the Americans, it soon expanded its limits, and encroached upon the plateau above. The streets in the newer portion are wide, and laid out at right angles. To the north and sauth of the city. which itself extends some two miles along the river, extensive suburbs have been laid out on the same plan. The city reaches back nearly three miles. Front Street, on the river bank, is built up of substantial stone warehouses, which luave an imposing appearance, and are generally appropriated to heavy businesses. The street immediately behind this is the principal seat of the wholesale dry goods business, although this and the grocery business are not 
confined altogether to these localities. The city is generally well built of brick chiefly, and sumetimes of stone, the limestone of the neighborhood furnishing abundance of material. Many of the residences, hotels, etc., are magnificent and costly structures, and in the new city the private $d$ wellings are mostly surrounded by garden plots and ornamental shrubbery. The whole area of the city covers about 36 sq. m., about onertenth of which is thickly built upon.

The principal public buildings are those appropriated to the county business, as the court-house, jail, and offices; the municipal buildings, as the City IIall, courts, markets. etc.; the churches, literary institutions, schools, and charitable foundations. The Court-house is an elegant building, situate on a public square, near the centre of the eity. The City Hall, the basement of which is used as a market, is on a square at the foot of Market Street, and is a splendid brick edifice. Among the churches, the Roman Catholie cathedral is the largest and most costly : it is 136 feet long, by 5s feet wide, with a massive Doric portico in front, and its steeple contains a chime of bells, the largest of which weighs 2,600 pounds. Many of the churches of other denominations are remarkable for chaste and beautiful design.

The annexed, an abstract of the late census, are the de finite statistics of the churches of the city :

Churches. No. Seats. Value, Churches. No, Seats, Value, R. Cathol 12.10,862.\$584,300 Unitarian .2. $2,100, . \$ 70,000$ Methodist 12.8,300、171,000 Evangel. ..2. . 600.. 4,700 Presb.... 8. 5.900. 200,000 Baptist....2. .1,600.. 33,000 Lutheran, 5. 3,300、44,500 Boatman's.1.. 500.. 15,000 Episcopal 5. 2,750. 136,000 Jews .....2. 470.. 7,000

-making a total of 49 churches, containing 35,712 seats, and ralued at $\$ 1,213,500$. The Roman Catholic population is ruch more numerous than is indicated by the number of seats in the churches, as a very large portion of that denomination worship in the aisles and vestibules, and an average of three several congregations assemble at each church at the different hours at the severol masses on Sunday morning. St. Louis is the see of the Catholic archdiocese of the same name, and also of the Protestant Episcopal diocese of Missouri.

Among the charitable institutions the most conspicuous are the Protestant and Catholic Orphan Asylums-the first under the direction of Protestant ladies, and the latter of the Sisters of Charity. There are also hospitals; dispensaries, and other charities, for the medical care of the destitute.

Literary institutions are numerous. The University of St. Lonis is some 3 or 4 miles north from the city, but for the accommodation of the medical department, there are appropriate buildings within its limits. The University was founded in $18: 32$, and has 17 professors; and in 1550 , had 160 students, and a library of 12,000 volumes; and at the same period the medienl department had 7 professors and 107 students. The Western Academy of Sciences is estab. lished here, and has a fine museum; and besides this there is a museum of Indian antiquities, etc. According to the census of $1<50$, there were within the city 44 common s.hools, with 2,847 pupils: 15 private schools, with 2,378 pupils ; 9 Roman Calholic schnols, with 1,356 pupils : a Catholic college, with 250 pupils : two medieal schools, with 14 professors, and 262 sullents. St. Louis is alsu the site of a [nited States arsenal, and a few miles below the city are Jefferson Barracks, with acenmmodations for a garrison of in men. The office of the Land District of St. Lotis is locnted here, and also the office of the surveyor-general. The city is supplied with water from the river, which is raised by a steam-engine into a reservoir upon the summit of an ancient mound, and is thence distributed through iron pipes. The streets and public buildings are generally lighted with gas, which is sujplicd by a company.

The public press of St. Louis consists of 7 daily, 3 triweekly, 1 semi-weekly, and 13 weekly newspapers, and 6 monthly p.riculicals. The "St. Louis Times" is issued in daily, tri-weekly, and weekly editions; the "St, I. Intelli gencer," daily and weekly ; the "Organ and Peveille," daily and weekly; the "St. L. Republican," daily, tri-weekly, and weekly; the "St. L. Union," daily, tri-weekly, and weekly; "Die Wochentliche Anseiger des Westens" daily; "Die Wochlentliche Deutsches Tribune," daily; the "St. L. Price Current," the "Union Banner," the "American Banner," the "Shepherd of the Valley," the "Unfere Beit," the "Western Watchman," and the "St. L. Presbyterian," are issued weekly; and the "Valley Farmer," the "St. I Probe," the "Insurance Reporter," the "Western Journal," the "Bank Note Detector," and the "Signet," are issued monthly. As a general thing, the press of St. Louis is conducted with a high standard of talent, and occupies a first rank in the great department of journalism. Many of its issues have a wide circulation.

The grow th of St. Louis, within the past 20 years, has been wonderfully rapid, and each great interest has kept pace with the whole. It is not alone in commerce that St. Louis is a great city, but in manufactures, the arts, and all other departments of industrial economy. Improvement has gone hand in hand with her general prosperity, and the old shanty of the settler has given place to the substantial dwelling of the resident. In every thing the change has been great, and a city of grand proportions, with all the elements of future success, has gained a footing where so lately a scattered village, depending on Indian trade and the trap. per for support, alone existed.

The census of 1550 gave St. Louis a population of 77,860 , of which $73, \$ 42$ were white $-42,381$ males, and $31,458 \mathrm{fe}$ males; 1,362 were free colored persons -725 males, and 637 females, and 2,656 were slaves. These numbers constituted 13,161 families, and occupied 9,662 separate dwellings. The population, in 1830 , was 4,377 ; in $1840,16,469$-increase 230.9 per cent. ; and in $1850,77,630$-increase 172.7 per cent.* The population of the city includes 23,774 Germans, 11,257 Irish, 2,933 English, and 2,450 natives of other countries, mak ing an aggregate of 40,114 natives of foreign countries, leav. ing $37,05 \perp$ for natives of the United States. This presents even a greater disparity between the native and immigrant population that has been supposed to have existed. The im. migrants, however, constitute one of the principal sources of the wealth and prosperity of the city. They have added millions to the value of its real estate, immensely increased the aggregate of the annual returns of its productive industry, and ereated an important market for the productions of the soil and the wares of the mechanic and the merchant.

The whole number of manufacturing establishments in operation on the 1st June, 1850 , and producing to the value of $\$ 500$ and upward, annually, was 1,308 , in which was invested a capital of $\$ 4,377,711$; and these employed 7,321 males, and 1,130 females. The annual product of this branch of industry amounted to $\$ 15,400,340$. The following table, showing the number of each kind of business, the capital invested, etc., is compiled from the census of the year specifled :

$$
\text { Business, }
$$

Capital, Handsemployed. Annual

104 Carpenters ..........\$150,265..557... _. $\$ 1,171,580$

9 Stone-cutters......... 29,100..90... 122,700

7 Shirt manufacturers .... $43,000 \ldots-\ldots 268 \ldots \quad 43,000$

106 Tailors .............. 205,500,.680..181.. 650,550

14 Hatters............. 26.700..72.. 16.. 85,150

8 Carriage-makers ..... 56,600,138, _. 130.000

9 Iron foundries . . . . . . $359,000, .545 \ldots \ldots$.. 569,000

2 Brass foundries ........ 17,000 . 22... - . 25,000

71 Blacksmiths ........ $72,430 \ldots 326 \ldots$. . 303,130

16 Breweries ............ 197,550. 81..... 285,925

50 Cabinet-makers ....... $72,760 \ldots 195 \ldots$. .. 182,800

* A censrig taken under the state authorittes in $1 \times 52$, gave the population of the city at 41,81 ' of which 118,38 ; were white persuns, 1,341 free persons of color, and 4,059 slaves. The census of white persons in the city gives 51,251 male and 40,791 fernales. 

Hands employed, Annual
Business, $\quad$ Capita:, Miles, Fein. Prodrect. 85 Tinners \& coppersmiths. 129,300 ..151... -

1 Type founder .......... 51,800.. 10. 10 .

10 Chandlers and lard oil melters ............

8 Tent and awning makers

7 Rope-makers...........

50 Bakers ..............

110 Boot and shoe makers

5 Gunsmiths...........

1 Fire-safe maker........

25 Painters and glaziers...

7 Bonkmbinders.........

3 Plune-makers.........

3 Trunk-makers .........

7 Locksmiths .............

1 Chair manufactory .....

6 Plumbers...............

5 Tobacco manufactories.

3 Spirit gas distilleries....

2 Drug and chem. factories

1 Flouring-mill ..........

1 Shot factory ...........

1 Bucket factory.........

9 Tanneries

9 Saw-mills........... 115,000.103.....

22 Milk dairies........... 12,830..25.....

10 Upholsterers .......... 49,960..46..112..

24 Saddlers ............. 38,916.178. 6. .

6 Turners ............ 2,330.. 8.....

2 Venetian blind makers.. $4,000 \ldots$ 5.. 3. .

5 Wire-workers......... 16,800.. 15... .

1 Gold-pen maker ....... 1,000.. 1.. - .

19 Flour-mills..........4 439,500..181.. - . 2,367,750

2 Planing-mills ......... 47,000.. 35... .. 96,000

8 Patent medi'ne manuf's. $14,000 \ldots . .8$. . . 96,000

53 Coopers.............. 82,485 ..248 ... - 288,522

2 Glass factories ........ 50,000 . 70 ... .. 64,000

8 Sugar refineries ....... 177,000. .211 .. - . 1,213,600

2 White lead, castor and $\} 146,000 \ldots 160 \ldots$ - .. 600,000

linseed oil factory ..... $\}$

4 Soda-water manufacto's. $16,000 \ldots 91$. . . .

10 Confectioners.......... 6,700.. 28.....

1 Whip-maker.......... 600.. 7...

4 Lime-kilns........... 2,330.. 14.....

1 Cork manufactory ...... 2.500.. 8., - .

88 Cigar-makers........ 20,180 . 92... - .

2 Rectifiers ............ 4,000.6. . .

5 Machinists............ $30,100 \ldots 100 \ldots-$.

3 Starch factories....... 25,000, 17 ....

44 Brick-yards.......... 89,000..619... .

6 Sausage-makers........ $505 . .6 \ldots-$.

1 Cotton-yarn factory..... $70,000 \ldots 40 \ldots 80$.

13 Bricklayers $. . \ldots \ldots \ldots .16,500 \ldots 104 \ldots-\ldots$

2 Organ builders......... 3,500.. 8... .

6 Cap-makers ......... $6,150, .11 \ldots \ldots$

2 Jewelers............ 2,100.. 4... .

8 Bandbox-makers...... 420.7 . . . .

8 Match factories.. ..... 5.500.. 39... .

49 Butchers ........... \$49,920..111.. - ..

1 Gas company ......... 220,000..40... -

1 Cotton batting factory .. $32,000 \ldots 35 \ldots-\ldots$

1 Fire and Waterproof roof manufactory ....

1 Spice-mill ............

1 Iead pipe and sheet lead fuctory .........

2 Brush-makers.........

2 Mustard factories......

1 Basket-maker.........

1 Umbrella-maker .......

7 Milliners ..............

2 Oil cloth manufactories.
287,328

50,000

6,300

215,000

276,640

402.900
10.360

7,000

217,000

55. 300

98,000

74,500

12,638
3,500

65,000

67,000

3,000

3,600

875,000

283,900

245,000

33,640

260,550

12,800

6,500

6,000

000

0

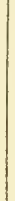

60,500

57,500

4.500

21,200

8,700

80,270

28,006

98,000

165,000

301,470

9,600

170,000

104,750

9,200

11,900

5,000

3,700

16,800

$\$ 349,650$

43,000

73,000

13,500

50,000

75,000

14.500

2,100

2,160

7,500

29,500

30,000
Business,

Capital. Hands empiojed, Annual
Males, Fem.

2 Saw factories ......... $16,500, .16 \ldots \ldots \ldots 84,000$

3 Vinegar factories...... $1,450 \ldots \quad 7 \ldots \ldots$... 12,500

2 Bellows-makers ....... 1.500.. 3.. -.. 32.000

8 Pork houses ......... 239,800, 23 . - . 799.522

1 Woolen factory ....... 20,000.. 15. 10.. 45,000

32 Wagon-makers ...... 27,275..121. - . 146,585

1 Boat (yawl) builder.... $150 . .1 \ldots \ldots . .750$

2 Distillers ........... $89.000 \ldots .37 \ldots \ldots$... 82,000

4 Piano-makers......... $5,500 \ldots \quad 4 \ldots \ldots . . \quad 8,000$

1 Comb-maker ......... $600 ., 1 \ldots \ldots 1,000$

2 Nailors............ $300 \ldots \quad 3 . . . \ldots \quad 2.000$

1 Mill-stone factory . .... 10,000.. 10... . 10,000

6 Daguerreans......... 8,000.. 8... . 18,000

2 Mathematical instru- $\} \quad 2,000 \ldots 2 \ldots-\ldots \quad 7,600$

ment makers...... $\} \quad 2,000 \ldots 2 \ldots-\ldots \quad 7,600$

2 Edge-tool makers ...... $3,500 \ldots 15 \ldots$... 8,500

1 Block and pump maker. $8,000 \ldots 17 \ldots$.. $\quad 9,000$

2 Sadule-tree makers..... $3,500 \ldots 34 \ldots$. . $\quad 15,000$

1 Ship (steamboat) yard . . 125,000 . 85. . - . 150,000

Total........\$ $\overline{\$ 4,377,711} \overline{7,321} \overline{1,130} \overline{\$ 15,400,340}$

St. Louis must, at no distant day, become important as a manufacturing city. The heaviest business, as shown above in this department, is that of iron-ware. The State boastg of her mountains of ore, and the coal region is at the immediate doors of the city. Within a few years past, the articles made of iron have multiplied beyond any expectation; railing, fencing for agricultural use, window-sashes, door-fronts, columns, caps, telegraph-wire, and water-pipe, are only a few of the uses to which iron has lately been applied; and already speculation begins to whisper about entire buildings being constructed, and entire streets paved with it. The shops of St. Louis already compete with the best artisans elsewhere, for the manufacture of steam-engines, and of every species of machinery. A connection with Pilot Knob, and Iron Mountain, by railway, will obviate at once the difficulties of transportation, by placing the ore at the furnace, cheaply and expeditiously, and thus bring into general use this great metal. Missouri contains, then, within her own bosom, an element of wealth that has not yet been brought into requisition, and which is destined, at uo distant day, to give a strong and vigorous pulsation to her growth in wealth. Besides this, lead and copper ore are abundant, exbaustless, and second in quality to the yield of no other region. The contiguity of these minerals to $5 \mathrm{t}$. Louis, render the mines of far more value than those of Lake Superior, and will bring a better return for capital than the investments made in the mines of that region.

If St. Louis, during the ten years preceding 1850 , increased from a fraction over 16,000 to nearly 80,000 without the impulse of railroads, and notwithstanding many drawbacks; what must be her progress, and what her population during the decade next succeeding, when, independent of other causes of increase, the city will have more railroads concentrating within her limits, than Boston now has. To say that it will have half a million of inhabitants, and be the third city in the Union in size, would be only relying upon what the past and present is proving, and what the future indicates unerringly. It has hilherto duplicatcd its population every four years, and hence the reader may easily calculate the result at the period alluded to.

The people of St. Louis and of the State have decided for themselves what shall be their destiny. They have entered upon measures of public improvement, the vastness of which is only equaled by the wisdom that has planned them; and such is the solid wealth, credit, and fixed purpose of the people, that they will certainly carry out what they have herun, and push on to completion the great railroads-the Pacific, the Hannibal and St. Joseph, the St. Louis and Northern Missouri, and others in various directions.

Knowing its own resources, St. Louis views with no jealous 
eye, the efforts made in Illinois and elsewbere, to carry out railroad enterprises, such as the Central R. R. from Gulena and Chicago to Cairo, and the various cross lines that are being extended from the lakes to the Mississippi-the latter, profitable as they may be to the parties interested, will yet mainly benefit St. Louis, by converting the thinly inhabited country through which they pass into populous and flourishing districts, whose people will resort to her to exchange their products for her manufactures, and the various supplies which now reach her from the West Indies, from the south and the east; while the Central Railroad, by developing a atill greater region, comparatively unimproved, and sparsely settled, extending through Illinois north and south, will create and open to the trade of St. Louis a populous belt of country in front and to the right and left, the main road through which will be reached in less than two hours' time, by the cross lines to the east.

By virtue of railroad connections, St. Louis will thus be made the immediate centre of commerce and manufacture of $1,500,000$ people in Tllinois and Missouri, while in ten years its own people, in all probability, will approach half a million, and itself be the acknowledged exchange mart of $4,000,000$ people.

The receipts at St. Louis of principal articles of produce for the years 1819 , '50, 'כ1, and '52, were as follows:

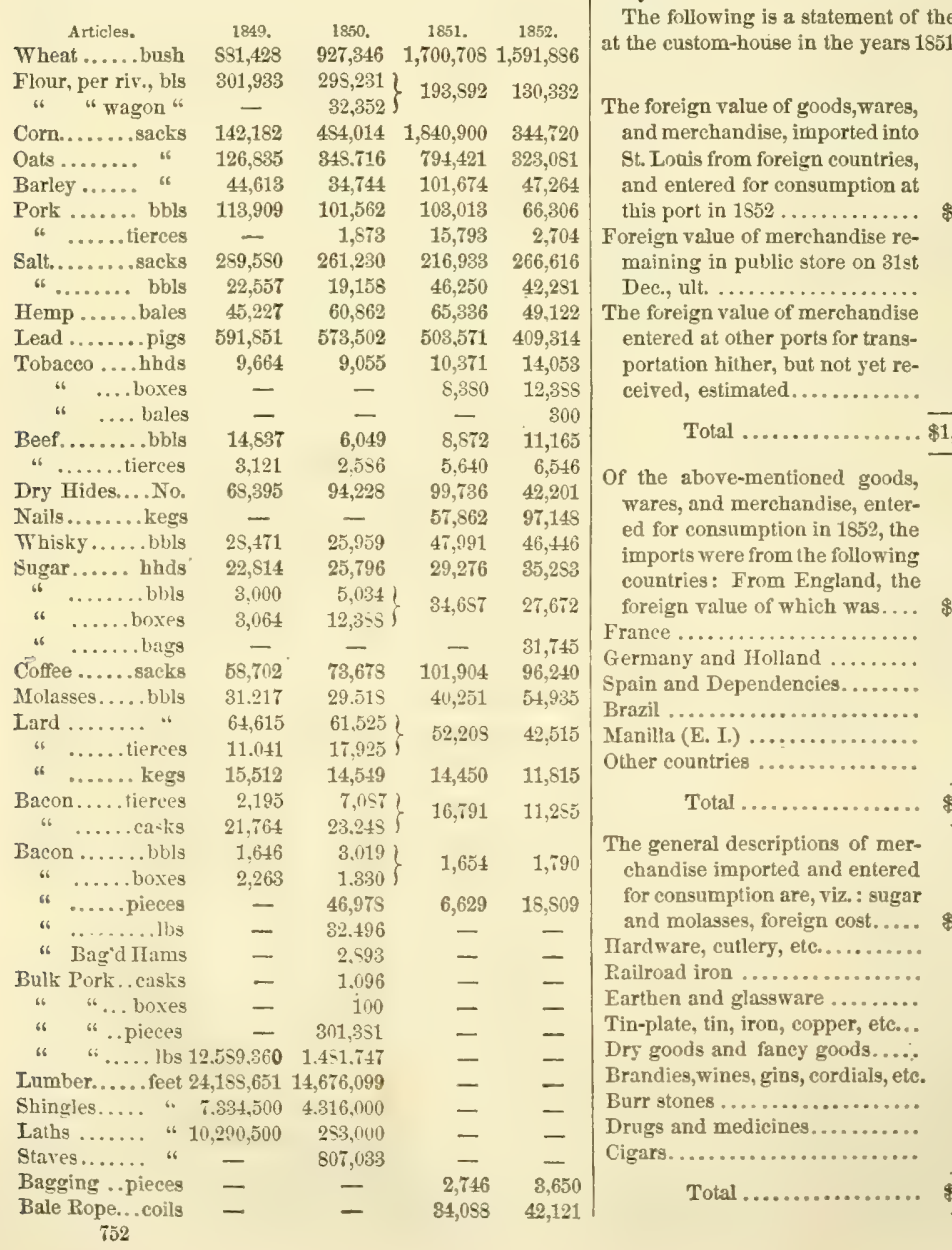

The commercial importance of the city is more readily made visible by a view of its shipping trade. Below will be found statements showing the arrivals, tonnage, etc., of

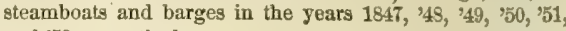
and '52 respectively :

Arrivals from 1847, 1848, 1849, 1850. 1851. 1852 New Orleans.....502...426...813...803...800...830 Ohio River ......430...429...401...4493...401_...520

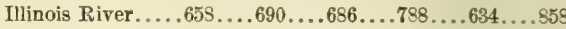
Upper Mississippi .717...697_...806 ...635 ...689_...705 Missouri River....314,..327...8555...390_..301...817 Cumberland...... - ... - ... - ... - . 43... 30 Cairo ..........146...194...122.... 75...119...223 Other ports......202...396_..217...215...175...201

Total .... $\overline{2,969} \ldots \overline{3,159} \ldots \overline{2,975} . \overline{3,289} \ldots \overline{2,612} \ldots \overline{8,174}$ Tonnage... - . - 633,892 681,252.. - . Keel boats. - .. - . 166.. 115.: - .. -

The imports from foreign countries, aceording to the U.S. Treasury Reports in 1850 , were valued at $\$ 359,643$. Tonnage owned in the district 28,907 tons, all of the class enrolled and licensed, and of which 24,956 tons were navigated by steam. Five steamers $(1,354$ tons) had been built during the year.

The following is a statement of the principal transactions and 1852 :

1852 .

1851.

$\$ 934,95600 \$ 757,50900$

$11,56600 \quad 8,26189$

$72,951 \quad 00 \quad 107,902 \quad 00$

$\$ 1,039,473 \quad 00 \$ 873,67289$

$\$ 431,34300 \$ 406,11300$

$75,258 \quad 00 \quad 38,40400$ $22,69500 \quad 23,23900$ $262,886 \quad 00 \quad 220,77000$ $93,08600 \quad 68,98300$

62,96300

6,70500

$\$ 954,94600 \$ 757,50900$

$\$ 413,17200 \$ 289,75300$ $\begin{array}{llll}118,276 & 00 & 138,401 & 00\end{array}$ $132,594 \quad 00 \quad 100,21100$ $80,72900 \quad 98,78600$

$59,826 \quad 00 \quad 31,452 \quad 00$

$\begin{array}{llll}110,814 & 00 & 24,257 & 00\end{array}$

$82,985 \quad 00 \quad 24,71206$

$52000 \quad 2,25700$

$75600 \quad 2,61800$

5,73300

$\$ 954,94600 \$ 757,50900$ 
Amounts of duties on imports collected

1852,

1851.

$\$ 290,165 \$ 5 \$ 239,31568$

Hospital moners ..............

Total amount enlected in 155

Amount expended in 1552 for re-

lief of sick and distressed seamen.

Tonnage on steam ressels remaining on 31st Dec., $1952 .$. $3.129 \$ 9 \quad 2,9+1 \quad 03$

\$29:3,29s $74 \$ 243,25971$

$\$ 3,162 \quad 01 \quad \$ 5,41144$

36,37200

St. Louis is clirided into six wards, and is governed by a mayor, aldermen, and common council. Besides the ordinary State courts, it has also a separate court of common pleas, with jurisdiction very similar to the circuit court, a criminal court, a court of probate, and a recorder's court. These are local courts, exercising jurisdiction only in the county, and the recorder's jurisdiction is confined to small offenses within the city limits. The following is the valuation of the old and new limits of each ward in 1851, together with the tax which each ward paid in that year.

VALUATION IN 1851.

Old Limits, New Timits, First Ward...... \$501,794_...\$3,267,934,... \$3,769,728 Second Ward .... $652,021 \ldots . \quad \$ 34,265 \ldots . \quad 1,486,286$ Third Ward...... 6,268,614.... 2,519,861... 8,753,505 Fourth Ward..... $6,379,725 \ldots . .61,952,429 \ldots . \quad 8,382,154$ Fifth Ward...... 2,920,093.... 1,2\$7,420,... 4,207.518 Sixth Ward..... $361,992 \ldots$... 4,790,021.... 5,152,013

Total.....\$17,079,274 $\$ \overline{\$ 14,651,930} \quad \overline{\$ 31,731,204}$ TATES IN 1551 .

Wards. Old Limits. New Limits. Total.

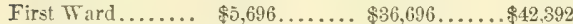

Second Ward..... 40,6s1...... 9,286......49,967 Third Ward....... 68,999....... 21,654,.....99,653

Fourth Ward...... 70,404...... $27,790 \ldots \ldots .98,194$ Fifth Ward....... 32,324...... 15,044......47,36s

Sixth Ward...... 4,026...... 53,988......58,014 Total ......\$222,130 \$164,458 $\overline{\$ 386,588}$

A list embracing the names of those citizens who own property within the city limits exceeding $\$ 100,000$ in value has been compiled from the assessment books. No one will misconceive the sense of the list. The figures opposite every name indicate, not the assessed value of all their real estate, nor the total of their wealih, but the value of their property within the city limits only, as affixed by the cily assessor :

Allen, Thomas .....\$374,600|Harney, W. S..... $\$ 1 \$ 1,900$ Ashley, Elizabeth... 121,300 Harney, Mary..... 265,000 Benoist, Louis A. . . 200,000 Lindell, Jesse G. . . 102,700 Berthold, B. est..... 101,600 Lindell, Peter....... 420,000 Biddle. John ....... 115,700 Lindell, P. and J. G. 148,400 Bogy, L. V........ 191,000 Lucas, James H. . . . 452,000 Boyce, Octavia..... 310,000 Lucas \& Hunt..... 593,000 Brant, J. B....... 312,600 Mullanphy, Bryan.. 291,000 Carr, Wm. C........ 128,000 O'Falton, Col. John. 328,300 Chamber, Charles... 125,000 Page, D. D........427,500 Chouteau, P., Jr.... 290,000 Pratte, Bernard..... 118,200 Chouteau, Henry.... 185,500 Rankin, Robert, est. 155,700 Clemens, James, Jr. 342,000 Shaw, Henry...... 204,100 Deaver, Larkin est. . 115,300 Stickney \& Scollay.. 132,000 Ewing, Benoist, et al 118,000 Tyler, Robert...... 337,000 Finney, J. and W... 163,600 Waddingham, Wm. 110,600 Gaty, McCune \& Co. 171,000 Walker, Isaac..... 307,500 Gay, J. H......... 115,800 Walsh, J. and E. .. 166,500 Graham, Pichard. .. 200,000 l Wood, James....... 107,000

Besides the above, there are 273 persons whose property is severally valued from 20,000 to 99,000 dollars.

The thirty years since 1820 have effected vast changes in the wealth and general circumstances of St. Louis, and an exhibit of the assessment of that day along with one of the present time can not prove altogether without interest Many wealthy citizens of the old times have now, from some cause or other, dwindled into poverty, and many others who a few years since did not own a foot of real estate, have become millionaires to-day. The contrast, if in some cases painful, is at all events curious. Only those taxpayers whose representatives, or who themselves are still living, are noticed in the following list. Of the 429 tax-payers that there were at that time, the names of only the principal Sõ are given.

Basseroa, Charles. ....\$6.225 ! M'Guire, Thomas.... \$ \$1.910 Berthold, Bartholomew 7,600 M'Knight \& Brady... . 8,800 Bates, Edw'd........ 1,00n O'Fallan, John. . . . . . 2,450 Bobb, John......... 2,800 Papin, Alexander.... 3,715 Benoist, Toussain and Provencher, J. L..... 1,500 Seraphim.......... 1,200 Provencher, Peter... 1,215 Chensa, Antoine ..... 9,175 Prim, John......... 1,200 Clark, Gov. William... 9,930 Paul, Rene......... 4,680 Chambers, William... 1,200 Paul, Gabriel, ........ 4,850 Chouteau, Sr. Pierre..13,025 Papin, Hypt. and Sylr. 5,985 Chouteau, Sr. Auguste 9,105 Papin. Theodore..... 2,000 Duchoquette, Baptiste. 3,500 Phillibert, Joseph.... 4,055 Duchoquette, Francois 1,245 Paul \& Ingram.......20,000 Duncan, Robert....... 1,865 Pratte, B. and Jos.....11,800 Everheart, George.... 720 Price Risdon H..... 8,800 English, Elkauah.... 1,020 Phillipsen, Jos........11,000 Essex \& Hough. . . . . . 3,600 Pratte, Bernard...... 10,165 Forsyth, Thomas..... 2,215 Quarlas, Pobert...... 3,000 Farren \& Walker, Drs. 1,700 Reed, Jesse......... . 4,000 Farrar, Barnard G.... 3,700 Rector, Wm........10,900 Furguson, Peter...... 1,925 Rankin, Robert...... $\$ 00$ Finney, John........ 240 Roubidox, Jas. and F. 9,055 Geyer, Henry \$...... 4,330 Reed, Jacob, est..... 1,500 Gratoist, Charles..... 8,310 Rector, Elias ........ 1,365 Gamble, Archibald... 2,500 Riddock, Thomas F... 7,070 Giddings, Salmon.... 1,200 Reynard, Hyacinth... 7,570 Hunt, Wilson P...... 600 Sullivan, William.... 2,435 Hawkin, Jacob...... 530 Sarrade Jean........ 1, 800 Hanley, Thomas.... . . 8,530 Smith, William, est... 5,500 Hunt, Theodore...... 1,200 Scott, Moses.... . . . . 1,012 Hammond, Samuel... 7,900 Smith, Oliver C.... . . 2,712 Kennerly, James..... 6,125 Simpson, Robert..... 4,200 Kennerly, Jas. \& Geo.. 8,000 Sarpy, John B....... 6, 6,870 Kerr, Bell \& Co.......20,000 Sanguinette, Marianne 6,415 Kerr, Matthew....... 3,600 Stokes \& Ashley..... 4, 4,000 Tisa's, est. ..........10,065 Scott, Alexander..... 2,500 Labadie, Maria Antoin- $\quad$ Thornton, John...... 50 ette, est........... 5,000 Tisson, Lonis H...... 800 Lindell, J. \& Co., com- Tesson, Michael...... 9,862 posed of P., J., \& J.L. 5,050 Town \& Dent........ 2, 2,000 Labeaume, Louis, est. . 300 Tracy \& Wahrendorff. . 3,570 Lareille, Francois..... 415 Vonphul, Henry. .... 5.460 Long, Gabriel....... . 2,000 Valois, Francois..... 3,615 Lakenan, James. ..... 1.720 Wigcins, Samuel. . . . 1,200 Lee, Mary Ann....... 1,720 Whetmore, Alphonzo. 1,387 Lane, William Carr... 1,000 White, Isaac W....... 412 Labbadie, Joseph L... 1,525 White, Joseph....... 800 Landreville, Andre... 7,875 Wolford, Ann....... 2,110 Lecompte, Margaret.. 9,305 Walker, David C.... 2, 2,345 Lucas, John, B. C....10,000 Willer \& Page...... 1,150 Mullanphy, John..... 8,100 Wherry, Mackay...... 1,085 Mackay, James...... 1,500 $\mid$ Wash, Robert. ...... . 3,975 Moore, James....... 1,2S0 Yoste, Theaste........4,790 M.Nair, Alexander....6,400

For the year 1821 the total taxes levied on property situated within the town limits and precincts, is $\$ 3 . \$ 2380$. St Louis at that period contained only some 367 buildings, and there were but sixty stores in the town. The total number of slaves was 316 .

The history of St. Louis is one of great interest. On the 15th February, 1764, La Clede and his party landed at the 
spot now occupied by the city, and proceeded to draw the town limits, which he named St. Louis, in honor of Louis XV. of France, a town which subsequently became the capital of Cpper Louisiana, and which is now the commercial capital of Missouri. For long years after this period, the beasts of the forest afforded nourishment to the settlers, and rude huts on the ground and scaffolding in the trees shelter and protection to the daring people who first exposed the bosom of the soil to the genial influences of social industry. From the time of its establishment up to the year 1768, St. Louis bad grown apace, and every thing connected with its position and prospects warranted the anticipation of a peaceful existence under a mild and patriarchal form of government. In the mean time, however, the fact of the cession of Louisiana to Spain became known, and disturbance at once interrupted the tranquillity of the settlers, who rebelled against the change of masters. The inhabitants clung closely to their loved government of France, and it was not until 1768 that St. Louis was occupied by Spanish troops. From this period, the settlements made but little progress. Upon the transfer of the country from Spain to the United States in 1503, the immigration of the AngloAmericans commenced, and the population slowly but steadily augmented in numbers. On the 26th March, 1804, the country was constituted a District of the United States, under the name of the District of Louisiana, and on the 19th October of the same year, W. H. Harrison, then governor of Indiana, instituted the American authority. On the 4th July, 1805, it was erected into the Territory of Louisiana, and on the 4th July, 1512, it received the name of the Territory of Missouri, "We have now arrived at a period," says Wilson Primm, in an address on the anniversary of the founding of the city in 1551, when a new era was to dawn, not only on St. Louis, but on all her northern and western dependencies, when a power greater than that of the fabled lamp of Aladdin was to be brought into requisition, and by its magic, to mature as it were in a day, in the western wilds of America, an existence, which on the shores of the eastern continents, the lapse of centuries had not been able to procure. In 1817, the 'General Pike,' the first steamhoat that ever ascended the Mississippi, made its appearance at St. Louis." The "Independence" was the first steamboat that ascended the Missouri (May, 1819). Passing over the fierce discussions which eventuated in the establishment of Missouri as one of the confederacy in 1520, we come to the year 1522, when St. Louis was erected into a city. Since that time what wonderful changes have taken place. Working its way to importance and greatness, St. Louis has still maintained its onward and upward flight. The advantages of education, the lights of science, the blessings of religion, placed within the reach of all; the establishment of a wise and vigorous municipal government, under the auspices of which its limits have been enlarged, and its interior improved and embellished; the erection of manufactures, the extension of the arts, the regulation of commerce-all these results have derived themselves from the natural resources of the city, and the intelligence and enterprise of its inhabitants. St. Louis has now a name and reputation at home and abroad of which all may be proud.

SArvt Lours river, Minn, and Wise. : rises by two principal head branches in Dead Fish and Seven Beaver lakes, fows southerly in winding course until it turns, and empties into the W. end of Lake Superior.

SAINT Lovisville, p. o. and sta., Licking co., Ohio: on the line of the Sandusky, Mansfield, and Newark R. R., 109 m. S. Sandusky City, and $7 \mathrm{~m}$. N. Newark, $31 \mathrm{~m}$. N. E. Columbus.

SATrT LUCIE county, Flor, Situate E., toward the S., and contains about 3,200 sq. m. Drained by Kissimmee river, which flows into Lake Okechobee, in the S. W., St. Lucie river, and branches of Indian river, which bounds it on the E. Surface level and low, a large portion being swamp; soil, where fit for cultiration, is fertile, and suited for the 754 growth of cotton. Chief productions, rice, eotton, wheat Indian corn, and fruits. Farms 0; manuf. 0; dFell. 2.2, and pop.-wh. 111, fr. col. 1, ol. 27-total 139. Capital: -

SanN Marie, p. v., Jasper co., $\Pi l_{\text {. }}$ : on the left bank of Embarras r., 105 m. S. E. Springfield.

Satnt Mark's, p. v., Wakulla co., Flor.: on St. Mark's r., near the confluence of the Wakulla, which together form Appalachee, $20 \mathrm{~m}$. S. by E. Tallahassee, with which it is connected by railroad, and of which it is the port. It has considerable other business.

SAINT MARK's river, Flor. : rises in a small pond, in Jefferson co., flows S. W. 20 m., and unites with the Wakulla, to form Appalachee $\mathbf{r}$, flowing $\mathrm{S}$. into the Gulf of Mexicn. Boats drawing 4 feet water ascend to its source. There is 8 feet of water to St. Mark's v., $6 \mathrm{~m}$. from the gulf, but the navigation is crooked, and impeded by oyster beds. At the mouth of the $r$. is a light-house.

SAINT MARE's, U. S. collection dist., Flor. : comprising St. Mark's r. and vicinity; had on June 30th, 1850, a tonnage of 353 tons, consisting of 282 tons enrolled and licensed, permanent, and employed in the coasting trade, and 71 tons licensed under 20 tons; with no foreign commerce or ship-building at that date. Port Leon is the port of entry

SaINT Martin parish, La, Situate S. W. of the E. district, and contains $1,117 \mathrm{sq} . \mathrm{m}$. Drained by Teche river in the S. W. and W., and branches of Grant river in the E., and numerous small streams faliing into Lake Chetimaches, which occupies the central and S. E. portion of the county Surface is varied, and there is some prairie land; soil along the streams is fertile and easy of cultivation, and yields considerable quantities of cotton, fruits, etc. Chief products, sugar, cotton, rice, indigo, and Indian corn. Farms 420 manuf. 0 ; dwell. 940, and pop.-wh. 4,741, fr. col. 581, sl. 5.535-total 11,107. Capitul: St. Martinsville. Putlic Works: New Orleans, Opelousas, and Texas R. R.

Saint Martur's, p. v., Worcester co., Mrd.: at the head of Sc. Martin's r., 77 m. S. E. Annapolis.

Saint Martin's river, Worcester co., $\boldsymbol{M} d$. : a large inlet, with a number of confluences, rising from the $\mathrm{E}$. edges of the Cypress swamp. The Isle of Wight divides its entrazce into Sinepuxent bay, into two channels.

Saint Martixsville, p. v., and cap. St. Martin's par., $L a$. : on both sides of Bayou Teche, and at the head of steamboat navigation, $43 \mathrm{~m}$. S. W. Baton Rouge. It contains a courthouse, jail, etc., and has considerable trade, principally in cotton.

SAINT MART's parish, La. Situate S. W. in E. district, and contains $720 \mathrm{sq} . \mathrm{m}$. Drained by Teche river, and Salle and Cypra Mort bayous. Surface level; soil diversified, in some parts being liable to inundation, and too wet for tillage. Where this is not the case it proves fertile, and is well fitted for the growth of cotton, sugar, rice, ete., which are the staple productions. Its S. W. coast is indented with large bars. Farms 19s; manuf. 0; dwell. 746, and pop. - wh. 3,423, fr. col. 424, sl. 4,961-total 8,508. Capital: Franklin. Public Works: New Orleans, Opelousas, and Texas R. R. SAINr MARY's county, Md. Situate W., and contains 315 sq. m. Drained by small streams flowing into the Potomac and Patuxent rivers. Surface level; soll fertile, and produces abundantly tobacco, which is the staple. Farms $\$ 13$; manuf. 9 ; dwell. 1.512, and pop.-wh. 6,225, fr. col. 1,631, 81. 5,842-total 13,698. Capital: Leosardstown.

SAIst MARY's, p. v., and port of entry, Camden co, Ga. on N. bank of St. Mary's r., 102 m. S. S. W. Savannah, 188 m. S. E. Milledgeville. It has a safe harbor, and vessels drawing 21 feet of water come to its wharves. It contains a church, academy, several stores, etc. Pop. about 700. The total tonnage of St, Mary's district, on June $30 \mathrm{th}, 1850$, was 1.425 tons, of which the registered tonnage was 492 tons, temporary, and the enrolled and licensed tonnage was 933 tons (692 t. permanent, 241 t. temporary) employed in the coasting trade. During the year preceding there was no 
foreign commerce nor ship-building. The tonnage and other importance of St. Mark's has decreased since the accession of Florida to the Union.

SaLNT Maris's, p. o., Wood co., Firg.: 240 m. N. W. Richmond.

SAINT MARY's, p. o., Hancock co., Ill. : on the left bank of Crooked cr., $77 \mathrm{~m}$. N. W. Springfleld.

SAINT MAEY's, p. 0., Linn co., Ia. : on a branch of Cedar r., 17 m. N. Iowa City.

SAIrt MARY's, p. o., Vigo county, Ind.: 70 m. W. S. W. Indianapolis.

SAIst MARY's, t. and p. v., Auglaize county, Ohio: $82 \mathrm{~m}$. T. N W. Columbus. Drained by St. Mary's r. and branches.

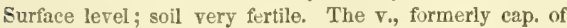
the co, is on the W. bank of the r. so called, and on the line of the Miami Canal, $133 \mathrm{~m}$. N. Cincinnati. It contains sereral stores, mills, etc. The "Sentinel and Democrat" (dom.) is issued weekly. Pop. of v. 874; of t. 1,867.

Sanit Mari's, p. o., Chester co, Penn.: 61 m. E. S. E. Harrisburg.

SAINT MArY's, v., St. Mary's co, $M d_{\text {. }}$ : on the E. side of St. Mary's r., about $8 \mathrm{~m}$. from its confluence with the Potomac, $53 \mathrm{~m}$. S. Annapolis. The site of St. Mary's City, founded by the first emigrants, the "Pilgrims of St. Mary's," 27th March, $167 t$, is a little $\mathrm{S}$. of this.

SarNT Marx's, p. 0., Lafayette co., Wisc. : 49 m. S. W. Madison.

SALTT MARY's river, Ga, and F'or, : rises in Okefinokee Swamp, in the S. E. part of Ware co., Ga., flows S. for some distance, then suddenly turns $\mathrm{N}$., and after flowing in that direction about $33 \mathrm{~m}$., it takes an E. course, until it empties by St. Mary's sound into the Atlantic. It is $105 \mathrm{~m}$. long, at low tide has $13 \frac{2}{2}$ feet of water on the bar at its mouth, and $19 \frac{1}{2}$ feet at ordinary high lide, and forms the best harbor on the E. coast of Florida.

SAINT MARX's river, Mrd. : a large inlet of Potomac $r_{\text {., in }}$ S. E. part of St. Mary's co. For statistics of St. Mary's U. S. collection distriet, see St. INrGoes.

SAITT MARY's river, Ohio and Ind.: rises in W. part of Auglaize co., flows $\mathrm{N}$. W. into Indiana to is confluence at Fort Wayne with St, Joseph's r, with which it forms Maumee river.

SAINT MART's strait, MFich. : is the outlet of Lake Superior, connecting it with Lake Huron. It is about $70 \mathrm{~m}$. long, but is naturally divided into two sections by the falls of St. Mary, $15 \mathrm{~m}$. bclow Lake Superior. These falls are more properly great rapids, $\frac{3}{4} \mathrm{~m}$. long, and have a descent of 22 feet 10 inches. A ship and steamboat canal is about being constructed around them. Below the falls the strait is navigable for small steamboats, and vessels drawing 6 feet of water, though the navigation is most difficult. It contains 4 very large islands, and several smaller ones, which divert its water into principal and cross channels. The usual ship channel is the W. strait, which has an average width of s. The entire fall of the $\mathrm{r}$. between the lakes is $\mathbf{4 4}$ feet 8 inches, and its current (exclusive of the rapids) has a medium rate of $1 \frac{1}{2} \mathrm{~m}$. per hour. The strait abounds with fish of various kinds, which are taken in great quantities, and extensively exported.

Satit Mary's Landing, p. v., St, Genevieve co., Mo. : on the W. bank of the Mississippi $\mathbf{r}$, at the mouth of Saline cr., $76 \mathrm{~m}$. below St. Louis and $126 \mathrm{~m}$. E. S. E. Jefferson City. Salt springs are numerous in the vicinity, and salt has been manufactured here.

Sarn MAtHews, p. v., Orangeburg dist., S. Car. : on Cawcaw Swamp of North Edisto r., 23 m. S. by E. Columbia.

Sarvt Michael's, p. v., Talbot $c_{0}, M d$.: on the W. side of St. Michael's r., a large inlet of Eastern bay of Chesapeake bay, $19 \mathrm{~m}$. S. E. Indianapolis. Pop. $\$ 63$.

Saint OMer, p. o., Decatur co., Ind.: on the N. side of Flat Rock cr., on the Lawrenceburg and Upper Mississippi R. R., 38 m. S. E. Indianapolis. It is a pleasint village with about 450 inhabitants.
Satnt Paris, p. v., Champaign co., Ohio: $51 \mathrm{m.} \mathrm{W.} \mathrm{by} \mathrm{N}$ Columbus.

Saint PaUl, p. v., and cap. Pamsey co, Minn. Ter.: on the left bank of the Mississippi, $15 \mathrm{~m}$. by water and $8 \mathrm{~m}$. by Iand below the Falls of $8 \mathrm{t}$. Anthony, and about half that distance below the mouth of Minnesota r., lat. $442^{\circ} 52^{\prime} 46^{\prime \prime} \mathrm{N}$., and long. $93^{\circ} 04^{\prime} 54^{\prime \prime} \mathrm{W}$. It is situate on two broad benches of land, the lowest of which is 50 feet above the high water mark of the Mississippi, which river flows past the town in an $\mathrm{E}$. by $\mathrm{N}$. direction. The town site is flanked by beautiful bluffs, from which issue springs of cold clear water, and nature has done every thing to make it a romantic and healthful situation. The first store, or trading house, was built in 1842, and seven years later it was the site of a Catholic mission, surrounded by stunted copse, and looking across the river from his elevated table rock, the pious recluse saw a gloomy and silent forest frowning upon the sluggish waters and rising with the river hills, falling back for miles into the prairie, presenting an aspect of interminable woodlands reaching to the distant sunset. The town has risen from this wilderness as if by magic. It has now an imposing State-house, 139 feet by 53 feet, a court-house, with metallic dome, glittering in the sun like a fairy castle, jail, nine churches for Christian worship, 518 dwellings, offices and shops, 70 manufactories and business houses, 4 hotels, 4 school-houses, public and private. In machinery of various kinds, including a flouring-mill, an iron foundry, a plow factory, 4 wagon shops, etc., $\$ 177,000$ is invested; and stocks of merchandise of all descriptions are valued at $\$ 790,000$ - the last sum including the amount invested in the Indian trade. These statisties refer to the spring of 1553 , at which period it contained between 2,500 and 3,000 inhabitants. In 1850 its population numbered only 1,135 Lines of steamers, coming and going daily, omnibuses, coaches, etc., and yet St. Paul's is in the wilderness. Look where you will, and the primitive features of the surrounding country remain unchanged, and the wild animal and Indian still haunt the grounds to which ages of occupancy have given them a prescriptive right. This new town, however, will "go ahead," and must eventually become a depo of a vast interior commerce. It will receive and distribute the merchant ware of the Upper Mississippi and the whole valley of the Minnesota, which is now being opened to settlement. Already the annual arrival of steamers from below averages 200 , bringing to the rising State a wealth of labor that will soon level the forests and make the land glad with its burden of agricultural profusion. "The society at St. Paul's," says a recent writer, "is a peculiar conglomeration of attractive and repellant elements, reaching through all shades of color, from the bronzed savage to the smoothy polished Circassian; and that confusion of tongues which distracted the builders of Babel is no comparison to the St. Paulian jargon. The Sioux, the French, the Patois, Dutch, German, Norwegian, Irish, English, and American alternately salute you in the street. *** There are but fer drones here; every body is busy, with no idle moneyed aristocrats to tyrannize over the industrious poor. *** * All here are strangers from different parts-all adventurers; all industrious, generally very orderly, and consequently very prosperous and happy."

Saint Paul, p. o., Madison county, Ark. : 106 m. N. W. Little Rock.

Saint PAUL, p. v., Greene co., MO. : on a fork of James r., $97 \mathrm{~m}$. S. by W. Jefferson City.

Sarnt Paul, p. 0., Clark county, Alan : 100 m. W. S. W. Montgomery.

Sarit Paul's, p. o., Robeson co., N. Car.: $63 \mathrm{~m} . \mathrm{S}$. by W. Raleigh.

Sarnt Peter's, p. 0., Chester con, Penn.: $63 \mathrm{~m}$. E. by S. Harrisburg.

Sarnt Petee's, p. o., Franklin co., Ind.: 59 m. E. S. E. Indianapolis.

SALNT REgIs river, $\mathcal{N} . Y_{.}$: rises in St. Regis lake, in 
Franklin county, and flows $\mathrm{N}$. by winding course into the St. Lawrence.

SAINT Siros's islands and sound, $G a$ : : lie off Glynn county, E, and N. E. Brunswick.

Satxt Stephen, p. 0., Fauquier county, Firg.: 79 miles N. by W. Richmond.

SAixt STEPHEN"8, p. Y., Washington co., Ala.: on the right bank of the Tombigbee r., $122 \mathrm{~m}$. S. W. Montgomery. It is located at the head of schooner navigation. It contains a number of workshops, stores, ete., and a U. S. land office. The buildings are chiefly of stone, but present a dilapidated appearance.

Satimt Tammany parish, $L a$. Situate $\mathrm{E}$. in the east district, and contains 1,043 sq. m. Drained by Tangipalica and Chifunete rivers, Bogue Fallia, and other small streams, Surface generally uneven and in parts hilly, and adapted to grazing; soil barren for the most part, but there are some fertile tracts on the streams, which are well cultivated and prove productive. Staple articles, cotton, sugar, and rice. Pine timber abounds extensively. Farms 90 ; manuf. 33 ; dwell. 786, and pop.-wh. 3,642, fr. col. 359, sl. 2,363-total 6,364. Capital: Covington.

Sant Tanranx's, p. o., Mecklenburg co., Virg.: $75 \mathrm{~m}$. S. W. Richmond.

SaINT Thomas, t. and p. v., Franklin eo., Penn.: $53 \mathrm{~m}$. S. W. Harrisburg. Drained by Back cr. Surface uneven; soil various. The village on the line of the proposed railroad from Gettysburg to Greensburg contains some manufactories, elc. In the town there is a furnace (constructed in 1S2S) of 1.400 tons annual capacity moved by water-power. Population of $t$, about 2,000 .

SALAMONIE river, Ind.: rises in S. E. corner of Jay co, near the Ohio boundary, flows N. W., and empties into Wabash r. opposite to Lagro. It is an excellent mill-stream, but not navigable.

SALEX county, $N$. Jer. Situate $\mathbf{S}$. W., and contains 318 8q. m. Drained by Stow, Salem, Alloway's, and Oldman's creeks, which flow into Delaware bay and river. Surface even; soil varied, but in general is fertile-in the $\mathrm{N}$. portion it consists principally of a deep loam with an intermixture of sand and clay, in the S. E. gravelly. Chief productions, wheat and Indian corn. Pork and beef are exported large1v. It contains extensive beds of marl. Farms 1,313; manuf. 142 ; dwell. 3,515 , and pop.-wh. 17,415 , fr. col. 2,052, sl. 0-total 19,467. Capital: Salem.

Salev, p. v., Russell county, Ala.: 69 miles E. by $\mathrm{N}$. Montgomery.

Salfev, p. v., Newton co., Tex.: on the Sabine r., at the mouth of Big Cow cr., 261 m. E. Austin City.

Saley, to and p. v., New London co., Conn.: 29 m. S. E. Hartford, 36 ra. E. N. E. New Haven. Is an agricultural township, with fertile soil, well watered by several streams. Gardner's lake lies on its $\mathrm{N}$. E. border. Incorporated in 1S19; and contains 4 churches. Pop. of t. 760 .

Sateir, po v., Clark co., Ga, : on Green Briar er., 39 m. N. by W. Milledgeville.

SAIEN, p. v, and cap. Marion co., $I U l_{0}$ : on the borders of Grand Prairie, at the head of Crooked cr., $90 \mathrm{~m}$. S. S. E. Springfield. It contains the county buildings, etc., and promises to become an important place upon the completion of the Ohio and Mississippi R. R., and the Massue and Sangamon R. R., which will pass through it.

SALEV, t., p. v., sta, and cap. Washington co., Ind.: near the head waters of Blue $\mathrm{r}$. and on the New Albany and Salem R. R., 35 m. N. N. W. New Albany and 79 m. S from Indianapolis. It is located near the centre of the county, on rolling ground, and is one of the pleasantest places in the State. This village suffered much from the cholera in 1882, and for several years it did not improve; but important improvements are now being made, and considerable business is carried on in manufactures, etc. The public buildings are a court-house, jail, fire-proof offices, a market-house, fine and commodious churches of all denom750 inations, a flourishing county seminary, a female acarlemy under the patronage of the Salem Presbytery, about 300 houses, mostly of brick and well constructed, and 1,500 inhabitants. The manufactories (which are various) are chiefly moved by steam. The public press consists of 3 papers: the "Salem News" (whig), "Washington Democrat" (dem.), and the "Salem Locomotive" (neut.), all weekly issues.

SALEM, p. v., Henry co., Ia.: 56 m. S. Iowa City, The village is surrounded by beautiful prairie land. Settled in 1834 by a number of Friends from Salem, N. J., and incorporated in 1839. It contains several stores, places of instruction, mechanic shops, ete.

SALEM, p. F., and cap. Livingston con, Ky.: near Clay Lick cr., 193 m. S. W. Frankfort. It contains the courthouse, jail, etc. Pop. about 300 .

SALEM, t. and p. v., Franklin co., MFe.: 48 m. N. N. W. Augusta. This is a good farming t., watered by Seven Mile brook. Mount Abraham commences in its N. part. Incorporated in 1828. Pop. of t, 454 .

SALEM, p. city, port of entry, and one of the caps. Essex co., Mass. : on Salem harbor of Massachusetts bay, $14 \mathrm{~m}$. N. E. by N. Boston. Lat. (E. I. M. Hall) $42^{\circ} 31^{\prime} 18^{\prime \prime}$ N., long. $70^{\circ} 53^{\prime} 53^{\prime \prime} \mathrm{W}$. It is chiefly built on a narrow peninsula, formed by two inlets from the harbor, called North and South rivers. The latter forms the main harbor, which affords good anchorage ground, but vessels drawing more than 14 feet of water must be partially unloaded before they can come to its wharves. The site of the eity is low, but pleasant and healthy. Its compact portion is about $1 \frac{1}{2} \mathrm{~m}$. Iong and 졸 $\mathrm{m}$, wide. Its streets are quite irregular, but of late many of them have been much improved. It is generally well built, and many of the houses and public buildings are very handsome structures. Washington Square is a fine public park of eight acres, ornamented with trees, etc. The principal publie buildings are, the City Hall, built in 1837 , a very fine building, with granite front; the Courthouse, a new edifice, handsomely situated; the Customhouse, Mechanic Hall, market-house, alms-house, and jail. The Museum of the East India Marine Society is a celzbrated collection of about 5,000 curiosities of nature and art, collected from almost every part of the world, kept in a spacious hall built by the society. This society was formed in 1799 of those who, as captains or supercargoes, had doubled the Cape of Good Hope or Cape Horn, and in 1823 the number of its members residing in Salem was 160. There are 20 eluurches, of which several are very handsome edifices. Much attention is given to education, and the public schools are of superior excellence. The Salem Athenæum, incorporated in 1810, has a spacious hall in Lawrence Place, with a very valuable library of 11,000 volumes. The Essex Institute has 2,500 volumes, with other collections; the Mechanics" Library contains 1,200 volumes; besides which there are two other libraries. In 1850 the periodical press consisted of 6 issues; viz., 1 tri-weekly, "Salem Gazette" (whig); 2 semi-weekly, "S. Register" (whig) and "Essex County Freeman" (F. S.); 3 weekly, "\$. Observer" (neut.), "S. Mercury" (neut.), and the "Villager" (fam.).

The manufactures of Salem are considerable. The Naumkeag Cotton Manufacturing Company have a capital of $\$ 1,000,000$, run about 28,000 spindles, employ about 600 operatives, and annually manufacture $5,000,000$ yards of goods. There are 2 cordage factories, each employing about 60 hands, 3 twine factories, an iron factory, brass foundry, and 4 large machine shops. The manufactures of leather, bonts and shoes, chemicals, and gum copal is very extensively carried on. There are 7 banks, with an agoregate capital of $\$ 1,750,000 ; 6$ insurance companies, with total capital of $\$ 900,000 ; 1$ marine insurance company, and an institution for savings. The lines of railroad leading from Salem are-Eastern R. R., passing through it from Boston to Portland ; Essex R. R., from Salem to Lawrence, $21 \mathrm{~m}$. Salem and Lowell R. R., 24 m. ; South Reading Branch R. R. 
to Boston, vic South Reading, $19 \mathrm{~m}$; and the Marblehead Branch R. R., $\neq \mathrm{m}$.

In foreign commerce Salem was for a long period the second town in New England, and was especially distinguished for its East India trade, by which it was very greatly enriched. In $151 \mathrm{~s}$ the number of vessels employed in this trade, belonging to Salem, was 53 , the tonuage of which was $14.2 \pi 2$ tons. This trade is not now earried on so extensively as formerly from this port, but many vessels therein engaged are owned here, and deliver their cargoes in Boston and New York. The total tonnage of Sulem district on 30 th June, 1850 , was 28,916 tons. The registered tonnage was 20,317 tons, of which 19,710 tons were permanent, and 607 tons temporary. The enrolled and licensed tonnage was 8,599 tons, all permanent; of which 8,430 tons were employed in the coasting trade, 97 tons in cod fishery, and 72 tons in the mackerel fishery. In neither class of tonnage was any portion employed in steam navigation. During the year preceding, the number of clearances for foreign countries was $372-35,003$ tons. The number of entranees during the same period, as given in the U. S. Treasury reports, are united with those of Beverly district, and their united total is $386-36,796$ tons. Of the entire foreign commerce about five-twelfths of the tonnage was American, seven-twelfths foreign. During the year 1 ship was built-299 tons. An U. S. naval officer is stationed at this port.

The city government is vested in the mayor, board of 6 aldermen, and common council, composed of 24 members, 6 from each of the 4 wards. The eity school committee is composed of 21 members. The territory of the city, including islands, contains 5,429 acres. An aqueduct supplies the city with excellent spring water. The city alms-house, erected in 1S16, is on the Neck, surrounded by a large furm. A bridge over the North r., 1,431 feet long, connects Salem with Beverly, N. of which is also the railroad bridge.

The population at different periods has been as follows:

Year. Pop. Year. Pop. Year. Pop. Year. Pop, \begin{tabular}{ll|l|l|l|l|l|l|l|}
$1637 \ldots$ & 900 & $1800 \ldots 9,457$ & $1530 \ldots 13,695$ & $1815 \ldots 16,762$
\end{tabular} \begin{tabular}{l|l|l|l|l|}
$1765 . . .4,42 T$ & $1810 \ldots 12,613$ & $1536 \ldots 15,002$ & $1550 \ldots 20,203$
\end{tabular} $1790 \ldots 7,921|1820 \ldots .12,731| 1540 \ldots 15,082 \mid$

Salem was settled in 1626, incorporated June 29, 1629, made shire town November 9,1641 , and incorporated as a city March 23, 1S36. Its Indian name was Naumkeag. In 1829 it containted 200 inhabitants, and the first church was then formed, In July, 1680,17 ships arrived, with 1,500 persons, by some of whom Boston was founded. In 1092 the witcheraft delusion prevailed, during which 19 persons were coudemned and hanged as witehes. In 1774, when Boston was a closed port, Gen. Gage ordered the removal of the general court to this place, which called out great remonstrance from its citizens. During the Revolution it was distinguished for patriotism, and especially for its various naval achievements. In the course of the war it fitted out about 60 vessels, manned by about 4,000 men. At the end of the war it commenced the East India trade. The first vessel thus engaged was at the Cape of Good Hope in 1794. and at Canton in 1786. In 1752 was established the first regular stage communication with Boston, which was tri-weekly; the railroad to Boston was opened August 28, 15:5. The usual time at presont of passing nver it to Boston is 45 minutes. On December $23,19+\%$, the telegraph wires wers completed to this place from Boston.

S.tey, t. and p. o. Washtenaw co., 3fich.: $53 \mathrm{~m}$. E. S. E Iansing. Drained by a fork of $\mathrm{W}$. branch of Rouge $r$. This is one of the best agricultural torns in the co., having a rery rich suil, anl well improved. Pop. 1.313.

Salfar, p. V., Tippah county, MFiss.: 182 m. N. N. E. Jackson.

Salfm, t., p. v.. and sta., Pockingham co., $N$. IIamp.: on Hanchester and Lawrence R. R., $19 \mathrm{~m}$. from Manchester, 7 m. from Lawrence, 34 m, S. S. E. Concord. Surface uneven watered by Spiggot $x$. and branches, which afford water. power, improved by mills of various kinds. Pop. in 1840 , 1,408 ; in $1850,1,555$.

SALEM, p. $\mathbf{v}_{*,}$ and cap. Salem co., $N_{\text {. Jer. : }}$ on E. side of Salem cr., $3 \frac{1}{2} \mathrm{~m}$. from its mouth, in Delaware bay, $57 \mathrm{~m}$. S. W. by S. Trenton. The soil of $t$, is a fertile sandy loam. The $\mathrm{v}$. was the first place settled in West Jersey, baving been founded in 1675. It contains a handsome brick court-house, with fire-proof county offices adjacent, a stone juil, academy, 8 churches, market-house, and bank, with capital of $\$ 75,000$. The "National Standard" (whig) and "Salem Sunbeam" (dem.) are published weekly. Vessel of 50 tons come up to the $\mathrm{v}$. ; the bar, at the mouth of the creek, has but 8 feet of water. A steamboat plies daily to Delaware City and New Castle, connecting wilh one from Philadelphia. Pop. of t. in $1840,2,007$; in $1850,3,052$.

SALEM, t., p. v., sta., and one uf the capitals of Washington co., $N . Y .: 44 \mathrm{~m}$. N. E. Albany. Drained by branches of Batten Kill r. Surfice undulating, in parts hilly; soil in general good, and under high state of eultivation. Butter, cheese, pork, ete., are produced in abundance. It was first settled in 1756 , by two companies of emigrants, one from Seotland and Irelend, and the nther from New England, and organized in 1788. The $\mathrm{v}$. is on White cr., in a pleasant valley, and on the Rutland and Washington $\mathrm{R} . \mathrm{P} ., 41 \mathrm{~m}$. N. by E. Troy It was incorporated in 1803 , and contains a part of the county buildings. It is surrounded by a rich and highly cultivated region of country, producing excellent grain, and raising large numbers of sheep ; it is celebrated as a mart for the purchase of wool. The Washington Academy, located here, is an old and flourishing institution. The $\mathrm{v}$, has some mannfactures, several mills, etc.; and the "Salem Press" (whig) is issued weekly. Pop. of t. 2,904.

SAleM, p. v., Forsyth county, N. Car,: $96 \mathrm{~m}$. W. N. W. Raleigh. Settled by Moravians, who have luere a celebrated female academy, with larce buildings on a handsome square. The v. also contains a church, a cotton fictory, paper factory, stores, etc., and a branch of the Bank of Cape Fear at Wilmington, with eapital of $\$ 150,000$. Pop. about 1,000 .

SAlem, p. v. and sta., Columbiana co., Ohio : on Ohio and Pennsylvania R. R., $65 \mathrm{~m}$. from Wooster, $69 \mathrm{~m}$. from Pitsburg; $122 \mathrm{~m}$. N. E. Colunbus. This v. is in Perry t. The "Homestead Journal" (land reform) and "Anti-Slavery Bugle" are issued weekly. Pop. about 1,000.

SAlem, t., Columbiana eo., Ohio: 123 m. N. E. Columbus. Surface rolling; soil fertile. The Ohio and Pennsylvania R. R. passes through the t. at $\mathrm{v}$. of Franklin Square, $69 \mathrm{~m}$. from Wooster, $65 \mathrm{~m}$. from Pittsburg. Pop. 1,960.

SAlem, to and p. o, Mercer co., Penn.: $195 \mathrm{~m}$. N. W. Harrisburg. Drained by Little Shenango and Crooked creeks. Surface even; soil fertile. It has sereral mills, mechanic shops, ete.

SalEm, p. v., Sumter dist., $S$. Car.: on the E. side of Blach r., $55 \mathrm{~m}$. E. by S. Columbia.

Salex, p. v., Franklin co., Tenn.: on Bean's cr., 77 m, S. S. E. Nashville.

SALEM, p. v., sta., and cap. Rornoke co., Virg. : on the N. side of the Roanoke $r_{\text {., and }}$ an the Viroinia and Tennessee R. R., $60 \mathrm{~m}$. from Lynchburg, $145 \mathrm{~W}$. by S. Richmond. It contains a court-house, jail, antl a branch of the Exelange Bank of Virginia, Norfolk, with capital of $\$ 100,000$.

Salex, p. V., and cap. Marion co, and capital of the Territory of Oregon: is situated on the $\mathrm{E}$. bank of the Tillamette river, and contains the State buildings, etc.

Salem, p. v., Racine co., Wisc. : on Lake Michigan, $87 \mathrm{~m}$. E. by S. Madison.

Salem Centre, p. V., Westchester county, N. $Y$.: $92 \mathrm{~m}$. S. by E. Albany.

SAlem Cinurci, p. $\nabla$. Randolph county, $N$. Car.: W. of Ultarie r., $78 \mathrm{~m}$. W. by S. Raleigh.

Salem Cross Roads, p, o., Chautauque co., N. Y. : $304 \mathrm{~m}$ W. by S. Albany. 
Salex Cross Rosds, p. o., Westmoreland co., Penn. : 133 m. W. IIarrisburg.

Salem Fauquier, p. v., Fauquier co., Firg. : on the Manassas Gap R. R., 91 m. N. by W. Richmond.

SAlfordville, p. o., Montgomery eo., Penn.: $7 \mathrm{~S}$ m. E. Harrisburg.

SALIVA, p. v., Jefferson co., $K y_{0}:$ on the E. side of Mill cr, of the Ohio r., $53 \mathrm{~m}$. W. Frank fort.

SALINA, t. and p. .., Onondaga county, N. T.: $183 \mathrm{~m}$. W. N. W. Albany. Drained by several small streams flowing into Onondaga lake, which bounds it on the W. Surfaco rolling; soil of great fertility, and well eultivated. It is celebrated for its salt manufactures-the Onondaga Salt Springs, owned by the State, being locater here, mostly on the "Onondaga Salt Spring Reservation," consisting of detached lots of various dimensions, situated promiscuously in the town. They are the largest and best in the United States. The making of salt, both by solar evaporation and by artificial heat, is carried on extensively in the villages of Salina, Syracuse, and Liverpool. The principal spring is at Salina v., which affords an inexhaustible supply of water, yielding to every 40 gallons about one bushel of pure salt. The water is forced up by hydraulic engines into a large reservoir, from which Syracuse and other places are supplied by means of pipes. In 1850 , there were manufactured at the Salina works 46,546 bushels of coarse salt, $1,866,495$ bushels of fine, and 262,730 bushels of ground or dairy salt-total, $2,175,711$ bushels. The amount of duty accruing to the State from these works was $\$ 44.364$. The $\mathrm{V}$, is located on the $\mathrm{E}$. bank of the lake, and on the Oswego Canal, $2 \mathrm{~m}$. N. Syracuse. It was incorporated in 1524, and contains-besides a number of stores and groceries, flouring and other mills-an extensive machine shop and a furnace worked by steam, for the purpose of manufacturing steam-engines and fine castings, several other machine shops, etc. Pop. of t. 2,142.

SALINe county, Ark. Situate centrally, and contains 931 sq. m. Drained by Hurricane cr. and branches of Saline r., which runs on its western border. Surface level; soil productive, and good cotton is raised. Farms 405, manuf. 16, dwell. 621, and pop.-wh. 3,392, fr. col. 6, sl. 503-total 3,901. Capital: Benton.

Salise county, $\mathrm{ll}$. Situate S., and contains 378 sq. m. Drained by south and middle fork of Saline cr., a tributary of the Ohio. Surface generally level; soil of a sandy nature. Chief productions, wheat and Indian corn. It has fine pasturage for cattle, large numbers of which are fattened and exported annually. It is well timbered, and has some salt springs, which were formerly of considerable value. Farms 678 , manuf. 11, dwell. 961, and pop.-wh. 5,495, fr. col. 93tutal 5.5is. Curvitul: Rilleish.

SAIINE county, MO. Situate N. W. centrally, and contains $727 \mathrm{sq}$. m. Drained by La Mine $\mathrm{r}$, and its branches. It is bounded on the N. E, N., and N. W. by Missouri r. Surface undulating; soil fertile; the land on the rivers boing rich and exceedingly productive. It has some fine timber and prairie land. Farms 5S7, manuf. S, dwell. 950, and pop.-wh. 6,108, fr. col. 16, sl. 2.719-total 8,843. Capital: Marshall.

SALiNe, t. and p. V., Washtenaw co., Mich.: 55 m. S. E. Lansing. Drained by Raisin r. affording good mill-power Surface even; soil rich loam, producing grains of all kinds, and of good quality. The v, on the river, in the N. E. part, contains several mills, ete. Pop. 1,631.

SALINE, p. v., Ralls co., $A L_{0}: 75 \mathrm{~m}$. N. by E. Jefferson City.

SAlrNeq p. o., Bienville par., La.: near a cr. so ealled, 165 m. N. W. Baton Rouge. Salt is manufactured in the vicinity.

SALINE creek, Mo.: rises in S. W. part of Perry co., makes a circnitous course in a N. direction, and enters the Mississippi r. near the S. E. corner of St. Genevieve co. There are numerous salt springs on its border, and salt has been manufactured here.

SALINE river, La.: rises in S. part of Claiborne parish, T58 flows S. $50 \mathrm{~m}$., and passing through Saline lake, empties into Black Lake r., in Natchitoches parish. There are salt works on its border.

SALINE river, $M l_{0}$ : rises by $\mathrm{N}$. , S., and middle forks, in Hamilton, Williamson, and Johnson counties, and forming a junetion at Equality, flows S. E., and enters the Ohio x. 9 $\mathrm{m}$. below Shawneetown. The great U. S. Salines are lncated on this r., about $2 \mathrm{~m}$. $\mathrm{S}$. of Equality. The manufacture of salt at this point is extensive. There are also other salt work 8 on the borders of this stream, and it is navigable for some distance.

SalINe Mrlis, p. o., Natchitoches par., La.; on the W. of Saline cr., and in the neighborhood of the salt works, $155 \mathrm{~m}$. N. W. Baton Rouge.

Salineville, p. v. and sta., Columbiana co, Ohio: on the Cleveland and Pittsburg R.R., $\$ 6$ m. S. E. Cleveland, $121 \mathrm{~m}$. E. N. E. Columbus, Pop. 237.

Saliever, p. o., Cass county, Ga.: $131 \mathrm{~m} . \mathrm{N}$. W. Milledgeville.

SALISBURY, t. and p. v., Litchfield county, Conn.: $41 \mathrm{~m}$ N.W. Hartford. Bounded on the N. by Connecticut r., E. by the Housatonic $x_{\text {. }}$ and on the W. by New York. Immense hydraulic power is derived from the Housatonic and Salmon rivers, and it is well watered by several lakes and ponds. The surface is formed by lofty elevations and deep valleys, but the soil is well adapted to all kinds of grain and to pasturage. Limestone predominates in the valleys, and the hills are of granite. Iron ore is the chief staple commodity, inexhaustible quantities of which, celebrated for its superior quality, are here found, and the manufactures of it are extensive. Wood, also, is abundant, large quantities of which are turned into charcoal, and with other materials found here, used for smelting the ore. The "Old Ore Hill," located near the New York line, has been worked since the year 1732. The first furnace was erected in 1762 , and a large amount of cannon-balls and boml-shells were manufactured here during the Revolutionary War. There are now in Salisbury several furnaces, forges, puddling establishments, manufactories of guns, anchors, scythes, engine cranks, hoes, trip-hammers, etc. The forges and puddling establishments produce an immense quantity of wrought iron, which is used for anchors, car axletrees, musket bar. rels, etc. Some of the oldest guns in our navy were made at the old furnace here, and muskets are still being made from the products of these mines. The ore is the brown hematite, and yields 40 per cent, of pig iron. The $\mathrm{v}$. of Salisbury is located on Salmon r., and is a pleasant place. Pop. of t. 3,103.

Salistider, p. v., Sangamon co., $1 l l$. on Richland cr. of Sangamon r., $11 \mathrm{~m}$. N. Springfield.

SALISBURY, p. v., Somerset $\mathrm{c}_{\text {. }}, M{ }^{\prime}$. : on the E. side of Wricomico $\mathrm{r}$, on the $\mathrm{E}_{\text {. }}$ line of the county, $14 \mathrm{~m} . \mathrm{N}$. N. $\mathrm{E}$. Princess Anne, and $95 \mathrm{~m}$. S. E. of Annapolis.

Salisidre, to and p. v., Essex eo., Mfass. : 36 m. N. by E. Boston. Bounded on the $N$. by the State line, E. by the Atlantic Ocean, $\mathrm{S}$, by the Merrimsc r., and W. by Powow $r$. Drained by several small streams flowing into the river and ocean. Surface generally uneven, but in the E. there is an extensive beach and some salt marsh; soil fertile. There are two important villages in the t., the principal on Pownw r., at the head of tide-water, part of which is in Amesbury. On the part loeated in Salisbury are flannel factories, known as the "Salisbury Manufacturing Company," eapital $\$ 400,000$, employing about 400 operatives, and manufacturing over $1,000,000$ yards of flannels, eloaking, etc., annually. Besides which are other manufacturies of wonlen and cotton goods, fulling mills, tanneries, ete. The other $v_{\text {. }}$ located on the Merrimac, on a point of land formed by the junction of that river with the Powow, is celebrated for its superior ship-building, which is the principal branch of trade here. A number of vessels are owned in this $v_{\text {.g }}$ and empinged in the costing trade and mackerd fishery. Salisbury is connected with Newburyport by a suspension 
brilge, which spans the Merrimac. The $\mathrm{v}$, is on the Eastern L.R., at which point the Salisbury Branch R. R. diverges $36 \mathrm{~m}$. N. by E. Boston. It is neatly laid out, and contains a number of places of business, a bank, etc. Pop. of t. 3,100.

Salisbury, t, and p. v., Merrimac co., N. Hamp.: $15 \mathrm{~m}$. N. W. Concord. Blackiwater r. passes through the W. part, from which is derived good water-power. Surface varied; in the N. W. is a portion of Kearsarge Mountain. The soil in the upland is mostly rich ; the hilly land abounds in excellent pasturage, and on Blackwater $\mathbf{r}$, there is very fertile intervale. There are several very valuable farms in the t., and the people are chiefly employed in agriculture. This t. was the birthplace of the Hon. Daniel Webster. The $\mathrm{v}$. is located on the E. side of Blackwater r. Pop. of t. 1,228.

SALrsbdRx, t. and p. v., Herkimer co., N.Y.: 63 m. N.W. Albany. Drained by East and West Canada creeks, the former forming in part its E. boundary. Surface generally hilly ; in parts mountainous ; soil fertile, and some grain is raised. The v. is about $7 \mathrm{~m}$. N. by E. Little Falls, and contains several mills, etc. Deposits of magnetic iron ore are found in the vicinity. The t. has some manufactures, mechanic shops, etc. Pop. 2,035.

Salisbery, sta., Orange co., $N . Y_{.}:$on the Newburg Branch R. P., $10 \mathrm{~m}$. N. E. Chester, 7 S. W. Newburg, and $85 \mathrm{~m}$. S. by W. Albany.

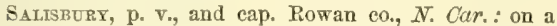
branch of Yadkin r., $108 \mathrm{~m}$. W. Raleigh. It contains a court-house, jail, an academy, ete. An ancient stone wall, from 12 to 14 feet high and 22 inches thick, reaching to within a foot of the surface and 300 feet in length, has been discovered here; and a similar one has been discovered $6 \mathrm{~m}$. distant from the first, 4 or 5 feet high and 7 inches thick. The origin of neither has been ascertained. The "Carolina Watehman" (whig) is a weekly issue.

SAlisburx, t. and p. O., Meigs co., Ohio: on the N. bank of the Ohio r., $76 \mathrm{~m}$. S. E. Columbus. Drained by Leading creek and branches. Surface rugged; soil fertile. This t. abounds with stone-coal of a good quality, and an extensive business is carried on in that article. Coalport village, on the bank of the river, is the principal mining point. Railways are here built for the purpose of running down the coal from the mines to boats in the river. The mining is principally done by natives of Wales. The salt-works in the town produce large quantities of salt annually. There is a number of stores, mills, and mechanic shops, ete. In the $S$. part, on the bank of the $r$, a mile above Coalport, is Pomeroy, the capital of the county, and the prineipal point of business for the coal region; its pop. is 1,637, and of t. 4,546.

Salisbury, t., p. v., and sta., Addison co., Term.: $34 \mathrm{~m}$. $\mathrm{S}$. W. Montpelier. In the centre of the t. is Lake Drummond, $4 \mathrm{~m}$. long, and from one half to three-fourths of a $\mathrm{m}$. wide, the outlet of which, called Leicester r., furnishes good water-power. Drained by Middlebury r. and the outlet of the lake. Surface rolling; soil fertile. Chartered in 1761, and first settled in 1775 . It is a manufacturing place, containing valuable manufactories of woolen goods, glass, iron, lumber, etc. The v. is located at the outlet of the lake, and the sta. is on the Rutland and Burlington R. R., $39 \mathrm{~m}$. S. by E. Burlington. Pop. of t. 1,027.

Salisbury Centre, p. v., Herkimer co., N.Y.: on Spruce creek, $64 \mathrm{~m} . \mathrm{N}$. W. Albany. It contains some manufactories. In the vicinity are extensive deposits of magnetie iron ore.

SAlisbery Cove, p. 0., Hancock co., Me.: 72 m. E. by N. Augusta.

Salisbury Mruts, p. o., Orange co., N. Y. : 90 m.S. by W. Albany. It is a small mill-seat, with but few inhabitants.

SAliraGUNDI, p. O., Wachita par., La. : $144 \mathrm{~m}$. N. N. W. Baton Rinuge.

SALuroN mountain, Klamath county, Calif.: between Salmon and Klamath rivers, $215 \mathrm{~m}$. N. by W. Vallejo. Covered with snow nine months in the year. Gold abounds in the vicinity, particularly on the rivers.
SALMON river, Calif.: rises in the mountains, in $\mathrm{E}$. part of Klamath co., and running W., empties into Klamath $r$. Gold is abundant in its whole course.

Salmox river, Conn.: rises in the S. part of Tolland co., and flows S. into Middlesex co., when it receives Moodus $r$, and empties into the Connecticut $r$. at East Haddam. There are several falls in its course which afford gond waterpower, and it is navigable a short distance from its mouth.

SALMON river, $N . Y_{.}$: rises in Osceola t., Lewis co., and flowing W. through Oswego co., empties into Lake Ontario, about $5 \mathrm{~m}$. S. from Great Sand bay. It has a tolerably good harbor at its mouth, and is boatable at high water as far up as the falls at Orwell, $14 \mathrm{~m}$. At the falls the river has a perpendicular fall of 107 feet, At high water the sheet is 250 feet wide, but at low water is reduced to one-half that width. The rocky strata is composed of slate and granite, or gneiss. The height of the bank above the fulls is from 80 to 90 feet, and below, 200 feet perpendicular rock.

SALMon river, Oreg. Ter.: rises in the Rocky Mounlains, and flowing $\mathrm{N}$. W., forms the $\mathrm{N}$. branch of Snake river, or Lewis fork of the Columbia river.

SALMon Falls, p. v., Strafford co., N. Hamp.: on the river so called, $2 \mathrm{~m}$. below the Great Falls, and on the Boston and Maine R. R., $39 \mathrm{~m} . \mathrm{S} . \mathrm{W}$. Portland, and $36 \mathrm{~m}$. E. Coneord.

Salmon Falls river, Me. and $N$. Hamp. : rises in East Pond, between Acton and Wakefield, flows S. by E., and joins the Piscataqua $r$. at Hilton's Point. On this river, between the towns of Rochester and Lebanon, are extensive lialls.

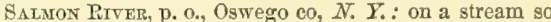
called, $183 \mathrm{~m}$. N. W. Albany.

SALron River mountains, Oreg. Ter.. a chain of mount ains extending from the Rocky Mountains W. along the $\mathrm{S}$. side of Salmon $\mathbf{r}$, to its junction with Snake or Lewis river.

Salona, p. v., Clinton county, Penn.: 63 m. N. N. W. Harrisburg. A furnace, located here, has an annual capacity of 1,100 tons

Salonia, p. o., Greene co., $K y$.: 63 m. S. by W. Frankfort SALT creek, Ind.: rises in the E. part of Brown con, flows W. into Monroe, then S. W. through Lawrence into the E. fork of White river. It is navigable at high water nearly $30 \mathrm{~m}$. It has several good mill-seats, and near it are salt springs, which have been worked to advantage.

Salt lake, Utah Ter. (See Great Salt Lake.)

SAIT lake, Cameron co.,Tex. : this famous salt lake, about $3 \mathrm{~m}$. in circumference, affords immense quantities of salt, supplying the vicinity and many neighboring States of Mexico. Its waters are evaporated in summer, leaving a crust of salt 4 or 5 inches thick

SALT river, $K y_{\circ}$ : rises in Mercer county, flows $\mathrm{N}$. into Anderson, and turning W. enters the Ohio r. at West Point, $20 \mathrm{~m}$. below Louisville. It is 200 yards wide at its mouth, and is boatable 150 miles. Its prineipal branch is Rolling fork. Some of the most fertile parts of the State are watered by this river and its branches.

SALT river, Mo. : is formed by three large forks in E. part of Monroe co., and flows eastwardly in a winding course, and enters the Mississippi r. about $38 \mathrm{~m}$. below Marion city. It is navigable to some extent.

$S_{A L T}$ Crefk, p. v., Davis co, $I \alpha_{*}$ : on a branch of Soap cr., $65 \mathrm{~m} . \mathrm{S}$. S. W. Iowa City.

Saltillo, p. vo, Itawamba county, Mfiss.: $169 \mathrm{~m} . \mathrm{N}$. E. Jackson.

Saltillo, p. o., Hardin county, Tenn.: 96 m. S. W. Nashville.

Sartillo, p. v., Jasper county, Mnd.: on the Iroquois or Pickamink r., $93 \mathrm{~m}$. N. N. W. Indianapolis.

Saltketcher Biridge, p. Y., Colleton district, $S . C A r$. ; on the left bank of Combahee r., in a swampy district, $87 \mathrm{~m}$. S. Columbia.

SALT LAKE CITY, or City of the Great Salt Lake, p. city, and cap. Salt Lake co., Utah Ter.: on Jordan river, a strait 
between $\mathrm{C}^{\mathrm{t}} \mathrm{th}$ and Great Salt lakes, $105 \mathrm{~m}$. N. by E. Fillnore City. This settlement of the Mormons is situated at the western base of the Wasateh Mountains, on an elevation of more than 4,000 feet. The Mormon communion was first organized in 1830, under the auspices of Joseph Smith, the prophet and founder, and the settlement commenced at this place under Brigham Young, his successor, in July, 1S47; soon after which it was laid out in streets and squares for a large city, and a fort or inclosure erected for defense against attacks by Indians. The streets are well planned, running at right angles $S$ rods wide, with sidewalks of 20 feet, the blocks 40 rods square, divided into 8 lots, each containing one acre and a quarter. The houses are built principally of sun-dried brick, and present a neat appearance. In October the colony was strengthened by the arrival of from 3,000 to 4,000 persons, since which time building and agriculture have been prosecuted to such an extent that it is now a place of considerable note. Agriculture and the raising of stock are the chief pursuits of the inhabitants; but establishments are being erected for the manufacture of woolen goods, sugar, etc.; wood, iron ore, and alum is found in the vicinity, and salt is manufactured from the waters of the lake, which contaius 20 per cent. of pure salt. By an Act of Congress, a mail line has been established from this city through the principal cities and towns to San Diego (California). A school for the education of teachers has been commenced, school-houses built for the instruction of children, a university is in contemplation (the site of which has been selected on one of the terraces of the mountain, overlooking the city), and altogether it is in a flourishing condition.

SAdT-LICK FALIS, p. 0., Preston co., Virg.: 181 m. N. W. Pichmond.

SAltPETRE, p. o., Washington co, Ohio: 83 m. E. S. E. Columbus.

Salt Pornt, p. 0., Duchess co., N. T.: 63 m. S. Albany.

SALt River, p. V., Audrian co., MO.: on Daris fork of Salt $\tau$., $39 \mathrm{~m}$. N. Jefferson City.

Saltsburg, p. v., Indiana co., Penn. : on the right bank of Conemaugh r., 133 m. W. N. W. Harrisburg. Salt works are operated in the vicinity. It contains several stores, mills, workshops, ete. Pop. 623.

Salt Spring, p. o., Campbell co., Ga.: 90 m. W. N. W. Milledgeville.

SALt Sprivg, p. 0., Bienville parish, La.: $168 \mathrm{~m}$. N. W. Baton Rouge.

Salt SPRingville, p. 0., Otsego county, $N . Y_{.}: 52 \mathrm{~m}$. W. by N. Albany.

Salt Sulphur Springs, p. v., Monroe co., Firg.: $169 \mathrm{~m}$. W. Richmoud. This is a pleasant watering-place, $24 \mathrm{~m}$. from White Sulphur Springs. The springs are encircled by mountains on every side, are much visited by invalids and others, and enjoy a high reputation. The temperature of their waters varies from $499^{\circ}$ to $56^{\circ}$ Fahrenheit.

SAlTville, p. F., Washington co., Virg.: on $\mathbf{S}$. side of N. fork Holston r., $243 \mathrm{~m}$. W. by S. Richmond. There are valuable salt springs in the vicinity; and gypsum is found. Water-power is good, and there are several mill-seats.

SALCBrity, p. V., Pickens district, S. Car,.: on Eighteen mile cre, tributary of Seneca $r ., 109$ m. N. W. Columbus.

SALUDA, p. o., Jefferson county, Ind.: on a cr, so called, $73 \mathrm{~m}$. S. S. E. Indianapolis.

SALUDA, p. 0., Coweta county, Ga.: $87 \mathrm{~m}$. W. by N. Milledgeville.

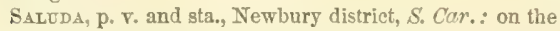
N. side of Saluda r., and on the Greenville and Columbia R. R., 61 m. W. by N. Columbia.

SAlUda, p. o., Middlesex co., Firg.: $51 \mathrm{~m}$. E. Richmond, SALUva river, $S$. Car.: rises in the eastern division of the Alleghany Mountains, in N. W. part of the State, and flows in a S. E. direction, separating Greenville, Laurens, and Newbury, from Pickens, Anderson, Abberille, and Edgefield districts, crosses Lexington district and unites with Broad river at Columbia, to form the Congaree.
SALUDA Mrlus, p. O., Newbury district, $S$. Car. : a millseat, $43 \mathrm{~m}$. W. by N. Columbia.

Stlunga, p. o., Lancaster county, Penn. : 63 m. E. S. E. Harrisburg,

Saluria, p. v., Calhoun co., $T$ ex.: on the N. E. end of Matag rda island, between Espiritu Santo and Mitagoria bays, $147 \mathrm{~m} . \mathrm{S}$. S. E. Austin City. It is a young city, and one of great promise, having been selected by the directors of the San Antonio and Nexican Gulf R. R. Company as the most suitable point for the terminus of their road. "The greater depth of water, and superior advantages as a sheltered harbor for vessels of every class, in all seasons, give it claims superior to all other points on Matagorda bay, and entitle it to be considered, at no distant day, the emporium of western Texas,"

Saluria, U. S. collection dist, Tex.: on June 30 th, 1850 , had a total tonnage of $5 \$ 9$ tons, enrolled and licensed, conslsting of 456 tons permanent, 116 tons temporary, and 17 tons licensed under 20 tons, all employed in the coasting trade, and of which 105 tons were propelled by steam. During the preceding year, it had no foreign commerce. One ressel was built, a steamer-106 tons. Its port of entry is La salle.

SALvisA, p. v., Mercer co., $K y$. : between Salt and Kentucky rivers, $18 \mathrm{~m}$. S. Frankfort. Pop. 154.

SAMANTHA, p. o., Highland county, Ohio: 59 m. S. S. W. Columbus.

Samuon's Pornt, p. v., Iroquois co., IUl. : on the W. bank of the Iroquois r., $125 \mathrm{~m}$. N. E. Springfield. The Chicago Branch R. R., will pass through this village.

Sammonsville, p. 0., Fulton county, $N . Y_{.: 47}$ m. N. W Albany.

SAupsor county, N. Car, Situate S. E. centrally, and contains $664 \mathrm{sq}$. m. Drained by Black r. and its branches, and branches of South r., all being tributaries of Cape Fear r. Surface undulating; soil moderately fertile, a large portion is well adapted to grain and grazing. Chief productions, cotton, rice, Indian corn, and potatoes. Farms 948 manuf. 53; dwell. 1,582, and pop.-wh. 8,424, fr. col. 476, sl. 5,685-total 14,5S5. Capital: Clinton.

Sampson, p. 0., Darke co., Ohio : $83 \mathrm{~m}$. W. Columbus.

SAMrsondale, v., Rockland co, $N$. $Y$.: $9 \mathrm{~S}$ m. S. Albany. It is a manufacturing village, and contains an extensive iron and wire factory, rolling and slitting mills, chemical works, ete.

Sampsonville, p. V., Ulster county, $N . Y .: 49$ m. S. W. Albany. It contains an extensive tannery, using oak and hemlock bark, and tanning annually 60,000 sides of sole leather, cap. $\$ 200,000$. This establishment is owned by General Pratt, present quartermaster of the State Military, and son of the celebrated Zadock Pratt, of Prattsville. It is a handsome village, containing also 3 saw-mills, 1 gristmill, 2 taverns, a Dutch Reformed Church, aboit 60 dwellings, and $4 S 0$ inhabitants.

SAMr's Creer, p. Y., Carroll co., Mra. : on the E. side of Sam's cr., 46 m. N. W. Annapolis.

SAY ANDREAs, T., Calaveras county, Calif: between the N. and S. branches of Calaveras r., $139 \mathrm{~m}$. E. Vallejo. It is surrounded by ravines and flats, rich in gold, and well adapted to winter mining.

San Axxomo, p. va, and cap. Bexar co., Tex.: near the source of the river so called, $73 \mathrm{~m}$. S. S. W. Austin City,

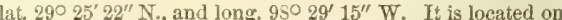
both sides of the river, abont $20 \mathrm{~m}$. above its junction with the Medina, and is one of the oldest towns in North America, containing many ancient structures. The Alamo in the N. E. part of the t. on the left bank of the river, is a large oblong walled inclosure, of about an acre in extent, once used as a fortress, but now in a ruinous condition. This t. is celebrated in history as the scene of several battles, and the Alamo was gallantly defended by Col. Travis for two weeks. A United States arsenal is located here, and an Ursuline convent, and sereral other Catholic institutions. 
The Mexican Gulf $R$. $R$. will verge from this place, and connect with Saluria (Calhoun co.). The "Western Texian" is a weekly issue. Pop. 3,268 .

SAN ANTonio river, Tex.: is formed by the Medina and Salado rivers, in Bexar co., and flows in a S. E. direction through Goliad and Refugio co's, and empties into Espiritu Santo bay. In its course it receives the Cibolo and Guadaloupe rivers, two considerable streams.

San Antonio Mrssion, Monterey county, Calif. : $138 \mathrm{~m}$. $\mathrm{S}$. by $\mathrm{E}$. Vallejo. The lands of this mission are principally owned by private persons, and contain some excellent vineyards.

Sar Augustine county, Tex. Situate E., and contains $612 \mathrm{sq}$. m. Drained by Ayish bayou and its affluents, and branches of Attoyae r., which flows on its western border. Surface undulating and somewhat elevated; soil very fertile, and produces abundantly, cotton, corn, and potatoes. There is some rich prairie land in the con, and a small portion is covered with pine. It contains many minerals, and several valuable mineral springs. Iron ore is abundant, and lead is found in small quantities. There are some quarries of excellent limestone. Farms 158; manuf. 14; dwell. 350, and pop.-wh. 2,056, fr. col -, sl. 1,561-total 3,647. Cupital: San Augustine.

San Augustine, p. v., and cap. San Augustine co, Tex.。 on the Ayish bayou, near its source, and on the old military post road, $23 \pi \mathrm{m}$. N. E. Austin City, and is one of the most flourishing villages in eastern Texas. It was laid off in August, 1838, and it now contains a court-house, jail, and many neat edifices. Being loeated some distance from navigable waters, it possesses few ecmmercial advantages. The "Red Sand Herald" is a weekly issue. Iron and lead ore is found near here, and there are some valuable mineral springs in the vicinity. The country round San Augustine is very rich, producing cotton, corn, rye, oats, ete., in abundance.

SAN BERNARD river Tea: rises near the source of Redgatis cr. of Colorado r., flows S. E. forming the N. E. boundary of Colorado and Wharton counties, and passing through Brazoria co., empties into the Gulf of Mexico, about $5 \mathrm{~m}$. below the mouth of Brazos iiver. It has several tributaries, and is navigable for steamboats about 40 miles.

San Bersardicio, p. v., Los Angelos co., Calif.: $60 \mathrm{~m}$. from Los Angelos City, and 279 m. S. E. Vallejo. The valley in which it is situate has a rich soil, and is well watered and timbered; and is noted for its hot springs. This place was originally the seat of a mission, but has lately been purchased by the Mormons, who have a considerable settlement here.

San Bermandino mountain, Los Angelos co, Calif: a lofty peak, $280 \mathrm{~m}$. S. E. Vallejo. At its base is a rich and beautiful valley.

Sanboriton, t, and p. v., Belknap co., N. Hamp.: $18 \mathrm{~m}$. N. Concord. Great bay, and Little bay, and Winnipiseogee $r .$, the outlets of the lake so called, form the E. and S. E. boundary. Drained by the outlet of Salmon Brook Pond, which is in the $\mathrm{N}$. of the t., affording good water-power. Surface uneven; soil fertile and well cultivated. There is a gulf here, extending nearly a mile through very hard, rocky ground, 38 feet in depth, the walls from 80 to 100 feet apart. Also a cavern on the hill, which may be entered in a horizontal direction to a distance of 20 feet. On the lake, at the head of Little bay, are the remains of an ancient fortification, in which have been found numbers of Indian relics, implements, ete. Incorporated in 1770 , and contains several manufactures of woolen and cotton goods, leather, lumber, etc. The $\mathrm{v}$. is situated S. of Salmon Brook Pond. Pop. of t. 2,695 .

Sasmornton Bridge, p. v., Belknap co., N. Hamp.: on the left bank of Winvipiseogee $r$, and on the Boston, Concord, and Montreal R. P., $18 \mathrm{~m}$. N. Concord.

San Buenatentura river, Santa Barbara county, Calif. riscs in a mountainous district near the Rancho of Ojai, has a N. by W. course of 25 or $30 \mathrm{~m}$. to the sea, which it enters near the mission so called, $\mathrm{N}$. of Monterey. The bottom along the stream is very fertile. The mission was one of the most flourishing in all California.

San Carlos, or Carmer, mission, Monterey co., Calif.: $175 \mathrm{~m}$. S. by E. Vallejo. The lands are rich and well cultivated, and there are many fine orchards. Gold and silver are found in the vicinity.

SaN Clemente, v., San Diego co., Califf: on the \$. E. end of the island so called (in the Pacific Ocean), $65 \mathrm{~m}$. W. San Diego, and $2 S s$ S. S. W. Vallejo; lat. $83^{2} 00^{\circ} \mathrm{X}$., and long. $118031^{\prime \prime} 00^{\prime \prime} \mathrm{W}$.

San Cosme, p. o., Rusk co, Tex.: 219 m. N. E. Austin City.

SAND creek, Ind.: rises in the centre of Decatur county, runs $\mathrm{S}$. W. through Jennings, and falls into the E. fork of White r., forming for the last 4 miles the boundary between Bartholomew and Jackson counties. It is about 50 miles in. length, and for the greater part is a good mill-stream. Its Indian name is Laque-ka-ou-a-nek, which means, "water running through sand."

Sand Bank, p. v., Oswego co., $N$. $Y$.: on the W. side of Salmon river, $133 \mathrm{~m}$. N. W. Albany. The Watertown and Rome R. R. passes near the village.

SANDBURG, p. o., Sullivan county, N. Y.: $79 \mathrm{~m}$. S. W. Albany.

SANDERSTILLE, p. F., and cap. Washington co., Ga.: on a branch of the Oconee r., $25 \mathrm{~m}$. E. Milledgeville. It contains a court-house, jail, academy, and stores. The "Central Georgian" (lit.) is issued weekly.

Sandersville, p. v., Chester district, $S$. $C a r .: 53$ miles N. by W. Columbia. The King's Mountain R. P. passes $2 \mathrm{~m}$. E. of this place.

SAND Flat, v., Yuba co, Calif.: on the Yubar., $123 \mathrm{~m}$. N. E. Vallejo. Fertile country and good mining.

Sand Fort, p. o., Russell county, Ala. : 63 miles E. Montgomery.

Sardeate, t. and p. 0., Bennington co, Verm.: 84 miles S. by W. Montpelier. Surface mountainous and broken. Drained by branches of the Battenkill. First settled in $17 \pi 1$. The t. contains several mills. The Rutland and Washington R. R. passes through its N. W. conner. Pop. 850 .

SAND HirL, p. o., Scotland county, MO. : on $\mathrm{N}$. side of $\mathrm{N}$. Fabius r., 120 m. N. Jefferson City.

SAND HrLls, v. and sta., Hamilion co., N. Jer.: on the Camden and Amboy R. R., 55 m. S. W. from New York, and $20 \mathrm{~m}$. S. E. Trenton.

Saxd Hills, p. 0., Rusk co., Tex, : 221 m. N. E. Austin City.

SAN DIEGo county, Calif. Situate S., being the extreme southern co. of the State, and contains about 10,000 sq. m. It is traversed centrally by the Coast Range of mountains, and bounded by the Rio Colorado, and W. by the Pacific, along which the coast extends from $320 \mathrm{~N}$. Iat. to the mouth of Santa Anna river, and including several valuable islands. San Diego bay is a splendid sheet of water, and has excellent harbors; and there are several other bays of minor importance. Its industry is eminently agricultural, with some commerce, but no mining. Pop. in $1552,2.932$; of which 537 were whites -397 males and 140 females; negroes 7 ; domesticated Indians, 2,273-1,249 males and 1,024 females; foreign residents, $95-91$ males and 7 females. Of the citizens of the United States 274 , of the negroes 7 , of the Indians, 2,474; and of foreigners 90 were adults. Capitul: San Diego.

SAy DIEgo, p. v., and cap. San Diego co., Calif.: near the $\mathrm{S}$. boundary of California, in lat. $322^{\circ} 41^{\prime} 5 \mathrm{~s}^{\prime \prime} \mathrm{Y}$., and long. $117^{\circ} 13^{\prime} 25^{\prime \prime}$ W. $425 \mathrm{~m}$. S. E. San Francisco, and 455 from Vallejo. It is on a wide and spacious bay, the $\mathrm{S}$. shore of which is low and sandy. From the opposite side a narrow strip of shingle beach projects into the sea, forming a natural breakwater, havine an entrance of not more than 300 yards wide, and is, with the exception of Actipuleo, the 
finest harbor on the Pacific. The $r$, which is small, is on a plain $3 \mathrm{~m}$. from the anchorage, which is at the foot of the hills just inside the bay, and from which it is scarcely visible. It was the first place occupied by the Spaniards in Upper California. There is a fort in the v., which is oceupied by a U. S. garrison. Coal is found in the vicinity. Population 700 .

SAN Diego bay, San Diego co., Calif.: makes up from the Pacific Ocean, 455 miles S. E. Vallejo, and is a good harbor.

SAvdigrs, p. 0., Amherst co, Virg.: $95 \mathrm{~m}$. W. Richmond. SANDisfield, t. and p. v., Berkshire co., Mass. : 108 miles W. by S. Boston. Surface elevated and uneven, Drained by Farmington river, which forms its E. boundary, and its branches, which afford water-power. Incorp. in 1736; first settied in 1730. The town contains 2 churches, several mills, and has woolen factories. Pop. of t. 907.

SAND LAKE, t. and p. v., Rensselaer county, $N . Y .: 9 \mathrm{~m}$. E. Albany. Drained by Poestenkill and Wynantskill creeks, and there are several small ponds in the town affording excellent water-power. Surface hilly, but has fertile soil in the valleys. The $v$. contains manufactories of woolen and cotton goods, a furnace, a glass factory, several flouring, grist, and saw mills, mechanic shops, etc. Pop. of t. 2,55s.

Sand Mountarn, p. o., De Kalb county, Ala.: 149 m. N. Montgomery.

SANDOVER, p. o., Abbeville district, $S$. Car.: $79 \mathrm{~m} . \mathrm{W}$ Columbia.

SAKiDOWN, t. and p. o., Rockingham county, N. Hamp. 27 m. S. E. by S. Concord. Surface uneven; watered by Squamscot $r$. The inhabitants are chiefly engaged in agriculture, but there are several mills. Pop. 566 .

Sand Pratrie, p. v., Pichland co., Wisc. : on the N. of the Wisconsin r., 64 m. W. by N. Madison

SaND's Mrlis, p. o., Westchester co., $N_{*} Y_{.:} 111 \mathrm{~m} . \mathrm{S}$. Albany.

Saxd Sperrg, p. o, Wood co, Tex.: $173 \mathrm{~m}$. N. E. Austin City.

Sandown, p. v., Campbell co., Ga.: on the Chattahoochee r., $87 \mathrm{~m}$. N. W. Milledgeville.

SANDUSKx county, Ohio, Situate N., and contains $45 \mathrm{~s}$ sq. m. Sandusky r. passes through it centrally, by which and its branches, and by Portage $\mathbf{r}$, it is drained. Surface level, and in parts very low; soil generally fertile. Agriculture is the leading pursuit. Pork and beef are exported in large quantities. Farms 1,391; manuf. 57; dwell. 2,437, and pop.-wh. 14,257, fr. col. 45-total 14,305. Capital: Fremont Public Works: Toledo, Norwalk, and Cleve-

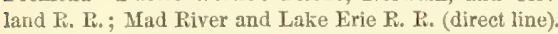

SANDUsky, p. v., Cattaraugus county, $N_{0} Y_{\text {.: }}$ on a fork of Cattarungus er., $244 \mathrm{~m}$. W. by S. Albany.

SANDUSkr Citr, p. V., port of entry, and cap. Erie co, Olio: on the S. side of the bay so called, fronting the opening into, and $8 \mathrm{~m}$. from, Lake Erie, N. $\frac{1}{2} \mathrm{E}$. Columbus. The v. is based on an extensive quarry of excellent stone, which has been used to a great extent as a building material in the city, as well as an article of export to other places. The ground on which the $\mathrm{v}$, is built has a gradual rise from the water for about half a mile, thereby affording a fine view of the lake. The wharves are substantial and commodious, and, with the exception of a short time in the winter season, are thronged with steamboats and other lake vessels arriving and departing with travelers and merchandise. There are ship-yards situated here, at which vessels and steamboats are built to a considerable extent. It is connected with Cincinnati by the Mad River and Lake Erie R. R. 218 miles, and to Newark by the Sandusky, Mansfleld, and Newark P. R. 116 miles distant, by which means a heavy transportation business is carried on with the interior and the Ohio river. Other roads are projected, and will ere long be built, as the Litke Shore line, ete.

From a detailed statement of the commerce of the port of Sandusky, and other places in the district, published in the 762
"Commercial Reporter," the following statistics are compiled, which exhibit a large increase in the business of 1852 as compared with that of 1851 :

COMMERCE OF BANDUSEY CITY.

Imports, Exports, Total Commerce

$1852 \ldots . \$ 40,596,085 \ldots \ldots \$ 18,789,814 \ldots \ldots \$ 59,655 . \$ 99$

$1851 \ldots . .13,917,564 \ldots \ldots \quad 4,755,729 \ldots \ldots 18,673,293$

Increase $. \$ 26,978,521 \ldots \ldots \$ 14,034,085 \ldots \ldots \$ 11,012,606$

COMMERCE OF OTHER PORTS OF DISTRICT.

Imports, Exports, Tutal Cummerce.

$1852 \ldots . . \$ 4,176,321 \ldots \ldots . \$ 1,237,267 \ldots \ldots . \$ 5,413,58 \$$

$1851 \ldots \ldots .1,411,918 \ldots \ldots .1,160,153 \ldots \ldots .2,572,071$

Increase. .\$2,764,403 ..... \$77,114 .....\$2,811,517

TOTAL OF BANDUSKY DISTRICT

Imports, Exports, Total Commerce.

$1852 \ldots \ldots \$ 45,072,406 \ldots \ldots \$ 20,027,081 \ldots \ldots . \$ 65,099,4 \$ 7$

$1851 \ldots . .16,329,452 \ldots \ldots \quad 5,915,582 \ldots \ldots .21,245,364$

Increase $. \$ 29,742,924 \ldots . . \$ 14,111,199 \ldots . . \$ 43,854,123$

To account in part for this great increase, it is proper to state, that the exhibit of the commerce for 1851 did not include money packages by express, which are included in that of 1852 .

The number of arrivals and departures for the same year, comparatively, were as follows:

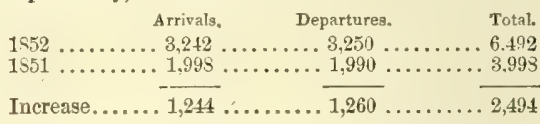

The Sandusky District extends from Black river to Por Clinton, and has a coast line of 50 miles. The shipping places are Vermilion, Huron, and Port Clinton on the lake, the eity of Sandusky, and Seneea within Sandusky bay, and Fremont, 36 miles up Sandusky river. The shipping owned in the district in 1850 was 7.328 tons. The port has also some small intercourse with the British provinces.

Sandusky was originally laid out in 1817 by two gentlemen from Connecticut, and the first dwelling erected in the fall of that year. The first church was built in 1830 . It now contains the county court-house, jail, and other public buildings, several churches, an academy built of stone, three stories high, a large number of stores, several commission houses, extensive machine shops, at which are manufuctured iron for railroad cars; two banks, printing-offices, hotels, and other establishments. A short distance back from the bay is a public square, around which are the principal public buildings and churches. On the whole, Sandusky is a well-planned and flourishing city, and rapidly inerensing in importance. There are five papers published here, the " $\mathrm{S}$ Mirror" (dem.) daily and weekly, "Commercial Register" (com.) daily, "S. Clarion," weekly (whig), "Daily Sanduskian" daily (whig), and "The Gleaner" monthly (neut.) Pop. 5,088, which inclndes Portland.

SANDrgkY river and bay, Ohio: the river rises in Richland and Crawford counties, flows E. into Wyandot county, thence $\mathrm{N}$. by meandering course into Sandusky bay. It is $90 \mathrm{~m}$. Iong, and though i rapid stream, affords good narigation at high water. 10 Crawford co, it is only 4 miles distant from a Lead branch of Scioto $r$. The bay is about 16 $\mathrm{m}$. long, and its average width $3 \frac{1}{2}$ miles. It communicates with Lake Erie by a narrow strait.

SANDWICE t and p. v., Barnstable county, Mass.: on the isthmus of Cape Cod, between Buzzard's and Cape Cod bays. Lat. (1st Cong, ch.) $41^{\circ} 45^{\prime} 31^{\prime \prime} \mathrm{N}$., long. $70^{\circ} 30^{\prime} 13^{\prime \prime}$ W. The $\mathrm{v}$, on Cape Cod bay contains 4 churches, an academy, and a very large glass factory, producing anuually $\$ 800,000$ worth of very superior giass. Here terminates the Cape Cud Brunch R. P. from Middleboro' on the Fall River R. R., $25 \mathrm{~m}$; ; distance by railroad from Boston $63 \mathrm{~m}$. The 
"Sandwich Observer" (neut.) is issued wcekly. In the t. there are three other $v_{\text {, }}$, and in it a considerable quantity of salt is annually manufactured. Pop. of t. in 1840, 3,719; in $1550,4,368$.

SANDwich, t. and p. o., Carroll co., N. Hamp.: $46 \mathrm{~m} . \mathrm{N}$. Concord. Surface uneven and mountainous, with some fertile soil. Watered by Beareamp r., flowing into Ossipee lake and other streams. Squam lake lies partly in its S. E. corner, and in its N. part commences Sandwich Mountain. Chartered in 1763. It contains numerous mills of various kinds, and several tanneries. Pop. 2,577.

SANDY, p. o., Columbiana county, Ohio: 121 m. E. N. E. Columbus.

SAXdy, p. o., Jackson co., Virg.: near Big Sandy creek, $247 \mathrm{~m}, \mathrm{~W}, \mathrm{~N}, \mathrm{~W}$, Richmond.

Sandy river, Me. : rises in Franklin co., flows S. E. until it reaches Farmington Falls vo, when it takes a N. E. course until it empties into Kennebec r., in Stark's t., Somerset co. It is about $45 \mathrm{~m}$. long, has several branches, and affords excellent water-power.

SANDX river, Virg. and $K y_{0}:$ rises in Tazewell co., and reccives numerous head branches. It flows in general N. N. W. course, and through its greater portion forms about one-half of the boundary between Virginia and Kentucky. It enters the Ohio r., at Carletsburg, Ky., by a mouth 100 yards wide. It is navigable for batteaux $50 \mathrm{~m}$. from its mouth. Its principal tributary is the West fork, which it receives at Louisa, $\mathrm{Ky}$.

SANDr Bottons, p. o., Middlesex county, Virg. : 41 m. E. Richmond.

S $\triangle$ NDY BRIDGe, p. v., Carroll co., Tenn.: on Big Sandy r., $83 \mathrm{~m} . \mathrm{W}$. Nashville.

SAXDY CREEK, t., p. v., and sta., Oswego co., $N . Y .:$ on Lake Ontario, $188 \mathrm{~m}$. N. W. Albany. Drained by Little Sandy cr., and other small streams flowing into the lake. Surface undulating; soil fertile. It contains a furnace, mills, ete. The $v$. is on the Watertown and Rome R. R., $47 \mathrm{~m}$. N. W. Rome, and has limited manufactures. Pop. of $1.2,456$.

SAXDY Creer, p. o., Randolph co., N. Car. : on a stream so called, $55 \mathrm{~m}$. W. Raleigh.

SANDY Creek, t., Mercer eo., Penn.: 180 m. N. W. Harrisburg. It eontains numerous saw and other mills, with several tanneries and distilleries. Pop. 1,100.

SandY Foundation, p. o., Lenoir co., N. Car.: $67 \mathrm{~m}$. S. E. Paleigh.

SANDY Grove, p. v., Chatham county, N. Car.: on one of the head branches of Rocky river, $51 \mathrm{~m}$. W. by $\mathrm{N}$. Raltigh.

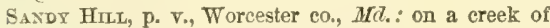
Chincoteague bay, $86 \mathrm{~m}$. S. E. Annapolis.

SANDY HLL, p. v., and cap. Washington co., N. Y.: on the left bank of the Hudson r., $46 \mathrm{~m}$. N. by E. Albany, and contains court-house and other county offices, etc. It is located on an elevation, was incorporated in 1510 , and is well laid out, the streets inclosing a triangular area in the centre. In its upper part is a fall of 12 feet in the r., below which-distant about 100 rods-is Baker's Falls, with an almnst perpendicular fall of 50 feet, producing immense lydraulic power, which is much improved by a number of mills and manufactories. Glenn's Falls, feeder of the Champlain Canal, passes through, and the Saratoga and Washington R. R. near the place. The "Sandy Hill Herald" (dem.), and Washington Telegraph" (whig) are weekly issues. This village is noted for its "stated preachings," of which B. F. Butler is the historian.

SANDY Hook, N. Jer.: is a sandy beach, extending $\mathrm{N}$. from Old Shrewsbury inlet, and the S. point of the highlands of Neversink. It is $6 \mathrm{~m}$. long, has an average width of z m., and is of note from its proximity to New York bay. A lighthouse is here erected, and a floating light, with beacons, is stationed off the coast.

SAXDY Hook, p. v., Harford co., $\mathrm{Mrd}_{0}$ : on Deer cr., $45 \mathrm{~m}$.
N. Annapolis. The vicinity has excellent farm lands, and is being improved rapidly; and on the creek there is abundance of fine stone, of which the houses are mostly built. Pop. 160.

SANDY LAKE, to and p. o., Mercer co., Penn.: $159 \mathrm{~m}$. N. W. Harrisburg. Drained by Sandy cr., which flows into the lake so called, in N. W. part of $t$. Surface even, with a productive soil. It contains a furnace, several mills, ete. Sandy Level, p. o, Pittsylvania co.; Virg.: $120 \mathrm{~m}$ S. W. Richmond.

Sandy Platrs, p. o., Rutherford co., N. Car, : on the $\mathrm{s}$. side of White Oak cr., $187 \mathrm{~m}$. W. S. W. Raleigh.

Sandx Pornt, Anne Arundel co., MId.: a cape of Chesapeake bay, opposite Kent Island. The bay is here at its narrowest dimensions.

SANDX Ponvt, sta., Prince William county, Virg.: on Washington and Wilmington R.R. route, $40 \mathrm{~m}$. from Washington, etc.

SANDY RIDGE, p. v., Lowndes co., Ala.: at the source of Big Swamp er., $27 \mathrm{~m}$. S. by W. Montgomery.

SAXDY RIDGE, p. v., Henry co., Ga.: 55 m. W. N. W. Milledgeville.

SANDY RIDGe, p. o., Steuben co., Ind.: 139 m. N. E. Indianapolis.

SANDY RIVER, p. v., Pittsylvania co., Firg.: at the head waters of a stream, so called, $126 \mathrm{~m} . \mathrm{S}$. W. Richmond.

Sandy Pun, p. 0., Cleveland co., N. Car.: on a creek so called, $169 \mathrm{~m}$. W. S. W. Raleigh.

S $\triangle$ NDY RUN, p. v., Lexington dist., S. Car.: on the S. side of a small stream so called, $15 \mathrm{~m}$. S. by E. Columbia.

SANDY SPRLVG, p. v., Montgomery eo., MId. : in the hilly region, W. of Patuxent r., $30 \mathrm{~m}$. N. W. Annapolis.

SANDY Sprive, p. o., Fayette co., Tenn.: 163 m. S. W. Nashville.

Sandyville, p. v., Tusearawas co., Ohio: on Sandy er. and on the line of the Sandy and Beaver Canal, $96 \mathrm{~m} . \mathrm{N} . \mathrm{E}$ Columbus. Pop. 223.

San Eleazario, p. v., El Paso co., Tex.: on the Rio Grande, $525 \mathrm{~m}$. W. by N. Austin Cily.

SAN FELIPE, p. v., Austin co., Tex.: the county seat, and formerly the capital of the Brazos jurisdiction, on the W. bank of the Brazos r., and on the border of an extensive prairie, $102 \mathrm{~m}$. E. by S. Austin City.

SANFORD, t. and p. v., York co., DIe. : $82 \mathrm{~m}$. S. W. by S. Augusta. Watered by Mousum $r$, which affords waterpower, improved by several large factories. The York and Cumberland R. R. will pass through the t. Pop, of t. 2,330。 SANFORD, p. O., Ingham co, MFich.

SANFORD, t. and p. o., Broome co., N. Y.: $97 \mathrm{~m} . \mathrm{S}$. W. Albany. Drained by tributaries of the Delaware r. Surface hilly, in parts mountainous; soil best adapted to grazing. It has several manufactories, mills, ete. The Erie $R$. R. passes through the t., on which is Summit station, $194 \mathrm{~m}$. from New York. Pop。 of t. 2,505.

SAMFORD's CorNers, p. o., Jefferson co., $N_{0}, Y_{\text {. }}: 144 \mathrm{~m}$. N. W. Albany.

SAN Fraxcisco county, Calif. Situate T. middle, and contains $400 \mathrm{sq} . \mathrm{m}$. It occupies a peninsula between the Bay of San Francisco and the Pacific Ocean. Drained by several creeks flowing into the bay ; and the surface somewhat hilly, with fertile valleys. San Francisquita creek divides it from Santa Clara county. Gold in small quantities has been found in this creek, which rises in the Sierro Moreno, or Brown Mountains, running along the coast, and in some places 2,000 feet high, affording protection to the valley from the coast winds. Coal has been discovered in the county, and there is excellent red wood in several Iocalities. Soil rich and productive, and agricultural resources great, but undeveloped. Assessed value of property $\$ 17,794,711$. Pop. in $1852,36,151$-whites 35,581 , negroes 323, mulattoes 141. Indians 159, and of the whites 19,308 are foreign residents-31,876 in the city. Cupitut: San Francisco. 
San Francisco, p. city, port of entry, and cap. San Francisco co., Calif.: on a narrow neck of land between the bay of the same name and the Pacific Ocean, fronting eastward on the bay, and having the ocean five miles on the west. Lat. of the Presidio, $37^{\circ} 47^{\prime} 35^{\prime \prime} \mathrm{N}$., and long. $1222^{\circ} 26^{\prime} 15^{\prime \prime} \mathrm{W}$.

The year that gave birth to the great Western Republic on the Atlantic shore also witnessed the first permanent settlement on the coast of California. In 1776, two Catholic missionaries-Francisco Palou and Benito Cambon--landed on the Bay of San Francisco, and proceeded to establish a central point for their operations in civilizing and Christianizing the native tribes. Finding a fertile tract, capable of irrigation, near $2 \mathrm{~m}$. $\mathrm{S}$. of the present city, they chose that for their home, and founded the Mission Dolores, a name commemorative of the sufferings of the Firgin. The missions of San José, Santa Clara, San Raphael, and others, were established subsequently, and were dependent on that of San Francisco. On the present site of the city a few houses were erected about the same time. This settlement was called Yerba Buena- "good herb," because a herb of that name, reputed medicinal and sometimes used as a substitute for Chinese tea, was found in abundance on the surrounding bills. The town retained this name until occupied by the Americans. All the buildinga were of adobes. The presidio, three miles $\mathrm{W}$. of the town, and near the entrance of the bay, was built about the same time for governmen purposes. Soon after its organization the mission flourished rapidly; the Indians learned to repose confidence in the padres, and embraced with avidity the new religion and many of the arts of eivilization; they lived in small communities, and were occupied in tilling the earth and other employments under the direction of the missionaries, Some ider of the extent of the operations of the padres may be formed from the fact that there belonged to the mission a one period 20,000 head of cattle, 3,000 horses, and 30,000 sheep. In 1810 the number of Christian baptisms hat reached 3.896 , and in 1831 , the period of greatest prosperity, the whole number had amounted to 6,883 . From this date the mission declined, and the Indians were driven off by political disturbances. From 1531 to 1519 the number of baptisms was only 468 . Of the entire list, it is computed that ninetenths were Indians, and the remainder Californians or immigrants and their descendants, principally from Mexico. In the mean time the town was slowly increasing, some importance being altached to it in consequence of the hides and tallow which it exported. In 1839 it was laid out as a town by Captain Joln Vioget, the few houses being previously seattered without regnlarity. In 1545 it contained 150 inhabitants. About this time it began to attract the attention of some adventurous Americans, and the popnlation increased in two years to nearly 500. It was, in fact, an American settlement long before it fell a conquest to the United States.

The bay on which the city stands extends $\mathrm{S}$. of it some $50 \mathrm{~m}$. parallel with the sea, from which it is only separated by a narrow strip of land, varying from 5 to $25 \mathrm{~m}$. in breadth. The city is on the extreme point of this peninsula. Its sit is handsome and commanding, being on an inclined plane half a mile in extent from the water's edge to the hills in the rear. Two points of land-Clark's Point on the N., and Pincon Point on the $\mathrm{S}_{\text {on }}$ one mile apart-project into the bay, forming a crescent between them, which is the water front of the eity, and which has already been filled in and corered with buildings for the extent of balf a mile. Those points and the lofly hills, $N$. and W., upon which the city is rapidly elimbing, afford a most extensive and picturesque view of the surrounding country. Standing on Telegraph Hill, to the $\mathbf{N}$. of the eity, and looking $\mathbf{E}_{\text {., the }}$ spectator sees the spacious bay, $8 \mathrm{~m}$. in width, crowded with ships of all nations, and the fertile coast of Contra Costa beyond, with its new eity of Oakland, behind which rises hill on hill, to the red wood forests on the summitstowering over the rest, the conical peak of Mount Diabolo, at a distance of $30 \mathrm{~m}$. To the $\mathrm{N}$. is the entrance from the ocean, and Saucilito, $6 \mathrm{~m}$. distant, at the foot of the opposite hills. The northern arm of the bay also stretches away till lost in the distance, studded with smoking steamers on their way to the numerous points on the Sacramento and San Joaquin rivers. To the $\mathrm{S}$, is the busy eity, the Mission Dolores, the sofithern arm of the bay lost in the horizon, and the dim, distant coast-range running parallel on the $\mathbf{E}_{\text {. }}$ Facing $\mathrm{W}$. is seen the narrow strait through which the restless ocean ebbs and flows, and into which the sea-breeze sweeps daily with its chilling but purifying mists-the Golden Gate, the Presidio, the fort, and the great ocean beyond.

The Bay of San Francisco, says Fremont, has been celebrated, from the time of its first discovery, as one of the finest n the world, and is justly entitled to that character, even under the seaman's view of a mere harbor. But when all the accessary advantages which belong to it-fertile and picturesque dependent country; mildness and salubrity of climate; connection with the great interior Valley of the Sacramento and San Joaquin; its vast resources for shiptimber, grain, and cattle-when these advantages are all taken into account, with its geographical position on the line of communication with Asia, it rises into an importance far above that of a mere harbor, and deserves a particular notice in any account of maritime California. Its latitudinal position is that of Lisbon; its climate is that of Southern Italy ; setllements upon it for more than half a century attest its healthiness; bold shores and mountains give it grandeur; the extent and fertility of its dependent country give it great resources for agriculture, commerce, and populatiof. (See article CALIFORNIA.)

The city, as it now exists, is regularly laid out into streets and squares, and contains a vast number of wholesale and and retail stores, well built, many of brick, and in its public buildings is not behind the majority of Atlantic cities in point of arehitecture and ornament. All is being built on a magnificent scale commensurate with the greatness of the golden lands of which it is the commercial depot. Its fucilities for shipping are excellent, and its anchorage safe and commodious. It would, however, be useless to describe such a place; its daily progress and general advancement render such an attempt nugatory, as a description of to-day would give but a poor idea of its condition on the morrum. To sum up its past and give its latest statistical returns is all that can be required. The city is governed by a mayor, aldermen, and recorder, and has various municipal courts, in which justice is regularly dispensed. The streets which so lately were mere sand-tracks, are now paved and lighted, and in regard of its police an unparalleled efficiency is maintained. There are many things in San Franeisco however, which would not be tolerated in New England; it has its gaming houses and swindling shops of every degree, and many of its hotels are absolute hells; but these are the incidents of its peculiar situation. The receptacle of the "fast men" of all countries, and the threadbare characters of the Atlantic States, it is only wonderful that it is not worse than it really is said to be. But this position of affairs can only be temporary, and will be gradually rëmoved as a permanent population is attained.

The corporation of San Francisen consists of a mayor, recorder, marshal, controller, treasurer, tax collector, eity attorney, street commissioner, three county assessors, county justice, constable, eight aldermen, and eight assistant aldermen. The police force consists of a captain, assistant captain, and thirty-two men. Several of the heavy merenntile houses employ special policemen, maintained at their own expense, but clothed with authority by the mayor and marshal. The health department levies one dollar from each passenger landing by sen, which entitles the sick to admission into the City Hospital free of charge for the subsequent six months.

The general condition of the city in 1852 may be gathered 
from the State census of that year, and other returns referring to other late periods.

Total population-34,876; of which 34,320 were whites29,166 males, and 5,154 females; 312 were negroes -260 males, and 52 females; 182 were mulattoes-99 males, and 33 females; 12 domesticated Indians -6 males, and $6 \mathrm{fe}-$ males. Persons over 21 years of age-Americans, 11,371, negroes, 275, mulattoes, 108, and foreigners, 15,937. The total number of foreigners was 18,854 , of which 16,144 were males, and 2,710 females.

Statement showing the national character, number, and tonnage of vessels which arrived at San Francisco during the year ending 31st December, 1852, and the countries whence they came:

\section{Conntries of \\ Depurture.}

$$
\overbrace{\text { Vess, }}^{\text {American. }}
$$

$\overbrace{\text { Tess, }}^{\text {French. }}$

$$
\overbrace{\text { Vess. }}^{\text {British. }}
$$

Other Coustries.

U. S. Pacific Ports....183 ... 78,721 ... - ... Vess. Tons, Vess. Tons. Tess, Tons,

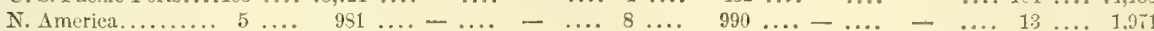

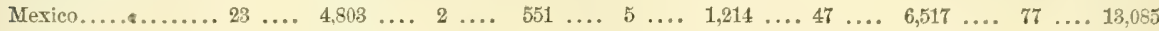

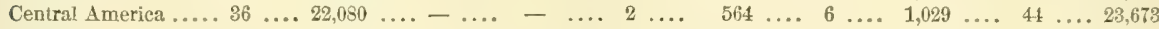

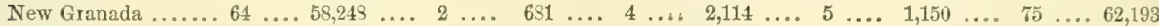

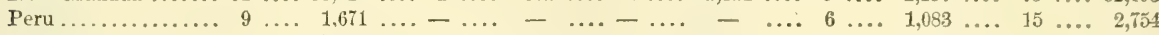

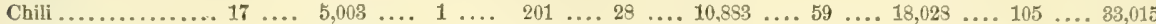

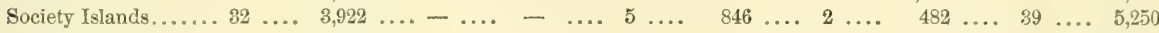

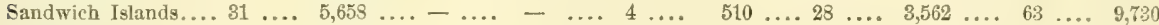

Other Pacific Ports... $12 \ldots . \quad 3,599 \ldots \ldots-\ldots . \ldots-\ldots-\ldots . \ldots-\ldots, \ldots, \ldots 99$

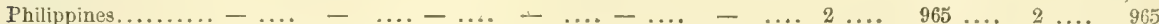

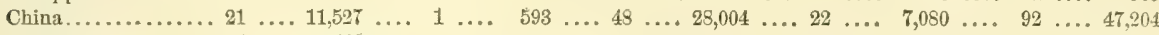

East Indies........ $1 \ldots . .197 \ldots \ldots-\ldots \ldots-\ldots \ldots-\ldots \ldots$

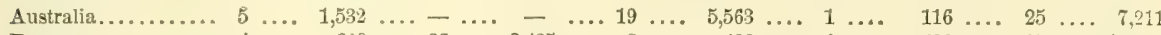

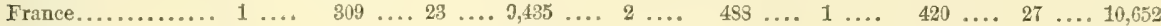

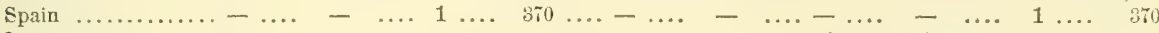

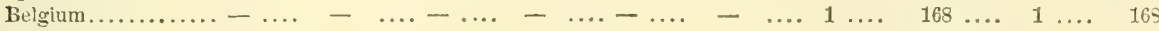

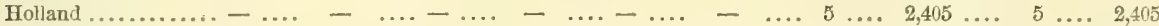

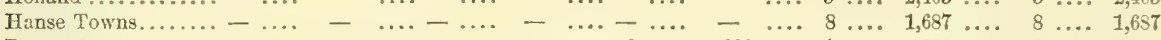

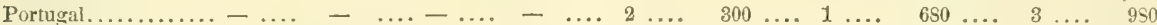

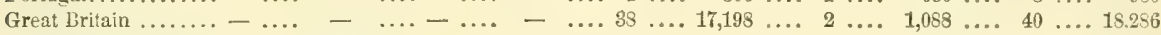

U. S. Atlantic Ports ..152 ...123,770 ... - ... - ... - .. - ... - ... - ... $152 \ldots 123,770$

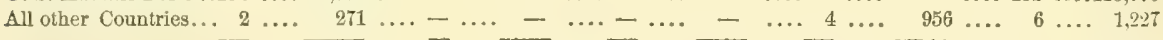

Total ........594 $\ldots . \overline{817,262} \ldots \overline{80} \ldots \overline{11,831} \ldots \overline{166} \ldots \overline{69,106} \ldots \overline{200} \ldots \overline{46,316} \ldots \overline{990} \ldots \overline{441,515}$

The following table, taken from Hunt's "Merchants' Magazine" for May, 1S53, though differing somewhat from the above, will nevertheless be most valuable on account of it showing the character of the shipping, both entered and cleared, at the port:

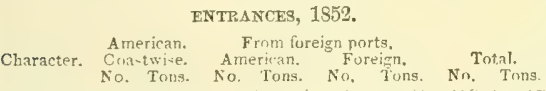

Steamers . 57. 46,046..69..72,441. 1. 359..127.118,876 Ships ....139.119,055 . .25..16,275.93..52,352 .260.187,712 Barks.... 55. 17,6S6..38,.10,279.141..51,814..237. 79,89

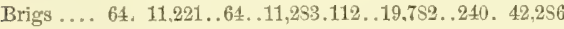
Schooners 26. 2,783 .53. 6,666.60..6,592.139. 16,321

Total ..344 196,7S1 252116,944407 181,289 1,003 445,014

$$
\text { CLEARANOES, } 1852 .
$$

Character. American, Foastwise, American. Foreign. Total,

Steamers. 90, 57,758.66. 65,511، 2. $778 . .158 .127,047$ Ships .... 22. 18,739.141.112,135. 93..51,429..256.182,302 Barks... 48, 12,170, 74, 21,868.134.,52,577..256.86,615 Brigs .... 92. 15,416. 64. 11,625.107..18,477..263. 45,515 Schooners453. 29,424.46.5,545.59., 6,723,.55S. 41,657

Total .. $\overline{705} 138,507 \overline{391} 219,614405129,9381,491483,139$

The following are the statistics of the arrivals from Eastern domestie ports during the year, with the ports from which they sailed, the tonnage, etc. :

wrienee. Boston, Mass. ......47...... 34,211....... 1451 days New York, N. Y.... 99 ....... 88,839 ....... 150 6 Philadelphia, Pa.... $7 \ldots \ldots . .2,539 \ldots \ldots .161$ " Baltimore, $\mathrm{M} d . \ldots . .6 . \ldots . .61,890 \ldots . . \ldots 179$ Frankfort, Me. ..... 1...... 199...... 156 " New London, Ct..... 1....... 135...... 185 "

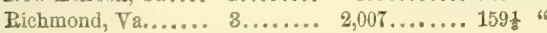

The arrivals during the different months of the year were as follows:

Monthis, Ves. Tons, Av, days. Months, Ves, Tons, Ar, days \begin{tabular}{lll|ll} 
Jan. . . 6. . $5,941 \ldots 140$ & July . . 18 . . 14,439 . . 146
\end{tabular} Feb... 8... 8,238... 145. Aug. . 17... 12,424... 145 Mar... 7... 4,557... 132 Sept. . 13... 10,622,.. 156

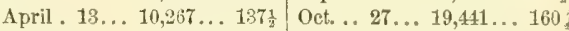
May .. 11... 7,695... 149 Nov. . 22. . 15,877... 161 June.. 3... 2,864... 129 Dec. . 18 . . 12,285 ... 15s

The twelve shortest passages of the year were as follows: Name. From, Date of arr. Days, Sworel Fish ..... New Tork......... Feb. 10...... 92 Flying Fish ...... Boston .........." $15 \ldots \ldots$. 99 Staffordshire..... " Sov, of the Seas... New York........ Nov. 15....... 108 Comet ......... "6 .......Jan. 13...... 104 Wild Pigeon...... "6 ....... " $29, \ldots \ldots$. 104 John Bertram .... Boston ........... Mar. 26....... 105 Shooting Star.... " .........Aug. 17...... 105 Celestial......... New York........Feb. 17....... 107 Courier.......... Boston ...........Ap. 28....... 108 Eclipse......... New York......" 22...... 10s Sea Witch....... "

The number of passengers arriving and elearing by sea at San Francisco, during the year ending 2Sth Dec., 1852, was as follows:

Passengers. Arriving, Clearing. Males .............. $57,316 \ldots \ldots \ldots \ldots . \ldots 22,551$

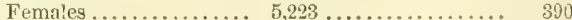

Children............ $1.651 \ldots \ldots \ldots \ldots \ldots \ldots .2$

Total .

64,190 22,916

-excess of arrivals 41,211 . The arrivals oxerland and at other ports may be set down at 10,000 , which would give to the State an increase of upward of 50,000 in the year, irrespective of natural increase. 
Subjoined is a statement of the number of ressels which have sailed from the Atlantic States for California, each month, since the discovery of gold.

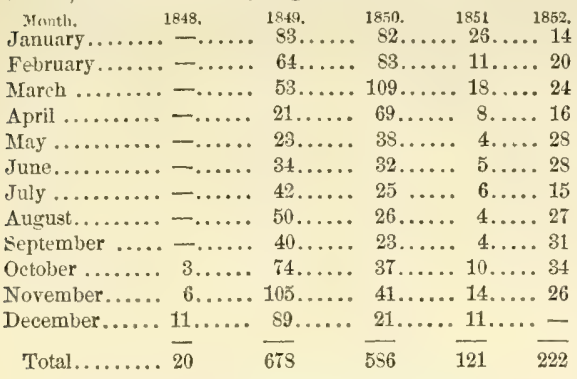

The amount of gold dust shipped by steamers from the port of San Francisco, during the year ending 31st December, 1852, was, according to a table carefully prepared by Adams $\&$ Co., $\$ 45,587,803$; of which $\$ 39,007,367$ was destined for New York, $\$ 470,783$ for New Orleans, $\$ 6,020,027$ for London, $\$ 46,000$ for Panama, and $\$ 43,626$ for San Juan. The shipments for the several months were, $\$ 2,905,770$ for January, $\$ 1,770,122$ for February, $\$ 2,173,304$ for Marcb, $\$ 3,467,293$ for April, $\$ 5,470,923$ for May, $\$ 3,570,266$ for June, $\$ 4,119,509$ for July, $\$ 3,619,929$ for August, $\$ 1,108,630$ for September, $\$ 5,067,356$ for October, $\$ 5,258,499$ for November, $\$ 4,056,172$ for December.

The amount of gold dust manifested and shipped by sailing vessels during the same time was \$213,518; of which $\$ 97,907$ was sent to Valparaiso, $\$ 22,611$ to Hong Kong, $\$ 47,000$ to Canton, $\$ 7,000$ to Shanghae, and $\$ 39,000$ to ports in China.

The amount of coin manifested during the same time was $\$ 45,253$; of which $\$ 195,061$ was shipped to Houg Kong, $\$ 12,000$ to Whampoa, $\$ 25,000$ to Shanghae, $\$ 75,850$ to ports in China, $\$ 32,432$ to Valparaiso, $\$ 49,850$ to Manilla, $\$ 4,000$ to Punta Arenas, and $\$ 71,000$ to Honolulu.

The total amount of gold dust and coin manifested and shipped on board steamers and sailing vessels during the year 1852 was $\$ 46,256,574$. This, of course, does not show all the gold dust exported during the year, as many vessels are in the habit of taking large amounts abroad without noting them on their manifests. To obtain the actual expor it would be necessary to add these unknown shipments, and also an estimate for the amount taken away in the hands of passengers. This last may safely be put down for the year at $\$ 10,000,000$, showing a total export of gold from California during the year 1552 of about $\$ 56,000,000$.

The history of San Franciseo since the Americen occupancy, is full of interest and instruction. Within the brief space of 5 or 6 years, it has risen from a comparatively small village, to a mighty city, commanding the trade of the world, and the destined port of a large moving population. The war with Mexico, which broke out in 1546, gave a first impulse to its commerce, by requiring the shipment of supplies for military purposes. In March, 1847, there were in the harbor the extraordinary number of six vessels-the imports for the last quarter of that year amounted to $\$ 49,600$, and the exports to $\$ 53,600$. At this period, the number of inhabitants, exclusive of Indians, was 375 . Eight months later, when a census was taken by the Board of School Trustees, the number exceeded 800 , of which 60 were of scholastic age. This increase of more than 100 per cent. in eight months, took place before the discovery of gold, and when California was sought merely for agricultural and commercial purposes. The first school-house was completed in Dec., 1547, and the town council passed a resolution, that " not exceeding $\$ 400$ be appropriated to the payment of the teacher of the public school of this place, $\$ 200$ to be paid at the expiration of the first six months, and $\$ 200$ to be paid at the expiration of twelve months, from the commencement of the schnol. This was the day of small things. Gold was a searce article, except as a hidden treasure. The first American school in California was duly opened on Monday, 3d April, 1848. It appears that the early settlers were bent on reducing the town to the order and deeorum of some Atlantic cities. Ordinances were passed in 1847 imposing a fine of $\$ 5$ on any person allowing hogs to run at large, and a fine of $\$ 20$ on any person discharging fire-arms within a mile of the public square. Complaints were even made in the newspaper, against the practice of smoking cigars in the magistrates' office and other public places. In January, 1847 , an ordinance was published, directing that the name of Yerba Buena, as applied to the town; be changed to San Franeiseo, in all public documents and records. On the 13th Sept., the first election was held, for six members of council. The number of votes polled was 200. The "steamboat" made its experimental trip on the 15th Nor. of that year. This pioneer in steam navigation was a diminutive vessel, the name of which is not given. In April, 1547, a semi-monthly mail was established to San Diego and other southward points. On the 1st of April next year, the "California Star Express" left by the overland route. This formidable enterprise, the first regular conveyance to the States, was announced to go through, as far as Independence, in 60 days. The postage on a letter was 50 cents. Early in 1848, an excitement appears to have taken hold of the public mind, in regard to the supposed mineral treasures of the ecuntry; but it is worthy of remark, that gold was the metal least thought of. The quicksilver mines near San José had long been known and worked. Copper was discovered somewhere, saltpetre and sulphur also, a quarry of limestone was opened, and coal had been found near San Francisco. Silver it was said hal also been discovered. To this metal, indeed, more than any other, was expectation directed, and people seemed to have an idea that the land was underlaid with silver ore. The first discovery of gold was made near Sutter's Fort, 30 miles from New Helvetia, in Dec., 1847 , and by the ensuing spring, the "yellow fever" as it was facetiously called, had carried off the greater part of the population. Stores were closed, and houses left tenantless, and every thing wore a desolate and sombre look. Lawyers, merchants, grocers, carpenters, and cooks, rushed in one motley assemblage to the mines. The newspapers ceased their issues. This suspension of trade and business, however, was soon succeeded by the most extraordinary activity. Adventurers from all nations, and merchandise of all kinds began to pour into the town, on its way to the mining regions. The forsaken buildings received a new tenantry, and the store-houses were in demand for mereantile purposes. In August, emigrants began to arrive at the rate of $500 \mathrm{a}$ month, and in the middle of September, the harbor is described as crowded-with shipping, the wharf lined with goods, and the streets filled with a busy throng. In the first two months of the golden age, the amount of dust brought into San Francisco was estimated at $\$ 250,000$; and in the next two months, at $\$ 600,000$. In Sept., 1548, an era took place in the history of the city: a square-rigged vessel-the brig Belfast, from New York, had arrived, laden with a valuable cargo. She hauled up at Broadway wharf, the ouly one accessible to such a vessel, and there discharged. No sooner was she known to be landing her eargo, than real estate rose 50 per cent. A vacant lot on the corner of Washington and Montgomery streets, at that time bordering on the water, which had been offered for $\$ 5,000$ and refused, sold readily the very next day for $\$ 10,000$. The first brick building was erected at the corner of Montgomery and Clay streets, in Sept., 1548.

About this time projects were started for establishing a temperance society and a lyceum, but most persons thought that a theatre was most the suitable moral exponent; a proposition was also made to establish a hospital for miners ete. In November, at a public meeting, the Rev. T, D 
Hunt was elected "chaplain for the city." At the election in October, 1848,158 votes were polled; in December, 1848, the voters numbered 347, and in the August next year 1,519 rotes were polled. In December, 1849, the public sehool was re-opened. In November, 1845 , when the people returned from the mines for the winter, the effects of the gold discovery were most generally fett, Lots that in the spring were sold at from $\$ 100$ to $\$ 2,000$, now ranged from $\$ 1,000$ to $\$ 15,000$, and rents had quintupled. In February, 1849 , the population was estimated at 2,000. The duties collected at the custom-house in 1848 were-1st quarter, $\$ 11,931$; $2 \mathrm{~d}$ quarter, $\$ \$, 835$; $3 d$ quarter, $\$ 74,827$, and 4 th quarter, $\$ 170.430$. The exports of merchandise amounted to about $\$ 1,000,000$, and the imports of coin to about the same amount, while the exports of gold dust for the last six months were $\$ 2,000,000$, or something less than the quantity regularly exported every two weeks four years after. The first fire, for which incidents San Francisco has become famous, occurred in January, 1849, burning the Shades Hotel, and in June, the ship Philadelphia was burnt in the harbor. On the 1st February of the same year the "California," the first steamship in the mail service, arrived. On the 18 th of May arrived the ship Grey Eagle, of Philadelphia, having made the passage in 117 days-thus far the quickest passage. It was computed that the number of emigrants in the country in June of this year was 15,000 , of whom the greater portion had debarked at this port. Sixty-four vessels were in the harbor. In the month of July there arrived by sea 3,614 souls. Some idea of the rapid march of the country in those times may be formed, from the fact that, on a single day, the 1st July, there arrived 17 vessels with 889 passengers. In August the population was computed at 5,000. The number of arrivals during the month had been 3,895 . In Sept., 5,802 arrived, and in Oetober about 4,000. The Baptists built the first Protestant house of worship in California, and dedicated it on the 5th August, 1849. Central wharf was finished in the latter part of this year. In October a little iron steamboat was launched, and was placed on the route to Sacramento. On one of her trips she brought a number of salmon from sacramento, which sold readily at $\$ 1$ per pound, and some of the fish brought as high a price as $\$ 45$. The steamboats M.Kim and Senator were shortly after put on the same route. All these vessels were crowded with passengers. An election to adopt the constitution, and to choose State officers, was held on the 13th November, when the number of ballots cast was 3,169 , of which only 5 were in the negative. In the winter of 1819-50 the business of San Francisco was almost suspended on account of the impassable condition of the streets from rain, and in numerous instances persons are said to have perished in the mud. At this period the most motley population in the world was congregated in San Francisco, and the eapricious taste of the citizens, in regard of dress, served to add to the apparent diversity. Every man had his own standard of fashion entirely independent of the rest of the world. As the female population increased, however, the costume of the men began to approach a more uniform standard, and now, even the slouch hat, which so long distinguished the Califoruian, has given place to trim and formal modes from. Broadway and Chestnut Street. In those days the humor of the people inclined them not in the slightest degreo toward intellectual pursuits. From the multitude of gambling and drinking houses, and the crowds that filled them, one might have inferred that drinking was a universal habit, and that gambling was a regular occupation of onehalf of the people, and the nightly diversion of the other half. In the progress of civilization and refinement, during the winter two theatres were kept in operation, and a portion of the citizens began to amuse themselves with concerts, balls, dinner parties, and military suppers. The flrst rash homeward took place in this winter. Driven from the mines by the weather, many of the most fortunate adventurers looked toward their distant friends. All tickets for the steamers being taken, extraordinary prices were offered for them-for steerage tickets, the original cost of which was $\$ 150$, as much as $\$ 450$ was frequently given.

The first of the series of calamitous conflagrations that have marked the history of the city, broke out on the 24th Dec., 1849 , and consumed, in houses and merchandise, property valued at $\$ 1,000,000$. The fire of Nov, 1852 , burned over a portion of the same ground, but with less destruction. Early in 1850 an express wagon made its appearance in the streets; and in January of this year, a curious inciclent transpired, in the public sale of three females from Sidney, to pay their passage money. They were sold for five months at $\$ 15$ each-the captain of the vessels pocketing the money with entire satisfaction. In March was formed the "Stranger"s Benevolent Society," for the relief of the indigent sick. Frnm the 12th April, 1849, to the 29th Jan., 1850, a period of little over nine months, there arrived by sea at San Francisco, 39,358 immigrants, of whom 1,421 were females. of 805 vessels from which they landed, 487 were American and 318 foreign. In the year ending 15 th April, 1850, there had arrived 62,000 passengers in 695 American and 418 forcign vessels. The winter of 1849-50 witnessed the first step toward the formution of the present enormous debt of the city. The expenditures for December were $\$ 135,000$, and the receipts $\$ 175,000$, being a balance in the treasury of $\$ 10,000$. In January and February the expenditures were $\$ 201,000$, and the receipts only $\$ 137,000$, leaving a deficit of $\$ 24,000$, which was the nucleus of the present debt. Two-thirds of the receipts were from the sale of city lots. The debt then begotten increased rapidly, and in a little more than a year reached the enormous sum of $\$ 1,000,000$. When the treasury was exhausted, serip was issued, bearing interest at 3 per cent per month. The eredit of the city growing worse and worse, the scrip depreciated until it would not command over one-third of its nominal value. Persons having claims against the city drew up bills for two or three times the amount of the claim, so that they might realize from the sale of the serip the full amount of the debt in cash. Thus a tradesman furnishing a $\$ 1,000$ worth of supplies to the hospital would present his bill for $\$ 3,000$, and receire that amount in scrip bearing interest as above. When the debt was funded and converted into 10 per cent. bonds, he received bonds equal to the amount of the scrip and interest, that is to say, if the scrip had run six months the city paid him $\$ 3,540$ in bonds, with an annual interest of $\$ 354$, or more than one-third the original debt. A more extraordinary specimen of financiering can searcely be conceived. In the course of the year $1 \mathrm{~S} 50$ the principal streets were graded and laid with planks. Commercial Street, from Montgomery to Kearny, was first completed. Anticipating another winter like the past, the preparation of the streets was hastened as the autumn advanced, and when the season of rain arrived, the chief thoroughfares were effectually eovered with wood. The winter, however, brought but little rain, and the fires of May and June following, destroyed a large portion of the costly expenditure which had added largely to the debt of the city. After introducing the subject, says Dr. Gibbons, from whose "Brief Sketch of San Francisco" the greater part of this article has been reduced, it would not be right to pass without commendatory notice, the arrangements finally adopted to redeem the credit of the city and to pay off the million and a half of debt. The funding of the debt and the issuing of bonds bearing interest at 10 per cent, per annum, has already been mentioned. The bonds were made payable in twenty years, and provision was made to redeem a portion annually. The citizens co-operated earnestly in the movement, and submitted cheerfully to the imposition of a heavy tax for the purpose. The credit of the city was at once restored, and the bonds rapidly approached to their par value. The transition from utter and hopeless bankruptcy to a basis of secure and permanent credit, and that, too, after the disastrous fires of May and June, 1850, and the still mare ruin- 
ous conflagrations of May and June, 1851, which laid the city in ashes a second time, was rapid and extraordinary, exhibiting a degree of energy and courage rarely met with in the history of municipal governments. In the spring of 1850 there were three daily papers published in the city, the "Alta Californian," the "Pacific News," and the "Journal of Commerce," To these were added during the year, the "Evening Picayune," the "Herald," and the "Courier." In less than a year after there were eight daily papers existing in San Franciseo.

Say Franctico river, $N$. Mex.: in the W. part of the Territory, is formed by two principal head branches, and flows S. into Salt r., just above the confluence of that stream with the Rio Gila.

SAN FrancrequTa creek, San Francisco cn., Calif.: rises in the Sierra Moreno, or Brown Mountains, runs eastwardly, dividing the co. from Santa Clara, and empties into San Francisco bay. Gold has been found in small quantities in this creek.

SAN GABRret, p. o., Williamson county, Tex.: $35 \mathrm{~m} . \mathrm{N}$. Austin City.

SANGAMON county, $I l l$. Situate centrally, and contains 936 sq. m. Sangamon r. passes through the N. E. portion, by which and its branches it is drained, and excellent water-power supplied. Surface undulating; soil a rich, calcareous loam, with sand intermixed, and very productive. Staples, wheat and Indian corn. It has fine timber land, and may be considered one of the richest counties of the State. Farms 1.578; manuf. 92; dwell. 3,173, and pop.-wh. 18,983, free colored 215-total 19,228. Capital Springfield. Public Works: Great Western Central $\mathbf{R}$. R. Cbieago and Mississippi R. R., etc.

SANGANON river, $I l l_{*}$ : one of the chief branches of Illinois r., rises in a small lake in Vermillion co, flows W. by changing course, and empties into the Illinois $\mathbf{r}$. between Cass and Macon counties. It is about $180 \mathrm{~m}$. long, of which about $120 \mathrm{~m}$. are navigable for small craft. It flows through one of the most fertile and pleasant portions of the State.

SANGERFIELD, t. and p. v., Oneida co, $N . Y_{.:} 17 \mathrm{~m} . \mathrm{S}$. Oriskany Falls, and $86 \mathrm{~m}$. W. by $\mathrm{N}$. Albany. Drained by Chenango r. and Oriskany cr. Surface uneven; soil rich and highly cultivated. The $\mathrm{v}$. is near Oriskany cr. There is in the t. a furnace and other manufactories, an oil, grist, and saw mills, ete. Pop. of t. 2,371.

Safgerfille, t. and p. o., Piscataquis co., Me. : on $\mathrm{S}$. side of Piscataquis r., $63 \mathrm{~m} . \mathrm{N} . \mathrm{N}$. E. Augusta. It has an uneven surface, with fertile soil, and contains 3 handsome ponds. Pop. 1,267.

Sangster's Station, p. o. and sta, Fairfax co., Virg.: on the Orange and Alexandria R. R., $83 \mathrm{~m}$. N. Richmond.

SANILAC county, $\boldsymbol{A}$ ich. Situate E, of the S. Peninsula, and contains $780 \mathrm{sq} . \mathrm{m}$. Drained by the Black and Cass rivers and their affluents. Surface generally even; soil fertile, and, with cultivation, adapted to the raising of wheat, grain, regetables, ete. Lake Huron bounds it on the $\mathrm{E}$. Farms 61; manuf. 27; dwell. 372, and pop.-wh. 2,112, fr. col. 0-total 2,112. Capital: Lexington.

Sanicac Mills, p. 0., Sanilac co., Mich.: 110 m. N. E. Lansing.

SAY JACIrTo, p. o., Harris county, Tex. : $152 \mathrm{~m}$. E. by S. Austin City.

$\mathrm{S}_{\text {Ar }} \mathrm{J}_{\mathrm{ACINT}}$ river, Tes.: rises in Walker county, flows $\mathrm{S} . \mathrm{S}$. $\mathrm{E}_{\mathrm{p}}$, receiving numerous tributaries, of which the principal oue is East fork, and empties into San Jacinto bay, an arm of Galveston bay. It is navigable about $45 \mathrm{~m}$, is very deep, and its water is very clear and wholesome.

SAX JOAQUIN county, Calif. Situate centrally, and contains about $11,600 \mathrm{sq}$. m. Drained by San Jorquin $r$. and its tributaries, Moquelumne, Calaveras, and Stanislaus rivers. Moquelumne r. on the N., and Stanislaus $\mathbf{r}$. on the S., form its boundaries in those directions. The banks of these rivers are rapidly being settled. A large portion bordering on the San Joaquin and Moquelumne, consisting of 768 overflowed or "Tule" is being improved, but there is much land that can not be brought into cultivation without great labor. Game of all descriptions is plentiful on the plains, The rivers abound in flsh, and many persons are engaged in taking and curing salmon. Oak is the principal timber. Located in the heart of a valley hundreds of miles in length, this is one of the finest agricultural counties in the State. Garden produce, melons, ete., are raised in abundance. Mining is but little engaged in. On the Stanislaus the placers average about $\$ 4$ a day per man. The Indians have mostly removed to the mountains; those remaining, in all 379 , are loeated in four pueblas, are perfectly friendly, and some cultivate the soil or work at the mines. Ferries and bridges have been established over the rivers, and the means of travel are convenient in all parts. Pop. in 1852, 5,029 -whites 4,569-males 3,582, and females 987; negroes 81 -males 60 , and females 21 ; Indians 379 -males 168 , and females 211 ; foreign residents 749 -males 450 , and females 299. Over 21 years of age-citizens of the United States, 2,451 . male negroes 53 , male Indians 125 , and foreign residents 516. Capital employed in the co., $\$ 2,896,050$. Capital: Stockton.

SAN JoAquiN, p. v., San Joaquin co., Calif. : on the r. so called, at the mouth of Stanislaus $r_{.}$, and opposite the city so called, $68 \mathrm{~m}$. S. E. Vallejo.

SAN JOAQUN river, Calif.: rises in Tulares lake and the Sierra Nevada or Snowy Mountains, winds its way semicircularly around the head of the Mercede in a N. W. direction, through a fine valley, and into the San Joaquin plains, about $15 \mathrm{~m}$. N. of the line dividing the county from Tulare county, thence continues in a $\mathbf{S}$. W. direction about $30 \mathrm{~m}$., when it gradually inclines $\mathrm{N}$., passing nearly through the centre of it, and joining the Sacramento river, flows W. into San Francisco bay. It has numerous tributaries, affording supplies of water to the surrounding country for mining purposes. This stream is navigable as far up as Stockton for vessels drawing over 9 feet of water, and for smaller craft as far up as the Tuolumne r., at which point vessels have arrived with 15 tons freight. It abounds in salmon and other fine fisb. Fort Miller is located at its entrance into the plains. Wild oats, clover, and other rich grains, grow in abundance along the course of this stream.

S.AN Jose, p. v., Santa Clara co, Calif. : the former seat of government; is located in one of the most pleasant and healthy valleys in the State, $50 \mathrm{~m}$. from San Fran'cisco, and $100 \mathrm{~m}$. S. Vallejo. It is an agricultural place, and its advantages for garden fruits and grains are of the highest order. There is a wharf here, and it is the depôt where the small craft that ply to and fro in the bay deposit and take in their freights. The vessels range from 10 to 20 tons. The principal quicksilver mines in the State are about $20 \mathrm{~m}$. S. of this place. Pop. 1,200.

SAN JUAN, p. v., Monterey county, Cabif.: at the base of Santa Cruz Mountain, in the valley of San Juan, 88 m. S. E Vallejo. There are several mines in the vicinity.

SAN JUAN Baptisto, mission, Monterey county, Calif.: about $104 \mathrm{~m}$. S. E.Vallejo. A tract of orchard land, in good state of cultivation, and well watered. Like other missions in California, it is in private bands, either by claim or preemption.

SAN LotIs, p. o., Brazoria county, Tex.: 154 m. E. S. E. Austin City.

SAN Luis OBIspo county, Calif: Situate $\mathbf{S}$. on the Pacific, and contains $4,600 \mathrm{sq}$. m. Surface hilly, being traversed by the Coast Range and other mountains. The streams are the Nacimiento, dividing it from Monterey co. : the Arroyo Grande and the Santa Maria, dividing it from Santa Barbara co. The bottoms on these streams are well timbered with sycamore, oak, and alamia, a species of cottonwood. Pine of large size and superior quality is abundant. Along the coast are fine harbors; that of San Luis Obispo is $9 \mathrm{~m}$. W. of the $t$. of the same name; that of San Simeon is $40 \mathrm{~m}$. N. W. of San Luis, and there is a fine harbor known as the 
Moro. Rich silver mines are found in tlec co, and copper and iron are supposed to exist, and a fine bituminous coal is found near San Simeon bay. There are many and large bituminous springs, and a warm sulphur spring-the panaera of the natives-about $10 \mathrm{~m}$. S. of San Luis Obispo. Lime-rock is plentiful. On the plains, in the N. E. part of the $c n$, wild horses range in large numbers. Horticulture is carried on to some extent. The vineyard of San Miguel is extensive, but much neglected. The mission of San Luis Obispo, though in ruins, has still remaining some fine olive, peach, pear, fig, and apple orchards, and a small vineyard. The capital invested in ranches and stock amounted in 1852 to $\$ 664, \$ 48$, and in village property to $\$ 40,000$. Pop. of that year, 954 - whites 494 -males 331 , and females 163 ; negroes 8-males 4, and females 4; foreign residents, 121-males 85 , and females 36 . Over 21 years of age-citizens of U.S., 143 , negroes 4 , and foreigners 77 . There are 37 ranches in the co, chiefly held under Mexican grants, containing in all 550,000 acres. Capital: San Luis Obispo.

SaN Luis Obispo, v., port, and cap. San Luis Obispo co. Calif.: half-way from Santa Barbara to Monterey, and 177 miles S. E. Vallejo. The v. is located on a small stream, $9 \mathrm{~m}$. from the harbor. An unsafe port in winter. Although having an extensive seaboard, it is not well watered. Lat. $85010^{\prime} 37.5^{\prime \prime} \mathrm{N}$., and long. $120^{\circ} 43^{\prime} 31^{\prime \prime} \mathrm{W}$. Ten miles S. of the $v$. are the warm sulphur springs-the panacea of the natives.

San Marco, p. o., Travis co., Tex.

SAN MAroos river, Tex.: the principal tributary of Guadalupe $r$. Is a large stream rising in the $\mathrm{S}$. E. corner of Gillespie county, and flows E. and S. E. to its confluence with the Guadalupe, near Gonzales.

SaN Migurl county, $N$. Mrexo. Situate centrally toward N., and immediately E. of Santa Fé. Area $3,500 \mathrm{sq.} \mathrm{m}$. Drained by the upper waters of Pecos and by Canarlian rivers, which are here comparatively small streams. Surface elevated, and in the W. mountainous, being traversed by the Jumanez range. Exं cept on the rivers there is very little agricultural land. Farms 177; manuf. 0 ; dwell. 1,731, and pop.-wh. 7,070, fr. col. 4-total 7,074. Capital: San Miguel.

SAN MIguex, v., San Louis Obispo co., Calif. : on the W side of Monterey or Salinas r., 71 m. S. E. Monterey and 156 m. S. S. E. from Vallejo.

SAN MIGuex river, Tex: : rises by two head branches in S. E. corner of Medina county, and flows S. S. E. through Bexar county, and empties into the Rio Frio near its mouth.

Sax Nicotas, v., Los Angelos eo., Catif. : on the S. E. end of the island of San Nicolas, in the Pacific Ocean, $52 \mathrm{~m}$. S. W. St. Vincent, in lat. $33^{\circ} 14^{\prime} 12.9^{\prime \prime}$ N., and long. $119 \circ 25^{\prime}$ $00^{\prime \prime}$ W., 339 m. S. S. E. Vallejo.

SAN PABLO, V., Contra Costa co., Calif.: at the entrance of the bay so ealled, $15 \mathrm{~m}$. S. by W. Vallejo.

SAN PABLo bay, Calif: : one of the northern divisions or arm of San Francisco bay, bordering on the counties of Contra Costa, Napa, Sonoma, and Marin. It receives the waters of Napa, Sonoma, and Petaluma creeks.

Sar Paseuel, v., San Diego co, Calif.: on the line of the Santa F'é route, $45 \mathrm{~m}$. N. of S. boundary of the State and $403 \mathrm{~m}$. S. E. Vallejo.

SAN Patricro county, Tero. Situate S., and contains 2,720 sq. m. Drained by West Aransas and other tributaries of Aransas r., and by branches of Rio Nueces, which runs along its southern border. Surface varied, in the $N$. being undulating and broken and somewhat elevated, but in the S. fine level tracts of land spreaciing over a large portion of the county. Along the streams are some strips of woodland. Farms 10; manuf. 0; dwell. 38, and pop.-wh. 197 , fr. col. 0, sl. 3-total 200. Capital: San Patricio.

Say Patricio, p. v., and cap. San Patricio co., Texo.: on the E. Jank of Nueces r., 166 m. S. Austin City.

SaX PfDro, p. o., Houston co., Tex. : $171 \mathrm{~m}$. N. E. by E Austin City.
SAN PEDro, v, and port, Los Angelos co., Calif. : on the bay of San Pedro, 332 m. S. E. Vallejo, lat, $83^{\circ} 43^{\prime} 19.6^{\prime \prime} \mathrm{N}$. and long. $118016^{\prime} 03^{\prime \prime} \mathrm{W}$. It is the port of Los Angelos, from which it is $27 \mathrm{~m}$. S., and $80 \mathrm{~m}$. N. W. San Diego. It is a good farming district, celebrated for the fine quality of its grapes, and was the former Spanish capital of California. The anchorage is good, and perfectly safe, except during the prevalence of the $\mathrm{S}$. $\mathrm{E}$. winds in the winter.

SAN PEDro river, Los Angelos co., Calif. : a small stream rising in the mountains in $\mathrm{S}$. part of county, flowing $\mathrm{S}$. empties into the bay so called.

SAN PETE county, Utah T'er. Situate between $38^{\circ} 30^{\prime}$ and $39^{\circ} 57^{\prime}$ lat. N., and extending from the Rocky Mountains W. to about $112 \circ$ long. W. It is drained by Green and Grand rivers, the constituents of the Rio Colorado, and in the hills which cross its W. portion. Nicollet $r$, has its sources. Timber of various kinds is abundant, and bituminous coal, gypsum, salt, etc., are found in abundance. Farms 51 manuf. 1 ; dwell. 62 , and pop.-wh. 365 , fr. col. 0-total 365. Capital: Manti City.

SAY RAFAEL, p. v., and eap. Marin co., Calif.: is laid out at the old mission of the same name, on the W. side of Pablo bay, an arm of San Franciseo bay, $23 \mathrm{~m}$. W. of ValIejo. It is a pleasant site, and when the resources of its undulating, wooded, and arable back country shall be developed, it will become an important point.

San Ramon, p. o., Contra Costa county, Calif.: 39 m. S. Vallejo.

SaN Srmeon, port, San Luis Obispo co., Calif.: on the bay so called, $40 \mathrm{~m}$. N. W. San Luis Obispo and $158 \mathrm{~m}$ S. S. E. Vallejo, lat. $35 \circ 38^{\prime} 24^{\prime \prime}$ N., and long. $121010^{\prime} 22^{\prime \prime} \mathrm{W}$. It has little or no harbor, being nearly an open roadstead.

Santa ANra county, N. Mex. Situate centrally toward N., and contains about 400 sq. m. The Rio Grande and Santa Fé county bound it on the E., and on the W. it is bounded by the Sierra Madre, the highest peak of which in this county is Mount Taylor. The Puerco and other tributaries of the Rio Grande, drain the surface, which, with the exception of the immediate valley of the river, is essentially mountainous. Farms 144; manuf. 0; dwell. 973, and pop.-wh. 4,644, fr. col. 1-total 4,645, Capital: Jemez.

SAnta ANnA, p. V., De Witt co., Ill : on the head branch of Salt er., $60 \mathrm{~m}$. N. E. Springfield.

Santa Barbara county, Calif. Situate S. on the Pacific, and coutains about $4,300 \mathrm{sq}$. $\mathrm{m}$. The principal streams are the Santa Clara, forming the S. E. boundary, the San Buenuventura, Santa Inez, and a small stream forming the $\mathrm{N}$. boundary. These are all small streams, rising in the Coast Range of mountains, which, on the E. border of the county rise to the height of from 3,000 to 4,000 feet, and are vol canic. The waters of the coast abound in corvinas, black fish, mackerel, crawfish, sardines, clams, and many other species of excellent fish and crustacre. A bed of oysters, 150 yards long and 25 yards wide, and 3 feet thick, has been discovered within the pueblo limits of Santa Barbara, the oysters being of uncommon size and good flavor. The islands off the coast are the rendezvous of otters, seals, sea elephants, and beaver. There are several fine valleys in the county, much of the soil of which is fertile arable land, and along the streams is susceptible of irrigation. About one-third the surface is adapted for cereal agriculture and horticulture. Fruit of all kinds, vines, melons, etc., grow finely. The grasses are luxuriant and nutritious, and vegetation generally fully developed. Agriculture, however, is in a very rude state, and the material for fencing scarce. For dairy farming the county cannot be excelled. Gold is found in the southern part, and was extensively worked in 1842. There are tar springs near Santa Barbara village, and the sea throws up bitumen for leagues along the coast. Salt is abundant, and is gathered at the salinas in $\mathrm{Aug}$. and Sept. in cart loads. A hot sulphur spring exists in the Montecito, near the village of Santa Barbara, temperature $100^{\circ}$ Fahr., and basin large enough to bathe in. In 1852 the 
population numbered 2,181 : whites 1,516 -males $\$ 34$, and females 652 ; mulattoes 9 -males 4 , and females 5 ; and foreign residents 230 -males 120 , and females 110 . Over 21 years of age: Americans 301, mulattoes 5 , and foreigner 106. Land under cultivation 699 acres. Capital: Santa Barbara.

SaxtA Barbard, p. v., and eap. Santa Barbara county, Calif.: a small sea-coast town, $253 \mathrm{~m}$. S. E. Vallejo. It is pleasantly situated, surrounded by mountains. A point so called projects out from the town. Lat, $34^{\circ} 24^{\prime} 24.7^{\prime \prime} \mathrm{N}$., and long. $119^{\circ} 14^{\prime} 18^{\prime \prime} \mathrm{W}$.

Saxta Cataliva island, Calif: $:$ is a large island in the Pacific Ocean, of irregular triangular form, $20 \mathrm{~m}$. long and the same width, attached to Los Angelos county, $20 \mathrm{~m}$. S. of San Pedro.

Santa Clara county, Calif. Situate W., and contains about 12,000 sq. m. It lies between the Coast Range and the Santa Cruz Mountains, and is watered by the Pajara, Santa Cruz, Guadalupe, and other rivers. The Guadalupe empties into the bay of San Franciseo at its S. extremity, and the others have short courses to the Pacific Ocean. The county occupies one of the most fertile valleys of the country, producing all the grains, fruils, and vegetables of the latitude. Its minerals are of the most valuable description -quicksilver, gold, silver, etc., and coal has been discovered. A great portion of the produce in the markets of San Francisco is brought from this county. The roads are generally good, and the Atlantic and Pacific R. R. will pass near to San José, the old eapital of the State. Forbes' quicksilver mines in the Santa Cruz Mountains, are said to be as rich as those of Mexico. In 1552 the county contained 6,664 inhabitants, of which the whites numbered 6,158males 4,096 , and females 2,062 ; negroes 58 -males 45 , and females 8; mulattoes, 3 females; Indians 550 -males 358 , and females 162; foreign residents $1,335-$ males 1,059 , and females $2 \pi \ell$. Over 21 years of age $-1, \pi 17$ citizens, $4 \pi$ negroes, 198 Indians, and 1,081 foreign residents. Capital: Santa Clara.

Sarta Clara, p. v., Santa Clara co., Calif.: in the Santa Cruz Mountains, $5 \mathrm{~m}$. S. of San Francisco bay, $26 \mathrm{~m}$. W. of the sea-coast and $53 \mathrm{~m}$. S. by E. from Vallejo. It was formeriy a mission, and is surrounded by one of the best farming tracts in the State. About $19 \mathrm{~m} . \mathbf{S}$. E. are extensive quicksilver mines. Pop. 800 .

Santa Clemente island, Calif: : a large island, $16 \mathrm{~m}$. long $6 \mathrm{~m}$, wide, attached to San Diego county, $65 \mathrm{~m}$. E. San Diego.

Santa Cruz county, Calif. Situate W. on the Pacific, and contains about 800 sq. m. The Santa Cruz Mountains bound it on the N. E. and the Pacific Ocean on the S. W. side. The interior is hilly, with intervening valleys, and along the coast there are precipitous bluffs. The Pajara $r$. forms its $\mathrm{S}$. boundary, and there are several small streams emptring into the sea. A good road connects the village with San Francisco. Gold and other minerals are found, and quartz mining is carried on, but to no great extent. The industry of the people is chiefly devoted to agriculture. trade, etc. The land under cultivation in 1852 was 5,472 acres. Pop, at that date 1,219 : whites 1,097 -males 723 , and females 374 ; negroes 4 -males 3 , and females 1 ; mulattoes, 8 females; Indians 110 -males 63 , and females 47 ; foreign residents 33 males. Over 21 years of age-279 Americans, 4 negroes, 8 mulattoes, 33 Indians, and 30 foreigners. Capital: Santa Cruz.

Santa Cruz, p. v., and eap. Santa Cruz co., Calif.: on Monterey bay, $75 \mathrm{~m}$. S. Tallejo, lat. $36^{\circ} 5 \overline{7}^{\prime} 26.9^{\prime \prime} \mathrm{N}$.. and Iong. $122^{\circ} 00^{\prime} 10^{\prime \prime} \mathrm{W}$. It is one of the oldest pueblas in the State, and presents many advantages for an agreeable residence.

SANT Croz island, Calif: : a large island in the Pacific, attached to Santa Barbara county, $23 \mathrm{~m}$. long, $13 \mathrm{~m}$. broad, $20 \mathrm{~m}$. S. Santa Barbara.

SANTA FÉ county, N. Mero. Situate centrally toward N., 770 and contains about $800 \mathrm{sq} . \mathrm{m}$. The Rio Grande forms its W. boundary, and supplies water for irrigation, but is not navigable. The cultivated lands are all on the river borders-farther E. is a sandy waste, but seldom ever traversed except by the trader and Indian. Gold, silver, and other metals are found in the county. Farms 713 ; manuf. 6 ; dwell. 1,561, and pop.-wh. 7,704, fr. col. 9-total 7,713 . Capital: Santa Fé.

SANTA FÉ, p. o., Maury co., Tenn.; 41 m. S. by W. Nashville.

SANTA FÉ, p. O., Bracken county, Ky.: 60 miles N. E. Frankfort.

Santa Fé, p. v., Miami co., Ind.: on Big Pipe cr. of the Wabash r., $61 \mathrm{~m}$. N. Indianapolis.

SANTA F'E, p. o., Alexander county, $I l l$. : 175 m. S. by E. Springfield.

SANTA FÉ, p. city, and eap. Santa Fé co., and capital of the Territory of Nero DFexico: is situated about $20 \mathrm{~m}$. E. from the Rio Grande. Lat. $35^{\circ} 41^{\prime} 6^{\prime \prime}$ N., long. $106^{\circ} 02^{\prime} 03^{\prime \prime}$ W. Its site is a wide plain, surrounded by lofty mountains. Its elevation above the sea is about 7,047 feet. A small creek, rising in the hills, and flowing past the city to the Rio Grande, supplies it with water. The land around is sandy, poor, and destitute of timber, but the mountains are covered with pine and cedar. The climate is delightful, without extremes; the sky is clear, and the atmosphere dry. The streets are irregular and narrow. The houses are built of adobes, one story high, with flat roofs, and in square form, with an area in the centre. There are two churches (Catholic) with steeples, but of ordinary construction. The inhabitants are chiefly a mixture of Spaniards and Indians, with a few Americans. Their manners and eustoms are those of the whole country, and similar to those of other settlements of Spanish origin. For many years this place has been the main point of trade in this region, and many of the companies engaged therein have amassed large fortunes. In 1850 two newspapers were published, "The New Mexican," weekly, and "Santa Fé Republican," tri-weekly. Pop. in $1,70,4,516$

Santa Fé was founded about 15S1. Its history, with that of the territory, previous to belonging to the United States, is a continuous record of barbarism and tyranny. It was taken by Gen. Kearney, on September 8th, 1846.

SANTA MARTA river, Calif.: constitutes about one half of the boundary between Santa Barbara and San Luis Obispo counties, and is about, $35 \mathrm{~m}$. long.

SANTA Rosa county, Flor. Situate W, and contains 1,500 sq. m. Drained by Blackwater and Yellow rivers and Cold Water, Clear Water, and Sweet Water creeks. Escambia r. runs along its W. border. Surface level; soil very fertile. Chief productions, cotton, rice, sugar, grain, fruits, and vegetables. Santa Rosa island runs along its S. shore, with inlets N. and S. to the sound. Farms 91; manuf. 28; dwell. 526 , and pop.-Wh. 2,095 , fr. col. 4, sl. 781 -total 2,883. Capital: Milton. Pullic Works: Fort Gaines and Pensacola R. R. ; Montgomery and Florida R. R., etc.

SA×TA Rosa island, Calif.: $13 \mathrm{~m}$. S.W. Santa Cruz island, 36 m. S. by W. Santa Barbara (Santa Barbara co.), and 273 m. S. S. E. Vallejo.

SANTEE, p. 0., Covington co., Miss.: on a tributary of the Pascagoula r., 62 m. S. S. E. Jackson.

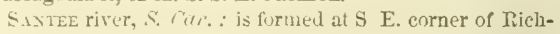
land $c o$, by the junction of the Congaree and Wateree rivers (the head streams of which rise in North Carolina), flows E. S. E., and empties into the Atlantic by two mouths. It is navigable for sloops about $130 \mathrm{~m}$.

SANтxarr eity, Linn co., Oreg.: st the confluence of Santy am $\mathrm{r}$. with the Willamette, and about equidistant between Salem and Albany.

SAMYBEe island, Flor.: lies off N. E. corner of Monroe co., is $9 \mathrm{~m}$. long and $2 \mathrm{~m}$. wide.

SAPELo island, Ga.: is E. of M'Intosh co., to which it belongs, between Saptlo sound and Doby inlet. It is $10 \mathrm{~m}$. long, 5 widc, and has a lighthouse at its $\mathrm{S}$. end. 
SAPLING Grove, p. o., Washington co., Virg.: $201 \mathrm{~m}$. W. S. W. Richmond.

SAPpLNGTon, p. o., St. Louis co., Mo. : $87 \mathrm{~m}$. E. Jefferson City.

SARAH, p. 0., Blair co, Penn.: $78 \mathrm{~m}$. W. Harrisburg. A furnace moved by water-power, of 1,400 tons annual eapacity, is located here.

Saraustille, p. o., Franklin co., $I l l .: 127$ m. S. S. E. Springfield.

SARAhStille, p. v., and cap. Noble co., Ohio: $76 \mathrm{~m}$. E. Columbus. It contains the county buildings, ete.

Sararac, t. and p. v., Clinton co., N. Y.: $16 \mathrm{~m}$.W. Plattsbura, and $15 \mathrm{~s}$ miles $\mathrm{N}$. Albany. Drained by the river so called, which runs through it in a S. W. direction, affording extensive water-power, and the soil along its banks is rich and well cultivated. The surface is hilly and mountainous, abounding in deposits of iron ore, and heavily timbered. The v. contains a forge and glass factory, several mills, etc. Pop. of t. 2,5s2.

Sararac lakes, Upper and Lower, Franklin co, $N_{\text {. }} Y_{\text {.: }}$ lie in the S. E. part of the co., and are connected by Round lake, which together form one body of water. Their outlet from the lower lake is by Saranac $r$. The length of the upper lake is $10 \mathrm{~m}$., that of the lower $7 \mathrm{~m}$., and the width of each is from 2 to $3 \mathrm{~m}$. Pound lake is about $4 \mathrm{~m}$. $\mathrm{long}$, and mostiy $3 \mathrm{~m}$. wide. Each abounds with trout and other fish.

SABANAC river, $N . Y$. : rises in lower Saranac lake, flows in N. E. general course, and empties into Cumberland bay of Lake Champlain at Plattsburg, where it descends 40 feet by a succession of falls, affording very great water-power.

Saratoga county, $N$. $\boldsymbol{Y}$. Situate E. toward the N., and contains 785 sq. m. Drained by Sacandaga and Mohawk rivers, tributaries of the Hudson, and $\mathrm{Fish}$ and Kayaderosseras creeks. Surface various, in the N. W. being mountainous, and in the S. E. and central parts hilly, with sandy plains interspersed; soil a deep sandy loam, with elay intermixed, and in many parts fertile. Chief products, wheat, Indian corn, and potatoeg. It contains many minerals, and has gnod granite, limestone, and slate quarries. In this co. are the celebrated mineral springs so much resorted to in the watering season. Farms 3,465; manuf, 349; dwell. 7.\$94, and pop.-wh. 45,066, fr. col. 580-total 45,646. Capital: Ballston. Public Works: Saratoga and Washington R. R.; Schenectady and Saratoga R. R.; Troy and Rensselaer R. R.; Albany Northern R. R. ; Saratoga and Sackett's Harbor R. R.

SAPATOGA SpRIvgs, t., p. Y., and sta, Saratoga co, N. Y.: 36 th. by railroad N. Albany. Drained by several small streams flowing into Kayaderosseras cr., which bounds it on the $\mathrm{B}$. Surface on the N. hilly, elsewhere level; soil sandy loam. It contains some manufactures, a number of mills, mechanic shops, etc. This is the most celebrated wateringplace in the United States. Located closely together are a number of mineral springs with various properties, principally medicinal. The $\mathrm{v}$. on the $\mathrm{N}$. is located on a sandy plain, surrounded in part by pine groves. Its principal street is apon the W. margin of a narrow vale, in which the springs are found. On this broad street the principal hotels, churches, and other public edifices are located. The hotels, etc., are numerous, and some of them large, and fitted up on a grand scale; the United States is the most conspicuous, being located within a short distance of all the principal mineral springs; it is built of brick, four stories high, with ample accommodations for 400 persons. Congress Hall and Union Hall, both popular establishments, are on the S. of the v., near Congress Spring, the most copious and most salubrious of all the springs in Saratoga. It was discovered in 1792 by a member of Congress named Gillman; the Pavilion, on the site of a spring so called, near the Elat Pock, is surrounded by highly cultivated grounds, and as is the case with a number of others, is only kept nper during the summer months for the accommoda- tion of visitors. A number of other hotels and boardinghouses are kept open throughout the year. High Rock and Black Rock springs were first discovered in 1773 , being then the resort of invalids; and now there are 10 or $12 \mathrm{im}$ portant mineral fountains, most of them located near the margin of a brook which runs through the $\nabla$. on the E. in whose waters the mineral elements of soda, magnesia, lime, and iron, with others of no less volume, are combined, in different proportions, with carbonic acid gas. The prevailing character is that of saline and chalybeate waters. Congress, Washington, Putnam's, Pavilion, Iodine, Hamilton. Empire, Flat Rock, and High Rock springs are the most celebrated for their medicinal qualities. Located east of Saratoga Springs is a cluster of mineral springs known as "Ten Springs," the most celebrated of which is called Union Spring. Large quantities of these waters are annually exported to different parts of the country, bringing in a handsome incume, most of them being owned by private individuals. The waters are highly efficacious in many inveterate cases of disease, and has an effect on the healthy system to renovate and invigorate its energies when relaxed from long confinement, etc. Their medicinal properties are of the cathartic and tonic kinds. The following is an analysis of several of the springs, taken from a work by Dr. R. L. Allen, a plijsician resident at Saratoga: Congress Springs.-To one cubic gallon: chloride of sodium, grs. 390.246; hydriodate of soda and bromide of potassium, 6.000 ; carbonate of soda, 9.213 ; carbonate of magnesia, 100.981 ; carbonate of lime, 103.416 ; carbonate of iron, 1.000 ; silex and alumina, 1.036 ; solid contents, $611 . \$ 92$; carbonic acid gas, 386.185; atmospheric air, 3.261. Gaseous contents, 359.449. High Rock Spring,-To one gallon: chloride of sodium, grs. 190.223; carbonate of magnesia, 62.100 ; carbonate of lime, 71.533 ; carbonate of soda, 2.177 ; silex and alumina, 2.500; hydrobromate of potash, a small quantity. Solid contents, 351.197. Carbonic acid gas, 331.666; atnospheric air, 2.000. Gaseous contents, 333.666 . Hamilton Spring.-To one gallon: chloride of sodium, grs. 290.500 carbunate of soda, 33.500 ; carbonate of lime, 95.721 ; carbonate of magnesia, 38.000 ; carbonate of iron, 4.500 ; hydriodate of soda, 3.500 ; bromide of potash, a trace; silex and alumina, 1.000. Solid contents, 466.321. Carbonic acid gas, 340.777; atmospheric air, 2.461. Gaseous contents, 313.28S. Temperature of the water, 480. Putnam's Spring.-To one gallon: chloride of sodium, grs. 220.000; carbonate of soda, 15.321; carbonate of magnesia 45.500 ; carbonate of lime, 70.433; carbonate of iron, 6.333 ; hydriodate of soda, 2.500 ; bromide of potash, a trace; silex and alumina, 1.500 . Solid contents, 370.587. Carbonic acid gas, 317.753 ; atmospheric air, 3.080. Gaseous contents, 320.S33. Temperature 48\%. Iodine Spring.-To one gallon: chloride of sodium, grs. 147.665; carbonate of magnesia, 73.34S; carbonate of lime, 28.955 ; carbonate of soda, 3.000 ; carbonate of iron, 900 ; hydriodate of soda, 3.566. Solid contents, 257.434. Carbonic acid gas, 344.000 ; atmospheric air, 2.500. Gaseons contents, 3.465. "The freedom of this water from iron is such that it can be drank by a certain class of iuvalids, with whom iron proves a decided injury." Pavilion Spring.To one gallon: chloride of sodium, grs. 1S3.814; carbonate of soda, 6.000 ; carbonate of lime, 59.593 ; carbonate of magnesia, 58.266; carbonate of iron, 4.133 ; iodide, sodium, and bromide of potassa, 2.566 ; sulphate of soda, 1.000 ; alumina, a trace; silex, 1.000. Solid contents, 316.373. Carbonic acid, 369.166 ; atmospheric air, 3.333. Gaseous contents, 372.499. Empire Spring.-To one gallon: chloride of sodium, grs. 215.756; bi-carbonate of lime, 24.678; bi-carbonate of magnesia, 113.459 : bi-carbonate of soda, 33.554 ; hydriodate of potassa, 9.600 ; iron, 0.500 ; silex and alumina, 1.300. Solid contents, 399.s77. Carbonie acid gas, 260.132; atmospheric air, 3.314. Gaseous contents, 263.466.

The Troy, Whitehall, and Castleton R. R., Saratoga and Schenectady R. R., and the Saratoga and Washington R. R. all connect in this village. Distance from New Fork city 
by R. R. $182 \mathrm{~m}$, from Troy $22 \mathrm{~m}$, from Schenectady $22 \mathrm{~m}$., and from Rutland, Verm, 89 miles. The village was incorporated in 1826, and contains an insurance office, a bank, an academy and female seminary, and other institutions of instruction, iron foundries, machine shops, an extensive carriage manufactory, printing-offices, etc. The "Saratoga Whig" is a daily and weekly (whig) issue, and the "Saratoga Republican" weekly (dem.) Pop. of $t$. 4,650 .

Sarcoxie, p. v., Jasper co., Mo. : on the S. side of Centre cr., 14 ŏ m. S. W. Jefferson City.

SARDINIA, t. and p. v., Erie co., $N . Y .: 252 \mathrm{~m}$. W. Albany. Drained by Cattaraugus cr., which bounds it on the S., and several small streams flowing into it. Surface uneven, in parts hilly; soil fertile. The $\mathbf{v}$, on a small stream in $\mathbf{S}$. part, contains flouring and saw mills, a woolen factory, and furnace. Pop. of t. 1,761.

SARDivia, p. 0., Decatur county, Ind. : 48 m. 5. E. Indianapolis.

SARDINIA, p. V., Brown co., Ohio: on S. side of White Oak cr., 74 m. S. S. W. Columbus. Pop. 198.

SAkDts, p. 0., Mason co, $\bar{k} y .: 72 \mathrm{~m}$. N. E. Frankfort.

Sardis, p. 0., Monroe county, Ohio: 99 miles E. $\frac{1}{2} \mathbf{S}$. Columbus.

Sarecta, p. v., Duplin co., $N$. Car.: on the E. side of N. E. cr, of Fear r., $72 \mathrm{~m}$. S. E. Raleigh.

SAREPTA, p. V., Lafayette co., Miss.: on a branch of Yallabusha r., 133 m. N. N. E. Jackson.

SarnetTA, p. o., Marion county, Firg.: 189 m. N. W. Richmond.

Sarversville, p. o., Butler co., Penn. : $161 \mathrm{~m}, \mathrm{~W} . \mathrm{N} . \mathrm{W}$. Harrisburg.

SASSAFras river, $M d$. : rises in Delaware, and flows $W$. between Cecil and Kent counties, into Chesapeake bay, of which its principal portion is properly a broad inlet.

SASSAFRAS HILL, p. v., Washington co, $I U l$.: on the W. side of Little Crooked cr., $93 \mathrm{~m}$. S. by E. Springfield.

Satartid, p. Y., Yazoo co., ifiss.: on a small stream flowing into the Yazoo r., 33 m. N. W. Jackson, Pop about 180 .

Saucelito, v., Marin co., Calif.: on the bay of San Franeisco, near the entrance to the harbor, $27 \mathrm{~m}$. (direct) S. W Vallejo. This place was laid out by a company of enterprising men, on the ranches of W. Richardson, Esq. It has one of the best anchorages to be found in the whole bay, and was formerly a favorite resort of whale ships, which visited the port for fuel, water, and supplies. The site of the town is small, but it is securely protected from the disagreeable winds which blow from the sea, by high hills behind it. It is surrounded by a fine agricultural country.

SAUCoN Tallex, p. o., Lehigh co, Penn. : Ss m. E. by N. Harrisburg.

Sadgatuck, p. O., Allegan co., Miich.: on the Michigan City and Grand Haven post route, $87 \mathrm{~m}$. W. Lansing.

SAdGertis, t. and p. o., Ulster $\cos , N . \bar{Y}$.: on the right bank of the Hudson r., 48 m. S. by W. Albany. Drained by Plattsville and Esopus creeks, tributaries of the Hudson $r$ Surface on the W. mountainous, being covered by the Catskill Mountains, and on the E. moderately uneven; soil of average fertility. It derives immense water-power, principally from the falls on Esopus cr., and is much improved by several manufactories, bloomeries, mills, etc. The p. o, is located in the v. of Clster, near the falls, at which point a bridge with one arch of 2,600 feet span crosses the river. Steamboats and sloops ply between this place and New York. It contains a bank and other places of business, and is one of the most flourishing manufacturing places in the State. The "Ulster Telegraph" is a weekly (dem.) issue. Pop. of t. 8,048 .

SAturs, t. and p. F., Essex co., MFus..: $7 \mathrm{~m}$. N. Boston, Taken from Lynn, and incorporated under its presen name in 1815. Drained by Saugus $r$., which passes through it, and enters Lynn bay on the $S$. Surface near the $r$, aut bay is level, but the uplands are rough and rocky. A greas part of the $t$. toward the sea is covered by salt meadows; in other parts the soil is rich and well cultivated. It contains some manufactories, a lumber-yard, etc. The $\mathrm{v}$. is on the Saugus Branch R. R. Pop. of t. 1,552.

SAUK county, Wisc. Situate toward the $\mathrm{S}$. W., and contains 985 sq. m. Baraboo r. flows through it from W. to E. by which and its branches, and by small streams of Wisconsin r., it is drained. Surface hilly; soil fertile; on the Wisconsin are some fine tracts of land, which are very produetive. It is well timbered. F'arms 245, manuf. 7 , dwell 814, and pop. -wh. 4,370, fr. col. 1-total 4,371. Capital: Adams.

SAUK RAPIDS, p. v., and cap. Benton co., Minn Ter. : at the second rapids, on the left bank of the Mississippi r., 67 m. N. W. St. Paul. It contains a court-house, etc.

Sauk Virlage, p. 0., La Porte co., Ind. : 125 m. N. N. W. Indianapolis.

SAUKVILLE, t. and p. v., Washington co., Wisc. : $75 \mathrm{~m}$. E. N. E. Madison. Drained by Milwaukie $r$. The $v$. is on the W. side of the r. Pop. of $\mathrm{V}_{-}$.840, and of t. 1,796.

SaUlT de Ste Marte, t, p. V., and cap. Chippewa co. Mich, : bordering on St. Mary's r. or strait, $255 \mathrm{~m} . \mathrm{N}$. Lansing. The v, has an elevated location on the border of the $r_{\text {. }}$ at the Falls of Ste Marie, and is an old Jesuit missionary station. It is a famous fishing-place, immense quantities of white fish being eaught and salted there for the markets of the West. The falls are merely rapids, with a fall of only 20 feet in. a mile. It contains a court-house, jail, and other publie buildings. At Fort Brady is a U.S. military post, and a storehouse of the American Fur Company, and there is also a U. S. land office located here. Vessels come to the foot of the rapids, and the cargoes are transported three-fourths of a mile by land to the head of the rapids, and re-shipped. The inhabitants are composed of Americans, French, and Indians. They employ themselves chiefly in trading for furs, and in the fisheries. In 1850 Sault de Ste Marie had 180 dwellings, 890 inbabitants, 15 of whom were colored; and the value of real estate owned, $\$ 101,930$. The imports for same year amounted to $\$ 151,134$, and the exports $\$ 340, \$ 00$. The "Lake Superior Journal" is a weekly (mining) issue. A canal is in course of construction around the Falls, to be 100 feet wide and 12 deep, with locks 250 feet long and 60 feet wide, the whole length to be one mile, so that the navigation of the lower lakes may pass readily these falls into Lake Superior.

SAUNDEESTLLE, p. V., Vanderburgh co., Ind.: on the Evansville and Illinois R. P., $133 \mathrm{~m}$. S. S. W. Indianapolis. It is a small but neat village, and has a fine agricultural country surrounding it.

SAUNDEeSTILLE, p. o., Worcester co., Mass, : $145 \mathrm{~m} . \mathrm{W}$ Boston.

Savorort, p. v., Oneida co., $N_{*}, \bar{Y} .:$ on both sides of Sauquoit cr., $81 \mathrm{~m}$. W. N. W. Albany. The water-power is good, and is much improved by manufactories, mills, etc. In the vicinity is an inflammable sulphur spring, the waters possessing valuable medicinal qualities, and the gas which escapes is used for lighting the public house, which is located near by.

SAUTA, p. v., Jackson co, Ala. : on a small cr. of the Tennessee r., $157 \mathrm{~m}$. N. Montgomery.

SAVAGE, p. $\nabla .$, Howard county, $M L d$ : on the Little $\mathrm{Pa}$ tuxent $r_{\text {s, }}$ and on the Washington Branch R. R., $20 \mathrm{~m}$. N. W. Annapolis, There are extensive iron works in the vicinity.

SAVAGE river, Alleghany co., Md. : a large stream draining the valley between Hoop Pole Mountain and Great Sarage Mountain, from both of which it derives its waters, and falling into the $\mathrm{N}$. branch of the Potomac r., about $2 \mathrm{~m}$. W. of Lonaconing er. Monro Run, Middle fork, and Crabtree cr. are its principal affluents. The Baltimore and Ohio R. R. takes the course of this stream to the junction of Crabtree creek. 
Satage Grant, p. 0., Wayne co., Tirg.: 275 m. W. by N. Richmond.

Savanian, p. v., and eap. Carroll co., $I l l .:$ on the bank of the Mississippi r., $27 \mathrm{~m}$. below Galena, $158 \mathrm{~m}$. N. by W. Springfield. It contains a court-house, jail, etc., and it is the terminus of the Savannah and Frankfort $R$. R.

Sarannak, p. v., and cap, Andrew co., Mo. : $3 \mathrm{~m}$. N. of the Missonri r., and $168 \mathrm{~m}$. N. W. Jefferson City. It contains a court-house, jail, etc.

SaVANNaH, p. eity, port of entry, and cap. Chatham ec. $G\left(c_{0}:\right.$ on the $\mathrm{S}$, side of the $\mathrm{r}$, of the same name, $18 \mathrm{~m}$, from the ocean, and in a direct line $157 \mathrm{~m}$., or by railroad $187 \mathrm{~m}$. E. S. E. Milledgeville. Lat. $32004^{\prime} 56^{\prime \prime} \mathrm{N}$., and long. $8100 \mathrm{~s}^{\prime}$ $18^{\prime \prime} \mathrm{W}$. Its site is on a dry sand bluff, elevated some 40 feet above low-water mark, from E. to W., extending along the river upward of a mile, terminating abruplly at either extremity. Opposite the city, lies Hutchinson's Island.

The ordinary elevation of the tide in the Savannah $r$, is about 8 feet, and the salt water approaches usually within 4 or $5 \mathrm{~m}$. of the eity. In ils course to the ocean the river is divided into numerous channels by small marsh islands. The bar at its mouth is the deepest and most accessible of any on the Southern Atlatitic coast, and its channel is from a half to three-fourths of a mile wide. The average depth is 19 feet at low water, and hence with a full tide a frigate may pass in safely. Just-inside of the bar is Tybee Island. abreast of which, about $4 \mathrm{~m}$. from the bar, is good anchorage in 5 or 6 fathoms of water. From this anchorage to Venus' Point, $9 \mathrm{~m}$. from the city, there is a depth of 18 feet; from the "Point" to "Five Fathom," $2 \mathrm{~m}$. from the eity, there is a depth of 17 feet, and thence to the eity, a depth of 15 feet. The Savannah is navigable for steamboats of moderate draft to Augusta, $230 \mathrm{~m}$. above its mouth. The port of Savannah has several light-houses, which are noted in the LIST OF LignT-HOUSES.

Savanuak, as a city, is one of the healthiest and most begutiful on the Sonthern coast. It is laid out with regularity, the streets crossing each other at right angles, and having between every second street a public square; these, about 18 or 20 in number, are generally inclosed and ornamented with shade trees, and many of the streets are ornamented in the same manner, which gives them a beautiful and rural appearance. The present dimensions of the eity are about a mile by three-quarters of a mile. The number of dwellings in the city is about 2,000 , ehiefly of wood, but the warehouses and stores, in number abont 400 , are almost without exception brick buildings. This preponderance of wooden structures had exposed the city to several serious conflagrations: the year 1820 is memorable for the destruction by fire of 463 buildings, which with their contents were valued at $\$ 400,000$; bat since this erent brick bas more generally been used as a building material. The warehouses are ranged along the river front, 3 or 4 stories high toward the river, accessible to the lower story from the wharves, and to the upper stories from the eity.

Among the public buildings, the most conspicuous are the Court-house, Jail, Custom-house, Exchange, Arsenal, United States Barraeks, City Hall, a market-house, several hospitals and asylums, a theatre, ete. The Exchange is a heavy Gothic structure, 5 stories high. The new Customhourse is in length 110 feet, depth 52 feet, and in height, from the pavement to the ridge of the roof, 52 feet. The basement story is devoted to the post-office and the appraiser's deparment; the first or principal floor for custom-house purposes, and the third or upper floor for United States court rooms. There are four banking institutions in Savannah-the Bank of the State of Georgia, capital $\$ 750,000$; the Planters' Bank, capital $\$ 535,400$; the Marine and Insurance Bank, capital $\$ 400.000$, with privilege to increase it to $\$ 800,000$; the Central Railroad and Banking Company, eapital $\$ 2,549,165$, of which $\$ 205,000$ is devoted to banking vurposes. The total banking capital of these institutions, appropriated to the trade and commerce of Savannah, is
$\$ 1,590,400$. There is also the Suvannah Inslitution for Savings. Fourteen foreign insurance companies have agencies in Savannah.

The churches of Sayannah, numbering in all 14 or 15 , are many of them handsome struetures. The Independent Presbyterian Church is one of the most splendid buildings of the city; it is built of light-colored granite, and cost $\$ 100,000$. The Episcopalians have 2 churches, the Poman Catholics 2, of which that of St. John the Baptist is the metropolitan church of the diocese; and the Methodists, Lutherans, Unitarians, and other principal denominations have severally places of worship. There is also a Mariner's Church and a Jews' Synagngue.

Savannah, in all that appertains to the education of youth, is not behind her sister cities. It is true, public education has not received that attention it has in many other places, still she has always had a respectable number of private seminaries, and has sent to institutions in other parts of the State and country hundreds of her youth of both sexes. Much, however, can be done for public education; but Savannah is no location for large institutions of a scholastic nature, which are well supplied by more eligible inland towns.

The newspaper press of Savannah consists of three dailies and one weekly. The dailies are the "Georgian" (dem.), the "Republican" (whig), and the "Daily News" (indept.); and the weekly is the "Friend of the Family" (literary). The circulation of these varies from 800 to 1,200 copies at each issue.

According to a census of the city, taken in 1852, the total population amounted to 18,301 souls, distinguished into castes and sexes in the following proportions:

Castes.

Males, Females,

Total.

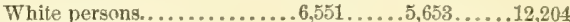

Colored persons, free........ 248 ..... $376 \ldots \ldots .624$

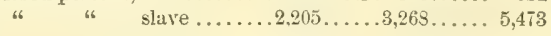

Total........... $\overline{9,004} \quad \overline{9,297} \quad \overline{18,301}$

The number of inhabitants, according to the federal census of 1850 , was 16,060 , and an enumeration, made in 1848 , showed the population to be then only 13,575 . Increase from 1848 to $1850,2,455$, or 18.3 per cent. ; and increase from 1850 to $1852,2,241$, or 13.9 per cent.; and increase in the four years ending $1552,4,726$, or 34.8 per cent. The decennial progress of the city from 1510 , has been as follows:

\begin{tabular}{|c|c|c|c|}
\hline \multirow[b]{2}{*}{ Years. } & \multirow[b]{2}{*}{ Total Population. } & \multicolumn{2}{|c|}{ Decennial Increase, } \\
\hline & & $\begin{array}{l}\text { Absolute. } \\
\ldots \text { - }\end{array}$ & $\begin{array}{l}\text { Relative. } \\
\ldots .\end{array}$ \\
\hline 1820 & $7,523 \ldots \ldots$ & $\ldots 2,328$ & $\ldots .44 .8$ \\
\hline 1830 & $7,776 \ldots$ & ... 253. & .. 3.4 \\
\hline 840 & $.11,214 \ldots$ & $\ldots 3,438$. & $\ldots 41.2$ \\
\hline 1550. & $\ldots 16,060 \ldots$ & $\ldots 4,846$ & $\ldots 43.2$ \\
\hline
\end{tabular}

The city is divided into 26 wards, and is governed by a mayor and 12 aldermen, annually chosen by the people, who, together, are styled the City Council. The police consists, besides the above, of a marshal, 5 constables, and the city watch, consisting of 64 members, with a captain and other officers. A Board of Health, consisting of two persons from each ward and district, is appointed by the mayor, on the 1st of May of each year. All subordinate officers are chosen by the City Council.

The occupations of the citizens comprise almost every calling found in large cities. The enumeration of 1818 classifies the male adult white population thus -263 merchants, factors, and wholesale dealers, 136 shopkeepers and retail grocers, 253 clerks, 15 druggists, 28 pilots, 24 bank officers, 28 captains of steamers and vessels, 1 eaptain revenue service, 24 butchers, 22 bakers, 22 connected with railroads, 55 seamen, 8 connected with hotels, 4 auctioneers, 5 lumber measurers, 6 clothing stores, 13 connected with steam and cutton presses, 2 lottery offices, 3 sailors' boarding-house 
keepers, and 1 of the sailors' home, and 164 laborers, 50 planters, 14 master builders, 1 marble and stone manufacturer, 380 mechanics, 15 ministers of the gospel, 4 judges of eourts, 36 physicians, 31 attorneys-at-law, 6 U. S. army and naval officers, $24 \mathrm{U}$. S. civil officers, 1 civil engineer, 30 engineers, 15 teachers, 5 teachers of music, 8 magistrates, 7 county officers, 27 boot and shoe makers, 14 printers, 3 booksellers, 8 watchmakers and jewellers, 18 painters, 6 manufacturers of tin-ware, 3 editors, 4 dentists, 2 artists, 4 brickmakers, 3 dyers, 7 cigar-makers, 4 public stables, 6 barbers, 1 soap and candle manufacturer, 1 engraver, 9 barrooms, 4 watehmen at banks, 5 saldle and harness makers, 6 millers, 6 lumber and wood yards, 9 steamboat yards, 4 U. S. soldiers, 9 constables, 12 city officers, 2 ice-houses, 1 keeper of hospital, a jailor, and a deputy, 70 connected with the city watch.

Of the colored population, 34 free, and 73 slaves, were mechanics, 2 free and 5 slaves butchers, 5 free and 1 slave barbers, 2 free and 4 slaves engineers and pilots, and 3 free preachers.

From the above returns, it will be seen that Savannah is well represented in all the great departments of industryat least two-thirds of the population are immediately or remotely connected with the commerce and trade, and the greater part of the remaining third with her manufactures and mechanic arts. The learned professions are also amply represented. Only 164 persons among the whites are noted as laborers, while among the colored 129 only are other than laborers and servants.

Savannah is one of the great commercial cities of the South, and as a market for cotton, rice, and lumber, ranks among the first. Its exports of cotton for the years 1:51 and 'כ2, ending 1st September of each year, were as follows :

$$
1851-52 \text {. }
$$

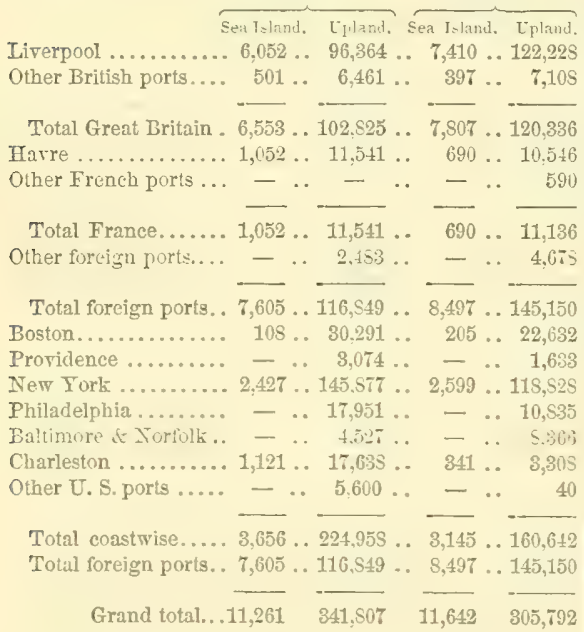

The following exhibits the number of bags exported in the past years, commencing 1512 :

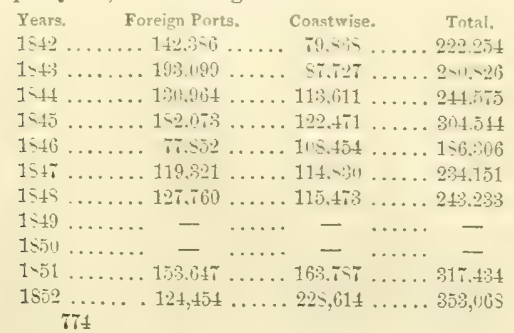

The export of rice in tierces for the last twelve years, bas been as follows:

\begin{tabular}{|c|c|c|c|}
\hline $\begin{array}{l}\text { Years, } \\
1 S 40-41\end{array}$ & $\begin{array}{r}\text { Tierces. } \\
23557\end{array}$ & $\begin{array}{l}\text { Years. } \\
19+6-4 i\end{array}$ & Tierces. \\
\hline $1841-42$ & ........ 22,065 & $1517-45$ & . 311,136 \\
\hline $1 \leqslant 42-43$ & ... 26,263 & $1515-19$ & $.37 .3+3$ \\
\hline $1643-41$ & ... $25,5 \pm 13$ & $1519-50$ & .42 .792 \\
\hline $1844-15$ & . . 29,217 & $1550-51$ & . 35,602 \\
\hline $1 S 15-46$ & $\ldots \ldots \ldots .32 .147$ & $15051-502$ & 39,929 \\
\hline
\end{tabular}

The lumber business has rapidly increased within the few last years, and it will be seen from the annexed table that the exports for the last-named year have exceeded those of any previous one by several millions of feet. There are six large steam saw-mills in the immediate vicinity of the city:

\begin{tabular}{|c|c|c|c|}
\hline Years. & Feet. & Years. & Feet. \\
\hline $1 s 40-41 \ldots$ & $14.275,200$ & $1816-1 i$ & ….. 10,731,353 \\
\hline $15+1-42 \ldots \ldots \ldots$ & $8,390,400$ & $15 \pm 7-15$ & ... 16.419,555 \\
\hline $1 \$ 42-13 \ldots$ & $7,519,5 \%$ & $15 \pm 5-49$ & ... 15,350,300 \\
\hline $513-14 \ldots$ & $5,93 \%, 351$ & 1849-כ0 & ... $17,719,100$ \\
\hline $.14-45 \ldots$ & $5,270,552$ & $1850-51$ & $\ldots \ldots 17,764,300$ \\
\hline $15-16$. & $85556+4$ & $1851-5$ & 95 \\
\hline
\end{tabular}

$1545-16 \ldots \ldots \ldots 15,555,644 \mid 1851-52 \ldots \ldots 25,508,500$

The foreign commerce of the collection district of which Savannah is the port of entry, for the year ending Junc 30 th, 1550 , is thus summed up in the U.S. Treasury Report. Value of exports $\$ 7,551,943$, and of imports $\$ 636,964$. En trances, 118 vessels, 57,017 tons and 1,940 men in crews; and clearances, 141 vessels, 72,263 tons and 2,285 men in crews. Tonnage of the distriet 19,931 tons, of which 10,437 tons were employed in foreign trade and 9,296 tons in coasting. The steam tonnage was 6,478 tons. The steam marine in 1852 , according to the returns of the $\mathrm{U}$. 8 . inspector, amounted to 27 vessels, 5,750 tons, of which 12 were highpressure vessels and 15 low pressure, which report indicates a decrease in the steam marine. The number of vessels built in 1550 were 5 ( 3 being steamboats), measuring together 681 tons. As the foreign commerce of Georgia all centres at Savannah, the progress of the commeree of Georgia, as exhibited in the description of the State, will also be that of Savannah.

The commerce of the city has thus become of great mag nitude, and its growth of late years has been more rapid than previously. The developments that are now making of the resources of the State, together with the increased facilities for transporting the products of the interior to this one seaport must insure a more rapid increase of business for the future than has occurred during any period of the past.

The port has regular communication with Florida on the S. and New York on the N., and other points by steam narigation. To the interior, the Savannah $\mathbf{r}$, on which numerous steamboats are constantly plying, and the great line of railroad reaching into Tennessee and Alabama, give it facile access, and bring down to it for exportation an immense tonnage. Another railroad is being built to Albany, on the Flint $\mathbf{r}$; and the Savannah and Ogeechee Canal has been thoroughly repaired. These will give it greater faclities than it has ever enjoyed, and open to its commerce the products of wide regions hitherto beyond its reach.

IIvtorical Nutices of Sicumnah.-The first settlement of Savannah was made in the month of February, 1733, by General Oglethorpe and sume 30 families. On the 7 th of July following, the settlers assembled on the strand (the bay) for the purpose of designating the lots. In a devotirnal service they mited in thanksgiving to God "that the lines had fallen to them in a pleasant place, and that they were about to have a good heritage." The wards and tithings were then named, each ward consisting of four tithings, and each titbing of ten houses, and a house and lot was given to each freeholder. After a dinner provided by the governor, the grant of a Court of Record was read. and the officers were appointed. The session of the magistrates was then held, a jury impanneled, and a case trited. This 
jury was the first impanneled in Georgia. The town was governed by three bailiffs, and had a recorder, register, and a town court, holden every six weeks, where all matters, eivil and criminal, were decided by grand and petit juries, as in England. No lawyers were allowed to plead for hire, nor attorneys to take money, but (as in old times in England) every man could plead bis own cause. In October, 1741 , the government of the colony was changed from bailiffs to trustees. In 1750 , the number of white persons in Georgia was computed at about 1,500. The first royal governor of Georgia, John Reynolds, Esq., arrived in Savannal in Oct., 1754. The first printing-press was established in 1763, and the "Georgia Gazette" printed on the 7th April of that year. In 1766, the city consisted of 400 dwelling houses, a church, an independent meeting-house, a council-house, a court-house, and a filature. In 1770 , the city extended on the west to what is now Jefferson Street, on the east to what is now Lineoln Street, and on the south to what is now South Broad Street, and contained six squares and twelve streets, besides the bay. On the 5th June, 1775 , the first libertypole was erected in Savannah. The flrst attack by the British on Savannah was made on the $3 \mathrm{~d}$ March, 1776. . It ended in the discomfiture of the regulars, under Majors Naitland and Grant. On the 29th December, 1778, Savannah was taken by the British. In Oetober, 1779 , an unsuccessful attempt was made by the French and American armies to recapture Savannah from the British. Count D'Estaing and General Lincoln were the commanders. Six hundred and thirty-seven of the French, and two hundred and forty-one of the continentals and militia were killed and wounded. In this attack Pulaski fell. The spot where he twas shot down is about one hundred rods from the present depôt of the Central R. R. On the 11th July, 1788, Savannah was formally given up by the British to the Americans. The first session of the Legislature of the State was held in Sarannah in January, 1784, in the brick house now standing in South Broad Street. In December, 1789, a law was passed by the legislature making Savannah a city. The first mayor (elected in 1790) was John Houstoun. In Nov., 1796 , the first destructive fire occurred in Savannah. It broke out in a bake-house in Market Square, and destroyed 229 houses, besides out-houses, etc. Estimated loss of propcrty, $\$ 1,000,00$. In May, 1814, arrived in the waters of Savannah the United States sloop-of-war Peacock, Lewis Warrington commander, bringing in as a prize H. B. M. brig-af-war Epervier, Cantain Wales, of 18 guns. The Epervier had on board $\$ 110,000$ in specie, which was condemned and distributed according to law. In April, 1819, arrived the steamship Savannah, from New York. This steamer was projected and owned in Savannah, and was the first steamship built in the United States, and the first that ever crossed the Atlantic. She left Savannah in May for Liverpool, and afterward proceeded to St. Petersburg. In January, 1820, occurred the largest fire which ever ravaged the city. It commenced on the east side of Old Franklin Ward. Four hundred and sixty-three buildings were destroyed, besides out-buildings. Loss upward of st.oinnoun.

SATATNAT, to and p. o., Wayne county, N. Y.: $160 \mathrm{~m}$. W. N. W. Albany. Crusoe lake is located centrally, by the outlet of which the to is drained. Surface level; on the E. swampy, covered by Montezuma Marsh, and on the W. fertile. The Rochester and Syracuse (direct) R. R. passes through this t. Pop. 1,700.

Sataryar, p. V., and eap. Ashland co, Ohio: near a branch of the Walhonding r., $70 \mathrm{~m} . \mathrm{N} . \mathrm{N}$. E. Columbus. It contains the county court-house and other publie buildings, mechanic shops, ete.

SaVANnati, p. V., and eap. Hardin county, Tenn.: on the right bank of the Tennessee r., $103 \mathrm{~m}$. S. W. Nashville, and contains the conrt-house, jail, and other public buildings. Pop. 502.

SaYazian, p. v., Ped River county, Tex, : on White
Oak creek of North fork of the Red river, $257 \mathrm{~m}$. N. E. Austin City.

SAVANNAII river, $G a .:$ has its sources in the north-east. ern part of the State of Georgia, and the north-western counties of South Carolina, near the southern boundary of North Carolina, and in about lat. $35^{\circ}$, and in lone. 60 to $6^{\circ} 30^{\prime}$ west of Washington City. The river is formed by the junction of the Tugalo and Keowee rivers, having their sources in a mountainons recoirn of primitive furmation, and its general course is southward, inclining from 350 to $35^{\circ}$ to the east, but the channcl is a very winding one, and at srome points the river flows in a direction $\mathrm{N}$. of $\mathrm{E}_{\text {s, }}$ or N. of W. The length of its channel from source to mouth is not less than $450 \mathrm{~m}$., whereas the direct distance is only about $250 \mathrm{~m}$.

The Savannah and its tributaries drain an extent of country equal to about $8,200 \mathrm{sq}$. m., and all the bratiches which flow in above Augusta have their rise in the mountains or hilly sections of country, and have considerable velocity of eurrent with rapids and falls at different points; in some degree, such is also the character of the main river to its source. Passing to the $\mathrm{S}$. of Augusta, the features of the bordering country change, becoming comparatively level and flat, and the currents in the river, as a consequence, are less rapid. In this lower portion of the river, the channel is more crooked; the distance from Angusta to Savanuah, by water, being about $230 \mathrm{~m}$., whereas the direct distance is about $115 \mathrm{~m}$.

The current in the upper part of the Savannah $x$, and its tributaries, being more rapid than they are when the river approaches the ocean, considerable quantities of earth are washed from the bottoms and banks as it passes through the hilly country, and carried in suspension to the more sluggish portions, forming bars and shoals. Some of the obstructions, even so far down as the city of Savannah, are probably formed in this way, and these bars are generally composed of a silicious gravel and sand, with a small proportion of alumina and lighter earths.

The products of the country bordering on the river above Augusta, are principally eorn, wheat, rye, potatoes, cotton, timber, hogs, sheep. oxen, mules, and horses; the main produetions of the middle and $\mathrm{S}$. sections are corn, potatoes cotton, rice, and timber.

The river above the city of Savannah is subject to the freshets, which often overfiow its banks, doing much injury to the borderirg plantations of corn, cotton, and rice. The losses, from overflow, however, are confined to localities above the city, the plantations below being but little ex posed to injury from like causes.

The Savannah r, near the mouth, becomes a tidal stream, and the flood-tides, in ordinary stages of the river, ascend to a point about $45 \mathrm{~m}$. from the ocean, or $28 \mathrm{~m}$. above the city of Savannah.

SAVERN, p. o., Owen co., Ky. : 47 m. N. Frankfort.

SAvIN HILL, sta., Norfolk co, Mass.: on the Old Colony Railroad, $8 \mathrm{~m}$. S. Boston.

Savona, p. o. and sta., Steuben co., N. $\boldsymbol{F}_{\text {.: }}$ on the Buffalo, Corning, and New York R. R., $13 \mathrm{~m}$. N.W. Corning, $315 \mathrm{~m}$. N. W. (by railroad) New York City, and 185 miles (direct) W. by S. Albany.

SAfox, t. and p. v., Berkshire co, Brass, $103 \mathrm{~m}$. W. by N. Boston. Drained by branches of Hoosick, Deerfield, and Westfield rivers. Surface mountainous and uneren; soil better adapted to grazing than tillage. Incorporated in 1797. The $v$. is at the confluence of two streams, which constitute the head waters of Westfleld r. Pop. of t. 955 .

SAw Mul, p. v., Dale co., Ala.: between the $\mathrm{E}$. and W. branches of Choctawhatchee r., S4 m. S. E. Montgomery.

$\mathrm{S}_{\Delta \mathrm{W}}$ MrLu river, Westchester co., N. I. $\therefore$ rises in Newcastle t., flows S. by W., and enters the Hudson r. at the $\mathrm{v}_{\text {. }}$ of Yonkers. Several mills and factories are located on its banks.

SAWYER's Mills, p. v., Lexington dist., S. Car.: on a head branch of North Edisto r., $39 \mathrm{~m} . \mathrm{S}$. W. Colnmbia 
SAwyerstille, p. 0., Randolph co., $N$. Car.: $67 \mathrm{~m} . \mathrm{W}$. Raleigh.

Sajenburg, p. v., Butler co., Penn.: 155 m. W. N. W. Harrisburg.

SAzE's Mulz, p. v., Franklin co., Verm.: on the E. of Mississquoi bay, $57 \mathrm{~m}$. N. W. Montpelier.

SAxonville, p. v., Middlesex co., Mass. : on the left bank of the Sudbury r., $18 \mathrm{~m}$. W. Boston. It is the terminus of the Saxonville branch of the Boston and Worcester R. P $5 \mathrm{~m}$. N. of junction at Natick.

SAxToN's RIver, p. v., Windham co., Term. : on left bank of Saxton's branch of Connecticut $r, 8 \mathrm{~m}$. $\mathrm{S}$. Montpelier.

SAxTON's river, Verm.: formed by the union of several streams in Grafton, and running in an E. direction about $10 \mathrm{~m}$., through the S. part of Rockingham, falls into Connecticut $r$. about $1 \mathrm{~m}$. below Bellows Falls.

SAxвroor, t., p. v., and sta., Middlesex co., Conn.: on W. side of Connecticut $r_{\text {, }}$, at its mouth, $36 \mathrm{~m}$. S. S. E. Hartford, and by New Haven and New London R. R., 31 m. E. New Haven. Surface uneven and stony; soil moderately fertile. Drained by the Connecticut and several creeks. Its interests in navigation are much affected by the bar at the mouth of the $\mathbf{r}$, from which its harbor sets up. At this place the river is not frozen in winter. A ferry crosses it to Lyme. Considerable ship-building is carried on, and several vessels are employed in the coasting trade. The shad fishery in the spring is diligently prosecuted, and is a source of considerable wealth, while large quantities of other fish are taken throughout the year. The $\mathrm{v}$. at the point was first settled in 1635. It contains 2 churches, and was once the location of Yale College. In the N. part of the $t$. is the flourishing v. of Essex. Pop. of t. in 1840,3,417; in 1850 , 3,848 .

SAYBRook, t., p. V., and sta, Ashtabula co., Ohio: near Lake Erie, $169 \mathrm{~m}$. N. E. Columbus. Drained by two smal streams flowing $\mathrm{N}$. into the lake. The village is centrally situated. The Cleveland and Erie R. R.passes through the N. of t., on which is the sta., $50 \mathrm{~m}$. N. E. Cleveland. Pop of t. 1,374 .

Satiorsburg, p. o., Monree county, Penn. : 95 m. N. E Harrisburg.

Saylorville, p. v., Polk co., $J a_{\text {. : }}$ on a cr. flowing into the Des Moines r., 108 m. W. Iowa City.

Saxville, p. v., Suffolk co., N. Y. : near Great South bay, $51 \mathrm{~m}$. E. New York city, and $145 \mathrm{~m}$. S. E. Albany.

Soarborndgr, p. v., Seriven co., Gan: on the Central (Georgia) R. R., E. side of Ogeechee r., 70 m. N. W. Savannah, and $91 \mathrm{~m}$. E. S. E. (direct) from Milledgeville.

ScARBoRodGH, t., p. V., and sta., Cumberland co., $M e^{\text {. }}$ between Saco and Portland, and bordering on the Atlantic Ocean, $61 \mathrm{~m}$. S. W. Augusta. Drained by Nonsuck river, flowing through it; soil rich, and it has large quantities of salt marshes. It is principally an agricultural t, but shipbuilding is carried on to some extent, and several ressels are employed in the coasting trade and fisheries. The distinguished statesman, Rufus King, and his half-brother, William King, the first governor of Maine, were born in thi town. The $\mathrm{v}$, is on the Portland, Seco, and Portsmouth Railroad, 45 m. N. E. Portsmouth (N. H.). Population of t. 1,837.

Scarsdare, t. and p. V., Westchester co., $N$. $Y$.: $133 \mathrm{~m}$ (by railroad) S. Albany. Drained by Bronx river. Surface rolling; soil fertile. The Harlem R. R. passes through the $\mathrm{t}$, on which the $\mathrm{v}$. is located, $22 \mathrm{~m}$, from New York city. It is a small but neat $\mathrm{v}$., with 312 inhabitants.

Schaghticoke, to and p. v., Rensselaer co., N. $Y_{0}: 9 \mathrm{~m}$ N. Troy, and $16 \mathrm{~m} . \mathrm{N}$. by E. Albany. Drained by Tomhanic creek and Hoosic river, flowing into the Hudson, which bounds it on the W. Surface moderately uneven; soil fertile. It has extensive water-power, and a number of manufactories, mills, etc. The $\mathbf{v}$, is located on Honsic r., $\mathbf{E}$. of the Hudson, and is a thriving manufacturing place; cotton, linen, and hemp goods, powder, and powder kegs are 776 largely manufactured. The Troy and Boston T. R. passes through, and the Troy and Rutland $R . R$. diverges from this r., $12 \mathrm{~m}$, from Troy. Pop. of t. 3,290.

Soratruestille, Berks co., Penn.: here are located four forges, two of which (in 1850) made 250 tons blooms and 80 tons bar iron ; moved by water-power.

Scheltsbera, p. v., Bedford co., Penn. : $91 \mathrm{~m}$. W. by \$. Harrisburg.

SCHENECTADY county, $N$. $Y$. Situate toward the E., and contains 186 sq. m. Drained by Mohawk river and Scho hariekill and Normanskill. Surface diversifed, with low hills and valleys; soil various, but fertile in general, particularly so along the banks of the Mohawk r. Chief products wheat, Indian corn, and potatoes. Agricultural pursuits are much followed by the inhabitants. It contains some minerals, and has good slate quarries. Farms 1,040 manuf. 107 ; dwell. 3,195 , and pop.-wh. 19,667, fr. col. 387 total 20,054. Capital: Schenectady. Public Works: Central R. R. ; Schenectady and Saratoga R. R.; Troy and Schenectady R.R.; Erie Canal.

SCHENECTADY, p, city, and cap. Sehenectady co., $N . Y$. ort S. side of Mohawk r., 17 m. N. W. Albany. Lat. 42048 N.; long. $73^{\circ} 55^{\prime} \mathrm{W}$. This is one of the oldest cities in the State, having been first settled by the Dutch about 1620 and chartered March 26, 1798. On February 8, 1690, the v. then consisting of 63 houses and a church, was taken a night by the French and Indians, sacked and burned, who murdcred 63 inhabitants and took 27 captives. The city contains a city hall, and jail, county offices, market, lyceum, female academy, and 10 churches. Its manufactures are considerable, chiefly of flour, paper, cotton goods, iron leather, and machinery. One broom factory in the vicinity makes annually about $1,800,000$ brooms. There are 2 banks, with aggregate capital of $\$ 315,000$, and 1 savings bank. The Erie Canal passes through the city, and 4 lines of ruil road here connect, viz., Albany and Schenectady R. R., 17 m.; Troy and Schenectady R. R., 20 m.; Saratoga and Schenectady R. R., $22 \mathrm{~m}$.; Utica and Schenectady R. R. $78 \mathrm{~m}$. The "S. Cabinet" (whig), and "S. Reflector" (dem.) are issued weekly. Union College, located here, was founded in 1795 , is pleasantly situated on an eminence overlooking the city, with spacious grounds and several large edifices. In 1850 it had 12 professors, 2,725 alumni, 266 students, and 15,000 volumes in its library. Pop. in 1840 , 6.784 ; in $1850,8,921$.

Schenevus, p. o., Otsego co., N. Y.: $72 \mathrm{~m}$. W. Albany.

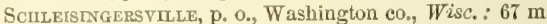
N. E. Madisun.

Schnecksville, p. 0., Lehigh co., Penn.: $10 \mathrm{~m}$. N. E. Harrisburg.

Scrod Ack, to Rensseleer county, $N . Y_{0}: 8$ miles $\mathrm{S}$. by $\mathrm{E}$. Albany, Drained by several small streams flowing into the Iudson river, which bounds it on the W. Surface uneven soil fertile. Its water-power is good, and there are some mills, etc. Schodack Centre, Schodack Depot, and Schodack Landing, are names of post-offices. The Hudson River $\mathrm{I}_{\text {. }} \mathrm{R}_{\text {., }}$ and Western $\mathrm{R}$. R. both pass through this town. Pop. 3,510.

Scrodack Centre, p. o., Rensselear co., $N . Y .:$ is a small settlement $7 \mathrm{~m}$. S. E. Albany.

Scחodack DEpôt, p. $\nabla$. and sta., Rensselaer co., $N$. $Y_{\text {. }}$ on the Western R. R., $8 \mathrm{~m}$. N. Kinderhook, and $8 \mathrm{~m}$. S. E. Albany.

Scrodack LANDING, p. v, and sta, Rensselaer co., $N$. $Y$. on the left bank of the Hudson r., and on the Hudson River R. P., 64 m. N. Poughkeepsie, $11 \mathrm{~m}$. S. Albany. It contains several stores, warehouses, and a hay press; and a number of sloops are owned here which ply between the $\mathrm{v}$. and New Tork.

Schoeneck, p. o., Lancaster county, Penn. : 35 m. \$. E. Harrisburg.

Sciomarie county, $\lambda$. $\Gamma$. Situate toward the F., and contains $621 \mathrm{sq}$. m. Drained by Schoharie cr. and its tribut- 
aries. Surface generally mountainous, and well adapted to grazing. The main branch of the Catskill Mountains cross the S. portion of the co, ; soil fertile, and on the streams the Iand is productive. Chief productions, wheat and Indian corts. It has some beds of bog-iron ore, and water limestone. Sulphur springs are found in different parts, which are gaining celebrity, particularly those at Sharon. Farms 2,439; manuf, 213 ; dwell. 5,578. and pop.-wh. 33,092, fr. col. 450-total 33,512. Capital: Schoharie. Public Works: Newburg and Syracuse R. R. (projected).

Schoharie, t., p. v., and cap. Schoharie co, $N$. $Y_{\text {. }}: 28 \mathrm{~m}$. W. Albany, Drained by Schoharie ereek, which passes through it fom N. to S., and Fox creek, affording excellent water-power. Surface various, in parts billy, with extensive valleys; soil of great fertility, and well cultivated. The v. is located on the right bank of the creek so called, and contains a court-house, jail, and other public buildings, an incorporated academy, and other places of instruction; printing offices, mechanic shops, etc, and the "S. Republican" (whig), and "S. Patriot" (dem.) are both weekly issues, Pop. of t. 2,5ss.

Scroonic lakes, $M e_{\text {e }}$ : these lakes are about twelve in number, lying in the $\mathrm{N}$. part of Washington $\mathrm{co}_{\text {, }}$, and from thence issues the Schoodic $c r$. W. branch of St. Croix $r$. The most E. of these is Big lake, of irregular form, about $9 \mathrm{~m}$. long, connected by a rapid stream 3 miles long, with Grand lake, 15 miles long, very deep, and remarkably clear. It is well stocked with fish. The other are on the S. W., Pocumeus, 4 miles long, and the $\mathrm{W}$ aboosis $3 \mathrm{~m}$. long. In a $\mathrm{W}$. direction lies the Siclabobsis, 10 miles in extent, and farther $\mathrm{N}$. is the Horse-shoe lake, so called from its form, and also the Junior lake, 6 miles long. Still farther on is Scraggled lake, of an irregular shape; also the Pleasant lake, 5 miles long, with some others of less size. They are all connected by considerable sized streams, and except between the Big and Grand lakes, there is a continuous boat navigation of nearly 100 miles in extent. The surrounding country is very fertile and well wooded.

Schoolcliart county, MFich. Situate centrally in the $\mathrm{N}$. peninsula, and contains 2,516 sq. m. Drained by the Monistique river and its branches, White Fish and Rapid rivers, and other streams. Surface in the interior level, on the lake shore rocky; soil various. Pine and other timbers abound. Farms 0; manuf. 0; dwell. 5, and pop.-wh. 16, fr. col. 0-total 16. Cupitul:-

Schoolcrafr, t. and p. V., Kalamazno co., Mich. : $66 \mathrm{~m}$. S. W. Lansing. Watered by a number of ponds, the outlets of which form in part the head waters of a branch of St. Joseph's river. It is a rich and fertile farming country, with good mill privileges. The v. near the centre of Prairie Ronde is a thriving place, and contains about 300 inhabitants. Pop. of t. 1,101.

Schooley's Mountain, p. ₹., Morris co., N. Jer. : $43 \mathrm{~m}$. N. Trenton. The spring located near the top of the mountain has a temperature of $56^{\circ}$ Fahrenheit, and discharges 30 gallons an hour. The region abounds with magnetic iron ore. In the neighborhood of the springs are well kept hotels, boarding schools, etc, and 7 miles farther on the mountain is Budd's Pond, 2 miles long and 1 broad, of great depth, and abounding with fish.

Schoolex's mountain, Morris co., $N$. Jer. : forms a part of a chain which extends in a N. E. and S. W. direction across the State, from the Delaware to the Hudson river. It crosses the N.W. part of the county with a height of 600 feet from its base, and about 1,100 feet above the level of the ocean. A mineral spring near its top has given it considerable celebrity.

Sciradeveurg, p. o., Bergen en., $N$. Jer.: on a creek of Hackensack r., 59 m. N. E. Trenton.

Schroepex, t., Oswego county, $N . Y .: 139 \mathrm{~m} . \mathrm{W} . \mathrm{N}$. W. Albany. Drained by Oneida and Oswegn $r$, the latter bounding it on the $\mathrm{S}$. W. Surface uneven; soil fertile. It has some small manufactures and several mills. Phoenix is the name of the post-office. Population of town, including Phoenix, 3,259.

Schroon LaKe, p. 0., Essex co, $N_{.} Y_{*}: 80$ m. N̈. Albany. Scuroon lake, $N$. $Y$.: lies partly in Essex county, and partly in Warren co. : it is 10 miles long, and from one to two in width, abounding with trout and other kinds of fish. Deer and wild gitme are found in abundance on its borders, which in the E. are surrounded by a dense forest.

Sorroon River, p. 0., Essex co., N. Y.: 77 m. N. Albany. Schultzsville, p. O., Duchess county, $N$. $Y$.: 63 m. S. Albany.

Schumla, p. o., Ritchie county, Virg.: 228 m. N. W. Richmond.

ScIuYLER county, $I l l$. Situate toward the W., and contains 384 sq. m. Drained by Sugar, Crane, and Crooked creeks, all tributaries of Illinois $r$, which runs on its S. E. border. Surface undulating; soil fertile. Chief productions, wheat and Indian corn. Pork and beef are largely exported. It is well wooded. Farms 624; manuf. 52; dwell. 1,783, and pop.-wh. 10,547, fr. col. 26-total 10,573. Cupital: Rushville

SoHUYLER county, Mo. Situate N., and contains 35 I sq. m. Drained by North, Middle, and South forks of Fabius $r$., and branches of Chariton creek. Surface undulating; soil fertile. A large portion of the land is well timbered. Farms 446 ; manuf. 5 ; dwell. 539, and pop.-wh. 3,230 , fr. col. 2 , sl. 55-total 3,287. Capital: Lancaster.

Schuyler, sta., Sangamor co., Ill.: on the Sangamon and Morgan R. R., 9 m. W. Springfield.

SchuYler's Faris, t, and p. o., Clinton co., N. Jer. : $5 \mathrm{~m}$. W. by S. Plattsburg, and $139 \mathrm{~m}$. N. Albany. The Saranac r. bounds it on the N., and it is drained by Salmon cr., affording extensive water-power. Surface in parts hilly; soil fertile. It has some extensive manufactories, and the surrounding country is rich in agricultaral and mineral productions. Pop. 2,110.

SchurleR's LAKE, p. o., Otsego co., $N . Y_{.}: 74 \mathrm{~m}$. W. by $\mathrm{N}$. Albany.

Schurlersvmue, p. ., Saratoga co., $N$. $Y$.: on the W. bank of the Hudson r., at its confluence with French cr. $7 \mathrm{~m}$. E. Saratoga Springs, $36 \mathrm{~m}$. N. Albany. Ineorporated in 1831. The Champlain Canal passes through, and, with the cr., furnishes extensive water-power. It is a thriving manufacturing village, containing cotton and woolen fuctories, iron foundries, machine shops, mills, etc. The British arms, under Burgoyne, sustained a defeat at Bemis' Heights, near this place, on the 17th October, 1777, by the Americans, under General Gates. The Schuylersville academy, an incorporated institution, is located in this $\mathrm{v}$. The "Old Saratoga" (neut.) is a weekly issue.

SchurLmill county, Penn. Situate E. centrally, and contains 684 sq. m. Drained by Schuylkill $r$, and its affluents, and small tributaries of Susquehanna $r$. Surface varied; on the streams there is some fine land, but the general feature of the co. is mountainous; soil, with the exception of the river bottoms, is poor and barren, and in many parts rocky. It contains extensive beds of mineral coal, which are much celebrated for their quality. Farms 1,247 ; manuf. 954 ; dwell. 10,671, and pop.-wh. 60,307, fr. col. 406-total 60,713. Capital: Orwigsburg. Public. Works: Philadelphia and Reading R. R. ; Catawissa R. R.; Little Schuylkill $R$. $R_{*}$; and a number of railroads extending to the mines; also Schuylkill Canal.

Schurlkml, t., Schuylkill county, Penn.: 55 m. N. E. Harrisburg. This is an extensive coal district, and the capital invested in the coal trade during the fiscal year 1950 was $\$ 133,815$, monthly wages paid, $\$ \$, 570$, annual product of the mines, $\$ 119,000$, valued at $\$ 231, \$ 00$. A railroad connects this place with the Mine Hill R. R., at Schuylkill Haven.

Scrurlikil, t. and p. o., Chester co, Penn.: on the W. side of Schuylkill r., $70 \mathrm{~m}$. E. Harrisburg. Drained by French and Stoney creeks. Surface level; soil fertile. The Philadelphia and Reading R. R. passes through its E. part. 
Schidenck's Store, p. O., Montgomery co., Penn.: 83 m, E. Harrisburg.

SchurL.kILl river, $P a$. : rises by three branches in Schuylkill co., and flowing $\mathrm{S}_{\text {. }} \mathrm{E}_{\text {., }}$ enters the Delaware $\mathrm{r}, 7 \mathrm{~m}$, below Philadelphia. Its length is $140 \mathrm{~m}$. The most important of its tributaries are Tulpehocken $\mathrm{cr}$. from the $\mathrm{W}$., and Perkiomen cr. from the E. Vessels of from 300 to 400 tons ascend to the W. wharves of Philadelphia, where its arerage depth at common tides is from 13 to 14 feet. By means of canals and pools, it is navigable $105 \mathrm{~m}$. An immense quantity of enal is transported on it.

Schicleill Bexd, p. o., Berks county, Penn.: 49 m. E. Harrisburg.

Schurleml Haven, p. v., Schuylkill co., Penn.: near the Schuylkill $r_{\text {, }}$ and on the Philadelphia and Reading $R$. R., $89 \mathrm{~m} . \mathrm{N}$. W. Philadelphia, and $43 \mathrm{~m} . \mathrm{N}$. E. Harrisburg. It is connected with the coal region in the vicinity by the Mine Hill $R, R_{\bullet}, 12 \mathrm{~m}$. Tremont, and with Philadelphia and Port Carbon by the Schuylkill Navigation Canal. A furnace of 800 tons annual capacity, operated by water-power, is located near the village. The " $\mathrm{S}$. H. Map" is a weekly whig issue. Pop. 2,061 .

Sorexcevtlue, p. 0., Stewart co., Ga.: 107 m. S. W. Milledgeville.

Scro, t. and p. v., Washtenaw co., Mich.: 45 m. S. E. Lansing. Drained by Huron r., Honey and Mill creeks, Surface undulating; soil very prolific, generally black, sandy loam, and clay. There is a great variety of excellent timber in the t. and vicinity. The Michigan Central R. R. passes through the $\mathrm{N}$. part, on which is Delhi station, $41 \mathrm{~m}$. W. Detroit. The $\mathrm{v}$. is $2 \mathrm{~m}$. S. of the R. R. Pop. of t. 1,195.

Scro, t., p. V., and sta., Alleghany county, $N_{.} Y_{0}: 148 \mathrm{~m}$. W. by S. Albany. Drained by Geneseer., and branches of the Alleghany r. Surface much broken, and heavily timbered; soil fertile. It has good water-power, and some mills. The v, and sta. are on the Erie R. R., $361 \frac{1}{2} \mathrm{~m}$. from New York and $98 \div \mathrm{m}$. from Dunkirk. Pop. of t 1,924.

Scro, p. o., Harrison county, Otico: 99 m. E. by N. Columbus.

Scrots, p. o. and sta., Clinton co., N. $Y$.: on the Plattsburg and Montreal R. R., $15 \mathrm{~m}$. N. Plattsburg, $157 \mathrm{~m}$. N. Albany.

Scroro county, Ohio. Situate S., and contains 504 sq. m. Seioto $r$. passes through it centrally, by which and its branches, and by. Little Scioto $r$. it is drained. Surface in general uneven; soil fertile, and on the streams very productive; wheat and Indian corn are the principal productions. It is bounded on the S. by the Ohio. Farms 751 ; manuf. 73 ; dwell. 3,086 , and pop.-wh. 1S,174, fr. col. 251 total 18,428. Capital: Portsmouth. Public Works: Scioto and Hocking Valley R. R.; Iron R. R.; Ohio Canal.

Scroto, p. o., Scioto co., Ohio: $78 \mathrm{~m}$. S. by E. Columbus. Scютo river, Ohio: rises in Hardin county, flows E, into Narion co., and S. into Franklin, where it receives Whetstone or Olentangy r. just above Columbus, and thence throush Pickaway, Lits. Prike, and scrinto cors, into the Ohio r. at Portsmouth, where it is 150 yards wide. It flows 160 miles through a fertile country, and is narigable $180 \mathrm{~m}$., to the mouth of Little Seioto river.

Scioto Bridge, p. o., Delaware co., Ohio: on the Sciotor. $24 \mathrm{m.}$. . . W. W. Colum! us.

Scrotovilus, p. o., Scioto county, Ohio: $80 \mathrm{~m}$. S. by E. Columbus.

Scrpio, p. v., Jennings co., Ind.: on Sand cr., and on the Madison and Indianapolis R. R., $55 \mathrm{~m}$. S. S. E. Indianapolis. It is located in an agricultural district, and much produce is exported from this point. Pop. about 200.

Scrpio, to and p. v., Caruga co, N. $Y_{*}: 149 \mathrm{~m} . \mathrm{W}$. by N. Albany. Drained by Salmon cr., flowing S, into Cayuga lake, and other smaller streams. Owasco lake forms its E. boundary. Surface undulating, with a fertile and highly cultivated soil. 'The $\mathrm{v}$. is near the head of Salmon cr., and has some manufactures, mills, etc. Pop. of t. 2,135.
Scrpio Centre, p. o., Hillsdale county, Afichn : $51 \mathrm{~m} . \mathrm{s}$. Lansing.

ScIPIoviLle, p. o., Cayuga co., $N . \bar{Y} .: 150 \mathrm{~m}$. W. by $\mathrm{N}$. Albany.

Scrtico, p. V., Hartford county, Conn.; on the N. side of Scautic r., $18 \mathrm{~m}$. N. by E. Hartford.

Scituate, to and p. v., Plymouth co., Mass.: on Massa chussets bay, of the Atlantic Ocean, 15 m. S. E. Boston. It is located at the mouth of North $r_{n}$, and has a small but convenient harbor, defended by rocky cliffs, and Cedar Point, on which latter are two lighthouses, with fixed lights 40 feet elevation. Latitude $42^{\circ} 12^{\prime} 17^{\prime \prime} \mathrm{N}$., and longitude $70^{\circ} 43^{\prime} 15^{\prime \prime} \mathrm{W}$. The river is very deep, but narrow and erooked, and is noted for the fine ships built on its borders. A number of vessels belonging to this town are engaged in the merchant service and coasting trade, and the mackerel fishing is carried on to a great extent. The manufactures consist of leather, boots, shoes, lasts, vessels, etc. The $r$, is located a short distance back from the har bor. Pop. of t. 2,149.

Scituate, t. and v., Providence co., R. I.: $10 \mathrm{~m}$. W. of Providence. Drained by Pawtuxet river and its branches, affording valuable water-power. Surface diversified with hills and valleys; soil adapted to grazing. Large manufactories of cotton and wool are located on the bank of the river, and there is a valuable quarry of freestone in the western part of the town. This town was taken from Providence in 1731. The $\mathrm{v}$, is on Pawtuxet river, Pop. of t. 4,582 .

Sconondos, p. o., Oneida co., N. Y.: $171 \mathrm{~m} . \mathrm{W} . \mathrm{N} . \mathrm{W}$. Albany.

Scoobes, p. O., Kemper county, Miss.: 90 m. E. by N. Jackson,

Scotch Platrs, p. v., Essex county, N. Jer.: on the E. side of Green brook of Raritan r., and on the New Jersey Central R. R., 12 m. W. Elizabethport, and 35 m. N. E. Trenton.

Scotcr RIDGe, p. o., Wood county, Ohio: 97 m. N. N. W. Columbus.

ScotchtowN, p. o., Orange co., $N_{.} Y_{.}: 8 \pi \mathrm{m} . \mathrm{S} . \mathrm{S} . \mathrm{W}$. Albany.

Scotia, p. v., Pope county, Ark.: on the left bank of the Arkansas r., $69 \mathrm{~m}$. N. W. Little Rock. Coal deposits are found in the viciuity.

Scotis, p. v., Schenectady co., $N$. Y.: on the N. bank of Mohawk r., $1 \mathrm{~m}$. W. Schenectady, and $18 \mathrm{~m}$. N. W. Albany. Pop. about 200 .

ScotLard county, Mro. Situate N. E., and contaius $477 \mathrm{sq}$. m. Drained by North and Middle forks of Fabius r., and $\mathrm{S}$. Tyaennda $\mathrm{r}$. Surface level; soil fertile. It is well timbered, and has excellent pasturage for cattle. Farms 384 ; manuf. 6 ; dwell. $5 \mathrm{ss}$, and pop.-wh. 3,631 , fr. col. 0 , sl. 151total 3,TS2. Capital: Memphis.

Scotıard, p. o., Franklin county, Penn.: 50 m. S. W. Harrisburg.

Scotland, p. v., Windham co., Conn.: on the Showtucket r., 31 m. E. Hartford.

Scotland, p. v., Jefferson county, Miss.: 65 m. S. W. Jackson.

Scotlaxd, p. T., Greene county, Ind.: 60 m. S. W. Indianapolis.

ScothaNd, p. o., York co., Me. : 81 m. S. W. Augusta.

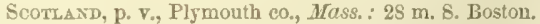

ScotLasd NECK, p. v., Halifax county, N. Car: between Fishing cr. and Roanoke r., $77 \mathrm{~m}$. N. E. Raleigh.

ScoTr county, $A r k$. Situate W., and contains $931 \mathrm{sq} . \mathrm{m}$. Drained by La Fare r., and other tributaries of Arkansas river. Surface level; soil fertile. Farms 365 ; manuf. 10 dwell. 514, and pop.-wh. 2,920, fr. col. 17, sl. 146-total 8,083. Capital: Booneville.

Scort county, Ia. Situate E. toward the S., and enntains $445 \mathrm{sq} . \mathrm{m}$. Drained by Walnut, Allen's, and Duck creeks. Surface rolling; soil fertile and very productive. Farms 851 ; 
manuf. 19; dwell. 991, and pop.-wh. 5,972, fr. col. 14total 5,986. Capitel: Davenport.

Scotr county, Ill. Situate toward the W., and contains $261 \mathrm{sq} . \mathrm{m}$. Drained by small tributaries of Illinois r., which forms its western boundary. Surface undulating; soil fertile. Wheat and Indian corn are produced abundantly. Pork and beef are exported. Prime timber abounds. Farms 712 ; manuf. 54 ; dwell. 1,300, and pop.-wh. 7,902, fr. col. 12total 7.914. Capitcl: Winchester. Public Works: Great Western Central R. R.

Scutr county, Int. Situate S. E., and contains 175 sq. m. Drained by Graham's fork of White $r$, and branches. Surface varied, it is most generally undulating, but in the W. is hilly and broken; soil fertile, and well adapted to grain and grazing. Chief productions, wheat, and Indian corn, with beef, pork, and regetables. It has some quantity of good timber, and contains several salt springs. Farms 719 ; manuf. 14; dwell. 1,040, and pop.-wh. 5.870, fr. col. 15total 5,\$S5. Capital: Lexington, Public Works: Jeffersonville R. R.

Scotr county, $\bar{K} y$. Situate toward the S., and contain 213 sq. m. Drained by North, Elkhorn, and Eagle creeks, Surface level; soil very fertile. Chief productions, wheat and Indian corn. Farms 758; manuf. 59; dwell. 1,566, and pop,-wh. 8,891, fr. col. 219, sl, 5,836-total 14,946. Capital: Georgetown.

Scort county, Dfiss. Situate centrally, and contains $559 \mathrm{sq} . \mathrm{m}$. Drained by branches of Pearl and Leaf rivers. Surface level; soil fertile, and adapted to grazing. Chief productions, cotton and Indian corn. Farms 257; manuf. 4 ; dwell. 422, and pop. - wh. 2,77s, fr. col. 1, sl. 1,182total 3,961. Capital: Hillsboro'. Pullic Works: Alabama and Mississippi R. R.

Scotr county, Mo. Situate S. E., and contains 379 sq، m. Drained by James and White Water rivers. Surface diversified; soil very fertile, and produces in abundance wheat and Indian corn. Tobacco is the staple. It contains many minerals. Farms 408; manuf. 9 ; dwell. 500, and pop.wh. 2,773, fr. col. 16, sl. 393-total 3,182. Capital Benton.

Scotr county, Virg. SituateS. W., and contains $718 \mathrm{sq} . \mathrm{m}$. Drained by Clinch r., and North fork of Holston r., and their branches. Surface broken and billy, in parts mountainous; soil moderately fertile. Chief productions, wheat and Indian eorn. Farms 614; manuf, 32 ; dwell. 1,523, and pop.-wh. 9,325, fr. col. 31, sl. 473-total 9,\$29. Capital. Estillville.

Scott, to and p. o., Sheboygan co,, Wisc, : $61 \mathrm{~m}, \mathrm{~N}$. E. Madison. Drained by branches of Milwaukee r. Surface varied; soil fertile. It has excellent water-power, and some excellent mill-sites.

Scotr, p. v., La Grangre county, Ind.: on the S. side of Pigeon r., $136 \mathrm{~m}$. N. by E. Indianapolis.

ScoTt, t. and p. v., Cortlandt co., $N . Y_{.: 22} \mathrm{~m}$. S. from Svracuse, and $130 \mathrm{~m}$. W. Albany. Drained by branches of Tioughnioga $r_{\text {., }}$ and the inlet of Skaneateles lake. Surface various, in parts much broken; soil very fertile, and in good state of cultivation. Its manufactures are limited, the chief pursuits being agricultural. The $\mathrm{v}$. is centrally situate. Pop. of t. 1,290.

ScotT, p. 0., La Salle county, Ill.: 120 m. N. N. E. Springfield.

ScotT, t. and p. o., Adams county, Ohio: $67 \mathrm{~m}$. S. by W. Columbus. Drained by a branch of Brush cr. Surface uneven; soil of average fertility. Iron ore of superior quality is found. Pop, 1,270 .

ScotT, p. Y., Mahaska county, Ia.: 69 m. W. S. W. Iowa City.

Scort, t. and p. o., Wayne co., Penn.: 130 m. N. E. Harrisburg. Drained by several small streams flowing $\mathrm{E}$. into the Delaware r., and W. by Starucea cr., branch of the Susquehanna r. Surface uneven, in parts hilly; soil fertile and good timber lands.
Scotr's creek, Calif.: rises in E. part of Yuba co., and flows $W$. into the Yuba $r$. Much gold is found in this stream, and the diggings are very profitable.

Scotrsberge, p. 0., Livingston co., N. Y.: $209 \mathrm{~m}$. W. Albany.

Scotrsburgh, p. v., Halifax co., Virg. : on the line of the Pichmond and Danville R. R., $87 \mathrm{~m}$. S. W. Pichmond. It is a small v., with about 50 or 60 inlabitants.

Scotx's CréEK, p. v., Haywood co., N. Car.: on a stream so called of Tuckascoge r., $258 \mathrm{~m}$. W. by S. Raleigh.

Sсотт's HiLl, p. o., Headerson co., Tenn.: 97 m. S. W. Nashville.

ScotT's Sirop, sta., Amelia co., $\nabla a$. ; on the Richmond and Danville R. R., 33 m. S. W. Richmond.

ScotTsville, p. v., Bibb co., Ala. : on a tributary of Cahawba branch of Alabama r., $69 \mathrm{~m}$. N. W. Montgomery. Good water-power is here afforded, and improved by the Tuscaloosa Manufacturing Company, who employ about 90 operatives. There is also a grist and saw mill, and a church, on the property of the company. Population about 200.

Scortsville, p. o., Claiborne par., La.: $169 \mathrm{~m} . \mathbb{N}$. W. Baton Rouge.

ScotTsville, p. V., Sullivan con, Mo.: on the E. side of Locust er., $117 \mathrm{~m}$. N. W. Jefferson City.

Scotrsville, p. v., and cap. Allen co., Ky. : on a fork of Big Barren r., 121 m. S. W. Frankfort, and contains a courthouse, jail, and other public buildings. The Lexington and Nashvilie R. R. passes through the village. Pop. 400 .

Scottsville, cap. Powhatan county, Virg. (See PowHataN C. H.)

Scottstille, p. v., Albemarle co., Firg. : on the N. bank of James r., and on the James River Canal, $73 \mathrm{~m}$. W. by N. Richmond. "The Independent" is a weekly issue.

ScotTstrLe, p. Y, Monroe co, $N$. $Y$ : on the left bank of the Genesee r., and on the Genesee Valley Canal, $12 \mathrm{~m}$. S. by W. Rochester, and $212 \mathrm{~m}$. W. by N. Albany. Exiensive hydraulic power is derived from the canal and river, and it has a number of mills, etc.

Scottspille, p. o., Wyoming co., Penn.: 95 m. N. N. E. IIarrisburg.

ScotTrmLe, p. v., Macoupin co., Ill.: on the S. of Apple cr., $33 \mathrm{~m}$. S. W. Springfield.

SCBarton, p. v., Luzerne co., Penn.: at the junction of the Lackawanna and Western R. R. with the Pennsylvania Coal Companies R. R., $50 \mathrm{~m}$. S. Great Bend, and $97 \mathrm{~m}$. N. N. E. Harrisburg. Cobb's Gap R. $R$. and a railroad to Sunbury will diverge from this place. There is near the $\mathrm{v}$. a furnace of 2,000 tons capacity, operated by water, and two of 3,500 tons each annual capacity, operated by steam, and a forge, which in 1830 produced 7,000 tons rail. Pop. 2,234. Screamerstilie, p. o., Maury co., Tenn.: 37 m. S. by W. Nashville.

ScribA, t, and p. v., Oswego co., $N . Y_{*}: 152 \mathrm{~m}, \mathrm{~N}$. W. Albany. Drained by a number of small streams flowing into Lake Ontario. Surface moderately hilly ; soil of middling fertility. It contains in part the county buildings. Old Fort Oswego, built in 1727 , is located near the mouth of the river. The $\mathrm{v}$, is $2 \mathrm{~m}$. E. of the lake; has good water-potver, and contains several mills, workshops, etc. Pop. of t. 3,70s.

SorIVEN county, $G a$. Situate E., and contains $i 18 \mathrm{sq} . \mathrm{m}$. It is bounded on the E. by Sarannah r., and on the S. and W. by Ogeechee r., by branches of which it is drained, Little Ogeechee r., passing through the centre, and Brier cr. in the northern portion. Surface undulating; soil fertile, and produces large crops of cotton, which is the staple. It has some minerals, and some fine timber land. Farms $49 \mathrm{~S}$ manuf. 0 ; dwell. 567, and pop.-wh. 3,173, fr. col.1, sl. S,673 -total 6,847. Capital: Jacksonboro?.

ScrogGrN's Minl's, p. o., Dale co, Ala : on the W. side of Pea r., $63 \mathrm{~m}$. S. E. Montgomery.

Scroggsfield, p. v., Carroll county, Ohio: $111 \mathrm{~m}$. N. E Columbus. 
Sorits Grass, p. o., Armstrong. county, Penn.: $135 \mathrm{~m}$. W. N. W. Harrisburg.

Scufflfirown, p. v., Laurens district, $S$. Car.: on a small tributary of Enoree r., $65 \mathrm{~m}$. N. W. Columbia.

Scull Camp, p. v., Surry co, N. Car.: at the source of Fisher's r., 187 m. W. N. W. Raleigh.

Scukl ShoAIs, p. v., Greene co., Ga.: on the Oconee r., $46 \mathrm{~m}$. N. Mulledgeville. Ponlain's bridge here spans the river, at which point several mills are in operation.

Sculltown, p. v., Salem co., N. Jer.: on the left bank of Oldman's cr., 46 m. S. W. Trenton.

Scotiock Porvт, Hancock co., Me. : a small cape situated in lat. $44^{\circ} 18^{\prime} \mathrm{N}$., and long. $67^{\circ} 58^{\prime} \mathrm{W}$.

Scuppermong, p. 0., Washington co., N. Car.: 113 m. E. Raleigh.

Searrook, to and p. v., Rockingham co., $N$. Hamp.: in the S. E. corner of the State, bordering on the Atlantic Ocean, 45 m. S. E. Concord. Drained by Black, Brown's, and Walton rivers, and several tributaries. Whale-boat building is carried on here to a greater extent than in any other town in New England. The inhabitants are occupied in mechanical pursuits and the fisheries. This $t$ is better adapted than any other in the State to the Bay and Labrador fisheries, which are extensively carried on. Bog iron ore is found on some of the streams. The Eastern $\mathrm{R}$. R. passes through the $t_{\text {. }}$ on which the $\mathrm{v}$. is located, $14 \mathrm{~m}$. S. from Portsmouth. Pop. of t. 1,296.

Seacocus, sta., Hudsun ca., N. Jer.: on the Union R. R., $4 \mathrm{~m}$. N. Jersey City, and $53 \mathrm{~m}$. N. E. Trenton.

SEAfolid, p. v., Sussex co., Det.: on W. side of Nanticoke river, $35 \mathrm{~m}$. S. by W. Dover.

Seal, p. o., Wyandott county, Ohio: $61 \mathrm{~m} . \mathrm{N}$. by W. Columbus.

Seat Cove, p. v., Hancock co., Mre. : at the head of the inlet so called, on Mount Desert island, $72 \mathrm{~m}$. E. Augusta.

SkA.rCY county, Ark. Situate N., and enntains 911 sq. m. Drained by Buffalo fork of White $r$ and Crooked er., a tributary of White r. Surface varied; in the N. it is level, or gently undulating, and in the S. hilly, being separated from the adjoining county by a low range of mountains; soil generally fertile, the hilly portions well adapted to graziug. Farms 246; manuf. 0 ; dwell. 322 , and pop.-wh. 1,950, fr. col. 0, sl. 29-total 1,979. Oupitul: Lebanon.

SEarcy, p. v., and eap. White co., Ark..: on the W. of Citlle Lien Lranch of th hite r., th m. N. N. E. Little Rock. It contains a court-house, jail, etc.

Sentigits's, p. o., Fayette county, Penn.: $143 \mathrm{~m}$. W. by S. Harrisburg.

Erariblig, p. o., Tompkins county, N. Y.: $160 \mathrm{~m}$. W. Alloany.

SeArsburg, t. and p. v., Bennington co, Term.: $52 \mathrm{~m} . \mathrm{S}$. Rutland. Drained by Deerfield r. Surface mountainous, being located on the Green Mountains, and in general unfit for cultivation. Chartered in $17 \mathrm{S1}$. The $\mathrm{v}$. is $\mathrm{S}$. of the $\mathrm{r}$. Pop. of t. 201.

Seargvont, to and p. ve, Waldo co, Mre: $31 \mathrm{~m}$. E. Augustr. Drained by St. George r., and a considerable pond is in N. part of t., from which flows a branch of the $r$. Surfice varied; soil fertile. The manufactures consist in leather, flour, and lumber. The $v$. is located on the St George $r$. Pop. of t. 1,696

Searsport, t. and p. v., Waldo co.. Me.: $45 \mathrm{~m}$. E. by N.

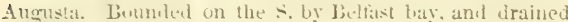
by a small stream flowing into it. Incorporated in 1545 , from Prospect and a part of Belfast. It has a good harbor. The $v$, is situated near the entrance of the stream into the the bav. Poll of t. 2.2ut.

Sfarstille, p. 0., Orange county, N. $Y: 81 \mathrm{~m} . \mathrm{S} . \mathrm{s} . \mathrm{W}$. Albany.

Searsville, p. v., Stewart co., Ga. : on Kacafoonee cr. 1(1.) m. \&. W. Millk laveville.

Seatuck, p. o., Suffolk eno, $N . Y_{.:}: 236$ m. S. E. Albany. Seaville, p. o., Cape May co., N. Jer.: 75 m. S. Trenton. 750
Sebago, t. and p. v., Cumberland co., Me.: bordering on the lake so called, $57 \mathrm{~m} . \mathrm{S}$. W. Augusta. There are several ponds in the t., by the outlets of which it is drained. Surfice pleasantly diversifled, and a fertile soil. Chartered in 1826, and contains several manufactories of flour, lumber etc. The $v$, is on the lake. Pop. of t. 850 .

Sebago lake, Cumberland co., Me.: is $12 \mathrm{~m}$. long, and $7 \mathrm{~m}$. wide. It discharges its waters by Presumpscot $\mathrm{r}$. into Casco bay. Connected on the N. by W. with Long Pond, by Songo strait, and receives Crooked $\mathrm{r}$. from the $\mathrm{N}$. The Cumberland and Oxford Canal, 501 $\mathrm{m}$. in length, connects it with Portland.

Sebastian county, Ark. Situate W., and containg 779 sq. m. Drained by affluents of Arkansas r., which forms its N. boundary, Surface unclulating, toward the W. hilly; soil fertile. It is well wooded, and in the $\mathrm{N}$. are some fine beds of coal, Capital: Black Jack.

Sebasticoor river, $M \theta_{\text {. }}$ : rises in a pond in the S. E. part of Penobscot co., passes through a lake in Newport t., and flowing S. W. empties into the Kennebec r. opposite Waterville. It is about $50 \mathrm{~m}$. in length, and affords in its course excellent water-power

SEBEC, t. and p. v., Piscataquis co., Mre. : $74 \mathrm{~m} . \mathrm{N} . \mathrm{N} . \mathrm{E}$. Augusta. A portion of Sebee Pond, $10 \mathrm{~m}$., lies in this t., and the Piscataquis r. crosses the S. part. Drained by Sebec r., outlet of the pond, which flowing S. E. empties into the Piscataquis r. in Milot. Surface moderately uneven; soil fertile, and well adapted to grain. Incorporated in 1812 . The manufactures consist in woolen goods, leather, lum-

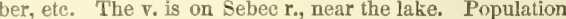
of $\mathrm{t} .1 .223$.

Sebec pond, Piscataquis co., Me.: lies in the towns of Sebec, Foxeroft, and Bowerbank; it is surrounded by a trell-timbered country, is about $10 \mathrm{~m}$. Iong, and averages about $1 \mathrm{~m}$. in width. Its ontlet is the river so called.

SEBEWA, t. and p. O. Ionia co., Mich. : $22 \mathrm{~m}$. W. Lansing. Drained by Looking-Glass r. Surface undulating; soil fertile. Pop. 2:7.

SERoors lakes, Penobseot co., Me : are ennnected sheets of water of irregular form, about $15 \mathrm{~m}$. in length, and from half a mile to one and a half in width, and constitute the hend waters of the E. branch of the Penobscot r. Seboois $r$ is the name of their outlet.

SECOND CreeE, p. v., Greenbrier co., Firg. : on a branch of Greenbrier r., $164 \mathrm{~m}$. W. Richmond.

SEDGWICK, t. and p. o., Hancock co., Me.: $5 \mathrm{~S}$ m. E. Augusta. It is on a peninsula having Blue Hill bay op the E. and separated from Deer island, on the S. by a strait. The soil is inferior, but sufficient produce is raised for its own people. It has good harbors, and considerable navigation. A number of vessels owned here are employed in the coasting and fishing trade, and ship-building is carried on to a considerable extent. Leather and lumber are the chief articles of manufacture. The $\mathrm{v}$. is on the bay so called, which makes up into the town. Pop. of t. 1,234.

SEEKONK, t. and p. v., Bristol co., Mfass.: 38 m. S. S. W. Boston. Separated from Rhode Island by Seekonk r., which bounds it on the W.; and Ten Mile cr. affords water-power. The v. of Pawtucket is partly in Seekonk. Seekonk v. is on Ten Mile cr., near its eonfluence with Providence $r_{\text {. }}$ and contains several factories, ete. Pop. of t. in $1840,1,996$, and in 1850, 2,244. The Boston and Providence R. R. passcs through the town.

Sfely CREeK, p. o., Chemung co., N. Y.: $170 \mathrm{~m} . \mathrm{W} . \mathrm{S} . \mathrm{W}$. Alliany.

SeElrsbtrg, p. T., Cattaraugus co., 1 . $Y$.: on a branch of Connewango cr., $275 \mathrm{~m}$. W. by S. Albany.

Seely's Statiox, p. o., Erie co., Penn.: 203 m. N. W. Harrisburg.

SEGO, P. O., Perry co, Ohio : $41 \mathrm{~m}$. E. by S. Columbus. SEGULY, D. $v_{\text {, }}$ and cap. Guadalupe co., Tex. : on the len bank of the Guadalupe r., $48 \mathrm{~m}$. S. Austin City. It contains the county buildings, etc. 
Sriberlivgrille, p. v., Lehigh co., Pern.: on a branch of Jordan cr., 65 m. E. N. E. Harrisburg.

Seisholtzville, p. o., Berks county, Penn.: 55 m. E. Harrisburg.

Sertzland, sta., York co, Penn. : on the Baltimore and Busquehanna R. R., 42 m. S. by E. Iarrisburg.

Selby, v., Bureau $c_{0}, M l_{\text {. }}$ : on the border of an extensive prairie, $4 \mathrm{~m}$. N. of the lllinois river, and $108 \mathrm{~m}$. N. by E. Springfield.

Selistsport, p. v., Alleghany co., $\boldsymbol{M} \boldsymbol{d}$. : on the W. side of Youghiogeny r., $3 \mathrm{~m}$. below the Pennsylvania State line, 154 m. W. N. W. Annapolis.

Selbitille, p. o., Sussex co., Del.: 33 m. S. Dover.

Selay's Grove, p. v., Union co., Penn. : at the junction of Penn's cr. with the Susquehanna r, $38 \mathrm{~m}$. N. Harrisburg. SELlek's point, Baltimore co., Md.: a narrow neck of Iand, projecting into Baltimore harbor, on the east side thereof.

Sellersburg, r. and sta., Clarke county, Ind.: on the Jeffersonville R. R., 9 m. N. Jeffersonville, and $93 \mathrm{~m}$. S. by E. Indianapolis.

Selma, p. v., Dallas co., Ala. : on the right bank of the Alabama r., $45 \mathrm{~m}$. W Montgomery. This $\mathrm{v}$, is pleasantly located, and has considerable trade. The "Selma Reporter" (whig) is a weekly issue. A company, known as the "Selma Manufacturing Company," has, under the supervision of J. P. Pesham, Esq., erected an establishment here for the manufacture of all kinds of iron work, from a steamengine down to a horse-shoe nail. Capital invested amounts to $\$ 22.000$; they have eight acres of land, affording plenty of room for enlargement. Selma is the most important $v$. on the $r_{.}$, and from this point large quantities of cotton are annually shipped. Two railroads, the Alabama and Tennessee River R. R. and the Alabama and Mississippi R. R. diverge from this place. Pop. about 1,200.

SELMA, p. $\nabla_{*}$ Jefferson co, Mo.: on the W. side of the Mississippi r., near the mouth of Plattin cr., $35 \mathrm{~m}$. below St. Louis, and $99 \mathrm{~m}$. E. by S. Jefferson City. It has a good landing. A shot factory is located here, and there is considerable trade carried on. Lead is extensively exported.

Selma, p. v., Clark co., Ohio: $41 \mathrm{~m}$. W. Columbus. It contains a few dwellings, and $4 \pi$ inhabitants.

Seminary, p. v., Wachita co., Ark.: on Sac Obert bayou of Wachita r., $99 \mathrm{~m}$. S. S.W. Little Rock.

SeMrrontus, t. and p. o., Cayuga co., N. Y.: $136 \mathrm{~m}$. W. Albany. Drained by several small streams flowing $N$. and W. Skaneateles lake is on the N. E. ; its water-power is good, and it contains several manufactures, several mills, cte. Pop. 1,266.

Sentatobia, v., De Soto co., Miss.: on a branch of Coldwater r., $157 \mathrm{~m}$. N. Jackson.

SENeCA county, $N$. $Y$. Situate W. centrally, and contains 30 sq. m. Drained by Seneca $\boldsymbol{r}$. and several small streams which flow into Seneca lake on the W. side, and Cayuga lake on the E. Surface uneren, and between the lakes is diversified with pleasant hills and fertile plains, the highest elevation being in the middle; soil fertile, and consists of a calcareous loam and mold. Chief products, wheat and Indian corn. It contains good beds of gypsum and quarries of variegated marble. A mineral spring, which emits hydrogen gas, is found here. Farms 1,555; manuf. 240; dwell. 4,541, and pop.-wh. 25,261, fr. col. 180-total 25,441. Capital: Waterloo. Pullic Wurkes: Cayuga and Susquehanna R. R.. ete.

Sevecs county, Ohio. Situate N., and contains $536 \mathrm{sq} . \mathrm{m}$. Sandusky river flows through it centrally, by which and its branches it is drained. Surface level; soil consists of a deep black loam, with clay intermixed, and is very productive. It has excellent pasturage, and large numbers of cattle and hogs are fattened and sent to eastern markets. It has some good timber land. Agriculture is the leading pursuit. Farms 2,582; manuf. 199; dwell, 4,645, and pop. -wh. 26,984, fr. col. 151-total 27,105. Oapital: Tiffin, Public Works: Mad River and Erie R. P.

SENECA, p. o., Anderson digt., S. Car. : on the r. so calted, $114 \mathrm{~m}$. W. N. W. Columbia

SENeOA, p. O., Tompkins county, $N_{0} Y_{0}: 152 \mathrm{~m}$. W. by $\mathrm{S}$. Albany.

SEATECA, p. o., Whitesides county, Ill.: $180 \mathrm{~m}$. .T. by W. Springfield.

SENECA, to and p. O., Lenawee con, Mfich. : $71 \mathrm{~m}$. S. by E. Lansing. Drained by Bear or. Soil excellent, and large crops of wheat, rye, etc., are raised. The stream affords good water-power, and moves several mills. Pop. 1,092.

SENECA creek, Montgomery co., Ma. : rises in the northern highlands of this county in numerous streamlets, which, uniting first into two, and afterward into one creek, flow into the Potomac river. All the western portion of the county is drained by this fine water ${ }^{\prime}$ course.

Seneca lake, $N . Y$. : lies in the counties of Seneca, Ontario, and Yates, $168 \mathrm{~m}$. W. from Albany. This is the largest of the series of lakes lying in the interior of western New Tork. It is $40 \mathrm{~m}$. long, and from 2 to 4 in width. Its elongated diameter is from $\mathrm{N}$. to $\mathrm{S}$.; elevation of surface 430 feet above tide-water, and being very deep, it is never entirely frozen over. About $12 \mathrm{~m}$. from the outlet it has been found to be about 560 feet in depth. The outlet is at the N. E. angle, which, flowing $\mathrm{E}$. to Cayuga lake, affords excellent water-power at Waterloo, and also at Seneca Falls. The whole descent in 12 miles is 80 feet. This lake is connected by canal with Crooked lake. Navigation is made easy through its outlet by means of locks at Waterloo, thereby connecting its commerce with that of the Erie Canal; it is connected also S. by R. R. with Elmira, Owego, and Binghampton, and N. with Rochester, Syracuse, and Oswego. The water has a gradual rise and fall through periods of several years, but the causes have never been ascertained. The lands upon the shores are bountifully adorned with the fruits of cultivation, with here and there a remaining tract of the primitive forest. Steamboats ply daily between Genera and Jefferson, a distance of 40 miles.

Sened river, S. Car.: rises in the Blue Ridge, $N$. Car. flows $\mathrm{S}$, through Pickens and Anderson districts, $S$. Car. and enters the Tugaloo. Length $50 \mathrm{~m}$., and it has numerous tributaries.

Seneca river, $N . Y .:$ outlet of Seneca lake, from the N. end of which it flows $E_{\text {, }}$ about $12 \mathrm{~m}$. to the $\mathrm{N}$. of Cayuga lake, after receiving the waters of which it runs $\mathrm{N}$, ard recoives a stream formed by the outlet of Canandaigua lake and other small tributaries from the W.; after which, flowing E., again it receives other tributaries from the outlets of Owasco, Skaneateles, and Onondaga lakes, until it meets that of the Oneida lake, when turning N.W., it becomes the Oswego $r$., and flows into Lake Ontario at Oswego. It is $60 \mathrm{~m}$. in length from its source to its confluence with the Oswego, It is navigable to the Erie Canal at Waterloo. There are falls at the $\mathbf{v}$. of Seneca Falls and at Waterloo, from which great water-power is obtained.

SEneCA CASTle, p. o., Ontario county, $N . Y .: 175 \mathrm{~m}$. W Albany.

Seveca Falis, t. and p. v., Seneca county, $N_{0} Y_{*}: 44 \mathrm{~m}$. E. S. E. Rochester, and $162 \mathrm{~m}$. W. by N. Albany. Drained by Seneca $r$, which passes through it from E. to W. Cayuga lake bounds it on the $\mathrm{E}$. Surface undulating; soil, in general, very fertile, and highly cultivated. The Cayuga and Seneca Canal passes through the to, connecting Seneea outlet with Cayuga lake. The $\mathrm{v}$. is on the Seneer outlet, the canal, and Rochester and Syracuse R. R.. $43 \mathrm{~m}$. from Syracuse, and $61 \mathrm{~m}$. from Rochester. It was first settled in 1829, and incorporated in 1831. Abundant hydraulie power is derived from Seneca outiet, the water of which is constant and steady, and is applied extensively to manufacturing purposes by means of several dams, having a total fall of some 47 feet. The manufactures ensist chiefly in cotton goods, flour (there being $S$ mills with 27 run of stone), lum- 
ber, iron, paper, etc. There is also a boat-yard, a lumberyard, etc. In the vicinity plaster or gypsum is abundant The "Seneca County Courier" (whig), and "The Lily" (temp.) are both weekly issues. Pop. of v. 3,045, of t. 4,297. SEneda Mruis, p. o., Montgomery co., Ma.: a mill-seat on Seneca cr., $40 \mathrm{~m}$. W. Annapolis, with but few inhabitants. Seneca River, p. o, Cayuga county, $N . Y_{\text {.: }} 156 \mathrm{~m}$. W. by N. Albany.

Senecaville, p. y., Guerasey county, Ohio: $81 \mathrm{~m} . \mathrm{E}$. Columbus. Pop. 457 .

SFrEX, p. 0., M'Lean co., Ill. : $63 \mathrm{~m}$. N. E. Springfield.

Sennet, t. and p. v., Cayuga co., N. $Y .: 145 \mathrm{~m}$.W. by N. Albany. Drained by several small streams flowing into the Seneea r. Surface uneven; soil fertile, and under good state of culture. The Rochester and Syracuse R.R. passes through the village, $22 \mathrm{~m}$. from Syracuse, and $88 \mathrm{~m}$. from Rochester. It has several mills, ete. Pop. of t. 2,347.

Senteli's Stoke, p. o., Bossier par., La. : 203 m. N. W. Baton Rouge.

Sepulga, p. o., Conecuh co., Ala. : on the river so called, $75 \mathrm{~m}$. S. S. W. Montgomery.

Sequatcher, v., Marion co., Tenn. : on the river so called, $97 \mathrm{~m}$. S. E. Nashville.

SEren A, p. v., La Salle co., $I l l$. : on the right bank of

Fox r., 122 m. N. E. Springfield.

Serepta, p. v., Warren co, $N$. Jer : on Beaver brook,

$44 \mathrm{~m} . \mathrm{N}$. W. by N. Trenton. This is a small manufacturing place.

Sergeantsville, p. v., Hunterdon co., $N$. Jer: $18 \mathrm{~m}$. N. W. Trenton.

Serryse, v., Lake co., $I U l_{0}:$ on the $\mathrm{S}$, boundary of the co., $161 \mathrm{~m}$. N. E. Springfield.

Sertice, p. 0., Beaver county, Penn.: $17 \mathrm{~S}$ m. W. by N. Harrisburg.

SETAUKET, p. v., Suffolk co, $N$. $Y_{.:}$on the N. side of

Long Island, at the head of an inlet of Long Island sound, $88 \mathrm{~m}$. E. N. E. New York, and $232 \mathrm{~S} . \mathrm{S} . \mathrm{E}$. Albany. It has a good harbor, and the $\mathrm{v}$. contains stores, mechanic shops, etc. Setzler's Store, p. o., Chester co.. Penn.: 63 m. S. E. Harrisburg.

Sfrer Beaver lake, Mo.: this sheet of water contains one or two islands, and is the source of the head branch of

St. Louis river.

Seter Islands, p. O, Fluvanna county, Firg.: $48 \mathrm{~m}$. W. by N. Richmond.

SEven Istanos, p. o., Butts co., $G a_{0}: 47 \mathrm{~m}$. W. by N. Milledgeville.

Sever Mute, p. o., Butler county, Ohio: 99 m. \$. W.

Columbus.

Sevex Mile Brook, Me.

SeveN Mite Creek, p. o., Sauk co, Wisc.: $37 \mathrm{~m}$. N. W. Madison.

Seten Mrte Ford, p. o., Smyth county, Virg. : $219 \mathrm{~m}$. TF. S. IT. Pichmond.

Seven Mrle Pratrie, p. 0., Darke co, Ohio: $85 \mathrm{~m}$. W. Columbus,

Sefen Mile Pump, sta, Charleston co, $S$. Car. $:$ on the South Carolina R. P., $7 \mathrm{~m}$. N. Charleston, and $112 \mathrm{~S}$. E. Columbia.

Seventy Sever, p. v., Johnston co, Ia.: on the E. side of the Iowa r., $14 \mathrm{~m}$. S. Iowa City.

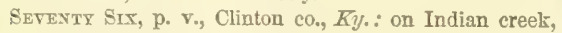
$97 \mathrm{~m}$. S. Frankfort.

Setrext SIx, p. o., Beaver co., Penn.: 181 m. W. by N. Harrisburg.

Seven Vallexs, p. o., York county, Penn.: $13 \mathrm{~m} . \mathrm{S}$. Harrisburg.

Seferv river, Anne Arundel co., Mrd.: rises in several creeks, a little $\mathrm{N}$. of the centre of the co.y and after the union of these, spreads into a long and wide inlet of Chesapeake bay, into which it falls, between Grceubury and Talley's points, opposite Kent Island. Annapolis, the State capital, is located in a projecting headland near its mouth.
Sevier county, Ark. Situate S. W., and contains 1,106 sq. m. Drained by Cosselose, Saline, and Rolling creeks, branches of North Little river, a tributary of Red river, which forms its western boundary. Surface level; soil in general fertile, and adapted to cotton, which is the chief production. Farms 326 ; manuf. 4 ; dwell. 500, and pop,-wh. 2,836, fi. col. 32, sl. 1,372-total 4,240. Capital: Paraclifta.

Sevier county, Tenn. Situate E., and contains $526 \mathrm{sq} . \mathrm{m}$. Drained by tributaries of Tennessee river. Surface uneven and broken; soil generally fertile, and produces wheat, Indian corn, and cotton. Pork is exported largely. On the S. E. is Smoky Mountain. Farms 581; manuf. 12 ; dwell. 1,071, and pop.-wh. 6,451, fr. col. 66, sl. 408-total 6,920. Capital: Sevier.

SEviEr, p. v. and cap. Sevier co., Tenn.: between the E. and W. forks of Little Pjgeon $\mathbf{x}, 208 \mathrm{~m}$. E. by S. Nashville. It contains a court-house, jail, etc.

Seville, p. 0., Madison county, Firg.: 72 miles N. W. Pichmond.

Sew ARD, t. and p. v., Schoharie co., N. Y.: $6 \mathrm{~m}$. S. from Sharon Springs, and $45 \mathrm{~m}$. W. by N. Albany. Drained by Cobbleskill cr., which passes through it in a $\mathrm{S}$. direction. Surface high and undulating; soil in general good. Cobbleskill er. affords excellent hydraulic power, and there are several grist and saw mills; but the manufactures are few, as is the case throughout the county. Pop. 2,203.

SEW ARD's PoINT, p. v., Montgomery co., $T l_{0}$ : on the West fork of Shoal er., $33 \mathrm{~m}$. S. Springfield.

Sewee, p. ò., Meig's co., Tenn. : 114 m. S. E. Nashville.

Sewell Mountatr, p. v., Fayette co., Vïrg.: $185 \mathrm{~m}$. W. by N. Richmond.

Sewellstille, p. o., Belmont $\mathrm{co}_{4}$, Ohio: $103 \mathrm{~m}$. W. $\frac{1}{2} \mathrm{~S}$. Columbus.

SEwicklex, sta., Alleghany co., Penn.: on the Ohio and Pennsylvania R. R., $12 \mathrm{~m}$. W. by N. Pittsburg and $268 \mathrm{~m}$. by railroad W. from Harrisburg.

Sewickly Botтou, p. o., Alleghany co., Penn.: $161 \mathrm{~m}$. W. Harrisburg.

Sextons, p. v., Boone co., Mo.: on the right bank of Rocheperee r., $33 \mathrm{~m}$. N. by W. Jefferson City.

SEXTON's CreeK, p. v., Clay county, $K y_{.}:$on a stream so called, 61 m. S. E. Frankfort.

Sextontille, p. o., Richland co., Wisc.: 61 m. W. N.W. Madison.

Sermour, t., p. v., and sta., New Haven co., Conn.: on both sides of Naugatuck r., 35 m. S. W. by S. Hartford, $11 \mathrm{~m} . \mathrm{N}$. W. New Haren. The v., formerly Humphreysville, is an important manufacturing place, containing 1 copper-rolling mill (one of the largest in the United States), 1 car manufactory with 6 shops, 1 large tool factory, 1 foundry, 3 paper factories, 3 auger do, 1 axe do., 1 power-loom silk do., 1 forge-hammer shop, with other mechanic shops - the whole employing about 450 hands, and producing annually nearly $\$ 1,500,000$. The water-power derived from the Naugatuck is very great, not more than one-half of which is now used. The $v$, also contains a bank and 4 churches. The Naugatuck R. R. passes through the $\nabla$., $20 \mathrm{~m}$. from Bridgeport, $42 \mathrm{~m}$. from Winsted, and has greatly advanced its prosperity. Pop. of t. 1,677.

SHADE mountains, Penn.: a ridge of the Alleghany chain, extending from Bedford county, through Huntington into Mifflin county, a distance of 40 miles.

SuAde Furnace, p. O., Somerset co., Penn.: in the v. of Stoystown, $107 \mathrm{~m}$. W. Harrisburg. A furnace of 1,400 tons annual capacity is located here.

SHIDE GAP, p. o., Huntingdon county, Penn. : 57 m. W. Harrisburg.

Sirade Mrux, p. o., Alleghany co., Mrd.: on a branch of Youghiogeny r., 145 m. W. N. W. Annapolis.

Shadewell, p. o. and sta., Albemarle co, Virg.: on the Virginia Central R. R., 93 m. W. N. W. Richmond.

Shadx, p. o., Johnson county, Tenn. : 275 m. E. by N. Nashville. 
SHADY DALE, p. o., Jasper county, Ga.: $81 \mathrm{~m} . \mathrm{N}$. W. Milledgeville.

Stlady Grove, p. o., Union co., Ga.: 132 m. N. N. W. Milledgeville.

Shady Grove, p. v., Dallas county, Mo.: at the head of

Greasy cr., 88 m. S. S. W. Jefferson City.

SHady Grove, p. V., Gibson co., Tenn. : on Rutherford

fork of Obion r., $108 \mathrm{~m}$. W. by S. Nashville.

SHady Grove, p. o., Franklin co., Virg.: 126 m. S. W.

Richmond.

SuAdr Grove, p. o., Washington par, $L a_{n}: 67 \mathrm{~m}$. N. E. Baton Rouge.

Shadr Hrl, p. 0., Henderson co., Tenn. : 108 m.W. S.W.

Nashville.

Simadx Spring, p. o., Raleigh county, Firg.: $210 \mathrm{~m}$. W.

Richmond.

Shamfrerstowr, p. v., Lebanon co., Penn.: $31 \mathrm{~m}$. E. Harrisburg. It contains several churches, stores, workshops, ete.

Shaftseury, $t_{\text {s }}$ and p. v., Bennington co., Term.: $97 \mathrm{~m}$. S. W. Montpelier. Drained by tributaries of the Battenkill and Walloomsack rivers, which afford power for several small manufactories. Surface elevated; soil fertile. West Mountain lies partly in this town. Valuable beds of iron ore, pine timber, and a fine quality of white marble are found here. The Western Vermont R. R. passes through the village, $49 \mathrm{~m}$. S. by W. Rutland. Pop. of t. 1,896 .

Shater Vulage, p. v., Merrimac co., N. Hamp.; $12 \mathrm{~m}$.

N. Concord. See W Atervilet.

Shater Village, sta., Berkshire county, Mass.: on the Western R. R., 121 m. W. N. W. Boston.

ShakelforD's, p. o., King and Queen co, Firg. : 33 m.

N. E. Richmond.

Shater's Milis, p. o., Knox county, Ohio: 42 m. N. E. Columbus.

Shalersvilue, t. and v., Portage co., Ohio: 122 m. N. E. Columbus. Drained by Curahoga r. Surface uneven; soil fertile. The v. is E. of the Cuyahoga r. Pop. of t. 1,190.

ShallotTy, p. v., Brunswick co, N. Car. : at the head of Shallotte inlet of the Atlantic Ocean, 127 miles S. Raleigh. Pop. 903.

Shallow Ford, p. o., Orange co., $N$. Car. : $39 \mathrm{~m} . \mathrm{N} . \mathrm{W}$. Raleigh.

Sнarokry, t. and p. $\nabla .$, Northumberland county, Penn. $40 \mathrm{~m}$. N. by E. Harrisburg. Drained by Shamokin creek. Surface uneven, in parts hilly; soil fertile. A furnace located here, moved by steam, has an annual capacity of 3,500 tons. Amount of coal sent from the mines to Philadelphia (in 1849) was 19,658 tons. The railroad from Pottsville to Danville and to Sunbury pass through the t. The ఛ. contains several mills, workshops, ete.

SHAmonis creek, Penn. : rises in the Mahony Mountains, flows W. in a circuitous course $30 \mathrm{~m}$., and empties into the Susquehanna r. $2 \mathrm{~m}$. below Sunbury.

SHAmoNx, p. v., Burlington co., $N$. Jer.: on both sides of a branch of Atsion r, $30 \mathrm{~m}$. S. Trenton.

Shamrock, p. $\nabla_{*}$, Callaway co., Mo.: on a fork of Loutre river, $41 \mathrm{~m}$. N. E. Jefferson City.

Shamroch Mrlis, p. O, Washington county, R. $l_{.}: 27 \mathrm{~m}$. \$. W. Providence.

Sifavandoan, p. o., Pichland co., Ohio: 49 m. N. by E. Columbus.

SHANDAKEX, t. and p. 0, Ulster co., $N . Y_{.:} 48 \mathrm{~m} . \mathrm{S} . \mathrm{W}$. Albany. Drained on the N. and E. by Esopus cr., on the S. by Neversink r., and on the W. by the E. branch of the Delaware r. Surface mountainous, being covered in the greater part by the Catskill Mountains; soil of inferior quality. It has good hydraulic power, and contains some manufactories, several mills, ete. Pop. 2,309.

Shanes' Crossings, p. o, Mercer co, Ohio: 99 m. N. W. Columbus.

Shaxesville, p. 0., Berks county, Penn. : 50 m. E. by N. Harrisburg.
Shangsville, p. v., Tuscarawas $c_{0}$, Ohio: on W. side Sugar er, $77 \mathrm{~m}$. N. E. Columbus. It contains several workshops and 382 inhabitants.

Shanesville, p. v., Somerset co., Penn.: 108 m. W. by S. Harrisburg, Iron ore is found in the vicinity.

SHANNox county, MO. Situate toward the S., and contains $789 \mathrm{sq} . \mathrm{m}$. Current river passes through the co, from. N. W. to S. E., by which and its numerous branches it is drained. Surface undulating; soil fertile. It is a fine mineral co., and there are extensive beds of iron and copper ores of a superior quality. It is partly timbered. Farms 152 ; manuf. 0 ; dwell. 204, and pop.-wh. 1,190, fr. col. 0, sl. 9-total 1,199. Capital: Eminence.

Shannor, p. o., Muskingum county, Ohio: 51 miles E. Columbus.

ShanNoN Hruc, p. ve, Goochland co, Virg. : 40 m. N. W. Richmond.

Srarron's, p. 0., Montgomery co., Tew. : 133 m. E. Austin City.

Shannonvtule, p. v., Montgomery co., Penn. : 80 m. E. Harrisburg.

Shapleigh, t. and p. v., York county, Me: $79 \mathrm{~m} . \mathrm{S} . \mathrm{W}$. Augusta. It is separated from Acton by two ponds, the source of Mousum r., by which the $t$. is drained. Surface level; soil fertile, and it is a good farming t. Bog iron ore is found here, and there are iron works and other manufactures. The $\mathrm{v}$. is centrally situated. Pop. of $\mathrm{t}, 1,348$.

Shark Rrver, p. v., Ocean county, N. Jer.: on Jumping brook of Shark r., $36 \mathrm{~m}$. E. Trenton.

Sharktown, v., Queen Anne co., $M d_{\text {s }}$ : a settlement on Kent Island, $12 \mathrm{~m}$. E. Annapolis.

Sharon, p. v., Chambers co., $A 2 \alpha_{\text {. : }}$ on a branch of Tallapoosa r., 57 m. N. E. Montgomery.

Strarox, t. and p. v., Litchfield county, Conn. : on the W: side of Housatonic r., $40 \mathrm{~m}$. W. by N. Hartford. Drained by a number of small streams, tributaries of the Housatonic river. Surface various, in parts mountainous and roeky; soil of arerage fertility, and agriculture is the chief pursuit of the inhabitants. It is connected with Cornwall by several bridges spanning the Housatoric. The $\mathrm{y}$, is located principally on one street on the $\mathbf{E}$. side of a pleasant valley, and contains many fine buildings. The manufactures consist of cotton, iron, leather, flour, lumber, ete. This t. took an active part in the war of the Revolution. Population of $t .2,517$.

Sharon, p. v., Whitesides co., Ill.: on the S. boundary of co., $3 \mathrm{~m}$. S. of Rock r., and $123 \mathrm{~m}$. N. by W. Springfield. SHaroy, t. and p. v., Norfolk co, Mass. : $16 \mathrm{~m}, \mathrm{~S}$. by W. Boston. Drained by Neponset r., which has its source in Mashapoag Pond in this $t$. Surface hilly; soil fertile, and much grain is raised. It has good water-power, and is much improved by several manufactories. The mamufactures consist of woolen and cotton goods, axes, bedsteads, straw goods, leather, machinery, joiners' tools, etc. The Boston and Providence R. R. passes through the $V_{*}, 17 \mathrm{~m}$. S. by W. Boston. Pop. of t. 1,128.

Sharon, t. and p. 0., Washtenaw co., Mich.: 41 m. S. E. Lansing. Drained by Raisin r., which crosses its S. part, The soil is very fertile, and the products in wheat, rye, and corn are large. Pop. 869.

Sindrov, p. V., Appanoose co., Ia.: on the left bank of Chariton r., $87 \mathrm{~m}$. S. W. Iowa Cily.

Sharow, p. v., Madison co., Miss.: on a branch of Big Black r., 33 m. N. N. E. Jackson.

Sharos, t. and p. v., Schoharie co., N.I.: $46 \mathrm{~m}$. T. br N Albany. Drained by Bowman's creek and branch of Schoharie cr. Surface high and uudulating, resting upon limestone, which in some places makes its appearance in the form of caverns, and displaying interesting stratifications This t. contains the celebrated mineral spring, so called (see Sharon Sprivg). The $\mathrm{v}$, is in S. E. of town, and contains several spacious hotels, and has some manufactures, mills, ete. Pop. of t. 2,632 . 
Siraros, p. o, Mecklenburg co, $N$. Car. : 121 m. S. W. Raleigh.

Sraron, p. v., Noble co, Otion: 75 m. E. by S. Columbus. Srraron, p. V., Mercer co., Penn.: on the left bank of Shenango cr., 195 m. W. N. W. Harrisburg. There are two furnaces near the v., one of 2,000 Lons, and the other 1,500 tons annual capacity, both operated by steam. The Beaver and Erie Canal passes near the village. Pop. 541.

SharoN, t. and p. v., Windsor co., Verm. : $43 \mathrm{~m}$ - 8. by E. Montpelier. Drained by White r., which passes through, affording excellent water-power. Surface much broken, but the soil is fertile and well cultivated. The manufacture of woulen goods, paper, etc, is carried on to some extent here. The $\mathrm{r}$. is on White $\mathrm{r}$, and the Vermont Central R. R. passes through it, $50 \mathrm{~m}$. S. by E. Montpelier. Pop. of t. 1,240 . SHARON, p. v., Wythe co., Virg. $^{2}$ at the source of North fork, Holston r., 212 m. W. by S. Pichmond.

SiraroN, t. and p. v., Walworth co., Wisc. : 51 m. S. E. Madison. Drained by branches of Turtle er. The land is excellent, and highly cultivated, and good water-power. The $\mathrm{r}$, is in the E. part. Pop. of t. 1,169.

Sharon Centre, p. on, Schoharie county, $N$. $Y .: 47 \mathrm{~m}$. W. by N. Albany.

Sharoy Centre, p. v., Medina co., Ohio: on Wolf cr., $99 \mathrm{~m} . \mathrm{N}$. E. Columbus. It contains an academy, several shops, etc.

Sharow Centre, p. v., Potter co., Penn. : 127 m. N. W. Harrisburg.

Siraron Springs, p. v., Schoharie co., $N$. $\boldsymbol{Y}$ : near the boundary line of Schoharie, Otsego, and Montgomery counties, $49 \mathrm{~m}$. W. by N. Albany. It is located on an eminence, surrounded by numerous caverns of much interest. Near the $\mathrm{v}$. are the celebrated Sharon Springs, greatly resembling the White Sulphur Springs of Virginia, and are highly efficacious in rheumatic, dyspeptic, and other complaints. There are two springs, the sulphur and magnesia, situated at the foot of a hill, about a half mile $N$. of the turnpike road. These waters have an exhilarating effect on tho spirits, invigorating the system, and in many respects possess medicinal and healing qualities unsurpassed by any other in the country. They are much resorted to during the summer months, and there is a commodious hotel here, called the Pavillion, which is usually thronged with visitors. From an analysis, made by Dr. Chilton, of New York, the result from one gallon of this water is: sulphate of magnesia, grs., 42.40 ; sulphate of lime, 111.62; chloride of sodium, 2.24 ; chloride of magnesium, 2.40 ; hydrosulphuret of sodium, hydrosulphuret of calcium, and vegetable extractive matter, 2.24; total grs., 160.94. Sulphuretted hydrogen gas, 16 eubic inches.

SHARONVILLE, p. v., Hamilton co, Ohio: on a branch of Mill cr., 87 m. S. W. Columbus.

Sharonville, p. 0, King William co, Firg. : 21 m. N. E. Richmond.

Smarpe's Stores, p. v., Lowndes co., Ga.: on the line of the Brunswick and Florida R. R. $151 \mathrm{~m}$. S. Milledgeville.

Sharpesvilixe, p. v., Montgomery county, $A$ la . : $12 \mathrm{~m}$. S. Montgomery.

Sharpsidrg, p. Y., Bath co., $\bar{K} y$.: 54 m. E. Frankfort.

SHARPSBUR, p. V., Washington co., MId.: a little W. of

Antietam r., 72 m. N. W. Annapolis.

SmarpsidrG, p. V., Marion co., MFo. : on the S. boundary of the co., $78 \mathrm{~m}$. N. by E. Jefferson City.

Sharpsiurg, p. V., Alleghany co., Penn.: on the right bank of the Susquehanna $r, 7 \mathrm{~m}$, above Pittsburg, and $155 \mathrm{~m}$. W. by $\mathrm{N}$. Harrisburg. It is a considerable manufac turing place, and much trade is carried on here. Pop. 1,229.

Sinarp's Fork, p. 0., Athens c0., Ohio: 63 m. S.E. Columbus Sirarp's Mitls, p, o., Harrison co., Ind. : on the left bank of Green Bank r., $101 \mathrm{~m}$. S. Indianapolis.

Snaresurx Pont, Chittenden co., Ferm.: a high, rocky point, on the $N$. side of Burlington bay, about a mile and a quarter from the S. wharf in Burlington.
Sirarptown, p. v., Somerset co, $M a d_{.}:$on the left side of Nanticoke r., 52 m. S. E. Annapolis.

Sharptown, p. F., Salem co, N. Jer. : is a manufacturing place, on the right bank of Salem r., 49 m. $\$$. W. Trenton.

Sirartlesville, p. v., Berks county, Penn。: 43 m. N. E. Harrisburg.

Suasté county, Calif. Situate N., and contains about 4,800 sq. m. Bounded on the W. by the Coast Range, and on the E. by the Sierra Nevada. The S. boundary is a line on the parallel of Red Bluff, the head of navigation in the Sacramento river, and its $\mathrm{N}$. boundary the line of the new county of Siskiyou, in lat. $41020^{\prime}$. The Sacramento runs directly through it from the north, and it is drained by its tributaries-Pitt river, Lower and Ark creeks, from the E, and Salt, Clear, Dry, Cottonwood, and Sandy creeks, from the W., all rising from the mountains. Surface, except in the immediate valley of the Sacramento, hilly and broken; but there is a vast amount of fine agricultural land in the county, of which, in 1852, only 908 acres were under cultivation. There are many springs strongly impregnated with minerals, of which the Sola Springs, near the Sacramento, and $60 \mathrm{~m}$. N. of Shasté City, are the most celebrated; and there are 12 or 15 salt springs, which would produce salt sufficient for the whole State. Not a river, ereek, gulch, or ravine that does not contain gold, and mining is extensively carried on. The eapital invested in quartz mining, in 1852, was $\$ 94,700$; in placer mining, $\$ 90,950$; and in other mining operations, $\$ 92,800$. The total industrial capital of the county was $\$ 958,500$. The principal mining localities are French gulch, Mad Mule Cañon, Mad Ox Cañon, Whiskey creek, OneHorse Town, One-Mule Town, Clear creek, Grizzly guleh, and Middletown. About 2,000 men were engaged in mining. and the annual product had been $\$ 2,492,000$. Pop. 4,050 wh. 3,700: males 3,448 , and females 252 ; negroes 48 -males 45 , and females 3 ; mulattoes 12 - males 10 , and females 2 Indians 73 - males 52 , and females 21 ; foreign residents 828 -males 814 , and females 14. Over 21 years of age-Americans 2,647 , negroes 45 , mulattoes 9 , Indians 59 , and foreigners 792. Cupital: Shasté City.

SHasté Crry, p. v., and cap. Shasté co., Calif.: is located in low hills, a little W. of the Sacramento r., $150 \mathrm{~m}$. from San Francisco, and $120 \mathrm{~m}$. N. from Vallejo. It is a place of considerable importance, being the terminus of land carriage, and a starting-place for packers to Oregon. There is a bank here, and considerable money is in circulation. Mines are numerous in the vicinity, every stream (of which there are many) containing more or less gold. Salt springs are also found. Pop. 1,000.

SHatcK's, p. o., Morrow co., Ohio: $37 \mathrm{~m}$. N. Columbus.

Shaumburg, p. v., Cook county, $1 l$.: $172 \mathrm{~m}$. N. E. Springfield.

Shater's Creek, p. o., Huntingdon co., Penn.: 59 m. W. Harrisburg. There is a forge and rolling mill here, the former made (in 1850) 475 tons blooms, and the latter 150 tons boiler and sheet iron, both moved by waternpower.

Shapertown, p. v., Delaware co., $N$. $Y$.: on the S. side of the E. branch of the Delaware r., $71 \mathrm{~m}$. S. W. Albany.

SirAwANAW county, Wisc. Situate E. of the centre, and contains $828 \mathrm{sq} . \mathrm{m}$. Drained by Wolf $\mathrm{r}$, and its branches. Surface varied; soil in parts fertile. Set off recently from southern portion of Oconto county.

SHAWANGUNE, t. and p. $\nabla$., Ulster county, $N$. $Y .: 74 \mathrm{~m}$. S. by W. Albany. Drained by Shawangunk er. and Wallkill. The surface in general is mountainous, the Shawangunk Mountains covering the principal portion-on the $E$. gently undulating; soil pleasantly diversified, and on the E. highly productive and good timber. Grain is raised in large quantities, but more attention is paid to the rearing of cattle and to the dairy. A number of skeletons of the mastodon have been found in this town and the vicinity. The $\mathbf{v}$. is on a branch of the Wallkill, and lumber, flour, cotton, and woolen goods are manufactured. Population of $t, 4,036$. 
SFATANGUNK mountains, $N, Y$, a continuation of the Alleghany chain, extending from the Delaware r., in Orange county, thence through Sullivan county to town of New Paliz, in Ulster county. On the E. they are well cultivated, but on the W. they are precipitous. Lead is found on them. Their greatest altitucle is $1, \$ 66$ feet.

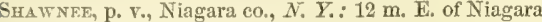
Falls and 236 m. W. by N. Albany.

Sumple, p, u., Monre county, Penn.: $91 \mathrm{~m}$. N. E. Harrisburg:

SHAW NEE creek, Ind.: rises in the N. F. corner of Montgomery county, runs W. through Fountain county, and flows into the Wabash r., $10 \mathrm{~m}$. above Covington. It is a valuable mill-stream, never failing, and the mills erected on it, and water-power that may still be used, will compare favorably with any part of the State.

Shawnee Mound, p. o., Tippecanoe county, Ind.: $61 \mathrm{~m}$. N. W. Indianapolis.

ShatrNeE Pratrte, p. o., Fountain co., Ind.: S. E. of the Wabash $\mathrm{r}, 61 \mathrm{~m}$. N. W. Indianapolis. It is situated on the border of a large and rich prairie so called, mostly well cultivated, the soil of which is favorable for wheat, corn, and grass.

Shawnetown, p. v, Gallatin con, $I l_{*}$ : on the Ohio r., $11 \mathrm{~m}$. below the mouth of the Wabash and $164 \mathrm{~m}$. S. E. from Springfield. Its situation, though pleasant looking, is low and liable to inundation. As a place of trade this is among the largest in southern Illinois. There is a paved levee here, almost as long as the one at Cincinnati, Ohio. A hog slaughtering and packing establishment, owned by Messrs. O. Poole \& Co., is quite an important feature, having facilities for hanging up 1,000 hogs per day. Tobacco is raised in considerable quantities, 300 hogsheads of which was shipped to different parts in 1852. Iron ore and coal is abundant on the river bank. The manufacture of salt is extensively carried on at the United States Saline, on the Saline cr., $12 \mathrm{~m}$. in the interior, and a railroad is in course of construction to connect them with this place. A United States land office is located here. The "Southern Illinois Advocate" is a weekly (dem.) issue. Pop. 1,764.

Sruw's Mrlus, p. ₹., Guilford county, $N$. Car.: $71 \mathrm{~m}$. W. by N. Paleigh.

Shawsyille, p. v., Harford co. MA. : 45 m. N. Annapolis. SHatwsille, p. V., Montgomery county, Virg.: $159 \mathrm{~m}$. W. S. W. Richmond.

Siratrsvile, p. o., Broome county, N. Y.: 104 m. S. W. Albany.

Shearers Cross Poado, p. o., Westmoreland co., Penn. $183 \mathrm{~m}$. W. Harrishurg.

Shemotgan county, Wisc. Situate $\mathrm{E}$. toward the $\mathrm{S}$., and contains $575 \mathrm{sq}$. m. Drained by Shebnygan $r$. and its afluents, and tributaries of Milwaukie r. Surface undulating; soil fertile. It is bounded on the E. by Lake Michigan. Farms 328; manuf. 29; dwell. 1,7S3, and pop.-wh. 8,371, fr. col. i-total S.37s. Cujitul: Sheboygan. Public Works: Chicago, Milwaukie, and Green Bay R. P.

Sirmorgar, p. v., and cap. Shebuygan co., Wisc.: on Lake Michigan, at the mouth of Sheboygan r., $95 \mathrm{~m}$. N. E. Madison. It contains a court-house, jail, etc., and has some trade. The exports during the year $184 \mathrm{~s}$ amounted to 812.191, and the imports for same year s571.801, making a total of \$sร $\$ 3,991$. It is surrounded by a well cultivated and flourishing country.

SFEBOYGAN river, Wisc.: rises near Winnebago lake, Fond du Lac co., passes through a small lake in the N. W part of theloygan enunty, and proceeding eastwardly in a winding course, flows into Lake Michigan at Sheboygan.

SHeBoygar Falis, t. and p. o., Sheboygan co., Wise. $91 \mathrm{~m}$. N. E. Madison. Drained by the Sheboygan $r$, and branches; soil fertile, and well culivated.

SIred's Crossing, sta. Middlesex county, Mass.: on the Lowell and Lawrence R. R., $8 \mathrm{~m}$. E. Lowell and $21 \mathrm{~m}$. N. by W. Boston.
Shelpscot river, $M e$ : rises by two branches in pond in Palermo, Waldo county, flows S. through the towns of Whitefield and Alva, meets the tide-water between Wiscas sett and New Castle, in Lincoln county, and empties into a bay of the same name. Its length from the source to the bay is $35 \mathrm{~m}$., and it is valuable for its bydraulic power and navigable facilities.

SHeerscot bay, Lincoln co., $M e_{\text {s }}$ : sets up from the sea between Booth bay and Georgetown, and receives the waters of the river so called. It is abont $3 \mathrm{~m}$. wide at its mouth and extends $10 \mathrm{~m}$. N. The mouth of the bay is about $6 \mathrm{~m}$. N. E. from the light at the mouth of Kernebee river.

Shempsot Bridge, p, $v_{.,}$Lincoln co., Me.: on the left bank of Sheepscot r., 25 m. S. E. Augusta.

Sueetz Mruls, p. v., Hampshire co., Virg.: on the S. branch of Potomac r., $145 \mathrm{~m}$. N. N. W. Richmond. It is a small village, has excellent water-power and several millseats.

SheFrerd, p. $\nabla$. , Favette co., Ala. : on North r. branch of Black Warrior, $123 \mathrm{~m}$. N. W. Montgomery.

Suefrietd, p. v., Newton co., $G a$. : on a branch of the Ocmulgee r., $65 \mathrm{~m}$. N. W. Milledgeville.

Shefrield, t. and p. v., Berkshire co., Mass.: $119 \mathrm{~m}$ S. W. by W. Boston. The Housatonic $r$. flows through the town, by which and its branches it is drained. Surface generally level, but in parts hilly; soil alluvial and very fertile, and excellent water-power is derived from the streams. This is the oldest town in the county; it was incorporated in 1733. The chief pursuit of the penple is agriculture, but there are also manufactories of leather, hats, farming utensils, spirits, lumber, ete. The village is neatly laid out on one extended street, on a plain surrounded by hills. one of which is 3.000 feet high, and contains some neat mansions The Housatonic $\mathbf{R}$. R. passes through the village, $31 \mathrm{~m}, \mathrm{~S}$. Pittsfield and $79 \mathrm{~m}$. N. Bridgeport, Conn, Iron ore and marble of a superior quality are found in the town. Population of t. 2,769.

SHEFFTELD, t. and p. o., Lorain co., Ohio: 107 m. N. N. E Columbus. Lake Erie washes its $\mathrm{N}$. border. Drained by Black r., which is navigable to near the centre of the town. Surface moderately uneven; soil fertile, adapted to grain. It contains an academy, conducted on the manual labor principle, several other places of instruction, mills, workshops, etc. Pop. 908 .

Shemfield, t. and p. o., Warren co, Penn. : $148 \mathrm{~m} . \mathrm{N} . \mathrm{W}$ Harrisburs. Drained by Teonista cr. and branches, from which is derived excellent mill-power. Surface various; soil in some parts fertile. It has several manufactories. The proposed route of the Sunbury and Erie R. R. passes through this town.

SIIEFFIELD, t. and p. $\nabla$. , Caledonia co., Term, : $36 \mathrm{~m} . \mathrm{N} . \mathbf{E}$ Montpelier. Drained by branches of the Passumsic and Barton rivers, having their sources in several ponds here Surface elevated and much broken; soil of an inferior quality. The village is located on a branch of Passumsic $r$. Pop. of t. 797.

SheFfield LAKE, p. o., Lorain co., Ohio: 108 m. N. N. E. Columbus.

Sherol. p. p. o., Pike co. Penn. . 121 m. N. E. Harrisburg, SmeIlifille, p. v., Hamilton co., Ind. : 31 m. N. Indianapolis. The Peru and Indianapolis R. R. passes near this village.

SHelbuRNE, t. and p. v., Coos con, $\mathcal{N}$. Hamp.: on both sides of the Androscoggin r., 81 m. N. by E. Concord. Drained by the Androscoggin and its tributaries, Rattle $r$. and other small streams. Surface varions, in parts mountainous, having a part of Mount Moriah, an elevated peals of the White Mountains, in the S., and on the S. side of the river, in the centre, is Moses' Rock, 60 feet high and 90 feet long, very smooth, and rising in an angle of nearly $50^{\circ}$. Incorporated in 1820. Soil along the rivers is fertile, but otherwise of an inferior quality. Chief pursuits of the peo- 
ple are agricultural. The Atlantic and St. Lawrence $\mathrm{R}$. $\mathrm{R}$. passes through the village, $36 \mathrm{~m}$. S. E. Northumberland. Pop. of t. 490 .

Sirmlburne, t., p. $v_{*}$, and sta., Chittenden county, Term. bordering on Lake Champlain, $32 \mathrm{~m}$. W. by N. Montpelier. Drained by La Platte $\mathbf{r}$, affording excellent water-power. A pond covering 600 acres is also in this town. Surface on the lake shore is level, otherwise uneven; soil in general fertile. A fine harbor is formed by Shelburne bay, which sets up into the town, $4 \mathrm{~m}$. from the lake, in a $\mathrm{S}$. W. direc tion. The village is located on the border of the lake, and the Rutland and Burlington R. R. passes through the town on which is the sta., 6 miles $\mathrm{S}$. Burlington. Population of town $1,25 \%$.

SHelbURNe, t. and p. o., Frauklin county, Mass.: $87 \mathrm{~m}$. N. W. by W. Boston. Bounded on the W. and S. W. by Deerfield r., which in its course has a fall of 50 feet in 40 rods, producing immense hydraulic power. Surface various soil fertile, and much wool is grown, and dairy produce raised. It has some manufactures of leather, lumber, etc Pop. of t. 1,239.

Smelibirne Falls, p. v., Franklin co, Dfass. : on the left bank of Deerfield r., $89 \mathrm{~m}$. N. W. by W. Boston. It is a neat village, surrounded by a rich agricultural country, and contains besides several fine buildings, a well-endowed academy.

SHELBY county, Ala. Situate centrally, and contains 993 sq. m. Cahawbar. flows through the W. portion, by which and its branches, and branches of Coosa $r$., which forms its E. boundary, it is drained. Surface generally level, in parts hilly; soil fertile. It has some good beds of coal, and timber is abundant. Farms 693 ; manuf. 9 ; dwell. 1,170, and pop.-wh. 7,153, fr. col. 7, sl. 2,376-total 9,596. Capital Columbiana, Public Works: Alabama and Tennessee River R. R.

SHELBY county, $7 l$. Situate $\mathrm{S}$. centrally, and contains 762 sq. m. Kaskaskia r. passes centrally through it, by which and its affluents, and by branches of S. fork of Sangamon r., it is drained. Surface level; soil in general fertile and very productive. Staples, wheat and Indian corn. Pork is exported largely. Farms 884; manuf. 7 ; dwell, 1,411, and pop.-wh. 7,762, fr. col. 45-total 7,807. Capital: Shelby ville, Public Works: Terre Haute and Alton $\mathbf{R}, \mathbf{R}$; Central R. R. ; Chicago Branch of Central R. R.

SHFLBY county, Ind, situate S. E. centrally, and contains $428 \mathrm{sq}$. m. Drained by E. branch of White r., Sugar cr. Big and Little Blue rivers, and Flat Rock cr., all which supply extensive water-power. Surface generally even soil fertile, and consists of a deep loam, with sand intermixed. Chief productions, wheat, Indian curn. sugar, and tobacco. Timber of excellent quality is found on the land. Farıns 1,620; manuf. 59; dwell. 2.721, and pop.-wh. 15.481, fr. col. 18-total 15,502. Capital: Shelbyrille. Public Works: Shelbyville Lateral Branch R. R.; Shelbyville and Nashville R. R.; Shelbyville and Knightstnwn R. R.; Lawrenceburg and Upper Mississippi P. R.; ete.

Smatw county, Ir. Situate $\mathbb{F}$. towaris the S., and contains $576 \mathrm{sq} . \mathrm{m}$. Drained by Boyer $r$, and branch of Nishnabatona r. Surface level; soil fertile, and adapled to grain. Set off since 1550 .

SHELsy county, $K y$. Situate $\mathrm{N}_{\text {.g }}$ and contains 426 sq. m. Drained by branches of Floyd's fork of Salt $r$. and its other numerous tributaries. Surface rolling; soil fertile, and in parts very productive. Staples, whent, Indian corn, and tobaceo. Farms 1.202; manuf. 132; dwell. 1. $>03$, anil pop). wh. 10.288, fr. col. 190, sl, 6,617-total 17.195. Capitur Shellyville, Pullic Works: Louisville and Frankfort R.R. Lexington and Frankfort R. R

Shexbr en, Mo. Situate toward the N. E., and contrins 495 sq. m. Drained by N. fork of Salt r. and North Two Rivers, by which good water-power is supplied. Surface Ievel; soil a fine deep mold, and very fertile. It has some good timber land, and excellent pasturage for cattle. Farms 786
397 ; manuf. 14, dwell. 632 , and pop.-wh. 3,741 , fr. col. 11 , sl. 498-total 4,258. Capital: Oakdale.

Syelby county, Ohio, Situate W., and contains 469 sq. m. Drained by Miami r. and its affluents. Surface rolling and pleasantly diversified; soil generally fertile. Chief productions, wheat and Indian corn. It exports a large quantity of pork and beef. Pine and other timber is found on the land. Farms 1,363; manuf. 28; dwell. 2,405, and pop.wh. 13,634, fr. col. 224 -total 13,958. Capitul: Sidney. Public Works: Bellefontaine and Indiana R. R.; Dirton and Michigan $\mathrm{R}$. R.; Miami Canal, ete.

SHelby county, Tenn. Situate S. W., and contains 916 sq. m. Drained by Wolf, Loosahatchy, and Big rivers, all tributaries of the Mississippi, which flows on its W. border. Surface level; excepting the bluffs on the Mississippi ; soil fertile, and adapted to cotton and tobaceo, wheat, and Indian corn. It exports large quantities of beef and pork. It is well timbered. Farms 1,115; manuf. 129; dwell. 2,926, and pop. wh. 16.591, fr. eol. 206, sl. 14,360-total 31,157 . Capital: Raleigh. Public Works: Memphis and Charleston R. R.; Memphis and Nashville R. R.

SHelby county, Texo. Situate E., and contains 912 sq. m. Drained by tributaries of Sabine r., which forms its eastern boundary. Surface undulating and interspersed with prairie and timber land; soil rich and very productive, and consists prineipally of a fine deep loam, with clay intermixed, the land on the Tenaha $r$, being remarkably fine and productive, and adapted to cotton. Pine, ash, elm, and beach are the principal timber trees. Farms 380 ; manuf. 6 ; dwell. 560, and pop.-wh. 8,278 , fr. col. 0, sl. 961-total 4,239. Capitul; Shelbyville

SIELBY, t. and p. v., Orleans co., $N . Y_{.}: 244 \mathrm{~m}$. W. by N, Albany. Drained by Oak Orehard er. Surface even; soil calcareous loam. The Erie Canal, and Rochester, Lockport, and Niagara Falls $R$. R. cross its $N$. W. part. The $\mathrm{r}$. has some manufactures, mills, etc. Pop. of t. 3,082.

Shelby, p. vo, and cap. Cleveland co, $N$. Car. : E. side First Broad river, $156 \mathrm{~m}$. W. by S. Raleigh. It eontains a court-house, jail, and otber public buillings, several mechanic shops, etc. A short distance $\mathbf{S}$. of the $\mathbf{v}$. is a fine sulphurous mineral spring.

Shelbr, p. r., Richland eo, Ohio: at the junction of the Cleveland, Columbus, and Cincinnati $R, R$, with the Mansfield and Sandusky, and Sandusky, Mansfield, and Newark R. R., 67 m. S. W. Cleveland, 45 m. S. Sandusky City, and 69 m. N. by E. Colurubus.

Shelby, p. o., Austin co., Tex. : 95 m. S. E. Austin City. Sheldy Bascr, p. v., Orleans co, $N_{\text {. }} Y_{\text {.: }}$ on the Erie Canal. 46 m. E. Buffalo, and 818 m. W. by N. Albany., and near the line of the Rochester, Lockport, and Niagara Falls R. R. It is a small vilage.

Shelby's Creer, p. o., Tippah co., Miss. : 175 m. N. N. E. Jackson.

SHELby Springs, p. v., Shelby co., Ala.: on a branch of Consa r., $57 \mathrm{~m}$. N. by W. Montgomery.

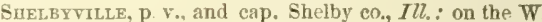
side of the Kaskaskia r., $53 \mathrm{~m}$. S. E. Springfield. It is situaterl on high groun l, in the centre of a fertile and well-cultivated country, and contains a neat court-house, built of brick, 2 stories high, surmounted by a cupola, other county buillings, etc. A copious sulphur spring is located here. The Alton and Terre Haute $\mathrm{R}$. $\mathrm{R}$. passes through the $\mathrm{v}$. Shelbytul, p. $\nabla_{a}$ and cap. Shelby co, Ind. : on the S. E. bank of Blue r., $26 \mathrm{~m}$. S. Indianapolis. It contains a court-house and jail, built of brick, stores of various kinds, a number of mechanic shops, 182 dwellings from two to three stories in height, some of which are of brik $k$, and 995 inhabitants. The river is navigable to this place at high water. and affords excellent water-power. The Shelbyville Lateral Branch R. R. the Knightstown and Shelbyville $R . R_{n}$ and the Rushville and Shelbysille $R . P$. all verge from this point, $16 \mathrm{~m}$. N. E. from Edinburg, $20 \mathrm{~m}$. from Rushville, and $27 \mathrm{~S}$. by W. from Knightstown. Taking into 
consideration these rnilroad connections, this place will now increase rapidly in business and population. The "National Volunteer" is a weekly issue.

SHELBYvHLE, p. v., and eap. Shelhy co., $\bar{K} y$. : on Brasher's cr. of Salt r., $21 \mathrm{~m}$. W. Frankfort. It contains a courthouse, jail, etc., and the Shelby College is located here, which in 1850 contained 4 professors, 4 alumni, 44 students, and a library containing 300 volume. The "Shelby News" is a weekly (whig) issue. Pop. about 800 .

Shelby vLle, p. v., and cap. Shelby co., Mo.: on the left bank of Jnck's er. of Salt r., $84 \mathrm{~m}$. N. Jefferson City. It is a small place, and contains a court-house, jail, etc. Population 301.

Shelby vile, p. v., and cap. Bedford co., Tenn.: on the right bank of Duck r., $45 \mathrm{~m}$. S. by E. Natshville. It contains a court-house, jail, and other public buildings, and a branch of the Bank of Tennessee is located here. The "Expositor" is a weekly (polit.) issue. Pop. about 800.

Shelbrpidue, p. v., and cap. Shelby co., Texo. : on S. side of Huana branch of Sabine river, on an elevated and fertile plain. 246 m. N. E. Austin City. It contains a court-house, jaill, ete.

Sneldox, t. and p. v., Franklin county, Verm.: $48 \mathrm{~m}$. N. W. by N. Montpelier. The Missisque r. divides the t., and with Black cr., its branch, drains it, and affords good hydraulic power. Its lands are good, producing grain, etc., in abundance. The v., on the Missisque r., is a thriving place, both in its manufactures and trade. Population of t. 1,814

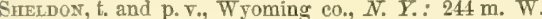
Albany. Drained by Tonawanda and Seneca creeks. Sarface hilly; soil fertile, better adapted to grazing than grain. Its manufactures consist in flour, lumber, leather, etc. The v. contains 2 churches, Pop. of $t_{n} 2,527$.

Sheldonvtlle, p. o., Norfolk co., Mass.

Sheldrake, p. o., Seneca co., N. Y.: $161 \mathrm{~m}$. W. Albany.

Sirflu Mound, sta., Marion co., Tenn. : on the Nashville and Chattanooga R. R., $130 \mathrm{~m}$. S. E. Nashville.

Shell Pont, p. 0., Wakulla county, Flor.: 24 miles S. Tallabassee.

Shelltows, p. o., Ocean co., N. Jer. : on S. side of Crosswick's cr., 12 m. S. E. by E. Trenton. Here is a Friends' meeting-house.

Shetocta, p. v., Indiana co., Penn. : on a fork of Crooked creek, $127 \mathrm{~m}$. W. by N. Harrisburg.

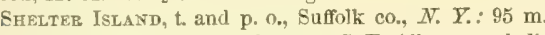
E. by N. New York city, and $214 \mathrm{~m}$. S. E. Albany, and directly opposite Greenport, the terminus of the Long Island Railroad, occupying the whole of the island so called, lying between Great Peeonic and Gardiner's bays. It is 6 miles Iong and $4 \mathrm{~m}$. wide, and was first settled in 1652 . Surface uneven; soil, though in general inferinr, has some fertile parts. There is a ship channel around the island, and a ferry connects it with Southold, 120 rods distant. Pop. 386.

SIfltowrile, p. o., Forsyth county, Ga.: 95 m. N. W. Milledgeville.

SHexandoar county, Virg. Situate toward the N., and contains $386 \mathrm{sq}$. m. Drained by N. fork of Shenandoah $r$. Surface uneven and mountainous; soll various, in some parts very fertile. Chief products, wheat and Indian corn. Farms 554; manuf. 7 ; dwell. 2,143, and pop.-wh. 12,595, fr. col. 262, sl. 911-total 13.768. Capital: Woodstock. Public Works: Manassas Gap R. R.

Shenandoah, p.. ., Duehess co., $N$. $Y .: 10 \mathrm{~m}$. E. from Fishkill Landing, $76 \mathrm{~m}$. S. Albany,

SHENANDOAH river, Firg. : is a large $\mathrm{S}$. branch of Potomac r. furmed from its $\mathrm{S}$. branch, which rises in Augusta $\mathrm{co}_{2}$, and the $\mathrm{N}$. branch, which rises in Rockingham co., and flows along the $W$, side of the Blue ridge, and parallel to the $\mathrm{S}$. branch, until near their confluence in Warren $\mathrm{cn.}$. whence the united stream flows N. E. to its junction with Potomac r., near its passage through the Blue ridge at Harper's Ferry.
Shenandoau Irox Works, p. o., Page co., Virg.: $88 \mathrm{~m}$. N. W. Richmond.

SHEPATG river, Conn.: a branch of the Housatonic, entering it at Southbury from the N., affording good waterpower.

Sirephend's Grove, p. 0., Culpepper co., $\nabla$ irg.: $66 \mathrm{~m}$, N. N. W. Richmond.

SHePIERDSTOWN, p. $\nabla$., Belmont co., Ohio: on E. side of a branch of Wheeling creek, 105 miles $\mathbf{E}$. by $\mathbf{N}$. Columbus, Pop. 90.

Sirepherdstown, p. v., Cumberland co., Penn.: 7 m. S. Harrisburg,

Sinepinerdstows, p. V., Jefferson co., Firg.: on the S. W. side of the Potomac river, $10 \mathrm{~m}$. above Harper's Ferry, and $129 \mathrm{~m}$. N. by W. Richmond. The water-power is excellent, and considerable flour is manufactured. The Baltimore and Ohio R. R. passes near the v. Three papers are issued weekly: the "Free Press" (whig), "Spirit of Jefferson" (dem.), and the "Shepherdstown Register" (neut.). Pop. 1,561 .

Shepherdstule, p. v, and eap. Bullitt co, $K y,:$ on $\mathrm{N}_{\text {. }}$ side of Salt r., $48 \mathrm{~m}$. W. S. W. Frankfort. It contains the co. buildings, a seminary, and about 350 inhabitants. The Louisville and Nashville R. R. will pass through it. Paroquette Springs, $1 \mathrm{~m}$. from the $\mathrm{v}$., is a watering place of considerable resort.

Sherbori, t. and p. $v_{\text {., }}$ Chenango co, $N$. $Y$.: $92 \mathrm{~m}$. W. Albany. Drained by Chenango river, and the Chenango Canal passes through, parallel with it. Surface hilly; soil fertile. The $t$. was settled by a party of 20 families from Connecticut, and incorporated in 1830 . The., on the Chenango $\mathrm{r}$. and canal, $41 \mathrm{~m} . \mathrm{S}$. W. Utica, is a flourishing place, and contains 4 churches, an academy, several forwarding houses, stores, etc. The name of the t. has been changed by the legislature from Sherburne to the present. Population 2,623 .

SHerburNe, t. and p. ₹., Middlesex county, Mass. : $18 \mathrm{~m}$. S. W. by W. Boston. Charies river forms itg E. boundary Incorporated 1674. Surface elevated; snil fertile. The Milford Branch R. R. passes through its W. part. The V. at the centre, contains 2 churches, and has some manufactures. Pop. of t. 1,023 .

Sherburve, t. and p. v., Rutland county, Term.: $45 \mathrm{~m}$ S. by W. Montpelier. Surface chiefly broken and mount ainous, rising in the $\mathrm{S}$. part into Killington Peak, the summit of which is 3,924 feet above tide-water. Drained by Quechee r. Pop. of t. 578 .

SHarberne Mults, p. v., Fleming co, $K y_{\bullet}:$ on E. bank of Licking r., $63 \mathrm{~m}$. E. by N. Frankfort.

Sherburnevilde, p. O., Lake co., Ind. : 125 miles $\mathrm{N}$. W. Indianapolis.

Sufridax, t. and p. o.. Chautauque co., N. Y.: $2 S 9 \mathrm{~m}$. W. by S. Albany. Lake Erie bounds it on the N. Drained by several small streams flowing into the lake. Surface hilly ; soil fertile. This is a highly cultivated farming district, with excellent water-power, several mills, and light manufactures. The New Tork and Erie, and Lake Shore railroads pass through the town, and connect at Dunkirk, three miles W. Pop. 2,172.

Sherman. t, and p. v., Fairfield co, Conn,: $47 \mathrm{~m}, \mathrm{~W}, \mathrm{~S}, \mathrm{~W}$. Hartford, 36 miles N. W. New Haven. Surface uneven Drained by Rock r., a branch of the Housatonic. It contains several mills, a few stores, and tanneries. Population of $t, 9 S 4$.

SHERMAN, p. V., Conk co., $I l_{\text {. }}$ : on the right bank of $\mathrm{N}$. branch Chicago river, $19 \mathrm{~m}, \mathrm{~N}$. by $\mathrm{W}$. Chicago, and $183 \mathrm{~m}$. N. E. from Springfield.

SHerMax, p. v., and cap. Grayson county, Tex.: on Chnctaw branch of Red river, 247 miles N. by E. Austin City.

SHFrmax, t. and $\mathrm{n}$. v., Chautauque enunty, $N . Y .: 308 \mathrm{~m}$. W. by S. Albany. Drained by head waters of French cr. Surface rolling; soil fertile. It has excellent watcr-power. 
The v. contains a furnace, several mills, and a tannery. Pop. of t. 1,292.

Simervar, t. and p. v., Huron co, Ohio: $81 \mathrm{~m}$. N. Columbus. Drained by branches of Huron r. Surface rolling: soil fertile. The Mansfield and Sandusky City R. R. passes through the E. part. The $\mathrm{v}_{\text {, }}$ on E. side of Pipe creek, has several mills, etc. Pop, of t, 1,134.

Sherman's Dale, p. o., Perry co., Penn.: $17 \mathrm{~m}$. W. by N. Harrisburg.

Snervay's Hollow, p. o., Yates co, $N . Y .: 177 \mathrm{~m}$. W. Albany.

Sherodstille, p. o., Carroll con, Otio: 99 m. E. N. E. Columbus.

Sherrill's Ford, p. o., Lincoln county, N. Car.: $138 \mathrm{~m}$. W. by S. Raleigh.

SHERWOOD, t. and p. O., Branch co., Mich.: 61 m. S. W. Lansing. Drained by St. Joseph's $r$. There is a pond in W. part. Surface rolling; soil excellent, and much grain is raised. It is one of the best farming towns in the county. Pop. 686 .

SherWOoD's, p. o., Cayuga co., N. Y.: 150 m. W. Albany. Sheshequin, t. and p. o., Bradford co., Penn. : on E. side of Susquehanna river, $107 \mathrm{~m}$. N. Harrisburg. Drained by several small streams flowing into the Susquehanna. Sur face billy; soil fertile. It has some manufactories, mills, ete. Pop. about 1,000 .

Shetuchet river, Conn.: rises by several branches in Tolland and Windham counties, flows S., receiving two large tributaries, the Natchaug and Willimantic rivers; thence flows S. S. E., and in E. part of Norwich t. receives the Quinebaug $r_{\text {, }}$ forming the main constituent of Thames river. It affords goiod water-power.

SHIA ASSEE county, Mrich. Situate centrally, and contains 576 sq. m. Drained by Shiawassee, Maple, Mishtegaycock, and Looking-glass rivers, which supply good water-power. Surface level; soil productive. In some parts of the county mineral coal is found. The agricultural products are wheat, Indian corn, and potatoes. The industry of the county is mostly applied to farming. Farms 640 ; manuf. 48 ; dwell. 972, and pop.-wh. 5,230, fr. col. 0-total 5,230. Capitul Corunna.

Sarawasser, t and p. v., Shiawassee co., Mich.: $25 \mathrm{~m}$. N. E. Lansing. Drained by the Shiawassee and Lnokiugglass rivers. Surface rolling; soil fertile. Mineral coal is found. The $v_{\text {., }}$ on the Shiawassee $r$, is a flourishing place, and has some inanufactures. Pop. of t. 810 .

Shickshixis, p. v., Luzerne county, Penn.: on the right bank of the Susquehanna r., and on the North Branch Division of the Pennsylvania Canal, $77 \mathrm{~m}$. N. E. Ilarrisburg. A furnace, lncated near the $\mathrm{v}$, operated by water-power, has an annual capacity of 1,500 lons.

ShieldsborovGi, p. V., port of entry, and cap. Hancock co., Niss.: on W. side of the mouth of Louis bay, $144 \mathrm{~m}$. S. S. E. Jackson. It contains the co. buildings, etc., and is the port of entry for Pearl river U. S. collection district, of which the commerciul statisties on 30 th June, 1550 , are as follows: total tonnage, 1.367 tons, all of which was enrolled and licensed, and engaged in the coasting trade; of which 831 tons were licensed under 20 tons, and 215 tons propelled by steam. During the preceding year it had no foreign commerce nor ship-building.

Smiloaf, p.. ., Camden county, $N$. Car. : between North and $P$ asquotank rivers, near their entrance into Albemarle Sound, 152 m. E. N. E. Raleigh.

Sirmor, p. v., Marengo county, Ala. : 90 miles W. by S. Montgnmery.

Shilor, p. O., Cumberland co., N. Jer. : 63 m. S. by W. Trenton.

SHilor, p. o., Callaway co., $\bar{k} y$. : 216 m. S.T. Frankfort. Simlor, p. o., Gibson county, Tenn.: 117 m. W. by S. Nashville.

Surlor, p. 0., King George co., Tirg. : $5 \mathrm{~L}$ m. N. by E. Richmond.
Sirlor, p. V., Sumter dist., S. Car. : on E. side Paulding swamp of Black r., $53 \mathrm{~m}$. E. Columbia.

Shlloe, p. o, Union parish, $L a .: 179 \mathrm{~m}$. N. N. W. Baton Rouge.

ShIFgle CreeK, p. o., St. Lawrence co, $N_{0} Y_{0}: 145 \mathrm{~m}$. N. N. W. Albany.

Shin Hollow, sta, Orange co., $N . \bar{Y}$ : : on the Erie R. R. $10 \mathrm{~m}$. W. Otisville, $92 \mathrm{~m}$. N. W. New York city, and $94 \mathrm{~m}$. S. W. Albany. At this place there is a deep cut through a snft soil three-fourths of a mile in length and thirty feet deep. This part of the road is of the most oppressive loneliness, for the valley is completely shut out of sight by a steep wall on each side of slate rock, 50 feet in height and 2.500 feet in length, beyond which is a beautiful open country.

SHINNECOCK bay, $N_{\text {. }} Y_{\text {. : }}$ is a beautiful body of water in S. part of Southampton t., Suffolk co., Long Island, $10 \mathrm{~m}$. long, and from 3 to $4 \mathrm{~m}$. wide-separated from the ocean by a narrow sand-beach, evidently formed by the waves. It has long been noted for producing large quantities of elams and other shell-fish of superior quality, affording employment to many persons.

Sinniston, p. v., Harrison co., Virg.: on the E. side of the W. fork of Monongahela r., $200 \mathrm{~m}$. N.W. Richmond. It contains several mills and lumber yards, and has an exten sive trade in lumber.

Smppen, t. and p. o., M'Kean county, Penn.: 111 m. N.W. Harrisburg. Drained by Driftwood branch and other tributaries of Sinemahoning $\mathrm{cr}$. Surface rough and mountainous, with some fertile soil in the valleys. It has salt-works and springs on Driftwood ereek. The Sunbury and Erie R. R. will pass through this place.

Shrppensburg, p. b. and sta., Cumberland co., Penm.: on a branch of Conedogwinit cr., and on the Cumberland Valley R. R., $45 \mathrm{~m}$. S. W. Harrisburg. It is located in the midst of a fertile country, and has excellent water-power. Four miles distant are two furnaces, with an annual capacity of 1,500 tons each. The "Weekly News" (whig) is published. Pop. 1,578.

Simprenstille, p. V., Clarion co, Penn.: on Paint cr. $149 \mathrm{~m}$. W. N. W. Harrisburg. Two furnaces, located here, have annual capacities of 1,100 tons and 1,400 tons; also a forge which in 1550 produced 1,500 tons bar iron.

Simremantown, p. v., Cumberland co., Penn.: $15 \mathrm{~m}$. W. by S. Harrisburg. The Cumberland Valley R. R. passes near the village.

Sirrzaxn, p. o, Alleghany co., Penn.: $155 \mathrm{~m}$. W. by $\mathrm{N}$. Harrisburg.

Smirlex, t. and p. o., Piscataquis county, Me.: $72 \mathrm{~m} . \mathrm{N}$ Augusta. Incorporated in 1834. Watered by head branches of Piscataquis $r_{\text {., }}$ on which are mills. Pop. 250.

Shrrley, t., p. v., and sta., Middlesex co., Mass, : 35 m. N. W. by W. Boston. Bounded on the S. E. by Nashua r. and on the $\mathrm{N}$. E. by Squanicook branch, each of which af fords fine water-power. Surface generally low and level. The Fitchburg R. R. passes through the v. $40 \mathrm{~m}$. from Boston, $10 \mathrm{~m}$. from Fitchburg. In the S. W. part of the t, is a Shaker settlement of about 150 members. Pop. of t. 1,158. Shlrlez, p. o., Erie co., N. Y.: $264 \mathrm{~m}$. W. Albany.

Shirley, p. o., Tyler con, Firg.: 232 m. N.W. Richmond

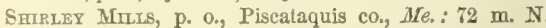
Augusta.

Shirlersiorg, p. o., Huntingdon co., Penn.: on E. side of Great Augwick cr., $53 \mathrm{~m}$. W. Harrisburg. It occupies the site and bears the name of an old provincial fortress, erected in the French war for the defense of the western frontiers.

Shrier Village, p. v., Middlesex co., Mass. : on Nashua river, $34 \mathrm{~m}$. N. W. by W. Boston, containing a church, several mills, and manufactories.

Shirlexpille, p. o, Abbeville district, $S$. Car.: 79 m. W. by N. Columbia.

Shodl Creer, p. o., Clinton co., $M$. : on the E. side of the 
stream so called, $80 \mathrm{~m}$. S. Springfield. It is located on the border of a fertile prairie.

Snoal Creek, p. o. Newton county, Mo.: 162 m. S. W. Jeffers n City.

SHOAL Ford, p. v., Limestone co., Ala.: on E, side of Limestone creek of Tennessee river, $169 \mathrm{~m}$. N. by W. Montgomery.

SIIUALS of OGECHEE, p. o., Hancock county, Gu. : on the

Ogechee r., 33 m. E. N. E. Milledgeville.

SHotl Sirixg, p. o., Giles co., Tenn. : 78 m. S. Nashville. Shozer's Mrlis, p. o., Carroll co., Ohio: 97 m. E. N. E. Columbus.

Shocco Sprtags, p. v., Warren co, $N$. Car.: on E. side of Fishing er, $45 \mathrm{~m}$. N. E. Raleigh.

SHommaker's, sta., Allegany county, $N . Y$ : on the New York and Erie R. R., $362 \mathrm{~m}$. New York, and $221 \mathrm{~m}$.

W. S. W. Albany

Srotola, sta, Sullivan co., $N . Y$ : on the Delaware r.:

Erie P. R., and Delaware and Hudson Canal, 107 11. N. W.

New York, $101 \mathrm{~m}$. S. WV. Albany.

SHokax, p. o., Ulster co., $N$. Y.: $56 \mathrm{~m}$. S. W. Albany.

SHококоN, p. v., Henderson county, $T l l .: 8 \mathrm{~m}$. E. of the

Mississippi $r_{.,}$and $95 \mathrm{~m}$. N. W. from Springfield.

Shongato, p. v., Carroll county, Briss.: on the W. of Big

Black $r$, $\tau$ (5 $\mathrm{m}$. N. by E. Jackson.

Snovgo, p. o., Allegany county, $N_{.} Y_{.}: 223$ m. W. S. W. Albany.

ShooborA, p. o., Clark co., Miss. : 87 m. E. by S. Jackson. Shooling Creik, p. o., Cherokee co, $N$. Car a: 320 m.

\section{W. S. W. Raleigh.}

Shopiere, p. o., Rock co., Wisc. : 35 m. S. E. Madison.

Shop Sprivg, p. o., Wilson county, Tenn. : 23 m. E. by N. Nashville.

SHop Spring, p. o., Newbury district, $S$. Car.: $41 \mathrm{~m}$ W. N. W. Columbia.

ShoremaM, t. and p. V., Addison co., Term. : on the E. side of Lake Champlain, $45 \mathrm{~m}$. S. W. Montpelier. Drained by Lemonfair r., sffording good water-power. Surface even; soil fertile, and it is one of the best farming towns in the Stute, with some manufactures. Most of the waters here are impregnated with epsom salts. The $\mathrm{v}$. is pleasnutly Eocater a little E. of the lake, and is the seat of Newton Academy. Pop. of t. 1,601.

Short Bexd, p. o., Dent co., Mro. : 62 m. S. E. Jefferson City.

Short Creek, t. and p. v., Harrison county, Otio: 105 ma E. by N. Columbus. Drained by an affuent of the Ohio $r$. which furnishes good mill-sites. Surfuce uneven; soil fertile and weli adapted to grain. The villages of Harrisville and Georgetown are in the town. The Y. has some manufactories, etc Pon, of t. 1.950 .

Sirort Creek, p. o., Grayson county, $\bar{k} y .: 95$ m. S. E. Erankfort.

Short Crekk, p. o., Brooke county, Firg.: $254 \mathrm{~m}$. N. W. Pichmond

Sifort Tract, p. V., Allegany co., $N$. $X_{0}$ : on a branch of the Genesee r., $225 \mathrm{~m}$. W. Albany.

Shortene's, sta., Macon co., Ala. : on the Montgomery atad West Point R. R., 25 m. E. Montgomery.

SHozt8vilue, v. and sta, Ontario ceunty, $N . Y_{\text {. }}$ : on the Rochester and Syracuse R. P., $41 \mathrm{~m}$. S. E. Ruchester, ana $18 \pm \mathrm{m}$. W. by $\mathrm{N}$. from Albany.

Sinomsfrown, sta., Alleghany co., Penn.: on the N. side of the Ohio r., and on the Ohio and Pennsylvania $R . R$. $14 \mathrm{~m}$. W. Pittsburg, and $175 \mathrm{~m}$. W. by N. Harrisburg.

Srreve. p. o., Wayne co., Ohto: $78 \mathrm{~m}$. N. E. Columbus.

Shreferopt, $p$. v., and cap. Cado parish, $L a$ : on the right bank of Red r.o about $1 \mathrm{~m}$. $\mathrm{S}$. of Soda lake, $201 \mathrm{~m}$. N. W. Baton Rouge. It contains a court-honse, jail, etc. It is the most important town in N. W. Louisiana, and will be intersected by the Vicksburg, Shreveport, and Texas 2. R.. now in progress. Pop. 3.133

SHREWELEv, t and p. v., Worcester co., Muss.: $33 \mathrm{~m}$.
W. by N. Boston. A large pond, abounding in fine fish, forms the S. W. boundary, and is the principal feeder of the BIackstone Canal. Drained by several struams and rivulets. Surface uneven and hilly, a range of high land extending through it from N. to S.: soil good. In the $\mathrm{S}$. W. part is a meadow, containing excellent peat. It has some manufactures, consisting of clothing, guns, hats, leather, etc. The v. is centrally situate. Pop. of t. 1,589.

Surcwsbury, t. and p. v., Monmoulh co., $N$. Jer. : $36 \mathrm{~m}$. E. by N. Trenton. Drained by Neversink, Shrewsbury, and Shark rivers, the two former forming the N. boundary, and the latter its S. W. boundary. Surface level ; soil clay loam, or marl. It is much resorted to by people from New York and Philadelphia in summer, as a bathing-place. The v. is located between Shrewsbury and Neversink rivers. The t. contains a furnace, tannery, lumber yard, several mills, etc. Pøp. of t. 3,180 .

Shrewsbury, t. and p. v., York eo., Penn.: 33 m. S. by E. Harrisburg. Drained ly branches of Codorus cr. Surface undulating; soil inftrior. The b. is in the $S$. part of the $t$. and has some manufactures, etc. There is in the t., independent of the b., manufactures of woolen goods and paper, several mills. etc. The Baltimore and Susquehanna $P_{v}, R$. crosses the W. part of the town

SHREwsburx, t. and p. $\mathrm{v}$, Rutland county, Ferm. $54 \mathrm{~m}$. $\mathrm{S}$. by Montuelier. Drained by Mill and Cold rivers, which afford water-power. Surfice mountainous, lying on the Green Mountain range. It contuins Shrewsbury Peak: height 4,100 feet above tide-water. The land is chiefly adapted to grazing, and there is good timber. It has some manufactures. The $\mathrm{v}$. is on Cold river, and the Rutland and Burlington R. R. erosses the S. W. part of the t. Pop of t. $1,26 \mathrm{~s}$.

SHrenseurs, p. o, Kanawha co., Fir .: 229 m. TV. N. T. Richmand.

SHrewsmoxx river, Monmouth co., $N$. Jer : a continuation of Sandy Hook bay, flowing $5 \mathrm{~m}$. partly through a salt marsh, averaging about $1 \frac{1}{2} \mathrm{~m}$. in width. It receives Shrewsbury river proper, a stream 6 or $7 \mathrm{~m}$. long.

Surub OAK, p. O., Westchester county, $\mathcal{N}$. $Y .: 93 \mathrm{~m}$. S. Albany.

SHULLSBURG, to and p. $v_{*}$, Lafayette county, Wisc. : on a branch of Fever r., 57 m. S. W. Madison. Large quantities of lead ore are here raised. Pop. 1,67s.

SuUnr, p. o., Sullivan co., Penn.: 75 m. N. Harrisburg.

Srovk, p. o., Henry county, Ohio: 105 miles N. W. Columbus.

SHunpike, v. and sta., Cayuga county, $N$. $Y$.: on the Rochester and syrmense R. R., 33 m. W. S. W. Syracuse, and $15 \pm \mathrm{m}$. W. by Y. from Albany.

Sinushris, p. v, and sta., Washington co, $N$. $Y$.: on the Battenkill, and on the Putland and Washington R. R., $34 \mathrm{~m}$. N. E. Troy, and $45 \mathrm{~m}$. from Albany.

Shutesburi, t. and p. v., Frankliu county, Mrass.: $69 \mathrm{~m}$. W. by N. Boston. Drained by branches of Mill r. and by Swift $r$. Surface elevated, in parts hilly and rocky ; soil of average fertility, most productive along the streams. Lock's Pond in N. W. part of t., covers 700 acres, and is well stocked with fish. There is also a mineral spring of some note noar the centre, abounding in muriate of lime. The manufactures of the t. are light. The $\mathrm{v}$.' is located centrally. Pop. of t. 912

Sur Poss, p. v., Aurrain co., MFo. : on the E. of Loutrie r., $42 \mathrm{~m}$. N. E. Jefferson City.

Sram, p. o., Leon co., Tex. : 123 m. N. E. Austin City.

Siasconser, v, Nantucket cu., Muss.: on the S. E. part of Nantucket island, $7 \mathrm{~m}$. from Nantucket $\mathrm{v}_{\text {., }}$ is an attractive summer resort, having a fine hotel and other aceommodations.

Srbila, p. v., Washington par., $L a_{0}$ : on a branch of Tangipahoa r., 49 m. N. E. Baton Rouge.

Siblex, p. v., Jackson co., Mo.: on the right bank of the Ohio r., 116 m. W. N. W. Jefferson City. 
Siblex's Mills, W ilkinson co., Jiks.: 101 m. S. W. Jackson. Srculy.p. o.,Highland co., Ohio: 61 miles S.S.W. Columbus. Sideling mountains, Penn. and $M d_{0}$ : a range of mountains traversing Huntingdon and Bedford counties, Pennsylvania, and Alleghany co., $\mathrm{Md}$.

SIDNey, p. v., Marshall co., Ind.: $101 \mathrm{~m}$. N. Indianapolis. SrDner, t. and p. v. Kennebec county, $Y_{.}: 7$ miles $\mathrm{N}$. Augusta. The Kennebec r. forms its E. boundary, and a portion of Snow's Pond is on the N. part, by which it is watered. Surface varied; soil fertile, and much grain is raised. Ineorporated in 1792 . Its manufactures consist of leather, lumber, etc. The village is on the right bank of the Kennebec river. Pop. of t, 1,955.

Sidxex, p. v., Hunterdon co., $N_{\bullet}$ Jer.: on the W. of South branch Raritan r., $26 \mathrm{~m}$. N. W. Trenton.

SIDNex, t. and p. v., Delaware co., N. $Y_{.:} 82 \mathrm{~m}$. W.S. W. Albany. Drained by Oleont ereek and other small streams flowing into the Susquehanna r., which bounds it on the N. Surface hilly, except along the $r_{*,}$ where it is even; soil of great fertility, and well cultivated. It has good waterpower, and some manufactures, consisting of woolen goods, flour, and lumber. The v, on Oleont creek has some mills, etc. Pop. of t. 1,807.

Sidner, p. v., and cap. Shelby co,, Ohio: on a branch of the Great Miami river and Iine of the Sidney feeder of the Miami canal, $65 \mathrm{~m}$. W. N. W. Columbus. It contains a fine brick court-house, a jail, several stores, manufactories, ete. and is destined to be a place of commercial importance. The Bellefontaine and Indiana $R$. R. passes through it, and is here intersected by the Dayton and Michigan R. R.-two lines connecting it with the great towns in every direction. Pop. in 1St0, 713, and in 1550, 1,302.

SIDNeY Centre, p. Y., Delaware co.s $N . \bar{Y}$ : on a small stream, tributary of the Susquehanna river, $\$ 3$ m. W. S. W. Albany.

Sidney Plains, p. v., Delaware co., $N . Y .:$ on S. side of Susquehanna ro, $92 \mathrm{~m}$. W. S. W. Albany.

Smoxsburg, p. o., York county, Penn. : $11 \mathrm{~m} . \mathrm{S}$. by W. Harrisburg.

Siegel's STORE, p. o., Lincoln county, N. Car.: 139 miles W. S. W. Raleigh.

Sterra county, Calif. Situate E. on the State line, and occupying the mountain sources of the Yuba river. Area about 800 sq. m. The principal mountains are Saddle Peak, 7,200 feet high; Table mountain 8,000 feet, and the Buttes at the head of the S. fork of the Yuba, 9,000 feet, and surrounded with quartz leads. This is one of the richest gold fields in the State, and has also muny facilities for successful agriculture, its great elevation nevertheless. Limestone of excellent quality abounds; but there are no mineral springs. In 1552 the capital intested in quartz mining amounted to $\$ 9,109$; in plactr nining. $\$ 1 \% 4,151$, and in other industries, $\$ 732,225$. The principal mining locations are Downieville, with 810 inhabitants; Pine Grove, with 504; Windsor, 210; Cox's and Snake Bars, 316, and Goodyear's Bar, 356 . Cultivated land 165 acres. Pupulation at same tate 4,450 -whites $3,692-3,600$ males, and 62 fenales : negroes 42 ; mulattoes 7 , and foreign residents $1,067-1,033$ males, and 84 females. Over 21 years of age-citizens of the United States 8,463 , negroes 41 , mulatioes 7 , and foreigners 976. Capitul: Downieville.

Sierra Morixo, or Bliow Micxtaiss, San Franciseo co, Culif: : the most remarkable commence at a point about 10 miles S. of San Francisco city, and run along the coast until they unite with the range of same name in the county of Santa Clara; they are above 2.000 feet in height, and protect the inhabitants of the valley from the coast winds. The soil in the valleys is rich and productive. Several streams have their sources here, and some gold is found

Sierra Nevada mountains, Califf. (See Caimoria.)

Sigotrier, p. r., Teokuk county, Iu.: on a braneh of Skunk r., 50 m. S. W. Iowa City, Pop. 162.
Sill's Creek, p. o., New Hanover co., N. Car.: $84 \mathrm{~m}$. S. S. E. Raleigh.

Siloan, p. v., Madison co., N. F.: 104 m. W. N.W. Albany. Silodi, p. o., Surry county, $N$. C'ur.: 126 m. W. N. IV. Raleigh.

Silver lake, Wyoming co., $N$. $Y$. : a heautiful lake, lying in the towns of Perry and Castile, $5 \mathrm{~m}$. long and three-quarters of a mile wide abounding with excellent fish, originally introdueed from Lake Erie.

Silver BltFr, $S$. Cur: an eminence extending about $2 \mathrm{~m}$. along the bank of the Savannah river, about $1 \mathrm{~m}$. wide, and elevated nearly 30 feet above the opposite shore.

Silver Creer: p. v., Stephenson co., $M l_{*}$ : on the S. side of Pekatonica r., at the mouth of Silver creek, 165 miles $\mathrm{N}$. Springfield. The Illinois Central R. R. passes 1 mile N. of this place.

Sulver Creex, p. o, Schuylkill co, Penn.: 42 m N. E. Harrisburg.

Silver Creek, t. and p. o., Cass co., Mich.: $93 \mathrm{~m}$. S. W. Lansing. Drained by Dorragiake river. Surface gently undulating, with an exceedingly fertile soil, producing grain in abundance. The stream affords good water-power. Pop. 491.

Silver Creek, p. v., and sta., Chautauque county, $N$. $Y$.: near the mouth of the creek so called and its confluence with Lake Erie, and on the Buffalo and State Line R. R., 31 miles $\mathrm{S}$. by W. Buffalo, $256 \mathrm{~m}$. W. from Albany. It is a manufacturing village, and has some trade in lumber, etc. The imports for 1815 amounted to $\$ 212,819$, and the exports $\$ 107,081$, making a total of $\$ 319,900$. Being connected with. Dunkirk and Buffalo by R. R. and the lake by water, it bids fair snon to become a place of some note. It has 1 bank, cap. $\$ 92, \$ 50$. The "Silver Creek Mail" (whig) is a weekly issue" Silver Creer, p. o., Maury county, Tenn.: 35 m. S. Nashville.

Silver Glade, p. v., Anderson district, S. Car.: E. of Twelve Mile ereek, $95 \mathrm{~m}$. N. W. by W. Columbia.

Silver Hilu, p. o., Davidson county, N. Car.: 89 m. W. Raleigh.

Silver Lake, p. o., Washtenaw co., Mfich.: 45 m. S. E. Lansing.

SILver LAkE, t. and p. v., Susquehanna co., Penn. : $59 \mathrm{~m}$. N. N. E. Harrisburg. Drained by tributaries of Chocout creek, and by Silver creek, outlet of Silver lake, a sheet of water three-quarters of a mile long and half a mile wide, N. E. of which is Quaker lake. Surface hilly ; soil fertile. The $v$. on Silver cr. has several mills, etc.

Silver Rux, p. 0, Meigs co., Ohio: 75 m. S. E. Columbus. Silver Run, p. v., Talladega co, Ala.: on Chockolocko creek, $86 \mathrm{~m}$. N. by E. Montgomery.

Srrvar Sprivg, p. o., St. Francois co., DYo. : 107 m. E. S. E. Jefferson City. Deposits of iron and lead are found in the vicinity.

Sirver Street, sta., Newbury dist., $S$. Car.: on the Greenville and Columbia R. P., 54 m. W. N.W. Columbia. Silvertos, p. o., Barnwell district, S. Car.: $63 \mathrm{~m}$. S. W. Columbir.

SILVER TOP, Obion en., Tenn.: $137 \mathrm{~m}$. W. Nashville.

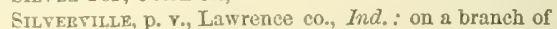
White r., 65 m. S. S. W. Indianapolis.

Srmuoss, p. o. Lawrence eo, Ohio: 99 m.S. byE. Columbus. Smorosinte, p. 0., Giles co., Virg. : 143 m. W. by S. Richmond.

Srmis Port, p. o., Arogelles par., La.: 73 m. N. W. Baton Rouge.

simoxswi.Le, p. v., Windsor co., Ferm.: on a branch of William's river, $73 \mathrm{~m}$. S. Montpelier.

SImpsox county, $K y$. Situate $S$. toward the W., and contains 234 sq. m. Drained by Drake's ereek and branches, which enter Big Barren $r_{\text {. }}$ in the $\mathrm{E}_{\text {. of Warren }} \mathrm{00.}$, and by branches of Red r., a chief tributary of Cumberland r. Surface level: soil fertile, and adapted to cotton and tohacco, which with wheat and Itulan eorz, form the staples. The 
boundary line of the State lies on its S. border. Farms 686 ; manuf. 37 ; dwell. 968, and pop.-wh. 5,755, fr. col. 43, sl. 1,935-total 7,723. Cupital: Franklin. Public Works: Louisrille and Nashville R. R.

SLupson county, Miss. Situate toward the S. W., and contains $581 \mathrm{sq} . \mathrm{m}$. Drained by branches of Pearl river, which bounds it on the W. Surface level; soil generally fertile, and adapted to grazing. Chief productions, rice and cotton. Farms 451; manuf. 8; dwell. 526, and pop. -wh. 3,190, fr. col. 3, sl. 1,541-total 4,734. Capital. Wiestrille.

SnIPsox's, p. o., Floyd county, Virg. : 137 m. W. by S. Richmond.

Srarpson"s, sta., Preston co., Virg. : on the Baltimore and Ohio R. R., 113 m. S. E. Wheeling, and 173 m. N. W. Richmond.

Stupsoy"s MrLu, p. o., Laurens dist., S. Car. : on E. side of Raeburn's cr., $66 \mathrm{~m}$. N. W. Columbia.

Srarpson's Store, p. 0., Washington co., Penn. : 175 m.W. Harrisburg.

Sinipsonvilue, p. v., Shelby co., Ky. : on Floyd's fork of Salt r., 181 m. S. W. Nashville.

Sinpsonvilue, p. o., Anne Arundel county, $M d$.

Simsbery, t., p. v., and sta., Hartford co., Conn.: on W. side of Farmington r., $11 \mathrm{~m}$. N. W. Hartford; by New Haven and Northampton or Canal $\mathrm{R}, \mathrm{R}, 42$ miles $\mathrm{N}$. from New Haven. Surface of $t$, is much diversified; soil various. In the N. E. corner is the ffourishing manufacturing village of Tariffville. Pop. of to in 1840, 1,895 ; in 18j0, 2,737.

Styclair's Bottom, p. 0., Smyth county, Virg.: $231 \mathrm{~m}$. W. S. W. Richmond.

Stveath, v. and sta., Charleston district, S. Car.: on the South Carolina R. R., 13 m. N. W. Charleston.

Sirepuxent bay, Worcester co., Md.: a large sheet of water inclosed from the Atlantic Ocean by the sand beach, called Assateague, or Fenwick's island. It is navigable only for very small craft.

SLYEPUXENT neck, Worcester co., Md.: a long neck of land projecting into the bay so called, almost separated from the main by Trap and Herring creeks, between the waters of which the construction of a canal has been propos $\because$ d.

STrg Srrg, p. v. and sta., Westchester con, N. Y.: on E. bank of Hudson river; by Hudson River R. R., $32 \mathrm{~m}$. from New York, and $118 \mathrm{~m}$. from Albany. Situated on elevated and uneven ground, and presenting a picturesque appearance. Incorporated in 1813. It has several landings, from which steamboats and other vessels ply daily to New York. with which it has a large trade. It contains an iron foundry, ship-yard, grist-mill, some small manufactories, and 5 churches. Mount Pleasant Academy, an incorporated institution for boys, has a handsome marble edifice, 3 stories high above the basement. The Mount Pleasant Female Seminary is also an incorporated institution, having a beautiful location. The Croton Aqueduct at this place is an object of much attraction; it crosses over the Sing Sing kill by a handsome arch, of which the space between its abutments is 88 feet, and its elevation frnm the creek 100 feet. Sing Sing is chiefly celebrated for its very extensive quarries of excellent marble, large quantities of which are annually quarried and sent to New York and other places; these are chiefly worked by the convicts of the State Prison, located about half a mile $\mathrm{S}$. of the village, on grounds comprising 130 acres. The main building is 484 feet long, 44 feet wide, 5 stories high, and contains 1,000 cells, Adjoining it are the various workshops, chapel, hospital, store-houses, etc., all built of rough-dressed marble. The female convicts are in a separate building. The annual receipts of labor from the convicts are nearly equaled by the expenditures. The average number of convicts in 1850 was 721 , of whom 80 were females. Pop. about 2,500.

Sixking CREEK, p. 0., Botetourt co., Virg.: $131 \mathrm{~m}$. W. Riclmond.
Sinkixg Spring, p. v., Highlend co., Ohio: on E. side of Brush cr., $61 \mathrm{~m}$. S. by W. Columbus.

Sinking Spring, p. v., Berks county, Penn.: $45 \mathrm{~m}$. E. Harrisburg.

Sinking Palley Mills, po o., Blair co., Penn.: $80 \mathrm{~m}$. W. by N. Harrisburg.

Sinnamahoning, p. o., Clinton co., Penn.: $89 \mathrm{~m} . \mathrm{N}$. W. Harrisburg.

Sinnamanonivg river, Penn.: a large tributary of the W. branch of Susquehanna r., from the N. W., $50 \mathrm{~m}$, long, emptying into the W. branch in N. W. part of Clinton co.

Sinsinawa mound, Wise : a noted elevation in Grant county, near the Illinois line, $12 \mathrm{~m} . \mathrm{N}$. W. Galena. Here has been established a Catholic college and Dominican convent.

Srovx county, $7 a$. Situate N. W., and contains 1,050 sq. m. Drained by head branches of Floyd's r., a tributary of Sioux r., which flows on its western border. Surface in general level, but in parts undulating, presenting a pleasing diversity in the nature of the county, Soil fertile, and favorable to the growth of fruit, wheat, Indian corn, etc. It has some excellent timber. Set off since 1850 .

Sroux river, Jinn. and Ia.: more commonly named Big Sioux r., rises in one of the numerous lakes near the head of the elevated prairie land in the central portion of Minnesota Territory-flows E. \$. E. about 200 miles, and empties into the Missouri $x$. Below $43^{\circ} 30^{\prime}$ N. lat., it forms the boundary betweeh Iowa and Minnesota.

Stresvinle, p. o., Somerset county, Penn.: 113 m.W.S.W. Harrisburg,

Sippican, p. V., Plymouth co, Mass. : on W. side of Sippican harbor of Buzzard's bay, $51 \mathrm{~m}$. S. by E. Boston. The principal business of this $\mathrm{v}$. is the manufacture of salt.

Sipsex TURNPtkE, p. o., Tuscaloosa co., Ala. : on the right bank of Sipsey r., $106 \mathrm{~m}$. W. N. W. Montgomery.

Sir Johr's Riun, p. o., and sta., Morgan co., Virg. : on the Baltimore and Ohio R. R., 49 m. N. W. Harper's Ferry. and $128 \mathrm{~m} . \mathrm{N}$. by W. Richmond.

Siskryou county, Calif. Situate N. E., between Shasté county and the $\mathrm{N}$. State line, and extending $\mathrm{E}$. and $\mathrm{W}$ between the E. line of the State and the Coast Range. Area about $8,000 \mathrm{sq}$. m. The surface is elevated and mount. airous, with valleys of great extent intervening. It contains Mount Shasté, a lofty eminence, 14,400 feet ahore the sealevel, and from the slopes of which the Sacramento has its head eonstituents. A large number of tributaries, of which Pitt r. is the most considerable, join it in this county, and there are also several mountain lakes, the outlets of which flow into it. Of these Phett and Deer lakes are the most extensive. Gold mining is the principal industry. In 1852 there were 9 quartz mills in operation. Capital invested in quartz mining, $\$ 35,550$; in placer mining, $\$ 39,165$; and in other mines, $\$ 11,950$. Capital employed in other oceupations, \$72.310. Land under cultivation, 309 acres. Population at the same period, 2,240 , of which were wh. $1,956-$ males 1,874 , and females 52 ; negroes $34-$ males 83 , and remale 1 ; mulattoes, 4 males; Indians 26-22 males, and 4 females; and firrign residents 220 -males 213 , and females 7. Over 21 years of age-citizens of the United States 1.517. negroes 32 , mulattoes 4, Indians 12, and foreigners 207. cupitul:

Sissonville, p. v., Kanawha co., Virg.: on a branch of Pocatalico r., 237 m. W. N. W. Richmond.

Sistersville, p. v., Tyler eo., Virg.: on the left bank of the Ohio r., $59 \mathrm{~m}$. below Wheeling, and $239 \mathrm{~m}$. N. W. Rich. mond. This place was originally laid out as the county seat, in 1814, which was subsequently transferred to Middletown, $9 \mathrm{~m}$. east.

Stx Corvers, p. o., Richland co., Ohio: $57 \mathrm{~m}$. N. by E. Columbus.

Six Mile, p. o., Jennings co., Ind. : on a creek so called, 58 m. S. S. E. Indianapolis.

Six Mrle Falls, p. o, Penobscot con, Ife. 
Six Mrre liun, p. o., Somerset co., $\lambda$. Jer.

Six Mrle Run, p. o., Bedford co., Penn. : $\$ 3$ m. W. S. W. Ilarrisburg.

Six Runs, p. v., Sampson co., N. Car. : on the E. side of a cr. so called, $66 \mathrm{~m}$. S. by E. Raleigh.

Seaneateles, t. and p. v., Onondaga co., $N . Y .: 140 \mathrm{~m}$. W. by N. Albany. The greater part of the lake so called is in this town, and its outlet, flowing $\mathrm{N}$. into Seneca $r$., drains it, and affirds excellent water-power. The surface, for 5 or 6 miles from the foot of the lake upward, slopes gently to to the water's edge, but toward the head of the lake it becomes more abrupt, and even mountainotus, and there are miniature palisades containing geologieal wonders. The soil is excellent, and the country is noted for its agricultural resources; and is well laid out in farms, with spacious farmhouses and out-buildings, giving every indication of abundance and thrift. The v. (incorporated in 1503) is at the outlet of the lake, and having a commanding site, presents a neat and tasteful appearance. Near it, at the base of a steep range of hills, some 600 feet high, is a commodious hotel and a water-cure establishment, It is a considerable manufacturing place, and contains flouring and saw mills, iron foundries, machine shops, two extensive carriage factories, woolen factories, and tanneries, besides a number of workshops of various kinds. The Skaneateles and Jordan Branch R. R. diverges from the $v_{\text {., }}$ and connects with the Rochester and Syracuse R. P. at the junction, $5 \mathrm{~m}, \mathrm{~N}$. Three papers are issued, 2 weekly, the "S. Columbian" (whig), and the "S. Democrat" (dem.), and 1 monthly, the "Family Companion." Pop. of t. 4,0 so.

Skaneateles lake, $N . Y$. : lies partly between Cayuga and Onondaga counties. It is a beauliful sheet of water, $15 \mathrm{~m}$. long, and about $1 \mathrm{~m}$. wide, and surrounded by romantic scenery. It is noted for its fine trout and other fish, with which it abounds.

Skeris' Cross Roads, p. o., Mercer co., Ohio: 89 m. W. by N. Columbus.

Skegg's Crekk, p. o., Barren co., $K y$, : on a stream so called, $116 \mathrm{~m}$. S. S. W. Frankfort.

Skinner's, p. O., Benton co., Oreg. Ter.: 50 m. S. S. E. Salem.

Strunner's Eddr, p. 0., Wyoming co., Penn.: on Susquehamna r., 95 m. N. N. E. Harrisburg.

SkinqUarter, p. o, Chesterfield co, Tirg.

Skippack, t. and p. o., Montgomery co., Penn.: $77 \mathrm{~m}$.

E. Harrisburg. Drained by the ur. so called. Surface hilly; soil fertile. Skippackville is in this town. Pop. of t. 1,622 .

Skow HEGAr, t. and p. v., Somerset co, Me. : on N. bank of Kennebec r., $32 \mathrm{~m}$. N. Augusta. Soil fertile and well eultivated. The $\mathrm{v}$. possesses the advantages of a great waterpower, furnished by Skowhegan falls, which are improved by mills of various kinds, a woolen factory, tannery, ete. It is well built, and has considerable trade. The "Penple's Press" (whig) and "Democratic Clarion" are published wcekly. Pop. of t. 1,756.

SKUNE river, $I a$. : rises in the highlands, in the central part of the State, flows by S. E. course nearly parallel to the Des Moines for $150 \mathrm{~m}$., and empties into the Mississippi. It drains a rich and fertile portion of the State, and abounding with timber, and affords many excellent mill sites.

St.abTown, p. o., Anderson dist., S. Cart, : on the E. side of Twenty-three Mile cr., $103 \mathrm{~m}$. N. W. Columbia.

Siantown, sta., Rush co., Ind. : on the Rushville and Shelbyville R. R. $14 \mathrm{~m}$. Shelbyville, and $32 \mathrm{~m}$. E. S. E. Indianapolis.

Slack, p. o, Mason co., $\bar{K} y_{.}: 71 \mathrm{~m}$. N. E. Frankfort.

Slade, p. o., Lee county, Ga.: 107 miles S. W. Milledgeville.

Sradesvilue, p. o, Hyde co., N. Car.: 183 m. E. by S. Raleigh.

StAte, p.. ., Bath co., $\overline{K y}$ : : at the confluence of Slate $\mathrm{cr}$. with Licking r., $67 \mathrm{~m}$. E. Frankfort.
Slateford, p. O., Northampton co., Penn.: $97 \mathrm{~m}$. X. E Uarrisburg.

Slate Hilu, p. o., York co., Penn。 : 25 m. S. Harrisburg. Sxate Hrul, p. o., Orange county, $N . Y_{0}: 97$ m. S. W. Albany.

Slate Liok, p. o., Armstrong co., Penn. : 137 m. W. N. W. Harrisburg

Su.1TE Milus, p. o., Rappahannock cnunty, Tirg.: na a branch of the Rappahannock river, 75 miles N. N. W. Richmont.

Slaterville, p. v., Tompkins co., N. Y. : on Six Mile cr. $155 \mathrm{~m}$. W. by S. Albany. It is a small manufacturing village containing about 350 inhabitants.

Slaterville, p. v., Providence co., $R$. $I_{\text {.: }}$ ou Branch r., $14 \mathrm{~m}$. N. W. by N. Providence. It contains several facturies, which are chicfly engaged in making cotton and print goods, etc. It is a pleasant $\mathrm{v}_{*}$, and contains also two churches.

Sledgeville, p. v., Panola co., Mriss.: on a branch of Tallahatchee r., $150 \mathrm{n}$. N. Jackson.

Slempy Creer, p. o, Wayne co, $N$. Car.: 43 m. S. E. Raleigh.

SLliepr Creek, sta., Berkley co., Fir $\gamma .:$ on the Baltimore and Ohio R. R., $35 \mathrm{~m}$. N. W. Harper's Ferry, and $13 \mathrm{~S}$. N. by W. Richmond.

Slempr Creek, p. v., Edgefield dist., S. Car.: on a branch of Lirtle r., $52 \mathrm{~m}$. W. Columbia.

Slemp Creek Bridge, p. o., Morgan co., Virg. : $80 \mathrm{~m}$. N. N. W. Richmond.

Sligo, p. o., De Kalb county, Tenn.: 55 m. E. by S. Nashville.

Sutgo, p. o., Henry co, Ky. : 25 m. N. W. Frankfort.

Strgo, p. o., Clinton co., Ohi̊o: 55 m. S. W. Columbus.

Slippery Rock, t. and p. o., Butler co., Penn.: $173 \mathrm{~m}$

W. N. W. Harrisburg. Drained by the cr. so called, and its tributary, Wolf cr. Surface uneven, with a very fertile soil, producing rrain, etc. The $\mathrm{v}$, of Centreville is located in the town. There are in the $t$. two furnaces, with an annual capacity of 1,100 tons each; several tanneries, grist, and saw mills. Pop. of t. 1,700.

Sloanspille, p. v., Schoharie co., $N$. $Y_{\text {.: }}$ on Fly cr., and on Cherry Valley tumpike, $32 \mathrm{~m}$. W. by N. Albany. It derives good water from the stream, improved by various sawmills, etc. Pop. about 350 .

Slontsmerg, p. v. and sta., Rockland co., N. $Y_{\text {. : }}$ on the Ramapo river, and on the New Fork and Erie P. R., 35 m. N. by W. New York, and $168 \mathrm{~m}$. S. by W. from Albany This beautiful and thriving manufacturing place presents a singular aspect to the traveler. From the sta. are to be seen two substantial cotton factories, and not a sign of a $\mathrm{r}$. or luamlet in sight, thuse emplused in them dwelling in the humble but neat abodes scattered along this "happy valley." The mills, embowered as they are in noble trees, look as though they were placed in some gentleman's park, did not the adjacent dingy blacksmith shops show that the precincts were those of a regular factory. These establishments were erected in 1820 , the brick portion in 1846, and are used exclusively for making cotton twoine, of which article 5.000 pounds are sent weekly "by rail" to New Tork. This improved town is the invention of the principal proprietor of the mills, and owner of the grounds on which they stand, Najor Jacob Sloat, from whom the place gets its name. He derives his domain from his grandfather, to whom it was assigned by five Indian chiefs in 1735, and the original deed of conveyance, being drawn up in a ehoice lingo, compounded of Dutch and Indian, is quite a curiosity.

Slotergyille, p. O., Luzerne co., Penn. : 77 m. N. N. E. Harrisburg.

Surars, sta., Monroe co., Ga.: on the Macon and Trestern R. R., $19 \mathrm{~m}$. W. by N. from Macon, and $51 \mathrm{~m}$. W. by S. from Milledgeville.

Syelset's Mills, p. o., Rush co., Ind.: $39 \mathrm{~m}$. L. by $\mathrm{S}$ Indianapolis. 
Sucltzer"s Grove, p. o., Grant co., Wisc.: $65 \mathrm{~m}$. S. W. Madison.

Suretzer's Modnt, p. o., Pickens dist., S. Car.: $135 \mathrm{~m}$. N. W. by W. Columbia.

Surcesperg, p. v., Indiana co., Penn. : on Mahoning cr., $12 \pi \mathrm{m} . \mathrm{W}, \mathrm{N} . \mathrm{W}$, Harrisburg.

Smitr county, Miss, Situate $\mathbf{S}$, centrally, and contains $615 \mathrm{sq} . \mathrm{m}$. Drained by head branches of Leaf river and branches of Pearl r. Surface uneven; soil in general good, and arlapted to cotton, which is the principal production of the co. It has some fine pasture land. Farms 425 ; manuf. 8; dwell. 515, and pop.-wh. 8,075 , fir. col. 0, sl. 998-total 4,071. Capital: Paleigh.

Sxrre county, Tenn. Situate toward the N., and contains $2 S S \mathrm{sq} . \mathrm{m}$. Cumberland $\mathrm{r}$, passes through the co, by which and its tributury, Caney fork, and also by their branches, it is orrained. Surface hilly; soil fertile, the land in general being very productive and adapted to tobaceo, which it produces abundantly. Good entton is also grown, and fine crops of whent and Indian corn are raised. It exports large quantities of beef and pork. Farms 1,310; manuf. 32; dwell. 2.422, and pop.-wh. 13,709, fr. col. 186, sl. 4,517total 18,412. Capital: Carthage.

SurTI county, Tex. Situate toward the N. E., and contains 1,046 sq. m. Drained by head branches of Angelina river and affluents of Neches r., which runs on its W. border. Surface undulating; soil varied; on the rivers the land is generally rich, and eonsists of a fine black mold, favorable to the growth of cotton and corn. Grapes grow wild, and might, by cultivation, be rendered valuable. It has many springs and numerous streams of excellent water. Farms 218, manuf. 1; dwell. 603, and pกp.-wh. 3,575, fr. col. 0, sl. 717-total 4,292. Capital: Tyler.

Smiri Date, p. o., Amité county, Miss. : 83 m. S. s. W. Jackson.

SmTrhfield, p. v., Delaware co., Ind.: on the N. bank of White r., and on the Indianapolis and Bellefontaine R. P. $60 \mathrm{~m}$. N. E. Indianapolis.

Surthrield, t. and p. v., Somerset county, $M$ e e $_{0}: 23 \mathrm{~m}$. N. Augusta. The town contains East Pond and part of Milk Pond; Tas a few saw-mills and some manufactures. Pop. of t. 873 .

SMITHFEt., p. v., and eap. Johnson en., N. Car.: on the E. side of Neuse river, $20 \mathrm{~m}$. S. E. Raleigh. It contains a court-house, jail, and other county buildings. Pop. 329.

SurtmFifld, t. and p. v., Jefferson eounty, Ohio: $111 \mathrm{~m}$. E. by N. Columbus. Drained by branches of a stream flowing $\mathrm{E}$. into the Ohio river, affording good mill-power. Surface much broken; soil adapted to grain and grass. The t. contains several stores and flouring-milis, a tannery, etc. Pop. of t. 1,882.

SinthField, sta., Mahoning co., Ohio: on the Ohio and Pennsylvania R. R., 57 m. E. by N. Wooster, and $117 \mathrm{~m}$. N. E. Columbus.

Saitifield, p. v., Polk co., Tex.: on E. bank of Trinity river, $174 \mathrm{~m}$. E. by N. Austin City.

Surturifiedd, t., Providence co, $R . I_{0}: 9 \mathrm{~m}$. N. Providence. This large and important manufacturing t. comprises several large factory villages, described in order, of which Woonsocket Falls and Slatersville are among the largest. Great water-power is furnished by Blackstone river (which bounds it on the $\mathrm{E}$.) and its branches, particularly at Woonsocket Falls, where it has a descent of about 20 feet in a short distance, over a rocky precipice. Surface undulating, and in some parts rough, but for the most part agreeably diversiffed; soil gravelly and sandy loam, and generally fertile, with some low and marshy tracts. Limestone abounds, and the manufacture of lime is extensive, employing many persons. There is a quarry of whitestone at Woonsocket Hill, valuable for furnace hearths, and 2 miles from this a quarry of excellent whetstones. In the S. part of the tow $\mathrm{n}$ is Scott's Pond, a consideralle body of water, of great depth and steep shores. The factories are chiefly en- gaceel in making print goods, cotton grods, ete., but other mills are numernus. In the t. are 5 banks, with aggregate capital of $\$ 334,775$. Population in $18 \pm 0,9,534$; in 1850 , 11,500 .

Sumtirifid, p. o., Fayette co., Penn.: in a hilly region, on left bank of the Youghiogeny r., $133 \mathrm{~m}$. W. S. W. Harrisburg.

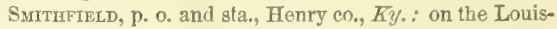
ville and Frankfort R. R., $30 \mathrm{~m}$. N. W. Frankfort.

Snitufield, p. v., and eap. Isle of Wight co., Tirg.: on an inlet of James' r., $25 \mathrm{~m}$. W. by N. Norfolk and $55 \mathrm{~m}$. S. E. Richmond. It contains a court-house and other county buildings. Pop. 43 S.

Smithland, p. $\nabla .$, Livingston co., $\bar{k} y_{*}:$ on the Ohio r., at the lower side of the mouth of Cumberland $r, 75 \mathrm{~m}$. below Paleigh, $205 \mathrm{~m}$. W. S. W. Frankfort. It is a place of some importance, enjoying considerable trade with the interior of Tennessee, being a point for the re-shipment of goods destined up the Cumberland $r$. It contains a bank, several manufactories, a boat-yard, etc.

Surthland, p. o., Cass county, Tex.: 280 miles N. E. Austin City.

SmithlaNd, p. ₹., Randolph co., Mo.: 50 m. N. N. W. Jefferson City.

SMithPort, p. v., and cap. MTean co., Penn.: on the W. side of Potato cr., $133 \mathrm{~m}$. N. W. Harrisburg. It contains the court-house, jail, and other public buildings brilt of brick, an academy, several mills, etc.

Surtu's, p. o., Gallia co, Olizo: 84 m. S. E. Columbus.

Sxrrth's island, Somerset co., Mrd: a long, narrow island, extending from Fog's Point, or Craig's Strait, nearly to Tangier Island. Liss than one-lialf the island is within the limits of Maryland.

Smitн"s island, New Hanover co, N. Car.: is located at the mouth of Cape Fear r. Cape Fear is on the S. extremity of the island, and a lighthouse stands on the W. side, overlooking the channel. Lat. $38^{\circ} 48^{\prime} \mathrm{N}$., and long. זร $9^{\prime} \mathrm{W}$.

Sмптн's point, Virg.: the eastern extremity of Northumberland co., extending into Chesapeake bay.

S.ITTH"S BAsin, po v. and sta., Washington co, N. Y.: on Wood cr. and on the Saratoga and Washington R. R. and Champlain Canal, $65 \mathrm{~m}$. by railroad and $57 \mathrm{~m}$. by canal, N. by E. Albany.

Suitrisborotgh, p. v., Tioga co., $N_{0} Y_{*}$ : on the $\mathrm{N}$. side of the Susquehanna r. and on the New York and Erie R. R. $246 \mathrm{~m} . \mathrm{N}$. W. New York and $146 \mathrm{~m}$. (direct) from Albany. It is a prettily situated village, $10 \mathrm{~m}$. beyond Owego, at which point a bridge crosses the Susquehanna.

Smixusisurg, p. v., Washington co, $M d^{2}$ : in the midst of a fine agricultural district, $72 \mathrm{~m} . \mathrm{N}$. W. Annapolis. In 1850 it contained 366 inhabitants-3ts white and 18 free colored. Suntu's Cross Roads, p. o., Rhea co, Tenn.: on W. side of Tennessee r., 103 m. S. E. Nashville.

Surtu's Cross Roans, p. o., Morgan co., Firg. : $141 \mathrm{~m}$. N. N. W. Pichmond.

Surtir's Ferry, p. o., Beaver co., Penn.: 179 m. W. N. W. Harrisburg.

Sirth's Ferry, vo and sta., Hampshire co., Mass.: on the right bank of the Connecticut $x$. and on the Connecticut River R. R., $12 \mathrm{~m}$. N. Springfield and $81 \mathrm{~m}$. W. by S. Boston. Surrer's Ford, p. v., York dist., S. Car.: on the left bank of Broad r., $67 \mathrm{~m}$. N. by W. Columbia.

SMIth's Fork, p. o., Hardin county, Tenn.: 97 m. S. W. Nashville.

Surte's GAP, p. o., Hampshire co., Firg. : 140 m. N. N.W. Richmond.

Swrth's Grove, p. o., Warren county, $K_{y}$ : 61 m. S. E. Nashville.

Smitu's Grove, p. v., Davie co., N. Cur.: $102 \mathrm{~m}$. W. Raleigh.

Sмiтn's Mruis, p. 0., Henderson co, Ey.: 97 m. S. W. Nashville. 
Smitris MrLis, p. v. and sta., Chautauque co., $N$. $Y$. : on Silver cr. and on the New York and Erie R. R., $12 \frac{1}{2} \mathrm{~m}$. E. Dunkirk, $447 \frac{1}{3} \mathrm{~m}$. N. W. by W. New York and $284 \mathrm{~m}$. W. Albany. The $\mathrm{v}$, is surrounded by a highly cultivated farming district.

Suite's Mills, p. v., Carroll co., Miss.: on a branch of Tallabusha r., $95 \mathrm{~m}$. N. Jackson.

Sмitn's Mruxs, p. o., Morrow county, Ohio: $42 \mathrm{~m}$. N. Columbus.

Suith's Mrlus, p. v., Clearfield eo., Penn.: on a branch of Clearfield cr., $85 \mathrm{~m}$. W. N. W. Harrisburg. Limestone is found in the vicinity.

SMith's Store, p. v., Spartanburg dist., S. Car.: on a branch of Tiger r., $69 \mathrm{~m} . \mathrm{N}$. W. Columbia.

SAithtown, t. and p. v., Suffolk co., $N . Y_{\text {. : }}$ bordering on Long Island Sound, 128 m. S. S. E. Albany. Drained by Nesaquake r., affording good water-power. Surface in most part level; soil inferior. The $\mathrm{v}$. is at the head of boat navigation on the Nesaquake r., and contains besides a number of stores and mechanic shops, a factory for the manufacture of woolen goods, ete. A bay so called makes up from the sound into the t., and affords good anchorage for vessels during easterly storms. It abounds with a variety of fish and wild fowl. Pop. of t. 1,972.

SMitetown Branch, p. o., Suffolk co., N. Y.: $131 \mathrm{~m}$. S. S. E. Albany.

Suithville, p. v. $_{\text {, and }}$ eap. Lawrence co., $A r k_{0}:$ on the left bank of Strawberry r, $105 \mathrm{~m}$. N. N. E. Little Rock. It contains a court-house, jail, ete.

SMITHVille, p. v., Monroe co., Miss. : on a small stream Hlowing W. into Tombigbee r., $161 \mathrm{~m}$. N. E. Jackson.

Smithville, p. v., Peoria co, Ill. : at the head of Copperas cr., $5 \$ \mathrm{~m}$. N. Springfield.

Surthville, p. v., Clay co, MLo. : on Smith's fork of Little Platle r., 138 m. W. N. W. Jefferson City.

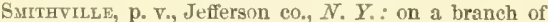
the Watertown and Rome R. R., 5 m. S. Sackett's Harbor and $150 \mathrm{~m} . \mathrm{N}$. W. Albany. It contains a carriage manufactory, several mills, etc.

Sminville, p. v., and eap. Brunswick co., N. Car.: on the W. side of Cape Fear r., near its mouth, and opposite Smith's Island. It has a good harbor, and contains a courthouse, jail, and hospital. It is the seat of an academy, and is a U. S. military post. Pop. 1,464

Smiterille, p. v., Wayne co., Ohio: on a branch of Tuscarawas $\mathrm{r}$., $\$ 3 \mathrm{~m}$. N. E. Columbus,

Smitiville, p. o, Lancaster county, Penn. : $33 \mathrm{~m}$. S. E. Harrisburg.

Surthyille, p. y, Abbeville dist, S. Car.: on W. side of Long Cane er., $75 \mathrm{~m}$. W. Columbia, The Abbeville Branch of Greenville and Columbia R. R. passes through this place.

Smiturille, p. v., and cap. De Kalb co., Tenn.: $53 \mathrm{~m}$. E. by S. Nashville, and contains the court-house, jail, etc.

Smrtirylle, p. o., Powhatan county, Vifg.: 21 m. W. Richmond.

Suitiville, p. V., Woreester co, Mrass.

Sniturille, to, Chenango co., N. Y.: $106 \mathrm{~m}$. W. by S. Albany. I)rained by tributaries of Chenango $r$. Surface undulating; soil fertile. It has good water-power and several mill-seats. Pop, 1,771 .

Smithrille Flats, p. v., Chenango co., N. Y.: on the E. side of Geneganslette cr., $109 \mathrm{~m}$. W. by S. Albany, I contains manufactories of scythes, axes, rakes, pails, and leather, also sereral mills, workshops, ete.

Sxoky Horlow, p. O., Columbia co, $N$. $Y$. : a small manufacturing place, $32 \mathrm{~m}$. S. by E. Albany. It contains a manufactory of woolen goods. machine shops, ete.

Snoky Ordinarx, p. 0., Brunswick co., Firg.: $58 \mathrm{~m}$. S. by W. Richmond.

Syut Ere, p. o., Coffee county, $A l a .: 81 \mathrm{~m}$. S. by E. Montgomery.

Buresa, p. vo, Kent co., Del. : on the S. side of Duck cr. $\pi 91$
It is a pleasant place, and contains stores of various kinds, shops, printing-offlces, etc. The "Delaware Herald," and "Smyrna Telegraph," are weekly issues.

Smyrna, p. o., Ionia county, Bfich : about $30 \mathrm{~m} . \mathrm{N}$. W. Lansing.

SMrrena, t. and p. o., Aroostook co, Me.: 157 m. N. E Augusta. Drained by the head waters of the Mattamaun keag r., and branch of the Meduxnekeag r. Pop. 172

SMYrNa, t. and p. v., Chenango co., N. Y.: $97 \mathrm{~m}$, W. Albany. Drained by small streams, tributaries of Chenango r., from which water-power is derived. Surface broken and hilly ; soil fertile. Settled in 1792. The manufactures consist in woolen goods, lumber, leather, flour, oil, etc. The $\mathrm{y}$. is on a small stream, has good water-power, and contains several mills, workshops, etc. Pop. of t. 1,940.

SMYrNa, p. o., Barnwell district, S. Car.: 57 m. s. Columbia.

Surran, sta., Rutherford co., Tenn.: on the Nashrille and Chattanooga R. R., $21 \mathrm{~m}$. S. Nashville.

Smyren, p. o., Harrison co., Ohio: $90 \mathrm{~m}$, E. by $\mathrm{N}$. Columbus.

SMrsee's, sta., York co, Penn. : on Codorus cr, of Susquehanna r., and on the Ballimore and Susquehanna R. R., at its junction with the Hanover Branch R. R., 36 miles $\mathrm{S}$. Harrisburg.

Siryth county, Firg, Situate S. W., and contains 516 sq. m. Drained by head branches of Holston river and New river. Surface broken and mountainous; soil on the banks of the streams fertile. Chief products wheat and Indian corn. Farms 460; manuf. 22; dwell. 1,146, and pop.-wh. 6,901, fr. eol. 197, sl. 1,064 - total 8,162. Capital: Marion. Public Works; Virginia and Tennessee R. R.

SNAKE island, $N . Y .:$ lies in the Niagara $r ., 4 \mathrm{~m}$. below Black Rock. It consists of 50 acres of grass land.

SNake Bars, v., Sierra co., Calif. : $137 \mathrm{~m}$. N. E. Vallejo.

Simaping Shoals, p. o., Newton co., Ga.: 59 m. N. W. Milledgeville.

SNEED's Ferry, p. O., Onslow co., $N$. Car.: 97 m. S. E. Columbia.

Sneensville, p. o., Haneock co., Tenn.: 192 m. E. by N. Nashville.

SNibar, p. v., Lafayette county, Mo. : $105 \mathrm{~m}$. W. N. W. Jefferson City.

Snickersville, p. v., Loudon co., Firg. : near Snicker's Gap, of the Blue Ridge Mountains, $108 \mathrm{~m}$. N. by W. Richmond. It is a small place, wilh about 135 or 140 inhabitants. SXIDER's, p. O., Washington county, $K y_{0}$ : 33 m. S. by W. Frankfort.

SNow CAMP, p. o, Orange co., N. Car.: $37 \mathrm{~m}$. N. W. Raleigh.

Snow Creek, p. o., Iredell co., N. Car.: on a stream so called, $123 \mathrm{~m}$. W. Raleigh.

SNow Creek, p. o., Pickens dist., S. Car.: 121 m. N. W. Columbia.

SNow Creek, p. o., Marshall co., Miss. : 175 m. N. by E. Jackson.

Sxow Creek, p. v., Franklin co., Virg.: on a stream so called, $130 \mathrm{~m}$. W. S. W. Richmond.

Sxow Falls, p. o., Oxford con, DLe. : $45 \mathrm{~m}$. W. Augusta. Srow Hilz, p. v., Wileox co., Ala.: on the left side of Cedar cr., 48 m. S. W. Montgomery.

Sxow HuL, p. o., Hamilton ec., Tens?.: 108 m. S. E. Nashville.

Sxow Hrut, p. v., Walker co., Ga.: on one of the head branches of Tennessee r., $152 \mathrm{~m}$. N. W. Milledgeville.

Sxow HrLL, p. v., eap., and port of entry, Worcester co, $M d_{\text {. }}$ : on the E. bank of Tomoke r., $25 \mathrm{~m}$, above its confluence with the bay of the same name, $81 \mathrm{~m}$. S. E. Annapolis. It contains a court-house, jail, an academy, and other public buildings. The total enrolled and licensed tonnage of the district in June, 1550, was 9,512 tons, 225 tons of which are vessels under 20 tons burthen; and of the whole tonuage 285 tons are employed in the coasting trade. The 
total number of vessels built during the year ending June, 1850 , was 26 schooners, 990 tons. The "Worcester Shield" is a weekly (whig) issue. Pup. 714 .

Sxow Hux, p. v., Clinton county, Ohio: 53 m. S. S. W. Columbus.

Snow Hilu, p. v., and eap. Greene co., N. Car.; on S. side of Contentnea cr., branch of Neuse r., $62 \mathrm{~m}$. E. \$. E. Raleigh. It contains a court-house, jail, and the usual number of county buildings.

Sxow Sroe, t. and p. v., Centre co, Penn.: $80 \mathrm{~m} . \mathrm{N}$. W. Harristourg. Drained by tributaries of Beach and Bald Eagle creeks, which furnish good water-power. Surface mountainous; the main ridge of the Alleghanies passing through the S. part. The v, is on a branch of Beach creek, and contains several mechanie shops, mills, etc.

SNow's STORE, p. v., Windsor co., Verm.: on a branch of White r., 39 m. S. Montpelier.

Snowsville, p. o., Choctaw co., Miss.: at the source of Yochamockany cr., $89 \mathrm{~m}$. N. N. E. Jackson.

Smyderstille, p. v., Monroe co., Penn. : 98 m. N. E. Harrisburg.

Syydertowa, p. v., Northumberland co., Penn.: $55 \mathrm{~m}$. N. Harrisburg.

SOAP CREeE, p. o., Davis county, Ia.: 73 m. S. W. Iowa Citr.

Soccopator, p. v., Coosa county, Ala.: on a tributary of Coosa r., $45 \mathrm{~m}$. N. by E. Montgomery.

Soctal Circle, p. v., Walton county, $G a_{.}$: on the Georgia R. R., $120 \mathrm{~m}, \mathrm{~W}$. by N. Augusta, and $52 \mathrm{~N}$. N. W. Millerlgeville.

Socrality, p. o., Cattaraugus co., N. Y.: on a tributary of Connewango cr., $276 \mathrm{~m}$. W. by $\mathrm{S}$. Albany.

SOcLetr HrLl, p. v., Macon $\mathrm{co}_{*}, A l a_{0}$ : on Ufaupee cr. of Tallapoosa r., 53 m. E. Montgomery.

SOCIETY Hru, p. v., Darlington dist., S. Car. : near Great Pedee $\mathrm{r}_{\text {. }}$ and on the Cheraw and Darlington R. R., $73 \mathrm{~m}$. N. E. Columbia.

Socorro, p. v., Socorro co., N. Drex.: on the right bank of the Rio Grande del Norte, 105 miles S. from Santa Fé There is an old Spanish fort in the village.

Sodus, t. and p. v., Wayne county, N. Y.: 27 miles S. W. Oswego, and 176 W. N. W. Albany. Lake Ontario bounds it on the N. Drained by Salmon and other creeks flowing into Solus bay and Lake Ontario. The surface has a gentle deelination toward the lake; soil fertile, and much grain and grass is raised. Sodus bay makes up into the town, and is the best harbor on the lake shore. The $\mathrm{v}$, is on the ridge road 5 miles 8 . of the lake, and has several mechanic shops, stores, etc. The to contains a number of manufactories, mills, etc. The manufactures are chiefly flour, lumber, and leather. Pop. of t. 4,59s.

Sopes bay, Wayne county, $N . Y$. : this bay makes up from Lake Ontario, about 30 miles W. from Oswego, and $30 \mathrm{E}$. from Rochester. It is a little more than $5 \mathrm{~m}$. long and from one and $a$ half to three broad, containing an area exceeding 12 square miles. The entrance to it on the lake is protected by substantial piers, built by the United States government, of more than a mile in length, and is easily accessible at all times to larger vessels than are encaged in the commerce of the lakes. A revolving light and beacon are maintained at the public expense; height of lantern 66 feet; lat. $43^{\circ} 19^{\prime} \mathrm{N}$. The bay is completely land-locked, so as to be protected from every wind, both from the lake and the shore. Its borders are high and salubrious. The average depth of the waters exceed 40 feet, and it is pronounced to be far the best harbor on any of the great lakes, and equal to any on this continent. It is sometimes called Great Sodus Bay.

Sodus Centre, p. O., Wayne co., N. Y.: 179 m. W. N. W. Albany.

Sropes PoINr, p. V., and port of entry, Wayne co., N. Y.: at the entrance of Sodus bay into Lake Ontario, 28 miles 8. W. Oswego, and 176 W. N. W. Albany (direet), and 228 by canal. Although at present but a comparatively small place, it is destined soon to become one of much importance. The Sodus canal, undergoing rapid eompletion, will connect it with the great channel of internal communication, the Erie Canal, and with other internal improvements. It is a tributary of the Erie Cunal, and will be the means of bringing a large business into that portion of it which lies between the junction at Clyde and Albany. It is allso a tributary to the Cayuga and Seneca canals, connecting the Cavuga and Seneca lakes with the Erie Cannl. The Surlus Canal is of the same capacity as the enlarged Erie Canal, 70 feet witth by 7 feet depth, with corresponding locks. It will easily admit ressels of 200 tons, which will pass from the Welland Cunal and the ports of Lake Ontario through to Albany or to Ithaca without breaking bulk. A railroad connects the $\mathrm{V}$, with the Rochester and Syracuse $P$. $R$. (direct line), and the Sodus Point and Southern R. R. connects it with the New York and Erie R. R. at Elmira. This will eventually be the great coal depôt on the lake, and the railroad will be the main channel of conveyance from the Pennsylvania mines. The building of wharves, etc., is in contemplation, which will much improve the harbor and facilitate the trade.

Solano county, Calif: Situate centrally, with its base resting on Suisson bay and Sacramento r., and contains about 800 sq. m. Putah r, makes its N. E., and Suseol Hills the $\mathbf{S} . \mathrm{W}$. boundary. The Putah rises in the mountains, winds through a rich, lovely, and fertile plain, and loses itself in the extensive "tules" which lie between the plains and the Sacramento. The western part of the county is mountainous, with many small valleys, well adapted to stock-raising. At the head of Green Valley is a conspicuous double peak, and another of lesser magnitude, between Green and Suscol valleys. Suscol Valley lies W. of Suscol Hills, running $\mathrm{N}$. from the city of Vallejo, and is $8 \mathrm{~m}$. long and $3 \mathrm{~m}$. in width, Napa bay washing its whole length. This is a desirable farming region, and is noted for its luxuriant growth of wild oats. Sulphur Spring Valley runs up from Suisson bay, $2 \mathrm{~m}$. N. of Benieia, winds through the Suscol Hills 5 or $6 \mathrm{~m}$., and has a width of from 100 to 400 yards; soil rich and well watered, Green Valley hies E. of Suscol Hills, and is about $6 \mathrm{~m}$. long and from 1 to $2 \mathrm{~m}$. wide; a large portion is always green-hence its name. Suisson Valley lies N. of Suisson bay, and is easily accessible by the Suisson r., which runs through its centre; it opens out on the E. into the Sacramento Valley. Soil exceedingly fertile, and much cultivated. Ulattis Valley lies farther to the N. E. and is $5 \mathrm{~m}$. long and $1 \frac{1}{6}$ wide, runs $\mathrm{N}$. W. between two hills, and opens out into the Sacramento Valley, which last extends as far as the eye can reach, and is covered with wild oats, and is not liable to inundation. North of Yallejo, four miles, there is a large soda spring running from Suscol Valley to Napa bay; and $3 \mathrm{~m}$. E. of this there is another, which, winding through low hills, and passing through the same valley, empties into the same bay. A sulphur spring, of warm temperature, about $3 \mathrm{~m}$. N. Benicia, gives name to the valley through which it passes. Mining is in this enunty only a secondary industry; its great and most raluable interest is agriculture, for which its climate and soil is peculiarly adapted. Orehards and vineyards are seen in several parts, and the productions of 5,949 acres under cultivation in 1852 were very large. Capital employed in quartz mining. $\$ \$, 000$; in other mining operations, $\$ 24,000$; and for other purposes, $\$ 110,900$. Pop, at the date specified 2,835- - Thites 2,726 - males 2,324 , and females 402 ; negroes $2:$-males 26 , and females 2: mulattoes, 25 males; Inulians 46 -males 31 , and females 15 ; and foreign residents $591-$ males 790 , and females 101; citizens of United States over 21 years of age, 1.298. Capital: Vallejo or Benicia. Public Works: Benicia and Marysville R. R.

Solem Grove, p.v., Moore co., N. Car.: S. side James' creek, $53 \mathrm{~m}$. S. S. W. Raleigh.

Solmad mission, Monterey county, Culif: : $19 \mathrm{~m}$. S. E. 
Yionterey, and $111 \mathrm{~m}$. S. S. E. Tallejo. It is loeated in a rich and fertile valley, and is celebrated for its fine vineyards. The lands are owned by private individuals.

Sorox, p. .., Johnson co., I $\iota_{\text {. }}$ : on a branch of the Iowa river, $11 \mathrm{~m}$. N. Iowa City.

Solon, to and p. v., Somerset co., Me.: on the E. side of Kennebec $x ., 45 \mathrm{~m} . \mathbf{N}$. Augusta. Drained by small streams, tributaries of the Kennebec. It has a considerable pond in the N. E. part. Soil fertile, and well adapted to general farming. The $\mathrm{y}$. is pleasantly located on the Kennebec $\mathrm{r}$. and his some manufuctures. Pop. of t. 1,419 .

Solon, t. and p. v., Cortlandt county, $N$. Y.: $116 \mathrm{~m}$. W. Albany. Drained by Otselic r. and branches of Tioughniogs river. Surface undulating; soil of gond quality, adapted to grazing. The $\mathbf{v}$. is on a branch of Tioughnioga $\mathbf{r}_{\text {.g }}$ and has some manufactures. Pop. of t. 1,150.

Solon, t. and p. v., Cuyahoga county, Ohio: $122 \mathrm{~m}$. N. E. Columbus. Drained by Chagrin r. and its branches, and by Tinker cr., on the former of which there are a number of falls which afford extensive water-power. Surface level; soil of the highest fertility, producing grains in abundance and excellent grass, The $\mathrm{v}$. is centrally situate. The $t$ contains several manufactories. Pop. 1,033.

Sorox MrLus, p. v., M·Henry county, $I l l$. : on S. side of Nipasink cr. $4 \mathrm{~m}$. S. of $\mathrm{N}$. boundary of the State, and $193 \mathrm{~m}$. N. E. Springfield.

Sotsville, p. o., Madison co., N. $Y_{*}: 96 \mathrm{~m}$. W. by N. Albany.

Somerfield, p. v., Somerset co., Penn.: on the E. bank of Toughiogheny r., $133 \mathrm{~m}$ m. W. S. W. Harrisburg.

Sovers, t, and p. v., Tolland county, Conn.: $20 \mathrm{~m}$. N. E. Hartford. Drained by Scantic r. Surface on the W. level and fertile; on the E. elevated and mountainous, with good pasturage for sheep. The $\mathrm{v}$. is located on one of the head branches of Scantic river, and contains a manufactory at which straw hats are extensively manufactured. Population of t. 1.510

Somers, t. and p. v., Westchester co., N.Y.: $92 \mathrm{~m}$. S. by E, Albany. Drained by Croton river and tributaries. Surface uneven, with some extensive plains; soil adapted to grain and grass. The village contains a bank and 2 churches, Pop. of t. 1.722 .

Soxresset county, Me. Situate toward the $\mathrm{N}$. W. of the State, and contains $3, \$ 40 \mathrm{sq}, \mathrm{m}$. Kennebec river having its rise in Moose-head lake, flows through the $\mathrm{cn}$. centrilly, by which and its tributaries, and by Penobseot and other fine streams it is drained. Surface varied -in some parts elevated, and its hills and valleys present a pleasant prospect. Soil fertile in the southern portions, but the $\mathrm{N}$. is mostly widlerness, witl numerous lakes interspersed. Chief productions, wheat, Indian enrn, and potatoes. Agriculture is the leading pursnit. Farms 3,513 ; manuf. 155; d dwell. 5,917, and pop.-wh, 35,5\%7, fr. col, 4 -total 35,5s1. Capital: Norrilgework

Soverset countr, Mrd. Situate toward the S. E, and contains $45 \overline{5}$ sq. m. Drained by Annemesic, Manokin. and Thicomico rivers, ant branch of Santicule river, which furms its N. W. boundary. Surface low and level, and a large portion is marshy. Soil, with cultivation, is fertile, and the swamp, when drained, makes gnod pasturage. It contains some sulpbur and mineral springs, and beds of bog-iron ore. Oak, pine, ash. cedar, chestnut, and maple are fount on the lant, which is in general well timbered. Farms 1.t.5: manuf. 76 ; dwell 3.15 s and pop.-wh. $13,3 \div 5$, fr. col. $3,4 S 3$, sl. 5,58s-total 22,456. Capital: Princess Anne.

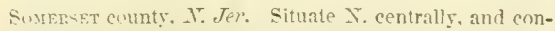
tains $282=80, \mathrm{~m}$. Riaritan $r$. pass $\mathrm{s}$ through it centrally, br which and its branches it is drained. Surfuce diversified: soil a fine deep mold on the streams, and very productive. Staples, wheat and Indian corn. It exports pork and sheep very largely. Farms 1,550; mannf. 137; dwell. 3,41s, and pop.-wh. 17,965 , fr. col. 1,696, sl. 27 -total 19,68S. Capitul: 790
Somerville. Putlic Trorks: New Jersey Central R. R.; Delaware and Raritan Canal.

Somerser county, Penn. Situate $\$$. toward the W., and contains $977 \mathrm{sq}$. m. Drained by affluents of Youghingheny and Conemaugh rivers. Surface hilly, and in the N.W. is Laurel Hill Mountain. The Alleghany range forms its eastern boundary. Sóil fertile, and produces wheat and grain in great abundance. It has excellent pasturage, and large numbers of cattle and hogs are fattened annually and exported. Farms 1,613; manuf, 88; dwell. 18,969, and pop. -wh. 24,317, fr. col. 99-total 24:416. Capital: Somerset.

SoMErSET, p. ., and cap. Pulaski county, Ky.: $78 \mathrm{~m}$.

S. by E. Frankfort. It contains a court-house, jail, county offices, etc.

Soumerset, t. and p. v., Bristol co., Mass.: on the W. side of Taunton r., and opposite Fall River, having Mount Hope bay on the S., $43 \mathrm{~m}$. S. Boston. Its navigable facilities are excellent. It has some shipping, and ship-building is carried on. In 1849 the imports of sperm oil amounted to 140 barrels. The $\mathrm{v}$. is located on Taunton r., and contains manufactories of stone and earthen ware. Pop. of t. 1,166.

SoMerset, t. and p. o., Hillsdale county, Mich. : $48 \mathrm{~m}$. S. Lansing. Drained by head branches of Raisin $r$. It cnntains the highest land in the State. Soil fertile, producing wheat, corn, oats, etc. Pop. 913.

Somerset, p. V., Monroe co., MFo.: on the W. side of Salt river, $68 \mathrm{~m}$. N. Jefferson City.

SOXERSET, p. ₹., Wabash co., Ind.; on the right bank of the Mississinewa river, on the State road, $63 \mathrm{~m}$. N. by $\mathrm{E}$. Indianapolis.

SOMERSET, to and p. v., Niagara co., $N$. $\boldsymbol{Y}$.: bordering on Lake Ontario, $31 \mathrm{~m}$. N. E. Niagara City, and $256 \mathrm{~W}$. by N. Albany. Drained by Golden Hill cr, and other streams flowing into the lake. Surface even; soil, sand and clay loam. It has some manufactures. The $\mathrm{v}$. is on a small stream near the lake. Pop. of t. 2.154

Somerset, p. v., and cap. Perry county, Ohio: on the Cincinnati, Wilmington, and Zanesville R. R., $37 \mathrm{~m}$. E. by S. Columbus. It contains the court-house, jail, and other county buildings, an acadeny (the St. Mary's-Catholic), several stores, etc. The "S. Post" (whig), and "Perry Co. Democrat" (dem.) are both weekly issues. Pop. 1,240. The Dominican Convent of St. Joseph's (Catholic) is located near the village.

Somerset, t., p. b., and cap. Somerset co., Penn.: $115 \mathrm{~m}$. W. by S. Harrishurg. Drained by Laurel Hill, Middle, and Cox's creeks. Surface undulating; soil fertile. It bas several small manufactories, mills, etc. The b. on Cox's cr., was incorporated in 1804, and contains the court-honse and jail, built of stone, county offices, built of brick, an academy, a number of mills, etc. Two papers are issued weekly, the "Herald" (whig), and the "Visitor" (dem.) Pop. 866.

Sovers Point, p. $\nabla_{0}$, A tlantic con, $N_{0}$. Jer : on Great Egg Harbor bay, $63 \mathrm{~m}$. S. by E. Trenton. It is the port of entry for Great Eqg Harbor district; its tonnage, acenrding to the rturns of 1850 , was 14,084 tons, enrolled and licensed, and all engaged in the coasting trade. It has no foreign commerce or ship-building.

Somersvilue, p. o., Tolland co., Conn.: 21 m. N. E. Hartford.

SoMERsworth, t., Strafford co., N. Hamp. : $32 \mathrm{~m}$. E Conenrd. Drained by small streams flowing into Salmon Falls r., which bounds it on the N. E. The soil is well adapted to all kinds of grain; red and yellow ochre, and iron ore are found. This is a large manufacturing town, but the manufactures are principally carried on at the village of Great Falls, at the head of tide-water. (See Great Falis v.) Otis' Hill is in this town, from the summit of which the White Mountains can be seen. There are two considerable ponds in the town. Pop. 4,945.

Sonereton, p. v., Belmont co., Ohio: on a branch of Captiva cr., $97 \mathrm{~m}$. E. Columbus. It contains several churches, stores, tobacco factories, etc. It is located in an exten- 
sive tobacco region, and large quantities are cultivated in the immediate vicinity. Pop. 192.

Somerton, p. o., Philadelphia co., Penn.: 97 m. E. S. E. Harrisburg.

Somertor, p. v., Nansemond co., Virg.: on the E. side of Somerton cr., $80 \mathrm{~m}$. S. E. Richmond.

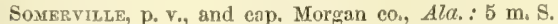
of the Tennessee river, and $150 \mathrm{~N}$. by W. Montgomery. It contains a court-house, jail, and other public buildings.

Somerville, t, and p. v., Middlesex co., Mass.: $3 \mathrm{~m}$. W. of Boston. This t. was set off from Charlestown, and incorporated in 18.2. It is bounded in part by Mystie r., Miller's creek, and an arm of Charles river. Drained by a small stream called the Shawshun. Surface elevated and hilly. The celebrated hills, ealled Winter and Prospect; are comprised in this town. The M.Lean Asylum for the Insane is located here, and the Milk kow Bleaching Company have their extensive works in this place. The Boston and Maine R. R., and the Fitchburg R. R. pass through the v. $10 \mathrm{~m}$. from Reading, $28 \mathrm{~m}$. from Lowell, and $47 \mathrm{~m}$. from Fitchburg. It is a place of considerable trade. Pop. 3,540.

SoMrerville, p. $v_{4}$, and cap. Somersel con, N. Jer.: on the $\mathbf{N}$. of Raritan river, $28 \mathrm{~m}$. N. by E. Trenton. The Now Jersey Central R. R. passes through, $26 \mathrm{~m}$. from Elizabethport, and 35 from Easton. It is a neat and well-built place, laid out in a fertile and highly cultivated country, and contains a court-house, jail, an academy, several churches, etc Copper ore is found about one and a half miles $\mathrm{N}$. of the $\mathrm{v}$. The "Somerset Messenger" (dem.) and the "Somerset Whig" (whig) are issued weekly.

Somerville, p. o., St. Lawrence county, $N$. Y.: $153 \mathrm{~m}$. N. W. Albany. The Rossie iron-works are in the vicinity. Somervilue, p. o., Butler co., Ohio: on a branch of the Miami r., and on the Cincinnati, Hamilton, and Eaton R. R., 90 m. W. S. W. Columbus. It contains se ral stores, workshops, etc.

Somervilue, p. v., and eap. Fayette eo., Tenn.; on the Loosahatehy r., $156 \mathrm{~m}$. S. W. Nashville. It contains a court house, jail, a male and female academy, and a branch of the bank of Tennessee is located here. Somerville College has been chartered here, and a building is erecting.

Somertille, p. v., Fauquier co., Virg.: on the left side of Cannon r., $65 \mathrm{~m}$. N. by W. Richmond.

Sononavk, p. v., De Kalb county, $l l l$.: on a cr, so called, $137 \mathrm{~m}$. N. E. Springfield In the vicinity are large groves of excellent timber, such as walnut, sugar tree, elm, aspen, etc.

Sonoma county, Calif. Situate W. between the Coast Range and the Pacific Ocean, and contains 1,200 sq. m. Surface mountainous and intersected by fertile valleys. which run in a direction $\mathrm{N}$. and $\mathrm{S}$. and watered by Sonoma, Petaluma, Russian, and other streams. Except Russian r., which flows to the Pacifie above Bodega, these empty into Pablo bay. American r. and Pablo bay, makes the S. boundary of the co. The rich valleys of this co., protected from the winds, are the seats of great agricultural operations, and supply to San Francisco a large share of vegetable products found in itg markets. In 1852 , there were $9,35 \%$ acres of land under cultivation, which produced grain and green crops in abundance. The stock of live animals is comparatively large, and feeds on the native grasses, which are highly nutritious. Value of town lots, $\$ 101,552$; of farming implements, $\$ 50,472$; of merchandise, $\$ 29,760$; and of land, etc., $\$ 47,665$. There was in the co., 5 threshing machines, 6 blacksmith's shops, a tan-yard, 21 carriages, and 218 wagons. It is not a mining county. Pop. at the date noted 2,337: whites 1,872-males 1,859 , and females 513 ; negroes 5-males 4 , and females 1 ; mulattoes 7 -males 5 , and females 2; Indians 276-males 223, and females 153; and fureign residents $118-$ males 85 , and females 29 . Over 21 years of age-citizens of United States 881, negroes 4, mulattoes 7, Indians 132, and foreign residents 79. Capital: sonoma.
Soroma, p. v, and cap. Sonoma co., Culif: : on the W. side of Sonoma er., 3 miles distant, and in the valley 80 called, $3 \mathrm{~m}$. N.W. Vallejo. This is an exceilent agricultural place, the land being good, the country healthy, and never very cold in winter-snow being seen only in the highest mountains. This part of the country contains the best grazing land, many places being covered with elover and with wild oats. It is the oldest town in the north side of the San Pablo bay, and now has the remains of wlat was once a flourishing mission. Its importances will depend upon the appropriation of the rich agricultural resources which the valley possesses. There is a fort located here, and it is also a United States military post. The residence of General Vallejo is in the village. Pop. 600.

Sonoma, D. v., and cap. Tuolumne county, Calif.: on the head waters of Tuolumne $\mathrm{r} ., 56 \mathrm{~m}$. E. by $\mathrm{S}$. Stockton, and $111 \mathrm{~m}$. Vallejo. It is located in the mountains, and is surrounded by an excellent agricultural enuntry. There are mines in its vicinity.

Soor's Ivw, p. o., Burlington co., N. Jer.: a small mill seat on the left bank of Litle Egg Harbor r., 41 m. S. E. Trenton.

Sopcroppex, p. v., Wakulla co., F'lor.: on the left bank of the Ocklocking $r$, at the mouth of Seckehooho cr. $31 \mathrm{~m}$. S. S. W. Tallahassee.

Sorbx, p. o., Wayne con, Tenn. : 79 m. \$. W. Nashville.

Sorrex. Horse, p. o., Montgomery co., Penn. : 79 m. E. Harrisburg.

Souchaнatohee, p. o., Tallapoosa county, Ala.: ou the r. so called, branch of the Tallapoosa, $88 \mathrm{~m}$. E. N. E. Montgomery.

Soutr Azington, p. v. and sta., Plymouth co., Mass. : on the Old Colony R. R., $21 \mathrm{~m} . \mathrm{S} . \mathrm{B}$ oston; and the Bridgewater Br. R. R. verges from here, $7 \mathrm{~m}$. N. E. Abington,

Sowth Acton, v. and sta., Middlesex co, Mrass.: on the

Fitehburg R. P., 25 m. N. W. by W. Boston.

South Acwortu, p. n., Sullivan county, N. Itump.: on Cold r., $36 \mathrm{~m}$. W. Coneord.

SoutII ADAMs, v, and sta., Berkshire co., HIass.: on the Pittsfield and North Adams R. R., $14 \mathrm{~m}$. Pittsfield, and 109 m. N. W. by W. Boston.

Soutr Alabama, p. o., Genesee county, N. Y.: 249 m. W. by N. Albany.

Sorth Albion, p. o., Kennebec co., Dre.: 23 m. N. E. Augusta.

South Albion, p. o., Calhoun co., Mich. : 39 m. S. by W. Lansing.

Soutr AxbIon, p. o., Oswego co., N. Y.: $184 \mathrm{~m}, \mathrm{~W} . \mathrm{N}$. W. Albany.

Soutr AlDEN, p. o., Erie county, N. Y.: $252 \mathrm{~m}$. W. Albany.

Soutix AlteN, p. o., Belknap co., N. Iamp.: near the line of the Cocheco R. R., $21 \mathrm{~m}$. N. E. Concord.

Sotтi Aмвот, p. o., Middlesex co., Mass.: 20 m. N. W. Boston

Soutr Amboy, t. and sta., Middlesex co., N. Jer.: on s. side of Raritan bay, $28 \mathrm{~m}$. N. E. Trenton. The Camden and Amboy R. R. terminates at the mouth of Raritan river, $63 \mathrm{~m}$. from Philadelphia, and is connected by the company's steamboats with New York, $27 \mathrm{~m}$. Here is a good harbor. In the vicinity is a large manufactory of stone-rare from excellent clay, which is here abundant. There are also in the $t$, several stores and mills.

Soutr A weinra, p. 0., Duchess co., $N_{0}, Y .: 64$ m. S. by E Albany.

Sovth AvmGrist, p. o., Hampshire co., Mass. : $74 \mathrm{~m}$. W Boston.

SOUth 614 sq. m. Drained by Nottaway 4 . and its branches. Sur face level ; soil fertile, adapted to grain and grazing. Chief products, Indian corn, cotton, and tobacco. Farms 722 . manuf. 6 ; dwell. 1,572 , and pop.-wh. 5,971, fr. col. 1,795, sl. 5,755-total 13,521. Capital: Jerusalem, 
Southaupton, t. and p. v., Hampshire co., Mass. : $87 \mathrm{~m}$. W. Boston. Watered by Manham r., which passes twice through the t., flowing S. E. and N. E., and affords good water-power. In the N. part is a lead mine, to which a subterraneous passage 900 feet long has been eut, mostly through solid rock. The t. contains several mills of various kinds, and a tannery. The $\mathrm{v}$, at the centre contains a chureh, academy, etc. The extension of the New Haven and Northampton R. R. on the line of the old canal, will pass throing the t. Pop. of t. 1,060.

Southaupton, p. o., Peoria county, $I l l .: 73 \mathrm{~m} . \mathrm{N}$. Springfield.

Sottrampton, t. and p. v., Suffolk co., $N$. $Y$.: on S. side of E. extremity of Long Island, between Great and Little Peconic bays and the Atlantic Ocean, $142 \mathrm{~m}$. S. S. E. Albany. Surface level; soil light sandy loam. The v. on the S. shore, contaius a church, academy, 3 wind-mills, with several taverns, stores, etc. Sag Harbor, in N. E. corner of the t., is its principal place, besides which are several small settlements. Pop. of t. 6,501.

Southaurpon, t. and p. o., Somerset co., Penn. : $105 \mathrm{~m}$ W. S. W. Harrisburg, Drained by Wills cr, and tributaries. Surface mountainous; soil adapted to grain and grazing. It conlains several small manufactures.

South Andover, p. 0., Oxford co., Me.: 51 m. W. N. W. Augusta.

Soute Arrs, p. o., Louisa county, Virg. : $45 \mathrm{~m}$. N. W. Richmond.

SOUTH ARGTLE, p. o., Washington county, $N_{0} . \bar{Y}: 40 \mathrm{~m}$. N. by E. Albany.

SOUTH AsHbLRNHAM, v. and sta., Worcester co., Mass,: at the junction of the Cheshire $R$. $R$ with the Vermont and Massachusetts R, R, 13 m. W. Fitchburg and 49 m.W. N.W. Boston.

South Assyrid, p. O., Barry county, Mich.: $35 \mathrm{~m}$. S. W. Lansing.

Sotth Aтtleborotgh, p. v., Bristol co., Mass. : $34 \mathrm{~m}$. S. S. T. Boston.

Soutr Auburn, p. o., Susquehanna co., Penn. : $103 \mathrm{~m}$.

N. N. E. Harrisburg.

Sotтн Avon, p. o., Livingston county, $N$. $Y$.: $214 \mathrm{~m}$.

W. by N. Albany.

Souty. BatNBridge, p. $\nabla_{\text {, }}$ Chenango $e_{n}, N, Y_{\text {. }}:$ on both sides of Susquebanna r., $98 \mathrm{~m}$. W. S. W. Albany. It contains a few stores and mills, and 2 churches.

Sotth Barre, p. v., Orleáns co., N. Y.; $234 \mathrm{~m}$. W. by N. Albany.

South Barre, p. V., Washington co, Ferm, : 8 m. S. S. E. Montpelier.

Sodtu Bellinguam, p. v., Norfolk county, Mass, : 29 m. S. W. Boston. The Norfolk County R. R. passes near it.

SotTu BExD, p. $\nabla .$, Arkansas county, Ark. : on the right bank of the Arkansas r., 65 m. S. E. Little Rock.

Socth BeNd, p. o, Armstrong county, Penn. 137 m. T. by N. Harrisburg.

SoUTh Berd, p. o., Lawrence co, JIO.: $132 \mathrm{~m}$. S. W. Jefferson City.

Soutu BexD, p. v., and cap. St. Joseph co., Ind. : on the south bend of the St. Joseph's r., from which it derives its name, $129 \mathrm{~m}$. N. Indianapolis. Its location is on a high bank. The settlement cummenced in 1831, previous to which it had been an Inclian trading post. L. M. Taytor and $\mathrm{A}$. Coquillard were among the first settlers. The public buildings consist of a court-house, jail, 4 churches, a county seminary, and a branch of the State bank, all built of brick. There are also 2 mills capable of making $150 \mathrm{bbls}$. of flour each per day, 1 woulen factory, 1 ofl mill that manufactures 80 gallons a day, establishments for building threshing machines, several saw-mills, an edge-tool factury, machine shops, an establishment for making pegs, lasts, veneering, lath, etc., all propelled by water-power created by a dam in the St. Joseph r. The village is improving rapidly. It is connected with Chicago by the Michigan southern, 799 and Northern Indiana R. R., distant from Chicago $58 \mathrm{~m}$. E. by S., which, with its fine situation, excellent waterpower, etc., gives assurance that it will soon rank with the largest town in northeru Indiana. The " $\mathrm{st}$. Joseph Valley Register" is a weekly (whig) issue. There are in the village over 300 houses and about 1,600 inhabitants.

South Berne, p. o., Albany co., N. $Y_{*}: 21 \mathrm{~m}$. W. by $\mathrm{S}$. Albany.

South Berwick, t. and p. $v_{0}, \bar{Y}$ ork co., $M e_{0}$ : on the S. E side of Salmon Falls. $95 \mathrm{~m}$. S. W. Augusta. Drained by a branch of the Piscataqua $r$., which bounds it on the W. The falls on the river supplies the town with immense hy draulic power, and it has extensive manufactories of cotton and woolen goods, leather, etc. The "Great Works" Manufacturing Company, located here, was incorporated in 1837. The village is located on the navigable waters of Piscataqua $r$. It contains a bank, and is a place of considerable trade. The Portland, Sacn, and Portsmouth R. R passes through, and the Boston and Maine R. R. connects at the village, $13 \mathrm{~m}$. from Portsmouth and $38 \mathrm{~m}$. from Portland. Pop. of t. 2,592

Sout't Bloomreld, p. v., Pickaway co, Ohio: $1 \mathrm{~m}, \mathrm{E}$ of the Scioto $\mathrm{r}$, and on the Ohio Canal, $\$ 1 \mathrm{~m}$. N. Portsmouth and $18 \mathrm{~m}$. S. Columbus.

Soutil Bloomfrecd, p. o., Somerset co., Me. : $30 \mathrm{~m}, \mathrm{~N}$ Augusta.

Sоттнвовотян, t., p. T., and sta., Worcester co., Mass. $27 \mathrm{~m}$. W. by S. Bosion. Drained by a branch of Sudbury $\mathbf{r}$ Surface undulating; soil rich, and well cultivated. It bas some light manufactures, but it is chiefly a farming town. The $\mathrm{v}$. is located $\mathrm{N}$, of the Boston and Worcester R. R., on which is the sta., $17 \mathrm{~m}$. E. Worcester. Pop. of t. 1,347.

Soctin Boston, p. o., Ionia co., Mich. : $39 \mathrm{~m} . \mathrm{W}$. by N. Lansing.

SoбтH Bostow, p. o., Washington co., Ind.: on a fork of Great Blue r., S0 m. S. by E. Indianapolis.

South Bradfoed, p. v., Merrimac co., N. Hamp. : 20 m. W. Concord.

Sovtr BradFord, p. 0, Orange co, Term. : $27 \mathrm{~m}, \mathrm{~S}$ E Montpelier.

Souti Bradford, p. o., Steuben county, $N_{\text {. }}$ Y.: $176 \mathrm{~m}$ W. by S. Albany.

Sovth Bralvmee, p. v. and sta., Norfolk co., Mass. : at the junction of the Old Colony and Fall River railroads $42 \mathrm{~m}$. N. by E. Fall Piver and $11 \mathrm{~m}$. S. Boston.

SodTHBmDge, sta, Niagara co., $N .1^{2}:$ on the Rochester Lockport, and Niagara Falls R. R., $9 \mathrm{~m}$. N. Buffalo and $276 \mathrm{~m}$. W. by N. Albany.

SotTHBRIDGE, t, and p. V., Worcester co., Mass.: $56 \mathrm{~m}$. S. W. Boston. Drained by the Quinnebaug r. and branches, affording good water-power. Surface uneven and hilly; soil adapted to fruit, grain, etc. It has several manufactories of cotton and woolen goods, among which are those of the "Central Manufacturing Company," at which are manufactured 1,500,000 yards of sheetings per annum. The $v_{0}$ is on the right bank of Quinnebaug r., and contains a bank. several churches, etc. Pop. of t. 2.824.

South Bridgeton, p. v., Cumberland co., Me.: 56 m. S. W. Augusta.

South Bristol, to and p. $\nabla_{*}$, Ontario co., $N . Y_{*}:$ on the TV. side of Canandaigua lake, $192 \mathrm{~m}$. W. Albany. Driined by small streams fowing into Camandaigua lake. Surface uneven; soil of moderate fertility. It contains some light manufactures. The $\mathrm{y}$. is on Mud er. Pop. of t. 1,180.

Soutr Bristol, p. 0., Racine co, Wisc. : 75 m. E. S. E Madison.

Soutn Britats, p. v*a New Haven co., Conn.: on Pompesaug river, $36 \mathrm{~m}$. S. W. Hartford. It is a fourishing and neat place, and contains several manufactories of carpets, hats, etc.

South Beookrield, p. o., Madison co., $N . Y_{.:} 84 \mathrm{~m}$. W. Albany.

Suttr Brusiwick, t. and p. 0., Middlesex co, $N$. Jer.: 
15 miles N. E. Trenton. Millstone river forms the S. W. boundary. Drained by branches of Millstone river and Lawrence's branch of Raritan $r$. "Sand Hills" are in the N.W. part, otherwise the surface is level; soil fertile and well cultivated. This is chiefly an agricultural town, and but few manufactures. The Trenton and New Brunswick R. P. passes through the W. part of the town. Population 3,36s.

Soctherry, to and p. v., New Haven co., Conn.: on the $\mathrm{N}$. side of the Housatonic river, $37 \mathrm{~m} . \mathrm{S}$. W. Hartford. Water-power is derived from the Pampesaug r., on which are located several mills. Surface uneven; soil in the uplands warm and productive, and along the river there is some good meadow land. The $\mathrm{v}$. is on Pampesaug river, a fine mill-stream. The t, contains some manufactories, and coal has been discovered. Pop. of t. 1,454.

Socth B שTLER, p. o., Wayne co., N. Y.: 162 m. N.W. by W. Albany.
South Buther. p. 0., Butler county, Alı.: 49 m. S. S. W. Montgomery. There are springs located in the vicinity. Sotta Brron, p. o., Genesee co., N. Y.: 228 m. W. by N. Albany.

SoUth CAIRo, p. o., Greene county, $N . T .: 29 \mathrm{~m} \mathrm{~S}$. by W. Albany.

Soutu Cayaar, p. o., Essex county, Term. : $70 \mathrm{~m}$. N. E. Montpelier.

Soutu Cananin, p. v., Litchfleld co., Conn.: on IIollenback $r$, on a tributary of the Ilousatonic. $85 \mathrm{~m}$. V. W. hy IV. Hartford. Establishments for the manufacture of anchors, ete., are located on the Hollenback and Irousatonic rivers, and there is also a satinet manufact ory in the v. Limestone is found here, and lime of a superior quality is manufactured and exported.

Soutr Candor, p. v. and sta., Tioga co, $N_{0}, Y_{0}$ : on the Cayuga and Susquehanna R. R., 5 miles N. Oswego, 65 S. E. Cayuga, and 138 S. W. by W. Albany.

\section{THE STATE OF SOUTH CAROLINA.}

Sottr Caroutra is situate between the latitudes $82^{\circ} 04^{\prime}$ and $35^{\circ} 12^{\prime}$ north, and between the longitudes $79^{\circ} 25^{\prime}$ and $83^{\circ} 19^{\prime}$ west from Greenwich, or $1023^{\prime}$ and $6^{\circ} 17^{\prime}$ from Washington. Its shape is irregularly triangular. The distance north and south on the meridian of Savannah is 212 miles, and from the head of Tugaloo River, on the west, to the mouth of Little River, on the east, 268 miles. On the south-east the Atlantic forms its boundary for upward of 200 miles; on the south-west, dividing it from Georgia, the Savannah River for 240 miles, or following the windings of the stream, upward of 500 miles; and the north line, separating it from North Carolina, is an irregular conventional boundary. Included within these limits the land aren is estimated at 24.500 square miles.

The coast region for 100 miles from the ocean is covered with forests of pitch pine, intersected with swampy tracts, and permeated by sluggish streams. In this respect, it assimilates the whole southern coast region. Beyond this, and parallel to it, is a belt of territory, called the "Middle Country," consisting of low sand hills, resembling the waves of an agitated sea. This tract oceasionally presents an oasis of verdure, or a plantation of maize, but ntherwise it is forbidding to the agriculturist. The middle country is bounded westward by another belt of land, called the "Ridge," where the country rises by a steep and sudden elevation, and afterward continues gradually to ascend. Beyond, the surface exhibits a beautiful alternation of hill and dale, interspersed with extensive forests, and watered by pleasant streams. There are a few lofty mountains in the western part, belonging to the Blue Ridge. Tablo Mountain, in this chain, rises to the height of 4,000 feet above the level of the sea. King's Mountain, in York Distriet, lies partly in North Carolina, and is an isolated eminence of considerable elevation.

The prineipal rivers of South Carolina have their sources in the Blue Ridge. The great Pee Dee, which bears the name of Yadkin, in North Carolina, reaches Winyaw Bay, after having received the waters of Lynch's Creek and Black River from the right, and the Little Pee Dee and Waccamaw from the left. It is navigable for steamboats to Cheraw, above which there is a fall of 15 feet in 18 miles. The Santee, the greatest river of the State, is formed by the junction of the Catawba, or Wateree, and the Congaree, and it reaches the sea without receiving any considerable tributary by two mouths. Steamboats ascend it to Camden and Columbia, and by the aid of eanals, there is navigation for boats to the mountains, The Congaree is itself formed by the junction of two considerable navigable streams, the Saluda and the Broad rivers. The Edisto, Cambahee, and Coosawatchie, are smaller streams, in the southern part of the State, navigable for snme distance by small vessels. Ashley River is navigable by schooners 20 miles, and Cooper's River, which joins it at Charleston, 30 miles to the Santee Canal. Although most of these rivers are navigable, as a general thing the lower parts of their courses are shallow, and obstructed by bars. The harbors of the State are almost valueless, but the coast presents numerous entrances, which are accessible to small ressels, and which afford advantages to an extensive and active coasting trade. The harbor of Charleston is obstructed by a dlangerous sand bar, and that of Georgetown will only admit small craft. The harbor of Beaufort, or Port Royal, is the best in the State, and is sufficient to receive a navy, but is little frequented, Stone Inlet has nine or ten feet of water, and was used during the blockade of Charleston, in 1775. St. Helena Sound is the most spacious opening for a great distance along the coast, but although about 3 miles wide and 10 miles long, it is too mneh beset by shoals to be of any great commercial value. The southern part of the coast is skirted by a range of islands, separated from the mainland by narrow channels, which afford an inland steamboat navigation from Charleston to Savannah. These islands, like the neighbnrirg continent, are low and flat, but are covered wilh forests of live oak, pine, and palmettoes, and they yield the black seed, or Sea Island cotton. Before the cultivation of cotton was commenced, many of them were the haunts of alligators, and their thick wonds and rank weeds rendered them impenetrable to man. At present they are under cultivation, and well inhabited, and as the royager glides by their shores, he is enchanted by the prospect of their lively verdure, interspersed by thick elumps of palmettoes and flowering groves of orange trees. The live oak, which is sn called from its being an evergreen, is a noble tree, with a trunk sometimes 12 feet girth-its inng branches are spread horizontally, and festoons of moss hang from them, almost sweeping the ground. The lanrel is here seen covered with large white blossoms, shaped like a lily, and a foot in cireumference. The long sand beaches, which border these islanis toward the sea, are covered with thousands of water-fowl.

The mineral resources of South Carolina are by no means insignificant. The primitive region of the western part of the State belongs to the auriferous belt of the Atlantic slope, and for a number of years past the production of gold has been such as to encourage the miner in continuing his pursuits. In several cases large nuggets of native metal have been dug up, but the largest quantities have been obtained from washings. Iron is also abundant in this region, and in quality the ore is not surpassed. Coal is not found within the State; and the rocks which include the coal formation, between the clay slate and the new red sandstone, are entirely wanting. Regarding the minerals used as building material, Prof. Tuomey says, "it is owing to the difference in the facilities for transportation that the granite, marble, and flagstone of 


\section{SOUTH CAROLINA.}

Mrssachusetts and Connecticut are better known in Charleston and other cities, than those of the State (South Carolina), notwilhstanding the abundance and quality of the latter. In choosing building materials, strength and resistance to external agents are among the principal rrquisites." **** "The granite and sienite around Columbia are of this character. Among the beautiful granites of the State, the porphyritic granite of Camden and Buffalo Creek, and the red granite near Columbia, are conspicuous. Of the sienites, those found in Abbeville, Fairfield, and Lexington are the most beautifu. The former resembles the Quincy granite, and the latter is remarkable for its white feldspar, contrasting so trikingly with the black crystals of hornblende. The white and variegated marble of Spartansburg and Laurens form excellent materials for building and ornamental purposes." **** "Gneiss, besides furnishing an excellent building stone, is often sufficiently slaty in its structure to allow of being split into slabs. A fine quarry of this sort is open at Piekens. In the lower part of York gneiss is found, having a sinilar strueture: it passes in to mica slate, which presents every appearance of making an excellent flagging stone." **** "The mica slate found in Fairfield is equally promising." Soapstone of very fine quality is found at some of the above-named localities; and porcelain earth abounds through the primary region. wherever the feldspathic granite is found in a state of disintegration. Localities are so well known as "chalk hills," that they need not be enumerated. A long-known locality oceurs above Pendleton, and along the base of the mountains in Pickens it is seen in several places; in Greenville, near where the Pendleton road crosses the Saluda; and in Abbeville, near the village, a remarkable locality is pointed out. This deposit is the result of the decomposition of eurite. A similar deposit is found near Cherokee Ford, where it is used as a fire clay, and it is seen again on the branches of King's Creek. But the finest exposures of this earth are found in the dilnvium. A good material for glazing pottery will be found in the undecomposed feldspar of the granites, where it abounds. Sand of fine quality for the manufacture of glass is also abundant. Red and yellow ochres abound in Chesterfield District, of rery fine quality, yet they seem scarcely to be used even for domestic purposes. There are many localities where the micaceous and talcomicaceous rocks occur, which answer well for whetstone. A noted locality occurs in York, and another in Chestcrfield, and in the upper part of Lancaster. Many of the precious stones are also found in various parts of the State.

In richness, variety, and abundance, perhaps no part of the habitable globe, of the same territorial exteni, exceeds South Carolina in agricultural capabilities. Governor Seabrook says, "Of the four great materials for human clothing, cotton, wool, silk, and flax, her climate and soil are peculiarly adapted to the first three, and in locations to the last. Of the prominent articles of food, she produces rice, wheat, Indian corn, oats, rye, barley, sweet and Irish potatoes, and different varieties of the pea tribe. For the habitation of man, the earth, her quarries, and forests, furnish an inexhaustible supply. Iron, so esaential to every class in society, is superior in quality, it has been ascertained, to any found in the country. Gold, not too abundant to divert from other and more profitable pursuits, excites the enterprise, and rewards the labor of a portion of our eitizens. In other minerals she is neither defieient in quantity nor value. While the woods abound in game, including the deer and turkey, the ocean, which laves her southern burder, and the numerous streams, bnth sait and fresh, that penetrate every part of her surface, yield almost every variety of the choicest fish. In relation to medicinal and culinary plants, her catalogue is large. To tobacco, indigo, and hemp, which once were staple commodities, fruits and esculent vegetables that everywhere meet the eye, and other productions that minister to the comfort or necessities of her people, it is needless in this place especially to direet your notice. So remarkable, indeed, is her topographical condition, that wheat and the sugar-cane grow profitably side by side, and the olive and orange ripen under the provident care of the same family of cultivators, who extract the saceharine matter of the maple, but essay in vain to secure the maturity of the native corn of America. Wheat is cultivated as low as $32 \circ 30^{\prime}$, and from bleak, cold winds, the northern side of the Glassy Mountains will not produce maize. To comprehend this subject in all its relations a more detailed examination is necessary.

"South Carolina is most favorably situated, not only with regard to the States of the Union, but to the other portions of the globe. Midway between the frozen regions of the north, and the burning heats of the tropics, in ber climate, seasons, and productions, it has been fully represented that she enjoys most of the advantages of all. If we except tropical fruits, to which frost is fatal, her capacity successfully to rear all the grains, fruits, and esculent roots, which enrich more southern countries, is nearly certain. Her latitude for cotton enjoys an extraordinary advantage. Much farther south, the forcing nature of a vertical sun derelops the plant too rapidly, thereby running it into weed and foliage; it is from the same cause most exposed to the ravages of the caterpillar and olher insects. Farther north, the season is too short to mature an abundant crop of bolls, while the staple degenerates, and becomes less valuable. From the Sea Island the best cotton known to commerce is exported. So circumscribed are the lands in which it can be grown, that a half degree $\left(32^{\circ} 10^{\prime}\right.$ to $32040^{\prime}$ north latitudes) of the sea-coast of North America seems to be the precise point where the length, strength, and firmness of the fibre are most happily blended. In reference to rice, our State enjoys almost a monopoly. South Carolina includes an area of 30,213 square miles, or $19,435,680$ acres (according to the last census 24,500 square miles, or $15,680,000$ acres). Of this area there is as little land in one body, the highest authorities assure us, unsusceptible of remunerating culture as the United States can furnish. Undistinguished by mountains with their agricultural disadvantages, it is worthy of remark that the spurs that make out from the great range which separates the waters falling into the Atlantic Ocean, and into the Gulf of Mexico, are capable of profitable tillage to their very summits.

"As a difference of 12 degrees of latitudes exists between the western and eastern hemispheres, the countries of the latter, which are subject to the same atmospherical influences with South Carolina, comprise the most delightful and fruitbearing portions of France, Italy, Turkey in Europe, Russia, Tartary, and China.

"Between the primitive and alluvial formation the State is nearly equally divided. The soils, though of every kind, may be said to comprehend six varieties, each the best suited to a certain crop, yet all of them eapable of advantageousily producing three-fourths of the vegetable products grown in its limits. While local differences are everywhere observable, the surface and soil of the upper districts present a great similarity; and this is equally true of the lower districts. In the former the lands are broken and hilly, in the latter level-oak is the natural growth of the one, pine of the other. Clay is the soil of much the largest portion of the State, and, except in the immediate vicinity of the ocean, is almost the universal substratum. A close, stiff land predominates generally in the parishes south-east, and an open sand on the sea islands. The highlands of the country above the falls of the rivers are naturally much superior to those of the pine-covered region, but the alluvial bottoms of the former are greatly surpassed in richness by the river swamps of the latter. In its capacity for permanent improvement, the granite half of the State has been more highly favored by nature than the alluvial. This is mainly ascribable to the open texture permeable to water of its elayey subsoil, and the potash in the soil and subsoil, formed by the decomposition of the feldspar and mica of the granite. In a few localities, however, the depth of the substratum and its proximity to the surface offer serious obstacles to its higher productions. These, among other causes, 


\section{SOUTH CAROLINA.}

seem yet to be operating against the cultivation of perhaps the greater part of those peculiar snils known as the "Flat Woods' of Abbeville; those in the neighborhood of Dutchman's and Wateree creeks, in Fairfleld, and the Black Jack lands of Chester. Deriving their fertility from the horneblende disintegrated rocks which lie below the close clay subsoil, it would appear that steady industry, incited and directed by ordinary skill, was alone wanting to preserve and perpetuate the uncommon productiveness which, in spite of long-continued and improvident tillage, still distinguishes these remarkable tracts of land. In reference to the soils of the primitive country, to one more peculiarly only shall I now advert. When the rocks lie horizontally, it is known that the snils derived from clay slates frequently siffer from the impenctrable nature of the subsoil and the position of the underlying rocks. In the regions to which they are confined in this State. they 'are all hlghly inclined, presenting their edges to the surface, and allowing the water to percolate through the strata'

"The swamps, covering 2,000 square miles of land of inexhaustible fertility, are capable of thorough and economical drainage and conversion into active and available capital. The pine lands, embracing $6,000,000$ of acres, constitute the most neglected portion of the State, while in some quarters they are erroneonsly regarded as valuable only for the abundance and quality of their timber, in others the belief is equally unsound, that their productive capacity is limited to plants which flourish only in a thin and feeble snil. That in all its relations it is a district of country of immeasurable ralue to our community, will hereafter be attempted to be shown.

"South Carolina is most bountifully supplied with water. The base of her triangular form is washed by the ocean, and one of her lateral sides rests on a river accessible to vessels more than one-half its length, and small boats 100 miles beyond. Many bold and navigable streams, with numerous tributaries crossing through her territory ih every direction, disembogue into the Atlantic at distances from each other, mosi suitable for the purpose of intercommunication and traffic. Before reaching the point where all traces of their distinctive character are lost forever, by united contributions they form a bold channel between the mainland and the sea islands the entire width of the State. Apart from the creeks and inlets of the sea, there is now an inland navigation equal to about 2,400 miles. Greenville is the only division of our domain without the benefit of navigation. In all the districts, however, water-courses abound which afford remarkably eligible sites for mills. The rocks cross the streams nearly at right angles, and hence form a serjes of natural dams across their beds, and make falls that vary from five to eighty feet in comparatively short distances. In perhaps no equal extent of territory are there so many advantages of this sort presented. In connection with this subject, it is proper to add that the metropolis of the State (Charleston) is only seven miles from the ocean; that its harbor is spacious, well protected from storms, and at all times accessible.

"Surprising to many as may be the declaration, South Carolina, in reference to her whole population, is a very healthy country, and by no means a sickly one with regard to her white inhabitants. If the alluvial region and a few of the middle districts are subject to fevers in summer, the whole State in winter is comparatively exempt from the diseases to which more northern climates are peculiarly liable. The assertion, too, is with entire confidence made, that even during the hot months, in perhaps one-half of her limits, foreigners may reside, not only with impunity, but with renovated constitutions. In the neighborhood of every locality in which mephitic exhalations show the fatality of their power, there are sites for settlements where vigorous health, under the ordinary safeguards, is always secured. The entire sand hill country and pine lands generally, as well as our towns and villages, furnish the most signal evidence of the salubrity of their atmospheric influence. It may here be appropriately observed, that while from causes, several of which are anong the arcana of nature, the lower division is becoming gradually but steadily healthier, a portion of the middle zone is decidedly more liable to maladies of a fatal character. If a better system of drainage and other improvements in the cultivation of the ground do not satisfactorily account for the one, certain agrieultural features are perhaps. sufficient to explain the other. For the diseases which occasionally clothe, in the habiliments of mourning, the people of Abbeville, Union, Chester, and York, it is supposed that the planters of those districts are competent to the diminution of the sources whence they spring. It is not unworthy of especial remark, that the atmosphere of the swamps and marshes, so poisonous to the white man, is at all times innocuous to his slave. If it were not for this merciful provision of an All Wise Being, the alluvial region of South Carolina in the immediate vicinity of its water-courses would soon become a dreary waste, and tenanted only by the beasts of the forest. Of the cities of the Union, Charleston, and it may be added Columbia, show a lower mortality among their acclimated inhabitants than any others. With regard to the former, the number of deaths from all fevers (the epidemic of the State), except from yellow fever, for the last 18 years, is 656, and in any one year 81 in a population of betwecn 30,000 and 40,000 . From yellow fever, which has prevailed as an epidemic but twice in 22 years, for the same period, the aggregate number of deaths is 646 . The average mortality for the last 6 years, all classes included, is 1 in 51 ; blacks alone 1 in 44 , and whites alone 1 in 53.

"The natural means of resuscitating the soil are abundant and widely diffused. A large portion of the lower country shows exhaustless beds of the rịchest marl. Limestone, though obtainable only in York, Spartansburg, Laurens, and Pickens, exists in such quantities in the first two districts, that by railroad communication the entire primitive region will, at no distant day, be furnished with this earth, so essential to the nutrition and development of plants. While the seashore parishes possess unfailing supplies of salt mud, salt grass, and shell lime, two-thirds of the State are most amply furnished with swamp mud and peat.

"Of minerals and the primitive rocks, the number of the former is 28, and of the latter more. (See account of minerals, antea.)

"The botany of the State consists of about 3,000 species of plants-of these 2,000 are flowering, and 1,000 unprovided with flowers, as parts of their organs of fructification. In relation to the former, about 65 are naturalized-that is, foreign plants introduced, and now growing wild. There are about 150 grasses, of which 15 are native; 30 species of esculents (for $\mathrm{man}$ ), of which three or four are naturalized, and about 70 more used in medicine, agriculture, and the arts, of which five or six are naturalized.

"As a member of the Union, South Carolina in population oceupies the eleventr rank (according" to the census of 1S50, the fourteenth), in territorial extent the twenty-second (since the admission of California, the twenty-third); in the value of her agricultural exports, the fifth; in the value of the goods, wares, and merchandise, of the growth, produce, and manufacture of the United States, the thirteenth. The very large contribution of this State to the national wealth, which is determined by the amount of her domestic exports, and not her imports, comes, too, from a limited part of her soil. The estimated number of acres in cultivation in 1520 , was 1,221,000; at present it does not exceed 2,000,000 (in 1850 , according to the census $4,072,651$ ), or about one-tenth, (one-fourth) of her arcible lands." 


\section{SOUTH CAROLINA.}

South Carolina is divided into 29 districts, the general statistics of which, and the capitals of each, in 1550 , were as follows:

Counties, Dwell, Pop. Farms Manuf, Capitals, Abberille... 3,391 .. 32,318 .. 1,814 . . 156 .. Abbeville Anderson ... 2,440 .. 21,475 . 1,986 . . 66 .. Anderson Barnwell.... 2,460 . 26,608 .. 1,558 .. 85 .. Barnwell Beaufort..... 1,355 . . 35,805 .. $812 \ldots 18 \ldots$ Gillisonville Charleston ... 5,213 .. 72,805 .. 682 .. 76 .. Charleston Chester .... 1,511 .. 18,038 .. 844 .. 50 .. Chester Chesterfield.. 1,263 .. 10,790 .. 519 . . 82 .. Chesterfield Colleton.... 1,515 .. 39,505 .. 888 .. 10 .. Walterboro" Darlington. . . 1,313 . 16,830 . . 857 .. 26 . . Darlingtou Edgefield . . 3, 3,019 . 39,262 .. 2,080 .. 197 .. Edgefield Fairfield.... 1,232 ..21,404 .. 675 .. 36 .. Winusboro' Georgetown . 575 .. 20,647 .. 550 .. 6 .. Georgetown Greenville... 2,851 . . 20,156 .. 1,065 .. 55 .. Greenville Horry ...... $950 \ldots 7,646 \ldots 731 \ldots 7$... Conwaysboro Kershaw .... 928 .. 14,473 .. 353 .. 21 .. Camden

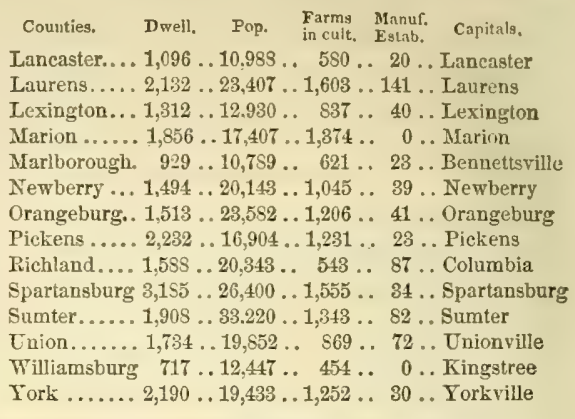

The whole number of dwellings in the State was, at the above date, 52,642 ; of families, 52,937 ; and of inhabitants, $66 S, 507$; viz, whites 274,628 -males 137.778 , and females 136,550 ; fr. col. 8,900-males 4,110, and females 4,790, and 8l. 384,984. Of the whole population there were, deaf and dumb-wh. 129, fr. col. 1, sl. 15-total 145; blind-wh. 152, fr. col. 14, sl. 56-total 222; insane-wh. 192, fr. col. 3, sl. 9-total 204; and idiotic-wh. 242, fr. col. 3, sl. 50-total 295. The number of free persons born in the United States was 274,813 , the number of foreign birth 8,662 , and of birth unknown 48. The native population originated as follows: Maine 68, N. Hamp. 39, Verm. 37, Mass. 407, R. I. 97, Conn. 228, N. York 884, N. Jer. 182, Penn. 362, Del. 14, Md. 320, Dist, of Col. 30, Virg. 1,621. N. Car. 6,173, South Carolina 262,160, Ga. 1,504, Flor. 55, Ala. 225, Miss.60, La. 30, Tex. 1, Ark. 9, Tenn. 188, Ky. 73, Ohio 23, Mich. 2, Ind. 11, Ill. 6, Mo. 3, Ia. 0, Wisc. 0, Calif. 1, Territories 0 ; and the foreign population was composed of persons from-England 921, Ireland 4,051, Scotland 651, Wales 10, Germany 2,150, France 274, Spain 30, Portugal 14, Belgium 0, Holland 9, Turkey 0, Italy 59, Austria 11, Switzerland 18, Russia 19, Denmark 24, Norway 7, Sweden 29, Prussia 44, Sardinia 0, Greece 1, China 1, Asia 4, Africa 9, British America 57, Mexico 4, Central America 0, South America 8, West Indies 177, Sandwich Islands 0, and other countries 50 .

The following table will show the decennial progress of the population since the first census of the State, taken by the United States authorities:

\begin{tabular}{|c|c|c|c|c|c|c|c|}
\hline \multirow{3}{*}{$\begin{array}{l}\text { Census } \\
\text { Years. } \\
1790 .\end{array}$} & \multirow{2}{*}{$\begin{array}{l}\text { White } \\
\text { Persons. }\end{array}$} & \multicolumn{3}{|c|}{ Colored Persons. } & \multirow{2}{*}{$\begin{array}{c}\text { Total } \\
\text { Population. }\end{array}$} & \multicolumn{2}{|c|}{ Decennial Increase. } \\
\hline & & Free. & Slave. & Total. & & Numerisal. & $P$ ex cent. \\
\hline & $.140,178$. & $.1,801$. & 107,094 & $.108,595$. & ..249,073.. & $\ldots \rightarrow$ & $\ldots-$ \\
\hline 1800. & $.196,25 ั 5 .$. & & .146 & $\therefore 44$ & ..345.551.. & ...96,518.. & $\ldots 85.7$ \\
\hline 1810. & $.214,196 \ldots$ & $.4,554$ & $.196,365$ & $.200,919$. & ..415.115.. & $\ldots 69,524 \ldots$ & $\ldots 20.1$ \\
\hline 1820 . & $.287,540 \ldots$ & $.6,726$. & .258 & .2 & $\ldots 5$ & $\ldots 87$ & $\ldots 21.1$ \\
\hline 1830. & $257,863 \ldots$ & $.7,921$. & $.315,401$ & $.323,322$ & ..5\$1,185. & $\ldots 78,444 \ldots$ & $\ldots 15.6$ \\
\hline 1540. & $.259,059 \ldots$ & .8 .271 & $317,03 \mathrm{~S}$ & .327 & ..594.39s. & $.13,213$ & .. 2.3 \\
\hline 1850. & $.274,623$. & 800 & & & $.668,2007$. & $.74,109$. & .12 .8 \\
\hline
\end{tabular}

The general statisties of the State regarding its productions, manufactures, commerce, and institutions, according to the census of 1550 , and other official returns for that year, were as follows:

Occupied Lands, etc.-Improved farm lands, 4,072,651 acres, and unimproved lands, 12,145,049 acres-valued together at $\$ \$ 2,431.654$. The whole number of farms under cultivation on the 30 th June, 1550 , was 29,969 . Falue of farming implements and machinery, $\$ 4,136,354$.

Lire-Stock:-The number of lire-stock or domestic animals for the two periods $1 S 10$ and $1 S 50$, according to the census of those years, was comparatively:

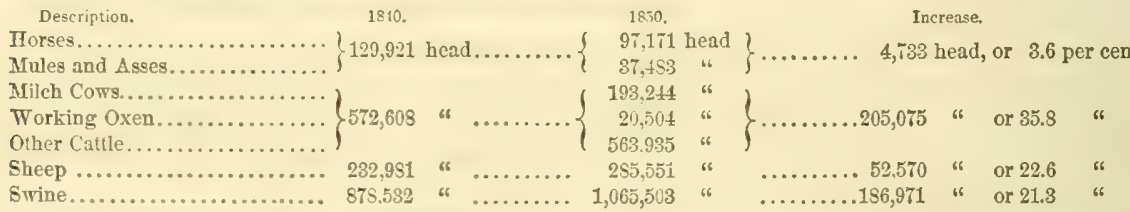

- the value of all lire-stock in 1850 , was $\$ 15,060,015$.

Prortucts of Animals.- Wool, $45, .233$ pounds; butter, $2,951, \$ 50$ pounds ; cheese, 4,970 pounds; and the value of animals slaughtered in the year had been $\$ 1,302,637$. The wool crop according to the census of 1540 amounted to 299,170 pounds; and hence the increase exbibited in 1850 , was 185,063 pounds, or 62.5 per cent. The product per tleece in 1840 , was 20.1 ounces, and in 1550, 27.3 ounces, showing an increase of 7.2 ounces, or 35.8 per cent.

Grain Crops.-Wheat, 1,066,277 bushels; rye, 43,790 bushels; Indian corn, 16,271,454 bushels; oats, $2,322,155$ bushels; barley, $\{.053$ tushels; and buckwheat, 253 bushels. Comparing the abore with the products according to the census of 1510 , the following results are obtained:

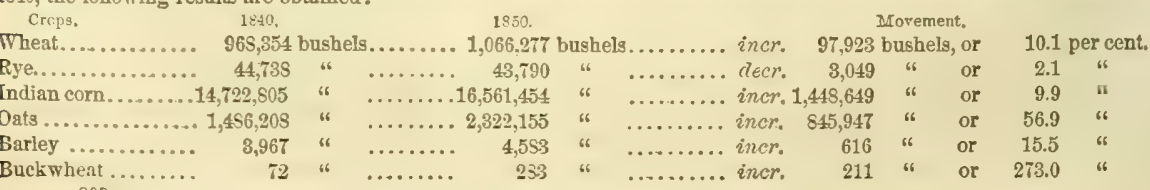




\section{SOUTH CAROLINA.}

Other Food Crops.-Rice, 159,930,613 pounds; peas and beans, 1,026,900 bushels; potatoes-Irish, 136.491 bushels, and sweet. $4,337,469$ bushels. The rice crop of 1840 was $60,590,561$ pounds, and the increase in 1550 was $99,339,752$ pounds, or 168.9 per cent. About three-fourths of the whole rice crop grown in the United States is produced in South Carolina, the proportions being as 1.599 to 2.153 . The crop of potatoes in 1840 , amounted to $2,698,313$ bushels, and hence the increase over this in 1850 was $1,775,650$ bushels, or 66.6 per cent.

Miscellaneous crops.-Tobacco, 74,255 pounds; cotton, 330,991 bales of 400 pounds; hay, 20,925 tons; clover-seed, 376 bushels; other grass seed, 30 bushels; hops, 26 pounds ; flax, 383 pounds; flax-seed, 55 bushels; silk cocnons, 128 pnunds; sugar-maple 200 pounds, and cane, 671 hogsheads of 1,000 pounds; molasses, 15,904 gallons; beeswax and honey, 216.251 pounds; wine, 5,830 gallons, etc. Value of orchard products $\$ 35,108$, and of market-garden produets $\$ 47,256$. The principal of these crops in 1840 and 1850 compare as follows :

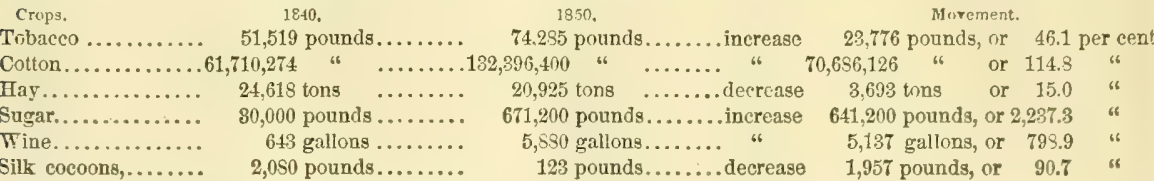

Home-made Manufactures were produced in the year ending 1st June, 1850 , to the value of $\$ 909,525$. The same class of goods for the year preceding the census of 1840 , were valued at $\$ 930,703$.

Manufactures.-Total capital invested, $\$ 0,000,000$; value of all raw material, fuel, etc. consumed, $\$ 0,000,000 ;$ bands employed 00,000 -males 0,000 , and females 0,000 ; monthly cost of labor $\$ 000,000$-male $\$ 000,000$, and female $\$ 00,000$; value of products for the year, $\$ 0,000,000$. The number of manufacturing establishments in operation and producing to the annual value of $\$ 500$ and upward on the 30 th June, 1850 , was 1,473, distributed to the counties according to the exhibit of the general table. Of this number 18 were cotton factories, 91 tanneries, and 6 iron works. The total capital invested in manufactures in 1810 , amounted to $\$ 3,216,970$.

Capital invested in cotton manufactures, $\$ 857,200$; cotton used, 9,929 bales; value of all raw material, $\$ 295,971$; hands employed, 919 -males 399 , and females 620 ; monthly cost of labor, $\$ 10,716$ - male $\$ 5,565$, and female $\$ 5,151$; annual products-sheeting, etc. $6,563,737$ yards, and yarn $1,348,343$ pounds; value of entire products, $\$ 749,338$. In 1840, there were in the State 15 cotton factories-capital $\$ 617,450$; hands, 570 ; value of manufactures, $\$ 359,000$.

Capital invested in tanneries, $\$ 184,335$; value of hides and skins used, \$131,679; hands employed, 264 ; monthly cost of labor, $\$ 3,667$; products of the year, 13,830 skins, and 110,000 sides of leather, valued together at $\$ 261,332 . \quad$ In 1810 , the capital invested in 97 tanneries was $\$ 212,020$; hands 281 , and products- 65,081 sides of upper leather, and 89,586 sides of sole leather.

The iron manufacture of South Carolina is confined to the manufacture of castings. In 1850 there were 6 establishments in operation, having an aggregate capital of $\$ 155,700$. The material used in these was 169 tons of pig iron, 2,800 tons ore, and 405,560 bushels of charcoal and coke, valued as raw material at $\$ 29,128$. Hands employed $155-m a l e s 153$, and females 2 ; average wages per month-to males $\$ 1359$, and to females $\$ 4$; castings manufactured, 1,286 tons; total value of annual products, $\$ \$ 7,653$. In 1840 there were in the State 4 furnaces, producing 1,250 tons, and 9 bloomeries, forges, and rolling-mills, producing 1,165 tons; fuel consumed, 6,384 tons; hands, 245 ; and capital invested, $\$ 138,300$.

In the manufacture of malt and spiritous liquors, the capital invested amounted to $\$ 3,475$; Indian corn consumed, 18,100 bushels; hands employed, 33 ; whisky and high wines produced, 43,900 gallons. In 1840, 251 distilleries employed 219 men, and produced 102,283 gallons; and the capital invested amounted to $\$ 14,342$.

The manufacturing establishments making up the whole number as ascertained, otherwise than those detailed above, consist chiefly of such as are usual in an agricultural State, as carriages, saddlery, ete, and the mills of various descriptions found in all parts of the country. At least one-half the whole capital is employed in these multifarious interests.

Foreign commerce.-The value of the foreign import and export trade in the year ending 30 th June, 1550, was as follows-of exports $\$ 11,448,800$, and of imports $\$ 1,933,785$. Of the exports, $\$ 11,446,992$ was the value of domestic productscarried in American ships $\$ 6,467,201$, and in foreign $\$ 4,979,691$; and $\$ 908$ was the value of foreign goods re-exported; and of the imports $\$ 1,313,658$ was the value of goods carried in American, and $\$ 620,127$ that of goods carried in foreign ships. The statistics of the shipping employed in this branch of industry in the year aforesaid, exhibit the annexed aggregates.

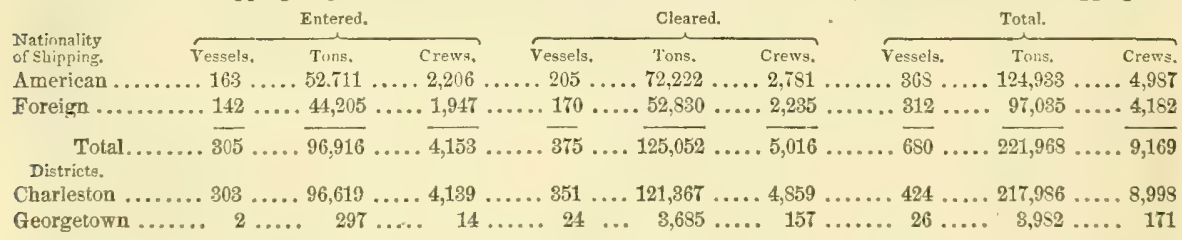

Coasting Trade, Internal Improvements, etc.-The great bulk of the commercial material of South Carolina and the States westward using its ports, is carried to New York for a market and for exportation, and in like manner these States are supplied with foreign goods from the same mart. This arrangement creates an immense coasting trade, which in. South Carolina chiefly centres at Charleston. (See Crarleston.) With Georgia, Florida, and the Gulf ports a large trade is kept up, and regular lines of steamers and coasting vessels ply between the ports. Navigation on the rivers is also carried on to a great extent, and the heavy products of the interior are mostly brought down to the sea-board through this means. The Santee and other canals in this State are little used as channels of commerce, but are of local utility. The lines of railroad terminating at Charleston also greatly facilitate internal commerce. These railroads, indeed, are ta Charleston what the Erie, Central, and other roads in New York are to the sea-board in that quarter, and have done more than all the natural facilities enjoyed by the country to swell the volume of its industry and wealth. These are noticed at length in the APPENDix. Except Georgia, no other Southern State has in operation such a successful system of railroads, and it was in South Carolina that the American railroad system was first tested as an agent in commercial movements. 


\section{SOUTH CAROLINA.}

The total amount of shipping owned in the State was 36,072 tons, of which 17,126 tons was registered shipping, 15,020 tons enrolled and licensed, and 69 tons licensed (nnder 20 tons). Of the registered tonnage 1,116 tons was navigated by steam, and of the enrolled and licensed shipping 6,339 tons. No shipping had been built during the year. The statistics of the value of the foreign commerce for a series of years exhibit the following movements:

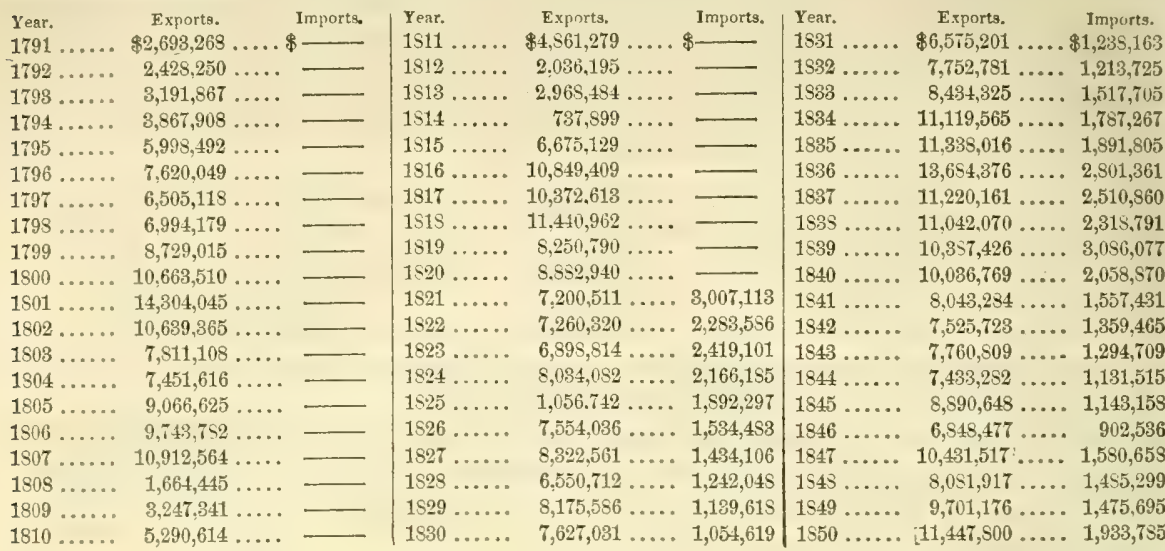

Banks, etc. - On the 1st January, 1850, there were 12 banks and 2 branch banks in the State, the condition of which at that date was as follows: liabilzties-capital, $\$ 18,139,571$; circulation, $\$ 8,741,765$; deposits, $\$ 3,322,132$; due other banks, $\$ 2,047,777$; and other liabilities, $\$ 642,231$; and assets-loans and discounts, $\$ 20,601,137$; stneks, $\$ 1,849,463$; real estate, $\$ 377,571$; other investments, $\$ 348,530$; due by other banks, $\$ 2,850,942$; notes of other banks, $\$ 715,093$; specie funds, $\$ 239,278$; and specie, $\$ 1,711,902$.

Government, etc.-The first constitution of South Carolina was framed in 1775. The constitution adopted in 1790 is the basis of the government as at present administered.

Every free white citizen of the State, 21 years of age, resident in the State two years, and owning a freehold of fifty acres, or a town lot, six months before the election, may rote wherever he so resides or holds such property. The general election is held on the second Monday of October annually.

The Legiszature consists of a House of Representatives and a Senate. Representatives, 124 in number, are chosen for two years on a mixed basis of population and taxation, and must be free white men, 21 years old, citizens and residents of the state for three years, and if resident in their election district, seized of a freehold estate of 500 acres and ten negroes, or of unencumbered real estate worth $£ 150$, and if non-residents, of an unencumbered freehold worth $£ 500$. Senators, 45 in number, shall be free white men, 30 years old, citizens and residents of the State for five years next befure the election: if residents of their districts, shall own a freehold of the clear value of $£ 300$; if non-residents, of the clear value of $£ 1,000$; and shall be chosen for four years, one-half the number of senators every two years. The legislature assembles at Columbia annually on the fourth $\mathrm{Nonday}$ in Norember.

The Governor and Lieutenant-governor shall be 30 years of age, residents and eitizens of the State for ten years, and owners of a settled estate within the State of the clear value of $£ 1,500$ each; and shall be chosen by joint ballot of both houses of the Legislature for two years, and shall be ineligible during the succeeding four years. If the office of governor be vacant, it shall be filied by the lieutenant-governor, and after him by the president of the senate, until it is filled by the General Assembly.

The administrative officers of the State are, the Secretary of State, the Comptroller-general, two treasurers, the surveyor-general, attorney-general, and the President of the Bank of the State of South Carolina.

The judiciary consists of a Law Court of Appeals, and an Equity Court of Appeals, Courts for the Correction of Errors, Courts of Common Pleas and General Sessions, etc. The Law Court of Appeals, consisting of all the law judges, for hearing appeals from the Courts of Law, and the Equity Court of Appeals, consisting of all the chancellors, for hearing appeals from the Courts of Equity, are held in the capital, in May and November, and at Charleston, for the determining of facts from the districts of Georgetown, Horry, Beaufort, Colleton, and Charleston, in the month of January. Courts for the Correction of Errors, consisting of all the judges in law and equity, to try constitutional questions, or questions where the law and equity courts are divided, and which are referred thereto by either of the courts, are held at such times, during the sitting of the Court of Appeals, as the chancellors and judges may appoint. Courts of Common Plcas and General Sessions have original jurisdiction in all civil cases where legal rights are involved (except in matters of contract, where the account is $\$ 20$ or under), and in all criminal cases affecting free white men; anu appellate jurisdiction in all apneals from the magistrates' courts, and in appeals from the Court of Ordinary in all cases except in matters of account They are held in each and every district of the State twice in each year. Courts of Equity take cognizance of all thatters in equity, as contra-distinguished from law, and a term is held annually in each district, except in that of Charleston, in which two are held. The City Conert of Charleston is an inferior court of both civil and criminal jurisdiction, and is presided over by a Recorder. An Ordinary's Count is established in each district. The principal duties of the Ordinary is to grant letters of administration, probate of wills, examining executors' and administrators' accounts, etc., and his office is the proper depository of wills and other papers relative to the administration of estates. Appeal lies from this court in matters of account to the Court of Equits, and in all other cases to the Common Plens. Mragistrates' Courts have exclusive jurisdiction in matters of contract and under $\$ 20$. Courts of Mragistrates and Freeholders are established for the trial of slaves and free people of color for criminal offenses. The judges and chancellors are elected by joint ballot of the Legislature, and hold office during good behavior. Sheriffs hold office for four years, and are ineligible for the succeeding four years. 


\section{SOUTH CAROLINA.}

Amendments to the constitution, if proposed by two-thirds of the members of each house of the Le gislature, must be published three months before the next election of representatives, and if agreed to by a vote of two-thirds of the members, at the next session, shall be adopted. No convention of the people shall be called unless by a vote of two-thirds of both houses.

Federal Representation.-South Carolina, in accordance with the law of 231 May, 1S50, is entitled to five representatives in Congress. This State is the only one of the Union in which Presidential electors are chosen by the Legislature.

The militia force of the State, as reported by the Adjutant-general of the United States, in 1850, consisted of 55,209 men of all arms, of which 2,591 were commissioned oflicers, and 52,618 non-commissioned officers, musicians, artiflcers, and privates. Of the commissioned offlcers 19 were general officers, 96 general stafi-officers, 452 fleld-oflicers, and 2,024 company-officers. The Governor is ex-officio Commander-in-chief in and over the State of South Carolina.

Public Finances, Debt, ete-The whole amount of moneys received into the treasury, during the year ending 30 th September, 1850 , was - from taxation $\$ 313,38155$, and from other sources $\$ 2 \$ 6,91122$; total $\$ 600,292 \$ 7$; and the whole amount expended was $\$ 50$ 10,\$64 42 ; leaving in the treasury $\$ 69,42845$.

The debt of the State, according to the report of the Legislature, in 1850, is as follows: 5 per cents. issued for the capital of the Railroad Bank, $\$ 46,71434$; Randolph Stock, $\$ 1,250$; Revolutionary debt, $\$ 78, \$ 1060 ; 6$ per cents. due 1550 , $\$ 3,726$; 84 ; 6 per cents. due $1852, \$ 175,42655 ; 5$ per cents. Fire Loan Foreign Debt due $185 S, \$ 471,111,12 ; 5$ per cents, $d o$. due $186 S$, $\$ 4 \$ 2,222$ 21; 5 per cents. domestic debt due $1560, \$ 452,222 \quad 23 ; 5$ per cents, do, due $1570, \$ 325,80892-$ total debt, $\$ 2,061,29281$.

Since the adjournment of the previous Legislature $\$ 198,43730$ of the domestic, and $\$ 23,25080$ of the foreign debt had been cancelled by the bank, besides $\$ 8,750$ of the Randolph Stock paid by the treasury.

The net profits of the State Bank, for the past year, including $\$ 95,000$ as arrears derived from business of former years, were $\$ 364,82559$. From this amount there has been transferred to the Sinking Fund $\$ 243,15891$, and been paid $\$ 73,45311$ for interest on the debt in Europe, and the balance that the bank was in advance for interest and expenses: also the interest on the 6 per cents. (fire loans), amounting to $\$ 48,17999$. The aggregate funds of the bank, on the 1 st October, were $\$ 6,353,660 \quad 06$, and the total liabilities $\$ 2,770,93486$, leaving as surplus the sum of $\$ 3,582,72520$.

The property of the State consists of bank capital $\$ 2,938,61110$, sinking fund $\$ 658,02272$, and balance due treasurers of State Bank $\$ 101,071$ 15; debt of railroad and canal companies, $\$ 523,396$ 69; shares in South Carolina Railroad Company and South-Western Railroad Bank, $\$ \$ 00,000$; and sundries, $\$ 9,415$ 61-total $\$ 5,020,51732$.

The State is possessed of several highly creditable charituble institutions, of which the Lunatic Asylum and the Deaf and Dumb Asylum are the prineipal. The State Lunatic Asylum is located at Columbia. On the 5th November, 1S50, it had 121 inmates; during the ensuing year 55 others were received, and 49 were discharged-22 cured, 18 improved, and 9 died, leaving in the institution at the end of the year 127. Receipts during the year $\$ 26,50143$, and expenditures $\$ 123,70254$. The Asylum for the Education of the Deaf and Dumb is situate at Cold Spring, and was instituted in 1849. In November, 1851, it had 27 pupils.

Education,-The number of public schools in this State, in 1849, was 1,023, the number of teachers 1,019, and the number of scholars 9,122. These schools are under the superintendence of Commissioners appointed by the Legislature. In 1848, the amount expended from the public funds, on account of public education, was $\$ 40.56153$. Throughout the State there are grammar schonls, academies, and private establishments, at one class of which, in preference to the public schools of the State, the great majority of young people are edueated. The State also supports several military institutes, the curriculum of instruction at which is based on that of the West Point Academy. The principal colleges, theological seminaries, and medical sehools in the State, and the statistics of each, are as follows:

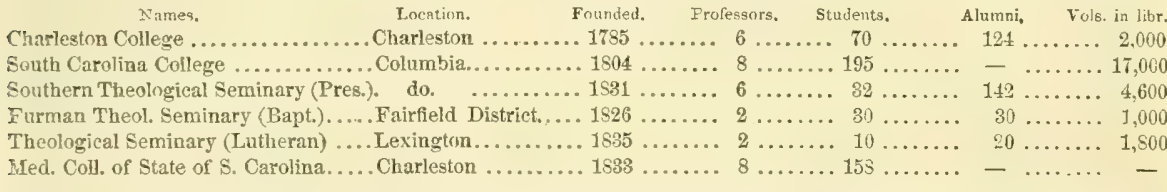

Public Libraries.-According to the report of the Librarian of the Smithsonian Institute, in 1S51, there were in the State the fullowing libraries : 2 social $-28,500$ volumes; 2 college $-19,000$ volumes ; 4 students-1,900 volumes; 5 academic and professional-10.264 volumes; 1 public school-250 volumes. Total 14 libraries, and 59.914 volumes.

Periodical Press.-The whole number of periodicals and newspapers published in the State on the 1st June, 1S50, was 47, of which rumber 7 were published daily, 4 tri-weekly, 2 semi-weekly, 25 weekly, 5 monthly, and 1 quarterly. Of the whole, 22 were democratic in politics, and 25 whig, or neutral, or devoted to religion, literature, etc. of the dailies, the aggregate circulation was 20,700 eopies at each issue; of the tri-weeklies, _; of the semi-weeklies, 925 ; of the weeklies, 25,990 ; of the monthlies, 5,700 ; and of the quarterly, 1,600 copies. The number and character of periodicals in each district, was as follows: Abberille, 2 w.; Anderson, 2 w. and 1 m.; Beaufort, 1 w. ; Charleston, 4 d., 1 t. w., 4 w., 3 m., 1 Bi-m., and 1 quarterly; Chesterfield, 1 w. ; Chester, 1 w.; Edgefield, 2 w.; Fairfield, 1 w. and 1 m.; Greenville, 1 w. and 1 t.-w.; Gecrgetown, 1 s.-w. and 1 w.; Kershaw, 1 s.-w.; Laurens, Marion, Newberry, and Pickens, each 1 w. ; Richland, 3 d., 2 t.-W., and 3 w.; Spartansburg, 1 w.; Sumter, 2 w.; and York, 1 weekly.

Puprerism.- Whole number of paupers who received relief or support within the year ending 1st June. 1550, 1.6421.313 natives, and 329 foreigners; and the whole number of paupers at that date, 1,293-1,113 natives, and 1 S0 foreigners annual cost of supprit, $\$ 15,337$.

Religious Denominutions.-The statistics of the several religious denominations in the State in 1550, were as follows:

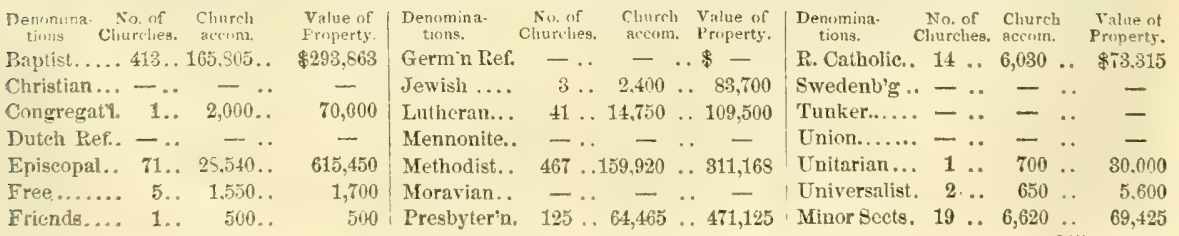


-making a total of 1,163 churches, having accommodation for 453,930 persons, and valued at $\$ 2,140,346$. South Carolina is a diocese of the Protestant Episcopal Church, and also forms a part of the Roman Catholic diocese of Charleston.

Historical Sketch.-South Carolina, for many years after its settlement, was united under the same government as North Carolina; but as early as 1671 it had been set off as the "County of Carteret in Carolina," and in 1715 had a sep. arate legislature. In 1727 it became a royal colony.

The general history of the colnny, from its first settlement to the division of Carolina into North and South, is given in connection with the description of North Carolina (which see). The germ of the population of South Carolina was planted at Port Royal in 1670 , but becoming dissatisfied with the locality, the colony remover the next year to the banks of Ashley River, where they founded old Charleston. A second removal took place in 1680 to Oyster Point, at the confluence of Ashley and Cooper rivers, where the present eity of Charleston was commenced.

On the seitlement of South Carolina, the proprietors engaged the celebrated John Locke to frame for them a constitution and body of laws. The system of government proposed by the philosopher consisted of 120 articles, and was partly aristocratic and partly feudal in its principles. Three classes of nobility were established, viz., barons, caciques, and Jandgraves. The first were to possess 12,000 , the second 24,000 , and the third 48,000 acres of land, which was to remain unalienable in their families. The legislature consisted of only one house, and was composed of the lords proprietors, the nobility, and deputies chosen by the free inhabitants holding heritable property. This plan of government, ill suited to the condition and views of the people, produced discord and anarchy. Its spirit was adverse to a democracy, and encour aged the proprietaries in arbitrary proceedings. Religious disputes, however, at this time, were the great causes of disturbance. The Episcopalians being in a majority, attempted to exclude dissenters from the legislature, and the at tempt succeeding, the Church of England was established by law. A train of evil consequences followed; and though the obnoxious law was annulled by the British Parliament, tranquillity was not restored, and soon after (1729) the people preferring a monarchy to an oligarchy, the colony became a royal government, the king purchasing the rights of the proprietaries.

From this period the colony was governed on the same plan as the other royal governments, and its growth became more rapid. Population began to pour in when discord subsided. The Dutch expelled from New York, the French Protestants, on the revocation of the Edict of Nantz, and others fleeing from tyranny and opposition, sought asylum in the young colony. These generally settled themselves on the Santee River, and perhaps more by their respectability and charaeter than by their numbers, contributed to the future welfare of the State. The insurrections of 1715 and 1745 in England also sent numbers to the settlement; many arrived from Germany and Switzerland, and 1,500 French colonists, expatriated from Nova Scotia, found sanctuary in South Carolina. The cultivation of rice was commenced about the end of the seventeenth century, and as is well known, to this event (which was purely accidental) the State has derived a lasting source of wealth.

The wars of the Spaniards, French, and Indians, undertaken by each for the extermination of the settlers, greatly impeded the progress of the country during the period commencing with the eighteenth century, and ending with the general peace of 1763 . The coasts were ravaged, the frontier settlements broken up, and numbers left the country in despair, and, to add to the misfortunes of this state of matters, the small-pox raged with violence during the latter portion of this calamitous period.

During the thirteen years intervening to the breaking out of the Revolution of 1776 , the province enjoyed uninterrupted peace and prosperity, and in that time nearly doubled its population; and the Southern colonies were at that time little inclined to disturb the peaceful order of things, then existing, by joining in the revolt against the mother country. But though this feeling animated the inhabitants generally, there was also a minority favorable to the revolution; and about this time a revulsion was brought about even among the monarchical party, by orders having been given the governor to use immediately and effectually the military in the subjugation of the dissentients. This circumstance seems to have determined the conduct of the colonists. During the long struggle that followed, this State suffered much both from the British and Indians, and the tory interest among themselves. The war in South Carolina was remarkable both for general actions of great importance to the public cause, and for the display of individual bravery and patriotism. The battles of Cowpens and Eutaw Springs may vie with any in the contest for skill and courage, and the names of Marion, Sumter, and Lee will ever live on the page of history. The eity of Charleston was twice besieged-once in 1776 , unsuccessfully, and once in 1750 , when after a determined resistance its inbabitants and garrison fell into the hands of the enemy. The victory of Eutaw Springs in 1781 relieved the State from the pressure of war, and contributed not a little to the successful issue of the contest. The scenes of the battles and sieges within South Carolina occurred in the following chronological order: Fort Mouttrie, 2sth June, 1776; Port Royal, 1779; St. John's, 1779; Monk's Corner, 14th April, 1780; Charleston, 12th May, 1750; Camden, 16th August, 1750; Broad River, Oetober, 1780; Tyger River, Oetober, 1780; Cowpens, 17th January, 17s1; Fort Wutson, 14th April, 1781; Hobkirk's Hill, 25 April, 1781; Ninety-Six, 18th June, 17s1; Eutaw Springs, Sth September, 1791, the scenes of American success being noted in italice.

The history of the State since this period has been one of interest. It notes many phases in politics which have startled the public mind, and though comparatively a small State, its proceedings have occupied a large share of public attention. Its attitude on several important federal questions has been peculiar and independent, and so tenacinus of "State rights" have the peiple appeared, that on several occasions they have even gone so far as to threaten a separation from the Union. In these manifestations of sovereignty, however, the patriotism of the people has not suffered in the general esteem of the world; and it may be added that the influence of the conduct of South Carolina has not been without its benefits to the C'nion, in restraining the federal aggressions and upholding the rights of States to the management of their niwn internal affairs. South Carolina, too, has given to its sister States an example worthy of imitation, in its adrocacy of Southern industry and improvernent. Among Southern States, this is second to none in its public works, and in many of its industrial employments ranks superior to any other in which slare labor is used as a producing power.

Coldusid, on the east side of Congaree River, is the political capital of the State.

Sotti Carroll, p. v., Carroll co., Tenn.: on a branch of Forked Deer r., $102 \mathrm{~m}$. S. W. by W. Tishville.

Sodth Carrolltox, p. 0., Mublenburg co., $\boldsymbol{K}_{y}: 143 \mathrm{~m}$. S. W. Frankfurt.

South CARver, p, o., Plymouth co., MFass.: 39 m. \$. by E. Bostun.
SotтII CAss, p. o., Ionia county, Mich.: 33 m. W. N. W. Lansing.

Sottu Cnarleston, p. F., Clark co, Ohio: on a branch of the Little Miami rirer, and on the Columbus and Xenia R. R.. $35 \mathrm{~m}$. Tr. by S. Columbus.

Solta Charlestows, p. r, and sta., Sulliran county, 
N. IIamp.: on the left bank of the Connecticut r., on the Sullivan R. R., 22 m. S. from Windsor, and 43 W. Concord,

Soutir Chesterville, p. o., Franklin county, Me.: on a pranch of Sandy r., $21 \mathrm{~m}$. N. W. Augusta.

South Caurs, p. 0., Kennebec county, Me.: 13 m. N. E. Augusta.

Soбтu Coldmbia, p. o., Herkimer county, $N$. $Y$.: $65 \mathrm{~m}$,

N. W. by W. Albany.

Souxh Corinte, p. v., Saratoga county, N. Y.: 36 m. N. Albany.

South Cortuandt, p. o., Cortlandt coin, $N . Y_{*}: 132 \mathrm{~m}$.

W. by N. Albany.

Souril Coventry, p. $\nabla_{*}$, Tolland co., Conn.: on the Willimantic r., and on the New London, Willimantic, and Palmer R. R., $34 \mathrm{~m} . \mathrm{N}$, by W. New London, and 22 E. from Hartford. This is a flourishing place, and contains several woolen factories for the manufacture of satinet warp, and the "Eagle Manufacturing Company" have their establishment for printing cloths in this v.-capital $\$ 20,000$. There are from 50 to 60 operatives employed in the manufactories.

South Craftsbura, p. v., Orleans co., Verm.: 30 m. N. by E. Montpelier. There is a manufactory of woolen goods in the village.

Soutr Cerez, t. and p. o., Bradford co., Penn.: $113 \mathrm{~m}$. $\mathrm{N}$. Harrisburg. Drained by a stream so called, which affords power to several mills. Surface hilly; soil gravelly loam. The Williamsport and EImira R. R. will pass through this town.

Soutu Daxbr, p. o., Tompkins co., $N . Y_{.:} 144$ m. S. W. Albany.

Soutr Dangrilie, p. F., Steuben county, $N$. $Y$.: on the

Canaseraga r., branch of the Genesee r., 208 m. W. Albany.

Soutr DAN vers, v. and sta, Essex county, Mass. : at the

junction of the Essex R. R. with the Salem and Lowell and South Reading Branch railroads, $19 \mathrm{~m}$. S. E. Lawrence, 22

S. E. by E. Lowell, and 17 N. E. by N. Boston.

South Dartmouth, p. v., Bristol co., Mass.: on Appone-

gansett bay, $57 \mathrm{~m}$. S. Boston.

Sotth Dedham, v, and sta., Norfolk co., Mass. : on the

Norfolk County R. R., 14 m. S. W. Boston.

Sotth DeERField, p. v., Rockingham co, $N$. Hamp. : on

2 branch of Lamprey r., $18 \mathrm{~m}$. S. E. Concord.

Soutif DeknField, $\mathrm{v}$. and sta., Franklin co, Mass.: on the Connecticut River R. R., $28 \mathrm{~m}$. N. Springfield, and $51 \mathrm{~m}$. W. by N. Boston.

Sodth Deer Isle, p. o., Hancock co., Me. : on S. part of the island so called, $58 \mathrm{~m}$. E. by S. Augusta.

Sotth Dennis, p. v., Barnstable co., Mass.: on the left bank of Bass river, 67 m. S. E. Boston. Common salt and epsom salt is manufactured in the vicinity.

South Drcknison, p. o, Franklin con, $N$. Y.: $150 \mathrm{~m} . \mathrm{N}$. by W. Albany.

SoutI Donset, p. 0., Bennington co., Term.: 79 m. S. by

W. Montpelier.

South Dover, p. v., Piscataquis co., Me.: 67 m. N. E. Augusta.

Sovth Dover, p. $\nabla$. and sta., Duchess co., $N$. $Y_{\text {. : on the }}$

Harlem R. R., $73 \mathrm{~m}$. N. by E. New York eity, and $79 \mathrm{~S}$. by

E. Albany.

SoutII Drespex, p. o, Lincoln co, Me. : on the E. of the

Kennebec r., 21 m. S. by li. Augusta

SoutII DuRHuM, p. o., Cumbcrland co., Me.: 31 m. S. W. Augusta.

Soutr DurhaM, p. o., Greene co., $N . Y_{\text {.; }}$; on a tributary of the Hudson r., 30 m. S. W. Albany.

Sotwh EAst, t. and p. o., Putnam county, $N_{*} Y_{*}: 88$ miles S. by E. Albany. The Harlem R. R. passes through, having a sta. at Brewster's, 55 m, from New York, 99 from East Albany. Surface hilly; soil fertile. Drained by Croton $r$ It contains several mills of various kinds, a paper factory, and tannery. Pop. 2,079.

Sruth E.SToN, p. o., Washington county, N. Y.: $24 \mathrm{~m}$. N. N. E. Albany.
Soutri Easton, p. 0., Bristol co., Mas8. : 25 m. \$. Boston. South EDMegton, p. o, Otsegu county, $N . Y_{:}: 75 \mathrm{~m}$. W Albany.

Soutu EdWArds, p. o., St. Lawrence $c_{0}, N$. $\boldsymbol{Y}$ : $138 \mathrm{~m}$ N. N. W. Albany.

Sotth Egremoxt, p. F., Berkshire co., Mas8. : on a smal branch of Housatonic r., $122 \mathrm{~m}$. W. by $\mathrm{B}$. Boston.

Sotti ENGLisi, p. v., Keokuk eo., Icr. : on a branch of English r., $33 \mathrm{~m}$. W. S. W. Iowa City.

Sovtri ERIN, p. 0., Chemung co., $N . Y .: 156 \mathrm{~m}$. W. S. W. Albany.

Southerla No, p. o., Jefferson county, F'lor.: 23 miles E. Tallahassee.

South F ARMs, p. v., Litehfield co., Conns: 28 m. W. by S. Hartford, and $30 \mathrm{~m}$. N. N. W. New Haven, It contains an academy and church.

SOUTHFiELD, t. and p. o., Oakland connty, Mich.: $69 \mathrm{~m}$ E. by S. Lansing. Drained by affluents of the branch of Rouge r. Surface diversified; sof́l deep and fertile, well wooded. Pop. in 1840, 1,061: in 1850, 1,65ร8.

Southrteld, p. o, Berkshire co., Mass.

Sourn FITCurtrg, $\mathrm{v}$, and sta. Worcester county, Mass. on the Fitchburg and Worcester R. P., $21 \mathrm{~m}$. N. Worcester, and $40 \mathrm{~W}$. N. W. Boston.

South Florence, p. v., Frantilin co., Ala.: on the left bank of Tennessee river, opposite Florence, $185 \mathrm{~m} . \mathrm{N}$. W. Montgomery.

Sourhford, p. o., New Haven co., Conn.

South Fork, p. 0., Owsley co., $\bar{K}$. : on a fork of Kentacky r., $77 \mathrm{~m}$. S. E. Frankfort.

Souty Fork, p. o., Ashe co., N. Car.: 169 m. W. N. W. Paleigh.

Soctr Fork, p. o., Wayne county, $I a_{\text {s: }} 111$ miles S. W. Iowa City.

South Foster, p. o., Providence co., R. I.: $18 \mathrm{~m} . \mathrm{W}$. by S. Providence.

Soutil Framingmax, p. v, and sta., Middlesex co., Mass. on the Boston and Worcester P. P., $21 \mathrm{~m}$. from Boston, and $24 \mathrm{~m}$. from Worcester.

South Franklix, p. o., Delaware county, $N . Y_{.}: 76 \mathrm{~m}$. W. S. W. Albany.

South Frankuts, p. o., Norfolk county, Mass. : 27 miles S. W. by S. Boston. The Norfolk County R. R. passes near it.

South Freedom, p. o., Waldo co., $M e_{.}$: 25 m. N. E. by E Augusta.

Sodth GaLwAY, p. o., Saratoga county, 24 m. W. N. W. Albany.

Soutu GARDINER, $\nabla$. and sta., Kennebec co., Me. : on W. bank of Kennebee r., and on Kennebec and Portland $R$ R., $12 \mathrm{~m}$. from Augusta, and $48 \mathrm{~m}$. from Portland.

SOUTH GARDINER, p. o., Worcester county, Mass. : $51 \mathrm{~m}$. W. N. W. Boston.

Sotтн Gate, p. 0., Franklin county, Ind.: 66 m. E. S. E. Indianapolis.

Sotth GeNesee, p. 0 , Waukesha county, Wisc: $47 \mathrm{~m}$.

E. by S. Marlison.

Soutil GIBson, p. v., Gibson co., Tenn. : $117 \mathrm{~m}$. W. by S.

Nashville.

Soutu Glastenbury, p. ₹., Hartford co., Conn.: on E. side of Connecticut r., 9 m. S. Hartford, $30 \mathrm{~m} . \mathrm{N} . \mathrm{N} . \mathrm{E}$ New Haven.

Sodtr Granix, p. o., Oswego county, $N_{0} Y_{0}: 144$ miles W. N. W. Albany.

SottII Granville, p. 0, Washington co, $N . \quad$. $: 54 \mathrm{~m}$,

N. N. E. Albany.

South Groton, p. o., Middlesex county, MFass, $80 \mathrm{~m}$.

N. W. by W. Boston.

South Grove, p. 0., De Kalb co, $I l_{*}: 161 \mathrm{~m}$. N. N. E. Springfield.

Soutu Grove, p. o., Walworth co., Wise. : 57 m. S. E, Madison.

SOJти HADLEY, ts and p. v, Hampshire co., Mas, : on 
E. side of Connecticut $\mathbf{r}_{*}, 79 \mathrm{~m} . \mathrm{W}$. Boston. Surface beantifully diversified; soil productive. The Connecticut $r$. has here a fall of 50 feet in about 80 rods, around which the first canal on the river was constructed, having the following dimensions: $2 \mathrm{~m}$. long, with 5 locks, and for a distance of 800 feet cut through rock, 40 feet deep. Muunt Holyoke is in the N. part of the town. The v, contains a church, ete., and the Mount Holyoke Female Seminary, a flourishing institution of much celebrity. Pop. of t, 2,491.

Sodth HadLex Falls, p. v., Hampshire co, Mass.: on the $\mathrm{E}$. bank of Connecticut $\mathbf{r}_{*}, 3 \mathrm{~m}$. $\mathrm{S}$. from South Hadley $\mathrm{v}_{\text {. }}$ $80 \mathrm{~m} . \mathrm{W}$. Buston. It contains several manufactories, and is a very prosperous village.

SoorH HAimax, p. o., Windham co, Term.: 108 m. S. Montpelier.

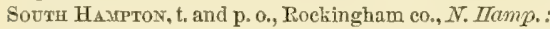
37 m. S. E. Boston. Surface uneven. Watered by Powow r., which affords mill-sites. Pop. 472.

South Hanoter, p. v., Jeffereon co., Ind.: on the W. of the Ohio r., $80 \mathrm{~m}$. S. S. E. Indianapolis. The Hanover College is located in this place. The college edifice is 100 feet by 40 , and 3 stories high. There are also other small buildings erected for dormitories. The Indiana Theological Seminary is also connected with the college. In 1550 the college had 6 professors, 100 alumni, and about 38 students. The libraries contain about 4,700 volumes.

South Haxson, p. o., Plymouth co, Mass. : 23 m. S.S. E. Boston.

Sotth Hardwick, p. o., Caledonia co., Term.: 20 m. N. N. E. Montpelier.

South Harpeti, p. v., Davidson co., Tenn.: on the S. side of Harpeth $r ., 15 \mathrm{~m}$. S. by W. Nashville.

South Harrasidra, p. 0., Lewis co., N. Y.: 129 m. N. W. Albany.

South HARTFORD, p. o., Oxford county, $M e .: 27 \mathrm{~m}$. W. Augusta.

SoutH HARTFord, p. v., Washington co., $N . Y_{.}: 51 \mathrm{~m}$. N. N. E. Albany. It contains 2 churches, tannery, gristmill, and stores.

Sootr Hartwick, p. o., Otsego co., $\lambda_{\text {. }} Y_{.:}: 68 \mathrm{~m}$. W. Albany.

Sodth Harwick, p. o., Barnstable co., Mass. : on S. side of Cape Cod peninsula, $1 \mathrm{~m}$. from the shore, $70 \mathrm{~m}$. S. E. Boston.

SoUTII HAWLEY, p. v., Franklin county, Mass, : $97 \mathrm{~m}$. W. by N. Buston.

Sovth Hermitage, p. O., Lancaster co, Penn.: $40 \mathrm{~m}$. S. E. Harrisburg.

Söth Hero, t, and p. v., Grand Isle co., Term. : on $\mathrm{S}$. part of Grand Isle in Lake Champlain, $43 \mathrm{~m}$. N. W. Montpelier. The surface rises gently from the lake; soil is various, but very fertile. Limestone is found. A ferry connects the $\mathrm{t}$. with Colchester Point. The $\mathrm{t}$. contains a tannery, store, and 2 churches. Pop. of t. 666.

Sotтh HuL, p. o., Steuben co, N. Y.: $201 \mathrm{~m}$. W. by S. Albany.

Sodтh Hrut, p. 0., Bradford co., Penn.: $90 \mathrm{~m}$. N. by E. Harrisburg.

Sotтп HrL, p. .., Mecklenburg co., Tirg..: on a tributary of the Roanoke r., $63 \mathrm{~m}$. S. W. Richmond.

South Hngham, p. V., Plymouth county, MLass.: $14 \mathrm{~m}$. S. E. by S. Boston.

SoutA Hope, p. o, Waldo con, Me. : 32 m. E. by S. Augusta. SouthingtoN, t., p. v., and sta., Hartford co., Conn. : on New Haven and Northampton R. R., $22 \mathrm{~m}$. N. from New Haren, 18 m. S. W. by S. Hartford. Surface uneven; soil fertile; watered by Quinnipiac river, which affords waterpower. The town cbntains several grist and saw-mills, an academy, and 4 churches. Pop. of t. 2,139.

Sodmingtow, th and p. o., Trumbull co., Ohio: $139 \mathrm{~m}$. N. E. Columbus, Drained by branches of Grand r. Surface undulating; soil fertile. The inbabitants are chiefly occupied in agricultural pursuits. Pop. 1,013. 808
SOUTH JACEsON, p. v., Jackson co., Jic $h_{*}: 39 \mathrm{~m}$. 4. by E, Lansing.

South Kent, p. v., Litchfield co., Conn.: 40 m. W. by $\$$. Hartford, 35 m. N. W. New Haven.

Soute Killingly, p. Y., Windham co., Conn.: 40 m. E. Hartford, 66 m. N. E. New Haven.

Soutir Kuigston, p. o., Rockingham county, N. Hamp.: $32 \mathrm{~m}$. S. E. by South Concord.

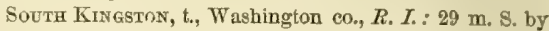
W. Providence. Bounded on the E. by Narragansett bay, and on the S. by Atlantic Ocean. This t., formerly part of North Kingston, is the largest $t$. in the State, comprising 98 sq. m. At its S. E. extremity is the noted Point Jadilh. Kingston village, in its $N$. part, is the capital of the county. The t. has an uneven surface; soil of gravelly loam, and contains a large salt pond, and about 20 fresh-water ponds, one of which contains 3,000 or 4,000 acres. The fisheries on its shores are extensive and valuable. Many of its citizens are employed therein, and in navigation. The town also contains several factories, chiefly making woolen goods. The Stonington and Providence $\mathbf{R}$. R. passes through its N. W. part. Pop. 3,802.

Soutu Krrtland, p. o., Lake co., Ohio: 138 m. N. N. E. Columbus.

Sodth Kontrigir, p. v., Delaware county, $N . \bar{Y}$ : $72 \mathrm{~m}$. S. W. by W. Albany.

South Laxsixg, p. o., Tomphins co, $N_{\text {. }} Y_{*}: 146 \mathrm{~m}$. W. Albany.

SoUner LEE, p. v. and sta., Berkshire co., MLass. : on Berkshire R. R., 15 m. S. Pittsfield, $114 \mathrm{~m}$. W. Boston. Here are several paper mills and an iron foundry.

South Leeds, p. o., Kennebee county, Me. : on E. side of Androscoggin r., 21 m. W. S. W. Montpelier.

Soutri Lincoln, p. v., Penobscot co., Me. : on E. bank of Penobscot r., 98 m. N. N. E. Augusta.

SodTI LIVONIA, p. o., Livingston co., $N$. $Y_{.}$: between Conesus and Hemlock lakes, $206 \mathrm{~m}$. W. Albany.

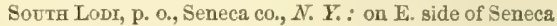
lake, $161 \mathrm{~m}$. W. Albany.

Sotth Lowelt Mrlus, p. o., Orange co, $N_{\text {. Car. : }} 38 \mathrm{~m}$. N. W' Raleigh.

Soutri Lxme, p. v. and sta., New London co., Conn.: on the New Haven and New London R. R, $40 \mathrm{~m}$. from New Haven, and $10 \mathrm{~m}$. from New London.

South LysoeborougH, p. o., Hillsboro" co., N. Homp.: $26 \mathrm{~m}$. S. S. W. Concord.

Sovth Lrox, p. O, Oakland co, Dfich.: 54 m. S. E. Lansing. South Masicarster, p. O., Hartford co, Conme: 9 m. E. Hartford.

Soutif Marcellos, p. o.g Onondaga co, $N_{*}, Y_{.:} 132 \mathrm{~m}$. W. by N. Albany.

Sotth Maxfueld, p. o., Penobseot con, Mb.: on Piscataquis r., $87 \mathrm{~m}$. N. E. by N. Augusta.

South Mezewac, p. v. and sta., Hillsboro' co, N. Hamp. : on Wilton Branch R. R., $5 \mathrm{~m}$. from Nashville, $45 \mathrm{~m}$. from Boston, $27 \mathrm{~m}$. S. Concord.

South Madreiorough, p. o. and sta., Plymouth county, DYass. : on Cape Cod Branch R. R., 8 m. from Middleboro', and $43 \mathrm{~m}$. from Boston.

South Mrford, p. o, Cecil county, Md.: 49 m. N. E Annapolis.

SodTH Mrlford, p. o., La Grange co., Ind.: 130 m. N.N.E. Indianapolis.

South Mmford, p. O., Otsega co., N. $\boldsymbol{Y}_{\text {.: }} 6 \mathrm{~S} \mathrm{~m}$. W. by $\mathrm{B}$. Albany.

SOUth MrfFord, p. o., Worcester con, Mass, : 29 m. S. W. Boston.

South Mruts, p. o, Camden co., N. Car. : 145 m. E. N. E. Raleigh.

South Molunous, p. O., Aroostook county, Me.: $142 \mathrm{~m}$. N. N. E. Augusta.

South Montirlue, p. o., Waldo co., Mfo.: $27 \mathrm{~m} . \mathrm{E} . \mathrm{by}$. Augusta. 
Soure mountain, Washington and Frederick counties, Ma.: a well-defined ridge of the Alleghanies, forming the boundary between the two counties.

South Nashville, p. o., Davidson co., Tenn.

Souty Nhticz, p. v, Middlesex co, Mass. : on W. side of Charles r., $1 \pm$ m. W. S. W. Boston.

Soctri Net Berlin, p. v., Chenango co, $N$. $Y$.: on W. bank of ' 'nadilla $r$. It contains a church and a few stores. Pop, about 180

Sedth New Burg, p. v., Penobscot co, $M e_{*}$ : on a creek of Sowadabscook r., 47 m. N. E. Augusta.

Sovтн New BuRx, p. O., Orange co., Verm. : 27 m. E. S. E. Montpelier.

Soutr Nswarry, p. o., Merrimac co., N. Hamp. : 25 m. W. by N. Concord.

Bodтh New CAsthe, p. O., Gallia co., Ohio: in a mineral coal region on the $\mathrm{N}$. bank of the Ohio $\mathrm{r}, 99 \mathrm{~m}, \mathrm{~S}, \mathrm{~S} . \mathrm{E}$. Columbus. It contains several stores, a furnace, forge, and rolling-mill, ete.

Sotra NEw MARKET, t., p. v., and sta., Rockingham co., N. Hamp. : 81 m. E. S. E. Concord. Bounded on the E. by Squawseat r. and part of Great bay. The Boston and Maine $\mathrm{R}$. R. passes through the $\mathrm{v}_{\text {. }}, 55 \mathrm{~m}$. from Boston, $56 \mathrm{~m}$. from Portland, and connects with the Portsmouth and Coneord R. R. $10 \mathrm{~m}$. from Portsmouth, $37 \mathrm{~m}$. from Concord. Pop. 516.

Soumi NewPort, p. v., M'Intosh co., Ga. : on the right bank of the river so called, about $9 \mathrm{~m}$. from its mouth, 130 m. S. E. Milledgeville.

Soder Newrx, p. o, Oxford con, Me. : on a branch of Androscoggin r., 54 m. W. Augusta.

South Nonwalk, p. v., and sta., Fairfleld co., Conn. : on W. side of Norwalk r., near its mouth, and on New York and New Haven R. R., $44 \mathrm{~m}$. from New York, $32 \mathrm{~m}$. from New Haven. This is the landing-place for steamboats, and the commencement of the Danbury and Norwalk R. R., $24 \mathrm{~m}$. from Danbury. The $\mathrm{v}$. has considerable manufactures, particularly of felt, beaver hats, and cloth. A most melancholy catastrophe and awful loss of life occurred here on Friday, May 6th, 10 A.M., 1853, when a locomotive, etc., with two passenger cars, were precipitated through the open drawbridge into the river below. The number of persons immediately killed and drowned was 47 ; 39 were very seriously injured, and many others much bruised, etc. The calamity was unprecedented since the introduction of railroads, and cast a gloom over the whole Union.

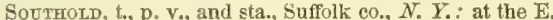
side of Long Island, between Long Island Sound and Great Peconic and Gardiner's bays. Several islands also belong to it. Surface level; soil sandy loam. The $\mathrm{V}$, is a scattered settlement on the Long Island R. R., $91 \mathrm{~m}$. from New York. The inhabitants are much engaged in the fisheries. Pop. in $1840,3,007$; in $1850,4,722$.

South Olive, p. o., Morgan co., Ohio: $75 \mathrm{~m}$. E. by S. Columbus.

South Oxondaga, p. o, Onondaga co, $N$. $Y .: 132 \mathrm{~m}$. W. by N. Albany.

South Opanar, p. o. and sta., Essex co., N. Jer.: on Morris and Essex P. R., $6 \mathrm{~m}$. from Newark, $15 \mathrm{~m}$. from New York, and $44 \mathrm{~m}$. N. E. by N. Trenton. In the viciuity is a water-cure establishment.

Soutu Orleans, p. 0., Barnstable co, MFass.: 70 m. S. E.

Boston.

South Orrngton, p. o., Penobscot county, $\boldsymbol{M e}_{\mathrm{s}}$ : on the E. bank of the Penobscot river, $5 \mathrm{~S} \mathrm{~m}$. N. E. by E. Augusta.

Souti Otselrc, p. o., Chenango co., N. Y.: $107 \mathrm{~m}$. W. Albany.

South Owego, p. o., Tioga co, $N . \bar{X}$.: on $\mathrm{S}$, side of Susquehanna r., $196 \mathrm{~m}$. W. S. W. Albany.

Soztr OxFord, p. o, Chenango $\mathrm{CO}_{*}, N . Y_{*}$; on the Chenango $r$ and canal, $102 \mathrm{~m}$. W. S. W. Albany.

Sottil Orster Bay, p. o., Queen's co., N. Y.: $138 \mathrm{~m} . \mathrm{S}$.
Albany. This is a seattered settlement, $1 \mathrm{~m}$. from the Great Suth bay, which it overlooks.

Soutr PARI8, p. va and sta., Oxford co, Me.: on the At. lantic and St. Lawrence R. R., $48 \mathrm{~m}$. from Portland, $88 \mathrm{~m}$. W. by $\mathbf{S}$. Augusta. In the vicinity is a flourishing wonlen factory, making principally cassimeres.

South Parsonsiteld, $p, v_{\text {, }}$ York county, $\not \mathrm{Ie}_{\mathrm{e}}: 74 \mathrm{~m}$. S. W Augusta.

South Perkr, p. 0., Hocking county, Ohio: 38 m. S. E. Columbus.

South Prymouth, p. o., Wayne co., Mfich.: 71 m. S. E. Lansing.

South Plymouth, p. o., Chenango co., N. Y.: $99 \mathrm{~m} . \mathrm{W}$. Albany.

South Point, p. o, Lincoln co, N. Car, : 138 m. W. by $\$$. Raleigh.

SótTh POMFreT, p. o., Windsor county, Term.: 43 miles S. by E. Montpelier.

Soutuport, p. b. and sta., Fairfield co., Conn.: on W. side of Mill river, at its entrance into a small bay of Long Island Sound; and on New York and New Haven R. R., $52 \mathrm{~m}$. from New York, $24 \mathrm{~m}$. from New Haven. The Larbor is convenient for vessels of 100 tons, is rarely frozen, and is protected by an extensive breakwater constructed by the United States. The b. contains 2 churches, an academy, and bank with capital of $\$ 100,000$.

Southport, p. 0., Marion co., Ind.: on the line of the Madison and Indianapolis R. R., $6 \mathrm{~m}$. S. from Indianapolis. Southrort, t. and p. o, Chemung cos, N. Y.: on S. W. and S. side of Chemung r., $168 \mathrm{~m}$. W. S. W. Albany. Surface diversified, with very fertile soil. The Erie R. R. runs through the t. along the W. bank of the Chemung, and has a sta. at Wellsburg, 276 miles from New York, and $193 \mathrm{~m}$. from Dunkirk. Pop. in 1840, 2,101; in 1850, 3.184.

South Prajrie, p. v., Boone county, $17 l$. : 163 m. N. N. E. Springfield.

South Prospect, p. o., Waldo co., Are. : on W. side of Penobscot r., near its mouth, $51 \mathrm{~m}$. E. by N. Aagusta.

South Pultiner, p. o., Steuben co., $N$. $Y_{.:}$on W. side of Crooked lake, $180 \mathrm{~m}$. W. Albany.

South Quar, p. V., Nansemond county, Firg.: on the E. bank of Blackwater r., 73 m. S. S. E. Richmond.

South Paymond, p. o, Rockingham county, $N_{0}$. Famp.: $22 \mathrm{~m}$. S. E. Concord.

Soutu Reading; t, p. $\mathbf{y}_{*}$, and sta, Middlesex co, MFoss. on the Boston and Maine R. R., $10 \mathrm{~m}$. N. from Boston, and by South Reading Branch R. R., $9 \mathrm{~m}$. W, from Salem. Incorporated from Reading in 1812 . The $v$. near Reading Pond is handsomely built, and contains 2 churches, with an academy. Many of its eitizens transact their daily business in Boston. Pop. in 1840, 1,517; in 1850, 2,407.

Soutr Reading, p. v., Windsor county, Ferm.: 57 m. S. Montpelier.

South Rrouland, p. 0., Oswego county, $N$. $Y .: 141$ miles W. N. W. Albany.

Sovth RIDGE, p. 0., Ashtabula co, Ohio: $157 \mathrm{~m}$. N. E. Columbus.

Soum river, Anne Arundel county, $\boldsymbol{M r} d$. : a large inlet of Chesapeake bay, which it enters at Thomas Point, on which there is a lighthouse, Lat. $35^{\circ} 54^{\prime} 25^{\prime \prime}$, long. $76027^{\prime} 34^{\prime \prime}$. Fixed light.

SourH river, $\boldsymbol{N}$. Car.: rises in Cumberland county, flows S. S. E., and empties into Cape Fear river, 16 miles abore Wilmington.

South River, Mitdlesex co., $\lambda^{\prime}$. Jer'

South RIver, p. O., Anne Arundel co., Mfd.: on the river so called, $8 \mathrm{~m}$. S. Annapolis.

Soutr Roxalrox, p. o, and sta., Worcester cn, Mrcse. on Miller's river, and the Fermont and Massachusetts R. R. $27 \mathrm{~m}$. from Fitchburg, $29 \mathrm{~m}$. from Greenfitd, and by Fitehburg $\mathrm{R}$. R. etc, $77 \mathrm{~m}$. from Boston.

South Royaltox, p. o., Niagara county, $N . Y .: 256 \mathrm{~m}$, W. by N. Albany, 
Sotte Roralton, p. o. and sta., Windsor co., Verm. : on Vermont Central R. R., $32 \mathrm{~m}$. from Windsor, and 125 miles from Rouse's Point, $31 \mathrm{~m}$. S. by E. Montpelier.

Sodth Rutland, p. o., Jefferson co., $N . Y_{\text {: : }} 188 \mathrm{~m} . \mathrm{N} . \mathrm{W}$. Albany.

South Rregate, p. o., Caledonia co., Verm. : on Wells r., $22 \mathrm{~m}$. E. by S. Montpelier.

Soutr Sanvt George, p. 0., Lincoln county, Me. : $40 \mathrm{~m}$. S. E. Augusta.

South SAlEMr, p. v., Westchester $c_{*}, N_{.} Y_{*}$ : on a small branch of Croton r., 98 m. S. Albany.

South Satev, p. 0., Ross co., Ohio: $42 \mathrm{~m}$. S. Columbus.

South Sardwich, p. o., Barnstable co., Mass.: $54 \mathrm{~m}$.

S. E. Boston.

South Frañkford, p. o., York co., Me.: 83 m. S. W. Augusta.

South Sargerville, p. o., Piscataquis co, Me.: $63 \mathrm{~m}$. N. E. Augusta.

SodTH SCHODACK, p. $\nabla_{\text {, }}$ Rensselaer co., $N . Y_{0}: 15 \mathrm{~m}$.

S. by E. Albany.

Sotth Scitudte, t. and p. o., Plymouth co., Mass. : on the N. side of North $r_{n}, 18 \mathrm{~m} . \mathrm{S}$. E. Boston. This town was taken from Seituate. Drained by branch of North river. A flourishing agricultural place. Pop. 1,770.

Sodth Scituate, p. V., Providence co, R. $I_{0}:$ on the E. side of Pawtuxet $\mathbf{r}_{0,} 11 \mathrm{~m}$. W. by S. Providence. A manufactory of cotton warp here makes from 15 to 16 tons annually.

South Sebec, p. 0., Piscataquis co., Me.: on N. side of

Piseataquis $\mathrm{r}_{0,} 72 \mathrm{~m}$. N. E. Augusta.

SoutI SEekoxk, p. V., Bristol co., Mass.: on a stream flowing into Providence bay, $43 \mathrm{~m}$. S. W. Boston.

South Shaftsbury, p. V., Bennington co., Term.: on

Western Vermont R. R., 49 m, from Rutland, and $100 \mathrm{~m}$.

S. S. W. Montpelier.

South Smenargo, to and p. O., Crawford co., Penn. : $200 \mathrm{~m}$.

N. W. Harrisburg. Drained by Shenango cr. Surface un-

dulating. It contains several workshops, mills, etc.

South Shrewsiury, p. v., Worcester co., Mass. : $34 \mathrm{~m}$.

W. by S. Boston.

Soutr SIDE, p. o., Richmond co, $N . Y_{0}: 144 \mathrm{~m} . \mathrm{S}$. Albany.

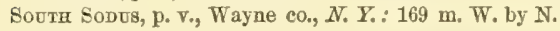
Albany.

Sorth SoloN, p. V., Somerset co., $M F_{\text {e. : }} 42 \mathrm{~m}$. N. Augusta.

It is surrounded by a fine agricultural country.

South Solon, p. o., Madison county, Ohio: $21 \mathrm{~m}$. W. Columbus.

Sotтh Stephentown, p. 0, Rennselaer co., $N . Y_{.:} 22 \mathrm{~m}$.

B. E. by E. Albany.

South Sterlixg, p. o., Wayne co., Penn. : $101 \mathrm{~m}$. N. E.

Harrisburg.

Soбth Stopdard, p. 0., Cheshire co., N. Hamp. : $31 \mathrm{~m}$.

S. W. Concord.

SoUth StrafFord, p. va, Orange co,, Ferm.: on a branch of the Ompomponoosuc r., 32 m. S. E. Montpelier. Sulphuret of iron is found in the vicinity.

Sotтh Taymorth, Carroll co., $N$. Hamp. : on Bearcamp

r., at the mouth of the Conway r., $43 \mathrm{~m}$. N. E. by N. Coneord, Socth Thomaston, t. and p. 0., Lincoln co., Me.: on the E. side of St. George's r., having Penobscot bay on the E.,

$41 \mathrm{~m}, \mathrm{~S}$. E. Augusta. A new town, taken from Thomaston, in 1845. It is largely engaged in the ship-building and coasting trade. The celebrated peninsula of "Owl's Head" is comprised in the t. It has a flne harbor, off which a lighthouse is located, in lat. $44003^{\prime} 50^{\prime \prime}$, and long. $69{ }^{\circ} 00^{\prime} v 0^{\prime \prime}$. Granite is abundant, and the quarrying and burning of lime, from limestone found here, is carried on to a considerable extent. Pop. 1,420 .

Soбrh Trompson, p. o., Geauga co., Ohio: $131 \mathrm{~m}$. N. E.

Columbus.

Souta Thurston, p. o., Stezben co., $N_{0} Y .: 204 \mathrm{~m}$. W. by S. Albany.

Soutr Trfaston, p. o., Oneida co, $N$. $Y_{\text {. }}$ on the $\mathrm{S}$, of Trenton Falls, $\$ 5 \mathrm{~m}$. I. W. Albany. 810
SoUTh UNION, p, v., Logan en., Ky. : on a tributary of Big Barren $r_{\text {, }} 138 \mathrm{~m}$. $\mathrm{S}$. W. Frankfort. The inhabitauts of this place are chiefly Shakers. They are divided into different families, each one having a separate house, with out-houses, work-shops, ete., attached. Pop. 245.

South VAllkY, p. v., Otsego co., N. Y.: $52 \mathrm{~m}$. W. Albany. Sou'rH Vassalboro', p. O, Kennebec county, $M e_{0}: 9 \mathrm{~m}$.

N. E. Augusta.

South VernoN, v. and sta., Windham co., Verm. : on the right bank of the Connecticut r., on the Connecticut River R. R., at its connection with the Vermont and Massachusetts, the Ashuelot, and the Brattleboro' Branch of the Vermont Valley Railroads, $50 \mathrm{~m}$. N. Springfield (Mass.), $19 \mathrm{~m}$. $\mathrm{W}$. by $\mathrm{S}$, Keene $(\boldsymbol{N}, \boldsymbol{H}$.), and $109 \mathrm{~m}, \mathrm{~S}$. by $\mathrm{E}$, from Montpelier.

SouthvuIE, p. o., Litchfield co., Conn. 82 m. W. by S. Hartford

Southviluz, p. o., Shelby co., $\bar{K} y$. : 25 m.W. Frankfort.

Southricte, p. v., St. Lawrence co, $N_{\text {. }} Y_{\text {. : }}$ on the E. side of St. Regis r., $152 \mathrm{~m}$. N. W. Albany.

Soutr W ALDEN, p. v., Caledonia co, Term.: 21 m. N. E. Montpelier.

South Wates, p. V., Erie co., $N_{0} Y_{\text {.: }}: 20$ m. S. E. Buffalo, and $254 \mathrm{~m}$. W. from Albany.

SoUTH WALLnFGoRD, p. o, and sta, Rutland co., Verm. : on E. side of Otter cr., on the Western Vermont R. R., 13 m. S. Rutland, and $63 \mathrm{~m}, \mathbf{S}$. W. by $\mathbf{S}$. Montpelier.

SoUTH W ALPOLE, p. v., Norfolk co,, Mass, : on a branch of Naponset r., $21 \mathrm{~m}$. S. W. Boston.

SOCTH WAREHAM, $\mathrm{v}$. and sta., Plymouth co., DTass.: on the E. side of the Weweantic river, on the Cape Cod Branch R. R., 50 m. S. E. by S. Boston.

Socthwark dist., Philadelphia co., Penn.: a suburb of the city of Philadelphia, from which it was separated in 1762 -is one and a quarter miles long, and the same in width. The streets, which are very straight, cross each other at right angles, and are well paved. The buildings, built chiefly of brick, are from 2 to 3 stories in height. It is lighted in most part with gas, and supplied with water from Schuylkill Water-works. The Navy Yard, several ship aud boat yards, a marine railway, and various manufactories are comprised in this district. There is also a lofty brick shot tower. For capital invested in manufactures, etc., see Philadeliphia, Pop. 33,799.

Souti W Arren, p. o., Bradford county, Penn.: $110 \mathrm{~m}$. N. by E. Harrisburg.

Sortr Warsaw, p. 0., Wyoming co., $N . Y_{0}:$ on the line of the Buffalo and New York City R. R., $47 \mathrm{~m}, \mathrm{E}$. by $\mathrm{S}$. Buffalo, and $280 \mathrm{~m}$. W. from $\Delta$ lbany.

SotTH WATERFORD, p. v., Oxford county, $M e_{.}: 51 \mathrm{~m}$ W. by S. Augusta.

South WEark, p. V., Hillsboro' co., N. Hamp.: $17 \mathrm{~m}$. S. W. Concord.

South Wellfleer, p. V., Barnstable co., Mass. : on an inlet of Wellfleet bay, $63 \mathrm{~m} . \mathrm{S}$. E. Boston. Salt is extensively manufactured in the vicinity, and the inhabitants are mostly erigaged in the cod and mackerel fisheries.

Soutr W fsterloo, p. v., Albany co., $N . Y_{\text {.: }} 19 \mathrm{~m}$. S. W Albany. It contains several manufuctories.

SouTrw Est HARBor, p. V., Hancoek co., Me.: on the $\mathrm{E}$ of an inlet of Bass harbor, $72 \mathrm{~m}$. E. Augusta.

Southwest Oswego, p. o., Oswego co., N. Y.: $152 \mathrm{~m}$. N. W. Albany.

South Wrstrort, p. o., Bristol co., Mass.: on the W. of Acoaksett r., $58 \mathrm{~m}$. S. Boston.

South Wermouth, p. o, and sta., Norfolk co., Mass.: on the Old Colony R. R., $22 \mathrm{~m}$. N. W. Plymouth, and $15 \mathrm{~m}$. 8. by E, Boston.

Socru WHIterazr, t, and p. o., Lehigh co., Penn.: on the W. side of the Lehigh river, $76 \mathrm{~m}, \mathrm{E} . \mathrm{N}$. E. Harrisburg. Drained by Jordan and Cedar creeks. Surface even; soil fertile, and under good culture. It contains gome manu factories, mills, workshops, etc. 
Soutg Whitley, p. o., Whitley co., Ind.: on the W. side of Eel r., at its confluence with Spring cr., $95 \mathrm{~m}, \mathrm{~N}$. by E. Indianapolis.

SorTHWick, t. and p. v., Hampden co., Mass : 93 m. S. W. by W. Boston. Drained by a branch of Westfleld $r$. Surface varied; in parts elevated, with a good soil. The State line forms the S. boundary. Gunpowder and leather form its chief manufactures. The $\mathbf{v}$. is centrally located. Pop. of t. 1,120.

Soutr Wilbrafax, p. v., Hampden county, Mass.: on Scantic r., $73 \mathrm{~m} . \mathrm{S}$. W. by W. Boston. There is a manufactory here employing 31 operatives, and manufacturing 80,000 yards woolen goods annually.

Sovtri Williamstown, p. v., Berkshire eounty, Mass. : on Green river, W. of Saddle Mountain, $115 \mathrm{~m} . \mathrm{N}$. W. by W.

\section{Boston.}

Sotth Wrinngtow, $\mathbf{v}$, and sta., Tolland co., Conn.: on the E. side of the Willimantic river, on the New London, Willimantic, and Palmer R. R.,42 m. N. by W. New London, and $21 \mathrm{~m}$. E. by N. from Hartford.

Sovth Wilsoy, p. o., Niagara co., N. Y.: about $25 \mathrm{~m} . \mathrm{N}$.

Buffalo, and $268 \mathrm{~m}$. N. W. by W. Albany.

South Windiak, p. v., Cumberland county, $\mathrm{Me}_{\mathrm{e}}$; on $\mathrm{N}$. side of Presumpscot r., $73 \mathrm{~m} . \mathrm{S}$. W. Augusta. The Cumberland and Oxford Canal passes along the river, opposite the village.

Sodth Wixphas, p. o., Windham co., Term.: $79 \mathrm{~m} . \mathrm{S}$. Montpelier.

South Windhax, p. v. and sta., Windham co., Conn.: on the Willimantic r., and on the New London, Willimantic, and Palmer R. R., $26 \mathrm{~m}$. N. New London, and $27 \mathrm{~m}$. E. by S. from Hartford.

South Wridsor, t. and p. v., Hartford co., Conn.: on the $\mathrm{E}$, side of the Connecticut river, $5 \mathrm{~m}$. N. by E. Hartford. Drained by several small streams flowing into the Counecticut $\mathbf{r}$. The $\mathrm{v}$. is located near the banks of the river. Pop. of t. $1,63 \mathrm{~S}$.

Sotri Wrindsor, p. o., Kennebec county, Me.: 11 m. E. Augusta.

Sогтн WовиR, v., Middlesex co., Mass. : a pleasant village on the Boston and Lowell R. R., $8 \mathrm{~m}$. N. by W. Boston. It is a place much resorted to, for a summer residence, by persons from the city. Various manufactures are carried on ; a stream passing the place, affords water-power. The Woburn Branch R. R., $2 \mathrm{~m}$. in length, extends henec to Woburn Centre.

Sovtr Wolfborougr, p. o., Carroll co, N. Hamp.: $30 \mathrm{~m}$. N. E. Concord.

South Woodstock, p. v., Windsor co, Term. : a neat and pleasant V., on a branch of Quechee river, $50 \mathrm{~m}$. S. Montpelier.

Sovth Worctster, p. o., Otsego co., $N_{0}$. Y.: on Charlotto r., $52 \mathrm{~m}$. W. Albany.

Souti Wresthayr, p. o., Norfolk county, Mass.: $30 \mathrm{~m}$. S. by W. Boston. There is a manufactory here, employing 41 persons, and manufacturing 80,000 yards of woolen carpets per annum.

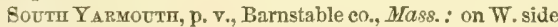
of Bass r., near the Atlantic coast, $67 \mathrm{~m}$. S. E. Boston. It contains three churehes, and has extensive salt works.

SoWADABSCOOK river, Me.: rises by 3 branches in the towns of Stetson, Etna, and Carmel, the branch in Etua having its source in a pond; flows eastwardly in a circuitous course, and empties into the Penobscot $r$. at Hampden, $5 \mathrm{~m}$. below Bangor. In its course it passes through 2 poids in the towns of Harman and Hampden. The country through which this $r$. flows is varied, having some good farming tracts, and a considerable portion is well wooded. It has seyeral falls, and there is a number of valuable mills on its banks.

Soxville, p. V., Monrne co., Penn.: at the junction of Tunkhanna er. with the Lehigh r., $83 \mathrm{~m}$. N. E. Harrisburg. SPAFFORD, t. and p. v., Onondaga county, N. Y.: $134 \mathrm{~m}$.
W. by N. Albany. It has Otisco lake and its inlet on the E. and Skaneateles lake on the W. Surface hilly, and in parts broken; soil various. The t. contains several mills and a tannery. Pop. of t. 1,903.

Spafford Hollow, p. O.g Onondaga co., $N . Y_{\bullet}: 135 \mathrm{~m}$ W. by N. Albany.

SPAFFORD's lake, Cheshire co., $N$. ITamp. : a beautiful collection of water in the town of Chesterfeld, containing 526 acres, and fed by springs at its bottom. Its waters are clear and pure, its bed being a white sand. There is an island in this lake of 6 acres.

Spanishidrg, p. o., Mercer county, Virg. : $196 \mathrm{~m}$. W. Richmond.

Spanish Pratrie, p. v., Crawford co., Mo.: 39 m. S. E. Jefferson City. The Maumee Iron Works are located about $5 \mathrm{~m}$. S. of this place.

SPARrow SWAMP, p. o. and sta, Darlington dist., S. Car.: on the Wilmington and Manchester $\mathrm{P}_{\mathrm{v}} \mathrm{R}_{\text {. }}, 65 \mathrm{~m}$. E. by $\mathbb{N}$. Columbia.

Sparta, p. vo, and eap. Conecuh co., Ala.: on Murder cr. of Conecuh r., $109 \mathrm{~m}$. S. W. Montgomery. It contains a court-house, jail, and U.S. land office,

Sparta, po o., Chickasaw county, Miss. : $\$ 1$ m. N. E. Jackson.

Sparta, p. $\nabla$. , and cap. Hancock co., Ga. : on the dividing ground between the Great Ogechee and Oconee rivers, $19 \mathrm{~m}$, N. N. E. Milledgevillc. It contaius a court-house, jail, a female academy, etc.

Sparta, p. v., Randolph co., $I l_{0}$ : on the line of the Illinoistown and Massac R. R., $113 \mathrm{~m}$. S. Springfield. It is situated on the N. W. border of Flat Prairie, in an excellent agricultural district. Two newspapers are published weekly -the "Sparta Freeman" (free soil) and the "Sparta Register" (dem.)

Sparta, p. o., Dearborn county, Ind.: 75 miles S. E. Indianapolis.

Sparta, p. o., Bienville par., La.: 168 m. N. W. Baton Rouge.

Sparta, p. o., Hillsdale co., Mich. : 58 m. S. Lansing.

Sparta, p. v., and cap. Buchanan co., Mro.: on the head waters of Bee cr. of Platte r., $157 \mathrm{~m}$. N. W. Jefferson City, and contains a court-house, jail, and other public buildings. The "Gazette" (dem.) and the "Adventurer" (whig) are both weekly issues.

Sparta, p. v., Sussex co, N. Jer. : on the Wallkill r., near its source. $56 \mathrm{~m}$. N. by E. Trenton. It contains several mills and forges. Iron and zine ores are found in the neighborhood.

Sparts, t. and p. V., Livingston co, N. Y. $: 205 \mathrm{~m}$. W. Albany. Drained by a small stream flowing $N$. into Hemlock lake. Surface uneven; soil fertile. The $\mathrm{v}$. is in the N. part. The t. contains some light manufactures. Pop. of $t .1,372$.

Sparta, p. o., Edgecomb co., N. Car.: on W. side of Tar r., $65 \mathrm{~m}$. E. Raleigh.

Sparta, p. v., Morrow county, Ohio: 35 m. N. by E. Columbus.

Sparta, p. v., Washington co., Penn. : on a tributary of the Monongahela r., $179 \mathrm{~m}$. W. Harrisburg,

Sparta, p. vo, and eap. White co, Tenn.: on Calf Filler cr., $75 \mathrm{~m}$. E. S. E. Nashville; and contains the eourt-house, jail, other county buildings, a bank, etc. The "S. Times" is a weekly (whig) issue.

Sparta, p. O., Caroline county, Firg.: $35 \mathrm{~m}$. N. by E. Richmond.

SPARTA CENTre, p. O., Kent con, Mich.: $66 \mathrm{~m}$. T. N. W. Lansing.

Spartan bURG district, S. Car. Situate N. toward the W., and contains 1,036 sq. m. Drained by Forest er., Ennoree, Tiger, and Pacolet rivers. Surface hilly; soil fertile; along the streams are some tracts of land proving very productive. Staples are cotton and Indian corn. Farms 1,כ5ว็ ; manuf. 34; dwell. 8,155, and pop. - wh. 15,312, fi. col. 49, sl. s,039- 
total 26,4no. Cir)itul: Spartanburg. Putlic Works: Union and Spartanburg R. R.

Spaptaśtra, p. v., Randolph co., Ind.: $72 \mathrm{~m}$. E. by N. Indianapolis.

Spartanberg, p. v., and cap. Spartanburg dist., S. Car.: at the terminus of the Union and Spartanburg R. R., $80 \mathrm{~m}$. N. W. Columbia. It contains a court-house, jail, and other public buildings. The Wofford College, a new institution, is located here. The "Spartan" is a weekly (dem.) issue.

Spartansburg, p. o., Crawford co., Penn. : 101 m. N. W. Harrisburg.

Spartapolis, p. o, Rockingham co., Firg.: $101 \mathrm{~m}$. N.W. Richmond.

Spears' Store, p. o., Union parish, La.: $169 \mathrm{~m} . \mathrm{N}$. W. Baton Rouge.

Spears' Turnout, sta., Jefferson co., Ga.: on the Central (Georgia) R. R., 112 m. N. W. Savannah, and 49 m. E. by S. Milledgeville.

SPECkLEd mountain, Oxford co., Me: lies on the N. H. line, partly in the 1. of Piley. Elevation 4,000 feet.

Speedsville, p. v., Tompkins co., N. $Y$.: on a tributary of the Susquehanna r., 134 m. S. W. by W. Albany. It contains several manufactories and a brick-yard.

SPEEDwell, p. .., Barnwell dist., S. Car.: on the E. side of Steel cr, N. of Savannah r., 67 m. S. by W. Columbia.

Speedweli, p. o., Claiborne co., Tenn. : 159 m. E. by N. Nashville. Deposits of iron ore are found in the vicinity.

SPEeDWELl, p. o., Wythe co., Virg.: on Cripple cr., and on the S. W. boundary of the county, $211 \mathrm{~m} . \mathrm{W} . \mathrm{S} . \mathrm{W}$. Richmónd.

SPeER's Landivg, p. 0., Shelby co., Ohio: 65 m.W. N.W. Columbus.

Speers rille, p. o., Fulton county, Penn.: 30 miles S. W

\section{Harrisburg.}

Speigmr's Bridge, p. v., Greene coo, N. Car.: on Mockosin cr., $51 \mathrm{~m}$. E. by S. Raleigh.

SpEtr's TURNoUT, p. v., Jefferson county, Ga.: on the N. side of Williamson's Swamp cr, and on the Central Georgia R. R., $112 \mathrm{~m} . \mathrm{N}$. W. Savannah, and $49 \mathrm{~m}$. E. by S. from Milledgeville.

SPENOER county, Ind. Situate S. toward the W., and contrins 40 sq. m. Drained by Anderson's, Little Pigeon, Big Sandy, and Little Sandy creeks. Surface generally hilly, with exceptions of some level or undulating lands; soil a black loam, and resting on a yellow clay mixed more or less with sand. The bottoms are extensive and thickly timbered. Coal is abundant. Farms 988; manuf. 2S; dwell. 1,485, and pop.-wh. 8,615 , fr. col. 1-total 8,616. Capital: Rockport.

Spexcer county, $K y$. Situate N. toward the W., and contains $125 \mathrm{sq} . \mathrm{m}$. Drainod by $\mathbf{E}$. fork of Salt r. and its branches. Surface level ; soil fertile, and in parts very productire. Chief articles for the markets, wheat, Indian corn, and tobacco. Farms 5is; manuf. 1s: dwell. S10, and pop.wh. 4,659, fr. col. 32 , sl. 2,151-total 6,842. Cupital: Taylorsville.

Spexcer, p. .., and cap. Owen co., Ind.: on the right bank of W. fork White r. It contains a court-house, jail, and other public buildings, warehouses, mechanic shops, an oil mill, ropewalk, copper and tin factory, and about $300 \mathrm{in}-$ habitants. The country around is very fertile, and its situation is favorable to a rapid increase in size and importance.

Spercer, t, p. Vo, and sta, Worcester co, Mass. : $48 \mathrm{~m}$. W. by S. Boston. Surface uneven, rough, and elevated 950 feet above tide-water in Boston harbor; soli fertile; watered by branches of Chicopee r. The Western R. R. passes through its S. W. part, $62 \mathrm{~m}$. from Boston, $138 \mathrm{~m}$. from Alhany. The town contains several grist and saw mills, and 3 churches, of which 2 are in the $\mathbf{y}$., near its centre. Pop. of $\mathrm{t}$ in $1510,1,604$; in $1550,2,243$.

Spencer, p. o, Davidson co, N. Car.: $90 \mathrm{~m}$. W. Raleigh. Spexcer, t. and p. vo, Tioga co, N. $Y_{0}: 146 \mathrm{~m} . \mathrm{W} . \mathrm{S} . \mathbb{W}$. Albany. Surface hilly; soil gravelly loam. Drained by 812
Cattotong creek and its branches, The $\mathrm{v}$, contains several mills, a tannery, 2 churches, ptc. Pop. of t. 1,7 \$ 2.

SPExcer, t. and p. o., Medina co., Ohio: 87 m. N. N. E Columbus. Drained by the $\mathrm{E}$. branch of Black $r$. Surface moderately uncven, with fertile soil. Centreville $\mathrm{v}$. is on the S. side of the r. Pop. of t. 1,336.

Spencer, p. v., and cap. Van Burea co, Tenn : on N. side of Laurel cr., $73 \mathrm{~m}$. S. E. Nashville. It contains the court-house, jail, etc.

Spexcerport, p. v, and sta., Monroe co, $N, Y$ : : on the Rochester, Lnckport, and Niagara Falls R. R., $10 \mathrm{~m}$. W. from Rochester, and on the Erie Canal; $218 \mathrm{~m}$. W. by N. Albany. Pop. about 400.

Spencersburg, p. Y., Pike co., Mo.: on the E. of a branch of Spencer cr., 68 m. N. N. E. Jefferson City.

Spexcertown, p. v., Columbia co., N. Y.: 27 m. S. S. E Albany. Pop. about 250 .

Spencerville, p. v., De Kalb county, Ind.; on the right bank of the St. Joseph's river of the Maumee, $121 \mathrm{~m}$. N. E. Indianapolis.

Spencerville, p. o., Marengo county, Ala.: $100 \mathrm{~m}$. W. Montgomery.

SPEONK, p. o., Suffolk co., $N . \Gamma .: 140 \mathrm{~m}$. S. S. E. Albany SPERRTPILLE, p. v., Rappahannock county, Virg.: $57 \mathrm{~m}$. N. N. W. Richmond. The Alleghany range is on the $W$. of the village.

Spesctie island, Harford co., $M I d_{0}$; an island of considerable extent in the Chesapeake bay, about $6 \mathrm{~m}$. S. of the confluence of Susquehanna r., and about a mile distant from the $\mathrm{E}$. coast of the county.

Spiceland, p. v., Henry co., Ind. : on a creek of Blue $r$. $37 \mathrm{~m}$. E. by N. Indianapolis.

Sptycerstown, p. v., Bucks county, Penn.: 88 m. E Harrisburg.

SpLUNG, D. V., Monroe county, Afiss: on a branch of Buttahatchee cr., $163 \mathrm{~m}$. N. E. Jackson.

Spottedvilize, p. 0., Stafford cos, Virg.: $61 \mathrm{~m} . \mathrm{N}$. by W. Richmond.

SPOTт\& wOOD, p. v. and sta., Middlesex county, N. Jer. on Camden and Auboy R. R., $52 \mathrm{~m}$. from Philadelyhiz, $38 \mathrm{~m}$. from New York, $22 \mathrm{~m}$. N. E. Trentoz. It contains 2 churches, etc.

Spottsylvania county, Virg. Situate toward the N. E. and contains $403 \mathrm{sq}$. m. Drained by head branches of North Anna and Mattapony rivers. Surface generally uneven; soil fertile, well adapted to grazing. Chief products, wheat, Indian corn, tobaeco, etc. The eity of Fredericksburce is in this co. Farms 429: manuf. 15; dwell. 1.41h, and pop.-wh. 6,903, fr. col. 527, sl. 7,481-total 14,911. Capital. Spottsylvania C. H. Public Works : Richmond, Frederick, and Potomac $\mathbf{R}, \mathbf{R}$.

Spottsyltaita C. H., p. v., and eap. Spottsylvania county, Firg.: on the Po river, tributary of Mattapony river, $44 \mathrm{~m}$. N. by W. Richmond. It contains the court house, ete.

Sprott Spring, p. 0., Appomattox connty, Firg.: $72 \mathrm{~m}$. W. by S. Richmond.

SpRageE"s Falis, p. 0., Washington county, Mre. : $131 \mathrm{~m}$. E. N. E. Augusta.

Spraguevirie, p. v., Jackson co., Ia.: on the E. bank of Makoqueta r., 60 m. E. N. E. Iowa City.

SPRAKER's BASIN, p. v. and sta., Montgomery co., N. $Y_{\text {o: }}$ on the Erie Canal, Mohawk $r_{0}$, and Utica and Schenectady R. R., $43 \mathrm{~m}$. from Utica, $35 \mathrm{~m}$. from Schenectady, and $53 \mathrm{~m}$. by R. R. from Albany.

Spread Eagle, p. v., Delaware co., Penn.: 81 m. E. by $\$$ Harrisburg.

SpreAd OAK, po o., Jefferson county, $G a_{0}: 54 \mathrm{~m}$. F. Milledgeville.

Sprixg, t, and p. y., Crawford co., Penn.: $205 \mathrm{~m}$. N. W. Harrisburg. Drained by the cr. so called. Surface undizlating and well wonded; soil of average fertility. It has good water-power, and manufactures flour, leather, lumber, 
ete. The $\mathrm{r}$, is on the Beaver and Erie Canal, $100 \mathrm{~m} . \mathrm{N}$. Beaver, near the Obio line. Pop. of $t$ about 2,000 .

SPEñG, p. o., Henry county, $G a_{0}: 61 \mathrm{~m}$. W. by N. Milledgeville.

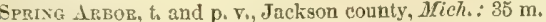
S. Lansing. Drained by the Kalamazoo, and branch of Grand $r$. The $y$, is located on the site of an ancient Indian village, and in the midst of burr oak plains. Pop. of $t$. in 1540,$775 ;$ in $1550,1,075$.

SPrixg Bar, p. V., Woodford co., $I l l_{s}$ : on the E. bank of Peoria lake of Illinois r., $69 \mathrm{~m}$. N. by E. Springtleld. It is located in a swampy and not very fertile district.

SpringborodgH, p. V., Warren co., Ohio : on the $\mathrm{N}$. side of Spring creek of Miami r., $4 \mathrm{~m}$. E. of the Miami Canal, and $70 \mathrm{~m} . \mathrm{S} . \mathrm{W}$. Columbus. It contains several churchesamong which are two Friends'-with manufactories, stores, etc. The $v$. derives its name from a spring situate here, which moves several mills,

Sprixgmorotgr, p. o, White co, Ind : $\$ 5$ m. N. N. W. Indianapolis.

Sprivg Brook, p. o., Erie county, N. Y.: $268 \mathrm{~m}$. W. Albany.

Sprive Brook, p. Y., Jackson county, $I a_{4}: 65 \mathrm{~m}, \mathrm{~N}$. E. Iowa City.

Spelig Cotrage, p, O., Marion county, Miss,: on E. side of Pearl r., 94 m. S. by E. Jackson.

Sprtivg Cвefe, p. v., M'Donough co, $I l l_{*}$ : on a stream so called, $77 \mathrm{~m}$. W. N. W. Springfield.

Spring Creik, t. and p. 0., Warren co., Penn.: $175 \mathrm{~m}$. N. W. Harrisburg. Drained by Broken Straw cr. Surface much broken and rocky; soil very inferior. There are deposits of 'iron in the vicinity.

Sprivg Crerk, p. 0., Brunswick county, N. Car.: $112 \mathrm{~m}$.

S. by E. Raleigh.

Spring Creek, p. o., Cass county, Ind.: 69 m. N. Indianapolis.

Sprnte Creek, p. V., Madison co., Tenn. : near a fork of

Deer r., 109 m. W. S. W. Nashville.

Sprivg Criek, p. o, Pandolph co., Ar7c. : 121 m. N. N. E. Little Rock.

Sprive Creek, p. v., Greenbrier county, Virg.: in a mountainous region, on Thunder Gap. cr., 169 m. W. by N.

Richmond.

Spring CreEk, p. O, Berrien co., Mich. : 112 m.W. S.W.

Lansing.

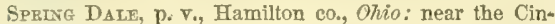
cinnati, Hamilton, and Dayton R. R., 91 m. S.W. Columbus. Spriva Dale, p. v., La Fayette county, Miss, : $134 \mathrm{~m}$.

N. by E. Jackson.

SprLyg Dale, p. o., Scott co., Ky.: 15 m. N. E. Frankfort. Sprixe Date, p. o., Dane co., Wísc.

Sprisafield, p. o., Greene co., Ala. : $3 \mathrm{~m}$. W. from Black Warrior r., 100 m. W. N. W. Montgomery.

SPREgField, p. v., and cap. Effingham co., Ga.: on a branch of Ebenezer cr., $13 \mathrm{~m}$. W. of the Savannah r., and $126 \mathrm{~m}$. E. S. E. Milledgeville. It contains a court-house, jail, etc.

Sprirgrield, p. v., and cap. Sangamon co., $1 l l$. , and capital of the State of Minois : $4 \mathrm{~m}$. $\$$. from Sangamon r., $174 \mathrm{~m}$. S. W. by S. Chicago, 84 m. N. N. E. St. Louis, 186 m. W. Indianapolis, Lat. $39048^{\prime} \mathrm{N}$., Iong. $89^{\circ} 88^{\prime} \mathrm{W}$. Its site is a level plain, on the borders of a broad and beautiful prairie, which is adorned with fine groves and some of the best farms in the State. It was laid out in Feb., 1822, according to a regular plan, with a public square in the centre, and wide streets crossing at right angles. The older portion of the $\nabla$. was purchased at the land sales in Nov., 1823, at which time it contained about 30 families, living in small $\log$ cabins. For several years its increase in population, etc. was slow. In 1887 the legislature selected it as the State capital after July 4th, 1839 , since which period it has been steadily increasing in business, wealth, and importance. The surrounding counties are very fertile, and their pro- ducts are brought here to market. The railroads now pass ing through Springfleld are-Great Western Central P. P. extending centrally across the gtate, from the $\mathrm{E}_{\text {t }}$ to the W. boundary, of which the portion completed, viz., from Springfield to Naples, $55 \mathrm{~m}$., Was formerly gtyled the Sangamon and Morgan R. R.; and Chicago and Mississippi R. R., of which $132 \mathrm{~m}$. (from Alton to Bloomington) will be com pleted in July, 1859, and the entire rosd will be completed to Chicago, $257 \mathrm{~m}$., in the spring of 1854 . The Massac and

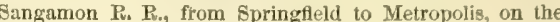
OHio r., passing through Vandalia, Salem, Frankfort, etc. is in construction. The capitol occupies the centre of the principal square, which has an area of 3 acres. It is constructed of hewn stone, 3 stories high, with handsome porticoes, and cost about $\$ 180,000$. The $v$. also contains a courthouge, U. S. land offlee, market-house, jail, 3 banks, several academies and other schools, with 8 churches, gone of which are handrome edifices. The $\mathrm{v}$. has some manufac. tures, an iron foundry, etc. The newspapers published in 1850 were- "Illinois Journal" (whig), issued daily, triweekly, and weekly; "Illinois State Register" (dem.), daily and weekly; and "Illinois Organ" (temp.), weekly. Pop. in $1840,2,579$; in $1850,4,533$.

Springfreld, p, v., Franklin $\mathrm{co}_{*}$, Ind.: near the source of Red Cedar Grove cr, 69 m. E. by S. Indianapolis.

Sprixgfield, p. v., Keokuk county, Ia. : on a branch of Skunk r., 47 m, S. W. Iowa City.

Spritgaleld, p. o., Richmond co., N. Car. : 71 m. S. W. Raleigh.

Sprivgfield, p. v., and cap. Washington co.g $\bar{K} .:$ : $39 \mathrm{~m}$. $\mathrm{S}$, by W. Frankfort. It contrins a court-house, jail, ete. It the vicinity are several Catholic institutions-Dominican Convent of St. Rose, established 1806, wilh 6 priests and 23 religious; St. Catharine's Feruale Convent, founded 1822 , having 26 members; and a female academy with more than 100 pupils.

SPRIFGFIELD, p. $\nabla_{\text {., }}$ and cap. Livingston par., $L a .:$ on Notatbaney er., a branch of Tickfaw r., 39 m. E. Baton Rouge. It contains a court-house, jail, etc.

SPRINGFIeld, t, and p. o., Penobscot co., Me.: $116 \mathrm{~m}$. N. E. by N. Augusta, Drained by branches of Mattawamkeag r., which afford water-power. Pop. 553.

SPrifgfield, t., p. city, and cap. Hampden co،, Mass.: on E. side of Connecticut $\mathbf{r} ., 81 \mathrm{~m}$. W. by \$. Boston; by railroad $98 \mathrm{~m}$. from Boston, $102 \mathrm{~m}$. from Albany, $185 \mathrm{~m}$. from New York. Lat. (Court-house) $42^{\circ} 06^{\prime} 04^{\prime \prime}$ N., long. $780^{\circ} 35^{\prime}$ $45^{\prime \prime} \mathrm{W}$. Its site along the river is a rich alluvial plain, back of which the ground rises gradually to a considerable elevation, called Armory Hill, terminating in a plain which extends $\mathrm{E}$. for several miles. Its general appearance is very beantiful, and it is surrounded by delightful sceners. The houses are generally well built, and many are elegant. The streets are generally payed, and the city is lighted with gas. The business part of the city is chiefly on and adjoining Main Street, which runs parallel with the river at some distance from it, is between 2 and $3 \mathrm{~m}$. long, quite broad, and generally intersected at right angles by cross streets, and contains many handsome buildings, with the principal hotels and railroad station-house. From the position of Springfield, and its great railroad connections, it has become one of the greatest inland thoroughfares of travel in the Union. Four railroads here connect at the central depôt from the four cardinal points, viz : Western R. R., from Worcester $54 \mathrm{~m}$. and from Albany $102 \mathrm{~m}$.; New Haven, Hartford, and Springfield R. R., $26 \mathrm{~m}$. from Hartford and $62 \mathrm{~m}$. from New Haven ; Connecticut River R. R. $17 \mathrm{~m}$. from Northampton and $50 \mathrm{~m}$. from South Vernon. The great number of trains arriving and departing daily render the vicinity of this depot strikingly interesting to the passing traveler. The hotels of the city established to accommodate the traveling public are numerous, of which several are of great repute. The city contains a court-house, jail, and 12 churches, some of which are handsome ediflces. These are 
-4 Congregational, 1 Baptist, 1 Episcopal, 2 Methodist, 1 Unitarian, 1 Catholic, 1 Universalist, 1 African. The principal cemetery is beautifully laid out and adorned. There are 5 banks, with an aggregate capital of $\$ 1,150,000$, and 2 institutions for savings. The manufactures of the city are of considerable importance. There is a large manufactory of cars, loeomotives, railroad machinery, steam-engines, etc.; also several factories of sheetings, satinets, etc. ; also 1 pistol factory. The "Springfield Republican" (whig), and "Hampden Post" (dem.), publish each daily and weekly editions.

The U. S. Armory located here is situated on Armory Hill, about one-half mile E. of Main Street. The buildings are of brick, handsomely arranged around a square, presenting a fine appearance. From 12,000 to 15,000 muskets are manufactured annually. The arsenal, a very large brick building 4 stories high, contains about 175,000 muskets Some of the machine shops are located on Mill $\mathbf{r}_{\text {, }}$ in the S. E. part of the t., and comprise 5 shops, with 18 waterwheels, 10 trip hammers, and 30 forges. The whole establishment employs from 250 to 300 workmen, and has contributed very much to the prosperity of the city.

Springfield was settled in 1635 , then called by its Indian name Agawam; it received its present name in 1640, and was incorporated in 1646 , and received its city charter May 25th, 1852. In 1786, during Shay's rebellion, it was in part the theatre of his movements. Since the construction of the railroads which now so closely connect it with other important eities, it has rapidly increased in population, wealth. and importance. Pop. in $1810,2,767$; in $1820,3,914$; in $1830,6,784$; in $1840,10,985$. When the census of 1840 was laken, it was a much larger township than at present, then comprising also Chicopee Falls, Cabotville, Willimansett, etc., now embraced in Chicopee township, the population of which with that of Springfield in 1850, amounted to 21,602. The separate population of Springfield $t_{0}$ in 1850 , and as at present constituted, was 11,766 .

SPRINGFIELD, t. and p. o., Oakland co., Mich.: $51 \mathrm{~m}$. E. Lansing. Drained by a part of the head waters of Shiawassee $r$. Surface level, and well wooded. Pop. 956.

SPRINGField, p. v., and cap. Greene co., M.o.: on Wilson's cr. of James $x_{0,} 109 \mathrm{~m}$. S. W. Jefferson City. It contains a court-house, jail, U. S. land office, ete. The country round about is hilly, with good timber lands. There are two weekly issues, the "Springfield Advertiser" and the "South Western Flag" (both democratic). Pop. 415.

SPRINGField, t. and p. o., Sullivan con, N. Hamp.: $31 \mathrm{~m}$ $\mathrm{N}$. W. by $\mathrm{N}$. Concord. It occupies the height of land between Connecticut and Merrimac rivers, and is drained by streams flowing into each. It has a rough surface, and contains several considerable ponds. Organized with its present name in 1794. Pop. 1,270.

Springrield, to and p. v., Essex county, N. Jer.: $42 \mathrm{~m}$. N. E. by N. Trenton. Bounded E. by Rahway r. and W. by Passaic $r$. The v. on Rabway $r$, is nnted for its paper factories. Through its N. part, called Millville, the Morris and Essex R. R. passes, $10 \mathrm{~m}$. from Newark, $19 \mathrm{~m}$. from New York. Summit is another sta, in the t, $8 \mathrm{~m}$. W. Millville. Pop. of $t$. in $1840,1,651$; in $1850,1,945$.

SpringField, t. and po o., Otsego county, $N . Y .: 59 \mathrm{~m}$. W. by N. Albany. Surface elevated and hilly. The N. end of Otsego lake extends to its centre. It contains numerous saw-mills, 3 tanneries, a furnace, woolen factory, and sereral fulling and grist mills. Pop. 2,322.

Springfiri.D, p. v., and cap. Limestone county, Tear : on N. E. bank of Navasota r., 119 m. N. E. by N. Austin City. SPRINGFIELD, t., p. city, and cap. Clark $\mathrm{CO}_{*}$, Ohio: on $\mathrm{S}$. side of E. fork of Mad r., $49 \mathrm{~m}$. W. by S. Columbus. It has great water-power, well improved by a variety of mills and maunfacturing establishments. It contains a handsome court-honse, and other county buildings, 2 banks (one is a branch of the State Bank), several academies, and 7 churches. Newspapers in 1850: "Republic" (whig), tri-weekly 814 and weekly; and 8 other weeklies, "Gospel Herald," "District Expositor" (dem.), and "Mad River Gazette" (whig) Here are located the Wittenberg College, and Theologica Seminary, both founded in 1845. In 1850 the college had 7 instructors, 37 students, and 4,500 volumes in library ; while the Thenlogical School had 2 professors and 8 students. Several important lines of railroad pass through the city, viz., Mad River and Lake Erie R. R., $134 \mathrm{~m}$. from Sandus$\mathrm{ky}$, and $24 \mathrm{~m}$. from Dayton, $84 \mathrm{~m}$. from Cincinnati: Lillle Miami R. R., from Cincinnati, $84 \mathrm{~m}$.; Springfleld, Mount Vernon, and Pittsburg R. R., in construction to Loudonville, on the Ohio and Pennsylvania R. R., $115 \mathrm{~m}$.; and the Springfield and Columbus R. R., $19 \frac{1}{2} \mathrm{~m}$. to connection at London with Columbus and Xenia R, R, $43 \mathrm{~m}$, to Columbus-all of which have connections with other principal railroads. Pop. of city in 1840 (then a village), 2,062 ; in $1850,5,108$. Pop. of to in $1840,2,349$; in 1850 (including city), 7,314 .

Springrietid, t. and p. o., Bradford co., Penn.: $107 \mathrm{~m}, \mathbb{N}$. Harrisburg. Drained by Bently, and branch of Sugar er. Surface mountainous; soil highly productive. The Williamsport and Eimira R. R. passes near the town.

SPRixgFirLD, p. V., and cap. Robertson co., Tenn.: on Sulphur fork of Red r., $24 \mathrm{~m}$. N. by W. Nashville. It contains the court-house and other public buildings.

SPRINGFIEL, p. v., Hampshire co., Tirg.: on the right bank of the South branch Potomae river, $145 \mathrm{~m} . \mathrm{N} . \mathrm{N}$. W. Richmond.

Sprixgreld, sta., Fairfax co., Tirg. : on the Orange and Alexandria R. R., $7 \mathrm{~m}$. W. Alexandria, and $85 \mathrm{~m} . \mathrm{N}$. Richmond.

SPRINGFIELD, t. and p. $\mathrm{V}_{n,}$ Windsor co., Term.: on W. side of Connecticut r., $70 \mathrm{~m}$. S. by E. Montpelier. Black r. flows through it from the N. W., and has an important fall, $4 \mathrm{~m}$. from its mouth, near the principal v., affording great water-power, and improved by numerous fulling, grist, and saw mills, also woolen and cotton factories. Pop. of t. 2,762. SPRINGFIELD, v., Sutter co., Calif: : on the left bank of Sacramento r, at the mouth of Feather r., opposite Fremont, and $66 \mathrm{~m}$. N. E. Vallejo.

Springeield Centre, p. O., Otsego county, $N . Y_{0}: 60 \mathrm{~m}$. W. by N. Albany.

Springrield Cross Ronds, p. 0., Erie co, Penn.: $213 \mathrm{~m}$. N. W. Harrisburg. The Cleveland and Erie R. R. passes through Springfield t. and sta, $75 \mathrm{~m}$. from Cleveland, $20 \mathrm{~m}$. from Erie.

Springrield Frriace, p. o., Blair county, Penn.: $80 \mathrm{~m}$ W. by N. Harrisburg. It contains a furnace with an annual capacity of 1,820 tons.

SPRiNGFieid Mrixs, p. o., Noble county, Ind.: on the N. side of Elkhart r., $121 \mathrm{~m}$. N. N. E. Indianapolis. Sprivg Forge, p. o, York county, Penn.: $25 \mathrm{~m}$. S. Harrisburg. It contains a forge which, in 1850 , produced 223 tons bars.

SPRIYG Fork, p. o., Pettis co., Jfo.: on a stream so called, $60 \mathrm{~m}$. W. Jefferson City.

Spring Garden, p. o., Cherokee county, Ala.: $138 \mathrm{~m}$. N. N. E. Montgomery.

Sprtivg Garden, p. o., Jefferson co., $M$. : 118 m. S. S. E. Springfield.

Spring Garden, p. district, Philadelphia co., Penn.: an integral part of the city of Philadelphia, though incorporated under separate charter, and governed by a board of commissioners. See Priladelphia, for statistics of its population, manufactures, water-works, etc.

Sprivg Gardex, p. v., Pittsylvania co., Tirg.: on N. side of Birch cr., $116 \mathrm{~m}$. S.W. by W. Richmond.

SPRINe Grove, p. o., Warren county, $I l l_{0}: 105 \mathrm{~m} . \mathrm{N}$. W. Springfield.

SPRING Grove, station, Hamilton county, Ohio: on the Cincinnati, Hamilton, and Dayton R. R., $7 \mathrm{~m} . \mathrm{N}$. Cincinnati, and $101 \mathrm{~m}$. W. S. W. Columbus.

Sprixg Grote, t. and p. v., Greene co., Wisc.: $37 \mathrm{~m} . \mathrm{s}$ 
Madison. Drained by a branch of Rock $r$. Surface level; soil rich, with some prairie and good pasturage. The v. is in S. part. Pop. of t. 703.

SPrivg Grote, p. O., Rowan co., $N$. Car.: $97 \mathrm{~m}$. W. Raleigh.

SPring Grove, p. 0., Linn co., Ia.: $27 \mathrm{~m}$. N. Iowa City.

Sprivg Grove, p. v., Laurens district, S. Car.: N. of

Saluda r., $55 \mathrm{~m}$. W. by N. Columbia.

SPRING Hill, p. On, Marengo county, Ala.: $91 \mathrm{~m}$. W.

Montgomery.

Spring Hru, v., Mobile co., Ala. : situated a little $\mathbf{S}$. W. of the city of Mobile, is a favorite summer resort of its citizens. Here is located Spring Hill College (Catholic), founded in 1830 , which in 1850 had 12 professors and 70 students, with 4,000 volumes in its library. There is also an ecclesiastical seminary.

Sprivg Hric, p. v., Hempstead co, Ark.: on a fork of

Bois d'Arc, 108 m. S. W. Little Rock.

Spring Hrux, p. v., Decatur county, Ind.: on a branch of

Clifty cr., $45 \mathrm{~m}$. S. E. Indianapolis.

Sprivg Hur, p. V., Whitesides co., $I U$.: on the S. boundary line of the co., $125 \mathrm{~m}$. N. Springfleld.

SPRIVG Hilu, p. o., Livingston co, Mo. : 109 m. N. W.

Jefferson City.

SPRING Hrut, p. o, Tippah co, Miss: 181 m. N. N. E. Jackson.

Sprivg HrLl, p. v., Maury county, Tenn. : 27 miles $\mathbf{S}$.

Nashville. The New Orleans and Nashville R. R. will pass through it.

SpIing Hul, p. o., Navarro co., Tex. : 152 m. N. E. by N.

Austin City.

Sprisg Hill Furnace, p. o., Fayette co., Penn. : 153 m.

W. S. W. Harrisburg. A steam and water-power furnace in

the vicinity has an annual capacity of 1,100 tons.

Sprive Hruss, p. o., Champaigne county, Ohio: 42 miles

W. by N. Columbus.

Sprevg House, p. o., Montgomery co., Penn.: on a tributary of the Schuylkill r., $86 \mathrm{~m}$. E. Harrisburg.

Sprivg HousE, p. o., Grainger county, Tenn.: 179 m. E. Nashville.

Spring Lakre, p. o., Williams co., Ohio: 133 m. N. W.

Columbus.

Spring Lake, t, Ottawa co., Mich. : on Lake Michigan, $86 \mathrm{~m}$. W. by N. Lansing. It contains 5 steam saw mills, producing to the value of $\$ 120,900$ annually. Pop. 545 .

SPRING Mrut, sta., Richland co., Ohio : on the Sandusky,

Mansfield, and Newark R. R., 51 m. from Sandusky, 65 m. from Newark.

Sprivg Mrrs, p. o., Lawrence ca, Ind.: $71 \mathrm{~m}$. S. by W. Indianapolis.

Sprivg Mrucs, p. o., Allegany co., $N . Y .: 224 \mathrm{~m}$. W. by $\mathrm{S}$. Albany.

Spratg Mrlus, p. V., Centre county, Penn.: on a fork of Penn's cr., near Brush mt., 54 m. N. W. Harrisburg.

Spring Mrlus, sta, Montgomery co., Penn. : on the left bank of the Schuylkill river, and on the Philadelphia, Germantown, and Norristown R. R., 12 m. N. W. Philadelphia, and $82 \mathrm{E}$. by S. Harrisburg.

SpRIng Place, p. V., and cap. Murray co., Ga.: about $3 \mathrm{~m}$. E. of Connesauga cr., and $162 \mathrm{~m}$. N. W. Milledgeville. It was at one time a missionary station among the Cherokees, and now contains the county court-house, jail, and other public offices, etc.

Sprixg Place, p. v., Marshall county, Tenn. : 141 miles $\$$. Nashville.

SPRINGPort, t. and p. o., Jackson county, Mich.: 25 m. S. Lansing. Drained by a branch of Grand $r$. Surface undulating; soil, rich sandy loam, with good timber lands. Pop. In 1840, 294; in 1850, 759 .

Sprivgport, p. v., Panola connty, Miss. : 137 miles $\mathrm{N}$. Jackson.

Sprtig Pramre, to and p. o., Walworth co, Wisc, : $59 \mathrm{~m}$. 8. E. Madison. Drained by Honey creek aud branches.
The $v$, is on the Milwaukie and Elkhorn plank road. Pop. of t. 1,344 .

Sprixg Proge, p. o., Hinds co, Miss. : W. Jackgon.

SPRING RIVEe, p. v., Lawrence co, Mo.: on a branch of the stream so called, 134 m. \$. W. Jefferson City.

Sprive Rock, p. V., Clinton county, Ia. : on Potain creek, and on the line of the proposed roate of the Damanche and Iowa City R. R., 85 m. E. by N. Iowa City.

SPRING Rock, p. v., York dist., S. Car.; on E. side of Fishing cr., $55 \mathrm{~m}$. N. Columbia. The Charlotte and South Carolina R. R. passes near the village.

Spring RuN, p. o., Franklin county, Penn.: 53 m. S. W. Harrisburg.

Springs, p. o., Suffolk co, $N_{0}, Y_{.}: 145$ m. S. E. Albany.

SPRIx gTown, p. v., Hendricks co., Ind. : on Mill cr., $25 \mathrm{~m}$.

W. by S. Indianapolis, The Terre Haute and Richnond

R. R. passes $S$, of this place.

Springtown, v. and sta., Warren $\mathrm{co}_{a}, N$. Jer.: on the New Jersey Central R. R., 68 m. W. from New York city, and $115 \mathrm{~m}$. N. W. Trenton.

Springtown, p. v., Bucks county, Penn.: 84 m. E. N. E Harrisburg.

Springtown, p. o., Polk co., Tenn.: near Focco r., $41 \mathrm{~m}$ S. E. Nashville.

Sprivgtown, p. 0., Oxford co., Me. : 49 m. W. Augusta.

Springrate, p. v., York co., Me.: on a fork of Mousam r., $82 \mathrm{~m} . \mathrm{S}$. W. Augusta.

Sprikgtale, p. 0., Jefierson county, Tenn.: 187 m. F Nashville.

Springrale, p. o., Sampson co., $\boldsymbol{N}_{\text {. }}$ Car.: 49 m. B. S. E Raleigh.

SPRLigrale, p. o., Fairfax co., Virg. : $90 \mathrm{~m}$. N. Richmond. Springtale, t. and p. o., Fond du Lac, Wisc.: $61 \mathrm{~m}$ N. N. E. Madison. Drained by several small streams, Soil excellent, and timber abundant. Pop. 5ss.

Spring VALLET, p. V. and sta., Greene co., Ohio : on the E. side of Little Miami r., and on the Little Miami Branch of Cleveland, Columbus, and Cincinnati R. R., $58 \mathrm{~m} . \mathrm{N}$. E Cincinnati, and $62 \mathrm{~m}$. S. W. Columbus.

Sprive VAlley, p. o, and sta., Rockland co., N. Y.: on the New York and Erie R. P., $11 \frac{1}{3}$ m. W. Piermont, and $105 \mathrm{~m}$. S. by W. from Albany.

Spring Valler, p. o., Bergen co., N. Jer. : 62 m. N. E. Trenton.

Spring Vallet, p. V., Marion co., Ind.: on the W. side of the West fork of White r., $9 \mathrm{~m}$. S. Indianapolis.

Sprivg Valuex, t. and p. 0, Rock co., Wisc.: $31 \mathrm{~m} . \mathrm{s}$ Madison. Drained by a branch of Sugar r., furnishing good water-power. It is a good agricultural town, embracing some of the best prairie land in the State. Pop. 766 .

SPRIFGVIlle, p. $\nabla$. ., St. Clair county, Ala.: 99 m, N. Montgomery.

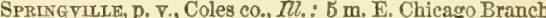
of Illinois Central R. R., and 75 m. E. S. E. Springfield.

Springville, p. v., Crawford co., Wisc.: on a branch of Coosa r., 99 m. N. Montgomery

SpRINGVIlLE, p. v., Lawrence co., Ind.: 61 m. S. S. W. Indianapolis. There is a small spring in this place, from which it derives its name. This pleasant village was first settled in 1816, and it now contains about 250 inbabitants Spriggrile, p. 0, Linn co., Ia. : $21 \mathrm{~m}$. N. Iowa City.

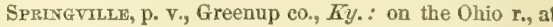
the mouth of Tygert cr., and opposite to Portsmouth, $111 \mathrm{~m}$. above Newport, $114 \mathrm{~m}$. En by N. Frankfort. It contains a foundry, several manufactories, etc. Beds of iron ore of superior quality abound in the vicinity.

SPRINGPILcE, p. V., Lenawee co, Difich.: 55 m. S. S. E. Lansing.

Springrille, p. V., Erie co., N. Y.: on Spring cr, $260 \mathrm{~m}$ W. by S. Albany. Water-power is derived from a spring which rises in the neighborhood. There are in the $\mathrm{v}$. an academy, several manufactories, a tannery, and furnace. The "S. Herald" (whig) is published weekly. 
Sprixaviluk, to and p. v., Susquehanna county, Penn.: 108 m. N. N. E. Harrisburg. Drained by a number of small streams, tributaries of the Susquehanna $r$. Surface hilly; soil fertile. It contains an academy and several manufactories. The $\mathrm{v}$. is centrally situate.

Sprineville, p. v., Utah co., Utah Ter.: 90 m. N. N. E. Fillmore City, It contains a grist mill, a saw mill, and a school, in which the German and French languages are taught. More than 130 fumiles are located here.

SPRINGWATER, to and p. v., Livingston co., $N . Y .: 200 \mathrm{~m}$. W. Albany. Drained by the inlet of Hemlock lake on the $\mathbf{N}$., and the head-waters of Conhocton $\mathbf{r}$. in the $\mathbf{E}$. Surface uneven, and in parts broken; soil adapted to grazing. It contains several manufactories and tanneries. The v. is located on the Buffalo, Corning, and New Fork R. R., $52 \mathrm{~m}$. N. W. Corning. Pop. of t. 2,670.

Sprout Brook, p. o., Montgomery co., N. Y.: $40 \mathrm{~m}$. N. W. Albany.

Sprout Creer, p. o., Duchess co., $N_{0}, Y_{\text {.: }}$ on a stream so called, $74 \mathrm{~m}$. S. Albany.

Sproce, p. v., Vernon co, Mo.: on the S. side of Deep Water er, $105 \mathrm{~m}$. W. by S. Jefferson City.

Spruoe Creer, p. o. and sta., Huntingdon county, Penn. : on the Eastern Division of the Pennsylvania Railroad, $111 \mathrm{~m}$. W. Harrisburg. There is in the vicinity a furnace, with an annual capacity of 1,400 tons, and a bloomery forge, the products of which, in 1850 , was 305 tons.

Spruce Gropk, p. 0., Monroe co., Penn.: 95 m. N. E. Harrisburg.

Spruce Hilt, p. o., Juniata county, Penn. : $35 \mathrm{~m}$. N. E. Harrisburg.

SPRUCE Hill, p. o., Highland co., Virg.: $131 \mathrm{~m}$. N. W. Richmond.

Sprece hill, Plymouth county, Mass. : an elevation in the township of Bridgewater; height, 2,588 feet.

Spur Track, sta., Cheshire county, N. Hamp.: on the Cheshire R. R., 43 m. N. W. Fitchburg (Mass.), and 40 S.W. Concord.

SPUYTEN Turvik, sta., Westchester county, $N . Y$. : on a stream so called, and on the Hudson River R. R., $12 \mathrm{~m} . \mathrm{N}$. from New York Cily Hall, and 139 S. Albany.

Squam lake, $N$. Hamp. This large sheet of water lies on the borders of Holderness, Sandwich, Moultonboro', and Centre Harbor. It is $6 \mathrm{~m}$. in length, and its greatest width is $6 \mathrm{~m}$., and covers a surface of between 6,000 and 7,000 acres, contains numerous islands, and is well stocked with fish. It is $36 \mathrm{~m}$. N. from Concord, and but a short distance from the celebrated "Centre House" at Centre Harbor.

Squam Vilinage, p. V., Monmouth co., N. Jer.: on the S. side of Wreck Pond inlet, 3 S m. E. by S. Trenton.

SQuankus, p. v., Monmouth co., N. Jer.: on S. side of Manasquan r., $82 \mathrm{~m}$. E. by S. Trenton. It is surrounded by a pine forest, and contains a Friends' church and several mills.

Sotanttar Road, sta., Norfolk county, Bfass. : on the Old Colony R. R., 6 m. S. Boston.

Square Poxd, p. v., Tolland co., Conn.: on the W. of a body of water so called, $21 \mathrm{~m}$. N. E. Concord. The pond is situated on the S. line of Stafford township, with an outlet flowing $\mathbb{N}$. into Willimantic river.

Sodatrermule, v., Contra Costa co., Calif: : 25 m. S. by E. Tallejo. Sulphur springs in the ricinity.

SoUAWBFrTr, p. o., Bristol county, Mfass. ; $50 \mathrm{~m}$. S. by W. Boston.

StAatsburg, p. $\nabla$, and sta., Duchess co., $N, Y$. near the Hudson r., on the IIudson River R. R., $85 \mathrm{~m}$. N. New York city, and $60 \mathrm{~S}$. from Albans.

StafFord county, Firg. Situate N. E., and contains 297 sq. m. Drained by Aquia and Potomac creeks, small tributaries of Potomac r. Surface level; soil fertile, and adapted to grain, ete. Chief products, Indian enrn and cotton, tobaceo, etc. Farms 360 manuf, 14, dwell. 922, and pop.wh. 4,415, fr. col. 318, sl. 3,811-total S,044. Capital : Fal- mouth. Public Works: Richmond, Frederick, and Potomac R. R.

STAFFORD, t., p. v., and sta., Tolland co., Conn.: $25 \mathrm{~m}$. N. E. Hartford. Furnace $r$, and Willimantic uniting in this t., and Roaring Branch, afford good water-power. Surface rough, and in parts mountainous, with a very inferior soil. The t. contains several minerals, but bog-iron ore is its principal, and is extensively manufactured. There are several furnaces, forges, tanneries, etc. The manufactures consist of pistols, carpenters' tools, tailors' shears, and other articles of cullery, cotton and woolen, machinery, cabinet ware, and wrought iron. In 1779 a blast furnace was erect ed here, and cannon-shot, hollow-ware, etc., were cast. There are also manufactories of woolen goods, employing S7 hands, and manufacturing 269,000 yards satinet and satinet warps annually; capital $\$ 76,000$. The $\mathrm{v}$. is situated on an elevated plain, with a large square in the centre, and contains several churches. The sta. is on the New London, Willimantic, and Palmer R. R., $50 \mathrm{~m}, \mathrm{~N}$. W. by N. New London. There are two celebrated springs in the $\mathbf{S}$. part of the town. (See StafFrond Springs.) Population of t. 2,941 .

ST $\triangle F F O R D, t$ and p. v., Genesee county, $N . Y_{.}: 228 \mathrm{~m}$ W. by N. Albany. Drained by Allen and Black creeks. Surface even; soll fertile. The water-power is good, and there are several manufactories of woolen goods, leather, etc. The $\mathrm{v}$. is on the line of the Canandaigua and Niagara Falls R. R., and contains several churches. The Buffalo and Rochester R. R. passes through the N. part of the town. Pop. of t 1,973 .

STAFFORD, p. o., Monroe county, Ohio: 107 m. E. by S. Columbus.

STAFFORD C. H., p. v., and eap. Stafford co., Virg.: on the S. W. side of Acquia cr. of Potomae r., $75 \mathrm{~m}$. N. Richmond. It contuins, besides the court-house, a jail and other county buildings.

STAFTORD SPRINGs, p. v., Tolland co., Conn。: 27 m. N. F. Hartford. There are two springs here of different qualities, the existence of which was first made known to the early inhabitants by the Indians, and recommended as eye-water, but gave as their reason for drinking it, that it "enlivened their spirits." One of these springs, and which has been longest known, on a branch of the Willimantic r., contains a solution of iron, sustained by carbonic acid gas; a portion of marine salt; some earthy substances, and an element alled natron or native alkali. This spring has been pronounced by chemists to be one of the most efflcacious of the chalybeate springs in the United States. The other spring, a little W. of the other, as analyzed by Professor Silliman, contains hydrogen gas and sulphur in large proportions, and a small proportion of iron. There is a commo dious hotel here, and it is much resorted to by invalids and others, the former deriving beneficial results from the use of these waters. The situation is one of many attractions. The New London, Willimantic, and Palmer R. R. passing near, and connecting at the latter place with the Western $R$. $R$. gives easy access from Boston, New York, and other places through New England. There are 2 manufactories here for the manufacture of woolen goods, employing 67 operatives; cap. $\$ 64,000$.

Stafrordville, p. o., Tolland co., Conn.: 26 m. N. E Hartford.

Stagrille, p. V., Orange co., N. Car.: on W. side of Flat r., $35 \mathrm{~m}$. N. W. Raleigh.

Staristown, p. 0., Westmoreland co, Penn.: $131 \mathrm{~m}, \mathrm{~W}$. Harrisburg.

STaIrwar Brook, $v$, and sta, Pike co, Penn.: on the S. of Delaware r., and on the New York and Erie R. R., $8 \frac{1}{2} \mathrm{~m}$. W. from Delaware village, $97 \mathrm{~N}$. W. New York city, and $132 \mathrm{~N}$. E. Harrisburg. It has a richly-wooded hill near it, around the base of which the Delaware and Hudson Canal curves.

STAMFord, t., p. v., and sta., Fairfleld co., Conn. : $67 \mathrm{~m}$. 
S. W. Hartford. Bounded on the S. by Long Island Sound. Drained by Mill and Miannus rivers. Surface undulating; soil fertile. Between Shipping and Greenwich points are good harbors for vessels of $\$ \frac{1}{3}$ feet draught of water. There are several ressels owned here, and an active trade is carried on with the surrounding country and New Iork. It is well supplied with mill-sites by Mill and Miannus rivers and there are several manufactories, lumber yards, etc. Th b. is located near the mouth of Mill r., on the New York and New Haven R. R., $36 \mathrm{~m}$. E. by N. New York, and 40 W. from New Haven, and contains several churches, a bank, cap. $\$ 60,000$, several foundries, a wire factory, print ing offices, etc. The "Advocate" is a weekly (whig) issue. Pop. of t. 5,004 .

StavFord, t. and p. v., Delaware co., $N . Y_{.}: 50 \mathrm{~m} . \mathrm{S} . \mathrm{W}$. Albany. Drained by the head waters of the Mohawk or West Branch of the Delaware r. Surface uneven; soil of average fertility. It contains several manufactories of woolen goods. leather, etc. The v. contains several mechanic shops, stores, ete., and is a pleasant place. Pop. of t, 1,70s.

StaAnFord, t. and p. v., Bennington co., Term.: on the Massachusetts line, 108 m. S. W. by S. Montpelier. Drained by the head waters of the Hoosick and Walloomsack rivers. Surface very uneven, lying on the W. border of the Green Mountain range, and poorly adapted to culture. The v. is in S. part of t. Pop. of $t$. S33.

Stavping Ground, p. $v_{\text {. }}$, Scott co., $K y$. : on a branch of Elkhorn ereek, 15 m. E. by N. Frankfort.

Stanardstille, p. v., and eap. Greene co., Virg. : near the Blue Ridge of the Alleghany mountains, 76 miles $\mathrm{N}$. W. Richmond, and contains a court-house, jail, etc. The manufactures are light, principally leather.

Staxdardville, p. o., Carroll co., Tenn.: $89 \mathrm{~m}$. W. by S. Nashville.

Standivg Rock, p. v., Stewart co., Tenn.: $3 \mathrm{~m}$. E. of the Tennessee river, $71 \mathrm{~m}$. W. N. W. Nashville.

STANDING Stone, t. and pe o., Bradford con Penn.: on the left bank of the Susquehanna river, $103 \mathrm{~m}$. N. by $\mathbf{E}$. Harrisburg. Drained by several streams flowing into the Susquehanna r. Surface hilly; soil gravelly loam. It has good water-power, and there are several mills, ete. The N. branch of the Susquehanna Canal passes through the town along the river.

Standise, t. and p. v., Cumberland co., Me.: 69 m.S. W. Augusta. Bounded on the N. by Sebago lake, and on the S. W. by Saco river. There are several small ponds in the towu. It has some water-power, and is a superior farming region. The v. is located near Sebago lake. The Cumberland and Oxford Canal crosses the N. E. part of the town, connecting Sebago lake with Portland, distance $201 \mathrm{~m}$. East Standish and South Standish are names of villages. Pop. of t. 2,290.

Stanford, p. v., Monroe county, Ind.: 52 m. S. S. W. Indianapolis.

STANFORD, p. v., and cap. Lincoln co., $K y_{.}:$on a branch of Dick r., $44 \mathrm{~m}$. N. by W. Frankfort. It contains a courthouse, jail, seminary, etc.

Stanford, t., Duchess county, $N . Y_{0}: 52 \mathrm{~m}$. S. Albany. Drained by Wappinger's cr. Surface hilly and mountainous; soil of average fertility. Wappinger's er. furnishes good water-power, and it has some good mill-sites, and some manufactures of paper. Attlebury, Hull's Mills, and Stanfordville are names of post-offlees. Pop. 2,15s.

Stamfordville, p. v., Putnam co, Ga.: on a branch of Oconee r., $21 \mathrm{~m} . \mathrm{N}$. W. Milledgeville.

Stanfordvilie, p. v., Duchess co., N. Y.: on E. side of Wappinger's cr., $53 \mathrm{~m}$. S. Albany. It contains several churches, and manufactures of woolens. This place is mostly inhabited by Quakers.

STANHOPE, p. v., Sussex eo., N. Jer.: on the N. bank of the Musconetcong river, and on the Morris Canal, $65 \mathrm{~m}$. W. Jersey City, and $47 \mathrm{~m}$. N. from Trenton. A fall in the r. at this point furnishes excellent hydraulic power, and the canal, by an inclined plane, overcomes an ascent of 76 feet. It contains some light manufactures.

Stanhope, p. v., Nash co., N. Car.: on the right bank of Tar r., 33 m. E. by N. Raleigh.

Stanhope, p. v., Monroe county, Penn.: 94 m. N. E. Harrisburg.

Stanislaus, v., San Joaquin county, Calif.: on the right bank of the r. so called, which is the first and largest tributary of the San Joaquin r., $13 \mathrm{~m}$. B. by E. Stockton, and $68 \mathrm{~m}$. S. E. Vallejo. It was laid out by $\mathrm{S}$. Brannan \& Co. on or near the site originally selected for agricultural operations by the Mormons. Both rivers are navigable to this place for vessels of ordinary draft of water. It is the nearest point of navigation to the rich and celebrated Placers of the Stanislaus, Tuolumne, etc., and has already become an important position for the disembarkation of passengers and merchandise destined for the mines.

Stanislaus river, Calif.: rises by 3 forks in the Sierra Nevada, flows westwardly dividing Calaveras and San Joaquin counties from Tuolumne co, and empties into the San Joaquin, at the city so called. It has numerous branches, The banks of the river are rapidly being settled, but little mining is done.

Stanlex county, N. Car. Situate S. centrally, and contains $353 \mathrm{sq} . \mathrm{m}$. Drained by branches of Rocky r, which runs on its southern border. Surface elevated and in some parts hilly; soil fertile, being well adapted to grain and grazing. Chief productions, cotton, tobaceo, wheat, and Indian corn. Farms 515; manuf. 10 ; dwell. 946, and pop.wh. 5,437, fr. col. 49, sl. 1,436-total 6,922. Capital: Albemarle.

STANLey CorNers, p. o., Ontario county, N.Y.: $41 \mathrm{~m} . \mathrm{W}$. from Albany.

SrANTON, p. v., Ifunterdon county, N. Jer.: on the N. of Round Mountain, $24 \mathrm{~m}$. N. by W. Trenton. It contains a church, 3 stures, and 400 inhabitants.

Stantor, p. o., Bracken co., Ky.: 59 m. N. E. Frankfort Stanton, p. v. and sta., New Castle county, Del. : on Red Clay cr., and on the Philadelphia, Wilmington, and Baltimore R. R., $6 \mathrm{~m}$. W. Wilmington, and $37 \mathrm{~m}$. N. from Dover.

Stantonszurg, p. v., Edgecomb co., $N_{0}$ Car.: on Contentnea cr., $48 \mathrm{~m}$. E. by $\mathrm{S}$. Raleigh.

Stantonville, p. v., Anderson district, S. Car. : $90 \mathrm{~m}$. N. W. Columbia. The Greenville and Columbia $R . \mathbf{R}$. passes to the W. of the village.

Stantonvilue, p. v., M.Nairy co., Tenn.: 119 m. S. W. Nashville.

Stanwieh, p. o., Fairfield co., Conn.: $6 \mathrm{~m}$. N. Greenwich sta., on New York and New Haven R. R.; 39 m. W. S. W. New Haven.

SraNwLX, p. o., Oneida county, N. Y.: $101 \mathrm{~m}$. W. N. W. Albany.

Stapleton, p. v., Richmond co., $N . Y_{.}$: on the N. E. side of Staten Island, $2 \mathrm{~m}$. N. of the "Narrows," $7 \mathrm{~m}$. S. S. W. New York, with which it is connected by steambost. It is a small settlement surrounded by delightful scenery, and of much resort, in common with other villages on Staten Island, for excursion parties, etc., from New York. It is chiefly of note from containing the Seamen's Retreat, an hospital for the reception of sick seamen, founded in 1580 , opened Oct. 1st., 1831, and supported from taxes levied by law, upon seamen. The principal building is of rough granite, 208 feet long, 52 feet wide, 3 stories high, with wings 2 stories high, and 32 feet deep, and cost $\$ 100,000$. Attached are 37 acres of land, which cost $\$ 10,000$.

Star, p. o., Assumption parish, La.: $42 \mathrm{~m}$. S. Baton Rouge.

Starfiedd, p. 0., Peoria county, Ill.: $63 \mathrm{~m} . \mathrm{N}$. by W. Springfield.

Star Furnace, p. O., Carter county, Ky.: 99 m. E. Frankfort,

STARK county, Ill. Situate toward the N. W., and con- 
tains 289 sq. m. Spoon r. a tributary of Illinois r., passes centrally through it, by which and its branches it is drained. Surface undulating; soil a deep loam and very productive Staples, wheat and Indian corn. Farms 343; manuf. 23; dwell. 594, and pop.-wh. 3,710 , fr. col. 0-total 3,710 Capital: Toulon.

STARK county, Ind. Situate N. W., and contains 432 sq. miles. Drained by Kankakee $r$. which traverses it N. E. and S. W., and which, in the centre of the county, extends into English lake. Extensive marshes lie on the borders of the river. It may be considered the most impracticable county in the State. Farms 53; dwell. 100, and pop.-wh. 557, fr. col. 0-total 557. Capital: Knox. Public Works: New Albany and Salem extension R. R.; Logansport and Chicago R. R.; Fort Wayne and Chicago R. R., etc.

STARK county, Ohio. Situate toward the N. E., and contains $587 \mathrm{sq} . \mathrm{m}$. Drained by Tuscarawas $\mathrm{r}$. and its affluents. Surface even; soil fertile, and well adapted to wheat, Indian corn, and potatoes, which it produces in abundance. It contains extensive beds of iron ore and mineral coal, and has some quarries of excellent limestone. Pork and beef are exported in large quantities. Timber is abundant Farms 3,177 ; manuf. 294 ; d well. 6,778, and pop.-wh. 39,733, fr, col. 145-total 39,578. Capital: Canton. Public Works: Ohio and Pennsylvania R. R. ; Cleveland and Pittsburg R. R.; Ohio Canal, and Canton Branch Canal.

Stark, t., p. o., and sta., Coos co., N. Hamp.: on S. side of Upper Ammonoosuc r., and on Atlantic and St. Lawrence R. R., $115 \mathrm{~m}$. from Portland: $98 \mathrm{~m}, \mathrm{~N}$. Concord. Surface very uneven and broken. Pop. 418.

Starkey, t., p. o., and sta., Yates co., N. $Y$.: on W. side of Seneca lake, $165 \mathrm{~m}$. W. Albany. Surface elevated and hilly; soil clay loam. Drained by small streams flowing into the lake. The principal $\mathrm{v}$. is Dundee, near which is a brine spring. The Canandaigua and Elmira R. R. passes through, $32 \mathrm{~m}$. from Elmira. Pop. 2,675.

StaRks, to and p. v., Somerset co., Me.: on Sandy r. near its entrance into Kennebec r, 30 m. N. N. W. Augusta. The t. has a fertile soil, and good mill privileges afforded by Sandy r. Pop. of t. 1,446 .

StaRLSBoroter, $t$, and p. $v_{.,}$Addison co., Verm. : $23 \mathrm{~m}$. W. Montpelier. Surface rough and mountainous; soil generally inferior. Drained by Lewis er. and Huntington $r$. which afford water-power. Pop. 1,400.

Starkville, p. v., and cap. Lee co, $G a_{*}$ : on the W. side of Muckalee cr. of Flint r., $107 \mathrm{~m}$. S. W. Milledgeville. It contains a court-house, jail, etc.

Starrvilue, p. v., and cap. Oltibbeha co., Miss. : near the Oktibbeha r., $116 \mathrm{~m}$, N. E. Jackson. It contains the county buildings, ete.

Starkville, p. v., Herkimer co., $N_{.} Y_{0}: 58 \mathrm{~m} . \mathrm{W} . \mathrm{N} . \mathrm{W}$. Albany.

Starlington, p. o., Butler county, Ala.: 68 m. S. S. W. Montgomery.

Starr county, Texo. Situate S., and contains 5,200 sq. m. Drained by ontlet of Salt Lagoon. The Rio Grande flows on its $\mathrm{S}$. W. border. Surface varied, in the N. being undulating and somewhat elevated, but in the S. level; soil near the streams is fertile. The greater portion of the county is one vast prairie, with occasional groves of oak and other trees interspersed. It has excellent pasturage. Capital: Rio Grande City.

StARR, t. and p. o., Hocking county, Olio: 47 miles S. E. Columbus. Drained by head waters of Raceon cr. The Hocking river and canal eross its N. E. part, 27 miles S. E. Laneaster. Surface much broken; soil fertile. Pop. 1,045. Starrspilie, p. .., Newton county, $G a,: 50$ miles N. W. Milledgeville.

Stardcoa, p. V., Wayne county, Penn.: 124 miles N. E. Harrisburg. The Starucea creek flows from this vicinity into the Susquehanna, near Lanesborough, gives name to the Starucca Viaduct of the Erie R. $R_{\text {s, }}$ one of the finest structures of its kind in the world, which here crosses a 818 deep ravine. It is 1,200 feet long, 110 feet high, and has 18 arches with spans of 50 feet. Its body is 24 feet wide, but its top is 30 feet, affording space for a double track. It was completed within one year, and cost $\$ 320,000$.

Stateburg, p. v., and eap. Sumter dist., S. Car.: on a small tributary of Santee r., E. of the Camden Branch R, R., and $30 \mathrm{~m}$. E. Columbia. It contains a court-house, jail, and other public buildings.

State Bridge, p. o., Oneida co., N. Y.: $110 \mathrm{~m}$. W.N. W. Albany.

Stateland, p. 0., Choctaw county, Miss.; 99 m. N. N. E. Jackson.

State Line, p. o., Trumbull county, Ohio: 143 m. N. E. Columbus.

State Line, p. o., M'Henry county, Tll. ; 204 m. N. N. E. Springfield.

State LiNe, p. 0., Walworth co., Wisc. :61 m. S.E. Madison. State Line, p. o., Franklin co., Penn. : 51 m. W. S. W. Harrisburg.

Staten Island, $N . Y$. : lies centrally, $12 \mathrm{~m} . \mathrm{S} . \mathrm{W}$. from the City Hall, New York, and forms Richmond co. It is 14 $\mathrm{m}$. long, from 4 to 8 miles wide, and is divided into 4 townships, containing many pleasant villages. Its surface is agreeably diversified, hilly in the $\mathrm{N}$., and more level in the $\mathrm{S}$. From its hills are afforded the most delightful views to be obtained in the vieinity of New York. The highest elevation is that of Richmond Hill, 307 feet above the bay. The numerous villages upon the shores of the island contain elegant summer country seats of New York citizens, also a large permanent population. Several steamboats ply hourly to New York. The construction of a railroad centrally through the island, and other improvements, have been projected. The fisheries on its borders are very valuable; the amount of market produce raised is also considerable. The Seaman's Retreat, and the Sailor's Snug Harbor are two noble institutions, occupying beautiful locations on its shores. The Quarantine Station for the port of New York is on its N. E. point.

State Rodo, p. 0., Lycoming county, Penn.: 75 miles $N$. Harrisburg.

Statesborougi, $p$. F., and cap. Bullock co., Ga.: at the head or source of Belcher's Mill ereek of Ogechee r., $105 \mathrm{~m}$. E. S. E. Milledgeville. It contains a court-house, jail, ete.

Statevilite, p. v., and cap. Iredeli en., N. Car.: $1 \frac{1}{2} \mathrm{~m}$. N. Third creek, $115 \mathrm{~m}$. W. Columbia, and contains the courthouse and other county buildings.

Statestrlle, p. v., Wilson county, Tenn.: $37 \mathrm{~m}$. E. by $\mathbf{S}$. Nashville.

Statron, p. o., Thomas county, Ga.: 169 miles W. by S. Mrilledgeville.

Staunton, p. o., Granville county, N. Car.: $53 \mathrm{~m} . \mathbf{N}$. Raleigh.

STAUNTON, p. v., Macoupin co., $M U$. : $1 \frac{1}{2}$ m. E. Cahokia cr., and $56 \mathrm{~S}$. Springfield. It is a pleasant $\mathrm{v}$., located on the border of a healthy and fertile prairie.

Stauston, p. v., Fayette county, Ohio: 83 miles S. W. Columbus. Pop. 87 .

STaUntox, p. V., and cap. Augusta co., Firg.: on Lewis creek, and on the Virginia Central R. R., 97 m. W. N. W. Richmond. The land rises from the creek, and the streets, though narrow, are uniformly laid out. The court-house and jail are situated here, the former a neat and commodious edifice. This is one of the oldest villages in Middle Firginia, and the Virginia Central $\mathbf{R}$. R. connects it with the Potomac and James rivers. The village contains a bank, capital $\$ 100,000,4$ churches, an academy, and the Wesiern Lunatic Asylum, a substantial and commodious building. The "Staunton Spectator" (whig), "Republican Vindicator" (dem.), and the "Virginia Messenger" (neut.) are issued weekly. The $\mathrm{v}$. is surrounded by a furttle and well-cultivated country. Pop. about 3,000 .

STEAdY RuN, p. v.; Keokuk co., Ia.: on a branch of Big creek, $37 \mathrm{~m}$. S. by W. Iowa City. 
Stranro at, sta, Chester co., Penn.: on the Philadelphia and Pennsylvania R. P., 26 miles W. Philadelphia, and 80 E. S. E. Harrisburg.

Steam Factoer, p. 0., Muscogee co, Ga.: 105 m. W. S.W. Milledgeville.

STEAM MrL, p. 0, Warren county, Penn.: 160 m. N. W. Harrisburge

Steasrport, p. o., Henderson co., $K y_{.}: 151 \mathrm{~m}$. W. by $\mathrm{s}$. Frankfort.

Steedman's, p. v. Lexington dist., S. Car.: on the E. side of North Edisto river, $27 \mathrm{~m}$. S. W. Columbia.

Strele Creek, p. o., Mechlenburg co., $N$. Car.: 129 m. S. W. Raleigh.

Steel. 's, p. o., Rush co., Ind. : $35 \mathrm{~m}$. E. by S. Indianapolis.

STEELF's, p. v., Anderson dist., S. Car, : between Twentythree and Twenty-six mile creeks, branches of Seneca r., $103 \mathrm{~m}$. N. W. Columbia.

Stgele's Landixg, p. o., Ottawa co., Mich. : 88 m. W. by N. Lansing.

STEErE's Mruls, p. o., Randolph co., Ill. : on the right side of St. Mary's r., 122 m. S. Springfield.

Stenle's Tatern, p. o., Augusta county, Firg.: 99 m. N. W. by W. Richmond.

Sifelevilue, p. 0., Chester county, Penn.: 41 m. S. E. Harrisburg.

Stenl's Pratria, Daviess co., Ind : is a sandy, level, tract of land, in the W. part of the co., $79 \mathrm{~m}$. S. W. Indianapolis. It is named from Nina Steele, the first settler, and contains about 1,000 acres, all in cultivation. Prairie creek passes through it, and flows into the West fork of White $\mathbf{r}$. Steele $\mathrm{v}$. is located on the border of the prairie, and contains about 450 inhabitants.

Steelsvilte, p. V., and cap. Crawford co., Mo.: on the $\mathrm{S}$. side of the Maramec r., 62 m. S. E. Jefferson City. It contains the county court-house, jail, and other public buildings. About $12 \mathrm{~m}$. W. are the Maramec Iron Works, and the country abounds in iron ore.

STEEN's Cretsk, p. o., Rankin county, Mriss.: 15 m. S. E. Jackson.

Steep Botrom, p. 0., Beaufort district, $S$. Car : $99 \mathrm{~m} \mathrm{S.}$ Columbia.

SteirP's Faxts, p. o., Cumberland co., Me.: $56 \mathrm{~m}$. $\mathrm{S} . \mathrm{W}$. Augusta.

Stger Creer, p. o., Gilmer co., Virg. : 213 m. W. N. W. Richmond.

Sterlacoom, p. v., and port, Lewis co., Oreg. Ter.: on Paget's Sonnd, $11 \mathrm{~m}$. N. Fort Nesqually, and $156 \mathrm{~m} . \mathrm{N}$. Salem. The $\mathrm{v}$. at this place is rapidly expanding, and from its position must eventually become important in a commercial point of view. Its exports are chiefly sawed lumber, piles, square timber, shingles, etc., which are purchased for the San Francisco and other Pacific markets.

Stemierstlle, p. o., Carbon co., Penn.: $71 \mathrm{~m}$. N. E. Harrisburg.

STEMmer's RuN, sta., Baltimore co., Md.: on Philadelphia, Wilmington, and Baltimore R. R., $9 \mathrm{~m}$. from Baltimore, $89 \mathrm{~m}$. from Philadelphia.

StepheNs BURGH, p. v., Hardin co., $K y_{\text {.: }}$ on the Nashville and Louisville R. R., $74 \mathrm{~m}, \mathrm{~S}$. W. Frankfort.

STEPHENSON county, $7 l$. Situate N., and contains 536 sq. m. Drained by Pekatonica and its affluents, and small tributaries of Plum river. Surface undulating; soil fertile. A large portion of the land is prairie, interspersed with barrens and oak openings. This county is rapidly increasing in importance. Farms 1,179; manuf. 75; dwell. 1.950 and pop.-wh. 11,658, fr. col. 8-total 11,666. Capital: Freeport, Public Works: Galena and Chicago Union R. R.; Galena Branch of Illinois Central $P_{0}, R$.

STEPHENSON's Depôt, p. O., Frederick co, Firg.: $119 \mathrm{~m}$. N. N. W. Richmond.

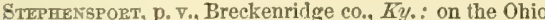
$r$., opposite Rome, at the mouth of Sinking cr., $101 \mathrm{~m}$. below Louisville, $91 \mathrm{~m}$. W. by S. Frankfort. It is a small but handsome village, and a considerable business is done here in shipping the productions of the interior.

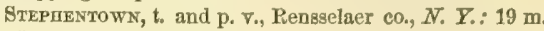
E. S. E. Albany. Surface hilly and mountainous, with a central valley, through which flows Kinderhook r., in 8. E

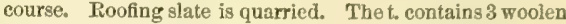
factories, with grist and saw mills. Pop. of t. 2,622 .

Stephensville, p. V., Wilkinson county, Ga.: $18 \mathrm{~m} . \mathrm{S}$. Milledgeville.

Stepnex, p. Y., Fairfield county, Conn : 18 m. W. New Haven.

Stepnex Derôt, p. o. and sta., Fairfield co., Conn.: on the Housatonic R. R., $10 \mathrm{~m}$. from Bridgeport, $17 \mathrm{~m}$. W. New Haven.

Sterlive, t. and p. 0., Windham co, Conn. : 45 m. E. by 8 . Hartford. Watered by branches of Moosup r., which afford water-power. Near its centre is a curious cavern, called the Devil's Den, which has a circular area of about 100 feet in diameter. Pop. 1,205.

Sterlung, p. v., Whitesides co, $I Z l$ : on the right bank of Rock r., $135 \mathrm{~m}$. N. Springileld.

Sterling, p. v., Phillips co., Ark. : on the Mississippi r. at the lower side of the mouth of St. Francis $r_{*}, 48 \mathrm{~m}$. below Memphis (Tenn.), and 96 E. from Little Rock.

STEELING, p. v., Crawford co., Ind.: on Little Blue r. $100 \mathrm{~m}$. S. by W. Indianapolis.

SterLing, t., p. v., and sta., Worcester co., Mass. : $37 \mathrm{~m}$. W. by N. Boston. Surface uneven ; soil moderately fertile. Watered by Still r. The $\mathrm{v}$, at the centre contains 2 churches, and is a station of Fitchburg and Worcester R. R., which connects at Sterling junction, $2 \mathrm{~m}$, below, with Worcester and Nashua R. R. Pop. of t. 1,800.

Sterl.ing, t. and p. v., Cayuga co., N. Y.: $161 \mathrm{~m} . \mathrm{W} . \mathrm{N} . \mathrm{W}$. Albany. Bounded N. by Lake Ontario, from which little Sodus bay, about $5 \mathrm{~m}$. long, extends $\mathrm{S}$. into the $\mathrm{N}$. W. part The $\mathrm{v}$. on Sodus cr. contains a few mills, tannery, and iron foundry. Pop. of t. 2,808.

Stering, t. and p. o., Wayne co., Penn.: $101 \mathrm{~m}$. N. E. Harrisburg. Drained by Waullenpaupack er. and tribntaries, and the Lehigh r., which furnish good water-power Surface hilly; soil gravelly loam. Pop. about 1,000 .

Stering Bottom, p. o., Meigs county, Ohio: $77 \mathrm{~m}$. S. E. Columbus.

Sterlutg Grove, p. o., Greenville dist., $S$. Car.: $95 \mathrm{~m}$. N. W. Columbia.

Sterldyg Hill, p. 0., Windham co., Conn.: $45 \mathrm{~m} . \mathrm{E}$. by S. Hartford.

Sterting Junotion, $\nabla$. and sta., Worcester cn, Mass.: on the Fitchburg and Worcester R. R., at its junction with the Worcester and Nashua R. R., $8 \mathrm{~m}$. N. Woreester, $33 \mathrm{~m}$ S. S. W. Nashua (N. H.), and 38 m. W. Boston

Sterliyg Villagk, v. and sta., Worcester county, Mass. on the Fitchburg and Worcester R. R., $10 \mathrm{~m}$. N. Worcester, and $38 \mathrm{~m}$. W. Boston.

Sterlingville, p. v., Jefierson co, $N_{0} Y_{0}:$ on a tributary of Indian r., $143 \mathrm{~m}$. N. W. Albany. Iron ore abounds in the vicinity, and is extensively Inanufactured in this place.

Sterlingrilize, p. o., Wyoming co., Penn. : 93 m. N. N. E Harrisburg.

Stetson, t. and p. V., Penobscot co., Me.: 53 m. N. E. Augusta. Drained by branches of Sebasticook and Sowadabseook rivers, having their sources in ponds in this Surface undulating, and soil fertile, producing good grain. The $\mathrm{v}$. is on a branch of Sebasticook $r$. The t. has some light manufactures. Pop, of t. 885 .

STEUBEN county, Ind. Situate N. E., and contains 324 sq. m. Drained by Pigeon r. and Crooked and Fish creeks, which are the principal streams; there are also several lakelets in the county. Surface level-one-half well timbered, and the residue barrens and prairies. Farms 586 ; manuf. 28; dwell. 1,109, and pop.-Wh. 6,102, fr. col, 2total 6,104, Capital: Angola.

STEuber county, $N$. $Y$. Situate $\$$, toward the W., and 
contains 1,400 sq. m. Drained by Tioga and Conhocton rivers (which, uniting, form Chemung), and their affluents. Surface pleasantly diversifled with hills and valleys; soil generally fertile, and well fitted for pasture. Chief products, wheat and Indian corn. Considerable quantities of live-stock and lumber are exported. It contains iron ore and some mineral springs. Farms 5,797; manuf. 576; dwell. 11,210, and pop.-wh. 63,409, fr. col. 362-total 63,771. Capital: Bath. Publie Works: New York and Erie R. R.; Buffalo, Corning, and New York R. R.; Buffalo and New York City R. R.; Corning and Blossburg R. R., ete.

STEUBEN, t. and p. v., Washington co., Me. : bordering on the Atlantic Ocean, having Narragaugas bay on the $\mathrm{S}$. E., and Goldsboro' Harbor bay on the S. W., and Dyer's bay and Pigeon Hill bay set up from the ocean on the S., $94 \mathrm{~m}$. E. by N. Augusta. It has several good harbors, and is engaged in the coasting trade and fisheries Incorporated in 1795. The village is on an inlet of Goldsboro' bay. Population of $\mathrm{t} .1,122$.

Steuben, p. 0., Craw ford county, Penn.: 190 m. N. W. Harrisburg.

STEUBEN, t. and p. 0, Oneida co.. $N . Y .: 92 \mathrm{~m} . \mathrm{N} . \mathrm{W}$ Albany. Drained by Cincinnati cr, and tributaries of the Mohawk r. Surface hilly, with excellent soil for grass or grain. It is a good farming town, and butter and cheese are exported. The manufactures are leather and lumber Pop. 1,744.

SteUibe, p. v., Huron county, Ohio: on a branch of Huron r., 78 m. N. $\frac{1}{8}$ E. Columbus. The Sandusky, Mansfield, and Newark R. R. passes to the W. of the v., $1 \mathrm{~m}$. distant.

Steuefirvili, p. v., Steuben co., Ind. : 137 m. N. N. E. Indianapolis.

StedbeNvilte, t., p. v., and cap. Jefferson county, Ohio : on an elevated plain on right bank of the Ohio river, $30 \mathrm{~m}$ above Wheeling, Firg.,122 m. E. N. E. Columbus. Drained by a tributary of the Ohio $r$. The $\nabla$, is neatly and regularly laid out, was incorporated in 1535, and has many fine mansions, several churches, a neat and commodious court-house, and other county buildings, a bank, and considerable manufactures, a rope-walk, boat-yard, and printing offices. The lower story of the court-house is occupied as a market The manufacture of woolen and cotton goods, steam engines, silver-plating, glass, etc., is carried on ; there are also iron and brass foundries. In the vicinity the manufactorie of copperas yield 160 tons per annum. Over a thousand persons are employed in the factories, and the town is fast increasing in importance. Much attention is paid in the neighboring country to the raising of Merino and other superior breed of sheep. Inexhaustible beds of stone coal are found throughout a great portion of this region. The $v$ contains 6,140 inhabitants. It has several academies of reputation, and is amply provided with common schools, etc. The niewspapers published here are the "Messenger" and "Herald," semi-weekly and weekly issues, and the "American Union," a weekly, Steubenville is on the $\mathbf{E}$. and W. line of railroads connecting Pennsylyania and Ohio, and it is also connected with Cleveland on the one hand and Wheeling on the other by an extension of the Cleveland and Pitsburg R. R. The t. of Steubenville in 1810 had 5,208 inhabitants, and in 1850, 7,224 .

Stevensburg, p. v., Culpepper co., Firg.: $61 \mathrm{~m}$. N. by W Richmond.

Stevensor, sta., Jackson co., Ala.: on the Nashville and Chattanooga R. R., 86 miles W. by S. Chattanooga (Tennessee), and $\mathbf{1 7 9}$ miles N. by E. Montgomery. The Memphis and Charleston R. R. will form a junction at this print.

Steven's Praing, p. v., Cumberland county, Me.: $52 \mathrm{~m}$. S. W. Angusta. The Tork and Cumberland R. R. passes this place $2 \mathrm{~m}$. W. Portland.

Steven's Potnt, p. V., Portage co., Wisc.: on the left bank of Wisconsin r., 105 m. N. Madison.
Stefrengrilte, p. O, Bradford co., Penn.: 109 m. N. Harrisbarg.

Stevensville, p. o., Sullivan co., N. Y.: 81 m. B. W. Albany.

Stevensville, p. o., King and Queen co, Firg.: 44 m. E. N. E. Richmond.

Stewart county, Ga. Situate W. toward the S., and contains $683 \mathrm{sq} . \mathrm{m}$. Drained by branches of Chattahoochee river, which bounds it on the W., and by Kitchafoona river and its branches, which enter Flint river. Surface level soil fertile, and produces cotton in abundance. Indian corn and wheat are raised, and there is some fine pasture land; timber is abundant. It contains several valuable minerals. Farms 990 ; manuf. 36 ; dwell. 1,432, and pop.-wh. 8,649 , fr. col. 5, sl. 7,373-total 16,027. Capital: Lumpkin. Pub. tic Works: South-western R. R.

StewArt county, Tenn. Situate $\mathrm{N}$. toward the $\mathrm{W}_{\text {., }}$ and contains 674 sq. m. Drained by Cumberland river and its branches, and by branches of Tennessee river, which forms its western boundary. Surface undulating. The soil consists of a deep mold, and is very fertile. Tobaceo is the staple, but excellent crops of wheat and grain are raised. Its facilities for commerce are great, easy access being bad to the different market towns by means of the rivers. Farms 986; manuf. 33 ; dwell. 1,225, and pop.-wh. 17,017, fr, col. 127, s], 2,575-total 9,719. Capital: Dover.

STEW ART's DRAFT, p. V., Augusta county, Virg.: on W. side of South r, $90 \mathrm{~m}$. W. N. W. Richmond.

Stewart's Ferry, p. o., Davidson co., Tenn.

Stewart's Rov, p. 0., Venango co., Penn.: 168 m. N. W. Harrisburg

Stewart's Sprngg, p. 0., Polk county, Ark. : $109 \mathrm{~m}$ W. by \$. Little Rock. There are several sulphur springs in the vicinity.

Stew ARtstown, t. and p. o., Coos county, N. Hamp.: on the E. side of the Connecticut river, $124 \mathrm{~m}$. N. Concord. Drained on the E. by outlets of Great and Little Diamond ponds, and on the W. by tributaries of the Connecticut $x$. Surface uneven; soil fertile. The Connecticut $r$, at this point is about 15 rods wide. Farming is the chief pursuit. The $\mathrm{v}$, is on a branch of Indian stream. Pop. of $t .747$.

STEW ART8Tow N, p. O., Monongalia county, Firg. : 203 m. N. W. Richmond.

STEWARTstown, p. v., Richmond co., N. Car : on the left bank of Yadkin r., $89 \mathrm{~m}, \mathrm{~S}$. W. Raleigh.

Stewartstown, p. o., York co., Penn.: 33 m. S. by E. Harrisburg.

Stewartstille, p. o, Warren county, $N$. Jer.: $36 \mathrm{~m}$ N. by W. Trenton.

Stewartsyille, p. v, Richmond co, $N$. Car, : on Leith's river, $7 \mathrm{~m}$. S. S. W. Raleigh.

Steit artsville, p. r., Westmoreland co., Penn.: $149 \mathrm{~m}$ W. Harrisburg, The Philadelphia and Pennsylvania $\mathbf{R} . \mathbf{R}$ passes within $2 \mathrm{~m}$. of the village.

Stice"s Sнолт, p. o., Cleveland county, $N$. Car. : $157 \mathrm{~m}$. W. S. W. Raleigh.

Strcklextille, p. 0, Lee con, Virg. : 208 m. W. S. W Pichmond.

Stickoth, p. o., Cherokee co., N. Car. : 312 m. W. by S. Raleigh.

Stilfsboro', p. v., Cass co., Ga. : on the \$. of Etowah river, $129 \mathrm{~m}$. N. W. Milledgeville.

STILESPILle. p. v., Hendricks co., Ind.: on the National Road, 25 m. W. S. W. Indianapolis.

STmL PIVRe, ₹. and sta., Worcester co., MFass.: on the Worcester and Nashua R. R., $23 \mathrm{~m}$. N. by F. Worcester, $32 \mathrm{~m}$. W. N. W. Boston.

Strul Valler, p. v., Warren co., $N$. Jer.: $35 \mathrm{~m}$. N. W. Trenton.

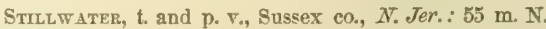
Trenton. Drained by Paulinskill er, and a tributary of it, flowing from Swartout's Pond, in the E. part of the t. Surface hilly; and on the N. W. mountainous, with a fertilt 
soil. It contains several tanneries, mills, ete. The $\mathrm{v}$, is on the N. side of Paulinskill, and contains a church, several mills, etc. Pop. of t. $1, \bar{i}+2$.

Stilltwater, to and p. v., Saratoga co., N. $Y_{0}:$ on the W. side of the Hudson r., $22 \mathrm{~m}$. N. Albany. Drained by Anthony's kill and other small branches of the Hudson river. Surface undulating; soil fertile. In the N. of the town is Bemus Heights, at wheh were fought the celebrated actions of Sept. 19 and Oct. 8, 1777, which led to the surrender of Burgoyne to the American arms under General Gates. The town has good water-power, and there are several manufactories. The Champlain Canal passes through the v., $24 \mathrm{~m}$. from Albany. Pop. of t. 2,y66.

Stillwater, p. O., Columbia co., Penn.: $59 \mathrm{~m}$. N. by E. Harrisburg.

Strllwater, p. v., Tuscarawas co., Ohio: on the N. side of a stream so called, a branch of the Tuscarawas r., $90 \mathrm{~m}$. E. N. E. Columbus. Extensive salt springs are found on the banks of the $r$. in the vicinity of the $v$.

Stuluwater, p. v., and eap. Washington co, Mrinn. Ter.: on the W. side of St. Croix lake, $31 \mathrm{~m}$. N. St. Paul. It receives its name from the circumstance that the current from the St. Croix $\mathbf{r}$. is no longer perceptible at this place. The v. was founded in 1813 , and eontains the territorial penitentiary, three churches-Presbyterian, Baptist, and Episcopal, two mills, one driven by water and the other by steam, two hotels, several stores, groceries. etc., and about 800 inhabitants, who are principally engaged in the lumber trade. The pop. in 1550 was 621 , and has since rapidly increased. A U. S. land office is located here.

Stillwell, p. o, Wood county, Tirg.: 227 miles N. W. Richmond.

STrluwell's, p. O., Butler county, Ohio: 96 m. W. S. W. Columbus.

STIP's Hru, p. V., Franklin co., Ind.: on the right bank of Salt er. of White r., 55 m. E. S. E. Indianapolis.

StrtTville, p. o., Oneida co., N.Y. : 95 m.W. by N.Albany.

Stockbridge, t. and p. v., Berkshire co., Mfass.: $117 \mathrm{~m}$. W. Boston. Drained by Housatonic r. and branches. Surface uneren, with extensive alluvial meadows; soil generally fertile, especially on the streams. Marble and limestone are found in large quantities. It has extensive hydraulicpower, and there are several manufactories of woolens, cotton goods, leather, ete. The "Centreville Manufacturing Company" manufacture 624,000 yards eloth per annum, and employ 96 operatives; cap. $\$ 100,000$. There is also a furnace and several mills here. The $\nabla$. is pleasantly located on a plain, on the $\mathbf{N}$. side of Housatonic r., and contains several churches, a bank (cap. $\$ 100,000$ ), and an academy. The Housatonic R. R. passes through the v., $17 \mathrm{~m}$. S. Pittsfield. Pop. of t. 1,940.

Stock BRIDGe, t. and p. 0., Ingham en., Mich.: 25 m. S. E. Iansing. Drained by branches of Huron and Grand rivers. Pกp. 657.

STOckвrTpge, t. and p.. ., Windsor co., Term.: $36 \mathrm{~m}$. S. by W. Montpelier. Drained by White $r$., which passes through it, affording good water-power, and a branch of Tweed r. Surface uneven; soil well adapted to the growth of grass. Steatite or soapstone is found in considerable quantities. It eontains several manufactories of woolens, leather, ete. The $\mathrm{v}$. is on the $\mathrm{N}$. side of White river. Pop. of t. 1.327 .

STOckBridge, p. v., Henry co., $G a_{0}:$ on a head branch of the Oemulgee r., $71 \mathrm{~m}$. N. W. Milledgeville.

STOckrrmge, to and p. v., Madison co, N. Y.: $100 \mathrm{~m}$. W. by N. Albany. Surface uneven, with a fertile and, in general, well-cultivated soil. Drained by Oneida creek. It has excellent water-power, and contains several manufactories. The $v$. is located on Oneida cr., and contains several ehurches and an academy. Pop. of t. 2,081.

STOCKBrIDGE, p. v., Calumet co., Wisc, : on the E. side of Winnchago lake, $91 \mathrm{~m}$. N. E. Madison.

Brock CeEer, p. v., Soutt co., Firg. : on a cr. so called,
$293 \mathrm{~m}$. W. S. W. Richmond. At this place thern is a re. markable natural tunnel, through which the cr. flows.

Btockerton, p. o, Northampton county, Penn.: 85 m. N. N. E. Harrisburg.

Sтоскноцх, p. o., Sussex co., N. Jer.: 54 m. N. Trenton. Stockhols, t., p. v., and sta., st. Lawrence $0_{n}, N . Y_{*}$ $152 \mathrm{~m}$. N. W. Albany. Drained by St. Regis river and branches, and a branch of Racket river. Surlice hilly and somewhat stony; soil fertile and heavily timbered. There are some manufactures, consisting of flour, lumber, fulled cloths, potash, and leather. The village is on the Northern (Ogdensburg) R. Ro, $82 \mathrm{~m}$. W. by S. Rouse's Point. Pop. of $t .3,661$.

Stockport, t., p. v., and sta., Columbia co., N.Y.: on the E. side of the Hudson river, $24 \mathrm{~m}$. 8 . Albany. Drained by Kinderhook ereek, flowing into the Hudson river. Surface uneven; soil fertile. Columbiaville is a manufacturing v. The t. contains several manufactories of woolen and cotton goods, leather, paper, flour, ete. The $v_{0}$ is on the Hudson River R. R., $24 \mathrm{~m}$. S. Albany, and $121 \mathrm{~m}$. N. from New York city. Pop. of t. 1,655.

STOCK PoRT, p. o., Morgan county, Ohio: $65 \mathrm{~m}$. E. by S. Columbus.

Stockport Station, p. v. and sta., Delaware co, $N, Y$.: on the E. side of the Delaware r., on the New York and Errie R. R., 169 m. N. W. New Fork eity, and $94 \mathrm{~m} . \mathrm{S} . \mathrm{W}$. (direct) Albany. Its location is in a pleasant bend of the r., 3 miles below the junction of the Mohawk and Popacton branches, and it is important as a lumber depôt, large quantities of which is manufactured in the neighborhood.

Stocksville, p. v., Buncombe co., N. Car.: on S. side of Ivy $r_{0,} 219 \mathrm{~m}$. W. Raleigh.

Stockton, p. v., Baldwin county, $A l \alpha_{*}$; on the E. side of Tensaw river, 25 miles N. E. Mobile, and $137 \mathrm{~m}$. S. W. of Aiontgomery.

Stockтon, p. o, Madison co, F'lor : 45 m. E. Tallahassee. Stockton, t. and p. o., Chautauque co., N. Y.: $12 \mathrm{~m} . \mathrm{S}$. Dunkirk, and $296 \mathrm{~m}$. W. by S. Albany. Bear and Cassadaga lakes are in the N. part, by the outlets of which the town is drained. Surface even; soil fertile. It has excellent waterpower, and several light manufacturs. Pop. 1,612.

Stockтox, p. v., and cap. San Joaquin co., Calif.: on the Stockton slough or canal (which contains the "back waters" formed by the junction of the Sacramento and San Joaquin rivers) about $3 \mathrm{~m}$. frorn its junction with the San Joaquin, $100 \mathrm{~m}$. E. by water from San Francisco, and $59 \mathrm{~m}$. direct from Vallejo. This is one of the prineipal cities of the State, ranking next to San Francisco and Sacramento. First settled in 1844, by C. M. Weber, who obtained a grant from the then governor of California for a large section of country; made a pueblo in 1845 , when there were seven residences, and was abandoned in the succeeding year. In $18 t 8$ the settlement was successfully established, and in 1819 it was a canvas city of 1,000 inhabitants, with a fleet of merchant vessels lying before it. The Stockton slough is divided into three branches; the city occupies the peninsula between the two northern, and extends also $\mathrm{S}$. to the third branch. The ground on which it is built is high, and not subject to overflow, and is in the centre of the two great tracts of arable land which eonstitute the valleys of the San Jorquin and Sacramento rivers. The San Joaquin is narigable at all seasons to this place for vessels drawing not over nine feet of water, and such is the peculiar formation of the bank that they can lay directly along it and discharge their cargoes. It is the depott for the supply of all the southern mines, and every thing indicates that this point is destined to become one of the great inland marts of this wonderful and growing country, and it is believed by some that it will outstrip all its rivals in the race of prosperity. The largest-sized brigs and schooners, and a great number of launches, ete., are engaged in the carrying trade, and steamers ply here regularly. The mines are situated among the hills and mountains forming the western slope of the Sierra Nerada, com- 
mencing some $20 \mathrm{~m}$. E. of the city, and extending thence $\mathrm{E}$, to the banks of the river. Two papers are published, and a military post is located here. A State hospital is erecting, which will be an ornament to the city. Pop. 3,000. STODDARD county, Mo. Situate S. E., and contains 937 sq. m. Drained by White Water $r$, and numerous outlets of the different lakes which cover a large portion of the co. Surface varied; in the $\mathrm{N}$. it is much broken, but in the $\mathrm{S}$. level and marshy; soil in general is good, and the swampy portions when cultivated are rendered fertile and productive. Farms 41s; manuf, 2; dwell. 719 , and pop,-wh. 4,221, fr. col. 6, sl. 50-total 4,277. Capital: Bloomfield. Stopdard, t. and p. v., Cheshire co., N. Irump.: $31 \mathrm{~m}$. S. W. Concord. There is a large number of ponds in the town. Drained by tributaries of the Merrimac on the E., and of the Connecticut $r$. on the W. Surface mountainous and very rocky; soil adapted to grass. Incorporated in 1774. There is some leather and lumber manufactured here. The $\mathrm{v}$, is in the N. part. Pop. of t. 1,100.

Stoddaristrie, p. v., Monroe co, Penn.: on the bank of the Lehigh r., $85 \mathrm{~m}$. N. E. Harrisburg.

Stokrs county, N. Car. Situate N. toward the W., and contains $72 S$ sq. m. Drained by Dan $\mathrm{r}$. and tributaries, and branches of Yadkin r. Surface diversified, the greater part of it being hilly; soil fertile, and making good pasture land. Chief productions, cotion and tobacco, wheat, and Indian corn. Farms 591; manuf. 34; dwell. 1,265, and pop.-wh. 7,264 , fr. col. 149, sl, 1,793-total 9,266. Capital: Germanton.

StoKes, p. 0., Oneida co., N. Y.: 104 m. N. W. Albany.

SToNe county, Mo. Situate S. toward the W., and contains 477 sq. m. Drained by James r., and Buffalo fork of White r. Surface unduluting; soil fertile, and produces wheat and Indian corn in abundance; it is also well adapted to the growth of tobaceo. Apple, pear, peach, and other fruit-trees are grown, and yield excellent fruit. Pine and other timber abounds.

Store Arabia, p. v., Montgomery county, N. Y.: about $4 \mathrm{~m}$. N. of the Mohawk river and $44 \mathrm{~m}$. W. N. W. Albany. This is one of the oldest settlements in the county, and in October, 1780, was the scene of a bloody conflict between the English and Americans, in which, through treachery and unequal numbers, the latter were defeated. It contains a Dutch Reformed church erected in 1788, and a Lutheran church built in 1791.

Stone Crurch. p. o., Genesee co., $N$. Y.: $224 \mathrm{~m}$. W. by N. Albany. The Buffalo and Rochester R. R. passes near this place.

Stone Church, p. o., Northampton county, Penn.: S5 m. E. N. E. Harrisburg.

Stose Creek, p. o., Tuscarawas co., Ohio: $69 \mathrm{~m}$. N. E. Columbus.

Sroxemar, t., p. $v_{\text {., }}$ and sta., Middlesex co., Drass.: $7 \mathrm{~m}$. $\mathrm{N}$. Bostun. There is a pond in the $\mathrm{S}$. part covering about 283 acres. Surface uneven and rocky; soil fertile and well wooded. The clief manufacture here is shoes, at which nearly two-thirds of the inhabitants are employed. The $y$. is centrally located, and entains several ehurches. The station is on the Boston and Maine R. T., $8 \mathrm{~m}$. . . Bostou. Pop. of t. 2,0 S5.

Stoxe Lick, p. 0, Randolph county, N. Car.: $71 \mathrm{~m}$. W. Riandoly.h.

Stove Mruts, p. o., Jefferson co, $N_{0} Y_{0}: 153 \mathrm{~m} . \mathrm{N}$. W. Alliany.

Stone Mountats, p. o. and sta., De Kalb co., Ga.: on Georgia R. R., 12 m. E. N. E. from Atlunta, $81 \mathrm{~m}$. N. W Milledgeville.

Stone Mountain, p. O., M'Dowell co., $N_{0}$ Car.: $198 \mathrm{~m}$ W. Tialeigh.

Srosirn, p. o, Seneca co, Ohio: $75 \mathrm{~m}$. N. $\frac{1}{3}$ W. Columbus, Stone Rider, p. v., Ulster eo., N. Y.: $1 \mathrm{~m}$. N. Rondout kill, $64 \mathrm{~m}$. S. S. W. Albany.

Stoner's Pratrie, p. o., Dane co., Wise. 822
StONER's Store, p. o., Roanoke co., Virg. : $187 \mathrm{~m}$. W. by S. Richmond.

Stonerstown, p. v., Bedford co., Penn: on E. bank of Rayston branch of Juniata $r_{0}, 71 \mathrm{~m}$, W. Harrisburg. Broad Top Mountain is in its vicinity.

Stonersville, p. o., Berks co., Penn.: 51 m. E. by N. Harrisburg.

Stonesvilue, p. v., Greenville dist., S. Car.: on a tributary of Ennoree r., $83 \mathrm{~m} . \mathrm{N}$. W. Columbia.

Stone Wall Mill, p. v., Appomattox co., Firg.: on James r. and canal, $15 \mathrm{~m}$. below Lynchburg, and $131 \mathrm{~m}$. W. by $\mathrm{S}$. from Richmond by canal, and $71 \mathrm{~m}$. direct.

Stonifgton, $t_{\text {s, }}$ p. b., and port of entry, New London co., Conn.: 51 m. S. E. Hartford, 53 m. E. New Haven. Bounded S. by Long Island Sound, E. by Pawcatuck r., separating it from Rhode Island, and W. by Mystic r., both of which afford water-power. ${ }^{x}$ This is a large $t$, with rocky and uneven surface, but moderately fertile soil, and contains three villages. The borough is on a narrow and rocky point of land, extending about $\frac{1}{3} \mathrm{~m}$. S. into the sound. The harbor is protected by a break-water, constructed by the United States government at a cost of $\$ 50,000$. It is handsomely laid out, well built, and was incorporated in 1801. Its citizens are noted for commercial enterprise, especially in the whaling and scaling business, in which a large aggregate capital is employed. Many vessels are owned here, which bring their cargoes into New York and other ports. It has a marine railway and lighthouse at the entrance of the harbor, etc. The total tonnage of Stonington district on 30th June, 1850, was 19,913 tons. The registered tonnage amounted to 18,189 tons, and all permanent, of which S,S61 tons were in the whale fishery. The enrolled and licensed tonnage amounted to 6,724 tons, consisting of 6,102 tons permanent, 144 tons temporary, employed as follows-coasting trade, 4,020 tons; cod fishery, 1,655 tons; mackerel fishery, 571 tons; steam navigation, 67 tons ; and the tonnage "licensed under 20 tons," viz.: 89 tons in coasting. trade, 359 tons in cod fishery. The number of clearances for foreign countries during the year preceding was $9-2,591$ tons; number of entrances do. $10-2,894$ tons. The number of ressels built during the year was $9-1,034$ tons; viz., 2 ships, 1 schooner, 5 sloops, and 1 steamer. During 1819 the whale fishery imports of Stonington were-1,628 bbls. of sperm oil, 15,334 bbls. whale oil, and $97,500 \mathrm{lbs}$. whalebone. The town contains several manufactories, of which three are extensively engnged in making plaid and plain linseys, etc. The b. contains 2 banks, with aggregate capital of $\$ 160,000,1$ savings bank, 2 academies, 4 churches, etc Here commences the Stonington R. R. to Providence, $50 \mathrm{~m}$, connecting with daily steamboats to and from New York. This place is of considerable resort in summer. The Waddawannuck House, the chief fashionable hotel, is kept in first-class style. Pop. of t. in 1810, 8,598; in 1850, 5,484. Stonivgton, p. V., Christian co, $I l_{*}$ : on the S. fork of Sangamon r., $29 \mathrm{~m}$. S. E. Springfield.

Stony Brook, sta., Middlesex co., Mass. : on Fitchburg R. R. $12 \mathrm{~m}$. from Boston.

SToNy Brook, p. v., Suffolk county, $N$. $Y$.: on N. side of Long Island, $122 \mathrm{~m}$. S. S. E. Albany. It has a good harbor, accessible at all seasons of the year, and carries on shipbuilding, with some manufactures. Pop. about 400 .

Stony Creek, p. o., Warren co., N. Y.: 54 m. N. Albany. Stony Creek, sła., New Haven county, Conns: on New Haven and New London R. R., 11 m. from New Haven, $39 \mathrm{~m}$. from New London.

Stony Creek, t. and p. o., Somerset co., Penn.: $108 \mathrm{~m}$. W. by S. Harrisburg. The Alleghany Mountain is on its E. border. Drained by Stony cr. and branches. Surface mountainous, with fertile valleys. Iron ore is abundant. It contains numerous saw-mills, with a few tanneries, gristmills, etc.

Stosy Cresk, p. o., Soott co., Firg.: 290 m. W. S, W 
Stovт Fork, p. o., Amherst county, Firg.: $90 \mathrm{~m}$, W. Richmond.

Stony Fork, p. o., Wautauga co., N. Car.: 157 m. N.W. Paleigh.

Stonx Hru, p. o., Richmond co., Fing.: 47 m. E. N. E。

Richmond.

Stony Mount, p. o., Brunswick co., Virg. : 67 m. S. by W. Richmond.

Stony Pornt, p. o., White co., Ark. : 49 m. N. E. Little Rocks.

Stony Poirt, p. o., E. Baton Rouge par., $L a$.

Stony Point, p. o., Alexander. co., N. Car.: $129 \mathrm{~m} . \mathrm{W}$. Ralejgh.

Stony Ponvt, Rockland co., N.Y.: is a high rocky promontory at the head of Haverstraw bay, in Hudson r., on which was a fort during the Revolutionary War, bravely taken by storm from the British on the night of July 16th, 1779, by the Americans under Gen. Wayne. A lighthouse has been erected on the site of the old fort.

Stony Pornt, p. v., Abbeville district, S. Car.: $65 \mathrm{~m}$. W. N. W. Columbia.

Stony Point, p. o., Bradley county, Tenn.: 125 m. S. E. Nashville.

Stonx Polvt, p. o., Albemarle co., Virg.: 67 m. W.N.W. Richmond.

-Stony Pont, p. 0., Jackson co., MFo. : 120 m. W. by N. Jeffersnn City.

Stony Ponst Mruis, p. v., Cumberland co., Virg.: on W. bank of Appomattox r., $42 \mathrm{~m}$. W. by S. Pichmond.

Stoxy RIDGe, p. v., Wood co., Ohio: at the source of a stream flowing $N$. E. into Lake Erie, $107 \mathrm{~m}$. N. by W. Columbus.

Stovy Pidge, p. o., Surry co., N. Car.: 121 m. N. W. Raleigh.

Stony RuN, p. o., Genesee co., Mich.: 46 m. E. N. E. Iansing.

Storeville, p. v., Anderson dist., S. Car. : $5 \mathrm{~m}$. E. of the Savannah r., $121 \mathrm{~m}$, W. by N. Columbia.

Stormertle, p. o., Duchess county, $N_{.} Y_{.}: 1 \mathrm{~m}$. S. of the

Fishkill, $78 \mathrm{~m}$. S. Albany.

STORR's, p. o., Hamilton county, Ohio: 96 m. S. W. Columbus.

StorR's, sta, Henrico county, Virg.: on Virginia Central Railroad, $6 \mathrm{~m}$. N. by E. Richmond.

STORx county, $I c$. Situate centrally, and contains 576 sq. m. Drained by Skunk r. and its tributaries. Surface undulating; soil fertile, and consists of a deep black mold, adapted to wheat and grain, and favorable to the cultivation of fruit, apples, pears, and peaches of good quality being produced. Erected since 1850.

Storx, p. O., Ogle co., Ill.; $155 \mathrm{~m}$. N. by E. Springfield. Stotcirbura, p. o., Berks county, Penn.: 35 m. N. E Harrisburg.

Stougristown, p. v., Cumberland county, Penn.: $29 \mathrm{~m}$. W. S. W. Harrisburg.

Stojghton, t., p. v., and sta., Norfolk co., Mass. ; $18 \mathrm{~m}$. S. Boston. Drained by head branches of Neponset $r$. The v. contains 1 woolen and 2 cotton factories, and 4 churches Here terminates the Stoughton Branch R. R., $4 \mathrm{~m}$. long, which connects with Boston and Providence P. R. at Canton. The $r$. and $t$. are noted for the manufaeture of boots and shoes. The Fall River R. R. touches the E. border of the t. at East Stoughton. Pop. of to in 1840, 2,142; in 1850, 3,594 .

Stovghton, t. and p. o., Dane co., Wise. Pop. 70.

StouT's, p. o., Adams county, Ohio: $79 \mathrm{~m}$. S. by W. Columbus.

Stotr's, p. o., Northampton county, Penn.: 83 m. N. E. Harrisburg.

STOUT's Grove, p. o, M'Lean county, Ill.: in N. W. corner of county, $57 \mathrm{~m} . \mathrm{N}$. N. K. Springfield.

STOVER, p. 0, Dallas county, Ark.: $55 \mathrm{~m} . \mathrm{S}$. by W. Littie Pock
Stovere's Puane, p. o., Centre co., Penn $: 67$ m. N. W. Harrisburg.

Stovertowa, p. o., Muskingum county, Ohio: $51 \mathrm{~m} . \mathrm{E}$. Columbus.

STow, t. and p. v., Oxford county, Me. : $68 \mathrm{~m}$. W. by S. Augusta, Bounded W. by New Hampshire. It contains several ponds, the outlets of which flow into Saco r. Pop. of t. 471.

Stow, t. and p. O., Middlesex co,, Mass, : 24 m. W. by N. Boston. Drained by Assobet river, which affords waterpower. The t. contains several grist and saw mills, and has considerable manufactures. The Lancaster and Sterling Branch R. R. (from South Acton, on Fitchburg R. R. to Feltonville) runs upon its E. border. Pop. 1,455.

Sтоw, t. and p. v., Summit county, Ohio: $111 \mathrm{~m}$. N. E. Columbus. Drained by Cuyahoga $r$ and one of its branches, affording excellent water-power. Surface rolling; soil fertile, and in a good state of cultivation. The Pennsylvania and Ohio Canal crosses the S. part, and the Akron Branch of the Cleveland and Pittsburg R. R. passes through the $\mathrm{v}$. Bituminons coal of a superior quality is found in the $\mathrm{S}$. W. of the town. It has several stores, mills, ete. Population. of $t, 1,702$.

Stow, t. and p. v., Lamoille eo., Verm.: 16 m. N. N. W. Montpelier. Surface level; soil fertile. Drained by Waterbury $r$. and its branches, which flow $\mathrm{S}$. into Onion $\mathrm{r}$., and afford water-power. The $t$, contains a woolen factory, 2 tanneries, and mills of various kinds. Pop. of $t, 1,771$.

STowelL's CorNers, p. o., Jefferson county, N. Y.: $152 \mathrm{~m}$ N. W. Albany.

Stow's Ferry, p. 0., Tallapoosa co., Ala.: 42 m. N. E Montgomery.

STow's SQUARE, p. o., Lewis co., N. Y.: 128 m. N. W Albany.

Sтонstillz, p. o., Gaston co., N. Car.: 133 m. W. S. W Raleigh.

Stoyestown, p. v., Somerset co., Penn.: on W. side of Stuny cr., $107 \mathrm{~m}$. W. by \$. Harrisburg. Near the v, are furnaces; annual capacity 700 and 1,400 tons; and a forge producing annually 30 tons bar iron. The village has some other manufactures, mills, etc.

StrabaNe, p. v., Lenoir co., $N$. Car.: on the S. side of Neuse r, 63 m. S. E. Columbia.

StrabaNe, t. and p. o., Washington co., Penn.: $170 \mathrm{~m} . \mathrm{W}$ Harrisburg. Drained by Chartiers and Little Chartiers creeks, uniting on its $\mathrm{N}$. W. boundary. Surface uneren soil fertile. It contained in 1850,8 schools and 200 scholars, male and female. Pop. about 1,250 .

Strafrord county, N. Hamp. Situate toward the S. E. and contains $408 \mathrm{sq.} \mathrm{m}$. Drained by Lamprey, Isinglass, and Cocheco rivers. Surface various, and diversified with small ponds; soil in most parts fertile, and producing good cropg of grain, etc. Agriculture is much attended to by a large number of the population. Chief products, wheat, Indian corn, and potatoes. Farms 1,844; manuf. 394; dwell. 4,764, and pop.-wh. 29,327, fr. col. 37-total 29,364. Capital: Dover. Public Works: Cocheco R. R.; Great Falls and Conway R. R. ; Boston and Maine R. R.

StrafFord, t. and p. v., Strafford co., N. Hamp. : $20 \mathrm{~m}$. E. by N. Coneord. Blue Hill crosses its N. part. Drained in its N. part by branches of Suncook r., and in S. part by Isinglass $\mathrm{r}$., flowing from Bow Pond, in its S. W. part (2 m. long, $1 \frac{1}{4} \mathrm{~m}$. wide), into Cocheco $\mathbf{r}$. The $t$. has generally a fertile soil, abounds with fine scenery, and contains four churches. Pop. of t. 1,920.

StrafTord, t. and p. V., Orange co., Verm.: $31 \mathrm{~m}$. S. S. E Montpelier. Surface uneven; soil fertile. Drained by a branch of Ompompanoosuc r., which affords water-power. In the S. E. corner is a bed of sulphuret of iron, half a mile long, 3 rods wide, and of unknown depth, from which large quantities are annually taken. The principal company engaged in the manufacture of copperas therefrom has a capital of $\$ 10,000$. Pop. of t. 1,516 . 
StrafroRd Corner, p. o., Strafford co., N. Hamp.: $22 \mathrm{~m}$. E. by $N$. Concord.

Straight Fork, p. o, Campbell county, Tenn.: 137 m. E. by N. Nashville.

Strait's Lake, p. o., Oakland co., Mich. : 59 m. E. by S. Lansing.

Strattovilue, p. o., New Haven co., Conn.

Stratrstille, p. v., Perry county, Ohio: 48 m. S. E. by E.

Columbus. In its vicinity (in Salt Lick t.) are found immense deposits of bituminous coal, some of the strata of which have been found to be 90,112 , and 138 feet deep. A vein of carbonate of iron is found $10 \mathrm{~m}$. S. of this coal-bed.

Strasberg, p. F., Tuscarawas county, Ohio: on the W. side of a branch of the Tuscarawas river, $84 \mathrm{~m} . \mathrm{N} . \mathrm{E}$. Columbus.

Stragburg, t. and p. v., Laneaster co., Penn. : 43 m. S. E. Harrisburg. Drained by Little Beaver er. Pecquea cr., on its $N$. and W. boundary, affords valuable water-power; and on its bank are several mill-seats. Surface hilly; soil fertile, and much grain is raised. The $\mathrm{v}$, is $2 \mathrm{~m}$. W. Mine Ridge Mountain, and contains an academy and several stores. Pop. of t. 4,734.

Strasburg, sta., Blair co., Penn. : on the Baltimore and Susquehanna R. R., $43 \mathrm{~m}$. S. Harrisburg, and $39 \mathrm{~m} . \mathrm{N}$. Baltimore.

Strasburg, p. v., Shenandoah co., Virg.: on N. branch of Shenandoah r., 109 m. N. N. W. Richmond. The inhabitants are chiefly of German origin. The v. contains 3 churches, several mechanic shops, stores, etc., and is on the line of the Manassas Gap R. R. Pop. 600.

Strata, p. 0., Montgomery county, Aca.: 72 m. S. S. E. Milledgeville.

STRATFORD, t, and p. o., Fulton county, $N_{0} Y_{\text {.: }} 56 \mathrm{~m}$. N. W. Albany. Surface hilly; soil best adapted to grazing. Drained by East Canada creek and its branches, upon which are numerous saw-mills. Fish lake on its E, border is a handsome sheet of water. Pop. 801

Stratford, t., p. v., and sta., Fairfield county, Conn. : on W. side of Housatonic r., at its entrance into Long Island Sound, 14 m. S. W. New Haven. Lat, $41011^{\prime} 07^{\prime \prime}$ N. ; long. $73^{\circ} 0 \mathrm{~S}^{\prime} 45^{\prime \prime} \mathrm{W}$. Surface generally level; soil fertile, especially on the $\mathbf{r}$. and harbor. The village is chiefly one street $1 \mathrm{~m}$. long, parallel to the $\mathrm{r}$, and pleasantly ornamented with shade trees, and contains 5 cburches, an academy, etc. The Episcopal church was founded in 1723, and is the oldest of the denomination in the State. The t. has considerable inland and coasting trade. The New York and New Haven R. R. passes through the $\mathrm{v}, 62 \mathrm{~m}$. from New York, $14 \mathrm{~m}$. from New Haven, and with it the Naugatuck R. R. connects at Stratford Junction, $1 \mathrm{~m}$, from the $\mathrm{v}$. Pop, of $\mathrm{t}$. in $1840,1,808$; in $1850,2,040$.

Stratford, p, o, Delaware county, Ohio: 19 m. N. Columbus.

Stratford, t., p. o., and sta., $\operatorname{Coos}$ con, N. Hutmp. : on E. side of Connecticut r., $106 \mathrm{~m}$. N. Concord. Surface rough; soil mostly sterile. Drained by small streams. The Atlantic and St. Lawrence $\mathrm{R}$. R. runs along the r., having stations at Stratford Hollow, $127 \mathrm{~m}$; and North Stratford, $184 \mathrm{~m}$. from Portland. Pop. in 1840, 441; in 1850, 552.

Stratzas, t., p. V., and sta., Rockingham co., $N$. I Iamp. 34 m. E. S. E. Concord. Bounded W. by Squamseot or Exeter r. flowing into Great bay. Surface level; soil generally fertile. The inhabitants are chiefly engaged in farming. In its E. part is a large peat swamp. The Portsmouth and Concord $R$. R. passes through, $8 \mathrm{~m}$. from Portsmouth, $39 \mathrm{~m}$. from Concord. Pop. 843.

StratToN, t. and p. o., Windham county, Verm. 90 miles $\mathrm{S}$. by $\mathrm{W}$. Montpelier. This is a mountainous town bordering on the Green Mountain Range, with poor soil, Pop. 286.

Stratron's Falts, p. 0. Delaware county, $N_{\text {. }} Y .: 78 \mathrm{~m}$. W. S. W. Albany.

Stbatron plule, p. v, Clarion co., Penn.: 144 m. N. W. 824
Harrisburg. There is a steam furnace in the vicinity, with an annual capacity of 1,850 tons.

Straustows, p. v., Berks county, Penn.: 39 m. N. E Harrisburg.

Strawberry Platis, p. vi, Jefferson co., Tenn : on $\mathbf{S}$. side Holston r., $171 \mathrm{~m}$. E. Nashville. The E. Tennessee and Virginia R. R. passes through the village.

Strawbrtoge, p. 0., Tork county, Penn. : 35 m. S. \$. E. Harrisburg.

Straw TowN, p. v., Hamilton county, Ind.: on E. bank of White r., $25 \mathrm{~m}$. N. by E. Indianapolis. It was once an Indian town, and derives its name from a house in it, thatched with straw. It is pleasantly located, and contains about 200 inhabitants.

Streetsboro', t. and p. v., Portage county, Ohio: $117 \mathrm{~m}$. N. E. Columbus. Surface gently uneven. Drained by Cuyahoga $r$, and one of its branches. The Cleveland and Pittsburg R. R. passes across the S. W. corner of the town. Pop. of t. 1,108.

Street's Run, p. v., Alleghany co., Penn. ; on Mononga hela r., 4.m. S. E. Pittsburg; $157 \mathrm{~m}$. W. Harrisburg. Strickerstille, p. v., Chester county, Penn.: on a small stream flowing $\mathrm{E}$. into the Delaware river, $67 \mathrm{~m} . \mathrm{S}$. E. Harrisburg.

STRTokLAND's, p. o., Ware county, Ga.: 114 m S. S. E. Milledgeville.

STrickland's Depôt, p. v. and sta., Duplin co., $N$. Car. : on the Wilmington and Weldon R. R., $37 \mathrm{~m}$. S. Goldsboro', and $87 \mathrm{~m}$. S. S. E. Raleigh.

Striokland's Ferry, sta., Kennebec co., Me. : on Androscoggin river and $R . R ., 12 \mathrm{~m}$. from Leeds sta., $21 \mathrm{~m}$. W. Augusta.

Strinestown, p. v., York county, Penn.; 13 m. 8. E. Harrisburg.

String Pramre, p. o., Lee co. Ta.: 69 m. S. Iowa City.

Strixg Pratrie, p. o., Burleson co., $T x . \therefore 66$ m. E. by N. Austin City.

Strungtown, p. v., Richland $\mathrm{co}_{\text {, }} I I_{\text {. }}$ : on the border of a fertile prairie, $110 \mathrm{~m}$. S. E. Springfield.

Stringtown, p. o., Ripley county, Ind.: 65 miles \$. E. Indianapolis.

Strode, p. o., Culpepper county, Firg. : 6כั m. N. N. W. Richmond.

Strode's Mrls, p. o., Miffin co., Penn.: 49 m. N. W. Harrisburg.

Strovg, t. and p. v., Franklin co., Me.: 48 m. N.W. by N. Augusta. Surface uneven in the $\mathbf{S}$.; well watered by

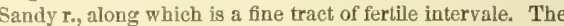
v. is very pleasant, Pop. of t. 1,C08.

Strongstown, p. V., Indiana co, Penn.: on Yellow cr., $108 \mathrm{~m}$. W. by N. Harrisburg.

Stroxgsyille, t. and p. v., Cuyahoga county, Ohio: $14 \mathrm{~m}$. S. S. W. Cleveland, $105 \mathrm{~m}$. N. E. Columbus, Watered by E. branch of Rocky r., upon which the $\mathrm{v}$. is situated. The v. contains several mills, stores, ete., and 3 churches. Pop. of $t .1,199$.

Stroudsburg, p. v., and cap. Monroe co., Penn.: on the $\mathrm{N}$. bank of Smithfield cr., $3 \mathrm{~m}$. N. W. from Delaware Gap, $98 \mathrm{~m} . \mathrm{N}$. E. Harrisburg. It is built upon one street, and contains a court-house, jail, and other public buildiugs, a forge moved by water-power, producing 230 tons annually, several mills, etc. Two weekly newspapers are published: "Jeffersomian Republican" (whig), and "Monroe Democrat" (dem.) Pop. 841.

STRYKERSTILLE, p. v., Wyoming co, N. $Y$ : on Buffalo creek, $244 \mathrm{~m}$. W. Albany. It contains 2 churches, a few mills, etc. Pop, about 250.

STUMP BRTDGe, p. 0., Madison county, AFiss.: $25 \mathrm{~m} . \mathrm{N}$ Jackson.

Sturbridge, t. and p. v., Worcester co., Mass. : $55 \mathrm{~m}$. W. S. W. Boston. Surface uneven-finely watered by Quinnebaug r. and its numerous branches, some of which flow through fine fish-ponds, Water-power is afforded by 
the Quimebaug, and improved by factories of cotton goods, grist and saw mills, ete. The $\mathrm{v}$, at the centre contains 2 churches. Pop. of t. 2,119.

Sturgeonvilie, p. 0. Brunswick county, Firg.: 58 m. S. by W: Fichmond.

STL Ritis, l p v and sta., St. Joseph's co., Mich.: $83 \mathrm{~m}$.

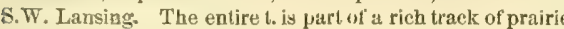
land. It is crossed by the Miehigan Southern and Northern Indiana $\mathrm{R}$. R.. on which the village is located, $131 \mathrm{~m}$. from Chicago, $116 \mathrm{~m}$. from Monroe. Pop. of t. 839.

Sturvesaxt, to and p. v., Columbia co., $N . Y_{.}:$on $\mathrm{E}$. side of Hudson river, and on Hudson River R. R., $18 \mathrm{~m} . \mathrm{S}$. Albany. Surface billy, with productive soil. The $\mathrm{v}$. on the river was formerly called Kinderhook Landing. It has considerable business with New York in supplying country produce. Pop. of t. 1,766.

StUyvesant Falts, p. v., Columbia county, N. Y.: on Kinderhook cr, which furnishes fine water-power to various mills, $23 \mathrm{~m}$. S Albany.

Sublett's Tarerin, p. o., Powhatan co., Virg. : $21 \mathrm{~m}$. W. Richmond.

Subligna, p. 0., Chattooga eounty, $G a_{0} ; 153 \mathrm{~m} . \mathrm{N}$. W. Milledgeville

Sucoess, p. o., Suffolk co., N. Y.: 134 m. S. E. by S. Albany.

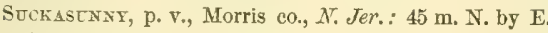
Trenton.

Stditry, t. and p. v., Middlesex co., Mass.: $20 \mathrm{~m}$. W. Boston. Bounded E. by Sudbury r., a branch of Concord river. The inhabitants are chiefly engaged in agricultural pursuits. The v. at the centre is very pleasant. Population of $t .1,578$.

SUdBury, t. and p. v., Rutland co., Term. : 45 m. S. W. Montpelier. Otter cr. forms part of its E. boundary. Surface elevated and uneven. Pop. of t. 794.

Sudlersville, p. ., Queen Anne con, Mrd.: on the W. side of the upper course of Tuckahoe cr., $42 \mathrm{~m}$. E. by N. Annapolis.

Sufferiv, p.o. and sta., Rockland co., $N, Y$.: on Erie R. R., at junction of Union R. R., $112 \mathrm{~m}$. S. by W. Albany. The vicinity is interesting, from its romantic scenery and Revolutionary history, and is noted for its abundant iron ore.

SuFFIELD, t. and p. v., Hartford co., Conn.: on W. side of Connecticut $\mathbf{r}$, and bounded $\mathrm{N}$. by Massachusetts, $16 \mathrm{~m}$. N. Hartford. Surface diversified; soil fertile loam, but without alluvial meadows, owing to the elevated banks, and affording some of the best farms in the State. The $\mathbf{v}_{\text {, }}$ on one street, one mile long, is pleasantly built on elevated ground, commanding fine views of the river and vicinity. The Connecticut Literary Institution, here located, was founded by the Baptists in 1835; it has a brick edifice, four stories high, and employs four teachers. The $\mathrm{v}$. and $\mathrm{t}$, have considerable manufactories. Pop. of t. 2,962.

Sutriteld, t. and p. o., Portage co., Ohio: 108 m. N. E. Columbus. Drained by branches of Cuyahoga $r$. Surface gently uneven. Pop. 1,275.

SUFFork county, Mars. Situate E., and contains 109 8q. m. Drained principally by the Charles $r$. It consists of Boston and Chelsea, in connection with several small islands. Surface generally level; soil fertile. Chief products, wheat, Indian corn, and potatoes. This county has many extensive manufactures, and is at the present time the most important in the State, the city of Boston constituting the greater part of its area. Farms 76 ; manuf, 1,989; dwell. 16,567, and pop.-wh. 142,484, fr. col, 2,023-total 142,507. Capital: Boston. Public Works: Eastern R. R.; Bnston and Maine R. R.; Norfolk County R. R.; Boston and Lowell R. R.; Fitchburg R. R.; Boston and Worcester R. R. ; Boston and Providence R. R.; Old Colony R. R. Grand Junction R. R., etc.

Suffolk county, $N . Y$. Comprehends the E. portion of Inng Island, with several considerable islands, the principal of which are Fisher's, Shelter, and Gardiner's islands, and contains 976 sq. m. Surface hilly and broken: soil a sandy loam. It contains extensive salt meadows, and has some minerals. Chief products, wheat and Indian corn. Salt is extensively manufactured. Fishing is much followed by the inhabitants. Farms 328 ; manuf. 96 ; dwell. 6,745 , and pop.-wh. 34,809, fr. col, 2,113-total 36,922. Carrital Suffolk C. H. Public Works: Long Island R. R.

SuEFoLK, sta., Suffolk con, $N . Y_{0}:$ in Islip t, on Long Island $R, R ., 43 \mathrm{~m}$. from New York.

SUFFoLK, p. V., sta., and cap. Nansemond county, Firg. on Nansemond r., $72 \mathrm{~m}$. \$. L. by S. Richmond. The Seat board and Roanoke R. R. passes through, $17 \mathrm{~m}$. from Portsmouth, $63 \mathrm{~m}$. from Weldon; as will also the Petersburg and Norfolk R. R., now in construction. The v. contains the county buildings and 4 churches. The "Suffolk Intelligencer" (whig), and "Nansemond Chronicle" are semi-weekly issues, Pop. about 1,700 .

Surfolk Court-House, p. o., Suffolk county, N. Y. (Sec Riverhead.)

Stgar Creek, p. o., Telfair co., Ga.: $77 \mathrm{~m}$. S. by E. Milledgeville.

Sugar Creek, p. v., Hancock eo., Ind. : on the N. bank of a stream so called, $14 \mathrm{~m}$. $\mathrm{E}$. by $\mathrm{S}$. Indianapolis,

Sugar Creek, p. o., Crawford co., Penn.: near a lake so called, $183 \mathrm{~m} . \mathrm{N}$. W. Harrisburg. $\Delta$ furnace operated by steam, near here, has an annual capacity of 1,100 tons.

Sugar Creek, p. o., Lawrence co., Tenn。: 69 m. S. S.W. Nashville.

Sogar Creek, t. and p. o., Walworth co., Wisc. : $47 \mathrm{~m}$. S. E. Madison. Drained by branches of Fox $r$. There are several small ponds in the town. Surface level, consisting of timber and prairie land; soil of great fertility. Population 1,229 .

Sugar Grove, p. o., Pendleton co., Tirg.: 128 m. N. W. Richmond.

SUgar Grove, p. o., Kane co., Ill.; on Blackberry er. of Illinois $\mathrm{r}$., $149 \mathrm{~m}$. N. E. Springfield.

Sugar Grove, p. o., Tippecanoe co., Ind.: $159 \mathrm{~m}$. N. W. Indianapolis.

Stgar Grovk, p. 0., Fairfield county, Ohio: 24 m. S. E. Columbus.

Sugar Groven, p. V., Poweshick co., Ia a : on a branch of South fork, Skunk r., $64 \mathrm{~m}$. W. Iowa City.

Sugar Grove, p. o., Butler county, Ky.: 113 m. S. W. Frankfort.

Sugar Grove, p. o., Ashe co., N. Car.: on the W. side of Watauga r., $183 \mathrm{~m}$. W. by N. Raleigh.

Sugar Grove, t. and p. v., Warren co., Penn.: $173 \mathrm{~m}$. N. W. Harrisburg. Drained by Jackson's Run. Stillwater cr., and other tributaries of Conewango cr., affording excellent mill-power. Surface undulating; soil moderately fertile. The v. on Stillwater er. is surrounded by groves of sugar maples, and contains several mills, etc.

Sugar Hill, p. o., Panola co, Texo: $251 \mathrm{~m}$. N. E. by E. Austin.

Sugar Hill, p. o., Grafton co., N. Hamp. : 72 m. N. by W. Concord.

Stgar Hril, p. o. Steuben co., $N_{1}$ Y.: $172 \mathrm{~m}$, W. by $\mathrm{S}$. Albany.

Sugar Hut, p. o., M.Dowell county, N. Car. : $191 \mathrm{~m}$. W. Raleigh.

Sugar Hrul, p. o., Hall county, Ga.: 98 m. N. N. W. Milledgeville.

Stgar Lake, p. o., Crawford co., Penn.: near a lake so called, $183 \mathrm{~m}$. N. W. Harrisburg.

Sugar Land, p. 0., Matagorda co.g Tex.: 142 m. S. E. Austin.

Sugar LoAF, p. v., Orange co., $N . Y_{.}: 102 \mathrm{~m} . \mathrm{S}$. by W. Albany.

Sugar LoAf, po o., Sebastian con, Ar\%o: $107 \mathrm{~m}$. W. by $\mathrm{N}$. Little Rock.

Sugarunaf mountain, Frederick co., Md.: a enspicuous elevation near Monocacy $r_{\text {, }}$ in the S. part of the county. It 
is the southern termination of the ridge called Catoctin Mountain, traversing in a N. and $\mathrm{S}$. direction.

Sugar Run, p. o., Bradford co.,Penn.: $99 \mathrm{~m}$. N. Harrisburg. Sugartown, p. o, Chester county, Penn.: 63 m. E. \$. E. Harrisburg.

Sugar Tree, p. o., Pittsylvania co, Tirg.: 160 m. S. W. Richmond.

Sugar Tree Ridge, p. o., Highland co, Ohio: $63 \mathrm{~m}$, S. W. Columbus.

Sugar VAllex, p. o., Murray co., Ga.: 160 m. N. W. Milledgeville.

Sugar Valley, p. o, Preble con, Ohio: 87 m. W. S. W. Columbus.

Sugar Tallex, p. o., Clinton co., Penn.: $71 \mathrm{~m}$. N. W.

Harrisburg.

Suggsplule, p. V., Clark co., Ala.: 100 m. S. W. by W. Milledgeville. Pop. about 200.

Sursur, $\nabla_{*}$, Solano $\mathrm{co}_{n}$, Catif. : is laid out on the W, bank of the Sacramento r., about $80 \mathrm{~m}$. from San Francisco, half way between it and Sacramento City, and 30 miles $\mathbf{E}$. from Vallejo. The country surrounding the town, and the site itself, is the first healthy and high ground after passing the tute marshes which lie at the junction of the Sacramento and San Joaquin. The town was surveyed and laid out by C. S. Lyman, and is a very pretty place. Large squares are reserved for a university and other public edifices, and lots are reserved for churches of every denomination. A commodious square on the river is appropriated to tho purposes of a market and a steamboat landing. The streets are very broad, and altogether it forms a pieturesque appearance. It is not supposed that this will ever become a great commercial position, but the beauty of the climate and scenery, and the agricultural capacities of the surrounding country, will eventually make it the "Hyde Park" of California.

Sursor bay, Solano co., Calif.: an arm or division of San Francisco bay. It is connected with an expansion of the river so called, formed by the junction of the Sacramento and San Joaquin, which enter San Francisco bay in the same latitude nearly as the mouth of the Tagus at Lisbon. $\Delta$ delta $25 \mathrm{~m}$. in length, divided into islands by deep channels, connects the bay with the valleys of the San Joaquin and Sacramento, into the mouths of which the tide flows, and which enter the bay together as one river. The country around Suisun bay presents low ridges and rounded hills clothed with wild oats and clover, and more or less openly wooded on their summits. The anchorage is good for vessels of the largest draught.

Sursur valley, Solano co., Calif.: $\mathbf{N}$. of Suisun bay, and E. of Green Valley, 6 m. square, covered by Spanish grant, opens on the $\mathbf{E}$. into Sacramento valley. The soil is exceedingly fertile and well cultivated. It is especially prolific in the grasses: the bay consists chiefly of wild oats and clover. Navigation is excellent. Large quantities of hay are shipped from here, and six vessels are constantly taking produce from the embarcadero.

Sulutras county, Ind. Situate S. W. on the Wabash r., and contains $430 \mathrm{sq} . \mathrm{m}$. The interior is drained by Turnman's, Turtle, and Busseron creeks. Surface generally level, and heavily timbered. The bottoms and prairies are of small extent. Many sections have excellent soil, and coal is found in abundance. Farms 1,215 ; manuf. 31 ; dwell. 1.675, and lop. -wh. 10,110, fr. col. 31-total 10,141. Capi$t a l:$ Sullivan.

Sulurvax county, Mo. Situate N., and contains 637 sq. m. Drained by Locust and Yellow creeks and their branches. Surface rolling and pleasantly diversified; soil very fertile, and produces abundantly wheat, Indian corn, and oats. The land is in general good, and in all portions where care has been had to cultivation, is highly productive. Farms 817; manuf. 5 : dwell. 457, and pop,-wh. 2,895, fr. col, 0, 8l. 3S-total 2,988. Capital: Milan.

Sullifax county, N. Hamp. Situate W. toward the s. part of the State, and contains $616 \mathrm{sq} . \mathrm{m}$. Drained by Sugar 820 and Cold rivers and their tributaries, which furnish abundant water-power to the county. Surface, though elevated, is not mountainous ; soil rich and very productive, particularly along the Connecticut, which forms its W. boundary. It has numerous ponds and lakes, the principal of which is Sunapee lake, toward the $\mathbf{S . ~ E . ~ P r i n c i p a l ~ p r o d u c t s ~ w h e a t , ~}$ Indian corn, and potatoes. Farms 2,129; manuf. 141; dwell. 3,649 , and pop.-wh. 19,311, fr. col. 34 -total 19,375. Capital: Newport. Public Works: Sullivan R, R.

Sullivan county, $N$. $Y$. Situate toward the $\mathrm{S}$. E, and contains $784 \mathrm{sq} . \mathrm{m}$. Drained by Mongoup and Neversink rivers, branches of the Delaware, and Bashe's, Beaver, and Little Beaver kills. Surface hilly, and in some parts mountainous, and well suited for grazing; soil various, but in general fertile, and in the valleys adapted to the raising of grain, etc. Chief products wheat and Indian corn. It contains several minerals. Near Wartzboro' lead ore of a good quality is found. Farms 1,889; manuf. 360 ; dwell. 4,355, and pop.-wh. 24,996, fr. col. 92-total 25,088, Capital: Monticello. Public Works: New York and Erie R. R.; Delaware and Hudson Canal.

Surutrax county, Penn. Situate toward the N. E., and contains 484 sq. m. Drained by Plunket's cr., a tributary of Susquehanna river. Surface uneven: soil fertile, adapted to wheat and Indian corn. Farms 425; manuf. 26; dwell. 660, and pop.-wh. 3,683 , fi. col. 11-total 3,694 . Capital: Laporte, Public Works: Towanda R. R.

SollivaN county, Tenn. Situate N. E., and contains 524 sq. m. Holston r. passes through it from E. to W., by which and its affluents it is drained. Surface mountainous; soil consists of deep loam with clay intermixed, and productive, fine crops of wheat and Indian corn being raised, and adapted to the culture of tobaceo. Timber is found on the land. Farms 816; manuf. 15 ; dwell. 1,826, and pop.-wh. 10,605, fr. col. 133, sl. 1,004-total 11,742. Capital: Blountville. Public Works: East Tennessee and Virginia R. R.

Sullivar, p. v., Moultrie co., $I l l$. : on the E. of a branch of Kaskaskia r., $58 \mathrm{~m}$. E. by S. Springfield.

Sullivar, to and p. o., Tioga co, Penn.: 108 m. N. Harrisburg. Drained by branches of Tioga r. Surface uneven; soil of inferior quality, well timbered. It contains numerous saw and other mills. Pop. about 1,500.

Sullivax, p. v., and cap. Sullivan co., Ind.: on the left bank of Busseron creek, $75 \mathrm{~m}$. $\mathbf{S}$. W. Indianapolis. It was laid out in 1S42, and contains a court-house, jail, county seminary, and two churches.

Suluivan, p. o., Jackson co., Ia. : 67 m. N. E. Iowa City.

Sullivan, t. and p. v., Hancock co., Me.: at the head of Frenchman's bay, with Taunton bay on the W., $82 \mathrm{~m}$. E. by N. Augusta. The ontlet of a pond in the N. E. part flows into Frenchman's bay, and furnishes mill privileges. Its location for navigation is good, and it has some shipbuilding. There are some light manufactories of woolen goods, flour, and lumber in the town. The v, is located on Taunton bay, at which point a bridge 1,400 feet long connects the town with Hancock. Pop. of t. 810 .

Suldivax, t. and p. v., Cheshire co., N. Hamp.: $36 \mathrm{~m}$. S. W. Concord. Drained by a branch of Ashuelot r., crossing its S. E. part. Incorporated in 1787. Water privileges are good, and it contains several mills. The village is in the centre of the town. Pop. of t. 468 .

Stluivar, p. 0., Ashland county, Ohio: $66 \mathrm{~m}$. N. N. E. Columbus.

Suzurtay, t. and p. o., Jefferson county, Wisc. : 41 miles E. by $\mathrm{S}$. Madison. Drained by branches of Rock river. Surface various; soil very fertile: grain and grass thrive equally, and this is a good farming town. Pop. 872.

Sullirax's island, Charleston dist, S. Car.: a small island lying at the mouth of Charleston harbor. It is resorted to by the citizens of Charleston for the enjoyment of its scenery and salubrious atmosphere.

Sulrivantille, p. 0 , Chemung county, $\mathcal{N}$. $Y_{\bullet}: 160$ miles S. W. by W. Albany. 
Sulpaur Bluff, p. o., Hopkins co, Tero, : 252 m. N. E. Austin City.

SulPhu Hils, p. o, Shelby county, Ind.: 25 miles S. E.

Indianapolis.

SUlPHor Liok, p. o., Lincoln county, $M 0 .: 72$ miles N. E.

Jefferson City.

Sulphut Liok, p. o., Monroe co., $K y$.: 109 m. \$. by W.

Frankfort.

Sulphur Rook, p. o., Independence county, Ark. : on a branch of White r., 90 m. N. N. E. Little Rock.

Sulphur Sprivg, p. o., Crawford county, Ohio : $57 \mathrm{~m} . \mathrm{N}$, Columbus.

Stzphue Sprixg valley, Solano co., Calif.: runs up from Suisun bay, 2 miles $\mathrm{N}$. of Benicia and near Vallejo, from 100 to 400 yards wide, and winds through the Suscul Hills for 5 or 6 miles. The soil is rich and well watered. The springs located here are of good temperature for bathing.

SulphUr Springs, p. $\nabla_{\text {., }}$ Williamson county, $\pi l_{\text {. : }}$ on the Sangamon and Massac R. R., 155 m. S. S. E. Springfield.

Sulphur Sprivgs, p. o., Madison co., Miss.: $27 \mathrm{~m} . \mathrm{N}$. Jackson.

Sulphur Sprivgs, p. o., Henry co., Ind. : 39 m. N. E. Indianapolis.

Sulpitur Sprivgs, p. V., Jefferson co., Mo.: on the W. side of the Mississippi river, $96 \mathrm{~m}$. E. by S. Jefferson City. There are a number of springs in the vicinity, and iron ore and lead also abound.

Sulphur Springs, p. o., Cherokee co, Tew.: 191 m. N. E. Austin City,

Sulphor Springs, p. 0., Benton county, Ala.: 103 miles

N. E. by N. Montgomery.

Sulphur Springs, p. V., Rhea co., Tenn.: on the W.

bank of the Tennessee r., 111 m. E. S. E. Nashville.

Sulphur Weri, p. o., Shelby co., Tenn. : 183 m. W. S.W.

Iashrille.

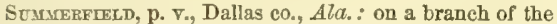

Cahawba r., 49 m. W. by N. Montgomery.

SEMMERFieid, t. and p. v., Monroe county, Mich. : $77 \mathrm{~m}$.

S. E. Lansing. Drained by Raisin r. Surface rolling, with prairie land and good timber ; soil fertile, producing excellent grain; and some sheep and hogs are raised. The $\mathrm{v}$. is on the Raisin r., and contains several mills, ete. The Michigan Southern and Northern Indiana $R_{\text {. }} R_{\text {. }}$ crosses the $N$. part, on which is Petersburg station, 23 miles W. Monroe. Pop. of t. 472 .

Sumcrerield, p. v., Guilford co., N. Car.: $71 \mathrm{~m}$. N. W. Raleigh.

Summerfeld, p. V., Noble co., Ohio: on the E. boundary, $85 \mathrm{~m}$. E. by S. Columbus.

Sommerford, t. and p. v., Madison co., Ohio: $24 \mathrm{~m}$. W. Columbus. Drained by the head waters of Deer er. tributary of Scioto r, affording good mill-power. The v. is on the cr. Pop, of v. 139 , and of the t. 755 .

Summer Grove, p. O., Smith county, Tex. : 209 m. N. E. Austin City.

Scmarer Hru, t. and p. v., Cayuga co., N. $Y_{\text {. }}$ : $134 \mathrm{~m}$. W. Albany. Drained by the head branches of Fall creek. Sur face hilly; soil of moderate fertility. It contains several mills and a tannery. The $\nabla$. is on a branch of Fall creek. Pop. of t. 1,251.

Summer Hild, t. and p. v., Cambria co., Penn. : $101 \mathrm{~m}$.W. by N. Harrisburg. Drained by branches of Kiskiminetas $r$. affording power to several mills. It contains some light manufactures. The Pennsylvania $R$. $R$. passes through the town, and a branch connects it with Ebensburg, about 11 miles $N$.

Summerset, p. v., Polk eo, Ia. : on the N. side of Middle river branch of the Des Moines, $112 \mathrm{~m}$. W. by S. Iowa City. Summersvilie, p. v., Greene co., $K y$. : on Pitman's er. $64 \mathrm{~m}$. S. by W. Frankfort.

Sumersvilue, p. ₹., Jefferson co., Penn.: 125 m. N. W. Harrisburg.

Somareryile, p. v., and cap. Chattooga county, $G a$.: on the W. bank of the Chattooga branch of Coosa rivcr, $158 \mathrm{ma}$ N. W. Milledgeville, and contains a court-house, jail, ete.

Summerville, p. 0., Cumberland county, N. Car : $41 \mathrm{~m}$. S. W. Raleigh.

Summerville, p. $\nabla$. , Cass co., Bfich.: on Dowagiake $r$, $101 \mathrm{~m}$. S. W. Lansing. The country in the vicinity consists of dry prairie land.

Summervilux, p. v., Charleston district, $S$. Car.: on the South Carolina R. R., 22 m. N. W. Charleston, and 104 by railroad S. E. Columbia

Somarerifle, p. v., Rock co., Wisc: : on the S. of Turtle cr., 47 m. S. E. Madison.

Summervixie, p. o., Boone co., Mo.: $29 \mathrm{~m}$. N.W. Jefferson City.

Summix county, Ohio. Situate toward the N. E., and contains $532 \mathrm{sq} . \mathrm{m}$. Cuyahoga river flows through the central portion, by which and its tributaries and by head branches of Tuscarawas river it is drained; good-water-power is supplied in their courses, Surface undulating, in parts hilly; soil a rich vegetable mold, and produces in abundance wheat, Indian corn, and potatoes. Large numbers of cattle and hogs are fattened and sent to market, transportation being greatly facilitated by means of the Ohio Caual. Timber is exported. Farms 2,329; manuf. 292; dwell. 4,885 , and pop.-wh. 27,422 , fr, col. 63-total 27,485. Capital: Akron. Public Works: Cleveland and Pittsburg R. R.; Cleveland, Zanesville and Cincinnati R. R.; Ohio Canal, ete.,

Sбмmт, p. o., Oakland county, Mrich.: 57 miles $\mathrm{E}$. by $\mathrm{S}$. Lansing.

Sumaт, p. o., Summit co., Ohio: 108 m. N. E. Columbus. Sumur, sta., Licking co, Ohio: on the Central Ohio R. R., $22 \mathrm{~m}$. E. Columbus.

Summr, p. v., Blount co., Ala. : on the W. boundary line of Marshall co., $128 \mathrm{~m}$. N. from Montgomery.

Sumir, p. o., Whitley county, Ind.: $99 \mathrm{~m}$. N. by E. Indianapolis.

Summit, p. va and sta., Essex co, $N$. Jer.: on the E. of the Passaic r, on the Morris and Essex R. R., $13 \mathrm{~m}$. W. from Newark, and 41 N. E. from Trenton.

Summi, t., p. v., and sta., Schoharie co., $N_{0} Y .: 46 \mathrm{~m}$ W. by $\mathbf{S}$. Albany. Drained by Charlotte $\mathbf{r}$., and tributaries of Schoharie cr. Surface high and hilly; soil adapted to grass. It contains several manufactories. The $\mathrm{v}$. is on a branch of the Schoharie cr. Pop. of t. 1,800 .

Summix, sta., Clinton co., $N_{\text {. }} Y_{\text {. : }}$ on the Northern (Ogdensburg) $\mathrm{R}, \mathrm{R}, 87 \mathrm{~m}$. W. Rouse's Point, and $162 \mathrm{~m}, \mathrm{~N}$. from Albany.

Summi, p. 0., Northampton co., $N$. Car.: 85 m. N. E. Raleigh.

Summt, sta, Broome co, N. $Y_{\text {: }}$ on the New Fork and Erie R. R., $194 \mathrm{~m}$. N. W. New York city, and $104 \mathrm{~m}$. S. W. (direct) from Albany. The road at this point has been cut through a solid rock, at an expense of $\$ 200,000$

Summit, sta., Rutland co., Verm.: on the Rutland and Burlingion R. R., $18 \mathrm{~m}$. S. Rutland, and $72 \mathrm{~m}$. S. W. Montpelier.

Summit, p. v., Cambria co., Penn.: on the head branch of Kiskiminetas $\mathbf{r}$, and on the Philadelphia and Pennsylvania R. R., $150 \mathrm{~m}$. W. by N. Harrisburg, A furnace of 1,100 tons annual capacity is near the village.

Summe, sta., Chester co., Penn. : on the Columbia and Philadelphia R. R., 44 m. E. by s. Harrisburg.

Suмmi, t. and p. Y., Waukesha co., Wisc.: $57 \mathrm{~m}$. E. Madison. Drained by branches of Rock and Fox creeks, and it has several ponds, which, with the streams, afford excellent water-power, and there are several mills. Surface level, and well wooded; soil fertile. The $\mathrm{r}$. is centrally situated. Pop, of t. 1,008 .

Summt Bringr, p. o., Newcastle co., Del, : on the Chesapeake and Delaware Canal, $27 \mathrm{~m}$. N. by W. Dover. At this point there is a brilge over a deep rut in the canal.

Summe Hric, p. v, and sta, Carbon co, Penn.: on the 
Mauch Chunk and Summit Hill R. R., 9 m. W. Mauch Chunk, and $61 \mathrm{~m}$. N. E. Harrisburg. Coal is found in the vicinity, and the inhabitants of the village are mostly employed in the mines. Pop. 2,501.

Susinit Mrlus, p. o., Somerset co., Penn»: 113 m. W.S.W. Harrisburg.

Sumurt Point, p. o., Jefferson co., Virg.: 117 m. N. by W. Richmond.

Sumutrille, p. v., Lee co., Ia.: $77 \mathrm{~m}$. S. Iowa city. The Dubuque and Keokuk R. R. will pass through this village. Summituleze, p. v., Madison county, Ind.: 30 m. N. E. Indianapolis.

SuMNer county, Tenn. Situate N., and contains 490 sq. m. Drained by affluents of Cumberland river, which forms its southern boundary. Surface rolling; soil, which consists of a deep, black mold, is fertile, and well adapted to tobacco and cotton, large quantilies of which are produced. Fine erops of wheat and Indian corn are raised, and the county is generally rich in agricultural productions. Farms 1,335 ; manuf. 103; dwell. 2,555, and pop.-wh. 14,511, fr. col. 200, sl. 8,006-total 22,717. Capitul: Gallatin. Pullic Works: Louisville and Nashville R. R.; Nashville and Cincinnati R. R.

Sumier, t. and p. v., Oxford co., Me.: 33 m. W. Augusta. There is a pond in the W. part. Drained by a branch of the Androscoggin r. Surface undulating; soil fertile, and much grain is raised. The to contains several tanneries, mills, etc. East Sumner and West Sumner are the names of villages. Pop, of t, 1,151.

Sunneytown, p. v., Montgomery co., Penn.: on Perkioman creek, and on line of Upper Salford and Marlboro' townships, $75 \mathrm{~m}$. E. Harrisburg. In the $\mathrm{v}$. is a furnace of 900 tons annual capacity, and a forge making 140 tons blooms and 100 tons bar iron, and powder is manufactured in the vicinity.

SEMTER county, $A l a$. Situate W., and contains $963 \mathrm{sq} . \mathrm{m}$. Drained by affluents of Tombigbee river and its W. fork. Surface hilly, and partly broken ; soil in general fertile. On the streams are sume fine tracts of land very productive, and adapted to cotton and other agricultural produclions. Farms 668 ; manuf. 12 ; dwell. 1,342, and pop.-wh. 7,369 , fr. col. 50, sl. 14,831-total 22,250. Capital: Livingston. Public Wurks: Alabama and Mississippi R. P.

Sumter county, Ga. Situate toward the S. W., and contains $589 \mathrm{sq} . \mathrm{m}$. Drained by branches of Flint river. Surface varied; soil fertile, and very productive. Wheat, Indian corn, and grain, are raised in considerable quantities, but cotton is the staple, the land being well adapted to its growth. Apple, pear, and other fruit trees, are grown, and there is some good timber on the land. It contains some minerals. Farms 765 ; manuf. 34 ; dwell. 1,109, and pop.-wh. 6,469, f. col. 18, sl. 3,835-total 10,322. Capital: Americus. Public Works: South-Western R. R.

SUMTER district, S. Car. Situate S. E. centrally, and contains 1,391 sq. m. Drained by Black river and its branches, and branches of Santee river. Surface level; soil moderately fertile, being of a sandy nature, Chief productions rice, cotton, and Indian corn. Farms 1,343 ; manuf. 82 ; dwell. 1,90s, and pop-wh. 9,815 , fr. col. 340, sl. 23,065 -total 33,220. Capital: Sumterville. Public Works: Wilmington and Manchester $R_{*} R_{*}$; Camden Branch $R_{.} R_{*}$; Columbia Branch R. R.

Sumter, p. 0., Trinity co., Tex.: $161 \mathrm{~m}$. N. E. by E. Austin City.

Semterviliz, p. v., Sumter co., Ala.: 119 m. W. by N. Montgomery.

Sumterville, p. $\nabla_{\text {., }}$ Lee $c_{0}, G a_{0}$ : on a branch of Flint r., $96 \mathrm{~m}$. S. S. W. Milledgeville.

Somterville, p. v., Sumter dist., $S$. Car.: on the Wilmington and Manchester R. R., $146 \mathrm{~m}$. W. S. W. Wilmington (N. C.), $48 \mathrm{~m}$. E. by S. Columbia. The "Black River Watchman" and "Sumpter Banner," both demoeratic, are losued weekly.
Sux, p. 0., St. Tammany parish, La. : 61 m. E. Baton Rouge.

SunApeE lake, $N . H$. : in the N. W. part of Merrimac co. and the E. part of Sullivan county, in the towns of Sunapee, New London, and Newbury, $9 \mathrm{~m}$. long, and about $1 \frac{1}{2} \mathrm{~m}$. in width. Its elevation above the sea level is 1,080 feet, and the descent of its outlet, Stigar river, to the Connecticut, is very rapid.

Sunbury, p. v., Livingston county, $I l_{0}: 97 \mathrm{~m}$. N. E. Springfield.

Sunbery, p. v., Delaware county, Ohio.: on Walnut er., $21 \mathrm{~m}$. N. Columbus. It contuins several stores, workshops, and is a thriving village.

Sunbury, p. y., Gates co, $N$. Car.: on the E. side of Bennett's cr., 121 m. N. E. Raleigh.

Sunbury, p. b., and cap. Northumberiand co, Penn.: on the E. bank of the Susquehanna r., below the confluence of its N. and W. branches, at Northumberland, $44 \mathrm{~m}$. N. Harrisburg. Its location is on a broad plain, in the township of Augusta. The Pennsylvania Canal is carried across the river by a basin created by the Shamokin dam, 2,783 feet long, a short distance below the t. nearly a mile in width. A railroad connects Sunbury with the Shamokin coal mines, 19 miles E., and Sunbury will be an important point on tho line of railroads from the Delaware to Lake Erie, now in progress of construction. A bridge across the $\mathrm{N}$. branch of the Susquehanna connects the town with Northumberland. It contains a court-house and county offices of brick, a jail built of stone, and several churches. Coal, iron, and lime stone are abundant in the vicinity, and there are some manufactures in the v. The "S. American," "S. Gazette," and the "Deutscher Americaner" are issued weekly. Pop. of $t, 1,218$.

Suncook, p. v., Merrimac co., N. Hamp. : on the W. side of Suncook r., near its junction with the Merrimac, and on the Portsmouth and Concord R. R., $40 \mathrm{~m}$. W. by N. Ports mouth, and $7 \mathrm{~m}$. S. E. from Concord. It coniains snme light manufactures.

Suncook river, $N$. Hamp. : rises in several ponds between Gilmanton and Guilford, near the summit of one of the Suncook mountains, elevated 900 feet above its base. It flows in $\mathbf{S}$. W. direction, and empties into the Merrimac, in the town of Allerstown.

Sunday Creek Cross Roads, p. o., Perry co., Ohio: near a cr. so called, $54 \mathrm{~m}$. S. E. Columbus.

SENDERzand, t. and p. v., Franklin co., Mass.: on the E. side of the Connecticut r., $79 \mathrm{~m}$. W. by N. Boston. Surface along the river is level, back of which it is mountainous; soil fertile. This is chiefly a farming town. The v. is built upon one street running parallel with the r., and contains several churches and some handsome dwellings. A bridge here crosses the river. Mount Toby lies partly in Sunderland, and partly in Leverett. Pop. of t. 792 ,

Stnderlaid, t. and p. V., Benningtom co., Verm. : $89 \mathrm{~m}$. S. W. by S. Montpelier. Drained by Battenkill r. and Roaring brook. Surface uneven, and in part mountainous; soil fertila. It has excellent water-power, and some light manufactures. Sulphuret of iron is found in considerable quantities, and lead ore has been discovered in granular limestone, The $\mathrm{v}$. is on the Western Vermont R. R., $36 \mathrm{~m}$. S. by W. Rutland. Pop. of t. 479 .

Sunfise, p. o., Monroe county, Ohio: in the village of Clarington, at the mouth of Sunfish creek, $111 \mathrm{~m}$. E, by $\mathrm{S}$. Columbus.

STN Flower county, MFiss. Situate W. toward the N., and contains $824 \mathrm{sq}$. m. Drained by Sun Flower r. and its branches. Surface moderately level; soil fertile, and adapted to cotton, which is the chief production. Farms 48 , dwell. 75, and pop.-wh. 348, fr. col. 0, sl. 754-total 1,102. Crupitul: M.Nutt.

Suskitaze, p. v., Penobscot co., Me. : on the E. side of the Penobscot $r$, at the mouth of Sunkhaze r., $77 \mathrm{~m}$. N. E. Augusta. 
Suñy Side, p. V., Lowndes co., Ala. : on a branch of Big Stvamp er., 29 m. S. W. Montgomery.

Scr Prairie, t. and p. o., Dane co., Wisc.: $21 \mathrm{~m}$. N. E. Madison. Drained by aftluents of Rock $r$. Surface rolling : soil fertile. Pop. 500.

Suxrise, p. o., Bath county, Virg.: $181 \mathrm{~m}$. W. by N. Richmond.

Sixvile, p. o, Venango county, Penn.: $174 \mathrm{~m} . \mathrm{N} . \mathrm{W}$. Harrisburg.

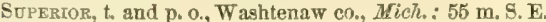
Lansing. Drained by Rouge and Huron rivers, from which good water-power is derived. Surface is gently undulating, with a rich soil. Timber is abundant. Pop. 1,127.

SUPERIOR lake, the largest of the 5 great Iakes of North America, and said to be the largest body of fresh water in the world. Its length is $350 \mathrm{~m}$., and greatest breadth $150 \mathrm{~m}$. It contains a number of islands of various sizes, the largest of which is Isle Royal, in the N. W., about $100 \mathrm{~m}$. long and 40 broad. The elevation of the lake's surface above the high tide of the ocean has been calculated to be 1,048 feet, and the average depth of its bottom 900 feet. The lake is subject to as violent gales as the Atlantic, and equally as difficult of navigation. The coast is generally elevated, rocky, and in some parts mountainous. The vessels navigating the lake are confined within its own waters, as the Falls of St. Mary present a complete obstruction to communication with the lakes below. This obstruction is in course of re moval, by the building of a ship channel around the Falls of St. Mary; and, when completed, the wide expanse of Lake Superior will be added to the present extent of the lake navigation. The length of the road to be cut by this canal is three-fourths of a mile, at an estimated expense of $\$ 230,000$. By this means access will be obtained to the whole country tributary to Lake Superior-a tract rich in timber and mineral wealth. It receives more than 30 rivers, and discharges its waters into Lake Huron by the Straits of St. Mary. The temperature of the water of the lake, during the summer, a fathom or two below the surface, is but a few degrees above the freezing point. In the western portion the water is much colder than in the eastern-the surface fiow becoming warmer as it approaches the outlet. The mirage which frequently occurs is occasioned by the difference between the temperature of the air and the lake. In the region about the shores of Lake Superior many valuable mines of copper and other ores have been discovered within a few years past, and are now being extensively worked. The products of the copper mines for the year 18501 amounted to about 2,500 tons, or about one-half the annual consumption of the United States. The copper, for certain purposes in the arts, stands unrivaled; and, according to present report, it surpasses all the ores of copper in density and tenacity. The per centage of silver, too inconsiderable in most cases to justify separation, still enhances its value, by protecting it in a considerable degree from the corrosive action of salt water. The boundary line between the U.S. and the British possessions passes from the outlet through the middle of the E. section of this lake ; but toward the W. it is carried clear round to the N. of Isle Royal, giving that island and the whole body of the lake below it to the U.S.; then passing round the $W$. extremity of the island, it inclines S. to the entrance of Pigeon river, leaving the largest portion of this section of the lake on the British side. The Pictured Rocks, so called, toward the E. end of the lake, are a great natural curiosity. They form a perpendicular wall, 300 feet ligh, extending about $12 \mathrm{~m}$. along the shore of the lake. They have numerous caverns and projections. The fishing stations about the coast are numerous, and several thousand of barrels of fish are put up and exported annually, the waters of this lake yielding an exhaustless supply of this article. The species caught are, the trout, white flsh, and sturgeon, the two former of which are highly prized in the markets.

Scrgeox"s Hald, p, v., Alleghany co., Penn.: on a small stream flowing into the Monongahela river, $160 \mathrm{~m}$. W. Harrisburg.

Surrounded Hills, p. o., Monroe con Ark.: 69 m. E. Little Rrock.

Surry county, N. Car. Situate N., toward the W., and contains $670 \mathrm{sq} . \mathrm{m}$. Drained by Yadkin r. and its branches, Surface varied, generally much broken, and mountainous; soll fertile, and the uplands adapted to pasturage. Chief productions, cotton, tobacco, Indian corn, wheat, and potatoes. Farms 1,503; munuf. 48; dwell, 2,787, and pop.wh. 16,171 , fr. col. 272, sl. 2,000-total 15,443. Capital: Puckford.

SurRy county, Firg. Situate toward the S. E. and contains $263 \mathrm{sq} . \mathrm{m}$. Drained by small branches of James and Blackwater rivers. Surface an extended plain: soil a deep loam, and fertile, in some portions making fine pasture land. Chief productions, cotton and Indian corn, potatoes, etc. Farms 301 ; manuf. 5 ; dwell. 650, and pop.-wh. 2,215, fr. col. 955, sl. 2,479-total 5,679. Capital: Surry C. H.

SurRr, t, and p. V., Hancock co, Mre. : $65 \mathrm{~m}$. E. by N. Augusta. This is a very fertile farming town, having a number of ponds and excellent water privileges. Union River bay bounds it on the E., affording navigable facilities. Its manufactures consist of leather, lumber, etc. The v. is situated at the head of an inlet of Union River bay. Pop. of t. 1,189.

Surry, t. and p. v., Cheshire county, N. Hamp. : $43 \mathrm{~m}$. 8. W. by W. Concord. Drained by Ashuelot r. Surface varied, in parts uneven. On the summit of a mountain, on

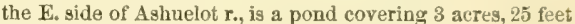
deep. Incorporated in 1769 . The village containg several shops and stores. Pop. of t. 550 .

SURRY C. H., p. v., and cap. Surry co., Virg. : near an inlet of James r., 43 m. S. E. Richmond. It contains a courl-house, jail, etc.

Suscou valley, Solano co., Calif: : a little W. of Suscol Hills; runs from the city of Vallejo to the northern part of the county; $8 \mathrm{~m}$. in length and 3 in width, Napa bay washing its whole length. It is a desirable and interesting country, well adapted to farming, and has a luxuriant growth of wild oats. Running through this valley are two large soda springs, which, after winding through low bills, empty into Napa bay. One of these springs, $4 \mathrm{~m}$. N. of Vallejo, is called Sulphur Spring Waters, and is of good temperature for bathing,

Sugpension Brmat, p. on, Niagara county, $N$. $Y$. : $276 \mathrm{~m}$. W. by N. Albany.

Susedehanya county, Penn. Situate N. E., and contains $712 \mathrm{sq}$. m. Drained by branches of Susquenanna $\mathrm{r}$., which flows through its N. part. Surface hilly, and the land in many places is much broken; soil fertile, and produces excellent crops of wheat and Indian corn. It is covered in different portions with a fine growth of timber, and has good pasturage for cattle. Farms 3,909 ; manuf. 322 ; dwell. 5,203, and pop.-wh. 23,529, fr. col. 159-total 2s,6s8. Capital: Montrose. Public Works: New York and Erie R. R.; Lackawanna and Western R. R.

SusquenanNa, p. o., Broome co., $N . Y$ : on W. bank of Susquehanna r., 124 m. W. S. W. Albany.

Susqueranna, t. and p. o., Dauphin con, Penn.: on E. side of the Susquehanna $r$. Drained by Paxton cr. Surface uneven; soil fertile. Blue Mountain crosses the $N$. part. Its manufactures are flour, lumber, etc. Harrisburg lies partly in this town. Pop, 1,526.

Susquenanna river, Penn. : this river, the largest in the Staie, rises in Otsego county, New Fork, and flows S. W. (receiving Unadilla river in Sidney t.) until it enters Pennsylvania. It then returns into New York by bending W. course, receives Chenango river at Binghampton, and flowing again into Pennsylvania receives Chemung river $3 \mathrm{~m}$ below the State line. Its general course in crossing the State is in form nearly that of an oxbow. It receives the western branch, its largest tributary, at Northumberland, the 
Juniata river at Bloomfleld, and empties into Chesapeake bay, in the north-east part of Maryland, at Havre de Grace, at which place it is $1 \frac{1}{6} \mathrm{~m}$. wide. It is about 450 miles long, but its importance for navigation is not commensurate with this great length. It is navigable for sloops 5 miles from its mouth to Port Deposit, at the head of the tide, beyond which it is entirely obstructed for $50 \mathrm{~m}$. by a frequent succession of rapids. In its upper parts the natural obstructions are not great, and might be easily overcome. During freshets a great amount of lumber and produce is sent down in rafts, etc. Canals are extensively constructed along its banks, which greatly facilitate the movements of commerce.

Suseufinanna Depôx, p. o. and sta., Susquehanna co., Penn. : on the Erie R. R., 202 m. from New York, 267 m. from Dunkirk, $115 \mathrm{~m}$. N. N. E. Harrisburg. At this station the Erie R. R. Company have large shops for repairing engines, cars, etc., and thus formed a small but flourishing gettlement.

Sussex county, Del. Situate S., and contains 994 sq. m. Drained by Nanticoke river and its branches, which enter Chesapeake bay, and Jones, Cold Spring, Cedar, Mispillion, and other small creeks which flow into Delaware bay. Surface in general level, and a large portion is marshy; soil varied, much of it being of a sandy nature. Chief productions wheat, Indian corn, and potatoes. There is fine grazing land in the co. Farms 2,746; manuf. 11; dwell. 4,819, and pop.-wh. 20,348, fr. col. 4,039, sl. 1,548-total 25,985. Capital: Georgetown.

Sussex county, $N$. Jer. Situate N. W., and contains 568 sq. m. Drained by Paulinskill, Wallkill, Pequannock, and Pequest creeks. Surface in general is hilly, and portions of it mountainous; soil fertile, consisting of a fine deep mold with sand intermixed. Wheat, Indian corn, and other grains are produced abundantly, and excellent crops of potatoes are raised. Farms 1,653; manuf. 154; dwell. 3,851, and pop.-wh. 22,678, fr. col. 310, sl. 1-total 22,989. Capital: Newton.

Scseex county, Tirg. Situate S. E., and oontains $45 \mathrm{~s}$ sq. $m$. Drained by Nottoway $\mathbf{r}$. and its branches. Surface even; soil fertile and easy of cultivation. Chief productions cotton, tobacco, and Indian corn; wheat is also grown extensirely. Farms 472 ; manuf. 23 ; dwell. 751 , and pop.wh. 3,056 , fr. col. 742, sl. 5,992-total 9,820. Capital. Sussex C. H. Public Works: Petersburg and Weldon R. R.; Petersburg and Norfolk R. R.

Sussex C. H., p. v., and cap. Sussex co. Virg.: $41 \mathrm{~m}$. S. by E. Ríchmond, and contains a court-house, jail, ete. Sussex, p. o., Waukesha co., Wiso. : $59 \mathrm{~m}$. E. Madison.

Sutherland's sta, Dinwiddie co., Virg.: on South Side R. R, $10 \mathrm{~m}$. W. Petersburg, $42 \mathrm{~m}$. from Burkville.

Sutherland Springs, p. o., Bexar county, Teo.

Sutrer county, Calif. Situate centrally, and chiefly between the forks of the Sacramento and Feather rivers, and contains 760 sq. m. Surface diversiffed, and in the N. are several high hills called Buttes. The portion of the county S. E. of Feather river contains the important towns of Vernon, Oro, and Nicholas, which are noted for their mineral wealth, and also for their commercial positions. Springfield, opposite Tremont, and Yuba City, opposite the mouth of Yuba $r$, are also considerable places. It is a rich mining region, and has been very productive. The quantity of land under cultivation in 1852 was only 1,401 acres, and in general little attention is here paid to any agricultural operations. Pop. at the date specified 1,207; whites 675 -males 590 , and females $\$ 5$; negroes 11 -males $\mathrm{S}$, and females 3 ; Indians 514 -males 262, and females 252 ; and foreign residents $10-$ males 7 , and females 3 ; above 21 years old-citizens 527 , negroes 11, Indians 314, and foreigners 10. Capital: Oro.

SutTerstiule, $\mathbf{y}$., Sacramento county, Calif: : on the left bank of Sacramento r., about $3 \mathrm{~m}$. S. Sacramento City, $48 \mathrm{~m}$. N. E. Vallejo.

SUTT⿰亻, t., p. Y., and sta., Worcester co., II ass, : $39 \mathrm{~m}$

W. S. W. Boston, Surface hilly; soil productive. Drained 830 by Blackstone river, which affords water-power, and along which passes the Blackstone Canal in its $N$. part. The Providence and Worcester R. R. touches on its $N$. border, $35 \mathrm{~m}$. from Providence, $8 \mathrm{~m}$. from Worcester. Soapstone and granite are found. The t, contains 5 churches, several cotton factories, with some other mills. Pop. of t. 2,595.

Sutrow, t. and p. v., Merrimae county, $N$. Hamp.: $23 \mathrm{~m}$. N. W. by N. Concord. Surface uneven; soil various. Watered by Warner $r$, and branches, which afford waterpower. The town contains tanneries and saw-mills. Pop. of t. 1,357 .

Sutton, t. and p. v., Caledonia co., Verm.: 39 m. N. E. by N. Montpelier. Surface mostly level, much of it low and wet. Watered by branches of Passumpsic river. A pond in its $N$. W. comer covers 200 acres. There are several bogs of marl in the town. Pop. of t. 1,001.

Sutron's Mrits, p. o. and sta., Essex county, Mass.: on Essex R. R., $1 \mathrm{~m}$. from Lawrence, $20 \mathrm{~m}$. from Salem.

SuWANE, p. v., Gwinnett co., Ga.: on a branch of Shallow fork of Chattahoochee r., $81 \mathrm{~m}$. N. W. Milledgeville.

SUWANNEE river, Flor.: rises in Okefinokee Swamp in Georgia, flows S., then W., receives the Allapahaw from the N., and the Withlacoochee from the N. W., then flows $\mathrm{S}$. and $S$. En, receives the Santa $F E$ from the $E$., and thence flows in southerly course until it empties into Waksase bay of Gulf of Mexico, which it enters by numerous shallow channels. The bar at its mouth has not more than 5 feet water, but above that it has 15 feet for 55 miles. Its bed is rocky, and in some places its banks are 100 feet high of perpendicular granite rock.

Suwarieg Shodls, p. 0., Columbia co., Flor.: $99 \mathrm{~m}$. W. Tallahassee.

Swatrsboro', p. vo, and eap. Emanuel county, Ga.: on a braneh of the Great Ohoopee r., 61 m. E. S. E. Milledgeville. It contains a court-house, jail, etc.

Swatrsville, sta., Wyoming co., $. N . \quad Y$.: on the Buffalo and Nery Fork R. R., 69 m. E. S. E. Buffalo, 219 m. W Albany.

SwatLow falls, Alleghany county, $M d_{\text {s }}$ : these falls of the Youghiogeny r. occur near the mouth of Hendorn $\mathrm{cr}$., in the S. W. part of the county. The general elevation of the country in the vicinity is 2,390 feet above tide-water.

Sw AMPsCoTt, p. o., Essex co., Mass.

Swan, p. v., Noble co., Ind. : at the source of Black cr., 114 m. N. N. E. Indianapolis.

SWAN, t. and p. o., Vinton county, Ohio: $49 \mathrm{~m}$. S. E. Columbus. Raccoon cr. flows through the t., affording excellent mill privileges. Surface much broken; soil fertile. Pop. 1,154.

Swar Creekr, p. v., Warren co., $M m_{0}$ : near the West fork of Spoon r., 80 m. N. W. Springfield.

Swan CrmeK, p. o., Warren countr, Ky.: 119 m. S. W. Frankfort.

Sway CReEK, p. o., Gallia county, Ohio: 83 m. S. S. E. Columbus.

SwAYCEY's FERRY, p. o., Abberille dist., S. Car.: $97 \mathrm{~m}$. W. Columbia.

Swangstown, p. v., Cleveland county, N. Car.: on the right bank of Buffalo $\mathrm{cr}_{\text {, }} 151 \mathrm{~m}$. W. S. W. Raleigh.

Swair LAKE, p. 0., Arkansas county, Ark.: 60 m. S. E. Little Rock.

Swankaro, p. v., Buncombe co., N. Car.: on a branch of French Broad r., $205 \mathrm{~m}$. W. Raleigh.

SWAN PoINT, p. o, Knox county, Ky.: 109 m. S. S. E. Frankfort.

SwaN Quabter, p. v., and cap. Hyde co, N. Car.: $123 \mathrm{~m}$. E. by S. Raleigh, and contains a court-house and other county buildings.

Swar Rrver (or Arthur's Ferry), p. 0., Benton co., Minn. Ter. : $107 \mathrm{~m}$. N. N.W. St. Paul. The ferry at this point is one well known, and is held by one of the oldest traders and pioneers of Minnesota. The settlement contains some 30 families. 
SWANsBoro, p. v., Onslow co., N. Car. : on W. side of the estuary of Whittock $r_{*}$ and opposite Bogue inlet, $105 \mathrm{~m}$. S. E. Raleigh.

Sw ANSEY, t. and p. ₹., Bristol co., Mas8.: 45 m. S. by W. Boston. Mount Hope bay sets up into its $\mathrm{S}$. part by two inlets, on one of which stands a small v. which has some navigation and ship-building. The $t$. was incorporated in 1667, and is noted for having been the t. in which King Philip's Indian War commenced on June 20th, 1675. In the $t$. are several tanneries, paper and other mills. Pop. of t. 1,554 .

SWAN"s IsLAND, t, and p. v., Hancock co., Me.: $67 \mathrm{~m}$. E. by S. Augusta. Pop. of t. 423.

SWaxsonvilue, p. 0., Pittsylvania co, Firg. : 116 m. S.W. Richmond.

Swanton, t. and p. o, Lucas co, Ohio: $113 \mathrm{~m}$. N. N. W. Columbus. The railroad from Sandusky City to Fort Wayne will pass through this town.

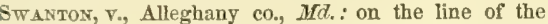
Baltimore and Ohio R. R., $221 \mathrm{~m}$, from Baltimore by railroad, and 143 m. W. N. W. Annapolis direct. Elevation, 2,272 feet above tide-water.

Swantox, t. and p. v., Franklin co., Ferm.: on the E. side of Lake Champlain, $66 \mathrm{~m}$. (by railroad) N. W. Montpelier. Drained by Missisqui $\mathrm{r}_{\text {, }}$ which is navigable for lake vessels to Swanton Falls, six miles up. These falls have a descent of twenty feet, from which are derived extensive hydraulic power. Bog-iron ore is found here, and there is an excellent quality of variegated marble quarried and extensively exported. The surface and soil of the $t$, are well adapted to agricultural pursuits, with the exception of a portion bordering on the lake. The $\mathbf{v}$. is located at the falls, and is the site of several manufactories, and of increasing irade. The Vermont Central R. R. passes through the $\mathbf{v}$ 13 m. S. E. Rouse's Point (N. Y.) Pop. of t. 2,824.

Swanton Centre, p. o., Franklin county, Ferm.: $67 \mathrm{~m}$. N. W. Montpelier.

SWANvHLE, t. and p. v., Waldo co., Me.: 43 m. E. by N. Augusta. Drained by the outlet of a pond in the N. part, emptying into Belfast bay. Surface even; soil fertile. The village is located in the N. part. Pop. of t. 944.

SWANvilik, p. o., Jefferson county, Ind.: $75 \mathrm{~m} . \mathrm{S}$. E. Indianapolis.

SWaizer, t. and p. v., Cheshire co.,. . Mamp.: $45 \mathrm{~m}$. S. W. Concord. Drained by Ashuelot river and branches. The $r$. is navigable for boats as far up as Keene, except a short curving place around the rapids in Winchester. Surface-as also the soil-is various. There is a mineral spring here, the waters of which are impregnated with iron, and iron ore is found. The manufacture of cottons, woolens, leather, and lumber, is earried on. The $\mathrm{v}$, is on the Connecticut River R. R., 6 m. S. Keene. Pop. of t. 2,106.

Swartsw 00D, p. 0., Sussex county, N. Jer.: $55 \mathrm{~m} . \mathrm{N}$. Trenton.

Swaertw otr, p. v., Polk county, Tex.: on the E. side of Trinity r., $161 \mathrm{~m}$. E. by \$. Austin City.

SWAptz CREeK, p. o., Genesee co., Mich : on a stream so called, $47 \mathrm{~m}$. N. E. Lansing.

Swearivgens, p. o., Austin con, Tex.: 95 m. E. by S. Austin City.

SWEDEN, t. and p. v., Oxford county, Me.: 67 m. S. W. Augusta. Saco r. crosses the W. part, and on the N. E. are two ponds, by the cutlets of which the $t$. is drained. Soil adapted to grains. The $\mathrm{v}$. is located in the centre. Pop. of t. 696 .

SWEDEN, to and p. o., Potter co., Penn.: $115 \mathrm{~m} . \mathrm{N} . \mathrm{N} . \mathrm{W}$ Harrisburg. Drained by one of the head branches of the Alleghany river. The greater portion of the $t$. remains in a wild, uncultivated state. Iron ore is found in the vicinity.

SWEDEN, t. and p. v., Monroe county, $N . Y .: 220 \mathrm{~m}$. W. by $\mathbb{N}$. Albany. Drained by Salmon creek, from which water-power is derived. Surface undulating; soil, moist, argillaceous loam, yielding large cropls of grass, grain, and fruits. The Rochester, Lockport, and Niagara Falls R. R. and the Erie Canal pass through the $t_{\text {, }}$ on both of which is located the manufacturing village of Brockport. The v. of Sweden is $2 \mathrm{~m}$. S. of Brockport, and contains a church and about 50 dwellings. Pop. of t. in 1840, 1,854; in $1850,3,623$.

Sweedum Hribl, p. o., Pendleton co., Farg.: 130 m. N.W. Richmond.

SwEEDsвoro', p. $\nabla$. , Gloucester county, $N$. Jer.: on the right bank of Raccoon cr., at the head of slonp navigation, $52 \mathrm{~m}$. S. S. W. Trenton. It contains a church, several mills, etc.

Sweer Arr, p. v., Baltimore co., Ind. : $37 \mathrm{~m}$. N. by W. Annapolis.

Sweet Springs, p. V., Monroe co., Virg. : in the valley of the Alleghany mountains, W. of Middle Mt., $153 \mathrm{~m}$. W. Richmond. This is one of the oldest watering-places in Virginia. The springs are situated $17 \mathrm{~m}$. from the celebrated White Sulphur Springs, and there is accommodation for 300 persons. The waters are celebrated for their medicinal properties, and are used both externally and internally. The power derived from the springs is sufficient to turn a mill at the distance of 200 yards from the source. Temperature of the water $73^{\circ}$ Fahrenheit.

Sweet Palleix, p. o., Luzerne co, Penn.: 79 m, N. E. Harrisburg.

SWEET WATER, p. v., Gwinnett co, Gan: on Yellow $r_{0}$ $73 \mathrm{~m}$. N. W. Milledgeville.

SWEET W ATER, p. v., Marengo co., Ala.: on a branch of Tombigbee r., $95 \mathrm{~m}$. W. by \$. Montgomery.

SweET W ATER, p. 0. and sta., Monroe co., Tenn.: on the East Tennessee and Georgia R. R, 14 m. S. by W. Loudon, and $147 \mathrm{~m}$. E. S. E. Nashville.

SWeEt WATER Faotori, p. on, Campbell con, $G a_{n}: 95 \mathrm{~m}$. W. N. W. Milledgeville.

SwIFT CreeK, p. o., Darlington dist., S. Car. : 61 m. N. E. Columbia.

Swift Creer Bridge, p. v., Craven co., N. Car, : on E. side of Swift cr., $90 \mathrm{~m}$. E. Raleigh.

Swift Islaxd, p. 0., Montgomery co., $N$. Car.: $72 \mathrm{~m}$. S. W. Raleigh

SwIFT river, Carroll co., N. Hamp.: rises in the mountains on the $\mathrm{N}$. of Waterville, and flowing in an easterly course empties into the Saco river at Conway. Its whole course is rapid, and in one place it falls 30 feet in the distance of six rods, through a channel in the solid rock, about 12 feet wide, the sides being from 10 to 30 feet perpendicular height.

Swineyards, p. 0., Charles City co., Tirg.: 29 m. S. E. Richmond.

SwIntor, p. v., Kane co., $I l .: 155$ m. N. E. Springfield. Switzerland county, Ind. Situate S. E. on Ohio $\mathrm{r}$. and contains $216 \mathrm{sq.} \mathrm{m.} \mathrm{Drained} \mathrm{by} \mathrm{Log,} \mathrm{Lick,} \mathrm{Indian,} \mathrm{Plum,}$ Brian's, and Grant's creeks. Large and fine bottoms lino the Ohio, and the hills back of these rise to a height of 400 or 500 fect; further back a high table-land is reached. Soils are everywhere good. Mills are numerous, and many are worked by steam-power. Farms 1,270 ; manuf. 79 ; dwell. 2,254, and pop.-wh. 12,866, fr. col. 66-total 12,932. Capital: Vevay.

Sybertsvilite, p. o., Luzerne county, Penn.: 85 m. N. E. Harrisburg.

Srcamore, p. V., and cap. De Kalb co., IU.: on the left side of the river so called, $\mathbf{1 5 7} \mathrm{m}$. N. E. Springfield. It contains the county court-house, etc. It is a pleasant place, located on a prairie near a clear brook, and contains 975 inhabitants.

SroAMORE, to and p. F., Wyandott co., Ohio: $66 \mathrm{~m}$. N. by W. Columbus. Drained by a branch of the Sandusky $r$. Surface level, with a productive soil. The v. is situate near the stream, and is a small agricultural settlement. Population of $t .850$.

SxcAurore, p. 0., Claiborne co., Tenn.: 187 m. E. by N. Nashville. 
Srcavore Altex, p. v., Halifax co., $N$. Car.: N. of Tar r., $57 \mathrm{~m}$. N. E. Raleigh.

Syoanore Grote, p. o., Overton co., Tenna: $81 \mathrm{~m}$. E. by N. Nashville.

Sxcamore Mruts, p. 0., Davidson co., Tenn.: 17 m.N.W. Nashville.

SydXoRsvili.e, p. v., Franklin co., Firg.: between Chestnut and snow creeks, 123 m. W. S. W. Richmond.

SYeestrlle, p. v., Carroll co., Md.: on N. side of W branch of Patapsen r., and on the Baltimore and Ohio R. R., $32 \mathrm{~m}$. W. by N. Baltimore, and $37 \mathrm{~m}$. N. N. W. Annapolis.

Srlacatga, p. v., Talladega co., Ala.: on the line of the

Alabama and Tennessee R. R., $53 \mathrm{~m}$. N. Montgomery.

SrLAmore, p. o., Izard co., Ark.. : 85 m. N. Little Rock.

Sylco, p. o., Polk co, Tenn.: 139 m. S. E. Nashville.

Sruta, p. v., Washington co., Ark. : on a cr. of Illinois r., $153 \mathrm{~m}$. N. W. Little Rock.

SYlvar, t, and p. v., Washtenau co., Mrich.: $3 S$ m. S. E. Lansing. Drained by the head waters of Huron r. Surface undulating; soil rich and productive. Wheat, corn, and oats of an excellent quality are raised. The Michigan Central R. R. passes through the t., near which is the village. Pup. of t. 954.

Sylpar, p. o., Franklin county, Penn.: 50 m. W. S. W. Harrisburg. In the vicinity is a lorge producing annually 100 tons blooms and 50 tons bars.

SiLvax Grove, p. v., Jefferson co., Ga. : at the source of Lambert cr., $59 \mathrm{~m}$. E. Milledgeville.

SrLtan Grove, p. o., Clark county, Ind.: 90 m. S. by E. Indianapolis.

Srlvavta, p. 0., Bradford county, Penn.: 101 miles N. Harrisburg.

Srlpanta, p. 0., Racine county, Wisc.: 171 m. E. S. E. Madison.

SrLvanta, p. v., and cap. Seriven co., Ga.: 105 m. E. S. E. Milledgeville. It contains a court-house, jail, etc.

Srlvanta, p. o., Parke co., Ind.: $53 \mathrm{~m}$. TV. Indianapolis. Srutania, p. 0., Licking county, Ohio: 25 miles N. E. Columbus.

Srlfanxa, sta., Lucas co., Olio: on the Erie and Kalamazoo R. R., $11 \mathrm{~m}$. N. W. Toledo, and $123 \mathrm{~m}$. N. N. W. Columbus.

Srltavus, p. o., Hillsdale co., Mreh. : 59 m. S. Lansing. Sxlvta, p. 0., Hardin co., Ohio: 57 m. N. W. Columbus SrLtester, t. and p. o., Greene county, Wisc.: $32 \mathrm{~m}$. S. Madison. Drained by a branch of Sugar r. Surface level; soil fertile. Pop. 712.

STMME's Corners, p. o., Butler co., Ohio: $90 \mathrm{~m}$. W. S.W. Columbus.

Symve's CrRek, p. o., Muskingum co., Ohio: $49 \mathrm{~m}$. E. Columbus.

SrMsonta, p. 0., Graves county, $\bar{k} y$ : $229 \mathrm{~m} . \mathrm{s} . \mathrm{W}$

Frankfort.

SYraCUSE, p. va, Kosciusko co, Ind.: on the N. W. border of Turkey lake, at the mouth of Turkey cr., its outiet, $113 \mathrm{~m}$. N. Indianapolis.

Srracuse. p. city, and cap. Onondaga county, $N . Y$. . on E. bank of Onondaga cr., near its entrance into Onondaga lake; from Albany, $180 \mathrm{~m}$. W. by N. (direct); by railroad, $148 \mathrm{~m}$. It is regularly laid out with wide streets crossing at right angles, and is for the most part handsomely built of brick. Many of the public buildings and churches are handsome edifices. The hotels are noted for their size, elegance, etc., and good fare. Its manufactures, besides the salt-works, are extensive, the principal of which are iron castings, machinery, and flour. According to the Report to the Bank Department of the State, for Oct. 25th, 1852 , there were then eight banks in Syracuse, with an aggregate capital of $\$ 1,040,000$. The enstraction of the various canals and railroads which pass through Syracuse bare made it the centre of a vast domestic trade with all parts of the State: these are, the Erie Canal, $171 \mathrm{~m}$. from Albany, $198 \mathrm{~m}$. from Buffulo; Oswego Canal, extending hence to 832
Oswego, $38 \mathrm{~m}$.; Syracuse and Utica R. I., $53 \mathrm{~m}$.; Rnchester and Syracuse R. R., 104 m.; Rochester and Syracuse Direct R. R., 68 m.; Oswego and Syracuse R. R., $85 \mathrm{~m}$. The Syracuse and Binghampton R. R. is in construction, and the Syracuse and Newburg R. R. has been projected. These great avenues of intercourse and trade have very rapidly increased the population and general prosperity of the city, and will continue to develop its permanent greatness and importance among the large eities of the State and of the Union. The newspapers published in 1850 comprised 17 issues, viz., 4 dailies: "Onondaga Standard" (dem.), "S. Journal" (whig), "S. Star" (whig), "Transeript" (neutral), each of which published weekly editions (the "Star" also a semi-weekly) ; 6 other weeklies: "Onondaga Sentinel" (whig), "Religious Recorder," "Free-School Clarion," "Liberty Party Paper" (abol.), "Archimedean," "Central New Yorker ;" 1 semimonthly, the "Temp. Protector;" and 2 montbly, "Syracusean" (indep.), and "Literary Union" (lit.) Pop. in 1830, 2,565 ; in $1840,6,502$; in $1850,22,271$.

Syracuse is celebrated for its great salt works. The salt water is conveyed in pipes from the springs or wells to the works. The coarse salt is produced by solar evaporation; fine salt by boiling, and other modes of applying artificial heat. The springs are pierced through the alluvial, and terwinate on gravel. The wells generally used are excavated about 18 or 20 feet deep. In one case a boring of 250 feet deep was made withont finding fossil salt, but the strength of the brine increased (as generally) with the depth of the well. From the strongest spring a cubic foot of water will afford 14 pounds of salt. In 1810, a new salt spring of great strength was discovered by boring to a depth of 265 feet, from which large quantities of salt are now manufactured, 30 gallons of the water producing one bushel of fine salt. From recent experiments in salting beef for the purpose of comparing the relative merits of Onondaga and Turks Island salt, it has been satisfactorily ascertained that the Onondaga is fully equal in all respects to the Turks Island salt, and in some points superior. The quantities of salt here manufactured during the year 1850 , were as follows : 257,552 bushels of coarse salt, $\$ 13,852$ bushels of fine salt, 53,600 bushels of ground or dairy salt-total $1,1 \$ 4,928$ bushels. This total is about one-half of the total of salt manufacture in Salina during 1S50, and about one-fourth of the aggregate amount manufactured in 1850 in this ant district.

\section{T.}

TABB's Creek, p. o., Granville co., N. Car.: $44 \mathrm{~m} . \mathrm{N}$. Raleigh.

TABEEg, p. $\nabla$, and sta., Oneida co., $N . Y_{\text {. }}$ on $\mathrm{W}$. bank of Fish cr., $110 \mathrm{~m}$. W. N. W. Albany. It contains a blast furnace, 2 grist and several saw mills, etc. The Watertown and Rome R. R. pnsses a little $S$. of the village, $11 \mathrm{~m}$. from Rome, $61 \mathrm{~m}$. from Watertown.

Tabernacle, p. o., Marion dist., S. Car.: $85 \mathrm{~m}$. E. by N. Columbia.

TABLE mountain, Greenville dist., S. Car.: this remarkable mountain, about $26 \mathrm{~m}$. N. W. Greenville, is elevated 3,168 feet above the surrounding country, and about 4,000 feet above sea level; one of its sides is an immense rocky precipice, with bold square front, presenting a very grand appearance.

TABLE mountain, Sierra co., Calif: : $151 \mathrm{~m}$. N. E. by N. Vallejo, is 8,000 feet high.

TABLE Grote, p. o., Fulton co., $\pi l_{0}: 65 \mathrm{~m} . \mathrm{N}$. W. by N. Springfield, surrounded by an elevated and beautiful tract of timber, from which it derives its name.

TABo, p. o., La Fayette county, $M_{0}: 96 \mathrm{~m}$. W. N. W. Jefferson City.

TABOR, P. O., Tuscarawas county, Ohio: 83 m. E. N. E Columbus. 
Tacalvene. p. o., Marshall county, Miss. : on N. side of branch of Tippah er., $169 \mathrm{~m}$. N. by E. Jackson.

T'achora, p. o, Marquette co., Wiəc. : $52 \mathrm{~m}$. N. by E. Mitdisun

Tacketr's Mili, p. o., Stafford county, Firg.: $61 \mathrm{~m} . \mathrm{N}$. Richmond.

TAcos, p. o., Gilmer county, Ga.: on W. side of Tacoa river, $144 \mathrm{~m}$. N. N. W. Milledgeville.

TAconx, sta. Philadelphia co., Penn. : on Delaware r., and the Trenton R. R., 8 miles N. E. Philadelphia.

Tafton, p. v., Pike co., Penn. : 123 m. N. E. Harrísburg.

TAFisfilie, p. v., Windsor county, Verm.: 46 m. S. Montpelier.

Tagukanic, t. and p. o., Columbia co., $N . Y .: 40 \mathrm{~m} . \mathrm{s}$ Albany. Surface hilly and mountainous; soil very fertile in the valleys. Drained by Copake or. The t. contains a few mills of different kinds. Pop. of t. 1.540.

TAGLKANIC mountains, $N$. $Y$.: a range in the E. part of the State, near the state line, commencing in Rensselaer county, and extending through Columbia and Duchess counties. They are partly in Massachusetts, and have their highest summils in sheffield, about 3,000 feet above tide-water. The range is about $50 \mathrm{~m}$. long, and is properly a division of the Green Mountains.

TahlequaH, p. v., and cap. Cherokee nation, Ind. Ter'.: on Illinois r. of the Arkansas, $53 \mathrm{~m}$. N.W.Van Buren, Ark. Here are licated the council-house, U.S. agency, missions, etc., of the Cherokees, and allogether it is a thriving settlement.

TaIls CreeK, p. o., Gilmer co., Gü : $136 \mathrm{~m}$. N. W. by W. Milledgeville.

Talahatah, p. o., Newton co., Miss. : 63 m. E. by N. Jackson.

Talasha, p. 0., Newton co., Miss. : 67 m. E. Jackson.

TALвот county, Ga. Situate toward the W.. and contains 451 sq. m. Drained by branches of Flint $r_{\text {., }}$ which forms its E. and N. E. boundary. Surface hilly; soil fertile, and is peculiarly adapted to cotton which is produced largely. Wheat and Indian corn are raised in large quantities, and there is some timber land. Farms 928; manuf. 46; dwell. 1,324 , and pop.-wh. $7, \mathbf{i} 93$, fr. col. 18 , sl. 8,723-total 16,534 . Cupitul: Tulboton. Public Works: Muscogee R. R.

TAlbot county, $M d$. Situate E. toward the $\mathbf{N}_{\text {., }}$ and eontains $336 \mathrm{sq}$. m. Drained by small streams which flow into Choptank $r$. and the several bays set up from the Chesapeake. Surface varied; soil fertile, well adapted to wheat and Indian corn, the chief productions of the co. Wye $\mathrm{r}$. runs along its N. W. border. Farms 793; manuf. 35; dwell. 1,751, and pop -wh. 7,080, fr. col. 2,597, sl. 4,184-total 13,511. Capital: Easton.

TАLвотток, p. v., and cap. Talbot county, Ga.: $73 \mathrm{~m}$. W. S. W. Milledgeville. It contains the county buildings, 2 academies, 2 churches, ete. Pop, about 600

Talraferro county, $G a$. Situate N. E. centrally, and contains 163 sq. m. Little r, runs through the N. E., by branches of which, and of Ogeechee $r$. it is drained. Surface level or rolling; soil fertile and produces cotton abundantly, also wheat and Indian corn, and fine crops of apples, pears, and other fruits. Pine timber is found on the land. Farms 294 ; manuf. 16 ; dwell.408, and pop.-wh. 2,051, fr. col. 51, sl. 8,0 4-total 5,146. Capital: Craw fordsville. Pultic Works: Georgia R. R.

Talibenela, p. 0., Pontotoc co., Miss. : 150 m. N. N. E. Jackson.

Talkng Rock, p. O., Gilmer co, Ga.: $132 \mathrm{~m} . \mathrm{N}$. W. by N. Miiledgeville.

Talladega county, Ala. Situate toward the N. E., and contains $1,206 \mathrm{sq}$. m. Drained by branches of Coosa river, which forms its western boundary, and also by branches of Tallapoosa r., which traverse its southern portion. Surface level; soil very fertile. Cotton is the staple, and is produced In abundance; wheat and Indian corn are raised in good crops, and there is some excellent pasture, on which large numbers of cattle and hogs are fattened. Agriculture is the leading pursuit with a large portion of the population. Farms 993; manuf. 21; dwell. 1,861, and pop.-wh. 11,618, fr. cul. 85, sl. 6,971-total 18,624. Capitral: Talladega Public Works: Alabama and Tennessee River $R . P$.

Talladega, p. v., and cap. Talladega county, Ala.: on a small branch of Coosa r., $75 \mathrm{~m}$. N. by E. Montgomery. It contains the county buildings, ete. The "Alabama Reporter" (whig), and "Democratic Watchtower" (dem.) are issued weekly. The Alabama and Tennessee Piver P. R. wil pass through this place. Pop. about 700.

TAllahasser, p. city, and cap. Leon county, Flor.: and capital of the State of Florida. Latiture $30^{\circ} 28^{\prime} \mathrm{N}$.; longitude $\$ 4^{\circ} 36^{\prime} \mathrm{W}$. from Greenwich. It is situated on a commanding eminence, and is regularly laid out with several public squares. Iis settlement. was commenced in 1824, upon its selection as the State capital. The legislature held its first session here in 1525 , and ineorporated the eity. It contains the State-house, court-house, U. S. land office, market-bouse, jail, academy, and three churches. Two newspapers are published weekly, "Sentinel," and "Floridian and Journal," The Tallahassee and St. Marks R. R. connecting it with Port Lenn on Appalachee bay, will be extended $\mathrm{N}$. to Thomasville, Ga, to connect with the proposed Brunswick and Florida R. R. A good mill-stream flowing from several springs, rüs on its E. border, falls 15 or 16 feet ints a pool scooped out by its own current, and after running a short distance, sinks into a cleft of the limestone. In the winter, it is a place of considerable resort Pop. in 1S50, 1,391.

TAllanatchie county, Miss. Situate toward the N. W. and contains 898 sq. m. Drained by Tallahatehie r. and its branches. Surface level ; soil fertile and adapted to cotton, it also is well fitted for grain, and makes good pasture land. Chief productions, cotton and Indian corn. Farms 282; manuf. 0 ; dwell. 368, and pop.-wh. 2,096, fr. col.-, sl. 2.547-total 4,648, Capital: Charleston.

Tallatoosa, p. o., Marshall county, Miss.: on S. side of branch of Oka Copasau r., $172 \mathrm{~m}$. N. by E. Jackson.

Tallapoosa county, Ala. Situate toward the E., and contains $916 \mathrm{sq}$. m. Tallapoosa r. enters it in the N. E., and flows through the western portion, by which and its branches it is drained. Surface level; soil fertile and adapted to cotton, wheat, and grain, fine crops of which are annually raised. Farms 1,270 ; manuf. 18 ; dwell. 2,037 , and pop.wh. 11.511, fr col, 0, sl, 4,073-total 15,584. Capital: Dadeville. Public Works: Montgomery and West Point Railroad.

Tallapoosa, p. o., Greene co., $A l \alpha .: 96$ m. W. N. W. Montgomery.

Tallapoosa, p. o., Carroll co., Ga.: on E. side of Tallapoosa r., 136 m. W. N. W. Milledgeville'

Tallapoosa river, $G \alpha_{0}$ and $A l a$. : rises in Carroll county, Ga, flows in soutberly winding course to its junction with Coosa r., $12 \mathrm{~m}$. N. Montgomery, which together form the Alabama river.

Tallassee, p. v., Tallapoosa county, $A l \alpha$. : on E, side of Tallapnosa r., 29 m. E. N. E. Montgomery.

TAlleyvilie, p. o., New Castle co., Del.: 49 m. N. by E. Dover.

Tarlmadge, t, and p.o., Ottawa county, AFech.: on both sides of Grand $r_{*}, 64 \mathrm{~m}$. W. by N. Lansing. This was, in 1850 , the most productive farming $t$, in the co, but not more than one-fiourth of its area was then cultivated. It contains 3 saw-mills using water-power, of which the annual product in 1850 , was valued at $\$ 15,820$. Population in 1810,139 ; in $18,50,34$.

Tallmadge, t, and p. v., Summit county, Ohio: $109 \mathrm{~m}$. N. E. Columbus. The Akron Branch R. R., and the Pennsylvania and Ohio eanal pass through its N. W. corner. The t. contains a large part of the $\mathrm{V}$. of Cuyahoga Falls, and Middleburg $v$. Tallmadge $v_{0}$, in the centre of the $t$, is pleasantly laid out. Near the Cuyahoga Falls is an extensive bed of bituminous coal. Pop, of t. 2,456 . 
Tallokas, p. o., Lowndes county, Ga.: 156 miles S. Milledgeville.

Tallolar, p. va, and cap. Issaquena co, Mfiss.: on $\mathbf{E}$. bank of Mississippi r., 62 m. N. W. by W. Jackson.

Tallolar river and falls, Ga.: rises in Rabun co. in the N. E. corner of the State, flows S. E., separating Rabun and Habersham counties, and unites with the Chatuga to form the Tugaloo, one of the two head streams of the Savannah $r$. The falls are not broad, but have a great descent, and present a most romantic and delightful appearance.

TALLT-Ho, p. o., Granville county, N. Car.: $36 \mathrm{~m} . \mathrm{N}$. Raleigh.

Talofa, p. o., Madison county, Flor. : 55 m. E. S. E. Tallahassee.

TAsca county, $T a$. Situate centrally, and contains 720 sq. m. Drained by Iowa $r$. and its branches, and affluents of Cedar r. Surface undulating and diversified; soil fertile, and adapted to wheat, grain, and other agricultural productions; it is also favorable to the cultivation of fruit. Pine and other timber is found on the land. Farms 0 ; manuf. 0 ; dwell. 1, and pop.-wh. 8, fr. col. 0-total 8. Capital:-

Tamaqua, p. b. and sta., Schuylkill co., Penn.: on Little Schuylkill river and $\mathrm{P}$. R., $20 \mathrm{~m}$. from Port Clinton, $5 \mathrm{~S}$. N. E. Harrisburg. It was founded in 1529. It is surrounded by a wild, mountainous, and sterile country, but abounding with excellent anthracite coal, the trade in which constitutes almost the entire business of the place. The following are the statistics of this trade for the year ending 30th June, 1850 :

Coal Operators, capital $\begin{gathered}\text { Monthly } \\ \text { invested, } \\ \text { wnges. }\end{gathered}$ Annual product.

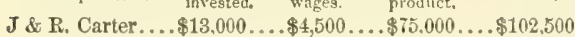
Heaton \& Carter. $5,500 \ldots .600 \ldots .8,400 \ldots . .6126,000$ R. Ratcliffe \& C $\% 10,000 \ldots 1,400 \ldots 20,000 \ldots 30,000$ Wm. Donaldson. $8,000 \ldots 1,200 \ldots 20,000 \ldots 30,000$ Jas. Taggart. .... $6,000 \ldots 1,800 \ldots 1, \ldots, 000 \ldots \quad 21,000$

The "Tamaqua Legion" (neut.) is issued weekly. Pop. about 600 .

TAuApaWA, p. V., Monroe co, $1 l_{\text {. }}$ : on W. bank of Kaskaskia r., 104 m. S. by W. Springfield.

TANPA, p. v., and cap. Hillsboro' county, Flor.: at the head of Tampa bay, $209 \mathrm{~m}$. S. E. by $\mathrm{S}$. Tallahassee. Here is Fort Brooke, garrisoned by U. S. Artillery.

TAMPA bay, Flor.: is the largest bay in the Gulf of Mexico. It sets up N. E. from the gulf into the N. part of Hillsboro' co., is about $40 \mathrm{~m}$. long, and i.l one place $35 \mathrm{~m}$. wide. It is easy of access, has 15 to 20 feet of water on the bar, and affords safe anchorage. It receives five small creeks. Little Tampa bay, in its N. part, is $10 \mathrm{~m}$. wide, but very shallow. Tampa bay abounds wilh fish and water fowls, and has several islands at its mouth.

TAMrico, p. 0., Oktibbeha co, MFiss. : on $\mathbf{S}$. side of Oka Tibbyhah r., 119 m. N. E. by N. Jackson.

TAmpico, p. o., Darke co., Ohin: $81 \mathrm{~m}$. W. Columbus.

TAmpico, p. o., Grainger co., Tenn.: 177 m. E. Nashville.

TANwoRth, to and p. o., Carroll en., N. Hamp.: $45 \mathrm{~m}$.

N. by E. Concord. Drained by Beareamp r. and branches, flowing into Ossipee lake, and affording water-power to several saw-mills. The interests of the to are chiefly agriculturat. Pop. of t. 1,766.

TaMwortil Inow-Works, p. 0., Carroll co., N. Eamp.: $46 \mathrm{~m} . \mathrm{N}$. by E. Coneord.

TANer county, Mo. Situate S. toward the W., and contains 1,071 sq. m. Drained by White r. and its tributaries, Bull, Swan, and Big and Little Beaver creeks, Surface level; soil in general fertile, and adapted to the culture of wheat, grain, cotton, and tobacco. It is well-timbered and has excellent pasturage. Farms 509; manuf. 0; dwell. 6S0, and pop.-wh. 4,274, fr. col. 0, sl. 99-total 4,373. Capital: Forsyth.

TANEx, p. on, Washington co, $A r k$ : 125 m. N. W. by W. Little Rock.

Tanestown, p. v., Carroll co, Ma. : 38 m. E. by S. An$\$ 34$ napolis. It contains several mills and iron-works, Pop. 279 (363 wh., 16 fr. col.),

TANexville, p. o., Lycoming co., Penn.: 72 m. N. by W. Harrisburg.

Tangapila, p. o., St. Helena parish, $L a .: 43$ m. E. N. E. Baton Rouge.

TangIr sound, Ma.: in Chesapeake bay, off Somerset county, $24 \mathrm{~m}$. long, 6 to $10 \mathrm{~m}$. wide. It contains numerous islands, and receives several rivers.

TANner's Cross RosDs, p. O., Jackson co., Firg. : 243 m. W. N. W. Richmond.

TANner's Store, p. o., Mecklenburg co., Tirg.: $72 \mathrm{~m}$. S. W. Richmond,

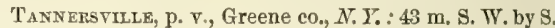
Albany.

Tannersville, p. v., Monroe co., Penn.: on E. bank of a creek of Delaware r., $93 \mathrm{~m}$. N. E. by E. Harrisburg.

Taos county, $N$. Mrew. Occupies a large territory in the N. E., extending from 1030 to $107^{\circ} \mathrm{W}$. long., and between $36^{\circ}$ and $38^{\circ}$ N. Iat. Surface generally mountainous, with large valleys, through which traverse the Rio Grande, etc. and from the E. slope of the mountains flow tributaries of the Arkansas, Canadian, and other large rivers. It is rich in minerals, as gold, silver, and iron, and in the Ratone Mountains bituminous coal exists. Farms 651; manuf. 13 dwell. 2,214, and pop.-wh. 9,507, fr. col. 0-total 9,507. Capital: Taos.

TAos, p. v., Cole county, MIo.: 7 m. S. E. by E. Jefferson City.

TAos, p. v., and cap. Taos co., $N$. Mex.: on a small tributary of the Rio Grande, $65 \mathrm{~m}$. N. by E. Santa Fé. It contains a Catholic church and school.

Tapleyville, p. o., Essex co., Mass.: 20 m, N. by E. Boston.

Tappahannock, p. v., port of entry, and cap. Essex co. Virg.: on S. W. side of Rappahannock r.. alout $50 \mathrm{~m}$. from its entrance into Chesapeake bay, $43 \mathrm{~m}$. N. E. by E. lichmond. Its site is low and unhealthy. It contains the $\mathrm{co}$. buildings, a church, and female seminary. It bas a good harbor. The total tonnage of Tappahannock district on 30 th June, 1850 , was 5,824 tons. The registered tonnage amounted to 503 tons (172 tons permanent, and 331 tous temprrary). The enrolled and licensed tonnage amounted to 5.321 tons, consisting of 4,975 tons permanent, 346 tons "Jicensed under 20 tons," all of which was employed in the consting trade. During the year preceding, the number of clearances for foreign countries was 7-802 tons; number of entrances do., $7-718$ tons; and one schooner was built43 tons.

TAPPAN, Harrison co., Ohio: 108 m. E. N. E. Columbus. TAPPAN bay, $N_{1} \boldsymbol{Y}_{\mathrm{*}}$ : is an expansion of Hudson river, between Rockland and Westehester counties, $11 \mathrm{~m}$. long, $3 \frac{\mathrm{m}}{\mathrm{m}}$. wide, terminating near Piermont, $24 \mathrm{~m}$. above $\mathrm{New}$ York.

TAPPANTOWN, p. v., Rockland en. N. Y.: $2 \mathrm{~m}$. W. of Iludson r., $108 \mathrm{~m}$. S. Albany. It contains 2 churches, a few stores, et. Major Andre was here executed, Oct. 2, 1780, and buried in the vicinity. In 1831 his remains were disinterred, removed to England, and interred in Westminster A bhey.

TAR river, $\lambda$. Car.: rises in Person county, and flows in general course E. S. E. into Pamlico Sound. Below Washington it expands into a wide estuary, commonly called Pamlico r. It reetives several streams, of which the principal is Fishing er. It is about $180 \mathrm{~m}$. long, aud is navigable for small steamboats to Tarboro', and to Washington for vessels drawing 9 feet of water.

Tarboro', p. V., and cap. Edgecomb county, $N$. Car. : on W. side of Tur r., $68 \mathrm{~m}$. E. by N. Raleigh. Small steamboats ascend the river to this place. It contains the courthouse, etc, an academy, and a branch of the Bank of State of North Carolina, with capital of $\$ 150,000$. Population about 700 . 
TARDyville, p. o., Pontotoc co., Miss.: 162 m. N. N. E. Jackson.

Tarevtris, p. v., Alleghany co., Penn.: on N. W. side of Alleglany r., $147 \mathrm{~m}$. W. by N. Harrisburg. The Western Dirision of Pennsylvania Canal passes through, $19 \mathrm{~m}$ N. E. from Pittsburg, Pop. 509.

TARifF, p. o., Butler co, Ohio: on E, side of branch of Miami r., 100 m. S. W. by W. Columbus.

Tariffrille, p. v. and sta., Hartford county, Oonn. : on Farmington r, $12 \mathrm{~m} . \mathrm{N} . \mathrm{N}$. W. Hartford, and on the Nerw Haven and Northampton R. R., $45 \mathrm{~m}$. from New IIaven. It contains the large carpet factories of the Tariff Manuficturing Co., which employs a captital of $\$ 300,000$ in this business.

TARKIO, p. o., Holt co., MOo : on W. bank of Big Tarkio cr., a tributary of the Missouri, $210 \mathrm{~m}$. N. W. by W. Jefferson City.

TARLton, p. v., Pickaway co., Ohio : on E. side of Salt cr., $30 \mathrm{~m}$. S. S. E. Columbus. It contains 3 churches, several stores, ete. Pop. about 450.

TARPaU LiN cove, MIass.; on S. E. side of Naushon island, in Tineyard Sound. This is a good harbor, and has a lighthouse on its W. side.

Tarrant county, Tex. Situate toward the N., and contains 1,018 sq. m. Drained by W. fork of Trinity r. and its affluents. Surface undulating; in the $\mathrm{N}$. are Stewart's Mt. and Pilot Hill, considerable eminences. Soil fertile, and vields good crops of wheat and Indian corn. It is thickly covered wilh timber, and contains minerals, Capital. Tarrant Court-house.

Tarrant, p. v., and eap. Hopkins co., Texo. : 249 m. N. E. Austin City. It contains the county buildings, and is surrounded by an undulating and very fertile country, abounding with good timber.

Tar River, p. o., Granville co., N. Car.: 32 m. N. by C. Kaleigh.

Tarritown, p. v. and sta., Westchester co, $N_{0} Y_{0}:$ on E. bank of Hudson r., and by Hudson Piver R. R. $27 \mathrm{~m}$. from New York, $117 \mathrm{~m}$. from Albany. It contains a female seminary, an academy for boys, and 3 churches. It has a large river trade with New York. Major Andre was captured near this $\mathrm{v}$. in September, 17S0. In the vicinity is "Sleepy Hollow," described by Washingtou Irving, who resides $2 \mathrm{~m}$. below the v. Pop. about 1,000 .

Tarversville, p. V., Twiggs co., Ga.; 42 m. S. S. W. Nilledgeville. It contains an academy, a few stores, and sereral dwellings.

TAssinong GRove, p. o., Porter co, Ind.: $115 \mathrm{~m}$. N. by W. Indianapolis.

Tatesville, p. on, De Soto county, Driss.: on N. side of branch of Cald Water r., $161 \mathrm{~m}$. N. Jackson.

TATEStreIE, p. 0., M·Nairy eo.,Tenn. : $120 \mathrm{~m} . \mathrm{S} . \mathrm{W}$. by W. Nashville.

TAtNALi county, $G a$. Situate toward the S. W., and contains $1,023 \mathrm{sq}$. m. Great Ohoopee r., a tributary of Ocmulgee $r .$, by which and also by Little Cannouchee r. and Pendleton's and Beard's creeks it is drained. Surface rolling; soil in general fertile, but a large portion of the land is covered with pine and other timber. It contains some minerals. Farms 327; manuf. 10 ; dwell. 434, and pop.wh. 2.378, fr. col.15, 8l. 831-total 3,227. Capital: Reidsville. Public Works: Savannah and Flint River R. R.

TAUNTON, t., p. V., and one of the capitals of Bristol co. Jfass. : on Taunton r., $33 \mathrm{~m}$. S. Boston. Lat. (Trin. Cong. Ch. $41054^{\prime} 11^{\prime \prime} \mathrm{N}$., long. $71^{\circ} 05^{\prime} 55^{\prime \prime} \mathrm{W}$. The t. contains some gond land, which is well cultivated, but the inhabitants are chiefly engaged in manufactures. The $\mathrm{v}$. is well built. and contains many handsome buildings and private residences. Taunton Green is a fine public ground, ornamented with trees, etc., fronting which is the court-house, a handsome edifice, with four Doric columns. There are 10 churches, several of which are beautiful structures, a townhouse, jail, etc. The Mount Pleasant Cemetery is beauti- fully laid out, and contains, among other fine monuments, one to the memory of Miss Elizabeth Poole, a chief founder of this place. Some of the hotels are noted for their excellence, and in summer acemmodate many persons here spending the season. The Taunton Branch R. R. diverges at Mansfield from the Boston and Providence P. R. (11 m. to Mansfleld, $35 \mathrm{~m}$. to Boston, $30 \mathrm{~m}$. to Providence), and here connects with the New Bedford and Taunton R. R. (20 m. to New Bedford), which intersects at Myrick's sta. $6 \mathrm{~m}$., with Fall River R. R. The Taunton $\mathrm{r}$. is navigable to this place for small vessels, and some shipping is here owned, which is employed in the coasting trade and fisheries. The manufactures for which Taunton is noted are various, but the largest are of printing cloths, castings, ma. chinery, hardware, nails, etc. Great water-power is afforded by Taunton r. and its branches, Canoe and Rumford rivers. Iron works were established here as early as 1652 . Britannia ware, of superior quality, is extensively manufactured. Among the principal factories of printing cloths are the Whittenton Mills, capital $\$ 100,000$, and Hopewell Factory, capital $\$ 75,000$, each making over $1,200,000$ yards annually. There is a large manufactory of railroad cars, steam-engines, ete. The village also contains 3 banks, with aggregate capital of $\$ 500,000$, and 2 institutions for savings, Newspapers: "Taunton Daily Gazette" (dem.), "Taunton Demoerat" (dem.), weekly, and "American Whig," weekly. Pop. of t. in $1820,4,520$; in $1830,6,042$; in $1840,7,645$; in $1850,10,431$.

Tadnton river, Mass.: rises in Plymouth co., and flows $\mathrm{S}$. W. into Mount Hope bay. It is navigable for sloops of 50 tons to Taunton v., about $20 \mathrm{~m}$. It affords extensive water-power, and abounds with alewives.

TaWaWa, p. o., Shelby county, Ohio: 64 m. W. N. W. Columbus.

TAW TAW, p. o., Allen co., Ind.: 104 m. N. E. by N. Indianapolis.

TAYCHEEDA, p. v, Fond du Lac co., Wisc. : on Winnebago lake, $75 \mathrm{~m}$. N. E. Madison.

TAYLOR county, $I u$. Siluate S. toward the W., and contains $522 \mathrm{sq} . \mathrm{m}$. Drained by affluents of Nodaway and La Platte rivers. Surface undulating; soil fertile, Farms 27 manuf. 0 ; dwell. 83 , and pop.-wh. 204, fr. col. 0-total 204 Capital: Taylor C. H.

TAYLOR county, $K y$. Situate centrally, and contains 205 sq. m. Drained by affluents of Green river. Surface undulating; soll fertile, and adapted to grain and grazing. Chief productions tobacco, wheat, Indian corn, and some entton and sugar. Farms 648; manuf. 22 ; dwell. 971, and pop.-wh. 5,463, fr. col. 147, sl. 1,610-total 7,250. Capital. Campbellsville.

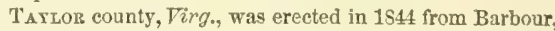
IIarrison, and Preston. Situate N. W., and contains 21 sq. m. Drained by Monongahela river, which passea through. Surface hilly and much broken; soil in some parts very fertile, best adapted to grazing. Chief products wheat, Indian corn, etc. Farms 519; manur. 19; dwell 818, and pop.-wh. 5,130, fr. col, 69, sl. 168-total 5,367. Capital: Prunty Town. Pullic Works: Baltimore and Ohio R. R.; North Western R. R.

TAYLOR, p. o., Cortlandt co., $N_{.}$. Y.: $122 \mathrm{~m}$. W. Albany.

TAYLoR, p. o., St. Charles parish, $L \alpha_{*}: 60 \mathrm{~m}$. S. E. Baton Rouge.

TAYLOR, p. o., Harford county, Md.: 89 miles N. by E. Annapolis

TAYLor, p. v., Ogle co., $\Pi l_{\star}$ : on S. side of Deep cr., 152 m. N. by E. Springfield.

TAYjoR, p. o, Davis co., Ia.: $72 \mathrm{~m}$. S. W. Iowa City.

TAYLOR, p. o., Posey county, Ind : 144 miles S. W. by S. Indianapolis.

TAYLOR's, p. v., Sumter dist., $S_{\text {. }}$ Car.: on $\mathbf{S}_{\text {. side of }}$ Lynch's creek, $60 \mathrm{~m}$. E. Columbia.

TAYLOR's, p. v., Jefierson co., $A l a_{*}$ : on the E. boundary of the county, $94 \mathrm{~m}$. N. by W. Montgomery. 
TAYLOR's Bridge, p. o., Sampson county, $N$. Car. : 54 m. S. W. by S. Raleigh.

TAYrorsburg, p. o., Bartholomew county, Ind.: 35 miles

\$. by E. Indianapolis.

TAYLor's Corners, p. o., De Kalb co., Ind. : 128 m. N. E. by $\mathrm{N}$. Indianapolis.

TAYLoR's CrekK, p. o, Iiberty county, Ga.: 133 m. S. E. Milledgeville.

Taylor's Falis, p. v., Washington en., Minn. Ter.: on the W. side of the St. Croix river, opposite the lower falls, $32 \mathrm{~m}$. above Stillwater, and $109 \mathrm{~m}$. N. br E. St. Paul's. It was laid out in 1550 by a Mr. Taylor, and it now (1853) contains 1 store, 1 hotel, 1 mill for grinding corn, etc.

TAYloR* IslaND, p. o., Durchester countr, MTd. : on an island so called, 34 miles $\mathrm{S}$. by E. Annapolis.

TAylon's Stand, p. o., Crawford county, Penn.: $190 \mathrm{n}$. N. W. by W. Harrisburg.

TAYLOR's SToRe, p. o., Franklin county, Firg.: 128 miles W. by S. Richmond.

TAylor's Store; p. o., Knox co., Mo. : 102 m. N. by E. Jefferson City.

TAYlorstows, p. v., Washington county, Penn. : $179 \mathrm{~m}$. W. Harrisburg.

Tarlorsvilue, p. 0., Christian co., Ky.:168 m. S. W. by W. Frank fort.

TAYLORSFrLLE, p. v., and cap. Spencer county, $\bar{K} y$. on N. side of Salt river, at junction of Brashear's creek, 29 miles W. S. W. Frankfort. It contains a court-house, jail, etc.

TArlonstille, p. o., Montgomery county, Ohio: $69 \mathrm{~m}$. W. S. W. Columbus.

Taylorsville, p. v., Clinton co, Ind. : 43 m. N. N. W. Indianapolis.

TAylorsville, p. $\nabla_{4}$, Bucks co. Penn.: on $\pi$. side of Delaware $\mathbf{r}$, and on the Delaware Division of the Peansylrania Canal, 106 m. E. Harrisburg.

TAYlorstille, p. v., an:d cap. Johnson co. Temn, : on W. side of Roan's creck, 273 m. E. by N. Nashville, It conlains a court-house, jail, etc.

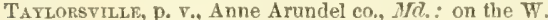
side of the W. branch of Patuxent r., $4 \mathrm{~m}$. N. W. of Lpper Marlboro', and $126 \mathrm{~m}$. S. W. Annapolis.

Taylonsville, p. o., Ontario county, $N . \quad Y .: 155$ miles W. Albany.

TAYLORSTILE, p. v., Oakland co., Hich. : 53 m. E. by S Lansing.

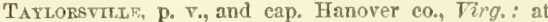
junetion of Newfound and South Anna rivers, $20 \mathrm{~m}$. N. Richmond. The Richmond, Frederickburg, and Potomac R. R. passes through this place, $110 \mathrm{~m}$. S. by W. from Washington (D, C)

Taylurstille, Patrick co., Firg.: (sce Patrick C. H.)

Tarrorstimle, p, vo, Snith co., Mriss, : on E, side of

Leaf r., $56 \mathrm{~m}$. S. E. by E. Jackson.

TATLORSville, p. v. Mudison county, Ga: $75 \mathrm{~m} . \mathrm{N}$. Milledgeville.

Taylorton, p. $v_{*}$, Tayne co., MFiss.: $4 \mathrm{~m}$. W. of Buckatung er., $102 \mathrm{~m}$. E. by S. Jackson.

TAylorvillz, P. V., and cap. Alexander co., N. Car. $182 \mathrm{~m}$. T. by N. Raleigh.

TArrorrilue, v. and sta., Bartholomew co., Ind.: on the Jefiersonville R. R., $73 \mathrm{~m}$. N. by W. Jeffersonville, $34 \mathrm{~m}$. S. by E. Iudianapolis.

TAZEWELr county, Tirg. Situate S. W., and contains $1,056 \mathrm{sq} . \mathrm{m}$. Drained by head waters of Clinch and Holston rivers, Tug fork of Sandy $r$. and its branches, and tributaries of Great Kanawha r. Surface elevated and somewhat mountainous; soil moderately fertile, adapted to grain and grass. Chief products, wheat, Indian corn, and potatoes. Farms 726; manuf. 12 ; dwell. 1,449, and pop. wh. 8.807, fr. col. 75, sl. 1,060-total 9,942. Capitul: Tazewell C. H.

TAZEWELL county, $\Pi l$. Situate $\mathrm{X}$. centrally, and contilins 8.36
$704 \mathrm{sq} . \mathrm{m}$. Illinois $\mathrm{r}$. runs on its $\mathrm{N}$. W. border, by branches of which and Sangamon $\mathbf{r}_{\text {, }}$ and also by Mackinaw er., it is drained. Surface undulating and diversified: soil fertile, of a sandy nature, and adapted to grain. Chief productions, wheat and Indian corn. There is some fine prairie and timber land. In the S. W. corner are some swamps. Pork and beef are exported. Agriculture is the leading pursuit. Farms 1,110; manuf. 76 ; dwell. 1,991. and pop.wh. 12,016, fr. col. 36-total 12,052. Capital: Fremont. Pullic Works: Oquawka and Peoria R. R.

TAZEWELL, p. v., and eap. Marion co., Ga.: on E. bank of S. Whitewater er., a tributary of Flint r., $90 \mathrm{~m}$. S. W. by W. Milledgeville. It contains a court-house, jail, academy, and several ehurches.

TAzewell, p. ., and cap. Claiborne co., Tenn. : $183 \mathrm{~m}$. E. by N. Nashville. It contains a court-house, jail, ete

TAzewell C. H. p. v., and cap. Tazewell co., Tirg. : on S. side of N. fork of Clineh r., $217 \mathrm{~m}$. W. by S. Richmond. The $\mathrm{r}$, is called Jeffersonville, and contains the court-house. jail, etc.

Tchula, p. o., Holmes co. Ifiss.: on E. bank of Yazoo r., at the mouth of Funnigusha cr., $63 \mathrm{~m}$. N. Jackson.

Tedcry's, p. o, and sta., Duplin co., N. Car.: on the Wilmington and Weldon R. R., $124 \mathrm{~m}$. S. Weldon and $74 \mathrm{~m}$. S. E. by S. Raleigh.

TEAzE's VALLEX, p. o, Kanawha county, Virg.: $248 \mathrm{~m}$. W. by N. Richmond.

TEBo, p. o., Henry county, Mo.: 78 miles W. by S. Jeffersinn City.

TECHÉ, U. S. collection district, La.: embracing 'Teché r. and vicinity; had, on June 30th, 1850, a total tonnage of 1.381 tons, consisting of 955 tons enrolled and licensed, permanent, and 426 tons licensed under 20 tons, of which the whole was employed in the coasting trade; and 538 tons were propelled by steam. During the year preceding, its foreign commerce was, 2 entrances, 904 tons, with no clearances. Vessels built during the year, 4 ( 2 schooners, 1 sloop, 1 steamer), 90 tons. Franklin is the port of entry.

TECHÉ river, $L a_{*}$ : rises near Red $r_{*}$, in Rapides parish, flows in a winding S. S. E. direction, and enters the outlet of Chetimeches lake, in St. Mary's parish. Its length is $150 \mathrm{~m}$., and it is 200 yards wide at the mouth. The channel is deep, and the tide ascends more than $100 \mathrm{~m}$. It is 20 feet deep, has $S$ feet water on the bar, and is navigable to New Iberia, 100 miles.

TecuMser, th and p. V., Lenawee county, Bich.: $56 \mathrm{~m}$. S. E. by S. Lansing, Drained by Raisin r. and branch. Surface undulating; soil fertile. It contains a number of mills and manufactories. The village of Clinton is in the $\mathrm{N}$. and Tecumseh in the $\mathrm{S}$. The latter has a pleasant location, and does a gond businese. It contains several flouring and saw mills: and the "Tecumseh Herald" is published weckly. Connected with the Michigan Southern and Northern Indiana $R$. $R$. by the Tecumseh Branch $R$. $R$. $8 \mathrm{~m}$. distant from junction. It was the former seat of justice for the county, and contains a court-house, jail, etc. Population of $t .2,673$

Tedrow, p. o., Fulton county, Ohio: 121 m. N. N. W. Columbus.

Terava, v., Colusi co., Catif.: on the right bank of Sacramento r., $127 \mathrm{~m}$. N. by E. Vallejo.

TEKONGAII, to and p. v., Calhoun county, Mich.: $46 \mathrm{~m}$. S. W. by S. Lansing. Drained by St. Joseph $\mathbf{r}$. Surface various; soil fertile. The $\mathrm{v}$. is pleasantly located on St. Joseph r. Pop. of t. 651 .

Trifare county, $G a$. Situate S. centrally, and contains $1,073 \mathrm{sq}$. m. Ocmulgee $r$, runs through it from $E$. to $W$. and then forms it $\mathrm{N}$. W. boundary. It is drained by the Ocmulgee and its principal branches, Horse, White, and Turnpike creelis, and tributaries of Santilla $r$. Surface even ; soil fertile, and produces enrn, rice, and Indian corn. A portion of the land is eovered with pine and other timber. Farms 980 ; manuf. 0 ; dwell. 840 , and pop.-wh. 
2096. fr. col, 0, sl, 930-total 2.126. Cavital: Jacksonville. Pullic Works: Savinnah and Flint R. R.

Teller's point, Westehester co., $N$. $Y_{\text {. : }}$ this peninsula lies on the E. side of IIudson $r_{\text {, }}$, in the town of Cortlandt, above the mouth of Croton $r$. It is $2 \mathrm{~m}$. long and stparates Haverstraw and Tappan bays.

Tellico Platis, p. o., Mouroe co., Tenn.: on W. side of Tellico r., 141 m. E. S. E. Nashville

Teloga Sprixgs, p. o., Chatooga co., Ga.: $165 \mathrm{~m}$. N. W. Milledgeville.

Truascal. v, Los Angeles co., Cilif: : on a branch of San Palro r., $22 \mathrm{~m}$. S. W. Míount Burnardino and $367 \mathrm{~m}$ S. E. Vallejo.

Temprerance, p. o., Telfair co, $G a$ : on E, side of Ocmulgee r., 84 m. S. Milledgeville.

Tfuperaxce, p. o., Amherst county, Fing.: $95 \mathrm{~m}$. W. Richmond.

Temperaxee Hald, p. o, De Kalb county, Tenn. ; $51 \mathrm{~m}$ E. by S. Nashville.

Temperanceyiluf, p. 0., Alleghany con, Penn.: $142 \mathrm{~m}$. W. by N. Harrisbure.

Temperanceville, p. v., Belmont county, Olio: $105 \mathrm{~m}$ E. by N. Columbus.

Temple, t. and p. v., Hillsboro' county, N. Hamp. : 32 m. S. S. W. Concord. Drained by branches of Souhegan r. which rises in this town. Surface uneven, and in parts quite mountainous; soil inferior. The village is located centrally. Pop. of t. 579 .

Temple Mrlis, p. o., Franklin county, Me. : 86 m. N. W. Augusta.

Temple of Health, p. o, Abbeville dist., $S$. Car.: on
W. side of branch of Savannah river, 89 miles W. by $\mathbf{N}$. Columbia.

TEMPLE, t. and v., Franklin entunty, JLe.: $35 \mathrm{~m} . \mathrm{N} . \mathrm{W}$. Augusta. Drained by a branch of Sandy $r$. Surface in the S. even, and on the $\mathrm{N}$. it las the Bluc Mumtains, 2,700 feet high. I'op. 755.

TEMIPLETON, t. and $\mathrm{p}$. v., Worcester co., Jrass. : $54 \mathrm{~m}$. W. by N. Boston. Druined by branches of Miller's and Chicopee rivers. Surface uneven-the elevated parts adapted to grazing, and in the valleys much grain is raised. Its manufactures consist of woolens, leather, farming implements, earriages, wooden-ware, etc. The Vermont and Massichusetts R. F. crosse's the N. E. part of the town. The village is pleasantly located on a branch of Miller's $r$. Pop. of t. 2,173.

Templeton, p. v., Prince George co., Vïrg.: 30 m. S. E. Pichmond.

Templeville, p. v., Queen Anne $c_{0}, M_{2}$; near the Delaware State line, 39 m. E. by N. Annapolis.

Tenalurtown, p. on, Washington $\mathrm{Co}_{\text {, }}$ D. of Col. : on the Georgetown and Frederick road, $2 \mathrm{~m}$. N. from Georgetown, and $5 \mathrm{~m} . \mathrm{N}$. W. from the Capitol.

Ten Mrue, p. o., Washington co., Penn. : on cr. of samo name, $167 \mathrm{~m}$. W. Harrisburg.

T'en Mrue, p. o., Macon co., Mo.: 90 m. N. Jefferson City.

Ten Mile Point, p. o., Prairie co., Ark: : 27 m. E. by N. Little Rock.

TEx Mrlf: Spring, p. o., Cattaraugus co, N. Y.: $253 \mathrm{~m}$. V. by S. Albany.

Ten Mrue Stand, p. o., Meigs co., Tenn.: on branch of Hiwassee r., 120 m. L. S. E. Nashville.

\section{THE STATE OF TENNESSEE.}

Texsmsse lies in the form of a parallelogram, with Kentucky and Vircinia on the north, North Carolina on the east, Georgia, Alabama, and Mississippi on the south, and the Mississippi Ruver on the west, which divides it from Missouri and Arkansas, and extends east and west between $\$ 1^{\circ} 37^{\prime}$ and $90^{\circ} 28^{\prime}$ west from Greenwich, or $4^{\circ} 35^{\prime}$ and $13 \circ 26^{\prime}$ west from Washington, and between the latitudes $355^{\circ}$ and $36^{\circ} 35^{\prime}$ north. From North Carolina it is separated chiefly by the Alleghanies. Its area is computed at 45,600 square miles.

Tennessee is perhaps more diversified in the character of its surface than any other of the central States. In the east, mountain jrevails, and in this section the ecountry is traversed in a nurth and south direction by several ridges of the Appalachian chain, and in its topography presents much picturesque and beatiful scenery. The midile portion of the State is less bold in its outlines, and the surface imperceptibly dectines by gradations from a region overspread by hills and swells of ever-changing and varying elevation and character, to a rolling country of exquisite fertility, and watered by innumerable streams, affluents of its great rivers, the Cumberland and Tennessee. Between the Tennessee and the Mississippi in the west, the surface is nearly level, the general evenness being interrupted only by the courses of the low water-shed dividing the tributaries of the two rivers, or by alternations of woodland and prairie. In all the country, hnivever, there are but few portions so hilly and broken as to interfere with its agricultural eapacities; the hills are clothed with wood to their summits, and the soil is everywhere sufficiently fertile for profitable cultivation, or yields nourishing/grasse's for pasturage to the hill-tops. The east abounds in minerals, the rich deposits of which are only now being disclosed, and the spurs of the mountains contain in the various rocks materials usefui for building purposes and ornamental architecture.

The Kittatinny range, under the local name of Stone, Bald, Iron, Smoky, and Unika mountains, forms the dividing line between Tennessee and North Carnlina, while the prolongation of the Alleghany chain, of Chestnut Ridge and of Laurel Ridge, traverse the State north and south. The latter, which here takes the name of Cumberland Mountains, spreads out in this Stite to a breadth of about fifty miles, filling that section of the country which lies between the Tennessee and the Cumberland rivers, before they take a western course, with long regular ridges of no great elevation. Perhaps none of their summils exceed 2,000 feet in height, but the chains are continuous, interrupted only at great intervals by gaps or passes. In some places they are rocky and rugged, while in others, and generally, they swell gently from their elevated bases and embosom numerous, delightful, and fertile valleys. The valleys of the small rivers are extremly beautiful, and rich bevond any of the same description west of the Alleghanies. The valleys of the great streams - the Tennessee and Cumberland-differ little from the alluvions of the other great rivers of the central region of the Union. In the small valleys are many fine plantations, so lonely that they seem lost among the mountains.

Noble rivers, open to navigation, and fine pure streams, furnishing ample power for economical purposes, are distingrishing features of Tennessee. The Mississippi washes the western border for 160 miles, and its banks within this Statc afford some of the most valuable commercial sites to be found in its long course. The Cumberland bas its sources and its mouth in Kenfuchy, but runs for about 250 miles in Tennessee, through which is its most southern bend; it enters this State ahout longitude $85 \circ 4{ }^{\prime} \prime^{\prime}$, and leaves it about longitude $85 \circ 12^{\prime}$, and within 10 miles to the east of Tennessee River. Steamboats have ascended to Burkesville, in Kentucky, but they rarely pass above Carthage, the point where Caney Fork meets the principal stream. To Nashville, the eapital of the State, steamboat navigation is easy and convenient. The Tennessee also rises beyond the limits of the State. The Clinch and Holston have their sources in the Alleghany ridge of Virginia, but the Watauga, a tributary of the Ilolston, the Nolichucky, and Big Pigeon, branches 
of the French Broad River, the Litlle Tennessee, and the Hiwassee-all rise in the Blue Ridge. The Little Tennessee is often considered as the main river. out it is much inferior to the Holston, with which it unites, and the confluence of the Holston and Clinch form the Tennessee River. Most of these rivers are navigable by boats, and they receive numerous valuable mill-streams. The junchon is effected at Kingston, whence the course of the Tennessee is south anil south-west until it enters Alabama, through which State its course is generally west to the Mississippi State line, on which it takes a north direction, through Tennessee and Kentucky, to the Ohio. After re-entering Tennessee, it flows 200 miles within its limits, and is navigable throughout that distance for steamboats. The Elk and Duck rivers are its only considerable tributaries: rising in the same district, on the western slope of the Cumberland Mountains, they reach their common recipient at a distance of 200 miles from each other, and are both navigable for a considerable distance. The Sequatchee is a smaller stream, flowing through a rich and beauliful valley in the Cumberland Mountains. Caney Fork, and Stone's River, the principal tributaries of the Cumberland, are navigable streams: the former rises within the mountailis, and the latter on their western slope. Western Tennessee is almost entirely drained by affluents of the Mississippi.

The mineral resources of Tennessee consist of valuable deposits of iron, copper, lead, etc., of whieh the ores are exceedingly rich; these are mostly located in the eastern and middle divisions of the State. Copper is of recent discovery, and promises to become a rich acquisition to the known resources of the country. Iron is extensively reduced along the borders of Cumberland River. In December, 1852, there were in this region 19 furnaces, 9 forges, and 2 rolling-mills in operation,* and producing in the aggregate 44,500 tons of metal annually. The lead-mines have been partially worked The gold region extends into the north-eastern part of Tennessee, but the metal has not been found in any large quanti. ties. Coal of excellent quality has been mined in the Cumberland Mountains, but, except for local purposes, ean be of little value, the means of transportation being inferior, and the coal-fields of the Ohin basin being much more aceessible and more cheap'y wrought. Formerly this coal was mined to a considerable extent, and carried from Crab Orehard Mountain, near Emory's River, down the Tennessee to New Orleans. The supposed coal of Williamson, Davidson, and Maury counties is, according to Professor Troost, aluminous slate. The State contains quarries of excellent marble and other calcareous formations; gypsum is aiso abundant; nitrous earths are found in the limestone caverns, and there are a variety of other useful minerals throughout the country; east of the Tennessee salt is abundant. In the eastern section there are numerous sulphur and other mineral springs. Many of the caverns are of great extent-some have been explored for a distance of ten miles, and contain spacious apartments, and are traversed by considerable streams.

The climate of Tennessee is mild and genial, being free from the scorching heats of the South and the ehilling blasts of the North. Cattle may graze on the plains throughout the winter. Its salubrity is unquestionable; the low valleys where the waters are stagnant, and the alluvions of the great rivers, being exceptions. The soil of East Tennessee, principally calcareous, is eminently fertile. In the west the soils vary, and the strata descend from the mountains in the fotlowing order: first, loamy soil, or mixtures of clay and sand; next, yellow clay; next, a mixture of red sand and red clay; and lastly, white sand. In the southern parts are immense beds of oyster shells, on high table-land, at a distance from any stream. Nearly all the forest trees of the central country are found in this State; juniper, red cedar, and savin cover the mountains. The pine-forests of the eastern section are valuable for their tar, turpentine, ete. The sugar-maple is very abundant. Fruit in all its varieties is raised in great perfection in every part of the State. The agricultural productions are similar to those of the Ohio Valley generally, with the addition of cotton, which is grown chiefly in the south and west. The east is ehiefly engaged in cattle-raising, and exports largely to the south. Tobacco and bemp are also staples of Tennessee, and in quality are excellent. perfect growth.

Tennessee is divided into 79 counties, the general statistics of which, and the capitals of each, in 1850 , were as follows:

Eastefi TenNessee -23 counties.

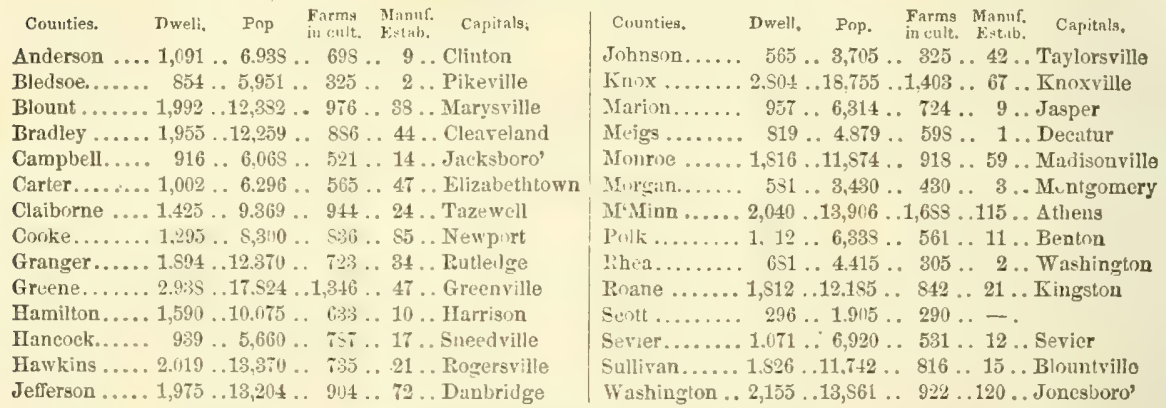

MIDDLE TEXNESEE-32 counties.

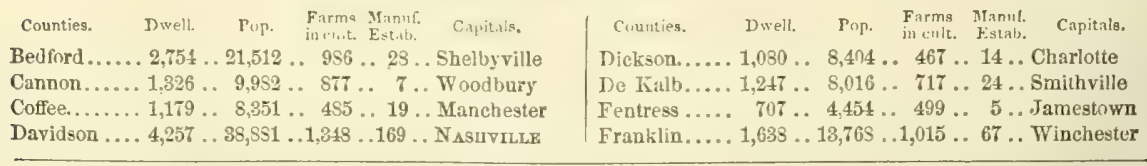

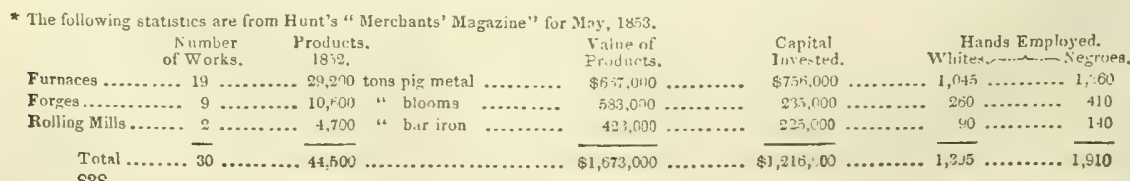




\section{TENNESSEE.}

\section{Middle Tennessee-32 counties-[continued].}

Counties, Dwell. Pop. Farms Manuf. Capitals,

Giles.......2,830 . 25,949 . 2,075 . .139 .. Pulaski

Grundy ..... $435 \ldots 2,773$.. 263 .. 2 . Altamont

Hickman.... 1,296 .. 9.397 . $778 \ldots 46$. . Centreville

Humphreys . . 919 . 6,422 .. $679 \ldots 46$.. Waverly

Jackson . . . 2 2,325 . 15,673 . 1,211 .. 4 .. Gainesboro'

Lawrence.... 1,364 .. 9,280 . . 993 . . 43 . Lawrenceburg

Lewis . . . . . . 599 . . 4,438 . . 394 . . 18 . Hampshire

Lincoln. . . . . 3,010 . 23.492 . 1,926 . .100 . . Fayetteville

Macon ....... 1,044 . 6.948 . . 7S2 .. 3 . . La Fayette

Marshall. . . 2, 2,061 . 15,616 ..1,032 . . 38 . Lewisburg

Mitury . ..... 2, 2,961 . 29,520 . 1.501 ..112 . Columbia

Montgomery . 2,086 . 21,045 ..1,227 . . 59 . Clarksville

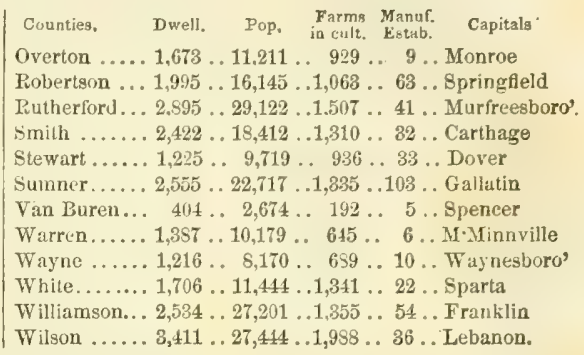

Western Texpessek-19 counties.

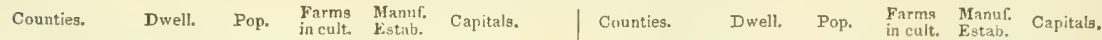
Benton...... 984 . 6,315 .. 706 . 2 . Camden $\quad$ Henry ... . . 2,245 .. 18,233 ..1,478 .. 51 . Paris Carroll ... . . 2,105 . 15,967 ..1,404 .. 24 .. Huntingdon $\quad$ Lauderdale... 565 .. 5,169 .. 287 .. 4 . . Ripley Decatur ..... 941 .. 6,003 . 443 .. 15 .. Decaturville Madison ... . 2,282 . 21,470 . .1,408 . . 49 . Jackson

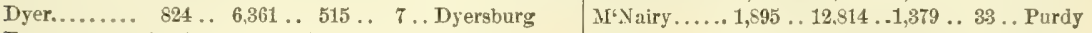
Fayette .... 1.951 . 26,719 ..1,172 . 29 .. Somerville $\quad$ Obion . . . . 1,131 . 7,683 . 653 . 6 .. Troy Gibson..... 2,529 . . 19,548 . 2,160 .. 48 . Trenton $\quad$ Perry . . . . . 927 . 5,822 . . 458 . 4 . . Linden Fenderson. . 1,798 . 13,161 . 973 . 25 . Lexington $\quad$ Shelby . . . . 2,926 . . 31,157 . 1,115 ..129 . . Raleigh Haywood ... 1,454 . 17,259 . . 967 .. 13 . Brownsville $\quad$ Tipton ..... 813 .. 8,887 . 6831 .. 16 .. Covington

\begin{tabular}{l|l} 
Hardeman ... 1,785 . 17,456 . 1,027 . . 64 . Bolivar & Weakley .... 1,943 . 14,608 . 1,467 . 13 . Dresden
\end{tabular}

The whole number of dwellings in the State was, at the above date, 129,420; of families, 130,005; and of inhabitants, 1,002,625; viz., whites 756,393-males 382,270 , and females 374,623 ; fr. col. 6,271 -males 3,072 , and females 3,199, and 81. 239,461. Of the whole population there were, deaf and dumz-wh. 335, fr. col. 2, sl. 40-total 877; blind-wh. 385, fr. col. 10, sl. 73-total 465; insane-wh. 453, fr. col. 4, sl. 21-total 478; and idiotic-wh. 789, fr. col. 4, sl. 61-total 854. The number of free persons born in the United States was 755,655 , the number of foreign birth $5, \pi 40$, and of birth unknown 1,759. The native population originated as follows: Maine 97, N. Hamp. 64, Verm. 179, Mass. 831, R. I. 38, Conn. 261, N. Tork 1,019, N. Jer. 248, Penn. 2,146, Del. 95, Md. 1,554, Dist. of Col. 101, Virg. 46,631. N. Car. 72,027, S. Car. 15,197, Ga. 4,863, Flnr. 369, Ala. 6,398, Miss. 2,137, La. 261, Tex. 100, Ark. 496, Tennessee 585,084, Ky. 12,069, Ohio 742, Mich. 7, Ind. 769, IH. 872, Mo. 920, Ia. 30, Wisc. 8, Calif. 0, Territories 2 ; and the foreign population was composed of persons from-England 706, Ireland 2,640, Seotland 327, Wales 17, Germany 1,168, France 245, Spain 3, Portugal 2, Belgium 4, Holland 57, Italy 59, Austria 10, Switzerland 266, Russia 9, Denmark \&, Norway 0, Sweden 8, Prussia 32, Sardinia 2, Greece 2, China 0, Asia 3, Africa 5, British America 76, Mexico 12, Central America 0, South America 0, West Indies 20, Sandwich Islands 0 , and other countries 59.

The following table will show the decennial progress of the population since the first census of the State, taken by the United States authorities:

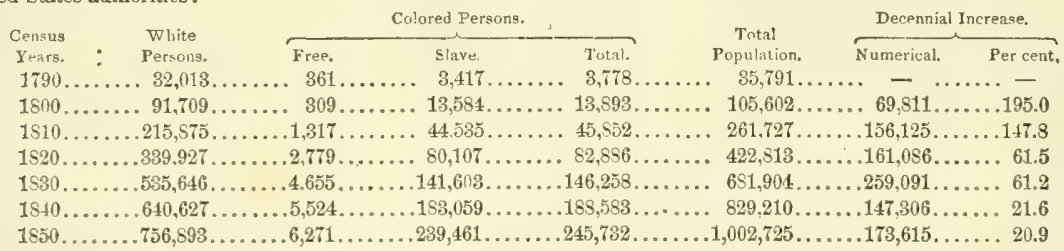

The general statistics of the industry, products, wealth, and institutions of the State, according to the census returns of 1850 , and other official documents referring to the same year, are as follows:

Occupied Lands, etc.-Improved farm Jands, 5,175,172 acres, and unimproved attached lands, 13,508,849 acres-valued together at $\$ 97.851 .212$. The whole number of farms under cultivation on the 1st June, 1850 , was 72,710 , of which 21,232 were in Eastern Tennessee, 32.545 in Middle Tennessee, and 15,933 in Westeru Tennessee. Total value of farming implements and machinery. \$5,360,220.

Live-Stock-Horses, 270,636; asses and mules, 75,303; milch cows, 250,456; working-0xen, 86,255; other eattle, 414,051; Eheep, 811,591; and swine, 3,114,111. These numbers, compared with the stock in 1840, exhibit the following results:

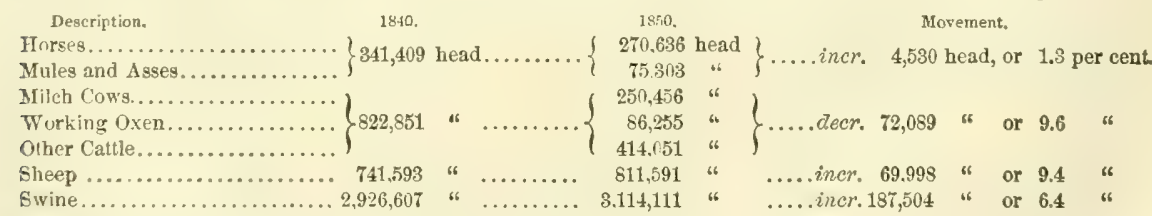

- the live-stock in 1850 was valued in the aggregate at $\$ 29,978,016$.

Products of Animals,-Wool, 1,364,378 pounds; butter, 8,139,595 pounds * cheese, 177,681 pounds; and the valne of ani- 


\section{TENNESSEE.}

mals slaughtered was $\$ 6,401.765$. The wool crop according to the census of 154() amounted to $1,060.332$ pounds; ankl hince the increase exhibited in 1550 , is 804.046 prunils, or 19.2 per cent. The prosiuct per fleece in $18 \pm 0$, was 2.2 .8 ounces, and in $1550,26.5$ ounees-increase in production 4 nunces per fleece, or 17.6 per cent.

Gl'ain Crops.-Wheat, $1,619,3 \$ 6$ busluels: rye, $\$ 9,163$ bushels; Indiau corn, $52.279,223$ bushels; oats, $7,703,056$ bushels ; barley, 2,737 bushels; and buckwheal, 19,427 bushels. Comparatively, the grain erops returued in 1840 and 1850 were as follows :

\begin{tabular}{|c|c|c|c|c|c|c|c|c|c|}
\hline $\begin{array}{c}1840 \\
4,569.692\end{array}$ & & s........ 1619.386 & $11 \mathrm{sh}$ & $8 \ldots . . . .$. & deer. $2,950,306$ & uven & & 64 & $\mathrm{ce}$ \\
\hline$\ldots \ldots \ldots \ldots \ldots . \quad 304,320$ & “ & $\ldots \ldots \ldots$ & $"$ & $\ldots \ldots \ldots$ & deci. 225,157 & 6 & or & 73.9 & " \\
\hline$\ldots 44,956,158$ & 4 & .......52,279,223 & "6 & $\ldots \ldots \ldots$ & iner. $7,293,035$ & " & or & 16.2 & “ \\
\hline$\ldots \ldots 7,035,678$ & $\because$ & $\ldots \ldots \ldots, 7,703,086$ & "6 & $\ldots \ldots \ldots \ldots$ & incr. $\quad 667.408$ & " & or & 9.4 & 65 \\
\hline 4,809 & 6 & $\ldots \ldots \ldots$ & " & $\ldots \ldots \ldots$ & decr. & 66 & or & 48.1 & " \\
\hline kwheat ......... & 6 & $\ldots \ldots \ldots$ & 66 & $\ldots \ldots \ldots$ & iner. & 66 & or & 13.4 & " \\
\hline
\end{tabular}

Other Food Crops.-Pice, 258,854 (in 1840,7,977) pounds; peas and beans, 369,321 bushels; potatoes-Irish, 1,060,844 bushels, and sweet. $2,777,716$ bushels. The potato crop of 154 ) amounted to $1,904.870$ bushels, and hence the inerease in 1650 was $1,931,190$ bushels, or 101.5 per cent. The cultivation of rice may be said to have been commenced within the decade.

Miscellaneous Crops.-Tobacco, 20,148,932 pounds; cotton, 194,032 bales of 400 pounds; hay, 74,092 tons; clover-seed, 6,096 bushels; other grass seed, 9,118 bushels; hops, 1,032 pounds; hemp-dew-rotted 3,913 tons, and water-rotted 1,183 tons : flax, 367,807 pounds; flax-seed, 18,905 bushels; silk eneoons, 1.923 pounds ; sugar-maple, 158,557 pounds, and cane, 248 hogsheads of 1,000 pounds; molasses, 7,223 gallons; beeswax and honey, 1,086,572 priunds; wine, 92 gallons, ete. The value of orchard products was $\$ 52, \$ 94$, and of market-garden products $\$ 97,183$. On comparison with the like products of 1840 the following are the results

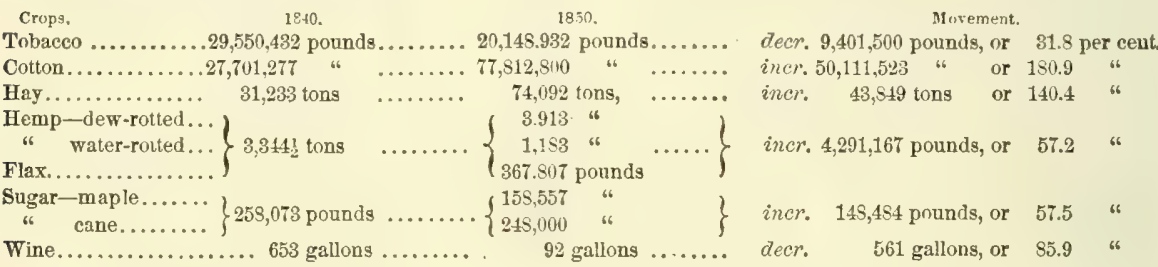

Home-made Manufactures were produced in the year ending 1st June, 1850, to the value of $\$ 3,137,710$. The same class of goods for the census year of 1840 , were valued at $\$ 2, \$ \$ 6,661$. Increase $\$ 251,049,0$ or 8.7 per cent.

Manufactures.-Aggregate capital invested, $\$ 0,000,000$; value of all raw material. fuel, etc., used and consumed, $\$ 0,000,000$; bands employed 00,000 -males 0,000 , and females 0,000 ; monthly cost of labor $\$ 00,000$ - male $\$ 00,0110$, and female $\$ 00,000$; value of the year's products, $\$ 0,000,000$. The whole number of manufacturing establishınents in operation on the 1 st June, 1850, and producing to the value of $\$ 500$ and upward annually, was 2,789-in the Eastern District 941, in the Middle District 1,297, and in the Western District 551, and distributed to the counties of each district as exhibiled in the general table. Of the aggregate number 33 were cotton factories, 4 woolen factories, 81 iron works- 16 making castings, 23 making pig iron, and 42 making wrought iron-and 394 were tanneries. The total capital employed in mauufactures, according to the returns of 1840 , amounted to $\$ 3,731,589$.

Ootton manufcctures employ a capital of $\$ 669,600$; consume annually 6,411 bales of cotton, and 3,010 tons of coal, valued at $\$ 297,500$; hands employed $\$ 91$ - males 310 , and females $5 \$ 1$; monthly cost of labor, $\$ 7,124$ - male $\$ 3,392$, and female $\$ 3,730$; products of the year-sheeting, ete., 363,250 yards, and yarn 2,326,250 pounds; value of entire products, $\$ 510,644$. In 1840 there were in the State 33 factories, with an aggregate capital amounting to $\$ 462,210$, employing 1,542 hands, and producing to the annual value of $\$ 325,719$.

Woolen manufactures have a capital of $\$ 10,900$; used 6.200 pounds of wool, valued at $\$ 1,675$; hands employed 17 males 15 , and females 2 ; monthly cost of labor $\$ 277$-male $\$ 265$, and female $\$ 12$; hats manufactured 2,220 , valued at $\$ 6,310$. There are probably other woolen factories producing to a less amount than $\$ 500$ annually. In 1540 , the 11 umber of factories was 26 , and fulling-mills 4 , with an aggregnte capilal of $\$ 25,600$, employing 45 hands, and producing to the value of $\$ 14,290$.

Iron manufactures euumerated in the census of 1850 , exhibit the following statistical details :

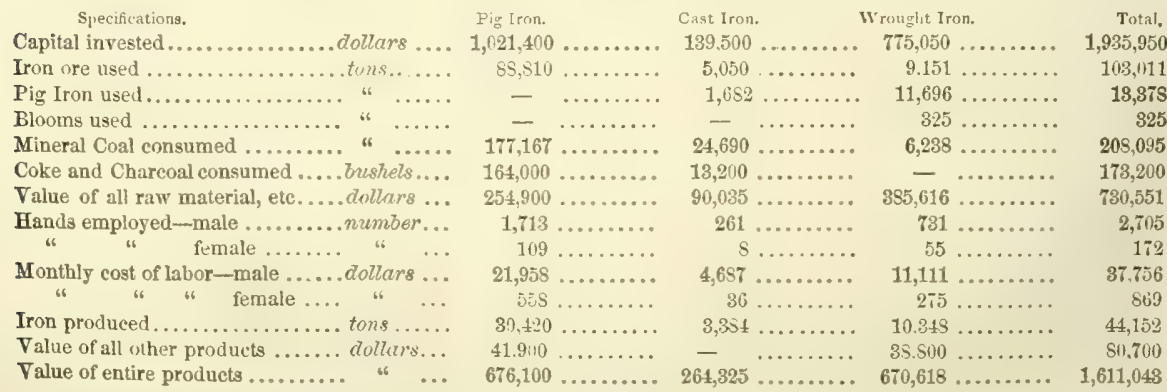

-in 1840 there wero in Tennessee 34 furnaces, producing 16,12St tons cast iron, and 99 bloomeries, forges, and rolling840 
mills, producing 9.673 tons bar iron; "fuel consumed,187,453 tons; hands employed 2,266, and aggregate capital invested in the manufiture, $\$ 1,514.736$.

Tinneries employ a capital of $\$ 490.320$; value of hides and skins, $\$ 396,159$; hands employed 921 -males 916 , and females 6 ; monthly enst of labor $\$ 14,37 /$ - male $\$ 14,338$, and female $\$ 32$; sides of leather tanned 333,888 , and skins tanned 43,4:9 : value of annual products, $\$ 746.484$. The number of tanneries in 1840 was 454 , employing a capital of $\$ 184,114$, and 9: 9 hatuds, and producing annually 133547 sides of sole leather, and 171.324 sides of upper leather.

Ifolt unt sprivitons liquors enploy in their manuficture $\$ 66.125$; quantitie's and kinds of grain, etc, consumed-barley

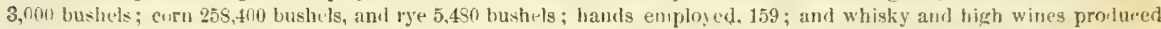
$65 \pi, 000$ galluns. In 1840 there were reported 1,426 distilleries, producing annually 1,109,107 gallons, and 6 breweries, producing 1,835 gallions; hands employed 1,341 , and capital invested $\$ 218.082$.

Tennessee has also large manufactories of machinery, hardware, and other metallic ware, brick-yards, tobacco factories, saddlery nianufactories, potteries, paper-milis, cordage factories, carriage factories, etc. Grist, saw, flour, and other mills commou to agricultural States, employ about one-third the whole capital invested in manufactures. The chief manufacturing ceatres are Nashville, Knoxville. Memphis, etc.., but the great bulk of the manufactures are distributed among the villagts. and as jet there are no manufacturing towns such as exist in the Eastern States.

Commerce and internal communication.-Tennessee has no direct foreign commerce. The internal trade carried on through its rivi.rs, railroads, and other channels, however, is extensive, and a large amount of produce, gonds, and merchandise is carried to the seaboard at New Orleans, Savannah, and Charleston, and much of the produce of the State is brought down the Teunessee and Cumberland rivers to the Ohio, and seeks a northern outlet by way of Pittburg and the lakes. The shipping owned in the district of Nashville in 1850 amounted to 8.776 tons, all of which was navigated by steam-power. The system of railroads in Tennessee is as yet but partially eompleted, but great progress has been made, and a magnificent system projected. The centres are Nushville and Knoxville. From Nashville, lines diverge toward every direction-north toward Henderson, Lovisville, Cincinnati, and Maysville, east toward Savanuah and Charleston, south toward Mobile and New Orleans. and west toward the Mississippi, at Memphis, etc. The great line from Mobile to Cairo also passes through this State. From Knoxville, lines also diverge to Louisville, on the Ohio, to Richmond on the Atlantic, and to the southern Atlantic ports. The Charleston and Memphis Railroad is also in part within this State, but chiefly in Mississippi and Alabama. Tennessee has no canals, but several of the rivers have been improved and rendered navigable. The county roads, turnpikes, etc., are of ordinary construction, and hitherto have been the only available channels of trade to and from the rivers. They are generally good, and, except in wet weather, answer the present demands of the country. The severil lines of railroad are detailed in the APPENDIx.

Banks. - On the 1st January, 1851, there were in Tennessee 4 banks and 19 branch banks. The Bank of Tennessee (head quarters at Nashville) has branehes at Athens, Clarksville, Columbia, Rogersville, Shelbyville, Somerville, Sparta, and Trenton; the Planters' bank of Tennessee (Nashville) has branches at Athens, Clarksville, Franklin, Memphis, and Pulaski ; the Union Bank of Tennessee (Nashville) has branehes at Columbus, Chattanooga, Jaekson, Knoxville, and Memphis; and the Bank of East Tennessee is located at Knoxville. The condition of the reporting banks at the date specified was as follows: liabitities-capital, $\$ 6,351,568$; circulation, $\$ 6, \$ 14,376$; deposits, $\$ 1,917,757$; due other banks, $\$ 61,638$; and other liabilities, $\$ 10,000$; and assets-loans and discounts, $\$ 10,992,139$; stncks, $\$ 432,902$; real estate, $\$ 662.520$; due by other banks. $\$ 1,559,418$; notes of other banks, $\$ 729,186$; and specie, $\$ 1,458,778$. A free banking law has come intn operatiou since the above returns were made, and several banks have commenced under its provisions.

Government.-The first constitution of Tennessed was adopted at Knoxville in 1796, and amended at Nashyille in 1834.

The right of suffirge is secured to every free male white citizen, 21 years old, resident in the county where he offers his vote six months next before the election. Every man is to be considered white who is a cumpetent witness in court against a white man. The general election is held every second year on the first Thursday of August.

The Legisluture consists of a Huuse of Representatives and a Senate. Representatives, in number not exceeding 75, until the prpulation of the State is 500.000, and thereafter not exceeding 99 (now 75), shall have the same qualifications as voters, and have resided in the State three years, and in the county one year next before the election. Senators, in number not exceeding nne-third of the representatives, shall have the qualifications of representatives, and shall be 30 yèrs of age. Representatives and Senators are chosen for two years. The sessions commence (every second year) on the first Monday of October. "A census shall be taken and an apportionment made in 1841, and in every tenth year thereafter."

The Governor must be 30 years of age, a citizen of the United States, and a citizen of the State for seven years. preceding the election, and is chosen by a plurality of votes for two years, but the same person is not eligible for more tha'2 six out of every eight years. If the office of Governor become vacant, the Speaker of the Senate, and after him the Speaker of the Honse of Representatives, shall act as Governor.

The administrative officers are, the Secretary of State, the Treasurer. Comptroller of the Treasury, Attorney-general, etc.

The judiciary is vested in a Supreme Court, a Court of Chancery, and Cireuit Courts. The supreme court is constituted of three judges, one of whom resides in each of the three grand divisions of the State. Judges of this cnurt must be at least 35 years of age. and are elected by joint ballot of the two houses of the General Assembly for 12 years, The court of chancery is presided over by a chancellor, one in each of the four ehancery districts of the State. There are fourteen circuit courts, alsn a special criminal court in Davidson eounty (Nishville), and a eommercial and criminal eourt of Shelby county (Memphis). The judges of all inferior courts must be at least 30 years of age. and are chosen in the same way as supreme court justices, but only for eight years. All judges receive a fixed ermpensation, and are removable on a vote of two-thiris of buth houses. Justices of the peace are elected in districts for six years; sheriffs in countius for two years, and registrars for eight years.

Among the provisions of the constitution are the following: No person who denies the being of a God or a future state of rewards and punishments, ean hold any office; any person directly or indirectly engaged in a duel shall bo disqualified for offlen; no fine exceeding $\$ \$ 0$ shall be laid on any citizen of the State, unless assessed by a jury ; lotteries anit the sale of lottery tickets are prohibited; the proportion and the proceeds of the sale of the public lands coming to the Stato shall be applied to education and internal improvement; the General Assembly can not emancipate slaves without the consent of the owners, etc.

Amendments to the constitution, if agreed to by a majority of the members of the two houses, shall be published six months before the next general election. and if approved by a vote of two-thirds of the members of the next Legislature, shall be submitted to the people, and if ratifled by a majority of votes, shall be adopted. But the Legislature shall not propose alterations oftener than ten years. 
Federal Representation.-In accordance with the law of $23 \mathrm{~d}$ May, 1850 , Tennessee is entitled to ten representatives in the Congress of the United Stales.

Finances, Debt, etc. - There had been paid into the treasury, during the biennial period ending on the first Monday in October, 1\$51, the sum of $\$ 1,004,00494$, and there had been paid out within the same period for all purposes, $\$ 933,43122$. Excess of receipts over disbursements for the two years, $\$ 70,57369$, which, adiled to balances from former years, amounting to $\$ 152,19311$, makes the resources of the treasury in October, $1851, \$ 222,77180$. The receipts have increased within the last two years from $\$ 790,69553$ to $\$ 1,004,00494$, and the disbursements from $\$ 562,43666$ to the sum of $\$ 933,43125$.

The State debt amounted at the date aforenamed to $\$ 3,651,85666$, and the annual interest on it to $\$ 195.62637$. The amount of productive property held by the State in 1851 was $\$ 4,128,72574$; school fund, $\$ 1,321,655$. Ordinary annual expenditure, exclusive of debts and sebool fund, $\$ 290,000$.

The principal benevolent institutions of Tennessee are, the Lunatic Asylum and Instilution for the Blind at Nashville, and the Deaf and Dumb School at Knnxville. The State appropriates about $\$ 5,000$ annually to each of these institutions.

Tennessee has made no general returns of its militia force to the United States Government since 1840. At that date the total number enrolled was 71,252 , of which 3,607 were commissioned officers, and 67,645 non-commissioned officers, musicians, artificers, and privates. Of the commissioned offlcers 25 were general officers, 79 general staff-officers, 859 fieldofficers, ete., and 2,644 company-officers. All white male persons between 18 and 45 years of age are subject to military duty : but all free colored men are exempt in time of peace, and exempt also from poll tax.

Education.-The only returns required of the District School Commissioners are of the scholastic population of their several districts. The amount of sthool fund apportioned among the several counties in July, 1817, was $\$ 117,28412$; increased by sums remaining undrawn, in treasury, and otherwise, to $\$ 191,24184$. Scholastic population at the same time, 266,078. Amount apportioned in July, 1848, $\$ 114,227$ 18. Scholastic population in $1548,272,000$ and a fraction. There are academies in all the prineipal towns and villages which receive a portion of the school fund. The principal colleges and professional schools within the State, and the statistics of each, as exhibited by their returns in 1850 , are as follows:

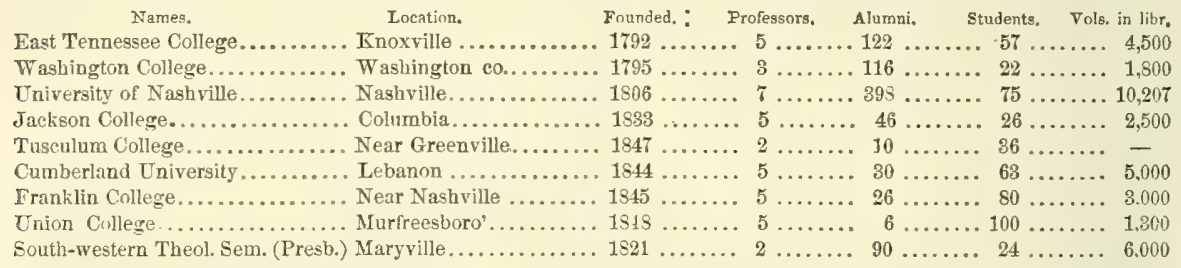

-the Cumberland Tniversity has a Law Department, which in 1850 had 3 professors and 58 students, and the University of Nashville has a Medical Department, which at the same time had 7 professors.

Public Libraries.-According to the report of the Librarian of the Smithsonian Institute, in 1s51, there were in the State 21 libraries and 47,856 volumes; 1 State library $-8,000$ volumes; 9 college $-20,844$ volumes; 8 students' $-9,712$ volsmes; 1 professional $-3,500$ volumes, and 2 public school $-5,000$ volumes. Total 21 libraries $-47,356$ volumes.

Periodical Press.-The whole number of periodicals published in the State on the 1st June, 1850, was 61, and of these 24 were whig. 17 demucratic, and 20 neutral in politics, the last named including such as are devoted to literalure. religion, science, etc., and of which the political principles were not ascertained. Of the aggregate number 8 wer $\theta$ published daily, 2 semi-weekly, 46 werkly. and 4 monthly: and the aggregate circulation of each class was as follows: of the dailies, 14,052 copies; of the semi-weeklies, 1,718 copies: of the weeklies, 41,477 copies, and of the monthlies, 10,600 copies at tach issue. Bedford County has 1 w.; Davidson (Nashville), 5 d., 7 w., and 2 m.; Franklin, Gibson, Greene, and Giles, each I w.; Hamilton, 2 w.; Henry and Hawkins, each 1 w.; Knox, 1 s. w. and 5 w.; Lawrence and Lincoln, each 1 w.; Montgomery, 3 w. and $1 \mathrm{~m}$.; Marshall, $1 \mathrm{w}$. ; Maury, $2 \mathrm{w}$, and $1 \mathrm{~m}$; M.Minn, $1 \mathrm{w}$. ; Rutherford, $2 \mathrm{w}$.; Shelby, 4 d., 1 8. W., and 6 w.; Sumner, 1 w.; Wilson, 2 w.; White, 1 W.; Weakley, 2 w.; Williamson and Washington, each 1 w.

Religions Denominations. - The statistics of the several religious denominations in the State in 1S50, as is shown by the census of that year, were as follows:

\begin{tabular}{|c|c|c|c|c|c|c|c|c|c|}
\hline $\begin{array}{c}\text { Demomina. No of } \\
\text { tions } \\
\text { cllurrelies. }\end{array}$ & $\begin{array}{l}\text { Chureh } \\
\text { actorm. }\end{array}$ & $\begin{array}{l}\text { Value of } \\
\text { Pruperty }\end{array}$ & $\begin{array}{l}\text { Denomina- } \\
\text { turns. }\end{array}$ & $\begin{array}{c}\text { No. of Church } \\
\text { Churches. accom. }\end{array}$ & $\begin{array}{l}\text { Value of } \\
\text { Property. }\end{array}$ & $\begin{array}{c}\text { Denomina- } \\
\text { tiuns. }\end{array}$ & $\begin{array}{l}\text { No. of } \\
\text { Churclies. }\end{array}$ & $\begin{array}{l}\text { Church } \\
\text { acrim. }\end{array}$ & $\begin{array}{l}\text { Value of } \\
\text { Pruperts. }\end{array}$ \\
\hline Baptist.....611.. & $188.815 .$. & $\$ 263,424$ & Germ n Ref, & $-\ldots$ & $\ldots \$-$ & R. Catholic. & 3 & 1,300 & $\$ 45,000$ \\
\hline Christian... 57.. & $17,800$. & $4 \$, 295$ & Jewish ..... & $-\ldots$ & - & Swedenb'g . & - & - & - \\
\hline Congregat'l. -.. & $-\ldots$ & - & Lutheran... & $12 \ldots 3,400$ & 2,600 & Tunker... . & $1 .$. & 500 & 300 \\
\hline Dutch Ref. - ... & $-\ldots$ & - & Mennonite. & $-\ldots$ & - & Union.... & 15 & 3,900 & $3,8 \div 0$ \\
\hline Episcopal.. 17.. & $7.810 \ldots$ & 85,310 & Methodist.. & $831 \ldots 240,353$ & .. 878,511 & Unitarian.. & - & - & - \\
\hline$\ldots 23$. & 6.90 & 6,665 & M & - & - & Universalist &.- & - & $\cdots$ \\
\hline Friends.... 4 .. & $1,600 \ldots$ & 1,300 & Presbyter'n. & $357 \ldots 1$ & .. 365,531 & Minor Sects. & 3 & 1,600 & 2,150 \\
\hline
\end{tabular}

-making a total of 1.939 churches, having accommodation for 606,695 persons, and valued as property at $\$ 1,208,876$. Tennessee forms a diocese of the Protestant Episcopal Church, and also the Roman Catholic diocese of Nashville.

Pauperism and Crime.-The whole number of paupers who received support within the year ending 1st June, 1850, was 1,005 , of which 99 were native born, and 14 foreigners ; and the whole number of paupers at the date specified was 591 , of which 577 were natives, and 14 foreigners. Annual cost of support, $\$ 30,931$. Of 195 convicts in the Tennessee Penitentiary on the 30th September, 1847, 56 had been ennvicted for crimes against life and person; 121 for crimes against property, including larceny, forgery, counterfeiting, burglary, ete., 14 for negro stealing, harboring. etc., 2 for incest, 8 for bigamy, 4 for arson, and 1 for perjury.

Historical Sketch.-Tennessee derives its name from its principal river. On the division of Carolina into two provinces this country fell to the lot of North Carolina. Between 1740 and 1750 the eastern parts of the country were explored, and large grants of land awurded for the service. No settlements however were made at this time. At the enmmencement of the French War in $175 \pm$, about fify families were located on the Cumberland River, but these were driven off by the $8 \pm 2$ 


\section{TENNESSEE}

Indians. About the same time the Shawnees, who had lived near the river Savannah, emigrated to the banks of the Cumberland and settled near the present site of Nashville, but they also were driven away by the Cherokees. In 1755 , a number of persons settled themselves beyond the present limits of North Carolina, and were the permanent colonists of Tennessee. In 1773 , population was found to have increased to a very comsiderable extent. In the suceeding year a war broke out with the northern. Indians residing across the Ohio, and terminated by their suing for peace. The year 1776 was rendered momoruble by a formidable invasion of the Cherokees, whom the British had incited to attack the infant settlements. The British superintendent had previously made proposals to the Tennesseans to join the British standard, and falling to lure them from the support of the colonies, thus directed against them the savage foe. A strong force from Virginia and the Carolinas, however, soon dispersed the enemy, and peace was again restored. When the constitution of North Carolina was formed in 1776, Tennessee (then the "District of Washington") sent deputies to the convention. In 1780 the mountaineers of the borders of North Carolina and Tennessee distinguished themselves in the southern campaign, at King's Mountuin, Guilford, and other battle scenes, and soon after these events they penetrated the Indian country and dispersed the savages. At the peace these brave men again sought their mountain homes, and devoted themseives to the improvement of their settlements. About this time, a small colony of about forty families, under the direction of James Robertson, crossed the mountains, and settled on the Cumberland River, where they founded the town of Nashville. The nearest white neighbors were the settlers of Kentucky, and between them was a wilderness of 200 miles. In 1783 the Legislature of North Carolina laid off a tract of land on the Cumberland River for the discharge of the military bounties and the officers and soldiers of the Continental Line. The district set apart included the colony at Nashville, a small tract having been allotted to the original settlers, After this period population began to increase rapidiy. Many to whom mailitary lands had been granted repaired thither with their families, while others sold their warrants to citizens of different States. In 1785, the inhabitants, feeling sensibly the jnconveniences of a government 80 remote as that at the capital of North Carolina, endeavored to form an independent one, to which they gave the title of the "State of Franklin," or Frankland, but the scheme was ultimately abandoned. In 1759, the Legislature of the State of North Carolina passed an act ceding the territory, on certain conditions, to the United States; and in the following year Congress accepted the cession, and by its act of 26 th May, 1790 , provided for its government under the title of "The Territory of the United States South of the Ohio," which included the present States of Kentucky and Tennessee, the former having been ceded by Virginia. In 1794 Tennessee was constituted a separate territory. Two years afterward Congress passed an act enabling the people to form a State constitution, which, having been adopted, was approved by Cungress 1st June, 1796 , and Tennessee was admitted as a sovereign State of the Union.

NASHVillE, on the left bank of the Cumberland River, is the political capital of the State.

ThNmessee river, chiefly in the State of same name, and the largest tributary of the Ohio r., rises in the Alleghany Mountains, in Tazewell and Wirt counties, Virginia. Its principal head tributaries are the Holston and the Clinch rivers, the former of which receives the French Broad r. and the latter Powell's r. The Holston and Clinch unite at Kingston, in Roan co. (Tenn.), and thence the course of the main stream is about $\mathrm{S}$. W., until it crosses the boundary of Alabama, near the N. E. corner of the State, continues 50 or $60 \mathrm{~m}$. in this direction, and then bends $\mathrm{N}$. W., passes through the Cumberland mountains, flows through the entire $\mathrm{N}$, end of Alabama, crosses the N. E. corner of Mississippi, and again enters Tennessee, when it takes a due N. course, crossing the State, enters Kentucky between Calloway and Stewart counties, and flows $\mathrm{N}$. W. into the Ohio r., at Padueah village, $12 \mathrm{~m}$, below Smithland $(\mathrm{Ky})$. The ralley of the Tennessee divides itself into two sections, the upper and the lower. The Upper valley is the part above the passage through the Cumberland mountains, and is included between the two parallel chains of the Appalachian system, which form a connection just below this pass. This section is mountainuus, and much elevated, embracing an area of about $24,000 \mathrm{sq}$. $\mathrm{m}$. The lower valley is composed of several physical sections, in N. Alabama, W. Tennessee, and Kentucky, comprising an area of $17,600 \mathrm{sq}$. m., making the extent of the whole valley $41,600 \mathrm{sq} . \mathrm{m}$. Its whole length is about 1,100 miles. In its course it receives numerous tributaries, rapid streams, but of no great length. The whole descent of the river, from its source to its mouth, is about 1,700 feet. There are no perpendicular falls, the greatest obstruction being the Muscle Shoals, in Alabama. Florence, at this point, on the N. side, is 259 miles from its mouth, to which steamboats come during high water. A canal has been made along these shoals. 36 miles long, to admit the passage of steamboats, and the navigation of the river above is unobstructed for 250 miles, to the pass of the Cumberland mountains. At the entrance of the pass, a suck or whirl is eaused by a large projecting rock, on the $\mathrm{N}$. side, producing a sudden bend in the river.

Teynessee Irox Works, p. o, Montgomery co, Tenn.: on Cumberland r., $3 i$ m, N.W. by W. Nashville. These works are very extensive, and produce 2,000 tons castings annually.
Tennessee Landing, p. o., Issaquena co, Aiss, : $63 \mathrm{~m}$ N. W. Jackson.

Tennesser Rrver, p. o, Macon county, N. Car.: on Tennessee r., $274 \mathrm{n}$. W. by S. Raleigh.

TENNILE, p. o., and sta., Washington co, Ga.: on the Central (Georgia) R. R., $186 \mathrm{~m}$. N. W. Savannal, and $26 \mathrm{~m}$. E. S. E. Milledgeville.

Tensas parish, La. Situate E., in the western district, and contains 619 sq. m. Drained by Tensas river, and branches of Mississippi river, which bounds it on the $\mathrm{E}$. Surface even and diversified, with small lakes; soil fertile. Along the banks of the Mississippi are some portions of rich land, suited to the raising of cotton, sugar, etc. It is bounded on the E. by Bayou Macon. Staple productions, cotton, sugar, Indian corn, etc. Farms 165; manuf. 6 ; dwell. 214, and pop.-wh. 900, fr. col. 2, 8]. 8,138-total 9,040. Capital: St. Josephs.

Tensas river, la. : rises in Chicot co., Ark., flows nearly parallel with the Mississippi. through Carroll and Madison parishes, forms the boundary between Concordia and Cattahoola parishes, and falls into Wachita river.

T'Ensaw, p. o., Baldwin county, Ala.: 150 m. S. W. Montgumery.

THNSA $w$ river, $A l \tau_{2}:$ the eastern outlet of Mobile $r_{.}$, which it leaves $8 \mathrm{~m}$. below the junction of Tombigbee and Ala bama rivers. It flows $\mathrm{S}$. past Blakely, and enters Mobile bay by several mouths. It contains a considerable island a little below where it leaves Mobile river.

Tenth Section, sta.. Cheshire county, $\mathcal{X}$. Famp.: on the Cheshire R.P., $8 \mathrm{~m}$. W. Keene, and $45 \mathrm{~m}$. S. W. from Coneord. Tentopolis, p. 0., Effingham county, $I l l .:$ is m. S. E. Springfield.

TeotsA, p. o.. Rnck co, Wisc. : on $\mathbf{S}$. side of Rock $r_{*}$ $28 \mathrm{~m}$. S. E. by E. Madison.

TEQUAMENON river and bay, Chipperra co., Afich.: rises in the S. W. part of the co, flows E. by $\mathrm{N}$. in a circuitous course, and empties into the bay so called, near the outle of Lake Superior. There are some falls in this river. The bay is loeated between the Siraits of St. Mary, on the S. E, and Lake Superior on the N. W., and separates Canads from Michigan.

Tenie AuX Bevf sta, St. Bernard par, La.: on tho 
Mexiean Gulf R. R., 14 m. S. E. New Orleans, and $81 \mathrm{~m}$. S. E. by E. Baton Rouge.

Terre Bunne parish, $L a$. Situate $\mathrm{S}$., in the eastern district, and contilins 1,618 sq. m. Drained by Terre Bonne, Grand Callion. Little Callion, Large and Black bayous. Surface level, but in many parts so low, that it is unfit for cultivation; soil various, along the streams being exceedingly productive; but in general too moist to allow of its being successfully tilled. Chief produets, sugar, cotton, rice, and Indian corn. It contains fine lakes, and its coast is indented with numerous bays. Farms 224; manuf. 4; dwell. 550, and population-wh. 3,324 . fr. col. 72, sl, 4,323-total 7,724 Cepital: Houma.

Terre Coupee, p. v., and sta., St. Joseph co., Ind, : 135 m. N. by W. Indianapolis. The Michigan Southern, and Northern Indiana R. R. passes through this place, $73 \mathrm{~m}$. E. by S. Chicago (IIl.)

T'erre Coupee, sta., Berrien co, Mich. : on the Michigan Central R. R., $202 \mathrm{~m}$. W. by S. Detroit, and $117 \mathrm{~m} \mathrm{~S}$. W. Lansing.

Telre Hatte, p. v., and cap. Vigo co, Ind : : on the left bank of Wabash r., $73 \mathrm{~m}$. W. Indianapolis. Its site is a high bank, from 50 to 60 feet above the river, and 15 or 20 feet above the arjacent prairie. This is one of the most important towns in the State, and being located on the Wabash and Erie Canal, and on the most available line of railroad travel east and west, is destined to become a principal centre of internal commerce. Among the public buildings, the most ecinspicuous are its fine court-house, town hall, State banking house, 13 churches, several good hotels-the Prairie House being one of the best in the State, etc.; and the dwelling hrouses amount to over 800 , of which about one-half are of brick, and many are built with much taste. The business, wholesale and retail, carried on at this point is extensive and valuable. There are 98 retail stores and groceries, 3 book-stores, 4 printing-offices, and several large warehouses and wholesale concerns. The principal manufacturing establishments are 2 foundries, a plow manufactory, 8 carriage and wagon factories, 2 soap factories, an oilmill, 3 steam flouring and 1 steam saw mill, 2 breweries, 2 distilleries, 18 coopers' shops, 4 large slaughter-houses, and the same number of packing establishments. The number of hogs packed at Terre Haute in $1849-50$ was 59,000 , valued at $\$ 300,000$. Among the religious establishments almost every denomination is represented. The means of education are ample, viz.: 2 seminaries, 4 select schools, and 5 district scools. Here are also three socitties for mutual improvement. The public press consists of 6 newspapers, viz. : the "Wabash Express" (whig), the "Wibash Courier," the "T. II. Journal" (dem.), the "Prairie City," the "Independent" (relig.), and the "Indiana Universalist" (relig.) - these are issued weekly. The railroads centering bere are, the Terre Haute and Richmond $R$. $R$, and the A tlantic and Mississippi R. R., forming links in the line from St. Louis to the East; the Terre Haute and Alton $\mathrm{R}$. I. via Paris to Alton; the Evansville and Illinois R. R. to Evansville, on the Obio, and several others projected to different points. In the vicinity are rich beds of coal and iron, which, with the eompletion of the grand works connecting at Terre Haute, will become a source of great wealth to the coun ry generally, and build up within the town a manufacturing interest equal to the wants of the neighborhor. Terre Haute was founded in 1816 : in 1580 it contained 600 inhabitants, in 1840 about 2,000 , and in 1850 about 4,900 .

Terre Haute, p. o., Champaigu county, Olvio: $45 \mathrm{~m}$ W. by S. Columbus.

Terre Hill, p. o., Lancaster co., Fenn.: 47 m. W. S. W Harrisburg.

TERrE NoIr, p. o., Clark county, Ark.: $72 \mathrm{~m} . \mathrm{S} . \mathrm{W}$ Little Rock.

Terry, p. o., Carroll county, Tenn.: $90 \mathrm{~m}$. W. by $\mathrm{s}$ Nashville.

Terryville, p. vo, Litchfield co., Conn.: 18 m. W. S. T. Hartford.

TERry YILLE, p. v., Abbeville dist., S. Car.: on a creek of Savannah r., $81 \mathrm{~m}$. W. Columbia.

Terrytown, p. v., Bradford co., Penn.: 112 m. N. by E. Harrisburg.

TÊTE DE MoRT, p. v., Jackson connty, Ia.: $57 \mathrm{~m}, \mathrm{~N} . \mathrm{E}$ Iowa City.

Tetersburg, p. v., Tipton co., Ind.: $43 \mathrm{~m} . \mathrm{N}$. by $\mathrm{E}$ Indianapolis.

ThWKesbURY, t. and p. v., Middlesex co,, Mrass.: $21 \mathrm{~m}$. N. N. W. Boston. Drained by Shawsheen r., which flows tbrough the town, and by branches of Merrimac and Concord rivers. Surface even; soil light and sandy. The village is on the Salem and Lowell and the Lowell and Lawrence railroads, $5 \mathrm{~m}$. E. Lowell and $7 \mathrm{~m}$. S. W. from Lawrence. Pop. 1.048

Tewockiny Springs, p. 0., Limestone co., Tex.: $123 \mathrm{~m}$. N. E. Austin City.

Texana, p. v., and cap. Jackson co., Tex.: on the right bank of the Naviuad r., 119 m. S. E. Austin City. Ils lo eation is at the head of steamboat navigation, on the bordex of an exceedingly rich and productive prairie. It contains the county buildings, ete.

\section{TIIE STATE OF TEXAS.}

Trxas is bounded north by New Mexico and the Indian Territories, from the latter of which it is divided chiefly by the Red and Arkansas rivers; east by Arkansas and Louisiana, the Sabine River being its boundary toward Lnuisiana ; south by the Gulf of Mexien, and west by Mexico, from which the Rio Grande separates it, and the Territory of New

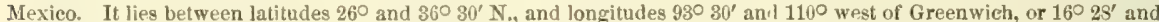
$32058^{\prime}$ from Washington. Its greatest extent north and south is 700 miles, and east and west 800 miles; but its average extent is much less. The superficies is pstimated at 237,321 square miles-an area more than equal to the whole of France, and nearly four times the area of New England.

Texas may be divided into three physieal districts or regions of country, each of which, in many respects, is entirely different. These are the level, the undulating, and the mountainous or hilly; or the lower, midule, and upper districts, or, as it may be more convenient, the country may be divided into Eastern, Middle, and Western Texas. Eastern Texas extends from the Sabine to the Trinity; Middle Texas from the Trinity to the Colorado, and Western Texas from the Colorado to the Rio Grande del Norte. The level region occupies the entire coast, extending from 30 to 60 miles into the interior. The undulating succeeds this, and embraces the whole of the interior and the north, and reaches westward to the mountainous tract, which is distant 150 to 200 miles from the boundaries of the level lands. The alluvial lands of the several rivers which make into the Gulf are from 8 to 20 miles in breadth, and are heavily timbered with live-oak, red, black, and white, and other species of oak; with ash, cedar, pecean, elm. hickory, mulberry, and all other varieties of forest trees and growths common in the rich alluvions of the Mississippi. The cane-brakes are of immense extent in the low enuniry, and on the Caney Creek may be seen 70 miles long and from 1 to 8 miles wide. Here may be grown cotton, sugar, rice, ete.

In the second division are the high, rolling, verdant prairies, the narrow-wnoded bottoms, the beauliful islands of timber, the quick-running sireams, the cool, refreshing springs, and the healthful clime of Texas. Here the soil, a little 
broken, is not inferior to that of the alluvial country below, is more easily workct, the products are greuter and more varied, and though not so convenient to a foreign market, will have a market at home. This is destined to be the mist densely populated part of Texas, if not of America. In this region the planter may raise all the cotton, rice, and tobacen, and the curn and grain he requires, and slock to any extent, without labor and almost without care. The table-lands are yot the home of the hunter and the range of the buffalo. Litte is known of then, but they are represented by travelers to riral the table-lands of Mfexien, to be rich in soil and climate, to be elothed in contstant verdure, beautitully variegated in surfice, and watered by streams as eleur as erystil-to be, in flue, a perfect paralise. Of the northern purtiun of 'Texas still less is known than of the table-lands. This region is said to be intersected by many streams furnishing water-puwer, and to be rich in the precious metals.

No part of the extensive coast of the Gulf of Mexico presents a greater number of commanding harbors, bays, and inlets, than that of Texas. The interior, intersected by numerous magnificent and navigable streams. in close vicinity in the great western tributaries of the Mississippi, and holung easy communication with the mighty "fuher of Waters," furnishes a commercial position very desirable and seldom surpassed. Led kiver may be considered in part as belonging to Texas. The vast region west of the muntains in which it rises and through which it rolls its turbid waters, has been yet scareely explored, but it is known to be of great fertility and of eurpassing beauty. In this region bas the Texan emigrut reared his cottage and planted his cutton, and his corn, and his wheat, which are borne alorg the current of Red River to the great mart of the south-west. The chief rivers, those which are more or less navigable for steamboats, are the Sabine or Neches, Trinity, Brazos, Colorado, Guadalupe, San Antonio, and the Ric) Grande. Besides these, there are whers of less note and magmiude, though navigable to a considerable extent-the Angelina, San Jaeinto, Buffalo Bayou, Oyster and Chocolate buyoux, San Beruard, Caney, Navidad, Lavacca, and Nueces. There are no lakes of any importance to be found in the coutry. A few small ones near the sources of the Guadalupe, and on some of the tributaries of lied River and the Trinity, are all that are worthy of the name, and they are jnconsiderable. To a country so well watered, intersected by rivers so numerous and important, and offering such valuable facilities for canal cominunication, they would be useless. Indeed, its vast water-courses might be united in one great navigable chain, which would render transportation from any section of this widespread territory to a commercial emporium at any point on the coast, a matter of the utmost ease and but very little expense.

Texas abounds with minerals, and is interesting in its geology. The silver mine of San Saba is among the richest in the world, and under the dominion of Spain afforded considerable revenue to the crown. Gold has been found on the Atoyac and other streams, especially toward the western hill country, and silver also on the Bedais. Iron ore pervades the greater portion of the country. Lead, copper, alum, etc., are found in several parts, and bituminous coal on the Trinity and Upper Brazos, Salt is exceedingly abundant, and immense quantities are annually taken from a fumous salt lake near the Rio Grande. Salt springs and lagoons abound near the Trinity, and a branch of the Brazos has its waters highly impregnated. Soda and potash are found near-the salt lagoons in dry seasons. Lime ean be plentifully furnished from limestone existing in the undulating and northern sections. In the level districts oyster-shell lime ean be substituted. Asphaltum is sometimes found on the corast. Agate, chalcedony, jasper, and some singular petrifactions are found near the mountains. The remains of whole forests are seen on the Trinity and Brazos rivers entirely petrified. Extensive quarries of red and white sandstone, or frestone, abound throughout the country. At Austin there is a quarry of white stone similar to that of the Paris basin, and of which the Louvre is built. It is soft and easily worked with the knife, and may be reduced to any form; but on exposure to the atmosphere it becomes a perfect freestone, and is as hard and compact as granite and marble. The same kind of stone is found on the Trinity and in the vieinity of San An onio de Bexar.

Mineral springs are numerous. The Salinilia Springs, both white and salt sulphur, in Walker County, are very remarkable. They rise near the salines, in a picturesque valley, and are highly appreciated for their medicinal virtues. Not fur from these, and near the Bedais, is a white sulphur spring, supersaturated with magnesia, and possessing all the healing properlies of the celebrated Virginia springs. Thirty miles west, in the same county, is a blue sulphur spriu . Near Cibolo, and about thirty miles from Bexar, is a mineral spring, the waters of which are in high repute. Besides these, there are others of great value. Near Carulina, in Montgomery County, is a white sulphur spring, the waters of which are efficacious in many distempers.

All who have visited Texas concur in ascribing to it the most delightful of climates. Though varying with location from tropical to temperate, it is remarkably plsasant and salubrious. The average notation of the thermometer in the summer season is about $80^{\circ}$ Fahr., and refreshing breezes from the south blow almost without interruption. During the winter ice is seluom seen, except in the northern part of the State. From March to November but little rain falls. The southerly wiuds are invigorating. In November the strong northers set in, and in the months of December and January the cold north wind sweeps down the plains with near as much regularity as the south wind of the summer. These periodical winds tend to purify the atmosphere, and contribute much to the salubrity which distinguishes Texas from other Guif States. The climate, indeed, is modified by so many favorable cireumstances, as to possess all the genial influences of Louisiana, while it escapes its attendant evils. In the river bottoms, which are periodieally overtowed, however, fever prevaile to a greater or less extent; but elsewhere the danger of endemic disease is trifling. The prairites are open and admit of a free circulation of air, and the forests, for the most part, are free from undergrowth. Miasmatic marshes and stagnant pools, which so frequently originate endemics, are se dom found in any portion of the country.

Texas, in general, is a prairie country, having all the streams skirted with timber. The sublime and beautiful are blended in these vast natural meadows-sublime in extent and beautiful in prospect. Leagues may be traveled over a continuous plain, with nothing to interrupt the utmost stretch of vision upon the living green, save the beautiful groves and islands of timber which are here and there interspersed, and flowers of every variety, hue, and fragrance, and herds of cattle and deer-delighting the eye with the view of splendid lawns and magnificent parks tastefully laid out by the hand of Nature, and presenting all the order and taste of civilization. Nothing in Nature can surpass the beauty and loveliness of a Texan landseape, Nothing can surpass its beauty in the spring and summer seasons, neither is it possible to form an estimate, even in imagination, of the number of useful domestic animals that are reared on them without trouble or expense. Even in the winter scason the pasturage is sufticiently verdant to dispense with feeding live-stock.

Texas in her forests has an infinite variety of timber suitable for building and ornamental purposes. Her forests of livenak and cedar are unrivaled. The whole coast nearly, including all the bayoux and river bottoms, from the Sabine to the Nueces, is one entire beit of timber. The eastern section probably embraces more woodland than any other. It is 


\section{TEXAS}

henvily timbered with pine, oak, ash, walnut, hickory, pecan, mulberry, cedar, cypress, and other forest trees which extend quite to the Red River, occasionally variegated with beautiful prairies containing from one hundred to several thousind acres. The soil is admirably adapted to grasses and other agricultural staples, and the lumber trade will soon become extensive and lucrative in this section.

Among the productions which may be regarded as naturally adapted to the soil, and which now form a chief and important article of commerce, cotton stands pre-eminent. This is the great erop of Texas, and the source of much of its wealth and power. Its staple is uniformly gond, and near the Gulf it equals in length and firmness the Sea Island cotton of Georgia. It is an indigenous plant, and in the western region needs to be planted only once in three or four years to yield an abundant crop. The climate is ever favorable, and the suil, whether upland or lowland, woodland or prairie, is admirably adapted to its culture. 'The sugar-cane grows luxuriantly throughout the whole level region; but its culture, for various reasons, will not be extensive, nor will the production of sugar, unless forced by unexpected circumstances, probably compete with that of Lnuisiana for many years to come. Tobaceo grows almost spontaneously throughout the country. It is an important production, equal in quality to that of Cuba, and will soon become an article of commerce and export. The indigenous indigo of Texas is greatly superior to the plant which is cultivated in the United States. It is manufactured in families for domestic use, and is preferable to the imported article.

Breadstuffs of every description are produced easily and abundantly in every district. Two erops of Indian corn annually is a common thing--the first planted in February, and the last in June. Wheat, buekwheat, millet, rye, oats, barley, and other small grain yield plentiful crops throughout the undulating region. Flax and hemp are well adapted to the soil. Rice is also produced in considerable quantities, and can be grown to any extent.

Fruits of all descriptions are profusely plentiful. The grape and mulberry are indigenons, and grow luxuriantly, indicating that wine and silk, as well as tobacco and cotton, will one day become valuable staples. The vanilla plant grows wild. It can be successfully cultivated as a commercial commodity. This delicious plant is highly esteemed in medicine, as a perfume to flavor the cigar, and in various culinary arts, ete. The nopal, celebrated for the production of the cochineal insect, grows luxuriantly. Its fruit, with the leaves, furnishes food for vast herds of cattle and horses; for building purposes and fencing its timber is superior, and in Texas it also forms a principal article of fuel. The raupan, or tea-iree, furnishes an acceptable and cheap beverage in lieu of the China product, and is not at all inferior in flavor to the common black tea of that eountry. Cayenne pepper, or the chilé of Mexico, grows exuberantly all over Texas. Many other sources of wealth and enjoyment abound here, and will in all good time be realized by the citizens, who are aiready industrinusly exploring the true springs of national greatness and individual prosperity.

The displays of vegetation in Texas are profuse, various, and valuable, presenting on the one hand the stately and magniflcent forest, and on the other delighting the eye with the rich and splendid scene of the luxuriant prairie, garnished with an endless variety of fragrant flowers, and forming a landscape of surpassing loveliness. All the varieties of the stellaria, vellow, blue, and purple, display their rich and gaudy tints. The fashionable dahlia, an exolic highly esteemed and carefully raised in foreign hot-houses, is indigenous to the south-west. Geraniums adorn and perfume with their fragrance the wild meadows, and the water lily, trumpet flower, and the cardinal, are common in the fields. The May apple, bearing a delicate flower, is abundant, and violets form a eommon carpeting for the prairies. The passion flower is frequent in its season, while the perpetual rose, multiflora, and chickasaws, and other varieties, grow without cultivation or care. The chaste and elegant primrose flowers everywhere; while the jonquil and hyacinth, honeysuckle and sweet seringa, form a variegated garland, or are thrown together in most admirable disorder throughout the paradise of filowers. The sbrinking mimnsa, an object of so much interest to the naturalist and philosopher, is also a natlve of the wilks, and the traveler, trampling over its drooping and apparently withered leaves, looks back in vain for the path his rude fontsteps had marked out, but not a vestige of the invasion remains, but all again is life and verdure.

The fruits of the tropics and of the north alike flourish in Texan soil. The fig is common, the peach unrivaled, the nectarine, quince, and grape luxuriant, and these, side by side, grow in the same sun and soil with the plum, apple, and pawpaw. The orange, lemon. and lime, the pine-apple, and olive ripen together. Berries are in great variety. The mulberry, dewberry, whortleberry, and gooseberry grow wild and in the greatest profusion. The pecan, walnut, and lickory nuls are very abundant. Garden vegetables of every description, and melons, are easily cultivated and yield in the greatest abundance.

Wild animals, formerly numerous and formidable tenants of the forests, are now comparatively strangers to the country. The black bear frequents the cane-brake, and is a farorite nbject of the hunt. Wolves abound. The pecary, or Mexican hog, and the wild hog, run at Iarge in the woods. These have degenerated from the domestic species, and are very ferocious. Mustangs roam in herds over the north and west. Many of them are of fine figure and spirit, and are highly prized for their fleetness. When domesticated, they are hards and active, and alike adapted to the saddlo or stirrup. Mingled with the herds of mustangs are found jacks, jennies, and mules. The buffalo or bison is found in Texas astonishingly gregarious. Thousands and tens of thousands in a drove are yet seen in the interior roving over the prairies, the luxuriant herbage affording them the means of subsistence. The deer is still more numerous than the buffalo, and the moose, antelope, and mountain goat are also found ranging upon the firontier or far-west. The fox peeps from every bush and bruke. Raccoons, opossums, rabbits, and squirrels are in great numbers; and a greater variety of smaller animals serve to stock the forests of Texas with game, and supply the hunter with endless and animated sport.

Wild fowl and game birds are everywhere plentiful, and one accustomed to the use of the fowling-piece may easily keep a table well supplied. Wild turkeys, prairie hens, geese, brant, teal, canvas-backs, partridges, quails, pheasants. grouse, pigeon, plovers, snipes, wondenck, ortolans, cranes, swans, pelicans, king-fishers, crows, blackbirds, starlings, and hundreds of other descriptions of the family "aves" are in endless numbers. The beautiful paroquet, the oriole, whip-poorwill, and cardinal, and the sweet-toned mocking-bird, eniiven the woods with the beauty of plumage and melody of voice which belong to them.

The rivers and bays of Texas abound in fish of an excellent quality, in great variety, and some of them of peculiar character. Redfish Bar, in Galveston Bay, takes its name from the number of red fish which are caught there. This fish is very delicious, and often weighs fifty pounds. Yellow, white, and blue codfish are found in the rivers and streams; sheep-head, buffalo, perch, mullet, pike, trout, flounders, suckers, and other fish common in American waters, are found not only in abundance, but of rare size and flavor. The gar is a worthless fish, with a snout of immense length. The alligator gar is very large-several yards in length; its back is covered with scales, and it resembles the alligator, which is very common in the rivers and bayoux, and of ennrmous size. Beds of oysters line the coasts; crabs, clams, muscles, and varions marine animals may be had all along the shore, and turtles are comomon to all the rivers and bays. Ser- 
pents, snakes, lizards, and many other curious, venomous, and vexatious species of erawling things of the earth are found in Texas. But of these few are as dangerous as troublesome. Insects swarm in myriads, some useful, some dangerous, some annoying, but most of them attractive on account of their beautiful forms and magniflcent colors. The cantharides and honey-bee are among the flrst; spiders and the tarantula represent the seend : mosquitoes, gad-files, ticks, and sandflies the third, and the wonderful variety of beetles, bugs, butterflies, etc., fll up the fourth chapter of inseet life. Many of these, if not carefully guarded against, will spoil the beauty of the fairest face in creation beyond the redemption of cosmeties for days to come. Their atrachment to suffering humanity is a wonderful instinct of their nature. The traveler, however, has a certain remedy against attacks in liquid ammonia, a small vial of which should at all times be accessible when passing through the brake or river bottom. Its application immediately neutralizes the venom even of the tarantula and renders it harmless.

Texas is divided into 77 counties, the general statistics of which, and the capitals of each, in 1S50, were as follows:

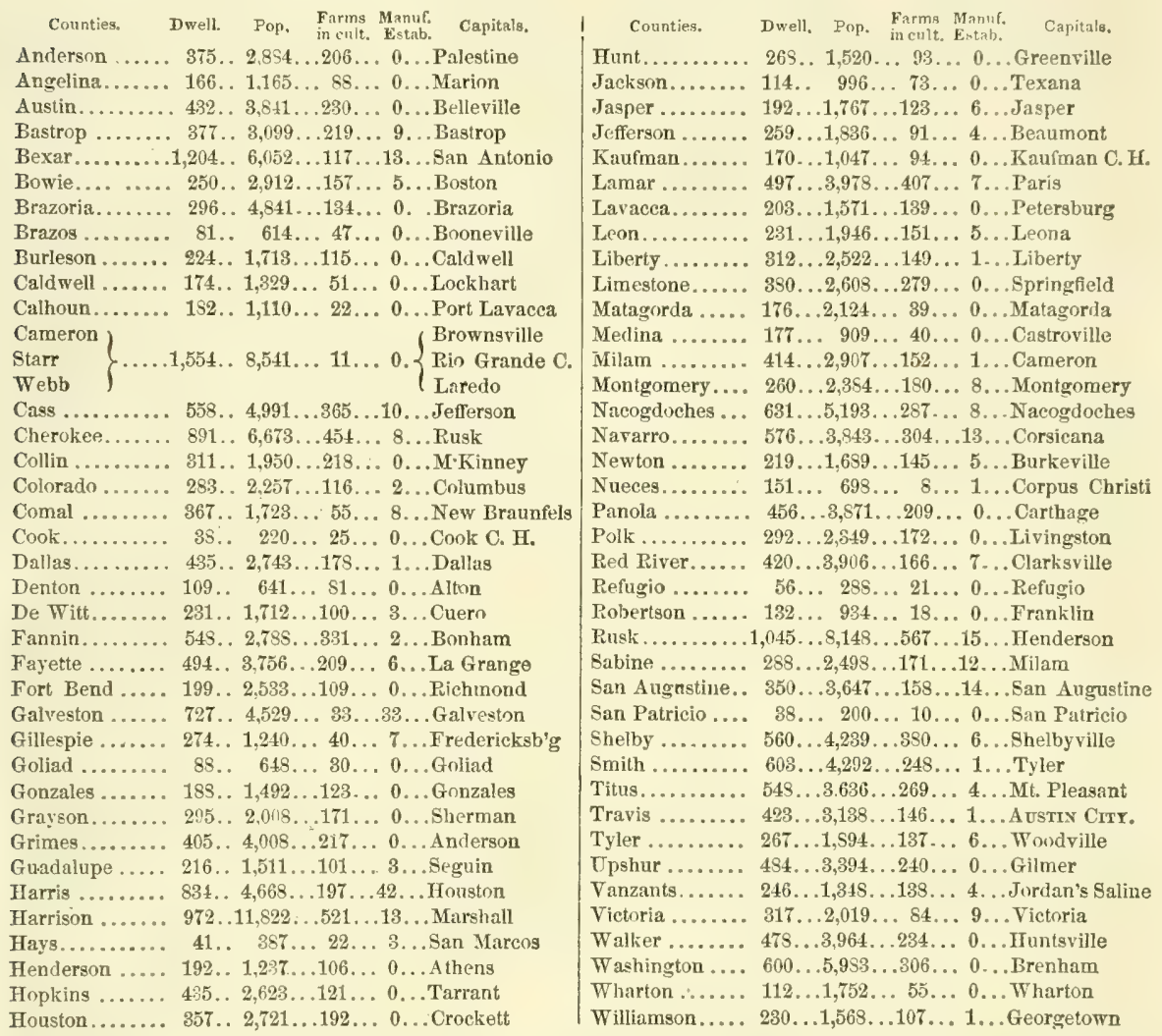

The whole number of dwellings in the State at the above date was 27.988 ; of families, 25,377 ; and of inhabitants, 212,592 ; viz., whites 151,100 -males 84,863 , and females 69.237 ; fr. col. 331 -males 171 , and females 160 ; sl. 58,161 . Of the whole population there were, deaf and dumb-wh. 49, fr. col. 0, sl. 9-total 58; blind-wh. 59, fr. col. 3, sl. 14-total 76 ; insane-wh. 39, fr. col. 1, sl. 0-total 40. The number of free persons born in the United States was 187,070, the number of foreign birth 16,774, and of birth unknown 604. The native population originated as follows: Maine 226 , N. Hamp. 97, Verm. 144, Mass. 414, R. I. 56, Conn. 369, N. Y. 1,589, N. Jer. 205, Penn. 1,005, Del. 61, Md. 521, Dist. of Col. 36, Virg. 3,580, N. Car. 5.155, S. Car. 4,452, Ga. 7,639, Flor. 365, Ala. 12.040, Miss. 6,545, La. 4,472, Tewas 49,177, Ark. 4,693, Tenn. 17,692, Ky. 5,478, Oh. 947, Mich. 125, Ind. 1,799, Ill. 2,855, Mo. 5,139, Ia. 109, Wisc. 42, Calif. 0, Territories 14; and the foreign population was composed of persons from-England 1,002, Ireland 1,408, Seotland 261, Wales 17 , Germany 8,191, France 647, Spain 62, Portugal 5, Belgium 8, Holland 14, Italy 41, Austria 11, Switzerland 134, Russia 10, Denmark 49, Norway 105, Sweden 45, Prussia 75, Greece 0, China 0, A frica 4, British America 187, Mexico 4,459, Central America 3, Snuth America 1, West Indies 22, Sandwich Islands 5, and othor countries 60.

The general statisties* of the products, manufactures, wealth, institutions, etc., of the State, in accordance with the census of 1850 and other official returns referring to the same period, are as follows :

Occupied Lands.-Improved farm lands, 639,107 acres, and unimproved lands attached to farms, 14,454,669 acresvalued together at $\$ 16,398,748$. The whole number of farms under cultivation in the State is 12,198 ; and the value of farming implements and machinery, $\$ 2,133,731$. 
Live-Stock.-Horses, 75,419; isses anil mules, 12,364 ; milch cows, 214,75s; working oxen, 49,952; other caltle, 636,805; sheep, 99,095 , aul swine, 683,914 . Total value of live-stock, $\$ 10,266,880$.

Animul Products.-Wool, 131,37t pounds; butter, 2,326,556 pounds; cheese, 91,619 pounds; and the value of animals slaughtered, \$1,106,032.

Grain C'ops.-Wheat. 41,699 bushels; rye, 3,108 bushels; Indian corn, 5,926,611 bushels; oats, 178,583 bushels; barley, 4,776 bushels; and buckwheat, 59 bushels.

Other Foud Crops.-Rice, 87,916 pounds; peas and beans, 179,332 bushels; potatoes-Irish, 93,548 bushels, and 8 weet, 1,32:3,170 bushels.

Miscellaneous Crops-Tobacco, 66,897 pounds; ginned cotton, 57,596 bales of 400 pounds; hay, 8,279 tons; cloversced, 10 bushels; hops, 7 pounds; flax, 1,043 pounds; flax-seed, 26 bushels; silk cocoons, 22 pounds; cane sugar, 7,351 hogsheads of 1,0110 pounds ; molasses, 441,6s5 gallıns; beeswax and honey, 380,532 pounds ; wine, 99 gallons, etc. Value of orchard products, $\$ 12,605$, and value of market-garden products, $\$ 12,251$.

Home-made Manufictures produced in the year ending 1st June, 1850, were valucd at \$255,719.

Ifunufuctures. - Total capital invested $\$ 000,000$; value of all raw material, fuel, etc., consumed in the year, $\$ 000,000$ hands employed, 0,000 -males 0,000 , and females 00 ; monthly cost of labor, $\$ 00,000$ - male $\$ 00,000$, and female $\$ 0 t 0$; valuo of products in the year, $\$ 000.000$. The whole number of manufacturing establishments in operation, on the 1st June, 1850 , was 307 , of which number 1 was a wookn factory, 2 iron works, and 22 tanneries.

In the zcoolen manufacture the invested capital amounted to $\$ 5,000$; wool used, 30,000 pounds; value of all raw material, $\$ 10,000$; hands employed, 8-males 4 , and females 4 ; monthly cost of labor, $\$ 160$-male $\$ 80$, and female $\$ 80$; annual proiluets-cloth 14.000 yards, and blankets 4,600 ; value of entire products $\$ 15,000$.

The iron manufacture employed a capilal amounting to $\$ 16,000$ : pig iron used. 250 tons; mineral coal consumed, 250 tons; value of all raw material, fuel, ete.. $\$ 8,400$; hands employed, 35 ; entire monthly cost of labor, $\$ 1,520$; castings made, 200 tons; other products valued at $\$ 15,000$; value of entire products, $\$ 55,000$.

The tumeries had a capital of $\$ 33 . \$ 50$; value of hiles and skins used, $\$ 18,624$; hands cmployed, 64-males 63 , and females 1 ; monthly cost of labor, $\$ 1,017$-male $\$ 1,007$, and female $\$ 10$; skins tanned, 1 , 700 , and sides of leather tanned, 18,700 ; value of products of the year, $\$ 52.050$.

The manufactures of Texas, otherwise than those enumerated, consist chiefly of those incident to agricultural countries, as carriages, harness, farming implements, and machinery, etc., and the great bulk of the capital is invested in milling and other like occupations.

Commence.-The exports direct to foreign countries, for the year ending $30 t h$ Junc, 1550 , were valucd at $\$ 24,958$, all carried in foreign boltoms, and the imports were valued at $\$ 25,650$, of which, to the value of $\$ 14,652$ were carried in American, and to that of $\$ 10,998$ in foreign bottoms. The great bulk of the commercial material of the State is carricd coastwise to New Orleans, New York, etc., and is thence shipped to other countries. The shipping employed in the foreign carrying trade was as follows:

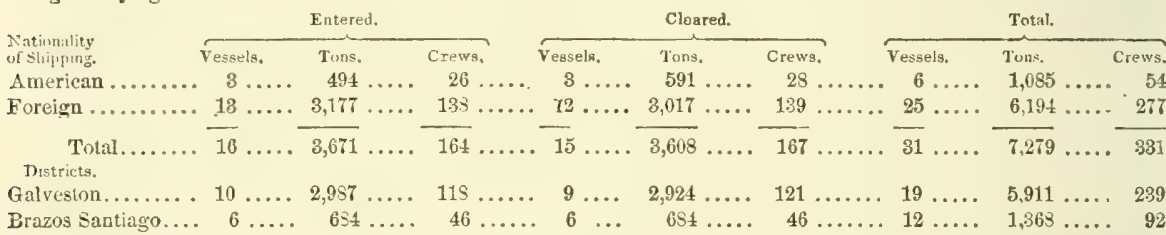

The total amount of shipping owned within this State, at the date specified, was 3,897 tons, of which 3,309 tons wero owned in the district of Galveston, and 585 tons in that of Saluria. The prineipal ports of the State are Sabine, Galveston, La Salle, and Point Isabel. The serial statistics of the commerce of the State are as follows:

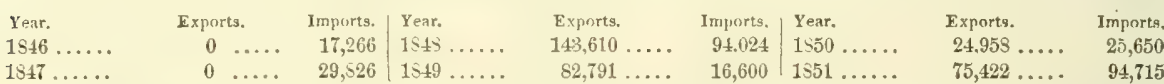

Codsting, inlund, etc., tracle.-In proportion as the direct forcign commerce of Texas is small, the coasting trade is extensive. As before remarked, the great bulk of its commercial material is carried to the other states for export, and hence a coasting trade commensurate with the staple and surplus products of the State is carried on. The interior is chiefly reached by the fine streams which in every direction penetrate it, the principal of which are the Red River, on the northern boundary, and Sabine, Neches, Trinity, Brazos, Colorado, Lavacca, Guadalupe, Nueces, and the Rio Grande emptying into the Gulf of Mexico. Most of these are naviguble for light-draft steamers, which ply regularly on their waters without interruption on account of season. The rivers are reached from the neighboring settlements by wagon roads, which are good except in the wet season. The railroad is practically unknown in Texas, but many are now in progress of construction, and a few miles of the Harrisburg railroad were brought into use in April, 1853. Texas will be intersected east and west by a Southern Pacific railroad, and many lines are projected between the principal ports and the interior, with lateral lines diverging to the various centres of commerce. It would, however, be immature to mention definitely any of the lines projected, as few are lncated, and fewer have made any advance toward construction. The great road will probably pass from Providence, on the Mississippi, through Shreveport, $L a_{n}$, and Marshall, Tex., and another from New Orleans, via Opelousas, etc., westward. A road will also be extended from the Red River to the Gulf. With these improvements the markets will be reached with fucility, and immigration and settlement be rapidly directed to the fertile interior. Cotton and sugar are as yet the only available exports of the State, the annual product of which articles has been given on a former page. The imports consist of manufactures of all kinds, groceries, etc.

Bunking.- With the exception of the Commercial and Agricultural Bank of Galveston, there would not appear to be any other recognized banking institution in the State.

Government, etc.-.The constitution of Texas was adopted at Austin City, 27th August, and ratifled by the people 13th October, 1815.

The right of suffrage is conceded to every free white male person, 21 years old, a citizen of the United States, or of $\$ 48$ 


\section{TEXAS.}

Texas, when resident in the State one year, and six months in the district, county, city, or town, where he offers to vote, The general election is held on the first Monday of August biennially.

The legislutive authority is vested in a House of Representatives and a Senate. Representatives in number not less than 45, nor more than 90 (now 66) are chosen for two years, and they must be qualifferl voters who have 3 ved two years in the State, and one year in the place where they are chosen. Senators in number not less than 19 , áor more than 38 (now 21), chosen for four years, one half leaving offlce biennially, and they must be qualifled voters, 30 years of age, who have lived in Texas three years, and the last year thereof in their district. The sessions of the Legishture are biennial, and commence on the 1st Monday in November. The fitth bienuial session commences in November, 1853.

The governor and lieutenant-governor are chosen, by a plurality of votes, for two years, and are not eligible for more than four out of any six years. They must have the qualiflcations of Senators, and the liertenant-governor is excofficio president of the Senate. The governor's veto to a bill is negatived by a subsequent cwo-trirds vote of both hoirses.

The administrative officers of the State are a secretary, niminated by the governor,and confirmed by the Senate for two years; and a treasurer and a comptroller of accounts, chosen biennially by joint fote of both houses. Other offcers are the attorney-general, auditor, adjutant-general, commissioner of the land offee and superintendent of penitentiary.

The judiciary consists of the Supreme Court, Distriet Courts, County Courts, Ac. The Supreme Court consists of a Chief Justice and two associates, who are chosen by the people for six years. nnree sessions are held annually : one at Austin, on the second Munday of November; one at Galveston, on the first yonday of January, and one at Tyler, on the first Monday of April. The Court has appellate jurisdiction only ; but in orminal eases, and appeals from interloeutory judgments, it is under legislative regulations. The judges of the Distret Courts are elected for six years, and hold a court twice a yeur in each county. District Courts have original juristztion in all commercial eases, and in all suits both is law and equity, in which more than $\$ 100$, exclusive of interest, is stake. In criminal cases, if the punishment be not specifically determined by law, the jury shall determine it. In quity causes, either party may dernand a jury. The judges of both courts may be removed by the governor on the ayress of two-thirds of each house; or, upon impeachment, to be tried by the Senate. There is also in each coun a County Court, sitting once a month, as a Court of Ordinary, and once in three months for the transaction of cours business. Justices of the Peace, with jurisdiction to the amount of $\$ 100$, are elected in precincts for two years. Am $\mathrm{g}$ the provisions of the constitution, the following are the most important: Any person concerned in a duel, sending f accepting a challenge, shall be ineligible to any public office; grants of money for private purposes, or for internal imyovement, must be made by two-thirds of both houses; a wife's property, both real and personal, acquired before or apor marriage, shall be her separate property; a homestead of not more than 200 acres, not included in a town or city, city and town lots, worth not more than $\$ 2,000$, shall not be subject to forced sale for any debt hereafter contracted; o corporation shall be created, renewed, or extended, with banking or discounting privileges; private corporations on only be created by a vote of two-thirds of both houses; the State may not borrow money unless by a like vote, $n$ - contract an aggregate amount of debt of more than $\$ 100,000$, except in case of war, invision, or insurrection ; no law hall be passed to emancipate slaves except by their owners' cousent, and after paying a fult compensation for them; digrants to the State shall not be prevented from bringing their slaves with them, but the importation of slaves as merdandise may be forbidden; laws may be passed obliging masters to treat their slaves with humanity, and to abstain fror injuries to them, affecting life or limb. In case of clisobedience of these laws, the slaves may be taken away, and sol for the benefit of the owners: slaves accused of higher crimes than petit larceny shall have a fair trial by jury; and av one who maliciously dismembers or deprives a slave of life, shall be punished as if he had committed the same cripo on a white person, except in case of insurrection of such slave; one-tenth of the annual revenue derived from tax fon shall be set aside as a primanent fund for the support of free publio sehools, and all public lands granted for suchóhools shall not be alienated in fee; nor leased for more than 20 years. The constitution may be amended on the propeal of two-thirds of both houses, which propositions shatl then be published three months before the next general elect $\mathrm{n}$; and if approved of at that election by a majority of the voters, and then ratifled by twothirds of both houses, in th next Legislature, they shall be valid, and form part of the enstitution.

Finances, Delt, etc.- ceording to the Comptroller's report, dated $12 \mathrm{th}$ November, 1851 , the debt of the late Republic of Texas, which has bes recognized and adopted by the State, including interest, amounted ostensibly to $\$ 12,436,991$, or at par to $\$ 6.527 .27 \mathrm{~s}$. $i$ the debt, $\$ 9,647.253$, or $\$ 4,807,774$. par. had buen filed aceording to the act of 20 th March, 1848 , and $\$ 2,759,735$, or $\$ 2019.514$, had not been fled, and would require further legislative action before its owners could benefit by the act of 1815. The debt is classified as fullows:

Ostensible.

Par value,

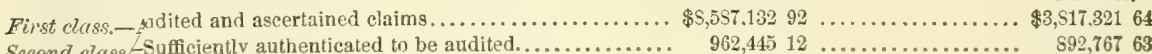

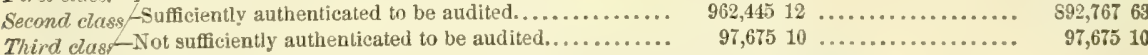

The fiot class embraces all consolidated funds, funded debts, treasury bonds, and audited paper, including the claims for nay ressels, loans from United States bank, etc.

Th/ second class embraces claims not audited, but for debts contracted by the government under the sanction of law.

The third class embraces claims not provided for by law, though many of them are highly meritorious. Among them ar many clitims for losses sustained during the war, from the appropriation or destruction of property by the Texan army a that of the enemy.

The act of Congress of 9 th of September, 1850 , provided that, as an indemnity for lands ceded by that act, for public property ceded by annexation, and for relinquishment for all claims upon the federal treasury, the United States should pay to Texas $\$ 10,000,000$ in 5 per cent. stock, redeemable at the end of fourteen years, with interest, payable half yearly ; $\$ 5,000,000$ of this stnck was not to be issued " until the creditors of the State holding bonds and other certificates of stock of Texas, for which duties on imports were specially pledged, shall first file in proper form, at the Treasury of the United States, releases of all claims against the United states on account of said bonds or certificates." The executive of the United States has decided "that all the public debt of Texas created prior to the act of Cungress of that Republic of the 14th January, 1840, and all the debt of said Republic made receivable for all public dues, are debts of Texas, for which the duties on imports are specially pledged, and that releases of all claims against the United States for or on account of such debts, should be filed in the Treasury Department, before the President will be justified in issuing the second $\$ 5,000,000$ stock to Texas." 
Besideg this immense sum, the State owns nearly $200,000.000$ acres of lands, and according to the census of the United States, the value of real and personal estate liable to taxation was valued at $\$ 52,740,473$.

The average annual expenses of the State government are about $\$ 100,000$, which is raised chiefly by a direct tax on assessments, and a capitation tax.

The military force of Texas consists of 19,766 men of all arms, of which 1,248 are commissioned officers, and 18,518 non-commissioned officers, musiciaus, artificers, and privates, of the officers, 15 are general officers, 45 general staff-offlcers, 248 field officers, etc., and 940 company officers. Every white male citizen between the ages of 18 and 45 years, unless exempt by law, is liable to military duty.

Federal Representation - In accordance with the act of $23 \mathrm{~d}$ May, 1850, apportioning representation, Texas is entitled to two representatives in the Congress of the United States.

Education-Primary and common schools are established in the chief towns and counties, and education is becoming universal and easy of attainmert. The State has a considerable school fund, which is being constantly augmented by grants and donations. The Colles: of Ruterville has been liberally endowed by the State, and is quite flourishing. Galveston University is also in full opertion, and is very popular. There are also theological institutions in various towns, supported by the several denominathns. Though in respect of educational means the State may at present occupy a secondary rank, the provisions made for its advancement insure the speedy enlargement of the sphere of their influence

Religious Denominations. - The statistig of the several religious denominations in the State, in 1550 , according to the census of that year, were as follows:

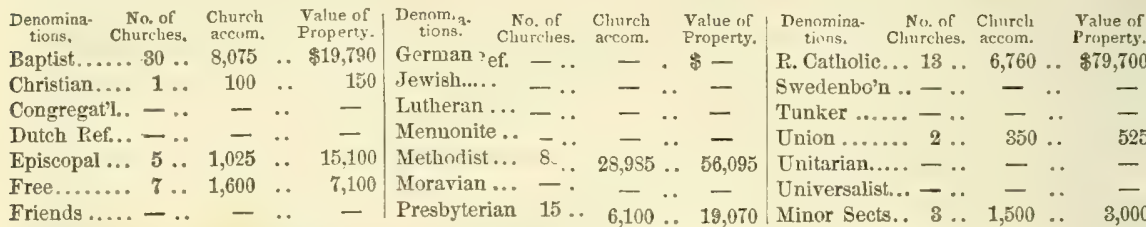

-making a total of 164 churches, haring accommodation for 71.75 persons, and ralued as property at $\$ 200.530$. Texas forms a missionary diocese of the Protestant Episcopal Church; nd also the Roman Catholic diocese of Galveston, a suffragan of the ecclesiastical province of New Crleans.

Public Libraries.-According to the report of the librarian of the $\mathrm{S}_{\perp_{i}}$ ithsorian Institution, in 1851, Texas contaiued but 4 public libraries, and 1,631 volumes-one State library, 1,001 volumes; ne college library, 300 volumes; and two public school libraries, 330 volumes.

Periodical Press. - The whole number of periodicals published in the Site, in 1550, according to the census, was S7, of which the political principles of three were "whig," and of 11 "democratis" and 23 were neutral in politics, includiug those devoted to literature, religion, science, ete. Of the whole number (37), 3 -ere issued tri-weekly, 2 semi-weekly, and 82 weekly. The aggregate circulation of the tri-weeklies was 2,500 copies at eaci issue, of the semi-weeklies 1.800 copies, and of the weeklies 14,837 copies. There were published-in Anderson county, 1 whkly; in Bexar (San Antonio), 2 weeklies; in Bowie, 1 weekly; in Cameron (Brownsville), 2 weeklies; in Cherokee, Calho 7 , Dallas, Fannin, and Fayette, each 1 weekly; in Galveston (Galveston City), 2 tri-weeklies, 1 semi-weekly, and 1 weekly; $;$ Harris (Houston), 1 tri-weekly and 4 weeklies; in Harrison (Marshall), 2 weeklies; in Jasper, Lamar, and Matagorda, vch.1 weekly; in Rusk (Henderson), 3 weeklies; in Red River and San Augustine, each 1 weekly; in Travis (Austin), 2 'eeklies; in Victoria, 1 weekly; in Walker (Huntsville), 2 weeklies; in Washington, 1 semi-weekly and 1 weekly.

Pauperism.-The whole number of paupers relieved or supported within the year endig 1 st Jume, 1550 , was 7 , all natives, and the whole number of paupers at that date was 4 . Cost of support, etc., $\$ 133$.

Historical Sketch.-The first settlements in Texas were made by the French at Matagorda; kt the settlers were soon after expelled by the Spaniards, who, in 1690, extended their cordons from New Spain over the whle territory. Previous to this time the Indians held undisputed sway over this fine country. Spanish forces were stationd at Goliad, Bexar, Nacogdoches, etc., and held military possession until the revolution which overthrew the Spanisı power in Mexico. On the consummation of Mexican independence, Texas became, in connection with the adjoining Sute of Coahuila, a province of the Republic. Soon after this period, several colonies of Americans, who had been invited $\eta$ to the territory by the Mexicans, settled in the eastern section, and were for a long time secured from the onerous bur ens of Mexico

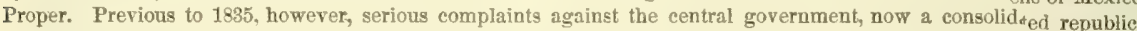
were uttered, and in the following year open rebellion was rife. The Mexican President invaded Texas vith a Iarge army, and was successively' victorious and defeated in numerous skirmishes. The American settlers declared heir inde pendence in March, 1836, and the defeat of the Mexicans and eapture of Santa Anna, at San Jacinto, 21st Apil, 1836, secured to the patriot party the acknowledgment of their assumption by that leader, and the whole of the country the Pio Grande was acceded to them. The acts of Santa Anna, however, were never confirmed by the Senate, a course their authority was, to say the least, equivocal. No serious attempts having been made by the Mexicans to regin Texas for eight or nine years, the political nationality of the country was considered as consolidated, and in 1845, the Enited States of America admitted the young republic as a State of the Union. The consequences of this act was wa with Mexico-a war which the United States virtually assumed by the annexation, at a time when Texas was in a state of war with Mexico. The history of this war is recent and well known. The arms of the United States were everywhere victorious; and when peace returned, not Texas alone, but New Mexico and Califurnia Alta were parceled off to the Americans, and forever lost to the Mexican Republic. The joint resolutions of Congress, admitting Texas into tho Union, were signed by the President of the United States, on the 1st March, 1845, and ratifed by the Congress of Texas, on the 4 th July of the same year. The State Government was organized on the 19th Feb., 1846. The boundary between New Mexico and Texas, the latter of which claimed the line of the Rio Grande, was adjusted by compromise in 1850.

Austiv Cris is the political capital of the State.

Texas county, Mo. Situate toward the S.. and eontains / Big Piney fork of Gasconade r. Sturface varied, in parts 1,247 sq. $m$. Drained by head branches of Current $r$. and : being hilly, but in gencral it is undulating; soil furtile. 850 
Chief productions, wheat and Indian eorn; it is also favorable to the growth of tobacco. Timber is abundant. It contains some minerals. Farms 282; masuf. 15; dwell. 394, and pop.-wh. 2,270 , fr. col. 0, sl. 42-totol 2,312. Cupital: Houston.

Texas, p. 0., Washington county, Ind.: $\$ 4$ miles $\mathrm{S}$. Indianapolis.

Texas, p. 0., Randolph co., $I U_{\circ}: 216$ m. S. Springfield.

Texas, p. v., Oswego co, $N_{*} Y_{\text {.: }}$ on Salmon r., near its entrance into Lake Ontario, 140 m. W. N. W. Albany.

Texss, p. o., Lycoming county, Penn. : 75 m. N. by W. Harrisburg.

Texas, p. on, Henry county, Ohio: 101 m. N. W. by N. Columbus.

Truas Valuex, p. o, Cortlandt co., N. Y.: 121 W. by S. Albany.

Thames river, New London co., Conn.: formed by the junction of the Quinnebaug, Shetucket, and Yantic rivers, near Norwich, from which it flows $\mathbf{S}$., and empties into Long Island Sound below New London. It is navigable to Norwich, 14 miles.

Trebes, p. $\mathbf{V}_{\text {, }}$ and cap. Alexander co, $I l l_{.}$: on E. bank of Mississippi r., $176 \mathrm{~m}$. S. Springfield. It contains the county buildings, etc., and tas many facilities for commerce.

The Conners, p. o., Ulster county, $N$. $Y$.: on Esopus er. $53 \mathrm{~m}$. S. S. W. Albany.

The Forks, p. o., Somerset co., MYe.: on W. side of Kenmebee r., at junction of Dead r., $73 \mathrm{~m}$. N. by W. Augusta,

The GleN, p. 0., Warren co., N. Y.: 63 m. N. by W Alhany.

The GuLPr, p. 0., Chatham county, $N_{\text {. Car : }} 8 \mathrm{~S}$ m. W. Raleigh.

THE NARRows, p. o., Crawford county, Ark: $120 \mathrm{~m}$. N. W. by W. Little Rock.

Treorogical Seminary, po O, Fairfax co, Firg. : $95 \mathrm{~m}$ ㄱ. Richmond. The Episeopal Theologieal School of Virginia is located here, and in 1850 bad 4 professors and 32 students, The library contains about 5,000 volumes.

The Planss, p. o., Fauquier co., Firg.; $91 \mathrm{~m}$. N. by W. Richmond.

The Percease, p. o., Westchester co., $N . \quad Y$.: $114 \mathrm{~m}$. S. Albany.

Theres A, t. and p. v., Dodge county, Wisc.: 57 miles N. E, by E. Madison. The village is on the N. side of Rock river.

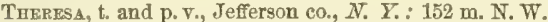
Albany. Surface uneven and broken. Drained by Indian r., on which is the V., containing about 200 inhabitants. Pop. of t. 2,342

The Square, p. o., Cayuga co., $N$. $Y$.: $150 \mathrm{~m}$. W. by N. Albany.

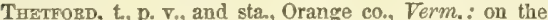
W. side of Connecticut r., $37 \mathrm{~m}$. S. E. by E. Montpelier. Surface uneven and rough. The $t$, is well watered by $0 \mathrm{~m}$ pomponoosuc r. and branches, which afford water-power, and also contains several ponds, one of which is very deep, without inlet or outlet, and noted for abundance of fish. The t. contains 3 villages. The central v. contains a church, an academy, several stores, etc. The Connecticut and Passumpsic Rivers $\mathrm{R}$. R. runs along the Conuecticut $\mathrm{r}_{\text {, }}$ having stations at Thetford and North Thetford. Pop. of t, 2,010.

TheтroRd, t. and p. o., Genesee county, Mïch.: $53 \mathrm{~m}$ N. E. by E. Lansing. Drained by branches of Upper Saginaw and Flint rivers. Pop. 303.

The Village, p. o., Point Coupee par., La.: 86 m. N. W. Baton Rouge.

THEODEAUX, p. V., $_{*}$ and cap. La Fourche par, $L a,:$ at junction of Blue and La Fourche bayoux. It contains the county buildings and 3 churches, The "Minerva" (whig) is published weekly. The New Orleans, Opelousas, and Texas $\mathrm{R} . \mathrm{R}$. will pass through this place. Pop. about 1,000 .

ThICKETY ForK, p. o., Spartanburgh dist., S. Car. : $80 \mathrm{~m}$. N. W. Columbia.
Thivener, p. o., Gallia county, Ohio: 88 m. 8. 8. E Columbus.

Tном county, $G a$. Situate $\mathrm{B}$. toward the W., and contains $1,348 \mathrm{sq}$. m. Ocblockonee river enters it in the N. W. and passes centrally through it, by which and its branches, and by branches of Withlachoochee, it is drained. Surface level ; soil fertile, and produces cotton, rice, and corn, in abundance. Apples, oranges, and lemons, etc., are grown and pine and other timber abounds. Farms 584: manuf 6 ; dwell. 838 , and pop.-wh. 4,943, fr. col. 4, sla. 5.156total 10,108. Oapital: Thomasville, Public Works: Brunswick and Florida R. R., and Branch to Tallahassee.

Tromas, sta., Burke co., Ga.: on the Augusta and Waynes boro' R. R., 36 m. S. from Augusta

Tiomaston, p. V., and cap. Upson county, $G a .: 69 \mathrm{~m}$. W. by S. Milledgeville. It contains the court-house and jail, an academy, 2 churches, stores, etc. Pop, about 180.

Thomaston, t. and p. v., Lincoln co., MLe : on $\mathbf{E}$. side of St. George's r., $36 \mathrm{~m}$. S. E. Augusta. This t. contains an abundance of limestone, from which 300,000 casks of lime are annually made. The Maine State prison here located has spacious and coramodious buildings, with 10 acres of ground attached. The prisoners are extensively employed in cutting granite. Large ships come up to this $t, 12 \mathrm{~m}$. from the ocean. The "Liucoln Miscellany" is issued semiweekly. Pop. of t. 2,723.

Thomastown, p. V., Leake co., Miss. : on W. bank of Gochamockamy cr., 51 m. N. E. by N. Jackson.

Thomastille, p. v., and cap. Thomas co., $G a$ : $169 \mathrm{~m}$ S. by W. Milledgeville. The projected Brunswick and Florida R. R. will pass through this place, with which the N. extension of the Tallahassee and St. Mark's R. R, will here connect. It contains the county buildings, etc., and is a village rapidly rising into commereial importance.

Thomasvilte, p. v., Oregon co., Mo.: 125 m. S. S. E. Jefferson City.

Tromastille, p. v., Robertson county, Tenn.: 28 m. N. Nashville.

Thompson, t., p. v., and sta, Windham co., Conn. : 46 m. E. N. E. Hartford. Drained by' French, Quinnebaug, and Fire-mile rivers, which afford good water-power. On their banks are the manufacturing villages of Thompson, $\mathrm{Ma}$ sousville, Fisherville, Wilsonsville, and New Boston, all of which, except New Boston, are on the Norwich and Worcester R. R. The t. is large, with hilly surface, and fine grazing soil. Pop. in 1840, 3,535; in 1850, 4,638.

Tномтsоn, p. v., Columbia co., Ga.: on the Georgia R. R., $88 \mathrm{~m}$. W. from Augusta, 56 m. N. E. by E. Milledgeville

Thompson, t. and p. o., Geauga co., Ohio: 149 m. N. E. Columbus. Pop. 1,211.

Tuompsox, to, Seneca co., Ohio : situate in N. E. corner of the co., $84 \mathrm{~m}$. N. Columbus. The Mad River and Lake Erie R. R. crosses it, 23 m. S. S. W. Sandusky. Pop. 1,668. Thompsox, t. and p. O., Susquehanna con, Penn.: $121 \mathrm{~m}$. N. by E. Harrisburg. Pop. about 400 .

Trompson's, p. 0., Fairfield dist., S. Car.: $19 \mathrm{~m} . \mathrm{N} . \mathrm{W}$. by N. Columbia.

Thompson's Cross Roads, p. o., Louisa co., Firg.: on $\mathbf{S}$. side of South Anna r., 31 m. N. W. Richmond.

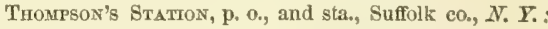
on Long Island R. R., 41 m. E. from New York.

Thompson's Store, p. 0., Guilford co, $N$. Car: $72 \mathrm{~m}$. W. N. W. Paleigh.

Thompsontown, p. V., Juniata co., Penn. : on N. side of Juniata r., and on Canal, 29 m. N. W. Harrisburg.

Thompsonville, p. v. and sta., Hartford co., Conn.: on E. bank of Connecticut r., and on New Haven and Springfield R. R., $18 \mathrm{~m} . \mathrm{N}$, by E. Hartford, It contains a carpet factory, which employs 400 operatives.

Thompsonvmle, p. o., Racine co., Wisc. : 44 m. E. S. E. Madison.

Thompsorville, p. v., Sullivan co., $N . Y_{0}$ : on small branch of Delaware r, $87 \mathrm{~m}$. S. W. by S. Albany Pop. about 200. 
THOMPSONVILLE, p. o., Washington co, Ky.: 33 m. S.S.W. Frankfort.

Thompsosvtuite, p. o., Culpepper co., Tirg.: on N. side of branch of Rapid Ann r., 75 m. N. N. W. Richmond.

Trox's creek, Colusi co., Calif. : flows E., and enters the Sacramento r., at Tehama village.

Thors burg, p. v., Spottsylvania county, Tirg.: $46 \mathrm{~m}$. స.. N. W. Richmond.

Thonvidry, t. and p. o., Chester county, Penns: $67 \mathrm{~m}$. E. Harrisburg. Drained by Chester er. and Brandywine $r$.

THorndike, p. v., Hampden co., Mass.: on S. bank of Chieopee r., 66 $\frac{1}{2} \mathrm{~m}$. W. by S. Boston. A manufacturing v. with superior water-power.

THORNDKE, to and p. o., Waldo co., Me.: 34 m. N. E. by E. Augusta. Drained by Sebasticook r. Pop. 1,029.

ThorN Hili, p. O, Walker co., Ala.: 132 m. N. N. W. Montgomery.

ThorN HiLl, p. o., Grainger county, Tenn.: $192 \mathrm{~m}$. E. Nashville.

Thora Hill, p. O., Orange co., Virg.: 50 m. N. W. by N. Richmond.

Thornlexspillue, p. v., Boone co, Ind.: $18 \mathrm{~m}$. N. W. Indianapolis.

Thовкток, t. and p. O., Cook co, Ill : on $\mathrm{N}$. side of Thorn er., 158 m. N. E. Springfield. Pop. about 400.

Trornton, t. and p. va, Grafton con, N. Hamp.: $57 \mathrm{~m}$. N. by W. Coneord. Surface uneven; watered by Pemigewasset river. On Mill brook there is a cascade, at which the water first falls 7 feet in 2 rods, and then falls over a rock 42 feet perpendicularly. Pop. of t. 1,012

Thornton, p. v., Delaware co., Penn.: 76 m. E. by S. Harrisburg.

Thornton's Ferri, p. o. and sta. Hillsboro" county, N. Hump.: on W. bank of Merrimac Y., and on Concord R. R, 6 m. from Nashua, 29 m. S. from Concord.

Thormtox's Mrics, p. O., Rappahannock co., Virg. : 85 m. N. N. W. Richmond.

Thorntown, p. v. and sta., Boone co., Ind. : on N. side of Prairie er., near jts junction with Sugar er., and on Lafayette and Indianapolis R.R... $37 \mathrm{~m}$. N.W. from Indianapolis. The $\mathrm{v}$, contains about 550 inhabitants.

Thornville, p. v., Perry en., Olio: 86 m. E. by S. Columbus. On the scioto and Hocking Valley $R . R$

TirorodghFare, p. v. and sta.. Prince William co., Virg. $88 \mathrm{~m}$. N. by W. Richmond. The Manassas Gap R. R. passes through it. It has flouxing-mills in the vicinity, on Brond run, which affords good water-power.

Thousand islands, $N$. $Y_{\text {. : }}$ situated in the St. Lawrence $r_{\text {. }}$ a little below Lake Ontario. The American portion of them belongs to Jefferson co, and the remainder to Canada. The St. Lawrence is here from 2 to $9 \mathrm{~m}$. wide. The number of these islands. many of which are very small indetr. is said to exceed 1,500 , within the distance of $27 \mathrm{~m}$. The largest belonging to the United States are CarIton, Grindstone, and Wells islands; and of those belonging to Canada, the largest are Grand and Howe islands. They are generally covered with cedar and hernlock to the water's edge: and many aro so clnse together, that a canoe can hardly pass between

Three Forks, p. o., Barren co, $K y,: 96 \mathrm{~m}$. S. W. Frankfort.

Three Forks. p. o. Wilson co, Tenn, : $35 \mathrm{~m}$. E. Nashville. Three Forks, p. o., Taylor county, Tirg. : 185 m. N. W Richmond.

Turee Mrle Bay, p. o., Jefferson county, $N . Y_{.}: 160 \mathrm{~m}$ N. W. by W. Albany.

Turee Rivfrs, p. v., St. Joseph's cn, Mich.: on St, Jnseph's r., near the junction of Portage r. and Rocky cr.; 74 m. S. W. Lansing. The St. Joseph's $r$, is navigable to this place for bonts of 30 tons.

Turee Rivrirs, p. o., Polk co., Ia. : $96 \mathrm{~m}$. W. Iowa City

THI:Ee PIVEPs, $p$, $v$, and sta. Ifampden co. Yuss. Chicopee $\mathbf{r}$, near junction of Ware and Swift rivers, $66 \mathrm{~m}$. W. by S. Boston. The Amherst and Belchertown $\mathrm{R}$. R. passes through it, $8 \mathrm{~m}$. from Palmer, $17 \mathrm{~m}$. from Amherst. 852
Three Roads, p. o., Cambria co., Penn.: 95 m. W. by N. Harrisburg.

Threx Sprivgs, p. o., Hart county, Ky.: 88 m. వ. W. Frankfort.

Three Spervgs, p. o., Huntingdon co., Penn。: $55 \mathrm{~m}$. W. Harrisburg.

Three Springs, p. o., Washington co., Firg.: $253 \mathrm{~m}$ W. by S. Richmond.

THrog's point, Westchester co, $N, Y_{0}$ : on $\mathrm{S} . \mathrm{E}$. point of Throg's Neck, projecting into East r, $13 \mathrm{~m}$. N. E. City Hall, New York. Here is Fort Schuyler, a very strong fortification, commanding the entrance of East $r$, from Long Island Sound. Here also is a lighthouse. (See Ligntrouses.)

Throopsville, p. v., Cayuga co, $N$. $Y$.: on Owasco outlet, 151 m. W. by N. Albany.

Thunder bay, Mich. This large bay sets up N. W. from Lake Huron into Alpena co., affording an excellent harbor, with 5 or 6 fathoms of water. Its waters are of reddish color. It receives Thunder Bay r., and other smaller streams. Several islands lie near the entrance of the bay.

Thurmar, p. o., Gallia county, Ohio: 85 miles S. by E. Columbus.

Thurstox, t. and p. o., Steuben co., N. Y.: $186 \mathrm{~m} . \mathrm{W}$. by S. Albany, Pop. 726

Trara, p. o., Montgomery co., Ala. : $18 \mathrm{~m}$. S. Montg mery. Tíbatt's Cross Roads, p. o., Campbell co., Ky. $: 57$ m. N. E. by N. Frankfort.

ThCONDERoga, t. and p. v., Essex $c_{0}, N_{*} Y_{*}$ : on both sides of outlet of Lake George; $87 \mathrm{~m}$. N. by E. Albany. Surface of $t$, is level or rolling on the E., hilly and mountainous on the W. ; soil clay loara and fertile, particularly near the lakes. The vo is situated at the lower falls, $2 \mathrm{~m}$. W. of Lake Champlain. The outlet has here a descent of 30 feet, affording great water-power; it is navigable to the lower purt of the v. for lake craft. The rains of old Fort Ticondersga are situated $2 \mathrm{~m}$. below the $\mathrm{v}$., on a point of land at the entrance of the outlet of Lake George into Lake Champlain. Their site is elevated about 70 feet abrve the lake. Abnut $1 \mathrm{~m}$. S. W. is Mount Defiance, rising 750 feet above the lake. Pop. of t. 2.669.

TIDioxto, p. o., Warren co., Penn.: on W. side of Alleghany $r_{0}, 162 \mathrm{~m} . \mathrm{N}$. W. Harrisburg.

TiFris. p. Yes sta, and eap. Seneea co., Ohio: on Sandusky river, $76 \mathrm{~m} . \mathrm{N}$. Columbus. The Mad River and Lake Erie R. R. passes through it. It contains a courthouse, jail, several churches, etc., and is the centre of considerable trade. Four weekly newspapers are published-"Seneca Whig," "Western Whig Standard," "Seneca Advertiser" (dem.), and "Northwestern Cuntinent" (neut.) Population 2,72S.

TIGER, p. 0., Rabun county, Ga. : 130 miles N. by W. of Milledgeville.

Tiger Creek, p. o., Claiborme par., La.: 195 m. N. W. by $\mathrm{N}$. Baton Rouge.

Tigeisville, p. o., Terre Bonne par., La.: at the junction of head-waters of Tiger bayou, $52 \mathrm{~m}$. S. by E. Baton Rouge.

TILLERE's FeEex, p. O., Kershaw dist, S. Car, , 50 m. N. E. by $\mathrm{E}$. Columbia.

Trutov, p. o, and sta, Murray en, Gav: $156 \mathrm{~m}, \mathrm{~N}$. W. Milledgeville. The Western and Allantic R. R. passes through it, $8 \mathrm{~m}$. S. Dilton, and $92 \mathrm{~m}$. from Allanta.

TIMBalter hay, $L a$. : sets up $\mathrm{N}$. W. from the moath of Bayou La Fourche; is $31 \mathrm{~m}$. long, 3 to $6 \mathrm{~m}$. wide. It is shallow with sandy and muddy bottom. At its mouth are several large islands.

TIMren, p. o., Peoria county, Ill.: 54 miles $\mathrm{N}$. by W. Springficld.

Timber CReEk, p. o., Mfarshall county, Ia.: on S. side of branch of Iowa r., $72 \mathrm{~m}$. W. Iowa City.

Trmber Creek, p. o., Hunt county, Tex.: $7 \mathrm{~m}$. E. by S. Greenville, 2:5 m. N. X. E. Austin City.

Tinber Grove, p. o., Washington co., Virg. : $266 \mathrm{~m}$. W. by S. Richnond. 
Truber Ridge, p. 0, Union dist., S. Car. : $60 \mathrm{~m} . \mathrm{N}$. W. Columbia.

Truber Rmgr, p. 0, Rockbridge co., Virg.: 101 m. W. by N. Richmond

Thimer Rloge, p. o., Greene county, Tenn.: 216 m. E, Nashville.

THBBRtLLE, p. v., Rockingham co., Virg.: 117 m. N.W.

Richmond.

Tmonid, v, and sta., Baltimore co., $M d_{*}:$ on the Baltimore and Susqnehanma R. R., 11 m. N. Baltimore.

Thnicer Kлos, p. o., Botetourt co., Virg.: 145 m. W. of Richnund.

Tinkfr Run, p. o., Westmoreland co., Penn.: 143 m. W. Harrisburg.

Thak re's Creer, p. o., Barnwell district, $S$. Car. : $60 \mathrm{~m}$. S. S. W. Columbia.

TrNmouth, t. and p. o., Rutland co., Verm. : 63 m. S. S.W. Montpelier. Surface elevated anil hilly, Drained by Furnace brook. It contains marble and iron ore. Poip. 717.

TrNak's Grove, p. o., Ray co., Mo.: 120 m. W. N. W. Jefferson City.

Tinton Falls, p. o., Monmouth co., $N$. Jer.: on E. side of branch of Neversink r., $34 ! \mathrm{m}$. E. by N. Trenton. This place and vicinity is of great resort in the summer.

Troga county, $N . Y$. Situate centrally, and contains 456 sq. $\mathrm{m}$. Drained by branches of Susquehanna r., the principal of which are E. and W. Owego creeks, and which afford good water-power. Surface diversified by hills and valleys; soil various, but fertile, consisting mostly of a gravelly loam, intermixed with clay; the uplands are arlapted to grazing, and the valleys to wheat, grain, etc. There is a quantity of white pine and other valuable timber on the land. It has some minerals, and marl is found, which takes the place of lime. It also contains sulphur springs. Chief productions, wheat, Indian corn, and potatoes. Farms 2,036; manuf. 351: dwell, 4.412, and pop.-wh. 2t.683, fr. col. 197-total 24.580. Cupital: Owego, Pullic Works: New Iork and Erie R. R. : Cayuga and Ithaca R. R.

Troga county, Penn. Situate N., and contains $1,056 \mathrm{sq} . \mathrm{m}$. Tinga r. passes through the eastern portion, by which and its branches, and aifluents of W. branch of Susquehanna r., it is drained. Surface pleasantly diversified, with low bills and fertile valleys. Soil fertile, and adapted to grain, Wheat and Indian curn are raised in large quantities. A part of the county is well wooded. Farms 2,153; manuf. 225 ; dwell. 4,222, and pop.-wh. 28,359 , fr. col. 98-total 25.977. Cajital: Wellsboro'. Public Horks: Corniug and Blussburg R. P

Tioga, to and p. o., Tioga co., Penn.; 110 m. N. by W. Harrisburg. Surface hilly; soil various. Drained by Tioga r. The Corning and Blossburg R. R. passes through the $t$.

Troga, t., Tioga co., N. Y.: on Susquehanna $r_{*}, 140 \mathrm{~m}$. W. S. W. Albany. Surface hilly. Pop. 2.839

Tioga Centre, p. v. and sta, Tioga co., $N$. $Y$.: on the Erie R. R , $252 \mathrm{~m}$. from New York, $217 \mathrm{~m}$, from Dunkirk.

Tionesta, t. and p. o., Venango co., Penn. : on E. side of Alleghany r., $157 \mathrm{~m}$. N. W. by W. Harrisburg.

TiPPAF county, Miss. Situate N. toward the E., and contains $1.037 \mathrm{sq}$. m. Drained by head branches of Tallahatchie river. Surface undulating. Farms 1,890; manuf, 26: dwell, 2.655 , and population-wh. 15,808 , fr. col. 5 , sl. 4,928-total 20,741. Capital: Ripley.

Trppecanow county, Ind. Situate N. W., on Wabash r., and contains $504 \mathrm{sq}$. $m$. The interior is drained by Tippecanoe r., Wild Cat and Burnett creeks. Surface gently undulating, or spread out into extensive level tracts: along the Wabash. the county is hilly. Farms 1,377; manuf. 204: dwell. 3.227, and pop.-wh. 19.818, fr. col, 159-total 19,37\%. - copitul: La Fayette. Public Works: New Albany ani Salem Extension R. $R$. ; Lafavette and Indianapolis $P_{v}$. R. Great Western Central R. R. : Wahash and Erie Canal, etc

Tippenanoe, sta., Montgomery $c 0 .$, Al $\ell .:$ on Montgomery and West Point R. T., $11 \mathrm{~m}$. E. from Montgomery.
TIPPECANOE, p. O., Harrison county, Ohio: $98 \mathrm{~m} . \mathrm{E}$, by N. Columbus.

Trppecanot, p. o, Henderson co, Tenn.: 96 m. W. S. W. Nashville.

Trppecanoe, p. o, Fayette co, Penn.: 145 m. W. by 8. Harrisburg.

Tippecanoe river, Ind.: rises in a lake in Kosciusko co, flows W. and then $\mathrm{S}$., and empties into Wabash river, $9 \mathrm{~m}$. above Lafayette. It is over $200 \mathrm{~m}$. long, but is narrow and shallow, though with a permanent supply of water.

Tipton county, Ind. Situate centrally, and contains 264 sq. m. Drained by Cicero and Duck ereeks. Surface mostly level and well timbered. Farms 839; manuf. 1; dwetl, 627, and pop.-wh. 3.525, fr. col. 7-total 3,532. Capitul: Tipton. Putlic Works: Indianapolis and Peru R. P.; New castle and Logausport R. R

Tiprox county, Tenn. Situate W., and contains 692 sq. m. Drained by branches of Big Hatchee and Lrnsihatchee rivers, both tributaries of Mississippi $r$, which flows on its W. border, Surface level, excenting the bluffs on the Mississippi. Soil fertile, and adapted to cotton and tobacco, which are produced in large quantities. Farms 631 ; manuf. 16 ; dwell. 818, and pop.-wh. 4,673, fr. col. 22, sl. 4,192total 8,887. Capital: Covington.

Tiptor, p. v., and cap. Cedar co., $I a$.: about $1 \frac{1}{4} \mathrm{~m}$. W. of Sugar cr., a tributary of Iowa r., $20 \mathrm{~m}$. E. by S. Iowa City. It is situated on a bandsome prairie, and is rapidly increasing in population. The "Tipton Times" (miscel.) is published monthly.

Trpton, p. o., Lenawee county, Mfich. : 62 m. S. S. E. Lansing.

TiptoN, p. v., sta., and cap. Tipton county, Ind.: on Peru and Indianapolis R. R., $40 \mathrm{~m}$. N. Indianapolis.

TIRo, p. 0., Marshall co. Mifss. : $157 \mathrm{~m}$. N. by E. Jackson. Tisnemingo eounty, Miss. Situate N. E., and containg 1,149 sq. m. Drained by Tuscumbia and Yellow creeks, and tributaries of $\mathrm{E}$. fork of Tombigbee $r$. Surface uneven, and on the Tennessee, which bounds it N. E*, presents high bluffs. Chief productions, cotton and Indian corn. Farms 1,2t7; manuf. 16 ; dwell. 2.201 , and pop.-wh. 13,528 , fr. col. 1, sl. 1,961-total 15,490. Capital: Jacinto. Putlic $W_{1} r^{2} k s$ : Mobile and obio R. R.

Tismuwa, p. o,, Bureau co., Tl. : 101 m. N. Springfield. Timicut, sta., Plymouth co., Muss.: on S. side of Taunton river, and on Fall River R. R., 31 m, from Boston.

Tirsworth, p. o., Malison county, Ar\%.: on N. side of Richland er., $125 \mathrm{~m}$. N. W. Little Ruck.

Trturor, p. o., Greenville district, $S$. Car.: $90 \mathrm{~m}$. N. W. Columbia.

- Tixus county, Texo. Situate N. E., and contains 1,143 sq. m. Drained by White Oak bayou, and affluents of Big Cypress river, which flows on its $\mathrm{S}$. horder. Farms 269; manuf. 4: dwell. 545, and pop.-wh. 3,168, fr. col. 1, sl. 468-total 3.686. Capitul: Mount Pleasant.

Titusville, p. v, and sta., Mercer county, N, Jer.: on Belvidere Delaware R. R., $9 \frac{1}{2} \mathrm{~m}$. N. W. Trenton.

Trtusvmle, p. o., Crawford co., Penn。: $171 \mathrm{~m}$. N.W. by. Harrisburg.

Trvertox, t. and p. o., Coshocton co, Ohio : $52 \mathrm{~m}$. N. E. Columbus. Drained by $\mathrm{W}^{\mathrm{a}} \mathrm{l}$ honding $\mathrm{r}$. Pop. 842 .

Trventov, t. and p.v., Newport co., R. I.: 13 m. N. E. by E. Newport, and 18 m. S. E. by S. Providence. Bounded W. by the $\mathrm{E}$. passage of Narragansett bay and Mount Hope bay, which afford great facilities for navigation. Surface gently uneven; soil gravelly loam, and fertile. It contains several ponds, abounding with fisb, the outlets of which affurd water-power. It is ennected with Rlzode Island by a stone bridge 1.000 feet long. The $r$, and $t$. contain numerous factories, chiefly of calicoes, cotton batting. thread, coirse yarn, cassimeres, and tweeds. The v. contains 1 bank, capital $\$ 200,000$, has considerable coasting trade, and is somewhat engaged in the fisheries. Pop. of $t$. in 1S40, 8,153 ; in $1850,4,699$. 
Trverton Four Coranes, p. v., Newport co., $R . I_{*}: 9 \mathrm{~m}$.

N. E. Newport, 21 m. S. E. by \$. Providence.

Tivou, p. v. and sta., Duchess co., $N . Y$.: on E. side of Hudson $\mathrm{r}, 44 \mathrm{~m}$. from Albany.

TrvorI, po o., Dubuque eounty, Ia.: $64 \mathrm{~m}$. N. N. E. Iowa City.

Toвacco Port, p. v., Stewart co., Tenn.: on N. E. side of Cumberland r., $69 \mathrm{~m}$. W. N. W. Nashville.

Tовассо Row, p. o., Amherst county, Virg.: $94 \mathrm{~m}$. W. Richmond.

Tовассо \$тіск, p. 0., Dorchester co., MI. : 38 m.S.S. E. Annapolis.

TobeY's, station, Bristol county, JFass.: on Boston and Providence R. $R_{\imath}, 17$ miles from Providence, 26 miles from Boston.

Tuccoa Falls, p. o., Habersham co., Ga.: $106 \mathrm{~m}$. N. Milledgeville.

Toccopola, p. o., Pontotoe county, Miss.: 147 m. N. N. E. Jackson.

ToDD county, $K y$. Situate $\mathrm{S}$. toward the W., and contains 362 sq. m. Drained by Elk fork of Red r., which flows into Cumberland $\mathbf{r}$. and tributaries of Green $r$. Surface even. Farms 930 ; manuf. 28 ; awell. 1,316, and pop. -wh. 7,361, fi. col. 97, sl, 4,819-total 12,268. Capital: Elkton.

TODD, t. and p. o., Huntingdon co., Penn.: $56 \mathrm{~m}$. W. Harrisburg. It contains a furnace, forge, and numerous mills. Pop. about 900 .

Tond's, p. 0., Spottsylvania county, Virg. : 43 m. N. N.W. Richmond.

Tond's Creek, p. o., Platte co., MFo.: 148 m. W. N. W. Jefferson City.

Todpsvilife, p. 0., Otsego county, $N_{0} \boldsymbol{Y}_{0}: 70 \mathrm{~m}$. W. Albany.

Togus Springs, p. 0., Kennebec county, Jre.: 5 m. S. E. Augusta.

ToHoperatrigo lake, Orange co., Flor. : near \$. boundary line of the co., $12 \mathrm{~m}$. long, $5 \mathrm{~m}$, wide, and connected with Lake Kissimear.

Toland Pratrie, p. 0., Washington county, Wisc.: $52 \mathrm{~m}$. E. by N. Madison.

Toledo, p. 0., Union county, $I l l .: 152$ miles S. by $\mathrm{E}$ Springfeld.

TOLEDO, p. city, and port of entry, Lueas co., Ohio: on W. bank of Maumee r. $5 \mathrm{~m}$. from its entrance into Maumce bay, $117 \mathrm{~m}$. N. by W. Columbus. The built portion of the eity extends for more than a mile along the bank of the river, but it is most compact at its upper and lower extremities or landings, which were originally two distinct settlements, called Port Lawrence and Vistula. The rapidly inereasing population is fast filling up wilh houses, whatever of ground remains unoccupied between these points. The city contains many fine blocks of warehouses, stores, and dwellings, with some handsome public buildings, and numerous churches. Its settlement was commeneed about 1831 ; and it was incorporated as a cily in $1 \$ 36$. It has had a very rapid growth, chiefly developed from its connection with the Wabash and Erie canal, which extends from Manhattan, 4 miles below Toledo, to Evansville, Indiana, on the Ohio river, $467 \mathrm{~m}$. The railroads here centering are, Toledo, Norwalk, and Cleveland R. R., 111 miles: Erie and Kalamazoo R. R. to Adrian, 32 mo; Daylon and Michigan $\mathrm{R}_{\mathrm{v}} \mathrm{R}_{\mathrm{v}}$; and the Junction $\mathrm{R}$. $\mathrm{R}_{\mathrm{v}}$, to Clereland via Sandusky.

The total tonnage of Miami district, of which Toledo is the port of entry, on June 30th, 1850, was 2,629 tons, all permanent and emploved in the coastivg trade; of which 589 tons were propelled by steam. The total tonnage of same on June 30,1851 , was 3,286 tons; of which 1,153 tons were propelled by steam. During the year ending June 30 th, 1850, it had no foreign commerce or ship-building. The following exhibits the value of the total amounts of imports and exports during the years mentioned.

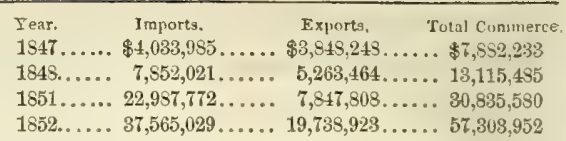

The value of the principal articles in the above, during the year 1852 , were as follows:

Salt............ $\$ 285,523$ Nails ........... $\$ 70,171$

Lumber, pine..... 200.592 Iron ............ 64,291

R. R. Iron ........1,793,275 Stoves, etc........ 93,192

Car wheels, etc.... 136,155 Hardware ....... 465,000

Locomotives ....... 196,000 Marble .......... 174.760

R. R. cars......... 42,650 Leather.......... 441,600

R. R. materials..... 120,120 Sugar .......... 171,612

\begin{tabular}{ll|l} 
Machinery ........ & 52,750 & Lfolasses.......... 225,505
\end{tabular} EXPORTS COASTWISE.

Wheat ..........\$2,250,092 Beef ..............\$187,990

Flour ........... 504,038 Tallow............ 186,665

Corn ........... 2,177,154 Spirits........... 456,484

Pork ........... 7102.162 Tubacco......... 120,925

\begin{tabular}{ll|l} 
Ilams........... 575,610 & Butter............. 44,786
\end{tabular}

Bacon........... 194.750 Staves........... 96900

Lard .......... 452,958 Pearl and potashes.. 137,425

Lard oil ......... 107.112 Oil cake......... 98,516

Live Hogs........ $336,79 \mathrm{~S}$ Wool ............. 190,893

Catlle .......... 111,640 Furs............ 210.000

The amount of duties collected at this port during 1852, on goods entered here, and on articles entered at New York and brought here in bond, was $\$ 50,00135$. The arrivals and departures during 1852, were as follows:

Vessels. $\quad \overbrace{\text { Number, }}^{\text {Arrivals, }} \overbrace{\text { Tomnage. }}^{\text {Depurtures. }}$

Vessels.
Steam......... $926 \ldots \ldots . \ldots 94,111 \ldots \ldots$
Number,

Sail ............ $1,127 \ldots \ldots 179,152 \ldots \ldots .1,129 \ldots \ldots 179,597$

Total ...... $\overline{2,053} \ldots \overline{673,293} \ldots \overline{2,057} \ldots \overline{674,618}$

The British tonnage in the abuve, consisted of 1 steam vessel, 156 tons, and 10 sail vessels, 1,001 tons.

The increase of the total number of vessels and their tonnage, which entered and cleared from Toledo, during 1852 , over 1851 , was as follows:

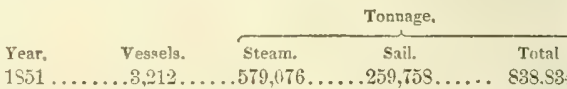

$1852 \ldots \ldots \ldots 4,110 \ldots \ldots 959,132 \ldots \ldots .358,779 \ldots \ldots 1,347,911$

Increase... $\overline{898} \ldots . \overline{410,056} \ldots . \overline{99,021} \ldots . \overline{509,077}$

The total lonnage arriving at, and departing from, Toledo by the Wabash and Erie canal, during 1850 , was 184,400 tons, and during $1851,250,000$ tons. Of this, by far the largest quantities brought to Toledo were those of wheat, flour, and corn; and of those sent from Toledo, the largest was railroad iron, of which the amount cleared in 1851, was $13, \$ 99,921$ pounds; and in 1S5\%, 41,933,592 pounds. The increase of grain, flour, and pork brought by the canal from the interior during 1852 , was 50 per cent. over the amounts brought during 1851. The receipts of grain and other produce brought by railroad during 1852 , were more than twice the amounts in 1851 , or any year preceding; and this was also the case with the receipts by wagon. Toledo promises to long retain its present pre-eminence over the other lake ports. as the leading market and exporting town of the great staples of N. W. Ohio.

The city is divided into 4 wards of nearly equal population. Its newspaper press in 1850 consisted of the "Toledo Blade" (whig), and "Toledo Republican" (free-soil dem.), each issuing daily, tri-weekly, and weekly editions. Pop. in 1840, 1,222 ; in $1850,3,819$; in $1853,6,512$.

Tolers, p. 0., Amité co., MFiss. : 94 m. S. S. W. Jacksnn.

Tolenville, p. v. and sta. Louisa county, Virg. : $40 \mathrm{~m}$ N. W. by N. Richmond. By Virginia Central R. R., which passes through it, $56 \mathrm{~m}$. from Richmond. 
Tolesвono', p. o., Lewis county, Ky.: 90 m. E. by N. Frankfort.

Tolraxd county, Conn. Situate N., inclining to the E., and contains 337 sq. m. Drained by Willimantie, Hop, Hockanum, Salmon, and Scantic rivers, and their affluents, which afford good water privileges. Farms 1,913; manuf. 241; dwell. 3,741, and pop.-wh. 19,946, fr. col. 145-total 20,091. Capital: Tolland. Public Works: New London, Willimantic, and Palmer R. R.; Hartford, Providence, and Fishkill R. R.

Tolland, t., p. v., and eap. Tolland county, Conn.: $18 \mathrm{~m}$. N. E. by E. Hartford. Surface rough and hilly ; soil rather sterile, but fertile in the valleys. Drained by $W$ illimantic $r$., which bounds it on the E., and by head branches of IIop $r$. Snipsic Pond, on its N. W. border, is $2 \mathrm{~m}$. long and $\frac{1}{8} \mathrm{~m}$. wide. The v., situated on an elevated plain, contains a court-house, jail, 1 bank, cap. $\$ \$ 1,000,1$ savings bank, with permanent deposits of over $\$ 125,000,1$ insurance company, cap. $\$ 253,000$, and 3 churches. The New London, Willimantic, and Palmer R. Ru, runs on the N. E. border of the t., having a station $45 \mathrm{~m}$. from New London $21 \mathrm{~m}$. from Palmer. Pop. of t, 1,410.

Tollavi, to and p. v., Hampden co, Mrass.: on E. side of Farmington r., 103 m. W. by S. Boston. Surface elevated ; soil best adapted to grazing. The inhabitants are chiefly engaged in farming. The $\mathrm{v}$, at the centre is neatly built, and contains a Congregational church. Pop. of t. 594.

Toli Gate, p. o., Marion co., Ala.: on W. side of Buttahatchee $r_{0}, 156 \mathrm{~m}$. N. W. Montgomery.

ToväAwK, sta, Powbattan co., Virg.: on Richmond and Danville P. R., $17 \mathrm{~m}$. W. by $\mathrm{S}$. Richmond.

Tomairami SpRING, p. 0., Berkeley county, Firg.: $133 \mathrm{~m}$. N. by W. Richmond.

Tovrigber river, Miss, and Ala.: rises by several sourecs in Tishemingo county, Miss., flows S., receiving numerous creeks, and bending to the E., enters Pickens county, Ala. In the N. part of Marengo co., it receives from the N. E. the Black Warrior r., nearly as large as itself, and thence flows $\mathrm{S}$. in a meandering course, until it unites with Alabama r. to form Mobile r., $45 \mathrm{~m}$. above Mobile. During nine months in the year, it is navigable for large vessels to St. Stephens, and for steamboats to Columbus, Miss.

Tous Corwiv, p. o., Allemakee co., Ia.: abont $2 \mathrm{~m}$. W. of the Mississippi, $96 \mathrm{~m}$. N. by E. Iowa City.

Toмналrock, p. o., Rensselaer county, N. Y.: $22 \mathrm{~m}$. N. E. by N. Albany.

Tomolta, p. O., Cherokee co., $N$. Car.: $297 \mathrm{~m}$. W. by $\mathrm{S}$. Raleigh.

ToMPKINS county, $N . T$. Situate W. centrally, and contains 580 sq. m. Drained by Fall, and Six Nile creeks, and Cayuga inlet, all of which enter Cayuga lake in their course, having considerable falls, and supplying good water privileges. Surface uneven; soil fertile, well adapted in the hilly portions to grazing, and in the valleys to grain, fruits, etc. The growth of wool is much attended to by the farmers. Its commerce is good, and it exports considerably. Chief products, wheat, Indian corn, and potatoes. It has some minerals, and marl and gypsum in abundance, also 2 or 3 sulphur springs. Farms 3,193; manuf. 4S4; diwell. 7,103, and pop.-wh. 38,440, fr. col. 298-total 38,738. Cupital: Ithaca. Public Works: Cayuga and Ithaca R. R.

Toupkiss, t. and p. o., Jackson county, Dfich.; $24 \mathrm{~m} . \mathrm{S}$. Lansing. Drained by Grand r. and Sandstone cr., a branch of same. The inhabitants are mainly engaged in farming. It has 1 steam saw-mill. Pop. in 1840, 219; in 1850, 628 .

ToMipkissville, p. o., Choctaw co., Ala.: on W. side of Tombigbee r., $105 \mathrm{~m}$. W. by S. Montgomery.

ToMp KINSviLfe, p. v., and cap. Monroe county, $k y$. . on small branch of Big Barren r., 111 m. S. S. W. Frankfort. It contains the county buildings, ete. Pop. about 240 .

Tompkinsville, p. v., Richmond county, $N$. $Y_{0}$ : on N E. part of Staten Island, $6 \frac{1}{2}$ miles S. W. by S. City Hall, New York, $140 \mathrm{~m}$. S. by W. Albany. It oceupies a very beauti- ful site, overlooking New York bay, the Narrows, etc., and contains many flne residences, with 3 churches, etc. Steam ferry boats ply hourly to New York. It is chiefly noted for containing the Quarantine Station of New York. The ground appropriated for the purposes of a lazaretto has a frontage on the bay of about 1,400 feet, and extends back 1,200 feet. It is inclosed by a high brick wall, and includes suitable hospitals for the sick, and offices for physicians and others employed at the quarantine. The largest hospital that for fever patients, is nearest the water; it is constructed of brick, 3 stories high, 186 feet long by 28 feet wide. The hospital for convalescents, on rising ground above, is of brick, 3 stories high, 50 feet long, 45 feet high, witl 2 wings 66 by 26 feet each. The small-pox hospital is 2 stories high, 80 feet long, 28 feet wide, and generally has the largest number of patients. There are other hospital buildings for various diseases, all of which are built of brick, with open galleries.

Tom's Brook, p. v., Shenandoah county, Virg.: $118 \mathrm{~m}$. N. N. W. Richmond.

ToM's Crkek, p. 0., Surry co., N. Car, : on creek of same name, $118 \mathrm{~m}$. W. N. W. Raleigh.

Tox's River, p. v., and cap. Ocean co., N. Jer. : on Tom's $r_{.,}$at head of Tom's r. bay, 35 m. S. E. by E. Trenton,

Tomsvilie, p. v., Chester dist., S. Car. : on N. side of branch of Broad r., $58 \mathrm{~m}$. N. by W. Columbia.

Tonawanda, t., p. v., and sta., Erie co., N. Y.: $269 \mathrm{~m}$. W. by N. Albany. Surface of $t$. level; soil fertile. Drained by Tonawanda creek. Grand island belongs to this town. The village is situated on E. side of Niagara r., at mouth of Tonawanda creek. Through it pass the Erie Canal ; Buffalo and Niagara Falls R. R., $11 \mathrm{~m}$. from Buffalo, and 11 miles from Niagara Falls; and the Buffilo and Lockport $R$. $R$. From the dam here in the creek there are outlet locks to Niagara river. It has a good harbor for steamboats and other vessels. Considerable manufacturing is carried on. The "T. Commereial" (neut.) is published weekly. Pop. of $t$. in $1840,1,261$; in $1850,2,072$.

TontLive, p. o., Steuben county, $N . \bar{Y} .: 188 \mathrm{~m} . \mathrm{W}$. by S Albany.

Tooele county, Utah Ter. Extends from the W. boundary of Salt Lake and Utah eounties to the Californian line, and contains about 15,000 sq. m. It is crossed by Humboldt and other mountains, and in the W. are Mud and Humboldt lakes, which receive many streams, but have no outlets. It is a fine farming region. Farms 27 ; manuf: 0 ; dwell. 33, and pop. - wh. 152, fr. col. 0, sl. 0-total 152 . Capital: Tooele City.

TookLE, p. v., and cap. Tooele co., Utah Ter.: $30 \mathrm{~m}$. W. Salt Lake City.

TooleY's, p. O., Concordia parish, $L a .: 76$ miles N. N. W. Baton Rouge.

Toolsboro', p. o., Louisa co., Ia. : $42 \mathrm{~m}$. S. E. by S. Iowa City.

TooL's Pornt, p. o., Jasper co., Ia. : 72 m. W. Iowa City. ToonsBoro', p. o., Wilkinson county, Ga.: 20 miles S. Milledgeville.

Topsatl Sound, p. O., New Hanover co., N. Car.: $106 \mathrm{~m}$. S. S. E. Paleigh.

TOPSFIELD, t. and p. v., Washington county, Me. : $131 \mathrm{~m}$. N. E. Augusta. Pop. of t. 263.

Topsfield, t. and p. r., Essex co., Mass. : $20 \mathrm{~m}$. N. by E. Boston. Surface diversified. Drained by Ipswich $\mathrm{r}$. First settled in 1639; incorporated in 1650 . The village contains a. church, academy, and some handsome dwellings. Bonts and shoes are among the principal manufactures. Population of t. 1,171

Topseass, t., p. v., and one of the caps. Lincoln co., Me. 28 m. S. S. W. Augusta. Bounded E. by Kennebee river and S. and W. by the Androseoggin, which affords great water-power, and extensive facilities for navigation and ship-building. Saw-mills are numerous, and lumber is largely exported. The $\mathrm{y}$, contains a court-house, $1 \mathrm{bank}$, 
cap. $\$ 50,000$, churches, etc. Through it passes the Kennebee and Portland R. R., 28 miles from Portland, $32 \mathrm{~m}$. from Augusta. It is connected by a substantial bridge with Brunswick, situated on the opposite side of the Androscoggin. Pop. of t. in $1810,1,853$; in $1550,2,010$.

Topshar, t. and p. v., Orange county, Verm. : 20 miles S. E. by E. Montpelier. Surface elevated, uneven, and stony. Watered by head branches of Wait's r., which furnish water-power to numerous mills. The to also contains several tanneries, and other manufactories. Granite is found abundantly. First settled in 1781. Pop. 1,668.

Tовнт's Store, Chester district, S. Car.: 42 miles N. Columbia.

Toron, p. 0., Athens co., Ohis: 69 m. S. E. Columbus.

Toro, p. o., Sabine parish, La.: 162 m. W. N. W. Baton Rouge.

Toronto, p. o., Vermillion county, Ind.: 65 miles W Indianapolis.

TORRINGFORD, p. v., Litchfield co, Conn. : 22 m. W. by N. Hartford.

Torrington, t. and p. v., Litehfield county, Conn. : $26 \mathrm{~m}$ W. by N. Hartford. Surface uneven. Drained by Naugatuck river and its branches. The Naugatuck R. R. passes through its E. part, having stations at the flourishing manufacturing v. of Wolcottville (which see), and at Burrville. Burrville contains a large tannery, and furnishes large quantities of agricultural and dairy productions, considerable timber and brick. Pop. of $t$. in $1840,1,707$; in $1850,1,916$.

Tosnot, sta., Edgecombe co., $N$. Car.: on Wilmington and Weldon R. R., 108 mailes from Wilmington, 51 m. from Weldon.

Totron's Wexus, p. O, Obion county, Tenn.: 126 miles W. by N. Nashville.

Tottenville, p. v., Pichmond co., $N . Y_{.: 143} \mathrm{~m}$. S. by W. Albany.

TotтY's Bend, p. 0., Hickman county, Tenn. : 43 miles S. W. by W. Nashville.

Toumminvicue, $v$, and sta., Mobile co, Ala, : on Mobile and Ohio R.R., $8 \mathrm{~m}$. N. by W. Mobile. It is of much resor in summer from Mobile, ete.

TouloN, p. $\mathbf{v}_{\text {s, }}$ and cap. Stark co., $I l l,: 88 \mathrm{~m} . \mathrm{N}$. by W. Springfield. Situated on the border of a prairie, near the head of a small stream; it is a pleasant, healthy place, contrining the county buildings, etc.

Towalliga, p. o., Butts county, $G a_{1}: 45$ m. W. N. W. Milledgeville.

Towanda, to, p. b., and cap. Bradford co, Penn : on W. side of Susquehanna $r$ and $N$. side of Towanda cr., $100 \mathrm{~m}$ $\mathrm{N}$. by E, Harrisburg. Surface of t. hilly; soil gravelly loam Drained by the above streams and Sugar er. It contains bituminous coal. The b., on the Susquehanna r., was incorporated in 1828, and contains the court-house. jail, a furnace, tannery, and other manufacturing establishments. Three newspapers are issued weekly - "B. Reporter" (free soil), "B. Argus" (whig), and "North Pennsylvanian (dem.) Pop. 1,171.

Towee Falis, p. o, Monroe co, Tenn.: on N. side of

Tennessee r., 157 m. E. by S. Nashville.

Tower Hru, p, o, Washington county, R. $I .: 8 \mathrm{~m} . \mathrm{W}$. Newport.

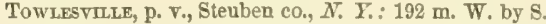
Albany.

Town BlufF, p. o., Tyler county, Tex.: on W. bank of Neches r., 216 m. E. by N. Austin City.

TOWN CREeK, U. S. collection district, $M d .:$ had, on the 30th June, 1850 , a total tonnage of 2,227 tons, all of which was enrolled and licensed, permanent, and employed in the coasting trade. During the year preceding, it had no foreign commerce or ship-building.

Towner's, p. o., Putnam co., N. $Y_{\text {.: }} 82 \mathrm{~m}$. S. Albany.

Tows HuL, p. o., Luzerne county, Penn. : 80 m. N. E Harrisburg.
Town Hotsen, p. 0., Smyth co., Virg. : $220 \mathrm{~m}$. W. by $\mathrm{S}$ Pichmond.

Town LiNe, p. o. and sta., Erie co., $N$. $Y$.: on Buffalo and New York City R. P., 15 m. E. fròm Buffalo; 254 W. Albany.

Townsburex, p. v., Warren co., $N$. Jer.: on both sides of Pequest cr., $44 \mathrm{~m} . \mathrm{N} . \mathrm{N}$. W. Trenton. It has several mills, moved by water-power afforded by the ereek.

Townsend, t. and p. v., Middlesex county, Mass.: $89 \mathrm{~m}$. N. W. by W. Boston. Surface undulating or level ; drained by Squanticook $\mathbf{r}$. and branches flowing into Nashua $\mathbf{r}$. The $t$. contains three flourishing villages, through which passes the Peterburo' and Shirley R. R. The $v$. at the centre eontains 2 churches, a good academy, and is neatly built. Pop. of t. 1,947.

Townsend, p. 0., Chemung co., $N$. Y.: $166 \mathrm{~m}$. W. by S. Albany.

TownSEND, t. and p. o., Sandusky co, Orio: on S. side of Sandusky bay, $96 \mathrm{~m}$. N. Columbus. The inhabitants are mainly engaged in agricultural pursuits. Pop. in 1840,692; in 1550,969

ToHnsend HARBor, p. va and sta, Middlesex co, Mfass. 37 m. N. W. by W. Boston. The Peterboro' and Shirley R. R. passes through, $8 \mathrm{~m}$, from Groton, there connecting with Fitchburg $\mathrm{R} . \mathrm{R}$, by which it is $43 \mathrm{~m}$. from Boston. This is a pleasant and flourishing Y., containing several mills, stores, etc.

Townsend's Inlet, p. 0., Cape May co., $N$. Jer.: $73 \frac{1}{\mathrm{~m}} \mathrm{~m}$. S. by E. Trenton.

Townsfindsille, p. o., Seneca county, $N . Y_{*}: 160 \mathrm{~m} . \mathrm{W}$. Albany.

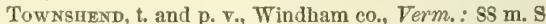
Montpelier. Surface uneven, with elevated and steep hills; watered by West $r$. flowing S. E. through it centrally, upon the $\mathrm{E}$. bank of which the $\mathrm{v}$, is situated, containing 2 churches and an excellent academy. The t. contains several tanneries, orist and saw mills. Pop. of t. 1.35 t.

Townilie, p. o., Anderson dist., S. Cur. : on N. side of Savannah r., $117 \mathrm{~m}$, W. N. W, Columbia.

Towsontows, p. o., Baltimore eo., MLd. : 28 m. N. by W Annapolis.

Tracr, p. o., Huntingdon co, Ind. : on N. side of Wabasb r., $81 \mathrm{~m} . \mathrm{N}$. E. by N. Indianapolis.

Tracr's Landran, p. v., Anme Arundel co., MLd.: 13 m. S. by W. Annapolis.

Tradersville, p. v., Madison co., Ohio: $25 \mathrm{~m}$. W. by S. Columbus.

TeAde's Hrut, p. 0., Chatham con, N. Car.: on New Hope r. $18 \mathrm{~m}$. W. Raleigh.

Traneurutx, p. 0., Granville county, $N$. Car.: $26 \mathrm{~m} . \mathrm{N}$. Raleigh.

Tranquility, p. on, Sussex co, $N$. Jer. : $66 \mathrm{~m}$. N. Trenton. Tranguluty, p. o., Adams co., Ohio: 76 m. S. by W. Columbus.

Traneutria, p. o., Jones co., Ga. : a little N. of branch of Oconee r., $20 \mathrm{~m}$. W. by N. Milledgeville.

Transit, p. o., Genesee co., N. I.: $_{2} 237 \mathrm{~m}$. W. by $\mathrm{N}$. Albany.

Transit BrtDge, p. o., Alleghany county, N. Y.: $223 \mathrm{~m}$. W. by S. Albany.

TraNsparent lake, $N . Y_{*}$ : lies partly in Hamilton and partly in Herkimer counties, $82 \mathrm{~m}$. N.W. Albany. It is $5 \mathrm{~m}$. long and $2 \mathrm{~m}$. wide. Its waters, noted for their clearness, abound with salmon, trout, ete., of very large size and delicious flavor. It is surrounded by a wild region, abounding with game.

Trap Hul, p, o, Wilkes co., N. Car. : 149 m. W. by N. Raleigh

TrapPE, p. v., Talbot co., DId.: 32 m. S. E. Annapolis.

Trappe, p. F., Montgomery county, Penn.: 73 m. E. Harrisburg.

Trascinto, p. 0., Neshoba county, Miss.: 70 m. E. N. E. Jackison. 
Trask, p. 0., Grant co., Ind. : 61 m. N. N. E. Indianapolis. Traveller's Repose, p. O., Pocahontas co., Virg. : 145 m. W. N. W. Richmond.

Traveluen's Repose, p. o, Franklin co, Mo.: on E. side of Bourbeuse cr., 65 m. E. by S. Jefferson City.

Traveller's Rest, p. v., Dooly co., Ga. : about $2 \frac{2}{8}$ m. E. Flint r., 75 m. S. W. Milledgeville.

Traveller's Rest, p. o., Coosa county, Ala.: $27 \mathrm{~m} . \mathrm{N}$. Montgomery.

Traveller's Rest, p. o, Greenville dist., S. Car.: 99 m. N. W. Colunibia.

Traverse De Sroux, p. v., Dakota county, Minn. Ter. situated on Minnesota $x_{\text {, }}$, by which it is $\$ 2 \mathrm{~m}$. from St. Paul; in direct course about $56 \mathrm{~m}$. W. S. W. St. Paul. It was laid out in 1552. In the spring of 1853 it contained 3 trading houses, several stores, etc., with good prospects of increasing trade.

Travis county, Teo. Situate centrally, and contains about $1,000 \mathrm{sq}$. $m$. The Rio Colorado passes centrally through it, by which and its affluents it is drained. To the N. W. is an extensive territory, which is attached to the co. Surface varied; in the northern portions, hills and valleys being interspersed, while in the southern it extends into broad, level plains, resembling the rich prairie lands of the adjoining territory. Soil fertile, and consists chiefly of a deep black mold, which is generally very productive. Farms 146 : manuf. 1; dwell. 423, and pop.-wh. 2,336, fr col. 11, sl. 791-total 3,138. Cropital: Austin.

Travis, p. 0., Austin co., Texo : in the N. part of the co., $86 \mathrm{~m}, \mathrm{E}$. by $\mathrm{S}$. Austin City.

Tearlonsville, p. o., Henry co., Firg.: on branch of Dan r., 148 m. W. S. W. Piehmond.

Treadway, p. o., Barnwell dist., S. Car.: 58 m. S. S. W. Columbia.

Treiblevilie, p. v., Monroe county, Penn. : 94 m. N. E. Harrisburg.

Treichleesville, p. v., Lehigh co., Penn.: 72 m. E. N. E. Harrisburg.

Tremainvilie, p. v., Lucas co., Ohio: 99 m. N. by W. Columbus.

Trewont, p. v., and cap. Tazewell co., $I U .: 50 \mathrm{~m}$. N. by E. Springfield. It is pleasantly situated on a beautiful elevated prairie, and is a place of considerable trade. It was laid out in 1885. It contains the court-house and jail, stores, etc.

Tremont, t., p. v., and sta., Schuylkill co., Penn. : $32 \mathrm{~m}$ N. E. Harrisburs. This t. and vicinity abound with coal. The Mine Hill R. R. extends to this place, $12 \mathrm{~m}$. from Schuylkill Haven. The following statistics of dealers in coal at this place are for the year ending June 30, 1850:

Coal Operators, Capital Mnnthly Annial Value.

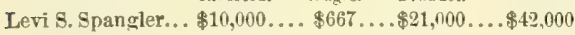
Henry Eckel..... 17,000 ... 1,667... 30,000 . . 60,000

Tremont, p. . and sta, Clark co., Ohio: on Mad River and Lake Erie R. R., $127 \mathrm{~m}$. from Sandusky, $7 \mathrm{~m}$. from Springfield, $46 \mathrm{~m}$. W. Columbus.

Tremont, t. and p. o., Hancock county, Me.: $72 \mathrm{~m}$. E. Augusta. It comprises the S. W. part of Mount Desert island. Pop. 1,425.

Trenton, p. v., Jackson co., Ala.: on W. side of Point

Rock r., a tributary of Tennessee r., $164 \mathrm{~m}$. N. Montgomery.

Trenton. p. v., and cap. Dade co, Ga: on W. side of branch of Tennessee r., 192 m. N. W. Milledgeville. It contains a court-house, jail, etc., and several dwellings.

Trexton, p. v., Henry county, Ia. : $40 \mathrm{~m}$. S. by W. Iowa City.

TrentnN, p. 0., Wachita parish, $L a$ : 150 m. N. N. W. Batnn Rouge.

Trex'ros, p. o., Randolph county, Ind.: 60 m. E. N. E. Indianapolis.

Trenton, p. v., Todd county, Ky.: 167 m. S. W. by W Frankfort.

TrextoN, p. Y., Wayne co., Mich.: on W. channel of
Detroit strait, $79 \mathrm{~m} . \mathrm{S}$. E. by E. Lansing. It has considerable lake trade. Exports in $1848, \$ 25,554$; imports, do., $\$ 7,325$. Total value of exports and imports in $15 \$ 8, \$ 32,579$. Trenton. p. v., and cap. Grundy co., Mfo.: on E. sirle of Crooked fork of Grand r., $191 \mathrm{~m}$. N. W. by W. Jeff.rson City. It contains the county buildings and several dwellings. Trenton, p. city, and cap. Mercer co., N. Jer., and cap. of the State of New Jersey: is situated on the E. side of j)elaware r., at the mouth of Assunpink cr., opposite the lower falls, and at the bead of steamboat and sloop navigation. Lat. $40^{\circ} 14^{\prime} \mathrm{N}$., long. $74^{\circ} 46^{\prime} 30^{\prime \prime} \mathrm{W}$. from Greenwich, and $2015^{\prime} \mathrm{E}$. from Washington. Its distance by the most direct railroad from Boston is $293 \mathrm{~m}$., from New York $55 \mathrm{~m}$., from Philadelphia $29 \mathrm{~m}$., from Baltimore $127 \mathrm{~m}$., from Washington $165 \mathrm{~m}$.

The eity is pleasantly located on ground somewhat uneven, and is laid out with general regularity. Many of the public buildings are handsome edifices. The State House, beautifully situated near the Delaware, commanding a fine view of it and of the vicinity, is built of stone, 100 feet long and 60 feet wide, and stuccoed to resemble granite, with a handsome portico of 6 columns, and beautiful dome. The pablic offices are fire-proof buildings. The Governor's House is a plain but commodious building. The Court-louse is a handsome edifice of brick, stuceoed, in Grecian architecture, with a portico of Ionic columns at each ent, and surmounted with a balcony. The State Lunatic Asylum is a very fine building, with ample grounds, etc. It was opened for patients May 15, 18tS. In January 1, 1851, it contaiued 162 patients ( 86 males and 76 females). During $1 \varangle 51$ it roceived 102 and discharged 93 patients, leaving on January 1. 1552, 171. The expenses of the asylum during 1551 were $\$ 27,170$, receipts $\$ 22,076$. The State Prison, in South Trenton, is well situated in an area of 4 acres, inclosed by walls 3 feet thick and 20 feet high. The number of prisuners on December 81, 1850, was 210, on Dectmber 31, 1S51, 207. Earnings of the prison in $1851, \$ 15,698$, expenses of do. $\$ 11,858$, balance paid the State $\$ 6,840$. The city also contains a public library, established in 1750 , a lyceum, and 10 churches. Newspapers in 1850- "True American" (dem.) "Trentonian," and "New Jersey State Gazette," each published daily and weekly; also the "New Jersey Weekly Visitor."

The railroad and steamboat connections of Trenton have made it a great thoroughfare and the centre of extensive trade. The New Jersey R. R. here eonnects with the PLiladelphia and Trenton R. R., constituting the principal route between New York and Philadelphia. The Trenton Branch R. R. extends hence to Bordentown, $6 \mathrm{~m}$, counecting with Camden and Amboy R. R. The Belvidere Delaware R. R. extends hence to Belvidere, $63 \mathrm{~m}$. The Delaware and Paritan Canal affords sloop navigation from Brunswick to this place. It is $42 \mathrm{~m}$. long, 75 feet wide, 7 feet deep, and was finished in 1534 at a cost of $\$ 2.010,500$. It is here entered by a feeder taken from the Delaware, $23 \mathrm{~m}$. above the city, and crosses the Assunpink cr. in a fine stnne aqueduct. The Delaware $r$. is navigable above the falls at Trenton, for large boats, as far as Easton, which adds much to the commercial advantages of the city.

Trenton possesses a fine site for manufacturing purposes, with abundance of permanent water-power, obtained from the fulls on the Delaware, and greatly increased by artificial means; also some water-power furnished by Assunpink or Among the principal manufactures are paper, leather, and lumber; there are also several flouring, grist, and saw mills, with various other establishments. The city contains two banks, with an aggregate capital of $\$ 310,000$. The Dela ware $\mathbf{r}$. is here crossed by an excellent covered bridge, 1,100 feet long, resting on 5 arches supported by stone piers which was built in 1806 at a cost of $\$ 180,000$. The adjoining villages of Mill Hill, Bloomsbury, and Lamberton are suburbs of the city. Trenton was first settled about the year 1720 , and was iucorporated as a city in 1792 . It is memor- 
able for the "Battle of Trenton," on the night of December 25th, 1776, when Gen. Washington crossed the Delaware, and suddenly captured 1,000 Hessians of the British army, which signal event, in that gloomy period of the Revolution, greatly encouraged the American forces. Pop, in $1840,4,035$; in $1850,6,766$.

Trenton, p. v., and cap. Jones co., $N$. Car. : on S. side of Trent r., $82 \mathrm{~m}$. S. E. Raleigh. It contains a court-house, jail, stores, ete. Pop. about 125 .

Trenton, p. v. and stu, Butler co., Ohio. : on W. side of Miami r., 82 m. W. S. W. Columbus. The Cincinnati, Hamilton, and Dayton R. R. passes through, $83 \mathrm{~m}$. from Cincinnati, $27 \mathrm{~m}$. from Dayton.

Trenton, t. and p. v., Oneida county, N. Y.: $86 \mathrm{~m}$. N. W by W. Albany. Surface hilly; soil clay loam, and fertile. Drained by Nine Mile and West Canada creeks. The town contains several villages, of which the principal aro Trenton and Trenton Falls-the former, near the centre of the town, $13 \mathrm{~m}$. N. from Utiea, was incorporated in 1819 , and contains about 450 inhabitants, 2 churches, with taverns, stores, ete. Pop. of t. 3,540 .

Trenton, p. v., and cap. Gibson co, Tenn. : on S. branch of Forked Deer r., $120 \mathrm{~m}$. W. Nashville. It contains a court-house, jail, 2 churches, stores, etc., and a branch of the Bank of Tennessee, with a capital of $\$ 254,208$. The "Star Spangled Banner" (whig) is published weekly. Pop. about 750 .

Trenton, t. and p. o., Dodge co., Wisc. : $45 \mathrm{~m}$. N. E. by N. Madison. Pop. 997.

Trenton Curners, po o, Dodge county, Wisc: $46 \mathrm{~m}$. N. E. by N. Madison.

Trenton Falls, p. vo, Oneida county, $N . Y_{\bullet}$ : at Trenton Falls, on West Canada cr., $84 \mathrm{~m}$. N. W. by W. Albany. These falls are six in number and separate. All these are formed by solid reefs of rocks which cross the bed of the stream. The first, called the Upper, decends 20 feet perpendicular; the seennd, the Cascades, 18 feet; the third, the Mill Dam, 14 feet; the fourth, the High Falls, which have three separate cascades of 48,11 , and 37 feet; the fifth, Sherman's, 35 feet; the sixth, Conrad's, 15 feet, terminates the ravine, where is a mill dam. Besides these falls there are several raceways, from 10 to 20 rods long, through which the water flows very rapidly. The entire descent of the stream, from the top of the Upper Fall to the foot of Conrad's Fall, is 312 feet, and the distance is about $2 \mathrm{~m}$. The ravine through which the creek passes is often 100 feet deep, with banks of stone almost perpendicular. The scenery thus presented is wild, picturesque, and beautiful, and when the water is high, is of much grandeur. The country adjoining is mostly covered with forest trees, thus retaining for the ravine its primeval appearanee, which, in fict, constitutes the greatest charm of these falls. The number of visitors is very large. These are accommodated in first-class style by an excellent hotel.

Trexillixy's DFiôr. p. o. and sta., Louisa co., Firg. $42 \mathrm{~m}$. N. W. Richmond. The Virginia Central R. R. passes through it, $67 \mathrm{~m}$. from Richmond.

Trevorton, p. o., Northumberland co, Penn.: $89 \mathrm{~m}$. N. by E. Harrisburg.

Trexlertown, p. v., Lehigh co., Penn。: 69 m. E. N. E. Harrisburg.

Triadeipima, p. v., Montgomery co., Md. : on Patuxent r., SS m. W. N. W. Annapolis. It contains a cotton factory, and is surrounded by a beautiful country.

Triadelpuia, p. v., Ohio county, Firg.: $24 S$ m. N. W. Richmond, Pop. 242

Triadelphi, p. V., Morgan c0, Ohio: 66 m. W. S. W. Colunibus.

Triaka, p. v., Madison co., $A l \alpha_{1} ;$ on N. side of Tennessee r., at the mouth of Indian cr., $156 \mathrm{~m}$. N. by W. Montgomery.

Triaxele, t. and p. v., Broome county, N. Y.: $116 \mathrm{~m}$. W. by S. Albany. Drained by Otsetie and Tiouglinioga rivers, which here unite. Surface hilly. It contains severil $85:$ mills, stores, etc. The $\mathrm{v}$. is located on a branch of the Tioughnioga r. Pop. of $t, 1,728$

TRIBE's HiLl, p. v., Montgomery co., $N_{\text {. }} \bar{Y}_{\text {: }}$; on N. bank of the Mohawk r., $34 \mathrm{~m}$. N. W. by W. Albany. The Utice and Schenectady R. R. passes through the $v_{\text {., }} 56 \mathrm{~m}$. E. Utica. Trice's Store, p. 0., Orange co., $N$. Car.: $30 \mathrm{~m}$. N. W. Raleigh.

Trier, p. o., Bexar co., Tex.: 134 m. S. W. Austin City.

Trigg county, $K y$. Situated S. toward the W., and contains $356 \mathrm{sq} . \mathrm{m}$. Drained by Little $\mathrm{r}$. and its branches, which enter the Cumberland r. Surface undulating; soil fertile. Chief productions, tobacco, cotton, wheat, and Indian corn. It is bounded on the W. by Tennessee $r$. Farm 843; manuf. 37 ; dwell. 1,281, and pop.-wh. 7,252, fr. col. 80 , sl, 2,797-total 10,129. Capital: Cadiz.

Trimble county, $K y$. Situate $N_{\text {., }}$ and contains $127 \mathrm{sq} . \mathrm{m}$. Drained by Little Kentucky and small tributaries of the Ohio. Surface undulating, and presenting high bluffs on the shore of the Ohio ; soil generally fertile Chief productions, tobaceo and Indian corn. Farms 469 ; manuf, 19 ; dwell. 865 , and pop.-wh. 4,997, fr. col. 25, sl. 941-total 5,963. Capital: Bedford.

Trimble, t. and p. o., Athens co., Ohio: $55 \mathrm{~m}$. S. E. Columbus. Drained by Sunday cr., branch of Hockhocking $\mathrm{r}$. Pop. 924.

Tranity county, Calif. Situate between the Cascade Range and the Pacific, and between $40^{\circ}$ and $41^{\circ} \mathrm{N}$. lat. Drained by Trinity r., a branch of Klamath $\mathbf{r}_{\text {., }}$ and Eel $\mathbf{r}$., which empties into the ocean. Humboldt bay is in the N. W. corner of the co. Surface considerably broken-in the E. hilly, and many of the summits of the range are very lofty. Mt. Linn is the highest peak. Pop. in 1852, 1,764: whites 1,761 -males 1,741 , and remales 23 ; negroes 6 ; mulattoes 8; Indians (domesticated) 4 ; foreign residents 1 õ of which only 5 were females. Over 21 years of age: 1.491 eitizens, 5 negroes, 6 mulattoes, \& Indians, and 138 foreigu residents. Land under cultivation, 275 acres. Capital employed : in placer mining, $\$ 34,440$; in other mining, $\$ 2 S, 820$; and for other purposes, $\$ 201,117$. Capital: Humboldt City.

TRINITy county, Tex. Situate toward the E, and contains 983 sq. m. Drained by Big Pine cr. and affluents of Trinity r., which forms its $\mathrm{S}$. W. boundary. Surface undulating, and presents a surface of gently-swelling lands, thickly covered with pine forest. Soil fertile, and adapted to cotton, corn, and potatoes. As yet, the land has been but little cultivated, and but few of its agricultural resourees developed. Capitul: Trinity C. H.

Trinity, p. o., Chatahoula par, La. : on W. side of Wachita r., $88 \mathrm{~m}$. N. N. W. Baton Rouge.

Trimrty, p. o., Morgan county, Ala.: $144 \mathrm{~m}$. N. by W. Montgomery.

TRIN ITY river, Tess $:$ is formed by a number of streams uniting in Dallas county, in a forest called the Cross Timbers; flows $\mathrm{S}$. $\mathrm{E}_{v}$, and empties into Galveston bay. It has numerous branches, and in its course affords excellent water-power.

TRINITY river, Klamath co, Calif: rises in the Cosat Range Mountains, in E. part of the co., flows S. W. into Trinity, where it receives Panther creek, when it takes a $\mathrm{N}$. W. course and empties in the Klamath river. Gold is found in all parts of its valiey.

Trinity Springs, p. 0., Martin c0., Ind.: on E. side of White r., $78 \mathrm{~m}$. S. S. W. Indianapolis.

Ternity valley, Klamath co., Calif.: $195 \mathrm{~m} . \mathrm{N}$. by W. Vallejo. A portion of this valley is set apart as an Indian reservation.

Trion, p. o., Jefferson co., Tenn。: $188 \mathrm{~m}$. E. Nashville.

Trion, p. o., Tuscaloosa con, $A l a_{*}$ : on a small branch of Black Warrior r, $79 \mathrm{~m}, \mathrm{~N}$. W. Montgomery.

Trion FACToRY, p. o. Chatooga co., Ga.: 163 m. N. W. Milledgeville.

Triplett, p. o, Fleming con, $K y_{0}:$ on cr. of same name $75 \mathrm{~m}$. E. by N. Fraukfort. 
Trlpoli, p. v., Tishemingo co., Miss. : 200 m. N. E. by N. Jackson.

Triune, p. ₹., Williamson county, Tenn.: $18 \mathrm{~m} . \mathrm{S}$. by W. Nashville.

Trivoli, p. vø, Peoria county, $M l: 62 \mathrm{~m} . \mathrm{N}$. by W. Springfield.

Troublesome, p. o., Rockingham county, N. Car.: on Troublesome cr., $57 \mathrm{~m}$. N. W. Raleigh. It contains iron works.

Troup county, $G a$.: situate W., and contains $417 \mathrm{sq}$. m. Drained by Chattahoochee $r$. and branches, of which Yellow Jacket cr. is the principal. Surface undulating; soil fertile, and in general very productive. It is well adapted to cotton, of which a large quantity is annually produced, and is the staple. Wheat and Indian corn are also raised. There is some good pine and other timber on the land. Farms 789 ; manuf. 8 ; dwell. 1,295 , and pop.-wh. 7,789 , fr. col. 42, sl. 9,048-total 16,879. Capital: La Grange. Public Works: La Grange R. R.

Trovf FActory, p. o., Troup county, Ga.: $106 \mathrm{~m}$. W. Millergeville.

Troupsidrg, t. and p. v., Steuben co., N. Y.: $199 \mathrm{~m}$, S. W. by S. Albany. Drained by Cowenesque cr. Surface undulating. It has good water-power, and some mill sites. The v, is on Cowenesque er. Pop. of t, 1,754.

Troupville, p. v., and cap. Lowndes co., Ga.: on E. side of Withlacoochee r., $178 \mathrm{~m}$. S. Milledgeville. It contains the county buildings, etc.

Troubdale, p. O., Warren co., Tenn.: 56 m. E. S. E. Nashville.

Trout island, Afich.: in the N. part of Lake Michigan, N. from Little Beaver Island.

Trout Creek, p. 0., Delaware co., N. Y.: 72 m. W. S. W. Albany.

Trout Creek, p. o., Saint Clair co., Ala.: 98 m: $\mathbf{N}$. Montgomery.

TROUT river, Verm: : rises by the junction of several branches in Montgomery, flows in a N. W. direction, and empties into the Missisqui, on the border of Enosburg and Berkshire. It is a good mill stream.

Trout Run, p. o. and sta., Lyeoming co., Penn.: on the Williamsport and Elmira R. R., $10 \mathrm{~m}$. N. from Williamsport, and $82 \mathrm{~m} . \mathrm{N}$. Harrisburg. In the vicinity is a forge and a rolling mill, the former producing annually 140 tons bar iron, and the latter 300 tons bars and nails, both operated by water-power.

Trox, p. v., and cap. Pike co., Ala. : on small branch of Conecuh r., $46 \mathrm{~m}$. s. S. E. Montgomery. It contains the county buildings, etc.

Trox, p. o., Cherokee eo., Ga. : on $\mathrm{S}_{0}$ side of Etowah $\mathbf{r}_{*}$, $104 \mathrm{~m}$. N. W. Milledgeville.

Trox, p. o., Madison co., $M l$. : 75 m. S. by W. Springfield. Trox, p. v., Perry co., Ind, : on the Ohio r., $6 \mathrm{~m}$, below Cannelton, $103 \mathrm{~m}$. S. S. W. Indianapolis.

Tror, t, and p. v., Waldo co., Me. : 36 m. N. E. Augusta. Drained by branches of Sebasticook r. Surface undulating, and well supplied with timber. It is a good farming t., and produces an abundance of wheat, and there are some light manufactures. The v, is located centrally. Pop. of t. 1,494.

Trox, t. and p. 0., Oakland co., Mich.: $72 \mathrm{~m}$. E. by S. Lansing. Drained by head branches of Red $r_{\text {, a a tributary }}$ of Clinton r. It contains some manufactures.

Troq, p. O. Yallabusha co, Miss. : $2 \mathrm{~m}$. N. of Yallabusha river, $106 \mathrm{~m}$. N. by $\mathrm{E}$. Jackson.

TrCY, p. v., Lincoln co., Mo : on Cuivre r., 71 m. E. N. E。 Jefferson City. It contains the county buildings, ete.

Trox, t. and p. v., Cheshire co, N. Hamp.: 44 m. S. W. Coneord. Drained by affiuents of Ashuelot $\boldsymbol{r}$. It has some manufuctures, but it is chiefly an agricultural town. The v. is on the Cheshire R. R., $10 \mathrm{~m}$. S. E. Keene. Pop. of t. 759 .

Trox, p. city, and eap. Rensselaer co., $N . Y$.: on E. side of Iudson r, $6 \mathrm{~m}$, N. by E, Albany. Lat, $42044^{\prime} \mathrm{N}$.; long $73^{\circ} 40^{\prime} \mathrm{W}$. It is built chiefly upon an alluvial flat, extend- ing along the $\mathbf{r}$. for about $8 \mathrm{~m}$, and $1 \frac{1}{2} \mathrm{~m}$. broad, and partly upon the hills in the E. part of the eity limits. It is very regularly laid out, with streets crossing at right angles, which are generally 60 feet wide, ornamented with fine shade trees, well paved, with good side walks, and kept remarkably clean. The main business street, called River Street, conforming to the Hudson river, is, however, somewhat curved. The eity plat is somewhat elevated above the river, affording good drainage. The bigh hills (of which the principal summits are called Mount Ida and Mount Olympus) afford most extensive and delightful prospects, embracing the city of Albany, the villages of West Troy Lansingburg, Waterford, and Cohoes, the Cohoes Falls, the Hudson r. and its beautiful valley for miles, a long extent of the Erie Canal, with the various railroads here centering, combining a variety of the most interesting scenery, rarely presented in the vicinity of any large city. From these hills descend two considerable streams, Poestenkil and Wynantskill, which have picturesque cataracts and cascades, and afford very great water-power to numerous mills, factories, etc. The blocks of stores and houses are generally built of brick, with considerable regularity and much taste. The more retired streets contain many elegant dwellings, surrounded by flower gardens, etc. The city is lighted with gas, and supplied with water from Piscawin creek, of which the reservoir, situated in the $\mathrm{N}$. part, and about $\frac{1}{3} \mathrm{~m}$. E. of the Hudson, is 90 feet above tide water, and thus naturally forcing the water above the highest houses, reuders it most serviceable for every purpose. of the public buildings the court-house is the most splendid; it is built of Sing Sing marble, in Grecian architecture, with fine front of the Doric order. Several of the church edifices are costly structures. The prineipal market buildings are well-built, and very commodious. Hotels of large size are numerous, and sereral of those of the first class are noted for excellent accommodations. The Troy City Hospital, under the direction of ten Sisters of Charity, has four attending physicians, and received during the year 1851-52, 689 patients.

Much attention is given to general education in the public schools and other academies. The Troy Female Seminary is one of the most popular institutions of the kind in the Union. It was established in 1821 (having been commenced in Middlebury, Vermont, in 1814, and removed to Waterford in 1821), at which time it received from the city corporation $\$ 4,000$ for the erection of suitable buildings. It is beautifully situated in the central part of the eity, with finely ornamented grounds, commodious buildings, etc. The Renssalaer Institute is a polytechnic school of high repute. The Young Men's Association has a large library and reading room, with cabinet of curiosities, etc., and annual courses of lectures. The Lyeeum of Natural History have valuable cabinets, a good library, etc. Newspapers in 1850, "Northern Budget" (dem.) daily, and 4 weeklies, "Troy Whig," "Troy Post," "Family Journal" (temp.), and "New York State Republican" (whig).

Troy is pre-eminently distinguished for the business onterprise of its capitalists and citizens generally. Its situation for trade and commerce has some natural advantages, bot these have been wonderfully improved and increased by the various important railroads and eanals which, eentering here, have made this a great thoroughfare of travel and trade, and developed the manufacturing interests of the eity. It directly connects by the Hudson with the Erie Canal at West Troy directly opposite, and with the Chumplain Canal at Waterford, $4 \mathrm{~m}$. above. The lines of railroad entering the city are-Hudson River R. R. from New York, $150 \mathrm{~m}$. ; from Worcester, $156 \mathrm{~m}$; ; from Boston, $200 \mathrm{~m}$.; Troy and Boston R. R., which is completed to North Hoosick, $27 \mathrm{~m}$, and connects at Eagle Bridge with Rutland and Washington R. R., and at North Hoosick with Troy and Benningr= ton R. R., and is in construction to Greenfield, Mass. ; Rensselaer and Saratoga R. R., $82 \mathrm{~m}$; ; and Schenectady and Troy R. R., $20 \mathrm{~m}$.; all of which dire tly connect with other 
extended and important railroads. The railroad bridge across the Hudson is a fine structure, 1,650 feet long. Troy is at the head of tide-water on the Hudson, and of its natural navigation. Steamboats, sloops, etc., come to its wharves. The trade of the eity with New York is very great, employing an aggregate of several hundred vessels, and daily steamboats of the first class ply between the two cities. Besides the immense amounts of merehandise received from the railroads and canals, it also receives from the very fertile rural districts surrounding (with which it is well connected by good plank and macadamized roads), very large amounts of agricultural and dairy produce, ete, for shipment to New York and other markets. By means of the State dam sloop navigation is secured to Lansingburg, etc.

The manufactures of the city comprise nearly all the leading branches of such industry, but the largest interests are those connected with iron, machinery, hardware, and cutlery, ete. Cotton factories, tanneries, and flouring mills are numerous. There are also several breweries and paper factories; and a large amount of capital is invested in numerous lumber-yards. The railroad-car manufactory of Eaton, Gilbert, \& $\mathrm{Co}$. employs a very large number of operatives, and is of wide celebrity for the number and superior excellence of the cars made. The iron rolling mills and nail factories in the city and suburbs are extensive establishments, as also those furnaces engaged in making stoves, castings for agricultural implements, etc. Immense water-power is here easily obtained from the two large streams from the hills on the E., and from a dam near the $\mathrm{N}$. boundary of the city, built by the State across the Hudson, which makes a fall of $11 \frac{1}{2}$ feet, affording unlimited hydraulic power, besides securing navigation to the river above. There are 6 banks in the city, with an aggregate capital of $\$ 1,768,000$; also several insurance companies and institutions for savings.

The first settlement of Troy was commenced about 1720 , in which year Derick Vauderheyden leased $\mathbf{4 9 0}$ acres of the propriter of Rensselaerwyck. This grant now constitutes the most densely populated portion of the city. This settlement bore the name of Vanderheyden's Ferry until 1789, when it received its present name. and was then laid out. It was matie the county seat in 1791 , incorporated as a village in 1796, and as a eity in 1816. In June, 1520 , a great conflagration consumed the wealthiest and most important part of the city. It recovered from this severe calamity in a few years, has since rapidly advanced in general prosperity, and now promises to long retain its present distinction as one of the most enterprising cities in the Union. Pop. in 1810, 3.815: in 1-211,5:264: in 1530, 11.405: in 1540, 19.3:4: in $1850,28, \pi 85$. The large and thriving village of West Troy, pop. 7,514 , on the opposite side of the Hudson, though in All any co., is in all business interests a part of Troy.

Trox, p. o., Montgomery eo., N. Car:: $75 \mathrm{~m}$. W. S. W. Raleigh.

Trox, p. v., and eap. Miami co., Ohio: on the W. bank of the Great Miami r., $63 \mathrm{~m}, \mathrm{~W}$. Columbus. It contains a court-house of brick, jail, and other county buildings, and publish 2 weeklies, the "Troy Times" (whig), and "The Touchstone" (F, S. D.) The Dayton and Michigan R. R., the Columbus, Pequa, and Indiana R. R., and the Miami Canal pass through this place. Pop. 1,956.

Tror, th and p. o., Bradford county, Penn.: $102 \mathrm{~m}$. N. Harrishurg. Drained by Sugar cr. Surface hilly. It contains several manufactories, etc.

Trur, p. r., and cap. Obion co.. Tenn.: on a branch of Obion $r_{*}, 135 \mathrm{~m}$. W. by N. Nashville, It contains the co. buildings, ete.

Troy, p. 0., Davis co, I $\alpha_{*}: 68$ m. S.W. by S. Iowa City.

Trox, t. and p. o., Walworth co., Wisc, : 50 m. E. S. E. Madison. Drained by Honey cr. It is an excellent farming town. Pop. 1,072 .

Troy, p. v., Freestone county, Tex。: 119 m. N. E. Austin City.

Teox, t. and p. v., Orleans co., Verm。: 46 m. N. by E. 860
Montpelier. Drained by Missisqui r. Surface level. Waterpower is derived from the falls on the Missisqui river, which pass down a ledge of rocks some 70 feet. Iron ore is found in the vieinity, It contains furnaces, forges, tanneries; mills, etc. The $\mathbf{v}$. is on the W. side of Missisqui r. Pop. of $t .1,008$.

Troy Centre, p. o., Walworth co., Wisc. : 52 m. E. S. E. Madison.

Trox Grove, p. o., La Salle county, I Il.: on W. bank of Little Vermillion r., $116 \mathrm{~m}$. N. by E. Springfield.

Tror LAKE, p. 0., Walworth co., Wisc.: 55 m. E. S. E. Madison.

Troy Mruls, p. o., Fulton co., $I l l$.: on S. side of W. fork of Spoon r., a tributary of Illinois $r_{\text {, }}, 70 \mathrm{~m} . \mathrm{N}$. W. by $\mathrm{N}$. Springfield.

Tror's Store, p. o., Randolph co., N. Car.: $62 \mathrm{~m} . \mathrm{W}$. Raleigh.

Trucksville, p. o., Luzerne co., Penn. : 84 m. N. E. by N. Harrisburg.

TRU ITtsville, p. 0., Greenup con, $K y_{0}: 115$ m. E. by N. Frankfort.

Trumansburg, p. v., Tompkins eo., $N . T .: 162 \mathrm{~m}$. W. Albany. It contains several manufactories, consisting of carriages, lumber, iron, etc.

Trumbaursville, p. v., Bucks co., Penn.: 89 m. E. Harrisburg.

TrunbUll county, Ohio. Situate N. E., and contains $\$ 92$ sq. m. Drained by Mahoning r., and Shenango, Mill, and Musquito creeks, and head branches of Grand river. Surface undulating, and pleasantly diversified. Soil fertile, consisting of a deep mold, intermixed with sand and clay, and adapted to graic, which with wheat, oats, and potatoes form the staples. It exports beef, pork, butter, and cheese, access being had to the Eastern markets by means of the Mahoning Canal, a branch of the Pennsylvania and Ohio Canal, which passes through the county. Agriculture is the leading pursuit. Farms 2,753; manuf 133; dwell. 5,459, and pop.-wh. 30,455, fr, col, 35-total 30,490. Capital: Warren. Public Works: Cleveland and Mahoning R. R. Pennsylvania and Ohio Canal.

Trumbull, t. and p. ve, Fairfield county, Conn.: $46 \mathrm{~m}$. S. W. by S. Hariford. Drained by Pequannock r. Surfuce varied by hills and valleys. Grain and hay is raised. It manufactures consist of woolen goods, lumber, etc. The $\mathrm{v}$. is on the $\mathrm{E}_{\text {. side }}$ of Pequannock river, near the Housatonic R. R., which passes through the town. Pop. of $t, 1,313$.

Trembull, t. and p. o., Ashtabula co., Ohio: $153 \mathrm{~m}$. N. E. Columbus. Drained by a branch of Grand r. Organized in 1825 . Pop. 805 .

Trembull Corsers, p. o., Tompkins eo., $N . Y_{.}: 144 \mathrm{~m}$. W. by S. Albany

Trembull Long Hill, p. v., Fairfleld co, Conin.: $49 \mathrm{~m}$ S. W. by S. Hartford. It is the first land seen from the ocean in this direction.

Tratinde's Cross Roads, p. o., Sevier co., Tenn.: 165 m. E. by S. Nashville.

TrUgo, t. and p. V., Barnstable co., MFass.: 56 m. E. S. E. Boston. It occupies the N. part of Cape Cod, having the Atlantic Qcean on the E. and Cape Cod bay on the W. Pamet $\mathbf{r}$, sets in from the bay $3 \mathrm{~m}$. long and about $\frac{8}{4}$ of a $\mathrm{m}$. wide. The soil is light and sandy, with a very seanty growth of regetation. The cod and mackerel fisheries are extensively carried on, from which the inhabitants derive their chief subsistence. Salt is extensively manufactured. There is a lighthouse on the Highlands, on the N. E, coast, near North Truro village, lat. $42^{\circ} 02^{\prime} 23^{\prime \prime} \mathrm{N}$., and long. $70^{\circ} 03^{\prime} 55^{\prime \prime}$ W. : height of lantern from the sea, 180 feet. The village is on the N. side of Pamet r. Pop. of t. 2,051.

Trero, p. 0., Knox county, Ill.: 76 m. N. N. W. Springfleld.

TRUSs, p. o., Jefferson co., Ala.: on S. side of head branch of Cahawba r., 88 m. N. by W. Montgomery.

Truxton, t. and p. v., Cortlandt co., N. Y.: $118 \mathrm{~m} . \mathrm{W}$. 
Albany, Drained by the Tioughnioga $r$. Surface undulating. The manufactures consist of woolens, leather, iron, lumber, etc. The $\mathbf{v}$. is on the Tioughnioga $r_{\text {., }}$ and contains several mills, sash factories, a furnace, tannery, etc. Pop. of t. 3.623 .

Trexron, p. o., Bureau co., $I Z$. : $113 \mathrm{~m}, \mathrm{~N}$. Springfield.

Tryor, p. o., Rutherford eo, $N$. Car,: on 8 , side of $\mathrm{N}$ Pacolet r., 195 m. W. S. W. Raleigh.

Tuckanoe, p. v., Cape May county, $N$. Jer.: $60 \mathrm{~m} . \mathrm{S}$. Trenton.

Tбскапов, p. o., Jefferson county, Tenn. : 193 m. E. Nashville.

Tuскаfiok, p. v. and sta., Westchester county, $N . Y_{0}:$ on the Iarlem R. R., 20 m, from the City Hall, New York city, and $153 \mathrm{~m} . \mathrm{S}$. Albany.

Tuchaleechee Cove, p. o., Blount co., Tenn.: on $\mathbf{S}$. side of Little r., $172 \mathrm{~m}$. E. by $\mathrm{S}$. Nashville.

Tuckasaga, p. o., Mecklenburg co., $N$. Car.: $120 \mathrm{~m}$. W. S. W. Raleigh.

Tucker's CABIs, p. 0., Henry co., Ga. : 66 m. W. N. W. Milledgeville.

Tuckerton, p. v., and port of entry for Little Egg Harbor district, Burlington co., N. Jer.: on the Atlantic Ocean, at the head of Tuckerton Mill cr., which empties into the bay of Little Egg Harbor, $45 \mathrm{~m}$. S. E. by S. Trenton. It is well laid out, the streets crossing at right angles, and lined with shade trees. Salt is manufactured, and wood and lumber are exported. Flat boats ascend the river from Litile Egg Harbor, $6 \mathrm{~m}$. The enrolled and licensed tonnage for the year ending June 30,1850 , was 6,183 tons, all of which were engaged in the coasting trade. It is a place of summer resort for sea bathing.

Tuftonbozo', t. and p. v., Carroll co., N. Hamp.: $34 \mathrm{~m}$. N. N. E. Concord. Winnipiseogee lake bounds it on the 8. W., and presents a delightful prospect. It has several ponds. The inhabitants are generilly engaged in farming, ete. First settled in 1780 ; incorporated in 1795 . Pop. of t. 1,305 .

Tug River, p. o., Tazewell county, Firg.: $245 \mathrm{m.} \mathrm{W.}$ Richmond.

Tulare county, Calif. Taken from the S, part of Mariposa county, and contains Tulare lake and all its tributaries. In 1852 it had $S, 575$ inhabitants, viz., wh. 174 -males 142 , and females 32 ; negro 1 : Indians 8,408-males 5,500, and females 2,607 . The Indians are contained in fourteen tribes.

Tulare lake, Tulare co., Calif. : is $52 \mathrm{~m}$. long, and from 6 to $10 \mathrm{~m}$. wide.

Tulip, p. o., Dallas co., Ark.: 49 m. S. S. W. Little Rock.

Tullahoмa, p. ₹. and sta., Franklin co., Tenn. : $70 \mathrm{~m}$. S. E. by S. Nashville. The Nashville and Chattanooga R. R. passes through, and here connects with the Mackminville and Manchester $\mathrm{P}$. R. (in construction).

TuLLY, p. V., Lewis co., Mo. : on E. side of Mississippi r., $112 \mathrm{~m}$. N. by E. Jefferson City.

Tullx, p. o., Van Wert co., Ohio: 112 m. N. W. Columbus. Telly, t. and p. v., Onondaga co., N. $Y .: 123 \mathrm{~m}$. W. by N. Albany. Surface generally level; soil clay loam. Drained by Onondaga cr., and Tioughnioga r. The v. contains 1 church, a few stores, and about 300 inhabitants. The Syracuse and Binghampton R. R. passes through this t. Pop. of t. 1,559 .

Tulctrows, p. v., Bucks county, Penn.: 94 m. E. Harrisburg.

Tully Vallex, p. o., Onondaga co., $N . Y_{*}: 127 \mathrm{~m}$. W. by N. Albany.

Tullyville, p. o., Monroe co., Ark.: on E. side of Big cr., 72 m. E. Litlle Rock.

T'ulpehoccas, t. and p. 0., Berks co., Penn. 42 m. E. by N. Harrisburg. Surface diversified; soil very fertile. Drained by tributaries of Tulpehocken cr. The Union Canal passes along its $\mathrm{S}$. border. It contains tanneries, distilleries, and saw mills, with some other manufacturing establishments. Pop. about 1,800 .

Tumble, sta., Hunterdon co., $N$. Jer. : on Belvidere DeIaware R. R., $8 \frac{1}{2} \mathrm{~m}$. from Milford, $25 \frac{2}{2} \mathrm{~m}$. from Trenton.

Tumbling Shoals, p. o, Laureng dist, S. Cur.: on W. side of branch of Saluda river, 74 miles $\mathrm{N}$. W. by W. Raleigh.

Tumlinsonville, p. o., Scott co., Ark.: on W. bank of King's er., 104 m. W. by N. Little Rock.

TUNBRIDGE, t, and p. $\mathrm{v}_{\iota}$, Orange county, Verm. : $28 \mathrm{~m}$, S. by E. Montpelier. Drained by the first branch of White r. Surface varied, in parts elevated. It is principally a farming town, a considerable quantity of the proilucts of which are sent to market. The $\mathrm{y}$, on the first branch of White r. contains several ehurches, mills, and trip-liammer works. There is a sulphur spring of some note in the W. part of the town. Pop. of t. 1,786.

TuNicA county, Miss. Situate N. W., and contains 574 sq. m. Drained by branches of Coldwater river, which flows through its $\mathrm{N}$. E. portion, and by numerous streams entering the Mississippi river. Surface pleasantly diversified with lakes; the land hilly toward the W., and terminating in high bluffs on the Mississippi river, which bounds it on the W. Chief productions Indian corn and potatoes. The soll is best adapted to grazing. Farms 41 ; manuf. 0 ; dwell. 73, and pop.-wh. 396, fr. col.1, sl. 917-total 1,314. Capitul: Austin.

Tunica, p. o., West Feliciana par, $L a .: 42 \mathrm{~m}$. N.W. by N. Baton Rouge.

Tunhraxsock, t. and p. ₹., and cap. Wyoming co., Penn.: on N. E. bank of Susquehanna r.,99 m. N. N. E. Harrisburg. Drained by Tunkhannock and Meshoppen creeks. Surface uneven, and well wooded. Tunkhannock Mountain crosses it diagonally, and near the $\mathbf{S}$. boundary has an elevation of 640 feet. The $t$. furnishes a large amount of lumber, and contains several manufactories. The $\mathrm{v}$. is at the mouth of Tunkhannock cr, on the North Branch'Division of the Pennsylvania Canal, and on the Lickuwanna and Western P. R., 27 m. S. W. Great Bend. It contains the county buildings, etc., and 561 inhabitants. Pup. of $t$. about 2,400 .

Tunnex, p, o. and sta., Indiana en, Penn.: on the line of the Alleghany Portage R. R., $168 \mathrm{~m}$.W. N. W. Harrisburg. Tunnel, sta., York co, Penn.: on the Baltimore and Susquehanna R. R., 32 m. S. by E. Harrisburg.

Tunnez, p. o., Franklin county, Tenn.: 71 m. S. S. E. Nashville.

TunNel, p. o., Augusta county, Virg. : 100 m. W. N. W. Richmond.

TunNel Hill, p. v. and sta., Murray co, Ga. : on the Western and Atlantic R. R., $108 \mathrm{~m}$. N. W. from Atlanta, and $165 \mathrm{~m}$. N. W. Milledgeville.

Tunnell's Śtore, p. o., Sussex co, Del. : 43 m. S. Dover. Tunungwant, sta., Cattaraugus $\operatorname{co}, N . Y .:$ on the New York and Erie R. R., 53 m. S. E. Dunkirk, 416 m. N. W. New York eity.

Tooudune county, Culif. Situate generally between the Stanislaus and Merced rivers, and extending from the Coast Range to the Sierra Nevada. The San Joaquin flows through its W. portion. This is a fine agricultural as well as mining county. In 1852, it had 17,6.7 inhubitants, viz. wh. 16,925-males 15,967 , and females 958 ; negroes, 100 ; mulattoes, 42 ; domesticated Indians, 590; foreign residents, 8.668. Over 21 years of age-citizens of the Enited States, 6.9'4: negrnes, 95; mulattoes, 40 ; and foreign residents, 8,600 . Land in cultivation, 1.870 aeres. Capital-in quartz mining, $\$ 49.900$; in placer mining, $\$ 76,055$; and in other mining, $\$ 1,900$. Total capital employed, $\$ 1,2 \$ 8,3 \$ 5$. Cupitul. Sonora.

Tuoldman Citr, v., Tuolumne co, Calif: : laid out at the head of navigation on the $\mathrm{N}$. side of Tuolumne $r ., 30 \mathrm{~m}$ above its junction with the San Jnaquin, and is m. S. E from Vallejo. It has quite a number of inhabitants, and its 
proximity to the mines will render it important as a pleasant winter residence for miners.

TUOLUMNe river, Tuolumne co., Calif.: rises by two branches in the Sierra Nevada Mountains, flows westwardly, and empties into the San Joaquin, aboul $30 \mathrm{~m}$. above San Joaquin City

Tuppel's Platns, p. o., Meigs co., Ohio: 74 m. S. E. Columbus.

Turbotvrlue, p. 0., Northumberland co., Penn.: $55 \mathrm{~m}$. N. Harrisburg.

Turin, t. and p. v., Lewis co., $N . Y_{.}: 112 \mathrm{~m} . \mathrm{N}$. W. Albany, Black r. bounds it on the E., and its branches drain the $t$. Surface rolling. The $v$, is on a branch of Black $r_{\text {., }}$ and contains several stores, and some manufactures. The manufactures of the t. consist of leather, flour, lumber, and oil. Pop. of t. 1,826.

TURKeY, p. o., Monmouth co., N. Jer.: $1 \mathrm{~m}$. N. Manasquin r., $27 \mathrm{~m}$. E. Trenton.

Turkey river, Ia.: in N. E. part of the State, flows S. E., and empties into the Mississippi, at Millville, in Clayton co.

TURKEY Cove, p. o., M.Dowell co., N. Car.: $187 \mathrm{~m}$. W. Pialeigh.

TUREEX Cote, p. 0., Lee co., Virg.: $304 \mathrm{~m}$. W. by $\mathbf{S}$. Richmond.

Turkey Crees, p. 0., Buncombe co., N. Car. : $303 \mathrm{~m}$. W. Raleigh.

Turkey Creek, p. o., Hunt county, Tex。 : 219 m. N. E. Austin City.

Turkey Creek, p. o., Benton co., Mo.: $67 \mathrm{~m}$. S.W. by W. Jefferson City.

TuRker Foot, t. and p. F., Somerset co., Penn.: $125 \mathrm{~m}$. W. by S. Harrisburg. Drained by Castleman's r. and Laurel Hill er. Surface hilly, Laurel Hill Mountain is on the W. and Negro Mountain on the E. boundary.

TURKEY Foot, p. o., Scott county, $\boldsymbol{K}_{0}: 18$ m. E. by N. Frankfort.

Turkex Grove, p. O., Dane co., Wisc.

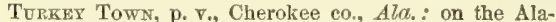
bama and Tennessee R. R., 123 m. N. by E. Montgomery.

TuRMaN's Creek, p. v., Sullivan co., Ind.: on E. side of creek of same name, $80 \mathrm{~m}$. S. W. by W. Indianapolis.

Turman's Ferry, p. o., Lawrence co., Ky.: on W. bank of Big Sandy r., $181 \mathrm{~m}$. E. Franktort.

Turnback, p. o., Dade co., Mo.: on E. side of branch of Sac r., 124 m. S. W. Jefferson City.

Turnbull, p. $\mathrm{V}_{0}$, Monroe co., Ala. $:$ on $\mathrm{S}$. side of branch of Flat er., $69 \mathrm{~m}$. S. W. Montgomery.

Turner, $t$ and p. o., Oxford co., Mfe.: on the W. side of Androsenggin r., $25 \mathrm{~m}$. W. S. W. Augusta. Drained by branch of Androseoggin r. Surface pleasantly diversified; soil fertile. Incorporated in 1786. It contains several lumber yards, grist and saw mills, tanneries, etc. There are a number of thriving villages in the town. Pop. of t. 2,537.

Turner Creer, p. o., Potter co., Penn.: 110 m. N. W. by N. Harrisburg.

Tuners, p. v., and sta., Orange co., $N . Y_{.}$: on the New York and Erie R. R., 47 m. N. W. New York eity.

Turner's Store, p. 0., Caroline county, Firg.: $33 \mathrm{~m} . \mathbf{N}$. Richmond.

TuRn frstili.e, p. $\nabla_{\text {. }}$, Robertson county, Tenn.: $31 \mathrm{~m}$. N. W. by N. Nashville.

Turnerstille, sta., Mobile con, Ala. : on the Mobile and Ohio R. R., $5 \mathrm{~m}$. N. Mobile and $157 \mathrm{~m}$. S. W. Montgomery. Turns, p. 0., Monroe county, Penn.: 95 m. N. E. by E. Farrisburg.

Turthe Creer, p. v., Alleghany co., Penn.: $150 \mathrm{~m}$. W. Harrisburg.

Turtle Town, p. on, Cherokee county, N. Car,:295 m. W. hy S. Raleigh.

Turtleville, p. O., Union co, Penn.: 40 m. N. N. W. Harrisburg.

Tuscanoma, p. o., Tallahatchee co.. Miss, : on the S. side of Tallabusha r., $110 \mathrm{~m}$. N. Jackson. 862
Tuscaloosa county, Ala. Situate N. W. centrally, and contains $1,507 \mathrm{sq} . \mathrm{m}$. Black Warrior $r$. flows through it from N. E. to S. W., by which and its affluents and by Sipsey r.o a tributary of Tombigbee $r$, it is drained. Surface undulating; soil consists of a rich mold, and is very fertile-it is well adapted to cotton, which is the staple production of the county. Farms 1,115; manuf. 32 ; dwell. 1,914, and pop.-wh. 10,553, fr. col. 26, sl. 7,477-total 18,056. Capital Tuscaloosa.

Tuscaloos., p. city, and cap. Tuscaloosa co., $A l \alpha_{0}$ : on S. E. bank of Black Warrior r., $94 \mathrm{~m}$. N. W. by W. Montgomery. Lat $32 \circ 12^{\prime} \mathrm{N}$., long. $87042^{\prime} \mathrm{W}$. It is situated on an elevated plain at the lower falls, and head of steamboat navigation on the river, and is regularly laid out with broad streets crossing each other at right angles. This city was until 1847 the capital of the State. It contains the former State-house, a court-house, jail, a Masonic ball, an academy, lyceum for boys, seminary for young ladies, the Alabama Institute, 5 churches, stores, etc. The University of Alabama, here located, has 5 buildings, with several houses for professors, which present a flne appearance. This institution was founded in 1831, in 1850 it had 9 in structors, 197 alumni, and 91 students, with 7,123 volumes in its libraries. In 1850, 3 weekly newspapers were here published, "Independent Monitor" (whig), "Tuscaloosa Observer" (dem.), and "Crystal Fount" (temp.) Pop. in $1840,1,949$; in $1850,2,961$.

Tugcarawas county, Ohio. Situate toward the E., and contains 704 sq. m. Drained by Tuscarawas $\mathrm{r}$., Sandy, Conotten, and Sugar creeks, and other small streams. Surface uneven, and in parts hilly and broken; soil fertile, and raises fine crops of wheat, Indian corn, and potatoes, and is generally rich in agricultural productions. Farms 2,250; manuf. 159 : dwell. 5,441, and pop.-wh. 31,672 , fr. col. 89 total 31.761. Capital: New Philadelphia, Public Worles: Springfield, Mount Vernon, and Pittsburg R. R.; Ohio Canal.

Tuscarawas, p. F., Tuscarawas co., Ohio: on Ohio Canal, W. side of Tuscarawas r., $84 \mathrm{~m}$. E. N. E. Columbus. Tuscarora, p. o., Lee co., I $\alpha_{0}: 67 \mathrm{~m}$. S. Iowa City. Tuscarora, p. v., Livingston county, N. Y.: 204 m. W. Albany.

Tuscola county, Mich. Situate E. centrally in the S. portion of the State, and contains 511 sq. m. Drained by Cass $r$, and its branches. Surface even; soil fertile, and produces good crops of wheat, oats, ete. It has good waterpower, which might be put to advantage in the establishment of factories. Farms 18; dwell 65, and pop-wh. 291, fr. col. 0-total 291. Capital: Tuscola.

Tuscou, t. and p. o., Livingston co., Mfich.: $30 \mathrm{~m} . \mathbf{E}$ Lansing. Drained by small branches of Shiawassee $r$. A farming town containing 544 inhabitants.

Tuscumbia, p. v., Franklin co, $A l a$.: about 2 m. S. Tennessee r., 182 m. N. N. W. Montgomery. The Memphis and Charleston R. R. passes through this place. It contains an iron foundry, several stores, ete. A spring here flows from a fissure in a limestone rock, which discharges 20,000 cubic fect of water per minute, and it flows a considerable stream $2 \frac{1}{2} \mathrm{~m}$. to Tennessee $\mathrm{r}$. The depth of the spring where it issues from the rock is 8 feet. The "North Alabamian" (whig) and "Franklin Democrat" (dem.), are both published weekly. Pop. about 2,300.

Tuscumbia, p. V., and eap. Miller co, MIo.: on right bank of Osage r., $28 \mathrm{~m}$. S. W. by S. Jefferson City. It contains the county buildings, etc.

Tuskegre, p. $\mathrm{v}_{\text {., }}$ and cap. Macon eo., $A l a_{0}$ : on a small branch of Tallapoosa r., $37 \mathrm{~m}$. E. Montgomery. It contains the co, buildings, etc. The "Macon Republican" (whig), and "Herald" (whig) are issued weekly, and the "Universalist" semi-monthly. Pop. about 600 .

Tusquites, p. 0., Cherokee co., N. Car.: $283 \mathrm{~m} . \mathrm{W}$. by $\mathrm{S}$. Raleigh.

TotwLL, p. v., Ulster co., N. Y.: 76 m. S. S.W. Albany 
TUTthe's Cornkrs, p. o., Sussex co., N. Jer.: 60 m. N. Trenton.

Twalttr Planns, p. o., Washington co., Oreg.Ter. : $30 \mathrm{~m}$. N. by E. Salem.

Tweite Mren, p. o., Pickens district, S. Car.: $117 \mathrm{~m}$. N. W. by W. Columbia.

Twelve Mixe, p. o., Cass co., Ind.: 68 m. N. by W. Indiauapolis.

Thelve Mile Creek, p. o., Steuben co, $N_{\text {. }}$.: $122 \mathrm{~m}$. W. by S. Albany

Twelte Mile Pratrie, p. 0., St. Clair co., $\pi l$. : $95 \mathrm{~m}$. S. by W. Springfield.

TWenty Mlle Stand, p. 0., Warren co, Ohio: $78 \mathrm{~m}$ S. W. by W. Columbus.

TwIGgs county, $G a$. Situate centrally, and contains 393 sq. m. Oemulgee r. forms its W. boundary, by branches of which it is drained. Surface hiliy; soil very fertile, consisting of a fine deep mold, productive, and well adapted to cotton, the prineipal production of the county. A portion of the land is covered with pine timber; it contains some minerals, Farms 367 ; manuf. - ; dwell. 696, and pop.wh. 3,517, fr. col. 42, sl.4,620-total 8,179. Capital: Marion. Public Works: Central Georgia R. R.

TwINsBurg, t. aud p. v., Summit co, Ohio: $120 \mathrm{~m}$. N. E. Columbus. Soil fertile. Drained by Tinker's cr., flowing centrally through the $t$. in a N. W. course, and affording water-power. The Cleveland and Pittsburg R. R. crosses the S. W. corner of the t. The village contains 2 churches, stores, mills, shops, etc. The $\mathrm{v}$. and to received their names from twin brothers who first settled here in 1827. Pop. of t. 1,281.

Two Mire BrairoH, p. o, Smyth co., Virg.: $220 \mathrm{~m}$. W. by S. Richmond.

Two Mile Pratrie, p. o., Pulaski co, Ind.: about $3 \mathrm{~m}$. E. Tippecanoe r., $85 \mathrm{~m}$. N. by W. Indianapolis.

Two Rivers, p. o., Pike co., Penn.: on Delaware and Hudson Canal, W. side of Delaware, 124 m. N. E. by N. Tiarrisburg.

Two Rivers, t. and p. os, Manitoowoc co, Wisc: $123 \mathrm{~m}$. N. E. Madison. Drained by E. and W. Twin rivers, flowing S. E. into Lake Michigan, which bounds it on the E. Population 924

Two Taverins, p. o., Adams county, Penn.: 36 m. S. W. Harrisburg.

Tye River W Arehouse, p. o., Nelson co., Virg.: on W. side of James river, at junction with Tye river, $69 \mathrm{~m}$. W. Richmond.

Tygert's CreEK, p. o, Greenup co., $K y_{\text {. : }}$ on cr. of same name, $110 \mathrm{~m}$. E. by N. Frankfort.

Truer county, Tex. Situate E., and contains 1,157 sq. m. Drained by affluents of Neches $r$, which forms its eastern brundary, and by branches of Big Sandy or Alabama cr., which runs along its S. border. Surface undulating; soil fertile, consisting of a fine deep mold on a sandy bottom, and is well adapted to cotton and corn. On the Trinity the land is in general rich and very productive, but subject to submersion. It is thickly wooded with oak, pine, and other trees. Farms 137; manuf. 6; dwell. 267, and pop.-wh. 1,476, fr. col. 0, sl. 418-total 1,894. Capital: Woodville.

TrLEE county, Firg. Situate N. W., and contains 373 sq. m. Drained by Fishing and Middle Island creeks, which enter the Ohio river. Surface generally uneven and rough; soil a strong loam, and fertile. Chief products, wheat, Indian corn, and potatoes. Farms 417 ; manuf. 15 dwell. 949 , and pop.-wh. 5,456 , fr. col. 4 , sl. 38 -total 5,498 . Capital: Middlebourne.

TrLeE, p. o., Winnebago county, $I U_{n}: 176 \mathrm{~m} . \mathrm{N}$. by W. Springfield.

Truern p. O., Smith county, Texo: 209 m. N. E. Austin City.

Truerseubg, p. 0., Clarion co., Penn. : 147 m. W. N. W. Harrisburg
Tylat's Port, p. 0., Montgomery co, Penn.: 70 m. E. Harrisbarg.

Truensville, p. 0., Laurens district, S. Car. : $70 \mathrm{~m}$. N. W. by W. Columbia

TyMan's STORE, p. 0., Spottsylvania county, Virg.: $55 \mathrm{~m}$. N. Richmond.

Trmocntee, t. and p. v., Wyandott co, Ohio: $68 \mathrm{~m}$. N. by W. Columbus. Drained by Sandusky and Tymochtee rivers. The Mad River and Lake Erie $\mathrm{P}, \mathrm{P}$. touches the N. W. corner of the $t$. Pop. of t. 1,817.

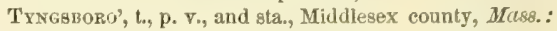
on both sides of Merrimac r., $29 \mathrm{~m}$. N. W. by N. Boston. The Nashua and Lowell R. R. passes through the $v$. on the W. bank of the Merrimac r., $32 \mathrm{~m}$. from Boston. The v. occupies a pleasant site, and contains a church and academy, with several neat dwellings. Pop. of t. 799.

TYRE, t. and p. o., Seneca co, N. $X_{*}: 150 \mathrm{~m}$, W. by N. Albany. Surface level; soil sandy and calcareous loam. Drained by Clyde $r$., flowing into Seneca $r$. The Erie Canal passes through its N. part. The inhabitants are generally engaged in farming. Pop. 1,356.

Trree Springs, p. 0., Sumner co., Tenn. : 21 m. N. by E. Nashville.

'Trrell, p. o., Venango co., Penn.: 168 m. N. W. by W. Harrisburg.

TrRINGHAM (Shaker settlement), t. and p. v., Berkshire county, Mass. : $112 \mathrm{~m}$. W. Boston. Watered by branches of Housatonic r., one of which flows from a pond in its S. E. part. The t. is twice crossed by two heavy ranges of hills. The $\mathrm{v}$, at the centre is neatly built. In its S. W. part is Shaker village. The $t$. also contains 3 churches, and several grist and saw mills. Pop. 821

Txro, p. v., Crawford county, Ohio: $66 \mathrm{~m}$. N. by E. Columbus.

Tyronk, t. and p. o., Livingston county, Bfich. : $40 \mathrm{~m}$. E. Lansing. Drained by Ore cr., a branch of Shiawassee $r$ The inhabitants are generally engaged in farming, etc. Pop. in 1840, 394; in 1850, 867.

Trrone, p. V., Blair county, Penn.: $76 \mathrm{~m}$, W. N. W Harrisburg. Situated on N. E. part of the county, and on Pennsylvania R. R., $118 \mathrm{~m}$. W. Harrisburg.

Trrone, p. o., Coshocton county, Otiio: $62 \mathrm{~m}$. E. N. E. Columbus.

Txrone, t. and p. v., Steuben co., N. Y.: $172 \mathrm{~m}$. W. by $\mathrm{S}$. Albany. Surface hilly; soil clay and calcareous loam. Drained by Mud er., which flows through two large pouds on its W. border. The v. contains 2 churches, stores, ete. The t. also contains several tanneries, grist and saw mills, etc. Pop. of $\mathbf{v}$. about 250 ; of the t. 1,894 .

Trrone Mirls, p. o., Fayette county, Penn.: 140 m. W Harrisburg,

TYrRelt county, N. Car. Situate $\mathrm{E}_{\text {o, }}$ and contains 727 sq. m. Drained by Alligator r. and its branches; which waters are discharged into Albemarle sound. Surface low and generally even, in many parts it is liable to submersion, and is too wet for cultivation; soil where fit for tillage is fertile, and produces rice, cotton, grain, etc., which form the staple articles of commerce. On the $\mathbf{E}$, in the Atlantic, are islands belonging to the county, of which the principal is Roanoke. Farms 210; manuf. 41; dwell. 635, and pop.wh. 3,301, fr. col. 130, sl. 1,702-total 5,133. Capital: Columbia.

Trbon Furack, p. 0., Windsor co, Term.: 55 m. S. by E. Montpelier.

\section{$\mathrm{U}$}

UCHEE, p. т., Russell co., Ala. : 59 m. E. Montgomery.

UCHEE ANNA, p. v, and cap. Walton $\mathrm{co}_{2}, F(0)$ : : on W. side of a branch of Choctawhatchie river, $115 \mathrm{~m}$. W. by N. Tallahassee. It contains a court-house, about 60 dwellings, and is surrounded by a very productive region.

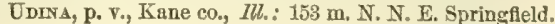


UfFington, p. v., Monongalia co., Virg. : 207 m. N. W. Richmond.

Uhlerstille, p. v., Northampton county, Penn.: $85 \mathrm{~m}$. E. N. E. Harrisburg.

Uhricksville, p. v., Tuscarawas co., Ohio: 95 m. E. N. E. Columbus. The Steubenville and Indiana R. R. passes through this place. Pop. 577.

Uintah river, Utah Ter.: a tributary of the Rio Colorado, which it joins a little above $40^{\circ} \mathrm{N}$. lat., in Utah county. The valley of this $r$. is one of the few fertile places in this part of the territory.

UINTAH ForT, Great Salt Lake co.s. Utah Ter. : a trading post on a branch of Uintah r., $167 \mathrm{~m}$. N. E. Fillmore City.

Ulao, p. o., Washington county, Wisc. : $67 \mathrm{~m}$. E. N. E Madison.

Ulatt's valley, Solano co., Calif: lies N. E. of the Suisun Valley, is $5 \mathrm{~m}$. long, ard $1 \frac{1}{3} \mathrm{~m}$, wide. It runs $\mathrm{N}$. W. between two ranges of hills, and opens out into the Sacramento Valley. It is a great thoroughfare, aad the admiration of all travelers.

Ulster county, $N . Y$. Situate tow ard the S. E., and contains 1,076 sq. m. Drained by Walkill, Esopus, Rondout, and Shawangunk creeks, which in their courses supply good water-power. Surface in general mountainous, the Shawangunk traversing it for a distance of 30 miles in a N. E. direction, and the Blue mountains spreading over its $W$. section, between these is a broad fertile valley; soil various, on the hills being adapted to grazing, and in the valleys very fertile. Chief products, wheat and Indian corn. This co. contains many minerals, and some sulphur springs, also large quarries of marble and limestone. It bas some important manufactures, and exports large quantities of coal, brought here by the canal, and lumber. Farms 3,539 ; manuf 411; dwe1t. 9.735, and pop. - wh. 57,503, fr. col. 1,581-total 59,35t. Capitul: Kingston. Pullic Works: Delaware anil Hudsou (anal; Albany and Hobolien R. R.

Utster, t. and p. o, Bradford county, Penn.: $107 \mathrm{~m} . \mathrm{N}$. Harrisburg. Drains into the Susquehanna r., which makes its E. border. Surfice diversified; soil in the valley exceedingly rich. There are several saw and flour mills in the $t$, and several stores.

Ulsterville, p. Y., Ulster county, $N . Y$. : 76 m. S. S. W. Albany.

Ultima Thule, p. o., Sevier co., Ark.: on Rock cr., a branch of Little r., 131 m. W. S. W. Little Rock.

Ulysses, t.. Tompkins co., $N_{0} . Y_{\text {. }}$ : on the W. side of Cayuga lake, $8 \mathrm{~m}$. N. W. Ithaca, and $152 \mathrm{~m}$. W. from Allany. Drained by small streams ruming into Cayuga lake, toward which its surface declines. It contains several manufacturies. Pop. 3,122.

Ulyssrs, t. and p. ๑., Potter co., Penn. : $121 \mathrm{~m}$. N. by W. Harrisburg. Drained by head waters of Pine cr. of Susquehanna $r_{0}$, and of the Genesee $r_{\text {. flowing in different }}$ directions. Surface elevated; soil fertile. Pop. 542.

Unbagog lake, $N$. Hamp. and $M e,:$ a large body of water located mostly in Maine, extending about 300 yards in width along the E. of the townships of Errol and Cambridge in N. H. It is aborut $15 \mathrm{~m}$. long. and in some parts $10 \mathrm{~m}$. wide, and is little inferior to the Winnepisiogee in extent and beauty. Its form is long and irregular, incrensing in wilth from $\mathrm{S}$. to N. Its outlet is on the N. W. side of Errol, and flows into the Androseoggin river.

Uncolcts, p. 0., Aroostook county, Me.: 172 m. N. E Augusta.

UMPQUA City. p. v., and port, Umpqua cn., Oreg. Ter.: at the mouth of Umpqua r., $92 \mathrm{~m}$. S. S. W. Salem. It lies on a neck between the river and Pacifle Ocean: has a gond hurbor. and promises to become a flourishing place.

UMPQU A river, Oreg. Ter: a considerable stream falling into the Pacific Ocean, about $40 \mathrm{~m}$. to the $\mathrm{N}$. of Cape Arago It rises by several branches from the coast range of monntuins, and some of the heads are separated from tributaries of Rogue r, by a well-defined watershed. Gold has been 564 found in the greater part of its length, and already several settlements are found on its banks. Umpqua City at its mouth, Providence and Gardiner on opposite sides of the $r$. $6 \mathrm{~m}$. up, Middleton on its S. bank $13 \mathrm{~m}$. up, Scottsburg Myrtle City, and Gagniersville on the N. bank 22 to $25 \mathrm{~m}$ up, and Elkton at the conffuence of Elk $r$. are the principal, and there are others on Elk r., and on the N. and S. Umpqua rivers, which latter are the chief constituents of the Umuqua.

Unadilla, t, and p. v., Livingston county, Mich : $31 \mathrm{~m}$. S. E. Lansing. Drained by Portage r., a branch of Huron river. Soil very fertile, and one of the best towns in the county. The inhabitants are chiefly engaged in farming Pop. in 1840,643 ; in $1850,1,027$.

Unamilla, t. and p. v., Otsego co., $N . Y_{.}: 30 \mathrm{~m} . \mathrm{S} . \mathrm{W}$ of the village of Cooperstown, $84 \mathrm{~m}$. W: by $\mathrm{S}$, Albany Drained by Unadilla and Susquehanna rivers. Surface hilly and somewhat broken, but has rich alluvial flats. It contains some manufactures of woolens, leather, tobacen, etc., and has considerable trade in lumber. The v. on $\mathrm{N}$. side of Susquehanna r. contains several mills, some mantfacturing establishments, a bank, cap. $\$ 100,000$, and about 600 inhabitants. Two covered bridges, each 250 feet Iong, resting on 3 arches, here span the river. Pop. of t. $\mathbf{z}, 463$

UNADILLA river, $N . Y .:$ rises in Bridgewater, Oneida $\mathrm{co}_{\text {, }}$ flows in a southerly direction, dividing the counties of Madison, Otsego, and Chenango, and falls into the Susquehanna, in the N. E. corner of Brainbridge. It is about $5 \mathrm{~m}$. in length, and affords immense hydraulic power. On its banks are situated several manufacturing villages.

Unadilla Centre, p. v., Otsego co, $N$. $Y$. : on a branch of Unadilla r., $84 \mathrm{~m}$. W. by S. Albany.

Unadilla Forks, p. v, Otsego co., N. Y.: at the junction of the E. and W. branches of the Unadilla r., $89 \mathrm{~m}$. W. by S. Albany. It contains several manufactories, and about 300 inhabitants.

Uncasville (Mohegan), p. v., New London co., Conn. : on the Reservation of the Mohegan Indians, $36 \mathrm{~m}$. S. E. Hartford. It contains a chapel, sehool-bouse, etc., erected at the expense of the general government. The New London, Willimantic, and Palmer R. R. passes it, $9 \mathrm{~m}$. from New London. In the vicinity is a large factory, making drillings, running 80 looms, 2,400 spindles, and employing about 100 operatives.

UNDERHill, to and p. v., Chittenden co., Verm.: $23 \mathrm{~m}$. N. W. Montpelier. Drained by head branches of Brown r., a tributary of Lamoille $r$,, which affords water-power to several saw-mills. Surface nneven, with an inferior soil. The $\mathrm{v}$. is on a branch of Brown r. Pop. of t. 1,599.

Underhill Centre, p. v., Chittenden co., Verm.: $25 \mathrm{~m}$. N. W. Montpelier.

UNDERW OOD, p. o., Hopkins co., Ky. : 161 m. E. by $\$$. Frankfort.

UNDER:WOOD's, p. o., Marion co.; Ohio: $47 \mathrm{~m}$. N. by W. Columbus.

UNIKA mountains, a name given to that portion of the Alleghany range that separates Tennessee from North Carolina, and which lies $\mathrm{S}$. W. of Tennessee river.

Usion county, Ark. Situate S., and contains 1.230 sq: m. Drained by Wachita river and its affluents. Surface level; soil fertile. Cotton is the chief production. Farms 679 manuf. 0 ; dwell. 964 , and pop.-wh. 5,526, fr. col. 5, sla. 4.767-total 10,298. Capitul; El Dorado.

Unios county, $G a$. Situate N., and contains 706 sq. m. Drained by head branches of Hiawassee river, and other small streams. Surface nneven; soil fertile. In the $\mathrm{S}$. and $E$. it is bounded by a mountainous range. Farms 911 ; manuf. 3 ; dwell. 1,141, and pop.-wh. 6,955, fr. col. 1, sla. 278-total 7,234. Capital: Blairsville.

UNION county, Ill. Situate S. W., and contains 390 so.m. Drained by Clear creek, a tributary of Mississippi river, which forms its western border, and by Cash river, a tributary of Ohio river. Surface hilly; soil fertile, and produces abundantly wheat, Indian corn, and other grains, 
Pork and beef are exported. Farms $\$ 10 ;$ manuf, 21 ; dwell. 1,259, and pop.-wh. 7.570, fr. col. 45, total 7,615. Capital: Jonesboro?. Public Works: Illinois Cantral R. R.

Uniox county, Ind. Situate E., and contains $168 \mathrm{sq} . \mathrm{m}$. Drained by E. fork of White river, and Hannah, Rockland, and Silver creeks. Surface Ev level, W. undulating or hilly. Seven-eighths of the country originally timbered upland. The soil is uniformly good. Farms 606; manuf. 35 ; dwell. 1,220, and pop.-wh. 7,106, fr. col. 38-total 7,144. Capital: Liberty. Public Works: Indiana Junction P. R.

Unios county, $I a$. Situate toward the S. W., and contains 432 sq. m. Drained by Crooked fork of Grand river and its branches. Surface level, extending into broad, open plains; soil fertile, and well adapted to wheat and grain. Set off since 1850 .

UNIoN county, $K y$. Situate N. W., and contains 355 sq. m. Drained by Highland creek and branches, and branches of Tradeswater creek. Surface undulating, the land rising gradually to the $\mathrm{Ohio}$, on the W. border, and on the shore terminating in high bluffs; soil moderately fertile. Chief productions tobacco and Indian corn. Some cotton is also produced. Farms 681; manuf. 7 ; dwell. 1,140, and pop. - wh. 6,704, fr. col. 16, sla. 2,292-total 9,012. Capital Morganfield.

UnIoN parish, $L a$. Situete $\mathrm{N}$., and contains $1,027 \mathrm{sq} . \mathrm{m}$. Drained by D'Arbonne river, and its branches, which traverse it from E. to W., and branches of Wachita river. Surface level; soil varied, that on the streems being generally Fich and fertile, adapted to the culture of cotton, rice, and Indian corn, which, with wheat, form the staple productions. Farms 717 ; manuf. 1; dwell. 942, and pop.-wh. 4.778, fr. col. 0 ; sl. 3,425-total 8,203. Capital: Farmersville.

UNION county, N. Car. Situate 8 ., and contains $475 \mathrm{sq} . \mathrm{m}$. Drained by branches of Yadkin river. Surface uneven; soil fertile, and well adapted to grain and grazing. Some portions of it are very productive, and yield a large quantity of cotton, etc. Staple articles of commerce, tobacco, cotton, rice, and wheat. Farms 877 ; manuf. 9 ; dwell. 1,422, and pop.-wh. 8,018, fr. col. 51, sl. 1,982 - total 10,051. Capital: Monroe.

UnIoN county, Ohio. Situate W. centrally, and contains 884 sq. $m$. Drained by Big Darby and Boques creeks, and other affluents of the Scioto river. Surface an extended plain, with oceasional swells, and pleasantly diversified; soil fertile, and produces abuadantly wheat, grain, and potatoes. Pork and beef are exported. Farms 1.255 ; manuf. 16 ; dwell. 2,059, and pop.-wh. 12,076, fr. col. 128-total 12,204. Capital: Marysville. Public Works: Springfield, Mount Vernon, and Pittsburg R. R. ; Columbus and Bellecontaine R. R, ete.

Usiox county, Penn. Situate E. centrally, and contains 576 sq. m. Drained by Penn's, Middle, Buffalo, and West Mahantanga creeks, tributaries of Susquehanna river, and its W. branch, which bound it on the E. Surface hilly, and in parts mountainous; soil fertile, and very productive. Staples, wheat and Indian corn. Farms 1,597; manuf. 160 ; dwell. 4,455, and pop.-wh. 25,932 ; fr. col. 101-total 26,053 . Capital: New Berlin.

Union dist., S.Car. Situate N., and contains $749 \mathrm{sq} . \mathrm{m}$. Drained by Pacolet and Tyger ricers, and their branches. Surface undulating; soil generally fertile, and adapted to grain. Chief produetions, cotton and Indian corn. Farms 869 ; manuf. 72 ; dwell. 1,734, and pop.-wh. 9,322, fr. col. 139, sl, 10.392-total 19,852. Capital: Unionville, Public Works: Union and Spartanburg R. R.

Union, p. o., Jasper co., Tex。: $22 \mathrm{~S}$ m. J. by N. Austin City.

Union, p. v., Greene co., Ala. : 98 m. W. by N. Montgomery. Pop. 290.

Union, t. and p. 0., Tolland co., Conn. : 81 m. N. E. by E. Hartford. Drained by head branches of Willimantic river, and other small streams. Surface hilly, with an inferior soil. Mashapaug and Breakneck ponds, sources of the
Quinnebaug, and a branch of the Natchaug rivers, are in this town. Pop. 729.

Union, p. o., York co., Penn. : 31 m. S. S. E. Harrisburg. UNTON, p. v., and sta., M.Henry co., IUl.: on the Galena and Chicago Union R. R., $62 \mathrm{~m}$. N. W. Chicago, and $175 \mathrm{~m}$. N. E. Springffeld.

Union, p. O., Pike county, Ind.: 110 m. . . W. by W. Indianapolis.

Uniox, v. and sta., Randolph co., Ind.: on the State line, $84 \mathrm{~m} . \mathrm{E} . \mathrm{N}$. E. Indianapolis. This is the point of union of the Indianapolis and Bellefontaine $R . P_{*}$, and the Ohio lines to Oleveland, Pittsburg and Cincinnati, viz., the Bellefontaine and Indiana R. R., the Columbas, Piqua and Indiana $R$. R., and the Greenville and Miami $R$. R. respectively, which, with their eastern connections, extend to the above named places, and thence connect with roads to the Atlantic, etc. It is one of the most important points of function in the west, and must soon become a thriving commercial centre.

Union, p. v., Boone co., Ky.: $51 \mathrm{~m} \mathrm{~N}$. by E. Frankfort.

UNIoN, t. and p. v., Lincoln co., Me.: $27 \mathrm{~m} . \mathrm{E} . \mathrm{S} . \mathrm{E}$ Augusta, Drained by St. George and Muscungns rivers, Surface gently meven. Incorporated in 1786. The $t$, contains a considerable number of saw, grist, and fulling mills The $\nabla$. is on St, George r. Pop. of t. 1,974.

Union, p. o., Cass co., Mich. : on the W. of a tributary of St. Joseph's r., 88 m. S. W. Lansing.

Union, p. v., Newton county, Miss.: $69 \mathrm{~m}$. E. by N. Jackson.

Untos, t., Branch co, Mich.: $52 \mathrm{~m}$. S. W. by S. Lansing. St. Joseph's r. crosses its N. W. corner, and receires at Union City the stream draining the $t$. The inhabitants are generally engaged in farming. Pop. in 1840,507 ; in 1850 1,271 .

UNoN, p. v., Franklin co., Mo.: a little N. of Bourbense cr., $64 \mathrm{~m}$. E. Jefferson City.

Unron, p. o., Carroll county, N. Hamp. : $40 \mathrm{~m}$. N. by E. Concord.

Unton, p. v., Van Buren co., Ia.: 72 m. S. S. W. Iowa City.

Unios; t, and p. v., Essex county, N. Jer. : 42 m. N. E. Trenton. Drained by Elizabeth and Rahway rivers. Surface uneven, with a fertile and well-cultivated soll. Pop. of t. 1,662 .

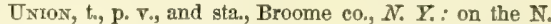
side of the Susquehanna r., $128 \mathrm{~m}$. W. S. W. Albany. Drained by Nanticoke r., a tributary of the Susquehanna. Surface undulating, and in parts hilly; soil fertile. The $\mathrm{v}$. is loeated $1 \frac{2}{2} \mathrm{~m}$. N. of the Susquehanna r., at the base of a round hill, which has excellent pasture to the top, facing the $v$., while on the opposite side it is covered with pine and hemlock. From its summit there are excellent views of the river and valley. It is a thriving place, and contains about 1,000 inhabitants. The sta. is $\frac{1}{8} \mathrm{~m}$. distant from the $r$., on the New York and Erie R. R., which passes along the Susquehanna $233 \mathrm{~m}$. from New York city, and $237 \mathrm{~m}$. from Dunkirk. The t. contains about 80 saw mills, with tanneries and grist mills. Pop. of t. 2,143.

Union, t. and sta., Licking county, Orio: on the Central Ohio R. R., $26 \mathrm{~m}$. E. by N. from Columbus. The Ohio Canal passes on its S. E. border. It enntains the p. $\mathrm{r}$. of Hebron (pop. 649), and Lura, pop. 8s. Pop. of t. 2,368.

Union, p. v., Montgomery co., Ohio: on the W. side of Greenville creek, $78 \mathrm{~m}$. W. by S. Columbus. Pop. about 800 .

Uniox, p. v., and cap. Monroe co., Firg. : 171 m. W. Rlchmond. It contains a court-house, jail, and an academy, several stores and tanneries. The "Union Republican" is issued weekly. Pop. 253.

Unios, to and p. o, Roek eo., Wisc.: $20 \mathrm{~m}$. \$. Madison. Drainerl by branch of Sugar r., and is a good farming town. Pop. 1,050.

Union, v., Trinity co., Calif. : at the head of Humboldt Harbor, 212 m. N. W. Vallejo. 
Uxion, p. v., Santa Clara county, Calif: : 78 m. S. S. E. Vallejo.

UNION river and bay, Haneock co., Me.: has its source a few miles S. of Passadumkeag r., flows $\mathrm{S}$., and empties into Union river bay, between Trenton and Surry. Its length is over $40 \mathrm{~m}$. It receives several tributaries and affords valuable water-power.

Union Bridge, p. v., Carroll co., Mfd.: on Little Pipe creek, $10 \mathrm{~m}$. N. from Westminster, and $53 \mathrm{~m} . \mathrm{N}$. W. Annapolis.

Union Bridge, v. and sta., Belknap co., N. Hamp.; on the W. border of Little Bay, and on the Boston, Concord, and Montreal $\mathrm{R}, \mathrm{R} ., 22 \mathrm{~m}$. from Concord.

Union Bridge, p. o., Titus co., Tex. : 266 m. N. E. Austin City,

Unton Ceartre, p. v., Broome co., $N$. ..$: 125$ m. W. S. W. Albany.

Union ChURCH, p. o., Jefferson co., Miss. : near a branch of Homochito r., $58 \mathrm{~m} . \mathrm{S}$. W. by $\mathrm{S}$. Jackson.

Union Citr, p. v., Branch eo., Mich.: on S. side of St. Joseph's r., at the junction of Coldwater r., $54 \mathrm{~m} . \mathrm{S}$. W. by S.

Lansing. Its location is at the head of navigation, and it possesses a considerable amount of water-power.

UNION CoRNER, sta., Queens co., $N$. $\boldsymbol{Y}_{\text {.: }}$ on the Long Island R. R., $8 \mathrm{~m}$. E. New York. Here is one of the most noted race courses in the Union.

Union Cornets, p. o., Livingston co., N. Y.: $214 \mathrm{~m}$. W. Albany.

UNION CORNERs, p. v., Van Buren co., Ia. : on South branch of Fox r., 75 m. S. S. W. Iowa City.

Union District, p. o., Washtenaw co., Jičc. : 46 m. S. E. Lansing.

Union Falis, p. v., Clinton co, $N_{0}, Y_{0}:$ W. side of Saranac $x$., which affords great water-power, $133 \mathrm{~m}, \mathrm{~N}$. Albany.

Union Funace, p. O., Huntingdon co., Penn.: $54 \mathrm{~m}$. W. Harrisburg.

Union Grove, p. v., Whitesides co., Ill.: on the W. side of Little Rock r., $143 \mathrm{~m}$. N. by W. Springfield.

Unтом Grove, p. 0., Racine co., Wisc.: 70 m. E. S. E. Madison.

Union Grove, p. v., Prince George co., Virg.: near the head waters of Blackwater r., $33 \mathrm{~m}$. S. by E. Richmond.

Union Hall, p. o, Franklin co, Virg.: 135 m. W. S. W.

Iichmond, In the vicinity, on Pig r., are several mills.

Unton Level, p. o., Mecklenburg county, Virg.: $88 \mathrm{~m}$.

s. W. Richmond

Union Meetrig House, p. o., Baltimore co., Mrd.: on Great Gunpowder Falls, $31 \mathrm{~m}$. N. of Baitimore city, and $51 \mathrm{~m} . \mathrm{N}$. by W. Annapolis.

Unton Milis, p. o., La Porte co., Ind.: on W. side of branch of Kankakee r., $159 \mathrm{~m}$. N. by W. Indianapolis,

Union MrLis, p. O, Carroll county, MM. : on side of Big

Pipe cr., 52 m. N. N. W. Annapolis.

Union Mrits, p. o., Fulton co., N. $Y_{.}: 88 \mathrm{~m} . \mathrm{N}$. W. by N.

Albany. It contains several mills

Union Mruis, p. o., Mahaska co., Ia.: on N. side of $\mathrm{N}$.

Skunk r., $58 \mathrm{~m}$. W. by S. Iowa City.

Union Mruis, p. V., Erie co., Penn, : on a branch of French cr., 191 m. N. W. Harrisburg.

Uvion Mrils, p. v., Fluvanna co., Virg.: on Rivanna r., $55 \mathrm{~m}$. N. W. Richmond. It contains several mills and a large cotton factory.

Union Plati, p. o., Brown co., Ohio: 89 m. S. E. by S. Columbus.

Union Pons, p. o. and sta., Greene co., $G a_{0}$ : on the Georgia P. R., at the junction of the Athens Branch R. R., $40 \mathrm{~m}$. from Alhens, $76 \mathrm{~m}$. from Augusta, and $42 \mathrm{~m}$. N. by E. Milledgeville.

Untos Porst, p. 0., Concordia par., La.: $78 \mathrm{~m} . \mathrm{N}$. by W. Faton Rouge.

Union Potat, p. $0_{\text {, }}$ Union co., $M_{0}$ : on E. side of Mississippi r., $3 \mathrm{~m}$, below the mouth of Big Muddy r., $162 \mathrm{~m}$. $\mathrm{S}$. Springfield.

866
Union Setrtement, p. o., Oswego county, $N . \quad Y$.: $142 \mathrm{~m}$. W. N. W. Albany,

Union Societr, p. 0., Greene co., $N . Y .: 38 \mathrm{~m} . \mathrm{S} . \mathrm{W}$. Albany.

Union Springs, p. o., Macon county, Ala.: on a fork of Cupia Hatchie er., 41 m. E. by \$. Montgomery. Population about 160

Union Springs, p. o., Harrison co., Texo.: 19 m. S. W Austin City.

Union Sprivgs, p. v. and sta., Cayuga co., $N . Y$. on E. side of Cayuga lake, $156 \mathrm{~m}$. W. Albany. The Cayuga and Susquehanna R. R. passes through this place, $64 \mathrm{~m}$. N. W. from Owego, and connects at Cayuga, $4 \mathrm{~m}$., with the Rochester and Syraeuse R. R. It has several mills, 1 iron foundry, and 1 woolen factory. There are two springs here which discharge sufficient water to supply the mills with power, there is also a mineral spring here of some celebrity. It has a steamboat landing, and a steam ferry connects the $\mathrm{v}$ with Canoga, in Seneea county. The "Cayuga Telegraph" (neut.) is here published. Pop. about 600 .

Union SquarE, p. o., Oswego co., $N . T .: 144 \mathrm{~m}$. W. N.W. Albeny.

Union Square, p. v., Montgomery co., Penn.: $\$ 3$ m. E. Harrisburg.

Unionrown, p. v., Perry co, Ala.: at the head-waters of Chilalohee creek, 77 miles W. Montgomery. Population about 500.

UnIontown, p. v., Knox county, Ill. $71 \mathrm{~m}$. N. by W. Springfleld.

UnIontown, p. v., Union county, $K_{y},: 167 \mathrm{~m}$. W. by \&. Frankfort.

UNIONTown, p. ₹., Wells co., Ind.: on S. side of branch of Little $\mathrm{r}_{0}, 117 \mathrm{~m}$. N. E. by N. Indianapolis.

Uniontown, p. v., Carroll co, Md : 51 m. N. W. by N. Annapulis. Pop. 339

Uxiontown, sta., Middlesex co., N. Jei? : on New York and Philadelphia R. R., $34 \mathrm{~m}$. N. E. Trenton.

UnIontown, p. o., Indian Territory.

Uniontown, p. v., Belmont co., Olio: $111 \mathrm{~m}$. E. by N. Columbus. Pop, 194.

Unioxtown, p. b., and eap. Fayette co., Penn. : on Redstone er., $153 \mathrm{~m}$. W. by S. Harrisburg. In this neighborhood are three cold blast furnaces, with a capacity of 1,100 tons each, and a rolling-mill, with an annual product of 700 tons. It contains several stores, workshops, and printing. offices, and three newspapers, the "Pennsylvania Democrat," the "Fayctte Whig," and the "Genius of Liberty" (whig), are issued weekly. Pop. 2,333.

Union Vale, t., Duchess con, $N . Y_{0}: 69 \mathrm{~m}$. S. Albany. Drained by Fishkill $r$. Surface rolling and hilly, having on the $\mathrm{E}$. Matteawan ridge; soil fertile. It has some manufactures, Pop. 1,552.

Union VALLex, p. v., Gortandt co., $N_{0} Y_{0}: 124 \mathrm{~m}$. W. Albany.

UNion VHuAge, p. $\nabla .$, Broome co, N. $Y . ; 120 \mathrm{~m}$. W. by S. Albany.

Uxion VIrLAge, p. v., Orange co., Verm.: on 8. side of branch of Connecticut r, $40 \mathrm{~m}$. S. E. by S. Montpelier.

Unxon Village, p. v., Northumberland co, Virg.: $65 \mathrm{~m}$. E. N. E. Richmond.

Umiox Viliage, v., Warren connty, Ohio: 84 m. S. W. Columbus. The inhabitants are chiefly Shakers, and are divided into families, each one with its separate house, having out-houses and work-shops adjoining. This is the oldest and largest society in the West.

Uxinsvillf, p. ₹., Monroe co., Ga.: on S. side of branch of Oemulgee r., $52 \mathrm{~m}$. W. by N. Milledgeville.

Untonvrule, p. v., Hartford county, Conn.: on E. side of Farmington r., on the Collinsville branch of the New Haven and Northampton, or Canal R. R., $28 \mathrm{~m}$. from New Haven, and $11 \mathrm{~m}$. W. from Hartford.

Usiostille, p. ₹., Monroe co., Ind.: 51 m. S. S. W. of Indianapolis, 
UNiontille, p. v., Appanoose county, $I l_{1}$ : on S. side of branch of Des Moines r., S1 m. S. W. Iowa City.

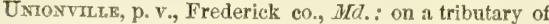
Linganore cr., $14 \mathrm{~m}$. E. N. E. of Frederick City, and $47 \mathrm{~m}$. N. W. Annapolis.

UNionthi.e, p. v., Orange co., $\mathcal{N}_{*} Y_{*}: 98 \mathrm{~m}$. S. S. E. of Albany. It contains a chureh, several stores, etc. PopuIation about 180 .

Untompilte, p. v. and sta., Lake co., Ohio: on Cleveland and Erie R. R., $42 \mathrm{~m}$. from Cleveland, $53 \mathrm{~m}$. from Erie, $165 \mathrm{~m}$. N. E. Columbus, It contains two churches, several stores, etc. In the vicinity are extensive iron-works.

Unionvilie, p. V., Chester co, Penn。: 66 m. E. S. E. of Harrisburg,

UNIONVILLE, p. v., sta., and cap. Union dist., S. Car. : on a small branch of Tiger $r ., 57 \mathrm{~m} . \mathrm{N}$. W. by N. Columbia. It contains the county buildings ete. The Union and Spartanburg R. R., diverging from Alston on Greenville and Columbia R. R, extends through this place to Spartanburg, $60 \mathrm{~m}$.

Unionville, p. v., Cass co., Tex. : 228 m. N. E. Austin City.

UntosvizLa, p. V., Bedford co., Tenn. : 45 m. S. S. E. of Nashville.

Unionville Centre, p. o., Union en, ohio: 23 m. N. W. by $\mathrm{N}$. Columbus.

Unropols, p. Vv, Auglaize county, Ohio: 77 miles N. W. Columbus.

Uxisos, p. ., Luudon co., Virg. : $99 \mathrm{~m}$. N. Richmond. Unison, p. v., Delarvare con, Ohio: 19 m. N. by W. Columbus.

Enitapia, p. o., Broome co., N. $Y_{*}: 125$ m. W. в. W. Albany.

Usזris, p. v., Blount county, Tenn. 141 m. E. by S. Nashville.

Uniry, p. $\nabla_{0}$, Alexander county, $I l_{0}: 1 \mathrm{~m}$. W. of Cash river, $5 \mathrm{~m}$. N. of the Mississippi r., and $189 \mathrm{~m}, \mathrm{~S}$. by $\mathrm{E}$, Springfield.

Unrry, t. and p. v., Waldo co., $M e_{\text {e.: }} 81 \mathrm{~m}$. N. E. Augusta Drained by branch of Sebasticuok $\mathbf{r}$. There is a pond on its $N$. border, $\mathrm{S}$. of which the $\mathrm{v}$. is located. The $\mathrm{t}$. contains fulling, grist, and saw mills, and tanneries. Pop. of t. 1,557.

UNıTx, p. v., Montgomery co., Md.: to the W. of Pataxent r., 36 m. W. N. W. Annapolis.

UNITr, t. and p. v., Sullivan co, N. $\operatorname{Tamp} .: 36 \mathrm{~m}$. W. Concord. Drained by Sugar r., and other small branches of Connecticut r. Perry's Mountain, in the S. W. part, is partly in this town. The inhabitants are generally engaged in farming. Pop. of t. 961 .

Uxiтx, t. and p. Ү., Columbiana county, Ohio: $149 \mathrm{~m}$. N. E. by E. Columbus. Drained by tributaries of Little Beaver river. The v, of Unity is situate about a mile $\mathrm{N}$. of the Ohio and Pennsylvania $R$. R., which passes through the t. in an E. and W. direction. Pop. of t. 2,095.

UNIT, p. .., Muhlenburg co., Ky. : 144 m. S. W. by W. Frankfort.

Unity, p. o., Crawford co., Penn.: 198 m. W. N. W. Harrisburg.

Unity, t., Westmoreland co., Penn. : $130 \mathrm{~m}$. W. Harrisburg. Drained by Crabtree and Big Sewickly creeks, and Nine Mile run, affording extensive hydrazlic power, improved by various tanneries, distilleries, flouring and saw mills. Pop. about 3,100 .

Universitx of ViRginta, p. o, Albemarle co,; Tirg.: at the University, $1 \mathrm{~m}$. W. Charlottsville, and $98 \mathrm{~m}$. from Richmond by the Virginia Central R. R. Lat. $35^{\circ} 02^{\prime} 03^{\prime \prime}$ N., and long. $78^{\circ} 31^{\prime} 29^{\prime \prime} \mathrm{W}$. The University was founded in 1819 , and in 1850 had 10 professors, and 383 students, 3,500 alumni, and a library of 10,000 rolumes. In the law department there were 70 students, and in the medical department 95 students. This is one of the most flourishing institutions of the kind in the United States.

Upature, p. v., Muscogee co., Ga. : on W. side of branch of Upotoy er, $98 \mathrm{~m}$. W. S. W. Milledgeville. The Muscogee R. R. passes through this place.

UPDEGRaFis, p. o., Jefferson co, Ohio: $111 \mathrm{~m}$. E. by $\mathrm{N}$. Columbus.

Upiraupee, p. $\vee .$, Macon co., Ala. : on Uphaupee cr., 81 m. E. by N. Montgomery.

Upeigr Alton, p. v., Madison co, $\eta_{\text {s }}$ : on elevated ground, $2 \frac{1}{2} \mathrm{~m}$. E. of Mississippi r., and $\mathbf{E}$. of Alton, $69 \mathrm{~m}$. S. by W. of Springfield. It contains several mills and stores, and about 2,000 inhabitants. In 1816 the $\mathrm{v}$. was laid out, and fir the past 20 years it has gradually increased in growth. It contains Shurtleff College, founderl in 1835 , having (in 1850) a president, 6 professors, and 45 students, with a library containing 1,600 volumes.

UPPER AQUeboquk, p. v., Suffolk co.s $N_{\text {. }}$ Y.: $132 \mathrm{~m}$. S. E. by S. Albany.

Uipper Black Edot, p. 0., Bucks co., Penn. : 105 m. E. Harrisburg

UpPerco, p. $\mathbf{v}_{\text {., }}$ Baltimore co., Ma. : situated E. of the $\mathrm{N}$. branch of Patapsco r., 21 m. N. N.W. Baltimore, 43 N. N.W. Annapolis.

Upper Cross Roans, p. o., Harford co., MId: $45 \mathrm{~m}$. N. by E. Annapolis.

Upper Dareq, t. and p. o., Delaware co., Penn.: $89 \mathrm{~m}$. E. by \$. Harrisburg. Drained by Cobb's and Darby creeks. Surface hilly; soil fertile. It has good water-power, and some manufactories.

Upper Dublin, t. and p. o, Montgomery co., Penn. : 99 m. E. Harrisburg. Drained by Darby and Cobb's creeks, by which good water-power is supplied. Surface hilly; soil fertile, consisting of black mold. It has several stores, and a number of mills and factories. Pop. 1,550.

UPPER EMBarRas, p. o., Coles co., $1 l l_{0}$ : about $2 \mathrm{~m}$. W. of head branch of Embarras r., 79 m. E. Springfield.

UpPer Falts, p. v., Windsor co., Verm. : 53 m. S. by E Montpelier.

Upper Freenord, t., Monmouth couniy, $N$. Jer.: $12 \mathrm{~m}$ E. by S. Trenton. It has Assunpink cr. on the N. E., and Crosswick's er, on the S. border. Drained by tributaries of Assunpink and Crosswick's creeks. Surface even, with forests of pine in the S. E. part. It has good water-power, and several manufactories and mills. Pop. 2,556

Upper Grlmanton, p. v., Belknap co., N. Hamp.: on the N. of Winnipisseogee r., $17 \mathrm{~m}$. N. by E. Concord.

Upper GLoUchster, p. v., Cumberland county, Me, : on Royals r., $35 \mathrm{~m}$. S. W. Augusta.

Upper Hanoter, t., Montgomery county, Penn.: $81 \mathrm{~m}$. E. by N. Harrisburg. Drained by Perkiemen or. and its branches. Surface hilly, and in parts rough and broken. Soil red shale. It contains sereral stores and a number of mills, and has about 1,570 inhabitants. The rillage, called New Goshenhoppen, is situate in the forks of Perkiamen creek.

Upper Hunturg creek, p, o, Caroline $\mathrm{co}, \mathrm{Md}$. : on a cr. so called, above its confluence with Choptank r., 35 m. S. E. Annapolis.

UpPer Iow A river, $I \alpha$. : rises in S. part of Minlesota Ter., flows S. E. into Winnisheik co., and then N. E., emptying into the Mississippi $r$. near the $\mathrm{N}$. boundary of the Strte. UPPER JAY, p. 0., Essex co., N. Y.: 120 m. N. Albauy. Upprer Lisle, p. 0., Broome co., $N$. $Y$.: $122 \mathrm{~m}$. W. by $\mathrm{S}$. Albany.

Upper Macungr, t, Lehigh co., Penn.: 74 m. E. N. E. Harrisburg, Drained chiefly by Lehigh cr. It contains several stores, and has a number of grist and saw mills. Pop. about 1,900.

Uppre Mauntango, t. and p. o., Schuylkill en., Penn.: $37 \mathrm{~m}$. N. E. by N. Harrisburg. Drained by two branches of Mahantango cr. Surface diversified, with collection of low hills; soil red shale and white gravel, in general barren. It contains several stores, and has a number of grist and saw mills

Uppeg Marietra, p. v., Lancaster co., Penn.: on the E 
bank of Susquehanna $r$. and on the line of the Columbia Branch R. R., $5 \cdot \mathrm{m}$. above Columbia.

UpPer Marleoro', p. v., and cap. Prince George co, $M d_{.}$: on the S. side of the W. branch of Patapsco r., $4 \mathrm{~m}$. above its mouth, $17 \mathrm{~m} . \mathrm{S} . \mathrm{W}$. Annapolis and $13 \mathrm{~m}$. E. by $\mathrm{S}$. Washington, D.C. It contains the county buildings, etcr, and is a well-built village. The "Marlboro' Gazette" (neut.) is published weekly. Pop. about 800 .

Upper Midduetown, p. v., Middlesex co., Conn.: on W. side of Connecticut r., $15 \mathrm{~m}$. S. Hartford. The name of this place has lately been changed to Cromwell. It contains 2 churches, academy, a few stores, etc.

Uprer Middletowx, p. v., Fayette co., Penn. : on bend of Redstone cr., $5 \mathrm{~m}$. N. Union, $155 \mathrm{~m}$. W. by $\$$. Harrisburg.

Upper Mount Bethei, t., Northampton co., Penn.: on the W. side of Delaware r., 99 m. N. E. Harrisburg. Surface mountainous. It contains several manufactories.

Upper Peach Tree, p. v., Wilcox co., Ala.: on the W. side of the Alabama r., $75 \mathrm{~m} . \mathrm{S}$. W. by W. Montgomery.

Upper Red Hook, p. v., Duchess eo., $N . Y_{.:} 3 \mathrm{~m}$. E from Hudson r., $42 \frac{1}{3} \mathrm{~m}$. S. Albany.

Upper St. Claxe, t. and p. o., Alleghany county, Penn. $173 \mathrm{~m}$. W. Harrisburg. Drained by Chartier's cr. Surface hilly ; soil black loam, and very fertile. It contains a number of stores and several mills and factories, and has a pop. of about 2,700 .

UPPER SANDUEKY, p. v., and cap. Wyandott co., Ohio: on W. side of Sandusky r., $60 \mathrm{~m}$. N. by W. Columbus. It contains the usual county buildings and is well built. Population 783.

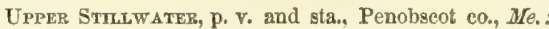
on the W. side of the Penobscot r., opposite Marsh's Island, $69 \mathrm{~m} . \mathrm{N}$. E. Augusta. The Bangor and Piscataquis R. R. passes through this place, $9 \mathrm{~m}$. from Bangor. Great waterpower is here afforded by the falls in the Penobscot river.

Upper Strasburg, p. v., Franklin co., Penn.: on a fork of Heyren's branch of Conedogwinit cr., $10 \mathrm{~m}$. N. W. Chambersburg, $47 \mathrm{~m}$. W. S. W. Harrisburg.

Upper Tract, p. V., Pendleton c $\mathrm{c}_{0}$, Firg. : on the W. side of $\mathrm{S}$, branch of the Potomac r., $119 \mathrm{~m}$. N. W. by W Richmond.

UPper Trappi, p. v., Somerset co., $M d$ : on the N. side of Wicomico cr., $65 \mathrm{~m}$. S. E. Annapolis.

UpPer Tygart, p. o., Carter co., Ky. : on Buffalo fork of Tygart cr., 102 m. E. by N. Frankfort.

UPPERVILLE, p. v., Fauquier co., Firg.: 103 m. N. by W. Richmond. It contains an academy, church, and several stores, and about 350 inhabitants.

U PPER Y ARMOUTI, p. F., Cumberland co., Me.: $41 \mathrm{~m}$. S. W. by S. Augusta.

UPSHUR county, Tex. Situate toward the N. E, and contains 1,053 $\mathrm{sq}$. m. Drained by Little Cypress $\mathbf{r}$, and its branches, and affiuents of Sabine and Big Cypress rivers. Surface undulating; soil fertile, and favorable to the growth of cotton and corn. Grapes grow wild, and might with a little care be rendered a valuable article in the manufacturing of wines. It is thickly wooded, and is interspersed with numerous streams of pure running water. Farms 240 ; manuf. 0 ; dwell. 494 , and pop.-wh. 2,712 , fr. col. 0 , El. 652-total 3,894. Cilpitul: Gilmer.

Upsher, p. o, Preble co., Ohio: $95 \mathrm{~m}$. W. by S. Columbus. It was formerly called New IJope.
UPSON county, Ga. Situate W. centrally, and contains 208 sq. m. Drained by branches of Flint $r$, which forme the S. W. and W. boundary. Surface uneven; soil fertile, and is adapted to cotton, which is produced in abundance, and also to wheat and Indian corn, good crops of which are raised. A portion of the land is eovered with pine. Some minerals are found. Farms 436 ; manuf. 19 ; dwell 795, and pop.-wh, 4,720, fr. col. 0, sl, 4,704-total 9,424 Capital: Thomaston.

Upsonvidle, p. v., Susquehanna county, Penn.: $127 \mathrm{~m}$ N. N. E. Harrisburg.

UPTOs, t. and p. $\mathbf{v}$, Worcester co., Mass. : $31 \mathrm{~m}$. W. S.W. Boston. A tributary of Blackstone r. has its source in this town, and furnishes water-power. Surface rough and hilly. It has several manufactories, among which are wool and leather. The $\mathrm{r}$. is on West $r$. Pop. of $t$ in 1840, 1,466; in $1850,2,023$.

UPToN, p. v., Dodge co., Frsc. : on W. of the W. branch of Rock r., 51 m. E. N. E. Madison.

Uprov, p. v., Franklin co., Penn.: on a branch of the Potomac r., 59 m. S. W. Harrisburg.

Urbana, p. v., and cap. Champaign co., Ill. : on S. side of Salt fork of Vermillion r., $76 \mathrm{~m}$. E. N. E. Springfield. It contains a court-house and jail, and about 400 inhabitants The Chicago Branch of the Illinois Central $\mathbf{R}$. $R$. intersecta this place.

URibava, p. v., Frederick co, $M d_{\text {. : }}$ on the E, side of Monocacy $Y_{r y}$ on the high ground between Back and Bennett's creeks, 844 m. W. N. W. Annapolig.

UrbaNa, p. v., Hickory co., Mo. : on the E. boundary of the county, $72 \mathrm{~m}$. S. W. Jefferson City.

Urbara, t, and p. v., Steuben county, $N_{0}, Y_{0}: 183 \mathrm{~m} . \mathrm{W}$ Albany. A portion of Crooked lake is in the t. Drained by several small streams flowing into the lake. Surface billy ; soil various. The $\mathrm{v}$. is located at the $\mathrm{S}$. end of the lake, at which point there is a landing. The $t_{\text {o contains }}$ numerous mills. Pop. of t. 2,079 .

Ú $39 \mathrm{~m}$. W. Columbus, The r, contains the county buildings, an academy, and several ehnrehes. The Columbus, Piqua, and Indiana R. R. and the Mad River and Lake Erie R. R.

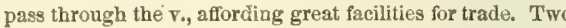
newspapers are issued weekly, "U. Expositor" (dem.), and "U. Citizen and Gazette" (whig). Pop. of v. in 1840, 1,070 in $1850,2,020$. Pop. of t. (including $\mathrm{v}$.) in 1840, 1,286 ; in $1550,3,414$

URB,Ne, p, Y., Jackson $\mathrm{CO}_{*}, I_{\text {. }}$ : $155 \mathrm{~m}$. S, by E. Springfleld. The Illinois Central R. R. passes $2 \frac{7}{3} \mathrm{~m}, \mathrm{E}$. of this place UrBansa, p. v, and cap. Middlesex co, Tirg.: on S. W. side of Rappahannock $r$, near the mouth of Urbanna cr. $46 \mathrm{~m}$. E. by N. Richmond. It contains a court-house, jail, several stores, and abont 200 inhabitants. Considerable pine timber is exported. Steamboats plying between Bal timore and Fredericksbarg make this one of the stopping places.

Drievilife, p. v., Kent co, MI.: on the E. side of Morgan's $c r$. of Chester r., 27 m. N. E. Annapolis.

Ursa, p. o, Adams co., $M l_{0}: 3 \mathrm{~m}$. E. of the Mississippi r., $91 \mathrm{~m}$. W. by N. Springfield.

Unine, p. 0., Grant co., Wisc. : $69 \mathrm{~m}$. W. by S. Madison.

UsqUEPAUGI, p. V., Washington eounty, R. I. : $18 \mathrm{~m}$. W. Newport.

\section{THE TERRITORY OF UTAH.}

UTAF, originally a portion of California Alta, hies between latiudes $37^{\circ}$ and $422^{\circ}$, and longitades $106^{\circ}$ and $120^{\circ}$ west from Greenwich, or about $29^{\circ}$ and $43^{\circ}$ west from $W$ ashington. It is bounded north by Oregnn, east by Nebraska and Now Nexico, south by New Mexico, and suuth-west and west by Califurnia. In extreme length east and west 740 miles, and in breadth 340 miles, it contains an area estimated at $15 \% .973$ square miles.

This territory oceupies the great basin lying between the Focky Uountains on one hand, and the Sierra Nevada on the other; and with the exception of its eastern portion, drained by the Culoradn and its tributaries, forms a distinct geographical region, having nountains, rivers, and lakes all its own, and which origiuate and terninate within its natural limits. It is one of the most peculiar countries of the world; and in many respects assimulates the topography of 568 
Palestine, and like that country has its Dead Sea, its mountain borders, its peculiar people as Palestine of old, and on its west the maritime Philistines of California. The characteristics, historical, geographical, and theocratical, of the two might be enmpared indefinitely; nor is the resemblance less striking in form of government, in manners, and in custoris. The physical elements of the countries are the same, and the moral and religious, modified, however, by external associations, only distinct in the perceptions of the sectarian.

The Great Basin, in which the larger portion of Utah lies, says Dr. Bernhisel, is about 500 miles long east and west, by 265 miles breadth. It has never been fully explored; but so far as it has been, a portion of it is found to consist of arid and sterile plains, another of undulating table-lands, and a third of elevated mountains, a few of whose summits are capped with perpetual snow. Some portions of the basin abound in rich and nutricious grasses. There are within its limits many streams and lakes, and of the latter, the most remarkable is the Great Salt Lake, which is about 70 miles in length, and 30 to 35 miles in breadth. Its waters are a saturated solution of muriate of soda or common salt. Indeed, they contain more salt than they are capable of holding in solution; and when low, considerable quantities of it are precipitated to the bottom of the lake, or rather are there crystallized. No living creature can exist in this lake. A striking feature in the topography of this region is, that none of the streams or lakes have any visible outlet either to the Atlantic or Pacific Ocean. The sources of the Colorado are in the Rocky Mountains, lying in Oregon and New Mexico, and the country in their vicinity is unfit for cultivation.

No portion of that vast extent of country between the Great Basin and the Pocky Mountains is habitable excepting the valley of the Uintah, and perhaps that of Green River. The valleys known in the Great Basin are the Great Balt Lake Valley, Bear River Valley, Utah Valley, Yuab Valley, South Valley, Sevier Valley, and Sand Pitch Valley. The Great Salt Lake Valley, which is much the largest, is about 115 to 120 miles long, and from 20 to 40 broad, but the Salt Lake occupies the greater part of the northern portion of it. The surface of the centre of the valley is level, but ascends gently on either side toward the mountains. There is in the immediate vicinity of the city bearing the name of this lake, a warm saline mineral spring issuing from the base of a mountain, the temperature of which is $108^{\circ}$, and two miles north of this is a similar spring, whose temperature is $125^{\circ} \mathrm{Fahr}$. The character of the best soil in the valleys that are inhabitable, is as follows: one portion of it is a vegetable loam, another a marly loam, and the third a gravelly shale containing some silica. The latitude of Great Salt Lake City is $40^{\circ} 45^{\prime} \mathbf{4 4 ^ { \prime \prime }}$ north. The altitude is 4,300 feet. The climate is milder and drier in general than it is in the same parallel on the Atlantic coast. The temperature in the Salt Lake Valley in the winter season is more uniform than that of the Atlantic States in the same season, the thermometer rarely descending to zero. There is but little rain except on the mountains between the 1 st May and the 1st October, and hence the necessity for irrigation in most places which are susceptible of it. The other valleys bear a general resemblance to the Salt Lake Valley, except that they are much smaller; South Valley being 30 miles long, by 20 broad; Utah Valley about 60 loug, by 20 broad, and Sand Pitch Valley some 40 or 50 long, and perhaps 20 wide. The only timber to be found in this region is in the cañons, on the banks of a few of the streams, and along the bases of some of the mountains. Wheat, rye, barley, buckwheat, oats, and Indian corn are its chief agricultural products; and all the garden vegetables peculiar to the Middle and Western States are produced in great perfection. Cotton, sugar, and rice, are not susceptible of cultivation in the region described; tobacco and sweet potatres can be produced in limited quantities. Only a few portions of the valleys are well supplied with water, and upon the rest but limited crops can be raised, as artificial irrigation in agriculture is indispensable to success. There are tracts of land of considerable extent in each of these valleys which are not susceptible of cultivation, because they can not be irrigated.

$\therefore$ But limited portions, therefore, adds Lrastus Snow, even of the most fertile and warmest valleys in this region, can ever ve made available for agricultural purposes, and only such as are adjacent to streams, and are well located for irrigation. Small valleys, surrounded by high mountains, are the most abundantly supplied with water, the streams being fed by the melting snow and summer showers. Broad extended plains, whether level or broken, are generally arid and unproductive. Such is the whole eastern portion of Utah, including the valley of Green River, and those of its tributaries, which extend from the Sierra Madre on the east, to the Bear Piver divide on the west, and from the Wind River Chain, aud Cascade mountains on the north, to a point at the south where Green River passes through the mountains, descending over rapids and cataracts, to the plains of the lower Colorado. Green River Valley is about 150 miles square; and though larger than several States of the Union, yet its elevation is such, and it is so badly watered, that it is doubted whether a single spot in it is adapted to agriculture. There is, however, a small valley on the Uintah River, about $60 \mathrm{miles}$ south of Fort Bridger, which is, perhaps, the warmest and most inviting in this portion of Utah, and in which a settlement will probably be made.

The Great Basin, although warmer than the eastern section, is, to a great extent, as arid and unproductive. A portion of a large desert, extending through the centre of the basin from north to south, and from the western shore of the Great Salt Lake toward the Sierra Nevada, was evidently once the bed of the lake, for various portions of it are covered with incrustations of salt, and abound in salt springs, but are destitute of fresh water. All the streams that have their sources in the eastern declivity of the Sierra Nevada for a distance of 500 miles, soon disappear beneath the surface, and none of them are known to disembogue themselves either into the lakes of the basin or into the Pacifte Ocean. There are several small valleys and oases along the eastern base of the Sierra Nevada, but these are included within the limits of the State of California. By far the most desirable portions of the Great Basin are the valleys on its eastern border, skirted by the Wasatch Range, which extend from near the mouth of Bear River to the Rio Virgin.

An analysis of the facts presented by Dr. Bernhisel and Mr. Snow, exhibits difficulties of signifeant importance. The whole country is isolated from the States on either side, by mountains impassible except in a few gaps, and even through those during a great portion of the year. Its seclusion in the middle of the continent, indeed, is more complete than if surrounded by waters in the middle of the ocean; and its distance from the settlements in Iowa, Missouri, and Arkansas, is too great to allow of any commereial connection. As to the latter point, witness the following statement: from Independence (on Missouri River) to Fort Kearny, is 400 miles; from the latter to Fort Laramie, 306 miles; thence to the north fork of the Platte River, 127 miles; thence to Rock Independence, 50 miles; thence to South Pass, 100 miles; thence to Fort Bridger, 118 miles; and thence to Salt Lake City, 113 miles; making a total distance of 1,214 miles. To this should be added, 400 miles between Independence and St. Louis, or in all 1,614 miles from the Great Salt Lake to the first considerable market. In, no part of this nast tract can the rains of heaven be relied. upon to any great extent for the cultivation of the soil. The earth is destitute of trees, and in great part also of any vegetation whaterer. Should the Great Pacific Railroad, however, be carried through this territory, the natural obstacles to intercourse would in a great measure be overcome, but at best, Utah must ever remain a country within itself naturally and politically, and as a 
member of the American Union, will ever be independent of that Union in all but in theory. Nor can the theological system held by the inhabitants of Utah, have the sympathies of the more dogmatic sectaries of the old States. The success of the State, then, depends on no external influences; but on the intelligence and forces of the people within.

Utah in 1850 was divided into seven counties, * the general statistics of which and the capitals of each were as follows:

Counties. Dwell. Pop, Farms Manuf. Capitals. | Counties. Dwell, Pop. Farms Manuf. Capitals.

Davis ........ 215 . 1,134 . 112 .. 1 .. Miller's Creek Tooele ...... 33 .. 152 .. 27 .. 0 .. Tooele City

Great Salt Lake $1,283 \ldots 6,157 \ldots 505 \ldots 6$.. . Salt Lake City $\mid$ Utah ........ $41.1 \ldots 2,000 \ldots 144 \ldots 4 \ldots$ Provo City

Iron ........ $86 \ldots 360 \ldots 54 \ldots 2 \ldots$ Cedar City $\mid$ Weber ...... 227 .. 1,186 .. 33 .. 2 .. Ogden City

Ban Pete..... 62 .. 365 .. $51 \ldots 1$... Manti City

The whole number of dwellings in the Territory was at the above date 2,322; of families, 2,322; and of inhabitants, 11,380 ; viz., whites 11,330 -males 6,022 , and females 5,308 ; fr. col. 24 -males 13 , and females 12 ; sl. 26 . Of the whole population there were deaf and dumb, $0 ;$ blind, 2 ; insane, 3 ; and idiotic, 2 . The number of free persons born in the United States was 9,355; the number of foreign birth 1,990, and of birth unknown 9. The native population originated as follows: Maine 151, N. Hamp. 123, Verm. 232, Mass. 350, R. I. 21, Conn. 193, N. Y. 1,430, N. Jer. 96, Penn. 50̃3, Del. 17, Md. 27, Dist. of Col. 1, Virg. 99, N. Car. 92, S. Car. 53, Ga. 12, Flor. 4, Ala. 62, Miss. 119, La. 8, Tex. 7, Ark. 7, Tenn. 294, Ky. 256, Oh. 694, Mich. 121, Ind. 303, III. 1,285, Mo. 519, Ia. 726, Wisc. 30, Calif. 14, Territories 76, and the foreign population was composed of persons from-England 1,056, Ireland 106, Scotland 232, Wales 125, Germany 50, France 13, Spain 1, Portugal 0, Belgium 0, Holland 0, Turkey 0, Italy 1, Austria 3, Switzerland 1, Russia 1, Denmark 2, Norway 82 , Sweden 1, Prussia 6, Greece 0, China 1, Asia 0, British America 33s, Mexico 7, Central America 0, South America 0, West Indies 2, and other countries 12.

The general statistics of the industry and wealth of the Territory, as derived from the census of 1850 and other official returns, are as follows:

Occupied Land, etc.-Improved farm Jand, 16,333 acres, and unimproved, 30,516; valued in cash at $\$ 311,799$. The number of farms under cultivation on the 1st June, 185n, was 926. Value of farming implements and machinery, $\$ \$ 1,288$.

Live Stock,-Horses, 5,429; asses and mules, 325 ; milch cows, 4,861; working oxen, 5,266 ; other cattle, 2,4S9; sheep, 3,262 , and swine, 914 . Value of live-stock, $\$ 546,968$.

Products of Animals,-Wool, 9,222 pounds; butter, $\$ 3,309$ pounds; cheese, 30,998 pounds, and the value of animals slaughtered during the year had been $\$ 67,985$.

Grain Crops.-Wheat, 107,702 bushels; rye, 210 bushels; Indian corn, 9,899 bushels; oats, 10,900 bushels; barley,

1,799 bushels, and buckwheat, 332 bushels.

Other Food Crop8.-Peas and beans, 289 bushels; potatoes-Irish, 43,968 bushels, and sweet 60 bushels.

Afiscellaneous Crops.-Tobaceo, 70 pounds; hay, 4,805 tons; clover-seed, 2 bushels; hops, 50 pounds; flax, 550 pounds: flax-seed, 5 bushels; molasses, 58 gallons; bees-wax and honey, 10 pounds, ete. Value of the produce of market-gardens, $\$ 23,868$.

Home-made Manufactures were produced to the value of $\$ 1,302$.

Manufactures. - In 1850 there were sixteen manufaeturing establishments producing to the annual value of $\$ 500$ and. upward.

The ascertained value of all property, real and personal, assessed for taxation in 1850 amounted to $\$ 986,083$.

Government.-The basis of the government of Utah is identical with that of New Mexico, except that in it there is no provision that "no citizen of the United States shall be deprived of his life, liberty, or property, except by the judgment of his peers or the laws of the land." (See New MExrco, p. 552.)

Historical Sketch.-The territory, now called Utah, formerly constituted a portion of the Mexican province of California Alta, and as such passed into the possession of the United States by the treaty of Guadalupe Hidalgo, 2d February, 1348. Previous to the Mexican War, few white men, except those engaged in scientifle explorations, had entered the country. About the period that the war had broken out, the Mormons were driven from their eity of Nauvoo, in Illinois, by mob violence, and shortly afterward emigrated to the borders of the Great Salt Lake. Their settiements beeame prosperous and populous, and within two years after the first pioneers had entered the country their numbers had increased to about Ifve thousand. After the ratification of peace, they found themselves without a government, and without protection for person or property. To remedy this anomalous condition of the body politic, a temporary government was organized under the style of "The State of Deseret," and under its sanction the usual government offlcials were elected, But the ultimate destiny of the country belonged to Congress, and that body, during the session of $1849-50$, remanded the State back to a territorial condition under its present title. The increase of its population, however, continues to be so rapid, that it must at no distant period be admitted as a State, and whenever such an event is consummated Utah will, no doubt, form as bright an independency as the brightest star of our national galaxy.

Frumore Crry, in Millard County, is the political capital of the Territory.

UтAн county, Utah Ter. Extends from the mountaing W. of the Utah lake to the Rocky mountains, and is about half a degree in width. Green $\boldsymbol{r}$. passes through it, and by its branches drains the whole country. It is everywhere a hilly country, but has extensive and fertile valleys, in which agriculture is pursued with success. Farms 144 ; manuf. 4 ; dwell. 411, and pop.-wh. 1,991, fr. col. 9, sl. 26-total 2,026 . Capital: Provo City

UтAн, p. 0., Warren county, $I l_{*} ; 90$ miles N. W. by N. Springfleld.

UTAI, p. V., La Grange county, Ind.: at head waters of Pigeon r., $132 \mathrm{~m}$. N. by E. Indianapolis.
Uтан, p. o., Lucas co., Ohio: 117 m. N. N. W. Columbus, UтAн lake, Utah co., Utah Ter.: \$. by E. of Great Salt lake, to which it is connected by the river Jordan. It receives Timpanogoo $r$. and Spanish Fork, with other smaller streams from the E., and Utah r. from the $\mathrm{S}$.

Uтан river, Utah Ter. : rises in W. part of San Pete co., flows W. into Juab county, where it takes a $\mathrm{N}$. course, and empties into the $\mathbf{S}$. end of the lake so called.

UтапI LAKE, p. 0, Utah county, Utah Ter.: 82 miles $\mathbf{N}$. Filmore City.

UTICA, p. V., Clark co., Ind.: on W. side of Ohio r., 5 m. below Charleston Landing, $130 \mathrm{~m}$. S. by E. Indianapolis.

* To these bave since been added the counties of "Desert," extending from the Salt Late to the Californian boundary - "Green River," in the N. E. part of the territory - "Millard," in the S. W.- "Washington," in wistil balf a degree, and running along the whole legth of the S. border and "Yuab," lying unmediately N. of Millard County - in all twelve countes. 
UTroA, p. V., Macomb co., Mich.: on E. side of Clinton r., 76 miles E. by S. Lansing. It contains an iron foundry, several mills, stores, etc., an academy, and 2 churches.

UTiCA, p. v., Hinds co, Miss. : 29 m. W. S. W. Jackson.

UTiCA, p. V., Livingston co., Mo. : on S. side of Grand r., at the head of steamboat navigation, $113 \mathrm{~m}$. N. W. Jefferson City.

Utroa, p. o., Dane co., Wisc.

UTroA, p. city, Oneida co., $N . \boldsymbol{Y}_{\text {. }}$ : on $\mathrm{S}$. side of Mohawk r., 84 m. W. N. W. Albany, direct, by railroad 95 m. Lat. (Dutch church) $43^{\circ} 06^{\prime} 49^{\prime \prime} \mathrm{N}$., long. $75^{\circ} 13^{\prime} \mathrm{W}$. The city is built upon ground rising from the river toward the $\mathbf{S}$., and commands a beautiful prospect of the Mohawk valley. It is laid out with general regularity, with spacious streets, many of which are 100 feet wide, and is well built, having many fine blocks of stores and elegant dwellings. It contains a court-house, 20 churches, 2 orphan asylums, a good public market, 5 banks, with aggregate capital of $\$ 1,610,200$, 1 savings bank, and 2 insurance companies. The State Lunatic Asylum is located about $1 \mathrm{~m}$. W. of the centre of the city, on elevated ground, with splendid buildings, surrounded by a farm of 160 acres. In 1850 it contained 449 inmates, 226 males, and 223 females. The total cost of these buildings at completion, according to the plan proposed, will be about $\$ 500,000$. Much attention is given to eduention in the public schools, private academies, etc. There are two flourishing incorporated seminaries, one for males, and the other for females, of which the latter especially has a high reputation; also three literary associations.

Utica is surrounded by one of the best agricultural and manufacturing distriets in the Union. Its connections by the Erie and Chenango canals, and the great line of railroads from Albany to Buffalo, which pass through the eity, give it great advantages for trade. By raitroad, it is $78 \mathrm{~m}$. from Schenectady, $58 \mathrm{~m}$. from Syracuse, $225 \mathrm{~m}$. from Buffalo. The Erie Canal has here been enlarged to 70 feet wide and 7 feet deep, presenting a fine appearance from several beautiful bridges by which it is spanned. A culvert between the canal and the river cost about $\$ 100,000$. The principal manufactures carried on in the city are those of iron and machinery, leather, carriages, and flour; but the smaller establishments are very numerous and various. The newspaper press in 1850 comprised 15 issues: viz., 4 dailies, "Evening Observer" (dem.), "Oneida Whig," "Oneida Herald" (whig), and "Utica Gazette" (whig), each of which issued weekly editions; 5 other weeklies, "Utica Democrat" (free soil), "Gospel Messenger" (free soil), "American Baptist," "New York Baptist Register," and "American Mes senger" (relig.); 3 temperance papers, "Utica Teetotaller," "Cadet's Banner," and "Central City Cadet," the last two semi-monthly; and 1 monthly, "The Mirror" (relig.)

Utica stands upon the site of old Fort Schuyler, erected in 1758, during the French War. In 1794 it contained four inferior houses; in 1798 it was incorporated as a village, and received its present name; in 1817 it was incorporated as a town, and in 1832 received its city charter. It is divided into six wards, and governed by a mayor and 12 aldermen, elected annually. Pop. in 1830, 8,323; in 1840, 12,782; in $1850,17,565$.

UTica, p. V., Van Buren co., Ia.: 63 m. S. S. W. Iowa City.

UTICA, p. Y., Licking co., Orio: on E. side of N. fork of Licking river, $47 \mathrm{~m}$. by the Central Ohio, and the Sandusky, Mansfield, and Newark R. R. from Columbus, Pop. 420.

Utrca, p. V., Yenango county, Penn. : on the W. side of Venango r., 173 m. W. N. W. Harrisburg.

Utrca Muls, p. V., Frederick co., Md.: on Fishing er branch of Monocacy r., $59 \mathrm{~m}$. N. W. Annapolis.

UToY, p. V., Dekalb county, Ga. : 91 miles N. W. by N. Milledgeville. The Macon and Western R. R. passes about $4 \mathrm{~m}$. W. of the village.

UtTef's Corners, p. 0., Walworth co., Wisc.: 58 m. S. E. Madison.
UVALDE county, Tex. Situate centrally, and contains about $1,300 \mathrm{sq} . \mathrm{m}$. Drained by the $\mathrm{R}$ io Frio and its branches, and branches of Nueces r., which runs on its W. border. Surface varied, the $N$. portion being billy and rather mountainous, but in the $\mathrm{S}$. it is undulating, and the land more capable of cultivation; soil in general a dark calcareous loam, and in parts very fertile, and producing abundantiy corn, wheat, colton, tobacco, indigo, and various culinary vegetables. The nopal, or prickly pear, abounds, forming thick hedges, and covering a large portion of land in the co.; the fruit of this tree attains a large size, and has an excellent flavor. It contains good prairie. and timber land.

Uwciland, t. and p. o., Chester county, Penn.: 85 miles E. S. E. II arrisburg. Drained by Brandywine ereek, which affords good water-power. Surface plane, with a slight declination; soil fertile, principally a sandy loam with clay. It contains several stores and a number of mills and factories, and has a population of about 1,600 .

UXBridge, t., p. v., and sta., Worcester co., Mass: $86 \mathrm{~m}$. S. W. Boston. The Blackstone r. crosses the E. part of t Drained by tributaries of Blackstone $r$, and has good waterpower. It contains several manufactories. The Uxbridge Woolen Company, and Messrs. Wheelock's establishment manufacture over 300,000 yards of woolen goods annually. The $\mathrm{v}$. is on the Providence and Worcester P. R., 18 miles S. E. Worcester, and contains a bank, capital $\$ 100,000,2$ churches. There are deposits of iron ore here, and a fine species of granite is quarried. Pop. of t. 2,457 .

\section{V.}

Varl's Cross Roads, p. o., Morrow county, Ohio: 44 m. N. by E. Columbus.

Vall's Gate, sta., Orange county, $N$. $Y_{\text {.: }}$ on Newburg Branch R. R., 5 m. S. W. from Newburg, $8 S$ miles $\mathrm{S}$. by W. Albany.

Varx's MrLus, p. o., Fulton co., N. Y.: 52 m. W. N. W. Albany.

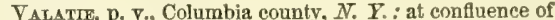
Valatie and Kinderhook creeks, 2 miles N. E. Kinderhook, $19 \mathrm{~m}$. S. by E. Albany. It contains 4 large cotton factories, some other mills, 2 iron foundries, 3 churches, etc. Pop. about 1,650 .

VaLcotr island, $N$. $Y$.: on Lake Champlain 5 miles S. by E. Plattsburg, $3 \mathrm{~m}$. long, and $1 \mathrm{~m}$. wide.

VALeene, p. v., Orange county, Ind. : 85 miles S. by W. Indianapolis.

Vale Mrlis, p. o., Giles co., Tenn. : 66 m. S. by W. Nashville,

Valencia county, $\boldsymbol{N}$. Mex. Situate S. E. and covers a large territory extending between $32^{\circ}$ and $35^{\circ} \mathrm{N}$. lat., and between Texas on the $\mathbf{E}$. and the Rio Grande on the W. The Sierra Blanco follows the course of the Rio Grande at a distance of about $40 \mathrm{~m}$., and is the watershed of the country, dividing the Pecos from the great river on the W. It abounds in gold and silver, etc., and at many places mining was once extensively engaged in. The Guadalupe mts. also extend $\mathrm{N}$. into this county, and beyond them are several detached elevations. The settlements are all on the Rio Grande, the E. portion being a wilderness. Farms 1,879; manuf. 1 ; dwell. 2,877 , and pop.-wh. 14,147, fr. col. a total 14,147. Capital: Valencia.

VAlextia, p. 0., Shelby county, Ohio: 45 m. W. N. W. Columbus.

Valie Crucis, p. o, Ashe co., N. Car.: $164 \mathrm{~m}$. W. by N. Raleigh. Here is an Episcopal missionary school.

Vallejo, p. v., Solano county, Calif.: and capital of the State of Califormia, is situated on the Napa Straits, 25 miles N. N. E. San Franciseo. The permanent location of the seat of government at this place is not certain, the legislature of 1S52-3 having adjourned to Benicia on Suisun bay, 8 miles E. by $\mathrm{S}$. Tallejo. The present general interests of Vallejo are entirely agricultural and grazing. The eminence 
designated for the capitol buildings commands an extensire prospect of beautiful scenery.

ValteiY, p. o., Tazewell county, Virg.: $230 \mathrm{~m}$. W. by S. Bichmold.

Fallex Falis, p. o., Providence co., $R$. $I$. : on E. side of Blackstone r., 30 miles $\mathrm{N}$. Newport. Here are large factories of print goods, running about 15,000 spindles, and making over $3,000,000$ yards per annum.

Vallex Forge, p. v. and sta., Chester co., Penn.: on the S. side of the Schuylkill r., near the mouth of Valley ereek, $70 \mathrm{~m}$. E. Harrisburg. It contains several factories and mills, which are also numerous upon the banks of the stream above. The Philadelphia and Reading $R$. R. passes through, $23 \mathrm{~m}$. from Philadelphia, $70 \mathrm{~m}$. from Pottsville. This locality is of historical interest, from laving been the winter quarters of the American army in 1777-8.

VALley Grove, p. 0., Monroe co., Ark. : 67 m. E. by S. Little Rock.

VAlLex Grove, p. 0., De Soto county, Miss.: $168 \mathrm{~m} . \mathrm{N}$. Jackson.

Vallex Head, p. o., De Kalb co., Ala. : 159 m. N. by E. Montgomery.

VAliey Pratrie, p. 0., Barry co., Mo. : 154 m. S. W. by S. Jefferson City.

VAlies Tows, p. o., Cherokee county, N. Car.: $304 \mathrm{~m}$. W. by S. Raleigh.

VAllonia Springs, p. o., Broome co., N. $Y .: 10 \mathrm{~s}$. W. S. W. Albany.

VALONIA, p. v., Jackson c0, Ind.: 621 m. S. Indianapolis.

Valparatso, p. v., and cap. Porter co., Ind. : on E. side of Salt cr., $123 \mathrm{~m} . \mathrm{N} . \mathrm{N}$. W. Indianapolis. It contains the county buildings, 3 hotels, churches, etc. First settled in 1836. The "Practical Observer" (dem.) is here published.

VAN BuRE: county, Ark. Situate N. centraily, and contains $1,456 \mathrm{sq} . \mathrm{m}$. Drained by Little Red $\mathrm{r}$. and its branches. Surface varied; soil fertile, and adapted to corn and grazing. Good crops of wheat are raised, and there is some fine timber on the land. Farms 380 ; manuf. 0 ; dwell. 448 , and pop.-wh. 2,761, fr. col. 0, sl. 103-Lotal 2,864. Capital: Clinton.

$V_{\triangle N}$ BUREN county, Ia. Situate S. E, and contains 450 sq. m. Des Moines r, a tributary of the Mississippi, flows through it from $\mathrm{N}$. W. to S. E., by which and its branches it is drained. Surface undulating, in parts hilly; soil fertile. It is a fine mineral country, and iron, copper, and tin ores are found abundantly. Marble of excellent quality is quarried here. Farms 998; manuf. 23 ; dwell. 2,069, and pop.-wh. 12,266, fr. col. 4-total 12,270. Capital: Keosauque. Putlic Works: Des Moines River Improvements. VAN BUREN county, Mich. Situate S. W. of the Southern Peninsula, and contains 620 sq. m. Drained by Pawpaw $\mathrm{r}$, and its branches; in the central part, by S. branch of Black r., and Brush and Dowagiake creeks, which supply good water-power. Surface level; soil fertilc, the chief productions of which are, wheat, Indian corn, and potatoes. The Pawpaw $\mathrm{r}$. is navigable for boats $70 \mathrm{~m}$. from its mouth. Farms 459; manuf. 18 ; dwell. 1,058, and pop.-wh. 5, 500 fr. col, 0-total 5,800, Capital: Pawpaw. Pullic Works. Michigan Central R. R.

Van Burev county, Tenn. Situnte N. centrally, aud contains $312 \mathrm{sq}$. m. Drained by Laurel er. and other branches of Caney fork of Cumberland $\mathbf{r}_{\text {, }}$ which flows on its N, border. Surface undulating; soil fertile, and adapted to wheat am grain. Farns 192: manuf. 5 : dwell. 414, and pop.-wh. 2,451, fr. col. 18, sl. 175--total 2,674. Capital: Spencer.

Tax Beres, p. v, De Falh co., Alu. : on E, side of Will's cr., 182 m. N. by E. Montgomery.

Van Buren, p. o, De Kalb co., IU.: 147 m, N. N, E. Springfield.

VAN Buren, p. o, Anderson $\mathrm{co}_{0,}, \bar{k} y_{0} ; 18 \mathrm{~m} . \mathrm{S}$. by W Frankfort.

VAY Buren, p. F., and eap. Crawford co, Ark.: on N. 872 side of Arkansas r., 124 m. W. N. W. Little Rock, It contains the county buildings, several stores, eten, and has considerable river trade. The "Van Buren Intelligencer" (dem.) is issued weekly. Pop. 547.

VaX Buren, p. o., Clay co., Ind.: $55 \mathrm{~m}$. W. S.'W. Indianapolis. The Terre Haute and Richmond R. R. passes near it, $10 \mathrm{~m}$. from Terre Haute.

VAN Buren, p. o. Itawamba co., Miss.: on W. side of Tombigbee r., 165 m. N. E. by N. Jackson. Pop. about 100.

Van Buren, p. v., and cap. Ripley co., Mo.: on E. bank of Current r., 123 m. S. E. by S. Jefferson City. It contains the county buildings and several $d$ wellings.

VAN BUREN, t. and p. o., Onondaga co., N. Y.: on S. side of Seneca r., $144 \mathrm{~m}$. W. by N. Albany. Surface undulating. Drained by Camp brook and other streams flowing S. into Seneca $\mathbf{r}$. The Oswego and Syracuse R. R. passes through its N. E. part, and the Erie Canal touches its S. border at Canal p. o. It contains mills of various kinds, and has considerable manufactures. Pop. of t. 3,873 .

VAN BUREN, p. o., Hancock co, Ohio: 95 m. N. W. by N. Columbus.

Vay Buren, p. 0., Washington co., Penn.: $180 \mathrm{~m}$. W. Harrisburg.

VAx Burex, p. v., Hardeman county, Tenn.: $144 \mathrm{~m}$. S. W. by W. Nashville,

Van Buren Centre, p. O., Onondaga co., $N . Y .: 9 \mathrm{~m}$. W. N. W. Syracuse, 142 m. W. by N. Albany.

Vax Buren Furnace, p. o., Shenandoah co., Firg.: $116 \mathrm{~m}$. N. W. by N. Richmond.

VaN Burki Harior, p. v., Chautauque co., $N, Y$.: on E. side of Lake Erie, $295 \mathrm{~m}$. W. Albany. The Buffalo and State Line R. R. passes near it, $4 \mathrm{~m}$. from Dunkirk. It is regularly laid out, and has a convenient landing.

VANCEBOBo', p. Vo, Winnebago county, $I l l_{0}: 177 \mathrm{~m} . \mathrm{N}$. Springfield.

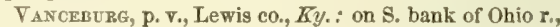
$93 \mathrm{~m}$. E. N. E. Frankfort. It contains a few stores, shops, etc. A good bed of copperas, a fine limestone quarry, and clay suitable for stone-ware and fire-brick are found in the vicinity.

VANCE's Ferry, p. o., Orangeburg district, S. Car,: on S. W. bank of Santee r., 50 m. S. E. by S. Columbia.

Vanceville, p. o., Washington co., Penn.: $165 \mathrm{~m}$. W. Harrisburg.

Van Clevestilife, p. o., Berkeley co, Virg.: $128 \mathrm{~m}$. N. by W. Richmond.

VANCOUVER (FORT), va, Clark cn, Oreg. Ter.: on N. bank of Columbia r., $12 \mathrm{~m}$. above the mouth of Willamette r., 60 m. N. N. E. Salem. Columbia Barracks, at this place, is a U. S. military post garrisoned by artillery.

VANDALIA, p. vo, and cap. Fayette co., Illo: on W. bank of Kaskaskia r., 66 m. S. E. by S. Springfield. Lat $35^{\circ} 50^{\prime}$ N., long. $89002^{\prime} \mathrm{W}$. Its site is high, undulating, and was originally a timbered tract. It was selected by commissioners, with 4 sections of land, granted by Congress in 131 , for the seat of government for 20 years. The capital was removed to Springfield Jnly 4 th, 1839 . It was regulariy laid out, with streets 80 feet wide, and erossing at right angles. In the centre is a public square, on elevated ground, containing the public buildings formerly used by the State. It also contains a U. S. land-office and several churches. The "Fayette Yeoman" is published weekly. From the important railroad connections which Vandalia will soon have with all parts of the State, it promises to become one of the greatest thoroughfares of trade and travel in Illinois. The railmads already in construction to pass through it are, Illinois Central R. R.; Massac and Sangamon R. R.; and Mississippi and Atlantic R. R. The National Road has preriously been of much beuefit. The surrounding country near the river is heavify timbered, and a few miles back are extensive prairies. Pop. about 1,100.

VAxidala, p. o., Owen county, Ind.: 51 miles $\mathbf{S}$. W. Indianapolis. 
Vandalta, p. 0., Cass co., Mich.: 96 m. S. W. Lansing. Vandalia, p. o. Montgomery co., Ohio: $2 \mathrm{~m}$. W. of Miami r. and canal, $62 \mathrm{~m}$. W. by S. Columbus.

Vaxderburg county, Ind. Situate S. W. on Ohio r., and contains 240 sq. m. Drained by Big Pigeon, Blue Grass, Little, and Locust creeks. The succession of bottoms, hills, and table-land, characteristic of the river counties, is here maintained. The uplands are undulating or rolling; snils everywhere productive. Farms 743; manuf. 76 ; dwell. 2,659, and pop.-wh. 11,187, fr. col. 227 -total 11,414. Cap. ital: Evansville. Pullic Works: Wabash and Erie Canal, and Evansville and Illinois R. R.

$\nabla_{\text {AN }}$ Dedsenville, p, v, and sta., Berkshire co., MCss.: on W. side of Housatonic r., $117 \mathrm{~m}$. W. by S. Boston. The Berkshire R. R. passes through the v., $23 \mathrm{~m}$. from Pittsfield, and the Stockbridge $R, R$. extends hence to the State line.

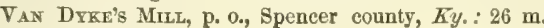
W. S. W. Frankfort.

Van Ettonville, p. o., Chemung co., $N_{0} Y_{0}: 156 \mathrm{~m}$. W. by S. Albany.

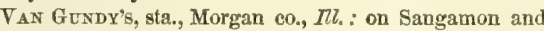
Morgan R. R., 50 m. from Springfield, 5 m. E. from Naples. VAN Hru, p. o., Hawkins co., Tenn. : 215 m. E. by N. Nashville.

VAN Hisevillei, p. 0., Mercer county, N. Jer

VAN Hook's STORz, p. o., Person county, N. Car.: $47 \mathrm{~m}$ N.N.W. Raleigh.

VAN Hornestrule, p. 0, Herkimer co, $N$. Y.: $60 \mathrm{~m}$. W. N. W. Albany.

VANLUE, p. o., Hancock county, Ohio: $74 \mathrm{~m}$. N. by W. Columbus.

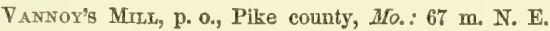
Jefferson City.

VANN's VALLEX, p. o., Floyd co., Ga.: 146 m. N.W. by W. Milledgeville.

VArN's VAllex, p. o., Delaware co., Ohio: 20 m. N. N. E. Columbus.

VAN SYCKLES, p. o., Hunterdon co, N. Jer, : at foot of Musconetong Mountain, 81 m. N. N. W. Trenton.

VAN Werx county, Ohio. Situate W. toward the N., and contains $396 \mathrm{sq} . \mathrm{m}$. Drained by St. Mary's and Little $\mathrm{Au}$ glaize rivers, and other small streams. Surface level; soi varied; in some portions consisting of a fine black mold, while in many parts it is sandy and of a light formation; $i$ is however in general fertile, and very productive. A dense forest of pine and other timber covers a large portion of the county. Farms 317 ; manuf. 13 ; dwell. 686 , and pop.wh. 4,766, fr. col. 47-total 4,813. Capital: Van Wert. Public Works: Ohio and Indiana R. R.; Miami Canal, ete

VAN Wert, p. $v_{\star,}$ and cap. Paulding co, Ga.: $130 \mathrm{~m}$ W. N. W. Milledgeville. It contains the county buildings, an academy, and church. Pop. about 150.

VAN WERT, p. v., and cap. Van Wert co., Ohio: $105 \mathrm{~m}$ N. W. by W. Columbus, It contains a court-house, jail, etc. The Ohio and Indiana R. R. will pass near this place. Two Democratic papers are published: "Van Wert Democrat," and "Section Ten Budget." Pop. 270.

VAnzandt county, Tex. Situate toward the N. E., and contains 919 sq. m. Drained by. afluents of Sabine and Neches rivers, and numerous small streams. Surface undulating and diversified; soil fertile, and is generally productive and favorable to the growth of cotton and corn. It has some beds of iron ore, and is thickly covered with forest trees. Farms 139 ; manuf. 4 ; dwell. 246 , and pop.whites 1,308, free col, 0, sl. 40--total 1,348. Capital: Jordan's Saline.

Varennes, p. v., Anderson dist., S. Car.: on W. side of Rocky r., 94 m. W. by N. Columbia.

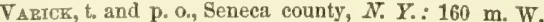
Albany. It is bounded E. by Cayuga lake, and W. by Seneca lake. Surface somewhat elevated in the middle; soil fertile. The inhabitants are generally engaged in farming. Pop. 1,372
'Varietr Mills, p. o., Nelson co., Virg.: 85 m. W. by $\mathbb{N}$ Richmond. It contains several dwellings and a few mills. VARNA, p. V., Tompkins county, N. Y.: $140 \mathrm{~m}$. W. by S. Albany, on Fall cr., which affords water-power to severa] mills. Pop. about 200.

Varrsburg, p. v., Wyoming con, $N . Y_{.}:$on $E$. side of head branch of Tonawanda creek, $236 \mathrm{~m}$. W. Albany. It contains several mills and stores, and 2 churches. Pop. about 250 .

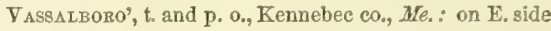
of Kennebec r., $10 \mathrm{~m}$. N. by E. Augusta. Vessels come from the ocean to this $\mathrm{t}$. by means of the dam and lock at Augusta. It contains several large ponds, the outlets from two of which furnish water-power. There is a large number of tanneries, grist and saw mills, etco, in the to Population 3.099 .

Vaughanstille, p. O., Putnam co, Ohio: $120 \mathrm{~m}$. N. W. Columbus,

VajghaN Vallex, p. o., Rutherford co., Tenn.: $30 \mathrm{~m}$. S. E. Nashville.

Velasco, p. v., Brazoria county, Tex.: at the mouth of the Brazos r. $170 \mathrm{~m}$. S. E. by E. Austin City. This place carly received a business impulse from the settlement of capitalists in the village and vicinity. The Brazos is here about 300 yards wide, with a good harbor. The village has some coasting trade, and promises to become one of the most important places on the coast of Texas.

Venango county, Penn. Situate toward the N. W., and contains $692 \mathrm{sq}$. m. Alleghany r. passes through its central portion, by which and its branches it is drained. Surface undulating; soil fertile, and produces excellent crops of wheat, Indian corn, and potatoes. It has good grazing land, on which large numbers of eattle and hogs are fattened-enough to supply the neighboring markets. Farms 1,730 ; manuf. 72 ; dwell. 3,065, and pop.-wh. 13.270, fr. col. 40-total 18,310. Capital: Franklin. Pultic Works: Alleghany Valley R. R.; Pitsburg and Erie R. R. ; Frankliu Canal and R. R.

Venango, p. o, Crawford con, Penn.: 193 m. N.W. by W. Harrisburg.

Venice, t. and p. 0., Cayuga county, $N_{0} Y_{0}: 144 \mathrm{~m} . \mathrm{W}$. Albany. Surface rolling; soil gravelly and clay loam. Drained $\mathrm{S}$. by Salmon cr. The inhabitants are generally engaged in farming. Pop. 2,028.

Venicr, p. v., Erie co., Olio : on S. side of Sandusky bay, at entrance of Cold er., 99 m. N. by E. Columbus, " It contains a large flouring-mill-and some others, a few warehouses and stores. The Junction R. R. from Toledo to Sandusky, will pass through this place. Pop. about 450.

Venice, p. o, Washington county, Penn. : 160 m. W. IIarrisburg.

VENICE, p. 0., Shiawassee co, Mfich,: 25 m. E. N. E. Lansing.

Venice, p. o., Madison co, $I l l .:$ on E, side of Mississippi river, $82 \mathrm{~m}$. S. S. W. Springfield.

Vera Cruz, p. o., Wells con, Ind.: 80 m. N. E. by N. Indianapolis.

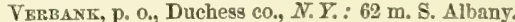

Ferdikrvilet, p. o., Orange co., Virg. : 58 m. N. W. Riehmond.

VerdoN, p. 0., Hanover co., Virg.: $22 \mathrm{~m}$. N. Richmond. VERgrines, p. o., Jackson county, $I l l:$ : 134 m. S. by E Springfield.

Vergenses, p. 0., Kent co., MFich. : 44 m. N. W. Lansing. Vhrgennes, p. city, Addison co, Term. : is beautifully situated on Otter cr., at the head of navigation, $7 \mathrm{~m}$. from its mouth, $38 \mathrm{~m} . \mathrm{W}$. by S. Montpelier. Otter cr. is here about 500 feet wide, and is divided by two islands, forming three channels, and separate falls of 37 feet each, furnishing immense water-power. The eity is neatly built, and presents 2 very picturesque appearance. The factories, mills, and tanneries, improving the water-power of the cr., are numerous. The manufacture of iron, obtained from Monkton, is 
carried on extensively. The city contains 1 bank, cap. $\$ 100,000$, an academy, an United States arsenal and ordinance depot, and 3 churehes. The Rutland and Burlington R. R. passes through, $98 \mathrm{~m}$. from Bellows Falls, $22 \mathrm{~m}$. from Burlington. Otter cr. is somewhat crooked between the city and the lake, but vessels of 300 tons can come to the wharves. Vergennes was first settled in 1766, and incorporated in 1788. Here was fitted out the squadron of $M \cdot$ Donough, which achieved the celebrated victory of Plattsburg, Sept. 11th, 1814. The "Vergennes Vermonter" (whig) is published weelily. Pop. in 1840, 1,017; in 1850, 1,378.

Veruilution county, Ill. Situate E., and contains 1,20s sq. m. Drained by Big and Little Vermillion rivers and their affuents, which traverse the eo. N. and S. Surface undulating; a large portion is prairie. Soil fertile, and produces wheat and grain in abundance. Farms 1,269; manuf 15; dwell. 1,985, and pop.-wh. 11,482, fr. col. 10-total 11,492. Capital: Danville. Public Works: Great Western Central R. R.

Vermulion county, Ind. Situate W., between Wabash r. and the Illinois State line, and contains $280 \mathrm{sq} . \mathrm{m}$. Numerous streams, of which Big and Little Vermillion rivers are the principal, and tributaries of the Wabash, drain the land. Surface high and level, with some bluffs, and twothirds of the whole is covered with forest. Soils excellent. Coal is abundant, and extensive beds of iron ore are found on Brouillet's creek. Farms 733; manuf. 46; dwell. 1,509, and pop.--wh. 8,613, fr. col. 18-total 8,661. Capital: Newport.

Vermilliox parish, $L a$, situate S. W., and contains 1,545 sq. m. Drained by small streams of Vermillion river. Surface generally level, and much of it covered with pine forest and other timbers; soil fertile, and, with cultivation, producing rice, cotton, sugar, etc, which form its staple. It contains part of Mermentau lake in its western portion, and small bays of the lake which indent its coast. On the eastern side is Vermillion bay, a large expanse of water, and washing part of the shore of St. Mary's co, in the N. W. In the extreme S. E. is Grand Island, separated from it by Grand Bass. Farms 198; manuf, 0; dwell. 406 and pop.-wh. 2,328, fr. col. 14, sl. 1,067-total 3,409. Capital: La Fayette.

Vermillion, p. o., Oswego co., $N$. Y. : 130 m. W. N. W. Albany.

Veemillion, t., p. v., and port, Erie co., Ohio: $98 \mathrm{~m}$. N. N. E. Columbus. Bounded N. by Lake Erie. The t. contains large deposits of iron ore, which is much wrought The v. at the mouth of Vermillion r. has a convenient harbor, improved by U. S. Government. Its imports, in 1848 amounted to $\$ 150,000$; exports, $\$ 207,200$-total lake trade, $\$ 307,200$. The Junction R. R. from Toledo to Cleveland will pass through this place. Pop. of t. 1,515.

Vermulion river, $M l l$. : rises in Livingston co., flows

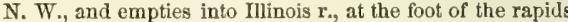
in La Salle co. It furnishes good water-power by falls and rapids in its lower part. On its banks are valuable quarries of limestone, coal, and sandstone.

Vermilion river and bay, La. : the r. rises in St. Landre par., and flows S. into W. part of Vermillion bay. It is navigable to Vermillionville. The bay is about $20 \mathrm{~m}$. long, with the same width, and has 10 or 12 feet water, but not more than 5 feet on the bar at its entrance. Côte Blanche bay connects it with the Gulf of Mexico.

VermLliontilie, p. v., and cap. La Fayette par., La.: $50 \mathrm{~m}$. W. by S. Baton Rouge. It is situated on a beautifu] plain, $1 \frac{1}{2} \mathrm{~m}$. from W. bank of Vermilion r., at the head of navigation, and contains the county buildings, etc. Pop. about 250 .

\section{THE STATE OF VERMONT.}

VERYONT, so ealled from the verdant aspect of its mountains, lies between $42^{\circ} 44^{\prime}$ and $45^{\circ}$ latitudes north, and between $71^{\circ} 88^{\prime}$ and $73026^{\prime}$ longitudes west from Greenwich, or between $3036^{\prime}$ and $5 \circ 24^{\prime}$ east from Washington. It is bounder on the north by Lower Canada, on the east by New Hampshire, on the south by Massachusetts, and on the west by New York. Its eastern boundary is formed by the Connecticut River, and on the west it is separated from New York chiefly by Lake Champlain. The length of the State from north to south is 157 miles, and its breadth from east to west from 40 to 92 miles, its widest part being on the northern State line. The superficial area of the country is estimated to contain 10,212 square miles.

The surface of Vermont, with some slight exceptions, is mountainous. The most striking feature in its topography is the range called the Green Mountains, which traverses the State in a direction north and south. Southward it is continued into Massachusetts, where it is known under the name of the Hoosic Mountains. In the centre of the State this ridge bifurcates: one branch, the Western, and principal, continuing in a northerly direetion, sinks down gradually, and terminates near the northern boundary; and the other, or Eastern branch, called also the "Height of Land," strikes a course to the north-east, and, passing into Canada, is lost on the shores of the St. Lawrence. The latter divides the streams of lakes Champlain and Memphremagog from the tributaries of the Connecticut, while the former, though lofier, presents a more broken outline, and is cut through by several rivers. It is a curious fact that this immense barrier has a passage through it, even without any high hills, and the southern branch of the Onion River, which passes through it and flows into Lake Champlain, has its source very near to, if not in, the same swamp with the head waters of White River, which flows into the Connecticut. The Vermont Central Pailroad also passes along these streams without any considerable elevations or depressions, although near the base of Camel's Rump, one of the highest peaks of the range. The part of the mountains which traverses the southern portion of the State forms the watershed between the Hudson and Connecticut rivers. The base of these mountains varies from ten to fifteen miles in width. Beautiful and fertile valleys intersect them everywhere, and the slopes are covered with growths of small evergreen trees and shrubs, and the summits with greun mosses and winter grasses. There are many flne farms among the hills, and much of the land upon them is excellent for grazing. Before the mountain bifurcates, the highest summit is Killington Peak, 3,675 feet above the level of the sea; but there are two higher culminations after it divides, and which are in the western range: these are Camel's Rump, on the south side of Onion River, which is 4,18s feet high; and Mansfleld Mountain, the highest of all, which is 4,279 feet high. Ascutney is an isolated mountain in the town of Windsor, near the Connecticut, the apex of which is 8,320 feet above tide-water. In the neighborhoods of Lake Champlain and the Connecticut River the country is only moderately uneven, and in many places extensive level tracts are found, which form a striking contrast to the gen eral features of the country.

The Connecticut River washes the enstern borders of the State, the watershed, or dividing ridge already mentioned being nowhere more than thirty-five miles from the river, and throughout most of its course not more than half that distance; its tributaries in this State, viz, the Deerfield, White, Black, and Passumpsic rivers are scarcely more than mountain torrents. On the western side of the ridge the streams bave chiefly a north-westerly course, and are considerably longer; but as they force their way through the westerly branch of the mountain ranges, their courses are alsn rapid 


\section{VERMONT.}

and much broken by falls. The Missisqui, Lamoille, Onion, and other creeks flowing into Lake Champlain, are the principal, and these affurd navigation for lake craft to their lower cascades, from five to six miles up. The Battenkil and Hoosic rivers have their rise in the $\mathrm{S}$. part of the range, but soon pass into New York. The whole State is abundantly watered by pure running brooks, many of which, as also the larger streans, are turned to use in operating numerous mills.

Lake Champlain extends along the western border a distance of 140 miles, and varies in width from one to sixteen miles, covering an area of 600 square miles. It is sufficiently deep for the largest class of shipping; it is, however, usually navigated by vessels of 80 or 100 tons, to which the rivers and canals are accessible, and several fine steamboats ply to and from different points on its shores. It receives the surplus waters of Lake George, and discbarges itself by the Sorrelle or Richelieu, which, by means of some canals round its rapids, affords a navigable communication with the St. Lawrence. At its southern base it is connected by canal with the Hudson River and the New York and Erie Canal. There are several large islands in the northern part of the lake, which, together with Alburg Peninsula, divide it in its broadest part into two unequal proportions. There are also some fifty or sixty smaller islands. The aspect of its shores is varied and pleasant; the peaks of the Green Mountains are visible in the distance, and well-cultivated farms line its shores. The harbors on the Vermont side of the lake are generally good, and the principal of these are Burlington, St. Albans, and Vergennes. Lake Memphremagog is partly in this State, but mostly in Canada; it is thirty miles long, and discharges its waters into the St. Lawrence through the ehannel of the St. Francis River. Between the mountains and New York State line there are several smaller lakes, which are known under the names of Bombazine Lake, Austin Lake, Great Trout Pond, ete., which are remarkable for the purity and clearness of their waters and the bland scenery that surrounds them.

The minerals produced in this State are iron, copper, zinc, and a great variety of rocks. Iron occurs in great abundance. Sulphuret of iron, or pyrites, is found at Strafford and Shrewsbury, from which an immense quantity of copperas is annually manufactured. Copper has been discovered near Brandon, and a few miles south-east of that place a bed of silver and copper. The ore of the latter is incorporated with milk quartz and argillaceous slate ; an average specimen, analyzed by W. H. Shepherd, mineralogist, yielded 31.13 per cent. of pure silver and 17.09 of copper. Lead, zine, and manganese are also found. At Monckton, near Burlington, there is also an extensive bed of kalin, or porcelain earth. Granite, however, is the great staple, and marbles of fine quality are extensively quarried at Middlebury, Swanton, Bennington, etc. The novaculite, or oil-stone, sold under the name of magog oil-stone, is found on one of the islands in Lake Memphremagog, and quarries of slate are wrought near Brattleboro'. Vermont has also several mineral springs, containing iron and sulphur, which are resorted to for relief in many cutaneous and chronic complaints.

The climate assimilates that of New Hampshire, and is variable and cold, but extremely salubrious. Snow lies on the ground from the middle of November to the end of April, and on the hill-sides it is often six or eight feet deep. The mean annual range of the thermometer is about $120^{\circ}$, the temperature in winter sinking sometimes to $25^{\circ}$ or $30^{\circ}$ below zero, and in summer rising to $90^{\circ}$ or $100^{\circ}$. Trees commence to. bud early in April, and flowers unfold themselves in May. The first frosts appear about the middle of September, but are light until November. The summer season is fair and serene, and although the heat of the day is sometimes excessive, the nights are always cool. Through September and October the finest weather prevails, with gentle winds and a blue sky.

The natural growths of Vermont are hemlock, spruce, and fir, which flourish on the mountain sides; the lower tracts abound with elm, oak, hickory, butternut, pine, beech, sugar-maple, and birch, and the cedar grows luxuriantly in the swamps. The indigenous animals are wolves, foxes, and others, similar in a great measure to those which are spread over Canada and the North-eastern States generally. The lakes and rivers abound with excellent fish.

The soils of 'Vermont are generally rich and loamy. On the borders of the rivers are fine tracts of valley land, which consist of a deep black alluvial deposit-these are sometimes a mile in width, and very productive in grain, grass, and garden vegetables. The uplands are in many places searcely inferior to the intervales, and are in general sufficiently free from stone to admit of easy cultivation. The hills and mountains, that are not arable on account of their steepness or the rocks, yield the best of pasturage. There is hardly any part of the country better adapted to the rearing of horses, horned cattle, and sheep, than the mountain regions of this State. Wheat is raised more abundantly on the western than on the eastern side of the mountains. The soils and climate of all parts are favorable to the growth of the apple and most other kinds of garden trees; but the peach seldom comes to perfection anywhere. The greater part of the State is better suited to grazing than to tillage. Springs and brooks are very numerous, and there is no extensive tract but is well supplied with running water.

Vermont is divided into 14 counties, the general statistics of which, and the capitals of each, in 1850, were as follows:

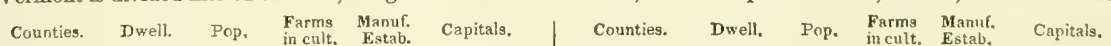

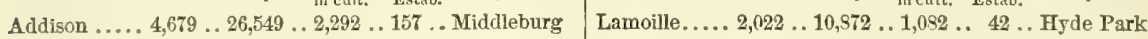

Bennington .. 8,404 . 18,539 . . 1,397 . . 147 .. Manchester $\quad$ Orange . . . . 5,192 . 27,296 .. 2,677 .. 86 .. Chelsea Caledonia... 4, $431 \ldots 23,086 \ldots 2,754 \ldots 245 \ldots$ Danville $\ldots$ Orleans . . . 2,780 . 15,707 .. 2,055 .. 68 .. Irasburg Chittenden . . 4,805 . 29,036 .. 1,908 . . 201 . Burlington Rutland . . . 6,661 . 39,059 . 2,668 .. 275 . Rutland

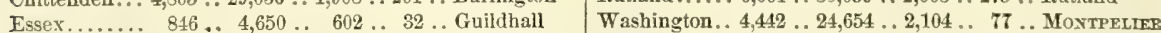

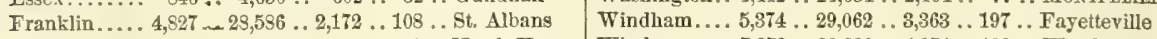
Grand Isle... 691 .. 4,145 .. 339 .. 8 .. North Hero $\mid$ Windsor . . . . 7,373 .. 38,320 .. 4,274 . 192 .. Woodstock

The whole number of dwellings in the State at the above date was 56,327 ; of families, 55,475 ; and of inhabitants, 313,611; viz., whites 312,902-males 159,374, and females 153,528; fr. col. 709 -males 366 , and females 343 . Of the whole population there were, deaf and dumb-wh. 148, fr. col. 1,-total 144; blind-wh. 138, fr. col. 0-total 135; insanewh. 552, fr. col. 0-total 552, and idiotic-wh. 280, fr. col. 1-total 281. The number of free persons born in the Cnited States was 250,966 , the number of foreign birth 32,831 , and of birth unknown 323 . The native population originated as follows: Maine 835, N. Hamp. 19,609, Vermont 232,086, Mass. 15,059, R. I. 801, Conn. 4,551, N. Y. 7,218, N. Jer. 171, Penn. 135, Del. 1, Md. 29, Dist. of Col. 5, Virg. 21, N. Car. 7, S. Car. 5, Ga. 18, Flor. 9, Ala. 6, Miss. 5, La. 12, Tex. 1, Ark. 2, Tenn. 6, Ky. 7, Oh. 166, Mich. 86, Ind. 15, Ill. 34, Mo. 10, Ia. 5, Wisc. 32, Calif. 0, Territories 1; and the foreign population was composed of persons from-England 1,546, Ireland 15,377, Seotland 1,045, Wales 57, Germany 218 , Franee 40, Spain 3, Portugal 5, Belgium 0, Holland 2, Italy 7, Austria 0, Switzerland 2, Russia 1, Denmark 1, Norway S, Sweden 0, Prussia 6, Greece 0, Asia 7, Africa 0, British America 14,470. Mexico 0, Central America 0, South Ameriea 3, West Indies 6 , Sandwich Islands 4 , and other countries 23. 


\section{VERMONT.}

The following table will show the decennial progress of the population since the first census of the State taken by the United States authorities:

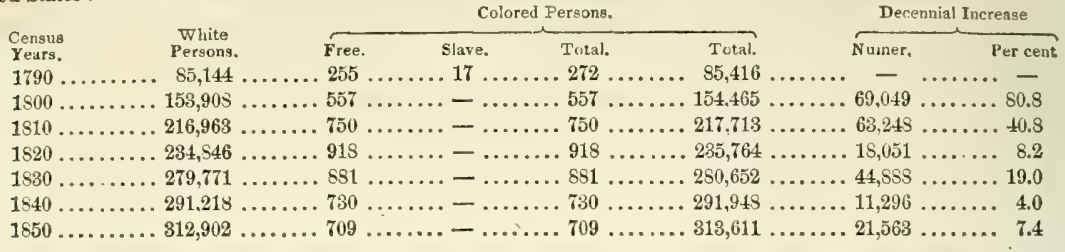

The general statisties of the wealth, industry, productions, manufactures, and institutions of Vermont, as ascertained by the census of 1850 , and other official reports made in the same year, afford the following results :

Occupied Lands, etc.--Improved farm lands 2,591,379 acres, and unimproved lands 1,525,368 acres-together valued in cash at $\$ 59,727,731$. The whole number of farms under cultivation on the 1st June, 1850, was $29,687 . \quad V$ alue of farming implements and machinery $\$ 2,790,237$.

Live-Stock.-Horses, 61,057 ; asses and mules, 218 ; milch cows, 146,146; working oxen, 48,497; other eattle, 154,025; sheep, 919,992 , and swine, 66,278 . Compared with the live-stock existing in the State in 1840 , the following morement is slown:

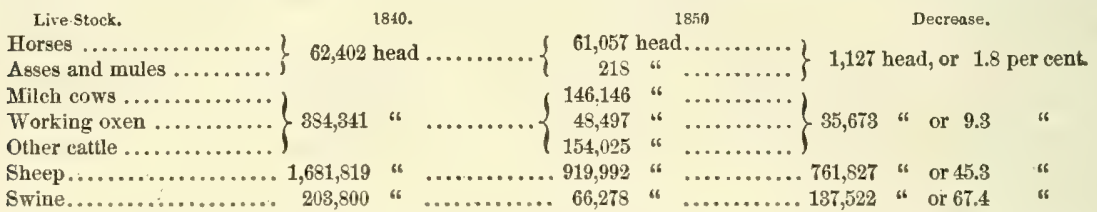

-in 1850 the aggregate ralue of live-stock in cash was $\$ 12,640,245$.

Products of Animals.-Wool 3,410,993 pounds, butter 11,871,451 pounds, cheese 8,729,834 pounds; and the value of animals slaughtered during the year had been $\$ 1,871,468$. The quantity of wool returned in the census of 1840 was $3,699,235$ pounds, or 288,242 pounds more than in 1850, and hence the decrease shown in the latter year amounts 7.8 per cent. The production in relation to the number of sheep, however, has been much larger at the latter than at the former period; in 1840 it was 35.2 ounces per fleece, and in $1850,59.3$ ounces. In the production of butter only five States surpass Fermont, and of cheese only two-New York and Ohio, and of the latter article it produces one-twelnh the quantity made in the Union.

Grain Crops.-Wheat 525,925 bushels, rye 176,207 bushels, Indian corn $2,032,016$ bushels, oats $2,307,714$ bushels, barley 42,147 bushels, and buckwheat 208,699. The crops of 1840 and their comparative quantities, with those of 1850 , are as follows:

Crops,

Wheat.....

Oats. .............2,222,584

Barley........... 54,781

Buckwheat . . ....... 228,416
1850.

Mrovement.

0,125 bushels, or 6.1 per cent. 525,925 bushels. incr.

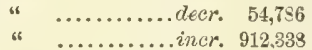
or 23.7 ......... 176,207 $\ldots \ldots \ldots \ldots 2,032,016$ $\ldots \ldots \ldots .2,807,714$ ........ 42,147 ........ 208,699 ...........2ner. 912,338 ............der 12,634 or 37.8 or 23.1 or 8.6

Other Food Crops.-Beans and peas 104 bushels; potatoes, Irish, 4,947,851 bushels. The potato crop reported in the census of 1840 amounted to $8,869,751$ bushels, and hence the decrease between the returns of 1840 and 1850 has been $3,922,400$ bushels, or 44.2 per centum.

Miscellaneous Crops.-Hay, 866,989 tons; clover-seed, 760 bushels; other grass-seed, 14,996 bushels; hops, 258,513 pounds ; flax, 20,752 pounds ; flax-seed, 939 bushels; silk cocoons, 268 pounds ; Maple sugar, $5,950,955$ pounds; molassez, 5,997 gallons; beeswax and honey, 249,482 pounds; wine 659 gallons, etc. Value of orchard products, $\$ 315,045$, and of market-garden products, $\$ 18, \$ 53$. A comparison of the principal productions of 1550 with those returned in 1840 , gives the following result:

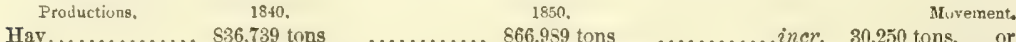

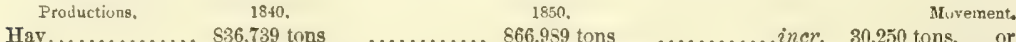

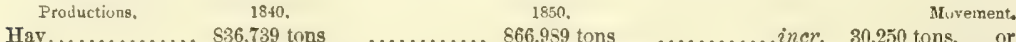

ops........... $4 \$, 137$ pounds ......... 25\$,513 pounds ......... iner. 210,376 pounds, or 434.9 .

Flax........... 66,080 " $\quad \ldots \ldots \ldots \ldots .20,752$ "6 $\ldots \ldots \ldots \ldots$ decr. 45,329 "

Maple sugar ......4,647,934 " $\quad \ldots \ldots \ldots \ldots .5,950,955 \quad$ :6 $\ldots \ldots \ldots \ldots . .2 n e r .1,333,021$ " or 29.6 "

Wine........... 94 gallons ......... 659 gallons .......... incr. 565 gallons, or $601.1 \quad$ "

Home-made manufactures were produced in the year ending 1 st June, 1850 , to the value of $\$ 278,331$. The same class of goods produced in the year represented in the census of 1840 , were valued at $\$ 674,548$.

Manufactures.-Aggregate capital invested, $\$ 0,000,000$; value of all raw material, fuel, etc., consumed in the year, $\$ 0,000,000$; average number of hands employed, 00.000 - males 00,000 , and females 00,000 ; monthly enst of labor, $\$ 000,000$ male $\$ 000,000$, and female $\$ 00,000$; total value of manufactures for the year $\$ 0,000,000$. The whole number of manufacing establishments in operation on the 1st June, 1550 , and produeing to the annual value of $\$ 500$ and upwards, was 1,835 , and these were distributed among the counties in proportion, as shown in the general table before given. Of these 9 were cotton factnries, 72 woolen factories, 37 iron factories-3 making pig iron, 26 making castings, and 8 making wrought iron; and 152 were tanneries. The manuficturing establishments others than those named were various, but chicfly such as are incident to an agricultural region, or such as the immediate wants of the people demand. The total capital invested in manufactures, in 1840 , amounted to $\$ 4,326,440$. 
In the cotton manufacture, the capital employed is $\$ 202,500$; cotton used, 2,243 bales; value of all raw material, etc. consumed, $\$ 114,415$; hands employed, $231-$ males 84 , and females 147 ; entire wages per month, $\$ 3,321-$ to males $\$ 1,460$, and to females $\$ 1, S 61$; products of the year-sheeting, etc., 1,651,000 yards, and yarn 53,050 pounds, valued at $\$ 106,100$. In 1840 , there were in the State 7 factories-capital $\$ 118,100$; hands 262 , and value of produets $\$ 113,000$.

In the manufacture of woolen goods, the capital employed is $\$ 886,300$; annual consumption of wool. $2,328,100$ pounds ; value of all raw material, etc., consumed, $\$ 830,684$; average hands employed, 1,393-males 683 , and females 710 ; entire monthly wages, $\$ 25,100$ - to males $\$ 16,712$, and to fenales $\$ 5,385$; products for the year, $2,8: 0,400$ yards of eloth, valued at $\$ 1,579,161$. The number of factories in 1840 was 95 , which, with 239 fulling mills, employed a capital of $\$ 1,406,950$; hands 1,450 ; annual value of products, $\$ 1,381,953$.

The statistics of the iron manufactures, in 1850, were in accordance with the annexed table:

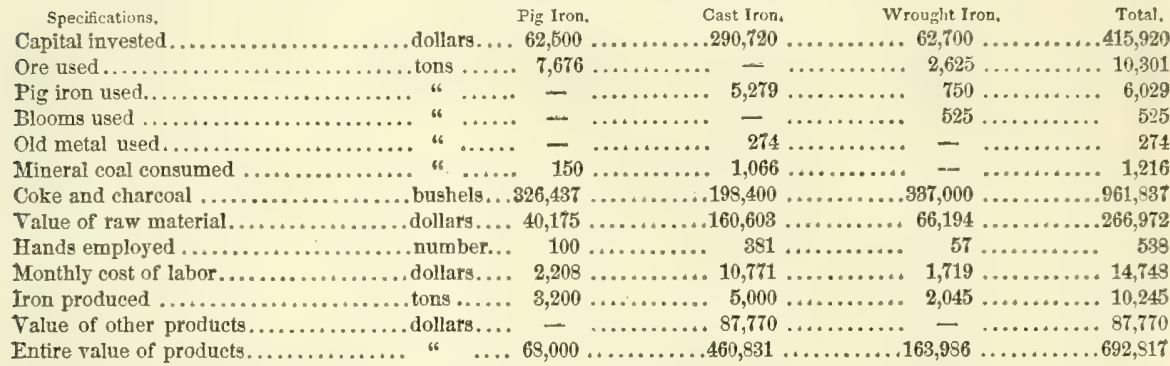

-in 1840 , there were in the State 26 furnaces, producing annually 6,743 tons cast iron, and 14 bloomeries, forges, and rolling mills, producing 655 tons bar ilon; fuel, etc., consumed, $38 \$, 407$ tons; hands, 788 ; capital invested, $\$ 664,150$.

The tanneries employ a capital of $\$ 346,250$; value of hides and skins, $\$ 357,946$; hands employed 397 ; monthly wages $\$ 8,807$; skins tanned, 44,330 , and sides of leather tanned, $\$ 250,104$; value of products $\$ 587,466$. In 1840 , there were 261 ianneries in the State, employing a capital of $\$ 403,093$, and 509 hands, and producing annually 102,763 sides of sole leather, and 102,937 sides of upper leather.

The capital invested in the manufacture of malt and spirituons liquors is $\$ 7,000$; quantities and kinds of grain, etc., consumed-barley 2,500 bushels, and hops 1 ton; hands employed, 2 ; ale manufactured, 800 barrels. No spirits are returned, and probably none is now manufactured as an article of commeree. In 1840, there were two distilleries, producing annually 3,500 gallons, and one brewery producing 12,800 gallons-the whole employing 5 men, and a capital of $\$ 8,850$.

Internal Improvements, etc.-The lines of railroad from Boston and the coast of New England, generally toward Canada and the north-west, pass through Vermont, and the lines from New York also form connection with those of the western districts of the State. Locally these roads have tended greatly to the development of the resources of the towns through which they pass, and bave opened seamboard markets to the great body of the State. The bulk of the merchandise and travel on the Vermont roads, however, is from and to places beyond the limits of the State, which has no large manufacturing towns or aggregated populations, beyond a few thousands in number. The several lines are noted In the "APPENDIX." On the 1st January, 1853, the railroads in operation had a total length of 427 miles, and there were some 50 miles additional in course of construction. There are no canals in Vermont, with the exception of three short cuts to overcome river falls, viz.: that around White River Falls, that at Bellows Valley, and that at Waterqueechy Falls. The macadamized and oidinary roads of the State are generally well kept, and in sufficient number for all purposes.

Foreign Commerce.-The commerce of Vermont is carried on chiefly at Burlington on Lake Champlain, and fluds an outlet by the Chambly river to Canada, and transmarine combtries. The exports in this direction, in the year ending 30th June, 1850 , were valued at $\$ 430,906$, of which $\$ 404,749$ was the value of demestic products exported, and $\$ 26,157$ that of foreign reexports, and the value of imports amounted to $\$ 463,002$. The shipping employed in carrying the mer chandise above represented, was as follows:

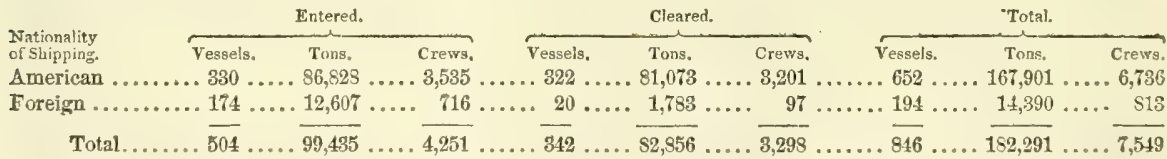

-the shipping owned in the State at the above period amounted to 4,530 tons, all of the class enrolled and licensed, and of this, 3,097 tons was navigated by steam. The commercial movement for a series of years had been as follows:

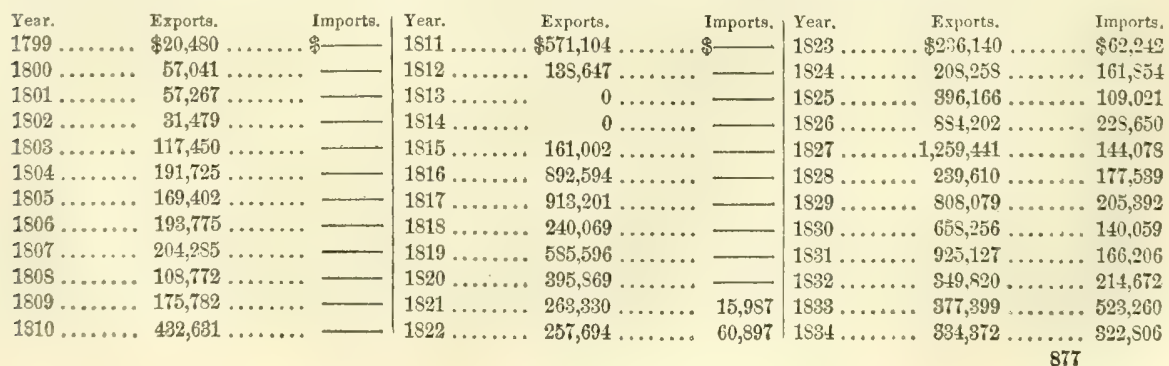




\section{VERMONT}

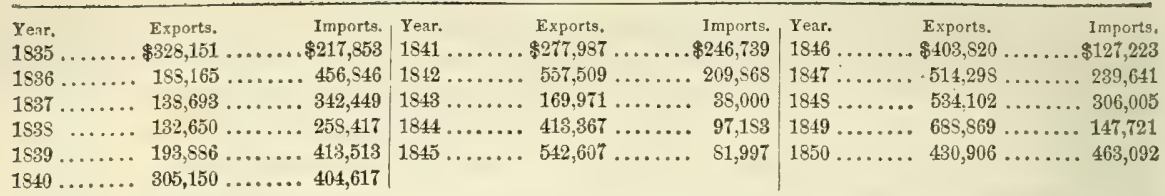

Banks.-The returns of August, 1850 , report 27 banks, and their condition as follows-Liabilities: capital, $\$ 2,197,249$; circulation, $\$ 9,856,027$; deposits, $\$ 546,703$; and debts to banks, $\$ 32,984$; and assets, loans and discounts, $\$ 4,423,719$; stocks, $\$ 40,500$; real estate, $\$ 94,497$; due by other banks, $\$ 1,001,789$; notes of other banks, $\$ 127,637$; specie fund, $\$ 2,376$; and specie, $\$ 127,825$.

Government.--The first Constitution of this State was formed in 1777; the one now in operation was adopted on the 4th July, 1793, but has since been modified at various periods. It secures to every man on altaining his 21 st year, the right of suffrage, provided he has been a resident of the State for the next preceding year, and is of a quiet and peaceable behavior. The annual elections are held on the first Tuesday of September.

The Legislature consists of a Senate (established in 1836), and a House of Representatives. The Senate consists of 30 members, chosen by a plurality of votes, apportioned in ratio of the population, but each county is entitled to at least one. The House of Representatives, at present, consists of 230 members, one from each town. Representatives shall be persons noted for wisdom and virtue, resident in the State for the last two years, and for one year in the town. Two-thirds of the members elected are required to form a quorum, when a State tax is roted. The Legislature is renewed annually. The Lieutenant-governor is ex-officio President of the Senate, otherwise the officers of both houses are chosen by the members thereof respectively.

The chief exceutive is vested in a Governor, chosen annually by a majority of votes. In ease of no choice being made, the three candidates having the highest poll numbers are presented to the Legislature, which in joint ballot elects one of their number to be governor. The Lieutenant-governor and Treasurer are elected in like manner. No one is qualifled for these offices unless he has resided in the State for the preceding four years. Twelve Councilors, assistants to the executive, are chosen annually by general ticket, and by a plurality of votes. The Governor and Council appoint to offices and fill vacancies, and may grant pardons for all crimes excepting treason and murder, in which they may grant reprieves until the end of the next session of the General Assembly, and excepting also impeachments, which can be reversed only by act of the Assembly. The Governor presides in the Council and has a casting vote only. He may veto a bill, but twothirls of both houses may pass it again, and it thus may become law notwithstanding. He is allowed a Secretary of civil and military affairs, chosen by himself and paid by the State.

Judiciary powers are vested in a Supreme Court, consisting of a chief and two assistant justices; in County Courts, or Courts of Common Pleas comprising four eircnits, each County Court being composed of one Judge of Circuit, elected by the Legislature, who is ex-officio chief justice of the County Courts of his Circuit, and two assistant judges for each county, elected by the people; and in Justices of the Peace. The Supreme Court sits in each county once, and the County Courts twiee in each year; an additional term of the Supreme Court is also held once a year in each district, at such time and place as the court may order. Each Judge of the Supreme Court is Chancellor of a Circuit. The Court of Chancery has two stated sessions annually in each county, and is always in session for all purposes, except the final hearing of a cause. An appeal from a decree of the Chancellor lies to the Supreme Court. Judges of the Supreme Court, county and probate Courts, sheriffs, and justices of the peace, are elected by the General Assembly in joint ballot.

The Constitution prohibits slavery, and permits imprisonment for debt only in cases of fraud. It abolishes perpetuities. Every alien of good character coming to settle in the State, and swearing allegiance thereto, is permitted to hold land. By a law of 1850 , a homestead of the value of $\$ 500$ is secured from attachment or execution.

Once in seven years, 13 censors are chosen on one ticket by the people, whose duty it is to inquire whether the Constitution has been observed in every particular, etc., and also to call a convention for amending the Constitution within two years, six months' publie notice being given of the amendments proposed.

The financial condition of this State is in an enviable condition-the expenses of government are small, and its liabilities insignificant. For the year ending 31st August, 1850, the receipts into the treasury, including a balance from 1849 of $\$ 5,330$, amounted to $\$ 125,3 \%$, of which $\$ 94,309$ was raised from taxes. The disbursements for the same year amounted to $\$ 122,203$, leaving a balance of $\$ 3,122$. The principal sums paid out, were the expenses of the Legislature, $\$ 36,043$; executive expenses, $\$ 2,618$, and pay of judiciary and for prosecuting crime, $\$ 49,738$. The minor items of expense were those on account of elections, pauper relief, common schools, agricultural societies, militia, etc. The expenses of 1850 exceed those of 1849 by $\$ 7,767$, but they embrace about $\$ 15,000$ of extraordinary expenditure.

Vermont has no public debt. It has, however, some temporary liabilities, which at the above-named date amounted to $\$ 58,036$.

Among the benevolent institutions of the State, the Vermont Asylum for the Insane, at Brattleboro', is the most conspicuous. Since the opening of the asylum there have been admitted to August 1st, 1850, 1,609 patients, and 1,281 have been discharged, and 328 remained in the institution. Of the discharged, 745 , or 46.3 per cent. had been recovered. Of those placed in the asylum within six months from the attack, nearly nine-tenths have recovered. During the year ending as above, the whole number of patients was 468 ; admitted 150 , and discharged 140 . Of those discharged, 79 were cured, 26 died, 16 were improved, and 19 not improved. Income $\$ 34,210$ 12, and expenditures $\$ 33,86892$. There is connected with the asylum a library of over 1,200 volumes, and a large number of periodicals and newspapers are taken. The deaf and dumb and the blind are supported at institutions in other States, for which purpose the Legislature appropriates a large sum of money annually.

Federal representution.--In accordance with the provisions of the Jaw of $28 d$ May, 1850, Vermont sends four representatives to the federal Congress.

Education. - In 1850 there were 2,594 school districts in the State, and the whole number of scholars was 90,110 ; average length of schools 24 weeks; average of scholars in each district, 39 ; expense of each scholar, $\$ 220$; average wages to teachers-male $\$ 1,355$, and female $\$ 554$ per month; whole wages-to males $\$ 65,75916$, and females $\$ 61,31265$; total $\$ 127,07181$; enst of board, $\$ 70,49287$; cost of fuel, $\$ 19,83764$; cost of wages, board, fuel, ete., $\$ 217,402$ 33. Public money divided for support of schools, $\$ 90, \$ 9391$. Vermont has no school fund. 
The collegiate institutions of the State are-the University of Vermont at Burlington, founded 1791; Middlebury College, founded in 1800 ; and Norwich University, founded in 1834. The University of Vermont in 1850 had 7 professors, 95 students, and 416 alumni, and a library of 10,000 volumes; Middlebury College, 6 professors, 63 students, 877 alumni, and 5,000 volumes; and Norwich University had 4 professnrs, 60 students, and 138 alumni, and 1,400 volumes. Merical schools are established at Castleton and Woodstock. The Castleton Medical College was founded in 1818 , and in 1850 had 7 professors, 104 students, and 555 graduates, and the Vermont Medical College at Woodstock was founded in 1535, and in 1850 had 7 professors, 90 students, and 332 graduates.

Academies are established in all the larger towns and villages, and tbronghout the State there are private schools of high reputation.

Pubtic Libraries,-According to a report of the librarian of the Smithsonian Institution in 1851, there were in Vermont 1 State library-8,500 volumes; 8 college libraries $-13,082$ volumes; 6 students' libraries-8,667 volumes; and 13 public school libraries-9,100 volumes; total 23 libraries, and 34,299 volumes.

Periodical Press.-The whole number of periodicals published in Vermont in 1850 was 36-14 whig, 7 democratin, and 15 neutral in politics. In the latter class are included religious, literary, and other general issues. Of the whole number 2 were published daily, 1 semi-weekly, 31 weekly, and 2 monthly. The dailies had an aggregate circulation of 550 copies, the tri-weeklies of 2,200 copies, the weeklies of 41,206 copies, and the monthlies of 2,000 copies. The counties in which issued are as follows: Addison, Bennington, and Caledonia, each 2 weeklies; Chittenden (Burlington), 2 dailies and 3 weeklies; Franklin, 1 wcekly and 1 monthly; Orange, 2 weekly and 1 monthly; Orleans, 1 weekly; Rutland, 4 weeklies; Washington, 6 weeklies; Windham, 5 weeklies; Windsor, 4 weeklies.

Puuperism and Crime.-The whole number of paupers relieved and supported within the year ending 1st June, 1850, Was 3,654, of which 2,043 were native, and 1,611 foreign born; and the whole number of paupers at the date specified was 1,879, of which 1,565 were natives, and 314 foreigners. Cost of support, eten. $\$ 120,462$. The total number of convicts sent to the State Prison in the year ending 1 st September, 1850, was 33, and at that date 76 were undergoing sentence. The convicts are chiefly employed in snath-making and shoe-making. Income $\$ 6,10709$, and expenses $\$ 6,251$ 61-balance against the prison, $\$ 14452$.

Religious Denominations.-The statistics of the several religious denominations in the State in 1850 , will be found by reference to the table annexed:

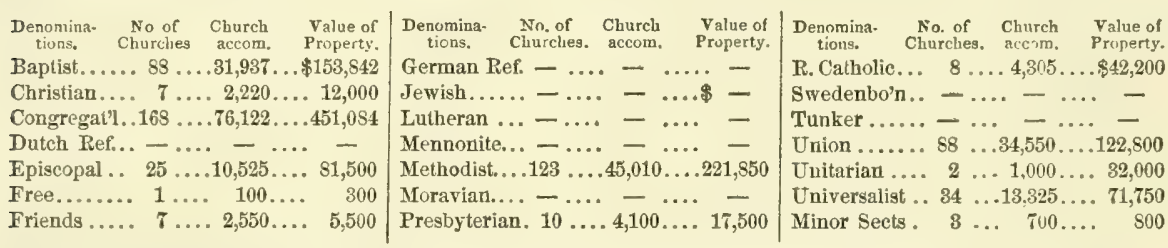

-making a total of 564 churches, with accommodation for 226,414 persons, and valued at $\$ 1,213,120$. Vermont forms a diocese of the Protestant Episcopal Chureh, and is included in the Poman Catholic diocese of Boston.

Historical Sketch, -The distance of Vermont from the coast prevented any settlement being made within its borders, either by the French or English, until the colonies of the latter extended themselves into its vicinity. The governments of New York and Massachusetts made large grants in the direction of this State, but it was not until 1724 that any actual possession was taken of lands within its prcsent bounds. In that year Fort Durance, or Dummer, was built on the Conneoticut River. On the other end of the State, in 1731, the French built a fort at Crown Point, and began a settlement on the eastern shore of Lake Champlain. Vermont, however, attracted little attention until the reduction of Quebec. After that event, New Hampshire, supposing the territory to fall within its limits, made large grants to settlers; but New York also elaiming it, the matter became involved in serious controversy. Having been referred to the crown, a decision was made confirmatory of the title of the latter to all the country west of the Connecticut, and in this determination New Hampshire seems to have acquiesced, with the understanding, that the titles of the lands purchased from her by the settlers should not be disturbed.

Had New York contented itself with the possession of the unsold lands and jurisdiction over those which had been fairly purchased from New Hampshire, Vermont would probably have been to this day an integral portion of that great State : a violent ana impolitic course, however, was pursued. The New Hampshire grants were declared invalid, and the settlers were required to take out new patents. The refusal to do this was nearly general, and in consequence decrees of ejectment were issued by the courts at Albany. At the head of the Vermonters was Ethan Allen, a bold and determined man, without mental cultivation, but of great natural powers. Under his guidance and counsel they resolved to maintain what they conceived to be their rights, at the risk of being treated as oullaws. The militia of New York was ealled out, but effected nothing. Appeal was now made by the inhabitants to the crown, and the government of New Xork was forbidden to make any grant of the lands in question. The order was evaded, however, and the same state of affairs continued as before. The battle of Lexington was fought, and more important objects then nccupied the attention of the government of New York.

The attempts of the British ministry upon the liberties of the coloniegtexcited as much indignation in Vermont as in those provinces which were more immediately obnoxious to the royal power. On the news that hostilities had commenced, Ethan Allen collected a body of about three hundred settlers, and, joined by some officers from Connecticut and New Hampshire, surprised the British post at Ticonderoga. The fort at Crown Point was surrendered soon afterward. These enterprises, executed with address, redounded greatly to the success of the revolutionary cause, and operated strongly on the public mind in favor of the Vermontese. In a bold attempt on Montreal, Allen was sbortly afterward taken prisoner, and carried to England in irons. In the following year the British succeeded in defeating the colonial navy on Lake Champlain, and on the advance of Burgoyne's army in 1777, Ticonderoga fell again into their possession. War now pressed heavily upon Vermont; the northern settlements were broken up, and the whole frontier subjected to savage incursion. Submission to the British, however, was never thought of. A force was raised and united with that of General Starke. The battle of Bennington, where upward of one thousand regular troops were assaulted in their intrenchments and compelled to surrender, will be long remembered as a proof of what an undisciplined militia are 
capable, when warmed by patriotism and animated by hatred to the oppressor. The surrender of Burgoyne's army restored the country to comparative tranquillity.

While thus fighting in favor of the general cause, the people of Vermont were placed, as regards their civil government, in an anomalous situation. At the commencement of hostilities they found themselves even without a form of government. The jurisdiction of New York was disclaimed, and the authority of the crown was thrown off. In this state of matters every thing was effected by voluntary agreement. Application was made to Congress for its in terference, but that body recommended submission to New York. Resolute in their determination not to submit, the people saw no alternative than to establish an independent State. In January, 1777, a general convention met, and proclaimed that the district of territory, previously known by the name of the New Hampshire grants, was of right a free and independent jurisdiction, to be thenceforth called by the name of "New Connecticut, alias Vermont." The convention now addressed Congress, and claimed admission into the confederation.

The petition. for admission was met by a counter-memorial from New York, and Congress refused to recognize ito separate existence. Embarrassment increased, and other circumstances soon after involved the Vermontese in a contest with the government of New Hampshire. The charter of the latter State circumseribed it by a line drawn at a distance of sixty miles from the sea. All the lands west of this line to the Connecticut were derived from royal grants; and the inhabitants of the towns within this strip, conceiving that the royal anthority expired with the Declaration of Independence, imagined they had a right to determine to what State they would be attached. Under this impression they applied to the Vermontese requesting a union with them. The assembly of Vermont acceded to the application, but the vote of union was subsequently rescinded on a representation that Congress would, on the connection with the revolted towns of New Hampshire being dissolved, admit Vermont as a separate State. This action was followed by great dise content within the State. The inhabitants of that part which lies near the Connecticut River determined to unite with the New Hampshire towns, and to form a State government. Encouraged by these dissentions, New Hampshire now advanced a claim before Congress for the whole of Vermont. New York did the same, and Massachusetts endeavored to obtain a part by reviving an antiquated tille.

Menaced from so many quarters, the Vermontese gave up their local dissentions, and united in their orrn defense. Ethan Allen, who had returned from captivity, was placed at the head of a body of militia, and made prisoners of the officers who were acting under the authority of New York. Complaint was made to Congress, but the discussion of the subject was postponed from time to time, as the Vermontese refused to become parties to it, and no decision was pro nounced. The British were naturally attentive to the progress of the contest, and flattered themselves that the people of Vermont, exasperated and neglected by Congress, would place themselves under their protection. Negotiations were actually opened for this purpose in 1780 , and were continued without any open result until 1783. Whatever the intontions of the leading men of Vermont were, there is no doubt but that the body of the people were still warmly attached to the revolutionary cause. The consequences of the negotiation in one respect, however, were favorable to Vermont, as she remained unmolested by the British during the remainder of the war.

The peace of 1783 found Vermont a sovereign and independent State de facto, and the Vermontese felt little desire to foin in a confederation, the rulers of which bad pursued such an evasive policy toward her during the war. New York still claimed a jurisdiction over the State, but was unable to enforce it, and the State government was administered as regularly as in any other part of the United States, Affairs remained in this singular condition until after the formation of the constitution in 1787, the advantages of which, under the administration of Washington, inclined the people of Vermont again to attempt an admission into the Union. The only obstacle arose from the opposition of New York, which was finally withdrawn in 1789. In that year commissioners from the two States met, and effected an amicable arrangement. The sum of $\$ 30,000$ was agreed to be paid to New York as a compensation for lands belonging to its citizens, which had been re-granted by Vermont, and New York consented that her claims to jurisdiction should cease. $\mathrm{A}$ convention was immediately called, by which it was resolved to join the Union. The consent of Congress was given, and on the 4th of March, 1791, Vermont became one of the United States.

During the war of 1812-15 with England, the vicinity of this State was the seat of a warm contest. On the invasion of New York, volunteers poured from the mountains and valleys of Vermont, and by their patriotism and valor proved that they had not degenerated from, or forgotten the prowess of, their fathers. The repulse of the British from Platts burg, and the capture of their squadron on Lake Champlain, delivered the soil of this district from the presence of an enemy. Aside from this interruption the prosperity of the State has been onward, but its history furnighes no event of sufficient importance to require detail.

Montpelter is the political capital of the State.

Texwoxt, p. v., Fulton county, Ill.: 51 miles N. W. Springfleld.

Vervont, p. o., Howard co., Ind.: on N. side of Wild Cat er., $50 \mathrm{~m}$. N. by E. Indianapolis.

Vkrusost, p. v., Cooper co., MLo.: 35 m. W. N. W. Jefferson City.

VervoNT, p. O, Chautauque co.. N. Y.: $287 \mathrm{~m}$. W. by S. Albany.

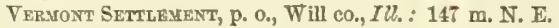
Springfield.

Vervontumle, t. and p. v., Eaton co., Afich.: $24 \mathrm{~m}$. W. by S. Lansing. The to derives its name from having been settled by a colony of forty families from Vermont. Pop. of t. in 1840, 182; in 1850, 324 .

Vernat, p. o., Greene county, Mis8.: on S. E. side of Chickasawha r., $125 \mathrm{~m}$. S. E. Jackson.

Verial, p. 0., Wyoming co., N. Y. : $232 \mathrm{~m}$. W. by N. Albany.

VERXox county, Mo. Situate W., and contains $612 \mathrm{sq} . \mathrm{m}$. Drained by Marais des Cygnes $\mathbf{r}$ a tributary of Osage $\mathbf{r}$., 880 and by its numerous branches. Surface undulating and diversiffed; soil fertile, and adapted to the growth of grain. It is well wooded, and has good pasturage for cattle.

VERNoN, p. v., Autauga $\mathrm{CO}_{2}$, Ala.: on N. side of Alabama river, near the junction of Swift cr., $19 \mathrm{~m}$. W. Montgomery.

Vervor, p. v. and sta., Tolland co., Conn. : 10 m. E. N. E Hartford. Drained by Hockanum r., which affords water. power to numerous manufactories. Surface diversified; soil of moderate fertility. The Hartford, Providence, and Fishkill $R . R$. touches the $S$. part of the t., $12 \mathrm{~m}$. from Hartford. The v. contains 2 churches, etc. Pop. of t. 2,900.

Verion, p. V., Kent co., Del. : on W. side of Marshy Hope creek, 18 m. S. S.W. Dover.

Verron, p. v., Troup co., Ga. : on W. side of Chattahoo chee river, $118 \mathrm{~m}$. W. Milledgeville. It contains an academy, church, and dwellings.

Verion, p. .., and cap. Jennings co., Ind.: on E. side of Vernon fork of Muscatuck r., 60 m. S. E. by S. Indianapolis. The Madison and Indianapolis R. R. passes through, $22 \mathrm{~m}$. from Madison, $64 \mathrm{~m}$. from Indianapolis. The $\mathrm{r}$. has 
a very pleasant site. It was laid out in 1515 . The county buildings are neat structures. Pop. about 600.

VERTON, p. o, Jackson parish, La.: $150 \mathrm{~m}, \mathrm{~N}$. W. by N. Baton Rouge.

Verron, t. and p. o., Shiawassee co, Mich. : 82 m. E. N. E. Lansing. This is one of the best agricultural townships in the county. Pop, 674,

Verion, p. v., Sutter co., Calif: : on E. bank of Feather river, at its confuence with the Sacramento, directly opposite Fremont. It is pleasantly situated at the head of navigation during high water, and is not liable to overflow. It is a market for the supply of the northern mines.

Verron, p. v., Madison co., Miss.; 3 m. S. E. Big Black river, $2 \mathrm{~m} . \mathrm{N}$. by W. Jackson. During a part of the year steamboats can ascend to this place. Pop. about 230 .

Verron, to and p. v., Sussex co., N. Ter.: 68 m. N. by E. Trenton. Surface very hilly and mountainous. Drained by several streams. The $v_{\text {. }}$ is situate centrally. Population of t. 2,619.

Vernor, t. and p. V., Oneida con, $N_{*} \boldsymbol{Y}_{\mathrm{*}}: 98 \mathrm{~m}$. W. by N. Albany. Surface rolling. Drained N. W. by Oneida and Skenandoa creeks. The v., incorporated in 1827 , contain an academy, 3 churches, stores, mills, etc., and 1 bank, capital $\$ 100,000$. Near the $y_{\text {, }}$ on Skenandoa creek, is an extensive glass factory. Pop. of v. about 750 ; of t. 3,093 .

Vernon, t. and p. 0., Trumbull co., Ohio: $150 \mathrm{~m}$. N. E. Columbus. Bounded Ev by Pennsylvania. Drained S. by Pymatuning creek flowing centraily through the t. Population $\$ 28$.

VirnoN, sta, Crawford co, Ohio: on Cincinnati, Cleveland, and Columbus $\mathrm{R}, \mathrm{R}, 75 \mathrm{~m}$. from Cleveland, $180 \mathrm{~m}$ from Cincinnati.

VERNoN, p. V., and cap. Hickman co., Tenn.: on E. side of Pine cr., $45 \mathrm{~m}$. W. S. W. Nashville. It contains the co, offices, a church, dwellings, ete.

VERNoN, p. v. and sta., Windham co., Term, : on W. side of Connecticut r., $105 \mathrm{~m}$. S. by E. Montpelier. Surface of $t$ rough and mountainous. Slate is quarried in the W. part Oak and chestnut timber is abundant. The Brattleboro Branch P. R. runs along the Connecticut $r$, having stations at Vernon v. and South Vernon. Pop. of t, 821.

VerNor, t. and p. o, Wankesha co., Wisc. : 60 m. E. by S. Madison. Pop. S59.

VERNOK, p. o, Washington co, Flor.: on E. side of Holmes cr., $79 \mathrm{~m}$. W. by N. Tallahassee.

Vernon Cenmee, p. v., Oneida co., N. Y.: $96 \mathrm{~m}$. W. by N. Albany.

VERONA, t, and p. o., Dane co., Wisc.: on head branch of Sugar r., 8 m. S. W. Madison. Pop. 488.

Verona, p. v., Boone co., Ky.: 49 m. N. Frankfort.

VEKONA, t. and p. v., Oneida county, $N . Y .: 106 \mathrm{~m}$. W. N. W. Albany, Surface generally level, with some swampy tracts; soil rich mold, with some sand. Drained by Oneida and Wood creeks, which bound it on the W. and N., flowing into Oneida lake on its N.W. border. The Erie Canal and Utica and Syracuse $R$. R. pass through the $t$. The $t$. contains numerous saw-mills, with several tanneries, and has considerable manufactures. Pop. of t. in 1840 4,504 ; in $1850,5,568$.

Verona Depôt, p. V. and sta., Oneida county, $N . Y$.: on Syracuse and Utica R. R., $23 \mathrm{~m}$. from Utica, and by railroad $118 \mathrm{~m}$. from Albany.

Yerona Mills, p. o, Oneida co, N. Y. : $104 \mathrm{~m}$. W. N.W. Albany.

VERPLANK, p. V. and sta., Westchester county, $N_{.}, Y_{0}$ : on Hudson River P. R., $42 \mathrm{~m}$. from New Tork, $102 \mathrm{~m}$. from Albany. It has a good steamboat landing, with stores and dwellings, etc.

$\checkmark$ ERSAILLES, p. V., Brown co., $I l_{0}$ : N. E. of M.Kee's cr., $54 \mathrm{~m}$. W. Springfield.

Versatrles, p. V., and cap. Ripley co., Ind. : on W. side of Laughery's cr., $65 \mathrm{~m}$. S. E. Indianapolis. The village is built upon a high bluff, and contains the county buildings, with stores, etc. First setlled in 1818. The Cincinnati and St. Louis R. R. passes through this place. The "Western Intelligencer" (whig) is issued weekly. The population (now about 800 ) is rapidly increasing, with the general importance of the place.

Versatlles, p. v., and cap. Wondford ce, $K y_{.}: 13 \mathrm{~m}$. S. E. Frank fort. It contains the county buildings

Versailles, p. V., and cap. Morgan county, Mo.: $37 \mathrm{~m}$. W. S. W. Jefferson City. It contains a court-house, jail, etc. Pop. about 600

VErsailles, p. o., Cattaraugus $\mathrm{co}_{*}, N, Y_{0}: 274 \mathrm{~m}$. W. Albany.

Versanlles, p. v., Rutherford co., Tenn.: 80 m. S. S. E. Nashville.

Vershire, t. and p. v., Orange county, Verm.: $24 \mathrm{~m}$. S. E. by S. Montpelier. Drained by Ompompanoosuc $\mathbf{r}$. Surface uneven and stony. The t. contains several saw and some other mills: Pop. 1,071.

Vesper, p. o., Onondaga co., N. Y.:125 m. W.by N. Albany.

Vestal, t, and p. V., Brome co, $N_{1}, Y_{1}:$ on S. side of Susquehanna r., 126 m. W. S. W. Albany. Surface uneven and broken. Drained by Choconut cr, and other streams flowing into the Susquehanna. This $\mathrm{t}$, is very heavily timbered, and contains numerous saw-mills. Pop, of t, in 1840 , 1,$253 ;$ in $1850,2,054$.

Vesuvius Furnade, p. o., Lincoln co., N. Car.: $152 \mathrm{~m}$. W. by S. Raieigh.

Veteray, t, and p. o., Chemung county, $N . Y_{.}: 160 \mathrm{~m}$. W. by S. Albany. Surface hilly; soil productive loam. Catharine's creek flows on its W. border, N. into Seneca lake, affording water-power. The t. contains several tanneries: farming is the ehief pursuit. Pop. 2,698.

Veto, p. o., Washington co, Ohio: 84 m. S. E. by E. Columbus, Probably John Tylersville.

Vevar, p. v, and cap. Switzerland co., Ind.: on the Ohin river, $83 \mathrm{~m}$. S. E. by S. Indianapolis. Lat. $38046^{\prime} \mathrm{N}$., long. $84^{\circ} 59^{\prime} \mathrm{W}$. This v. occupies part of the tract of land granted on credit by the United States in 1502 to a colony of families from Switzerland for the cultivation of the vine. The colony soon received a large addition from Switzerland. The $\nabla$. was laid out in 1813. It has one of the most pleasant sites on the Ohio $r$. It contains a court-house, jail, academy, several stores, ete. Many of the dwellings are neatly built of brick. The cultivation of the grape and manufacture of wine resembling claret is very extensively carried on. The "Palladium" (dem.) is here published. Pop. about 1.500 .

Viandct, sta., Cambria county, Penn.: on Alleghany Portage R. R., 5 m. from Con maugh, $28 \mathrm{~m}$. from Hollidaysburg.

Vickerv's Crese, p. os, Forsyth county, Ga.: $103 \mathrm{~m}$. $\mathrm{N} . \mathrm{W}$. Milledgeville.

Vicksaurg, p. city, port of entry, and cap. Warren co, Miss : on E. bank of Mississippi r., $\mathbf{4 1} \mathrm{m}$. W. by N. Jackson. It is principally built on a high bluff, 200 feet above highwater mark, but the more business part of the eity is on the bottom, along the river. About $25 \mathrm{~m}$. above the city are tho Wainut Hills, which rise to an elevation of 500 feet above the river, presenting very fine scenery: The city contains a court-house and jail, 1 large public school, several private academies, and 5 churches. An orphan asylum is about to be established. The business interests of the city are chiefly commercial. Immense quintities of entton are annually sent from this place to New Orleans and other points on the Mississippi. There is an excellent harbor for steamboats, with very convenient landings. The surrounding country is remarkably fertile, having a black loamy soil, well adapted to the cultivation of cotton, tobaceo, and grain. The Vicksburg, Jackson, and Brandon R. R. extends hence through Jackson, $46 \mathrm{~m}$. to Brandon, $60 \mathrm{~m}$., and will ultimately form a link in the Alabama and Mississippi R. R. from Montgomery and Selma westward; and Vicksburg will also be a starting point for one of the lines of railroad 
toward the Paciflc, via Streveport and Texas. The tonnage of Vicksburg district on 80th June, 1850, was 460 tons, all of which was enrolled and licensed, permanent, employed in the coasting trade, and propelled by steam. During the year preceding it had no foreign commerce or ship-building. The newspaper press in 1850 consisted of the "V. Sentinel" (dem.) and the " $V$. Whig," each issuing tri-weekly and weekly editions. Vicksburg was incorporated as a town in 1825 , and as a eity in 1836. Pop. in $1850,3,678$.

Vicksville, p. o., Southampton county, Firg. : $58 \mathrm{~m}$. S. by E. Richmond.

VICToR, t., p. v., and sta., Ontario county, N. Y.: $192 \mathrm{~m}$. W. by N. Albany. Surface of t. rolling. Drained in E. and S. E. parts by Mud er. and branches. The t. contains numerous saw, grist, and flouring mills, with several manufacturing establishments. The Roehester and Syracuse R. R. passes through the $\mathrm{v}$., $20 \mathrm{~m}$. from Rochester, $84 \mathrm{~m}$. from Sy* racuse. The $\mathbf{v}$ is a thriving place, with about 350 inhabitants. Pop. of t. 2,230.

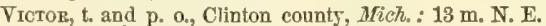
Lansing. A farming township. Pop. 277.

Vicroria county, Tew. Situate S. E., and contains 804 sq. m. Drained by Guadalupe r., which passes through its western portion, and by Garcitas, Zarilla, and Casa Blanca creeks. Surface undulating and diversified. A large portion is prairie, with timber interspersed; soil very fertile and productive. Limestone is found. Farms 84 ; manuf. 9 ; dwell. 327, and pop.-wh. 1,448, fr. col. 0, sl. 571-total 2,019. Capital: Victoria C H.

Victoria, p. 0., Knox county, Ill.: 87 miles N. by W. Springfield.

Victoria, p. o., Daviess county, MFo.: 138 miles N. W. Jefferson City.

Victoria, p. v., Bolivar co., Miss. : on E. bank of Mississippi r., $100 \mathrm{~m}$. N. N. W. Jackson.

Victorta, p. v., and eap. Víctoria co., Tex. : on E. bank of Guadalupe r., $113 \mathrm{~m}$. S. S. E. Austin City. Lat. 250 $56^{\prime} 47^{\prime \prime} \mathrm{N}$., and long. $97^{\circ} 7^{\prime} 30^{\prime \prime}$. The $\mathrm{r}$. is pleasantly situated, and is rapidly increasing in population. It contains the county buildings, etc. The Guadalupe when improved is easily navigable for steamborts $70 \mathrm{~m}$. from its mouth. It is here crossed by a bridge. The "Texas Adrocate" (Indep.) is published weekly.

Victory, t. and p. v., Cayuga co., N. Y.: $153 \mathrm{~m}$. W. by N. Albany. Surface roling. Drained by Little Sodus cr. The t. contains several tanneries, grist, and saw mills. The v. contains a church, stores, etc., and about 220 inhabitants. Pop. of t. 2,299,

Victory, p. 0., Wayne co, Tenn.: 77 m. S. W. Nashville.

Vidalla, v., and cap. Concordia par., $L a_{n}$ : on W. bank

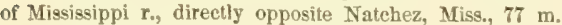
N. by W. Baton Rouge. It is built on one street parallel with the r., and contains the county offices. The "Concordia Intelligencer" (neut.) is issued weekly.

VIenNa, p. V., Pickens county, Ala.: on the Tombigbee r., near the junetion of Sipsey r., $120 \mathrm{~m}$. W. N. W. Montgomery. Pop, about 140.

Vienna, p. Ys, and eap. Dooly $\mathrm{co}_{*}, G a_{*}$ : on N. side of branch of Flint r., $78 \mathrm{~m}$. S. S. W. Milledgeville. It cortains the court-house, jail, and several dwellings.

Viensa, p. v., and cap. Johnson co., $I U .: 167 \mathrm{~m}$. S. by E. Springfield. This is a pleasant little $\mathrm{v}$. on Cash cr., containing the county buildings, etc. The projected Massac and St. Louis R. R. will pass through this place. Pop. 142.

Vrevisa, p. v., and sta., Sentt co., Ind.: 68 m. S. by E. Indianapolis. The Jeffersonville $R$. R. passes a little W. of the v., $27 \mathrm{~m}$. from Jeffersonville, $50 \mathrm{~m}$. from Edinburg.

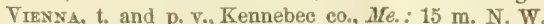
Augusta. It contains a large pond in $\mathrm{S}$. part, and is watered on the W. by M.Curdy stream of Sandy $\mathbf{r}$. Population of t. 851 .

Frenca, p. v. and port of entry, Dorchester co., Mfd. : on
W. side of Nanticoke r., $48 \mathrm{~m}$. S. E. Annapolis. It has considerable trade, the river being navigable for sea-going vessels to this place, $24 \mathrm{~m}$. above Chesapeake bay. It contains several stores, 2 churches, etc. The total tonnage of his distriet on June 30 th, 1850 , was 15,478 tons enrolled and licensed, and 537 tons "licensed under 20 tons," all of which was employed in the coasting trade. During the year proceding 27 sehooners were built- $-1,533$ tons.

VienNa, p. o., Jackson par., La.: 150 m. N. W. by N. Baton Rouge.

Vienna, p. v., Macomb county, Arich.: 82 miles $\mathrm{E}$. Lansing.

VIENNA, t. and p. v., Oneida co., $N, Y_{0}: 112 \mathrm{~m}$. W. N. W. Albany. Bounded S. W. by Oneida lake. Surface rolling. Drained by Fish cr. and other streams. The t. contains numerous saw-mills, ete. Pop. 3,393.

Vizenna, t., Dane co., Wisc. : 14 m. N. Madison.

Viesisa, p. 0., Walworth co., Wisc.: 48 m. S. E. Madison.

VIENNA, t. and p. v., Trumbull county, Otio: 144 miles N. E. by E. Columbus. Soil good. Drained by several small streams. Pop, of t. 1,007.

VIrnNa Cross Roads, p. o., Clark connty, Ohio: $83 \mathrm{~m}$. W. by S. Columbus.

Vrao county, Ind. Situate W. on Wabash r., and contains $408 \mathrm{sq}$. m. It is drained by numerous streams falling into the Wabash, Surface level, or gently undulating, finely timbered, with prairies of small extent; soil rich and productive. Coal, freestone, and limestone abound. Farms 1,113 ; manuf. 130 ; dwell. 2,645 , and pop.-wh. 14,556 , fr col. 733-total 15,259. Capital: Terre Haute. Prublio Works: Wabash and Erie Canal; Terre Haute and Richmond R. R.; Evansville and Illinois Extension R. R.; the National Road, etc.

Village Green, p. v., Delaware county, Penn.: $77 \mathrm{~m}$. L. S. E. IIarrisburg.

VIrLAge Springs, p. o., Blount co., Ala $: 100$ m. N. by W. Montomery.

Vilimanora, t. and p. o., Chantauque co., N. Y.: $2 S 0 \mathrm{~m}$. W. Albany. Surface broken and uneven; soil best adapted to grazing. Drained by Conewango cr. The t. contains mills of various kinds. Pop. 1,536.

Villanota, p. o., Walker county, Ga.: $156 \mathrm{~m}, \mathrm{~N}$. W. Milledgeville.

Vilia Rica, p. 0., Carroll co., Ga.: 114 m. W. N. W. Milledgeville.

Ville Platte, p. o., St. Lazdry par., La. : 69 m.W. by N. Baton Rouge.

Virtla, p. o., Russell county, Ala.: 71 miles W. by S. Montgomery.

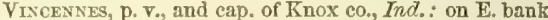
of Wabash r., $100 \mathrm{~m}$. S. W. In dianapolis. Lat. $38^{\circ} 48^{\prime} \mathrm{N}$. long. $87 \circ 25^{\prime} \mathrm{W}$. The $\mathrm{v}$. has a fine site along the river bank, and is regularly laid out, with wide streets crossing each other at right angles. It contains the county buildings, a fine town hall, good market-house, a U.S. land office, and several churches. The Catholic cathedral is a spacious and well-finished edifice. Considerable attention is given to education. Of the principal institutions several are Roman Catholic, viz., an ecelesiastical seminary, female aeademy, with 150 pupils, and 2 orphan asylums, which, in 1852 , contained 73 girls and 60 boys. The v. contains a branch of the State Bank of Indiana, cap. $\$ 147,200$, and has some manufactures. The Wabash $\mathrm{r}$. is here $\frac{1}{\mathrm{~g}} \mathrm{~m}$. wide, and is navigable to this place for steamboats. The railrnads passing through Vincennes are-Evansville and Illinois R. R. ; and Ohio and Mississippi R. R.; to which may be added a projected road, extending hence to Indianapolis. The "Vincennes Gazette" is here published This place is the oldest settlement in the State, and is invested with much historical interest. The French established a trading prist about 1702. A Catholic church had been established here as early as 1749 , in which year it received its name. In 1789 all the families in the place were of French origin, except 


\section{VIRGINIA.}

iwelve. A considerable proportion of the present population is their descendants. In 1805, the first territorial legislature assembled here, and, among other acts, incorporated Vincennes as a borough. In 1813, the seat of government was removed to Corydon. The country around is very fertile prairie land. Pop. 2,070.

Vincext, t. and p. o., Chester co., Penn.: on S. W. side of Schuylkill r., $67 \mathrm{~m}$. E. Harrisburg. Pop. about 2,500.

Fincentox, p. $\mathrm{V}_{v}$, Burlington co., $\mathcal{N}_{\text {. Jer, }}$ on $\mathrm{S}$. branch of Rancocus r., at junction of Stop-the-jade cr., 19 miles S. Trenton. It contains several stores and mills, and 2 churches.

Vineyard, p. o., Grand Isle co., Verm.: 53 m. N. N. W. Montpelier.

Viveyard Milis, p. 0., Huntingdon co., Penn. : $65 \mathrm{~m}$. W. Harrisburg. Here is a hot-blast charcoal furnace, with an annual capacity of 1,600 tons.

Viner Grove, p. 0., Lincoln co., Tenn. : 72 m. S. by E. Nashville.

VIncaNd, to and p. o, Winnebago county, Wisc: : 84 miles N. N. E. Madison. Pop. 756.

VIxton county, Ohio. Situate toward the S. E., and contains $416 \mathrm{sq}$. m. Drained by Raceoon cr. and its affluents, and by branches of Scioto $r$. Surface hilly, and in parts broken; soil in general fertile, and favorable to the culture of wheat and grain. Coal is found. Farms 806 ; manuf. 24 dwell. 1,569, and pop.-wh. 9,246, fr. col. 107-total 9,353. Capital: M'Arthurstown. Public Works: Scioto and Hocking Valley $\mathrm{P}$. R.; Cincinnati and Marietta $\mathrm{R} . \mathrm{R}$.

Vrnton, p.. ., and cap. Benton co., Ia. : on a branch of Cedar r., 40 m. N. W. Iowa City. It contains the county buildings, etc.

Vivton, p. V., Gallia co, Ohio : on W. side of Raccoon r., $75 \mathrm{~m}$. S. E. by 8 . Columbus. It contains an aeademy, a few stores and mills. Iron ore and mineral coal are found in the vicinity.

Vrous, p. 0., Delaware co.. Ia. : $54 \mathrm{~m}$. N. Iowa City.

Viouy, p. o., Blount co., Ala.: on N. side of Little Warrior r., 104 m. N. by W. Montgomery.

VIRGEN river, Utah: rises in the Wahsatch mountains, flows in southerly course, to its confluence with the Rio Colorado.

VirgiL, t. and p. V., Cortland co., N. Y.: 128 m. W. by S. Albany. Surface uneven; soil fertile loam. Drained S. by Tioughnioga r. The v. contains 3 churches, stores, etc. Pop. of t. 2,410.

VirglL, p. o., Fulton county, $I l l .: 64 \mathrm{~m}, \mathrm{~N} . \mathrm{W}$, by N. Springfleld.

\section{THE STATE OF VIRGINIA.}

TIRGINIA, perhaps, in natural resources, as well as in geographical position, one of the most important States of the Union. lies generally between the latiudes $36^{\circ} 30^{\prime}$ and $39^{\circ} 43^{7}$ north, and extends east and west between longitudes $75^{\circ} 40^{\circ}$ and $83^{\circ} 33^{\prime}$ west, and is bounded on the north by Pennsylvania and Maryland, on the east by the Atlantic Ocean and Chesapeake Bay, on the south by North Carolina and Tennessee, and on the west by Kentucky and Obio. With the exccption of the long tongue of land between Pennsylvania and the Ohio River, and the peninsular projection between the Chesapeake Bity and the ocean, the State has an average length of 355 miles, and a breadth of 218 miles, and comprises an irea computed at 61,352 square miles.

Virginia is naturally divided into east and west by the Blue Ridge, a division which obtains also in the distribution of the federal judiciary; but according to the State constitution, it is divided into four districts or sections-the Tide Water, below the lower falls of the rivers; the Piedmont, between those falls and the Blue Ridge; the Valley, between the Blue Ridge and the Alleghany; and the Trans-Alleghany-ihe latter comprising all the country west of the mountain ranges. The first mountains are found in the Piedmont section, which is traversed by a low ridge, under the local names of White Oak, Southern, etc, and running nearly parallel with the Blue Ridge, at a distance of 25 or 30 miles. The Blue Ridge, although pierced by the Potomac, James, and Staunton rivers, constitutes a well-marked and continuous chain of more than 250 miles in length. In general, it forms rounded, swelling masses, but in several places, and especially the Peaks of Otter, shoot up in projecting summits to the height of 4,260 feet. The Kittatiny, or Blue Mountain, enters the State farther west, under the name of Great North Mountain, and forming the centre of the great plateau or table-land of Virginia, is continued, under various local names, until it takes the name of Iron Mountain, and enters North Carolina. It is pierced by the Potomac and James rivers running eastwardly, and by the New River running westwardly. West of this great ridge lie several detached masses, bearing the local names of Sideling Hill, etc. Still farther west is the great Alleghany chain, which is broken through by New River and other streams to the north. Powell's Mountain appears to be an out-lier of this chain, and reaches to the height of 4,500 feet. Westward of the Alleghany there is a general slope toward the Ohio; but several other considerable chains traverse this section, the principal of which is Laurel Mountain, of which Greenbrier, Great Flat Top, and the Cumberland Mountains appear to form a part. With the exception of Penusylvania, Virginia is the only other State of the Union that has territory on both sides of the Alleghany Mountains.

Virginia has noble rivers and streams, useful as channels of commerce or for industrial purposes. With few exceptions, the Obio River west, and Chesapeake Bay east of the mountains, are the recipients of the waters of the whole State: those of Eastern Firginia flow, with an almost uniform south-easterly course, into the bay, carrying with them also the waters of the great valley, excepting only those of New River and the Holston, on the extreme southern part.

The Potomac rises in the Great Back Bone, but a few miles from the Youghiogeny, and pursuing a devious course, forces its way through the several intermediate mountain chains to the Piedmont section, where it is broken by falls nine miles above Georgetown, at which place it meets the tide-water, and about 100 miles below, after a course of 350 miles, it reaches the Chesapeake. At Alexandria, 290 miles from the ocean, it is $1 \frac{1}{4}$ miles wide, and below the city gradually expands, till at its mouth it forms a broad estuary, 10 miles in breadth. Ships-of-the-line ascend to the nary-yard at Washington; above this it is obstructed by numerous falls and rapids. The principal tributaries of the Potomac are its South Branch, which rises near the head-streams of James River, the Great Cacapon, and the Shenandoah, the latter of which flows about 120 miles along the western base of the Blue Ridge, and joins the main river at Harper's Ferry. "The passage of the Potomac through the Blue Ridge," says Mr. Jefferson, "is perhaps one of the most stupendous scenes in nature."

The Rampahannock rises in the Blue Ridge, and receives the Rapid Ann from the same ridge, and falling over the primary ledge of Fredericksburg, 100 miles from its mouth, there reaches tide-water. Vessels of 140 tons ascend it to this point. Tork River, formed by the union of the Pamunky and Mattapony, partakes rather of the character of a long narFow bay than of a river; to the junction, 40 miles from the bay, it is from two to four miles wide, and large vessels pass to Yorktown-smaller-ones ascend some distance above the bifureation.

Jumes Piver, the principal river of Virginia, rises in the Alleghany Mountains in several head streams, of which Jack- 


\section{VIRGINIA.}

son's River must be considered the main constituent; after having received the Cow Pasture and the Calf Pasture rivers from the north, it forees its way through the Blue Pilge, and falling over numerous pitches, meets the tide 100 miles from its mouth at Richmond, which is accessible to vessels of 140 tons. The only considerable tributary of this river below the Blue Ridge is the Appomattox, which carries seven feet of water to Petersburg, 12 miles. The James River and Kanawha Canal, now complete to Balcony Falls, at the passage of the Blue Ridge, is constructed along the valley of the river, and is one of the most stupendous and important works in the United States.

The Meherrin and Nottonoay are small rivers, which unite in North Carolina, and form the Chowan. The Roanoke is formed in Virginia by the junction of Dan River and Staunton River, two rapid mountain streams, which rise, the former in the Blue Ridge, and the latter in the North Mountain. The larger part of the Roanoke is through North Curolina, which State it enters about 40 miles below the union of its constituent rivers.

The great rivers of Western Virginia, flowing to the Ohio River are-the Monongahela, one of the constituents of that river; the Kanawha; the Guyandotte; the Big Sandy, etc. The.Monongabela is formed in Virginia by the junctiou of the West Branch and Tygart's Valley Piver, and beyond the Pennsylvania line it receives Cheat Piver, which descends from Greenbrier Mountain, and which is navigable for boats for a considerable distance. Little Kanawha River rises in the same district with the west branch of Monongahela River, and enters the Ohio at Parkersburg. The Kanawha, the prineipal river of Western Virginia, rises in the Blue Ridge, in North Carolina, and bears the name of New River until it unites with Gauley River, a small affluent from Greenbrier Mountain. The Greenbrier, above the latter, and the Elk and Coal rivers below it, are its principal tributaries. It is navigated by steamboats to Charleston, 60 miles from its mouth. The Covington and Ohio R. R, and the James River and Kanawha Canal traverse the valley of this river. The Guyandotte and Big Sandy enter the Ohio below the Kanawha-the latter forming part of the boundary between Kentucky and Virginia. The Holston and Clinch, which drain the south-western section of the Great Valley of Virginia, pass into Tennessee, and uniting at Kingston in that State, form the Tennessee River.

Virginia is an almost houndless fleld of mineral wealth, and within its limits, not only the useful, but also the precious metals are found in one part or the other. Gold, copper, lead, iron, coal, salt, lime, marls, gypsum, magnesian and alum earths, marbles, granites, soap-stones, and sand-stones are among the treasures, as yet for the most part lying unheeded in the bowels of the earth. Mining industry, however, has been commenced, and within the past few years has been wonderfully developed.

The first coal-field is found at the junction of the Tide- Water and Piedmont sections, and this extends from the Pamunky by Richmond to the Appomattox, a distance of about thirty-five miles, with a breadth of from one or two to eight miles. The coal is bituminsus, in seams of enormous thickness, being 30,40 , and even 60 feet thick, and of excellent quality. Coal has also been found on both sides of the Upper Appomattox. The coal of the Richmond basin is now extensively mined, and a railway to the principal mines has been built to facilitate its transportation to tide-water. Anthracite of great purity is found in the valley from the Potomac to the James River, south of which it contains a considerable portion of bitumen. Beyond the Alleghanies there are some of the most extensive and valuable deposits of bituminous coal in the United States, which derive additional value from their being associated with not less important beds of iron and salt. At Wheeling, on the Ohio, and for fourteen miles down the river, the bank presents an uninterrupted bed of highly bituminous coal, upward of 16 feet thick. The Wheeling basin, indeed, extends for 30 miles up and down the river in Ohio and Virginia. Another vast field stretches above Clarksburg, on the Monongabu la to Pittsburg, and far beyond to the north-east in Pennsylvania. There is also a valuable coal-fleld on the head-waters of the north branch of the Potomae. Thus we have five tiers of coal seams, with an average thickness of from 30 to 35 feet. There are also coal seams associated with salt springs on the Little Kanawha, and springs of petroleum, or rock oil, oceur in the same tract. On the Great Kanawha is also a very rich and extensive coal-field; and on Coal, Gauley, and other rivers in this portion of Western. Virginia, the beds of this mineral are frequently brought to view, and in fact no better general description can be presented of its extent than that it is almost continuous with the rast beds of saudstone which spread in neariy horizontal planes over nearly the whole of this broad region.

The salines of Virginia are almost wholly in the west. Salt-springs nccur on the Holston, on the New River, and on the Greenbrier; but the most important works are on the Great and Little Kanawha rivers. The brine is raised by steam-power, and evaporated in large east-iron pans over furnaces. The brine of the Kanawha wells contains very little gypsum or sulphuret of lime, and the process of crystalization is therefore attended with fewer difficulties than usual. The average yield of salt is about one bushel from every 65 or 70 gallons of brine.

The mineral springs of Virginia have long been noted for their efficiency in numerous chronic complaints, and as the resort of the fashionable world in the summer season. The State abounds with these, but the best known are the White and Blue Sulphur Springs of Greenbrier county, the Salt and Red Sulphur, and the Sweet in Monroe county, Hot and Warm in Bath, Berkley in Uorgan, Fanquier Thite Sulphur in Fauquier, Shannondale in Frederick, Alum in Rockbridge, Jordan`s White Sulpnur in Frederick, Red in Alleghany, Grayson in Carroll, Botetourt in Roanoke, Holston in Scott, $\Delta u-$ gusta Springs and Daggus Springs in Botejourt.

of the metalic products of Virginia, gold is at present perbaps the most important. It is found on both the North and Rapid Anu rivers, of the North and South Anna near their sources, of the Rivanna, in the lower part of its course, and of James River, above and below the mouth of the Rivanna. Within the past few years, several rich mines have been opened and worked successfully in these and other sections of the State. We believe that Commodore Stockton was one of the first who introduced into Virginia effective machinery for reducing on a large seale the quartz-rock, and demonstrating that a prefitable business cnuld be done in this branch of mining. The Stockton mines are located in Fluvanna county. Among other at present productive mines are those of William M. Mosely \& $\mathrm{Co}_{0}$ and of the Garnett Mining Company, in Buckingham county. There are also mines more or less productive in spottsylvania, in Stafford, in Fauquier, in Culpepper, in Orange, in Louisa, and in Gonchland counties.

"It is a matter of not less mortification," says a Report of the Manufacturers" Convention, 1S51, " than astonishment, that Virginia, with an area of coal messures covering not less than 21,000 square miles, very much of which lies on or near narigable waters. and capable of yielding all the rarieties of British coal, and of equal quality, should be reduecd to the actual production of less than 200,100 tons, of the ralue of $\$ 650,000$, while Great Britain with little more than half the extent of coal measures, produces annually $37,000,000$ tons, of about the value of $\$ 37,000,000$ at the mines, and $\$ 180,000,000$ at the market of sale. And in regard to the iron-trade, while Virginia has an unlimited supply of the finest ores, easily accessible for use and transportation, with the greatest abundance of coal, wood, and limestone for their man- 


\section{VIRGINIA.}

ufacture, set under the operation of the present revenue laws of the country, her production, in spits of all the efforts of the State to encourage it, has shrunk to an almost inconsiderable amount, and is in danger of utter ruin."

The soils of Virginia are naturally of a most fertile nature, but in the old settlements they have been exhausted by a vicious system of tillage. In many parts, however, a renovation has been effected by the application of proper fertilizers, and the adoption of a more scientific mode of culture. The Eastern and Piedmont sections are chiefly engaged in the production of Indian corn and tobaceo, the latter of which is one of the great staples of the State. Cotton is also produced in these sections. In the valley, the crops are much the same, excepting that wheat takes the place of cotton, and the system of agriculture is superior to that followed in the lower country. Beyond the mountains, and westward to the Ohio river, is a fine country, adapted in soil and climate to the successful culture of all the gruins, roris, and yrorlucts of the Middle States, and equally propitious to the breeding and rearing of eattle and other domestic animals. It is not only a great agricultural district, but it is alike rich in minerals and metals of the greatest importance and value, and will eventually become the workshop of the State, as it is now the granary.

Bold scenery is one of the dislinguishing features of Virginia; and no other State presents so many or so magnificent results of Nature convulsed. At Harper's Ferry, where the Potomac breaks through the Blue Ridge, the disruption has left behind it indelible marks of its force. The "Natural Bridge" below Lexington, according to Jefferson, is "the most sublime of Nature's works. It is an arch reaching across a narrow ravine, which extends for some distance above and below, at the height of 215 feet above the stream which flows under it, 80 feet wide and 93 feet long;" and again he says, "so beautiful and arch, so elevated, so light, and springing as it were up to heaven! the rapture of the spectator is really indescribable." These are but a moiety of the magnificent scenes of the country; everywhere in the Great Valley, and among its mountain borders, are found spectacles of grandeur and sublimity. Virginia has also numerous caves and caverns, of which Madison's Cave and Weir's Cave, both in the vicinity of Staunton, are those best known. Madison's Cave extends about 800 feet into the earth, branching into subordinate caverns, and terminating in two basins of water, of about 30 or 40 feet in depth. Weir's cave is much more extensive, and its numerous halls and chambers are pillared with an astonishing profusion of stalactites, which in some places resemble stiffened water-falls, in others hanging in rich festoons and folds like tapestry, or seem to rise from the floor like columns, thrones, lowers, or statues; it extends 1,260 feet into the ground, and contains upward of 20 large rooms, besides numerous passages and galleries. One of these halls is 260 feet in length, 33 feet high, and from 10 to 20 feet wide; and another is 153 by 15 feet, with a height of 60 feet.

Virginia is divided into 137 eounties, the general statistics of which, and the capitals of each, in 1850, were as follow :

Eastern Virginia-69 counties.

Counties. Dwell. Pop. Farms Manuf. Capitale.

Accomac .... 2,510..17, $990 . .1,007$. 17..Accomac Albemarle .... 2,022 ..25,800 .. 935. 102..Charlottesville Alexandria .... 1,454..10,008.. 94.. 89..Alexandria Amelia ........ 569. 9.770.. 354.. 5..Amelia Amherst....... 1,127. 12,699.. 728. . 0..Amherst Appomattox.... 755. 9,193.. 502. . 10.. Appomattox Bedford .......2,396 . 24,080 ..1,364.. 16. Liberty Brunswick.... 1,051 ..13,594.. 655. . 4. Luwrenceville Buckingham ... 1,062,.13,837. 616. 5..Buckingham Campluell..... 2.203 ..23,245.. 755..119..Campbell Caroline..... . 1,451..18,456.. 715.. 51.. Bowling Green Charlotte.... 903..13,955.. 563.. 6..Charlotte Charles City ... 486.. 5,200.. 199., 6.. Charles City Chesterfield .... 1,757 .17,489. . 564.. 30..Chesterfield Culpepper..... 1,034..12.252. .504.. 53.,Culpepper Cumberland ... 640. 9,751.. 395.. 9..Cumberland Dinwiddie.... . 2,745. 25,118. . 703.. 71.. Dinwiddie Elizabeth City.. $456 . .4,586 \ldots$ 173. . 12..Hampton Essex....... 725..10,206.. 328.. 17..Tappahannock Fairfax....... 1,380..10,6s2.. 610.. 8. Fairlax Fauquier ..... 1,899..20.\$68.. 889..62.. Warrenton Fluvanna..... 878. 9.487.. 454.. 51..Palmyra Franklin ..... 2,024..17,480 . 1,299 . 47. . Rocky Mount Gloucester .... 1,000.. 10,527.. 573.. 53..Gloucester Goochland.... $876 . .10,352$. 4 45.. 49.. Goochland Greene.... ... 494. 4,400. 301.. 24..Stannardsville Greenville.... $385 \ldots 5,639 \ldots 242 \ldots$ 8. Hicksford Halifax. ...... 2,152 . 25,962 . 1,309. . 21. . Halifax Hanover ..... 1,327..15.153. . 603. . 32 . . Hanover Henrico ..... $5,317,43,572 \ldots 454,230 \ldots$ RICHMOND Henry........ 986.. 8.872.. 528.. 41.. Martinsville Isle of Wight. . 1,200 . 9.353.. 629.. 13. . Smithfield James City .... 395. . 4,020.. 129.. 0.. Williamsburg King George... 526.. 5,971.. 279.. 8..King George King William., 625. . 8,779.. 388,. 10..King William

\section{Counties.}

King \& Queen. $\quad 892.10,319 \ldots 502 \ldots$ 6.. King \& Q. C. H Lancaster..... 426. . 4,708. . 299. . 4..Lancaster Loudion . . . . . 2,\$34..22,079 . 1,256. . 139. . Leesburg Luuisa . . . . . . 1,254. 16,691 . . 883 . . 22. Louisa Lunenburg .... 820. .11,692 . . 548. . 13..Lunenburg Madison....... 827.. 9.381.. 513.. 38.. Madison Matlicws..... 711...6,714.. 298.. 3.. Mathews Mecklenburg .. 1,500..20,680. 666.. 25..Boydtown Mirldesex ..... 401.. 4,394.. 280.. 14..Urbanna Nansemond . . 1,523. .12,283. . 731.. 32..Suffolk Nelson ....... 1,217. .12,758.. 635.. 70..Livingston New Kent.... 5 535. . 6,061.. 313.. 12.. New Kent Norfolk ...... 3,906..38,036.. 648.. 75. $\left\{\begin{array}{l}\text { Norfolk and } \\ \text { Portsmouth }\end{array}\right.$ Northampton .. 693.. 7,498.. 371.. 11..Eastville Northumberl'd. 639.. 7,346. 492.. 3.. Northumberl'd Nottoway...... 492.. 8,437.. 342.. 17.. Nottoway Orange...... $756 . .10,067 \ldots$ 335.. 45... Orange Patrick....... 1,248. 9.609 . 748.. 27..Patrick Pittsylvania ... 2,804 . 28, 796. 1,524..109.. Competition Powhatan ..... 517.. S,17S. 312.. 0..Scottsville Prince Edward. 805..11.857.. 421.. 86..Prince Edward Prince George. 661.. 7,596.. 312.. 0..Prince George Princess Anne. $\$ 93 \ldots 7,669$. 712.. 8..Princess Anne Prince William 995. 8,129.. 579.. 25..Brentsville Rappahannock, $990 \quad 9.782 . .472 . .84$. Washington Richmond..... S05. 6,448.. 336.. 4.. Warsaw Southampton... 1.572..18.521. 722.. 6..Jerusalem Spottsylvania.. 1,416..14,510., 429.. 15..Spottsylvania Stafford ...... $922 \ldots 8,044$. $360 \ldots 14 \ldots$ Stafford Surry ....... 650.. 5,679.. 301.. 5.., Surry Sussex ...... 751.. 9,520.. 472.. 23..Sussex Warwick..... 132..1,546.. 91.. 0.. Warwick Westmoreland. $869 \ldots 8,050 \ldots 443 . .5$.. Westmoreland Tork........ 442..4,460.. 161.. 0.. Yorktown

Western Vrrgini -68 counties.

Counties, Dwell, Pop. Farms Manuf. Capitals. Alleghany .... 461. 3.515.. 216.. 11... Corington Augusta..... 3.207, 24,610..1,264..181 . . Staunton Barbour. ... 1,467.. 9,005..1,075. 0 0..Philippa
Connties. Dwell. Pop. Farms Manuf. Cap̧itals. Bath ........ 410. 8,426.. 261.. 17..Bath Berkeley...... 1,668..11,771.. 570.. 81... Martinsburg Boone........ 495.. 3,237.. 361.. 3.. Boone 
VIRGINIÁ.

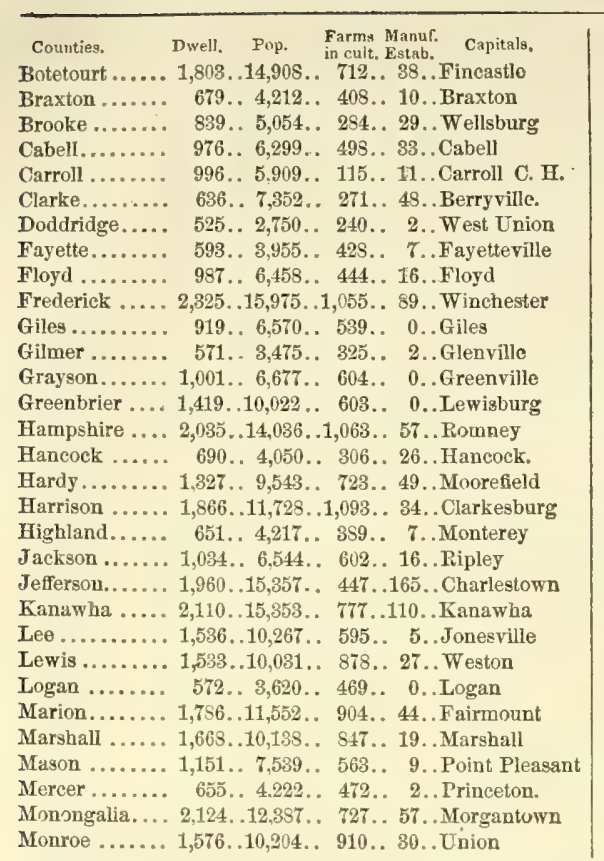

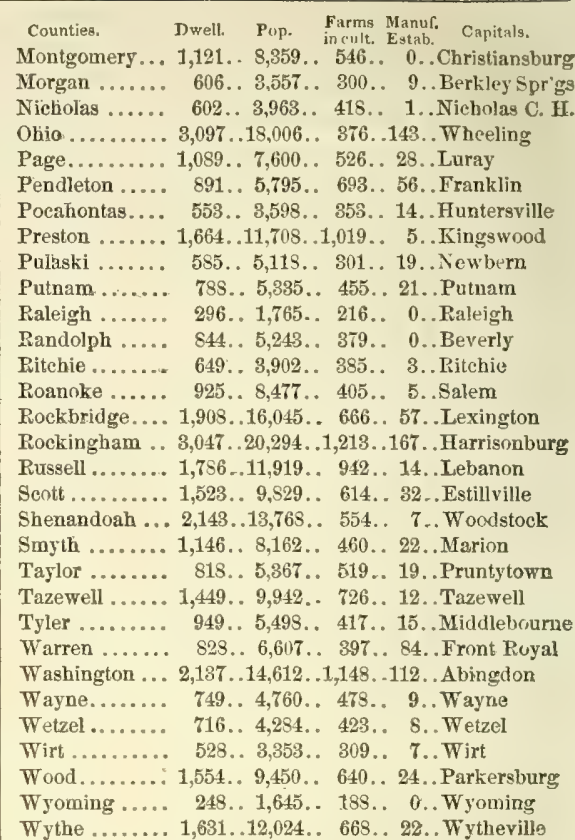

The whole number of dwellings in the State, at the above date was, 165,815 ; of families, 167,530 ; and of inhabitants, $1,421,661$; viz., whites 895,304 -males 451,552 , and females 443,$752 ; \mathrm{r}$. col, 53,829-males 25,843 , and females 27,986 , aur 81. 472,528. Of the whole population there were, deaf and dumb-wh. 581, fr. col. 18, sl. 112-total 711; blind-wh. 536, fr. col. 121, sl.339-total 996; insane-wh. 922, fr. col. 46, sl. 58-total 1,026; and idiotic-wh. 945, fr. col. 120, sl. 220-total 1,255. The number of free persons born in the United States was 925,795 , the number of foreign birth 22,394 , and of birth unknown 585. The native population originated as follows: Maine 271, N. Hamp. 239, Verm. 231, Mass. 1,193, R. I. 100, Conn. 556, N. York 2,934, N. Jer. 11,447, Penn. 6,523, Del. 542, Md. 10,328, Dist. of Col. 1,184, Tirginin 872,828, N. Car. 7,343, S. Car. 281, Ga. 93, Flor. 26, Ala.92, Miss. 7s, La. 93, Tex. 7, Ark, 150, Tenn. 1,501, Ky. 2,029, Ohio 5,206, Mich. 33, Ind. 2S8, Ill. 126, Mo. 223, Ia. 37, Wisc. 11, Calif. 4, Territories 3; and the foreign population was compused of persons from-England 2,998, Ireland 11,613, Scotland 947, Wales 173, Germany 5,511, France 321, Spain 29, Portugal 51, Belgium 7, Holland 65, Italy 65, Austria 15, Switzerland 83, Russia 8, Denmark 15, Norway 5, Sweden 16, Prussiu 36, China 3, Asia 4, Africa 3, British America 235, Mexič 4, Central dmerica 1, South America 7, West Indies 72, Sandwich Islands 1 , and other coantries 76 .

The following table will show the decennial progress of the popalation since the first census of the State, taken by the United States authorities:

\begin{tabular}{|c|c|}
\hline Census & Wlute \\
\hline $\begin{array}{l}\text { Years. } \\
1790 .\end{array}$ & $\begin{array}{l}\text { Persons. } \\
.442,115 \ldots\end{array}$ \\
\hline $1 S e n$ & $\ldots 51+.2 \$ 1) \ldots$ \\
\hline $1 S 10$. & ..551.5:34. \\
\hline $1 \leq 20$. & . 63.117. \\
\hline $1 \leq 34)$ & .694 .3110 \\
\hline $\begin{array}{l}1840 . \\
1550 .\end{array}$ & $\begin{array}{l}.740 .953 \\
.505,804\end{array}$ \\
\hline
\end{tabular}

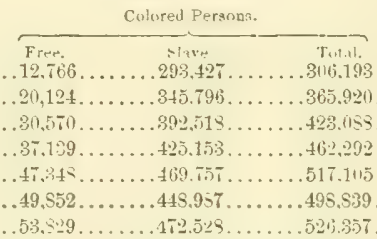

\begin{tabular}{|c|c|c|}
\hline \multirow{3}{*}{$\begin{array}{c}\text { Tntal } \\
\text { Popul.tion. } \\
749,311 \mathrm{~S} .\end{array}$} & \multicolumn{2}{|c|}{ Decennial Incrense. } \\
\hline & Numerical. & Ters \\
\hline & & \\
\hline $850,200$. & .131 .892 & $\ldots 17.6$ \\
\hline 974,6 & 94. & $\ldots 10.7$ \\
\hline $.1 .065,379$. & . . 90.757. & $\ldots 9.3$ \\
\hline $.1 .211,405$ & .146 .026 . & $\ldots 18.7$ \\
\hline 1.239 .797$. & . 28.392 . & 2.3 \\
\hline $1,421,661$ & 131.864 . & .14 .6 \\
\hline
\end{tabular}

The aggregate statistics of the resourees, wealth, protuctions, manufatctures, and institutions of the State, aceording to the census of $155 \%$, and other official returns referring to the same periof of time, are as exhibited in the following summary: Oecupied Lunds, etc.-Injuroved farm lanis, 10,311.155 aures, and unimproved lands, 15, 792,176 acres-valued in casl at $\$ 216,401,411$. The whole number of farms under cultivation on the 1st June, 1S51, was 77,013 -in the Eastern Distriet 87,741 , and in the Western District 39.272 . Value of farming implements and machinery, $\$ 7,021,772$.

Live-Siock - -Horses, 272,403 ; asses and mules, 21,450; milch cows, 317,619 ; working-oxen, 89,513 ; other cattle, 669,137; sheep, 1,310, ,104; and swine, 1,830,743. The live-stock of 1540 , and the comparison of that with the live-stock of 1550 , exhibit the following results :

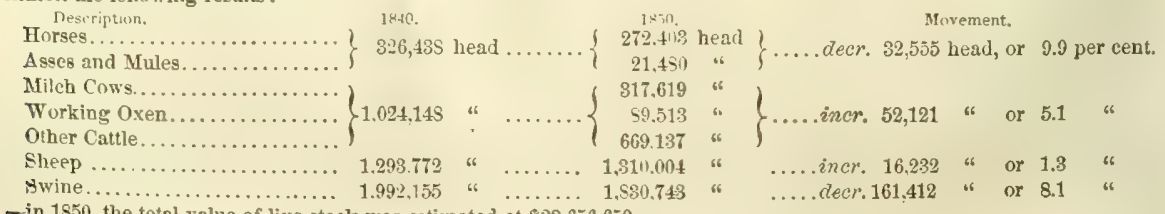

- in 1850 , the total value of live-stock was estimated at $\$ 33,656,659$ 856 


\section{VIRGINIA.}

Products of Animals -Wool, 2,860,765 pounds; butter, 11,089,859 pounds; cheese, 436,29s pounds; and the value of animals slaughtered during the year was $\$ 7,505,006$. The wool crop accounted for in the census of 1840 amounted to $2,538,374$ pounds; and hence the increase in the crop of 1850 was 322,391 pounds, or in the ratio of 12.7 per centum. In 1840, the average clip per fleece was 31.4 ounces, and in 1850, 34.9 ounces-making an increase in 1850 of 3.9 ounces per fleece, or 12:4 per centum.

Grain Crops.-Wheat, $11,232,616$ bushels; rye, 455,930 bushels; Indian corn, $35,254,319$ bushels; oats, 10,179,045 bushels; barley, 25,437 bushels; and buckwheal, 214,898 bushels. The several yields compared with those returned in the census of 1840 give the following results:

Crops. 1810 . 1850. Movement. Wheat. ............10,109,716 bushels.........11,232,616 bushels....... incr.1,122,900 bushels, or 11.1 per cent.

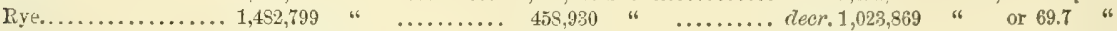

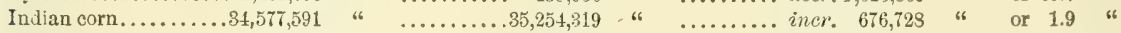
Oats ..............13,451,062 " " $\ldots \ldots \ldots \ldots 10,179,045$ " $\ldots \ldots \ldots$. decr. $3,272,017$ "

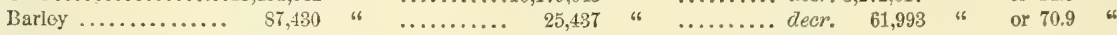

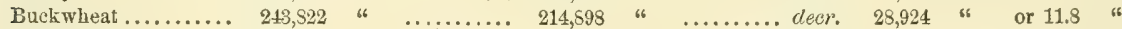

Other Food Crops,-Rice, 17,154 (in 1840, 2,596) pounds; peas and beans, 521,581 bushels; potatoes-Irish, 1,816,938 bushels, and sweet, 1,815,671 bushels. The potato crop of the census of 1840 amounted to $2,944,660$ bushels, and hence the increase in 1850 is 185,941 bushels, or at the rate of 6.3 per centum.

Miscellaneous Crops:-Tobacco, 56,803,218 pounds; cotton, 3,947 bales of 400 pounds; hay, 369,098 tons; clover-8eed, 29,727 bushels; other grass seed, 23,428 bushels; hops, 11,506 pounds; hemp-dew-rotted 90 tons, and water-rotted 51 tons ; flax, 999,450 pounds; flax-seed, 52,318 bushels; silk cocoons, 517 pounds ; maple-sugar, 1,227,665 pounds; molasses, 40,322 gallons; beeswax and honey, 850,767 pounds; wine, 5,408 gallons, etc. The value of orchard products $\$ 177,137$ and of market-garden products $\$ 1 S 3,047$. The principal crops exhibited in the censuses of 1840 and 1850 are comparatively as follows:

Crops. 1840.

1850.

Murement.

Tobacco ..........75,347,106 pounds....... $56,803,218$ pounds....... decr. 18,533,888 pounds, or 24.6 per cent.

Cotton........... $3,494,493$ " $\ldots \ldots \ldots .1,578,800$ " $\ldots \ldots \ldots$ decr. $1,915,683$ " or 54.8 "

Hay............ 364.7081 tons $\ldots \ldots \ldots$. 369,098 tons ...... incr. $4,390 \frac{1}{2}$ tons. or 1.2 "

Hops ............ 10,597 pounds...... 11,506 pounds...... iner. 909 pounds, or 8.6 "

Hemp-dew-rotted...

Flax...............

$\{5,5011$ tons 90 ton.

Silk coconns ..............

(2.101 pounds..........

999,450 pounds............

3.191 pounds..... 517 " $\quad \ldots \ldots \ldots$ decr. 2.674 "

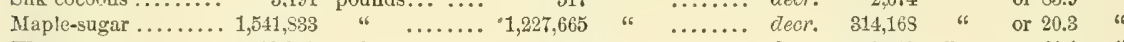

Wine ........... 13,911 gallons....... 5,408 gallons....... decr. 8,503 gallons or 61.1 "6

"The correctness of the returns as to hemp, in the seventh census, has not yet been perfectly verified. There has been some doubt, whether, in a number of instances, the marshals have not written tons where they meant pounds. (Has not the reporter in this instauce written tons where He meant pounds, and vice versa?-Ed. of Gaz.). If, however, the returns are allowed to stand without reduction, it would appear that the cultivation of hemp or flax has materially changed since 1840. In the returns of that year as stated above, both of these articles were included under the same head. In 1840 , those of Virginia gave 25,594 tons of hemp and flax together. In 1850, only 141 tons of hemp, and 500 tons of flax were returned. Such a falling off would amount to almost an abandonment of the culture of hemp in that State, which there is no reason to suppose has taken place."-Report of Superintendent of the Census, Dec. 1st., 1852.

Uome-made Dranufuctures were produced in the year endiug 1 st June, 1850 , to the value of $\$ 2,156,312$. The same description of manufactures returned in the census of 1840 were valued at $\$ 2,441,672$.

Manufactures.-Tolal capital invested, $\$ 00,000,000$; value of all raw material, fuel, etc., consumed in the year, $\$ 00,000,000$; average number of bands employed 00,000-males 00,000, and females 0,000 ; monthly enst of labor $\$ 000,000$ male $\$ 000,000$, and female $\$ 00,000$; value of manufactures produced in the year, $\$ 00,000,000$. The whole number of manufacturing establishments in operation on the 1st June, 1850, and producing to the value of $\$ 500$ and upward anuually, was 4,435-in the Eastern District 2.293, and in the Western District 2,140, and these were distributed to the several counties as exhibited in the general table. Of the whole namber 27 were cotton factories; 121 woolen factorics; 122 iron manufactories-29 making pig iron, 54 making castings, and 39 making wrought iron; 341 tanneries, etc. The total capital invested in manufactures, in the year represented in the census of 1840 , amounted to $\$ 11.360,861$.

In the manufacture of cotton goods, the capital employed is $\$ 1,908,900$; cotton consumed 17,785 bales, and coal 4,805 tons; value of all raw material, fuel, etc., $\$ 825,375$; hands employed 2,963 -males 1,275 , and females 1,658 ; monthly cost of labor, $\$ 24,774-$ male $\$ 12,983$, and female $\$ 11,791$; products of the year-sheeting, $15,640,107$ yards, and yarn $1,755,915$ pounds, valued at $\$ 1,486,354$. In 1840 there were in the State 22 cotton mills, and 1 dyeing and printing establishment, together employing 1,816 hands, and a capital of $\$ 1,299,020$, and producing in the year, goods to the value of $\$ 446,063$.

In the manufacture of roolen goods, capital to the amount of $\$ 392,640$ is invested; wool consumed in the year, $1,554,110$ pounds, and coal 357 tons, valued together at $\$ 488.899$; hands employed 658 -males 478 , and females 190 ; monthly cost of labor $\$ 10,571$ - to males $\$ 8,688$, and to females $\$ 1,883$; products of the year-cloth $2,037.025$ yards, and yarn 395,705 pounds, valued at $\$ 841,013$. The capital invested in the woolen manufacture in 1840 , was $\$ 112,350$, hands employed 222 ; value of yearly manufactures $\$ 147,792$; which statements include also the statistics of fuling-mills.

The condition of the iron manufacture is exhibited in the following statistical aggregates :

Specifications.

Capital invested

Ore used.

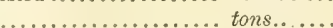

Pig Iron used ................ " " .....

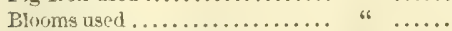

Olil melal used ................ "

Mineral Coal consumed .........

Coke and Charcoal consumed.... bushels....

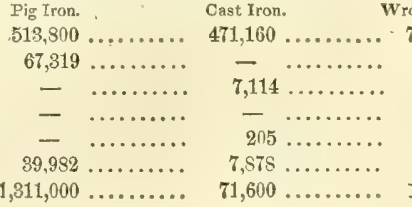

Wrought Iron.

$791,211 \ldots \ldots \ldots$

- $\cdots \cdots \cdots$

$17,296 \ldots \ldots \ldots$

$2,500 \ldots \ldots \ldots$

- $\ldots \ldots \ldots$

66, $15 \ldots \ldots \ldots$

108,000 .
Total,

$1,776,171$

67.819

24,410

2,500

205

114,375

$1,4 \$ 5,600$ 
VIRGINIA.

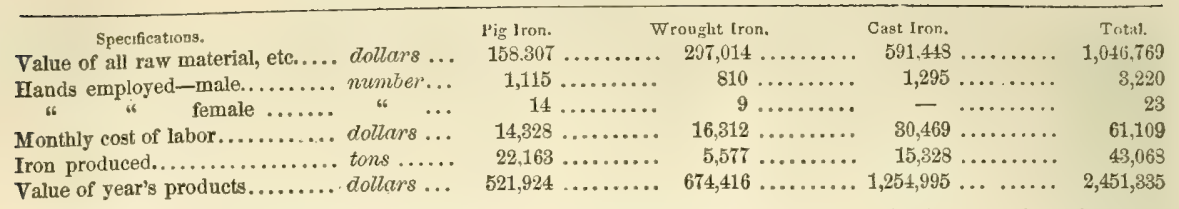

-in 1840, Virginia had in operation 42 furnaces, that in the preceding year had produced $18,810 \frac{1}{9}$ tons of cast iron, and 52 bloomeries, forges, and rolling-mills, which had produced 5,836 tons of bar iron.

The tanneries employ a capital of $\$ 6 \tau 6,983$; hands émployed 906 - males 900 , and females 6 ; monthly cost of labor $\$ 13,705-$ male $\$ 13,643$, and female $\$ 62$; sides of leather tanned 378,400 , and skins tanned 74,573 , together valued at $\$ \$ 94,876$. In 1840 there were in the State, 660 tanneries employing 1,422 hands, and a capital amounting to $\$ 533,141 ;$ and which had produced during the preceding year, 135,7S2 sides of sole leather, and 206,216 sides of upper leather.

The capital invested in the manufacture of malt and spirituons liquors amounts to $\$ 100,915$. Quantities and kinds of grain, etc., consumed-barley 20,000 bushels, corn 250,700 bushels, rje 62,650 bushels, oats 450 bushels, anu hops 14 tons; hands employed 123; quantities of liquor produced-ale, ete., 5,500 barrels, and whisky, etc., 879,440 gallons. In the census year 1540, Virginia had 1,454 distilleries, producing in the year 865,725 gallons, and 5 breweries, produeing 32,960 gallons; hands employed 1,631 , and capital invested $\$ 187,212$.

The manufactures, others than the above specified, consist of a great variety of important productions, as machinery of all kinds, carriages, harness, ete, and Virginia has also a large number of merchant and other mills. As a flour-producing State it stands first in its brands, and is only behind one or two other States in the extent of production. It has also large and valuable tobacco manufactories.

Foreign Commerce.-Virginia, in respect of foreign commerce, holds a seventh or eighth rank among the States of the Union. According to the official returns for the year ending 30th June, 1850, the value of its exports to foreign countries amounted to $\$ 3,415,646$, and of its imports $10 \$ 426,599$. This would indicate that the great bulk of its commercial material is carried to the ports of other States for exportation, and the foreign merchandise consumed within the State is brought through the same channels. That such is the case is well known, and hence we find that the coasting trade is unusually extensive, chiefly carried on by the shipping of northern ports. This was not always so, for at one time Virginia stood at the head of the commercial States, and its shipping held the same rank in. foreign ports as that now occupied by the mercantile marine of New York. Of the total exports in $1850, \$ 3,413,158$ was the value of domestic products, and of these to the value of $\$ 2.365,241$ was shipped in American and $\$ 1,047,917$ in foreign vessels-the remainder of the aggregate value $(\$ 2,485)$ was foreign produce re-shipped in American vessels. Of the imports $\$ 172,378$ was the value of merchandise landed from American and $\$ 253,721$ from foreign vessels. The shipping employed in the carrying trade consisted as follows:

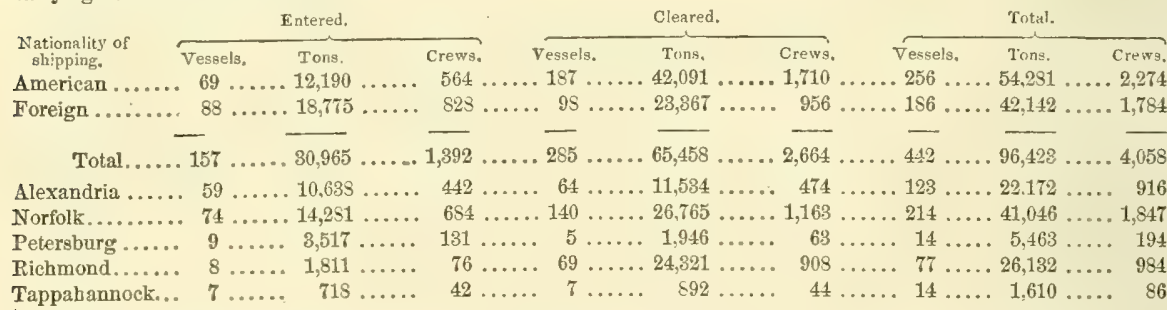

The shipping owned in the several districts of the State in 1850, amounted to 74,071 tons; of this 18.043 tons was "registered" shipping-7,092 permanent, and 10,591 temporary; 52,535 tons was "enrolled and licensed"-51,514 tons permanent, and 1,021 temporary; and 8,493 tons was "licensed under 20 tons." The tonnage of the districts was as follows-Alexandria, 8,738 tons; Norfolk, 24,185 tons; Petcrsburg, 2,708 tons; Richmond, 8,45s tous; Yorktown, 4,807 tons; Tappahannock, 5,824 tons; Accomae, 4,083 tons; East River, 4,869 tons; Yeocomico, 3,284 tons; Cherrystone 1,232 tons, and Wheeling, 5,934 tons. Of the enrolled and licensed tonnage, all of which is employed in the coasting and river trade, 8.726 tons are navigated by steam-power-in the Atlantic districts, 2,792 tons, and in Wheeling district. on Ohio River, 5,934 tons. Within the year specified there were built in the State -1 ship, 1 brig, 27 schooners, and 5 steamers-total, 34 vessels, of an aggregate burden of 3,584 tons. The serial statistics of the foreign commerce from 1791 to 1850 , are comprised in the following table:

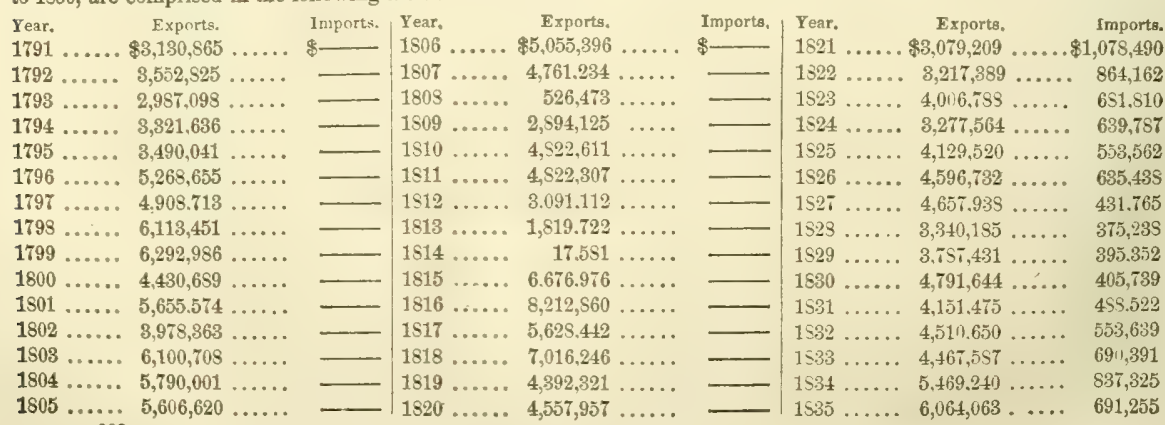


VIRGINIA.

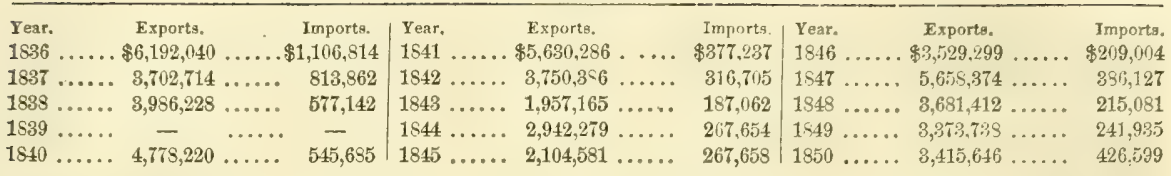

Internal Communication, etc.-The railroads and canals of Virginia, which are among the most magnificent works of the kind in the Union, extend generally from the Atlantic ports to the West, and are continued through Ohio, Kentucky, and Tennessee, to all the chief places in the north-west, west, and south-west. Alexandria. Richmond, and Norfolk are the initial points on the Atlantic; from Alexandria diverge the Orange and Alexandria Railroad and the Manassas Gap R. R.-the one directed toward Gordonville, where it joins the Central road, and the other crossing the first mountains, and passing down the valley to Harrisburg and Staunton, there unites with the same line; the Central Railroad, starting at Richmond, passes through Gordonsville, Staunton, etc., to Covington, and there unites with the Covington and Ohio Railroad, extending westward to Point Pleasant, on the Ohio, there uniting with the Ohio system, and to the mouth of Big Sandy River, where it joins the Kentucky lines to Maysville, Lexington, and Louisville, and through them connects with the lines stretching to the north and toward Nashville and New Orleans, and from Nirfilk and Petersburg a line extends through the southern counties to the Tennessee line, whence it is continued to Knoxville, connecting at that point with numerous lines directed to every important central station in the sonth-west, ete. These railroads furnish to the State ample means of transportation, and will earry to and from the seaboard an immense commercial material. They will also be the means of reviving the general commerce of the State, and of furnishing an outlet at Virginian ports for much of the produce of Ohio, Kentucky, and Tennessee, which now finds its way to more northern markets:- In the north-west several lines are being built to connect the systems of Pennsylvania and Maryland with those of Ohio and the West, and of these the North-western Railroad is, perhaps, the most important, as it will furnish the shortest route from Cineinnati to Baltimore. In the south-east the Seaboard and Roanoke Railroad furnishes an important route from the seaboard into North Carolina. The great southern line of xailroads also passes through Virginia, having Fredericksburg, Richmond, and Petersburg in its route, and being continued south and south-west to Wilmington, Columbia, ete. This is the route of the great southern mail. There are, besides these, numerous short lines, branches, etc., diverging from the main lines to several important points. The whole extent of completed railroad in the State on the 1st January, 1853, was 624 miles, and about 800 miles more were in course of construstion.

The canals of Virginia are-the James River and Kanawha Canal, the Dismal Swamp Canal. and the Alexandria Canal. The Baltimore and Ohio Canal, though in Maryland, is to all intents and purposes as much a canal of Virginia as of that State, being only separated from it by the channel of the Potomac River. The Alexandria Canal, which is a continuation of the Baltimore and Obio Canal, from Georgetown to Alexandria, is $7 \frac{1}{3}$ miles long, and is carried orer the Potomac on a splendid aqueduct. The James River and Kanawha Canal, second only in extent and importance to the Erie Canal of New York, is carried through the valley of James River, and is now complete to Baleony Falls, from which point it will be continued along the valley of Kanawha River to the Ohio. This great work has been of vast advantage to the interior of Virginia, and on an average transports about $\$ 12,000,000$ valuation of merebandise "Without the Erie Canal," says Governor Floyd, "the city of New York would have been second still to Philadelphia. Great as the advantages of this work unquestionably are, those of the James River and Kanawha Canal are undoubtedly superior. It possesses' the striking advantage of lying five degrees south of the great northern work, and is therefore free from the ice which obstructs the navigation there for so large a portion of the year. It touches the Ohio River far south of any water communication from the Atlantic whatever, and at a point south of which there can be acrnss the country no other water connection. It will command all the trade of a great part of Ohio, Kentucky, Indiana. Illinois, and Missouri, and most probably those regions lying still higher up toward the sources of the Missouri after that period it is unsafe to send produce north. We will see," says the governor, "canal boats laden at the Falls of St. Anthony or Council Bluff discharging their eargoes at Lynchburg, Richmond, and Norfolk," etc. This work is now rapidly progressing to completion. The Dismal Swamp Canal connects Chesapeake Bay with Albemarle Sound, extending from Deep Creek to Joyce's Creek. 23 miles. At present it is chiefly valuable as an avenue for the transportation of the lumber, naval stores, etc., of the region through which it passes. Wilh such works as the above, who can not but foresee that Virginia will, at no distant day, be one of the most successful commereial States of the Union, and its ports, so long forsaken, the marts of a trade not surpassed by that of the present great emporia of the country.

Banks.-In October, 1550, Virginia had 6 hanks and 31 branch banks. The condition of these establishments. at that date, was as follows: liabilities-capital, $\$ 9, \$ 14,545$; circulation, $\$ 10,256,967$; deposits, $\$ 4,717,732$; due other banks, $\$ 338,841$; and assets-loans and discounts, $\$ 19,646.777$; stocks, $\$ 269,914$; real estate, $\$ 764,252$; other investments, $\$ 210,498$; due by other banks, $\$ 1,925,652$; notes of other banks, $\$ 552,153$; and specie, $\$ 2,928,174$. Since the date of these returns several banks have been established in aceordance with the new banking law, depnsiting security for the redemption of their notes. The returns above given are those of the old chartered banks, which enjoy a high credit at home and abroad. These are--the Bank of the Valley, at Winchester, with branches at Charlestown, Leeshurg. Romney, Staunton, and Christianburg; the Bank of Virginia, at Richmond, with branches at Buchanan, Charlestown, Danville, Fredericksburg, Lynchburg. Norfolk, Petersburg, and Portsmouth; the Exehange Bank of Virginia, at Norfolk, with branches at Abington, Alexandria, Clarkesville, Petersburg, Richmond, Salem, and Weston: the Farmers' Bank of Firginia, at Richmond, with branches at Alexandria, Charlottesville, Danville, Farmville, Fredericksburg, Lynehburg. Norfolk, Petersburg, Winchester, and W'ythesville; the Merchants' and Mechanics' Bank, at T'beeling, with branch at Morgantown; and the North-western Bank of Virginia, at Wheeling, with branches at Jeffersonville, Parkersburg, and Wellsburg.

Government, etc.-The present constitution of Virginia was adopted in convention on the 1st of August and ratified bv the penple on the 25th of October, 1851. It superseded the constitution of 1776 and the amendments of 1531.

The right to vote is given to every white male eitizen 21 years old, resident of the State two years, and of the comnty, city, or town one year next preceding an election. The exceplions are those common to other Stales. Totes are given vira voce, and not by ballot; but dumb persons may so vote. The general election is held on the fourth Thursday of October bienuially.

The Legislature is styled the General Assembly, and consists of a House of Delegates and a Senate. The house con- 


\section{VIRGINIÃ.}

sists of 152 members, chosen biennially, apportioned on the basis of the white population. The Senate is based on population and taxation combined, and consists of 50 members, elected in districts by the voters therein for the term of four years, one-half the number being chosen biennially. Delegates must have attained the age of 21 and senators that of 25 years, and none but qualified voters are eligible for election. Persons holding lucrative offices, ministers of the Gospel, salaried officers of banks, and attorneys of the Commonwealth are ineligible. Any elective officer removing from his district vacates his office. In 1865 , and decennially thereafter, there shall be a re-apportionment. The sessions of the Legislature commence on the second Monday of January biennially, and continue not more than 90 days, unless a prolongation be concurred in by three-fifths of all the members, nor in any case shall a session be extended beyond the ordinary term for more than 30 days. Bills may originate or be amended in either house.

The executive power is vested in a Governor, elected by the people for four years, commencing from the 1st January succeeding election. The governor is ineligible for any other office during his term, and can be elected for two successive terms. He must be 30 years of age, a native eitizen of the United States, and for 5 yearg a citizen of the State. He must reside at the seat of government. A Lieutenant-governor, with like qualifications, etc., is elected for a like term, and is the constitutional successor of the governor in ease of death or disability; he is also ex-officio president of the Senate.

The principal administrative officers are-a Secretary of the Commonwealth, a Treasurer, and an Auditor of Public Accounts. These are elected by joint vote of the General Assembly for two years. For the purpose of electing the Board of Public Works, the State is divided into three districts, each of which shall elect one commissioner. Their term is six years, and they are so classifled that one of their number shall retire every two years. The General Assembly by a three-fitths vote may abolish the board.

The judiciary is vested in a Supreme Court of Appeals, District Courts, and Circuit Courts. In each circuit (21 in number), a judge is elected by the voters for the term of eight years, and who holds two circuit courts in the counties of his circuit annually. In each district (10 in number), a district court is held by the judges of the circuits constituting the District, and the Judge of the Supreme Court for the Section, any three of whom may hold a court. Judges of the Supreme Court of Appeals are also elected by the voters for 12 years, each section ( 5 in number), electing 1 Judge. The 5 judges so elected constitute the Supreme Court, any three of whom may hold a circuit. It has jurisdiction only where the matter in controversy is not less in value than $\$ 500$, except in certain specifled cases. Special Courts of Appeal may be organized. Circuit Judges nust not be less than 30, nor Supreme Court Judges less than 85 years of age, and no election for judges shall be held within 80 days of the time of holding the election for President, for Congressmen, or for members of the State Legislature. Offlcers of the Supreme and District Courts are appointed by the Judges thereof; but Clerks of Circuits are elected by the voters for six years. When a Governor is elected, an Attorney-general is also elected for the term of four years.

County Courts are held monthly by not less than three, nor more than five Justices. Each county is divided into districts, and each district elects 4 Justices for the term of 4 years. The Justices so elected choose one of their own body to attend each term of the Court, and classify the rest for the performance of their duties. The voters of each county elect also a Clerk of the County Court, and a Surveyor, for 6 years, an Attorney of the Commonwealth for 4 years, and a Sheriff, and Commissioner of the Revenue, for 2 years. Constables and overseer 3 of the poor are elected by the voters.

Among the miscellaneous provisions of the constitution are the following : the writ of habeas corpus shall not be suspended, nor shall any bill of attainder be passed, nor any ex-post-facto law, nor any law impairing the obligation of contracts, or taking private property without just compensation, or abridging the freedom of speech, or of the press, or establishing any religion, or prescribing any religious test, or conferring any privileges or advantages on any one sect or denomination; no law shall embrace more than one object, and when amended, shall be reënacted at length; provision may be male, rendering ineligible for office those who figbtorare engaged in a duel; the Senate shail try impenchments made by the House, and may sit for this purpose during recess; slaves hereafter emancipated shall forfeit their freedom by remaining in the Commonwealth mole than 12 months; restrictions may be imposed upon emancipation, but the General Assembly shall not emancipate; it may relieve the State from the free negroes by removal or otherwise; yeas and nays shall be taken on all tax and appropriation bills; no incorporated company shall be released from its liability to the State, nor shall the faith of the State be pledged for the debts of any company ; seven per cent. of the State debt existing, 1st January, 1S52, shall be annually set apart as a sinking fund to redeem said debt; no loans shall be contracted for a longer period than 34 years; whenever a debt is contracted, there shall be set apart annually for 34 years, a sum exeeding by one per cent. the aggregate amount of the annual interest agreed to be paid thereon at the time of its contraction, which sum shall be a part of the sinking fund; stocks held by the Commonwealth may be sold, but the proceeds must be applied to the payment of the public debt; no charter shall be granted to any church, but title to chureh property may be granted to a limited extent; no lottery shall be authorized, and the buying and selling of tickets shall be prohibited; no new county shall be formed with an area less than 600 square miles; powers shall be conferred on the Courts exclusively to grant divorces, to change the names of persons, and direct the sale of infants' estates; there shall be a periodical registration of voters, and of births, marriages, and deaths, annually; a census shall be taken every five years after the national census.

Federal Representation. - In accordance with the act of $23 \mathrm{~d}$ May, 1853 , Virginia elects thirteen representatives to the Congress of the United States.

The militia force of the State, in 1851. consisted of 125,125 men of all arms, of which number 6,494 were commissioned officers, and 118,634 non-commissioned officers, musicians, artiflcers, and privates. Of the commissioned nfficers 32 were

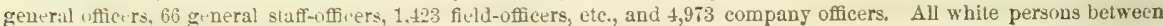
the ages of 18 and 45 are subject to military duty.

The principul tenevolent institutions of the State are the Lunatic Asylum, at Staunton, and the Institution for the Deaf and Dumb and the Blind, at the same place. These institutions are liberally supported by annual legislative appropriations.

Public Finances, etc.-The aggregate debt of Virginia, on the 1st April, 1851, was as follows: Revolutionary War debt $(6$ p. c.), \$24.039 17; war debt of 1812 (7 p. c.), $\$ 319,000$; internal improvement debt (6 p. c.), $\$ 9,364.91604$; internal improvement debt ( 5 p. c.), $\$ 1,065,600$ : internal improvement debt (5\% p. c.), $\$ 25.300$; debt for subseription to banks, $\$ 450,107$-total debt, $\$ 11,24 \$, 96221$; but of this there was held by State agents, under the control of the Legislature-by Literary Fund $\$ 1.125,60650$, and by Board of Public Works $\$ 375.91241$. or in all $\$ 1.501 .51991$, leaving an actual outstanding debt of $\$ 9.747 .43$ s0. The State is also liable conditionally for guaranteed bonds for internal improvements $\$ 3,947,>94$. The Stute holls assets. consisting of stoeks and debts due-productive of $\$ 7,060,56548$, and-not now pro- 


\section{VIRGINIA.}

ductive, $\$ 6,052,26653$; total $\$ 18,112,83211$. The valuation of property, real and personal, assessed for taxation, in 1550 , amounted to $\$ 3 \$ 1,376,660$. The valuation of the same, according to the U. $\mathrm{S}$. census of that year, was $\$ 130,701,082$. The valuation for taxes in May, 1852 , amounted to $\$ 115,5+2,18970$, being an increase of over $\$ 34,0,00,000$ in two yeurs, and it was estimated that there was other property not taxed to the value of $\$ 50,000,000$.

The chief sourees of income for the year were as follows: ordinary revenue and taxation, $\$ 676,25609$; dividends on bank stock, $\$ 286,54294$; bunus on bank dividends, $\$ 46,09836$; internal improvements, $\$ 64,029$; interest on loans to internal improvement companies, $\$ 90,77161$; militia fines $\$ 13,50976$; annuity from Old James River Company, $\$ 21,000$; loans obtained to pay subseriptions to joint-stock companies, etc., $\$ 1,235,39519$; temporary loans, $\$ 100,000$; Washinglon Monument Fund, $\$ 22,11569$; and sales of articles made at the Penitentiary $\$ 11,000$. The expenditures were as follow: expenses of General Assembly, $\$ 103,86725$; officers of government, $\$ 93,64745$; criminal charges, $\$ 39,551$ (22; contingent expenses of Courts, $\$ 32,93165$; militia, $\$ 19,34455$; Virginia Military Institute, $\$ 20,710$; public guard at Richmond, $\$ 21.34018$; comm. of revenue, $\$ 32,10690$; lunatics and lunatic asylums, $\$ 100,39071$; deaf and dumb, and blind asylums, $\$ 18,90129$; interest on public debt, $\$ 559,63447$; contingent fund, $\$ 16,67240$; public roads, $\$ 5,60150$; general appropriations, $\$ 27,16202$; revision of laws, $\$ 28,801$; penitentiary, $\$ 27,50284$; redemption of public debt, $\$ 239.500$; advance to Board of Public Works, $\$ 197,000$; Washington monument, $\$ 29,86025$; dividends to stockholders of Old James River Company, $\$ 20,895$; surveys, $\$ 3,500$; subscriptions to internal improvement companies out of loans received, $\$ 1,185,52728$; primary schools, $\$ 45,67403$; and annuity to University of Virginia, $\$ 150,000$.

Educational Statistics.-The number of schools reported in 126 counties and towns, for the year 1850-51, was 3,901, and the number of poor children 72,876 , of which 31,655 had attended schools during the year. Amount expended for tuition, including books, compensation of officers, and all other expenses $\$ 68,13593$. Average actual attendance of $\in$ ach child at common schools, 52s days. Average cost per annum of each scholar, \$2 15. The permanent eapital of the Literary Fund amounted, on the 1st October, 1850 , to $\$ 1,538,71082$; and the revenue derived therefrom, for the year, amounted to $\$ 97,88366$. Academies, seminaries, and private schools, are numerous in all the cities and towns, and many of these are institutions of favorable reputation. The statistics of the collegiate establishments and professional schools, in 1851, are as follow:

Coliegiate Institutions.

Location.

Founded. Professors, Alumni. Students. Vols, in libr.

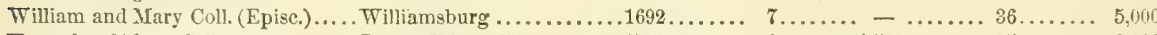
Hampden-Sidney College . . . . . . . Prince Edward's co. . . . . .1783 . . . . . 6. . . . . 1,500 . . . . . 25. . . . . 8,000

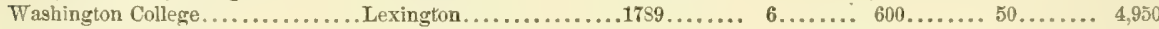

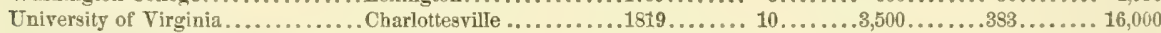

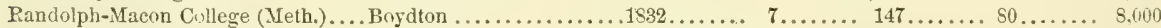

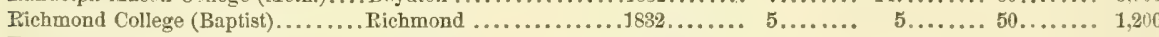
Emory and Henry College (Meth.) ..Emory................1838...... 5...... 65......100...... 7.807

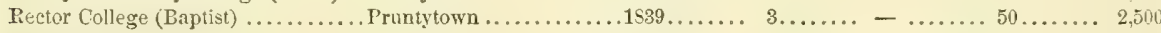

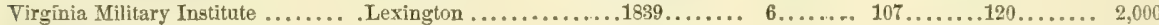

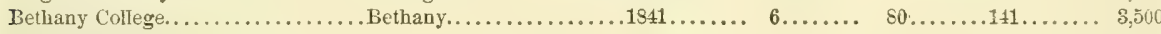
Professionat Schools:

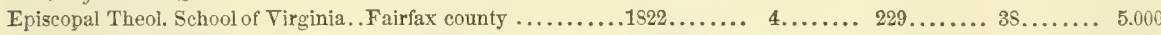
Unin:- Theol. Seminary (Presb.)..... Prince Edward co.......1524...... 3..... 175 ...... 20...... 4.000 Virginia Baptist Seminary ........ Richmond ...........1832...... 3..... _ ......67...... 1,000

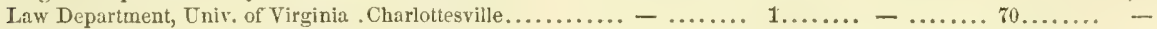

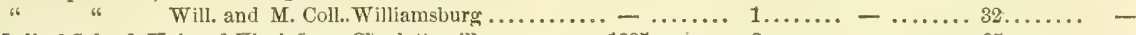
Medical School, Univ, of Virginia ... Charlottesville .........1825...... 3...... - ...... 95...... -

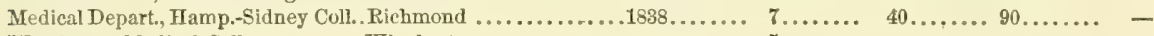
WInchester Medical College ....... Winchester........... ...... $5 \ldots . \ldots \ldots \ldots \ldots \ldots$

William and Mary College is, with the exception of Harvard University, the oldest literary institution in the country, and is distinguished for its large proportion of graduates who have risen to eminenee, some of whom have. held the highest stations in the nation. Thomas Jefferson was a graduate of this college. It was founded on a donation of land, 20,000 acres, granted in the reign of William and Mary. The buildings are of brick, and sufficient to accommodate 100 students. It was formerly allowed a representative in the General Assembly. Hampden-Sidney College was established in 1774, and named after those martyrs, who perished in the good old cause-John Hampden, and Algernon Sidney. It was chartered in 1783. More instructors have emanated from this college than from any other Southern institution. Connected with the college is a Literary and Philosophic Society, and an Institute of Education. There are also several societies among the students. The university owes its origin and peculiar organization to Mr. Jefferson. It possesses philosophical and chemical apparatus, together with a fine cabinet of minerals and fossils, and an anatomical and miscellaneous museum. The observatory, a short distance from the university, is furnished with the requisite astronomical instruments. The organization of the university differs materially from that of any other institution in the Union. The students are not divided into four classes, with a course of studies embracing four years, but the different branches are styled "schools," and the student is at liberty to attend which he pleases, and graduate in each when prepared. In order to attain the degree of M. A., the student must graduate in the several schools of mathematics, ancient languages, moral philosnphy, natural philosophy, chemistry, and in some two of the modern languages. This institution is in every respect organized, and justly regarded as a university of the first class. The Virgiaia Military Institute is conducted on the plan of instruction observed at West Point, and is a highly valued institution, and has been liberally encouraged by State appropriations.

Public Libraries.-The Report of the Librarian of the Smithsonian Institution made in 1851, states the publie libraries of Virginia as follows: one State library -14.000 volumes; 4 sncial $-3,313$ volumes; 9 college $-45,790$ volumes; $S$ students' 10,466 volumes; 5 academic and professional- 12,951 volumes; 1 scientifle and historical-1,200 volumes; 2 public - 1,460 volumes. Total-30 libraries, and 89,180 volumes.

Periarticul Press.-Firginia, on the 1st June, 1850, had 100 periodical issues-in politics 31 were whig. 22 democrat, and 47 neutral, the latter including those devoted to literature, science, religion, and all the character of which had not been ascertained. Of the whole number 20 were published daily, 6 tri-weekly, 7 semi-weekly, 60 weekly, 4 monthly, and 1 quarterly; and the circulation of the dailies was 32,750 copies at each issue; of the tri-wecklies, 700 copies; of the semi- 


\section{VIRGINIA.}

weeklies, 6,500 copies; of the weeklies, 41,936 copies; of the monthlies, 13,150 copies; and of the quarterly, 1,000 copies. There were published in Augusta County (Staunton), 8 weekly; Albemarle ( 8 in Charlottesville), 8 w. and $1 \mathrm{~m}$.; in Alexandria, 1 d., 1 to-w., and 1 w.; in Botetourt, Berkeley, and Brooke, each 2 w.; in Campbell (Lynchburg), 3 s.-w.; in Dinwiddie (Petersburg), 2 d. and 1 t.-W.; in Fauquier, 2 w.; in Fairfax, 1 w.; in Frederick (Winchester), 2 w.; in Greenbrier, 1 w.; in Harrison, 2 w.; in Hardy, 1 w.; in Hampshire, 2 w.; in Henrico (Richmond), 6 d., 1 s.-W., 2 w., 5 m., and 1 quarterly; in Jefferson, 8 w.; in Kanawha, 1 w.; in Loudon, 2 w.; in Lewis, Marshall, and Monroe, each 1 w.; in Monongalia, 3.w.; in Marion and Nansemond, each 1 w.; in Norfolk (Portsmouth 6, and Norfolk 7 ), 7 d., 4 t.-w., and 2 w.; in Ohio (Wheeling), 3 d. and 2 w.; in Preston, Prince Edward, and Pittsylvania, each 1 w.; in Rockbridge, Rockingham, and Shenandoah, each $2 \mathrm{w}$; in Spottsylvania (Fredericksburg), 1 d., 2 s.-w., and 3 w.; in Tazewell, $1 \mathrm{~W}$; ; in ashington, $2 \mathrm{w}$, ; and in Wood and Wythe, each 1 weekly.

Religious Denominutions.-The statistics of the several religious denominations in the State in 1550 were as follows:

\begin{tabular}{|c|c|c|c|c|c|c|c|c|c|c|}
\hline $\begin{array}{c}\text { Denomina. No. of } \\
\text { tions. }\end{array}$ & $\begin{array}{l}\text { Chureh } \\
\text { accom. }\end{array}$ & $\begin{array}{l}\text { Value of } \\
\text { Property. }\end{array}$ & $\begin{array}{l}\text { Denomina- } \\
\text { tons. }\end{array}$ & $\begin{array}{l}\text { No. of } \\
\text { Churches. }\end{array}$ & $\begin{array}{l}\text { Church } \\
\text { accom. }\end{array}$ & $\begin{array}{l}\text { Value of } \\
\text { Property. }\end{array}$ & $\begin{array}{l}\text { Denomina- } \\
\text { tions. }\end{array}$ & $\begin{array}{l}\text { No. of } \\
\text { Cliurches }\end{array}$ & $\begin{array}{l}\text { Clurch } \\
\text { accom. }\end{array}$ & $\begin{array}{l}\text { Value of } \\
\text { Property. }\end{array}$ \\
\hline Baptist..... 639.. & $241,689$. & $\$ 687,918$ & Germ'n Ref. & $9 \ldots$ & 8,800 & .. $\$ 16,200$ & R. Catholic. & 17 & 7,930 & $\$ 126,100$ \\
\hline n... 16. & 4,900 . & 6,08 & .... & $1 \ldots$ & 600 & 4,000 & ab'g . & . - & 一 & - \\
\hline at'l. & - & - & a... & $50 \ldots$ & 18 & 145 & & 8 & 4,400 & 8,200 \\
\hline ef. - & - & - & aite. & $6 .$. & 2,250 & 5,550 & Un & . 47 & 3,250 & 24,025 \\
\hline 1.. 167 . & 88 & 527,150 & t. . & 1,002 & 3 & 93 & a... & - & - & - \\
\hline 1 & & 1,900 & & 8 & & & ist & 1 & 200 & 500 \\
\hline 14. & 6,300 & 8,825 & resbyter'n. & 236 & 625 & 7,165 & Minor Sects. & 8 & 2,825 & 18,050 \\
\hline
\end{tabular}

-making a total of 2,336 churches, with accommodation for 834,691 persons, and valued at $\$ 2, \$ 49,176$.

Virginia forms a diocese of the Protestant Episcopal Church, and comprises the Roman Catholic Dioceses of Richmond and Wheeling, and also a portion of the Archdiocese of Baltimore, the last being that portion of the District of Columbia retroceded in 1846.

Pauperism.-The whole number of paupers relieved and supported within the year ending 1st June, 1850, was 5,118, of whom 4.933 were native born and 185 foreigners; and the whole number of paupers at the date specifed was 4,45s, of whom 4,356 were natives and 102 foreigners. Cost of support, etc., during the year $\$ 151,722$.

Historical Sketch, -The name of Virginia, though now belonging only to the present State of that name, was originally given to the whole extent of country afterward divided into the thirteen colonies. It was bestowed upon the country, which he attempted to colonize, by Sir Walter Raleigh, in honor of Elizabeth, England's virgin queen. The settlement within the limits of the present State were not, however, effected until April, 1607, and this was the first permanent settlement by the English in America. Previous to this many ineffectual efforts had been made to plant colonies on the Atlantic coast. At length the matter was undertaken by a cornpany, to which a patent was granted by James I. and which was called the London Company, to distinguish it from the Plymouth Company, which subsequently settled New England. Three ships, with 105 persons, sailed from London in December, 1606, and after a tedious and circuitous passage entered the Bay of Chesapeake in April, 1607. On a peninsula a little distance up James River, a settlement ealled Jamestown was begun. The colonists soon experienced the difficulties of their new position, and to the great exertions of Captain John Smith, distinguished among the adventurers of the age, the colony was indebted to its preservation. An incident which occurred at this period has lent to his history the attractions of romance. While on a foraging expedition he was taken prisoner by the Indians, who determined to put him to death; his head was placed on a stone, and the savages were about to dispatch him with clubs, when Pocahontas, the daughter of the principal chief, Powhatan, after in vain imploring mercy for him, rushed forward, and resting her head upon that of the captive, appeared determined to share his fate. Powhatan relented, and soon afterward permitted Smith to return home. Two years after, when the Indians had plotted the destruction of the colony, Pocahontas, faithful to the attachment she had formed, diselosed the plot to the English, and the Indians finding them on their guard, abandoned the project. Such was the distress of the colonists in 1610, that the survivors had actually embarked to return to England, when Lord Delaware, who had been appointed governor, arrived with supplies and $150 \mathrm{men}$, and persuaded the colonists to remain. Under this governor and his successor the setlement prospered; useful industry succeeded to their previous habits, and, aided by a fertile soil, they were enabled to raise large stocks of provisions. In 1619 the first legislature was convened, and about this period 1,200 additional emigrants arrived, among whom were 150 young women, who were sold to the planters.for wives. Negro slaves were first brought into the country at this time. In 1622 the Indians surprised the settlements and massacred some 347 of the colonists; and the whole colony would have shared the same fate, but that timely information had been given the inhabitants of Jamestown of the conspiracy. To this famine succeeded, which was, however, alleviated by the arrival of provisions from England. A reinforcement arriving at the same time, war was levied against the Indians, and in a short time most of the neighboring tribes were subdued or slain. Two years afterward the company was dissolved and the charter resumed by the king. All power was vested in eommissioners, and under their rule the colony suffered grievously. Sir John Harvey, the royal governor appointed in 1629, was seized by the people and sent home a prisoner. He was succeeded by Sir William Berkeley, who called an assembly of burgesses, and governed the province with mildness and prudence.

On the revolution in England, the Virginians adhered to the cause of the monarch, and even after the death of Charles I. refused to acknowledge the commonwealth. Submission was forced by sending against them an armament; but the sentiments of the colonists were again declared, for even before the restoration in England the authority of Charles II. had been acknowledged in Virginia. In 1661, an assembly was called by the governor, and in the succeeding year the Church of England was established by law. Notwithstanding this remarkable loyalty of the Virginians, they were made to suffer grievously from the arbitrary and monopolizing system of the home government. The navigation act, and other measures of a similar nature adopted to this time, weighed heavily on the people, and in addition to these grievances, the king, regardless of the rights of the landed proprietors, granted to his courtiers large tracts of land, to which the settlers were legally entitled. From these causes arose an insurrection, memorable in the history of Virginia, and known as Bacon's Rebellion. Colonel Bacon, an eloquent and ambitious man, put himself at the head of the people, who had assembled with the ostensible object of a foray against the Indians. The governor, by advice of the legislature, issued a proclamation of rebellion against them, and so exasperated the leaders of the expedition as to direct its object from hostilities against the Indians to war against the government. They marched to Jamestown, and after dispersing 
the assembly, Bacon called a convention, and assumed the reins of government. Civil war with all its horrors now ensued. Jamestown was burnt, and the colony given up to pillage. After several months' bloodshed and confusion, Bacon died suddenly, and for want of a leader his party dispersed. It was long, however, before prosperity revived in the colony. Soon after these events, Berkeley returned to England, and was succeeded by Lord Culpepper, who brought with him several bills drawn up by the ministry of England, to which he required the assent of the legislature, on pain of being treated as rebels. The object of these acts was the increase of his emoluments. During the reigns of Charles 1L. nnd James the colony suffered much, and rejoiced greatly in the change of government that drove the Stuarts from the throne. The Revolution, indeed, brought to Virginia internal tranquillity, and a long succession of prosperous years Nothing occurred to interrupt its growth in wealth and power. In 1732, she gave birth to the most illusirious of her sons, the great statesman and warrior, who was destined afterward to achieve and consolidate the independence of all the colonies. During the war between France and England, prior to 1754, her local situation exempted her from hostilities. From 1754 to 1758 , when the French began to put in operation their scheme to unite Canada and Louisiana, the frontiers of Virginia were harassed by incursions of French and Indian parties; to repel which a regiment was raised, in which Washington first distinguished himself. On the conclusion of peace, when the British attempted to raise a revenue within the colonies, the statesmen of Virginia were among the first to raise the voice of opposition. The eloquence and talents of $\mathrm{hel}$ orators contributed greatly to excite public feeling on this occasion. The services and sufferings of Virginia in the war of the Revolution were at least as great as those of any other State, and in Virginia the last important measure of the war took place, in the surrender of Cornwallis. Since the peace of 1783 , Virginia has retained an elevated rank in the family of States. Fruitful of illustrious men, that State has given seven presidents to the Union, During the war of 1312, her eitizens displayed great patriotism in opposing the common enemy, and her maritime frontier suffered severely from predatory incursions. Within the last few years the progress of the State in population and material greatness has been wonderfully rapid; and her territory beyond the mountains-a wilderness to the last generation, has become equal to the old settlements in all that constitutes national wealth. In 1850 the constitution of the State was adjusted to its present condition and circumstances.

Rurchrond, on the bank of James River, 130 miles above its entrance into Chesapeake Bay, is the political capital of the State.

Vrginia, p. v., Cass co., Ill. : $32 \mathrm{~m} . \mathrm{W}$. by N. Springfield. This v. was formerly the eapital of the county, now removed to Beardstown, but continues to be a thriving place. Pop. about 300 .

Virglita Grove, p. o., Louisa co., Ia.: 33 m. S. S. E. Iowa City.

Virginia Mruls, p. o., Buckingham co,, Tirg.: about $2 \mathrm{~m}$. S. James r., $51 \mathrm{~m}$. W. by N. Richmond.

Viretnia Mrees, p. O, Franklin co., Mo.: on W. side of Maramec r., 70 m. E. by S. Jefferson City.

Virgunsvirle, p. V., Berks county, Penn. : 59 m. E. Harrisburg,

VISCHER'S FERRY, p. o., Saratoga co., N.Y.: 15 m. N. by W. Albany.

VISTA, p. 0., Westchester co., N. Y. : 90 m. S. by E. Albany.

Vlate marsh, Fulton co., $N_{.} Y_{.}:$in the E. part of the county, is annually overflowed by the surplus waters of the Sacandaga r. and other streams. This is a place of much resort by sportsmen, on account of the abundance of game, for which it is famous.

Vogansvilue, p. 0., Lancaster co., Penn. : 40 m. E. S. E. Harrisburg.

Volcaxo, p. o., Calaveras co., Calif: : at head-waters of Jackson cr., in extreme E. part of the co, $78 \mathrm{~m}$. W. Vallejo. The gold-mines of the vicinity are among the richest in the State, and quartz-mining here, more than elsewhere, has been successfully engaged in.

Volinta, t, and p. O., Cass co., Mich. : $85 \mathrm{~m}$. \$.W. Lansing. The inhabitants are generally engaged in farming. Pop. in 1840,411 ; in 1850,607 .

Vounex, p. o., Logan co., Ky. ; 144 m. S.W. Frankfort.

Volney, t. and p. O., Oswego co, $N . Y_{0}$; on E. side of Oswego r., $144 \mathrm{~m} . \mathrm{W} . \mathrm{N} . \mathrm{W}$. Albany. Surface undulating; soil sandy loam. Drained by Big Black cr. The t. contains several saw-mills, and has some manufactures. Pop. of $t$. with Fulton, 5,310 .

Voluntown, t. and p. v., Windham county, Conn. : $46 \mathrm{~m}$. E. S. E. Hartford. Surface uneven. Drained W. by Pachang $r$ : The t. contains 2 cotton factories, a few stores, and 2 churches. Pop. 1,061.

Volusta, p. 0., Chautauque co., N. Y.: $307 \mathrm{~m}$. W. by $\$$. Albany.

Volusta, p. v., Orange co., Flor. : on E. side of St. John's river, between lakes George and Dexter, 190 m. E. S. E Tallahassee. It was formerly occupied as a military post. Vur de L'Ėav, p. o., Bristol co., Mass.

\section{W.}

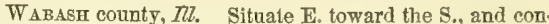
tains 198 sq. m. Drained by Jordan, Coffee, and Crawfish creeks. Surface undulating; a large portion is prairie. Soil fertile, and produces fine crops of wheat and grain. It fattens large numbers of eattle and hogs, which are annually exported. Pine timber abounds. The Wabash $r$ bounds the co. on the S. and E. Farms 533; manuf. 9; dwell. 808, and pop.-wh. 4,640, fr. col. 50-total 4,690. Capital: Mount Carmel.

W ABASH county, Ind. Situate N. middle, and contains 420 sq. m. Wabash and Eel rivers, with their tributaries, drain this county. Nowhere billy, the greatest portion is rolling or undulating, but there are also extensive level tracts and bottoms. Timber abundant, and the soil is everywhere rich and productive. Corn and hogs are the great staples. Farms 1,068; manuf. 57 ; dwell. 2,079, and pop.wh. 12,124, fr. col, 14-total 12,138. Capital: Wabash. Public Works: the Wabash and Erie Canal; and the R. R. between Fort Wayne and Lafayette.

WABASH, p. v., and cap. Wabash county, Ind.: $72 \mathrm{~m}$ N. by E. Indianapolis. It is very pleasantly situated on the $\mathrm{N}$. bank of Wabash $\mathrm{r}$, and is built partly on the first, and partly on the second bottom, elevated about 40 feet above the first. It contains the court-house, jail, ete., and several churches. The "Wabash Gazette" (whig) is here published. The Wabash and Erie Canal passes through, 155 m. from Toledo, $312 \mathrm{~m}$. from Evansville, and creates a large business. First settled in 1835. Pop. about 1,100.

WABASH river, Ind. : is formed by two creeks rising in Mercer and Darke counties, Ohio, and flows in a N. W. course into Indiana. In Huntington co. it receives Little river, and flows W. until it passes Logansport; thence in a S. W. course until it reaches Covington; thence nearly $\mathrm{S}$. until it reaches Terre Haute; after which it forms the boundary line between Indiana and Illinois, to its entrance into the Ohio $r$. It is navigable to Lafayette for steamboats, and connects the Ohio r. with Lake Erie by means of the Wabash and Erie Canal. Its entire length is about $600 \mathrm{~m}$, of which more than $450 \mathrm{~m}$. have been navigated by steamboats in high water.

WABASHAW county, Minn. Ter. Occupies all that rast territory extending from the Mississippi to the Missouri, and between the $\mathrm{N}$. boundary of Iowa and the parallel of $44^{\circ}$ $40^{\prime} \mathrm{N}$. lat. Drained in the E. by Minnesota and its tributa- 
ries, and in the W. by Tchan-sausan, or Riviere à Jaques, Sioux r., and other large affluents of the Missouri. The surface is elevated, chiefly level, interspersed with numerous lakes, and very fertile. Farms 8 ; manuf. 0 ; dwell. 55 , and pop.-wh. 242, fr. col. 1-total 243 . Capital:

W ABSIPINECON river, $I a$. (See WAPSIPINICON.)

W ACAHOOLTE, p. o., Marion co, Ind.

WACCAMAW river, $N$. Car. and $S$. Car.: rises in Waccamaw lake ( $N$. Car.), flows W. S. W., and nearly parallel with the coast, to its entrance into Winyaw bay. It is about $100 \mathrm{~m}$. long, and navigable for steamboats to Conwayboro', about $40 \mathrm{~m}$. from its mouth.

W Achira river, $A r k$. and $L a .:$ the principal N. tributary of Red r., rises in Polk co. (Ar\%), and flows E., S. E., and S., receiving numerous branches. It has a large volume of Water, and, upon the removal of small obstructions, will be easily navigable for small steamboats.

WACHUSETX mountain, Worcester co., Mass. : is an isnlated peak in the $N$. part of Princeton $t_{n}, 42 \mathrm{~m}$. W. by $\mathrm{N}$. Boston. Its summit is elevated 2,021 feet above Massachusetts bay, and affords a most extensive and delightful prospect.

Wacousta, p. V., Clinton co., Mich. : on N. bank of Looking-glass r., 9 m. N. W. Lansing.

Waco Village, p. o., Milan county, Tex.: on W. side of the Rin Brazos, 99 m. N. N. E. Austin City.

WADDAM's GROVE, t. and p. o., Stephenson county, $I l l$. $174 \mathrm{~m}$. N. Springfield. Pop. about 450.

W Addingtor, p. v., St. Lawrence co., $N . Y_{\text {. }}$ : on $\mathrm{S} . \mathrm{E}$ side of St. Lawrence $\mathbf{r}, 168 \mathrm{~m}$. N. N. W. Albany. Incorporated in 1839 . It contains varions mills and manufacturing establishments, and is connected by a bridge with Ogden's island, Iying opposite. Pop. about 650 .

W ADEBORO', p. o., Livingston par., La.

WADE's, p. 0., Bedford county, Firg.: $105 \mathrm{~m}$. W. by S. Richmond.

W $\triangle$ DESBORO', p. v., and cap. Callaway co., $\bar{K} y . \therefore$ about $2 \mathrm{~m}$. W. Clark's r., 236 m. S.W. by W. Frankfort. It contains the county buildings. Pop, about 200 .

W ADEsBoro', p. v., and cap. Anson co., $N$. Car.: $86 \mathrm{~m}$. S.W. by W. Raleigh. It contains a court-house, jail, stores, etc., and 1 bank, capital $\$ 200,000$. The "North Caroliaa Argus" (whig) is issued weekly, and the "Cadet of Temperance" semi-monthly. Pop. about 650 .

WADEstows, p. 0., Monongalia con, Virg.: $203 \mathrm{~m} . \mathrm{N}$. W Richmond.

W adesville, p. v. and sta., Clark co., Virg. : on Winchester and Potomac R. R., 23 m. from Harper's Ferry, 9 m. from Winchester, $109 \mathrm{~m}$. N. by W. Richmond.

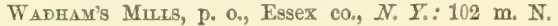
Albany.

W Adivg Rrver, p. v., Suffolk co., $N$. $\bar{Y}$.: on small inlet of same name, $181 \mathrm{~m}$. S. S. E. Albany.

W A.SWORTI, t. and p. v., Medina co., Ohio: 94 m. N. E. Columbus. Drained by $\mathrm{N}$. branch of Chippewa $r$. Interests of $t$. are chiefly agricultural, but has some manufactures, with several milis. Pop. of t. 1,622.

W ADsworti's, sta., Norfolk county, MCass.: on Norfolk County R. R., $30 \mathrm{~m}$. from Boston.

W AGGONER's RIPPLE, p. 0., Adams county, Orio: $75 \mathrm{~m}$. S. by W. Columbus.

WAgontows, p. v., Chester co., Penn.: 60 m. E. S. E. Harrisburg. Here is located a chareral forge, which in 1849 mude 300 tons of blooms, and a rolling mill, with annual capacity of 400 tons.

W AGruM, p. 0, Accomac county, Virg.: $97 \cdot \mathrm{m}$. E. by N. Pichmond.

W Aнкоण county, Ia. Situate W., and contains $770 \mathrm{sq} . \mathrm{m}$. Drained by Little Sioux $r$. and branches. Surface in general undulating; soil fertile, and adapted to wheat and grain. Set off since 1850 .

WaHna sissippi to the Missouri, and between $45^{\circ} 25^{\prime}$ and $46^{\circ} 20^{\prime} \mathrm{N}$. 894 lat, and is drained centrally by the Minnesnta and à Jaques rivers, and $\mathbf{E}$. and $W$. by rivers flowing to the border rivers. Surface elevated, and generally level, interspersed with thousands of lakes, and covered in many parts with valuable timber. The Minnesota and Red rivers of the north have their rise in two adjoining lakes, separated only by a short portage. Farms - ; manuf. - ; dwell. 26, and pop. -wh. 160, fr. 0-total 160. Capital:

W AFOLOCK, p. o., Kemper co., Miss.: 110 m. E. N. E. Jackson.

WAHsaTCH mountains, Utah Ter,: extends across the territory in S, S. W. direction from the Green river range of the Rocky Mountains, to the Sierra Nevada range of California.

WAITr, p. o, Washington county, $M e_{\text {e : }} 126$ m. E. N. E. Augusta. Pop, of Waite Plantation, 81.

W Aitefielo, t. and p. v., Washington co., Term. : $11 \mathrm{~m}$. \$.W. Montpelier. Drained by Mud r. and branches, which furnish water-power to grist and saw mills, ete. The inhabitants are chiefly engaged in farming. Pop. of t. 1,021.

WAIr's river, Verm. : flows through N. E. part of Orange co. into the Connecticut, and with its branches, affords great water-power.

W AIT's CoRNERs, sta., Washington co., N. Y.: on Rut land and Washington R. R., $25 \mathrm{~m}$. from Troy, $59 \mathrm{~m}$. from Riutland.

WAKAsassa, p. o., Levy co., Flor.: on Wakasassa river, 114 m. \$. E. by E. Tallahassee.

WaKasassa bay, Flor.: bounds Levy co, on the $\mathrm{S}$. W. it receives several rivers, and contains a number of islands.

Wақатомса, p. o., Coshocton co., Ohio: 49 m. E. N. E. Columbus.

WAKE county, $N$. Car. Situate centrally, and contains 1,018 sq. m. Drained by Neuse $r$, and its branches. Surface even; soil various, but in general very fertile. Chief productions, cotton, tobacco, wheat, and grain. Farms 1,410; manuf. 56 ; dwell. 2,844 , and pop.-wh. 14.177 , fr. col 1.301, sl. 9,409-total 24,857. Capital: Raleigh. Publio Works: North Carolina Central R. R.; Gaston and Raleigh R. P.

W AKEFIELD, p. v., Carroll county, Mrd. : 60 m. N. N. W. Annapolis.

Wakerield, t. and p. $\nabla_{.}$, Carroll co., N. $\operatorname{Hamp}$ : $82 \mathrm{~m}$. N. E. Concord. This is a pleasant t, with good soil, and possessing water-power. It contains 3 large ponds, of which Lovewell's Pond, in the S. part, is celebrated as the scene of a battle with the Indians in 1725. Pop. of t. 1,405.

Wakefteld, p. v., Wake co, $N$. Car. : 18 m. E. N. E. Raleigh.

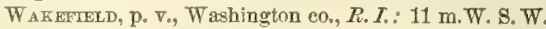
Newport. It contains a church, a factory of satinets and jeans, and one bank, eapital $\$ 100,000$.

WAKE Forest, v., Wake co., $N$. Car.: on Gaston and Raleigh R. R, $17 \mathrm{~m} . \mathrm{N}$. Raleigh. Here is located Wake Forest College, a Baptist institution, founded in 1838, which in 1850 had 3 professors and 24 students, with 4,700 vols. in library.

W AKEMAN, t, p. o, and sta, Huron ce, Ohio: $89 \mathrm{~m}$ N. N. E. Columbus. The Toledo, Norwalk, and Cleveland R. R. passes through, $69 \mathrm{~m}$. from Toledo, $43 \mathrm{~m}$. from Cleveland. The t. has fertile soil, and is drained N. by Vermillion r., flowing through it centrally. It contains flouring, saw, and grist mills; also woolen factories. Pop. 704.

W AKulla county, Flor. Situate N., and contains 492 sq. m. Drained by branches of Ockatockany r. Surface level: soil fertile, and productive in a high degree. Chief products, cotton, sugar, rice, wheat, Indian corn, and fruits of all kinds. Farms 100 ; manuf 5 ; dwell. 227, and pop.wh. 1,164, fr. col.1, sl. 790-total 1,955. Capital: Newport W ALcoTr, p. 0., Greene co., $A r k$ : 126 m. N. E. Little Rock.

W ALDEN, p. v., Orange co., $N . Y$. : on E. side of Walkill 
T., $80 \mathrm{~m}$. S. by W. Albasy. It contains several woolen factories and mills. Pop. about 440.

Waturer, t. and p. v., Caledonia co., Verm.: 21 m. N. E. Montpelier. Surface elevated and rough. Drained by head branches of Lamoille river. Pop. of t. 910 .

W ALDEN's Creer, p. o., Sevier co., Tenn.: 180 m. E. by S. Nashville.

W ALDENSVILle, p. o., Sehoharie county, N. Y.: $25 \mathrm{~m}$. W. Albany.

WALDO county, Me. Situate S., and contains 931 sq. m. Drained by Marsh and St. George rivers, and tributaries of Sebasticook river. Suriace undulating and diversified, with numerous lakes and streams of running water, the latter supplying fine water-power; soil fertile, and favorable to the growth of wheat and grain, and other agricultural productions. On the E., the Penobscot stretches out into a broad expanse of water, forming a noble bay, and affords, by means of the many excellent harbors on the line of coast, facilities for navigation and the fisheries, that can not at all times be commanded, It is well wooded, and has large beds of excellent limestone, great quantities of which are exported. Farms 4;415; manuf. 347; dwell. 7,631 , and pop. -wh. 47,191, fr. col. 39-total 47,230. Capital: Belfast.

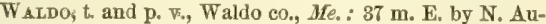
gusta. Drained by small streams flowing into Belfast bay, furnishing good water-power. Pop. of t. 812 .

WALDO, p. O., Delaware county, Ohio: on W. branch of Whetstone r., $38 \mathrm{~m}$. N. by W. Columbus.

WALDO, p. 0., Wright co., MO.: $97 \mathrm{~m}$. S. by W. Jefferson City.

WАLDOBORO', t., p. v., and port of entry, Lincoln co., Me.: on Muscongus r. The $v$, has considerable ship-building and navigation. The total tonnage of Waldoboro' district on June 30 th. 1850 , was 96,330 tons. The registered tonnage amounted to 38,483 tons, consisting of 30,612 tons permanent, and 7,871 ions temporary. The enrolled and licensed tonmage amounted to 57,847 tons, consisting of 56,094 tons enrolled, and licensed, and permanent, of which 51,832 tons were in the coasting trade, 3,718 tons in the cod fishery, and 544 tons in the mackerel fishery, and 1,753 tons "licensed under 20 tons," of which 283 tons were in the coasting trade, and 1,470 tons in the cod fishery. The foreign commerce during the year preceding consisted of 18 clearances-2,548 tons, and 6 entrances -192 tons. Vessels built during the year 71-32 ships, 17 brigs, 22 schooners-23,632 tons. Pop. of t. in $1840,3,661$; in $1850,4,199$.

W $\triangle L D R O N$, p. 0., Scott co., Ark. : 96 m. W. by N. Little Rock.

WALDWTCH t. and p. o, Iowa co., Wisc.: $30 \mathrm{~m}$. S. W. by W. Madison, Pop. 423.

WALes, t. and p. v., Kennebec co., Me.: 18 m. S. W. Augusta. Pop. of $t$. 612.

WALES, p. t., Hampden co., Mass.: 63 m. W. S. W. Boston. Drained by a head stream of Quinnebaug $\mathrm{r}$. and other small creeks. The v. contains 2 churches and 2 factories, making principally satinets, and employing 50 operatives. Pop. of t. 711.

WALES, p. o., Ogle co., Ill.: $156 \mathrm{~m}$. N. by E. Springfield. WALEs, t. and p. v., Erie co., N. $Y_{.}: 248$ m. W. Albany. Surface undulating; soil fertile loam. Drained $\mathrm{N}$. W. by Seneca er. The inhabitants are generally engaged in farming, etc. Pop. of t. 2,124.

WALEs, t. and p. O., St, Clair co., Mich.: 98 m. E. by N. Lansing. Pop. 189 .

Walte Centre, p. o:, Erie county, $N . \quad Y .: 250$ miles W. Albany.

WALESKA, p. o., Floyd county, Ga. : $150 \mathrm{~m}$. N. W. by W. Milledgeville.

WALESVILLE, p. v., Oneida co., N. Y.:90 m. W. N. W. Albany. It contains several paper and other mills.

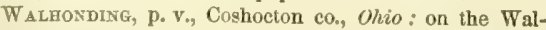
honding Canal and river, $50 \mathrm{~m}$. N. E. by E. Columbus.

WALHONDLNG river, Ohio: is formed in the N.W. part of Holmes county, by the confluence of Muddy and Black forks, thence flows \$. and E., and at Coshocton unites with the Tusearawas $r$, forming Muskingum $r$.

WALKER county, Ala. Situate toward the N., and contains $1,687 \mathrm{sq} . \mathrm{m}$. Drained by Mulberry fork of Black Warrior $x$. and its branches, Sipsey $r$ and Blackwater and Lost creeks. Surface uneven and broken, in parts hilly; soil fertile, and on the streams are some level bottom-lands adapted to cotton, the staple production. Coal is abundant. It is well timbered, and interspersed with numerous streams of clear running water. Farms 909; manuf. 11; dwell. 799, and pop.-wh. 4,857, fr. col. 1, sl. 266-total 5,124. Capital: Jasper.

W ALKER county, Ga. Situate N. W., and contains 645 sq. $m$. Chatogga $\mathbf{r}$. drains it in the $\mathrm{S}_{\text {., }}$ and Chickamanga in the N., flowing into Tennessee r. Surface varied, in general it is hilly, with broad fertile vallevs interspersed; soil fertile, and produces fine crops of wheat and grain. Gond timber is on the land. About 12 miles $\mathrm{N}$. of the $\mathrm{C} . \mathrm{H}$. is Crawfish Spring, which at its source affords sufficient water to float a small vessel, and at about 50 yards distant a large steamboat. Farms 600 ; manuf. 1 ; dwell. 1,847, and pop.-wh. 11,408, fr, col: 37, sl. 1,664-total 13,109. Oapitul: Lafayette Public Works: Western and Atlantic P. R.

WALKEe county, Tex. Situate toward the S., and contains $1,042 \mathrm{sq} . \mathrm{m}$. Drained by head branches of San Jacinto $r$. and affluents of Trinity $r_{a}$, which flows on its N. E. border Surface hilly and broken; in the S. are some bottom lands, the soil of which is generally a black mold, and very fertile. A large portion is prairie, the soil adapted to grazing. It is well wooded, and is interspersed with streams of clear and wholesome water. Iron ore and limestone have been found, and in the $\mathrm{E}$. is a valuable salt-water spring. Farms 234 manuf., 0 ; dwell. 478 , and pop.-wh. 2,663, fr. col. 0 , sl. 1,301 -total 3,964. Cupital: Huntsville.

W Alker, to and p. v., Centre co., Pennn: $60 \mathrm{~m}, \mathrm{~N}$. W. Harrisburg.

W City. It lies at the base of the Sierra Nevada range, is 30 $\mathrm{m}$. long, $7 \mathrm{~m}$. wide, and receives Walker river.

W ALKER's; p. O., M'Donough co., Ill. : on S. side Turkey cr., $64 \mathrm{~m} . \mathrm{N}$. W. by W. Springfield.

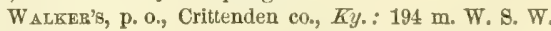
Frankfort.

W ALKER's sta., Strafford co., N. Hamp. : on Cocheco R. R., $14 \mathrm{~m}$. from Dover.

W ALKER's, p. o., Colleton dist., S. Car.: 80 m. S. by E. Columbia.

W AlKer's ChURCH, p. o., Appomattox co., Firg.: 58 m. W. S. W. Richmond.

W ALKER's Grove, p. o., Fulton co, $I l l .: 28 \mathrm{~m} . \mathrm{N}$. N. W. Springfield.

W ALkER's Mruls, p. o., Alleghany co., Penn.: $168 \mathrm{~m}$. W. Harrisburg.

W Springfield.

W ALKersville, p. v., Frederick co., MUd.: $70 \mathrm{~m} . \mathrm{N}$. W. Annapolis.

W AlEERSVILle, p. V., Union county, $N . C^{\prime}(a r$ : : $114 \mathrm{~m}$, W. S. W. Raleigh.

Walkerton, p. v., King and Queen co., Fir'g, : $30 \mathrm{~m}$ N. E. Richmond.

WALKERTOWN, p. o., Forsyth co, $N_{0}$. Car. : 95 m. W. by N. Naleigh.

W ALKervilize, p. 0., Lycoming county, Penn.: $62 \mathrm{~m} . \mathrm{N}$. Harrisburg.

W ALIABOUT bay, $N . Y_{*}:$ lies between the cilies of Brooklyn and Williamsburg. It is about one $\mathrm{m}$. long, and threefliths m. wide. On its S. W. side is the U. S. Navy Yard, covering some 40 acres, with the greatest dry dock in the Union. In the vicinity is the tomb, containing the remains of 11,000 Americans, who died on board the British prison ships moored in this bay during the Revolution. 
Wallace, p. o., Jones county, Ga.: 16 miles S. W. Milledgeville.

WaLla oe, p. o., Fountain co., Ind.: $62 \mathrm{~m}$. N. W. by W.

Indianapolis.

Wallace, p. o, Iowa county, Wisc. : 49 miles W. by $N$.

Madison.

Wallace, p. o., Chester co., Penn.

Wallace UreeK, p. o., Independence co., Ark. : on W. side of White r., $73 \mathrm{~m}$. N. N. E. Little Pock.

WAllace's, sta., Steuben co., $N$. $\bar{Y}$.: on Buffalo, Corning, and New York R. R., $31 \mathrm{~m}$. from Corning.

Wallace's Cross Roads, p. o., Anderson county, Tenn.: 144 m. E. Nashville.

Wallaceville, p. o., Venango county, Penn.: 168 miles W. N. W. Harrisburg.

Wallawalla xiver, Oreg. Ter.: rises in the Blue mountains, flows N., then W., and empties into Columbia r. near Fort Wallawalla.

WALlDEN's Ridge, p. o., Marion co., Tenn.: 90 m. S. E. Nashville.

WAlled LAkE, p. o., Oakland co., Mich.: 54 m. E. by S. Lansing.

W Aller, p. o., Ross co., Ohio: $45 \mathrm{~m}$. S. Columbus.

W AldingFord, t., p. Y., and sta., New Haven co., Conn. 23 miles S. S. W. Hartford. Surface pleassntly diversified, with good soil. Drained by Quinnipiac r., which furnishes water-power. The $\mathrm{v}$. at the centre is pleasantly situated and neatly built, and contains 3 churches. A little W. of the $\mathrm{v}$. is the sta. on the New Haven, Hartford, and Springfield R. R., $12 \mathrm{~m}$. from New Haven, $21 \mathrm{~m}$. from Hartford. Pop. of t. 2,639.

W ALLingFord, p. o., Will county, $I l .: 133$ miles N. E. Springfield.

W Allixgrord, t., p. v., and sta, Rutland county, Verm. 59 m. 8. S. W. Montpelier. Surface uneven and mountainous. Drained on the W. by Otter creek, and by its branch, Mill river, on the $\mathrm{E}_{*}$, which rises in Hiram's Pond in the S. part, covering 350 acres. There are other ponds in the $t$, which are very handsome, and abound with fish. Limestone and excellent naarble is abundant. The $\nabla$. in the $N$. part, near otter ereek, is very pleasant, and surrounded by beautiful scenery. The Western Vermont R. R. passe through it, $9 \mathrm{~m}$. from Rutland, $42 \mathrm{~m}$. from $\mathrm{N}$. Bennington, $74 \mathrm{~m}$. from Troy. Pop. of t. 1,683.

W alling's Ferry, p. 0., Rusk county, Tex. : $226 \mathrm{~m}$. N. E. Austin City.

W ALLKILL river, $N_{0}$ Jer, and $N_{0} Y_{0}:$ rises in $\mathrm{S}$. E. part of Sussex county, New Jersey, flows N. N. E. through Orange and Ulster counties, New York, and empties into Rondoutkill, $7 \mathrm{~m}$. from the entrance of that stream into the Hudson. It furnishes great water-power.

W Allonis, p. V., Trigg county, $\bar{K} y_{.}:$on small branch of Cumberland r., $180 \mathrm{~m}$. S. W. by W. Frankfort.

Walloomsac, sta., Rensselaer co, $N . Y_{\text {.: }}$ on Troy and Bennington $R$. R, 28 miles from Troy, 4 miles from North Bennington.

WALLOOSTOOK river, $M_{e_{0}}$ : is the main branch of the St. John's $x_{0}$; rising in Somerset co, it flows in general $\mathrm{N} . \mathrm{N} . \mathrm{E}$. course, through Aroostook county, to its confluence with St. Francis $r_{\text {., at the }}$. boundary of the State.

Wallsvilue, p. 0., Luzerne co., Penn.: 105 m. N. E. by N. Harrisburg.

W ALNFoRD, p. 0., Monmouth co., N. Jer.: 12 m. E. S. E Trenton.

Walvur, p. o, Juniata county, Penn.: 35 miles $\mathrm{N}$. W. Harrishurg.

WALNUT, p. o, Jefierson county, $I a .: 49$ m. S. W. by S. Iowa City.

W Rock.

Walnut Botrox, p. o., Cumberland co, Penn.

WAtndt CAMP, p. 0., Poinsett co, Ark,: 96 m. E. N. E. Little Reck.
Waunut Cove, p. o., Stoke co., N. Car.: 108 m. W. N.W. Paleigh.

W alNut Crezk, p. o., Claiborne par, $L a .: 190$ m. N. W. by N. Baton Rouge.

WalNut CreEK, p. o., Grant co., Ind.: 55 m. N. N. E. Indianapolis.

WalNut Creek, t. and p. o., Holmes co., Ohio: $74 \mathrm{~m}$. N. E. by E. Columbus, Drained by cr. of same name, a branch of Tuscarawas r. Pop. 1,077.

W alnut Creek, p. o., Buncombe co., N. Car. : $216 \mathrm{~m}$. W. Raleigh.

WaLNUT FLAT, p. o., Lincoln co, $\not{k} y$ : on a branch of Dick's r., 48 m. S. S. E. Frank fort.

Walndt Forest, p. o., Areene co., Mo. : 105 m. S. S. W. Jefferson City.

W.LNUT Fork, p. 0., Newton co., Ark. : 95 m. N.W. by N. Little Rock.

WaLvuT Fork, p. 0., Jones co., Ia.: 26 m. N. E. by N. Iowa City.

W ALNUT Grove, p. 0, Blount co., Ala. : 112 m. N. by W. Montgomery.

W Alnut Grove, p. o., Knox co., $\pi l_{\text {. : }} 91 \mathrm{~m}$. N. by W. Springfield.

WALNUT GRove, p. o., Seott en., Ia : on S. side Wapsipinicon r., $42 \mathrm{~m}$. E. Iowa City.

W alnut Grove, p. o., Morris co., N. Jer.: 41 m. N. by E. Trenton.

Walnut Grove, p. o., Orange co, $N$. Car. : 39 m. N. W. Raleigh.

WALNUT Grove, p. 0, Overton co., Tenn. : 80 m. E. by N. Nashville.

W ALnot Grove, p. o., Spartanburg dist., S. Car. : $62 \mathrm{~m}$.

N. W. Columbia.

WALnut Grover, p. o., Walton county, Ga.: 62 miles N. W. by W. Milledgeville.

Walnut Grove, p. o., Kanawha co., Firg. : $225 \mathrm{~m}$. W. N. W. Richmond.

Wadivur Hilı, p. o., La Fayette county, Ark.: $185 \mathrm{~m}$. \$. W. by S. Little Rock.

WalNut HrLL, p. o, Franklin county, Ga.: 93 m. N. Milledgeville.

Walvot Hri, p. o., Panola connty, Tex.: 247 m. N. E. Austin City.

W Alnut Hill, p. o., Marion co., $\pi l .: 95 \mathrm{~m}$. \$. by E. Springfleld.

WALNUT HrL, p. on, Buchanan county, Mo.: $160 \mathrm{~m}$. N. W. by W. Jefferson City.

WaLnut Hill, p. o., Lee co, Firg.: 333 m. W. by S. Richmond.

Walnut HrLt, p. o, Rapides par., La. : 102 m. N. W. by W. Baton Rouge.

Warnut Hill, p. o., Fayette co., Ky.: 27 m. E. S. E. Frankfort.

WaLNUT HiLl, p. o, Hamilton county, Ohio: $86 \mathrm{~m}$. S. W. by W. Columbus.

W ALXUT LANR, p. o., Surry co., N. Car.: 124 m. W. N.W. Raleigh.

Walnut Peak, p. 0., Tishemingo co., Miss. : $195 \mathrm{~m}$. N. E. by N. Jackson.

WAL iruT Post, p. o., Lauderdale co., Tenn.: $158 \mathrm{~m}$. W. by S. Nashville.

Walnut Rider, p. o., Phillips co., Ark. : 84 m. E. Little Rock.

Walivut Springs, p. o., Greene co., Wisc.: 31 m. S. W. Madison.

Walnut Vallex, p. o., Madison co., $\bar{K} y .: 48$ m. \$. E. Frankfort.

WALNUT VALLEY, p. o., Rock Island county, IU. : $120 \mathrm{~m}$ N. N. W. Springfield.

Walnut Valley, p. o, Marion co, Tenn.: 86 m. \$. E. Nashville.

WalNUT VAlteE, p. O., Warren co, $N$. Jer, : on N. side Paulin's kill, $52 \mathrm{~m}$. N. by W. Trenton. 
WALPOLE, t., p. v., and sta., Norfoll co., Mass.: $18 \mathrm{~m}$. S. W. by S. Boston. Surface uneven. Drained by Neponset $r$. and branches, which furnish water-power to several factories of woolen and cotton goods. The town contains several pleasant villages. The Norfulk Co, R. R. passes through Walpole $\mathrm{v}, 18 \mathrm{~m}$, from Boston. Pop. of t. 1,929.

W ALPOLE, t., p. v., and sta., Cheshire county, N. Ham.p. $41 \mathrm{~m} . \mathrm{W} . \mathrm{s} . \mathrm{W}$. Concord. Connecticut $\mathrm{r}$. bounds it on the W. Surface beautifully diversifled. The v. is very pleasantly situated in S. E. part of the t., on an elevated plain at the foot of Fall Mountain, which is 750 feet above the Connecticut $\mathbf{r}$. The $t_{n}$ contains several woolen factories, tanneries, grist and saw mills. The Cheshire P. R. runs along the bank of the Connecticut, having stations at Walpole v. and Cold river; the former is $59 \mathrm{~m}$. from Fitchburg. Pop. of $\mathrm{t} .2,034$.

WALPOLE EAST, p. o., Norfolk co., Mass. : 19 m. W. S. W. Boston.

WaLser's MrLi, p. 0., Davidson co., N. Car. : $97 \mathrm{~m} . \mathrm{W}$. Raleigh.

W ALTERBORO', p. V., and cap. Colleton dist., S.Car. : $94 \mathrm{~m}$. 8. by E. Columbia. It contains the county buildings, ete, Pop. about 300 .

W ALTHAM, t., p. v., and sta., Middlesex co., Mrass.; $8 \mathrm{~m}$. W. N. W. Boston. Surface generally level; drained by Charles river, which afiurds water-power to several factories. The principal v. is pleasantly situated, and is very neatly built with many elegant dwellings, surrounded by fine gardens. Many of the inhabitants transact their daily business in Boston, with which it is connected by Fitchburg $\mathrm{R}$. $\mathrm{R}$. It contains several handsome churches, a lyceum, and $1 \mathrm{bark}$, capital $\$ 100,000$. Prospect Fill, N. W. of the V., elevated 482 feet above the level of the sea, affords delightful prose pects of the vicinity, and Boston city and harbor, ete. Pop. in $1840,2,504$; in $1850,4,464$.

WALTHOURVILLE, p. 0., Liberty county, Ga. : 134 m. S. E. Milledgeville.

WAITON county, Flor. Situate W., and contains 1,157 sq. $m$. Drained by Yellow and Shoal rivers, with White and Alequa creeks. Surface generally level; soil varied in the $N$., being fertile and more productive than in the other parts of the co. Chief products cotton, sugar, and Indian corn. Choctarwhachie bay beunds it on the $\mathbf{S}$. Farms 161; manuf. 0 ; dwell. 185, and pop.-wh. 1,037, fr. col. 6, sl. 336total 1,379. Capital: Uchee Anna.

Walrox county, Ga. Situate N. centrally, and contains 354 sq. m. Drained by head branches of Oconee and Ocmulgee rivers. Surface undulating; soil fertile, and is a deep mold, with clay intermixed; it is well adapted to cotton, which is one of the principal productions of the county. Farms 861 ; manuf. 56 ; dwell. 1,191, and pop.-wh. 6,896, fr. col. 16, 8l. 3,909-total 10,821. Capital: Monroe. Public Works: Georgia R. R.

WALTON, p. o., Bnone co., Ky.: $53 \mathrm{~m}$. N. by E. Frankfort.

WaltoN, t. and p. V., Delaware co., $N . Y_{\text {. }}: 78 \mathrm{~m} . \mathrm{s}$. W. by W. Albany. Drained by W. branch of Delaware r. and its affluents. Surface hilly; soil best adapted to grazing. The $\mathrm{v}$. on Delaware river contains several mills, 2 churches, and about 400 inhabitants. Pop. of t. 2,271.

WaltoN, p. o., Kanawha co., Virg.: 218 m. W. N. W. Pichmond.

Walton, p. o., Newberry district, $S$. Car.: $40 \mathrm{~m} . \mathrm{N}$. W. Columbia.

WALTOSIIAM, p. v., St. Louis co., MIo.: 102 m. E. by N. Jefferson City.

WALTON's ForD, p. o., Habersham co., Ga.: 105 m. N. Mitledgeviile.

WALWORTH county, Wisc. Situate S. E., and contains $576 \mathrm{sq} . \mathrm{m}$. Drained in the W. portion by Turtle cr. and its affluents, and in the E. by Fox r. and its branches. Surface level and diversified, with numerous lakes, the principal being Geneva and Duck lakes; soil fertile, and adapted to wheat and grain. It is well timbered, and has some fine prairio land. Farms 1,\$34; manuf. 81 ; dwell. 3,112, and pop.-wh. 17,858, fr. col. 3-total 17,861. Capital: Elkhorn. Public Works: Chieago and Wiseonsin R. R. Milwaukie and Mississijppi R. L.; I lacine and Janesville Plank-road, etc.

WALWOBTH, t. and p. vo, Wayne co., N. Y.: $165 \mathrm{~m}$. W. by N. Albany. Surface undulating; soil fertile, gravelly loam. Drained by streams flowing into Lake Ontario. The v. contains several stores, 2 churches, and about 180 inhabitunts. Pop, of t. 1,981.

WALWORTH, t. and p. 0., Walworth $\mathrm{co}_{\text {. }}$ Wisc. : $46 \mathrm{~m} . \mathrm{S}$. E Madison. Surface diversified, with exeellent land, chiefly prairie, but considerable timber, and highly enltivated. Part of Geneva lake lies on its E, border. Pop. of town in 1840,226 ; in $1550,987$.

W AMPMissic, sta., Suffolk county, $N . Y$. : on Long Island R. R., $61 \mathrm{~m}$. from New York.

Wasmpville, p. v. and sta., Madison co, N. Y.: $90 \mathrm{~m}$ W. by N. Albany. The Syracuse and Utica R. R. passes through, $30 \mathrm{~m}$. from Utica, $23 \mathrm{~m}$. from Syracuse. Pop. about 420 .

WANANRI river, Minn. Ter.: a N. tributary of Missouri river, which it enters a little below Niobrarah $\mathrm{r}$. It is about $180 \mathrm{~m}$. long, and flows in direct $\mathrm{S} . \mathrm{E}$, course.

WAXCOND $\Delta$, p. o., Lake county, $\Pi l_{0}$ : 150 m. N. E. by $N$. Springfield.

W $\triangle P A U K O N E T T A$, p. v., and cap. Auglaize co., Ohio: on S. side of Big Auglaize river, $74 \mathrm{~m}$. N. W. by W. Columbus, This $\mathrm{v}$. was formerly near the centre of the reservation of the Shawnee tribe of Indians, but they have all been removed West. It contains the county buildings, etc. Population 504.

W.APELLo county, Ia. Situate toward the S. E., and contains $482 \mathrm{sq}$. m. Drained by Des Moines river, which flows through it from N. W. to S. E., and by W. branch of Skunk river. Surface level; soil fertile, and adapted to wheat and grain; it is also favorable to the cultivation of fruits and vegetables. Farms 828 ; manuf. 7 ; dwell. 1,416, and pop. -wh. 8,466, fr. col. 5-total 8,471. Capital: Ottumwa. Public Works: Des Moines Riyer Improvements.

W $\triangle$ PELLO, p. v., and cap. Louisa county, I $u_{.}: 1 \frac{1}{2} \mathrm{~m} . \mathrm{W}$. Iowa r., 36 miles $\mathrm{S}$. E. by S. Iowa City. It occupies a very level but pleasant site on the border of the Wapello prairie. It is regularly laid out, and contains the court-house, etc. The "Louisa County Times" (indep.) is issued weekly. Pop. 937.

W APPINGER's FalLs, p. o., Duchess co., $N . T .: 3 \mathrm{~m}$. W. Hudson r., 76 m. S. Albany.

WAPSIPINIOON river, $I a_{0}:$ flows through $N$. I. part of the State, in nearly direct S. E. course for $180 \mathrm{~m}$., and enters the Mississippi $5 \mathrm{~m}$. N. Princeton.

WAquorT, p. o., Barnstable co., Mrass.: 36 m. S. S. E Boston.

WARDBORO', p. o., Warren co., N. Y.: 64 m. N. Albany.

WARDENSvilizi, p. 0., Hardy co., Virg.: 145 m. N. W. Richmond.

WAEDBBono, t. and p. v., Windham co., Verm.: $90 \mathrm{~m}$, S. by W. Montpelier. Surface hilly. Drained by branches of West r. Pop. of t. 1,125.

WARD'S GRove, p. 0., Jo Daviess county, $I l l_{*}: 160 \mathrm{~m}$. N. by W. Springfield.

WARe county, $G a$. Situate S. E., and contains 1,652 sq. m. Drained by Santilla $r$. and its affluents, and other small streams. Surface level, and much of it is low and subject to submersion; soil fertile, and where fit for cultivation, is well adapted to cotton and grain. Okefinoke $S$ wamp occupies the whole of the southern portion, and extends some distance into Florida; it resembles in wet seasons an inland sea or large lake, with numerous islands. St. Mary's river has its source in this stvamp. Farms 389 ; manuf. 0 ; dwell. 561, and pop.-wh. 3,597, fr. col. 3, sl. 238-total 3,S88. Oapitat: Waresboro' Public Works: Brunswick and Florida $\mathrm{R} . \mathrm{R}$. 
WARE, t. and p. v., Hampshire co., Mass. : 61 m.W. by $\mathrm{S}$. Boston. Drained by Ware r. and branches, which by the falls at Ware $\mathrm{v}$. affords good water-power. The v. has several large factories of cotton and woolen goods. The Otis Company, manufacturing sheetings, etc., has a capital of $\$ 450,000$. It also contains a bank, capital $\$ 200,000$. The "Village Gazette" (neut.) is published weekly. Pop. of t. in $1840,1,890$; in $1850,3,785$.

WAR EAgle, t. and p. o., Madison co., Ark.: $129 \mathrm{~m}$. N. W. Little Rock. It contains several grist-mills and tanneries. Pop. about 850 .

WArfina, tr, p. v., and sta., Plymouth co., Mass. : $45 \mathrm{~m}$. 8. S. E. Boston. Drained by Awagon r. and small streams, which afford great water-power, and flow into Buzzard's bay, bounding the $t$, on the $s$. The t. contains several pleasant villages. Wareham $\nabla$., at the head of the bay, has a good harbor, admitting vessels of 200 tons to its wharves. It contains a bank, capital $\$ 100,000$, an institution for savings, and is largely engaged in the manufacture of iron, nails, ete. The Tremont Iron Company, making railroad rails, have a capital of $\$ 200,000$, and 3 very extensive uail factories employ several hundred operatives. The Cape Cod Branch R. R. passes through W. and S.Wareham, and and Wareham $\mathrm{v}$.; the latter $15 \mathrm{~m}$. from Middleboro, $50 \mathrm{~m}$. from Boston. Population of town in 1840, 2,002; in $1850,3,156$.

Wareeouse Point, p. v. and sta, Hartford co., Conn. on E. side of Connecticut r., and on New Haven, Hartford, and Springfield R. R., $12 \mathrm{~m}$. N. from Hartford. It contains 2 churchies, and some large woolen factories.

Waresboro', p. v., and cap. Ware co., Ga. : about $3 \mathrm{~m}$. S. Eantilla r., 67 m. N. W. by W. St. Mary's, 107 m. S. S. E. Milledgeville. It contains the county buildings, etc.

W arfieldoburg, p. v., Carroll co., Ma. : $42 \mathrm{~m}$. N.W. by N. Annapolis.

W ArFordsburg, p.v., Fulton co., Penn. : $75 \mathrm{~m}, \mathrm{~S} . \mathrm{W}$. by W. Harrisburg.

WAR GAP, p. O., Hawkins co., Tenn. : 204 m. E. by N. Nashville.

WAR HrLr, p. o., Hall county, Ga. 92 m. N. N. W. Milledgeville

Warminster, p. v., Nelson co., Virg.: on James River Canal, and N. side of James r., $70 \mathrm{~m}$. W. Richmond.

W Arm Springs, p. 0., Meriwether co., Ga. : 90 m. W. by S, Milledgeville.

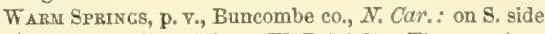
of French Broad $r, 237 \mathrm{~m}$. W. Raleigh. These springs have valuable medicinal properties, and are of much resort during the summer.

Warm Sprligs, p. V., Bath co, Tirg. (See Batr.)

WARNER, t., p. v., and sta., Merrimac co, N. Hamp. $14 \mathrm{~m}$. W. by N. Concord. Surface uneven. Drained E. by Warner r. The v. contains some manufactories and one bank, capital $\$ 50,000$. The Merrimac and Connecticut Rivers R. R. passes through it. Pop. of $t, 2,038$.

WARner's Landing, p. O., Bad Ax co., Wisc. : on E. bank of Mississippi r., $98 \mathrm{~m}$. W. N. W. Madison.

W ARNePFIlle, p. o., Schuharie co., 1 . $Y_{\text {.: }} 25 \mathrm{~m}$. W. Albany.

W ARNerVHLE, p. O., Livingston co, Mich. : 33 m. E. S. E. Lansing.

W ARREx county, Ga. Situate E. toward the N., and contains $486 \mathrm{sq}$. $\mathrm{m}$. Drained by branches of Ogeechee and Little rivers, and of Brier cr., which runs on its S. E. border. Surface undulating: soil fertile, and arlapted to cotton and other agricultural productions, wheat and grain being produced in abundance. It has gnod pasturage, and fattens large numbers of caltle and hogs. Farms 605 ; manuf, 42 ; dwell. 1,135, and pop.-wh, 6,168, fr. col. 149, sl. 6,108-total 12,425. Cupitul: Warrenton. Pullic Works : Georgia R. R. : and Warrenton Branch R. R.

W ARREN county, Ill. Situate W. toward the N., and contains $510 \mathrm{sq}$. m. Drained by Hendersou's r. and its affu- ents, and by Ellison's cr. and branches of Spoon $r$. Surface level; soil fertile; on the streams are some rich tracts of land which are very productive, and yield fine crops of wheat and grain, the staple productions of the co. Pork and beef are exported. Farms 956 ; manuf. 42 ; dwell. 1,401, and pop.-wh. 8,162, fr. col.14-total 8,176. Capital: Monmouth. Public Works: Central Military Track R. R. Peoria and Oquawka R. R.

W $\triangle$ RREN county, Ind. Situate N. W. middle, on the Illinois State line, and contains 360 sq. m. Peru, Rock, and Red Wood creeks drain the interior; and, except on the Wabash, on which blufis bound an extensive bottom-land, the surface is gently undulating, rising toward the W. Woodland and prairie about equally divided. The soil is good-in some parts very fertile, Live-stock and grain are exported. Farms 782 ; manuf. 18 ; dwell. 1,273, and pop.wh. 7,381, fr, col, 6-total 7,387. Capital: Williamsport.

WARREN county, $I a$. Situate $\mathrm{S}$. centrally, and contains 432 sq. m. Drained by tributaries of Des Moines r. Surface undulating; soil consists of a fine deep mold, and is very fertile. It is well timbered, and contains good pasturage for cattle. Farms 47; manuf. 0 ; dwell. 152, and pop.wh. 960, fr. col.1-total 961. Capital: Indianola.

WARrEN county, $\overline{K y}$. Situate $\mathrm{S}$. toward the W., and contains $546 \mathrm{sq}$. m. Drained by Big Barren r. and its branches, which enter Green r, in the N. Surface level ; soil fertile, and makes excellent pasture land. Chief productions, tobacco, wheat, and Indian corn; fruits and vegetables are also produced. Farms 1,145; manuf. 38 ; dwell. 1,798, and pop.-wh. 10,597, fr. col. 209, sl, 4,317-total 15,123. Capital: Bowling Green. Public Works: Louisville and Nash ville $R$. R.

W $A$ RReN county, Miss. Situate W., and contains 570 sq. m. Drained by Yazoo r. and branches of Big Black $r$. Surface varied; in the eastern portion the land is much broken and hilly; in the west level, and in parts lying so low that it is liable to inundation. Soil very fertile, and in some portions exceedingly rich. There is much fine grazing land in the county. Chief productions, cotton and Indian corn. Of the former is raised upward of $16,000,000$ of $1 \mathrm{bs}$, Farms 435 ; manuf, 25 ; dwell. 1,230, and pop.-wh. 5,998, fr. col. 27, sl. 12,096-total 18,121. Capital: Vicksburg. Public Works: Vicksburg, Jackson, and Brandon R. R.

WARREN county, Mo. Situate toward the E., and contains $342 \mathrm{sq}$. m. Drained by affluents of Missouri r., which forms its southern boundary, and in the northern portion by branches of Cuivre r. Surface diversifled; soil fertile; the bottom-lands consist chiefly of a fine black mold, and are very productive. Tobacco is the staple, but wheat and grain are raised in large crops. It is well timbered. Farms 744; manuf. 11; dwell. 899 , and pop.-wh. 4,921 , fr. col. 4 , sl. 935-total 5,860. Capital: Warrênton.

W Arren county, N. Jer. Situate N. W., and contains 414 sq. m. Drained by Paulinskill, Request, and Pohatcong rivers, tributaries of Delaware r., which forms its western boundary. Surface broken and hilly; soil fertile, and adapted to grain. Staples, wheat, Indian corn, and potatoes. Pine timber abounds. Schooley's Mountain forms its S. E. boundary. Farms 1,537; manuf. 341 ; d well. 3,554, and pop.-wh. 21,990, fr. col. 366, sl. 2-total 22,358. Capital: Belvidere. Pullic Works: Belvidere Delaware R. R.: Morris Canal, etc.

WARRF county, $N . \bar{Y}$. Siluate E. toward the N., and contains $912 \mathrm{sq}$. m. Drained by Hudson r., Schroon branch of the Hudson, and Jessup's cr. Surface generally hilly and broken, but in the $\mathrm{S}$. is some level land; soil in most parts barren and unfit for cultivation; there is, however, some good land in the level portions, and in the valleys, where agricultural pursuits are followed, and much corn, oats, etc. are produced-these, with wheat and Indian corn, make the staple articles of commerce. This co, is rich in minerals, and contains some quarries of granite and limestone. The Palmertown range traverses the $\mathbf{E}$. section, Clinton 
range the $W$., and the Kayadirosseras the central. Lumber is exported in a large quantity. Farms 1,505; manuf, 128; dwell. 2,976, and pop.-wh. 17,153, fr. col. 46-total 17,199. Capital: Caldwell.

W ARREN county, $N_{*}$ Car. Situate N. toward the E., and contains 439 sq. m. Drained in the N. by Poanoke r. and its branches, and in the $\mathrm{S}$. by Fishing cr. and its branches. Surface somewhat elevated and diversifted; soil in general fertile. Chief productions, tobacco, cotton, wheat, and Indian corn. Farms 543; manuf. 20 ; dwell. 905, and pop.wh. 4,604 , fr. col. 441, sl. 8,86i-total 13,912. Capital: Warrenton. Pultio Works: Gaston and Ralejgh R. R.; loanoke Valley R. R.

Warrea county, Penn. Situate N. W., and contains 782 sq. m. Alleghany river enters it in the N. E., and passes through its central portion, by which and its branches, Broken Straw and Conewango creeks, it is drained. Surface uneren, and in parts hilly and broken; soil varied-on the streams being very fertile. Staples, wheat, grain, and potatoes. It has some good timber land and excellent pasturage for cattle. Farms 1,207; manuf. 216 ; dwell. 2,489, and pop.-wh. 13,593, fr. col. 78-total 13,671. Capital: Warren. Public Works: Sunbury and Erie R. R.; Alleghany Valley R. R.

WARreir county, Tenn. Situate S. E. centrally, and contains 372 sq. m. Caney fork of Cumberland $r$, flows on its N. E. border, by branches of which it is drained. Surface hilly ; soil fertile, and adapted to grain. Farms 645 ; manuf. 6 ; dwell. 1,387 , and pop.-wh. 8,386 , fr. col. 88 , sl. 1, T10-total 10,179. Capital: M'Minnsville Public Works: Lexington and $\mathbf{M}^{\cdot}$ Minnsville $\mathbf{R} . \mathbf{R}$.

WARREN county, Virg. Situate $N_{*}$, and contains 226 sc. m. Drained by Shenandoah r., which passes through its centre. Surface mountainous and broken; soil fertile, Chief productions, wheat and Indian corn. Farms 397 ; manuf. 84; dwell. 828, and pop.-wh. 4,492, fr. col. 367 , sl.1,748-total 6,607. Capital: Front Royal. Public Works : Nanassas Gap R. R.

WARREN, t. and p. v., Litchfield co., Conn.: $33 \mathrm{~m}$. W. Hartford. Drained by Shepaug r., a tributary of Housatonic r. Raumaug Pond lies in its S. part. Pop. of t. 831.

WARREN, p. o., Huntingdon co., Ind.: on E. side of Salamonie r., $70 \mathrm{~m}$. N. E. by N. Indianapolis.

WARREN, t., p. v., and one of the capitals, Lincoln co., Me : $31 \mathrm{~m}$. S. E. by E. Augusta. Drained by St. George river, which is navigable for sloops. The manufacture of lime is carried on extensively, with some ship-brilding and large iumber business. The $\mathrm{v}$, is well located, and contains the county buildings, an academy, etc. Pop. of t. 2,428.

WARREN, to and p. o, Macomb co., Mich.; $71 \mathrm{~m}$. E. by S. Lansing. Interests entirely agricultural. Pop. in 1840, 337 ; in 1850,700 .

WARREN, p. T., Fannin co., Texo. : on S. bank of Red r., $217 \mathrm{~m}$. N. E。 Austin.

WAREEN, p. v., Baltimore co., M $d_{*}$ : on E. bank Gunpowder r., 32 m. N. Annapolis.

WARgev, t., p. v., and sta., Worcester co., Mass. : $58 \mathrm{~m}$. W. by S. Bosion, Drained W. by Chicopee r., on which the $\mathrm{v}$. is situated. The Western R, R. passes through it, 29 mailes from Worcester ( $73 \mathrm{~m}$. from Boston). It contains several manu facturing establishments, with 2 churches, stores, etc. Pop. of t. in 1840,1,290; in 1850, 1,776.

WARREN, t. and p. O, Marion co., MYo.: $84 \mathrm{~m}$. N. by E. Jefferson City. Pop. of $t$, about 2,000.

WARREN, t, p. v., and sta., Grafton co.n. N. Famp.: $52 \mathrm{~m}$. N. N.W. Concord (direct), and by the Boston, Concord, and Montreal R. R., which passes through, $71 \mathrm{~m}$. from Coneord. Surface diversified; in S. part mountainous, having Carr's Mountain on its S. E. border. Pop. of t. 872 .

W ARREX, p. v., Jo Daviess county, $I l l_{0}: 182$ miles $\mathrm{N}$. Springfield. The Illinois Central R. R. will pass through this place

WARREX, p. o, Lee co., Ia.: $72 \mathrm{~m}$. S. Iowa City.
W Arrev, sta., Du Page con, Ill: on Galena and Chicago Union R. R., $25 \mathrm{~m}$. from Chicago.

W ARRE, t, and p. o., Herkimer county, $N$. $Y .: 62 \mathrm{~m}$. W. by N. Albany. Surface hilly; soil excellent loam. The inhabitants are generally engaged in agricultural pursuits, but the t. also contains mills of various kinds. Pop. 1,756.

W ARREN, p. v., and cap. Trumbull co., Ohio: on Mahoning r., $140 \mathrm{~m}$. N. E. by E. Columbus. The v. is regularly laid out with strects crossing at right angles. It contains the onunty buildings, a bank, several churches, ete. In 1550 three newspapers were published-"T. Whig," "T. Democrat," and "Western Reserve Chronicle" (neut.) Pop. of $t .734$

Warren, p. b., and cap. Warren co, Penn : on N. side of Alleghany r., at the confluence of Conewango cr., $158 \mathrm{~m}$. N. W. Harrisburg. It occupies an elevated site, 35 feet above the river, of which it commands a fine view in either direction. It is regularly laid out with streets crossing at right angles, and has a fine public square in the centre containing the county buildings. It contains 3 churches, an academy, stores, etc., and has some manufactures. The "W. Ledger" (dem.) and "W. Mail" (whig) are here published. Two lines of railroad are projected to pass through this place, Sunbury and Erie R. R. and the Alleghany Valley R. R. Pop. in 1540, 787; in 1850, $1,013$.

W.ARREN, to and $\mathrm{p}$. v, Bristol co, R. T.: $16 \mathrm{~m}$. N. by E. Newport. Surface of t. rolling, with very fertile soil. The $\mathrm{v}$. in the S. E. part of the t. is handsomely situated on elevated ground. Its harbor readily admits vessels of 300 tons. Ship-building, coasting trade, the fisheries, and some manufacturing of cotton goods are carried on. It contains an excellent female seminary and some other schools, 2 churches, and 2 banks, cap. $\$ 260,000$. The "Northern Star" (miscel.) issued weekly. Pop. in 1840, 2,437; in 1850, 8,103.

WARREN, to and p. v., Washington co., Verm, : $14 \mathrm{~m}$. S. W. by S. Montpelier. Drained W. by Mud r, which af fords water-power. Pop. of t. 962.

WARrei, p. v., Albemarle co., Firg.: on James River Canal, N. side of James r., $62 \mathrm{~m}$. W. by N. Richmond.

WARren, p. o., Rnek co., Wisc.: 26 m. S. S. E. Madison.

Warren CoURT-House, p. v., and cap. Bradley co., Ark. $3 \mathrm{~m}$. W. Saline r., $75 \mathrm{~m}$. S. by E. Little Rock. It contains the co, buildings, ete. Pop. 679 .

W arrenhas, p. 0., Bradford co., Penn.; $115 \mathrm{~m}$. N. by E Harrisburg.

W Arimensburg, p. v., and cap. Johnson county, Mo.: on Post Oak cr., near its confluence with Black r., $87 \mathrm{~m}$. W. by N. Jefferson City. It contains the county buildings, etc Pop. 195

W AREENSBUR, t, and p. V., Warren co., $N . Y_{0}: 58 \mathrm{~m} . \mathrm{N}$. Albany. Drained by Hudson and Schroon rivers, which here unite. Surface hilly, with very fertile soil on the streams. The v. on Schroon r. contains several stores, mills, 2 ehurches, and about 450 inhabitants. Population of t. 1,874 .

WARrensburg, p. V., Greene co., Tenns: on N. side of Nolichucky r., 205 m. E. Nashville. Pop. about 100.

WARrensville, p. v., Mahaska co., Ia.: on S. W. side Skunk r., $66 \mathrm{~m}$. W, by S. Iowa City.

Warrenstillie, p. v., Du Page eo., Ill.; on E. side of Mill brook, $158 \mathrm{~m}$. N. E. by N. Springfield.

W ARRENSVILLE, $t_{\text {. }}$ and p. v., Cuyahoga co., Ohio: $8 \mathrm{~m}$. E. S. E. Cleveland, 123 m. N. E. by N. Columbus. Population of $t .1,409$.

Warpensyille, p. $\nabla_{1}$, Lycoming county, Penn: $72 \mathrm{~m}$. N. by W. Harrisburg.

W arren Tafern, p. 0., Chester co., Penn.: 70 m. E. by S. Harrisburg.

W arrenton, p. v., and cap. Marshall co., Ala.: a little S. Tennessee $r_{0}, 187 \mathrm{~m} . \mathrm{N}$. Montgomery. It contains a court-house, jail, etc. The "Southern Guard" (dem.) is issued weekly

W ARrentox, p. v., and cap. Warren co, Ga. : 45 m. N. E. 
by E. Milledgeville. It contains the county buildings, a church, stores, etc. The Warrenton Branch R. R. extends hence to Camak, $4 \mathrm{~m}$, connecting with the Georgia $R$. R., by which it is $51 \mathrm{~m}$. from Augusta and $120 \mathrm{~m}$. from Atlanta

WARRENTON, p. V., Gibson co., Ind.: 126 m. S. W. by S. Indianapolis.

WARRENTON, p. จ., Warren county, Ky.: 120 m. \$. W. Frankfort.

WARRENTON, p. V., Warren co., Miss. : on E. bank of Mississippi r., $44 \mathrm{~m}$. W. by S. Jackson.

WARRENTON, p. v., and cap. Warren county, MOo.: $60 \mathrm{~m}$. E. by N. Jefferson City. It contains the county buildings, several stores, etc. Pop. about 150.

W ArRenton, p. v., sta, and cap. Warren co., N. Car.: $48 \mathrm{~m}$. N. N. E. Raleigh. It contains the oourt-house and jail, several stores, a church, etc. The "Warrenton News" is published weekly. The Gaston and Raleigh R. R. passes near it, $24 \mathrm{~m}$. from Gaston, $63 \mathrm{~m}$. from Raleigh. Pop. about 750 .

WARRENTON, p. v., Jefferson co., Ohio: on W. bank of Ohio r., 119 m. E. by N. Columbus. Pop. about 300 .

WARRENroN, p. v., Abbeville dist., S. Car.: on E. side of Little r., $80 \mathrm{~m}$. W. Columbia.

Warrenton, p. v and cap., Fauquier co., Firg.: $80 \mathrm{~m}$. $\mathrm{N}$. by W. Richmond. It contains a court-house, town-hall, jail, and 3 churches. The "Piedmont Whig" and "Flag of ' 95 " are issued weekly. The Warrenton Branch R. R. extends hence to junction with the Orange and Alexandria I. R. Pop. about 1,300 .

Warrenton Sprnigs, p. v., Fauquier co., Tirg.: $85 \mathrm{~m}$. N. by W. Richmond.

WARrentilie, p. v., Somerset county, $N_{0}$ Jer.: $30 \mathrm{~m}$ N. E. by N. Trenton.

WARrIoz county, Ind. Situate S. W., on Ohio river, and contains 360 sq. n. Little Pigeon river, and several slowmoving streams drain the interior. Except the Ohio bottom, and the abutting bluffs, the surface is rolling, but at the head of Pigeon river there are some wet prairies. Corn and tobacco are staples, and coal is abundant. Farms 994; manuf. 22 ; dwell. 1,513, and pop. - Wh. 8,782, fir. col. 29total 8,811. Capital: Booneville. Public Works: Wabash and Erie Canal.

Warrington, t. and p. V., Bucks co., Penn.: $90 \mathrm{~m}$. E. Harrisburg.

W ARRTington, p. v., Hancock co., Ind.: 29 m. E. N. E. Indianapolis.

W ARRLigton, p. v., Escambia co., Flor . : 192 m. W. by N. Tallahassee.

W arrior Ceeek, p. o., Wilkes county, N. Car. : $140 \mathrm{~m}$. W. by N. Raleigh.

WARRIor's MTARK, t. and p.. ., Huntingdon co., Penn.: $66 \mathrm{~m}$. W. N. W. Harrisburg, Surface of t. mountainous. The $\mathrm{r}$. in $\mathrm{N}$. part contains several stores, dwellings, etc. In the vicinity are two charcoal furnaces, one a hot-blast, of 1,650 tons annual capacity, and another, cold-blast, with annual capacity of 1,330 tons. The t. also contains several grist and saw mills, tanneries, and distilleries. Pop. of $t$. about 2,000 .

Warrior Staxd, p. o., Macon county, Ala.: $36 \mathrm{~m}$. E. Montgomery.

WARSAW, p. v., Sumter co., Ala.: on W. side of Okatibby-hah r., 121 m. W. N. W. Montgomery.

WARSAW, p. ve, Forsyth co., Ga.: on E. side of Chattaboochee r., $90 \mathrm{~m}$. N. W. Milledgeville.

WAEEAT, p. v., Haneock co., $M l$.: on E. bank of Mississippi r, $100 \mathrm{~m}$. W. N. W. Springfield. It has a fine site, with good landing, does considerable business in exporting corn and pork, and is surrounded by a good farming country. The "Warsaw Signal" (whig) is issued weekly.

WAPgAW, $p, y$, and cap. Koscinsko co, Ind. $100 \mathrm{~m}$ $\mathrm{N}$. by E. Indianapolis. It is beautifully sitnated near Tippecanoe $\mathrm{r}$. and two of the lakes. It contains grood county buildings, and two churches. The "Koscinsko Republican" 900 (whig), and "Warsaw Democrat," are here publisbed. Lines of railroad are projected from Peru and Fort Wayne to pass through this place. Pop. 304.

WAESAW, p. T. and cap., Gallatin co., $K y_{0}$. on S. bank of Ohio r., $36 \mathrm{~m}, \mathrm{~N}$. Frankfort. It contains a court-house and other county buildings, and two churches. It has considerable trade, and exports a large quantity of produce and tobacco. The surrounding country is hilly, but very productive of wheat, corn, and tobacco; and also abounds with fine timber. Pop. about 700.

WARSAT, p. v., and eap. Benton co., MFo.: on NN. side of Osage r., $68 \mathrm{~m}$. W. S. W. Jefferson City. It contains the court-house and jail, several stores, etc. The "Warsaw Weekly Whig" is here published. Pop. about 500.

WARSAW, p. 0., Portage county, Wisc. : $105 \mathrm{~m}$. N. by W. Madison.

WARSAW, p. ₹., and sta., Duplin county, N. Car. : $50 \mathrm{~m}$. S. E. by S. Raleigh. The Wilmington and Weldon R. R. passes through, $55 \mathrm{~m}$. from Wilmington, $107 \mathrm{~m}$. from Weldon.

WARSAW, t., p. v., sta., and cap. Wyoming co., $N$. $Y_{\text {. }}$ $280 \mathrm{~m}$. W. Albany. Surface diversified; soil extremely fertile. Drained by Allen's cr., flowing N. through the t. centrally. The v. on Allen's er. contains the county buildings, 5 churches, an academy, various manufacturing establishments, 1 bank, capital $\$ 100,000$, and about 900 intzabitants. The Buffalo and New York City R. R. passes through it, $48 \mathrm{~m}$. from Buffalo, and $43 \mathrm{~m}$. from Hornellsville. The Western New Yorker" (whig) is issued weekly. Pop. of t. 2,624 .

WARSAT, p. V.y Coshocton co., Orio : on the Ohio Canal, and $\mathrm{N}$. side of Walhonding $\mathrm{r} ., 58 \mathrm{~m}$. E. N. E. Columbus,

WARsaW, t. and p. Oo, Jefferson co., Penn. : on N. side of Sandy Lick cr., $126 \mathrm{~m}$. N. W. by W. Harrisburg

WARSAW, p. v., and cap. Richmond co., Virg.: $47 \mathrm{~m}$ N. E. by E. Richmond. It occupies a pleasant site, $3 \mathrm{~m}$. from Rappahannock r., and contains the county buildings, a female academy, church, several stores, etc. Pop. about 150 .

Warsaw Praxrie, p. o., Henderson co., Teso. : $173 \mathrm{~m}$. N. E. by N. Austin.

WARTHEX's Store, p. o., Washington connty, Ga.: $31 \mathrm{~m}$. E. by N. Montgomery.

WARTrace DEPồ, p. o., and sta., Bedford co., Tenn.: on Nashville and Chattanooga R. R., $55 \mathrm{~m}$. from Nashville, $96 \mathrm{~m}$. from Chattanooga. A branch $\mathrm{R}$. R. extends hence, $8 \mathrm{~m}$. to Shelbyville.

W ARWYK county, Virg. Situato toward the S. E., and contains $55 \mathrm{sq.} \mathrm{m}$. Drained by small streams of James river. It occupies the $\mathrm{S}$. W. portion of the peninsula, botween York and James rivers. Surface level; soil moderately fertile. Chief prodacts wheat and Indian corn. Farms 91 ; manuf, 0 ; dwell. 182, and pop.-wh. 598, fr. col. 43, sl. 905-total 1,5 6. Cupitul: Warwick C. H.

WABWICK, p. v., Cecil county, Ifd.; $49 \mathrm{~m}$. N. E. by E. Annapolis.

WATwick, p. v., Dooly county, Ga.: 85 m. S. S. W. Milledgeville.

WATW LCK, t. and p. V., Franklin co, Mrass. : $69 \mathrm{~m}$ W. N. W. Boston. Surface elevated and uneven; soil bes? adapted to grazing. The central $\mathrm{r}$. is neatly built, and very pleasant. Pop. of t. 1,021.

WARTIEK, t. and p. v., Orange co, $N . Y .: 96$ m. S. S. W Albany. Surface hilly; soil fertile. Drained by branches of Wallkill and Passaic rivers. In its W. part is a portion of the "drowned lands," and in S. E. part, a portion of Greenwood lake. The $\nabla$. contains 2 churches, and about 450 inhabitants. The $t$. is very large, and contains other settlements. Pop. of t. 4,902.

W APRTCK, t, p. $\gamma_{.}$, and sta., Kent co., R. T.: on Stonington and Providence R.R., $8 \mathrm{~m}$. S. from Providence. Bounded E. by Narragansett bay. Surface of $t$. varied; soil gravelly loam. Drained in N. part by Pawtuxet $r_{0}$, which affords great water-power, improred by numerous factorieg. $\mathrm{Paw}$ tuxet v., at its mouth, lies partly in this t., and partly is 
Cranston. Other villages in the t. are also noted for their , S. E. by E. Richmond. It contains a court-house, jail, etc., manufactures. Warwick v. contains, besides factories, 2 and is a pleasant village,

banks, an academy, church, ete. The "Kent Co. Allas" WАsнa lake, La.: $17 \mathrm{~m}$. \$. \$. W. New Orleans. It is (miscel.) is issued weekly. Pop. of t. in $18 \pm 0,6.726$; in $15 \mathrm{~m}$. long, with average breadth of $5 \mathrm{~m}$., and connects by $1850,7.740$.

WARттск, p. o., Waukesha co., Wisc.: on W. side White s., $69 \mathrm{~m}$. N. by E. Madison.

WARWICK, p. V., and eap. Warwick ca, Virg. : 58 m. wide bayous with Cotoucbe and Little lakes.

Washbourx Prairie, p. o., Barry county, Mo.: $163 \mathrm{~m}$. S. W. by $\$$. Jefferson City.

\section{THE TERRITORY OF WASHINGTON.}

Tms Territory, until 1853 a portion of Oregon Territory, oecupies all the country lying generalty between the parallels of $46^{\circ}$ and $49^{\circ}$ of north latitude, and extendling from the Pocky Mountains on the east to the Pacific Ocean on the west. The Columbia River forms the southern boundary below the line of $46^{\circ}$ to the sea. It comprises somewhat more than one-third the original territory, or about 180,000 square miles.

Of the physical characteristics of this Territory much bas yet to be learned. It includes the waters of Puget's Sound, equal in the magnificence of their scenery and in their secure and spacious harbors to the waters of San Francisco Bay. Vancouver's Island and the Gulf of Georgia indent its north-western extremity. The Columbia River is its great interior water-course, and there are numerons other important streams which empty either into the sound above named, or into the Pacific, through bays which may hereafter become valuable to commerce. The Columbia River has been thoroughly surveyed by Belcher, R. N., and Wilkes, U. S. N., and the Coast Survey has twice examined its mouth. Shoal-Water Bay, Grey's Harbor, and Chickaes River have also been surveyed by the United States offecrs, and the English Admiralty charts cover the Straits of Fuca, and many harbors on the mainland and Vancouver's Island. The surveys of Captain Wilkes give full information of all the group of jslands in the Galf of Georgia, and the channels leading to and making up Puget's Sound. The shores of this wonderful network of channels are so favorable in soil and location, that they must soon possess great value. Through a surprising extent of line they are directly accessible for ocean vessels, and form, as it were, an immense network of harbor. They present the foundation for a kind of agricultural Venice far into the heart of the west balf of Washington, the resourees of which they will greatly aid in develnging. Fort Nesqually and Olympia, at the southern extremity of Puget's Sound, must rapidly advance with the growth of the Territory, and in fact are already important places. The interior is bat imperfectly known. The land-nffice surveys north of the Columbia have as yet made but little progress. On penetrating further toward the Rocky Mountains, the country is essentially unknown. The narrative of Lewis and Clarke, the book on Oregon Missions by Father De Smet, and Irving's Astoria, are the chief publications of value on this ground. These serve merely to show that the country bordering the Rocky Mountains, between $46^{\circ}$ and $49^{\circ}$ on both sides, is still a fine field for exploration. Much may be expected from Dr. Evans, who is engaged in a geological reconnoissance of the old Oregon Territory, which has taken him much among the Rocky Mountains, and over their basaltic plains.

There are several important geographical problems connected with the establishment of this new Territory. The boundary, initial points, and parallels will have to be determined, and it must soon be decided where the crest of the Rocky Mountains really is. "This latter problem may not be easy of solution, for Lewis and Clarke, De Smet, the Irving Astoria map, and the Indian Bureau and Topographical Bureau maps all represent these mountains differently. Lewis and Clarke exhibit four distinct ranges, with which the best recent explorations essentially agree, and indicate at least three parallel ranges ruming nearly north-west, instead of the more prevalent indication of a single north and south range. Exploration may show the necessity of a more definite eastern boundary. On the north the mouth of Frazer's River is so near to latitude $49^{\circ}$, that a portion of it may be found to fall in the United States, though this is improbable. Thus, with a field every way so requiring examination, it is fortunate that the newly-appointed governor of Washington possesses so many peculiar qualifications for his station, and especially a thorough training in geographieal science. Col. Isaac I. Stevens has been assistant in charge of the Coast Survey offee for over three years. A head graduate of West Point, a highly efflcient construeting offlcer of engineers, distinguished in General Seott's staff in Mexico, he has discharged the laborious and difficult administrative duties of his recent positions in so excellent a manner, as to afford every guarantee that he will make himself most usefully felt in the sphere on which he is entering. It is expected, and that expectation will not be without its fruits, that he will not permit his term to expire without presenting to the public a complete map of the Territory, and such reports as will give a clear conception of the surface, soil, resources, products, and peculiarities of a region so soon to become a State, with a voice in our national councils. Those who best know the governor are confident he will be able to aceomplish this and much more, in addition to those important and laborious duties which will devolve upon him in organizing and putting into thorough operation the machinery of a new territorial government.

Since the appointment of Col. Sterens as governor of this Territory, the President has further honored him by placing him at the head of a party to explore what is termed the Northern Pacific Railroad line, under a recent act of Congress, making an appropriation to explore the different proposed roates to the Pacific. The first thing to be ascertained in the survey of this route is the practieability of the undertaking, and the labors of the governor and his associates will relate only to the route upon which they are to be engaged, and their reports will be of those things alone that are sought for by the department under which they are to act. The officers of the army appointed to assist Gov. Stevens are Capt. Jolnn W. T. Gardiner, 1st Dragoons; Bvt. Capt. George B. M·Clelian; 2d Lieut. J. K. Duncan, 3d Artillery; 2d Lieut. Rufus Saxton, Jr., 4th Artillery; 2 L Lieut. Cuvier Grover, 4th Artillery; 2 d Lieut. A. J. Donelson, Corps of Engineers; Brt. 2d Lient. John Mullan, Jr., 1st Artillery; and Drs. Luckley and Cooper, Surgeons and Naturalists. The scientifle corps will consist of some 12 or 14 persons, among whom are named John Erans, geolngist; J. M. Stanley, artist; G. W. Stevens and A. Remenyi, astronomers; A.W. Tenkham and F. W. Lander, civil engineers; and John Lambert draughtsman. The escort consists of 10 non-commissioned officers, artificers, and privates of the engineer company, under command of Lieut. Donelson, and one sergeant, two corporals, one musician, and 16 privites of Co. D, 1st Dragoons, under command of Capt. Gardiner. Capt. M'Clellan will depart from Puget"s Sound for the purpose of exploring the Cascade range, with two officers furnished him by the brigadier-general in command on the Pacific, and thirty men, and proceed eastward. A portion of the main party, under Lieut. Donelson, will leave St. Louis and ascend the Missouri River to Fort 
Union, at the mouth of the Yellowstone, the place of rendezvous on the east, where they will be joined by the remaindes of the party, under the immediate command of Gov. Stevens.

A topographical survey, says the Wushington (D. C.) Republic of 7th May, 1853, will be made of the Rocky and Cascade mountains, between the $46 \mathrm{th}$ and 49 th parallels, and of the intervening country, to determine the general course of the railroad, and to guide the civil engineers in establishing its precise route. This reconnoisance will embrace the prominent features of the eountry, the mountain ranges and passes, the windings of rivers and streams, and their dividing ridges, the prairies, and every thing necessary for the construction of a map of the country. This will comprehend the important points of the Missouri and Columbia rivers, the debonches of the Cascade and Rocky mountain ranges, the fixing of the latitude and longitude of all important points, and all the facts bearing upon the construction of the road including the natural facilities for the transportation of iron, supplies, ete., required for the road. In crossing rivers the height of the banks will be noted, the depth of the water, the apparent bighest water, the nature of the bottom on whicb abutments and piers must rest, the width between the banks, and all information leading to correct estimates of the means and cost of carrying a road over the stream.

It is not doubled that the controlling points will prove to be the passes of the Cascade and Rocky mountains, and the opinion is entertained that the location of a road between the two ranges, and for a long distance east of the Rocky Mountains, may be suspended until these passes shall be thoroughly examined, and a practical avenue discovered.

It is proposed to construet a general map from the head waters of the Mississippi River to the Pacifle Ocean, a map of Washington Territory, and thence eastward to the head waters of the Mississippi ; maps of the Caseade range, Rocky Mountains, and other eritical points of the route and of the mountain passes.

As it will be necessary to determine the capacity of the adjacent country to supply materials for the construction of the road, and of the Columbia and Missouri rivers and their tributaries to transport them, attention will be given to the geography and meteorology of the whole intermediate region; to the seasons and the characters of the freshets; to the quantities and continuance of its rains and snows, especially in the mountain ranges; to its geology in arid ranges, keeping in view the bringing of water to the surface by means of artesian wells; to the botany, natural history, and agrieultural and mineral resourees; to the location, numbers, history, traditions, and customs of the Indian tribes; and such other facts as may tead to the solution of the railroad problem.

We learn, further, that after the completion of the survey of the mountain passes, probably in October or November next, such portions of the escort and scientific corps as will not be needed in the operations toward the Pacific, will be dispatched homeward by new routes, in order to obtain still further knowledge of the geography of the country; and it is hoped that a satisfactory report may be made to Congress in February next.

The preparation and equipment of this expedition have been well considered, and every man, from the principal to the humblest subaltern, has been selected with reference to his peculiar fitness for the duty assigned him. The most effective means have already been employed to conciliate and secure the good will of the various Indian tribes inhabiting the region to be traversed; but for any demonstration of an opposite feeling, the party will be well prepared.

The Hudson's Bay Company has manifested a laudable disposition to render every aid in its power to facilitate the operations of the expedition, and the hospitality of its posts, and the friendly offices of its agents, may be depended upon.

Though some of the Indian tribes of this territory are reputed to be ferocious and malignant in character, they are generaliy superior to those of their race with whom we are better acquainted. In industry, thrift, and intelligence, they far excel the eastern tribes. To act justly toward them, and to merit their respect and confldence, will be the policy of Governor Stevens and his companions, in commendation of whom we might say much, wid we not know that they possess the entire confidence of the administration and of the country. Their duty is one of some peril, and will be attended with great privations and hardships. Often, we doubt not, apparent impossibilities will arise before them in such form as would deter irresolute men from the consummation of the task assigned them. But the reality of such appearances will undoubtedly in each instance be fully tested by this chosen band, in whose safety and welfare, and in the triumph and success of whose enterprise, their whole country will feel the deepest interest.

WAsmington county, Ala. Situate S. W., and contains $1,049 \mathrm{sq}$. m. Drained by numerous branches of Tombigboe r., which forms its E. boundary, and by Escatawpa creek. Surface varied-in tire N. undulsting, and in the S. generally level. Soil fertile, and adapted to cotton and corn. Pine and other timber abounds. Farms 141; manuf. 0; dwell. 258, and pop.-wh. 1,195, fr. col. 22, sl, 1,496-total 2,713. Capital: Washington, Public Works: Mobile and Ohio R. R.

W ASHIxGtoN county, Ark. Situate N. W., and contains 929 sq. m. Drained by nllinois r., a tributary of Arkansas r., and by a head branch of White r. Surface monntainons; soil fertile, and adapted to cotton. Farms 850 ; manuf. 27 ; dwell. 1.430, and pop.-wh. 8,636 , fr. col. 14, sl. 1,199-total 9,\$49. Capital: Fayetteville.

Wasmingtos county, $D$. of Col.: co-extensive with the District of Coldanela.

W $A$ SHINGTON county, Flor. Situate toward the W., and contains $1,226 \mathrm{sq}$. m. Drained by several branches of Choctawhatchee $r_{n}$, which bounds it on the west. Surface level; soil generally poor, but there are some fertile tracts, adapted to cotton; rice is also grown. In the $\mathrm{S}$. is $\mathrm{St} . \mathrm{An}$ drew's bay, the banks of which contain a quantity of live oak. Farms 155 ; manuf. 4 ; dwell. 278, and pop.-wh. 1,434, fr. col. 12, sl. 504-total 1,950. Capital: Roche's Bluff.

W AsmingtoN county, $G a$. Situate E. centrally, and con902 tains 962 sq. m. Drained by branches of Oconee r., which flows on its western border, and of Ogeechee and Great Ohoopee rivers. Surface varied; soil fertile in some portions, but in general is of a light sandy nature, and very indifferent. Wheat and grain are produced, but cotton is the staple. Pine and other timber is found on the land. Farms 632 ; manuf, 6 ; dwell. 1,077, and pop.-wh. 5,993, fi. col. 35, sl. 5,738-total 11,766. Capital: Sandersville. Public Workes: Georgia Central R. R.

WAsHrgtor county, $I l l$. Situate toward the S. W. and contains $5 \$ 3$ sq. m. Drained by Elkhorn and Muddy creeks, and small branches of the Kaskaskia $\boldsymbol{r}$, which forms its N. W. boundary. Surface level, and a large portion is low and wet. Soil poor, and nnft for eultivation. It has good pasturnge, on which large numbers of cattle and hogs are fattened, and the exportation of which is considerable. In the $\mathrm{S}$. are some fine prairies. Farms 829 ; manuf. 9 dwell. 1,258, and pop.-wh. 6,929, fr. col. 24-total 6,953. Capital: Nashville. Public Works : Illinois Central R. R., Sangamon and Massac R. R.

Wasmington county, Ind. Sitnate S., and contains 540 sq. m. Drained by Muscatatuck $\mathbf{r}$. and E. fork of White $\mathbf{r}$., Lost r., and hend streams of Blue r. Surface diversiffedhills, levels, and undulations succeed each other rapidly, and forests, prairies, and barrens intermingle strangely. Sink holes and caverns abound, the substratum being limestone Soils unusually fertile. Farms 1,715; manuf. 88; dwell. 
2,897, and pop.-wh. 16,788, fr. col. 252-total 17,040. Capital: Salem. Public Works: New Albany and Salem R. R. WASIINGToN county, $I a$. Situate toward the S. E., and contains 569 sq. m. Iowa r. flows through its N. E. corner, by which and its branches, and by Skunk $r$. and Long and Crooked creeks, it is drained. Surface level or rolling; soil consists of black mold, with sand intermixed, and fertile, and well adapted to grain. Timber abounds. Farms 428; manuf. 1 ; dwell. 856 , and pop.-wh. 4,957, fr. col. 0 -total 4,95i. Capital: Washington.

WASHINGTON county, $K y$. Situate $N$. centrally, and contains $307 \mathrm{sq}$. m. Drained by Chaplin's fork of Salt r., and its branches. Surface level; soil generally fertile, and adapted to grain and grazing, Chief productions, tobacco and Indian corn. Farms 867 ; manuf. 21 ; dwell. 1,517, and pop.-wh. 9,086, fr. col. 63, sl. 3,045--total 12,194. Capital: Springfield.

W AsHingtos parish, $L a$. Situate N. E. in the eastern district, and contains $858 \mathrm{sq}$. m. Drained chlefly by Bogue Chitto, and Cbifuncte rivers. Surface hilly and broken, and much of it covered wlth pine forests; soil in general is barren, but there are some portions of fertile land, and cotton and rice are grown, which form the staple articles of commerce. Farms 260; manuf. 0; dwell. 406, and pop.wh. 2,367, fr. col. 4, sla. 1,037-total 3,408. Capital: Franklintown.

WASHNGTON county, Me. Situate S. E., and containg 2,470 sq. m. Machias, Pleasant, and Naraquagas rivers, with other large streatns, drain the co. Surface uneven and broken, and is diversifled with numerous lakes, the principal of which is the Schoodic in the N. Soil fertile, adapted to wheat and grain. A large number of cattle and bogs are fattened in this co. The eastern boundary is formed by the st. Croix $\mathbf{r}$., which separates it from New Brunswick. The numerous bays which indent the Atlantic shore afford excellent harbors, and also advantages for navigation and the flsheries. It is well timbered. Farms 1.875; manuf. 310 ; dwell. 5,835, and pop.-wh. 38,684, fr. col. 126-total 38,810. Capital: Machias. Public Works: Franklin R. R.; European and N. American R. R.; Calais and Baring R. R.

WASHINGTON county, Md. Situate $W$., and contains 518 sq. m. Drained by branches of Patuxent $r$., which forms its E. and N. E. boundary, and by Piscataway, Broad, Conecocheague, and other creeks, affluents of the Potomac, which flows on its $\mathrm{S}$. W. border. Surface varied, in some parts being hilly and much broken; soil a deep mold, and in the valleys and the river bottoms is very rich and productive. Staples wheat and grain. Live-stock and grain are exported. Farms 1,292; manuf. 170 ; dwell. 5,052, and pop.-wh. 26,929, fr. col. 1,829, sl. 20,903-total 30,848 . Capital: Hagerstown. Public Works: Baltimore and Ohio R. R. ; Franklin R. R. ; Chesapeake and Ohio Cansl.

WAshuxgtoN county, Minn. Ter. On the Wisconsin boundary, from which state it is separated by St. Croix r., and extending back to the 16 th meridian W. of Washington City. The Mississippi makes its S. boundary, and its N. is the 47 th parallel of latitude. Surface generally level, and well drained by creeks of the St. Croix. It has numerous lakes and in all parts; as a farming co. it is one of the best and most accessible in the Territory, and has been the longest settled. Farms 48; manuf. 4; dwell. 161, and pop.wh. 1,052, fr. col. 4-total 1,056. Capital: Stillwater.

WASHINGTON county, Miss. Situate W.; and contains $1,219 \mathrm{sq} . \mathrm{m}$. Drained by Williams' bayou, and Sun Flower rivers and their branches and small streams, all of which are tributaries of Yazoo river. Surface diversified with lakes, and in the W, the land rises toward the Mississippi, and forms high natural embankments to that river; soil very fertile, and well adapted to cotton, which is the ehief production. Farms 109; manuf. 0; dwell. 126, and pop.wh. 553, fr. col. -, sla. 7,836-total 8,389. Capital. Greenville.
W ASHINGTON county, MFo. Situate toward the S. E., and contains $937 \mathrm{sq} . \mathrm{m}$. Big river and its branches, and head branches of St. Francois and Big Blackwater rivers, drain this $c 0$. Surface varied, for the most part it is hilly and much broken, but there is some level land; soil fertile, and adapted to grain. It contains part of the celebrated "Iron Mountain," which is one vast mass of micaceous oxide of iron; it rises in height about 800 feet above the plain; the ore is so pure that it yields 70 or 80 per cent. good iron. It contains lead and copper, and is rich in minerals of all kinds. Farms 713 ; manuf. 41 ; dwell. 1,291, and pop.-wh. 7,713 , fr. col, 23, sl. 1,075-total 8,811. Capital: Potosi. Public Works: Iron Mountain R. R.

W Ashivgton county, $N . T$. Situate E. toward the N. and contains 807 sq. m. Drained principally by Hoosick and Battenkill rivers, which flow into the Hudson, and Pawlet and Poultney rivers, Wood cr., and Moseskill. Surface various, generally hilly and interspersed with pleasant valleys; soil fertile, and in the valleys and on the plain producing good crops of wheat; the uplands are well adapted to grazing, and much live-stock is raised. Chiel productions, wheat and Indian corn. It contains many minerals, and in the $\mathrm{N}$, granite forms the principal portion of the under-stratum of rock. Limestone and slate are

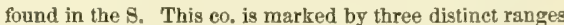
of mountains, viz.: the Taghkanic in the E. portion, the Peterboro' extending from N. to S., and the Palmerstown occupying the country between Lake George and Lake Champlain. Farms 3,037; manuf. 270; dwell. 8,043, and pop.-wh. 44,402, fr. col. 348-total 44,750. Capitals: Salem and Sandy Hill. Public Works : Rutland and Washington R. R.; Saratoga and Washington R. R.; Champlain Canal WAsHington county, $N$. Car. Situate $\mathrm{E}_{\text {, }}$ and contains 378 sq. m. Drained by several small streams falling into Lake Phelps in the E., and Albemarle Sound in the $\mathrm{N}$ Surface level, much of it being low and swampy; soil moderately fertile. Chief productions, cotton and Indian corn. Farms 444; manuf. 24 ; dwell. 670 , and pop.wh. 3,216 , fr. col. 235, sl, 2,215-total 5,666. Capital: Plymouth.

Washington county, Ohio, Situate toward the S. E. and contains 612 sq. m. Muskingum r. passes centrally through it, by which and its branches, and by Little Muskingum r., and Duck, Wolf, Bear, and Cat creeks, it is drained. Surface in general is hilly and broken, there are, however, sotne tracts of level land along the Ohio and Muskingum rivers; soil fertile and adapted to grain. Staples wheat and Indian corn. Apple, pear, peach, and other fruit-trees produce well. It contains some salt-beds, and iron ore of a good quality is found. On Big and Little Muskingum rivers bituminous coal abounds. Farms 1,776; manuf. 108; dwell. 4,906, and pop. - wh. 29,149, fr. col. 391-total 29,540. Capital: Murietta. Public Works: Cincinnati and Marietta R. R.; Cincinnati and Belpré R. R., ete.

Washingtos county, Oregon Ter. Extends from the E. boundary of Clatsop co. to the Columbia and Willamette rivers, which make its $\mathrm{N}$. $\mathrm{E}_{\text {。 }}$ and $\mathrm{E}$. borders, and into these its rivers and ereeks empty. Area abont $5,000 \mathrm{sq}, \mathrm{m}$. It is one of the most important counties of the Territory, both in regard to situation and resources; and being possessed of ample navigation and water-power, is destined to a high rank in wealth and prosperity. St. Helen's, on the Columbia, and Portland, and Linn City on the Willamette, are already flourishing towns. Farms 116; manuf, 5; dwell. 418, and pop.-Wh. 2,613, fr. col. 8-total 2,651. Capital: Hillsboro?

W A8Hivgton county, Penn. Situate S. W., and contains 795 sq. m. Drained by branches of Monongahela r., which forms its eastern boundary, and by Buffalo, Raccoon, and Cross creeks. Surface somewhat elevated, and in parts much broken; soil generally fertile, and produces abundantly wheat, grain, and potatoes. A large quantity of livestock is raised and exported. Coal of bituminous nature is found abundantly, and extensively mined. Farms 3,572; 
manuf. 247 ; dwell. 8,045, and pop.-wh. 43,380, fr. col. 1,559total 44,989. Capital: Washington. Public Works: Pittsburg and Steubenville R. R.; Hempfield R. R.

Wasungton county, $R$. I. Situate $\mathrm{S}$., and contains 367 8q. m. Drained by Pawcatuck $r_{\text {, }}$, and Charles and Wood rivers, its chief branches, both of which supply good water privileges. Surface uneven; soil a strong gravelly loam, with clay intermixed, and is well suited for pasture. It has many fine harbors, and has great commercial advantages. Chief products, wheat, Indian corn, and potatoes. Farms 1,808; manuf. 95; dwell. 2,891, and pop.-wh. 15,911, fr. col. 519-total 16,430. Capital: Kingston. Public Works: Providence and Stonington R. R.

Wasmingron county, Tenn. Situate F, and contains 512 sq. m. Drained by Nolichucky r. and its affuents, and branches of Watauga $r_{\text {, }}$ a tributary of Holston river. Surface hilly, and in parts somewhat mountainous and broken. Soil fertile, and produces good crops of wheat and grain. Pork is exported in large quantities. It has some important manufactures. A portion of the county is well timbered. Farms 922; manuf. 120 ; dwell. 2,155, and pop.-wh. 12,672, fr. col. 259, sl. 930-total 13,821. Capital: Jonesboro?.

W ABHINGTON county, Texs. Situate E. centrally, and contains 937 sq. m. Drained by Yegua, Jackson, New Year's, and Caney creeks, by which good water-power is supplied. Surface undulating, and is mostly prairie land with occasional groves of timber; soil fertile, particularly on the streams, where it consists of a deep black loam. Staples, cotton, corn, and potatoes. The soil of the prairies is generally rich, and makes excellent pasturage. Farms 306; manuf. 0 ; dwell. 600 , and pop.-wh. 3,166, fr. col. 0, sl. 2,817total 5,983, Oapital: Brenham.

Wasmington county, Verm. Situate in the centre, toward the N. part of the State, and contains $550 \mathrm{sq} . \mathrm{m}$. Drained by Onion $r$. and its ehief branches, which afford good waterpower to the co. Surfuce hilly; soil in general fertile, and there is some fine land along the streams. There are some fine quarries of granite and slate found here. Chief productions, wheat, Indian corm, and potatoes. It has some important manufactures. Farms 2,104; manuf. 77 ; dwell. 4,442, and pop.-wh. 24,641, fr. col.13-total 24,654. Capital Montpelier. Public Works: Vermont Central R. R.

W AsmingtoN county, Firg. Situate $S$. W. and contains $547 \mathrm{sq}, \mathrm{m}$. Drained by New $\mathrm{r}_{*}$, and branches of Great Kanawha and Clinch rivers. Surfitce diversifled, mostly valleys between mountain ridges; soil various, in the valleys being fertile, and on the mplands adapted to grazing, The Blue Ridge forms its N. W. boundary. Chief produetions, wheat and Indian corn, with pork, potatoes, cte. Farms 1,148; manuf. 112 ; dwell. 2,137, and pop.-wh. 12.372, fr. col. 109, sl. 2,181-total 14,612. Capital: Abingdon. Public Works: Virginia and Tennessee R. R.

WAsHingtoN county, Utah Ter. Extends along the $\mathrm{S}$ line of the Territory, from the Rocky mountains to the California line, and is 85 miles wide. Drained by Colnrado river and its tributaries. Formerly a part of Iron county.

Wasungron county, Wisc. Situate E. toward the S., and contains $663 \mathrm{sq}$. m. Drained by Milwaukie and Menomonee rivers. Surface undulating; soil fertile. It is well timbered. Farms 1,353; manuf. 22; dwell. 3,770, and pop.-Wh. 19,494, fr. col. 0.-total 19,484. Capital: Port Washington.

Wasmivgton, p. city, District of Columbia: and cap. of the United States, beautifully and conveniently situate on the N. bank of Potomac r., between Rock creek and the Anacosti or Eastern Branch. Lat. $35^{\circ} 55^{\prime} 45^{\prime \prime}$ north, and long. $77^{\circ} 1^{\prime} 30^{\prime \prime}$ west from Greenwich. It is the first meridian of American geographers.

The site has a gently undulating surface. The city extends N. W. and S. E. about $4 \frac{1}{2} \mathrm{~m}$., and E. to S. about $2 \frac{1}{2} \mathrm{~m}$. The public buildings occupy the most elevated situations. The streets run $N_{\text {. and }} \mathrm{S}$. and $\mathrm{E}_{\text {. and }} \mathrm{W}$., crossing each other at right angles, with the exception of 15 , which point to the
States, of which they severally bear the names. The Capitol commands the streets called Maryland, Delaware, and Pennsylvania avenues; the President's House, Pennsylvania, Vermont, New York, and Connecticut avenues, and all these different intersections form 1,170 squares. Pennsylvania avenue, which stretches in a direct line from Georgetown to the Eastern Branch, passing the President's House to the Capitol, is $4 \mathrm{~m}$. in length, and 160 feet wide between those ediflees, and beyond them 130 feet. The streets, which are from 70 to 100 feet wide, will give a fine appearance to the eity; but as yet few are built upon. The whole area of the city is about 3,016 acres, and its periphery about 14 miles.

Washington is nearly surrounded by a fine amphitheatre of hills of moderate elevation, covered with trees and shrubbery, and commanding from many points picturesque scenery, and extensive views of the " River of Swans, " which descending from the Alleghany mountains and winding its way for nearly $400 \mathrm{~m}$. through a fertile and most attractive country, expands into Chesapeake bay. The environs of the city abound in the most eligible sites for villas and country seats, and such will doubtlessly be multiplied, as the great advantages of the metropolis become more extensively known.

The first record in regard to the laying out of the eity, is from the pen of Washington, dated 11th March, 1771, and in a letter dated 30th April of the same year, he calls it the "Federal City." Its present name was adopted by the commissioners appointed to lay it out. The original proprietors, in consideration of the benefits they expected to derive from the location of the seat of government, conveyed in trust to the commissioners, for the purpose of establishing the city, the whole of their respective lands which were included within the eity limits, upon condition that after retaining for the public the ground of the streets, and any number of squares that the president might think proper for public improvements or other public uses, the lots should be equally divided between the public and the respective proprietors. By this means the public obtained possession of more than 10,000 lots, from which, in addition to a donation of $\$ 192,000$ from Maryland and Virginia, funds were to be raised to defray the expenses of the public buildings, etc. The city was founded, and the corner-stone of the Capitol laid with Masonic honors, on the 18th Sept., 1793 , and the city was first occupied as the seat of government in 1800.

The public buildings of Washington are the Capitol, the Executive Mansion, the State Offlces, Treasury Buildings, War Offices, Navy Offices, Offlces of the Secretary of the Interior, Post-office, Office of the Attorney-general, National Observatory, the Arsenal, Navy Yard, Smithsonian Institute, National Medical College, Columbian College, Coast Survey Office, City Hall, National Instifute, numerous churches, the hotels, and many others devoted to a variety of useful, literury, and benevolent purposes.

The Capitol is situate on an area of 30 acres, inclosed by an iron railing. The building stands on the western portion of this plat, and is so elevated as to command a view of the entire city, including Georgetown Heights, the windings of the Potomac, and the city of Alexandria. It was commenced in 1793. Daring the embargo the works were suspended, and as the British subsequently demolished much of what had been accomplished, the government in 1815 found it necessary to reconstruct the whole edifice. The exterior exhibits a rusticated basement of the beight of the first story, the two other stories are comprised in a $\mathrm{Co}$ rinthian elevation of pilasters and columns; these columns, which are 30 feet in height, form an advancing portico on the east, 160 feet in extent, the centre of which is crowned with a pediment of 80 feet span: while a receding loggia, 100 feet in extent, distingulshes the centre of the west front. The building is surrounded by a balustrade of stone, and covered with a lofty dome in the centre, and a flat dome on 
each wing. The dimensions of the building are: length of front 352 feet 4 inches, depth of wings 121 feet 6 inches, and the height to the top of centre dome 145 feet. The cost up to $182 S$, when it may be said to have been completed, was nearly $\$ 1,800,000$. During the session of Congress 1850-51, appropriations were made for the further enlargement of the Capitol by the addition of two new wings of 238 by 140 feet each wing; and when these are completed, the whole Capitol, including the space between the wings and the main building, will cover an area of four and one-third acres. The corner stone of the extension was laid by President Fillmore, on the 4th of July, 1851, with Masonic ceremonies, on which occasion the Hon. Daniel Weluster delivered a brilliant oration.

The Senate Chamber is in the second story of the north wing, of a semicircular form, 75 feet long and 45 high; a screen of Ionic columns, with capitals, support a gallery to the east, forming a loggia below; and a gallery of iron pillars and railings of a light structure projects from the circular walls, and the dome ceilings are enriched with square caissons of stucco. The walls are partially covered with drapery, and columns of breccia, or Potomac marble, support the eastern gallery. The only painting which adorns the Senate Chamber is a portrait of Washington.

The Hall of Representatives is also of a semicircular form, and of course much larger than the Senate Chamber. It is in the second story of the south wing, 96 feet long and 60 feet high. It is surrounded with 24 columns of the variegated Potomac marble, with capitals of white Italian marble of the Corinthian order, and surmounting a base of freestone, and the dome of the hall is painted in imitation of that of the Pantheon of Rome. From the centre of the dome hangs a massive gilt chandelier, and high over the speaker's chair, which is elevated and canopied, is placed the model of a colossal figure of Liberty, supported by an eagle just ready to fly, the work of Italian artists named Causici and Valaperti. In front of the chair, and immediately over the main entrance, stands a statue in marble representing History recording the events of the nation. She is placed on a winged car, rolling around a globe, on which are delineated the signs of the Zodiac, and the wheel of the car is the face of the clock of the hall; and this is also the work of a foreign artist named Franzoni. Two full-length portraits-one of Washington and one of Lafayette-adorn the walls on either side of the chair, and in every direction are displayed ample folds of crimson drapery. The galleries of this hall are so extensive as nearly to encircle it, and the general arrangement of the room is such as to render the members and the audience as comfortable as possible.

The Rotundo occupies the centre, and is 96 feet in diameter and the same number of feet high. The dome is hemispherical and fllled with large plain caissons; the room in Its circuit is divided into eight panels, intended for paintings, seven of which are already flled; and stationed between these panels are four bas-relievos of historical subjects, one representing the Preservation of Capt. Smith by Pocahontas, one the Landing of the Pilgrims on Plymouth Rock, one the Conficts betrceen Daniel Boone and the Indians, and the other Penn's Treaty with the Indians. In addition to these, specimens of sculpture are also displayed, encircled with floral wreaths, the heads of Columbus, Raleigh, La Salle, and Cabot-all these productions of the chisel being from the hands of Causici and Capellano. In niches on the outside of the east door are also two statues of colossal size representing Peace and War, from the chisel of Persico. Of the paintings, four are by Cot. John Trumbull, one by Weir, one by Vanderlyn, and one by Chapman -the order for the remaining vacancy not having yet been flled. The subjects of Trumbull's pictures are, the Declaration of Independence, the Surrender of General Burgoyne, the Surrender of the British Army, commanded by Lord, Cormoallis, at Yorktonm, in Firginia, and the Resignation of General Washington at Annapolis. The subjects of the remaining pictures are the Embarkation of the Pilgrims from Leyden, by Weir; the Landing of CoCumbus, by Vanderlyn; and the Baptism of Pocahontas, by Chapman. As these illustrate seenes connected with the very earliest history of our country, none but the leading figures are to considered in the aspect of authentic portraits.

The Congressional Library is unquestionably one of the chief attractions of the Capitol. The principal room, of which there are three, faces the W., and is a large and handsome affair, 92 feet long, 84 wide, and 86 high; divided into twelve alcoves, ornamented with fluted pilasters, and in every direction are displayed portraits and busts, cases of medals, and other works of art. The number of volumes which it contains is about 50,000. The original library, which was collected under the direction of Mr. Gallatin and Mr. Mitchell, in 1800 , was destroyed by fire during the last war, and that which now enriches the Capitol, was founded upon one which was purchased by Congress, in 1814, of Thomas Jefferson, for $\$ 23,000$. The yeariy average increase is about 1,800 volumes. The sum of $\$ 5,000$ is annually appropriated by Congress for miscellaneous books, and $\$ 1,000$ for law books. In 1851 the library lost many valuable works from an accidental fire.

The apartment for the accommodation of the supreme Court is an ill-arranged, inconvenient, and badly lighted room, in the basement under the Senate Chamber. It is semicircular in shape, with manifold arches; and on the wall is an emblem of Justice, holding her scales, in bold relief, and also a figure of Fame crowned with the rising sun, and pointing to the Constitution of the United States. The members of the bar are accommodated with seats and desks in the body of the room; and the justices occupy a row of elevated seats, and appear in their official capacity clothed in black silk gowns or robes.

In addition to the apartments of the Capitol already speciffed, it should be mentioned, that there is also a large number of ordinary, but well-furnished rooms, which are occupied by the Vice-President, the Speaker of the House, and other officers, by the Postmasters of Congress, the Public Documents, and the committees of the two houses.

The Capitol grounds are not only extensive, but are kept in the very neatest order, constituting one of the pleasantest and most popular resorts for promenading to be found in the metropolis. They command most charming prospects of the surrounding country, are adorned with a great variety of American trees, fountains and basins of pure water enliven them in various parts, and an air of superior refinement is given to them by a number of pieces of statuary, the most attractive specimens being a statue of Washington, by Greenough, and a pair, of Columbus and an Indian Woman, by Persico, the former occupying the centre of a square east of the Capitol, and the two others appropriate places on the eastern portico.

Near the western entrance of the Capitol stands a monument erected by the officers of the navy to the memory of their brother officers who fell in the war with Tripoli. It is of marble, rises out of a pool or basin of water, and is 40 feet high. On one side of the base is a view of Tripoli and the American fleet, on another the words, "To the memory of Somers, Caldwell, Decatur, Wordsworth, Dorsey, Israel," and on another side, a brief but comprehensive history. At the base of the column are four marble emblematic figures-Mercury, Fame, History, and Ameriea; the column has also appropriate embellishments, and is surmounted by an eagle.

The Executive Mansion is situated at the west end of the eity, at the intersection of Penusylvania, New York, Connecticut, and Vermont avenues. It occupies the centre of a plot of 20 acres, and has an elevation of 44 feet above the waters of the Potomac. The grounds are partially laid out in gardens, etc, but are still in an unfinished state. The mansion is 170 feet front and 86 feet deep, built of white 
freestone, with Ionic pilasters, comprehending two lofty stories of rooms, crowned with a stone balustrade. The north front is ornamented with a lofty portico of four Ionic columns in front, and projecting with three columns. The outer inter-columniation is for carriages to drive under, and place company under shelter; the middle space is for those visitors who come on foot-the steps from both leading to a broad platform in front of the door of entrance. The garden front is raried by having a rusticated basement story ander the Ionie ordonnance, and by a semi-circular projecting colonnade of six columns, with two flights of steps leading from the ground to the level of the principal story. The interior arrangements of the Executive Mansion are, of course, elegant and convenient, well adapted to the various purposes to which the building was designed.

In the centre of the small square immediately in front of the President's House, stands a bronze statue of Thomas Jefferson, exeeuted by whom we know not, but presented to the government by Capt. Lery of the United States Navy, the present proprietor of Monticello, the former abode of Mr. Jefferson. It is a handsome piece of statuary, and in its present position has quite a commanding appearance. Directly across Pennsylvania Aveuue from the above-mentioned square, is Lafayette Square, which has recently been laid out in fashionable style, and planted with new shrubbery. Mills' equestrian statue of General Jackson, which occupies its centre, is a work of superior merit. It is in bronze, and cast from certain cannon captured by General Jackson in some of his military engagements.

The State Department, which stands north-east of the President's House and within the same inclosure, is a plain brick building, two stories high, 160 feet long and 55 wide with a broad passage on both floors, and containing in all 32 rooms. It contains a handsome library of books, maps, and charts, numbering perhaps some 15,000 distinct works, which are indispensable in the performance of the extensive and varied duties of the department. In addition to this collection, the Copyright Bureau contains some 10 or 12,000 volumes published in this country, which are kept with care as part and parcel of the archives of the government. It is the department through which alone the diplomatic corps and all foreigners can hold any intercourse with the government of the United States, and is of course the head-quarters of all the American ministers and consuls.

The Treasury Department stands at the eastern extremity of the President's Square, so called, and is a stone edifice painted white, 340 feet long, and 170 wide, but when the northern and southern wings are added, it will be 457 feet in length. In front is an imposing colonnade, stretching the entire length of the building. It has three floors upon which business is transacted, on each of which are neariy fifty apartments. This is the department where all the financial and commercial affairs of the country are attended to. A good legal library is attached to this department.

The War Department building occupies the north-west corner of the President's Square, and is precisely similar in design to the State Department. It is the head-quarters of all the officers of the army, and the mainspring of all the military movements. This department comprises the War Ofilice proper, the Quartermaster's Department, the Engineer's Department, Bureau of Topographical Engineers, Ordnance Office, Subsistence Department, Pay Department, Medical Department, Office of Adjutant-general, and the head-quarters of the Major-general or military Commander-in-chief of the Army. The War Department is furnished with a valuable library of some 10,000 volumes.

The Nary Department building lies directly west of the President's House, and in the rear of the War Department. It has five bureaus, exclusive of the Secretary's office, viz. : Burean of the Navy Yards and Docks, Bureau of Construction, Equipment, and Repair; Bureau of Provisions and Clothing, Bureau of Ordnance and Hydrography, and Bureau of Medicine and Surgery.
The Department of the Interior, or Home Department, is the most extensive connected with the government. The building which it is destined to occupy is yet unfinished, but when completed, it will be the most extensive and most interesting in the metropolis. A portion of it is already occupied by one of the bureaus of the department (the Patent Office), and also by the museum of the National Institute. The titles of the bureaus connected with the Interior Department are as follows: Land Office, Patent Office, Indian Office, and Pension Office. As its name indicates, this department has to do exclusively with all those matters bearing upon the internal economy of the United States, and is, of course, increasing in importance with every successive year. A library of some 5,000 volumes is attached to this department. In the second story of the building now ocenpied by the Patent Office, are the invaluable relies of Washington, including his camp chest, the Original Declaration of Independence, the gifts presented from time to time to the government by foreign powers, Franklin's printing press, a collection of Indian portraits by King, the treasures of the National Institute, interesting memorials of the late James Smithson, and the extensive and rare treasures se. cured by the U. S. Exploring Expedition, under Captain Wilkes, in almost every department of national history and human ingenuity. ETery thing here is open to the inspection of the public. In the first story of the same building are collected all the models of the machines which have been patented since the foundation of the government.

The Post-office Department is of white marble, and after the Corinthian order. It is 3 stories high, and 204 feet long, and 102 deep; it contains 27 rooms on each floor, making 81 in all. It occupies a central position in the city, near the Department of the Interior, both of which are about half a mile from the President's Square and the other departments.

With regard to the Office of the Attorney-general, which we have classed with the Executive branches of the government, we have only to say that it derives its chief attraction from the person who may occupy it, who must be, of necessity, a man of distinguished ability. Rooms are assigned to him in the Treasury building, and it is to him that all knotty questions, in all the departments, are submitted for final settlement.

The National Observatory is situated on the banks of the Potomac, in an oblique direction from the President's House, toward Georgetown. The site is a beautiful one, having a commanding view of Washington and Georgetown, of the Potomac river, and surrounding country as far down as Fort Washington, opposite to Mount Vernon. It is a naval institution, under the control and management of Lieutenant M. F. Maury, U. B. N. The force employed at it consists principally of naval officers. Besides the astronomical duties of the establishment, here are kept all the nautical books, charts, and instruments belonging to the navy. The apartment in which the chronometers are kept is a very interesting one. Before one of these instruments is purchased by government, it is required to be put on trial by the Superintendent of the Observatory for one year; during which period it is compared daily with the great astronomical clock of the Observatory, which regulates the time for the whole city. The temperature of the room in which it is kept is also carefully observed, and recorded every day. The test is a severe one, and in ease the instrument fails to come up to it, it is returned to the maker at the end of the year. The observations on the temperature in connecfion with the performance of the chronometer, enable the maker to improve the instrument, and on a second trial of another year it rarely fails to pass. There are from 60 to 100 chronometers always in this room, all of which are daily wound, and compared and treated in the manner described. Thus a complete and minute history is kcpt of each one. Here also are conducted the celebrated researches connected with the "wind and current charts," 
the habits of the whale, and a variety of phenomena connected with the great deep. The National Observatory of Washington occupies a high rank among the observatorics of the world, there being but two-those of Russia and Greenwich-superior to it. The largest telescope, called the equatorial, is a 14 feet refractor, with an object-glass of 9 inches. It is mounted in the revolving dome on the top of the main building; and is so arranged with clock-work and machinery, that being directed to a star in the morning, it may be left alone, when on returning to it in the evening, it will have followed the path of the star so exactly, that it will be found still pointing to the star, and the star will be visible through it. With its powers the stars are visible at mid-day. In one room below are the meridian and mural circles; in another, the transit instrument; in another, the prime vertical instrument; and in another yet, the great refraction circle, invented by the superintendent: it is made by Ertel \& Son, Munich, and taken altogether is, perbaps, one of the finest instruments anywhere to be found. But perhaps the most wonderful object at this interesting establishment is the electro-chronograph, invented by Dr. Locke, of Cincinnati. It is in the room with the transit instrument, and is so arranged, by its connection with an electrical battery in the building, that its ticks may be heard in any part of the country to which the magnetic wires lead, provided they be put in connection with it. Thus it may be made of itself to record the time, and in such a manner, that the astronomer in Boston, New Orleans, or elsewhere, will know it, and tell the time of day by his clock, as well as one who stands before it and reads the hands on its face. The $\mathrm{Ob}$ servatory regulates the time for Washington and Georgetown by the falling of a ball. At ten minutes before mean noon every day, a large black ball is hoisted to a flag staff, standing on the top of the dome. This is to give warning for those who wish to get the exact time of the day to look out. Precisely at twelve the ball drops. The whole city is informed of the exact time.

The Arsenal occupies a fine position on the extreme southern point of the city (called Greenlears Point), at the junction of the eastern branch with the Potomac, commanding a beautiful and extensive view, over a broad expanse of water, toward the cities of Washington and Georgetown on the N., and Alexandria on the S. The channels of both rivers running near the Arsenal shore, afford all requisite facilities for receiving and shipping ordnance and other military stores. Although this site was originally reserved for the purpose of an arsenal, it was not occupied by any building of importance until after the peace of 1814, when the building of the present establishment was commenced under the direction of the late Col. George Bomford. From the small square embraced in the first plan, the buildings have been gradually extended until they occupy nearly the whole reservation, and form one of the principal arsenals of eonstruction in the United States. The workghops contain much useful and in wenious machinery, propelled by steam, for manufacturing gun-carriages and equipments for artillery, and for preparing ammunition of all kinds. Among these may be noticed particularly the machines for planing and boring iron and wood, those for tenoning and morticing the spokes and hubs of wheels; Blanchard's ingenious lathe for turning irregular forms in wood, such as spokes, axe-handles, etc.; the machinery for making leaden bullets by pressing them out of the bar-lead instead of casting them; and, above all, the lyeautiful machine for making and charging pereussion caps for small arms, invented by Mr. George Wright, a workman at the Arsenal. By this last-mentioned machine, a sheet of copper being inserted on one side, and some percussion powder put in a hopper on the other, the finished caps are produced without any further agency of the workman. In the spacious storehouses of the Arsenal are to be seen arms and equipments for the troops; also a large number of gun-carriages, and other apparatus for the service of the artillery in the forts and in the fleld, from the ponderous Columbiad for the defense of the coast, to the little mountain howitzer which may be transported, with its miniature smith's forge, on the back of a mule. The model office contains a collection of models or patterns of the various arms and military equipments used in our service, and also of such of those used in the armies of other nations as have been obtained by the ordnance department. Here may also be seen some specimens of old and new inventions, repeating arms, revolvers, etc., which have been suggested at home or abroad by the organ of destructivemess. In the gun lot are arranged many pieces of ordnance and piles of balls, mostly of heavy calibre for the armament of the forts. In front of the old Arsenal Square a small collection of foreign brass cannon will attract the notice of the visitor, who will perceive by the inscriptions that some of them are trophies of the suceess of our arms at Saratoga, Yorktown, Niagara, and Vera Cruz. The guns and cannons of Duncan's fleld-battery, which performed distinguished services on nearly every field of battle in the Mexican War, are likewise preserved at the Arsenal as a saluting battery. On the W. side of the Arsenal grounds, near the river, are 2 pyramida structures, which often attract the curiosity of visitors, and of persons passing by the Arsenal. These buildings contain an apparatus called a Ballistic Pendulum, which is used for testing the force of gunpowder when fired in heavy ordnance, and also for trying many other interesting experiments in gunnery.

The Nary Yard is situated on the "Anacostia," a branch of the Potomac r., at the southern termination of Eighth Street, east. It was established in the year 1800 . The area covers about 20 acres, and is inclosed by a substantial brick wall, having a prineipal entrance at the foot of Eighth Street, through a handsome arched gatewar. Several comfortable residences have been erected for the accommodation of the commodore; the executive officers, the first lieutenant, surgeon, sailing-master, boatswain, and gunner, whose official duties require their constant attendance in the yard. The mechanical operations of this establishment are various and extensive, and the skill of the workmen and the excellence of the materials employed have been satisfactorily tested in every sea. Anchors of all sizes, for the naval service, are manufactured by the use of two heavy steam hammers (termed the "Nasmyth Hammer"), one of which weighs 3,600 pounds, the other 2,240 pounds. The forges for this work are kept in blast by a fan-blower attached to the steam-engine in the machinist's department. There is also in operation, in the anchor department, a direct action steam-hammer (called the "Kirk Hammer"), in connection with a blast-furnace for working up into looms and bars all the serap iron of the navy. The massive chaincables are made in another shop, which is provided with a powerful hydrostatic press for testing their strength. These cables are highly esteemed for their superior finish, great strength, and durability. Another department is engaged in the manufacture of galleys, cabooses, and copper powdertanks, and of the various kinds of brass work appertaining to ships of war. The different machines employed in making these articles are driven by a steam-engine of about 15 horse-power. A brass foundry is connected with this range of buildings on the eastern side of the yard. $\Delta$ large and extensive iron foundry has recently been erected of sufficient capacity and with the necessary facilities for molding and casting the heaviest work. Connecled with this foundry are the machines for boring, turning, and planing the steam cylinders and other massive machinery required for the naval service. Adjoining the iron foundry are the ordnance and boiler-making departments, which are provided with a steam-engine of about 12 horse-power. The ordnance department is engaged in the fabrication of light brass ordnance, howitzers for boat and Iand service, of shot and shells, percussion-caps, musket and pistol balls, etc. Some of this machinery is very ingenious and highly inter- 
esting. The boiler shop contains all the machinery necessary for the construction of boilers. Clnse by this range of buildings is a very extensive machine-shop, in which are placed all the tools required in the manufacture of steamengines aud machinery of every description. When completed it will afford room for the employment of from 150 to 200 workmen. Attached to this shop is an engine of 60 horse-power, which also gives motion to the block-making machinery, and to the fan-blowers of the anchor-making department. On the western side of the yard is the pyrotechnical laboratory, in which are prepared all the articles for the navy appropriate to this department. There are two large ship-houses for building ships, under one of which is about to be constructed a marine railway for hauling up steamers for repair. The grounds are beautifully laid ont, the avenues shaded with fine trees, the plats neatly inclosed, and the whole preserved in handsome order.

The Smithsonian Institution was founded upon a bequest of more than half a million of dollars made to the United States by an Englishman named James Smithson. The object of the bequest, according to his will, was " to found at Washington, under the name of the Smithsonian Institution, an establishment for the increase and diffusion of knowledge among men," On the 1st of July, 1836, Congress solemnly accepted this important trust, and the money was paid into the Treasury of the United States in 1838. The Act of Congress establishing the Institution as it now exists, was passed in 1846. The Institution is situated on the Mall, below the Capitol; and though the edifice is yet in an unfinished state, it presents a noble appearance, and is unquestionably one of the great attractions of the metropolis. The style of the arehitectore is the Romanesque, the material a reddish freestone of fine grain; its extreme length is 450 feet, its width 140 feet, and it has nine towers, varying in height from 75 to 150 feet. The grounds which surround it are very extensive, and are now in progress of being beautified. The library room is capable of holding 100,000 volumes. The building is supplied with a lecture-room, which will seat 1,200 persons; and its museum is 200 feet Iong; its rooms for chemical experiments are more spacious and convenient than any to be found in the country; and in the western wing, which is 120 feet long, will hereafter be located a gallery of art.

The Washington Monument stands on the Mall, between the President's House and the Potomac, and embraces the idea of a grand circular colonnaded building, 250 feet in diameter, 100 feet high, from which springs an obelisk shaft, 70 feet in diameter at the base, and 500 feet high, making a total elevation of 600 feet. The vast rotundo, forming the grand base of the monument, is surrounded by 30 columns of massive proportions, 12 feet in diameter, and 45 feet high, elevated upon a base of 20 feet in height and 300 feet square, surmounted by an entablature 20 feet high, and crowned by a massive balustrade 15 feet in height. The terrace outside the colonnade is 25 feet wide, and the walk within the colonnade 25 feet. The front portico is adorned with a triumphal car and statue of the illustrious chief; and over each column around the entire building are sculptured escutcheons, coats of arms of each State of the Union, surrounded by bronze civic wreaths, banded together by festoons of oak-leaves, while the centre of the portico is emblazoned with the coat of arms of the United States. Around the rotundo are stationed statues of the Signers of the Deelaration of Independence: in niches prepared for the purpose, statues of the Fathers of the Revolution, cotemporary with Washington; and directly opposite to the entrance is placed a statue of Washington himself. The interior of the shafl is embellished with a great variety of inseriptions; a one point it is ornamented with four of the leading events of Washington's career, sculptured in basso relievo, above which is placed a single star, cmulematic of the glory which the name of Washington has attained : and in the centre of the monument will be placed the tomb of the Father of his Country.

$7 \mathrm{he}$ National Medical College, instituted in 1823 , is now in successful operation. It was, until a few years past, known as the Medical Department of the Columbian Col lege, from which institution it derives its authority to confer degrees, under an act of incorporation from the Congress of the United States. The requisites for graduating are, that the candidate shall have attended the lectures of each professor two full courses, or one full course in this school, and one full conrse in some other respectable institution. He must have a fair moral character, and he shal have dissected during at least one session. He shall have entered his name with the dean of the faculty as a candidate for graduation, and delivered to him an inangura] dissertation upon some medical subject, thirty days before the close of the session, and pass a satisfactory examination.

The Columbian College, which was incorporated in 1821 , is beautifully situated on an eminence, adjoining the City Corporation, on the north, and on Fourteenth Street, west It is a fine brick edifice, four stories high, and overlooks the city, the Capitol, and other public buildings; and commands a fine riew of the Potomac, with the surrounding country, for many miles in extent. In beauty and healthfulness of position, it is unsurpassed; and its local advantages are such as no other situation in the country can afford. The College has a good library, a valuable philosophical apparatus, and other means and facilities for pursuing a thorough and liberal course of studies. The last catalogue $(1850)$ embraces a president, and twelve professors and teachers-including those of the National Medical College, which is under the same corporation -100 students, and between 200 and 800 alumni.

The Coast Survey Office Buildings, occupied for the use of the United States Coast Survey, are situated on the west side of New Jersey Avenue, about a sixth of a mile from the Capitol. They consist of four old houses, in a block, presenting a decidedly rusty exterior, and in no way looking like public buildings.

The National or Congressional Burial Ground, situated about one mile east of the Capitol, embraces about ten acres, commands an extensive view of the country, and is rell inclosed with a brick wall, laid out with taste, and beautifled with trees and shrubbery. It was located in 1807, and has since been in the keeping of an incorporated company. The monuments are manifold, and many of them beautiful; and in addition to several private vauits is one spacious and well constructed, inclosed by a neat railing, built by the order and the expense of Congress, as a place of deposit for the dead whose remains it may be the purpose of friends subsequently to remore.

The City Hall, the official home of the City Fathers, was commenced in 1820 , and finished in 1850 , it having remained a kind of ruin during most of the intervening time. It is a large and handsome ediflce, and occupies a commanding position on Judiciary Square, is 200 feet in length, and after the stucco style of architecture. The Circuit and Criminal Courts hold their sessions in this hall; also the members of the City Councils. The mayor has his office here, and so also have a large number of the city attorneys.

The Public Schools of Washington are quite numerous: of free public schools there are four, with quite a large retinue of primary schools, which are carried on at an annual expense of about $\$ 12,000$. Select sehools and seminaries for the education of both sexes also exist in different parts of the city, several of them of a high and established character. Public attention has been strongly directed to these institutions, and perhaps in no other eity are there to be found superior advantages of education, which are annualiy on the increase. There are also several excellent boarding-schools in Washington, and two or three in Georgetown. 
The National Institute was founded in 1540, and has for Its object the promotion of science in all departments. It holds its meetings and has its head-quarters at the Patent Office. It has a miscellaneous library of nearly 4,000 vols., pamphlets, maps and charts, with a few interesting manuscripts, and in the cabinet are many medals and coins. The library is always open to the inspection of the public.

The Metropolis is well supplied with churches, and considering its extent is quite as well supplied with eloquent preachers as any city in the Union. Of Baptist churches here are four-one on Tenth Street, one on E., and two on Firginia A venue; their congregations are all large, and their pastors popular. Of Catholic churches thcre are four-St. Matthew's, on H. street; St. Peter's, on Second; St. Patrick's, on F.; and St. Mary's, on Fifth. Of Episcopal churches there are flve, viz. : Christ church, on G Street; St. John's, on H; Trinity, on Third; Epiphany, on G; and Ascension, on H. The Trinity church edifice is the handsomest, devoted to religion, in the city. In this church, as indeed in all other churches of the city, a certain number of pews are assigned to strangers, St. John's chureh stands directly in front of the President's House. There is also one Quaker meeting held in the city on I Street; and two Lutheran churches, the English on H Street, and the German on G Street. Of Methodist churches there are seven in the cityone on 4th, one on 14th, one on 5th, one on Massachusetts Avenue, one on Maryland Avenue, one on 9th Street, and one on Virginia Avenue. Of Presbyterian churches there are six-one on F Street, one on 8th Street, one on $4 \frac{4}{4}$ Street, one on H, and two on 9th Street. There is also one Unitarian church in the city, on D Street; and of colored churches, there are some half dozen scattered about the city.

Hotels are quite numerous, but not sufficiently so, even now, to accommodate the public. With one or two unimportant exceptions, they are all situated on Pennsylvauia Avenze. The names of the principal ones are the National Hotel, Brown's Hotel, Willard's Hotel, Gadsby's Hotel, the Irving Hotel, the United States Hotel, the Potomac Hotel, and Tyler's Hotel. The finest hotel edifice in Washiugton is that recently erected by Mr. Brown, which is very large, and has a beautiful marble front. All these hotels are supplied with the best of a first-rate market, and with numerous and generally accommodating servants. From the doors of each, the stranger may at almost any moment step into a convenient and elegant omnibus, and go to almost any part of the eity he may desire. Pop. in 1800, 3,210 ; in $1810,8,208$; in $1820,18,247$; in $1830,18,327$; in $1840,23,364$; and in $1850,40,001$.

The general statisties of Washington will be found under the caption of District of Coluaria.

Washivgton, p. v., and cap. Hempstead county, Ark.: $101 \mathrm{~m} . \mathrm{S}$. W. Little Rock. It contains the county buildings, an Tnited States land office, stores, etc. The "Washington 'Telegraph" (whig) is published weekly. Pop. 469.

W ASHINGTON, V., Yolo co., Califf.: on W. bank of Sacramento river, 49 m. E. N. E. Vallejo. In 1852, it contained 4. hotels, 2 stores, and 3 foundries.

WASHIngtox, t. and p. v., Litchfield county, Conn.: $32 \mathrm{~m}$. W. by S. Hartford. Surface elevated. Drained by Shepaug river, on which the $\mathrm{v}$. is situate. It contains 3 churches and a factory of satinets. The t. also contains several mills, and quarries of limestone and marble. Pop. of t. 1,802.

Washington, p. v., and cap. Wilkes county, Ga. : $52 \mathrm{~m}$. IV. E. by N. Milledgeville. It contains a briok court-house and jail, 1 bank, an academy, 3 churches, Masonic hall, ete. The "Washington Gazette" is issued weekly. The construction of a branch R. R. from the Georgia R. R. to this place is contemplated. Pop. about 850.

Washiveron, p. o., Tazewell co., Ill.: on E. side of Holland's Grove, $62 \mathrm{~m}$. N. by E. Springfield.

WASHIN GTOX, p. v., and cap. Daviess co., Ind.: $4 \mathrm{~m} . \mathrm{E}$ of W. fork of White r., $90 \mathrm{~m}$. S. W. by S. Indianapolis. It contains good county buildings and 5 churches. It was laid out in 1817. Tho "Literary Journal" is here published Pop. 2,578.

Wasmixgton, p. v., and cap. Washington countr, Ia.: E side of Adams ereek, $25 \mathrm{~m}$. S. by W. Iowa City, It is well situated on a fine prairie, contains the county buildings, etc. and is a thriving $\mathrm{v}$. The Dubuque and Keokuk R. P. will pass through the place. Pop. 742.

Washington, p. v., and cap. Mason county, Ky.: $60 \mathrm{~m}$. E. N. E. Frankfort. It contain the county buildings, 4 churches, an academy, etc. The Lexington and Maysville R. R. passes through it. Pop. about 650 .

WASHington, p. V., St. Landry par., La.: on E. bank of Vermillion r., $52 \frac{1}{2} \mathrm{~m}$. W. by N. Baton Rouge. It is at the head of steamboat navigation, contains several stores, a Catholic church, ete. Pop, about 250.

W Asmington, t. and p. v., Lincoln county, Me.:: 22 miles E. S. E. Augusta. Drained by branches of Muscongus $r$, one of which rises in a large pond in the centre of the $t . N$. of the v. Pop. of t. 1,756.

Wasmington, to and p. v., Warren co, N. Jer.: $37 \mathrm{~m}$. N. by W. Trenton. Drained by the Musconetong r., which bounds it on the S. E, and Pohatcong creek. Population of $t .1,567$.

WASHIF GTON, t., p. v., and sta., Berkshire county, Mass. 104 miles W. Boston. Surface very diversifled; soil best adapted to grazing. The Western R. R. passes through the v., $13 \mathrm{~m}$. from Pittsfleld, $40 \mathrm{~m}$. from Springfield, $138 \mathrm{~m}$. from Boston. Pop. of t. 953.

Wasmingtor, t. and p. o., Maeomb co., Mich.: $76 \mathrm{~m}$. E. Lansing. This is one of the most fertile and best cultivated agricultural townships in the $c_{0}$. Drained by branches of Clinton $r$. In its $N$. E. corner is the thriving $\nabla$. of Pomeo. Pop. of t. 1,511.

W asmington, p. o., Adams co., Miss. : 6 m. E. Natchez, $82 \mathrm{~m}$. S. W. by W. Jackson. Lat. $81036^{\prime} \mathrm{N}$.; Iong. $91030^{\prime}$ W. It contains 2 academies, 2 churches, stores, etc. Pop about 400 .

Wasmington, p. v., Franklin county, Mo.: on S. bank of Missouri r., 63 m. E. Jefferson City.

WASHINGTON, t. and p. v., Sullivan co., N. Hamp.: $27 \mathrm{~m}$. W. by S. Concord. Drained by Ashuelot and Contoocook rivers, which rise from large ponds, of which the town contains sixteen, abounding with fish, and surrounded by beartiful scenery. Surface hilly; soil moist and deep. Pop. of t. 1,054 .

Wasgington, t. and p. o., Duchess co., $N . Y_{.:} 60 \mathrm{~m} . \mathrm{S}$. Albany. Surface rolling and hilly. Drained by small creeks. Contains several cotton factories, tanneries, with flouring, grist, and saw mills. Pop. 2,305.

WASmingtoN, p. v., port of entry, and cap. Beaufort co. N. Car.: on N. side of Tar r., at its entrance into Pamlico r., $91 \mathrm{~m}$. E. by S. Raleigh. It contains the court-house, jail, 8 churches, and 2 banks, cap. $\$ 300,000$. The "North \$tate Whig" is issued weekly. Vessels drarving 9 feet water can come to its wharves. The total tonnage of Washington district on June 30 th, 1850 , was 5,703 tons, chiefly employed in the coasting trade. Pop, of v. about 1,300 .

WASHINGTON, p. v., and cap. Fayette co., Ohio: $31 \mathrm{~m}$. S. S. W. Columbus. It contains the coanty buildings, eter, and a branch of the State bank of Ohio, and is on the line of the Cincinnati, Wilmington, and Zanesville R. R. The "Fayette New Era" (whig) is here published. Pop. 569.

WAgalicton, t. and p. v., Guernsey county, Ohio: $79 \mathrm{~m}$. E. by N. Columbus. Pop. of v. 757; pop. of t. including village 1,729 .

Washtraton, p. b., and cap. Washington county, Penn. 170 miles W. Harrisburg. It contains the court-house and jail, a female academy, and 5 churches. Washington College, here located, was chartered in 1806 ; in 1850 it had S instructors, 187 students, 111 alumni, and 3,300 rolumes in its libraries. The b. also contains a woolen factory, with various manufacturing establishments, and 1 bank, capital $\$ 120,000$. Three newspapers are published, "The Com- 
monwealth" (whig), "W. Reporter" (whig), and "W. Examiner" (dem.) The Hempfleld R. R. passes through this place. Pop. in $1840,2,062$; in $1850,2,662$.

Washington, p. v., and cap. Rhea co., Tenn. : on W. side Tennessee r., 108 m. E. S. E. Nashville. It contains the co. buildings, several stores, ete. Pop. about 150.

WashingtoN, p. v., and one of the caps. Washington co., Tex.: on W. bank of Brazos river, opposite the mouth of Navasoto r., 94 m. E. Austin City. The "Lone Star," semiweekly, and "Texas Ranger," weekly, are published at this place. It is beautifully situated on high post-oak land; and the surrounding country, being diversified by numerous hills, presents delightful scenery. It contains a court-house and jail, stores, etc.

W ASHINGion, $t_{0}$ and p. v., Orange county, Verm. : $19 \mathrm{~m}$. S. E. by S. Montpelier. Soil fertile; drained by several small creeks. The inhabitants are chiefly engaged in farming, ete. The $\mathrm{v}$. is neatly built. Pop. of t. 1,348.

WASHINGTON, p. v., and eap. Rappahannock co., Virg. $87 \mathrm{~m}$. N. N. W. Richmond. It contains the co. buildiugs, several stores, an academy, and church. Pop. about 400 .

Wasmington lake, Yolo county, Calif: : $52 \mathrm{~m}$. N. N. E. Vallejo, $3 \mathrm{~m}$. long, and $1 \frac{1}{\mathrm{t}} \mathrm{m}$. wide.

W ASHINGTON College, p. o., Washington county, Tenn.: 231 miles E. Nashville. Washington College, here located, was founded in 1795 ; in 1850 it had 3 professors, 116 alumni, 22 students, and 1,800 volumes in its libraries.

Washington Hollow, p. o., Duchess co., $N, Y$.: $62 \mathrm{~m}$. S. Albany.

W ashivgton Mrlis, p. 0. , Oneida county, $N . Y_{*}: 80 \mathrm{~m}$. W.N. W. Albany.

W ASHingtonville, p. v. and sta., Baltimore co., Mrd. : on Baltimore and Susquehanna R. R., 6 m. N. Baltimore.

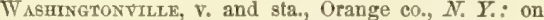
Newburg Branch R. R., 12 m. Newburg, 7 m. Chester.

Washingtonville, p. v., Columbiana co., Ohio : $128 \mathrm{~m}$. N. E. by $\mathrm{E}$. Columbus.

Washingtonvilie, p. ₹., Montour co., Penn.: $54 \mathrm{~m} . \mathrm{N}$. by E. Harrisburg.

WASHTA county, Ark. Situate S., and contains 815 sq. $m$. Drained by Washita $r$, and its branches. Surface generally even; soil fertile, and adapted to cotton. Timber is found in some quantity. Farms 697 ; manuf. 1 ; dwell. 1,122, and pop.-wh. 6,285 , fr. col. 0, sl, 3,304-total 9,591. Capital: Camden.

W Asmrx parish, La. Situate N., and contains 752 sq. m. Drained by $W$ ashita $r$. and its branches. Surface diversifled; much of the land is covered with pine timber, and a portion of it is rendered unft for cultivation on account of its low situation; soil, where fit for tillage, is productive. Staples, cotton and Indian corn. Farns $242 ;$ manuf, 4 , dwell. 442, and pop. -wh. 2,293, fr. col. 7, sl. 2,708-total 5,008. Capital: Monroe.

Wasmita, p. o., Grayson county, Tex.: $297 \mathrm{~m}$. N. by E. Austin City

W ASHTENAW county, MFich. Situate S. E. of the Southern Peninsula, and contains 720 sq. $\mathrm{m}$. Drained by the Huron, Saline, Macon, and Raisin rivers, and Mill, Honey, Mullet's and Paint creeks. Surface slightly undulating, and diversified with numerous lakes; soil very productive, being a rich black loan with clay intermixed. There is some prairie land and some gond timber in the co. Fine waterpower is supplied by the branches of IIuren and Taisin rivers. The principal productions are wheat, Indian corn, and potatoes, Agriculture is the leading pursuit. Farms 2.543; manuf. 154; dwell. 5,142, and pop.-wh. 2S,343. fr. col. 22t-total 25.567. Copjitul: Anu Arbor. Public Trurk: Nichigan Central R. F.

Wassarc, p. O. and sta., Duchess co., $N$. $Y$.: on the Harlem I. R., $85 \mathrm{~m}$. from Jew Turk, $69 \mathrm{~m}$. from Mlhans.

Wassama lake, Wisce: in S. W. part of La Pointe co, $7 \mathrm{~m}$. lons, and $4 \mathrm{~m}$. wide, connceting by short outlet with St. Croix river.

WAssonville, p. o., Washington co., Firg. 910
WАтAB, p. v., Benton co., Minn. Ter.: on E. bank of Mississippi r., opposite the mouth of Watab r., $72 \mathrm{~m}$. N. W. St. Paul ; by the river 82 miles. It was laid out in 1850 by Messrs. Gilman, Vincent, and $\mathrm{Co}$. This was the highest point attained by the volunteers in the Winnebago cam paign of 1850.

W ATAREE river, $S$. Car.: rises in N. Car., but in that State is called the Catawba. In $\mathrm{S}$. Car. it flows through the N. central portion of the State, in general course S. by E. and near the centre of the State it unites with Congaree $r_{\text {. }}$ forming Santee river.

WATAUGA counity, N. Car. Situate N. W., and contains $548 \mathrm{sq} . \mathrm{m}$. Drained by Stony fork of Yadkin r., and affluents of New river. Surface mountainous, having the Blue Ridge passing through it; soil in the valleys and most of the level portions is fertile, and adapted to grain. It is well wooded. Farms 442; manuf. 1; dwell. 569, and pop.-wh. 3,242, fr. col. 29, sl. 129-total 3,400. Capital: Boone.

Watadga Bend, p. o, Washington co., Tenn. : $242 \mathrm{~m}$. E. by N. Nashville.

Watensaw, p. o., Monroe co, $A r k$. : 60 m. E. Little Rock. W ATERBoro', to and p. v., York co., Mee.: $72 \mathrm{~m} . \mathrm{s} . \mathrm{W}$. Augusta. Surface diversified; drained by head branches of Mousum r., and by Little Ossipee r. The inhabitants are mainly engaged in farming, etc. The York and Cumber land R. R. will pass through S. E. part of the town. Pop. of t. 1,989.

W ATERBoro' Centre, p. o., York co., Me.: 71 m. S. W. Augusta.

W ATERBdra, p. 0., Tompkins co., N. Y.: $148 \mathrm{~m} . \mathrm{W}$. by $\mathrm{S}$. Albany.

W ATERBuRy, t., p. b., and sta., New Haven co., Conn. on both sides of Naugatuck r., $19 \mathrm{~m}$. N. N.W. New Haven, $25 \mathrm{~m}$. S.W. Hartford. The Naugatuck R. R. passes through the v. $32 \mathrm{~m}$. from Bridgeport, $30 \mathrm{~m}$. from Winsted. The t. has generally a rough surface. The Naugatuck $r$. and its branches afford great water-power, well improved by numerous factories. Of these, the principal are-that of the "Ameriean Pin Company," which (with another at Poughkeepsie, are the only ones of the kind in the Union) has a capital of $\$ 100,000$, employing 150 operatives; three factories of gilt and plated buttons, silver ware, etc. ; Indiarubber webbing factories; rolling mills of brass and copper, making articles of all sorts, and the woolen factories. The manufacturing interests of this place have for several years been steadily and rapidly increasing. During 1851 and ' 52 , 21 manufacturing establishments were organized with an aggregate capital of over $\$ 1,000,000$. The capitalists thus interested, and the citizens generally, are among the most enterprising in the State. The $\mathrm{b}$. is generally well built, with many elegant dwellings. It contains a bank, with a capital of $\$ 510,000$, two first-class hotels, a good high-school, with fine building, and 6 churches, of which the Episcopal Society has a superior church edifice. The "Waterbury American" (fam.) is issued weekly. Pop, of t. in $1840,3,668$; in $1550,5,187$.

W $A$ TERBURY, p. v. and sta., Washington co., Verm.: $12 \mathrm{~m}$. N. W. Montpelier. Drained by Waterbury river and other branches of Onion $r$., which bounds it on the $\mathbf{S}$. W. The $\mathrm{V}$. near Onion $\mathbf{r}$. is neatly built, and contains 2 churches. The Vermont Central R. R. passes through it $88 \mathrm{~m}$. from Windsor, $69 \mathrm{~m}$. from Rouse's Point. The "Industrial Excelsior" (adrertising) is issued weekly. Pop. of t. 2,352 .

W ATtrarord, t., p. v., and sta., New London co., Conn.: $39 \mathrm{~m}$. S. E. Hartford. Bounded S. by Long Island Sound, and $\mathrm{E}$, by Thames r. Surface uneven; soil gravelly loam. Drained by Jordan and Niantic rivers, the Jatter flowing into Niantic bay, which sets up from the sound 4 miles-is navigable for sloops, and is quite a resort for flshermen. The village, situate centrally $5 \mathrm{~m}$. W. New London, is neatly built. The ata. is on the New Haven and New London R. R., 4 m. S. W. New London. Pop. of t. 2,262.

W $\triangle$ TERFORD, t, and p. $\nabla .$, Oxford co., $M e_{n}: 49 \mathrm{~m}$.W. by $\mathrm{S}$. 
Augusta. The t. contains numerous large ponds, with level surface and fertile soil. Crooked river flows through its $N$. and N. E. part. Pop. of t. 1,448.

WATERFORD, p. o., Racine co, Wisc. : on E. side Fox $x_{\text {, }}$ $65 \mathrm{~m}$. E. S. E. Madison.

WATERFord, t. and p. O., Oakland county, MFich.: $60 \mathrm{~m}$. E. by S. Lansing. It contains a large number of ponds, which with their tributaries and outlets water it abundantIy ; also 2 large flouring-mills. Pop. 1,0s5.

WATERForD, p. v., Marshall co., Miss.: on small branch of Tallahatchie $r_{.}, 165 \mathrm{~m}$. N. by E. Jackson.

W $\triangle$ TERFord, p. o., Fulton county, Ill. : on E. side Spoon river, $44 \mathrm{~m}$. N. W. by N. Springfleld.

Waterford, p. o., Spencer county, $\bar{K} y_{.}: 29$ m. 8. W. Frank fort.

W Aterford, t., p. v., and sta., Saratoga co, $N . Y_{\text {. : }} 10 \mathrm{~m}$. N. Albany. Bounded E. by Hudson r., and W. by Mohawk river, which unite at $S$. end of the $t$. Surface rolling; soil alluvial and sandy. The v, is on W. bank of Hudson r., at the head of sloop navigation. The Champlain Canal passes through it, and communicates with the Hudson by locks. The Rensselaer and Saratoga R. R. also passes through, 4 miles from Troy, $28 \mathrm{~m}$. from Saratoga. The trade carried on by these annually is very extensive. The manufactures of the $\mathrm{v}$. are also of large amount and importance. Here are 5 churches, 2 academies, and 1 bank, capital $\$ 50,000$. The v. is connected with Lansingburg by a bridge across the Hudson. The "Sentinel" is here published. Pop. of v. about 1,800. Pop. of t. in 1840, 1,824; in 1850, 2,683 .

WATERFORD, t. and p. v., Washington co, Ohio: on both sides of Muskingum $\mathrm{r}_{\text {s, }} 74 \mathrm{~m}$. E. S. E. Columbus. Surface rolling and broken; soil fertile on the $r$. The village, on $\mathrm{S}$. bank of the river, contains several mills, etc. Pop. of t. in $1840,1,166$; in $1850,1,693$.

Waterford, t. and p. b., Erie county, Penn. : $195 \mathrm{~m}$. N. W. by W. Harrisburg. The b. contains several stores, and 498 inhabitants. The Sunbury and Erie R. R. will pass through it. Pop. of $t$. about 1,300

Watrrford, sta., Propidence co., R. I.: on Blackstone river, and Providence and Worcester $R . R, 18 \mathrm{~m}$. from Providence, $25 \mathrm{~m}$. from Worcester.

Waterford, p. v., Gibson co., Tenn. : on branch Obion river, $110 \mathrm{~m}$. W. by $\mathrm{S}$. Nashville.

W Aterford, t. and p. v., Caledonia co., Verm.: $31 \mathrm{~m}$. E. by N. Montpelier. Bounded S. by Connectieut r. The Connecticut and Passumpsic Rivers R. R. passes through the W. corner of the t., having a station at Passumpsic, $4 \mathrm{~m}$. from St. Johnsbury, $57 \mathrm{~m}$. from White River Junction. Pop. of t. 1,412.

W $\triangle$ TERFord, p. . ., Loudon eN., Firg. : on S. side of Kittoctan cr., $116 \mathrm{~m}$. N. Richmond. It contains 2 churches, several mills and stores. In the vicinity are cotton factories. Pop. about 500 .

W AtERFord Centre, p. o, Oakland co., Afich, : $61 \mathrm{~m}$. E. by S. Lansing.

W ATERFORD Works, p. o., Camden county, N.Jer. : $34 \mathrm{~m}$ S. by W. Trenton.

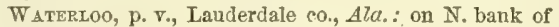
Tennessee r., $200 \mathrm{~m}$. N. E. by N. Montgomery.

W Aterloo, p.v،, and cap. Monroe co., 17 . : 114 m. S. by W. Springfield. Situated on elevated ground, containing the county buildings, churches, ete. The "Waterloo Patriot" (whig) is issued weekly.

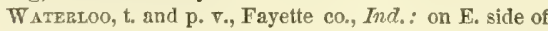
Whitewater river, 52 m. E. by S. Indianapolis, Pop. of t. about 1,000 .

Waterloo, p. 0., Pulaski county, $\hbar y .: 68$ m. S. S. E. Erankfort.

Waterloo, sta, Merrimac co., N. Hamp. : on Merrimac and Connecticut Rivers R. R., $17 \mathrm{~m}$. from Concord, $8 \mathrm{~m}$. from Bradford.

Waterloo, p. 0., Sussex co., N. Jer.; on N. side Musconetecong $\mathrm{r}_{.}, 46 \mathrm{~m}$. N. Trenton.
W Aterloo, p. V., Point Coupee par., $L a$ : near the outlet of Fausse r., on W. side of Mississippi r., $20 \mathrm{~m}$. N.W. by N. Baton Rouge. It is a very beautiful settlement, surrounded by fine plantations. Pop, about 150 .

WaterLuo, t. and p. O., Jackson county, Mich.: $29 \mathrm{~m}$. S. E. by S. Lansing. Drained by Portage cr. of Grand r. flowing through several large ponds. It contains two large flouring-mills. Pop. 1,090.

W Atertoo, p. v., and cap. Clark co., Mo.: on $\mathbb{N}$. side Fox r., 131 m. N. by E. Jefferson City.

WATERLOo, t., p. V., sta., and one of the capitals of Seneca co., N. $Y$. : on N. side of Seneca outlet, $166 \mathrm{~m}$. W. by N. Albany. The $\mathrm{v}$. is an important manufacturing place, with considerable trade. It contains the county buildings, an academy, one bank, capital $\$ 200,000$, and 4 churches. The "Observer and Union" (dem.) is issued weekly. The Pochester and Syracuse R. R. passes through, $58 \mathrm{~m}$. from Rochester, $46 \mathrm{~m}$. from Syracuse; also he Cayuga and Seneca Canal. Pop. of v. about 2,800. Pop. of to in $1840,3,036$ in $1850,3,795$

W aterloo, p. v., Granville county, $N$. Car.: $45 \mathrm{~m} . \mathrm{N}$ Raleigh.

W AtExLoo, t. and p. O., Jefferson co., Wisc. : 22 m. E. by N. Madison. Drained by Rock cr. Pop. 881 .

Waterloo, p. o., Lawrence co., Ohio : 96 m. S. S. E Columbus.

Waterloo, p. v., Juniata co., Penn.: on Tuscarora cr. $42 \mathrm{~m}$. W. Harrisburg.

Waterloo, p. o., Fauquier co., Virg.: $85 \mathrm{~m} . \mathrm{N}$. by W. Richmond.

Waterloo, p. v., Laurens dist., S. Car. : 60 m. W. N. W. Columbia.

W Aterport, p. 0, Orleans co, $\boldsymbol{N}_{*} \boldsymbol{Y}_{*}: 242 \mathrm{~m}$. W. by $\mathrm{N}$. Albany.

Water Proof, p. o., Tensas par., La. : $102 \mathrm{~m}$. N. Baton Pouge.

W ater Street, p. v., Huntingdon co., Penn. : on Juniata r., $70 \mathrm{~m}$. W. N. W. Harrisburg. It contains a charcoal forge, which in 1849 made 1,150 tons of blooms.

Watertown, t. and p. v., Litehfield co., Conn.: $25 \mathrm{~m}$, W. S. W. Hartford. Bounded E. by Naugatuck r. and drained by its branches. The Naugatuck R. R. runs along the river side. The $\mathrm{v}$. contains 2 churches and some manufactures, Pop. of $t, 1,533$.

W atertown, t. and p. r., Middlesex co., Mass. : 5 ; m. W. by N. Boston. Drained by Charles r., which bounds it on the $\mathrm{S}$., and is navigable to the $\mathrm{v}$. for vessels requiring 6 feet of water. Surface of $t$. beantifully diversifled. In its E. part is Mount Auburn Cemetery and part of Fresh Pond. The v. contains 8 churches and a U.S. arsenal. The Watertown Branch P. R. extends to the $\mathbf{v}$, from West Cambridge on Fitchburg R. $\mathbf{R}$., which is much used by the citizens, many of whom transact their daily business in Boston. Pop. in $1840,1,810$; in $1850,2,837$.

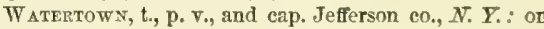
S. side of Black r., at the falls, $145 \mathrm{~m}$. N. W. by W. Albany. Surface of t. gently uneven; soil sandy loam and clay, very fertile, and well cultivated, lying upon limestone foundation. Drained by Black r. on the N. and by Sandy and Stoney creeks flowing S. W., and Lake Ontario.' Black r., in passing the $\mathrm{v}$. , descends $S S$ feet in $1 \mathrm{~m}$. by 5 natural caseades and 7 artificial dams, creating an immense water-power, unrivaled in the Union for its natural availability, and of which only a small portion is yet used. The factories already erected are chiefly engaged in making woolen and cotton goods and paper; but there are also extensive flouring, grist, and saw mills, besides tanneries, iron furnaces, and a large varicty of smaller manufacturing establishments. The v. was first settled in 1800 , and incorporated in 1831. It contains a court-house and jull, of stone, 2 flourishing academies, a State arsenal, of brick, and 9 churches. There are 5 banks, with agoregate capital of $\$ 600,000$. The Watertown and Rome R. R. extends through this place, 
$71 \mathrm{~m}$, from Rome, to Cape Vincent $25 \mathrm{~m}$. The construction of a line of railroad hence to Stockholm, on the Northern R. R., is contemplated, also a railroad to Utica through the valley of the Black $r$. Five newspapers were here published in 1850 - "Northern New York Journal" (whig), " Democratic Union," "Jeffersonian" (dem.), Jefferson County Democrat," and "New York Reformer" (temp.) Pop. of t. in $1840,5,027$; in $1850,7,201$.

WATERTOWN, t. and p. v., Washington co., Ohio: $74 \mathrm{~m}$. E. S. E. Columbus. Soil well eultivated, and drained N. by Wolf er., which affords water-power. Pop. of t. 1,374.

WAterstown, $t$ and p. v., Jefferson co., Wisc.: $35 \mathrm{~m}$. E. by N. Madison, Surface diversifled; soil generally very fertile, well watered by Rock r., which here makes a great bend, flowing on both its W. and E. borders. The $\mathrm{V}$. is handsomely sitnated in the $N$. part of the t., on both sides of Rock r., at the great bend, and at the foot of Johnson's rapids, where a dam across the river creates very great water-power. It has had a rapid growth, and is in a very flourishing condition. Two newspapers are here published -"W. Chronicle" (whig) and "State Register" (dem.) Two lines of railroad are projected to pass through Watertown, viz., Fond du Lac and Rock River R. R.; and Milwaukee, Portage, and $\mathrm{La}$ Crosse $\mathrm{R}$. R. ; and a plank-road from Lake Michigan to Madison passes through this place. Pop. of $t$, in 1840, 218; pop. of $\mathrm{v}$. in 1850, 1,561; pop. of $t_{\text {, }}$ Including $\mathrm{v}_{\text {. }}$ in $1850,2,888$.

W.ATERvale, p. $v_{*}$ Onondaga $c_{*}, N . Y_{*}$ : on W. side of Limestone or., $120 \mathrm{~m}$. W. by N. Albany. Pop. about 200.

W ATER VAllex, p. o. Erie county, N. Y.:268 m. W. Albany.

Water Vallet, p. o., Yalabusha co., Miss. : on N. side of branch of Tallahachie r., $129 \mathrm{~m}$. N. by E. Jackson.

Water. Trldage, po v., Carroll co., N. Hump.: $37 \mathrm{~m}$. N. N. E. Concord.

Wateritlle, p. v. and sta, New Haven co., Conn.: on the Naugatuck r., 22 m. N. N. W. New Haven, 24 m. S. W.

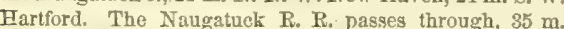
from Bridgeport, $27 \mathrm{~m}$. from Winsted. The $\mathrm{v}$, is chiefly noted as containing a very extensive pocket cutlery establishment, which has been as successful as any other in the Enion.

W AtERyille, t., p. v., and sta., Kennebec co., Me : on W. bank of Kennebee r., 17 m. N. N. E. Augusta. Surface diversifed; soil alluvial and well cultivated. The Kennebee $r$. is navigable to the $\nabla_{\text {. }}$ handsomely situated at the Ticonic Falls, which extend across the river, are 18 feet high, and afford immense water-power. The other waterpower in the vicinity is very great, and could be improved by a very large number of factories. The $\mathrm{v}$. contains various mills and manufactories, 2 banks, capital $\$ 125,000$, an academy, and 4 churches. Waterville College, located here, is a Baptist institution, founded in 1520, which in 1 1550 had 5 professors, 267 alumni (of whom 82 had entered the ministry), SS students, and a library of 15,500 volumes. The Androscoggin and Kennebec R. R. extends to this place from Portland $82 \mathrm{~m}$; the Kennebec and Penobscot R. R. is in construction to Bonsor, and the Kennebec and Portland $\mathrm{R}$. R. will also extend hence to Augusta. Pop. of $t$, in $1810,2,971$; in $1550,8,965$.

W ATERVille, p. v., Onelda con, $N_{.} Y_{.}: 86 \mathrm{~m}$. W. by N. Albany. This $\mathrm{v}$. is noted for its manufactures of woolen goods, carriage springs, flour, starch, lumber, and iron. It contains also an organ manufactory. 1 bank, capital $\$ 120,000$, 2 academies, and 2 clurches. Pop. about $1,000$.

WV ATERvilie, to and p. v., Lucas co., Ohio: on N. W. side of Maumee r, $110 \mathrm{~m}, \mathrm{~N} . \mathrm{N}$. W. Columbus, The Wa. bash and Erie Canal passes through the v. Pop. of $t$ in 1840,565 ; in 1850,958 .

WATERVILIE, p. v., Waukesha county, Wisc. : 50 m. E. Madison.

Titerrmlt, t, and $\mathrm{p}, \mathrm{v}$, Lamoille co., Term.: $31 \mathrm{~m}$

N. by W. Montpelier. Surfaco mountainous Drained by 912
N. branch of Lamoille $r$, which affords good mill-sites, The t. contains several saw-mills, and 1 large woolen factory having 2,000 spindles. Pop. of t. 753.

WATEiville, p. o., Lycoming co., Penn. : $78 \mathrm{~m}$. N. by E Harrisburg.

WATERVLIET, t. and p. on, Albany co, $N . Y_{0}: 5 \mathrm{~m} . \mathrm{N}$. Albany. It occupies the N. E. corner of the county, being bounded N. by Mohawk $\mathrm{r}_{\text {, }}$ and $\mathrm{E}$. by the Hudson. At the confluence of these rivers are numerous islands breaking the mouth of the Mohawk into several channels. Surface level or undulating; soil generally sandy or swampy, except on the Hudson, where are extensive and fertile flats. The Erie and Champlain canals separate in this t., and in the former are many locks to orercome the Falls of Cohoes. The Troy and Schenectady $R$. R. runs along the $\$$. bank of the Mohawk. West Troy, the site of the U. S. Arsenal, is in Watervliet, and occupies about 130 acres, inclosed by walls and iron paling. There is also in this town the celebrated Shaker settlement "Niskayuna," of which a detailed description is appended. The manufactures of this $\mathrm{t}$ employ upward of a million dollars capital, and embrace many valuable branches of industry in the fabrication of iron, cotton and woolen goods; and there are also numerous flour, grist, and saw mills. Pop. of t. in 1840,10,141; and in 1850, 16,675 -increase in the decade, 64.4 per centum.

The following is a description of the Shaker settlement in this town, as communicated (24th May, 1853) by S. Buck ingham, a member of the society:

"The United Society."-The founder of this Society, or peculiar sect of people, commonly called "Shakers," was Ann Lee, daughter of John Lee, a native of Manchester in England, was born on the 29th of February, in the year 1736. She, with her little company of followers, embarked for America in 1774, where they arrived the 6th of Angust. Those that came over with her as companions and fellowlaborers in the work of her calling, were eight in number.

In the year 1776 , as many of her followers as had kept their rectitude and remained with her, took up their residence at Watervliet, 8 miles $\mathrm{N}$. W. from the centre of Albany, in a wilderness country, which required great toil and labor to render useful either to man or beast, or pro ductive of the necessaries of life; but by their industry, zeal, and frugality, together with the additions, culture, and im. provements of their successors, up to the present time, a permanent settlement has been established, much admired by those who visit the place; and though once a dreary and solitary spot of earth, is now a situation becoming an industrious and enlightened people, productive of nearly all the ordinary comforts of life.

This branch of the "United Society" possess and occupy about 2,510 acres of land, much of which is tillable, and produces corn, grass, wheat, rye, oats, barley, potatoes, pease and beans, to tolerable advantage; and by manuring, may be rendered highly productive. They have also flne orchards, yielding an abundance of fruit in favorable sea sons, such as apples and peaches, with some plums and pearg; and much of the smaller kinds, as currants, gooseberries, and strawberries, which are raised in their gardens.

A small stream of water, called the Bchulune kill, runs through the south and easterly part of the village, and flows northward into the Mohawk r. On this creek they have several artificial ponds, which afford their main privileges in water-power. The land bordering upon this stream is a deep, mucky soil, but the upland is of a sandy and gravelly quality.

A bout 300 acres of the most raluable part of their land lie upon the banks of the Mohawk r., in the town of Niskayu$\mathrm{na}$, near the mouth of the Schulune kill, a little above Fast's Ferry, and in the town of Rotterdam, a short distance above the city of Schenectady, where is raised the principal part of their broom-corn, which they manufacture into brooms of the first quality, and vend them in the public markets throughout the country. By the overflowing of 
the river upon its banks, the low land along here is rendered highly productive without manuring, and is thereby made profitable to those who possess it.

The population of the Society numbers some 300 or more, being divided into four distinet families, located from a half to three-fourths of a mile distant from each other, a little back from the main road leading from Troy to Schenectady, so that the village is somewhat central between the above-mentioned places and the city of Albany, and may be approached within two and a half or three miles by railroads, connecting the aforesaid eities.

As you pass along the village from east to west, you ascend a moderate rise of land from which an agreeable scenery springs to view, extending from the Helderberg Mountains on the west to the Kayaderosseras Mountains on the north, and the Green Mountains on the east, overlooking the valleys of the Hudson and Mohawk rivers.

The whole number of buildings in the village may be estimated at some 150 or 160 , many of which are built of the best materials, and are quite valuable. Among the number there is a commodious building for divine worship, erected in the'year 1848; besides which there are three offices for the transaction of all public business, two schoolbouses, eight dwelling houses, suitable to accommodate from fifty to one hundred persons each, and many workshops and storehouses, built in the most commodious style They bave also two grist-mills, three saw-mills, and three machine-shops, in which various branches of mechanical business are carried on, such as carding wool, turning broom-handles, turning iron, and sawing firewood.

Their principal domestic employments being agriculture, horticulture, the manufacture of brooms, and various kinds of medicines, they have buildings and machinery appropriated to each branch of business sufficient to render each profitable ; and the many articles they manufacture for sale are noted for their neatness, durability, and good quality.

No pains is spared in the raising and preparing of their garden seeds, of which they raise a general assortment; and the botanical herbs, roots, barks, and extracts which they procure for market are prepared in the most punctual and faithful manner. Their brooms, also, have an extensive sale, which need but be used to receive commendation Thus, all the articles manufactured by them and offered for sale are of the most durable quality, and may be relied on as genuine and pure.

They generally perform the most part of their own Black-smithing, joiner, and carpenter work, tailoring, and shoe-making; and the females are not less. industrious in their various branches of business, including dressmaking, spinning, weaving, braiding whip-lashes, manufacturing bonnets, small fancy baskets, fans, brushes, with a variety of other small saleable articles.

The society generally keep from forty to fifty good horses, eighty cows, sixteen yoke of oxen, five hundred sheep, and young cattle and other stock in proportion.

The manner of life by them adopted seems not at all deleterious to longevity, for from their statistical reports of the ages of those who have deceased in their socicty since its first establishment in this country, show an average of fifty-four years. It is a fact, that these singular people strictly adhere to a life of chastity and virgin purity, and do neither marry, nor are given in marriage, but believe that true Christianity consists in purity of heart, and a life deroted to God in all things-being ingrafted into the true vine, and living the life and imitating the example of Him who overcame the world, with all its affections and lusts. Consequently, they have nothing to do with war and bloodshed, and the political strifes of the world, but choose to live in peace with all men. They are temperate and sober in their habits, discarding entirely the use of ardent spirits and its attendant evils, excepting occasionally in medicinal preparations.

In this society, as in other branches of their community, equal rights and privileges are enjoyed, as no one claims aught as his own; but each and all receive according to their needs and circumstances; possessing all things in common, whether of a spiritual or temporal nature.

The first established and largest Society of Sbakers is at New Lebauon, Columbia county, New York, $2 \frac{1}{2} \mathrm{~m}$. S. of Lebanon Springs. There is also another small Society in this State, at Groveland, Livingston county.

The following is a brief statement of the several societies located in the other States.

Massachusetts.-HANcock, Berkshire county, $5 \mathrm{~m}$. W. of Piltsfield.-TYRINGHAM, in the same county, $16 \mathrm{~m}$. S. of Hancock.-HARvarD, Worcester county, 30 miles N. W. from Boston.-Sirulex, Middlesex county, 7 miles W. from Harvard.

New Lampshire-Cantmibury, Merrimac county, $12 \mathrm{~m}$ N. by E. from Concord,-ENFieLd, Grafton county, 12 m. S. from Dartmouth College.

Connecticut.-ENFIELD, Hartford county, $5 \mathrm{~m}$. F. of the Connecticut $r_{\text {., }}$ and $18 \mathrm{~m}$. N. E. from Hartford.

Maine-ALFRED, York county, 30 m. B. W. from Portland.-New Gloucestra, Cumberland county, $25 \mathrm{~m}$. N. W from Portland.

Ohio.-UnION VILLAGE, Warren county, $4 \mathrm{~m}$. W. from Lebanon, and $27 \mathrm{~m}$. N. by E. from Cincinnati; this is the oldest and largest Society in the Western country.-Also Watervilet, Montgomery county, $6 \mathrm{~m}$. $\mathrm{S}$. E. from Dayton. -WHTEWATER, Hamilton county, $22 \mathrm{~m}$. N. W. of Cincinnati.-North UnioN, Cuyahoga county, 7 m. S. E. from Cleveland.

Kentucky.-Pleasant Hill, or Shakertown, Mercer county, 8 m. E. from Harrodsburg : pop. 342.-Sоб TH UNION, Logan county, nearly central between Russellville and Bowling Green, $14 \mathrm{~m}$. from the latter, and $50 \mathrm{~m}$. N. of Nashville (Tenn.); pop, in 1550,245 .

W Atervinet, t. and p. o., Berrien county, Mfich. : $96 \mathrm{~m}$ W. S. W. Lansing.

W aterfliet Centri, p. o., Albany co., $N, Y .: 9 \mathrm{~m} . \mathrm{N}$ Albany.

Watkins, p. o., Union co., Ohie : $32 \mathrm{~m} . \mathrm{N}$. W. Columbus,

WATKINSVILLE, p. ., and cap. Clark co., Ga.: $56 \mathrm{~m}$ N. by W. Milledgeville. It contains a court-house, jail, an academy, sereral stores, etc. Pop. 935.

W ATsor, t. and p. o., Lewis co., N. Y.: $110 \mathrm{~m}$. N. W. Albany. Surface hilly and mountainoug. Pop. 1.138.

Watson's Bridee, p. o., Moore co., $N$. Car.: 50 m. S. W: Paleigh.

W atsontown, p. 0., Northumberland co., Ponn.: on E. side of Susquehanna $x_{.,} 54 \mathrm{~m}$. N. Harrisburg.

W AтTSBORo', p. V., Lunenburg co., Virg. : on N. bank of Meherrin r., 58 m. S. W. Richmond.

Wattshurg, p. b., Erie co, Penn. : on French cr., $190 \mathrm{~m}$. N. W. by W. Harrisburg. Pop. about 180 .

WatT's Mrlus, p. o., Appanoose co., Ia.: 87 m. S. W. Iowa City.

Wart's Mris, p. 0., Westmoreland co., Penn。: $130 \mathrm{~m}$. W. Harrisburg.

W adratches, p. o., Dade en., Ga. : on E. side of Lookout cr., $192 \mathrm{~m}$. N. W. Milledgeville.

W AUHOo, p. o., Vigo county, Ind.: 69 miles W. by S. Indianapolis.

WAUKAర, p. O., Winnebago co, Wisc: : 83 m. N. N. E. Madison.

W AUKEENAH, p. 0, Jefferson co.,Flor, : 19 m. E. S. E Tallahassee.

W AUKEGAN, p. v., port, and cap. Lake co., $I U$.: $196 \mathrm{~m}$ N. E. by N. Springfitd. Its site is a very attractive location, rising from the lake to a considerable eminence, with a hill in the centre, on which stands the court-house. It has had a very rapid growth, which will probably continue for years. It is already well built, containing many handsome and substantial buildings. The surrounding country 
is of great fertility, being the best prairie land, and with considerable timber. It has a good harbor, piers, etc., and carries on an extensive lake trade. During 1848, its exports amounted to $\$ 283,107$, and its imports to $\$ 69,081$. The "Waukegan Chronicle" (dem.) and the "Gazette" (whig) are issued weekly. The Chicago and Milwaukie R. R. will pass through this place. Pop. about 4,000.

W AUKESHA county, Wisc. Situate S. E., and contains 576 sq. m. Drained by Fox r. and its affluents, and other streams. Surface undulating, and diversified with numerous lakes, which are the sources of many of the streams which traverse the co. in all direetions. Soil fertile, and produces good crops of wheat and grain. Pine and other forest trees cover a considerable portion of the land. The water-power supplied by the streams affords good advantages for manufacturing establishments. Farms 1,703; manuf. 78 ; dwell. 3,408 , and pop.-wh. 19,136, fr. col. 38total 19,174, Capital: Waukesha. Public Works: Milwaukie and Mississippi R. R. ; Milwankie and Portage R. R. WAUKESHA, t., p. $\nabla_{\text {. }}$, sta., and cap. Waukesha co., Wisc. $60 \mathrm{~m}$. E. by S. Madison. Surface diversifled; soil fine prairie and timber land. Drained by Pishtaka river and branches. The $\mathrm{v}$. is on the Pishtaka $\mathrm{r}$. and the border of a rich prairie. It contains the county buildings and many neat dwetlings, The Milwaukie and Mississippi $\mathbf{R}$. $\mathbf{R}$ passes through it, $20 \mathrm{~m}$. from Milwaukie, $50 \mathrm{~m}$. from Janesville. The "Waukesha Democrat" is issued weekly. Pop. of t. 2,314 .

WATK8AIK, p. 0., Cook county, IIl.: $175 \mathrm{~m}$. N. E. by N. Springfield.

WAUPAKA, p. o., Marquette co., Wisc.: on S. side Waupaka r., $95 \mathrm{~m}$. N. by E. Madison.

W $\triangle U P U N$, t. and p. v., Fond du Lac co., Wisc. : $57 \mathrm{~m}$. N. E. Madison. Drained by head streams of Rock r., which, immediately $\mathrm{S}_{\text {. of }}$ of the $t_{\text {c, }}$ enters a large marsh, from which it escapes about $12 \mathrm{~m}$. below. Surface handsomely varied; soil of great depth, and productive. The $\mathrm{v}$. is a thriving and healthy place, and contains about 300 inhabitants; and within a short distance is the railroad from Fond du Lac to Chicago. The State prison is located here. Pop. of t. 882.

WaUsat, t., p. v., and cap. Marathon co., Wisc.: on E. bank Wisconsin r., $135 \mathrm{~m}$. N. by E. Madison. This is the principal settlement in the $\mathrm{co}_{0}$ The inhabitants in and around it for several miles are chiefly engaged in lumbering and sugar-making. Pop. of t. 466 .

Wacshara, t. and p. v., Dodge county, Wise. : $43 \mathrm{~m}$. N. E. by N. Madison. Fox lake occupies about one-fourth of the surface of the $t_{\text {. The }} \mathrm{v}$. is situato on its $\mathrm{S}$. side. Pop. of t. $\$ 56$.

WaUtoma, p. o., Waukesha co., Wisc.: on W. bank of White r., $52 \mathrm{~m}$. N. by E. Madison.

WAOWATnsa, t., p. v., and sta., Milwaukie co., Wisc.: 72 m. E. Madison. The Milwaukie and Mississippi R. R. passes through the $\nabla_{0,} 5 \mathrm{~m}$. from Milwaukie, $65 \mathrm{~m}$. from Janesville. Pop. of t. 2,056 .

W AVELAND, p. o., Mfontgomery co., Ind.: $45 \mathrm{~m} . \mathrm{W} . \mathrm{N} . \mathrm{W}$. Indianapolis.

WAYERLY, p. o., Lowndes co., Ifiss.: on W. side Tombigbee r., $130 \mathrm{~m}$. N. E. Jackson.

WA ARRRY, p. Y. and sta., Tioga county, $N . Y_{0}: 136 \mathrm{~m}$. W. S. W. Albany. The Erie R. R. passes near it, $266 \mathrm{~m}$. from New York, $203 \mathrm{~m}$. from Dunkirk.

W Averly, p. v.. Morgan county, $I l_{0}: 22$ miles $\$$. W. Springfleld.

W A VERLY, p. 0., Henry co., Mfo.: $97 \mathrm{~m}$. W. by S. Jefferson City.

W AverLY, p. V., Pike co, Ohio: on W. bank of Scioto r., $57 \mathrm{~m}$. S. Columbus. The Ohio Canal passes through it. Pop. 67s.

W AVFRLY, p. ४., and eap. Humphreys co., Tenn。: $57 \mathrm{~m}$. W. by S. Nashville. Contains the county buildings, etc.

Waverty, p. o., Luzerne co., Penn。 : 80 m. N. E. by E. Harrisburg: 914
WaverLy HaLi, p. o., Harris co., Ga.: on \$. side of Mulberry cr., $100 \mathrm{~m}$. W. by S. Milledgeville.

WAWARsING, t. and p. o., Ulster co., $N$. Y.: 70 m. S. S.W. Albany. Surface hilly and mountainous, having on the S. E. the Shawangunk range of mountains; soil fertile, gravelly loam and clay. Drained by Rondout kill and branehes, which afford abundant water-power. The t. is large, containing several settlements and post-offices; also, about 50 saw-mills, numerous tanneries, and woolen factories, with other manufactories. It contains ores of iron, plumbago, and lead. The Delaware and Hudson canal passes through its S. E. part. Population in $1840,4,044$; in $1850,6,459$.

W AWPECONG, p. o., Miami county, Ind.: 52 miles $\mathrm{N}$. Indianapolis.

WAXAHACHE, p. v., and cap. Ellis county, Texs.: on N. side of Waxahachie r., $157 \mathrm{~m} . \mathrm{N}$. N. E. Austin City. It contains the court-house, jail, etc.

WAY, p. o., Ripley county, Ind.: $65 \mathrm{~m}$. S. E. by E. Indianapolis.

WaYLand, t. and p. v., Middlesex co., Mass. : $14 \mathrm{~m}$. W. Boston. Surface of t. pleasantly diversifled. Drained by Sudbury river, which forms the principal part of its W. boundary. It contains Pelham and Dudley ponds, and part of Long Pond. Pop. of t. 1,115.

W ATLAND, t. and p. o., Allegan co., Mich. : $53 \mathrm{~m}$.W. by S. Lansing. Surface somewhat uneven, and diversifed by several handsome ponds. Pop. 406.

WaYlaNo Depôt, p. o. and sta., Steuben co., $N . Y_{\text {.: }}$ on Buffalo, Corning, and New York R. R., $46 \mathrm{~m}$. from Corning, $201 \mathrm{~m}$. W. Albany.

Waylandsburg, p. v., Culpepper county, Virg.: $72 \mathrm{~m}$. N. N. W. Richmond.

WAYLAND'S Speings, p. o., Lawrence county, Tenn.: $70 \mathrm{~m}$. S. S. W. Nashville.

Waymart, p. v., Wayne county, Penn.: $115 \mathrm{~m} . \mathrm{N}$. E. Harrisburg. Pop. about 100.

WAYNE county, $G a$. Situate S. E., and contains 716 sq. m. Drained by Little Santilla and Turtle rivers, and by Finholloway er. and other small streams of Alatamaha r., which forms its N. boundary. Surface low and level; soil in general fertile, but there are some portions of marshy ground unfit for cultivation-these, when drained, make good grazing land. Farms 172; manuf. 0 ; divell. 182, and pop.-wh. 1,088, fr. col. 5, sl. 406-total 1,499. Capital: Waynesville.

WAYNE county, $I l l$. Situate toward the $\$_{.} . \mathrm{E}_{*}$, and contains $719 \mathrm{sq} . \mathrm{m}$. Little Wabash $\mathrm{r}$. passes through its eastern section, by which and its branches, Skillett fork and Elm cr., it is drained. Surface level, or gently undulating; soil fertile, and produces wheat and grain, and tobacco in a small quantity. Pork and beef are exported, ready aceess being had to other markets by means of the Little Wabash. A large portion of the county is prairie and woodland. Farms 492 ; manuf. 6 ; dwell. 1,209 , and pop.-wh. 6,822 , fr. col, 8-total 6,825. Capital: Fairfleld.

WAYNE county, Ind. Situate E. on Ohio State line, and contains $420 \mathrm{sq} . \mathrm{m}$. The streams are $\mathbf{E}$. and W. forks of White river. Surface level or pleasantly rolling-in S. E. somewhat hilly. Dense forests originally covered the co. Soil a rich loam, berded on clay. Manufactures have a good footing. Farms 1,934; manuf. 213; dwell. 4,515, and pop.-wh. 24,823, fr. col. 9,917-total 25,320. Capital: Centreville. Pullic Works: Thitewater Canal; Indiana Centra! R. R. ; Richmond and Newcastle R. R., and the Nat. Road. WAYNE county, Ia. Situate $\mathrm{S}_{\text {., }}$ and contains $50 \mathrm{sq}$. m Drained by branches of Chariton and Weldon rivers, and Muddy cr., all tributaries of Crooked Fork of Grand r. Surface level or rolling " soil fertile, and consists of black mold, with sand and clay untermixed, and favorable to the cultivation of wheat and grain. It has good pasturage, and is well wooded. Farms - ; manuf. - ; dwell. 57, and pop.wh. 839 , fr. col. 1-total 340 . Capital : Cambria. 
WAYKE county, $\overline{k y}$. Situate S. toward the E., and contains $637 \mathrm{sq} . \mathrm{m}$. Drained by S. fork of Cumberland r. and its branches, and Beaver creek. Surface even; soil moderately fertile; a large portion is well adapted to grazing. Chief productions, wheat and Indian oorn; tobacco and cotton axe also grown. It is bounded on the N. by Cumberland r. Farms 929 ; manuf. 17 ; dwell. 1,359, and pop. wh. 7,856, fr. col. 6, sl. 830-total 8,692. Capital: Monticello,

WAYNE county, Mich. Situate S. E. in the Southern Peninsula, and contains about $600 \mathrm{sq} . \mathrm{m}$. Drained by Huron and Rouge rivers and their branches, which flow into Detroit $r$. on the S. E. Surface level; soil various-a sandy loam, with clay intermixed, prevailing. In most parts it is fertile, and produces abundantly. Good water-power is supplied by the Rouge $x$. and its tributaries. Iron ore of good quality, and limestone are found in this county; also sulphur springs, the waters of which are used medicinally. The chief products are wheat, Indian corn, oats, and potatoes. Farms 1,6S5; manuf. 244; dwell. 7,063, and pop.wh. 42,085 , fr, col. 721 -total 42,756. Capital: Detroit. Public Works: Michigan Central R. R.; Detroit and Pontiac R. R. ; Toledo and Detroit R. R.

W AYNE county, Miss. Situate E. toward the S., and contains $764 \mathrm{sq} . \mathrm{m}$. Drained in the E. by Chickasawha $\mathrm{r}$. and its branches, which extend through the $\mathrm{N}$. portion of the county, and in the W. and $\mathrm{S}$. by branches of Leaf creek. Surface uneven; soil barren; along the streams there is some good land which proves productive. Staples, cotton and Indian corn. Farms 162; manuf. 0 ; dwell. 281, and pop.-wh. 1,399, fr. col. -, sl. 1,398-total 2,792. Capital: Winchester. Public Works: Mobile and Ohio R. R.

WAYNE county, Mo. Situate S. E., and contains 946 sq. m. St. Francois $r$. flows through it centrally, by which and its branches, and by Big Blackwater r. and Castor er. it is drained. Surface uneven, and in parts broken. Soil in parts very fertile; on the rivers are some bottom-lands which are very productive, and raise fine crops of wheat and grain It contains many minerals, and has excellent timber land. Lake Micola lies on its S. E. border. Farms 478; manuf. 2 ; dwell. 699, and pop.-wh. 4,152, fr. col. 6-total 5,233. Cap. ital: Greenville.

W AYNe county, $N . Y_{\text {. }}$ Situate N. W., and contains 572 sq. $\mathrm{m}$. Drained by Clyde $\mathrm{r}$., which is formed by the junction of Mud cr. and Canandaigua $r$. Surface uneven, and diversified in $\mathrm{S}$. portion by hills and valleys. Soil fertile, and productive in a great degree in the $\mathrm{S}$., but principally adapted to grazing and the culture of grain. It contains many minerals, and has some salt and sulphur springs, the former of which yielded a short time back a considerable revenue. Some good beds of iron ore are found. The mountain ridge which runs from $\mathrm{E}$. to $\mathrm{W}$. divides the waters of the N. from those which run S. Sodus bay, Port bay, and East bay are on the lake coast. Chief products, wheat and Indian corn. Farms 3,957 ; manuf. 250; dwell. 8,074, and pop.-wh. 44,701, fr, col. 252-total 44,953. Capital: Lyons. Public Works: Syracuse and Rochester R. R.; Sodus and Southern R. R.; Erie Canal; Sodus Canal, etc.

W AXNe county, N. Car. Situate S. E. centrally, and contains $328 \mathrm{sq} . \mathrm{m}$. Drained by Neuse $\mathbf{r}$. and its branches. Surface undulating; soil fertile, and adapted to grazing. Chief productions, cotton, wheat, and Indian corn. Farms 668; manuf. 69 ; dwell, 1,576, and pop.-wh. 7,802, fr. col. 664, sl. 5,020-total 13,486. Capital: Waynesboro'. Puzblic Works: Wilmington and Weldon R. R.; North Carolina Central R. R., etc.

WAYNE county, Ohio. Situate toward N. E. of the centre, and contains $569 \mathrm{sq} . \mathrm{m}$. Chippewa $\mathrm{r}$, and Sugar cr. drain the E. portion, and Killbuck cr. and its branches the central and eastern. Surface varied, parts being level, and much of it rolling and pleasantly diversified. Soil consists of deep mold, and on the streams is very fertile. Staples, wheat, Indian corn, and potatoes. Live-stoek and grain are ex- ported largely. Farms 2,904; manuf. 380; dwell. 5,712, and pop.-wh. 82,958, fr. col. 28-total 32,981. Capital: Wooster. Public Works: Ohio and Penusylvania R. R.; Cleveland, Zanesville, and Cineinnati R. R., etc.

WAYNE county, Penn. Situate N. E., and contains 762 sq. m. Drained by Lackawaxen er. and its affluents and tributaries of Delaware r., which forms its $\mathrm{N}$. E. boundary, Surface billy and broken; on the streams are some fine tracts of level land; soil fertile. Farms 1,336 ; manuf. 200 ; dwell. 3,719, and pop.-wh. 21,811, fr, col. 49-total 21,890. Capital: Bethany. Public Works: Delaware and Hudson Canal; Pennsyivania Coal Company's R. R.

WAYNE county, Tenn. Situate S. toward the W., and contains $694 \mathrm{sq}, \mathrm{m}$. Buffalo river and Shoal cr. and their branches, with other afluents of the Tennessee, drain the co. Surface varied, the larger portion being hilly, and in parts brokeu; soil, which is a deep mold on the streams, is fertile; it is adapted to wheat and grain, arid cotton and tobaceo are produced in considerable quantities. Live-stock and grain are exported. Farms 689 ; manuf. 10; dwell. 1,216, and pop.-wh. 7,232, fr. col. 8, sl. 980-total 8,170. Capital: Waynesboro', Public Works: Nashville and Memphis R. R.

WAYNE county, Virg. Erected from Cabell in 1842. Situate W., and contains 412 sq. m. Drained by Twentypole cr. and branches of Sandy $r$. Surface broken, and in parts mountainous; soil in general is indifferent, but there are some tracts of land which are fertile, and adapted to the culture of grain. Chief produets, wheat and Indian corn. Some tobaceo is raised. Farms 478; manuf. 9; dwell. 749 , and pop.-wh. 4,564, fr. col. 7, sl. 159-total 4,760. Capital: Wayne C. H. Public Works: Covington and Ohio R. R.

WAYNE. sta., Du Page co., Ill.: on Galena and Chicago Union R. R., 33 m. from Chicago.

WATNE, t., Allen co., Ind.: 103 m. N. N. E. Indianapolis. Pop. in $1840,2,080$; in $1850,5,283$.

W AXNE, $_{\text {, }}$ and p. v., Kennebee county, Me.: $17 \mathrm{~m}$. W. Angusta. Androsenggin Pond occupies a large part of this t., which has generally a fertile soil, and pleasantly diversified surface, Pop. of t. 1,367 .

WAYNE, p. Y. and sta., Wayne co., Mich.: on S. branch of Rouge r., and Michigan Central R. R., $18 \mathrm{~m}$. from Detroit, 65 m. E. S. E, Lansing.

W $\triangle Y N E$, t. and p. v., Steuben co., N. Y.: $176 \mathrm{~m}$.W. by S. Albany. Bounded in part on the E. by Little and Mud lakes, and on the W. by Crooked lake. Surface hilly in N. part; soil, loam and clay. The v. contains 2 churches, and about 150 inhabitants. Pop. of t. 1,347.

WAYNe, t. and p. 0., Erie co, Penn.: $182 \mathrm{~m}$. N.W. by W. Harrisburg. Pop. of t. about 1,000.

W asNe Centre, p. o., Du Page county, Ill.: $162 \mathrm{~m}$. N. E. by N. Springfield.

W AYNE CoURT-HoUSE, p. v., and cap. Wayne co., Virg.: $279 \mathrm{~m}$. W. by N. Richmond. It contains the county buildings, etc.

WAYNESBORO', p. v., sta., and cap. Burke co., $G a_{0}$ : on the Augusta and Waynesboro' R. R., 30 m. from Augusta, 66 m. E. Milledgeville. It contains a court-house, jail, 2 churches, an academy, stores, etc. Pop. about 200.

W AYNESBORO', p. F., and cap. Wayne co., N. Car.; on N. side of Neuse river, near the mouth of Little river, $49 \mathrm{~m}$. S. E. by E. Raleigh. It contains the county buildings, ete. The North Carolina Central R. R., connecting with the Wilmington and Weldon R. R. at Goldsboro', extends W. through this place to Greensboro'. Pop, about 400 .

Waxnesboro', p. b., Franklin co., Penn.: 49 m. S. W. Harrisburg. It contains 8 ehurches, an academy, and 1 bank, capital $\$ 100,000$. The "Village Record" (neutral) is issued weekly. Pop, about $\$ 50$.

WAYNesBoro', p. v., and cap. Wayne co., Tenn.: $75 \mathrm{~m}$. S. W. Nashville. It contains a court-house, jail, stores, etc., and about 100 inhabitants. 
WAYNESBORO', p. V., Augusta co, Firg.: on the line of the Virginia Central R. R., $86 \mathrm{~m}$. W. N. W. Richmond.

WA Tnesburg, p. v., Lincoln co., Ky.: 31 m. S. by E. Frankfort.

WAYNESBURG, p. V., Stark co., Ohio: on Sandy cr. and Sandy and Beaver Canal, 98 m. N. E. by E. Columbus. It contains several stores, manufacturing establishments, etc. A line of railroad from Bayard to New Philadelphia, passing through this place, is contemplated. Pop. about 550 .

Waynesburg, p. b., and cap. Greene co., Penn. : $170 \mathrm{~m}$. W. by $\mathrm{S}$. Harrisburg. It contains the county buildings, an academy, and 3 churches, several tanneries, stores, etc. The "Waynesburg Messenger" (dem.), and "Greene Co. Whig" are issued weekly. Pop. S52.

Warnesville, p. vo, and cap. Wayne co., Ga.: $153 \mathrm{~m}$. S. E. by S. Milledgeville. It contains the county buildings, an academy, stores, etc. Pop. about 200.

WA rnesville, p. v., De Witt co., IU. ; on S. side Kickapoo cr., $42 \mathrm{~m}$. N. E. Springfield.

WArNesville, p. Y., and cap. Pulaski co., Mo.: on E. side Robidoux fork of Gasconade r., $50 \mathrm{~m}$. S. Jefferson City. It contains the county buildings, etc. Pop, about 200.

Warnesville, p. V., and cap. Haywood co., $N$. Car. : on branch of Big Pigeon r., 248 m. W. by S. Raleigh. It contains a court-house, jail, etc. Pop, about 120.

WAYNESVILLE, p. V., Warren co., Ohio: on W. side of Little Miami river, 62 m. S. W. by S. Columbus, Settled chiefly by Friends. The "Miami Visitor" (literary) is here published. Pop. about 600 .

W A YNETOWN, t. and p. v., Montgomery co., Ind. : $70 \mathrm{~m}$. W. N. W. Indianapolis.

Warnansville, p., O, Upson co, Ga. : 62 m. W. by $\mathrm{S}$ Milledgeville.

Weakler county, Tenn, Situate N. W., and contains $972 \mathrm{sq}$. m. Drained by numerous tributaries of Obion r., an sffluent of the Mississippi. Surface level or rolling; soil consists of rich black mold, and is in general productive. Wheat, grain, tobacco, and cotton are raised, and pork is exported considerably. Farms 1,467; manuf, 13 ; dwell. 1,948, and pop.-wh. 11,523, fr. col. 15 , sl. 3,070 - total 14,508. Cupital: Dresden. Pullic Works: Nashville and Mississippi R. R.

WeAre, t. and p.v., Hillsboro' co., N. Hamp.: $14 \mathrm{~m}$. 5. W. Concord. Surface uneven. Drained by Piscataquis $r$, which affords water-power. The t. contains numerous grist and saw mills, with several tanneries, cotton and woolen factories, etc. The v. near the centre is pleasantly situated. The Merrimate and Connecticut fivers R. P. passes thrubgh the $\mathrm{v}$. of East Weare and North Weare, the former $16 \mathrm{~m}$. the latter $19 \mathrm{~m}$. from Nanchester. Pop. of t. 2,436.

Wean's Cove, p. o., Sevier co., Tenn. : 177 m. E. by S. Tashville.

Weatarerix, p. o., Carbon county, Penn.: 70 m. N. E. Harrisburg.

Weathersfect, t. and p. Y., Windsor co., Verm.: on W. side of Connecticut $\mathbf{r}_{\text {, }} 63 \mathrm{~m}$. S. by E. Montpelier. Surface uneven; watered in S. W. part by Black r., which affords water-power. Mount Aseutney lies on its $\mathbf{N}$. border. The t. contains several pleasant settlements. It has sereral woolen factories, tanneries, and a rariety of mills. Pop. of t. 1,851 .

Meitrote, sta., Hertforl co., Conn.: on New Haven and Nurthampton $R, R, 40 \mathrm{~m}$. from New Haven, $9 \mathrm{~m}$. N. W. Hartford.

Weatensvicue, p. 0, Northampton co, Penn.: 90 m.

E. N. E. Harrisburo

Weavepsvithe, p. O., Fauquier co., Virg. : $87 \mathrm{~m}$. N. by W. Tichmonil.

Wearkestule, p. V., Trinity county, Calif.: 1 SS m. N. Vallejo.

W EBB county, Texs. Situate S. W., and contains abou 3,500 sq. m. Drainet f,y sivall streans of the Pin Grante and Nueces rivers. Surtice level or rulling. aril is n. witly 916 prairie, the undulations and swells giving it the appellation of the rolling prairie; soil is generally a dark sandy loam, very productive, and yielding very large crops of wheat, grain, cotton, tobacco, sugar, and indigo. Potatoes and other vegetables are also grown. The napal, or prickly pear, abounds. It is extensively wooded. Capital: Laredo.

WeBber's, sta., Cuumberland $\mathrm{co}_{\text {, }}, M e_{0}$ : on Atkantic and St. Lawrence R. R., $18 \mathrm{~m}$. from Portland, $39 \mathrm{~m}$. S. W. by $\mathrm{S}$. Augusta.

Webber's Pratrie, p. o, Travis co., Text : $16 \mathrm{~m}$. E. by $\mathrm{S}$. Austin City.

Wевв's ForD, p. o., Rutherford co., $N$. Car. : $190 \mathrm{~m}$ W. by $\mathrm{S}$. Raleigh.

WeBB's Mrlus, p. o., Ritehie co, Firg. : 225 m. N. W. by W. Riehmond.

Webe's Mrus, p. o., Chemung co., $N . Y_{.}: 164 \mathrm{~m}$. W. by \$. Albany.

WebEr county, Utah Ter. Extends from the Bear River mountains to the California boundary, and is about $40 \mathrm{~m}$. wide. The E. portion is drained by Bear and Weber rivers, which empty into the Great Salt lake, one-half of which lies in this county. Farms 33; manuf. 2 ; dwell. 227, and pop.-wh. 1,186, fr. col. 0-total 1,186. Capital: Brownsville.

WEBSTER, t. and p. v., Lincoln county, Mre.: $21 \mathrm{~m}$. S. W. Augusta. Surface of t. is pleasantly diversified by several small ponds. Interests chiefly agricultural. Population of t. 1,110 .

WEBSTER, t., p. V., and sta., Worcester co., Mass.: $45 \mathrm{~m}$. S. W. by W. Boston. French r. flows on its W. border and receives the outlet of a large pond, each of which af fords great water-power. The v. contains 2 churches and several very large factories of cotton goods. The Norwich and Worcester $\mathrm{P}$. $R$. passes through it, $43 \mathrm{~m}$. from Norwich and $16 \mathrm{~m}$. from Worcester. Pop. of $\mathrm{t}$. in 1840, 1,403; in $1850,2,371$.

WEBSTER, t. and p. o., Washtenaw co, Mich.: $44 \mathrm{~m}$. S. E Lansing. Soil fertile. Watered by Huron r., several ponds, and Portage lake in its $\mathrm{N}$. W. corner. A part of Dexter $\mathrm{v}$. is in this town. Pop. 924.

WeBster, t. and p. 0., Monroe co., N. Y.: $194 \mathrm{~m}$. W. by N. Albany. Drained by small streams flowing into Lake Ontario. Soil very fertile. Interests entirely agricultural. Pop. 2,446.

Webster, p. 0., Wayne county, Ind.: 60 m. E. by $\mathbf{N}$. Indianapolis.

Webstek, p. 0., Hancock co., $I l l$ : on branch of Crooked cr., $81 \mathrm{~m}$. N. W. by W. Springfield.

Weister, p. o., Winston county, MFis8: $97 \mathrm{~m}$. N. E. Jackson.

Webster's Mruts, p. 0., Fulton co., Penn.: $68 \mathrm{~m}$. W. by $\$$. Harrisburg.

WEEDowEE, p. v., Randolph county, Ala.: on S. side of branch of Tallapoosa r., $80 \mathrm{~m}$. N. E. by E. Montgomery.

TreeD's Port, p. v. and sta., Cayuga co., $\boldsymbol{N}$. $\boldsymbol{Y}$.: on the Erie Canal and Rochester and Syracuse Direct R. R., 149 m. W. by N. Albany. It contains 2 churches, stores, etc., and about $\$ 50$ inbabitants.

Weнadiet, p, 0., Randolph co., Ala.: 83 m. N. E. by E. Montgomery.

WeEK's MrLrs, p. o., Kennebec co., Me.

Weelaunee, p. 0., Winnebago co., Wisc. : 75 m. N. N. E. Madison.

Weeworavilue, p. o., Talladega co., Ala.: $62 \mathrm{~m}$. N Montgomery.

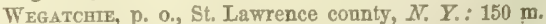
N. W. by N. Albany.

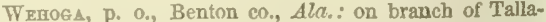
poosa r., 100 m. N. E. by N. Montgomery.

Werg's BRTEGe, p. o, and sta., Belknap co., N. Hamp.: on $W$. shore of Winnipiseogee lake, and on the Boston, Cincert, and Mfoniral Ii. Ii., $35 \mathrm{~m}$. from Concord. It is if wec: strum r r.surt by visitors to the lake, upon which 
a steamboat, starting from this point, plies daily on excursion trips.

WEIR'S CAVE, Virg.: this cavern is generally ennsidered one of the most beautiful in the world, is $16 \mathrm{~m}$. N. E. Staunton, $81 \mathrm{~m}$. N. W. by W. Richmond. It is about 1,260 feet long, and divided into numerous apartments, each abounding with white limestone pillars, stalactites, and stalagmites of great brilliancy, as seen by torches, and with considerable variety of form and color.

Weisengurg, t. and p. o., Lehigh county, Penn.: $66 \mathrm{~m}$. E. N. E. Harrisburg. The t. contains numerous distilleries, tanneries, grist and saw mills. Pop. about 1,600.

Werseburg, p. v., Baltimore co., MId.: $44 \mathrm{~m}$. N. Annapolis.

Weisport, p. o., Carbon co., Penn.: 72 m. N. E. by E Harrisburg.

WELAKA, p. v., Orange cə., Flor.; on the E. bank of St, John's r., $27 \mathrm{~m}$. above Pilatka, and $238 \mathrm{~m}$. E. S. E. Tallahassee. This is a new settlement, but is expected to become a place of considerable commerce, since, by running steamers up to this point, the present pole-boat navigation to Pilatka, which is frequently dangerous, would be ayoided. Very near the $\mathrm{v}_{\text {., }}$ and near the bank of the $\mathrm{r}_{\text {, }}$, are the Welaka Sulphur Springs, and about $2 \mathrm{~m}$. distant are the Magnolia Springs $\rightarrow$ one sulphur and the other magnesia. Game and fish are abundant.

Welch's Mrlls, p. o., Cabarras county, N. Car.: $96 \mathrm{~m}$. TW. by $\mathrm{S}$, Raleigh.

Welchville, p. o., Oxford co, Me.: $45 \mathrm{~m}$. W: Augusta.

WELD, t. and p. o., Franklin co., Me. : $40 \mathrm{~m}$. N. W. by N Augusta. Drained by streams flowing into Weld Pond, in the S. central part. Surface diversified, with fertile soil. Pop. 995.

WExDOr. p. v., and sta., Halifax co., N. Car.: on S. W. bank of Roanoke r., $70 \mathrm{~m}$. N. E. Raleigh. The Roanoke here has a great fall, but is navigable for ressels of 75 tons. A canal around the falls, $12 \mathrm{~m}$. long, with lockage of 100 feet, extends navigation to Staunton r, about $200 \mathrm{~m}$. The Wilmington and Weldon R. R (from Wilmington $162 \mathrm{~m}$.), here connects with Petersburg R. P., 64 m. long., Sea-board and Roanoke R. P. to Portsmouth, $80 \mathrm{~m}$, and Gaston and Weldon R. R. The $\mathrm{r}$. has a good site, and possesses considerable trade. The "Weldon Herald" (whig) is issued weekly. Pop. about 600 .

WeLd's Landerg, p. o., Dubuque co., Ia.: on S. W. bank of Mississippi r., $72 \mathrm{~m}$. N. E. by N. Iowa City.

Welborn, p. v., and eap. Coffee co, Ala.: 81 m. S. S. E. Montgomery. It contains the county buildings.

WellborN's Miris, p. o., Houston co., Ga. : on S. side of branch of Oemulgee r., $42 \mathrm{~m}, \mathrm{~S}$. W. by S. Milledgeville.

Wellersiurg, p. v., Somerset co., Penn. : 105 m.W. S.W. Harrisburg.

Welteprille, p. o., Crawford county, Ohio: $60 \mathrm{~m}$. N. Columbus.

Wellfeeret, t. and p. v., Barnstable co., Mass. : $58 \mathrm{~m}$. S. E. by E. Boston. The to extends across Cape Cod, and has a sandy soil. Wellfeet bay, upon which the $\mathbf{v}$. is situated, affords good harborage. The v. employs considerable shipping in the fisheries and coasting trade. and is largely engaged in the manufacture of salt, Pop. of t. 2,411.

Welington, t. and p.o., Piscataquis co., Me.: $53 \mathrm{~m}$. N. by E. Augusta. Pop. 600 .

WelitNGToN, p. v., Lafayette c0., Mfo.: on S. bank of Missouri r., 106 m. W.N. W. Jefferson City.

WelinigtoN, p. oc, Morgan co., Ga. $42 \mathrm{~m}$. N. by W. Milledgeville.

Welingtos, t., p. v., and sta., Lorain co., Ohio: $89 \mathrm{~m}$. N. N. E. Columbus. Drained by W. branch of Black $r$. The Cincinnati, Cleveland, and Columbus R. R. passes through, $36 \mathrm{~m}$. from Cleveland, $99 \mathrm{~m}$. from Columbus, and $219 \mathrm{~m}$. from Cincinnati. Pop. of t. in 1840, 781; in 1850, 1,556 .

WellivetoN, p. $0_{0}$ Lake co, $m_{\bullet}: 190$ m. N. E, by N. Springfield.
WeLL county, Ind, situate N. E. middle, and contains 372 só. m. Drained by Upper Wabash and Salamonie rivers. Surface level, or gently undulating, well timbered, and the soil universally good. There are some wet prairies and marshes. Farms 640; manuf. 14; dwell. 1,021, and pop.-wh. 6,141, fr. col.11-total 6,152. Capital: Blufton. Puthlic Works: Fort Wayne and Southern P. P.

Welts, t., p. V., and sta., York co, Me.: 81 m. 8. S. W. Augusta. Soil inferior and marshy. Drained by small streams flowing into the Atlantic Ocean. The harbor of the v. admits small vessels, of which a considerable number are employed in the coasting trade. The t. contains numerous mills, with several tanneries. The Portland, Saco, and Portsmonth R. R. passes through the t., 23 miles from Portland, and $23 \mathrm{~m}$. from Portsmouth. Pop. of t. 2,945 .

WELLs, t. and p. 0., Familton co., N. Y. :.69 m. N. N. W. Albany. Surface diversified. Drained by Sacandaga $r$. Pop. about 400 .

WELIS, t. and p. T., Rutland co., Verm.: $67 \mathrm{~m}$. S. \$. W. Montpelier. Surface of t. diversified, containing Lake Austin, extending nearly through the t. from Poultney centrally S., the outlet of which flowing into Pacolet $\mathbf{r}_{\text {, }}$ affords waterpower. The $\mathrm{v}$, is situated on this outlet. Pop. of t. S04.

WELL's island, Jefferson co., $N . Y_{.}:$is one of the largest of the Thousand Islands, in the St. Lawrence river. It is attached to the $t$. of Clayton, and is of note, from the burning of the steamer Sir Robert Peel in the vicinity, during the Canadian Rebellion.

WeLLs river, Verm. : is an important mill-stream, flowing from Long Pond, in Groton, S. E. to its entrance into the Connecticut at Wells River village.

Wellsboro, p. b., and eap., Tioga co, Penr.: $102 \mathrm{~m}$. N. by W. Harrisburg. It contains a court-house, jail, stores, etc., and an academy, A plank road extends hence to Tioga. The "Wellsboro' Advertiser" (whig) is here published. Pop. 620.

Wellsiurg, p. o., St. Charles co., Mo. : $78 \mathrm{~m}$. E. by $\mathrm{N}$. Jefferson City.

Wellsburg, $\mathrm{p}, 0_{\text {. and }}$ sta., Chemung co, $N_{0} Y_{\text {. }}$ : on Erie R. R., $276 \mathrm{~m}$. from New York, $193 \mathrm{~m}$. from Dunkirk, and $162 \mathrm{~m}$. W. S. W. Albany.

Weltasurg, p. v. and cap. Brooke co., Virg. : on the E. side of Ohio r., at the mouth of Buffalo cr., $250 \mathrm{~m}$. N. W. Richmond. It has an elevated and beautiful situation, and was laid out in 1789 . It contains the county buildings, 5 churches, 3 seminaries, and 1 bank, eapital $\$ 118,000$. It has very extensive trade with the river towns and New Orleans. Its principal manufactures are earthen and stone ware, glass and flour. The "Millennial Harbinger," and "Wellsburg Herald" (indep.), are issued weekly. In the vicinity are great beds of bituminous coal. Pop. about 2,200.

Well's Coriner, p. o., Orange co., N. Y.; 96 m. S. S. W. Albany.

Well's Corners, p. o., Erie co., Penn. : 195 m. N. W. by W. Harrisburg.

Wellscot, p. O., Union county, Ga.: $137 \mathrm{~m} . \mathrm{N}$. by W. Milledgeville.

Well's DepôT, p. o. and sta., York co., Me.: on Portland, Saco, and Portsmouth R. R., $28 \mathrm{~m}$. from Portland, $28 \mathrm{~m}$. from Portsmouth, 83 m. S. S. W. Augusta.

Well's Mrlis, p. o., Appanoose co., Ia. : on E. side of Chariton r., $90 \mathrm{~m}$. S. W. Iowa City.

WeLL's River, p. v. and sta., Orange co., Verm.: on W. side of Connecticut $r_{\text {., }}$ at the mouth of Wells $\mathrm{r}_{\text {. }}, 26 \mathrm{~m}$. E. S. E. Montpelier. It is surrounded by very high hills, preventing any great growth; but it is a place of much business. The Connecticut and Passumpsic Rivers R. R. passes through, $40 \mathrm{~m}$. from White river junction, $81 \mathrm{~m}$. from Soulh Johns. bury. The Boston, Concord, and Montreal $\mathrm{R}$. $\mathrm{R}$. will here cross the Connecticut. The village contains one bank, cap. $\$ 75,000$, and has some manufactures.

Wellsville, p. v., Alleghany co., N.T.: $227 \mathrm{~m}$. W. by S. Albany. 
Wercsvicle, p. $\mathrm{v}$. and sta., Columbiana co., Ohio: on W. bank of Ohio river, $126 \mathrm{~m}$. E. N. E. Columbus. It was laid out in 1824 by William Wells. It has very extensive trade with river towns and with the interior. The Cleveland and Pittsburg R. R. here connects by steamboat to Pittsburg with the other or railroad portion of the route, to Cleveland, $100 \mathrm{~m}$. An extension of the railroad to Wheeling is now in progress. Pop. in 1840, 759; in $1850,1,549$.

Weltsville, p. o., Newberry district, $S$. Car.: 47 miles W. N. W. Columbia.

Wershruerd, p. o., Geauga county, Ohio: 180 m. N. E. Columbus.

Welsh Run, p. o., Franklin co., Penn.: 35 m. W. S. W. Harrisburg.

W ENDE station, Erie co., $N . Y_{:}$: on Buffalo and Rochester R. R., $18 \mathrm{~m}$. from Buffalo, $50 \mathrm{~m}$. from Rochester.

WENDELL, $t$, p. v., and sta., Franklin co., Mrass.: $68 \mathrm{~m}$. W. by N. Boston. Bounded N. by Miller's r., which affords water-power. The $\mathrm{v}_{\text {. }}$ situate centrally, is neatly built. The Vermont and Massachuselts R. R. passes through its N. part. Pop. of t. 920.

WeNDElı DEPôt, p. o. and sta., Franklin co., Mass. : on Vermont and Massachusetts R. R., $40 \mathrm{~m}$. from Fitchburg, 29 m. from Brattleboro', 69 m. W. by N. Boston.

WENHAM, t., p. V., and sta., Essex co., Mass.: on Eastern R. R., 20 m. N. N. E. Boston, Surface pleasantly diversified. Wenham Pond, about $1 \mathrm{~m}$. sq., is a beautiful sheet of water, noted for its transparency ; it abounds with fish, and in winter great quantities of ice are here cut for market. Pop. of t. 977 .

W ENTwORtн, t., p. V., and sta, Grafton co., N. Hamp. $48 \mathrm{~m} . \mathrm{N} . \mathrm{N} . \mathrm{W}$. Concord. The $t$, is drained by Baker river, which affords water-power to several mills and factories. The Boston, Concord, and Montreal R. R. passes through the v., $67 \mathrm{~m}$. from Concord. Pop, of t. 1,197.

Wentworta, p. o., Lake co., IU.: 192 m. N. E. by N. Springfield.

W entworth, p. v., and eap. Rockingham co., $N$. Car. on E. side of small branch of Dan r., $76 \mathrm{~m} . \mathrm{N}$. W. by $\mathrm{T}$. Raleigh. It contains the county buildings. Population about 120 .

Wrentworte's Location, p. o., Coos county, N. Hamp. $117 \mathrm{~m} . \mathrm{N}$. Concord.

Wescosvrute, p. 0., Lehigh cos, Penn.: 70 m. E. N. E. Harrisburg.

Wraser, p. 0., Fulton co., Ind.: $55 \mathrm{~m}$. N. Indianapolis.

Wesler, p. O., Monroe co, Mfiss.: on E. side of Tombigbee r., $142 \mathrm{~m}, \mathrm{~N}$. E. Jackson.

Weslex, p. o., Hickman county, $K y .: 125$ m. W. s. W. Frankfort

Wesher, t. and p. o., Washington con, $M e_{\mathrm{n}}$ : $114 \mathrm{~m}$. E. N. E Augusta. Pop. of t. 329 .

Wesley, p. 0., Venango co., Penn. : $168 \mathrm{~m}$. W. N. W. of Harrisburg.

T EsLEy, t. and p. v., Washington co., Orio: $47 \mathrm{~m}$. E. S. E. Columbus, Surfece of $t$. rolling. Drisined by small streiula flowing into Ohio r. Pop. of t. 1,561.

Wesuex, p. v., Haywood county, Tenn. : 3 m. S. of Big Hatcbee $r_{n}, 150 \mathrm{~m}$. W. S. W. Nashrille.

Weslex City, p. 0., Tazewell county, $I \chi_{n}$ : on E. side of Illinois r., $56 \mathrm{~m}$. N. Springfield.

Wiesley Chapel, p. o., Tippecanoe connty, Ind.: $54 \mathrm{~m}$. N. W. Indianapolis.

Wesleyville, p. v., Erie co., Penn. : 200 m. N. W. by W. Harrisburg.

Wfsorulga, p. 0., Randolph co., Ala. : SS.m. N. E. by N. Montgonatry.

W EsT river, Windham county, Term. : an excellent millstream rises in Weston, flows in general course S. S. E., and enipties into the Connecticut river in $\mathrm{J}$. E. part of Brittleburs?.

WEst river. Anne Arunilel co., Mfl. : a large estuary of Chesapeikw bay, in 5 . part of the eumay. 918
West Acton, p. v. and sta:, Middlesex co, Mas.: on Fitehburg R. R., 27 m. from Boston.

West Adprson; p. 0r, Steuben county, N. Y.: $190 \mathrm{~m}$. W. by S. Albany.

West Alberg, p. o. and sta., Grand Isle co., Verm.: 62 m. N. W. Montpelier. The Vermont Central R. R. passes through, 1 mile E. Rouse's Point and 1561 miles from Windsor.

West Alexandria, p. v., Washington co., Penn. : near the Ohio State line, $182 \mathrm{~m}$. W. Harrisburg. The Hempfield R. R. will pass near it.

West Alexandria, p. v., Preble co., Ohio : on W. side of Twin er. of Miami r., $80 \mathrm{~m}$. W. by \$. Colambus.

WESt Almond, t. and p. o., Alleghany co., N. Y.: $218 \mathrm{~m}$. W. by S. Albany. Surface hilly. Drained by branches of Genesee r. Pop. 976.

Wrst Azton, p. v., Belknap co., N. Hamp. : on W. shore of Winnipiseogee lake, $23 \mathrm{~m}$. N. E. by N. Concord.

West AMmseury. p. 0., EsseX county, Mass.: $85 \mathrm{~m} . \mathbf{N}$. Boston.

WEST ANDover, p. v. and sta., Merrimac co., N. Hamp. : on Northern R. R., $33 \mathrm{~m}$. from Concord.

WEST ANDover, p. 0., Ashtabula c0., Ohio: 162 m. N. E。 Columbus.

West Arsow, p. 0., Somerset co., Me. : 36 m. N. N. W. Angusta.

West Aplington, p. o., Bennington co., Verm.: 85 m. S. S. W. Montpelier.

West Ashrord; p. 0, Windham co, Conn. : 28 m. E. N. E. Hartiord.

Whst Aurupa, p. 0., Susquehanna co, Penn.: $100 \mathrm{~m}$. N. N. E. Harrisburg.

West Avrora, p. o., Erie co, $N_{.}, Y_{\text {: }}: 258 \mathrm{~m}$. W. Albany.

West Avor, p. O., Hartford county, Conn.: 10 10 m. W. Hartford.

Wrat Bain brnde, p. o, Chenango co., $N . \quad Y .: \$ 2 \mathrm{~m}$. W. S. W. Albany.

WEST BALDWIN, p. o., Cumberland co., Me.: on E, side of Saco r. 63 m. S. W. by W. Augusta.

West Baltimore, p. O., Montgomery co., Ohio: $66 \mathrm{~m}$. W. by S. Columbus.

West Barnstable, p. V*, Barnstable co., Mass. : $64 \mathrm{~m}$. S. E. by S. Boston.

WhSt Barre, p. 0, Huntingdon county, Penn.: $58 \mathrm{~m}$. W. N. W. Harrisburg.

Trest Barre, p. 0., Fulton co, Ohio: 123 m. N. N. W. Columbus.

West Bath, $t$ and p. o, Lincoln county, $M e_{.}: 27 \mathrm{~m} . \mathrm{S}$. Augusta. Pop. 560 .

West Beavez, p. o., Columbiana county, Orio.: $128 \mathrm{~m}$. E. N. E. Columbus.

WEST Becket, p. 0., Berkshire co., Mass. : 101 m. W. Boston.

WFST BFDFORD, p. 0., Coshocton county, Ohio: $67 \mathrm{~m}$. J. I. by E. Columbus.

West BExp, t., p. V., and capital of Washington county, TH: : 6.3 n. E. . T. E. Madison. Jrained by Milwankie $r$. and branches. The $\mathrm{v}$. contains a court-house, jail, ete. Pop. of $\mathrm{L} .672$.

W FST Bergex, p. o. and sta, Genesee co., $N . Y_{.: \text {on Buf- }}$ falo and Pochester R: R., $22 \mathrm{~m}$. from Rochester, $46 \mathrm{~m}$. from Buffaln, $224 \mathrm{~m}$. W. by $\mathrm{N}$. Albany.

TEST Berkshire, p. O., Franklin county, Verm. : 50 m. Y. X. IT. Montpelier.

West Berlix, p. O., St. Clair co., MFich. : $82 \mathrm{~m}$. E. by N. Lansiug.

West Berlit, p. O., Rensselaer co., $N . \quad Y$ : 15 m. E. Albatly:

Wfst Betrair, p. o, Genesee co., N. $\boldsymbol{Y}_{0}: 232 \mathrm{~m}$. W. Albany.

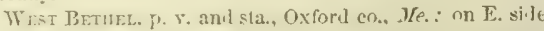

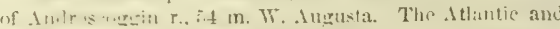
st. Lisurince la. I., posses thrumgh. it m. from Portiand. 
Wrst Bloomfield, t. and p. v., Oakland co, $M F i c h .: 60 \mathrm{~m}$. E. by S. Lansing. Pop. of t. 1,085.

What Bloompteld, p. v., Essex county, N. Jér.: $48 \mathrm{~m}$. N. E. by N. Trenton. It contains several stores, ete. Shoemaking is carried on extensively.

West Bloomfreld, t. and p. v., Ontario co., $N_{.} Y_{*}: 198$ miles W. Albany. Surface of t. somewhat hilly; drained by Honeoye cr., which affords water-power. The v. has an elevated site, and contains 3 churches, with stores, etc. The Canandaigua and Niagara Falls R. R. passes through it. Pop. of t. 1,698.

West Bolton, p. o., Chittenden county, Term. : 18 m. N. W. by W. Montpelier.

W FstвORO', t, p. v., and sta., Worcester co., Mass. : 28 m. W. by S. Boston. Surface pleasantly diversified, and containing several ponds; soil fertile. Drained by branches of Sudbury and Concord rivers, which afford water-power. The Boston and Worcester R. R. passes through S. part of t. $32 \mathrm{~m}$. from Boston, $13 \mathrm{~m}$. from Worcester. In this $\mathrm{t}$, is located the State Reform School for boys, which generally contains about 300 inmates. Pop. of t. 2,376.

Westroro', p. o., Clinton county, Ohio: 54 m. S. W. Columbus.

Wrst Boscawer, p. 0., Merrimac co., N. Hamp.: $12 \mathrm{~m}$ N. W. Concord.

West Boxford, p. o., Esssx co., Mass. : 24 m. N. Boston.

Wrst Boylston, t., p. V., and sta., Woreester co., Mass. : $36 \mathrm{~m}$. W. Boston. Drained by branches of Nashua r., which afford water-power to various factories. The Worcester and Nashua R. R. passes through the $\mathrm{v}_{\text {. }} 9 \mathrm{~m}$. from Worcester, $36 \mathrm{~m}$. from Nashua. Pop. of t. 1,749.

West Braintree, p. 0., Orange county, Term.: $22 \mathrm{~m}$. W. by S. Montpelier.

West Branch, p. o., Oneida co., $N . Y .:$ on branch of Mohawk r, 102 m. W. N. W. Albany.

Whst Brattleboro', p. v. Windham co., Term.: $102 \mathrm{~m}$, 5. Montpelier.

West Brewstrak, p. 0., Barnstable co., Mrass : 63 m. S. E Boston.

West Bridgewatere, t. and p. v., Plymouth co., Mass. : $24 \mathrm{~m}$. S. Boston. Surface level; drained by a large branch of Taunton $r$, which affords water-power. The Fall River $R$. R. touches its E. border. Pop. of t. 1,447.

W est Brook, t., p. v., and sta., Middlesex eo., Conn.: 36 m. S. by E. Hartford. Bounded S. by Long Island Sound. The New Haven and New London R. R. passes through, $26 \mathrm{~m}$. from New Haven, $24 \mathrm{~m}$. from New London. Population of $t .1,203$.

West Broor, p. o., Bladen co., N. Car.: on W. side of Cape Fear r., 88 m. s. by E. Raleigh.

W שest BROOKFRED, $t_{\text {, }}$ p. v., and sta., Woreester co. Mass. $57 \mathrm{~m}$. W. by S. Boston. Surface pleasantly diversified, and contains a handsome pond. The Western R. R. passes through the $\mathrm{B}$. part of t., $25 \mathrm{~m}$. from Worcester, $69 \mathrm{~m}$. from Boston. Pop. of t. 1,34t.

Wrst Brookfreld, p. 0., Stark county, Ohio: 100 miles X. E. by E. Columbus.

West Brooktrlif, p. v., Hancock co., Me.: $52 \mathrm{~m}$. E. Augusta.

West Brookvruet, p. v., Sullivan co., N. Y.: 84 m. S. S.W. Albany.

W fst Brownstrele, p. v., Washington co., Penn.: 175 m. W. Harrisburg. Pop. 477.

W fst BuckFirLd, p. 0., Oxford co., Me. : $32 \mathrm{~m}$. W. by $\mathrm{S}$. Augusta.

West Buffato, p. o., Seott co., Ia.: on W. side Missigsippi r., 41 m. E. S. E. Iowa City.

West Burlington, p. o., Otsego co., N. Y.: $74 \mathrm{~m}$. W. Albany.

Wfat Burdington, p. o, Bradford co., Penn。: $102 \mathrm{~m}$. N. Harrisburg.

W.estbuge, p. o., Warne co., N. Y.: $160 \mathrm{~m}$. W. by N. Albany.
Wrst ButLer, p. o., Wayne co., N. Y.: 163 m. W. by N. Albany.

West Buxton, p. o., York county, Me.: 63 m. S. W. Augusta.

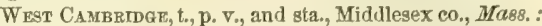
$6 \mathrm{~m} \mathrm{~N}$. W. Boston. Surface in S. E. part level, low, and somewhat marshy; in the middle more elevated and dry; in N. W. part broken and rocky. It contains Spy and Little ponds, with part of Fresh Pond, which are very beautiful sheets of water, abounding with fish, and furnishing great quantities of ice for Boston market and exportation. Soil fertile and highly cultivated. Great quantities of garden vegetables and fruit are raised for the Boston marketa, Manufacturing establishments are not numerous, Many persons here residing transact their daily businese in Boston, to which trains run hourly, over the Fitchburg $\mathrm{R}, \mathrm{R}$. The Lexington and West Cambridge Branch $R$. $\mathrm{R}$ extends hence to Lexington $\mathrm{v}_{0}, 5 \mathrm{~m}$. This $\mathrm{t}_{0}$ and vicinity are of much historical interest. The valuation of property in this t., in 1940, was $\$ 472,423$; in $1850, \$ 1,671,644$. Pop, of t. in $1840,1,363$; in $1850,2,202$.

West CaMDEN, p. 0., Waldo county, Me.: 39 m. E. S. E. Augusta.

WesT CAMOEN, p. o. and sta, Oneida co, $N . Y_{0}:$ on Watertown and Rome R. R., 23 m. from Rome, $120 \mathrm{~m}$. W. N. W. Albany.

West CaMeron, p. o., Steuben co., $N . Y .: 196 \mathrm{~m}$. W. by S. Albany.

W rst Cass, p. v., Uister co., $N . \bar{Y}$. : on W. side of Hudson r., $38 \mathrm{~m} . \mathrm{S}$. by W. Albany.

West Campton, p. o, Grafton county, N. Hamp.: $42 \mathrm{~m}$. N. by W. Concord.

Wegt CaNada creek, $N . Y$. : rises in Hamilton co, flows S. W., S. E., and S., and empties into Mohawk r., $1 \mathrm{~m}$. below Herkimer v. It has a very rapid current, affording great water-power. Its principal descent is at Trenton Falls, $20 \mathrm{~m}$. above its mouth, where it has a descent of more than 300 feet in 4 miles.

West CANAAN, p. o. and sta., Grafton co., N. Hamp.: on Northern $\mathrm{R} . \mathrm{R}, 56 \mathrm{~m}$, from Concord, $13 \mathrm{~m}$. from W. Lebanon.

West Candor, p. o., Tioga co., $N . Y_{.}: 140 \mathrm{~m}$. W. by.S. Albany.

West Carltale, p. v., Coshocton co., Ohio: 35 m. E.N.E. Columbus.

West Carlton, p. o., Orleans county, N. $Y_{a}: 240 \mathrm{~m}$. W. by $\mathrm{N}$. Albany,

West CAYUTh, p. o, Chemung co., N. Y.: $153 \mathrm{~m}$. W. by $\$$. Albany.

West Charleston, p. o., Penobscot county, $\mathbb{P}_{\varepsilon_{0}}: 64 \mathrm{~m}$. N. E. Augusta.

West Cilarleston, p. v., Miami co., Ohio: $58 \mathrm{~m}$. W. Columbus.

West Charleston, p. v., Orleans co., Term. : on N. side of Clyde r., 50 m. N. N. E. Montpelier.

West Charlton, p. v., Saratoga county, N. $Y .: 24$ m. N. W. by N. Albany.

Wrst ChazY, p. y., and sta., Clinton co., $N$. $Y$.: on Plattsburg and Montreal R. R., $10 \mathrm{~m}$. from Plattsburg, $52 \mathrm{~m}$. from Montreal, $152 \mathrm{~m}$. N. Albany. It contains a churę, stores, ete., and several mills on Little Chazy $\mathbf{r}$.

West Chelmaford, p. v., Middlesex co., Mfass.: $23 \mathrm{~m}$ N. W. Boston.

Westohester county, $N$. $Y$. Situate S. E., and contains $470 \mathrm{sq} . \mathrm{m}$. Drained by Croton, Sawmill, and Bronx rivers, which supply good water. Surface generally hilly, being broken by numerous ridges, running chiefly from S. W. to N. E. ; soil naturally indifferent, but where cultivated is productive. Good crops of corn are raised, and fruits and vegetables in considerable quantity. These, with wheat and Indian corn, form the staple productions. This county is rich in minerals. At Sing-Sing marble is found in abundance, and in the vicinity is a copper mine formerly wrought, 
but for some time abandoned. It contains Croton lake, which, by means of an aqueduct, supplies New York with a constancy of fresh water. Farms 2,557; manuf. 396; dwell. 8,754, and pop.-wh. 56,217, fr. col. 2,046-total 58,208. Cupitals : Bedford and White Plains. Putlic Works: Hudson River R. R.; Harlem R. R.; New York and New Haven R. R.; Croton Aqueduct.

Westchester, p. v., New London county, Conn. : $20 \mathrm{~m}$.

S. E, by S. Hartford. It contains a church, academy, several stores, etc.

Westchester, to and p. v., Westchester co., N. Y.: $123 \mathrm{~m}$. S. Albany. Bounded E. and S. by East r., and W. by Bronx r. Surface pleasantly diversified; soil clay loam, and highly cultivated, producing immense quantities of garden vegetables, ete., for the New York markets. The v., on Westchester er., $12 \mathrm{~m}$. from the City Hall, New York, contain 8 churches, stores, etc., and about 500 inhabilants. Sloops ply hence to New York. Pop. of t. 2,492.

Westchester, p. v., Butler co., Ohio: 84 m. S. W. by W. Columbus.

W estchester, p. b., and cap. Chester co., Penn.: $70 \mathrm{~m}$. E. by S. Harrisburg. It is regularly laid out with streets, crossing each other at right angles. Incorporated.as a borough in 1799. It contains the county buildings, 2 markethouses, 1 bank, capital $\$ 225,000$, and 6 ehurches. It has considerable trade and manufactures, and is connected by a branch of the Columbia R. R., with Philadelphia. A direct railroad to Philadelphia is also being constructed. Its citizens are noted for enterprise and intelligence, and have several literary associations. Five weekly newspapers were published in 1850- "Village Record" (whig), "Register and Examiner" (whig), "Republican" (dem.), "Jeffersonian" (dem.), and "Phoenix Ledger" (dem.) Pop. about 2,500.

Whist Chesterfleld, p. o, Hampshire con, DLass. : $92 \mathrm{~m}$. W. Boston.

West Claremont, p. v., Sullivan co., N. Hamp.: $41 \mathrm{~m}$. W. by N. Concord.

West Clarksvillie, p. v., Alleghany co., N. Y.: $242 \mathrm{~m}$, W. by S. Albany.

West Climax, p. 0., Kalamazoo co., Mich. : 55 m. . W. Lansing.

West Colfesville, p. v., Broome county, $\lambda . Y_{\text {. }}: 92 \mathrm{~m}$.

W. S. W. Albany.

West Columbia, p. v., Mason co, Virg.: 263 m. W.N.W. Richmond.

Wrst Concord, p. v., Erie county, $N . Y_{\text {. }}: 262$ miles W. Albany.

Wres Concord, p. v. and sta., Merrimac co, N. Hamp. on Northern R. R., 3 m. W. N. W. Coneord. It contains a cotton factory, carriage manufactory, etc. The Merrimac and Connecticut Rivers R. R. passes through the place.

West Concord, p. v., Essex co., Verm, : 86 m. E. by N. Montpelier.

West Conesus, p. $\nabla_{*}$, Livingston co., N. $\boldsymbol{Y}_{*}: 208 \mathrm{~m}$. W. Albany.

West Constable, p. 0., Franklin county, $N . Y_{0}: 162 \mathrm{~m}$. W. by N. Albany.

West Cornwal, p. F, and sta, Litchfield co, Conn: on E. side of Housatonic $\mathbf{r}_{.}, 86 \mathrm{~m}$. W. by N. Hartford. The Housatonic R. R. passes through, $61 \mathrm{~m}$. from Bridgeport, $49 \mathrm{~m}$. from Pittsfleld. It contains a church and several manufacturing establishments.

West Connwarr, p. o., Addison county, Ferm. : 36 m. S. W. by W. Montpelier.

Whst CrenK, p. 0., Lake county, Ind.: $68 \mathrm{m.} \mathrm{N}$. N. W. Indianapolis.

West Creek, p. o., Ocean county, $\Lambda$. Jer.: 84 m. S. E. Trenton,

Wras Courbertand, p. o, Cumberland co., Me.: $48 \mathrm{~m}$. S. W. by S. Augusta.

Wrest Daxis, p. V., Tompkins co, $N$. Y.: $144 \mathrm{~m}$. W. by 8. Albany.
West Danvirs, sta, Essex co., Mass.: on Salem and Lowell R. R., 6 m. from Salem, 18 m. from Lowell.

Whst Danville, p. v., Cumberland co., Me.: 81 m. S.W. Augusta.

West Datenfort, p. v., Delaware co., $N . \quad Y$ : $62 \mathrm{~m}$. W. by $\mathrm{S}$. Albany.

Wrst DAx, p. 0., Sarntoga co., $N . Y_{\text {.: }}$ on Sacandaga $r_{*}$, 44 m. N. N. W. Albany.

West DedhaM, p. v. and sta., Norlolk county, Mass. : on Norfolk County R. R., 12 m. B. W. from Boston, 231 m. from Blackstone.

WeSt DeErFLetD, p. v., Rockingham co., N. Hamp.: 13 m. S. E. by E. Concord.

West Dexnis, p. 0., Barnstable co., Mass. : 63 m. S. E. Boston.

West Derbi, p. V., Orleans con, Ferm.: 53 m. N. N. E. Montpelier.

West Doter, p. V., Windham county, Verm.: 77 m. S. Montpelier.

West Dover, p. o., Piscataquis co., Me.: $65 \mathrm{~m}$. N. E. by N. Augusta.

Wret Dresden, p. o., Yates co., N.Y. : $176 \mathrm{~m}$. W. Albany. West Drrden, p. v., Tompkins co., $N$. $Y$.: $140 \mathrm{~m}$. W. Albany.

West Dublin, p. v., Fulton co., Penn. : 5 S m. W. by $\mathrm{S}$. Harrisburg.

West Dumarerstox, p. v., Windham co., Term.: $80 \mathrm{~m}$. S. Montpelier.

West DukHan, p. 0., Cumberland eo., Me.: $32 \mathrm{~m}$. S. W. by $\mathrm{S}$. Augusta.

West Duxbury, p. v., Plymouth co., Mass. : 36 m. S. E. Boston.

West Edmeston, p. v. Otsego co., $N_{*} \boldsymbol{Y}_{.}$: on E. side of Unadilla r., $80 \mathrm{~m}$. W. Albany.

West Eltzaвeth, p. V., Alleghany county, Penn。: on W. side Monongahela r, $155 \mathrm{~m}$. W. Harrisburg.

West Elkton, p. o., Preble co., Ohio: 86 m. W. by S. Columbus.

West Ellery, p. 0., Chautauque co., N. Y.: 297 m. W. by S. Albany.

West Ely, 1. O., Marion county, Mo. : $85 \mathrm{~m}$. N. N. E. of Jefferson City.

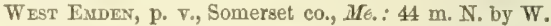
Augusta.

West End, p. 0., Bedford co., Penn.: 84 m. W. by 8. of IIarrisburg.

West Exfield, p. 0., Grafton county, $N$. Ilamp.: $39 \mathrm{~m}$. N. W. Concord.

West ENFLeLd, p. 0., Penobscot co, $B r_{0}: 72 \mathrm{~m}$. N. E. of Augusta.

West Exosburg, p. v., Franklin co., $\operatorname{Ver}^{2}$. : 54 m. W. by $\mathrm{N}$. Montpelier.

Westerioo, t. and p. V., Albany $c_{0}, N . Y_{.:} 17 \mathrm{~m} . \mathrm{S} . \mathrm{W}$. Albany. Drained by Provost er. and other branches of Catskill $r$. The t. contains several grist and saw mills, but the inhabitants are generally engaged in farming, etc. Pup. 2,ऽ60.

Wrsterloo island, Albany co., $N$. $Y$.: lies in the Hudson $r_{\text {. }}$ in Albany co., opposite Bethlehem, to which t. it is attached. It is $2 \mathrm{~m}$. long, $\frac{1}{4}$. wide, and of extraordinary fertility.

Westerly, t., p. v., and sta., Washington co., R. $\ddot{I}$ : $26 \mathrm{~m}$. W. by S. Newport. Bounded S. by the Atlantic and W. by Connecticut. Pawtucket $r$. flows on its N. and W. border, affording water-power to numerous mills and factories. The t. has an uneven surface, and contains sereral stores, 3 churches, and 3 banks, capital $\$ 325,000$. It has considerable coasting trade and ship-building. The Stonington and Providence R. R. passes through it, $5 \mathrm{~m}$. from 8tonington $45 \mathrm{~m}$. from Providente. Pop. of $\mathrm{L}$ in $1540,1,912$; in 1850 , 2,766 .

Westeryañ's Milzs, p. o, Baltimore co, Mfr. : on Baltimore and Susquehanna R. R., $18 \mathrm{~m}$, from Baltimore. 
Western Ford, p. o., Randolph co., Virg.: on W. side of Cheat r., $163 \mathrm{~m} . \mathrm{N}$. W. Richmond.

Westernport, p. v., Alleghany co., Md. : on $\mathrm{N}$. side Potomac r., $185 \mathrm{~m}$. W. by N. Annapolis. It is connected by railroad with the coal mines, and will become an important place of deposit.

Whstern Prong, p. o., Bladen co, $N$. Car.: about $2 \mathrm{~m}$. W. White Marsh cr., $84 \mathrm{~m}$. S. Rateigh.

Western Saratoga, p. 0., Union co., Ill. : $162 \mathrm{~m}$. S. by E. Springfield.

Western Star, p. o., Summit county, Ohio: 96 m. N. E. Columbus.

Westernvtule, p. v., Oneida co, $N_{\text {. }} Y_{\text {.: }}$ on Mohawk r. and Black River Canal, $80 \mathrm{~m}$. W. N. W. Albany. It contains 2 churches, several stores, and mills. Pop. about 300.

Westeraville, p. v., Franklin co., Ohio: $12 \mathrm{~m}$. Columbus.

West Exeter, p. 0., Otsego co., N. Y. . $70 \mathrm{~m}$. W. by N. Albany.

West Farrereld, p. v., Westmoreland co., Penn. : on a small branch of Conemaugh $\mathrm{r} ., 115 \mathrm{~m}$. W. Harrisburg. In the vicinity is a chareoal hot-blast furnace, with annual capacity of 1,800 tons, employing 80 men; also a charcoal coal-blast furnace, with annual capacity of 1,100 tons, employing 40 men.

West FatRLEe, t. and p. $v_{*}$, Orange co., Verm.: $28 \mathrm{~m}$. S. E. Montpelier. Surface mountainous. Drained by branches of Ompompanoosuc r. Pop. 696.

West Falls, p. o., Erie co., $N$. $Y .: 264 \mathrm{~m}$. W. Albany.

West Falmovth, p。 v., Cumberland county, Me.: $48 \mathrm{~m}$. S. W. by 8 . Augusta.

West FaLmotth, p. v., Barnstable county, Mass. : $58 \mathrm{~m}$. 8. S. E. Boston.

West Farmington, p. o., Ontario county, N. Y.: $169 \mathrm{~m}$. W. by N. Albany.

W EST FARMS, t. and p. v., Westchester co., N. $Y_{0}: 126 \mathrm{~m}$. $\mathrm{S}$. Albany, The to is bounded E. by Bronx r. and W. by Harlem $r_{\text {og }}$ and contains several pleasant villages on the Harlem R. R. The v. on Bronx r. contains 4 churches and several factories. Several sloops ply to New York, conveying country produce to the eity markets. Pop. of t, 4,436.

West FaYetTe, p. o., Seneca co., $N . Y .: 165 \mathrm{~m}$. W. by N. Albany.

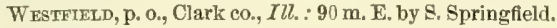
Westrield, p. 0., Hamilton county, Ind.: 18 miles $\mathrm{N}$. Indianapolis,

W estrield, t., p. v., and.sta., Hampden co., Mass.: $74 \mathrm{~m}$. W. by S. Boston. Surface diversified. Drained by Wesifield $r$, and its branch, Little $r$., which afford water-power to numerous manufactories. The $\mathrm{v}$. is handsomely situated on a plain, and is neatly built. In the centre is a public ground, fronting which are the principal churches and hotels. The v. contains a town-house, State normal school, an academy, several churches, and 2 banks, capital $\$ 200,000$. The Western R. R. passes through it, $9 \mathrm{~m}$. from Springfield, $61 \mathrm{~m}$. from Worcester, $108 \mathrm{~m}$. from Boston, and $92 \mathrm{~m}$. from Albany. The "News-Letter" (whig) and "Standard" (dem.) are issued weekly. Pop. of $t_{0}$ in $1840,3,526$; in $1850,4,186$.

W estrield, t., p. v., and sta., Essex co., N. Jer.: $86 \mathrm{~m}$. N. E. by N. Trenton. Surface in S. part level, in N. part hilly. The t. contains several flouring and grist mills. The New Jersey Central R. R. passes through, $23 \mathrm{~m}$. from New York, 55 m. from Easton. Pop. 1,575.

Westrield, t., p. v॰, and sta., Chautauque eo, $N . Y_{\text {.: }} 306$ m. W. by S. Albany. Surface hilly, declining toward Lake Erie, which bounds it on the N. Drained by Chautauque cr. and other streams. The $\mathrm{v}$. on Chautauque cr., $1 \frac{1}{2} \mathrm{~m}$. from the lake, contains several manufacturing establishments and mills, a bank, 4 churches, an academy, ete., and about 1,000 inhabitants. The Buffalo and State Line R. R. passes through it, $57 \mathrm{~m}$. from Buffalo. The "Westfeld Messenger" (whig) is here published. Pop. of t. 3,100.

WrstField, t. and p. v., Morrow co, Ohio: $81 \mathrm{~m} . \mathrm{N}$. Columbus. Drained by E. branch of Whetstone $r$. The
Cleveland, Columbus, and Cincinnati R. R. passes through its E. part. Pop. of t. 1,414.

Westriexd, to and p. o, Tioga co., Penn. : on 8. side of Cowanesque cr., $117 \mathrm{~m}$. W. by N. Harrisburg. Population of t. 1,000 .

WestField, t. and p. o, Orleans county, Verm.: $41 \mathrm{~m}$. N. by E. Montpelier. Surface diversified. Drained by branches of Missisque r. Pop. 502.

WestrieLd, p. 0., Marquette co., Wisc. : $60 \mathrm{~m}$. N. by E. Madison.

West Frneex, t. and p. v., Washington co., Penn.: surface very hilly. Drained by branches of Wheeling cr. The Hempfield R. R. will pass through its N. part. Population about 1,200 .

WEST FITOHBURG, p. v. and sta., Worcester co, Mass. : on Vermont and Massachusetts R. R., 2 m. W. by 8 . Fitchburg, 43 m. W. N. W. Boston.

West Florence, p. v., Preble co., Ohio: $93 \mathrm{~m}$, W. by $\mathrm{S}$. Columbus.

W rstFord, p. v., Windham co., Conn。: 29 m. E. N. E. Hartford. It contains 2 ehurehes, stores, etc.

Westrord, t., p. v., and sta., Middlesex co., Mass. : $23 \mathrm{~m}$. N. W. by W. Boston. Surface elevated. Drained by Stony r., which affords water-power. The v, near the centre contains 2 churches, an academy, stores, ete. The station on Stony Brook R. R., is $10 \mathrm{~m}$. from Groton, $7 \mathrm{~m}$. from Lowell. The t. contains several mills and manufacturing establishments. Pop. of t. 1,473.

Westrord, t. and p. o., Otsego county, $N . Y .: 53 \mathrm{~m}$. W. Albany. The inbabitants are generally engaged in agricultural pursuits. Pop. 1,423.

WESTFORD, t. and p. v., Chittenden co, Verm. : $81 \mathrm{~m}$. N. W. Montpelier. Drained by Brown's r., tributary to Lamoille r, flowing through the t. centrally. Surface rough; soil best adapted to grazing. Pop. of t. 1,45s.

West ForK, p. 0., Overton co., Tenn.: 85 m. E. by N. Nashville.

West Fort AnN, p. o., Washington co., N. Y.: $55 \mathrm{~m}$. N. by E. Albany.

West Fow Ler, p. O., St. Lawrence county, N. $Y_{.}$: on $\mathrm{S}$. Oswegatchie $r_{\text {r, }} 144 \mathrm{~m}$. N. W. by N. Albany.

West Forbogo', p. v., Norfolk co., Mfass. : 23 m. S. S. W. Boston.

West Frankirn, p. v., Posey co., Ind.: 150 m. S. W. by $\mathrm{S}$. Indianapolis.

West Franejin, p. v. Bradford co., Penn.: $90 \mathrm{~m} . \mathrm{N}$. Harrisburg.

West Freedom, p. o., Waldo co., Me.: 26 m. N. E. by E. Augusta.

West Frezman, p. 0., Franklin county, Me.: 45 miles N. W. by N. Augusta.

West Fulton, p. 0., Schoharie co, $N . Y .: 36 \mathrm{~m}$. W. by $\mathrm{S}$. Albany,

West Fulton, p. o., Itawamba county, Miss.: on E. side Tombigbee $\mathrm{r}, 168 \mathrm{~m}$. N. E. by N. Jackson.

West GarNes, p. o., Orleans co., N. $Y .: 240 \mathrm{~m}$. W. by N. Albany.

West GalWaY, p. 0., Fulton co, N. Y.: 40 m. N. W. Albany.

West Garland, p. o., Penobscot co., Me.: $61 \mathrm{~m} . \mathrm{N}$. E. by N. Augusta.

West Genesee, p. v., Alleghany county, $N . Y_{*}: 240 \mathrm{~m}$. W. by S. Albany.

West GIlboa, p. o., Schoharie co, $N . Y: 42 \mathrm{~m}$. W. S. W Albany.

West Guaze, p. 0., Camden county, MIo : 47 m. S. S. W. Jefferson City.

West Glenburn, p. o., Penobscot co., Jre.: 63 m. N. E Augusta.

WEST GLovcrsTER, p. O., Cumberland co, MFe.: $36 \mathrm{~m}$, S. W. Augusta.

W est GorHaM, p. V., Cumberland co., Me. : 57 m. S. W. by $\mathrm{S}$. Augusta. 
Wrest Goshrs, p. 0., Litchfleld co., Conn. : 31 m. W. by N. Hartford.

West Gouldsioro', p. v., Hancock co., Me.: 85 m. E. Augusta.

West Granbt, p. o., Hartford co., Conn.: on N. side of branch of Farmington r., $19 \mathrm{~m}$. N. W. by N. Hartford.

West GraNviliE, p. o., Hampden county, Mass.: $99 \mathrm{~m}$.

W. by S, Boston.

West Great Works, p. 0., Penobseot county, Me.: on Penobscot r., $78 \mathrm{~m}$. N. W. by W. Augusta.

West Greece, p. o., Monroe co., N. Y.: $212 \mathrm{~m}$. W. by N. Albany.

W est Greenfield, p. v., Saratoga county, $N . Y_{.}: 33 \mathrm{~m}$. N. by W. Albany.

WESt Greenvilliz, t. and p. v., Mercer co., Penn. : $194 \mathrm{~m}$ W. N. W. Harrisburg. The t. contains several mills. Pop. about 700 .

West Greenwich, t. and p. v., Kent co., R. $I_{0}: 23 \mathrm{~m}$. W. N. W. Newport. Drained by Wood r. and branches, and by $\mathrm{S}$. branch of Pawtuxet r., which afford water-power to several large factories of sheetings, cotton-yarn, etc. ; and to numerous grist and saw mills. Tho vo contains a church, stores, ete. Pop. 1,350 .

West Greenwich Centre, p. v., Kent co., $R$. $I_{\text {. : }} 24 \mathrm{~m}$. W. N. W. Newport.

West Greenwood, p. o., Steuben county, N. T.: $211 \mathrm{~m}$. W. by S. Albany.

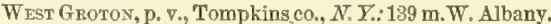

West GrotoN, p. v, and sta., Middlesex co., Mass。: on Peterboro' and Shirley R. R., $4 \mathrm{~m}$. from Groton, $19 \mathrm{~m}$. from Mason village; $81 \mathrm{~m}$. N. W. by W. Boston.

West Grove, p. o., Chester co., Penn。: $60 \mathrm{~m}$. E. by S. Harrisburg.

West HadeEY, p. o., Saratoga co., $N_{0}, Y_{0}: 48 \mathrm{~m} . \mathrm{N}$. by W. Albany.

West Haltrax, p. 0, Windham co., Term.: 106 m. s. Montpelier.

West HaMpdew, p. 0, Penobseot county, Me.: כ2 m. N. E. by E. Augusta.

West FAMPTON, t. and p. o., Hampshire co., Mass. $87 \mathrm{~m}$. W. Boston. Surface rough ; drained by North r. and branch. Pop. 602.

West Hanover, p. v., Dauphín coa, Penn。: $10 \mathrm{~m}$. N. E. Harrisburg. Here is a hot-blast charcoal furnace, with annual capacity of 2,215 tons, employing $100 \mathrm{men}$.

W ist Harpeth, p. o., Williamson co., Tenn, : $14 \mathrm{~m}$. S. W. Nashville.

West HarpswerL, p. 0., Cumberland eo., Me.: $37 \mathrm{~m}$. S. by W. Augusta.

West Il $a$ Rtford, p. v., Hartford co., Comn.: 4 m. W. Hartford.

W Fst Hartrord, p. v. and sta., Windsor co., Term. : on N. E. bank of White r., $41 \mathrm{~m}$. S. by E. Montpelier. The Vermont Central R. R. passes through, $21 \mathrm{~m}$. from Windsor, $56 \mathrm{~m}$. from Montpelier, and $136 \mathrm{~m}$. from Rouse's Point. The water-power at this place is partially improved, and the manufacture of woolens and leather is carried on to some extent.

West Hartland, p. v., Hartford co., Conn, : 22 m. N. W. TIartord.

West HARTuaNd, p. o, Somerset co, $M \mu_{0}: 40 \mathrm{~m}, \mathrm{~N}$. by E. Augusta.

West Harwick, p. O., Barnstable co., Mfas8. : 65 m. S. E. Boston.

West HAVRN, t. and p. v., Rutiand co., Term. : 58 m. S. W. by S. Montpelier. Bounded W. by Lake Champlain, and s. by Poultney $r$. Drained by Ilubbardton's $r$, and Cogman's er, which afford mill privileges, Pop. 718.

Wrat Haves, $n . v$, and sta. New Haven co., Conn.: on New York and New Haven R. R., 8 m. S. W. New Haven, and $78 \mathrm{~m}$. from New York.

West Haferford, p. 0., Delaware co., Penna: $85^{\prime} \mathrm{m}$. E. by S. Harrisburg.

922
WEST HAWLEY, p. v., Franklin co., Mas8. : 97 m. W. by N. Boston.

W est Hebro⿰, p. 0., Washington co., N. Y. : 46 m. N. N. E Albany.

West Hebron, p. v., M'Henry co., $M$. . 192 m. N. N. E Springfleld.

W rst Henntker, sta, Merrimac co., $N$. Hamp. : on Contoocook Valley R. R., $16 \mathrm{~m}$. W. by S. Concord.

West Henrietra, p. o., Monroe county, N. T.: $209 \mathrm{~m}$. W. by N. Albany.

West Hruss, p. o., Suffolk co., N. Y.: $132 \mathrm{~m}$. S. by E. Albany, on Palisade bluff, $18 \mathrm{~m}$. from Hoboken.

Wrst Новоқen, p. v., Hudson co., $N$. Jer.: ferry $3 \frac{1}{2} \mathrm{~m}$.

N. N. W. from City Hall, New York ; 54 m. N. E. Trenton.

It has a fine site, and is a rapidly growing village.

West Hopkinton, sta., Merrimac co., N. Hamp.: on Contoocook Valley R. R., $10 \mathrm{~m} . \mathrm{W}$. Concord.

West Hurlex, p. 0. , Ulster co., $N . Y_{0}: 75 \mathrm{~m}$. S. by W Albany.

WeST J JFFERsoN, p. o., Lineoln co., Me.: 16 m. S. E. Augusta

Wegt JeFFerson, p. v. and sta, Madison co, Ohio: on W. bank of Little Darby cr., and on Columbus and Xenia R. R., $14 \mathrm{~m}$. W. by S. Columbus。 Pop. 436.

W EST JERSEX, p. v., Stark co., $M$. : $90 \mathrm{~m}$. N. Springffeld.

West Junius, p. o., Seneca co., N. $Y_{0}: 167 \mathrm{~m}$. W. by $\mathrm{N}$. Albany.

Wrest Kendalu, p. v., Orleans co., $N_{0}, \boldsymbol{Y}_{.}: 282 \mathrm{~m}$. W. by N. Albany.

West KrL., p. v., Greene county, $N_{0} Y_{\bullet}: 46 \mathrm{~m} . \mathrm{S} . \mathrm{W}$ Albany.

West Krimgl.Y, p. V., Windham co., Conn. : 42 m, E. Hartford. It contains several factories and stores. The "True Democrat" is here published.

West Kivderhook, p. v., Tipton county, Ind.: $31 \mathrm{~m}$. N. by E. Indianapolis. The Peru and Indianapolis R. R. passes $2 \mathrm{~m}$. W. from it.

West La Fayetre, p. o., Coshocton co., Ohio: $65 \mathrm{~m}$.

E. N. E. Columbus,

Westlakd, p. v., Halifax county, $N$. Car.: 73 m. N. E. Raleigh.

Wrst Laurens, p. F., Otsego county, N.Y.: $75 \mathrm{~m}$. W. Albany.

Wrest Lemanon, p. v., Warren eo., Ind.: 70 m. W. N.W. Indianapolis.

West Lebanon, p. o., York co., Me. : on E. side of Salmon river, $90 \mathrm{~m}$. S.W. by. S. Augusta.

West LebanoN, p. v. and sta., Grafton co, N. Hamp.: on E. side of Connecticut r., at mouth of Mascomy r., $51 \mathrm{~m}$. N.W. by N. Concord. Here terminates the Northern R. R. from Concord, $69 \mathrm{~m}$. long, which here connects with the Vermont Central P. Rs, and the Connecticut and Passumpsic Rivers R. R., which cross the Connecticut to receive passengers. The $\mathrm{r}$. contains extensive car-houses, shops, etc. of the Northern R. R.

Wrst Lebanon, p. v*, Wayne co., Ohio: 84.m. N. E, Columbus

West Lebanon, p. v., Indiana county, Penn.: $115 \mathrm{~m}$. W. by $\mathbf{N}$. Harrisburg.

Wrest Levant, p. Oa, Penobscot $\mathrm{con}_{2}, \mathrm{Me}_{1}: 58 \mathrm{~m}$. N. E。 Augusta.

West Lextngton, p. o., Lewis co., N. Y.: $46 \mathrm{~m} . \mathrm{S} . \mathrm{W}$. Albany.

WFST LEYDEN, p. v., Lewis co., N. T.: $105 \mathrm{~m} . \mathrm{N}$. W. by W. Albany.

WrSt LIBERTr, p. v., Muscatine county, Ia.: 12 m. S. E. Iowa City.

W F.s LiBertr, p. v., and cap. Morgan county, $F y .:$ on $\mathrm{N}$. side Licking r., $100 \mathrm{~m}$. E, by $\mathrm{S}$. Frankfort. It contains the county buildings and several dwellings.

Wrst Liberty. p. v, and sta, Logan con, Ohio: $42 \mathrm{~m}$. W. N. W. Columbus. Laid out in $\mathbf{1 8 1 7}$, and now contains several churches, etc. The "West Liberty Banner" (neut.) 
is here published. The Mad River and Lake Erie R. R. passes through it, $110 \mathrm{~m}$. from Sandusky, $43 \mathrm{~m}$. from Dayton, and $118 \mathrm{~m}$. from Cincinnati. Pop. about 500.

W EsT LiberTy, p. V., Liberiy county, Tex. : 169 m. E. Austin City.

West Libenty, p. v., Ohio co, Virg. : 242 m. N. W. Richmond.

West Lodi, p. V., Seneca co., Ohio : 88 m. N. Columbus.

West Lowrille, p. v., Lewis co., $N . Y .: 126 \mathrm{~m}$. N. W. Albany.

West LuBic, p. o., Washington co., $M L$. : 139 m. E. by N. Augusta.

West Macedon, p. o., Wayne co., N. Y.: 190 m.W. by N. Albany.

Wrat Manchester, p. v., Alleghany co., Penn. : $165 \mathrm{~m}$. W. by $\mathbf{N}$. Harrisburg.

West Martinsburg, p. v., Lewis county, $N$. $Y .: 120 \mathrm{~m}$. N. W. by W. Albany.

WEST Medford, p. v, and sta., Middlesex co, Mass. : on

Boston and Lowell R. R., 5 m. N. N. W. Boston.

W EST MEDW AT, p. V., Norfolk co, Mass. : 25 m. S.W.byW. Boston.

WhST Meredith, p. v., Delaware county, $N . \bar{Y} .: 67 \mathrm{~m}$. W. by S. Albany.

West Meriden, p. v., New Haven co, Conn。: 18 m. S. S. W. Hartford.

West MIDdLeburg, p. Y., Logan county, Ohio: $39 \mathrm{~m}$.

W. N.W. Columbus.

West Midplesex, p. O, Mercer county, Penn $: 190 \mathrm{~m}$

W. N. W. Harrisburg。

West Middelewn, p. b., Washington co, Penn. : $180 \mathrm{~m}$.

W. Harrisburg. Pop. about 300 .

West Milan, sta., Coos co., $N$. Hamp.: on the Atlantic and St. Lawrence R. R, $110 \mathrm{~m}$. from Portland; $95 \mathrm{~m}, \mathrm{~N}$ Coneord.

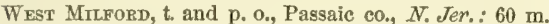
N. N. E. Trenton. The t. contains a large number of forges, with several tanneries, grist and saw mills. Pop. 2,624.

West MILFoed, p. 0., Harrison county, Virg.: $200 \mathrm{~m}$.

N. W. by W. Richmond.

Wrat Millbuky, p. v., Worcester county, Mass. : 38 m. W. S. W. Boston.

West Milu Grove, p. o., Wood eo., Ohio : 89 m. N. N. W. Columbus.

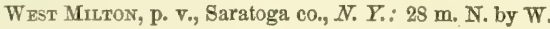
Albany.

West Mrlton, p. o, Miami county, Ohio: 72 m. W. Columbus.

West Milton, p. v., Chittenden co., Verm.: on S, side of Lamoille r., $36 \mathrm{~m}$. N. W. Montpelier.

West Mnnot, p. o, Cumberland co, Me. : $81 \mathrm{~m}$. S.W. by W. Augusta.

Westminster, p. v., Windham co., Conn. : 34 m. E. by S. Hartford.

Westminster, p. $\nabla_{\text {., }}$ and cap. Carroll county, $M d_{.}: 47 \mathrm{~m}$ N. W. by N. Annapolis, It contains the county buildings, several churches, and 1 bank, cap. $\$ 110,000$. The "Carrolltonian" (whig), and "Carroll Co. Democrat," are issued weekly. The Westminster Branch R. R., diverging from the Baltimore and Susquehanna R. R. at the Relay House, $7 \mathrm{~m}$. N. to Baltimore, is in construction to this place. Pop. in $1550 \tau \$ \mathrm{wh}$., and $51 \mathrm{fr}$. col.-total $\$ 35$.

Wesmuinster, t., p. $\mathbf{v}_{\text {., }}$ and sta., Woreester co., Mass.: $45 \mathrm{~m}$. W. by N. Boston. Drained by affluents of Nashua $r$. The $\nabla$. contains 3 churches. The sta., on Vermont and Massachusetts R. R., $5 \mathrm{~m}$. from Fitchburg, is in its N. E. part. Pop. of t. 1,916.

Westmryster, p. v., Guilford co., N. Car. : $70 \mathrm{~m}, \mathrm{~W}, \mathrm{~N}, \mathrm{~W}$. Raleigh.

Westunster, p. V., Allen county, Ohio: $72 \mathrm{~m}, \mathrm{~N}$ : W. Columbus.

Westumster, p. v., Shelby co, Ohio: $69 \mathrm{~m}$. W. N. W. Columbus.
WesTMNвTER, $t_{\text {, }}$ p. v, and sta, Windham co, Term.: on W. side of Connecticut r., $84 \mathrm{~m}$. 8. by $\mathbf{E}$. Montpelier. The v. is beautifully situated, and neatly built. The Vermon Valley R. R. passes through it, $4 \mathrm{~m}$. from Bellows Falls, $20 \mathrm{~m}$. from Brattleboro'. Pop. of t. 1,721.

Westurneter West, p. v., Windham co., Verm.: $86 \mathrm{~m}$ \$. by E. Montpelier.

West Monrox, t, and p, 0, Oswego co., N. Y, $130 \mathrm{~m}$ W. by N. Albany. Bounded S. by Oneida lake. Surface level. Drained by Bog er. Pop. 1,197.

Westmoreland county, Penn. Situate toward the S. W. and contains 989 sq. m. Drained by Loyalhanna and Youghiogheny rivers, and by Sewickly cr. and Beaver Dam cun. Surface uneven and in parts mountainous; soil very productive. Staples, wheat, Indian corn, and potatoes Tobacco is also cultivated. The N. W. is bounded by the Alleghany river. Farms 4,018; manuf. 586; dwell. 8,350 , and pop.-wh. 51,280, fr. col. 446 - total 51,726. Capital. Greensburg. Public Works: Pennsylvania R. R.; Hempfield R. R.; Alleghany Valley R. R.; Pennsylvania Canal.

WestmormLand county, Virg. Situate N. E., and contains $162 \mathrm{sq} . \mathrm{m}$. Drained by small streams flowing into the Potomac and Rappahannock rivers. Surface level soil fertile and adapted to grain and grazing. Chief products, wheat and Indian corn, with cotton. Farms 413 ; manuf. 5 ; dwell. 869, and pop.-wh. 3,410 , fr. col 1,113 , sl. 3,557-total 8,080. Capital: Westmoreland C. H.

Westmoreland, p. o., Dallas county, Ala.: $50 \mathrm{~m}$. W Montgomery.

Westmoreland, t. and p. o., Cheshire co., N. Hamp.: on E side of Connecticut r., 45 m. W. S. W. Concord. Surface uneven; soil moderately fertile. The Cheshire R. R. passes through its N. E. part: Pop. 1,677.

W Estmoreland, t. and p. o., Oneida county, $N . Y_{.}: 93 \mathrm{~m}$. W. N. W. Albany. Surface of t. level; soil rich loam. Interests chiefly agricultural, but contains several saw-mills and tanneries. Pop. 3,291

Westmoretand C. H., p. vo, and eap. Westmoreland co.g Firg.: $50 \mathrm{~m}, \mathrm{~N}$. E. Richmond. It contains the county buildings, several stores, etc. Pop. about 180.

Westmoreland Depôt, p. v, and sta., Cheshire county, N. Hump. : on Cheshire R. R., 54 m. from Fitchburg, and $10 \mathrm{~m}$. from Bellows Falls.

Westmorelandvili,e, p. F., Lauderdale co., Alat. : $193 \mathrm{~m}$. N. N. W. Montgomery.

W Est NeEDHAM, p. v. and sta., Norfolk co., Mass.: on Boston and Worcester R, R, $15 \mathrm{~m}$, from Boston.

West NeWARK, p v., Tioga co., N. Y.: 130 m. W. by S. Albany.

West Newbery, t. and pi v., Essex co, Mrass.: on S. side of Merrimac r, $31 \mathrm{~m}$. N. Boston. Interests of t. are chiefly agricultural. Pop. 1,746.

West NewFirLD, p. o., York co., dre. : on N. side of Little Ossipee r., 78 m. S. W. Augusta.

West Newpont, p. o., Orleans co., Verm.: $46 \mathrm{~m}$. N. by E. Montpelier.

W est Newstead, p. o., Erie con, N. $Y_{*}: 252 \mathrm{~m}$. W. by N. Albany.

Wrst Newtor, p. v, and sta., Middlesex co., Mas..: on Boston and Worcester R. R., 9 m. from Boston. It is handsomely built, and contains a State Normal school for female teachers.

West NewtoN, p, o, Allen co, Ohio: 88 m. W. N. W Columbus.

West NewTor, p. v., Westmoreland co., Penn. : on E bank of Youghiogheny r., $146 \mathrm{~m}$. W. Harrisburg. The Hempleld R. R. will pass through this place. Pop. 71 .

Wrst Miles, p. o., Cayuga co., N. Y.: 142 m. W. Albany.

West Nonfork, p. Y., Litchfield county, Conn.: $32 \mathrm{~m}$

N. W, by W. Hartford.

WESt Northfield, p. 0., Franklin county, Mass. : $74 \mathrm{~m}$, W. N. W. Boston. 
WEST NORTHWOOD, p. o., Roekingham co., N. Hamp.: $16 \mathrm{nr}$. E. Concord.

West OGden, p. 0., Lenawee co., Mich: 75 m. S. S. E. Lansing.

Weston, t. and p. v., Fairfield cr., Conn.: 53 m. S. W. Harlford. Surface uneven. Drained by Saugatuck $r$, and branch, which afford water-power. The $\mathrm{v}$. contains an academy and ehurch. The chief interests of the $t_{0}$ are agricultural. Pop. of t. 1,063.

Weston, p. v., Jo Daviess co., $M l_{0}$ : $175 \mathrm{~m}$. N. by W, Springfield.

Weston, t. and p. 0., Aroostook co., Me. : $135 \mathrm{~m} . \mathrm{N} . \mathrm{W}$. Augusta. Pop. 293.

Weston, t., p. v., and sta., Middlesex co., Mass.: $11 \mathrm{~m}$. W. Boston. Surface of t. pleasantly diversiffed. The central v., built chiefly on one street, contains 2 ehurches. The station is in N. part of t., on Fitchburg R. R., $13 \mathrm{~m}$. from Boston. The Boston and Worcester R. R. crosses $\mathrm{S}$. E. corner of t. Pop. of $t .1,205$.

Weston, p. v., Platte co., Mo. : on N. E. side of Missouri c., $161 \mathrm{~m} . \mathrm{W} . \mathrm{N}$. W. Jefferson City. It has a good situation, and carries on extensive business and trade. The "Weston Reporter" (whig), and "Platte Argus" (dem.), are published weekly.

Weston, p. v., Somerset co., N. Jer.: on the Delaware and Raritan Canal, and E, side of Milistone $\mathrm{r}, 22 \mathrm{~m}$. N.N.E. Trenton.

Weston, t. and p. v., Wood co., Ohio: on S. side of Maumee r., 107 m. N. N. W. Columbus, Drained by Beaver er. Pop. 546.

Westow, p. o., Steuben county, N. Y.: $188 \mathrm{~m}$. W. by S Albany.

Westor, t. and. p. v., Windsor co, Verm.: $66 \mathrm{~m}$. $\mathrm{s}$ Montpelier. Drained by West $r_{\text {s, }}$ which furnishes mill sites. The $v$. near the centre contains several manufacturing establishments, and two churches. Pop. of t. 950.

Weston, p. V., and cap. Lewis co., Virg.: on W. fork of Monongahela r., 188 m. N. W. by W. Richmond. It contains the county buildings, several stores, etc. The "Weston Sentinel" (dem.) is issued weekly. Pop. about 250.

Whist ONeonta, p. o., Otsego co., N. $Y .: \tau 2 \mathrm{~m}$. W. by S. Albany.

West ONONDAGA, p. v., Onondaga co., $N . \bar{Y}: 133 \mathrm{~m}$. W. by N. Albany.

Wrst Ossiper, p. vo, Carroll co, N. Hamp.: on $\mathrm{S}$. side of Bear Camp r, $40 \mathrm{~m}$. N. by E, Concord.

WrST Otis, p. V., Berkshire co., Mass: $106 \mathrm{~m}$. W. by S Boston.

West Parsonsfied., p. v., York co., Mee: 76 m. S.W. by W. Augusta.

West Pexw, t. and p. v., Schuylkill co., Penn.: $60 \mathrm{~m}$, N. E. Harrisburg. The t. has a hilly surface, gravelly and sterile soil, and abounds in anthracite coal. Pop. about 1,500.

TVest Perrysiburg, p. O, Cattaraugus co., $N, Y_{0}: 275 \mathrm{~m}$. W. Albany.

West PERth, p. o, Fulton co., N. $Y: 36 \mathrm{~m}$. N. W. Albany.

Wrst Pert, p. o., Oxford county, Me.: $86 \mathrm{~m}$. W. by $\mathrm{N}$. Augusta.

W estphalis, p. V., Osage co., Mo. : on W. bank Maupais cr., a tributary of Osage r., 13 m. S. E. Jefferson City.

West Pmilanelphia, p. district, Philadelphia co., Penn. on $\mathbf{W}$. side of Scbuylkill $\mathbf{r}_{*}$, directly opposite the city proper, with which it is partly associated in municipal government, but has also a separate local givernment of eommissioners. In its W. part are the extensive buildings of the Pennsylrania Hospital for the Insane. Pop. in $1840,2,596$; in $15511,5,6 \pi 11$

Thest Prerpont, p. v., Ashtabula co., Ohio: 168 m. N. E. Columbus.

W est Pike, p. o., Potter co., Penn.: $110 \mathrm{~m}$. N. N. W. Harrisburg.

West PtTtskindd, p. vo, Berkshire co, Mass. : $117 \mathrm{~m}$. W. Boston.
West Planns, p. v., Oregon co., Mo.: $127 \mathrm{~m}$. S. by E. Jefferson City.

West Platrsburg, p. v., Clinton county, N. Y.: $142 \mathrm{~m}$. N. by E. Albany.

West Plymodxh, p. von, Grafton co., N. Hamp.: $37 \mathrm{~m}$. N. by W. Concord.

Wrst Point, p. v. and sta., Troup co., Ga.: on E. side of Chattahoochie r., $119 \mathrm{~m}$. W. by $\mathbf{S}$. Milledgeville. The Lagrange $R . R$. extends to this place from Atlanta, $87 \mathrm{~m}$. and connects with Montgomery and West Point $\mathbf{R}$. R. thence to Montgomery, $88 \mathrm{~m}$. These important thoroughfares have made this a place of considerable trade. Pop. about 45 .

Wrat Pornt, p. 0, Cass co., Mo.: $120 \mathrm{~m}$. W. Jefferson City.

W ғsт Point, p. v., Tippecanee co., Ind. : 60 m. N. W. Indianapolis. Pop. about 350 .

West Point, p. o., Lee co., Ia. : 62 m. S. Iowa City.

West Point, p. v., Hardin eo., $K y .:$ on S. side of Ohio r., at mouth of Salt $r_{*}, 58 \mathrm{~m}$. W. by S. Frankfort. Population about 200 .

West Pornt, p. v., Lowndes co;, Afiss,: $2 \mathrm{~m}$. N. Okatibbehah r., $125 \mathrm{~m}$. N. E. Jackson.

West Point, p. v, Orange co, N. Y: on W. bank of Hudson r., $91 \mathrm{~m}$. 'S. by W. Albany. Lat, $41^{\circ} 23^{\prime} 31.2^{\prime \prime} \mathrm{N}$., long. $73^{\circ} 57^{\prime} 03^{\prime \prime} \mathrm{W}$. The U. S. Military Academy, here löcated, was established in 1802 . Its site, with 250 acres attached, was ceded by New York to the United States in 1S26. It occupies an elevated plain, commanding most delightful views of the river and vicinity, and is surrounded by high hills. The buildings are numerous, and handsomely built of stone. The number of cadets is 250 , of instructors 35. The course of instruction, chiefly military and scientific, is of the highest order, and occupies four years. Upon graduation, the cadets are immediately appointed as officers in the U. S, army. The average annual appropriation of Congress for this academy is $\$ 160,000$. This place is of great historical interest, from its connection with the Revolution. In 1777 it was fortified and occupied by the American army, and during the war was garrisoned by a strong division of troops. A very massive chain was here stretehed across the Hudson, thus preventing, with the aid of the forts, the British from ascending the Hudson and communicating with the Canadian provinces. The ruins of Fort Putnam are still seen. In 1794 a military school was here commenced, but the building was destroyed by fire two years afterward, and the school suspended until 1802, when the present academy was organized.

West Ponst, p. v., Orange co., N. Car.: $25 \mathrm{~m}$. N. W Raleigh.

West Pornt, p. v., Columbiana co., Ohio: on N. side of branch of Little Beaver r., 126 m. E. N. E. Columbus.

West Polnt, p. o., Lawrence co, Tenn. : 72 m. S. S. W. Nashville.

Wrst Poland, p. o., Cumberland county, Mre.: $86 \mathrm{~m}$. S. W. by W. Augusta.

Wrstrozt, t., p. v., and sta., Fairfield co, Conn. : $55 \mathrm{~m}$. S. W. Hartford, Drained by Saugatuck r., which affords water-power. The v., $_{\text {, }}$ on both sides of the Saugatuck r., contains 2 churches, the Saugatuck iron-works, a very extensive establishment, with several cotton and other factories. The New York and New Haven R. R. passes through it, $47 \mathrm{~m}$. from New York, $29 \mathrm{~m}$. from New Haven. Pop. of $t$. in $1840,1,803$; in $1850,2,649$.

WestroRt, p. v., Decatur co., Ind.: on W. side of Sandy cr., $70 \mathrm{~m}$. S. E. by S. Indianapolis.

TV FstPORT, p. $y_{\text {, }}$ and cap. Oldham co., Ky, $;$ on $\mathbf{S .}$ E. bank of Ohin r. $86 \mathrm{~m}$. W. N. W. Frankfort. It contains the county buildings, 2 churches, and several stores. Population about 800 .

Westrort, p. o., Clinton co., Penn.: $80 \mathrm{~m}$. N. W. by N. Harrisburg.

WESTPORT, t. and p. 0., Lincoln co, $M e_{0}: 29 \mathrm{~m}$. \$. by $\mathrm{E}$. 
Augusta. Bounded E, by Sheepseot r. and S. and W. by Sheepscot bay. Pop. 761.

Whstrort, t. and p. v., Bristol co., Mass. : on W. side of Acoaksett $\mathrm{r}_{\mathrm{s}}, 51 \mathrm{~m}$. S. Boston. The t, contains several manufactories. Many of the inhabitants are engaged in the fisheries. Pop, of t. 2,795.

Westrort, p. V., Jackson co., Mo.: on W. line of the State, 4 m. S. Missouri r., $136 \mathrm{~m}$. W. by N. Jefferson City. Pop, about 300 .

Wrstport, p. v. and sta., Cheshire co., N. Hamp.: on Ashuelot R. R., 8 m. from Keene, 49 m. S. W. by S. Concord. Wrstrort, t. and p..v. Essex co., $N . Y_{\text {.: }}$ on W. side of Lake Champlain, 106 miles N. by E. Albany. Drained by small streams flowing into the lake. The $\mathrm{v}$, at the head of Northwest bay contains 3 churches, several stores, and about 650 inhabitants. The "Westport Courier" (dem.) and "Old Settler" (lit.) are here published. A ferry plies hence across the lake to Basin Harbor, Verm. Pop, of t, 2,352.

Westpont PoInt, p. o., Bristol county, Mfass.: 59 m. S. Boston.

West Potsdax, p. v., St. Lawrence con, $N . Y_{.}: 156 \mathrm{~m}$. W. by N. Albany.

West Poultwey, p. v., Rutland co., Verm.: 61 m. S. W. by $\mathbf{S}$. Montpelier. Here is located the Troy Conference Academy, a flourishing Methodist institution.

West Pramrie, Stoddard co., Mo. : $180 \mathrm{~m}$. S. E. Jefferson City.

West Randolph, p. v. and sta., Orange co., Verm.: 25 m. S. Montpelier. It contains several mills on a branch of White river, a church, stores, ete. The Vermont Central R. R. passes through, $46 \mathrm{~m}$. from Windsor, $31 \mathrm{~m}$. from Montpelier, $111 \mathrm{~m}$, from Rouse's Point.

Wrst Riplex, p. o., Somerset co., Me. : 49 m. N. N. E, Augusta.

West Rrver, p. o., Anne Arundel co, $M I d_{4}: 7$ m. S. S.W. Annapolis.

West Rives, p. o., Jackson co., Mich.: 27 m. E. by S. Lansing.

West Rochester, p. 0., Windsor co., Verm. : 28 m. \$. by E. Montpelier.

West Rosendale, p. o, Fond du lac co., Wisc. : 61.m. N. E. by N. Madison.

West Roxbury, t., p. v., and sta., Norfolk co., Mass, : on Dedbam Branch R. R., 6 m. S. W. Boston. Incorporated in 1851.

West Rumney, p. o. and sta., Grafton co., N. Hump. : on S. side of Baker's r., 44 m. N. N. W. Concord. The Boston, Concord, and Montreal R. R. passes through, $62 \mathrm{~m}$. from Concord.

Wrst Rupert, p. v. and sta., Bennington county, Term..: $76 \mathrm{~m} . \mathrm{S} . \mathrm{S}$. W. Montpelier. The Rutland and Washington R. R. passes through it, 47 miles from Troy, 38 miles from Rutland.

West Rush, p. o., Monroe co., N. Y. : $208 \mathrm{~m}$. W. by N. Albany.

W Est RushVILLE, p. v., Fairfleld co., Ohio: on W. side of Rush cr., 31 m. E. S. E. Columbus.

West Rurland, p. v, and sta., Rutland co, Ferm.: on W. side of Otter cr., 51 m. S. S. W. Montpelier. The Rutland and Washington $R$. R. passes through it, 4 miles from Rutland, 21 miles from Troy. It is beautifully located in a fertile valley, surrounded on all sides by high hills. It is noted for containing the flnest quarries of marble in America. At the two main quarries in this vicinity 500 men are employed; and besides 5 mills, which are turned by water, there is a steam-mill sawing an immense quantity of slabs daily. Their annual product is about $\mathbf{1 7 5 , 0 0 0}$ cubic feet of marble, valued at about $\$ 500,000$.

Wrst Rutland, p. V., Worcester co., Mass.: $49 \mathrm{~m}$. W. Boston.

WrsT's, sta., Middlesex county, $N$. Jer.: on Camden and Amboy R. R., $4.5 \mathrm{~m}$. from Philadelphia, 42 miles from New York.
West SAliem, p. o, Morgan county, Ind, : 80 m. S. W Indianapolis,

WEST SALEM, p. o., Wayne county, Ohio: on E. side of Muddy Fork of Walhonding r., 79 m. N. N. E. Columbus. West Salisbury, p V., Addison co., Verm. : 36 m. \$. W. Montpelier.

WTST SAKD LAKE, p. V., Rensselaer co., $N_{*} \bar{Y}_{*}: 10 \mathrm{~m}$. E. by S. Albany.

WEST SANDWIOH, p. \%. and sta, Barnstable co., Mass.: on Cape Coil Branch R. P., 25 m. from Mildleboro', $49 \mathrm{~m}$. S. E. by S. Boston.

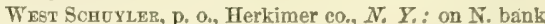
of Mohawk r., $77 \mathrm{~m}$. W. N. W. Albany.

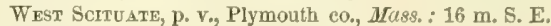
Boston.

WEST SEDGWICK, p. o., Hancock co, $M e_{0}: 56 \mathrm{~m} . \mathrm{E}_{\text {e }}$ Augusta.

West Shandaken, p. o, Ulster co, $N . Y$.: $54 \mathrm{~m}$. S. W. Albany.

West Shongo, p. o., Alleghany co., N. $Y_{0}: 229 \mathrm{~m}$. W. by S. Albany.

West Smatr, p. v., Kennebec co., Me.: 6 m. N. by W. Augusta.

West's Mruss, p. o., Franklin co., Me. : 32 m. N. N. W. Augusta.

West Somere, p. v., Westchester county, $N_{0}, Y_{0}: 94 \mathrm{~m} . \mathrm{S}$. Albany.

West Somerset, p. o., Niagara county, $N$. Y.: $256 \mathrm{~m}$. W. by N. Albany.

Wist Spring Creek, p. 0., Warren co., Penn.: $176 \mathrm{~m}$. N. W. by W. Harrisburg.

West SPRINGField, t., p. v., and sta., Hampden county Mass. : on W. side of Connecticut river, $82 \mathrm{~m}$. W. by $\mathrm{S}$. Boston. Surface of t. pleasantly diversified. Drained by Westfield r., which affords water-power. The t. contains several pleasant villages or settlements. The principal village, $2 \mathrm{~m}$. from Springfield, is very pleasant. The Western $R$. R. passes through it, $100 \mathrm{~m}$. from Boston, and $100 \mathrm{~m}$ from Albany. Pop. of t. 2,979.

West Sprix grield, pi v., Shelby county, Mo.: $82 \mathrm{~m} . \mathrm{N}$. Jefferson City.

West Sprivgrietd, p. v., Frie county, Penn.: $214 \mathrm{~m}$ N. W. by W. Harrisburg.

West StafFord, p. v., Tolland co., Conn.: 22 m. X. E. Hartford.

Wrst Stephentown, p. $v_{2}$, Rensselaer co., N. $Y_{.}: 18 \mathrm{~m}$ E. by S. Albany.

West Sterling, p. v., Worcester county, Muss. : $37 \mathrm{~m}$. W. by N. Boston.

W est Stewardstown, p. v., Cass co., $N$. Hamp. : on E side of Connectient river, $123 \mathrm{~m} . \mathrm{N}$. Coneord.

West Stockbridge, t., p. v., and sta., Berkshire county, Mass. : $120 \mathrm{~m}$. W. Boston, Surface uneven and hilly. Drained by William's r., which affords water-power. Limestone is abundant, and some excellent marble is found. The Western and Stoekbridge railroads cross this t., and connect at State line with Hudson and Berkshire R. R. The village on Stockbridge $R . R ., 3 \mathrm{~m}$. from State line, contains 3 churebes, several stores, manufactories, etc. Population of t. 1,713 .

West Stockbridge Centre, p. v., Berkshire co., MYas.. $123 \mathrm{~m}$. W. Boston.

West Stockirolu, p. v., St. Lawrence co., $N$. $\Gamma_{\text {. }}: 140 \mathrm{~m}$. N. N. W. Albany.

Wr.st Sufrigld, p. v., Hartiord co., Conn. : $17 \mathrm{~m} . \mathrm{N}$ Hartford.

West Sullivar, p. o., Hancock county, Mre.: $\$ 2 \mathrm{~m} . \mathrm{E}$ Augusta.

West Sumner, p. o., Oxford co., Me. : 86 m. W. Augusta. WEst Sutron., p. v., Worcester co., Ifass. : 40 m.W. S.W Boston. It contains 2 churches, stores, ete.

West Swanzer, p. o, Cheshire co, $N$. Hamp. : $45 \mathrm{~m}$. S. W. by W. Concord. 
WeSt TAGHKanio, p. o., Columbia county, $N . Y_{0}: 36 \mathrm{~m}$. S. by E. Albany.

WEst Therkesa, p. o. Jefferson co., N. Y. : $150 \mathrm{~m} . \mathrm{N}$. W. Albany.

West Thorkton, p. $\nabla .$, Grafton co., $N$. Hamp.: on W. side of Pemiwagasset river, $51 \mathrm{~m}$. N. by W. Concord.

West Tisbukr, p. v., Dukes co., Mass.: 72 m. S. S. E. Boston. It enntains 2 churehes, stores, etc.

West Topsham, p. v., Orange co., Verm.: on N. side of Wait's river, $18 \mathrm{~m}$. S. E. by E. Montpelier.

West Town, p. v., Orange con, N. $Y_{*}: 96$ m. S. S. W Albany. It contains several stores, an academy, and church. Pop. about 230.

West Townskand, p. v., Middlesex co., Mass.: on branch of Nashua r., $41 \mathrm{~m} . \mathrm{N} . \mathrm{W}$. by W. Boston. The Peterboro' and Shirley R. R. passes through it, 12 miles from Groton junction. It contains a female seminary of high repute.

West Townsaend, p. v., Windham co., Verm.: $87 \mathrm{~m}$. S. Montpelier.

West Treanton, p. v., Hancock co., Me.: 70 m. E. by N. Augusta.

Wrast Troúpsburg, p. Y., Steuben co., N. Y.: $202 \mathrm{~m} . \mathrm{W}$. by S. Albany.

Wzest Trox, p. Y., Albany county, $N$. $Y_{\text {. : }}$ on W. bank of Hudson $\mathrm{r}, 6 \mathrm{~m}$. N. by E. Albany. This flourishing vlllage was incorporated in 1836, and has had a rapid growth. The Erie Canal here connects with the Hudson $r$. by lateral canals and locks, and transfers to it a large proportion of the canal-boats with their freight of produce, merchandise, etc., unbroken, which are thence towed by steamboats to New York. A large number of steam-barges, sloops, and schooners are here owned and employed in transportation. The surplus waters of the canal afford very great waterpower, improved by numerous factories and mills. Other manufacturing establishments using steam-power, are also numerous. The Meneely bell foundry is the most extensive of the kind in the Union. The general interests of this place are directly connected with Troy, of which it is properly a suburb. It also contains 10 churches, and the WaterFliet arsenal, established here in 1813 by the United States, This is the largest arsenal of construction in the Union, comprising about 40 buildings upon its grounds of 100 aeres, employs about 200 men, and at all times has on hand immense quantities of munitions of war. The "W. Troy Advocate" (neut.) is issued weekly. Pop. 7,564.

What Union, p. v., Knox co., Ind. : 4 m. E. Wabash $r_{*}$ $90 \mathrm{~m}$. S. W. Indianapolis.

West UntoN, D. Y, and cap. Adams co., Ohio: $79 \mathrm{~m}, \mathrm{~S}$. by $W$. Columbus. It contains the county buildings, two churches, stores, ete. The "Adams County Democrat" is here published. Pop. 462.

West Union, p. 0., Fayette county, Ia. $: 84 \mathrm{~m}$. N. by W. Iowa City.

West UnioN, p. v., Pickens dist. S. Car.: 128 m.W.N.W. Columbia.

Wrest Unron, p. 0., Steuben co., N. Y.: $203 \mathrm{~m}$. W. by $\mathrm{S}$. Albany.

W pst Unton, p, v, and cap. Doddridge county, Virg. : $212 \mathrm{~m}$. N. W. by W. Richmond. It contains a court-house, jail, and several stores. Pop. 161.

Wrst Unitx, p. o., Williams co., Ohio: 133 m. N. W. by N. Columbus. The "Equal Rights" (dem.) is here published. West Vermillion, p. o., Erie co, Ohio: 98 m. N. by E. Columbus.

W est VIFNA , p. o, Onelda co, $N_{0} Y_{\bullet}: 116 \mathrm{~m}$. W. N. W. Albany.

Wrest VIEW, p. O., Angusta co., Virg.: 98 m. W. N. W. Fiehmond.

W FST VIET, p. 0., Hamilton co., Tenn. : 108 m. S. E. of Nashrille.

Westrille, p. v., New Haven co., Conn. : $8 \mathrm{~m}$. N. W. of New Haven. It contains several manufactories.

W estrille, p. vo, and cap. Simpson county, 1fiss.: $38 \mathrm{~m}$. 926
S. S. E. Jackson. It contains the county buildings, Pop about 130 .

Westrilute, p. $\nabla_{\star}$, Otsego co., $N_{*} Y_{*}$ : on E. side of Susquehanna r., $58 \mathrm{~m}$. W. Albany.

Westrille, p. v., Champaign co, Ohio: $4 \frac{7}{\mathrm{~m}} \mathrm{~m}$, W. Urbana, $43 \mathrm{~m}$, W. by N. Columbus.

Wrest Vndoent, p. o., Chester co., Penn。: 67 m. E. by S. Harrisburg.

WeSt Walworte, p. O., Wayne county, N. $Y_{.}: 192 \mathrm{~m}$. W. by N. Albany.

WEST W ARDSBORO', p. v., Windham co., Termi.: $90 \mathrm{~m}$. S. by W. Montpelier.

W EST W AREHAM, p. v. and sta, Plymouth oo, Mass, : on the Cape Cod Branch R. R., $11 \frac{1}{8} \mathrm{~m}$. from Middleboro', and, by railroad, $46 \mathrm{~m}$. $\mathrm{S}$. S. E. from Boston. It contains several manufactories.

West Waterville, p. v. and sta, Kennebec co, Me. : at N. end of Snow's Pond, $17 \mathrm{~m}, \mathrm{~N}$. Augusta. Emerson's stream here affords great water-power. The Androscoggin and Kennebee R. R. passes through, $75 \frac{1}{\mathrm{~m}} \mathrm{~m}$. from Portland, $61 \mathrm{~m}$. from Waterville.

West Webster, p. o., Monroe co., N. Y.: 197 m. W. by N. Albany.

West WilliamsField, p. 0., Ashtabula co., Ohio: $160 \mathrm{~m}$. N. E. Columbus.

West Whrteland, to and p. 0., Chester co., Penn. : $72 \mathrm{~m}$. E. by S. Harrisburg.

West Willington, p. 0., Tolland county, Conn.: $22 \mathrm{~m}$. E. N. E. Hartford. The New London, Willimantic, and Palmer R. R. passes near it, $45 \mathrm{~m}$, from New London, $21 \mathrm{~m}$. from Palmer.

West W INCheSter, p. v. and sta., Cheshire co., N. Hamp.: on Ashuelot R. R., 15 m. from Keene, 8 m. from South Vernon, $55 \mathrm{~m}$. $\mathrm{S}$. W. Concord. It contains several manufactories.

Wesx Windhas, p. o., Rockingham co., N. Hamp.: $83 \mathrm{~m}$. S. by E. Concord

West Windham, p. v., Bradford county, Penn。: $120 \mathrm{~m}$. N. by E. Harrisburg.

West W INDSor, p. v., Broome co., N. Y. : 112 m. W. S. W. Albany.

W EST W INDSOE, p. Y., Richland co., Otio: 63 m. N. N. E. Columbus.

W Fst WINDSOR, p. 0., Eaton county, Mfich.: $10 \mathrm{~m}$. S. W. Lansing.

W EST WINFTELD, p. o, Herkimer county, $N . Y_{0}: 76 \mathrm{~m}$, W. by N. Albany.

WEST WINSTED, p. Y, and sta., Litchfield co, Conns: on Mad r., a branch of Farmington r., $23 \mathrm{~m}$. N. W. by W. Hartford, $45 \mathrm{~m} . \mathrm{N}$. by W. New Haven. Here terminates the Naugatuck R. R., $62 \mathrm{~m}$. from Bridgeport, This $\mathrm{v}$. is noted chiefly for its manufactures. Water-power is furnished by the outlet of Long Lake, an interesting pond $3 \frac{1}{2}$

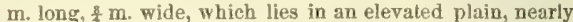
1 $\mathrm{m}$. above the plain below. This outlet is but a small stream, in a narrow channel, but affords great and permanent power to the factories on its banks. Among these are an extensive cutlery establishment ; one coach axle do.; a large machine shop; a tannery 140 feet long, and 4 stories high; various establishments making hoes, shovels, edge tools, sashes, and blinds; also large scythe factories; 2 woolen do., making satinets and cassimeres ; an iron foundry, etc. The flourishing condition and prospects of Winsted have most furorably affected its growth. and many new buildings are erecting to accommodate the increase of population; among which is a flne hotel, containing over 100 rooms. The Winsted Bank has a cap. of $\$ 100,000$.

West Wood, p. v., Woodford co., $M_{\text {. }}$ : on N. side Mackinaw cr., $66 \mathrm{~m}$. N. N. E. Springfleld. The nlinois Central R. R. will pass a little E. of this place.

West Woodstock, p. V., Windham co., Conn. : on E. side of branch of Natchaug r., $38 \mathrm{~m}$. E. N. E. Hartford. It contains a church and sereral dwellings. 
West Woodrilue, p. v., Clermont co., Ohio: on W. side of Stonelick er., $71 \mathrm{~m}$. S. W. Columbus. The Cincinnati, Hillsboro', and Parkersburg R. R. passes a little N. of this place.

West Worthongton, p. v., Hampshire co., Mass.: $97 \mathrm{~m}$. W. Boston.

W TST WreNrHay, p. v., Norfolk county, Mass. : $28 \mathrm{~m}$. S. W. by S. Boston.

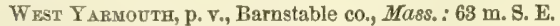
Buston. It contains 2 churches, etc.

W est Yorkshtre, p. O., Cattaraugus co., $N . Y_{.}: 252 \mathrm{~m}$. W. by N. Albany.

WETHEREDVIL,LE, p. v., Baltimore co., Md. : on Gwinn's Falls, $4 \frac{1}{2} \mathrm{~m}$. W. N. W. Baltimore. It is 300 feet above tidewater, with a fall within its limits of 90 feet, which affords immense water-power. The cassimere factories of Wethered Brothers are here located, with several mills making coarse cotton cloth, besides numerous flouring and other mills in the vicinity. Pop. of neighborhood about 750 .

Wethersfered, t. and p. v., Hartford co., Conn.: on W. side of Connecticut r., $3 \frac{1}{\mathrm{t}} \mathrm{m}$. S. Hartford. Surface of $t$. generally level ; soil sandy loam, and very fertile, producing large crops of regetables, especially onions. The v. in N. E. part of $t$ is very pleasant, having wide streets, beautifully shaded with elms; and contains 2 academies and 3 churches. The Connecticut State Prison, here located, is a massive building of Portland (Conn.) sandstone; and contained, on March 31st., 18ṽo, 175 inmates-163 males, 12 females. Pop. of t. 2,523 .

Wettersfield, p. v., Henry co., $M l_{*}: 98 \mathrm{~m} . \mathrm{N}$. by W. Springfield.

WeTHERsFied, to and p. 0. , Wyoming co.; N. $Y_{0}: 235 \mathrm{~m}$. W. Albany, Pop. 1,459.

WethersField SPRings, p. v., Wyoming county, $N_{0} \mathbf{Y}$. : $237 \mathrm{~m}$. W. Albany. It contains 3 churches, several stores, etc. Pop, about 160 .

Wetumpka, p. c., Coosa co., Ala : on E. side of Coosa r. $18 \mathrm{~m}$. N. N. E. Montgomery. It has a fine site, at the head of steamboat navigation, and is a place of considerable trade. It contains 5 churches, with numerous stores, etc. The "State Guard" (dem.) is published tri-weekly and weekly. The State Penitentiary, here located, on Oct. 1st., 1851, contained 156 convicts. Pop. 3,016. The Harrowgate Springs, S. of the city, possess valuable properties, and are of great resort during the summer.

Wetzex county, Virg. Organized from Tyler in 1846. Situate N. W., and contains $55 \mathrm{~S}$ sq. m. Drained by branches of Ohio r. Surface hilly and broken; soil moderately fertile, adapted to grain and grazing. Chief products wheat, Indian corn, and tobacco. It contains a large quantity of bituminous coal. Farms 423, manuf. 8 , dwell. 716 , and pop.-wh. 4,261, fr. col. 6, sl. 17-total 4,284. Capital: Wetzel C. H. Public Works: Baltimore and Ohio R. R.

WEVERTON, p. v. and sta., Frederick co, Md.: on W side of Potomac r., at confluence of Israel cr., $66 \mathrm{~m}$. W. N. W. Annapolis. The Chesapeake and Ohio Canal passes through it ; also the Baltimore and Ohio $\mathrm{R} . \mathrm{R} ., 80 \mathrm{~m}$. from Baltimore, and $300 \mathrm{~m}$. from Wheeling.

WEXFord county, Mich. Situate N. W. of the Southern Peninsula, and contains 576 sq. m. Drained by the Manistee r. and its branches. Surface even, diversified with small lakes; soil fertile, and with cultivation adapted to the raising of wheat, corn, etc. Organized since 1850 .

WEXford, p. v., Alleghany co., Penn。: 166 m. W. by N. IIarrisburg,

WEYAUWEYA, p. o., Winnebago co., Wise.: $86 \mathrm{~m}$. N. N.E. Madison.

Weybridge Lower Falls, p. o., Addison co., Term.: $83 \mathrm{~m}$. S. W. by W. Montpelier.

Weymouth, t., p. v., and sta., Norfolk co., Mass. : $11 \mathrm{~m}$. 8. S. E. Boston. Surface of t. pleasantly diversified, well watered by large ponds, and several streams flowing into two large inlets of Boston harbor called Fore and Back rivers. The t. contains several pleasant villages, of which Weymouth $v_{.}$, or Weymouth landing is the largest. This is well situated, at the head of Fore r., contains several stores, etc., and 1 bank, cap. $\$ 100,000$, and has considerable business and coasting trade. The manufacture of boots and shoes is carried on extensively. The South Shore R. R. passes through it, $12 \mathrm{~m}$. from Boston. Pop. of $t_{t}$ in 1840, 8,738 ; in $1850,5,369$.

Weirmouru, p. o., Atlantic $\mathrm{co}_{0}, N_{*}$ Jer.: on Great Egg Harbor r, $47 \mathrm{~m}$. S. Trenton.

Wетмовтн, p. v., Medina co., Ohio : ou branch of Rocky r., $102 \mathrm{~m}$. N. E. by N. Columbus.

Whaleystille, p. v., Woreester co., Ma.: on E. bank of Pocomoke r, $81 \mathrm{~m}$. S. E. Annapolis.

Whallousiburg, p. o., Essex co., $N . Y_{0}:$ on E. side of Boquet r., $110 \mathrm{~m}$. N. by E. Albany.

WHARToN county, Texo. Situate S. E., and contains 1,256 sq. m. Drained by Colorado river, which passes through the county, and by branches of San Bernardo $x_{\text {., }}$ and other small streams. Surface in general level, but in parts it is undulating; soil fertile, and is a rich black mold, very productive, and well adapted to cotton, corn, and tobacco. The soil of the prairies is good, and supports a dense crop of grass, Farms 55; manuf. 0; dwell. 112; and pop.-wh. 510, fr. col. 0-total 1,242. Oapital: Wharton.

Whartow, t. and p. 0., Potter co., Penn。: 105 m. N. W. Harrisburg. Drained by E. branch of Sinnermahoning cr. Interests agricultural.

WharToN, p. v. and cap., Wharton co., Tex.: on N. E. bank of Colorado r., $117 \mathrm{~m}$. S. E. by E. Austin City. It contains the county buildings.

Wrakton's, p. o., Noble county, Ohio: $71 \mathrm{~m} . \mathrm{E}$. by S. Columbus.

Whateley, t., p. v., and sta., Franklin co., Mass. : $80 \mathrm{~m}$. W. Boston. Bounded E. by Connecticut r. Drained by Mill r., which affords water-power to various millz. The $\mathbf{v}$. is on Connectieut River $\mathrm{R} . \mathrm{R}_{\mathrm{o}}, 26 \mathrm{~m}$. from Springfield. Pop. of $t, 1,101$.

Wheal Pronerer Mine (formerly "Fentress Mine"), Guilford co., N. Car. : $10 \mathrm{~m}$. S. Greensboro', and $73 \mathrm{~m}$. W.N.W. Raleigh. This mine, which is owned by the North Carolina Copper Mining Company, is located on the geological range, between the slates and granites, which is the great metalliferous line E. of the Alleghanies. The mine was formerly worked for gold, the vein having been explored to the depth of 60 feet, but the gold giving out, it is now worked solely for its copper. The vein is entirely on the Company's property, but in its comparatively short extent, it has proved to be the best in the country, and, compared with the veins of Europe, probably the richest and largest ever discovered. While at the surface the thickness of the vein is inconsiderable, at the depth of 60 feet it measures 5 feet, and at 70 feet has increased to over 8 feet, the regular dip beginning at this point in such a manner that while the inclination of the hanging wall is $35^{\circ}$, that of the lower wall is $45^{\circ}$, thus occasioning for every few feet advanced, an increase of a foot in the thickness of the vein. The vein is a regular one, and consists of alternate layers of quartz and copper pyrites, and spathic iron, containing 33 per cent. of metal. It is supposed that when machinery is applied to the working of the mine, that 50 men will take out monthly 400 tons of ore. Several other mines have been discovered in the vicinity, which, if equally rich with the Whesl Pioneer, will add greatly to the resources of the State, and stimulate the people to enterprise and energy.

Wheatland, p. o., Ionia co., Mich: $32 \mathrm{~m}$. W. N. W. Lansing.

Wheatrayd, t. and p. 0., Monroe county, $N . Y .: 214 \mathrm{~m}$. W. by N. Albany. Drained by Allen's er, tributary of Genesee river. The $t$, contains several mills and tanneries, but the inhabitants are chiefly engaged in agriculture, etc. Pop. 2,917.

Wheatland, to and p. 0., Kenosha county, Wisc.: $71 \mathrm{~m}$. 
S. E. by E. Madison. Fox r. flows through its N. E. part, and receives branches from the interior. Pop. 1,193.

Wheatlard, p. o., Loudon county, Firg.: $205 \mathrm{~m} . \mathrm{N}$.

Richmond.

Wheatland Centre, p. o., Hillsdale co, Fich $_{*}: 52 \mathrm{~m}$.

S. by E. Lansing.

Wheatley, p. o., Fauquier co., Virg.: 65 m. N. by W. Richmond.

Wheat Ridge, p. o, Adams co., Ohio: 73 m. S. S. W. Columbus.

Wheatrille, p. v., Genesee co., N. Y.: 236 m. W. by N. Albany.

Wreetar, t. and p. o, Steuben co., $N . Y_{.}: 157 \mathrm{~m}$. W. Albany. Drained by branch of Conhocton r. Pop. 1,471.

Wneelersbura, p. v., Scioto co., Olio : on Ohio r., $56 \mathrm{~m}$. S. by E. Columbus. Pop. about 300 .

Wunering, p. o., Cook co., $11 \%$.: on E. side Des Plaines r., $182 \mathrm{~m}$. N. E. by N. Springfield:

Wheeling, p. v., Delaware co., Ind.: on $\mathrm{S}$. W. side of Mississinewa r., 53 m. N. E. Indianapolis.

WIrening, p. o., Holmes co., Miss, : on W. side of Big Black r., 65 m. N. N. E, Jackson.

WHEELING, p. city, port of entry, and cap. Ohio county, Firg.: on E, bank of the Ohio $\mathrm{r}_{*}, 247 \mathrm{~m}$. N. W. Richmondlat. $40^{\circ} 07^{\prime} \mathrm{N}$.; long. $80^{\circ} 42^{\prime} \mathrm{W}$. It occupies a fine site on a high bank of the river, along which it extends about $2 \mathrm{~m}$., but its extension W. is restrained by high hills. It is divided by Wheeking cr, here emptying into the Ohio, over which here is a beautiful stone bridge. The Ohio river is crossed by a wire suspension bridge, which is one of the finest structures of the kind in the world, and has the fol. lowing measurements: length of span, from centre to centre of the stone supporting towers, 1,010 feet; height above low-water mark, 97 feet; height of towers on Wheeling side, $153 \frac{1}{3}$ feet above low-water mark, and 160 feet above the abutment on which they stand. It is supported by 12 wire cables, laid in pairs, 3 pairs on each side of the flooring, each of which is 4 inches in diameter, composed of 550 strands, and 1,3S0 feet long. It has a carriage way 17 feet wide, and 2 footwalks, each $3 \frac{1}{3}$ feet wide. The wire used in its construction was manufactured by D. Richards \& Co., of Wheeling. It is capable of supporting a pressure of 618 pounds to the square foot, and cost $\$ 210,000$. In front of the city lies Zane's island, which contains 350 acres, and to which a bridge is constructed.

Wheeling is distinguished for enterprise in manufactures and trade. In the city and vicinity flouring-mills are very numerous, and form the leading interest of manufactures. The next most important manufactures are those of glass, nails, stoves, and all kinds of iron castings, steam-engines, woolen and coston goods, white and sheet lead, paper, etc. The Virginia Iron Works, here located, make about 1,100 kegs of nails per week. The silk factory of $J$. W. Gill is the largest in the Union; but is in operation only 3 months during the year, because of scarcity of stock. The city early experienced the advantages of its position for navigation on the Ohio, and its connections E. and W. by the National Road. The Baltimore and Ohio R. R. here terminates, $8 S 0 \mathrm{~m}$. from Baltimore. The Central Ohio R. R., now completed below Columbus and Zanesville, will here connect with the Hempleld R. R., now in construction to junction with the Pennsylvania I. I. at Grensburg. The Clevelind and Pittsburg R. R. is also being extended to Wheeling. The tonnage of Wheeling district on June 30th, 1850, was 5.934 tons, all of which was of the class "enrolled and licensed," permanent, employed in the coasting trade, and propelled by steam. Vessels built during the jear preceding, 4 steamers, 885 tons. In 1552, 38 steamboats, all high pressure, were here owned, with aggregate tonnage of 6.813 tons.

The city contains, besides the county buildings, 13 churches, several academies, and 2 banks, with aggregate capital of strit $111 \%$. Its newspaper press in 1550 consisted of the "Wheeling Guzette" (whig), and "Wheeling Even925 ing Argus" (dem.), each issuing daily and weekly editions and the "Virginische Staats Zeitung" (dem.) in German language, issued weekly. Pop. in 1810, 914; in 1820, 1,567; in $1830,5,221$; in $1840,7,855$; in $1850,11,391$.

Wheeling Vallex, p. o., Marshall co., Virg.: 289 m. N. W. Richmond.

WInelook, p. 0, Choctaw Nation, Ind. Ter.

WHEELock, p. o., Robertson co., Tex, : 90 m. N. E. by E. Austin City.

WheElock, t. and p. o., Caledonia county, Ferm. $29 \mathrm{~m}$ N. E. Montpelier. Drained by branches of Passumpsic $r$ Pop. 855 .

Whetstone, p. o., Morrow county, Otio: 48 m. N. by E. Columbus.

WhETSTONE river, Ohio: see OLENTANGY river.

Waigville, p. v, Lapeer eo, Mich. : 68 m. N.E. Lansing.

Whippx Swamp, p. 0., Beaufort dist., S. Car.: $73 \mathrm{~m}$. S. Columbia.

Wнттсомв, p. Y., Franklin county, Ind. : 60 m. E. S. F Indianapolis.

W ніте county, Ar\%c. Situate N. E. centrally, and contains 1,043 sq. m. Drained by Little Red r., tributary of White river, which forms its $\mathrm{E}$. boundary, and by other streams. Surface even; soil fertile, and adapted to grazing. Farms 307 ; manuf. 2 ; dwell. 455 , and pop.-wh. 2,309, fr. col. 2, sl. 308-total 2,619. Capital: Searcy.

WHIte county, $I l$. Situate $\mathrm{s}$. E., and containg $447 \mathrm{sq}$. m. Little Wabas h river and Skillet fork of same drain the co. Surface partly level, and partly undulating; soil fertile; staples, wheat and Indian corn. Tobacco is cultivated. It has some excellent prairie land in the $\mathrm{E}$. portion. The country bordering the streams is well wooded. Farms 1,101 ; manuf. 22 ; dwell. 1,587 , and pop.-wh. 8,816 , fr. col. 109-total 8,925. Capital: Carmi.

W Hнте county, Ind. Situate N. W: middle, and contains 504 sq. m. Drained by Tippecanoe r. and its several tributaries. Two-thirds of the surface is prairie, and at least one-half dry and gently undulating; soil rich, and the forest grow ths extensive. Farms 458; mariuf. 10; dwell. 821, and pop.-wh. 4,752, fr. col. 9-total 4,761. Capitur : Monticello. Public Works: New Albany and Salem Extension R. R

Wurte county, Tenn. Situate E. centrally, and contains $346 \mathrm{sq}$. m. Drained by Caney fork of Cumberland river and its affluents, Surface uneven, in parts hilly; soil fertile; staples wheat, grain, and tobacco. Pork and grain are exported. Farms 1,311; manuf. 22 ; dwell, 1,706, and pop.wh. 10,095, fr, col. 132, sl, 1,214-total 11,444. Capitul: Sparta Public Works: Lexington and M'Minnville R. R.

Wште mountains, $A$. Elamp.: these mountains, in the N. part of the State, are the highest in.New England, and among the highest in the United States. The range is in form nearly square, extending $\mathrm{N}$. and $\mathrm{S}$. about $26 \mathrm{~m}$, and E. and W. about $22 \mathrm{~m}$; but the more elevated summits are comprised within a range of 8 miles. The highest summits are covered with snow during the greater part of the year, and in clear weather are visible at sea more than 50 miles from shore. The elevations of the highest peaks are as (i) Llows:

Mount Washington . 6,226 feet / Mount Madison ...5,620 feet Mount Adams.....5,560" ". Mount Monroe...5,510 " Yount Jefferson. ...5,560 "6 Mount Franklin...5,050 6

besides which several others are little inferior in elevation. The ascent of these mountains is fatiguing, but not dangerous; and is frequently accomplished by summer visitors. The scenery from their summits is of surpassing interest, and of raried character. The construction of the Boston, Concord, and Montreal P. R., Atlantic and St. Lawrence $R_{\text {. }} \mathrm{R}_{\text {. }}$, and other lines of railroad toward this interesting vicinity, has greatly increased the number of summe: visitors, for whose accommodation there are numerous hotels kept in first-class style.

W HIтs river, $A r k .:$ is formed in Washington co, by the 
confuence of 3 branches, flows N. N. E., crosses into Missouri, then turns to the S. E., and holds this general course for $150 \mathrm{~m}$. until it receives Black r., its principal N. branch, after which it flows by winding course in general direction S. by E., until it empties into the Mississippi $r$. in Desha co. About 8 miles from its mouth it connects by a broad bayou, usually boatable, with Arkansas river; after which its course is through a great marsh or swamp. Its length is vver 600 miles; and although it is at present choked up in many places by accumulations of drift-wood, steamboats ascend to Batesville, $260 \mathrm{~m}$., and on the removal of these obstructions will ascend 200 miles farther. It receives numerous tributarics, of which several are large streams, and flows through a very fertile region.

WHITE river, Ind. : is formed by the confluence of the $\mathrm{E}$. and W. forks of White r., $20 \mathrm{~m} . \mathbf{S}$. E. Vincennes, and flows W. S. W. in winding course about $35 \mathrm{~m}$. to its entrance into Wabash $r$. Its stream is but little inferior to the Wabash, is about 600 feet wide, and navigable in high water for steamboats. The W. fork rises in Randolph co, ; in high water it is navigable for steamboats to Indianapolis, and flat-boats have descended it from near Winchester. The $\mathbf{E}$, fork is about 225 miles long, and boatable $150 \mathrm{~m}$. The numerous branches of these forks drain the entire central portion of the State.

W ruTE river, Jich. : rises in Newago county, flows S. W. through Oceana co., and enters Lake Michigan by a broad estuary.

WHTE river, Utah Ter.: a principal head branch of Colorado r., flowing through E. part of Utah co., about 150 $\mathrm{m}$. in W. course.

W fure river, Term. : rises in Granville, flows $\mathrm{S} . \mathrm{S} . \mathrm{E}$, N. E., and S. E., and empties into the Connecticut river in Firtford t. It is about 55 miles long, and receives several tributaries, each of which affords valuable water-power.

Wh нгте Asr, p. o., Alleghany county, Penn. : 168 m. W. Farrisburg.

Wнтте Chnorexs, p. о., Caroline county, Virg. : $28 \mathrm{~m} . \mathrm{N}$. Richmond.

White Cottage, p. o., Muskingum co., Ohio: $55 \mathrm{~m}, \mathbf{E}$. Columbus.

White Cotrage, p. o., Shelby co., Tex. : 244 m. E. N. E. Austin City.

White Creak, t. and p. v., Washington co., N. $Y .: 30 \mathrm{~m}$. N. E. Albany. Drained by Owl and Little White cr. flowing $\mathrm{S}$. into Hoosic $\mathrm{r}$. The $\mathrm{v}$. contains 2 churches, and several stores. Pop, of t. 2,994 .

White Cross, p. o., Orange co., N. Car. ; 35 m. N. W. Raleigh.

W arte DAצ, p. 0., Monongalia co., Virg. : 258 m. N. W. Richmond.

Whiтs Deer, p. o., Lycoming county, Penn.: $68 \mathrm{~m} . \mathrm{N}$. Harrisburg.

Whitr Deer Mruss, p. o., Union co., Penm. : $55 \mathrm{~m} . \mathrm{N}$. Harrisburg.

White Exe's Plains, p. o, Coshocton co, Ohio: on S. side of Tuscarawas r., 69 m. E. N. E. Columbus.

Wmitaface mountain, $N$. $Y .:$ on E. side of Wilmington r., in N. W. part of Essex co., is 4,855 feet above the Atlantic ocean.

Whitreicld, p. O., Oktibbeha co, Afiss. : on branch of Okanoxubee r., $95 \mathrm{~m}$. N. E. Jackson.

Whitefieid, p. o., Marshall county, $I l_{\text {. }}: 80 \mathrm{~m}$. N. by E. Springfield.

Whrtertetd, t. and p. o., Lincoln co, Me.: $14 \mathrm{~m} . \mathrm{S} . \mathrm{E}$. Augusta. Watered by Sheepscot river, which affords water-power. Interests of the town chiefly agricultural. Pop. 2,160.

Whitefield, t. and p. o., Coos co., N. Hamp. : 79 m. N. Concord. Drained by John's $\mathbf{r}$, on which are saw-mills. Pop. 857.

Wurte-Frse point, Chippewa co., Mich. : separates Tequamenon bay from Lake Superior.
W niteford, p. o., Lucas co., Ohio: 120 m. N. N. W Columbus.

White HaLL, p. v., Greene co., $M l_{\text {.: }} 48 \mathrm{~m}$. W. S. W. Springfield. It contains 3 churches, several stores, etc Pop. about 400 .

Writre HALL, p. 0, Hunterdon county, N. Jer.: $38 \mathrm{~m}$ N. by W. Trenton.

White Hall, p. o., Madison county, $K y_{*}: 44$ m. 8. E. Frankfort.

Writte Hals, t, p. vo, and sta, Washington co, $N$. $Y_{\text {. }}$ 58 m. N. N. E. Albany. Surface hilly. Drained by Pawlet river, Wood creek, and Pouitney river, which flow into the head of Lake Champlain. The $\mathrm{V}$. at the head of the lake is well situated for trade. The Champlain Canal extends hence $78 \mathrm{~m}$. to Albany. The Saratoga and Wasbington R. R. passes through, $13 \mathrm{~m}$. from Castleton, and it is proposed to build a railroad hence to Plattsburg. It contains four churches, several mills and manufactories, and two banks, with aggregate capital of $\$ 208,200$. The "Democrat," and "Chronicle" (whig) are here published. Pop. of v. about 3,000 ; of $\mathrm{t} .4,726$.

White HaLx, p. 0, Owen co., Ind.: 43 m. S. W. by S. Indianapolis.

WнITE HalL, p. V, Mecklenburg co, $N_{\text {. }}$ Car.: $120 \mathrm{~m}$. W. S. W. Raleigh. Pop. about 100.

Winte Hair, sta., Delaware co., Penn.: on Philadelphia and Columbia R. R., $10 \mathrm{~m}$. W. Philadelphia.

White Hall, p. o., Montour co., Penn. : 54 m. N. by E. Harrisburg.

White Hald, p. v., Fayette co., Tenn.: 160 m. W. S. W Nashville.

White Halt, p. o. and sta., Baltimore county, MLd.: on Baltimore and Susquehanna R. R., $26 \mathrm{~m}$. N. from Baltimore, $56 \mathrm{~m}$, from Harrisburg, $45 \mathrm{~m}$. N. by W. Annapolis.

White Hall, p. v., Frederick co, Virg. : 123 m. N. by W Pichmond. Pop, about 100.

White Hall, p. o., Clark county, Mo. : 128 m. N. by E. Jefferson City.

Whitemalitrlie, p. o., Bueks co., Penn. : 96 m. E. by N. Harrisburg.

White Hare, p. o., Cedar co., Mo.: 116 m. \$. W. by W. Jefferson City.

White Haven, p. v., Somerset co., Ma. . on W. side of Wicomico river, $60 \mathrm{~m}$. $\mathrm{S}$. E. by S. Annapolis. It has some coasting trade by vessels of considerable burden.

Write Haven, p. v., Luzerne co., Penn.: on W. bank of Lehigh r., and on the line of the Lehigh and Susquehanna R. R., $78 \mathrm{~m}$. N. E. Harrisburg.

WhiteheAd island, Lincoln county, $M e,:$ S. W. of W. entrance of Penobscot bay, $45 \mathrm{~m}$. S. E. Augusta. It contains a light-house. (See LrGHT-Houses.)

Whrте Hrul, p. 0., Giles county, Tenn.: 70 miles S. Nashville.

White House, p. o., Henry co, Ga. : 64 m. N. W. by W. Milledgeville.

White House, p. 0. Randolph co., $N$. Car.: $72 \mathrm{~m}$. W. Raleigh.

W mite House, p. O., Mecklenburg co, Virg.; on S. side of Roanoke river, $84 \mathrm{~m} . \mathrm{S}$. W. Richmond. The Roanoke Valley P. R. will pass through this place.

White House, p. o., Williamson co., Tenn

White House, p. v. and sta., Hunterdon co., $N$. Jer.: on S. E. side of Rockaway cr., $26 \mathrm{~m}$. N. Trenton. The New Jersey Central R. R. passes through, $50 \mathrm{~m}$. from New York, $28 \mathrm{~m}$. from Easton.

White House, p. o., Cumberland county, Penn.: $18 \mathrm{~m}$. W. S. W. Harrisburg.

White LaKe, p. o., Sullivan county, $N . Y_{.:} 88 \mathrm{~m} . \mathrm{s} . \mathrm{W}$. Albany. White lake, in the vicinity, is a small but very beautiful sheet of water, abounding with fish, ete. $\mathbf{A}$ good hotel accommodates summer visitors.

Whiteley, t, and p. o., Greene co., Penn. : $168 \mathrm{~m} . \mathrm{W}$. by S. Harrisburg. Drained by Whiteley cr.,flowing into Nonon- 
gahela r. It contains several tanneries, grist and saw mills.

Pop. about 2,500.

Wiutelexsbulg, p. V., Kent co., Del. : 17 m. S. W. by S.

Dover.

White Marsh, p. o., Columbus county, $N$. Car. : $99 \mathrm{~m}$.

S. Raleigh.

White Maese, t. and p. o., Montgomery county, Penn.:

$85 \mathrm{~m}$. E. Harrisburg. Drained by Wissahickon er., which

affords water-power to various mills. Pop. of t. about 2,400.

Write Mills, p. o., Wayne county, Penn. : 124 m. N. E.

Harrisburg.

White Mountan, p. o., Coos co., N. Hamp. : $74 . \mathrm{m} . \mathrm{N}$.

Concord.

Whіте OАк, p. o., Columbia co., Ga.: 64 m. N. E. by E.

Milledgeville.

WHite OAF, p. o., Pitchie co., Virg.: 223 m. N. W. by W.

Richmond.

White $O_{A k}$, t. and p. o., Ingham county, Dich.: $522 \mathrm{~m}$.

S. E. by E. Lansing. Pop, in 1S40, 270; in 1850, 508 .

Wнite OAK, p. o., Hopkins co., Teख. : 247 m. N. N. E.

Austin City.

WHite OAk, p. o., Humphreys co., Tenn. : 48 m. W. by N. Nashville.

White OAK Grove, p. o., Dubois county, Ind. : $102 \mathrm{~m}$. S. S. W. Indianapolis.

White OaK Grove, p. o., Greene county, DLo.: $117 \mathrm{~m}$. S. W. by S. Jefferson City.

Whте OAK HпL, p. 0., Fleming co, $\bar{k} y_{0}: 72$ m. E. by N.

Frankfort.

Whte OAK Sprive, p. v., La Fayette co., Wisc. : near

Illinois State line, 66 m. S. W. Madison.

White OAK Springs, p. o, Brown county, $17 \eta_{0}: 60 \mathrm{~m}$. W. Springfield.

Wuite Pati, p. o., Gilmer co., Ga, : $152 \mathrm{~m}$. N. W. by N. Milledgeville.

White Pigeon, t., p. V., and sta,, St. Joseph's co., Mich.

$80 \mathrm{~m}$. S. W. by S. Lansing, Drained by Pigeon and Fawn rivers, branches of $\mathrm{St}$. Joseph $\mathbf{r}$. The $\mathrm{v}$, contains 2 churches and several stores, The Michigan Southern $R$. R. passes through, $119 \mathrm{~m}$. from Chicago, $12 \mathrm{~s} \mathrm{~m}$. from Mouroe. Pop. of t. 794 .

Winte Plans, p. v., Benton county, Ala.: on W. side of Chneolucko cr., $105 \mathrm{~m}$. N. N. E. Montgomery.

White Plains, p. v., Greene co., Ga.: 80 m. N. N. E. Milledgeville, It contains an academy, 2 churches, and several stores, etc.

W mixe Pralws, t., p. V., sta., and cap. Westchester county,

N. Y.: $116 \mathrm{~m}$. S. Albany. Bounded W. by Bronx r., and E. by Mamaroneck er. The $r$. continins the cotanty buildings, 2 academies, 6 churches, and about 750 inbabitants The II:riem R. R. passes IF. of the v.,20 n. from the City Iall, Now Turk; 12s m, frum Allany. P(I), of t. 1, 114 .

Whre Prarvs, p. v., Cleveland county, N. Car.: $153 \mathrm{~m}$ W. by S. Raleigh.

Trute Puans, p. จ., Jackson co., Tenn. : 75 m. E. N. E. Nashrille.

Winte Plans, p. v., Brunswick county, Firg.: $65 \mathrm{~m}$. S. s. W. Richmond.

Whinte Poxd, p. Oo, Barnwell districh, $S_{0}$ Car.: $60 \mathrm{~m}$. S. by W. Columbia.

White Post, p. Os, Pulaski county, Ind. : $82 \mathrm{~m}$. N. N. W. Indianapolis.

THite Post, p. ₹., Clark co., Firg.: $115 \mathrm{~m} . \mathrm{N}$, by W Richmomil

WIITE RTER, p. O., Desha $n_{0,3}$ Arz: on White r., at its entrance into the Mississippi, $\$ 3$ m. S. E. by E. Little Rock. W nirte River, p. o., Morgan county, Ind.: $32 \mathrm{~m}$. S. W. Indianapolis.

W Hite Piver Juxctios, p. v. and sta., Windsor co., Verm. on W. side of Connecticut r., at confluence of White $r$. by I. li. $62 \mathrm{~m}$. S. E. by S. Muntpelier. The $v$, is pleasantly built, and contains an extensive iron-foundry and machineshop; but derives its busiues and importance from the 930 railroads here connecting: viz, Vermont Central $P, R$. Connecticut and Passumpsic Rivers R. R., and Northern (N. Hamp.) R. R.

White River Village, v. and sta, Windsor co., Verm. on White $r_{\text {., }}$ and Vermont Central R. R., $1 \mathrm{~m}$. from White River Junction, and by railroad, $61 \mathrm{~m}$. from Montpelier. It is built upon an elevated plain, principally upon the N. side of the r., and is encircled on the N. by a hill. A dam is here thrown across the stream, affirding water-power on both sides.

White Road, p. o., Forsyth co, N. Car.: 99 m. W. N. W. Raleigh.

Wнite Rock, t. and p. v., Ogle co, $17 \%$ : $153 \mathrm{~m}$. N. by E. Springfield. The t. contains considerable prairie land, and is drained by Stillman's river.

White Rock, p. o., Yancey county, N. Car.: 192 m. W. Raleigh.

Wirte Rock, p. o., Navarro co, Tea.: 146 m. N. N. E. Austin City.

Whites Boro', . and sta., Oneida county, $N$. $Y_{\text {. : }}$ on $\mathrm{S}$. W. bank of Mohawk r., 87 m. W. N. W. Albany. Settled in $17 \mathrm{S1}$; incorporated in 1813. It is very pleasantly bailt, and its streets are finely ornamented with shade trees. It contains the county buildings, 5 churches, 2 excellent academies, several large manufactories, and 1 bank, cap. $\$ 120,000$. The New York Central R. R. passes through it, $4 \mathrm{~m}$. from Utica, $99 \mathrm{~m}$. from Albany, $49 \mathrm{~m}$. from Syracuse. Pop. about $2,000$. Whitesburg, p. v., Madison cnunty, $A l a$ : on N. side of Tennessee r., $158 \mathrm{~m}$. N. Montgomery.

W nitksburg, p. v., and cap. Letcher county, Ky.: $123 \mathrm{~m}$. E. S. E. Frankfort. It contains the counly buildings.

Wute's Corvers, p. o, Erie county, $N . Y$. : $256 \mathrm{~m}$. W. Albany.

White's Corwers, p. 0., Potter county, Penn. : $110 \mathrm{~m}$ N. N. W. Harrisburg.

White's Creek, p. o., Bladen co., $\boldsymbol{N}$. Car?. : $80 \mathrm{~m}$. S. by E. Raleigh.

WHitesros ccunty, $\pi l$. Situate N. W., and contains $729 \mathrm{sq}$. m. Rock r. flows through the co. from E. to S. W., by which and its branches it is drained. Surface varied, part being level and part undulating; soil productive. Wheat and Indian corm are exported. Farms 1,404; manuf. 24; dwell. 923, and pop.-wh. 5,359, fr. col, 2total 5.861. Capitcl: Sterling C. H. Public Works: Chicago, Albany, and Camanche R. R.

W IIITEside's CorNers, p. on, Saratoga con, N. Y.: $40 \mathrm{~m}$. N. Albany.

White Springs, p. v., Hamilton county, Flor : 86 m. E. Tallahassee.

Write Stone, p. o., Lancaster co., Firg. : 55 m. E, by $\mathbf{N}$. Richmond.

Wute's Store, p. o, Chenango $\mathrm{Co}_{n}, N$. $Y_{\text {.: }}$ on W. side of Unadilla r., $87 \mathrm{~m}$. W. by S. Albany.

W нтте's Stokg p. 0., Anson co., N. Car.: 96 m. 8. W Paleigb.

Writestown, t., p. v., and one of the caps, Oneida co., N. Y. 88 miles W. N. W. Albany. Bounded N. E. by Mohawk r., and drained by Sadaquada and Oriskany creeks, which afford water-power. It contains several flourishing villages, of which Whitesboro' contains the Whitestown p. o. and the county buildings. The Erie Canal, and C'entral R. R. pass through its $\mathrm{N}$, part. Pop. of t, in 1840 5,$156 ;$ in $1850,6,810$.

Wutrfsown, v., Adams co., Penn. : 22 m. S. W. Harrisburg. It contains a cold-blast chareoal furnace, with annual capacity of 1,100 tons, employing 56 men.

Whitestown, p. 0., Butler co., Penn.: 168 m. W. N. W. Harrisburg.

WHTE SULPHUR, p. 0., Scott county, Ky.: 20 m. N. E. Frankfort.

White Solpior Sprixgs, p. v., Limestone county, Ala.: 175 m. X. by W. Montenumery.

Waite Sulphur Sphivgs, p. Y., Merriwether county, Ga.: 
on small branch of Chattahoochie river, $96 \mathrm{~m}$. W. by $\mathrm{s}$. Milledgeville.

White Sulperr Springs, p. o., Catahoula parish, La. : 108 m. N. W. by N. Baton Rouge.

White Sulphur Springe, p. v., Greenbrier co, Virg.: on a branch of Greenbrier r., $156 \mathrm{~m}, \mathrm{~W}$. by N. Richmond. These valuable medicinal springs have for many years been the principal summer resort in Virginia. Their location is in an elevated and beautifully picturesque valley surrounded by mountains. The average number of visitors per annum is usually 5 to 6,000 ; and upon the completion of the Covington and Ohio R. R., which will pass through this place, will be greatly inereased.

Whitestille, p. v., Harris co., Ga. : on branch of Chattahoochie $r_{.,} 111 \mathrm{~m}$. W. by S. Milledgeville.

Wuitesville, p. v., Wilkinson eo., Miss.: near Louisiana State line, $109 \mathrm{~m}$. S. S. W. Jackson.

Whrtestule, p. o., Halifax co., Virg. : 94 m. S. W. Richmond.

Whitesville, p. $\nabla_{0}$, Alleghany $c_{0}, N_{.} Y_{0}:$ on branch of Genesee r., 218 m. W. S. W. Albany. It contains several mills, stores, ete., and 2 churches.

Whitesville, p. v., sta., and cap. Columbus co., N. Car.: on W. side Whitemarsh cr., $93 \mathrm{~m}$. S Raleigh. It contains the county buildings, stores, etc. The Wilmington and Manchester R. R. passes through it, $43 \mathrm{~m}$. from Wilmington, Pop. abnut 350 .

WiItTesville, p. o., Andrew co., Mo.: $170 \mathrm{~m}$. N. W. Jefferson City.

White Top, p. o., Sullivan co., Tenna : 240 m. E. by N. Nashville.

Whiteville, p. v., Hardeman co., Tenn. : 145 m. W. S.W. Nashville, Pop, about 100.

White W ATER, p. o., Pike co., Ala. : on E. side of branch of Pea r., $54 \mathrm{~m}$. S. E. by $\mathrm{S}$. Montgomery.

W Hite W ATER, t, Hamilton co., Ohio: $102 \mathrm{~m}$. S. W. by W.

Columbus. Drained by Whitewater r. It contains several pleasant villages, among which is a Shaker settlement. See WatFrvilifet, ete. Pop. 1.567 .

White WaTer, p. o., Fayelte co., Ga.: 80 m. W. N. W. Milledgeville.

White Water, p. o., Wayne co., Ind.: near Ohio State line, $64 \mathrm{~m}$. $\mathrm{E}$. by $\mathrm{N}$. Indianapolis.

W HITE WATER, t., p. v., and sta., Walworth co., Wise. 39 m. S. E. by E. Madison. Watered by tributaries of Rock r. The Milwaukie and Mississippi R. R. passes through the v. in N. W. part of t, $50 \mathrm{~m}$. from Milwaukie, $20 \mathrm{~m}$. from Janesville. Pop. of t. 1,252

W FITE WATER river, Inds : is formed at Brookville, Franklin $\mathrm{cos}_{0}$ by the confluence of the $\mathrm{E}$. and W. forks; thence it flows S, E. and S., to its entrance into Miami r., 6 m. above its mouth. It affords water-power, has an average width of 300 feet, and is navigable in high water.

WhITE WATER river, Mo. and Ark.: is formed in Cape Girardeau co., Mo., by several head branches; thence flows in general course S. by W., and nearly parallel to the Mississippi, until it enters St. Francis bay, in Mississippi county, Arkansas.

Whiтivg, t. and p. o., Washington county, Me.: $109 \mathrm{~m}$. E. by N. Augusta. Surface diversiffed by numerous ponds. Machias bay lies on its $\mathrm{S}$. W. border. Pop. 470 .

W Hiting, t., p. o., and sta, Addison co., Verm. $41 \mathrm{~m}$ 8. W. Montpelier. An agricultural township. The Rutland and Burlington R. R. passes through its E. part, along the banks of Otter ereek, $75 \mathrm{~m}$. from Bellows Falls, $45 \mathrm{~m}$. from Burlington. Pop. of $\mathrm{t} .629$.

WHITINGHAY, to and p. o., Windham co, Vermo: $106 \mathrm{~m}$. S. by W. Montpelier. Drained by Deerfield $r$. and branches It contains abundance of limestone, and an excellent mineral spring. Pop. 1.380

Whrtiss, sta., Worcester co., Mass. : on Providence and Worcester P. R., $17 \mathrm{~m}$, from Worcester, $26 \mathrm{~m}$. from Providence, $34 \mathrm{~m}$. 8 . W. by W. Boston.

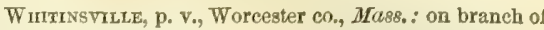
Blackstone r., $36 \mathrm{~m}$. \$. W. by W. Boston

WHTLEY county, Ind. situate N. E., and contains 324 sq. m. Drained principally by Eel $r$, and its tributaries, In the $N$. and middle portions the surface is undulatingsometimes hilly; but in the \$. level. Forest land, interspersed with wet prairies, preponderate; but there are also considerable bottoms and barrens. Farms 522 ; manuf. 8 dwell. 918, and pop.-wh. 5,095, fr. col, 95-total 5,190. Capital: Columbia.

WhItLEy county, $K y$. Situate S. E., and contains $704 \mathrm{sq}$ m. Drained by Cumberland r. and its branches, Surface hilly; soil fertile, and in general very productive, the uplands being well adapted to grazing, and much grain is raised. Chief productions, Indian corn and tobacco, Farm 980 ; manuf. 0 ; dwell. 1,214, and pop.-wh. 7,227, fr. col. 19, sl. 201-total 7,447. Capital: Williamsburg. Public

Works : Knoxville and Lexington R. R.

WIITtuEY C. H., p. V., and cap. Whitley con, Ind. : in Columbia $v_{s}$, on N. W. side of Eel river, 101 m. N. N. E Indianapolis

Whircey C. H., p. V., and eap. Whitley co., $K y_{0}:$ in

Williamsburg v., on S. side of Cumberland r., $88 \mathrm{~m}$. S. S. E. Frankfort.

Whitley's Point, p. o., Shelby co, $\pi l$. : 65 m. E. S. E Springfield.

Whitleytrle, p. o., Jackson co., Tenn. : 55 m. E. N. E. Nashville.

Whitnex's Corners, p. o., Jefferson co., N. Y.: $152 \mathrm{~m}$. N. W. by W. Albany.

Whitney's Point, p. o., Broome county, N. Y.: $116 \mathrm{~m}$. W. by S. Albany.

Whitney's VAliex, p. v. and sta., Alleghany co., $N$. $Y$. : on Buffalo and New York City R. R., $78 \mathrm{~m}$. from Buffalo, $13 \mathrm{~m}$. from Hornelisville, $214 \mathrm{~m}$. W. Albany. It contains 2 churches, several stores, ete.

WhITNEYTILLe, p. v, and sta, Washington co, Me.: on S. W. side Machias r., and on the Franklin P. R, $9 \mathrm{~m}$. from Machiasport, 114 m. E. by N. Augusta.

Wuitneyville, p. o., Kent co., Mich.: 58 m. W. N. W. Lansing.

W irtTlesey, p. o., Medina co., Ohio: $96 \mathrm{~m}$. N. E. by N. Columbus.

Whitrle's Mills, p. o, Mecklenburg co., Virg. : $87 \mathrm{~m}$. S. W. by S. Richmond.

Wrck, p. o., Tyler county, Virg.: $280 \mathrm{~m}$. N. W. by W. Richmond.

WICKFORD, p. V., Washington co, $R, I_{\text {. }}$ : on W, side of branch of Narragansett bay, $9 \mathrm{~m} . \mathrm{N}$. W. Newport. It has a good harbor, and employs considerable tonnage in the fisheries and coasting-trade. It contains three churches, an academy, and one bank. Pop. about 500. The Stonington and Providence R. R. passes through Wickford Depott, $3 \mathrm{~m}$. $\mathrm{W}$. of the village, 30 miles from Stonington, 20 miles from Providence.

WickirfFe, p. v., Chambers county, Alla.: $66 \mathrm{~m}$. E. N. E. Montgomery.

WiCKLiFFe, p. v., Crawford co., Ind.: $98 \mathrm{~m} . \mathrm{S}$. by W. of Indianapolis

WICKLIFFE, p. v., Jackson co., Ia.: $54 \mathrm{~m}$. N. E. of Iowa City.

WrckLirfe, p. v., Lake co., Otio: 140 m. N. E. by N. of Columbus.

Wicomico Churce, p. o., Northumberland co., Firg. $5 \mathrm{~S}$ m. E. N. E. Richmond.

WiconisoA, to and p. o., Dauphiu co, Penn. : $22 \mathrm{~m}$. N. of Harrisburg. Pop. of t. about 500 .

WIdEMAN's, p. o., Abbeville district, S. Car: : $75 \mathrm{~m}$. W Columbia.

WILRRAhAN, to and p. v., Hampden co., Mrass. : $72 \mathrm{~m}$ W. by S. Boston. Drained by head branches of Seantic river, and other streams flowing into the Connecticut $r$. The $\mathrm{y}$. contains two churches and the Weslevan Academy, a flour- 
ishing Methodist institution. The Western R. R. passes through the N. part of the t. Pop. of t. 2,127.

Wiloox county, Ala. Situate toward the S. W., and contains $906 \mathrm{sq} . \mathrm{m}$. Alabama r. flows through it, by which and its branches it is drained. Surface uneven; soil in some parts very fertile; on the streams the land is in general very productive. Staples, Indian corn and other grain, cotton, rice, and potatoes. It has some good timber land. Farms 666; manuf. 6 ; dwell. 983, and pop.-wh. 5,516, fr. col. 1, sl, 11,835-total 17,352. Capitul: Camden C. H.

Wricox's Store, p. 0., Casey county, Ky. : 60 miles S. of Frankfort.

WrLd CAT, p. o., Carroll county, Ind. : 53 milés N. N. W. Indianapolis.

WILDERness, p. o., Spottsylvania county, Virg.: 44 miles N. by W. Richmond.

Wruderness, p. o., Clark co., Ala.: on small branch of Tombigbee r., $109 \mathrm{~m}$. W. S. W. Montgomery.

Wild Haus, p. 0., Izard co., Ark. : 91 m. N. by E. Little Rock.

Wiley's Cove, p. o., Searcy co., Ark. : on E. side of Cove cr. $74 \mathrm{~m}$. N. by W. Litile Roch.

Wileyville, p. o., Desha co., Ark.: 74 m. S. W. by S. Little Rock

Wrikrs county, Ga. Sitnate toward the N. E., and contains $486 \mathrm{sq} . \mathrm{m}$. Fishing cr, and its branches, and affluents of Broad and Little rivers drain the county. Surface level; soil fertile, and adapted to cotton, which is the chief production, and also to wheat and grain, fine crops of which are raised. Pork and beef are exported. Farms 46s; manuf. 9 ; dwell. 709 , and pop.-wh. 3,805 , fr. col. 21 , sl. 8,281-total 12,107. Capital: Washington.

Wrukes county, $N$. Car. Situate N. W., and contains 579 sq. m. Drained by Yadkin r. and its branches. Surface elevated, and diversified with mountains and valleys; soil fertile, and well fitted for pasture. Chief productions, tobaceo, eotton, and Indian corn. This county is bounded on the N. W. by the Blue Ridge. Farms 1.097 ; manuf. 9 ; dwell. 2,050 , and pop.-wh. 10,746, fr. col. 211, sl. 1,142-total 12,099. Capital: Wilkesbors'.

Wrlesparre, p. b., and cap. Luzerne co., Penn.: on S. F. bank of Susquehanna r., $\$ 2 \mathrm{~m}$. N. I. by N. IIarrisburg. The t. has a diversified surface, and is in the midst of the anthracite coal region. The b, occupies a rery beautiful and elevated situation, and is surrounded by delightful seenery. It is laid out according to a beautiful plan of general regularity, and is neatly built. The county buildings are liandsomely located on a publlic square at its centre. It

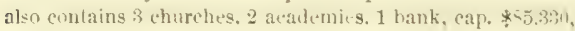
1 anthracite blast furnace, with annual capacity of 1.500 tons, employing 50 men, one of the largest rolling-mills in the Union, employing 250 men, and producing annually about 3,500 tons, besides other manufacturing establishments. The North Branch Dirision of the Pennsylvania Canal passes through the borough. The "Luzerne Democrat" and "Dem. Wachter" are issued weekly. This place, with the vicinity surrounding it, are of much historical interest. It was first settled under the Susquehanna Land Company of Connecticut, and was laid out in 1773 . Its founders were of the best citizens of $\mathrm{New}$ England, intelligent, enterprising, and patrintic. Their conflicts in the Revolution with the allied British and Indians, especially that of the disastrous "Massacre of Wyoming," are recorded in the annals of the nation, and commemorated on the field of their battle by a beautiful monument. Pop. in $1840,1,718$; in 1850 , 2.723

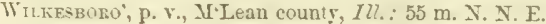
Springfeld.

Wilkesвoro, p. v., and cap. Wilkes co., N. Car.: on $\mathrm{s}$. side of Yadkin r., $133 \mathrm{~m}$. W. by $\mathrm{N}$. Raleigh. It contains the court-hnuse, jail, stores. etc. Pop, about 180.

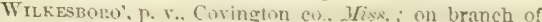
Pearl r., 65 m. S. S. E. Jackson.
WILKFSVILle, t. and p. v., Vinton co, Ohio: $68 \mathrm{m.} \mathrm{S.} \mathrm{E.}$ by $\mathrm{S}$. Columbus. Drained by Raceoon cr., which affords water-power to several grist and saw-mills, The Cincinnati, Hillsboro', and Parkersburg $R$. $R$. will pass through this t Pop. of t. 1,037 .

WrlkiNs, p. o., Union co., Ohio: $41 \mathrm{~m}$. N. W. Columbus.

WiLkINs, t. and p. 0., Alleghany co., Penn.: $10 \mathrm{~m}$. E. by S. Pittsburg, 148 milles W. by N. Harrisburg. Population about 2,500 .

Wпктssburg, p. v. and sta., Alleghany co., Penn.: on Pennsylvania R. R., $7 \mathrm{~m}$. from Pittsburg, $151 \mathrm{~m}$. W. by N. Harrisburg.

WIKINSoN county, $G a$. Situate centrally, and contains 388 sq. m. Drained by Big Sandy and Commissioner creeks, branches of Oconee r., which forms its eastern boundary. Surface level or undulating; soil fertile, and in part very productive. Cotton is the staple, but excellent crops of wheat and grain are raised, and fruit is much cultivated, oranges, lemons, eitrons, peaches, plums, pears, and pomegranates being produced of excellent flavor and quality. Farms 645; manuf. 0; dwell. 953 , and pop.-wh. 5,467 , fr. col. $0 ;$ sl. 2,745-total 8,212. Capital : Irwinton. Putlic Works: Georgia Central R. R.; Milledgeville and Gordon R. R.

WILKIrson county, Miss. Sitaate S. W., and contains $654 \mathrm{sq} . \mathrm{m}$. Drained principally by Buffalo cr., which passes through it centrally. Surface in general is hilly, and in parts much broken. On the Mississippi, which bounds it on the W., the land is high, from which it inclines to the interior; soil fertile, and is well adapted to cotton, which is the chief production. Farms 404; manuf. 15; dwell. 736, and pop.-wh. 3.624, fr. col. 30, sla. 13,260-total 16,914. Capital: Woodville.

WiLkissoyrille, p. v., Worcester co., MIass.: on \$. side of Blackstone r., 35 m. W. S. W. Boston.

Wrektnsonville, p. v., Union dist., S. Car. : on W. side of Broad r., $70 \mathrm{~m} . \mathrm{N}$. N. W. Columbia.

WILl county, $I U l$. Situate N. W., and contains 1,152 sq. m. Drained by Iroquois and Kankakee rivers, tributaries of Illinois river. Surface generally even; in parts it is hilly and broken. Soil in many portions very productive. Staples, wheat, grain, and potatoes. Farms 1,200; manuf, 94; dwell. 2796, and pop-wh. 16.670, fr. col, 33-total 16,708. Capital: Joliet. Public Works: Chicago Branch of Central R. R.; Chicago and Mississippi R. R.; Illinois and Michigan Canal.

WILLAMETTE river, $\mathrm{Or}^{\circ} \mathrm{eg}$. Ter. : rises in Lane $\mathrm{co}_{\text {, flows }}$ N. E. and N., and empties into Columbia r., nearly opposite Fort Vancouver.

Willaxiette Forks, p. o., Linn co., Oreg. Ter. : 60 m. S. Salem.

WrLet, t. and p. o., Cortlandt co., N.Y.: $114 \mathrm{~m} . \mathrm{W}$. by S. Albany. Drained by Otselic r. Pop. 923.

Willet, p. o., Greene co., Wisc.: 35 m. S. S.W. Madison Willetrmle, p. o., Highland county, Ohio: $59 \mathrm{~m}$.S.S.TV. Columbus.

Wllitaus county, Ohio. Situate N.W., and contains 432 sq. m. Drained by St. Joseph's branch of the Maumee $r$. and its affluents, and Tiffin $r$. and its branches, which supply good water-power. Surface undnlating; soil fertile. It contains a mineral spring, which is much frequented on account of its medicinal qualities, and the odor of which is perceived at the distance of a quarter of a mile. It is well wooded. Farms 651; manuf, 29; dwell. 1,390, and pop.wh. 8,018, fr. col. 90-total 8,108. Capital: Bryan.

Willays, p. o. Christian co., Ky.: 159 m. W. S. W Frankfort.

Williamsmoro', p. v.. Granville county, N. Car.: $42 \mathrm{~m}$. N. by E. Raleigh. Pop. about 100 .

Wrlita.s's BrIDge, sti., Westchester county, $N$. $Y_{0}:$ on Bronx r. and Iarlem R. I., 14 m. from City IIall. New York.

Wrlliansing diatrict, S. Car. Situate toward the E. and contains 1, 1 is so. m. Drained by Black $r$ and its tributuries, and Cedar cr. Surfuce even; soil varied-in gen- 
eral fertile ani fromluctive. Staples, rice and eotion. Farms 454; manuf. 0; dwell. 717, and pop.-wh. 3,902, fr. col. 37, sl.8,50s-total 12.477. Capital: Kingstree. Public Works : North-eastern R. R.

WilliausbuBg, p. v., Wayne co., Ind. : on Green's fork, 55 m. E. by N. Indianapolis. Pop. about 400.

Wrlliarsburg, t. and p. o., Piscataquis co., Me. : $80 \mathrm{~m}$. Y. N. E. Augusta. Drained by Pleasant $r$. and its branehes. Pop. 124.

Wrltiamsedrg, t. and p. v., Hampshire co., Mfass. : $85 \mathrm{~m}$. W. Boston. Drained by Mill river, which affords waterpower to several mills and manufactories. The $\mathrm{v}$. contains 3 churches, Pop. of t. 1,537.

Wrullaysburg, p. vo, and cap. Covington county, Miss. : $57 \mathrm{~m}$. S. E. by S. Jackson. It contains the co. buildings. Pop. about 100.

Wrltausburg. p. v., Callaway county, $\not[0 .: 28 \mathrm{~m} . \mathrm{N} . \mathrm{L}$. Jefierson City. Pop. about 120.

Williayserga, p. eity, Kings co., $N$. $Y$.: on E. bank of East river, $2 \mathrm{~m}$. E. by $\mathrm{N}$. City Hall, New York, $145 \mathrm{~m} . \mathrm{S}$. Albany. This flourishing city occupies a handsome and elevated site, is planued and laid out with regularity, and is increasing in population and general prosperity corresponding to the growth of New York, of which it is properly a suburb, being connected by the most intimate ties of business. It is well built and paved, and lighted with gas. It was incorporated as a village in 1827 , and chartered as a city April 7, 1851. Its situation for business is most favorable, and its manufactures are varied and very extensive. The ship-yards in its $\mathrm{N}$. W. part are among the largest and most important in the vicinity of New York, employing several hundred men. A very large proportion of its citizens are engaged in daily business in New York, to which four steam ferries have boats constantly plying. The general municipal government is vested in a mayor and twelve aldermen (four from each of three wards), who hold office for two years. The police, fire, and other departments are constituted upou plans similar to those of New York, but varied by the particular wants of this city. The City WaterWorks, commenced in 155\%, are in progress toward completion. The churches are about thirty in number, many of which are very commodious and handsome edifices. Among the public buildings, the Odeon is the principal hall for public entertainment, ete. Its public schools, arranged according to the general State system, are well conducted, and considerable interest is manifested in education by the eitizens generally. The newspaper press, in 1850 , consisted of four dailies, viz., "W. Gazette" (whig), "W. Times" (neut.), "Independent Press" (dem.), and "Democratic Advocate." In 1853, the construction of avenue railroads and other improvements, are operating with most beneficial influence upon the growth of the eity. Pop. in 1835 , about 3,000 ; in $1840,5,094$; in $1845,11,338$; in 1850 , 30,786. The population at the present time (July, 1S5̌3) is perhaps little less than 50,000 .

Willamsburg, p. v., De Kalb co., $\eta_{n}$ : on Sycamore $r_{\text {, }}$ 155 m. N. N. E. Springfield.

Willumsetra, p. V., Iredell co., $N$. Car.: on E. side of Rock cr., 116 m. W. by N. Raleigh.

Wilumamsburg, t. and p. v., Clermont co, Ohio: $82 \mathrm{~m}$. S.W. by S. Columbus. Drained by $\mathbf{E}$. fork of Little Miami river. Pop. of v. about 500 ; of $\mathrm{t} 1,8 \mathrm{~S} 5$.

Winciausburg, p. b., Blair county, Penn.: on S. side Juniata $\mathrm{r}_{\text {. }}, 72 \mathrm{~m}$. W. by $\mathrm{N}$. Harrisburg. Incorporated in 1528. It contains 5 churehes, several mills, and other manufacturing establishments, 1 hot-blast chareoal furnace, with annual capacity of 1,400 tons, and 2 charcoal forges, each annually producing 600 tons blooms, and employing 30 men. Pop. about 850 .

Wrlltamsiurg, p. V., and cap. James City co., Firg. 46 m. E. S. E. Richmond. Pleasantly situated on elevated land between James and York rivers. It was first settled in 1632. and was the seat of the colonial government. It is handsomely laid out with streets crossing at right angles The county buildings gtand upon a public square. It also contains 3 churches, and the College of William and Mary, which was founded in 1692 , and in 1959 had 7 professors, 36 students, and 5,000 volumes in its library, and a flourishing law department of 32 students. Pop. 877.

William's Cester, p. V., William's co., Ohio: $134 \mathrm{~m}$. N. W. Columbus.

William's Cross Roads, p. 0., Choctaw co., Ala. : $115 \mathrm{~m}$. W. by S. Montgornery.

Wicliamsfield, to and p. o., Ashtabula co., Ohio: $158 \mathrm{~m}$. N. E. Columbus. Drained by branches of Shenango and Pymatuning creeks. Pop. 982

WILlIAMson county, IUt. Situate S., and contains 432 sq. m. Drained by Muddy and Saline creeks, the former being a tributary of the Mississippi, and the latter of the Ohio. Surface varied; in some parts hilly and broken, but in general it is level. Soil fertile, and raises good crops of wheat and grain, and is favorable to the cultivation of tobaceo and cotton. Pine timber is to be found on the land. Farms 752; manuf. 10; dwell. 1,195, and pop.-wh. 7,149 , fr. col. 67-total 7,216. Capital: Marion. Public Workes: Sangamon and Massac R, R.

WILliamson county, Tenn. Situate W. centrally, and contains 536 sq. m. Harpeth r., a branch of Tennessee r., passes through the co., by which and its branches it is drained. Surface level or gently undulating; soil fertile. Staples, wheat, grain, tobaceo, and cotton. It has a good growth of timber. Farms 1,355; manuf. 54; dwell 2.534, and pop.-wh. 14,267, fr. col. 70, sl. 12,861-total 27,201 . Capital: Franklin. Public Works: Nashville and New Orleans R. R.

WILLIAMSON county, Tex. Situate E, centrally, and contains 1,187 sq. m. Drained by San Gabriel r. and its N. and S. forks, and by Brushy cr. and its branches. Surface varied, part of it being mountainous, and part level or rolling - the latter portions being mostly prairie, with groves of timber interspersed. Soil fertile and very productive, yielding large crops of grain, cotton, and potatoes. Indigo grows wild, and might, by cultivation, be rendered very valuable. Wheat, also, suceeds well, and the land is in general favorable to all agricultural productions. Farms 107 ; manuf. 1 ; dwell. 230, and pop.-wh. 1,410, fr. col. 3, sl. 155-total 1,568. Capital: Georgctown.

Willtamson, t. and p. v., Wayne county, N. Y.: $182 \mathrm{~m}$. W. by N. Albany. Drained by small streams flowing into Lake Ontario, which bounds it on the N. Pop. of v. about 160 ; of $t, 2,380$.

Williamson, p. v., Jefferson county, ky. : $40 \mathrm{~m}$. W. Frankfort.

Willramson, p. V., Owen co, Ind.: $47 \mathrm{~m}$. S. W. by S. Indianapolis.

Willramson's Mrics, p. o., Lexington district, S. Car.: on small branch of $\mathrm{N}$. Edisto r., $42 \mathrm{~m}$. S. S. W. Columbia.

Williamsonville, p. v., Macon co., Dfo.: $90 \mathrm{~m}$. N. by W. Jefferson City.

Williansport, p. v., and cap. Warren co., Ind.: on W. bank of Wabash r., $69 \mathrm{~m}$. N. W. by W. Indianapolis. It has a good landing for steamboats, carries on an important trade, and is surrounded by a very fertile region. First settled in 1529. It contains the county buildings, etc. The "Wabash Commercial" (whig) is here published. Pop. about 450 .

Williamsport, p. o., Point Coupee parish, La.: $87 \mathrm{~m}$. N. W. Baton Rouge.

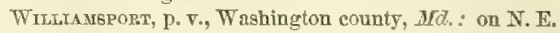
bank of Potomac r., $79 \mathrm{~m} . \mathrm{N}, \mathrm{W}$. by W. Annapolis. This is the depott of an extensive fertile region, and has excellent shipping facilities. The Chesapeake and Ohio Canal passes through it, and the Franklin R. R. from Chambersburg will be extended to this place. It contains a bank, capital \$135,000. Pop. about 450 .

TVilliamspost, p. b., and cap. Lycoming co., Penn.: on 
N. bank of W. branch of Susquehanna r., $66 \mathrm{~m}$. N. by W. Harrisburg. It contains the county buildings, 1 bank, capital $\$ 100,000,2$ aeademies, and 4 churches. The "L. Gazette" (dem.) and "L. Democrat" are issued weekly. The West Branch Division of Pennsylvania Canal passes through it. The Williamsport and Elmira $R$. R. (constructed to Ralston, $25 \mathrm{~m}$.), and the Sunbury and Erie $\mathbf{R}$. R, with other projected lines, will greatly increase the business interests of this place. Pop. in 1840, 1.353 ; in 1850, 1.615.

Williamsport, p. v., Pickaway co., Ohio: on E, side of Darby er., $26 \mathrm{~m}$. S. Columbus.

Williamsport, p. v., Maury co., Tenn.: on S. side of Duek cr., 38 m. S. W. by S. Nashville.

Williamsport, p. v.. Hardy co., Virg.: on branch of Potomac r., 143 m. N. N. W. Richmond.

Williak's Store, p. o., Berks co., Penn. : $5 \frac{1}{2}$ m. E. N. E. Harrisburg.

William?s Store, p. o., Hardeman co., Tenn。: $125 \mathrm{~m}$. W. S. W. Nashville.

Williamston, p. v., and eap. Martin co., N. Car.: $8 \delta \mathrm{m}$. E. Raleigh. It contains the county buildings, etc. Pop. about 300 .

Williamston, p. v. and sta., Anderson dist., S. Car.: on Greenville and Columbia R. R., 93 m. W. N. W. Columbia.

Willianstown, p. v., Deeatur co., Ind.; 48 m. S. E. by E. Indianapolis.

Wrlliavstown, p. v., and cap. Grant co, $K y .: 36 \mathrm{~m}$. N. N. E. Frankfort, It contains the court-house and several dwellings.

Williamstown, t. and p. v., Berkshire co., Mrass. : $19 \mathrm{~m}$. N. Pittsficld, $111 \mathrm{~m}$. W. by N. Boston. Drained by Honsic $r$. and branches, which afford water-power to several mills and factories. The $\mathrm{v}$, is on uneven ground, but very pleasant, Lat. of Cong. ch. $42^{\circ} 42^{\prime} 49^{\prime \prime} \mathrm{N}$. long. $73013^{\prime} 10^{\prime \prime} \mathrm{W}$. Williams College, hore located, was foumted in 1693 , and in 1850 had $S$ professors, 1,317 alumni, 179 students, and 13,751 yolumes in its libruries. Pop of t. 2.626 .

Willta ustowis, p. o., Inglaam co., Mich.

Wrltaustown, t., p. v., and sta., Oswego co., $N . Y_{\text {. }}$ $124 \mathrm{~m}$. W. N. W. Albany. The Watertowe and Rome R. P passes through, $28 \mathrm{~m}$. from Rome, $54 \mathrm{~m}$. from Watertown. Pop. in 1840, 842 ; in $1850,1,121$.

Williarstown, p. o, Camden county, N. Jer.: 37 m. S. by W. Trenton.

Williarstown, $t$. and p. o., Orange co., Verm.: $10 \mathrm{~m}$. S. by E. Montpelier. The t. las an elevated and uneven surface, and contains 5 churches, several nills, cte. Population 1.452

Willamstille, p. v., Erie eo, I. T.: n N. F. side of Ellicott's cr., $202 \mathrm{~m}$. W. Altany, It contains ? churelts several mills, and other manufacturing establishments, and a large water-lime mill.

Wiliiamstille, p. v., Kent co., Del.; 15 m. S. S. W. Dover.

Wilita astille, p. v., Person en, N. Car.: on branch of Dan r.. $56 \mathrm{~m}$. N. W. by N. Raleigh.

Williansville. p. v., Elk co., Penn.: on N. county line, $127 \mathrm{~m} . \mathrm{N}$. W. Harrisburg.

Tillianstille, p. o., Diekson co, Tenn.: 37 m. $\Pi$. Nashville.

Wirliavstrure, n, v., Windham co, Term。: on branch of $W$ est r.. $95 \mathrm{~m}$. S. MLuntpelier.

Willanstille. p. v., Delaware co, Otio: $13 \mathrm{~m}$. N. by W. Columbus.

Williamsville, p. 0., Bath co, Firg.: 128 m. W. N. W Richmond.

Wilima nsetr, p. v, and sta., Hampden co., Mrass.: on E. bank of cornecticut r., 7 m. W. by S. Bust.n. The Connecticut River R. R. passes through, 6 m. from Springfield.

Wroltarastic, p. b. and sta., Windham en.. Conn.: on N. side of Willimantic r., $23 \mathrm{~m}$. E. by S. Hartford. It contains several very large colton fuctories, other mills, and 4 $93+$ ehurehes. The "Public Medium" (neut.) is issued weekly, The railroads passing through this place are, Hartford, Providence, and Fishkill R. R., $32 \mathrm{~m}$. from Hartford; Newr London, Willimantic, and Palmer R. R., $30 \mathrm{~m}$. from New London, $36 \mathrm{~m}$. from Palmer; and the projected New York and Boston Direct R. R.

Wrllivg, p. o., Alleghany co., $N . Y .: 224 \mathrm{~m}$. W. by $\mathrm{S}$. Albany.

Willington, t, and p. v., Tolland county, Conn.: $21 \mathrm{~m}$. E. by N. Hartford. Drained by branches of Willimantic $r_{\text {.a }}$ which supply good water-power. The New London, Willimantic, and Palmer R. R. passes on its W. border. In the $\mathrm{v}$. are 2 churehes. Pop. of t. 1,399.

Wilmivgton, p. Y., Abbeville dist., S. Car.: $80 \mathrm{~m}$. W. Columbia.

WILXISBURG, p. o, Washington co., Ky.: 35 m. S. S. W. Frankfort.

Wrluistox, p. v. and sta., Barnwell dist., S. Car.: on South Carolina R. R., $99 \mathrm{~m}$. from Charleston, $38 \mathrm{~m}$. from Augusta., 45 m. S. S. W. Columbia.

Williston, p. o., Potter co., Penn.: 110 m. N. W. by N. Harrisburg.

Williston, t., p. т., and sta., Chittenden co., Verm.: on S. side of Onion r., $26 \mathrm{~m}$. W. N. W. Montpelier. Surface uneven. Drained by small streams. The Fermont Central R. R. passes through its N. E. part, $106 \mathrm{~m}$. from Windsor. The v. is handsomely built. Pop. of t. 1,699.

Willoughry, t., p. v., and sta., Lake co., Ohio: $183 \mathrm{~m}$. N. E. by N. Columbus. Chagrin r. flows on its E. borler into Lake Ontario, which bounds it $\mathrm{N}$. The v. contains 2 churches, several stores, etc. The Cleveland and Erie R. R. passes through it, $18 \mathrm{~m}$. from Cleveland, $77 \mathrm{~m}$. from Erie. Pop. of t. 2.081.

WrLloughis lake and rirer, Orleans co., Term.: the lake in Westmortland town is a large and handsome sberi of water, and the river, its outlet, is the principal tributary of Barton river.

Willow Creek, p. o., Marquette county, Wisc.: $76 \mathrm{~m}$. N. by E. Madison.

Willow Creek, p. o., Lee co., Ill.: 130 m. N. by E. Springfield.

Willow Creek, p. o., Marion dist., S. Car.: 90 m. E. Crilumbia.

Wu,Low Dale, p. 0., Trumbull co., Ohio: $145 \mathrm{~m}, \mathrm{~N}$. E. Columbus.

Willow Grove, p. o., Coweta eo, Ga.: 104 m. W. by N Millerlgeville,

Willow Grote, p. v., Montgomery co., Penn.: 90 m. E. II:rristuarg.

WILLOW Grove, p. o., Sumter dist., $S$. Car.: on W. side Lyneh's er. 5x m. E. Columbia.

Willow Istasd, p. O., Wood co., Firg. : 226 m. W.N.W. Richmond.

Willuw Spring, p. Oo, Claiborne county, Miss.: $43 \mathrm{~m}$. TV. S. W. Jackson.

Tillow Sprixgs, t. and p. v., Lafayette co., Wisc. : $45 \mathrm{~m}$. S. W. by W. Madison. Watered by Pekatonica r. Pop. of t. 606 .

Willow Street, p. o., Lancaster co., Penn. : 36 m. S. E. by E. Harrisburg.

Willisbono?, t, and p. T., Essex cn., N. Y.: on W. side of Lake Champlain, $118 \mathrm{~m}$. N. by E. Albany. The $\mathbf{v}$, on Boquet r. contains several mills, etc. Pop. of v. about 500 ; of t. 1.932

Wrilis' Creek, p. O., Coshncton co., Ohio: on creek of same name, $65 \mathrm{~m}$. E. by N. Columbus.

Wir.LSEYville, p. v. and ta., Tinga con, $N$. $Y$.: on Cayuga and Su-qutrehanna R. R., 1 m. from Oswego, 19 miles from I:haed, 1:s m. W. by S. Allany.

Millsum, t. and p. Y. Tan Wert county, Ohio: 93 miles W. N. W. Columbus, Drained by St. Mary's r., on the S bank of which is the v.. c.nutaining in 1550147 inkabitants. Pop. of $t$, in 1540, 4: 4 ; in 155io, $1,053$. 
Wilts' Poivt, p. o., Benton county, Tenn. : 72 miles W. Nashville.

Wilmivgton, p. v., Union co., Ark. : on S: side of Wachita r., 99 m. S. Little Rock.

Wimmington, p. city, port of entry, and one of the caps. Newcastle co., Del. : is pleasantly situated between Brandy wine and Christiana creeks, $1 \mathrm{~m}$. above their confluence, $2 \mathrm{~m}$. W. Delaware r., 37 miles N. Dover. Lat. $39041^{\prime} \mathrm{N}$.; long. $75^{\circ} 2 S^{\prime} \mathrm{W}$. Distance by railroad from Washington I $\| S$ m. ; Baltimore, 70 m. ; Philadelphia, $2 S \mathrm{~m}$. ; New York, $115 \mathrm{~m}$. Its site is pleasant and healthy, on ground rising gradually to the height of 112 feet above tide-water. It is regularly laid out, with wide streets crossing at right angles, and is well built, chiefly of brick. It is supplied with water from the Brandy wine, by extensive water-works, constructed Iike those of Philadelphia. It contains a city hall, several county buildings, an arsenal, 2 market-houses, several excellent academies, and 19 churches. The hospital, located upon a fine eminence, is 126 feet long and 3 stories high. There are 4 banks, with aggregate capital of $\$ 700,000$. The manufactures of Wilmington are various and most extensive. Great water-power is afforded by the falls of the Brandywine, and improved by mills and factories of all kinds. The flouring-mills are, however, the most numerous and extensive, and among the largest in the Union. The making of gunpowder has for many years been extensively carried on in the vicinity. The navigation interests of Wilmington are also large. Vessels drawing 14 feet water come to its wharves in Christiana cr., and Brandywine ereek admits those drawing 8 feet water. The total tonnage of this district on June 30 th, 1850 , was 9,460 tons. The register tonnage amounted to 1,651 tons, viz., 681 tons permanent, and 970 tons temporary. The enrolled and licensed tnnnage amounted to 7,809 tons, mostly permanent, and all employed in the coasting trade, of which 1,429 tons were propelled by steam. During the year preceding it had no foreign commerce. Vessels built during the year, 16 (12 sehooners, 3 sloops, 1 steamer $)-1,849$ tons. In 1852 it had among its vessels 11 steamboats $-2,651$ tons. The general business and prosperity of this eity are steadily increasing. It is surrounded by a very fertile agricultural district, has great natural advantages for manufacturing, indestry, and trade, and its connections by railroad insure constant communication with the great cilies of the nation. Its newspaper press in 1550 consisted of "Delaware Republican," " Del. State Journal," each publishing tri-weekly and weekly editions; "Del. Gazette," semi-weekly and weekly; and 2 weeklies, "Blue Hen's Chicken" (whig), and "Irdependent Delawarian" (dem.) Pop. in 1s10, 4,416; in $1520,5,263$; in $1830,6,625$; in $1840,8,367$; in 1550 , 13,979. An enumeration taken in 1853 gives the following: 6,587 white males, 7,359 white females, 920 colored males, 1,257 colored females-total 16,153.

WiLurngton, p. v., Will eo, $M l_{0}$ : on E. side of Kankakee r., 127 m. N. E. Springfield.

Wrumington, p. v., Dearborn enunty, Ind.: on S. side of Tanner's cr. 77 m. S. E. by E. Indianapolis.

Wrumington, t., p. v., and sta., Middlesex co., D/ass. $15 \mathrm{~m} . \mathrm{N}$. W. by N. Boston. The t. has a level surface, light eandy soil, and produces large quantities of hops. It is crossed by the Bnston and Lowell R. R.; Boston and Maine R. R. ; Salem and Lowell R.R.; and a junetion branch R. R. The $\mathrm{v}$, is small but neatly built. Pop. of $\mathrm{t} .876$.

WILMINGTON, p. city, port of entry, and cap. New Hanover county, $N$. Car.: on Cape Fear r., near the confluence of the N. E. and N. W. branches, about $35 \mathrm{~m}$. from the Atlantie Ocean; 128 m. S. S. E. Raleigh. Latitude $34^{\circ} 11^{\prime}$ N.; longitude $78^{\circ} 10^{\prime} \mathrm{W}$. Its site is rather low, and considered somewhat unhealthy. Iis favorable position for trade has, howerer, secured a large population, and permanent business interests. In 1919 , it suffered most severely by a conflagration which destroyed 200 buildings, at at loss of over $\$ 1,000,00 \%$. It contains a enurt-bouse, jail, several churches, and 3 banks, with aggregate cap. of $\$ 1,050,000$. It is lighted by gas distilled from wood. In 1550, jts newspaper jress comprised 6 issues, viz., "Commercial" (whig), tri-weekly and weekly; 2 senui-weeklies, "Aurora" (neutral), and "Journal" (dem.); 2 wecklies, "Chronicle" (whig), and "Religious Intelligencer" (Bapt.).

The railroads entering Wilmington are, Wilmington and Weldon R., K. (from Welron $162 \mathrm{~m}$.) ; and Wilmington and Manchester R. R. (from Manchester $155 \mathrm{~m}$.); loth of which are very important avenues of travel and trade. The harbor has a shoal at its entrance, but almits vessels of 300 tons. The $r$. is divided into 3 channels by 2 islands, which are the finest rice ficlits in the State. The total tonnage of this district on June 30 th, 1850, was 15,198 tons. The registered tonnage amounted to 9,123 tons, consisting of 1.406 tons permanent, and 7,717 tons temporary. The enrolled and licensed tonnage amounted to 6,075 tons, all permanent, and employed in the coasting trade, of which 2,949 tons were propelled by steam. Its foreign cummerce during the year preceding, consisted of 175 clearances--31,098 tons, and 118 entrances, 20,670 tons. Vessels built during the year, 4 (1 brig, 1 schnoner, 2 steamers)-483 tons. The principal exports of Wilmington during 1852, were as follows:

\begin{tabular}{|c|c|c|c|}
\hline Lumber & $\begin{array}{l}\text { Coastwise. } \\
17,135, S 89 .\end{array}$ & $\begin{array}{c}\text { Foreign. } \\
15.201,000\end{array}$ & $\begin{array}{c}\text { Total. } \\
\ldots 32.336 .859\end{array}$ \\
\hline Timber ..... " & $1,025,202 \ldots$ & $2,383.814$ & .. $3,409,016$ \\
\hline Turpentine .. bbls. .. & $63.071 \ldots$ & 38,596 . & 96,663 \\
\hline Rosin ....... " " & $320,219 \ldots$ & $18,981$. & 339,200 \\
\hline Tar........." " & $17,522 \ldots$ & 2137. & 19.659 \\
\hline Pitch........ " .. & $6,660 \ldots$ & 1,146 . & 7,80 \\
\hline Peanuts ..... bush... & - & 一 & 93,255 \\
\hline Cotton ....... bales.. & - & - & 4,136 \\
\hline
\end{tabular}

In 1852 , the nunber of steamboats of this port was 15 (10 high pressure, 5 low pressure), with aggregate tonnage of 3,014 tons, An U. S. naval officer is stationed at this port. Pop. in $1830,2,700$; in $1840,4,744$; in $1850,7,264$.

Wilmington, t. and p. v., Essex co., N. Y.: $124 \mathrm{~m}$. N. Albany. Drained by Wilmington $r$, on which the village is situate. Excellent iron ore is abundant and extensively wrought. Pop. of t. 1,176.

Wrumington, p. v., and cap. Clinton co., Ohio: $54 \mathrm{~m}$ S. W. Columbus, It contains the county buildings and 5 churches. Laid out in 1810. The Cincinnati, Wilmington, and Zanesville R. P. is in eonstruction through this place. The "Clinton Republican" (whig), and "Weekly Em. pyrean" (fr. soil) are here published. Pop. 1,238.

WILMington, t. and p. v., Windham co., Verm.: $102 \mathrm{~m}$. S. by W. Montpelier. Drained by Deerfield river and branches. The v. near the centre is pleasant and neatly built. The "Green Mountain Eagle" is here published. Pop, of t. 1,372.

WILxngton, p. Y., Fluvanna co., Firg.: on E. side of Rivanna $r, 44 \mathrm{~m}$. W. N. W. Richmond.

Wilmore, p. o., Cambria co., Penn.: $101 \mathrm{~m}$. W. by N. Harrisburg.

Wilnot, $t$, and p. o., Merrimac eo., $N$. Hamp.: $25 \mathrm{~m}$. N. W. Conenrd. Drained by small streams which afford water-power. Pop. 1,272.

Wтимот, p. o., Buone co., Ill. : near Wisconsin State line, $166 \mathrm{~m}$. N. by E., Springfield.

WrLarot, p. o., Kenosha co., Wisc.: 81 m, E. S. E Marlison.

Wilvot, p. o., Noble county, Ind.: 114 miles N. N. E. Indianapolis.

Wilмoт Flat, p. o., Merrimac county, N. Hamp.: $22 \mathrm{~m}$. N. W. by W. Concord.

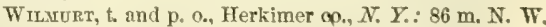
Albany. Pop. in 1S40, 60 ; in 1850), 112.

Wilna, p. v., Houston co., Ga.: on branch of Ocmulgee r., $50 \mathrm{~m}$. S. W. by S. Milleogeville.

Wills, t. and p. O., Jefferson co., N. Y.: $184 \mathrm{~m} . \mathrm{N}$. W. 
Albany. Drained by Black and Indian river and their branches. Pop. 2,993.

Wusor county, Tenn. Situate N. centrally, and contains 468 sq. m. Drained by affluents of Cumberland $r$., which forms it N. boundary. Surface hilly, and in parts much broken; soil fertile, and produces large crops of tobaceo and cotton, which are the staples. Large crops of wheat and grain are also raised, and pork and beef are exported. Timber is abundant. Farms 1,988; manuf. 36 ; dwell. 3,411, and pop.-wh. 19,915 , fr. col. 402 , sl, 7,127 -total 27,444 . Capital : Lebanon.

WILson, t. and p. o., Piscataquis co, Me.: 94 m. N. by E. sugusta. Drained by Wilson's ereek.

Wilson, p. o., Edgecomb co., N. Car.: 56 m. E. by N. Raleigh.

Wruson, p. o., Marion county, Ohio: 42 miles N. N. W. Columbus.

Winsos, t. and p. o., Niagara co., N. Y.: $266 \mathrm{~m}$. W. by

N. Albany. Interests exclusively agricultural, Surface generally level. Drained by small strearns. Pop. in 1840 , 1,753 ; in $1850,2,955$.

WrLsov's p. o., Anderson county, Temn.: $150 \mathrm{~m}$. E, Nashrille.

WILson's Crees, p. o., Graves co., Ky.: on er, of same name, $228 \mathrm{~m}$. W. S. W. Frankfort.

WrLson's Creez, p. O., Abbeville dist., S. Car.: 83 m. W. Columbia.

WILson's Dep6̂T, p. o. and sta., Dinwiddie co., Tirg. : on South Side R. R., 28 mo. from Petersburg; 36 m. S. W. Richmond.

Wrlson's Mriss, p. o., Venango county, Penn.: $160 \mathrm{~m}$. W. N. W. Harrisburg.

Wrlsonss Statron, p. o., Clinton co., Ohio: $53 \mathrm{~m} . \mathrm{S}$. W. Columbus.

Wrisonville, p. v., Shelby co., Ala.: on W. side of Coosa r., 59 m. N. by W. Montgomery.

Wrusonville, p. o., Spencer co., Ky.: 28 m. W. S. W. Frankfort.

Wrlsonvile, p. o., Cocke co., Tenn.: 210 m. E. by S. Nashville.

Wrisox ville, p. o., Highland co., Virg. : 180 m.W. N.W. Richmond.

Wruton, t., p. v., and sta., Fairfleld co,, Conn.: $54 \mathrm{~m}$ s. W. Hartford. Drained by Norwalk $\mathbf{r}$, and branches, which affords water-power. The $\mathrm{v}$. contains 2 churehes, etc. The Danbury and Norwalk R. R. passes through it, $7 \mathrm{~m}$. from S. Norwalk, $17 \mathrm{~m}$. from Danbury. Population of $\mathrm{t} .2,066$.

Wrutov, t. and $\mathrm{p}, \mathrm{v}$, Franklin co., Me, : $27 \mathrm{~m}, \mathrm{~N} . \mathrm{W}$. br W. Augusta. Drained by branches of Sandy r., which flow from two handsome ponds, and afford water-power to various mills. Pop. of t. 1,909.

Wiltor, t., p. r., and sta., Hillsboro' co., N. Hamp.: 29 m. S. S. W. Concord. Drained by Souhegan r. and branches which afford water-power. The t. contains several stone quarries. The $\mathrm{v}$. is neatly built, and is the terminus of Wilton R. R. from Nashville, $15 \mathrm{~m}$. The Peterboro' and Shirley $R$. R. touches the $S$. border of the $t_{\text {. }}$ where is a sta., $20 \mathrm{~m}$. from Groton Junction. Pop. of t. 1,161.

Wiltow, p. o., Pike county, Ark.: $96 \mathrm{~m}$. S. W. by W. Little Rock.

WiLtor, th and p. o., Saratoga county, $N, Y_{2}: 32 \mathrm{~m}, \mathrm{~N}$. Albany. Drained by a tributary of Hudson $r$. Surface diversified. Interests chiefly agricultural. The Saratoga and Washington $R$. R. crosses the $t$. Pop. 1,458,

WrrcrendoN, to, p. V., and sta., Worcester co., Mfass. 54 m. W. N. W. Boston. Drained by Miller's r., which affords excellent water-power. One cotton factory contains 5,700 spindles. The t. contains several stone quarries. The $\nabla$. near the centre is neatly built. The Cheshire $R$. R. passes a little $\mathrm{N}$. of it, $18 \mathrm{~m}$. from Fitchburg, $46 \mathrm{~m}$. from Bellows Falls. Pop, of t. in 1S40, 1,754; in 1550, 2,445.

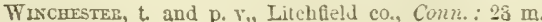
936
W. N. W. Hartford. Drained by Mad $r$, which affords great water-power. The principal $\mathrm{v}$. in this to is West Winsted, which see. Pop. of t, in 1810, 1.667; in 1850, 2,179.

Winchester, t. and sta., Middlesex co., Mass. : on Boston and Lowell R. R., 8 m. N. N. W. Boston. Pop. 1,353.

Winchester, p. v., and cap. Scott co.. $T U l_{.}$: on N. W. bank of Sandy er., $44 \mathrm{~m}$. W. by S. Springfield. It eontains the county buildings, several mills, and manufacturing establishments. It has a fine location, and is a thriving place. Pop. about 800 .

Winchester, p. V., and eap. Randolph co., Ind.: on S. side of W. fork of White r., $64 \mathrm{~m}$. E. N. E. Indianapolis. First settled in 1819. It contains the county buildings, ete. The Indianapolis and Bellefontaine $\mathrm{I}$. R., in construction, passes through this place. The "W. Patriot" (whig) is here published. Pop. about S00.

Winchester, p. v., Van Buren co., Ta.: 65 m. S. S. W. Iowa City.

Winchester, p. v., and cap. Clark county, $K y .: 40 \mathrm{~m}$. E. by S. Frankfort. It contains the county buildings, 2 churches, etc. A north and south railroad, passing through this place, is projected. Pop. about 1,100 .

WiNchester, p. V., and cap. Wayne co., Difss: on $\mathbf{E}$. bank of Chickasawha r., 104 m. E. S. E. Jackson. It contains the court-house and jail. Pop, about 100

WINCHESTER, p. v., Clark co., MYo.: on a branch of Fox r., 120 m. N. by E. Jefferson City.

Wincrester, t., p. v., and sta., Cheshire co., N. Hamp.: 53 m. S. W. by W. Concord. Drained by Ashuelot r., which affords extensive water-power. The $\mathrm{v}$. near the centre is very handsome, and contains 3 churches, 1 bank, capital $\$ 100,000$, and several manufactories. Three principal woolen factories run about 1,500 spindles. The Ashuelot R. R. passes through it, $13 \mathrm{~m}$. from Keene. The "Northern Advocate" (free soil) is published weekly. Pop. of t. in 1540, 2,065 ; in $1850,3,296$.

Wrichrster, p. v., Guernsey co, Ohio: $82 \mathrm{~m}$. E. by N. Columbus.

Winchester, p. o., Union co., N. Car.: $110 \mathrm{~m} . \mathrm{S}$. W. by W. Raleigh.

Wincirester, p. v., and cap. Franklin co., Tenn.: on small branch of Elk r., $73 \mathrm{~m}$. S. S. E. Nashville. It contains the county buildings, several stores, ete. The "W. Independent" (dem.) is issued weekly. The Winchester and Alabama R. R. is projected. Pop. about $\$ 00$.

WiNchester, p. v., and cap. Frederick co., Virg.: $116 \mathrm{~m}$. N. N. W. Richmond. It is regularly laid out, with strcels crossing at right angles, which are generally well paved. It, contains the county buildings, lyceum, academy, Masonic hall, and 14 churches. Its manufactures and trade are extensive and increasing. The Winchester and Potomac R. R. extends hence, $32 \mathrm{~m}$., to Harper's Ferry and junetion with the Baltimore and Ohio R. R. The v. also contains the Winchester Medical School, having 5 professors; 2 banks, with aggregate capital of $\$ 680,000$, and 1 savings' institution. The "W. Republican" (whig) and the "Virginian" (dem.) are issued weekly. This place was founded in 1752 , and is of considerable historical interest. Pop. in 1810, 8,454 ; in 1550 , about 4,800 .

Winchester Centre, p. v., Litchfleld co., Conn.: $25 \mathrm{~m}$. N. W. by W. Hartford.

Whi Creek, p. o., Tallapoosa co., Ala.: 35 m. N. E. by E. Montgomery.

WIND GaP, p. 0., Northampton co., Penn. : 90 m. E. N. E. Harrisburg. The Wind Gap is an opening in the Blue Monntain, extending nearly from the bottom to the top. Its sides are very abrupt, and it is surrounded by ronantic scenery. The road from Easton to Wilkesbarre passes through it.

Wrxpens county, Comn. Situate $\mathbb{N}$. E., and contains 620 sq. m. Drained by Quinnebaug and Shetucket rivers and their branches. Surface uneven, and in some parts rough and stouy; soil fertile, the larger portion adapted to 
grazing, while on the streams is some fine meadow land. This co. has excellent water privileges, and some extensive manufactures. Chief products, wheat, Indian corn, and potatoes. Farms 2,445 ; manuf. 380 ; dwell. 5,494, and pop. -wh. 30,512, fr. col. 567-total 31,079. Capitat: Brooklyn. Public Works: Norwich and Worcester R. R.; New York and Boston (air-line) R. R.; Hartford, Providence, and Fishkill R. R.; Plainfield R. R.

Wirdhas county, Verm, Situale S. E., and contains \%65 sq. m. Drained by Williams, West, and Saxton rivers and their tributaries, which supply abundant water-power. Surface hilly, and in the western portion mountainous; soil fertile in some parts, generally suited for pasture and the growth of grain. It has excellent granite and limestone quarries. Chief products, wheat, Indian corn, etc. Farms 3.363; manuf. 197 ; dwell. 5,374, and pop.-wh. 29,025 , fr. col. 37-total 29,062. Capital: Fayetteville. Putlic Works: Vermont Valley R. R., ete.

Wixdhar, t. and p. vo, Windham co., Conn.: $28 \mathrm{~m}$. E. by S. Hartford. Drained by Shetuckel r. and branches, which aftord good water-power. The t. contains several flourishing villages, of which Willimantic is the principal. The v. near the centre contains 2 churches, an academy, several stores, and 1 bank, cap. $\$ 60,000$. Pop. of t. in 1840 , 3,352 ; in $1850,4,636$.

Wivpmay, t. and p. v., Cumberland county, $M e .: 47 \mathrm{~m}$. S. W. Augusta. Drained by branches of Presumpscot $r$, which furnish mill privileges. Interests entirely agricuitural. Pop. of t. 2,380 .

Winnham, t., p. v., and sta., Rockingham co., N. Hamp. $3 \tilde{m}$ m. S. S. E. Concord. Watered by several ponds and branches of Merrimac r. The Manchester and Lawrence R. R. crosses N. E. corner of the t, $15 \mathrm{~m}$. from Manchester, $12 \mathrm{~m}$. from Lawrence. Pop. of t. 818 .

WINDFAM; t. and p. o., Greene co., $N . \bar{Y} .: 32 \mathrm{~m} . \mathrm{S} . \mathrm{W}$. Albany. Drained by Pataviakill or Red Kill cr. Surface hilly and mountainous, with intervening valleys; soil on the flats rich and productive-the hills good grazing lands. Hemlock is abundant, and is extensively used in the tanneries. About $2 \mathrm{~m}$. apart, on Pataviakill, are the Windham and Big Hollow tameries, employing each about 30 hands and Windham Centre in this $t$. is also a flourishing v. Pop. of t. $2,04 \mathrm{~S}$.

Windham, t. and p. v., Portage co., Orio: 130 m. N. E. Columbus. Drained by branch of Mahoning $r$. Interests, agricultural. Pop. 813 .

WindHax, t. and p. o., Bradford county, Penn.: $115 \mathrm{~m}$. N. by E. Harrisburg. Drained by Wepassening cr., on which are grist and saw mills. Pop. of t. about 1,000 .

Wriderar, t. and p. $\nabla$. , Windham co, Verm. ; $76 \mathrm{~m} . \mathrm{S}$. Montpelier. Drained by small streams. Interests, chiefly agricultural. Pop. of t. 763 .

WindHax Centre, p. v., Greene co., N. $Y$.: on Redkil cr., $33 \mathrm{~m} .8$. W. Albany. It contains the largest carpet-bag manufactory in the Union, employing a capital of $\$ 50,000$. and an extensive manufactory of wooden combs, with a capital of $\$ 20,000$. It is a pretty village, the Squirekill Bridge turnpike passing through it, and has between 600 and 700 inhabitants.

Wind Hili, p. o., Montgomery county, N. Car.: $72 \mathrm{~m}$. W. S. W. Raleigh.

Windridge, p. o., Greene co., Penn. : 173 m. W. by S. Harrisburg.

WIND Rrver mountains, Oreg. Ter, are a range of the Rocky mountains, forming in part the boundary of Oregon on the S. E., and comprising some of the highest peaks of that great chain.

WINDSOr county, Term. Situate E. toward the S., and contains 912 sq. m. Drained by Black, Queechee, Williams', and White rivers; these supply immense water-power. Surface uneven; soil fertile, particularly along the banks of the Connecticut, where fine erops of grain, vegetables, and fruit are raised, Chief products, wheat, Indian corn, oats, and potatoes. In different parts of the co. steatite, or soapstone, is found. Gold is also found near queechee r., not in washings, but in veins. The rock in which the gold lies is quartz, containing also the sulphurets of iron, lead, and zinc, particles of gold being in these as well as in the quartz. This discovery is of recent date, and is communicated by Professor Hubbard, of Dartmouth College. Farms 4,274; manuf. 192; dwell. 7,378, and pop.-wh. 38,208, fr. col. 112-total 38,320. Capital: Woodstock. Public Works: Vermont Central R. R.; Rutland and Burlington R. R., etc

Winpsor, t, p. $\nabla_{*}$, and sta., Hartford co, Conn. : on W. side of Connecticut $r ., 7 \mathrm{~m}$. N. Hartford. Drained by Farmington $r$., which passes through the t. centrally, and affords good water-power. The t. contains several pleasant and flourishing villages. Windsor $\mathrm{v}$, extends along the bank of the Connecticut over a mile, and is beautifully shaded with trees. The New Haven, Hartford, and Springfield R. P. passes through it, $42 \mathrm{~m}$. from New Haven, $20 \mathrm{~m}$. from Springfield. Pop, of to in 1840, 2,2S3; in 1850, 3,251.

Windsor, t. and p. o., York county, Penn. : 32 m. S. E. Harrisburg, An agrieultural township.

Windsor, p. v., Walton co., Ga, : on branch of Ocmulgee r., $69 \mathrm{~m} . \mathrm{N}$. W. by N. Milledgeville.

WiNDSOR, p. v., Mercer co., N. Jer,

WrNDsor, p. v., Randolph co., Ind. : on W. fork of White r., $53 \mathrm{~m}$. E. N. E. Indianapolis.

WINDsor, t. and p. $\nabla .$, Kennebec county, $M F_{0}$ : $10 \mathrm{~m}$. E. Augusta. Drained by Sheepscot $x$. It contains several mills, but its interests are chiefly agricultural. Population of $t, 1,793$.

WINDsor, t. and p. o., Eaton county, Mich.: 8 m. S. W. Lansing. Drained by S. branch of Grand r. Pop. 253.

WrNDsor, t. and p. o., Dane co., Wisc. : $12 \mathrm{~m}$. N. by W. Madison. Drained by small streams flowing into Fourth lake. A proposed railroad from Madison to Portage will pass through it. Pop. 860 .

WINDSor, t, and p. v., Berkshire co, MLass.: $83 \mathrm{~m}$.W.by N. Boston. Drained by branches of Westield $r$. The $v$. contains 2 churches. Pop. of t. 899 .

WINDSor, t. and p. v., Broome county, N. $Y_{\text {.: }} 106 \mathrm{~m}$. W. S. W. Albany. Drained by Susquehinna 1., on the W. bank of which the $\mathrm{r}$. is situate, containing 2 churches, several stores, ete. Pop. of v. about 410 , of t. 2,615 .

Windsor, p. v., and cap. Bertie $\mathrm{co}_{\text {, }}, N$. Car . : on Cashie r. $93 \mathrm{~m}$. E. by N. Raleigh. It contains the county buildings, several stores, etc. The $r$. is navigable for small vessels to this place, but its banks are low and swampy, preventing, by their unhealthiness, any great settlement.

Wrindsor, t. and p. v., Ashtabula co., Ohio: 146 m. N. E. Columbus. Drained by Grand r. and branches. The town contains several mills, tanneries, etc., and a quarry of grindstones. Pop. of $t, 1,033$.

Windsor, t., p. v., and sta., Windsor eo., Term.: on W. side of Connecticut $r_{\text {, }} 54 \mathrm{~m}$. S. by E. Montpelier. Drained by Mill br., which has a fall of 60 feet in $\frac{1}{3} \mathrm{~m}$., afforling excellent water-power. Surface uneven, rising in S. part into Ascutney Mountain, 3,320 feet above tide-water. The town contains 3 pleasant villages. Windsor v., on W. bank of Connecticut $r$, is noted for the beanty of its site and surrounding scenery. It is irregularly laid out, but well built, and contains 3 churches, a seminary, bank, eapital $\$ 50,000$, stores, etc. The "Chronicle" (whig) and "Journal" (whig) are issued weekly. The State prison, here located, contained on Sept. 1, 1S50, 76 convicts. The Sullivan R. R. extends to this place from Bellows Falls, $25 \mathrm{~m}$., and connects with Vermont Central R. R., hence to Rouse's Point, $15 \mathrm{~m}$. These railroads, with the manufactures of the $\mathrm{v}$., have made this place one of a very active business and trade. Pop. of t. $1,92 \mathrm{~S}$.

Windsor Lncks, p. v. and sta., Hartford ca., Cann.: on W. bank of Connecticut r., $12 \mathrm{~m}$. N. IIartford. The lucks here constructed by the Connecticut River Company allow 
the passage of small steamboats and freight boats of 85 tons burden, and furnish an immense water-power, which, as yet, is but partially improved. The New Haven, Hartford, and Springfield R. R. passes along the banks of this great water privilege, having a sta, in the v., $14 \mathrm{~m}$. from Springfield, 48 from New Haven.

Winpsorvilue, p. v., Hariford co., Conn.

Wrinesburg, p. v., Holmes co., Ohio: $80 \mathrm{~m}$. N. E. by E. Columbus.

Winfield, p. v., Putnam co., Tirg.: 248 m. W. by N. Richmond.

Winfield, to and p. v., Herkimer county, N. $Y .: 74 \mathrm{~m}$. W. by N. Albany. Drained by head branches of Unadillar. The $v$. and to contain several mills and manufactures. Pop. of $t .1,481$.

Winfield, p. o., Carroll co., Md.: $38 \mathrm{~m}$. E. Annapolis.

Winfield, p. v., Union county, Penn.: $40 \mathrm{~m}$. N. by W. Harrisburg.

WxNFIELD, p. o., Lake county, Ind.: $165 \mathrm{~m}$. N. W. by N. Indianapolis.

Winfield, p. o., Columbia co, Ga.: $68 \mathrm{~m}$. N. E. by E. Milledgeville.

Winfield, p. v., Tuscarawas co., Ohio: 84 m. E. N. E. Columbus.

Winiralu, t. and p. v., Bennington county, Verm.: $80 \mathrm{~m}$. S. by W. Montpelier. Drained by Winhall r. Pop. 762.

Winnamac, p. v., and cap. Pulaski co., Ind.: on W. side of Tippecanoe $\mathrm{r}_{,}, 90 \mathrm{~m}$. N. by W. Indianapolis. First settled in 1839. It contains the county buildings, and an U. S. land office. The Indiana Central R. R. passes near it. Pop, about 240 .

Winzebago county, $I l l$. Situate $\mathrm{N}$., and contains 534 sq. $m$. Rock river flows through the co., by which and its branches Kishwaukie and Pekatonica rivers it is drained. Surface undulating and diversifed; soil deep mold, and very productive. Staples, whent, grain, and tobacco Farms 919 ; manuf. 62 ; dwell. 1,959, and pop.—wh. 11,761. fr. col. 12-total 11,773. Capital: Rockford. Putlic Works: Galena and Chicago Union R. R., and Beloit Branch R. R.

Winnebago county, $T a$. Situate N., and contains 432 sq. m. Drained by affluents of Mankato river. Surfuce undulating, and is mostly prairie and timber land. Set off since 1850 .

Winsebago county, Wisc. Situate S. E. of the centre, and contains $471 \mathrm{sq} . \mathrm{m}$. Drained by Neenah or Fox, and Panwaggun rivers and their affluents. Surface level and diversifted, with large lakes; soil deep mold, very productive. Farms 388; manuf. 32; dwell. 1,889, and pop.wh. 10,107, fr. col. 18-total 10,125. Capital: Oshkosh.

Wiximebaco, p. o., Lureal county, $17 l .: 116$ m. N. Springfield.

Wixirbago lake, Wisc.: lies in E. part of the State, $30 \mathrm{~m}$. W. Lake Michigan, between Winnebago and Calumet counties, anil in N. part of Fond du Lac county. It is 32 milis king, with average width of $\mathrm{S} \mathrm{m}$. It has sufficient depth for navigation by steamboats, several of which ply from Fond du Lac to various points on the lake and Neenah river. The water is hard and elear, though rendered turhid by winds. Its E. shore for $15 \mathrm{~m}$. is composed of a high rocky wall, which is also found on portions of the IF. shure. The N. shore is low, having for $\mathrm{Sm}$. a narrow sandy beach. It receises several streams, of which Neenah $r$, is the principal, and is its outlet into Green bay.

Winzegance, p. o., Lincoln co., Me.

Winsesurek county, $I a$. Situate N. E., and contains 732 sq. m. Drained by Upper Iowa and Turkey r. and their branches. Surface undulating, and a large portion prairie and timber land: soil fertile, and favorable to the growth of wheat, grain, and potatoes. It has good pasturage fir cattle, and is well wooded. Farms - ; manuf, - ; dwell. 100, and pop.-wh. 516. Capital: Winneshiek.

Wiscipisege lalie and river, $X$. Hetmp.: the lake 9 ss lying between Belknap and Carroll counties is of very irres. ular form, having an extreme length of about 23 miles, and its main portion an average width of $6 \mathrm{~m}$. Its branches are also large sheets of water, and combine with the main lahe to form one of the most beautiful lakes in the Union, Its shores are winding, and generally rocky, affording most de. lightful scenery. Several pleasant villages upon its banks occupy picturesque sites. The water is remarkabły clear and cold, derived extensively from springs at its bottom. It contains about 300 islands, some of which are Iarge and very fertile, containing farms of from 200 to 500 acres. and abounds with excellent fish. This lake and vicinity have always been very popular resorts in summer, and by the recent construction of railroads to its shores, the annual number of visitors has since been very greatly increased. Its elevation above the sea is 472 feet, and thus affords to its outlets, Wirmipiseogee and Merrimac rivers, abundance of water-power, used by the great factories at Manchester, Lowell, etc.

Wrinibigoshish lakes, Minn. Ter.: $180 \mathrm{~m}$. N. by W. St. Paul. The larger is $14 \mathrm{~m}$. long and $9 \mathrm{~m}$. wide.

WINNICONNET, to and p. o., Winnebago co., Wise.: $84 \mathrm{~m}$. N. N. E. Madison. Pop. 1,948 .

Winnipank, p. v. and sta., Fairfield co., Conn. : on Danbury and Norwalk R. R., 3 m. from S. Norwalk, 59 m. S.W. Hartford.

Winssiono', p. v., Franklin par., La.: 118 m. N. by W. Baton Rouge.

Winnsioro', p. v., sta., and eap. Fairfield dist., $S$. Car.. on the Charlotte and $\mathrm{S}$. Carolina R. R., $24 \mathrm{~m}$. N. by W. Columbia, It has an elevated and healthy site, and is generally well built. The county buildings are handsome struetures. It also contains 5 churches, 4 academies, and the Furman Theological Seminary (Baptist), founded in 1526, which in 1550 had 2 professors, 30 students, 30 alumni, and 1.000 volumes in library, and occupies 4 handsome buildings of granite on a pleasant location. The "Fairfield Herald" (dem.) is issued weekly, and the "Christian Magazine (relig.) monthly. Pop. about 1,050 .

Winons, p. o., Trimble co., $k y$. : 38 m. N. W. Frankfort. Winooski Falig, p. v. and sta., Chittenden co., Verm. on $\mathrm{N}$. bank of Onion river, $88 \mathrm{~m}$. N. W. by W. Montpelier. Here is excellent water-power, improved by first-class factories, etc. A branch R. R. from Burlington to Essex Junction passes through it, $8 \mathrm{~m}$. from Burlington.

Winooski river, Verm.: (see ONION river.)

Wrvslow, p. v., Pike co., Ind.: on Patoka cr., $107 \mathrm{~m}$. S. W. by S. Indianapolis.

Winslow, to and p. $v$., Stephenson co., $I l l_{0}$ : on branch of Pekatonica r., $182 \mathrm{~m}$. N. Springfield.

Wussuow, t. and p. v., Kennebec co., Me. : on E. bank of Kennebec r., 17 m. N. N. E. Augusta, Excellent waterpower is afforded by Sebasticook r., which empties into the Kiennebec at the $v$, opposite Waterville. The Kennebec and Penouscot R. R. will pass through this place. Pop. of $t .1,796$.

Wrisslow, t. and po v., Camden co., $N$. Jer.: $38 \mathrm{~m} . \mathrm{S}$. Trenton. Drained by Great Egg Harbor r. and a brancl

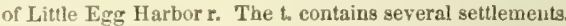
Pop. of t. 1,540.

Winsted, Litchfield co., Conn.: (see W Est Winsted.)

Wriston county, Miss. Situate N. E. centrally, and contains $718 \mathrm{sq} . \mathrm{m}$. Drained by head branches of Pearl $r$. and affluents of Noxubee $r$. Surface level, and somewhat elerated. presenting the appearance of table-land; soil a deep rich mold, and very fertile; it produces in abundance cotton and Indian corn, and is favorable to the cultivation of fruit, peaches, melons, and grapes. It is traversed by numerous streams of pure running water. Farms 556; manuf. 18: dwell. \$\$6, and pop.-wh. 5,178, fr. col. 10, sl, 2,765-intal 7,956. Capitul: Louisville.

Winstow, p. v., and eap. Forsyth co., N. Car.: $101 \mathrm{~m}$. W. N. W. Raleigh. It contains the county buildings. 
Winston, p. v., Alleghany co., Md.: $142 \mathrm{~m}$. W. by N. Annapolis.

Winston, p. o., Randolph co., Ala.: 85 m.-N. E. by N.

Montgomery.

Wriston, p. o., Weakley county, Tenn.: 107 miles W.

Nashville.

Winter Harbor, p. o., Hancock county, $M \sigma_{0}$ : 86 m. E. Augusta.

Winterpock, p. o., Chesterfield co., Virg.

Winter Seat, p. 0., Abbeville disto, S. Car. : $75 \mathrm{~m} . \mathrm{W}$. Columbia.

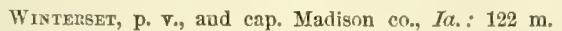

W. by S. Iowa City. It contains the county buildings.

Wintersville, p. v., Jeffersun co., Ohio: 120 m. E. by N. Columbus.

Wintersville, p. o., Decatur county, Ind.: 45 m. S. E. Indianapolis.

Winthrop, p. o., Middlesex co., Conn.

Wrintirao, p. o., Kane county, $I l l .: 150$ m. N. N. E. Springfield.

Wisthrop, t. and p. V., Kennebec county, Me.: $10 \mathrm{~m}$. W. by S. Augusta. Drained by Cobbeseconte $r_{a}$, flowing through the large ponds in $\mathrm{E}$. part of $\mathrm{t}$. The $\mathrm{v}$. is situated at the S. end of the North Lake, the outlet of which affords water-power. The Androscoggin and Kennebec R. R. passes through it, $53 \mathrm{~m}$. from Portland, $29 \mathrm{~m}$. from Waterville. Pop. of t. 2,154.

Winton, p. v., and cap. Hertford co., N. Car. : on S. W. bank of Chowan r., $102 \mathrm{~m}$. N. E. by E. Raleigh. It contains the county buildings and several stores. Pop. about 140.

Wrivon, p. o., Butler county, Ohio: 92 m. W. S. W. Columbus.

WINYAW bay, Georgetown dist., $S$. Car. : sets up N. W. from the Atlantic, is $14 \mathrm{~m}$. long, $2 \mathrm{~m}$. wide, and navigable for large vessels. It receives Black, Great Pedee, and Wacamaw rivers.

Wrota, t. and p. v., Lafayette co., Wisc. : $40 \mathrm{~m} . \mathrm{S}$. W. by S. Madison. Wasscommon r. flows through its E. part. Pop. of $t .711$.
Wiota, p. o., Laclede co., DLo.: 60 m. S. S. W. Jefferson City.

Wiretows, p. $V_{.}$, Ocean co., N. Jer.: on Barnegat bay, $42 \mathrm{~m} . \mathrm{S}$. E. Trenton.

Wint county, rivg. Created from Wond and Jickwn in 1849. Situate N. W. and contains $296 \mathrm{sq} . \mathrm{m}$. Druined by Little Kanawha $r$, and its |ributaries. Surfice num h broken: soil in general fertile. Chief proulusts, wheat and Indian enrn. Farms 3119 ; manuf. 7 ; wwell. 523 , and [w. w.wh. 3.319 , fr. col. 2, sl. 32-totial 3.353. Cepitul: Wirl C. 11. Pulice Works: North-western P. R.

WIRT, to and p. o., Alleghany co., N. Y.: $230 \mathrm{~m}$. W. by $\mathrm{S}$. Albany. Drained by small creeks. Interests chiefly agricultural. Pop. 1,544.

Wirt C. H., p. v., and cap. Wirt co., Firg.: on S. W. bank of Little Kanawha r., $232 \mathrm{~m}$. W. N. W. Richmond. It contains the county buildings, etc.

Wirt College, p. y., Sumner co, Tenn.: 30 m. N. E. Nashville.

WIscassetT, $t_{\text {. }}$ p. v., port of entry, and cap. Lincoln co., Me.: on W. bank of Sheepscot r, $22 \mathrm{~m}$. S. S. E. Augusta. The v. has an elevated and very beautiful site, and contains the county buildings, several churehes, 1 bank, eapital $\$ 50,000$, and many handsome dwellings. It is one of the most important seaports in the State, being largely engaged in the eoasting trade, fisheries, ship-building, ete. Its foreign commerce is not 80 extensive as formerly. The total tonnage of this district on June 30 th, 1850 , was 15,211 tons. The registered tonnage amounted to 6,024 tons, of which 4,748 tons were permanent, and 1,276 tons temporary. The enrolled and licensed tonnage amounted to 12,217 tons, consisting of 5,540 tons in the coasting trade, 6,092 tons in the cod fishery, 26 tons "licensed under 20 tons" in coasting trade, and 359 tons "licensed under 20 tons" in the cod fishery. At that date it had no steam tonnage. It: foreign commerce during the year preceding, consisted of 28 clearances $-4,509$ tons, and 4 entrances $-1,025$ tous. Vessels built during the year 18 ( 4 ships, 4 brigs, 10 schooners) $-2,535$ tons. Pop. of t. 2,313.

\section{THE STATE OF WISCONSIN.}

Wrisconsin embraces all of that portion of the northwest territory lying north of the parallel of $42^{\circ} 30^{\prime}$ north latitude, and west of Lake Michigan, excepting the Upper Peninsula of Michigan, and that part of Minnesota lying east of the Mississippi Piver. It is bounded north by Minnesota and Michigan; northeast and east by Lake Michigan; south by Illinois, and west by Iowa and Minnesota; or, according to the constitution, as follows, to wit: "Beginning at the northeast corner of the State of Illinois, that is to say, at a point in the centre of Lake Michigan, where the line of $42{ }^{\circ} 30^{\prime}$ of north latitude crosses the same; thence running with the boundary line of the State of Michigan, through Lake Michigan and Green Bay, to the mouth of the Menomonee River; thence up the channel of the said river to the Brûle River; thence up said last-mentioned river to Lake Brûle; thence along the southern shore of Lake Brûle, in a direct line to the centre of the channel between Middle and South islands, in the Lake of the Desert: thence in a direct line to the head waters of the Montreal River, as marked upon the survey made by Captain Cram; thence down the main channel of the Mintreal River to the middle of Lake Superior: thence through the centre of Lake Superior to the mouth of the St. Louis River; thence up the main channel of said river to the first rapids in the same, above the Indian village, according to Nicollet's map; thence due south to the main branch of the river St. Croix; thence down the main channel of said river to the Mississippi; thence down the centre of the main channel of that river to the northwest corner of the State of Illinnis; thence due east with the northern boundary of the State of Illinois, to the place of beginning." Its greatest extent north and south is 255 miles, and east and west 255 miles. Its land area is 53,924 square milcs.

The natural feature peculiar to Wisconsin, says J. W. Hunt, Esq., in his Gazetteer of the State, published 1553 , is the uniformity of its elevation, and shape of its surface, which is neither mountainous, hilly, nor flat, but gently unilulating. The country west of Sugar River and south of the Wisconsin is somewhat broken, principally by the dividing ridge upon which the road from Madison to Prairie du Chien passes. In this section, knowu as the Mines, are several peetliar elevations called Mounds. West of the Wisconsin River is a range of high hills, being the only elevations in the State either deserving or assuming the dignity of mountains. The south-eastern portion of the State is marked by ravines at the streams, but little depressed below the surrounding level. Its prominent features are the prairie, destitute of tree or shrub, covered only by a luxuriant growth of grass, interspersed with flowers of every hue; the onk opening, the lake, the woodland on the border of streams, and the natural meadow. Proceeding north. to the Fox and Wisconsin rirers, and Green Bay, the timber increases, and the soil gradually changes from the vegetable mold of the prairie to a sandy loam. The surface also becomes somewhat depressed and uneven, diversified with timber, rolling prairie, large marshes and extensive swamps, having an abundant growth of cranberries and wild rice. Still, north and west the surface becomes more uneven, and the streams rapid, affording an abundance of water-power for the manufucture of lumber from the immense forests of evergreen, scarcely surpissed on the Western Continent. 
The soil of the prairie consists of a dark brown vegetable mold, from one to two feet in depth, very mellow, and entirely destitute of stone or gravel, and, for fertility and agricultural properties, can not be surpassed. The subsoil is a clayish loam, similar to the soil of the timbered lands, and is also suitable for cultivation. The soil of the timbered land is less rich than the prairie, not so deep, and contains less carbonate of lime, which enters into the composition of the latter in the proportion of from 20 to 40 per cent. The mining region, unlike that of any other mineral district, promises a liberal reward, as well to the farmer as to the miner. The soil of the evergreen district is mostly sandy, and not so rich as in other portions of the State. It is nevertheless well adapted to agriculture and grazing. The prairies of Wisconsin are not so extensive as those of other States, and are so skirted and belted by timber, that they are well adapted to immediate and profitable occupation. The openings, which comprise a large portion of the finest land of the state, owe their present condition to the action of the anuual fires which have kept under all other forest growth, except those varielies of oak which can withstand the sweep of that element. This annual burning of an exuberant growth of grasses and of under-brush, has been adding, perhaps for ages, to the productive power of the soil, and preparing it for the plowshare. It is the great fact, nature has thus " cleared up" Wisconsin to the hand of the settler, and enriched it by yearly burnings, and has at the same time left sufficient timber on the ground for fence and fire wood, that explains, in a great measure, the capacity it has exhibited, and is now exhibiting, for rapid settlement and early maturity. There is another fact important to be notied in this conneetion. The low level prairie, or natural meadow, of moderate extent, is so generally distributed over the face of the country, that the settler on a fine section of arable land finds on his own farm, or in his immediate neighborhood, abundant pasturage for his stock in summer, on the open range; and hay for the winter for the cutting-the bounty of Nature supplying his need in this behalf till the cultivated grasses may be introduced and become sufficient for his use.

The limestone underlying the coal flelds of Mlinois forms the immediate basis of the alluvion of Sonthern Wisconsin. This geological district, in addition to that portion of the State which lies southerly of the valley of the Wisconsin River, comprises the whole of the slope toward Lake Michigan. In many portions of this district the lime rock disappears, and the out-cropping standstone furnishes a fine material for building. The lead-bearing rock of the mineral region is a porous limestone, prevailing throughout Grant, Lafayette, and Iowa counties, comprising four-fifths of the "lead district" of the Upper Mississippi, the remaining one-fifth being in the States of Illinois and Iowa. Deposits of iron ore, water limestone, and beds of gypsum, together with other varieties of minerals, are found in Iocalities more or less numerous throughout the limestone region. All of that section of the State which lies between Lake Superior on the north and the Falls of St. Anthony on the Mississippi, and the falls of the other rivers flowing southerly, is primitive in its prevailing geological character; and it is within this prinitive region that the copper mines of Lake Superior are found-probably the richest in the world, and apparently inexhaustible. In all that portion of the State lying betwcen the primitive region just described and the limestone formation of the south and east, the transition sandstone prevajls, interspersed with limestone and more sparsely with rock of a primitive character. This formation comprises that section of the country drained by the Wisconsin and other rivers tributary to the Upper Mississippi and below the falls of those streams. Within this geological district are found quarries of white marble, which promise to be abundant and valuable.

Wisconsin, says J. A. Lapham, Esq., does not fall behind the other portions of the Western country in the monu ments it affurds of the existence of an ancient peaple who once inhabited North America, but of whom nothing is known except what ean be gathered from some of the results of their labors. The works at Aztalan, in Jefferson County, aro most known and yisited, but there are many other localities which are said to equal them in interest and importanee. The substance called brick at this place is evidently burned clay, showing marks of having been mixed with straw, but they were not molded into regular forms. There is a class of ancient earth-works in Wisconsin, not before found in any other country, being made to represent quadrupeds, birds, reptiles, and even the human form. These representations are rather rude, and it is often difficult to decide for what species of animal they are intended; but the effects of time may have modified their appearance very much since they were originally formed. Some have a resemblance to the buffalo, the eagle or crane, or to the turtle or lizard. One representing the human form, near the Blue Mounds, is, according to R. C. Taylor, Esq., 120 feet in length; it lies in an east and west direction, the head toward the west, with the arms and legs extended. The body or trunk is 30 feet in breadth, the head 25 , and its elevation above the general surface of the prairio is about 6 feet. Its conformation is so distinct that there can be no possibility of mistake in assigning it to the human figure**A mound at Prairieville, representing a turtle, is about 5 feet high, the body is 56 feet in length, it represents the animal with its legs extended and its feet turned backward. It is to be regretted that this interesting mound is now nearly destroyed. The ancient works are found in all parts of the territory, but are most abundant at Aztalan, on Rock River, near the Blue Mounds, along the Wisconsin, the Neenah, and the Pishtaka rivers, and near Lake Winnebago. The mounds are generally scattered about without any apparent order or arrangement, but are occasionally arranged in irregular rows, the animals appearing as if drawn up in a line of march. An instance of this kind is seen near the road, seven miles east from the Blue Mounds, in Iowa County. At one place near the Four Lakes it is said that one hundred tumuli, of various shapes and dimensions, may be counted-those representing animals being among others that are round or oblong. Fragments of ancient pottery of a very rude kind are often found in various localities. They were formed by hand, or molded, as their appearance shows evidently that these vessels were not urned on a "potter's wheel," Parts of the rim of vessels, usually ornamented with-small notches or figures, are most abundant. A mound is said to have been discovered near Cassville, on the Mississippi, which is supposed to represent an animal having a trunk like the elephant, or the now extinct mastodon. Should this prove true, it will show that the people who made these animal earth-works, were cotemporaries with that buge monster whose bones are still occasionally found; or that they had then but recently emigrated from Asia, and had not lost their knowledge of the elephant.

The salubrity of the climate (Mr. Lapham is again quoted), the purity of the atmosphere and of the water, which is usually obtained from copious living springs, the coolness and short duration of summer, and the dryness of the air during winter, all conspire to render Wisconsin one of the most healthy portions of the United States. The wet meadows, marshes, and swamps are constantly supplied with pure water from springs; and as they are not exposed during summer to a burning heat, they do not send forth those noxious and deleterious qualities so much dreaded in more southern and less favored latitudes. Many of our most flourishing towns and settlements are in the immeliate vicinity of large swamps,

* The reader is referred to the " Notice of Indian Mounds, etc., in Wisconsin"" in silliman's Juurnal, rol, xxxiv, p. 8s, by R. C. Taylor, and to the "Description of Ancient Remains in Wisconsin," by S. Taylor, rol. rliv, p. 21, of the same work, fur more detaitod descriptions and drawings of these interesting animal mounds. 


\section{WISCONSIN.}

and partially overflown meadows, yet no injurious effects upon the general health are produced by them. It has usually been found, in making new settlements in the Western wilderness, that as the foresty are cleared away, and the surface thereby exposed to the direct infuence of the sun and winds, a deleterious effect is produced on the general health-ihe decaying vegetable matter being thus suddenly mado to send forth its malarious qualities. But in Wisconsin no such result is apprehended, or can be produced, for a large proportion of the country consists of oak-opening and prairie, and may therefore be considered as already cleared. The removal of the few remaining "burr oaks" can not have the same effect upon the soil as the cutting down of the dense forests of the other States. And besides this, the fires that have annually raged over the surface, often kindled purposely by the Indians, on their hunting excursions, have prevented that rapid aceumulation of vegetable matter which is always found in deep sharly wonds, where the fres do nrit so oflen penetrate. It is believed that the facts here stated will be sufficient to satisfy the reader of the truth of the opinith exprisserl by our most intelligent physicians, that Wisconsin is, and will continue to be. one of the most healthy places in the world.

The amount of lead shipped from Galena during the last year was $40,000,000$ pounds, nine-tenths of which was raised in Wisconsin. Considerable more than the remaining one-tenth of the amount above stated has been shipped from ports in this State, from which it will be seen that this estimate is small. To the practical miner, as capitalist or operative, the lead region of the Upper Mississippi offers the most substantial inducements to settlement. The exceeding abundance and richness of the mineral, the comparative ease with which it may be mined, and the high price it commands the moment it is brought to the surface, open to the industrious and prudent operator a highway to wealth. New leads of the richest promise have been recently discovered in the mineral district, and an increasing emigration to that section of the State promises to replace the California draft, and to meet the growing demand for the mineral.

The copper mines of Lake Superior are of established celebrity throughout the world, and open an inviting fleld for enterprise. The mining interest in that region is fast losing its character of adventure, and is attracting the attention of the prudent capitalist and the practical miner, as a renunerative branch of business.

The iron mines of Wisconsin have not yet been opened to any extent, but are worthy the attention of the immigrant. There are rich localities of ore near the head-waters of the Rock, and on the Upper Mississippi and its branches.

The following statement exhibits the shipment of lead from Galena from the year 1811 to 1852 inclusive, and the value of the same at four dollars per hundred weight:

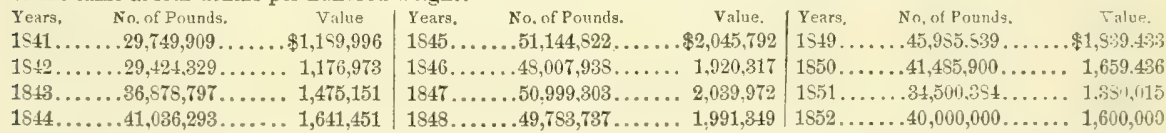

There are also large quantities of lead shipped at different points along the Wisconsin and Mississippi rivers, the precise amount of which no data has been furnished upon which an intelligent estimate can be made. In reviewing the foregoing statement, it should be recollected that Wiscorsin is rapidly increasing, not only in population and wealth, but in the amount and quality of its resources, manufactures, and products.

The richness of the soil of Wisconsin, and its ability to produce in abundance all kinds of grain, as well as the facility by which the lands are brought under subjection, create a permanent demand for all kinds of agricultural implements and mechanical labor. Architectural elegance in public and private buildings, and elaborate perfection in complicated machinery is not to be expected in new settlements; but many of them in Wisconsin compare favorably with those of the older States. The rapid growth of towns, and the great influx of farmers with their families, create a necessity for temporary buildings, soon to be superseded by comfortable dwellings and out-houses, and give constant employ for the mason, the carpenter, and all other mechanics. The immense flouring-mills of the State already in operation, as well as those in progress of erection. provide labor for the millwright and machinist, and furnish not only their respective vicinities with all kinds of mill stuff, but more than 100,000 barrels of flour annually for exportation.

To the lumberman, the pineries of Wisconsin present inducements for investment and settlement, which can be hardly overrated. That of the Upper Wisconsin and its tributaries is the most extensive; and distinguished still more for the fine quality than the inexhaustible quantities of its timber. The other localities of the white pine and other evergreens are mainiy on the Wolf, the great northern affluent of the Fox, the tributaries of Green Bay, and on the La Crosse, the Black, Chippewa, and the St. Croix, branches of the Upper Mississippi. The rapids of these streams furnish abundant water-power for the manufacture of Iumber, and on the annual spring rise, and occasional freshets at other seasons of the year, the yield of the mills is floated from the Wolf into Lake Winnebago and the Lower Fox, and from most of the other streams into the Mississippi. Searcely ten years have elapsed since the Alleghany pine of Western New York and Pennsylvania had undisputed possession of the market, not only of the Ohio Valley, but of the Mississippi and its tributaries above New Orleans, at which point it competed with the lumber of Maine and New Brunswick. The course of the lumber trade may now be considered as permanently changed. The pineries of Wisconsin now eontrol, and will hold exclusive possession of the market of the valleys of the Mississippi and its great western affluents. The amount of pire lumber estimated to be sawed in Wisconsin anuually, is as follows: Black River, 15,000,000; Chippewa, 2S,500,000; Green Bay, 21,000,000; Manitouwoc, 24,500,000; St. Croix, 20,009,000; Wisconsin, 58,500,000; Wolf, 25,500,000-total number of feet, $193,000,000$.

Aside from the manufacture of pine lumber, reaching as it does nearly $200,000,000$ feet per year, saw-mills, driven by both steam and hydraulio power, are now in operation in every section of the State where timber is found, and large quantities of oak scantling and plank, and basswood siding and lath, are yearly manufactured.

Wisconsin is divided into 31 counties, the general statistics of which, and the capitals of each, in 1850, were as follows:

$$
\text { Counties. Dwell. Pop. Farms Manuf. Capitals. }
$$

Adams........ $40 . .157 \ldots \quad 0 \ldots, 0 .$. Adams C. H.

Brown.........1,003.. 6,215. . 190. 27..De Pere

Calumet....... 383.. 1,743.. 125. . 4..Stockbridge

Chippewa..... 94.. 614.. 0. 3..ChippewaC.H.

Columbia.......1,853.. 9,565.. 833.. 24. Ft. Winnebago

Craw ford ...... 571.. 2,498 80.. 11..Prair. du Chien

Dane.........3.203. 16,641 ..1,501.. 87.. MAdison

Dodge ........3,600..19,138, 2,132.. 28. .Juneau
Counties. Dwell. Pop.
Fond du Lae. . . . 2,721 . 14,468. .
Grant
70. . 704. . 78. . Lancaster
Greene .........1,451.. 8,563. . 768. . 45... Monroe
Iowa ... . . . . . . . 1, $846 \ldots 9,550 \ldots 470 \ldots 24 \ldots$ Mineral Point
Jefferson........2,984..15,317.. 9S2.. 74..Jefferson
Kenosha ......1,812.10,732. . 914. . 51..Kenosha
Lafayette ..... 2,076. .11,541.. 899. . 21. . Shullsburg.
La Pointe ..... 74.. $459 \quad 5$. 1.. La Pointe

$9 \pm 1$ 
WISCONSIN.

\begin{tabular}{|c|c|c|}
\hline Dwell. Pop. & $\begin{array}{l}\text { Farms Manuf. } \\
\text { in cult. Estab. }\end{array}$ & $\begin{array}{l}\text { Farms Manuf. Capitale. } \\
\text { in cult. Estab. }\end{array}$ \\
\hline .. $715 \ldots 3,702 \ldots$ & 35.. 22. . Manitouwoc R. & 4.. 2.. Willow River \\
\hline Marathon....... & 7.. 15.. Wausau & Sauk ........ 814.. 4,371.. 245.. 7..Baraboo \\
\hline Marquetle ......1,778.. 8,642. . & 327.. 7 .. Marquette & Sheboygan .....1,783.. 8,378.. 328.. 29..Sheboygan \\
\hline Milwaukie.....5,630..81,077.. & $935 . .286 .$. Milwaukie & 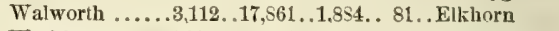 \\
\hline Portage ....... 204. 1,250.. & 5.. 15... Plover Portage & Washington ....8,770..19,484,.1.853. 22... Ozaukee \\
\hline Rucine ......2,578,.14,973.. & 971..104. . Racine & Waukesha. .....3,408 ..19,174,.1,703 . 78. . Waukesha \\
\hline $\begin{array}{l}\text { Richland ..... 178.. 903.. } \\
\text { Rock........ } 3,618, .20,708 \text {. }\end{array}$ & $\begin{array}{l}\text { 53.. 4.. Richland Cent. } \\
\text { 1,965. 125. .Janesville }\end{array}$ & Winnebago ....1,\$\$9..10,125.. 838.. 32.. Oshkosh \\
\hline
\end{tabular}

The whole number of dwellings in the State was, at the above date, 56,316 ; of families, 57,608 ; and of inbabitants' 305.191 ; viz., whites 304,565-males 164,221, and females 140,344; fr. col. 626-males 365 , and females 261. Of the whole population there were, deaf and dumb-wh. 65, fr. col. 0-total 65 ; blind-wh. 50, fr. col. 0-total 50; insane-wh. 49, fr. col. 0 -total 48; and idiotic-wh. 76, fr, col. 1 -total 77 . The number of free persons born in the United States was 197,912, the number of foreign birth 106,695, and of birth unknown 784 . The native population originated as follows. Maine 3,252, N. Hamp. 2.520, Verm. 10,157, Mass. 6,285, R. I. 690, Conn. 4,125, N. Tork 6s,595, N. Jer. 1,566, Penn. 9,571, Del. 141, Md. 462, Dist. of Col. 83, Virg. 1,611, N. Car. 322, S. Car. 107, Ga. 495, Flor. 4, Ala. 49, Miss. 35, La. 78, Tex. 4, Ark. 67, Tenn. 449, Ky. 1,429, Ohio 11,402, Mich. 1.900, Ind. 2.778, Ill. 5,292, Mo. 1,012, Ia. 445, Wisconsin 63,015, Calif, 0. Territories 26; and the foreign population was composed of persons from-England 18,952 , Ireland 21,043, Seotland 3,527 , Wales 4,319, Germany 34,519, France 775, Spain 4, Portugal 4, Belgium 45, Holland 1,157, Italy 9, Austria 61, Switzerland 1,244, Russia 71, Denmark 146, Norway 8,651, Sweden 88, Prussia 3,545, Sardinia 1, Greece 1, Asia 17, Africa 1, British America 8,277, Mexico 9, Central America 11, South America 6, West Indies 20, and other countries 191.

The following table will show the decennial progress of the population since the first general census of the Stato:

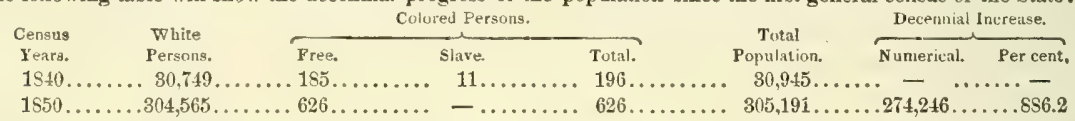

The general statistics of the resources, productions, manufactures, wealth, and institutions of Wisconsin, in accordance with the census of 1850 , and other authentic reports referring to the same period of time, are as follows:

Occupied Lands, etc.-Improved farm lands, 1,045,499 acres, and unimproved lands, 1,931,159 acres-together valued at $\$ 28,528,563$. The total number of farms in operation on the 1st June, 1550, was 20,177. Value of farming implements and machinery $\$ 1,641,568$

Live-Stock.-Horses, 30,179 ; asses and mules, 156 ; milch cows, 64,389 ; working-oxen, 42,801; other cattle, 76,293 ; sheep,

124,892 ; and swine, 159,276 . The live-stock of 1540 and of 1550 compared, give the following results :

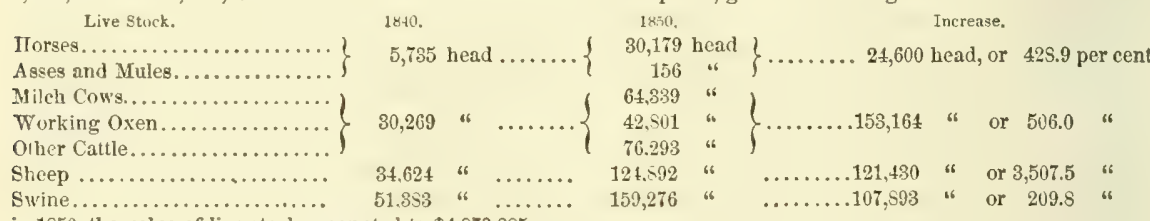

-in 1850 , the value of live-stock amounted to $\$ 4,879,385$.

Products of Animals.-Wool, 253,963 pounds; butter, 3,683,750 pounds; cheese, $400,2 S 3$ pounds; and the value of animals slaughtered in the year had been $\$ 920,178$. The wool crop of the census year of 1840 amounted to 6,777 pounds; and hence that of 1850 exhibits an increase of 247,156 pounds, or of $3,499.8$ per centum. The clip per fteece, in 1840 , was 31.3 ounces, and in $1850,32.5$ ounces - being an average increase of 1.2 ounces per fleece.

Grain Crops.-Wheat, 4,286,131 bushels: rye, 81,253 bushels; Indian corn, 1,988,779 bushels; oats, $3,414,672$ bushels;

barley, 209,692 bushels; and buckwheal, 79,5 is bushels. These erops, compared with the crops of 1510 , result as follows: Crops. 1840, 1850, Increase,

Wheat ........... 212,116 bushels........4,2s6,131 bnshels........4,074,015 bushels, or $1,920.6$ per cent.

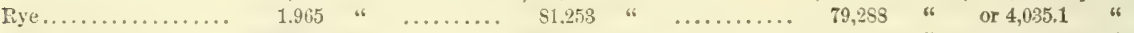

Indian corn ........ 379.359 " $\ldots \ldots \ldots \ldots .1,955,979$ " $\ldots \ldots \ldots \ldots .1,609,620$ "

Oats............ 406,514 " $\ldots \ldots \ldots .3,414.672$ " $\ldots \ldots \ldots \ldots 3,008,158$ "

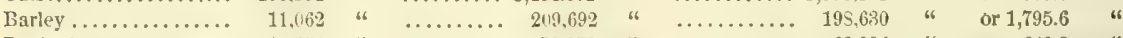

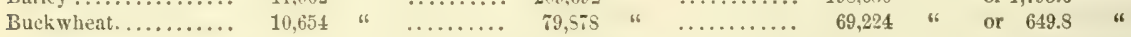

Other Food Crops.-Peas and beans, 20,657 bushels; potatoes, Irish, 1,402,077 bushels, and sweet 879 bushels. The potato crop of 1840 amounted to 419,608 bushels; and hence the crop of 1850 exhibits an increase of 983,348 bushels, or 234.3 per centum.

Mfiscellaneous Crops.-Tobacco, 1,268 pounds; hay, 275,662 tons; clover-seed, 483, and other grass-seed, 312 bushels; hops, 15,930 pounds; hemp-dew-rutted, But tons. and-water-rotted, 2 tons ; flax, 6 - .393 pounds; flax-seed, 1.191 bushels; maple sugar, 610,976 pounds; molasses, 9,874 gallons: beeswax and honey, 131,005 pounds; wine, 113 gallons, ete., ete. Value of orchard products, $\$ 4,823$, and of market-garden products, $\$ 32,142$. The principal crops, compared with simila crops of 1510 , exhibit the results appended :

\begin{tabular}{|c|c|c|c|c|c|}
\hline Crins. & $1 \varepsilon+0$. & 18.50 & & crease. & \\
\hline Hay ................ & 30,938 tons & $2 \pi 5.662$ tons & 244,724 tons & S02.6 & per cent \\
\hline Iops.................. & 133 pounds........ & 15,930 pounds............ & 15,797 pounds, & or $11,125.5$ & a6 \\
\hline Hemp-dew-rotted... & & $\ldots \ldots \ldots$, & & & \\
\hline $\left.\begin{array}{c}\text { " water-rotted... } \\
\text { Flax................ }\end{array}\right\}$ & 2 tons & 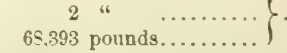 & 741,392 & or $16,526.6$ & 6 \\
\hline aple-sugar ........... & 185,255 pou & ........... & 475,658 & or & " \\
\hline Wine $\ldots \ldots \ldots \ldots \ldots$ & 0 gallons........ & 113 gallons ........... & 113 gallons & or $11,300.0$ & 66 \\
\hline
\end{tabular}


Home-made manufuctures were produced, in the year ending 1st June, 1550 , to the value of $\$ 43,621$. The same class of goods made in the census year of 1840 , was valued at $\$ 12,56 \%$.

Ifunufactures.-Aggregate capital invested, $\$ 0,000,000$; value of all raw material, fuel, etc., consumed, $\$ 000,000$; a verage number of hands employed, 00,000 - males 00,000 , and females 0,000 ; monthly cost of labor, $\$(10,010$ - to males $\$ 00,000$, and to females $\$ 0,000$; value of products of the year, $\$ 0,000,000$. The whole number of manufacturing establishments in operation on the 1st June, 1850, and manufacturing to the value of $\$ 500$ and upward annually, was 1,273 , the great portion of them being mills of various descriptions, and other agricultural manufactories, and of the strictly national manufactures the following: 9 woolen factories, 16 iron works-one making pig iron, and 15 making castings; and 8 tanneries. The total capital invested in manufactures, in 1840 ; amounted to $\$ 635,926$.

In the woolen manufacture there is a capital of $\$ 31,225$ invested; wool consumed, 134,200 pounds; value of all ratr material, etc., $\$ 32,630$; hands employed, 25 ; monthly wages paid, $\$ 562$; products of the year-cloth 36,000 yards, and Jarn 94,350 pounds; value of products $\$ 87,992$. This interest has risen to its present condition since 1840 .

The capital invested in the manufacture of pig iron is $\$ 15,000$; ore used, 8,000 tons ; coke and charcoal consumed, 150,000 bushels ; hands employed, 60 ; monthly wages $\$ 1,800$; pig iron produced in the year 1,000 tons; value of entire products, $\$ 27,000$.

In the manufacture of iron castings, a capital of $\$ 116,350$ is invested; pig iron used, 1,371 tons: old metal, 1 s tons; coal 595 tons; and coke and chareoal, 2,700 bushels; value of all raw material, ete., used in the year, $\$ 56.930$; hands empioyed, 22S; average monthly wages, $\$ 2673$; products of the year-castings 1,342 tons, and, including $\$ 64,025$, the value of other products, these were valued at $\$ 216,195$. In 1840 , there was but one furnace in the 8tate, which produced only 3 tons cast iron, and employed 3 hands, and a capital of $\$ 800$.

In tanneries, the capital invested amounts to $\$ 78,950$; value of hides and skins used, $\$ 93,380$; hands employed, 75 ; monthly cost of labor $\$ 1,710$; tanned during the year, 14,900 skins, and 59,600 sides of leather, valued at $\$ 175,710$. In 1540 , but one tannery was reported, employing 3 hands and $\$ 2,000$, and producing annually 150 sides of sole leather, anc 150 sides of upper leather.

The capital invested in the manufacture of malt and spirituous liquors amounts to $\$ 98,700$; quantities and kinds of grain, ete., consumed-barley, 91,020 bushels ; corn, 29,900 bushels; rye, 9,200 bushels; hops, 28 tons; hands employed, 98; quantities of liquors produced-ale, ete., 31,320 barrels; whisky, 127,000 gallons. In 1840, there were 3 breweries, producing 14,200 gallons ale, etc., and 3 distilleries, producing 8,300 gallons spirits, etc., together employing 11 hands, and a capital of $\$ 14.400$.

Commerce and Internal Improvements,-The commerce of Wisconsin, chiefly carried on at its lake ports, is very valuable and extensive. The statistics of its foreign trade with Canada are embraced in those of the districts of Michillimackinae and Chicago, and hence can not be stated separately. The trade in that direction, however, is not large. The coasting trade is relatively of immense importance, both on the lake and on the Mississippi. The exports and inports at the lake ports are shown under the head of Lake Michigan. The chief ports of the Mississippi are Prairie du Chien, Cassville, etc., and the exports from those are chiefly mineral. The internal commerce of the State is carried on with great activity, radiating from the principal commercial towns to every portion, and large supplies are needed in the northern pineries, which supply so valuable a material to general commerce. The internal improvements of Wisconsin are more prospective than existing, but great progress has been made in building railroads, one of which will extend along the lake shore from Chicago to Fond Ju Lac, and other roads diverge from Chicago, Milwaukie, elc., toward the Mississippi, centering at Madison. A line will also extend frum the latter point to Portage City on the north, and to Beloit and Janesville on the south, and these will be carried to a junction with the Galena and Chicago Union R. R. The only line yet complete is that from Milwaukie to Madison, which, under the name of Milwaukie and Mississippi R. R., will stretch across the State. The improvement of Fox and Wisconsin rivers is in progress, with the intention ultimately of connecting the rivers by a eanal, and thus giving uninterrupted navigation from the lake to the Mississippi.

Banks,-The only banking institutions of the State, of which the names are known in the markets are, the Milwaukie Bank, Richmond's Exchange Bank, and the Wisconsin Marine and Fire Insurance Company, all at Milwaukie. The State constifution does not recognize banks of any description.

Government,-The constitution now in force was adopted in convention on the 1st February, 1548, and approved by the people at the election beld in April following.

All males 21 years old, residents of the State for one year next before the election, who are white citizens of the United States, or white foreigners who have declared their intention to become such citizens, or persons of Indian blond once declared by the laws of the United States to be cilizens, subsequent laws to the contrary notwithstanding, or "civilized persons of Indian descent" not members of a tribe, are entitled to vote at all elections: and the right of suffrage may be extended by a law approved by a majority of votes at a general election. The exceptions refer to incompetent persons and those convicted of treason or crime. The general elections are held on the Tuesday after the first Monday in November annually.

The Legislature consists of an Assembly and Senate. Members of the Assembly (in number between 54 and 100) are chnsen amnually, and Senators (not more than one-third nor less than one-fourth the number of Assemblymen) are chosen for two years, one-half each year. Both must be qualified voters in their districts. An apportionment is mide after each federal census and after each decennial State census, the first of which will be taken in 1855. The Legislature meets at Madison on the first Monday of January annually.

The Governor shall be a qualified voter and citizen of the United States, and is chosen for two years by a plurality of votes, and if there be no choice the Legislature shall, by joint ballot, chnose one of the persons having the highest equal number of votes. In default of the governor, his duties are discharged by the Lieutenant-governor, who is chnsen with the same qualification and for the same term as the governor. He is ex-officio President of the Senate. If the lieutenantgovernor defaults, then the Secretary of State fills the office. The governor's veto may be defeated by a vote of twothirds of the members present in each house.

The Judiciary is comprised in a Supreme Court, Circuit Courts, County Courts, and Justices of the Peace. Justices of the Peace are elected in the several towns, hold office two years, and have jurisdiction throughout their counties in civil matters when the debt or damages claimed do not exceed $\$ 100$. A county court is established in each county, and the judge is elected by the voters of the county for the term of four years; his court has jurisdiction concurrent with the circuit cours in all civil actions arising within the county, and in civil actions originating out of the county, when the damages claimed are not more than $\$ 500$, and exelusive appellate jurisdiction in all cases of appeal or certiorari from 


\section{WISCONSIN.}

justices of the peace, also probate powers and jurisdiction. The State is divided into six judicial circuits, the voters of each of which elect a judge for six years. The circuit courts have general original jurisdiction in actions civil and criminal at law and equity within their circuits. The supreme court is composed of the judges of the circuits, one of whom is elected by the other judges Chief Justice. Except the power to issue writs of mandremus, quo voarranto, and the like, this court has appellate jurisdiction only, and is the court of last resort. There can be no trial by jury in this court. Tribunals of conciliation may be established, and in every organized county the Legislature may appoint one or more persons with powers not exceeding those of a circuit judge at chambers. Sheriffs, coroners, registrars of deeds, and district attorneys are chosen by the people for two years.

Among the miscellanenus provisions of the constitution are the following : no lottery or divorce can be granted by the Legislature; Iaws shall be passed providing a way for suing the State; the credit of the State shall never be lent, nor shall any debt be contracted nor money paid for internal improvements, unless the State hold trust property dedicated to such uses; except in cases of war, invasion, or insurrection, no debt exceeding $\$ 100,000$ shall be contracted; a university without "sectarian instruction" shall be established; the Legislature shall prevent towns and cities from contracting debts; no general or special law to create a bank or banks shall be passed till a majority of the votes at a general election shall have been in favor of a bank, and until such a majority have afterward approved the act as passed; any person implicated in a duel loses the right of suffrage and of holding office; no public defaulter shall hold office; in criminal proseentions for libel the jury are judges of law and fact; all lands are allodial, and leases of agricultural lands, with rent or service reserved for more than finteen years, are void; resident aliens have all the property rights of citizens; imprisonment for debt on contract is prohibited; no religious opinions shall disqualify a witness, etc.

Amendments to the constitution, agreed to by a majority of members of both houses, shall be published for three months before the next election, and referred to the Legislature then chosen; and if again approved by such majority, shall be submitted to the people. A convention may be called in like manner.

Federal Representation.-Wisconsin, in accordance with the apportionment act of the 23rd May, 1850, has three representatives in the United States Congress.

The militic force of the State as reported to the Adjutant-General of the United States army consists of 32,203 men of all arms, of which 1,804 are commissinned officers, and 30,399 non-commissioned officers, musicians, artificers, and privates. Of the commissioned officers, 9 are general officers, 31 general staff officers, 212 field officers, etc., and 1,552 company officers.

The principal benevolent institution of the State is the Asylum for the Education of the Blind at Janesville, a tax of one-fifteenth of a mill on every dollar of taxable property in the State is levied for its aid. It was opened 1st August, 1550 , and on the 18th December, 1S51, had 8 pupils-6 boys and 2 girls. Annual cost of support, $\$ 1,830$.

Finances, Delit, etc.-The total receipts for the year ending 31 st December, 1850 , amounted to $\$ 93,88958$, and the expenditures to $\$ 62,74620$. The total receipts since the organization of the State government had been to date, $\$ 160,21853$, and the total expenditures, $\$ 152,969$ 61-excess of receipts, $\$ 7,24892$. The chief sources of revenue are taxes and the sales of lands. The principal expenditures are those-for salaries of executive and judicial officers, 13.592 33; legislative expenses, $\$ 14,30953$; printing, $\$ 5,79344$; State convicts (there being no prison), $\$ 3,09352$; miscellaneous (including revision of statutes in 1849), $\$ 16,35659$. There is a territcrial debt of $\$ 12,59275$, which would be due in June, 1851.

Stutistics of Education.-The superintendent of public instruction reported the capital of the school fund as amounting on the 1st June, 1851, to $\$ 53 \$, 09 \pm 41$, which at 7 per cent. interest yielded an annual revenue of $\$ 37,66661$. This had been derived from sales of school-lands in 1849 and 1850, from the 5 per cents., and from fines. It is expected that $\$ 5,301,94344$ will be eventually realized from the sales of the school-lands. The sum of $\$ 47,41677$ was, Jan. 1st., 1851 , in the treasury, to be apportioned among the several towns, which would give about 50 cents for each child attending school. For the year ending August 1st, 1850, out of 2,105 districts, 1,700, and out of 764 part distriets, 650 had reported schools. In the districts reported, each school had been taught on an average 4.96 months, and all received $\$ 65,60426$ of public money. Out of 92,047 children between the ages of 4 and $20,61,597$ attended schools, and 1,020 under 4 , and $6 S 5$ orer 20 , also attended. A verage wages to teachers-male $\$ 1714$, and female $\$ 902$. There were at the date indicated 88 school-houses of brick, 51 of stone, 565 of $\mathrm{lngs}$, and $540 \mathrm{framed}$, and all valued at $\$ 173,216$ 67. The highest valuation of any school-house was $\$ 5,000$, and the lowest, 5 cents. There were also in the State 87 private or select schools, with an average of 75 pupils. The State University is located at Madison; it was founded in 1848, and is well endowed. The Beloit College was founded in 1846, and in 1850 had 6 professors, and 25 students; and its library contained about 2,000 volumes. These institutions promise to be of essential utility when their organization is perfected.

Public Libraries.-One State library-4,000 volumes; 1 social-1,000 volumes; 33 public sehool-2,163; total, 35 libraries and 7,168 volumes.-Report of Libr. of Smithsonian Institution, 1851.

Periodical Press.-The whole number of periodicals published in Wisconsin in 1850 was 49 , of which 11 were conducted on whig principles, 29 on democratic principles, and 9 were neutral in politics, including literary, religious, and all issues, the character of which had not been ascertained. Of the whole number, 6 were daily newspapers, 5 tri-weeklies, 36 weeklies, and 1 monthly. The circulation of the dailies amounted to 3,365 copies at each issue, the tri-weeklies to 1.525 copies, the weeklies to 25,624 copies, and the monthly to 1,500 copies. There was published in Brown county, in Culumbus and in Cruwford countr, each 1 w.; in Dane, 3 w. ; in Fond du Lac, 2 w.; in Greene and Grant, each 1 w. in Jefferson, 2 w.; in Kenosha, 2 w.; in Milwaukie, 6 d., 5 t.-w., 6 w.; in Racine, 4 w. and 1 m.; in Rock, 3 w.; in Sauk, 1 w.; in Sheboygan, 3 w.; in St. Croix and Washington, each 1 w.; in Winnebago, 2 w. ; and in Walworth and Waukesha, each 1 weekly.

Retigious Denuminations. - The statistics of the sereral religious denominations in the State in 1550 were as follows:

\begin{tabular}{|c|c|c|c|c|c|}
\hline $\begin{array}{l}\text { expmina- No ur } \\
\text { ripus. } \\
\text { Churches }\end{array}$ & $\begin{array}{c}\text { Church Value of } \\
\text { aceom. Property. }\end{array}$ & 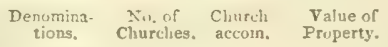 & $\begin{array}{l}\text { No. of } \\
\text { Churches. }\end{array}$ & $\begin{array}{l}\text { Church } \\
\text { acerom. }\end{array}$ & $\begin{array}{l}\text { Yalue of } \\
\text { Priperity: }\end{array}$ \\
\hline & $0.5(15 \ldots \ldots * 52.540)$ & erman Ref. $-\ldots$ - & R. Catholic... 57 . & 23,717 . & $. \$ 66,085$ \\
\hline ian. & 1,200 & Jew & Swedenbo'n. & - & - \\
\hline at'1.. 33 & 61,260 & $5,000 \ldots 13,650$ & $\mathrm{Tu}$ & & - \\
\hline f... 2 . & 55 & te... - & Eni & 400. & 500 \\
\hline 1.. 19 & 45,750 & 62,430 & - & & - \\
\hline Free....... 2 & 25 & - & .. 1 & 800. & 8,000 \\
\hline $\begin{array}{c}\text { Friends ...... } \\
\qquad 914\end{array}$ & - & 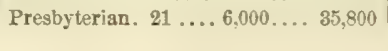 & Sects.. - & - & - \\
\hline
\end{tabular}


-making a total of 244 churches, having accommodation for 78,450 persons, and valued at $\$ 350,600$. Wisconsin forms a missionary diocese of the Protestant Episcopal Church, and comprises the Roman Catholic diocese of Milwaukie.

Purperism and Crime.-The whole number of paupers who received support within the year ending 1st June, 1950, was 666 , of which number 169 were native, and 497 foreign born; and the whole number of paupers at the date specified was 338 , of which 72 were natives, and 166 foreigners. Cost of support within the year, \$14,743. A State prison has just been erected at Waupun, in Fond du Lac County.

Historical Sketch.*-Wisconsin was first visited by French missionaries in 1660, in October of which year Mesnard reached Che-goi-me-gon, on Lake Superior. In 1672, Aloues and Dablon visited Green Bay, and the country between the Fox River and the south end of Lake Michigan. In the year following, on the 13th of May, Marquette, a Jesuit missionary, and Joliet, an agent of the government of France, with flve other Frenchmen, embarked from their mission, near Mackinac, and arrived at Green Bay, where they found an Indian village and procured guides to accompany them up Fox River to the Portage with the Wisconsin. They descended this river to its mouth, where they arrived on the 17 th of June, 1673, and made the flrst discovery of the Upper Mississippi River. The Territory remained under the government of the French, who claimed it, until 1768, when, at the treaty of Paris, it was ceded to Great Britain, who retained it until the Independence of the United States was acknowledged by that country in 1783, when it was elaimed by Virginia, as a part of the Illinois country conquered by Col. George Rogers Clark. It, however, remained in the possession of Great Britain until 1796, when it was surrendered in accordance with Jay's treaty, ratified the previous year. On the first day of March, 1784, it was ceded by Virginia to the United States. By the celebrated ordinance passed the 13th of July, 1787, a government.was provided for the Territory north-west of the Ohio River, which territory was divided into two separate governments, the western called Indiana, by an act passed May 7th, 1800. An act dividing the Indiana Territory and organizing Illinois, was passed and approved February 3d, 1809. By the act of Congress to enable the people of Illinois to form a State government, approved April 18th, 1818, all that portion of said territory north of the parallel of latitude $42^{\circ} 30^{\prime}$ west of the middle of Lake Michigan, was attached to the Territory of Michigan, which had been set off from Indiana in 1805 .

In 1835, Michigan having assumed a State government, John S. Horner, Secretary and Acting Governor, convened a session of the Legislature, at Green Bay, from the remainder of said Territory. No business was transacted, except the passage of several memorials to Congress, among which was one asking for the organization of the Territory of Wisconsin, with the seat of government at Cassville, on the Mississippi.

An act establishing the Territorial government of Wisconsin, was passed and approved April 20th, 1836, and the Territory fully organized July 4 th, 1836.

On the 12th of June, 1838, an act was passed diviling the Territory of Wisconsin, and establishing that portion on the west side of the Mississippi (which had been attached to Michigan in 1834) into a separate government, under the name of Iowa.

In 1836, Governor Dodge, by proclamation dated Sept. 9th, convened the Legislature at Belmont, now in Lafayette County, on the 25 th day of October in that year. The second session was held at Burlington, now in the State of Iowa, November 6th, 1837, at which session the seat of government was located at Madison, where the first session of the $2 \mathrm{~d}$ Legislative Assembly of Wisconsin was held November 26th, 1838.

A Convention was held at Madison, October 5th, 1846, for the purpose of drafting a State constitution, which was adopted in convention, December 16th, 1846, but rejected by the people at the election held on the first Tuesday in April, 1847. A second convention was held December $16 \mathrm{th}, 1847$, and a constitution agreed to February 1st, 1818, which was approved of by the electors at the election held April, 1848, and Wisconsin was admitted into the Union, on an equal footing with the other States, on the 29 th day of May, 184 S.

MADISON, on the isthmus between Third and Fourth Lake, is the political capital.

Wisconser river, Wisc. : rises in Vieux Desert lake, on the $\mathrm{N}$. E. boundary of the State, and flows $\mathrm{S}$. in general course for $250 \mathrm{~m}$. until it reaches Portage, when it turns, and flows S. W. and W. S. W. $114 \mathrm{~m}$. to its confluence with Mississippi r., near Prairie du Chien. Above Portage it has numerous rapids, which afford great water-power, used at many places by saw-mills. At Portage it is 1,200 feet wide, and gradually increases in width to its mouth, where it is 1,800 feet wide. Its current is usually quite rapid, but is shallow, and there are numerous islands and shifting sand-bars, rendering navigation somewhat difficult. Steamboats of light draft can usually ascend to Portage. In Richmond county, where it is 1,350 feet wide, it is bordered by high sandstone bluffs, from 150 to 200 feet high, presenting grand and beautiful scenery. Proposed improvements of this river will render it a very important channel of trade and travel between the lakes and Western rivers.

Wiscor, p. o., Alleghany co, $N . Y$. : 220 m. W. by S. Albany.

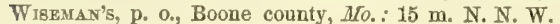
Jefferson City.

Witakanta river, Minn. Ter.: a large tributary of Minnesota $r$., flowing $\mathrm{S}$. by $\mathrm{E}$. from Washtey lake.

Witcher's Cross Roads, p. 0., Smith co, Tenn. : $46 \mathrm{~m}$. E. Nashville.

Withamsville, p. o., Clermont co., Ohio: $3 \mathrm{~m}$. N. W. Ohio r., 87 m. S. W. Columbus. Pop. about 320.
Wrttenberg's, p. o., Alexander co., N. Car.." $156 \mathrm{~m}$. W. Raleigh.

Witten's, p. 0., Monroe co, Ohio: on W. bank of Ohio r., $108 \mathrm{~m}$. E. by S. Columbus.

Wrtrsiurg, p. v., St. Francis co., $A r k_{*}$ : on W. side of St. Francis r., $91 \mathrm{~m}$. E. N. E. Little Rock.

Woburn, t., p. v., and sta., Middlesex co., Mass. : $10 \mathrm{~m}$. N. N. W. Boston. Surface of t. pleasantly diversified, containing several ponds; drained by Mystic $r$. The $r$. near the centre contains 3 churches and an excellent academy. The Woburn Branch R. R. extends hence $2 \mathrm{~m}$, to junction at Winchester with the Boston and Lowell $R_{v}$. R. Pop. of $\mathrm{t} .3,954$.

Wolcotr, t. and p. v., New Haven co., Conns: $19 \mathrm{~m}$. S. W. Hartford. Drained by Mad r. Pop. 603.

WorcotT, t. and p. V., Wayne co., N. Y.: $162 \mathrm{~m} . \mathrm{W}$. by N. Albany. Drained by small streams flowing into Lake Ontario, which bounds it on the W. The v. contains 8 churches, several stores, etc. The "W. Banner" (neut.) is here published. Pop. of $\mathrm{v}$. about 650 ; of t. 2,751 .

Wolcotr, $t_{*}$ and p. v., Lamoille co., Term.: 20 m. N. by E. Montpelier. Drained by Lamoille $r$. and its branches, which afford water-power to several mills. Pop. of t. 909

Wolcott's Mills, p. o., La Grange county, Ind. : $125 \mathrm{~m}$. N. by E. Indianapolis.

Wolcottrule, p. v. and sta., Litchfield co., Conn. : sita-

* This aketch of the history of Wisconsin is taken from "Hunt's Gazetteer" of that State, advance sheets of which were kindly furnished to the Editor of the $\mathrm{S}, \mathrm{G}$. of U. S. It is a work of great value, and reflects high credit on the industry and ability of the learned author. 
ated at the confluence of the head branches of Naugatuck r., $23 \mathrm{~m}$. W. Hartford, $37 \mathrm{~m}$. N. N. W. New Haven. The Naugatuck R. R. passes through, $52 \mathrm{~m}$. from Bridgeport, $10 \mathrm{~m}$. from Winsted. Good water-power is here furnished, and improved by various manufactories. In the vicinity is a good bed of eopper ore.

Wolf, p. o., Knox co., Ohio: 41 m. N. E. Columbus.

Wolf Bayou, p. o., Independence co., Ark.: on small stream of same name, $67 \mathrm{~m}$. N. N. E. Little Rock.

Wolfвoro', t. and p. ve, Carroll county, N. Hamp.: $29 \mathrm{~m}$. $\mathrm{N}$. E. by N. Concord. This t, is noted for its fine scenery, and the beautiful views here presented of Lake Winnipiseogee, which bounds it on the W. It contains numerous saw-mills, several tanneries, and other manufacturing establishments. Pop. of to 2,038.

Wolf Creek, p. O., Lenawee co, Mich.: on cr. of same name, $54 \mathrm{~m}$. S. S. E. Lansing.

Wolf Creek, to and p. o., Mercer co., Penn.: $184 \mathrm{~m}$. W. N. W. Harrisburg. Drained by Wolf cr., and contains mills of various kinds. Pop. about 2,000.

Wolf Creek, p. o., Pickens dist., S. Car. : 112 m. N. W. by W. Columbia.

Wolf LAKE, p. o., Noble county, Ind.: 110 m. N. by E. Indianapolis,

Wolf RTVER, p. o., Fayette co., Tenn.: 158 m. W. S. W. Nashville.

Wolf Run, p. o, Lycoming co., Penn. : $72 \mathrm{~m}$. N. by W. Harrisburg.

WoLFsviLL, p. V., Frederick county, Md.: $61 \mathrm{~m}$. N. W. Annapolis.

Wolf8ville, p. v., Union co., N. Car. : 99 m. W. S. W. Raleigh.

Womelsdorp, p. b., Berks county, Penn, : on S. side of Tulpehocken cr., $36 \mathrm{~m}$. E. by N. Harrisburg. Its inhabitants are chiefly of German origin. It contains seyeral mills, stores, ete., and is surrounded by a fertile and well-cultivated district. Pop. about 950 .

Wonasedatucker river, Providence co, $R, I .:$ an important mill-stream, rising in Smithfield, and flowing S. E. into Providence Cove.

Woon county, Ohio. Situate N. toward the W., and contains 612 sq. m. Drained by Portage $r$. and its branches, and branches of Maumee r. Surface varied, and descends gradually toward Lake Erie in the N., with which connection is had by means of Maumee $r$ and bay ; soil a deep loam, with sand intermixed, and very fertile. Staples, wheat and Indian corn. Live-stock and grain are exported. A large portion of the "Black Swamp" is within the limits of the $\mathrm{co}_{2}$, which, if drained, might be rendered productive. Farms 704; manuf, 21; dwell. 1542, and pop,wh. 9,189, fr. col. 18-total 9,157. Oapital: Perrysburg. Public Works: Toledo and Fort Tayne R. R.; Wabash and Erie Canal.

Woon county, Texo. Situate toward the N. E., and contains $1,046 \mathrm{sq} . \mathrm{m}$. Drained by Sabine r. and its branches, Lake Fork, Big Sandy cr., and other small streams. Surface undulating and diversifled; snil fertile, and is adapted to cotton, corn, and other agricultural productions. There is a considerable quantity of pine timber on the land, and some prairie. It contains some springs of excellent water and has some ferw minerals. Capitul: Quitman,

WOoD county, Firg. Situate N. W.. and contains 476 sq. m. Drained by Little Kanawha river and its brauches. Surface hilly and broken; soil fertile, adapted to grain and grazing. Chief products, wheat and Indian corn, with tobaeco, etc. Farms 640 ; manuf. 24 ; dwell. 1,554, and pop,wh. 9,008, fr. col. 69, sl. 378-total 9,450. Capital : Parkersburg. Pullic Wrorks: North Western R. R.

Woodberer, p. v., Butler co., Ky. : 110 m. S. W. by W. Frankfort.

Woodberry, p. v., Merriwether co., Ga.: on W, side of Flint $r, 81 \mathrm{~m}$, W. Milledgeville.

WoODBLxe, p. v, and sta, Carroll co, Ma. : on Baltimore 916 and Ohio R. R., 38 miles from Baltinore, 50 miles $N$. W. Annapolis.

Woonbine, p. o., Whitley county, $K_{y} .: 107$ m. S. S. E. Frankfort.

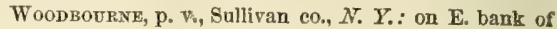
Neversiak r., 74 m. S. W. by S. Albany.

Woopbourne, p. v., Knox county, Tenn. : 168 m. E. Nashville.

WOODBRIDGe, p. v., Cedar eo., Ia.

Woodbridge, t. and p. v., Middlesex co., N. Jer. : $33 \mathrm{~m}$. N. E. Trenton. The t, contains several flourishing villages, with part of Rahway $\mathbf{v}$. The New Jersey $R$. R. passes through it. Woodbridge v., $3 \mathrm{~m} . \mathrm{S}$. Rahway, contains a church, several stores, etc. Pop. of $t$. in $1840,-4,821$; in $1850,5,141$.

Woodbern, p. v., Burke county, Ga. : on Mill cr., $68 \mathrm{~m}$. E. by $\mathrm{N}$. Milledgeville.

Woodiurn, p. v., Macoupin county, Ill.: 54 m.S.S. W. Springfield.

WoonbuRa, p. o, Warren county, Ky.: 120 m. S. W. Frankfort.

WOODBURx, to and p. v., Litchfield county, Conn.: $31 \mathrm{~m}$. W.S. W. Hartford. Drained by Pomperaug r. and branches, which unite near the v., and afford water-power to woolen factories, and other mills. The v. is neatly built, and contains 3 churches, several stores, ete. Pop. of t. 2,150.

Woodsery, p. v., Cumberland county, $7 l$. : a branch of Embarrass ro, 82 m. E. S. E. Springfield. The National road passes through it.

Woodidry, p. v., Hamilton county, Ind. : 20 m. N. E. Indianapolis.

Wоopвury, sta., Baltimore co., MId.: on Baltimore and Susquehanna R. R., 3 m. N. Baltimore.

WooDBURX, p. v., Wright county, Mfo. : on Osage fork of Gasconade r., 84 m. S. S. W. Jefferson City.

WOODBURY, p. v., and cap. Gloucester co., N. Jer. $83 \mathrm{~m}$. S. W. by S. Trenton. It contains a fine brick court-house, fire-proof county offices, stone jail, an academy, severial stores, and 3 churches. "The "Constitution" is issued weekly. Woodbury cr. flows on N. side of the V., and is boatable to this place. Pop. about 900 .

WoodBury, p. v., Wood county, Ohio: 94 m. N. N. W. Columbus.

Woodiury, t. and p. v., Bedford co., Penn.: $75 \mathrm{~m}$. W. Harrisburg. Drained by Yellow er. and branches, which afford water-power to numerous flouring and saw mills. Iron ore is here found, and smelted by several furnaces, Pop. of t. about 4,000 .

Woopiury, p. v., and cap. Cannon county, Tenn. : $42 \mathrm{~m}$. S. E. by E. Nashville. It has a good site, and is drained by a branch of Stone's er. of Cumberland $r$. It contains the county buildings, several stores, etc. Pop. about 200.

WoopBcisy, t. and p. v., Washington co., Verm: $17 \mathrm{~m}$. N. E. by N. Montpelier. Watered by numerous ponds, and branches of Lamoille and Onion rivers. Pop. of t. 1,070.

Woodcock, t. and p. v., Crawford co, Penn.: $187 \mathrm{~m}$. N. W. by W. Harrisburg. Drained by Woodeock creek. The $t$. contains a large number of mills and other manufacturing establishments. Pop. about 2,000.

WOODFORD county, $I l l$. Situate N. centrally, and contains $532 \mathrm{~m}$. Mackinaw r., a tributary of Illinois r., drains the eastern portion, and other branches of same river the N. and W. Surface undulating; soil fertile. Staples; wheat and grain. The W. is bounded by the Illinois, which in this part opens into a broad basin. Farms 506; manuf. 14 ; dwell. 747 , and pop-wh. 4,416 , fr. col. $0-$ total 4,416. Capital: Metamora, Public Works: Central IUlinois $\mathrm{R}, \mathrm{R}$.

WOODFORD county, $\bar{K} y$. Situate N. E. centrally, and contains $141 \mathrm{sq}$. m. Drained by branches of Kentucky $r$. which bounds it on the W. Surface level; soil a fine deep regetable loam and very productive. Staples, tobaceo, wheat, and Indian corn. Farms 580 ; manuf. 98 ; dwell. 1,053, 
and pop.-wh. 5,382, fr. col. 165, sl. 6,376-total 12,423. Cupital: Versailles. Pullic Works: Lexington and Frankfort $\mathbf{R}, \mathrm{R}$.

WOODFORD, t. and p. v., Bennington co., Verm.: $103 \mathrm{~m}$. S. S. W. Montpelier. Surface elevated and broken; soil sterile. Drained by ponds and small streams. Pop. 423.

WOODFord's sta, Cumberland eounty, Me. : on York and Cumberland R. R., $2 \mathrm{~m}$. W. Portland.

Wood Grove, p. 0., Morgan co., Ohio: $66 \mathrm{~m}$. E. by S. Columbus.

WoopHuLr, to and p. v., Steuben county, $N . Y$. . $194 \mathrm{~m}$. W. by S. Albany. Drained by Tuscarora er. Surface uneven, and covered with heavy timber. Pop. in $1 \$ 40,827$; in $1850,1,769$ 。

WoopHULi, t. and p. O., Shiawassee co., Fich.: $10 \mathrm{~m}$ E. N. E. Lansing. Drained by branches of Looking Glass river. Pop. in 1840, 147; in 1850, 259.

Woonivgton, p. o., Darke county, Ohio: $84 \mathrm{~m}$. W. Columbus.

WooplaND, t. and p. o., Barry county, Mich.: $28 \mathrm{~m}$. W.

Lansing. Drained by creeks of Grand r. Pop. 377

Woodland, p. 0., Barren county, Ky.: 98 m. S. W. by $\$$.

Frankfort.

Woopland, p. o., Clearfield con, Penn.: 95 m. W. N. W. Harrisburg.

Wooplasd, p. 0., East Feliciana par., La.: $29 \mathrm{~m}$. N. by E Baton Rouge.

Wooduands, p. o., Marshall county, Virg.: on E. side of Ohio r., $232 \mathrm{~m}$. N. W. Richmond.

Woodes Wx, p. v., Dallas county, Ala.: 40 m. W. N. W. Montgomery.

Woodlawn, p. 0., Murray county, Ga.: $158 \mathrm{~m}$. N. W. Milledgeville.

WooduAwN, p. o., Itawamba county, Miss. : $165 \mathrm{~m}$.

N. E. by N. Jackson.

WoodhaWr, p. 0., Washita co., Ark.: 92 m, S. S. W. Little Rock.

Woodtawn, p. V., Cecil co, $M_{*} d_{*}: 51 \mathrm{~m}$. N. E. by N. Annapolis. The vieinity is highly cultivated, and furrishes cattle and wheat for market. Granite of the finest texture is extensively quarried. The Chesapeake fisheries are aiso prosecuted. Pop. 130.

Woodlawn, p. 0., Monroe co., Mo.: on S. fork of Salt $\mathbf{r}_{\text {, }}$ $66 \mathrm{~m}$. N. Jefferson City.

WooDLAWN, p. V., Appomattox co., Virg.: 81 m. W. by S. Pichmond.

Wooduawn, p. v., Lincoln co., N. Car.: on W. side of Catawba r., 126 m. W. S. W. Raleigh.

WoonLAWN, p. V., Edgefield disto, S. Car?: 62 m.W.S.W. Columbia.

WOODRIDGE's STORE, p. o., Christian county, Ky.: $170 \mathrm{~m}$.

S. W. by W. Frankfort.

WoodeurF's, p. o., Spartanburg dist., $S_{0}$ Car: $72 \mathrm{~m}$. N. W. by W. Columbia.

Woon's, p. 0., Perry county, Tenn : $75 \mathrm{~m}$. S. W. by W. Nashville.

Woodsвoro', p. v., Shelby co., $A l a .: 62$ m. N. N. W. Montgomery.

WoodsBoso', p. ₹., Montgomery co, $I l_{\text {. }}: 45$ m. S. by E. Springfield.

Woonsioro', p. o., Frederick county, $M d_{0}: 52 \mathrm{~m} . \mathrm{N}$. W. Annapolis. Pop, about 100.

Wood's Corners, p. o., Hillsdale county, Mich.: 59 m. S. Lansing.

Woop's Cross Roans, p. 0., Gloucester co, Firg, : 44 m. E. Pichmond.

Woodsdale, p. v., Person co., N. Car. : 50 m. N. N. W. Raleigh.

WoodsFreld, p. v., and cap. Monroe county, Ohio: on S. side of Sunfish creek, $96 \mathrm{~m}$. E. Columbus. It has an elevated and pleasant site, and contains good county buildings, with several stores. The "Spirit of Democracy" (dem.) is here published. Pop. 395.
Wood's HiLL, p. v., Roane co., Tenn。: on N. side Tennessee r., $162 \mathrm{~m}$. E, by S. Nashville.

WOOD'B HoLE, p. v., Barnstable co., Mass. : 62 m. s. S. E. Boston. It has a good harbor, admitting vessels of the largest class, and protected by islands on the $\mathrm{S}$. and $\mathrm{W}$. The $v$. is of considerable summer resort for sea air and bathing. Naushon IIouse is a fine hotel.

Woon Snop, p. o, Dale county, Alav; 40 m. S. E. by S. Montgomery.

Wood's Mrics, sta., Vigo co., Ind.: on Terre Haute and Richmond R. R, $8 \mathrm{~m}$. E. from Terre Haute, $65 \mathrm{~m}$. from Indianapolis.

W Green r., 80 m. S. W. Frankfort.

Wood's Station, p. 0., Walker co., Ga, : 172 m. N. W. Milledgeville.

WoodsTock, t. and p. v., Windham co., Conn.: $36 \mathrm{~m}$ E. N. E. Hartford. The t. has a hilly surface. Drained by several streams, of which Muddy brook affords waterpower. It contains 3 villages, each pleasant and flourishing, and having some manufactures. Woodstock $\mathbf{v}$., in S. E. part of t, has an elevated site, and is neatly built Pop. of t. in 1840, 3,053; in 1850, 4,686.

Woodstock, p. v., Cherokee eounty, Ga. : on branch of Etowah r, 108 m. N. W. Milledgeville.

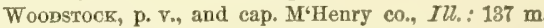
N. N. E. Springfield. It is situated in a pleasant grove, near a small brook, and contains the county buildings.

Woonsтock, t. and p. v., Oxford county, Me.: $37 \mathrm{~m}$. W Augusta. Drained by branch of Little Androseoggin $\mathbf{r}$., and by several large ponds. Surface partly mountainous. The Atlantic and St. Lawrence $\mathrm{R}$. R. passes through its S. W. part, having a station at Bryant's Pond, $62 \mathrm{~m}$. from Portland. Pop. of t. 1,012.

Woenstock, p. v. and sta., Howard county, Mrd.: on Baltimore and Ohio R. R., $25 \mathrm{~m}$, from Baltimore, $29 \mathrm{~m}$. N. W. by N. Annapolis.

Woopstock, to and p. Y., Lenawee county, Mich.: $48 \mathrm{~m}$. S. by E. Lansing. Watered by head branches of Raisin river, several ponds, and a large lake on its S. border. Interests mainly agricultural. It contains flouring mills, the annual product of which, as valued in 1850 , is $\$ 90,365$. Pop. in 1840,674 ; in $1850,949$.

Woopstock, t. and p. o, Grafton co., N. Hamp. : $54 \mathrm{~m}$ N. by W. Concord. Surface mountainous; drained by Pemigewassett $r$. Pop. 418.

Wоорвтоск, t. and p. v., Ulster county, $N_{0} Y_{0}: 45$ miles S. S. W. Albany. Surface mountainous; drained by Saghkill cr. The v. contains 2 ehurches. Pop. of t. 1,650.

Woonstock, p. v., Champaign co., Ohio: 30 m. N.N.W. Columbus. Pop. 205.

Woodstocs, sta., Windsor county, Term.: on Vermont Central R. R., $17 \mathrm{~m}$. from Windsor, $60 \mathrm{~m}$. from Montpelier.

Woopsrock, t., p. v., and eap. Windsor county, Verm. $45 \mathrm{~m}$. S. by E. Montpelier. Drained by Otta Queechee r. and its branches, which afford water-power. The $\mathrm{v}$. in $\mathrm{N}$. part of the $t$. is very pleasant, and contains a beautiful public green. The courthouse is one of the best edifices of the kind in New England. It also contains 5 churches, 1 bank, cap. $\$ 60,000$, and the Vermont Medical College, founded in 1535 , which in 1850 had 7 professors, 90 students, and 832 graduates. The "Mercury" (whig), and "The Age" (dem.) are issned weekly. Pop. of t. 3,041 .

Woodstock, p. v., and cap. Shenandoah connty, Firg. 106 miles N. W. by N. Richmond. It contains the county buildings, 4 churches, an academr. The "Tenth Legion" (dem.) is issued weekly. Pop. about 1,000 .

Woodstock Mrlis, p. O., Nassau co., Flor. : on S. side of St. Mary's r., 142 m. E. by N. Tallahassee.

Woodstows, p. v., Salem co, N. Jer.: on N. side of Salem er., $48 \mathrm{~m}$. S. W. by S. Trenton. It contains several stores, and 3 churches. Valuable beds of marl are in the vicinity. Pop, about 750 . 
Woopstilux, p. o., Mercer co., $N$. Jer.: $11 \mathrm{~m}$. N. N. W. Pittsburg. The "Wayne Co. Democrut" (dem.), and Trenton.

Woodrale, p. o., Fayette eo., Penn.: 146 m. W. by S. Harrisburg.

Woodview, p. o., Morrow co., Ohio: $36 \mathrm{~m}$. N. Columbus. Woonville, p. v., and one of the eaps. Jackson eounty, Ala.: $58 \mathrm{~m}$. N. Montgomery. The Memphis and Charleston $R$. R. will pass near it.

Woodvilue, p. v., Litehfield county, Conn.: $32 \mathrm{~m}$. W. Hartford.

Woopville, p. v., Adams county, $Y Z l_{*}: 85^{\circ} \mathrm{m}$. W. by $\mathrm{N}$. Springfield.

Woopville, p. V., Jackson co., Ind.: on branch of E. fork of White r., $62 \mathrm{~m}$. S. Indianapolis.

Woodville, p. 0., Haywood co., Tenn.: 146 m. W. by S.

Nashville.

Woodville, p. v., Middlesex co., Mass.

Woodville, p. v., and cap. Wilkinson co., Miss.: $105 \mathrm{~m}$. S. W. by S. Jackson. It contains the county buildings, 3 churches, 2 academies, ete. The West Feliciana $R$. R. extends hence to Bayou Sara, on the Mississippi river, $26 \mathrm{~m}$. The "W. Republican" (dem.), and "Wilkinson Whig" are issued weekly. Pop. about 900.

Woodvilus, p. V., Macon co., Mo.: on S. fork of Salt r., 73 m. N. Jefferson City.

Woodville, p. v., Jefferson county, $N . Y_{\text {. }}$ : on $\mathrm{S}$. side of Sandy cr., $147 \mathrm{~m}$. N. W. by W. Albany. It contains several mills and stores, with a church. Pop. about 200.

Woopville, sta., Queens county, $N_{\text {. }} \boldsymbol{Y}_{\text {: : on Long Island }}$ R. R., $9 \mathrm{~m}$. from New York.

Woopville, p. v., and cap. Tyler co., Tero. : on W. side of Turkey er, $200 \mathrm{~m}$. E. by N. Austin City. It contains the county buildings.

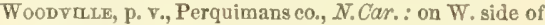

Little r., 126 m. E. N. E. Raleigh.

Woopvilut, t. and p. v., Sandusky co., Ohio: $104 \mathrm{~m}$.

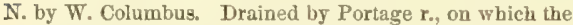
v. is situated. Pop. of $t$, in 1840, 4S6 ; in 1850, 1,069

Woodville, p. v. and sta, Greene co., Ga.: on Athens

Branch R. R., 43 m. N. by E. Milledgeville.

Woodville, sta., Albemarle county, Firg.: on Virginia

Central R. R., 7 m. from Charlottesville, 104 miles from Richmond.

Woobville, p. v., Rappahannock county, Virg.: $84 \mathrm{~m}$. N. N. W. Richmond,

WOODWARD, p. O., Centre county, Penn.: 66 m. N. W. Harrisburg.

Woodwardsvim, p. v., Essex county, $N$. $\boldsymbol{Y}_{\text {. }}: 55 \mathrm{~m} . \mathbf{N}$. Albany.

Woopworth's, p. o., Granville co., $N_{0}$ Car.: $45 \mathrm{~m} . \mathrm{N}$. Raleigh.

Tuodrards, p. o., Athens co., Ohio: $6 \pi$ m. S. E. by E. Columbus.

Wonzwich, t. and p. v. Lincoln county, Me.: 26 m. S. Augusta. Drained by suall streams flowing into Keunebec river which bounds it on the W. It is somewhat engaged in the fisheries. Pop. of t. 1,420 .

Woossocket Falls, p. $V_{\text {, and }}$ sta., Providence co, $R . I_{\text {. }}$ : on Blackstone r., 15 m. N. N. W. Providence. The r. here descends in a short distance 21 feet, falling over a precipice of rocks, and affording very great water-power. The factories are in number abont 20 , and chiefly engaged in making cotton gouls. The $r$. also contains 6 churcles, and 1 bank, cap. $\$ 100,000$. The Providence and Worcester R. R. passes through, $16 \mathrm{~m}$. from Providence, $27 \mathrm{~m}$. from $W$ orcester. The New York and Boston Direct R. R. will also pass through this place. The "W. Patriot" (indep.) is issued weekly. Pop. about 3,000 .

Wooster, t., p. v., sta, and cap. Warne co, Ohio: $73 \mathrm{~m}$. N. E. Columbus. Surface of t. very fertile. Drained by Killbuck er. and branches. The $\mathrm{v}$. is pleasantly situated, and contains the county buildings, and 6 churches. The Ohio and Pennsylvania P. F. passes through if, $131 \mathrm{~m}$. from 9.18

"Wonster Democrat" (whig), are here published. Pop. of v. in 1541), 1,913: in $1 \leqslant 50,2,797$. Pop. of t. including $\mathrm{r}$. in $1840,3,120$; in $1850,4,030$.

Worcester county, $M d$, Situate S. E., and contains 616 sq. m. Pocomoke r. flows through the co, from N. to $\mathrm{S}$, by which and its branches it is drained. Surface level or rolling; soil is in general of a sandy nature, in parts it is fertile. Staples, wheat and grain. Large numbers of eattle and hogs are fattened in the co. Timber is abundant. Sinepuxent bay bounds it on the $\mathbf{E}_{\text {, }}$, and is inclosed by a number of islands with inlets to the inner waters. Farms 1,318 ; manuf. 29 ; dwell. 2,884, and pop.-wh. 12,401, fr. col. 3,014 , sl. 3,444-total 18,859. Capital: Snowhill.

Worcester county, Mass. Situate in the central part of the State, and contains 1,450 sq. m. Drained by Blackstone, Quinnebaug, Ware, Miller's, Nashua, and Mill rivers. Surface undulating; soil fertile, being a rich black loam, and very produetive. This co. has many important manufactures, and good water privileges. Chief products wheat, Indian corm, oats, potatoes, and tobacco. Farms 7,239; manuf. 1,161; dweil. 21,709, and pop.-wh. 130,152, fr. col, 637-total 130,789. Capital: Worcester. Public Works: Boston and Worcester R. R.; Providence and Worcester R. R.; Worcester and Fitchburg R. R.; Western R. R.; Nashua and Worcester R. R.; Fitchburg R. R.; Vermont and Massachusetts R. R ; Norwich and Worcester R. R.; Cheshire R. R., etc.

W Orcester, p. city, and cap. Woreester co., Mass. : $45 \mathrm{~m}$. by railroad, W. by S. Boston. Lat. (Ant. Hall) $42 \circ 16^{\prime} 17^{\prime \prime} \mathrm{N}$.; long. $7104 \mathrm{~S}^{\prime} 13^{\prime \prime} \mathrm{W}$. It is pleasantly situated in a valley surrounded by hills of gentle acclivity, its soil is generally fertile, and is drained by branches of Blackstone $r$. It surface is somewhat diversified, affording a picturesque variety in its general appearance. Many of its streets are very handsome, of which the most important is Main Street, which is about $2 \mathrm{~m}$. long, straight, broad, ornamented with beautiful shade trees, and contains the prineipal hotels, stores, banks, churches, public buildings, with severa splendid private residences. In the $\mathrm{S}$. part of the city is a spacious public green. Many of the principal buildings are fine structures. The hall of the American Antiquarian Society is a large and handsome ediflce, erected in 1820, at cost of $\$ 10,000$, and contains 7,000 volumes. The State Lunatic Asylum is finely situated on an eminence $\mathbf{E}_{\text {. }}$ of the city, and surrounded by extensive and beautiful grounds, It consists of a large central edifice, 4 stories high, with wings 8 stories high, and 134 feet long. This noble institution was founded in 1838, and usually contains from 450 to 500 inmates. The College of the Holy Cross (Roman Catholic) has a fine location on a rounded hill, $1 \frac{1}{2} \mathrm{~m} . \mathrm{S}$. W of the eity, but its buildings were lately destroyed by fire. In 1850, it had 4 professors, 120 students, and 4,220 volume in its library. Great attention is generally given to education in the public schools and private academies, which are of the best order. The newspaper press, in 1850, consisted of the "Massachusetts Spy" ( $f$. soil), daily and weekly "Daily Tribune" (neut.); 4 weeklies, "Nutional Egis" (whig), "Palladium" (dem.), "Mass. Cataract" (temp.) "Christian Citizen" (reform.); and 1 monthly, "N. E. Temperance Journal."

Worcester is one of the most important thoroughfares in New England. The railroads here centering are flve in number: viz., Boston and Worcester R. R., $45 \mathrm{~m}$. long; Western $R$. R. $57 \mathrm{~m}$. to Springfield, $156 \mathrm{~m}$. to Albany Providence and Worcester P. R., 43 m.; Norwich and Worcester R. R., 66 m.; Worcester and Nashua R. R., $45 \mathrm{~m}$.; and Fitchburg and Worcester R. R., $26 \mathrm{~m}$., which uses between Worcester and Sterling Junction, 8 miles, the road of the Worcester and Nashua $R$. R. These very important arenues of intercommunication have effectually secured to Worcester the greatest facilities for inland trade, and have greatly developed and increased its manufactures 
and gener:t prosperity. Its manufactures embrace nearly all branches, and form an aggregate annual product of about $\$ 2,500,000$. There are five banks, with aggregate cap. of $\$ 1,000,000$, and 2 institutions for savings.

The aggregate wealth of Worcester is very great, showing an unusually large average amount per head. The general increase of the city in wealth during the last 20 years has also been very rapid, hardly surpassed in New England. The following table exhibits the valuation of property in various years, from 1800 to 1852 , inclusive:

Yesrs. Val, wif prop Years. Val. of prop. Years. Val, of prop. $1800 \ldots . \$ 296,542 \quad 1840 \ldots \$ 4,288,950 \quad 1848 \ldots \$ 8,721,100$ \begin{tabular}{l|l|l|l}
$1810 \ldots . .1,476.853$ & $1845 \ldots 6,004,050$ & $1849 \ldots$. & $10,750,252$
\end{tabular} \begin{tabular}{l|l|l|l}
$1820 \ldots .2,015,750$ & $1846 \ldots 7,116,700$ & $1851 \ldots . .11,925,055$
\end{tabular} \begin{tabular}{ll|l|l|l}
$1830 \ldots .2,747,800$ & $1847 \ldots$ & $7,690,850$ & $1852 \ldots . . .12,575,566$
\end{tabular} In 1549 , the number of persons whose property amounted to $\$ 20,000$ and upward, was 91 ; and 99 persons were assessed for $\$ 10,000$ and upward, but below $\$ 20,000$.

The settlement of Worcester was commenced in 1675 , but owing to the Indian border warfare, was not made permanent until 1713. In 1718, it contained " 58 humble dwelling houses." In 1765 , its citizens instructed their representatives to join in no measure countenancing the "Stamp Act ;" and soon again manifested their patriotic spirit by prompt action upon many matters of national concern. During the revolutionary struggle it sustained a most honorable part. Its career of prosperity during the last thirty years is the natural result of the intelligent enterprise of its citizens. They have ever been among the foremost in the State, in contributing to the construction of works of internal improvement, in building up home manufactures, and in the promotion of agriculture; and they are now receiving their just reward. The city was incorporated in 1848. Its government is vested in a mayor, 8 aldermen, and common council of 24 members (being composed of 3 members from each of the 8 wards). The appropriation of city expenses in 1851 , was $\$ 75,500$; in $1852, \$ 85,700$. The population at different periods has been as follows:

Year. Pop. Year. Pop. $\mid$ Year. Pop. $\mid$ Year. Pop. $1765 \ldots . .1,479 \quad 1800 \ldots 2,411 \quad 1830 \ldots 4,173 \quad 1847 \ldots 15,643$ \begin{tabular}{l|l|l|l|l}
$1776 \ldots . .1,925$ & $1810 \ldots 2,577$ & $1840 \ldots 7,497$ & $1850 \ldots 17,049$
\end{tabular} \begin{tabular}{l|l|l|l|l|}
$1790 \ldots 2,095$ & $1820 \ldots 2,962$ & $1845 \ldots 11,556$ & $1553 \ldots 20,271$
\end{tabular}

Worcester, t. and p. v., Otsego county, N. $Y_{s}: 50 \mathrm{~m}$. W. Albany. Surface of t. hilly. Drained by Charlotte r. and branches. The $\mathrm{v}$. contains 2 churches, several stores and mills. Pop. of v. about 200 ; of t. 2,047 .

Worcester, t. and p. o., Montgomery co., Penn. : $80 \mathrm{~m}$ E. Harrisburg. Interests agrictiltural. Pop. about 1,400.

Worcester, t. and p. V., Washington co., Verm.: $7 \mathrm{~m}$. N. Montpelier. Surface in part mountainous. Drained by $\mathrm{N}$. branch of Onion r., which affords water-power, and on which the $\mathrm{v}$. in its $\mathrm{S}$. part is situate. Pop. of $\mathrm{t} 702$.

Worth county, Ia. Situate N., and contains 432 sq. m. Drained by English $r$, and Lime creek. Surface level or slightly undulating; soil fertile and adapted to the culture of wheat and grain. The N. is diversified with large lakes, Set off since 1850 .

Worth, p. 0., Mercer county, Penn. : 187 m. W. N. W. Harrisburg.

Worth, p. o., De Kalb county, Ala.: 140 m. N. by E. Montgomery.

Wolith, p. o., Perry co., Ohio: 45 m. E. S. E. Columbus. Wortr, t. and p. o., Tuscola county, Mich.: $77 \mathrm{~m}$. N. E. Lansing. Pop. of t. 600 .

Wozth, p. 0, Cook co., Ill. : 163 m. N. E. Springfield.

Worti, p. o., Marion co., Ark. : on S. side of White r., $93 \mathrm{~m}$. N. by W. Little Rock.

Worti, p. O., Dubois co., Ind.: on S. side of Patoka cr., $100 \mathrm{~m}$. S. S. W. Indianapolis.

Worthington, p. va, Mecklenburg county, ky.: $132 \mathrm{~m}$. W. S. W. Frankfort.

Wormingrox, t. and p. v., Hampsbire co., Mass. : $95 \mathrm{~m}$
W. Boston. Surface elevated and pleasantly diversified. Drained by Westield $\mathrm{r}$. and its branches. Interests, ehiefly agricultural. Pop. of t. 1,134.

Wortringtov, p. v. and sta., Franklin cn., Ohio: on E. side of Olontangy r., $9 \mathrm{~m}$. N. by W. Columbus, It is regularly laid out, with streets crossing at right angles, and is very neatly built. It contains 3 churches and 2 flourishing seminaries. The Cleveland, Columbus, and Cincinnati P. P passes through it, $126 \mathrm{~m}$. from Clevelaud, $129 \mathrm{~m}$. from Cineiunati. Settled in 1801 by the Scioto Compuny from Granby, Connecticut. Pop. 501.

Wonturngton, p. o., Greene co, Ind.: on W. fork of White r., $60 \mathrm{~m}$. S. W. Indianapolis.

Worthingtow, p. V., Armstrong county, Penn.: $145 \mathrm{~m}$ W. N. W. Harrisburg. In the vicinity is a charcoal hot blast furnace, with annual capacity of 1800 tons, employing 80 men; also 1 charcoal cold-blast furnace, with annual capacity of 1,100 tons, employing 40 men.

Worthin gron, p. o., Marion co., Virg. : 200 m. N. W. by W. Richmond.

- Worthrille, p. $\nabla_{\circ}$ Carroll con Ky,: 31 m. N. by W. Frankfort.

Worthyille, p. v., Butts county, Ga. : 50 m. W. N. W. Milledgeville.

Wonthville, p. v., Jefferson co., N. $\bar{Y}_{*}: 132 \mathrm{~m}$. N. W. bg W. Albany.

WorthyILLe, p. ₹., Johnson co., Ind, : $12 \mathrm{~m}$. S. by E. Indianapolis.

W pentilam, t. and p. v., Norfolk county, Mfas.s.: $23 \mathrm{~m}$ S. W. by S. Boston. Surface pleasantly diversified. Drained by branches of Taunton, Charles, and Neponset rivers, which afford considerable water-power. The $t$ contains several pleasant villages. The Norfolk County R. R. crosses its N. W. part. Wrentham v., near the centre, is neatly built. Pop. of t. 3,087 .

WRIGHT county, $T a$, Situate toward the N., and contains 576 sq. m. Drained by Boone r. and head branch of Iowa $\mathbf{r}$. Surface undulating; soil fertile, and adapted to grain. Set off since 1850 .

Wright county, Mo, Situate toward the S. W., and contains 913 sq. m. Gasconade r., and Osage fork of same, with their branches, drain the county. Surface uneven and varied; soil in general fertile, and adapted to the cultivation of wheat and grain, and is also favorable to the growth of tobacco. Timber is abundant. Farms 371 ; manuf. 0 ; dwell. 541, and pop.-wh. 3,305 , fr. col. 0 , sl. 82 -total 3,357 . Cupital: Hartsville.

Wrigilt, p. o., Ottawa county, Mich. : 65 m. W. N. W. Lansing.

Wright, p. 0., La Salle co., $1 l l$. : on Vermillion $\boldsymbol{r}_{\text {., }} 104 \mathrm{~m}$. N. N. E. Springfield.

Wright, p. 0., Greene county, Ind.: 66 m. S. W. by S. Indianapolis.

Wrigat's BluFF, p. o., Sumter district, S. Car.: $50 \mathrm{~m}$. E. by S. Columbia.

Wrightsвoro,' p. v., Columbia co, Ga. : on a branch of Little r., $54 \mathrm{~m}$. N. E. Milledgeville. It contains an academy and church. Pop. about 150 .

Wrignt's Corners, p. o., Niagara co., $\lambda$. $Y_{*}: 262 \mathrm{~m}$. W. by N. Albany.

Wrightstows, p. v., Burlington county, $N$. Jer. : on $\mathbf{N}$. branch of Crosswick's cr., 15 m. S. S. E. Trenton.

Wrightsville, p. b., York co., Penn. : on W. bank of Susquehanna r., $24 \mathrm{~m}$. S. E. Harrisburg. It is connected with Columbia, on the opposite side of the river, by a bridge 5,690 feet long. The York and Wrightsville R. R. extends hence to York. Pop. about 750.

Wrightsville, p. v., Roane co., Tenn.: on S. side of Tennessee r., $132 \mathrm{~m}$. E. by S. Nashville.

Wrightsville, p. $\mathbf{v}_{\text {, }}$ Pontotoc county, Miss.: $146 \mathrm{~m}$. N. E, by N. Jackson.

Wirgetsvilie, p. v., Clinton county, $\mathcal{N}_{*} \boldsymbol{Y}_{*}: 140 \mathrm{~m} . \mathrm{N}$. Albany. 
Wurtemberg, p. v., Lawrence county, Penn.: $174 \mathrm{~m}$ W. by $\mathrm{N}$. Harrisburg.

Wurtsboro,' p. v., Sullivan co., $N_{\text {. }} Y_{\text {.: }} 86 \mathrm{~m}$. S. S. W Albany. It contains 2 churches and several stores. In the vicinity is a valuable lead mine. The Delaware and Hudson Canal passes near this place.

Wraconda, p. o, Seotland co., Mo. : $127 \mathrm{~m}$. N. Jefferson City.

Wrakomme lake and river, La Pointe con, Wisc.: the lake in $\mathrm{S}$. central portion of the county is $8 \mathrm{~m}$. long, of varying width. The river is its outlet, flows W., and is the pricipal head branch of St. Croix river.

Wralusing, t. and p. o., Bradford co., Penn. : $103 \mathrm{~m}$. N. N. E. Harrisburg. Drained by Wyalusing ereek and branches.

Wralusing, p. v., Grant county, Wisc. : 76 m. W. by $\$$. Madison.

Wrardotr county, Mich. Situate $\mathrm{N}$. middle in the $\mathrm{S}$. part of the State, and contains $576 \mathrm{sq}$. m. Drained by the Sheboygan and Skooawargurmish rivers, which are received by large lakes in the $N$., and other considerable streams, the waters of all being discharged into the Mackinaw straits. Surface generally even; soil fertile. Set off since 1550;

WYANDotT county, Otino. Situate toward the N. W., and contains $351 \mathrm{sq} . \mathrm{m}$. Sandusky r. passes centrally throngh it, by which and by Tychmochte $r$, and other branches it is drained. Surface somewhat elevated; soil a fine deep mold, and is in general fertile. Wheat, grain, and potatoes are the staples. Live-stock and grain are exported, Farms 92S; manuf. 37 ; dwell. 1,964, and pop.-wh. 11.243, fr. col. 49-total 11,292. Capital: Upper Sandusky. Public Work: Mad River and Lake Lrie P. IR.; Finlay Lranel R. R.; Ohio and Indiana R. R., ete.

WraydoTt, p. v., Wyandott co., Ohio: $51 \mathrm{~m}$. N. by W. Coiumbus.

WrandoTrE, p. o, Tippecanoe co., Ind.: $55 \mathrm{~m} . \mathrm{N}$. W. Indianapolis.

WraxoKe, sta., Amelia co. Tirg. on Richmond and Danville R. R. $43 \mathrm{~m}$. from Richmond.

Wуatт, p. v., La Fayette co., Mriss.: on N. side of Tallahatchie r., $156 \mathrm{~m}$. N. by E. Jackson. Pop. about 250.

Wye river, $M d$.: flows between Talbot and Queen Ann counties, and enters Eastern bay of the Chesapeake by a broad estuary.

Wre Mruls, p. o., Talbot co., Mrd.: on S. bank of Wye r., $25 \mathrm{~m}$. E. by S. Annapolis.

WYkertown, p. v., Sussex co, N. Jer, : 65 m. N. Trenton.

Wrllifsburg, p. 0., Charlotte co., Virg.: 75 m. W. \$. W. Richmond.

WYNANT, p. o., Shelby county, Ohio: 69 m. W. N. W. of Columbus,

Wyastskill, p. F., Renssilaur co., 1: I: : on creek of same natme, 7 m. E. X. E. Albany.

Wricoop's Creek, p. O., Chemung co.g. N. Y.: $160 \mathrm{~m}$ W. by S. Albany.

Wrss, p. o., Franklin county, Ind.: 60 miles E. S. E Indianapolis,

Wrocena, t. and p. o, Columbia co., Wisc. : $30 \mathrm{~m} . \mathrm{N}$. by E. Madison. Soil fertile prairie land, with some growth of timber. Drained by Duck cr. and smail streams. Population 506.

Wromsig county, $\lambda$. $\boldsymbol{Y}$. Situate $W$, and contains $5 \mathrm{SO}$ sq. m. Drained by Allen, Cayuga, Tonawanda, Seneca, and other crecks. Surface undulating, and forming for the most part a series of elevated plains or terraces; soil fertile, and particularly so along the valley of the Genesee. being a gravelly loam, moist, and adapted to grain, etc. the $\mathrm{S}$. portion is best suited for grazing. Chief productions, wheat, oats, and potatoes. It contains some minerals, and some fossil shells and vegetable substances. Agriculture is the leading pursuit. Gom water-power is supplieis by the falls of the Genesee. Farms 3,960; manuf. 299; divell. 5,918, and pop.-wh. 81,935 , fr. col. 46-total 31,981. Cap950 ital: Warsaw. Public Works: Buffulo and New Fork City R. R. ; Genesee Valley R. R.; Genesee Valley Canal.

Wroxnse county, Penn. Situate N.E., and contains 455 sq. m. Susquehanna river passes centrally through it, by which and its branches it is drained. Surface varied, being pleasantly diversified with low hills and fertile valleys; soil in parts very fertile. Staples, wheat, corn, and potatoes. It has gond pasturage, on which numbers of cattle and hogs are fed. Anthracite coal is found. Farms 895 ; manuf. 59 . dwell. 1,834, and pop.-wh. 10,650, fr, col. 5-total 10.65. Capital: Tunkhannock. Pullic Works: Lackawanna and Western R. R. ; North Branch Canal, ete.

Wyonise county, Virg. Erected from Logan en. in 1850. Situate W., and contains $1,342 \mathrm{sq}$. m. Drined by head branches of Guyandotte $r$, branches of Tug fork of Sandy r. and Camp cr. Surface much broken and hilly, in parts mountainous; soil various, generally adapted to grazing. Chief products, wheat and Indian corn. Farms 188; manuf. 0 ; dwell. 218 , and pop.-wh. 1,5\$3, fr. col. 1, sl. 61 total 1,615. Capital: Wyoming.

Wromng, p. v., Stark co., $1 u_{.}$: on E. side Spoon r., $85 \mathrm{~m}$. N. by W. Springfield.

Wromivg, sta., Middlesex county, Mass: on Boston and Maine R. R., $6 \mathrm{~m}$. from Boston.

Wrokise, p. v., Wyoming co., $N_{\text {. }} Y_{\text {.: }}$; on W. bank of Allen's cr., $229 \mathrm{~m}$. W. Albany. It contains three churches, an academy, several stores, etc. Pop. about 700 .

Wromng, p. v., Luzerne $\mathrm{Co}_{*}$, Penn.: on W. side of Sus. quebanna r., 85 m. N. E. by N. Harrisburg.

Wromine, p. V., Dinwiddie county, Virg.: on N. side of Nottoway r., 43- m. S. S. W. Richmond.

Wroming, t. and p. o, Iowa co, Wisc.: $32 \mathrm{~m}$. W. Madison. Drained by Pipe cr. and other small streams which flow into Wisconsin r. Pop. 206.

Wrsox, t. and p. 0., Bradford co., Penn. : $105 \mathrm{~m}$. N. by E. Harrisburg. Surface hilly. Drained by Wysox and Pumfield creeks. The t. contains several grist and saw mills. Pop. about 2,000.

Wrтве county, Firg. Situate toward the S.W., and contains 573 sq. m. Drained by New r. and its branches, and branches of Holston $\mathbf{r}$. Surface level, somewhat elevated, forming a table land; soil fertile, making good pasture. Chief products, wheat, oats, and Indian corn. Farms 665; manuf. 22 ; dwell. 1,681, and pop.-wh. 9,618, fr.col. 221, sl. 2,155-total 12,021. Capital: Wytheville. Public Works: Virginia and Tennessee R. R.

W rume, p. 0., Hancock county, $\pi l .: 90 \mathrm{~m}$. W. N. W. of Springfield.

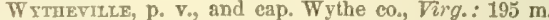
W. by $\mathrm{S}$. Richmond. It contains the county buildings, one bank, several stores, etc. The "Republican and Constitutionalist" (dem.) is issued weekly. The Tirginia and Teunessee I. R. passes through this place. Pop. about 600 .

\section{$\mathrm{X}$.}

Trxid, t., n. v.. sta., and eap. Greene co., Olio: $47 \mathrm{~m}$ W. $\mathrm{IV}$. Columbus. The township is large, and contains some of the most fertile land in the State. Drained by Little Miami r, and branches, one of which, Shawnee creek, flows through the $v_{\text {, }}$, situate near the centre of the $t$. The $v$ is regularly litid out, with strects crussing ench other at right angles, and is generally well built. It contains handsome county buildings of brick and stone, a bank, and 5 churches. The " Innia Torth Light" (whig) is here published. The railmads here centering are Little Miam R. P.. from Cincinnati $65 \mathrm{~m}$.; Columbus and Xenia R. R. $55 \mathrm{~m}$.: Daytim aud Xenia R., T., $15 \mathrm{~m}$. : each of which is but a portion of extended and very important routes. Pop. uf $\mathrm{v}$, in 154 , ahout $1.2 \mathrm{~m}$; in $1-5$, almut 2,200 ; pi)p. of $t$. including $\mathrm{v}$., in $1540,4.913$; in 15511, 7.450.

Xexis, p. O., Clay county, $I U .: 93$ miles $\mathbf{S}$. E. by $\$$. Springfielu. 
X. Pratrie, p. o., Noxubee co., Miss. : 122 m. N. E. by E. Jackson.

\section{Y.}

TADkin river, $N_{0}$ Car.: rises in the Blue Ridge, flows E. and S. E. through the State, into South Carolina, when it takes the name of Great Pedee r., until it empties into Winyari bay, near Georgetown. In Montgomery county it passes through the "Narrows," where it is contracted in willth from 600 to 100 feet. It is navigable for boats and small vessels throughout the greater part of its course.

Y $\triangle$ KLUMA river, Oreg. Ter.: rises in the Cascade Range, flows S. S. E, and E., and empties into Columbia river, near the confluence of Lewis river.

Y $\triangle L E$, p. o., Jasper co., Ill.: 85 m. S. E. Springfield.

Yaliabusira county, Miss. Situate toward the N., and contains 897 sq. m. Yallabusha r. passes through the S. portion from E. to W., by which and its branches it is drained. Surface undulating and somewhat elevated; soil a deep rich mold, very fertile, and produces fine crops of grain and potatoes, it is also favorable to the growth of cotton, which is produced abundantly, and is one of the staples. Farms S72 ; manuf. 32 ; dwell. 1,491, and pop.-Wh. 8,652, fr. col. 9, sl. 8,597-total 17,258. Capital: Coffeeville. Public Works: Mississippi Central R. R.

TAx Hruc county, Oreg. Ter. Divided from Clatsop and Washington counties by a line on the parallel of Cape Lonkout to the Willamette river, and from Polk and Marion counties by a line on the parallel of the mouth of Yaquina river, a small stream of the Pacific Ocean which lies on the W. The E. line is the Willamette and Drift cr., one of its affuents from the $\mathbf{S}$. Drained chiefly by Yam Hill and Chehalem rivers, tributaries of the Willamette from the W. The county has immense water-power and fine agricultural resources. Farms 142; manuf. 4: dwell. 243, and pop.wh. 1,511, fr. col. 1-total 1,512. Copital: Lafayette.

Y ANPA river, Utah Ter, : rises on W. side of the Rocky mts, and flows W. to its confluences with Green river.

YANABY, p. o., Oktibbeha county, Miss.: 112 m. N. E. Jackson.

Y ANCER county, N. Car. Situate W., and contains 657 sq. m. Drained by Nolichucky $x_{0}$ and its branches. Surface elevated and mountainous; soil in parts fertile, and adapted to the cultivation of grain and other agricultural productions. It contains a copperas mine. Black mt., elevaled 6,476 feet above the ocean level, is within the limits of this county. Farms 970 ; manuf. 10 ; dwell. 1,322, and pop.-wh. 7,809, fr. col. 50, sl. 346-total 8,205. Capital: Burnsville.

Y ANCEY's MrLLs, p. 0., Albemarle county, Virg.: $75 \mathrm{~m}$. W. N. W. Richmond.

Yanceyville, p. v., and eap. Caswell co., N. Car : $60 \mathrm{~m}$. N. W. Raleigh. It contains the county buildings. Pop. about 300 .

Y YNHANA , p. o., Georgetown distriet, S. Car.: $100 \mathrm{~m}$. E. S. E. Columbia.

Y ANKEE HrLL, p. o.,Menard co, $M l .: 16 \mathrm{~m}$. N.W. Springfield.

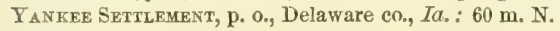
Iowa City.

Y ANKeE Speings, to and p. o., Barry co, wïch.: $44 \mathrm{~m}$. W. by S. Lansing. Drained by branekes of Thornapple $\mathrm{r}$. Pop. in 1840,180 ; in 1850, 292.

YANKEETOWN, p. o., Darke co., Ohio: 84 m.W. Columbus.

Yantre, p. v. and sta., New London eo., Conn.: on Yantic river, and New London, Willimantic, and Palmer R. R., $16 \mathrm{~m}$. from New London, $50 \mathrm{~m}$. from Palmer, $31 \mathrm{~m}$. E. S. E. Hartford. It has several factories.

Y ANTIC river, New London co., Conn.: is formed in Lebanon $t$. by 3 branches, flows E. and S. E., and below Norwich empties into Thames $\mathbf{r}$. One mile above its mouth it has a beautiful ?all of 11 feet over a rocky precipice, affording great water power, improved by numerous manufactories.
YAPMANK, p. o. and sta., Suffolk co., N. Y.: on Long Island R. R., $60 \mathrm{~m}$. from New York, $158 \mathrm{~m}$. 8. S. E. Albany Y Ardleyville, p. vo, Bucks co, Penn.: oll W. bank of Delaware river, $102 \mathrm{~m}$. E. Harrisburg. It contains several stores and mills. A ferry here crosses the Delaware. Pop. about 150.

YARDVIrLE, p. O., Mercer $c_{0}, N_{0}$ Jer : 6 m. E. Trenton.

Yararouti, t., p. v., and sta., Cumberland $\mathrm{con}_{*}, M e_{\text {. }}: 41 \mathrm{~m}$. S. S. W. Augusta, Drained by a small stream which affurds water-power. The Kennebec and Portand R. R., and Atlantic and 8t. Lawrence R. R., pass through the to and connect $1 \mathrm{~m}$. from the $\mathrm{r} ., 12 \mathrm{~m}$. from Portland, $47 \mathrm{~m}$. from Augusta. Pop. of t. 2,144.

YARMOUTH, t. and p. v., Barnstable county, Mass. : $63 \mathrm{~m}$. S. E. Boston. The t, extends across Cape Cod, and has a sandy and sterile soil. It contains 4 thriving villages, each engaged in the flsheries and coasting trade. The manufacture of salt is earried on extensively. Pop. of t. 2,595.

YARMoUth PoRT, p. vo, Barnstable con, Mass, : on inlet of Cape Cod bay, 61 miles S. E. Boston. It containg 2 churches, several stores, and 1 bank, cap. $\$ 300,000$. The "Yarmouth Register" (whig) is issued weekly.

Y ATES county, $N$. $\boldsymbol{Y}$. Situate W. centrally, and contains 320 sq. m. Drained by Flint creek, West r., Crooked lake outlet, and Big and Rock streams, the two latter flowing into Seneca lake; much good water-power is supplied in their courses. Surface diversifled by hills and valleys, much of it being greatly elevated; soil very fertile; in $\mathbf{S}$. portions a warm, clayey mold prevailing, and productive in grain and fruits. It contains some good meadow land. Chief productions, wheat, Indian corn, and potatoes. Here are some minerals, and a valuable sulphur spring. A brine spring. lately found near Dundee, has proved productive, and yields a considerable revenue. Farms 1,673; manuf. 165 ; dwell. 8,784, and pop.-wh. 20,442, fr. col. 148-iotal 20,590. Capitul: Penn Yan. Public Works: Canandaigua and Elmira R. R.

YATES, t. and p. v., Orleans co, $N . Y_{:}: 152 \mathrm{~m}$. W. by N. Albany. Drained by Johnson's ereek, flowing into Lake Ontario, which bounds it on the N. The v. on Johnson's cr. contains several mills and stores. Pop. of t. 2,242.

Y ATEStille, p. o., Yates co., N. Y.: $282 \mathrm{~m}$. W. Albany.

YaTeSville, p. o, Lunenburg co., Virg.: $61 \mathrm{~m} . \mathrm{S} . \mathrm{W}$. Richmond.

Y

Y Azoo county, Mfiss. Situate W. centrally, and contains 731 sq. m. Drained by tributaries of Big Black and Yazoo rivers. Surface undulating; soil fertile, and well adapted to grain. Chief productions, cotton and Indian corn. Farms 464; manuf, 17; dwell, 935, and pop.-wh, 4,069, fr. col. -, sl, 10,349-total 14,418. Capital: Benton. Public Works: Mississippi Central R. R.

YAzoo river, Miss. : is formed at W. boundary of Carroll co., by the confluence of Tallahatchee and Yallabusha rivers, and flows S. S. W. in very meandering course, about $160 \mathrm{~m}$. to its entrance into the Mississippi river, near Vicksburg. This is an excellent stream, affording easy navigation for steamboats, of which a considerable number are constantly employed in the transportation of cotton.

Y $A Z 00$ CitY, p. eity, and cap. Yazoo co., Ariss. : on E. side of Yazoo r., $40 \mathrm{~m}$. N. by W. Jackson. It is situated on a Low bluff, which, back of the city, rises to a very considerabje elevation. The main street follows the river in bending course, but the rest of the city is laid out with general regularity. The county seat was removed to this place from Benton in 1852. The court-house is an elegant structure of brick. There are 5 churches, of which the Episcopal Society has a handsome edifice. The houses are chiefly built of wood, and are not characterized for their elegance The trade of the eity is almost exclusirely in cotton, of which from 75,000 to 100.000 bales are shipped annually to New Orleans. There are 3 steam saw-mills, with no other manufacturing establishments. A plank-road extends hence 
to Benton, 10 miles. Two newspapers, the "Yazoo Demcrat" and "Yazoo City Whig," are issued weekly. Pup. about 2,000 .

YELL county, Ark. Situate W. centrally, and contains $1,027 \mathrm{sq} . \mathrm{m}$. Drained by Petite Jean, and other tributaries of Arkansas, which forms its N. E. boundary. surface raried, in the $\mathbf{S}$. E. being hilly, but in general it is level; soil fertile, and adapted to grain. Cotton and tobacco are produced in small quantities. Timber is found of a good quality, and there are some excellent coal beds. Farms 330 ; manuf. 20 ; dwell. 473 , and pop.-wh. 2,902, fr. col. 15, sl. 424-total 3,341. Capital: Danville.

YELt county, $I a$. Situate centrally, and contains 615 sq. m. Drained by Des Moines river and its branches. Surface diversified by gentle swelling lands; soil fertile, and favorable to the cultivation of grain. It has good timber and prairie land. Set off since 1850 .

YeLLow lake, Jefferson county, N. Y.: 160 miles N. W. Albany. It is $4 \mathrm{~m}$. long, $\frac{1}{2} \mathrm{~m}$. wide, and abounds with excellent fish.

YELLOW river, Ind.: rises in $\mathrm{N}$. W. part of Koscuisko co., flows W. S. W. and W., and empties into English lake. It is about $60 \mathrm{~m}$, long, and in high water is navigible 30 or 40 miles. Its average width below Plymouth is 100 feet. Its course is not generally rapid, but it affords considerable water-power.

YeLlOW Braxch, p. O. Campbell co, Firg.: on branch of Taunton r., $91 \mathrm{~m}$. W. by S. Richmond.

YELLOW Bud, p. 0., Ross co., Ohio: $42 \mathrm{~m}$. S. Columbus.

YeLLOW BusH, p. o., Chickasaw county, Miss.: $125 \mathrm{~m}$. N. N. E. Jaclison.

Yellow Ceeek, p. o., Knox co., $\bar{K}_{y}$ : on stream of same name, $126 \mathrm{~m}$. S. E. by S. Frankfort.

YeLLOW CREeK, t, and p. va, Chariton Co., MO.: $89 \mathrm{~m}$. N. W. by N. Jefferson City. Drained by Yellow ereek.

Yellow Creek, p. o., Lumpkin co., Ga.: 120 m. N.N.W. Milledgeville.

Yellow CrekK, p, v., Tishemingo co., Miss, : $206 \mathrm{~m}$. N. E. by N. Jackson.

YrLlow Creak, p. O., Stephenson co., Il.: 169 m. N. Springfield.

Yellow Creek Furnaok, p, o., Montgomery co., Tenn.

$85 \mathrm{~m}$. W. N. W. Nashville.

YELLOW HEAD Grove, p. 0., Will county, $I l_{\circ}$ : 144 miles

N. E. by E. Springfield.

Yellow Mountain, p. o, Yancey co., N. Car": $203 \mathrm{~m}$. W. Ralejgh.

YelLow River, p. s., Gwinnett co., Ga.: on Fellow r., $78 \mathrm{~m}$. N. W. Milledgeville.

YeLLow RIVER, p. o., Marshall county, Ind. : $102 \mathrm{~m} . \mathrm{N}$. Indianapolis.

YelLow Sprivg, p. o, Johnson county, Ind.: $12 \mathrm{~m} . \mathrm{S}$. Indianapolis.

Yellow Spativg, p. Y., Des Moines co, Ia.: 48 m. S.S.E. Iowa City.

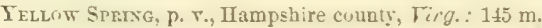
N. W. by N. Richmond.

Yeltow Sprivg, p. V., Blair co, Penn。: $72 \mathrm{~m}$. W. by N. Harrisburg. In the vicinity is a hot-blast charcoal furnace, with annual capacity of 1,400 tons, employing 100 men: also 1 charcoal forge, which in 1549 made 400 tons of blooms, employing 30 men.

Yellow Springs, p. v. and sta, Greene co, Orio : on the Little Miami $R, R, 72$ miles from Cincinnati, 47 miles W. by S. Culumbus. It is pleasantly siluater, and untatins a sulphur spring, which is nuch resurted to in the summer.

Yexiow Springs, p. 0., Claiborne county, Tenn.: $190 \mathrm{~m}$. E. by N. Nashville.

Yellow StoNe, p. 0., Paulding co, Ga : $182 \mathrm{~m} . \mathrm{N}$. W. by W. Milledgeville.

YELLOW STORE, p. 0., Hawkins co., Tenn. 212 m. E. of Nashville:

YELLOW TATER river, $A l \alpha$, and Flor.: riges in Corington 95\% so., Ala., flows S. S. W. and S. W., and empties into Yellow Water bay of Pensacola bay.

Yellville, p. v., and cap. Marion co., Ark. : on N. side of Crooked cr., a iributary of White r., $102 \mathrm{~m}$. N. by W. Little Rock. It contains a court-house and jail. Pop. about 100 Felvivgton, p. V., Daviess co., Ky.: 132 m. W. by S. of Frankfort.

Yeосомто river, $\bar{V}$ rg. : a branch of Potomac r., separating Northumberland and Westmoreland counties.

Yеосомго, U. S. collection dist., Firg. : total tonnage on June 30,1550 , amounted to 3,284 tons, all of which was employed in the consting-trade. During the year one vessel a schooner of 57 tons, was built.

Yrouskr, p. o., Kalamazoo co., Mich.: 64 m. S. W. byW. Lansing.

Yocony, p. o., Itawamba co., Mriss.: $186 \mathrm{~m}, \mathrm{~N} . \mathrm{E}$. by N. Jackson.

Yocum Station, p. o., Lee co., Firg.: 319 m. W. by S. Richmond.

Yoountown, p. v., York co., Penn. : 17 m. S. Harrisburg. Yohogany, p. o., Westmoreland co., Penn.: 136 m. W. Flarrisburg.

Yolo county, Calif. Occupies the tract between the Sacramento r. and Putah er., and the Coast Range. The $\mathrm{N}$. boundary is a line on the parallel of 39020 . N. Jatilude, meeting the Sacramento about $3 \mathrm{~m}$. below Colusi. Drained by Cache and other creeks of Clear lake, and several streams falling into the Sacramento and Putah. There are several lakes in the co,-Washington, $3 \mathrm{~m}$. by $+\mathrm{m}$.; Clear, $6 \mathrm{~m}$. by $2 \mathrm{~m}$. ; and Tule, $\frac{1}{2} \mathrm{~m}$. by $\frac{1}{2} \mathrm{~m}$. The principal settlements are Washington, Fremont, Caché Creek, Cottonwood, Merrit, and Putab. Pop. in 1852, 1,307; whites 1,274males 1.085 , and females 189 -negroes 11 , mulattoes 3 , Indians 152 -males 109 , and females 43 ; foreign residents 86 males $\$ 3$, and fernales 3 . Over 21 years of age-citizens 1,016, negroes 10, mulattoes 3 . Indians 90 , and foreigners 51. It is one of the best agricultural counties in the State, and produccs large quantities of truck for the city markets. Acres in cultivation, 3,846. Mining is but a subordinate oceupation. Capital: Frémont.

Foncala, p. v., Benton co., Oreg. Ter. : on S. bank of Elk r., 92 m. S. by W. Salem.

Yovguesville, p. v. and sta., Fairfield dist., S. Car. : on Charlotte and South Carolina Railroad, 32 miles $\mathrm{N}$. by W. Columbia. Pop. about 100 .

YoNkers, t. and p. v., Westchester co., N. Y.: $132 \mathrm{~m} . \mathrm{S}$. Albany. Drained by Bronx r. on the E, and by Saw-Mill or Nepperhan r., an affuent of the Hudson, which latter forms its W. border. Surface somewhat uneven and broken soil clay and sandy loam, generally well cultivated. It is one of the pleasantest and most healthy towns on the Hudson, and of late years has been selected by great numbers of the merchants of New York city as a suitable residence for their families. The v., on Nepperhan $r$, has been rapidly built up with substantial and splendid dwellings, and has also several extensive manufacturing establishments and mechanic shops. A steam bedstead factory, one of the lirgest in the Union, and two very extensive hat factories, are found here; while on the river are two grist-mills and many shops which are operated by water-power. Yonkers has six church s-1 Kirman Catholic, 1 Episeopal, 2 Buptist, and 2 Presbyterian. There are also in the $\mathrm{v}$, two academies for females. and one for boys, and two public schools. The business of the place is extensive, it being a point of supply and deposit for a rich back country. It has an ample river front and several landings, which afford every fucility to steambuats and river craft; and the Iudson Iiver $l i . r$. which passes through the $t$. on the immediate bank of the river, secures frequent communication with New York city, 14 or 15 passenger ears passing up and down during the day. Three steamboats ply daily on the Hudson between the two places. For the accommodation of visitors, there is a splenvid Lutel a: the corner of Broadway and Mochanic 
Strest, frunting on buth, and containing between 500 and 300 rooms. Attached to the hotel is a fine hall, used for exhibitions, theatricals, lectures, ete, There are other hotels and taverns in various parts. Broadway is the principal seat of retail trade, and not a few of the stores rival in assortment and elegance those of New York city. On the same avenue stands the market-house, which is well provided with substantials and luxuries in their seasons. The Croton Aqueduct passes through the $\mathrm{v}$, and some of the streets are arched over for that purpose. Yonkers, indeed, has all the charms of a fine and varied country, and at the same time all the accommodations of a city; and society at this place has many ornaments, and is endowed with all the advantages of wealth, learning, and refinement. Pop. of $t$, in $1840,2,96 \mathrm{~S}$, and in $1850,4,160$. The village at the present time (155:i) is supposer to have a population equal to that of the whole town in 1550

York county, Me. Situate S. W., and contains $822 \mathrm{sq} . \mathrm{m}$. Drained by Saco and Monsam rivers and their branches, and aftuents of Piscataqua r., which runs on its S. W. border. Surface uneven and diversifled, with numerous lakes, which add beauty to the scenery of the surrounding country; soil in the interior is fertile and productive, but bordering on the shore is rough and rocky, and unfit for cultivation. Staples, wheat, Indian corn, and potatoes. On the S. E., along the Atlantic shore, are excellent harbors, which afford good advantages for navigation and the fisheries; there are also several light-houses. Farms 5,004; manuf 852 ; dwell. 10,564, and pop.-wh. 60,065, fr. col. 36-total 60,101. Capital: Alfred. Public Works: Portland, Saco, and Portsmouth R. R.; York and Cumberland R. R., etc.

York county, Penn. Situate S, toward the W., and contains 831 sq. m. Drained by Conewago, Codorus, and Yellow Breeches creeks, tributaries of Susquehanna r., which flows on its N.E. border. Surface uneven; soil in most parts is very fertile, and produces in abundance wheat, grain, and potatoes; fine crops of tobacco are also raised. It has good timber and excellent pasturage for cattle. Live-stock and grain are exported annually. Farms 3,734 ; manuf. 583; dwell. 9,927, and pop,-wh. 56,324, fr. col. 1,126-total 57,450. Capital: York. Putlic Works: York and Cumberland $R$. R. ; Baltimore and Susquehanna P. R.; Hanover Branch R. R.; York and Gettysburg R. R.; Susquehanna and Tide-Water Canal.

York district, S. Car. Situate N., and contains 731 sq. m. Drained by King's, Bullock's, Turkey, and Buffalo creeks, principal branches of Broad and Catawba rivers. Surface an extended plain, inclining on both sides a little to the Catawba and Broad rivers; soil fertile. Chief productions, cotton and Indian corn. Farms 1.252 ; manuf. 30 ; dwell. 2,190, and pop.-wh, 11,300, fr. col. 126, sI. 8,007-total 19,433. Capital: Yorkville. Public Works: Charlotte and Soùth Carolina R. R. ; King's Mountain R. R., etc.

York county, Virg. Situate toward the S. E., occupying the middle portion of the peninsula between James and Tork rivers. It contains 132 sq. m. Drained by small streams which flow into York r. and James $r$. Surface even and diversified ; soil fertile. Chief productions, wheat and Indian corn. Farms 161 ; manuf. 0 ; dwell. 442, and pop.-wh. 1,825, fr. col. 454, sl. 2,181-total 4,460. Capital: Yorktown.

York, p. v., Fayette county, $G \alpha .: 80$ miles W. N. W. of Milledgeville.

Yopk, t. and p. o., Union co., Ohio: $42 \mathrm{~m}$. N. W. by N. Columbus. Drained by Rush and Boques ereeks of Sciota river. Pop. of t. in 1840,439 ; in 1850,831 .

YoRK, p. V., Walker co., Ala. : on E. side of Lost creek, $110 \mathrm{~m}$. N. W. by N. Montgomery.

York, t. and p. V., Dane co., Wisc. : $20 \mathrm{~m}$. N. E. Madison A projected railroad from Madison to Fond du Lac will pass through the $\mathrm{v}$. Pop. of t. 615 .

York, t., p. v., and port of entry, York co., Me. : $94 \mathrm{~m}$. \$. S. W. Augusta. The t. has a diversified surface and soil.
The $\mathrm{v}$. on $\mathrm{N}$, bank of York $\mathrm{r}$. is regularly laid out, with structs cressiog at right angles. Lat. 4:30 $111^{\prime}$ X., Jong. ijo 10 W. It was formerly the capital of the erunty. Its harior admits vessels of 250 tons. The tonnage of this district on June 30th, 1550, was 1,361 tons, all of the class "enrollet and liceused," which was employed chiefly in the coastingtrade, but partly in the end and mackerel fisheries. During the year previous, 2 vessels, 1 brig and 1 scisuner, wore built-253 tons. Pop. of t. 2,930.

York, p. v., Gibson co., Ind.: 120 m. S. W. by S. Indianapolis. The Evansville and Inlinois R. R. passes a little W. of this place.

York, p. v., Crawford co., Ill.: on W. side of Wabash river, $115 \mathrm{~m}$. E. $\mathrm{S}$. E. Springfield. It contains several stores and mills. Pop. about 500 .

York, t. and p. o., Washtenaw co., MFich.: 61 m. S. E. Lansing. Drained by small creeks of Raisin river. Population 1,360.

YoRK, t. and p. V., Livingston co., N. Y.: $220 \mathrm{~m}$. W. Albany. Drained by branches of Genesee river, which forms its E. boundary, and along which the Genesee Vulley Canal passes. Pop. of t. 2,755.

York, p. b., and cap. York co, Penn.: 21 m. S. S. E. Harrisburg. Lat. $39 \circ 58^{\prime} \mathrm{N}$., long. $76040^{\prime} \mathrm{W}$. It is regnlarly laid out, with streets crossing each other at right angles. It contains several handsome county buildings, buil of brick and stone, and 13 churches. There are two banks, wilh aggregate capital of $\$ 320,000$. It carries on extensive manufactures, and has considerable trade. The York and Cumberland R. R., from Harrisburg $25 \mathrm{~m}$., here connects with the Baltimore and Susquehanna $\mathrm{R}$. $\mathrm{P}$. hence to Baltimore, $57 \mathrm{~m}$.; and the York and Wrightsville R. P. extends to Wrightsville, on Susquehanna r., connecting with Philadelphia and Columbia R. R. Its newspaper press in 1550 consisted of "Penn. Republican" (whig), "People's Advrocate" "Democratic Press," and the "Tork Gazette" (whig), printed both in the English and German languages; all issuct weekly. Pop. about 6,000 .

Yonk river, York co, Me. : in S. part of York t., flowing E. into the $\Lambda$ ulantic, which it enters by a brual mouth. atforling for eight miles good harborage for vessels of 200 tons.

York river, Firg. : is formed at S. E. extremity of Kiug William co, by the confluence of Pamunkey and Mattapony rivers. It is about $30 \mathrm{~m}$. long, and is navigable for large vessels. At Georgetown it is $1 \mathrm{~m}$. wide, affording the best harbor inVirginia. Below Georgetown its width increases gradually until it enters Chesapeake bay, where it is $3 \mathrm{~m}$, wide.

York Centre, p. o., Du Page co., 1ll.: $160 \mathrm{~m}$. N. E. by . . Springfield.

YoRk HATEN, p. Y., York co., Penn.: on S. W. bank of Susquehanna r., 12 m. B. E. Harrisburg. Conewago cr. here enters the Susquehanna, and by its falls above affords good water-power. The York and Cumberland Railroad passes through the place.

York North Rmge, p. o., Sandusky co., Orio: $94 \mathrm{~m}$. N. Columbiss,

Yorksmre, t. and p. v., Cattaraugus co., N. Y.: $250 \mathrm{~m}$. W. Albany. Drained by Cattarangus creek and branches, Surface of t. level ; soil fertile. The v., situate on S. side of Cattaraugus cr., contains a church and several stores. Pop. of t. 2,010 .

York South Rmge, p. o., Sandusky co., Ohio: 92 m. N. Columbus.

York Sulpiur Sprivgs, p. v., Adams co., Penns: 20 m. S. S. W. Harrisburg. These snrings possess valuable mejicinal properties, and are of much resort in summer from Philadelphia and Baltimore.

YoRktown, p. v. and sta., Delaware co., Ind.: on the Indianapolis and Bellefontaine R. R., $4 \mathrm{~S}$ m. N. E. from Indianapolis. The West fork of $T^{\prime}$ hite $r$. flows near the $\mathrm{v}$. and receives Buck cr, each of which afford water-power, improved by Jarge mills. Pop. about :300.

Yorктошs, t. and p. o., West Chester co., $\mathcal{N} . Y_{.}: 94 \mathrm{~m}$. 
S. Albany. Drained by Croton $\mathrm{r}$. and branches, from which, by means of a dam, 250 feet long, and 40 feet high, is formed Croton Pond, which supplies New York eity with water. Pop. of t. 2,273.

Yorktown, p. 0., Bureau co., Ill.: $120 \mathrm{~m}$. N. Springfield. Yorktown, p. v., De Witt county, Tex. : 84 m. S. by E. Austin City.

Yolistown, p. v., port of entry, and cap. York co., Virg. : on S. side of York river, 55 miles E. S. E. Richmond. Lat. $37013^{\prime} \mathrm{N}$.; long. $76^{\circ} 34^{\prime} \mathrm{W}$. It contains the county buildings and several stores. The tonnage of Yorktown distriet on June 30 th, 1850 , was 4,807 tons, all of which was employed in the coasting trade. Vessels built during the year preceding, 2, schooners-61 tons. Yorktown was incorporated in 1705. Among its buildings are some of the oldest in Virginia. It is ever memorable in American history, as the place where Lord Cornwallis surrendered to the American forces, Oetober 19th, 1781, which glorious event was the means of terminating the Revolutionary War.

Yorkville, p. v., Pickens co., Ala.: 184 m. N. W. by W. Montgomery.

Yorkville, p. v., Dearborn county, Ind.: 70 m. \$. E. Indianapolis

Yorkville, p. v., Kalamazoo county, Mich.: $50 \mathrm{~m}$. S. W. by W. Lansing.

Yonk viLle, p. V., and cap. York dist, S. Car. : on branch of Broad r., $63 \mathrm{~m}$. N. by W. Columbia. It contains the county buildings, an academy, and 3 churches. The King's Mountain R. R. extends hence to Chester, 22 miles. The "I. Miscellany" (democrat) is issued weekly. Population about 850 .

Yorkville, p. v., Gibson eounty, Tenn. : on a branch of Obion r., $128 \mathrm{~m}$. W. Nashville.

York Madison. Drained by Des Plaines r. Surface undulating ; soil fertile. The $\mathrm{v}$. is pleasantly situated and neatly built Pop. of t. 998.

Yorkville, p. $\nabla .$, New York co., $N . Y .:$ on the Harlem R. R., 5 m. N. N. E. City Hall, New York, This flourishing suburb, properly a part of the eity, is on the $3 \mathrm{~d}$ and $4 \mathrm{th}$ avenues, between soth and 100 th streets. In common with all other parts of New York island, the increase of the population, and the erection of new buildings are rapidly advancing. It contains several churches, and numerous manufactures. It is in the $12 \mathrm{~h}$ ward of the city.

Yougur GLADES, p. o., Alleghany co., Mrd.: on N. side of Deep cr., near its junction with Youghiogheny $\mathrm{ra}_{a}, 151 \mathrm{~m}$ Wr. by N. Aunapolis.

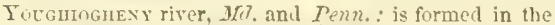
W. part of Alleghany co, Mid., by the confluence of sereral creeks, flows N. and N. W., and empties into Monongahela river, $18 \mathrm{~m}$. S. E. Pittsburg. It is navigable to the Ohiowhe falls, 31$) \mathrm{m}$. from its mouth. where it has a perpendicular descent of 20 feet, which in high water presents a very interesting appearance.

TotNG, p. o, $M \cdot$ Donough county, $I U_{0}: 86$ miles $N$. $W$. Epringtich.

Yourg CANE, p. o., Union county, Ga, : $142 \mathrm{~m}$. N. N. W. Milledgeville

Toungen's, p. o., Boone county, MFo.: 88 m. N. Jefferson City.

Fouve Hickors, p, o., Will county, $I U_{0}: 143 \mathrm{~m} . \mathrm{N} . \mathrm{E}$. Springfield.

Tousg Hickors, p. o., Muskingum co., Ohio: 54 m, E. Columbus.

Yooxe Hickory, p. 0., Washington county, Wiscs: $63 \mathrm{~m}$. E. N. E. Maslison.

Young's Cross Roans, p. O., Granville con, N. Car.: $55 \mathrm{~m}$. N. Raleigh.

Young's Pornt, p. o., Madison parish, Lan: $125 \mathrm{~m}, \mathrm{~N}$. Baton Pouge.

Torve's S FTrLenext, p. o., Bastrop county, Tex. : $29 \mathrm{~m}$. E. S. E. Austin City,
Young's STORE, p. o., Laurens district, S. Car.: $72 \mathrm{~m}$ N. W. by W. Columbia.

YoUNG8TOWN, p. vi and port of delivery, Niagara county, $N . Y_{0}$ : on E. side of Niagara r., near its entrance into Lake Ontario, $276 \mathrm{~m}$. W. by N. Albany. It is a landing-place for passengers to and from the lakes, and communication is had with Newark v., Canada, by means of a ferry for some time established here. It is a place of much historical interest as connected with the late war with the British. In the vieinity is Fort Niagara, celebrated in the French war: and opposite, in Canada, is Fort George. Population about 550 .

Youngstown, t. and p. v., Mahoning co., Ohio: $138 \mathrm{~m}$. N. E. by E. Columbus. Drained by Mahoning river and branches. Surface of t. nearly level; soil fertile. The y. is situate on the N. side of the r., on the Pennsylvania and Ohio Canal, and has considerable trade. Pop. of t, 3,002.

Youngstown, p. b., Westmoreland co., Penn.: between head branches of Loyalhanna r., $127 \mathrm{~m}$. W. Harrisburg. It is pleasantly situated, and contains several stores, mills, ete. Pop. about 600 .

Youngsville, p. V., Tallapoosa co., $A l a$. ; 43 m. N. N. E. Montgomery.

Youngsvilie, p. o., Sullivan co., $N$. Y.: 84 m. S. W. Albany.

Yodngsville, p. v., Warren county, Penn, : on Broken Straw er., about $3 \mathrm{~m}$. from its mouth, $167 \mathrm{~m}$. N. W. by W. Harrisburg. It lies in the midst of a fertile and higbly cultivated country, and is on the line of the projected Sunbury and Erie R. R. The "Youngsville Express" (independent) is issued weekly. Pop. about 400 .

YodNGSVILle, p. 0., Adams county, Ohio: 85 m. S. by W. Columbus.

Young Woranstown, p. v., Clinton co., Penn.: on N. side of W. branch of Susquehanna r., $85 \mathrm{~m} . \mathrm{N}$. W. by N. Harrisburg.

Yountsvil, e, p. v., Montgomery county, Ind.: $45 \mathrm{~m}$. W. N. W. Indianapolis.

YrsLANTr, t., p. vo, and sta., Washtenaw co, Afich. : $60 \mathrm{~m}$ $\mathrm{S}$. E. Lansing. The $\mathrm{v}$, is pleasantly situated on both sides of Huron $r_{\text {s, }}$ which here affords excellent water-power, improved by numerous mills and manufuctories. In 1850, it contained 4 flouring-mills, the value of the annual product of which was $\$ 165,000$; and 2 saw-mills, with annual product of $\$ 11,87 \mathrm{~s}$. The $\mathrm{v}$. also contains a State normal school, a branch of the State university, and 5 churches. The Michigan Central R. R. passes through, $30 \mathrm{~m}$. from Detroit, $248 \mathrm{~m}$. from Chicago. The "Y. Chronicle" (whig) and "Y. Sentinel" are issued weekly. Pop. of $\mathrm{y}$. about 2,$000 ;$ of t. 3,052

YUAB or Juab county, Utah. Lies between Tooele and Yillard counties, and extends from San Pete co; to the California line. It is chiefly a barren wilderness, crossed by mountain ranges, with some fertile spots near the water courses. There are several small lakes in the co. which receive the streams, but have no outlets. Nicollet $r$, and lake are the largest. Yuab was formerly a part of San Pete co. Capital: Nephi City.

YuBA, p. o., Hancock county, $I l l .: 90$ m. W. N. W. Springfield.

YUBA river, Calif.: is formed in Yuba co. by the confluence of three head forks, and flows W. S. W. to its entrance into Feather $r$. The gold diggings on Yuba r. and its branches have been among the most profitable in the State.

YUвA CIту, p. v., Sutter county, Calif.: on W. bank of Feather $r_{\text {., }}$ opposite mouth of Yuba r., $96 \mathrm{~m} . \mathrm{N}$. N. E Vallejo.

YUBA county, Calif. In the country on Fuba river. Drained by Bear river, Dry ereek, Yuba river, on which are the principal mining operations, Indiana creek, Clark's run, Deer creek, Middle Tuba, Cañon ereek, Slate creek, etc., on all of which gold is found in abundance. Many of these 
streams have been turned by canalling. The highest peak of the mountains-Oregon Hill, rises 2,800 feet high. Farm lands under cultivation in $1852,7,008$ acres. The county contains 18 saw-mills, producing annually $9,050,000$ feet timber, and one flour-mill. Capital employed in quartz mining $\$ 121,400$, in placer mining $\$ 710,900$, in river mining $\$ 1,6 \$ 7,150$, and in merchandise and trade $\$ 1,939,600$. Whole capital, exclusive of real. estate, $\$ 4,570,500$. Pop. in 1852, 22,005 : viz., whites 17,299 males 16,666 , and females 685 ; negroes 194 - males 182 , and females 12 ; mulattoes, 45 males; domesticated Indians 120 ; foreign residents 3,055 -males 2,309 , and females 246 Chinamen 2,100. Over 21 years of age-citizens 15,215, negroes 170 , mulattoes 45 , Indians 102 , foreign residents 2,\$46. The principal towns and settlements are-Marysville, pop. 4,500; Ousley's Bar, pop. 390 ; Kennebec, pop. 120 ; Long's Bar, pop. 450 ; Park's Bar, etc. Nevada county has been taken from Yuba. Capital: Marysville. Putlic Works: Benecia and Marysville R. R. (projected).

\section{Z.}

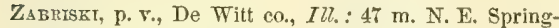
field. The Illinois Central $\mathrm{R}$. R. will pass through it.

ZACHARY, p. o., Marshall county, Ala. : on N. W. side of Tennessee r., $146 \mathrm{~m}$. N. Montgomery.

ZACKVILLE, p. V., Wirt co., Virg. . 232 m. W. N. W. of Richmond.

ZANESFIELD, p. v., Logan co., Ohio: 43 m. N. W. by W. Columbus, Laid out on Oetober 11th, 1819. Population about 250 .

ZaNesville, p. v., Montgomery county, $\pi l$ : $32 \mathrm{~m}$. S, of Springfield.

ZANestille, p. v., and cap. Muskingum co., O7io: on E. bank of Muskingum r., opposite the mouth of Licking r., $51 \mathrm{~m}$. E. Columbus. This flourishing v. has experienced a rapid growlb, and is one of the most thriving places in the State. The Muskingum $r$. in passing the $t$. has a natural descent of 9 feet in $1 \frac{8}{4}$ miles, which, by means of a dam, is increased to 16 feet, thus affording efficient water-power. The manufactories improving this great privilege are of all kinds, and many of them are extensive. The number of factories using steam-power is also large, arising mainly from the abundance of bituminous coal supplied from the surrounding bills. The Muskingum has been made navigable for steamboats to Dresden, 15 miles above, where a navigable side-cut, $2 \frac{1}{2} \mathrm{~m}$. long, connects with the Ohio Canal, thus affording to Zanesville the advantages of direct connection with the great canals of the State. Steamboats ply regularly from this place to Pittsburg and Cincinnati. The lines of railroad passing through Zanesville are, Central Ohio R. R., now completed from Columbus to this village, $59 \mathrm{~m}$., and in construction to Wheeling; Cincinnati, Wil. mington, and Zanesville R. R.,125 m., in construction; and the Cleveland, Zanesville, and Cincinnati R. R., formerly Akron Branch R. R., which will be completed in 1854. The viliage contains very handsome county buildings, 3 banks, and 14 churches. The general interests of education are well provided for in excellent public schools and numerous private academies. Among the former are 2 high sehools, one for males and one for females, which are of high repute, and among the latter is an academy liberally estallishrol and endowed by the late John M.Intire, the founder of Zanesville. The citizens have an enviable reputation fo: general intelligence, as well as for business enterprise. A popular Athenæum, having a library of 10,000 volumes, with. reading-room, etc., and annual lectures, is well sustained. The newspapers here published in 1 (5) were, "Zuses ille Courier" (whig), issuing daily, tri-weekly, and weekly erlitions, "Z. Gazette" (neut.), and "Z. Aurora" (dem.), each issued weekly : "Clarion of Freedom" (free soil), "Western Peeorder" (Meth.), "Family Quarto" (Presby.); besides which, the "Annual Register" is a regular publication. The $v$. is, abundantly supplied with water, which is raised from the Muskingum by a powerful forcing-frump. ints a reservoir on a hill 160 feet high, and custinining $75.1 \%$. gallons, and is thence distributed through the village in irn: pipes. Bridges connect the v. with Putnam, South Zanes. ville, and West Zanesville, which are intimately connected with the business interests of Zanesville. Pop. of $\mathrm{V}$. in $1840,4,766$; in $1850,7,791$.

Zavalla, p. v., Jasper co., Tex. : on E. side of Angelina river, 220 m. E. by N. Austin City.

Zebulon, p. V., and cap. Pike co., Ark. : 90 m. W. S. W. Little Pock. It contains the county buildings and several stores. Pop. about 150 .

Zebulon, p. v., and cap. Pike co., Ga.: 68 m. W. Mi!ledgeville. It contains the county buildings. 3 churches, an aeademy, several stores, ete. Pop. about 300 .

Zelienople, p. v., Butler co., Penn. : on S. side of Conequennessing cr., $164 \mathrm{~m}$. W. by $\mathrm{N}$. Harrisburg. It is a pleas-

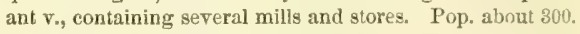

Zkxas, p. v., Jennings county, Ind.: on Vernon fork of Drusilla r., $55 \mathrm{~m}$. S. S. E. Indianapolis.

Zeno, p. o., York dist., S. Car., $66 \mathrm{~m}, \mathrm{~N}$. Columbia.

ZinarermaN, p. o., Greene co., Ohio: $52 \mathrm{~m}$. S. W. by W. Columbus.

Zion, p. v., Centre co., Penn.: 65 m. N. W. Harrisburg. In the vicinity is a hot-blast charcoal furnace, with annuil capacity of 1,400 tons; also a rolling-mill making plate and sheet iron, employing 16 men.

ZioN, p. O., Iredell county, $N$. Car. : 120 miles W. by N. Raleigh.

Zion, p. o., Cecil co., MId.: 52 m. N. E. Annapolis.

Zion, p. o., Grant co., Ind.: 55 m. N. N. E. Indianapolis. Zion HILL, p. o., Hamilton county, Tenn. 108 m. S. E. Nash ville.

Zion Seminary, p. o., Covington co., Dhiss.: on E. side of Bowie er., $65 \mathrm{~m}$. S. E. Jaekson.

Zronsville, p. 0., Lehigh co., Penn.: 70 m. E. N. E. of Harrisburg.

ZoAr, p. o., Erie co., N. Y.: 267 m. W. Albany.

ZoAr, p. v., Tusearawas co., Ohio: on E. bank of Tuscarawas r., 90 m. E. N. E. Columbus, Settled by a German communist colony, called Separatists, under the gorernment of a palriarch. Their farms and gardens are well cultivated, and the general appearance of the village betokens industry and virtue. Pop. 249.

Zoar Bridge, p. v., New Haven co., Conn. : $46 \mathrm{~m}$. S. S. T. Hartford.

Zollersville, p. 0., Washington co., Penn. : $166 \mathrm{~m}$. W. Harrisburg. 


\section{APPENDIX TO FISHER'S STATISTICAL GAZETTEER.}

\section{RAILROADS OF THE UNITED STATES, 1853.}

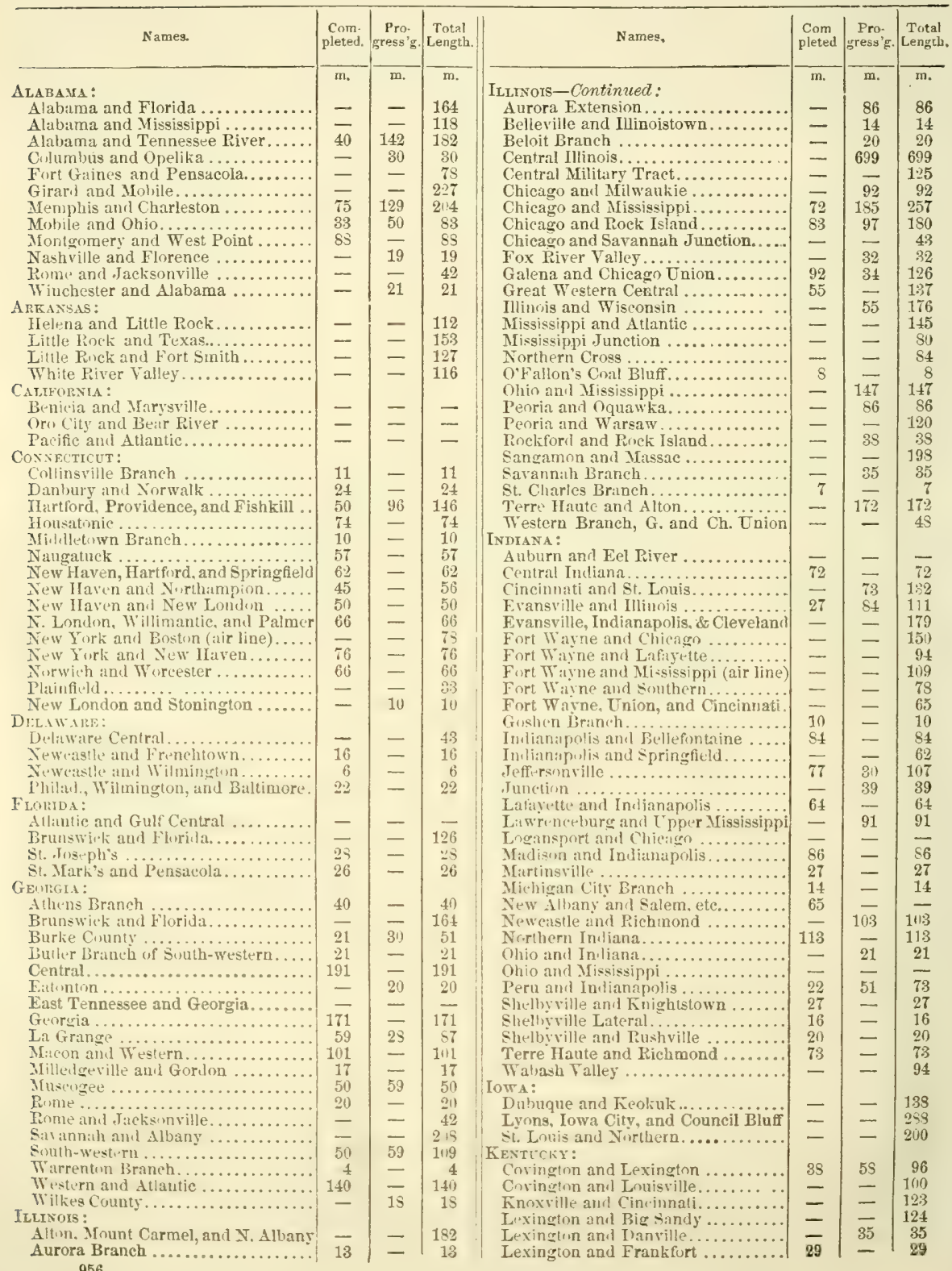


APPENDIX.RAILROADS.

\begin{tabular}{|c|c|c|c|c|c|c|c|}
\hline Nantes. & $\begin{array}{c}\text { rom- } \\
\text { pleted. }\end{array}$ & $\begin{array}{l}\text { Pro: } \\
\text { gress'g. }\end{array}$ & $\begin{array}{c}\text { Tuthil } \\
\text { Length. }\end{array}$ & Names. & $\begin{array}{l}\text { Com. } \\
\text { pleted. }\end{array}$ & $\begin{array}{c}\text { Pro. } \\
\text { resto }\end{array}$ & $\begin{array}{l}\text { Tontal } \\
\text { literist is. }\end{array}$ \\
\hline KENTCCKY-Contin? & $\mathrm{m}$. & $\mathrm{m}$. & & Massacméts-Continued & $\mathrm{m}$. & $\mathrm{m}$. & $\mathrm{m}$. \\
\hline Louisville, Clarkes & - & - & 102 & Grand Junction and Depôt Company & 6 & - & 6 \\
\hline Louisville and Nas & - & - & 180 & IIarfured and New Hav & 6 & - & G \\
\hline Louisville and Fran & 65 & 一 & 65 & IIarvaril Braneh. & 3 & - & 2 \\
\hline Maysrille and Big S & - & 91 & 91 & Lexington and West & 7 & 一 & 7 \\
\hline M:Iysville and Le. & - & 66 & 67 & Lowell and Lawrenes & 12 & - & 13 \\
\hline Mobile and ohio & - & 39 & 39 & Marlboro' Braneh.... & - & - & - \\
\hline Nashville and Henderson......... & - & 130 & 130 & Merlway Branch.. & 4 & - & 4 \\
\hline LoUISIANA: & & & & Nashua and L' & 15 & - & 15 \\
\hline 1 and Port & 24 & - & 24 & New Bedfurd and Taunton......... & 21) & 一 & 21) \\
\hline Mexic & $2 \overline{7}$ & - & 27 & 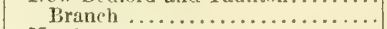 & 1 & - & 1 \\
\hline Milntburg and Lake Pont & 6 & - & 6 & port.. & 16 & 一 & 16 \\
\hline Nashville and New Orlear & - & 一 & - & tic, \& Palmer & 66 & - & 66 \\
\hline New Orleans and $\mathrm{C}$ & 6 & - & 6 & ounty. & 26 & - & 26 \\
\hline Northern & - & 51 & 51 & $h$ and Wo & 59 & 一 & 53 \\
\hline N. Orlea & 一 & - & 213 & $\ldots \ldots \ldots \ldots$ & 37 & 一 & 37 \\
\hline Vicksburo & $\overline{0}$ & 一 & 207 & $\ldots .$. & 8 & - & 9 \\
\hline West $\mathrm{F}$ & 26 & - & 26 & $\cdots$ & 14 & - & 14 \\
\hline MiI & 20 & 32 & & cee and Bristol. & 19 & 二 & 19 \\
\hline A & 55 & 32 & $\begin{array}{l}52 \\
55\end{array}$ & $\begin{array}{l}\text { and Bristol..... } \\
\text { and Worcester. }\end{array}$ & $\overline{44}$ & - & $\overline{41}$ \\
\hline Atl & 149 & - & 149 & Lowell.......... & 17 & - & 17 \\
\hline enobscot) ..... & - & 13 & 13 & ch... & 9 & - & 9 \\
\hline .......... & - & - & 38 & and Bia & - & - & - \\
\hline$\ldots \ldots \ldots$ & 12 & - & 12 & Peading Branch... & 8 & - & $S$ \\
\hline$e \ldots \ldots$ & - & 一 & 75 & $\ldots$. & 22 & 一 & 22 \\
\hline$\ldots \ldots \ldots$ & 9 & - & 9 & $\ldots$. & 11 & - & 11 \\
\hline $\mathrm{Bo}$ & 3 & - & 3 & ..... & 22 & 一 & 22 \\
\hline Bue & 13 & 17 & 30 & ... & 13 & - & 13 \\
\hline …. & 12 & - & 12 & $\cdots$ & 4 & - & 4 \\
\hline n.... & - & - & 7 & ....... & 11 & - & 11 \\
\hline n.... & - & - & 96 & $\mathrm{Br}$ & 1 & $\overline{19}$ & 1 \\
\hline ...... & $\bar{n}$ & - & 18 & Tr & $\overline{60}$ & 43 & 43 \\
\hline$\ldots \ldots$ & $\underline{-}$ & - & 9 & nd $\mathrm{Mi}$ & $\begin{array}{l}69 \\
18\end{array}$ & - & 69 \\
\hline $\begin{array}{l}\ldots \ldots \\
\ldots \ldots\end{array}$ & $\overrightarrow{60}$ & - & $\begin{array}{l}16 \\
60\end{array}$ & $\cdots \cdots$ & 15 & - & 8 \\
\hline$\frac{\mathrm{Ke}}{\mathrm{Le}}$ & - & 二 & $\begin{array}{l}60 \\
20\end{array}$ &. & $\overline{155}$ & - & $\overline{155}$ \\
\hline $\mathrm{Pe}$ & - & 56 & 56 & t & 3 & - & 3 \\
\hline tsmouth ... & 51 & - & 51 & r.and Nashua. .......... & 46 & - & 46 \\
\hline ..... & - & 8 & 8 & Mri & & & \\
\hline I & 13 & 35 & 53 & C & 4 & $\ldots$ & 4 \\
\hline$\ldots$ & - & - & 39 & $\cdots \cdots$ & 25 & - & $2 \overrightarrow{5}$ \\
\hline Saeo & - & $\rightarrow$ & 60 & d' Toledo......... & - & - & - \\
\hline boro' and Chir & - & - & 20 & $0 \ldots . . .$. & 35 & - & 35 \\
\hline Mar & & & & $\mathrm{Mi}$ & 229 & $\longrightarrow$ & 223 \\
\hline lge & 21 & - & 21 & M & 131 & - & 131 \\
\hline i & 380 & - & 330 & and $c$ & - & - & - \\
\hline 'g, & 57 & 一 & 57 & h Branch.... & 10 & 一 & 10 \\
\hline Coal Company's........ & - & - & - & Mis & & - & \\
\hline 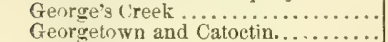 & - & - & - & s & - & $\overline{150}$ & 148 \\
\hline d Catoctin. . & - & - & - & $\begin{array}{l}\ldots \ldots \ldots \\
\ldots \ldots \ldots\end{array}$ & - & $\begin{array}{l}1511 \\
273\end{array}$ & $\begin{array}{ll}180 \\
073\end{array}$ \\
\hline Fr & 3 & - & 3 & Sii Northeri & - & $101)$ & $\begin{array}{l}2+3 \\
100\end{array}$ \\
\hline 1 & - & 一 & - & ........ & - & - & 230 \\
\hline ......... & - & - & - & $\mathrm{P}$ & 7 & - & 7 \\
\hline $\mathrm{N}$ & - & - & - & St. Fr & 25 & - & 29 \\
\hline nd Baltimore & 56 & 一 & 56 & ¿ Brandon... & 60 & 一 & 60 \\
\hline$\ldots \ldots \ldots \ldots \ldots$ & 31 & - & 31 & Miss & & & \\
\hline 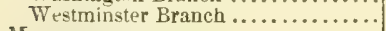 & 17 & 一 & 17 & $\mathrm{C}:$ & - & - & - \\
\hline (1) & & & & ph"s.. & - & - & 210 \\
\hline Brat & - & - & - & Iri & - & - & 70 \\
\hline hertown .. & 20 & - & 43 & inty & & - & - \\
\hline 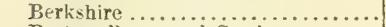 & 25 & - & 25 & $\mathrm{~N}$ & 0. & - & 50 \\
\hline ner. & - & 一 & - & Pacific. & 40 & 240 & 250 \\
\hline Bosto & 26 & 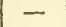 & 26 & Platte Co & - & - & - \\
\hline 2 & 2 & - & 2 & South-we & - & 一 & 800 \\
\hline ....... & 74 & - & 74 & NEW H & & & \\
\hline Bra & 9 & 一 & 9 & t. Lawrer & 51 & - & 51 \\
\hline Bosto & 41 & 一 & 41 & & 24 & - & 24 \\
\hline & 12 & - & 12 & & 34 & - & 31 \\
\hline 2 & 45 & - & 45 & real.. & 71 & 33 & 109 \\
\hline Bra & 24 & 一 & 24 & Branch. & 13 & - & 13 \\
\hline Branch.. & 27 & - & 27 & gire .......... & 43 & - & 43 \\
\hline & 2 & - & 2 & & 25 & - & 23 \\
\hline 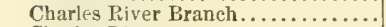 & 12 & - & $1 \overline{2}$ & & 3.5 & - & 35 \\
\hline$\cdots$ & - & 一 & - & nd Clar & 25 & 26 & 51 \\
\hline 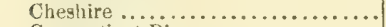 & 54 & - & 54 & geonk Valley... & 14 & - & 14 \\
\hline & 50 & $\longrightarrow$ & 50 & & 16 & - & 16 \\
\hline Bro & 3 & - & 3 & & 8 & - & 8 \\
\hline $\mathrm{Da}$ & - & - & - & G & 13 & - & 13 \\
\hline East & 38 & 一 & $3 S$ & ches & 26 & - & 26 \\
\hline & 20 & - & 20 & New Hampshire Central ........ & 26 & - & 26 \\
\hline Ess & 20 & - & 20 & & 69 & - & 69 \\
\hline & 1 & 一 & 1 & and $\mathrm{Co}$ & 47 & - & $4 \pi$ \\
\hline Fall River... & 42 & - & 42 & Sullivan. & 26 & 一 & 26 \\
\hline Fit.r. & 51 & - & 51 & hite Mounta & - & - & 25 \\
\hline Fitehbure & 17 & - & 17 & & 15 & 一 & 15 \\
\hline Fitchburg an & 14 & - & 14 & ad Nashu & & & \\
\hline
\end{tabular}


APPENDIX - RAILROADS

\begin{tabular}{|c|c|c|c|c|c|c|c|}
\hline Nimes. & $\begin{array}{c}\text { Com- } \\
\text { pleted. }\end{array}$ & $\begin{array}{c}\text { Pro: } \\
\text { gress }\end{array}$ & $\left|\begin{array}{c}\text { Total } \\
\text { Lengtlı. }\end{array}\right|$ & Names. & $\begin{array}{l}\text { Com- } \\
\text { pleted. }\end{array}$ & $\begin{array}{l}\text { Pro- } \\
\text { gress'g. }\end{array}$ & $\begin{array}{l}\text { Total } \\
\text { Length. }\end{array}$ \\
\hline NhW JERSEY: & $\mathrm{m}$. & $\mathrm{m}$. & $\mathrm{m}$, & North Carolina-Continued: & $\mathrm{m}$, & m. & m. \\
\hline Belvidere Delaware........ & 34 & 29 & 63 & Wilmington and Weldon. & 162 & 一 & 162 \\
\hline Burlington and Mount Holly & 6 & 一 & 6 & Wilmington and Mauchester ....... & 一 & 一 & - \\
\hline Camden and Amboy .......... & $\begin{array}{l}64 \\
26\end{array}$ & - & $\begin{array}{l}64 \\
26\end{array}$ & $\begin{array}{l}\text { Oमt०: } \\
\text { Bainbridge Branch. }\end{array}$ & & & \\
\hline $\begin{array}{l}\text { Camden and Amboy Branch. } \\
\text { Camden and Atlantic ......... }\end{array}$ & 20 & - & 60 & $\begin{array}{l}\text { Bainbridge Branch ........ } \\
\text { Bellefontaine and Indiana. }\end{array}$ & $\overline{118}$ & $\overline{-}$ & 119 \\
\hline Camden and Cape May ...... & - & - & - & Carrolton Branch......... & 110 & $\overline{20}$ & 20 \\
\hline Flemington Branch..... & - & 11 & 11 & Central Ohio ..... & 59 & 82 & 141 \\
\hline Morris and Essex..... & 44 & 86 & 80 & Cincinnati and Dayton. & - & 52 & 52 \\
\hline New Jersey ....... & 31 & - & 81 & Cineinnati, Hamilton, and Iayton... & 60 & - & 60 \\
\hline New Jersey Central...... & 78 & - & 78 & Cincinnati, Cleveland, and Columbus & 135 & - & 135 \\
\hline Trenton Branch ........ & 6 & - & 6 & Cincinnati, Hillsboro', \& Parkersburg & 37 & 137 & 174 \\
\hline 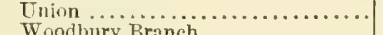 & 33 & 一 & 33 & Cincinnati Western ....... & - & - & 75 \\
\hline Wondbury Branch. & 9 & - & 9 & Cincinnati, Wilmington, \& Zanesville & 一 & 126 & 126 \\
\hline $\begin{array}{l}\text { New YoRk: } \\
\text { Albany Northern }\end{array}$ & & & & Cleveland and Mahoning. & - & - & 102 \\
\hline Albany Northern ....... & 32 & - & 32 & Cleveland, Medina, and Tusc & - & - & 130 \\
\hline Albany and Plattsburg... & 一 & $\approx$ & - & Cleveland, Painesville, \& A & 71 & - & 71 \\
\hline Albany and Susquehann & $\overrightarrow{17}$ & 153 & 153 & Cleveland, Zanesville, and Cincinnati & 28 & 86 & 114 \\
\hline Albany and Schenectady ........... & 17 & 一 & 17 & Cleveland and Pittsburg..... & 100 & - & 100 \\
\hline Albany and West Stockbridge...... & 38 & - & 38 & Clinton Line................... & - & - & $\overline{c o s}$ \\
\hline Attica and Alleghany Valley ....... & $\overline{11}$ & 一 & 74 & Columbus and Lake Eri & 60 & 一 & 60 \\
\hline Batavia Bran & 11 & - & 11 & Columbus and Parkersbu & $\overline{55}$ & 一 & $\overline{55}$ \\
\hline Buffalo and & $\overline{57}$ & $\overline{\tau 0}$ & 30 & Columbus and Xenia & 55 & $-\overline{0}$ & 55 \\
\hline Buffalo, Corning, and N & 57 & 76 & 133 & Columbus, Piqua, at & 一 & 102 & 102 \\
\hline $\begin{array}{l}\text { Buffalo and New York Ci } \\
\text { Buffalo and Niagara Falls }\end{array}$ & 91 & 一 & 91 & Dayton and Michigan & - & 141 & 141 \\
\hline $\begin{array}{l}\text { Buffalo and Niagara Falls } \\
\text { Fuffalo and Lockport }\end{array}$ & 22 & - & 22 & Dayton and West & 36 & - & 36 \\
\hline & 20 & - & 20 & gfiel & 24 & - & 24 \\
\hline $\begin{array}{l}\text { Buffalo and State Line. } \\
\text { Buffalo and Fochester. }\end{array}$ & 69 & 一 & 69 & Dayton and Xenia..... & - & 15 & 15 \\
\hline $\begin{array}{l}\text { Buffalo and Rochester .... } \\
\text { Buffulo and Black Rock... }\end{array}$ & 63 & - & 68 & Erie and Kalamazoo & $\overrightarrow{10}$ & 一 & $\overrightarrow{10}$ \\
\hline $\begin{array}{l}\text { Buffalo and Black Rock... } \\
\text { Canandaigua and Fimira. }\end{array}$ & 8 & 一 & 3 & Findlay Branch ......... & 16 & - & 16 \\
\hline & 67 & $\rightarrow$ & 67 & Franklin and War & $\overline{0}$ & 106 & 106 \\
\hline $\begin{array}{l}\text { Canandaigua and Niagara Falls .... } \\
\text { Caynga and Susquehanna......... }\end{array}$ & 50 & 42 & 92 & Greenville and Mia & 87 & - & 37 \\
\hline $\begin{array}{l}\text { Caynga and Susquehanna........... } \\
\text { Corning and Bloseburg ........... }\end{array}$ & 33 & - & 83 & Hamilton and Eator & 44 & - & 44 \\
\hline 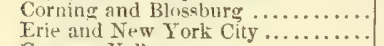 & 14 & - & 14 & Hanover Branch... & 13 & - & 13 \\
\hline $\begin{array}{l}\text { Erie and New York City ... } \\
\text { Grnesee Valluy............ }\end{array}$ & - & 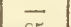 & 42 & Iron $\ldots \ldots \ldots \ldots \ldots$ & 13 & 14 & 27 \\
\hline & - & 85 & \$5 & ( & - & - & 110 \\
\hline $\begin{array}{l}\text { Hamburg and Erie................ } \\
\text { Hartford, Providence, and Fishkill .. }\end{array}$ & 一 & 一 & 50 & Little Mi & 84 & - & 84 \\
\hline & - & 一 & - & (r and Lake Erie.......... & 134 & - & 134 \\
\hline 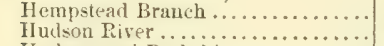 & 2 & 一 & 2 & Mansfield and Sandusky ............ & 56 & 一 & 56 \\
\hline $\begin{array}{l}\text { Hudson I } \\
\text { Hudson }\end{array}$ & 144 & - & 141 & a Cincinn & $\overline{-1}$ & - & 237 \\
\hline $\begin{array}{l}\text { Hudson and Berkshire............. } \\
\text { Lake Ontario, Auburn, and Ithaca.. }\end{array}$ & 34 & - & 34 & Newark and Mar & 61 & & 61 \\
\hline $\begin{array}{l}\text { Lake Ontario, Auburn, and Ithaca.. } \\
\text { I.tbanon Springs ................. }\end{array}$ & - & - & 80 & Ohis and India & $\overline{107}$ & 132 & 132 \\
\hline 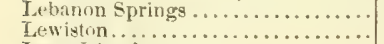 & $\overrightarrow{3}$ & 一 & 50 & (Hhio and Pennsyly & 197 & - & 187 \\
\hline d....... & $\begin{array}{r}3 \\
95\end{array}$ & - & $\begin{array}{r}3 \\
95\end{array}$ & Ohio and Mississip & 一 & $\overline{10}$ & $\overline{10}$ \\
\hline sland.... & $\stackrel{95}{-}$ & $\overline{7 S}$ & $\begin{array}{l}95 \\
78\end{array}$ & $\begin{array}{l}\text { Pomeroy Branch } \\
\text { Pittsburg. Maysville........... }\end{array}$ & 二 & 10 & 10 \\
\hline $\begin{array}{l}\text { Mohitwk Valley ........ } \\
\text { Montreal and Plattsburg }\end{array}$ & - & - & $\underline{78}$ & $\begin{array}{l}\text { Pittsburg, Maysville, and Cincinnati. } \\
\text { Scinto and Hocking Valley .......... }\end{array}$ & $\overline{20}$ & $\overline{105}$ & $\overrightarrow{125}$ \\
\hline Newburg Branch....... & 19 & - & $\overline{19}$ & 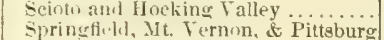 & 20 & 112 & $\begin{array}{l}123 \\
112\end{array}$ \\
\hline I New Haven... & 17 & - & 17 & $\begin{array}{l}\text { 14, Mt. Fernon, \& Pittsburg } \\
\text { ille and Indiana ............ }\end{array}$ & 二 & 149 & $\begin{array}{l}112 \\
149\end{array}$ \\
\hline New York : & 445 & - & 445 & 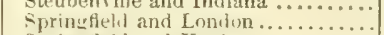 & - & 39 & 19 \\
\hline New York : & 130 & - & 130 & Ienia ... & $2 n$ & - & 20 \\
\hline New Iork a & - & - & 315 & Toledo. Norwalk. and $\mathrm{Cl}$ & 87 & 一 & 87 \\
\hline Northern (Ogilensburg) ... & $11 \mathrm{~s}$ & - & 115 & Toledo and St. Louis... & - & - & - \\
\hline Oswego & 35 & - & 35 & Twin Creek ........... & - & 20 & 20 \\
\hline Platshurg and $\mathrm{Wb}$ & - & - & $\bar{z}$ & Wellsville and Wheeling . & - & 38 & 38 \\
\hline $\begin{array}{l}\text { Pulsilam } \\
\text { Ron=siel: }\end{array}$ & $\overline{0.7}$ & 75 & 75 & PENNSYLVAN & & & \\
\hline $\begin{array}{l}\text { Rensed: } \\
\text { linchest }\end{array}$ & 32 & $\overline{-}$ & 32 & Alleghany Portage. & 86 & 108 & 36 \\
\hline $\begin{array}{l}\text { E Niagara Fulls } \\
\text { Onterio ........ }\end{array}$ & 76 & - & i6 & Alleghany Falley & - & 108 & 108 \\
\hline $\begin{array}{l}\text { Rochester and Lake Ontario ........ } \\
\text { Riochester and limeove Falls ....... }\end{array}$ & 8 & - & S & $\ldots \ldots$ & - & - & - \\
\hline $\begin{array}{l}\text { If limeove Falls ........ } \\
\text { I Syracuse (direct) ... }\end{array}$ & $\overline{s 0}$ & - & $\overline{s \theta}$ & Beaver Meadow and Brat & 38 & - & 38 \\
\hline $\begin{array}{l}\text { use (direct) ..... } \\
\text { use........... }\end{array}$ & So & - & 80 & rsville Branch. & 3 & & 3 \\
\hline $\begin{array}{l}\text { Rochester and sir } \\
\text { liirbland and Wias }\end{array}$ & 104 & - & 104 & to rand Ht & 24 & $0 \pi$ & 24 \\
\hline $\begin{array}{l}\text { Hirchland and Was } \\
\text { Sackett's Harbor a }\end{array}$ & 60 & $\overrightarrow{10}$ & 60 & vissa. Williamsport, & - & 25 & 90 \\
\hline $\begin{array}{l}\text { Sackett's Harbor and Ellisburg....... } \\
\text { Sarntnga and Sackett's Harbor..... }\end{array}$ & 一 & 15 & 15 & Charliers Valley ........ & $\overline{15}$ & $\rightarrow$ & 39 \\
\hline 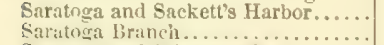 & - & - & - & Chestnut Hill and Doylestown. & 15 & & 15 \\
\hline 0 h & & 13 & 15 & Valley. & 10 & 13 & 23 \\
\hline $\begin{array}{l}\text { igit and Schent } \\
\text { git amd W ashi }\end{array}$ & 22 & 一 & 22 & hial Braneh. & 18 & & 18 \\
\hline $\begin{array}{l}\text { Ta amd Wushin } \\
\text { ectady and Tro }\end{array}$ & 63 & 一 & 63 & all and Pine Grove .......... & - & 27 & 27 \\
\hline $\begin{array}{l}\text { Schenectady and Tro } \\
\text { Stianeateles and Jord }\end{array}$ & 211 & - & 20 & berland Valley & 56 & - & 56 \\
\hline & 5 & - & 5 & (1) $P_{11}$ & 44 & & 44 \\
\hline Sodus Point & 一 & 85 & 35 & ville and Shamokin. & - & 20 & 20 \\
\hline use ar & - & 70 & 76 & phin and si & 16 & - & 16 \\
\hline mol Etic & 53 & - & 53 & \& Tyom. Talley & - & & 10 \\
\hline$\ldots \ldots \ldots$ & 6 & - & 6 & $t \ldots \ldots \ldots \ldots \ldots . . . .$. & 19 & 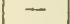 & 19 \\
\hline Troy and Buston & 89 & - & 39 & Frankilin Canal.. & 26 & - & 26 \\
\hline Ylicat a & - & 一 & 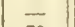 & Framklin .... & 22 & - & 22 \\
\hline Tritea a & 73 & - & is & n:1ntown Braneh. & 6 & a & 6 \\
\hline Y'tien an & $\overrightarrow{7}$ & 60 & 60 & shurg & & 41 & 41 \\
\hline Watertown an & 97 & - & 97 & isburg a & 88 & - & 33 \\
\hline Whlliamsport and Elmira.......... & 一 & 一 & - & Hazeitun and Lehigh ....... & 10 & 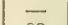 & 10 \\
\hline North & & & & & - & $\$ 2$ & 82 \\
\hline Atlantic and North C & - & $\$ 9$ & 89 & II & 6 & & $B$ \\
\hline Chatrlotte and s & - & - & - & Huntington and Broad Top Mountain & - & & $\pi$ \\
\hline Gast & ST & 一 & 57 & and Western ......... & 50 & $\overline{r a}$ & 50 \\
\hline Greenville an & 21 & - & 21 & Lebanon Valley. & - & 56 & 56 \\
\hline North Carnlin & 223 & - & 223 & Lehigh and Susqueh & 20 & 20 & 41) \\
\hline Roanol & - & 32 & 32 & Lewisburg, Centre, and Spruce Creek & - & - & $\overline{0}$ \\
\hline $\begin{array}{l}\text { Seaboard and Roanoke. } \\
953\end{array}$ & & - & - & Litue Schuylkill .................. & 26 & & 26 \\
\hline
\end{tabular}


APPENDIX.-RAILROADS.

\begin{tabular}{|c|c|c|c|c|c|c|c|}
\hline Names. & $\begin{array}{l}\text { Com. } \\
\text { pleted. }\end{array}$ & $\begin{array}{c}\text { Pro: } \\
\text { gress'g. }\end{array}$ & $\mid \begin{array}{c}\text { Tutal } \\
\text { Length. }\end{array}$ & Names. & $\begin{array}{c}\text { Com- } \\
\text { pilezted. }\end{array}$ & Pro: & $\begin{array}{l}\text { Total } \\
\text { Lwingtli. }\end{array}$ \\
\hline Pannspitania-Continued: & $m$, & $n$ & & TENNESSEE-Continued: & $m$, & $\mathrm{m}$. & $\mathrm{m}$ \\
\hline Little Schuylkill and Susquehanna... & 28 & 86 & 114 & Mobile and Ohio. & - & 119 & 119 \\
\hline Lykens Valley ... & 16 & $一$ & 16 & Nashville and Chattar & 105 & 46 & 151 \\
\hline Mahonny and Wisconisco. & 17 & $\longrightarrow$ & 17 & Nashville and Cincint & - & - & - \\
\hline Mauch Chunk and Summit Hill .... & 8 & - & 8 & Nashville and Hender & - & - & - \\
\hline Creek ..................... & 9 & - & 9 & Nashville and Me & - & - & 120 \\
\hline$M$ & 12 & - & 12 & Nashville and Mississi & 一 & - & $1 \frac{14}{43}$ \\
\hline 9 & $\frac{7}{5}$ & - & 7 & Nashville and New Or & - & 一 & 19i) \\
\hline Doyleston, \& New Hope & $\underline{5}$ & $\overline{28}$ & $\begin{array}{r}5 \\
28\end{array}$ & $\begin{array}{l}\text { South-western ............. } \\
\text { Western and Atlantic ..... }\end{array}$ & $\bar{z}$ & - & - \\
\hline Norristown and Freemansburg.... & - & - & 20 & 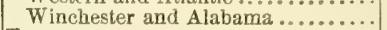 & - & $2 t$ & $\overline{21}$ \\
\hline 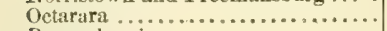 & - & $\rightarrow$ & 63 & Texas: & & & \\
\hline Pernsylvania........ & 221 & 36 & 257 & wnsville and Rio Grande & - & - & \\
\hline a Coal Company's...... & 47 & $\overline{50}$ & 47 & n and Houston. . & 一 & - & - \\
\hline all $\ldots \ldots \ldots$ & - & 56 & 56 & $\cdots$ & - & - & 一 \\
\hline $\mathbf{P}$ & 6 & - & 6 & Har & 6 & - & - \\
\hline ap & - & 一 & - & Housto & - & 53 & 53 \\
\hline dingia............. & $\begin{array}{l}80 \\
93\end{array}$ & 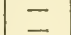 & 80 & Houston and Re & 一 & - & 一 \\
\hline \& Norristown & $\begin{array}{l}93 \\
17\end{array}$ & - & $\begin{array}{l}93 \\
17\end{array}$ & $\begin{array}{r}\mathrm{Sa} \\
\mathrm{VER}\end{array}$ & - & - & 一 \\
\hline$\ldots$ & 80 & - & 30 & ingion $\mathrm{Br}$ & 6 & - & 6 \\
\hline Weateh & 9 & - & 9 & tleboro' Branch. & - & 19 & 19 \\
\hline ilmington, \& Baltimore & 20 & 一 & 20 & ton Branch... & 7 & & 7 \\
\hline 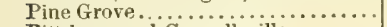 & 4 & - & 4 & psic Rivers & 61 & 53 & 114 \\
\hline ille.......... & - & - & - & $\ldots \ldots$ & 119 & - & 119 \\
\hline$\cdots$ & - & 141 & 141 & .... & 12 & - & 12 \\
\hline$\cdots$ & - & 42 & 42 & Rutlan & $\overline{8}$ & 一 & $\overrightarrow{0}$ \\
\hline$\cdots$ & 6 & - & 6 & $\mathrm{Ve}$ & 39 & 一 & 33 \\
\hline and Brar & 13 & - & 13 & .... & 114 & $\longrightarrow$ & 113 \\
\hline $\begin{array}{l}\text { alley and Brar } \\
\ldots \ldots \ldots \ldots\end{array}$ & 25 & $\rightarrow$ & 25 & n................. & 24 & 一 & 24 \\
\hline$\ldots \ldots$ & 7 & $\overline{17}$ & 7 & Vermont ..... & 53 & - & 53 \\
\hline $\begin{array}{l}\text { Erie } \\
\text { Pott }\end{array}$ & - & 47 & 240 & $\begin{array}{r}\text { VIRG } \\
\mathrm{Al}\end{array}$ & & & \\
\hline Shat & - & - & 40 & shire & $\overline{10}$ & - & - \\
\hline …... & - & 二 & 20 & nd 0 & 10 & - & 10 \\
\hline$\cdots \cdots$ & 26 & 二 & $\begin{array}{l}52 \\
26\end{array}$ & $\begin{array}{l}\text { more and } \mathrm{C} \\
\text { Ridge.... }\end{array}$ & 91 & $\overline{19}$ & 91 \\
\hline and Mahonoy & 15 & - & 15 & $\cdots$ & 12 & 10 & \\
\hline & - & - & 20 & & 15 & 一 & 15 \\
\hline .... & - & 26 & 26 & $\mathrm{C}$ & $\div$ & 229 & 228 \\
\hline .... & 20 & - & 20 & $\ldots$. & 21 & 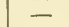 & 21 \\
\hline Wil & 25 & 52 & 77 & $\ldots$ & 4 & - & \\
\hline .......... & 25 & - & 25 & . & - & - & - \\
\hline rightsville............ & 13 & - & 13 & $\cdots$ & 37 & 39 & 75 \\
\hline Ruo & & & & $\mathbf{M n}$ & 一 & - & \\
\hline e) $\ldots$... & 一 & - & $\rightarrow$ & No & & & 120 \\
\hline$\ldots \ldots$ & $\overline{50}$ & 32 & 32 & Orange and Al & 62 & 36 & 95 \\
\hline$\ldots .$. & 50 & - & 50 & hall Br: & 3 & 一 & 3 \\
\hline Worcester......... & 18 & 一 & 18 & $\cdots$ & 64 & - & 61 \\
\hline Sou & & & & $\mathrm{Pi}$ & - & - & \\
\hline$\cdots$ & 11 & - & 11 & Ric & 73 & 74 & 147 \\
\hline ... & 12 & - & 12 & Cotomac. & 76 & - & 76 \\
\hline & 37 & - & 37 & & 22 & - & 22 \\
\hline $\mathrm{C}$ & 109 & 一 & 109 & d Roanoke. & 80 & - & S0 \\
\hline $\mathrm{C}$ & - & 40 & 40 & 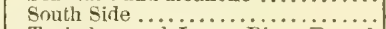 & 62 & 60 & 122 \\
\hline $\mathrm{Col}$ & 67 & - & 67 & Tuckahoe a & & - & \\
\hline Gre & 114 & 26 & 140 & $\cdots$ & 107 & 85 & 195 \\
\hline untain. & 32 & - & 32 & $\nabla$ & 60 & 142 & 202 \\
\hline & 15 & 16 & 31 & & 20 & - & 20 \\
\hline & 一 & 103 & 103 & WVi & 32 & - & 32 \\
\hline $\mathrm{Ra}$ & $\overrightarrow{07}$ & $\ldots$ & 39 & Waterford and Point of Rocks... & - & - & - \\
\hline Sou & 137 & - & 137 & Williamsport and North-Western... & - & 一 & - \\
\hline & & 60 & 60 & Wrsconsin: & & & \\
\hline Ion and Manchester & 115 & 47 & 162 & $\mathrm{Be}$ & - & 51 & 1 \\
\hline ENN & & $\pi$ & $\ldots$ & & 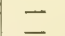 & - & - \\
\hline harleston & $\overline{-}$ & 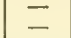 & $\overline{-}$ & $\begin{array}{l}\text { Chicago, Milw } \\
\text { Fond du Lac }\end{array}$ & 二 & - & $2 \overline{10}$ \\
\hline & - & 30 & 30 & Fox River Va & - & 36 & 36 \\
\hline & 82 & $2 S$ & 110 & La Crosse... & & - & - \\
\hline M & - & 122 & 122 & & - & $\ldots$ & - \\
\hline$=$ & - & - & & sissippi........... & 70 & $121)$ & 190 \\
\hline Fin & $\longrightarrow$ & - & $\begin{array}{r}140 \\
30\end{array}$ & Mineral Point..... & - & 32 & \\
\hline Memphis and & - & 50 & 30 & Racine, Janesville, & - & 91 & 92 \\
\hline Memphis and & & & & & & & \\
\hline
\end{tabular}


TELEGRAPHS OF THE UNITED STATES.

\begin{tabular}{|c|c|c|c|c|c|c|c|}
\hline Names of Companies. & 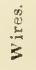 & Miles. & $\begin{array}{c}\text { Total } \\
\text { miles of } \\
\text { wire. }\end{array}$ & Names of Companies. & $\stackrel{\frac{2}{2}}{\frac{2}{3}}$ & Miles. & $\begin{array}{l}\text { Total } \\
\text { miles of } \\
\text { wire. }\end{array}$ \\
\hline New York and Boston Telegrap & 3 & 250 & 750 & hicago to Galena, Whitew & 1 & 310 & 810 \\
\hline Merchants' Tel. Co., N. Y. & 2 & 250 & 500 & hicago and Ja & 1 & 100 & 100 \\
\hline Ilouse's Printing 'Telegraph & 1 & 250 & 250 & Buffalo and Canada Ju & 1 & 200 & 200 \\
\hline Biston and Portiand.... & 1 & 100 & 100 & N. York and New Orleans, by Charleston & 1 & 1,966 & 1,966 \\
\hline Merchants'Tel. Co., Boston and Portland & 1 & 100 & 100 & Harper"s Ferry to Winches & & 32 & 32 \\
\hline 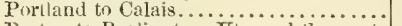 & 1 & 350 & 350 & Baltimore to Cumberland............ & 1 & 324 & 324 \\
\hline Buston to Burlington, $\nabla t$, and the & & & & Baltimore to Harrisburg ............. & 1 & 72 & 72 \\
\hline Ogisensbi & 1 & 350 & 350 & York and La & 1 & 22 & 22 \\
\hline Bnston to Newburyport. & 1 & $3 \pm$ & 34 & Philadelphia and Lewisto & 1 & 12 & 12 \\
\hline Wo & 1 & 97 & 97 & Philadelphia and New York & 6 & 120 & 720 \\
\hline W & 1 & 74 & 74 & delphia and Pittsburo & & 309 & 309 \\
\hline Ne & 3 & 513 & 1,5 & ill & 1 & $9 \mathrm{~S}$ & 98 \\
\hline Sy & 2 & 550 & 1, & and 1 & 1 & 51 & 51 \\
\hline Tri & $\frac{1}{1}$ & $\begin{array}{r}150 \\
36\end{array}$ & $\begin{array}{r}150 \\
36\end{array}$ & d White & 1 & 72 & 72 \\
\hline to Osin & 1 & 40 & $\begin{array}{l}30 \\
40\end{array}$ & and Fl & $\frac{1}{2}$ & $\begin{array}{r}75 \\
310\end{array}$ & 620 \\
\hline Honse Tel. Co., New York to Buffalo... & 2 & $55^{\prime \prime}$ & 1,100 & bus and Portsmouth, 0 & & 90 & $\begin{array}{r}620 \\
90\end{array}$ \\
\hline N.Y. and Erie Tel., New York to Dunkirk & 1 & 440 & 410 & Columbia and New Orleans.. & 1 & 638 & 63 \\
\hline N. Y. and Erie Railroad Telegraph, New & & & & & 1 & 90 & 03 \\
\hline York to Dunk & 1 & 460 & 460 & Maysville, $\overline{\mathrm{K}}$. & 1 & 60 & b \\
\hline Magnetic Tel. Co., N. Y. to Washi & 7 & 260 & $1 . \$ 20$ & d Galer & 1 & 380 & 38 \\
\hline House Line, New York to Philadelphia. & 1 & 100 & 100 & 8 and Ind & 1 & 25 & 2 \\
\hline Troy and Canada Junction Telegraph & & & & Louis and Chi & 1 & 330 & 330 \\
\hline Co., T & 1 & 260 & 260 & $\mathrm{k}$ and Zan & 1 & 40 & 4 \\
\hline n Telegraph Co., Buf- & & & & 1 & 1 & 40 & \\
\hline falo to Milw & 2 & 800 & 1,600 & ( & 1 & 30 & \\
\hline Cleveland in & 2 & 250 & 500 & I & 1 & 26 & \\
\hline i to St. Lou & 1 & 400 & 41 & 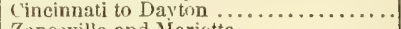 & 1 & 100 & 10 \\
\hline via Vinc & 1 & 410 & 410 & 2 & 1 & 66 & 6 \\
\hline Clt & 2 & 150 & 310 & Pittsbur & 1 & 200 & 20 \\
\hline 1 and Zanes & 1 & 150 & 150 & d Cape Mav, N. Jer.. & 1 & 100 & 10 \\
\hline Lake Erie Tel. Co., Bu & 1 & 40 & 4011 & t Holly, N. Jer. & 1 & 25 & \\
\hline i hnd San lusky City... & 1 & 21 & 218 & New York and Sandy Hook ........ & 1 & 80 & \\
\hline $\begin{array}{l}\text { Trledo and Terre Haute...... } \\
\text { Chicago and St. Louis........ }\end{array}$ & 1 & 310 & 300 & Cleveland and N. Orleans, by Cincin & 1 & 1,200 & 1.200 \\
\hline Mil & $\hat{1}$ & 20 & 20 & & s9 & 16,735 & $23,2 S$ \\
\hline Mrilwauki & 1 & 2.319 & 250 & & & & \\
\hline
\end{tabular}

\section{CANALS OF THE UNTTED STATES.}

Names of Canuls. Length in Miles.
Matwe:
Cinmberland and Oxford...... 20.5
Songo River Improvement.... 30.5

Bow Falls

Hookset ralls

Uninn Falls

Midillesex

White River Falls.

Bellow's Falls

Waterquechy :

MASSACHUSETT:

Middlestex

Pawtucket

Blackstone .....

Hamplaice and lian

Montague Falls.............

South Hadley Falls .......... 2

RTONE ISLAND:

Blackstoue

Conseoticut

Farmington (6lled in) ....... 56.

Enfleld Falls ............... 5.5

New YoRL:

Erie

Champlain Junction

Waterfurd Junction

Oswego

Carnusa ani Seneca.

Cronked Lake

Chenung

Chemung Feeder

Chenango

Gentsee Vialley

Danville Branch .............. 11.

Black River . ............. 77.5

Delaware and Hư H.............. 10.

Harlem (not used).......... 3.

Croton Aqueduct .............. 40.5 960

\section{Names of Canus. Lenctit in Miles.}

Delaware and Raritan ...... 42,

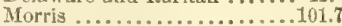

Silem ...........................

PENNSYLTANIA:

Delaware Division........... 59.7

Fastern do. $\ldots \ldots \ldots \ldots \ldots .4 .5$

Susquehanna do. .......... 89.

Juniata

West Branch

North Branch

Franklin. Dirisinn...........

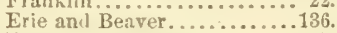

Frenci Creek Feeder ...... 27.

Latkawaxen .............. 22.

Bald Eagle................... 25.

Susquehanna, or Tide Water. 45.

Conesterga ............... 15.

Codorus.................... 11.

Enion

Schuylkill

Lthirh Vavigation ...............4 4

DELAWARE:

Chesapeake and Delaware ... 14.

Maprlaid :

Chesapeake and Ohio........184.

Chesapeake and Delaware.... -

District of Colombia:

Chesilperke and OLio....... -

Pirgnia:

Alexandria ................ 7.2

James River and Kanawha ..14s.

Dismal swamp ............ 23.

Branches.

Norti Carolina

Weldon .................. 12.

Club Fort and Harlow ....... 1.5

South Cakomina:

Santee .................. 22.
Names of Canals. Length in Miles Saluda .................. 6.2 Drehr's ................. 1.8 Lnrick .................. 1.

Lockhart's............... 2.7

Wateree .................. 4.

Catawaba ..................... 7.8

Georgia :

Savannah and Ogeechee..... 16. Brunswick ............. 12 . ALABAMA :

Muscle Shoal ............... 35.7

II untsville.................... 16.

LOUISIANA:

Orleans Bank............. 4.2

Canal Carondelet.............. 2.

Barataria ................. 85.

Lake Veret............... 8.

Kentuoxy :

Kentucky River Navigation ..100.

Licking do. ..99.

Green do. $\quad \ldots 190$.

Barren do. $\quad .100$.

Louisville and Portland ...... 2.5

ILLINOIS :

Illinois and Michigan ........118.

INDIANA ;

Wabash and Erie...........458.7

Whitewater ............... Onro:

Ohio and Erie..............307.

Zanesville Branch ............. 14.

Columbus do. ............ 10.

Lancaster do. .......... 9.

Hocking Valley ............ 56.

Walhonding Branch........ 25 .

Eastport, do. ........ 4 .

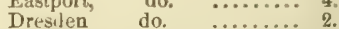

Mresiami and Branches.......... 87.7

Miami Extension and do........ 189.

Wabash and Erie...........

Muskingum Improvement.... 91.

Sandy and Beaver, Mahoning. 86 


\section{J. H. COL T'ON'S

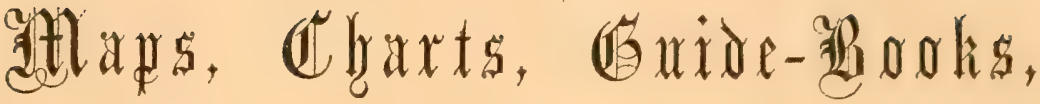 \\ Axis}

\section{GEOGRAPHICAL AND STATISTICAL WORKS.}

Office, No. 86 Cedar Street, New York.

The general accuracy and exactness of the works published from this long-established hruse has been fully appreciated by the learned and intelligent of all parts of the world; and it is with pleasure that the pul,lisher can refer to this fact, in soliciting a continuance of the public favor. It has ever been his care to prucure the earliest and most reliable information on all topics connected with the peculiar branch in which he is engaged, and being assisted in the several departments of his business by competent co-laborators, he has been enabled to invest his publications with that authenticity which has gained for him the conflience and approbation of all persons interested in gengraphical and statistical inquiries. His efforts in the same direction are unremitted, and by frequent revisions and the issue of new works, the public may rely upon receiving, in an authentic form, every new geographical and statistical fact at the earliest period. The following worhs from his Citalogue for 1958 (which nay be had on application), are worthy of special nutice:

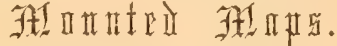

CALIFORNTA GOVERNMENT MAP, 70 by 59 inches. WORLD, in Mfereatur's projection, engraved on steel, and ìighly embellished, in three sizes, viz. : 80 by 60 inches; 44 by 30 in'hes: and 2 s by 22 inche's.

WORLD, in hemispheres. for the use of schools and churclses. wash hemisphere sir feet in diameter.

NORTH AIVERICA,

SOUTH AMERICA, in two series; the size of nne beEUROPE,

ASIA,

AFRICA,

NORTH AND SOUTH AMERICA, 32 by 25 inches.

WEST INDIES, 32 by 25 inches.

UNITED STATES, etc., engraved on steel, in three sizes, viz. : 82 by 6 sinches; 62 by 55 inches; and 45 by 36 inches.

MEXICO, 4 by 32 inches.
NEW YORK, in townships, 60 b5 50 inches.

INDIAN 1 , in sections, of treo sizes, viz. : 66 by 48 inches, and 43 by 32 inches.

ILLINOIS, in sections, 43 by 32 inches.

MICHIG.AN, in sections, 25 by 25 inches.

TOWNSHIP MLAPS, of the States severally, a tXIFORM selifs. size of each 32 by 29 inches, now in progress, and of which the following are completed:

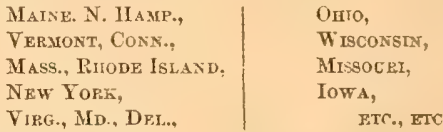

NEW ENGLAND, in townships, on steel and embellished, 64 by 56 inches.

SOUTHERN STATES, size, 80 by 60 inches (in progress) WESTERN STATES, in towns, 48 by 36 inches.

Alst, mounted Maps of PALESTINE, in two sizer, viz. : 80 by 62 inches, and 43 by 32 inches; EgrPT, Arabia PrTR.s, ete., 32 by 25 inches; and a great variety of loeal Maps. Also, the Strears of Tiur, an bistorical chart; Puktrats of tue Ph:Rsidexts, etc.

\section{COLTON'S AMERICAN ATLAS, $\$ 1250$ and $\$ 15$. COLTON'S ATLAS OF THE WORLD, $\$ 15$ and $\$ 18$.}

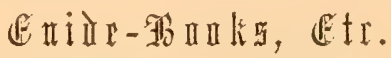

Guide-Book through the United States, Canada, etc., with a large Map. Route Book through the United States, Canada, etc., with a large Map. Guide-Book through New England and the Middle States, with a new Map.

Western Tourist and Emigrant's Guide, with a township Map.

Overland Guide to California and Oregon, by Horn, with a Map.

Is hmus of Panama Guide, with thee Naps, by Dr. E. L. Autenrieth.

Wes ern Portraiture, with a township Map. by D. S. Curtiss.

Progress of the United Sta:es, by Dr. Fisher.

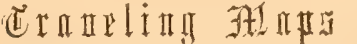

UNITED STATES, in several sizes.

NEW YORK, in two sizes.

MAINE, NEW BRUNSWICK, elc.

NEW HAMPSHIRE an VERMONT.

MASS, RHOD ISLAND, CONNECTICUT.

VIRGINIA, DELAWARE, and MARYLAND

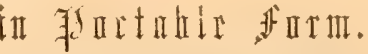 \\ WESTER N STATES, viz. : Ohio. Iudians, etc. \\ OHIO, MICRIGAN, W SCONSIN. \\ ILLINOIS, IOWA, INDIANA. \\ NORTH an SOUTH CAROLINA. \\ MISSOURI, TEXAS, GEORGLA. \\ NEW YORK VICINTTY, LONG ISLAND.
}

X. B. All of the above Maps are complete in regard of railroads, canals, ete., up to the date which appears in the title, and in all respecis are much more correct and detailed than any others hitherto published.

Besides his onu publications, J. H. C. has constantly on hand on assortment of American and ,forergn Atlases; Maps, Globes, and other geographical works. 








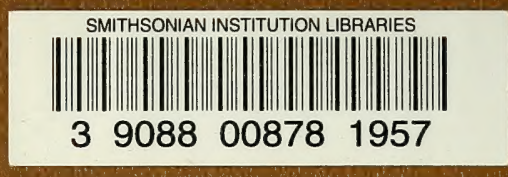

